UNITED

NATIONS

International Tribunal for the

Case No.: IT-95-5/18-T

Prosecution of Persons

Responsible for Serious Violations

Date: $\quad 24$ March 2016

of International Humanitarian Law

Committed in the Territory of the

former Yugoslavia since 1991

Original: English

IN THE TRIAL CHAMBER

Before: $\quad$ Judge O-Gon Kwon, Presiding Judge Judge Howard Morrison

Judge Melville Baird

Judge Flavia Lattanzi, Reserve Judge

Registrar: $\quad$ Mr. John Hocking

Judgement of: $\quad 24$ March 2016

PROSECUTOR

v.

RADOVAN KARADŽIĆ

PUBLIC

PUBLIC REDACTED VERSION OF JUDGEMENT ISSUED ON

24 MARCH 2016

VOLUME I OF IV

Office of the Prosecutor

Mr. Alan Tieger

Ms. Hildegard Uertz-Retzlaff

The Accused

Mr. Radovan Karadžić 


\section{TABLE OF CONTENTS}

\section{VOLUME I}

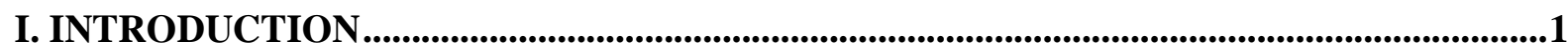

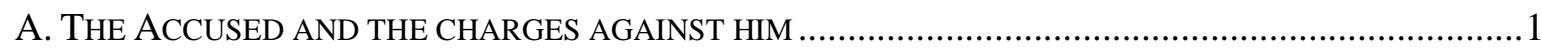

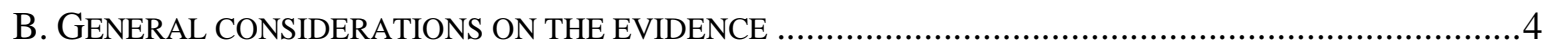

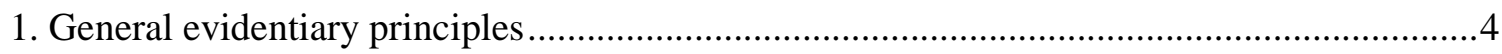

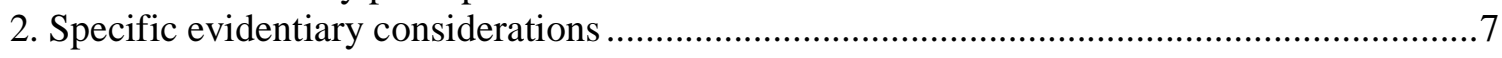

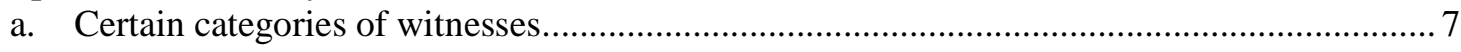

i. Persons associated with the parties to the proceedings ......................................................... 7

ii. Individuals convicted of crimes arising from events charged in the Indictment .................. 7

iii. Individuals whose trial is currently ongoing, at trial or on appeal .................................... 8

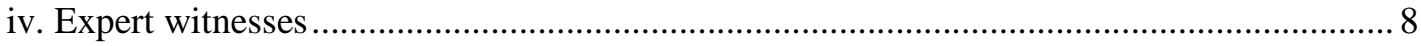

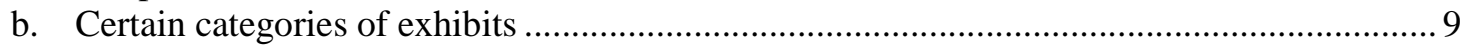

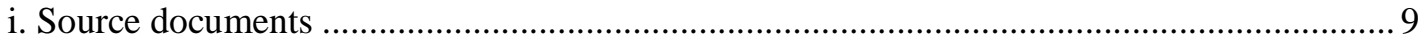

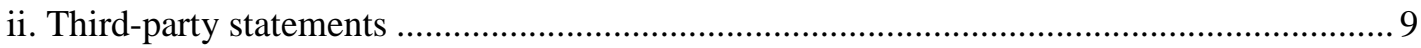

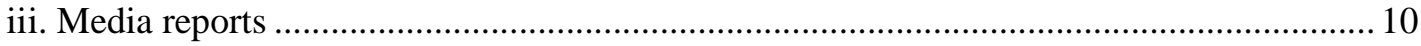

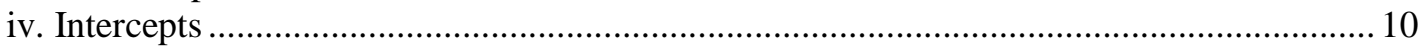

c. Evidence admitted in writing and the issue of corroboration........................................... 11

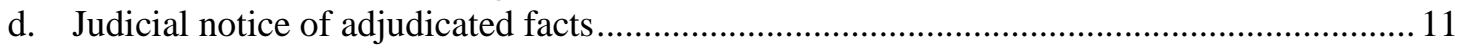

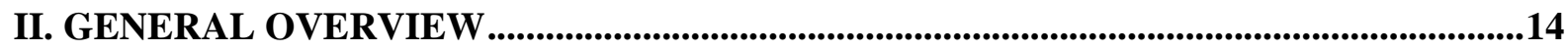

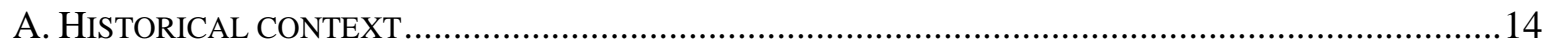

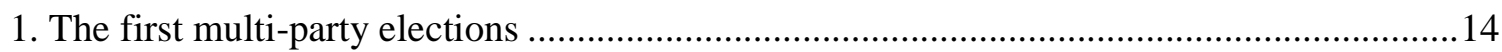

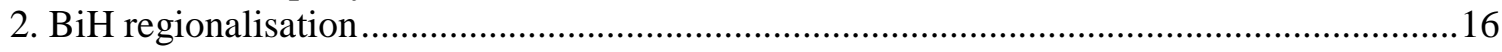

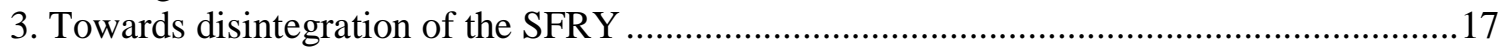

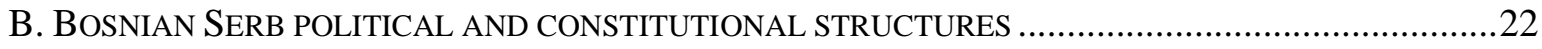

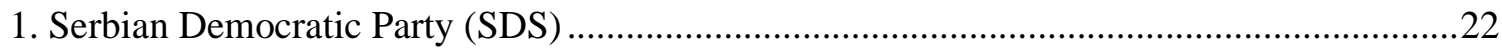

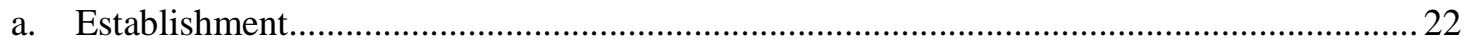

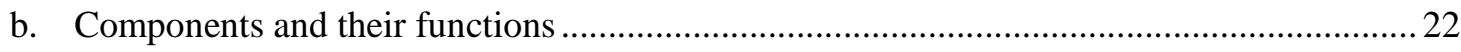

c. Organisation and structure

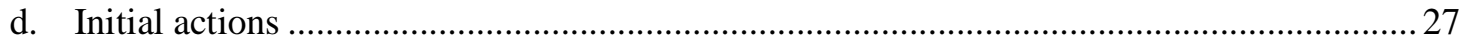

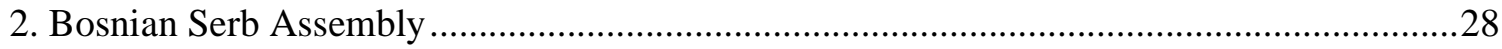

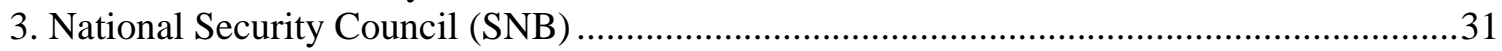

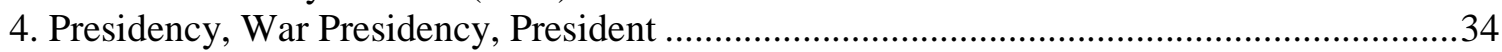

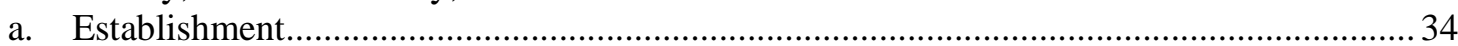

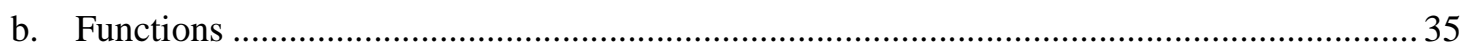

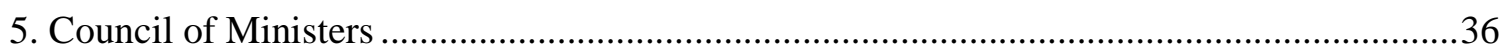

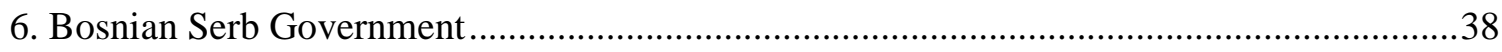

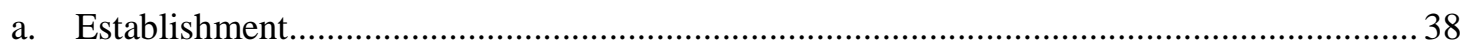

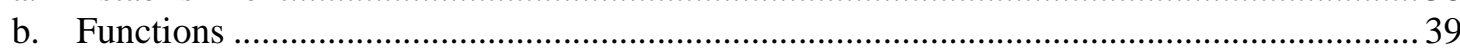

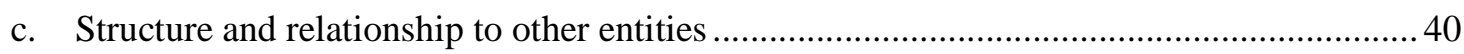

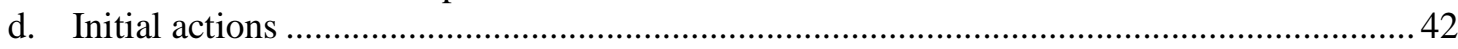

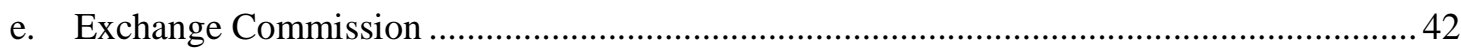

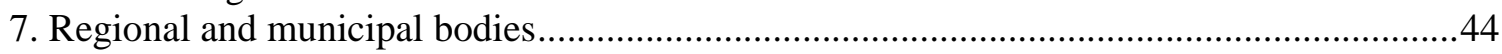

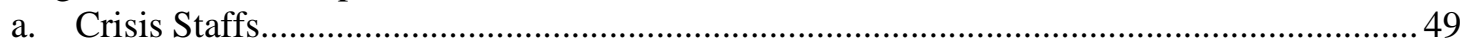

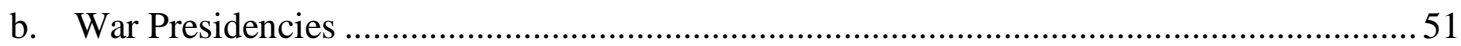

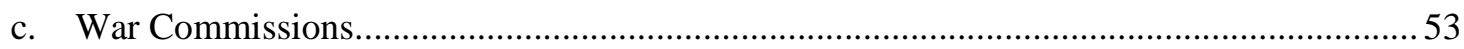

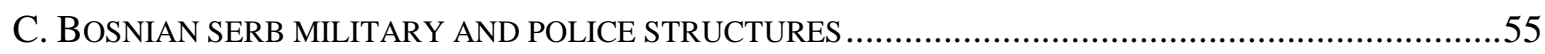

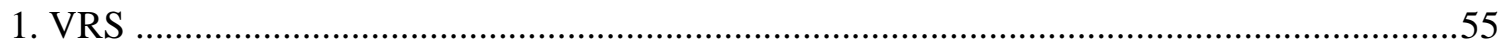

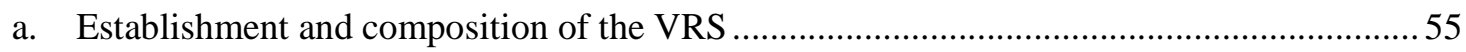

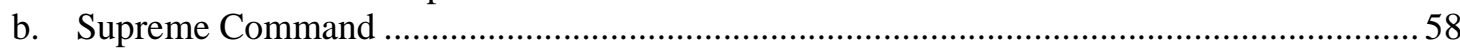




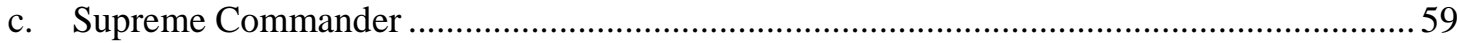

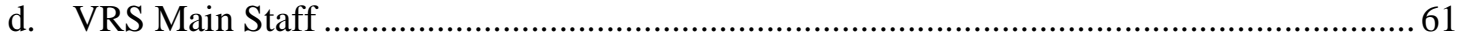

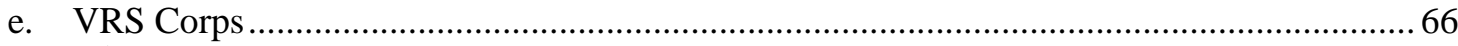

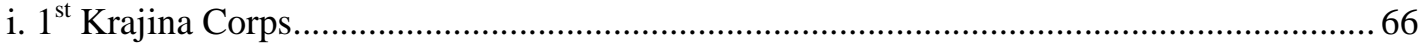

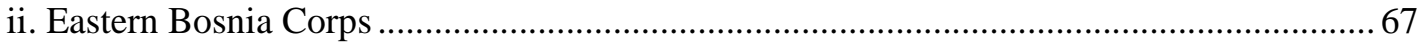

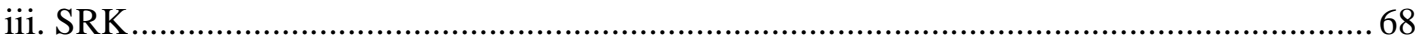

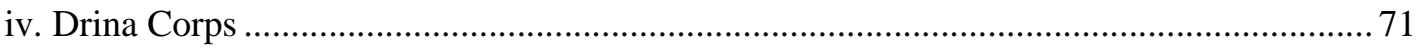

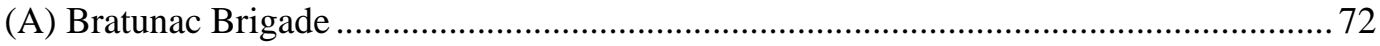

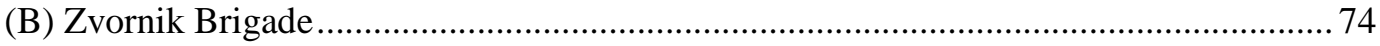

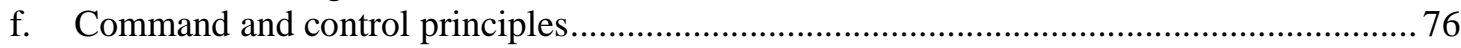

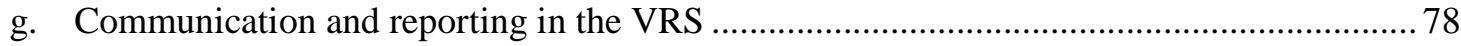

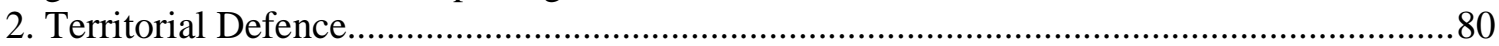

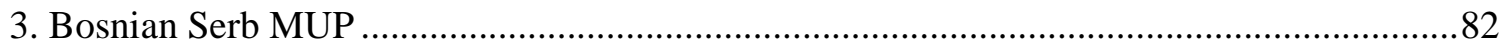

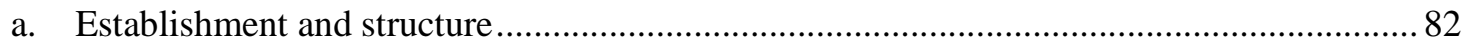

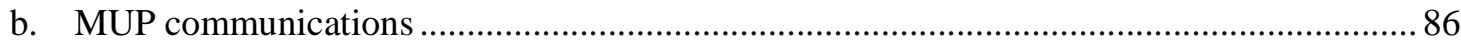

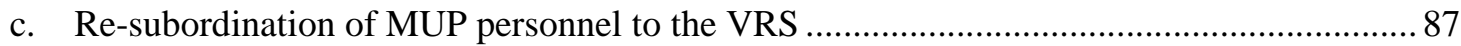

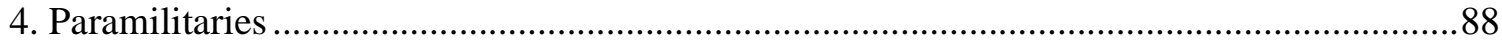

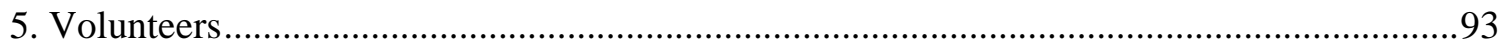

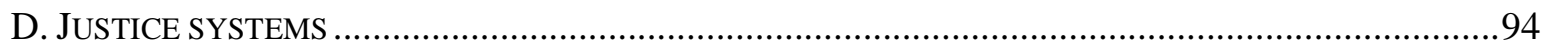

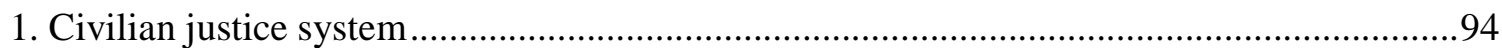

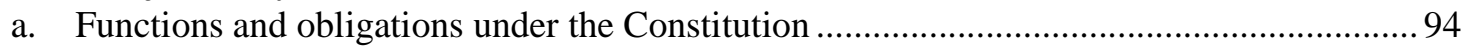

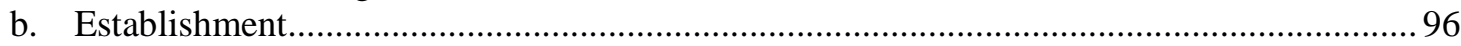

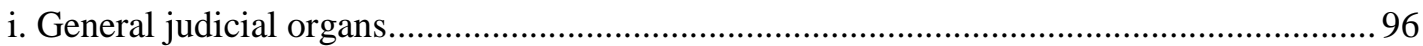

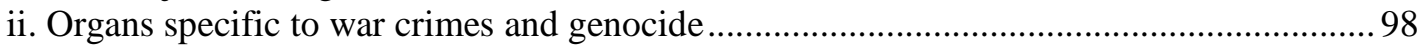

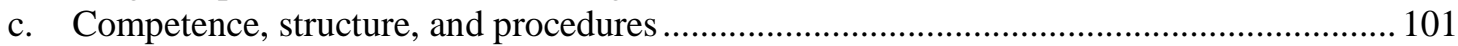

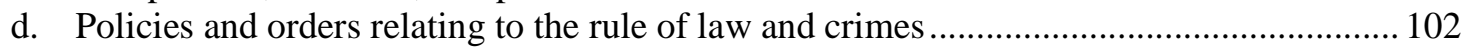

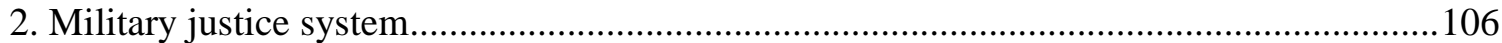

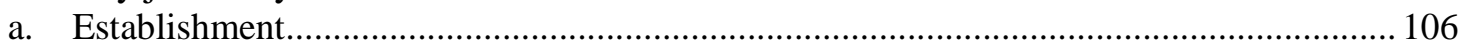

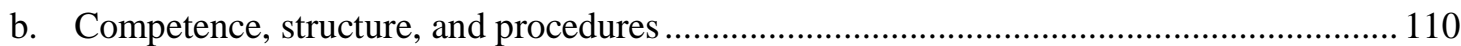

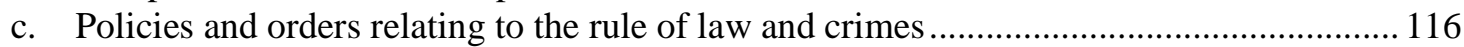

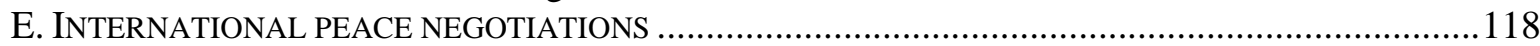

1. European Community Peace Conference on Yugoslavia .....................................................118

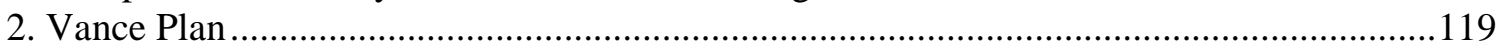

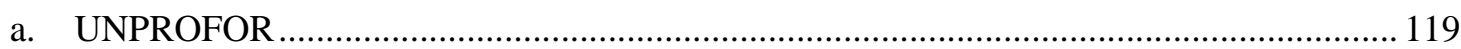

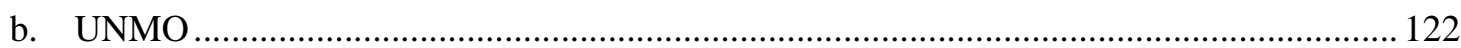

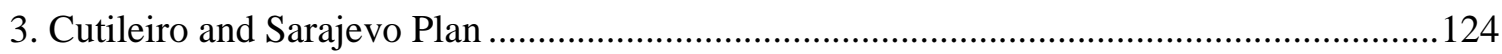

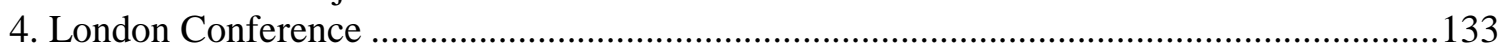

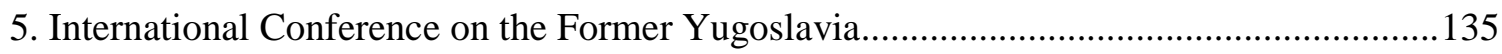

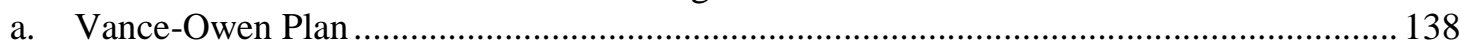

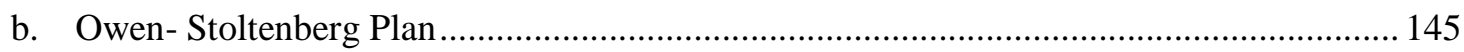

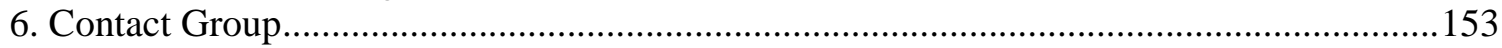

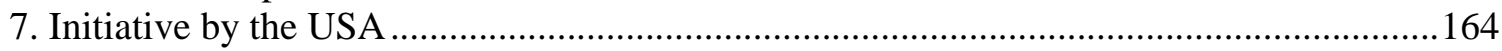

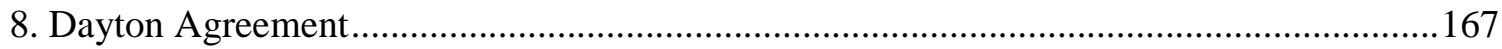

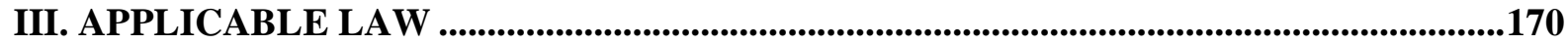

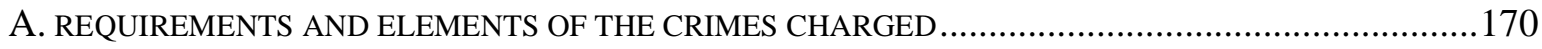

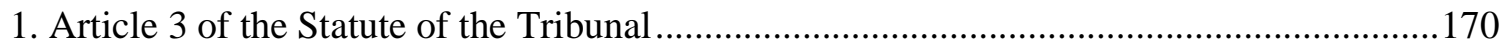

a. General requirements for violations of the laws or customs of war ................................ 170

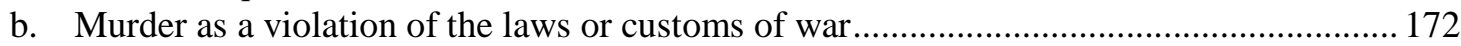

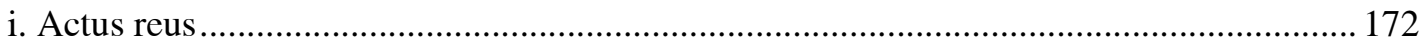

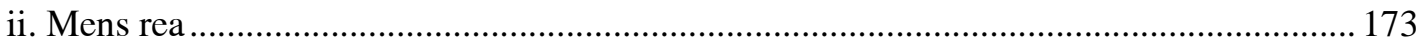

c. Unlawful attacks on civilians as a violation of the laws or customs of war...................... 173

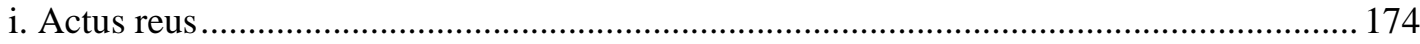

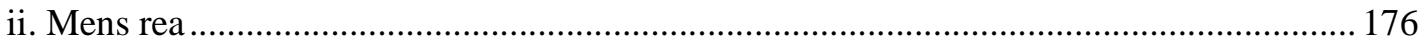




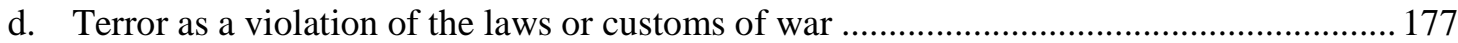

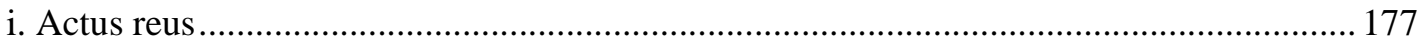

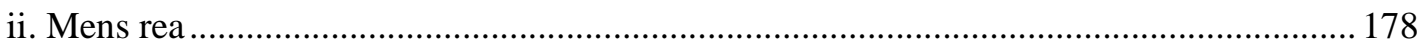

e. Taking of hostages as a violation of the laws or customs of war ..................................... 179

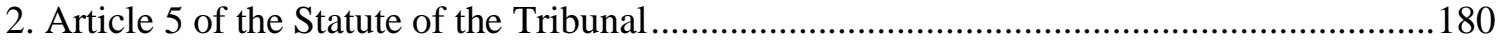

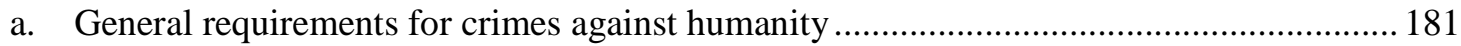

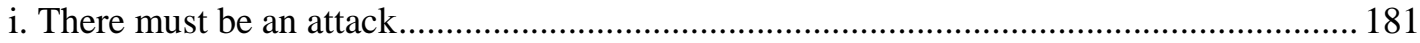

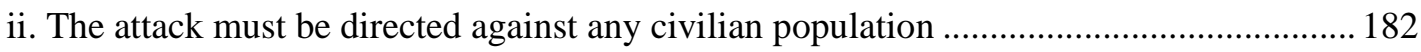

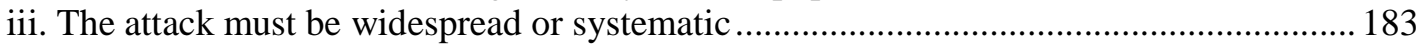

iv. The acts of the perpetrators must be part of the attack.................................................... 183

$\mathrm{v}$. The perpetrator must know that there is a widespread or systematic attack against a civilian population and know that his acts constitute part of this attack ........................ 184

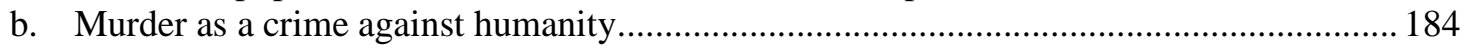

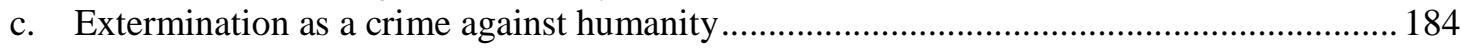

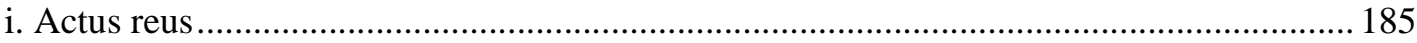

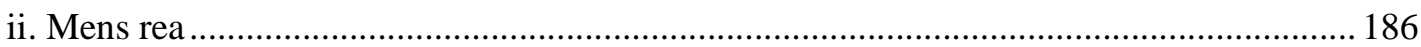

d. Deportation and inhumane acts (forcible transfer) as crimes against humanity .................. 187

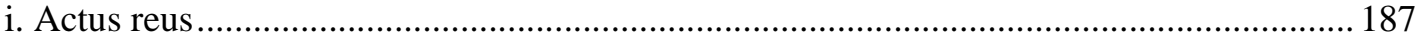

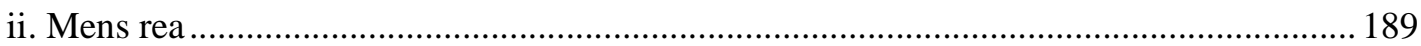

iii. Forcible transfer as "other inhumane acts" pursuant to Article 5(i) ............................... 189

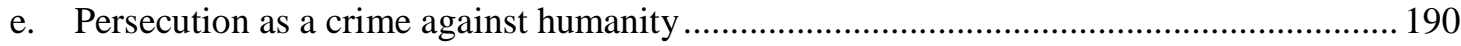

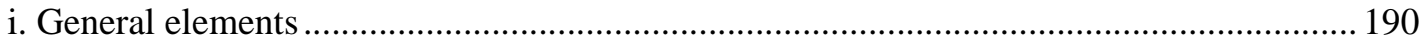

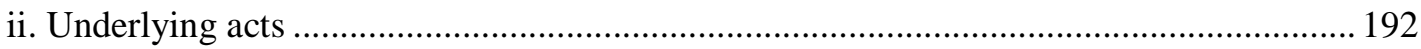

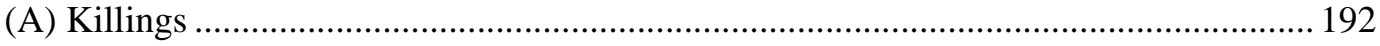

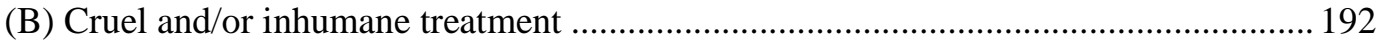

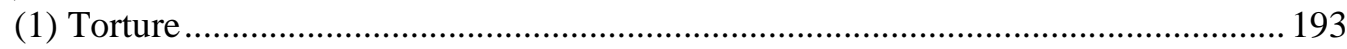

(2) Beatings and physical and psychological abuse ................................................ 195

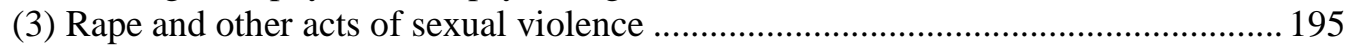

(4) Establishment and perpetuation of inhumane living conditions............................. 196

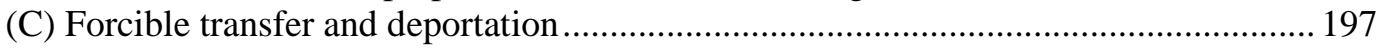

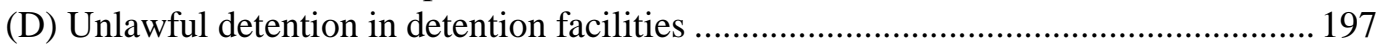

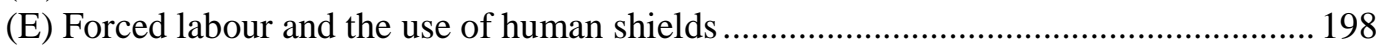

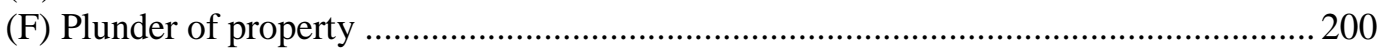

(G) Wanton destruction of private and public property, including cultural monuments

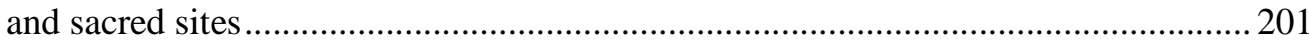

(H) Imposition and maintenance of restrictive and discriminatory measures.................. 202

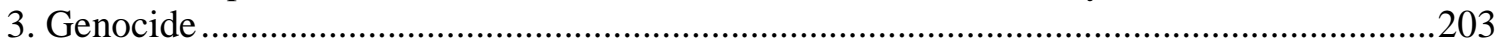

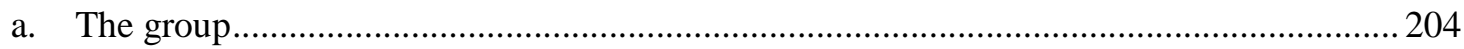

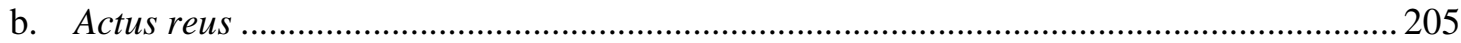

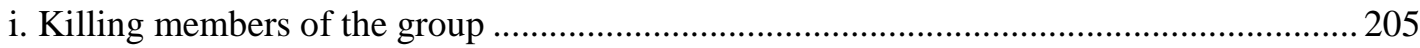

ii. Causing serious bodily or mental harm to members of the group ...................................2.205

iii. Deliberately inflicting on the group conditions of life calculated to bring about its physical destruction in whole or in part .................................................................... 207

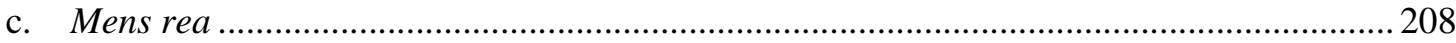

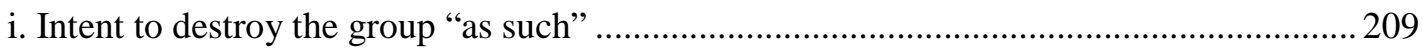

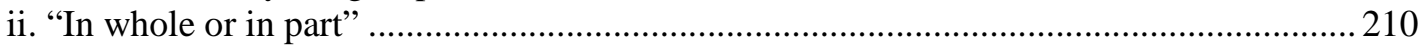

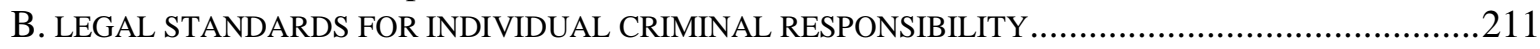

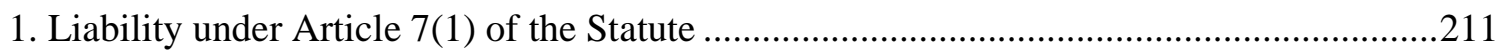

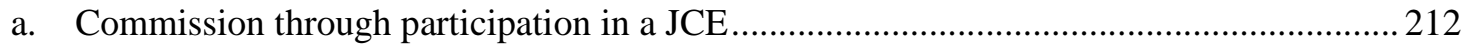

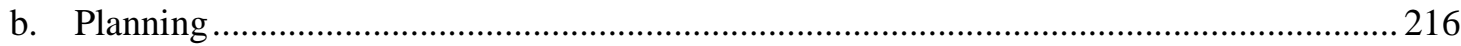

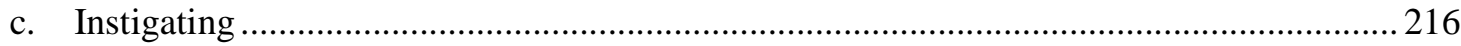

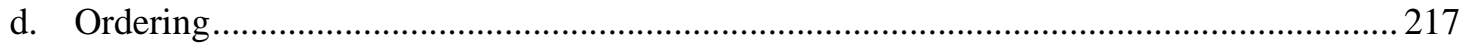

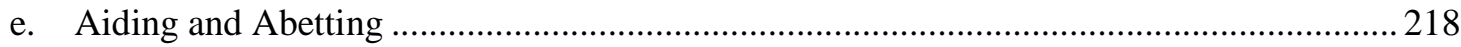

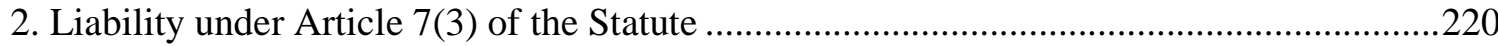




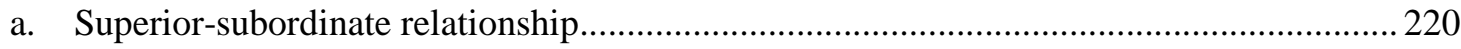

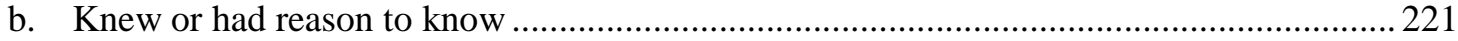

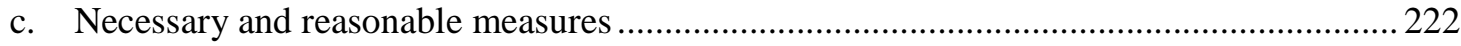

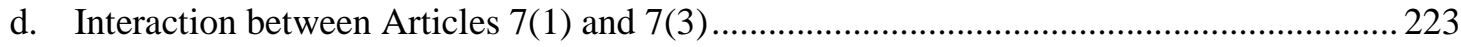

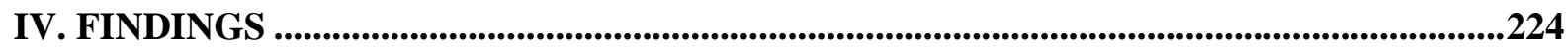

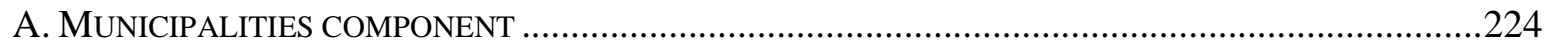

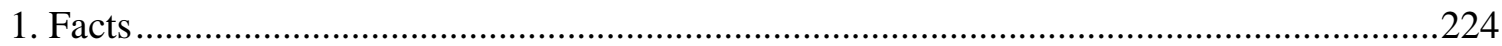

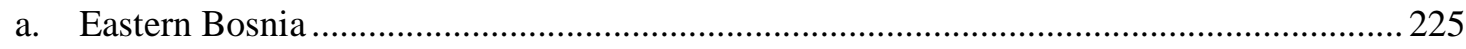

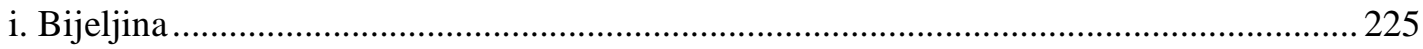

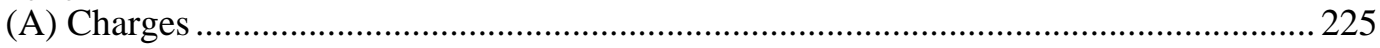

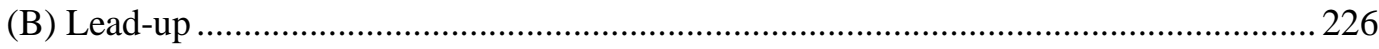

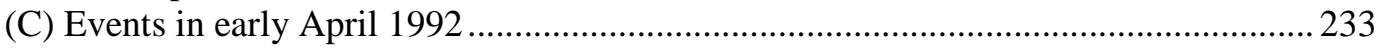

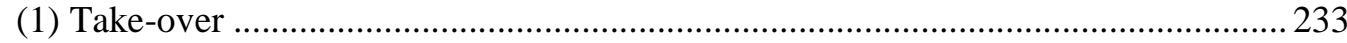

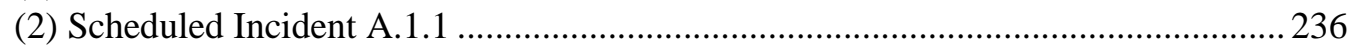

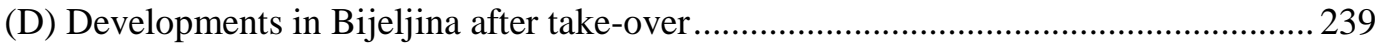

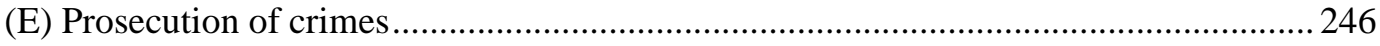

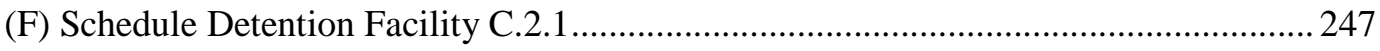

(1) Establishment of camp and arrival of detainees .................................................... 247

(2) Conditions of detention and treatment of detainees ...........................................250

(3) Conclusion on conditions of detention and treatment of detainees .........................254

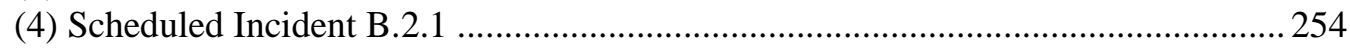

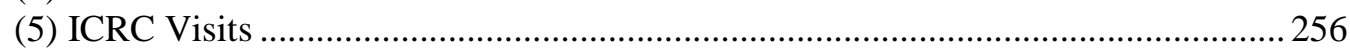

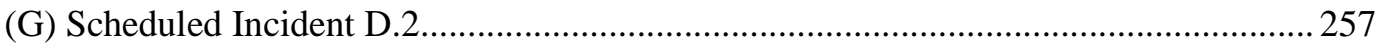

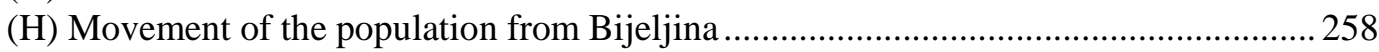

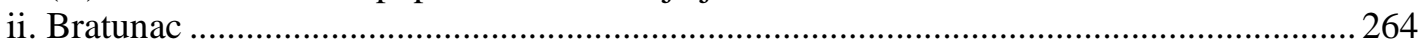

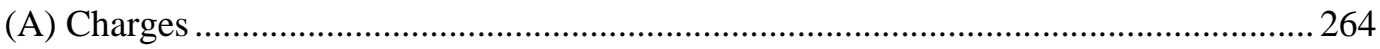

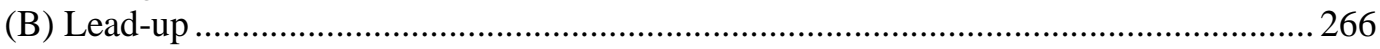

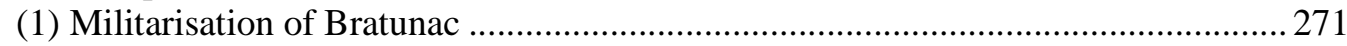

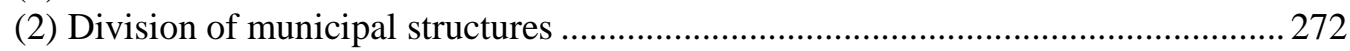

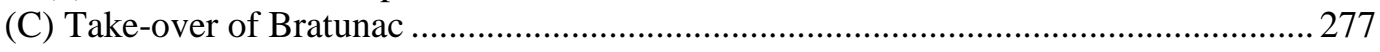

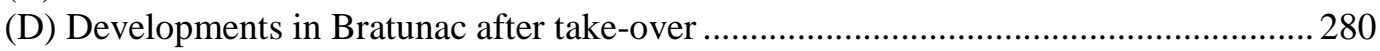

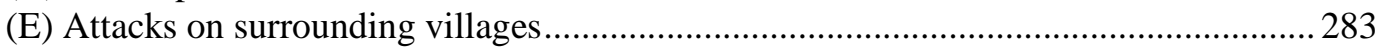

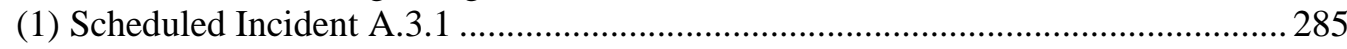

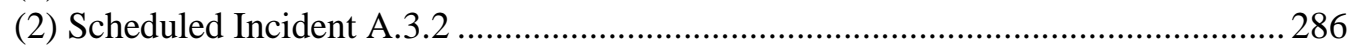

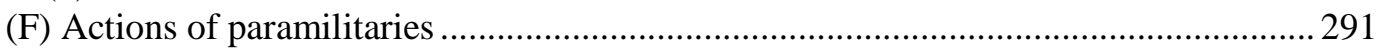

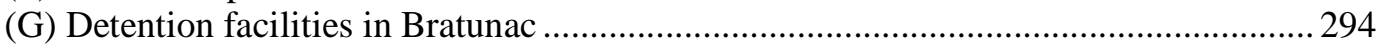

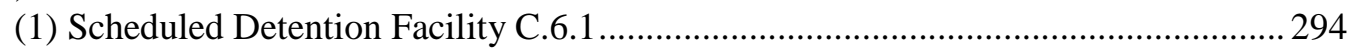

(2) Scheduled Detention Facility C.6.2 and Scheduled Incident B.4.1........................296

(a) Arrival of detainees and control of facility ....................................................296

(b) Conditions of detention, treatment, and killing of detainees..............................298

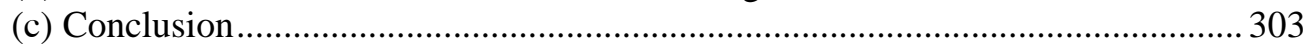

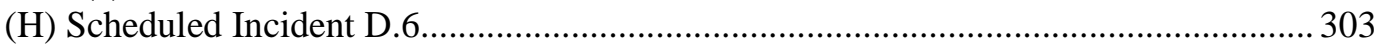

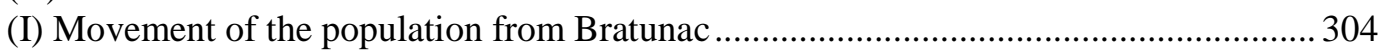

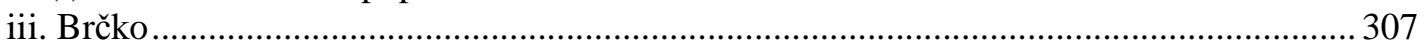

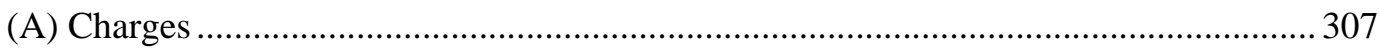

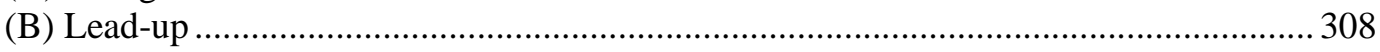

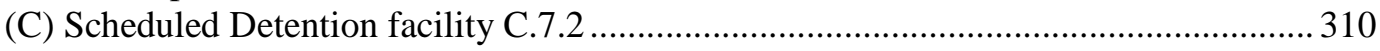

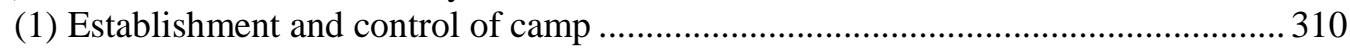

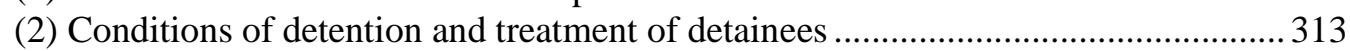

(3) Conclusion on conditions of detention and treatment of detainees ............................... 316

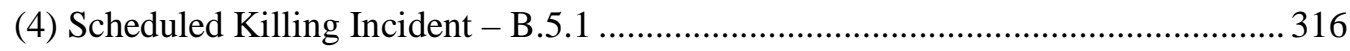

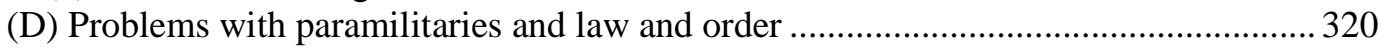

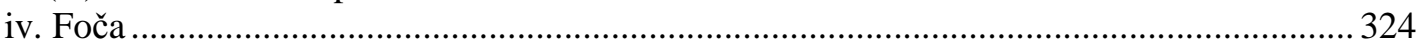




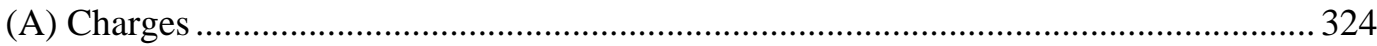

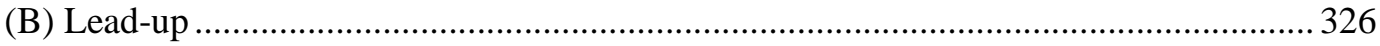

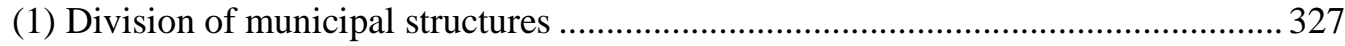

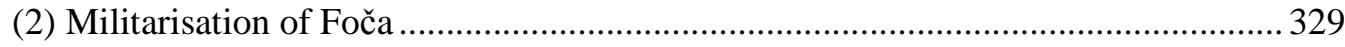

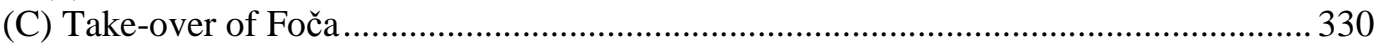

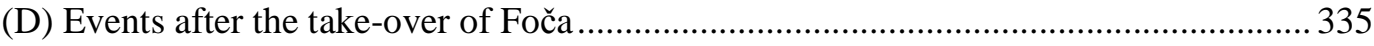

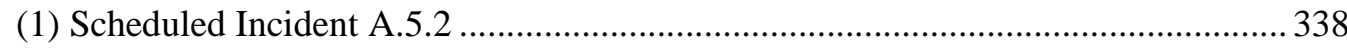

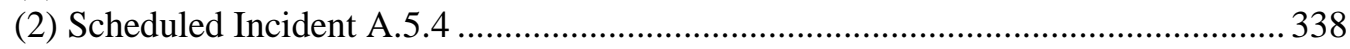

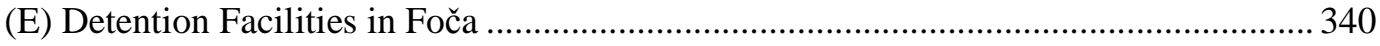

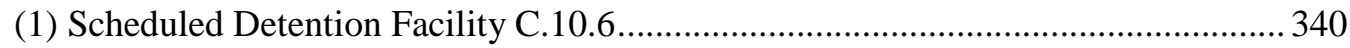

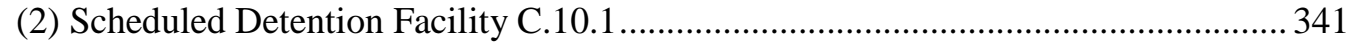

(a) Arrival of detainees and control over the detention facility ................................ 341

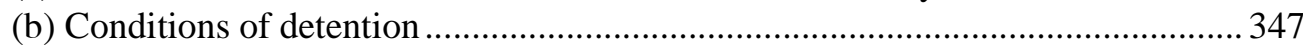

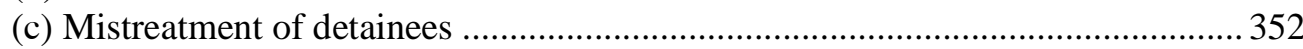

(d) Conclusion on conditions of detention and treatment of detainees..................... 356

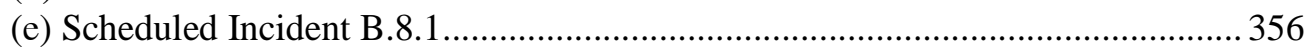

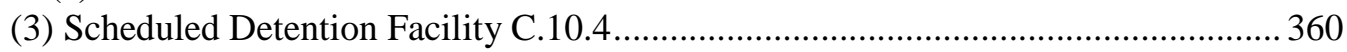

(4) Scheduled Detention Facilities C.10.5 and C.10.7 …......................................... 360

(5) Scheduled Detention Facility C.10.2 and other evidence of rape and other acts of sexual violence during and after the take-over of Foča ...........................................362

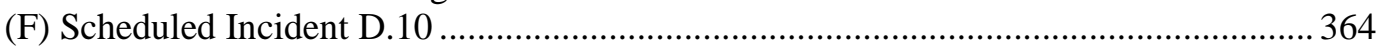

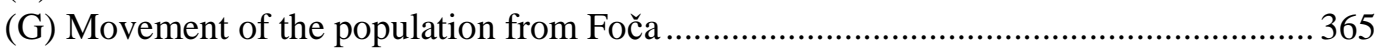

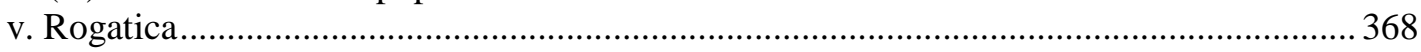

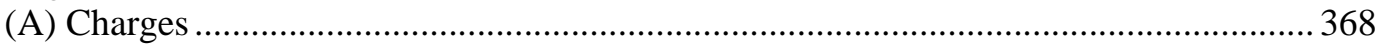

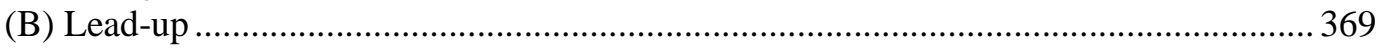

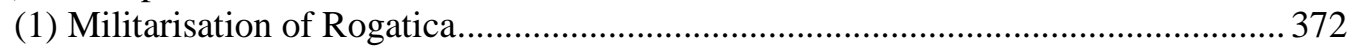

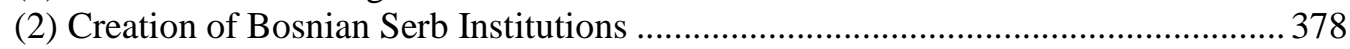

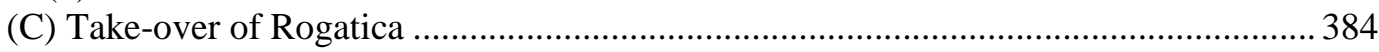

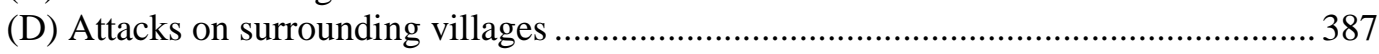

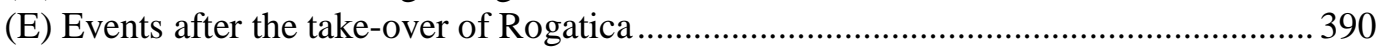

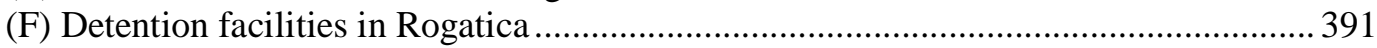

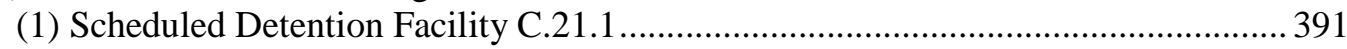

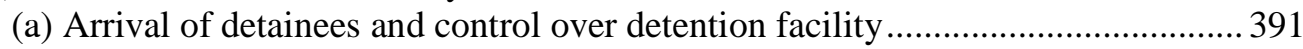

(b) Conditions of detention and treatment of detainees .............................................395

(c) Conclusion on conditions of detention and treatment of detainees ......................398

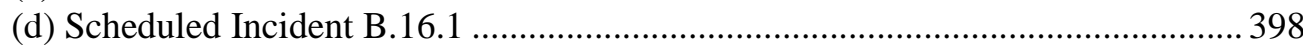

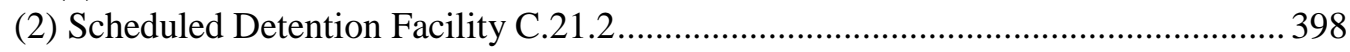

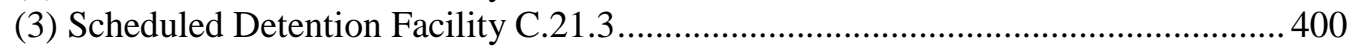

(a) Arrival of detainees and control over detention facility .................................... 400

(b) Conditions of detention and treatment of detainees ............................................403

(c) Conclusion on conditions of detention and treatment of detainees .....................408

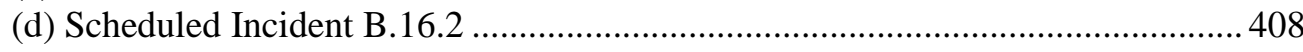

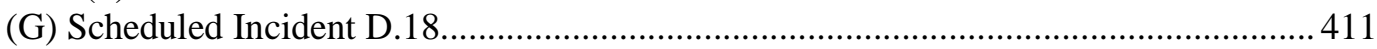

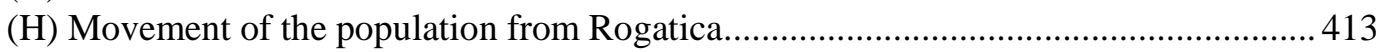

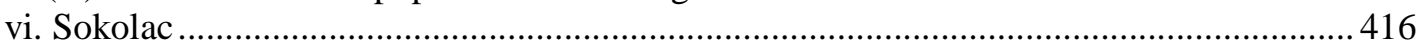

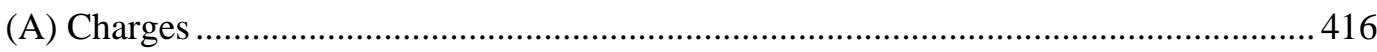

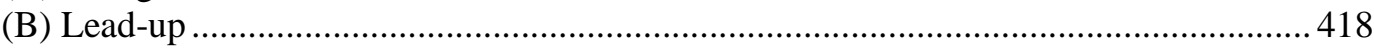

(C) Attacks against Bosnian Muslim villages .................................................................423

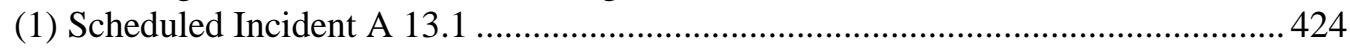

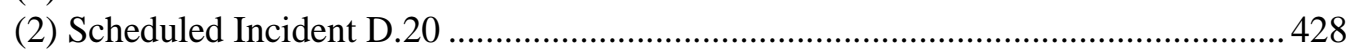

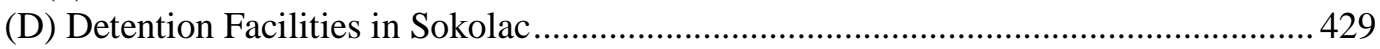

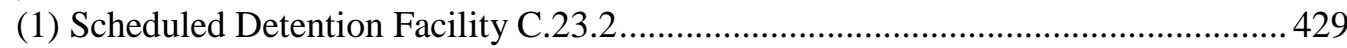

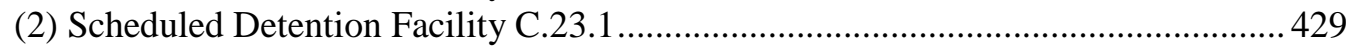

(E) Movement of the population from Sokolac …….................................................... 430 


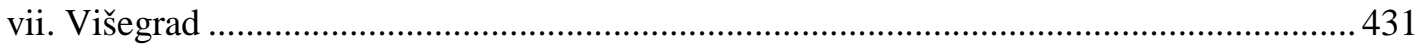

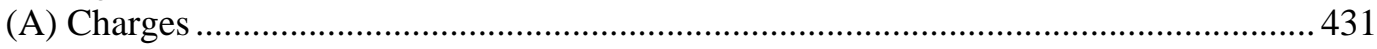

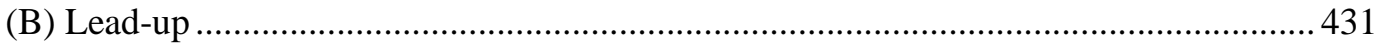

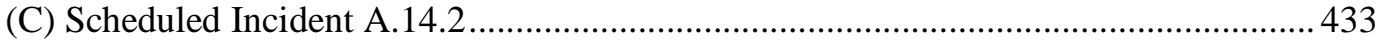

(1) Forensic and documentary evidence regarding Scheduled Incident A.14.2 …....... 438

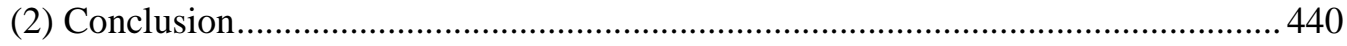

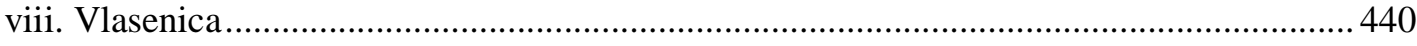

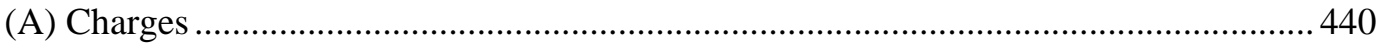

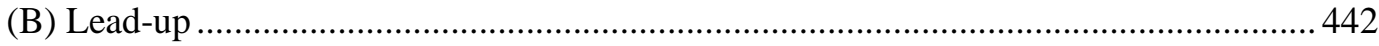

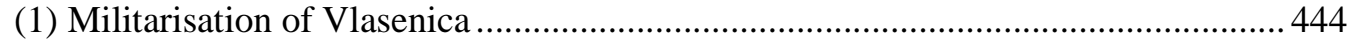

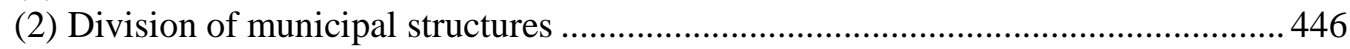

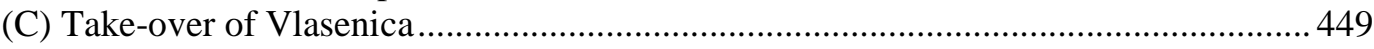

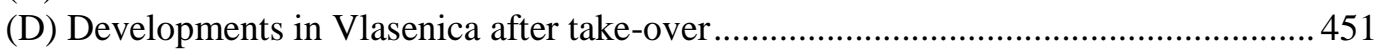

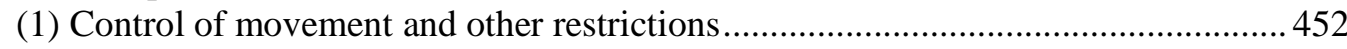

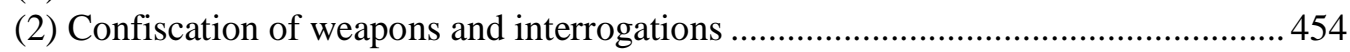

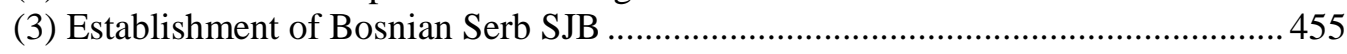

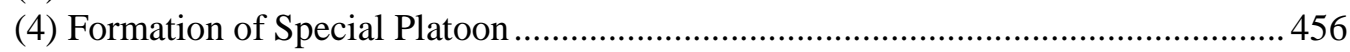

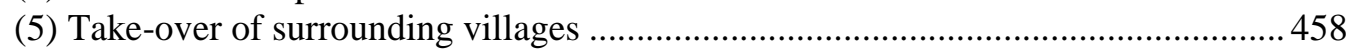

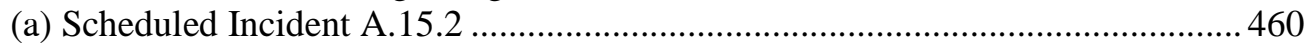

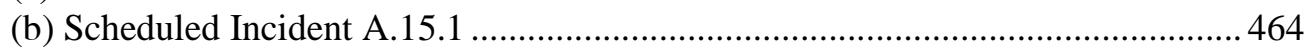

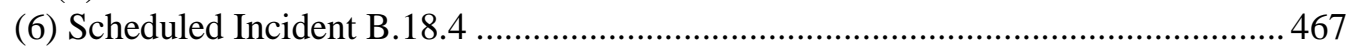

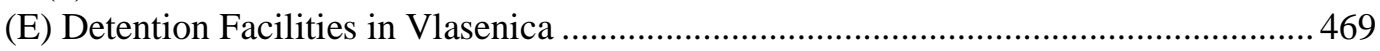

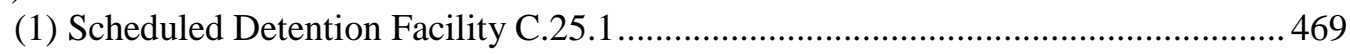

(a) Arrival of detainees and control over the detention facility ...............................469

(b) Conditions of detention and treatment of detainees ...........................................470

(c) Conclusion on conditions of detention and treatment of detainees.................... 471

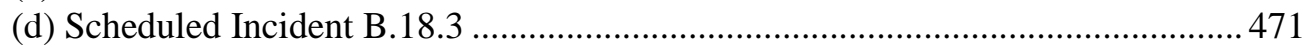

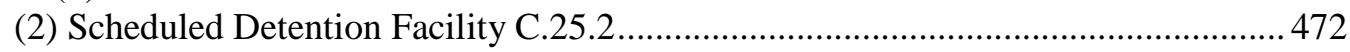

(a) Arrival of detainees and control over detention facility ...................................472

(b) Conditions of detention and treatment of detainees ..........................................473

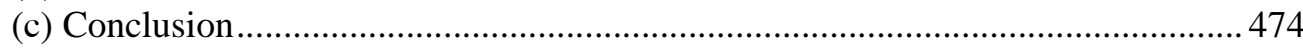

(3) Scheduled Detention Facility C.25.3 .................................................................474

(a) Arrival of detainees and control over the detention facility ..............................475

(b) Conditions of detention and treatment of detainees ..........................................479

(c) Transfer of detainees and inspection of camp ......................................................484

(d) Conclusion on conditions of detention and treatment of detainees.....................486

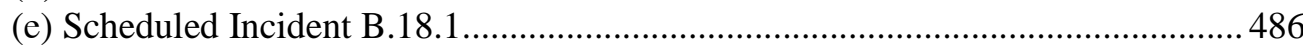

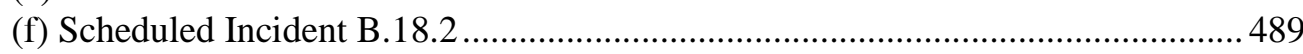

(F) Movement of the population from Vlasenica and appropriation of property............... 491

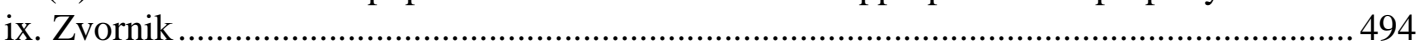

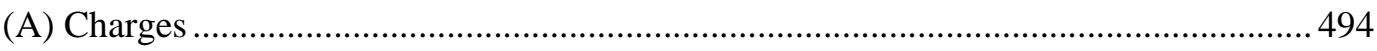

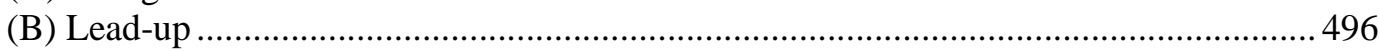

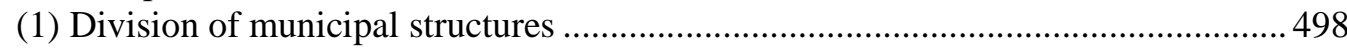

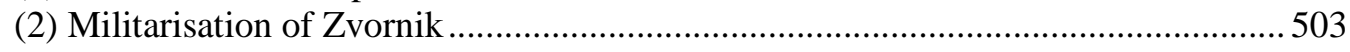

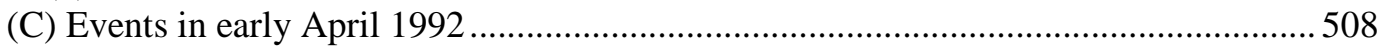

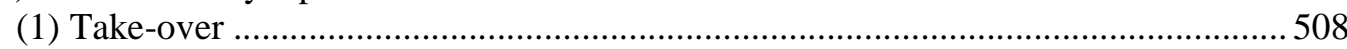

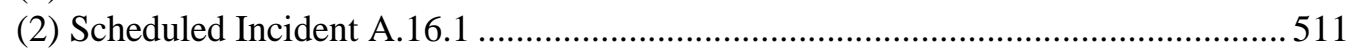

(D) Events in other villages in Zvornik municipality ..................................................513

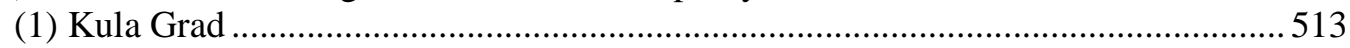

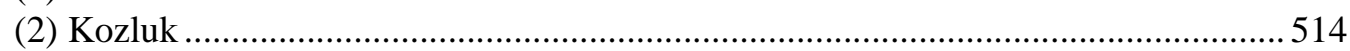

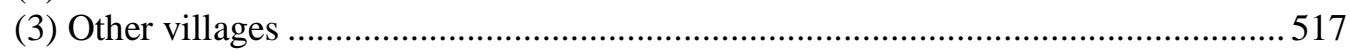

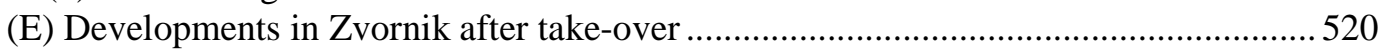

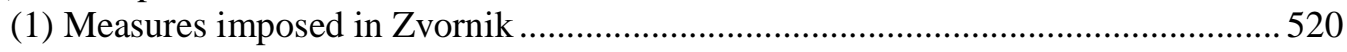

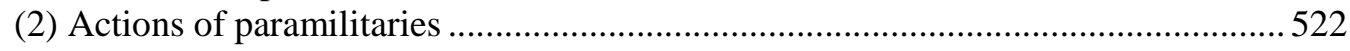




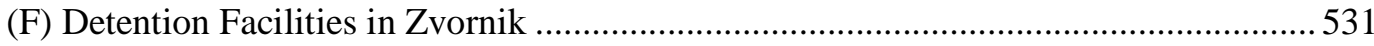

(1) Scheduled Detention Facility C.27.1 and Scheduled Incident B.20.2 ....................551

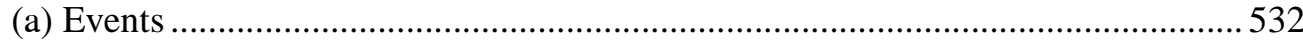

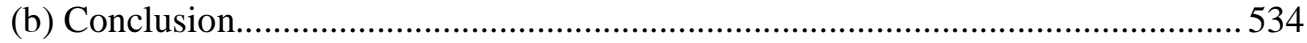

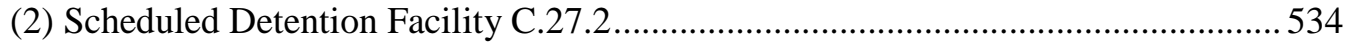

(a) Arrival of detainees and control of facility ....................................................5. 534

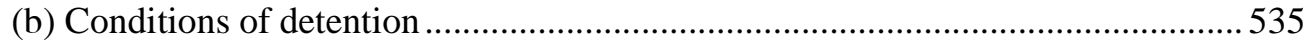

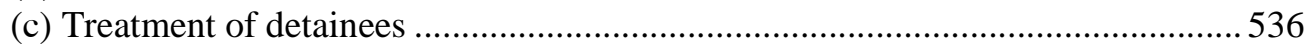

(d) Conclusion on conditions of detention and treatment of detainees....................536

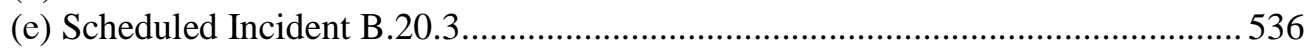

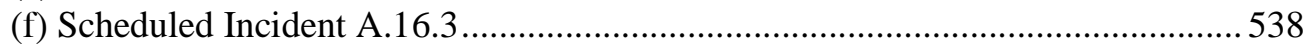

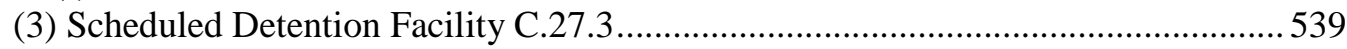

(a) Arrival of detainees and control of facility .....................................................539

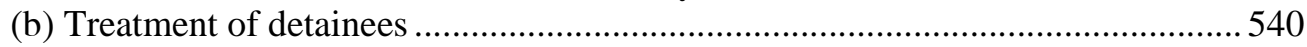

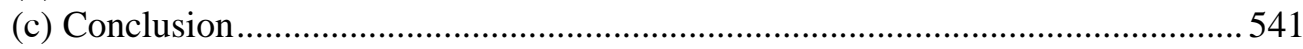

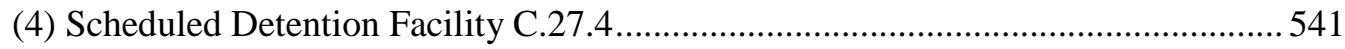

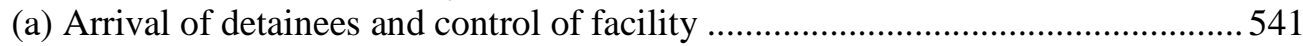

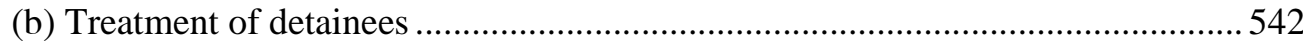

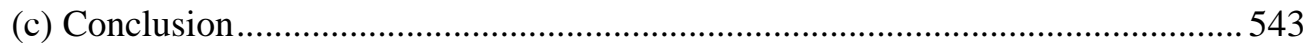

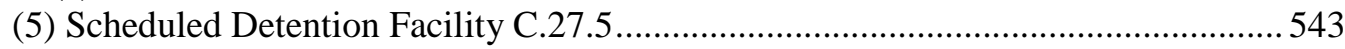

(a) Arrival of detainees and control of facility ....................................................54

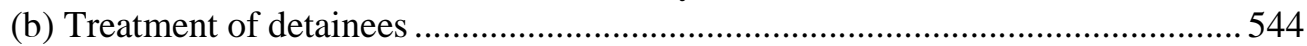

(c) Conclusion on conditions of detention and treatment of detainees .....................545

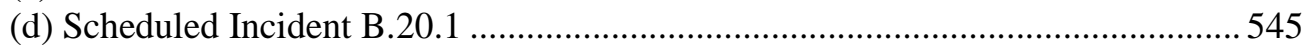

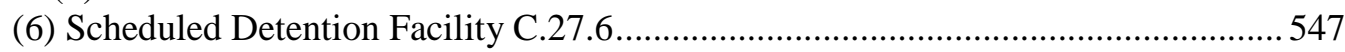

(a) Arrival of detainees and control of facility ……..............................................54

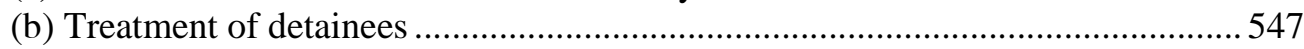

(c) Conclusion on conditions of detention and treatment of detainees .....................549

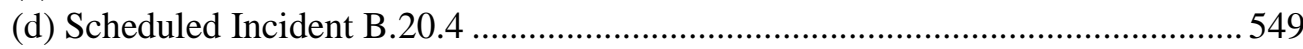

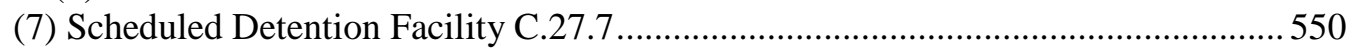

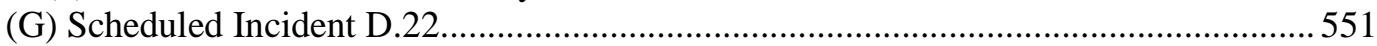

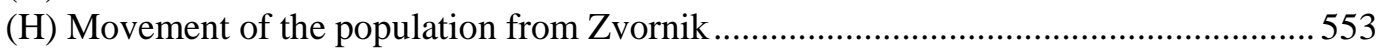

\section{VOLUME II}

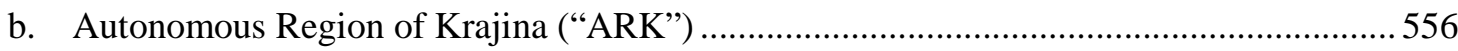

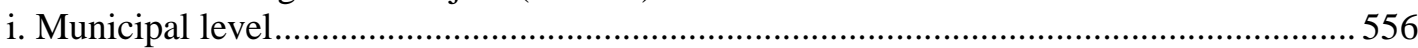

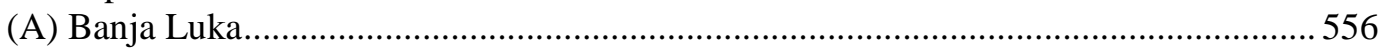

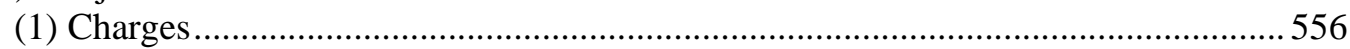

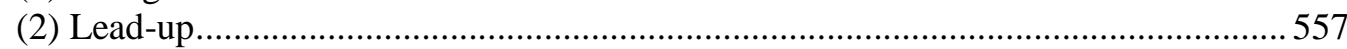

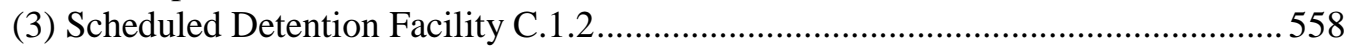

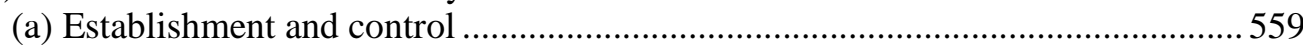

(b) Conditions of detention and treatment of detainees ............................................5 564

(c) Visits to Manjača and transfer of detainees.......................................................571

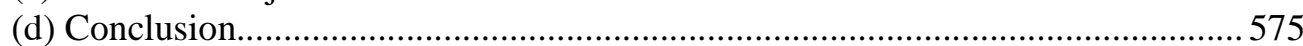

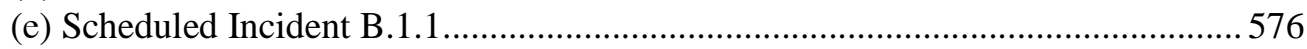

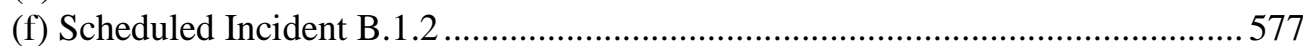

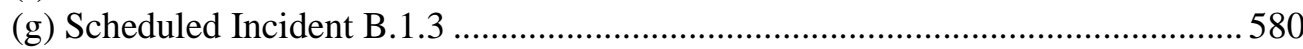

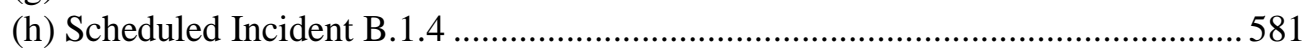

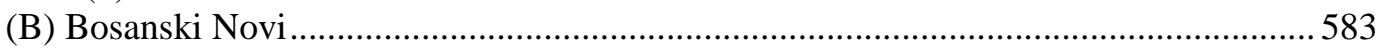

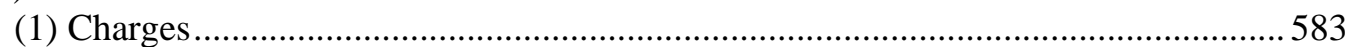

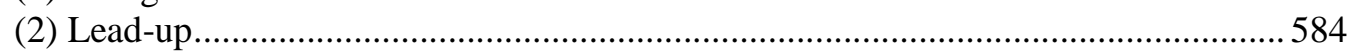

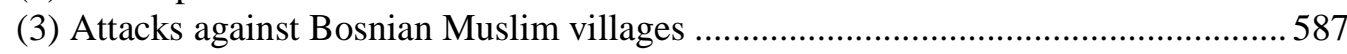

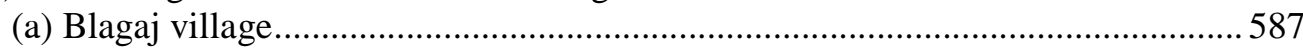

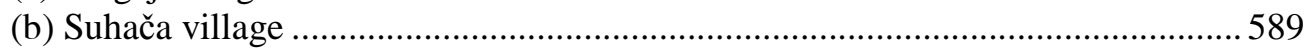




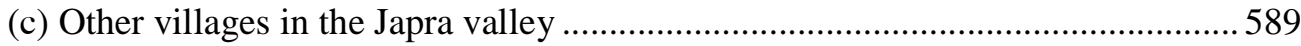

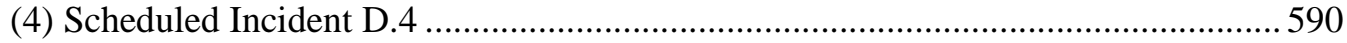

(5) Movement of the population within and from Bosanski Novi ...............................591

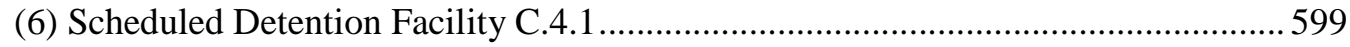

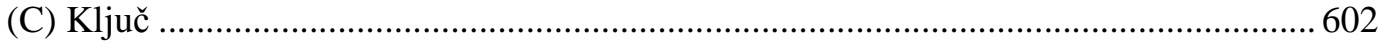

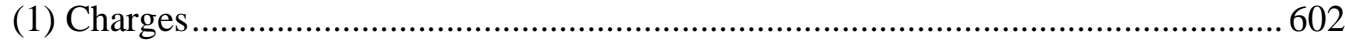

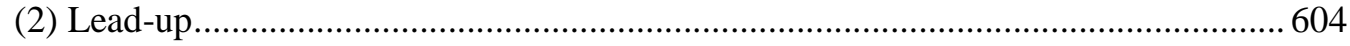

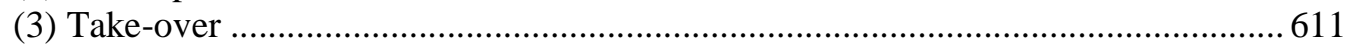

(a) Expulsion of Bosnian Muslims from police, administrative organs and work force

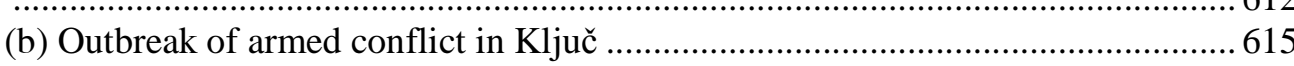

(c) Destruction of houses and looting of movable property ....................................619

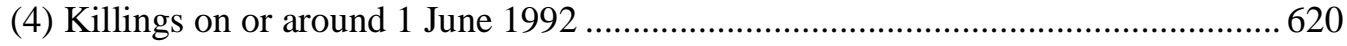

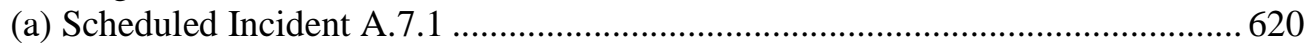

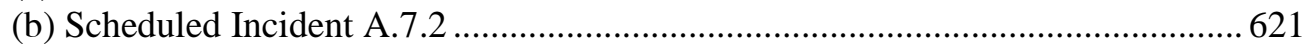

(5) Arrests, detentions, and killings associated with detention facilities ......................624

(a) Scheduled Detention Facility C.15.3 and Scheduled Incident B.10.1.................624

(b) Scheduled Detention Facility C.15.1 ….........................................................627

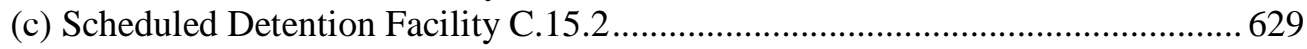

(6) Killings after June 1992: Scheduled Incident A.7.3 ..............................................631

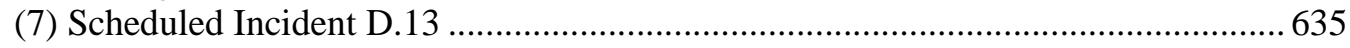

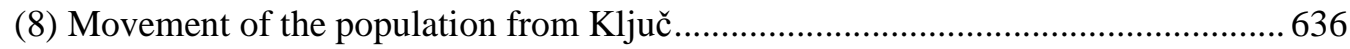

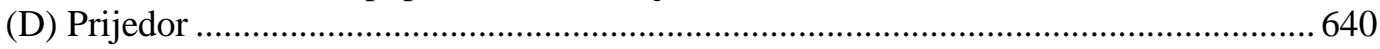

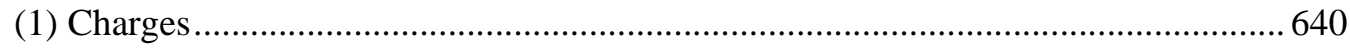

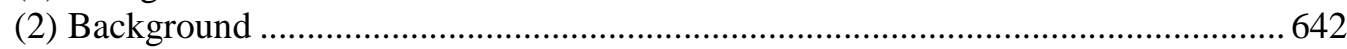

(a) Division of municipal structures and establishment of Bosnian Serb institutions

(b) Propaganda and militarisation of Prijedor.

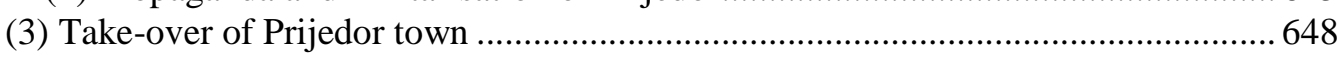

(a) Expulsion of non-Serbs from police, administrative and judicial organs, and work force

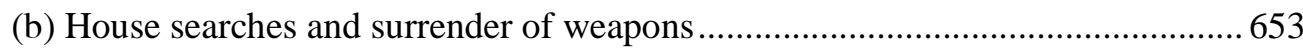

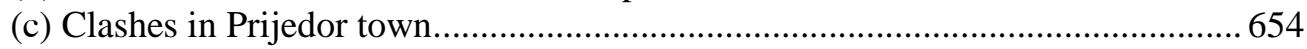

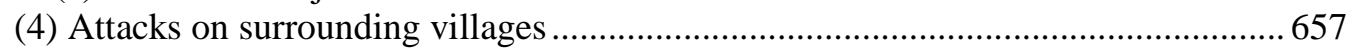

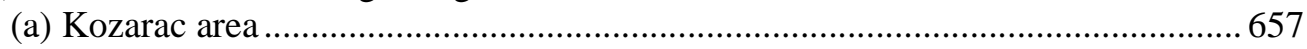

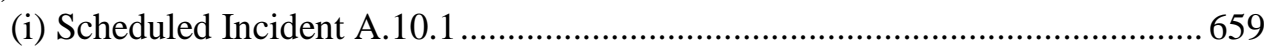

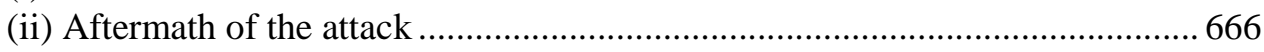

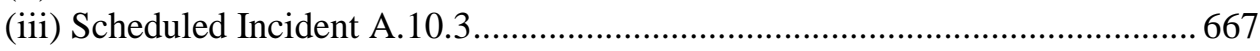

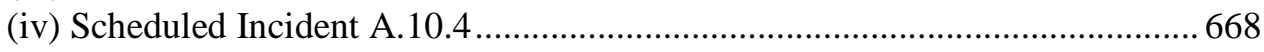

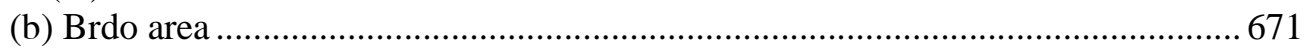

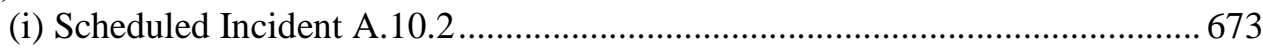

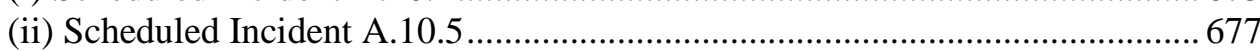

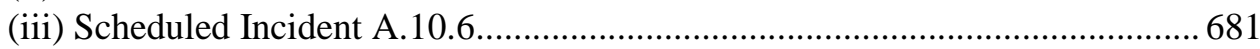

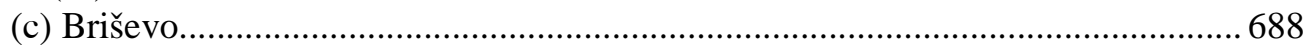

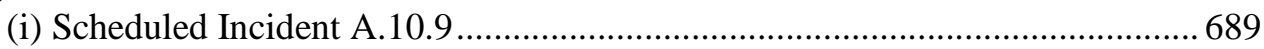

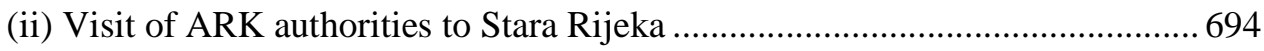

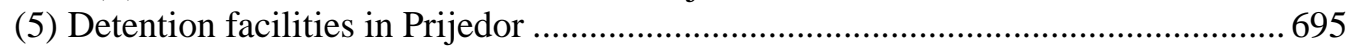

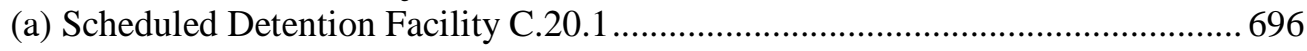

(i) Arrival of detainees and control over the detention facility............................696

(ii) Conditions of detention and treatment of detainees.......................................697

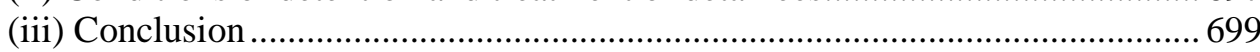

(b) Scheduled Detention Facility C.20.2 and Scheduled Incident B.15.2 …............699

(i) Arrival of detainees and control over detention facility ................................699

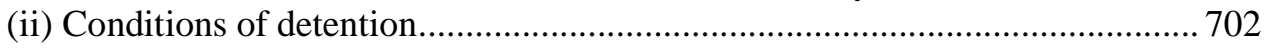




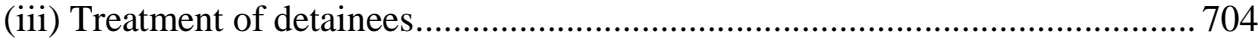

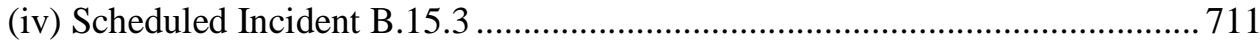

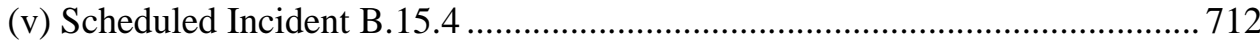

(vi) Visits to Omarska and transfer of detainees ................................................. 713

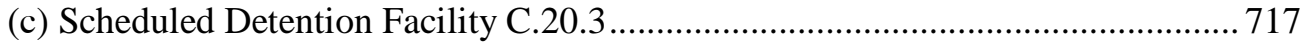

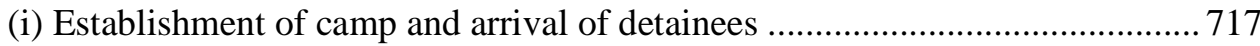

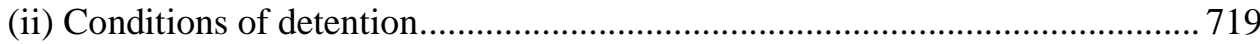

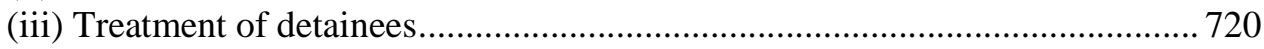

(iv) Conclusion on conditions of detention and treatment of detainees ............... 723

(v) Scheduled Incident B.15.1 ...................................................................... 724

(d) Scheduled Detention Facility C.20.4 and Scheduled Incident B.15.5 ............... 728

(i) Arrival of detainees and control over detention facility ................................ 728

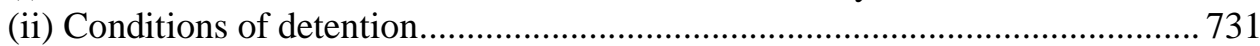

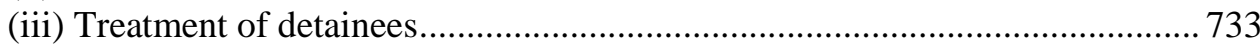

(iv) Conclusion on conditions of detention and treatment of detainees ............... 736

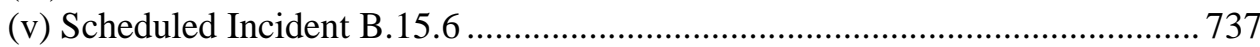

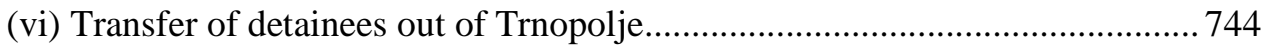

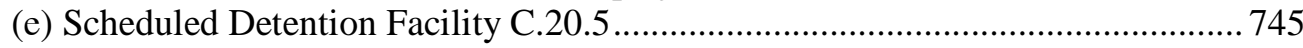

(i) Arrival of detainees and control over the detention facility............................ 745

(ii) Conditions of detention and treatment of detainees........................................ 747

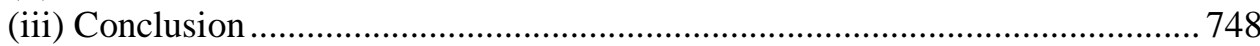

(f) Scheduled Detention Facility C.20.6 and Scheduled Incident A.10.8 ................. 748

(i) Arrival of detainees and control over the detention facility......................... 748

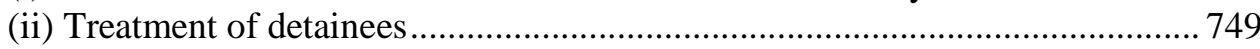

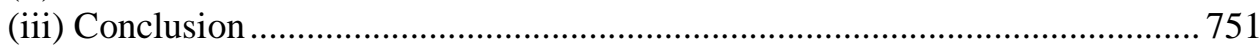

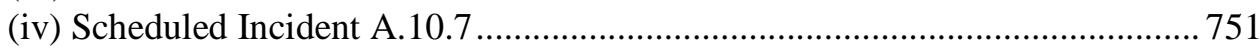

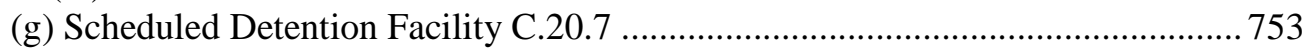

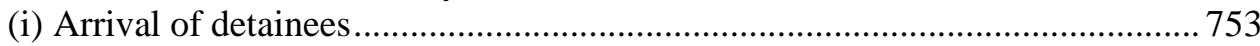

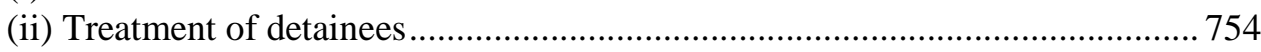

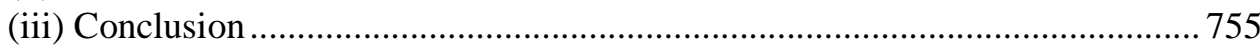

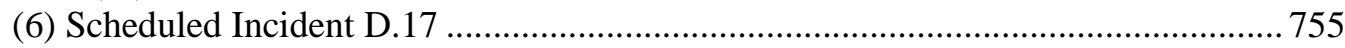

(7) Movement of the population from Prijedor and appropriation of property..............758

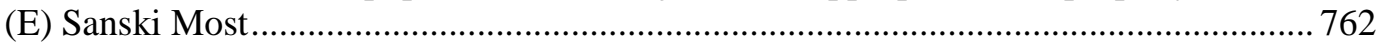

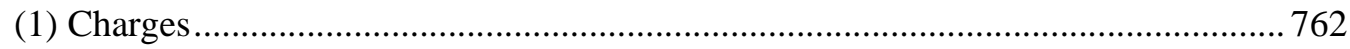

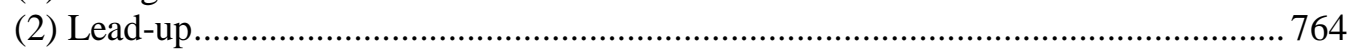

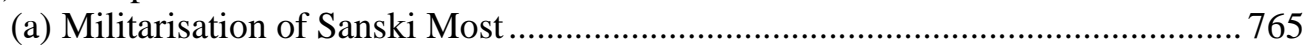

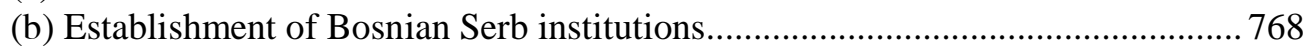

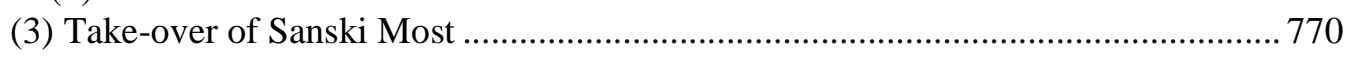

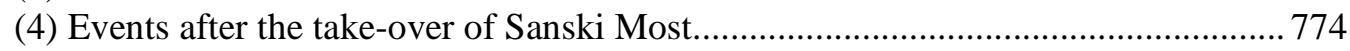

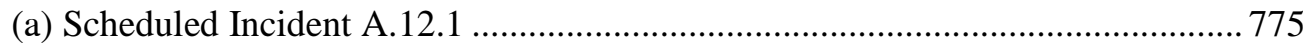

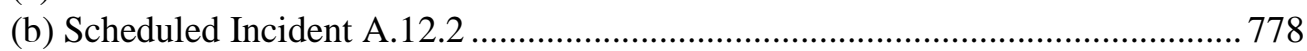

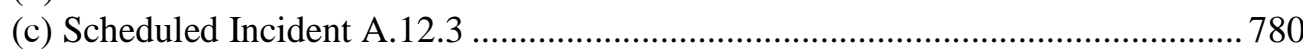

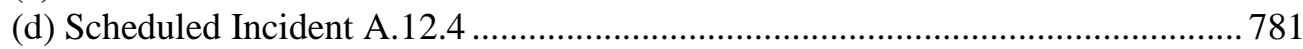

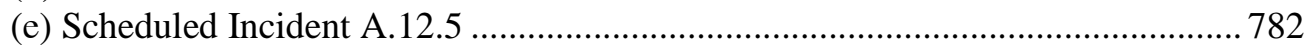

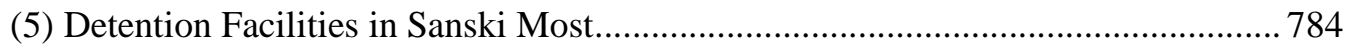

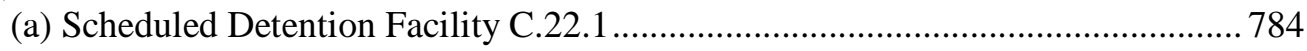

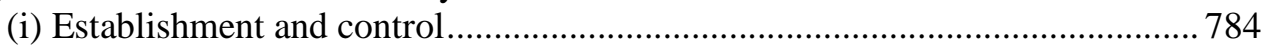

(ii) Conditions of detention and treatment of detainees.................................... 785

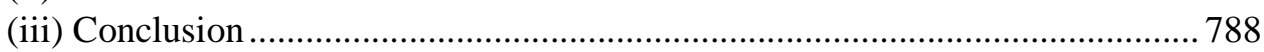

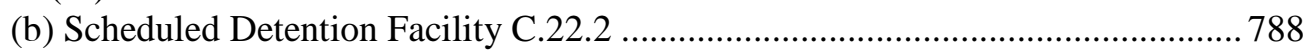

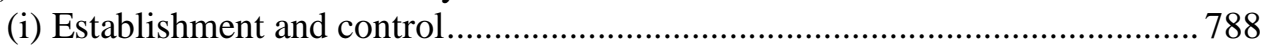

(ii) Conditions of detention and treatment of detainees........................................ 789

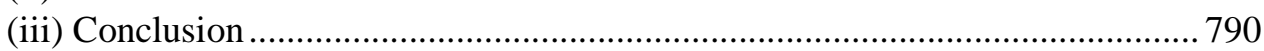

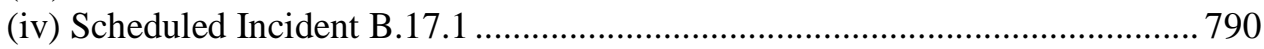


(c) Scheduled Detention Facility C.22.3 …............................................................ 792

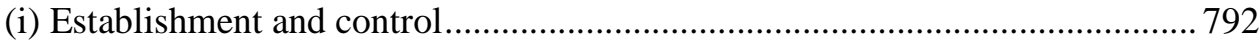

(ii) Conditions of detention and treatment of detainees...................................... 793

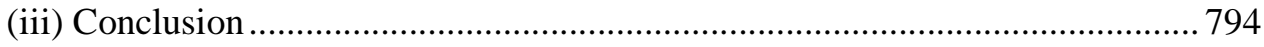

(d) Scheduled Detention Facility C.22.4 ……........................................................ 794

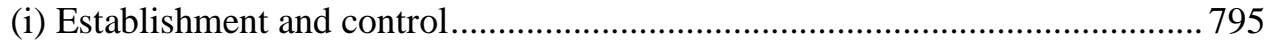

(ii) Conditions of detention and treatment of detainees..................................... 795

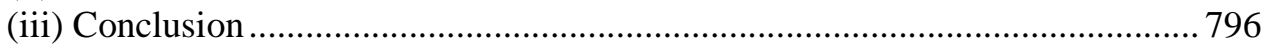

(e) Scheduled Detention Facility C.22.5 ................................................................ 796

(6) Scheduled Incident D.19 ................................................................................. 798

(7) Movement of the population from Sanski Most and appropriation of property...... 800

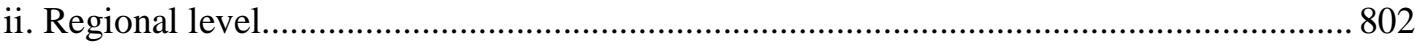

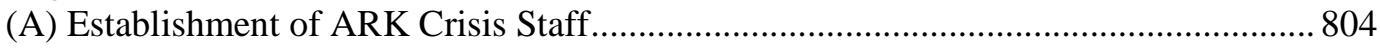

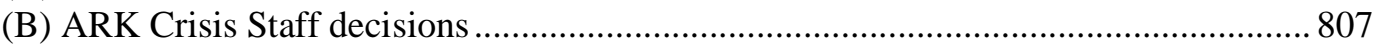

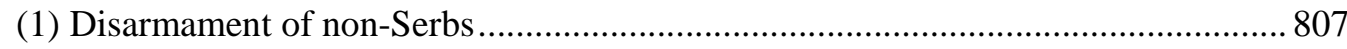

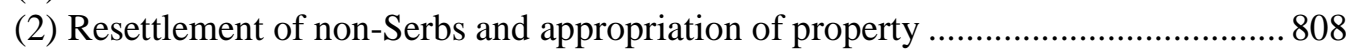

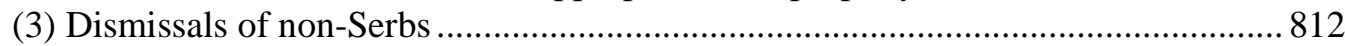

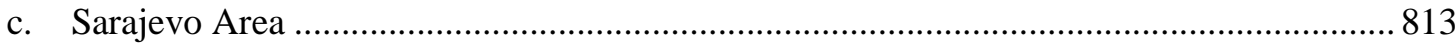

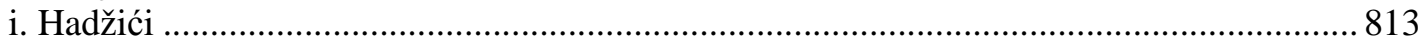

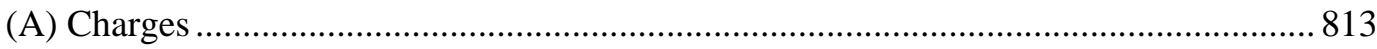

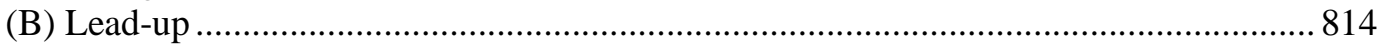

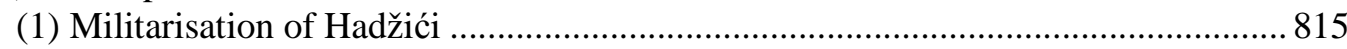

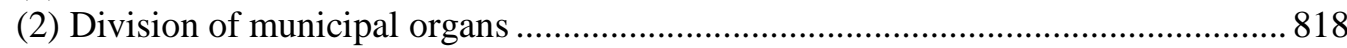

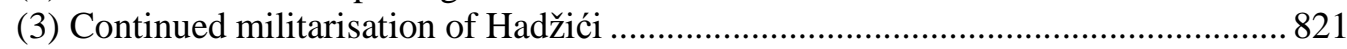

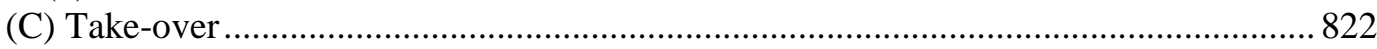

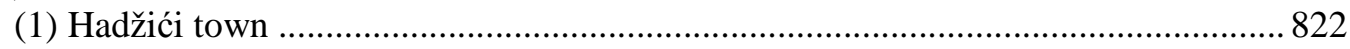

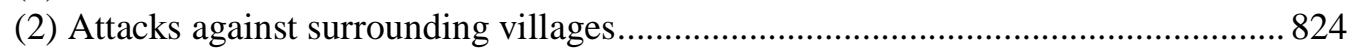

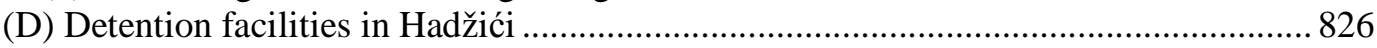

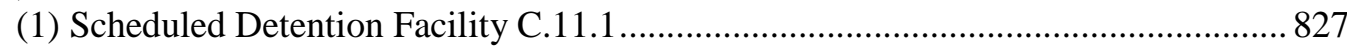

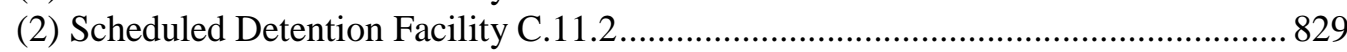

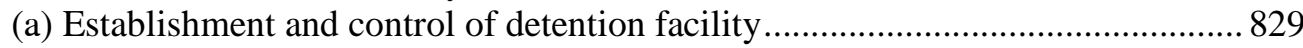

(b) Conditions of detention and treatment of detainees ............................................. 830

(c) Transfer and exchange of detainees at the Culture and Sport Centre..................832

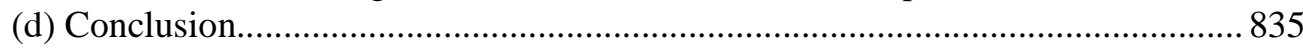

(E) Movement of the population from Hadžići and appropriation of property.................835

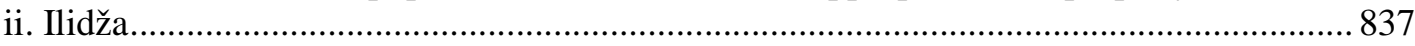

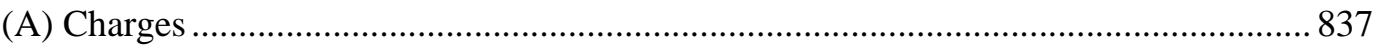

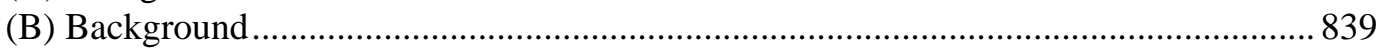

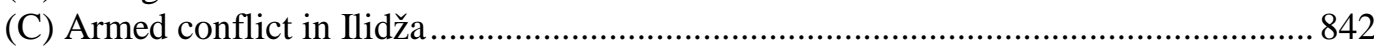

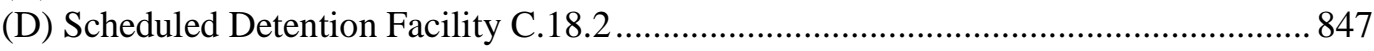

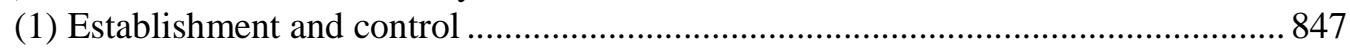

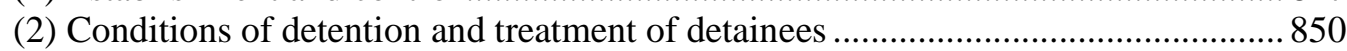

(3) Conclusion in relation to conditions of detention and treatment of detainees ........ 853

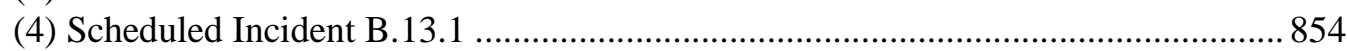

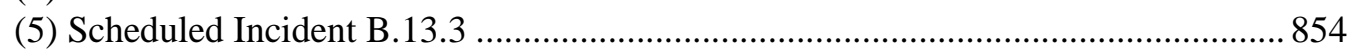

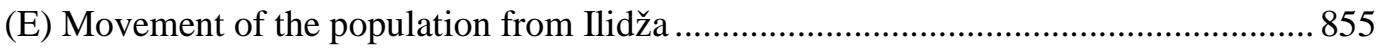

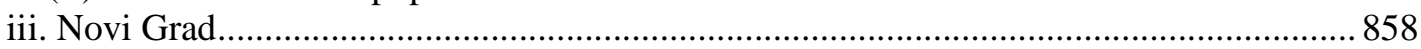

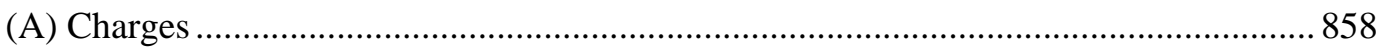

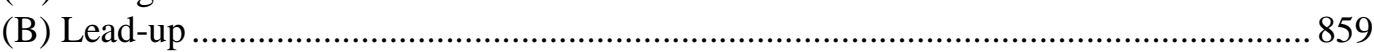

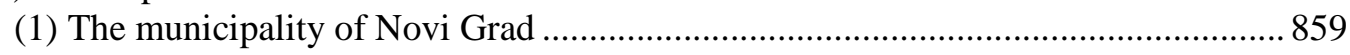

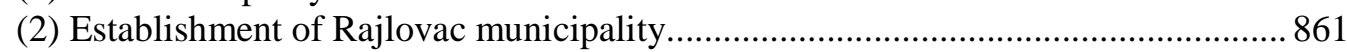

(3) The arming and mobilisation of Bosnian Serbs in Novi Grad ............................... 862

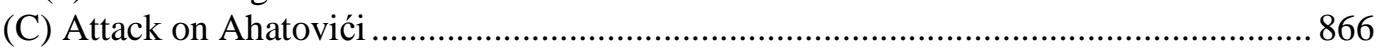

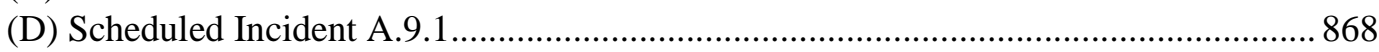




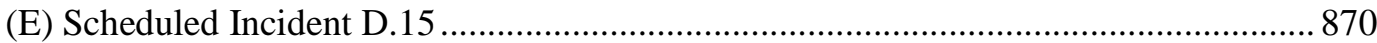

(F) Scheduled Detention Facility C.17.1 and Scheduled Incident B.12.1 .......................8. 871

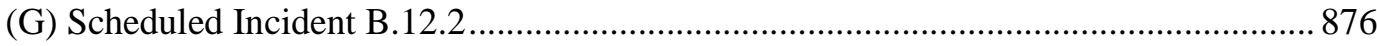

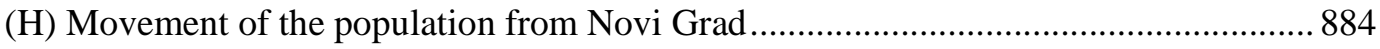

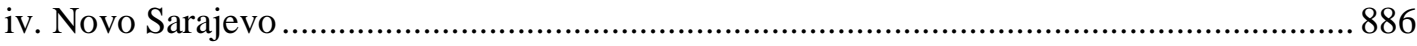

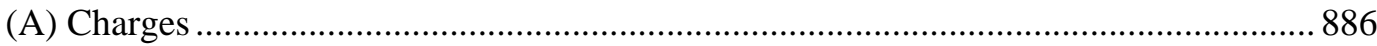

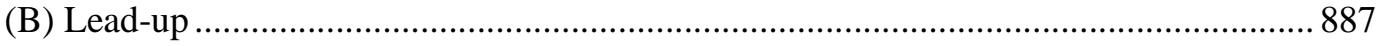

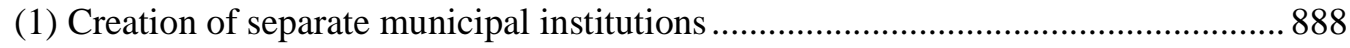

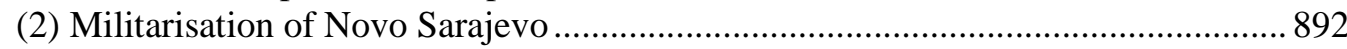

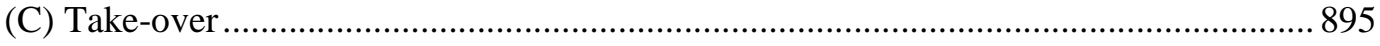

(1) Searches of Bosnian Muslim and Bosnian Croat houses ........................................ 896

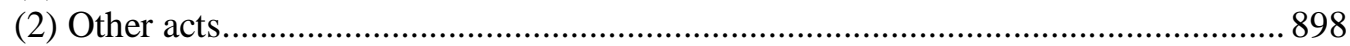

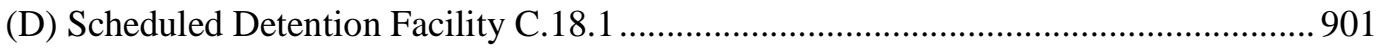

(E) Movement of the population from Novo Sarajevo and appropriation of property ..... 904 v. Pale.

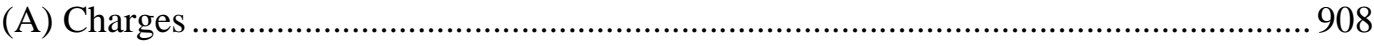

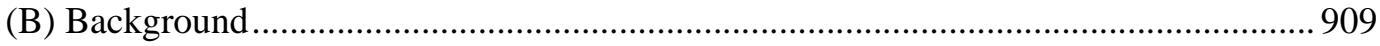

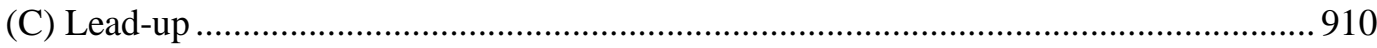

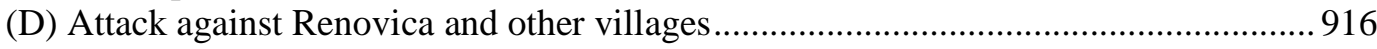

(E) Movement of the population from Pale and appropriation of property ...................... 917

(F) Scheduled Detention Facility C.19.2 and Scheduled Incident B.14.1 …....................922

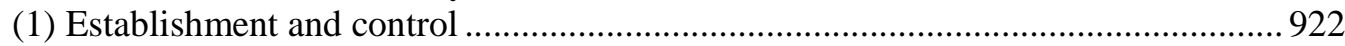

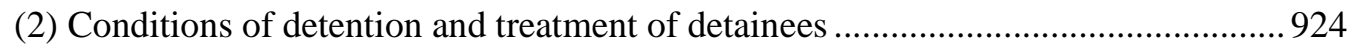

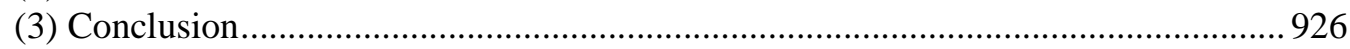

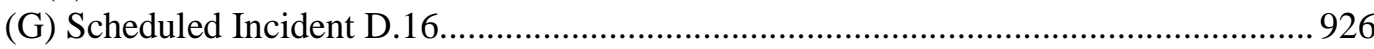

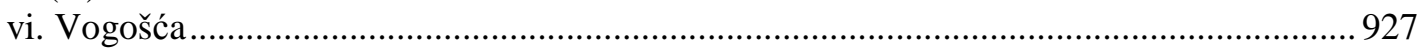

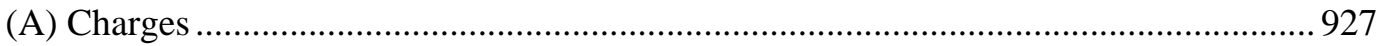

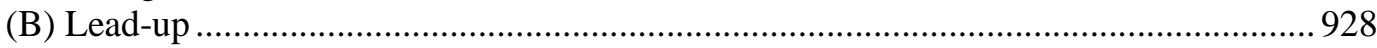

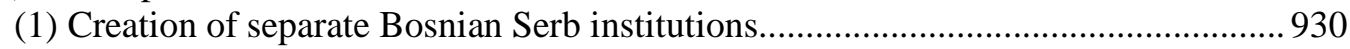

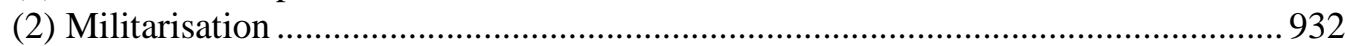

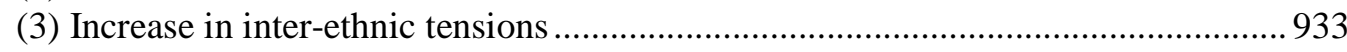

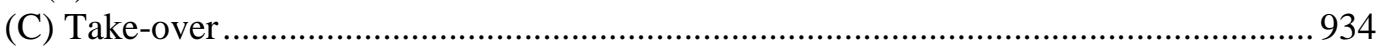

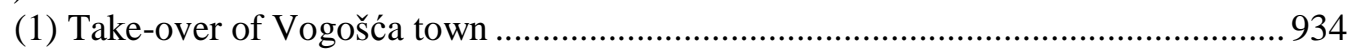

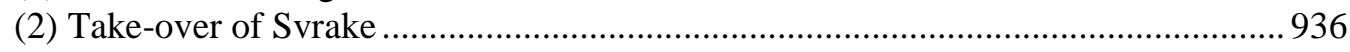

(D) Developments in Vogošća after the take-over of the municipality ...........................9937

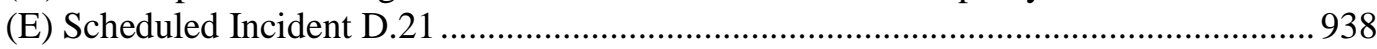

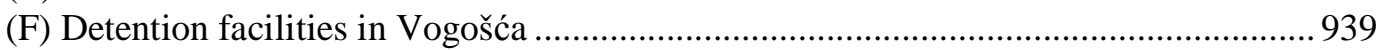

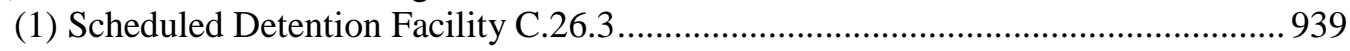

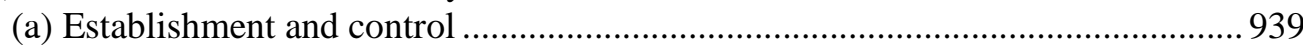

(b) Conditions of detention and treatment of detainees ..........................................941

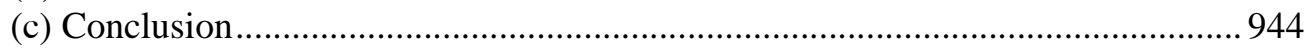

(2) Scheduled Detention Facility C.26.1 .................................................................... 944

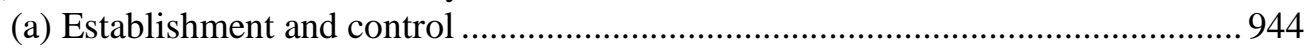

(b) Conditions of detention and treatment of detainees .......................................... 946

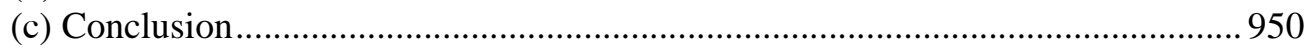

(d) Scheduled Incident B.19.1 …............................................................... 950

(G) Movement of the population from Vogošća and appropriation of property...............952

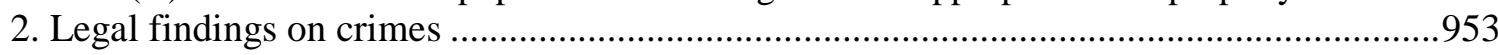

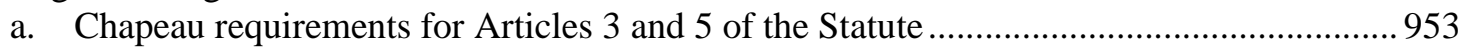

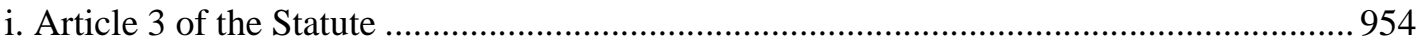

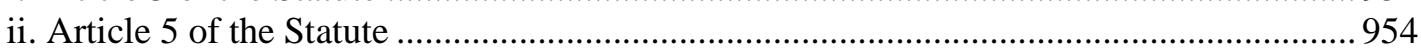

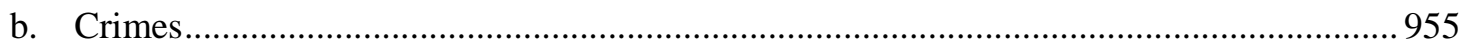

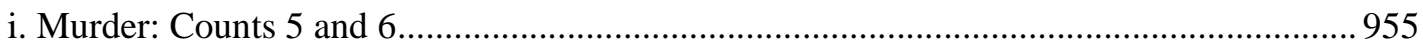

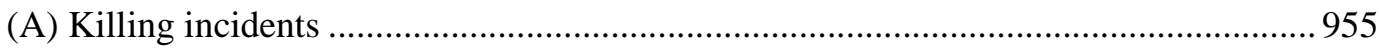




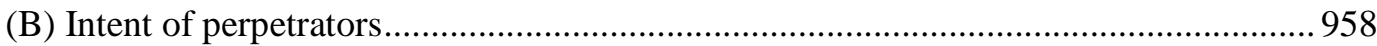

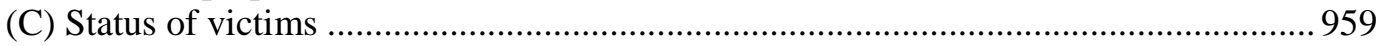

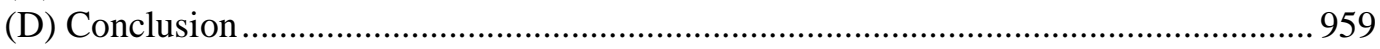

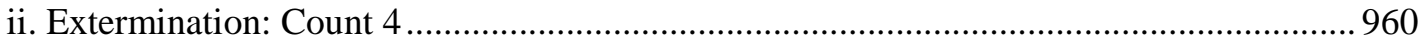

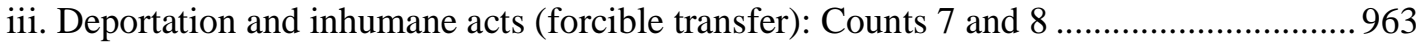

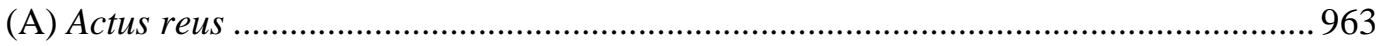

(1) Movement of population ................................................................................. 963

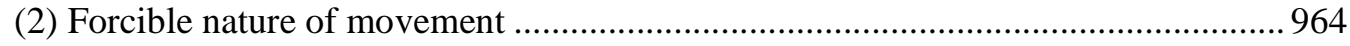

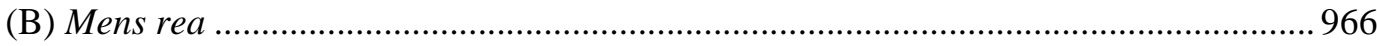

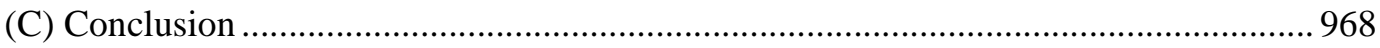

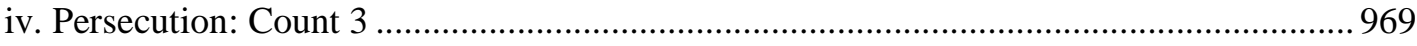

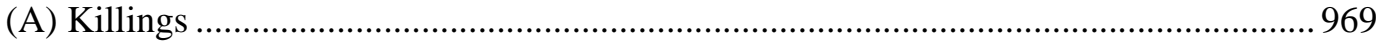

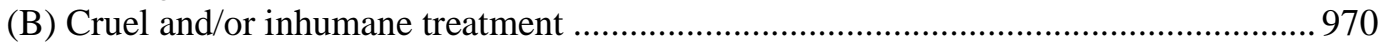

(1) Torture, beatings, physical and psychological abuse …........................................... 970

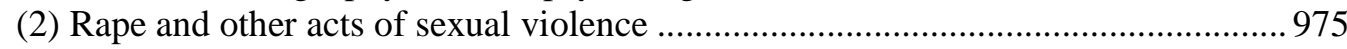

(3) Establishment and perpetuation of inhumane living conditions..............................977

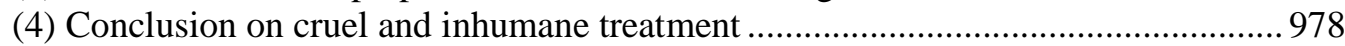

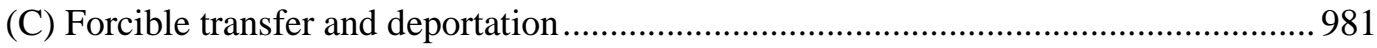

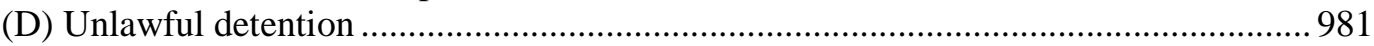

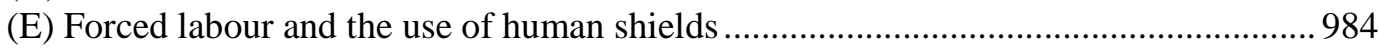

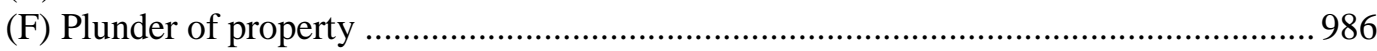

(G) Wanton destruction of private property and public property including cultural

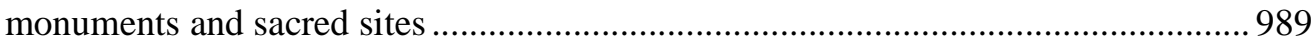

(H) Imposition and maintenance of restrictive and discriminatory measures...................992

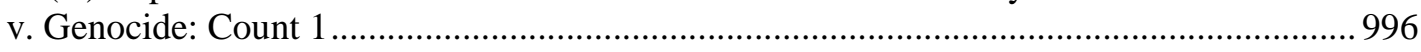

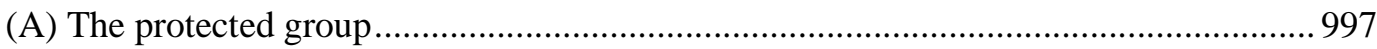

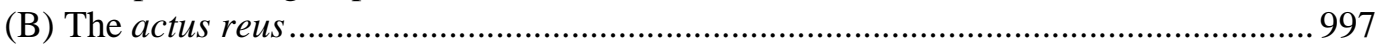

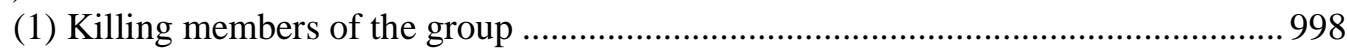

(2) Causing serious bodily or mental harm to members of the group.......................... 998

(3) Deliberately inflicting on the group conditions calculated to bring about its

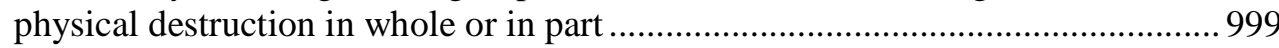

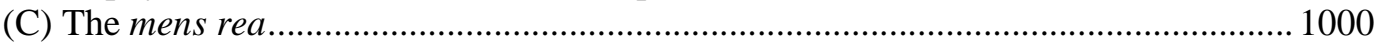

(1) Intent to destroy the group as such, in part........................................................ 1002

(2) Evidence of genocidal intent of the Accused and named alleged Overarching JCE members

(3) Evidence of genocidal intent of Bosnian Serbs not named as alleged members of

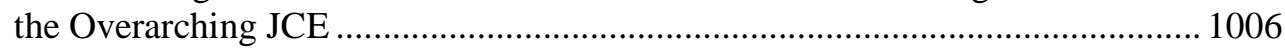

(4) Evidence of genocidal intent of the physical perpetrators ................................. 1008

(5) Evidence of genocidal intent through the pattern of crimes................................. 1009

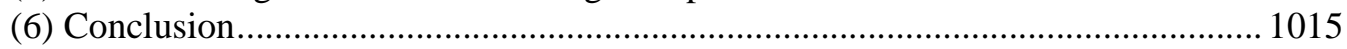

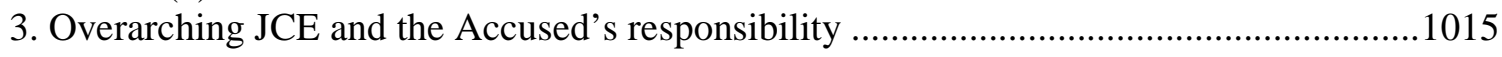

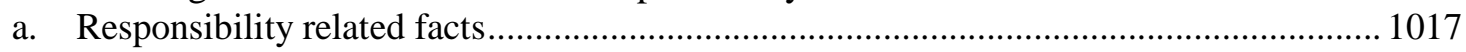

i. Objectives of the Accused and the Bosnian Serb leadership ........................................... 1017

(A) Unity of the Serb people and promotion of Serb interests...................................... 1017

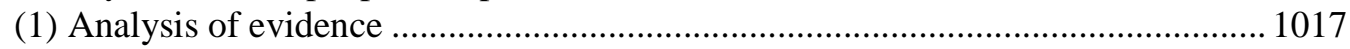

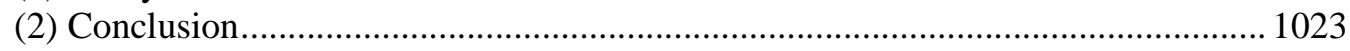

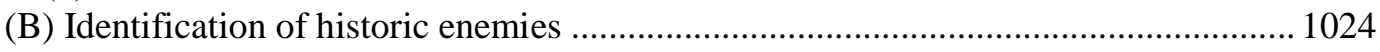

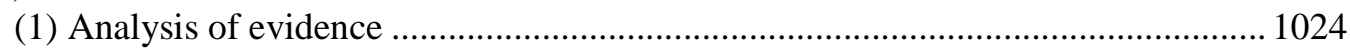

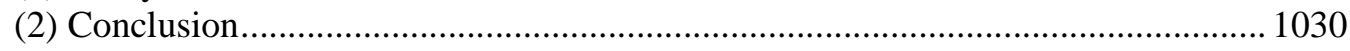

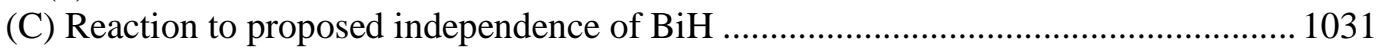

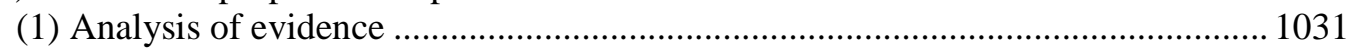

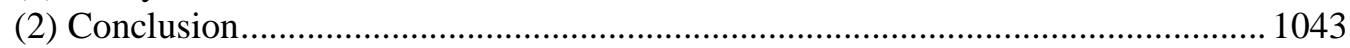

(D) Advocating separation of population and creation of a Bosnian Serb state .............. 1045

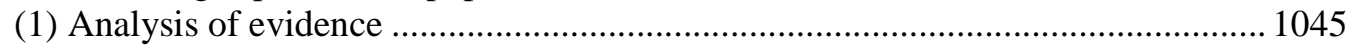


(a) Separation of population-inability to co-exist .............................................. 1045

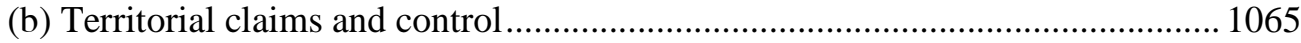

(c) Creation of a Bosnian Serb state .................................................................... 1079

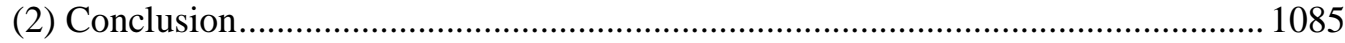

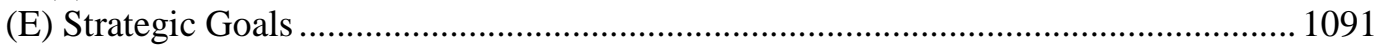

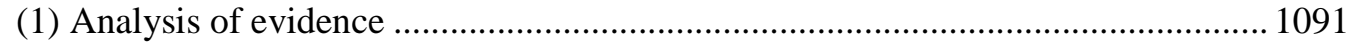

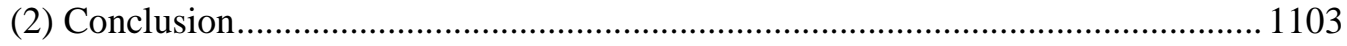

ii. Bosnian Serb political and governmental structures ..................................................... 1104

(A) Authority over political and governmental structures ............................................. 1105

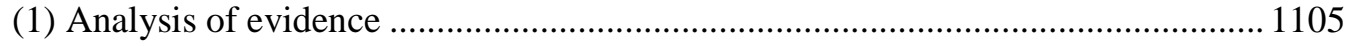

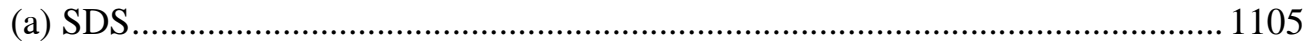

(b) Bosnian Serb Assembly and governmental structures .................................... 1110

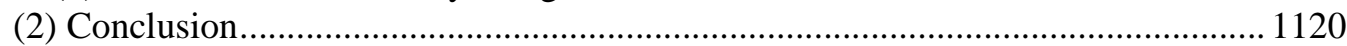

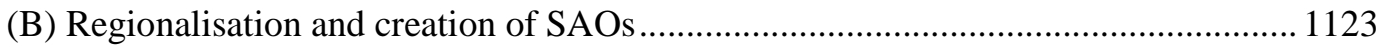

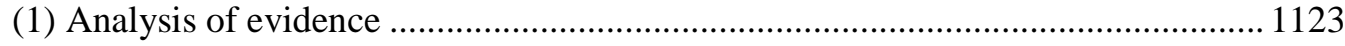

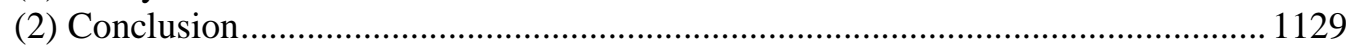

(C) Split in the MUP and creation of a Bosnian Serb MUP ........................................ 1130

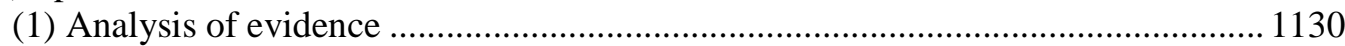

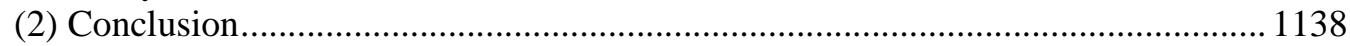

(D) Variant A/B Instructions and take-over of power ...................................................1139

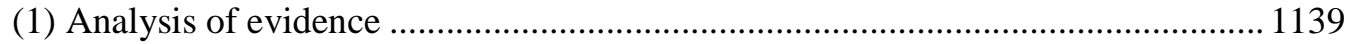

(a) Distribution and contents of the Instructions..................................................1139

(b) Implementation of the Instructions at the municipal level.............................. 1142

(c) Monitoring of developments and implementation of Instructions .................... 1144

(d) Activation of second level of the Instructions............................................. 1150

(e) Activation of Crisis Staffs and other structures...............................................1153

(f) War Presidencies / War Commissions ........................................................... 1159

(g) Take-over of power in the Municipalities …............................................... 1162

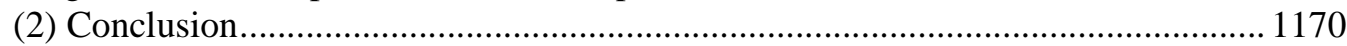

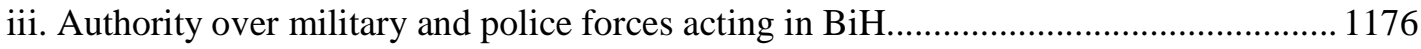

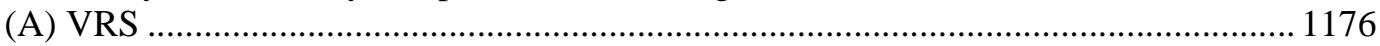

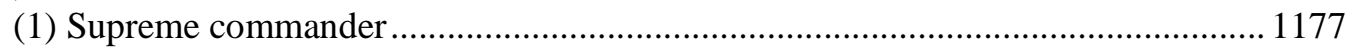

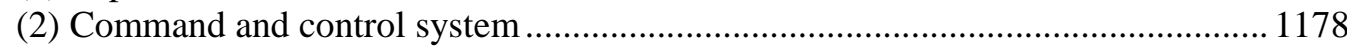

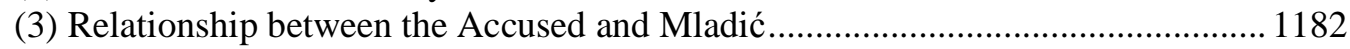

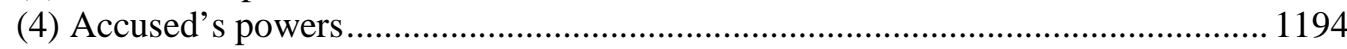

(5) The issuance of military directives in pursuance of the Strategic Goals............... 1197

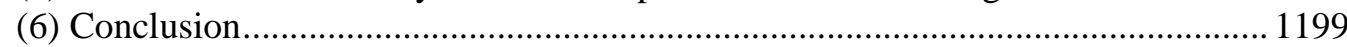

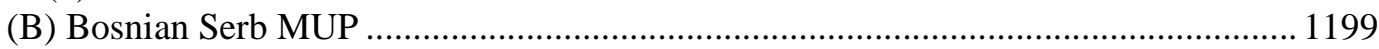

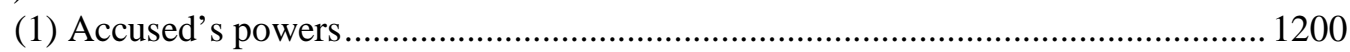

(2) Communication and Bosnian Serb MUP reporting system.................................. 1202

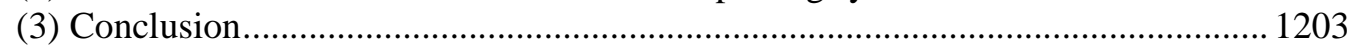

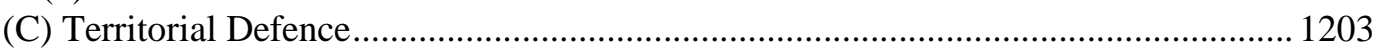

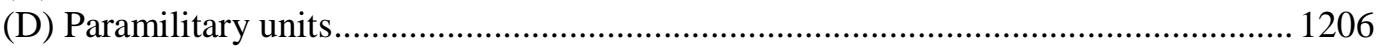

(1) Accused's initial attitude towards paramilitary units ........................................... 1206

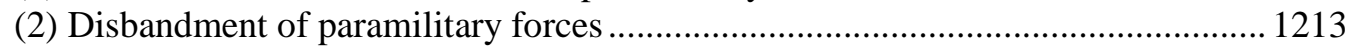

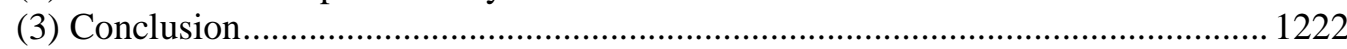

iv. Knowledge and acts of named alleged JCE members ................................................ 1224

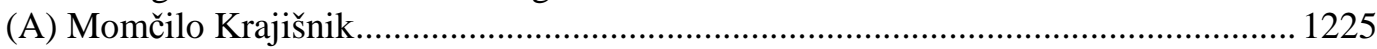

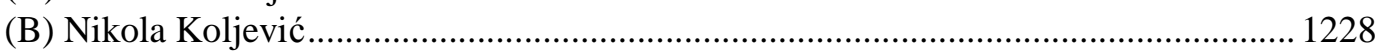

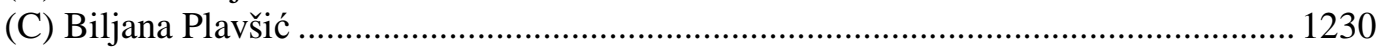

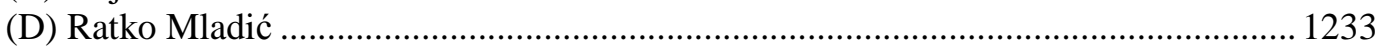

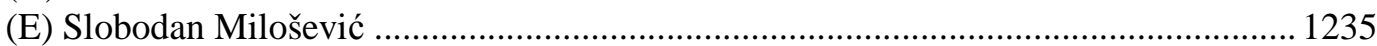

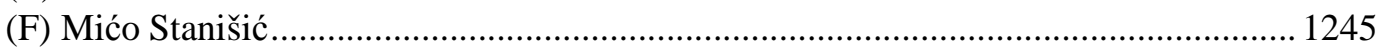

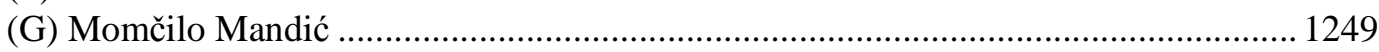


(H) Jovica Stanišić ………………………………………………………………... 1250

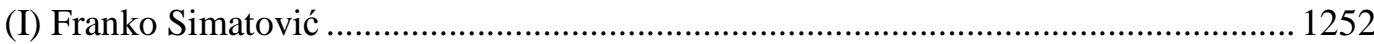

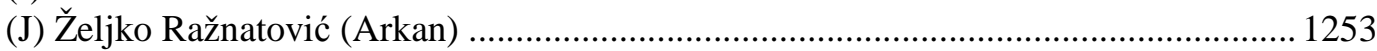

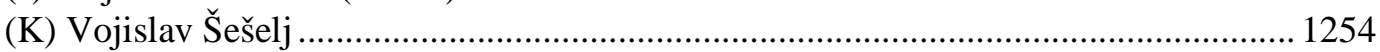

v. Accused's knowledge of crimes and measures he took to prevent and punish them.......1256

(A) Knowledge of crimes committed throughout the Municipalities .............................. 1256

(B) Knowledge of inadequate conditions and mistreatment of non-Serbs in detention centres

(C) Misleading statements made by the Accused ........................................................... 1269

(D) Prevention of criminal activity ............................................................................. 1271

(1) Unlawful detention and inadequate conditions in detention facilities .................. 1271

(2) Forced removal of non-Serbs and protection of non-Serbs remaining in Serb

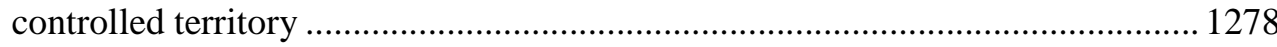

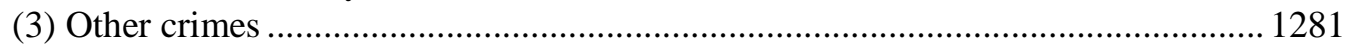

(E) Investigation and prosecution of crimes committed against non-Serbs..................... 1283

(F) Rewarding of those who committed crimes against non-Serbs ............................... 1292

b. Existence of a common plan shared by a plurality of persons ....................................... 1294

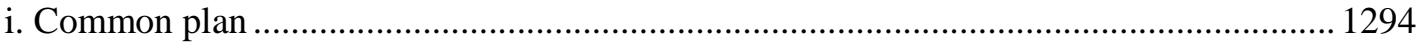

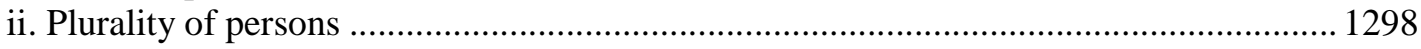

iii. Scope of common plan....................................................................................... 1304

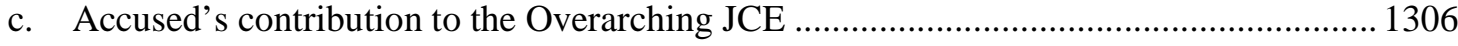

i. Submissions of the Parties........................................................................................... 1306

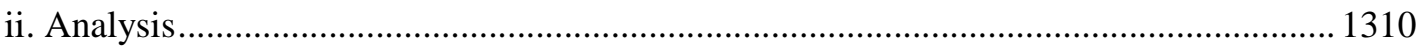

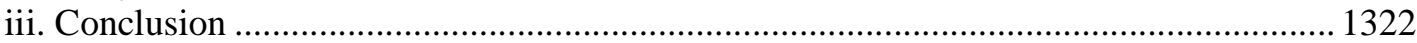

d. Link to crimes committed by non-members of the JCE ................................................. 1322

e. Accused's responsibility for crimes outside the scope of the Overarching JCE ...............1325

f. Conclusion: Accused's individual criminal responsibility ............................................... 1330

\section{VOLUME III}

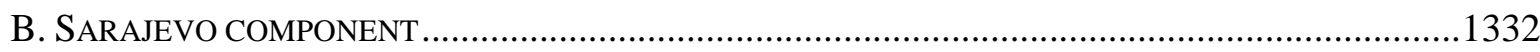

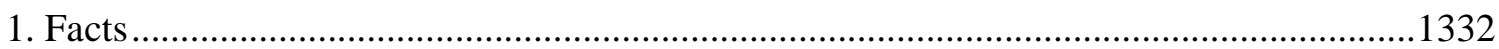

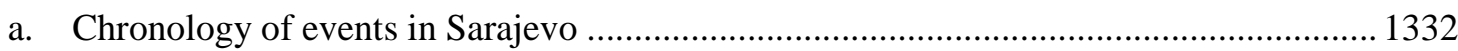

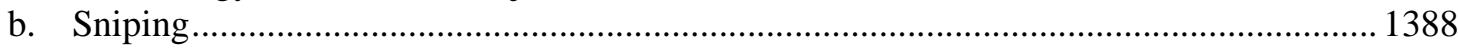

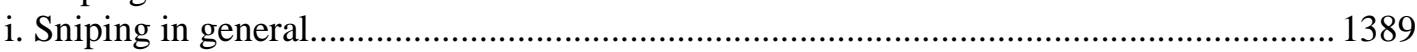

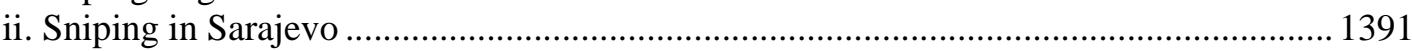

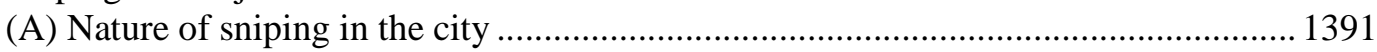

(B) $\mathrm{ABiH}$ sniping practices .................................................................................... 1398

(C) Sniping investigations and anti-sniping measures undertaken in the city ................. 1399

iii. Scheduled sniping incidents.................................................................................... 1410

(A) Zmaja od Bosne street (formerly Vojvode Putnika) ................................................ 1410

(1) Confrontation lines in the area ........................................................................ 1414

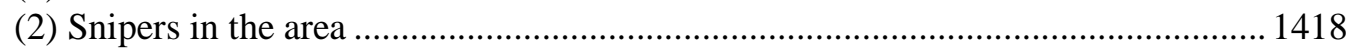

(3) Zmaja od Bosne street, 19 June 1994 (Scheduled Incident F.8) ............................. 1426

(4) Zmaja od Bosne street, 8 October 1994 (Scheduled Incident F.11)........................ 1433

(5) Zmaja od Bosne street, 18 November 1994 (Scheduled Incident F.12)................. 1443

(6) Zmaja od Bosne street, 23 November 1994 (Scheduled Incident F.14)................ 1452

(7) Zmaja od Bosne street, 27 February 1995 (Scheduled Incident F.15) ................... 1459

(8) Zmaja od Bosne street, 3 March 1995 (Scheduled Incident F.16) ……………..... 1469

(B) Southwestern suburbs: Dobrinja, Nedžarići, Alipašino Polje.................................... 1477

(1) Confrontation lines and snipers in the area ...................................................... 1480

(2) Dobrinja, 11 July 1993 (Scheduled Incident F.3) .............................................. 1485

(3) Nikole Demonje street, 6 January 1994 (Scheduled Incident F.6)........................ 1492 
(4) Nikole Demonje street and Bulevar AVNOJ, 25 May 1994 (Scheduled Incident F.7)

(5) Adija Mulaobegovića street (formerly Đure Jakšića street), 26 June 1994 (Scheduled Incident F.9)

(C) Sedrenik

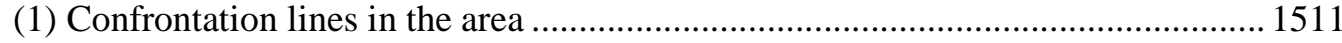

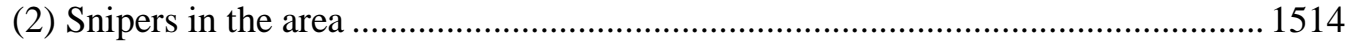

(3) Sedrenik, 17 April 1993 (Scheduled Incident F.2).......................................... 1517

(4) Sedrenik street, 6 March 1995 (Scheduled Incident F.17) .................................... 1523

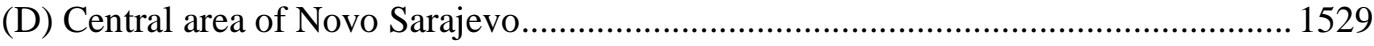

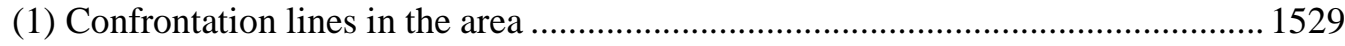

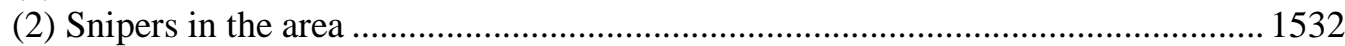

(3) Azize Šećerbegović street, formerly Ivana Krndelja street, 3 September 1993

(Scheduled Incident F.4)

(4) Ferde Hauptmana street, formerly Miljenka Cvitkovića street, 22 July 1994

(Scheduled Incident F.10)

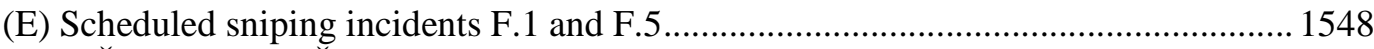

(1) Žagrići street, Šrokača, 13 December 1992 (Scheduled Incident F.1).................. 1548

(2) Briješko Brdo street, 2 November 1993 (Scheduled Incident F.5) ....................... 1555

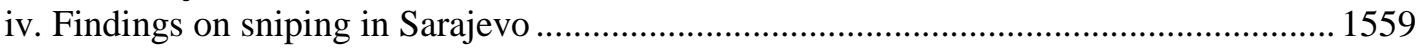

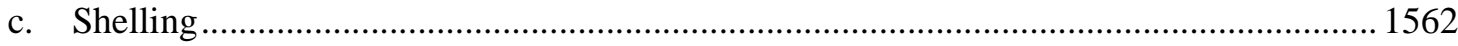

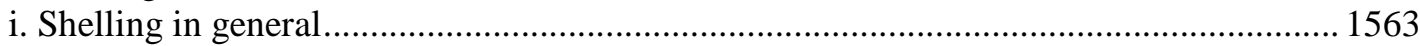

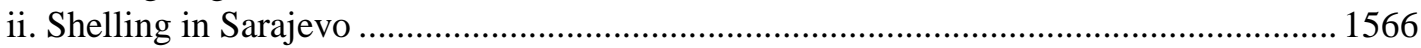

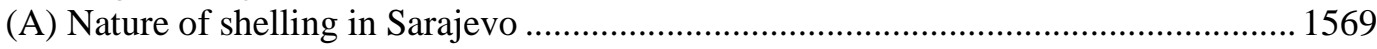

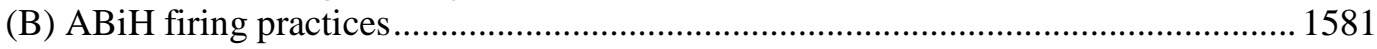

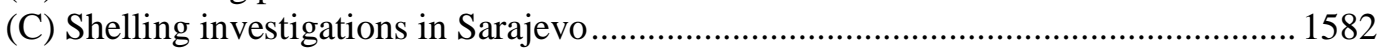

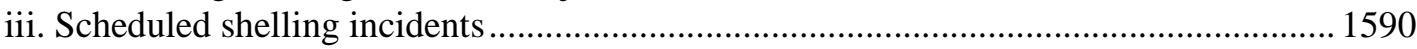

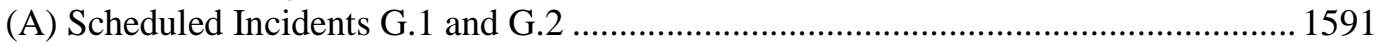

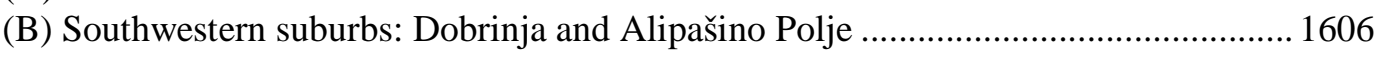

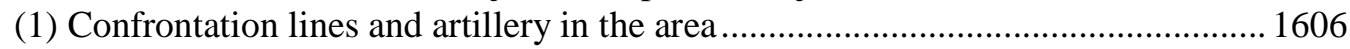

(2) Dobrinja, 1 June 1993 (Scheduled Incident G.4) ................................................. 1608

(3) Hakije Turajlića, Dobrinja, 12 July 1993 (Scheduled Incident G.5) ..................... 1622

(4) Alipašino Polje, 22 January 1994 (Scheduled Incident G.6) ................................ 1632

(5) Dobrinja, 4 February 1994 (Scheduled Incident G.7) .......................................... 1646

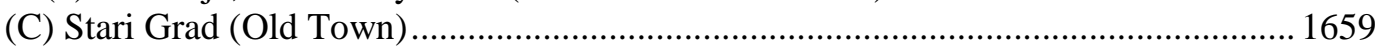

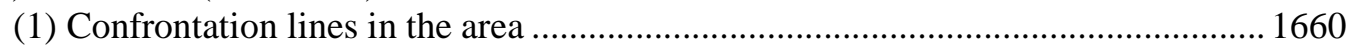

(2) Markale Market, 5 February 1994 (Scheduled Incident G.8) …........................... 1662

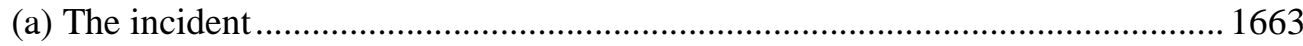

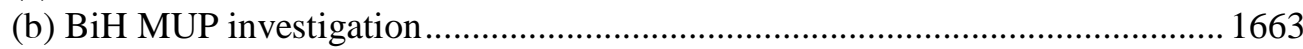

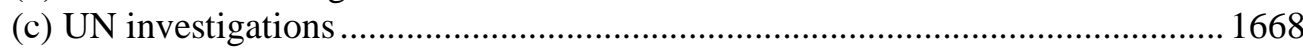

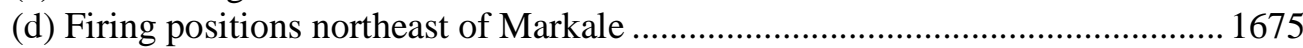

(e) Bosnian Serb calls for joint investigation..................................................... 1678

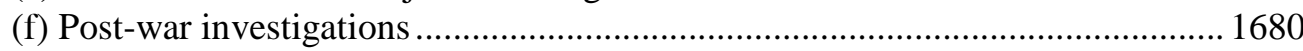

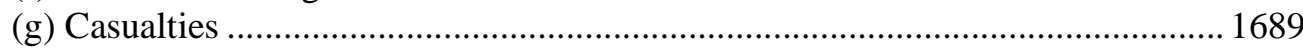

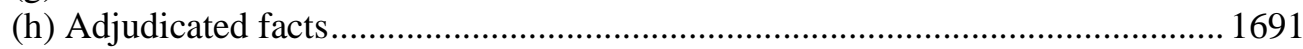

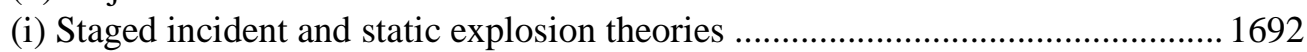

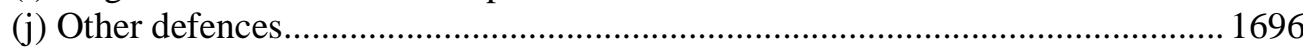

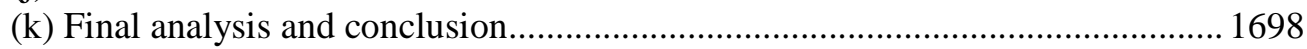

(3) Baščaršija fleamarket, 22 December 1994 (Scheduled Incident G.9)..................... 1704

(4) Mula Mustafe Bašeskije street, 28 August 1995 (Scheduled Incident G.19)........ 1710

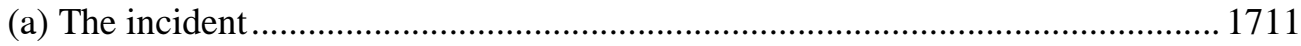

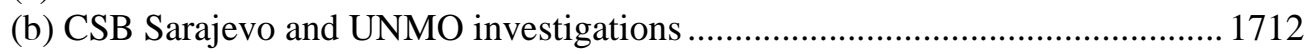

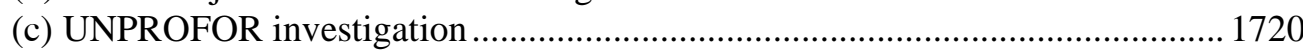

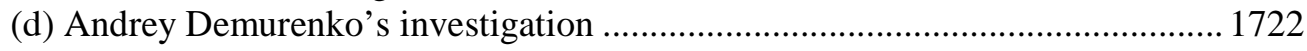


(e) Aftermath and NATO air strikes

1725

(f) Firing positions south and southeast of Markale .......................................... 1730

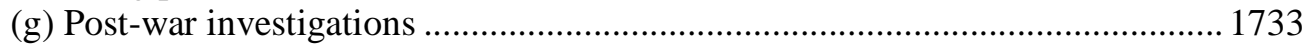

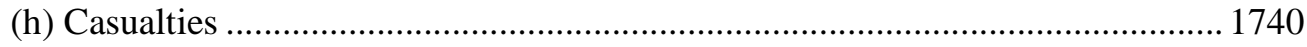

(i) Markale area as a potential military target ....................................................... 1742

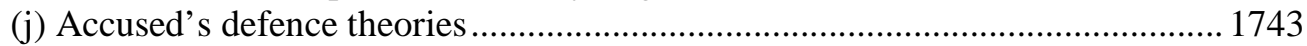

(k) Final analysis and conclusions ...................................................................... 1746

(D) Scheduled modified air bomb incidents ............................................................ 1750

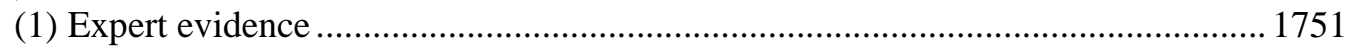

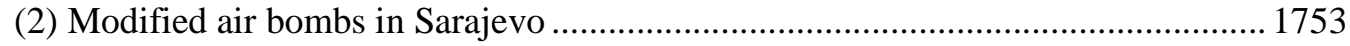

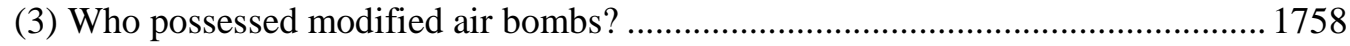

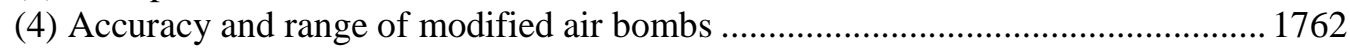

(5) Damage caused by modified air bombs ............................................................. 1769

(6) Investigations of modified air bomb incidents ................................................ 1770

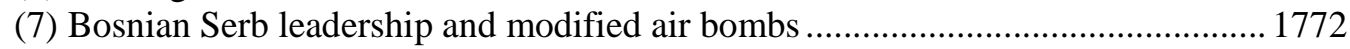

(8) Scheduled incidents involving modified air bombs .......................................... 1772

(a) Alekse Šantića street, Hrasnica, 7 April 1995 (Scheduled Incident G.10)........ 1772

(b) Safeta Zajke street (formerly 21. Maja street) and Majdanska street, 24 May 1995

(Scheduled Incidents G.11 and G.12) ............................................................. 1785

(c) Safeta Hadžića street, 26 May 1995 (Scheduled Incident G.13)...................... 1796

(d) UMC/Oncology Department at Dositejeva street, 16 June 1995 (Scheduled

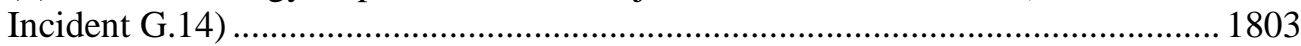

(e) Trg Međunarodnog Prijateljstva, Alipašino Polje, 16 June 1995 (Scheduled

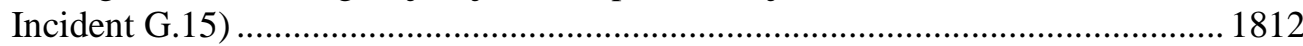

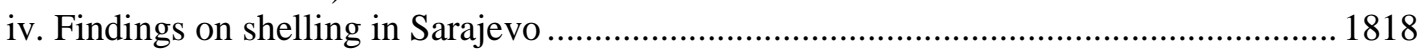

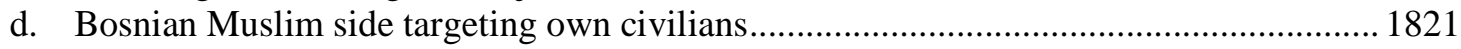

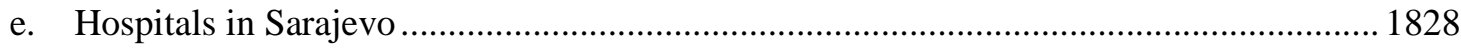

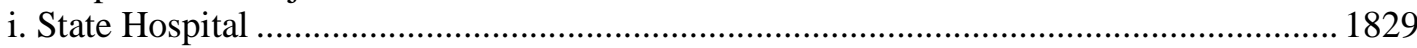

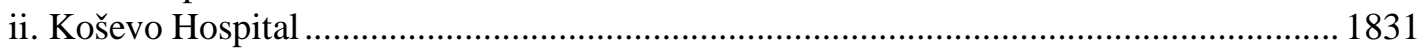

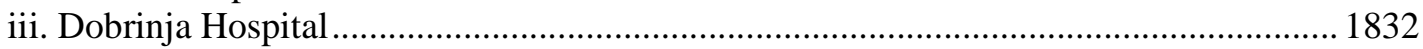

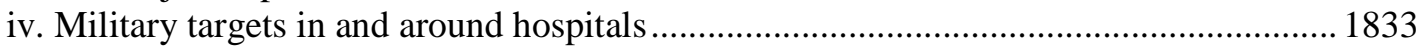

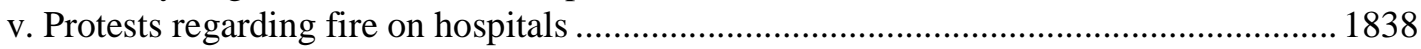

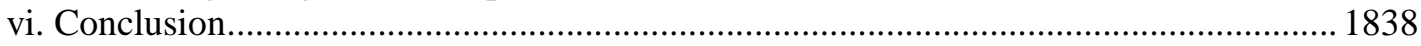

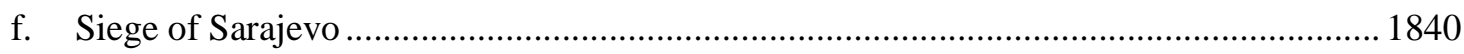

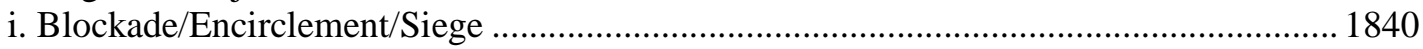

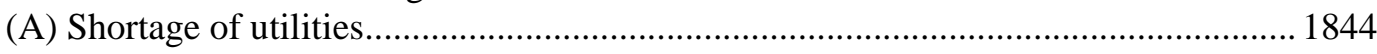

(B) Shortage of food and other supplies in Sarajevo ............................................... 1850

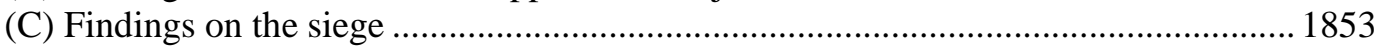

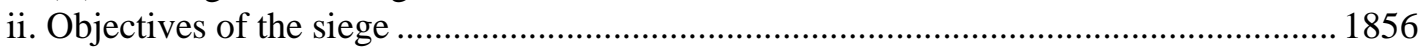

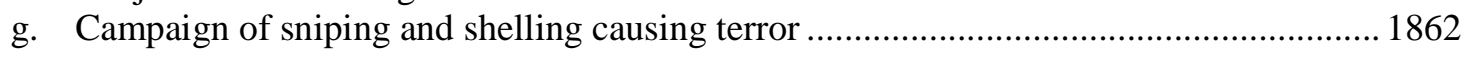

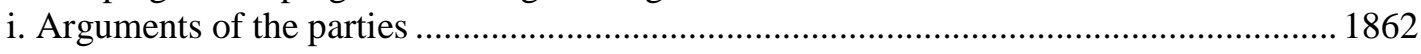

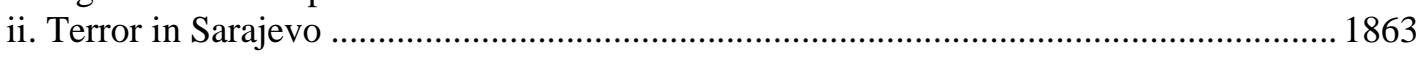

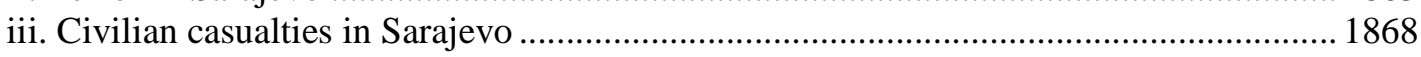

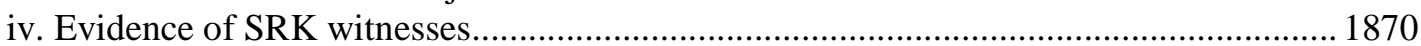

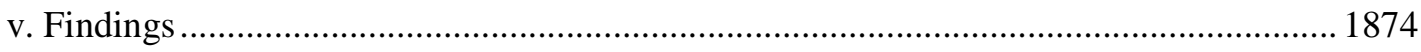

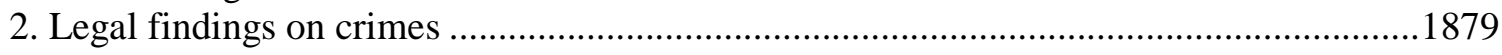

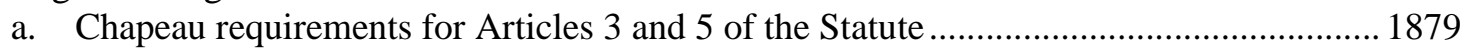

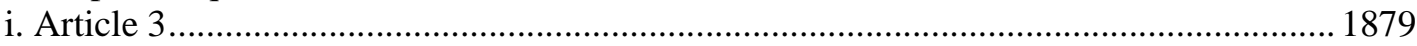

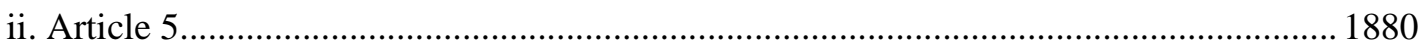

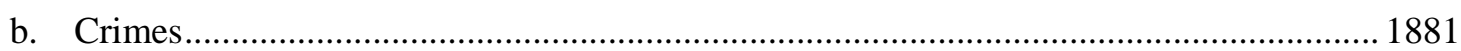

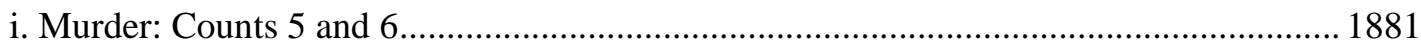

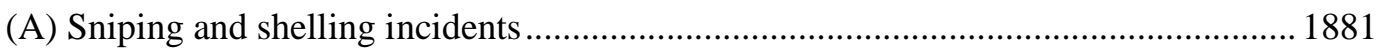

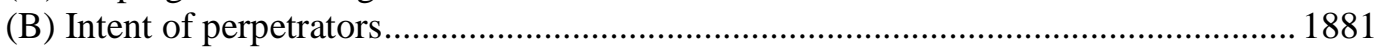

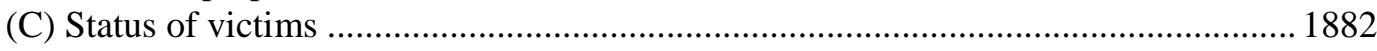




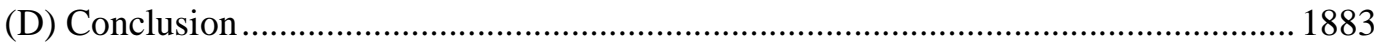

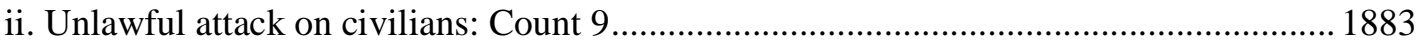

(A) Acts of violence causing death or serious injury to body or health......................... 1883

(B) Directed against a civilian population or individual civilians ................................. 1884

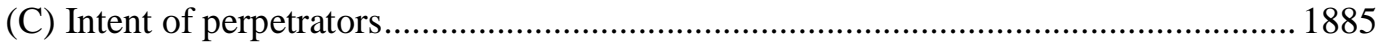

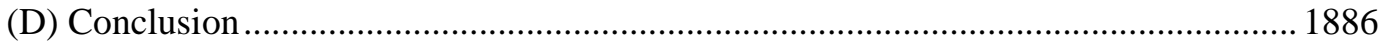

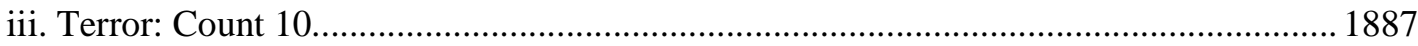

(A) Acts of violence directed against a civilian population or individual civilians ........ 1887

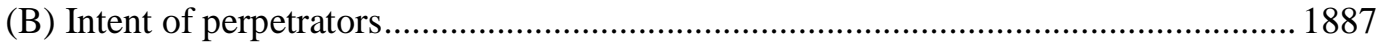

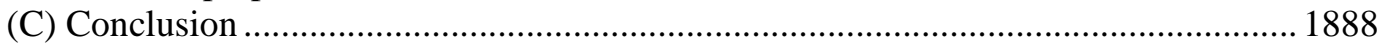

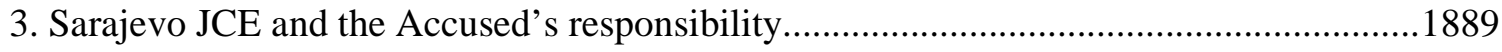

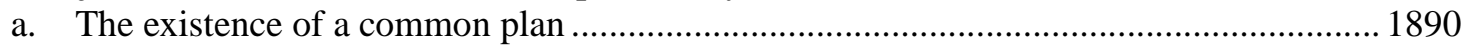

i. Pattern and longevity of the campaign of sniping and shelling ...................................... 1892

ii. Control over snipers and heavy weapons used by the SRK ........................................... 1894

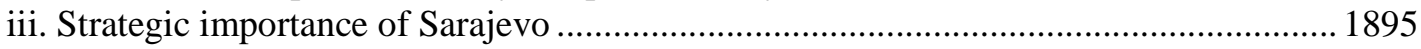

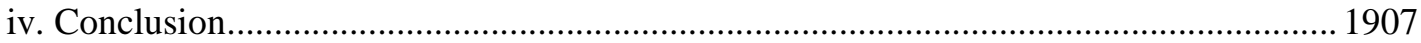

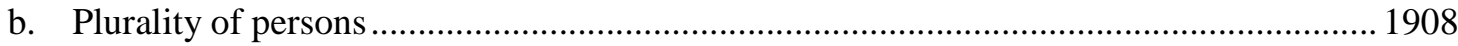

i. Military leadership: Ratko Mladić, Stanislav Galić, and Dragomir Milošević................. 1909

ii. Political leadership: Momčilo Krajišnik, Nikola Koljević, and Biljana Plavšić .............. 1920

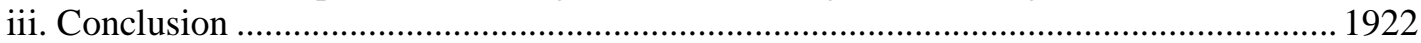

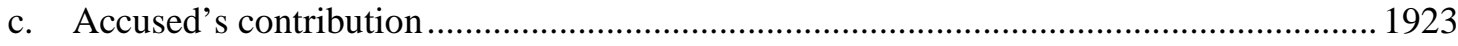

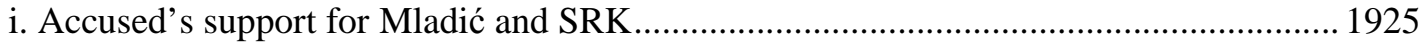

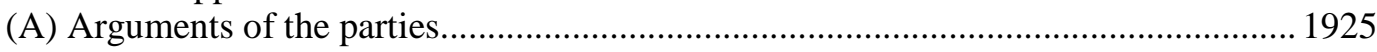

(B) Accused's support for Mladić and SRK in relation to Sarajevo................................. 1926

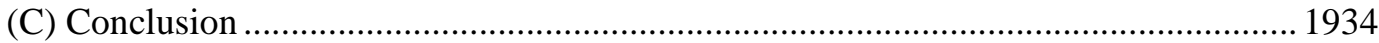

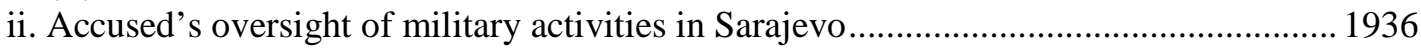

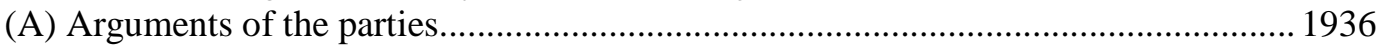

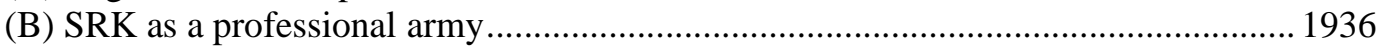

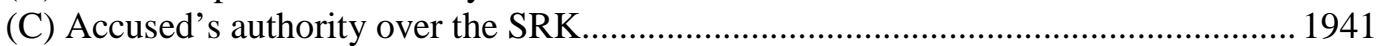

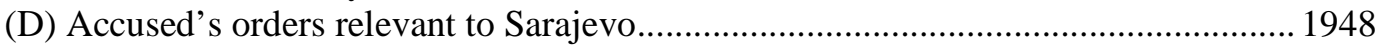

(E) Accused receiving information about the military situation in Sarajevo................... 1962

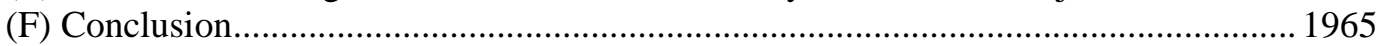

iii. Accused's knowledge of crimes and the measures he took to prevent them ................. 1968

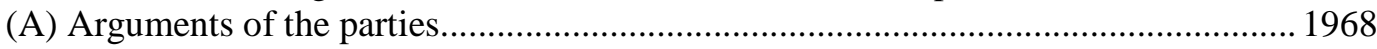

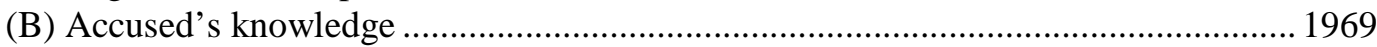

(1) Accused directly informed of the campaign...................................................... 1969

(2) Accused informed of the campaign through media reports................................. 1983

(C) Accused's deflection of criticism and/or denial of crimes....................................... 1985

(D) Accused's measures to deal with crimes in Sarajevo .................................................1987

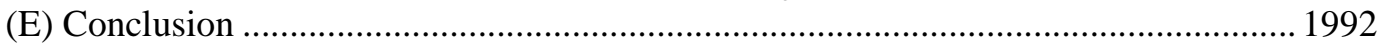

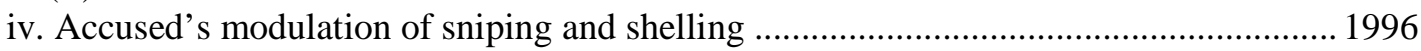

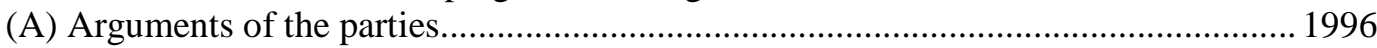

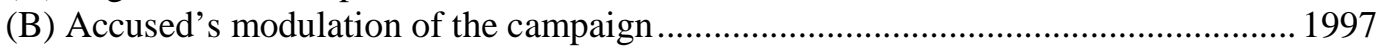

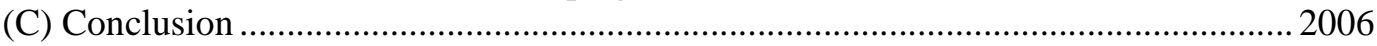

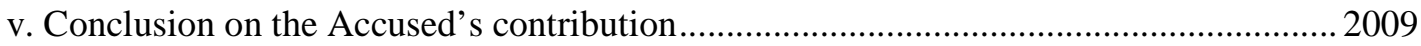

d. Accused's intent for murder, unlawful attacks on civilians, and terror .............................2009

e. Conclusion: Accused's individual criminal responsibility .......................................... 2028

\section{VOLUME IV}

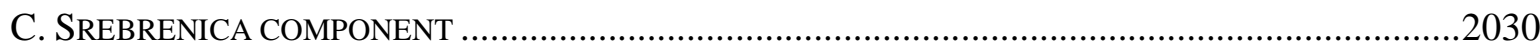

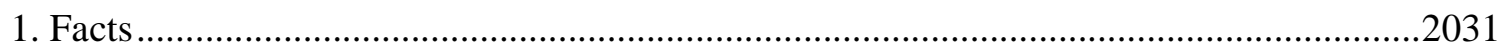

a. Events in eastern BiH between May 1992 and December 1994 ...................................... 2031

i. Issuance of Directive 4 and the VRS Spring 1993 Offensive .........................................2032 


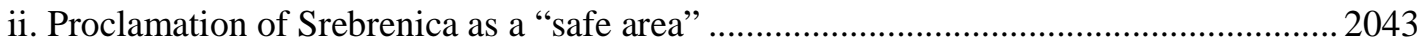

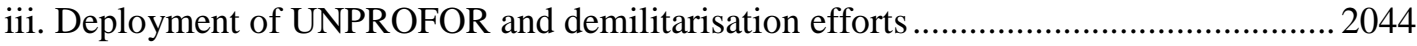

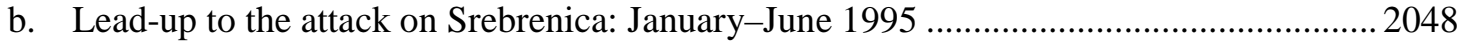

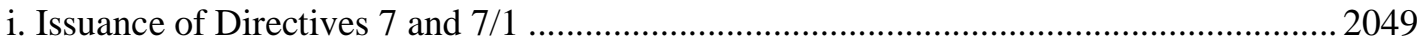

ii. Restrictions on humanitarian convoys and the humanitarian situation in Srebrenica..... 2052

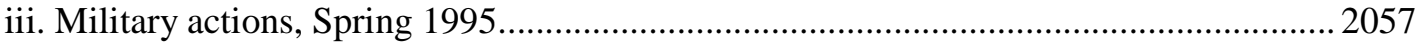

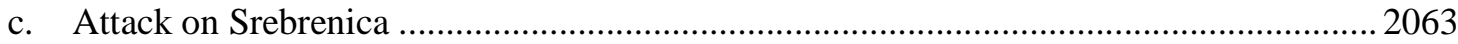

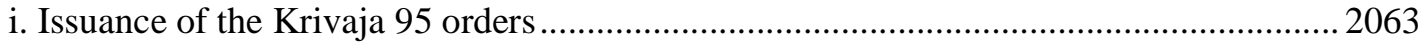

ii. Commencement of VRS combat operations and shelling of Srebrenica and Potočari ... 2066

iii. Expansion of the Krivaja 95 Orders and continued shelling of Srebrenica ....................2069

iv. The fall of Srebrenica and movement of the population to Potočari...............................2075

v. Formation and departure of the column of Bosnian Muslim men................................... 2080

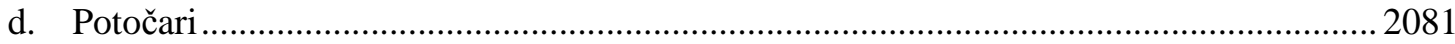

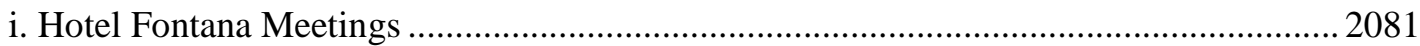

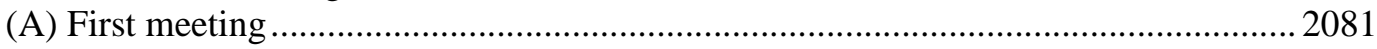

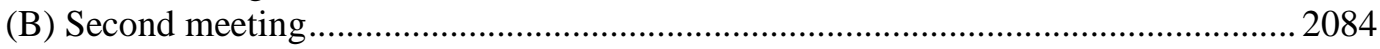

(C) Conversation between Momir Nikolić, Popović, and Kosorić prior to third meeting2086

(1) Summary of Momir Nikolić's evidence ............................................................... 2086

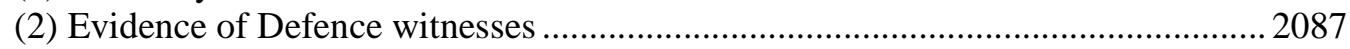

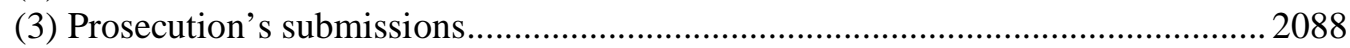

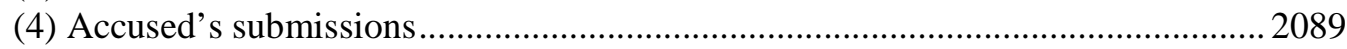

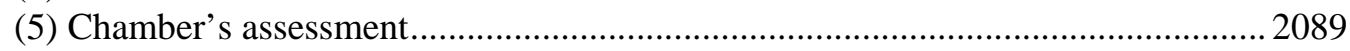

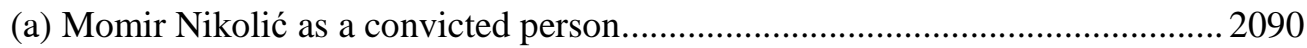

(b) Momir Nikolić's avowed lie ........................................................................22090

(c) Contradiction between the alleged plan to kill all balijas and Nikolić's

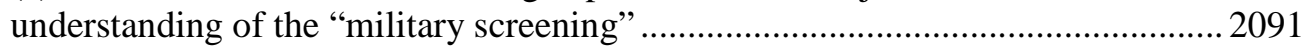

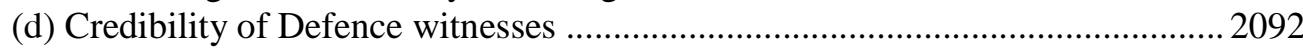

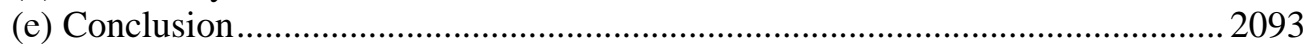

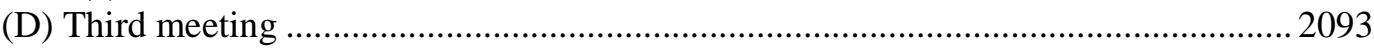

ii. Humanitarian situation and atmosphere in Potočari ......................................................2096

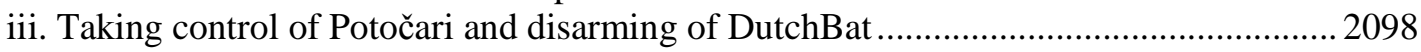

iv. Transportation from Potočari between 12 and 21 July 1995 .......................................2100

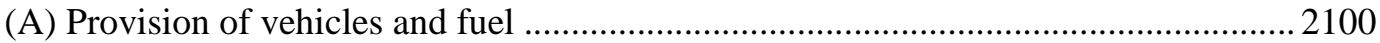

(B) Arrival of vehicles, the boarding process, and the separation of men ..................... 2104

(C) Transportation of women, children, and elderly men to Bosnian Muslim-held

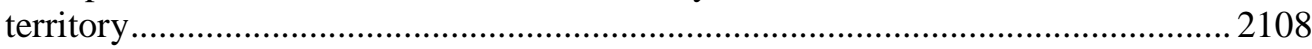

(D) Detention of the separated Bosnian Muslim men at the White House and

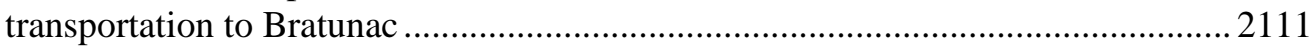

(E) Presence and involvement of the Bosnian Serb Forces ........................................... 2116

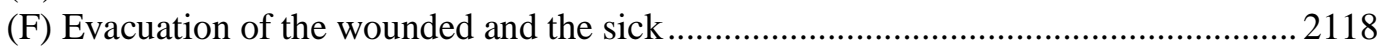

(G) Meeting of VRS, Bosnian Serb civilian officers, and ICRC ..................................22120

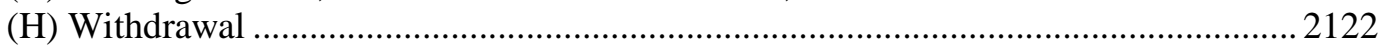

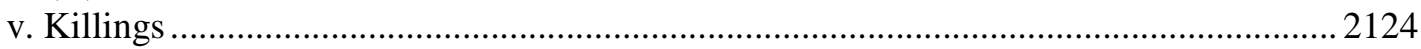

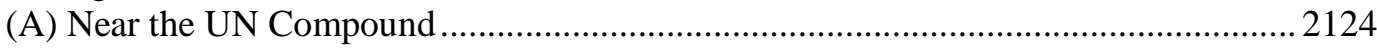

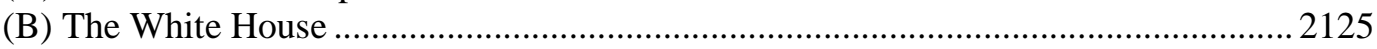

(C) Killings at Luke School near Tišća.............................................................. 2126

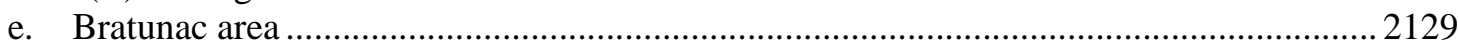

i. Deployment of Bosnian Serb Forces in the Bratunac area...........................................22130

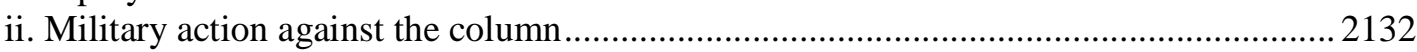

iii. Detention of Bosnian Muslim men from the column ................................................. 2135

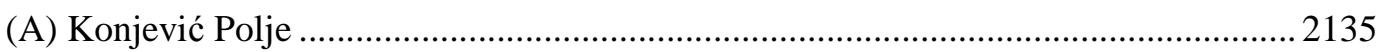

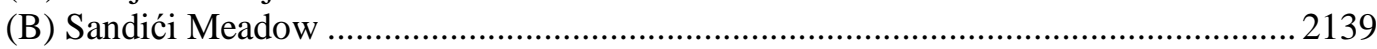

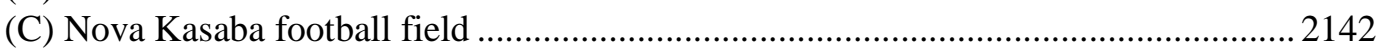

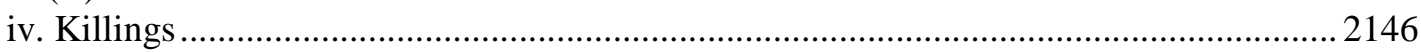




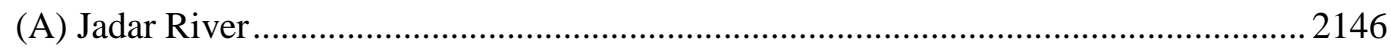

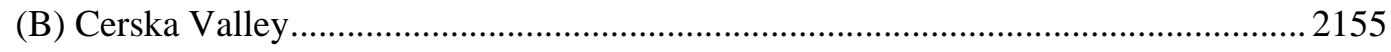

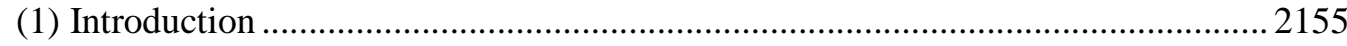

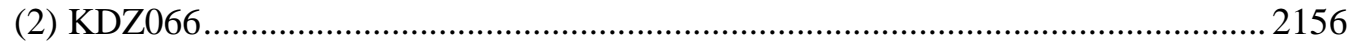

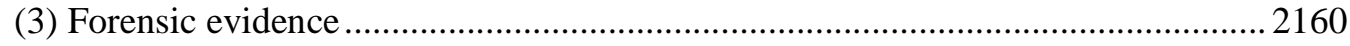

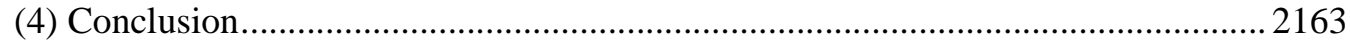

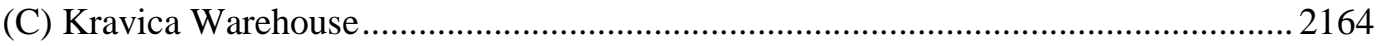

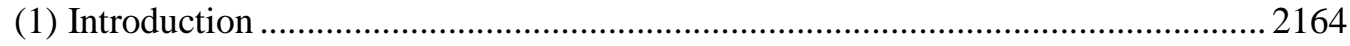

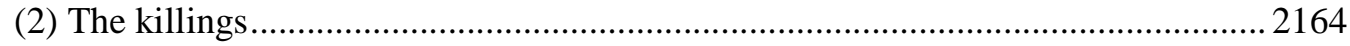

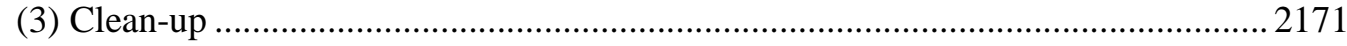

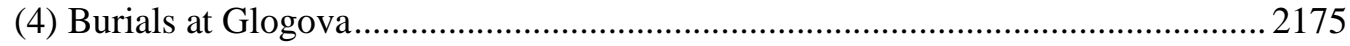

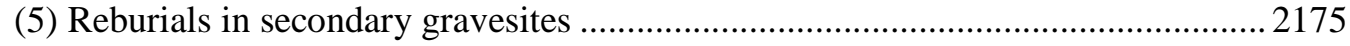

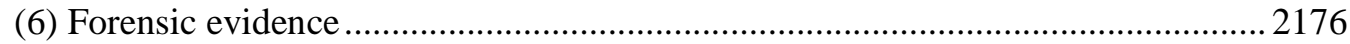

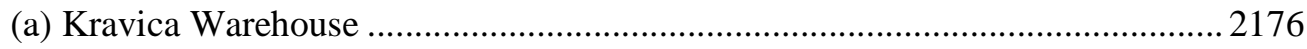

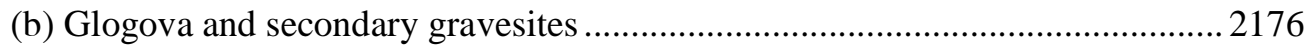

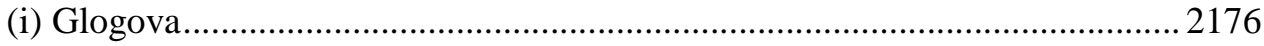

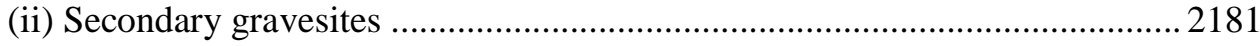

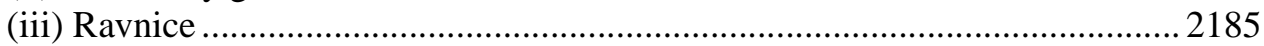

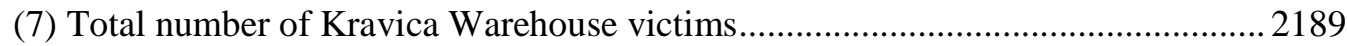

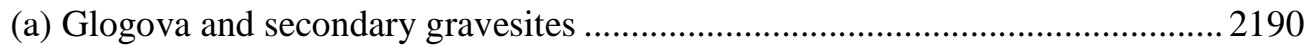

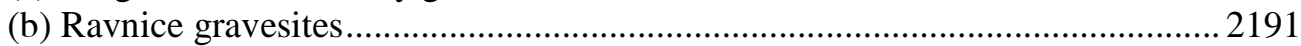

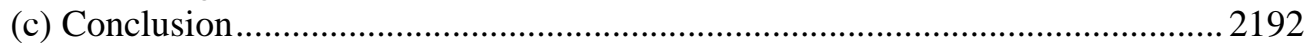

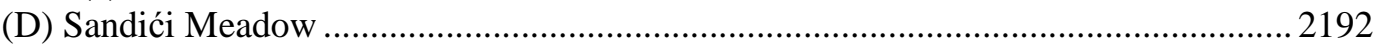

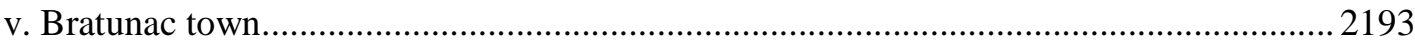

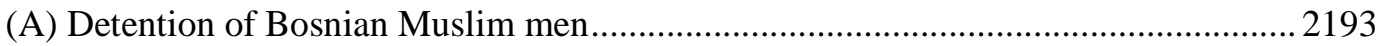

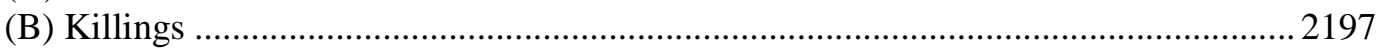

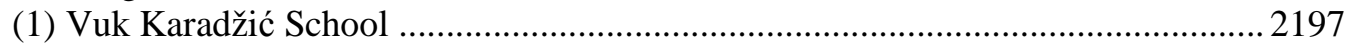

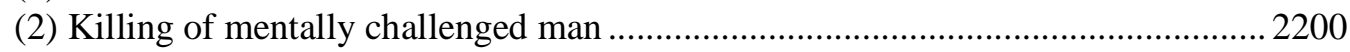

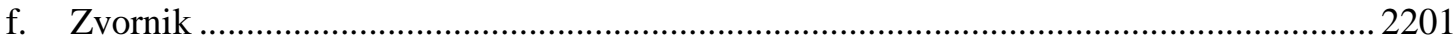

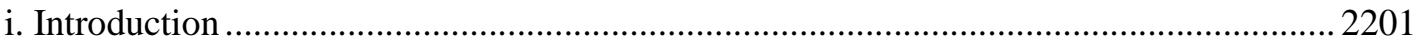

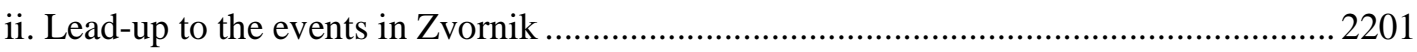

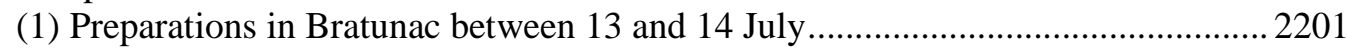

(2) Transportation of detainees from Bratunac to Zvornik ........................................2204

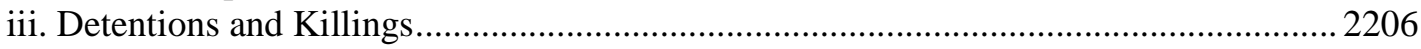

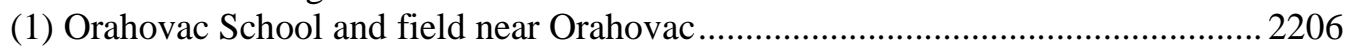

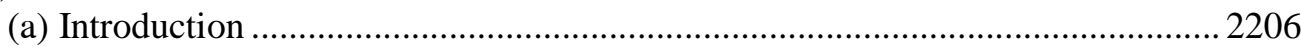

(b) Detention at the Orahovac School and killing of two men ................................ 2207

(c) The killings at the field near Orahovac ............................................................ 2213

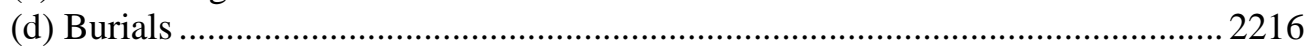

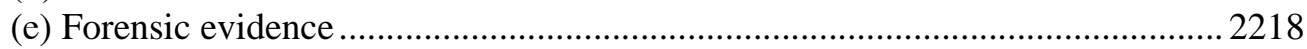

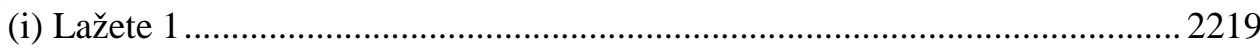

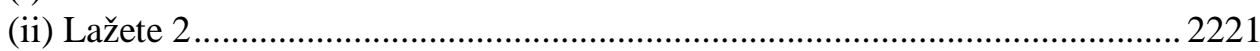

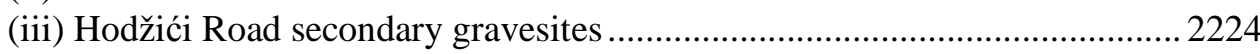

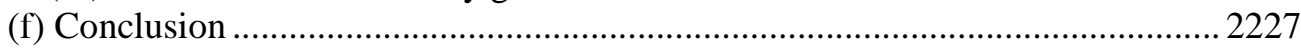

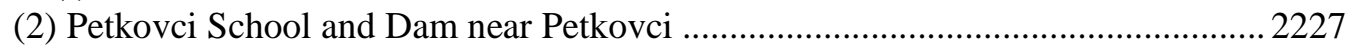

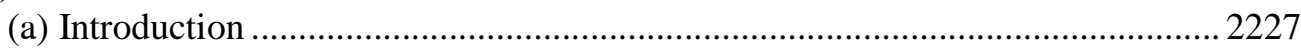

(b) Detention and killings at the Petkovci School ............................................... 2228

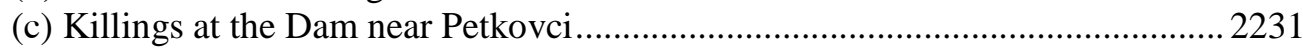

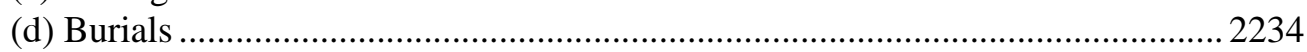

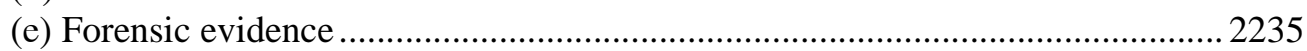

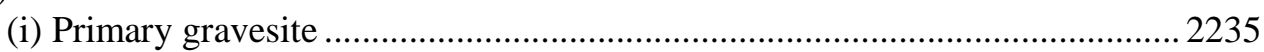

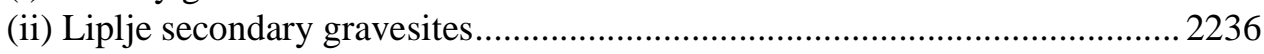

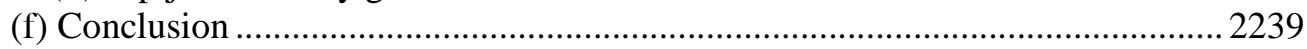

(3) Ročević School and Drina River near Kozluk ..................................................... 2239 


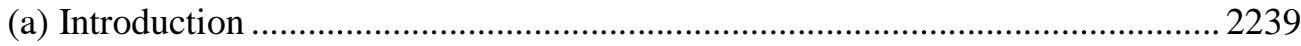

(b) Detention and killings at the Ročević School .................................................22240

(c) The killings at the Drina River near Kozluk .................................................... 2246

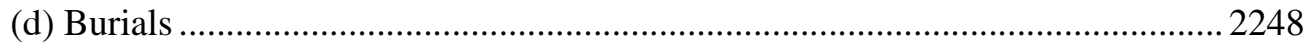

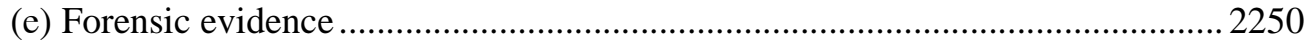

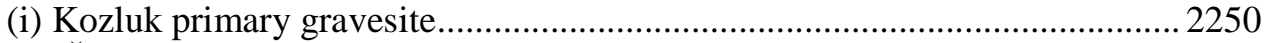

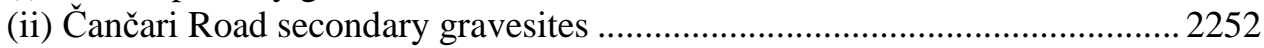

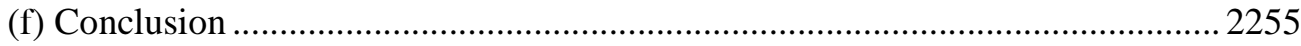

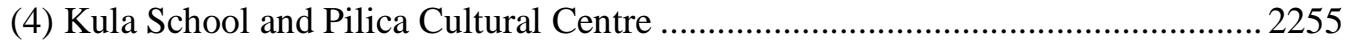

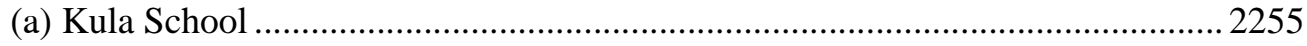

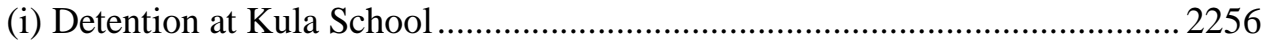

(ii) Transportation of detainees from the Kula School .................................... 2259

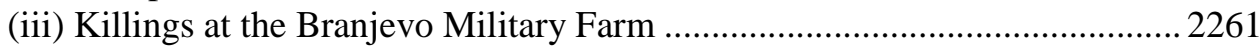

(b) Killings at the Pilica Cultural Centre ........................................................... 2268

(c) Burials of detainees killed at the Branjevo Military Farm and the Pilica Cultural

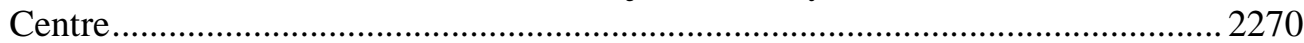

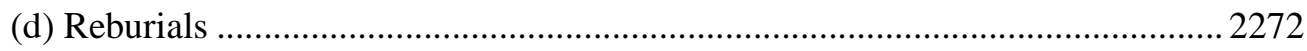

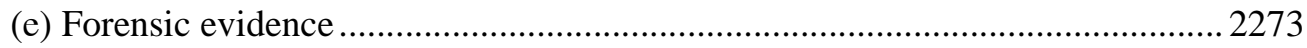

(i) The Branjevo Military Farm primary gravesite ......................................... 2273

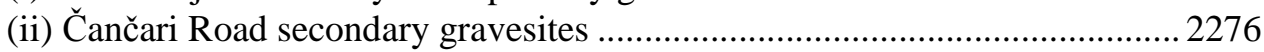

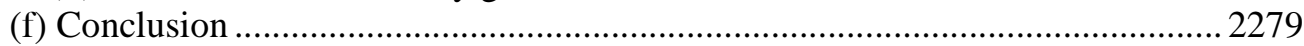

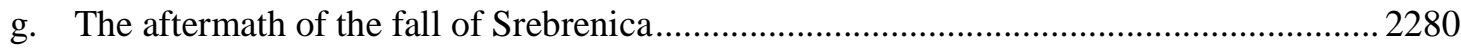

i. Opening a corridor for the passage of the column ........................................................228

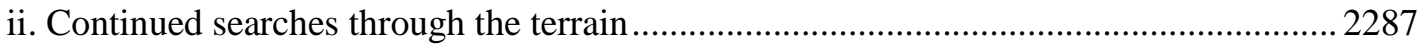

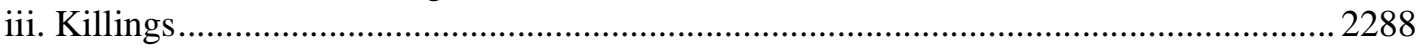

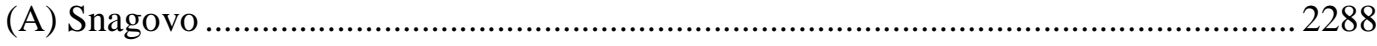

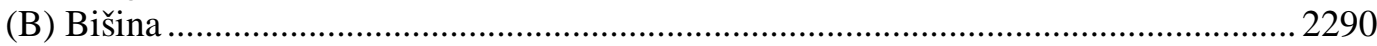

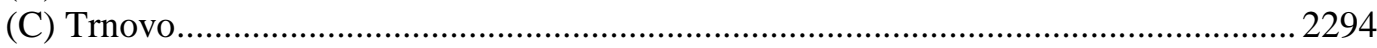

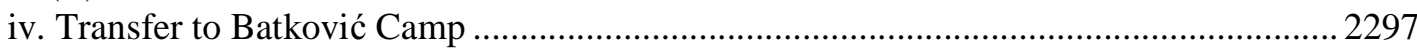

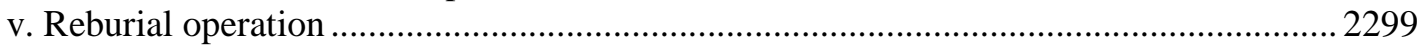

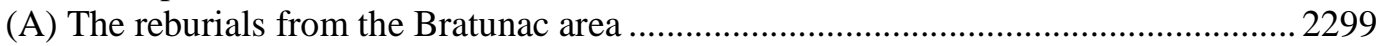

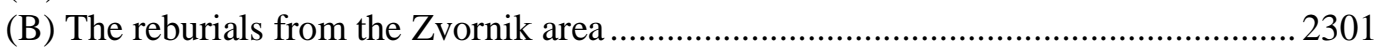

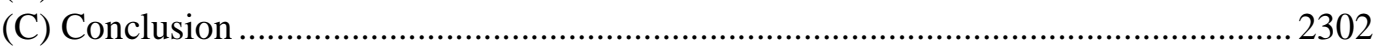

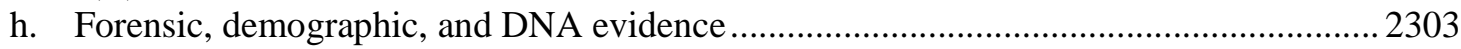

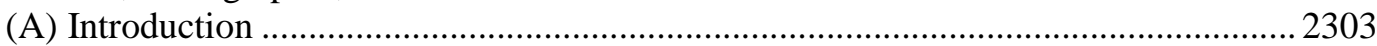

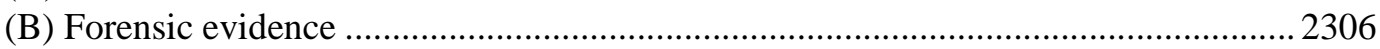

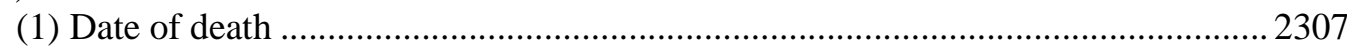

(a) Information provided to Prosecution experts .................................................. 2308

(b) Mixed gravesites ...................................................................................... 2309

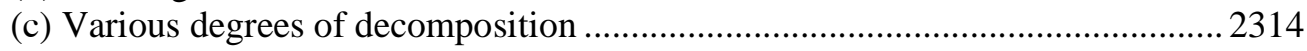

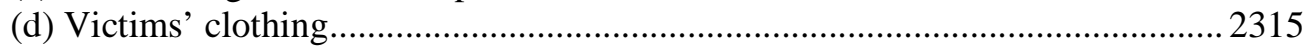

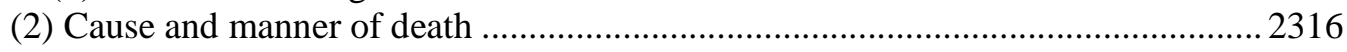

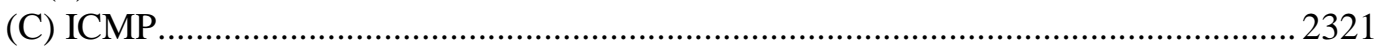

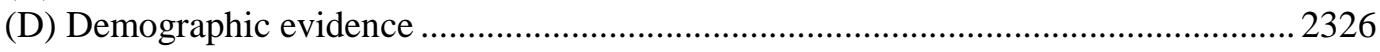

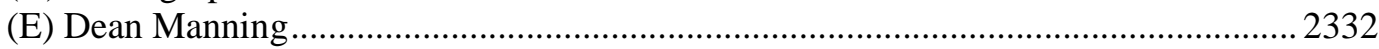

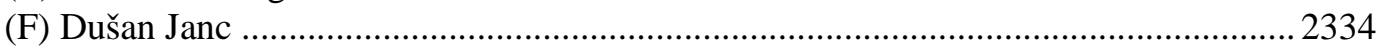

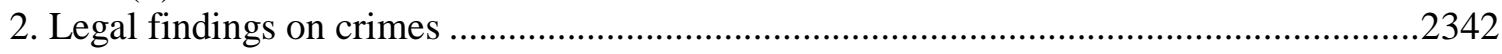

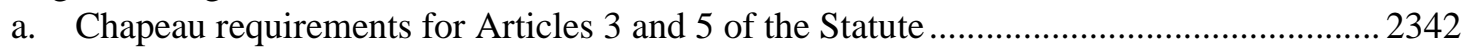

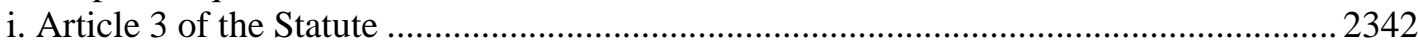

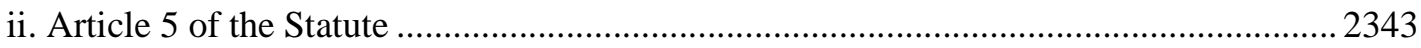

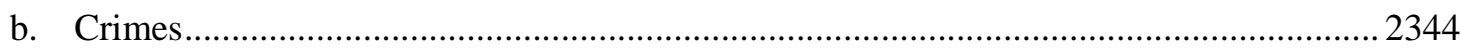

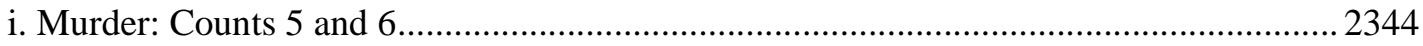

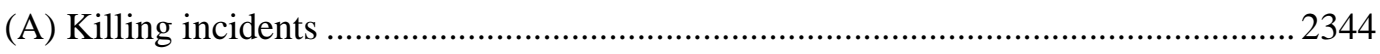

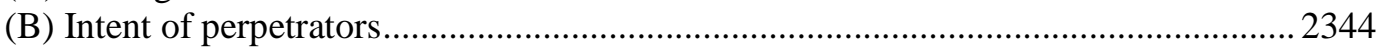




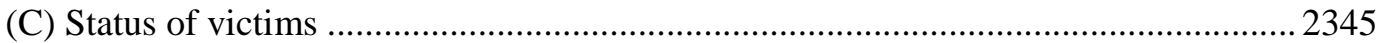

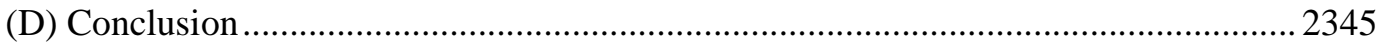

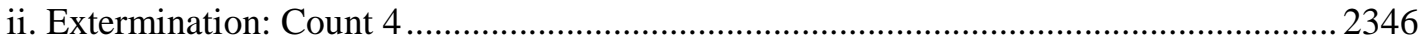

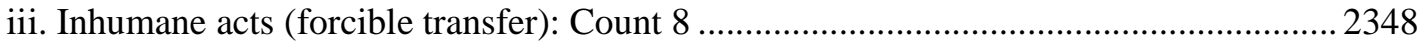

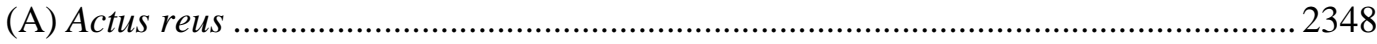

(1) Movement of population .............................................................................. 2348

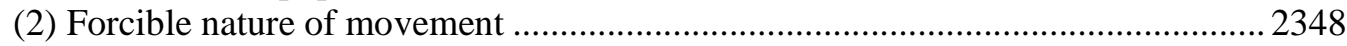

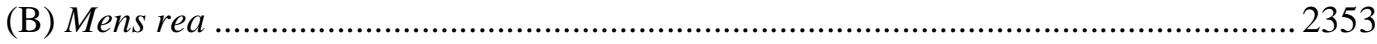

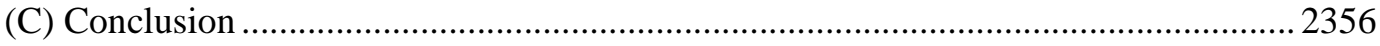

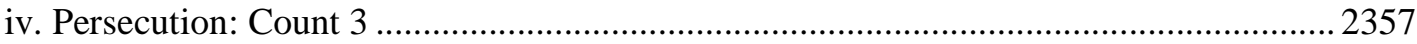

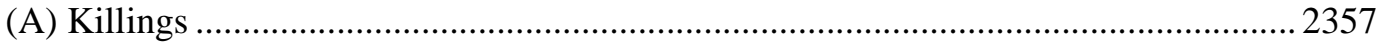

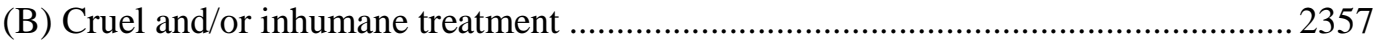

(1) Terrorising and abuse of Bosnian Muslims of Srebrenica in Potočari .................... 2357

(2) Beating of men and boys of Srebrenica prior to their execution ...........................2359

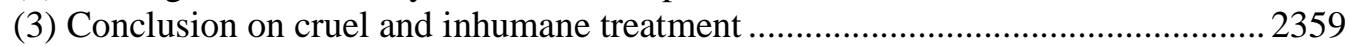

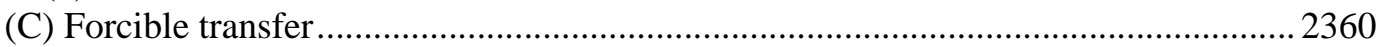

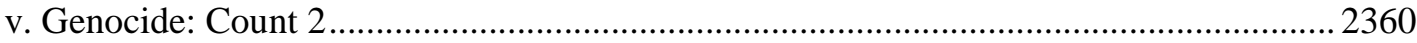

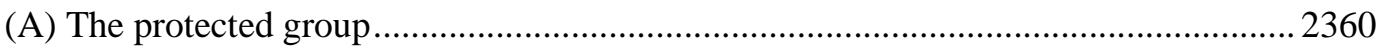

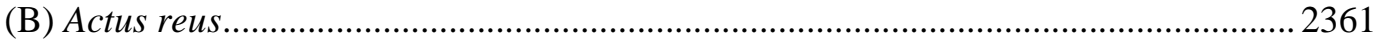

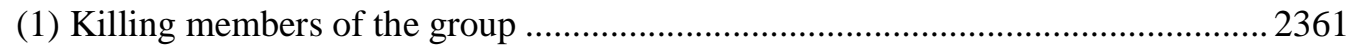

(2) Causing serious bodily or mental harm to members of the group.........................22361

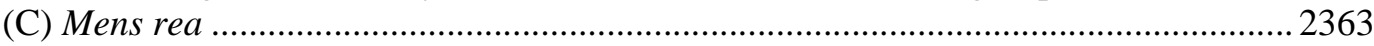

(1) Intent to destroy a part of the protected group as such....................................... 2364

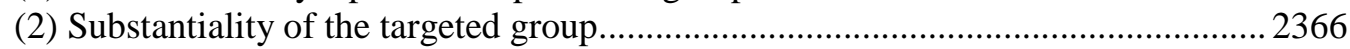

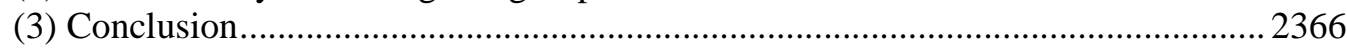

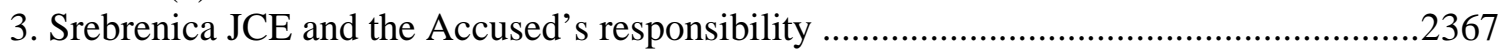

a. The existence of a common plan to eliminate the Bosnian Muslims in Srebrenica......... 2368

i. Overarching JCE and a long term plan to remove the Bosnian Muslim population from

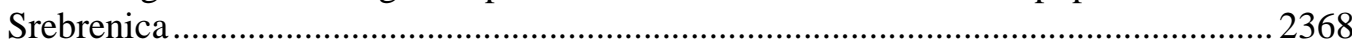

ii. Development of the plan to eliminate the Bosnian Muslim population in Srebrenica.... 2370

(A) Forcible removal of the Bosnian Muslim women, children, and elderly men ......... 2374

(B) Killing of the Bosnian Muslim men and boys ...................................................... 2379

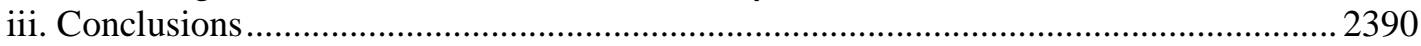

(A) The formation of a common plan to eliminate the Bosnian Muslims in Srebrenica by

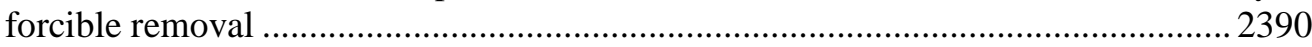

(B) The expansion of the common plan to eliminate the Bosnian Muslims in Srebrenica by killing all the able-bodied men and boys

(C) Participants in the plan to eliminate the Bosnian Muslim population in Srebrenica 2394

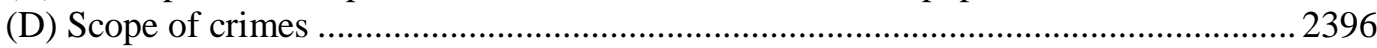

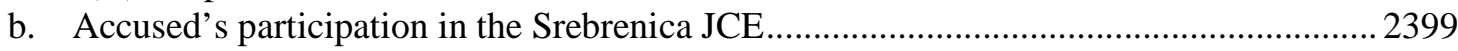

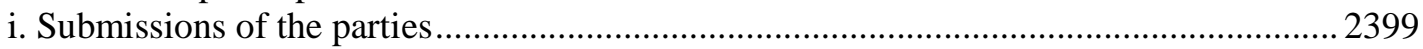

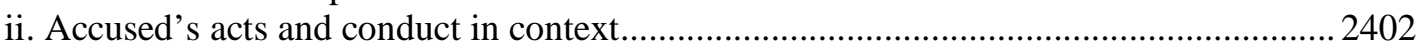

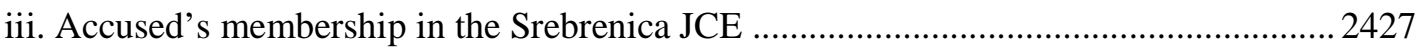

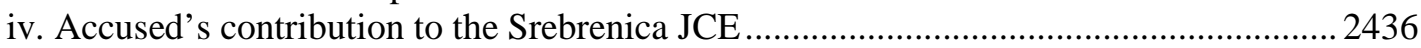

v. Accused's responsibility for crimes pursuant to the Srebrenica JCE ............................22440

(A) Murder, extermination, and inhumane acts (forcible transfer) ............................... 2440

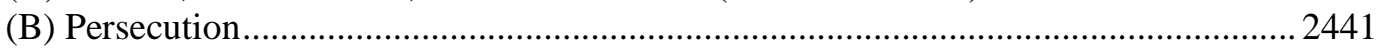

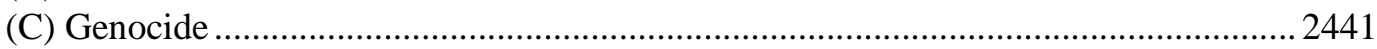

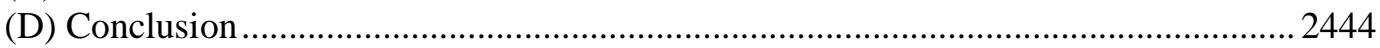

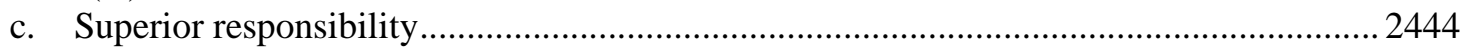

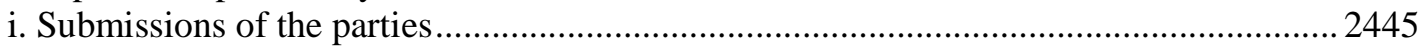

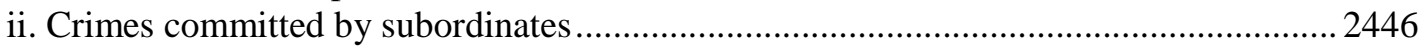

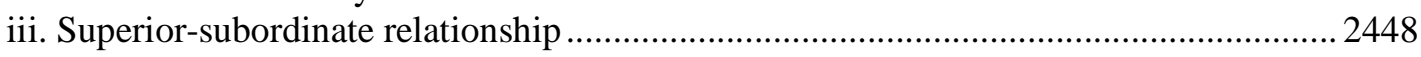

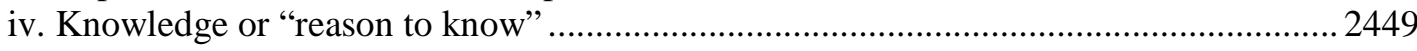


v. Failure to take necessary and reasonable measures........................................................2450

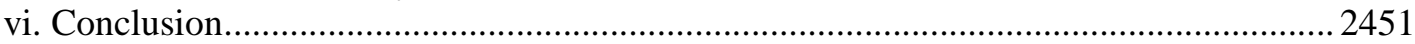

d. Conclusions: Accused's individual criminal responsibility ............................................2451

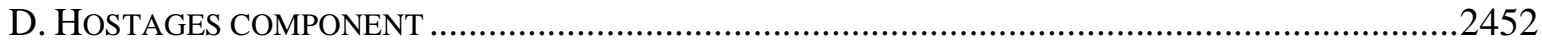

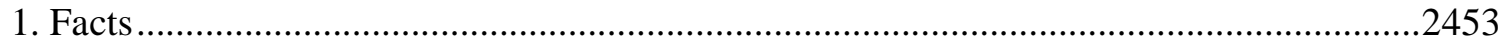

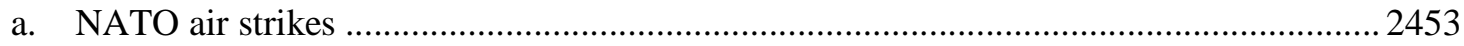

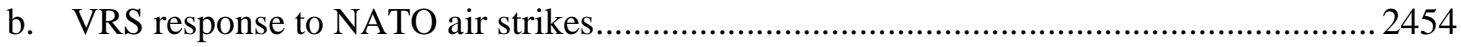

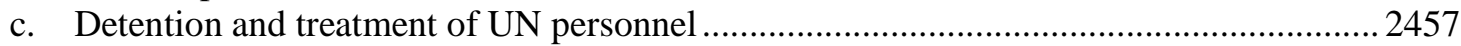

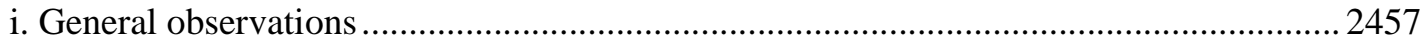

ii. Evidence from the UkrBat team in Sarajevo.............................................................2459

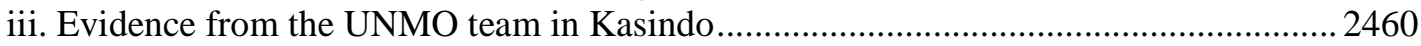

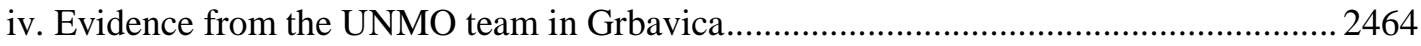

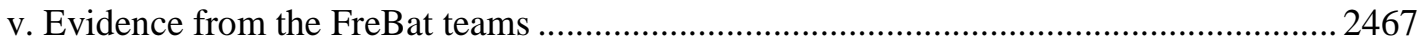

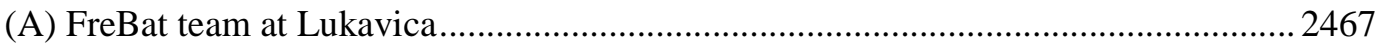

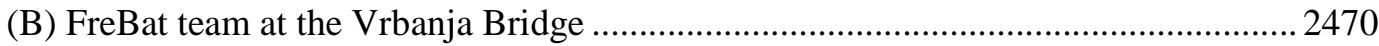

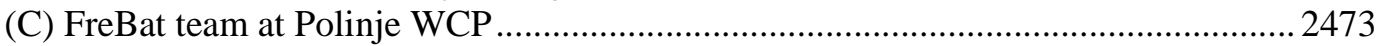

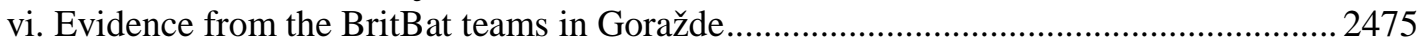

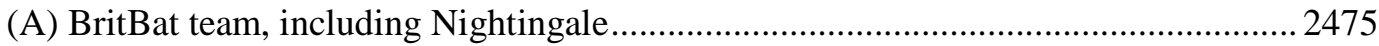

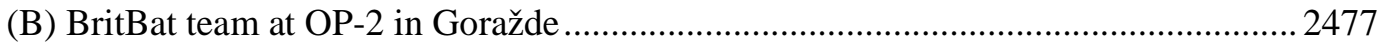

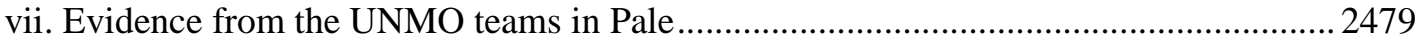

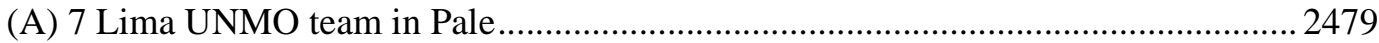

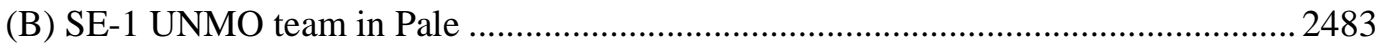

(C) Detention of the 7 Lima and SE-1 UNMO teams in Pale.........................................2484

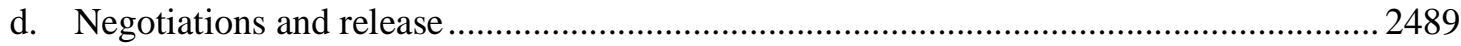

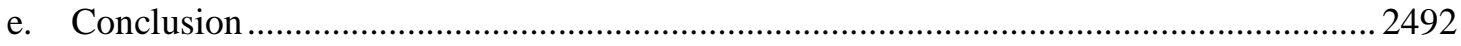

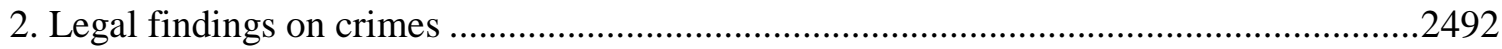

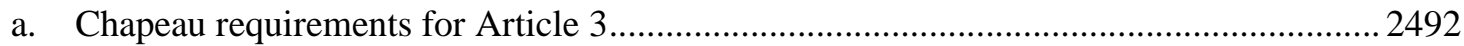

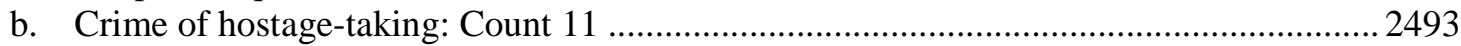

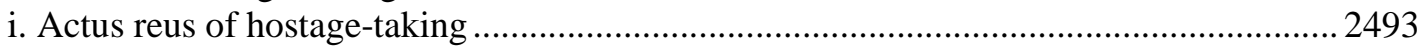

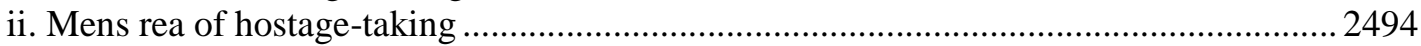

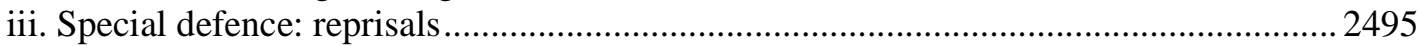

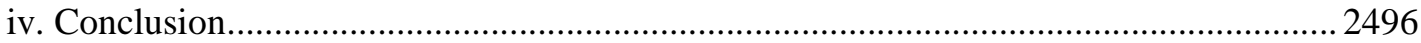

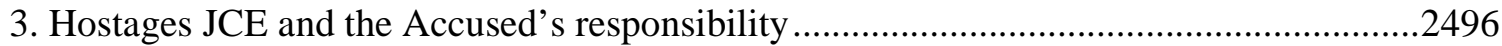

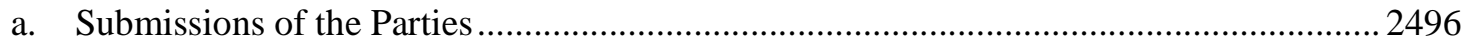

b. Findings on the common purpose and plurality of persons ............................................. 2497

c. Findings on the Accused's intent: whether the Accused shared the common purpose of

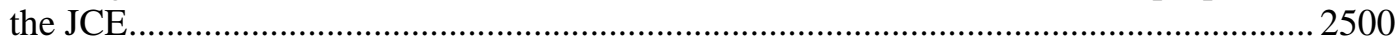

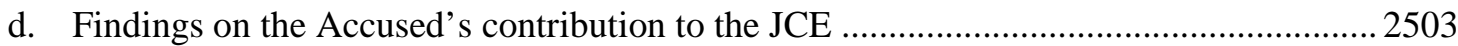

i. The Accused involvement in the lead up to NATO air strikes .......................................2503

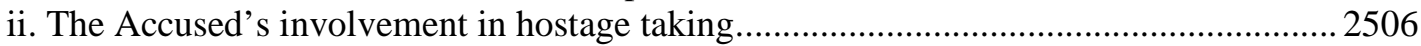

iii. The Accused's involvement in the release of UN hostages ........................................2509

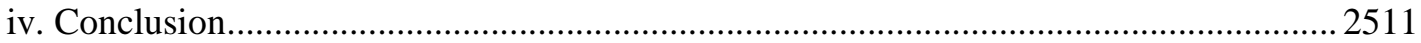

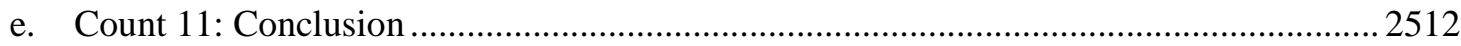

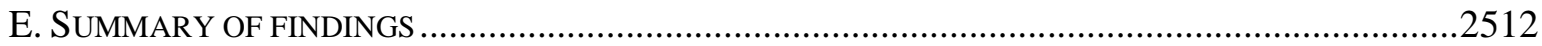

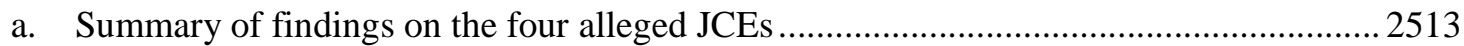

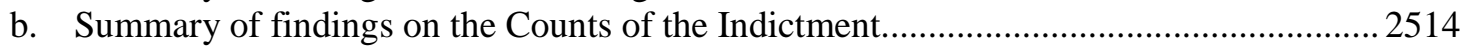

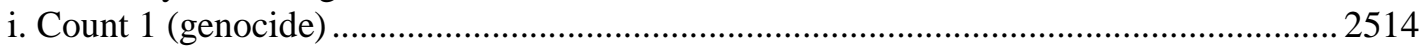

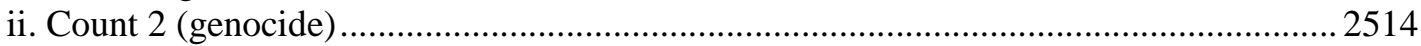

iii. Count 3 (persecution, a crime agains humanity)........................................................ 2515

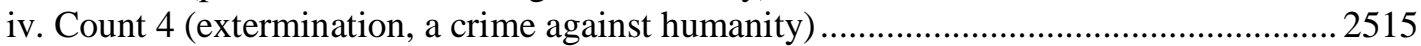

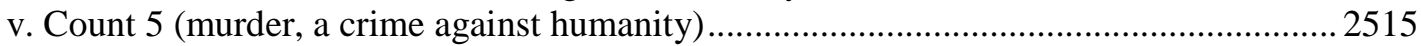

vi. Count 6 (murder, a violation of the laws or customs of war) ........................................2516

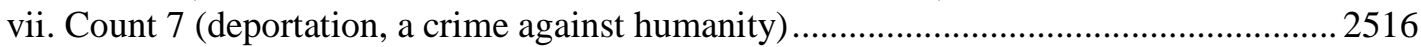

viii. Count 8 (inhumane acts-forcible transfer, a crime against humanity) .........................2516 
ix. Count 9 (terror, a violation of the laws or customs of war) ........................................2516

x. Count 10 (unlawful attacks on civilians, a violation of the laws or customs of war)......2516

xi. Count 11 (hostage taking, a violation of the laws or customs of war) ...........................2516

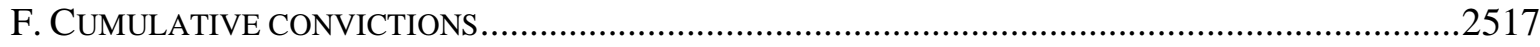

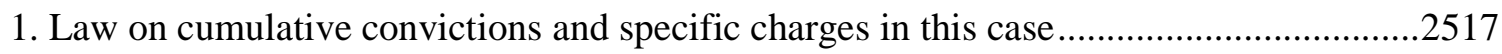

a. Cumulative convictions under Articles 3 and 5 of the Statute .......................................2517

b. Cumulative convictions for terror and unlawful attacks on civilians under Article 3 of the

Statute

.2518

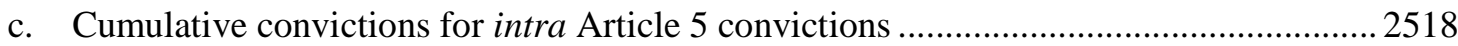

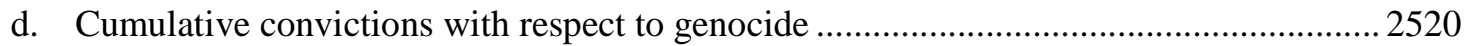

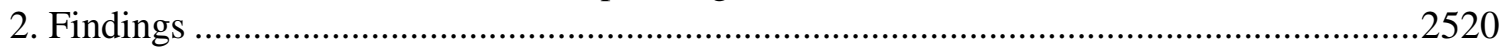

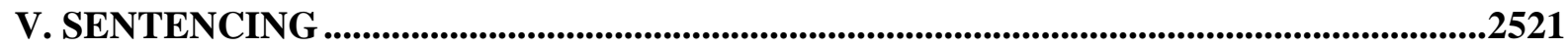

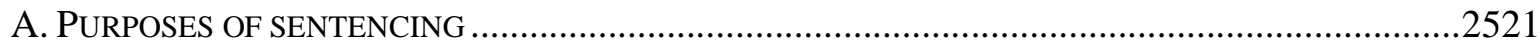

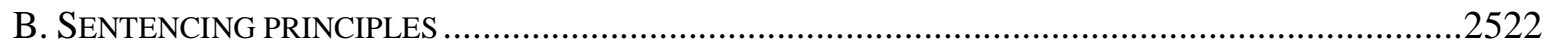

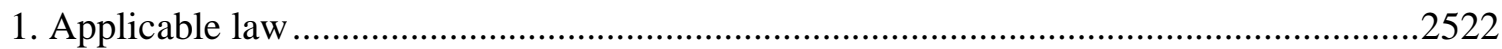

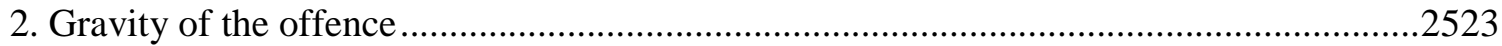

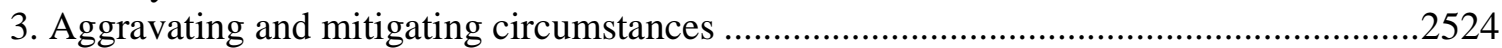

4. General practice regarding prison sentences in the courts of the former Yugoslavia .......2526

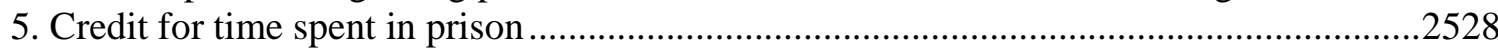

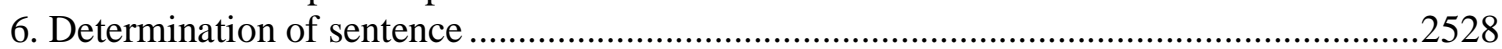

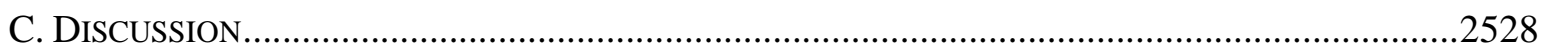

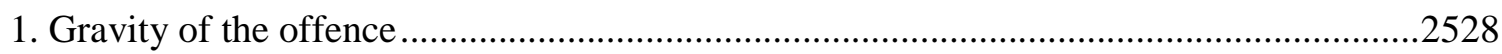

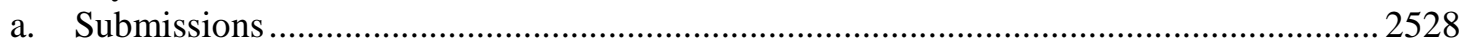

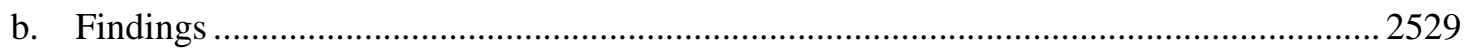

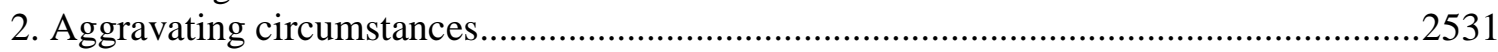

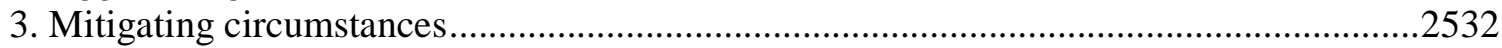

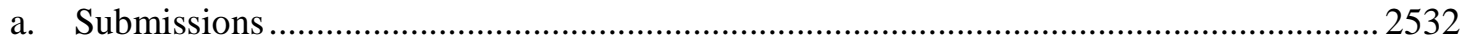

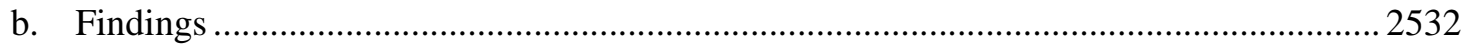

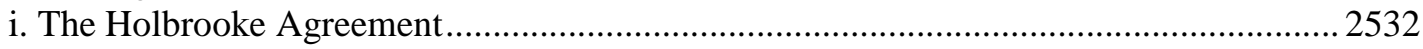

ii. The Accused's conduct during the proceedings and at the UNDU...............................2534

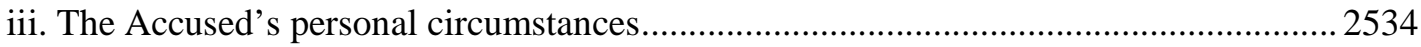

iv. Other mitigating circumstances identified by the Accused ......................................... 2534

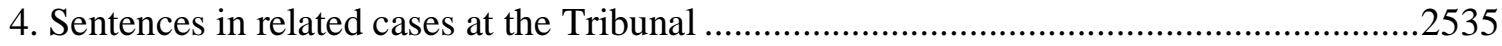

5. General practice regarding prison sentences in the courts of the former Yugoslavia .......2536

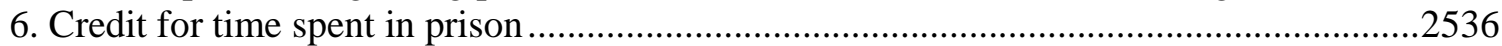

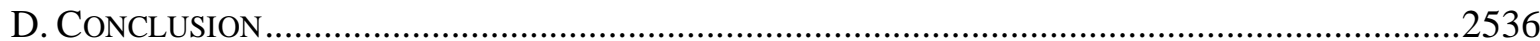

VI. DISPOSITION

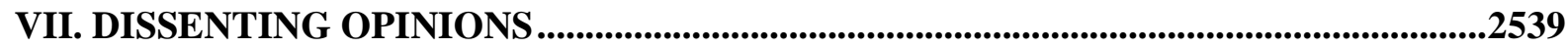

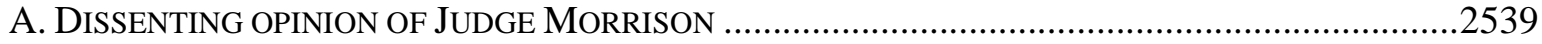

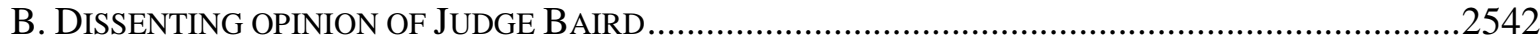

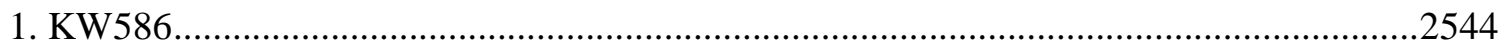

2. KW570

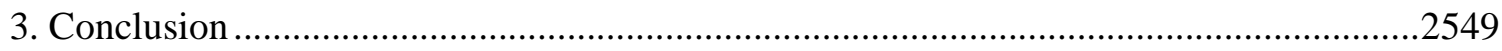

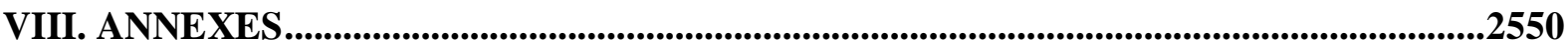

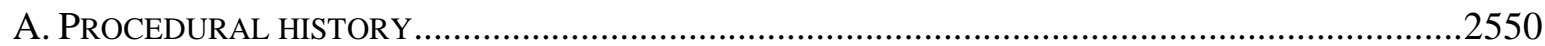

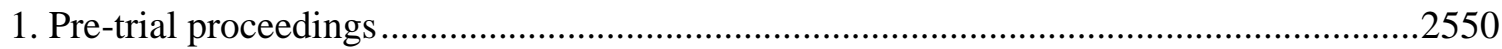

a. From confirmation of the Indictment to the Accused's plea ..........................................2550

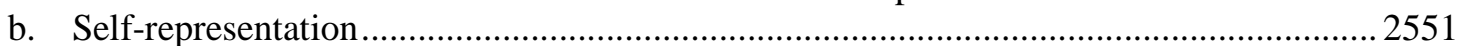

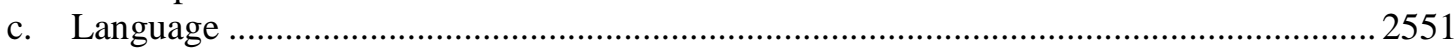

d. Challenges to jurisdiction and to the form of the Indictment .........................................251 


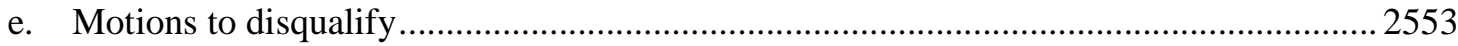

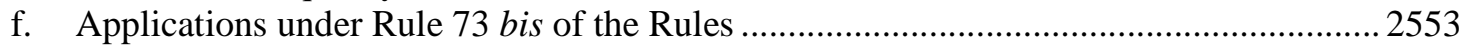

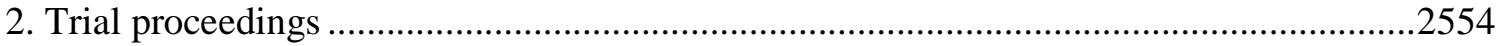

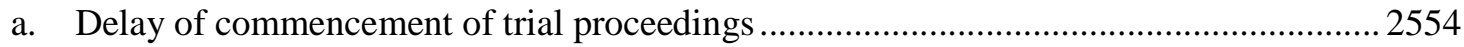

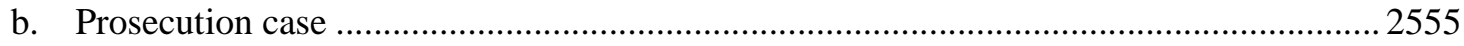

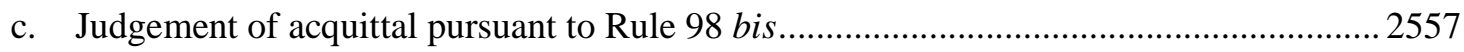

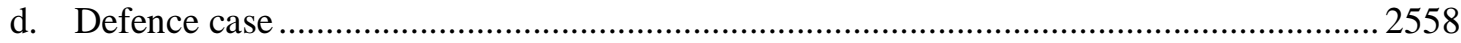

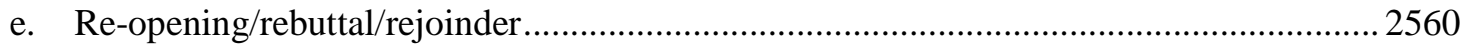

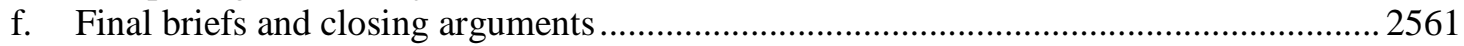

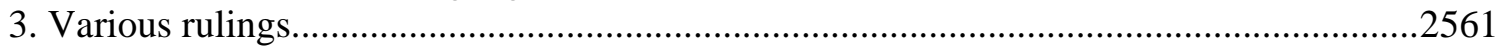

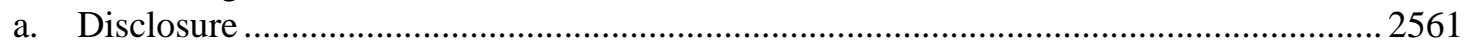

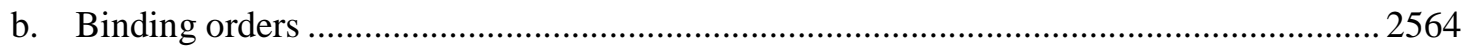

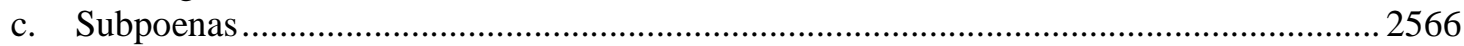

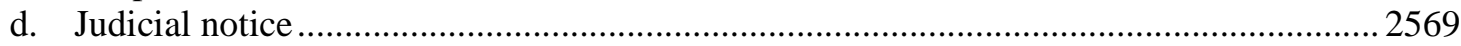

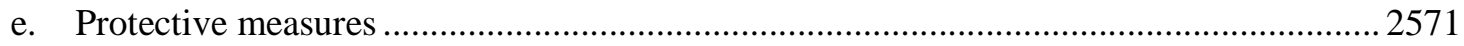

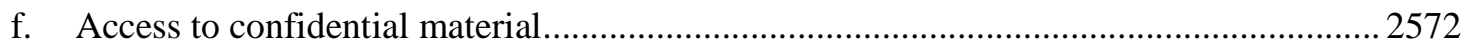

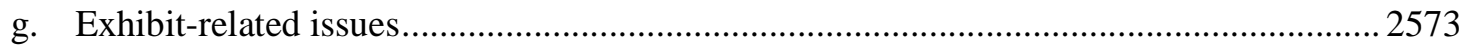

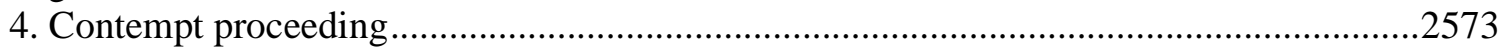

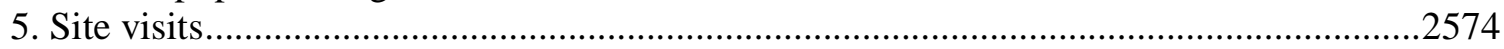

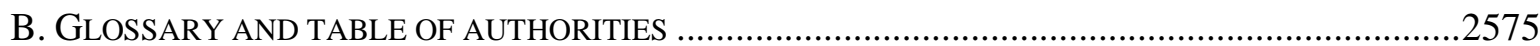

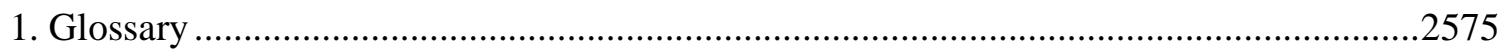

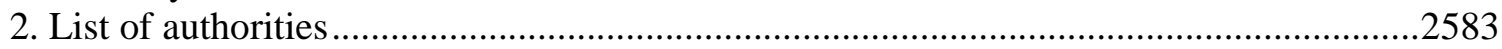

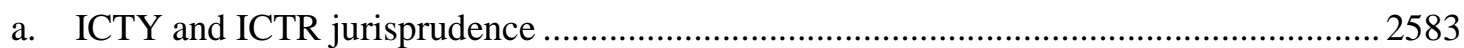

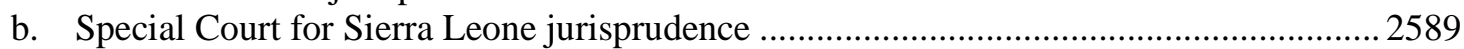

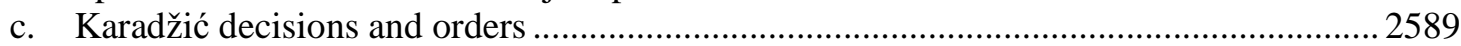

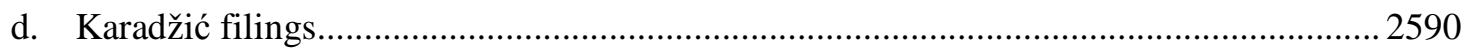

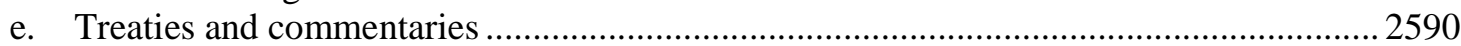

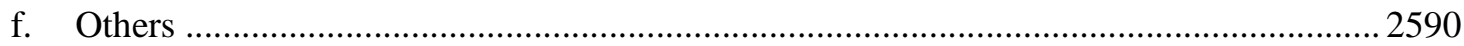




\section{INTRODUCTION}

\section{A. The AcCused And the Charges Against Him}

1. This case relates to events alleged to have occurred from October 1991 to November 1995 in various locations in $\mathrm{BiH}$, including Sarajevo, Srebrenica, and 20 municipalities of the ARK, the Sarajevo region, and eastern $\mathrm{BiH}$ (“Municipalities”).

2. The Accused was born on 19 June 1945 in the municipality of Šavnik, Republic of Montenegro. He was a founding member of the SDS and served as its President from 12 July 1990 to 19 July 1996. ${ }^{1}$ The Accused also acted as President of the National Security Council of SerBiH, which was created on 27 March 1992 and held sessions until around May 1992.2 On 12 May 1992, the Accused was elected as the President of the three-member Presidency of SerBiH. ${ }^{3}$ At the beginning of June 1992, the Presidency increased to five members, and the Accused continued as President of that Presidency. ${ }^{4}$ From 17 December 1992, he was sole President of the RS and Supreme Commander of the RS armed forces. ${ }^{5}$

3. In the Indictment, the Accused is charged under Article 7(1) of the Statute for his alleged participation in four related JCEs in BiH. The Prosecution alleges the following:

i) From at least October 1991 to 30 November 1995, the Accused participated in an "overarching" JCE, the objective of which was to permanently remove

1 Patrick Treanor, T. 14000-14002 (1 June 2011); P2536 (Patrick Treanor's expert report entitled “The Bosnian Serb Leadership 1990-1992”, 30 July 2002), para. 7; D255 (Radovan Karadžić's speech at the constituent SDS Assembly), p. 2; D269 (Article from NIN entitled "Serbs in Bosnia", 20 July 1990), p. 1; D4424 (Written agreement between Radovan Karadžić, Momčilo Krajišnik, Biljana Plavšić and Aleksa Buha, 18 July 1996). See also Section II.B.1: Serbian Democratic Party (SDS).

2 P2536 (Patrick Treanor's expert report entitled "The Bosnian Serb Leadership 1990-1992”, 30 July 2002), paras. 236, 255-256; Patrick Treanor, T. 14060 (1 June 2011) (erroneously referring to 27 March 1991); Momčilo Mandić, C2 (Transcript from Prosecutor v. Krajišnik), T. 8743. See paras. 89, 95. The Chamber notes that when it refers to a paragraph or a footnote number without specifying the source, it refers to a paragraph or footnote in this Judgement.

3 P3032 (Minutes of $1^{\text {st }}$ constitutive session of "SerBiH" Presidency, 12 May 1992); Patrick Treanor, T. 14060 (1 June 2011); P2536 (Patrick Treanor's expert report entitled "The Bosnian Serb Leadership 1990-1992", 30 July 2002), paras. 236, 260; Momčilo Mandić, T. 5000 (13 July 2010). See para. 96.

4 Patrick Treanor, T. 14060-14061 (1 June 2011); P2536 (Patrick Treanor's expert report entitled "The Bosnian Serb Leadership 1990-1992”, 30 July 2002), paras. 236, 261-264; D428 (Minutes of $4^{\text {th }}$ expanded meeting of SerBiH War Presidency, 9 June 1992). See para. 97.

5 Patrick Treanor, T. 14060-14061 (1 June 2011); P2536 (Patrick Treanor's expert report entitled "The Bosnian Serb Leadership 1990-1992”, 30 July 2002), paras. 236, 265-267; Dušan Kovačević, T. 39657, 39659-39660 (11 June 2013); Momčilo Mandić, C2 (Transcript from Prosecutor v. Krajišnik), T. 8618, 8633-8634, 91079110. 
Bosnian Muslims and Bosnian Croats from Bosnian Serb claimed territory in $\mathrm{BiH}$ through the crimes charged therein (“Overarching JCE”);

ii) Between April 1992 and November 1995, the Accused participated in a JCE to establish and carry out a campaign of sniping and shelling against the civilian population of Sarajevo, the primary purpose of which was to spread terror among the civilian population (“Sarajevo JCE”); ${ }^{7}$

iii) Between the days preceding 11 July 1995 and 1 November 1995, the Accused participated in a JCE to eliminate the Bosnian Muslims in Srebrenica by killing the men and boys of Srebrenica and forcibly removing the women, young children and some elderly men from Srebrenica ("Srebrenica JCE"); ${ }^{8}$ and

iv) Between approximately 26 May and 19 June 1995, the Accused participated in a JCE to take hostage over $200 \mathrm{UN}$ peacekeepers and military observers in order to compel NATO to abstain from conducting air strikes against Bosnian Serb military targets ("Hostages JCE"). ${ }^{9}$

4. In addition, the Accused is charged for having planned, instigated, ordered, and/or aided and abetted the crimes in the Indictment. ${ }^{10} \mathrm{He}$ is also charged as a superior pursuant to Article 7(3) of the Statute for these crimes. ${ }^{11}$

5. The Indictment charges the Accused with 11 Counts as follows:

i) Count 1: genocide (in relation to the Municipalities);

ii) Count 2: genocide (in relation to Srebrenica);

iii) Count 3: persecution, a crime against humanity (in relation to the Municipalities and Srebrenica);

\footnotetext{
6 Indictment, paras. 9-14, 30-31. The Prosecution charges the Accused with the first and the third form of JCE in relation to the Overarching JCE. See Indictment, paras. 9-10.

7 Indictment, paras. 15-19. The Prosecution charges the Accused only with the first form of JCE in relation to the Sarajevo JCE. See Indictment, paras. 15-16.

8 Indictment, paras. 20-24. The Prosecution charges the Accused only with the first form of JCE in relation to the Srebrenica JCE. See Indictment, paras. 20-21.

9 Indictment, paras. 25-29. The Prosecution charges the Accused only with the first form of JCE in relation to the Hostages JCE. See Indictment, paras. 25-26.

Indictment, paras. 30-31.

Indictment, paras. 32-35.
} 
Count 4: extermination, a crime against humanity (in relation to the Municipalities and Srebrenica);

v) Count 5: murder, a crime against humanity (in relation to the Municipalities, Sarajevo, and Srebrenica);

vi) Count 6: murder, a violation of the laws or customs of war (in relation the Municipalities, Sarajevo, and Srebrenica);

vii) Count 7: deportation, a crime against humanity (in relation to the Municipalities); ${ }^{12}$

viii) Count 8: inhumane acts (forcible transfer), a crime against humanity (in relation to the Municipalities and Srebrenica);

ix) Count 9: acts of violence the primary purpose of which is to spread terror among the civilian population, a violation of the laws or customs of war (in relation to Sarajevo);

x) Count 10: unlawful attacks on civilians, a violation of the laws or customs of war (in relation to Sarajevo); and

xi) Count 11: taking of hostages, a violation of the laws or customs of war. ${ }^{13}$

6. The prodigious amount of evidence in this case included the testimony of 434 witnesses who appeared before the Chamber, the evidence in writing of 152 other witnesses and a total of 11,469 exhibits representing 191,040 pages. A total of 48,121 transcript pages recorded the daily proceedings and 94,917 pages of filings were submitted to the Chamber. The scope of the Indictment and the high profile of the Accused conjointly contributed to the unprecedented nature of this case.

12 During closing arguments, the Prosecution specified that it does not seek a finding that the Accused is responsible for deportation, under Count 7, in relation to Srebrenica. See Closing arguments, T. 48034 (7 October 2014).

13 The Chamber notes that the Indictment used, in numerous instances, the open-ended term "including" in relation to the charges therein. As the Accused is entitled to be clearly informed of the charges against him, the Chamber has taken a restrictive approach of the term "including". For instance, in paragraph 60(a) and 60(k) of the Indictment, the Chamber has confined its analysis, respectively, to the Scheduled Killing Incidents listed in the Indictment and to the five specific restrictive and discriminatory measures identified. The same is true for instance for the acts of murder charged in relation to Sarajevo in paragraph 65 of the Indictment and the Chamber limited its findings to the Scheduled Sniping and Shelling Incidents. See Hearing, T. 5480 (19 July 2010). The Chamber further notes the Prosecution's statement that "it will not present evidence in order to secure a conviction in respect of any crime sties or incidents not listed in the Schedules to the Indictment". Rule 73 bis Submission, para. 16(b). 
7. This Judgement is divided into four volumes. This Judgement starts by the Chamber's approach to evidence and its findings on contextual aspects of the case, it then sets out the Chamber's analysis of the evidence in relation to the crimes charged in the Indictment, its factual and legal findings in relation thereto, and its assessment of the Accused's alleged responsibility. The Chamber has divided the presentation of this analysis according to the four components identified in the Indictment: (i) the Municipalities component; (ii) the Sarajevo component; (iii) the Srebrenica component; and (iv) the Hostages component. Finally, the Judgement addresses matters related to cumulative convictions and sentencing.

\section{B. GENERAL CONSIDERATIONS ON THE EVIDENCE}

\section{General evidentiary principles}

8. The Chamber assessed the evidence adduced at trial in light of the entire trial record and in accordance with the Statute and the Rules. As provided for in Rule 89(B), where no guidance was given by the Rules, the evidence was evaluated in a way that would best favour a fair determination of the case and that is consistent with the spirit of the Statute and the general principles of law, including the principle of in dubio pro reo. ${ }^{14}$

9. At the outset of the proceedings, for the benefit of the smooth conduct of the trial, the Chamber issued orders which provided the parties with guidelines on the conduct of trial and the rules that would govern the admission or exclusion of evidence. ${ }^{15}$ In accordance with the Rules, the Chamber adopted an approach that favoured the admissibility of evidence, provided it was relevant and had probative value, ${ }^{16}$ and assessed the weight to be ascribed to each piece of evidence in its overall consideration of the entire trial record. ${ }^{17}$

14 According to the principle of in dubio pro reo, any doubt as to the evidence must be resolved in favour of the accused. The Appeals Chamber stated in the Limaj case that the principle of in dubio pro reo "applies to findings required for conviction, such as those which make up the elements of the crime charged", but "is not applied to individual pieces of evidence and findings of fact on which the judgement does not rely". Limaj et al. Appeal Judgement, para. 21.

15 First Order on Conduct of Trial; Further Order on Conduct of Trial; Guidelines for Admission of Evidence.

16 Hearing, T. 1953 (6 May 2010) (the Chamber holding: "In addition to relevance and authenticity, the Chamber must be satisfied as to the probative value of a piece of proposed evidence, and this requires that the witness to whom it is shown is able to confirm its content or make some other positive comment about it"), as reaffirmed in Guidelines for Admission of Evidence, para. 11 (specifying that "it is desirable that a witness speak to the origins and/or content of a document to be tendered into evidence, to allow the Chamber to properly assess the relevance, authenticity, and reliability of that document, and thus its probative value, and, ultimately, be able to make use of that document in a meaningful way in its overall consideration of the evidence in the case").

17 Hearing, T. 10070 (13 January 2011), T. 17934 (25 August 2011). The Chamber notes that in the footnotes to this Judgement, it did not refer to all of the evidence it reviewed and considered in entering its findings but only to the most important pieces of evidence. 
10. Article 21(3) of the Statute provides that the Accused shall be presumed innocent until proven guilty. The Prosecution bears the burden of establishing each element of the alleged crimes and of the mode of individual criminal responsibility with which the Accused is charged, as well as any fact which is indispensable for a conviction beyond reasonable doubt. ${ }^{18}$ The Chamber has therefore determined whether the ultimate weight of all of the evidence is sufficient to establish beyond reasonable doubt the elements of the crimes charged in the Indictment, and ultimately, the responsibility of the Accused. When the Prosecution relied upon proof of a certain fact such as, for example, the state of mind of an Accused by inference, the Chamber considered whether that inference was the only reasonable inference that could have been made based on that evidence. ${ }^{19}$ Where that inference was not the only reasonable inference, it found that the Prosecution had not proved its case. The Chamber further notes that while it has not always reiterated the phrase "beyond reasonable doubt" in all of its findings, this standard of proof was applied throughout the Judgement. The Chamber also notes that when it has made a negative finding in respect of the evidence of a witness it did not deem reliable, this does not entail that the Chamber made a positive finding to the contrary.

11. In its evaluation of witnesses testifying viva voce or pursuant to Rule 92 ter, the Chamber had regard to, inter alia, the demeanour of witnesses, as well as to the passage of time since the events charged in the Indictment and its possible impact on the reliability of the evidence. With regard to all witnesses, the Chamber also assessed the probability and the consistency of their evidence as well as the circumstances of the case and corroboration from other evidence.

12. The Appeals Chamber has held that the testimony of a single witness on a material fact does not, as a matter of law, require corroboration. ${ }^{20}$ When such a situation occurred, the Chamber examined the evidence of the Prosecution witness with the utmost caution before accepting it as a sufficient basis for a finding of guilt. Insignificant discrepancies between the evidence of different

18 Šainović et al. Appeal Judgement, para. 132; Martić Appeal Judgement, para. 55; Halilović Appeal Judgement, para. 125. See also Ntagerura Appeal Judgement, para. 174, fn. 356 (holding that "[e]ven if some of the material facts pleaded in the indictment are not established beyond reasonable doubt, a Chamber might enter a conviction provided that having applied the law to those material facts it accepted beyond reasonable doubt, all the elements of the crime charged and of the mode of responsibility are established by those facts" and considering that "the 'material facts' which have to be pleaded in the indictment to provide the accused with the information necessary to prepare his defence have to be distinguished from the facts which have to be proved beyond reasonable doubt").

19 Vasiljević Appeal Judgement, para. 120.

20 Čelebići Appeal Judgement, para. 506 (" $[\mathrm{T}]$ here is no legal requirement that the testimony of a single witness on a material fact be corroborated before it can be accepted as evidence. What matters is the reliability and credibility accorded to the testimony."). But see para. 24. 
witnesses, or between the evidence of a particular witness in court and his prior statements, in general have not been regarded as discrediting such evidence. ${ }^{21}$

13. Hearsay evidence is any statement other than one made by a witness while giving evidence in the proceedings and which is offered to prove the truth of the matter asserted in the statement. ${ }^{22}$ It is admissible under the case law of the Tribunal. The weight to be attributed to that evidence depends upon the specific circumstances and as such, the Chamber assessed hearsay evidence on a case-by-case basis. ${ }^{23}$ The Appeals Chamber has held that

Trial Chambers have a broad discretion under Rule $89(\mathrm{C})$ to admit relevant hearsay evidence. Since such evidence is admitted to prove the truth of its contents, a Trial Chamber must be satisfied that it is reliable for that purpose, in the sense of being voluntary, truthful and trustworthy, as appropriate; and for this purpose may consider both the content of the hearsay statement and the circumstances under which the evidence arose; or, as Judge Stephen described it, the probative value of a hearsay statement will depend upon the context and character of the evidence in question. The absence of the opportunity to cross-examine the person who made the statements, and whether the hearsay is "first-hand" or more removed, are also relevant to the probative value of the evidence. The fact that the evidence is hearsay does not necessarily deprive it of probative value, but it is acknowledged that the weight or probative value to be afforded to that evidence will usually be less than that given to the testimony of a witness who has given it under a form of oath and who has been cross-examined, although even this will depend upon the infinitely variable circumstances which surround hearsay evidence. ${ }^{24}$

14. Circumstantial evidence is evidence of a number of different circumstances surrounding an event from which a fact at issue may be reasonably inferred. ${ }^{25}$ Where an inference is drawn from circumstantial evidence to establish a fact on which a conviction relies, that inference must be the only reasonable one that could be drawn from the evidence presented. ${ }^{26}$

$21 \quad$ See for instance Milutinović et al. Trial Judgement, Vol. I, para. 49.

22 See Archbold, Criminal Pleading, Evidence \& Practice § 11-1 (2010); Black's Law Dictionary 739 (8th ed. 2004); Fed. R. Evid. 801(c); Criminal Justice Act 2003 Ch. 2, Sec. 114(1). See also Aleksovski Appeal Decision on Admissibility, para. 15.

23 See Aleksovski Appeal Decision on Admissibility, para. 15. See for instance Hearing, T. 24908 (21 February 2012) (stating that the fact that evidence may be triple hearsay is a factor to consider when assessing the weight of the evidence).

$24 \quad$ Aleksovski Appeal Decision on Admissibility, para. 15 (footnotes omitted).

25 See Čelebići Appeal Judgement, para. 458.

26 Kvočka et al. Appeal Judgement, para. 237, as recalled in Šainović et al. Appeal Judgement, para. 995. 


\section{Specific evidentiary considerations}

\section{a. Certain categories of witnesses}

\section{i. Persons associated with the parties to the proceedings}

15. The Chamber heard the evidence of a number of investigators associated with either the Prosecution or the Accused's defence team. ${ }^{27}$ Their status as current or former investigators for one of the parties in this case does not in itself render their evidence unreliable. In determining the weight to be attributed to each witness of this category, the Chamber has taken into consideration, inter alia, their expertise and knowledge of the investigation that they were involved in, as well as other relevant evidence. It has, however, been mindful to exercise caution in evaluating their evidence in view of their association with a party to the proceedings.

\section{ii. Individuals convicted of crimes arising from events charged in the Indictment}

16. A large number of individuals who were convicted either by the Tribunal or by domestic courts for crimes arising from events which are alleged in the Indictment have testified as witnesses before the Chamber both for the Prosecution and the Defence. ${ }^{28}$ In approaching the evidence of these witnesses, the Chamber considered the following guidance from the Appeals Chamber:

[I]t is well established in the jurisprudence of both ad hoc Tribunals that nothing prohibits a Trial Chamber from relying on evidence given by a convicted person, including evidence of a partner in crime of the person being tried before the Trial Chamber. Indeed, accomplice evidence, and, more broadly, evidence of witnesses who might have motives or incentives to implicate the accused is not per se unreliable, especially where such a witness may be thoroughly cross-examined; therefore, reliance upon this evidence does not, as such, constitute a legal error. However, "considering that accomplice witnesses may have motives or incentives to implicate the accused person before the Tribunal, a Chamber, when weighing the probative value of such evidence, is bound to carefully consider the totality of the circumstances in which it was tendered". As a corollary, a Trial Chamber should at least briefly explain why it accepted the evidence of witnesses who may have had motives or incentives to implicate the accused; in this way, a Trial Chamber shows its cautious assessment of this evidence. ${ }^{29}$

27 The Chamber heard the following Prosecution's investigators, either former or current: Jean-René Ruez, Dean Manning, Tomasz Blaszczyk, Dušan Janc, and Stefanie Frease. The Chamber also heard from Milomir Savčić who is an investigator on the Accused's defence team. The Chamber refers to its detailed analysis of Janc's evidence in the section on forensic, demographic, and DNA evidence in relation to the Srebrenica component of the case. See Section IV.C.1.h.F: Dušan Janc.

28 The following such witnesses appeared for the Prosecution: KDZ523, Momir Nikolić, Dražen Erdemović, KDZ122. In addition, the Chamber granted the Prosecution's request to admit the evidence of Milan Babić in writing pursuant to Rule 92 quater. The following such witnesses appeared for the Defence: Dragomir Milošević, Stanislav Galić, Milan Martić, Branko Grujić, Mendeljev Đurić, Franc Kos, Momčilo Krajišnik, Radoslav Brđanin, Željko Mejakić, KW679, Vidoje Blagojević, Milomir Stakić, Miroslav Kvočka, and Momčilo Gruban. In addition, the Chamber granted the Accused's request to admit the evidence of Milorad Krnojelac and Radislav Krstić in writing pursuant to Rule 92 quater. 
17. With the exception of Milan Babić, Miroslav Krnojelac, and Radislav Krstić, whose testimonies in prior proceedings were admitted pursuant to Rule 92 bis or quater, all of the witnesses in this category testified before the Chamber either live or pursuant to Rule 92 ter. The Chamber was thus able to observe their demeanour on direct and cross-examination. As with all witnesses, the Chamber ultimately weighed their evidence against the totality of the evidence. In conducting this individual assessment, it kept in mind the possibility that they may have had motives to implicate the Accused and thus reviewed their evidence with close scrutiny. The credibility of witnesses in this category will be explained further below in this Judgement where relevant.

\section{iii. Individuals whose trial is currently ongoing, at trial or on appeal}

18. A number of individuals whose proceedings before the Tribunal were currently ongoing, either at trial or on appeal, testified before the Chamber, including some who were subpoenaed to testify. ${ }^{30}$ The issue of "whether an accused or appellant compelled by subpoena to testify in another case before the Tribunal is in effect exposed, in relation to his own case, to the possibility of compelled self-incrimination" ${ }^{31}$ was highly litigated in this case. ${ }^{32}$ The Appeals Chamber held that "an accused or appellant may be compelled to testify in other cases before the Tribunal due to the fact that any self-incriminating information elicited in those proceedings cannot be directly or derivatively used against him in his own case". ${ }^{33}$ Since these witnesses testified before the Chamber, it was able to observe their demeanour while they were on the stand. In weighing their evidence against the totality of the evidence on the record, the Chamber reminded itself of the possibility that these witnesses may have had motives to distance themselves from the events in relation to which they were testifying.

\section{iv. Expert witnesses}

19. The Chamber heard the testimony of a large number of witnesses as experts called pursuant to Rule 94 bis both by the Prosecution and the Accused. ${ }^{34}$ In weighing this evidence, the Chamber

\footnotetext{
30 Ljubomir Borovčanin, Vojislav Šešelj, and Vujadin Popović testified voluntarily. Zdravko Tolimir, Ljubiša Beara, Ratko Mladić, and Mićo Stanišić were subpoenaed to testify. See para. 6163, fn. 20799.

31 Appeal Decision on Tolimir Subpoena, para. 34

32 See Appeal Decision on Tolimir Subpoena. See also para. 6164.

33 Appeal Decision on Tolimir Subpoena, para. 50. This Chamber later noted that it considered that " $\mathrm{t}] \mathrm{he}$ terminology used by the Appeals Chamber indicates that the applicability of the [Appeal Decision on Tolimir Subpoena] is broader than Tolimir himself". Decision on Mladić Motion for Reconsideration, para. 15.

34 The following witnesses were called by the Prosecution under Rule 94 bis: Robert Donia. Richard Philipps, Patrick van der Weijden, Berko Zečević, Dorothea Hanson, András Riedlmayer, Richard Butler, Ewa Tabeau, Patrick Treanor, Christian Nielsen, Reynaud Theunens, Ewan Brown, Jose Baraybar, Christopher Lawrence, John Clark, Freddy Peccerelli, William Haglund, Thomas Parsons, Richard Wright, and Richard Philipps. The following witnesses were called by the Accused under Rule 94 bis: Mirjana Lukić-Anđeljković, Stevo Pašalić,
} 
considered factors such as the professional competence of the expert, the methodologies used, and the reliability of the findings made in light of these factors and other evidence accepted by the Chamber. ${ }^{35}$ The Chamber did not rely on the evidence given by witnesses called pursuant to Rule 94 bis which pertained to topics falling outside the realm of their expertise.

\section{b. Certain categories of exhibits}

\section{i. Source documents}

20. The Chamber did not admit the sources used by an expert in compiling his report as a matter of course. ${ }^{36}$ It considered that the purpose of having an expert report is to assist the Chamber by providing an understandable compilation and analysis of technical material and, as such, should be complete and understandable in itself, such that there is no need to tender for admission the sources used by the expert. The Chamber allowed, however, the presenting party to request the admission of certain sources upon providing clear reasons as to why these sources should be admitted in addition to the expert report itself. ${ }^{37}$ As the purpose of admitting source material was to enable the Chamber to verify, if necessary, the basis upon which the expert reached his conclusions as well as how the relevant analysis was conducted, source documents so accepted were thus not admitted for their substantive content. ${ }^{38}$ However, if at a later date, a witness discussed the content of a document previously admitted as a source document in such a way that rendered that document admissible for its content, its status was changed to reflect its admission for all purposes. ${ }^{39}$

\section{ii. Third-party statements}

21. Throughout these proceedings, the Chamber considered that third-party statements produced for the purpose of current criminal proceedings may only be admitted pursuant to the modalities of Rules 92 bis, ter, quater, and quinquies. It held that the strict requirements of these rules, which are lex specialis, may not be circumvented by tendering such material pursuant to the

Derek Allsop, Kosta Cavoški, Zorica Subotić, Mile Poparić, Dragomir Kešerović, Radovan Radinović, and Dušan Dunjić. The Chamber refers in particular to the detailed section on the forensic, demographic, and DNA evidence in relation to the Srebrenica component of the case. See Section IV.C.1.h: Forensic, demographic, and DNA evidence.

35 Milutinović et al. Trial Judgement, Vol. I, para. 40. See also Martić Trial Judgement, para. 29; Blagojević and Jokić Trial Judgement, para. 27; Vasiljević Trial Judgement, para. 20. In weighing the evidence from expert witnesses, the Chamber has, in particular, considered corroboratory evidence of a different nature. First Order on Conduct of Trial, Appendix A, para. P.

Further Order on Conduct of Trial, para. 5.

Philipps Decision, para. 10, as applied in Hanson Bar Table Decision, paras. 15, 17-19.

Philipps Decision, para. 10. See P2913 (Letter from Zvornik's Interim Government, 6 June 1992); P2915 (Summary of conclusions of Prijedor's Executive Committee, 29 April-17 August 1992). 
more general Rule $89 .^{40}$ In relation to any other third-party statement not prepared for the purposes of criminal proceedings, the Chamber followed the practice that they may only be admitted if they are commented upon, confirmed, or adopted by the witness on the stand. ${ }^{41}$ A number of such statements were admitted in this manner and, as any evidence on the record, were attributed the appropriate weight in light of the totality of the trial record at the end of the proceedings. ${ }^{42}$

\section{iii. Media reports}

22. The Chamber considered that written media reports, whether they be reports, articles or interviews, were not admissible from the bar table as they would not meet the reliability and probative value requirements; they were admitted only when a witness testified to the accuracy of the information contained therein and attested that they had not been manipulated in any way. A number of such media reports were admitted in this manner and, as any evidence on the record, were attributed the appropriate weight in light of the totality of the trial record.

\section{iv. Intercepts}

23. Throughout the case, the Chamber treated intercepts as a "special category of evidence" given that they bear no indicia of authenticity or reliability on their face and accordingly, they may only be admitted into evidence after the Chamber has heard from the relevant intercept operators or the participants in the intercepted conversation. ${ }^{43}$ Towards the end of the Defence case, however, it found that, based on the agreement between the parties as to the authenticity of some intercepts, its past admission of a number of intercepts through intercept operators and numerous interlocutors, and the Prosecution's possible authentication of those intercepts based upon its "evidence collection", it had a basis to establish the authenticity of these intercepted conversations and proceeded to admit them. ${ }^{44}$ Once admitted, however, the Chamber treated intercepts as any other evidence and assessed their respective weight in light of the entire trial record.

40 Hearing, T. 31199-31200 (11 December 2012).

41 Hearing, T. 31199-31200 (11 December 2012), as recalled in Defence Municipality Bar Table Decision, para. 59.

42 See D130 (Video footage of Mirko Šošić, with transcript); D3120 (Statement of Behadil Hodžić to Milići SJB, 11 May 1992).

43 Decision on the Prosecution's First Motion for Judicial Notice of Documentary Evidence Related to the Sarajevo Component, 31 March 2010, para. 9.

44 Hearing, T. 47255-47259 (18 February 2014). See also Decision on Accused's Motion to Admit Intercepts from Bosnia and Herzegovina Previously Marked for Identification or as Not Admitted, 26 February 2014, para. 1; Decision on Accused's Bar Table Motion for Admission of Intercepts, 7 April 2014, para. 16. 
c. Evidence admitted in writing and the issue of corroboration.

24. On many occasions, the Chamber reminded the parties that it could not base a conviction on the uncorroborated evidence of a witness whose evidence was admitted pursuant to Rule 92 quater. $^{45}$ The Appeals Chamber in Popović et al. reaffirmed that "findings that are indispensable for a conviction must not rest solely or decisively on untested evidence" and that such findings must be sufficiently corroborated. ${ }^{46}$

\section{d. Judicial notice of adjudicated facts}

25. In the present case, the Chamber took judicial notice pursuant to Rule 94(B) of 2,379 adjudicated facts proposed by the Prosecution. ${ }^{47}$ The Appeals Chamber has held that "by taking judicial notice of an adjudicated fact, a Chamber establishes a well-founded presumption for the accuracy of this fact, which therefore does not have to be proven again at trial, but which, subject to that presumption, may be challenged at that trial". ${ }^{4}$

$45 \quad$ Babić Rule 92 quater Decision, paras. 30, 42.

46 Popović et al. Appeal Judgement, para. 1222 ("in order for a statement admitted pursuant to Rule 92 quater of the Rules to support a conviction, it must be corroborated"). See also Popović et al. Appeal Judgement, paras. 103, 104 (observing that evidence that demonstrates a pattern of conduct may be used as corroborative evidence), 1226, 1264; Dordević Appeal Judgement, para. 807; Lukić and Lukić Appeal Judgement, para. 570; Haradinaj et al. Appeal Judgement, para. 101, fn. 252; Haraqija and Morina Appeal Judgement, paras. 61-62, 64; Blagojević and Jokić Appeal Judgement, para. 316; Prosecutor v. Prlić et al., Case No. IT-04-74-AR73.6, Decision on Appeals against Decision Admitting Transcript of Jadranko Prlić's Questioning into Evidence, 23 November 2007, paras. 53, 57-59; Prosecutor v. Martić, Case No. IT-95-11-AR73.2, Decision on Appeal against the Trial Chamber's Decision on the Evidence of Witness Milan Babić, 14 September 2006, para. 20; Prosecutor v. Galić, Decision on Interlocutory Appeal Concerning Rule 92bis(C), 7 June 2002, fn. 34 . In Popovic et al., two appellants challenged their convictions on the grounds that untested and uncorroborated evidence admitted pursuant to former Rule 92 bis(D) of the Rules was the only evidence in relation to a charge, i.e: the Kravica Supermarket killings. Popović et al. Appeal Judgement, paras. 97-102. The Appeals Chamber examined whether the appellants' convictions rested solely, or in a decisive manner, on the evidence at issuethe transcript of a witness's testimony in the Krstic case-and found that no conviction for "opportunistic" killings was based on the Kravica Supermarket events alone. Popović et al. Appeal Judgement, paras. 101-103. Thus, the Appeals Chamber concluded, the allegations related to Kravica Supermarket were not indispensable for any of the appellants' convictions and that these would stand even without the findings on the Kravica Supermarket killings. Popović et al. Appeal Judgement, para. 103. The Appeals Chamber also noted that "the Trial Chamber's approach is consistent with the reasoning in Stakić, where the conviction on the charge of killing 77 Croats was upheld, despite highlighting that the only evidence supporting the relevant finding was admitted under Rule 92 bis of the Rules and was untested". Popović et al. Appeal Judgement, para. 104. See also Stakić Appeal Judgement, para. 201(8). Addressing another challenge to findings in which the Trial Chamber relied upon a transcript of testimony admitted pursuant to Rule 92 quater, the Popović et al. Appeals Chamber found that these findings did not rest decisively on untested evidence, but rather, on "a body of mutually corroborating evidence". Popović et al. Appeal Judgement, paras. 1218-1229.

47 See Section VIII.A.3.d: Judicial Notice. The Chamber notes that it denied the Accused's motion for judicial notice of 26 facts relating to Count 1. Decision on Accused's Motion for Judicial Notice of Adjudicated Facts Related to Count One, 21 January 2014.

48 Prosecutor v. S. Milošević, Case No. IT-02-54-AR73.5, Decision on the Prosecution's Interlocutory Appeal against the Trial Chamber's 10 April 2003 Decision on Prosecution Motion for Judicial Notice of Adjudicated Facts, 28 October 2003, p. 4, cited in Decision on First Prosecution Motion for Judicial Notice of Adjudicated Facts, 5 June 2009, para. 8. See also Prosecutor v. Ratko Mladić, Case No. IT-09-92-AR73.1, Decision on Ratko Mladić's Appeal against the Trial Chamber's Decisions on the Prosecution Motion for Judicial Notice of Adjudicated Facts, 12 November 2013, para. 24 ("adjudicated facts of which judicial notice is taken are 
26. As the Appeals Chamber has stated, adjudicated facts are "facts that have been established in a proceeding between other parties on the basis of the evidence the parties to that proceeding chose to introduce, in the particular context of that proceeding" 49 They are therefore not conclusive in other proceedings wherein judicial notice is taken of them, and parties have the opportunity to contest them. ${ }^{50}$

27. The Chamber assessed the weight and relevance of the adjudicated facts, taking into consideration the totality of the trial record and, in particular, any evidence submitted by the Accused to rebut the adjudicated fact. ${ }^{51}$ Where an unchallenged adjudicated fact was the only evidence in support of a finding and there was no evidence contradicting it, the Chamber considered the judicially noticed fact sufficient to support the finding.

28. Where adjudicated facts and other evidence addressed the same subject matter, the Chamber assessed whether the other evidence was consistent with the adjudicated facts or rebutted them. ${ }^{52}$ Where the Chamber has accepted evidence that contradicts an adjudicated fact, it has considered the presumption of accuracy of the adjudicated fact to have been rebutted. ${ }^{53}$ The Chamber applied this principle where the Accused challenged an adjudicated fact and presented credible evidence to rebut or bring into question the accuracy of the adjudicated fact and where the evidence presented by the Prosecution on the point addressed by the adjudicated fact was internally contradictory or inconsistent with the adjudicated fact.

29. In relation to the evidence adduced by the Prosecution, the Chamber recalls that in its decision of 31 March 2010, the Chamber did not find it to be in the interests of justice to preclude

admitted as rebuttable presumptions that may be disproved by the opposing party through the presentation of evidence at trial"); Karemera Appeal Decision on Judicial Notice, para. 42.

$49 \quad$ Karemera Appeal Decision on Judicial Notice, para. 40.

50 See Karemera Appeal Decision on Judicial Notice, paras. 40, 42; Prosecutor v. Momčilo Krajišnik, Case No. IT00-39-PT, Decision on Prosecution Motions for Judicial Notice of Adjudicated Facts and for Admission of Written Statements of Witnesses Pursuant to Rule 92bis, 28 February 2003, para. 16.

51 This was the approach adopted by other chambers. See Tolimir Trial Judgement, para. 77; Popović et al. Trial Judgement, para. 71; Krajišnik Trial Judgement, para. 1197; Prosecutor v. Momčilo Krajišnik, Case No. IT-0039-T, Decision on Third and Fourth Prosecution Motions for Judicial Notice of Adjudicated Facts, 24 March 2005, para. 17; Prlić et al. Trial Judgement, para. 385; Prosecutor v. Prlić et al., Case No. IT-04-74-PT, Decision on Motion for Judicial Notice of Adjudicated Facts Pursuant to Rule 94(B), 14 March 2006, para. 11.

52 See Stanišić and Simatović Trial Judgement, para. 37 ("When assessing the evidence before it, the Trial Chamber was often faced with situations where evidence duplicated adjudicated facts of which the Trial Chamber had taken judicial notice. The Trial Chamber, in executing its obligation to review all evidence presented, analysed such evidence and then determined whether it was consistent with the Adjudicated Facts or rose to such a level so as to rebut them."); Tolimir Trial Judgement, para. 77 ("Where the Chamber has accepted evidence that contradicts an Adjudicated Fact, the presumption of the accuracy of the Adjudicated Fact will have been rebutted. The Chamber has made numerous factual findings in which Adjudicated Facts have been supported or amplified by other evidence that has been admitted.").

53 See Tolimir Trial Judgement, para. 77 ("Where the Chamber has accepted evidence that contradicts an Adjudicated Fact, the presumption of the accuracy of the Adjudicated Fact will have been rebutted."). 
the Prosecution from bringing witnesses to give evidence that overlaps with the content of adjudicated facts that have been the subject of judicial notice in this case. ${ }^{54}$ The Chamber reasoned that at that stage of the case it was open to the Accused to challenge any or all of the judiciallynoticed facts in this case and that the Prosecution was at that time not in possession of specific information as to those aspects of its case or what particular evidence the Accused intended to rebut, including adjudicated facts admitted prior to the submission of the Defence Pre-Trial Brief, and therefore a considerable extension in the length of the case might result from the presentation of evidence in rebuttal following the hearing of the defence case. ${ }^{55}$

30. The Chamber also recalls its previous statement in the aforementioned decision of 31 March 2010 that

the Chamber may base its final conclusions as to the individual criminal responsibility of the Accused on the evidence presented to it along with any adjudicated facts from prior proceedings which have been the subject of judicial notice. This will not mean, however, that witness evidence led at trial is to be considered corroborated by adjudicated facts from prior proceedings which are based on evidence from the same witness. ${ }^{56}$

Put another way, "adjudicated facts based on evidence from a witness may not be considered corroborative of that witness's evidence". 57 The Chamber reiterates its approach, outlined above and in accordance with other chambers' approaches, to assess adjudicated facts in light of the totality of the evidence adduced at trial and more particularly to analyse whether other evidence in the record is consistent with or contradicts the adjudicated facts. ${ }^{58}$ Other evidence in the record was assessed for inconsistency with the adjudicated facts, and where reliable evidence contradicted an adjudicated fact, be it presented by the Accused or the Prosecution, the adjudicated fact was not used as the basis of a finding in this case.

31. In a number of instances, the adjudicated fact in the source judgement cited the same witness who gave evidence in this case on the same point and this latter evidence was the only

\footnotetext{
54 Decision on Accused's Motion to Preclude Evidence or To Withdraw Adjudicated Facts, 31 March 2010 , para. 18.

55 Decision on Accused's Motion to Preclude Evidence or To Withdraw Adjudicated Facts, 31 March 2010, paras. $16-18$.

56 Decision on Accused's Motion to Preclude Evidence or To Withdraw Adjudicated Facts, 31 March 2010 , para. 12.

57 Decision on Accused's Motion to Preclude Evidence or To Withdraw Adjudicated Facts, 31 March 2010 , para. 14.

58 See Tolimir Trial Judgement, para. 77; Popović et al. Trial Judgement, para. 71; Prlić et al. Trial Judgement, para. 385. See also Prosecutor v. Karemera et al., Case No. ICTR-98-44-AR73.17, Decision on Joseph Nzirorera's Appeal of Decision on Admission of Evidence Rebutting Adjudicated Facts, 29 May 2009, para. 21 ("adjudicated facts that are judicially noticed by way of Rule 94(B) of the Rules remain to be assessed by the Trial Chamber to determine what conclusions, if any, can be drawn from them when considered together with all the evidence brought at trial").
} 
evidence in this case on the point, other than the adjudicated fact. In these situations, again, the Chamber did not consider the adjudicated fact to corroborate the witness's evidence in this case. ${ }^{59}$

\section{GENERAL OVERVIEW}

\section{A. HistoricAl CONTEXT}

32. $\mathrm{BiH}$, which was known as the $\mathrm{SRBiH}$ prior to the conflict, was one of the six republics that once constituted the SFRY. Before the conflict, the situation of the SRBiH was unique in that, unlike the other republics, it possessed no single majority ethnic grouping and thus there was no recognition of a distinct "Bosnian nation". 60

33. Throughout the SFRY during the 1980s, opposition between the various national movements steadily grew, fuelled by a growing economic crisis and an increasingly dysfunctional political system in the wake of the death of Marshal Josip Broz Tito in 1980. ${ }^{61}$ The JNA was the only military formation with an integrated command structure and large numbers of heavy weapons and aircraft, and was constitutionally mandated to "defend the homeland" and preserve the SFRY. ${ }^{62}$ The JNA was an entirely federal force, with its headquarters in Belgrade, ${ }^{63}$ and with the SFRY Presidency as its "supreme command and control organ". ${ }^{64}$

34. On 23 January 1990, upon the departure of the Slovene delegation, the Congress of the League of Communists of Yugoslavia was postponed indefinitely, paving the way for the organisation of multi-party elections in each of the six republics. ${ }^{65}$

1. The first multi-party elections

35. On 21 February 1990, the Assembly of the SRBiH adopted a law that permitted political parties to organise but forbade this organisation to be based on nationality or religion. Political

59 In such situations, the Chamber used the phrase "See also". This does not indicate that the Chamber considered the adjudicated fact to corroborate the evidence in this case of the witness cited to in the original judgement.

60 See Adjudicated Fact 363. The Chamber acknowledges that the term "ethnic" or "ethnicity" may not comprehensively describe the distinguishing features of Bosnian Muslims, Bosnian Croats, and Bosnian Serbs, since other facts such as religion and nationality, are also relevant to the definition of those groups. However, for the sake of brevity and following other Chambers of the Tribunal, the Chamber will use the terms "ethnic" or "ethnicity" throughout this Judgement where it considers appropriate to do so.

61 Herbert Okun, T. 1559-1560 (23 April 2010).

62 P3033 (Reynaud Theunens's expert report entitled "Radovan Karadžić and the SRBiH TO-VRS (1992-1995)"), e-court p. 50. See Adjudicated Fact 415.

63 See D1358 (SFRY Law on All People's Defence), arts. 99-101; Adjudicated Fact 417.

64 D1358 (SFRY Law on All People's Defence), art. 106. 
parties nonetheless formed on such bases although they were careful not to openly contravene the law. On 11 June 1990, the Constitutional Court of SRBiH declared this prohibition unconstitutional, ${ }^{66}$ and ethnic parties began to form. ${ }^{67}$

36. The most prominent political parties in SRBiH were the SDA, the SDS, ${ }^{68}$ and the HDZ. ${ }^{69}$ They were formed in 1990 in the lead-up to the election and initially co-operated to defeat their common opponents, the former League of Communists of SRBiH, which had been newly renamed as the League of Communists-Social Democratic Party, and the Alliance of Reformist Forces of Yugoslavia. $^{70}$

37. On 31 July 1990, amendments to the 1974 Constitution were adopted to determine the structure of governing institutions for which elections would be held. The new legislation provided for a seven-member Presidency, composed of two Serbs, two Croats, two Muslims, and one representative of "others" ${ }^{71}$ It also provided that the legislature would consist of a 130-member Chamber of Citizens and a Chamber of Municipalities ${ }^{72}$ with 110 deputies. $^{73}$ The legislation further provided for elections to assemblies in each of SRBiH's 109 municipalities. ${ }^{74}$

38. On 18 November 1990, the first free, multi-party elections were held for both municipal assemblies and for the legislative body at the republican level. ${ }^{75}$ The SDA won 86 of the total 240 seats in both chambers, the SDS won 72 seats, and the HDZ won 44 seats. Eight different parties

Isak Gaši, P3002 (Transcript from Prosecutor v. Krajišnik), T. 393. See also Vitomir Žepinić, T. 33622 (13 February 2013). P971 (Robert Donia's Expert Report entitled “The Origins of Republika Srpska, 1990-1992, 30 July 2002), ecourt p. 18.

67 Robert Donia, T. 3226 (2 June 2010).

68 See Section II.B.1: Serbian Democratice Party (SDS).

69 See Adjudicated Fact 404.

$70 \quad$ P971 (Robert Donia's Expert Report entitled "The Origins of Republika Srpska, 1990-1992, 30 July 2002), ecourt p. 20; Robert Donia, T. 3160-3162 (1 June 2010), T. 3284, 3301-3302 (3 June 2010). See also Nenad Kecmanović, T. 39088-39089 (31 May 2013). Both the SK-SDP and the SRSJ pledged allegiance to ideals of a multi-ethnic BiH. P971 (Robert Donia's Expert Report entitled "The Origins of Republika Srpska, 1990-1992, 30 July 2002), e-court p. 20. P971 (Robert Donia's Expert Report entitled "The Origins of Republika Srpska, 1990-1992, 30 July 2002), ecourt p. 19 (specifying that each voter was allowed to vote for seven candidates for the Presidency: two Bosnian Serbs, two Bosnian Croats, two Bosnian Muslims, and one in the category identified as "Other").

72 The Chamber shall hereinafter refer collectively to the Chamber of Citizens and the Chamber of Municipalities as the SRBiH Assembly.

73 D1263 (Amendments to the Constitution of SRBiH, 31 July 1990), amendment LXX (5); P971 (Robert Donia's Expert Report entitled "The Origins of Republika Srpska, 1990-1992, 30 July 2002), e-court p. 19. The Chamber of Municipalities would consist of one deputy for each of the 109 municipalities of SRBiH and one for the city of Sarajevo.

74 D1263 (Amendments to the Constitution of SRBiH, 31 July 1990), amendment LXX (6).

$75 \quad$ P971 (Robert Donia's Expert Report entitled "The Origins of Republika Srpska, 1990-1992, 30 July 2002), ecourt pp. 19, 23; Momčilo Mandić, C3 (Transcript from Prosecutor v. Stanišić and Župljanin), T. 9586; see Adjudicated Fact 403. 
shared the remaining 38 seats. $^{76}$ In effect, the outcome of the elections generally reflected the ethnic census of the population with each ethnic group voting for its own national party. ${ }^{77}$

39. After the elections in $\mathrm{SRBiH}$, a coalition government was formed according to an interparty agreement and headed by a seven member Presidency, with the leader of the SDA, Alija Izetbegović, as the first President. ${ }^{78}$ The SDS selected Momčilo Krajišnik to be President of the Assembly and Jure Pelivan was named by the HDZ to be Prime Minister. ${ }^{79}$ In each municipality, executive positions were apportioned according to the national composition of the municipality in question. $^{80}$

\section{BiH regionalisation}

40. The regionalisation process began with the establishment of communities of municipalities, which led to the creation of autonomous districts and regions. ${ }^{81}$ In 21 January 1991, SDS presidents of 21 municipal assemblies in the northwestern BiH region of Bosnian Krajina began preparations for the formation of the ZOBK ${ }^{82}$ The SDS regional board formally approved the initiative to create the ZOBK on 7 April $1991 .^{83}$

41. Soon thereafter, the ZOBK initiative faced opposition and criticism. The SRBiH Assembly passed a resolution requesting that regionalisation be suspended until a political agreement could be reached. ${ }^{84}$ On 21 April 1991, the SDA organised a rally in Banja Luka to protest the "national regionalisation" of $\mathrm{BiH}^{85}$ In the wake of these criticisms, the Accused, as President of the SDS,

$76 \quad$ P971 (Robert Donia's Expert Report entitled "The Origins of Republika Srpska, 1990-1992, 30 July 2002), ecourt p. 23; Robert Donia, T. 3252 (2 June 2010). See also Adjudicated Fact 405.

$77 \quad$ See Adjudicated Fact 406.

78 See Adjudicated Fact 408; D356 (Inter-party agreement regarding BiH Ministries, January 1991).

79 Momčilo Mandić, T. 4770 (7 July 2010); Momčilo Krajišnik, T. 43153-43154 (7 November 2013). See Adjudicated Fact 1897.

80 See Adjudicated Fact 1905; D257 (SDA, HDZ, and SDS Criteria for Joint Government in Municipalities, 22 December 1990).

81 P2536 (Patrick Treanor's expert report entitled “The Bosnian Serb Leadership 1990-1992”, 30 July 2002), paras. 100, 113-161. For a more detailed description of this process, see Section II.B.7: Regional and municipal bodies.

82 P2536 (Patrick Treanor's expert report entitled “The Bosnian Serb Leadership 1990-1992”, 30 July 2002), paras. 117-118.

83 P971 (Robert Donia’s Expert Report entitled “The Origins of Republika Srpska, 1990-1992, 30 July 2002), ecourt p. 25. Vojislav Kuprešanin was elected President of the ZOBK. D4011 (Witness statement of Vojislav Kuprešanin dated 11 November 2013), para. 1.

84 D284 (SRBiH Assembly recommendation on regionalisation, 11-12 April 1991).

85 P971 (Robert Donia’s Expert Report entitled “The Origins of Republika Srpska, 1990-1992, 30 July 2002), ecourt p. 26 (citing Izetbegović: "Those who say that there are 51\% of Serbs here and that therefore this is a Serbian municipality are not well-intentioned. [...] What about the $49 \%$ who are Muslims and Croats; to what do they belong? Bosnia is nationally mixed and no one can divide it, except if someone wishes disorder and blood. And we won't do that".) 
denounced the concentration of power in Sarajevo and called to defend regionalisation as the solution to the economic crisis. ${ }^{86}$

42. By the time the founding assembly of the ZOBK was held on 25 April 1991, assemblies of 14 municipalities with large Serb majorities had voted to affiliate with the ZOBK, including Ključ. ${ }^{87}$ Following the lead of the Bosnian Krajina, two other communities of municipalities were created in May 1991 in Romanija and in Eastern and Old Herzegovina. ${ }^{88}$ Communities of municipalities were renamed SAOs in September, including the ZOBK which was renamed ARK on 16 September $1991 .^{89}$

43. In June 1991, a number of SDS members from Croatia and the Bosnian Krajina, led by Milan Babić, undertook plans to declare the unity of the Croatian and Bosnian Krajinas and signed an "Agreement on Co-operation". 90 On 27 June 1991, delegates unanimously endorsed this agreement and passed a "Declaration of Unification", the purpose of which was described as the "integration of Serbian people as a whole, all in the aim of creating a united state in which all Serbs in the Balkans will live". ${ }^{11}$ Despite further efforts by Babić in October 1991, the Accused and other BiH SDS members remained opposed to the idea, which never materialised. ${ }^{92}$

\section{Towards disintegration of the SFRY}

44. In the SRBiH Assembly, co-operation between the political parties proved increasingly difficult. $^{93}$ What was initially a coalition government broke down in October $1991 .{ }^{94}$ The

$86 \quad$ P971 (Robert Donia's Expert Report entitled “The Origins of Republika Srpska, 1990-1992”, 30 July 2003), ecourt p. 26. See also Robert Donia, T. 3544-3545 (9 June 2010).

87 P2536 (Patrick Treanor's expert report entitled “The Bosnian Serb Leadership 1990-1992”, 30 July 2002), paras. $117,122$.

88 P971 (Robert Donia's Expert Report entitled “The Origins of Republika Srpska, 1990-1992”, 30 July 2003), ecourt pp. 26-27; P6284 (Announcement of Assembly of the Community of Eastern and Old Herzegovina municipalities, 28 May 1991).

89 P971 (Robert Donia's Expert Report entitled “The Origins of Republika Srpska, 1990-1992, 30 July 2002), ecourt pp. 26-27. See para. 130.

$90 \quad$ P971 (Robert Donia’s Expert Report entitled “The Origins of Republika Srpska, 1990-1992”, 30 July 2003), ecourt pp. 27-28.

91 P746 (Declaration on Unification of SAO Krajina and Bosanska Krajina), 27 June 1991, p. 3; Milan Babić, P741 (Transcript from Prosecutor v. S. Milošević), T. 13806; P971 (Robert Donia's Expert Report entitled "The Origins of Republika Srpska, 1990-1992, 30 July 2002), e-court pp. 28-29.

92 P2555 (Intercept of conversations between Radovan Karadžić, Anđelko Vukić and Boro Sendić, 16 October 1991); Milan Martić, T. 38105-38106 (13 May 2013).

93 See Adjudicated Fact 409. See also D264 (Radovan Karadžić's letter to Presidents of SDS municipal and regional boards, 27 August 1991); D266 (SDA instructions on full readiness of communications and monitoring, 26 September 1991).

$94 \quad$ Adjudicated Fact 409; Robert Donia, T. 3557-3558 (9 June 2010). 
disintegration of multi-ethnic SFRY was swiftly followed by the disintegration of multi-ethnic BiH, and the prospect of war in $\mathrm{BiH}$ increased. ${ }^{95}$

45. Due to the manpower shortages resulting from the defection of non-Serbs from the JNA during the conflict in Croatia, the JNA ordered reservists in SRBiH to active duty during the summer of $1991 .^{96}$ The Presidency of SRBiH then denounced the JNA's mobilisation order as illegal, asked for the withdrawal of the reservists who had entered the territory of SRBiH from Serbia, and exhorted citizens of SRBiH "to exercise patience, avoid all potential provocations and allow these units to return in peace". ${ }^{97}$ Most Croat and Muslim reservists did not answer the mobilisation order while a majority of the Serb reservists responded and were mobilised to locations in SRBiH or Croatia. ${ }^{98}$

46. At a meeting of the SRBiH Assembly held during the night of 14 to 15 October 1991, the Accused gave a speech, at the end of which he stated: "Don't think you won't take Bosnia and Herzegovina to hell and Muslim people in possible extinction. Because, Muslim people will not be able to defend itself if it comes to war here!"99 After Krajišnik, as President of the SRBiH Assembly, had adjourned the SRBiH Assembly session for the day, HDZ and SDA delegates reconvened without Serb delegates and passed a declaration of sovereignty. ${ }^{100}$ Shortly thereafter, the SDS leadership demanded that the declaration be repealed before 24 October 1991. ${ }^{101}$

47. On 24 October 1991, the Bosnian Serb deputies of the SRBiH Assembly met separately and decided to establish the Assembly of the Serbian People in BiH. ${ }^{102}$ Opening the session, Krajišnik explained that the main reason for doing so lay "in a serious attempt to compromise the national sovereignty of the Serbian people in $\mathrm{BiH}$ and their constitutional and legal position in Yugoslavia,

$95 \quad$ See Adjudicated Fact 410. The BiH Presidency established a Crisis Staff in September 1991, with Ejup Ganić in charge. Robert Donia, T. 3440 (8 June 2010); Neđeljko Prstojević, T. 13614-13615 (17 March 2011).

96 P973 (Robert Donia's Expert Report entitled "Bosnian Serb Leadership and the Siege of Sarajevo, 1990-1995", January 2010), p. 41; D2665 (Witness statement of Izo Golić dated 15 December 2012), paras. 4, 6 ; D2376 (Report of $4^{\text {th }}$ Corps, 21 August 1991), pp. 1-2.

$97 \quad$ D368 (Minutes of $35^{\text {th }}$ Session of SRBiH Presidency, 21 September 1991), p. 1.

98 P973 (Robert Donia's Expert Report entitled "Bosnian Serb Leadership and the Siege of Sarajevo, 1990-1995", January 2010), p. 41; KDZ072, P68 (Transcript from Prosecutor v. Šešelj), T. 8691-8692 (under seal); D3065 (Witness statement of Aleksandar Vasiljević dated 16 February 2013), para. 213.

99 D267 (Video Footage and Transcript of Radovan Karadžić's speech at the $8^{\text {th }}$ Session of SRBiH Assembly, 15 October 1991), pp. 3-4; P971 (Robert Donia's Expert Report entitled “The Origins of Republika Srpska, 1990-1992, 30 July 2002), e-court p. 34.

$100 \quad$ P971 (Robert Donia's Expert Report entitled "The Origins of Republika Srpska, 1990-1992, 30 July 2002), ecourt p. 35; Robert Donia, T. 3101-3102 (1 June 2010); Robert Donia, T. 3372 (7 June 2010); P974 (SRBiH Assembly Platform on the Position of BiH, 14 October 1991), pp. 1-2; see Adjudicated Fact 393.

101 Robert Donia, T. 3570 (9 June 2010); D294 (Minutes of SDS Council Meeting, 15 October 1991), pp. 1-3; D295 (Article from Politika entitled "Demand for Withdrawal of Illegal Acts", 25 October 1991).

102 P1343 (Transcript of $1^{\text {st }}$ Session of SerBiH Assembly, 24 October 1991), p. 2. See also Robert Donia, T. 3107 (1 June 2010); see Adjudicated Fact 413. See para. 77. 
which in turn compromises their survival in the territory of $\mathrm{BiH}$, where they have lived from time immemorial". ${ }^{103}$ On 9 and 10 November 1991, a plebiscite was held to determine whether Serbs in $\mathrm{BiH}$ wished to remain in a joint state of Yugoslavia, together with Serbia, Montenegro, the SAOs of Krajina, Slavonia, Baranja and Western Srem, and "any others who decide in favour of such a survival". ${ }^{104}$ The overwhelming majority of Serbs voted in favour of remaining in Yugoslavia. ${ }^{105}$ By that time, in the wake of Croatia's declaration of independence, ${ }^{106}$ JNA forces were withdrawing from Croatia into SRBiH. ${ }^{107}$ On 11 December 1991, Krajišnik, on behalf of the Assembly of the Serbian People in $\mathrm{BiH}$, formally requested the JNA "to protect, with all available means the territories of $[\mathrm{BiH}] " .108$

48. On 17 December 1991, foreign ministers in the EC created a commission composed of EC judges, known as the Badinter Commission, to assess applications for independence from the republics of the SFRY based on their adherence to certain guidelines. On 20 December 1991, the SRBiH Presidency, Nikola Koljević and Biljana Plavšić dissenting, voted to apply to the Badinter Commission for the recognition of $\mathrm{SRBiH}$ as an independent state. ${ }^{109}$

49. On 19 December 1991, the Main Board of the SDS issued a document entitled "Instructions for the Organisation and Activity of Organs of Serbian People in Bosnia and Herzegovina in Extraordinary Circumstances" ("Variant A/B Instructions"). ${ }^{110}$ The stated purpose was to carry out the results of the plebiscite at which the Serbian people in $\mathrm{BiH}$ decided to live in a single state and to "enhance mobility and readiness to protect the interests of the Serbian

103 P1343 (Transcript of $1^{\text {st }}$ Session of SERBiH Assembly, 24 October 1991), p. 6; P6245 (SerBiH Assembly Ballot for Serbs); P6246 (SerBiH Assembly Ballot for non-Serbs).

104 P1343 (Transcript of $1^{\text {st }}$ Session of SerBiH Assembly, 24 October 1991), p. 25; P6244 (Minutes of $4^{\text {th }}$ session of SDS Executive Board, 25 October 1991); D83 (Shorthand Record of $2^{\text {nd }}$ Session of SerBiH Assembly, 21 November 1991), p. 4. See also P5473 (Instructions on Implementation of Plebiscite of Serbian People in $\mathrm{BiH}, 28$ October 1991).

105 D83 (Shorthand Record of $2^{\text {nd }}$ Session of SERBiH Assembly, 21 November 1991), pp. 19-23.

106 P971 (Robert Donia's Expert Report entitled “The Origins of Republika Srpska, 1990-1992, 30 July 2002), ecourt p. 15.

107 P946 (ECMM report re meeting with Prime Minister Pelivan, 27 November 1991); P5805 (Intercept of conversation between Radovan Karadžić and Momčilo Krajišnik, 6 December 1991), p. 2.

108 P5556 (Request of the Serb People of BiH to the JNA, 11 December 1991). See Herbert Okun, P776 (Transcript from Prosecutor v. Krajišnik), T. 4408-4409. See also Herbert Okun, T. 1638 (22 April 2010).

109 P971 (Robert Donia's Expert Report entitled "The Origins of Republika Srpska, 1990-1992, 30 July 2002), ecourt p. 36. See also Herbert Okun, P776 (Transcript from Prosecutor v. Krajišnik), T. 4142, 4310-4312. On 11 January 1992, the Badinter Commission issued its Opinion No. 4 and assessed "that the will of the peoples of Bosnia-Herzegovina to constitute the SRBH as a sovereign and independent State cannot be held to have been fully established". D1279 (Opinion No. 4 on international recognition of SRBiH by the European Community and its members states, 11 January 1992), p. 3. The Chamber notes that while it is only in 1993 that the European Economic Community was officially re-named European Community ("EC"), for ease of reference, the Chamber shall refer to the EC even when referring to the period before 1993.

110 P5 (SDS Instructions for Organisation of Organs of the Serbian People in BiH, 19 December 1991). 
people". ${ }^{111}$ The Chamber will address the creation, contents, and dissemination of the Variant A/B Instructions later in this judgement. ${ }^{112}$

50. The members of the Assembly of the Serbian People in BiH met on 21 December 1991, expressed their strong opposition to the Badinter Commission process, and approved preparations for the formation of a Serb Republic. ${ }^{113}$ On 9 January 1992, the Assembly of the Serbian People in BiH proclaimed the SerBiH, which on 12 August 1992 was renamed RS. ${ }^{114}$

51. International efforts to achieve a comprehensive diplomatic solution to the situation in Yugoslavia were initially formalised throughout the second half of 1991 and continued in different forms and in various fora throughout the conflict. These efforts will be discussed in detail in another section of this Judgement. ${ }^{115}$

52. By early 1992, and partly due to the refusal of non-Serbs to mobilise for the war in Croatia as discussed above, the JNA units in BiH were progressively becoming "all-Serb units", and the JNA openly favoured Serbs in its personnel policy. ${ }^{116}$ By early 1992, there were some 100,000 JNA troops in SRBiH with over 700 tanks, 1,000 armoured personnel carriers, heavy weaponry, 100 planes and 500 helicopters, all under the command of the General Staff of the JNA in Belgrade. $^{117}$

53. On 15 January 1992, the Badinter Commission recommended that SRBiH be required to hold a referendum to determine the will of its people regarding independence. On 20 January, the SRBiH Assembly voted to hold such a referendum on 29 February and 1 March $1992 .{ }^{118}$ At its 26 January 1992 session, members of the SerBiH Assembly denounced the decision as illegal. ${ }^{119}$

\footnotetext{
111 P5 (SDS Instructions for Organisation of Organs of the Serbian People in BiH, 19 December 1991), p. 2.

112 See paras. 132-136; Section IV.A.3.a.ii.D: Variants A/B Instructions and take-over of power.

113 D86 (Shorthand Record of $4^{\text {th }}$ Session of SERBiH Assembly, 21 December 1991), pp. 4, 9-10, 29.

114 Robert Donia, T. 3564 (9 June 2010); P1346 (Minutes of $5^{\text {th }}$ Session of SerBiH Assembly, 9 January 1992), pp. 2-3. See also Adjudicated Fact 394.

115 See Section II.E: International peace negotiations.

116 P5433 ( $1^{\text {st }}$ Krajina Corps document analysing combat readiness in 1992, February 1993), p. 17; P3914 (Ewan Brown's expert report entitled "Military Developments in the Bosanska Krajina - 1992", 27 November 2002), para. 1.8; Adjudicated Fact 2096. By April 1992, more than 90 per cent of all JNA officers were Serbs or Montenegrins. Adjudicated Fact 2097. In early April 1992, Izetbegović ordered a general mobilisation in BiH and ordered that Bosnian Muslims block roads and JNA barracks all across BiH. D3724 (Witness statement of Branko Grujić dated 22 June 2013), para. 23; see also Martin Bell, T. 9942-9943 (15 December 2010).

117 Adjudicated Fact 486.

118 P971 (Robert Donia's Expert Report entitled “The Origins of Republika Srpska, 1990-1992, 30 July 2002), ecourt p. 36. See also P1349 (Transcript of $6^{\text {th }}$ Session of SerBiH Assembly, 26 January 1992), p. 16.

119 P1349 (Transcript of $6^{\text {th }}$ Session of SerBiH Assembly, 26 January 1992), pp. 16-19.
} 
On 28 February 1992, the SerBiH Assembly unanimously adopted the Constitution of the SerBiH. ${ }^{120}$

54. The referendum on the question of independence was held on 29 February and 1 March 1992. It was largely boycotted by the Bosnian Serbs and yielded an overwhelming majority of votes in favour of independence. ${ }^{121}$

55. On 28 March 1992, the SDS sponsored a congress in Sarajevo on the "Yugoslav Crisis and the Serbian Question". ${ }^{122}$ The congress was attended by 500 participants who were greeted by the Accused and focused on sacrifices and losses suffered by the Serbs during WWII. ${ }^{123}$ In evoking fears of a "Serbian genocide", Bosnian Serb leaders suggested that territorial claims beyond Serbinhabited areas were justified. ${ }^{124}$

56. The EC and the USA recognised the independence of $\mathrm{BiH}$ in April 1992. ${ }^{125} \mathrm{BiH}$ was admitted as a State member of the UN, following decisions adopted by the Security Council and the General Assembly on 22 May 1992. ${ }^{126}$

57. During the $16^{\text {th }}$ session of the Bosnian Serb Assembly on 12 May 1992, the Accused presented the Strategic Goals. These were: (i) the creation of a border separation with the other two national communities; (ii) the creation of a corridor between Semberija and Krajina; (iii) the creation of a corridor in the Drina Valley, namely elimination of the Drina as a border between Serbian states; (iv) the creation of a border on the Una and Neretva rivers; (v) division of the city of Sarajevo into Serbian and Muslim parts and implementation of an effective state government in each of these parts; (vi) and access of the SerBiH to the sea. ${ }^{127}$ The Strategic Goals were adopted by the Bosnian Serb Assembly at the same session. ${ }^{128}$

120 D89 (Shorthand Record of $9^{\text {th }}$ Session of SerBiH Assembly, 28 February 1992), p. 14. See also P1351 (Transcript of $7^{\text {th }}$ Session of SerBiH Assembly, 15 February 1992) (containing lengthy discussions on the draft constitution); see Adjudicated Fact 414.

$121 \quad$ See Adjudicated Fact 395; P5427 (Proclamation of the SDS Executive Board, undated); P5530 (Proclamation of the SDS Executive Board, 20 February 1992), p. 3.

122 D90 (Shorthand Record of $11^{\text {th }}$ Session of SerBiH Assembly, 18 March 1992), p. 48

123 P971 (Robert Donia's Expert Report entitled “The Origins of Republika Srpska, 1990-1992, 30 July 2002), ecourt p. 38.

124 P971 (Robert Donia's Expert Report entitled “The Origins of Republika Srpska, 1990-1992, 30 July 2002), ecourt pp. 41-42 (referring to Article 2 of the 28 February 1992 SerBiH Constitution: "The territory of the Republic consists of autonomous regions, municipalities and other Serbian ethnic entities, including territory on which genocide was committed against Serbs in the Second World War.").

125 See Adjudicated Fact 396; P2284 (UNSG report entitled “The Fall of Srebrenica”, 15 November 1999), para. 15.

126 See Adjudicated Fact 397.

127 P956 (Transcript of $16^{\text {th }}$ Session of SerBiH Assembly, 12 May 1992), e-court pp. 8-10; P955 (SerBiH Assembly Decision on Strategic Goals of Serbian People in BiH, 12 May 1992).

128 P955 (SerBiH Assembly Decision on Strategic Goals of Serbian People in BiH, 12 May 1992). 


\section{B. Bosnian SERB POLITICAL AND CONSTITUTIONAL STRUCTURES}

\section{Serbian Democratic Party (SDS)}

a. Establishment

58. The SDS was established on 12 July 1990 at a founding assembly in Sarajevo. ${ }^{129}$ It was founded in advance of the first multi-party elections in the SRBiH which were to be held in November $1990 .{ }^{130}$ The assembly elected the Accused as president of the party, ${ }^{131}$ and he remained the president through 1995. ${ }^{132}$ The Accused gave a speech in which he stated the objectives of the party, which included "a federative Yugoslavia, and in it an equal federal Bosnia and Herzegovina". ${ }^{33}$ The Accused also stated that the party would be organised along republic, regional, subregional, municipal, and communal levels with regional and lower-level boards making "completely autonomous [...] local and political assessments and personnel decisions". ${ }^{134}$

59. In 1990 and 1991, the SDS was funded by voluntary contributions and enjoyed the support of the overwhelming majority of Bosnian Serbs. ${ }^{135}$

\section{b. Components and their functions}

60. The main organs of the SDS included the party Assembly, formally the supreme body; the SDS Main Board, the highest party organ at times when the Assembly was not in session; the SDS Executive Board, the executive arm of the Main Board; the President of the party, who was also the President of the Main Board; and several advisory bodies, such as the SDS Political Council. ${ }^{136}$

129 P2536 (Patrick Treanor's expert report entitled “The Bosnian Serb Leadership 1990-1992”, 30 July 2002 ), para. 7; Patrick Treanor, T. 14000 (1 June 2011). See also D4650 (Statute of the BiH SDS, 12 July 1990), p. 2. The assembly adopted a statute that outlined the organisation and operations of the party. Patrick Treanor, T. 14000 (1 June 2011); D4650 (Statute of the BiH SDS, 12 July 1990). For a list of members in 1990 and 1991, see P6626 (List of the SDS Main Committee members during 1990 and 1991).

$130 \quad$ P2536 (Patrick Treanor's expert report entitled “The Bosnian Serb Leadership 1990-1992”, 30 July 2002 ), para. 7; Patrick Treanor, T. 14000 (1 June 2011).

131 P2536 (Patrick Treanor's expert report entitled “The Bosnian Serb Leadership 1990-1992”, 30 July 2002 ), para. 7; Patrick Treanor, T. 14000 (1 June 2011).

132 P2537 (Patrick Treanor's expert report entitled “The Bosnian Serb Leadership 1993-1995 - Addendum to the Bosnian Serb Leadership 1990-1992”, 1 May 2009), para. 5.

133 D255 (Radovan Karadžić's speech at the constituent SDS Assembly), p. 2; P971 (Robert Donia's expert report entitled "The Origins of Republika Srpska, 1990-1992", 30 July 2002), p. 20; Patrick Treanor, T. 14001 (1 June 2011).

134 D255 (Radovan Karadžić's speech at the constituent SDS Assembly), p. 2.

135 Adjudicated Fact 1892.

136 See Adjudicated Fact 1893; D4650 (Statute of the BiH SDS, 12 July 1990), arts. 12-13; Radomir Nešković, P2568 (Transcript from Prosecutor v. Krajišnik), T. 16599-16600; Neđeljko Prstojević, T. 12935 (3 March 2011). 
61. The party Assembly was responsible for adopting and amending the party programme and statutes and for electing, inter alios, the President of the party and the members of the Main Board. $^{137}$

62. The Main Board's responsibilities included the election of members of the Executive Board and the preparation of drafts of all acts and decisions adopted by the party Assembly. ${ }^{138}$ The Main Board made SDS policy and important political decisions. ${ }^{139}$ The Accused was ex officio president of the Main Board of the SDS. ${ }^{140}$ Krajišnik became a member of the Main Board in July $1991 .{ }^{141}$ Under a new party statute provision approved on 12 July 1991, the party president could nominate and effectively select up to one-third of the members of the Main Board. ${ }^{142}$

63. Duties of the Executive Board included preparing materials for the use of the Main Board and implementing its decisions. ${ }^{143}$ On 31 July 1991, Rajko Dukić, who was nominated by the Accused, was unanimously elected President of the Executive Board. ${ }^{144}$ As such, Dukić was to carry out the establishment and operation of the party staff apparatus. ${ }^{145}$ Radomir Nešković was elected as the Deputy President of the Executive Board on the same day. ${ }^{146}$ The Accused attended some meetings of the Executive Board. ${ }^{147}$

137 P2536 (Patrick Treanor's expert report entitled “The Bosnian Serb Leadership 1990-1992”, 30 July 2002), para. 20; D4650 (Statute of the BiH SDS, 12 July 1990), art. 15; P761 (Statute and platform of SDS, 17 February 1990), art. 9.

138 D4650 (Statute of the BiH SDS, 12 July 1990), art. 19; P2536 (Patrick Treanor's expert report entitled "The Bosnian Serb Leadership 1990-1992”, 30 July 2002), para. 28. See, e.g., D3989 (Minutes of the SDS Main Board, 21 November 1991).

139 Predrag Radić, P1 (Transcript from Prosecutor v. Krajišnik), T. 7365; D4368 (Witness statement of Jovan Šarac dated 10 February 2014), para. 7.

140 P2536 (Patrick Treanor's expert report entitled “The Bosnian Serb Leadership 1990-1992”, 30 July 2002), para. 14; P6558 (List of SDS Main Board members).

141 P2536 (Patrick Treanor's expert report entitled “The Bosnian Serb Leadership 1990-1992”, 30 July 2002), para. 14.

142 Radomir Nešković, P2568 (Transcript from Prosecutor v. Krajišnik), T. 16590-16591, 16601.

143 P2536 (Patrick Treanor's expert report entitled "The Bosnian Serb Leadership 1990-1992", 30 July 2002), paras. 32-34; D4650 (Statute of the BiH SDS, 12 July 1990), art. 21; P761 (Statute and platform of SDS, 17 February 1990), art. 12. See also P6243 (Notes of SDS Assembly session, 12 July 1991), p. 7.

144 D1274 (Minutes of $1^{\text {st }}$ session of SDS Executive Board, 31 July 1991); P2536 (Patrick Treanor's expert report entitled “The Bosnian Serb Leadership 1990-1992”, 30 July 2002), para. 35.

145 D1274 (Minutes of $1^{\text {st }}$ session of SDS Executive Board, 31 July 1991).

146 Radomir Nešković, P2568 (Transcript from Prosecutor v. Krajišnik), T. 16589; Radomir Nešković, T. 14221 (6 June 2011).

147 D1274 (Minutes of $1^{\text {st }}$ session of SDS Executive Board, 31 July 1991), p. 1; D1275 (Minutes of $2^{\text {nd }}$ session of SDS Executive Board, 6 September 1991), p. 2; P2585 (Minutes of $5^{\text {th }}$ meeting of SDS Executive Board, 7 November 1991), p. 2. 
64. The President of the SDS had statutory powers that included, by 1991, representing the SDS, convoking the SDS Assembly, Main Board, and Executive Board, and co-ordinating the work of organs and bodies of the SDS. ${ }^{148}$ The President was the central, most important party organ. ${ }^{149}$

65. Another body that stemmed from the SDS was the Serbian Deputies' Club, a parliamentary caucus of the SDS in the SRBiH Assembly. ${ }^{150}$ The Deputies' Club was headed by Vojo Maksimović. ${ }^{151}$ The Accused, as the party leader, attended meetings of the Deputies' Club. ${ }^{152}$ Members of the Deputies' Club formed the Assembly of the Serbian People in Bosnia and Herzegovina on 24 October 1991. ${ }^{153}$ Radomir Nešković described the Deputies' Club as “a constituent organ which passed all constituent acts and documents which lay the grounds for Republika Srpska". ${ }^{154}$

\section{c. Organisation and structure}

66. In 1991 and into 1992, "expanded" meetings of the members of the formal and ad hoc bodies of the party played an important role in policy-setting, decision-making, and communications from the top to the grassroots level. ${ }^{155}$ The SDS also utilised "expanded" meetings of different groups of middle-level government leaders and lower-level party officials to convey instructions or information to the grassroots level and to reach broader party consensus on policy or strategy. ${ }^{156}$ These meetings often included SDS-nominated ministerial-level SRBiH government officials, and many of them would later become part of the Bosnian Serb Government. $^{157}$

\footnotetext{
148 P2536 (Patrick Treanor's expert report entitled “The Bosnian Serb Leadership 1990-1992”, 30 July 2002), para. 23; D4650 (Statute of the BiH SDS, 12 July 1990), art. 17; P761 (Statute and platform of SDS, 17 February 1990), art. 11.

149 P2536 (Patrick Treanor's expert report entitled “The Bosnian Serb Leadership 1990-1992”, 30 July 2002), paras. 24, 41, 67; Radomir Nešković, P2568 (Transcript from Prosecutor v. Krajišnik), T. 16600.

150 P2536 (Patrick Treanor's expert report entitled “The Bosnian Serb Leadership 1990-1992”, 30 July 2002), para. 44.

151 Radomir Nešković, P2568 (Transcript from Prosecutor v. Krajišnik), T. 16605.

152 Patrick Treanor, T. 14012 (1 June 2011). See P2543 (Minutes of meeting of SDS Deputies' Club, 30 September 1991); P2581 (Minutes of meeting of SDS Deputies' Club, 18 October 1991).

153 P2536 (Patrick Treanor's expert report entitled “The Bosnian Serb Leadership 1990-1992”, 30 July 2002), paras. 47, 165. See para. 77.

154 Radomir Nešković, T. 14242 (6 June 2011).

155 P2536 (Patrick Treanor's expert report entitled “The Bosnian Serb Leadership 1990-1992”, 30 July 2002), paras. 41, 56, 64, 67.

156 P2536 (Patrick Treanor's expert report entitled “The Bosnian Serb Leadership 1990-1992”, 30 July 2002 ), para. 49.

157 P2536 (Patrick Treanor's expert report entitled “The Bosnian Serb Leadership 1990-1992”, 30 July 2002), para. 50 .
} 
67. Another key feature of SDS organisation in late 1991 into 1992 was collective leadership in the form of decision-making in small groups, most importantly, collaboration by four core leaders, the Accused, Krajišnik, Plavšić, and Koljević. ${ }^{158}$

68. The party was a hierarchical structure, organised into municipal assemblies and boards resembling the republican organs. ${ }^{159}$ Larger towns had both municipal boards and local boards corresponding to the local communes. ${ }^{160}$ Local boards were the basic units of party organisation. ${ }^{161}$ Each member of the local board represented 15 to 20 households and informed the local board, which in turn informed the municipal board; the municipal board then informed the President of the party, the Main Board, or the Executive Board. ${ }^{162}$ Municipal boards comprised presidents of local boards. ${ }^{163}$ Members of the Main and Executive Boards were to be involved in the work of the municipal boards in the area where they lived. ${ }^{164}$

69. Decisions were implemented in accordance with the hierarchy by all bodies, including regional, municipal, and local boards, ${ }^{165}$ and by lower-level officials. ${ }^{166}$ Local boards received tasks from and answered to the municipal boards. ${ }^{167}$ Municipal boards were obligated to implement the instructions issued by the Main Board or Executive Board. ${ }^{168}$ The Main Board had

158 P2536 (Patrick Treanor's expert report entitled “The Bosnian Serb Leadership 1990-1992”, 30 July 2002), paras. 18, 68-75. See also Radomir Nešković, P2568 (Transcript from Prosecutor v. Krajišnik), T. 16605; Momčilo Mandić, C2 (Transcript from Prosecutor v. Krajišnik), T. 8618.

159 Adjudicated Fact 1894; P2536 (Patrick Treanor's expert report entitled "The Bosnian Serb Leadership 19901992”, 30 July 2002), para. 22; Milorad Dodik, T. 36872-36875 (9 April 2013); P2526 (Witness Statement of Radomir Kezunović dated 21 May 2011), para. 21; Neđeljko Prstojević, T. 12935 (3 March 2011); D4368 (Witness statement of Jovan Šarac dated 10 February 2014), para. 3.

160 Predrag Radić, P1 (Transcript from Prosecutor v. Krajišnik), T. 7386; Neđeljko Prstojević, T. 12935 (3 March 2011).

161 Radomir Nešković, P2568 (Transcript from Prosecutor v. Krajišnik), T. 16600, 16749-16750; Radomir Nešković, T. 14216, 14252-14253 (6 June 2011). See also P2529 (Letter from Radovan Karadžić to SDS Municipal Boards, 15 August 1991), p. 1.

162 Radomir Nešković, T. 14216-14217 (6 June 2011); Dževad Gušić, T. 17802-17804 (24 August 2011); Neđeljko Prstojević, T. 12936-12937 (3 March 2011). See also P2539 (Radovan Karadžić's interview in NIN, 9 November 1990), p. 1; P2529 (Letter from Radovan Karadžić to SDS Municipal Boards, 15 August 1991); P12 (Extended session of Main and Executive Boards of the SDS, 14 February 1992), p. 9.

163 P3023 (Witness statement of Đorde Ristanić dated 15 June 2011), para. 51.

$164 \quad$ P2573 (Minutes of $6^{\text {th }}$ session of SDS Executive Board, November 1991), p. 3; see Adjudicated Fact 1895.

165 Radomir Nešković, P2568 (Transcript from Prosecutor v. Krajišnik), T. 16602, 16751; Radomir Nešković, T. 14235 (6 June 2011).

166 Radomir Nešković, P2568 (Transcript from Prosecutor v. Krajišnik), T. 16623-16627. See also Dževad Gušić, T. 17793 (24 August 2011).

167 Predrag Radić, P1 (Transcript from Prosecutor v. Krajišnik), T. 7386.

168 Predrag Radić, P1 (Transcript from Prosecutor v. Krajišnik), T. 7386; Neđeljko Prstojević, T. 12936-12939 (3 March 2011); Milorad Dodik, T. 36873 (9 April 2013). See, e.g., P6121 (Decision of Vlasenica's SDS Municipal Board, 4 April 1992). 
the power to dismiss municipal bodies if it considered them to not be functioning well or not implementing the party's policies. ${ }^{169}$ The municipal boards sent delegates to the RS Assembly. ${ }^{170}$

70. From 1990 to 1995 , the Accused was at the head of the hierarchical structure of the SDS. ${ }^{171}$

71. The party strove to develop and put into place an efficient system of communications to convey instructions from the top down and to receive reports from the bottom up. ${ }^{172}$ The evidence shows communication in both directions between the top and local levels. Members of the Main Board or Executive Board were designated by the Main Board, Executive Board, or the Accused to go to specific municipalities to communicate with lower-level bodies and address municipal-level problems and to report back. ${ }^{173}$ Members of the Main Board were obligated to regularly attend sessions of the municipal board of their respective municipalities. ${ }^{174}$ The Main Board informed municipal boards about its decisions and work. ${ }^{175}$ SDS municipal leaders met and communicated with SDS leaders at the republic level, including the Accused and the Main Board. ${ }^{176}$ The Accused stated at the SerBiH Assembly session on 15 February 1992 that he would establish teams composed of Main Board members and deputies from the respective region to attend meetings of Deputies' Clubs in municipalities. ${ }^{177}$

169 Radomir Nešković, P2568 (Transcript from Prosecutor v. Krajišnik), T. 16602.

170 Radomir Nešković, P2568 (Transcript from Prosecutor v. Krajišnik), T. 16620. For example, Srđo Srdić was the Assembly deputy from Prijedor. P2536 (Patrick Treanor's expert report entitled "The Bosnian Serb Leadership 1990-1992”, 30 July 2002), pp. 151, 153. He was also for a time president of the SDS municipal board of Prijedor, replaced by Simo Mišković. Radomir Nešković, P2568 (Transcript from Prosecutor v. Krajišnik), T. 16621-16622. Milenko Vojinović was the president of the SDS in Brčko and a deputy of the Bosnian Serb Assembly. P3023 (Witness statement of Đorđe Ristanić dated 15 June 2011), para. 13.

171 Patrick Treanor, T. 14001 (1 June 2011); Radomir Nešković, P2568 (Transcript from Prosecutor v. Krajišnik), T. 16602, 16841; Milorad Dodik, T. 36872 (9 April 2013). See also P2529 (Letter from Radovan Karadžić to SDS Municipal Boards, 15 August 1991); P6238 (Radovan Karadžić's Decision, 18 October 1991) (the Chamber notes that although the date on the document is partly illegible, the date of 18 October 1991 was not contested by the parties when the document was tendered into evidence, see Rodoljub Đukanović, T. 36179, 36204 (27 March 2013); P2548 (Telex entitled “The Sarajevo SDS Order”, 29 October 1991); Patrick Treanor, T. 14023-14024 (1 June 2011).

172 Patrick Treanor, T. 14001 (1 June 2011).

173 Radomir Nešković, P2568 (Transcript from Prosecutor v. Krajišnik), T. 16619, 16627, 16760-16763, 1678316784; Radomir Nešković, T. 14217-14218 (6 June 2011); P2526 (Witness Statement of Radomir Kezunović dated 21 May 2011), para. 21. See also Momčilo Krajišnik, T. 43862-43863 (20 November 2013); P6516 (Excerpt from Momčilo Krajišnik’s testimony from Prosecutor v. Krajišnik), T. 25069-25070.

174 Radomir Nešković, P2568 (Transcript from Prosecutor v. Krajišnik), T. 16630-16632; Radomir Nešković, T. 14216 (6 June 2011).

175 P6369 (Excerpts from KW317's statement to OTP, 14 June 2002) (under seal), e-court p. 2; KW317, T. 39327 (5 June 2013).

176 Radomir Nešković, P2568 (Transcript from Prosecutor v. Krajišnik), T. 16632, 16752, 16758, 16759 ; P2296 (Witness statement of Tihomir Glavaš dated 13 February 2011), para. 25; Nebojša Ristić, T. 15391-15392 (24 June 2011); P4982 (Witness Statement of Branko Đerić dated 5 April 2012), para. 41; KW317, T. 39328 (5 June 2013); Radomir Kezunović, T. 13886-13887 (31 May 2011).

$177 \quad$ P1351 (Transcript of $7^{\text {th }}$ session of SerBiH Assembly, 15 February 1992), p. 58. 


\section{d. Initial actions}

72. During the first months of 1991 the SDS began to organise Serb-majority municipalities in $\mathrm{BiH}$ into communities of municipalities, in some cases severing ties with pre-existing communities of municipalities. ${ }^{178}$ SDS party leaders justified the associations of municipalities in terms of economic necessity. ${ }^{179}$

73. A confidential SDS document, dated 23 February 1991, considered specific actions to be taken should $\mathrm{BiH}$ move towards independence. ${ }^{180}$ In such a case municipal authorities were to ensure that only Yugoslav (federal) law would apply, suspending the implementation of republican regulations. ${ }^{181}$ This policy was adopted by the SDS Deputies' Club and was made public in a document dated 10 June $1991 .^{182}$

74. In late 1991, the SDS started implementing a policy of "regionalisation" ${ }^{183}$ This consisted in taking steps towards the creation of "regions" in which Serbs were the relative majority. ${ }^{184}$ In the fall of 1991, the SDS also made preparations for the establishment of Serb municipalities and Serb municipal Crisis Staffs, at the municipal level. ${ }^{185}$

75. On 16 September 1991 the SDS Executive Board approved the appointment of a Regionalisation Staff. ${ }^{186}$ At least three communities of municipalities-Eastern and Old Herzegovina, ARK, and Romanija-became SAOs in September 1991. ${ }^{187}$ More SAOs were formed between September and November 1991: Semberija-Majevica, Northern Bosnia, and Birač. ${ }^{188}$ On 24 February 1992, the SDS Executive Board assigned "coordinators" for the SAOs. ${ }^{189}$

\footnotetext{
178 Adjudicated Fact 1913. But see Momčilo Krajišnik, T. 43244-43246 (7 November 2013) (stating that the joining of or separating from communities of municipalities by a municipality was at the will of the citizens, required the consent of the municipal assembly, and was not initiated by the SDS).

179 Adjudicated Fact 1914.

$180 \quad$ Adjudicated Fact 1917.

$181 \quad$ See Adjudicated Fact 1918.

182 See Adjudicated Fact 1919; D4654 (Report of SDS Deputies Club, 10 June 1991).

183 See Adjudicated Fact 1921; P2584 (Minutes of $3^{\text {rd }}$ meeting of SDS Executive Board, 16 September 1991), p. 1; P2530 (SDS decision on appointment of staff, 25 September 1991); P2585 (Minutes of $5^{\text {th }}$ meeting of SDS Executive Board, 7 November 1991), p. 5; P2586 (Minutes of session of SDS Deputies' Club, 3 December 1991), pp. 1-3; Radomir Nešković, T. 14357-14361 (7 June 2011).

184 See Adjudicated Fact 1922. See also Patrick Treanor, T. 14016 (1 June 2011); Robert Donia, T. 3100-3101 (1 June 2010).

185 P2589 (Dorothea Hanson's expert report entitled "Bosnian Serb Crisis Staffs, War Presidencies and War Commissions 1991-1995", 10 September 2009), paras. 16, 19. See Section IV.A.1: Municipalities component (Facts) for a discussion on the establishment of Serb municipalities and Crisis Staffs in each of the Municipalities.

186 Adjudicated Fact 1923; P2584 (Minutes of $3^{\text {rd }}$ meeting of SDS Executive Board, 16 September 1991), p. 1.

187 Adjudicated Fact 1923.

$188 \quad$ Adjudicated Fact 1924.

189 See Adjudicated Fact 2181.
} 
For instance, the SDS Executive Board appointed Radislav Vukić, a member of the SDS Executive Board, as co-ordinator for SAO Krajina. ${ }^{190}$

\section{Bosnian Serb Assembly}

76. As described above, ${ }^{191}$ by October 1991 the three-party coalition of the SDA, HDZ, and SDS was falling apart over the question of an independent $\mathrm{BiH}$. During the night of 14 and 15 October 1991, the President of the SRBiH Assembly adjourned the session but a vote proceeded in the absence of the Serb deputies and a declaration of sovereignty was adopted. ${ }^{192}$ On 15 October 1991, the SDS Political Council met to assess the situation. ${ }^{193}$ During this and other meetings, the idea emerged that the SDS should form its own institutions, which would function in parallel to those of $\mathrm{BiH}^{194}$

77. The Bosnian Serb deputies of the SRBiH Assembly proclaimed a separate Assembly of the Serbian People on 24 October $1991^{195}$ and elected Krajišnik as President of the Assembly. ${ }^{196}$ The newly established Assembly was essentially a new form of the SDS Deputies' Club, with the minutes and transcript of the Assembly's first session indicating it as a session of the Deputies' Club. $^{197}$

78. In 1991 into 1992, the Bosnian Serb Assembly ${ }^{198}$ was composed of 78 deputies and all but six were SDS members. ${ }^{199}$ Twenty-three sessions of the Bosnian Serb Assembly were held

$190 \quad$ P6530 (Decision of SDS Executive Board, 24 February 1992). See also Adjudicated Fact 2181. His duties were, inter alia, to co-ordinate the activities of SDS municipal boards in SAO Krajina, to work in co-operation with the Assembly president and the SAO Krajina prime minister to implement the decisions of the Bosnian Serb Assembly and Council of Ministers, and to take part in the work of the SAO Krajina Crisis Staff. P6530 (Decision of SDS Executive Board, 24 February 1992).

$191 \quad$ See paras. 44-46.

192 See Adjudicated Facts 1929-1936.

193 Adjudicated Fact 1937; D294 (Minutes of SDS Council meeting, 15 October 1991); Robert Donia, T. 3107 (1 June 2010).

194 Adjudicated Fact 1938; P2581 (Minutes of meeting of SDS Deputies' Club, 18 October 1991); P2536 (Patrick Treanor's expert report entitled “The Bosnian Serb Leadership 1990-1992”, 30 July 2002), para. 164.

195 See Adjudicated Fact 413; P1343 (Transcript of $1^{\text {st }}$ session of SerBiH Assembly, 24 October 1991), pp. 12-15; P3121 (Session of the Club of Deputies from the SDS, 24 October 1991); P2536 (Patrick Treanor's expert report entitled "The Bosnian Serb Leadership 1990-1992", 30 July 2002), para. 163.

196 P2538 (Patrick Treanor's research report entitled "Radovan Karadžić and the Serbian Leadership 1990-1995", 1 May 2009), para. 80.

197 P1342 (Minutes of $1^{\text {st }}$ session of SerBiH Assembly, 24 October 1991), p. 3; P1343 (Transcript of $1^{\text {st }}$ session of SerBiH Assembly, 24 October 1991), p. 3; P3121 (Session of the Club of Deputies from the SDS, 24 October 1991), p. 3; P2536 (Patrick Treanor's expert report entitled “The Bosnian Serb Leadership 1990-1992”, 30 July 2002), paras. 47, 165.

198 The term "Bosnian Serb Assembly" will be used henceforth to collectively refer to the body that was called at different points in time the Assembly of the Serbian People in Bosnia and Herzegovina, SerBiH Assembly, and RS National Assembly. 
between October 1991 and December 1992. ${ }^{200}$ On 12 August 1992, the Assembly voted to change the name of the Republic from the SerBiH to RS. ${ }^{201}$

79. Chaired by a President (Speaker) and two vice-presidents, this legislative body could adopt laws and determine the budget and territorial organisation of the Republic. ${ }^{202}$ It could also call referendums and elections. ${ }^{203}$

80. Proposals for legislation could be launched by the deputies, the Government, the President of the Republic, municipal assemblies, or a minimum of 3,000 voters. ${ }^{204}$ Thereafter, a draft would be prepared by the relevant Ministry, adopted by the Government, and then forwarded to the Assembly. ${ }^{205}$ This meant that, regardless of who initiated the legislation, the body officially

199 P2536 (Patrick Treanor's expert report entitled “The Bosnian Serb Leadership 1990-1992”, 30 July 2002), pp. 151-152, para. 165. The Bosnian Serb Constitution of 17 December 1992 states that the Assembly has 120 deputies. P5578 (Amended Text of the Constitution of RS and Rules of Procedure of RS Assembly, 17 December 1992), art. 71 (p. 15).

200 Adjudicated Fact 1941. See also P2536 (Patrick Treanor's expert report entitled “The Bosnian Serb Leadership 1990-1992”, 30 July 2002), para. 186, pp. 184-185. See P1342 (Minutes of $1^{\text {st }}$ session of SerBiH Assembly, 24 October 1991); P1343 (Transcript of $1^{\text {st }}$ session of SerBiH Assembly, 24 October 1991); P1344 (Minutes of $2^{\text {nd }}$ session of SerBiH Assembly, 21 November 1991); D83 (Shorthand Record of $2^{\text {nd }}$ session of SerBiH Assembly, 21 November 1991); D85 (Minutes of $3^{\text {rd }}$ session of SerBiH Assembly, 11 December 1991); D84 (Shorthand Record of $3^{\text {rd }}$ session of SerBiH Assembly, 11 December 1991); P1345 (Minutes of $4^{\text {th }}$ session of SerBiH Assembly, 21 December 1991); D86 (Shorthand Record of $4^{\text {th }}$ session of SerBiH Assembly, 21 December 1991); P1346 (Minutes of $5^{\text {th }}$ session of SerBiH Assembly, 9 January 1992); P1347 (Shorthand record of $5^{\text {th }}$ session of SerBiH Assembly, 9 January 1992); P1348 (Minutes of $6^{\text {th }}$ session of SerBiH Assembly, 26 January 1992); P1349 (Transcript of $6^{\text {th }}$ session of SerBiH Assembly, 26 January 1992); P1350 (Shorthand record of $7^{\text {th }}$ session of SerBiH Assembly, 15 February 1992); P1351 (Transcript of $7^{\text {th }}$ session of SerBiH Assembly, 15 February 1992); P1352 (Minutes of $8^{\text {th }}$ session of SerBiH Assembly, 25 February 1992); D88 (Shorthand Record of $8^{\text {th }}$ session of SerBiH Assembly, 25 February 1992); D89 (Shorthand Record of $9^{\text {th }}$ session of SerBiH Assembly, 28 February 1992); P1353 (Shorthand record of $10^{\text {th }}$ session of SerBiH Assembly, 11 March 1992); D90 (Shorthand Record of $11^{\text {th }}$ session of SerBiH Assembly, 18 March 1992); P961 (Shorthand Record of $12^{\text {th }}$ session of SerBiH Assembly, 24 March 1992); P1354 (Minutes of $13^{\text {th }}$ session of SerBiH Assembly, 24 March 1992); P1634 (Minutes of 14 ${ }^{\text {th }}$ session of SerBiH Assembly, 27 March 1992); D304 (Shorthand Record of $14^{\text {th }}$ session of RS Assembly, 27 March 1992); P1355 (Minutes of $16^{\text {th }}$ session of SerBiH Assembly, 12 May 1992); P956 (Transcript of $16^{\text {th }}$ session of SerBiH Assembly, 12 May 1992); P1356 (Minutes of $17^{\text {th }}$ session of SerBiH Assembly, 24-26 July 1992); D92 (Transcript of $17^{\text {th }}$ session of SerBiH Assembly, 2426 July 1992); P1357 (18 ${ }^{\text {th }}$ session of SerBiH Assembly, 11 August 1992); P1358 (Minutes of $19^{\text {th }}$ session of SerBiH Assembly, 12 August 1992); D422 (19 ${ }^{\text {th }}$ session of SerBiH Assembly, 12 August 1992); P1359 (Minutes of $20^{\text {th }}$ session of SerBiH Assembly, 14-15 September 1992); D456 (Transcript of $20^{\text {th }}$ session of RS Assembly, 14-15 September 1992); P1468 (Minutes of $21^{\text {st }}$ session of RS Assembly, 30 October-1 November 1992); P1360 (Transcript from Joint session ( $21^{\text {st }}$ session) of RS Assembly and Assembly of Serbian Krajina, 31 October 1992); P1361 (Minutes of $22^{\text {nd }}$ session of RS Assembly, 23-24 November 1992); P1362 (Shorthand Record of $22^{\text {nd }}$ session of RS Assembly, 23-24 November 1992); P1363 (Minutes of $23^{\text {rd }}$ session of RS Assembly, 17 December 1992); P1364 (Transcript of $23^{\text {rd }}$ session of RS Assembly, 17 December 1992). 
proposing would always be the Government. ${ }^{206}$ In the event of war or immediate threat of war, deputies could, in accordance with the evaluation of the political and security situation, propose to the Assembly that a law be passed without the draft being discussed. ${ }^{207}$

81. The Bosnian Serb Assembly was to exercise control over matters within the competence of the Bosnian Serb Government. ${ }^{208}$ It elected the Prime Minister and voted to appoint the Government Ministers. ${ }^{209}$ In addition, the Assembly debated matters related to the work of the Supreme Court, the Public Prosecutor, and the constitutionality of the laws of the Republic upon advice given to it by the Constitutional Court. ${ }^{210}$ It was also tasked with co-operating with the assemblies of other republics, autonomous provinces, and municipalities, through information exchange and visits by Assembly deputies. ${ }^{211}$

82. The President of the Assembly had the power to propose the agenda of Assembly sessions and to convene the Assembly at his initiative, or upon demand of the Bosnian Serb Government or one-third of the deputies of the Assembly. ${ }^{212}$

83. Sessions of the Bosnian Serb Assembly were sometimes preceded by meetings of the SDS Deputies' Club, which proposed conclusions for adoption by the Assembly. ${ }^{213}$

84. The Assembly was an important avenue for deputies to be informed of policies, plans, and instructions, including for purposes of dissemination to the field. ${ }^{214}$ Municipal bodies were briefed on Assembly sessions and the decisions reached therein. ${ }^{215}$ For instance, at the $7^{\text {th }}$ Assembly session, the Accused requested that the Krajina deputies "work a lot with our people there, with

\footnotetext{
$206 \quad$ See Adjudicated Fact 2018.

207 P5578 (Amended Text of the Constitution of RS and Rules of Procedure of RS Assembly, 17 December 1992), art. 241 (p. 76).

208 Adjudicated Fact 2019; P5578 (Amended Text of the Constitution of RS and Rules of Procedure of RS Assembly, 17 December 1992), art. 70 (p. 15).

209 Adjudicated Fact 2020; P5578 (Amended Text of the Constitution of RS and Rules of Procedure of RS Assembly, 17 December 1992), art. 176 (p. 62).

210 Adjudicated Fact 2021; P5578 (Amended Text of the Constitution of RS and Rules of Procedure of RS Assembly, 17 December 1992), art. 228-232 (pp. 72-74).

211 See Adjudicated Fact 2022; P5578 (Amended Text of the Constitution of RS and Rules of Procedure of RS Assembly, 17 December 1992), arts. 233-237 (pp. 74-75).

212 See Adjudicated Fact 2024; P5578 (Amended Text of the Constitution of RS and Rules of Procedure of RS Assembly, 17 December 1992), art. 74 (p. 16), arts. 26, 82, 89 (pp. 36, 47, 48).

213 See, e.g., D115 (Transcript of $25^{\text {th }}$ session of RS Assembly, 19-20 January 1993), p. 69; P1379 (Transcript of $34^{\text {th }}$ session of RS Assembly, 27-29 August, 9-11 September, 29 September to 1 October 1993), p. 2; P1405 (Transcript of $48^{\text {th }}$ session of RS Assembly, 29-30 December 1994), pp. 35-40, 40-41.

214 See P1369 (Transcript of $27^{\text {th }}$ session of RS Assembly, 3 April 1993), p. 7; P961 (Shorthand Record of $12^{\text {th }}$ session of SerBiH Assembly, 24 March 1992), p. 22; P956 (Transcript of $16^{\text {th }}$ session of SerBiH Assembly, 12 May 1992), pp. 13-14; P988 (Transcript of 53 ${ }^{\text {rd }}$ session of RS Assembly, 28 August 1995), p. 68.

215 See P3439 (Minutes of meeting of Ključ Crisis Staff, 13-14 May 1992), p. 2; Rajko Kalabić, T. 44577-44578; P6589 (Minutes of Prijedor Municipal Board meeting, 18 May 1992), p. 1; P3590 (Minutes of meeting of presidents of municipalities in the zone of responsibility of the $1^{\text {st }}$ Partisan Brigade, 14 May 1992), p. 3.
} 
party membership, to explain our strategic goals and to explain our tactics on a daily basis" and stated that "[a] deputy is a representative and is vested with the highest representative authority" and "[a]t the same time, he will report to the Assembly here". 216

85. At Assembly sessions, deputies reported on events in the municipalities. ${ }^{217}$ The Accused stated at the $12^{\text {th }}$ Assembly session on 24 March 1992:

If the Assembly agrees, [...] it is my opinion and request that in this period when the State is being created and getting on its feet, deputies will have to be the pillars of our power in the areas where they are located. They must, therefore, remain in permanent contact with presidents of municipalities and work on the establishment of local government. $^{218}$

86. Statements by deputies indicate that they ascribed to the Assembly a degree of authority over municipal bodies. At the $8^{\text {th }}$ Assembly session, amid remarks on the "discord" in Bosnian Krajina, Vojo Kuprešanin spoke of the Assembly as "our supreme authority because it can annul all our decisions". ${ }^{219}$ The Accused stated earlier in the same session: "This Assembly is the supreme power of the Serbian people in $[\mathrm{BiH}] .[\ldots]$ This Assembly has the authority to cancel all decisions of any Serbian Assembly in [BiH], and of the Regional Assembly.",220

87. The Assembly established many of the Bosnian Serb state political organs, including the SNB, the three and five-member Presidency and sole President, the Council of Ministers, and the Government, as well as the judicial system. ${ }^{221}$

\section{National Security Council (SNB)}

88. On 27 March 1992, the Bosnian Serb Assembly established the SNB. ${ }^{222}$ It was to be an advisory organ to the Assembly, on political, legal, constitutional, and other issues relevant to the

\footnotetext{
$216 \quad$ P1351 (Transcript of $7^{\text {th }}$ session of SerBiH Assembly, 15 February 1992), p. 58.

217 See D92 (Transcript of $17^{\text {th }}$ session of SerBiH Assembly, 24-26 July 1992), pp. 66-67, 71-75.

218 P961 (Shorthand Record of $12^{\text {th }}$ session of SerBiH Assembly, 24 March 1992), p. 15.

219 D88 (Shorthand Record of $8^{\text {th }}$ session of SerBiH Assembly, 25 February 1992), pp. 60-61.

220 D88 (Shorthand Record of $8^{\text {th }}$ session of SerBiH Assembly, 25 February 1992), p. 45.

221 See paras. 88, 96-98, 103, 107. See also Radomir Nešković, P2568 (Transcript from Prosecutor v. Krajišnik), T. 16779; P2536 (Patrick Treanor's expert report entitled “The Bosnian Serb Leadership 1990-1992”, 30 July 2002), paras. 168-188.

222 P1634 (Minutes of $14^{\text {th }}$ session of SerBiH Assembly, 27 March 1992), p. 14; D304 (Shorthand Record of $14^{\text {th }}$ session of RS Assembly, 27 March 1992), p. 10; P2536 (Patrick Treanor's expert report entitled "The Bosnian Serb Leadership 1990-1992”, 30 July 2002), para. 185. See also Adjudicated Fact 2028. Its decisions were sometimes published in the Official Gazette of the SerBiH. See Adjudicated Fact 2030.
} 
security of "the Serbian people in $[\mathrm{BiH}]$ ", and it was to be responsible to the Assembly. ${ }^{223}$ It was also envisioned as being able to issue binding decisions on executive organs, including the Ministries of Interior and of National Defence. ${ }^{224}$

89. The Accused was President of the SNB. ${ }^{225}$ Ex officio members of the SNB also included the President of the Bosnian Serb Assembly, the SerBiH Prime Minister, and the Ministers of Defence and Interior. ${ }^{226}$

90. The SNB was one of the interim bodies that served as the de facto Presidency of the SerBiH in 1992. ${ }^{227}$ Plavšić and Koljević, who were members of the SRBiH Presidency, functioned as acting presidents of the SerBiH. ${ }^{228}$ The SNB, usually in joint sessions with the Government, made decisions relating to, inter alia, security, defence, the military, and political strategy, ${ }^{229}$ and charged various ministries with tasks ${ }^{230}$. Decisions of joint sessions were then formalised through Plavšić and Koljević, who were members of the SNB, or a decision of the relevant Government organ. ${ }^{231}$

223 Adjudicated Fact 2029; P961 (Shorthand Record of 12 $2^{\text {th }}$ session of SerBiH Assembly, 24 March 1992), pp. 1015; P2536 (Patrick Treanor's expert report entitled “The Bosnian Serb Leadership 1990-1992”, 30 July 2002), para. 185.

224 P961 (Shorthand Record of $12^{\text {th }}$ session of SerBiH Assembly, 24 March 1992), pp. 14-15.

225 Patrick Treanor, T. 14060 (1 June 2011); P2536 (Patrick Treanor's expert report entitled "The Bosnian Serb Leadership 1990-1992”, 30 July 2002), para. 256; P4982 (Witness Statement of Branko Đerić dated 5 April 2012), para. 28. The Accused signed minutes of meetings of the SNB (often joint sessions with the Government) as President of the Council. See, e.g., P3050 (Minutes of joint meeting of SNB and SerBiH Government, 15 April 1992); D405 (Minutes of extended session of the NSC, 16 April 1992); P1087 (Minutes of meeting between SNB and SerBiH Government, 24 April 1992). Some of the minutes are signed by the Accused and the Prime Minister. See, e.g., P3078 (Minutes of meeting of the National Security Council and the SerBiH Government, 8 May 1992); P3079 (Minutes of joint session of the National Security Council and the SerBiH Government, 14 May 1992).

226 See Adjudicated Fact 2079.

227 P2536 (Patrick Treanor's expert report entitled "The Bosnian Serb Leadership 1990-1992", 30 July 2002), paras. 236, 255, 258.

228 P2536 (Patrick Treanor's expert report entitled “The Bosnian Serb Leadership 1990-1992”, 30 July 2002), paras. 236, 254; D89 (Shorthand Record of $9^{\text {th }}$ session of SerBiH Assembly, 28 February 1992), pp. 9-10, 15; P961 (Shorthand Record of $12^{\text {th }}$ session of SerBiH Assembly, 24 March 1992), p. 24.

229 See, e.g., P3050 (Minutes of joint meeting of SNB and SerBiH Government, 15 April 1992); P3077 (Minutes of expanded session of the National Security Council and the SerBiH Government, 20 April 1992); P3051 (Minutes of expanded meeting of SNB and SerBiH Government, 22 April 1992); P1087 (Minutes of meeting between SNB and SerBiH Government, 24 April 1992); D406 (Minutes of meeting of SNB and SerBiH Government, 27 April 1992) D409 (Minutes of SNB and the Government of the SerBiH session, 10 May 1992); P3080 (Minutes of unified session of the National Security Council and the SerBiH Government, 15 May 1992).

230 See, e.g., D405 (Minutes of extended session of the SNB, 16 April 1992), paras. 3-4, 7, 12; P3051 (Minutes of expanded meeting of SNB and SerBiH Government, 22 April 1992), p. 2; D406 (Minutes of meeting of SNB and SerBiH Government, 27 April 1992), p. 1.

231 P2536 (Patrick Treanor's expert report entitled “The Bosnian Serb Leadership 1990-1992”, 30 July 2002), para. 259. For instance, at one of its first sessions, on 15 April 1992, the SNB in a joint meeting with the Government determined that the conditions had been met to propose that the Presidency of the Republic declare a state of imminent threat of war. P3050 (Minutes of joint meeting of SNB and SerBiH Government, 15 April 1992), p. 1. This was effected through a decision of Plavšić and Koljević, as the Presidency. P3922 (Decision of SerBiH Presidency, 15 April 1992). 
91. The SNB and Government made a number of decisions regarding the $\mathrm{TO}^{232}$ in April 1992: On 15 April 1992, the SNB and Government decided that the Minister of Defence shall organise and supervise the TO until the appointment of the commander. ${ }^{233}$ On 22 April 1992, the SNB and Government decided that the President of the SNB should co-ordinate matters relating to the commanding of TO forces. ${ }^{234}$ They also adopted the conclusion that the SerBiH TO Staff appoint staff commanders in regions, municipalities, and towns. ${ }^{235}$ On 24 April 1992, the SNB decided to form a Town TO Staff composed of municipal TO commanders, with the Accused responsible for "its realisation". ${ }^{236}$ On 27 April 1992, a joint session decided that salaries for members of the TO would be secured with the help of municipal assemblies. ${ }^{237}$

92. In April 1992, the SNB was issuing instructions to, and receiving reports from, municipal crisis staffs and TOs. ${ }^{238}$

93. On 24 April 1992, at a meeting with the SerBiH Government, the SNB decided that "the Ministry of Justice shall take over the exchange of prisoners once the organs of the interior have completed their work" ${ }^{239}$ At the same meeting, the SNB decided to establish a state commission for war crimes and to compile instructions for the work of the commission. ${ }^{240}$ On 8 May 1992, a joint session of the SNB and SerBiH Government decided to set up a state commission for assistance to refugees. $^{241}$

94. With respect to communication structures, in April 1992 the SNB and Government ordered that the ministers of the MUP and Ministry of National Defence "submit daily reports on the situation in the field, on the establishment of possible accountability and the measures taken" and that the MUP minister "submit a daily report on the security situation in the territory of the $[\mathrm{SerBiH}] "{ }^{242}$

232

See paras. 212-214.

P3050 (Minutes of joint meeting of SNB and SerBiH Government, 15 April 1992), p. 2.

P3051 (Minutes of expanded meeting of SNB and SerBiH Government, 22 April 1992), p. 1. See also Reynaud Theunens, T. 16888-16889 (19 July 2011).

P3051 (Minutes of expanded meeting of SNB and SerBiH Government, 22 April 1992), p. 2.

P1087 (Minutes of meeting between SNB and SerBiH Government, 24 April 1992), p. 1.

D406 (Minutes of meeting of SNB and SerBiH Government, 27 April 1992).

See Adjudicated Fact 2080. See, e.g., D394 (Announcement of SNB, 4 April 1992), p. 2; P2615 (Decision of Birač Crisis Staff, 29 April 1992); P3051 (Minutes of expanded meeting of SNB and SerBiH Government, 22 April 1992), p. 2; P2627 (Minutes of meeting of SNB and SerBiH Government, 28 April 1992), p. 1.

P1087 (Minutes of meeting between SNB and SerBiH Government, 24 April 1992), p. 1.

P1087 (Minutes of meeting between SNB and SerBiH Government, 24 April 1992), p. 1; P2536 (Patrick Treanor's expert report entitled “The Bosnian Serb Leadership 1990-1992”, 30 July 2002), para. 275.

P3078 (Minutes of meeting of the National Security Council and the SerBiH Government, 8 May 1992), p. 1. P3051 (Minutes of expanded meeting of SNB and SerBiH Government, 22 April 1992), p. 2. 
95. The SNB effectively ceased convening sessions or fulfilling a central role around May 1992, when the Presidency was established. ${ }^{243}$

4. Presidency, War Presidency, President

a. Establishment

96. On 12 May 1992, the Bosnian Serb Assembly established a three-member Presidency and elected the Accused, Plavšić, and Koljević to the Presidency. ${ }^{244}$ The Presidency then elected the Accused as President of the Presidency. ${ }^{245}$ The President of the Presidency was to issue orders, adopt and present decisions, and command the VRS ${ }^{246}$ on behalf of the Presidency. ${ }^{247}$

97. On or around 2 June 1992, the Presidency was enlarged to five members to include the Prime Minister, Branko Đerić, and the President of the Bosnian Serb Assembly, Krajišnik. ${ }^{248}$ On 6 July 1992, the five-member Presidency allocated tasks among themselves: military issues to the Accused; international relations as well as information and propaganda-related questions to Koljević; contacts with UNPROFOR, except for military issues, and questions related to refugees and humanitarian aid, inter alia, to Plavšić; questions related to commissioners and the economy to Krajišnik; and questions related to supplies to Đerić. ${ }^{249}$ The Presidency that met from 2 June until 17 December 1992 is sometimes referred to as the "War Presidency", because it was considered to be "held during an imminent threat of war", as indicated in some of the meeting minutes from this period. ${ }^{250}$ On 17 December 1992 the Bosnian Serb Assembly adopted a "Declaration on the End of the War," proclaiming the war in the former BiH over for the RS. ${ }^{251}$

\footnotetext{
243 P2536 (Patrick Treanor's expert report entitled “The Bosnian Serb Leadership 1990-1992”, 30 July 2002 ), paras. 260-261, fn. 723.

244 P956 (Transcript of $16^{\text {th }}$ Session of SerBiH Assembly, 12 May 1992), p. 58; P1355 (Minutes of $16^{\text {th }}$ session of SerBiH Assembly, 12 May 1992), p. 2; Patrick Treanor, T. 14051, 14060 (1 June 2011); P2536 (Patrick Treanor's expert report entitled “The Bosnian Serb Leadership 1990-1992”, 30 July 2002), paras. 180, 260.

245 P3032 (Minutes of $1^{\text {st }}$ constitutive session of SerBiH Presidency, 12 May 1992). See also Patrick Treanor, T. 14060 (1 June 2011); P2536 (Patrick Treanor's expert report entitled “The Bosnian Serb Leadership 19901992”, 30 July 2002), paras. 180, 260; P956 (Transcript of $16^{\text {th }}$ Session of SerBiH Assembly, 12 May 1992), p. 58.

246 For ease of reference the acronym "VRS" will be used throughout this section to also cover the period prior to 12 August 1992, when the Army of SerBiH was renamed the VRS. See fn. 422.

247 P956 (Transcript of $16^{\text {th }}$ Session of SerBiH Assembly, 12 May 1992), p. 58.

248 Patrick Treanor, T. 14060-14061 (1 June 2011); P2536 (Patrick Treanor's expert report entitled "The Bosnian Serb Leadership 1990-1992”, 30 July 2002), paras. 236, 261-265.

249 D440 (Minutes of $15^{\text {th }}$ session of SerBiH Presidency, 6 July 1992), p. 3.

250 See, e.g., P3061 (Minutes of the $3^{\text {rd }}$ session of the SerBiH Presidency, 8 June 1992); P1093 (Minutes of $5^{\text {th }}$ session of SerBiH Presidency, 10 June 1992); D440 (Minutes of $15^{\text {th }}$ session of SerBiH Presidency, 6 July 1992); P1465 (Minutes of $19^{\text {th }}$ session of SerBiH Presidency, 13 July 1992).

$251 \quad$ P1363 (Minutes of $23^{\text {rd }}$ session of RS Assembly, 17 December 1992), p. 3; P1364 (Transcript of $23^{\text {rd }}$ session of RS Assembly, 17 December 1992), e-court pp. 7-16.
} 
98. On 17 December 1992, the Bosnian Serb Assembly replaced the structures of the Presidency by establishing a single president and two vice-presidents of the Republic. ${ }^{252}$ The Assembly elected the Accused to the position of President of the RS and elected Plavšić and Koljević as Vice-Presidents. ${ }^{253}$

\section{b. Functions}

99. Under the Bosnian Serb Constitution, the President's duties were to represent the Republic, propose to the National Assembly candidates for the posts of Prime Minister and the posts of president and judges of the Constitutional Court, pronounce laws by decree, ${ }^{254}$ give amnesty, award decorations and commendations determined by the law, and perform other duties in accordance with the Constitution. ${ }^{255}$

100. The President also possessed contingent powers such as the authority, when the Assembly was unable to meet due to a state of emergency, to pronounce such a state and "order measures for its elimination, in accordance to the Constitution and the law", "in co-ordination with the opinion of the Government". ${ }^{256}$ The President also had the power, during a state of war or imminent threat of war, on his own initiative or at the Government's suggestion, to establish enactments on issues within the authority of the Assembly and forward them to the Assembly for confirmation as soon as the Assembly could meet. ${ }^{257}$ In exercise of this contingent power, the Presidency passed the Law

252 P1364 (Transcript of $23^{\text {rd }}$ session of RS Assembly, 17 December 1992), e-court pp. 57-58; Patrick Treanor, T. 14061 (1 June 2011).

253 P1364 (Transcript of $23^{\text {rd }}$ session of RS Assembly, 17 December 1992), e-court pp. 114-115; Patrick Treanor, T. 14061 (1 June 2011); P2536 (Patrick Treanor's expert report entitled "The Bosnian Serb Leadership 19901992", 30 July 2002), paras. 188, 266.

254 The President's authority to pronounce laws by decree under article 80 of the Bosnian Serb Constitution refers to the authority to promulgate laws adopted by the Assembly. P5578 (Amended Text of the Constitution of RS and Rules of Procedure of RS Assembly, 17 December 1992), art. 80 (p. 17). See, e.g., P2315 (Law on Establishment of Rajlovac Municipality, 11 May 1992 and corresponding Decree on promulgation, 15 May 1992); P2964 (SerBiH Decree on the promulgation on the Law of Internal Affairs, 23 March 1992). This authority is distinct from the authority of the President, under paragraph 2 of article 81, during a state of war or imminent threat of war, to enact laws, which would later be confirmed by the Assembly. See para. 100.

255 P5578 (Amended Text of the Constitution of RS and Rules of Procedure of RS Assembly, 17 December 1992), arts. 69, 80 (pp. 14, 16-17).

256 P5578 (Amended Text of the Constitution of RS and Rules of Procedure of RS Assembly, 17 December 1992), art. 81 (p. 17); P2536 (Patrick Treanor's expert report entitled “The Bosnian Serb Leadership 1990-1992”, 30 July 2002), para. 240.

257 P5578 (Amended Text of the Constitution of RS and Rules of Procedure of RS Assembly, 17 December 1992), art. 81 (p. 17); P2536 (Patrick Treanor's expert report entitled “The Bosnian Serb Leadership 1990-1992", 30 July 2002), para. 240. At its $16^{\text {th }}, 17^{\text {th }}$, and $20^{\text {th }}$ sessions, the Assembly verified a number of decisions adopted by the SerBiH Presidency. P1355 (Minutes of $16^{\text {th }}$ session of SerBiH Assembly, 12 May 1992), p. 2; P1356 (Minutes of $17^{\text {th }}$ session of SerBiH Assembly, 24-26 July 1992), pp. 8-9; D456 (Transcript of $20^{\text {th }}$ session of RS Assembly, 14-15 September 1992), pp. 107-117; P1359 (Minutes of $20^{\text {th }}$ session of RS Assembly, 14-15 September 1992), pp. 2-3, 10. 
on Defence and the Law on the Army on 1 June $1992 .^{258}$ The Presidency also elected ministers to the Government when the Assembly was unable to convene, with subsequent confirmation by the Assembly. ${ }^{259}$

101. The President of the Republic served as the Commander in Chief, or Supreme Commander, of the VRS. ${ }^{260}$

102. Under the Bosnian Serb Constitution, the President could ask the Government to give its position on issues important to the Republic. ${ }^{261}$ The Presidency "regularly received reports through the Government, which was in regular contact with municipalities, Crisis Staffs and Serbian Autonomous Regions". ${ }^{262}$ The Presidency and President also received reports from the MUP ${ }^{263}$ and the Main Staff of the VRS. ${ }^{264}$

\section{Council of Ministers}

103. On 21 December 1991, the Bosnian Serb Assembly named a Council of Ministers. ${ }^{265}$ The Council of Ministers was composed of a president, 18 ministers, and the five presidents of the

258 P2536 (Patrick Treanor's expert report entitled “The Bosnian Serb Leadership 1990-1992”, 30 July 2002), para. 241; P2602 (SerBiH Defence Act, 1 June 1992); P2603 (SerBiH Law on the Army, 1 June 1992). The Assembly verified the Law on Defence and Law on the Army at its $17^{\text {th }}$ session. P1356 (Minutes of $17^{\text {th }}$ session of SerBiH Assembly, 24-26 July 1992), p. 8.

259 See P1355 (Minutes of $16^{\text {th }}$ session of SerBiH Assembly, 12 May 1992), p. 3.

260 P2603 (SerBiH Law on the Army, 1 June 1992), art. 174; P5578 (Amended Text of the Constitution of RS and Rules of Procedure of RS Assembly, 17 December 1992), art. 106 (p. 22); P5416 (Decision of the Assembly of the Serbian People in BiH, 12 May 1992), Amendment III; Patrick Treanor, T. 14061-14062 (1 June 2011); P2536 (Patrick Treanor's expert report entitled “The Bosnian Serb Leadership 1990-1992”, 30 July 2002), para. 246. For a description of the duties of the President as Supreme Commander, see paras. 167-168.

261 P5578 (Amended Text of the Constitution of RS and Rules of Procedure of RS Assembly, 17 December 1992), art. 82; P2536 (Patrick Treanor's expert report entitled “The Bosnian Serb Leadership 1990-1992”, 30 July 2002), para. 277.

262 P2536 (Patrick Treanor’s expert report entitled “The Bosnian Serb Leadership 1990-1992”, 30 July 2002), para. 274.

263 Christian Nielsen, T. 16270-16271 (7 July 2011); P2958 (Christian Nielsen's expert report entitled "The Bosnian Serb Ministry of Internal Affairs: Genesis, Performance and Command and Control 1990-1992", 19 May 2011), para. 389; P2761 (RS MUP report on work for period April to December 1992), p. 23.

264 See, e.g., P4206 (VRS Main Staff Report to RS President and Drina Corps re talks with General Morillon, 15 March 1993); P4449 (VRS Main Staff Report, 10 July 1995); P3054 (VRS Main Staff Report, 12 July 1995); P4464 (VRS Main Staff Report 13 July 1995); P4457 (VRS Main Staff Report, 14 July 1995). See also P1478 (Ratko Mladić's notebook, 27 May 31-31 July 1992), e-court p. 126; P1467 (Minutes of $21^{\text {st }}$ session of SerBiH Presidency, 2 August 1992), p. 2; Richard Butler, T. 27505 (17 April 2012); P3033 (Reynaud Theunens's expert report entitled "Radovan Karadžić and the SRBiH TO-VRS (1992-1995)"), pp. 308-313.

265 P1345 (Minutes of $4^{\text {th }}$ session of SerBiH Assembly, 21 December 1991), pp. 6-8; D86 (Shorthand Record of $4^{\text {th }}$ session of SerBiH Assembly, 21 December 1991, pp. 35-37; D296 (Decision of SDS and SPO deputies on the establishment of the Assembly of the SerBiH, 24 October 1991), pp. 23-25; Patrick Treanor, T. 14030 (1 June 2011); P2536 (Patrick Treanor's expert report entitled “The Bosnian Serb Leadership 1990-1992”, 30 July 2002), para. 176. 
Governments of the SAOs, the latter designated as ex officio members. ${ }^{266}$ Many of the members named on 21 December 1991 held positions in ministries of the joint government of $\mathrm{BiH}^{267}{ }^{267}$ Council of Ministers was to function as the executive organ of the Bosnian Serb Assembly. ${ }^{268}$

104. On 11 January 1992, the Council of Ministers held its first session, where it established interim commissions on economic and development policy, public services, domestic policy, justice, and administration. ${ }^{269}$ According to the minutes of the meeting, the Council of Ministers also discussed the "[e]xecution of tasks resulting from the Declaration of the Promulgation of the Republic of the Serbian People of Bosnia and Herzegovina" and identified priorities in relation to the Declaration as "the defining of ethnic territory, establishment of government organs in the territory and the economic disempowerment of the current authorities in the [SRBiH]". ${ }^{270}$ The Accused as the President of the SDS, Krajišnik as the President of the Bosnian Serb Assembly, the Secretary of the Bosnian Serb Assembly, the President of the SDS Executive Board, the President of the Chamber of Municipalities of the SRBiH Assembly, and Plavšić-a member of the SRBiH Presidency - attended the meeting. ${ }^{271}$

105. At its second meeting, held on 17 January 1992, the Council of Ministers addressed the Draft Work Programme of the Council and discussed the need to adopt the Constitution of the Republic as soon as possible and to consolidate and organise the territory of the regions, including through the formation of new municipalities. ${ }^{272}$

106. The Council of Ministers, under the Constitutional Law passed by the Bosnian Serb Assembly on 28 February $1992,{ }^{273}$ was to carry out the rights and duties of the Government until

\footnotetext{
266 D296 (Decision of SDS and SPO deputies on the establishment of the Assembly of the SerBiH, 24 October 1991), pp. 23-25; P2536 (Patrick Treanor's expert report entitled “The Bosnian Serb Leadership 1990-1992”, 30 July 2002), paras. 149, 221, p. 162. See P2536 (Patrick Treanor's expert report entitled “The Bosnian Serb Leadership 1990-1992”, 30 July 2002), para. 51.

268 P1082 (Minutes of $1^{\text {st }}$ meeting of Ministerial Council of SerBiH Assembly, 13 January 1992), p. 3; D86 (Shorthand Record of $4^{\text {th }}$ session of SerBiH Assembly, 21 December 1991), p. 36.

269 P1082 (Minutes of $1^{\text {st }}$ meeting of Ministerial Council of SerBiH Assembly, 13 January 1992), p. 2; P2536 (Patrick Treanor's expert report entitled “The Bosnian Serb Leadership 1990-1992”, 30 July 2002), para. 227.

$270 \quad$ P1082 (Minutes of $1^{\text {st }}$ meeting of Ministerial Council of SerBiH Assembly, 13 January 1992), pp. 2-3; P2536 (Patrick Treanor's expert report entitled “The Bosnian Serb Leadership 1990-1992”, 30 July 2002), para. 227.

$271 \quad$ P1082 (Minutes of $1^{\text {st }}$ meeting of Ministerial Council of SerBiH Assembly, 13 January 1992), p. 1; P3111 (Minutes of the $2^{\text {nd }}$ meeting of the Ministerial Council of SerBiH Assembly, 17 January 1992), pp. 2-3.

272 P3111 (Minutes of the $2^{\text {nd }}$ meeting of the Ministerial Council of SerBiH Assembly, 17 January 1992), p. 5.

273 D89 (Shorthand Record of $9^{\text {th }}$ session of SerBiH Assembly, 28 February 1992), pp. 15-16.
} 
the Government was elected and operative and effectively served as a precursor to the Bosnian Serb Government. $^{274}$

107. At its $13^{\text {th }}$ session held on 24 March 1992, the Bosnian Serb Assembly adopted a decision relieving from duty the Council of Ministers of the Bosnian Serb Assembly and elected members of the first Bosnian Serb Government. ${ }^{275}$

\section{Bosnian Serb Government}

a. Establishment

108. While he was a member of the BiH Government, Đerić was nominated by Plavšić for the post of Prime Minister in the Bosnian Serb Government. ${ }^{276}$ Serbs who had been serving in ministerial posts in the Government of $\mathrm{BiH}$ were appointed by the Bosnian Serb Assembly as Ministers to equivalent positions in the Bosnian Serb Government. ${ }^{277}$ Where no Serb sat as Minister or deputy Minister in the BiH Government, the Prime Minister was to propose candidates for ministerial posts in the Bosnian Serb Government to the Bosnian Serb Assembly. ${ }^{278}$

109. On 24 March 1992, the Bosnian Serb Assembly elected Đerić as the Prime Minister, Aleksa Buha as Minister of Foreign Affairs, and Mićo Stanišić as Minister of Internal Affairs in the SerBiH Government. ${ }^{279}$ At the same session, the Assembly instructed the Government to prepare and submit to the Assembly for adoption an operational plan "of assuming power and rendering operational the authorities in the territory of the Serbian Republic of Bosnia and Herzegovina". ${ }^{280}$

110. In the first days of April 1992, following international recognition of $\mathrm{BiH}$ as an independent state and the beginning of the conflict, the Bosnian Serb leadership relocated to Pale, about 20 kilometres from Sarajevo. ${ }^{281}$ From 15 April 1992, the Government held regular meetings in

\footnotetext{
274 P2536 (Patrick Treanor's expert report entitled “The Bosnian Serb Leadership 1990-1992”, 30 July 2002), paras. 210, 222; D90 (Shorthand Record of $11^{\text {th }}$ session of SerBiH Assembly, 18 March 1992), p. 7. See Adjudicated Fact 2044.

275 P1354 (Minutes of $13^{\text {th }}$ session of SerBiH Assembly, 24 March 1992), pp. 3-7; P2536 (Patrick Treanor's expert report entitled "The Bosnian Serb Leadership 1990-1992", 30 July 2002), para. 223. The term "Bosnian Serb Government" will be used henceforth to refer to the Government of the SerBiH and, after 12 August 1992, of the RS.

276 See Adjudicated Fact 2045; P961 (Shorthand Record of 12 $2^{\text {th }}$ session of SerBiH Assembly, 24 March 1992), pp. 24-25.

277 P4982 (Witness Statement of Branko Đerić dated 5 April 2012), para. 7. See also Adjudicated Fact 2046.

278 P4982 (Witness Statement of Branko Đerić dated 5 April 2012), para. 7. See also Adjudicated Fact 2047.

279 P1354 (Minutes of $13^{\text {th }}$ session of SerBiH Assembly, 24 March 1992), pp. 4-7; P2536 (Patrick Treanor's expert report entitled “The Bosnian Serb Leadership 1990-1992”, 30 July 2002), para. 223.

280 P1354 (Minutes of $13^{\text {th }}$ session of SerBiH Assembly, 24 March 1992), pp. 8-9; P2536 (Patrick Treanor's expert report entitled “The Bosnian Serb Leadership 1990-1992”, 30 July 2002), para. 223.

$281 \quad$ Adjudicated Fact 2052.
} 
Pale in joint sessions with the new SNB. ${ }^{282}$ The Kikinda Hotel functioned as the seat of the Bosnian Serb institutions, namely the Assembly, the Presidency, and the Government, until June $1992 .^{283}$

111. The Government met in several joint sessions with the SNB in April and May $1992 .^{284}$ From around 18 May 1992, the Government began convening by itself. ${ }^{285}$

\section{b. Functions}

112. The Bosnian Serb Constitution vested the Bosnian Serb Government with executive authority, under the formal control of the Assembly. ${ }^{286}$ Under the Bosnian Serb Constitution, the Government's functions were, inter alia, to propose and ensure the implementation of laws and regulations, to give its opinion regarding laws and regulations proposed to the National Assembly by other persons, to establish principles for the internal organisation of ministries and other bodies of the republic, and to coordinate and supervise the work of ministries and other bodies of the republic. $^{287}$

113. The Government was headed by the Prime Minister, two deputy Prime Ministers, and 13 Ministers. ${ }^{288}$

114. Aleksandar Buha, Minister of Foreign Affairs, was in charge of contacts with international representatives. $^{289}$ The Ministry of Information, under Velibor Ostojić, dealt with general public information, and would distribute and report on the statements from Government sessions, press briefings, and news conferences. ${ }^{290}$ Dragan Kalinić, Minister of Health and Social Affairs, was in charge of co-operation with international humanitarian organisations. ${ }^{291}$

\footnotetext{
282 P2536 (Patrick Treanor's expert report entitled “The Bosnian Serb Leadership 1990-1992”, 30 July 2002 ), para. 229.

284 See, e.g., P3050 (Minutes of joint meeting of SNB and SerBiH Government, 15 April 1992); P3077 (Minutes of expanded session of the National Security Council and the SerBiH Government, 20 April 1992); P3079 (Minutes of joint session of the National Security Council and the SerBiH Government, 14 May 1992).

285 See P2625 (Minutes of $11^{\text {th }}$ session of SerBiH Government, 18 May 1992).

286 Adjudicated Fact 2038; P5578 (Amended Text of the Constitution of RS and Rules of Procedure of RS Assembly, 17 December 1992), arts. 69, 70, 94 (pp. 14, 15 19).

287 P5578 (Amended Text of the Constitution of RS and Rules of Procedure of RS Assembly, 17 December 1992), art. 90 (pp. 18-19). See, e.g., P2625 (Minutes of $11^{\text {th }}$ session of SerBiH Government, 18 May 1992); P3081 (Minutes of the $12^{\text {th }}$ session of SerBiH Government, 21 May 1992).

288 Adjudicated Fact 2039; P2536 (Patrick Treanor's expert report entitled "The Bosnian Serb Leadership 19901992”, 30 July 2002), para. 211.

289 See Adjudicated Fact 2048.

$290 \quad$ Adjudicated Fact 2049.

291 Adjudicated Fact 2050.
} 
115. In April 1992, Koljević proposed to JNA colonel Bogdan Subotić that he set up a Ministry of Defence. ${ }^{292}$ Subotic accepted the assignment, moved to Pale, and with the assistance of the SFRY Ministry of Defence, started organising the Ministry and preparing drafts of the Law on Defence and Law on the Army. ${ }^{293}$ These drafts were eventually adopted by the Government and submitted to the Bosnian Serb Assembly. ${ }^{294}$

c. Structure and relationship to other entities

116. Under the Bosnian Serb Constitution, the Government was responsible to the Assembly. ${ }^{295}$ The Bosnian Serb Government was to report to the Assembly on its progress in policy implementation and law enforcement. ${ }^{296}$ Based on an evaluation of the Government's work, the Assembly could hold a vote of no-confidence. ${ }^{297}$ The Government could propose the convening of sessions of the Assembly. ${ }^{298}$

117. In a letter to the Government, the Chairman of the SDS Executive Board stated that the Government was to implement the policy of the party and that at all levels from the municipality to the Republic, appointments were not possible without the party's approval. ${ }^{299}$ While the Bosnian Serb Constitution provided that the prime minister propose candidates for ministerial positions to the Assembly, ${ }^{300}$ in fact it was the SDS and the SDS President that chose the nominees. ${ }^{301}$ For

\footnotetext{
292 See Adjudicated Fact 2054.

293 Adjudicated Fact 2055.

$294 \quad$ Adjudicated Fact 2056.

295 P5578 (Amended Text of the Constitution of RS and Rules of Procedure of RS Assembly, 17 December 1992), arts. 70, 94 (pp. 15, 19); P2536 (Patrick Treanor's expert report entitled “The Bosnian Serb Leadership 19901992”, 30 July 2002), para. 212. See also Momčilo Krajišnik, T. 43358 (13 November 2013).

296 Adjudicated Fact 2040; P5578 (Amended Text of the Constitution of RS and Rules of Procedure of RS Assembly, 17 December 1992), art. 217 (pp. 69-70).

297 Adjudicated Fact 2041; P5578 (Amended Text of the Constitution of RS and Rules of Procedure of RS Assembly, 17 December 1992), art. 94 (p. 19), art. 221 (pp. 70-71).

298 P5578 (Amended Text of the Constitution of RS and Rules of Procedure of RS Assembly, 17 December 1992), art. 74 (p. 16), art. 82 (p. 47); P2536 (Patrick Treanor's expert report entitled "The Bosnian Serb Leadership 1990-1992", 30 July 2002), para. 212.

299 P6337 (Letter from SDS Executive Board to RS Government, 12 April 1993).

$300 \quad$ P5578 (Amended Text of the Constitution of RS and Rules of Procedure of RS Assembly, 17 December 1992), art. 93.

$301 \quad$ P4982 (Witness Statement of Branko Đerić dated 5 April 2012), paras. 7-9; P1105 (Transcript of $22^{\text {nd }}$ session of RS Assembly, 23-24 November 1992), p. 12. The SDS and the Accused exercised control over personnel appointments more generally, including to assistant minister positions and public enterprises, though the Government could propose candidates. See Vladimir Lukić, T. 38760-38764 (23 May 2013); P6338 (Letter from RS Government to SDS Executive Board, 29 August 1993); P6339 (Letter from SDS Executive Board to RS Government, 28 December 1993); P6340 (Letter from RS Government to SDS Executive Board, 12 March 1994).
} 
instance, the Accused, as President of the SDS, asked that Đerić nominate Mićo Stanišić and Buha. $^{302}$

118. The Government was to take decisions by a simple majority vote, in sessions with a majority of the members attending. ${ }^{303}$ It was to co-operate with municipal executive organs by having their representatives participate in Government sessions, as well as by having Ministers participate in sessions of the municipal organs. ${ }^{304}$

119. A new "Law on the Government of the Republika Srpska" was passed by the Bosnian Serb Assembly on 15 September $1992 .{ }^{305}$ Under the new Law on the Government, the Bosnian Serb Government could propose to the President of the Republic the declaration of a state of emergency as well as adequate measures and decisions could be made by a majority of the Government members present at a Government session. ${ }^{306}$

120. The Government was in regular contact with municipalities and SAOs. ${ }^{307}$ The Government regularly received letters, reports, and requests from Government organs and requested or received reports from individual ministries; ${ }^{308}$ some reports were conveyed to the Presidency ${ }^{309}$ or submitted to the Assembly. ${ }^{310}$ Minutes of Government sessions also indicate that ministries were assigned

302 Branko Đerić, T. 27943 (24 April 2012); P4982 (Witness Statement of Branko Đerić dated 5 April 2012), para. 9.

$303 \quad$ See Adjudicated Fact 2042.

304 Adjudicated Fact 2043. But see D3321 (Witness statement of Milorad Skoko dated 1 April 2013), para. 31 (stating that this was not the case while he was deputy minister of the economy during 1992). The Chamber does not consider the evidence of this witness to be reliable on this point. P2536 (Patrick Treanor's expert report entitled “The Bosnian Serb Leadership 1990-1992”, 30 July 2002), para. 217.

306 P2536 (Patrick Treanor's expert report entitled “The Bosnian Serb Leadership 1990-1992”, 30 July 2002 ), paras. 218-219.

307 P2536 (Patrick Treanor's expert report entitled “The Bosnian Serb Leadership 1990-1992”, 30 July 2002), para. 233.

308 P2536 (Patrick Treanor's expert report entitled "The Bosnian Serb Leadership 1990-1992”, 30 July 2002), para. 233. See, e.g., P3086 (Minutes of the $21^{\text {st }}$ session of SerBiH Government, 5 June 1992), p. 2; P3089 (Minutes of the $31^{\text {st }}$ session of SerBiH Government, 19 June 1992), pp. 3-4; P3098 (Minutes of the $48^{\text {th }}$ session of SerBiH Government, 28 July 1992), p. 10; P3099 (Minutes of the $49^{\text {th }}$ session of RS Government, 7 September 1992), pp. 5-6; P3100 (Minutes of the 53 ${ }^{\text {rd }}$ session of RS Government, 1 October 1992), pp. 7-9; P3102 (Minutes of the $57^{\text {th }}$ session of RS Government, 27 October 1992), pp. 6-7; P3103 (Minutes of the $58^{\text {th }}$ session of RS Government, 27 October 1992), pp. 9-11.

309 P2536 (Patrick Treanor's expert report entitled "The Bosnian Serb Leadership 1990-1992”, 30 July 2002), para. 233. See, e.g., P1092 (Minutes of $25^{\text {th }}$ session of Government SerBiH, 10 June 1992), p. 3; P1093 (Minutes of $5^{\text {th }}$ session of SerBiH Presidency, 10 June 1992), p. 2; P3088 (Minutes of the $27^{\text {th }}$ session of SerBiH Government, 13 June 1992), p. 2.

310 See, e.g., P3101 (Minutes of the $56^{\text {th }}$ session of RS Government, 21 October 1992), p. 3; P3103 (Minutes of the $58^{\text {th }}$ session of RS Government, 27 October 1992), p. 9. 
tasks with direction from the Presidency. ${ }^{311}$ The Ministry of Justice and municipalities or municipal-level bodies had communications about matters relating to detained persons. ${ }^{312}$

\section{d. Initial actions}

121. In the course of 1992, the Bosnian Serb Government held around 90 sessions. ${ }^{313}$ Legislative proposals were forwarded to the Assembly, while decisions within the competence of the Government were published in the Official Gazette. ${ }^{314}$

122. The Government was also concerned with the issue of deserted houses and apartments in the municipalities, as well as the issue of Muslim-owned property in general. ${ }^{315}$ It would send individual Ministers to visit municipal assemblies in order to be kept up to date on the situation. ${ }^{316}$

123. By early May 1992, the Government had at its disposal in Pale a Republican Information Centre which connected with regional communication centres in the Bosnian-Serb territory. ${ }^{317}$ It operated 24 hours per day and had five employees. ${ }^{318}$ By June 1992, written reports, as well as dozens of telegrams, were received daily by the Centre and sent on to the intended recipients. ${ }^{319}$

\section{e. Exchange Commission}

124. Pursuant to a decision at the 24 April 1992 SNB-Government meeting, after the MUP had conducted an investigation of prisoners, the Ministry of Justice was to conduct their exchange. ${ }^{320}$

$311 \quad$ See P2536 (Patrick Treanor's expert report entitled “The Bosnian Serb Leadership 1990-1992”, 30 July 2002), para. 234. See, e.g., P1095 (Minutes of $28^{\text {th }}$ session of SerBiH Government, 15 June 1992), p. 4; P3090 (Minutes of the $32^{\text {nd }}$ session of SerBiH Government, 24 June 1992), p. 9; P3100 (Minutes of the $53^{\text {rd }}$ session of RS Government, 1 October 1992), p. 8.

312 P1142 (Letter from Ministry of Justice of SerBiH to Vogošća War Presidency, 10 August 1992); P1606 (Request from Vogošća Municipality to Ministry of Justice of SerBiH, 6 August 1992); P1130 (Letter from Ministry of Justice of SerBiH to Municipality of Ilidža, 4 July 1992); P1151 (Letter from SJB Novi Grad to the Ministry of Justice of SerBiH, 25 May 1992).

$313 \quad$ See Adjudicated Fact 2057.

$314 \quad$ Adjudicated Fact 2059.

315 Adjudicated Fact 2061.

316 Adjudicated Fact 2062. But see D3321 (Witness statement of Milorad Skoko dated 1 April 2013), para. 32 (stating that this only occurred in particular circumstances and that communications with the field were irregular and extremely difficult). The Chamber does not consider the evidence of this witness to be reliable on this point.

317 Adjudicated Fact 2063. But see D3321 (Witness statement of Milorad Skoko dated 1 April 2013), para. 33 (disputing that the centre functioned as described). The Chamber does not consider the evidence of this witness to be reliable on this point. See para. 120.

318 Adjudicated Fact 2064. But see D3321 (Witness statement of Milorad Skoko dated 1 April 2013), para. 33 (disputing that the centre functioned as described). The Chamber does not consider the evidence of this witness to be reliable on this point.

$319 \quad$ Adjudicated Fact 2065.

$320 \quad$ P1087 (Minutes of meeting between SNB and SerBiH Government, 24 April 1992), p. 1; Momčilo Mandić, C2 (Transcript from Prosecutor v. Krajišnik), T. 8743-8745; Momčilo Mandić, T. 4529-4537 (1 July 2010). 
The latter work was done through the state-level Exchange Commission formed after the April meeting. ${ }^{321}$

125. On 8 May 1992, the Bosnian Serb Government established a Central Commission for the Exchange of Prisoners of War and Arrested Persons. ${ }^{322}$ The Commission's jurisdiction was to extend over the entire territory of the SerBiH and cover "all cases of negotiating and exchanging prisoners-of-war, arrested persons and the bodies of those killed". ${ }^{323}$ If the Commission was unable to do its work throughout the territory of the Republic, presidents of Serb districts, in co-operation with the commanders of TO staffs and chiefs of CSBs, were to form a commission for the area of the district. ${ }^{324}$ The commissions for districts were to "submit reports on measures taken to the Central Commission". ${ }^{325}$ The Commission worked through local commissions. ${ }^{326}$

126. On 10 May 1992, the SNB and the Government appointed the members of the Commission, who included representatives from the Bosnian Serb Ministry of Defence, the MUP, and the Ministry of Justice. ${ }^{327}$ The Commission was initially headed by Rajko Čolović, ${ }^{328}$ who was replaced as president of the Commission by Slobodan Avlijaš by a decision of the SerBiH Government; ${ }^{329}$ however, Avlijaš asked to be relieved of the position and Nenad Vanovac was appointed president of the Commission. ${ }^{330}$ Instructions on the Treatment of Captured Persons

Mandić specified that the prisoners included detained persons of civilian status. Momčilo Mandić, C2 (Transcript from Prosecutor v. Krajišnik), T. 8758; Momčilo Mandić, T. 4552-4553 (5 July 2010).

321 Momčilo Mandić, C2 (Transcript from Prosecutor v. Krajišnik), T. 8744-8746, 8749-8750.

322 Adjudicated Fact 2075; P1088 (Decision of SerBiH, 8 May 1992); Momčilo Mandić, T. $4537-4538$ (1 July 2010). The Chamber notes that the Commission was dissolved in March 1993 and that a new commission was formed immediately thereafter. See para. 2935.

323 P1088 (Decision of SerBiH, 8 May 1992), p. 1.

324 P1088 (Decision of SerBiH, 8 May 1992), p. 1.

325 P1088 (Decision of SerBiH, 8 May 1992), p. 2.

326 P1088 (Decision of SerBiH, 8 May 1992); P1090 (Order of Central Commission for Exchange of Detained Persons, 6 June 1992), p. 1; Momčilo Mandić, C2 (Transcript from Prosecutor v. Krajišnik), T. 8754; P4850 (Witness statement of Amor Mašović dated 23 March 2012), para. 14.

327 Adjudicated Fact 2076; D409 (Minutes of SNB and the Government of the SerBiH session, 10 May 1992), p. 2; P1088 (Decision of SerBiH, 8 May 1992), p. 1. See also Momčilo Mandić, C2 (Transcript from Prosecutor v. Krajišnik), T. 8746, 8770; Momčilo Mandić, T. 4536-4538 (1 July 2010).

328 Momčilo Mandić, C2 (Transcript from Prosecutor v. Krajišnik), T. 8752, 8770; Momčilo Mandić, T. 4537-4538 (1 July 2010); P1088 (Decision of SerBiH, 8 May 1992), p. 1; D3105 (Witness statement of Slobodan Avlijaš dated 9 March 2013), para. 6.

329 P3091 (Minutes of the 33 ${ }^{\text {rd }}$ session of SerBiH Government, 26 June 1992), p. 5; D3105 (Witness statement of Slobodan Avlijaš dated 9 March 2013), paras. 6, 49.

330 P1130 (Letter from Ministry of Justice of SerBiH to Municipality of Ilidža, 4 July 1992); D3105 (Witness statement of Slobodan Avlijaš dated 9 March 2013), paras. 6, 49. 
published in the Official Gazette on 13 June 1992 and signed by the Minister of Defence Bogdan Subotić stated that the Commission operates under the jurisdiction of the Ministry of Justice. ${ }^{331}$

127. The Commission's official role was to co-ordinate exchanges and to provide information on captured persons. ${ }^{332}$ As part of that role the Commission was to differentiate between civilians and prisoners of war, with a view to releasing the former and preventing crisis staffs or paramilitary formations from committing crimes against the latter. ${ }^{333}$ The report on the activities of the Ministry of Justice and Administration in the period May-October 1992 indicates that the Ministry "urged the Presidency to establish a Central Commission for the exchange of prisoners of war, incarcerated and wounded persons, and dead bodies" to address "the increased influx of incarcerated persons". 334 According to Mandić, the impetus for establishing the Commission was to provide "rule of law and legal security" for people detained, many of whom were civilians from conflict areas. $^{335}$

128. On 6 June 1992, the Commission issued an order signed by the Commission President Čolović that stated that SJBs "engaged in safeguarding of facilities where prisoners of war, or detainees are located, shall keep evidence of all the persons who have been brought in" and "shall submit lists of detainees or persons deprived of liberty to municipal commissions for exchange of prisoners of war on regular basis". 336 The order further stated that municipal commissions were to submit the lists to regional commissions or to the Central Commission. ${ }^{337}$ According to the order, detainees or persons deprived of liberty could not be released or exchanged without a prior order of the Commission. ${ }^{338}$

\section{Regional and municipal bodies}

129. During the first half of 1991, several municipalities in BiH having a Serb majority or plurality formed new communities of municipalities. ${ }^{339}$ Among these were the Community of

\footnotetext{
331 P1134 (SerBiH Ministry of Defence of Instructions on the Treatment of Captured Persons, 13 June 1992), para. 19. But see Momčilo Mandić, C2 (Transcript from Prosecutor v. Krajišnik), T. 8746, 8750 (stating that the Commission was at the state level and not solely under the jurisdiction of the Ministry of Justice).

332 Adjudicated Fact 2077. See also Momčilo Mandić, T. 4604 (5 July 2010).

333 Adjudicated Fact 2078. See also Momčilo Mandić, C2 (Transcript from Prosecutor v. Krajišnik), T. 87618764.

334 P1089 (Ministry of Justice Report on the Ministry's Activities in May-October 1992 Period, 16 November 1992), p. 2.

335 Momčilo Mandić, C2 (Transcript from Prosecutor v. Krajišnik), T. 8750.

336 P1090 (Order of Central Commission for Exchange of Detained Persons, 6 June 1992), pp. 1, 4.

337 P1090 (Order of Central Commission for Exchange of Detained Persons, 6 June 1992), p. 1.

$338 \quad$ P1090 (Order of Central Commission for Exchange of Detained Persons, 6 June 1992), p. 1.

339 P2536 (Patrick Treanor's expert report entitled “The Bosnian Serb Leadership 1990-1992”, 30 July 2002), para. 117; Robert Donia, T. 3100-3101 (1 June 2010). See paras. 40-42.
} 
Municipalities of the Bosnian Krajina (ZOBK), established on 25 April 1991, Community of Municipalities of Romanija, established on 8 May 1991, and Community of Municipalities of Eastern and Old Herzegovina, established on 27 May 1991. ${ }^{340}$ For instance, the ZOBK had an assembly, a president and two vice presidents, and a secretary. ${ }^{341}$ The ZOBK Assembly was authorised to enact decisions, conclusions, positions, and other acts. ${ }^{342}$

130. Around the fall of 1991, several areas declared themselves SAOs. ${ }^{343}$ These included the SAO Herzegovina (formerly, Community of Municipalities of Eastern and Old Herzegovina), Autonomous Region of Krajina (formerly, ZOBK), SAO Northeastern Bosnia, SAO Romanija, SAO Northern Bosnia, and SAO Birač. ${ }^{344}$ The Bosnian Serb Assembly approved on 21 December 1991 the appointment of Jovan Čizmović as the co-ordinator of activities of the executive bodies of the SAOs. ${ }^{345}$

131. On 11 December 1991, the Bosnian Serb Assembly adopted a recommendation that SDS deputies in municipal assemblies in $\mathrm{BiH}$ in which the SDS did not have a majority establish "municipal assemblies of the Serbian people". ${ }^{346}$ The recommendation was directed to groups of SDS deputies in municipal assemblies in $\mathrm{BiH}$ "on whom decisions contrary to the interests of the Serbian people are imposed". ${ }^{347}$ The recommendation stated that the assemblies would be composed of SDS deputies and "other deputies of Serb nationality who make a statement on joining the Assembly". ${ }^{348}$ Attached to the recommendation was a model decision on the establishment of an assembly of the Serbian people to be adopted by individual municipalities. ${ }^{349}$ These decisions were to be verified by the Bosnian Serb Assembly. ${ }^{350}$

\footnotetext{
$340 \quad$ P2536 (Patrick Treanor's expert report entitled “The Bosnian Serb Leadership 1990-1992”, 30 July 2002), para. 117; Radomir Nešković, T. 14355 (7 June 2011); Asim Egrlić, P6586 (Transcript from Prosecutor v. Krajišnik), T. 4642.

341 P2536 (Patrick Treanor's expert report entitled “The Bosnian Serb Leadership 1990-1992”, 30 July 2002), para. 124.

342 P2536 (Patrick Treanor's expert report entitled “The Bosnian Serb Leadership 1990-1992”, 30 July 2002), para. 125.

343 P2536 (Patrick Treanor's expert report entitled “The Bosnian Serb Leadership 1990-1992”, 30 July 2002), para. 136; Radomir Nešković, T. 14355-14356 (7 June 2011).

344 P2536 (Patrick Treanor's expert report entitled “The Bosnian Serb Leadership 1990-1992”, 30 July 2002), para. 136.

345 D86 (Shorthand Record of $4^{\text {th }}$ session of SerBiH Assembly, 21 December 1991), p. 34.

346 D84 (Shorthand Record of $3^{\text {rd }}$ session of SerBiH Assembly, 11 December 1991), pp. 10-30; D1183 (SerBiH Assembly recommendation on establishment of municipal assemblies, 11 December 1991); P2589 (Dorothea Hanson's expert report entitled "Bosnian Serb Crisis Staffs, War Presidencies and War Commissions 19911995”, 10 September 2009), para. 19; Robert Donia, T. 3108 (1 June 2010). D84 (Shorthand Record of $3^{\text {rd }}$ session of SerBiH Assembly, 11 December 1991), p. 29; D1183 (SerBiH Assembly recommendation on establishment of municipal assemblies, 11 December 1991).

348 D84 (Shorthand Record of $3^{\text {rd }}$ session of SerBiH Assembly, 11 December 1991), p. 11.

349 D84 (Shorthand Record of $3^{\text {rd }}$ session of SerBiH Assembly, 11 December 1991), pp. 11, 18-20.

350 D84 (Shorthand Record of $3^{\text {rd }}$ session of SerBiH Assembly, 11 December 1991), p. 29.
} 
132. Instructions dated 19 December 1991 were issued by the Main Board of the SDS regarding Serb-dominated municipalities, designated Variant A, and Serb-minority municipalities, designated Variant $\mathrm{B}^{351}$ The Variant A/B Instructions directed SDS municipal officials to form Serb municipal institutions in municipalities where Serbs were a minority. ${ }^{352}$ The instructions were communicated from SDS leaders to municipal SDS leaders and boards. ${ }^{353}$ Copies of the document itself were distributed by the Accused for viewing only by high-ranking municipal officials, such as presidents of municipalities or other municipal authorities, at a meeting on or around 20 December $1991^{354}$ attended by all members of the Main Board and Executive Board, deputies, municipal representatives, and members of the government. ${ }^{355}$

133. The Variant A/B Instructions called for, in the first phase in Variant A and B municipalities, convening and proclaiming an assembly of the Serbian people and carrying out preparations for the

351 P5 (SDS Instructions for Organisation of Organs of the Serbian People in BiH, 19 December 1991); Patrick Treanor, T. 14027-14028 (1 June 2011); P2536 (Patrick Treanor's expert report entitled "The Bosnian Serb Leadership 1990-1992", 30 July 2002), paras. 61-63; P2589 (Dorothea Hanson's expert report entitled "Bosnian Serb Crisis Staffs, War Presidencies and War Commissions 1991-1995”, 10 September 2009), paras. 20-21; P973 (Robert Donia's expert report entitled "Bosnian Serb Leadership and the Siege of Sarajevo, 1990-1995", January 2010), pp. 19-20. Radomir Nešković testified that the Variant A/B Instructions were not produced through regular SDS party procedures, and he believed that the document was written by a group of officers outside the SDS and wrote "Crisis Staff of the SDS", a non-existing entity, as the header. Radomir Nešković, T. 14262-14264 (6 June 2011), T. 14325, 14365-14366 (7 June 2011). However, the Chamber does not place any weight on Nešković's belief and speculation in this regard.

352 P5 (SDS Instructions for Organisation of Organs of the Serbian People in BiH, 19 December 1991), pp. 2, 6-7; P2536 (Patrick Treanor's expert report entitled “The Bosnian Serb Leadership 1990-1992", 30 July 2002), para. 63; Patrick Treanor, T. 14027-14028 (1 June 2011); Robert Donia, T. 3109-3113 (1 June 2010); P2589 (Dorothea Hanson's expert report entitled "Bosnian Serb Crisis Staffs, War Presidencies and War Commissions 1991-1995”, 10 September 2009), para. 21.

353 Predrag Radić, P1 (Transcript from Prosecutor v. Krajišnik), T. 7385; Neđeljko Prstojević, T. 12940 (3 March 2011); P4374 (Witness statement of Milenko Katanić dated 11 October 2011), para. 15; P6369 (Excerpts from KW317's statement to OTP, 14 June 2002) (under seal), p. 11; Branko Grujić, T. 40367 (25 June 2013). See also P2592 (Minutes of $6^{\text {th }}$ Session of the Executive Board of the Ključ SDS Municipal Board, 23 December 1991), p.1; P6661 (Minutes of $3^{\text {rd }}$ session of Bosanska Krupa SSO Executive Board, 24 December 1991), p. 1; P2595 (Minutes of meeting of Prijedor's SDS Municipal Board, 27 December 1991), p. 1; P2598 (Minutes of meeting of Bratunac's SDS Municipal Board, 23 December 1991), p. 1.

354 Radomir Nešković refers to 19 December 1991 as the date of the meeting. Radomir Nešković, P2568 (Transcript from Prosecutor v. Krajišnik), T. 16647, 16783-16784. However, other evidence indicates that the meeting likely took place the next day, on 20 December 1991. See D215 (Excerpts from Ljubo Grcković's diary), p. 59; P2536 (Patrick Treanor's expert report entitled “The Bosnian Serb Leadership 1990-1992”, 30 July 2002), para. 62; P2550 (Intercept of conversation between Radovan Karadžić and Momčilo Krajišnik, 21 December 1991), p. 3, Patrick Treanor, T. 14029-14030 (1 June 2011); P5792 (Intercept of conversation between Radovan Karadžić and Milan Novaković, 19 December 1991), pp. 1-2; Momčilo Krajišnik, T. 4385643857 (20 November 2013). The Chamber does not consider the date discrepancy to affect the reliability of Nešković's evidence on the substance of the meeting. Miroslav Toholj stated that the Variant A/B Instructions were not presented during this meeting. D3981 (Witness statement of Miroslav Toholj dated 31 October 2013), para. 92. Having considered the weight of evidence which demonstrates that the Variant A/B Instructions were presented at this meeting, the Chamber does not find Toholj's evidence to be reliable in this regard. In reaching that conclusion the Chamber also had regard to the evasiveness, contradictions and indicators of partiality in his testimony.

355 Radomir Nešković, P2568 (Transcript from Prosecutor v. Krajišnik), T. 16647-16650, 16655-16657, 1678816790; D1278 (Transcript of Radomir Nešković's interview with Karadžić's legal associate, 8 October 2009), pp. $27-28$. 
establishment of municipal state or government organs. ${ }^{356}$ According to the instructions, the tasks laid out therein were to be implemented over the entire territory of the SRBiH or in every municipality where the Serbian people live, in their entirety in Variant A municipalities and partially in Variant B municipalities. ${ }^{357}$ The instructions addressed the formation of Crisis Staffs in Variant A and B municipalities as part of the first phase. ${ }^{358}$

134. In the second phase in Variant A and B municipalities, the Variant A/B Instructions called for, inter alia, convening a session of the Serb municipal assembly, establishing a municipal executive board and municipal state or government organs, mobilising and resubordinating all Serb police forces in co-ordination with JNA command and staff, and ensuring the implementation of the order for mobilisation of JNA reserve and territorial defence units. ${ }^{359}$

135. On 14 February 1992, at an extended session of the SDS Main and Executive Boards, the Accused referred to the implementation of phase two of the Variant A/B Instructions. ${ }^{360}$ The presidents of SDS municipal boards, presidents and members of regional boards, presidents of assemblies, and executive boards of municipalities were invited to this meeting. ${ }^{361}$ This discussion and a directive to implement phase two were conveyed to municipal boards. ${ }^{362}$

136. On 24 March 1992, the Bosnian Serb Assembly verified the decisions of numerous municipal assemblies on the proclamation of newly established Serbian municipalities, including Vogošća, Srebrenica, Bratunac, Prijedor, Višegrad, Foča, Brčko, and Zvornik. ${ }^{363}$ Earlier in the Assembly session, the Accused stated: "Newly established municipalities must establish their organs as soon as possible, have their stamps made and start to work. The police, that is, our organs must be positioned at the border.",364

\footnotetext{
356 P5 (SDS Instructions for Organisation of Organs of the Serbian People in BiH, 19 December 1991), pp. 3-4, 7.

357 P5 (SDS Instructions for Organisation of Organs of the Serbian People in BiH, 19 December 1991), p. 2.

358 P5 (SDS Instructions for Organisation of Organs of the Serbian People in BiH, 19 December 1991), pp. 3, 6-7.

359 P5 (SDS Instructions for Organisation of Organs of the Serbian People in BiH, 19 December 1991), pp. 5-6, 910.

360 P12 (Extended session of Main and Executive Boards of the SDS, 14 February 1992), pp. 5-7, $17,24$.

361 P12 (Extended session of Main and Executive Boards of the SDS, 14 February 1992), p. 1.

362 P5516 (Minutes of Meeting of SDS Prijedor Municipal Board, 17 February 1992); P6587 (Excerpts from Simo Mišković's testimony from Prosecutor v. Stanišić \& Župljanin), T. 15184-15188; P2597 (Minutes of meeting of Bratunac's SDS Municipal Board, 24 February 1992), p. 1; P4374 (Witness statement of Milenko Katanić dated 11 October 2011), para. 18; KW317, T. 39337 (5 June 2013). [REDACTED].

363 P961 (Shorthand Record of $12^{\text {th }}$ session of SerBiH Assembly, 24 March 1992), pp. 23-24.

364 P961 (Shorthand Record of $12^{\text {th }}$ session of SerBiH Assembly, 24 March 1992), p. 17.
} 
137. Municipalities had an SDS municipal board and president thereof, ${ }^{365}$ a municipal assembly and president thereof, ${ }^{366}$ and a municipal executive board and chairman or president thereof. ${ }^{367}$ From late 1991 on, municipalities had a Crisis Staff (some were re-established or re-formed around April or May 1992) ${ }^{368}$, a War Presidency, a War Commission, and/or a republican commissioner. ${ }^{369}$ Municipal Crisis Staffs were headed by the municipal executive board or assembly president or SDS municipal board president. ${ }^{370}$ The president of the municipality was usually the executive board president, assembly president, or president of the SDS in the municipality. ${ }^{371}$

365 See P3023 (Witness statement of Đorde Ristanić dated 15 June 2011), paras. 13, 62; Asim Egrlić, P6586 (Transcript from Prosecutor v. Krajišnik), T. 4746; P3454 (Decision of Ključ Crisis Staff, 13 July 1992); P2595 (Minutes of meeting of Prijedor's SDS Municipal Board, 27 December 1991), pp. 1-2; P2632 (Report of Bosanski Novi's Crisis Staff, undated), p. 1; P2590 (Conclusions of Zvornik's SDS Municipal Board, 22 December 1991); P2450 (Ilidža SDS Declaration for working in wartime, 6 February 1993), pp. 1, 4; P5515 (Letter from SDS Municipal Board of Foča to SDS Crisis Staff in Sarajevo, 2 March 1992); P6121 (Decision of Vlasenica's SDS Municipal Board, 4 April 1992); P2598 (Minutes of meeting of Bratunac's SDS Municipal Board, 23 December 1991); P6542 (Report of Sanski Most SDS Municipal Board, 10 September 1993); P2576 (Minutes of $13^{\text {th }}$ session of Novo Sarajevo's SDS Municipal Board, 28 February 1992); P5249 (Letter from Milan Tupajić to Sokolac SDS Municipal Board, 9 October 1992).

366 See P5411 (Minutes of the $13^{\text {th }}$ session of the Ključ Municipal Assembly, 31 July 1992); P3536 (Decision of Prijedor Municipal Assembly dated 20 May 1992, published in Prijedor Official Gazette on 25 June 1992), pp. 1, 7; P975 (Decision of Serbian Municipal Assembly of Ilidža, 3 January 1992); P5481 (Request of Foča Municipal Assembly, 17 March 1992); P6139 (Decision of Vlasenica Municipal Assembly, 30 March 1992); P3199 (Minutes of $1^{\text {st }}$ meeting of Bratunac Municipal Assembly, 30 December 1991); P3407 (Report on the work of the Rogatica Municipal Assembly and Executive Board from July 1992 to September 1993); P2297 (Minutes of meeting of Hadžići Municipal Assembly, 11 April 1992); P3325 (Decision of Sanski Most Municipal Assembly, 3 April 1992); P5523 (14 ${ }^{\text {th }}$ session of Pale Municipal Assembly, 18 June 1992); P5511 (Minutes of the $3^{\text {rd }}$ meeting of the Vogošća Municipal Assembly, 14 November 1992); P6524 (Excerpt of Minutes of the $19^{\text {th }}$ Banja Luka Municipal Assembly Session, 23 June 1992); P6236 (Letter from Sokolac Municipal Assembly to Radovan Karadžić, 15 July 1992).

367 See P3589 (Decision of Ključ Executive Board, 12 May 1992); P3484 (Decision of Prijedor Executive Board, 21 July 1992); D4727 (Decisions of Zvornik Executive Board, September 1992); P3340 (Decision of Foča Executive Board, 26 April 1992); P3271 (Report of Rogatica's Executive Board, 24 March 1992); P3309 (Minutes of meeting of Sanski Most's Executive Board, 5 March 1992); P6034 (Report of Pale Executive Board, 7 July 1992). Ključ had an executive board of its SDS municipal board, as well as an executive board of the municipality or municipal assembly as in the other municipalities. See P3438 (Minutes of $8^{\text {th }}$ session of Ključ SDS Municipal Board Executive Board, 29 April 1992); P3589 (Decision of Ključ Executive Board, 12 May 1992).

See, e.g., Radomir Nešković, P2568 (Transcript from Prosecutor v. Krajišnik), T. 16683-16685, 16706; Radomir Nešković, T. 14282-14283 (6 June 2011); P2643 (Ključ Crisis Staff Report, 15 May - 29 July 1992), p. 2; P2605 (Prijedor Assembly's decision on the organization and work of Prijedor Crisis Staff, May 1992); P2632 (Report of Bosanski Novi's Crisis Staff, undated), p. 7; P2835 (Report of Rogatica Crisis Staff, April June 1992), p. 1.

369 See paras. $388,403,410$.

370 See para. 139, Section IV.A.1: Municipalities component (Facts). For instance, Žarko Đurović, the president of the municipal executive board, was the head of the Crisis Staff formed in Novo Sarajevo, a Variant A municipality, in December 1991. See Radomir Nešković, P2568 (Transcript from Prosecutor v. Krajišnik), T. 16684; Radomir Nešković, T. 14275-14276 (6 June 2011); T. 14352-14354 (7 June 2011); P2575 (Excerpt from session of Novo Sarajevo's Crisis Staff, 23 December 1991). In Ključ, the president of the municipal assembly, Jovo Banjac, was the president of the Crisis Staff. See Asim Egrlić, P6586 (Transcript from Prosecutor v. Krajišnik), T. 4643; P3442 (Proposed work schedule of Ključ Crisis Staff, May 1992), p. 5; P3454 (Decision of Ključ Crisis Staff, 13 July 1992). In Hadžići and Zvornik, the president of the Crisis Staff was the president of the SDS in the municipality. See P2296 (Witness statement of Tihomir Glavaš dated 13 February 2011), paras. 23-25; P2590 (Conclusions of Zvornik's SDS Municipal Board, 22 December 1991), pp. 1-2.

371 For instance, in Novo Sarajevo, the president of the executive board of the municipality, who was the president of the municipal government, was Žarko Đurović. Radomir Nešković, P2568 (Transcript from Prosecutor 
138. The exact setting up and transformation from Crisis Staff to War Presidency to War Commission varied from municipality to municipality. Some of the factors determining this variation were location, time, and personalities. ${ }^{372}$

\section{a. Crisis Staffs}

139. The Variant A/B Instructions ordered SDS municipal boards in Variant $\mathrm{A}$ and B municipalities in the first phase to "establish immediately Crisis Staffs of the Serbian People in the municipality", comprising all members of the SDS municipal board secretariat, SDS candidates in certain municipal organs (Variant A) or SDS candidates in every municipal organ (Variant B), deputies of the Assembly of the Serbian People in $\mathrm{BiH}$, and members of the SDS Main Board from the municipality. ${ }^{373}$ The Commander of the Crisis Staff was, in Variant A municipalities, the president of the municipal assembly or the chairman of the municipal executive board and, in Variant B municipalities, the president of the SDS municipal board. ${ }^{374}$ This composition and leadership of the Crisis Staffs provided for close links between the Crisis Staffs and the SDS and its leadership. ${ }^{375}$

140. On 27 March 1992, at a session of the Bosnian Serb Assembly, the Accused reiterated the instructions to "urgently establish" Crisis Staffs in the municipalities and for the presidents of municipalities and executive boards to "hold the highest ranks in the crisis staffs". ${ }^{376}$ The Accused stated: "I urge you to undertake, with the full authorisation of the Assembly, the task of introducing discipline and organising crisis staffs, headed by reserve and retired officers in order to organise the people for defensive purposes. Exclusively for defensive purposes". 377

v. Krajišnik), T. 16641; Radomir Nešković, T. 14276 (6 June 2011). In Ključ, the president of the municipal assembly and the president of the municipality was Jovo Banjac. Asim Egrlić, P6586 (Transcript from Prosecutor v. Krajišnik), T. 4637, 4643; P3454 (Decision of Ključ Crisis Staff, 13 July 1992). Similarly, in Zvornik, the president of the Serb municipal assembly, Jovo Mijatović, was the president of the municipality. P2591 (Decision regarding the formation of the Serbian Municipality of Zvornik, 27 December 1991), p. 4; P2590 (Conclusions of Zvornik's SDS Municipal Board, 22 December 1991), p. 2. In Hadžići, Ratko Radić was the president of the SDS and the president of the municipality. P2296 (Witness statement of Tihomir Glavaš dated 13 February 2011), paras. 23-25.

$372 \quad$ Adjudicated Fact 2204.

373 P5 (SDS Instructions for Organisation of Organs of the Serbian People in BiH, 19 December 1991), pp. 3, 7.

374 P5 (SDS Instructions for Organisation of Organs of the Serbian People in BiH, 19 December 1991), pp. 3, 7.

375 P2589 (Dorothea Hanson's expert report entitled "Bosnian Serb Crisis Staffs, War Presidencies and War Commissions 1991-1995”, 10 September 2009), para. 24. See also Adjudicated Fact 2188.

376 P1634 (Minutes of $14^{\text {th }}$ session of SerBiH Assembly, 27 March 1992), pp. 23-24; P2589 (Dorothea Hanson's expert report entitled "Bosnian Serb Crisis Staffs, War Presidencies and War Commissions 1991-1995", 10 September 2009), para. 34.

377 P1634 (Minutes of $14^{\text {th }}$ session of SerBiH Assembly, 27 March 1992), p. 24; P2589 (Dorothea Hanson's expert report entitled "Bosnian Serb Crisis Staffs, War Presidencies and War Commissions 1991-1995", 10 September 2009), para. 34. 
141. On 4 April 1992, the Accused, as President of the SNB, ordered the activation of Crisis Staffs. $^{378}$

142. On 26 April 1992, the Bosnian Serb Government under Prime Minister Đerić issued "Instructions for the Work of Crisis Staffs of the Serbian People in Municipalities", which stated: "In wartime conditions, the Crisis Staff shall take over all the prerogatives and functions of municipal assemblies, when they are not in a position to meet." ${ }^{379}$ The record of the session of the SNB and Government on 27 April 1992 states that "[i]t was concluded that comprehensive instructions for crisis staffs should be drafted in which the manner of political work on the ground and organisation of the functioning of the authorities will be presented". 380

143. The 26 April 1992 Instructions provided that the Crisis Staff "shall co-ordinate governmental functions for the purpose of the defence of territory, safety of the population and its property, establishment of authority and organisation of all other aspects of life and work". ${ }^{381}$ The instructions further stated that the Crisis Staff would, through these "co-ordination efforts", "create the conditions for the municipal executive board to exercise legal executive power, manage the economy and other aspects of life". ${ }^{382}$ The instructions stated that "[t]he work of the Crisis Staff shall be based on the provisions of the Constitution and the law, and on the decisions of the Assembly, the Presidency and the Government of the [SerBiH]". ${ }^{383}$

144. According to the 26 April 1992 Instructions, the Crisis Staffs were "obliged to gather information on the situation in the field and notify and consult the competent authorities in [SerBiH], i.e. commissioners of the Government appointed for the areas and regions especially threatened by war". 384

145. The relationship between Crisis Staffs and the various military forces present in the municipalities (JNA units, the TO, paramilitary units, and the VRS) differed from municipality to

\footnotetext{
378 D394 (Announcement of SNB, 4 April 1992); P2589 (Dorothea Hanson's expert report entitled "Bosnian Serb Crisis Staffs, War Presidencies and War Commissions 1991-1995”, 10 September 2009), para. 36.

$379 \quad$ P2717 (SerBiH Government instructions for Crisis Staffs, 26 April 1992); P2589 (Dorothea Hanson's expert report entitled "Bosnian Serb Crisis Staffs, War Presidencies and War Commissions 1991-1995", 10 September 2009), para. 38.

380 D406 (Minutes of meeting of SNB and SerBiH Government, 27 April 1992), p. 2.

$381 \quad$ P2717 (SerBiH Government instructions for Crisis Staffs, 26 April 1992), para. 3. In the same 26 April 1992 Instructions, the Government of SerBiH mandated that all Crisis Staffs include the commander of the TO Staff. P2717 (SerBiH Government instructions for Crisis Staffs, 26 April 1992), para. 2. The Instructions also stated that the Crisis Staffs were to "create all the conditions for the life and work of members of the JNA". P2717 (SerBiH Government instructions for Crisis Staffs, 26 April 1992), para. 8.

382 P2717 (SerBiH Government instructions for Crisis Staffs, 26 April 1992), para. 3.

383 P2717 (SerBiH Government instructions for Crisis Staffs, 26 April 1992), para. 6.

384 P2717 (SerBiH Government instructions for Crisis Staffs, 26 April 1992), para. 11
} 
municipality. ${ }^{385}$ At a minimum, however, the relationship involved a co-ordinating and supporting role for the Crisis Staffs. In at least one municipality, Zvornik, the local JNA commander was listed as a member of the Crisis Staff. ${ }^{386}$ Crisis Staffs also provided various forms of general assistance to the TO, such as calling for mobilisation within their municipalities and providing financial assistance. ${ }^{387}$

146. As will be further discussed later in this judgement, Crisis Staffs were formed and in existence between 1991 and 1993 in municipalities relevant to the charges in the Indictment. ${ }^{388}$ There were also Crisis Staffs of SAOs, including for SAO Semberija and Majevica, ${ }^{389}$ ARK, ${ }^{390}$ and SAO Birač. ${ }^{391}$

\section{b. War Presidencies}

147. The Bosnian Serb Government decided on 23 May 1992 to abolish the Crisis Staffs. ${ }^{392}$ The Government concluded that "the conditions for functioning of the regular governing organs should be created as soon as possible" and War Presidencies established in municipalities. ${ }^{393}$ A preceding

$385 \quad$ Adjudicated Fact 2205.

$386 \quad$ Adjudicated Fact 2206.

$387 \quad$ Adjudicated Fact 2215.

388 See P2590 (Conclusions of Zvornik’s SDS Municipal Board, 22 December 1991); P3154 (Decision of Zvornik's Crisis Staff, 6 April 1992); P2592 (Minutes of $6^{\text {th }}$ Session of the Executive Board of the Ključ SDS Municipal Board, 23 December 1991); P2606 (Minutes from sessions of Ključ's Crisis Staff, 27 May - 10 July 1992); P2575 (Excerpt from session of Novo Sarajevo's Crisis Staff, 23 December 1991); D885 (Letter from Novo Sarajevo Crisis Staff to Radovan Karadžić, 5 June 1992); P6055 (Minutes of the Crisis Staff meeting, 25 December 1991); Neđeljko Prstojević, T. 12951-12953, 12955, 12957-12959 (8 March 2011); P2410 (Ilidža Crisis Staff Order on implementation of general mobilisation, 6 April 1992); P2595 (Minutes of meeting of Prijedor's SDS Municipal Board, 27 December 1991); P2741 (Decision of Prijedor Crisis Staff, 2 June 1992); P2835 (Report of Rogatica Crisis Staff, April - June 1992); P3407 (Report on the work of the Rogatica Municipal Assembly and Executive Board from July 1992 to September 1993), e-court p. 5; P5250 (Minutes of meeting of Sokolac Crisis Staff, 10 April 1992); P5240 (Sokolac Crisis Staff conclusions, 20 April 1992); P6121 (Decision of Vlasenica's SDS Municipal Board, 4 April 1992); P3214 (Decision of Vlasenica Crisis Staff, 19 April 1992); P2598 (Minutes of meeting of Bratunac's SDS Municipal Board, 23 December 1991); P3202 (Decision of Bratunac Crisis Staff, 1992); D2061 (List of decisions and orders issued by the Crisis Staff, War Staff, and Wartime Presidency of Bratunac Municipality, 29 August 1992), p. 2; D3116 (Bratunac Crisis Staff decision, 6 May 1992); P4374 (Witness statement of Milenko Katanić dated 11 October 2011), paras. 15-16; Milenko Katanić, T. 24526-24527 (10 February 2012); P734 (Order of Pale Crisis Staff, 7 May 1992); P2364 (Vogošća Crisis Staff Order, 14 May 1992); P2635 (Conclusions of Vogošća's Crisis Staff, 16 May 1992); P2613 (Conclusions of Sanski Most's Crisis Staff, 22 May 1992); P2626 (Report of Bijeljina Crisis Staff, 1 April 1992); P2632 (Report of Bosanski Novi’s Crisis Staff, undated); P2918 (Order of Bosanski Novi's Crisis Staff, 8 June 1992); P3346 (Order of Foča Crisis Staff, 9 May 1992); D1084 (Hadžići Crisis Staff Decision, 26 May 1992).

389 See P2875 (Freedom of movement pass issued by Semberija \& Majevica Crisis Staff).

390 P6 (Decision on the formation of ARK Crisis Staff, 5 May 1992). See Section IV.A.1.b.ii.A: Establishment of ARK Crisis Staff.

391 P2615 (Decision of Birač Crisis Staff, 29 April 1992).

392 P3082 (Minutes of the $13^{\text {th }}$ session of SerBiH Government, 23 May 1992), para. 4; P2589 (Dorothea Hanson's expert report entitled "Bosnian Serb Crisis Staffs, War Presidencies and War Commissions 1991-1995", 10 September 2009), para. 46.

393 P3082 (Minutes of the $13^{\text {th }}$ session of SerBiH Government, 23 May 1992), para. 4; P2589 (Dorothea Hanson's expert report entitled "Bosnian Serb Crisis Staffs, War Presidencies and War Commissions 1991-1995", 
joint session of the SNB and Government, on 22 April 1992, concluded that the Government was to appoint a war presidency and war executive boards in all municipalities where executive boards "are not functioning". 394

148. On 31 May 1992, the Presidency issued, pursuant to Article 5 of the Constitutional Law on the Implementation of the Constitution of the $\mathrm{SerBiH}$, a decision constituting War Presidencies "in the municipalities of the Serbian Republic of Bosnia and Herzegovina where the assembly and the executive organ are unable to exercise authority". 395 The War Presidencies were to be composed of a republican commissioner and the president of the municipal assembly or his deputy, the chairman of the executive board or his deputy, or citizens who are deputies or assemblymen. 396

149. The 31 May 1992 Decision stated that the War Presidency "shall organise, coordinate and adjust activities for the defence of the Serbian people and the establishment of legal organs of authority in the municipality"; "shall perform all the functions of the assembly and the executive organ until there is a possibility for these organs to convene and work"; and "shall create and secure conditions for the work of military organs and units on the defence of the Serbian people", inter alia. $^{397}$

150. The republican commissioner, who would be a member of the War Presidencies, was to be appointed by the SerBiH Presidency and have the "right and duty [...] to ensure permanent coordination and implementation of the policies and measures that are established and adopted by the republican state organs and the Main Staff of the [VRS]". 398

151. According to the 31 May 1992 decision, the Crisis Staffs in the municipalities were to cease operating on the date the War Presidencies were constituted. ${ }^{399}$ On 31 May 1992, the Secretary of the SDS Executive Board sent a notice to SAOs Herzegovina, Romanija-Birač, and Semberija

10 September 2009), para. 46. See also D3715 (Article from Glas entitled "Crisis Staffs Abolished", 7 July 1992), p. 1.

394 P3051 (Minutes of expanded meeting of SNB and SerBiH Government, 22 April 1992), p. 2.

395 P2607 (SerBiH Presidency decision on constituting war presidencies in municipalities at a time of imminent threat of war or state of war, 31 May 1992), p. 1 (art. 1); P3060 (Minutes of the $2^{\text {nd }}$ session of the SerBiH Presidency, 31 May 1992); P2536 (Patrick Treanor's expert report entitled “The Bosnian Serb Leadership 19901992", 30 July 2002), para. 262. 
stating that the Crisis Staffs whose structure and method of work were established by the 26 April 1992 Instructions have been abolished under the 31 May 1992 decision and that War Commissions/Presidencies instead were being established in the municipalities at a time of imminent threat of war or state of war. ${ }^{400}$ This communication stated that it was the duty of the recipients, hitherto presidents of regional Crisis Staffs and now war commissioners, ${ }^{401}$ to ensure the implementation of the 31 May 1992 decision and instructed them to contact the Presidency directly with any remarks or suggestions related thereto. ${ }^{402}$

152. Records such as reports, orders, and meeting minutes indicate the existence of War Presidencies including in the following municipalities: Vogošća, Brčko, Ključ, Zvornik, Sanski Most, Ilidža, and Prijedor. ${ }^{403}$

\section{c. War Commissions}

153. On 10 June 1992, the Presidency issued, pursuant to Article 5 of the Constitutional Law on the Implementation of the Constitution of the SerBiH, a decision establishing War Commissions in SerBiH municipalities "which are either affected by war or are facing imminent threat of war". 404 The War Commissions were to be composed of "a state commissioner and four members from the ranks of the most influential citizens within the crisis staff, the economy and the ruling party". 405 The decision stated that the SerBiH Presidency would "appoint state commissioners to provide

\footnotetext{
$400 \quad$ P2608 (Report of the SDS Executive Board on the formation of war presidencies, 31 May 1992).

401 The communication makes reference, in relation to war commissioners, to the duties set out in article 4 of the 31 May 1992 decision, which discusses the Presidency-appointed republican commissioners. See para. 150.

402 P2608 (Report of the SDS Executive Board on the formation of war presidencies, 31 May 1992). See also Dorothea Hanson, T. 14538-14539 (9 June 2011).

403 P1142 (Letter from Ministry of Justice of SerBiH to Vogošća War Presidency, 10 August 1992); P2391 (Vogošća War Presidency order, 6 November 1992); P2874 (Freedom of movement pass issued by Brčko War Presidency, 7 May 1992); P3025 (Travel permit issued by Brčko's War Presidency, 9 May 1992); P2888 (Brčko War Presidency Summary of events in Brčko Municipality); P3452 (Extract from Minutes of Ključ War Presidency, 10 July 1992); P3453 (Decision of Ključ War Presidency, 13 July 1992); P3462 (Decision of Ključ War Presidency, 30 July 1992); D4365 (Report from Ključ War Presidency to Banja Luka SJB dated 22 August 1992); P5205 (Minutes from $3^{\text {rd }}$ session of the Zvornik Municipality War Presidency, 2 August 1995); P5536 (Decision of the War Presidency of Sanski Most Municipality, 14 July 1992); D2563 (Radovan Karadžić's Decision on appointment of Ilidža War Presidency, 20 June 1995); D4472 (Conclusions of Prijedor War Presidency, 6 August 1995).

404 P2611 (SerBiH Presidency Decision on the establishment of War Commissions in municipalities, 10 June 1992), p. 1 (art. 1); P1093 (Minutes of $5^{\text {th }}$ session of SerBiH Presidency, 10 June 1992); P2536 (Patrick Treanor's expert report entitled “The Bosnian Serb Leadership 1990-1992”, 30 July 2002), para. 262.

405 P2611 (SerBiH Presidency Decision on the establishment of War Commissions in municipalities, 10 June 1992), p. 1 (art. 2).
} 
expert and other assistance to the war presidencies". 406 The state commissioners could appoint and dissolve War Commissions in consultation with the War Presidency at the Republic level. ${ }^{407}$

154. The War Commissions were to "maintain the closest possible cooperation with the legal authorities", "convey directives issued by the War Presidency of the Republic", "convey information about the problems, needs and work of the municipal bodies via their commissioners", and "cooperate with the authorities with a view to creating conditions for the work of military organs and units engaged in defending the Serbian people". ${ }^{408}$

155. The War Commissions, once constituted, were to supersede the Crisis Staffs, and the decision itself was to supersede the 31 May 1992 decision establishing War Presidencies in municipalities in time of imminent threat of war or during a state of war. ${ }^{409}$

156. Records such as confirmations of appointments, orders, reports, or meeting minutes indicate the existence of War Commissions including in Foča, Pale, Zvornik, Vlasenica, Bratunac, Novo Sarajevo, Vogošća, and Ilidža. ${ }^{410}$ For instance, a decision of the Vogošća war commission states that it worked with civilian and military, municipal and republic-level authorities and it was to ensure that municipal civilian and military organs carried out their duties in accordance with laws and regulations. ${ }^{411}$

157. State commissioners were appointed by the Presidency in June 1992, including Nikola Poplašen for Vogošća, ${ }^{412}$ Vojislav Maksimović for Foča, ${ }^{413}$ and Dragan Đokanović for Zvornik, ${ }^{414}$ Bratunac, $^{415}$ and Vlasenica. ${ }^{416}$

406

P2611 (SerBiH Presidency Decision on the establishment of War Commissions in municipalities, 10 June 1992), p. 1 (art. 4).

P2611 (SerBiH Presidency Decision on the establishment of War Commissions in municipalities, 10 June 1992), p. 1 (art. 4).

P2611 (SerBiH Presidency Decision on the establishment of War Commissions in municipalities, 10 June 1992), p. 1 (art. 3).

P2611 (SerBiH Presidency Decision on the establishment of War Commissions in municipalities, 10 June 1992), p. 1 (arts. 5,6$)$.

P2642 (Report of Foča's War Commission, 18 June 1992); P5417 (Confirmation of a decision of the Pale SDS, 25 June 1992); P5479 (Radovan Karadžić's confirmation of appointment of Zvornik War Commission members, 17 June 1992); D1623 (Order of Zvornik War Commission, 1 July 1992); P5486 (RS Presidency Confirmation of Appointment of Members of the War Commission in Vlasenica, 17 June 1992); P5491 (RS Presidency Confirmation of Appointment of Members of the War Commission in Bratunac, 17 June 1992); P5543 (Decision of Radovan Karadžić appointing a War Commission in Novo Sarajevo, 21 July 1992); D4031 (Decision of Vogošća War Commission, 18 June 1992); P6001 (Request of Vogošća Municipality War Commission, 27 June 1992); P6059 (Order of Vogošća War Commission, 29 July 1992); P2390 (Vogošća War Commission order, 6 November 1992); D1244 (Ilidža War Commission Decision, 4 April 1993).

11 See D4029 (Decision of Vogošća War Commission, 1 July 1992).

D4027 (Witness statement of Nikola Poplašen dated 11 November 2013), para. 1; Nikola Poplašen, T. 4358543586 (15 November 2013).

P3339 (Certificate of appointment signed by Radovan Karadžić, 4 June 1992). 
158. On 17 December 1992, the Bosnian Serb Assembly decided that the decision on forming War Commissions in the municipalities during an imminent threat of war or a state of war ceased to be valid. ${ }^{417}$

\section{BOSNIAN SERB MILITARY AND POLICE STRUCTURES}

159. During the time period relevant to the Indictment, the armed forces in the RS consisted of the VRS and Bosnian Serb MUP personnel. ${ }^{418}$ The Prosecution defines the "Serb Forces" as "members of the MUP, VRS, JNA, VJ, TO, the Serbian MUP, Serbian and Bosnian Serb paramilitary forces and volunteer units, and local Bosnian Serbs". 419 The Prosecution further defines the "Bosnian Serb forces" as members of "the VRS, the TO, the MUP and Bosnian Serb paramilitary forces and volunteer units". ${ }^{420}$ For ease of reference, the Chamber adopts these definitions. The structure of the respective components of these forces will be addressed in turn in this section.

\section{VRS}

a. Establishment and composition of the VRS

160. On 12 May 1992, the Bosnian Serb Assembly decided to establish the Army of SerBiH. ${ }^{421}$ On 12 August 1992, when SerBiH was renamed RS, the denomination of the army also changed from Army of SerBiH to the VRS. ${ }^{422}$ The Accused, in his capacity as President of the RS, was also

\footnotetext{
414 P5479 (Radovan Karadžić's confirmation of appointment of Zvornik War Commission members, 17 June 1992).

415 P5491 (RS Presidency Confirmation of Appointment of Members of the War Commission in Bratunac, 17 June 1992).

416 P5486 (RS Presidency Confirmation of Appointment of Members of the War Commission in Vlasenica, 17 June 1992).

417 P1364 (Transcript of 23 $3^{\text {rd }}$ session of RS Assembly, 17 December 1992), e-court pp. 83-84; D1229 (RS National Assembly Decision, 17 December 1992).

418 P5416 (Decision of the SerBiH Assembly, 12 May 1992), amendment II, art. 110; P2602 (SerBiH Defence Act, 1 June 1992), art. 7.

419 Indictment, para. 13. See also Prosecution Final Brief, Appendix I.

$420 \quad$ Indictment, para. 14(b). See also Prosecution Final Brief, Appendix I.

421 Manojlo Milovanović, T. 25431 (28 February 2012); P956 (Transcript of $16^{\text {th }}$ session of SerBiH Assembly, 12 May 1992), pp. 6, 57-58. See also Adjudicated Facts 17, 501 (referring to 19 May 1992 as the date of the "formal" establishment of the Army of SerBiH).

$422 \quad$ P1358 (Minutes of $19^{\text {th }}$ session of SerBiH Assembly, 12 August 1992), pp. 2-3; D422 (19 ${ }^{\text {th }}$ session of SerBiH Assembly, 12 August 1992), pp. 32-34, 37. For ease of reference the acronym "VRS" will be used throughout this section to also cover the period prior to 12 August 1992. On 18 August 1992, the Presidency adopted provisional service regulations for the VRS. D3834 (1 $1^{\text {st }}$ Krajina Corps dispatch, 25 August 1992; VRS Main Staff dispatch to $1^{\text {st }}$ Krajina Corps, 18 August 1992; Provisional Service Regulations of VRS, 18 August 1992); Dragomir Keserović, T. 40966-40967 (8 July 2013).
} 
the Supreme Commander of the VRS. ${ }^{423}$ Ratko Mladić was appointed the Commander of the Main Staff. $^{424}$ Manojlo Milovanović was appointed as both the Chief of Staff and Deputy Commander of the Main Staff. ${ }^{425}$

161. The VRS was formed from parts of the JNA, TO, and volunteer units. ${ }^{426}$ Each of the former JNA corps in $\mathrm{BiH}$ retained most of its personnel and weaponry. ${ }^{427}$ The VRS inherited both officers and other ranks from the JNA, many of whom were of Bosnian Serb origin, as well as a substantial amount of weaponry and equipment. ${ }^{428}$ In places where there were no former JNA infantry units, the VRS created units. ${ }^{429}$ Weapons from the former JNA were distributed to the infantry units by officers and SDS members. ${ }^{430}$ The official withdrawal of the JNA was announced on 5 May 1992 and by 19 May 1992 it was said to be nearly completed. ${ }^{431}$ On 21 May 1992, the Accused, in his capacity as President of the Presidency, issued an order on general mobilisation. ${ }^{432}$

$423 \quad$ P2603 (SerBiH Law on the Army, 1 June 1992), art. 174; Manojlo Milovanović, T. 25441 (28 February 2012); Mićo Stanišić, T. 46360 (3 February 2014), T. 46577 (5 February 2014); Momčilo Mandić, C2 (Transcript from Prosecutor v. Krajišnik), T. 9108. See also P3034 (Track changes version of Reynaud Theunens's expert report entitled "Radovan Karadžić and the SRBiH TO-VRS (1992-1995)"), e-court pp. 287-288.

424 Ewan Brown, T. 21504-21505 (17 November 2011); P3914 (Ewan Brown's expert report entitled "Military Developments in the Bosanska Krajina - 1992", 27 November 2002), para. 1.64; P956 (Transcript of $16^{\text {th }}$ Session of SerBiH Assembly, 12 May 1992), p. 57; Manojlo Milovanović, T. 25439 (28 February 2012); Dušan Kovačević, T. 39707 (11 June 2013). See also Adjudicated Fact 510. Prior to this, on 25 April 1992, Mladić was appointed by the Presidency of the SFRY as the Chief of Staff and Deputy Commander of the JNA $2^{\text {nd }}$ Military District. As of 10 May 1992, Mladić had taken over command of the JNA $2^{\text {nd }}$ Military District. D3680 (30 ${ }^{\text {th }}$ Partisan Division dispatch, 16 May 1992); Dušan Kovačević, T. 39707-39708 (11 June 2013); Milosav Gagović, T. 31865 (15 January 2013).

425 Manojlo Milovanović T. 25431-25432 (28 February 2012); Ljubomir Obradović, P4444 (Transcript from Prosecutor v. Tolimir), T. 11935-11936, 12017-12021; P4446 (Organisational Chart of the VRS Main Staff Structure for July 1995).

426 Adjudicated Fact 2803.

427 Mirsad Mujadžić, P3702 (Transcript from Prosecutor v. Stakić), T. 3716 (under seal); D1218 (Ilidža National Security Service report, 17 May 1992), p. 2; P1505 (SRK Order, 22 May 1992); D1839 (Combat report of JNA $5^{\text {th }}$ Corps, 17 May 1992). See also Adjudicated Fact 2805.

D325 (VRS Main Staff analysis of combat readiness and army activities in 1992, April 1993), pp. 14, 69; P4913 (Richard Butler's expert report entitled "VRS Corps Command Responsibility Report", 5 April 2000), paras. 1.0-1.1; P3914 (Ewan Brown's expert report entitled "Military Developments in the Bosanska Krajina - 1992", 27 November 2002), paras. 1.65, 3.10; Ewan Brown, T. 21536 (17 November 2011); Colm Doyle, T. 27382741 (26 May 2010); P3921 (Report of $1^{\text {st }}$ Krajina Corps, 21 May 1992), pp. 1-2; P4915 (Richard Butler's expert report entitled "VRS Brigade Command Responsibility Report", 31 October 2002), para. 1.2; Radovan M. Karadžić, T. 41378-41379 (17 July 2013). See, e.g., D1218 (Ilidža National Security Service report, 17 May 1992), p. 2; D1838 (Regular Combat Report from JNA $5^{\text {th }}$ Corps Command to $2^{\text {nd }}$ Military District Command dated 1 May 1992); D1839 (Combat report of JNA $5^{\text {th }}$ Corps, 17 May 1992); P1505 (SRK Order, 22 May 1992); Richard Philipps, T. 3772-3775 (15 June 2010), T. 3896-3897 (16 June 2010); Fadil Banjanović, P57 (Transcript from Prosecutor v. S. Milošević), T. 20664-20665; KDZ166, T. 8350-8351 (26 October 2010); Dragomir Milošević, T. 32559-32560 (23 January 2013). See also Adjudicated Facts 504, 506, 2092, 2099; Ljubomir Obradović, P4444 (Transcript from Prosecutor v. Tolimir), T. 12123-12124.

429 D325 (VRS Main Staff analysis of combat readiness and army activities in 1992, April 1993), p. 13.

$430 \quad$ D325 (VRS Main Staff analysis of combat readiness and army activities in 1992, April 1993), p. 14.

431 P4917 (Richard Butler's expert report entitled "VRS Main Staff Command Responsibility Report", 9 June 2006), paras. 1.10, 1.12; P3914 (Ewan Brown's expert report entitled "Military Developments in the Bosanska Krajina - 1992", 27 November 2002), para. 1.63. See also Adjudicated Fact 502; P950 (Agreement on withdrawal of JNA from BiH); Colm Doyle, P918 (Transcript from Prosecutor v. S. Milošević), T. 25295- 
162. According to the Defence Act, the Accused, as the President, had the power to organise and implement plans for defence, order mobilisation, command and control the army, and define the basis for the organisation and size of the police force. ${ }^{433}$ The Accused, as President, also had the power to issue orders for the deployment of the police during the war. ${ }^{434}$

163. On 15 June 1992, the Accused, in his capacity as President of the Presidency, established a system of command and control in the VRS. ${ }^{435}$ It consisted of a Main Staff and operative groups, including Corps of land forces consisting of brigades, regiments, and units. ${ }^{436}$ The Main Staff had command and control over the operative groups. ${ }^{437}$ The Main Staff was also directly subordinated to the President, as the Supreme Commander. ${ }^{438}$ The operative groups initially consisted of (i) the $1^{\text {st }}$ Krajina Corps with headquarters in Banja Luka; (ii) the $2^{\text {nd }}$ Krajina Corps with headquarters in Drvar; (iii) the Eastern Bosnia Corps with headquarters in Bijeljina; (iv) the SRK with headquarters in Pale; (v) the Herzegovina Corps with headquarters in Bileća; and (vi) the Air Force and Air Defence Corps with headquarters in Banja Luka. ${ }^{439}$ On 1 November 1992, the Drina Corps was formed. $^{440}$

25296. On 27 April 1992, Izetbegović issued a decision ordering the withdrawal of the JNA from BiH. Members of the JNA were given the choice to join the "newly formed forces" of the TO of BiH or to leave the territory. D224 (Alija Izetbegović's decision re JNA withdrawal from BiH, 27 April 1992).

432 P3919 (Radovan Karadžić's Decision, 20 May 1992); D325 (VRS Main Staff analysis of combat readiness and army activities in 1992, April 1993), pp. 69-70. See also P3920 (Order of $1^{\text {st }}$ Krajina Corps, 21 May 1992), p. 1.

433 P2602 (SerBiH Defence Act, 1 June 1992), art. 7.

434 P2602 (SerBiH Defence Act, 1 June 1992), art. 7.

435 P3035 (Decision on Army of SerBiH, 15 June 1992). Soldiers were required to take an oath when joining the VRS. D4004 (Amendment on the Law of the Army, as published in Official Gazette, 25 June 1992); Momčilo Krajišnik, T. 43369-43370 (13 November 2013).

436 P3035 (Decision on Army of SerBiH, 15 June 1992), p. 1; D325 (VRS Main Staff analysis of combat readiness and army activities in 1992, April 1993), p. 70. See also P3034 (Track changes version of Reynaud Theunens's expert report entitled "Radovan Karadžić and the SRBiH TO-VRS (1992-1995)"), e-court pp. 315-317.

437 P3035 (Decision on Army of SerBiH, 15 June 1992), p. 3.

438 P3035 (Decision on Army of SerBiH, 15 June 1992), p. 3; P4917 (Richard Butler's expert report entitled "VRS Main Staff Command Responsibility Report", 9 June 2006), paras. 2.0-2.1. In 1992, the Main Staff was subordinated to the Presidency. The Chamber recalls that on 17 December 1992, the Bosnian Serb Assembly replaced the structures of the Presidency by establishing a single President and two vice-Presidents; from then on the VRS Main Staff was subordinated to the President of the RS. See paras. 97-98.

P3035 (Decision on Army of SerBiH, 15 June 1992), pp. 2-3; Ljubomir Obradović, P4444 (Transcript from Prosecutor v. Tolimir), T. 11963-11965; D325 (VRS Main Staff analysis of combat readiness and army activities in 1992, April 1993), pp. 11, 70-71; Petar Škrbić, P4523 (Transcript from Prosecutor v. Popović et al.), T. 15466. See also P3914 (Ewan Brown's expert report entitled "Military Developments in the Bosanska Krajina - 1992", 27 November 2002), para. 1.63; P3034 (Track changes version of Reynaud Theunens's expert report entitled "Radovan Karadžić and the SRBiH TO-VRS (1992-1995)"), e-court pp. 315-317; P4913 (Richard Butler's expert report entitled "VRS Corps Command Responsibility Report", 5 April 2000), para. 1.0; P4917 (Richard Butler's expert report entitled "VRS Main Staff Command Responsibility Report", 9 June 2006), para. 1.0; D3864 (Radovan Radinović's expert report entitled "The Control Authority of Dr. Radovan Karadžić in the Strategic Command System of the VRS”, 2012), para. 83; D3688 (Excerpt from the Directive for use of the VRS, December 1993), pp. 8-10. See also Adjudicated Fact 2094.

$440 \quad$ P3914 (Ewan Brown's expert report entitled "Military Developments in the Bosanska Krajina - 1992", 27 November 2002), para. 1.63; Richard Butler, T. 27442-27433 (17 April 2012); P976 (Directive 4, 
164. The basic structure and principles of the VRS, including the warfare doctrine, command and control principles, operational and tactical methods, and regulations followed those of the JNA. ${ }^{441}$ Organs and branches of the VRS were specifically directed to comply with the existing regulations of the SFRY, including the SFRY Law on All People's Defence, until regulations for the VRS were published. $^{442}$

\section{b. Supreme Command}

165. On 30 November 1992, the Accused, in his capacity as the President of the Presidency, established the Supreme Command for the purpose of co-ordinating and improving the efficiency of the command system of the VRS. ${ }^{443}$ The Supreme Command consisted of the Supreme Commander who was the President of the Presidency, the RS Assembly President, the Prime Minister, the Minister of Defence, and the Minister of the Interior. ${ }^{444}$ The Commander of the Main

Staff of the VRS, his assistants and other members of the Main Staff, and Commanders of the Corps were also allowed to attend meetings of the Supreme Command by invitation. ${ }^{445}$

19 November 1992), pp. 2, 5; P3037 (VRS Main Staff Order, 20 November 1992). See also D325 (VRS Main Staff analysis of combat readiness and army activities in 1992, April 1993), p. 11; Adjudicated Fact 1442.

P4913 (Richard Butler's expert report entitled "VRS Corps Command Responsibility Report", 5 April 2000), paras. 1.0-1.7; P4915 (Richard Butler's expert report entitled "VRS Brigade Command Responsibility Report", 31 October 2002), paras. 1.0-1.9; P3914 (Ewan Brown's expert report entitled "Military Developments in the Bosanska Krajina - 1992", 27 November 2002), paras. 1.66, 3.6-3.9, 3.11; Ljubomir Obradović, P4444 (Transcript from Prosecutor v. Tolimir), T. 11958, 12183-12191; Richard Philipps, T. 3746-3747 (15 June 2010); P990 (JNA $4^{\text {th }}$ Corps Instructions, 29 August 1991); P3033 (Reynaud Theunens's expert report entitled "Radovan Karadžić and the SRBiH TO-VRS (1992-1995)"), e-court pp. 13-14, 310-315.

442 D436 ( $1^{\text {st }}$ Krajina Corps information on political and security situation, 20 June 1992), p. 3; P4913 (Richard Butler's expert report entitled "VRS Corps Command Responsibility Report", 5 April 2000), paras. 1.0-1.7; P3914 (Ewan Brown's expert report entitled "Military Developments in the Bosanska Krajina - 1992", 27 November 2002), paras. 1.66, 3.6-3.9, 3.11.

443 P3036 (Radovan Karadžić's Decision on the establishment of the VRS Supreme Command, 30 November 1992), art. 1. See also P3149 (Minutes of the $14^{\text {th }}$ session of Supreme Command, 31 March 1995), p. 7; Manojlo Milovanović, T. 25467 (28 February 2012); P3034 (Track changes version of Reynaud Theunens's expert report entitled "Radovan Karadžić and the SRBiH TO-VRS (1992-1995)"), e-court p. 288; P2537 (Patrick Treanor's expert report entitled "The Bosnian Serb Leadership 1993-1995 - Addendum to the Bosnian Serb Leadership 1990-1992", 1 May 2009), para. 140.

444 P3036 (Radovan Karadžić's Decision on the establishment of the VRS Supreme Command, 30 November 1992), art. 2; P192 (Decree on the Promulgation of Law on Implementation of Law of the Army during Threat of War, 29 November 1994), art. 3 (specifying that the President, as commander-in-chief, shall establish the Supreme Command, consisting of the Vice-President, President of the Bosnian Serb Assembly, the Prime Minister, Minister of Defence and Minister of Interior); Petar Škrbić, P4523 (Transcript from Prosecutor v. Popović et al.), T. 15544-15545. See also P3149 (Minutes of $14^{\text {th }}$ session of Supreme Command, 31 March 1995), p. 2.

445 P3036 (Radovan Karadžić's Decision on the establishment of the VRS Supreme Command, 30 November 1992), art. 3; Ljubomir Obradović, T. 25126-25127 (23 February 2012); P3034 (Track changes version of Reynaud Theunens's expert report entitled "Radovan Karadžić and the SRBiH TO-VRS (1992-1995)"), e-court p. 288. 
166. The Supreme Command held both regular and extraordinary sessions in which various strategic issues were discussed and conclusions and tasks were adopted. ${ }^{446}$ When military decisions had to be made, members of the Main Staff attended meetings of the Supreme Command as observers without voting rights. ${ }^{447}$ The Supreme Command's decisions were adopted by the Supreme Commander. ${ }^{448}$ The Supreme Commander also periodically issued directives, which assigned tasks to subordinate units in order to carry out the planning and execution of combat operations. $^{449}$

\section{c. Supreme Commander}

167. According to the Law on the Army and the Amended RS Constitution, the President of the Republic was the Supreme Commander and thus the Commander-in-Chief of the VRS. ${ }^{450}$ Accordingly, the Accused, as Supreme Commander, held the highest authority in respect of the VRS. ${ }^{451}$ The Accused remained the Supreme Commander until July $1996 .{ }^{452}$ The powers of the

446 Manojlo Milovanović, T. 25526-25532, 25545 (29 February 2012); Dušan Kovačević, T. $39653-39654$ (10 June 2013), 39656-39657 (11 June 1993). See, e.g., P1469 (Minutes of VRS Supreme Command meeting, 20 December 1992); P3148 (Handwritten notes of Supreme Command meeting, 8 May 1994); P3149 (Minutes of $14^{\text {th }}$ session of Supreme Command, 31 March 1995).

447 Manojlo Milovanović, T. 25470 (28 February 2012); P3036 (Radovan Karadžić's Decision on the establishment of the VRS Supreme Command, 30 November 1992), art. 3; P2537 (Patrick Treanor's expert report entitled "The Bosnian Serb Leadership 1993-1995 - Addendum to the Bosnian Serb Leadership 1990-1992", 1 May 2009), paras. 141-142. See, e.g., the meeting of 20 December 1992 attended by the commander of the VRS Main Staff and his deputy, Mladić and Milovanović. P1469 (Minutes of VRS Supreme Command meeting, 20 December 1992); Manojlo Milovanović, T. 25467-25470 (28 February 2012); P3034 (Track changes version of Reynaud Theunens's expert report entitled "Radovan Karadžić and the SRBiH TO-VRS (1992-1995)"), e-court p. 543; P2537 (Patrick Treanor's expert report entitled “The Bosnian Serb Leadership 1993-1995 - Addendum to the Bosnian Serb Leadership 1990-1992”, 1 May 2009), para. 141. See, e.g., the meeting of 31 March 1995 attended by several members of the Main Staff including Mladić, Milovanović, Tolimir, and Gvero. P3149 (Minutes of the $14^{\text {th }}$ session of Supreme Command, 31 March 1995), p. 1.

448 P3036 (Radovan Karadžić's Decision on the establishment of the VRS Supreme Command, 30 November 1992), art. 5. See also P3034 (Track changes version of Reynaud Theunens's expert report entitled "Radovan Karadžić and the SRBiH TO-VRS (1992-1995)”), e-court pp. 304-306; P2537 (Patrick Treanor's expert report entitled "The Bosnian Serb Leadership 1993-1995 - Addendum to the Bosnian Serb Leadership 1990-1992", 1 May 2009), para. 140; Petar Škrbić, P4523 (Transcript from Prosecutor v. Popović et al.), T. 15544-15545. During the $29^{\text {th }}$ Session of the Bosnian Serb Assembly, held on 24 to 25 March 1994, the Accused stated that the Supreme Command had been established so that he did not make decisions by himself. P1388 (Transcript of $39^{\text {th }}$ Session of RS Assembly, 24-25 March 1994), p. 85.

449 Ljubomir Obradović, P4444 (Transcript from Prosecutor v. Tolimir), T. 11992-12000; Manojlo Milovanović, T. 25493-25494 (29 February 2012). See, e.g., P3039 (Directive 6, 11 November 1993); P838 (Directive 7, 8 March 1995). For further detail on Directive 7 specifically, see Section IV.C.1.b.ii: Issuance of Directives 7 and $7 / 1$.

$450 \quad$ P2603 (SerBiH Law on the Army, 1 June 1992), art. 174; D422 (19 th $^{\text {th }}$ session of SerBiH Assembly, 12 August 1992), pp. 63-64; P5578 (Amended Text of the Constitution of the RS, 17 December 1992), art. 106, p. 22; Patrick Treanor, T. 14061 (1 June 2011); Momčilo Mandić, C2 (Transcript from Prosecutor v. Krajišnik), T. 9108; KDZ088, T. 6357 (8 September 2010) (private session); Jovan Šarac, T. $47162-47163$ (14 February 2014).

451 See P3036 (Radovan Karadžić's Decision on the establishment of the VRS Supreme Command, 30 November 1992); P1388 (Transcript of 39 ${ }^{\text {th }}$ session of RS Assembly, 24-25 March 1994), pp. 85-86; Ljubomir Obradović, T. 25108-25109 (22 February 2012). See, e.g., P3041 (VRS Main Staff Report, 31 March 1994), p. 5; P4493 (VRS Main Staff Order, 7 February 1994); P4447 (Order of Radovan Karadžić, 24 April 1994); P4495 (Radovan Karadžić's Order to VRS Main Staff and RS MUP, 29 March 1995); Rupert Smith, T. 11326-11328 
Supreme Commander included defining the organisation of the VRS, establishing a system of command, monitoring the implementation of orders, establishing a plan for deployment and mobilisation, and issuing regulations. ${ }^{453}$ The Supreme Commander also had the authority to appoint, promote, and dismiss officers of the VRS. ${ }^{454}$

168. The Supreme Commander exercised authority at the strategic level. ${ }^{455} \mathrm{He}$ had the power to issue decrees, instructions, orders, and requests related to the general planning for the preparation of the army, ${ }^{456}$ the mobilisation of the army, ${ }^{457}$ and its deployment; ${ }^{458}$ he could delegate certain command duties to the Commander of the Main Staff. ${ }^{459}$ Occasionally, the Accused sent direct orders to corps and brigade commanders to answer directly to him. ${ }^{460}$

(8 February 2011); Manojlo Milovanović, T. 25444-25445 (28 February 2012), T. 25484-25486 (29 February 2012); Dusan Kovačević, T. 39657 (11 June 2013); Jovan Šarac, T. $47162-47163$ (14 February 2014); P3034 (Track changes version of Reynaud Theunens's expert report entitled "Radovan Karadžić and the SRBiH TOVRS (1992-1995)"), e-court pp. 501-503; Reynaud Theunens, T. 16841, 16844-16845 (19 July 2011), T. 17171-17172 (22 July 2011); P3037 (VRS Main Staff Order, 20 November 1992); P4913 (Richard Butler's expert report entitled "VRS Corps Command Responsibility Report", 5 April 2000), para. 5.3; Petar Škrbić, T. 26024-26026 (8 March 2012); Richard Butler, T. 27430-27431 (17 April 2012).

P3036 (Decision on the Establishment of the Supreme Command of the Army of Republika Srpska, 30 November 1992); P1469 (Minutes of VRS Supreme Command meeting, 20 December 1992); P3148 (Handwritten notes of Supreme Command meeting, 8 May 1994); P3149 (Minutes of $14^{\text {th }}$ session of Supreme Command, 31 March 1995); Milan Ninković, T. 40505 (26 June 2013).

453 P2603 (SerBiH Law on the Army, 1 June 1992), art. 174.

$454 \quad$ P5578 (Amended Text of the Constitution of the RS, 17 December 1992), art.106, p.22; P2603 (SerBiH Law on the Army, 1 June 1992), art. 11, 369. See also P3034 (Track changes version of Reynaud Theunens's expert report entitled "Radovan Karadžić and the SRBiH TO-VRS (1992-1995)"), e-court pp. 332-333; Manojlo Milovanović, T. 25530 (29 February 2012); P3149 (Minutes of $14^{\text {th }}$ session of Supreme Command, 31 March 1995), p. 9; P4913 (Richard Butler's expert report entitled "VRS Corps Command Responsibility Report", 5 April 2000), paras. 4.0-4.4; P3914 (Ewan Brown's expert report entitled "Military Developments in the Bosanska Krajina - 1992”, 27 November 2002), paras. 3.1-3.4; Radovan Radinović, T. 41533-41534 (19 July 2013)

455 D3864 (Radovan Radinović's expert report entitled "The Control Authority of Dr. Radovan Karadžić in the Strategic Command System of the VRS”, 2012), paras. 2, 121-129; KDZ088, T. 6357-6359 (8 September 2010) (closed session).

456 See, e.g., P3037 (VRS Main Staff Order, 20 November 1992), p. 1. The Chamber notes that the "request" by the Supreme Command referred to in this document dates from 20 November 1992, which is before the official creation of the Supreme Command on 30 November 1992.

457 See, e.g., P5482 (Order from Radovan Karadžić to Municipal Assembly Presidents and VRS Main Staff, 26 March 1995); P2248 (Radovan Karadžić's Order to RS Government, VRS Main Staff, and Presidents of Municipalities, 26 March 1995); P2249 (VRS Main Staff Order, 26 March 1995). See also P3034 (Track changes version of Reynaud Theunens's expert report entitled "Radovan Karadžić and the SRBiH TO-VRS (1992-1995)"), e-court pp. 507-509.

458 See, e.g., P856 (VRS Main Staff Order, 20 April 1994); P5580 (VRS Main Staff Order, 20 April 1994); P3045 (VRS Main Staff Order, 20 April 1994); P2252 (Radovan Karadžić's Order to VRS Main Staff and RS MUP, 29 March 1995).

459 P2603 (SerBiH Law on the Army, 1 June 1992), art. 175.

460 P846 (Radovan Karadžić's Order to VRS, 7 February 1994); P4493 (VRS Main Staff Order, 7 February 1994). 


\section{d. VRS Main Staff}

169. Commanded by Mladic, ${ }^{461}$ the Main Staff was the highest operative body of the VRS. ${ }^{462}$ The Main Staff directed and planned the conduct of army operations. ${ }^{463}$ It was responsible for the mobilisation, training, and deployment of troops; co-ordination between the Corps; ${ }^{464}$ the drafting of military documents; ${ }^{465}$ the engagement of armed forces; ${ }^{466}$ the relationship with UNPROFOR regarding military activities and cease-fires; ${ }^{467}$ and the implementation of discipline and control over subordinate units. ${ }^{468}$ The headquarters of the Main Staff was located at Crna Rijeka and the logistics (rear) command post was at Han Pijesak. ${ }^{469}$ The code name for the Main Staff command post was "Panorama". 470

461 See para. 160. On 15 December 1992, the Accused reaffirmed the appointment of Mladic as Commander of the Main Staff of the VRS. P3034 (Track changes version of Reynaud Theunens's expert report entitled "Radovan Karadžić and the SRBiH TO-VRS (1992-1995)"), e-court pp. 287, 293. Mladić was given an exceptional promotion to the rank of Colonel-General on 28 June 1994. P3046 (Radovan Karadžić's Decree on promotion of Ratko Mladić, 28 June 1994), Reynaud Theunens, T. 16863 (19 July 2011). Mladić remained in that position until 8 November 1996. P3034 (Track changes version of Reynaud Theunens's expert report entitled "Radovan Karadžić and the SRBiH TO-VRS (1992-1995)"), e-court pp. 287, 293; Ewan Brown, T. 21504-21505 (17 November 2011); P3914 (Ewan Brown's expert report entitled "Military Developments in the Bosanska Krajina - 1992", 27 November 2002), para. 1.64; P1355 (Minutes of $16^{\text {th }}$ Session of Assembly of SerBiH), 12 May 1992, p. 2; Manojlo Milovanović, T. 25439 (28 February 2012); P4446 (Organisational Chart of the VRS Main Staff Structure for July 1995).

462 D325 (VRS Main Staff analysis of combat readiness and army activities in 1992, April 1993), p. 158; P4917 (Richard Butler's expert report entitled "VRS Main Staff Command Responsibility Report”, 9 June 2006), para. 2.0.

463 See, e.g., D2143 (VRS Main Staff Order, 18 April 1993); D2144 (VRS Main Staff Order, 18 April 1993); D2145 (VRS Main Staff Order, 8 May 1993).

464 See, e.g., P3037 (VRS Main Staff Order, 20 November 1992); P4475 (VRS Main Staff Order, 21 July 1995); P4498 (Report of $1^{\text {st }}$ Romanija Infantry Brigade, 3 September 1992).

465 Manojlo Milovanović, T. 25495 (29 February 2012).

466 D325 (VRS Main Staff analysis of combat readiness and army activities in 1992, April 1993), pp. 7-13. See also P3034 (Track changes version of Reynaud Theunens's expert report entitled "Radovan Karadžić and the SRBiH TO-VRS (1992-1995)"), e-court pp. 313-314.

467 D1019 (Ratko Mladić letter to UNPROFOR, 11 February 1995); D1020 (Ratko Mladić letter to UNPROFOR, 13 February 1995); P2273 (UNPROFOR report re meeting with Ratko Mladić, 4 June 1995); P2278 (UNPROFOR report re aftermath of fall of Srebenica, 13 July 1995); P2280 (UNPROFOR report re meeting with Ratko Mladić, 19 July 1995); P2281 (UNPROFOR report re meeting with Ratko Mladić, 26 July 1995); D1023 (Ratko Mladić letter to UNPROFOR, 24 February 1995); D1024 (Ratko Mladić letter to UNPROFOR, 3 March 1995); D1028 (UNPROFOR report re agreement on demilitarisation of Srebrenica, 18 April 1993); D2143 (VRS Main Staff Order, 18 April 1993). See also D2169 (Letter from Manojlo Milovanović to UNPROFOR Command, 30 March 1993).

468 D2161 (VRS Main Staff Order, 22 November 1992).

469 Petar Škrbić, T. 25988, 25998 (8 March 2012); Petar Škrbić, P4523 (Transcript from Prosecutor v. Popović et al.), T. 15468; D3688 (Excerpt from the Directive for use of the VRS, December 1993), p. 13. Crna Rijeka's facility housed the VRS Main Staff Communications Centre, the $67^{\text {th }}$ Communication Regiment, parts of the $65^{\text {th }}$ Motorised Protection Regiment (" $65^{\text {th }}$ Protection Regiment"), the Staff Sector as well as the Administration for Planning, Development, and Finance and the Administration for Air Force and Anti-Aircraft Defence. The logistics sector and the sector for moral guidance, religious, and legal affairs was housed in Han Pijesak. Ljubomir Obradović, T. 25079-25081 (22 February 2012); P2794 (Witness statement of Ranko Vuković dated 24 May 2011), paras. 21-23.

470 Ranko Vuković, T. 15098-15099 (21 June 2011); Richard Butler, T. 27437-27438, 27518 (17 April 2012 ). 
170. As the Commander of the Main Staff, Mladic commanded the VRS in compliance with the authority that the President delegated to him. ${ }^{471}$ He issued regulations, orders, and instructions relating to the implementation of orders that the President had issued. ${ }^{472}$

171. The Staff Sector, headed by Milovanović, who served as both Chief of Staff and Deputy Commander, ${ }^{473}$ consisted of several branches, including the Administration for Operations and Training headed by General Radivoje Miletić. ${ }^{474}$ The Chief of Staff and units subordinated to him were tasked with operative duties in relation to the services of the army, including planning and monitoring the situation on the ground. ${ }^{475}$

172. The Main Staff consisted of sectors and administrations, each providing specific technical expertise to the Main Staff Commander. ${ }^{476}$ The sectors and administrations headed by assistant commanders included (i) the Sector for Morale, Religious, and Legal Affairs, which included a Civil Affairs Administration, and was headed by General Milan Gvero, ${ }^{477}$ (ii) the Sector for Logistics, also called the Sector for Rear Services, headed by General Đordje Đukić; ${ }^{478}$ (iii) the

471 P2603 (SerBiH Law on the Army, 1 June 1992), art. 175. See also P3034 (Track changes version of Reynaud Theunens's expert report entitled "Radovan Karadžić and the SRBiH TO-VRS (1992-1995)"), e-court p. 299.

472 P2603 (SerBiH Law on the Army, 1 June 1992), art. 175.

473 Manojlo Milovanović T. 25431-25432, 25442 (28 February 2012); Ljubomir Obradović, P4444 (Transcript from Prosecutor v. Tolimir), T. 11929, 11935-11939, 12017-12021, 12138-12139, 12185; Ljubomir Obradović, T. 25106 (22 February 2012). See also P4446 (Organisational Chart of the VRS Main Staff Structure for July 1995); P4917 (Richard Butler's expert report entitled "VRS Main Staff Command Responsibility Report", 9 June 2006), paras. 2.6-2.9; P4920 (Diagrams of various VRS Military Command structures), p. 1.

474 Manojlo Milovanović, T. 25442 (28 February 2012); Petar Škrbić, P4523 (Transcript from Prosecutor v. Popović et al.), T. 15495-15503; Ljubomir Obradović, P4444 (Transcript from Prosecutor v. Tolimir), T. 11929, 11931-11932, 11935, 11938, 11941-11944, 12091-12092, 12138-12139, 12185 . See also P4446 (Organisational Chart of the VRS Main Staff Structure for July 1995); P4917 (Richard Butler's expert report entitled "VRS Main Staff Command Responsibility Report", 9 June 2006), paras. 2.6-2.9; P4920 (Diagrams of various VRS Military Command structures), p. 1. Ljubomir Obradović was the Chief of Staff of the operative detachment in the Administration for Operations and Training. Ljubomir Obradović, P4444 (Transcript from Prosecutor v. Tolimir), T. 11929; P4446 (Organisational Chart of the VRS Main Staff Structure for July 1995).

475 Ljubomir Obradović, P4444 (Transcript from Prosecutor v. Tolimir), T. 11936.

476 Manojlo Milovanović, T. 25441-25442 (28 February 2012); Petar Škrbić, P4523 (Transcript from Prosecutor v. Popović et al.), T. 15495-15503; Ljubomir Obradović, P4444 (Transcript from Prosecutor v. Tolimir), T. 11940, 12039-12040, 12134-12136; P4446 (Organisational Chart of the VRS Main Staff Structure for July 1995). See also P3034 (Track changes version of Reynaud Theunens's expert report entitled "Radovan Karadžić and the SRBiH TO-VRS (1992-1995)”), e-court p. 311; P4917 (Richard Butler's expert report entitled "VRS Main Staff Command Responsibility Report", 9 June 2006), para. 2.6.

477 Manojlo Milovanović, T. 25442 (28 February 2012); Ljubomir Obradović, P4444 (Transcript from Prosecutor v. Tolimir), T. 11937, 11948; Petar Škrbić, P4523 (Transcript from Prosecutor v. Popović et al.), pp. 1549515503. See, e.g., P4545 (VRS Main Staff document regarding the treatment of journalists and representatives of international organisations, 20 June 1992). See also P4446 (Organisational Chart of the VRS Main Staff Structure for July 1995).

478 Manojlo Milovanović, T. 25442 (28 February 2012); Ljubomir Obradović, P4444 (Transcript from Prosecutor v. Tolimir), T. 11937; Petar Škrbić, P4523 (Transcript from Prosecutor v. Popović et al.), pp. 15495-15503. See also P4446 (Organisational Chart of the VRS Main Staff Structure for July 1995). 
Sector for Intelligence and Security Affairs headed by General Zdravko Tolimir, ${ }^{479}$ which was comprised of the Intelligence Administration headed by Colonel Petar Salapura and the Security Administration headed by Colonel Ljubiša Beara; ${ }^{480}$ (iv) the Sector for Organisation, Mobilisation, and Personnel Affairs headed by General Petar Škrbić; ${ }^{481}$ (v) the Administration for Planning, Development, and Finance headed by General Stevo Tomić; ${ }^{482}$ and (vi) the Administration for Air Force and Anti-Aircraft Defence headed by General Jovo Marić. ${ }^{483}$

173. Directly linked to the Commander was the Department for Civilian Affairs headed by Colonel Miloš Đurđić. ${ }^{484}$ It was responsible for liaising with foreign military representatives and other organisations, and for co-ordinating between the VRS and international organisations regarding humanitarian aid. ${ }^{485}$ On 14 March 1995, the Accused issued a decision to form a State Committee for Co-operation with the United Nations and International Humanitarian Organs. ${ }^{486}$ Koljević was appointed as its President, and Đurđić was appointed as the co-ordinator for the committee's relations with the Ministry of Defence and the VRS. ${ }^{487}$ Notwithstanding the formation

479 Manojlo Milovanović, T. 25442 (28 February 2012); Petar Škrbić, P4523 (Transcript from Prosecutor v. Popović et al.), T. 15495-15503; Ljubomir Obradović, P4444 (Transcript from Prosecutor v. Tolimir), T. 11937-11949, 11962; D325 (VRS Main Staff analysis of combat readiness and army activities in 1992, April 1993), pp. 83-93. See also P4446 (Organisational Chart of the VRS Main Staff Structure for July 1995).

480 Ljubomir Obradović, P4444 (Transcript from Prosecutor v. Tolimir), T. 11949, 12191-12197; Ljubomir Obradović, T. 25124-25125 (23 February 2012); P4446 (Organisational Chart of the VRS Main Staff Structure for July 1995); Ljubisa Beara, T. $45202-45203$ (17 December 2013); Momir Nikolić, T. 24570 (13 February 2012); P4917 (Richard Butler's expert report entitled "VRS Main Staff Command Responsibility Report", 9 June 2006), paras. 2.13-2.15; Adjudicated Fact 1461.

481 Petar Škrbić, P4523 (Transcript from Prosecutor v. Popović et al.), T. 15467-15469; Ljubomir Obradović, P4444 (Transcript from Prosecutor v. Tolimir), T. 11937; Manojlo Milovanović, T. 25442 (28 February 2012). See also Manojlo Milovanović, T. 25442 (28 February 2012); P4446 (Organisational Chart of the VRS Main Staff Structure for July 1995).

482 Manojlo Milovanović, T. 25442 (28 February 2012); Petar Škrbić, P4523 (Transcript from Prosecutor v. Popović et al.), T. 15495-15503. See also P4446 (Organisational Chart of the VRS Main Staff Structure for July 1995).

483 Manojlo Milovanović, T. 25442 (28 February 2012); Petar Škrbić, P4523 (Transcript from Prosecutor v. Popović et al.), T. 15495-15503; Ljubomir Obradović, P4444 (Transcript from Prosecutor v. Tolimir), T. 11937-11940. See also P4446 (Organisational Chart of the VRS Main Staff Structure for July 1995); P4920 (Diagrams of various VRS Military Command structures), p. 1.

484 Ljubomir Obradović, P4444 (Transcript from Prosecutor v. Tolimir), T. 11963; Petar Škrbić, P4523 (Transcript from Prosecutor v. Popović et al.), T. 15539; Ljubomir Obradović, T. 25110-25112 (22 February 2012),

485 Slavko Kralj, D3245 (Transcript from Prosecutor v. Popović et al.), T. 29228, 29256; Petar Škrbić, P4523 (Transcript from Prosecutor v. Popović et al.), T. 15539; Ljubomir Obradović, P4444 (Transcript from Prosecutor v. Tolimir), T. 11963; Ljubomir Obradović, T. 25110-25112 (22 February 2012).

486 P4543 (Decision of Radovan Karadžić, 14 March 1995), p. 1. See also Slavko Kralj, D3245 (Transcript from Prosecutor v. Popović et al.), T. 29233-29234.

487 P4543 (Decision of Radovan Karadžić, 14 March 1995), p. 3; Manojlo Milovanović, T. 25443 (28 February 2012); Slavko Kralj, D3245 (Transcript from Prosecutor v. Popović et al.), T. 29233-29244; Ljubomir Obradović, T. 25110-25112 (22 February 2012). 
of this committee, the Main Staff retained control of processing the authorisation for UNPROFOR re-supply convoys. ${ }^{488}$

174. On 2 August 1995, pursuant to a decision issued by the Accused, in his capacity as President and Supreme Commander, the Main Staff was renamed as the VRS General Staff and would be called the Supreme Command Staff in "times of war". 489 According to this decision, which provided for Mladić's appointment as Special Advisor to the Supreme Commander, the Supreme Command Staff was to be under the direct command and control of the Supreme Commander. ${ }^{490}$ Mladić and the VRS Generals criticised and challenged the decision, which was annulled by the Accused on 27 August $1995 .^{491}$

175. There were various units that were directly subordinated to the Main Staff. They included the $65^{\text {th }}$ Protection Regiment, the $10^{\text {th }}$ Sabotage Detachment, and the $67^{\text {th }}$ Communication Regiment. $^{492}$

Ljubomir Obradović, T. 25110-25112 (22 February 2012), T. 25133-25134 (23 February 2012); P4447 (Order of Radovan Karadžić, 24 April 1994); P839 (VRS Report regarding UN convoys, 7 April 1995); Slavko Kralj, D3245 (Transcript from Prosecutor v. Popović et al.), T. 29233-29244, 29258. See also D4842 (VRS Main Staff notification, 28 March 1995). Prior to the establishment of that committee, the Main Staff issued decisions regarding humanitarian convoys, and the VRS was charged with monitoring the convoys, ensuring their safe passage, and allowing their entry where aid was needed. Manojlo Milovanović, T. 25443-25444 (28 February 2012); Ljubomir Obradović, T. 25110-25115 (22 February 2012), T. 25139-25140 (23 February 2012); D2172 (Letter from Radovan Karadžić to VRS Main Staff, 8 January 1994); P4448 (VRS Main Staff Report, 6 March 1995). See, e.g., for the period of October 1993: D2109 (VRS Main Staff Notification, 25 September 1993); D2110 (VRS Main Staff Notification, 2 October 1993); D2111 (VRS Main Staff Notification, 8 October 1993); D2112 (VRS Main Staff Notification, 15 October 1993).

489 D3879 (Radovan Karadžić's Decision, 2 August 1995); P3034 (Track changes version of Reynaud Theunens's expert report entitled "Radovan Karadžić and the SRBiH TO-VRS (1992-1995)"), e-court pp. 569-571.

490 D3879 (Radovan Karadžić's Decision, 2 August 1995); D2157 (Radovan Karadžić's Decree, 4 August 1995). See also Manoljo Milovanović, T. 25669-25670 (1 March 2012); Petar Škrbić, T. 26027-26028 (8 March 2012); P5156 (Fax from UNPROFOR, attaching a press release from Radovan Karadžić, 4 August 1995), p. 2.

491 D4861 (Letter from Radovan Karadžić to VRS Main Staff, 27 August 1995); P3034 (Track changes version of Reynaud Theunens's expert report entitled "Radovan Karadžić and the SRBiH TO-VRS (1992-1995)"), e-court pp. 572-579.

492 Ljubomir Obradović, T. 25119-25125 (23 February 2012); Ljubomir Obradović, P4444 (Transcript from Prosecutor v. Tolimir), T. 11934, 11960-11961; P4487 (VRS Main Staff Order, 4 December 1994); P4524 (VRS Main Staff Order, 25 December 1994); Petar Škrbić, T. 25969-25970 (7 March 2012); Dragan Todorović, P4350 (Transcript from Prosecutor v. Popović et al.), T. 13991-13992 (under seal); P3034 (Track changes version of Reynaud Theunens's expert report entitled "Radovan Karadžić and the SRBiH TO-VRS (19921995)”), e-court pp. 315-317. See also Adjudicated Fact 1462; P4446 (Organisational Chart of the VRS Main Staff Structure for July 1995). The $67^{\text {th }}$ Communication Regiment was in charge of organising and providing the communication needs of the Main Staff. Ljubomir Obradović, P4444 (Transcript from Prosecutor v. Tolimir), T. 11934; Ljubomir Obradović, T. 25119-25121 (23 February 2012). This regiment trained the VRS and MUP units in all aspects of communications. Ranko Vuković, T. 15085-15086 (21 June 2011). 
176. The $65^{\text {th }}$ Protection Regiment was commanded by Colonel Milomir Savčić. ${ }^{493}$ The main tasks of the $65^{\text {th }}$ Protection Regiment included providing security to the Main Staff and carrying out its orders. ${ }^{494}$ It was also tasked with carrying out "counter-sabotage and anti-terrorist tasks". 495 Its headquarters was in Crna Rijeka. ${ }^{496}$ The MP Battalion of the $65^{\text {th }}$ Protection Regiment was commanded by Major Zoran Malinić. ${ }^{497}$ Along the professional chain of command, it reported to the Security Administration headed by Colonel Ljubiša Beara. ${ }^{498}$ The MP headquarters was in Nova Kasaba. ${ }^{499}$

177. As a special unit of the Main Staff and directly subordinated to the Intelligence Administration, ${ }^{500}$ the $10^{\text {th }}$ Sabotage Detachment consisted of to approximately 50 to 60 men divided into two platoons. ${ }^{501}$ It was commanded by Milorad Pelemiš. ${ }^{502}$ The $1^{\text {st }}$ platoon was based in Vlasenica, commanded by Franc Kos, and the $2^{\text {nd }}$ platoon was based in Bijeljina, commanded by Luka Jokić. $^{503}$ The detachment was primarily used for wartime sabotage activities. ${ }^{504}$ It also engaged in reconnaissance missions because it was subordinated to the Intelligence Administration. ${ }^{505}$ The members of the $10^{\text {th }}$ Sabotage Detachment had several uniforms in

493 D3918 (Witness statement of Milomir Savčić, undated), para. 24; Manojlo Milovanović, T. 25442 (28 February 2012); Ljubomir Obradović, T. 25123 (23 February 2012); Ljubomir Obradović, P4444 (Transcript from Prosecutor v. Tolimir), T. 11962-11963; P4446 (Organisational Chart of the VRS Main Staff Structure for July 1995); P4920 (Diagrams of various VRS Military Command structures), p.1; P4917 (Richard Butler's expert report entitled "VRS Main Staff Command Responsibility Report", 9 June 2006), para. 4.0.

494 Manojlo Milovanović, T. 25442 (28 February 2012); Ljubomir Obradović, P4444 (Transcript from Prosecutor v. Tolimir), T. 11962-11963; Ljubomir Obradović, T. 25123 (23 February 2012); P4446 (Organisational Chart of the VRS Main Staff Structure for July 1995); P4920 (Diagrams of various VRS Military Command structures), p. 1; P4917 (Richard Butler's expert report entitled "VRS Main Staff Command Responsibility Report", 9 June 2006), para. 4.0; D3918 (Witness statement of Milomir Savčić, undated), para. 25. See also Adjudicated Fact 1462.

495 D3918 (Witness statement of Milomir Savčić, undated), para. 25.

496 D3918 (Witness statement of Milomir Savčić, undated), para. 27.

497 D3918 (Witness statement of Milomir Savčić, undated), para. 26.

498 P4446 (Organisational Chart of the VRS Main Staff Structure for July 1995).

499 D3918 (Witness statement of Milomir Savčić, undated), para. 26.

500 Dražen Erdemović, P332 (Transcript from Prosecutor v. Popović et al.), T. 10931-10935; Petar Salapura, T. 40236 (24 June 2013); P4920 (Diagrams of various VRS Military Command structures), p. 1; Ljubomir Obradović, P4444 (Transcript from Prosecutor v. Tolimir), T. 11960.

501 Dražen Erdemović, P332 (Transcript from Prosecutor v. Popović et al.), T. 10931-10932; Dragan Todorović, P4353 (Transcript from Prosecutor v. Popović et al.), T. 13991-13993.

502 Dražen Erdemović, P332 (Transcript from Prosecutor v. Popović et al.), T. 10935; D3927 (Witness statement of Franc Kos dated 26 July 2013), pp. 3, 5; Dragan Todorović, P4353 (Transcript from Prosecutor v. Popović et al.), T. 13994.

503 D3927 (Witness statement of Franc Kos dated 26 July 2013), pp. 3-4; Dražen Erdemović, P332 (Transcript from Prosecutor v. Popović et al.), T. 10931-10932; Dragan Todorović, P4353 (Transcript from Prosecutor v. Popović et al.), T. 13991-13993.

504 Dragan Todorović, P4353 (Transcript from Prosecutor v. Popović et al.), T. 13991-13993; Ljubomir Obradović, T. 25121-25123 (23 February 2012).

505 Ljubomir Obradović, P4444 (Transcript from Prosecutor v. Tolimir), T. 11960-11961; Ljubomir Obradović, T. 25121-25123 (23 February 2012). See also Dražen Erdemović, P332 (Transcript from Prosecutor v. Popović et al.), T. 10934-10935, 10950. 
July 1995, including a black uniform, a VRS uniform, a uniform of the US Army, a uniform of the $\mathrm{ABiH}$, and a uniform of the HVO. ${ }^{506}$

\section{e. VRS Corps}

178. While the Main Staff would provide general guidance to the Corps on the various objectives, it was the responsibility of the Corps to plan the details of combat operations and to conduct them on the ground within their designated zone. ${ }^{507}$

\section{i. $1^{\text {st }}$ Krajina Corps}

179. The $1^{\text {st }}$ Krajina Corps was commanded by General Major Talić from 17 March 1992 and he remained the Commander during the Indictment period. ${ }^{508}$ Its headquarters was in Banja Luka. ${ }^{509}$ The $1^{\text {st }}$ Krajina Corps consisted of various brigades (motorised and light infantry), regiments, and battalions. $^{510}$

180. The area of responsibility of the $1^{\text {st }}$ Krajina Corps, which was initially identical to the area of responsibility of the $5^{\text {th }}$ JNA Corps ${ }^{511}$ included Bosanska Krupa, Banja Luka, Gradiska, Prijedor, Kotor Varoš, Ključ, and Sanski Most. ${ }^{512}$ The corps was strengthened by light infantry

506 Dražen Erdemović, P332 (Transcript from Prosecutor v. Popović et al.), T. 10939.

507 Richard Butler, T. 27452 (17 April 2012), T. 3765, 3770-3771 (15 June 2010); P4913 (Richard Butler's expert report entitled "VRS Corps Command Responsibility Report", 5 April 2000), para. 1.6. The Corps command would brief the details of an operation to the Main Staff. The Main staff would then review the operation and give its approval. Richard Butler, T. 27452 (7 April 2012).

508 Ewan Brown, T. 21536 (17 November 2011); P3914 (Ewan Brown's expert report entitled "Military Developments in the Bosanska Krajina - 1992", 27 November 2002), paras. 1.72-1.73, 3.5; Ljubomir Obradović, P4444 (Transcript from Prosecutor v. Tolimir), T. 11963-11964. See also Adjudicated Fact 511.

509 P3914 (Ewan Brown's expert report entitled "Military Developments in the Bosanska Krajina - 1992", 27 November 2002), para. 1.72.

$510 \quad$ P3920 (Order of $1^{\text {st }}$ Krajina Corps, 21 May 1992), p. 4. See also Ewan Brown, T. 21536 (17 November 2011); P3914 (Ewan Brown's expert report entitled "Military Developments in the Bosanska Krajina - 1992", 27 November 2002), paras. 1.76, 1.81.

511 P3914 (Ewan Brown's expert report entitled "Military Developments in the Bosanska Krajina - 1992", 27 November 2002), para. 1.85; P5433 ( $1^{\text {st }}$ Krajina Corps document analysing combat readiness in 1992, February 1993), pp. 2-4; P3656 (1 ${ }^{\text {st }}$ Krajina Corps report, 1 June 1992).

512 P3914 (Ewan Brown's expert report entitled "Military Developments in the Bosanska Krajina - 1992", 27 November 2002), paras. 1.85-1.97; P5433 ( $1^{\text {st }}$ Krajina Corps document analysing combat readiness in 1992, February 1993), pp. 2-4; P3656 (1 ${ }^{\text {st }}$ Krajina Corps report, 1 June 1992); KDZ163, P3716 (Transcript from Prosecutor v. Stanišić \& Župljanin), T. 5365 (under seal). The Corps began its operations with 1,650 men, but by June 1992 it had approximately 25,000 men, and by April 1993, 72,330 men. P5433 (1 ${ }^{\text {st }}$ Krajina Corps document analysing combat readiness in 1992, February 1993), p. 2; D325 (VRS Main Staff analysis of combat readiness and army activities in 1992, April 1993), p. 76. 
brigades, which were created from both Serb TO units and newly mobilised personnel. ${ }^{513}$ The corps was also supplemented by volunteers who were assigned to units and to the headquarters. ${ }^{514}$

\section{ii. Eastern Bosnia Corps}

181. Headquartered in Bijeljina, ${ }^{515}$ the Eastern Bosnia Corps' area of responsibility was in northeast $\mathrm{BiH}$, with the Sava River to the north and Drina River to the east. ${ }^{516}$ However, before the creation of the Drina Corps in November 1992, it also extended as far south as Zvornik and Vlasenica. ${ }^{517}$ In May 1992, the Corps Commander was Colonel Nikola Denčić, who was replaced by Colonel Dragutin Ilić on 7 June 1992. ${ }^{518}$ In July 1995, General Novica Simić was the Corps Commander. ${ }^{519}$ The Chief of Security was Dušan Tanasković. ${ }^{520}$

182. The Eastern Bosnia Corps was a small corps in terms of troop numbers. ${ }^{521}$ By 7 June 1992 , it consisted of eight brigades, namely, the Posavina Brigade, the Brčko Brigade, the $1^{\text {st }}$ Semberija Brigade, the $2^{\text {nd }}$ Semberija Brigade, the $1^{\text {st }}$ Majevica Brigade, the $2^{\text {nd }}$ Majevica Brigade, the Zvornik Brigade, and the Birač Brigade. ${ }^{522}$

513 P3914 (Ewan Brown's expert report entitled "Military Developments in the Bosanska Krajina - 1992", 27 November 2002), para. 1.81.

$514 \quad$ P5433 ( $1^{\text {st }}$ Krajina Corps document analysing combat readiness in 1992, February 1993), pp. 18-19; P3914 (Ewan Brown's expert report entitled "Military Developments in the Bosanska Krajina - 1992”, 27 November 2002), para. 1.82 .

515 P3035 (Decision of Army of SerBiH, 15 June 1992), p. 2.

516 Momčilo Mandić, T. 5103-5104 (14 July 2010); P4919 (Map of BiH marked by Richard Butler); Richard Butler, T. 27434 (17 April 2012); P2796 (Map showing communications plan of Drina Corps).

517 P5400 (Order of Eastern Bosnia Corps, 7 June 1992), p. 1.

$518 \quad$ KDZ531, T. 15847-15848 (1 July 2011) (closed session); Dragomir Andan, D3774 (Transcript from Prosecutor v. Stanišić \& Župljanin), T. 21676-21677; D1457 (Order of Eastern Bosnia Corps Command, 6 June 1992); P3384 (Report of Eastern Bosnia Corps, 7 June 1992).

519 Ljubomir Obradović, P4444 (Transcript from Prosecutor v. Tolimir), T. 11964; P4446 (Organisational Chart of the VRS Main Staff Structure for July 1995). See also Dragomir Andan, D3774 (Transcript from Prosecutor v. Stanišić \& Župljanin), T. 21676-21677.

$520 \quad$ KDZ531, T. 15847-15848 (1 July 2011) (closed session).

521 Momčilo Mandić, T. 5103-5104 (14 July 2010); P4919 (Map of BiH marked by Richard Butler); Richard Butler, T. 27434 (17 April 2012); P2796 (Map showing communications plan of Drina Corps).

522 P5400 (Order of Eastern Bosnia Corps, 7 June 1992), pp. 3-6; P3172 (Report of Birać Brigade, 6 July 1992); P3171 (Combat Report of the Eastern Bosnia Corps, 6 July 1992), p. 2. In addition to the brigades, the Eastern Bosnia Corps had an engineering detachment, an anti-aircraft light artillery regiment, the Smoluće infantry battalion, the Okresanice infantry battalion, and the Bijeljina mixed artillery regiment, as well as a combat security and a logistics security section. P5400 (Order of Eastern Bosnia Corps, 7 June 1992), pp. 3-6; P3171 (Combat Report of the Eastern Bosnia Corps, 6 July 1992), p. 2. 


\section{iii. $S R K$}

183. The area of responsibility of the SRK was the greater Sarajevo area between Višegrad, Kladanj, and Igman, which was the former zone of responsibility of the $4^{\text {th }}$ JNA Corps. ${ }^{523}$ The SRK's main forces were positioned around the inner ring of Sarajevo, in the areas of Ilidža, Neđarići, and Grbavica. ${ }^{524}$ The rear command post of the SRK was immediately northwest of Pale town while the main command post was at the Lukavica barracks. ${ }^{525}$

184. Colonel Tomislav Šipčić was the Commander of the SRK from 8 July to early August 1992. ${ }^{526}$ General Stanislav Galić was the Commander from 10 September 1992 until August 1994. ${ }^{527}$ Thereafter, Dragomir Milošević, the SRK Chief of Staff, assumed command. ${ }^{528}$ Dragomir Milošević remained Corps Commander until 1996. ${ }^{529}$ During the period covered by the

523 See Adjudicated Facts 20, 2823; P3034 (Track changes version of Reynaud Theunens's expert report entitled "Radovan Karadžić and the SRBiH TO-VRS (1992-1995)"), pp. 444-445; Richard Philipps, T. 3747 (15 June 2010), T. 3897-3899 (16 June 2010); C1 (Map of Sarajevo, Marked by Richard Philipps).

524 See Adjudicated Fact 21. From August 1994 to November 1995, the SRK's areas of responsibility included Ilidža, Osijek, Butila, Blažuj, Lukavica, Ilijaš, Vrace, Grbavica, Zlatište, parts of Dobrinja, the area up to Mount Trebević, the hills south and southwest of Sarajevo, Rajlovac, Špicasta Stijena, the northeast of Sarajevo, Nedžarići (north of the airport), and Vogošća. Most of Grbavica was controlled by the SRK but it was surrounded on three sides by the $\mathrm{ABiH}$. On the eastern confrontation line in Grbavica, the area from the Vrbanja Bridge towards the Jewish cemetery up to Debelo Brdo was controlled by the SRK. There were two confrontations lines and control over areas of Dobrinja was divided between the SRK and ABiH. See Adjudicated Facts 2824, 2826, 2828, 2832, 2833, 2835, 2840, 2841. For more detail, see Section IV.B.1: Sarajevo component (Facts).

525 P989 (Witness statement of Richard Philipps dated 25 May 2010), pp. 11, 17; KDZ088, T. 6277-6278 (7 September 2010) (closed session).

526 P1510 (Radovan Karadžić's Order, 8 July 1992) (under seal); [REDACTED]. See also P993 (Organisation chart of SRK, 1992-1994); P989 (Witness statement of Richard Philipps dated 25 May 2010), p. 11. Šipčić took over command of the SRK on 19 May 1992 but his official appointment came on 8 July 1992 and he left the SRK in early August 1992. [REDACTED]; Stanislav Galić, T. 37154-37155 (15 April 2013); P1478 (Ratko Mladić's notebook, 27 May-31 July 1992), pp. 279-280.

527 Stanislav Galić, T. 37155 (15 April 2013); P993 (Organisation chart of SRK, 1992-1994); P994 (Organisation chart of SRK, 1994-1995); P989 (Witness statement of Richard Philipps dated 25 May 2010), p. 11. See also Adjudicated Fact 27. On 16 December 1992, the Accused awarded Galić an exceptional promotion to the rank of Major-General. P2650 (Radovan Karadžić's decree on exceptional promotion, 16 December 1992). He was awarded an early promotion to the rank of Lieutenant-General on 7 August 1994 by the Accused. P2649 (Radovan Karadžić's decree on early promotion, 7 August 1994).

528 Dragomir Milošević, T. 32503 (23 January 2013) (testifying that he was commander until early 1996); P2678 (Radovan Karadžić's decree on appointment of Dragomir Milošević as SRK Commander, 8 August 1994), p. 2 (appointing Dragomir Milošević as SRK Commander effective as of 15 August 1994); P994 (Organisation chart of SRK, 1994-1995); P989 (Witness statement of Richard Philipps dated 25 May 2010), pp. 11-12. On 24 March 1994, Dragomir Milošević was awarded an exceptional promotion to the rank of Major-General by the Accused. P2677 (Radovan Karadžić's decree on Dragomir Milošević's promotion, 24 March 1994). See also Adjudicated Fact 27; P2676 (Radovan Karadžić's decree on appointment of Dragomir Milošević as SRK Chief of Staff, 10 July 1993) (appointing Dragomir Milošević as Chief of Staff and Deputy Commander of the SRK).

529 Dragomir Milošević, T. 32503 (23 January 2013); P989 (Witness statement of Richard Philipps dated 25 May 2010), pp. 11-12. 
Indictment, the Chiefs of Staff were Dragan Marčetić, ${ }^{330}$ Dragomir Milošević, ${ }^{331}$ and Čedo Sladoje, ${ }^{532}$ successively.

185. There were four staff divisions and a liaison division within the Corps headquarters. ${ }^{533}$ The operational division was headed by the Assistant Corps Commander for Organisation and Mobilisation. ${ }^{534}$ Its main responsibility was ensuring the operations and training of the troops. ${ }^{535}$ The morale division was headed by the Assistant Corps Commander for Morale, Legal, and Religious Affairs and responsible for informing the Corps Commander about the status of morale within the corps. ${ }^{536}$ The security division was headed by the Assistant Corps Commander for Intelligence and Security and responsible for disseminating intelligence information. ${ }^{537}$ The logistics division was headed by the Assistant Commander for Logistics and Corps Rear Services. ${ }^{538}$ Finally, the liaison division was responsible for liaising with UNPROFOR. ${ }^{539}$

186. The SRK had approximately 18,000 troops. ${ }^{540}$ The number of operative units, in particular brigades and battalions, varied between 1992 and 1995. ${ }^{541}$ The brigades included the $1^{\text {st }}$ Romanija Infantry Brigade, the $2^{\text {nd }}$ Sarajevo Light Infantry Brigade, the $1^{\text {st }}$ Sarajevo Mechanised (Motorised) Brigade, the Koševo Light Infantry Brigade, the $3^{\text {rd }}$ Sarajevo Light Infantry Brigade, ${ }^{542}$ the $4^{\text {th }}$

530 From 29 September 1992 to 20 June 1993. P997 (List of SRK personnel), p. 11; P994 (Organisation chart of SRK, 1994-1995).

531 From 6 July 1993 to August 1994. P997 (List of SRK personnel), p. 13; P994 (Organisation chart of SRK, 1994-1995).

532 From August 1994 to September 1995. P994 (Organisation chart of SRK, 1994-1995).

533 P989 (Witness statement of Richard Philipps dated 25 May 2010), pp. 12-14.

534 P989 (Witness statement of Richard Philipps dated 25 May 2010), p. 13.

$535 \quad$ P989 (Witness statement of Richard Philipps dated 25 May 2010), p. 13.

536 P989 (Witness statement of Richard Philipps dated 25 May 2010), p. 13.

537 P989 (Witness statement of Richard Philipps dated 25 May 2010), p. 14.

$538 \quad$ P989 (Witness statement of Richard Philipps dated 25 May 2010), p. 14.

539 P989 (Witness statement of Richard Philipps dated 25 May 2010), p. 14.

540 Dragomir Milošević, T. 32744 (28 January 2013). KDZ304 estimated that the SRK had between 13,000 to 15,000 soldiers. P2407 (Witness statement of KDZ304), e-court p. 7. David Harland testified that the UN estimate was approximately 20,000 troops in the SRK. David Harland, T. 2106 (7 May 2010).

541 Stanislav Galić, T. 37157 (15 April 2013); D3864 (Radovan Radinović's expert report entitled "The Control Authority of Dr. Radovan Karadžić in the Strategic Command System of the VRS”, 2012), para. 249. See also P1505 (SRK Order, 22 May 1992); P1509 (Order of JNA $4^{\text {th }}$ Corps, 17 May 1992). [REDACTED]. Galić testified that when he arrived at the SRK (in September 1992), there were "nine light brigades [...] a mixed antiarmour regiment, a mixed armour artillery regiment $[\ldots]$ a light artillery regiment $[\ldots]$ a battalion, communications battalion, medical battalion, and transport battalion". Stanislav Galić, T. 37157 (15 April 2013). The areas of responsibility of each brigade were discussed by Stanislav Galić, T. 37157-37168, 3717837185 (15 April 2013); D3381 (Map of Sarajevo marked by Stanislav Galić). KDZ304 stated that the SRK had 11 brigades "deployed within and outside the exclusion zone". P2407 (Witness statement of KDZ304), e-court p. 7. See also P1021 (VRS map of Sarajevo); P6295 (VRS map of Sarajevo); D718 (Map of Sarajevo and surrounding areas); D311 (VRS map of Sarajevo); P842 (VRS map of Sarajevo, 31 August 1995); P1494 (ABiH map of Sarajevo, 15 June-20 July 1992); D2788 (Map of Sarajevo marked by Dragomir Milošević).

542 In late 1993, the Vogošća Light Infantry Brigade was renamed the $3^{\text {rd }}$ Sarajevo Light Infantry Brigade and both the Rajlovac Brigade and Koševo Brigade were incorporated into the $3^{\text {rd }}$ Sarajevo Light Infantry Brigade. P989 (Witness statement of Richard Philipps dated 25 May 2010), pp. 9, 15; P993 (Organisation chart of SRK, 1992- 
Srpska Light Infantry Brigade, the Rogatica Brigade, the Igman Infantry Brigade, the Ilidža Light Infantry Brigade, the Ilijaš Light Infantry Brigade, the Vogošća Light Infantry Brigade, and the Rajlovac Light Infantry Brigade. ${ }^{543}$ Brigades were supported by an artillery group, an anti-aircraft defence light artillery regiment, an engineering battalion, and a medical battalion. ${ }^{544}$ The SRK also had an MP company. ${ }^{545}$

187. When the Drina Corps was established in November 1992, the $1^{\text {st }}$ Romanija Infantry Brigade and the Rogatica Brigade became part of the Drina Corps. ${ }^{546}$

188. In general, the names and areas of responsibility for the SRK brigades were based on the locations of the brigades. ${ }^{547}$ For example, the Ilidža Light Infantry Brigade was deployed in Ilidža and held positions in Nedžarići towards Dobrinje, Alipašino Polje and the Stup Junction, as well as Golo Brdo in the southwest area of Sarajevo. ${ }^{548}$

189. The Igman Infantry Brigade controlled the areas of Blazuj and Hadžići. ${ }^{549}$ The $1^{\text {st }}$ Sarajevo Mechanised Brigade held positions east of Mojmilo Brdo, near eastern Dobrinja, Zlatište, and Grbavica through the Jewish cemetery until Debelo Brdo. ${ }^{550}$ The $1^{\text {st }}$ Romanija Infantry Brigade

1994); Stanislav Galić, T. 37182-37183 (15 April 2013) (testifying that the Vogošća Brigade merged with the Rajlovac and Centar Brigades to make the $3^{\text {rd }}$ Sarajevo Brigade), T. 37539 (22 April 2013) (testifying that it was the Koševo or Centar Brigade, "depending on what we called it at which point"), T. 37969 (8 May 2013); D2774 (Witness statement of Milenko Inđić dated 19 January 2013), para. 21 (stating that the Koševo and Rajlovac Brigades merged to become the $3^{\text {rd }}$ Sarajevo Brigade). 
controlled the areas of Grbavica to Vraca, the area below Mount Trebević and the Jewish cemetery. ${ }^{551}$ The $2^{\text {nd }}$ Sarajevo Light Infantry Brigade held positions in the southern area of Sarajevo, in Dobrinja, Grlinca, and Vojkovići towards Lukavica. ${ }^{552}$ The Famos factory separated the $2^{\text {nd }}$ Sarajevo Light Infantry Brigade from the ABiH's $104^{\text {th }}$ Motorised Brigade in Hrasnica. ${ }^{553}$ The $3^{\text {rd }}$ Sarajevo Light Infantry Brigade was deployed in the southeastern area of Sarajevo and its zone of responsibility included Rajlovac, Vogosča, and an area towards Hresa. ${ }^{554}$

\section{iv. Drina Corps}

190. The Drina Corps' area of responsibility was the Podrinje region, which included the municipalities of Srebrenica, Bratunac, Vlasenica, Milići, Šekovići, and Zvornik. ${ }^{55}$ The Drina Corps headquarters was first based in Han Pijesak and later moved to Vlasenica. ${ }^{556}$ The specific objective of the Drina Corps was to secure the middle Podrinje region, including the municipalities of Srebrenica, Bratunac, and Zvornik. ${ }^{557}$

191. General Milenko Živanović assumed the role of Drina Corps Commander at the time of its formation in November 1992. ${ }^{558}$ Colonel Radislav Krstić was the Chief of Staff and Deputy

VRS”, 2012), para. 256. Galić testified both that the SRK did and did not have control of the Sucuri settlement, an area near Mojmilo Brdo and Dobrinja. See Stanislav Galić, T. 37408 (18 April 2013), T. 37542 (22 April 2013). See also Blagoje Kovačević, T. 29041-29044 (18 October 2012).

551 Dragomir Milošević, T. 32499-32501 (23 January 2013); Stanislav Galić, T. 37184 (15 April 2013), T. 37360 (18 April 2013); D3412 (SRK combat report, 19 May 1993), p. 1. Stevan Veljović stated that the zone of responsibility was "Zlatište on the right, Đukića Potok on the left, and as far back as Tilava-Tvrdinići”. D2351 (Witness statement of Stevan Veljović dated 19 October 2012), para. 12. Veljović testified that Zlatište became part of the $1^{\text {st }}$ Sarajevo Mechanised Brigade's area of responsibility later and that the composition of a brigade would change and the zone would change slightly too. Stevan Veljović, T. 29249-29250 (23 October 2012).

552 Dragomir Milošević, T. 32523 (23 January 2013), T. 32743-32744, 32784 (28 January 2013); D3445 (SRK combat report, 7 June 1993), para. 1(c). In total, the $2^{\text {nd }}$ Sarajevo Light Infantry Brigade had about 1,200 persons registered. However, Dragomir Milošević testified that he could only depend on approximately 800 to 1,000 to be ready for combat. Dragomir Milošević, T. 32523 (23 January 2013), T. 32743-32744, 32784 (28 January 2013). The $2^{\text {nd }}$ Sarajevo Brigade was also referred to as the $2^{\text {nd }}$ Sarajevo Light Infantry Brigade. D2809 (SRK combat report, 13 September 1993).

553 The confrontation line was a single wall in the factory. Dragomir Milošević, T. 32787-32789 (29 January 2013), T. 33179-33180 (5 February 2013); D2903 (SRK combat report, 25 May 1995).

554 Stanislav Galić, T. 37538-37539 (22 April 2013), T. 37969 (8 May 2013); Dragomir Milošević, T. 32513 (23 January 2013).

555 P4917 (Richard Butler's expert report entitled "VRS Main Staff Command Responsibility Report", 9 June 2006), paras. 3.0-3.3; P4941 (Srebrenica court binder containing maps), p. 5. See also P976 (Directive 4, 19 November 1992), p. 2; Adjudicated Facts 1421, 1442.

556 See Adjudicated Fact 1444. See also P6566 (Order of VRS Main Staff, 20 October 1992).

557 Richard Butler, T. 27423-27434 (17 April 2012); P976 (Directive 4, 19 November 1992), pp. 2, 5. See also D325 (VRS Main Staff analysis of combat readiness and army activities in 1992, April 1993), p. 73; P4941 (Srebrenica court binder containing maps), p. 5.

558 Adjudicated Fact 1450. 
Commander of the Drina Corps from 29 September 1994. ${ }^{59}$ He became the Corps Commander on 13 July 1995.560

192. The Security Department of the Drina Corps was headed by Lieutenant-Colonel Vujadin Popović in April 1995, and it was responsible for issues of security in the corps, including the arrest and detention of prisoners of war and other persons. ${ }^{561}$ The MP battalion was commanded by Lieutenant Ratko Vujović. ${ }^{562}$

193. By July 1995, the Drina Corps was composed of the following subordinate units, including the $1^{\text {st }}$ Bratunac Light Infantry Brigade ("Bratunac Brigade"), $1^{\text {st }}$ Zvornik Light Infantry Brigade ("Zvornik Brigade"), $1^{\text {st }}$ Vlasenica Light Infantry Brigade, $2^{\text {nd }}$ Romanija Motorised Brigade, $1^{\text {st }}$ Birač Infantry Brigade, $1^{\text {st }}$ Milići Light Infantry Brigade, $1^{\text {st }}$ Podrinje Light Infantry Brigade, $5^{\text {th }}$ Podrinje Light Infantry Brigade, and Skelani Independent Battalion. ${ }^{563}$ These units were supported by the $5^{\text {th }}$ Mixed Artillery Regiment, $5^{\text {th }}$ Engineer Battalion, $5^{\text {th }}$ Communications Battalion, and $5^{\text {th }}$ MP Battalion. ${ }^{564}$

194. Code names were used to refer to the corps commands and other operative units, such as "Palma" for the Zvornik Brigade, "Badem" for the Bratunac Brigade and "Zlatar" for the Command of the Drina Corps. ${ }^{565}$

\section{(A) Bratunac Brigade}

195. In July 1995, the Bratunac Brigade was headquartered in Bratunac town and commanded by Colonel Vidoje Blagojević. ${ }^{56}$ Major Novica Pajić was the Chief of Staff and Deputy Commander. ${ }^{567}$ The Bratunac Brigade branches consisted of three branches: Rear Service

559 Radislav Krstić, D4136 (Transcript from Prosecutor v. Krstić) T. 5972. See also Adjudicated Fact 1451. Krstić was promoted to Major-General on 2 May 1995. D3951 (Order of Drina Corps, 2 May 1995).

560 P4485 (Drina Corps information, 13 July 1995).

561 D3993 (Witness Statement of Vujadin Popović dated 2 November 2013), para. 3; Momir Nikolić, T. 24569_ 24570 (13 February 2012). See also Adjudicated Fact 1453; D2243 (Instructions from the Drina Corps, 15 April 1995); P4920 (Diagrams of various VRS Military Command structures), p. 2.

562 P4920 (Diagrams of various VRS Military Command structures), p. 2; KDZ391, P4761 (Transcript from Prosecutor v. Popović et al.), T. 32567-32568, 32599-32600 (under seal).

563 P4920 (Diagrams of various VRS Military Command structures), p. 2. See also Adjudicated Fact 1448.

$564 \quad$ See Adjudicated Fact 1448.

565 See Adjudicated Fact 1460.

566 P4914 (Richard Butler's expert report entitled "Srebrenica Military Narrative (Revised): Operation 'Krivaja 95'”, 1 November 2002), paras. 2.8, 3.6, 13.2; Momir Nikolić, T. 24568-24569 (13 February 2012); Mile Janjić, P1194 (Transcript from Prosecutor v. Blagojević \& Jokić), T. 9781; KW582, D4291 (Transcript from Prosecutor v.Blagojević \& Jokić), T. 3627; D4189 (Witness statement of Vidoje Blagojević dated 8 October 2013), pp. 1-2; P4920 (Diagrams of various VRS Military Command structures), p. 4. See also Adjudicated Facts 1458, 1459, 1636.

567 P4920 (Diagrams of various VRS Military Command structures), p. 4; P4914 (Richard Butler's expert report entitled “Srebrenica Military Narrative (Revised): Operation 'Krivaja 95'”, 1 November 2002), para. 2.8. 
commanded by Major Dragoslav Trišić; Morale, Legal and Religious Affairs commanded by Major Ratomir Jevtić; and the Security and Intelligence Organ commanded by Captain Momir Nikolić, with Dragiša Jovanović as his deputy. ${ }^{568}$

196. The Bratunac Brigade had four infantry battalions; ${ }^{569}$ an MP platoon commanded by Mirko Janković; ${ }^{570}$ an Artillery Company; and a Logistics Company. ${ }^{571}$

197. Momir Nikolić was the Chief of the Security and Intelligence Organ from November 1992 until the end of the conflict. ${ }^{572}$ The responsibilities of the Security and Intelligence Organ included collecting, processing, analysing, and forwarding intelligence data to commanding personnel, assessing counter-intelligence threats, and taking measures to repel sabotage of the unit's arsenal, personnel and equipment. ${ }^{573}$ Nikolić reported to the Drina Corps Intelligence and Security Organ. ${ }^{574}$ Nikolić also acted as liaison officer to UNMOs, UNPROFOR, and other international organisations in the Srebrenica area in $1995 .{ }^{575}$

568 P4920 (Diagrams of various VRS Military Command structures), p. 4; P4914 (Richard Butler's expert report entitled "Srebrenica Military Narrative (Revised): Operation 'Krivaja 95”", 1 November 2002), para. 2.8; Momir Nikolić, T. 24715 (14 February 2012); D4189 (Witness statement of Vidoje Blagojević dated 8 October 2013), p. 4; KW582, D4291 (Transcript from Prosecutor v. Blagojević \& Jokić), T. 3662. See also Adjudicated Facts $1520,1868$.

569 P4920 (Diagrams of various VRS Military Command structures), p. 4; P4914 (Richard Butler's expert report entitled "Srebrenica Military Narrative (Revised): Operation 'Krivaja 95'”, 1 November 2002), para. 2.8. The battalions included: the $1^{\text {st }}$ Battalion, commanded by Lazar Ostojić; the $2^{\text {nd }}$ Battalion, commanded by Goran Stakić; the $3^{\text {rd }}$ Battalion, commanded by Dragomir Zekić; and the $4^{\text {th }}$ Battalion, commanded by Radika Petrović. P4920 (Diagrams of various VRS Military Command structures), p. 4; P4914 (Richard Butler's expert report entitled "Srebrenica Military Narrative (Revised): Operation 'Krivaja 95'”, 1 November 2002), para. 2.8. The $4^{\text {th }}$ Battalion operated on the Bratunac-Konjević Polje Road area since September 1993 and was assigned to the Zvornik Brigade. However, it was commanded by the Commander of the Bratunac Brigade who had operational control over combat related activities and controlled this unit until 19 July 1995. P4914 (Richard Butler's expert report entitled "Srebrenica Military Narrative (Revised): Operation 'Krivaja 95", 1 November 2002), paras. 6.15-6.16. See also Momir Nikolić, T. 24563 (13 February 2013). The $3^{\text {rd }}$ Infantry Battalion had an intervention platoon called the "Red Berets". P4920 (Diagrams of various VRS Military Command structures), p. 4; P4914 (Richard Butler's expert report entitled "Srebrenica Military Narrative (Revised): Operation 'Krivaja 95'”, 1 November 2002), para. 2.8.

570 Momir Nikolić, T. 24570 (13 February 2012), T. 24651, 24681, 24721 (14 February 2012), T. 24864 (16 February 2012); KW582, D4290 (Transcript from Prosecutor v. Blagojević \& Jokić), T. 3499-3500 (under seal); Mile Janjić, P372 (Transcript from Prosecutor v. Popović et al.), T. 17951, 17968; P4920 (Diagrams of various VRS Military Command structures), p. 4; P4914 (Richard Butler's expert report entitled "Srebrenica Military Narrative (Revised): Operation 'Krivaja 95'”, 1 November 2002), para. 2.8.

571 P4920 (Diagrams of various VRS Military Command structures), p. 4.

572 Momir Nikolić, T. 24558 (13 February 2012).

573 Momir Nikolić, T. 24565, 24567-24569 (13 February 2012); D4189 (Witness statement of Vidoje Blagojević dated 8 October 2013), p. 4.

$574 \quad$ Momir Nikolić, T. 24569 (13 February 2012).

575 Momir Nikolić, T. 24572-24578 (13 February 2012). 
198. In July 1995, the Zvornik Brigade was headquartered at the Standard Barracks in Karakaj on the Konjević Polje-Zvornik-Bijeljina road. ${ }^{576}$

199. It was commanded by Lieutenant Colonel Vinko Pandurević. ${ }^{577}$ Major Dragan Obrenović served as Chief of Staff and Deputy Commander. ${ }^{578}$ The brigade staff included the Intelligence Section, with Duško Vukotić as the Assistant Chief. ${ }^{579}$ The organs of the Zvornik Brigade were headed by three Assistant Commanders subordinated to Pandurević. ${ }^{580}$ Sreten Milošević was the head of the Logistics Organ. ${ }^{581}$ Drago Nikolic was the head of the Security Organ, with Milorad Trbić as his deputy. ${ }^{582}$ Nikolić's immediate superior at the brigade level was Pandurević but his

$576 \quad$ Ljubo Bojanović, P116 (Transcript from Prosecutor v. Blagojević), T. 11688, 11722; KDZ407, P378 (Transcript from Prosecutor v. Popović et al.), T. 6440 (under seal); Milorad Birčaković, P360 (Transcript from Prosecutor v. Popović et al.), T. 11011.

577 Pandurević assumed the role of the Zvornik Brigade Commander on 12 December 1992, and remained in this position until November 1996. Ljubo Bojanović, P116 (Transcript from Prosecutor v. Blagojević), T. 11674; Ostoja Stanišić, P382 (Transcript from Prosecutor v. Popović et al.), T. 11703; D3720 (Witness statement of Petar Salapura dated 17 June 2013), p. 19; P4914 (Richard Butler's expert report entitled "Srebrenica Military Narrative (Revised): Operation 'Krivaja 95'”, 1 November 2002), para. 2.8; see Adjudicated Fact 1454.

578 Srećko Aćimović, P343 (Transcript from Prosecutor v. Popović et al.), T. 12939; Ljubo Bojanović, P116 (Transcript from Prosecutor v. Blagojević), T. 11674-11675; Ostoja Stanišić, P382 (Transcript from Prosecutor v. Popović et al.), T. 11703; P4920 (Diagrams of various VRS Military Command structures), p. 3; P4914 (Richard Butler's expert report entitled "Srebrenica Military Narrative (Revised): Operation 'Krivaja 95”,, 1 November 2002), para. 2.8. See also Adjudicated Fact 1455.

579 KDZ122, T. 26149 (13 March 2012) (closed session); P4920 (Diagrams of various VRS Military Command structures), p. 3; P4914 (Richard Butler's expert report entitled "Srebrenica Military Narrative (Revised): Operation 'Krivaja 95'”, 1 November 2002), para. 2.8.

$580 \quad$ Ljubo Bojanović, P116 (Transcript from Prosecutor v. Blagojević), T. 11674; Ostoja Stanišić, P382 (Transcript from Prosecutor v. Popović et al.), T. 11703; KDZ122, T. 26106 (12 March 2012) (closed session), T. 26152 (13 March 2012) (closed session); D3720 (Witness statement of Petar Salapura dated 17 June 2013), p. 19; P4914 (Richard Butler's expert report entitled "Srebrenica Military Narrative (Revised): Operation 'Krivaja 95'”, 1 November 2002), para. 2.8; P4920 (Diagrams of various VRS Military Command structures), p. 3.

581 Ljubo Bojanović, P116 (Transcript from Prosecutor v. Blagojević), T. 11675, 11739; Vujadin Popović, T. 43105 (6 November 2013); KDZ122, T. 26129 (12 March 2012) (closed session); P4920 (Diagrams of various VRS Military Command structures), p. 3.

582 Ljubo Bojanović, P116 (Transcript from Prosecutor v. Blagojević), T. 11675, 11682-11683; Tanacko Tanić, P369 (Transcript from Prosecutor v. Popović et al.), T. 10338; Srećko Aćimović, P343 (Transcript from Prosecutor v. Popović et al.), T. 12931-12932; Milorad Birčaković, P360 (Transcript from Prosecutor v. Popović et al.), T. 11011-11012, 11116; KDZ122, T. 26109-26110, 26120, 26130 (12 March 2012) (closed session), T. 26155 (13 March 2012) (closed session); P4920 (Diagrams of various VRS Military Command structures), p. 3; P4914 (Richard Butler's expert report entitled "Srebrenica Military Narrative (Revised): Operation 'Krivaja 95'”, 1 November 2002), para. 2.8; Nebojša Jeremić, P348 (Transcript from Prosecutor v. Popović et al.), T. 10418, 1042; see Adjudicated Fact 1457. Drago Nikolić had the authority to carry out tasks without the permission of the Zvornik Brigade Commander. The security organs had the right to use vehicles without the knowledge of the Zvornik Brigade Commander, as provided for in the book of regulations. Military police officers fell under the security organ's chain of command, separate from the command of the Zvornik Brigade. Radislav Krstić, D4136 (Transcript from Prosecutor v. Krstić) T. 6477-6478. 
professional superior was Popović. ${ }^{53}$ Nenad Simić was the head of the Morale, Religious, and Legal Affairs Organ. ${ }^{584}$

200. The infantry battalions subordinated to the Zvornik Brigade in 1995 were the following: $1^{\text {st }}$ Battalion, ${ }^{585} 2^{\text {nd }}$ Battalion, ${ }^{586} 3^{\text {rd }}$ Battalion, ${ }^{587} 4^{\text {th }}$ Battalion, ${ }^{588} 5^{\text {th }}$ Battalion, ${ }^{589} 6^{\text {th }}$ Battalion, ${ }^{590} 7^{\text {th }}$ Battalion $^{591} 8^{\text {th }}$ Battalion, ${ }^{592}$ Logistics Battalion, ${ }^{593}$ Light Anti-Aircraft Rocket Artillery Battalion, ${ }^{594}$ and the Rear Battalion (also called the " $\mathrm{R}$ " battalion). ${ }^{595}$

201. The Zvornik Brigade had other units including an MP company commanded by Milomir Jasikovac; the Engineering Company, commanded by Dragan Jevtić; the Communications Company, commanded by Dragisa Radić; the Mixed Artillery Division, commanded by Miloš Maksimović; and the $1^{\text {st }}$ Battalion's Work Platoon, commanded by Radivoje Lakić. ${ }^{596}$

\footnotetext{
583 KDZ122, T. 26109-26110 (12 March 2012) (closed session).

584 Ljubo Bojanović, P116 (Transcript from Prosecutor v. Blagojević), T. 11716; KDZ122, T. 26130 (12 March 2012) (closed session); P4920 (Diagrams of various VRS Military Command structures), p. 3.

585 P4920 (Diagrams of various VRS Military Command structures), p. 3; P4914 (Richard Butler's expert report entitled "Srebrenica Military Narrative (Revised): Operation 'Krivaja 95”, 1 November 2002), para. 2.8.

586 Srećko Aćimović, P343 (Transcript from Prosecutor v. Popović et al.), T. 12930-12931; Veljko Ivanović, P384 (Transcript from Prosecutor v. Popović et al.), T. 18174; Mitar Lazarević, P363 (Transcript from Prosecutor v. Popović et al.), T. 13362; P4920 (Diagrams of various VRS Military Command structures), p. 3; P4914 (Richard Butler's expert report entitled "Srebrenica Military Narrative (Revised): Operation 'Krivaja 95", 1 November 2002), para. 2.8.

P4920 (Diagrams of various VRS Military Command structures), p. 3; P4914 (Richard Butler's expert report entitled "Srebrenica Military Narrative (Revised): Operation 'Krivaja 95'”, 1 November 2002), para. 2.8.

588 P4920 (Diagrams of various VRS Military Command structures), p. 3; P4914 (Richard Butler's expert report entitled "Srebrenica Military Narrative (Revised): Operation 'Krivaja 95'”, 1 November 2002), para. 2.8.

589 P4920 (Diagrams of various VRS Military Command structures), p. 3; P4914 (Richard Butler's expert report entitled "Srebrenica Military Narrative (Revised): Operation 'Krivaja 95'”, 1 November 2002), para. 2.8.

Ostoja Stanišić, P382 (Transcript from Prosecutor v. Popović et al.), T. 11594; P4920 (Diagrams of various VRS Military Command structures), p. 3; P4914 (Richard Butler's expert report entitled "Srebrenica Military Narrative (Revised): Operation 'Krivaja 95'”, 1 November 2002), para. 2.8.

591 P4920 (Diagrams of various VRS Military Command structures), p. 3; P4914 (Richard Butler's expert report entitled "Srebrenica Military Narrative (Revised): Operation 'Krivaja 95'”, 1 November 2002), para. 2.8.

592 P4920 (Diagrams of various VRS Military Command structures), p. 3; P4914 (Richard Butler's expert report entitled "Srebrenica Military Narrative (Revised): Operation 'Krivaja 95'”, 1 November 2002), para. 2.8.

593 P4920 (Diagrams of various VRS Military Command structures), p. 3.

594 P4920 (Diagrams of various VRS Military Command structures), p. 3.

595 Damjan Lazarević, P352 (Transcript from Prosecutor v. Popović et al.), T. 14462; Milenko Tomić, P390 (Transcript from Prosecutor v. Popović et al.), T. 20998-20999.

596 Cvijetin Ristanović, P652 (Transcript from Prosecutor v. Blagojević \& Jokić), T. 5363; KDZ122, T. 26112, 26142-36144 (12 March 2012) (closed session), T. 26174 (13 March 2012) (closed session); Jevto Bogdanović, P385 (Transcript from Prosecutor v. Popović et al.), T. 11314; Milorad Birčaković, P360 (Transcript from Prosecutor v. Popović et al.), T. 11012, 11115-11116, 11171; Srećko Aćimović, P343 (Transcript from Prosecutor v. Popović et al.), T. 12987; D2266 (Nada Stojanović's interview with OTP), pp. 5-6; Nebojša Jeremić, P348 (Transcript from Prosecutor v. Popović et al.), T. 10418; P4920 (Diagrams of various VRS Military Command structures), p. 3; P4914 (Richard Butler's expert report entitled "Srebrenica Military Narrative (Revised): Operation 'Krivaja 95'", 1 November 2002), paras. 2.8, 7.7. See also Adjudicated Fact 1775 (the Chamber notes that Milomir Jasikovac's name is misspelled in the Adjudicated Fact).
} 
202. The so-called "Drina Wolves" was a special unit of the Zvornik Brigade housed in Kiseljak. ${ }^{597}$ It could be deployed when necessary in order to defend certain territories. ${ }^{598}$ The unit was commanded by Dragan Jolović, also referred to as "Legenda". 599 Members of the Drina Wolves were identified by a patch of a wolf head on the left shoulder of their uniforms. ${ }^{600}$

\section{f. Command and control principles}

203. The VRS system of command and control had three levels: strategic, operational, and tactical. ${ }^{601}$ Applying the same definition and principles of command and control as the JNA, ${ }^{602}$ the VRS organised unified and centralised command according to the following: (i) a "corps-brigadebattalion" model directly subordinated to a corps command; ${ }^{603}$ (ii) a subordinate-commander relationship in which every superior had the responsibility to monitor and assess the work of their subordinates and subordinates had to follow strict procedures of reporting and actions; ${ }^{604}$ and (iii) centralised decisions that followed a unified chain of command. ${ }^{605}$ For example, based on directives from the Main Staff, the SRK Commander would issue and/or approve orders to the subordinate commands. ${ }^{606}$ Subordinate commands would report back to the SRK command. ${ }^{607}$ On

597 KDZ407, P378 (Transcript from Prosecutor v. Popović et al.), T. 6437 (under seal); Dražen Erdemović, P332 (Transcript from Prosecutor v. Popović et al.), T. 10944-10945; Milorad Birčaković, P360 (Transcript from Prosecutor v. Popović et al.), T. 11170.

$598 \quad$ KDZ407, P378 (Transcript from Prosecutor v. Popović et al.), T. 6437; Dražen Erdemović, P332 (Transcript from Prosecutor v. Popović et al.), T. 10944-10945.

599 KDZ340, T. 17551-17552 (19 August 2011) (private session); KDZ508, P388 (Transcript from Prosecutor v. Popović et al.), T. 8876-8877 (under seal); Momir Nikolić, T. 24626 (13 February 2012). See also Dražen Erdemović, P332 (Transcript from Prosecutor v. Popović et al.), T. 10944-10945; D3927 (Witness statement of Franc Kos dated 26 July 2013), p. 7.

600 KDZ084, P4904 (Transcript from Prosecutor v. Popović et al.), T. 14811 (under seal).

601 D3864 (Radovan Radinović's expert report entitled "The Control Authority of Dr. Radovan Karadžić in the Strategic Command System of the VRS”, 2012), para. 2.

602 P034 (Track changes version of Reynaud Theunens's expert report entitled "Radovan Karadžić and the SRBiH TO-VRS (1992-1995)"), e-court pp. 310-311; D3864 (Radovan Radinović's expert report entitled "The Control Authority of Dr. Radovan Karadžić in the Strategic Command System of the VRS”, 2012), paras. 57-66.

603 P4915 (Richard Butler's expert report entitled “VRS Brigade Command Responsibility Report”, 31 October 2002), para. 1.1.

604 Ljubomir Obradović, P4444 (Transcript from Prosecutor v. Tolimir), T. 11945-11946.

605 P3914 (Ewan Brown's expert report entitled "Military Developments in the Bosanska Krajina - 1992", 27 November 2002), para. 1.62. See also Manojlo Milovanović, T. 25477-25478, (29 February 2012), T. 25632 (1 March 2012). See also Ljubomir Obradović, T. 25106-25107 (22 February 2012) (specifying that he did not know of any specific instances in which such bypassing the normal chain of command occurred but that this possibility was envisaged within the rules).

606 Stanislav Galić, T. 37429, 37432 (18 April 2013). See, e.g., D3430 (Letter from Stanislav Galić to SRK members, undated); D2800 (SRK Order, 18 February 1994) (an order issued by Galić based on the cease-fire agreement reached by the Accused and Akashi on 18 February 1994); D2567 (SRK Order, 22 May 1993); D2813 (VRS Main Staff Order, 8 August 1995); D2814 (SRK Order, 19 August 1995); (while Dragomir Milošević was on sick leave from mid-August until 9 or 10 September 1995, his Chief of Staff Čedomir Sladoje issued the order); Dragomir Milošević, T. 32750, 32755 (28 January 2013)); D2815 (SRK report, 30 August 1995); P1201 (SRK Order, 6 April 1995) (written by Chief of Artillery Tadija Manojlović, approved by Dragomir Milošević); D2840 (SRK request for information, 15 July 1993) (request for information, based on order from VRS Main Staff, sent to all brigades); Dragomir Milošević, T. 32876 (29 January 2013); P1309 (SRK Order, 21 April 1995); P1201 (SRK Order, 6 April 1995); P1670 (SRK Order, 21 August 1994. See also 
occasion, the SRK Commander would receive information and directives directly from the Supreme Command and the Accused. ${ }^{608}$

204. On 1 June 1992, the Law on the Army was issued by the SerBiH Presidency; it provided that the command in the VRS "shall be founded on principles of a unified command regarding the use of forces and means, single authority, obligations to enforce decisions, command and orders issued by superior commanders". ${ }^{609}$ It vested the President, as Commander-in-Chief, with the authority to command the army, establish plans for its development and deployment, establish the system of command, and issue a variety of regulations. ${ }^{610}$ The Main Staff Commander would command the VRS in compliance with the authority that the President delegated to him. ${ }^{611}$

205. There were two parallel chains of command in the VRS: the regular chain of command and the professional chain of command. ${ }^{612}$ With regard to the security and intelligence organs, for instance, their chain of command was largely based on the work of the organs, the majority of which included intelligence and counter-intelligence activities and a smaller portion of military police tasks and criminal investigative tasks. ${ }^{613}$ Along the regular chain of command, the security and intelligence organs were directly subordinated to the commander of the VRS unit or institution of which they formed a part. ${ }^{614}$ However, with regards to their professional activities, they were controlled by the security and intelligence organs of the superior command authorised to command

D2812 (Warning of SRK, 27 October 1994); D232 (VRS Main Staff Order, 6 June 1992) (a directive for further action issued by Mladić of the Main Staff to his commanders); P998 (SRK instructions, 7 June 1992) (instructions for further activities issued by SRK command); P1498 (Order of $2^{\text {nd }}$ Motorised Brigade, 8 June 1992) (order, based on the SRK command instructions, issued by the commander of the $2^{\text {nd }}$ Motorised Brigade to his units). 
it. $^{615}$ Intelligence and counter-intelligence tasks were part of the security organs specialised work and professional competence. ${ }^{616}$

\section{g. Communication and reporting in the VRS}

206. The military reporting chain in the VRS followed a hierarchical structure with the information originating from the lower military units being reported up to the intermediate military units, then to the Main Staff, and finally to the Supreme Commander. ${ }^{617}$ The VRS used the vojni post, military post. numbers to identify operative units and these numbers also indicated the command and control relationship between units. ${ }^{618}$

207. For daily combat and situations reports, all the brigade reports were integrated into one report at the corps level that provided an overview of the situation on the ground as well as an overview of the situation within the corps, i.e., combat readiness, operations, and other relevant information at approximately 4 or 5 p.m. ${ }^{619}$ The corps would integrate the brigade reports into a corps report which would be sent to the Main Staff at approximately 6 p.m. ${ }^{620}$ Similarly, the Main

615 P4480 (VRS Main Staff Order, 24 October 1994), p. 1; Ljubomir Obradović, P4444 (Transcript from Prosecutor v. Tolimir), T. 12195-12201. See also P4478 (SFRY Rules of Service of Security Organs in the Armed Forces, 1994), para. 16

616 See P4478 (SFRY Rules of Service of Security Organs in the Armed Forces, 1994), para. 18.

617 Ljubomir Obradović, P4444 (Transcript from Prosecutor v. Tolimir), T. 11973-11974; KDZ088, T. 6299-6302 (7 September 2010) (closed session); D232 (Directive 1, 6 June 1992); [REDACTED]; P998 (SRK instructions, 7 June 1992); P1498 (Order of $2^{\text {nd }}$ Motorised Brigade, 8 June 1992); Stanislav Galić, T. 38033-38034 (9 May 2013) (testifying that sometimes directives came directly from the Supreme Command and the Accused, as the President, however most of the information, orders, and directives went through the Main Staff); Stevan Veljović, T. 29241 (23 October 2012). See also D2774 (Witness statement of Milenko Inđić dated 19 January 2013), para. 33; P4446 (Organisational Chart of the VRS Main Staff Structure for July 1995); Ljubomir Obradović, T. 25092-25093 (22 February 2012).

618 Richard Philipps, T. 3750 (15 June 2010). Each corps, brigade, battalion and sub-unit had a specific VP number that consisted of four numbers, a stroke and then two other numbers in order to be identified by others notably in written documents. Richard Philipps, T. 3750 (15 June 2010).

619 Ljubomir Obradović, P4444 (Transcript from Prosecutor v. Tolimir), T. 11973-11974; Ljubomir Obradović, T. 25093-25096 (22 February 2012). See also Ewan Brown, T. 21542-21543 (17 November 2011); Momir Nikolić, T. 24605-24607 (13 February 2012); Stevan Veljović, T. 29239-29243 (23 October 2012). See e.g. P3042 (Report of VRS Main Staff, 11 April 1994); D1940 (Report of $1^{\text {st }}$ Krajina Corps, 6 May 1992); D1942 (Report of $1^{\text {st }}$ Krajina Corps, 14 July 1992); P3931 (Report of $1^{\text {st }}$ Krajina Corps, 16 December 1992); P3043 (VRS Main Staff Report, 12 April 1994); P3054 (VRS Main Staff Report, 12 July 1995); P4930 (Combat Report of Drina Corps, 8 July 1995); P4456 (Drina Corps report, 14 July 1995); P2256 (SRK combat report, 12 March 1995); P4500 (VRS Zvornik Brigade report to Main Staff, 4 March 1993); D2838 (SRK Order, 16 September 1992). Stevan Veljović testified that the latest the reports would be sent was 8 p.m. Steven Veljović, T. 29242 (23 October 2012); D2774 (Witness statement of Milenko Inđić dated 19 January 2013), para. 30. Reports to the SRK Command were to include, “(i) situation and activities of the enemy, (ii) combat readiness of units, (iii) security and morale, (iv) decision for further action, (v) situation in the territory of the zone of responsibility, (vi) situation and problems in the rear, (vii) unusual incidents and casualties, and (viii) proposals and requests". D2838 (SRK Order, 16 September 1992). See also Stevan Veljović, T. 29242-29243 (23 October 2012).

620 Ljubomir Obradović, P4444 (Transcript from Prosecutor v. Tolimir), T. 11973. See, e.g., D1970 (Drina Corps report, 13 July 1995). IKMs were required to write daily operations and combat reports, just like all other units for the area for which they had been established; this information was sent in encrypted form to the operations centre of the Main Staff, which was a third body within the administration for operations and training of the 
Staff would integrate reports from the corps into its daily combat reports, which were sent to the Supreme Commander and Corps Commanders. ${ }^{621}$ Extraordinary and interim reports, often in relation to a specific area or event, were also sent, when necessary, by the corps to the Main Staff or by the Main Staff to the Supreme Commander. ${ }^{622}$ Intelligence reports were also used to share information within the VRS. ${ }^{623}$ In particular, the Accused received both military intelligence reports and state security intelligence reports on a daily basis. ${ }^{624}$

208. By the end of 1992 there was regular phone and radio communication within the VRS, and in particular between the corps or other operative units and the Main Staff; within the corps; and between the Main Staff and the Supreme Commander. ${ }^{625}$ Meetings and briefings within the corps and between the corps and the Main Staff were held to share information. ${ }^{626}$

Main Staff. Ljubomir Obradović, T. 25093-25095 (22 February 2012). As regulated, daily combat reports from the SRK command would go to the Main Staff every evening. See, e.g., D3396 (SRK combat report, 15 January 1993); D3403 (SRK combat report, 12 February 1993); D3404 (SRK combat report, 14 February 1993); D3405 (SRK combat report, 15 March 1993). As Chief of Staff, Dragomir Milošević occasionally sent the combat reports to the VRS Main Staff. Dragomir Milošević, T. 32723-32724 (28 January 2013); D2811 (SRK combat report, 20 October 1993); D2796 (SRK combat report, 14 August 1993); D2797 (SRK combat report, November 1994); D2798 (SRK combat report, July 1993); D2799 (SRK combat report, 30 September 1993); D2805 (SRK combat report, 9 January 1994); D2806 (SRK combat report, 23 January 1994); D2808 (SRK combat report, 1 July 1994). When Dragomir Milošević was the Chief of Staff for the SRK, he would occasionally sign the combat reports on behalf of Galić. Dragomir Milošević, T. 32719 (28 January 2013); D2809 (SRK combat report, 13 September 1993); D2823 (SRK combat report, 6 November 1994); D2819 (SRK combat report, 10 July 1993); D2820 (SRK combat report, 16 July 1993); D2821 (SRK combat report, 3 August 1993); D2822 (SRK combat report, 10 August 1993); D2827 (SRK combat report, 19 August 1993); D2831 (SRK combat report, 10 November 1994); D2903 (SRK combat report, 25 May 1995). Interim reports would go to the Main Staff daily, usually around 2 p.m. Stanislav Galić, T. 37216 (15 April 2013). See, e.g., D3393 (SRK combat report, 25 December 1992); D3394 (SRK combat report, 31 December 1992). Dragomir Milošević testified that he believed that the reporting system in 1995 "functioned meticulously". Dragomir Milošević, T. 32879 (29 January 2013).

621 Ljubomir Obradović, P4444 (Transcript from Prosecutor v. Tolimir), T. 11973-11974; Ljubomir Obradović, T. 25100 (22 February 2012); Manojlo Milovanović, T. 25646 (1 March 2012). See e.g. P4449 (VRS Main Staff Report, 10 July 1995); P4450 (VRS Main Staff Report, 11 July 1995); P4464 (VRS Main Staff Report 13 July 1995); P4457 (VRS Main Staff Report, 14 July 1995); P4460 (VRS Main Staff Report, 15 July 1995); D2101 (VRS Main Staff Report, 16 July 1995); D2102 (VRS Main Staff Report, 17 July 1995); P4459 (VRS Main Staff Report, 18 July 1995); P4461 (VRS Main Staff Report, 19 July 1995) ); D3453 (VRS Main Staff report, 25 May 1994). Obradović testified that the Main Staff reports would be sent to Milovanović, who would review and forward them to the Accused. Ljubomir Obradović, P4444 (Transcript from Prosecutor v. Tolimir), T. 11974, 11979. These reports contained information about the possible intentions and situation of the enemy, as well as information about the grouping intentions and task of the VRS, along with losses in materiel and personnel and any new corps commanders' decisions. Ljubomir Obradović, T. 25144-25145 (23 February 2012). See, e.g., P4455 (VRS Main Staff Report, 5 July 1995).

622 Ljubomir Obradović, T. 25100-25102 (22 February 2012). ). See, e.g., P5943 (VRS Main Staff Report, 7 April 1995).

623 KDZ122, T. 26154-26156 (13 March 2012) (closed session). See, e.g., D2168 (Drina Corps Intelligence Report, 13 December 1993); D2171 (VRS Main Staff Intelligence Report, 8 November 1994).

624 John Zametica, T. 42443 (29 October 2013); D3695 (Witness statement of Bogdan Subotić dated 16 June 2013), paras. 2, 51, 82 (Subotic also served as the Chief of the Military Office of the President and the Accused's military advisor). When asked whether the Accused would have had direct communication with an assistant commander of the Main Staff deployed to an IKM, Obradović replied that IKMs had established means of communication with the Main Staff. Ljubomir Obradović, T. 25105-25106 (22 February 2012).

625 Ljubomir Obradović, P4444 (Transcript from Prosecutor v. Tolimir), T. 11966-11967, 11973-11974; Ljubomir Obradović, T. 25095-25097 (22 February 2012); Richard Butler, T. 27537-27538 (18 April 2012); D325 (VRS 
209. In general, after the establishment of the Republican Communications Centre in Pale in April 1992, there was communication between the municipalities, the MUP, and the VRS. ${ }^{627}$ The three main types of communications existed: (i) the telephone system ("PTT"); (ii) radio and radio relay communications; and (iii) coded communications. ${ }^{628}$ The PTT was the civilian telephone system. ${ }^{629}$ The VRS could protect certain PTT lines for their own use. ${ }^{630}$ Radio was used for both encrypted and unprotected communication. ${ }^{631}$ When the radio system was not working, the radio relay system was used. ${ }^{632}$ Coded communication was used for confidential information sent over the radio on unprotected lines and it was a back-up system for communication for both the VRS and MUP. ${ }^{633}$ At the Republican Communications Centre, the Accused used a direct secure telephone line to communicate to the Main Staff Communications Centre at Crna Rijeka. ${ }^{634}$ Additionally, Mladić had permanent direct and encrypted communication with the Corps Commands, as well as relay communication with the IKMs. ${ }^{635}$

\section{Territorial Defence}

210. As part of the SFRY military doctrine known as the "All People's Defence", the TO was comprised of organised armed formations that were not part of the JNA or the police. ${ }^{636}$ The TO

Main Staff analysis of combat readiness and army activities in 1992, April 1993), pp. 30-35; Dragan Kezunović, T. 14967-14968 (20 June 2011); P4445 ( $1^{\text {st }}$ Podrinje Light Infantry Brigade Report, 14 July 1995); P4568 (Zvornik Brigade telephone booklet); Ranko Vuković, T. 15091-15098 (21 June 2011) in connection with P2796 (Map showing communications plan of Drina Corps); Richard Philipps, T. 3860-3865 (16 June 2010). 
was comprised of units, institutions, staff, and other organisations of individuals "for a general popular armed resistance" that could be mobilised during times of war. ${ }^{637}$ The TO was organised with staff at both the republic level and the municipal level. ${ }^{638}$

211. On 27 March 1992, before the Bosnian Serb Assembly, the Accused gave instructions to the newly-formed municipalities to "organise the people so that they can defend themselves" as a TO and place them under the command of the JNA present at that time. ${ }^{639}$

212. On 15 April 1992, an imminent threat of war was declared by the SerBiH Presidency and the following day, the mobilisation of the TO was ordered. ${ }^{640}$ The TO was declared to be part of the armed forces. ${ }^{641}$ Accordingly, all military conscripts were to put themselves at the disposal of the municipal TO staffs in the territory of the RS, and the newly formed TO units were to "cooperate with the JNA units, and where possible, put them under single command" ${ }^{642}$ Colonel Vidoje Lukić was appointed as Chief of the SerBiH TO. ${ }^{643}$ In April 1992, it was decided that the Accused, as President of the SNB, was to co-ordinate command over the TO forces. ${ }^{644}$ The SerBiH TO was composed of reserve men who carried out their regular jobs and who, in case of war, were called up to defend a certain territory. ${ }^{645}$

213. Until the TO was integrated into the VRS, all defence activities were under the competence of the TO and organised by the Crisis Staffs in the municipalities. ${ }^{646}$ The TO units were equipped

40020 (19 June 2013). There was a distinct TO in each Republic, funded by that Republic and under the control of the Minister of Defence of that Republic. Adjudicated Fact 419.

637 D1358 (SFRY Law on All People's Defence), art. 102.

638 Manojlo Milovanović, T. 25450-254511 (28 February 2012); D1358 (SFRY Law on All People's Defence), art. 102; P3034 (Track changes version of Reynaud Theunens's expert report entitled "Radovan Karadžić and the SRBiH TO-VRS (1992-1995)"), e-court pp. 51-53.

639 P1634 (Minutes of 14 $4^{\text {th }}$ Session of SerBiH Assembly, 27 March 1992), p. 23; P3914 (Ewan Brown's expert report entitled "Military Developments in the Bosanska Krajina - 1992", 27 November 2002), para. 2.26.

640 P3922 (Decision of SerBiH Presidency, 15 April 1992); P2412 (SerBiH Ministry of Defence Decision, 16 April 1992); P3034 (Track changes version of Reynaud Theunens's expert report entitled "Radovan Karadžić and the SRBiH TO-VRS (1992-1995)"), e-court pp. 274-277; Ewan Brown, T. 21570-21571 (17 November 2011); Ranko Vuković, T. 15119 (21 June 2011).

641 P2412 (SerBiH Ministry of Defence Decision, 16 April 1992), p. 1.

642 P2412 (SerBiH Ministry of Defence Decision, 16 April 1992), p. 2.

643 D3709 (Decision of SerBiH Government, 15 April 1992).

644 P3051 (Minutes of expanded meeting of SNB and SerBiH Government, 22 April 1992), p. 1; P3034 (Track changes version of Reynaud Theunens's expert report entitled "Radovan Karadžić and the SRBiH TO-VRS (1992-1995)"), e-court p. 279. See also para. 91.

645 KDZ192, P3416 (Transcript from Prosecutor v. Brđanin), T. 11710-11711 (under seal); Momčilo Mandić, C2 (Transcript from Prosecutor v. Krajišnik), T. 9110-9111.

646 Manojlo Milovanović, T. 25451-25453 (28 February 2012); Momir Nikolić, T. 24703-24704 (14 February 2012); Milomir Šoja, T. 7209-7210 (30 September 2010); Ranko Vuković, T. 15118-15119 (21 June 2011); Bogdan Subotić, T. 40021-40022 (19 June 2013); Branko Davidović, T. 45929-45930 (23 January 2014); Richard Philipps, T. 3828 (16 June 2010); Ranko Vuković, T. 15118-15119 (21 June 2011). See, e.g., D1195 (Ilidža Crisis Staff order, 10 April 1992). See also D1358, (SFRY Law on All People's Defence), art. 102. See also para. 145. 
with infantry weapons, rifles, light machine-guns, some small calibre artillery, mortars, and antipersonnel mines. ${ }^{647}$ The uniforms worn by the SerBiH TO were similar to JNA uniforms. ${ }^{648}$

214. On 12 May 1992, after the formal establishment of the VRS, the SerBiH TO was directly integrated into the VRS. ${ }^{649}$ The Accused, as the President, would determine the organisation of the integrated SerBiH TO units and staff. ${ }^{650}$

\section{Bosnian Serb MUP}

a. Establishment and structure

215. On 28 February 1992, the Bosnian Serb Assembly passed the Law on Internal Affairs, which established the MUP, effective 31 March 1992. ${ }^{651}$ On 24 March 1992. Mićo Stanišić was appointed Minister of the MUP and he was in this position until the end of 1992 and again from January 1994 until July 1994. ${ }^{652}$ Momčilo Mandić was the Assistant Minister of the MUP from April until May 1992. ${ }^{653}$ Tomislav Kovač was the Assistant Minister of the MUP in August 1992

Adjudicated Fact 420. The TOs did not have tanks and TO weapons were stored locally, within each municipality. See Adjudicated Facts 421, 422.

648 Isak Gaši, P3002 (Transcript from Prosecutor v. Krajišnik), T. 548-549.

649 P956 (Transcript of $16^{\text {th }}$ session of SerBiH Assembly, 12 May 1992), pp. 53-56; P3914 (Ewan Brown's expert report entitled "Military Developments in the Bosanska Krajina - 1992", 27 November 2002), para. 2.32; P3034 (Track changes version of Reynaud Theunens's expert report entitled "Radovan Karadžić and the SRBiH TOVRS (1992-1995)"), e-court pp. 289, 316-318. See, e.g., P5548 (Decision of Prijedor Crisis Staff, 29 May 1992). For example, on 22 May 1992, the SRK Commander Šipčić issued an order requesting that the existing TO units be restructured into discrete TO brigades, formed from locals of distinct territories. P1505 (SRK Order, 22 May 1992). On 28 May 1992, the Birač Brigade commander ordered the subordination of the local Bosnian Serb TOs into the VRS. P3055 (Order of Birač Brigade, 28 May 1992). In the area of responsibility of the Drina Corps, men were mobilised from the summer 1992 to join the TO and after 1992, the TO was divided into units that were integrated into the Drina Corps battalions and companies. Mile Simanić, P355 (Transcript from Prosecutor v. Popović et al.), T. 14621.

650 P956 (Transcript of $16^{\text {th }}$ session of SerBiH Assembly, 12 May 1992), pp. 53. See also D3864 (Radovan Radinović's expert report entitled "The Control Authority of Dr. Radovan Karadžić in the Strategic Command System of the VRS", 2012), paras. 79-80.

651 P2964 (SerBiH Decree on the promulgation on the Law of Internal Affairs, 23 March 1992); P2958 (Christian Nielsen's expert report entitled "The Bosnian Serb Ministry of Internal Affairs: Genesis, Performance and Command and Control 1990-1992", 19 May 2011), para. 95. See also Adjudicated Facts 514, 2147. According to Article 130, the law would enter into effect eight days after its publication but Nielsen notes that in practice the Bosnian Serb MUP began functioning on 1 April 1992. P2958 (Christian Nielsen's expert report entitled "The Bosnian Serb Ministry of Internal Affairs: Genesis, Performance and Command and Control 1990-1992", 19 May 2011), para. 172. This new Law on Internal Affairs was almost identical to the law on internal affairs of the Socialist Republic of Bosnia and Herzegovina. P2958 (Christian Nielsen's expert report entitled "The Bosnian Serb Ministry of Internal Affairs: Genesis, Performance and Command and Control 1990-1992", 19 May 2011), paras. 96, 98.

652 Mićo Stanišić, T. 46327, 46353 (3 February 2014), T. 46440 (4 February 2014); P1354 (Minutes of $13^{\text {th }}$ session of SerBiH Assembly, 24 March 1992). See also Adjudicated Fact 2146.

653 Momčilo Mandić, T. 4426-4427 (30 June 2010). See also P2848 (Witness statement of Milorad Davidović dated 22 June 2011), para. 101; Mandić informed all security centres and all public security stations that the SerBiH established a MUP on 27 March 1992. See also Adjudicated Fact 515. 
and again from 1994 to September 1995, and he was acting Minister from September 1993 until January $1994 .^{654}$

216. The location of the MUP was moved four times in $1992 .{ }^{655}$ First it was located in Vraca, near Sarajevo, then moved to Mount Jahorina, Pale, and finally to Bijeljina. ${ }^{656}$

217. The Law on Internal Affairs, which was largely based on the April 1990 SerBiH Law on Internal Affairs, ${ }^{657}$ established a network of Security Services Centres ("CSB") to carry out the work of the MUP and set out the structure and functions of the Public Security Stations ("SJB") and the National Security Service. ${ }^{658}$

218. The CSBs were considered important as they united both the SJBs and the National Security Service while directing and co-ordinating the functions relating to the SJBs. ${ }^{659}$ There were five locations for the CSBs: Banja Luka (for the ARK), Trebinje (for the SAO Herzegovina), Doboj (for the SAO of Nothern $\mathrm{BiH}$ ), Sarajevo (for the SAO of Romanija-Birač), and Bijeljina (for the SAO of Semberija). ${ }^{660}$ Each CSB covered a certain territory and each municipality within that territory had a subordinate SJB. ${ }^{661}$ Each CSB consisted of the following organisational units: (i) Sector of the National Security Service; (ii) Sector of the Public Security Service; (iii) Department for Communications; (iv) Department for Foreigners, Legal, Administrative and Personnel Affairs; (v)

654 D3960 (Witness Statement of Tomislav Kovać dated 28 October 2013), paras. 4-5; Christian Nielsen, T. 16300 (7 July 2011). See also Ljubomir Borovčanin, T. 39435-39437 (6 June 2013); P2848 (Witness statement of Milorad Davidović dated 22 June 2011), para. 101.

655 Mićo Stanišić, T. 46359 (3 February 2014). See Adjudicated Fact 2153.

656 Mićo Stanišić, T. 46359 (3 February 2014).

657 P2958 (Christian Nielsen's expert report entitled “The Bosnian Serb Ministry of Internal Affairs: Genesis, Performance and Command and Control 1990-1992”, 19 May 2011), paras. 96-98. See also Adjudicated Fact 2125.

658 P2964 (SerBiH Decree on the promulgation on the Law of Internal Affairs, 23 March 1992); P2958 (Christian Nielsen's expert report entitled "The Bosnian Serb Ministry of Internal Affairs: Genesis, Performance and Command and Control 1990-1992”, 19 May 2011), paras. 112, 115; see Adjudicated Fact 518. The National Security Service was previously known as the State Security Service ("SDB") and was renamed the National Security Service in the 1992 Law on Internal Affairs. P2958 (Christian Nielsen's expert report entitled "The Bosnian Serb Ministry of Internal Affairs: Genesis, Performance and Command and Control 1990-1992", 19 May 2011), para. 112; P2964 (SerBiH Decree on the promulgation on the Law of Internal Affairs, 23 March 1992), Section II. See also Adjudicated Fact 2126.

659 P2964 (SerBiH Decree on the promulgation on the Law of Internal Affairs, 23 March 1992); P2958 (Christian Nielsen's expert report entitled "The Bosnian Serb Ministry of Internal Affairs: Genesis, Performance and Command and Control 1990-1992", 19 May 2011), para. 8; P2962 (Document entitled "Possible ways of decentralising Internal Affairs in BH", undated), p. 1.

660 P2964 (SerBiH Decree on the promulgation on the Law of Internal Affairs, 23 March 1992), art. 28; P2958 (Christian Nielsen's expert report entitled “The Bosnian Serb Ministry of Internal Affairs: Genesis, Performance and Command and Control 1990-1992”, 19 May 2011), para. 116; P2965 (RS Rulebook on internal organisation of the MUP under the circumstances of immediate threat of war and war, September 1992), art. 3; Adjudicated Fact 2129.

661 P2958 (Christian Nielsen's expert report entitled "The Bosnian Serb Ministry of Internal Affairs: Genesis, Performance and Command and Control 1990-1992”, 19 May 2011), paras. 115, 179. 
Department for Material-Financial and Technical Affairs; and (vi) Police Station. ${ }^{662}$ Stojan Župljanin was the Chief of the CSB in Banja Luka from 1991 until $1994{ }^{663}$ In 1994, Župljanin left the MUP and was promoted as the advisor to the President, namely the Accused, on security matters. $^{664}$

219. The SJBs were established within the territory of each municipality. ${ }^{665}$ The SJBs were tasked with dealing with all public security issues, including protecting citizens, preventing and detecting criminal acts, and maintaining law and order. ${ }^{666}$ Information gathered by the SJBs was reported to the Bosnian MUP officials. ${ }^{667}$

220. The National Security Service was organised into five Sectors which operated at each CSB, i.e., in Banja Luka, Bijeljina, Doboj, Sarajevo, and Trebinje. ${ }^{668}$ It dealt with all issues of state security, including intelligence, such as gathering information on individuals or groups who conspire to violate the constitutional order and state security. ${ }^{669}$

221. In 1994, due to re-structuring of the MUP, the Public Security Service ("RJB") and the State Security Service ("RDB”) were separated. ${ }^{670}$ Milenko Karišik was the head of the RJB. ${ }^{671}$ Dragan Kijac was the head of the RDB. ${ }^{672}$

222. The civilian police were organised into two sections: the regular police force and the Special Police Brigade (“SBP”). ${ }^{673}$ The SBP functioned as a combat unit and was divided into five detachments located in Banja Luka, Trebinje, Doboj, Sarajevo, and Bijeljina. ${ }^{674}$ Goran Sarić was

662 P2965 (RS Rulebook on internal organisation of the MUP under the circumstances of immediate threat of war and war, September 1992), art. 19.

663 Christian Nielsen, T. 16301 (7 July 2011).

664 Christian Nielsen, T. 16301, 16343 (7 July 2011).

665 P2964 (SerBiH Decree on the promulgation on the Law of Internal Affairs, 23 March 1992), art. 26.

666 P2958 (Christian Nielsen's expert report entitled "The Bosnian Serb Ministry of Internal Affairs: Genesis, Performance and Command and Control 1990-1992”, 19 May 2011), paras. 109-110.

667 P2958 (Christian Nielsen's expert report entitled "The Bosnian Serb Ministry of Internal Affairs: Genesis, Performance and Command and Control 1990-1992”, 19 May 2011), para. 236; P2964 (SerBiH Decree on the promulgation on the Law of Internal Affairs, 23 March 1992), art. 22.

668 P5557 (Report of the Bijeljina National Security Service, 30 April 1993), p. 3.

669 P2958 (Christian Nielsen's expert report entitled "The Bosnian Serb Ministry of Internal Affairs: Genesis, Performance and Command and Control 1990-1992”, 19 May 2011), para. 343.

670 Christian Nielsen, T. 16320 (7 July 2011). Nielsen explained that at the beginning of 1994, the CSBs were renamed as CJBs and that the Public Security Service was in the CJB at the regional level and the State Security Service was in the CRDB at the regional level. Christian Nielsen, T. 16320 (7 July 2011).

671 D3749 (Witness statement of Milenko Karišik dated 23 June 2013), para. 5. Christian Nielsen, T. 16308 (7 July 2011).

672 Christian Nielsen, T. 16308-16309 (7 July 2011).

$673 \quad$ See Adjudicated Fact 1464.

674 P2965 (RS Rulebook on internal organisation of the MUP under the circumstances of immediate threat of war and war, September 1992), arts. 10, 23; P2958 (Christian Nielsen's expert report entitled “The Bosnian Serb 
the Commander of the SBP. ${ }^{675}$ On 24 February 1994, Ljubomir Borovčanin was appointed to the position of Deputy Commander of the SBP. ${ }^{676}$ Borovčanin remained Deputy Commander through June and July $1995 .{ }^{677}$

223. Beginning in April 1992, special police units ("PJP") were organised by the CSBs at the regional level. ${ }^{678}$ These units were lightly armed and participated in combat activities. ${ }^{679}$ From 1992 until 1994, Milenko Karišik was the Commander. ${ }^{680}$ The PJPs had five detachments, one located at each of the five CSBs. ${ }^{681}$ By 1995, the Zvornik CJB had six PJP companies subordinated to it. ${ }^{62}$ Dragomir Vasić was the Chief of the Zvornik CJB and Mendeljev, a.k.a. "Mane", Đurić was his deputy. ${ }^{683}$ The Commander of the PJP units was Danilo Zoljić. ${ }^{684}$

224. One of the SBP detachments was the $2^{\text {nd }}$ Šekovići Detachment. ${ }^{685}$ From mid-June 1995, the Commander was Rade Čuturić, also known as "Oficir". ${ }^{686}$ In July 1995, the $2^{\text {nd }}$ Šekovići Detachment had three infantry platoons. ${ }^{687}$

225. The SBP had a training centre in Mount Jahorina, which catered for between 300 and 350 men ("Jahorina Recruits"). ${ }^{68}$ Duško Jević, a.k.a. "Stalin", was the director of the Jahorina

Ministry of Internal Affairs: Genesis, Performance and Command and Control 1990-1992”, 19 May 2011), paras. 183, 220. See also Adjudicated Fact 2158.

675 Ljubomir Borovčanin, T. 39436 (6 June 2013); Milenko Pepić, P373 (Transcript from Prosecutor v. Popović et al.), T. 13539, 13543.

676 Ljubomir Borovčanin, T. 39435-39436 (6 June 2013); D3660 (Decision of RS MUP, 24 February 1994).

677 Milenko Pepić, P373 (Transcript from Prosecutor v. Popović et al.), T. 13539-13540, 13543.

678 P2958 (Christian Nielsen's expert report entitled "The Bosnian Serb Ministry of Internal Affairs: Genesis, Performance and Command and Control 1990-1992”, 19 May 2011), para. 220; P2848 (Witness statement of Milorad Davidović dated 22 June 2011), para. 56.

679 P2958 (Christian Nielsen's expert report entitled "The Bosnian Serb Ministry of Internal Affairs: Genesis, Performance and Command and Control 1990-1992”, 19 May 2011), paras. 218, 220-222.

680 D3749 (Witness statement of Milenko Karišik dated 23 June 2013), para. 33; P2958 (Christian Nielsen's expert report entitled "The Bosnian Serb Ministry of Internal Affairs: Genesis, Performance and Command and Control 1990-1992”, 19 May 2011), para. 219; P2848 (Witness statement of Milorad Davidović dated 22 June 2011), para. 56.

681 P2958 (Christian Nielsen's expert report entitled "The Bosnian Serb Ministry of Internal Affairs: Genesis, Performance and Command and Control 1990-1992”, 19 May 2011), para. 220.

682 P4914 (Richard Butler's expert report entitled "Srebrenica Military Narrative (Revised): Operation 'Krivaja 95'”, 1 November 2002), paras. 2.16-2.17; P4970 (Report of Zvornik CJB, 28 July 1995). See also P4949 (Report of Zvornik CJB, 14 July 1995); Nenad Deronjić, D3760 (Transcript from Prosecutor v. Blagojević \& Jokić), T. 8201-8202.

683

684

685

686

687

P4914 (Richard Butler's expert report entitled “Srebrenica Military Narrative (Revised): Operation 'Krivaja 95'”, 1 November 2002), para. 2.16. See also Dušan Mićić, T. 36244-36245 (27 March 2013).

D3196 (Witness statement of Dušan Mićić dated 24 March 2013), para. 16; P4960 (Combat report signed by Ljubiša Borovčanin, 10-20 July 1995), p. 5.

Milenko Pepić, P373 (Transcript from Prosecutor v. Popović et al.), T. 13538. See also P4960 (Combat report signed by Ljubiša Borovčanin, 10-20 July 1995), p. 1.

Milenko Pepić, P373 (Transcript from Prosecutor v. Popović et al.), T. 13539.

Milenko Pepić, P373 (Transcript from Prosecutor v. Popović et al.), T. 13540. The $3^{\text {rd }}$ platoon was based in Skelani and also referred to as the Skelani platoon. Milenko Pepić, P373 (Transcript from Prosecutor v. Popović et al.), T. 13541. 
Training Centre. ${ }^{689}$ The Jahorina Recruits wore a two-piece camouflage uniform and a light blue bullet-proof vest. ${ }^{690}$ They were divided in two companies and each company was divided into four platoons; each of these four platoons was in turn divided into four smaller units. ${ }^{691}$ The $1^{\text {st }}$ Company was commanded by Mendeljev Đurić, also called "Mane". ${ }^{692}$ The $2^{\text {nd }}$ Company was commanded by Neđo Ikonić. ${ }^{693}$

226. On 11 July 1995, the Accused ordered the establishment of an SJB for "Serb Srebrenica after the [RS] control has been established in the municipality of Serb Srebrenica". ${ }^{694}$ This SJB was to carry out its duties in accordance with the Law of Internal Affairs and establish close cooperation with Miroslav Deronjić, the Civilian Commissioner for the municipality of "Serb Srebrenica". 695

\section{b. MUP communications}

227. The MUP communication centre was established in Pale and Bijeljina. ${ }^{69}$ Methods of communication employed by the MUP included shortwave radio, ultra shortwave radio, telephone, telegraph, teleprinter, courier, and fax. ${ }^{697}$ Communications were sent and received through a

688 D3903 (Witness statement of Mendeljev Đurić dated 26 July 2013), para. 4; KDZ084, T. 27331 (11 April 2012 ) (closed session); KDZ084, P4904 (Transcript from Prosecutor v. Popović et al.), T. 14789-14790 (under seal). See also D3903 (Witness statement of Mendeljev Đurić dated 26 July 2013), para. 4; P4906 (RS MUP letter to Radovan Karadžić, 23 June 1995). The training facility was located at the Jahorina hotel. KDZ084, P4904 (Transcript from Prosecutor v. Popović et al.), T. 14788 (under seal). The Jahorina Recruits received fitness training, weapons training, and training in hostage situations. KDZ084, P4904 (Transcript from Prosecutor v. Popović et al.), T. 14797-14798 (under seal).

689 KDZ084, T. 27332 (11 April 2012) (closed session); KDZ084, P4904 (Transcript from Prosecutor v. Popović et al.), T. 14789, 14798-14800 (under seal). See also Ljubomir Borovčanin, T. 39459 (7 June 2013); D3903 (Witness statement of Mendeljev Đurić dated 26 July 2013), para. 7.

690 KDZ084, P4904 (Transcript from Prosecutor v. Popović et al.), T. 14790 (under seal).

691 KDZ084, P4904 (Transcript from Prosecutor v. Popović et al.), T. 14791, 14794-14796 (under seal).

692 Mendeljev Đurić, T. 42076-42077 (29 July 2013). See also Ljubomir Borovčanin, T. 39459 (7 June 2013 ); KDZ084, P4904 (Transcript from Prosecutor v. Popović et al.), T. 14791 (under seal); P4960 (Combat report signed by Ljubiša Borovčanin, 10-20 July 1995), p. 5.

693 KDZ084, P4904 (Transcript from Prosecutor v. Popović et al.), T. 14792 (under seal); Mendeljev Đurić, T. 42076-42078 (29 July 2013); Tomasz Blaszcyk, T. 23566 (25 January 2012). See also P4960 (Combat report signed by Ljubiša Borovčanin, 10-20 July 1995), p. 5.

694 P2994 (Radovan Karadžić's Order, 11 July 1995); P2995 (Radovan Karadžić's Order, 12 July 1995).

695 P2994 (Radovan Karadžić's Order, 11 July 1995); P2995 (Radovan Karadžić's Order, 12 July 1995).

696 P2743 (Witness statement of Dragan Kezunović dated 14 June 2011), pp. 2-3, 12, 28-29 (prior to April 1992, it was based at Vrača; P2760 (SerBiH MUP performance report, April to June 1992), p. 8. Dragan Kezunović was the chief of communications for the MUP and appointed by Mićo Stanišić. P2743 (Witness statement of Dragan Kezunović dated 14 June 2011), pp. 11-12.

697 P2743 (Witness statement of Dragan Kezunović dated 14 June 2011), pp. 3-4, pp. 20-21. Communications could be encrypted and decrypted. P2743 (Witness statement of Dragan Kezunović dated 14 June 2011), pp. 3, 5; P2769 (Telegram from Sanski Most SJB to Banja Luka CSB, 2 July 1992). 
network connecting the MUP headquarters in Pale to the CSBs and the SJBs. ${ }^{698}$ The MUP communications centre had a telephone connection to the Republican Communications Centre. ${ }^{699}$

228. The system of reporting within the MUP consisted of daily reports and other reports about more significant security information. ${ }^{700}$ Information was collected from the municipal level by the $\mathrm{SJB}$, then sent to the regional level to the CSB, and finally sent to the MUP. ${ }^{701}$ The information was also sent from the MUP to the RS government, including to the Presidency. ${ }^{702}$ From February 1994, Gordan Milinić was appointed as the security advisor to the Accused for state security matters. ${ }^{703}$ He collected, processed, and reported information on military intelligence and state security intelligence to the Accused. ${ }^{704}$

\section{c. Re-subordination of MUP personnel to the VRS}

229. On 22 April 1995, the Accused issued an order clarifying the MUP re-subordination to the VRS. $^{705}$ He ordered that the Main Staff must precisely and concretely define their requests for engagement and employment of MUP units in combat. ${ }^{706}$ The order reiterated that police units shall participate in combat operations by order of the Supreme Commander and the MUP. ${ }^{707}$ While the police units are engaged in combat activities, they "shall be subordinated to the commander of the unit in whose area of responsibility they are conducting combat operations". ${ }^{708}$

\footnotetext{
698 P2743 (Witness statement of Dragan Kezunović dated 14 June 2011), pp. 2-3, 5-6; P2760 (SerBiH MUP performance report, April to June 1992); P2771 (Order of SerBiH MUP, 23 July 1992); P2774 (Order of Banja Luka CSB to all SJBs, 27 August 1992).

699 P2794 (Witness statement of Ranko Vuković dated 24 May 2011), para. 13.

700 P2958 (Christian Nielsen's expert report entitled "The Bosnian Serb Ministry of Internal Affairs: Genesis, Performance and Command and Control 1990-1992", 19 May 2011), paras. 236. See, e.g., P2749 (SerBiH MUP daily report, 25 April 1992); P2753 (SerBiH MUP daily report, 22 May 1992); P2754 (SerBiH MUP daily report, 23 May 1992); P2755 (SerBiH MUP daily report, 25 May 1992); P2756 (SerBiH MUP daily report, 27 May 1992); P2762 (SerBiH MUP daily report, 18 May 1992); P2789 (SerBiH MUP daily report, 13 May 1992); P2790 (SerBiH MUP daily report, 12 May 1992); P2791 (SerBiH MUP daily report, 15 May 1992); P2792 (SerBiH MUP daily report, 16 May 1992); P2989 (Record of coded telegrams of the RS Republican Communications Centre, 1995); P2990 (Excerpt of logbook of telegrams received, 12-18 July 1995); P2991 (Excerpt of logbook of telegrams sent, 8-16 July 1995).

701 Christian Nielsen, T. 16270 (7 July 2011).

702 Christian Nielsen, T. 16271 (7 July 2011).

703 D3682 (Witness statement of Gordan Milinić dated 8 June 2013), paras. 1A, 9-10; John Zametica, T. 42443 (29 October 2013). Milinić stated that he did not have any connection to the MUP because Stojan Župljanin was the advisor to the President for the MUP. However, Milinić did receive regular reports from the state security department and submit this information to the Accused. D3682 (Witness statement of Gordan Milinić dated 8 June 2013), paras. 9-10.

704 Gordan Milinić, T. 39729-39730 (11 June 2013).

705 P4923 (RS Presidential Order, 22 April 1995).

$706 \quad$ P4923 (RS Presidential Order, 22 April 1995), p. 1.

707 P4923 (RS Presidential Order, 22 April 1995), p. 1 (referring to article 13 of the Law on Application of the Law on Interior Affairs during imminent threat of war and state of war).

708 P4923 (RS Presidential Order, 22 April 1995), p. 2; Adjudicated Fact 1465.
} 
230. On 15 May 1992, Mićo Stanišić issued an order that the MUP personnel would be organised into "war units" for the purpose of defending the territory. ${ }^{709}$ It authorised all the chiefs of the CSBs to organise the MUP personnel in their territory accordingly. ${ }^{710}$ This order formalised the cooperation of the MUP with the VRS. ${ }^{711}$ Stanišić further ordered that while participating in combat activities, the units of the MUP would be subordinated to the command of the VRS. ${ }^{712}$ However, these units would be directly commanded by MUP officials. ${ }^{713}$ Reserve police officers were made available for transfer to the frontlines and assignment into the VRS. ${ }^{714}$ In 1992, over $50 \%$ of policemen were engaged in combat activities through their re-subordination to the VRS. ${ }^{715}$ Units of the MUP were engaged in specialist operative duties, such as "neutralising sabotage and terrorist groups, organised criminal activities of armed individuals" in co-operation with the VRS. ${ }^{716}$

\section{Paramilitaries}

231. In December 1991, it was reported that Serbian paramilitary groups were operating in the RS. $^{717}$ According to a Main Staff report in July 1992, the paramilitaries lacked a cohesive unity, expressed hatred of non-Serbs, were motivated by war profiteering or looting, had links to corrupt political leaderships, and were not affiliated with the SDS but with opposition parties from Serbia (e.g., the Serbian Renewal Movement or Serbian Radical Party). ${ }^{718}$ It further reported that the paramilitaries did not partake in directly fighting with the enemy, but instead operated behind the lines of the regular VRS units, engaging in the killing of civilians as well as in looting and burning property. $^{719}$

P2966 (Order of SerBiH MUP, 15 May 1992), p. 1. See also Adjudicated Fact 2162.

P2966 (Order of SerBiH MUP, 15 May 1992); P6633 (Guidelines of SerBiH MUP, 6 July 1992); Christian Nielsen, T. 16268-16269 (7 July 2011); P2958 (Christian Nielsen's expert report entitled “The Bosnian Serb Ministry of Internal Affairs: Genesis, Performance and Command and Control 1990-1992”, 19 May 2011), para. 215; Mićo Stanišić, T. 46481-46484 (4 February 2014).

711 P1096 (SerBiH MUP Report on Some Aspects of Work Done to Date and the Tasks Ahead, 17 July 1992); P2958 (Christian Nielsen's expert report entitled "The Bosnian Serb Ministry of Internal Affairs: Genesis, Performance and Command and Control 1990-1992", 19 May 2011), para. 215. See also Adjudicated Fact 2163.

712 P2966 (Order of SerBiH MUP, 15 May 1992), para. 7.

713 P2966 (Order of SerBiH MUP, 15 May 1992), para. 7; Mićo Stanišić, T. $46483-46484$ (4 February 2014); P6633 (Guidelines of SerBiH MUP, 6 July 1992); Christian Nielsen, T. 16264 (7 July 2011); P2958 (Christian Nielsen's expert report entitled "The Bosnian Serb Ministry of Internal Affairs: Genesis, Performance and Command and Control 1990-1992”, 19 May 2011), para. 216.

714 D1532 (Order of RS MUP, 23 October 1992).

715 Mićo Stanišić, T. 46360 (3 February 2014).

716 P6633 (Guidelines of SerBiH MUP, 6 July 1992); Mićo Stanišić, T. 46482-46484 (4 February 2014).

717 P2958 (Christian Nielsen's expert report entitled "The Bosnian Serb Ministry of Internal Affairs: Genesis, Performance and Command and Control 1990-1992”, 19 May 2011), paras. 49-54.

718 P2855 (VRS Main Staff report on paramilitary formations, 28 July 1992), pp. 1-2.

719 P2855 (VRS Main Staff report on paramilitary formations, 28 July 1992), p. 2.
} 
232. Arkan's men were a Serbian paramilitary group named after their commander Željko Ražnatović, a.k.a. Arkan. ${ }^{720}$ According to Milorad Davidović, Arkan's men were controlled and subordinated to the Serbian MUP. ${ }^{721}$ They referred to themselves as the "Serbian Tigers". 722 Arkan's men were also known as the Serb Volunteer Guard. ${ }^{723}$ Marko Pejić was the deputy commander of Arkan's men. ${ }^{724}$ In the spring of 1992, they operated in Bijeljina ${ }^{725}$ and Zvornik; ${ }^{726}$ they wore camouflage uniforms bearing an emblem with a tiger and red berets. ${ }^{727}$

233. Mauzer's Panthers, commanded by Ljubiša Savić, a.k.a. Mauzer, were a paramilitary formation operating in Bijeljina, Zvornik, and Brčko. ${ }^{728}$ They referred to themselves as the Serbian National Guard. ${ }^{729}$ Savić was an influential member of the SDS and a leader of the Bijeljina Crisis Staff. $^{730}$ The core of this unit were SDS members and close to the leadership of the Crisis Staff in Bijeljina and most of the members had been trained by Arkan on the border between the municipality and Serbia. ${ }^{731}$ It was estimated that there were over 1,000 men in the Mauzer's

720 Svetozar Mihaljović, T. 35720-35721 (20 March 2013); P2858 (Video footage of Radovan Karadžić and Arkan at award ceremony in Bijeljina) at 00:28-03:00; KDZ446, P29 (Transcript from Prosecutor v. S. Milošević), T. 21055; P6211 (Four video clips of interviews with Arkan and others, with transcript); Cvijetin Simić, T. 35659-35660 (20 March 2013). See also Adjudicated Fact 2241.

$721 \quad$ P2848 (Witness statement of Milorad Davidović dated 22 June 2011), para. 125.

722 P2021 (BBC news report re interview with Arkan, with transcript).

723 Dragomir Andan, D3774 (Transcript from Prosecutor v. Stanišić \& Župljanin), T. 21652-21653.

$724 \quad$ KDZ446, P29 (Transcript from Prosecutor v. S. Milošević), T. 21006.

725 P6209 (JNA 2nd Military District report, 1 April 1992), p. 3; Manojlo Milovanović, T. 25447 (28 February 2012); Aleksandar Vasiljević, T. 34700-34701 (4 March 2013); P2848 (Witness statement of Milorad Davidović dated 22 June 2011), paras. 64, 66, 117-118. See also Cvijetin Simić, T. 35671-35672 (20 March 2013); D3065 (Witness statement of Aleksandar Vasiljević dated 26 February 2013), para. 174. See paras. 611616.

726 Čedomir Zelenović, T. 40341-40342 (25 June 2013); Branko Grujić, T. $40362-40365$ (25 June 2013). See paras. 1242-1243, 1245-1246, 1249-1252.

727 KDZ446, P29 (Transcript from Prosecutor v. S. Milošević), T. 21006; Isak Gaši, P3002 (Transcript from Prosecutor v. Krajišnik), T. 468; KDZ240, P2935 (Transcript from Prosecutor v. Krajišnik), T. 6990 (under seal); Petko Panić, P3380 (Transcript from Prosecutor v. Stanišić \& Župljanin), T. 2878; Milorad Davidović, T. 15822 (1 July 2011); P2848 (Witness statement of Milorad Davidović dated 22 June 2011), para. 80; Suad Dzafić, T. 18187-18188 (1 September 2011).

728 Dragomir Andan, D3774 (Transcript from Prosecutor v. Stanišić \& Župljanin), T. 21436-21438, 21652-21654; Milorad Davidović, T. 15479-15480 (28 June 2011); P2848 (Witness statement of Milorad Davidović dated 22 June 2011), paras. 89, 93, 120-123; P2856 (Video footage of Radovan Karadžić at public ceremony); Pero Marković, T. 34737 (4 March 2013); Isak Gaši, P3002 (Transcript from Prosecutor v. Krajišnik), T. 488-490; Dušan Spasojević, T. 35902-35903 (22 March 2013); Manojlo Milovanović, T. 25446-25447 (28 February 2012). See paras. 608, 611-612, 798, 824, 1244, fn. 2691.

729 Milorad Davidović, T. 15479-15480 (28 June 2011); Pero Marković, T. 34735 (4 March 2013); KDZ446, P29 (Transcript from Prosecutor v. S. Milošević), T. 21055-21056; Zivan Filipović, T. 35815-35816 (21 March 2013); Dušan Spasojević, T. 35902-35903 (22 March 2013). See also Adjudicated Fact 2237.

730 Milorad Davidović, T. 15583-15584 (29 June 2011); Cvijetin Simić, T. 35698 (20 March 2013); KDZ446, P29 (Transcript from Prosecutor v. S. Milošević), T. 21056.

731 P2848 (Witness statement of Milorad Davidović dated 22 June 2011), para. 89; D1612 (Video footage of Arkan in "My Guest, His Truth", July/August 1994), pp. 11-12; Dragomir Andan, D3774 (Transcript from Prosecutor v. Stanišić and Župljanin), T. 21817, 21563. 
Panthers. ${ }^{732}$ In June 1992, an order of the Commander of the Eastern Bosnia Corps was issued that Mauzer's Panthers were to be integrated into the Corps. ${ }^{733}$

234. Men affiliated with Vojislav Šešelj, president of the SRS, operated throughout BiH and most notably with regard to the Municipalities, in Bijeljina, Zvornik, Brčko, Ilidža, and Novo Sarajevo. ${ }^{734}$ In Ilidža, a group of Šešelj's men was commanded by Branislav Gavrilović, also called Brne. ${ }^{735}$ In Vogošća, there was a group of "Šešelj’s men” commanded by Vaske Vidović and another group commanded by Jovo Ostojić called the "Šoša Detachment". ${ }^{736}$ In Novo Sarajevo, Gavrilović and his group were also present and Slavko Aleksić led another group of Šešelj’s men. $^{737}$

235. The White Eagles operated in Ključ, Zvornik, Foča, and Ilidža. ${ }^{738}$ They were a paramilitary formation from Serbia. ${ }^{739}$ They were commanded by Desimir Dida. ${ }^{740}$ The members of the White

732 Dragomir Andan, D3774 (Transcript from Prosecutor v. Stanišić \& Župljanin), T. 21817.

733 D1458 (Order of Eastern Bosnia Corps, 3 June 1992); Manojlo Milovanović, T. 25454-25455 (28 February 2012). But see Milorad Davidović, T. 15812-15814 (1 July 2011) (testifying that although the order was issued, it was not carried out in practice). The Accused submits that Mauzer's unit acted independent of government command. Defence Final Brief, para. 1381 (referring to Cvijetin Simić, T. 35698-35699 (20 March 2013)). The Chamber does not consider that the evidence cited nor the other evidence received in this case supports this proposition. Dragomir Ljubojević testified that Mauzer's Panthers was a unit of the VRS and "never a party army" and consisted of people from all areas including from Bijeljina itself and it was not formed by the SDS but by the staff of the TO of the municipality. Dragomir Ljubojević, T. 35902-35903 (22 March 2013). The Chamber notes his evidence but does not accept that Mauzer's unit was initially formed as a unit of the VRS.

734 See paras. 608, 611, 824, 1249, fn. 2691. See also P6388 (Excerpt from video of interview with Vojislav Šešelj for "Death of Yugoslavia" documentary, with transcript) (stating that his volunteers were in Zvornik); P5035 (Order of Vojislav Šešelj, 13 May 1993), pp. 1-2.

735 See paras. 2131, 2255. See also P2296 (Witness statement of Tihomir Glavaš dated 13 February 2011), para. 74; Momčilo Mandić, T. 4644-4645 (5 July 2010); P6640 (Certificate of SerBiH MUP, 11 April 1992) (SerBiH MUP authorisation from Mićo Stanišić noting that Gavrilović is an active participant in the TO and issuing him weapons and ammunition); P2302 (Approval of the War Board of Commissioners of Ilidža Municipality, 9 July 1992) (authorisation from Nedeljko Prstojević in Ilidža to allow Gavrilović and his "Serbian volunteer units" the use of facilities for training); P5035 (Order of Vojislav Šešelj, 13 May 1993), p. 3; P2228 (Intercept of conversation between Vojislav Šešelj and Branislav Gavrilović, April 1992). See also D3665 (Witness statement of Vojislav Šešelj dated 1 June 2013), para. 58.

736 See para. 2382. See also P3033 (Reynaud Theunens's expert report entitled "Radovan Karadžić and the SRBiH TO-VRS (1992-1995)"), para. 56; P5035 (Order of Vojislav Šešelj, 13 May 1993), p. 5.

737 See para. 2255.

738 Asim Egrlić, P3570 (Transcript from Prosecutor v. Krajišnik), T. 4888-4889 (under seal); KDZ340, T. 17490 (19 August 2011) (private session); KDZ379, P3332 (Transcript from Prosecutor v. Krnojelac), T. 3111; Ferid Spahić, P61 (Transcript from Prosecutor v. Vasiljević), T. 351; P2296 (Witness statement of Tihomir Glavaš dated 13 February 2011), para. 73. See also paras. 855, 1244,1249, 1498, 1511, 2142.

739 KDZ379, P3332 (Transcript from Prosecutor v. Krnojelac), T. 3111; P2296 (Witness statement of Tihomir Glavaš dated 13 February 2011), para. 73.

$740 \quad$ KDZ379, T. 18874-18875 (15 September 2011). 
Eagles wore uniforms with white ribbons on their sleeves and on their heads. ${ }^{741}$ The insignia of the White Eagles was a symbol of a skull and cross bones. ${ }^{742}$

236. The Red Berets were a paramilitary group which operated in Brčko and Zvornik. ${ }^{743}$ They were commanded by Dragan Vasilkjović, a.k.a. Captain Dragan. ${ }^{744}$

237. The Yellow Wasps consisted of around 100 to 300 men. $^{745}$ They were commanded by Vojin (Žućo) Vučković ${ }^{746}$ and operated in Zvornik from April to May 1992. ${ }^{747}$ They had close cooperation with the TO and were issued arms by the TO's logistics staff. ${ }^{748}$

238. In the spring of 1992, some paramilitary formations worked in co-ordination with the TO and municipal Crisis Staffs. ${ }^{749}$ The Bosnian Serb leadership and military commanders increasingly expressed opposition to having units that were outside of the command and control of the army. ${ }^{750}$ This led to various VRS and Bosnian Serb MUP leaders attempting to control paramilitary groups in the RS territory. ${ }^{751}$ The Main Staff recommended that every armed Serb should be placed under

$741 \quad$ KDZ041, T. 12104 (17 February 2011)

742 Suad Džafić, T. 18188 (1 September 2011)

743 D1412 (Report of Republic of Serbia MUP, 8 August 1992), pp. 7-8; P2888 (Brčko’s War Presidency Summary of events in Brčko Municipality), p. 3; Dragomir Andan, D3774 (Transcript from Prosecutor v. Stanišić \& Župljanin), T. 21414-21415; P104 (Witness statements of Fadil Banjanović dated 30 March 2002), para. 19; Petko Panić, P3380 (Transcript from Prosecutor v. Stanišić \& Župljanin), T. 2923. This unit arrived in Zvornik some time after 25 May 1992.

744 Dragomir Andan, D3774 (Transcript from Prosecutor v. Stanišić \& Župljanin), T. 21414-21415, 21668; P4263 (Video footage of award ceremony of the Red Berets) at 00:43:20-00:43:50; Milan Martić, T. 38120 (13 May 2013); D1412 (Report of Republic of Serbia MUP, 8 August 1992), pp. 7-8; P2888 (Brčko's War Presidency Summary of events in Brčko Municipality), p. 3.

745 See Adjudicated Fact 2108. See also Reynaud Theunens, T. 17090-17092, 17093-17095 (21 July 2011). The MUP in Bijeljina reported, in July 1992, that the group had approximately 100 armed men. P36 (Report by CSB Bijeljina re security situation in the Zvornik Municipality, 20 July 1992) (under seal), p. 1, reference to the group commanded by "Žućo". Milorad Davidović states that there were approximately 300 men in Zvornik. P2848 (Witness statement of Milorad Davidović dated 22 June 2011), para. 126.

746 See Adjudicated Fact 2109. See also Milorad Davidović, T. 15491 (28 June 2011); P2848 (Witness statement of Milorad Davidović dated 22 June 2011), para. 126; D3695 (Witness statement of Bogdan Subotić dated 16 June 2013), para. 205.

747 Reynaud Theunens, T. 17090-17095 (21 July 2011); Aleksandar Vasiljević, T. 34700-34701 (4 March 2013); P2848 (Witness statement of Milorad Davidović dated 22 June 2011), paras. 126-129. See also Adjudicated Fact 2108.

748 See Adjudicated Fact 2108. See also Reynaud Theunens, T. 17090-17092 (21 July 2011); Milorad Davidović, T. 15491 (28 June 2011).

749 See generally Petko Panić, P3380 (Transcript from Prosecutor v. Stanišić \& Župljanin), T. 2887-2889; Milorad Davidović, T. 15492-15495 (28 June 2011); P2862 (Yellow Wasps payroll, 1 May 1992); P2863 (Yellow Wasps payroll, June 1992); P2865 (White Eagles' payroll, June 1992). See also Adjudicated Facts 2107, 2108.

750 Momčilo Krajišnik, T. 43334-43335 (12 November 2013); P2958 (Christian Nielsen's expert report entitled "The Bosnian Serb Ministry of Internal Affairs: Genesis, Performance and Command and Control 1990-1992", 19 May 2011), para. 362

751 P2958 (Christian Nielsen's expert report entitled "The Bosnian Serb Ministry of Internal Affairs: Genesis, Performance and Command and Control 1990-1992", 19 May 2011), paras. 361-378; D1933 (Fax from Radovan Karadžić to Boutros Ghali, 13 June 1992); P3914 (Ewan Brown's expert report entitled "Military Developments in the Bosanska Krajina - 1992", 27 November 2002), paras. 2.57-2.58, 2.62-2.64; Ewan Brown, T. 21699-21701 (22 November 2011); Momčilo Mandić, C2 (Transcript from Prosecutor v. Krajišnik), T. 9119; 
the exclusive command of the VRS, or else be disarmed with "legal measures taken" ${ }^{752}$ The MUP also attempted to integrate paramilitaries into the existing police units where it was possible. ${ }^{753}$

239. On 13 June 1992, the Accused banned the formation and operation of armed groups and individuals on the territory of the RS which were not under the control of the VRS. ${ }^{754}$ The Accused also stated that he disowned groups that continued independent operation and those groups would suffer the strictest sanctions for their operations. ${ }^{755}$ Following this order, Arkan's men left BiH, Captain Dragan's unit was driven out by the VRS, and Mauzer's Panthers were to be integrated into the Eastern Bosnia Corps. ${ }^{756}$ A group of individuals, referred to as "Chetniks", remained around Sarajevo and according to Milovanović sometimes co-operated with the VRS but may have been under the control of the MUP. ${ }^{757}$

240. On 28 July 1992, Mladić ordered the disarming of paramilitaries. ${ }^{758} \mathrm{He}$ noted that paramilitaries engaged in looting were operating in all territories under Bosnian Serb control and ordered that all paramilitary formations with "honest" intentions be placed under the command of

Momčilo Mandić, T. 4649-4650 (5 July 2010), T. 5147-5148, 5157-5158 (14 July 2010), T. 5179 (15 July 2010); Momčilo Krajišnik, T. 43334-43335 (12 November 2013).

752 P2855 (VRS Main Staff report on paramilitary formations, 28 July 1992), p. 6. P2958 (Christian Nielsen's expert report entitled "The Bosnian Serb Ministry of Internal Affairs: Genesis, Performance and Command and Control 1990-1992”, 19 May 2011), para. 363. For instance, at a meeting held on 18 May 1992, the Crisis Staff of the ARK concluded that all formations not in the VRS or in the Banja Luka Services Centre, but located in the ARK, would be considered paramilitary formations and would be disarmed. P3924 (Decision of ARK Executive Council, 5 May 1992; Conclusions of ARK Crisis Staff, 8-18 May 1992), p. 5. On 21 May 1992, Talić issued an order to the $1^{\text {st }}$ Krajina Corps with the instruction, "[d]o not allow the presence of any paramilitary formations or other special organisations within the zones of responsibility. Disperse individual members among various units as volunteers, but if they refuse that, break them up and, if necessary, destroy them". P3920 (Order of 1st Krajina Corps, 21 May 1992), p. 3.

753 P2958 (Christian Nielsen's expert report entitled "The Bosnian Serb Ministry of Internal Affairs: Genesis, Performance and Command and Control 1990-1992”, 19 May 2011), para. 361. See also Neđeljko Prstojević, T. 12986, 12988 (8 March 2011); P2302 (Approval of the War Board of Commissioners of Ilidža Municipality, 9 July 1992); D3960 (Witness statement of Tomislav Kovač dated 28 October 2013), para. 74; Tihomir Glavaš, T. 11803-11805 (14 February 2011).

754 P3057 (Radovan Karadžić's Decision, 13 June 1992), p. 2. See also D1933 (Fax from Radovan Karadžić to Boutros Ghali, 13 June 1992); P3034 (Track changes version of Reynaud Theunens's expert report entitled "Radovan Karadžić and the SRBiH TO-VRS (1992-1995)"), e-court p. 321; P2958 (Christian Nielsen's expert report entitled "The Bosnian Serb Ministry of Internal Affairs: Genesis, Performance and Command and Control 1990-1992”, 19 May 2011), para. 362.

755 P3057 (Radovan Karadžić's Decision, 13 June 1992), p. 2. See also P3034 (Track changes version of Reynaud Theunens's expert report entitled "Radovan Karadžić and the SRBiH TO-VRS (1992-1995)"), e-court p. 321.

756 Manojlo Milovanović, T. 25454-25455 (28 February 2012). However, Arkan's men returned to Bijeljina from time to time. See para. 616.

757 Manojlo Milovanović, T. 25455 (28 February 2012); John Hamill, P1994 (Transcript from Prosecutor v. Galić), T. 6218-6219.

758 P1500 (VRS Main Staff Order, 28 July 1992); P3034 (Track changes version of Reynaud Theunens's expert report entitled "Radovan Karadžić and the SRBiH TO-VRS (1992-1995)"), e-court pp. 325-326. See also Adjudicated Fact 2114. 
the VRS. ${ }^{759}$ No individual or group responsible for crimes was to be incorporated into the army, and any member of a paramilitary unit who refused to submit to the unified command of the VRS was to be disarmed and arrested. ${ }^{760}$

241. On 30 July 1992, the $1^{\text {st }}$ Krajina Corps Commander Talić issued an instruction, ordering that all paramilitary formations be offered an opportunity to join the VRS except for individuals or groups involved in criminal activity. ${ }^{761}$ Talić further ordered co-operation with the Bosnian MUP to disarm or arrest those individuals or groups who refuse to come under the unified command of the VRS. ${ }^{762}$ By the end of August 1992, the $1^{\text {st }}$ Krajina Corps reported that paramilitary formations were either disarming or placing themselves under the control of the Corps' units. ${ }^{763}$

242. In the other Corps there were serious attempts to control the paramilitary forces. ${ }^{764}$ For instance, Mauzer's Panthers were initially placed under Main Staff command and then subsequently integrated into the Eastern Bosnia Corps. ${ }^{765}$

\section{Volunteers}

243. The SFRY Law on All People's Defence specifically provided that volunteers were "persons not subject to military service who have been accepted in and joined in the Armed Forces at their own request". ${ }^{766}$ Article 9 of the Law on the Army provided that during a state of war, imminent threat of war, or state of emergency, the army may be replenished with volunteers who

759 P1500 (VRS Main Staff Order, 28 July 1992); P3034 (Track changes version of Reynaud Theunens's expert report entitled "Radovan Karadžić and the SRBiH TO-VRS (1992-1995)"), e-court pp. 325-326. See also Adjudicated Fact 2115. 
were defined as "persons joining the Army at their own request" and enjoying the same rights and duties as members of the military. ${ }^{767}$

244. The term "volunteers" was also used by individuals in paramilitary formations when referring to themselves. ${ }^{768}$ Nevertheless according to the Law on the Army, volunteers were individuals who placed themselves under the command of the army without a wartime assignment, while paramilitary formations were groups outside of anyone's control at least in the early days of the war. ${ }^{769}$ VRS commanders used the concept of volunteers to integrate members of paramilitary formations into VRS operative units. ${ }^{770}$

\section{JUSTICE SYSTEMS}

\section{Civilian justice system}

\section{a. Functions and obligations under the Constitution}

245. The Bosnian Serb Constitution provided for courts that are "independent and autonomous and are trying in accordance [with] the Constitution and the Law", ${ }^{71}$ The Constitution further stated: "Courts are protecting human rights and freedoms, determined rights and interests of legal subjects and legality."772

246. Under the Constitution, the Supreme Court of the Republic, "as the highest court in the Republic", was to "secure [...] the uniform application of the law". ${ }^{773}$ Lower courts were to ensure

767 P2603 (SerBiH Law on the Army, 1 June 1992), art. 9. See also P3034 (Track changes version of Reynaud Theunens's expert report entitled "Radovan Karadžić and the SRBiH TO-VRS (1992-1995)"), e-court p. 321.

768 KDZ072, P68 (Transcript from Prosecutor v. Šešelj), T. 8717-8718 (under seal); P2958 (Christian Nielsen’s expert report entitled "The Bosnian Serb Ministry of Internal Affairs: Genesis, Performance and Command and Control 1990-1992”, 19 May 2011), paras. 49-52.

769 P2603 (SerBiH Law on the Army, 1 June 1992), art. 9; Ratomir Maksimović, T. 31611 (17 December 2012); Tihomir Glavas, T. 11991-11992 (16 February 2011); KDZ555, T. 17387-17388 (17 August 2011). See also P3034 (Track changes version of Reynaud Theunens's expert report entitled "Radovan Karadžić and the SRBiH TO-VRS (1992-1995)"), e-court p. 321.

770 D1076 (MUP Administration for the Police Duties and Affairs report, 3 August 1992), p. 2; Dragomir Milošević, T. 32864-32865 (29 January 2013); P3920 (Order of $1^{\text {st }}$ Krajina Corps, 21 May 1992). For instance, on 21 May 1992, the Commander of the $1^{\text {st }}$ Krajina Corps, Talić, issued an order forbidding the presence of any paramilitary formations and instructing that, instead, individual members be dispersed among various units as volunteers. P3920 (Order of $1^{\text {st }}$ Krajina Corps, 21 May 1992).

771 P5578 (Amended Text of the Constitution of RS and Rules of Procedure of RS Assembly, 17 December 1992), art. 121 (p. 25). See also Adjudicated Facts 2066, 2067.

772 P5578 (Amended Text of the Constitution of RS and Rules of Procedure of RS Assembly, 17 December 1992), art. 121 (p. 25). See also Adjudicated Fact 2067.

773 P5578 (Amended Text of the Constitution of RS and Rules of Procedure of RS Assembly, 17 December 1992), art. 123 (p. 25). Below the Supreme Court, there were High Courts and Lower Courts. See P1358 (Minutes of $19^{\text {th }}$ session of SerBiH Assembly, 12 August 1992), pp. 1-2; D456 (Transcript of $20^{\text {th }}$ session of RS Assembly, 14-15 September 1992), pp. 107-110, 112-115; P1468 (Minutes of $21^{\text {st }}$ session of RS Assembly, 30 October1 November 1992), pp. 14-21; P1361 (Minutes of $22^{\text {nd }}$ session of RS Assembly, 23-24 November 1992), p. 9; P1362 (Shorthand Record of $22^{\text {nd }}$ session of RS Assembly, 23-24 November 1992), pp. 96, 99. 
that all coercive actions on behalf of the state authorities were conducted in accordance with the rule of law. ${ }^{774}$ No one could be deprived of his or her freedom without a valid court decision. ${ }^{775}$ Furthermore, the Constitution set forth the principle of fair trial in criminal proceedings. ${ }^{776}$ This included that accused persons had the right to be informed of the nature of the allegation against them in the shortest time provided by the law, and guilt could not be established except by pronouncement of a valid court verdict. ${ }^{777}$ An official could enter an apartment or other premises against the will of their owner and conduct a search only on the basis of a court order, unless such entry and search were necessary to capture a criminal or save the lives of people and property. ${ }^{778}$

247. The Bosnian Serb Constitution defined the Public Prosecutor's Office as an "independent state body that prosecutes perpetrators of criminal and other activities punishable by law and applies legal means for the protection of legality". 779

248. The Supreme Court and other courts, as well as the public prosecutors, submitted reports to the Bosnian Serb Assembly. ${ }^{780}$

249. According to the Bosnian Serb Constitution, the Constitutional Court, comprising seven judges, was vested with the power to, inter alia, decide on the conformity of laws with the Constitution; resolve conflict of authority among the legislative, executive, and judicial bodies and among the republican, regional, and municipal bodies; and decide on the conformity of the program and statute of political organisations with the Constitution and the law. ${ }^{781}$ Reports from the Constitutional Court about matters of constitutionality and legality were to be considered by the Constitutional Committee of the Bosnian Serb Assembly and then by the Bosnian Serb Assembly itself. $^{782}$

776 See Adjudicated Fact 2073. See also P5578 (Amended Text of the Constitution of RS and Rules of Procedure of RS Assembly, 17 December 1992), art. 18 (p. 5).

777 See Adjudicated Fact 2074. See also P5578 (Amended Text of the Constitution of RS and Rules of Procedure of RS Assembly, 17 December 1992), arts. 18, 20 (p. 5).

778 See P5578 (Amended Text of the Constitution of RS and Rules of Procedure of RS Assembly, 17 December 1992), art. 24 (p. 6). See also Adjudicated Fact 2071.

779 P5578 (Amended Text of the Constitution of RS and Rules of Procedure of RS Assembly, 17 December 1992), art. 128 (p. 26).

780 P5578 (Amended Text of the Constitution of RS and Rules of Procedure of RS Assembly, 17 December 1992), art. 232 (pp. 73-74).

781 P5578 (Amended Text of the Constitution of RS and Rules of Procedure of RS Assembly, 17 December 1992), arts. 115-116 (p. 24). See also Adjudicated Fact 2066.

782 P5578 (Amended Text of the Constitution of RS and Rules of Procedure of RS Assembly, 17 December 1992), arts. 59-60, 228 (pp. 42-43, 72-73). The Assembly Chairman was to inform the Constitutional Court of the Assembly's position when the Assembly found it necessary to change or amend a law, regulation, or general
} 
250. Judges and public prosecutors were to be elected or appointed and dismissed by the Bosnian Serb Assembly. ${ }^{783}$

\section{b. Establishment}

\section{i. General judicial organs}

251. Momčilo Mandić was appointed Minister of Justice and Administration at the meeting of the SNB and Government on 22 April 1992. ${ }^{784}$ He served as Minister of Justice until 23 November 1992. ${ }^{785}$ As Minister of Justice, Mandić carried out the organisation of the courts, prosecutor's offices, and correctional institutions of the civilian justice system. ${ }^{786}$ According to Mandić, the military justice system was completely separate and located within the Ministry of Defence, with the Main Staff organising it. ${ }^{787}$

252. On 27 April 1992, a session of the SNB and Government adopted a decision "to organise the prosecutor's office, judicial organs and prisons". ${ }^{788}$ On 10 May 1992, another SNBGovernment session decided "to take the necessary measures to gather professionals and ensure conditions for the work of the state and judicial organs". 789

253. A decision of the SerBiH Presidency dated 16 May 1992, signed by the Accused as the President of the Presidency, established a lower court in Vlasenica with jurisdiction over four Serbian municipalities, including Vlasenica, and a lower court in Sokolac for the areas of the Serbian municipalities of Pale, Rogatica, and Sokolac. ${ }^{790}$ A 20 May 1992 decision of the SerBiH Presidency stated that "[1]ower courts have subject-matter jurisdiction to conduct legal proceedings in the first instance for all criminal offences". ${ }^{791}$ The decision further stated that "[h]igh courts are

legal document. P5578 (Amended Text of the Constitution of RS and Rules of Procedure of RS Assembly, 17 December 1992), art. 229 (p. 73).

783 Adjudicated Fact 2068; P5578 (Amended Text of the Constitution of RS and Rules of Procedure of RS Assembly, 17 December 1992), art. 130 (p. 27).

784 P3051 (Minutes of expanded meeting of SNB and SerBiH Government, 22 April 1992), p. 3. According to Mandić, he was appointed and took the oath at an Assembly meeting in Banja Luka on 12 May 1992. Momčilo Mandić, T. 4532, 4535 (1 July 2010), T. 4895-4896 (8 July 2010).

785 Momčilo Mandić, T. 4428 (30 June 2010). See also P1361 (Minutes of $22^{\text {nd }}$ session of RS Assembly, 2324 November 1992), p. 5.

786 Momčilo Mandić, T. 4575-4576 (5 July 2010). However, on 8 August 1992, the Government tasked Deputy Prime Minister Milan Trbojević and Mandić with providing assistance in finding staff for military judicial organs. D453 (Minutes of $45^{\text {th }}$ session of Government of SerBiH, 7 August 1992), p. 4. See also Momčilo Mandić, T. 5197 (15 July 2010).

787 Momčilo Mandić, T. 4576 (5 July 2010).

788 D406 (Minutes of meeting of SNB and SerBiH Government, 27 April 1992), p. 1.

789 D409 (Minutes of SNB and the Government of the SerBiH session, 10 May 1992), p. 2.

$790 \quad$ P2617 (SerBiH Presidency Decision on subject-matter jurisdiction of regular courts, 8 June 1992), p. 2.

791 P2617 (SerBiH Presidency Decision on subject-matter jurisdiction of regular courts, 8 June 1992), p. 1. 
obliged to conclude criminal proceedings in cases where indictments were submitted prior to the date when this decision takes effect". ${ }^{792}$

254. Mandić tried to create a single justice system during 1992 and asked in July and August 1992 that the Assembly amend the law to form a single justice system, but he was not successful. ${ }^{793}$ In a letter dated 10 July 1992 signed by Mandić, the Ministry of Justice informed the President of the Presidency that it had organised and set up regular courts, public prosecutor's offices, and municipal misdemeanour courts in the territory of the $\mathrm{SerBiH}$, "except for the Northern Bosnia District (Doboj Region) where the work could not be done due to war activities", though preparations were under way. ${ }^{794}$ The letter also stated that a large number of the criminal offences came under the subject-matter jurisdiction of the military judiciary, which had not yet been established. ${ }^{795}$ The Ministry proposed that, until the military judicial bodies were established, regular judicial bodies temporarily take over the role of the former, stating, "[t]his would to a considerable degree help prevent the commission of these criminal offences and help establish legal order and legal security throughout the $[\mathrm{SerBiH}]$ " ${ }^{796}$ The Ministry also proposed that "the Law on the Enforcement of Criminal and Misdemeanour Sanctions should be amended so as to include the possibility of staying the enforcement of prison sentences until the end of the war, by means of assigning convicts to military units". ${ }^{797}$ The Ministry requested that the Presidency examine these proposals and "communicate its position to the Ministry which would move for the adoption of appropriate decisions". ${ }^{798}$

255. In a 5 August 1992 letter to the SerBiH Presidency and the Accused in particular, signed by Mandić, the Ministry of Justice reiterated its proposal that regular courts and public prosecutor's offices take over the competence of military courts and military prosecutor's offices until the establishment of military legal organs, combining the military and civilian justice systems into one. ${ }^{799}$

\footnotetext{
792 P2617 (SerBiH Presidency Decision on subject-matter jurisdiction of regular courts, 8 June 1992), p. 1.

793 Momčilo Mandić, T. 4576-4577 (5 July 2010).

794 D442 (SerBiH Ministry of Justice letter to Radovan Karadžić, 10 July 1992), p. 1. See also Momčilo Mandić, T. 5115-5116 (14 July 2010).

795 D442 (SerBiH Ministry of Justice letter to Radovan Karadžić, 10 July 1992), p. 1. See also Momčilo Mandić, T. 5116 (14 July 2010).

796 D442 (SerBiH Ministry of Justice letter to Radovan Karadžić, 10 July 1992), p. 1. See also Momčilo Mandić, C2 (Transcript from Prosecutor v. Krajišnik), T. 8920; Momčilo Mandić, T. 5116-5117 (14 July 2010).

797 D442 (SerBiH Ministry of Justice letter to Radovan Karadžić, 10 July 1992), p. 1. See also Momčilo Mandić, T. 5117-5118 (14 July 2010).

798 D442 (SerBiH Ministry of Justice letter to Radovan Karadžić, 10 July 1992), p. 2.

799 P1136 (Letter from Ministry of Justice of SerBiH to Radovan Karadžić, 5 August 1992). See also Momčilo Mandić, C2 (Transcript from Prosecutor v. Krajišnik), T. 8920-8923; Momčilo Mandić, T. 5118-5119, 5121 (14 July 2010).
} 
256. Between August and November 1992, the Assembly discussed and voted on the appointment and dismissal of judges and prosecutors. ${ }^{800}$ The appointments included the republican Public Prosecutor; judges of the Supreme Court of the RS; judges of the Lower Court in Banja Luka, Prijedor, Vlasenica, Zvornik, Foča, Sokolac, Sarajevo, Brčko, and Bosanski Novi; judges of the High Court in Banja Luka and Bijeljina; public prosecutors in Zvornik, Sokolac, Vlasenica, Prijedor, Sarajevo, Bijeljina, Višegrad, and Bosanski Novi; deputy public prosecutors in Banja Luka, Zvornik, Foča, Sarajevo, Bosanski Novi, and Prijedor; and a senior public prosecutor and deputy senior public prosecutor in Sarajevo. ${ }^{801}$

257. The appointment of judges and prosecutors proceeded by way of the Ministry of Justice asking SAOs to nominate candidates meeting the formal and legal requirements and inform the Ministry of the ethnic make-up of the municipality from which the candidates came. ${ }^{802}$ The Ministry would then send the nominations to the Assembly, which would appoint the nominees; if the Assembly could not meet, nominations would be sent to the President, who would proceed with the appointments. ${ }^{803}$

\section{ii. Organs specific to war crimes and genocide}

258. On 16 April 1992, the SNB decided to form a "Commission to Determine War Crimes". 804

On 24 April 1992, a session of the SNB and the Government adopted the decision to set up a state

$800 \quad$ See Adjudicated Fact 2069; P1357 (18 ${ }^{\text {th }}$ session of SerBiH Assembly, 11 August 1992), pp. 30-32; P1358 (Minutes of $19^{\text {th }}$ session of SerBiH Assembly, 12 August 1992), pp. 1-2; D422 (19 ${ }^{\text {th }}$ session of SerBiH Assembly, 12 August 1992), pp. 10-29; P1359 (Minutes of 20 ${ }^{\text {th }}$ session of SerBiH Assembly, 14-15 September 1992), pp. 2-3; D456 (Transcript of $20^{\text {th }}$ session of RS Assembly, 14-15 September 1992), pp. 107-117; P1468 (Minutes of $21^{\text {st }}$ session of RS Assembly, 30 October-1 November 1992), pp. 2-4; P1361 (Minutes of 22 $2^{\text {nd }}$ session of RS Assembly, 23-24 November 1992), pp. 8-9; P1362 (Shorthand Record of $22^{\text {nd }}$ session of RS Assembly, 23-24 November 1992), pp. 95-99.

801 P1357 (18 ${ }^{\text {th }}$ session of SerBiH Assembly, 11 August 1992), p. 32; P1358 (Minutes of $19^{\text {th }}$ session of SerBiH Assembly, 12 August 1992), pp. 1-2; D456 (Transcript of 20 ${ }^{\text {th }}$ session of RS Assembly, 14-15 September 1992), pp. 107-110, 112-117; P1468 (Minutes of $21^{\text {st }}$ session of RS Assembly, 30 October-1 November 1992), pp. 1421; P1361 (Minutes of $22^{\text {nd }}$ session of RS Assembly, 23-24 November 1992), p. 9; P1362 (Shorthand Record of $22^{\text {nd }}$ session of RS Assembly, 23-24 November 1992), pp. 96-97, 99. Records in evidence indicate that there was also a lower court in Sanski Most. See P3518 (Report of Sanski Most's Lower Court Investigating Judge, 9 November 1992); D1785 (Banja Luka Military Court's Decision, 13 December 1993) (under seal), p. 1.

See Momčilo Mandić, T. 5018 (13 July 2010). For an example of the proposal of candidates from the local level, see D417 (Proposal from Presidency of Bijeljina Municipal Assembly to the Ministry of Justice of the SerBiH, 5 June 1992). See also Momčilo Mandić, T. 5018-5019 (13 July 2010).

803 Momčilo Mandić, T. 5020 (13 July 2010); P5578 (Amended Text of the Constitution of RS and Rules of Procedure of RS Assembly, 17 December 1992), art. 130 (p. 27). The Assembly would have to verify the appointment decisions of the Presidency or President. See P5578 (Amended Text of the Constitution of RS and Rules of Procedure of RS Assembly, 17 December 1992), art. 81 (p. 17); Momčilo Mandić, T. 5020 (13 July 2010). For examples of the Presidency adopting decisions on the appointment of judges and prosecutors under article 81 of the Bosnian Serb Constitution, see D418 (Decisions on appointment of judges in Bijeljina and Banja Luka, 20 June 1992) and D419 (Decisions on appointment of prosecutors in Bijeljina, 20 June 1992). See also Momčilo Mandić, T. 5020-5025 (13 July 2010).

804 D405 (Minutes of extended session of the SNB, 16 April 1992), p. 2. 
commission for war crimes and to compile instructions for the commission's work. ${ }^{805}$ On 3 June 1992, the Government concluded that "[a] procedure for determining war crimes should be initiated" and assigned the task to the MUP and the Commission for War Crimes formed by the Government. $^{806}$

259. On 16 May 1992, Mićo Stanišić instructed the five CSBs to submit to the MUP daily fax reports containing, inter alia, information on measures and activities to document war crimes. ${ }^{807}$

260. On 17 June 1992, the SerBiH Presidency decided that the Government would draft a decision on the establishment of a State Documentation Centre "which will gather all genuine documents on crimes committed against the Serbian people during this war" ${ }^{808}$ On 17 June 1992, the Accused, as President of the Presidency, issued a decree forming the State Documentation Centre for Investigating War Crimes against Serb People. ${ }^{809}$ The State Documentation Centre was to, inter alia, "collect [...] and keep [...] evidence on preparation and encouragement of crimes against Serb people in the [SerBiH], committed shortly before, during, and after war clashes". 810 At its next session, on 21 June 1992, the SerBiH Presidency appointed Miroslav Toholj as the director of the State Documentation Centre of the SerBiH. ${ }^{811}$ According to Mandić, the documentation institute was not involved with investigations in the criminal or legal sense and its task was to document events in $\mathrm{BiH}$ at the time. ${ }^{812}$ 
261. On 11 July 1992, the Presidency decided that the Commission for Investigating War Crimes Committed against the Serbian People in BiH should be established and appointed Mandić, Momir Tošić, and Jovan Šarac as deputy members of the Commission. ${ }^{813}$

262. On 11 July 1992, senior MUP officials tasked the National Security Service and Crime Investigation Service with preventing and documenting war crimes and filing criminal reports. ${ }^{814}$ The MUP report on the meeting to the President of the Presidency and Prime Minister several days later noted that "[d]ocuments are also provided for war crimes committed by Serbs". 815

263. The Operative Programme of Measures to Prevent Social Disruption in Conditions of a State of War, issued by the Government on 17 July 1992, stated that the work of the State Commission for the Identification of Crimes and Genocide against the Civilian Population and of Victims of War was to be intensified, with the Ministry of Justice responsible for the action. ${ }^{816}$ According to Mandić, the purpose of the state commission was to establish whether there were instances of such crime or genocide in the territory of the RS. ${ }^{817}$

264. On 22 April 1993, the Government established a "Commission for War and Other Crimes related to war operations in the territory of [RS]" and appointed Dragan Dangubić as its president. $^{818}$ The Commission's duties were the investigation of events that took place in the territory of the RS that could be classified as "war crimes and other war-related crimes" and the "collection of evidence on the aforementioned crimes, its analysis, legal qualification and safekeeping". 819

265. On 3 December 1993, the Government established a "Commission for Gathering Information on Crimes Committed against Humanity and International Law", with the task of investigating and gathering documentation on events in the territory of the RS that could qualify as "war crimes related to war operations". 820

813 D444 (Minutes of $17^{\text {th }}$ session of SerBiH Presidency, 11 July 1992), pp. 1-2. See also Momčilo Mandić, T. 5132 (14 July 2010).

814 D447 (SerBiH MUP, Analysis of functioning of the MUP, July 1992), e-court p. 22; P1096 (SerBiH MUP Report on Some Aspects of Work Done to Date and the Tasks Ahead, 17 July 1992), pp. 3, 6.

815 P1096 (SerBiH MUP Report on Some Aspects of Work Done to Date and the Tasks Ahead, 17 July 1992 ), p. 3.

816 D448 (Government of SerBiH, Operative programme to prevent social disruption in conditions of a state of war, 17 June 1992), p. 15. See also Momčilo Mandić, T. 5170-5171 (14 July 2010).

817 Momčilo Mandić, T. 5171 (14 July 2010).

818 D3577 (Decision of RS Government, 22 April 1993), p. 1; D3563 (Witness statement of Vladimir Lukić dated 18 May 2013), para. 40 (stating that the Commission was to "determine war crimes regardless of the ethnicity of the victims and perpetrators").

819 D3577 (Decision of RS Government, 22 April 1993), p. 1.

820 D3595 (Second report on the work of RS Commission for Gathering Information on Crimes against Humanity and International Law, 15 May 1994), p. 1. 
266. On 15 September 1994, the Bosnian Serb Government adopted a decision authorising the MUP and the Ministry of Justice "to collect information on crimes against humanity and international law that had been committed". ${ }^{821}$ According to Dušan Kozić, this decision related to victims of all nationalities and had the support of the Accused. ${ }^{822}$

c. Competence, structure, and procedures

267. When an incident involving a crime was reported, the police, usually civilian, would conduct an on-site investigation under the direction of the investigating judge. ${ }^{823}$ The police would determine if the incident fell under the jurisdiction of the military or the civilian justice system. ${ }^{824}$ Investigating judges would then send a report of all the evidence collected to the prosecutor, who would determine whether the elements of crime were sufficiently met to initiate criminal proceedings. ${ }^{825}$ At this stage, the prosecutor could submit to the investigating judge of the lower court a request to open an investigation. ${ }^{826}$

268. The Operative Programme issued by the Government on 17 July 1992 tasked the Ministry of Justice with issuing instructions "to the organs of justice to intensify and decide cases by summary procedure". 827 The Programme stated under this task: "Priority shall be given to

821 D3373 (Excerpt from minutes of $4^{\text {th }}$ session of RS Government, 15 September 1994), p. 2. See also D3364 (Witness statement of Dušan Kozić dated 7 April 2013), para. 18.

$822 \quad$ D3364 (Witness statement of Dušan Kozić dated 7 April 2013), para. 18.

823 Momčilo Mandić, T. 5126-5127 (14 July 2010). See also Mićo Stanišić, T. 46354-46355 (3 February 2014 ). See, e.g., D1733 (Investigation report of Ključ Lower Court, 28 April 1992); D1734 (Investigation report of Ključ Lower Court, 2 May 1992); D4680 (Ključ Lower Court on-site investigation report, 30 May 1992); D3784 (Investigation report of Bijeljina Lower Court, 2 June 1992); D3193 (Investigation report of Sokolac Lower Court, 20 July 1992); D1735 (Investigation report of Ključ Lower Court, 30 July 1992); D4366 (Report of Ključ Public Prosecutor's Office, 1 February 1993; Ključ Lower Court's on-site investigation report, 30 July 1992), pp. 2-4; D4381 (Prijedor Basic Court's on-site investigation report, 29 August 1992); P3518 (Report of Sanski Most's Lower Court Investigating Judge, 9 November 1992); D4355 (Sanski Most Lower Court's on-site investigation report, 4 December 1992); D48 (Zvornik Lower Court's on-site investigation report, 22 February 1993); D4386 (Prijedor Lower Court's on-site investigation report, 3 March 1993). See also D4382 (Prijedor SJB record of on-site investigation, 29 October 1992); D4348 (Sanski Most SJB record of on-site investigation, 3 December 1992) (under seal); D2949 (Milići SJB record of on-site investigation, 26 May 1993); D4351 (Sanski Most SJB record of on-site investigation, 22 July 1993) (under seal); P2931 (Bijeljina Military Court indictment of Zoran Tomić and Dragan Matović, 24 June 1993), e-court pp. 3-6. As the on-site investigation reports indicate, usually members of SJBs and/or CSBs and lower court investigating judges and sometimes a member of the prosecutor's office were present at on-site investigations.

824 Momčilo Mandić, T. 5126-5127 (14 July 2010).

825 Momčilo Mandić, T. 5128 (14 July 2010). See also Mićo Stanišić, T. 46355 (3 February 2014).

826 See P6597 (Request from Prijedor Prosecutor's Office, 3 July 1992); D4236 (Report of Banja Luka Lower Court, 24 September 1992). See paras. 301-308 for a more detailed description of the criminal process and detention procedures.

827 D448 (Government of SerBiH, Operative programme to prevent social disruption in conditions of a state of war, 17 June 1992), p. 14. 
decisions on misdemeanours and criminal offences that weaken the Republic's power of defence". 828

269. The Accused, as President of the Presidency, issued orders to MUP that investigations be conducted and perpetrators brought to account for specific incidents. ${ }^{829}$

270. According to Krajišnik, the Bosnian Serb MUP, the Ministry of Justice, and the military were the three main institutions, aside from separate commissions, responsible for investigating matters related to alleged crime, establishing the truth, and punishing the perpetrators. ${ }^{830} \mathrm{He}$ stated that the Presidency and the Assembly did not have any investigative instruments at their disposal and that no one outside of the three institutions could influence investigative and judicial work. ${ }^{831}$ He also stated that ex officio nobody was supposed to inform the Assembly President or Republic President about crimes and that crimes were to be reported to the competent institutions. ${ }^{832} \mathrm{He}$ stated that only if the relevant institutions refused to take measures in response to the information, those reporting crimes would have the right to inform the prime minister, the government, and the president of the republic. ${ }^{833}$

271. There are instances in which lower courts issued decisions releasing for military service people who had been detained on suspicion of crime. ${ }^{834}$

272. Lower courts transferred cases to the military courts when the accused was a member of the military and the case therefore beyond their subject-matter jurisdiction. ${ }^{835}$

d. Policies and orders relating to the rule of law and crimes

273. In addition to evidence referred to in other sections of this Judgement in relation to specific municipalities, the Chamber makes the following findings below.

\footnotetext{
828 D448 (Government of SerBiH, Operative programme to prevent social disruption in conditions of a state of war, 17 June 1992), p. 14.

829 See P3609 (Radovan Karadžić's Order to RS MUP, 19 August 1992).

830 Momčilo Krajišnik, T. 43316-43318 (12 November 2013).

831 Momčilo Krajišnik, T. 43317-43318 (12 November 2013).

832 See Momčilo Krajišnik, T. 43934 (20 November 2013).

833 Momčilo Krajišnik, T. 43935 (20 November 2013).

834 See P6598 (Decision of Prijedor Lower Court, 9 July 1992).

835 See D1775 (Srbac Lower Court's Ruling, 12 October 1992) (under seal); KDZ492, T. 20119 (18 October 2011$)$ (closed session). Conversely, military courts transferred cases to the civilian courts when the accused was not a member of the military at the time the charged crime was committed. See D1489 (Bijeljina Military Court decision, April 1993), pp. 1-2 (under seal); D1785 (Banja Luka Military Court's Decision, 13 December 1993) (under seal), pp. 1-2.
} 
274. Mićo Stanišić issued an order on 15 April 1992 that "[i]ndividuals involved in seizure, robbery, [...] or in any other criminal activity aimed at acquiring property and proceeds by unlawful conduct, ought to be identified and most rigorously prosecuted, including arrest and detention". ${ }^{836}$ On 26 May 1992, he instructed the five CSBs to send a report containing, inter alia, the total number of criminal offences against life and limb, crimes of degradation of personhood and property, and crimes against property, and the total number of such cases which were solved. ${ }^{837}$

275. On 5 June 1992, Assistant Minister for Crime Prevention and Detection Planojević, in a document to the five CSBs, noted that in the previous two months after the outbreak of war in $\mathrm{BiH}$, a sharp increase had been observed in the rate of property crimes, war profiteering, and especially war crimes. ${ }^{838}$ Planojević requested that "vigorous measures be taken against the perpetrators of all types of crimes, and in more extreme cases, orders should be issued on their detention". 839 The document called for "establish[ing] maximum cooperation with judicial organs and the Military Police" and "[p]ay[ing] special attention to discovering the perpetrators of war crimes, documenting the criminal activities of individuals and groups, arresting them and bringing them to justice". ${ }^{840}$ The document also stated that the CSBs would likely face obstacles to their work and directed them to make official notes of all information to allow criminal prosecution to be brought later. ${ }^{841}$ Further, it told the CSBs that they were required to strictly observe the international laws of war in the treatment of civilians and prisoners of war. ${ }^{842}$

276. On 5 July 1992, Mićo Stanišić asked the Command of the Eastern Bosnia Corps to use the authority of its organs and help prevent and detect crimes and their perpetrators, especially members of the VRS, after noting "the increasingly frequent and serious crimes committed by individuals and groups, usually armed" and the inability of the crime investigation service and police to carry out the duties within the competence of the internal affairs organs. ${ }^{843}$

\footnotetext{
836 D404 (SerBiH MUP Order, 15 April 1992). On 17 April 1992, Mićo Stanišić sent to the CSBs and SJBs a related communication stating that cases of unlawful appropriation of property by members of MUP had been recorded in certain SJBs and that in the future "the most stringent measures", including criminal prosecution, would be taken against such individuals. D1671 (Warning of SerBiH MUP, 17 April 1992); Mićo Stanišić, T. 46364-46365 (3 February 2014).

837 P6240 (SerBiH MUP request for information, 26 May 1992).

838 D1527 (Report of SerBiH MUP, 5 June 1992), pp. 1-2. Stojan Župljanin, Chief of the Banja Luka CSB, forwarded the communication to SJBs. D425 (CSB Banja Luka dispatch to all SJBs, 8 June 1992).

839 D1527 (Report of SerBiH MUP, 5 June 1992), p. 1.

840 D1527 (Report of SerBiH MUP, 5 June 1992), p. 1.

841 D1527 (Report of SerBiH MUP, 5 June 1992), pp. 1-2.

842 D1527 (Report of SerBiH MUP, 5 June 1992), p. 2.

843 D1408 (Request of SerBiH MUP, 5 July 1992), p. 1. See also Milorad Davidović, T. 15608-15609 (29 June 2011). According to Mandić, the MUP and the corps on whose territory the paramilitaries were, as well as the military police of that corps, had the competence to investigate their acts. See Momčilo Mandić, T. 5102-5103 (14 July 2010). On 3 July 1992, the Presidency issued an order, signed by the Accused as President of the
} 
277. On 19 July 1992, Mićo Stanišić ordered that CSBs submit information on, inter alia, “[p]roblems related to activities of some paramilitary units, especially in cases where crimes have been committed or the public peace and order violated to a large extent, [...] [p]roblems related to the prevention and detection of crimes and perpetrators, and [...] [p]rocedures and jurisdiction in the treatment and custody of prisoners, persons evacuated from the combat-operation zones, collection camps into which the Army brings Muslim residents". 844 On 27 July 1992, in an order addressed to, inter alia, CSBs, Stanišić instructed that individuals who had been held criminally responsible for officially prosecuted crimes and "individuals who committed crimes during the war in the former $[\mathrm{BiH}]$ but against whom, for known reasons, criminal proceedings [had] still not been initiated", be removed from the MUP. ${ }^{845}$ He also ordered the removal of all groups and individuals not under VRS control from areas where they were active and the collection of information about anyone having committed a crime, as well as the handover of such individuals to the competent institutions and taking of measures in accordance with the Law on Criminal Procedure. ${ }^{846}$

278. In its session of 6 August 1992, the SerBiH Presidency noted, in the discussion of detainees in prisons in Serb territory, that the treatment of prisoners of war had to abide by international conventions and concluded that the MUP would be ordered to examine through its municipal branches the behaviour of all civilian authorities and individuals guarding prisoners of war. ${ }^{847}$ The information was to be passed to the MUP and then to the SerBiH Presidency. ${ }^{848}$

279. On 8 August 1992, Deputy MUP Minister for Police Affairs and Tasks, Tomislav Kovač, wrote to the Accused and Đerić that a major problem in the field was that people were not "properly categorised in the facilities or collection centres" as civilians or prisoners of war, and among the latter, prisoners of war who have committed criminal acts. ${ }^{849}$ He stated that prisoners of war suspected of having committed criminal acts and war crimes were to be treated as detainees,

Presidency, that the Bosnian Serb MUP conduct an investigation into paramilitary group activities in the area of the Gacko and Nevesinje municipalities and thereafter "submit an exhaustive report to the Presidency on the established state of facts in the area of the two municipalities". D439 (Order of SerBiH Presidency, 3 July 1992). See also D438 (Minutes of $14^{\text {th }}$ session of SerBiH Presidency, 3 July 1992), p. 1.

844 D450 (Letter from SerBiH MUP to CSB Chiefs in Banja Luka, Bijeljina, Doboj, Sarajevo, Trebinje, 19 July 1992), pp. 1-2.

845 D4273 (Order of SerBiH MUP, 27 July 1992), pp. 1-2.

846 D4273 (Order of SerBiH MUP, 27 July 1992), p. 2.

847 D465 (Minutes of $24^{\text {th }}$ session of SerBiH Presidency, 6 August 1992), p. 2. See also D3105 (Witness statement of Slobodan Avlijaš dated 9 March 2013), para. 54; D3796 (SerBiH MUP instructions to CSBs, 8 August 1992); D3795 (Romanija-Birač CSB request to SJBs, 9 August 1992); D3817 (Bijeljina SJB dispatch to Eastern Bosnia Corps, 11 August 1992). Based on the decision by the SerBiH Presidency, the Government set up two commissions to examine the situation in the detention centres and prisons in Manjača and Bileća. D3105 (Witness statement of Slobodan Avlijaš dated 9 March 2013), para. 55.

848 D465 (Minutes of $24^{\text {th }}$ session of SerBiH Presidency, 6 August 1992), p. 2.

849 P1100 (Letter from SerBiH MUP to Radovan Karadžić and Branko Đerić, 8 August 1992), p. 1. See also D3960 (Witness Statement of Tomislav Kovać dated 28 October 2013), para. 84. 
held exclusively in prison facilities, and investigated by the judicial organs and the police. ${ }^{850}$ On 9 August 1992, the Government decided to establish commissions for the inspection of collection centres and other facilities for prisoners in the $\mathrm{SerBiH} .{ }^{851}$

280. In August 1992, Mićo Stanišić issued other orders regarding the application and conditions of detention and the treatment of prisoners of war and civilians. ${ }^{852}$

281. On 23 July 1992, the Accused issued an order which stated, inter alia: "The Serbian authorities must act in accordance with the law and the Geneva Convention towards the civilian population of any ethnicity who do not exert aggression and combat operations against our army and the civilian population." 853 At the end of July 1992, before the Bosnian Serb Assembly, he criticised crimes such as robbery and unlawful acquisition of property. ${ }^{854}$ At a session in September 1992, the Accused spoke of the need to abide by the Geneva Conventions with respect to captured persons. ${ }^{855}$ At the $34^{\text {th }}$ Assembly session in August to October 1993, the Accused stated that the courts and the legality of their work were to be monitored constantly. ${ }^{856} \mathrm{He}$ also stated that the work of the Bosnian Serb MUP was to be strengthened in all its departments and that all abuses of power and other criminal acts that were committed in the MUP were to be investigated and punished by law. ${ }^{857}$ He stated: "Legal state exists when you don't have to intervene in order for someone to be prosecuted. Legal state exists when one is not allowed to intervene when a person is to be prosecuted." ${ }^{, 858}$

\footnotetext{
$850 \quad$ P1100 (Letter from SerBiH MUP to Radovan Karadžić and Branko Đerić, 8 August 1992), p. 1.

851 D466 (Decision of Government of SerBiH on establishment of Commission for Inspection of Collection Centres and Other Facilities for Prisoners, 9 August 1992). See also D3960 (Witness Statement of Tomislav Kovač dated 28 October 2013), para. 85.

852 D467 (Order of SerBiH MUP to CSBs Sarajevo, Trebinje, Doboj, Bijeljina, Banja Luka, 10 August 1992); D469 (Order of SerBiH MUP, 17 August 1992); D4280 (Letter from RS MUP to all CSBs, 17 August 1992). See also D474 (CSB Banja Luka dispatch to all SJBs, 20 August 1992); D473 (SerBiH MUP, Summary from the MUP management meeting held on 20 August 1992), pp. 3, 15.

853 D96 (Radovan Karadžić's Order to Serbian authorities, 23 July 1992). See also D94 (Radovan Karadžić's letter to SDS members, 11 July 1992) (the Chamber refers to the date of 11 July 1992 appearing on the document in the original language as opposed to the date of 7 July 1992 appearing on the English version).

854 See D92 (Transcript of $17^{\text {th }}$ session of SerBiH Assembly, 24-26 July 1992), p. 17.

855 See D456 (Transcript of 20 ${ }^{\text {th }}$ session of RS Assembly, 14-15 September 1992), p. 55.

856 P1379 (Transcript of 34 ${ }^{\text {th }}$ session of RS Assembly, 27-29 August, 9-11 September, 29 September to 1 October 1993), p. 408.

857 P1379 (Transcript of $34^{\text {th }}$ session of RS Assembly, 27-29 August, 9-11 September, 29 September to 1 October 1993), p. 408.

858 P1379 (Transcript of $34^{\text {th }}$ session of RS Assembly, 27-29 August, 9-11 September, 29 September to 1 October 1993), p. 408.
} 
2. Military justice system

a. Establishment

282. On 8 May 1992, a session of the SNB and the Government decided to establish courts martial. $^{859}$

283. On 12 May 1992, the Bosnian Serb Assembly adopted a decision promulgating an amendment to the SerBiH Constitution such that Article 112 read: "Military courts and military prosecutors are established by law. Military courts are independent courts and conduct trials on the basis of the law." 860

284. On 31 May 1992, a decision signed by the Accused as President of the Presidency established three military courts of first instance and a Supreme Court in Sarajevo at the appeal level. ${ }^{861}$ The decision also established three regional military prosecutors' offices, ${ }^{862}$ one each for the $1^{\text {st }}$ Krajina Corps Command seated in Banja Luka, the SRK Command seated in Sarajevo, and the Eastern Bosnia Corps Command seated in Bijeljina, as well as a Senior Military Prosecutor's Office with the $\mathrm{VRS}^{863}$ Main Staff. ${ }^{864}$ The three military courts of first instance were to operate "[w]ithin the framework of their subject matter jurisdiction" in the territory of the Corps designated for the corresponding military prosecutor's office: the Military Court in Banja Luka in the territory of the $1^{\text {st }}$ and $2^{\text {nd }}$ Krajina Corps, the Military Court in Sarajevo in the territory of the SRK and Herzegovina Corps, and the Military Court in Bijeljina in the territory of the Eastern Bosnia Corps. ${ }^{865}$ A Presidency decision added the Drina Corps to the territorial jurisdiction of the Military

859

860

861

862

864

865
P3078 (Minutes of meeting of the National Security Council and the SerBiH Government, 8 May 1992), p. 1.

P5416 (Decision of the Assembly of Serbian People in BiH, 12 May 1992), p. 1.

P3602 (Radovan Karadžić's Decision on the Establishment, Seat and Jurisdiction of Military Courts and Military Prosecutors' Offices, 31 May 1992), p. 1. See also D1756 (The Law on Military Courts, published in the RS Official Gazette, 31 December 1993), art. 9.

The Report on the Work of the VRS Military Prosecutor's Offices for 1992 mentions a fourth lower military prosecutor's office, that attached to the Command of the Herzegovina Corps and mandated to deal with persons under the jurisdiction of the Military Court in Bileća. P3629 (Report on the work of the VRS Military Prosecutor's Office for 1992), p. 4. See also D1756 (The Law on Military Courts, published in the RS Official Gazette, 31 December 1993), art. 9.

863 For ease of reference the acronym "VRS" will be used throughout this section to also cover the period prior to 12 August 1992, when the Army of SerBiH was renamed the VRS. See fn. 422.

P3602 (Radovan Karadžić's Decision on the Establishment, Seat and Jurisdiction of Military Courts and Military Prosecutors' Offices, 31 May 1992), p. 1.

P3602 (Radovan Karadžić's Decision on the Establishment, Seat and Jurisdiction of Military Courts and Military Prosecutors' Offices, 31 May 1992), pp. 1-2. See also KDZ531, T. 15847-15848, 15862-15863 (1 July 2011) (closed session); Momčilo Mandić, T. 5007-5008 (13 July 2010), T. 5128 (14 July 2010); D3076 (Witness statement of Savo Bojanović dated 2 March 2013), para. 5; Dragomir Milošević, T. 32859 (29 January 2013). The Banja Luka Military Court's territorial jurisdiction included the municipalities Banja Luka, Prijedor, and the municipalities of Ključ and Sanski Most were within territory controlled by the $1^{\text {st }}$ Krajina Corps. [REDACTED]. 
Court in Sarajevo. ${ }^{866}$ On 5 August 1992, General Milan Gvero informed Prime Minister Đerić that the VRS had established these first-instance military courts and prosecutor's offices as well as the Supreme Military Court and Senior Military Prosecutor's Office with the VRS Main Staff. ${ }^{867}$

285. The 31 May 1992 decision provided that until the passing of the Criminal Code, Law on Criminal Procedure, Law on Military Courts, and Law on Military Prosecutors' Offices, inter alia, of the SerBiH, the Criminal Code, Law on Criminal Procedure, Law on Military Courts, and Law on Military Prosecutor's Offices, inter alia, of the FRY were to be applied in proceedings before military courts. ${ }^{868}$ On 30 December 1993, the Accused, as RS President, proclaimed the Law on Military Courts as approved by the RS Assembly. ${ }^{869}$

286. Reports discussed at the Government session of 8 July 1992 indicate that the military judicial organs had not begun operating as of that time, resulting in "one of the greatest obstacles in establishing order, legality and a state ruled by law in present conditions". ${ }^{870}$ The Government concluded that "it be proposed to the authorised organs to form and qualify the Public Prosecutor's Office and the courts for work as soon as possible" and that, for emergency reasons, the possibility of delegating authority from the military to regular judicial organs would be examined ${ }^{871}$ The Government assigned this task to the Ministry of Defence and the Ministry of Justice. ${ }^{872}$ As previously mentioned, on 10 July 1992 and again on 5 August 1992, Mandić proposed that the civilian and military justice systems be combined but this was not carried out. ${ }^{873}$ At a meeting on

\footnotetext{
866 D412 (RS Presidency Amendment to the Decision on Establishment of Military Courts and Prosecutors, 31 May 1992). See also Momčilo Mandić, T. 5007 (13 July 2010). According to a 15 December 1994 order signed by the Accused as President of the Republic, the territorial jurisdiction of the military courts comprised: the Banja Luka Military Court responsible for the territory within the zone of responsibility of the First and Second Krajina Corps, the Bijeljina Military Court responsible for the same of the Eastern Bosnia and Drina Corps, the Sarajevo Military Court responsible for the same of the Sarajevo-Romanija Corps, and the Bileća Military Court responsible for the same of the Herzegovina Corps. D1492 (Radovan Karadžić's order to VRS Military Prosecutor's Office, 15 December 1994).

D1752 (Request from VRS Main Staff, 5 August 1992). The Accused, at the proposal of the Minister of Defence, later moved the military courts to the authority of the Ministry of Defence while leaving the military prosecutor's offices within the army system. Momčilo Mandić, T. 5008 (13 July 2010); P3149 (Minutes of $14^{\text {th }}$ session of Supreme Command, 31 March 1995), pp. 10-11.

868 P3602 (Radovan Karadžić's Decision on the Establishment, Seat and Jurisdiction of Military Courts and Military Prosecutors' Offices, 31 May 1992), p. 2. See P3603 (SFRY Law on Military Courts, published in SFRY's Official Gazette, 14 January 1977); P3604 (SFRY Law on the Office of Military Prosecution, published in SFRY's Official Gazette, 14 January 1977).

869 D1756 (The Law on Military Courts, published in the RS Official Gazette, 31 December 1993).

870 D441 (Minutes of $37^{\text {th }}$ session of Government of SerBiH, 8 July 1992), p. 5.

871 D441 (Minutes of $37^{\text {th }}$ session of Government of SerBiH, 8 July 1992), p. 5.

872 D441 (Minutes of $37^{\text {th }}$ session of Government of SerBiH, 8 July 1992), p. 5.

873 See paras. 254-255.
} 
11 July 1992, senior MUP officials discussed the fact that the military courts and prosecutor's offices were not functioning. ${ }^{874}$

287. The Operative Programme issued by the Government on 17 July 1992 ordered the military judicial organs ${ }^{875}$ and military police organs to "intensify activities of discovering and arresting perpetrators of misdemeanours and criminal offences, and especially in controlling theft, war profiteering and other crimes", in co-operation with the state justice organs. ${ }^{876}$ The Programme made the MUP, in co-operation with the Ministry of Justice and Ministry of Defence, responsible for this action. ${ }^{877}$

288. The Chamber received diverging evidence as to when the military courts were established and began operating. Savo Bojanović stated that military courts were established in June or July 1992 in the entire territory under Bosnian Serb control and that the Bijeljina Military Court was established in mid-July 1992 and began investigations in August 1992. ${ }^{878}$ There is also evidence that the Banja Luka Military Court was functioning from May to July $1992^{879}$ and that criminal proceedings took place from as early as September and October $1992 .{ }^{880}$ According to Novak Todorović, the president of the Supreme Military Court, ${ }^{881}$ however, the establishment of the first military courts began in the autumn of 1992 and these courts were operating as of $1993 .{ }^{882}$

289. Records indicate that the Military Prosecutor's Office attached to the Command of the $1^{\text {st }}$ Krajina Corps issued requests for investigation and indictments ${ }^{883}$ and that the Banja Luka Military

874 D447 (SerBiH MUP, Analysis of functioning of the MUP, July 1992), e-court pp. 8, 9, 11, 14. See also Momčilo Mandić, T. 5140-5142 (14 July 2010).

875 These organs were not yet functioning in July 1992. See paras. 286, 288, 292.

876 D448 (Government of SerBiH, Operative programme to prevent social disruption in conditions of a state of war, 17 June 1992), p. 12.

877 D448 (Government of SerBiH, Operative programme to prevent social disruption in conditions of a state of war, 17 June 1992), pp. 12-13.

878 D3076 (Witness statement of Savo Bojanović dated 2 March 2013), paras. 4-5; Savo Bojanović, T. 3484534846 (5 March 2013). See also [REDACTED].

879 See [REDACTED]. But see KDZ492, T. 20056-20058, 20061 (18 October 2011) (closed session) (stating that the military courts were not operational between May 1992 and the end of August 1992).

880 See [REDACTED]. See also P3605 (Report of $1^{\text {st }}$ Krajina Corps, 2 September 1992), p. 2; D2999 (Article from Politika entitled "Serbs, Muslims and Croats are All before the Court", 13 December 1992).

881 D2986 (Witness statement of Novak Todorović dated 17 February 2013), para. 2.

882 Novak Todorović, T. 34071 (20 February 2013); D2986 (Witness statement of Novak Todorović dated 17 February 2013), para. 3. See also D4226 (Witness statement of Dragan Radetić dated 17 January 2014), para. 8 (stating that no military court had been established until September or October 1992); KDZ492, T. 20057, 20061 (18 October 2011) (closed session) (stating that between May 1992 and the end of August 1992 the military courts were not operational and that the first military court judges were appointed in August 1992 and they became seised of cases only in early September).

883 See, e.g., P3630 (Indictment of the Military Prosecutor of the $1^{\text {st }}$ Krajina corps, 5 January 1993); P3513 (Request for investigation by the $1^{\text {st }}$ Krajina Corps Military Prosecutor's Office, 8 March 1993); P3519 (Indictment of the $1^{\text {st }}$ Krajina Corps Military Prosecutor's Office, 2 June 1993); D1757 (Indictment of the Military Prosecutor's Office attached to the $1^{\text {st }}$ Krajina Corps, 18 July 1993); P3623 (Excerpt of logbook of Banja Luka Military 
Court issued rulings and judgements. ${ }^{884}$ The Military Prosecutor's Office in Banja Luka also submitted proposals to the Banja Luka Military Court to halt or resume investigative proceedings. ${ }^{885}$ During the course of 1992, the Military Prosecutor's Office attached to the Command of the SRK also submitted requests to initiate investigations. ${ }^{886}$ Records further indicate that the Military Prosecutor's Office attached to the Command of the Eastern Bosnia Corps issued requests for investigation and indictments ${ }^{887}$ and that the Bijeljina Military Court issued decisions and rulings. ${ }^{888}$ Finally, records indicate that, in 1992, the Military Prosecutor's Office attached to the Command of the Herzegovina Corps submitted requests to carry out investigations and six indictments were issued against six soldiers. ${ }^{889}$

290. The Report on the Work of the VRS Military Prosecutor's Offices for 1992 indicates that, for the period from the beginning of the work of the military prosecutor's offices until 31 December 1992, criminal reports against 4,008 persons, including 3,228 soldiers, 37 noncommissioned officers, 49 officers, 688 civilians, and 6 unknown perpetrators, were submitted to all of the military prosecutor's offices. ${ }^{890}$ The Report states that in the specified period, military prosecutors submitted requests to carry out investigations against 1,983 persons and indictments were issued against 376 persons. ${ }^{891}$

291. An order of 22 September 1993, signed by the Accused as President of the Republic and Supreme Commander of the VRS and sent to the VRS Main Staff Commander, the President of the

Prosecutor's Office, 1992), p. 6. See also P3629 (Report on the work of the VRS Military Prosecutor's Offices for 1992), p. 12; P6595 (Cover page of $1^{\text {st }}$ Krajina Corps Military Prosecutor case, 24 August 1992).

884 See, e.g., P6599 (Decision of Banja Luka Military Court, 29 August 1992); P6601 (Decision of Banja Luka Military Court, 8 October 1992); [REDACTED].

885 See P3616 (Proposal of the Military Prosecutor's Office attached to the $1^{\text {st }}$ Krajina Corps, 29 July 1993); P3774 (Order of Banja Luka Military Prosecutor's Office, 31 May 1996).

886 P3629 (Report on the work of the VRS Military Prosecutor's Offices for 1992, 10 February 1993), p. 6. See D2832 ( $1^{\text {st }}$ Romanija Brigade combat report, 4 July 1992), p. 3 (stating that four criminal reports had been processed against soldiers who committed theft in the area of responsibility of the brigade and that the reports would be passed on to the military prosecutor for further action); Dragomir Milošević, T. 32860-32861 (29 January 2013).

887 See, e.g., D1473 (Bijeljina Military Prosecutor request re Rade Mihajlović case, 30 September 1992); P6182 (Request for investigation by Bijeljina Military Prosecutor's Office, 9 November 1992); P6183 (Request for investigation by Bijeljina Military Prosecutor's Office, 17 November 1992); D1476 (Bijeljina Military Court indictment of Rade Mihajlović, 5 January 1993); D1465 (Bijeljina Military Court indictment of Radovan Mićanović, 17 August 1993). See also P3629 (Report on the work of the VRS Military Prosecutor's Offices for 1992), pp. 23-24.

888 See, e.g., D1485 (Bijeljina Military Court ruling in Cvjetković/Jurošević case, 20 November 1992); P6179 (Bijeljina Military Court's Decision, 30 December 1992); P6180 (Bijeljina Military Court's Decision, 5 January 1993); D1478 (Bijeljina Military Court order in Rade Mihajlović case, 21 February 1993); D3082 (Bijeljina Military Court's Verdict, 24 June 1993); D1466 (Bijeljina Military Court judgement in Radovan Mićanović case, 22March 1995).

889 P3629 (Report on the work of the VRS Military Prosecutor's Offices for 1992), p. 19.

890 P3629 (Report on the work of the VRS Military Prosecutor's Offices for 1992), p. 5.

891 P3629 (Report on the work of the VRS Military Prosecutor's Offices for 1992), p. 5. 
VRS Supreme Military Court, and the VRS Prosecutor's Office, stated: "Until the final adoption and passing of legislation on the organisation and work of military disciplinary courts, I am placing the Supreme Military Court and the Prosecutor's Office attached to the [VRS] Main Staff under my direct authority." 892 The order made the Commander of the Main Staff and the President of the Supreme Military Court responsible for the implementation of the task. ${ }^{893}$

292. The Chamber finds that the military courts were established between June and August 1992 and began functioning around August 1992.

\section{b. Competence, structure, and procedures}

293. The military courts had jurisdiction over any crime committed by a member of the military, namely, the VRS. ${ }^{894}$ The military courts also had jurisdiction over civilians accused of committing particular crimes, including acts against a military installation or a member of the military ${ }^{895}$ and the crime of armed rebellion. ${ }^{896}$

294. According to some witnesses, military courts did not have jurisdiction over cases of war crimes, which the State Commission of the Investigation of Crimes against Serbs had authority to investigate. ${ }^{897}$ However, in at least one case, a military prosecutor's office submitted a request to open an investigation against individuals for a suspected crime under Article 142 of the adopted Criminal Code of the SFRY, ${ }^{898}$ war crimes against the civilian population, and a military court ordered detention of the said individuals. ${ }^{899}$

892 P3776 (Radovan Karadžić's order to VRS Commander and President of VRS Supreme Military Court, 22 September 1993), p. 2. See also P1379 (Transcript of $34^{\text {th }}$ session of RS Assembly, 27-29 August, 9-11 September, 29 September to 1 October 1993), p. 427.

893 P3776 (Radovan Karadžić's order to VRS Commander and President of VRS Supreme Military Court, 22 September 1993), p. 2.

894 P3773 (Witness statement of KDZ532 dated 31 October 2011), para. 10 (under seal); D1756 (Law on Military Courts, published in the RS Official Gazette, 31 December 1993), art. 10. KDZ532 stated that paramilitaries, as persons in uniform, were also under the jurisdiction of the military courts. P3773 (Witness statement of KDZ532 dated 31 October 2011), paras. 10, 24 (under seal). Mandić stated that paramilitaries, as "armed persons in wartime", fell under the jurisdiction of the military justice system. Momčilo Mandić, T. 5101 (14 July 2010). See also Mićo Stanišić, T. 46386-46387 (3 February 2014) (stating that paramilitaries' "affiliation with the military" excluded MUP jurisdiction over them). According to Mandić, the military justice system's jurisdiction extended to persons who committed a crime in a war zone, in combat operations, or related to war activities. Momčilo Mandić, T. 4579 (5 July 2010), T. 5125-5126 (14 July 2010). Mandić also stated that all military conscripts from age 16 to 50 or 60 , during an imminent threat of war, fell under the jurisdiction of the military justice system. Momčilo Mandić, T. 4579 (5 July 2010).

895 D1756 (Law on Military Courts, published in the RS Official Gazette, 31 December 1993), art. 10.

896 See D1773 (Teslić Lower Court Ruling, 7 December 1992), p. 1. [REDACTED].

897 P2929 (Witness statement of KDZ531 dated 25 June 2011), p. 11 (under seal); Momčilo Mandić, T. 5015 (13 July 2010). See para. 258.

898 The RS utilised the SFRY Criminal Code. D2986 (Witness statement of Novak Todorović dated 17 February 2013), para. 27; Novak Todorović, T. 34080 (20 February 2013). See also KDZ492, T. 20059 (18 October 
295. Under the Law on Military Courts, military courts were to "determine the status of prisoners-of-war and try them for criminal acts committed against humanity and international law as described in Articles 141 through 155 of the Criminal Code of [RS] as well as for criminal acts committed by them while prisoners-of-war". ${ }^{900}$ Military courts of first instance were to, inter alia, conduct investigations, hear indictment appeals, first-instance criminal cases and appeals against rulings by military court investigating judges, and handle certain matters concerning the execution of sentences. ${ }^{901}$ The Supreme Military Court was to, inter alia, consider appeals against rulings by first-instance military courts in cases determined by law, rule against the enactments of military organs, resolve conflicts of jurisdiction among the first-instance military courts, and provide fundamental legal interpretations of issues significant to the uniform application of laws by the military courts. ${ }^{902}$

296. A first-instance military court was composed of three to five judges. ${ }^{903}$ The corresponding prosecutor's office usually had one prosecutor and two deputy prosecutors. ${ }^{904}$ The Supreme Military Court had five judges by the end of the war. ${ }^{905}$

297. The Accused as President appointed all prosecutors and judges of the military courts. ${ }^{906}$ Under the Law on Military Courts, candidates for the posts of military court judges were to be proposed by the Ministry of Defence upon recommendations from the Supreme Military Court's president and the military court to which they would be appointed. ${ }^{907}$ Military court judges were to

2011) (closed session) (stating that the judicial administration law of the RS allowed for the application of relevant SFRY and $\mathrm{BiH}$ legislation). 
be dismissed by the President of the Republic. ${ }^{908}$ Proposals to dismiss military court judges were to be submitted by the Defence Minister. ${ }^{909}$

298. The military prosecutor's offices attached to the four corps commands were required to submit monthly reports on crime trends for the preceding period to the Senior Military Prosecutor's Office with the VRS Main Staff. ${ }^{910}$ The reports were to include, inter alia, the number of criminal reports received by the prosecutor's office and against whom as well as the number rejected and the reason for such rejection. ${ }^{911}$ The three highest priority crimes, in order, were crimes against the state order, crimes against the armed forces, and crimes against humanity and violations of international law. ${ }^{912}$

299. The Banja Luka Military Court sent monthly reports to the $1^{\text {st }}$ Krajina Corps Command and the appellate military court, namely the Supreme Military Court. ${ }^{913}$ The Military Court and Military Prosecutor's Office for Banja Luka had meetings with the Command of the $1^{\text {st }}$ Krajina Corps in which they discussed how cases were proceeding and how the Court and Prosecutor's Office functioned. ${ }^{914}$ In these meetings, the Corps Command asked that the cases of those not responding to mobilisation calls and those avoiding military service be prioritised. ${ }^{915}$ The Military Court for Banja Luka also had meetings with the Supreme Military Court as needed and some meetings were attended by the other military courts as well. ${ }^{916}$ Bogdan Subotić, an advisor of the President, the Accused, in the beginning of 1992 and later the Minister of Defence, made visits to the Military Prosecutor for the $1^{\text {st }}$ Krajina Corps, Srboljub Jovičinac, a number of times. ${ }^{917}$ At the

D1756 (Law on Military Courts, published in the RS Official Gazette, 31 December 1993), arts. $27,36$.

909 D1756 (Law on Military Courts, published in the RS Official Gazette, 31 December 1993), art. 36.

910 P3627 (Report of the VRS Military Prosecutor's Office, 9 September 1992), p. 4. See, e.g., P3628 (Monthly Report of the Military Prosecutor's Office attached to the $1^{\text {st }}$ and $2^{\text {nd }}$ Krajina Corps, October 1992).

911 See P3627 (Report of the VRS Military Prosecutor's Office, 9 September 1992), p. 4.

912 P3627 (Report of the VRS Military Prosecutor's Office, 9 September 1992), p. 4.

913 [REDACTED].

914 [REDACTED].

915 [REDACTED]. The applicable provisions for these offences were Articles 214 and 217 of the Criminal Code. P3606 (Guidelines for the Establishment of Criteria for Criminal Prosecution, VRS Military Prosecutor's Office, 1992), pp. 2-3. The Guidelines highlighted and addressed three types of crimes: the crime of failure to report in response to a call-up and evasion of military service, the crime of unauthorised departure and desertion from the armed forces, and crimes against humanity and international law. See P3606 (Guidelines for the Establishment of Criteria for Criminal Prosecution, VRS Military Prosecutor's Office, 1992). The Guidelines were to be implemented by all officers, military judicial organs, military police, security organs, and all organs required to detect and report perpetrators of crimes and authorised to conduct proceedings against them, for a consistent policy on prosecution. See D2833 (SRK instructions, 15 October 1992, with 1992 Guidelines for the Establishment of Criteria for Criminal Prosecution), p. 1; Dragomir Milošević, T. 32861-32862 (29 January 2013).

916 [REDACTED].

917 [REDACTED].
} 
Military Court in Bijeljina, the priority cases were those that involved non-response to mobilisation and desertion from the military, under articles 214 and $217 .{ }^{918}$

300. The procedures for military courts were the same as those for civilian courts and the RS rules and regulations were taken from the Yugoslav rules and regulations. ${ }^{919}$ According to the Law on Military Courts, provisions of the Law of Criminal Procedure were to apply to military courts' criminal procedure if not otherwise stipulated by the Law on Military Courts. ${ }^{920}$ Todorović instructed the judges of the Supreme Military Court to prepare guidelines for criminal prosecution and the criteria for criminal prosecution. ${ }^{921}$

301. With respect to VRS military justice system procedures, first, the prosecutor's office received the criminal report by the police ${ }^{922}$ and then the prosecutor determined whether there was sufficient evidence to initiate criminal proceedings. ${ }^{923}$ If so, the prosecutor would send a request for investigation to the investigating judge. ${ }^{924}$ If there was none, with the assistance of the police and other organs, the prosecutor collected all the information and forwarded it to the Court. ${ }^{925}$ Under the Law on Military Courts, the investigation was to be conducted by the military court investigating judge. ${ }^{926}$ After completing his investigation, the investigating judge sent the case

\footnotetext{
918 [REDACTED].

919 [REDACTED].

920 D1756 (The Law on Military Courts, published in the RS Official Gazette, 31 December 1993), art. 56. The powers and regulations of organs of internal affairs under the Law on Criminal Procedure also applied to the security organs of the VRS and the military police. D1892 (Instruction re authorities of military police), p. 1.

921 D2986 (Witness statement of Novak Todorović dated 17 February 2013), para. 7.

922 If the civilian police investigated, it would, upon completion of its investigation, hand over the case to the relevant prosecutor's office, civilian or military. Momčilo Mandić, T. 5103-5104 (14 July 2010). See also D2986 (Witness statement of Novak Todorović dated 17 February 2013), para. 13 (stating that the military prosecutor could act upon a criminal report by the civilian or military police).

923 [REDACTED]; D2986 (Witness statement of Novak Todorović dated 17 February 2013), para. 13; Dragan Radetić, T. 45697 (21 January 2014); [REDACTED]. The military prosecutor had the authority to dismiss a criminal report without giving an explanation for the decision. D2986 (Witness statement of Novak Todorović dated 17 February 2013), para. 13; [REDACTED].

924 [REDACTED]; D2986 (Witness statement of Novak Todorović dated 17 February 2013), para. 13. See, e.g., D1473 (Bijeljina Military Prosecutor request re Rade Mihajlović case, 30 September 1992); P6182 (Request for investigation by Bijeljina Military Prosecutor's Office, 9 November 1992); P6183 (Request for investigation by Bijlejina Military Prosecutor's Office, 17 November 1992); P3513 (Request for investigation by the $1^{\text {st }}$ Krajina Corps Military Prosecutor's Office, 8 March 1993); D1896 (Letter re Banja Luka Military Prosecution request to conduct investigation, 16 November 1993). A request for investigation by the military prosecutor followed an on-site investigation report compiled by the investigating judge of the military court, the filing of a criminal report by the military police with the military prosecutor, and a report of forensic documentation by the military police. See KDZ531, T. 15893-15896 (1 July 2011); D1470 (Bijeljina Military Court on-site investigation report, 28 September 1992); D1471 (Bijeljina Military Police criminal report in Rade Mihajlović case, 29 September 1992); D1472 (Bijeljina Military Police forensic-technical report, 30 September 1992).

925 [REDACTED].

926 D1756 (Law on Military Courts, published in the RS Official Gazette, 31 December 1993), art. 64. See also D2986 (Witness statement of Novak Todorović dated 17 February 2013), para. 13.
} 
back to the prosecutor, who could decide to discontinue the proceedings, bring an indictment, or request additional investigation. ${ }^{927}$

302. In accordance with his legal responsibility to institute process against every person who committed a crime, the prosecutor could also initiate criminal proceedings once he became aware of a crime. ${ }^{928}$ A soldier of any rank or a civilian victim could inform the Prosecutor of a crime, but the investigation had to be initiated by the prosecutor. ${ }^{929}$ For cases of failure to respond to a call to military service, the Ministry of Defence would file a criminal report against the individual. ${ }^{930}$ The military court could not act without first a request from the military prosecutor and an indictment issued by the prosecutor. ${ }^{931}$

303. According to the Law on Military Courts, the military court's investigating judge or, under exceptional circumstances as prescribed by the Law of Criminal Procedure, authorised superior officers in the security organs of the VRS or those in the MP could require the detention of a member of the military, an employee of the VRS, or a civilian for a criminal offence falling under the jurisdiction of a military court. ${ }^{932}$ In the latter case, the officers were to immediately inform a military prosecutor or the military court investigating judge of their detention decision. ${ }^{933}$

304. Under the Law on Criminal Proceedings, the duration of custody was to be "kept to the shortest necessary time" and throughout the proceedings custody was to be terminated as soon as the grounds on which it was ordered ceased to exist. ${ }^{934}$

305. When a person was arrested by the MP and a criminal report was given to the Prosecutor's Office, the person could be initially detained by the MP for three days. ${ }^{935}$ The military prosecutor

927 D2986 (Witness statement of Novak Todorović dated 17 February 2013), para. 13. For instances where the prosecutor decided to discontinue the prosecution after the investigating judge's investigation, see P2930 (Bijeljina Military Court file for Slavan Lukić et al., 8 September 1992), e-court pp. 6, 7; P6180 (Bijeljina Military Court's Decision, 5 January 1993). P3773 (Witness statement of KDZ532 dated 31 October 2011), para. 9 (under seal); KDZ532, T. 21014 (8 November 2011) (closed session).

929 See P3773 (Witness statement of KDZ532 dated 31 October 2011), para. 9 (under seal); KDZ532, T. 2101421015 (8 November 2011) (closed session).

$930 \quad$ P3773 (Witness statement of KDZ532 dated 31 October 2011), para. 7 (under seal).

931 KDZ531, T. 15848 (1 July 2011) (closed session); P3773 (Witness statement of KDZ532 dated 31 October 2011), paras. 23, 30 (under seal); KDZ532, T. 20998-20999 (8 November 2011) (closed session); D2986 (Witness statement of Novak Todorović dated 17 February 2013), paras. 12-13; Novak Todorović, T. 34077 (20 February 2013); KDZ492, T. 20091 (18 October 2011) (closed session).

932 D1756 (Law on Military Courts, published in the RS Official Gazette, 31 December 1993), art. 67.

933 D1756 (Law on Military Courts, published in the RS Official Gazette, 31 December 1993), art. 67.

934 P6178 (Excerpt from SFRY Law on Criminal Proceedings), art. 190. Article 191(2) laid out specific conditions under which custody could be ordered against a person suspected of having committed a criminal act, where the conditions for mandatory custody did not exist. P6178 (Excerpt from SFRY Law on Criminal Proceedings), art. 191(2). See also KDZ532, T. 21019 (8 November 2011) (closed session). Custody was mandatory "if there 
could then recommend to the investigative judge that the accused be detained for one month, during which an investigation would begin, and then a panel of judges could decide to extend detention for another two months. ${ }^{936}$ For alleged criminal acts for which more than five years' sentence or a more severe penalty was prescribed, the prosecutor could next propose, to the Supreme Military Court, another three months of detention. ${ }^{937}$ During this six-month pre-trial detention, the prosecutor could propose, to the investigating judge, the termination of detention. ${ }^{938}$ The prosecutor could also propose, to the judge, to drop the case during the investigative stage. ${ }^{939}$ If the prosecutor dropped the charges by withdrawing the indictment, the court could not reinstate proceedings for the charges without the prosecutor initiating proceedings. ${ }^{940}$

306. Todorović stated that release from custody was distinct from a discontinuation of proceedings and might occur, for example, after witnesses were questioned and the risk of the suspect influencing witnesses ceased to exist. ${ }^{941}$ Persons accused of serious crimes such as murder were to remain in custody until the end of the trial. ${ }^{942}$ According to Todorović, courts had the discretion to grant a prosecutor's request for release of a person from custody. ${ }^{943}$

is founded suspicion that he has committed a criminal act for which the law prescribes the death penalty". P6178 (Excerpt from SFRY Law on Criminal Proceedings), art. 191(1).

935 P3773 (Witness statement of KDZ532 dated 31 October 2011), para. 23 (under seal). See also KDZ492, T. 20063 (18 October 2011) (closed session). Likewise, the police could detain civilians for a period of three days before they had to be taken before an investigative judge. See Mladen Tolj, T. 34632, 34647 (1 March 2013). According to Tolj, the same procedure applied to "prisoners of war". Mladen Tolj, T. 34647 (1 March 2013). See [REDACTED]; P6178 (Excerpt from SFRY Law on Criminal Proceedings), art. 197(1)-(2); [REDACTED]; D1485 (Bijeljina Military Court ruling in Cvjetković/Jurošević case, 20 November 1992); D1800 (Banja Luka Military Court's Ruling, 24 August 1995) (under seal). The same procedures appear to have been used in the civilian courts. See, e.g., P2905 (Decision of Bijeljina Lower Court, 28 August 1992), p. 2. P3773 (Witness statement of KDZ532 dated 31 October 2011), para. 23 (under seal); P6178 (Excerpt from SFRY Law on Criminal Proceedings), art. 197(2).

938 P3773 (Witness statement of KDZ532 dated 31 October 2011), para. 23 (under seal); KDZ492, T. 20064 (18 October 2011) (closed session). See also P6178 (Excerpt from SFRY Law on Criminal Proceedings), art. 198.

939 P3773 (Witness statement of KDZ532 dated 31 October 2011), para. 23 (under seal); D2986 (Witness statement of Novak Todorović dated 17 February 2013), para. 13. See P3616 (Proposal of the Military Prosecutor's Office attached to the $1^{\text {st }}$ Krajina Corps, 29 July 1993); Novak Todorović, T. 34073-34074 (20 February 2013).

940 [REDACTED]. See also D1894 (Ruling of RS Military Court, Banja Luka, 27 May 1993); [REDACTED].

941 D2986 (Witness statement of Novak Todorović dated 17 February 2013), para. 14. See also KDZ532, T. 20997 (8 November 2011) (closed session) (stating that lower-ranking commanders would request that soldiers detained for alleged crimes be released and sent back to their units and their criminal liability be determined at a later point in time).

942 D2986 (Witness statement of Novak Todorović dated 17 February 2013), para. 14.

943 Novak Todorović, T. 34074-34075 (20 February 2013); D2986 (Witness statement of Novak Todorović dated 17 February 2013), para. 14. 
307. According to KDZ532, all military organs had an obligation to report every criminal act to the military prosecutor, and failure to report a crime for which more than five years' imprisonment was prescribed would itself constitute a criminal act. ${ }^{944}$ The Law on Military Courts stated:

Every superior officer is obligated to take steps to prevent the person who has committed an act which is subject to criminal prosecution from hiding or fleeing, to preserve the traces of the crime and items which may serve as evidence, and to collect all information which may prove useful for the proceedings. The superior officer is obliged to inform the military prosecutor, directly or through a higher-ranking officer, of the criminal offence. $^{945}$

308. The 1992 Guidelines for the Establishment of Criteria for Criminal Prosecution of the Military Prosecutor's Office of the VRS Main Staff explained the specific provisions of the Criminal Code relevant to the category of crimes against humanity and violations of international law and specific acts which entailed criminal responsibility. ${ }^{946}$ The Guidelines spoke of the responsibility of VRS officers, as individuals in commanding positions and whose subordinates are capable of, or are, committing some of the crimes, to deal with and prevent such conduct. ${ }^{947}$ The Guidelines also discussed the corresponding duty of officers to write reports on all cases possibly qualifying as crimes against humanity and to submit them to the command. ${ }^{948}$ The commands would then be responsible for informing the military prosecutor's office, which would then 'take the appropriate steps prescribed by law and the policy on prosecution". ${ }^{949}$ The Guidelines stated that all the commands must, inter alia, "work on uncovering all cases of war crimes against humanity and international law in the territories and zones of their responsibility", "inform the nearest military police, security and military judicial organs of the discovered crime", and secure the crime scene until the aforementioned organs arrived to conduct the on-site investigation. ${ }^{950}$

c. Policies and orders relating to the rule of law and crimes

309. On 13 June 1992, the Accused as President of the SerBiH Presidency issued an order that in an armed conflict the VRS and Bosnian Serb MUP "shall apply and respect the rules of the

\footnotetext{
944 P3773 (Witness statement of KDZ532 dated 31 October 2011), paras. 9, 27 (under seal).

945 D1756 (Law on Military Courts, published in the RS Official Gazette, 31 December 1993), art. 65.

946 P3606 (Guidelines for the Establishment of Criteria for Criminal Prosecution, VRS Military Prosecutor's Office, 1992), p. 7.

947 P3606 (Guidelines for the Establishment of Criteria for Criminal Prosecution, VRS Military Prosecutor's Office, 1992), p. 8.

948 P3606 (Guidelines for the Establishment of Criteria for Criminal Prosecution, VRS Military Prosecutor's Office, 1992), p. 8.

949 P3606 (Guidelines for the Establishment of Criteria for Criminal Prosecution, VRS Military Prosecutor's Office, 1992), p. 8.

950 P3606 (Guidelines for the Establishment of Criteria for Criminal Prosecution, VRS Military Prosecutor's Office, 1992), p. 9.
} 
international law of war". ${ }^{951}$ The order stated that commanders of all units, as well as each member of the army or other armed formation who takes part in combat activities, were responsible for the application of the rules. ${ }^{952}$ The order further stated that it was the duty of the competent superior officer to initiate proceedings for legal sanctions against individuals who violate the rules. ${ }^{953}$ In accordance with the 13 June 1992 order, Bogdan Subotić as Minister of Defence, prepared and issued instructions on the treatment of captured persons. ${ }^{954}$ Early in the summer of 1992, the Accused issued an order to all local civilian and police authorities regarding the authority of ICRC delegates to visit all prisons and included a statement that any soldier who did not comply with the instructions would be punished. ${ }^{955}$

310. On 19 August 1992, the Accused issued an order addressed to the VRS Main Staff, MUP, and all CSBs, and with reference to the 13 June 1992 order, that all actors carry out their obligation to observe international humanitarian law, especially the Third and Fourth Geneva Conventions. ${ }^{956}$ The order issued the general instruction that "[i]n case of any suspicion or sign that international humanitarian rights have been violated, all organs of the Army and Police shall conduct energetic investigation in the zone of responsibility". 957

311. On 4 January 1995, the Accused as RS President promulgated the Law on the Mandatory Submission of Information on Crimes against Humanity and International Law, which the Bosnian Serb Assembly had passed at its session on 29 to 30 December $1994 .^{958}$ The law required that anyone in possession of information that could serve as evidence of "crimes against humanity and international law committed during the internal armed conflicts and civil war in [RS] and other parts of the former [BiH] which began in 1992" make the information available for inspection and, if necessary, submit them to the body in charge of gathering information on such crimes. ${ }^{959}$

951 D434 (Radovan Karadžić's Order on the application of laws of war, 13 June 1992).

952 D434 (Radovan Karadžić's Order on the application of laws of war, 13 June 1992).

953 D434 (Radovan Karadžić's Order on the application of laws of war, 13 June 1992).

954 P1134 (Ministry of Defence of SerBiH Instructions on the Treatment of Captured Persons, 13 June 1992); D434 (Radovan Karadžić's Order on the application of laws of war, 13 June 1992). See also D3695 (Witness statement of Bogdan Subotić dated 16 June 2013), paras. 191-192.

955 D477 (Order of SerBiH Presidency, undated); Momčilo Mandić, T. 5271-5273 (15 July 2010).

956 D101 (Radovan Karadžić's Order to VRS Main Staff and RS MUP, 19 August 1992), pp. 1-2.

957 D101 (Radovan Karadžić's Order to VRS Main Staff and RS MUP, 19 August 1992), p. 2.

958 D1424 (Radovan Karadžić's Decree on promulgation of Law on mandatory submission of information on crimes against humanity and international law, 4 January 1995), p. 1; P1405 (Transcript of $48^{\text {th }}$ session of RS Assembly, 29-30 December 1994), p. 129.

959 D1424 (Radovan Karadžić's Decree on promulgation of Law on mandatory submission of information on crimes against humanity and international law, 4 January 1995), p. 2. The Law also stated that anyone who refused to do so or thwarted the delivery or availability for inspection of such information would be punished with either a fine or maximum one year's imprisonment. D1424 (Radovan Karadžić's Decree on promulgation 


\section{E. INTERNATIONAL PEACE NEGOTIATIONS}

312. From 1991 until the end of 1995 , there were numerous attempts made by the international community to broker a negotiated peace settlement in $\mathrm{BiH}$. Over the course of four years, talks were held in various cities across Europe and a number of cease-fires were agreed upon. However, it was only with the Dayton Agreement signed on 14 December 1995 that peace was formally established in $\mathrm{BiH}$.

\section{European Community Peace Conference on Yugoslavia}

313. The EC Peace Conference on Yugoslavia began its work in the summer of 1991 under the chairmanship of Lord Peter Carrington, the former Foreign Minister of the UK. ${ }^{960}$ The conference included representatives from the six former Yugoslav republics and the government of the SFRY. ${ }^{961}$ The conference met intermittently in The Hague, Brussels, Lisbon, and London. ${ }^{962}$ Its mission was to achieve a peaceful settlement of the conflict, including the peaceful separation of the republics of the SFRY. ${ }^{963}$

314. On 1 October 1991, as a result of the EC efforts, a multi-national monitoring mission in $\mathrm{BiH}$, the ECMM, was established. ${ }^{964}$ The ECMM had the goal of securing a cease-fire between parties to the conflict by deploying teams of different nationalities to start a dialogue with the military commanders on both sides. ${ }^{965}$

315. In October 1991, Carrington proposed a plan, developed by the conference, which allowed for the peaceful separation of all the republics of the SFRY. ${ }^{966}$ Slovenia, Croatia, SRBiH, Macedonia, and Montenegro agreed, but Serbia rejected the plan. ${ }^{967}$ Cyrus Vance, Special Envoy

of Law on mandatory submission of information on crimes against humanity and international law, 4 January 1995), p. 4.

960 Herbert Okun, T. 1470-1471 (22 April 2010); Herbert Okun, P776 (Transcript from Prosecutor v. Krajišnik), T. 4139; P919 (ECMM Brief on HOM's visit to BiH, 20 February 1992), e-court pp. 10-15; P6513 (Press release on Yugoslavia Peace Conference, 7 September 1991).

961 Herbert Okun, P776 (Transcript from Prosecutor v. Krajišnik), T. 4139.

962 Herbert Okun, P776 (Transcript from Prosecutor v. Krajišnik), T. 4140; P6513 (Press release on Yugoslavia Peace Conference, 7 September 1991); D3015 (Witness statement of Vladislav Jovanović dated 22 February 2013), paras. 26, 30.

963 Herbert Okun, P776 (Transcript from Prosecutor v. Krajišnik), T. 4139, 4141.

964 P919 (ECMM Brief on HOM's visit to BiH, 20 February 1992), e-court pp. 10-15.

965 Charles McLeod, P712 (Transcript from Prosecutor v. Brđanin) (specifying that once dialogue had been established, the goal was to enact confidence building measures and humanitarian actions), T. 7281; P919 (ECMM Brief on HOM's visit to BiH, 20 February 1992), e-court pp. 10-15.

966 Herbert Okun, P776 (Transcript from Prosecutor v. Krajišnik), T. 4139, 4141.

967 Herbert Okun, P776 (Transcript from Prosecutor v. Krajišnik), T. 4141. 
to the Secretary General, and Ambassador Herbert Okun, his special advisor, attended some of the meetings of the conference as representatives of the Secretary General. ${ }^{968}$

\section{Vance Plan}

316. In January 1992, a cease-fire with respect to the conflict in Croatia was signed by the parties under the authority of the UN. ${ }^{969}$ In accordance with the cease-fire, a plan was presented by Vance, which called for the creation of UN Protected Areas in Croatia and the establishment of UNPROFOR. ${ }^{970}$ The Vance Plan had three main points, namely (i) the establishment of UNPROFOR to facilitate the demobilisation and demilitarisation of the UN Protected Areas; (ii) the deployment of a local police force for the maintenance of law and order in areas that had been demilitarised under the supervision of UNPROFOR; and (iii) the creation of safe conditions for the voluntary return of all displaced persons. ${ }^{971}$

\section{a. UNPROFOR}

317. On 21 February 1992, the Security Council passed Resolution 743 which established UNPROFOR. ${ }^{972}$ Its mandate was to assist in the implementation of the Vance Plan. ${ }^{973}$ On 13 March 1992, UNPROFOR headquarters was established in Sarajevo because the city was perceived as a neutral location at that time. ${ }^{974}$ Teams of UNPROFOR personnel were tasked with monitoring the UN Protected Areas in Croatia, which were to be demilitarised in accordance with the Vance Plan. ${ }^{975}$ The duties of UNPROFOR also included protecting civilians residing in those areas and assisting humanitarian agencies in carrying out their functions. ${ }^{976}$ UNPROFOR members

\footnotetext{
968 Herbert Okun, P776 (Transcript from Prosecutor v. Krajišnik), T. 4139. John Wilson, the former chief of the UNMOs, was appointed as military adviser to Vance and UNPROFOR liaison officer to the ICFY in December 1992. P1029 (Witness statement of John Wilson dated 4 November 2008), paras. 6, 8; P1046 (John Wilson's Report to Australian Army, 15 November 1992), p. 9.

969 P753 (Vance Plan), e-court p. 4; P4203 (Witness statement of Pyers Tucker dated 12 May 2010), para. 9; P2284 (UNSG report entitled "The Fall of Srebrenica", 15 November 1999), paras. 11, 13.

970 P753 (Vance Plan), e-court p. 4; P4203 (Witness statement of Pyers Tucker dated 12 May 2010), para. 9; P2284 (UNSG report entitled "The Fall of Srebrenica", 15 November 1999), paras. 11, 13.

971 P3804 (Witness statement of Charles Kirudja dated 17 November 2010), paras. 5-7.

972 P2284 (UNSG report entitled "The Fall of Srebrenica", 15 November 1999), para. 14.

973 P2284 (UNSG report entitled "The Fall of Srebrenica", 15 November 1999), para. 14.

974 P2284 (UNSG report entitled "The Fall of Srebrenica", 15 November 1999), para. 14; P753 (Vance Plan), ecourt p. 5; P4203 (Witness statement of Pyers Tucker dated 12 May 2010), para. 9; P3804 (Witness statement of Charles Kirudja dated 17 November 2010), para. 21.

975 P753 (Vance Plan), e-court p. 5; P2538 (Patrick Treanor's research report entitled "Radovan Karadžić and the Serbian Leadership 1990-1995", 1 May 2009), paras. 84, 92.

976 P753 (Vance Plan), e-court p. 5; P1638 (Witness statement of Michael Rose dated 26 March 2009), para. 20. On 8 June 1992, with Resolution 758, the Security Council enlarged the mandate and strength of UNPROFOR. See Adjudicated Fact 9. On 29 June 1992, Security Council Resolution 761 tasked UNPROFOR with protecting Sarajevo airport and assisting with its functioning. See Adjudicated Fact 10. In September 1992,
} 
patrolling the UN Protected Areas were lightly armed; they established check-points on roads, searching vehicles and individuals entering the UN Protected Areas so that no weapons, ammunition, or military equipment would be brought in. ${ }^{977}$

318. Although UNPROFOR was initially established for Croatia, its mandate was expanded to include BiH in June 1992. ${ }^{978}$ UNPROFOR headquarters, initially established in Sarajevo, was moved to Zagreb, and in turn UNPROFOR BiH Command was established in Sarajevo. ${ }^{979}$ The Commanders of UNPROFOR BiH Command were Generals Philippe Morillon, Francis Briquemont, Michael Rose, and Rupert Smith, successively. ${ }^{980}$ BiH Command included Sector Sarajevo, Sector Northeast, and Sector Southwest. ${ }^{981}$ There was a UN Civil Affairs component also posted with UNPROFOR BiH Command in Sarajevo. ${ }^{982}$ In March 1995, the Security Council restructured UNPROFOR, placing its headquarters in Zagreb under the overall command and control of the Special Representative of the Secretary General, Yasushi Akashi. ${ }^{983}$ UNPROFOR

UNPROFOR's mandate was broadened by Security Council Resolution 776 to include the protection of humanitarian aid convoys. See Adjudicated Fact 12.

$977 \quad$ P753 (Vance Plan), e-court p. 5.

978 John Wilson, T. 3913-3914 (21 June 2010); P820 (Witness statement of David Harland dated 4 September 2009), para. 9. See also P937 (UNSG Report re peacekeeping operation in BiH, 12 May 1992), p. 4. An initial deployment of "UNPROFOR military observers" went to four locations in 1 May 1992: Medjugorja, Mostar, Stolac, and Trebinje. P937 (UNSG Report re peacekeeping operation in BiH, 12 May 1992), p. 4.

979 P820 (Witness statement of David Harland dated 4 September 2009), paras. 7-9; P3804 (Witness statement of Charles Kirudja dated 17 November 2010), paras. 2, 21; P1258 (Witness statement of Hussein Ali Abdel-Razek dated 16 July 2002), e-court p. 3; P1638 (Witness statement of Michael Rose dated 26 March 2009), para. 12; P1029 (Witness statement of John Wilson dated 4 November 2008), para. 64. A UN report dated 12 May 1992 states that for "operational and security" reasons, UNPROFOR's headquarters should be relocated from Sarajevo. P937 (UNSG Report re peacekeeping operation in BiH, 12 May 1992), p. 13. From 18 May until 25 June 1992, UNPROFOR headquarters relocated to Belgrade. It was then relocated to Zagreb on 31 July 1992. P1046 (John Wilson's Report to Australian Army, 15 November 1992), p. 3; P1029 (Witness statement of John Wilson dated 4 November 2008), paras. 7, 64. UNPROFOR BiH Command was directly subordinated to UNPROFOR headquarters in Zagreb. P820 (Witness statement of David Harland dated 4 September 2009), para. 9.

P820 (Witness statement of David Harland dated 4 September 2009), para. 9; P1638 (Witness statement of Michael Rose dated 26 March 2009), paras. 5, 13, 195; Rupert Smith, T. 11296-11298 (8 February 2011). See also P1762 (Witness statement of David Fraser dated 17 October 2010), p. 5; P1029 (Witness statement of John Wilson dated 4 November 2008), para. 105.

981 P820 (Witness statement of David Harland dated 4 September 2009), para. 10; P1638 (Witness statement of Michael Rose dated 26 March 2009), para. 12; Rupert Smith, T. 11298 (8 February 2011); P1649 (Map of BiH). Harland states that Bihać was added later to UNPROFOR BiH Command. P820 (Witness statement of David Harland dated 4 September 2009), para. 10. Commanders of each of the Sectors were directly subordinated to UNPROFOR BiH Command. P820 (Witness statement of David Harland dated 4 September 2009), para. 11.

P820 (Witness statement of David Harland dated 4 September 2009), paras. 10-11; P1638 (Witness statement of Michael Rose dated 26 March 2009), para. 15. From May 1993, David Harland was a Civil Affairs Officer at UNPROFOR BiH Command working under Victor Andreev, the Civil Affairs Co-ordinator. In January 1995, Harland became the head of Civil Affairs for UNPROFOR Sector Sarajevo and in August 1995, he became the Political Adviser to UNPROFOR BiH Commander General Smith. P820 (Witness statement of David Harland dated 4 September 2009), paras. 5, 12.

983 P2284 (UNSG report entitled "The Fall of Srebrenica", 15 November 1999), para. 182. UNPROFOR was restructured with three separate missions in Croatia, $\mathrm{BiH}$, and Macedonia and collectively referred to as the United Nations Peace Force. P2284 (UNSG report entitled "The Fall of Srebrenica", 15 November 1999), para. 182. Akashi was appointed Special Representative of the Secretary General in January 1994. Yasushi Akashi, 
$\mathrm{BiH}$ Command remained headquartered in Sarajevo and reported to UNPROFOR Force Command in Zagreb. ${ }^{984}$

319. Sector Sarajevo included the city of Sarajevo, the DMZ, the TEZ of Mt. Igman, and Žepa. ${ }^{985}$ The Sector Sarajevo headquarters was located in the PTT Engineering Building in Alipašino Polje. ${ }^{986}$ The Commanders of UNPROFOR Sector Sarajevo included Major-Generals Lewis MacKenzie and Hussein Abdel Razek, and Generals Andre Soubirou, Hervé Gobilliard, and JeanRené Bachelet successively. ${ }^{987}$ In Sector Sarajevo, UNPROFOR troops were mainly from France, Russia, Ukraine, and Egypt. ${ }^{988}$ In 1992, Sector Sarajevo had three battalions; by 1994, this was increased to six battalions and one detachment in charge of the Sarajevo airport. ${ }^{989}$ UNPROFOR's responsibilities in Sarajevo included monitoring the DMZ and the TEZ, and reporting any incoming or outgoing fire. ${ }^{990}$ The UNPROFOR teams were also tasked with escorting UNHCR convoys into

T. 37665 (24 April 2013). See also P2284 (UNSG report entitled "The Fall of Srebrenica”, 15 November 1999), para. 44; P820 (Witness statement of David Harland dated 4 September 2009), para. 8. 
the city and overseeing the supply of water, gas, and electricity in Sarajevo. ${ }^{991}$ Sector Sarajevo had liaison officers for both parties to the conflict; one liaison officer at the SRK and one at the $1^{\text {st }}$ Corps of the $\mathrm{ABiH}$, both of them would report directly to the Sector Sarajevo UNPROFOR Commander. ${ }^{992}$ Milenko Inđić was the VRS liaison officer to UNPROFOR. ${ }^{993}$ There was also an ABiH liaison officer posted at the PTT building. ${ }^{994}$

\section{b. UNMO}

320. The Vance Plan also established UNMOs for the purpose of monitoring the demilitarisation of the UN Protected Areas and reporting any cease-fire agreement violations. ${ }^{995}$ Generally, their tasks included patrolling areas, liaising with local authorities and parties to the conflict, as well as monitoring and reporting any disturbances. ${ }^{996}$ UNMOs were unarmed and mainly acted as mediators. ${ }^{997}$ They also provided support to humanitarian operations conducted by UNHCR and other humanitarian agencies. ${ }^{998}$ The UNMOs were deployed in BiH in early June $1992 .{ }^{999}$ In July 1992, the UNMO headquarters was moved to Zagreb. ${ }^{1000}$

321. UNMO and UNPROFOR were two distinct organisations with different functions; however at each level within UNPROFOR, there was an UNMO office which was co-located. ${ }^{1001}$ For

$991 \quad$ P2447 (Witness statement of KDZ182 dated 8 March 2011), p. 4.

P2447 (Witness statement of KDZ182 dated 8 March 2011), p. 10

993 Milenko Inđić, T. 32414-32415, 32428-32429 (22 January 2013), T. 32600-32601 (24 January 2013); D2774 (Witness statement of Milenko Inđić dated 19 January 2013), paras. 39, 41-44, 54; P1762 (Witness statement of David Fraser dated 17 October 2010), p. 8; P2117 (Witness statement of Marcus Helgers dated 3 August 1995), p. 3. Inđic stated that the liaison office moved from the PTT building to Lukavica barracks. D2774 (Witness statement of Milenko Inđić dated 19 January 2013), paras. 46-51.

994 D2774 (Witness statement of Milenko Inđić dated 19 January 2013), paras. 48-49.

995 P753 (Vance Plan), e-court p. 6; John Wilson, T. 3913 (21 June 2010); P1029 (Witness statement of John Wilson dated 4 November 2008), para. 35; P4140 (Witness statement of Joseph Kingori dated 8 January 2002), para. 4. Security Council Resolution 743 provided for the UNMOs to patrol limited areas in $\mathrm{BiH}$ after the demilitarisation of the UN Protected Areas in Croatia. P2284 (UNSG report entitled "The Fall of Srebrenica", 15 November 1999), para. 14.

996 P753 (Vance Plan), e-court p. 5; John Wilson, T. 3913 (21 June 2010); P1029 (Witness statement of John Wilson dated 4 November 2008), para. 35; P2170 (Witness statement of Patrick Rechner dated 31 January 2011), para. 7; P1558 (Witness statement of Francis Roy Thomas dated 13 May 2009), para. 29.

997 P753 (Vance Plan), e-court p. 5; P4140 (Witness statement of Joseph Kingori dated 8 January 2002), para. 5; P1558 (Witness statement of Francis Roy Thomas dated 13 May 2009), para. 27.

998 P1426 (Witness statement of Richard Mole dated 7 May 2010), p. 10; P4140 (Witness statement of Joseph Kingori dated 8 January 2002), para. 4; P1558 (Witness statement of Francis Roy Thomas dated 13 May 2009), para. 19.

999 P981 (UNSC Resolution 758, 8 June 1992). See also Adjudicated Fact 9.

1000 P1046 (John Wilson's Report to Australian Army, 15 November 1992), para. 10; P1029 (Witness statement of John Wilson dated 4 November 2008), para. 7. Prior to this, on 24 June 1992, UNMO headquarters was relocated from Sarajevo to Belgrade. P1029 (Witness statement of John Wilson dated 4 November 2008), para. 93.

1001 Patrick Rechner, T. 11146 (2 February 2011). See also P1638 (Witness statement of Michael Rose dated 26 March 2009), para. 18 (stating that UNMOs were indepedendent of UNPROFOR and reported directly to the UN headquarters in New York via Zagreb). 
instance, the UNMO main headquarters was co-located with the UNPROFOR headquarters in Zagreb. ${ }^{1002}$ The UNMO reporting system utilised both daily situation reports to headquarters and incident reports. ${ }^{1003}$ Daily reports were sent to the Chief UNMO in Zagreb, copying UNPROFOR BiH Command. ${ }^{1004}$ The UNMO senior military observer would attend the Sector Command briefing meetings with the UNPROFOR Sector Commander and other UNPROFOR staff. ${ }^{1005}$

322. In Sector Sarajevo, the UNMOs were commanded by senior military observers, including Richard Gray, Richard Mole, and Francis Roy Thomas, successively. ${ }^{1006}$ The UNMOs had accommodations provided to them by the Bosnian Muslims in the Presidency Building and by the SRK in the Lukavica barracks. ${ }^{1007}$ The UNMOs also had an operations room and staff stationed at the PTT building with direct access to UNPROFOR Sector Sarajevo Command and UNPROFOR BiH Command. ${ }^{1008}$ The UNMOs in Sector Sarajevo were divided into two groups, positioned on opposite sides of the confrontation lines. ${ }^{1009}$ One group of UNMOs was posted within the city, in the territory controlled by the Bosnian Muslims, which was designated as the "Papa" side. ${ }^{1010}$ The other group of UNMOs was stationed in the Bosnian Serb-controlled territory around the city,

1002 P1046 (John Wilson's Report to Australian Army, 15 November 1992), para. 10.

1003 P1029 (Witness statement of John Wilson dated 4 November 2008), paras. 18, 22. See also P1426 (Witness statement of Richard Mole dated 7 May 2010), paras. 24-27; P1558 (Witness statement of Francis Roy Thomas dated 13 May 2009), para. 36; John Hamill, P1994 (Transcript from Prosecutor v. Galić), T. 6127.

1004 P1426 (Witness statement of Richard Mole dated 7 May 2010), para. 27. In addition to daily reports, a monthly report summarising the events of the month would also be prepared and sent accordingly. P1426 (Witness statement of Richard Mole dated 7 May 2010), paras. 27, 101. See, e.g., P1433 (UNMO report for October 1992); P1434 (UNMO report for November 1992); P1429 (UNMO report for December 1992).

1005 P1258 (Witness statement of Hussein Ali Abdel-Razek dated 16 July 2002), e-court p. 14.

1006 P1029 (Witness statement of John Wilson dated 4 November 2008), para. 4; P1558 (Witness statement of Francis Roy Thomas dated 13 May 2009), para. 13. Mole served from September to December 1992. P1426 (Witness statement of Richard Mole dated 7 May 2010), para. 3. Thomas served from October 1993 to July 1994. His predecessor was Lieutenant Colonel Kukkola (for four months) and his successor was Major Skov (for two months). P1558 (Witness statement of Francis Roy Thomas dated 13 May 2009), para. 13.

1007 P1426 (Witness statement of Richard Mole dated 7 May 2010), para. 7; John Hamill, P1994 (Transcript from Prosecutor v. Galić), T. 6068-6069. UNMOs also had a liaison officer for the ABiH and SRK. John Hamill, P1994 (Transcript from Prosecutor v. Galić), T. 6066-6067.

1008 P1426 (Witness statement of Richard Mole dated 7 May 2010), para. 7.

1009 P1426 (Witness statement of Richard Mole dated 7 May 2010), para. 5. See also P1557 (UNMO map of confrontation line in Sarajevo, February 1994); P1567 (Map of Sarajevo marked by Francis Roy Thomas). In 1992, there were approximately 60 UNMOs in Sector Sarajevo. P1426 (Witness statement of Richard Mole dated 7 May 2010), para. 5. UNMOs within Sector Sarajevo also included those posted in Žepa and Goražde. P1558 (Witness statement of Francis Roy Thomas dated 13 May 2009), paras. 16-19.

1010 P1426 (Witness statement of Richard Mole dated 7 May 2010), para. 5. See also P1557 (UNMO map of confrontation line in Sarajevo, February 1994); P1431 (Map of Sarajevo showing UNMO positions). The number of OPs on the Papa and the Lima sides changed during the conflict. By October 1992, there were 10 OPs on the Lima side and four on the Papa side and by end of November 1992, there were 11 OPs on the Lima side and three on the Papa side. Richard Mole, T. 5805-5806 (17 August 2011). See also Adjudicated Fact 16. In October 1993, there were six OPs on the Papa side and seven OPs on the Lima side. The UNMO structure changed again by June and July 1994. P1558 (Witness statement of Francis Roy Thomas dated 13 May 2009), paras. 17-18, 21, 24-25; P1557 (UNMO map of confrontation line in Sarajevo, February 1994); P1565 (UNMO map of confrontation line in Sarajevo, 21 February 1994); P1566 (UNMO map of confrontation line in Sarajevo, 21 April 1994). 
designated as the "Lima" side. ${ }^{1011}$ The UNMOs' tasks in Sarajevo included monitoring weapons sites, reporting heavy weapons activity to UN headquarters in New York, and facilitating in the delivery of humanitarian aid. ${ }^{1012}$ The UNMOs at the OPs monitored weapons and conducted observation patrols around the area. ${ }^{1013}$

323. Following the established procedure described above, each UNMO team in Sector Sarajevo was required to submit a daily situation report to the "Papa" or "Lima" team leader. ${ }^{1014}$ This report was then consolidated into an "UNMO Sarajevo sitrep" sent at 6 p.m. to the UNMO chief military officer in Zagreb and copied to Sector Sarajevo. ${ }^{1015}$ In June 1994, the UNMOs in Sector Sarajevo were reorganised into 17 OPs and their areas of responsibility were divided into five districts, allowing each of the UNMO teams to work with both the Bosnian Muslims and the Bosnian Serbs within each district. ${ }^{1016}$

\section{Cutileiro and Sarajevo Plan}

324. In January 1992, Portugal took over the EC Presidency and, the following month, Ambassador José Cutileiro was appointed as the chairman of the talks on the Future Constitutional Arrangements for BiH. ${ }^{1017}$ The talks were held in Sarajevo, Brussels, and Lisbon. ${ }^{1018}$

1011 P1426 (Witness statement of Richard Mole dated 7 May 2010), para. 5; P1558 (Witness statement of Francis Roy Thomas dated 13 May 2009), para. 19. See also P1557 (UNMO map of confrontation line in Sarajevo, February 1994).

1012 P1426 (Witness statement of Richard Mole dated 7 May 2010), para. 11; John Hamill, P1994 (Transcript from Prosecutor v. Galić), T. 6062. See also Adjudicated Fact 2779. By 1993, UNMO teams were deployed to Goražde, Tuzla, Bihać, Žepa, and Srebrenica. P1558 (Witness statement of Francis Roy Thomas dated 13 May 2009), para. 16; P2284 (UNSG report entitled "The Fall of Srebrenica", 15 November 1999), para. 67; see also paras. 4966-4971. In addition to their regular activities, on the Papa side, UNMOs were responsible for investigating "activity", when requested by Thomas. P1558 (Witness statement of Francis Roy Thomas dated 13 May 2009), para. 19.

1013 P1426 (Witness statement of Richard Mole dated 7 May 2010), para. 13.

1014 P1558 (Witness statement of Francis Roy Thomas dated 13 May 2009), para. 39. See also para. 321.

1015 P1558 (Witness statement of Francis Roy Thomas dated 13 May 2009), para. 40. Any information that came after the issuance of the "UNMO Sarajevo sitrep" would be in a supplemental situation report. P1558 (Witness statement of Francis Roy Thomas dated 13 May 2009), para. 39. An UNMO liaison officer was permanently attached to the UNPROFOR Sector Sarajevo headquarters and provided information from the UNMO reports to UNPROFOR. P2119 (Witness statement of KDZ450 dated 17 January 2011), p. 7 (under seal).

1016 P1558 (Witness statement of Francis Roy Thomas dated 13 May 2009), paras. 24-25.

1017 D2968 (Witness statement of Jose Cutileiro dated 11 April 2012), para. 3; Herbert Okun, P776 (Transcript from Prosecutor v. Krajišnik), T. 4318-4139; Momčilo Krajišnik, T. 43218 (7 November 2013); D3015 (Witness statement of Vladislav Jovanović dated 22 February 2013), para. 37; P2538 (Patrick Treanor's research report entitled "Radovan Karadžić and the Serbian Leadership 1990-1995", 1 May 2009), para. 109.

1018 D2968 (Witness statement of Jose Cutileiro dated 11 April 2012), paras. 5-17; Herbert Okun, P776 (Transcript from Prosecutor v. Krajišnik), T. 4320; Colm Doyle, P918 (Transcript from Prosecutor v. S. Milošević), T. 25259-25260; D4484 (Cryptofax from Cyrus Vance to de Soto, 5 March 1992), paras. 4, 8; P2538 (Patrick Treanor's research report entitled "Radovan Karadžić and the Serbian Leadership 1990-1995”, 1 May 2009), para. 111. 
325. On 23 February 1992, the conference proposed a new plan, entitled the Statement of Principles for New Constitutional Arrangements for BiH, also known as the Lisbon Agreement or Cutileiro Plan. ${ }^{1019}$ The plan called for an independent and geographically continuous BiH, comprised of the three constituent units that represented the Bosnian Muslims, Bosnian Croats, and Bosnian Serbs. ${ }^{1020}$ The plan set forth constitutional principles for $\mathrm{BiH}$ and proposed the structure of the Assembly and government of $\mathrm{BiH} .{ }^{1021}$ The Cutileiro Plan did not grant territorial continuity to SerBiH nor did it establish a corridor linking Serbia to the Krajina region. ${ }^{1022}$ Furthermore, the Cutileiro Plan did not call for the physical division of Sarajevo into Bosnian Muslim and Bosnian Serb parts of the city. ${ }^{1023}$ On 25 February 1992, the Accused summarised the outcome of the talks at a session of the Bosnian Serb Assembly and stated that the Bosnian Serbs had agreed to the three main principles, namely that $\mathrm{BiH}$ would (i) be an independent state, (ii) maintain its present borders; and (iii) consist of three constituent parts. ${ }^{1024}$

326. On 18 March 1992, a Statement of Principles, referred to as the Sarajevo Plan, was agreed upon by the three parties as the basis for further negotiations. ${ }^{1025}$ The agreement was a refinement

1019 Herbert Okun, P776 (Transcript from Prosecutor v. Krajišnik), T. 4320-4321; P798 (Statement of Principles, Lisbon Agreement, 23 February 1992).

1020 Herbert Okun, P776 (Transcript from Prosecutor v. Krajišnik), T. 4195; P798 (Statement of Principles, Lisbon Agreement, 23 February 1992), p. 1; D4484 (Cryptofax from Cyrus Vance to de Soto, 5 March 1992), p. 2; P2538 (Patrick Treanor's research report entitled "Radovan Karadžić and the Serbian Leadership 1990-1995", 1 May 2009), para. 111.

1021 P798 (Statement of Principles, Lisbon Agreement, 23 February 1992); Herbert Okun, P776 (Transcript from Prosecutor v. Krajišnik), T. 4195; D4484 (Cryptofax from Cyrus Vance to de Soto, 5 March 1992), p. 2.

1022 Herbert Okun, P776 (Transcript from Prosecutor v. Krajišnik), T. 4195. According to Okun, the political objectives of the Bosnian Serbs were the following: (i) the establishment of a separate state called the RS, (ii) the RS would have continuous territory and be connected with Serbia, (iii) the RS would be ethnically homogeneous, (iv) the RS would have a special relationship with Serbia, (v) Sarajevo would be divided into a Bosnian Serb and Bosnian Muslim section, and (vi) the RS would have veto power over any residual powers held by the central BiH government. Herbert Okun, T. 1474-1475 (22 April 2010); Herbert Okun, P776 (Transcript from Prosecutor v. Krajišnik), T. 4157-4158. Okun also testified that the Accused would make references to the genocide suffered by the Bosnian Serbs during the Second World War and that the Bosnian Serbs had a right to reclaim the land they lost during the war. Herbert Okun, T. 1489-1490 (22 April 2010); Herbert Okun, P776 (Transcript from Prosecutor v. Krajišnik), T. 4166-4167, 4370.

1023 Herbert Okun, P776 (Transcript from Prosecutor v. Krajišnik), T. 4196.

1024 See D88 (Shorthand Record of $8^{\text {th }}$ session of SerBiH Assembly, 25 February 1992), pp. 5-12, 16-20; P798 (Statement of Principles, Lisbon Agreement, 23 February 1992). Krajišnik testified that the Strategic Goals, later presented by the Accused at the $16^{\text {th }}$ session of the Bosnian Serb Assembly, were not military goals but were actually requests put by the Bosnian Serbs to Cutileiro. Momčilo Krajišnik, T. 43768-43771 (19 November 2013).

1025 P782 (Statement of Principles, Sarajevo Agreement, 18 March 1992); D2968 (Witness statement of Jose Cutileiro dated 11 April 2012), para. 10. Negotiations were held in Sarajevo on 27 February 1992, in Brussels on 7 March 1992, and again in Sarajevo on 16-18 March 1992. D2968 (Witness statement of Jose Cutileiro dated 11 April 2012), paras. 5, 7, 9; D4484 (Cryptofax from Cyrus Vance to de Soto, 5 March 1992), p. 2. See, e.g., P952 (Letter from Jose Cutileiro to Radovan Karadžić, 12 June 1992), D2975 (Letter from Radovan Karadžić to Jose Cutileiro, 13 June 1992), D2981 (Letter from Jose Cutileiro to The Economist, undated), D2980 (Article from International Herald Tribune entitled "Vance and Owen Got It Right", 16 February 1993), referencing the fact that an agreement was reached on 18 March 1992. 
of the Cutileiro Plan. ${ }^{1026}$ It stated that $\mathrm{BiH}$ would be one state, "composed of three constituent units, based on national principles and taking into account economic, geographic, and other criteria", and included the respect for human rights, religious freedom, and protection of minorities. ${ }^{1027}$ Further it stated that a working group would be established to define the territory of the constituent units. ${ }^{1028}$ The map annexed to the Sarajevo Plan showed the division of BiH into the Bosnian Serb, Bosnian Muslim, and Bosnian Croat areas which represented the three constituent units. ${ }^{1029}$

327. Following the agreement, the Bosnian Serb negotiators reported back to the Bosnian Serb Assembly. ${ }^{1030}$ The new draft proposal, they explained to the deputies, aimed at a division of $\mathrm{BiH}$ into three constituent units based not only on nationality, but also on economic and geographic considerations. ${ }^{1031}$ The proposal was marked as "basis for further negotiations". ${ }^{1032}$

328. On 3 April 1992, Krajišnik, as President of the Bosnian Serb Assembly, sent a letter to Cutileiro suggesting a continuation of negotiations based on the Statement of Principles as agreed to on 18 March 1992. ${ }^{1033}$

329. As mentioned above, on 6 April 1992, the independence of $\mathrm{BiH}$ was recognised by the USA and the EC. ${ }^{1034}$ The following day, the Security Council passed Resolution 749 authorising the full deployment of UNPROFOR generally into the SFRY. ${ }^{1035}$ Five days later, a cease-fire agreement was signed by leaders of all three parties. ${ }^{1036}$ It declared an immediate and total cease-fire in BiH,

\footnotetext{
1026 Herbert Okun, P776 (Transcript from Prosecutor v. Krajišnik), T. 4320-4321.

1027 P782 (Statement of Principles, Sarajevo Agreement, 18 March 1992), p. 1; D2968 (Witness statement of Jose Cutileiro dated 11 April 2012), paras. 11, 18. See also D486 (Cutileiro Plan map, March 1992).

1028 P782 (Statement of Principles, Sarajevo Agreement, 18 March 1992), p. 3; D2968 (Witness statement of Jose Cutileiro dated 11 April 2012), paras. 13, 15.

1029 P782 (Statement of Principles, Sarajevo Agreement, 18 March 1992), pp. 4, 9. The Bosnian Serb municipalities included Bosanski Novi, Bosanska Dubica, Bosanska Gradiška, Srbac, Derventa, Modriča, Banja Luka, Laktaši, Prnjavor, Bosanski Petrovac, Ključ, Mrkonjić Grad, Skender Vakuf, Čelinac, Kotor Varoš, Teslić, Drvar, Glamoč, Šipovac, Kupres, Lopare, Ugljevik, Bijeljina, Šekovići, Ilijaš, Sarajevo (not including the city of Sarajevo), Pale, Sokolac, Han Pijesak, Čajniče, Rudo, Kalinobik, Nevesinje, Gacko, Bileća, Ljubinje, and Trebinje. D486 (Cutileiro Plan map, March 1992).

1030 D90 (Shorthand Record of $11^{\text {th }}$ session of SerBiH Assembly, 18 March 1992), pp. 6-14; Momčilo Krajišnik, T. 43252-43523 (27 November 2013). See also Adjudicated Fact 2005.

1031 D90 (Shorthand Record of $11^{\text {th }}$ session of SerBiH Assembly, 18 March 1992), p. 6; Momčilo Krajišnik, T. 43252-43523 (27 November 2013). See also Adjudicated Fact 2006.

1032 D90 (Shorthand Record of $11^{\text {th }}$ session of SerBiH Assembly, 18 March 1992), pp. 6, 32, 44; Momčilo Krajišnik, T. 43252-43523 (27 November 2013). See also Adjudicated Fact 2007.

1033 D2971 (Letter from SerBiH Assembly to Jose Cutileiro, 3 April 1992); D2968 (Witness statement of Jose Cutileiro dated 11 April 2012), para. 20.

1034 See para. 56; P2284 (UNSG report entitled "The Fall of Srebrenica”, 15 November 1999), para. 15.

1035 D227 (UNSC Resolution 749, 7 April 1992). See para. 317.

1036 P947 (Cease-fire Agreement, 12 April 1992); Colm Doyle, P918 (Transcript from Prosecutor v. S. Milošević), T. 25283-25284.
} 
including in Sarajevo, starting at midnight on 12 April 1992. ${ }^{1037}$ It stipulated that artillery should be removed and placed under the control of EC monitors. ${ }^{1038}$ Six days later, the Sarajevo RTV building was hit by mortar fire. ${ }^{1039}$ On 23 April 1992, Carrington, Cutileiro, Doyle, Izetbegović, the Accused, and Koljević met at the Sarajevo airport and reaffirmed the 12 April cease-fire agreement. $^{1040}$ Despite this, the UN reported that the cease-fire "has proved impossible to implement". 1041

330. On 1 May 1992, Cutileiro suspended the scheduled peace talks until 13 May because of the parties' failure to honour the cease-fire agreement. ${ }^{1042}$ On 11 May 1992, Cutileiro again suspended the talks due to the deteriorating situation in Sarajevo and the theft of 12 tons of ICRC supplies from the Sarajevo airport. ${ }^{1043}$ On 15 May 1992, the Security Council passed Resolution 752 demanding that all parties to the conflict stop the fighting immediately, respect the cease-fire agreement signed on 12 April 1992, and co-operate fully with UNPROFOR and the ECMM. ${ }^{1044}$ On 17 May 1992, the Accused wrote a letter to Cutileiro stating that the Bosnian Serb Assembly had declared a unilateral cease-fire, which expired the following day, and he blamed Izetbegović and the Bosnian Muslims for continuing the conflict. ${ }^{1045}$

331. On 26 May 1992, Krajišnik informed Cutileiro that an agreement had been reached establishing a cease-fire in the area of the Sarajevo airport and opening the airport for humanitarian

1037 P947 (Cease-fire Agreement, 12 April 1992); Colm Doyle, P918 (Transcript from Prosecutor v. S. Milošević), T. 25283-25284.

1038 P947 (Cease-fire Agreement, 12 April 1992).

1039 See para. 3542.

1040 Colm Doyle, P918 (Transcript from Prosecutor v. S. Milošević), T. 25283-25284; P937 (UNSG Report re peacekeeping operation in BiH, 12 May 1992), p. 3. Others present at the meeting were the EU Council of Ministers President, Dr. Pinhiero, UNPROFOR Generals Morillon and MacKenzie, and the JNA Commander, Kukanjac. Colm Doyle, P918 (Transcript from Prosecutor v. S. Milošević), T. 25283. On 5 May 1992, Fikret Abdić, Stjepan Kljuić, and General Aksentijević for the JNA met with Carrington and Doyle in Sarajevo and agreed to an immediate cease-fire in Sarajevo and BiH. The Bosnian Serbs did not attend because, according to Doyle, the Bosnian Serbs thought it was dangerous to come to the PTT building in Sarajevo. Doyle testified cease-fires were broken fairly quickly. Colm Doyle, P918 (Transcript from Prosecutor v. S. Milošević), T. 25295-25296; P948 (Sarajevo Cease-fire Agreement, 5 May 1992). P937 (UNSG Report re peacekeeping operation in BiH, 12 May 1992), p. 3.

1042 P937 (UNSG Report re peacekeeping operation in BiH, 12 May 1992), p. 3; P948 (Sarajevo Cease-fire Agreement, 5 May 1992). Following the killing of an ECMM member in Mostar on 1 May 1992, the ECMM completely withdrew its monitors from BiH. P937 (UNSG Report re peacekeeping operation in BiH, 12 May 1992), p. 3. On 7 May 1992, the ECMM reported that the HDZ had reached an agreement with the SDS to end the armed conflict between the Serbs and Croats and had agreed to territorial delimitation and a cease-fire. D238 (ECMM letter to Ambassador Cutileiro, 7 May 1992). On 6 May 1992, Boban and the Accused signed an agreement for the "complete and permanent cease-fire" in BiH under the auspices of the EC beginning on 6 May 1992 at 12 a.m.. D4060 (Article from Novi Vjesnik entitled "Agreement between Boban and Karadžić, 8 May 1992); D4061 (Public Announcement of Radovan Karadžić and Mate Boban, 06 May 1992); Momčilo Krajišnik, T. 43972-43973 (21 November 2013).

1043 P937 (UNSG Report re peacekeeping operation in BiH, 12 May 1992), pp. 3-4.

1044 P980 (UNSC Resolution 752, 15 May 1992).

1045 D233 (Letter from Radovan Karadžić to Jose Cutileiro, 17 May 1992). 
purposes. ${ }^{1046}$ However, the following day, after a bread queue in Sarajevo was shelled, the Bosnian Muslim delegation walked out of the peace talks in Lisbon. ${ }^{1047}$ The Accused told Cutileiro and Doyle that the Bosnian Serbs were not responsible for the shelling. ${ }^{1048}$ On 27 May 1992, the Accused and the SDS leadership "announced its readiness" to open the Sarajevo airport for humanitarian transports and its willingness to move heavy weapons under UNPROFOR supervision. $^{1049}$

332. On 30 May 1992, the Security Council passed Resolution 757 which placed economic sanctions on the FRY and demanded that all parties create the conditions for the unimpeded delivery of humanitarian aid to Sarajevo and other destinations in $\mathrm{BiH} .{ }^{1050}$ This resolution also established a security zone which encompassed Sarajevo and its airport. ${ }^{1051}$ As a result, from 2 to 4June 1992, UN representatives, including John Wilson and Hussein Abdel-Razek, held negotiations with the Accused, Plavšić, Mladić, and Krajišnik on the Bosnian Serb side, and Ejup Ganić and Izetbegović on the Bosnian Muslim side, on the opening of Sarajevo airport for humanitarian purposes. ${ }^{1052}$ According to Wilson, the Bosnian Serbs were reluctant to hand over the airport to the UN but agreed to do so as their military position would not be substantially affected and doing so would help repair their "poor international image". ${ }^{1053}$ Thus, on 5 June, the Agreement on the Re-Opening of Sarajevo Airport for Humanitarian Purposes ("Airport

\footnotetext{
1046 D2974 (Letter from Momčilo Krajišnik to Jose Cutileiro and others, 28 May 1992), p. 1.

1047 D230 (Report re humanitarian activity, 1 June 1992) (under seal), p.1; D2974 (Letter from Momčilo Krajišnik to Jose Cutileiro and others, 28 May 1992); Colm Doyle, P918 (Transcript from Prosecutor v. S. Milošević), T. 25299; P1029 (Witness statement of John Wilson dated 4 November 2008), para. 61.

1048 Colm Doyle, P918 (Transcript from Prosecutor v. S. Milošević), T. 25299-25300. See also D2973 (Letter from SerBiH Presidency to Jose Cutileiro and others, 27 May 1992); D2974 (Letter from Momčilo Krajišnik to Jose Cutileiro and others, 28 May 1992).

1049 See para. 4026. P949 (Announcement of SDS leadership re Sarajevo airport and humanitarian supplies, 27 May 1992); Colm Doyle, P918 (Transcript from Prosecutor v. S. Milošević), T. 25299-25300; Stanislav Galić, T. 37552 (22 April 2013) (testifying that the main purpose in handing over the airport was to facilitate the supply of humanitarian aid to Sarajevo and material and technical equipment to UNPROFOR); John Zametica, T. 42462 (29 October 2013) (testifying that the handing over of the airport exemplified the Accused's cooperative approach to humanitarian issues); D3695 (Witness statement of Bogdan Subotić dated 16 June 2013), para. 286 (testifying that the Bosnian Serbs facilitated the use of the airport for the humanitarian needs of Sarajevo).
}

1050 P1031 (UNSC Resolution 757, 30 May 1992); P2284 (UNSG report entitled "The Fall of Srebrenica", 15 November 1999), para. 27.

1051 P1031 (UNSC Resolution 757, 30 May 1992), p. 6; P2284 (UNSG report entitled "The Fall of Srebrenica", 15 November 1999), para. 27.

1052 P1029 (Witness statement of John Wilson dated 4 November 2008), paras. 84, 85; John Wilson, T. 3925 (21 June 2010); P1039 (UNPROFOR report re airport meetings in Sarajevo, 3 June 1992); P1045 (UNPROFOR report re airport talks, 4 June 1992). On the Bosnian Serb side, Plavšić was in charge of humanitarian issues and Koljević was head of the RS Committee on Co-operation with the UN. See para. 97; KDZ240, T. 16116 (5 July 2011); Milenko Inđić, T. 32466 (22 January 2013); John Zametica, T. 42488 (29 October 2013); Velibor Ostojić, D2361 (Transcript from Prosecutor v. Krajišnik), T. 26670.

1053 P1029 (Witness statement of John Wilson dated 4 November 2008), paras. 88-89; P1045 (UNPROFOR report re airport talks, 4 June 1992), p. 3 (reporting that Plavšić told UNPROFOR representatives at the meeting that the Bosnian Serb leadership had "sworn an oath to the people not to give away an inch of their territory"); Colm Doyle, T. 2873 (27 May 2010). 
Agreement") was signed. ${ }^{1054}$ It provided for the opening of Sarajevo airport for the purpose of delivering humanitarian aid to Sarajevo under the supervision of the UN. ${ }^{1055}$ The parties undertook not to interfere in any way with the free movement of UNPROFOR-supervised air traffic into and out of Sarajevo airport. ${ }^{1056}$

333. Although the parties had agreed to the Statement of Principles, in June 1992, Izetbegović withdrew his agreement to the Cutileiro Plan. ${ }^{1057}$ The Secretary General urged parties to reconvene talks and the Accused offered an unconditional cease-fire starting on 15 June 1992, freedom of access to UNMOs, and the re-opening of the Sarajevo airport. ${ }^{1058}$ In the meantime, however, violence continued in Sarajevo and other parts of $\mathrm{BiH} .{ }^{1059}$

334. On 4 June 1992, the Accused, Plavsić, and Mladić met with Cedric Thornberry and Wilson on behalf of UNPROFOR in Sarajevo regarding the Sarajevo airport. ${ }^{1060}$ The Accused's explained that his position in Lisbon was that the UN supervision of Sarajevo involved the establishment of a "green line" between the Bosnian Serb and Bosnian Muslim sides of the city, each side being secured with their own police. ${ }^{1061}$ Only then, would the Bosnian Serbs agree to the withdrawal of heavy weapons. The UNPROFOR representatives commented that there was a disparity between the Bosnian Serbs' current position and what had been understood by Cutileiro and others in Lisbon. ${ }^{1062}$ Cutileiro's understanding was that UNPROFOR would have full control over Sarajevo airport. ${ }^{1063}$ The Bosnian Serbs submitted a list of their proposed conditions concerning the reopening of the airport. ${ }^{1064}$

335. On 5 June 1992, the Accused signed an agreement with the Bosnian Muslims, who were represented by UNPROFOR, on the re-opening of the Sarajevo airport for humanitarian

\footnotetext{
1054 P1032 (Agreement on opening of Sarajevo airport, 5 June 1992); P2284 (UNSG report entitled "The Fall of Srebrenica", 15 November 1999), para. 27; John Wilson, T. 3928-3929 (21 June 2010); P1029 (Witness statement of John Wilson dated 4 November 2008), para. 98.

1055 P1032 (Agreement on opening of Sarajevo airport, 5 June 1992), para. 8. See also Adjudicated Fact 10 (providing that Security Council Resolution 761 of 29 June 1992 tasked UNPROFOR with protecting the airport and helping it function so that humanitarian aid could reach the population).

1056 P1032 (Agreement on opening of Sarajevo airport, 5 June 1992), paras. 2, 3, 8.

1057 Herbert Okun, P776 (Transcript from Prosecutor v. Krajišnik), T. 4177, 4196, 4324-4326, 4328; D2968 (Witness statement of Jose Cutileiro dated 11 April 2012), paras. 10-19.

1058 D228 (Report re humanitarian activity, 12 June 1992), p. 2 (under seal).

1059 D228 (Report re humanitarian activity, 12 June 1992), p. 1 (under seal). See, e.g., paras. 861, 967-970, 1610, 2131-2132, 3558-3559.

1060 P1045 (UNPROFOR report re airport talks, 4 June 1992); P1029 (Witness statement of John Wilson dated 4 November 2008), paras. 85, 89.

1061 P1045 (UNPROFOR report re airport talks, 4 June 1992), p. 2.

1062 P1045 (UNPROFOR report re airport talks, 4 June 1992), p. 2.

1063 P1045 (UNPROFOR report re airport talks, 4 June 1992), p. 2.

1064 P1045 (UNPROFOR report re airport talks, 4 June 1992), pp. 8-9; D2968 (Witness statement of Jose Cutileiro dated 11 April 2012), para. 28;
} 
purposes. ${ }^{1065}$ The cease-fire declared on 1 June 1992 in and around Sarajevo was reaffirmed by the parties and it was agreed that UNPROFOR would monitor its implementation. ${ }^{1066}$ The agreement stipulated that anti-aircraft weapons, artillery, mortars, missile systems, and tanks would be moved to areas agreed by UNPROFOR and subject to observation by UNPROFOR. ${ }^{1067}$ The parties agreed to allow free movement of UNPROFOR-supervised air traffic in and out of the airport for humanitarian aid and UNPROFOR-related missions. ${ }^{1068}$ The UN would supervise the delivery of humanitarian aid, with the parties facilitating such delivery and ensuring safe movement. ${ }^{1069}$

336. On 8 June 1992, the Security Council passed Resolution 758 which noted the re-opening of the Sarajevo airport under the exclusive authority of the UN and the establishment of the security zone around Sarajevo and the airport. ${ }^{1070}$ The Security Council enlarged the mandate of UNPROFOR troops in $\mathrm{BiH}$, strengthened them, and also authorised the deployment of UNMOs to BiH. ${ }^{1071}$ This marked the beginning of UNPROFOR's formal mandate in $\mathrm{BiH}$ with its mission to keep the Sarajevo airport open for humanitarian purposes and to provide security for humanitarian convoys and UNHCR. ${ }^{1072}$

337. On 12 June 1992, the Accused offered an unconditional cease-fire in BiH starting on 15 June 1992 and the re-opening of the Sarajevo airport. ${ }^{1073}$

1065 P1032 (Agreement on opening of Sarajevo airport, 5 June 1992); P2284 (UNSG report entitled "The Fall of Srebrenica", 15 November 1999), para. 27; D2774 (Witness statement of Milenko Inđić dated 19 January 2013), para. 5, Milenko Inđić, T. 32418-32419 (22 January 2013). The Bosnian Muslim government would not meet directly with the Bosnian Serb leadership, therefore UNPROFOR had to use shuttle diplomacy and had the parties sign separate copies of the same document containing the airport agreement. John Wilson, T. 3928-3929 (21 June 2010). 
338. On 27 June 1992, another cease-fire went into effect in Sarajevo. ${ }^{1074}$ On the same day, the Accused, in a letter to the EC, Cutileiro, and Carrington, informed them that the last phase of the opening of Sarajevo airport was underway and that the Bosnian Serbs were respecting the ceasefire. ${ }^{1075}$ He further stated that the adherence to the cease-fire opened the possibility for the continuation of talks on the constitutional arrangements for $\mathrm{BiH} .{ }^{1076}$

339. On 29 June 1992, the Security Council passed Resolution 761 and the Bosnian Serbs handed the airport over to UNPROFOR. ${ }^{1077}$ The airport was only to be used by the UN. ${ }^{1078}$ The airport opened the following day, however, as a convoy of UN vehicles accompanied by Bosnian Serbs left the airport, the convoy was fired upon, injuring four UN personnel. ${ }^{1079}$ As a result, the UN decided to temporarily cease its operations at the airport. ${ }^{1080}$

340. On 3 July 1992, Carrington made a statement following his visit to Sarajevo. ${ }^{1081}$ According to Carrington, Izetbegović set two conditions for the resumption of peace talks, namely a one-week cease-fire throughout $\mathrm{BiH}$ and that all heavy weapons formerly belonging to the JNA be placed under UN control. ${ }^{1082}$ Izetbegović further stated that he could not agree to certain elements of the Statement of Principles but that he would propose alternatives. ${ }^{1083}$ The Accused, while he agreed with the Statement of Principles as agreed upon in March, stated that the proposal of BiH being a unitary state was not satisfactory. ${ }^{1084}$

341. On 5 July 1992, UNPROFOR reported that the cease-fire was not holding but that humanitarian aid flights had been arriving at Sarajevo airport and that UNHCR convoys were

\footnotetext{
1074 D2977 (Letter from Radovan Karadžić to Jose Cutileiro and others, 27 June 1992); D4489 (TANJUG news report, 26 June 1992). D2977 (Letter from Radovan Karadžić to Jose Cutileiro and others, 27 June 1992). See also D4564 (Fax from Radovan Karadžić to Milan Panić, 27 June 1992).

1076 D2977 (Letter from Radovan Karadžić to Jose Cutileiro and others, 27 June 1992).

1077 P1996 (Witness statement of Martin Bell dated 8 March 2010), para. 75; P2038 (BBC news report re Radovan Karadžić's press conference, with transcript). See also Adjudicated Facts 10, 11 (UNPROFOR was tasked with protecting the airport and helping with the delivery of humanitarian aid). See para. 3560.

1078 See Adjudicated Fact 11.

1079 D2409 (UNPROFOR memo re shooting at UN vehicles near the airport, 30 June 1992); D590 (UNPROFOR report, 30 June 1992); KDZ088, T. 6551-6556 (13 September 2010) (closed session). The UNMOs reported that the firing on the UN vehicles was quite deliberate, the fact that the Bosnian Serb vehicle was targeted first may indicate that the origin of fire came from the Presidency, and the fire was directed from the northern part of Dobrinja. D2409 (UNPROFOR memo re shooting at UN vehicles near the airport, 30 June 1992), paras. 5-6; D2398 (Witness statement of Richard Gray dated 22 April 2012), para. 25. D2409 (UNPROFOR memo re shooting at UN vehicles near the airport, 30 June 1992), para. 5.

1081 D4695 (Lord Carrington's statement, 3 July 1992).

1082 D4695 (Lord Carrington's statement, 3 July 1992), p. 2.

1083 D4695 (Lord Carrington's statement, 3 July 1992), p. 2.

1084 D4695 (Lord Carrington's statement, 3 July 1992), p. 2.
} 
distributing aid in the city. ${ }^{1085}$ However, according to Nambiar, the airport remained "very vulnerable". 1086 UNPROFOR's assessment was that both sides have "agendas which have little to do with humanitarian concerns" and that both sides seemed "locked in a fight to the death over the future shape, character and even existence of the new state of $[\mathrm{BiH}] " .{ }^{1087}$

342. On 13 July 1992, the Security Council passed Resolution 764 in response to continuing violations of the 5 June 1992 Sarajevo airport agreement. ${ }^{1088}$ It authorised the UN SecretaryGeneral to deploy additional UNPROFOR troops to ensure the security of the Sarajevo airport and delivery of humanitarian aid. ${ }^{1089}$ On 14 July, UNPROFOR reported that aid continued to arrive in Sarajevo, but that the airport faced "an almost unacceptable degree of risk" and that the situation in Sarajevo continued to deteriorate. ${ }^{1090}$

343. On 17 July 1992, in London, the parties agreed to a cease-fire throughout the entire territory of $\mathrm{BiH}$, for a period of 14 days, effective beginning at 6 p.m. on 19 July $1992 .^{1091}$ The next round of peace talks was scheduled to resume on 27 July 1992 in London. ${ }^{1092}$ However, on 23 July 1992, Carrington and Cutileiro noted that all parties to the conflict had violated the cease-fire agreement. ${ }^{1093}$ Carrington called on the parties to respect and implement the cease-fire but noted that the violations cast a shadow over the resumption of talks scheduled in London for 27 July 1992. ${ }^{1094}$ The talks did not resume again in July. ${ }^{1095}$

\footnotetext{
1085 D4647 (Memo from Nambiar to Goulding, 7 July 1992), paras. 1-3, 5.

1086 D4647 (Memo from Nambiar to Goulding, 7 July 1992), para. 12.

1087 D4647 (Memo from Nambiar to Goulding, 7 July 1992), para. 8.

1088 P982 (UNSC Resolution 764, 13 July 1992).

1089 P982 (UNSC Resolution 764, 13 July 1992).

1090 D2411 (UNPROFOR report, 14 July 1992), paras. 1-2 (reporting also that UNPROFOR was being subjected to a smear campaign by the BiH Presidency which led to a number of incidents of UN personnel being threatened in the performance of their duties).

1091 D4710 (Text of Agreement signed by Boban, Radovan Karadžić and Silajdžić at London on 17 July 1992), pp. 1-2 (the agreement provided that all heavy weapons were to be placed under international supervision and that all refugees be permitted to return to the places from which they had been expelled. The parties requested that the Security Council make arrangements for this supervision). See also D593 (VRS Main Staff Order, 22 July 1992), p. 2. Milovanović stated that the Accused signed this cease-fire without consultation with the Main Staff. D2149 (Aide mémoire of Manojlo Milovanović), p. 6.

1092 D4710 (Text of Agreement signed by Boban, Radovan Karadžić and Silajdžić at London on 17 July 1992 ), p. 1.

1093 D2978 (Letter from Jose Cutileiro to Radovan Karadžić, 23 July 1992). See also D4710 (Text of Agreement signed by Boban, Radovan Karadžić and Silajdžić at London on 17 July 1992); D4711 (Letter from Biljana Plavšić to General McKenzie, 19 July 1992); D4713 (Letter from Radovan Karadžić to Boutros Boutros Ghali, Lord Carrington and Ambassador Cutileiro, 20 July 1992).

1094 D2978 (Letter from Jose Cutileiro to Radovan Karadžić, 23 July 1992).

1095 See D2968 (Witness statement of Jose Cutileiro dated 11 April 2012), para. 30.
} 
344. On 25 July, the SRK reported that ABiH forces were focusing artillery fire on Dobrinja and the airport area with the "probable goal" of preventing the safe landing of planes. ${ }^{1096}$ In response to the difficulties faced by UNPROFOR at the airport, the Security Council passed Resolution 770 on 13 August, in which it demanded that the parties take necessary measures to ensure the safety of UN and other personnel delivering humanitarian assistance. ${ }^{1097}$ The Security Council demanded that the parties to the conflict cease fighting immediately, that the ICRC be allowed to access prisons and detention centres, and that necessary measures be taken to ensure the safety of UNPROFOR personnel. ${ }^{1098}$

345. The work of the EC Peace Conference on Yugoslavia terminated in August 1992, when the UK, which held the Presidency of the EC at that time, convened a new international conference in London. $^{1099}$

\section{London Conference}

346. The London Conference on the former SFRY was held on 26 and 27 August 1992. ${ }^{1100}$ On the eve of the conference, the Accused stated that on 19 August 1992, he had issued an order that the forced transfer of the civilian population must be prevented and any written statements by refugees that they would not return were considered legally invalid. ${ }^{1101}$ He reiterated his hope that the conflict could end through negotiations. ${ }^{1102}$

347. On 26 August 1992, the Accused and Koljević met with Vance and Carrington. ${ }^{1103}$ The Accused stated that the Bosnian Serbs were willing to negotiate and even return some territory as part of an overall agreement, as long as Serb property rights in predominantly Croat and Muslim areas were protected. ${ }^{1104}$ The Accused stated that Bosnian Serb territory could be geographically

\footnotetext{
1096 D592 (SRK combat report, 25 July 1992), para. 1; D591 (SRK combat report, 25 July 1992), para. 1; KDZ088, T. 6558 (13 September 2010) (closed session) (testifying that it was the "routine position" of the ABiH to target the airport and then blame the Bosnian Serbs for it).

1097 P983 (UNSC Resolution 770, 13 August 1992), pp. 1-2, para. 6.

1098 P983 (UNSC Resolution 770, 13 August 1992).

1099 Herbert Okun, T. 1471 (22 April 2010); Herbert Okun, P776 (Transcript from Prosecutor v. Krajišnik), T. 4147; Charles McLeod, P712 (Transcript from Prosecutor v. Brđanin), T. 7287.

1100 Herbert Okun, T. 1471 (22 April 2010); Herbert Okun, P776 (Transcript from Prosecutor v. Krajišnik), T. 4147-4148, 4327; P2284 (UNSG report entitled "The Fall of Srebrenica”, 15 November 1999), para. 29. See also D2980 (Article from International Herald Tribune entitled "Vance and Owen Got It Right", 16 February 1993).

1101 D4720 (Letter from Radovan Karadžić re London Peace Conference, 25 August 1992).

1102 D4720 (Letter from Radovan Karadžić re London Peace Conference, 25 August 1992). The Accused stated in a Newsnight interview that he was not as optimistic about the London Conference, Izetbegović did not represent the interests of all of $\mathrm{BiH}$, and that "ethnic cleansing was never part of our policy". D4493 (Video footage of BBC interview with Radovan Karadžić).

1103 D2979 (Record of London Conference, 26 August 1992) (also present were Cutileiro, Okun, and Doyle).

1104 D2979 (Record of London Conference, 26 August 1992), p. 1.
} 
continuous but Vance asked how this would be possible without causing a movement of the population. ${ }^{1105}$ With respect to Sarajevo, the Accused stated that he would accept the presence of UN monitors at all Serb artillery positions in and around Sarajevo. ${ }^{106}$ Also on this day, the President of the ICRC appealed to the conference participants to resolve the conflict and to restore respect for international humanitarian law. ${ }^{1107}$

348. On the same day, the London Conference adopted a Statement of Principles as the basis for a negotiated settlement to end the conflict. ${ }^{1108}$ The principles included, inter alia, agreeing to a cease-fire, engaging in negotiations, implementing respect for human rights and protection of minorities, condemning forcible expulsion, complying with international humanitarian law and all Security Council resolutions, providing protection for the delivery of humanitarian aid, and agreeing that the settlement to the conflict would be through negotiation and consensus. ${ }^{1109}$

349. On 27 August 1992, the London Conference adopted a "Statement on Bosnia" condemning the continuing armed conflict in $\mathrm{BiH}$, the attempts to gain territory by force, and the expulsion of civilians. ${ }^{1110}$ It stated that a political settlement in $\mathrm{BiH}$ must include, inter alia, a permanent cessation of hostilities, recognition of $\mathrm{BiH}$ by all former SFRY republics, respect for current boundaries, guarantees for national community and minority rights protected by democratic and legal structures, and the right to return and compensation for civilians who were forcibly expelled. ${ }^{1111}$ It urged all parties to continue negotiations and discuss issues such as the grouping of heavy weapons under international control, demilitarisation of major towns with international observers present, the provision of refugee relief and humanitarian aid, and the further deployment of UN peacekeeping forces to monitor $\mathrm{BiH}^{1112}$

350. The parties and UNHCR agreed to a "Programme of Action on Humanitarian Issues Agreed Between the Co-Chairmen to the Conference and the Parties to the Conflict". ${ }^{1113}$ Under this agreement, the Accused and Izetbegović undertook to ensure the delivery of humanitarian aid by road throughout $\mathrm{BiH}$, and to take specific steps to develop a system of land convoys to that

\footnotetext{
1105

P941 (London Conference record of a meeting with Radovan Karadžić, 26 August 1992), pp. 1-2. P941 (London Conference record of a meeting with Radovan Karadžić, 26 August 1992), p. 2.

P807 (Address by ICRC President at the London Conference, 26 August 1992); D2968 (Witness statement of Jose Cutileiro dated 11 April 2012), para. 32.

1110 D1604 (London Conference statement on BiH, 27 August 1992), p. 2. See also D4723 (Excerpt from book entitled "Yugoslavia Through Documents from its Creation to its Dissolution").

1111 D1604 (London Conference statement on BiH, 27 August 1992), pp. 2-3.

1112 D1604 (London Conference statement on BiH, 27 August 1992), p. 4.

1113 D4723 (Excerpt from book entitled "Yugoslavia Through Documents from its Creation to its Dissolution”).
} 
effect. ${ }^{1114}$ On 9 September 1992, Nambiar sent a protest letter to Izetbegović over the shelling of a $\mathrm{UN}$ humanitarian convoy by the $\mathrm{ABiH}$ at the entrance to Sarajevo airport, which caused the death of two French soldiers. ${ }^{115}$ As a result of this incident, humanitarian flights were suspended for one month. ${ }^{116}$ On 14 September 1992, UNPROFOR's mandate was broadened again by Security Council Resolution 776, to include protection of humanitarian aid convoys. ${ }^{117}$

351. The Accused and Koljević, representing the Bosnian Serbs, agreed to notify the UN, within 96 hours, of the grouping of all heavy weapons around Sarajevo, Bihać, Goražde, and Jajce. ${ }^{1118}$ They agreed to complete this process within seven days and for the weapons to be placed under the supervision of UN observers. ${ }^{1119}$ They also agreed to "withdraw from a substantial portion of the territory now under the control of their forces", to secure the release of detained civilians, to repatriate them, and allow refugees and displaced persons to return to their place of origin. ${ }^{1120}$ Finally, they agreed to support the initiative that "all units of armed forces across the entire territory of $[\mathrm{BiH}]-$ regardless of their allegiance- come under the supervision of competent UN officers". ${ }^{121}$

\section{International Conference on the Former Yugoslavia}

352. The London Conference proposed the creation of a new peace conference called the ICFY. ${ }^{1122}$ Under the co-chairmanship of Secretary General Boutros Boutros-Ghali and UK Prime Minister John Major, in his capacity as President of the EC Council of Ministers, the ICFY began its work in September 1992. ${ }^{1123}$ The activities of the ICFY were supervised by a steering committee and co-chaired by representatives from the Secretary General's office and the EU

\footnotetext{
1114 D4723 (Excerpt from book entitled "Yugoslavia Through Documents from its Creation to its Dissolution"), paras. 1-2.

1115 D2399 (UNPROFOR report, 9 September 1992), pp. 2, 4; D2398 (Witness statement of Richard Gray dated 22 April 2012), para. 41.

1116 P1262 (UN report on Sarajevo, 8 October 1992), para. 3.

1117 Adjudicated Fact 12.

1118 D1604 (London Conference statement on BiH, 27 August 1992), p. 5. Milovanović stated that the Accused informed the Main Staff that he had "offered" that the Bosnian Serbs "cede $20 \%$ of its territory" for the sake of peace. D2149 (Aide mémoire of Manojlo Milovanović), p. 8.

1119 D1604 (London Conference statement on BiH, 27 August 1992), p. 5.

1120 D1142 (Programme of Action of the London International Conference, 27 August 1992), pp. 1-2.

1121 D4724 (Letter from Radovan Karadžić to Boutros Boutros Ghali, 27 August 1992).

1122 Herbert Okun, T. 1471 (22 April 2010); Herbert Okun, P776 (Transcript from Prosecutor v. Krajišnik), T. 4147-4148, 4327; P2284 (UNSG report entitled “The Fall of Srebrenica”, 15 November 1999), para. 29.

1123 Herbert Okun, P776 (Transcript from Prosecutor v. Krajišnik), T. 4327-4328. See also D4474 (Report on visit by Steering Committee to Zagreb, Sarajevo and Belgrade 9-12 September 1992) (Owen and Vance reported that all three parties agreed to resume peace talks in Geneva on 18 September 1992); P1046 (John Wilson's Report to Australian Army, 15 November 1992), p. 9. The seat of the ICFY was at the UN in Geneva. D1144 (UN Secretary-General letter to UNSC with attached report, 8 July 1994), p. 2; P1046 (John Wilson's Report to Australian Army, 15 November 1992), p. 9.
} 
Presidency's office. ${ }^{1124}$ The ICFY had six working groups, including one on BiH. ${ }^{1125}$ The BiH working group had two objectives: establishing a cessation of hostilities and implementing a constitutional arrangement that would satisfy the three constituent units of $\mathrm{BiH} .{ }^{1126}$

353. The ICFY recognised that there was no viable way to create three territorially distinct states based on ethnicity but that a centralised state was also not acceptable to the parties. ${ }^{1127}$ It concluded that the only viable solution was the establishment of a decentralised state. ${ }^{1128}$

354. The ICFY held meetings mainly in Geneva with representatives from the parties to the conflict and also with representatives from the international community and non-governmental organisations. ${ }^{1129}$ Included in those meetings were representatives from the ICRC, UNHCR, and UNPROFOR. ${ }^{1130}$

355. During the negotiation process, the Bosnian Serbs pushed for an agenda consistent with the Strategic Goals. ${ }^{1131}$ In turn, the Bosnian Muslims maintained their request to create a unitary state of $\mathrm{BiH}$ with centralised powers in which they possessed a majority. ${ }^{1132}$ The Bosnian Croats wished to take $\mathrm{BiH}$ out of the FRY, to declare independence, and to establish their own state called the Community of Herceg-Bosna. ${ }^{1133}$ This new state would have territorial contiguity with Croatia and have a special relationship with Croatia, with the possibility of uniting with Croatia in the future. $^{1134}$

1124 D1144 (UN Secretary-General letter to UNSC with attached report, 8 July 1994), p. 2. The Steering Committee of the ICFY was initially co-chaired by David Lord Owen for the EC, the former British Foreign Secretary, and Vance as the UN SG's representative. Herbert Okun, T. 1471 (22 April 2010). See also D4474 (Report on visit by Steering Committee to Zagreb, Sarajevo and Belgrade 9-12 September 1992) (listing Owen and Vance as CoChairmen of the Steering Committee). Okun was the deputy co-chairman for the UN and Ambassador Peter Hall was the deputy co-chairman for the EU. Wilson received situation reports from UNPROFOR headquarters in Zagreb and would provide situation reports to the Co-Chairmen and other committee heads of the ICFY. See Herbert Okun, T. 1471-1472 (22 April 2010); P1029 (Witness statement of John Wilson dated 4 November 2008), para. 109.

1125 P1046 (John Wilson's Report to Australian Army, 15 November 1992), p. 9. The other working groups included: humanitarian matters; confidence building, security, and verification measures; economic issues; communities, ethnic, and national minorities issues; and succession matters. P1046 (John Wilson's Report to Australian Army, 15 November 1992), p. 9.

1126 P2538 (Patrick Treanor's research report entitled "Radovan Karadžić and the Serbian Leadership 1990-1995", 1 May 2009), para. 130.

1127 P2284 (UNSG report entitled "The Fall of Srebrenica”, 15 November 1999), para. 29.

1128 P2284 (UNSG report entitled "The Fall of Srebrenica", 15 November 1999), para. 29.

1129 Herbert Okun, T. 1472 (22 April 2010).

1130 Herbert Okun, T. 1472-1473 (22 April 2010).

1131 Herbert Okun, T. 1474-1475 (22 April 2010); P781 (Decision on six strategic goals for Bosnian Serb people, 12 May 1992); Herbert Okun, P776 (Transcript from Prosecutor v. Krajišnik), T. 4157-4158.

1132 Herbert Okun, T. 1476 (22 April 2010).

1133 Herbert Okun, T. 1476 (22 April 2010).

1134 Herbert Okun, T. 1476 (22 April 2010). 
356. The ICFY continued to engage in meetings with all three parties in BiH. ${ }^{1135}$ The Bosnian Serb leadership identified the areas of BiH they wanted to be under Bosnian Serb control. ${ }^{1136}$ The Accused stated that the Bosnian Serbs were firmly committed to the principles as agreed upon on 18 March 1992 and that a political settlement was absolutely essential. ${ }^{1137}$ As a result of negotiations, the Accused agreed that the Bosnian Serb heavy weapons in certain locations of BiH would be concentrated and monitored by UNMOs. ${ }^{1138}$

357. During a meeting on 17 September 1992, when Owen expressed his concern to the Accused about the siege of Sarajevo, the Accused denied that it was a siege, stating rather that the Bosnian Serbs were "protecting" their suburbs. ${ }^{1139}$ The Accused reiterated his position that the Bosnian Serbs, Bosnian Croats, and Bosnian Muslims could not live together in $\mathrm{BiH}$ and that Sarajevo should be divided into Bosnian Muslim and Bosnian Serb entities. ${ }^{1140}$ During a meeting the following day, the Accsed and Koljević stated again that the Bosnian Serbs and the Bosnian Croats would not accept a unitary $\mathrm{BiH}$ state; a state based on one-man, one-vote. ${ }^{1141}$ Koljević also stated that the Bosnian Serbs would not accept the internal borders of $\mathrm{BiH}$ without some form of cantonisation. $^{1142}$

358. On 30 September 1992, the Accused and Koljević met with Vance, Owen, Okun and others in Geneva to further discuss the situation in Sarajevo. ${ }^{1143}$ The Accused stated that it was not the Bosnian Serbs who were "besieging" Sarajevo and that they could not take unilateral steps but needed reciprocal actions by the Bosnian Muslims. ${ }^{1144}$ The Accused repeated that the Bosnian Serbs who wished to leave the city should be allowed to do so. ${ }^{1145}$ Okun noted that the Accused

\footnotetext{
1135 Herbert Okun, T. 1477-1483 (22 April 2010).

1136 Herbert Okun, T. 1478- 1483 (22 April 2010); P784 (First notebook of Herbert Okun's ICFY diary), e-court p. 45; P783 (Ethnic map of BiH).

1137 D2975 (Letter from Radovan Karadžić to Jose Cutileiro, 13 June 1992); D2968 (Witness statement of Jose Cutileiro dated 11 April 2012), para. 29. See, e.g., D2976 (Letter from Radovan Karadžić to Lord Carrington and Jose Cutileiro, 16 June 1992); D2968 (Witness statement of Jose Cutileiro dated 11 April 2012), para. 30. See also para. 326.

1138

1139

1140

1141

1142

1143

1144

1145

Herbert Okun, P776 (Transcript from Prosecutor v. Krajišnik), T. 4203-4204; P785 (Second notebook of Herbert Okun's ICFY diary), e-court p. 24. See generally Section IV.B.1.f: Siege of Sarajevo.

Herbert Okun, P776 (Transcript from Prosecutor v. Krajišnik), T. 4204-4205; P785 (Second notebook of Herbert Okun's ICFY diary), e-court pp. 24-25.

141 Herbert Okun, P776 (Transcript from Prosecutor v. Krajišnik), T. 4214-4215; P785 (Second notebook of Herbert Okun's ICFY diary), e-court p. 33. See also D2149 (Aide mémoire of Manojlo Milovanović), p. 9.

Herbert Okun, P776 (Transcript from Prosecutor v. Krajišnik), T. 4215; P785 (Second notebook of Herbert Okun's ICFY diary), e-court pp. 34.

P786 (Third notebook of Herbert Okun's ICFY diary), e-court pp. 6-8.

P786 (Third notebook of Herbert Okun's ICFY diary), e-court p. 6. See generally Section IV.B.1.f: Siege of Sarajevo.

1145 Herbert Okun, P776 (Transcript from Prosecutor v. Krajišnik), T. 4225.
} 
and Koljević were resistant to any agreements. ${ }^{1146}$ The meeting ended with an agreement to continue discussions and with Owen pressing for an overall cease-fire in $\mathrm{BiH} .{ }^{1147}$

\section{a. Vance-Owen Plan}

359. The culmination of the work of the ICFY resulted in the Vance-Owen Plan which was formally introduced on 2 January 1993. ${ }^{1148}$ The plan consisted of three main parts: first, the constitutional arrangements for $\mathrm{BiH}$, second, the military arrangements, and third, a map of the provincial structure. ${ }^{1149}$ Each part of the plan had to be signed separately by all three parties. ${ }^{150}$

360. The constitutional arrangements of the Vance-Owen Plan stipulated that the laws of $\mathrm{BiH}$ that related directly to the vital interests of each of the three constituent populations would be agreed upon by consensus. ${ }^{1151}$ All other legislation would not be subject to a veto. ${ }^{1152}$

361. On 11 January 1993, there were bilateral discussions with the Bosnian Serbs and the ICFY. ${ }^{1153}$ The Accused asked the ICFY to look at the previous Bosnian Serb proposals. ${ }^{1154}$ Krajišnik stressed their desire for territorial continuity and named three conditions from the Bosnian Serb Assembly: (i) BiH must be a "composite state community"; (ii) the Bosnian Serbs must have relations with other "states"; and (iii) they must have territorial continuity. ${ }^{1155}$ Mladić told Okun and Owen that the Bosnian Serbs wanted "peace with justice" for all three peoples but that the Bosnian Muslims could not "beat", "exterminate", or "cause [the Serbs] to disappear". ${ }^{1156}$ The following day, at a plenary meeting, the Accused expressed his reservations about the ICFY's

\footnotetext{
1146 P786 (Third notebook of Herbert Okun's ICFY diary), e-court p. 7.

1147 P786 (Third notebook of Herbert Okun's ICFY diary), e-court p. 7.

1148 Herbert Okun, T. 1518 (23 April 2010); P2284 (UNSG report entitled "The Fall of Srebrenica", 15 November 1999), para. 31.

1149 Herbert Okun, T. 1517 (22 April 2010); D1593 (BiH Map from Vance-Owen Peace Plan, 2 January 1993); Herbert Okun, P776 (Transcript from Prosecutor v. Krajišnik), T. 4237-4238; P2284 (UNSG report entitled "The Fall of Srebrenica", 15 November 1999), para. 31.

1150 Herbert Okun, T. 1517 (22 April 2010).

1151 Herbert Okun, P776 (Transcript from Prosecutor v. Krajišnik), T. 4238.

1152 Herbert Okun, P776 (Transcript from Prosecutor v. Krajišnik), T. 4238. Okun testified that one of the Bosnian Serb goals was to have veto power over anything that the central BiH government did and at a 6 January 1993 meeting with Slobodan Milošević in Belgrade, Milošević stated that he had spoken to the Accused and Krajišnik who wanted the consensus rule to apply to everything. Slobodan Milosević stated that he would do all he could to convince the Accused to accept the Vance-Owen Plan. Herbert Okun, P776 (Transcript from Prosecutor v. Krajišnik), T. 4238; P789 (Sixth notebook of Herbert Okun's ICFY diary), e-court p. 26; P4221 (Excerpt from UNSC report, 16 November 1993). Momir Bulatović stated that beginning in 1993, a split began to develop between the Bosnian Serb leadership and the FRY resulting from a difference in opinion about the peace plans proposed. Bulatović stated that the FRY wanted the war to end at all costs and to accept the peace plans but the Bosnian Serb leadership opposed this. D3051 (Witness statement of Momir Bulatović dated 25 February 2013), para. 42.

1153 P789 (Sixth notebook of Herbert Okun's ICFY diary), e-court pp. 42-43.

1154 P789 (Sixth notebook of Herbert Okun's ICFY diary), e-court p. 43.

1155 P789 (Sixth notebook of Herbert Okun's ICFY diary), e-court p. 43.
} 
constitutional principles and stated he could not accept them but he would convey the ICFY's proposals to the Bosnian Serb Assembly. ${ }^{1157}$

362. On 15 January 1993, at a meeting with Okun and Vance, the representative for the Bosnian Serbs, Aleksa Buha, stated that the Bosnian Serbs needed the Posavina "corridor", which was a road that connected Belgrade to Banja Luka via Bijeljina and Brčko. ${ }^{1158}$ For territories still under dispute, Buha noted the Accused's request for a resolution by referendum. ${ }^{1159}$

363. On 23 January 1993, at a plenary summit meeting, ${ }^{1160}$ Izetbegović stated that he objected to the map on the basis that regions from which population had been removed could not come under the control of those who removed them, and that while the peace conference was ongoing, the "aggression" continued. ${ }^{1161}$ The Accused stated that he finally agreed to accept the nine constitutional principles and in relation to the proposed map, he acknowledged that considerable success had been achieved but certain territories were still under dispute. ${ }^{1162}$ Later in the day, during a discussion on the proposed map, the Accused asked for a larger Bosnian Serb territory and proposed his own boundaries. ${ }^{1163}$

\footnotetext{
1156 P789 (Sixth notebook of Herbert Okun's ICFY diary), e-court p. 45.

1157 P789 (Sixth notebook of Herbert Okun's ICFY diary), e-court p. 48. According to Milovanović, in November 1992, the Accused issued a public statement that $\mathrm{BiH}$ should be made of its three constituent states with the RS as a "single whole" and rejecting the Vance-Owen proposal for a "centralised BiH with ten cantons". D2149 (Aide mémoire of Manojlo Milovanović), p. 12.

1158 Herbert Okun, P776 (Transcript from Prosecutor v. Krajišnik), T. 4244-4245; P789 (Sixth notebook of Herbert Okun's ICFY diary), e-court p. 58.

1159 Herbert Okun, P776 (Transcript from Prosecutor v. Krajišnik), T. 4245 (opining that this system would benefit Bosnian Serbs in territories from which non-Serbs had been removed).

1160 The attendees at the meeting included the following: (i) Izetbegović, Silajdžić, Siber, Lazović, and Filipović for the Bosnian Muslims; (ii) Karadžić, Krajišnik, Buha, Mladić and Lukić for the Bosnian Serbs; (iii) Boban, Akmadžić, Petković, and Rudman for the Bosnian Croats; (iv) Tuđman, Šušak, Radić, Tus, and Madey for Croatia; and (v) Ćosić, Slobodan Milošević, Bulatović, Đokić, and Stojanović for the FRY. P790 (Seventh notebook of Herbert Okun's ICFY diary), e-court p. 9.

1161 P790 (Seventh notebook of Herbert Okun's ICFY diary), e-court p. 9.

1162 P790 (Seventh notebook of Herbert Okun's ICFY diary), e-court p. 9 (the Accused protested that Croatia had violated the January 1992 peace agreement with "brutal aggression" against the RS). The nine constitutional principles were proposed for the basis of the $\mathrm{BiH}$ Constitution. The principles included: (i) $\mathrm{BiH}$ would be a decentralised state with three constituent groups; (ii) the provinces would not have international legal personality; (iii) full freedom of movement would be allowed throughout $\mathrm{BiH}$; (iv) matters of vital concern to any of the constituent units would be regulated in the Constitution, amended by consensus of the three constituent units, and there was no veto; (v) provinces and the central government would have democratically elected legislatures, the central Presidency would be composed of three elected representatives from each constituent group; (vi) a Constitutional Court would resolve disputes between the central government and provinces; (vii) $\mathrm{BiH}$ would be demilitarised under UN/EC supervision; (viii) the highest level of internationallyrecognised human rights would be provided for in the Constitution; and (ix) international monitors would remain in $\mathrm{BiH}$ until the constituent groups agreed by consensus to dispense with them. P2538 (Patrick Treanor's research report entitled "Radovan Karadžić and the Serbian Leadership 1990-1995", 1 May 2009), para. 146. 
364. By 25 January 1993, after several additional meetings, Okun reported that Owen feared that the negotiations would break down. ${ }^{1164}$ The following day, at a bilateral meeting, ${ }^{1165}$ the Accused stated that he was prepared to make concessions and was willing to be more flexible. ${ }^{1166}$ On 27 January 1993, Owen outlined the new ICFY proposals that for an interim period there would be no change in the Sarajevo boundaries and there would be no constitutional changes, except by consensus. ${ }^{1167}$ Krajišnik maintained that the Bosnian Serb position was to divide Sarajevo. ${ }^{1168}$

365. By 30 January 1993, the Bosnian Croats had signed all three arrangements, namely the constitutional arrangements, military arrangements, and the map of the provincial structure. ${ }^{169}$ The Bosnian Muslims had only accepted the military arrangements. ${ }^{1170}$ The Bosnian Serbs had rejected all three arrangements. ${ }^{1171}$ Meetings with the Bosnian Serbs continued in February and March to discuss details of the proposed arrangements, in particular the map of $\mathrm{BiH}^{1172}$

366. Also in January 1993, the ICFY proposed an "Agreement for Peace in [BiH]" in the hopes of establishing a cessation of hostilities. ${ }^{1173}$ The agreement called for a cessation of hostilities and a subsequent demilitarisation of Sarajevo; monitoring by UNPROFOR of the confrontation lines and the removal of heavy weapons; and restoration of civil infrastructures and humanitarian aid, including through the establishment and opening of Blue Routes for the freedom of movement of people and humanitarian assistance. ${ }^{1174}$ It called for the creation of a Joint Commission to execute and implement the details of the plan. ${ }^{1175}$ The areas in which all heavy weapons were to be withdrawn included Mojmilo, Dobrinja, Lukavica, Gornji, Kotorac, Vojkovići, Hrasnica,

\footnotetext{
1164 P790 (Seventh notebook of Herbert Okun's ICFY diary), e-court p. 15.

1165 Okun testified that bilateral meetings with the Accused and Krajišnik were often conducted by Vance and Owen as part of the larger negotiations. Herbert Okun, P776 (Transcript from Prosecutor v. Krajišnik), T. 4246.

1166 P790 (Seventh notebook of Herbert Okun's ICFY diary), e-court p. 22.

1167 P790 (Seventh notebook of Herbert Okun's ICFY diary), e-court p. 30.

1168 Herbert Okun, P776 (Transcript from Prosecutor v. Krajišnik), T. 4251; P790 (Seventh notebook of Herbert Okun's ICFY diary), e-court p. 30.

1169 Herbert Okun, T. 1518-1519 (23 April 2010).

1170 Herbert Okun, T. 1518-1519 (23 April 2010). Izetbegović stated publicly that with support from the USA, he would be able to accept an amended Vance-Owen Plan and there was no other solution but to negotiate the details. D1497 (UNPROFOR Assessment, 15 February 1993), p. 2.

1171 Herbert Okun, T. 1519 (23 April 2010). See also Momir Bulatović, T. 34532-34535 (28 February 2013); P6159 (Excerpt from Momir Bulatović's book entitled "Rules of Silence").

1172 P790 (Seventh notebook of Herbert Okun's ICFY diary), e-court p. 57; P791 (Eighth notebook of Herbert Okun's ICFY diary), e-court pp. 38-40; P2538 (Patrick Treanor's research report entitled "Radovan Karadžić and the Serbian Leadership 1990-1995", 1 May 2009), paras. 147-154.

1173 D924 (ICFY Agreement for Peace in BiH, 3 March 1993).

1174 D924 (ICFY Agreement for Peace in BiH, 3 March 1993). The concept of Blue Routes included the agreement by all parties to secure the routes, not interfere with them or with check-points and patrols by UNPROFOR/ECMM, to ensure freedom of passage for humanitarian aid, and to ensure the absolute freedom of movement for UN forces. A separate concept for Blue Routes in Sarajevo, specifically, was appended to the agreement. D924 (ICFY Agreement for Peace in BiH, 3 March 1993), pp. 9-14. It is only in February 1994 that there was an agreement to establish Blue Routes in Sarajevo. See para. 389.
} 
Sokolovići, Butmir, Ilidža, Otes, Stup, and Nedžarići. ${ }^{1176}$ On 30 January 1993, the Accused and Boban signed the agreement, witnessed by Vance and Owen. ${ }^{1177}$ On 3 March 1993, with guarantees from the UN that heavy weapons would be placed under its control, Izetbegović also signed the agreement. ${ }^{1178}$

367. On 26 March 1993, Wahlgren, Morillon, and others met with Mladić in Belgrade. ${ }^{1179}$ Morillon criticised the recent attack on Srebrenica; Mladić stated that the ABiH began the offensive and the VRS had retaliated. ${ }^{1180}$ On 6 April 1993, Wahlgren and Morillon met with Milovanović, Gvero, and others at the Sarajevo airport to discuss the offensive in Srebrenica. ${ }^{1181}$ Wahlgren informed the participants that the Bosnian Muslims had set two conditions for this meeting, namely that the Bosnian Serbs should stop their attack on Srebrenica and that UN observers and one company of CanBat should be allowed into Srebrenica. ${ }^{182}$ Milovanović responded that the Bosnian Serbs were not attacking Srebrenica but that once Bosnian Muslims agreed to a cease-fire throughout $\mathrm{BiH}$, the Bosnian Serbs would stop their offensive. ${ }^{1183}$

368. On 12 April 1993, Wahlgren met with Mladić in Sarajevo to discuss the offensive in Srebrenica; José Mendiluce of UNHCR was also present at the meeting. ${ }^{1184}$ Mladić told Mendiluce that there was no problem with Mendiluce assisting in the evacuation of the Bosnian Muslims from Srebrenica. ${ }^{185}$ However, Mladic stated that the RS had no respect for the "no fly zone" set forth in Security Council Resolution 781 and requested that no NATO planes fly over the RS. ${ }^{1186}$ In addition, he refused requests that UNPROFOR deploy extra troops in Srebrenica and the eastern

\footnotetext{
1175 D924 (ICFY Agreement for Peace in BiH, 3 March 1993), p. 20.

1176 D924 (ICFY Agreement for Peace in BiH, 3 March 1993), p. 20.

1177 D924 (ICFY Agreement for Peace in BiH, 3 March 1993), p. 2.

1178 P2538 (Patrick Treanor's research report entitled "Radovan Karadžić and the Serbian Leadership 1990-1995", 1 May 2009), para. 155.

1179 D1500 (UNPROFOR report re. meeting with Ratko Mladić, 29 March 1993); P4203 (Witness statement of Pyers Tucker dated 12 May 2010), para. 243; P1474 (Ratko Mladić's notebook, 29 January-31 March 1993), pp. 164-172.

1180 D1500 (UNPROFOR report re. meeting with Ratko Mladić, 29 March 1993), p. 3; P4203 (Witness statement of Pyers Tucker dated 12 May 2010), paras. 244-245; P1474 (Ratko Mladić's notebook, 29 January-31 March 1993), p. 167.

1181 D2779 (VRS Main Staff notes of meeting at Sarajevo airport, 7 April 1993); P4203 (Witness statement of Pyers Tucker dated 12 May 2010), para. 245; Milenko Inđić, T. 32441-32443 (22 January 2013).

1182 D2779 (VRS Main Staff notes of meeting at Sarajevo airport, 7 April 1993), p. 1.

1183 D2779 (VRS Main Staff notes of meeting at Sarajevo airport, 7 April 1993), p. 1.

1184 D2748 (UNPROFOR report re meeting with Ratko Mladić, 13 April 1993); D2745 (Witness statement of Vere Hayes dated 14 January 2013), para. 10; P1483 (Ratko Mladić's notebook, 2 April-24 October 1993), pp. 1719. See also D328 (ICFY report re military talks in Sarajevo on 12 April 1993) (reporting that Halilović of the $\mathrm{ABiH}$ did not turn up for the talks because he believed that the VRS had attacked Srebrenica); D4481 (Memorandum from John Wilson to Lord Owen, 16 April 1993).

1185 D2748 (UNPROFOR report re meeting with Ratko Mladić, 13 April 1993), p. 1.

1186 D2748 (UNPROFOR report re meeting with Ratko Mladić, 13 April 1993), p. 2.
} 
enclaves. ${ }^{1187}$ Wahlgren reported that when Mladić was asked directly whether he intended to take Srebrenica by force, he did not answer the question, rather he stated that he was ready to discuss a political solution to the Srebrenica problem. ${ }^{1188}$ Wahlgren reported that Srebrenica had become a key issue and a test case for the future survival of the Vance-Owen Plan. ${ }^{1189}$

369. On 16 April 1993, the Security Council passed Resolution 819 establishing Srebrenica as a safe area. ${ }^{1190}$ The resolution demanded the immediate cessation of armed attacks by "Bosnian Serb paramilitary units" against Srebrenica and their immediate withdrawal. ${ }^{1191}$

370. On 18 April 1993, an Agreement for the Demilitarisation of Srebrenica was signed. ${ }^{1192}$ It called for a total cease-fire in Srebrenica, the demilitarisation of Srebrenica within 72 hours, the deployment of an UNPROFOR company into Srebrenica, and the opening of a corridor between Tuzla and Srebrenica for the evacuation of the seriously wounded and ill. ${ }^{1193}$ All weapons were to be handed over to UNPROFOR. ${ }^{194}$ CanBat was deployed to Srebrenica pursuant to this agreement. $^{1195}$ The following day, a working group met to discuss how to implement the demilitarisation process. ${ }^{196}$ The VRS and ABiH disagreed on the area to the demilitarised. ${ }^{1197}$ UNPROFOR reported that while the Bosnian Serbs seemed ready to adhere to the 18 April agreement, the Bosnian Muslims did not and were considering going to the Security Council. ${ }^{1198}$ The Bosnian Muslims expressed concern that the VRS would redeploy to Žepa and Goražde after withdrawing from Srebrenica. ${ }^{1199}$

\footnotetext{
1187 D2748 (UNPROFOR report re meeting with Ratko Mladić, 13 April 1993), p. 2.

1188 D2748 (UNPROFOR report re meeting with Ratko Mladić, 13 April 1993), p. 3. See also P1483 (Ratko Mladić's notebook, 2 April-24 October 1993), p. 19.

1189 D2748 (UNPROFOR report re meeting with Ratko Mladić, 13 April 1993), p. 3.

1190 P4209 (UNSC Resolution 819, 16 April 1993); P2284 (UNSG report entitled "The Fall of Srebrenica", 15 November 1999), paras. 55-58 Pyers Tucker, T. 23211-23212 (17 January 2012).

1191 P4209 (UNSC Resolution 819, 16 April 1993), p. 2; P2284 (UNSG report entitled "The Fall of Srebrenica", 15 November 1999), para. 55.

1192 D1028 (UNPROFOR report re agreement on demilitarisation of Srebrenica, 18 April 1993); D2745 (Witness statement of Vere Hayes dated 14 January 2013), para. 15; P2284 (UNSG report entitled "The Fall of Srebrenica", 15 November 1999), para. 60.

1193 D1028 (UNPROFOR report re agreement on demilitarisation of Srebrenica, 18 April 1993), paras. 1-4; D2745 (Witness statement of Vere Hayes dated 14 January 2013), paras. 15-16.

1194 D1028 (UNPROFOR report re agreement on demilitarisation of Srebenica, 18 April 1993), para. 4; D2745 (Witness statement of Vere Hayes dated 14 January 2013), para. 16.

1195 D2745 (Witness statement of Vere Hayes dated 14 January 2013), para. 18; P2284 (UNSG report entitled "The Fall of Srebrenica", 15 November 1999), para. 61.

1196 D2750 (UNPROFOR report, 20 April 1993) (present at the meeting were Gvero for the VRS, a colonel of the $\mathrm{ABiH}$, and Brigadier Hayes of UNPROFOR).

1197 D2750 (UNPROFOR report, 20 April 1993), p. 1.

1198 D2750 (UNPROFOR report, 20 April 1993), p. 2.

1199 D2750 (UNPROFOR report, 20 April 1993), p. 2.
} 
371. On 24 April 1993, the Accused, Krajišnik, Mladić, Okun, Owen and others met in Belgrade to continue negotiations, in particular with respect to the proposed Vance-Owen Plan's map of BiH. $^{1200}$ The Accused was unhappy with the Vance-Owen Plan, particularly with the maps, and suggested that the Bosnian Serbs trade some land in $\mathrm{BiH}$ for land in Croatia, which Owen rejected. $^{1201}$

372. On 2 May 1993, in Athens, the Accused signed the Vance-Owen Plan for the Bosnian Serbs but it was subject to ratification by the Bosnian Serb Assembly. ${ }^{1202}$ However, the Bosnian Serb Assembly rejected the plan. ${ }^{1203}$ During this period there was never a complete cessation of hostilities and the armed conflict continued despite the peace efforts. ${ }^{1204}$

373. On 6 May 1993, the Security Council passed Resolution 824 which established the safe areas of Sarajevo, Tuzla, Žepa, Goražde, and Bihać. ${ }^{1205}$ The resolution declared that these safe areas should be free from armed attack or any other hostile acts by all parties. ${ }^{1206}$ In addition, the resolution provided for an immediate cease-fire and the withdrawal of all Bosnian Serb military or paramilitary units from the areas. ${ }^{1207}$ Further, it declared that all parties should respect the rights of

1200 Herbert Okun, P776 (Transcript from Prosecutor v. Krajišnik), T. 4273-4276; P792 (Ninth notebook of Herbert Okun's ICFY diary), e-court p. 46.

1201 Herbert Okun, P776 (Transcript from Prosecutor v. Krajišnik), T. 4274-4276; P792 (Ninth notebook of Herbert Okun's ICFY diary), e-court p. 47. According to Milovanović, on 26 April 1993, the Accused called a referendum to reject the Vance-Owen Plan which was, in their view, to "cantonise" BiH. The referendum was endorsed by the VRS. D2149 (Aide mémoire of Manojlo Milovanović), p. 22.

1202 Herbert Okun, P776 (Transcript from Prosecutor v. Krajišnik), T. 4117, 4150, 4235, 4344; P792 (Ninth notebook of Herbert Okun's ICFY diary), e-court p. 74-77.

1203 Herbert Okun, P776 (Transcript from Prosecutor v. Krajišnik), T. 4117, 4150, 4235-4236, 4344-4345; P2284 (UNSG report entitled "The Fall of Srebrenica", 15 November 1999), para. 67; P820 (Witness statement of David Harland dated 4 September 2009), para. 45. For discussion of the Vance-Owen Plan in the Bosnian Serb Assembly, see generally P1371 (Transcript of 30 ${ }^{\text {th }}$ session of RS Assembly, 5-6 May 1993); P1373 (Transcript of $31^{\text {st }}$ session of RS Assembly, 9 May 1993); P1375 (Transcript of 32 ${ }^{\text {nd }}$ session of RS Assembly, 19-20 May 1993). See also the Bosnian Serb city council in Sarajevo rejecting the Vance-Owen Plan. P5038 (Conclusions of meeting of the City Council of Sarajevo, 9 May 1993), p. 2. On 11 May 1993, the SDS Main Board had also rejected the plan. P2538 (Patrick Treanor's research report entitled "Radovan Karadžić and the Serbian Leadership 1990-1995", 1 May 2009), para. 175. On 6 May 1993, at a joint meeting between the President (the Accused), President of the Assembly (Krajišnik), and Prime Minister (Lukić), and others, it was decided afterwards that a referendum would be held to vote on the plan. D3611 (Minutes of joint meeting of RS President, National Assembly President and RS Prime Minister, 6 May 1993).

1204 Herbert Okun, P776 (Transcript from Prosecutor v. Krajišnik), T. 4150.

1205 P984 (UNSC Resolution 824, 6 May 1993) (declaring that "Sarajevo and other such threatened areas, in particular the towns of Tuzla, Žepa, Goražde, Bihać, as well as Srebrenica, and their surroundings should be treated as safe areas"); P2284 (UNSG report entitled "The Fall of Srebrenica”, 15 November 1999), para. 67. See also P820 (Witness statement of David Harland dated 4 September 2009), para. 102; David Harland, T. 2058 (7 May 2010); P897 (UNPROFOR Weekly Situation Report (Sarajevo), 15 July 1995), p. 3.

1206 P984 (UNSC Resolution 824, 6 May 1993), p. 2.

1207 P984 (UNSC Resolution 824, 6 May 1993), p. 2. 
UNPROFOR and international humanitarian agencies to free and unimpeded access and demanded full co-operation with UNPROFROR. ${ }^{1208}$

374. On 8 May 1993, the Bosnian Serbs and the Bosnian Muslims came to an agreement concerning the status of Žepa and Srebrenica; the Bosnian Serbs "reconfirmed" Security Council Resolution 824, and the Bosnian Muslims agreed to demilitarise the area. ${ }^{1209}$ However, UNPROFOR reported that this agreement was not implemented by either party. ${ }^{1210}$

375. On 15 and 16 May 1993, a referendum held in the RS on whether to accept the VanceOwen Plan resulted in a majority of votes against it. ${ }^{1211}$

376. On 4 June 1993, the Security Council passed Resolution 836 reaffirming the establishment of the safe areas and condemning military attacks. ${ }^{1212}$ While commending the Bosnian Muslims and Bosnian Croats for signing the Vance-Owen Plan, it was gravely concerned that the Bosnian Serbs had not signed it. ${ }^{1213}$ This resolution extended the mandate of UNPROFOR to include participating in the delivery of humanitarian aid. ${ }^{1214}$ It authorised UNPROFOR to act in selfdefence and take "necessary measures", including the use of force in response to bombardments or incursions into the safe areas and obstruction in and around those areas to the freedom of movement of UNPROFOR or humanitarian convoys. ${ }^{1215}$ It also decided that national or regional organisations, under the authority of the Security Council and subject to close co-ordination with the Secretary General and UNPROFOR, may take all necessary measures, through the use of air power, in and around the safe areas, to support UNPROFOR in the performance of its mandate. ${ }^{1216}$

\footnotetext{
1208 P984 (UNSC Resolution 824, 6 May 1993), p. 2.

1209 P897 (UNPROFOR Weekly Situation Report (Sarajevo), 15 July 1995), p. 3; P2284 (UNSG report entitled "The Fall of Srebrenica", 15 November 1999), para. 65.

1210 P897 (UNPROFOR Weekly Situation Report (Sarajevo), 15 July 1995), p. 3.

1211 P2284 (UNSG report entitled "The Fall of Srebrenica", 15 November 1999), para. 70; D2149 (Aide mémoire of Manojlo Milovanović), p. 24; P2538 (Patrick Treanor's research report entitled "Radovan Karadžić and the Serbian Leadership 1990-1995”, 1 May 2009), para. 176.

1212 P985 (UNSC Resolution 836, 4 June 1993); P2284 (UNSG report entitled "The Fall of Srebrenica", 15 November 1999), para. 78-79. See also P897 (UNPROFOR Weekly Situation Report (Sarajevo), 15 July 1995), p. 3; D3490 (UNPROFOR report, 15 January 1994), Yasushi Akashi, T. 37678-37679 (24 April 2013).

1213 P985 (UNSC Resolution 836, 4 June 1993).

1214 P985 (UNSC Resolution 836, 4 June 1993); D3490 (UNPROFOR report, 15 January 1994), p. 4.

1215 P985 (UNSC Resolution 836, 4 June 1993). See also David Harland, T. 2122-2123 (7 May 2010).

1216 P985 (UNSC Resolution 836, 4 June 1993). See also David Harland, T. 2122-2123 (7 May 2010), T. 2294 (11 May 2010).
} 


\section{b. Owen- Stoltenberg Plan}

377. Following the failure of the Vance-Owen Plan, the ICFY continued working through September 1993, under the co-chairmanship of Owen for the EC and Thorvald Stoltenberg, who replaced Vance, for the UN. ${ }^{1217}$

378. A new round of talks was initiated by Owen and Stoltenberg. ${ }^{1218}$ On 23 June 1993, the CoChairmen met with representatives from the parties. ${ }^{1219}$ Nine "constitutional principles" were proposed by the close of this meeting. ${ }^{1220}$ The Accused promised to do everything in his power to ensure the delivery of food, water, electricity, and gas to Sarajevo. ${ }^{1221}$ As for the eastern enclaves, the Accused stated that the Bosnian Serbs were prepared to "desist from all attacks [...] provided that "the armed forces within them are disarmed". ${ }^{222}$ Another round of talks took place in Geneva on 27 July 1993, with representatives from all sides, including the Accused, Izetbegović, Tuđman, and Slobodan Milošević. ${ }^{1223}$ On 30 July 1993, the parties agreed to the creation of three republics, representing the three constituencies in $\mathrm{BiH}$, under a centralised and joint government authority. ${ }^{1224}$

On the same day, a cessation of hostilities agreement was signed at the Sarajevo airport between Mladić and Delić. ${ }^{1225}$

379. The Bosnian Serbs agreed in principle to a proposal to open the Sarajevo airport by 4 August 1993. ${ }^{1226}$ The Accused informed the Co-Chairmen that Mladić was prepared to withdraw the VRS and allow the UN to take control of the area. ${ }^{1227}$ On 7 August 1993, the Accused wrote a

1217 Herbert Okun, P776 (Transcript from Prosecutor v. Krajišnik), T. 4295; P2538 (Patrick Treanor's research report entitled "Radovan Karadžić and the Serbian Leadership 1990-1995”, 1 May 2009), para. 178.

1218 P2538 (Patrick Treanor's research report entitled "Radovan Karadžić and the Serbian Leadership 1990-1995", 1 May 2009), para. 178.

1219 P2538 (Patrick Treanor's research report entitled "Radovan Karadžić and the Serbian Leadership 1990-1995", 1 May 2009), para. 178.

1220 P2538 (Patrick Treanor's research report entitled "Radovan Karadžić and the Serbian Leadership 1990-1995", 1 May 2009), para. 178. These nine constitutional principles were very similar to those proposed under the Vance-Owen Plan. Some changes included: binding arbitration for disputes between the republics, the reorganisation of $\mathrm{BiH}$ along confederal lines (three internal republics: Serbian, Croatian, and Muslim) instead of ten provinces, and the fact that Sarajevo would be an UN-administered city. P2538 (Patrick Treanor's research report entitled "Radovan Karadžić and the Serbian Leadership 1990-1995", 1 May 2009), para. 178.

1221 D4782 (Letter from Radovan Karadžić to Lord Carrington and Stoltenberg, 25 July 1993), p. 1.

1222 D4782 (Letter from Radovan Karadžić to Lord Carrington and Stoltenberg, 25 July 1993), p. 1.

1223 D2149 (Aide mémoire of Manojlo Milovanović), p. 28; P2538 (Patrick Treanor's research report entitled "Radovan Karadžić and the Serbian Leadership 1990-1995", 1 May 2009), para. 180.

1224 P2538 (Patrick Treanor's research report entitled "Radovan Karadžić and the Serbian Leadership 1990-1995", 1 May 2009), para. 182

1225 P5040 (Military Agreement on Cessation of Hostilities in BiH, 31 July 1993); P2538 (Patrick Treanor's research report entitled "Radovan Karadžić and the Serbian Leadership 1990-1995”, 1 May 2009), para. 182.

1226 P2538 (Patrick Treanor's research report entitled "Radovan Karadžić and the Serbian Leadership 1990-1995", 1 May 2009), para. 185.

1227 P2538 (Patrick Treanor's research report entitled "Radovan Karadžić and the Serbian Leadership 1990-1995", 1 May 2009), para. 188. The Accused, Mladić, and Krajišnik, among others, met with UNPROFOR in Pale on 5 August 1993 to discuss a number of proposals "designed to unblock the talks in Geneva". The Accused 
letter to the Co-Chairmen stating that the Bosnian Serbs were prepared to hand over Mt. Bjelašnica and Mt. Igman to UNPROFOR. ${ }^{1228}$ On 11 August 1993, the respective military commanders signed the Military Agreement for Peace in $\mathrm{BiH}^{1229}$ A few days later, the three parties met again and agreed to allow UNMOs to have freedom of movement throughout $\mathrm{BiH}$ and that the administration of Sarajevo, with the exclusion of Pale, would be organised by the UN. ${ }^{1230}$ On 14 August 1993, a DMZ around Mt. Igman and the Sarajevo airport was established. ${ }^{1231}$

380. At the $34^{\text {th }}$ Session of the Bosnian Serb Assembly, the Accused voiced his support for the constitutional arrangements proposed earlier in the negotiations, noting that they recognised the sovereignty of the RS within the BiH confederation. ${ }^{1232}$ The plan was adopted by the Bosnian Serb Assembly with the constitutional agreement as a condition for peace. ${ }^{1233}$

381. The ICFY continued to work on other arrangements for peace. ${ }^{1234}$ The parties agreed to a "Joint Declaration on Peace" which included a cessation of hostilities effective 18 September 1993 and proposed the resumption of talks on 21 September at the Sarajevo airport. ${ }^{1235}$ On 20 September 1993, the ICFY met with the parties on a British Royal Navy aircraft carrier in the Adriatic Sea,

presented proposals on the VRS withdrawal from Mt. Igman, the establishment of safe routes in and out of Sarajevo, and the restoration of utilities. He agreed to the establishment of a Joint Commission to ensure the restoration of utilities and infrastructure. P824 (UNPROFOR report re meeting with Radovan Karadžić, 5 August 1993); David Harland, T. 2031-2032 (6 May 2010).

1228 D4645 (Letter from Radovan Karadžić to Boutros Boutros Ghali, Bill Clinton, Lord Owen and Stoltenberg, 7 August 1993) (the letter was also addressed to Boutros Boutros Ghali and Bill Clinton). On 11 August 1993, Milovanović wrote a letter to UNPROFOR stating that the VRS would withdraw from Mt. Bjelašnica and Mt. Igman and allow UNPROFOR to take over their positions. D4786 (Letter from VRS Main Staff to UNPROFOR, 11 August 1993).

1229 P5041 (Military Agreement for Peace in BiH, 11 August 1993) (Mladić representing the Bosnian Serbs, Rasim Delić the Bosnian Muslims, and Milivoj Petkov the Bosnian Croats). See also P5051 (SRK forward of Military Peace Agreement for BiH, 12 August 1993) (wherein Galić orders all SRK units to pass on the Military Agreement for Peace in $\mathrm{BiH}$ to all subordinate units).

1230 P2538 (Patrick Treanor's research report entitled "Radovan Karadžić and the Serbian Leadership 1990-1995”, 1 May 2009), para. 191.

1231 P2414 (Witness statement of KDZ182 dated 8 March 2011), p. 57 (under seal); KDZ182, T. 13160 (10 March 2011); D1135 (Map of Sarajevo marked by KDZ182); P2447 (Witness statement of KDZ182 dated 8 March 2011), p. 4; D2753 (UNPROFOR report, 14 August 1993); D2745 (Witness statement of Vere Hayes dated 14 January 2013), para. 39. See also D722 (UNPROFOR report re letter from Ambassador Sacirbey, 19 October 1994); Adjudicated Fact 2783. KDZ182 stated that neither party respected the DMZ and it was not actually demilitarised until the beginning of 1995. P2414 (Witness statement of KDZ182 dated 8 March 2011), p. 57 (under seal); Milenko Inđić, T. 32461-32462, 32464-32465 (22 January 2013) (testifying that the Bjelašnica and Igman areas were never fully demilitarised).

1232 P1378 (Minutes of $34^{\text {th }}$ Session of RS Assembly, 27-29 August, 9-11 September, 29 September to 1 October 1993); P1379 (Transcript of $34^{\text {th }}$ Session of RS Assembly, 27-29 August, 9-11 September, 29 September to 1October 1993).

1233 P1378 (Minutes of $34^{\text {th }}$ Session of RS Assembly, 27-29 August, 9-11 September, 29 September to 1 October 1993); P1379 (Transcript of $34^{\text {th }}$ Session of RS Assembly, 27-29 August, 9-11 September, 29 September to 1 October 1993).

1234 Herbert Okun, P776 (Transcript from Prosecutor v. Krajišnik), T. 4295; P820 (Witness statement of David Harland dated 4 September 2009), para. 56.

1235 D4648 (Memo from Stoltenberg to UN Secretary-General, 16 September 1993); D4649 (Memo from Thorvald Stoltenberg to the UN Secretary-General, 16 September 1993). 
and the plan that emerged was referred to as the "Invincible Plan". ${ }^{1236}$ The plan allocated $49 \%$ of the territory of $\mathrm{BiH}$ to the Bosnian Serbs, $33 \%$ to the Bosnian Muslims, and $17.5 \%$ to the Bosnian Croats. ${ }^{1237}$ Sarajevo would remain undivided and administered by the UN for two years. ${ }^{1238}$

382. The Bosnian Muslims rejected the Owen-Stoltenberg Plan at the end of September 1993. ${ }^{1239}$ UNPROFOR reported that the Bosnian Serbs had invested heavily in the Owen-Stoltenberg Plan and since its failure, had become "more politically frustrated and increasingly volatile". ${ }^{240}$

383. At the $35^{\text {th }}$ Session of the Bosnian Serb Assembly, the Accused proposed the adoption of a declaration on the continuation of the peace process, expressing his commitment to negotiations despite the Bosnian Muslims' rejection of the peace plan. ${ }^{1241}$ However, the Accused stipulated that the RS was forced to withdraw all of its prior concessions. ${ }^{1242}$

384. On 18 November 1993, the ICFY issued a Joint Declaration on the provision of humanitarian relief in BiH signed by the Accused, Silajdžić, Boban, and Ogata in Geneva. ${ }^{1243}$ The parties agreed to (i) ensure complete and secure freedom of movement for the personnel of the UN and humanitarian organisations; (ii) allow the UNHCR and ICRC to determine without any

1236 P2284 (UNSG report entitled "The Fall of Srebrenica", 15 November 1999), para. 114. The name of the British naval ship was the HMS Invincible. Reynaud Theunens, T. 17056 (20 July 2011); Herbert Okun, P776 (Transcript from Prosecutor v. Krajišnik), T. 4295; David Harland, T. 2065 (7 May 2010); P2538 (Patrick Treanor's research report entitled "Radovan Karadžić and the Serbian Leadership 1990-1995”, 1 May 2009), para. 202.

1237 P2538 (Patrick Treanor's research report entitled "Radovan Karadžić and the Serbian Leadership 1990-1995”, 1 May 2009), para. 202.

1238 P2538 (Patrick Treanor's research report entitled "Radovan Karadžić and the Serbian Leadership 1990-1995", 1 May 2009), para. 202.

1239 P820 (Witness statement of David Harland dated 4 September 2009), paras. 57-60; David Harland, T. 21462147 (10 May 2010). The Accused and Fikret Abdić signed a separate peace treaty on 22 October 1993 agreeing to, inter alia, the mutual recognition the RS and the "Autonomous Province of Western Bosnia" and freedom of movement. D4807 (Declaration of Radovan Karadžić and Fikret Abdić, 22 October 1993). Okun testified that the Accused was seeking to undermine the Bosnian government and exploit divisions within the Bosnian Muslims. Herbert Okun, T. 1608 (26 April 2010).

1240 P823 (UNPROFOR Weekly Political Assessment, 3 November 1993), p. 6.

1241 P1380 (Minutes of $35^{\text {th }}$ Session of RS Assembly, 2 October 1993); P1381 (Transcript of $35^{\text {th }}$ Session of RS Assembly, 2 October 1993).

1242 P1380 (Minutes of $35^{\text {th }}$ Session of RS Assembly, 2 October 1993); P1381 (Transcript of $35^{\text {th }}$ Session of RS Assembly, 2 October 1993). On 22 October 1993 in Belgrade, the Accused signed an agreement with Fikret Abdić mutually recognising the RS and the Autonomous Province of Western Bosnia. D3587 (Joint declaration of Radovan Karadžić and Fikret Abdić, 22 October 1993; Joint statement of Jadranko Prlić, Vladimir Lukić and Zlatko Jušić, 7 November 1993).

1243 P1462 (Joint declaration on humanitarian relief in BiH, 18 November 1993); Adrianus van Baal, T. 8412 (27 October 2010); P1484 (Ratko Mladić's notebook, 28 October 1993-15 January 1994), pp. 35-40; Tomasz Blaszczyk, T. 6073-6074 (20 August 2010). See P5252 (Report of SRK, 20 March 1994), p. 2. 
conditionality or linkage the content of humanitarian assistance; and (iii) ensure that such assistance reached the civilian population and was not diverted to the military. ${ }^{1244}$

385. On 2 February 1994, Akashi met with the Accused in Belgrade to discuss the demilitarisation of Srebrenica, Žepa, and the opening of the Tuzla airport. ${ }^{1245}$

386. Following the shelling of the Markale market in Sarajevo on 5 February 1994, Owen and Stoltenberg met with the Accused in Pale and agreed upon the UN administration of Sarajevo. ${ }^{1246}$ On 6 February 1994, Akashi, Rose, and others visited the Markale market in Sarajevo, one day after it was shelled. ${ }^{1247}$ Following this visit, Akashi's group met first with Izetbegović and then with the Accused in an attempt to secure an immediate cease-fire in Sarajevo. ${ }^{1248}$ The Bosnian Muslims stated they were willing to sign a cease-fire agreement on the condition that the Bosnian Serbs moved their artillery and heavy weapons out of the range of Sarajevo and place them under UNPROFOR control. ${ }^{1249}$ The Bosnian Serbs would not accept the weapons withdrawal but would accept "on-site monitoring". ${ }^{1250}$ A draft joint declaration was drawn up as a basis for further negotiations. $^{1251}$

387. On 8 February 1994, Rose met with Milovanović at the Lukavica Barracks. ${ }^{1252}$ Milovanović stated that he had been given full authority from the Accused and Mladić to agree to the principles for the cease-fire, withdrawal of heavy weapons, and demilitarisation of Sarajevo. ${ }^{1253}$

\footnotetext{
1244 P1462 (Joint declaration on humanitarian relief in BiH, 18 November 1993), pp. 1-2. See also Tomasz Blaszczyk, T. 6073-6074 (20 August 2010) (testifying that the third item of the joint declaration addressed concerns raised by Mladić at the negotiations in Geneva); P1484 (Ratko Mladić's notebook, 28 October 199315 January 1994), p. 37.

1245 D3492 (UNPROFOR report, 2 February 1994), p. 3.

1246 P2538 (Patrick Treanor's research report entitled "Radovan Karadžić and the Serbian Leadership 1990-1995", 1 May 2009), para. 209. According to Harland and UNPROFOR, the shelling of the Markale market in Sarajevo on 5 February 1994 and threat of NATO air strikes led to an overall stabilisation of the situation in Sarajevo and also led the Bosnian Serbs to make numerous concessions on both humanitarian and military issues. P820 (Witness statement of David Harland dated 4 September 2009), paras. 76, 79; P827 (UNPROFOR Weekly Political Assessment, 17 February 1994), pp. 2, 6. See Scheduled Incident G.8.

1247 D713 (UNPROFOR report re talks with Radovan Karadžić and Alija Izetbegović, 6 February 1994).

1248 D713 (UNPROFOR report re talks with Radovan Karadžić and Alija Izetbegović, 6 February 1994).

1249 D713 (UNPROFOR report re talks with Radovan Karadžić and Alija Izetbegović, 6 February 1994 ), p. 1.

1250 D713 (UNPROFOR report re talks with Radovan Karadžić and Alija Izetbegović, 6 February 1994 ), p. 1.

1251 D713 (UNPROFOR report re talks with Radovan Karadžić and Alija Izetbegović, 6 February 1994), pp. 1, 3-4. Rose met with $\mathrm{ABiH}$ representatives again on 8 February 1994. See para. 4187; D2772 (Redacted diary of KW570), pp. 3-4 (under seal).

1252 D830 (UNPROFOR report re cease fire negotiations in Sarajevo, 8 February 1994), p. 3; D2772 (Redacted diary of KW570), pp. 3-4 (under seal).

1253 D830 (UNPROFOR report re cease fire negotiations in Sarajevo, 8 February 1994), p. 3; D2772 (Redacted diary of KW570), pp. 3-4 (under seal).
} 
An immediate cease-fire would be agreed upon the following day between the parties and a Joint Commission would be set up at the Sarajevo airport to work out the details of the agreement. ${ }^{1254}$

388. A cessation of hostilities agreement was arrived at on 9 February 1994, effective 12 p.m. on the following day. ${ }^{1255}$ As part of the agreement, a TEZ in Sarajevo was established which consisted of a 20 kilometre radius from the centre of the city in which all weapons of a $12.7 \mathrm{~mm}$ calibre or higher were to be removed or turned over to UNPROFOR at a designated WCP. ${ }^{1256}$ In addition, a Joint Commission was created under the chairmanship of the UNPROFOR Sector Sarajevo Commander in order to determine a timetable for the withdrawal of the heavy weapons. ${ }^{1257}$ WCPs were also established. ${ }^{1258}$ WCPs were locations where all the weapons systems for each party to the conflict were being held. ${ }^{1259}$ In a subsequent agreement, the Accused and Akashi agreed upon the locations of the WCPs and that UNPROFOR would have unrestricted access throughout the TEZ. ${ }^{1260}$

1254 D830 (UNPROFOR report re cease fire negotiations in Sarajevo, 8 February 1994), p. 3. After this meeting with the Bosnian Serbs, Rose held a meeting with the Bosnian Muslims who agreed to the principles as laid out and agreed to by the Bosnian Serbs. D2770 (Witness statement of KW570 dated 21 November 2012), para. 13 (under seal); D2772 (Redacted diary of KW570), p. 4 (under seal).

1255 P820 (Witness statement of David Harland dated 4 September 2009), paras. 79-80; P826 (UNPROFOR Weekly Political Assessment, 9 February 1994), p. 4; P827 (UNPROFOR Weekly Political Assessment, 17 February 1994), p. 2; D715 (UNPROFOR report re situation in BiH, 15 February 1994), p. 2; Michael Rose, T. 7256, 7260 (5 October 2010); D2772 (Redacted diary of KW570), p. 4 (under seal); Adjudicated Fact 2784. For more detailed evidence related to the cease-fire agreement, see para. 3582.

1256 P1638 (Witness statement of Michael Rose dated 26 March 2009), paras. 44-45; Michael Rose, T. 7256,7260 (5 October 2010); P2447 (Witness statement of KDZ182 dated 8 March 2011), p. 4; P820 (Witness statement of David Harland dated 4 September 2009), paras. 79-80; Michael Rose, T. 7260-7261 (5 October 2010); P1818 (Witness statement of Adrianus van Baal dated 26 October 2010), paras. 13-16 (stating that due to the winter weather conditions, it was impossible that all heavy weapons could physically be moved out and it was decided that the weaspons in the TEZ should be brought under the control of UNPROFOR); Adjudicated Facts 2784, 2785. A proposal dated 10 February 1994 from Dragomir Milošević to the VRS Main Staff suggests that in order to comply with the agreement, the SRK could "use a diversionary tactic to set aside equipment that is out of order and for which we [SRK] do not have sufficient quantities of ammunition". P1641 (SRK proposal re artillery, 10 February 1994). Rose testified that this proposal conformed to what UNPROFOR thought was happening on the ground. Michael Rose, T. 7262 (5 October 2010). Dragomir Milošević issued an order to the SRK to cease all fire at 12 p.m. on 10 February 1994 and to co-operate with UNPROFOR. P1642 (SRK Order, 10 February 1994).

1257 P820 (Witness statement of David Harland dated 4 September 2009), para. 79.

1258 P820 (Witness statement of David Harland dated 4 September 2009), para. 80. Harland stated that both parties to the conflict were disingenuous to an extent in complying with the agreements. P820 (Witness statement of David Harland dated 4 September 2009), para. 81. See also P847 (VRS Main Staff Order, 9 February 1994); P848 (Order of Drina Corps, 9 February 1994). There were nine WCPs in and around Sarajevo; two were in ABiH-controlled territory and seven were in SRK-held territory. Adjudicated Fact 2786. See para. 3582, fn. 11479.

1259 P1762 (Witness statement of David Fraser dated 17 October 2010), p. 20.

1260 P1654 (Agreement between Yasushi Akashi and Radovan Karadžić, 18 February 1994); KDZ450, T. 10558 (19 January 2011) (private session); P2118 (UNPROFOR report re weapon collection points in Sarajevo, 12 September 1994), p. 2; D717 (UNPROFOR report re weapons collection points in Sarajevo, 16 August 1994). See also Rupert Smith, T. 11365-11366 (8 February 2011); P1638 (Witness statement of Michael Rose dated 26 March 2009), para. 49; D2800 (SRK Order, 18 February 1994); D2801 (SRK combat report, 19 February 1994); D2802 (SRK combat report, 20 February 1994); Stanislav Galić, T. 37957-37958 (8 May 2013); D717 (UNPROFOR report re weapons collection points in Sarajevo, 16 August 1994), pp. 4-5; P1820 
389. On 24 February 1994, the creation of Blue Routes within Sarajevo to ensure freedom of movement and delivery of humanitarian aid was agreed to in principle. ${ }^{1261}$ The routes included a Dobrinja-Butmir route for Bosnian Muslim civilians, a Lukavica-Ilidža route for Bosnian Serbs civilians, and a pedestrian crossing in downtown Sarajevo at the Bratstvo Jedinstrvo Bridge. ${ }^{1262}$ However, on 27 February 1994, Milovanović stated in a meeting with Rose and Delić that the VRS would block UN convoys moving over Bosnian Serb territory regardless of the joint declaration signed on 18 November 1993, and would not allow the UN or anyone else to use the Bratstvo Jedinstvo Bridge. ${ }^{1263}$

390. UNPROFOR reported that the beginning of March 1994 was an encouraging time for Sarajevo and the cease-fire continued to hold. ${ }^{1264}$ On 17 March 1994, the Agreement on Freedom of Movement in Sarajevo ("Blue Routes Agreement") was signed by Krajišnik and Hasan Muratović and as a result a number of Blue Routes were established for civilians and humanitarian aid. ${ }^{1265}$ The Blue Routes were, specifically (i) Sarajevo-Vogošća-Zenica; (ii) Lukavica-Ilidža and Dobrinja-Butimir, through the Sarajevo airport (“Airport Routes”); and (iii) Bratstvo Jedinstvo

(Agreement between Yasushi Akashi and Radovan Karadžić, 18 February 1994); P1818 (Witness statement of Adrianus van Baal dated 26 October 2010), para. 11; Milenko Inđić, T. 32658-32662 (24 January 2013). Yasushi Akashi, T. 37755-37756 (25 April 2013). Five sites were agreed upon during negotiations on 16 February 1994, these sites included Lukavica barracks, Morko, Blagovac, Blazuj, and Radava. P2120 (UNPROFOR report re meeting with Stanislav Galić, 16 February 1994). See para. 3582.

1261 P820 (Witness statement of David Harland dated 4 September 2009), para. 89; Michael Rose, T. 7258 (5 October 2010); P1638 (Witness statement of Michael Rose dated 26 March 2009), para. 54; D2774 (Witness statement of Milenko Inđić dated 19 January 2013), para. 161. The concept of Blue Routes in Sarajevo was first proposed in January 1993, see para. 366. Harland testified that negotiations for the opening of Blue Routes went "nowhere" until the Bosnian Serbs felt an urgent need to forestall NATO air strikes through "bold and conciliatory gestures". P820 (Witness statement of David Harland dated 4 September 2009), para. 89; Michael Rose, T. 7258 (5 October 2010); D2774 (Witness statement of Milenko Inđić dated 19 January 2013), para. 161. Rose testified that the Blue Routes were designated as "being central to the re-supply of Sarajevo" and there was one such route that came down Mt. Igman. Michael Rose, T. 7258 (5 October 2010)

1262 P820 (Witness statement of David Harland dated 4 September 2009), para. 89. Milovanović stated that the Bosnian Serb forces would block UN convoys regardless of the agreement and would not allow the UN or anyone else to use the Bratstvo Jedinstrvo Bridge. P820 (Witness statement of David Harland dated 4 September 2009), paras. 92-93; P849 (UNPROFOR Weekly Political Assessment, 1 March 1994), p. 5.

1263 P820 (Witness statement of David Harland dated 4 September 2009), paras. 92-93; P849 (UNPROFOR Weekly Political Assessment, 1 March 1994), p. 5; P1638 (Witness statement of Michael Rose dated 26 March 2009), para. 54

1264 P849 (UNPROFOR Weekly Political Assessment, 1 March 1994), p. 1; P820 (Witness statement of David Harland dated 4 September 2009), paras. 91, 95, 97.

1265 P820 (Witness statement of David Harland dated 4 September 2009), para. 97; P5422 (UNPROFOR report, 8 May 1994), para. 21; P5252 (Report of SRK, 20 March 1994), p. 2 (stating that the basis of the agreement was the desire to implement the 18 November 1993 joint declaration); D2774 (Witness statement of Milenko Inđić dated 19 January 2013), para. 161; P1638 (Witness statement of Michael Rose dated 26 March 2009), paras. 54, 56, 58; P1655 (UNPROFOR report re meeting with Radovan Karadžić and Alija Izetbegović, 7 March 1994), para. 3; Michael Rose, T. 7258 (5 October 2010). 
Bridge. $^{1266}$ UNPROFOR and humanitarian organisations had unlimited freedom of movement along the Blue Routes. ${ }^{1267}$ The Blue Routes were set to open on 23 March $1994 .^{1268}$

391. At the end of March and into the beginning of April 1994, attacks were launched on the safe area of Goražde. ${ }^{1269}$ On 9 April 1994, a cease-fire agreement was discussed. ${ }^{1270}$ It proposed a complete cease-fire in $\mathrm{BiH}$ for 14 days and the Bosnian Serbs' withdrawal from Goražde. ${ }^{1271}$ Mladić stated that he was "uninterested in signing anything other than a total agreement for the cessation of hostilities". ${ }^{1272}$ The Bosnian Muslims stated that they would agree to a cessation of hostilities for a period of four months, on the condition that the Bosnian Serb withdraw from Goražde. $^{1273}$

392. On 10 and 11 April 1994, the Bosnian Serbs shelled the town of Goražde. ${ }^{1274}$ NATO responded with air strikes targeting a VRS artillery command post. ${ }^{1275}$ In response, Bosnian Serbs

\footnotetext{
1266 P5252 (Report of SRK, 20 March 1994), pp. 2-7; P820 (Witness statement of David Harland dated 4 September 2009), para. 97; D2774 (Witness statement of Milenko Inđić dated 19 January 2013), para. 161.

1267 P5252 (Report of SRK, 20 March 1994), pp. 2-7.

1268 P5252 (Report of SRK, 20 March 1994), p. 2; P2470 (UNPROFOR report, 1 September 1994), p. 2.

1269 P2284 (UNSG report entitled "The Fall of Srebrenica", 15 November 1999), paras. 132-135; KW570, T. 32242-32246 (18 January 2013). See also P2451 (Witness statement of Anthony Banbury dated 19 May 2009), para. 13; Anthony Banbury, T. 13417-13418 (16 March 2011); D687 (UNPROFOR report re Goražde, 18 April 1994); D704 (UNPROFOR report re meeting with Radovan Karadžić, 19 August 1994); Yasushi Akashi, T. 37703-37706 (24 April 2013); P1818 (Witness statement of Adrianus van Baal dated 26 October 2010), para. 20. See generally P1638 (Witness statement of Michael Rose dated 26 March 2009), paras. 67-89.
}

1270 P851 (UNPROFOR report re meeting between Bosnian and Serb Army Commanders, 9 April 1994). Present at the meeting were Delić, Karavelić, Mladić, Gvero, Tolimir, Rose, Andreev, Charles Redman (US Special Envoy), and Victor Jackovich (US Ambassador to BiH). P851 (UNPROFOR report re meeting between Bosnian and Serb Army Commanders, 9 April 1994), p. 1. A few days earlier, on 4 April 1994, Rose met with the Accused and Milovanovic in Pale to discuss the possibility of extending the scope of the cease-fire in Sarajevo to cover all of BiH. P1638 (Witness statement of Michael Rose dated 26 March 2009), para. 66. Rose met again with the Bosnian Serbs and Bosnian Muslims, separately, on 7 and 8 April 1994 to try to come to a cease-fire agreement. P1638 (Witness statement of Michael Rose dated 26 March 2009), para. 71.

1271 P851 (UNPROFOR report re meeting between Bosnian and Serb Army Commanders, 9 April 1994), pp. 1-2.

1272 P851 (UNPROFOR report re meeting between Bosnian and Serb Army Commanders, 9 April 1994), p. 2; P1638 (Witness statement of Michael Rose dated 26 March 2009), para. 74.

1273 P851 (UNPROFOR report re meeting between Bosnian and Serb Army Commanders, 9 April 1994), p. 2; P1638 (Witness statement of Michael Rose dated 26 March 2009), para. 74.

1274 P1638 (Witness statement of Michael Rose dated 26 March 2009), paras. 77-84; Michael Rose, T. 7272-7273 (5 October 2010); P1659 (UNPROFOR report re meeting with Radovan Karadžić, 10 April 1994); P852 (UNPROFOR Update on Goražde, 17 April 1994), p. 1; P820 (Witness statement of David Harland dated 4 September 2009), para. 104; P2284 (UNSG report entitled “The Fall of Srebrenica”, 15 November 1999), para. 136. On 15 April 1994, Goražde was shelled again. D3496 (UNPROFOR report, 16 April 1994), p. 2. On 16 April 1994, UNPROFOR reported that the enclave of Goražde had collapsed. P829 (UNPROFOR Weekly Political Assessment, 16 April 1994), pp. 1-2; P1638 (Witness statement of Michael Rose dated 26 March 2009), para. 93; P2284 (UNSG report entitled "The Fall of Srebrenica", 15 November 1999), para. 138.

1275 P1638 (Witness statement of Michael Rose dated 26 March 2009), paras. 81-83; P1660 (Order of Drina Corps, 10 April 1994); P829 (UNPROFOR Weekly Political Assessment, 16 April 1994), p. 2; P829 (UNPROFOR Weekly Political Assessment, 16 April 1994), p. 2; D2149 (Aide mémoire of Manojlo Milovanović), p. 43; KW570, T. 32254-32256 (18 January 2013). 
detained UN personnel. ${ }^{1276}$ In addition, the city of Sarajevo and the Tuzla airport were shelled. ${ }^{1277}$ The Sarajevo airport remained closed. ${ }^{1278}$

393. On 17 April 1994, UNPROFOR representatives went to Pale to speak to the Accused, who declared that the "right bank of the Drina will be ours" and no agreement could be reached on a proposed three-kilometre TEZ around Goražde. ${ }^{1279}$ The negotiations only yielded the release of a few of the UN personnel who had been detained by the Bosnian Serb forces. ${ }^{1280}$ UNPROFOR representatives reported that "no agreement was reached on the boundaries of the safe areas, the deployment of UNPROFOR and UNMO troops, or anything at all specific. [Nor] is there reason to believe that even the promises made will be kept. In the words of Russian envoy [Vitaly] Churkin, 'I have heard more lies here in 24 hours than I've heard in my entire life'". ${ }^{1281}$

394. On 22 April 1994, the Security Council passed Resolution 913 condemning the Bosnian Serbs for the attacks on Goražde. ${ }^{1282}$ The following day, an agreement was reached between Akashi and the Bosnian Serbs for an immediate and total cease-fire around Goražde starting at 12 p.m. ${ }^{1283}$ It established that UNPROFOR would monitor the three kilometre radius from the centre of Goražde and heavy weapons would be withdrawn from a 20 kilometre radius. ${ }^{1284}$

395. On 21 May 1994, an agreement between the parties to demilitarise the Goražde TEZ was concluded. $^{1285}$ It included a cessation of all hostilities in and around Goražde effective

\footnotetext{
1276 P829 (UNPROFOR Weekly Political Assessment, 16 April 1994), pp. 1, 3; KW570, T. $32248-32250$ (18 January 2013); P1638 (Witness statement of Michael Rose dated 26 March 2009), para. 90.

1277 P829 (UNPROFOR Weekly Political Assessment, 16 April 1994), p. 3; P882 (UNPROFOR Weekly Situation Report (Sarajevo), 14 April 1995).

1278 P882 (UNPROFOR Weekly Situation Report (Sarajevo), 14 April 1995), p. 2.

1279 P852 (UNPROFOR Update on Goražde, 17 April 1994), p. 2.

1280 P852 (UNPROFOR Update on Goražde, 17 April 1994), p. 2. Only 14 Canadians and three UNMOs were released while 130 UN personnel remained in detention. P852 (UNPROFOR Update on Goražde, 17 April 1994), p. 2.

1281 P852 (UNPROFOR Update on Goražde, 17 April 1994), p. 2; P820 (Witness statement of David Harland dated 4 September 2009), para. 112. On 23 April 1994, Akashi met with the Accused, Mladić, Gvero, Koljević, Krajišnik, and Buha in Belgrade at a meeting chaired by Slobodan Milošević. Topics discussed included the situation in Goražde, normalising relations between UNPROFOR and the Bosnian Serbs, and an agreement for an overall cessation of hostilities. D3498 (UNPROFOR report, 23 April 1994); Yasushi Akashi, T. 3770937713 (24 April 2013).

1282 P2284 (UNSG report entitled "The Fall of Srebrenica", 15 November 1999), para. 142.

1283 D3498 (UNPROFOR report, 23 April 1994), p. 7; P2284 (UNSG report entitled "The Fall of Srebrenica", 15 November 1999), para. 143.

1284 D3498 (UNPROFOR report, 23 April 1994), p. 7.

1285 P1664 (UNPROFOR report re meeting on Goražde, 21 May 1994); P1638 (Witness statement of Michael Rose dated 26 March 2009), para. 105.
} 
22 May 1994. ${ }^{1286}$ UNPROFOR would monitor and maintain the security of the TEZ to ensure compliance by the parties. ${ }^{1287}$

\section{Contact Group}

396. The Contact Group was comprised of representatives from France, Germany, the UK, the Russian Federation, and the USA. ${ }^{1288}$ Talks were held in Geneva between 1 to 8 June 1994 in order to come to a political settlement of the conflict, the main issue being the concept of a unified state. ${ }^{1289}$ The situation in Goražde remained a problem as the Bosnian Muslims stipulated that the presence of armed VRS soldiers inside the Goražde TEZ violated one of their preconditions for the resumption of the cessation of hostilities talks. ${ }^{1290}$ UNPROFOR dispatched additional soldiers to Goražde to patrol the TEZ. ${ }^{1291}$ According to UNPROFOR, the Accused made a commitment to Akashi that all armed VRS soldiers would leave the TEZ in Goražde by 6 p.m. on 2 June 1994. ${ }^{1292}$ However, UNPROFOR observed that VRS soldiers in the TEZ simply changed their uniforms into civilian attire and kept their weapons with them. ${ }^{1293}$

397. On 8 June 1994, the parties signed an Agreement on the Cessation of Offensive Actions which would last for one month. ${ }^{1294}$ They further agreed to release all prisoners of war and detainees and exchange information on missing persons. ${ }^{1295}$ The ABiH launched an offensive in

1286 P1638 (Witness statement of Michael Rose dated 26 March 2009), para. 105; P1664 (UNPROFOR report re meeting on Goražde, 21 May 1994), e-court p. 2; P2520 (UNPROFOR Weekly Political Assessment, 28 May 1994), p. 3. See also D4822 (Radovan Karadžić's Order to VRS Main Staff, 26 April 1994) (wherein the Accused ordered the VRS Main Staff to allow an UkrBat convoy into Goražde and to withdraw all heavy weapons from a 20 kilometre radius from the centre of Goražde). Rose stated that a discussion for an agreement was brokered on 23 April 1994 in Belgrade between Akashi, the Accused, and Mladić, among others. The agreement included, inter alia, a cease-fire in and around Goražde and the creation of a three kilometre exclusion zone around Goražde. P1638 (Witness statement of Michael Rose dated 26 March 2009), para. 99; Michael Rose, T. 7283 (5 October 2010).

1287 P1664 (UNPROFOR report re meeting on Goražde, 21 May 1994), e-court p. 2.

1288 P820 (Witness statement of David Harland dated 4 September 2009), para. 121,

1289 P1638 (Witness statement of Michael Rose dated 26 March 2009), para. 108; P1666 (UNPROFOR report re meetings with Radovan Karadžić, 4 June 1994); P2462 (UNPROFOR Weekly BiH Political Assessment, 3 June 1994), p. 2.

1290 P2462 (UNPROFOR Weekly BiH Political Assessment, 3 June 1994), pp. 1-2; P2462 (UNPROFOR Weekly BiH Political Assessment, 3 June 1994), pp. 1-2.

1291 P2462 (UNPROFOR Weekly BiH Political Assessment, 3 June 1994), p. 2.

1292 P2462 (UNPROFOR Weekly BiH Political Assessment, 3 June 1994), pp. 1-2.

1293 P2462 (UNPROFOR Weekly BiH Political Assessment, 3 June 1994), p. 2. See, e.g., P2463 (Letter from Višegrad Tactical Group to Drina Tactical Group, 10 May 1994) (an order from the VRS Main Staff to the Drina Corps Tactical Group that soldiers within the three kilometre TEZ are to be dressed civilian clothing). See also P2451 (Witness statement of Anthony Banbury dated 19 May 2009), para. 24.

1294 P2470 (UNPROFOR report, 1 September 1994), p. 3; D1147 (UNPROFOR report, 21 June 1994); P1638 (Witness statement of Michael Rose dated 26 March 2009), para. 113; P1665 (Agreement on Cessation of Hostilities in BiH, June 1994); D2149 (Aide mémoire of Manojlo Milovanović), p. 44.

1295 P2470 (UNPROFOR report, 1 September 1994), p. 3. 
the Ozren mountain range in mid-June. ${ }^{1296}$ However, by the end of June, the parties agreed to extend the 8 June agreement by one month. ${ }^{1297}$

398. The Contact Group unveiled a revised peace plan on 7 July 1994 which contained a new set of territorial arrangements. ${ }^{1298}$ The Contact Group plan proposed that $51 \%$ of $\mathrm{BiH}$ would be administered by a newly formed Bosnian-Croat Federation and that $49 \%$ be administered by the Bosnian Serbs. ${ }^{1299}$ On 18 July 1994, the Bosnian Muslims accepted the plan. ${ }^{1300}$

399. On 19 July 1994, at the Bosnian Serb Assembly, the Accused spoke about the Contact Group's proposed plan stating that the acceptance of the plan would not be a guarantee for peace. ${ }^{1301}$ On 21 July 1994, the Bosnian Serbs officially rejected the plan stating that the plan was unfair and their demands were not met. ${ }^{1302}$ The Contact Group met again in Geneva on 30 July 1994 to negotiate a new plan. ${ }^{1303}$ A few days earlier, the Bosnian Serbs effectively closed access to the Sarajevo airport and the tunnel under it through Mt. Igman, which had been used for humanitarian aid. ${ }^{1304}$ The Accused claimed this was done because of the smuggling of weapons into the city. ${ }^{1305}$ Rose, due to security reasons, closed the Sarajevo airport to civilian traffic and the UN reported that without the airport, the situation in Sarajevo would be dire. ${ }^{1306}$ Rose reported: "[F] or the first time in many months, we are moving backwards". ${ }^{1307}$

400. An anti-sniping agreement for Sarajevo was signed by the parties on 14 August $1994 .{ }^{1308}$ It stipulated that each side would issue orders explicitly forbidding sniping activities against military,

\footnotetext{
1296 P2470 (UNPROFOR report, 1 September 1994), p. 3.

1297 P2470 (UNPROFOR report, 1 September 1994), p. 3.

1298 P820 (Witness statement of David Harland dated 4 September 2009), para. 121; Herbert Okun, P776 (Transcript from Prosecutor v. Krajišnik), T. 4295; P1638 (Witness statement of Michael Rose dated 26 March 2009), para. 121; P2470 (UNPROFOR report, 1 September 1994), p. 5; P6160 (Exerpt from transcript of interview with Momir Bulatović, 7 October 1994), e-court p. 6.

1299 P820 (Witness statement of David Harland dated 4 September 2009), para. 121.

1300 P2470 (UNPROFOR report, 1 September 1994), p. 5.

1301 P1394 (Transcript of $42^{\text {nd }}$ Session of RS Assembly, 18-19 July 1994), pp. 15-18. See also D2149 (Aide mémoire of Manojlo Milovanović), p. 45-46.

1302 P2470 (UNPROFOR report, 1 September 1994), p. 5.

1303 P2470 (UNPROFOR report, 1 September 1994), p. 5.

1304 P1638 (Witness statement of Michael Rose dated 26 March 2009), para. 127; P1668 (UNPROFOR report re negotiations in $\mathrm{BiH}, 2$ August 1994), p. 1; P2124 (UNPROFOR report re negotiations with parties in BiH, 2 August 1994); P2470 (UNPROFOR report, 1 September 1994), p. 6. See also para. 3593.

1305 P1638 (Witness statement of Michael Rose dated 26 March 2009), para. 128; P1668 (UNPROFOR report re negotiations in BiH, 2 August 1994), p. 1. See also para. 3593.

1306 P1638 (Witness statement of Michael Rose dated 26 March 2009), para. 128. See also para. 3593.

1307 P1638 (Witness statement of Michael Rose dated 26 March 2009), para. 128.

1308 P820 (Witness statement of David Harland dated 4 September 2009), paras. 64, 128-129; P1638 (Witness statement of Michael Rose dated 26 March 2009), para. 139; P861 (UNPROFOR report re agreement on elimination of sniping in Sarajevo, 14 August 1994); P863 (Excerpt from SRK Order, 18 August 1994); Dragomir Milošević, T. 32839-32842 (29 January 2013); P2470 (UNPROFOR report, 1 September 1994), p. 9;
} 
civilian, and UN personnel in Sarajevo. ${ }^{1309}$ They also agreed that UNPROFOR would take measures to identify and prevent sniping with both parties. ${ }^{1310}$ UNPROFOR reported that following this agreement, sniping activities ceased almost entirely for a six-week period. ${ }^{1311}$

401. On 27 August 1994, in a referendum held in Bosnian Serb-held territory, 96\% of the voters rejected the Contact Group plan. ${ }^{1312}$ Despite this, the Contact Group continued its work throughout the remainder of year and into the following year. ${ }^{1313}$

402. On 20 September 1994, Rose, Andreev, and Harland met with the Accused, Koljević, Krajišnik, and Milovanović in Pale. ${ }^{1314}$ The Accused was angry about a Bosnian Muslim attack in Sarajevo a few days prior and stated there could be no talks on demilitarisation after such an attack. $^{1315}$ In reference to the possibility that the Security Council would tighten sanctions on Pale, the Accused responded, "if the international community treats us like a beast, then we will behave like a beast". ${ }^{1316}$ Krajišnik demanded, inter alia, that UNPROFOR formally recognise the Bosnian Serb ownership of the Sarajevo airport and that UNPROFOR pay rent for the use of the airport. ${ }^{1317}$ Krajišnik stated that "it would be difficult to stop Serb soldiers from shooting at airplanes" if these

D2782 (UNPROFOR Memo, 18 August 1994); Milenko Inđić, T. 32460-32461 (22 January 2013); Adjudicated Fact 2789.

P861 (UNPROFOR report re agreement on elimination of sniping in Sarajevo, 14 August 1994), p. 4. See also D2782 (UNPROFOR Memo, 18 August 1994).

1310 P861 (UNPROFOR report re agreement on elimination of sniping in Sarajevo, 14 August 1994), p. 4.

1311 P820 (Witness statement of David Harland dated 4 September 2009), para. 133; P864 (UNPROFOR report re violations of anti-sniping agreement, 12 September 1994); P1638 (Witness statement of Michael Rose dated 26 March 2009), para. 141.

1312 P872 (UNPROFOR Weekly Situation Report, 10 December 1994), p. 4; P2471 (UNPROFOR Weekly BiH Political Assessment, 3 September 1994), pp. 2, 4; P2470 (UNPROFOR report, 1 September 1994), p. 7; P2457 (UNPROFOR Weekly BiH Political Assessment, 28 August 1994), p. 4; P820 (Witness statement of David Harland dated 4 September 2009), para. 121; Martin Bell, T. 9897 (15 December 2010). The Accused called the Contact Group plan a "devilish one”. P2563 (Minutes of meeting between Milan Martić and Radovan Karadžić, 20 August 1994), p. 5. See also P2451 (Witness statement of Anthony Banbury dated 19 May 2009), para. 56. On 21 September 1994, the Contact Group presented a new proposal for a territorial settlement outlined in a map. The proposal was accepted by all the parties with the exception of the Bosnian Serbs. D1594 (Letter from UNSC to UNSG, 21 September 1994).

1313 Anthony Banbury, T. 13354-13355 (15 March 2011). On 9 September 1994, Sergio Vieira de Mello met with the Accused in Pale and informed the Accused that the Contact Group intended to "sustain its policy of heavy pressure on the Bosnian Serbs". D1136 (UNPROFOR report, 9 September 1994), p. 1. In May 1995, the Contact Group restated that its two main objectives were the continuation of the cessation of hostilities agreement of 31 December 1994 and mutual recognition of Serbia, Croatia, and BiH. D1151 (UNPROFOR Weekly Situation Report, 8 May 1995), pp. 2-3.

1314 P820 (Witness statement of David Harland dated 4 September 2009), paras. 134-138; P834 (UNPROFOR report re meetings with Bosnian Serb and Bosnian Muslim leadership, 20 September 1994); P1638 (Witness statement of Michael Rose dated 26 March 2009), para. 150.

1315 P834 (UNPROFOR report re meetings with Bosnian Serb and Bosnian Muslim leadership, 20 September 1994), para. 1.

1316 P834 (UNPROFOR report re meetings with Bosnian Serb and Bosnian Muslim leadership, 20 September 1994), paras. 1-2; P820 (Witness statement of David Harland dated 4 September 2009), para. 135.

1317 P834 (UNPROFOR report re meetings with Bosnian Serb and Bosnian Muslim leadership, 20 September 1994), para. 4. 
demands were not met. ${ }^{1318}$ Milovanović agreed to move all of the heavy weapons out of the Sarajevo TEZ by midnight the following night. ${ }^{1319}$

403. On 23 September 1994, the Security Council passed Resolution 941 in which it noted that UNHCR and the ICRC had reported grave violations of international humanitarian law in Banja Luka, Bijeljina, and other areas of $\mathrm{BiH}$ under Bosnian Serb control which it described as ethnic cleansing. ${ }^{1320}$ It condemned these practices and demanded that the Bosnian Serb authorities immediately cease their "campaign of ethnic cleansing" and give immediate access to the Special Representative of the Secretary General, UNPROFOR, UNHCR, and ICRC to Banja Luka, Bijleljina, and other areas. ${ }^{1321}$ On 5 October 1994, Akashi and UNPROFOR met with the Accused and others in Pale to continue negotiations. ${ }^{1322}$ Topics for discussion included, inter alia, the reopening of the Sarajevo airport, re-opening of land routes into Sarajevo, demilitarisation of Sarajevo, and freedom of movement for UNPROFOR, UNHCR, and civilizians. ${ }^{1323}$

404. On 10 October 1994, Rose, Gobilliard, and Harland met in Pale with Mladić and Tolimir to discuss a sniping incident on a tramway in Sarajevo and the freedom of movement of fuel convoys. ${ }^{1324}$ On 19 October 1994, Rose reported to Akashi that Mladić was not allowing fuel convoys across Bosnian Serb-held territory until UNPROFOR guaranteed that $\mathrm{ABiH}$ forces were out of the DMZ around Mt. Igman or unless UNPROFOR hand over 50\% of the convoys to the Bosnian Serbs. ${ }^{1325}$ Accordingly, Rose recommended that a letter be written to the Accused informing him of this situation. ${ }^{1326}$

\footnotetext{
1318 P834 (UNPROFOR report re meetings with Bosnian Serb and Bosnian Muslim leadership, 20 September 1994), para. 4.

1319 P834 (UNPROFOR report re meetings with Bosnian Serb and Bosnian Muslim leadership, 20 September 1994), para. 5.

1320 P5424 (UNSC Resolution 941, 23 September 1994), p. 1. Rose testified that the cessation of hostilities agreed upon in February 1994 came to an end in September 1994 when the ABiH launched an attack against the VRS. Michael Rose, T. 7256 (5 October 2010).

$1321 \quad$ P5424 (UNSC Resolution 941, 23 September 1994), p. 2.

1322 D3500 (UNPROFOR report, 7 October 1994); Yasushi Akashi, T. 37717-37718 (24 April 2013); P1638 (Witness statement of Michael Rose dated 26 March 2009), para. 154. Others present at the meeting included UNPROFOR Force Commander General de Lapresle, Viera de Mello (Head of Civil Affairs), Rose, Andreev, Koljević, Krajišnik, Buha, Mladić and Gvero. D3500 (UNPROFOR report, 7 October 1994), para. 1.

1323 D3500 (UNPROFOR report, 7 October 1994), p. 3.

1324 P867 (UNPROFOR report on meeting with Ratko Mladić, 10 October 1994); P1638 (Witness statement of Michael Rose dated 26 March 2009), para. 156. See para. 3601.

1325 P868 (UNPROFOR report on Serb fuel blockade, 19 October 1994), p. 1; P820 (Witness statement of David Harland dated 4 September 2009), para. 144.

1326 P868 (UNPROFOR report on Serb fuel blockade, 19 October 1994).
} 
405. On 22 October 1994, Akashi and Rose met with the Accused, Koljević, Buha, Zametica, and Tolimir in Pale. ${ }^{1327}$ The Bosnian Serbs stated that they had opened the Sarajevo airport and restored utilities to the city. ${ }^{1328}$ Rose reported that this was untrue. ${ }^{1329}$

406. On 19 November 1994, Gobilliard and Andreev met with the Accused and Tolimir in Pale to discuss the deteriorating situation in $\mathrm{BiH}$, including the attacks around Sarajevo and Bihać in violation of Security Council Resolution 836. ${ }^{1330}$ According to UNPROFOR, the Accused made it clear that the Bosnian Serbs would not respect any agreements until the Bosnian Muslims completely withdrew from the DMZ. ${ }^{1331}$ Akashi reported that he spoke to the Accused and urged him to accept the Contact Group plan but "to no avail". ${ }^{1332}$

407. On 1 December 1994, Rose went to Pale to speak to the Accused about the deteriorating relationship between the Bosnian Serbs and UNPROFOR. ${ }^{1333}$ The Accused was upset about NATO activity and Rose explained to him that NATO air support could be used (i) in support of UNPROFOR troops who are in danger, (ii) in support of the TEZ, and (iii) to deter attacks on the safe areas. ${ }^{1334}$ Rose also told the Accused that approximately 500 UNPROFOR personnel were being detained in eastern $\mathrm{BiH}$ and the Accused promised that he would look into it but assured him that the detainees were being treated well. ${ }^{1335}$ Rose told the Accused that unless minimum conditions were met, UNPROFOR would begin withdrawing from $\mathrm{BiH}$ as its mission had become almost impossible. ${ }^{1336}$ Gvero told Rose that the Sarajevo airport could not be re-opened until the Bosnian Serbs received written guarantees from the UN that NATO would not attack Bosnian Serb targets and that the safe areas would be respected when they were demilitarised. ${ }^{1337}$ However, within a few days, Koljević made assurances that UNPROFOR personnel would be released and by

\footnotetext{
$1327 \quad$ P1638 (Witness statement of Michael Rose dated 26 March 2009), para. 159.

1328 P1638 (Witness statement of Michael Rose dated 26 March 2009), para. 159.

1329 P1638 (Witness statement of Michael Rose dated 26 March 2009), para. 159.

1330 P1776 (UNPROFOR report re meeting with Radovan Karadžić and General Tolimir, 20 November 1994).

1331 P1776 (UNPROFOR report re meeting with Radovan Karadžić and General Tolimir, 20 November 1994).

1332 P3864 (UNPROFOR report, 24 November 1994), p. 1.

1333 P1638 (Witness statement of Michael Rose dated 26 March 2009), para. 177; P869 (UNPROFOR report on meeting with Radovan Karadžić, 1 December 1994); P820 (Witness statement of David Harland dated 4 September 2009), para. 148.

1334 P869 (UNPROFOR report on meeting with Radovan Karadžić, 1 December 1994), p. 2. With respect to Bihać, Rose explained that NATO air support would only be used if the Bosnian Serbs "bombarded the civilian centre of town”. P869 (UNPROFOR report on meeting with Radovan Karadžić, 1 December 1994), p. 2.

1335 P869 (UNPROFOR report on meeting with Radovan Karadžić, 1 December 1994), p. 2.

1336 P872 (UNPROFOR Weekly Situation Report, 10 December 1994), p. 2. The minimum conditions included (i) re-opening of the Sarajevo airport which had been closed since 23 November 1994; (ii) free movement of UN convoys to eastern Bosnia "to a point where UNPROFOR has at least seven days of stocks" in Srebrenica, Žepa, and Goražde; (iii) access to Bihać for UNPROFOR and UNHRC; (iv) passage of UN vehicles through Bosnian Serb checkpoints in Sarajevo, which had been blocked for weeks; and (v) release of UNPROFOR hostages. P872 (UNPROFOR Weekly Situation Report, 10 December 1994), p. 2. 
week's end, all UNPROFOR detainees were released and some convoys were moving through BiH again. ${ }^{1338}$ Buha issued a public statement that the Bosnian Serb Assembly should accept the Contact Group plan on the understanding that the acceptance of the plan would be immediately followed by "talks on territorial swaps". ${ }^{1339}$

408. On 7 December 1994, the Accused made public statements on Serb television that he was willing to negotiate on the basis of the Contact Group plan but that the map was still unacceptable. ${ }^{1340}$ Subsequent meetings took place in Pale over the issue of the restrictions on UNPROFOR's freedom of movement, the demilitarisation of Bihać, and the Mt. Igman DMZ. ${ }^{1341}$

409. On 14 December 1994, Akashi and Rose met with the Accused and others in Pale. ${ }^{1342}$ Akashi proposed a plan to implement further negotiations on the basis of the Contact Group plan and suggested, inter alia, a cease-fire and demilitarised zone for Bihać, a cease-fire for all of BiH, and a cessation of hostilities. ${ }^{1343}$ The Accused expressed his opinion that the Bosnian Serbs had been treated unequally and that there would be no cease-fire until an actual peace plan to end the conflict was proposed and that he would only consider the Bihać proposal once agreements on Srebrenica, Žepa, Goražde, and the Mt. Igman DMZ were fulfilled. ${ }^{1344}$

410. On 31 December 1994, the parties signed an Agreement on Complete Cessation of Hostilities ("COHA") following the cease-fire agreement signed on 23 December 1994. ${ }^{1345}$ The complete cessation of hostilities was to go into effect from 12 p.m. on 1 January 1995 along all the confrontation lines. ${ }^{1346}$ The COHA was signed by the Accused, Izetbegović, Rasim Delić, Mladić,

\footnotetext{
1338 P872 (UNPROFOR Weekly Situation Report, 10 December 1994), p. 3.

1339 P872 (UNPROFOR Weekly Situation Report, 10 December 1994), p. 4.

1340 P1638 (Witness statement of Michael Rose dated 26 March 2009), para. 181; P872 (UNPROFOR Weekly Situation Report, 10 December 1994), p. 4.

1341 Present at the meeting were Rose, Andreev, Koljević, Krajišnik, Gvero, and Tolimir. P1640 (UNPROFOR report, 12 December 1994); P1638 (Witness statement of Michael Rose dated 26 March 2009), para. 182; Michael Rose, T. 7253-7256 (5 October 2010).

1342 Others present at the meeting were Andreev, General de Lapresle, Koljević, Krajišnik, Buha, and Tolimir. P1638 (Witness statement of Michael Rose dated 26 March 2009), para. 184.

1343 P1638 (Witness statement of Michael Rose dated 26 March 2009), para. 184.

1344 P1638 (Witness statement of Michael Rose dated 26 March 2009), para. 185.

1345 P1648 (Agreement on Cessation of Hostilities, 31 December 1994), p. 1; P1638 (Witness statement of Michael Rose dated 26 March 2009), para. 190; Yasushi Akashi, T. 37725-37726 (24 April 2013); D4835 (Fax from UNPROFOR re Draft Agreement on Complete Cessation of Hostilities, 25 December 1994); P820 (Witness statement of David Harland dated 4 September 2009), para. 158; D3505 (Letter from Yasushi Akashi to Radovan Karadžić, 24 December 1994); D2786 (VRS Main Staff Order, 1 January 1995), p. 1; Milenko Inđić, T. 32469 (22 January 2013); Rupert Smith, T. 11298-11299 (8 February 2011); Adjudicated Fact 2790. A draft of the cease-fire agreement was agreed up on 19 December 1994. D3503 (UNPROFOR fax, 19 December 1994); Yasushi Akashi, T. 37721-37723 (24 April 2013); D3504 (UNPROFOR fax, 20 December 1994); P1638 (Witness statement of Michael Rose dated 26 March 2009), para. 187.

1346 P1648 (Agreement on Cessation of Hostilities, 31 December 1994), p. 1.
} 
Krešimir Zubak, Vladimir Soljić, and witnessed by Akashi and Rose. ${ }^{1347}$ The COHA stipulated that the agreement would be in effect for an initial period of four months, subject to renewal by agreement of the parties. ${ }^{1348}$ The COHA would be monitored by UNPROFOR through the establishment of a Central Joint Commission (“CJC"), which would have an initial meeting at the Sarajevo airport and a Regional Joint Commission would also be established in permanent session, "as needed and as determined" by the CJC. ${ }^{1349}$ The COHA provided for (i) the separation of forces to mutually agreed upon positions and the positioning of UNPROFOR forces for observation and monitoring; (ii) the parties refraining from use of all explosive munitions, and (iii) the organisation of talks for the withdrawal of heavy weapons of calibre $12.7 \mathrm{~mm}$ and above and their monitoring by UNPROFOR. ${ }^{1350}$ The parties agreed to full freedom of movement for UNPROFOR and other international agencies, in particular UNHCR, and to monitor human rights and the delivery of humanitarian aid. ${ }^{1351}$

411. On 1 January 1995, the first meeting of CJC was convened at the Sarajevo airport. ${ }^{1352}$ Points of discussion included (i) the exchange of liaison officers; (ii) the implementation of the 5 June 1992 Sarajevo airport agreement; (iii) the 8 May 1993 Srebrenica and Žepa agreements; (iv) the 14 August 1994 anti-sniping agreement; (v) the 14 August 1993 Mt. Igman DMZ agreement; (vi) the confrontation lines and WCPs; (vii) the Blue Routes; and (viii) the withdrawal of foreign troops. ${ }^{1353}$ Despite holding one or two additional meetings, the CJC did not function in an effective way. $^{1354}$

412. On 11 January 1995, an agreement on the military implementation of the COHA was signed by Mladić, Delić, and Blaškić, and witnessed by Rose. ${ }^{1355}$

413. On 31 January 1995, an agreement for the reopening of the Airport Routes for official international humanitarian organisations within the protocol of the COHA was signed by Krajišnik,

\footnotetext{
1347 P1648 (Agreement on Cessation of Hostilities, 31 December 1994), p. 3.

1348 P1648 (Agreement on Cessation of Hostilities, 31 December 1994), p. 1.

1349 P1648 (Agreement on Cessation of Hostilities, 31 December 1994), p. 1; P820 (Witness statement of David Harland dated 4 September 2009), para. 158.

1350 P1648 (Agreement on Cessation of Hostilities, 31 December 1994), p. 2.

1351 P1648 (Agreement on Cessation of Hostilities, 31 December 1994), p. 2.

1352 P820 (Witness statement of David Harland dated 4 September 2009), para. 158 (with Rose, Gobilliard, Tolimir, Indić, Hajrulahović, and Karavelić in attendance); P1638 (Witness statement of Michael Rose dated 26 March 2009), para. 191.

1353 P820 (Witness statement of David Harland dated 4 September 2009), para. 158 (opining that the meeting did not achieve much).

1354 P820 (Witness statement of David Harland dated 4 September 2009), para. 159.

1355 P873 (Cease-fire Agreement, 11 January 1995); P820 (Witness statement of David Harland dated 4 September 2009), para. 160; P874 (UNPROFOR report re cease-fire agreement, 11 January 1995).
} 

1995. ${ }^{1357}$

414. Despite the COHA, by March 1995 UNPROFOR reported that the situation in Sarajevo had deteriorated. $^{1358}$ The situation in $\mathrm{BiH}$, generally, saw an upsurge in military activity with the shelling of Tuzla and Goražde. ${ }^{1359}$ In addition, Mladić told Smith in early March 1995 that he anticipated that the ABiH would attack the eastern enclaves in a "Tuzla to Srebrenica and Žepa and Tronovo to Goražde" axis and that in response the Bosnian Serbs would attack into the enclaves. ${ }^{1360}$ Smith responded that such an action would be interpreted as an attack on the safe areas. $^{1361}$ UNPROFOR reported that the prospects for a political solution to the conflict remained "remote" as Slobodan Milošević rejected proposals by the Contact Group and the Bosnian Serbs were firmly maintaining their refusal to negotiate on the basis of the Contact Group plan. ${ }^{1362}$ Further, both the Bosnian Serbs and the Bosnian Muslims complained about the other side's noncompliance with the COHA. ${ }^{1363}$ On 31 March 1995, the Security Council extended UNPROFOR's mandate in $\mathrm{BiH}$ for an additional eight months, ending on 30 November $1995 .^{1364}$

415. On 7 April 1995, UNPROFOR reported that the Bosnian Serbs refused to allow the UN passage through the Blue Routes around the Sarajevo airport and that the Bosnian Muslims had refused to attend the CJC. ${ }^{1365}$ The following day, the Bosnian Serbs closed the Sarajevo airport, including for humanitarian relief, alleging that UNPROFOR was violating the 5 June 1992 Sarajevo airport agreement. ${ }^{1366}$ On 20 April 1995, Akashi and Smith met with the Accused, Koljević, Krajišnik, and Gvero in Pale. ${ }^{1367}$ The Accused stated that the COHA had been "breached

\footnotetext{
1356 P875 (Agreement re opening of Sarajevo airport, 31 January 1995); P820 (Witness statement of David Harland dated 4 September 2009), para. 163.

1357 P875 (Agreement re opening of Sarajevo airport, 31 January 1995), p. 1; P820 (Witness statement of David Harland dated 4 September 2009), para. 163. On 4 February 1995, Rupert Smith wrote to Koljević to indicate UNPROFOR's intention to open the Airport Routes to civilian traffic on 6 February 1995 . See D1018 (UNPROFOR letter to Nikola Koljević, 4 February 1995).

1358 P820 (Witness statement of David Harland dated 4 September 2009), para. 171; P878 (UNPROFOR report re cease-fire agreement, 29 March 1995). See also P2257 (UNPROFOR Weekly Situation Report, 18 March 1995); P2482 (UNPROFOR Weekly Situation Report (Sarajevo), 26 March 1995); Rupert Smith, T. 11341 (8 february 2011).

1359 P878 (UNPROFOR report re cease-fire agreement, 29 March 1995), p. 1.

1360 P820 (Witness statement of David Harland dated 4 September 2009), para. 168; P877 (UNPROFOR Memo re meeting with Ratko Mladić, 7 March 1995), p. 2.

1361 P877 (UNPROFOR Memo re meeting with Ratko Mladić, 7 March 1995), p. 2.

1362 P2478 (UNPROFOR Weekly Situation Report (Sarajevo), 4 March 1995), p. 2.

1363 P2478 (UNPROFOR Weekly Situation Report (Sarajevo), 4 March 1995), p. 3.

1364 P2483 (UNPROFOR Weekly Situation Report (Sarajevo), 1 April 1995), p. 2.

1365 D1124 (UNPROFOR report, 7 April 1995), para. 5.

1366 P820 (Witness statement of David Harland dated 4 September 2009), para. 173.

1367 P2261 (UNPROFOR report re meetings with Bosnian Serb and Bosnian Muslim leadership, 22 April 1995); D3511 (UNPROFOR report, 22 April 1995); Yasushi Akashi, T. 37733 (24 April 2013).
} 
so massively by the Muslims that it does not exist". ${ }^{1368}$ He also stated that the Bosnian Serbs would not accept any form of a cease-fire but only accept a complete cessation of hostilities. ${ }^{1369}$ A visit of the Contact Group's representatives from the USA and Germany to Sarajevo on 21 April 1995 was blocked by the Bosnian Serbs. ${ }^{1370}$ On 22 April 1995, the Accused held a press conference and stated that if peace was not possible through political means, the Bosnian Serbs would put an end to the war by military means. ${ }^{1371}$

416. The situation in Sarajevo and BiH deteriorated further in May 1995. ${ }^{1372}$ On 1 May 1995, the parties were unable to agree to a renewal of the COHA, thus resulting in its expiration. ${ }^{1373}$ The Security Council expressed its deep concern about the failure of the parties to extend the COHA. ${ }^{1374}$ The Contact Group restated its two main objectives, namely the extension of the COHA and the mutual recognition of Serbia, Croatia, and BiH. ${ }^{1375}$ UNPROFOR reported that "unless the Contact Group somehow finds a way to initiate a viable negotiation process the parties will continue on a path of mutual destruction". ${ }^{1376}$ UNPROFOR also reported that on 7 May 1995, the VRS had shelled Butmir and the Igman road. ${ }^{1377}$ The Sarajevo airport had remained closed to humanitarian flights since 8 April $1995 .^{1378}$

417. On 21 May 1995, Smith and the Accused met in Pale to discuss the future mandate of UNPROFOR, the eastern enclaves, Sarajevo, and the Contact Group peace process. ${ }^{1379}$ The Accused complained to Smith about the "partial nature of UN Mandates" with respect to UNPROFOR but that the Bosnian Serbs wished for a negotiated settlement and that the UN should remain in $\mathrm{BiH}$ for a future political settlement. ${ }^{1380}$ With respect to the eastern enclaves, the Accused stated that he could not respect the safe areas mandates because in his opinion, the safe

\footnotetext{
1368 P2261 (UNPROFOR report re meetings with Bosnian Serb and Bosnian Muslim leadership, 22 April 1995), p. 2.

1369 P2261 (UNPROFOR report re meetings with Bosnian Serb and Bosnian Muslim leadership, 22 April 1995 ), p. 2. statement of David Harland dated 4 September 2009), para. 174.

1372 P886 (UNPROFOR Weekly Situation Report (Sarajevo), 13 May 1995); P820 (Witness statement of David Harland dated 4 September 2009), para. 183. See paras. 3608-3609.

1373 D1151 (UNPROFOR Weekly Situation Report, 8 May 1995), p. 2.

1374 D1151 (UNPROFOR Weekly Situation Report, 8 May 1995), p. 3.

1375 D1151 (UNPROFOR Weekly Situation Report, 8 May 1995), p. 3.

1376 D1151 (UNPROFOR Weekly Situation Report, 8 May 1995), p. 3.

1377 P886 (UNPROFOR Weekly Situation Report (Sarajevo), 13 May 1995), p. 2; D1151 (UNPROFOR Weekly Situation Report, 8 May 1995), p. 8.

1378 P886 (UNPROFOR Weekly Situation Report (Sarajevo), 13 May 1995), p. 2.

1379 P2266 (UNPROFOR report re meeting with Radovan Karadžić, 21 May 1995).

1380 P2266 (UNPROFOR report re meeting with Radovan Karadžić, 21 May 1995), pp. 1-2.
} 
areas were safe havens for the $\mathrm{ABiH} .{ }^{1381}$ The Accused maintained his position that he would not accept the Contact Group plan but he would accept negotiations on the basis of the Contact Group plan. $^{1382}$

418. On 22 May 1995, the VRS removed two heavy weapons from the WCPs near Sarajevo. ${ }^{1383}$ The $\mathrm{ABiH}$ removed their heavy weapons and the fighting escalated. ${ }^{1384}$ The VRS removed more heavy weapons in response. ${ }^{1385}$ On 24 May 1995, Smith issued an ultimatum to both parties that NATO air strikes would be called in unless all heavy weapons ceased firing by 12 p.m. the following day. ${ }^{1386}$ A second deadline, 24 hours later, was established for the parties to either remove their heavy weapons from the exclusion zone or to place them in the collection points. ${ }^{1387}$ The Bosnian Serbs failed to comply with the deadlines and Akashi authorised NATO to conduct air strikes. $^{1388}$

419. Following NATO air strikes on Bosnian Serb military targets on 25 and 26 May 1995, the Bosnian Serb forces detained UN personnel in BiH. ${ }^{1389}$ The VRS shelled Sarajevo and the safe areas, including Tuzla. ${ }^{1390}$ On 27 May 1995, in an order to all SRK units, Dragomir Milošević stated that the Bosnian Serbs would have full control of Sarajevo airport and "stand ready to take it over with complete UNPROFOR combat equipment". ${ }^{1391}$ The Accused declared that all Security Council resolutions and NATO ultimatums were null and void. ${ }^{1392}$ The UN also reported that the

\footnotetext{
1381 P2266 (UNPROFOR report re meeting with Radovan Karadžić, 21 May 1995), p. 2.

1382 P2266 (UNPROFOR report re meeting with Radovan Karadžić, 21 May 1995), p. 3.

1383 P2284 (UNSG report entitled "The Fall of Srebrenica”, 15 November 1999), para. 188; P820 (Witness statement of David Harland dated 4 September 2009), para. 183.

1384 P2284 (UNSG report entitled "The Fall of Srebrenica", 15 November 1999), para. 188; P820 (Witness statement of David Harland dated 4 September 2009), para. 183.

1385 P2284 (UNSG report entitled “The Fall of Srebrenica”, 15 November 1999), para. 188; P820 (Witness statement of David Harland dated 4 September 2009), para. 183; P5012 (UNPROFOR report re Sarajevo heavy weapon exclusion zone, 25 May 1995). See also D987 (Intercept of conversation between Radovan Karadžić and General Milovanović, 25 May 1995); Dragomir Milošević, T. 33225-33226 (5 February 2013).

1386 P2284 (UNSG report entitled "The Fall of Srebrenica", 15 November 1999), para. 188; P820 (Witness statement of David Harland dated 4 September 2009), para. 183; P5012 (UNPROFOR report re Sarajevo heavy weapon exclusion zone, 25 May 1995). See para. 5855.

1387 P2284 (UNSG report entitled “The Fall of Srebrenica”, 15 November 1999), para. 188; P820 (Witness statement of David Harland dated 4 September 2009), para. 183.

1388 P2284 (UNSG report entitled “The Fall of Srebrenica”, 15 November 1999), paras. 188-189; P820 (Witness statement of David Harland dated 4 September 2009), para. 183; P5012 (UNPROFOR report re Sarajevo heavy weapon exclusion zone, 25 May 1995).

1389 See Section IV.D: Hostages component.

1390 P2284 (UNSG report entitled "The Fall of Srebrenica”, 15 November 1999), para. 189; P820 (Witness statement of David Harland dated 4 September 2009), para. 183.

$1391 \quad$ P2416 (SRK Order, 27 May 1995), p. 2.

1392 P887 (SRNA news report, 29 May 1995); P888 (UNPROFOR Weekly Situation Report (Sarajevo), 3 June 1995), p. 3.
} 
food situation in Sarajevo was rapidly deteriorating due to the continued closure of the airport and of land routes. ${ }^{1393}$ In addition the gas and electricity in Sarajevo had been cut off. ${ }^{1394}$

420. In early June 1995, heavy fighting around Sarajevo broke out. ${ }^{1395}$ The Accused and Koljević agreed to re-open the land routes to Sarajevo for UNHCR convoys. ${ }^{1396}$ By 3 June 1995, 120 UN personnel were released by the Bosnian Serbs but the UN estimated that 200 more were still in detention. ${ }^{1397}$ On 9 June 1995, the Security Council approved the deployment of British and French rapid reaction forces equipped with heavy artillery to UNPROFOR in BiH. ${ }^{1398}$ Also on this day, UNHCR, UNPROFOR, and the Bosnian Serbs came to an agreement to start the delivery of humanitarian aid by land routes to Sarajevo. ${ }^{1399}$

421. On 16 June 1995, the Security Council passed Resolution 998 demanding the immediate and unconditional release of the remaining UN personnel. ${ }^{1400}$ It further demanded the unimpeded access for humanitarian aid, access to Sarajevo, and respecting the safe areas. ${ }^{1401}$ It also authorised the increase in UNPROFOR personnel by up to 12,500 additional troops. ${ }^{1402}$ Harland reported that there were what he believed to be targeted shelling against UNPROFOR by the SRK in Sarajevo. ${ }^{1403}$ Smith wrote to Mladić expressing his concerns about the reports about the shelling of Bihac, Srebrenica, Goražde, and Sarajevo. ${ }^{1404}$ Smith reminded Mladić that the safe areas regime according to Security Council Resolution 836 was still in place but that there were increasing attacks on the civilian population. ${ }^{1405}$ On 30 June 1995, Colonel Robert Meille, the Acting Sector Sarajevo UNPROFOR Commander, wrote a letter to Dragomir Milošević condemning the attacks

\footnotetext{
1393 P888 (UNPROFOR Weekly Situation Report (Sarajevo), 3 June 1995), p. 3.

1394 P888 (UNPROFOR Weekly Situation Report (Sarajevo), 3 June 1995), p. 4.

1395 P890 (UNPROFOR Weekly Situation Report (Sarajevo), 10 June 1995), p. 2.

1396 P890 (UNPROFOR Weekly Situation Report (Sarajevo), 10 June 1995), p. 2.

1397 P888 (UNPROFOR Weekly Situation Report (Sarajevo), 3 June 1995), p. 2. See also P889 (Radovan Karadžić's Order to VRS and to RS MUP, 2 June 1995). The remaining UN personnel were released by the end of June 1995. P890 (UNPROFOR Weekly Situation Report (Sarajevo), 10 June 1995), p. 2; P891 (Radovan Karadžić's Order to VRS and RS MUP, 6 June 1995); P893 (Radovan Karadžić's Order to VRS, 17 June 1995); P892 (UNPROFOR Weekly Situation Report Sarajevo), 24 June 1995), pp. 2-3. See para. 5933. General regarding the rapid reaction forces); Rupert Smith, T. 11498-11507 (10 February 2011). 
in Sarajevo, including in the Alpašino Polje neighbourhood and the attack on the PTT building, which housed the headquarters of UNPROFOR Sector Sarajevo. ${ }^{1406}$

7. Initiative by the USA

422. On 21 August 1995, the Accused, Krajišnik, and Buha met with UNPROFOR's Chief of Mission to discuss the current peace initiative. ${ }^{1407}$ The Accused agreed that it was a good time to find a political solution to the conflict; however, he rejected any notion of a united $\mathrm{BiH}$ and maintained that each constituent republic should have sovereignty. ${ }^{1408}$

423. On 28 August 1995, the Markale market in Sarajevo was shelled. ${ }^{1409}$ On the same day, the Bosnian Serb Assembly adopted a resolution welcoming the initiative by the USA for a political resolution to the conflict and affirming the readiness of the Bosnian Serbs to negotiate a lasting peace. ${ }^{1410}$

424. On 29 August 1995, a meeting of the Serbian and Bosnian Serb leaderships took place in Dobanovći, near Belgrade. ${ }^{1411}$ The purpose of this meeting was to discuss the contents of the Contact Group plan along with a possible NATO response to the recent shelling of the Markale market in Sarajevo. ${ }^{1412}$ At the meeting, Slobodan Milošević urged the parties to endorse a collective negotiation team to represent the interests of both the RS and FRY in future peace talks. ${ }^{1413}$ Milošević proposed that he be the head of that team. ${ }^{1414}$ The Bosnian Serb leaders

\footnotetext{
1406 P895 (Letter from UNPROFOR to Dragomir Milošević, 30 June 1995). See also P896 (UNPROFOR Weekly Situation Report (Sarajevo), 2 July 1995).

1407 P2287 (UNPROFOR report re meetings with Bosnian Serb leadership, 22 August 1995.

1408 P2287 (UNPROFOR report re meetings with Bosnian Serb leadership, 22 August 1995), pp. 1-2.

1409 See Scheduled Incident G.19. Harland stated that in relation to this shelling incident a neutral statement was advised in order to prevent another hostage taking incident because UNPROFOR was going to call in large-scale air strikes against the VRS. This allowed a team of BritBat soldiers to safely leave Bosnian Serb-held territory near Goražde prior to the air strikes. P820 (Witness statement of David Harland dated 4 September 2009), para. 233.

1410 P988 (Transcript of $53^{\text {rd }}$ session of RS Assembly, 28 August 1995), pp. 59, 98. See also P2538 (Patrick Treanor's research report entitled "Radovan Karadžić and the Serbian Leadership 1990-1995", 1 May 2009), para. 316.

1411 D3058 (Record of meeting between leaderships of FRY and RS, 29 August 1995); D3051 (Witness statement of Momir Bulatović dated 25 February 2013), para. 35A; P2538 (Patrick Treanor's research report entitled "Radovan Karadžić and the Serbian Leadership 1990-1995", 1 May 2009), paras. 314, 317. Present at this meeting were Slobodan Milošević, Zoran Lilić, Momir Bulatović, Radoje Kontić, Momčilo Perišić, the Accused, Krajišnik, Koljević, Dušan Kozić, Buha, Tolimir, Đukić, Gvero, Mladić and Plavsić. D3058 (Record of meeting between leaderships of FRY and RS, 29 August 1995), pp. 1, 11. See also P5039 (Minutes of SDC meeting, 30 August 1995), p. 1.

1412 P2538 (Patrick Treanor's research report entitled "Radovan Karadžić and the Serbian Leadership 1990-1995", 1 May 2009), para. 317; D3051 (Witness statement of Momir Bulatović dated 25 February 2013), para. 35B. See para. 4299.

1413 D3058 (Record of meeting between leaderships of FRY and RS, 29 August 1995); P2538 (Patrick Treanor's research report entitled "Radovan Karadžić and the Serbian Leadership 1990-1995”, 1 May 2009), para. 317.
} 
conceded, signing an agreement which stipulated that the Accused, Mladić, and Krajišnik would be part of a six-member delegation led by Slobodan Milošević. ${ }^{1415}$ This delegation would conduct negotiations for peace in $\mathrm{BiH}^{1416}$ The Accused and Mladić were replaced by Koljević and Buha. $^{1417}$

425. Towards the end of August 1995, UNPROFOR reported the situation in Sarajevo and Goražde to be on "alert state orange" and very tense due to shelling. ${ }^{1418}$ Smith asked Harland to inform the Accused that large-scale air strikes would begin on VRS positions. ${ }^{1419}$ Harland attempted to call the Accused in Pale at 1 a.m. on 30 August 1995. ${ }^{1420}$ Harland stated that the Pale switchboard could not be contacted at this time. ${ }^{1421}$ In addition to NATO air strikes, Smith ordered that VRS positions around Sarajevo be shelled by UNPROFOR's rapid reaction force on Mt. Igman in an effort to suppress the SRK's artillery fire. ${ }^{1422}$ On 30 August 1995, Akashi sent a letter to the Accused stating that NATO air strikes had started in BiH that day in response to the shelling of the Markale market in Sarajevo two days earlier. ${ }^{1423}$

426. On 1 September 1995, there was a formal pause in the air strikes to allow for a meeting between Smith and Mladić. ${ }^{1424}$ UNPROFOR opened the Sarajevo airport under the Blue Routes regime despite a threat from Krajišnik that the VRS would shoot any vehicles attempting to cross

1414 D3058 (Record of meeting between leaderships of FRY and RS, 29 August 1995), p. 12; P2538 (Patrick Treanor's research report entitled "Radovan Karadžić and the Serbian Leadership 1990-1995”, 1 May 2009), para. 317.

1415 D3058 (Record of meeting between leaderships of FRY and RS, 29 August 1995), pp. 12-13; P2538 (Patrick Treanor's research report entitled "Radovan Karadžić and the Serbian Leadership 1990-1995”, 1 May 2009), para. 318.

1416 D3058 (Record of meeting between leaderships of FRY and RS, 29 August 1995), p. 12; P2538 (Patrick Treanor's research report entitled "Radovan Karadžić and the Serbian Leadership 1990-1995", 1 May 2009), para. 318.

1417 P2538 (Patrick Treanor's research report entitled "Radovan Karadžić and the Serbian Leadership 1990-1995", 1 May 2009), para. 319.

1418 P906 (UNPROFOR daily report, 28-29 August 1995), p. 3.

1419 P820 (Witness statement of David Harland dated 4 September 2009), para. 235. NATO air strikes started during the night on 29 August 1995 and lasted until 1 September 1995. They resumed again on 5 September and lasted until 14 September 1995. See Adjudicated Facts 2798, 2799.

1420 P820 (Witness statement of David Harland dated 4 September 2009), para. 235.

1421 P820 (Witness statement of David Harland dated 4 September 2009), para. 235.

1422 P820 (Witness statement of David Harland dated 4 September 2009), para. 236; Rupert Smith, T. 11507-11509 (10 February 2011); Dragomir Milošević, T. 33244-33245 (5 February 2013).

1423 P820 (Witness statement of David Harland dated 4 September 2009), para. 236. See also P906 (UNPROFOR daily report, 28-29 August 1995), p. 3. Smith also called the Accused to inform him of the same. P820 (Witness statement of David Harland dated 4 September 2009), para. 235. See also para. 300.

1424 P820 (Witness statement of David Harland dated 4 September 2009), para. 239. 
the airport without their approval. ${ }^{1425}$ Harland reported that this was the first time that traffic flowed freely in and out of Sarajevo since the siege had started in $1992 .^{1426}$

427. On 2 September 1995, Mladić made a number of concessions to Smith and UNPROFOR, including that the VRS would not conduct any combat operations or attacks in Sarajevo, Bihać, Tuzla, or Goražde; heavy weapons would be withdrawn; and a meeting of the Commanders would be organised. ${ }^{1427}$ However, a few days later, Janvier at UNPROFOR headquarters in Zagreb reported that despite the assurances from the Bosnian Serbs, there was no evidence of heavy weapon withdrawal from the Sarajevo area. ${ }^{1428}$

428. On 20 September 1995, Smith met with Miletić and Dragomir Milošević to discuss the progress of the removal of weapons from the TEZ and UNPROFOR's freedom of movement. ${ }^{1429}$ Smith told them that progress on talks about a cease-fire in Sarajevo was contingent on the full restoration of utilities to the city. ${ }^{1430}$

429. Between 6 and 8 October 1995, meetings were held between UNPROFOR and the Bosnian Serbs at Hotel Serbia in Ilidža, in order to negotiate a cease-fire arrangement between the Bosnian Serbs and Bosnian Muslims. ${ }^{1431}$

430. On 11 October 1995, the UN received letters from both Muratović and Buha stating that they agreed to the cease-fire agreement of 5 October 1995, which would enter into force at 12:01 a.m. on 12 October 1995. ${ }^{1432}$ On the same day, President Bill Clinton announced that the "Proximity Peace Talks" were forthcoming in Dayton, Ohio, USA. ${ }^{1433}$

\footnotetext{
1425 P820 (Witness statement of David Harland dated 4 September 2009), para. 240.

1426 P820 (Witness statement of David Harland dated 4 September 2009), para. 240.

1427 P820 (Witness statement of David Harland dated 4 September 2009), para. 241. See also D1053 (UNPROFOR letter to Ratko Mladić, 4 September 1995).

1428 P820 (Witness statement of David Harland dated 4 September 2009), para. 242; P907 (UNPROFOR update re Sarajevo, 5 September 1995), p. 1.

1429 D2899 (Fax from UNPROFOR, 20 September 1995).

1430 D2899 (Fax from UNPROFOR, 20 September 1995), p. 3.

1431 P820 (Witness statement of David Harland dated 4 September 2009), para. 243; P908 (Minutes from the first meeting on the implementation of cease-fire agreement, 6 October 1995); P909 (Minutes from the second meeting on the implementation of cease-fire agreement, 8 October 1995). The Accused, in an interview with $\mathrm{CNN}$, claimed that NATO bombings did not in fact push RS leaders toward peace talks, but rather pushed RS leaders away from peace negotiations. D4490 (Article from CNN entitled "Transcript of Interview with Karadžić”, 28 November 1995), p. 3.

1432 P910 (BiH Government's acceptance of the cease-fire agreement, 11 October 1995); P911 (RS Government's acceptance of the cease-fire agreement, 11 October 1995); P820 (Witness statement of David Harland dated 4 September 2009), para. 245. This cease-fire agreement contained negotiated agreements regarding the restoration of electricity and gas to the Kokoska and the Visegrad-Sokolać-Velesići areas. Additionally, the cease-fire agreement provided for the opening of several routes surrounding Sarajevo for humanitarian aid delivered by the UNPROFOR. P908 (Minutes from the first meeting on the implementation of cease-fire
} 


\section{Dayton Agreement}

431. On 29 October 1995, consistent with the meeting on 29 August 1995, the Accused authorised the Bosnian Serb delegation to negotiate, together with the delegation of the FRY, at the upcoming peace talks in Dayton. ${ }^{1434}$

432. The Bosnia Proximity Peace Talks began at the Wright-Patterson Airforce Base in Dayton on 1 November 1995. ${ }^{1435}$ In attendance were delegates from the EU, USA, Russian Federation, UK, France, Germany, FRY, Bosnian Serbs, Croatia, and the Muslim-Croat Alliance. ${ }^{1436}$ Despite the removal of the Accused from the RS negotiating team he played a central consultative role in regards to RS negotiations at Dayton. ${ }^{1437}$

433. On 21 November 1995, the Bosnian Proximity Peace Talks concluded, producing the "General Framework Agreement for Peace in Bosnia and Herzegovina", otherwise known as the Dayton Agreement. ${ }^{1438}$ The agreement consisted of 17 separate agreements drawn up during negotiations, organised into 11 separate annexes. ${ }^{1439}$ The first of these agreements-the Agreement on the Military Aspects of the Peace Settlement-invited the Security Council to authorise NATO and non-NATO nations to establish a multinational Military Implementation Force ("IFOR") under NATO command in order to assist in implementing the Dayton Agreement. ${ }^{140}$ The agreement provided for the cessation of hostilities in $\mathrm{BiH}$, the withdrawal of all foreign forces-including

agreement, 6 October 1995); P909 (Minutes from the second meeting on the implementation of cease-fire agreement, 8 October 1995). January 2010), p. 103; P2538 (Patrick Treanor's research report entitled "Radovan Karadžić and the Serbian Leadership 1990-1995”, 1 May 2009), para. 321.

1434 D3604 (Radovan Karadžić's authorisation, 29 October 1995). P988 (Transcript of $53^{\text {rd }}$ session of RS Assembly, 28 August 1995), p. 98.

1435 D4127 (Report of VRS Main Staff, 25 November 1995) p. 1.

1436 D4127 (Report of VRS Main Staff, 25 November 1995) pp. 1-3.

1437 Intercepted telephone conversations, as well as the RS negotiation team authorisation attest to the Accused's role. D3604 (Radovan Karadžić's authorisation, 29 October 1995). P4829 (Intercepts of conversations between (i) Radovan Karadžić and Momčilo Krajišnik and (ii) Radovan Karadžić, Nikola Koljević, and Momčilo Krajišnik, 15 November 1995) in which Karadžić instructs the RS delegation to reject a proposed constitutional agreement. See also P4830 (Intercept of conversation between Radovan Karadžić, Momčilo Krajišnik, Ratko Mladić, and General Tolimir, 15 November 1995); P4831 (Intercept of conversation between Radovan Karadžić, Ratko Mladić, and General Tolimir, 20 November 1995); P4832 (Intercept of conversation between Radovan Karadžić, Ratko Mladić, and General Tolimir, 20 November 1995); P4833 (Intercept of conversation between Radovan Karadžić, Momčilo Krajišnik, General Miletić, and General Tolimir, 21 November 1995). 
UNPROFOR - from BiH territory, the creation of a corridor of free movement between Goražde and Sarajevo, and the exchange of prisoners between parties to the conflict. ${ }^{1441}$

434. While the Dayton Agreement nominally maintained a single Bosnian state, the envisioned geographical division saw the creation of two sub-national entities: the Federation of $\mathrm{BiH}$ and the RS. ${ }^{1442}$ The Dayton Agreement allotted $49 \%$ of the disputed territory to the newly created RS, while $51 \%$ of the disputed territory remained under the control of the Federation of $\mathrm{BiH}^{1443}$ The Dayton Agreement mandated that a four kilometre zone of separation would be created along the border between these two entities, from which all parties would withdraw all forces, explosives, or other lethal assets. ${ }^{1444}$ The RS consisted of every town along the Sava and Drina River, with the exception of Goražde. ${ }^{1445}$ They were connected by the Posavina corridor near Brčko. ${ }^{1446}$ Meanwhile Goražde and much of Sarajevo were allotted to the Federation of $\mathrm{BiH}^{1447}$ To the dismay of Bosnian Serb leaders, 61\% of Sarajevo's pre-war territory was given to the Federation, including several neighbourhoods which had been under Bosnian Serb control since 1992. ${ }^{1448}$ Finally, the parties agreed to demilitarise Sarajevo, and specified that Sarajevo would remain BiH's capital city. ${ }^{1449}$

435. The RS delegation was unsatisfied with the course of negotiations at Dayton, as well as their treatment as part of the FRY negotiation team. ${ }^{1450}$ The RS delegation was particularly

\footnotetext{
1441 D4127 (Report of VRS Main Staff, 25 November 1995) pp. 4-12

1442 Herbert Okun, T. 1730 (27 April 2010); D1595 (BiH Map from Dayton Agreement, 21 November 1995); P6135 (Map of $\mathrm{BiH})$.

1443 P2604 (Minutes of 47 $7^{\text {th }}$ session of SDC, 28 November 1995), p. 7; D1595 (BiH Map from Dayton Agreement, 21 November 1995).

1444 D4127 (Report of VRS Main Staff, 25 November 1995) p. 6.

1445 D4127 (Report of VRS Main Staff, 25 November 1995) pp. 14-15; D1595 (BiH Map from Dayton Agreement, 21 November 1995); P2604 (Minutes of $47^{\text {th }}$ session of SDC, 28 November 1995), p. 7; Momčilo Krajisnik, T. 43237 (7 November 2013). In the evening of 20 November 1995, Slobodan Milošević and General Wesley Clark agreed that Goražde should remain with the Muslim Croat Federation. Herbert Okun, T. 1743 (27 April 2010).

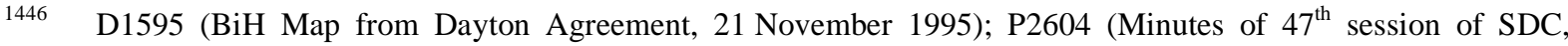
28 November 1995), p. 7.

1447 See Herbert Okun, P776 (Transcript from Prosecutor v. Krajišnik), T. 4266; Momčilo Krajisnik, T. 43237 (7 November 2013); D4127 (Report of VRS Main Staff, 25 November 1995) pp. 8-10; D1595 (BiH Map from Dayton Agreement, 21 November 1995).

1448 P973 (Robert Donia's expert report entitled "Bosnian Serb Leadership and the Siege of Sarajevo, 1990-1995", January 2010), p. 103.

1449 P973 (Robert Donia's expert report entitled "Bosnian Serb Leadership and the Siege of Sarajevo, 1990-1995", January 2010), p. 103. Further agreements within the General Framework dealt with regional stabilisation, elections, the $\mathrm{BiH}$ constitution, arbitration, human rights, refugees and displaced persons, the preservation of national monuments, public corporations within $\mathrm{BiH}$, civilian implementation of the agreement, and the International Police Task Force. D4128 (Dispatch of VRS Main Staff to Security and Intelligence Affairs, 6 December 1995), p. 4.

1450 P2538 (Patrick Treanor's research report entitled "Radovan Karadžić and the Serbian Leadership 1990-1995", 1 May 2009), para. 321. See also D4127 (Report of VRS Main Staff, 25 November 1995) p. 12; John Zametica, T. 42449-42450 (29 October 2013).
} 
unhappy about the division of Sarajevo, the Posavina, Brčko and Goražde corridors, and the RS's lack of access to the sea. ${ }^{1451}$ They were also unsatisfied with the Agreement on the Military Aspects of the Peace Settlement. ${ }^{1452}$ As a result, the members of the RS delegation refused to attend the final plenary session of the peace talks as well as the ceremonial initialling of the peace agreement. $^{1453}$

436. Despite the absence of the RS representatives, on 21 November 1995, the peace negotiations officially concluded, and the Dayton Agreement was initialled by Tuđman, Slobodan Milošević, and Izetbegović. ${ }^{1454}$ On 22 November 1995, the Security Council passed Resolution 1022 suspending sanctions against the FRY. ${ }^{1455}$ Members of the delegation, as well as the Accused, signed a statement declaring that the leadership of RS had accepted the Dayton Agreement, and that RS would fully implement the Accord and all obligations deriving from it. ${ }^{1456}$ However, in the following weeks, members of the RS delegation met with officials from the UN and the USA in an attempt to make adjustments to the Dayton Agreement, especially in regards to Sarajevo. ${ }^{1457}$ Despite their efforts at the follow-up conference held in London on 8 and 9 December 1995, neither Koljević nor Buha were able to obtain any significant changes to the Dayton Agreement. ${ }^{1458}$

437. On 14 December 1995 in Paris, the Dayton Agreement was signed by those who had initialled the plan on 21 November, formally establishing peace in $\mathrm{BiH}^{1459}$ On 21 December 1995, UNPROFOR was replaced by IFOR. ${ }^{1460}$

1451 The RS delegation wanted the city of Sarajevo to remain undivided and to be run by a joint government composed of both Serbian and Muslim members. Further, the RS delegation proposed freedom of movement between Goražde and Sarajevo rather than a formal corridor, and wanted the Posavina corridor to be expanded to 20 kilometres. D4127 (Report of VRS Main Staff, 25 November 1995) p. 18. See also D4490 (Article from CNN entitled "Transcript of Interview with Karadžić", 28 November 1995), p. 2. D4127 (Report of VRS Main Staff, 25 November 1995) pp. 12-13.

P2538 (Patrick Treanor's research report entitled "Radovan Karadžić and the Serbian Leadership 1990-1995", 1 May 2009), para. 322. See also D4127 (Report of VRS Main Staff, 25 November 1995) p. 4; John Zametica, T. 42450 (29 October 2013).

1454 Milenko Todorović, T. 13101 (20 April 2011).

1455 P2538 (Patrick Treanor's research report entitled "Radovan Karadžić and the Serbian Leadership 1990-1995", 1 May 2009), para. 323.

1456 P2604 (Minutes of $47^{\text {th }}$ session of SDC, 28 November 1995), pp. 8-9. D4490 (Article from CNN entitled "Transcript of Interview with Karadžić", 28 November 1995), p. 2.

1457 See also D4127 (Report of VRS Main Staff, 25 November 1995) p. 15.

1458 P2538 (Patrick Treanor's research report entitled "Radovan Karadžić and the Serbian Leadership 1990-1995", 1 May 2009), para. 327.

1459 P2538 (Patrick Treanor's research report entitled "Radovan Karadžić and the Serbian Leadership 1990-1995", 1 May 2009), para. 331.

1460 P820 (Witness statement of David Harland dated 4 September 2009), para. 246. 


\section{APPLICABLE LAW}

\section{A. REQUIREMENTS AND ELEMENTS OF THE CRIMES CHARGED}

1. Article 3 of the Statute of the Tribunal

438. The Accused is charged with four counts of violations of the laws or customs of war pursuant to Article 3 of the Statute. Under Counts 6 and 11, the Accused is charged, respectively, with murder and the taking of hostages, both recognised by Common Article 3 of the 1949 Geneva Conventions ("Common Article 3"). Count 9 charges the Accused with acts of violence, the primary purpose of which is to spread terror among the civilian population. Finally, Count 10 charges the Accused with unlawful attacks on civilians.

439. The Chamber will first assess the general requirements for offences charged under Article 3 of the Statute before proceeding with its analysis of the elements in relation to each of these offences.

a. General requirements for violations of the laws or customs of war

440. Article 3 of the Statute provides that the Tribunal "shall have the power to prosecute persons violating the laws or customs of war", and its sub-paragraphs identify a non-exhaustive list of offences that qualify as such violations. Accordingly, Article 3 is a general clause which confers jurisdiction over any serious violation of international humanitarian law not covered by Articles 2, 4, or 5 of the Statute, in addition to those expressly listed under Article $3 .{ }^{1461}$

441. For Article 3 to apply, two preliminary requirements need to be fulfilled, namely there must be an armed conflict and the crime must be closely related to that armed conflict ("nexus requirement"). ${ }^{1462}$ In relation to the requirement that there exist an armed conflict, the Appeals Chamber in the Tadić case articulated the test as follows: "[A]n armed conflict exists whenever there is a resort to armed force between States or protracted armed violence between governmental authorities and organized groups or between such groups within a State". ${ }^{1463}$ To determine the existence of an armed conflict, both the intensity of the conflict and the organisation of the parties

\footnotetext{
1461 Tadić Jurisdiction Decision on Interlocutory Appeal, para. 91; Čelebići Appeal Judgement, paras. 125, 131, 133; Boškoski and Tarčulovski Appeal Judgement, para. 47.

1462 Tadić Jurisdiction Decision on Interlocutory Appeal, paras. 67-70; Stakić Appeal Judgement, para. 342.

1463 Tadić Jurisdiction Decision on Interlocutory Appeal, para. 70.
} 
to the conflict must be considered on a case-by-case basis. ${ }^{1464}$ It is immaterial whether the armed conflict was international in nature or not. ${ }^{1465}$

442. In relation to the nexus requirement, while there must be a connection between the alleged offences and the armed conflict, the Prosecution need not establish that the armed conflict was causal to the commission of the crime. ${ }^{1466}$ However, it needs to be shown that the conflict played a substantial part in the perpetrator's ability to commit the crime, his decision to commit it, the manner in which it was committed, or the purpose for which it was committed. ${ }^{1467}$ To find a nexus, it is sufficient that the alleged crimes be closely related to hostilities occurring in other parts of the territories controlled by the parties to the conflict. ${ }^{1468}$

443. In addition to these two preliminary requirements, the Tribunal's jurisprudence has established the following general requirements for the application of Article 3 of the Statute, also known as the "Tadić Conditions":

(a) the violation must constitute an infringement of a rule of international humanitarian law;

(b) the rule must be customary in nature or, if conventional, the treaty must be unquestionably binding on the parties at the time of the alleged offence and not in conflict with or derogating from peremptory norms of international law;

(c) the violation must be serious, namely it must constitute a breach of a rule protecting important values and the breach must involved grave consequences for the victim; and

(d) the violation of the rule must entail, under customary or conventional law, the individual criminal responsibility of the person breaching the rule. ${ }^{1469}$

444. Where a crime punishable under Article 3 of the Statute derives from protections found in Common Article 3, the victims of the alleged violation must have taken no active part in the hostilities at the time the crime was committed. ${ }^{1470}$ Such victims include members of armed forces who have laid down their arms and those placed hors de combat by sickness, wounds, detention, or

1464 Tadić Trial Judgement, para. 562; Limaj et al. Trial Judgement, paras. 89-90; Orić Trial Judgement, para. 254.

1465 Tadić Jurisdiction Decision on Interlocutory Appeal, para. 137; Galić Appeal Judgement, para. 120.

1466 Kunarac et al. Appeal Judgement, para. 58.

1467 Stakić Appeal Judgement, para. 342 (specifying that the Trial Chamber must establish the existence of a geographical and temporal linkage between the crimes ascribed to the accused and the armed conflict); Kunarac et al. Appeal Judgement, para. 58.

1468 Stakić Appeal Judgement, para. 342 (referring to Tadić Jurisdiction Decision on Interlocutory Appeal, para. 70).

1469 Tadić Jurisdiction Decision on Interlocutory Appeal, paras. 94, 143. 
any other cause. ${ }^{1471}$ In addition, the Chamber must be satisfied that "the perpetrator of a Common

Article 3 crime knew or should have been aware that the victim was taking no active part in the hostilities when the crime was committed". 1472

b. Murder as a violation of the laws or customs of war

445. Under Count 6 of the Indictment, the Accused is charged with murder as a violation of the laws or customs of war, punishable under Article 3 of the Statute. ${ }^{1473}$ Murder is not explicitly listed in Article 3 but stems from the prohibition in Common Article 3(1)(a) of the Geneva Conventions, which provides that:

In the case of armed conflict not of an international character occurring in the territory of one of the High Contracting Parties, each Party to the conflict shall be bound to apply, as a minimum, the following provisions:

1. Persons taking no active part in the hostilities, including members of armed forces who have laid down their arms and those placed 'hors de combat' by sickness, wounds, detention, or any other cause, shall in all circumstances be treated humanely [...]

To this end, the following acts are and shall remain prohibited at any time and in any place whatsoever with respect to the above-mentioned persons:

(a) violence to life and person, in particular murder of all kinds [...]. ${ }^{1474}$

\section{i. Actus reus}

446. The actus reus of murder is an act or omission resulting in the death of an individual. ${ }^{1475}$ It is not necessary that proof of a dead body be produced if the victim's death can be inferred circumstantially from other evidence which has been presented to the Chamber. ${ }^{1476}$ With regard to the requisite causal nexus, the requirement that death must have occurred "as a result of" the

\footnotetext{
1470 Čelebići Appeal Judgement, para. 420.
}

1471 See Čelebići Appeal Judgement, para. 420 (referring to the wording of Common Article 3).

1472 Boškoski and Tarčulovski Appeal Judgement, para. 66.

1473 Indictment, paras. 61-67. See also Schedules A and B Killing Incidents.

1474 For the residual nature of Article 3 of the Statute, see para. 440.

1475 Kvočka et al. Appeal Judgement, para. 261. See also Dragomir Milošević Appeal Judgement, para. 108 (in relation to Article 5 of the Statute); Milutinović et al. Trial Judgement, Vol. I, para. 137; Galić Appeal Judgement, paras. 147-150 (also in relation to Article 5).

1476 Kvočka et al. Appeal Judgement, para. 260. Relevant factors to be considered when assessing whether a victim died include but are not limited to proof of incidents of mistreatment directed against the victim; patterns of mistreatment and disappearances of other victims; the coincident or near-coincident time of death of other victims; the fact that the victims were present in an area where an armed attack was carried out; the time, location, and circumstances in which the victim was last seen; the behaviour of soldiers in the vicinity, as well as towards other civilians, at the relevant time; and the lack of contact by the victim with others whom he/she would have been expected to contact, such as his/her family. See Lukić and Lukić Trial Judgement, para. 904; Martić Trial Judgement, para. 59, fn. 112; Halilović Trial Judgement, para. 37; Krnojelac Trial Judgement, para. 327. 
perpetrator's act or omission does not require this to be the sole cause for the victim's death; it is sufficient that the "perpetrator's conduct contributed substantially to the death of the person". ${ }^{147}$

\section{ii. Mens rea}

447. In order to satisfy the mens rea of murder, the Prosecution must prove that the act was committed, or the omission was made, with an intention to kill (animus necandi) or to wilfully cause serious injury or grievous bodily harm which the perpetrator should reasonably have known might lead to death. ${ }^{1478}$

448. Thus, the mens rea of murder includes both direct intent (dolus directus), which is a state of mind in which the perpetrator desired the death of the individual to be the result of his act or omission, and indirect intent (dolus eventualis), which is knowledge on the part of the perpetrator that the death of a victim was a probable consequence of his act or omission. ${ }^{1479}$

c. Unlawful attacks on civilians as a violation of the laws or customs of war

449. In Count 10 of the Indictment, the Accused is charged with criminal responsibility for unlawful attacks on civilians as a violation of the laws or customs of war, punishable under Article 3 of the Statute. ${ }^{1480}$ While Article 3 does not explicitly prohibit "unlawful attacks on civilians" as such, the Appeals Chamber has held that attacks on the civilian population or individual civilians meet the threshold requirements for war crimes and are therefore covered by Article 3 of the Statute. ${ }^{1481}$ In so ruling, Chambers of the Tribunal have relied on Article 51(2) of Additional Protocol I and Article 13(2) of Additional Protocol II, both of which read in relevant parts that the civilian population and individual civilians shall not be the object of attack. ${ }^{1482}$ Thus, the targeting of civilians has been deemed by this Tribunal to be absolutely prohibited at all times and, as such, cannot be justified by military necessity or by the actions of the opposing side. ${ }^{1483}$

1477 Orić Trial Judgement, para. 347. See also Đorđević Trial Judgement, para. 1708; Popović et al. Trial Judgement, para. 788; Milutinović et al. Trial Judgement, Vol. I, para. 137; Lukić and Lukić Trial Judgement, para. 899.

1478 Kvočka et al. Appeal Judgement, para. 261. See also Dragomir Milošević Appeal Judgement, para. 108; Milutinović et al. Trial Judgement, Vol. I, para. 138; Orić Trial Judgement, para. 348.

1479 Delić Trial Judgement, para. 48; Martić Trial Judgement, para. 60; Strugar Trial Judgement, paras. 235-236; Stakić Trial Judgement, para. 587. See also Stakić Appeal Judgement, paras. 236, 239, 242 (discussing the application of dolus eventualis as the requisite mens rea of murder).

1480 Indictment, paras. 76-82.

1481 Kordić and Čerkez. Appeal Judgement, paras. 40-46; Galić Appeal Judgement, para. 123 (confirming the findings in the Galić Trial Judgement, paras. 16, 19-32).

1482 Dragomir Milošević Appeal Judgement, para. 53; Kordić and Čerkez Appeal Judgement, para. 48; Galić Trial Judgement, paras. 16-19.

1483 Galić Appeal Judgement, para. 130 (confirming Galić Trial Judgement, paras. 44, 49); Dragomir Milošević Appeal Judgement, paras. 53, 69. See also Blaškić Appeal Judgement, para. 109; Martić Appeal Judgement, 
450. As for the elements of the offence of unlawful attacks on civilians, they consist of (i) acts of violence directed against the civilian population or individual civilians not taking a direct part in hostilities causing death or serious injury to body or health within the civilian population (actus reus) and (ii) the offender wilfully making the civilian population or individual civilians not taking a direct part in hostilities the object of those acts of violence (mens rea). ${ }^{1484}$

\section{i. Actus reus}

451. Article 49 of Additional Protocol I defines "attacks" as "acts of violence against the adversary, whether in offence or defence". ${ }^{1485}$ Accordingly, the issue of who made use of force first is irrelevant. ${ }^{1486}$

452. The meaning of civilian for the purposes of unlawful attacks on civilians stems from Article 50(1) of Additional Protocol $\mathrm{I}^{1487}$ which provides that a "civilian is any person who does not belong to one of the categories of persons referred to in Article 4(A)(1), (2), (3) and (6) of the Third [Geneva] Convention ${ }^{1488}$ and in Article 43 of [Additional] Protocol [I] ${ }^{1489}$." This is a negative

paras. 268, 270; Strugar Appeal Judgement, para. 275. The Tribunal's jurisprudence here is consistent with that of the International Court of Justice which, at paragraph 78 of the ICJ Advisory Opinion on Nuclear Weapons, held that civilians must never be made the object of an attack.

1484 Galić Trial Judgement, para. 56; Dragomir Milošević Trial Judgement, paras. 942, 951. See also Kordić and Čerkez Trial Judgement, para. 328; Kordić and Čerkez. Appeal Judgement, paras. 47-68. This is consistent with the three fundamental principles of international humanitarian law, namely the principles of distinction, precaution, and protection. Under Article 48 of Additional Protocol I, the principle of distinction obliges the warring parties to distinguish at all times between the civilian population and combatants, and between civilian objects and military objectives. Article 57(2)(a)(ii) of Additional Protocol I requires that those planning an attack take all reasonable precautions in the choice of the means and methods of attack in order to avoid or minimise the incidental loss of civilian life, injury to civilians, and damage to civilian property. Finally, the principle of protection, as referred to in Article 51(1) of Additional Protocol I and Article 13(1) of Additional Protocol II, ensures that the civilian population and individual civilians enjoy general protections against dangers arising from military operations. See also Dragomir Milošević Trial Judgement, para. 941.

1485 Kordić and Čerkez Appeal Judgement, para. 47.

1486 Kordić and Čerkez Appeal Judgement, para. 47.

1487 Given that the origin of the offence of unlawful attacks against civilians can be found in Additional Protocols I and II, the definition of "civilians" and "civilian population," relied upon in cases dealing with this offence is derived from Article 50 of Additional Protocol I. See Galić Trial Judgement, paras. 47 and the footnotes therein; Dragomir Milošević Trial Judgement, para. 945; Kordić and Čerkez Appeal Judgement, para. 48-50. See also Dragomir Milošević Appeal Judgement, para. 50 (where the Appeals Chamber held that the definition of civilians contained in Article 50(1) of Additional Protocol applies to crimes under both Article 3 and Article 5 of the Statute).

1488 Article 4 of Geneva Convention III states, inter alia:

"A. Prisoners of war, in the sense of the present Convention, are persons belonging to one of the following categories, who have fallen into the power of the enemy: (1) Members of the armed forces of a Party to the conflict, as well as members of militias or volunteer corps forming part of such armed forces. (2) Members of other militias and members of other volunteer corps, including those of organized resistance movements, belonging to a Party to the conflict and operating in or outside their own territory, even if this territory is occupied, provided that such militias or volunteer corps, including such organized resistance movements, fulfil the following conditions: (a) that of being commanded by a person responsible for his subordinates; (b) that of having a fixed distinctive sign recognizable at a distance; (c) that of carrying arms openly; (d) that of conducting their operations in accordance with the laws and customs of war. (3) Members of regular armed forces who profess allegiance to a government or an authority not recognized by the Detaining Power. [.... (6) Inhabitants of a non-occupied territory, who on the approach of the 
definition of "civilian" as it includes anyone who is not a member of the armed forces or an organised military group belonging to a party to the conflict. ${ }^{1490}$ Article 50(1) of Additional Protocol I also provides that in case of doubt whether a person is a civilian, that person shall be considered to be a civilian. ${ }^{1491}$ The protection from attack afforded to individual civilians by Article 51 of Additional Protocol I continues until such time as they take direct part in hostilities, that is until they engage in acts of war which, by their very nature and purpose, are likely to cause actual harm to the personnel or materiel of the enemy forces. ${ }^{1492}$ Thus, in order to establish that unlawful attacks against civilians have been committed, the Chamber has to find that the victims of these attacks were civilians and that they were not participating in the hostilities. ${ }^{1493}$

453. The jurisprudence is also clear that the presence of individual combatants within the civilian population attacked does not necessarily change the fact that the ultimate character of the population remains a civilian one. ${ }^{1494}$ In determining whether the presence of soldiers within a civilian population deprives the population of its civilian character, the number of soldiers, as well as whether they are on leave, must be examined. ${ }^{1495}$

454. As stated above, ${ }^{1496}$ for the attack to constitute an unlawful attack on civilians, the Prosecution has to show that it was directed against individual civilians or the civilian population. Whether this is the case can be determined from a number of factors, including the means and methods used in the course of the attack, the status and the number of victims, the distance between the victims and the source of fire, the ongoing combat activity at the time and location of the incident, the presence of military activities or facilities in the vicinity of the incident, the nature of the acts of violence committed, the indiscriminate nature of the weapons used, and the extent to

enemy spontaneously take up arms to resist the invading forces, without having had time to form themselves into regular armed units, provided they carry arms openly and respect the laws and customs of war."

Article 43 of Additional Protocol I provides as follows:

" 1 . The armed forces of a Party to a conflict consist of all organized armed forces, groups and units which are under a command responsible to that Party for the conduct of its subordinates, even if that Party is represented by a government or an authority not recognized by an adverse Party. Such armed forces shall be subject to an internal disciplinary system which, 'inter alia', shall enforce compliance with the rules of international law applicable in armed conflict. 2. Members of the armed forces of a Party to a conflict (other than medical personnel and chaplains covered by Article 33 of the Third Convention) are combatants, that is to say, they have the right to participate directly in hostilities. 3. Whenever a Party to a conflict incorporates a paramilitary or armed law enforcement agency into its armed forces it shall so notify the other Parties to the conflict."

1490 Galić Trial Judgement, para. 47; Milošević Trial Judgement, para. 945.

1491 See also Galić Trial Judgement, para. 50; Dragomir Milošević Trial Judgement, para. 946.

1492 Dragomir Milošević Appeal Judgement, para. 57; Galić Trial Judgement, para. 48. See also Dragomir Milošević Trial Judgement, para. 947 (where the Trial Chamber, relying on the ICRC Commentary 1945, made a distinction between direct participation in hostilities and "participation in war effort"). Dragomir Milošević Appeal Judgement, para. 57.

1494 Galić Appeal Judgement, paras. 136-138. See also Galić Trial Judgement, para. 50; Dragomir Milošević Trial Judgement, para. 922; Dragomir Milošević Appeal Judgement, paras. 50-51.

1495 Galić Appeal Judgement, para. 137, citing to Blaškić Appeal Judgement, para. 115. See also paras. 474-476.

1496 See para. 450. 
which the attacking force has complied or attempted to comply with the precautionary requirements of the law of war. ${ }^{1497}$ In this respect, the jurisprudence is also clear that both indiscriminate attacks and disproportionate attacks may qualify as attacks directed against civilians or give rise to an inference that an attack was directed against civilians. ${ }^{1498}$ This is to be determined on a case by case basis, in light of the available evidence. ${ }^{1499}$

455. Finally, before criminal responsibility can be incurred for the unlawful attacks on the civilian population or individual civilians, the Chamber has to find that they have resulted in the death or serious injury to body or health of the victims in question. ${ }^{1500}$

\section{ii. Mens rea}

456. For unlawful attacks on civilians to be established, the Prosecution must show that the perpetrator wilfully made the civilian population or individual civilians the object of the acts of violence. ${ }^{1501}$ In other words, the perpetrator has to act consciously and with intent, willing the act and its consequences. This encompasses the concept of recklessness but not negligence. ${ }^{1502}$

457. For the mens rea to be established, the Prosecution must also show that the perpetrator was aware, or should have been aware, of the civilian status of the persons attacked. In cases of doubt as to the status of those persons, the Prosecution must show that a reasonable person could not have believed that the individuals attacked were combatants. ${ }^{1503}$ In addition, it is not required to establish the intent to attack particular civilians; rather, it is prohibited to make the civilian population as such, as well as individual civilians, the object of an attack. ${ }^{1504}$

1497 Galić Appeal Judgement, para. 132 (citing to Kunarac Appeal Judgement, para. 91 and Blaškić Appeal Judgement, para. 106); Dragomir Milošević Appeal Judgement, para. 66; Strugar Appeal Judgement, para. 271. See also Dragomir Milošević Trial Judgement, para. 948.

1498 Galić Appeal Judgement, paras. 132-134 (confirming Galić Trial Judgement, paras. 57-58, 60); Dragomir Milošević Appeal Judgement, para. 66; Strugar Appeal Judgement, para. 275.

1499 Galić Appeal Judgement, paras. 132-133 (confirming Galić Trial Judgement, para. 60); Dragomir Milošević Appeal Judgement, para. 67.

1500 Kordić and Čerkez. Appeal Judgement, paras. 55-68. The discussion in these paragraphs concerns not only unlawful attacks on civilians but also unlawful attacks on civilian objects as both were charged in the Kordić and $\check{C}$ erkez case. In the present case, however, the Indictment charges only unlawful attacks on civilians. See Indictment, paras. 76-82.

1501 Galić Appeal Judgement, para. 140 (confirming Galić Trial Judgement, para. 54). See also Dragomir Milošević Trial Judgement, para. 951; Strugar Appeal Judgement, para. 270.

1502 ICRC Commentary on Additional Protocols, Commentary 3474.

1503 Dragomir Milošević Appeal Judgement, para. 60 (citing to Kordić and Čerkez Appeal Judgement, para. 48 and Blaškić Appeal Judgement, para. 111). See also Dragomir Milošević Trial Judgement, para. 952; Strugar Appeal Judgement, para. 271; Galić Trial Judgement, paras. 50, 55.

1504 Strugar Appeal Judgement, para. 271. 


\section{d. Terror as a violation of the laws or customs of war}

458. In Count 9 of the Indictment, the Accused is alleged to be criminally responsible for acts of violence the primary purpose of which was to spread terror among the civilian population of Sarajevo as a violation of the laws or customs of war, punishable under Article 3 of the Statute. ${ }^{1505}$ While Article 3 does not explicitly refer to the offence of terror as such, the Appeals Chamber has held that this offence meets the threshold requirements for war crimes and is therefore covered by Article 3 of the Statute. ${ }^{1506}$ The prohibition of terror stems from Article 51(2) of Additional Protocol I and Article 13(2) of Additional Protocol II, both of which prohibit "acts or threats of violence the primary purpose of which is to spread terror among the civilian population" and both of which have been deemed by the Appeals Chamber to be part of customary international law. ${ }^{1507}$

459. The following elements need to be established before the Chamber can enter a conviction for terror:

(a) acts or threats of violence directed against the civilian population or individual civilians not taking direct part in hostilities;

(b) the perpetrator wilfully made the civilian population or individual civilians not taking direct part in hostilities the object of those acts of violence;

(c) the above was committed with the primary purpose of spreading terror among the civilian population. ${ }^{1508}$

\section{i. Actus reus}

460. The actus reus of terror ${ }^{1509}$ consists of acts or threats of violence directed against the civilian population or individual civilians not taking direct part in hostilities. ${ }^{1510}$ As such, it is similar to the actus reus of unlawful attacks on civilians. ${ }^{1511}$ Accordingly, as is the case with unlawful attacks on civilians, the acts or threats of violence constituting terror need not be limited

\footnotetext{
1505 Indictment, paras. 76-82.

1506

1507

1508

1509

1510

Galić Appeal Judgement, paras. 87-98 (confirming Galić Trial Judgement, paras. 87-130).

Galić Appeal Judgement, paras. 87-90; Dragomir Milošević Appeal Judgement, paras. 31-33.

Galić Appeal Judgement, paras. 100-101.

The Galić Trial Chamber defined terror as "extreme fear". The Galić Appeals Chamber later stated that terror "could" be defined in that way. See Galić Trial Judgement, para. 137; Galić Appeal Judgement, footnote 320.

1510 The Chamber notes that, with respect to Count 9 of the Indictment, the Prosecution alleges that the Accused is responsible only for acts of violence designed to spread terror and makes no mention of threats of violence. See Indictment, para. 82.

1511 See para. 451. The Chamber also reiterates that Article 49(1) of Additional Protocol I defines "attacks" as "acts of violence" which in turn means that terror can encompass attacks or threats of attacks on civilian population. See also Galić Appeal Judgement, para. 102.
} 
to direct attacks on civilians or threats thereof, but may include indiscriminate or disproportionate attacks. ${ }^{1512}$ In addition, they do not include legitimate attacks against combatants. ${ }^{1513}$

461. The nature of the acts or threats of violence directed against the civilian population or individual civilians can vary. ${ }^{1514}$ The Appeals Chamber has held that causing death or serious injury to body or health represents only one of the possible modes of commission of terror and thus is not an element of the offence per se. What is required-for this offence to fall under the jurisdiction of the Tribunal-is that the victims suffer grave consequences resulting from the acts or threats of violence, which may include but are not limited to death and/or serious injury to body or health. ${ }^{1515}$ However, while "extensive trauma and psychological damage form part of the acts or threats of violence", the actual infliction of terror on the civilian population is not a legal requirement of this offence. ${ }^{1516}$

462. The definition of civilians and civilian population has already been discussed by the Chamber in the preceding section and, therefore, shall not be repeated here. ${ }^{1517}$

\section{ii. Mens rea}

463. The mens rea of terror consists of both general intent and specific intent. ${ }^{1518}$ As in the case of unlawful attacks on civilians, to have the general intent the perpetrator must wilfully make the civilian population or individual civilians the object of acts or threats of violence. ${ }^{1519}$ The Chamber has already discussed the definition of "wilfully" in the context of unlawful attacks on civilians above, and shall therefore not repeat it here. ${ }^{1520}$

464. The specific intent for this offence is the intent to spread terror among the civilian population. ${ }^{1521}$ The prohibition on terror also excludes terror which is not intended by the perpetrator but is merely an incidental effect of acts of warfare which have another primary object and are in all other aspects lawful. ${ }^{1522}$ Accordingly, the particular circumstances must be taken into

\footnotetext{
1512 Galić Appeal Judgement, para. 102.

1513 Galić Trial Judgement, para. 135.

1514 Galić Appeal Judgement, para. 102.

1515 Dragomir Milošević Appeal Judgement, paras. 32-33 (overturning Dragomir Milošević Trial Judgement, para. 880).

1516 Dragomir Milošević Appeal Judgement, para. 35; Galić Appeal Judgement, paras. 102-104.

1517 See paras. 452-454.

1518 Dragomir Milošević Appeal Judgement, para. 37. See also Dragomir Milošević Trial Judgement, para. 878.

1519 Dragomir Milošević Appeal Judgement, para. 37.

1520 See paras. $456-457$.

1521 Galić Trial Judgement, para. 136; Dragomir Milošević Trial Judgement, para. 878.

1522 Galić Appeal Judgement, para. 103. See also Dragomir Milošević Trial Judgement, para. 888.
} 
account in determining whether the perpetrator intended to spread terror among the civilian population or individual civilians. ${ }^{1523}$

465. The fact that the spreading of terror is referred to as the "primary purpose" does not mean that the infliction of terror is the only objective of the acts or threats of violence. Accordingly, the co-existence of other purposes behind the acts or threats of violence would not disprove the charge of terror, so long as the intent to spread terror was the "principal among the aims". ${ }^{1524}$

466. The intent to spread terror can be inferred from the circumstances surrounding the acts or threats of violence, including their nature, manner, timing, and duration. ${ }^{1525}$ While, as stated above, ${ }^{1526}$ the actual infliction of terror on the civilian population is not a legal requirement of this offence, the evidence of actual terrorisation may contribute to establishing other elements of the offence, including the specific intent to terrorise. ${ }^{1527}$ The Appeals Chamber has also affirmed that the indiscriminate nature of an attack can be a factor in determining specific intent for terror. ${ }^{1528}$

\section{e. Taking of hostages as a violation of the laws or customs of war}

467. Count 11 charges the Accused with the taking of hostages as a "violation of the laws or customs of war, as recognised by Common Article 3(1)(b), and punishable under Article 3 of the Statute". ${ }^{1529}$ The crime of hostage-taking is not explicitly mentioned as one of the offences listed under Article 3 but stems from the provision in Common Article 3(1)(b), ${ }^{1530}$ which protects "persons taking no active part in the hostilities, including members of armed forces who have laid down their arms and those placed hors de combat by sickness, wounds, detention, or any other cause" from a list of prohibited acts, including hostage-taking. ${ }^{1531}$ The plain text of Common Article 3 indicates that the prohibition on hostage-taking is both absolute and without exception. ${ }^{1532}$

\footnotetext{
1523 Dragomir Milošević Trial Judgement, para. 888.

1524 Galić Appeal Judgement, para. 104; Dragomir Milošević Appeal Judgement, para. 37.

1525 Galić Appeal Judgement, para. 104; Dragomir Milošević Appeal Judgement, para. 37. See also Galić Trial Judgement, para. 134.

1526 See para. 461.

1527 Dragomir Milošević Appeal Judgement, paras. 35, 37; Dragomir Milošević Trial Judgement, para. 880.

1528 Dragomir Milošević Appeal Judgement, para. 37; Dragomir Milošević Trial Judgement, para. 881.

1529 Indictment, paras. 83-87.

1530 For the residual nature of Article 3 of the Statute, see para. 440.

1531 Common Article 3(1)(b) of the Geneva Conventions of 1949; Appeal Decision on Count 11, para. 22 (citing ICRC Commentary III, p. 40). See also Kordić and Čerkez Trial Judgement, para. 319. While Article 2(h) of the Statute prohibits taking civilians as hostages as a grave breach of the Geneva Conventions of 1949, Article 3 of the Statute prohibits hostage-taking of all persons not taking direct part in the hostilities pursuant to Common Article 3.

1532 Appeal Decision on Hostage-Taking, para. 16.
} 
468. In addition to fulfilling the chapeau requirements for Article 3, the offence of hostagetaking requires the following elements. The actus reus of this offence is the detention of persons and the use of a threat concerning the detained persons, including a threat to kill, injure or continue to detain, in order to obtain a concession or gain an advantage. ${ }^{1533}$ The Appeals Chamber has held that the prohibition on the taking of hostages pursuant to Common Article 3 applies to "all detained individuals, irrespective of whether their detention is explicitly sought in order to use them as hostages and irrespective of their prior status as combatants". ${ }^{1534}$ The mens rea required for hostage-taking is the intention to compel a third party to act or refrain from acting as a condition for the release of the detained persons. ${ }^{1535}$ Because the essential feature of the offence of hostagetaking is the use of a threat to detainees to obtain a concession or gain an advantage, ${ }^{1536}$ which may happen at any time during the detention, the requisite intent may be formed at the time of the detention or it may be formed at some later time, after the person has been detained. ${ }^{1537}$ The erroneous belief that detained combatants are not entitled to Common Article 3 protections is not a defence should the elements of hostage-taking be met. ${ }^{1538}$

\section{Article 5 of the Statute of the Tribunal}

469. The Accused is charged with five counts of crimes against humanity under Article 5 of the Statute. Count 3 charges him with persecution on political, racial, and religious grounds punishable under Article 5(h) of the Statute. ${ }^{1539}$ In Counts 4 and 5, the Accused is charged, respectively, with extermination under Article 5(b) of the Statute and murder under Article 5(a). ${ }^{1540}$ Finally, Counts 7

1533 Blaškić Appeal Judgement, para. 639, in which the Appeals Chamber cites to Article 1 of the International Convention Against the Taking of Hostages, adopted by the UN General Assembly on 17 December 1979, which states:

"Any person who seizes or detains and threatens to kill, to injure or to continue to detain another person (hereinafter referred to as the "hostage") in order to compel a third party, namely, a State, an international intergovernmental organization, a natural or juridical person, or group of persons, to do or abstain from doing any act as an explicit or implicit condition for the release of the hostage commits the offence of taking hostages ("hostage-taking") within the meaning of this Convention."

1534 Appeal Decision on Hostage-Taking, para. 21. The Accused argues that unlawful detention is an element of the crime of hostage taking and that this element has not been proven because the "Bosnian Serbs were lawfully entitled to detain UN personnel as prisoners of war after they had become combatants by virtue of the NATO air strikes". Defence Final Brief, para. 2738. The Chamber notes that the Appeals Chamber also recalled that under Common Article 3, the detention of a combatant during an armed conflict automatically renders him hors de combat and that such detention triggers the protections of Common Article 3. Appeal Decision on HostageTaking, paras. 16-17.

1535 Blaškić Appeal Judgement, para. 639.

1536 Blaškić Appeal Judgement, para. 639.

1537 Appeal Decision on Hostage-Taking, para. 17. See also Sesay et al. Appeal Judgement, paras. 597-598.

1538 Appeal Decision on Hostage-Taking, para. 22.

1539 Indictment, paras. 48-60.

1540 Indictment, paras. 61-67. 
and 8 charge him with deportation and inhumane acts (forcible transfer) punishable, respectively, under Articles 5(d) and 5(i) of the Statute. ${ }^{1541}$

470. As it did for Article 3 above, the Chamber will first assess the general requirements for offences charged under Article 5 of the Statute before proceeding with its analysis of the elements in relation to each of these offences.

a. General requirements for crimes against humanity

471. Article 5 of the Statute gives the Tribunal jurisdiction over various offences "when committed in armed conflict, whether international or internal in character, and directed against any civilian population". Unlike the exigency in Article 3 that the offences be closely related to the armed conflict, the requirement under Article 5 that the offence be committed in armed conflict is a purely jurisdictional prerequisite which is satisfied by proof that there was an armed conflict at the time and place relevant to the indictment but does not mandate any material nexus between the acts of the accused and the armed conflict. ${ }^{1542}$

472. Tribunal jurisprudence has identified the following five general requirements for crimes against humanity under Article 5 of the Statute:

(i) There must be an attack;

(ii) the attack must be directed against any civilian population;

(iii) the attack must be widespread or systematic;

(iv) the acts of the perpetrator must be part of the attack; and

(v) the perpetrator ${ }^{1543}$ must know that there is a widespread or systematic attack directed against a civilian population and know that his acts constitute part of this attack. ${ }^{1544}$

\section{i. There must be an attack}

473. The concepts of "attack" and "armed conflict" are not identical. ${ }^{1545}$ An attack could precede, outlast, or continue during the armed conflict but need not be part of it. ${ }^{1546}$ Furthermore,

\footnotetext{
$1541 \quad$ Indictment, paras. 68-75.

1542 Šě̌elj Appeal Jurisdiction Decision, para. 13. See also Kunarac et al. Appeal Judgement, para. 83; Tadić Appeal Judgement, para. 249.

1543 The use of the term "perpetrator" by the Chamber in this context includes the direct perpetrator as well as any indirect perpetrator or individual at whose behest the perpetrator is operating.

$1544 \quad$ Kunarac et al. Appeal Judgement, para. 85.
} 
in the context of a crime against humanity, an attack is not limited to the use of armed force but encompasses any mistreatment of the civilian population. ${ }^{1547}$

\section{ii. The attack must be directed against any civilian population}

474. A population is considered to be a civilian population under Article 5 of the Statute if it is predominantly civilian in nature. ${ }^{1548}$ The presence within a population of persons who do not come within the definition of civilians ${ }^{1549}$ does not necessarily deprive the population of its civilian character. ${ }^{1550}$ The Appeals Chamber has held that a determination as to whether the presence of soldiers within a civilian population deprives the population of its civilian character will depend on the number of soldiers, as well as whether they are on leave. ${ }^{1551}$

475. For the purpose of Article 5 of the Statute, an attack can be considered to have been directed against a civilian population if the civilian population was the "primary rather than an incidental target of the attack". ${ }^{1552}$ In order to determine whether the attack was so directed, the Appeals Chamber has identified a non-exhaustive list of relevant factors, such as the means and method used during the course of the attack, the status of the victims, their number, the discriminatory nature of the attack, the nature of the crimes committed in the course of the attack, the resistance to the assailants at the time of the attack, and the extent to which the attacking force may be said to have complied or attempted to comply with the precautionary requirements of the laws of war. ${ }^{1553}$ The term "population" does not mean that the entire population of the geographical entity in which the attack is occurring was subjected to the attack. ${ }^{1554}$ However, the attack must have targeted more than "a limited and randomly selected number of individuals" within the population. ${ }^{1555}$

\footnotetext{
$1545 \quad$ Kunarac et al. Appeal Judgement, para. 86.

1546 Kunarac et al. Appeal Judgement, para. 86. See also Šě̌elj Appeal Jurisdiction Decision, para. 13 (stating that "there is no requirement that an attack directed against a civilian population be related to the armed conflict").

1547 Kunarac et al. Appeal Judgement, para. 86.

1548 Tadić Trial Judgement, para. 638 (cited in numerous trial judgements, including Blagojević and Jokić Trial Judgement, para. 544; Milutinović et al. Trial Judgement, Vol. I, para. 146).

1549 Article 50(1) of Additional Protocol I provides that a civilian is any person who does not belong to one of the categories of persons referred to in Article 4(A)(1), (2), (3) and (6) of Geneva Convention III and in Article 43 of Additional Protocol I. For Article 4(A) of Geneva Convention III and Article 43 of Additional Protocol I, see fn. $1488,1489$.

1550 See Kordić and Čerkez. Appeal Judgement, para. 50, reiterated in Mrkšić and Šljivančanin Appeal Judgement, para. 31.

1551 Blaškić Appeal Judgement, para. 115 (quoting the Trial Judgement which refers to the ICRC Commentary to Additional Protocol I, Article 50, p. 612, para. 1922, which specifies that the presence of soldiers does not alter the civilian character of a civilian population as long as "these are not regular units with fairly large numbers").

1552 Kunarac et al. Appeal Judgement, para. 92. See also Dragomir Milošević Trial Judgement, para. 921; Galić Trial Judgement, para. 142.

1553 Kunarac et al. Appeal Judgement, para. 91 (reiterated in Mrkšić and Šljivančanin Appeal Judgement, para. 25).

1554 Kunarac et al. Appeal Judgement, para. 90 (confirming Kunarac et al. Trial Judgement, para. 424).

1555 Kunarac et al. Appeal Judgement, para. 90 (as recalled in Kordić and Čerkez Appeal Judgement, para. 95).
} 
476. Finally, as discussed above, while the civilian status of the victims, the number of civilians, and the proportion of civilians within a civilian population are factors relevant to the determination as to whether an attack is directed against a "civilian population", there is no requirement that individual victims of crimes against humanity be civilians. ${ }^{1556}$ It is therefore possible for a person hors de combat to be a victim of an act amounting to a crime against humanity. ${ }^{1557}$

\section{iii. The attack must be widespread or systematic}

477. The attack must be widespread or, in the alternative, systematic. ${ }^{1558}$ While the term "widespread" refers to the large-scale character of the attack and the number of persons targeted, the term "systematic" refers to the organised nature of the acts of violence and the improbability of their random occurrence. ${ }^{1559}$ The assessment of what constitutes "widespread" or "systematic" is to be conducted on a case by case basis and may take into account the consequences of the attack upon the targeted population, the number of victims, the nature of the acts, the possible participation of officials or authorities, and any identifiable patterns of crimes. ${ }^{1560}$ While the existence of a plan or policy may be used to demonstrate the existence of a widespread or systematic attack directed against a civilian population, it is not a legal element under Article 5 of the Statute. ${ }^{1561}$

\section{iv. The acts of the perpetrators must be part of the attack}

478. The acts of the perpetrator must be part of the attack on the civilian population, although they need not be committed in the midst of that attack. ${ }^{1562}$ An offence which is committed before or after the attack against the civilian population or away from it could still, if sufficiently connected, be part of that attack. ${ }^{1563}$ Whether a given offence is sufficiently connected to the attack

\footnotetext{
1556 Mrkšić and Šljivančanin Appeal Judgement, paras. 29, 32 (citing Martić Appeal Judgement, para. 307).

1557 Martić Appeal Judgement, paras. 313-314.

1558 Kunarac et al. Appeal Judgement, para. 93 (citing Tadić Appeal Judgement, para. 248).

1559 Blaškić Appeal Judgement, para. 101 (citing Kunarac et al. Appeal Judgement, para. 94).

1560 Kunarac et al. Appeal Judgement, para. 95.

1561 Kunarac et al. Appeal Judgement, para. 98 (reiterated in Blaškić Appeal Judgement, para. 120).

1562 Kunarac et al. Appeal Judgement, para. 100 and Blaškić Appeal Judgement, para. 124 (referring to the "acts of the accused") But see Milutinović et al. Trial Judgement, Vol. I, para. 152 (holding that "[i]t is the conduct of the physical perpetrator that must form part of the attack") and para. 155 (recalling that the then practice of the Tribunal demonstrated that the requirement that the conduct charged related to the attack on the civilian population was satisfied by proof that the underlying offences comprised part of the attack regardless as to whether they were physically committed by the accused or by those for whose acts he bore responsibility); Popović et al. Trial Judgement, paras. 751, 757 (referring to both the "acts of the perpetrator" and the "acts of the accused"); and Stanišić and Župljanin Trial Judgement, Vol. I, para. 29 (referring to the "acts of the perpetrator").

1563 Kunarac et al. Appeal Judgement, para. 100 (as reiterated in Mrkšić and Šljivančanin Appeal Judgement, para. 41).
} 
will depend on the factual circumstances of the case but, in any event, it should not be so far removed from the attack so as to constitute an isolated act void of any nexus to the attack. ${ }^{1564}$

$\mathrm{v}$. The perpetrator must know that there is a widespread or systematic attack against a civilian population and know that his acts constitute part of this attack

479. The perpetrator must know that there is a widespread or systematic attack on the civilian population and know that his acts comprise part of that attack. ${ }^{1565}$ For the purpose of Article 5, the perpetrator need not have the knowledge of the details of the attack. ${ }^{1566}$ Furthermore, his motives are irrelevant. ${ }^{1567}$ It is the attack, not his acts, which must be directed against the targeted population and the perpetrator need only know that his acts are a part of that attack. ${ }^{1568}$

b. Murder as a crime against humanity

480. Under Count 5 of the Indictment, the Accused is charged with murder, a crime against humanity, punishable under Article 5(a) of the Statute. ${ }^{1569}$

481. The elements of murder under Article 5 of the Statute are the same as those articulated for murder as a violation of the laws or customs of war under Article $3 .^{1570}$ The Chamber therefore refers here to its earlier discussion as to the elements of murder pursuant to Article 3 of the Statute.

c. Extermination as a crime against humanity

482. Under Count 4 of the Indictment, the Accused is charged with extermination, a crime against humanity, punishable under Article 5(b) of the Statute. ${ }^{1571}$

1564 Mrkšić and Šljivančanin Appeal Judgement, para. 41.

1565 See Tadić Appeal Judgement, para. 248; Kunarac et al. Appeal Judgement, para. 102; Blaškić Appeal Judgement, para. 124; Kordić Appeal Judgement, para. 99 (referring to the requisite knowledge of the accused); Šainović et al. Appeal Judgement, para. 264; Mrkšić and Šljivančanin Appeal Judgement, para. 42 (assessing the nexus of the crimes charged to the attack through the acts of the perpetrators); Stanišić and Župljanin Trial Judgement, Vol. I, para. 213 and Stanišić and Simatović Trial Judgement, Vol. I, para. 972 (both assessing the knowledge of the perpetrators). But see Popovic et al. Trial Judgement, para. 786 (assessing the knowledge of the accused). See also Milutinović et al. Trial Judgement, Vol. I, paras. 153-162, (conducting an in-depth analysis of Tribunal jurisprudence on this requirement and concluding as follows: "Either the physical perpetrator or the person who planned, ordered, or instigated the acts of the physical perpetrator or a member of the joint criminal enterprise, must know that there is an attack on the civilian population and know, or take the risk, that his acts comprise part of this attack").

1566 Kunarac et al. Appeal Judgement, para. 102.

1567 Kunarac et al. Appeal Judgement, para. 103.

1568 Kunarac et al. Appeal Judgement, para. 103.

1569 Indictment, paras. 61-67.

1570 See Stanišić and Župljanin Trial Judgement, Vol. I, para. 42; Tolimir Trial Judgement, para. 714; Popović et al. Trial Judgement, para. 787; Milutinović et al. Trial Judgement, Vol. I, para. 136; Lukić and Lukić Trial Judgement, para. 903; Martić Trial Judgement, para. 58; Blagojević and Jokić Trial Judgement, para. 556.

1571 Indictment, paras. 61-67. 


\section{i. Actus reus}

483. The actus reus of extermination consists of "the act of killing on a large scale". ${ }^{1572}$ This involves "any act, omission or combination thereof which contributes directly or indirectly to the killing of a large number of individuals". ${ }^{1573}$ In determining what is sufficient for a finding that a large number of individuals were killed, the Tribunal's jurisprudence has consistently held that there is no minimum numerical threshold of victims that must be reached. ${ }^{1574}$ Furthermore, it is not necessary that the victims of extermination be precisely identified by name, and it suffices to establish that killings occurred on a mass scale. ${ }^{1575}$ An assessment of whether the element of "massiveness" has been met must be made on a case by case basis, taking into account all the relevant factors. ${ }^{1576}$ Relevant factors include, for example, the time and place of the killings, the selection of the victims and the manner in which they were targeted, and whether the killings were aimed at the collective group rather than victims in their individual capacity. ${ }^{1577}$ There is no requirement to establish that there was a "vast scheme of collective murder". ${ }^{1578}$

484. Trial Chambers have previously found that it was possible to establish extermination "on an accumulation of separate and unrelated incidents, meaning on an aggregated basis". 1579 The Appeals Chamber recently stated in Tolimir that the actus reus of extermination "may be established through an aggregation of separate incidents". ${ }^{1580}$ The Chamber notes that, in this formulation, the possibility of accumulating "unrelated" incidents was removed. The Tolimir Appeals Chamber went on to state that for the purpose of aggregating separate incidents, it is not

\footnotetext{
1572 Lukić and Lukić Appeal Judgement, para. 536; Stakić Appeal Judgement, para. 259; Seromba Appeal Judgement, para. 189.

1573 Seromba Appeal Judgement, para. 189. See also Ntakirutimana and Ntakirutimana Appeal Judgement, para. 522 (in relation to the notion of contributing "directly" and "indirectly" to the killing of a large number of individuals).

1574 Lukić and Lukić Appeal Judgement, para. 537; Rukundo Appeal Judgement, para. 185; Brđanin Appeal Judgement, paras. 471-472; Ntakirutimana and Ntakirutimana Appeal Judgement, para. 516; Stakić Appeal Judgement, para. 260.

1575 Ntakirutimana and Ntakirutimana Appeal Judgement, paras. 521-522; Stakić Appeal Judgement, para. 259, fn. 552. See also Rukundo Appeal Judgement, para. 186.

1576 Lukić and Lukić Appeal Judgement, para. 538. See also Tolimir Appeal Judgement, para. 146; Tolimir Trial Judgement, para. 725; Perišić Trial Judgement, para. 107; Popović et al. Trial Judgement, para. 800.

1577 Lukić and Lukić Appeal Judgement, para. 538 (citing Martić Trial Judgement, fn. 120; Krajišnik Trial Judgement, para. 716; Nahimana et al. Trial Judgement, para. 1061; Stakić Trial Judgement, para. 653; Vasiljević Trial Judgement, para. 227).

1578 Stakić Appeal Judgement, paras. 258-259.

1579 Brđanin Trial Judgement, para. 391. See also Tolimir Trial Judgement, para. 725; Lukić and Lukić Trial Judgement, para. 938; Martic Trial Judgement, para. 63. The Appeals Chamber in Brđanin noted that the approach of the Trial Chamber to "consider all of the killings in the territory of the ARK as a whole rather than to distinguish them by location and incident" was not challenged in that case. The Appeals Chamber thus decided that it need not consider the issue but found that, with respect to specific killing incidents, the actus reus for extermination had been established and upheld the Trial Chamber's assessment that the scale of killings met the threshold of massiveness for the purposes of extermination. Brđanin Appeal Judgement, paras. 471-472. Tolimir Appeal Judgement, para. 147 (referring to Karemera Appeal Judgement, paras. 661-662).
} 
required that the killing be on a vast scale in a concentrated location over a short period of time. However, even with respect to separate incidents, the Appeals Chamber made it clear that killing incidents which did not form part of the same murder operation could not be accumulated for the purposes of extermination. ${ }^{1581}$ In assessing whether specific killing incidents formed part of the same murder operation, the Tolimir Appeals Chamber also recalled that the ICTR Appeals Chamber stated that "as a general matter, the element of killing on a large scale cannot be satisfied by a collective consideration of distinct events committed in different prefectures, in different circumstances, by different perpetrators, and over an extended period of time". ${ }^{1582}$

\section{ii. Mens rea}

485. The mens rea of extermination requires the intention that a large number of individuals be killed. ${ }^{1583}$

486. In line with jurisprudence on the actus reus, the mens rea of extermination similarly does not require the intent to kill a certain threshold number of victims. ${ }^{1584}$ Additionally, there is no

1581 Tolimir Appeal Judgement, para. 147. The Tolimir Appeals Chamber found that the killing of three Bosnian Muslim leaders from Žepa in late August and September 1995 was not part of the same murder operation as the mass killings of the Bosnian Muslim men and boys of Srebrenica which began on 13 July 1995, such that these incidents could not be accumulated for the purposes of extermination. Tolimir Appeal Judgement, 135, 145150. The Appeals Chamber noted the Trial Chamber's findings of five shared factors between the killings, including the fact that the victims were all Bosnian Muslims, "the general identity of the perpetrators of the killings as members of the Bosnian Serb Forces", and "the link to the overall goal of the Bosnian Serb Forces of 'ridding the enclaves of its Bosnian Muslim population'”. Tolimir Appeal Judgement, para. 148. The Appeals Chamber noted, however, that the three leaders were killed "after the main attack against the civilian population" of the enclaves of Srebrenica and Žepa and that the incidents in question were charged under two different JCEs. Tolimir Appeal Judgement, para. 149. The Appeals Chamber concluded that the killings of the three leaders were killed in a "different context and [...] circumstances" from the Bosnian Muslim males of Srebrenica. Tolimir Appeal Judgement, paras. 149-150.

1582 Tolimir Appeal Judgement, para. 147; Karemera Appeal Judgement, para. 661 (citing Bagosora Appeal Judgement, para. 396). The Chamber notes that in Karemera, the Appeals Chamber found that it had not been demonstrated in the context of that case that it was impermissible to aggregate killings to establish the largescale requirement for extermination. Karemera Appeal Judgement, paras. 661-662. For some of the killings, the Appeals Chamber considered that "the [...] facts as found by the Trial Chamber reflect that these incidents individually satisfy the element of killings on a large scale". Karemera Appeal Judgement, para. 661. Karemera Appeal Judgement, para. 661, fns. 1796-1797; Karemera Trial Judgement, paras. 1199, 1294, 1450, 1612, 1649-1653, 1662. The Appeals Chamber noted that "[w]ith respect to the remaining massive killings throughout Rwanda by mid-July 1994, [...] the Trial Chamber connected sets of massive killings to specific acts of a member of the joint criminal enterprise or a particular group of assailants". Karemera Appeal Judgement, para. 662 (citing Karemera Trial Judgement, paras. 1619-1648). In Bagosora, the Appeals Chamber found that the incidents in question "presented distinct features" and "could not be considered to constitute one and the same crime sharing the same actus reus". Bagosora Appeal Judgement, para. 396. See also Bagosora Appeal Judgement, paras. 111, 125, 140, 155, 174, 236, 304, 332, 349, 396, fn. 922; Bagosora Trial Judgement, paras. 1064, 2140-2157.

1583 See Lukić and Lukić Appeal Judgement, para. 536; Stakić Appeal Judgement, paras. 259-260; Tolimir Trial Judgement, para. 726.

1584 Stakić Appeal Judgement, para. 260. See also Tolimir Trial Judgement, para. 726; Popović et al. Trial Judgement, para. 801; Krajišnik Trial Judgement, para. 716. 
requirement that the act of extermination be carried out with the intent to destroy the group or part of the group to which the victims belong, ${ }^{1585}$ or pursuant to a pre-existing plan or policy. ${ }^{1586}$

d. Deportation and inhumane acts (forcible transfer) as crimes against humanity

487. Under Counts 7 and 8 of the Indictment, the Accused is charged with deportation and inhumane acts (forcible transfer) as crimes against humanity pursuant to Articles 5(d) and 5(i) of the Statute, respectively. ${ }^{1587}$ The Accused is also charged with persecution, pursuant to Article 5(h) of the Statute, through the underlying act of forcible transfer or deportation. ${ }^{1588}$

\section{i. Actus reus}

488. The elements of deportation and forcible transfer are substantially similar. ${ }^{1589}$ Deportation and forcible transfer are defined as: (i) the forced displacement of one or more persons by expulsion or other forms of coercion, (ii) from an area in which they are lawfully present, (iii) without grounds permitted under international law. ${ }^{1590}$ There is an important distinction between the two crimes; for deportation, the displacement of persons must be across a de jure border between two states or, in certain circumstances, a de facto border, ${ }^{1591}$ and for forcible transfer, the removal may take place within national boundaries. ${ }^{1592}$

489. To establish deportation and forcible transfer, there must be a forced displacement of persons carried out by expulsion or other forms of coercion. ${ }^{1593}$ The term "forced" may include physical force, as well as the threat of force or coercion, such as that caused by fear of violence, duress, detention, psychological oppression, or abuse of power, or the act of taking advantage of a

\footnotetext{
1585 Tolimir Trial Judgement, para. 726; Popović et al. Trial Judgement, para. 801; Stakić Trial Judgement, para. 639; Vasiljević Trial Judgement, para. 227.

1586 Krstić Appeal Judgement, para. 225.

1587 Indictment, paras. 68-75.

1588 Indictment, para. 60(f).

1589 See Simić et al. Trial Judgement, para. 123. See also Popović et al. Trial Judgement, para. 890; Milutinović et al. Trial Judgement, Vol. I, para. 163.

1590 Krajišnik Appeal Judgement, para. 304; Stakić Appeal Judgement, paras. 278, 317. See also Stanišić and Župljanin Trial Judgement, Vol. I, para. 61; Tolimir Trial Judgement, para. 793; Popović et al. Trial Judgement, para. 891; Milutinović et al. Trial Judgement, Vol. I, para. 164.

1591 Đorđević Appeal Judgement, paras. 532, 535; Krajišnik Appeal Judgement, para. 304; Stakić Appeal Judgement, paras. 278, 289-300, 317. See also Stanišić and Župljanin Trial Judgement, Vol. I, para. 61; Tolimir Trial Judgement, para. 793; Popović et al. Trial Judgement, para. 892; Milutinović et al. Trial Judgement, Vol. I, para. 164.

1592 Stakić Appeal Judgement, para. 317. See also Stanišić and Župljanin Trial Judgement, Vol. I, para. 61; Tolimir Trial Judgement, para. 793; Popović et al. Trial Judgement, para. 892; Milutinović et al. Trial Judgement, Vol. I, para. 164.

1593 Stakić Appeal Judgement, para. 279.
} 
coercive environment. ${ }^{1594}$ The forced character of the displacement is determined by the absence of genuine choice by the victim in his or her displacement. ${ }^{1595}$ As such, while persons may consent to, or even request, their removal, any consent or request to be displaced must be given voluntarily and as a result of the individual's free will, assessed in light of the surrounding circumstances of the particular case. ${ }^{1596}$

490. Furthermore, the involvement of a non-governmental organisation in facilitating displacements does not in and of itself render lawful an otherwise unlawful transfer. ${ }^{1597}$ An agreement among military commanders, political leaders, or other representatives of the parties in a conflict cannot make a displacement lawful either; it is the consent of the individual that determines whether a displacement is voluntary. ${ }^{1598}$

491. As stated above, an element of deportation and forcible transfer is that the victim must be "lawfully present" in the area from which the forced displacement takes place. ${ }^{1599}$ In analysing this element of deportation and forcible transfer, the terms "lawfully present" should be given their common meaning and should not be equated to the legal concept of lawful residence. ${ }^{1600}$

492. International law recognises certain grounds permitting forced removals, such as the evacuation of: (i) a civilian population for its security or for imperative military reasons; and (ii) prisoners of war out of combat zones and into internment facilities, subject to the conditions set out therein. $^{1601}$ If an act of forced removal is carried out on such bases, that act cannot constitute the actus reus of deportation or forcible transfer. ${ }^{1602}$ Evacuation is an exceptional measure which is permitted to protect the civilian population. However, it is unlawful to use evacuation measures based on imperative military reasons as a pretext to remove the civilian population and seize

\footnotetext{
1594 Šainović et al. Appeal Judgement, para. 366; Krajišnik Appeal Judgement, para. 319; Stakić Appeal Judgement, paras. 279, 281; Krnojelac Appeal Judgement, paras. 229, 233; Simić et al. Trial Judgement, para. 126.

1595 Stakić Appeal Judgement, para. 279; Krnojelac Appeal Judgement, paras. 229, 233; Blagojević and Jokić Trial Judgement, para. 596; Brđanin Trial Judgement, para. 543.

1596 Stakić Appeal Judgement, paras. 279, 282.

1597 Stakić Appeal Judgement, para. 286.

1598 Tolimir Trial Judgement, para. 796; Popović et al. Trial Judgement, para. 897; Simić et al. Trial Judgement, paras. 127-128; Naletilić and Martinović Trial Judgement, para. 523.

1599 See para. 488.

1600 Popović et al. Trial Judgement, para. 900 (finding that the prohibition against forcible transfer and deportation should protect the right of victims to live in their homes and communities, whether long term or temporarily; therefore encompassing, for example, "internally displaced persons who have established temporary homes after being uprooted from their original community"). See also Tolimir Trial Judgement, para. 797.

1601 Stakić Appeal Judgement, paras. 284-285 (quoting Article 19 of Geneva Convention III, Article 49 of Geneva Convention IV, and Article 17 of Additional Protocol II). See also Popović et al. Trial Judgement, paras. 901902; Milutinović et al. Trial Judgement, Vol. I, para. 166; Blagojević and Jokić Trial Judgement, para. 597.

1602 Stakić Appeal Judgement, para. 284.
} 
control over a desired territory. ${ }^{1603}$ Although forced removal for humanitarian reasons is justifiable in certain situations, it is not justified where the humanitarian crisis that caused the displacement is itself the result of the perpetrator's own unlawful activity. ${ }^{1604}$

\section{ii. Mens rea}

493. The mens rea required for deportation is the intent to forcibly displace the population across a de jure or de facto border. ${ }^{1605}$ The mens rea for the crime of forcible transfer is the intent to forcibly displace the population within a national border. ${ }^{1606}$ Deportation and forcible transfer do not require intent that the victims be displaced permanently, only that they be intentionally displaced. ${ }^{1607}$

\section{iii. Forcible transfer as "other inhumane acts" pursuant to Article 5(i)}

494. The category of "other inhumane acts" contained in Article 5(i) of the Statute is a residual category of crimes against humanity which includes serious criminal acts that are not exhaustively enumerated in Article 5. ${ }^{1608}$ The following elements are required for an act or omission to constitute an inhumane act under Article 5(i): (i) there was an act or omission of similar seriousness to the other enumerated acts under Article 5; (ii) the act or omission caused serious mental or physical suffering or injury or constituted a serious attack on human dignity; and (iii) the act or omission was committed with the intent to inflict serious physical or mental suffering or to commit a serious attack on the human dignity of the victim(s), or with the knowledge that this act or omission was likely to cause such suffering or a serious attack upon human dignity. ${ }^{1609}$

495. The Appeals Chamber has confirmed that "specific "acts of forcible transfer may be sufficiently serious as to amount to other inhumane acts". ${ }^{1610}$ A Trial Chamber must therefore

\footnotetext{
1603 Popović et al. Trial Judgement, para. 901; Blagojević and Jokić Trial Judgement, para. 597.

1604 Stakić Appeal Judgement, para. 287. See also Popović et al. Trial Judgement, para. 903.

1605 See Tolimir Trial Judgement, para. 801; Popović et al. Trial Judgement, para. 904; Milutinović et al. Trial Judgement, Vol. I, para. 164; Martić Trial Judgement, para. 111. See also Stakić Appeal Judgement, para. 278.

1606 Stakić Appeal Judgement, para. 317. See also Tolimir Trial Judgement, para. 801; Popović et al. Trial Judgement, para. 904; Milutinović et al. Trial Judgement, Vol. I, para. 164; Martić Trial Judgement, para. 111.

1607 Brđanin Appeal Judgement, para. 206; Stakić Appeal Judgement, paras. 278, 304, 307, 317. See also Tolimir Trial Judgement, para. 801; Popović et al. Trial Judgement, para. 905; Milutinović et al. Trial Judgement, Vol. I, para. 164.

1608 Stakić Appeal Judgement, paras. 315-316; Kordić and Čerkez Appeal Judgement, para. 117 (quoting Kupreškić et al. Trial Judgement, para. 563).

1609 Kordić and Čerkez Appeal Judgement, para. 117. See also Vasiljević Trial Judgement, paras. 234-236; Krnojelac Trial Judgement, paras. 130-132; Kayishema and Ruzindana Trial Judgement, paras. 153-154.

1610 Stakić Appeal Judgement, para. 317 (emphasis added). See also Krajišnik Appeal Judgement, para. 331.
} 
assess on a case-by-case basis if the specific instances of forcible transfer are sufficiently serious to amount to "other inhumane acts" pursuant to Article 5(i) of the Statute. ${ }^{1611}$

\section{e. Persecution as a crime against humanity}

496. Under Count 3 of the Indictment, the Accused is charged with persecution pursuant to the following underlying acts: (a) killings; (b) torture, beatings, and physical and psychological abuse; (c) rape and other acts of sexual violence; (d) establishment and perpetuation of inhumane living conditions; (e) terrorising and abuse ${ }^{1612}$ (f) forcible transfer or deportation; (g) unlawful detention; (h) forced labour at front lines and the use of human shields; (i) appropriation or plunder of property; (j) wanton destruction of private property, including cultural monuments and sacred sites; and (k) imposition and maintenance of restrictive and discriminatory measures. ${ }^{1613}$ The Prosecution charges the acts listed in (b), (c), (d), and (e) above as forms of "cruel and/or inhumane treatment".

\section{i. General elements}

497. Persecution is defined in the jurisprudence of the Tribunal as an act or omission (i) which discriminates in fact and denies or infringes upon a fundamental right laid down in international customary law or treaty law (actus reus); and (ii) is carried out deliberately with the intention to discriminate on political, social or religious grounds (mens rea). ${ }^{1614}$ Although the Statute refers to the listed grounds in the conjunctive, the presence of discriminatory intent on any one of these listed grounds is sufficient to fulfill the mens rea requirement for persecution. ${ }^{1615}$

498. Persecution may take different forms. ${ }^{1616}$ It may be committed through acts or omissions, some of which are listed in the Statute. ${ }^{1617}$ For persecution to be established, the act or omission

\footnotetext{
1611 Krajišnik Appeal Judgement, para. 331; Stakić Appeal Judgement, para. 317; Kordić and Čerkez Appeal Judgement, para. 117.

1612 This allegation only pertains to the Srebrenica component of the case, see Indictment, para. 60(e).

1613 Indictment, paras. 48-60; Schedules A, B, C, D, and E (Parts 1 and 2).

1614 Stakić Appeal Judgement, para. 327; Kordić and Čerkez Appeal Judgement, para. 101; Blaškić Appeal Judgement, para. 131; Vasiljević Appeal Judgement, para. 113; Krnojelac Appeal Judgement, para. 185.

1615 See Simić et al. Trial Judgement, para. 52; Tadić Trial Judgement, para. 713.

1616 Krnojelac Appeal Judgement, para. 219.

1617 Brđanin Appeal Judgement, para. 296; Kvočka et al. Appeal Judgement, paras. 321-323; Krnojelac Appeal Judgement, para. 219; Stanišić and Simatović Trial Judgement, Vol. I, para. 1239.
} 
must discriminate in fact. ${ }^{1618}$ An act, or omission, is discriminatory if the victim is targeted due to his membership in one of the protected groups. ${ }^{1619}$

499. For the alleged underlying acts or omissions to be considered serious enough to amount to persecution, they must be of equal gravity to the other crimes listed in Article 5 of the Statute, whether considered in isolation or in conjunction with other underlying acts. ${ }^{1620}$ The Appeals Chamber held that in considering which underlying acts could amount to persecution, it must be demonstrated that "these acts must constitute a denial of or infringement upon a fundamental right laid down in international customary law". ${ }^{1621}$

500. Persecution requires the specific intent to discriminate on political, racial or religious grounds and it is this discriminatory intent which distinguishes this offence from other offences listed in Article 5 of the Statute. ${ }^{1622}$ This discriminatory intent requires that the perpetrator acted with the intent to harm the victim because he belongs to a particular community or group. ${ }^{1623}$ While the discriminatory intent may not be inferred solely from the "general discriminatory nature of an attack characterised as a crime against humanity", ${ }^{1624}$ it may be inferred from the context as long as the circumstances surrounding the commission of the alleged acts substantiate the existence

1618 Lukić and Lukić Appeal Judgement, para. 455; Kvočka et al. Appeal Judgement, para. 320; Krnojelac Appeal Judgement, para. 185 .

1619 Kvočka et al. Appeal Judgement, paras. 366, 455; Kordić Appeal Judgement, para. 111; Brđanin Trial Judgement, paras. 992-993; Simić et al. Trial Judgement, para. 51; Kupreškić et al. Trial Judgement, paras. 635 636.

1620 Brđanin Appeal Judgement, para. 296; Simić Appeal Judgement, para. 177 ; Naletilić and Martinović Appeal Judgement, para. 574 ; Kvočka et al. Appeal Judgement, paras. 321, 323; Kordić and Čerkez. Appeal Judgement, paras. 102-103, 672; Blaškić Appeal Judgement, paras. 135, 139; Krnojelac Appeal Judgement, paras. 199, 221; Nahimana et al. Appeal Judgement, para. 985. The Appeals Chamber has recently stated that it is not required that each underlying act be a violation of international law and that a "trial chamber does not need to establish the elements of the underlying acts, including the mens rea, even when the underlying act also constitutes a crime under international law". Popović et al. Appeal Judgement, para. 738. However, the Chamber is of the view that while it may not be necessary to look to the strict elements of the underlying acts to establish whether persecution has been committed, when those elements have been satisfied, this assessment is instructive in determining whether the underlying acts also amount to other crimes under Article 5 of the Statute or are of equal gravity to the other crimes listed under Article 5 of the Statute. For this purpose, the Chamber will set out how the underlying acts of persecution as charged in the Indictment have been defined.

1621 Blaškić Appeal Judgement, para. 139. Some Trial Chambers have stated that this gravity test is met when the act or omission amounts to a gross or blatant denial of fundamental human rights. Brđanin Trial Judgement, para. 995; Krnojelac Trial Judgement, para. 434; Kupreškić et al. Trial Judgement, paras. 620-621. This is also broadly similar to the ICC definition of persecution which refers to the "intentional and severe deprivation of fundamental rights contrary to international law [...]”. Rome Statute, Article 7(2)(g).

1622 Tadić Appeal Judgement, para. 305; Krnojelac Trial Judgement, para. 435; Kordić and Čerkez Trial Judgement, para. 217; Blaškić Trial Judgement, para. 235.

1623 Kordić and Čerkez Appeal Judgement, para. 111 (holding that the discriminatory intent to cause injury to "a human being because he belongs to a particular community or group" does not require the perpetrator to possess a "specific persecutory intent" over and above a discriminatory intent); Blaškić Appeal Judgement, para. 165.

1624 Kordić and Čerkez. Appeal Judgement, para. 110; Blaškić Appeal Judgement, para. 164; Krnojelac Appeal Judgement, para. 184. 
of the discriminatory intent. ${ }^{1625}$ The Appeals Chamber has held that circumstances which may be taken into account include the systematic nature of the crimes committed against a certain group and the general attitude of the alleged perpetrator as demonstrated by his behaviour. ${ }^{1626}$ However, the existence of a discriminatory policy is not a requirement for proving persecution, although persecutory acts may form a part of a discriminatory policy or practice. ${ }^{1627}$

\section{ii. Underlying acts}

(A) Killings

501. Under Count 3, the Accused is charged with persecution, pursuant to Article 5(h) of the Statute, through the underlying act of killings. ${ }^{1628}$

502. Murder is set out as a crime against humanity under Article 5(a). Accordingly killings can constitute persecution, provided the general elements for persecution are met. ${ }^{1629}$ The Chamber has already found that the elements of murder under Article 5 of the Statute are the same as those articulated for murder as a violation of the laws or customs of war under Article 3 of the Statute. ${ }^{1630}$ The Chamber thus refers to this earlier discussion. ${ }^{1631}$

(B) Cruel and/or inhumane treatment

503. The Accused is charged under Count 3 with persecution, pursuant to Article 5(h) of the Statute, through the underlying act of "cruel and/or inhumane treatment". The Prosecution charges the following forms of cruel and/or inhumane treatment in the Indictment: (i) "torture, beatings, and physical and psychological abuse during and after the takeovers in the Municipalities and in detention facilities in the Municipalities"; (ii) "rape and other acts of sexual violence during and after takeovers in the Municipalities and in detention facilities in the Municipalities"; (iii) the establishment and perpetuation of inhumane living conditions in detention facilities in the

\footnotetext{
1625 Kordić and Čerkez. Appeal Judgement, para. 110; Blaškić Appeal Judgement, para. 164; Krnojelac Appeal Judgement, para. 184.

1626 Kvočka et al. Appeal Judgement, para. 460; Krnojelac Appeal Judgement, para. 184.

1627 Popović et al. Trial Judgement, para. 967; Blagojević and Jokić Trial Judgement, para. 582; Brđanin Trial Judgement, para. 996; Stakić Trial Judgement, para. 739; Krnojelac Trial Judgement, para. 435; Kupreškić et al. Trial Judgement, paras. 615, 625.

1628 Indictment, para. 60(a).

1629 Popović et al. Trial Judgement, para. 972.

1630 See para. 481.

1631 See paras. 446-448.
} 
Municipalities; and (iv) "terrorising and abuse of Bosnian Muslims of Srebrenica in Potočari and the beating of men and boys of Srebrenica prior to their execution". ${ }^{1632}$

504. The Appeals Chamber has held that the right to be free from "cruel, inhuman or degrading treatment or punishment" is recognised under customary international law and enshrined in international human rights instruments. ${ }^{1633}$ Cruel and/or inhumane treatment is defined as an act or omission which causes serious mental or physical suffering or injury, or which constitutes a serious attack on human dignity. ${ }^{1634}$ The act or omission must be committed with the intent to cause serious mental or physical suffering or injury or a serious attack on human dignity, or with the knowledge that serious mental or physical suffering or injury or the serious attack on human dignity was a probable consequence of the act or omission. ${ }^{1635}$ The Chamber will now examine, in turn, the various forms of cruel or inhumane treatment listed by the Prosecution as underlying acts of persecution under Count 3 of the Indictment.

\section{(1) Torture}

505. Torture is expressly prohibited in Article 5(f) of the Statute and may constitute persecution if the general requirements of persecution are met. ${ }^{1636}$ The Appeals Chamber has held that the definition of torture, as set out in the Convention Against Torture may be considered to reflect customary international law. ${ }^{1637}$ Torture constitutes one of the most serious attacks upon a person's mental or physical integrity. ${ }^{1638}$ The seriousness of torture lies in the infliction of severe mental or

1632

1633

1634

Indictment, paras. 60(b)-(e).

Kordić and Čerkez Appeal Judgement, para. 106; Blaškić Appeal Judgement, para. 143.

Čelebići Appeal Judgement, paras. 424, 426. The Chamber notes that it is settled jurisprudence that the material elements of cruel treatment under Article 3 and "inhuman" treatment under Article 2 are the same and that the sole distinct element between cruel and inhuman treatment stems from the protected person requirement under Article 2. Čelebići Appeal Judgement, para. 426; Blagojević and Jokić Trial Judgement, para. 586, fn. 1938. Furthermore, it is settled that these offences and other inhumane acts under Article 5(i) of the Statute are also the same. See, e.g., Simić et al. Trial Judgement, para. 74. While in this present case cruel and/or inhumane treatment is charged as an underlying act of the offence of persecution, the Tribunal's jurisprudence has established that the definition of this underlying act is same as cruel treatment and inhuman treatment. See, e.g., Gotovina et al. Trial Judgement, Vol. II, para. 1791; Tolimir Trial Judgement, para. 853; Popović et al. Trial Judgement, para. 975.

Popović et al. Trial Judgement, para. 974; Strugar Trial Judgement, para. 261; Limaj et al. Trial Judgement, para. 231.

See paras. 497-500.

Brđanin Appeal Judgement, para. 246; Kunarac et al. Appeal Judgement, para. 146; Furundžija Appeal Judgement, para. 111. See also Article 1(1) of the Convention Against Torture which defines torture as:

"[A]ny act by which severe pain or suffering, whether physical or mental, is intentionally inflicted on a person for such purposes as obtaining from him or a third person information or a confession, punishing him for an act he or a third person has committed or is suspected of having committed, or intimidating or coercing him or a third person, or for any reason based on discrimination of any kind, when such pain or suffering is inflicted by or at the instigation of or with the consent or acquiescence of a public official or other person acting in an official capacity. It does not include pain or suffering arising only from, inherent in or incidental to lawful sanctions".

Krnojelac Trial Judgement, para. 180. 
physical pain in order to attain a certain result or purpose. ${ }^{1639}$ Accordingly, the level of harm an act or omission must cause in order to constitute torture must be "severe pain or suffering, whether physical or mental". ${ }^{1640}$

506. Torture has been defined as follows:

i) The infliction, by act or omission, of severe pain or suffering, whether physical or mental;

ii) the act or omission must be intentional; and

iii) the act or omission must be aimed at obtaining information or a confession, or at punishing, intimidating or coercing the victim or a third person, or at discriminating, on any ground, against the victim or third person. ${ }^{1641}$

507. There is no exhaustive enumeration of all the acts or omissions which may constitute torture. ${ }^{1642}$ The allegations of torture must be considered on a case by case basis, so as to determine whether, in light of the acts committed and their context, severe physical or mental pain or suffering was inflicted. ${ }^{1643}$ Acts inflicting physical pain may amount to torture even when they do not cause pain of the type accompanying serious injury, as long as severe pain or suffering is inflicted. $^{1644}$

508. The perpetrator must intentionally act in such a way which, in the normal course of events, would cause severe pain or suffering, whether physical or mental, to the victim(s), in pursuance of one of the purposes prohibited by the definition of the crime of torture as stated above. ${ }^{1645}$ This purpose need not be the "predominant or sole purpose" behind inflicting the severe pain or suffering. ${ }^{1646}$ There is no requirement that the perpetrator acted in an official capacity as a state official or other person in authority. ${ }^{1647}$

\footnotetext{
$1639 \quad$ Krnojelac Trial Judgement, para. 180.

1640 Brđanin Appeal Judgement, para. 246. See also Furundžija Appeal Judgement, para. 111; Convention Against Torture, Article 1(1).

1641 Haradinaj et al. Appeal Judgement, para. 290; Kunarac et al. Appeal Judgement, para. 142.

1642 Naletilić and Martinović Appeal Judgement, para. 299, affirmed by Brđanin Appeal Judgement, para. 251.

1643 Naletilić and Martinović Appeal Judgement, para. 299, affirmed by Brđanin Appeal Judgement, para. 251.

1644 Brđanin Appeal Judgement, para. 251.

1645 Kunarac et al. Appeal Judgement, para. 153.

1646 Simić et al. Trial Judgement, para. 81; Krnojelac Trial Judgement, para. 184; Kvočka et al. Trial Judgement, para. 153; Čelibiči Trial Judgement, para. 470.

1647 Kvočka et al. Appeal Judgement, para. 284 (affirming Kunarac et al. Appeal Judgement, para. 148).
} 
(2) Beatings and physical and psychological abuse

509. Beatings and physical abuse, although not expressly prohibited under Article 5 of the Statute, may constitute cruel and/or inhumane treatment as persecution if they reach the same level of gravity as the other acts prohibited in Article 5. ${ }^{1648}$ Beatings constitute cruel or inhumane treatment if (i) the beatings caused serious mental or physical suffering or injury or constituted a serious attack on human dignity, and (ii) the beatings were performed deliberately. ${ }^{1649}$ The Chamber considers that the same elements apply to physical abuse.

510. Psychological abuse, including harassment and humiliation, is also not explicitly listed under Article 5 of the Statute, but may constitute persecution if the abuse reaches the same level of gravity as the other crimes listed under Article 5 of the Statute and the general requirements of persecution are met. ${ }^{1650}$ For example subjecting victims to constant humiliation and degradation may amount to psychological abuse as an underlying act of persecution. ${ }^{1651}$

\section{(3) Rape and other acts of sexual violence}

511. Rape is listed as a crime against humanity under Article 5(g) of the Statute and may constitute an underlying act of persecution if the general requirements of persecution are met. ${ }^{1652}$ Rape involves sexual penetration, however slight: (a) of the vagina or anus of the victim by the penis of the perpetrator or any other object used by the perpetrator or (b) of the mouth of the victim by the penis of the perpetrator, where such sexual penetration occurs without the consent of the victim. ${ }^{1653}$ Consent for this purpose must be given voluntarily, as a result of the victim's free will,

1648 Simić et al. Trial Judgement, paras. 77, 83; Stakić Trial Judgement, paras. 751-753. See also Kordić and Čerkez Appeal Judgement, para. 672. See paras. 497-500.

1649 Simić et al. Trial Judgement, para. 78.

1650 Blaškić Appeal Judgement, paras. 154-155. See paras. 497-500.

1651 Stakić Trial Judgement, paras. 758-760, 807-808. Conditions of detention in camps including "gross overcrowding in small rooms without ventilation, requiring detainees to beg for water, and forcing them to relieve bodily functions in their clothes" which were intended to harass, humiliate and inflict mental harm on the detainees and "constant berating, demoralising and threatening of detainees, including guards' coercive demands for money from detainees, and housing of detainees in lice-infected and cramped facilities, both of which were calculated by participants in the operation of the camp to inflict psychological harm upon the detainees", and witnessing "torturous interrogations and random brutality perpetrated on fellow inmates" were all found to constitute psychological abuse. Kvočka et al. Trial Judgement, paras. 190, 192.

1652 See paras. 497-500.

1653 Kunarac et al. Appeal Judgement, paras. 127-128; Kvočka et al. Appeal Judgement, para. 395 (confirming Kunarac et al. Trial Judgement, para. 460). 
and is assessed in the context of the surrounding circumstances. ${ }^{1654}$ The perpetrator must intend to effect this penetration and have the knowledge that it occurs without the consent of the victim. ${ }^{1655}$

512. Other acts of sexual violence encompass acts which may fall short of rape, including crimes such as sexual slavery or molestation, but are of equal gravity to other crimes under Article 5 of the Statute. ${ }^{1656}$ These acts are often characterised as "sexual assault". ${ }^{1657}$ Serious abuses of a sexual nature inflicted upon the integrity of a person by means of coercion, threat of force, or intimidation in a way that is humiliating and degrading to the victim's dignity may constitute other acts of sexual violence. ${ }^{1658}$ These acts are not limited to the physical invasion of the human body and may include acts which do not involve penetration or even physical contact. ${ }^{1659}$

513. Sexual violence is found when (i) the perpetrator commits an act of a sexual nature on another or requires the victim to perform such an act, (ii) that act infringes on the victim's physical integrity or amounts to an outrage to the victim's personal dignity, and (iii) the victim does not consent to the act. ${ }^{1660}$ The perpetrator must intentionally commit the act, and be aware that the victim did not consent to the act. ${ }^{1661}$

\section{(4) Establishment and perpetuation of inhumane living conditions}

514. While there is no offence of "inhumane living conditions" recognised as such in international humanitarian law, inhumane living conditions is a factual description of the environment in which detainees are held and the treatment they receive. ${ }^{1662}$ The establishment and perpetuation of inhumane living conditions has been considered a sub-category of cruel and/or inhumane treatment, which may constitute persecution if the acts reach the same level of gravity as the other crimes listed under Article 5 of the Statute and if the general requirements for persecution are also met. ${ }^{1663}$

\footnotetext{
1654 Kunarac et al. Appeal Judgement, paras. 127-128; Kvočka et al. Appeal Judgement, para. 395 (confirming Kunarac et al. Trial Judgement, para. 460).

1655 Kunarac et al. Appeal Judgement, paras. 127-128 (confirming Kunarac et al. Trial Judgement, para. 460).

1656 Kvočka et al. Trial Judgement, para. 180.

1657 Đorđević Trial Judgement, para. 1766; Akayesu Trial Judgement, para. 688.

1658 Brđanin Trial Judgement, para. 1012; Stakić Trial Judgement, para. 757. See also Brima et al. Trial Judgement, para. 720.

1659 Akayesu Trial Judgement, para. 688; Furundžija Trial Judgement, para. 186.

1660 Đorđević Trial Judgement, para. 1768; Milutinović Trial Judgement, Vol. I, para. 201.

1661 Đorđević Trial Judgement, para. 1768; Milutinović Trial Judgement, Vol. I, para. 201.

1662 See Čelebići Trial Judgement, paras. 554, 556.

1663 Krajišnik Trial Judgement, paras. 755-756; Krnojelac Trial Judgement, paras. 439, 443. See paras. $497-500$.
} 


\section{(C) Forcible transfer and deportation}

515. In Count 3 of the Indictment, the Accused is charged with persecution, punishable under Article 5(h) of the Statute, through the underlying act of forcible transfer or deportation. ${ }^{1664}$

516. Deportation is set out as a crime against humanity under Article 5(d) of the Statute and it has been settled that acts of forcible transfer may be sufficiently serious as to amount to "other inhumane acts" set out in Article 5(i) of the Statute. ${ }^{1665}$ Accordingly, they can both constitute persecution provided the general elements for persecution are met. ${ }^{1666}$ The Chamber thus refers to its discussion on the elements of deportation and inhumane acts (forcible transfer). ${ }^{1667}$

\section{(D) Unlawful detention in detention facilities}

517. The Accused is charged under Count 3 with persecution, pursuant to Article 5(h) of the Statute, through the underlying act of "unlawful detention in detention facilities in the Municipalities". 1668

518. The Chamber interprets the charge of unlawful detention in paragraph $60(\mathrm{~g})$ of the Indictment as relating to the crime of imprisonment, which is a crime under Article 5(e) of the Statute. ${ }^{1669}$

519. The term "imprisonment" pursuant to Article 5(e) of the Statute is understood as arbitrary imprisonment; that is the deprivation of liberty of an individual without the due process of law. ${ }^{1670}$ The crime of imprisonment consists of the following elements: (i) an individual is deprived of his or her liberty; (ii) the deprivation of liberty is carried our arbitrarily, i.e., there is no legal basis for it; and (iii) the accused or perpetrator acted with the intent to deprive the individual arbitrarily of his or her liberty. ${ }^{1671}$

\footnotetext{
1664 Indictment, para. 60(f).

1665 See para. 495.

1666 Blaškić Appeal Judgement, para. 153; Krnojelac Appeal Judgement, paras. 221-223.

1667 See paras. 488-495.

1668 Indictment, paras. $60(\mathrm{~g})$.

1669 Other Trial Chambers have similarly found that unlawful detention as a crime against humanity relates to imprisonment pursuant to Article 5(e) of the Statute. See Gotovina et al. Trial Judgement, Vol II, para. 1814; Krajišnik Trial Judgement, para. 751.

1670 Kordić and Čerkez. Appeal Judgement, para. 116; Krajišnik Trial Judgement, para. 752.

1671 Krnojelac Trial Judgement, para. 115; Krajišnik Trial Judgement, para. 752.
} 
520. If there is a legal basis for the deprivation of liberty, it must apply throughout the period of imprisonment, for the deprivation of liberty will become arbitrary as soon as the legal basis ceases to exist. ${ }^{1672}$

521. Unlawful detention, carried out on discriminatory grounds, and for which the general elements of persecution are fulfilled, may constitute persecution. ${ }^{1673}$

\section{(E) Forced labour and the use of human shields}

522. In Count 3 of the Indictment, the Accused is charged with persecution, pursuant to Article 5(h) of the Statute, through the underlying act of forced labour at frontlines and the use of Bosnian Muslims and Bosnian Croats as human shields. ${ }^{1674}$

523. While not all forms of forced labour are per se unlawful, ${ }^{1675}$ acts of forced labour have, in certain circumstances, and when performed with discriminatory intent, been considered to constitute persecution as a crime against humanity. ${ }^{1676}$ Furthermore, the use of prisoners of war and civilian detainees as human shields is prohibited under international law, ${ }^{1677}$ and has been held to constitute inhuman or cruel treatment under Articles 2 and 3 of the Statute, respectively, ${ }^{1678}$ and persecution as a crime against humanity pursuant to Article 5 of the Statute. ${ }^{1679}$

524. The Prosecution needs to demonstrate that an individual was forced to perform labour and that the labour in question was prohibited under international law. The assessment as to whether the labour was performed involuntarily is done on a case-by-case basis and requires a consideration of both objective and subjective criteria. ${ }^{1680}$ The following criteria may be examined in

1672 Stanišić and Župljanin Trial Judgement, Vol. I, para. 79; Gotovina et al. Trial Judgement, Vol. II, para. 1816; Krajišnik Trial Judgement, para. 753; Krnojelac Trial Judgement, para. 114.

1673 Blaškić Appeal Judgement, para. 154; Tadić Trial Judgement, paras. 714, 717.

1674 Indictment, para. 60(h).

1675 See para. 525.

1676 Krajišnik Trial Judgement, paras. 759, 761; Simić et al. Trial Judgement, para. 93.

1677 Article 23 of Geneva Convention III provides: "No prisoner of war may at any time be sent to, or detained in areas where he may be exposed to the fire of the combat zone, nor may his presence be used to render certain points or areas immune from military operations." See also Article 83 of Geneva Convention IV, which provides that the "Detaining Power shall not set up places of internment in areas particularly exposed to the dangers of war." Finally, Article 51(7) of Additional Protocol I provides: "The presence or movements of the civilian population or individual civilians shall not used to render certain points or areas immune from military operations, in particular in attempts to shield military objectives from attacks or to shield, favour or impede military operations. The Parties to the conflict shall not direct the movement of the civilian population or individual civilians in order to attempt to shield military objectives from attacks or to shield military operations."

1678 Blaškić Appeal Judgement, para. 653 (referring to Naletilić and Martinović Trial Judgement, para. 303).

1679 Blaškić Appeal Judgement, paras. 155, 653; Krajišnik Trial Judgement, para. 764.

1680 Krnojelac Appeal Judgement, para. 195 (specifying that "[i]n this case, given the particular circumstances of the detention centre, there was sufficient objective evidence to prove that the detainees were in fact forced to work, thus bearing out their conviction that the labour they performed was forced"). 
determining whether an individual was not in a position to make a real choice to undertake labour: (i) the substantially uncompensated aspect of the labour performed; (ii) the vulnerable position in which the detainees found themselves; (iii) the allegations that detainees who were unable or unwilling to work were either forced to do so or put in solitary confinement; (iv) claims of longer term consequences of the labour on the detainees, including on their health; and (v) the fact and the conditions of the detention. ${ }^{1681}$

525. In relation to the second prong and whether the performed labour was prohibited under international law, the Chamber notes that not all forms of forced labour are per se unlawful during armed conflict. ${ }^{1682}$ In that regard, the Appeals Chamber has held that " $[t]$ here is a principle which states that the work required of a person in the ordinary course of lawful detention is not regarded as forced or compulsory labour."1683 Furthermore, individuals deprived of liberty, if made to work, shall have the benefit of working conditions and safeguards similar to those enjoyed by the local civilian population. ${ }^{1684}$ For instance, compelling individuals to dig trenches or to prepare other forms of military installations has been found to constitute cruel treatment and persecution punishable under Articles 3 and 5 of the Statute, respectively. ${ }^{1685}$ The use of human shields, namely the placement or detention of persons in areas where they may be exposed to combat operations, for the purpose of rendering certain areas or activities immune from military operations or armed attack, is prohibited under international law. ${ }^{1686}$ The prohibition of the use of human shields is not dependent on actual harm or attack. ${ }^{1687}$

526. In relation to forced labour, the perpetrator must have intended the victim to perform prohibited work involuntarily. ${ }^{1688}$ In the absence of direct evidence, intent can be inferred from the circumstances in which the labour was performed. ${ }^{1689}$ In relation to the use of human shields, the

1681 Naletilić and Martinović Trial Judgement, para. 259; Krnojelac Trial Judgement, paras. 373, 378.

1682 See Article 49 of Geneva Convention III; Article 51. See also Blaškić Appeal Judgement, para. 597.

1683 Krnojelac Appeal Judgement, para. 200.

1684 Article 5(1)(e) of Additional Protocol II (referred to in Simić et al. Trial Judgement, para. 90). See also Article 52 of Geneva Convention III (prohibiting the forced use of prisoners of war to perform unhealthy or dangerous work); Commentary to Geneva Convention III, Article 52 (distinguishing between (a) work which is not dangerous in itself but which may be dangerous by reason of the general conditions in which it is carried out (i.e.: work done in the vicinity of military objectives or the battlefield), (b) work which is by its very nature dangerous or unhealthy (e.g: mine-lifting), (c) work which is not in itself dangerous but which may be or may become so if it is done in inadequate conditions).

1685 Blaškić Appeal Judgement, para. 597; Krajišnik Trial Judgement, para. 760; Simić et al. Trial Judgement, para. 835.

1686 Krajišnik Trial Judgement, para. 763 (referring to Blaškić Appeal Judgement, paras. 652-654).

1687 Blaškić Appeal Judgement, para. 654.

1688 See Naletilić and Martinović Trial Judgement, para. 260 (defining the mens rea as the Prosecution being required to establish "that the perpetrator had the intent that the victim would be performing prohibited work").

1689 See Naletilić and Martinović Trial Judgement, para. 260. 
perpetrator must intend to shield a military objective from attack or shield, favour, or impede military operations. ${ }^{1690}$

\section{(F) Plunder of property}

527. In Count 3 of the Indictment, the Accused is charged with persecution, a crime against humanity punishable under Article 5(h) of the Statute, through the underlying act of appropriation or plunder of property. ${ }^{1691}$ The Chamber considers that the formulation in the Indictment of the charge as "appropriation or plunder of property" is properly construed as "plunder of property", since the term "appropriation" has been used by the Appeals Chamber to define plunder. ${ }^{1692}$

528. Acts of plunder, which have been deemed by the Tribunal to include pillage, infringe various norms of international humanitarian law. ${ }^{1693}$ The prohibition against plunder is general in scope and extends both to acts of looting committed by individual soldiers for their private gain and to the organised seizure of property undertaken within the framework of a systematic economic exploitation of occupied territory. ${ }^{1694}$

529. Plunder involves the intentional and unlawful appropriation of private or public property. ${ }^{1695}$ Furthermore, pursuant to Articles 1 and 5 of the Statute, the offence must involve grave consequences for the victim. ${ }^{1696}$ The assessment as to when a piece of property reaches the threshold level of a certain value so as to create grave consequences for the victim can only be made on a case by case basis in conjunction with the particular circumstances of the case. ${ }^{1697}$ The threshold of seriousness can be met in circumstances where appropriation is vis-à-vis a large number of individuals even though there are no grave consequences for each individual as the

\footnotetext{
1690 The Chamber notes that the mens rea of the use of human shields has not been defined in the Tribunal's jurisprudence. The Chamber therefore relies on the definition as set out in the ICC Elements of Crimes, see ICC Elements of Crimes, Article 8(2)(b)(xxiii).

1691 Indictment, para. 60(i).

1692 Kordić and Čerkez. Appeal Judgement, para. 84. The Prosecution in its closing arguments clarified that with respect to footnote 8 of the Indictment, it did not allege criminal responsibility for both appropriation and plunder in certain municipalities, even though the footnote only referred to plunder. Closing Arguments, T. 47694 (30 September 2014).

Kordić and Čerkez. Appeal Judgement, para. 77; Blaškić Appeal Judgement, para. 147. Pillage is expressly prohibited in Articles 28 and 47 of The Hague Regulations, Article 33 of Geneva Convention IV, and Article 4 (2)(g) of Additional Protocol II. See also Hadžihasanović and Kubura Rule 98 bis Appeal Decision, paras. 37 38 , for a discussion as to the customary nature of the prohibition against plunder both in international and noninternational armed conflicts.

1694 Čelebići Trial Judgement, para. 590.

1695 Kordić and Čerkez Appeal Judgement, para. 84.

1696 See para. 499.

1697 Kordić and Čerkez. Appeal Judgement, paras. 80-83.
} 
overall effect on the civilian population and the multitude of offences committed would render the violation serious. $^{1698}$

(G) Wanton destruction of private and public property, including cultural monuments and sacred sites

530. In Count 3 of the Indictment, the Accused is charged with persecution, a crime against humanity punishable under Article 5(h) of the Statute, through the underlying act of wanton destruction of private property, including homes and businesses, and public property, including cultural monuments and sacred sites. ${ }^{1699}$

531. The destruction of various types of property is prohibited by a number of international instruments. ${ }^{1700}$ In this context, the term of property is understood to cover both private and public property, including cultural and religious property. ${ }^{1701}$ While the destruction of property is listed as an offence under Articles 2 and 3 of the Statute in various forms, ${ }^{1702}$ Article 5 makes no mention of it. However, the Appeals Chamber has held that, depending on the nature and the extent of the destruction and if committed with discriminatory intent, the destruction of property can be of equal gravity to other crimes listed under Article 5 and as such may constitute persecution as a crime against humanity. ${ }^{1703}$

532. For wanton destruction of property to be established, the Prosecution must prove the following elements: (i) the property was destroyed or damaged extensively; (ii) the destruction was not justified by military necessity; and (iii) the destruction was committed with the intent to destroy. ${ }^{1704}$

1698 Kordić and Čerkez Appeal Judgement, para. 83.
1699 Indictment, para. 60(j). See also Schedule D.

1700 See Article 23(g) of the Hague Regulations (prohibiting "to destroy [...] the enemy's property, unless such destruction [...] [is] imperatively demanded by the necessities of war"); Article 53 of Geneva Convention IV (providing: "Any destruction by the Occupying Power of real or personal property belonging individually or collectively to private persons, or to the State, or to other public authorities, or to social or cooperative organizations, is prohibited, except where such destruction is rendered absolutely necessary by military operations"); Article 147 of Geneva Convention IV (prohibiting the "extensive destruction [...], not justified by military necessity and carried out unlawfully and wantonly"); Article 52 of Additional Protocol I (protecting civilian objects); Article 53 of Additional Protocol I (protecting "historic monuments, works of art or places of worship which constitute the cultural or spiritual heritage of peoples"). See also the Nuremberg Principles, Principle 6( referring to the "wanton destruction of cities, towns, or villages, or devastation not justified by military necessity" as a crime punishable under international law).

1701 See Blaškić Appeal Judgement, para. 145.

1702 Article 2 of the Statute prohibits the "extensive destruction and appropriation of property, not justified by military necessity and carried out unlawfully and wantonly" while Article 3 refers to the "wanton destruction of cities, towns or villages, or devastation not justified by military necessity".

1703 Blaškić Appeal Judgement, para. 146. See also Kordić and Čerkez Appeal Judgement, para. 108.

1704 See Kordić and Čerkez Appeal Judgement, para. 74; Blaškić Appeal Judgement, paras. 144-146; Milutinović et al. Trial Judgement, Vol. I, paras. 206-210; Strugar Trial Judgement, para. 308. 
533. The property must not have been used for a military purpose at the time it suffered the destruction or extensive damage. It is for the Prosecution to establish that the destruction or extensive damage was not justified by military necessity. ${ }^{1705}$ The Appeals Chamber has held that determining whether destruction occurred pursuant to military necessity involves a determination of what constitutes a military objective with reference to the definition in Article 52(2) of Additional Protocol I, according to which military objectives are "those objects which by their nature, location, purpose or use make an effective contribution to military action and whose total or partial destruction, capture or neutralisation, in the circumstances ruling at the time, offers a definite military advantage". ${ }^{1706}$

534. The act resulting in the destruction of property must have been committed with the intent, albeit direct or indirect, to destroy or damage extensively the property in question. ${ }^{1707}$

(H) Imposition and maintenance of restrictive and discriminatory measures

535. Finally, in Count 3 of the Indictment, the Accused is also charged with persecution, a crime against humanity punishable under Article 5(h) of the Statute, through the underlying act of imposition and maintenance of restrictive and discriminatory measures. ${ }^{1708}$ According to the Indictment, the alleged restrictive and discriminatory measures include (i) the denial of freedom of movement; (ii) the removal from positions of authority in local government institutions and the police, and the general dismissal from employment; (iii) the invasion of privacy through arbitrary searches of homes; (iv) unlawful arrest and/or the denial of the right to judicial process; and/or (v) the denial of equal access to public services. ${ }^{1709}$

\footnotetext{
1705 Brđanin Appeal Judgement, para. 337; Kordić and Čerkez Appeal Judgement, para. 495 (within the context of Article 3 of the Statute); Milutinović et al. Trial Judgement, Vol. I, para. 208.

1706 Brđanin Appeal Judgement, para. 337.

1707 Kordić and Čerkez. Appeal Judgement, para. 74; Milutinović et al. Trial Judgement, Vol. I, paras. 206, 210; Orić Trial Judgement, para. 589.

1708 Indictment, para. 60(k). In relation to this specific charged form of persecution, the Accused requested that the Chamber dismiss paragraph $60(\mathrm{k})$ of the Indictment on the grounds that the acts of persecution described therein were not sufficiently grave to qualify as a crime against humanity, punishable under Article 5(h) of the Statute. The Accused further argued that paragraph $60(\mathrm{k})$ was so devoid of facts that it is impossible to prepare a defence to the allegations therein. Preliminary Motion to dismiss Paragraph 60(k) for Lack of Jurisdiction, 10 March 2009, paras. 5-6. On 28 April 2009, the Chamber issued a decision on this motion in which it dismissed, inter alia, the motion on the grounds that it did not raise a genuine jurisdictional challenge, or valid challenge to the form of the Indictment. The Chamber concluded that the underlying offences enumerated in paragraph $60(\mathrm{k})$ of the Indictment, when considered together, are capable of satisfying the equal gravity test and thus of amounting to persecution in terms of Article 5 of the Statute. Decision on Motions Challenging Jurisdiction, paras. 37-44, 81. 
536. It has been held that these restrictive and discriminatory measures can constitute persecution when considered in isolation or in conjunction with other acts amounting to persecution under Article 5(h) of the Statute. ${ }^{1710}$

\section{Genocide}

537. The Accused is charged with two counts of genocide under Article 4 (3)(a) of the Statute. Count 1 charges him with genocide against a part of the Bosnian Muslim and/or Bosnian Croat national, ethnical, and/or religious groups as such in the following municipalities: Bratunac, Foča, Ključ, Prijedor, Sanski Most, Vlasenica, and Zvornik, through (a) the killing of Bosnian Muslims and Bosnian Croats, including leading members of these groups; (b) the causing of serious bodily or mental harm to thousands of Bosnian Muslims and Bosnian Croats, including leading members of these groups, during their confinement in detention facilities where they were subjected to cruel or inhumane treatment, including torture, physical and psychological abuse, rape, other acts of sexual violence, and beatings; and (c) the detention of thousands of Bosnian Muslims and Bosnian Croats, including leading members of these groups, in detention facilities, under conditions of life calculated to bring about their physical destruction, namely through cruel and inhumane treatment, including torture, physical and psychological abuse, rape, other acts of sexual violence, inhumane living conditions, forced labour and the failure to provide adequate accommodation, shelter, food, water, medical care or hygienic sanitation facilities. ${ }^{1711}$

538. Count 2 charges the Accused with genocide against a part of the Bosnian Muslim national, ethnical, and/or religious group as such in Srebrenica, through (a) the killing of over 7,000 Bosnian Muslim men and boys of the Srebrenica enclave through executions; and (b) the causing of serious bodily or mental harm to thousands of Bosnian Muslims of Srebrenica, including, but not limited

1710 Brđanin Appeal Judgement, paras. 295, 297 (holding that (a) the denial of freedom of movement; (b) the denial of employment; and (c) the denial of the right to judicial process fall under the jurisdiction of the Tribunal as underlying acts of persecution for the purposes of Article 5(h) of the Statute). The denial of the right to proper medical care was also alleged in Brđanin, however, the Appeals Chamber did not consider it as the accused in that case was not convicted of the crime of persecution with respect to this specific allegation. Brđanin Appeal Judgement, para. 294, fn. 595 (referring to Brđanin Trial Judgement, para. 1076). See also Brđanin Trial Judgement, para. 1049. In addition, the Trial Chambers in the Stanišić and Župljanin and Krajišnik cases found that the same five specific restrictive and discriminatory measures alleged in paragraph $60(\mathrm{k})$ of the Indictment constituted persecution when considered in conjunction with other acts amounting to persecution. Stanišić and Župljanin Trial Judgement, Vol. I, paras. 91-92; Krajišnik Trial Judgement, paras. 736, 738-741 (citing to judgements issued by the Nuremberg Tribunal and by tribunals applying the Allied Control Council Law No. 10 which found that various acts committed against Jews were crimes against humanity, including the denial of freedom of movement, the denial of the right to judicial process, the denial of access to public services, and the invasion of privacy through arbitrary searches of homes).

1711 Indictment, para. 40(a)-(c). See also Schedule C Detention Facilities. 
to, the separation of men and boys from their families and the forcible removal of the women, young children and some elderly men from the enclave. ${ }^{1712}$

539. The crime of genocide punishable under Article 4 of the Statute adopts the definition and list of punishable acts enumerated in Article II of the Genocide Convention. ${ }^{1713}$ These provisions of the Genocide Convention have been considered to form part of customary international law and to constitute jus cogens. ${ }^{1714}$ Genocide as defined in the Statute was thus a punishable crime under customary international law at the time of the acts alleged in the Indictment.

540. Article 4(2) of the Statute provides that the following acts constitute genocide when "committed with intent to destroy, in whole or in part, a national, ethnical, racial or religious group, as such":

(a) killing members of the group;

(b) causing serious bodily or mental harm to members of the group;

(c) deliberately inflicting on the group conditions of life calculated to bring about its physical destruction in whole or in part;

(d) imposing measures intended to prevent births within the group; and

(e) forcibly transferring children of the group to another group. ${ }^{1715}$

a. The group

541. Article 4 of the Statute protects national, ethnical, racial or religious groups "as such" ("protected group"). The crime of genocide pertains to the destruction of a race, tribe, nation, or other group with a particular positive identity, not to the destruction of various people lacking a distinct identity. ${ }^{1716}$ The group targeted for genocide thus cannot be defined in terms of a negative characteristic, such as "non-Serbs" for instance. ${ }^{1717}$ The determination of the composition of the

\footnotetext{
1712 Indictment, para. 47(a)-(b). See also Schedule E Killing Incidents.

1713 Genocide Convention, Article II.

1714 ICJ Advisory Opinion on Genocide, p. 23; 1993 Secretary General Report, para. 45, ICJ Bosnia Judgement, para. 161; Jelisić Trial Judgement, para. 60; Akayesu Trial Judgement, para. 495; Rutaganda Trial Judgement, para. 46.

1715 As discussed above, the Chamber notes that the acts listed in Article 4(2)(d) and (e), namely imposing measures intended to prevent births within the group and forcibly transferring children of the group to another group, are not charged in this case.

1716 Stakić Appeal Judgement, para. 21. See also Stakić Appeal Judgement paras. 22-24.

1717 Stakić Appeal Judgement, paras. 16-27. See also Jelisić Trial Judgement, paras. 71-72.
} 
group is necessarily made on a case-by-case basis. ${ }^{1718}$ When more than one group is targeted, the elements of the crime of genocide must be considered in relation to each group separately. ${ }^{1719}$

\section{b. Actus reus}

\section{i. Killing members of the group}

542. The requirements for "killing" referred to under Article 4(2)(a) are equivalent to those for murder under Article 5. ${ }^{1720}$ Murder as an act of genocide requires proof of a result. ${ }^{1721}$ The elements of murder have already been detailed in the sections on murder as a crime against humanity and as a violation of the laws or customs of war. ${ }^{1722}$ A numeric assessment of the number of people killed is not required for the actus reus of genocide to be established. ${ }^{1723}$

\section{ii. Causing serious bodily or mental harm to members of the group}

543. Article 4(2)(b) refers to an intentional act or omission which causes serious bodily or mental harm to members of the protected group and requires proof of a result. ${ }^{1724}$ The harm must go "beyond temporary unhappiness, embarrassment or humiliation", and result "in a grave and longterm disadvantage to a person's ability to lead a normal and constructive life". ${ }^{1725}$ It need not be permanent and irreversible. ${ }^{1726}$

544. The Chamber notes that according to the Seromba Appeals Chamber "[t]o support a conviction for genocide, the bodily or the mental harm inflicted on members of a group must be of such a serious nature as to threaten its destruction in whole or in part." ${ }^{1727}$ However, in its assessment of the facts, the Seromba Appeals Chamber did not examine whether the evidence

\footnotetext{
1718 Stakić Appeal Judgement, para. 25. fn. 68; Blagojević and Jokić Trial Judgement, para. 667; Brđanin Trial Judgement, para. 684; Muvunyi Trial Judgement, para. 484.

1719 Stakić Trial Judgement, para. 512; Brđanin Trial Judgement, para. 685.

1720 Kayishema and Ruzidana Appeal Judgement, para. 151.

1721 Brđanin Trial Judgement, para. 688; Stakić Trial Judgement, para. 514.

1722 See paras. 446-448, 481.

1723 Rule 98 bis Appeal Judgement, para. 23. However, the scale of atrocities is relevant to the assessment of the mens rea of genocide. See para. 550.

1724 Tolimir Trial Judgement, para. 737; Popović et al. Trial Judgement, para. 811; Brđanin Trial Judgement, para. 688; Stakić Trial Judgement, para. 514.

1725 Krstić Trial Judgement, para. 513.

1726 Tolimir Trial Judgement, para. 738; Krstić Trial Judgement, para. 513.

1727 Seromba Appeal Judgement, para. 46 (italics added) (citing Kajelijeli Trial Judgement, para. 814 (the Chamber notes that the Seromba Appeals Chamber erroneously cites para. 184 of the Kajelijeli Trial Judgement); Krajišnik Trial Judgement, para. 862; 1996 ILC Report, p. 46 (stating "The bodily harm or the mental harm inflicted on the members of a group must be of such a serious nature as to threaten its destruction in whole or in part")).
} 
demonstrated that the inflicted harm was so serious as to threaten the group's destruction. ${ }^{1728}$ Similarly, Trial Chambers of the Tribunal and the ICTR which recite the language in question have only examined the seriousness of acts without referring to any showing that the harm was such as to threaten the group's destruction. ${ }^{1729}$ Moreover, the majority of trial judgements rendered prior to and after the Seromba Appeal Judgement consistently reiterate the language of Article 4(2)(b) of the Statute without requiring a showing that the harm was such as to threaten the group's destruction. ${ }^{1730}$ Furthermore, in the instant case, the Appeals Chamber in the Rule 98 bis Appeal Judgement simply recalled Article 4(2)(b) without indicating the existence of an additional requirement. ${ }^{1731}$ In light of the foregoing, the Chamber is therefore of the view that there is no additional requirement that the serious bodily or mental harm to members of the group be of such serious nature as to threaten the destruction of the group in whole or in part. The degree of threat to the group's destruction may, however, be considered as a measure of the seriousness of the bodily or mental harm.

545. Determination of what constitutes serious harm depends on the circumstances of each case. ${ }^{1732}$ Examples of serious bodily or mental harm as an act of genocide include torture, inhumane or degrading treatment, sexual violence including rape, interrogations combined with beatings, threats of death, and harm that damages health or causes disfigurement or serious injury to the external or internal organs of members of the group. ${ }^{1733}$ While forcible transfer does not of

1728 Seromba Appeal Judgement, paras. 47-48 (discussing the Seromba Trial Chamber's failure to differentiate between the actus reus of causing serious bodily or mental harm and the physical elements of aiding and abetting the crime).

1729 See, e.g., Karemera and Ngirumpatse Trial Judgement, paras. 1609, 1666 (finding that "the sexual assaults, mutilations and rapes that Tutsi women were forced to endure from April to June 1994 certainly constituted acts of serious bodily and mental harm"); Tolimir Trial Judgement, paras. 738, 753-759; Popović et al. Trial Judgement, paras. 811, 844-847 (finding that through the killing operation, serious bodily and mental harm was inflicted upon the Bosnian Muslim males); Nyiramasuhuko et al. Trial Judgement, paras. 5731, 5868 (wherein the Trial Chamber made no factual findings due to its holding that the Indictment in that case was defective in failing to plead rape as genocide); Gatete Trial Judgement, paras. 584-608; Kanyarukiga Trial Judgement, paras. 637-641.

1730 See, e.g., Blagojević and Jokić Trial Judgement, para. 645; Brđanin Trial Judgement, para. 690; Stakić Trial Judgement, para. 51; Krstić Trial Judgement, para. 513; Ntawukuliyayo Trial Judgement, para. 452; Kalimanzira Trial Judgement, para. 159; Renzaho Trial Judgement, para. 762; Bagasora Trial Judgement, para. 2117; Gacumbtsi Trial Judgement, para. 291; Ntagerura Trial Judgement, para. 664; Semanza Trial Judgement, paras. 320-323; Ntakirutimana Trial Judgement, para. 784; Bagilishema Trial Judgement, para. 59; Musema Trial Judgement, para. 156; Rutaganda Trial Judgement, para. 51; Akayesu Trial Judgement, paras. 502-503.

1731 Rule 98 bis Appeal Judgement, para. 33. The Chamber notes that the ICJ did not apply any additional requirement to its factual findings in the ICJ Bosnia Judgement, see ICJ Bosnia Judgement, para. 319 (finding that "members of the protected group were systematically victims of massive mistreatment, beatings, rape and torture causing serious bodily and mental harm, during the conflict, and in particular in the detention camps. The requirements of the material element, as defined by Article II(b) of the [Genocide] Convention are thus fulfilled.").

1732 Popović et al. Trial Judgement, para. 811; Blagojević and Jokić Trial Judgement, para. 646; Krstić Trial Judgement para. 513.

1733 Seromba Appeal Judgement, para. 46; Blagojević and Jokić Trial Judgement, para. 645; Brđanin Trial Judgement, para. 690; Krstić Trial Judgement, para. 513. See also ICJ Bosnia Judgement, para. 319. 
itself constitute an act of genocide, ${ }^{1734}$ depending on the circumstances of a given case, it may cause such serious bodily or mental harm as to constitute an act of genocide under Article $4(2)(b) .{ }^{1735}$

iii. Deliberately inflicting on the group conditions of life calculated to bring about its physical destruction in whole or in part

546. The acts punishable under Article 4(2)(c) are construed as "the methods of destruction by which the perpetrator does not immediately kill the members of the group, but which, ultimately, seek their physical destruction". ${ }^{1736}$ Contrary to the acts prohibited by Articles 4(2)(a) and 4(2)(b), this provision does not require proof of that a result was attained; as such, it does not require proof that the conditions actually led to death or serious bodily or mental harm of members of the protected group. ${ }^{1737}$ When such "a result is achieved, the proper charge will be paragraphs (a) or (b)" of Article $4 .{ }^{1738}$

547. Examples of such acts include, but are not limited to, subjecting the group to a subsistence diet; failing to provide adequate medical care; systematically expelling members of the group from their homes; and generally creating circumstances that would lead to a slow death such as the lack of proper food, water, shelter, clothing, sanitation, or subjecting members of the group to excessive work or physical exertion. ${ }^{1739}$ Yet, Article 4(2)(c) applies only to acts that are deliberately

1734 Krstić Appeal Judgement, para. 33 (referring to Stakić Trial Judgement, para. 519, which notes: “The expulsion of a group or part of a group does not in itself suffice for genocide"; Blagojević and Jokić Appeal Judgement, para. 123). See also ICJ Bosnia Judgement, para. 190 (noting: "Neither the intent, as a matter of policy, to render an area 'ethnically homogeneous', nor the operations that may be carried out to implement such policy, can as such be designated as genocide: the intent that characterizes genocide is to 'destroy, in whole or in part,' a particular group, and deportation or displacement of the members of a group, even if effected by force, is not necessarily equivalent to destruction of that group [...] (emphasis in original)" and referring to Stakić Trial Judgement, para. 519; Tolimir Trial Judgement, para. 739; Popović et al. Trial Judgement, para. 813).

1735 Tolimir Appeal Judgement, paras. 209, 212; Blagojević and Jokić Trial Judgement, para. 646; Krstić Trial Judgement, para. 513.

1736 Akayesu Trial Judgement, para. 505. See also Stakić Trial Judgement, paras. 517-518.

1737 Popović et al. Trial Judgement, para. 814; Brđanin Trial Judgement, para. 691; Stakić Trial Judgement, para. 517.

1738 Tolimir Appeal Judgement, paras. 227-228; Brđanin Trial Judgement, para. 905, fn. 2255. See also Eichmann Jerusalem District Court Judgement, para. 196, limiting the charge of imposing living conditions upon Jews calculated to bring about their physical extermination to persecution of Jews who had survived the Holocaust and ruling that Jews who were not saved should not be included "as if, in their case, there were two separate actions: first, subjection to living conditions calculated to bring about their physical destruction, and later the physical destruction itself". See also Popović et al. Trial Judgement, para. 814, fn. 2930. In this case the acts charged under Article 4(2)(c) are the same as those charged under Article 4(2)(b). Indictment, para. 40(b), (c); Schedule C.

1739 Brđanin Trial Judgement, para. 691; Stakić Trial Judgement, para. 517; Musema Trial Judgement, para. 157; Kayishema and Ruzidana Trial Judgement, paras. 115-116; Akayesu Trial Judgement, para. 506. 
calculated to cause a group's physical destruction and, as such, these acts must be clearly distinguished from those acts designed to bring about the dissolution of the group. ${ }^{1740}$

548. In the absence of direct evidence of whether the conditions of life imposed on the group were deliberately calculated to bring about its physical destruction, a chamber can be guided by the objective probability of these conditions leading to the physical destruction of the group in part. ${ }^{1741}$ The actual nature of the conditions of life, the length of time that members of the group were subjected to them, and the characteristics of the group such as its vulnerability are illustrative factors to be considered in evaluating the criterion of probability. ${ }^{1742}$

\section{c. Mens rea}

549. The mens rea required for the crime of genocide - "intent to destroy, in whole or in part, a national, ethnical, racial or religious group" as defined in Article 4 of Statute-has been referred to variously as, for instance, special intent, specific intent, dolus specialis, particular intent and genocidal intent. ${ }^{1743}$ Genocide requires not only proof of intent to commit the alleged acts of genocide, but also proof of the specific intent to destroy the protected group, in whole or in part. ${ }^{1744}$ Therefore, when genocide is charged through the framework of JCE I, the accused needs to share genocidal intent with other members of the JCE. ${ }^{1745}$

550. In assessing evidence of genocidal intent, a Chamber should consider whether "all of the evidence, taken together, demonstrates a genocidal mental state", instead of considering separately whether an accused intended to destroy a protected group through each of the relevant acts of genocide. ${ }^{1746}$ Where direct evidence of genocidal intent is absent, the intent may still be inferred

\footnotetext{
1740 Brđanin Trial Judgement, paras. 692, 694; Stakić Trial Judgement, para. 519.

1741 Tolimir Trial Judgement, para. 742; Popović et al. Trial Judgement, para. 816; Brđanin Trial Judgement, para. 906.

1742 Tolimir Trial Judgement, para. 742; Popović et al. Trial Judgement, para. 816; Brđanin Trial Judgement, para. 906. See also Krajišnik Trial Judgement, para. 863; Kayishema and Ruzindana Trial Judgement, para. 548.

1743 Jelisić Appeal Judgement, para. 45; Akayesu Trial Judgement, para. 498. See also Rule 98 bis Appeal Judgement, para. 22.

1744 Krstić Appeal Judgement, para. 20.

1745 Rule 98 bis Appeal Judgement, para. 79 (stating that "[...] in accordance with the allegations underlying Count 1 of the Indictment, it is the genocidal intent of Karadžić and other alleged JCE members, not the physical perpetrators of the underlying alleged genocidal acts, that is determinative for purposes of JCE I"). The Appeals Chamber stated that it was not persuaded that the Chamber's conclusions on genocidal intent were restricted to the physical perpetrators of the acts or that it failed to assess Karadžić's genocidal intent and that of other alleged JCE members. It went on to conclude that the Chamber's focus on physical perpetrators in relation to the allegations of genocide in Srebrenica under Count 2 did not demonstrate that the Chamber "necessarily considered that liability under JCE I requires a showing of the physical perpetrators' genocidal intent or that, in assessing the evidence of Count 1 of the Indictment, [it] failed to consider the genocidal intent of Karadžić and the other alleged JCE members". Rule 98 bis Appeal Judgement, para. 83.

1746 Stakić Appeal Judgement, para. 55; Rule 98 bis Appeal Judgement, para. 56. See also Tolimir Appeal Judgement, paras. 246-247.
} 
from all the facts and circumstances. ${ }^{1747}$ Factors relevant to this analysis may include, but are not limited to, the general context, the scale of atrocities, the systematic targeting of victims on account of their membership in a particular group, the repetition of destructive and discriminatory acts, or the existence of a plan or policy. ${ }^{1748}$ Display of intent through public speeches ${ }^{1749}$ or in meetings ${ }^{1750}$ may also support an inference as to the requisite specific intent.

\section{i. Intent to destroy the group "as such"}

551. The specific intent to destroy the group "as such" makes genocide an exceptionally grave crime and distinguishes it from other serious crimes, such as persecutions as a crime against humanity. ${ }^{1751}$ The term "as such" has great significance as it shows that the crime of genocide requires intent to destroy a collection of people because of their particular group identity based on nationality, race, ethnicity, or religion. ${ }^{1752}$

552. For example, the Krstic Trial Chamber found that the destruction of a sizeable number of men would inevitably result in the physical disappearance of the Bosnian Muslim population at Srebrenica. ${ }^{1753}$ The Appeals Chamber in that case upheld this finding, stating that " $\left.\mathrm{t}\right]$ he physical destruction of the men therefore had severe procreative implications for the Srebrenica Muslim community, potentially consigning the community to extinction". ${ }^{1754}$ The Krstić Appeals Chamber further held that " $[\mathrm{t}] \mathrm{he}$ finding that some members of the VRS Main Staff devised the killing of the male prisoners with full knowledge of the detrimental consequences it would have for the physical survival of the Bosnian Muslim community in Srebrenica further supports the Trial Chamber's conclusion that the instigators of that operation had the requisite genocidal intent". ${ }^{1755}$

553. The Genocide Convention and customary international law prohibit only the physical and biological destruction of a group, not attacks on cultural or religious property or symbols of the

1747 Popović et al. Appeal Judgement, para. 468; Hategekimana Appeal Judgement, para. 133; Stakić Appeal Judgement, para. 55; Krstić Appeal Judgement, para. 34; Jelisić Appeal Judgement, para. 47.

Tolimir Appeal Judgement, para. 246; Popović et al. Appeal Judgement, paras. 430, 440 (holding that the existence of a state policy is not a legal requirement of genocide), 468; Hategekimana Appeal Judgement, para. 133; Jelisić Appeal Judgement, paras. 47-48; Rule 98 bis Appeal Judgement, paras. 80, 99.

1749 Gacumbitsi Appeal Judgement, para. 43.

1750 Kamuhanda Appeal Judgement, paras. 81-82. See also Tolimir Trial Judgement, para. 745.

1751 ICJ Bosnia Judgement, para. 187 (noting that "[i]t is not enough that the members of the group are targeted because they belong to that group, that is because the perpetrator has a discriminatory intent. Something more is required. That acts listed in [Article 4 of the Statute] must be done with intent to destroy the group as such in whole or in part. The words 'as such' emphasise that intent to destroy the protected group."); Brđanin Trial Judgement, para. 699; Krstić Trial Judgement, para. 553; Kupreškić et al. Trial Judgement, para. 636.

1752 Stakić Appeal Judgement, para. 20; Niyitegeka Appeal Judgement, para. 53.

1753 Krstić Trial Judgement, para. 595.

1754 Krstić Appeal Judgement, para. 28.

1755 Krstić Appeal Judgement, para. 29. 
group. ${ }^{1756}$ However, while such attacks may not constitute underlying acts of genocide, they may be considered evidence of intent to physically destroy the group. ${ }^{1757}$ Forcible transfer alone would not suffice to demonstrate the intent to "destroy" a group but it is a relevant consideration as part of the Chamber's overall factual assessment. ${ }^{1758}$

554. Specific intent is distinguished from personal motive; however, the existence of a personal motive does not exclude the possession of genocidal intent. ${ }^{1759}$

\section{ii. "In whole or in part"}

555. It is well established that where a conviction for genocide relies on the intent to destroy a group "in part", such part must be a substantial part of the whole protected group. ${ }^{1760}$ The targeted portion must be a "significant enough [portion] to have an impact on the group as a whole". ${ }^{1761}$ The Krstić Appeal Chamber stated that in determining substantiality, the following considerations can be made:

The numeric size of the targeted part of the group is the necessary and important starting point, though not in all cases the ending point of the inquiry. The number of individuals targeted should be evaluated not only in absolute terms, but also in relation to the overall size of the entire group. In addition to the numeric size of the targeted portion, its prominence within the group can be a useful consideration. If a specific part of the group is emblematic of the overall group, or is essential to its survival, that may support a finding that the part qualifies as substantial within the meaning of Article $4 .{ }^{1762}$

$1756 \quad$ Krstić Appeal Judgement, para. 25.

1757 Tolimir Appeal Judgement, para. 230 (finding that the Trial Chamber erred in concluding that the destruction of mosques was an additional act of genocide under Article 4(2)(c) of the Statute); Krstić Trial Judgement, para. 580 .

1758 Krstić Appeal Judgement, para. 33. See also Blagojević and Jokić Appeal Judgement, para. 123; Krstić Appeal Judgement, para. 133 (holding that Krstić harboured no genocidal intent as "his own particular intent was directed to a forcible displacement. Some other members of the VRS Main Staff harboured the same intent to carry out forcible displacement, but viewed this displacement as a step in the accomplishment of their genocidal objective. It would be erroneous, however, to link Krstić's specific intent to carry out forcible displacement with the same intent possessed by other members of the Main Staff, to whom the forcible displacement was a means of advancing the genocidal plan (footnotes omitted)."); ICJ Bosnia Judgement, para. 190 (holding: "Neither the intent, as a matter of policy, to render an area 'ethnically homogeneous', nor the operations that may be carried out to implement such policy, can as such be designated as genocide: the intent that characterizes genocide is to 'destroy, in whole or in part,' a particular group, and deportation or displacement of the members of a group, even if effected by force, is not necessarily equivalent to destruction of that group [...] (emphasis in original)" and referring to Stakić Trial Judgement, para. 519).

1759 Simba Appeal Judgement, paras. 88, 269; Stakić Appeal Judgement, para. 45; Jelisić Appeal Judgement, para. 49.

1760 Krstić Appeal Judgement, paras. 8, 12.

1761 Krstić Appeal Judgement, para. 8. See also Tolimir Trial Judgement, para. 749; Popović et al. Trial Judgement, paras. 831-832.

1762 Krstić Appeal Judgement, para. 12. See also Rule 98 bis Appeal Judgement, para. 66; Gacumbitsi Appeal Judgement, para. 40. 
Furthermore, the area of the perpetrators' activity, control, and the possible extent of their reach should be considered. ${ }^{1763}$ The applicability of these factors and their relative weight will vary depending on the circumstances of a particular case. ${ }^{1764}$

\section{B. LEGAL STANDARDS FOR INDIVIDUAL CRIMINAL RESPONSIBILITY}

\section{Liability under Article 7(1) of the Statute}

556. The Indictment charges the Accused with individual criminal responsibility under Article 7(1) for having, inter alia, committed crimes referred to in Articles 3, 4, and 5 of the Statute. ${ }^{1765}$ The Prosecution does not allege that the Accused physically committed any of the crimes charged personally. ${ }^{1766}$ Rather, he is alleged to have participated in four JCEs. ${ }^{1767}$

557. The Accused is alleged to have shared the intent for the commission of each crime encompassed within each of the JCEs, ${ }^{1768}$ and to have made significant contributions to each of them. ${ }^{1769}$ Alternatively, the Prosecution asserts that if the implementation of the objective of the Overarching JCE only included the commission of forcible transfer and deportation, the Accused was aware of the risk that genocide and persecution, as well as murder and/or extermination, were possible consequences of the implementation of that objective, ${ }^{1770}$ and the Accused willingly took those risks. ${ }^{1771}$

558. The Prosecution further alleges that through the acts and omissions outlined in the Indictment, ${ }^{1772}$ the Accused is also responsible for planning, ${ }^{1773}$ instigating, ${ }^{1774}$ and/or ordering the crimes charged in the Indictment. ${ }^{1775}$ According to the Prosecution, the Accused either "directly intended or was aware of the substantial likelihood that the execution of his plans and orders,

\footnotetext{
1763 Krstić Appeal Judgement, para. 13.

1764 Krstić Appeal Judgement, para. 14.

1765 Indictment, para. 5.

1766 Indictment, para. 5.

1767 See para. 3 (referring to paras. 9-31 of the Indictment).

1768 Indictment, paras. 9, 16, 21, 26, 39, 42, 50, 58, 75, 77, 84.

1769 Indictment, paras. 14, 19, 24, 29.

1770 Indictment, paras. 10, 39, 50, 64.

1771 Indictment, paras. 10, 39, 43, 50, 59, 64, 67.

1772 Indictment, para. 14.

1773 Indictment, paras. 30-31 (referring to acts described in paras. 14(a) and/or (e)).

1774 Indictment, paras. 30-31 (referring to acts and omissions described in paras. 14(a)-(f) and/or (h)).

1775 Indictment, paras. 30-31 (referring to acts described in paras. 14(d) and/or (j)).
} 
and/or the carrying out of the the acts and conduct which he instigated, would involve or result in the crimes charged" in the Indictment. ${ }^{1776}$

559. According to the Prosecution, the Accused's acts and omissions also render him responsible for aiding and abetting the crimes charged in the Indictment. ${ }^{1777}$ In this regard, the Prosecution submits that the Accused was aware of the probability that the crimes charged would be committed and that his acts or omissions would contribute to their commission. ${ }^{1778}$

\section{a. Commission through participation in a JCE}

560. When two or more persons act together to further a common criminal purpose, the jurisprudence of the Tribunal recognises three forms of criminal responsibility which may accrue to all members of the group. ${ }^{1779}$ The first, "basic" category of JCE encompasses situations where all participants, acting pursuant to a common purpose, possess the same criminal intention to effectuate that purpose. ${ }^{1780}$ The second, "systemic" form of JCE pertains to organised systems of ill-treatment. ${ }^{1781}$ The third, "extended" type of JCE involves the liability of a JCE participant for a crime which falls outside the common purpose or design, but which is nevertheless a natural and foreseeable consequence of effectuating that common purpose. ${ }^{1782}$

561. In order to find an accused criminally responsible on the basis of his participation in any of the three types of JCE, the following elements must be established: (i) the existence of a plurality of persons who act pursuant to a common purpose; ${ }^{1783}$ (ii) the existence of a common plan, design, or purpose which amounts to or involves the commission of a crime provided for in the Statute; and (iii) the participation of the accused in furthering the common design or purpose. ${ }^{1784}$ The Chamber will discuss each of these requirements in more detail below.

\footnotetext{
1776 Indictment, para. 31.

1777 Indictment, paras. 30-31 (referring to acts and omissions described in paras. 14(a)-(i), and/or (j)).

1778 Indictment, para. 31.

1779 Tadić Appeal Judgement, paras. 195-226; Brđanin Appeal Judgement, para. 364; Kvočka et al. Appeal Judgement, para. 82; Vasiljević Appeal Judgement, paras. 96-99. See also Milutinović et al. May 2003 Appeal Decision, paras. 18-23, 25-26, 28-30.

1780 Tadić Appeal Judgement, para. 196 (as confirmed in Kvočka et al. Appeal Judgement, para. 82; Vasiljević Appeal Judgement, para. 97).

1781 Tadić Appeal Judgement, paras. 202-203 (as confirmed in Kvočka et al. Appeal Judgement, para. 82; Vasiljević Appeal Judgement, para. 98).

1782 Tadić Appeal Judgement, para. 204 (as confirmed in Kvočka et al. Appeal Judgement, para. 83; Vasiljević Appeal Judgement, para. 99).

1783 Action by a "plurality" of persons denotes the concerted action of two or more persons. See Tadić Appeal Judgement, paras. 195-226.

1784 Tadić Appeal Judgement, para. 227 (as confirmed in Brđanin Appeal Judgement, paras. 364, 430; Stakić Appeal Judgement, para. 64; Kvočka et al. Appeal Judgement, para. 81; Vasiljević Appeal Judgement, para. 100; Krnojelac Appeal Judgement, para. 31).
} 
562. The Appeals Chamber has held that the plurality of persons need not be organised in a military, political, or administrative structure, ${ }^{1785}$ and it may be sufficient to identify the plurality as a category or a group rather than as individuals by name. ${ }^{1786}$ However, the criterion used to identify the group must be sufficiently specific to prevent vagueness and ambiguity. ${ }^{1787}$

563. All three forms of JCE require proof of the existence of a "common plan, design or purpose which amounts to or involves the commission of a crime provided for in the Statute". ${ }^{1788}$ The existence of a common plan or purpose can be inferred from the fact that the plurality of persons acts in unison, ${ }^{1789}$ and the plan may materialise extemporaneously rather than being previously arranged or formulated. ${ }^{1790}$ Additionally, the Chamber must "specify the common criminal purpose in terms of both the criminal goal intended and its scope (for example, the temporal and geographic limits of this goal, and the general identities of the intended victims)". ${ }^{1791}$ A JCE can come to embrace expanded criminal means, as long as the evidence shows that the JCE members agreed on such an expansion of means. ${ }^{1792}$ Such an expanded agreement need not be explicit, may also materialise extemporaneously, and can be inferred from circumstantial evidence. ${ }^{1793}$

564. An accused must have participated in furthering the common purpose at the core of the JCE by assisting in or contributing to the execution of the common plan or purpose, but need not have performed any part of the actus reus of the crime charged. ${ }^{1794}$ The accused's contribution need not be sine qua non, without which the crime would not have been committed, nor must it necessarily be a substantial contribution to the JCE. ${ }^{1795}$ However, the accused must "contribut[e] to the common purpose in a way that lends a significant contribution to the crimes". 1796

\footnotetext{
1785 Stakić Appeal Judgement, para. 64; Vasiljević Appeal Judgement, para. 100; Krnojelac Appeal Judgement, para. 31; Tadić Appeal Judgement, para. 227.

1786 Krajišnik Appeal Judgement, para. 156 (citing Limaj et al. Appeal Judgement, para. 99).

1787 Krajišnik Appeal Judgement, para. 157; Stanišić and Župljanin Trial Judgement, Vol. I, para. 101; Tolimir Trial Judgement, para. 889; Đorđević Trial Judgement, para. 1861.

1788 Tadić Appeal Judgement, para. 227(ii).

1789 Vasiljević Appeal Judgement, para. 109; Tadić Appeal Judgement, para. 227(ii).

1790 Brđanin Appeal Judgement, para. 418 (citing Tadić Appeal Judgement, para. 227(ii); Vasiljević Appeal Judgement, para. 100; Kvočka et al. Appeal Judgement, para. 117).

1791 Brđanin Appeal Judgement, para. 430.

1792 Krajišnik Appeal Judgement, para. 163.

1793 Krajišnik Appeal Judgement, para. 163.

1794 Tadić Appeal Judgement, para. 227(iii); Krajišnik Appeal Judgement, para. 215; Brđanin Appeal Judgement, para. 427; Stakić Appeal Judgement, para. 64; Kvočka et al.Appeal Judgement, para. 99; Vasiljević Appeal Judgement, paras. 100, 119.

1795 Krajišnik Appeal Judgement, paras. 215, 675; Kvočka et al. Appeal Judgement, paras. 97-98.

1796 Krajišnik Appeal Judgement, paras. 662, 706. See also Brđanin Appeal Judgement, para. 430. The Appeals Chamber has observed that any disparity in the scope of the contributions of JCE members would be adequately dealt with at the sentencing stage. Brđanin Appeal Judgement, para. 432.
} 
565. The question of whether the accused significantly contributed to a JCE is a question of fact to be determined on a case by case basis. ${ }^{1797}$ In determining whether an accused's conduct constituted a significant contribution to a JCE, the Chamber may consider the size of the criminal enterprise, the function(s) performed by the accused, and the accused's position as well as other relevant factors. ${ }^{1798}$

566. A significant contribution to a JCE may consist of an act or, where there is a legal duty to act, an omission. ${ }^{1799}$ While the Accused accepts that, in theory, an omission may constitute a significant contribution, by reference to the Mrkšić and Šljivančanin Appeal Judgement, he contends that "the Appeals Chamber has held that the actus reus for 'commission by omission' is a higher standard than for aiding and abetting by omission, namely, the accused must exert 'concrete influence' on the perpetration of the crime". ${ }^{1800}$ However, the Chamber observes that the relevant passages of both the Mrkšić and Šljivančanin Appeal Judgement as well as the Orić Appeal Judgement-to which the Mrkšić and Sjivančanin Appeals Chamber cited-primarily concern other forms of liability, namely aiding and abetting under Article 7(1) and superior liability under Article 7(3) of the Statute. ${ }^{1801}$ The Chamber considers that the relevant enquiry-which should be done on a case by case basis ${ }^{1802}$ - is whether an accused was obligated by law to act, and if so, whether such an omission significantly contributed to the JCE. ${ }^{1803}$

567. In order to hold an accused criminally responsible where the person who carries out the actus reus of the crime charged is not a member of the $\mathrm{JCE},{ }^{1804}$ there must be a link between that accused and such conduct. ${ }^{1805}$ This link, which must be assessed on a case-by-case basis, is established if criminal responsibility for the other person's conduct can be imputed to one of the JCE members who, when using the other person, acted in accordance with the common plan. ${ }^{1806}$ In such instances, "the crime in question"-meaning the crime with which the accused is charged-

\footnotetext{
1797 Krajišnik Appeal Judgement, para. 696.

1798 See Tolimir Trial Judgement, para. 893; Milutinović et al. Trial Judgement, Vol. I, para. 105 (citing Kvočka et al. Trial Judgement, para. 311).

1799 See Tadić Appeal Judgement, para. 188; Blaškić Appeal Judgement, para. 663; Brđanin Appeal Judgement, para. 274; Galić Appeal Judgement, para. 175 (holding that an omission may lead to individual criminal responsibility pursuant to Article 7(1) where there is a legal duty to act); Mrkšić and Šljivančanin Appeal Judgement, para. 134; Ntagerura Appeal Judgement, p. 334; Tolimir Trial Judgement, para. 894, fn. 3528; Milutinović et al. Trial Judgement, Vol. I, para. 103.

See Mrkšić and Šljivančanin Appeal Judgement, paras. 155-156; Orić Appeal Judgement, paras. 36-49.

Krajišnik Appeal Judgement, para. 696.

Further, the Chamber notes that responsibility pursuant to the first form of JCE requires that the Accused shares the intent of the relevant crime, or crimes, with other members of the JCE.

Brđanin Appeal Judgement, para. 410.

Brđanin Appeal Judgement, paras. 412, 430.

Brđanin Appeal Judgement, paras. 413, 430.
} 
must also "for[m] part of the common criminal purpose". ${ }^{1807}$ This, in turn, may be inferred from the close co-operation of the accused - or any other JCE member-with the non-member in order to further the common criminal purpose. ${ }^{1808}$ It is not necessary, however, to establish the existence of an additional understanding or agreement between the accused and the non-member to commit that particular crime. ${ }^{1809}$

568. The mental elements differ substantially according to the relevant category of JCE. ${ }^{1810}$ Since only the first and third categories are charged in the Indictment, the Chamber will limit its discussion to the jurisprudence relevant to these forms of JCE.

569. With regard to the basic category of JCE, the accused must both share the intent to effect the common purpose of the JCE as well as intend the commission of the crime with which he is charged. ${ }^{1811}$ Where an accused is charged with a crime requiring specific intent which allegedly formed part of the JCE's common purpose, he and the other JCE members must share the requisite specific intent for that crime. ${ }^{1812}$

570. For a crime that falls outside the common purpose of the JCE ("extended crime"), an accused may nevertheless incur responsibility pursuant to the third category of JCE liability even when he does not share the intent to commit the extended crime if (i) he intended to participate in and contribute to the furtherance of the common criminal purpose, (ii) it was foreseeable to him that the extended crime might be perpetrated in carrying out the common purpose, and (iii) the accused willingly took the risk that the extended crime might occur by participating in the common purpose. ${ }^{1813}$ This is true even where the extended crime is a specific intent crime such as genocide

1807 Brđanin Appeal Judgement, paras. 410, 418.

1808 Brđanin Appeal Judgement, para. 410 (finding that when a member of the JCE uses a person outside the JCE to carry out the actus reus of a crime, the fact that the person in question knows of the existence of the JCEwithout it being established that he or she shares the mens rea necessary to become a member of the JCE-may be a factor to be taken into account when determining whether the crime forms part of the common criminal purpose. However, this is not a sine qua non for imputing liability for the crime to that member of the JCE).

1809 Brđanin Appeal Judgement, para. 418.

1810 Tadić Appeal Judgement, para. 228. See also Brđanin Appeal Judgement, para. 365; Stakić Appeal Judgement, para. 65.

1811 Kvočka et al. Appeal Judgement, para. 82; Brđanin Appeal Judgement, para. 365; Blaškić Appeal Judgement, para. 33; Vasiljević Appeal Judgement, paras. 97, 101.

1812 Kvočka et al. Appeal Judgement, para. 110; Krnojelac Appeal Judgement, paras. 111-112; Stanišić and Župljanin Trial Judgement, Vol. I, para. 105; Milutinović et al. Trial Judgement, Vol. I, para. 109. See also Rule 98 bis Appeal Judgement, para. 79 ("[I]t is the genocidal intent of [the accused] and other JCE members, not the physical perpetrators of the underlying alleged genocidal acts, that is determinative for purposes of [the basic form of] JCE [...].”). See also para. 549.

1813 Kvočka et al. Appeal Judgement, para. 83. The actus reus of the extended crime may be perpetrated either by a JCE member or by a non-member who was used by a JCE member for that purpose. Brđanin Appeal Judgement, para. 411. 
or persecution. ${ }^{1814}$ Where that crime is genocide, the prosecution will be required to establish that it was reasonably foreseeable to the accused that an act specified in Article 4(2) would be committed and that it would be committed with genocidal intent. ${ }^{1815}$ Moreover, the possibility of the crime being committed must be sufficiently substantial as to be reasonably foreseeable, based on the information available to the accused at the time, ${ }^{1816}$ but an accused need not understand that the extended crime "would probably be committed". ${ }^{1817}$ In other words, the accused must have sufficient knowledge that the extended crime was a natural and foreseeable consequence of the common criminal purpose. ${ }^{1818}$

\section{b. Planning}

571. To be found criminally responsible for planning under the Statute, the accused-either acting alone or with another-must have designed criminal conduct that is later carried out and which constitutes one or more crimes enumerated in the Statute. ${ }^{1819}$ The planning must have been a factor substantially contributing to the criminal conduct, ${ }^{1820}$ but the Prosecution need not establish that the crime would not have been committed but for the accused's plan. ${ }^{1821}$ The accused must intend to plan the commission of a crime or, at a minimum, must be aware of the substantial likelihood that a crime will be committed in the execution of the acts or omissions planned. ${ }^{1822}$

\section{c. Instigating}

572. Criminal liability for instigation would be incurred when an accused prompts another person to commit an offence, ${ }^{1823}$ which is actually committed. ${ }^{1824}$ The prompt may be either

\footnotetext{
1814 Brđanin 2004 Decision on Interlocutory Appeal, paras. 5-7, 9.

1815 Brđanin 2004 Decision on Interlocutory Appeal, para. 6.

1816 Appeal Decision on JCE III Foreseeability, para. 18; Brđanin 2004 Decision on Interlocutory Appeal, para. 5; Tolimir Trial Judgement, para. 897; Milutinović et al. Trial Judgement, Vol. I, para. 111.

1817 Appeal Decision on JCE III Foreseeability, para. 18.

1818 Kvočka et al. Appeal Judgement, para. 86.

1819 Dragomir Milošević Appeal Judgement, para. 268; Kordić and Čerkez Appeal Judgement, para. 26.

1820 Dragomir Milošević Appeal Judgement, para. 268; Kordić and Čerkez Appeal Judgement, para. 26. See also Dragomir Milošević Appeal Judgement, para. 270, fn. 793 (citing Brđanin Trial Judgement, paras. 357-358: "Responsibility for [planning] a crime could [...] only incur if it was demonstrated that the Accused was substantially involved at the preparatory stage of that crime in the concrete form it took, which implies that he possessed sufficient knowledge thereof in advance. [...] Although the Accused espoused the Strategic Plan, it has not been established that he personally devised it. [...] the Trial Chamber finds the evidence before it insufficient to conclude that the Accused was involved in the immediate preparation of the concrete crimes. This requirement of specificity distinguishes 'planning' from other modes of liability. [...]") (emphasis added).

1821 Popović et al. Trial Judgement, para. 1006; Milutinović et al. Trial Judgement, Vol. I, para. 82.

1822 Dragomir Milošević Appeal Judgement, para. 268; Kordić and Čerkez Appeal Judgement, paras. 29-31. This is true regardless of whether the mens rea of the crime is general or specific. See Kordić and Čerkez Appeal Judgement, para. 112 (citing Blaškić Appeal Judgement, para. 166).

1823 Kordić and Čerkez Appeal Judgement, para. 27; Kvočka et al. Trial Judgement, para. 252.
} 
express or implied, ${ }^{1825}$ it need not be direct or public, ${ }^{1826}$ and it may consist of either an act or an omission. ${ }^{1827}$ The accused's prompting must have been a factor "substantially contributing to the conduct of another person committing the crime", but the Prosecution need not prove that the crime would not have been committed but for such prompting, ${ }^{1828}$ or that the accused had effective control or any other sort of authority over the perpetrator. ${ }^{1829}$ The accused must intend to instigate another person to commit a crime, or at a minimum, he must be aware of the substantial likelihood that a crime will be committed in the execution of the act or omission instigated. ${ }^{1830}$

\section{d. Ordering}

573. To be held criminally responsible for ordering the commission of a crime, an accused must have instructed another person to engage in an act or an omission, ${ }^{1831}$ and such instruction must have resulted in the commission of a crime. ${ }^{1832}$ The accused must have held a position of authority over the other person, but it need not be formal and may even be temporary. ${ }^{1833}$ However, there must be "proof of some position of authority on the part of the accused that would compel another to commit a crime in following the accused's order". ${ }^{1834}$ The order need not be in written or any particular form, ${ }^{1835}$ nor must it be transmitted directly to the physical perpetrator. ${ }^{1836}$ As with planning and instigating, it need not be shown that the crime would not have been perpetrated but

1824 Brđanin Trial Judgement, paras. 267, 269 (citing, inter alia, Blaškić Trial Judgement, para. 280; Galić Trial Judgement, para. 168). See also Orić Trial Judgement, para. 269.

1825 Tolimir Trial Judgement, para. 902; Brđanin Trial Judgement, para. 269; Blaškić Trial Judgement, paras. 280281.

1826 Akayesu Appeal Judgement, paras. 477-478, 483; Stanišić and Župljanin Trial Judgement, Vol. I, para. 96; Popović et al. Trial Judgement, para. 1008.

1827 Orić Trial Judgement, para. 273 (citing Blaškić Trial Judgement, paras. 270, 280; Kordić Trial Judgement, para. 387; Naletilić Trial Judgement, para. 60; Brđanin Trial Judgement, para. 269; Limaj Trial Judgement, para. 514; Kamuhanda Trial Judgement, para. 593)

1828 Kordić and Čerkez. Appeal Judgement, para. 27.

1829 Semanza Appeal Judgement, para. 257; Tolimir Trial Judgement, para. 902; Orić Trial Judgement, para. 272 (holding that instigating does not presuppose any kind of superiority). See also Brđanin Trial Judgement, para. 359 (finding it immaterial whether the physical perpetrators were even subordinate to the instigator so long as a causal link between the instigation and the commission of a crime exists).

1830 Nahimana et al. Appeal Judgement, para. 480; Kordić and Čerkez Appeal Judgement, paras. $29,32$.

1831 Kordić and Čerkez Appeal Judgement, para. 28; Blaškić Appeal Judgement, para. 42. Such instruction necessarily requires a positive action on the part of the instructor. Galic Appeal Judgement, para. 176.

1832 Nahimana et al. Appeal Judgement, para. 481; Stanišić and Župljanin Trial Judgement, Vol. I, para. 98; Martić Trial Judgement, para. 441 (citing Brđanin Trial Judgement, para. 267).

1833 Kordić and Čerkez Appeal Judgement, para. 28; Semanza Appeal Judgement, para. 363.

1834 Semanza Appeal Judgement, para. 361 (citing Kordić and Čerkez. Appeal Judgement, para. 28); Galić Appeal Judgement, para. 176. See also Brđanin Trial Judgement, para. 270 (finding that sufficient authority may be reasonably implied from the circumstances); Mrkšić et al. Trial Judgement, para. 550.

1835 Kamuhanda Appeal Judgement, para. 76 (citing Kordić and Čerkez Trial Judgement, para. 388); Stanišić and Župljanin Trial Judgement, Vol. I, para. 98. The order's existence may also be proven by circumstantial evidence. Mrkšić et al. Trial Judgement, para. 550 (citing, inter alia, Galić Appeal Judgement, paras. 170-171).

1836 Blaškić Trial Judgement, para. 282. See also Tolimir Trial Judgement, para. 905; Popović et al. Trial Judgement, para. 1012; Strugar Trial Judgement, para. 331; Brđanin Trial Judgement, para. 270; Naletilić and Martinović Trial Judgement, para. 61; Kordić and Čerkez Trial Judgement, para. 388. 
for the accused's order, ${ }^{1837}$ but the order must have had "a direct and substantial effect on the commission of the illegal act" ${ }^{1838}$ The accused must intend to order a crime, or must be aware of the substantial likelihood that a crime would be committed in the execution of the act or omission ordered. $^{1839}$

\section{e. Aiding and Abetting}

574. Aiding and abetting is a form of liability in which the accused contributes to the perpetration of a crime that is committed by another person. ${ }^{1840}$ The Prosecution must establish that the crime for which it seeks to make the accused responsible in fact occurred. ${ }^{1841}$

575. The physical element of aiding and abetting consists of acts or omissions "specifically directed to assist, encourage or lend moral support to the perpetration of a certain specific crime [...]." ${ }^{1842}$ This support must have a substantial effect upon the perpetration of the crime. ${ }^{1843}$ Liability for "aiding and abetting by omission proper", which must be distinguished from aiding and abetting by tacit approval and encouragement, ${ }^{1844}$ may only attach where an accused had both a legal duty to act and the means to fulfil this duty. ${ }^{1845}$

$1837 \quad$ Strugar Trial Judgement, para. 332.

1838 Kamuhanda Appeal Judgement, para. 75. See also Stanišić and Župljanin Trial Judgement, Vol. I, para. 98; Tolimir Trial Judgement, para. 905; Strugar Trial Judgement, para. 332.

1839 Kordić and Čerkez Appeal Judgement, paras. 29-30; Blaškić Appeal Judgement, paras. 41-42.

1840 Blagojević and Jokić Appeal Judgement, para. 127; Simić Appeal Judgement, para. 85; Vasiljević Appeal Judgement, para. 102(i). This other person may be either the person who carries out the actus reus of the crime with which the accused is charged or a participant in a JCE. See Vasiljević Appeal Judgement, para. 102. See also Popović et al. Trial Judgement, para. 1015.

1841 Aleksovski Appeal Judgement, para. 165.

1842 Tadić Appeal Judgement, para. 229(iii). See also Blaškić Appeal Judgement, para. 45 (construing the Vasiljević Appeals Chamber's quotation of the Tadić Appeal Judgement as "set[ting] out the actus reus and mens rea of aiding and abetting"); Orić Appeal Judgement, para. 43; Simić et al. Appeal Judgement, para. 85; Kvočka et al. Appeal Judgement, paras. 89-90. See further para. 576.

1843 Aleksovski Appeal Judgement, paras. 162, 164 (confirming the Aleksovski Trial Chamber's reliance on the Furundžija Trial Judgement, paras. 233-235). See also Krstić Trial Judgement, para. 601 (citing Aleksovski Appeal Judgement, paras. 162-164) (“"[A]iding and abetting' means rendering a substantial contribution to the commission of a crime.”); Perišić Trial Judgement (Majority Opinion), para. 126; Đorđević Trial Judgement, paras. 1873-1874; Lukić and Lukić Trial Judgement, para. 901; Milutinović et al. Trial Judgement, Vol. I, para. 89; Boškoski and Tarčulovski Trial Judgement, paras. 401-402; Mrkšić et al. Trial Judgement, paras. 551-552; Limaj et al. Trial Judgement, paras. 516-517; Blagojević and Jokić Trial Judgement, para. 726; Galić Trial Judgement, paras. 168-169; Naletilić and Martinović Trial Judgement, para. 63; Kvočka et al. Trial Judgement, paras. 243, 253.

1844 Brđanin Appeal Judgement, paras. 273-274 (referring, for example, to the failure of an accused who holds a position of authority to intervene when physically present at the scene of a crime may be considered to amount to tacit and encouragement approval-as opposed to an omission proper-if found to have substantially contributed to the crime). In order for tacit approval to constitute a substantial contribution to the crime, however, the principal perpetrators must be aware of the encouragement and moral support. Brđanin Appeal Judgement, para. 277.

1845 Mrkšić and Šljivančanin Appeal Judgement, paras. 49, 154 (citing Orić Appeal Judgement, para. 43). See also Mrkšić and Šljivančanin Appeal Judgement, para. 134 (citing Blaškić Appeal Judgement, para. 47 and stating that the Appeals Chamber has "consistently found that, in the circumstances of a given case", the actus reus of 
576. Whether an act or omission had a substantial effect on the commission of a crime is a factbased inquiry. ${ }^{1846}$ The aider and abettor's conduct may occur in a location remote from the scene of the crime. ${ }^{1847}$ It is unnecessary to establish that the crime would not have been committed without the contribution of the aider and abettor. ${ }^{1848}$ Nor must the Prosecution prove the existence of a plan or agreement between the aider and abettor and the perpetrator; the latter may not even know of the aider and abettor's contribution. ${ }^{1849}$ Finally, specific direction is not an element of aiding and abetting responsibility under customary international law. ${ }^{1850}$ This means that there is no requirement of a showing that the acts of the Accused were specifically directed to assist, encourage, or lend moral support to the commission of the crimes. ${ }^{1851}$

577. The requisite mental element for aiding and abetting is "knowledge that the acts performed by the aider and abettor assist the commission of a specific crime". ${ }^{1852}$ The aider and abettor must be aware of the essential elements of the crime which was ultimately committed, ${ }^{1853}$ including the perpetrators' state of mind and any relevant specific intent, ${ }^{1854}$ although he need not share that specific intent. ${ }^{1855}$ Moreover, an accused may be convicted for having aided and abetted a crime, including one which requires specific intent, even where the specific individuals who committed the crime have not been tried or identified. ${ }^{1856}$ If an accused is aware that one or more crimes

aiding and abetting may be perpetrated through an omission). See further Brđanin Appeal Judgement, para. 274 (holding that "omission proper" may lead to individual criminal responsibility under Article 7(1) of the Statute where there is a legal duty to act); Galić Appeal Judgement, para. 175; Blaškić Appeal Judgement, para. 663.

Lukić and Lukić Appeal Judgement, para. 438 (citing Blagojević and Jokić Appeal Judgement, para. 134); Mrkšić and Šljivančanin Appeal Judgement, paras. 146, 200.

Mrkšić and Šljivančanin Appeal Judgement, para. 81; Blaškić Appeal Judgement, para. 48.

Mrkšić and Šljivančanin Appeal Judgement, para. 81 (citing Blaškić Appeal Judgement, para. 48); Brđanin Appeal Judgement, para. 348; Simić Appeal Judgement, para. 85.

Brđanin Appeal Judgement, para. 263 (citing, inter alia, Tadić Appeal Judgement, para. 229(ii)); Krnojelac Appeal Judgement, para. 33.

Šainović et al. Appeal Judgement, paras. 1649, 1651.

Šainović et al. Appeal Judgement, para. 1651.

Tadić Appeal Judgement, para. 229(iv). See also Lukić and Lukić Appeal Judgement, para. 428; Mrkšić and Šljivančanin Appeal Judgement, paras. 49, 159; Orić Appeal Judgement, para. 43; Blagojević and Jokić Appeal Judgement, para. 127; Brđanin Appeal Judgement, para. 484; Simić Appeal Judgement, para. 86; Blaškić Appeal Judgement, paras. 45, 49; Vasiljević Appeal Judgement, para. 102; Śainović et al. Appeal Judgement, para. 1649. This knowledge need not have been explicitly expressed, but may be inferred from all relevant circumstances. Tolimir Trial Judgement, para. 911; Đorđević Trial Judgement, para. 1876; Milutinović et al. Trial Judgement, Vol. I, para. 94; Strugar Trial Judgement, para. 350.

Mrkšić and Šljivančanin Appeal Judgement, paras. 49, 159; Orić Appeal Judgement, para. 43; Brđanin Appeal Judgement, paras. 484, 487.

Blagojević and Jokić Appeal Judgement, para. 127; Krstić Appeal Judgement, para. 140; Vasiljević Appeal Judgement, para. 142; Krnojelac Appeal Judgement, para. 52.

Simić Appeal Judgement, para. 86 (citing Krnojelac Appeal Judgement, para. 52; Aleksovski Appeal Judgement, para. 162).

Brđanin Appeal Judgement, para. 355 (approving the Trial Chamber's identification of the perpetrators as "members of the 'Bosnian Serb forces'”); Krstić Appeal Judgement, para. 143. 
would probably be committed, and one of these crimes is in fact committed, he is deemed to have intended the facilitation of the commission of that crime and is guilty as an aider and abettor. ${ }^{1857}$

\section{Liability under Article 7(3) of the Statute}

578. The Accused is also charged with individual criminal responsibility under Article 7(3) of the Statute on the basis that as the highest civilian and military authority in the RS, he was the superior of, and had effective control over, the Bosnian Serb Forces and Bosnian Serb Political and Governmental Organs who participated in the crimes alleged in the Indictment. ${ }^{1858}$ It is alleged that the Accused knew or had reason to know that the alleged crimes were about to be committed or had been committed and that he failed to take necessary and reasonable measures to prevent and/or punish these alleged crimes. ${ }^{1859}$

579. Under Article 7(3) of the Statute, a superior may incur criminal responsibility with respect to a crime for which his subordinate is criminally responsible if the following three elements are established: (i) there was a superior-subordinate relationship between the accused and the perpetrator of the underlying crime; (ii) the superior knew or had reason to know that the criminal act was about to be or had been committed; and (iii) the superior failed to take the necessary and reasonable measures to prevent the criminal act or punish the perpetrator thereof. ${ }^{1860}$ A superior can bear responsibility under Article 7(3) with respect to the criminal conduct of his subordinates under "all other modes of participation under Article 7(1)", namely the "planning, instigating, ordering, committing or otherwise aiding and abetting a crime" by his subordinates. ${ }^{1861}$

\section{a. Superior-subordinate relationship}

580. In order to establish that a superior-subordinate relationship exists between the accused and the perpetrator of an underlying crime, it must be proven that he exercised "effective control" over the perpetrator. ${ }^{1862}$ A superior is someone who possesses "the power or authority in either a de jure or a de facto form to prevent a subordinate's crime or to punish the perpetrators of the crime". In assessing whether there is a superior-subordinate relationship it does not matter whether the

\footnotetext{
1857 Mrkšić and Šljivančanin Appeal Judgement, para. 159 (citing Simić Appeal Judgement, para. 86; Blaškić Appeal Judgement, para. 50).

1858 Indictment, paras. 32-33.

1859 Indictment, paras. 34-35.

1860 Perišić Appeal Judgement, para. 86; Gotovina Appeal Judgement, para. 128; Orić Appeal Judgement, para. 18; Halilović Appeal Judgement, para. 59; Blaškić Appeal Judgement, para. 484; Aleksovski Appeal Judgement, para. 72.

1861 Orić Appeal Judgement, para. 21; Blagojević Appeal Judgement, para. 280.

1862 Orić Appeal Judgement, paras. 20, 91; Halilović Appeal Judgement, para. 59. See also Čelebići Appeal Judgement, paras. 196-197, 266.
} 
accused was a civilian or military superior. ${ }^{1863}$ An evaluation of effective control is more a question of fact than of law and requires consideration of factors that show "that the accused had the power to prevent, punish, or initiate measures leading to proceedings against the alleged perpetrators where appropriate." 1864

581. Factors to be considered in assessing whether a superior exercised effective control include, inter alia, (i) his capacity to issue orders and whether those orders were in fact followed, ${ }^{1865}$ (ii) the authority to issue disciplinary measures, and (iii) the power to promote personnel and terminate positions held. ${ }^{1866}$ The superior's de jure authority “constitutes prima facie a reasonable basis for assuming that he has effective control over his subordinates" but still requires the Prosecution to prove that he exercised effective control. ${ }^{1867}$

582. In assessing effective control what is relevant is whether the "superior has the material ability to prevent or punish the criminally responsible subordinate". ${ }^{1868}$ In this regard the Appeals Chamber has held:

Whether the effective control descends from the superior to the subordinate culpable of the crime through intermediary subordinates is immaterial as a matter of law; instead; what matters is whether the superior has the material ability to prevent or punish the criminally responsible subordinate. The separate question of whether - due to proximity or remoteness of control - the superior indeed possessed effective control is a matter of evidence, not of substantive law. ${ }^{1869}$

583. Furthermore, for the purposes of liability under Article 7(3), the accused need not know the exact identity of a subordinate perpetrator. ${ }^{1870}$

b. Knew or had reason to know

584. For the accused to be held responsible under Article 7(3), the accused must have known or had reason to know that the subordinate committed a crime or was going to do so. ${ }^{1871}$

\footnotetext{
1863 Alekovski Appeal Judgement, para. 76; Čelebići Appeal Judgement, paras. 195-196.

1864 Perišić Appeal Judgement, para. 87; Blaškić Appeal Judgement, para. 69; Aleksovski Appeal Judgement, para. 76.

1865 Strugar Appeal Judgement, para. 254; Halilović Appeal Judgement, para. 207. See also Blaškić Appeal Judgement, para. 609

1866 Perišić Appeal Judgement, para. 97. See also Čelebići Appeal Judgement, paras. 190, 206.

1867 Hadžihasanović and Kubura Appeal Judgement, para. 21. See also Orić Appeal Judgement, paras. 91-92; Čelebići Appeal Judgement, para. 197.

1868 Čelebići Appeal Judgement, paras. 192, 195-198, 256. See also Orić Appeal Judgement, paras. 91-92; Halilović Appeal Judgement, para. 59; Limaj et. al. Appeal Judgement, para. 273.

1869 Orić Appeal Judgement, para. 20 (citing Blaškić Appeal Judgement, para. 69). See also Čelebići Appeal Judgement, para. 252.

1870 Blagojević Appeal Judgement, para. 287.
} 
585. Knowledge may be inferred from circumstantial evidence ${ }^{1872}$ but requires an assessment of the specific circumstances of each case and the "specific situation of the superior concerned at the time in question". 1873

586. To prove that the accused had reason to know of crimes committed, it is necessary to show that he had information available to him which would have put him on notice of unlawful acts committed or about to be committed by his subordinates. ${ }^{1874}$ In this regard "it must be established whether, in the circumstances of the case, he possessed information sufficiently alarming to justify further inquiry". ${ }^{1875}$ This information does not need to contain extensive or specific details about the unlawful acts committed or about to be committed. ${ }^{1876}$ A failure by the accused to punish the past offences of his subordinates may be relevant to determining whether he "possessed information that was sufficiently alarming to put him on notice of the risk that similar crimes might subsequently be carried out by subordinates and justify further inquiry". ${ }^{1877}$

\section{c. Necessary and reasonable measures}

587. For the accused to be held responsible under Article 7(3), it must be established that he failed to take the necessary and reasonable measures to prevent or punish the commission of the crimes charged. ${ }^{1878}$ Determining what measures are necessary and reasonable to prevent or punish crimes committed by subordinates is a question of fact and not of substantive law. ${ }^{1879}$ The degree of effective control can be used to determine "the necessary and reasonable measures within the competence of a superior", 1880

588. The measures which are "necessary" are those which are "appropriate for the superior to discharge his obligation" to prevent or punish the underlying crime, while "reasonable" measures are those "reasonably falling within the material powers of the superior". ${ }^{1881}$ Reasonable and necessary measures can include reporting the matter to competent authorities where this report is

\footnotetext{
1871 Kordić and Čerkez. Appeal Judgement, para. 839. See also Orić Appeal Judgement, para. 18; Čelebići Appeal Judgement, para. 222.

1872 Galić Appeal Judgement, paras. 171, 180-184.

1873 Krnojelac Appeal Judgement, para. 156; Čelebići Appeal Judgement, para. 239.

1874 Čelebići Appeal Judgement, paras. 238, 241. See also Blaškić Appeal Judgement, para. 62.

1875 Strugar Appeals Judgement, paras. 297-301; Hadžihasanović and Kubura Appeal Judgement, para. 28 (footnotes omitted).

1876 Hadžihasanović and Kubura Appeal Judgement, para. 28; Galić Appeal Judgement, para. 184; Krnojelac Appeal Judgement, para. 155; Čelebići Appeal Judgement, para. 238.

1877 Hadžihasanović and Kubura Appeal Judgement, paras. 30-31; Krnojelac Appeal Judgement, para. 155.

1878 Orić Appeal Judgement, para. 18.

1879 Blaškić Appeal Judgement, para. 72. See also Hadžihasnović and Kubura Appeal Judgement, para. 33.

1880 Boškoski and Tarčulovski Appeal Judgement, paras. 230-231; Strugar Appeal Judgement, paras. 297-301; Halilović Appeal Judgement, para. 63; Blaškić Appeal Judgement, para. 72.
} 
likely to trigger an investigation or initiate disciplinary or criminal proceedings, ${ }^{1882}$ carrying out an effective investigation to establish the facts, ${ }^{1883}$ issuing specific orders prohibiting or stopping the criminal activities and securing implementation of those orders, ${ }^{1884}$ protesting or criticising criminal action and taking disciplinary measures against the commission of crimes. ${ }^{1885}$

589. The duty to prevent a crime is distinct from the duty to punish a crime as it involves "different conduct committed at different times". ${ }^{1886}$ The failure to punish relates to past crimes committed by subordinates and the failure to prevent concerns future crimes of subordinates. ${ }^{1887}$ The obligation to prevent or punish "does not provide an accused with two alternative and equally satisfying options" in that where the accused knew or had reason to know that subordinates were about to commit a crime and failed to prevent that crime, "he cannot make up for his failure to act by punishing the subordinates afterwards". ${ }^{1888}$

590. For the purposes of Article 7(3), there is no requirement of causality between the superior's failure to prevent and the occurrence of the crime. ${ }^{1889}$

\section{d. Interaction between Articles 7(1) and 7(3)}

591. Where both Article 7(1) and Article 7(3) responsibility are alleged under the same count, and where the legal requirements of both are met, a conviction should only be entered on the basis of Article 7(1) and the accused's superior position should be considered as an aggravating factor in sentencing. ${ }^{1890}$ The Appeals Chamber in Popović further specified that it was "improper to

\footnotetext{
1881 Halilović Appeal Judgement, para. 63.

1882 Boškoski and Tarčulovski Appeal Judgement, paras. 230, 234; Blagojević and Jokić Trial Judgement, para. 793; Blaškić Trial Judgement, para. 335;

1883 Limaj et al. Trial Judgement, para. 529; Halilović Trial Judgement, paras. 97, 100; Strugar Trial Judgement, para. 376 (referring to Kordić Trial Judgement, para. 446).

1884 Halilović Trial Judgement, paras. 74, 89; Strugar Trial Judgement, para. 374.

1885 Halilović Trial Judgement, para. 89; Strugar Trial Judgement, para. 374.

1886 Perišić Appeal Judgement, para. 88 (citing, inter alia, Blaškić Appeal Judgement, para. 83). See also Orić Trial Judgement, para. 326.

1887 Blaškić Appeal Judgement, para. 83.

1888 Blaškić Trial Judgement, para. 336. See also Strugar Trial Judgement, para. 373.

1889 Blaškić Appeal Judgement, paras. 73-77. See also Hadžihasanović and Kubura Appeal Judgement, paras. 3840.

1890 Blaškić Appeal Judgement, paras. 91-92 (citing Aleksovski Appeal Judgement, para. 183 and Čelebići Appeal Judgement, para. 745). See also Galić Appeal Judgement, para. 186; Kvočka et. al., Appeal Judgement, para. 104.
} 
maintain a conviction under Article 7(3) of the Statute in addition to a conviction under Article 7(1) of the Statute for the same count and the same set of facts". ${ }^{1891}$

\section{FINDINGS}

\section{A. Municipalities COMPONENT}

1. Facts

592. The Prosecution alleges that from at least October 1991 until 30 November 1995, the Accused participated in an overarching JCE to permanently remove Bosnian Muslim and Bosnian Croat inhabitants from the territories of $\mathrm{BiH}$ claimed as Bosnian Serb territory by means which included the commission of the following crimes: genocide, persecution, extermination, murder, deportation, and inhumane acts (forcible transfer). ${ }^{1892}$ In this component, the Prosecution refers to the following municipalities: Bijeljina, Bratunac, Brčko, Foča, Rogatica, Višegrad, Sokolac, Vlasenica, and Zvornik (in relation to Eastern BiH); Banja Luka, Bosanski Novi, Ključ, Prijedor, and Sanski Most (in relation to the ARK); Hadžići, Ilidža, Novi Grad, Novo Sarajevo, Pale, and Vogošća (in relation to the Sarajevo area). ${ }^{1893}$

593. The Prosecution alleges that under the direction of the Accused and the Bosnian Serb leadership, civilian, military, and paramilitary organs collaborated to take over municipalities and territories throughout $\mathrm{BiH}$ in order to establish Serb control and permanently remove non-Serbs by force or threat of force. It is alleged that the physical take-overs of the Municipalities began in late March 1992 and that during and after these take-overs, Serb Forces and authorities, acting under the direction of the Accused, killed and mistreated thousands of individuals and expelled hundreds of thousands, while others fled in fear of their lives. ${ }^{1894}$

594. The Accused's case in relation to the Municipality component is that (i) the Bosnian Serb leadership in Pale did not control events in the field and other organs of the RS; ${ }^{1895}$ (ii) the Bosnian Serb leadership in Pale lacked meaningful communications with the Municipalities to be able to control events in the field; ${ }^{1896}$ (iii) the Bosnian Serb leadership in Pale instructed Municipalities to protect the non-Serb civilian population; ${ }^{1897}$ (iv) the Bosnian Serb leadership in Pale took all

\footnotetext{
1891 Popović et al. Appeal Judgement, para. 1806 (referring to Nahimana et al. Appeal Judgement, para. 487; Blaškić Appeal Judgement, para. 91) (emphasis added).

1892

1893

1894

1895

1896

1897

Indictment, para. 9.

Indictment, para. 48.

Prosecution Final Brief, para. 4.

Defence Final Brief, paras. 402-499, 904-965.

Defence Final Brief, paras. 500-540.

Defence Final Brief, paras. 541-554.
} 
possible measures to prevent and punish crimes against non-Serbs; ${ }^{1898}$ (v) the Bosnian Serb leadership in Pale did not create a climate of impunity that furthered crimes against non-Serbs; ${ }^{1899}$ and (vi) the Bosnian Serb leadership did not commit crimes or support the perpetrators of crimes. $^{1900}$

595. The Chamber will examine the allegations with respect to each of these Municipalities in turn.
a. Eastern Bosnia

i. Bijeljina

\section{(A) Charges}

596. Under Count 3, the Prosecution alleges that persecution, a crime against humanity, was committed in Bijeljina as part of the objective to permanently remove Bosnian Muslims and/or Bosnian Croats from the Municipalities. ${ }^{1901}$ Acts of persecution alleged to have been committed by Serb Forces and Bosnian Serb Political and Governmental Organs include killings during and after the take-over of Bijeljina; ${ }^{1902}$ killings related to detention facilities; ${ }^{1903}$ and killings committed during, and deaths resulting from, cruel and inhumane treatment at scheduled detention facilities. ${ }^{1904}$ The Prosecution also characterises these killings as extermination, a crime against humanity, under Count 4; murder, a crime against humanity, under Count 5; and murder, a violation of the laws or customs of war, under Count $6 .{ }^{1905}$

597. Other acts of persecution alleged to have been committed in Bijeljina by Serb Forces and Bosnian Serb Political and Governmental Organs include (i) torture, beatings, and physical and psychological abuse, during and after the take-over and in scheduled detention facilities, as cruel or inhumane treatment; ${ }^{1906}$ (ii) rape and other acts of sexual violence, during and after the take-over and in scheduled detention facilities, as cruel and inhumane treatment; ${ }^{1907}$ (iii) the establishment and perpetuation of inhumane living conditions in detention facilities in Bijeljina, including the

\footnotetext{
1898 Defence Final Brief, paras. 642-760.

1899 Defence Final Brief, paras. 761-898.

1900 Defence Final Brief, paras. 966-1219.

1901 Indictment, paras. 48-49.

1902 Indictment, para. 60(a)(i). See Scheduled Incident A.1.1.

1903 Indictment, para. 60(a)(ii). See Scheduled Incident B.2.1.

1904 Indictment, para. 60(a)(ii). See Scheduled Detention Facility C.2.1.

1905 Indictment, para. 63(a), 63(b).

1906 Indictment, para. 60(b). See Scheduled Detention Facility C.2.1.

1907 Indictment, para. 60(c). See Scheduled Detention Facility C.2.1.
} 
failure to provide adequate accommodation, shelter, food, water, medical care, or hygienic sanitation facilities, as cruel or inhumane treatment; ${ }^{1908}$ (iv) forcible transfer or deportation of Bosnian Muslims and Bosnian Croats from their homes; ${ }^{1909}$ (v) unlawful detention in scheduled detention facilities; ${ }^{1910}$ (vi) forced labour at the frontline and the use of Bosnian Muslims and Bosnian Croats as human shields; ${ }^{1911}$ (vii) the appropriation or plunder of property, during and after the take-over, during arrests and detention and in the course of or following acts of deportation or forcible transfer; ${ }^{1912}$ (viii) the wanton destruction of private property including homes and business premises and public property including cultural monuments and sacred sites; ${ }^{1913}$ and (ix) the imposition and maintenance of restrictive and discriminatory measures. ${ }^{1914}$

598. Under Counts 7 and 8, the Prosecution alleges deportation and inhumane acts (forcible transfer), respectively, as crimes against humanity. ${ }^{1915}$ In this regard, the Prosecution alleges that by the end of 1992 Serb Forces as well as Bosnian Serb Political and Governmental Organs had forcibly displaced Bosnian Muslims and Bosnian Croats from areas in Bijeljina in which they were lawfully present. ${ }^{1916}$ It is alleged that from March 1992, restrictive and discriminatory measures, arbitrary arrest and detention, harassment, torture, rape and other acts of sexual violence, killing, destruction of houses, cultural monuments and sacred sites, as well as the threat of further such acts caused Bosnian Muslims and Bosnian Croats to flee in fear while others were physically driven out. $^{1917}$

\section{(B) Lead-up}

599. Bijeljina is a municipality located in the northeast of $\mathrm{BiH}$ in the Semberija region. ${ }^{1918}$ Approximately two-thirds of its municipal boundaries form part of the border between $\mathrm{BiH}$ and Serbia with the municipality bound by the Sava River to the north and the Drina River to the

\footnotetext{
1908 Indictment, para. 60(d), 60(h). See Scheduled Detention Facility C.2.1.

1909 Indictment, para. 60(f).

1910 Indictment, para. 60(g). See Scheduled Detention Facility C.2.1.

1911 Indictment, para. 60(h).

1912 Indictment, para. 60(i).

1913 Indictment, para. 60(j). See Scheduled Incident D.2.

1914 Indictment, para. 60(k). The restrictive and discriminatory measures alleged include the denial of freedom of movement; the removal from positions of authority; the invasion of privacy through arbitrary searches of homes; unlawful arrest and/ or the denial of the right to judicial process; and/or the denial of equal access to public services.

1915 Indictment, paras. 68-75.

1916 Indictment, paras. 69, 72

1917 Indictment, para. 71.

1918 D484 (Map of BiH); Adjudicated Fact 2233; P3033 (Reynaud Theunens's expert report entitled "Radovan Karadžić and the SRBiH TO-VRS (1992-1995)"), e-court p. 374.
} 
east. ${ }^{1919}$ Bijeljina is the closest municipality in BiH to Belgrade with one of the roads connecting Sarajevo and Belgrade crossing the municipality. ${ }^{1920}$ Prior to the war, approximately $60 \%$ of the population in the municipality of Bijeljina were Bosnian Serbs and approximately $30 \%$ were Bosnian Muslims. ${ }^{1921}$

600. Bijeljina controlled access to the "Posavina Corridor" which was the only land link connecting Krajina, Western Slavonia and the western part of SerBiH with Serbia, and the establishment of this corridor formed part of the Strategic Goals. ${ }^{1922}$

601. Following the formation of national parties in mid-1990, inter-ethnic relations in Bijeljina deteriorated. ${ }^{1923}$ The SDS in Bijeljina was formed in July 1990 by Predrag Ješurić. ${ }^{1924}$ Milan Novaković was the President of the SDS in Bijeljina ${ }^{1925}$ and other members of the SDS leadership included Dragomir Ljubojević, Marko Stanković, and Dragan Vuković. ${ }^{1926}$ Mirko Blagojević, an SDS member, established the Board of the SRS in Bijeljina. ${ }^{1927}$

1919 P3033 (Reynaud Theunens's expert report entitled "Radovan Karadžić and the SRBiH TO-VRS (1992-1995)"), e-court p. 374. See Adjudicated Fact 2233.

1920

1921
See Adjudicated Fact 2234.

P3033 (Reynaud Theunens's expert report entitled "Radovan Karadžić and the SRBiH TO-VRS (1992-1995)”), e-court p. 374; P4994 (Addendum to Ewa Tabeau's expert report entitled "Ethnic Composition in Internally Displaced Persons and Refugees from 27 Municipalities of BiH 1991 to 1997", 3 February 2009), p. 30. Defence evidence suggested that the figures provided by the "international experts" exaggerated the number of Bosnian Muslims in Bijeljina in 1991. D3125 (Stevo Pašalić's expert report entitled "Ethnic Composition, Displaced Persons and Refugees from 27 Municipalities in the Territory of BiH, 1991-1997", August 2012), paras. 8, 85-91; Stevo Pašalić, T. 35426-35434 (14 March 2013); P6198 (Diagram re percentage of Bijeljina population born before 1980). However, the Chamber notes that Pašalić and his methodology fails to successfully explain why he concluded that the international experts were in error in their calculation of the number of Bosnian Muslims in Bijeljina in 1991. In addition the Chamber notes that his evidence was marked by evasiveness and bias which substantially compromised the veracity of his evidence. The Chamber thus does not consider his evidence to be reliable in this regard.

P3033 (Reynaud Theunens's expert report entitled "Radovan Karadžić and the SRBiH TO-VRS (1992-1995)"), e-court pp. 374-375. See also P2561 (Map of BiH re six Strategic Goals).

D3140 (Witness statement of Živan Filipović dated 18 March 2013), para. 3.

D3089 (Witness statement of Milivoje Kićanović dated 3 March 2013), para. 3 (stating that the SDA, HDZ and Party of Democratic Unity were formed before the SDS); D3133 (Witness statement of Cvijetin Simić dated 16 March 2013), paras. 2-3; P2848 (Witness statement of Milorad Davidović dated 22 June 2011), para. 11. The Chamber notes that the wording of several paragraphs in Kićanović's statement was almost identical to the statement provided by another defence witness Cvijetin Simić. Milivoje Kićanović, T. 34879-34881 (6 March 2013); P6184 (Comparison of witness statements of Milivoje Kićanović and Cvijetin Simić). While Kićanović's explanation for this does not seem plausible, the Chamber does not find that this completely undermines the content of their evidence. However, the Chamber has had regard to the identical wording of certain portions of their respective statements in assessing and weighing the evidence of both Kićanović and Simić.

P2929 (Witness statement of KDZ531 dated 25 June 2011), p. 3 (under seal) (testifying that Novaković was replaced by Savo Kojić who was in turn replaced by Savo Andrić); Milorad Davidović, T. 15541 (28 June 2011); P2848 (Witness statement of Milorad Davidović dated 22 June 2011), paras. 10-11, 116 . See also Dragomir Andan, D3774 (Transcript from Prosecutor v. Stanišić \& Župljanin), T. 21658.

P2929 (Witness statement of KDZ531 dated 25 June 2011), p. 3 (under seal).

P2901 (SRT video footage of interview of Mirko Blagojević), p. 3. 
602. Following the multi-party elections, in November 1990, the SDS won an absolute majority in Bijeljina but formed a coalition government with the SDA in which official positions were divided between Bosnian Serbs and Bosnian Muslims. ${ }^{1928}$ After 1991, people in Bijeljina started joining the SDS to keep their positions. ${ }^{1929}$ Milorad Davidović who had been the Chief of SJB in Bijeljina was dismissed from his position as he did not join the SDS and was replaced by Ješurić. ${ }^{1930}$

603. By mid-1991, ethnic divisions were rife between Bosnian Muslims and Bosnian Serbs in Bijeljina. ${ }^{1931}$ Tensions in Bijeljina continued to increase following the war in Croatia ${ }^{1932}$ and even more so in September 1991 after Bosnian Muslims boycotted the JNA mobilisation and started leaving their units; this resulted in the JNA units being manned almost completely by Serbs. ${ }^{1933}$ Inter-ethnic relations in the municipality were further strained in the lead-up to and following the referendum on the independence of $\mathrm{BiH} .{ }^{1934}$

1928 D3089 (Witness statement of Milivoje Kićanović dated 3 March 2013), paras. 5-6; Milivoje Kićanović, T. 34883-34884 (6 March 2013); D3090 (Result of Bijeljina municipal elections, 28 November 1990); D3144 (Witness statement of Dragomir Ljubojević dated 18 March 2013), para. 11; D3133 (Witness statement of Cvijetin Simić dated 16 March 2013), paras. 5-6; D3140 (Witness statement of Živan Filipović dated 18 March 2013), paras. 5-6; Živan Filipović, T. 35793 (21 March 2013). See also P2929 (Witness statement of KDZ531 dated 25 June 2011), pp. 2-3 (under seal).

1929 P2848 (Witness statement of Milorad Davidović dated 22 June 2011), para. 10.

1930 P2848 (Witness statement of Milorad Davidović dated 22 June 2011), paras. 8, 10, 12-13; Milorad Davidović, T. 15579, 15639-15640 (29 June 2011); Milorad Davidović, D1411 (Excerpt of transcript from Prosecutor v. Krajišnik) T. 14400; P2629 (Bijeljina's SJB report, 9 April 1992), p. 1. Ješurić replaced Davidović and was appointed Bijeljina SJB Chief.

1931 D3141 (Witness statement of Dušan Spasojević dated 18 March 2013), para. 6; Živan Filipović, T. 35795 (21 March 2013); D3133 (Witness statement of Cvijetin Simić dated 16 March 2013), para. 18. The SDA also organised and staged demonstrations in 1990 and 1991 which contributed to the deterioration of inter-ethnic relations and there were also incidents of harassment of Bosnian Serbs. D3140 (Witness statement of Živan Filipović dated 18 March 2013), paras. 3-4; D3089 (Witness statement of Milivoje Kićanović dated 3 March 2013), paras. 10-11; D3144 (Witness statement of Dragomir Ljubojević dated 18 March 2013), para. 4. See also D3137 (Witness statement of Svetozar Mihajlović dated 17 March 2013), para. 2; D3133 (Witness statement of Cvijetin Simić dated 16 March 2013), paras. 4, 37.

1932 D3089 (Witness statement of Milivoje Kićanović dated 3 March 2013), para. 7; D3144 (Witness statement of Dragomir Ljubojević dated 18 March 2013), para. 6; D3133 (Witness statement of Cvijetin Simić dated 16 March 2013), para. 7. See also D3141 (Witness statement of Dušan Spasojević dated 18 March 2013), paras. 4-5 (stating that the SDA sent Bosnian Muslim men from the reserve police to Croatia for training).

1933 P2929 (Witness statement of KDZ531 dated 25 June 2011), p. 2 (under seal); KDZ531, T. 15864 (1 July 2011) (closed session); D3089 (Witness statement of Milivoje Kićanović dated 3 March 2013), para. 8; D3144 (Witness statement of Dragomir Ljubojević dated 18 March 2013), para. 6; D3133 (Witness statement of Cvijetin Simić dated 16 March 2013), para. 8; D3141 (Witness statement of Dušan Spasojević dated 18 March 2013), paras. 4-5.

1934 D3140 (Witness statement of Živan Filipović dated 18 March 2013), para. 3; D3089 (Witness statement of Milivoje Kićanović dated 3 March 2013), para. 4; D3144 (Witness statement of Dragomir Ljubojević dated 18 March 2013), paras. 3, 7; D3137 (Witness statement of Svetozar Mihajlović dated 17 March 2013), para. 2; D3133 (Witness statement of Cvijetin Simić dated 16 March 2013), paras. 15-17; D3141 (Witness statement of Dušan Spasojević dated 18 March 2013), paras. 3-4; D3142 (Criminal report against Hasan Tirić), pp. 21-22. 
604. At a meeting in Banja Luka on 11 February 1992, attended by senior officials including Mićo Stanišić and Mandić, there was discussion about the creation of a Bosnian Serb MUP; thereafter the SJB in Bijeljina was instructed by Mandić to begin preparations for this purpose. ${ }^{1935}$

605. The existence of a Crisis Staff in Bijeljina was strongly contested by the Accused ${ }^{1936}$ and Defence evidence suggested that there was no Crisis Staff in Bijeljina. ${ }^{1937}$ However, the Chamber is satisfied, based on the evidence about the establishment and actions of the Crisis Staff, that there was a Crisis Staff in Bijeljina by the beginning of April 1992. ${ }^{1938}$ In addition, local crisis staffs were also established in villages surrounding Bijeljina. ${ }^{1939}$

606. Milan Novaković1940 and Ljubiša Savić ("Mauzer") were leaders in the Bijeljina Crisis Staff. ${ }^{1941}$ Members of the Crisis Staff were all either from the SDS or prominent local people who were loyal to the party. ${ }^{1942}$ The Crisis Staff took on authority which previously belonged to other municipal bodies and took on the role as "commanding body of defence and military forces" and also provided logistical support to the JNA which had barracks in Bijeljina. ${ }^{1943}$ Initially, the Crisis

1935 P1083 (Minutes of meeting of representatives of SerBiH MUP, 11 February 1992), p. 1; P1112 (Order of SRBiH MUP to all CSBs and SJBs, 13 February 1992); Momčilo Mandić, C2 (Transcript from Prosecutor v. Krajišnik), T. 8649.

1936 Defence Final Brief, para. 1378.

1937 See D3144 (Witness statement of Dragomir Ljubojević dated 18 March 2013), para. 11; Dragomir Ljubojević, T. 35899 (22 March 2013); D3133 (Witness statement of Cvijetin Simić dated 16 March 2013), paras. 34, 42; Cvijetin Simić, T. 35691-35695 (20 March 2013); D3089 (Witness statement of Milivoje Kićanović dated 3 March 2013), para. 27.

1938 P2929 (Witness statement of KDZ531 dated 25 June 2011), p. 3 (under seal); P2848 (Witness statement of Milorad Davidović dated 22 June 2011), para. 89; P2626 (Report of Bijeljina Crisis Staff, 1 April 1992). For evidence on the existence and actions of the Bijeljina Crisis Staff, see P6214 (Report of JNA $17^{\text {th }}$ Corps, 7 April 1992), p. 1. When Filipović was asked about this order he was not very clear and tried to suggest that this was not the Crisis Staff; however, the Chamber does not find his answers convincing in this regard. Živan Filipović, T. 35808 (21 March 2013). Similarly, on cross-examination, Kićanović acknowledged that when the municipal Assembly could not be convened a municipal Presidency was set up comprising 10 people who managed the municipality, but he did not consider this to be a Crisis Staff. The witness was presented with a number of documents which made reference to the Bijeljina Crisis Staff (see P2626, P5587, P2855) but maintained that he was not aware of any Crisis Staff in Bijeljina. However, when questioned by the Chamber, Kićanović acknowledged that a Bijeljina SDS Crisis Staff probably did exist but that it was different from the municipal Crisis Staff. Milivoje Kićanović, T. 34886, 34888-34889, 34903-34907 (6 March 2013). Other witnesses were also shown documents with references to the Bijeljina Crisis Staff (P2626, P6211, P2629) but maintained that there was no Crisis Staff in Bijeljina. Cvijetin Simić, T. 35655-35660, 35667 (20 March 2013); Dragomir Ljubojević, T. 35900-35901 (22 March 2013). The Chamber does not find the witnesses' answers in this regard to be convincing. The Chamber also received evidence about Biljana Plavšić meeting with the Bijeljina Crisis Staff which supports the fact that it did exist. See para. 626.

1939 P2848 (Witness statement of Milorad Davidović dated 22 June 2011), para. 89.

1940 P2929 (Witness statement of KDZ531 dated 25 June 2011), p. 3 (under seal).

1941 Milorad Davidović, T. 15583-15584 (29 June 2011), 15753, 15771 (30 June 2011). See also KDZ446, P29 (Transcript from Prosecutor v. S. Milošević), T. 21056; Dragomir Andan, T. 40872 (5 July 2013) (identifying Mauzer's role as an SDS leader in Bijeljina).

1942 P2929 (Witness statement of KDZ531 dated 25 June 2011), p. 3 (under seal); P2848 (Witness statement of Milorad Davidović dated 22 June 2011), para. 89; Cvijetin Simić, T. 35698-35699 (20 March 2013).

1943 P2929 (Witness statement of KDZ531 dated 25 June 2011), p. 3 (under seal). 
Staff met every day with only the closest group of leaders in attendance. ${ }^{1944}$ It however evolved to become the Presidency of the Municipal Assembly ${ }^{1945}$ and subsequently the War Presidency. ${ }^{1946}$ There was a very close relationship between the Bijeljina branch of the SDS and the SDS party in Pale; and the SDS leadership, including the Accused and Krajišnik, often visited Bijeljina. ${ }^{1947}$ The Bijeljina Crisis Staff kept the SDS Main Board informed of its activities. ${ }^{1948}$ In addition, the Chief of the Bijeljina SJB reported to Mićo Stanišić on the situation in the municipality. ${ }^{1949}$

607. In the two or three months leading up to the conflict, both sides established units and armed themselves. ${ }^{1950}$ The SDS and SDA armed Bosnian Serbs and Bosnian Muslims respectively. ${ }^{1951}$ Weapons were distributed to supporters of the SDS by the village level crisis staffs. ${ }^{1952}$ By the time the conflict broke out in Bijeljina, an armed intervention unit had been formed by the SDS from villagers trusted by the party. ${ }^{1953}$ Ješurić also sought and received material assistance from the Serbian MUP in the lead-up to the conflict. ${ }^{1954}$ In contrast, by 11 April 1992 while there remained some armed Bosnian Muslims, most had handed in their weapons to the local authorities. ${ }^{1955}$

\footnotetext{
1944 P2929 (Witness statement of KDZ531 dated 25 June 2011), p. 3 (under seal).

1945 P2629 (Bijeljina's SJB report, 9 April 1992), p. 2.

1946 P2929 (Witness statement of KDZ531 dated 25 June 2011), p. 3 (under seal). See also D3144 (Witness statement of Dragomir Ljubojević dated 18 March 2013), para. 11; Dragomir Ljubojević, T. 35899 (22 March 2013) (testifying that while he was not aware of the Crisis Staff, he was aware that the War Presidency had an active role in decision making in the municipality and acted openly).

1947 P2929 (Witness statement of KDZ531 dated 25 June 2011) p. 4 (under seal).

1948 For example see P2626 (Report of Bijeljina Crisis Staff, 1 April 1992) in which the Bijeljina Crisis Staff reported to the SDS Main Board on the situation in the municipality.

1949 P2629 (Bijeljina's SJB report, 9 April 1992).

1950 KDZ059, P67 (Transcript from Prosecutor v. S. Milošević), T. 29101. See also D3065 (Witness statement of Aleksandar Vasiljević dated 26 February 2013), paras. 172-173; D3089 (Witness statement of Milivoje Kićanović dated 3 March 2013), paras. 9. 11; D3133 (Witness statement of Cvijetin Simić dated 16 March 2013), paras. 10-11; D3141 (Witness statement of Dušan Spasojević dated 18 March 2013), paras. 4, 9, 15-16; Dušan Spasojević, T. 35829-35830 (21 March 2013); D3142 (Criminal report against Hasan Tirić), pp. 3, 16, 21-23, 27, 30; Živan Filipović, T. 35793-35794 (21 March 2013); D1608 (Official note of the Croatian Security Information Service Centre, 9 May 1996), p. 1; KDZ555, T. 17366-17367 (17 August 2011). The Chamber is satisfied based on the above-mentioned evidence that Bosnian Muslim military formations, including the Patriotic League, were also established and operated in Bijeljina.

1951 P2929 (Witness statement of KDZ531 dated 25 June 2011), p. 8 (under seal).

1952 P2929 (Witness statement of KDZ531 dated 25 June 2011), p. 3 (under seal).

1953 P2929 (Witness statement of KDZ531 dated 25 June 2011), p. 3 (under seal). Simić testified that the Bosnian Serb authorities were against the formation of illegal organisations and the arming of the population and when officers from the Bijeljina garrison who were members of the League of Communists secretly distributed weapons to civilians, the authorities asked that the weapons be returned to the barracks and the officers were held to account. D3133 (Witness statement of Cvijetin Simić dated 16 March 2013), para. 10. The Chamber does not find this evidence to be reliable and notes that Simić's evidence was marked by indicators which led to the conclusion that he withheld information from the Chamber, was evasive, and lacked sincerity.

1954 P1083 (Minutes of meeting of representatives of SerBiH MUP, 11 February 1992), p. 2. See also P2875 (Freedom of movement pass issued by Semberija \& Majevica Crisis Staff).

1955 D3142 (Criminal report against Hasan Tirić), p. 30; D3141 (Witness statement of Dušan Spasojević dated 18 March 2013), para. 15.
} 
608. As discussed earlier in this Judgement, the Serbian National Guard, was a unit commanded by Mauzer, and later known as Mauzer's Panthers. ${ }^{1956}$ Mauzer was also commander of the SAO Semberija TO and operated in Bijeljina with the support of the Presidency of the Bijeljina Municipal Assembly. ${ }^{1957}$ There was also a local paramilitary group of approximately 50 men affiliated with the SRS under the command of Mirko Blagojević in Bijeljina. ${ }^{1958}$ Prior to the war, the SDS had called on the youth to attend Arkan's training camp across the Drina and later the Bijeljina Crisis Staff and Mauzer invited Arkan to the municipality after which his men arrived in Bijeljina. ${ }^{1959}$ Plavšić at the $22^{\text {nd }}$ session of the RS Assembly in November 1992 acknowledged that

1956 See para. 233; P2848 (Witness statement of Milorad Davidović dated 22 June 2011), paras. 79, 89; Milorad Davidović, T. 15479-15480 (28 June 2011); see Adjudicated Fact 2237; P2855 (VRS Main Staff report on paramilitary formations, 28 July 1992), p. 5; D1450 (Milorad Davidović's statement to Belgrade District Court, 26 December 2007), pp. 36-37; P3033 (Reynaud Theunens's expert report entitled "Radovan Karadžić and the SRBiH TO-VRS (1992-1995)"), e-court pp. 270-271; D1612 (Video footage of Arkan in "My Guest, His Truth", July/August 1994), pp. 11-12; Manojlo Milovanović, T. 25447 (28 February 2012); P2044 (BBC news report re interview with Major Mauzer, with transcript), p. 1; KDZ446, P29 (Transcript from Prosecutor v. S. Milošević), T. 21053-21054, 21056; Dragomir Andan, T. 40872 (5 July 2013). Predrag Ješurić was also involved in the operations of this unit. Čedomir Kljajić, T. 42219 (30 July 2013).

1957 P2884 (Article from List SAO Semberije I Majevice entitled “Semberija Lost for Alija's Islamic State”, 15 June 1992), p. 4. The Chamber received evidence from Šešelj that Mauzer and his group were not under the control of the Accused or the Bosnian Serb leadership and he had heard the Accused complain about this group. D3665 (Witness statement of Vojislav Šešelj dated 1 June 2013), para. 47. The Chamber considers that Šešelj's assessment that Mauzer was not under the control of the Accused or the Bosnian Serb leadership to be his own opinion, and is therefore of little value.

1958 Adjudicated Fact 2241; KDZ531, T. 15867 (1 July 2011) (closed session); P3033 (Reynaud Theunens's expert report entitled "Radovan Karadžić and the SRBiH TO-VRS (1992-1995)"), para. 50, e-court pp. 256, 348, 381; D1612 (Video footage of Arkan in "My Guest, His Truth", July/August 1994), p. 11; P2901 (SRT video footage of interview of Mirko Blagojević), pp. 5-6; P2073 (BBC news report re Bijeljina, with transcript), p. 1; KDZ446, P29 (Transcript from Prosecutor v. S. Milošević), T. 21008-21010. See also D3065 (Witness statement of Aleksandar Vasiljević dated 26 February 2013), para. 173; Dragomir Andan, D3774 (Transcript from Prosecutor v. Stanišić \& Župljanin), T. 21652; P2848 (Witness statement of Milorad Davidović dated 22 June 2011), para. 118. But see D3665 (Witness statement of Vojislav Šešelj dated 1 June 2013), para. 45 (stating that not a single man was sent by the SRS from Serbia to Bijeljina and that the local SRS members who fought in Bijeljina were not under his control). The Chamber does not find this evidence to be reliable given the interest of Šešelj in minimising his own involvement in this regard. The Chamber also notes that Šešelj himself granted the title of "Vojvoda" to Blagojević for his role in the Serbian Chetnik Movement and for his active participation in commanding units which operated in Bijeljina, Zvornik, and Brčko. P5035 (Order of Vojislav Šešelj, 13 May 1993), pp. 1-2. See also para. 234.

1959 P2848 (Witness statement of Milorad Davidović dated 22 June 2011), paras. 76, 117; Milorad Davidović, T. 15479-15484 (28 June 2011), T. 15716 (30 June 2011); KDZ446, P29 (Transcript from Prosecutor v. S. Milošević), T. 21052-21055. See also Živan Filipović, T. 35799 (21 March 2013); P6211 (Four video clips of interviews with Arkan and others, with transcript), pp. 3-4; KDZ531, T. 15868-15869, 15879 (1 July 2011) (closed session); D1459 (Video interview of Arkan in Bijeljina, April 1992); D1612 (Video footage of Arkan in "My Guest, His Truth", July/August 1994), p. 11; D1611 (Video footage depicting Arkan's pre-election campaign in Zvornik, 8 September 1996); KDZ555, T. 17381-17384 (17 August 2011); Dragomir Andan, D3774 (Transcript from Prosecutor v. Stanišić \& Župljanin), T. 21652-21563; D3065 (Witness statement of Aleksandar Vasiljević dated 26 February 2013), para. 174. See also D1442 (Conclusion of Bijeljina's Municipal Assembly Presidency, 29 May 1992) (which imposed a ban on engaging any individuals or groups which had not been invited by the legal authorities). However, Defence evidence suggested that no armed groups came to the municipality at the invitation of the municipal authorities. Svetozar Mihajlović, T. 35678 (20 March 2013); D3140 (Witness statement of Živan Filipović dated 18 March 2013), para. 13; Živan Filipović, T. 35800-35801 (21 March 2013); Cvijetin Simić, T. 35681-35682 (20 March 2013); The Chamber does not find the evidence of these witnesses to be reliable in this regard considering the other credible evidence received on this issue. In addition the Chamber notes that the evidence of Mihajlović and Simić was marked by contradictions and other indicators that they were not being straighforward in their testimony. Furthermore, the Chamber notes that Filipović's evidence on this point is contradictory in the sense that he testified that he did 
she had sent letters to many people including Arkan and others willing to fight in the RS for the "Serbian cause". 1960

609. At the end of March 1992, there were two violent incidents at a Bosnian Muslim and Bosnian Serb café respectively. In one incident a young Bosnian Serb threw a hand grenade into the Istanbul café, injuring a number of people. ${ }^{1961}$ This café was frequented by Bosnian Muslims and the young man had previously been beaten and kicked out of the Istanbul café following an argument. ${ }^{1962}$ In the other incident, a Bosnian Muslim set out from the Istanbul café on horseback on 31 March 1992, intending to throw a grenade at the Srbija café; this resulted in an exchange of fire between Bosnian Muslims and Bosnian Serbs. ${ }^{1963}$ Following these incidents, barricades were erected by Bosnian Muslims at all the important points in Bijeljina and were secured by armed men with the support of the SDA. ${ }^{1964}$ On 31 March 1992 there were armed clashes and shooting incidents between armed Bosnian Muslims, and Serb Forces. ${ }^{1965}$

not know how Arkan and his men came to the municipality but at the same time testified that the authorities did not invite him.

1960 P1105 (Transcript of $22^{\text {nd }}$ session of RS Assembly, 23-24 November 1992), p. 20. See also Vojislav Šešelj, T. 39594 (10 June 2013).

1961 P2929 (Witness statement of KDZ531 dated 25 June 2011), p. 7 (under seal); Živan Filipović, T. 35796 (21 March 2013); D3141 (Witness statement of Dušan Spasojević dated 18 March 2013), para. 8. See also D3065 (Witness statement of Aleksandar Vasiljević dated 26 February 2013), para. 173; D3133 (Witness statement of Cvijetin Simić dated 16 March 2013), para. 18.

1962 D3133 (Witness statement of Cvijetin Simić dated 16 March 2013), para. 18; D3141 (Witness statement of Dušan Spasojević dated 18 March 2013), para. 8.

1963 P2929 (Witness statement of KDZ531 dated 25 June 2011), p. 7 (under seal); Živan Filipović, T. 35796 (21 March 2013); D3141 (Witness statement of Dušan Spasojević dated 18 March 2013), paras. 7-8, 10. See also D3065 (Witness statement of Aleksandar Vasiljević dated 26 February 2013), para. 173; D3133 (Witness statement of Cvijetin Simić dated 16 March 2013), paras. 18-20; D3142 (Criminal report against Hasan Tirić), pp. 21-23; P2901 (SRT video footage of interview of Mirko Blagojević), p. 4; KDZ446, P29 (Transcript from Prosecutor v. S. Milošević), T. 21058.

1964 P2901 (SRT video footage of interview of Mirko Blagojević), pp. 5-6; P2929 (Witness statement of KDZ531 dated 25 June 2011) p. 8 (under seal); D3133 (Witness statement of Cvijetin Simić dated 16 March 2013), paras. 21-23; D3142 (Criminal report against Hasan Tirić), pp. 23, 25; D3137 (Witness statement of Svetozar Mihajlović dated 17 March 2013), para. 4; KDZ446, P29 (Transcript from Prosecutor v. S. Milošević), T. 21059 (testifying that he could not enter Bijeljina because of the barricades erected in both the Muslim and Serb settlements); D3140 (Witness statement of Živan Filipović dated 18 March 2013), para. 8; D3141 (Witness statement of Dušan Spasojević dated 18 March 2013), paras. 11-12; Dušan Spasojević, T. 35831 (21 March 2013). See also KDZ531, T. 15867 (1 July 2011) (closed session). The Accused submits that the speed at which barricades were erected indicated prior planning by the Bosnian Muslims and that they intended to take power in the municipality. Defence Final Brief, para. 1380, referring to D3133 (Witness statement of Cvijetin Simić dated 16 March 2013), para. 22; D3141 (Witness statement of Dušan Spasojević dated 18 March 2013), para. 11; D3140 (Witness statement of Živan Filipović dated 18 March 2013), paras. 7-8; D3137 (Witness statement of Svetozar Mihajlović dated 17 March 2013), para. 6. However, the Chamber does not accept this evidence given that it based purely on speculation by these witnesses.

1965 Adjudicated Facts 2240, 2235; D3140 (Witness statement of Živan Filipović dated 18 March 2013), paras. 7-8; D3141 (Witness statement of Dušan Spasojević dated 18 March 2013), para. 14; D3065 (Witness statement of Aleksandar Vasiljević dated 26 February 2013), para. 174; Aleksandar Vasiljević, T. 34700-34701 (4 March 2013) (testifying that the first clashes occurred when Arkan's men entered Bijeljina). For evidence on actions by Bosnian Muslims forces, see D3140 (Witness statement of Živan Filipović dated 18 March 2013), paras. 7-8, 10; D3137 (Witness statement of Svetozar Mihajlović dated 17 March 2013), para. 6; D3141 (Witness statement of Dušan Spasojević dated 18 March 2013), paras. 11-12, 13-14; Dušan Spasojević, T. 35831 (21 March 2013); 


\section{(C) Events in early April 1992}

\section{(1) $\underline{\text { Take-over }}$}

610. By 1 April 1992, Bijeljina was completely surrounded by check-points. ${ }^{1966}$ Members of the Bosnian Serb leadership in the municipality in a live radio broadcast asked for all citizens to get off the streets and lift the barricades; they also called for restraint. ${ }^{1967}$ On 1 April 1992, negotiations between Bosnian Serb and Bosnian Muslim representatives failed to reach an agreement on the lifting of barricades and fighting continued. ${ }^{1968}$

611. The take-over of Bijeljina began on 1 April 1992 and the Serb Forces involved included Arkan's men, a local unit affiliated with the SRS under the command of Mirko Blagojević, Mauzer's unit, the local TO, the police, the JNA and the local Bosnian Serb population. ${ }^{1969}$

612. Arkan's men came to Bijeljina on 1 April 1992 and, in co-operation with a local unit affiliated with the SRS under the command of Mirko Blagojević, took control of important town structures ${ }^{1970}$ which were then guarded by the police. ${ }^{1971}$ Arkan's men and Mauzer's unit operated

D3142 (Criminal report against Hasan Tirić), pp. 17, 23-26; D3140 (Witness statement of Živan Filipović dated 18 March 2013), para. 10; Živan Filipović, T. 35796 (21 March 2013); Milivoje Kićanović, T. 34882 (6 March 2013); D3137 (Witness statement of Svetozar Mihajlović dated 17 March 2013), para. 6; D3133 (Witness statement of Cvijetin Simić dated 16 March 2013), paras. 21, 23-24; P6211 (Four video clips of interviews with Arkan and others, with transcript), pp. 1-2.

1966 P2929 (Witness statement of KDZ531 dated 25 June 2011), p. 7 (under seal).

1967 D3133 (Witness statement of Cvijetin Simić dated 16 March 2013), para. 25.

1968 D3133 (Witness statement of Cvijetin Simić dated 16 March 2013), para. 27; Cvijetin Simić, T. 35638-35639 (19 March 2013), 35675, 35692-35693 (20 March 2013); P6209 (JNA 2 $2^{\text {nd }}$ Military District report, 1 April 1992), p. 3. See also D3065 (Witness statement of Aleksandar Vasiljević dated 26 February 2013), para. 171; D3140 (Witness statement of Živan Filipović dated 18 March 2013), para. 12. The Accused submits that the meeting failed because the SDA representatives refused to negotiate due to their belief that they had gained control of the municipality. Defence Final Brief, para. 1381. The Chamber does not consider that the evidence in the record supports this proposition.

1969 See Adjudicated Fact 2241; KDZ531, T. 15867 (1 July 2011) (closed session); D1612 (Video footage of Arkan in "My Guest, His Truth", July/August 1994), pp. 11-12; P2901 (SRT video footage of interview of Mirko Blagojević), pp. 5-6; P6209 (JNA 2nd Military District report, 1 April 1992), pp. 1, 3, 5. See also P3033 (Reynaud Theunens's expert report entitled "Radovan Karadžić and the SRBiH TO-VRS (1992-1995)"), e-court pp. 256, 348; Adjudicated Facts 2235, 2242; Richard Butler, T. 27655 (19 April 2012); P2848 (Witness statement of Milorad Davidović dated 22 June 2011), para. 118; D3665 (Witness statement of Vojislav Šešelj dated 1 June 2013), para. 49; KDZ446, P29 (Transcript from Prosecutor v. S. Milošević), T. 21008-21010, 21055, 21109; P2629 (Bijeljina's SJB report, 9 April 1992), p. 2.

1970 See Adjudicated Fact 2241; KDZ531, T. 15867 (1 July 2011) (closed session); D1612 (Video footage of Arkan in "My Guest, His Truth", July/August 1994), pp. 11-12; P2901 (SRT video footage of interview of Mirko Blagojević), pp. 5-6; P6209 (JNA $2^{\text {nd }}$ Military District report, 1 April 1992), pp. 1, 3, 5. See also Adjudicated Fact 2235; Richard Butler, T. 27655 (19 April 2012); P2848 (Witness statement of Milorad Davidović dated 22 June 2011), para. 118; D3665 (Witness statement of Vojislav Šešelj dated 1 June 2013), para. 49; KDZ446, P29 (Transcript from Prosecutor v. S. Milošević), T. 21008-21010, 21055, 21109. Spasojević testified that municipal structures remained unchanged and that neither Arkan nor any other paramilitary took over a single municipal structure or post. D3141 (Witness statement of Dušan Spasojević dated 18 March 2013), para. 21; Dušan Spasojević, T. 35837-35838 (21 March 2013). The Chamber does not consider that this evidence is of much significance or contradicts the other credible evidence received on this point. 
under the supervision of the Bijeljina Crisis Staff and started to remove the Bosnian Muslim barricades in the centre of Bijeljina ${ }^{1972}$ which resulted in clashes. ${ }^{1973}$ Arkan's men also received the help of the local Bosnian Serb population who collected weapons that had been distributed to them from various depots. ${ }^{1974}$ Members of the local TO were also present in Bijeljina town. ${ }^{1975}$

613. On 1 or 2 April 1992, armed JNA reservists surrounded the town and columns of JNA tanks and other vehicles were seen in the area. ${ }^{1976}$ On 1 April 1992, the Bijeljina Crisis Staff reported to the SDS Main Board about the imposition of a curfew and about the use of ethnically mixed patrols of the JNA to control vital buildings and areas in the town. ${ }^{1977}$ The army barracks were blocked by Bosnian Serbs and Arkan's men who threatened to attack the JNA if it were to interfere in the conflict. $^{1978}$ Arkan also encouraged Bosnian Serbs to leave the army and join his formations after which a large number of reservists took their weapons and did so. ${ }^{1979}$

614. On 2 April 1992, the Serbian flag was raised on the high-rise building in the centre of the city $^{1980}$ and by 4 April 1992, the town of Bijeljina was controlled by the SDS and Arkan's men. ${ }^{1981}$ Arkan was welcomed in Bijeljina and "treated like a god"; some of his men were given official

1972 P2629 (Bijeljina's SJB report, 9 April 1992), pp. 1-2. See also D3065 (Witness statement of Aleksandar Vasiljević dated 26 February 2013), para. 171; Aleksandar Vasiljević, T. 34700 (4 March 2013); P6211 (Four video clips of interviews with Arkan and others, with transcript), pp. 2, 4-5; P2884 (Article from List SAO Semberije I Majevice entitled "Semberija Lost for Alija's Islamic State", 15 June 1992), p. 1.

1973 D3142 (Criminal report against Hasan Tirić), pp. 26-27. See also Dušan Spasojević, T. 35887 (22 March 2013); D3133 (Witness statement of Cvijetin Simić dated 16 March 2013), para. 30; D3089 (Witness statement of Milivoje Kićanović dated 3 March 2013), para. 15; KDZ555, T. 17367 (17 August 2011); D1459 (Video interview of Arkan in Bijeljina, April 1992).

1974 D1612 (Video footage of Arkan in "My Guest, His Truth", July/August 1994), p. 11.

1975 See Adjudicated Fact 2242.

1976 Adjudicated Fact 2241.

1977 P2626 (Report of Bijeljina Crisis Staff, 1 April 1992), p. 1. See also P2629 (Report of Bijeljina SJB, undated) a report sent to Mićo Stanišić about the situation in Bijeljina in April 1992. But see P3033 (Reynaud Theunens's expert report entitled "Radovan Karadžić and the SRBiH TO-VRS (1992-1995)"), e-court p. 381 (reporting on Blagojević's observation that there was no significant support from the JNA).

1978 D3065 (Witness statement of Aleksandar Vasiljević dated 26 February 2013), para. 176.

1979 D3065 (Witness statement of Aleksandar Vasiljević dated 26 February 2013), para. 177; P5474 (Report of JNA $17^{\text {th }}$ Corps, 4 April 1992), p. 1.

1980 P2901 (SRT video footage of interview of Mirko Blagojević), pp. 6-7. See also Milivoje Kićanović, T. 34892 (6 March 2013); P6185 (Article from Slobodna Bosna entitled "The Bloody Byram in Bijeljina", 10 April 1992), p. 2.

1981 P5474 (Report of JNA 17 $7^{\text {th }}$ Corps, 4 April 1992), pp. 1-2; P3033 (Reynaud Theunens's expert report entitled "Radovan Karadžić and the SRBiH TO-VRS (1992-1995)"), e-court pp. 377-378, 381; P2901 (SRT video footage of interview of Mirko Blagojević), pp. 5-6; P2073 (BBC news report re Bijeljina, with transcript), p. 1 See also Milivoje Kićanović, T. $34892-34894$ (6 March 2013); P6211 (Four video clips of interviews with Arkan and others, with transcript), pp. 5-6. But see D239 (Report of 17 ${ }^{\text {th }}$ Corps, 3 April 1992), p. 1 (in which the JNA $17^{\text {th }}$ Corps reported that the situation was out of control and that party leaders were "incapable of ensuring peace and preventing the anarchical behaviour of individuals and groups"). 
positions and based themselves in the local SDS building; they accompanied regular police patrols for several days and were involved in arresting members of Bijeljina's SDA presidency. ${ }^{1982}$

615. On 3 April 1992, the JNA $17^{\text {th }}$ Corps reported that even though the situation in Bijeljina had "calmed somewhat" there was still "general chaos, anarchy and panic in the town" with rumours that Bosnian Muslims were being slaughtered. ${ }^{1983}$

616. Arkan left Bijeljina on 6 April 1992, but some of his men came to Bijeljina after that date from time to time. ${ }^{1984}$ In late April or early May 1992 some of Arkan's men had taken over the SUP and threatened the police. ${ }^{1985}$ When Davidović reported to Petar Gračanin, the Federal Minister of the Interior, and Mićo Stanišić that Arkan's men had taken over the SUP, Stanišić commented that he knew, that nothing else could be done, and that's "how it ha[d] to be". ${ }^{1986}$ Mićo Stanišić told Davidović that Arkan's men were in Bijeljina and Zvornik "helping to liberate territory they believed should become part of the [RS]" and that "there was an agreement with Arkan that whatever area they took, they could take any property, any war booty and that would have been the price to pay for their engagement there."1987

1982 P2848 (Witness statement of Milorad Davidović dated 22 June 2011), para. 117. See Adjudicated Fact 2242. Defence witnesses disputed the arrest of members of the SDA presidency in Bijeljina. D3133 (Witness statement of Cvijetin Simić dated 16 March 2013), para. 40; D3137 (Witness statement of Svetozar Mihajlović dated 17 March 2013), para. 18. However, the Chamber does not find this evidence to be reliable. In reaching that conclusion the Chamber noted that Simić's evidence was marked by indicators which led to the conclusion that he was withholding information from the Chamber, was evasive and lacked sincerity. The Chamber cannot rely on Mihajlović's qualified evidence on this point as he simply stated that he did not know of anyone arresting members of the SDA presidency.

1983 D239 $\left(17^{\text {th }}\right.$ Corps Command combat report, 3 April 1992), p. 1; P3033 (Reynaud Theunens's expert report entitled "Radovan Karadžić and the SRBiH TO-VRS (1992-1995)"), e-court p. 377. See also D3140 (Witness statement of Živan Filipović dated 18 March 2013), para. 14 (stating that a meeting was held on 6 April 1992 in Janja where Bosnian Muslims were informed that the rumours about the massacre of Bosnian Muslims were false after which they surrendered their weapons).

1984 Živan Filipović, T. 35806 (21 March 2013). See also KDZ531, T. 15876 (1 July 2011) (closed session); Adjudicated Fact 2249. Defence evidence suggested that Arkan's men arrived on 1 April 1992 but only remained in Bijeljina for about five days. D3137 (Witness statement of Svetozar Mihajlović dated 17 March 2013), para. 19; Svetozar Mihajlović, T. 35724 (20 March 2013). See also D3133 (Witness statement of Cvijetin Simić dated 16 March 2013), para. 41; D3141 (Witness statement of Dušan Spasojević dated 18 March 2013), para. 23. The Chamber does not consider that evidence which suggested that Arkan left the municipality after a few days is inconsistent with the evidence that some of his men were in Bijeljina from time to time. See also P2881 (Report of Bijeljina CJB, July 1992), p. 2; P2848 (Witness statement of Milorad Davidović dated 22 June 2011), para. 64; D1450 (Milorad Davidović's statement to Belgrade District Court, 26 December 2007), p. 57; P2900 (Letter from Bijeljina CSB to Radovan Karadžić, 29 July 1992), p. 2.

1985 P2848 (Witness statement of Milorad Davidović dated 22 June 2011), paras. 64, 66; D1450 (Milorad Davidović's statement to Belgrade District Court, 26 December 2007), p. 57; P2900 (Letter from Bijeljina CSB to Radovan Karadžić, 29 July 1992), p. 2.

1986 P2848 (Witness statement of Milorad Davidović dated 22 June 2011), paras. 66, 73.

1987 P2848 (Witness statement of Milorad Davidović dated 22 June 2011), para. 66. 
617. The Prosecution alleges that at least 48 civilians were killed in the town of Bijeljina on 1 and 2 April 1992.

618. The Chamber took judicial notice of the fact that at least 48 civilians, were killed by Serb paramilitaries during the Bosnian Serb take-over of Bijeljina ${ }^{1988}$ and a total of 48 bodies, including those of women and children, were collected from the town's streets and houses, 45 of these victims were non-Serbs and none wore uniforms. ${ }^{1989}$ The Chamber also took judicial notice of the fact that most of the dead had been shot in the chest, mouth, temple, or back of the head, some at close range. ${ }^{1990}$

619. Witnesses also testified that civilians were killed in Bijeljina on 1 April 1992. ${ }^{1991}$ A total of 55 individuals who went missing from Bijeljina between 1 April 1992 and 15 September 1993 were exhumed from individual or mass graves in the area. ${ }^{1992}$ However, of these 55 exhumed bodies, only five are linked to this scheduled incident. ${ }^{1993}$ The Chamber will not make a finding with respect to the remaining 50 exhumed bodies.

1988 Adjudicated Fact 2243. The Chamber notes that the Accused's submits that there was paramilitary activity prior to Scheduled Incident A.1.1. The Accused also submits that at the time of the incident the "local and military forces" were in a state of disarray and could not prevent the incident from occuring. See Defence Final Brief, para. 1388. However, the Chamber does not consider that the evidence cited by the Accused or the other evidence received in this case supports the conclusion that the local forces were unable to prevent the incident from occuring. The Accused also cites to D3142 to support his proposition that a criminal report was filed against the perpetrators of the attack who could be identified. The Chamber notes that D3142 is a criminal report filed against Bosnian Muslims for armed rebellion.

1989 Adjudicated Fact 2245.

$1990 \quad$ Adjudicated Fact 2246.

1991 KDZ531, T. 15866, 15930-15933 (1 July 2011) (closed session); Martin Bell, T. 9781-9782 (14 December 2010); P2001 (BBC news report re Zvornik, with transcript), p. 1; D3065 (Witness statement of Aleksandar Vasiljević dated 26 February 2013), para. 176; P2848 (Witness statement of Milorad Davidović dated 22 June 2011), para. 117; P2919 (Witness statement of KDZ023 dated 29 September 1996), pp. 11, 28 (a photograph depicting a soldier identified as one of Arkan's men kicking bodies). KDZ446 testified about the killings of tens of people behind the SDS building and that he heard that some men were taken by Arkan's men to their garrison and shot: KDZ446, P29 (Transcript from Prosecutor v. S. Milošević), T. 21108. The database of the Missing Persons Institute of $\mathrm{BiH}$ included five individuals who had been exhumed and identified who were allegedly killed in Bijeljina in early April 1992 and who were linked by Mašović to Scheduled Incident A.1.1. P4853 (Updated Table 2 to the Report of Amor Mašović), pp. 1-2 (the Chamber notes that when the English translation of a document is incomplete, the references cited in this Judgement are to the original version); P4850 (Witness statement of Amor Mašović dated 23 March 2012), para. 118; Amor Mašović, T. 27218-27219 (10 April 2012). The Chamber notes that Amor Mašović was a member of the State Commission for Exchange of Prisoners of War, Captured Persons and Bodies of People Killed and Record of People Killed, Injured, and Missing on the Territory of the Republic of $\mathrm{BiH}$, also referred to as State Commission for Tracing Missing Persons and the Missing Persons Institute. P4850 (Witness statement of Amor Mašović dated 23 March 2012), para. 2.

1992 P4853 (Updated Table 2 to the Report of Amor Mašović), pp. 1-2; Amor Mašović, T. 27218-27219 (10 April 2012).

1993 P4853 (Updated Table 2 to the Report of Amor Mašović), pp. 1-2 (referring to Adnan Komšić, Mustafa Komsić, Rijad Komšić, Muhamed Mulabdić, and Ajruš Ziberi). 
620. The Accused disputed (i) the number of Bosnian Muslim victims; (ii) their status as civilians; (iii) the circumstances in which they were killed; and (iv) the identity of the perpetrators, and tendered evidence in support. ${ }^{1994}$ However, the Chamber does not find the Accused's arguments to be convincing or the evidence adduced by the Accused on these issues to be reliable. In reaching this conclusion the Chamber considered that the evidence of the witnesses was either based on speculation or hearsay information and when cross-examined the source of the information was unclear. ${ }^{1995}$ The Chamber does not accept the self-serving video of Arkan that he only killed "Albanian extremists" in Bijeljina. ${ }^{1996}$

621. A report of the $17^{\text {th }}$ Corps of the JNA dated 7 April 1992 noted that the Bijeljina MUP had provided them with information that the conflict in Bijeljina had resulted in 43 casualties consisting of 28 Bosnian Muslims, two Bosnian Croats, eight Albanians, and five Bosnian Serbs and that some victims had been buried without identification. ${ }^{1997}$ An article dated 10 April 1992 referred to the killing of 40 individuals in Bijeljina whose bodies were buried without religious rites. ${ }^{1998}$

1994 See Defence Final Brief, para. 1388. The Accused tendered the following evidence in support of his position: D3140 (Witness statement of Živan Filipović dated 18 March 2013), para. 22; Živan Filipović, T. 35796 (21 March 2013); D3089 (Witness statement of Milivoje Kićanović dated 3 March 2013), para. 24. Kićanović also claimed that there were 42 victims and that this number included seven Bosnian Serbs and that the Bosnian Muslims who had previously shot at him were not in uniform. On cross-examination he confirmed that this information was provided to him by those who conducted an on-site investigation at the hospital and that he had not seen the bodies himself. Milivoje Kićanović, T. 34889-34890 (6 March 2013). See also D3133 (Witness statement of Cvijetin Simić dated 16 March 2013), para. 39; Cvijetin Simić, T. 35633 (19 March 2013). Simić also stated that the armed Bosnian Muslims who guarded barricades were not in uniforms. Defence witnesses also denied knowledge of the killings. D3076 (Witness statement of Savo Bojanović dated 2 March 2013), para. 20. See also P2901 (SRT video footage of interview of Mirko Blagojević), p. 7. The District Council of Bijeljina on 16 April 1992 wrote to Cyrus Vance and the Accused that there had been false information regarding the number of victims in the town and invited them to visit Bijeljina to observe the situation and that the total number of victims was 41 and included "Muslim Fundamentalists and Albanian Mercenaries". D1463 (Bijeljina District Council letter to Cyrus Vance and Radovan Karadžić, 16 April 1992). KDZ531 confirmed that this was the figure of victims which was mentioned in public and that a three-member delegation did visit Bijeljina. KDZ531, T. 15877-15878 (1 July 2011) (closed session).

1995 For example see Dušan Spasojević, T. 35839, 35842-35843 (21 March 2013); Dušan Spasojević, T. 35841 (21 March 2013) (private session); P2919 (Witness statement of KDZ023 dated 29 September 1996), p. 28.

1996 D1461 (Video interview of Arkan in Bijeljina, April 1992); P5588 (Video footage of interviews with Ivan Rakić and Željko Ražnatović, Arkan), p. 3; D1612 (Video footage of Arkan in "My Guest, His Truth", July/August 1994), p. 11. Arkan in an interview suggested that after Serb Forces broke through to the hospital, Bosnian Muslims were treated fairly and those who did not carry weapons had no problems. P6211 (Four video clips of interviews with Arkan and others, with transcript), p. 5. However, the Chamber does not consider this media clip to be reliable for the purposes of making a finding in this regard. Similarly the Chamber does not regard Arkan's own denial of mistreatment to be reliable. See KDZ531, T. 15869, 15871-15872, 15932-15933 (1 July 2011) (closed session); D1459 (Video interview of Arkan in Bijeljina, April 1992); D3142 (Criminal report against Hasan Tirić), p. 22; P6211 (Four video clips of interviews with Arkan and others, with transcript), pp. 34; D1460 (Video interview of Arkan in Bijeljina, April 1992); D1461 (Video interview of Arkan in Bijeljina, April 1992). The Chamber also considered that KDZ531 testified that Arkan made unsubstantiated claims that Albanian extremists had arrived in the municipality. KDZ531, T. 15872 (1 July 2011) (closed session).

1997 P6214 (Report of JNA $17^{\text {th }}$ Corps, 7 April 1992), p. 1.

1998 P6185 (Article from Slobodna Bosna entitled "The Bloody Byram in Bijeljina”, 10 April 1992), p. 1. Of the 40 individuals referred to in the article, one was unidentified and four other individuals had been buried previously 
622. The Bijeljina SJB in a report to the Bosnian Serb MUP referred to 31 individuals who were killed at a barricade near the hospital in Bijeljina. ${ }^{1999}$ The SJB report also suggests that six of the individuals named as victims of this incident ${ }^{2000}$ were killed by armed Bosnian Muslims. ${ }^{2001}$ The Chamber does not accept the conclusion of the SJB report that 31 individuals were killed while "putting up armed resistance" at the barricade or that the six individuals were killed by Bosnian Muslims. ${ }^{2002}$ In reaching that conclusion the Chamber noted that the language used in the Bijeljina SJB report is highly inflammatory and one-sided, which undermines its reliability and the weight which can be attributed to it. ${ }^{2003}$ Similarly, while there are differing contemporaneous reports as to the number of individuals killed, the Chamber does not consider that these reports undermine the evidence that in total at least 45 non-Serb civilians were killed on 1 and 2 April 1992, that most of the dead had been shot in the chest, mouth, temple, or back of the head, some at close range and that the victims included women and children and were not wearing uniforms. ${ }^{2004}$ Considering (i) the nature of the injuries; (ii) that the victims did not wear uniforms and were identified as civilians; and (iii) that the victims included women and children, the Chamber finds that these individuals were not killed during armed clashes.

623. The Chamber also received evidence which referred to the killing of Bosnian Muslims after 2 April 1992. ${ }^{2005}$ However, beyond noting this evidence for the purpose of setting the general

and appear to be Bosnian Serbs. The 39 named individuals in this article correspond to the names of listed victims. Prosecution Final Brief, Appendix, G.

D3142 (Criminal report against Hasan Tirić), pp. 26-27. Of the 31 named individuals in this report, 27 correspond to the names of listed victims. Prosecution Final Brief, Appendix, G.

2000 Bisera Bišanović, Mirsada Bišanović, Nermina Bišanović, Zvonko Lazarević, Radmila Novaković and Ivo Vrhovec.

2001 D3142 (Criminal report against Hasan Tirić), pp. 16, 26-27.

2002 See D3142 (Criminal report against Hasan Tirić), p. 27.

2003 For example the report refers to the Muslim "fanatics", "extremists", "fundamentalists [...] [who] wanted to establish a Muslim state". It also refers to the crushing of barricades and Muslims who "have stained their hands with the Serbs' blood". D3142 (Criminal report against Hasan Tirić), p. 27. The Chamber also notes that on cross-examination Spasojević acknowledged that he did not know the source of the information which suggested that these Bosnian Muslims were killed while putting up armed resistance. Dušan Spasojević, T. 35842 (21 March 2013).

2004 Adjudicated Facts 2243, 2245, 2246.

2005 P2929 (Witness statement of KDZ531 dated 25 June 2011), pp. 7-8 (under seal); KDZ531, T. 15846-15847 (1 July 2011) (closed session) (testifying about the killing of SDA leaders); P2629 (Bijeljina's SJB report, 9 April 1992), p. 2; P6218 (Excerpt from report on war crimes trials in Serbia in 2012), pp. 2-5; P6219 (Order of Bijeljina Prosecutor's Office, 14 July 2009), pp. 2-3; Dušan Spasojević, T. 35857-35860 (22 March 2013); KDZ531, T. 15853 (1 July 2011) (closed session); P6217 (Certificate of Bijeljina Red Cross, 20 May 2002), pp. 1-2; P2878 (Announcement of SRS, September 1992), p. 1; P3033 (Reynaud Theunens's expert report entitled "Radovan Karadžić and the SRBiH TO-VRS (1992-1995)"), e-court p. 383; P2848 (Witness statement of Milorad Davidović dated 22 June 2011), paras. 121, 151-152; Milorad Davidović, T. 15507 (28 June 2011), T. 15585-15591 (29 June 2011). See also Dragomir Ljubojević, T. 35897 (22 March 2013); Dragomir Andan, D3774 (Transcript from Prosecutor v. Stanišić \& Župljanin), T. 21737, 21740, 21824-21826; D3807 (Official note of BiH Prosecutor's Office, 12 December 2007), p. 1. While some steps were taken to investigate these incidents there was an ultimate failure of the authorities in Bijeljina to initiate proceedings against the perpetrators. Dušan Spasojević, T. 35858, 35860-35864 (22 March 2013); P6218 (Excerpt from report on war crimes trials in Serbia in 2012), pp. 4, 5; P6219 (Order of Bijeljina Prosecutor's Office, 14 July 2009), pp. 3-5; 
background in Bijeljina after the take-over, the Chamber did not consider this evidence for the purpose of establishing the occurrence of crimes charged in the Indictment and the Accused's responsibility thereon. ${ }^{2006}$

624. The Chamber therefore finds that at least 45 civilians were killed by Serb Forces on 1 and 2 April 1992 in the town of Bijeljina.

\section{(D) Developments in Bijeljina after take-over}

625. Following the removal of barricades from the municipality, Serb Forces continued with a "global mopping-up" in Bijeljina until 6 April 1992. ${ }^{2007}$

626. On 4 April 1992 a commission consisting of, amongst others, Biljana Plavšić and Fikret Abdić, and high-ranking army officials visited Bijeljina to assess the situation. ${ }^{2008}$ The removal of bodies from the streets of Bijeljina was ordered by Serb Forces in anticipation of the visit of this delegation. ${ }^{2009}$ Plavšić visited the Bijeljina Crisis Staff and congratulated Arkan for saving the Bosnian Serbs and was filmed kissing and hugging Arkan. ${ }^{2010}$ When, in the course of the visit, Plavšić asked Arkan to hand over control of Bijeljina to the JNA, he replied that he had not yet

Dragomir Andan, D3774 (Transcript from Prosecutor v. Stanišić \& Župljanin), T. 21827; P2929 (Witness statement of KDZ531 dated 25 June 2011), p. 8 (under seal); Milorad Davidović, T. 15506-15507 (28 June 2011); P2848 (Witness statement of Milorad Davidović dated 22 June 2011), para. 159; D3807 (Official note of BiH Prosecutor's Office, 12 December 2007), p. 2; KDZ531, T. 15854 (1 July 2011) (closed session); Svetozar Mihajlović, T. 35735-35736, 35741 (20 March 2013); D3141 (Witness statement of Dušan Spasojević dated 18 March 2013), para. 25; Dušan Spasojević, T. 35844, 35846-35847 (21 March 2013); P6215 (Letter from Bijeljina CJB to Bijeljina Prosecutor's Office, 14 June 2002), p. 1; P6216 (Official note of Bijeljina SJB, 3 June 2002), pp. 1-2.

2006 The Chamber notes that the killing incidents alleged with respect to Bijeljina are limited to Scheduled Incident A.1.1 (killings on 1 and 2 April 1992 in Bijeljina town) and Scheduled Incident B.2.1 (killings at Batković camp from June 1992 until June 1995).

2007 P2629 (Report of Bijeljina SJB, undated), p. 2.

2008 D3137 (Witness statement of Svetozar Mihajlović dated 17 March 2013), para. 9; Svetozar Mihajlović, T. 35726 (20 March 2013); D3133 (Witness statement of Cvijetin Simić dated 16 March 2013), para. 32. See also P6211 (Four video clips of interviews with Arkan and others, with transcript), pp. 5-6; Milivoje Kićanović, T. 34893 34894 (6 March 2013); P6185 (Article from Slobodna Bosna entitled "The Bloody Byram in Bijeljina", 10 April 1992), p. 5; Živan Filipović, T. 35806 (21 March 2013); Momčilo Krajišnik, T. 43336 (12 November 2013); D1694 (Intercept of conversation between Ješirić and Čedo Kljajić, 16 April 1992), pp. 1-2; KDZ531, T. 15876-15877 (1 July 2011) (closed session).

2009 See Adjudicated Fact 2247.

2010 Momčilo Mandić, T. 4656 (6 July 2010); P1108 (Video footage of Biljana Plavšić and Arkan in Bijeljina); KDZ446, P5587 (Video footage of interviews with Biljana Plavšić), p. 3; P29 (Transcript from Prosecutor v. S. Milošević), T. 21012-21013; KDZ555, T. 17267-17268 (16 August 2011); P3212 (Witness statement of Ibro Osmanović dated 23 August 2011), para. 16; Aleksandar Vasiljević, T. 34701-34702 (4 March 2013); see Adjudicated Fact 2248; P6185 (Article from Slobodna Bosna entitled "The Bloody Byram in Bijeljina", 10 April 1992), p. 5; P6211 (Four video clips of interviews with Arkan and others, with transcript), p. 8. See also P2828 (Witness statement of Asim Džambasović dated 18 June 2011), para. 96; Vojislav Šešelj, T. 39594 (10 June 2013) (testifying that Arkan had come to Bijeljina with Plavšić's "blessing”). But see D3137 (Witness statement of Svetozar Mihajlović dated 17 March 2013), paras. 8-9; Svetozar Mihajlović, T. 35723-35725 (20 March 2013). See also Svetozar Mihajlović, T. 35727 (20 March 2013); P1106 (Intercept of conversation between Biljana Plavšić and "Rus", 23 April 1992). 
finished his "business" there. ${ }^{2011}$ At a dinner with UNPROFOR representative, Cedric Thornberry, on 20 April 1992, Plavšić described Bijeljina as a "liberated" town. ${ }^{2012}$

627. After the fighting ended, the local authorities including the TO Municipal Staff returned to Bijeljina. $^{2013}$ The Bijeljina SJB began operations in accordance with the instructions and guidelines of the Bosnian Serb MUP. ${ }^{2014}$ On 28 April 1992, the Presidency of the Bijeljina Municipal Assembly issued a decision which provided that only members of the active and reserve police forces and members of the armed forces should maintain public law and order and strictly prohibited the establishment of local check-points by civilians and unauthorised persons without the approval of the Bijeljina SJB. ${ }^{2015}$

628. On 24 June 1992, the Bijeljina Municipal Assembly issued a decision on its composition and rules of procedure and provided that the Bijeljina Municipal Assembly would consist of members of "Serbian nationality". ${ }^{2016}$

629. In April and May 1992, Bosnian Muslim employees were dismissed from their jobs and Bosnian Muslim members of the local municipal government were dismissed from their positions and expelled from their apartments. ${ }^{2017}$ Family members of Bosnian Muslim intellectuals and leaders were dismissed from their positions and harassed. ${ }^{2018}$ Bosnian Muslim police officers were

2011 Adjudicated Fact 2248; P6185 (Article from Slobodna Bosna entitled "The Bloody Byram in Bijeljina", 10 April 1992), p. 5. See also P6211 (Four video clips of interviews with Arkan and others, with transcript), p. 6.

2012 Adjudicated Fact 2236. See also P2849 (Intercept of conversation between Goran Sarić and Mićo Davidović, 21 April 1992), p. 4; Milorad Davidović, T. 15459 (24 June 2011) (testifying that he was informed on 21 April 1992 by Goran Sarić that Bijeljina and Zvornik had been "solved" which he understood to mean that Bosnian Serbs had taken over power and there was no longer a problem).

2013 D3140 (Witness statement of Živan Filipović dated 18 March 2013), paras. 9, 11. See also P2748 (SerBiH MUP daily report, 22 and 23 April 1992), p. 3; P2884 (Article from List SAO Semberije I Majevice entitled "Semberija Lost for Alija's Islamic State", 15 June 1992), p. 1.

2014 P2629 (Bijeljina's SJB report, 9 April 1992), pp. 1-2 (which also reports that the Bosnian Serb police wore berets and badges with the "tricolours from the Serbian MUP" from 4 April 1992).

2015 D1441 (Bijeljina’s Municipal Assembly Presidency decision, 12 May 1992), p. 1.

2016 D3136 (Bijeljina Municipal Assembly decision, 24 June 1992), p. 1. See also Svetozar Mihajlović, T. 35686 (20 March 2013). The Chamber notes that Simić testified that this decision was taken in accordance with the law. Cvijetin Simić, T. 35706 (20 March 2013). The Chamber does not consider Simić's evidence in this regard to be of relevance to its assessment of the evidence on this issue given that the effect of the decision was to reduce the size of the Municipal Assembly to include only Bosnian Serb representatives.

2017 P2929 (Witness statement of KDZ531 dated 25 June 2011), pp. 2, 8 (under seal); KDZ531, T. 15842-15844 (1 July 2011) (closed session) (testifying that Bosnian Muslims were forced to leave their jobs in April or May 1992 by VRS soldiers who used slurs and threatened them). See also Svetozar Mihajlović, T. 35686 (20 March 2013) (testifying about the replacement of the Bosnian Muslim TO commander with a Bosnian Serb). Kićanović testified that patients at Bijeljina hospital received treatment without discrimination. D3089 (Witness statement of Milivoje Kićanović dated 3 March 2013), paras. 16-17. However, the Chamber does not consider that this evidence is of relevance to the allegations with respect to Bijeljina given that the Prosecution has not led any evidence to suggest that there was discrimination with respect to access or treatment at the hospital.

2018 P2929 (Witness statement of KDZ531 dated 25 June 2011), p. 8 (under seal). The Accused tendered evidence to suggest that Bosnian Muslims continued to be appointed to the commission for the enrolment of students in Bijeljina on 14 April 1992. D1440 (Decision of Bijeljina's Municipal Assembly Presidency, 12 April 1992), pp. 
forced to pledge loyalty to the Bosnian Serb authorities and wear the Serb flag on their caps to retain their jobs. $^{2019}$

630. On 15 June 1992, Mauzer stated that the presidency of SAO Semberija-Majevica had decided to replace Bosnian Muslims in managerial positions in Bijeljina, and should "the genocide against the Serbian people" in BiH continue, all Bosnian Muslims would be fired from their jobs and expelled from the territory. ${ }^{2020}$ Mauzer also stated that the 2,500 Bosnian Muslims aged between 18 and 35 who had fled Bijeljina in the aftermath of the take-over would lose their jobs, and their apartments would be seized and sealed, and he advised them not to return. ${ }^{2021}$

631. Paramilitary formations were involved in mistreating and stealing from the population. ${ }^{2022}$ More specifically, Arkan's men destroyed property of individuals involved with the SDA, ${ }^{2023}$ engaged in looting, and went to the homes of wealthy Bosnian Muslims demanding money. ${ }^{2024}$ Bosnian Muslims feared for their lives if they refused the demands of Arkan's men. ${ }^{2025}$ Croat

1-2. However, the Chamber finds that in light of Davidović's evidence on this document, it is not of much significance given that some Bosnian Muslims who were appointed in this period were eventually removed from office. Milorad Davidović, T. 15761-15762 (30 June 2011). P2929 (Witness statement of KDZ531 dated 25 June 2011), p. 8 (under seal) (stating that a Bosnian Muslim police officer who signed an oath of loyalty and agreed to wear the Serb insignia was fired and was put under pressure, which forced him to leave Bijeljina).

2020 Adjudicated Fact 2238; P2884 (Article from List SAO Semberije I Majevice entitled "Semberija Lost for Alija's Islamic State", 15 June 1992), p. 2. Defence witnesses disputed Adjudicated Fact 2238. D3140 (Witness statement of Živan Filipović dated 18 March 2013), para. 23; D3137 (Witness statement of Svetozar Mihajlović dated 17 March 2013), para. 20. However, the Chamber notes that the evidence of Filipović and Mihajlović simply states that they had not heard of this statement or decision but does not contradict the evidence that Mauzer did make such a statement or that the SAO did reach such a decision.

$2021 \quad$ Adjudicated Fact 2239.

2022 D1412 (Report of Republic of Serbia MUP, 8 August 1992), pp. 2, 6; P2899 (Report of Bijeljina CSB, 29 July 1992), p. 1; P3033 (Reynaud Theunens's expert report entitled "Radovan Karadžić and the SRBiH TO-VRS (1992-1995)"), e-court pp. 383-384; D3665 (Witness statement of Vojislav Šešelj dated 1 June 2013), para. 46. See also Dragomir Andan, D3774 (Transcript from Prosecutor v. Stanišić \& Župljanin), T. 21436-21437, 21563; Dragomir Andan, T. 40836 (5 July 2013); P2900 (Letter from Bijeljina CSB to Radovan Karadžić, 29 July 1992), p. 2.

2023 P2929 (Witness statement of KDZ531 dated 25 June 2011), p. 7 (under seal).

2024 P2848 (Witness statement of Milorad Davidović dated 22 June 2011), paras. 117-118; Dragomir Andan, T. 40860-40861 (5 July 2013); KDZ531, T. 15868-15869, 15879 (1 July 2011) (closed session); Čedomir Kljajić, T. 42210 (30 July 2013) (testifying that he received reports about Arkan's operations in Bijeljina and that he had been involved in looting). See also Dragomir Andan, T. 40837-40838, 40857-40858 (5 July 2013). Arkan himself denied claims which he attributed to media controlled by the SDA that his men had come into the town, were terrorising and mistreating people and looting homes. D1459 (Video interview of Arkan in Bijeljina, April 1992); D1612 (Video footage of Arkan in "My Guest, His Truth", July/August 1994), p. 11. The Chamber does not find this evidence reliable given that it is based on Arkan's own interview where he has a clear interest in distancing himself from these incidents.

2025 P2848 (Witness statement of Milorad Davidović dated 22 June 2011), para. 117. The Accused submits that Arkan's men fought against Bosnian Muslim, Bosnian Croat, and Albanian paramilitary units, that both Bosnian Serbs and Bosnian Muslims were in a state of fear in Bijeljina and that Arkan publicly guaranteed safety to both the Bosnian Serbs and Muslims, see Defence Final Brief, confidential, paras. 1076-1077. In support, the Accused refers to a video which depicts a person who identified herself as a Muslim woman who refuted the allegations of looting, and destruction by Arkan's men and that they did not fear them as they had come to help. D1462 (Video interview of Arkan and Bijeljina residents, April 1992); [REDACTED]. The Chamber does not find this video evidence to be reliable, as it is unclear under what circumstances the video was made and it 
companies were also looted by Arkan's men. ${ }^{2026}$ There was also an incident in June 1992 when paramilitaries raped two Bosnian Muslim women and paraded them naked through a town before they took them away by car and raped them again. ${ }^{2027}$

632. After some time, when the paramilitaries ran out of Bosnian Muslim houses to steal from, they started robbing Bosnian Serb houses and committed crimes against Serbs as well. ${ }^{2028}$ There were some difficulties in controlling the actions of paramilitaries. ${ }^{2029}$ However, the Chamber finds that paramilitaries were allowed to operate with impunity; all the police not aligned to the Crisis Staff or the SDS had been removed ${ }^{2030}$ and some of the crimes were carried out with the assistance of members of the SJB. ${ }^{2031}$ In addition the paramilitaries continued to receive support from local Bosnian Serbs. ${ }^{2032}$

633. The Chamber concludes that it was only after paramilitaries started undermining the authority of the local institutions by forming their own parallel authorities ${ }^{2033}$ and also attacking Bosnian Serbs that the municipal authorities sought to exercise some real control over these

cannot verify whether or not it was made for propaganda purposes and that in addition Arkan is present and accompanied by armed men in this video. The Chamber therefore does not accept the Accused's submission that this video demonstrated that Arkan did not create fear among Bosnian Muslims. The Chamber does accept, however, that some Bosnian Serbs also feared Arkan's men. [REDACTED]. See also P2901 (SRT video footage of interview of Mirko Blagojević), p. 7; P2900 (Letter from Bijeljina CSB to Radovan Karadžić, 29 July 1992), p. 2. P2848 (Witness statement of Milorad Davidović dated 22 June 2011), para. 118. While Davidović referred to Croatian owned companies, the Chamber finds that this related to Bosnian Croat owned companies.

2027 Dušan Spasojević, T. 35857-35860 (22 March 2013); P6218 (Excerpt from report on war crimes trials in Serbia in 2012).

2028 Dragomir Andan, T. 40829-40830 (5 July 2013). See also P2848 (Witness statement of Milorad Davidović dated 22 June 2011), para. 78; P2855 (VRS Main Staff report on paramilitary formations, 28 July 1992), pp. 23; P2899 (Report of Bijeljina CSB, 29 July 1992), pp. 1-2; D1412 (Report of Republic of Serbia MUP, 8 August 1992), pp. 2-3; Milorad Davidović, T. 15644 (29 June 2011); P2900 (Letter from Bijeljina CSB to Radovan Karadžić, 29 July 1992), p. 2. As a result, some Serbs also left Bijeljina. P2899 (Report of Bijeljina CSB, 29 July 1992), p. 2; D1412 (Report of Republic of Serbia MUP, 8 August 1992), pp. 2-3.

2029 P2929 (Witness statement of KDZ531 dated 25 June 2011), p. 9 (under seal); Bogdan Subotić, T. 40002 (19 June 2013); P2853 (Report of Bijeljina CSB, 21 May 1992), p. 1; Milorad Davidović, T. 15474-15475 (28 June 2011); P2848 (Witness statement of Milorad Davidović dated 22 June 2011), paras. 76, 84; Čedomir Kljajć, T. 42219-42220 (30 July 2013). See also Dragomir Andan, D3774 (Transcript from Prosecutor v. Stanišić \& Župljanin), T. 21436-21437; Dragomir Andan, T. 40836, 40838-40839 (5 July 2013); Živan Filipović, T. 35814 (21 March 2013).

2030 P2848 (Witness statement of Milorad Davidović dated 22 June 2011), paras. 76, 83.

2031 P2899 (Report of Bijeljina CSB, 29 July 1992), pp. 1, 3; D1412 (Report of Republic of Serbia MUP, 8 August 1992), pp. 2-3 (reporting that members of the SJB were also involved in registering stolen vehicles and weapons, failing to file criminal reports against perpetrators and participation in the commission of crimes); P2848 (Witness statement of Milorad Davidović dated 22 June 2011), paras. 65, 91; P2881 (Report of Bijeljina CJB, July 1992), p. 2. The Chamber considered that Davidović's evidence was marked by indicators of reliability and sincerity and considered his evidence to be credible. The Accused in cross-examination of Davidović introduced a number of documents which related to a case against Davidović and his son in an attempt to attack his character and credibility (D1405, D1404, D1403, D1402, and D1401). Having considered this line of cross-examination by the Accused the Chamber finds that the cross-examination and the documents introduced by the Acccused failed to cast doubt as to the character or credibility of Davidović.

2033 D1412 (Report of Republic of Serbia MUP, 8 August 1992), pp. 2, 6. 
units. $^{2034}$ In this regard the Chamber notes that the Presidency of the Bijeljina Assembly imposed a ban in May 1992 on armed formations which arrived in the municipality without invitation by the legal authorities. ${ }^{2035}$ In addition on 11 June 1992, the Presidency of the Bijeljina Municipal Assembly issued an order that all armed formations in the municipality be placed under the single command of the VRS and tasked the MP with ensuring implementation of the order. ${ }^{2036}$

634. Davidović was tasked to lead a special unit of the Federal SUP to address problems with paramilitaries in northeastern BiH and arrived in Bijeljina on 27 June 1992. ${ }^{2037}$ While Davidović's unit came from the Federal SUP in Belgrade it was re-subordinated to the command in Bosnian Serb MUP. ${ }^{2038}$ Davidović's special unit, in co-ordination with Dragomir Andan from the Bosnian Serb MUP, disarmed and broke up the paramilitary formations in the area of the Bijeljina CSB and arrested those "most deeply involved in criminal activities". 2039 Davidović had the support of Ratko Mladić to take these measures. ${ }^{2040}$ Following the arrival of Davidović and his unit, and until

2034 See P2848 (Witness statement of Milorad Davidović dated 22 June 2011), paras. 78, 121. Šešelj stated that on a number of occasions the Bijeljina Municipal Board issued public statements and held press conferences which "condemned and severely criticised" the actions of Mauzer. D3665 (Witness statement of Vojislav Šešelj dated 1 June 2013), para. 46. However, the Chamber does not find this evidence to be reliable. It notes that Ššelj's testimony was marked by political commentary which limited its reliability. Furthermore, in light of other accepted evidence to the contrary and noting that it has no other evidence to suggest that the municipal authorities condemned the actions of these units other than this unsupported statement of Šešelj, the Chamber does not find Šešelj's evidence in this regard to be reliable.

2035 D1442 (Conclusion of Bijeljina's Municipal Assembly Presidency, 29 May 1992). See also Cvijetin Simić, T. 35681-35682, 35699 (20 March 2013); D3133 (Witness statement of Cvijetin Simić dated 16 March 2013), paras. 33, 35; D3134 (Bijeljina Municipal Assembly decision, 25 July 1992). Restrictions were also placed on paramilitaries entering the police station with long barrelled weapons. Dragomir Andan, D3774 (Transcript from Prosecutor v. Stanišić \& Župljanin), T. 21437.

2036 D1443 (Order of Bijeljina's Municipal Assembly Presidency, 11 June 1992); D1444 (Conclusion of Bijeljina's Municipal Assembly Presidency, 25 June 1992); D1445 (Order of Bijeljina's Municipal Assembly, 25 June 1992). The Chamber also finds that the local authorities prohibited the sale of alcoholic beverages to uniformed persons in the municipality. D1437 (Order of Bijeljina's Municipal Assembly Presidency, 8 April 1992). Mihajlović testified that the local authorities tried to prevent and punish crimes committed against non-Serbs. D3137 (Witness statement of Svetozar Mihajlović dated 17 March 2013), para. 14. However, the Chamber does not find this evidence to be reliable. In reaching that conclusion the Chamber found that Mihajlović's evidence was marked by contradictions and indicators that he was not straighforward in his answers to the Chamber.

2037 P2848 (Witness statement of Milorad Davidović dated 22 June 2011), paras. 73-74, 76; Milorad Davidović, T. 15554 (28 June 2011), 15645-15646 (29 June 2011), 15735, 15765 (30 June 2011); D1450 (Milorad Davidović's statement to Belgrade District Court, 26 December 2007), pp. 4, 15; P2899 (Report of Bijeljina CSB, 29 July 1992), pp. 2, 4-5; D1412 (Report of Republic of Serbia MUP, 8 August 1992), pp. 1-2, 4-5; P2900 (Letter from Bijeljina CSB to Radovan Karadžić, 29 July 1992), pp. 3-4.

2038 Dragomir Andan, D3774 (Transcript from Prosecutor v. Stanišić \& Župljanin), T. 21454, 21667. See also D3807 (Official note of BiH Prosecutor's Office, 12 December 2007), p. 2.

2039 D1412 (Report of Republic of Serbia MUP, 8 August 1992), p. 9; Milorad Davidović, T. 15604-15605, 15607 (29 June 2011); D1450 (Milorad Davidović's statement to Belgrade District Court, 26 December 2007), p. 72. See also Dragomir Andan, T. 40837-40838, 40857-40858 (5 July 2013) (testifying that some paramilitaries were arrested for crimes committed against Bosnian Muslims); Dragomir Andan, D3774 (Transcript from Prosecutor v. Stanišić \& Župljanin), T. 21425, 21434-21436, 21829-21830.

2040 Milorad Davidović, T. 15604-15605, 15607 (29 June 2011); D1450 (Milorad Davidović's statement to Belgrade District Court, 26 December 2007), p. 72. 
they left on 27 July 1992, there was a significant improvement in the security situation. ${ }^{2041}$ Pursuant to orders from the Bosnian Serb MUP approximately 40 policemen with criminal records were removed from the SJB which was reinforced by personnel from other centres including the SJB Sarajevo. ${ }^{2042}$

635. Davidović also arrested some military personnel; complaints were then made to Mićo Stanišić, who instructed Davidović not to take action against members of the military as this should be done by the MP. ${ }^{2043}$ However, subsequently, Stanišić confirmed Davidović's authority ${ }^{2044}$ and requested the command of the Eastern Bosnia Corps to extend their "full cooperation" to him and to take measures against "possible perpetrators" in their ranks. ${ }^{2045}$ Following this, Davidović in cooperation with the Military Security Service from the Main Staff command and the MP arrested and prosecuted military personnel. ${ }^{2046}$

2041 P2899 (Report of Bijeljina CSB, 29 July 1992), po. 4-5; Milorad Davidović, T. 15645-15646 (29 June 2011); D1412 (Report of Republic of Serbia MUP, 8 August 1992), pp. 4-5. Measures taken by Davidović and his unit to normalise conditions in Bijeljina included (i) preventing the carrying of weapons without permits, (ii) reporting incidents to the authorities in Pale daily; (iii) imposing a curfew and (iv) seizing stolen goods, see Milorad Davidović, T. 15722, 15753, 15766 (30 June 2011), 15810 (1 July 2011); P2848 (Witness statement of Milorad Davidović dated 22 June 2011), paras. 87, 90-91, 121; D1438 (Order of Bijeljina's Municipal Assembly Presidency, 8 April 1992); P2899 (Report of Bijeljina CSB, 29 July 1992), pp. 3-5; Milivoje Kićanović, T. 34909 (6 March 2013); D1412 (Report of Republic of Serbia MUP, 8 August 1992), pp. 3-4. See also Dragomir Andan, D3774 (Transcript from Prosecutor v. Stanišić \& Župljanin), T. 21437-21438, 2144021442, 21454-21455, 21499-21500, 21664-21666; D3782 (Report of Bijeljina SJB, 28 June 1992); P6434 (Excerpt from Dragomir Andan's interview with OTP), p. 6; P2881 (Report of Bijeljina CJB, July 1992), p. 1; D1436 (Report of SerBiH MUP, 17 June 1992), p. 6; P3033 (Reynaud Theunens's expert report entitled "Radovan Karadžić and the SRBiH TO-VRS (1992-1995)"), e-court p. 382. Andan also testified about measures taken by Davidović with respect to a detention facility used by Mauzer's unit. Dragomir Andan, D3774 (Transcript from Prosecutor v. Stanišić \& Župljanin), T. 21442-21443; P2848 (Witness statement of Milorad Davidović dated 22 June 2011), para. 95; Prosecution Final Brief, Appendix A, Bijeljina, para. 12. However, given that this is not a scheduled detention facility, the Chamber will not address this evidence.

2042 Dragomir Andan, D3774 (Transcript from Prosecutor v. Stanišić \& Župljanin), T. 21437, 21454-21455, 21499_ 21500, 21664-21666; P2899 (Report of Bijeljina CSB, 29 July 1992), p. 4; D1412 (Report of Republic of Serbia MUP, 8 August 1992), p. 4. See also P6434 (Excerpt from Dragomir Andan's interview with OTP), p. 6; Dragomir Andan, D3774 (Transcript from Prosecutor v. Stanišić \& Župljanin), T. 21499-21501; Dragomir Andan, T. 40860-40861 (5 July 2013) (testifying that the police presence in the village of Janja was upgraded and a check- point was established to prevent looting and attacks against the predominantly Bosnian Muslim population); P2881 (Report of Bijeljina CJB, July 1992), p. 1.

2043 P2808 (Letter from Zdravko Tolimir to Radovan Karadžić and Mićo Stanisić, 4 July 1992), p. 1; P2848 (Witness statement of Milorad Davidović dated 22 June 2011), para. 85; P2895 (Order of SerBiH MUP, 5 July 1992); Milorad Davidović, T. 15605 (29 June 2011). See also Dragomir Andan, D3774 (Transcript from Prosecutor v. Stanišić \& Župljanin), T. 21466-21467, 21675-21676, 21818-21819; Dragomir Andan, T. 40858 (5 July 2013); D3819 (Report of Bijeljina SJB, 7 July 1992), pp. 1-2.

2044 Milorad Davidović, T. 15609 (29 June 2011) (testifying that Stanišić confirmed that there should be no more objections or confrontation between Davidović and the organs of the VRS).

2045 D1408 (Request of SerBiH MUP, 5 July 1992), pp. 1-2. See also P2881 (Report of Bijeljina CJB, July 1992), pp. 1-2 (indicating that measures were taken to improve the capacity to process criminal cases committed by military personnel).

2046 Milorad Davidović, T. 15608-15609 (29 June 2011); D1450 (Milorad Davidović's statement to Belgrade District Court, 26 December 2007), p. 39. 
636. During a visit to Bijeljina on 20 July 1992 by Prime Minister Đerić, Andan asked for assistance in light of continuing problems. ${ }^{2047}$ Đerić gave his support for the efforts displayed by Andan and Davidović ${ }^{2048}$ and a special unit led by Duško Kljajić was sent to assist them. ${ }^{2049}$

637. Despite these measures, there were difficulties in controlling Mauzer and his unit which opposed the attempts by Davidović and Andan to restore order in the municipality. ${ }^{2050}$ In one incident, the Bijeljina municipal authorities intervened and secured the release of Mauzer following pressure from his unit. ${ }^{2051}$ Davidović made requests to the military command to control Mauzer's unit and while promises were made, no action was taken and Mauzer continued to have political support in the municipality and was close to the structures of power in the municipality. ${ }^{2052}$ Davidović and his team were also threatened by Arkan's men. ${ }^{2053}$

638. In August 1992, following demands by Mauzer for his expulsion and the arrest of a member of Arkan's men by Davidović's unit, Davidović's authority was obstructed by the Bijeljina Crisis Staff and his unit was ordered to leave for Belgrade. ${ }^{2054}$ Andan and another MUP official who had

2047 Dragomir Andan, D3774 (Transcript from Prosecutor v. Stanišić \& Župljanin), T. 21484; D3789 (Dragomir Andan's notes), p. 2.

2048 Dragomir Andan, D3774 (Transcript from Prosecutor v. Stanišić \& Župljanin), T. 21484; D3789 (Dragomir Andan's notes), p. 2.

2049 Dragomir Andan, D3774 (Transcript from Prosecutor v. Stanišić \& Župljanin), T. 21459-21460, 21464, 21485, 21462, 21671-21674, 21677-21678, 21730-21731, 21737, 21759-21760, 21762-21763. See also D3807 (Official note of BiH Prosecutor's Office, 12 December 2007), p. 1. This included a unit led by Duško Malović, known as Mićo Stanišić's unit or "Mićo's Specials".

2050 P2848 (Witness statement of Milorad Davidović dated 22 June 2011), paras. 94, 96; Milorad Davidović, T. 15579 (29 June 2011); Momir Nikolić, T. 24732 (15 February 2012); Dragomir Andan, D3774 (Transcript from Prosecutor v. Stanišić \& Župljanin), T. 21445, 21652, 21655-21658, 21703-21704, 21719-21722, 2181721818; Dragomir Andan, T. 40871 (5 July 2013); P6434 (Excerpt from Dragomir Andan's interview with OTP), p. 3. In contrast to Mauzer, Blagojević issued a proclamation that Bosnian Muslims be protected from ethnic cleansing and opposed the expulsion or killing of Bosnian Muslims. Milorad Davidović, T. 15506 (24 June 2011); P2848 (Witness statement of Milorad Davidović dated 22 June 2011), para. 121.

2051 Dragomir Andan, D3774 (Transcript from Prosecutor v. Stanišić \& Župljanin), T. 21657 ; P2848 (Witness statement of Milorad Davidović dated 22 June 2011), paras. 94, 96.

2052 Dragomir Andan, D3774 (Transcript from Prosecutor v. Stanišić \& Župljanin), T. 21656, 21703-21704, 2172121722, 21818; Dragomir Andan, T. 40874 (5 July 2013). See also P6434 (Excerpt from Dragomir Andan's interview with OTP), pp. 3-4; Manojlo Milovanović, T. 25455 (28 February 2012). Davidović also testified about visiting a private detention facility run by Mauzer but since this is not a scheduled detention facility, the Chamber will not make findings in this regard. P2848 (Witness statement of Milorad Davidović dated 22 June 2011), para. 95; P2896 (Report of Bijeljina CSB, 7 July 1992), pp. 3-5; P2899 (Report of Bijeljina CSB, 29 July 1992), p. 3. See also Dragomir Andan, D3774 (Transcript from Prosecutor v. Stanišić \& Župljanin), T. 2144321444; D3783 (Bijeljina garrison record, 1 July 1992).

2053 P2898 (Official note of Bijeljina SJB, 8 July 1992), p. 2. See also P2900 (Letter from Bijeljina CSB to Radovan Karadžić, 29 July 1992), p. 5.

2054 P2848 (Witness statement of Milorad Davidović dated 22 June 2011), paras. 93, 96-97, 99-100, 147-148; P2899 (Report of Bijeljina CSB, 29 July 1992), p. 6; D1412 (Report of Republic of Serbia MUP, 8 August 1992), p. 6; D1450 (Milorad Davidović's statement to Belgrade District Court, 26 December 2007), p. 57; Milorad Davidović, T. 15579-15581 (29 June 2011); P2897 (Official note of Bijeljina CJB, 7 July 1992), p. 1. The Municipal Assembly also called for the removal and expulsion of Jovo Miskin, a Republic Commissioner who supported Davidović's actions. P2848 (Witness statement of Milorad Davidović dated 22 June 2011), para. 97; Milorad Davidović, T. 15580-15581, 15648-15649 (29 June 2011). 
taken action against paramilitaries were also removed from Bijeljina and dismissed from the Bosnian Serb MUP while the paramilitaries continued to operate in Bijeljina. ${ }^{2055}$

\section{(E) Prosecution of crimes}

639. The Chamber finds that there was some record and investigation of crimes committed against Bosnian Muslims by Bosnian Serbs; ${ }^{2056}$ however, some of the investigations were discontinued. $^{2057}$ The Chamber finds that there was inbalance in the treatment of cases associated with the killing or mistreatment of Bosnian Muslims by Bosnian Serbs. Many incidents went unpunished or sentences were passed but not carried out. ${ }^{2058}$ This added to the fear and uncertainty

2055 Dragomir Andan, D3774 (Transcript from Prosecutor v. Stanišić \& Župljanin), T. 21656; D1409 (Decision of SerBiH MUP, 11 September 1992); Dragomir Andan, D3774 (Transcript from Prosecutor v. Stanišić \& Župljanin), T. 21777-21781. Andan also testified about the circumstances surrounding his removal from his position in the MUP. Andan testified that he was removed from the MUP in September 1992 because he allegedly took poker machines for private use but that this was an excuse for his removal given that individuals were against his professional approach. However, Andan could not confirm that he was removed because of measures he had taken in Bijeljina. See Dragomir Andan, T. 40825-40826, 40867-40868, 40877, 40883, 40897-40900, 40901-40905 (5 July 2013); D3807 (Official note of BiH Prosecutor's Office, 12 December 2007), p. 1; P6434 (Excerpt from Dragomir Andan's interview with OTP), pp. 3-4.

2056 Savo Bojanović, T. 34819-34820 (5 March 2013); D3076 (Witness statement of Savo Bojanović dated 2 March 2013), paras. 9-12, 16, 18-19, 21, 23-26; Savo Bojanović, T. 34817-34819, 34829, 34850, 34857-34860, 34847-34848 (5 March 2013). For documents relating to the investigation and prosecution of crimes, see D1481 (Bijeljina Military Prosecutor request re Cvjetković/Jurošević case, 29 October 1992); D1482 (Bijeljina Military Court record re Cvjetković/Jurošević case, 29 October 1992); D1483 (Bijeljina Military Prosecutor request re Cvjetković/Jurošević case, 30 October 1992); D1484 (Statement of Amira Rendić to Bijeljina Military Court, 30 October 1992); D1485 (Bijeljina Military Court ruling in Cvjetković/Jurošević case, 20 November 1992); D3080 (Bijeljina Military Court's Proposition, 26 April 1993); D1486 (Bijeljina Military Court order in Cvjetković/Jurošević case, 17 December 1992); D1487 (Bijeljina Military Court order in Cvjetković/Jurošević case, 19 January 1993); D1488 (Bijeljina Military Court record re Cvjetković/Jurošević case, 23 January 1993); D1489 (Bijeljina Military Court decision in Cvjetković/Jurošević case, 1 April 1993) (under seal); D1490 (Indictment of Brčko Public Prosecutor, 28 July 1993); D1465 (Bijeljina Military Court indictment of Radovan Mićanović, 17 August 1993); D1466 (Bijeljina Military Court judgment in Radovan Mićanović case, 22 March 1995); D1467 (Bijeljina High Court judgement in Branko Đurić case, 27 October 1995), pp. 1-2, 10-11; D1468 (Correspondence between Bijeljina Lower Court and Radovan Karadžić, 9 June 2011); D1469 (Correspondence between Bijeljina District Prosecutor and Radovan Karadžić, 24 August 2009), pp. 1-5; D1470 (Bijeljina Military Court on-site investigation report, 28 September 1992); D1471 (Bijeljina Military Police criminal report in Rade Mihajlović case, 29 September 1992); D1472 (Bijeljina Military Police forensic-technical report, 30 September 1992); D1473 (Bijeljina Military Prosecutor request re Rade Mihajlović case, 30 September 1992); D1477 (Bijeljina Military Court correspondence in Rade Mihajlović case, 30 January 1993); D1476 (Bijeljina Military Court indictment of Rade Mihajlović, 5 January 1993); D3079 (Bijeljina Military Court's Ruling, 19 June 1993); D3077 (Supreme Military Court's Judgement, 16 May 1994); D3081 (Bijeljina Military Court's Verdict, 18 January 1994); D3799 (Report of Bijeljina SJB, undated). See also D3798 (List of criminal records submitted to Bijeljina Prosecutor's Office between 26 June and 25 July 1992); Dragomir Andan, D3774 (Transcript from Prosecutor v. Stanišić \& Župljanin), T. 21453-21454, 21537-21538, 21542-21544 (testifying about the treatment of cases when he and Davidović were in Bijeljina).

2057 P6179 (Bijeljina Military Court's Decision, 30 December 1992); P6180 (Bijeljina Military Court's Decision, 5 January 1993); D1478 (Bijeljina Military Court order in Rade Mihajlović case, 21 February 1993); D1479 (Bijeljina District Court verdict in Rade Mihajlović case, 18 June 2001); D1480 (RS Supreme Court judgement in Rade Mihajlović case, 30 September 2003); P6181 (Bijeljina Military Court's Dispatch to Military Prosecutor's Office, 28 January 1993); D3078 (Bijeljina Military Court's Ruling, 22 January 1993), p. 1. With respect to one of the cases, Bojanović maintained that there was nothing unlawful and that the appropriate procedures and law were followed. Savo Bojanović, T. 34812, 34831-34834, 34863-34864 (5 March 2013).

2058 [REDACTED]; P2930 (Bijeljina Military Court file for Slavan Lukić et al., 8 September 1992), pp. 5-7; [REDACTED]; P2931 (Bijeljina Military Court indictment of Zoran Tomić and Dragan Matović, 24 June 1993), pp. 3-5, 17-18, 34-36, 61, 86-87. See also Dragomir Andan, D3774 (Transcript from Prosecutor v. Stanišić \& 
of the Bosnian Muslim population and contributed to individuals leaving Bijeljina. ${ }^{2059}$ In addition, while proceedings were initiated against Bosnian Serbs for general crimes, no cases for war crimes against the civilian population were ever tried before the Bijeljina Military Court. ${ }^{2060}$

640. Spasojević testified that all crimes against non-Serb citizens of Bijeljina were handled by members of the SJB, that if the perpetrators were found they were handed over for prosecution, and that there was no pressure from government organs to cover up crimes. ${ }^{2061}$ However, the Chamber does not find this evidence to be reliable given that he was contradicted on cross-examination and acknowledged examples of cases involving murder of Bosnian Muslims which were still pending. ${ }^{2062}$

(F) Schedule Detention Facility C.2.1

641. The Indictment refers to the use of the Batkovic camp as a detention facility at least between 1 June 1992 and 31 December $1995 .^{2063}$

\section{(1) Establishment of camp and arrival of detainees}

642. On 17 June 1992, the Command of the Eastern Bosnia Corps issued an order requiring the selection of "locations and facilities to accommodate prisoners of war" pursuant to an order from the Main Staff. ${ }^{2064}$ Ratko Mladić had issued an order to set up a camp for "war prisoners" at the corps level to relieve the Birać Brigade from guarding up to 600 prisoners who were in their custody. ${ }^{2065}$ Following this order the Batković camp was established. ${ }^{2066}$ The civilian and military

Župljanin), T. 21446-21449; Dragomir Andan, T. 40824-40827, 40890-40891 (5 July 2013); D3813 (Decision of Bijeljina SJB, 3 August 1992); D3787 (Report of Bijeljina SJB, July 1992), p. 2; D3786 (Bijeljina SJB criminal report, 3 August 1992), pp. 1-3; D3785 (Decision of Bijeljina SJB, 3 August 1992), p. 1; D3784 (Investigation report of Bijeljina Lower Court, 2 June 1992); P6218 (Excerpt from report on war crimes trials in Serbia in 2012); P6219 (Order of Bijeljina Prosecutor's Office, 14 July 2009); Svetozar Mihajlović, T. 35736 (20 March 2013); P6218 (Excerpt from report on war crimes trials in Serbia in 2012), p. 5, fn. 101; Dušan Spasojević, T. 35860-35862 (22 March 2013).

2059 KDZ531, T. 15854 (1 July 2011) (closed session).

2060 Savo Bojanović, T. 34849-34850 (5 March 2013); Predrag Drinić, P374 (Transcript from Prosecutor v. Blagojević \& Jokić), T. 10864-10865. D3141 (Witness statement of Dušan Spasojević dated 18 March 2013), para. 18.

2062 Dušan Spasojević, T. 35844-35845 (21 March 2013).

2063 Indictment, Scheduled Detention Facility C.2.1. In Appendix B to the Prosecution Final Brief, however, the Prosecution only refers to the period between 25 June 1992 and 24 December 1995.

2064 D3237 (Order of Eastern Bosnia Corps, 17 June 1992), pp. 1-2; D3236 (Witness statement of Gojko Čekić dated 31 March 2013), para. 9. See also Ljubomir Obradović, T. 25167 (23 February 2012).

2065 P3238 (Order of the VRS Main Staff, 17 June 1992), pp. 1-2; P3227 (Witness statement of KDZ033 dated 7 April 2010), para. 90 (under seal). See also Dragomir Andan, D3774 (Transcript from Prosecutor v. Stanišić \& Župljanin), T. 21529.

2066 P3227 (Witness statement of KDZ033 dated 7 April 2010), para. 90 (under seal); D3237 (Order of Eastern Bosnia Corps, 17 June 1992), p. 2. 
authorities took over the hangars belonging to the agricultural company in Batković which was approximately 12 kilometres from Bijeljina towards the Sava River. ${ }^{2067}$

643. The order for the establishment of the camp provided that (i) Momčilo Despot be appointed commander of the camp (ii) the treatment of the prisoners of war be "in accordance with provisions of the international law of war"; (iii) the detainees be treated appropriately; (iv) unauthorised persons be prevented from entering the camp; and (v) the provision of food would be organised at the Corps Command level. ${ }^{2068}$ Despot ordered that records be kept of detainees and of items seized from them, including valuables and money. ${ }^{2069} \mathrm{He}$ also ordered that detainees could be used for work, including maintenance and agricultural work, but not for work directly linked to combat operations, and that interrogations would be conducted by the Eastern Bosnia Corps. ${ }^{2070}$ This order also provided for a list of all detainees to be communicated to the Red Cross and for detainees to be treated humanely without violence, with "exemplary hygiene" and regular medical checks. ${ }^{2071}$ While these rules were promulgated, the evidence below as to the conditions of detention and treatment of detainees indicates that the rules were not complied with. ${ }^{2072}$

644. The camp was guarded by VRS soldiers who were mainly from the military reserve ${ }^{2073}$ and the army had jurisdiction over the camp. ${ }^{2074}$ From August 1992, the commander of the Batković camp was Velibor Stojanović. ${ }^{2075}$

2067 P2929 (Witness statement of KDZ531 dated 25 June 2011), p. 11 (under seal); P3212 (Witness statement of Ibro Osmanović dated 23 August 2011), para. 151; Milorad Davidović, T. 15782-15783 (30 June 2011); D1450 (Milorad Davidović's statement to Belgrade District Court, 26 December 2007), p. 24; P6263 (Photographs of Batković camp). See also Dragomir Andan, T. 40833-40835 (5 July 2013); Dragomir Andan, D3774 (Transcript from Prosecutor v. Stanišić \& Župljanin), T. 21471-21472, 21528-21529; D3796 (SerBiH MUP instructions to CSBs, 8 August 1992), p. 1; D3817 (Bijeljina SJB dispatch to Eastern Bosnia Corps, 11 August 1992).

2068 D3237 (Order of Eastern Bosnia Corps, 17 June 1992), p. 2; P2890 (Order of Eastern Bosnia Corps, 2 July 1992), p. 2; D3236 (Witness statement of Gojko Čekić dated 31 March 2013), paras. 9-10. See also P2890 (Order of Eastern Bosnia Corps, 2 July 1992), p. 1; Milorad Davidović, T. 15545-15546 (28 June 2011); Petar Salapura, T. 40304 (24 June 2013).

2069 D1449 (Instructions of Eastern Bosnia Corps, 2 July 1992), pp. 1-3. The Chamber notes that this order refers to "Ekonomija", but the Chamber has other evidence that this facility was located in Batković and thus considers it to be another name for Scheduled Detention Facility C.2.1. D3239 (Instruction of Batković Collection Centre, 12 July 1992).

2070 D1449 (Instructions of Eastern Bosnia Corps, 2 July 1992), p. 2.

2071 D1449 (Instructions of Eastern Bosnia Corps, 2 July 1992), p. 2.

2072 But see Milorad Davidović, T. 15784-15786 (30 June 2011). While Davidović testified that Despot complied with these instructions, the Chamber does not find that this is entirely consistent with the other evidence on the conditions of detention and treatment of detainees. For example, the Chamber notes that P2891 (Instructions of the Eastern Bosnia Corps, 2 July 1992), p. 2, which was signed by Despot as commander of the camp, implicitly acknowledged that detainees were subject to forced labour.

2073 P2929 (Witness statement of KDZ531 dated 25 June 2011), pp. 11-12 (under seal); P3262 (Witness statement of KDZ603 dated 30 August 2011), para. 36 (under seal); P3212 (Witness statement of Ibro Osmanović dated 23 August 2011), para. 160. See also Elvir Pašić, P59 (Transcript from Prosecutor v. Tadić), T. 872; P84 (Witness statement of Mirsad Kuralić dated 27 June 1996), p. 7.

2074 Savo Bojanović, T. 34850-34852 (5 March 2013). See also Dragomir Andan, T. 40834-40835 (5 July 2013 ). 
645. From at least June until December 1992, Bosnian Muslims and Bosnian Croats were detained in the Batković camp. ${ }^{2076}$ The first groups brought to Batković were Bosnian Muslims after which Bosnian Croats were also brought to the facility. ${ }^{2077}$ The detainees held at the Batković camp originated from a large number of different municipalities, including Kalesija, Brčko, Ključ, Lopare, Rogatica, Sanski Most, Sokolac, Ugljevik, Vlasenica, Živinice, and Zvornik. ${ }^{2078}$ Some people were taken from their homes and transported in buses to the Batković camp. ${ }^{2079}$ Many were transferred from other detention facilities, including Sušica camp in Vlasenica and Manjača camp in Banja Luka. ${ }^{2080}$ Some individuals were detained for over a year. ${ }^{2081}$

646. When KDZ603 arrived from Sušica camp he was in a hangar with approximately 1,600 Bosnian Muslims from various municipalities who were placed in groups depending on their municipality of origin. ${ }^{2082}$ There were also some women, children, and elderly persons detained in a separate hangar. ${ }^{2083}$

2075 See Adjudicated Fact 2252. But see D3236 (Witness statement of Gojko Čekić dated 31 March 2013), para. 22 (stating that Stojanović was the commander of the guards).

2076 See Adjudicated Fact 2250. In August 1992 there were over 1,200 Bosnian Muslim men detained in a single warehouse at Batković camp. See Adjudicated Fact 2253.

2077 P3212 (Witness statement of Ibro Osmanović dated 23 August 2011), para. 153. When Andan asked why a Bosnian Croat associate had been taken away from Brčko and detained at the camp he was told that "there was no reason" and it appeared that the only reason was because he was a Bosnian Croat: Dragomir Andan, T. 40870 (5 July 2013).

2078 Adjudicated Fact 2251; P3212 (Witness statement of Ibro Osmanović dated 23 August 2011), para. 153; P84 (Witness statement of Mirsad Kuralić dated 27 June 1996), p. 7; Mirsad Kuralić, P63 (Transcript from Prosecutor v. Krajišnik), T. 12568-12569; P58 (Witness statement of Sakib Husrefović dated 27 May 1995), p. 10; Elvir Pašić, P59 (Transcript from Prosecutor v. Tadić), T. 872; P2848 (Witness statement of Milorad Davidović dated 22 June 2011), para. 153.

2079 P58 (Witness statement of Sakib Husrefović dated 27 May 1995), p. 10.

$2080 \quad$ Adjudicated Fact 2251; P3212 (Witness statement of Ibro Osmanović dated 23 August 2011), para. 153; P111 (Witness statement of KDZ044 dated 28 September 1994), p. 6 (under seal), KDZ044 was transferred in a group of detainees from Sušica camp on 30 June 1992; P3262 (Witness statement of KDZ603 dated 30 August 2011), paras. 35, 37 (under seal); KDZ044, P109 (Transcript from Prosecutor v. Nikolić), T. 269 (under seal); Asim Egrlić, P3570 (Transcript from Prosecutor v. Krajišnik), T. 4796 (under seal); Asim Egrlić, T. 19980 (5 October 2011); Svetozar Andrić, T. 41668-41669 (22 July 2013) (testifying that the commander of the Main Staff on 17 June 1992 ordered that detainees at Sušica should be transferred to the Batković camp on 17 June 1992). In late June 1992 approximately 400 detainees from Sušica camp were told they would exchanged but were transported to Batković camp on buses which were heavily guarded by guards in JNA uniforms. The detainees had not engaged in military activities. P3212 (Witness statement of Ibro Osmanović dated 23 August 2011), paras. 4546, 149, 156; Ibro Osmanović, T. 17999 (29 August 2011); KDZ044, P107 (Transcript from KDZ044's testimony), T. 488-489 (under seal). Over 500 detainees were brought to Batković camp in late 1992 after the Manjača camp was dismantled. P3212 (Witness statement of Ibro Osmanović dated 23 August 2011), para. 154; Ibro Osmanović, T. 17947-17948 (25 August 2011); KDZ163, T. 20748-20749 (1 November 2011).

2081 Elvir Pašić, P59 (Transcript from Prosecutor v. Tadić), T. 872; P3212 (Witness statement of Ibro Osmanović dated 23 August 2011), paras. 145-147, 180; KDZ044, P107 (Transcript from KDZ044's testimony), T. 491 (under seal).

2082 P3262 (Witness statement of KDZ603 dated 30 August 2011), para. 37 (under seal); KDZ603, T. 18165 (1 September 2011).

2083 Mirsad Kuralić, P63 (Transcript from Prosecutor v. Krajišnik), T. 12568-12569; Adjudicated Fact 2253. See also P3213 (List of persons detained at Batković camp); P3212 (Witness statement of Ibro Osmanović dated 23 August 2011), para. 155 (testifying that there were only two women at the camp, and some children who did 
647. On arrival in Batković, the detainees were ordered by Serb soldiers to empty their pockets of money and valuables and were forced to pass a cordon of soldiers who beat them with chains and batons before being taken to a hangar. ${ }^{2084}$ The detainees were informed by a platoon leader that they were "war prisoners" on Serb territory and had no rights. ${ }^{2085}$

648. Between 2,000 and 3,000 non-Serbs went through the camp after its establishment with new groups arriving when other groups left. ${ }^{2086}$ The exchange of detainees in groups of 50 to 100 began in August 1992. ${ }^{2087}$ In 1995, Bosnian Muslims from Karakaj ${ }^{2088}$ and Bosnian Muslims from Srebrenica, including elderly and children who were captured were brought to Batković. ${ }^{2089}$

\section{(2) Conditions of detention and treatment of detainees}

649. The detainees in Batković were forced to sleep on their sides on the concrete floor where they "were packed into the hangar like sardines". 2090 Initially two detainees would share a single military mattress but subsequently these mattresses were taken away and the detainees had to sleep on straw and hay. ${ }^{2091}$

not want to be separated from their fathers). But see D3236 (Witness statement of Gojko Čekić dated 31 March 2013), para. 19; Gojko Čekić, T. 36508-36509 (3 April 2013) (testifying that there were no women, children, or elderly at the camp).

2084 P58 (Witness statement of Sakib Husrefović dated 27 May 1995), p. 10; P3212 (Witness statement of Ibro Osmanović dated 23 August 2011), para. 160.

2085 P58 (Witness statement of Sakib Husrefović dated 27 May 1995), p. 10. See also Mirsad Kuralić, P63 (Transcript from Prosecutor v. Krajišnik), T. 12575-12577 (testifying that he was charged before a court but was not afforded proper procedure).

2086 P2929 (Witness statement of KDZ531 dated 25 June 2011), p. 11 (under seal); P3212 (Witness statement of Ibro Osmanović dated 23 August 2011), para. 153; Ibro Osmanović, T. 17948 (25 August 2011). In a list of detainees recorded as having arrived at Batkvović detention facility between 27 June 1992 and 22 December 1995, a total of 2,468 detainees were listed. Of these detainees, 28 were listed as having died, 2,002 were listed as having been exchanged, 406 were listed as having been released, 7 were listed as deported, 20 escaped or went missing, and 5 were remanded to another prison. P3213 (List of persons detained at Batković camp).

2087 P58 (Witness statement of Sakib Husrefović dated 27 May 1995), p. 12-13. These exchanges continued, and for example in July 1993, 400 men from Batković were taken by bus to Lopare municipality and exchanged for Bosnian Serb civilians. P3212 (Witness statement of Ibro Osmanović dated 23 August 2011), para. 180; P111 (Witness statement of KDZ044 dated 28 September 1994), p. 7 (under seal); P107 (Transcript from KDZ044's testimony), T. 492 (under seal). Following his appointment as commander of the camp in August 1994, Cekić with the agreement of the Corps Command released 50 older detainees. D3236 (Witness statement of Gojko Čekić dated 31 March 2013), para. 19; Gojko Čekić, T. 36508-36509 (3 April 2013); Gojko Čekić, T. 3652836529 (4 April 2013). For evidence on exchange of detainees in 1995, see P5440 (RS Ministry of Defence list of persons exchanged from the Batković Collection Centre, 13 March 2002), pp. 1-9; D2052 (Statement of KDZ333 to State Commission on Gathering Facts on War Crimes, 20 July 1996), p. 6 (under seal).

2088 D2052 (Statement of KDZ333 to State Commission on Gathering Facts on War Crimes, 20 July 1996), p. 5 (under seal); KDZ333, T. 24162-24163 (2 February 2012).

2089 D3236 (Witness statement of Gojko Čekić dated 31 March 2013), paras. 13, 21; Gojko Čekić, T. 36504-36505, 36508-36509 (3 April 2013); D3244 (Drina Corps combat report, 26 July 1995), p. 2; P3213 (List of persons detained at Batković Camp), e-court pp. 9, 11, 25, 40, 47, 52, 78, 84, 92, 106, 131, 133, 149, 157, 168, 170, 175, 184, 188, 191, 193. See also para. 5131.

2090 P58 (Witness statement of Sakib Husrefović dated 27 May 1995), p. 11.

2091 P3212 (Witness statement of Ibro Osmanović dated 23 August 2011), para. 159. See also D3238 (Report of Batković Collection Centre, 11 January 1996). The Chamber does not place weight on this report which reflects 
650. The detainees were forbidden from sitting with their legs crossed, and were required to seek permission before using the toilet or getting water. ${ }^{2092}$ They had a makeshift toilet which was a 10 metre long dug-up hole which they could use during the day but not at night. ${ }^{2093}$ They were also required to seek permission before addressing the guards by making the three fingered Serb sign, bowing their heads to the ground, and saying "Sir Serb soldier let me address you". ${ }^{2094}$ When detainees walked they had to have their hands behind their back and keep their heads bowed. ${ }^{2095}$

651. Sanitary conditions at Batković camp were poor and detainees were given little food. ${ }^{2096}$ The detainees received a slice of bread for breakfast, had some cooked food at lunch and boiled corn flour for dinner. ${ }^{2097}$ Given the lack of food, detainees sold valuables to soldiers "for just a few loaves of bread". ${ }^{2098}$ Some detainees experienced extreme weight loss during their detention while four or five older prisoners died of starvation or exhaustion. ${ }^{2099}$

652. Bosnian Serb soldiers who came to the area were given access to the camp and allowed to enter the hangar whenever they wanted to beat the detainees. ${ }^{2100}$ If a Bosnian Serb soldier was killed on the frontline, the soldiers would take revenge on the detainees. ${ }^{2101}$ The soldiers forced some of the detainees to hit each other, beat all of them randomly with different objects, and

the number of blankets in the camp when the facility was closed in 1996, thus falling outside the time frame of the allegations in the Indictment with respect to the Batković camp.

P58 (Witness statement of Sakib Husrefović dated 27 May 1995), p. 11.

P3212 (Witness statement of Ibro Osmanović dated 23 August 2011), para. 159.

P58 (Witness statement of Sakib Husrefović dated 27 May 1995), p. 11.

P58 (Witness statement of Sakib Husrefović dated 27 May 1995), p. 11.

See Adjudicated Fact 2254. The conditions in Batković while similar to Manjača, were "somewhat better" with less beatings, fewer people called out at night and better access to water. Asim Egrlić, P3570 (Transcript from Prosecutor v. Krajišnik), T. 4797 (under seal). See also D2052 (Statement of KDZ333 to State Commission on Gathering Facts on War Crimes, 20 July 1996), p. 5 (under seal). Čekić disputed this adjudicated fact and testified that the food received by the detainees was the same as the VRS soldiers and they all had three meals a day and that the detainees had several showers and toilets. D3236 (Witness statement of Gojko Čekić dated 31 March 2013), para. 23. The Chamber does not consider that this evidence is of much weight given that Čekić was commander of the camp only from August 1994. The Chamber also found that Čekić's evidence was marked by indicators of evasiveness and did not consider his evidence to be reliable in this regard.

P3212 (Witness statement of Ibro Osmanović dated 23 August 2011), para. 159. While Adjudicated Fact 2254 suggests that detainees were given little water, the Chamber accepts that in light of the evidence of Osmanović and that of Egrlić, detainees did have access to water. P3570 (Transcript from Prosecutor v. Krajišnik), T. 4797 (under seal).

P58 (Witness statement of Sakib Husrefović dated 27 May 1995), p. 12.

P58 (Witness statement of Sakib Husrefović dated 27 May 1995), p. 12; P84 (Witness statement of Mirsad Kuralić dated 27 June 1996), p. 8; P74 (Supplemental information sheet for Mirsad Kuralić), pp. 2-3.

Elvir Pašić, P59 (Transcript from Prosecutor v. Tadić), T. 874; P58 (Witness statement of Sakib Husrefović dated 27 May 1995), pp. 11-12. These soldiers wore grey, olive green camouflage uniforms and some had the insignia of the SerBiH. The Chamber notes that KDZ333 who only arrived at Batković in July 1995 testified he was not maltreated when interrogated during his detention. D2052 (Statement of KDZ333 to State Commission on Gathering Facts on War Crimes, 20 July 1996), p. 5 (under seal).

P58 (Witness statement of Sakib Husrefović dated 27 May 1995), pp. 11-12. 
ordered them to kneel with their heads bowed and hands behind their backs. ${ }^{2102}$ After 30 June 1992, there were daily beatings until the first visit of the ICRC in August 1992. ${ }^{2103}$ The beatings of the detainees increased to five or six times a day after two detainees escaped ${ }^{2104}$ and when a detainee who escaped was returned he was beaten. ${ }^{2105}$

653. There were approximately ten detainees accused by the guards of being "extremists" or "Alija's specialists" who were subjected to daily beatings and additional mistreatment and some of these detainees died from these beatings. ${ }^{2106}$ The detainees in this group were beaten at least three times a day, forced to beat each other, knocked over by fire hoses, and forced to have sexual intercourse with each other, often in front of other detainees. ${ }^{2107}$ The guards were aware of these

2102 P58 (Witness statement of Sakib Husrefović dated 27 May 1995), pp. 11-12 (testifying that a soldier from around Gorazde known as "Gligor" was responsible for most of the beatings). Guards at Batković camp who carried out beatings at Batković included Veselin Nikolić, Zoran Zarić, a person identified as "Major" from the Semberija company, Panić from Sarajevo and Gligor from Goražde. P3212 (Witness statement of Ibro Osmanović dated 23 August 2011), paras. 163-164. Osmanović also identified four individuals who were singled out for beating, including one person who was accused of making knives used to kill Serbs. Ibro Osmanović, T. 17942 (25 August 2011). Other individuals who beat detainees in the hangar included Daco, Fikret Piklić from Brezovo Polje, and Džemal called "Pajzer" from Zenica. P58 (Witness statement of Sakib Husrefović dated 27 May 1995), pp. 11-12.

2103 P111 (Witness statement of KDZ044 dated 28 September 1994), p. 6 (under seal); KDZ044, P107 (Transcript from KDZ044's testimony), T. 491-492 (under seal). [REDACTED]. See also Elvir Pašić, P59 (Transcript from Prosecutor v. Tadić), T. 874-875 (testifying that treatment of the detainees improved slightly and the beatings occurred less frequently after the commander of the camp was replaced).

2104 P58 (Witness statement of Sakib Husrefović dated 27 May 1995), p. 11.

2105 KDZ010, P416 (Transcript from Prosecutor v. Jelisić), T. 86, 119.

2106 P58 (Witness statement of Sakib Husrefović dated 27 May 1995), p. 12; Elvir Pašić, P59 (Transcript from Prosecutor v. Tadić), T. 873; P84 (Witness statement of Mirsad Kuralić dated 27 June 1996), p. 8; Mirsad Kuralić, P74 (Supplemental information sheet), p. 2; Mirsad Kuralić, P63 (Transcript from Prosecutor v. Krajišnik), T. 12569, 12571-12572 (under seal); P3212 (Witness statement of Ibro Osmanović dated 23 August 2011), para. 171. See also Adjudicated Fact 2256.

2107 P84 (Witness statement of Mirsad Kuralić dated 27 June 1996), p. 8. See also Adjudicated Fact 2256. Čekić disputed Adjudicated Fact 2256 and suggested that nobody beat the detainees or forced them to engage in degrading sexual acts and that the guards at the facility were "family men" or older people who would never do such things. Cekić also testified about the conditions in the camp and the absence of mistreatment of detainees in 1994. D3236 (Witness statement of Gojko Čekić dated 31 March 2013), paras. 4-5, 8-9, 11-12, 15-16, 20, 25. The Chamber does not find this evidence to be credible. In reaching that conclusion, the Chamber noted that Čekić was commander of the camp only from August 1994 and that when confronted with evidence of abuse and poor conditions in 1992, Čekić stated that he was not at the centre at the time and was not aware of it. The Chamber also noted that Čekić had an interest in minimising his involvement in any mistreatment of detainees. See Gojko Čekić, T. 36490-36491, 36493-36495, 36503, 36511-36512 (3 April 2013). The Chamber also found that Čekić's evidence was marked by indicators of evasiveness and did not consider his evidence to be reliable in this regard. The Chamber also does not find Čekić's evidence that many detainees "discretely asked not to be exchanged" as they were safer in the camp than in their own territory where they would be mobilised and sent to the frontline to be credible. See D3236 (Witness statement of Gojko Čekić dated 31 March 2013), para. 20. 
actions but did nothing but laugh. ${ }^{2108}$ Some detainees suffered lasting harm which was both physical and psychological including post traumatic stress disorder. ${ }^{2109}$

654. Even though there was a doctor at the camp, the detainees in the Batković camp, including those who had heart attacks, were not provided with medical treatment or were refused medication and, as a result, a number of detainees died. ${ }^{2110}$ When a detainee complained of toothache, the doctor threatened to call the soldiers to pull out the tooth. ${ }^{211}$

655. The police would take away detainees for work at factories while VRS soldiers took the detainees away for labour on the frontlines. ${ }^{2112}$ Detainees at Batković were forced to perform manual labour daily, including digging trenches, clearing mines and carrying munitions at the frontline, and burying bodies. ${ }^{2113}$ While compelled to dig trenches on the frontline the detainees were forced to sing Serb national songs and bury the dead. ${ }^{214}$ On two occasions, the detainees worked on the frontlines when combat was ongoing. In one incident, a man named Ahmed Pašić was killed and, in December 1992, two detainees were wounded and two others were killed. ${ }^{2115}$ The detainees were forced to work in all weather conditions, including in extreme heat, which affected their health. ${ }^{2116}$ They were not allowed to refuse to work at Batković. ${ }^{2117}$ An order of the

2108 P3212 (Witness statement of Ibro Osmanović dated 23 August 2011), para. 173.

2109 P84 (Witness statement of Mirsad Kuralić dated 27 June 1996), pp. 9-10; Mirsad Kuralić, P63 (Transcript from Prosecutor v. Krajišnik), T. 12578-12579 (under seal). See also P58 (Witness statement of Sakib Husrefović dated 27 May 1995), p. 13. Referred to in Prosecution Final Brief, Appendix B, p. 4.

2110 P58 (Witness statement of Sakib Husrefović dated 27 May 1995), pp. 11-12; Mirsad Kuralić, P63 (Transcript from Prosecutor v. Krajišnik), T. 12578 (testifying that he received no treatment for his wounds and had to use salt or his own clothes as bandages).

2111 P58 (Witness statement of Sakib Husrefović dated 27 May 1995), pp. 11-12.

2112 P3212 (Witness statement of Ibro Osmanović dated 23 August 2011), para. 178.

2113 See Adjudicated Fact 2257; P58 (Witness statement of Sakib Husrefović dated 27 May 1995), p. 12; Elvir Pašić, P59 (Transcript from Prosecutor v. Tadić), T. 875-876, 889; P3212 (Witness statement of Ibro Osmanović dated 23 August 2011), para. 175; P111 (Witness statement of KDZ044 dated 28 September 1994), p. 6 (under seal); P107 (Transcript from KDZ044's testimony), T. 491-492 (under seal); P5421 (Letter from humanitarian organisation to Radovan Karadžić, 16 September 1993), p. 2 (under seal); D2052 (Statement of KDZ333 to State Commission on Gathering Facts on War Crimes, 20 July 1996), p. 5 (under seal); Mirsad Kuralić, P74 (Supplemental information sheet), p. 3; P5483 (ICRC press release, 30 August 1994). Čekić testified that detainees were not forced to dig trenches, carry munitions to the frontlines or bury dead bodies and that detainees only buried three other prisoners of war in a Muslim graveyard. In addition Čekić testified that detainees were selected for work according to their skills and "their wishes were also respected" and that the detainees had a "huge interest" in going to work as they were freer, had more food, tobacco and drinks. D3236 (Witness statement of Gojko Čekić dated 31 March 2013), paras. 20, 24; Gojko Čekić, T. 36495, 36499 (3 April 2013). The Chamber does not find this evidence to be reliable. In reaching that conclusion, the Chamber refers to its credibility assessment in fn. 2096 in assessing Čekić's evidence.

2114 Elvir Pašić, P59 (Transcript from Prosecutor v. Tadić), T. 875-876, 889; P3212 (Witness statement of Ibro Osmanović dated 23 August 2011), para. 175.

2115 P3212 (Witness statement of Ibro Osmanović dated 23 August 2011), para. 175.

2116 P58 (Witness statement of Sakib Husrefović dated 27 May 1995), pp. 11-12; Mirsad Kuralić, P63 (Transcript from Prosecutor v. Krajišnik), T. 12578.

2117 P3212 (Witness statement of Ibro Osmanović dated 23 August 2011), para. 176. But see KDZ603, T. 1816618167 (1 September 2011) who testified that men were asked, not ordered, to work and that these men usually returned well-fed and bringing food for the others in the camp. The Chamber does not consider that it can rely 
commander of the Batković camp implicitly acknowledged the practice of forced labour by outlining the procedure for guarding detainees who were "performing forced labour". ${ }^{2118}$

656. The ICRC received information about the detainees at the facility from the POW exchange commission of the Eastern Bosnia Corps and this information was also relayed on a daily basis to the Main Staff level. ${ }^{2119}$

\section{(3) Conclusion on conditions of detention and treatment of detainees}

657. Based on the above, the Chamber finds that Bosnian Muslims and Bosnian Croats from multiple locations were brought to and detained at Batković camp from June 1992 until 1995 by Serb Forces. The detainees were held in poor conditions which included lack of space, inadequate bedding, poor sanitary conditions, lack of food, and inadequate medical care. Detainees were subjected to regular beatings, sexual mistreatment and were forced to work at a number of locations in extreme conditions including on the frontlines digging trenches and clearing mines. The Chamber finds that some detainees died as a result of starvation, exhaustion or while working on the frontlines. ${ }^{2120}$

\section{(4) Scheduled Incident B.2.1}

658. The Prosecution alleges that at least six men were killed in the Batković camp between June 1992 and June 1995.

659. A detainee known as "professor" was taken out one night by 10 guards, beaten through the night, and found dead the next day. ${ }^{2121}$ Executions were also carried out at the camp, with intellectuals and SDA leaders specifically targeted ${ }^{2122}$ and the bodies of detainees were removed from the hangar wrapped in blankets. ${ }^{2123}$ Pašić saw two elderly men killed at the camp following

on KDZ603's evidence in this regard given that he never left the facility himself for the purposes of work in contrast to other witnesses, including Osmanović, who were personally forced to work.

2118 P2891 (Instructions of the Eastern Bosnia Corps, 2 July 1992), p. 2.

2119 Milenko Todorović, D4124 (Transcript from Prosecutor v. Tolimir), T. 12959-12961.

2120 This finding does not include the persons alleged to have been killed in Scheduled Incident B.2.1 which is discussed below.

2121 Elvir Pašić, P59 (Transcript from Prosecutor v. Tadić), T. 873; P58 (Witness statement of Sakib Husrefović dated 27 May 1995), p. 12.

2122 P2929 (Witness statement of KDZ531 dated 25 June 2011), pp. 11-12 (under seal) (testifying that he heard that Ferid Zečević and Muhamed Ćurtić were killed at Batković and that a guard named Ljubiša Mišić was rumoured to have been one of the worst killers in the camp but was still rewarded by the SDS). See also P4850 (Witness statement of Amor Mašović dated 23 March 2012), para. 54.

2123 P58 (Witness statement of Sakib Husrefović dated 27 May 1995), p. 12; Elvir Pašić, P59 (Transcript from Prosecutor v. Tadić), T. 873; see Adjudicated Fact 2260. See also P4853 (Updated Table 2 to the Report of Amor Mašović), p. 73. KDZ044 also saw detainees who died two or three days after being beaten. P111 (Witness statement of KDZ044 dated 28 September 1994), p. 7 (under seal). Cekić testified that when he was commander of the camp from August 1994, he heard about the death of only two detainees at the camp and this 
beatings. $^{2124}$ Of the two elderly men, one was Zulfo Hadžiomerović, ${ }^{2125}$ a 70 year old man accused of having a "U" tattooed under his arm; he was beaten on many occasions and in early July 1992 died as a result of a beating. ${ }^{2126}$ Gligor and "Major" had started the beating and Veselin Nikolić and some police from Zenica joined and once Hadžiomerović died, other detainees were ordered to take the body out and load it onto a military truck. ${ }^{2127}$ His body was covered with bruises, but men wearing doctors' insignia in JNA uniforms arrived about an hour later and pronounced that he had died of natural causes. ${ }^{2128}$ Two other men, including a jeweller named "Husein" and Ferid Zečević also died on or about the same day. ${ }^{2129}$ While Osmanović did not see the beatings, Husein and Zečević had been beaten at the army barracks before their arrival at Batković and he saw both bodies placed outside and put onto a truck. ${ }^{2130}$

660. Pašić also testified about the shooting of one detainee. ${ }^{2131}$ With respect to this shooting, in the late summer 1992, there was an investigation into the death of Muhamed Čudić but no one was charged. ${ }^{2132}$

661. The Chamber therefore finds that at least six Bosnian Muslim men were killed by Serb Forces at the Batković camp between June 1992 and June 1995.

involved two detainees who returned from work drunk and attacked a guard who shot them in "self-defence" and that there was an investigation into this incident. D3236 (Witness statement of Gojko Čekić dated 31 March 2013), para. 18; Gojko Čekić, T. 36524-36525 (4 April 2013). The Chamber does not find this evidence to be reliable. In reaching that conclusion, the Chamber recalls its credibility assessment in fn. 2096 in assessing Čekić's evidence. In addition it was not clear whether Čekić was able to speak about killings which occurred before he was commander of the camp. 


\section{(5) $\underline{\text { ICRC Visits }}$}

662. The ICRC first visited the Batković camp in August or September 1992, registered the detainees, and issued them with identity cards. ${ }^{2133}$ Before the ICRC visits, all children, the elderly and those that had been beaten badly, including the group of ten men who had been targeted for additional beating and mistreatment, were taken away and hidden in other locations. ${ }^{2134}$ These detainees were similarly hidden during the visits of journalists. ${ }^{2135}$ In order to cover for the absence of detainees who had been hidden and the detainees who had been killed, other people including guards or police were substituted in their place. ${ }^{2136}$

663. The detainees were also instructed to lie and tell the ICRC representatives that conditions were fine, that food was good, that they were provided with cigarettes, and had not been beaten. ${ }^{2137}$ Anyone who did not say what they were instructed to say was beaten severely. ${ }^{2138}$ While the ICRC provided the detainees with supplies, such as blankets, soap, shoes, gloves and cigarettes, the soldiers would take anything they wanted once the ICRC left the camp. ${ }^{2139}$ However, the conditions at Batković did improve after the ICRC began to visit the facility. ${ }^{2140}$ The ICRC was given access to and visited Batković camp until late $1995 .^{2141}$

664. The Batković facility was disbanded in early $1996 .^{2142}$

2133 P3212 (Witness statement of Ibro Osmanović dated 23 August 2011), para. 179; P81 (ICRC identification document of Sakib Husrefović). See also Bogdan Subotić, T. 40178 (21 June 2013); D3242 (VRS Main Staff instructions, 1 December 1995); Gojko Čekić, T. 36519-36520 (4 April 2013); Adjudicated Fact 2258.

2134 Elvir Pašić, P59 (Transcript from Prosecutor v. Tadić), T. 877; P3212 (Witness statement of Ibro Osmanović dated 23 August 2011), para. 179; P84 (Witness statement of Mirsad Kuralić dated 27 June 1996), p. 8; Mirsad Kuralić, P74 (Supplemental information sheet), p. 2 (Mirsad Kuralić was not a civilian as he had been drafted into the AbiH in April 1992 and was on the frontlines when captured); Mirsad Kuralić, P63 (Transcript from Prosecutor v. Krajišnik), T. 12572-12573; KDZ010, P416 (Transcript from Prosecutor v. Jelisić), T. 86-87, 120, 157-158. See also Adjudicated Fact 2258.

Mirsad Kuralić, P63 (Transcript from Prosecutor v. Krajišnik), T. 12572-12573.

Mirsad Kuralić, P63 (Transcript from Prosecutor v. Krajišnik), T. 12572-12573; P2929 (Witness statement of KDZ531 dated 25 June 2011), p. 12 (under seal) [REDACTED]; P3212 (Witness statement of Ibro Osmanović dated 23 August 2011), para. 179.

Elvir Pašić, P59 (Transcript from Prosecutor v. Tadić), T. 878, 890. Čekić testified that the ICRC maintained lists of detainees who only complained about the lack of showers and toilets after which the ICRC provided the material for extra showers and toilets were built at Batković. D3236 (Witness statement of Gojko Čekić dated 31 March 2013), para. 11; Gojko Čekić, T. 36491-36492, 36497-36498, 36503 (3 April 2013); P6258 (Report of facilities handed over by Batković Collection Centre, 5 January 1996). The Chamber does not find this evidence to be conclusive as to the actual conditions at Batković, given the credible evidence about the hiding of detainees and detainees being instructed to not complain about conditions.

Elvir Pašić, P59 (Transcript from Prosecutor v. Tadić), T. 878, 890.

P58 (Witness statement of Sakib Husrefović dated 27 May 1995), p. 12.

See Adjudicated Fact 2259.

Bogdan Subotić, T. 40178 (21 June 2013); D3242 (VRS Main Staff instructions, 1 December 1995); Gojko Čekić, T. 36519-36520 (4 April 2013).

See para. 5502. 


\section{(G) Scheduled Incident D.2}

665. The Indictment refers to the destruction of three mosques in Bijeljina in the summer of 1992. ${ }^{2143}$

666. Riedlmayer reported that the Atmačići mosque was almost destroyed. ${ }^{2144}$ The Janjari mosque was lightly damaged and vandalised with graffiti with the initials of the SRS written on the walls in Cyrillic. ${ }^{2145}$ The Srendja Tnova mosque was completely destroyed. ${ }^{2146}$ There was evidence of blast damage to two of the mosques and the adjacent buildings to all three mosques were in good condition. ${ }^{2147}$ While the Chamber relies on Riedlmayer for the purposes of finding that the mosques were destroyed, and the nature and extent of the damage to the mosques and surrounding buildings, it does not rely on his evidence as to when and who was responsible for the destruction of the mosques which fall outside his expertise and are based on informant statements which he received. ${ }^{2148}$ Riedlmayer also reported on damage to other cultural monuments and sacred sites in Bijeljina, ${ }^{2149}$ but given that these sites are not alleged in Schedule D of the Indictment, the Chamber will not make findings in this regard.

667. While KDZ531 testified that the destruction of the mosques was a "clear signal to nonSerbs" that they should leave Bijeljina, the Chamber considers this to be the witness's speculation and will not rely on his opinion in this regard. ${ }^{2150}$ KDZ531 also stated that in the summer of 1992 , the Department of Urbanism and Construction supervised the destruction of religious and cultural

\footnotetext{
2143 Specifically, the mosques are the Atmačići mosque, the Janjari mosque, and the Srednja Trnova mosque.

2144 P4069 (Cultural destruction database), record 39; P4070 (Attachment to the expert report of András J. Riedlmayer, entitled "Destruction of Cultural Heritage in $\mathrm{BiH}^{\prime}$ prepared for the Karadžić case, formatted records), pp. 11-17. See also KDZ531, T. 15857 (1 July 2011) (closed session) (testifying that he heard that the three mosques listed in Schedule D.2 were also destroyed).

2145 P4070 (Attachment to the expert report of András J. Riedlmayer, entitled "Destruction of Cultural Heritage in BiH” prepared for the Karadžić case, formatted records), pp. 11-17; P4069 (Cultural destruction database), record 40.

2146 P4069 (Cultural destruction database), record 42.

2147 P4069 (Cultural destruction database), records 39, 41-42.

2148 P4070 (Attachment to the expert report of András J. Riedlmayer, entitled "Destruction of Cultural Heritage in $\mathrm{BiH}$ " prepared for the Karadžić case, formatted records), pp. 11-17. Riedlmayer's report, which is based on his visits to the sites in 2002 and on information he received from the Islamic Community of BiH and other sources, identifies the following mosques and the level of damage: Atmačići mosque (almost destroyed), Janjari mosque (lightly damaged), and Srednja Trnova mosque (completely destroyed). P4069 (Cultural destruction database), records $39,41-42$.

2149 P4069 (Cultural destruction database), records 28-40; P4068 (András Riedlmayer's expert report on Destruction of Cultural Heritage in Bosnia and Herzegovina during 1992-1995, 7 May 2009), para. 55. KDZ531 also testified about the destruction of other religious and cultural sites. P2929 (Witness statement of KDZ531 dated 25 June 2011), p. 12 (under seal); KDZ531, T. 15857 (1 July 2011) (closed session). However, the Chamber will not make findings with respect to these unscheduled sites.

2150 See P2929 (Witness statement of KDZ531 dated 25 June 2011), p. 12 (under seal); KDZ531, T. 15857 (1 July 2011) (closed session).
} 
monuments in Bijeljina which was carried out by the engineering group of the $1^{\text {st }}$ Krajina Corps. ${ }^{2151}$ He also stated that the rubble from destroyed religious and cultural monuments was removed with the assistance of Bosnian Muslims on work detail who were required to perform this work. ${ }^{2152}$ During his testimony, KDZ531 confirmed that he heard that the Atmačići mosque, the Janjari mosque, and the Srednja Trnova mosque had been destroyed. ${ }^{2153}$ However, when questioned about how he knew that the mosques were destroyed by the engineering group of the $1^{\text {st }}$ Krajina Corps, he qualified his statement and testified that his knowledge about who destroyed the mosques was based on unattributed hearsay and what he heard people and soldiers talking about as he had no direct knowledge about this issue. ${ }^{2154}$ Having regard to the way in which KDZ531 qualified his evidence, the Chamber is not satisfied that it can rely on his evidence to establish who destroyed the mosques charged in the Indictment.

668. Therefore, based on its review of the evidence, while the Chamber finds that the Atmačići, Janjari, and Srednja Trnova mosques were destroyed, it does not have sufficient evidence to identify, beyond reasonable doubt, who destroyed those mosques. The Chamber is not satisfied that the evidence presented by the Prosecution with respect to Bijeljina is sufficient to allow for an inference to be drawn that Serb Forces destroyed these three mosques.

\section{(H) Movement of the population from Bijeljina}

669. As found above, ${ }^{2155}$ in 1992 many Bosnian Muslims left Bijeljina out of fear ${ }^{2156}$ while others were expelled. ${ }^{2157}$ The media coverage and Bosnian Serb propaganda at the time also

2151 P2929 (Witness statement of KDZ531 dated 25 June 2011), p. 12 (under seal); KDZ531, T. 15858 (1 July 2011) (closed session). See also Milorad Davidović, T. 15486 (28 June 2011) (testifying that the mosque in Bijeljina was destroyed in the second half of 1993). The Chamber notes that Davidović does not identify who destroyed the mosque and his evidence does not appear to be linked to the specific mosques charged in the Indictment. In the Accused's submission in light of the presence of paramilitaries and the chaos in the municipality there is no evidence that the mosques in Schedule D.2 were destroyed by either the local authorities or the VRS. Defence Final Brief, para. 1393.

2152 P2929 (Witness statement of KDZ531 dated 25 June 2011), p. 12 (under seal). KDZ531 also stated that the Catholic church was "spared, apparently at the intervention of the orthodox Bishop from Tuzla". KDZ531, T. 15857 (1 July 2011) (closed session).

2153 KDZ531, T. 15857-15858 (1 July 2011) (closed session).

2154 KDZ531, T. 15858 (1 July 2011) (closed session).

2155 See para. 630.

2156 P2929 (Witness statement of KDZ531 dated 25 June 2011), pp. 4, 8-9 (under seal).

2157 Milorad Davidović, T. 15528-15529 (28 June 2011); P2884 (Article from List SAO Semberije I Majevice entitled "Semberija Lost for Alija's Islamic State", 15 June 1992), p. 1; Živan Filipović, T. 35811 (21 March 2013). The Chamber finds that some Bosnian Serbs also left the municipality at the beginning of April 1992 out of fear but returned when Bosnian Serb authorities took measures to stabilise the security situation. D3089 (Witness statement of Milivoje Kićanović dated 3 March 2013), para. 13; Milivoje Kićanović, T. 34882 (6 March 2013); D3137 (Witness statement of Svetozar Mihajlović dated 17 March 2013), paras. 5, 7 . See also KDZ240, T. 16057, 16080, 16081-16082 (5 July 2011) (closed session); KDZ240, P2935 (Transcript from Prosecutor v. Krajišnik), T. 6754 (under seal); Colm Doyle, T. 2932 (28 May 2010); P1029 (Witness statement of John Wilson dated 4 November 2008), paras. 94-95; John Wilson, T. 3968-3969 (21 June 2010) (who 
contributed to the fear among the Bosnian Muslim population. ${ }^{2158}$ Mauzer in an interview stated that the Bosnian Muslims who had fled Bijeljina "will not come back and I would advise them not to". 2159

670. By August 1992, there were approximately 17,000 Bosnian Muslims who remained in Bijeljina and 12,000 in Janja. ${ }^{2160}$ Davidović testified that he was present when five days after his arrival in Bijeljina a plan was discussed "for the ethnic cleansing" of Bosnian Muslims who remained in municipalities, including Bijeljina and Zvornik. ${ }^{2161}$ Davidović testified that this plan was discussed by Mauzer, other members of the SDS, and the Bijeljina Crisis Staff and he informed Mićo Stanišić about the plan. ${ }^{2162}$ According to Davidović, the plan consisted of three phases. In the first phase, scheduled to start in September or October 1992, there would be a division of the city and the creation of an atmosphere of fear to convince the Bosnian Muslims to leave. ${ }^{2163}$ In the second phase, Bosnian Muslims who refused to respond to the call for mobilisation would be fired from their positions, and would have their services cut and would be required to report for work obligation including on the frontlines. ${ }^{2164}$ In the third phase, wealthy and intellectual Bosnian Muslims were to be targeted for humiliation by assigning them to menial tasks such as sweeping the streets. ${ }^{2165}$

671. Having reviewed the evidence, the Chamber finds that this three phase plan existed and was discussed by Bosnian Serb authorities in Bijeljina and in accordance with this plan, Duško Malović's special police unit, following the lead of Drago Vuković who was a member of the

received reports of "ethnic cleansing" in Eastern Bosnia from late March through April 1992 which mentioned the involvement of the JNA in providing perimeter security while paramilitaries would enter settlements "commit demonstration killings and rapes as examples to villages that they would meet the same fate unless they left the area").

2158 P2848 (Witness statement of Milorad Davidović dated 22 June 2011), para. 161; Milorad Davidović, T. 1552715528 (28 June 2011).

2159 P2884 (Article from List SAO Semberije I Majevice entitled "Semberija Lost for Alija's Islamic State", 15 June 1992), p. 3.

2160 P2848 (Witness statement of Milorad Davidović dated 22 June 2011), paras. 149-150.

2161 P2848 (Witness statement of Milorad Davidović dated 22 June 2011), paras. 149-150, 156; Milorad Davidović, T. 15582 (29 June 2011); Adjudicated Fact 2261.

2162 P2848 (Witness statement of Milorad Davidović dated 22 June 2011), para. 150; Milorad Davidović, T. 1558215584 (29 June 2011). The Chamber observes that Davidović in a prior interview did deny specific knowledge about the killing of Bosnian Muslim families, but contrary to the Accused's submission this does not undermine his evidence with respect to informing Mićo Stanišić about the plan to remove the Bosnian Muslim population from Bijeljina. See Defence Final Brief, para. 1116; Milorad Davidović, T. 15589 (29 June 2011); D1407 (Official note of BiH's Prosecutor's Office in Sarajevo, 14 January 2008), p. 2.

2163 P2848 (Witness statement of Milorad Davidović dated 22 June 2011), para. 151. Davidović identified Drago Vuković who was a member of the Crisis Staff and Predrag Ješurić as being in charge of this phase of the plan.

2164 P2848 (Witness statement of Milorad Davidović dated 22 June 2011), paras. 98, 153; D1450 (Milorad Davidović's statement to Belgrade District Court, 26 December 2007), p. 21. See also Adjudicated Fact 2264.

2165 P2848 (Witness statement of Milorad Davidović dated 22 June 2011), paras. 98, 153-154. See also Adjudicated Fact 2264. 
Bijeljina Crisis Staff, instilled fear in the Bosnian Muslims who remained in Bijeljina by September 1992. ${ }^{2166}$ The Chamber also finds that in accordance with the second and third phase of the plan Bosnian Muslims, including prominent Muslims who did not comply with demands for mobilisation or work obligation, were sent to Batković camp or expelled from the municipality. ${ }^{2167}$ The police knew about this and condoned it and did nothing to prevent people from being taken to Batković camp or to prevent expulsions. ${ }^{2168}$ The simultaneous execution of the three phases of this SDS operation caused large numbers of Bosnian Muslims to flee Bijeljina out of fear. ${ }^{2169}$

672. The Bijeljina SDS also compiled a list of names of Bosnian Muslims to be expelled, including the wealthy, which was done with the help of Mauzer. ${ }^{2170}$ Dragomir Ljubojević, the President of the Municipal Assembly and SDS leader, was responsible for drawing up the lists and co-ordinating the expulsions. ${ }^{2171}$ Aided by Mauzer's unit, Vojkan Đurković who was an SDS field

2166 P2848 (Witness statement of Milorad Davidović dated 22 June 2011), paras. 151-152. See also Adjudicated Fact 2264. The Chamber does not see any merit in the Accused's submission that because Vuković had to go through a very thorough clearance process before being appointed an adviser to the joint BiH presidency that this somehow undermines the evidence that he carried out expulsions of Bosnian Muslims. See Defence Final Brief, para. 1117; Milorad Davidović, T. 15591-15594 (29 June 2011). Fear was created by the killing of Bosnian Muslim families and looting of their homes. P2848 (Witness statement of Milorad Davidović dated 22 June 2011), paras. 151-152; Milorad Davidović, T. 15506-15507 (28 June 2011). While the Chamber received specific evidence about killings carried out by Malović's group, given that these are not scheduled killing incidents the Chamber will not make a finding with respect to these killings, but accepts this evidence for the purposes of concluding that an environment of fear was being created.

2167 P2848 (Witness statement of Milorad Davidović dated 22 June 2011), paras. 98, 153; Milorad Davidović, T. 15517 (28 June 2011); D1450 (Milorad Davidović's statement to Belgrade District Court, 26 December 2007), p. 21. See also Adjudicated Fact 2264.

2168 P2848 (Witness statement of Milorad Davidović dated 22 June 2011), para. 153.

2169 P2848 (Witness statement of Milorad Davidović dated 22 June 2011), para. 160. See also Adjudicated Fact 2264. Defence witnesses disputed Adjudicated Fact 2264 and suggested that the SDS did not have such a plan nor had they heard of these things occurring in the municipality and that any problems Bosnian Muslims faced did not come from the authorities in Bijeljina which treated all citizens equally: D3133 (Witness statement of Cvijetin Simić dated 16 March 2013), para. 42; D3089 (Witness statement of Milivoje Kićanović dated 3 March 2013), para. 27; D3137 (Witness statement of Svetozar Mihajlović dated 17 March 2013), para. 21 ; D3141 (Witness statement of Dušan Spasojević dated 18 March 2013), para. 25. The Chamber does not find this evidence to be reliable. In reaching this conclusion the Chamber concluded that the evidence of the relevant witnesses was marked by insincerity, evasiveness, the withholding of information, contradictions, and bias.

2170 P2848 (Witness statement of Milorad Davidović dated 22 June 2011), paras. 70, 92, 150, 162, 206; Milorad Davidović, T. 15593-15594 (29 June 2011) (testifying that (i) he saw Bosnian Serb officials compile a list of Bosnian Muslim names for "cleansing"; (ii) that a list of wealthy Bosnian Muslims that were to be robbed and killed was found with Arkan's and Mauzer's men; and (iii) he intervened on a number of occasions to have people removed from the list, and while the Bosnian Serb leadership complied in most cases, sometimes they refused); P2929 (Witness statement of KDZ531 dated 25 June 2011), pp. 3, 6 (under seal); KDZ531, T. 1584415845 (1 July 2011) (closed session). See also Adjudicated Facts 2261; 2262.

2171 P2929 (Witness statement of KDZ531 dated 25 June 2011), p. 6 (under seal); KDZ531, T. 15845 (1 July 2011) (closed session). Ljubojević disputed his involvement and denied that he ever planned or expelled Bosnian Muslims. Ljubojević also testified that he never received orders from the SDS leadership to expel non-Serbs from the municipality. He also testified that it was not in his zone of responsibility and that he was not present in the municipality because he was on sick leave. D3144 (Witness statement of Dragomir Ljubojević dated 18 March 2013), para. 11. However, the Chamber is not convinced that this evidence is reliable and finds that Ljubojević had a clear interest in distancing himself from the events in question. The Chamber noted that the witness was evasive in his testimony in this regard, which was marked by insincerity. His testimony is also contradicted by direct evidence that he was seen twice advocating the expulsion of Bosnian Muslims from Bijeljina. [REDACTED]. 
operative in Bijeljina as well as one of Arkan's men, ${ }^{2172}$ paid visits to those on the list in order to extort property from them. ${ }^{2173}$ Đurković promised to take some Bosnian Muslims across the Drina for a fee while others who remained were "subjected to threats and intimidation." ${ }^{2174}$ In some cases the residents were given ten-minutes to leave after which they were loaded onto trucks. ${ }^{2175}$

673. Some Bosnian Muslims initially paid to be able to stay in Bijeljina. ${ }^{2176}$ From the beginning of April 1992 until the end of the war, Ješurić, along with his counterpart in the Serbian MUP Puzović, arranged for the daily transport of Bosnian Muslims through Serbia to a third country, and those Bosnian Muslims who wanted to leave had to pay "exorbitant fees" to obtain the necessary travel documentation. ${ }^{2177}$ Others were detained immediately, stripped of their valuables, and transferred to "no-man's land" between the warring factions, where they remained, sometimes for days, before being able to cross into Muslim-controlled territory. ${ }^{2178}$

674. According to Defence witnesses, (i) there was no organised campaign for the expulsion of Bosnian Muslims from Bijeljina by the local authorities; (ii) Bosnian Muslims were not expelled and they voluntarily left combat areas and areas where Bosnian Muslims were no longer a majority;

2172 Dragomir Andan, T. 40869 (5 July 2013); Milorad Davidović, T. 15714-15716 (30 June 2011); Dragomir Ljubojević, T. 35897-35898 (22 March 2013). See also P2858 (Video footage of Radovan Karadžić and Arkan at award ceremony in Bijeljina with transcript) (Davidović identified Đurković in this video footage); Živan Filipović, T. 35799 (21 March 2013); D1136 (UNPROFOR report, 9 September 1994), para. 6.

P2848 (Witness statement of Milorad Davidović dated 22 June 2011), paras. 70, 159. See also Adjudicated Fact 2262. Davidović testified that a portion of the extorted proceeds from Bijeljina was sent to the Accused and Krajišnik in Pale and Vojkan Đurković boasted about going to see the Accused and Krajišnik and giving them money. P2848 (Witness statement of Milorad Davidović dated 22 June 2011), paras. 70, 165; Milorad Davidović, T. 15725, 15730 (30 June 2011). However, the Chamber does not find that it can rely on this evidence in the absence of further corroboration given that Davidović in cross-examination acknowledged that Đurković was a person who liked to boast and he could not say how much truth there was in what he was saying and whether it was bragging or a lie. Milorad Davidović, T. 15728-15730 (30 June 2011). Đurković was also known as Puškar. Živan Filipović, T. 35799 (21 March 2013); Milivoje Kićanović, T. 34900 (6 March 2013).

2174 P2848 (Witness statement of Milorad Davidović dated 22 June 2011), paras. 70, 159-160, 165; Milorad Davidović, T. 15532-15533 (28 June 2011), 15724-15725 (30 June 2011); P2929 (Witness statement of KDZ531 dated 25 June 2011), p. 5 (under seal); KDZ531, T. 15855 (1 July 2011) (closed session); P5421 (Letter from humanitarian organisation to Radovan Karadžić, 16 September 1993), p. 2 (under seal). See also Jeremy Bowen, T. 10100-10101 (13 January 2011); P2073 (BBC news report re Bijeljina, with transcript), pp. 1-2; Svetozar Mihajlović, T. 35738-35739 (20 March 2013); D3137 (Witness statement of Svetozar Mihajlović dated 17 March 2013), para. 14.

2175 Milorad Davidović, T. 15532-15533 (28 June 2011), T. 15594-15595 (29 June 2011), T. 15728 (30 June 2011 ); P2848 (Witness statement of Milorad Davidović dated 22 June 2011), paras. 70, 160; P2929 (Witness statement of KDZ531 dated 25 June 2011), p. 5 (under seal); P5421 (Letter from humanitarian organisation to Radovan Karadžić, 16 September 1993), p. 1 (under seal).

2176 Adjudicated Fact 2262.

2177 P2848 (Witness statement of Milorad Davidović dated 22 June 2011), paras. 162-163; P2885 (Excerpt from video from TV BiH Studio Tuzla re expelled people from Semberija); D1450 (Milorad Davidović's statement to Belgrade District Court, 26 December 2007), p. 26; Milorad Davidović, T. 15533 (28 June 2011); P2929 (Witness statement of KDZ531 dated 25 June 2011), pp. 4-5 (under seal).

2178 P2848 (Witness statement of Milorad Davidović dated 22 June 2011), paras. 70, 160; Milorad Davidović, T. 15532-15533 (28 June 2011), 15724-15725 (30 June 2011); P2929 (Witness statement of KDZ531 dated 25 June 2011), p. 5 (under seal); KDZ531, T. 15855 (1 July 2011) (closed session); P5421 (Letter from 
(iii) Bosnian Muslims who wanted to stay, could do so and worked normally throughout the war; (iv) Bosnian Muslims requested to leave the municipality because of a number of factors, including the increasing number of Bosnian Serb refugees in the municipality and the increasing ethnic polarisation; (v) there was no list of Bosnian Muslim names identified for expulsion; (vi) Đurković was never a member of the SDS and while he took Bosnian Muslims to the demarcation line, he simply helped them to leave the territory upon their request; (vii) Đurković did not have a large unit of armed men that would be able to forcibly expel such a large group of Bosnian Muslims; and (viii) the authorities facilitated the voluntary departure of Bosnian Muslims, calling for measures to be taken against groups that were trying to disturb relations and pressure Bosnian Muslims to leave the municipality. ${ }^{2179}$ However, the Chamber does not find this evidence to be reliable. In reaching this conclusion the Chamber noted that this evidence was based to a large extent on the witnesses' own assumptions and speculation and that the evidence of the relevant witnesses was marked by substantial contradictions and evasiveness. The Chamber also noted that this is contrary to the credible evidence which the Chamber received with respect to the involvement of Bosnian Serb authorities in the expulsion of the Bosnian Muslim population. ${ }^{2180}$

675. A private agency staffed by the MUP but not formally part of the MUP was established to "expel non-Serbs and to confiscate their property". ${ }^{2181}$ Many Bosnian Muslims were required to sign a statement which left all their property to the agency which subsequently put Serb refugees into these houses. $^{2182}$ Abandoned Bosnian Muslim houses were looted at night by village guards who were under the control of the SDS Main Board in Bijeljina after which the property was taken to Serbia and the houses allocated to Serbs. ${ }^{2183}$

humanitarian organisation to Radovan Karadžić, 16 September 1993), p. 2 (under seal). See also Adjudicated Facts 2261, 2262.

2179 D3089 (Witness statement of Milivoje Kićanović dated 3 March 2013), para. 25; Milivoje Kićanović, T. 3489734898, 34900-34901, 34908, 34910-34913 (6 March 2013); D3141 (Witness statement of Dušan Spasojević dated 18 March 2013), para. 24; D3137 (Witness statement of Svetozar Mihajlović dated 17 March 2013), paras. 15, 21; Svetozar Mihajlović, T. 35738-35739 (20 March 2013); D3144 (Witness statement of Dragomir Ljubojević dated 18 March 2013), para. 18; Dragomir Ljubojević, T. 35910, 35920 (22 March 2013).

2180 See paras. 669-671.

2181 P2929 (Witness statement of KDZ531 dated 25 June 2011), p. 4 (under seal).

2182 P2929 (Witness statement of KDZ531 dated 25 June 2011), pp. 4-5 (under seal); Milorad Davidović, T. 15789 (30 June 2011). See also P2451 (Witness statement of Anthony Banbury dated 19 May 2009), paras. 62-63. Ljubojević testified that refugees were not only accommodated in houses of Bosnian Muslims but also in the houses of Bosnian Serbs and that a commission existed which made lists of property which was assigned for the use of displaced persons but after the war this property was returned to its previous owners. Dragomir Ljubojević, T. 35906, 35917-35918 (22 March 2013). The Chamber does not find evidence that abandoned Bosnian Serb homes were also used for the accommodation of refugees undermines the evidence about the way in which Bosnian Muslims were forced to sign over their property. The Chamber also noted that Ljubojević showed signs of insincerity and evasiveness when questioned about the expulsion of Bosnian Muslims from Bijeljina.

2183 P2848 (Witness statement of Milorad Davidović dated 22 June 2011), paras. 70, 89; P2929 (Witness statement of KDZ531 dated 25 June 2011), p. 5 (under seal). See also Adjudicated Fact 2263. 
676. Đurković was arrested after he expelled a Bosnian Muslim who was on good terms with senior SDS members who had established a military unit of Bosnian Muslims in the VRS. ${ }^{2184}$ However, these proceedings were stopped and Đurković was released when he provided documents which suggested that he was authorised and had orders to expel Bosnian Muslim residents from Bijeljina. $^{2185}$ In July 1995, there was a request by the Bijeljina SJB to commence proceedings against Đurković for having expelled Bosnian Muslims without the knowledge of municipal authorities. $^{2186}$ However, the Chamber notes that this request relates to one specific incident in July 1995 , and the evidence is equivocal as to whether or not these proceedings were concluded or whether Đurković was released. ${ }^{2187}$ Filipović testified that Đurković was acquitted in BiH for forcibly expelling Bosnian Muslims. ${ }^{2188}$ The evidence led, however, does not provide any detail about when these proceedings were concluded; further, the evidence does not reveal whether the proceedings related to a specific incident or time frame. The Chamber finds the evidence led on this issue to be inconclusive and lacking detail and does not consider that it establishes, as the Accused submits, that the accusations against Đurković were false. ${ }^{2189}$

677. On 9 September 1992, the Bosnian Serb Assembly in Bijeljina issued a declaration inviting all citizens who had left their homes to return and assured citizens of "other nationalities" that their rights would be recognised and that all who were members of the "enemy forces" but who had not committed crimes against the Serb people would not be criminally prosecuted. ${ }^{2190}$ While some Bosnian Muslims did return to Bijeljina, ${ }^{2191}$ even by May 1993 the number of Bosnian Muslims who were present in Bijeljina was limited ${ }^{2192}$ and by September 1993, the expulsion of the

\footnotetext{
2184 P2929 (Witness statement of KDZ531 dated 25 June 2011), p. 5 (under seal); KDZ531, T. 15856 (1 July 2011) (closed session); Dragomir Ljubojević, T. 35914-35915 (22 March 2013).

2185 P2929 (Witness statement of KDZ531 dated 25 June 2011), p. 5 (under seal); KDZ531, T. 15856 (1 July 2011 ) (closed session); Svetozar Mihajlović, T. 35738-35739 (20 March 2013).

2186 D1429 (Request of Bijeljina's Municipal Assembly, 24 July 1995), pp. 1-2; D3137 (Witness statement of Svetozar Mihajlović dated 17 March 2013), para. 14.

2187 D3137 (Witness statement of Svetozar Mihajlović dated 17 March 2013), para. 14; Svetozar Mihajlović, T. 35738-35739 (20 March 2013).

2188 Živan Filipović, T. 35811-35812 (21 March 2013)

2189 Defence Final Brief, para. 1387.

2190 D114 (Declaration of RS Assembly, 9 September 1992), p. 1.

2191 Momčilo Mandić, T. 5278 (15 July 2010); Milorad Davidović, T. 15732 (30 June 2011); D473 (SerBiH MUP, Summary from the MUP management meeting held on 20 August 1992), p. 10 (which suggests that some Bosnian Muslims returned to their homes in Bijeljina influenced by statements made by the Accused and Panić); Milivoje Kićanović, T. 34912 (6 March 2013).

2192 P820 (Witness statement of David Harland dated 4 September 2009), para.273; David Harland, T. 2116-2117 (7 May 2010).
} 
remaining Bosnian Muslims by Đurković and men under his command intensified. ${ }^{2193}$ The same process of expulsions of Bosnian Muslims continued into August and September 1994. ${ }^{2194}$

678. The systematic expulsion of Bosnian Muslims continued until the signing of the Dayton Accords with only 500 to 1,000 Bosnian Muslims remaining in Bijeljina by the time the Dayton Accords were signed. ${ }^{2195}$ This resulted in Bijeljina effectively being turned into an "ethnically Serb town". 2196

679. Having considered the totality of the evidence and assessed the circumstances in which departures occurred, the Chamber finds that Bosnian Muslims were forced to leave Bijeljina.

\section{ii. Bratunac}

\section{(A) Charges}

680. Under Count 3, the Prosecution alleges that persecution, a crime against humanity, was committed in Bratunac as part of the objective to permanently remove Bosnian Muslims and/or

2193 P5421 (Letter from humanitarian organisation to Radovan Karadžić, 16 September 1993), pp. 1-2 (under seal); P2471 (UNPROFOR Weekly BiH Political Assessment, 3 September 1994), p. 4; P5423 (UNPROFOR report, 20 September 1994), p. 2. But see P2073 (BBC news report re Bijeljina, with transcript), p. 1 (in which Đurković denies the reports about his actions). The Chamber sees this as an attempt by Đurković to distance himself from mistreatment of Bosnian Muslims and will therefore not rely on this part of the evidence.

2194 P2457 (UNPROFOR Weekly BiH Political Assessment, 28 August 1994), pp. 2, 4; P2471 (UNPROFOR Weekly BiH Political Assessment, 3 September 1994), p. 4; P5483 (ICRC Press Release re Forced Population Transfers, 30 August 1994); P2087 (UNHCR protest letter to Radovan Karadžić, 5 September 1994); P2458 (UNPROFOR Weekly BiH Political Assessment, 11 September 1994), pp. 2-3; P2885 (Excerpt from video from TV BiH Studio Tuzla re expelled people from Semberija); P5423 (UNPROFOR report, 20 September 1994), p. 2; P2929 (Witness statement of KDZ531 dated 25 June 2011), p. 7 (under seal); P2932 (ICRC report re Bijeljina, 19 September 1994). Ljubojević disputed the accuracy of this ICRC document. Dragomir Ljubojević, T. 35912 (22 March 2013). The Chamber does not find Ljubojević's evidence to be reliable in this regard. The witness failed to explain why he considered the document to be inaccurate and simply stated that he was not aware of these incidents or the pattern of expulsions. The Chamber also noted that the witness's evidence was marked by evasiveness and a lack of forthrightness in this regard.

2195 P2848 (Witness statement of Milorad Davidović dated 22 June 2011), paras. 162, 164. See also P1473 (Ratko Mladić's notebook, 27 January-5 September 1995), pp. 87-88.

2196 Jeremy Bowen, T. 10100-10101 (13 January 2011); P2073 (BBC news report re Bijeljina, with transcript), pp. 1-2; P2932 (ICRC report re Bijeljina, 19 September 1994); Milorad Davidović, T. 15531-15532 (28 June 2011); Milorad Davidović, T. 15717 (30 June 2011). See also P2929 (Witness statement of KDZ531 dated 25 June 2011), p. 7 (under seal); D4002 (Letter from BiH MUP to Vasvija Vidović, 4 July 1995), p. 30. Mihajlović testified that the Bosnian Serb leadership in Bijeljina never received instructions from the republican organs for the movement of non-Serbs from Bijeljina and that no such orders were issued to staff at the municipality level: D3137 (Witness statement of Svetozar Mihajlović dated 17 March 2013), para. 13. The Chamber does not consider this evidence to be reliable. In reaching that conclusion the Chamber observed that the witness had an interest in distancing himself from alleged crimes in Bijeljina and that his evidence was marked by contradictions. Ljubojević also testified that by 1995 there were approximately 10,000 Bosnian Muslims who remained in the municipality and that he was not aware of the pattern of expulsions. D3144 (Witness statement of Dragomir Ljubojević dated 18 March 2013), para. 14. See also Dragomir Ljubojević, T. 35915 (22 March 2013). The Chamber does not find Ljubojević's evidence to be reliable in this regard. The witness's evidence was marked by evasiveness and insincerity with respect to this issue. 
Bosnian Croats from the Municipalities. ${ }^{2197}$ Under Count 1, the Prosecution further alleges that in certain municipalities, including Bratunac, this persecutory campaign included or escalated to include conduct that manifested an intent to destroy in part the national, ethnical and/or religious groups of Bosnian Muslims and/or Bosnian Croats as such. ${ }^{2198}$

681. Acts alleged to have been committed in Bratunac by Serb Forces and Bosnian Serb Political and Governmental Organs include killings during and after the take-over, ${ }^{2199}$ killings related to detention facilities; ${ }^{2200}$ and killings committed during, and deaths resulting from, cruel and inhumane treatment at scheduled detention facilities. ${ }^{201}$ The Prosecution characterises these acts as killing, an underlying act of genocide, under Count 1; persecution, a crime against humanity, under Count 3; extermination, a crime against humanity, under Count 4; murder, a crime against humanity, under Count 5 ; and murder, a violation of the laws or customs of war, under Count $6 .{ }^{2202}$

682. Other acts alleged to have been committed in Bratunac by Serb Forces and Bosnian Serb Political and Governmental Organs include torture, beatings, and physical and psychological abuse, during and after the take-over and in scheduled detention facilities, as well as the establishment and perpetuation of inhumane living conditions in detention facilities, as cruel or inhumane treatment, an act of persecution under Count $3 .^{2203}$ In relation to Count 1 , the Prosecution alleges that in scheduled detention facilities in Bratunac, thousands of Bosnian Muslims and Bosnian Croats were subjected to cruel or inhumane treatment, including torture, physical and psychological abuse, and beatings by Serb Forces and Bosnian Serb Political and Governmental Organs; the Prosecution characterises this inhumane treatment as causing serious bodily or mental harm to Bosnian Muslims and Bosnian Croats, an underlying act of genocide. ${ }^{2204}$ In addition, under Count 1, the Prosecution alleges that thousands of Bosnian Muslims and Bosnian Croats were detained under conditions of life calculated to bring about physical destruction, namely through cruel and inhumane treatment, including torture, physical and psychological abuse, inhumane living conditions, and the failure to

\footnotetext{
2197 Indictment, paras. 48-49.

2198 Indictment, paras. 37-38.

2199 Indictment, para. 60(a)(i). See Scheduled Incidents A.3.1, A3.2.

2200 Indictment, para. 60(a)(ii). See Scheduled Incident B.4.1.

2201 Indictment, para. 60(a)(ii). See Scheduled Detention Facilities C.6.1, C.6.2.

2202 Indictment, paras. 40(a), 60(a), 63(a), 63(b).

2203 Indictment, para. 60(b), 60(c), 60(d) (specifying that the conditions included the failure to provide adequate accommodation, shelter, food, water, medical care, or hygienic sanitation facilities). See Scheduled Detention Facilities C.6.1, C.6.2. The Chamber notes that the Prosecution does not allege criminal responsibility for rape and other acts of sexual violence or for forced labour at the frontlines in Bratunac. Indictment, fns. 5, 7.

2204 Indictment, para. 40(b).
} 
provide adequate accommodation, shelter, food, water, medical care or hygienic sanitation facilities. $^{2205}$

683. Under Count 3, other acts of persecution alleged to have been committed in Bratunac by Serb Forces and Bosnian Serb Political and Governmental Organs, include (i) forcible transfer or deportation of Bosnian Muslims and Bosnian Croats from their homes; ${ }^{2206}$ (ii) unlawful detention in scheduled detention facilities; ${ }^{2207}$ (iii) the appropriation or plunder of property, during and after the take-over of Bratunac, during arrests and detention and in the course of or following acts of deportation or forcible transfer; ${ }^{2208}$ (iv) the wanton destruction of private property, including homes and business premises, and public property, including cultural monuments and sacred sites; ${ }^{2209}$ and (v) the imposition and maintenance of restrictive and discriminatory measures. ${ }^{2210}$

684. Under Counts 7 and 8, the Prosecution alleges deportation and inhumane acts (forcible transfer), respectively, as crimes against humanity. ${ }^{2211}$ In this regard, the Prosecution alleges that, by the end of 1992, Serb Forces and Bosnian Serb Political and Governmental Organs had forcibly displaced Bosnian Muslims and Bosnian Croats from areas in Bratunac in which they were lawfully present. $^{2212}$ It is alleged that from March 1992, restrictive and discriminatory measures, arbitrary arrest and detention, harassment, torture, killing, destruction of houses, cultural monuments and sacred sites, as well as the threat of further such acts caused Bosnian Muslims and Bosnian Croats to flee in fear while others were physically driven out. ${ }^{2213}$ It is further alleged that acts of forcible displacement continued between January and March 1993 when Serb Forces attacked the Konjević Polje area in Bratunac. ${ }^{2214}$

\section{(B) Lead-up}

685. Bratunac is a municipality in eastern $\mathrm{BiH}$ located to the south of Zvornik, the east of Vlasenica, and the north of Srebrenica. ${ }^{2215}$ The Drina River forms a border between Bratunac and

Indictment, para. 60(j). See Scheduled Incident D.6.

Indictment, para. 40(c). See Scheduled Detention Facilities C.6.1, C.6.2.

Indictment, paras. 56, 60(f).

Indictment, para. 60(g). See Scheduled Detention Facilities C.6.1, C.6.2.

Indictment, para. 60(i).

Indictment, para. $60(\mathrm{k})$. The restrictive and discriminatory measures alleged include the denial of freedom of movement; the removal from positions of authority; the invasion of privacy through arbitrary searches of homes; unlawful arrest and/or the denial of the right to judicial process; and/or the denial of equal access to public services.

2211 Indictment, paras. 68-75.

2212 Indictment, paras. 69, 72.

2213 Indictment, para. 71.

2214 Indictment, para. 72.

2215 D484 (Map of BiH).
} 
Serbia to the east. ${ }^{2216}$ Prior to the war, the population of Bratunac was approximately 33,000 and consisted of about $62 \%$ Bosnian Muslims, 36\% Bosnian Serbs, and 2\% from other groups. ${ }^{2217}$ The town of Bratunac itself had a population of between 7,000 and 8,000. ${ }^{2218}$

686. The SDS was formed in Bratunac following a meeting on 8 August 1990 and Miroslav Deronjić was elected president of the SDS Municipal Board and subsequently chairman of the municipal board. ${ }^{2219}$ Deronjić was the most influential Bosnian Serb official in Bratunac. ${ }^{2220}$ The constituent assembly of the SDA was held in Bratunac in September $1990 .^{2221}$ Following the formation of the national parties, and as relations between ethnic groups deteriorated, fear in the municipality increased. ${ }^{222}$

687. The SDA won the majority of seats in Bratunac after the multi-party elections. A coalition government was formed and leadership positions were divided between representatives of the SDA and SDS. ${ }^{2223}$ Nijaz Dubišić, a Bosnian Muslim, was the President of the Municipality, the

2216 P3196 (Witness statement of Dževad Gušić undated), para. 26(a).

2217 P4994 (Addendum to Ewa Tabeau's expert report entitled "Ethnic Composition in Internally Displaced Persons and Refugees from 27 Municipalities of BiH 1991 to 1997", 3 February 2009), e-court pp. 30, 33, 36, 39; P3196 (Witness statement of Dževad Gušić undated), para. 3; Dževad Gušić, T. 17813 (24 August 2011); D3398 (Witness statement of Ljubisav Simić dated 7 April 2013), para. 4; P3205 (Witness statement of KDZ605 dated 22 August 2011), para. 4 (under seal); KDZ605, T. 17882 (25 August 2011); P4374 (Witness statement of Milenko Katanić dated 11 October 2011), para. 10; D3126 (Witness statement of Jovan Nikolić dated 10 March 2013), para. 28; D225 (Ethnic map of BiH based on 1991 census).

2218 D3398 (Witness statement of Ljubisav Simić dated 7 April 2013), para. 4.

2219 P4376 (Minutes from first meeting of the Initial Board for the formation of the SDS in Bratunac, 8 August 1990), pp. 1-2. See also P4374 (Witness statement of Milenko Katanić dated 11 October 2011), paras. 6-7, 12; P3188 (Witness statement of Mušan Talović dated 14 July 2011), para. 8; Mušan Talović, T. 17638 (22 August 2011); P3196 (Witness statement of Dževad Gušić undated), para. 6; P3204 (List of Bratunac leadership prepared by Dževad Gušić, 2 May 2003); P3205 (Witness statement of KDZ605 dated 22 August 2011), para. 9 (under seal).

2220 Srbislav Davidović, P4100 (Transcript from Prosecutor v. Popović), T. 9260; Srbislav Davidović, T. 24384 (9 February 2012). Ljubisav Simić and Rodoljub Đukanović were both members of the SDS leadership in Bratunac. D3118 (Witness statement of Aleksandar Tešić dated 10 March 2013), para. 19; P3204 (List of Bratunac leadership prepared by Dževad Gušić, 2 May 2003).

2221 D3194 (Witness statement of Rodoljub Đukanović dated 24 March 2013), para. 10. On or around 20 March 1992 Dževad Gušić was appointed president of the SDA in Bratunac. Dževad Gušić, T. 17778 (24 August 2011); P3196 (Witness statement of Dževad Gušić undated), paras. 5, 71; P3204 (List of Bratunac leadership prepared by Dževad Gušić, 2 May 2003); P3203 (Summary of Dževad Gušić's personal background, 2 May 2003); P3205 (Witness statement of KDZ605 dated 22 August 2011), paras. 9, 17 (under seal).

2222 P4374 (Witness statement of Milenko Katanić dated 11 October 2011), para. 10; D3115 (Witness statement of Branimir Tešić dated 9 March 2013), paras. 3-4; D3398 (Witness statement of Ljubisav Simić dated 7 April 2013), paras. 7, 10. See also D3194 (Witness statement of Rodoljub Đukanović dated 24 March 2013), paras. 8-9; D3126 (Witness statement of Jovan Nikolić dated 10 March 2013), para. 21; D3852 (Witness statement of Mirko Perić dated 1 July 2013), para. 6; D3115 (Witness statement of Branimir Tešić dated 9 March 2013), para. 8.

2223 P3188 (Witness statement of Mušan Talović dated 14 July 2011), para. 7; P3204 (List of Bratunac leadership prepared by Dževad Gušić, 2 May 2003); P3196 (Witness statement of Dževad Gušić undated), paras. 4, 10a; Dževad Gušić, T. 17813, 17843, 17846 (24 August 2011); D1658 (Report of Bratunac Municipal Assembly, 5 March 1991); P3205 (Witness statement of KDZ605 dated 22 August 2011), para. 12 (under seal); D3126 (Witness statement of Jovan Nikolić dated 10 March 2013), para. 30; D3194 (Witness statement of Rodoljub Đukanović dated 24 March 2013), para. 12; Milenko Katanić, T. 24513-24514 (10 February 2012). See also P3197 (Minutes of sessions of Bratunac SDS Crisis Staff and Municipal Board), p. 6. 
President of the Executive Board was a Bosnian Serb and there was equal representation between Bosnian Serbs and Bosnian Muslims on the Executive Board. ${ }^{2224}$ Senad Hodžić was appointed as head of the police in late 1991 and Džemo Hodžić was the Bosnian Muslim commander of the TO staff. $^{225}$ Over time, there were disagreements between the SDS and SDA regarding those who were recommended for certain posts. ${ }^{2226}$

688. From 1991, there was growing Bosnian Serb nationalist sentiment with increasing intimidation of Bosnian Muslims. ${ }^{2227}$ SDS members wrote slogans on street and traffic signs as well as on public and private property, which were derogatory towards Bosnian Muslims, including messages to the effect: "Muslims, Balijas, Turks move out, you're going to be slaughtered", "there is no Bosnia any more". ${ }^{2228}$ Other slogans included the names of Slobodan Milošević, the Accused, "Chetnik" commanders from the Second World War and phrases such as:"This is Serbia, Greater Serbia". 229 These developments coincided with SDS representatives stating that co-existence was not possible and that Bratunac was a "Serb municipality". 2230

689. There was also an increase in Bosnian Muslim rhetoric that Serbs should go to Serbia and that $\mathrm{BiH}$ belonged to the Muslims, which led to many Bosnian Serbs moving from Bratunac to Serbia. $^{2231}$ Tensions increased further when (i) there were attacks against Bosnian Serb leaders ${ }^{2232}$ and SDS members; (ii) Bosnian Muslims boycotted the JNA mobilisation but started going to

2224 Dževad Gušić, T. 17815-17819 (24 August 2011); P3196 (Witness statement of Dževad Gušić undated), paras. 5-6, 10, 71; P3204 (List of Bratunac leadership prepared by Dževad Gušić, 2 May 2003); Rodoljub Đukanović, T. 36163 (27 March 2013); D3194 (Witness statement of Rodoljub Đukanović dated 24 March 2013), paras. 2, 12. See also Milenko Katanić, T. 24515 (10 February 2012).

2225 P3204 (List of Bratunac leadership prepared by Dževad Gušić, 2 May 2003); P3196 (Witness statement of Dževad Gušić undated), paras. 10b, 71; Dževad Gušić, T. 17818-17819 (24 August 2011). See also Milenko Katanić, T. 24515 (10 February 2012).

2226 D3126 (Witness statement of Jovan Nikolić dated 10 March 2013), para. 30; D3194 (Witness statement of Rodoljub Đukanović dated 24 March 2013), para. 12. See also Dževad Gušić, T. 17843 (24 August 2011).

2227 P3196 (Witness statement of Dževad Gušić undated), paras. 13-14, 16.

2228 Dževad Gušić, T. 17789 (24 August 2011).

2229 Dževad Gušić, T. 17779-17780, 17789 (24 August 2011); P3196 (Witness statement of Dževad Gušić undated), para. 42.

2230 P3196 (Witness statement of Dževad Gušić undated), paras. 14, 17.

2231 D3194 (Witness statement of Rodoljub Đukanović dated 24 March 2013), paras. 7-11; D3398 (Witness statement of Ljubisav Simić dated 7 April 2013), para. 13; Milenko Katanić, T. 24516, 24530 (10 February 2012). See also D3174 (Witness statement of Vujadin Stević dated 23 March 2013), paras. 8, 12; D3115 (Witness statement of Branimir Tešić dated 9 March 2013), para. 6. But see P3196 (Witness statement of Dževad Gušić undated), para. 17.

2232 D3398 (Witness statement of Ljubisav Simić dated 7 April 2013), para. 20; D3194 (Witness statement of Rodoljub Đukanović dated 24 March 2013), paras. 14, 23; Rodoljub Đukanović, T. 36148 (27 March 2013); D3126 (Witness statement of Jovan Nikolić dated 10 March 2013), para. 24. 
Croatia for training; ${ }^{2233}$ and (iii) in the autumn of 1991 there was a mobilisation of the reserve police force, which in Bratunac consisted of over $60 \%$ Bosnian Muslims. ${ }^{2234}$

690. At a meeting of the SDS Municipal Board of Bratunac in February 1991, Deronjić and others were chosen to conduct negotiations with the SDA. ${ }^{235}$ At another meeting of the SDS Municipal Board on 12 April 1991, it was agreed that instructions would be requested from the SDS headquarters "regarding the referendum, our behaviour and functioning" and that the regional redrawing of municipal borders which was occurring in Banja Luka was "fully supported, and those questions should be posed in our areas as well". 236 It was also noted that the Presidency of Bratunac should meet with the Accused urgently with respect to the questions raised. ${ }^{2237}$

691. In that period, there was increasing intimidation of Bosnian Muslim professionals and incidents where prominent Bosnian Muslim men were beaten. ${ }^{2238}$ Road-blocks were erected by Bosnian Serbs. $^{2239}$ In the SJB there was greater distrust between Bosnian Muslim and Bosnian Serb police officers. ${ }^{2240}$ Dževad Gušić, the President of the SDA in Bratunac, was subjected to intimidation and was shot at on a number of occasions while leaving his home. ${ }^{2241}$ There was also shooting at night from Bosnian Serb villages at Bosnian Muslim villages and some Bosnian Muslims were taken from their homes and killed. ${ }^{2242}$ There were also increasing confrontations and division between ethnic groups in the work place. ${ }^{2243}$

2233 D3398 (Witness statement of Ljubisav Simić dated 7 April 2013), paras. 15, 19-20; D3399 (Letter from Bratunac SJB to Tuzla CSB, 17 March 1992); D3194 (Witness statement of Rodoljub Đukanović dated 24 March 2013), paras. 8-11, 13, 15; D260 (SDA letter re MUP training in Croatia, 11 July 1991); P3205 (Witness statement of KDZ605 dated 22 August 2011), para. 20 (under seal); KDZ605, T. 17895 (25 August 2011). See also D3126 (Witness statement of Jovan Nikolić dated 10 March 2013), paras. 20, 22; D3118 (Witness statement of Aleksandar Tešić dated 10 March 2013), paras. 5-6; D3174 (Witness statement of Vujadin Stević dated 23 March 2013), para. 3.

2234 This mobilisation was ordered by Alija Delimustafic of the MUP. D3194 (Witness statement of Rodoljub Đukanović dated 24 March 2013), para. 18; Rodoljub Đukanović, T. 36149-36150 (27 March 2013). See also D3174 (Witness statement of Vujadin Stević dated 23 March 2013), para. 6.

2235 P3197 (Minutes of sessions of Bratunac SDS Crisis Staff and Municipal Board), p. 10.

2236 P3197 (Minutes of sessions of Bratunac SDS Crisis Staff and Municipal Board), p. 13. The Chamber rejects Đukanović's evidence that, except for one order in relation to a humanitarian convoy from the Accused, there was practically no communication between Bratunac and Pale (D3194 (Witness statement of Rodoljub Đukanović dated 24 March 2013), para. 51; Rodoljub Đukanović, T. 36147, 36169-36170, 36172-36173, 36178, 36179, 36191-36192, 36202, 36209-36210 (27 March 2013). The Chamber finds that Đukanović's testimony was marked by contradictions, extreme evasiveness and indicators of insincerity and does not find his evidence to be reliable in this regard.

2237 P3197 (Minutes of sessions of Bratunac SDS Crisis Staff and Municipal Board), p. 13.

2238 P3196 (Witness statement of Dževad Gušić undated), para. 15; Dževad Gušić, T. 17795 (24 August 2011).

2239 Mušan Talović, T. 17647-17649 (22 August 2011). See also P3196 (Witness statement of Dževad Gušić undated), paras. 77-78; Dževad Gušić, T. 17849 (24 August 2011).

2240 D3115 (Witness statement of Branimir Tešić dated 9 March 2013), paras. 3-5.

2241 P3196 (Witness statement of Dževad Gušić undated), paras. 44-47.

2242 P3205 (Witness statement of KDZ605 dated 22 August 2011), paras. 31-33 (under seal); P3196 (Witness statement of Dževad Gušić undated), paras. 45a, 74. See also P3263 (Witness statement of Suad Džafić dated 
692. Inter-ethnic relations deteriorated further in late August 1991, following failed attempts by SDS supporters, with the help of a JNA unit and members of the Bosnian Serb police, to demand military documentation from the Municipal Secretariat to identify the names of men who could be mobilised. ${ }^{2244}$ Their attempts to secure these military records were blocked by a large crowd of SDA supporters and Bosnian Muslim members of the police. ${ }^{2245}$ Following this incident there were increased inter-ethnic clashes in Bratunac, ${ }^{2246}$ which disrupted the coalition government. ${ }^{2247}$

693. Tensions and mistrust increased even further in September 1991 following an incident in Kravica in which Bosnian Muslims were ambushed, wounded, and some killed. ${ }^{2248}$ A large crowd of Bosnian Muslims demanded that the incident be investigated and called for the perpetrators to be brought to justice. $^{2249}$ The situation was only calmed down when political leaders, including Nikola Koljević, arrived in Bratunac and made public assurances to Bosnian Muslims that there

31 August 2011), paras. 6-8; Suad Džafić, T. 18193 (1 September 2011). The Chamber has only had regard to these killings for the purpose of setting the general background in Bratunac given these killings are not charged pursuant to Schedules A or B of the Indictment. See fn. 13.

2243 P3205 (Witness statement of KDZ605 dated 22 August 2011), para. 30 (under seal).

2244 P3196 (Witness statement of Dževad Gušić undated), paras. 20, 25; Dževad Gušić, T. 17822 (24 August 2011). See also D1657 (Excerpt from book entitled "The Truth about Bratunac"), p. 1; D3118 (Witness statement of Aleksandar Tešić dated 10 March 2013), para. 10; D3115 (Witness statement of Branimir Tešić dated 9 March 2013), para. 11.

2245 P3188 (Witness statement of Mušan Talović dated 14 July 2011), para. 12; P3196 (Witness statement of Dževad Gušić undated), paras. 20-25; P3205 (Witness statement of KDZ605 dated 22 August 2011), paras. 19-20 (under seal); D3126 (Witness statement of Jovan Nikolić dated 10 March 2013), para. 23; D3115 (Witness statement of Branimir Tešić dated 9 March 2013), para. 11; D3398 (Witness statement of Ljubisav Simić dated 7 April 2013), paras. 20-23; KDZ605, T. 17894-17895 (25 August 2011); Momir Nikolić, T. 24713 (14 February 2012). See also D3194 (Witness statement of Rodoljub Đukanović dated 24 March 2013), paras. 1516; D3195 (Official note of Tuzla CSB, 4 September 1991), p. 2; D3118 (Witness statement of Aleksandar Tešić dated 10 March 2013), paras. 7, 10-12; D3115 (Witness statement of Branimir Tešić dated 9 March 2013), paras. 11-13.

2246 D3398 (Witness statement of Ljubisav Simić dated 7 April 2013), para. 24; D3194 (Witness statement of Rodoljub Đukanović dated 24 March 2013), para. 17; D3126 (Witness statement of Jovan Nikolić dated 10 March 2013), para. 24; D3118 (Witness statement of Aleksandar Tešić dated 10 March 2013), para. 14.

2247 Milenko Katanić, T. 24517 (10 February 2012).

2248 P3196 (Witness statement of Dževad Gušić undated), paras. 33, 79; Dževad Gušić, T. 17824 (24 August 2011); D3115 (Witness statement of Branimir Tešić dated 9 March 2013), para. 14; D3398 (Witness statement of Ljubisav Simić dated 7 April 2013), paras. 25-26, 28; D3194 (Witness statement of Rodoljub Đukanović dated 24 March 2013), paras. 19-20, 22-24; D3126 (Witness statement of Jovan Nikolić dated 10 March 2013), paras. 23, 25-26. See also P3205 (Witness statement of KDZ605 dated 22 August 2011), paras. 13-14 (under seal); D3194 (Witness statement of Rodoljub Đukanović dated 24 March 2013), para. 21; D3195 (Official note of Tuzla CSB, 4 September 1991), p. 2. Đukanović testified that this incident was used by Bosnian Muslims to their advantage to be "even more brutal in their behaviour" and as justification to arm themselves on a large scale. D3194 (Witness statement of Rodoljub Đukanović dated 24 March 2013), paras. 21, 24. See also D3195 (Official note of Tuzla CSB, 4 September 1991), p. 2. The Chamber notes that Đukanović's testimony was marked by extreme evasiveneses, contradictions, speculation, and indicators of insincerity which undermined the reliability of his evidence in this regard.

2249 P3196 (Witness statement of Dževad Gušić undated), paras. 33-34. See also P3205 (Witness statement of KDZ605 dated 22 August 2011), para. 14 (under seal). 
would be an investigation. ${ }^{2250}$ However, Koljević subsequently went to the site and reassured Bosnian Serbs who had gathered there that the investigation would not take place; the Accused himself in a radio broadcast guaranteed that there would be no investigation. ${ }^{251}$ The increased tension contributed to a feeling of insecurity, which prompted both ethnic groups to start performing night guard duty around their homes. ${ }^{2252}$

694. The SDS issued an ultimatum before the Municipal Assembly was due to be convened; this insisted on a 50:50 power sharing arrangement even though they were in the minority. ${ }^{2253}$ The SDA accepted this ultimatum. ${ }^{2254}$

\section{(1) Militarisation of Bratunac}

695. Before the multi-party elections, the JNA had withdrawn the local TO weapons and placed them under their control. ${ }^{2255}$ In late August 1991, SDS officials, including Deronjić, and the JNA were involved in training and arming local Bosnian Serbs with these weapons. ${ }^{2256}$ At the end of 1991 and early into 1992, JNA military formations moved closer to Bratunac, and there was an increasing movement of military vehicles and personnel in the surrounding villages and hills. ${ }^{2257}$

2250 D3398 (Witness statement of Ljubisav Simić dated 7 April 2013), paras. 27-28; P3196 (Witness statement of Dževad Gušić undated), para. 35. See also D3194 (Witness statement of Rodoljub Đukanović dated 24 March 2013), para. 22.

2251 P3196 (Witness statement of Dževad Gušić undated), para. 35.

2252 D3398 (Witness statement of Ljubisav Simić dated 7 April 2013), paras. 29-30, 32; D3194 (Witness statement of Rodoljub Đukanović dated 24 March 2013), para. 25. See also D3174 (Witness statement of Vujadin Stević dated 23 March 2013), paras. 7, 9; D3115 (Witness statement of Branimir Tešić dated 9 March 2013), para. 8; P3205 (Witness statement of KDZ605 dated 22 August 2011), para. 14 (under seal).

2253 P3196 (Witness statement of Dževad Gušić undated), paras. 10-10a; Dževad Gušić, T. 17813-17814 (24 August 2011). See also D3398 (Witness statement of Ljubisav Simić dated 7 April 2013), para. 17.

2254 P3196 (Witness statement of Dževad Gušić undated), para. 10. Prior the multi-party elections, the SDS was able to lobby the deputies of the Municipal Assembly to change the statute of the Assembly to require a two-third majority for decisions which effectively prevented the SDA, after the elections, from passing any decisions without support from the SDS. P3196 (Witness statement of Dževad Gušić undated), paras. 7-8; Dževad Gušić, T. 17813-17814 (24 August 2011).

2255 P3196 (Witness statement of Dževad Gušić undated), paras. 18, 74. The JNA took over the stock of TO weapons and ammunition pursuant to an order of Federal Secretariat for National Defence of the SFRY on 14 May 1990. P3201 (Order of SFRY Federal Secretariat for National Defence, 14 May 1990), pp. 1-2.

2256 P4374 (Witness statement of Milenko Katanić dated 11 October 2011), para. 25; P3196 (Witness statement of Dževad Gušić undated), paras. 19, 27-27a, 30b, 62; Dževad Gušić, T. 17794-17795 (24 August 2011). See also D3195 (Official note of Tuzla CSB, 4 September 1991), p. 2; P3205 (Witness statement of KDZ605 dated 22 August 2011), paras. 21, 23 (under seal). Defence witnesses testified that Bosnian Serbs only began to buy weapons in response to the massive scale arming of the Bosnian Muslim population and also denied their own involvement in the distribution of weapons. D3126 (Witness statement of Jovan Nikolić dated 10 March 2013), para. 32; D3194 (Witness statement of Rodoljub Đukanović dated 24 March 2013), paras. 24, 54; Rodoljub Đukanović, T. 36148-36149 (27 March 2013). The Chamber does not find this evidence to be reliable. In reaching that conclusion, the Chamber notes that the evidence of the relevant witnesses was marked by extreme evasiveneses, contradictions, and indicators of insincerity.

2257 P3196 (Witness statement of Dževad Gušić undated), paras. 26-26a; P3205 (Witness statement of KDZ605 dated 22 August 2011), paras. 10, 21 (under seal). 
696. The SDA was also involved in the distribution of weapons to Bosnian Muslims ${ }^{2258}$ and a Bosnian Muslim crisis staff was established. ${ }^{2259}$ Bosnian Muslim villagers organised local guards. $^{2260}$

\section{(2) Division of municipal structures}

697. In October 1991, following the Accused's declaration of a state of emergency of the SDS, an emergency meeting of the SDS Municipal Board of Bratunac was held. ${ }^{2261}$ There, Deronjić informed those present about the SDS Main Board instructions. ${ }^{2262}$ At this meeting, the SDS Crisis Staff of Bratunac was formed with Deronjić as its chief. ${ }^{2263}$ In addition, the President of the Executive Board of the Bratunac Municipal Assembly briefed the participants about preparations for regionalisation. ${ }^{2264}$ On 25 October 1991, the SDS Municipal Board gave authorisation to expand the SDS Crisis Staff. ${ }^{2265}$ The SDS Crisis Staff met on 26 October 1991 and discussed the formation of regions. ${ }^{2266}$

698. On 23 December 1991, the SDS Municipal Board held a meeting where the Variant A/B Instructions were presented. ${ }^{2267}$ Deronjic informed the members about the session of the SDS

2258 D3195 (Official note of Tuzla CSB, 4 September 1991); D3398 (Witness statement of Ljubisav Simić dated 7 April 2013), para. 30; Momir Nikolić, T. 24712 (14 February 2012). See also D3174 (Witness statement of Vujadin Stević dated 23 March 2013), para. 8; D3115 (Witness statement of Branimir Tešić dated 9 March 2013), paras. 6-7; P3205 (Witness statement of KDZ605 dated 22 August 2011), para. 10 (under seal).

2259 P3205 (Witness statement of KDZ605 dated 22 August 2011), para. 17 (under seal). See also D3398 (Witness statement of Ljubisav Simić dated 7 April 2013), para. 50. Dževad Gušić, T. 17818, 17826-17827, 17831, 17836-17837 (24 August 2011); P3196 (Witness statement of Dževad Gušić undated), paras. 71, 73-74. The Chamber finds that there were armed Bosnian Muslim formations in Bratunac. KDZ480, T. 24236 (7 February 2012); D1657 (Excerpt from book entitled "The Truth about Bratunac"), pp. 1-3.

2260 P3196 (Witness statement of Dževad Gušić undated), para. 73. See also D1657 (Excerpt from book entitled "The Truth about Bratunac"), p. 2.

2261 P3197 (Minutes of sessions of Bratunac SDS Crisis Staff and Municipal Board), p. 1; Dževad Gušić, T. 1779717798 (24 August 2011). P5831 (Intercept of conversation between Radovan Karadžić and Miljana LNU, 17 October 1991). See also P6238 (Radovan Karadžić's Decision, 18 October 1991); Dorothea Hanson, T. 14857-14859 (17 June 2011).

2262 P3197 (Minutes of sessions of Bratunac SDS Crisis Staff and Municipal Board), p. 1. See also P2589 (Dorothea Hanson's expert report entitled "Bosnian Serb Crisis Staffs, War Presidencies and War Commissions 19911995”, 10 September 2009), fn. 13.

2263 P3197 (Minutes of sessions of Bratunac SDS Crisis Staff and Municipal Board), pp. 1-2; P3196 (Witness statement of Dževad Gušić undated), paras. 6, 11; Dževad Gušić, T. 17794 (24 August 2011); P3188 (Witness statement of Mušan Talović dated 14 July 2011), para. 8; Mušan Talović, T. 17638 (22 August 2011); P3204 (List of Bratunac leadership prepared by Dževad Gušić, 2 May 2003); P3205 (Witness statement of KDZ605 dated 22 August 2011), para. 9 (under seal). See also P4374 (Witness statement of Milenko Katanić dated 11 October 2011), paras. 6-7, 13; D3126 (Witness statement of Jovan Nikolić dated 10 March 2013), para. 29; D3118 (Witness statement of Aleksandar Tešić dated 10 March 2013), para. 19.

2264 P3197 (Minutes of sessions of Bratunac SDS Crisis Staff and Municipal Board), p. 2.

2265 P3198 (Minutes of $2^{\text {nd }}$ session of Bratunac SDS Municipal Board, 25 October 1991), p. 2.

2266 P3197 (Minutes of sessions of Bratunac SDS Crisis Staff and Municipal Board), p. 3.

2267 P2598 (Minutes of meeting of Bratunac SDS Municipal Board, 23 December 1991), p. 1; P4374 (Witness statement of Milenko Katanić dated 11 October 2011), para. 15; P5 (SDS Instructions for Organisation of Organs of the Serbian People in BiH, 19 December 1991). 
Presidency and said that a decision had been reached to establish the SerBiH and that Variant B was envisaged for Bratunac since Bosnian Serbs were a minority in the municipality. ${ }^{2268}$ In accordance with these instructions, a decision was made to form the Bratunac Crisis Staff which would start working immediately. ${ }^{2269}$ The Bratunac Crisis Staff included the Commander of Police, representatives of the military, Ministry of Defence and "distinguished civilians". ${ }^{2270}$ In addition to the Bratunac Crisis Staff, crisis staffs were also formed at the local commune level and they informed the Bratunac Crisis Staff about issues at the local level. ${ }^{2271}$

699. On 30 December 1991, the first session of the Serbian Municipal Assembly of Bratunac was held, Ljubisav Simić was appointed as President of the Assembly, and Radoljub Đukanović was appointed as Chairman of the Executive Board. ${ }^{2272}$ At this session a proposal to join the region of Birač was adopted and there was discussion about "regionalisation". 2273 Bratunac became part of the SAO Birač and Rodoljub Đukanović was elected to the Executive Council of the SAO. ${ }^{2274}$

700. At a meeting of the SDS Municipal Board on 22 January 1992, Deronjić stated that the policies pursued and advocated by Milošević, the Accused and Babić had "met with failure after failure" and that the objective of the SDS of preserving the SFRY was history. ${ }^{2275}$ At this same

2268 P2598 (Minutes of meeting of Bratunac SDS Municipal Board, 23 December 1991), p. 1; Milenko Katanić, T. 24525-24526 (10 February 2012). Defence witnesses testified that they were not aware of any meeting in Bratunac where the Variant A/B Instructions were discussed and the Bosnian Serb authorities resolved all problems on their own. D3194 (Witness statement of Rodoljub Đukanović dated 24 March 2013), para. 27; Rodoljub Đukanović, T. 36181-36183 (27 March 2013); D3398 (Witness statement of Ljubisav Simić dated 7 April 2013), para. 53. The Chamber refers to its credibility assessment in fn. 2248 above as to why it does not consider Đukanović's evidence to be reliable in this regard. Further, with respect to Simić, the Chamber notes that his evidence is qualified, given that he simply states that he did not know about such a meeting. In addition, Simić's evidence was marked by contradictions and inconsistencies.

2269 P2598 (Minutes of meeting of Bratunac SDS Municipal Board, 23 December 1991), pp. 1-2; P4374 (Witness statement of Milenko Katanić dated 11 October 2011), paras. 15-16. But see Rodoljub Đukanović, T. 36202, 36206 (27 March 2013); D3126 (Witness statement of Jovan Nikolić dated 10 March 2013), para. 33; Jovan Nikolić, T. 35487 (14 March 2013); D3398 (Witness statement of Ljubisav Simić dated 7 April 2013), para. 50. The Chamber refers to its credibility assessment in fns. 2248, 2256, and 2268 as to why it does not consider that the evidence of these witnesses is reliable with respect to the issue of when and why the Bratunac Crisis Staff was formed.

2270 P4374 (Witness statement of Milenko Katanić dated 11 October 2011), paras. 15-16; Milenko Katanić, T. 24526-24527 (10 February 2012).

2271 D3398 (Witness statement of Ljubisav Simić dated 7 April 2013), para. 51.

2272 P3199 (Minutes of $1^{\text {st }}$ meeting of Bratunac Municipal Assembly, 30 December 1991), pp. 2-3; D3398 (Witness statement of Ljubisav Simić dated 7 April 2013), para. 3; P3196 (Witness statement of Dževad Gušić undated), para. 11; Dževad Gušić, T. 17794 (24 August 2011); P3204 (List of Bratunac leadership prepared by Dževad Gušić, 2 May 2003). The decision proclaiming the establishment of a Serbian Municipality of Bratunac was subsequently verified and approved at the $12^{\text {th }}$ session of the Bosnian Serb Assembly. P961 (Shorthand Record of $12^{\text {th }}$ session of SerBiH Assembly, 24 March 1992), pp. 23-24.

2273 P3199 (Minutes of $1^{\text {st }}$ meeting of Bratunac Municipal Assembly, 30 December 1991), pp. $3,5$.

2274 D3194 (Witness statement of Rodoljub Đukanović dated 24 March 2013), para. 26; Rodoljub Đukanović, T. 36163-36164 (27 March 2013).

2275 D3127 (Excerpt from minutes of meeting of Bratunac SDS Municipal Board, 8 July 1991), p. 1. 
meeting, Deronjić demanded to meet with the Accused and Koljević in Bratunac and Simić alerted that if necessary the Bratunac leadership "will refuse obedience even to Sarajevo". 2276

701. On 24 February 1992, the SDS Municipal Board discussed the implementation in Bratunac of the second level of the Variant A/B Instructions. ${ }^{2277}$ At this meeting, it was noted that since the first phase of the instructions had been implemented, the second phase, which was a state of emergency, would be activated. ${ }^{2278}$ Deronjić read the instructions at the meeting and said that they imposed a duty to "act accordingly". These instructions included creating a municipal Executive Board and forming a reserve structure of the Bosnian Serb police. ${ }^{2279}$ In addition local boards were tasked with reporting on measures taken with respect to safety and with the collection and storage of food in Bosnian Serb areas. ${ }^{2280}$ Deronjić also instructed that guard duties should be set-up and citizens should co-operate with the Bratunac Crisis Staff. ${ }^{2281}$

702. At the 24 February 1992 meeting of the SDS Municipal Board, Branko Obrenović commented that he feared that the war would find them unprepared and that they needed to "activate the Crisis staffs that would take care of everything" and a war plan was needed. ${ }^{2282}$ Deronjić agreed with this proposal. ${ }^{2283}$ It was also reported that contact with the army had been established and there was discussion about the formation of military units and training of individuals. $^{2284}$

703. On 28 February 1992, the Serbian Municipal Assembly of Bratunac adopted the proposal to appoint one person to take on the role of national defence secretary and chief of the SJB. ${ }^{2285}$ At this meeting, Deronjić stressed the importance of setting up a Bosnian Serb police. ${ }^{2286}$

\footnotetext{
2276 D3127 (Excerpt from minutes of meeting of Bratunac SDS Municipal Board, 8 July 1991), p. 1.

2277 P4374 (Witness statement of Milenko Katanić dated 11 October 2011), para. 18.

2278 P2597 (Minutes of meeting of Bratunac's SDS Municipal Board, 24 February 1992), p. 1; Milenko Katanić, T. 24527-24528 (10 February 2012).

2279 P2597 (Minutes of meeting of Bratunac SDS Municipal Board, 24 February 1992), p. 1; P4374 (Witness statement of Milenko Katanić dated 11 October 2011), para. 18.

2280 P2597 (Minutes of meeting of Bratunac SDS Municipal Board, 24 February 1992), p. 1; Milenko Katanić, T. 24527 (10 February 2012).

2281 P2597 (Minutes of meeting of Bratunac SDS Municipal Board, 24 February 1992), p. 1.

2282 P2597 (Minutes of meeting of Bratunac SDS Municipal Board, 24 February 1992), p. 1. The Chamber refers to para. 698, where it found that the Bratunac Crisis Staff had already been established in December 1991. The Chamber finds that this reference in February 1992 relates to the activation of that crisis staff for the purposes of war. In accordance with the second phase of the Variant A/B Iinstructions, the Crisis Staff was given the responsibility for "organisation of defence". P5 (SDS Instructions for Organisation of Organs of the Serbian People in BiH, 19 December 1991), p. 9.

2283 P2597 (Minutes of meeting of Bratunac SDS Municipal Board, 24 February 1992), p. 1,

2284 P2597 (Minutes of meeting of Bratunac's SDS Municipal Board, 24 February 1992), p. 2.

2285 P3199 (Minutes of $1^{\text {st }}$ meeting of Bratunac Municipal Assembly, 30 December 1991), p. 6.

2286 P3199 (Minutes of $1^{\text {st }}$ meeting of Bratunac Municipal Assembly, 30 December 1991), p. 7.
} 
704. At a meeting with SDA representatives, Deronjić stated that "Serbs need to keep their own Serbdom, their own history, their own tradition, their own culture" and in order to do that they should live separately from the Bosnian Muslim people. ${ }^{2287}$ Deronjić explained "[w]e in the SDS have plans that were prepared. I even have certain instructions how to act with regard to these questions". ${ }^{2288}$ After this, a meeting was held which was attended by directors of major companies, and Deronjić informed them that the Bosnian Serbs should live separately, that there were plans, and that Bratunac and $\mathrm{BiH}$ should be divided. 2289

705. At the beginning of April 1992, in a meeting between SDS and SDA representatives, Deronjić reiterated that the police should be divided and that separate Bosnian Muslim and Bosnian Serb police units should be formed. ${ }^{2290}$ When the SDA representatives opposed the idea as it would lead to greater tensions, Deronjić threatened that if they did not comply "Muslims would disappear". 2291

706. Deronjić said that if the Bosnian Muslim representatives agreed to the division, it "would be the best way for the Muslims to prevent violence from breaking out". ${ }^{2292}$ The SDS representatives also promised that if the police was split, the JNA would remove weapons from the surrounding hills and the town and non-Serbs would be protected. ${ }^{2293}$

2287 Dževad Gušić, T. 17790-17792 (24 August 2011).

2288 Dževad Gušić, T. 17791 (24 August 2011).

2289 Dževad Gušić, T. 17791 (24 August 2011). Gušić stated that when he spoke to an SDA official about the division of $\mathrm{BiH}$, the SDA official said that the Accused had told him "we'll have to split up. There's no other way out" and the Accused insisted on this division even when he was told that Bosnian Serbs, Bosnian Muslims, and Bosnian Croats lived together in the same buildings. P3196 (Witness statement of Dževad Gušić undated), paras. 11-12. However, Gušić clarified that the SDA official later spoke to him and was not sure whether he had spoken to the Accused or to another official. Dževad Gušić, T. 17778-17779, 17783-17785, 17810 (24 August 2011). Given this qualification, and the hearsay nature of the evidence, the Chamber does not consider that it can rely on it solely, in the absence of further corroboration, to determine whether or not it was the Accused who made such a statement. Simić stated that the proposed division of the municipality contributed to easing tensions and improved security. D3398 (Witness statement of Ljubisav Simić dated 7 April 2013), paras. 32-33. The Chamber refers to its credibility assessment in fn. 2268 as to why it does not consider Simić's evidence as to the effect of the proposed division of the municipality to be reliable.

2290 P3196 (Witness statement of Dževad Gušić undated), para. 31; Dževad Gušić, T. 17793-17794 (24 August 2011); P3205 (Witness statement of KDZ605 dated 22 August 2011), para. 26 (under seal).

2291 P3196 (Witness statement of Dževad Gušić undated), para. 32; Dževad Gušić, T. 17793 (24 August 2011).

2292 P3196 (Witness statement of Dževad Gušić undated), paras. 31a-32, 36, 39; Dževad Gušić, T. 17793-17794 (24 August 2011). Gušić further testified that Deronjić said that the Accused himself had strongly pressured him to have the police in Bratunac divided and would be pleased if the division was agreed. However, the Chamber in the absence of further corroboration does not rely on this evidence with respect to the involvement of the Accused. In reaching that conclusion the Chamber had regard to evidence that while Deronjić was very close to the Accused, he often used the Accused's name in negotiations "as a lever" to get agreement for his demands. P3196 (Witness statement of Dževad Gušić undated), paras. 40-41; Dževad Gušić, T. 17793 (24 August 2011); D3194 (Witness statement of Rodoljub Đukanović dated 24 March 2013), para. 28; Rodoljub Đukanović, T. 36173 (27 March 2013); D3126 (Witness statement of Jovan Nikolić dated 10 March 2013), para. 29; Jovan Nikolić, T. 35485-35486, 35490-35491 (14 March 2013).

2293 P3205 (Witness statement of KDZ605 dated 22 August 2011), para. 26 (under seal). See also Dževad Gušić, T. 17794 (24 August 2011). 
707. The SDA representatives initially refused to divide the police, following which the situation in Bratunac deteriorated even further. ${ }^{2294}$ However, on 8 April 1992, after Deronjić had guaranteed that there would be peace and security in Bratunac, the SDA agreed to the split. ${ }^{2295}$ This agreement also provided for equal numbers of Bosnian Serb and Bosnian Muslim policemen and that both SJBs should guarantee the peace and safety of all citizens. ${ }^{2296}$ The decision on the separation of the police was adopted at a meeting of the Municipal Assembly. ${ }^{2297}$

708. The Bosnian Serb police left the police building and moved into the primary school next to the municipality building while the Bosnian Muslim police remained in the police station. ${ }^{2298}$ Following this separation, Milutin Milošević who had been working in Serbia was appointed as head of the Bosnian Serb police ${ }^{2299}$ and it was agreed that joint patrols would operate in Bratunac town while separate patrols would be carried out in Bosnian Serb and Bosnian Muslim villages. ${ }^{2300}$

709. After the Bosnian Serbs established their own police force, they also set up additional barricades and check-points, and carried out attacks with firearms and explosives; two coffee bars, one owned by a Bosnian Muslim and another by a Bosnian Croat were blown up. ${ }^{2301}$ Bosnian $^{2}$ Muslims also established check-points around their villages. ${ }^{2302}$

\footnotetext{
2294 P3188 (Witness statement of Mušan Talović dated 14 July 2011), para. 11; P3196 (Witness statement of Dževad Gušić undated), para. 36.

2295 P3196 (Witness statement of Dževad Gušić undated), para. 36; Dževad Gušić, T. 17793 (24 August 2011). See also D3174 (Witness statement of Vujadin Stević dated 23 March 2013), para. 13; D297 (Agreement between SDA and SDS on division of Bratunac Municipality, 8 April 1992), p. 1.

2296 D297 (Agreement between SDA and SDS on division of Bratunac Municipality, 8 April 1992), p. 2. See also Milenko Katanić, T. 24520 (10 February 2012).

2297 P3196 (Witness statement of Dževad Gušić undated), para. 39.

2298 D3398 (Witness statement of Ljubisav Simić dated 7 April 2013), para. 34; Suad Džafić, T. 18178-17179 (1 September 2011); D3852 (Witness statement of Mirko Perić dated 1 July 2013), para. 5; Vujadin Stević, T. 36059 (26 March 2013); D3115 (Witness statement of Branimir Tešić dated 9 March 2013), paras. 15-16; Srbislav Davidović, T. 24377 (9 February 2012).

2299 P3196 (Witness statement of Dževad Gušić undated), paras. 37-38; D3194 (Witness statement of Rodoljub Đukanović dated 24 March 2013), para. 33; D3852 (Witness statement of Mirko Perić dated 1 July 2013), para. 7; D3115 (Witness statement of Branimir Tešić dated 9 March 2013), paras. 9, 16. Luka Bogdanović was the commander of the police, Branimir Tešić was deputy commander. D3115 (Witness statement of Branimir Tešić dated 9 March 2013), para. 15.

2300 D3194 (Witness statement of Rodoljub Đukanović dated 24 March 2013), para. 34. See also D3126 (Witness statement of Jovan Nikolić dated 10 March 2013), para. 31; D3852 (Witness statement of Mirko Perić dated 1 July 2013), paras. 4-5.

2301 See Adjudicated Fact 2308. See also P3196 (Witness statement of Dževad Gušić undated), para. 64. Defence witnesses testified that they had no knowledge about the existence of barricades or of any attacks against coffee bars. D3194 (Witness statement of Rodoljub Đukanović dated 24 March 2013), para. 59; D3398 (Witness statement of Ljubisav Simić dated 7 April 2013), para. 87; D3115 (Witness statement of Branimir Tešić dated 9 March 2013), para. 42. The Chamber refers to its credibility assessment in fns. 2248, 2268, and 2336 as to why it does not find the evidence of these witnesses to be reliable with respect to these attacks and the establishment of barricades.
}

2302 Momir Nikolić, T. 24711-24712 (14 February 2012). 
710. Bosnian Serbs also asked for the division of Bratunac into two municipalities but the SDA representatives did not agree to this proposal. ${ }^{2303}$ It was practically impossible to divide the territory of the municipality given the distribution of Bosnian Serb and Bosnian Muslim villages and of mixed villages, which were neighbouring each other. ${ }^{2304}$ The division of the police and of businesses, as well as the attempt to divide the municipality in general increased tensions between the communities. ${ }^{2305}$

\section{(C) Take-over of Bratunac}

711. There was increasing fear that Bratunac would be taken over by Serb Forces after news was received about what had happened in Bijeljina and Zvornik. ${ }^{2306}$ Given the increasing tensions in Bratunac, in April 1992 a joint meeting was organised by the SDA and SDS leadership with prominent citizens of Bratunac to discuss the political and security situation in the municipality. ${ }^{2307}$ Deronjić addressed those who attended this meeting and told them: "[i]f it has to be that conflicts break out all over Bosnia then we will do our best to ensure that Bratunac is the last place where this will happen". 2308 During this meeting the Bosnian Serb representatives were asked about why they "were rushing into war", why the JNA was training "Serbian civilians" in the handling of weapons and why heavy artillery had been deployed and pointed at Bratunac. ${ }^{2309}$ The Bosnian Serb representatives gave vague responses and assured them that there was no need to worry. ${ }^{2310}$ After this meeting it was decided that a joint-declaration would be issued by SDS and SDA representatives on the "peaceful co-existence" of all citizens in Bratunac in order to reassure the population. ${ }^{2311}$

712. The Bratunac Crisis Staff adopted a decision which proclaimed a state of emergency and provided that it would temporarily take over the competencies of the organs of the Assembly and

2303 D3174 (Witness statement of Vujadin Stević dated 23 March 2013), para. 10; Vujadin Stević, T. 36059 (26 March 2013); KDZ605, T. 17888-17889 (25 August 2011). See also Momir Nikolić, T. 24710-24711 (14 February 2012); Milenko Katanić, T. 24521 (10 February 2012); D3690 (Witness statement of Neđo Nikolić dated 8 June 2013), para. 5. The Chamber noted inconsistencies in Defence evidence as to whether or not there was an agreement on the division of the municipality. D3194 (Witness statement of Rodoljub Đukanović dated 24 March 2013), para. 33; D3126 (Witness statement of Jovan Nikolić dated 10 March 2013), para. 30 ; D297 (Agreement between SDA and SDS on division of Bratunac Municipality, 8 April 1992). Momir Nikolić, T. 24711 (14 February 2012). See also Milenko Katanić, T. 24517-24518 (10 February 2012). Momir Nikolić, T. 24710-24711 (14 February 2012).

P3196 (Witness statement of Dževad Gušić undated), para. 43a. P3196 (Witness statement of Dževad Gušić undated), paras. 28, 29c; P3205 (Witness statement of KDZ605 dated 22 August 2011), para. 16 (under seal).

P3205 (Witness statement of KDZ605 dated 22 August 2011), para. 16 (under seal).

P3196 (Witness statement of Dževad Gušić undated), para. 28.

P3196 (Witness statement of Dževad Gušić undated), paras. 28-29a.

P3196 (Witness statement of Dževad Gušić undated), para. 29-29c. 
the Executive Board, which would cease to operate. ${ }^{2312}$ On 13 April 1992, on the basis of the state of emergency, ${ }^{2313}$ the Bratunac Crisis Staff decided that the Bratunac TO and the SJB would take over the defence of the Serb municipality of Bratunac. ${ }^{2314}$

713. On 16 April 1992, following an order by the Presidency of the SerBiH, the Bratunac Crisis Staff issued an order for general mobilisation and also required military conscripts assigned to Bratunac TO units to immediately respond to the mobilisation. ${ }^{2315}$ Only the Bosnian Serb population was mobilised and the Bosnian Muslim population did not receive the call-up papers. ${ }^{2316}$

714. On or about 17 April 1992, Serb Forces entered the town of Bratunac without facing any resistance from Bosnian Muslims and formed a guard around the Hotel Fontana. ${ }^{2317}$ The Serb Forces consisted of JNA troops from the Novi Sad and Užice Corps, TO members, and local reservists and were joined later by heavily armed paramilitary units from Serbia, including the White Eagles, Šešelj’s men, and Arkan's men. ${ }^{2318}$ Members of the SJB also provided support. ${ }^{2319}$

2312 P3202 (Decision of Bratunac Crisis Staff, 1992), p. 1; D2061 (List of decisions and orders issued by the Crisis Staff, War Staff, and Wartime Presidency of Bratunac Municipality, 29 August 1992), p. 1. See also P3196 (Witness statement of Dževad Gušić undated), para. 60.

2313 D3123 (Order of Bratunac Crisis Staff, 13 April 1992), p. 1; Aleksandar Tešić, T. 35341 (13 March 2013 ).

2314 D2061 (List of decisions and orders issued by the Crisis Staff, War Staff, and Wartime Presidency of Bratunac Municipality, 29 August 1992), p. 4; P3202 (Decision of Bratunac Crisis Staff, 1992), pp. 1-2. [REDACTED].

2315 P4383 (Order of Bratunac Crisis Staff, 16 April 1992), p. 1; D2061 (List of decisions and orders issued by the Crisis Staff, War Staff, and Wartime Presidency of Bratunac Municipality, 29 August 1992), p. 4. See also Adjudicated Fact 2309; D3118 (Witness statement of Aleksandar Tešić dated 10 March 2013), para. 16. The SAO Birač Crisis Staff also proclaimed a state of war and, on 29 April 1992, ordered mobilisation in the entire SAO of Birač following mobilisation orders issued by the Ministry of Defence on 16 April 1992. P2615 (Decision of Birač Crisis Staff, 29 April 1992); P2412 (Decision of SerBiH Ministry of Defence, 16 April 1992).

2316 P4374 (Witness statement of Milenko Katanić dated 11 October 2011), para. 23. See also Suad Džafić, T. 18185-18187 (1 September 2011).

2317 P3196 (Witness statement of Dževad Gušić undated), paras. 50, 53b, 61, 73; Dževad Gušić, T. 17782,17831 (24 August 2011); KDZ605, T. 17903 (25 August 2011). See also D3194 (Witness statement of Rodoljub Đukanović dated 24 March 2013), para. 29; D3126 (Witness statement of Jovan Nikolić dated 10 March 2013), para. 35; Aleksandar Tešić, T. 35334 (13 March 2013).

2318 P3263 (Witness statement of Suad Džafić dated 31 August 2011), para. 5; P3205 (Witness statement of KDZ605 dated 22 August 2011), paras. 22, 24, 31 (under seal); KDZ605, T. 17896-17897 (25 August 2011). See also Adjudicated Fact 2309; Srbislav Davidović, T. 24371-24372 (9 February 2012); Milenko Katanić, T. 2453124532 (10 February 2012); D3118 (Witness statement of Aleksandar Tešić dated 10 March 2013), para. 48. Jovan Nikolić stated that the JNA arrived in Bratunac to calm down the situation in agreement with the municipal organs. D3126 (Witness statement of Jovan Nikolić dated 10 March 2013), para. 37. The Chamber does not consider the evidence of Nikolić to be reliable in this regard. In reaching that conclusion the Chamber refers to its credibility assessment in fn. 2256 and notes that his evidence is equivocal as to who tasked the JNA with calming down the situation in the municipality. The Chamber does not find the evidence of Simić and Nikolić that the municipal authorities were not aware of, and were even shocked by the arrival of the paramilitaries to be reliable. D3398 (Witness statement of Ljubisav Simić dated 7 April 2013), paras. 35-37. See also D3126 (Witness statement of Jovan Nikolić dated 10 March 2013), paras. 35-36. In reaching that conclusion the Chamber refers to its credibility assessment in fns. 2256, 2268.

2319 Dževad Gušić, T. 17782 (24 August 2011). See also P2761 (RS MUP report on work for period April to December 1992), p. 7. 
Local Bosnian Serbs also joined the paramilitary units, including Arkan's men and the White Eagles, while others joined JNA reserve units ${ }^{2320}$

715. The Bosnian Muslim leadership in the municipality met to discuss the developments which were contrary to the assurances they had received from the SDS that no external unit would enter the municipality. ${ }^{2321}$ Deronjić later informed the Bosnian Muslim leadership that some military formations had entered Bratunac and directed them to a meeting at the Hotel Fontana with the officers of the "Serbian army units". 2322

716. At this meeting, the Bosnian Muslim representatives were told by officers, who wore JNA and camouflage uniforms, that Bratunac was a "Serbian municipality and that they had taken power, that Serbian laws would be introduced", that Bosnian Muslims could remain, and there would be no killings. ${ }^{2323}$ These officers warned however, that if a Bosnian Muslim "fired so much as a single bullet they would eliminate the whole of his family". ${ }^{2324}$ They told the Bosnian Muslim representatives to draw up a list of Bosnian Muslims in the municipality and that they would "settle accounts with them". ${ }^{2325}$ As the Bosnian Muslims left this meeting, they saw 40 to 50 uniformed local Bosnian Serbs being issued with weapons. ${ }^{2326}$ A deadline was also given for the surrender of weapons, ${ }^{2327}$ and non-Serbs then handed over hunting rifles and some private weapons. ${ }^{2328}$

717. On 19 April 1992, the Bratunac Crisis Staff issued a decision authorising the Bratunac SJB and Bratunac TO to disarm citizens. ${ }^{2329}$ While the decision did not specify which citizens were to be disarmed, ${ }^{2330}$ in practice only Bosnian Muslims were disarmed. ${ }^{2331}$ On 25 April 1992, Mićo Stanišić reported that weapons were handed over in the area of Bratunac. ${ }^{2332}$

\footnotetext{
2320 P3263 (Witness statement of Suad Džafić dated 31 August 2011), para. 9; Suad Džafić, T. 18186-18187 (1 September 2011).

2321 P3196 (Witness statement of Dževad Gušić undated), paras. 50, 61.

2322 P3196 (Witness statement of Dževad Gušić undated), paras. 52-53a, 61.

2323 P3196 (Witness statement of Dževad Gušić undated), para. 53.

2324 P3196 (Witness statement of Dževad Gušić undated), para. 53.

2325 P3196 (Witness statement of Dževad Gušić undated), para. 54. See also D3194 (Witness statement of Rodoljub Đukanović dated 24 March 2013), para. 30; Rodoljub Đukanović, T. 36186 (27 March 2013); D3126 (Witness statement of Jovan Nikolić dated 10 March 2013), para. 35.

2326 P3196 (Witness statement of Dževad Gušić undated), para. 56.

2327 P3196 (Witness statement of Dževad Gušić undated), para. 54.

2328 P3205 (Witness statement of KDZ605 dated 22 August 2011), para. 26 (under seal).

2329 P4377 (Order of Bratunac Crisis Staff, 19 April 1992), p. 1; D2061 (List of decisions and orders issued by the Crisis Staff, War Staff, and Wartime Presidency of Bratunac Municipality, 29 August 1992), p. 1.

2330 P4377 (Order of Bratunac Crisis Staff, 19 April 1992), p. 1.

2331 P4374 (Witness statement of Milenko Katanić dated 11 October 2011), para. 24. See also P3188 (Witness statement of Mušan Talović dated 14 July 2011), para. 14; Mušan Talović, T. 17659 (22 August 2011).

2332 P2749 (SerBiH MUP daily report, 25 April 1992), p. 3.
} 
718. The Bosnian Muslim representatives met again with Deronjić who tried to convince them that "everything would be all right". ${ }^{2333}$ However, on the same day, Deronjić arrived with some officers at the police station, kicked the doors open and searched for weapons. ${ }^{2334}$ One soldier threatened to throw a grenade if the Bosnian Muslim representatives did not obey and Gušić was ordered to compile a list of Bosnian Muslim extremists and nationalists by the next morning. ${ }^{2335}$ The police station was taken over, the members of the Bosnian Muslim police were disarmed and sent home, and the Bosnian Serb police and new civilian recruits started wearing their own uniforms with Serb insignia. ${ }^{2336}$

\section{(D) Developments in Bratunac after take-over}

719. On 17 April 1992, threatened by Serb paramilitaries and aware of the situation in other municipalities, the Bosnian Muslim leadership left Bratunac. ${ }^{2337}$ Serb soldiers looted abandoned Bosnian Muslim properties. ${ }^{2338}$

$\begin{array}{ll}2333 & \text { P3196 (Witness statement of Dževad Gušić undated), para. } 57 . \\ 2334 & \text { P3196 (Witness statement of Dževad Gušić undated), para. } 58 . \\ 2335 & \text { P3196 (Witness statement of Dževad Gušić undated), para. } 58 . \\ 2336 & \text { P3205 (Witness statement of KDZ605 dated } 22 \text { August 2011), }\end{array}$

2336 P3205 (Witness statement of KDZ605 dated 22 August 2011), paras. 27-28 (under seal); see Adjudicated Fact 2308. Defence witnesses testified inter alia that (i) the Bosnian Muslim police wanted to set up a new police station; (ii) the Bosnian Serb police only took over the police station after the Bosnian Muslim police had abandoned it. Rodoljub Đukanović, T. 36142 (27 March 2013); D3194 (Witness statement of Rodoljub Đukanović dated 24 March 2013), paras. 36-37; D3126 (Witness statement of Jovan Nikolić dated 10 March 2013), para. 40; D3852 (Witness statement of Mirko Perić dated 1 July 2013), para. 7; D3115 (Witness statement of Branimir Tešić dated 9 March 2013), paras. 17-19, 43; D3398 (Witness statement of Ljubisav Simić dated 7 April 2013), para. 38. Having reviewed their testimony, the Chamber does not find that their evidence with respect to the circumstances surrounding the take-over of weapons and the police building to be reliable. In reaching that conclusion the Chamber refers to its credibility assessment in fn. 2248 and 2256 with respect to Đukanović and Nikolić. The Chamber further notes that the testimony of Branimir Tešić and Perić were also marked by extreme evasiveness, contradictions and indicators of bias and attempts to mislead the Chamber.

2337 See Adjudicated Fact 2310; KDZ605, T. 17910 (25 August 2011). See also D3398 (Witness statement of Ljubisav Simić dated 7 April 2013), para. 38; D3194 (Witness statement of Rodoljub Đukanović dated 24 March 2013), para. 37; P3196 (Witness statement of Dževad Gušić undated), paras. 63, 65-66, 70. The Bosnian Muslim leaders while stopped at a check-point were provided an escort out of Bratunac. But see D3398 (Witness statement of Ljubisav Simić dated 7 April 2013), para. 88. While Simić stated that he was not aware of any threats, this is not determinative of whether such threats were made. He did acknowledge that prominent Bosnian Muslims left after Bosnian Serb refugees from Srebrenica started arriving in the municipality. The Chamber finds however, that by July 1992, the Bosnian Muslim authorities had re-established some structures for Bratunac such as a TO, a War Presidency, and a military police and that measures were taken to establish Bosnian Muslim forces in the municipality. D4707 (Decisions of Bratunac TO Municipal Staff, 16 July 1992); D1596 (Order of ABiH General Staff, 10 July 1992), p. 1.

2338 Adjudicated Fact 2313. See also P3205 (Witness statement of KDZ605 dated 22 August 2011), paras. 33-34 (under seal). Defence witnesses testified that only paramilitaries were involved in looting and both Bosnian Serb and Bosnian Muslim properties were looted and that the police prevented looting as much as they could. D3194 (Witness statement of Rodoljub Đukanović dated 24 March 2013), para. 60; D3115 (Witness statement of Branimir Tešić dated 9 March 2013), para. 44; D3118 (Witness statement of Aleksandar Tešić dated 10 March 2013), para. 44. The Chamber does not find the evidence of these witnesses as to who was involved in looting, and whether the police tried to prevent looting to be reliable. In reaching that conclusion the Chamber refers to its credibility assessment in fns. 2248 and 2336 with respect to Đukanović and Branimir Tešić. Further 
720. The situation in Bratunac was relatively calm between 18 and 29 April 1992. At that time, people were called back to work and allowed to move freely in the town but most of the Bosnian Muslim population had already left in that period and many did not return to work as they were too afraid. $^{2339}$ The Bosnian Serb authorities also announced that Bosnian Muslims who left the area could come back, sign loyalty pledges to the new Bosnian Serb authorities in Bratunac, and be protected; however, if they did not return, "the safety of their personal property could not be guaranteed". 2340

721. The deadline for Bosnian Muslims to sign documents pledging their loyalty to the Serb Municipality of Bratunac was 29 April 1992. ${ }^{2341}$ Most Bosnian Muslims had left Bratunac by this date. $^{2342}$ Most of those who remained signed these documents because they were afraid and felt they had no choice. ${ }^{2343}$ After this deadline had passed, Bosnian Muslim homes continued to be searched, their property stolen and more Bosnian Muslims were killed. ${ }^{2344}$

722. One or two days after the remaining Bosnian Muslim population had signed these loyalty oaths, announcements were made with the use of loudspeakers on military vehicles that all men were to assemble in town. ${ }^{2345}$ A JNA officer accompanied by a dozen soldiers told the Bosnian Muslims that all weapons had to be surrendered in order for their freedom and safety to be guaranteed. ${ }^{2346}$

the Chamber notes that the evidence of Aleksandar Tešić was marked by indicators of evasiveness and contradictions which undermined his evidence in this regard.

2339 (25 August 2011).

2340 P3205 (Witness statement of KDZ605 dated 22 August 2011), paras. 35, 37-39 (under seal); KDZ605, T. 17911-17912 (25 August 2011).

2341 P3205 (Witness statement of KDZ605 dated 22 August 2011), para. 35 (under seal). See also Adjudicated Fact 2311.

2342 See Adjudicated Fact 2312; P3196 (Witness statement of Dževad Gušić undated), paras. 61, 80 (stating that in the first month of military occupation 21,000 Bosnian Muslims were "expelled"). But see D3174 (Witness statement of Vujadin Stević dated 23 March 2013), para. 37 (stating that Bosnian Muslims did not start leaving in large numbers before May 1992). The Chamber notes that Stević's evidence was marked by contradictions, evasiveness, and indicators of bias which undermine the reliability of his evidence in this regard. The Chamber also notes that the evidence that both Bosnian Muslims and Bosnian Serbs left Bratunac is not inconsistent with Adjudicated Fact 2312. D3398 (Witness statement of Ljubisav Simić dated 7 April 2013), para. 89; D3690 (Witness statement of Neđo Nikolić dated 8 June 2013), para. 6.

2343 P3205 (Witness statement of KDZ605 dated 22 August 2011), para. 35 (under seal); KDZ605, T. 17909, 17912 (25 August 2011).

2344 P3205 (Witness statement of KDZ605 dated 22 August 2011), paras. 40, 42 (under seal). The Chamber also received evidence that approximately 1,000 Bosnian Muslims were killed in Bratunac in the first month of military occupation. P3196 (Witness statement of Dževad Gušić undated), paras. 61, 80; Dževad Gušić, T. 17781 (24 August 2011). The Chamber notes that with the exception of the scheduled killings in specific villages, these killings are not charged pursuant to Schedules A or B of the Indictment. See fn. 13.

2345 P3205 (Witness statement of KDZ605 dated 22 August 2011), para. 41 (under seal).

2346 P3205 (Witness statement of KDZ605 dated 22 August 2011), para. 41 (under seal); KDZ605, T. 17913 (25 August 2011). 
723. After the Serb Forces arrived in Bratunac, Bosnian Muslims in factories and municipal bodies were fired from their jobs and all key positions in the local government were taken over by Bosnian Serbs. ${ }^{2347}$ At the $17^{\text {th }}$ session of the Bosnian Serb Assembly on 26 July 1992, Rajko Dukić stated that he hoped they would not be judged for having expelled all Muslim judges from the municipalities of Vlasenica, Bratunac, and Zvornik. ${ }^{2348}$ Serb Forces began patrolling Bratunac and took away the most prominent Bosnian Muslims, some of whom were detained at the Vuk Karadžić School. ${ }^{2349}$

724. On or around the night of 9 May 1992, there was shooting mostly from the direction of Bratunac towards Srebrenica and the village of Mihaljevići, which was above the Drina on the border with Serbia, was burnt. ${ }^{2350}$ Following this incident, a number of Bosnian Serb families moved to Serbia. ${ }^{2351}$ Soldiers and paramilitaries were everywhere in Bratunac and Arkan's men were stationed at the Jasen hotel. ${ }^{2352}$

725. A large number of Bosnian Serb refugees from Srebrenica arrived in Bratunac in May 1992 and entered abandoned Bosnian Muslim homes. ${ }^{2353}$

726. On 17 June 1992, the appointment of members of the War Commission of Bratunac was confirmed by the Accused. ${ }^{2354}$ At the $43^{\text {rd }}$ Session of the Bosnian Serb Government on 29 July 1992 it was reported that the security and political situation in Bratunac and Foča was "extremely complex" and that "all necessary steps should be taken to prevent conflict and protect the population". 2355

\footnotetext{
2347 P3263 (Witness statement of Suad Džafić dated 31 August 2011), para. 6; Suad Džafić, T. 18184 (1 September 2011).

2348 D92 (Transcript of $17^{\text {th }}$ session of SerBiH Assembly, 24-26 July 1992), p. 72.

2349 P3263 (Witness statement of Suad Džafić dated 31 August 2011), paras. 6-8. See also Suad Džafić, T. 18193 (1 September 2011).

2350 P3205 (Witness statement of KDZ605 dated 22 August 2011), paras. 43, 45 (under seal); KDZ605, T. 17913 (25 August 2011); Mirsada Malagić, T. 23505 (24 January 2012).

2351 KDZ480, T. 24242 (7 February 2012). See also D3194 (Witness statement of Rodoljub Đukanović dated 24 March 2013), para. 41; D3126 (Witness statement of Jovan Nikolić dated 10 March 2013), paras. $28,43$.

2352 P3205 (Witness statement of KDZ605 dated 22 August 2011), para. 44 (under seal); KDZ605, T. 17903 (25 August 2011).

2353 Srbislav Davidović, T. 24389, 24392 (9 February 2012). See also P4394 (Article from The Independent entitled "Bosnian Serbs Flee Muslim Vengeance", 29 December 1992), p. 2. Simić stated that the arrival of a large number of Bosnian Serb refugees created an environment of "total chaos, because the civilian organs of authority were not functional”. D3398 (Witness statement of Ljubisav Simić dated 7 April 2013), para. 47. While the Chamber finds that the arrival of these refugees created difficulties in the municipality, it does not consider that Simić's evidence that the civilian authorities were not functional to be reliable. In reaching that conclusion the Chamber refers to its credibility assessment in fn. 2268.

2354 P5491 (RS Presidency Confirmation of Appointment of Members of the War Commission in Bratunac, 17 June 1992).

2355 D452 (Minutes of $43^{\text {rd }}$ session of Government of SerBiH, 29 July 1992), p. 7.
} 
727. However, by November 1992, at a meeting attended by Bosnian Serb leaders, including Branko Đerić and Bogdan Subotić, it was reported that the entire territory of Bratunac was under the control of Bosnian Muslim forces. ${ }^{2356}$

\section{(E) Attacks on surrounding villages}

728. In the days following the take-over of Bratunac town, Bosnian Serb paramilitary units went to the Bosnian Muslim villages surrounding Bratunac starting from the villages closest to the town and moving outwards. ${ }^{2357}$ The JNA and Bratunac TO were involved in disarming Bosnian Muslim villagers throughout Bratunac municipality. ${ }^{2358}$ During these disarming operations paramilitaries "harassed locals and pillaged abandoned Muslim homes". 2359 They entered the villages and asked for weapons to be handed over. The villages were then attacked and set on fire while the villagers were sent to the Bratunac Football Stadium. ${ }^{2360}$ Many villagers were killed during these attacks. ${ }^{2361}$

729. In the village of Voljevci, barricades were set up. ${ }^{2362}$ Prominent and educated people from the village were taken away and people were killed. ${ }^{2363}$ The population surrendered weapons in compliance with the ultimatum issued. ${ }^{2364}$ In May 1992, individuals who introduced themselves as the representatives of the "Serb people" came to Voljevci and told the population that they could no longer live in the village; they had to leave, go to the local commune in Pobrdje; and sign a statement to the effect that they were leaving their homes and property voluntarily and would never

2356 D3696 (Minutes of RS Government session, 7 November 1992), p. 5. See also D2231 (Report of Tuzla District Defence Staff, 1 October 1992), p. 2 (relating to operations by Bosnian Muslim forces and their control of some territory in Bratunac, Vlasenica and Zvornik); P4394 (Article from The Independent entitled "Bosnian Serbs Flee Muslim Vengeance", 29 December 1992), p. 2; [REDACTED]. See Section IV.C.1: Srebrenica component (Facts), which addresses who was in control of areas of Bratunac in 1995.

2357 P3263 (Witness statement of Suad Džafić dated 31 August 2011), para. 10.

2358 See Adjudicated Fact 2310; P4374 (Witness statement of Milenko Katanić dated 11 October 2011), para. 24. Defence witnesses testified that the decision was taken to disarm people who had obtained weapons illegally and did not distinguish based on nationality. D3115 (Witness statement of Branimir Tešić dated 9 March 2013), paras. 20-21, 43; D3126 (Witness statement of Jovan Nikolić dated 10 March 2013), para. 38. However, the Chamber does not find their evidence to be reliable in this regard. In reaching that conclusion it refers to its credibility assessment in fns. 2236 and 2256.

2359 See Adjudicated Fact 2310.

2360 P3263 (Witness statement of Suad Džafić dated 31 August 2011), para. 10. See also D3194 (Witness statement of Rodoljub Đukanović dated 24 March 2013), para. 43; P3205 (Witness statement of KDZ605 dated 22 August 2011), para. 107 (under seal); see Adjudicated Fact 2329. But see D3194 (Witness statement of Rodoljub Đukanović dated 24 March 2013), para. 63; Rodoljub Đukanović, T. 36154-36155 (27 March 2013). Đukanović testified that he had no knowledge about the burning of specific Bosnian Muslim villages. The Chamber does not consider this qualified evidence to be of significance.

2361 P3263 (Witness statement of Suad Džafić dated 31 August 2011), para. 10. See also P3205 (Witness statement of KDZ605 dated 22 August 2011), para. 107 (under seal). The Chamber notes that these killings are not charged pursuant to Schedules A or B of the Indictment. See fn. 13.

2362 Mirsada Malagić, T. 23461-23462, 23503-23504 (24 January 2012).

2363 Mirsada Malagić, T. 23462 (24 January 2012). The Chamber notes that these killings are not charged pursuant to Schedules A or B of the Indictment. See fn. 13.

2364 Mirsada Malagić, T. 23498 (24 January 2012). 
return there again. ${ }^{2365}$ The population was told they would be evacuated by bus towards Kladanj for their safety and security. ${ }^{2366}$ Some Bosnian Muslims decided not to sign the papers, and left the village for Srebrenica. $^{2367}$

730. On 10 May 1992, Serb Forces attacked the Bosnian Muslim villages of Suha and Mihaljevići, near the town of Bratunac. ${ }^{2368}$ The village of Mihaljevići was set ablaze. ${ }^{2369}$

731. The village of Krasanpolje was also attacked on 10 May 1992. ${ }^{2370}$ Houses were burnt, there was shooting, and a number of people were killed. ${ }^{2371}$ After the attack on Krasanpolje, Bosnian Muslims in the village of Vitkovići were told that it would be safer for them to flee to the woods, which they did. ${ }^{2372}$ The villagers returned to Vitkovići after they were told the situation had calmed down. $^{2373}$ The next day, the Bosnian Serb police patrolled Vitkovići to ensure the population remained in the village. ${ }^{2374}$ Armed local Bosnian Serbs dressed in camouflage uniforms surrounded the village. ${ }^{2375}$ The Novi Sad Corps entered Vitkovići in search of weapons. ${ }^{2376}$ On 17 May 1992, Serb Forces shelled the Muslim settlement of Konjević Polje, near Hrnčići, and attacked it on 27 May. $^{2377}$

732. On 17 May 1992, the police chief came to Vitkovići and gave an ultimatum that all Bosnian Muslims in the village had to hand over their weapons, and if they did not do so, their safety could

2365 Mirsada Malagić, T. 23458, 23495 (24 January 2012); Mirsada Malagić, P356 (Transcript from Prosecutor v. Krstić), T. 1940-1941.

2366 Mirsada Malagić, T. 23458 (24 January 2012).

2367 Mirsada Malagić, T. 23458 (24 January 2012).

2368 See Adjudicated Fact 2321.

2369 P3205 (Witness statement of KDZ605 dated 22 August 2011), para. 45 (under seal). Defence witnesses testified that this was part of a disarming operation and that the village was not torched. D3174 (Witness statement of Vujadin Stević dated 23 March 2013), paras. 23-25; Vujadin Stević, T. 36042-36043 (26 March 2013); D3118 (Witness statement of Aleksandar Tešić dated 10 March 2013), para. 24; D3115 (Witness statement of Branimir Tešić dated 9 March 2013), para. 26. The Chamber refers to its credibility assessment in fns. 2336, 2338, and 2342 in concluding that the evidence of these witnesses is unreliable with respect to the attack on these villages.

2370 P3263 (Witness statement of Suad Džafić dated 31 August 2011), para. 12. See also Adjudicated Fact 2325. Đukanović stated Krasanpolje was a majority Bosnian Serb village and that to his knowledge it was not burnt. D3194 (Witness statement of Rodoljub Đukanović dated 24 March 2013), para. 64. The Chamber notes that even if the village had a majority Bosnian Serb population, Đukanović's qualified evidence does not undermine the accepted evidence that Bosnian Muslim homes in that village were attacked.

2371 P3263 (Witness statement of Suad Džafić dated 31 August 2011), para. 12; Suad Džafić, T. 18192 (1 September 2011). The Chamber notes however, that there is no scheduled killing incident with respect to this village.

2372 P3263 (Witness statement of Suad Džafić dated 31 August 2011), para. 13; Suad Džafić, T. 18191 (1 September 2011).

2373 P3263 (Witness statement of Suad Džafić dated 31 August 2011), para. 13.

2374 P3263 (Witness statement of Suad Džafić dated 31 August 2011), para. 14.

2375 See Adjudicated Fact 2322.

2376 Suad Džafić, T. 18189 (1 September 2011).

2377 See Adjudicated Fact 2315. The Chamber finds that there was Bosnian Muslim resistance to the attack on Konjević Polje. Dževad Gušić, T. 17839-17840 (24 August 2011). See also Momir Nikolić, T. 24709 (14 February 2012). 
not be guaranteed. ${ }^{2378}$ Soldiers from the Novi Sad Corps entered and told the villagers they had to leave with whatever they could carry and gather by noon as they would be taken towards Tuzla. ${ }^{2379}$ Villagers from Vitkovići were loaded onto two buses by the Bosnian Serb police. Soldiers then started looting the houses and cattle. ${ }^{2380}$

\section{(1) Scheduled Incident A.3.1}

733. The Prosecution alleges that at least 12 people were killed in the village of Hranča between 3 and 9 May 1992.

734. Hranča is a village located to the west of Bratunac. ${ }^{2381}$ The Chamber took judicial notice that on 3 May 1992, members of the Bratunac TO surrounded the Muslim village of Hranča and torched 43 houses. ${ }^{2382}$ Over the following week, they attacked and arrested residents of Hranča. They captured nine villagers, and killed four of them, including a six year old girl. ${ }^{2383}$

735. The Chamber also took judicial notice that on 9 May 1992, members of the Bratunac TO shot eight Muslims. ${ }^{2384}$ However, with respect to the killing of these eight victims, the Chamber is not satisfied that it has sufficient evidence pertaining to their status and the circumstances in which they were shot and killed to make a finding with respect to this incident.

2378 P3263 (Witness statement of Suad Džafić dated 31 August 2011), para. 15; see Adjudicated Fact 2322; Suad Džafić, T. 18181 (1 September 2011) (testifying that the legally held weapons in the village had already been surrendered).

2379 P3263 (Witness statement of Suad Džafić dated 31 August 2011), para. 17; Suad Džafić, T. 18195-18196 (1 September 2011) (testifying that the Bosnian Muslims were not mistreated during this process); see Adjudicated Fact 2322.

2380 P3263 (Witness statement of Suad Džafić dated 31 August 2011), para. 19; Suad Džafić, T. 18195 (1 September 2011); see Adjudicated Fact 2322.

2381 P268 (Map of BiH marked by Mevludin Orić).

2382 Adjudicated Fact 2316. See also Mirsada Malagić, T. 23504 (24 January 2012); P3188 (Witness statement of Mušan Talović dated 14 July 2011), para. 16; Mušan Talović, T. 17659-17660 (22 August 2011).

2383 See Adjudicated Fact 2317. See also P3188 (Witness statement of Mušan Talović dated 14 July 2011), para. 16; Mušan Talović, T. 17659-17660 (22 August 2011).

2384 Adjudicated Fact 2318. The Chamber notes that this figure corresponds to the number of individuals identified by Mašović who were reported to have gone missing on 9 May 1992 from Hranča and exhumed from a mass grave. P4853 (Updated Table 2 to the Report of Amor Mašović), pp. 2-5. Defence witnesses testified that there was a "firefight" following a Bosnian Muslim attack on a JNA column and also testified about those involved in this incident. D3194 (Witness statement of Rodoljub Đukanović dated 24 March 2013), para. 39; Rodoljub Đukanović, T. 36142 (27 March 2013); D3126 (Witness statement of Jovan Nikolić dated 10 March 2013), para. 43; D3852 (Witness statement of Mirko Perić dated 1 July 2013), para. 10; D3174 (Witness statement of Vujadin Stević dated 23 March 2013), para. 13; D3118 (Witness statement of Aleksandar Tešić dated 10 March 2013), paras. 20, 23, 46; D3115 (Witness statement of Branimir Tešić dated 9 March 2013), paras. 22-23; D3398 (Witness statement of Ljubisav Simić dated 7 April 2013), para. 56. See also D3690 (Witness statement of Neđo Nikolić dated 8 June 2013), paras. 8, 11; D1644 (Video footage of attack on JNA troops). Having reviewed this evidence, the Chamber does not consider the evidence of these witnesses in this regard to be reliable. In reaching that conclusion the Chamber refers to its credibility assessment in fns. 2248, 2256, 2268, 2336, 2338, and 2342 and also notes that their evidence is to a great extent based on hearsay information. See also Mušan Talović, T. 17660-17661 (22 August 2011) (denying any knowledge of an attack on a JNA 
736. A total of 14 individuals from Hranča were exhumed from mass graves. ${ }^{2385}$ Six of them are reported to have gone missing after 9 May 1992 and as such cannot be linked to this scheduled incident. $^{2386}$

737. The Chamber therefore finds that at least four people were killed by Serb Forces in the village of Hranča between 3 and 9 May 1992.

\section{(2) $\underline{\text { Scheduled Incident A.3.2 }}$}

738. The Prosecution alleges that at least 65 men were killed in the village of Glogova on or about 9 May 1992.

739. The village of Glogova, which had a majority Bosnian Muslim population prior to the conflict, is located approximately 10 kilometres from Bratunac. ${ }^{2387}$ From 1 April 1992, members of the Bosnian Serb police walked around Glogova with loudspeakers and called on people to surrender weapons and promised their safety if they did so. ${ }^{2388}$ Villagers were invited to surrender their weapons to the local SDS authorities. ${ }^{2389}$ As Bosnian Muslim villagers surrendered their weapons, JNA soldiers from the Novi Sad Corps shot in the air with automatic weapons. ${ }^{2390}$ The villagers were instructed to continue their daily activities without fear but Mušan Talović was told by his employer that he would receive a phone call if he was required at work. ${ }^{2391}$

740. On 8 May 1992, following the killing of Goran Zekić, a prominent SDS member and Judge, ${ }^{2392}$ in an ambush by Bosnian Muslims, the Bratunac Crisis Staff met and planned an attack

column). In any event, the Chamber does not consider that the occurrence of an attack against a JNA column is of much significance.

2385 P4853 (Updated Table 2 to the Report of Amor Mašović), pp. 2-5.

2386 The Chamber notes that two other individuals referred to by the Prosecution as victims of Scheduled Incident A.3.1 were reported as having gone missing on 9 May 1992 from locations other than Hranča and therefore cannot be linked to the scheduled incident. See Prosecution Final Brief, Appendix G.

2387 P3188 (Witness statement of Mušan Talović dated 14 July 2011), paras. 6-7; KDZ605, T. 17886 (25 August 2011).

2388 P3188 (Witness statement of Mušan Talović dated 14 July 2011), para. 13.

2389 P3188 (Witness statement of Mušan Talović dated 14 July 2011), para. 13.

2390 P3188 (Witness statement of Mušan Talović dated 14 July 2011), para. 13; Mušan Talović, T. 17654-17655 (22 August 2011).

2391 P3188 (Witness statement of Mušan Talović dated 14 July 2011), para. 15; Mušan Talović, T. 17656, 17659 (22 August 2011).

2392 P3205 (Witness statement of KDZ605 dated 22 August 2011), para. 44 (under seal); KDZ605, T. 17908 (25 August 2011) (private session); P4374 (Witness statement of Milenko Katanić dated 11 October 2011), para. 27; Milenko Katanić, T. 24536 (10 February 2012); KDZ480, T. 24241 (7 February 2012). 
on the village of Glogova the following morning. ${ }^{2393}$ Deronjic told the Bratunac Crisis Staff that the village of Glogova would be encircled and the Bosnian Muslims would be disarmed. ${ }^{2394}$

741. Milenko Katanić received call-up papers before the attack on Glogova and proceeded to the municipal building. ${ }^{2395}$ Deronjić informed Katanić that Goran Zekić had been "murdered" and that an operation was being prepared and that it would be launched against Glogova. ${ }^{2396}$ Deronjić also said that the purpose of the operation was to defend the line "so if Muslims started retreating towards Srebrenica” they would be arrested and prevented from retreating. ${ }^{2397}$

742. On 9 May 1992, Serb Forces, including the JNA and Bratunac TO units, surrounded Glogova; there was no armed resistance to the Serb advance because the village had already been disarmed. $^{2398}$ Apart from the JNA and Bratunac TO units, volunteers ${ }^{2399}$ and armed members of the SJB were also part of this operation. ${ }^{2400}$ The stated plan was for the Novi Sad Corps to enter Glogova in APCs and disarm the population, with the TO units stationed around the village to

2393 See Adjudicated Fact 2319. See also Srbislav Davidović, T. 24384-24385. (9 February 2012). But see D3398 (Witness statement of Ljubisav Simić dated 7 April 2013), para. 90. Witnesses testified that the attack on Glogova was not carried out because of the killing of Zekić. D3194 (Witness statement of Rodoljub Đukanović dated 24 March 2013), para. 62; D3118 (Witness statement of Aleksandar Tešić dated 10 March 2013), para. 47. Katanić for example testified that the decision to attack Glogova had been made before the killing of Zekić, but his death accelerated the operation. P4374 (Witness statement of Milenko Katanić dated 11 October 2011), para. 26; Milenko Katanić, T. 24455-24456 (9 February 2012). The Chamber does not consider the issue of what prompted the attack on Glogova and whether or not the killing of Zekić played a role in that decision to be of significance.

2394 D3194 (Witness statement of Rodoljub Đukanović dated 24 March 2013), paras. 41; D3398 (Witness statement of Ljubisav Simić dated 7 April 2013), para. 57. See also Ljubisav Simić, T. 37317 (16 April 2013); D3690 (Witness statement of Neđo Nikolić dated 8 June 2013), paras. 9-10; D3126 (Witness statement of Jovan Nikolić dated 10 March 2013), para. 44; D3174 (Witness statement of Vujadin Stević dated 23 March 2013), paras. 14-15; D3118 (Witness statement of Aleksandar Tešić dated 10 March 2013), paras. 20-21; Branimir Tešić, T. 35260 (12 March 2013).

2395 P4374 (Witness statement of Milenko Katanić dated 11 October 2011), para. 28.

2396 P4374 (Witness statement of Milenko Katanić dated 11 October 2011), paras. 27-29. Katanić stated that he did not think that Deronjić ordered or was aware that such a large number of people would be killed in Glogova or that Deronjić considered it to be a legitimate military target. The Chamber finds this to be speculative opinion and of limited weight. See also D3118 (Witness statement of Aleksandar Tešić dated 10 March 2013), para. 22

2397 P4374 (Witness statement of Milenko Katanić dated 11 October 2011), para. 31; Milenko Katanić, T. 24537 (10 February 2012).

2398 See Adjudicated Fact 2320; P3188 (Witness statement of Mušan Talović dated 14 July 2011), para. 19. While the village had been disarmed the stated purpose of the operation in Glogova was to disarm the population and prevent anyone escaping with weapons. P4374 (Witness statement of Milenko Katanić dated 11 October 2011), para. 33; Milenko Katanić, T. 24537 (10 February 2012); D3118 (Witness statement of Aleksandar Tešić dated 10 March 2013), para. 21; D3126 (Witness statement of Jovan Nikolić dated 10 March 2013), para. 46 (stating that the military police was also involved in ensuring that nobody withdrew from the village with weapons). See also D3174 (Witness statement of Vujadin Stević dated 23 March 2013), para. 15.

2399 D3118 (Witness statement of Aleksandar Tešić dated 10 March 2013), para. 21.

2400 P4374 (Witness statement of Milenko Katanić dated 11 October 2011), paras. 32-33, 35. 
prevent anyone from trying to escape with weapons. ${ }^{2401}$ At sunrise, Serb Forces entered the village. There was then shooting and houses were set on fire. ${ }^{2402}$

743. Mušan Talović's cousin came to his house and told him that the hamlet of Tarat had also been attacked. ${ }^{2403}$ Talović's neighbours gathered at his house and 23 men decided to hide in the underbrush at a nearby creek. ${ }^{2404}$ When Meho Delić joined this group, the Bosnian Serb soldiers who were chasing him, found the hidden Bosnian Muslims and ordered them out at gun-point. ${ }^{2405}$ The Bosnian Muslim men were ordered to put their hands on their heads and were searched for weapons. Talović's pistol was confiscated and they were then ordered to walk to a field and line up. ${ }^{2406}$ One of the Bosnian Serb soldiers contacted their "Vojvoda", Najdan Mlađenović, by radio and asked what they should do with the captured "Balijas". 2407 The soldiers were instructed to take the Bosnian Muslim men to the centre of Glogova in front of the supermarket. Mlađenović would then decide what to do with them. ${ }^{2408}$

744. En route, the soldiers provoked the Bosnian Muslims by saying that "this is a Serb country" and that they "should be expelled". ${ }^{2409}$ The men were lined up against the wall of the supermarket and ordered to put their hands up and stand in that position for half-an-hour. ${ }^{2410}$ Many Bosnian Serb soldiers were gathered in the area near the supermarket. ${ }^{2411}$ These soldiers were not regular

2401 P4374 (Witness statement of Milenko Katanić dated 11 October 2011), para. 33; Milenko Katanić, T. 24537 (10 February 2012); D3118 (Witness statement of Aleksandar Tešić dated 10 March 2013), para. 21 ; D3126 (Witness statement of Jovan Nikolić dated 10 March 2013), para. 46. See also D3174 (Witness statement of Vujadin Stević dated 23 March 2013), para. 15.

2402 P3188 (Witness statement of Mušan Talović dated 14 July 2011), paras. 19, 37. See also Mirsada Malagić, T. 23504 (24 January 2012); P4374 (Witness statement of Milenko Katanić dated 11 October 2011), para. 34. The Chamber does not consider that Katanić's observation that he did not know whether this was part of the assignment or whether individuals set fire to homes on their own accord to be of much weight. Similarly, the Chamber places no weight on Stević's assumption that the shooting and fire indicated that Serb Forces met with resistance. D3174 (Witness statement of Vujadin Stević dated 23 March 2013), para. 16.

2403 P3188 (Witness statement of Mušan Talović dated 14 July 2011), para. 20.

2404 P3188 (Witness statement of Mušan Talović dated 14 July 2011), para. 20; Mušan Talović, T. 17666 (22 August 2011).

2405 P3188 (Witness statement of Mušan Talović dated 14 July 2011), paras. 21-22. See also D3174 (Witness statement of Vujadin Stević dated 23 March 2013), para. 18.

2406 P3188 (Witness statement of Mušan Talović dated 14 July 2011), paras. 23-24.

2407 P3188 (Witness statement of Mušan Talović dated 14 July 2011), para. 24. But see D3174 (Witness statement of Vujadin Stević dated 23 March 2013), paras. 19-22; Vujadin Stević, T. 36037-36039 (26 March 2013). The Chamber does not find Stević's evidence that he did not know anyone named Mlađenović and that the Bosnian Muslims were ordered to stand against a wall for their own protection to be reliable. In reaching that conclusion the Chamber refers to its credibility assessment in fn. 2342. It more specifically notes that Stević was contradicted by evidence that both he and Mlađenović were members of the SDS Municipal Board. Vujadin Stević, T. 36040-36041 (26 March 2013); P6233 (Minutes of meeting of Bratunac SDS Municipal Board, 22 September 1993), p. 2.

2408 P3188 (Witness statement of Mušan Talović dated 14 July 2011), para. 24.

2409 P3188 (Witness statement of Mušan Talović dated 14 July 2011), para. 24.

2410 P3188 (Witness statement of Mušan Talović dated 14 July 2011), paras. 25-26.

2411 P3188 (Witness statement of Mušan Talović dated 14 July 2011), para. 33; Mušan Talović, T. 17668 (22 August 2011). 
JNA soldiers but included local Bosnian Serbs. ${ }^{2412}$ There was also a tank with JNA markings and an APC in the centre of Glogova. ${ }^{2413}$

745. Talović saw Momir Nikolić arrive from the direction of Bratunac with a group of four or five armed Bosnian Serbs in uniform. ${ }^{2414}$ At that time, Momir Nikolić was a member of the Bratunac Crisis Staff and a high ranking officer of the Bratunac TO. ${ }^{2415}$ When Najdan Mlađenović arrived from the direction of Kravica with his driver, he said that he did not need to hide because the men were "going to be killed and no one can tell that he was there". 2416

746. Three of the Bosnian men from the group were taken away in Mlađenović's car. ${ }^{2417}$ After this, Mlađenović told Dragan Stević to "[e]xecute the punishment and kill them all". ${ }^{2418}$ The remaining 20 Bosnian Muslims were taken by four Bosnian Serb soldiers armed with rifles and automatic weapons and ordered to line up on the riverbank with their faces towards the river. ${ }^{2419}$ This group included two boys who were 11 and 13 years old; the rest were young men. ${ }^{2420}$ The soldiers then started to shoot at the men. ${ }^{2421}$ Talović and a man named Šećo Delić, though injured, were the only two men who survived this shooting. ${ }^{2422}$ When the shooting started, Talović was hit,

2412 P3188 (Witness statement of Mušan Talović dated 14 July 2011), para. 33.

2413 Mušan Talović, T. 17638-17639 (22 August 2011).

2414 P3188 (Witness statement of Mušan Talović dated 14 July 2011), para. 27; Mušan Talović, T. 17667 (22 August 2011).

2415 P3188 (Witness statement of Mušan Talović dated 14 July 2011), para. 32; Mušan Talović, T. 17638 (22 August 2011).

2416 P3188 (Witness statement of Mušan Talović dated 14 July 2011), paras. 28-29.

2417 P3188 (Witness statement of Mušan Talović dated 14 July 2011), paras. 31, 34; Mušan Talović, T. 1763917640, 17667-17668 (22 August 2011). Talović testified that two of those who were taken away by car were killed on the same night However, the Chamber does not consider that Talović's evidence is sufficient to make a finding with respect to the killing of these two individuals.

2418 P3188 (Witness statement of Mušan Talović dated 14 July 2011), paras. 31, 34. The men who were sent to Mlađenović's car were Mustafa Golić, Sejid Ibišević, and Almaz Talović. The men who were returned to the main group were Mušan Talović and Dževad Ibišević.

2419 P3188 (Witness statement of Mušan Talović dated 14 July 2011), para. 35; Mušan Talović, T. 17640 (22 August 2011). The men who were taken to the river were identified as Mušan Talović, Hušo Junuzović, Abid Junuzović, the son of Abid Junuzović, Redo Delić, Meho Delić, Bego Delić, Dževad Ibišević, Kemal Ibišević, Ilijaz Ibišević, Ramo Ibišević, Sabrija Ibišević, Mustafa Ibišević, Mujo Ibišević, Muharem Ibišević, Selmo Omerović, Mirzet Omerović, Šećo Delić, a man with the surname Gušić, and a man with the surname Hasibović. Mušan Talović, T. 17668 (22 August 2011). Of these names identified by Talović, 10 bodies were identified by Mašović as having been exhumed from a mass grave. P4853 (Updated Table 2 to the Report of Amor Mašović), pp. 3-6.

2420 Mušan Talović, T. 17640-17641 (22 August 2011).

2421 P3188 (Witness statement of Mušan Talović dated 14 July 2011), para. 36.

2422 Mušan Talović, T. 17640 (22 August 2011); P3188 (Witness statement of Mušan Talović dated 14 July 2011), para. 37. Šećo Delić jumped into the river when the shooting started and was shot at when he got out of the river. 
he fell into the river unconscious, and was washed down the stream; when he awoke there were bodies on and around him. ${ }^{2423}$

747. As Talović and Delić returned to the village, they found 68 bodies in three piles. ${ }^{2424}$ In one of the piles were the bodies of the men who had been shot along with Talović and Delić. The bodies were all of people from Glogova, 24 of whom Talović could identify by name, and included two women. ${ }^{2425}$ Having regard to the circumstances surrounding the attack on Glogova and the evidence about the capture and execution of villagers, the Chamber is satisfied that the bodies that Talović and Delić saw in the village were killed by Serb Forces in a similar manner. When Talović returned to his home, he saw that his house had been burnt down and found approximately 100 women and children gathered in his yard. ${ }^{2426}$ The survivors split in two groups and left the village with one group heading in the direction of Konjević Polje while the other group headed to Srebrenica. ${ }^{2427}$ Bosnian Serbs were involved in the collection and movement of the bodies with tractors. $^{2428}$

748. The Chamber took judicial notice that approximately 65 inhabitants of Glogova were killed during the operation and that most of the buildings in the village were then burned. ${ }^{2429}$ The

2423 P3188 (Witness statement of Mušan Talović dated 14 July 2011), para. 36. The bodies of Dževad and Kemal Ibišević which were lying on top of Talović were exhumed from a mass grave. P4853 (Updated Table 2 to the Report of Amor Mašović), p. 3.

2424 P3188 (Witness statement of Mušan Talović dated 14 July 2011), para. 38. See also P3263 (Witness statement of Suad Džafić dated 31 August 2011), para. 11 (stating that "[s]ome 60 villagers" were killed in the attack on Glogova on 9 May 1992).

2425 P3188 (Witness statement of Mušan Talović dated 14 July 2011), para. 38; Mušan Talović, T. 17641 (22 August 2011). Talović saw the bodies of Adem Junuzović, Banovka Junuzović, Hamed Delić, Đafo Delić, Uzeir Talović, Avdo Golić, Nezir Omerović, Šaban Gerović, Medo Delić, Šaban Mušić, Jusuf Ibišević, Mehmed Ibišević, Hajdar Alihromić, Selmo Omerović, Ćamil Rizvanović, Jasmin Rizvanović, Mustafa Rizvanović, Nermin Omerović, Ramo Golić, Ramiz Gerović, Halid Milačević, Osman Ibišević, Ramo Gerović, and Refik Ibišević. The witness confirmed that the name Selmo Omerović appears twice, once on this list and once on the previous list referred to in fn. 2419 because they were two different people. Mušan Talović, T. 17642 (22 August 2011). Of these names identified by Talović, nine were identified by Mašović as having been exhumed from individual or mass graves. P4853 (Updated Table 2 to the Report of Amor Mašović), pp. 3-6.

2426 P3188 (Witness statement of Mušan Talović dated 14 July 2011), para. 39.

2427 P3188 (Witness statement of Mušan Talović dated 14 July 2011), para. 41.

2428 P3188 (Witness statement of Mušan Talović dated 14 July 2011), para. 42; P4374 (Witness statement of Milenko Katanić dated 11 October 2011), paras. 37-40; Milenko Katanić, T. 24538 (10 February 2012).

2429 See Adjudicated Fact 2320. Defence witnesses testified inter alia (i) that during the fighting in Glogova there was mayhem as paramilitary units also joined and that 25 people of military age were killed by volunteers who sought revenge; (ii) the Bratunac Crisis Staff intended to disarm and not kill civilians; (iii) some people were killed during the operation to disarm Bosnian Muslim "extremists"; and (iv) Serb Forces were under strict orders not to kill anyone unless attacked. D3194 (Witness statement of Rodoljub Đukanović dated 24 March 2013), paras. 42, 48, 51; D3852 (Witness statement of Mirko Perić dated 1 July 2013), para. 11; D3126 (Witness statement of Jovan Nikolić dated 10 March 2013), para. 46. See also D3690 (Witness statement of Neđo Nikolić dated 8 June 2013), paras. 9-10; D3115 (Witness statement of Branimir Tešić dated 9 March 2013), para. 25; Branimir Tešić, T. 35259 (12 March 2013); D3174 (Witness statement of Vujadin Stević dated 23 March 2013), para. 15. Having reviewed this evidence, the Chamber does not find the testimony of the relevant witnesses to be reliable in this regard. In reaching that conclusion the Chamber refers to its credibility assessment in fns. 2248, 2256, 2336, 2338, and 2342. The Chamber further notes that when challenged on 
villagers from Glogova who were not killed were taken into the custody of the Serb Forces and transported to the Bratunac Stadium; the able-bodied men were separated and taken to the Vuk Karadžić School while the women and children were loaded on buses and taken to Bosnian Muslim controlled areas. $^{2430}$

749. The Chamber therefore finds that at least 65 Bosnian Muslims were killed by Serb Forces in the village of Glogova on or about 9 May 1992.

\section{(F) Actions of paramilitaries}

750. The municipal authorities faced problems with paramilitaries and volunteers who arrived in Bratunac, tried to take power, terrorised the population ${ }^{2431}$ and did not accept the command structures or local authorities. ${ }^{2432}$ In contrast, volunteers who came to the municipality and placed themselves at the disposal of the JNA or joined the Bratunac Brigade were welcomed. ${ }^{2433}$ For instance, representatives of the volunteers were also included in the War Staff of Bratunac which was proclaimed on 8 May 1992. ${ }^{2434}$ Đukanović and Deronjić were involved in bringing volunteers from Vukovar to Bratunac. ${ }^{2435}$

751. On 1 May 1992, the Bratunac Crisis Staff decided that all volunteers who did not want to place themselves under the command of the army would be expelled from Bratunac and forbade all paramilitary formations, "illegal citizens", and other groups who illegally possessed weapons from

cross-examination, Perić conceded that he only testified about what he had heard and he did not know anything about the killings. Mirko Perić, T. $40802-40804$ (3 July 2013).

2430 P3263 (Witness statement of Suad Džafić dated 31 August 2011), paras. 10-11. See also D3852 (Witness statement of Mirko Perić dated 1 July 2013), para. 12. Defence witnesses testified that the population stated they wanted to leave voluntarily for their own security. D3126 (Witness statement of Jovan Nikolić dated 10 March 2013), para. 47; D3398 (Witness statement of Ljubisav Simić dated 7 April 2013), para. 59. The Chamber refers to its credibility assessment in fns. 2256 and 2268 in concluding that the evidence of the relevant witnesses about the voluntariness of the departure of the Bosnian Muslim population to be unreliable.

2431 Milenko Katanić, T. 24531-24532 (10 February 2012); P6196 (Romanija-Birač CSB report, 27 August 1992), pp. 2-3; Aleksandar Tešić, T. 35334(13 March 2013); KDZ480, T. 24235-24237 (7 February 2012). But see Branimir Tešić, T. 35261-35264 (12 March 2013) (denying the suggestion that the authorities in Bratunac only became concerned with the actions of volunteers after they started attacking Bosnian Serbs).

2432 D3115 (Witness statement of Branimir Tešić dated 9 March 2013), para. 30; D3126 (Witness statement of Jovan Nikolić dated 10 March 2013), paras. 36, 40. See also Srbislav Davidović, T. 24439 (9 February 2012); D3118 (Witness statement of Aleksandar Tešić dated 10 March 2013), para. 17.

2433 Milenko Katanić, T. 24533 (10 February 2012).

2434 D2061 (List of decisions and orders issued by the Crisis Staff, War Staff, and Wartime Presidency of Bratunac Municipality, 29 August 1992), p. 3.

2435 P1477 (Ratko Mladić's notebook, 14 February-28 May 1992), p. 253. But see Rodoljub Đukanović, T. 3618536188 (27 March 2013) (who denied the truth of this diary entry which suggested that they were responsible for bringing "all the cutthroats from Vukovar" to the municipality and testified that he was not aware of who brought the volunteers to Bratunac). Simić testified that the local authorities tried unsuccessfully to prevent some volunteers from arriving in the municipality. D3398 (Witness statement of Ljubisav Simić dated 7 April 2013), paras. 42-45. However, the Chamber does not find Simić's evidence to be entirely reliable in this regard. In reaching that conclusion, it refers to it credibility assessment in fn. 2268. 
acting in the municipality. ${ }^{2436}$ The Bratunac Crisis Staff also issued a decision that if paramilitaries did not comply with the decision to leave the municipality, military formations would be ordered to intervene. ${ }^{2437}$ Despite these orders, the paramilitary units did not leave the municipality. ${ }^{2438}$ On 6 May 1992, the Crisis Staff issued a decision that all paramilitary formations should leave Bratunac by the next day, however, Bosnian Serb citizens rallied in support of the paramilitary units. $^{2439}$

752. The Bratunac Crisis Staff issued a number of other decisions in May 1992, including restrictions on the sale of alcohol, and measures to combat looting, smuggling, and the illegal movement by individuals into apartments. ${ }^{2440}$

753. Following an inspection by the Romanija-Birač CSB in August 1992, it was reported that the Bratunac SJB had been involved in investigating and documenting war crimes committed against Bosnian Serbs. ${ }^{2441}$ This report also indicated that while volunteers had become involved in

2436 D2060 (Order of Bratunac Crisis staff, 1 May 1992), pp. 3-4; Milenko Katanić, T. 24532, 24535 (10 February 2012); D2061 (List of decisions and orders issued by the Crisis Staff, War Staff, and Wartime Presidency of Bratunac Municipality, 29 August 1992), p. 4; D3126 (Witness statement of Jovan Nikolić dated 10 March 2013), paras. 38-39; D3398 (Witness statement of Ljubisav Simić dated 7 April 2013), paras. 64-65; Ljubisav Simić, T. 37295 (16 April 2013). See also Adjudicated Fact 2314; D3194 (Witness statement of Rodoljub Đukanović dated 24 March 2013), para. 45; Rodoljub Đukanović, T. 36199 (27 March 2013); D3117 (Bratunac Crisis Staff order, 1 May 1992); Branimir Tešić, T. 35261, 35273, 35277-35278 (12 March 2013); D3118 (Witness statement of Aleksandar Tešić dated 10 March 2013), para. 26; Aleksandar Tešić, T. 35331-35333 (13 March 2013).

2437 D2061 (List of decisions and orders issued by the Crisis Staff, War Staff, and Wartime Presidency of Bratunac Municipality, 29 August 1992), p. 3.

2438 See Adjudicated Fact 2314. But see D3194 (Witness statement of Rodoljub Đukanović dated 24 March 2013), paras. 45, 48; D3126 (Witness statement of Jovan Nikolić dated 10 March 2013), para. 39; Ljubisav Simić, T. 37296 (16 April 2013); Aleksandar Tešić, T. 35331-35333 (13 March 2013). The Chamber does not consider their evidence that the TO Staff and police were unable to remove paramilitaries because they were too strong to be reliable. In reaching that conclusion the Chamber refers to its credibility assessment in fns. 2248, 2256, 2268, and 2338.

2439 D3116 (Bratunac Crisis Staff decision, 6 May 1992); Branimir Tešić, T. 35274-35275 (12 March 2013).

2440 D2061 (List of decisions and orders issued by the Crisis Staff, War Staff, and Wartime Presidency of Bratunac Municipality, 29 August 1992), pp. 3, 5; Milenko Katanić, T. 24542 (10 February 2012). See also D4698 (Order of Bratunac Interim Government, 8 July 1992). The local authorities, including the police, faced problems from paramilitaries and volunteers and some measures were taken to try and control them. D3115 (Witness statement of Branimir Tešić dated 9 March 2013), para. 30; D3118 (Witness statement of Aleksandar Tešić dated 10 March 2013), para. 18; D3196 (Witness statement of Dušan Mićić dated 24 March 2013), para. 3; D3126 (Witness statement of Jovan Nikolić dated 10 March 2013), para. 50.

2441 P6196 (Romanija-Birač CSB report, 27 August 1992), p. 2. See also P6197 (Romanija-Birač CSB report, 8 September 1992), p. 4. Branimir Tešić testified that when filing criminal reports no distinction was made based on ethnicity. However, when confronted with these documents which suggested that the SJB was successful in conducting war crimes investigations into crimes committed by Bosnian Muslims and did not mention investigations into crimes committed by Bosnian Serbs, he distanced himself and claimed that this was not his job. Branimir Tešić, T. 35264-35268, 35284 (12 March 2013). Having regard to his evasiveness on the issue and apparent contradictions, the Chamber does not find Tešić's evidence to be reliable in this regard. The Chamber also refers to its credibility assessment in fn. 2236. However, the Chamber finds that in May 1992, the police were involved in preventing the rape of a Bosnian Muslim woman. D4673 (Bratunac SJB criminal report, 25 May 1992); D4277 (Request from Zvornik Prosecutor's Office, 26 May 1993). 
"robberies and troublemaking", Ljubisav Simić said that the police should be engaged to prevent further lootings since Bosnian Serb houses were now being looted too. ${ }^{2442}$

754. In September 1992, paramilitaries remained in Bratunac and the SJB, with the assistance of the military and civilian authorities, sought to place them under the command of the VRS. ${ }^{2443}$ On 17 December 1992, it was reported that there were still a number of paramilitary formations in the zone of responsibility of the Bratunac Brigade and they were only there to loot. ${ }^{244}$ On 29 December 1992, the Accused ordered the establishment of military rule in Bratunac. ${ }^{245}$

755. On 1 February 1993, Deronjić delivered a speech at a meeting of the SDS Municipal Board attended by the RS commissioner, Jovo Mijatović. ${ }^{2446}$ Deronjić provided an overview of events from 1 April 1992 and assessed that, with the assistance of the SDS Main Board and local boards, operations had been carried out very well in the municipality. ${ }^{2447}$ At this same meeting, objections were voiced to the SJB due to their "indolence" with respect to crime prevention, in particular in relation to the unauthorised appropriation of property, which was sometimes covered up or allowed. $^{2448}$ The SDS Main Board thus proceeded to pass a no-confidence vote in the chief of the SJB. Jovo Mijatović then nominated Ljubiša Borovčanin as the commander. ${ }^{2449}$

756. The municipal authorities continued to face problems with paramilitaries, including a paramilitary unit which, in March 1993, was involved in looting and had no respect for the Bosnian Serb civilian and military authorities in Bratunac. ${ }^{240}$ Momir Nikolić reported on the activities of this paramilitary unit, demanded that they stop mistreating members of the Bratunac Brigade, and asked that they be withdrawn from the municipality. ${ }^{2451}$

P6196 (Romanija-Birač CSB report, 27 August 1992), p. 3.

P6197 (Romanija-Birač CSB report, 8 September 1992), para. 6. See also P1107 (SerBiH MUP report to the Minister of Interior re inspection of Romanija-Birač CSB and SJB, 10 August 1992), p. 3. The Chamber also received evidence that a paramilitary group was involved in the killing Bosnian Muslims in August 1992. P3264 (Report of Milići SJB, 3 August 1992), pp. 1-2. But see Branimir Tešić, T. 35267-35268 (12 March 2013). The Chamber notes that this killing is not charged pursuant to Schedules A or B of the Indictment. See fn. 13.

P2955 (Report of the Drina Corps, 17 December 1992), pp. 3-4.

D3122 (Bratunac Brigade report, 30 December 1992), p. 1; Aleksandar Tešić, T. 35338 (13 March 2013).

P4378 (Minutes of the Bratunac SDS Municipal Board meeting, 1 February 1993), p. 1.

P4378 (Minutes of the Bratunac SDS Municipal Board meeting, 1 February 1993), pp. 1-3; P4374 (Witness statement of Milenko Katanić dated 11 October 2011), para. 19; Milenko Katanić, T. 24529 (10 February 2012).

P4378 (Minutes of the Bratunac SDS Municipal Board meeting, 1 February 1993), pp. 2-3.

P4378 (Minutes of the Bratunac SDS Municipal Board meeting, 1 February 1993), p. 3; Milenko Katanić, T. 24530 (10 February 2012).

D2062 (Report of Bratunac Brigade, 5 March 1993); Momir Nikolić, T. 24730-24734 (15 February 2012).

Momir Nikolić, T. 24733 (15 February 2012). 


\section{(G) Detention facilities in Bratunac}

\section{(1) Scheduled Detention Facility C.6.1}

757. The Indictment refers to the use of the Bratunac Football Stadium as a detention facility from at least 10 to 18 May $1992 .^{2452}$

758. The Bratunac Football Stadium was located close to the Bratunac SJB and the Vuk Karadžić School. ${ }^{2453}$

759. Following the attack by Serb Forces on Mihaljevići and Suha on 10 May 1992, male villagers were arrested and taken to the Vuk Karadžić School, while women and children were taken to the Bratunac Football Stadium. ${ }^{2454}$ Serb Forces drove Bosnian Muslims from their homes and told them not to lock their doors and to head to Bratunac. ${ }^{2455}$ Through loudspeakers, the men were threatened that if they did not surrender the women and children would be killed. ${ }^{2456}$ Those who surrendered formed a column and were led on foot towards the Bratunac Football Stadium by Bosnian Serb reserve soldiers, including local Bosnian Serbs wearing JNA uniforms. ${ }^{2457}$ The Bosnian Muslims were reassured by one soldier that nothing would happen to them, that they would be taken to the stadium for their own protection, and that they would be protected from Arkan's men. ${ }^{2458}$

760. On or about 17 May 1992, villagers from Vitkovići were taken by bus to the Bratunac Football Stadium, along with a third bus filled with villagers from Krasanpolje and other villages close to Bratunac. ${ }^{2459}$

2452 Indictment, Scheduled Detention Facility C.6.1, fn. 7, referring to Rule 73 bis Submission, Appendix B, p. 13.

2453 P4308 (Book of photographs and maps prepared by Jean-René Ruez, 22 June 2009), p. 282; Branimir Tešić, T. 35253 (12 March 2013); P290 (Aerial photograph of Bratunac marked by KDZ107).

2454 See Adjudicated Fact 2321; Mirsada Malagić, T. 23505 (24 January 2012); P3205 (Witness statement of KDZ605 dated 22 August 2011), paras. 50-52 (under seal). See also D3194 (Witness statement of Rodoljub Đukanović dated 24 March 2013), para. 44; KW12, T. 44742, 44745 (9 December 2013).

2455 P3205 (Witness statement of KDZ605 dated 22 August 2011), para. 46 (under seal).

2456 P3205 (Witness statement of KDZ605 dated 22 August 2011), para. 47 (under seal).

2457 P3205 (Witness statement of KDZ605 dated 22 August 2011), paras. 47-49 (under seal); KDZ605, T. 17914 (25 August 2011). See also P4374 (Witness statement of Milenko Katanić dated 11 October 2011), para. 50. Đukanović stated that he sought information about the detention of Bosnian Muslims and tried to take steps to prevent it but was ordered not to interfere. D3194 (Witness statement of Rodoljub Đukanović dated 24 March 2013), para. 44. The Chamber does not find Đukanović's evidence with respect to what he tried to do and what he was told about the Bosnian Muslims who he saw outside the Bratunac stadium to be reliable. In reaching that conclusion the Chamber refers to its credibility assessment in fn. 2248.

2458 P3205 (Witness statement of KDZ605 dated 22 August 2011), para. 48 (under seal); KDZ605, T. 17915 (25 August 2011).

2459 P3263 (Witness statement of Suad Džafić dated 31 August 2011), paras. 21-22; Suad Džafić, T. 18193-18194 (1 September 2011); Adjudicated Fact 2322. Džafić also testified about the killing of a man who was taken off 
761. After the attack on Glogova, ${ }^{2460}$ Deronjic informed the Bratunac Crisis Staff that he had information that "volunteers had gathered the Muslim population at the stadium in Bratunac" and some men had been taken out to the Vuk Karadžić School. ${ }^{2461}$

762. Milenko Katanić was able to speak to a commander of a paramilitary group and secure the release of his best man who had been detained at the stadium. ${ }^{2462}$ Thousands of Bosnian Muslims, including women, children and the elderly, ${ }^{2463}$ were detained at the Bratunac Football Stadium before being transported to locations such as Tuzla. ${ }^{2464}$ People were being constantly brought to and taken away from the stadium from Bratunac and surrounding villages. ${ }^{2465}$ Soldiers used loudspeakers to call out names of people who would be taken away from the stadium. ${ }^{2466}$ Money, jewellery, and identification documents were taken away and soldiers threatened children that they would cut off their ears if they did not give them their earrings. ${ }^{2467}$ One man was also beaten and stabbed. $^{2468}$

763. After being held for some time, the Bosnian Muslims in the stadium were informed via loudspeaker that they had to move; they were taken to buses and trucks outside the stadium, and told they were going to Tuzla. ${ }^{2469}$ A large number of soldiers separated the able-bodied men and sent the women and children to the buses which headed to Tuzla; the men were taken under guard

the bus. The Chamber notes that this killing is not charged pursuant to Schedules A or B of the Indictment. See fn. 13 .

2460 For general evidence on the attack against Glogova, see paras. 738-749.

2461 D3398 (Witness statement of Ljubisav Simić dated 7 April 2013), para. 59. See P3207 (Aerial photograph of Bratunac marked by KDZ605) (under seal) for location of the school; P3205 (Witness statement of KDZ605 dated 22 August 2011), para. 5 (under seal). Tešić stated that Deronjić had gone to the stadium and asked the paramilitaries not to mistreat people. D3118 (Witness statement of Aleksandar Tešić dated 10 March 2013), para. 24. The Chamber notes that Tešić's evidence in this regard is of very little weight given that he claimed that he did not know that Bosnian Muslims had been brought to the stadium but then states that he was later told about Deronjić's actions to protect the Bosnian Muslims.

2462 P4374 (Witness statement of Milenko Katanić dated 11 October 2011), paras. 50-51; Milenko Katanić, T. 24539 (10 February 2012).

2463 P3205 (Witness statement of KDZ605 dated 22 August 2011), paras. 62-64 (under seal).

2464 P4374 (Witness statement of Milenko Katanić dated 11 October 2011), para. 50.

2465 P3205 (Witness statement of KDZ605 dated 22 August 2011), paras. 63-64 (under seal); P4374 (Witness statement of Milenko Katanić dated 11 October 2011), para. 45.

2466 P3205 (Witness statement of KDZ605 dated 22 August 2011), para. 62 (under seal).

2467 P3205 (Witness statement of KDZ605 dated 22 August 2011), para. 62 (under seal).

2468 P3205 (Witness statement of KDZ605 dated 22 August 2011), para. 62 (under seal). See also P43 (Witness statement of Mirsad Smajš dated 18 December 1993), pp. 3-4 (stating that approximately 430 detainees were brought from the Bratunac Football Stadium and detained at the gym in Pale and they told him they had been beaten at the stadium and some had been mutilated). While the Chamber finds that Bosnian Muslims were taken from the Bratunac Football Stadium and detained in Pale, in the absence of further evidence, it does not consider that it can rely on Smajš' hearsay evidence alone to establish that detainees were mutilated at the Bratunac Football Stadium by Serb Forces. For evidence relating to the detention in Pale Gym, see Scheduled Detention Facility C.19.2.

2469 P3205 (Witness statement of KDZ605 dated 22 August 2011), para. 66 (under seal). See also D3115 (Witness statement of Branimir Tešić dated 9 March 2013), para. 28; Branimir Tešić, T. 35255-35256, 35272 (12 March 2013) (private session). 
to the Vuk Karadžić School. ${ }^{2470}$ Women and children from Suha who could not fit on the buses were told to go home and return the next morning to be taken by bus to Tuzla. ${ }^{241}$ They were warned not to leave and told that if they complied they would guarantee the lives of their husbands. $^{2472}$ From mid-May 1992 on, detainees held at the Bratunac Football Stadium were forced on buses and sent to Vlasenica municipality where some men were detained at the Vlasenica municipal prison. ${ }^{2473}$

764. The Chamber therefore finds that in mid-May 1992, Bosnian Muslims from Bratunac and surrounding villages, including women, children and the elderly, were brought to and detained at the Bratunac Football Stadium by Serb Forces. The Bosnian Muslims were detained at this location until their transportation to other municipalities or detention facilities. Detainees were threatened and their valuables were confiscated and at least one man was beaten and stabbed.

\section{(2) $\underline{\text { Scheduled Detention Facility C.6.2 and Scheduled Incident B.4.1. }}$}

765. The Indictment refers to the use of the Vuk Karadžić School as a detention facility at least between 1 May and 31 December 1992. ${ }^{2474}$ The Prosecution alleges that approximately 50 people were killed while being detained at the Vuk Karadžić School between 10 and 16 May $1992 .{ }^{2475}$

\section{(a) Arrival of detainees and control of facility}

766. After the arrival of Serb Forces in Bratunac, some prominent Bosnian Muslims were brought to the Vuk Karadžić School and detained there. ${ }^{2476}$ Groups of volunteers would select individuals from the Bosnian Muslim population in Bratunac, interrogate them, and then bring them to the Vuk Karadžić School. ${ }^{2477}$

\footnotetext{
2470 P3205 (Witness statement of KDZ605 dated 22 August 2011), paras. 67-69 (under seal); P3263 (Witness statement of Suad Džafić dated 31 August 2011), para. 10; P4374 (Witness statement of Milenko Katanić dated 11 October 2011), para. 45. See also Branimir Tešić, T. 35253-35259 (12 March 2013).

2471 P3205 (Witness statement of KDZ605 dated 22 August 2011), para. 67 (under seal).

2472 P3205 (Witness statement of KDZ605 dated 22 August 2011), para. 67 (under seal).

2473 P3263 (Witness statement of Suad Džafić dated 31 August 2011), paras. 24-29; see Adjudicated Fact 2323. For evidence of detention at the Vlasenica prison, see Scheduled Detention Facility C.25.2.

2474 The Prosecution submits that the evidence presented shows that the facility was operational from 3 May 1992 until on or about 14 May 1992. Prosecution Final Brief, Appendix B, fn. 136.

2475 Indictment, Scheduled Incident B.4.1.

2476 P3263 (Witness statement of Suad Džafić dated 31 August 2011), paras. 6, 8; P4375 (Aerial photograph of Bratunac marked by Milenko Katanić); P4308 (Book of photographs and maps prepared by Jean-René Ruez, 22 June 2009), p. 282. See also P3188 (Witness statement of Mušan Talović dated 14 July 2011), paras. 31 , 40. 
767. On 10 May 1992, after the attack on Krasanpolje by paramilitaries, over 500 Bosnian Muslim men from villages in Bratunac were detained in the Vuk Karadžić School. ${ }^{2478}$ On 11 May 1992, the Bratunac TO brought approximately 250 of Hranča's inhabitants to the municipal hall of Bratunac and from there, approximately 60 men were taken to the school. ${ }^{2479}$ Further, as mentioned, a very large group of able-bodied Bosnian Muslim men were separated from women and children held at the Bratunac Football Stadium and taken under guard to the school. ${ }^{2480}$ This group included some elderly men. ${ }^{2481}$ On the same day, hundreds of men were brought to the school in groups every hour. ${ }^{2482}$ The people detained at the school were Bosnian Muslim civilians; some were captured while they were trying to escape but most were rounded up from their homes by Bosnian Serb soldiers. ${ }^{2483}$

768. There were approximately 30 soldiers on guard around the school. ${ }^{2484}$ The soldiers were wearing reserve military uniforms and carried automatic and semi-automatic rifles. ${ }^{2485}$ Some of Arkan's men were present when Bosnian Muslims were brought to the school. ${ }^{2486}$ Bosnian Serb officials, including Deronjić and Momir Nikolić, also visited the school and the gym where the detainees were held. ${ }^{2487}$ Detainees were threatened to give statements indicating their involvement in the distribution of arms and the killing of Bosnian Serbs. ${ }^{2488}$

\footnotetext{
$2478 \quad$ See Adjudicated Fact 2325.

2479 Adjudicated Fact 2327. Simić denied any knowledge of this incident and stated that the municipality building was unable to accommodate that many people. D3398 (Witness statement of Ljubisav Simić dated 7 April 2013), para. 91. The Chamber refers to its credibility assessment in fn. 2268 in concluding that it does not find Simić's evidence with respect to the transfer and detention of residents from Hranča to be reliable. In addition his evidence on this issue is qualified, in that he denied any personal knowledge about this incident.

2480 P3205 (Witness statement of KDZ605 dated 22 August 2011), paras. 51, 69-70 (under seal). See also KW12, T. 44745-44746 (9 December 2013).

2481 P3205 (Witness statement of KDZ605 dated 22 August 2011), para. 70 (under seal).

2482 P3205 (Witness statement of KDZ605 dated 22 August 2011), para. 71 (under seal).

2483 P3205 (Witness statement of KDZ605 dated 22 August 2011), para. 73 (under seal).

2484 P3205 (Witness statement of KDZ605 dated 22 August 2011), para. 53 (under seal).

2485 P3205 (Witness statement of KDZ605 dated 22 August 2011), para. 54 (under seal).

2486 P3205 (Witness statement of KDZ605 dated 22 August 2011), para. 54 (under seal).

2487 P3205 (Witness statement of KDZ605 dated 22 August 2011), para. 105 (under seal). KDZ605 recognised Deronjić but was told about Nikolić by the other detainees.

2488 P3205 (Witness statement of KDZ605 dated 22 August 2011), para. 56 (under seal); KDZ605, T. 17917 (25 August 2011) (private session), T. 17918-17919 (25 August 2011).
} 
(b) Conditions of detention, treatment, and killing of detainees

769. Detainees at the Vuk Karadžić School were severely mistreated and beaten repeatedly. ${ }^{2489}$ For example, on 9 May 1992, after the attack on Glogova, Mustafa Golić was taken to the school and severely beaten. ${ }^{2490}$ Similarly, a former Bosnian Muslim policeman was taken out and beaten. $^{2491}$ On 11 May 1992, detainees were severely beaten in the sports hall with, inter alia, iron tubes, heavy wooden sticks, and a rifle butt. ${ }^{2492}$ One of the detainees was threatened before being cut with a knife. ${ }^{2493}$ Detainees were thrown to the ground, kicked, and some were beaten till they lost consciousness while others were killed. ${ }^{2494}$ These killings and mistreatment were carried out by three soldiers while other soldiers guarded the door or stood in the corridors or at the entrance to the school. ${ }^{2495}$ Some of the soldiers inside the school identified themselves as Arkan's men and told the detainees they were paid to do what they were doing and would make more money if they killed more people. ${ }^{2496}$ One of the detainees was saved from further mistreatment by a soldier who knew him and was told that he could be taken to the Bratunac Football Stadium but that he and

2489 Adjudicated Fact 2326. See also KW12, T. 44746 (9 December 2013). Mićic stated that the members of the military police did not see any detainees being beaten, did not hear any shots, or see any bodies near the school. D3196 (Witness statement of Dušan Mićić dated 24 March 2013), paras. 7, 12. The Chamber does not find Mićić's evidence with respect to the mistreatment of detainees to be reliable. In reaching that conclusion the Chamber notes that his evidence was marked by contradictions and indicators that he was not being forthright in his testimony. In addition the Chamber notes that the value of Mićić's evidence in this regard is further undermined given that he stated that he did not go to the school himself. 
other Bosnian Muslims would have to go from there to Tuzla because Bosnian Serbs were going to live in Bratunac. ${ }^{2497}$

770. A man who identified himself as Goran Zekić's father came to the school on one occasion and said that " 300 people had to pay for the death of his son". ${ }^{2498}$ When an individual named Zaim Huseinović from Potočari was identified, he was questioned about who killed Zekić and Arkan's men in Potočari; he was then beaten and fell to floor. ${ }^{2499}$ A man named Krke intervened to stop the beating but once Krke left, Huseinović was hit several times until his brains spilled out and he died. $^{2500}$ On his arrival at the facility, KDZ605 saw five or six bodies including the body of Safet Karić who was lying on his stomach in the toilet. ${ }^{2501}$

771. A soldier who called himself Zoka and was known as the "Macedonian", would often come in and out of the sports hall, mistreat, and kill detainees. ${ }^{2502}$ Zoka was accompanied by two others, including a man from Serbia named Bane Topolović who identified himself as one of Arkan's men and a man who identified himself as "Dragan from Milići". 2503 These men, along with other guards, beat the detainees severely for three days with steel rods, tubes, handles from rakes and shovels. $^{2504}$

772. The detainees were told to squeeze into the sports hall and when they told the guards that they would not all fit, the guards told them that whoever was left outside the door would be killed. Approximately 10 to 20 of the men were taken outside; there was then screaming and gunfire. ${ }^{2505}$ The detainees were taken to one side of the sports hall and "stacked almost up to the ceiling"; they were then beaten, provoked, and asked if they still wanted their independence. Some of the detainees were made to sing "Chetnik" songs and display the "Serb three-finger sign". ${ }^{2506}$ Topalović, Dragan, and Zoka identified the main Muslim priest in Bratunac, Mustafa

\footnotetext{
2497 P3205 (Witness statement of KDZ605 dated 22 August 2011), paras. 60-61 (under seal); KDZ605, T. 17898 (25 August 2011).

2498 P3205 (Witness statement of KDZ605 dated 22 August 2011), paras. 97, 104 (under seal); KDZ605, T. 17922 (25 August 2011).

2499 P3205 (Witness statement of KDZ605 dated 22 August 2011), paras. 86, 96 (under seal).

2500 P3205 (Witness statement of KDZ605 dated 22 August 2011), para. 86 (under seal).

2501 P3205 (Witness statement of KDZ605 dated 22 August 2011), para. 55 (under seal); KDZ605, T. 17922 (25 August 2011). The body of Safet Karić was exhumed from a mass grave. P4853 (Updated Table 2 to the Report of Amor Mašović), p. 4.

2502 P3205 (Witness statement of KDZ605 dated 22 August 2011), para. 74 (under seal). KDZ605 stated that Zoka appeared to be drunk or on drugs.

2503 P3205 (Witness statement of KDZ605 dated 22 August 2011), para. 74 (under seal).

2504 P3205 (Witness statement of KDZ605 dated 22 August 2011), para. 75 (under seal).

2505 P3205 (Witness statement of KDZ605 dated 22 August 2011), para. 72 (under seal).

2506 P3205 (Witness statement of KDZ605 dated 22 August 2011), para. 76 (under seal).
} 
Mujkanović. ${ }^{2507}$ He was ordered to take off his coat so that he could be beaten more easily; he was then forced to sing "Chetnik" songs, drink beer, and join the men in the corner of the hall who had to make the "Serb three-finger sign". When Mujkanović refused to make this sign and showed only two fingers, he was stabbed in the throat by Bane Topalović and was taken out to the hangar. ${ }^{2508}$ Mujkanović showed signs of life as he was taken out and shot. ${ }^{2509}$

773. A military commander in JNA uniform entered the room and ordered the three soldiers to stop beating the detainees. Seven or eight detainees at the bottom of the pile were found to have died of suffocation. ${ }^{2510}$ The military commander ordered that the detainees be given food and water and he shouted at the soldiers saying: "What are you doing to these people?"2511 After this, the Bosnian Serb guards told the detainees that their fight against the paramilitaries had not been successful thus far but that the "Bosnian Serb leadership" would soon be able to throw them out. ${ }^{2512}$

774. However, after the commander left, the three soldiers returned and started calling out names of detainees at random, after which those called out were severely beaten or killed. ${ }^{2513}$ People who worked in the school and intellectuals from Bratunac were also called out and some men were killed. $^{2514}$ KW12 estimated that approximately 20 detainees were beaten and then killed in his presence. ${ }^{2515}$ The soldiers played Serbian music, drank a lot of beer, and made the detainees swear against the Bosnian State and President and sing "Chetnik" songs. ${ }^{2516}$ On the first day of these killings and acts of mistreatment, the detainees were not given any food. ${ }^{2517}$ On the second day the

P3205 (Witness statement of KDZ605 dated 22 August 2011), para. 90 (under seal). P3205 (Witness statement of KDZ605 dated 22 August 2011), para. 90 (under seal).

P3205 (Witness statement of KDZ605 dated 22 August 2011), para. 90 (under seal). The body of Mustafa Mujkanović was exhumed from a mass grave. P4853 (Updated Table 2 to the Report of Amor Mašović), p. 5.

P3205 (Witness statement of KDZ605 dated 22 August 2011), para. 78 (under seal). KDZ605 identified three of those who died, namely Omer Muhić, Husnija Hadžibulić, and Hazim Muratović. The bodies of Husnija Hadžibulić and Omer Muhić were identified as having been later exhumed from a mass grave. P4853 (Updated Table 2 to the Report of Amor Mašović), pp. 3-4.

P3205 (Witness statement of KDZ605 dated 22 August 2011), para. 79 (under seal); KDZ605, T. 17919 (25 August 2011).

P3205 (Witness statement of KDZ605 dated 22 August 2011), para. 77 (under seal); KDZ605, T. 17919 (25 August 2011). See also P3206 (Video footage re people from Bratunac in Visoko sports hall, with transcript); P3209 (Video still of the face of a man) (under seal); KDZ605, T. 17871-17874, 17876-17878 (25 August 2011) (private session).

P3205 (Witness statement of KDZ605 dated 22 August 2011), paras. 80, 82, 84-86, 94-95, 98, 133-134 (under seal); KDZ605, T. 17920-17921 (25 August 2011).

P3205 (Witness statement of KDZ605 dated 22 August 2011), para. 81 (under seal). The Chamber has insufficient evidence to identify how many detainees were killed or the manner in which they were killed.

KW12, T. 44746-44747, 44755 (9 December 2013).

P3205 (Witness statement of KDZ605 dated 22 August 2011), para. 98 (under seal).

P3205 (Witness statement of KDZ605 dated 22 August 2011), para. 93 (under seal). 
guards were ordered to provide the detainees with food and water, and some sandwiches and juice were thrown into the room but it was only sufficient for half of the detainees. ${ }^{2518}$

775. When detainees were beaten they were threatened and subjected to political comments such as "You wanted a state: here is a state for you", "where is now your Alija to save you?", "Where is Naser, your liberator?"2519 In one incident, the shape of a cross was cut on the arm of one detainee with a knife. ${ }^{2520}$ If detainees made eye-contact with Topolović he would call them out and they would be beaten. ${ }^{2521}$

776. Topalović beat some of the detainees to death. ${ }^{2522}$ For example, Ramo Karić was called out, beaten, and shot in the elbow by Topalović before being beaten again, this time to death. ${ }^{2523}$ Ahmet Salkić was selected and called "Ustasha". He was hit on the forehead close to the eye before falling to the ground and sustaining another blow. His body was then carried out by the detainees. ${ }^{2524}$ Hajrudin Čomić was ordered to kneel down and place his forehead on the floor before Topalović shot him in the back of his lower neck with a pistol. ${ }^{2525}$ The beatings and killings continued through the night and KDZ605 saw at least 50 Bosnian Muslims killed with the use of different objects, including wooden handles, iron pipes, iron bed legs, and pistol butts. ${ }^{2526}$

777. One old man was beaten and killed after he was told that his son had shot at Bosnian Serb troops. ${ }^{2527}$ Another man named Džemo Hodžić was accused of being a military expert and of arming the Bosnian Muslims; he was beaten until the soldiers thought he was dead and then he was placed on a truck with bodies. ${ }^{2528}$ When Hodžić was found to be still alive, he was then taken back

\footnotetext{
2518 P3205 (Witness statement of KDZ605 dated 22 August 2011), paras. 94-95 (under seal).

2519 P3205 (Witness statement of KDZ605 dated 22 August 2011), para. 92 (under seal).

2520 P3205 (Witness statement of KDZ605 dated 22 August 2011), paras. 133, 135 (under seal); P3210 (Video still of exposed torso of a man) (under seal); KDZ605, T. 17875 (25 August 2011) (private session); KDZ605, T. 17897-17902 (25 August 2011).

$2521 \quad$ KDZ605, T. 17897-17898 (25 August 2011).

2522 KDZ605, T. 17898 (25 August 2011).

2523 P3205 (Witness statement of KDZ605 dated 22 August 2011), para. 99 (under seal). The body of Ramo Karić was exhumed from a mass grave. P4853 (Updated Table 2 to the Report of Amor Mašović), p. 4. The Chamber does not consider that KDZ605's estimation that Topalović was responsible for approximately $90 \%$ of the killings at the school to be of much weight.

2524 P3205 (Witness statement of KDZ605 dated 22 August 2011), para. 100 (under seal). The body of Ahmet Salkić was exhumed from a mass grave. P4853 (Updated Table 2 to the Report of Amor Mašović), p. 5.

2525 P3205 (Witness statement of KDZ605 dated 22 August 2011), para. 101 (under seal). The body of Hajrudin Čomić was exhumed from a mass grave. P4853 (Updated Table 2 to the Report of Amor Mašović), p. 2.

2526 P3205 (Witness statement of KDZ605 dated 22 August 2011), para. 91 (under seal). See also P3206 (Video footage re people from Bratunac in Visoko sports hall, with transcript).

2527 P3205 (Witness statement of KDZ605 dated 22 August 2011), para. 92 (under seal); KDZ605, T. 17906-17907 (25 August 2011).

2528 P3205 (Witness statement of KDZ605 dated 22 August 2011), para. 102 (under seal); KDZ605, T. 17922-17923 (25 August 2011).
} 
inside, beaten, and then stabbed to death. ${ }^{2529}$ Several men detained at the Vuk Karadžić School were taken out by the guards and killed. ${ }^{2530}$ For example, Mensur Husić was brought to the school and beaten. ${ }^{2531}$ Husić screamed and begged not to be killed. He was then taken outside, and a burst of fire, and another scream was heard. ${ }^{2532}$ Detainees were assigned to take away the bodies of those who had been killed in the sports hall and to take them to the hangar. ${ }^{2533}$ There was a large pile of bodies in the hangar. ${ }^{2534}$

778. Đukanović was informed that people brought from Hranča in May 1992 had been taken to the Vuk Karadžić School and killed there. ${ }^{2535}$ The Bosnian Serb authorities arranged for the Civilian Protection to bury the Bosnian Muslim bodies at the hangar. ${ }^{2536}$ A mass grave was dug in which between 100 and 150 bodies of Bosnian Muslims who KDZ107 identified as having been killed at the Vuk Karadžić School were buried in a field by the Drina River. ${ }^{2537}$

2529 P3205 (Witness statement of KDZ605 dated 22 August 2011), para. 102 (under seal); KDZ605, T. 17922-17923 (25 August 2011). The body of Džemo Hodžić was exhumed from a mass grave. P4853 (Updated Table 2 to the Report of Amor Mašović), p. 3.

2530 Adjudicated Fact 2328. See also KW12, T. 44746 (9 December 2013); P3205 (Witness statement of KDZ605 dated 22 August 2011), para. 106 (under seal) (stating that some detainees were taken away but that he did not know what happened to them).

2531 P3205 (Witness statement of KDZ605 dated 22 August 2011), para. 103 (under seal).

2532 P3205 (Witness statement of KDZ605 dated 22 August 2011), para. 103 (under seal). The body of Mensur Husić was exhumed from a mass grave. P4853 (Updated Table 2 to the Report of Amor Mašović), p. 3.

2533 P3205 (Witness statement of KDZ605 dated 22 August 2011), paras. 87-88 (under seal).

2534 [REDACTED]. The Chamber received evidence about the exhumation and disappearance of a large number of Bosnian Muslims from Bratunac in 1992. P4854 (Updated Table 1 to the Report of Amor Mašović), p. 1; P4852 (Report of Amor Mašović, 20-21 October 2009), p. 3; P4853 (Updated Table 2 to the Report of Amor Mašović), pp 1-107; D2250 (Ewa Tabeau's report entitled "Deaths and Disappearance of BiH Muslims 19921995," 25 April 2012); Ewa Tabeau, T. 28411-28412 (2 May 2012); Ewa Tabeau, T. 28411-28412 (2 May 2012); Dževad Gušić, T. 17780-17781 (24 August 2011). However, the Chamber will not rely on this evidence in the absence of a positive connection with a scheduled killing incident charged in the Indictment.

2535 D3194 (Witness statement of Rodoljub Đukanović dated 24 March 2013), paras. 40, 46. The Chamber notes an inconsistency in his evidence with respect to the lack of involvement of the authorities in the matter and his evidence that he convened a Bratunac Crisis Staff meeting to discuss how to save people who were in danger. Similarly Tešić testified that the Bratunac Crisis Staff was shocked to hear about the killings, that it condemned this action, and agreed that such conduct by paramilitaries should be prevented. D3118 (Witness statement of Aleksandar Tešić dated 10 March 2013), para. 25. The Chamber does not find the evidence of Tešić and Đukanović to be reliable in this regard as they tried to distance themselves and the local authorities from this incident. In reaching that conclusion the Chamber also refers to its credibility assessment in fns. 2248 and 2338 with respect to Đukanović and Tešić.

2536 D3194 (Witness statement of Rodoljub Đukanović dated 24 March 2013), para. 47. Tešić testified that they only found approximately 20 dead bodies which were taken away and buried correctly following autopsies. D3118 (Witness statement of Aleksandar Tešić dated 10 March 2013), paras. 27-29. The Chamber does not find Tešić's evidence as to the number of bodies buried or that they were buried correctly following autopsies to be reliable. In reaching that conclusion the Chamber refers to its credibility assessment in fn. 2338.

2537 KDZ107, P345 (Transcript from Prosecutor v. Popović et al.), T. 9397-9399, 9557. While KDZ107 testified that these victims had been killed at the Vuk Karadžić School, he does not clarify on what basis he knew this. The Chamber is therefore not satisfied that it can rely on his evidence to conclude beyond reasonable doubt that all of these bodies were of detainees who had been killed at the school as charged in this scheduled incident. 
779. On 14 May 1992, following a decision of the Bratunac Crisis Staff, approximately 400 Bosnian Muslim detainees were packed onto trucks and buses, ${ }^{2538}$ transported to Pale under the escort of the MP and civilian police, and from there transferred to Bosnian Muslim controlled territory. $^{2539}$

\section{(c) Conclusion}

780. The Chamber therefore finds that hundreds of Bosnian Muslim men, including the elderly, were detained by Serb Forces at the Vuk Karadžić School in May 1992. Detainees were subjected to severe beatings, including with iron tubes, wooden sticks and rifle butts, and some were stabbed. Detainees were held in cramped conditions and on one occasion some detainees died of suffocation. Detainees were also subjected to acts of humiliation and threats while detained at the school. A number of detainees died following beatings while others were taken out and shot. The Chamber finds that in total at least 50 detainees were killed by Serb Forces while detained at the Vuk Karadžić School between 10 and 16 May 1992.

\section{(H) Scheduled Incident D.6}

781. The Indictment refers to the destruction of four cultural monuments and sacred sites in Bratunac between April and May 1992. ${ }^{2540}$

782. The Chamber took judicial notice that four Muslim monuments in Bratunac municipality were heavily damaged or completely destroyed between April and June 1992, including the mosque in Bratunac town and the mosque in Glogova, which was demolished with explosives during the

2538 P3208 (List of men taken from Bratunac to Pale); P3205 (Witness statement of KDZ605 dated 22 August 2011), paras. 108-111, 127 (under seal); D2850 (Witness statement of Tomislav Hršum dated 27 January 2013), para. 17; D3118 (Witness statement of Aleksandar Tešić dated 10 March 2013), para. 26. See also P733 (Witness statement of Sulejman Crnčalo dated 1 November 2009), para. 56.

2539 KW12, T. 44746-44748, 44751 (9 December 2013); D3194 (Witness statement of Rodoljub Đukanović dated 24 March 2013), paras. 46-47; D2850 (Witness statement of Tomislav Hršum dated 27 January 2013), para. 17; P4374 (Witness statement of Milenko Katanić dated 11 October 2011), para. 49. See also D3196 (Witness statement of Dušan Mićić dated 24 March 2013), para. 13; D3115 (Witness statement of Branimir Tešić dated 9 March 2013), para. 29; Milan Tupajić, P5238 (Transcript from Prosecutor v. Krajišnik), T. 15395-15396. For evidence relating to treatment of detainees in Pale, see Scheduled Detention Facility C.19.2. Defence witnesses also testified that the Bosnian Muslims could not be returned to Bratunac and were transferred to Pale to save and protect them from the volunteers when the Bratunac Crisis Staff heard about the killings. D3194 (Witness statement of Rodoljub Đukanović dated 24 March 2013), paras. 46, 48; D3118 (Witness statement of Aleksandar Tešić dated 10 March 2013), paras. 26, 31. However, having reviewed the evidence, the Chamber does not consider this evidence to be reliable in this regard. In reaching that conclusion the Chamber also had regard to its credibility assessment in fn. 2236 above and also notes that the evidence was marked by indicators that the witnesses in question were seeking to distance themselves from any responsibility with respect to events at the Vuk Karadžić School.

2540 These are the Bratunac town mosque, Glogova mosque, a Qur'an school in Glogova, and the Islamic archives of Bratunac. 
attack on 9 May 1992. ${ }^{2541}$ During attacks on Muslim villages, including Glogova, Serb Forces deliberately torched and destroyed mosques. ${ }^{2542}$ The Bratunac town mosque, the Islamic archive in Bratunac and the Qur'an school in Glogova were completely destroyed while the Glogova mosque was heavily damaged. ${ }^{2543}$

783. Therefore the Chamber finds that four cultural monuments and sacred sites were heavily damaged or completely destroyed by Serb Forces between April and June 1992.

\section{(I) Movement of the population from Bratunac}

784. The increasing intimidation and the reports that Bosnian Serbs were being armed by the SDS and JNA prompted people to slowly move out of Bratunac even before the conflict began. ${ }^{2544}$ In the months leading up to the conflict in Bratunac, Bosnian Serbs, consisting mostly of women, children and the elderly left the municipality. ${ }^{2545}$ Large numbers of citizens also left Bratunac out of fear after the armed conflict began in Bijeljina and Zvornik. ${ }^{2546}$ As discussed above, following the killing of Goran Zekić by Bosnian Muslims in May 1992, Serb Forces launched a number of attacks against Bosnian Muslim villages. ${ }^{2547}$ The killing of Goran Zekić at the beginning of May 1992 created great fear and caused both Bosnian Serbs and Bosnian Muslims to leave Bratunac. ${ }^{2548}$

785. After Bosnian Serbs took over the police station, Bosnian Muslims left Bratunac daily. ${ }^{2549}$ Some Bosnian Muslims left after being told by their neighbours that they had to leave and that it would be better for them if they left Bratunac because "some people" would come to the

2541 See Adjudicated Fact 2330; P3196 (Witness statement of Dževad Gušić undated), para. 69; P4374 (Witness statement of Milenko Katanić dated 11 October 2011), para. 55. While Gušić testified to the destruction of ten mosques in Bratunac, not all are charged in the Indictment.

$2542 \quad$ See Adjudicated Fact 2331.

2543 P4070 (Attachment to the expert report of András J. Riedlmayer, entitled "Destruction of Cultural Heritage in BiH" prepared for the Karadžić case, formatted records), pp. 65-72; P4071 (Slide images of damaged religious sites in $\mathrm{BiH}$ ), p. 19; P4069 (Cultural destruction database), records 82-85. See also P4068 (András Riedlmayer's expert report on Destruction of Cultural Heritage in Bosnia and Herzegovina during 1992-1995, 7 May 2009), paras. 16, 54; András Riedlmayer, T. 22544-22545 (9 December 2011). Riedlmayer surveyed a total of 12 religious sites in Bratunac which were destroyed but the Chamber notes that only four are charged in the Indictment.

2544 P3196 (Witness statement of Dževad Gušić undated), paras. 45(a), 49.

2545 P3196 (Witness statement of Dževad Gušić undated), para. 75; P3205 (Witness statement of KDZ605 dated 22 August 2011), para. 29 (under seal). Gušić also stated that Bosnian Serbs claimed to be leaving Bratunac because they were in danger but they were in fact leaving in order to achieve a number of objectives, including to allow them be placed under a unified command to later occupy Bratunac. The Chamber places no weight on the views and speculation of Gušić's and KDZ605 views as to why the Bosnian Serbs left Bratunac.

2546 D3852 (Witness statement of Mirko Perić dated 1 July 2013), para. 6; D3690 (Witness statement of Neđo Nikolić dated 8 June 2013), para. 6. See also D3174 (Witness statement of Vujadin Stević dated 23 March 2013), para. 8; D3115 (Witness statement of Branimir Tešić dated 9 March 2013), paras. 9-10. Branimir Tešić acknowledged that especially Bosnian Muslims left the municipality.

2547 See paras. 740-742.

2548 D3398 (Witness statement of Ljubisav Simić dated 7 April 2013), paras. 39, 46.

2549 D3852 (Witness statement of Mirko Perić dated 1 July 2013), para. 8. 
municipality. ${ }^{2550}$ Bosnian Muslims left Bratunac and surrounding villages out of fear, inter alia, of the paramilitaries. ${ }^{2551}$ Other Bosnian Muslims were forcibly moved out of their villages. ${ }^{2552}$ The last group of Bosnian Muslims left after Bosnian Serb refugees arrived in Bratunac. ${ }^{2553}$

786. In mid-April 1992, after Serb Forces had entered Bratunac, some Bosnian Muslims asked for permission from Bosnian Serb municipal officials to leave Bratunac for Tuzla and were allowed to do so. ${ }^{2554}$ The Bosnian Serb authorities were requested to secure escorts and passes for their safe passage by Bosnian Muslim leaders. ${ }^{2555}$ A large number of permits were issued for both Bosnian Muslims and Bosnian Serbs to leave the municipality. ${ }^{2556}$ At that time, a large group of Bosnian Muslims gathered in front of the municipality building and asked to be escorted to Konjević Polje and then police patrol escorted this group. ${ }^{2557}$ While Bosnian Muslims may have asked to leave the municipality, the Chamber finds that these requests were not made voluntarily when considering the surrounding circumstances in which they left after Serb Forces had entered Bratunac.

787. A municipal commission was established in Bratunac, which drew up a list of all Bosnian Muslim houses and sealed them off and when Bosnian Serb refugees arrived they were accommodated in these houses. ${ }^{2558}$ However, when large numbers of refugees arrived, some of the

2550 KDZ065, P336 (Transcript from Prosecutor v. Krstić, and Prosecutor v. Popović et al.), T. 3212.

2551 Srbislav Davidović, T. 24450 (9 February 2012); P4374 (Witness statement of Milenko Katanić dated 11 October 2011), paras. 41, 43; Milenko Katanić, T. 24520-24521, 24540 (10 February 2012). The Chamber does not find Katanić's evidence to be plausible that Bosnian Muslims were transported from their villages to be protected from volunteers who could not be controlled. See also P405 (Witness statement of Amer Malagić dated 19 June 2000), p. 3.

2552 KDZ605, T. 17891 (25 August 2011).

2553 D3118 (Witness statement of Aleksandar Tešić dated 10 March 2013), para. 30.

2554 D3194 (Witness statement of Rodoljub Đukanović dated 24 March 2013), paras. 30-31; Rodoljub Đukanović, T. 36186 (27 March 2013); D3126 (Witness statement of Jovan Nikolić dated 10 March 2013), para. 35.

2555 D3194 (Witness statement of Rodoljub Đukanović dated 24 March 2013), para. 32; D3126 (Witness statement of Jovan Nikolić dated 10 March 2013), para. 40.

2556 D3398 (Witness statement of Ljubisav Simić dated 7 April 2013), para. 52. See also D3690 (Witness statement of Neđo Nikolić dated 8 June 2013), para. 6; Mirko Perić, T. 40807 (3 July 2013).

2557 D3194 (Witness statement of Rodoljub Đukanović dated 24 March 2013), para. 33. While the Chamber finds that the Bosnian Serb authorities arranged for the transport of Bosnian Muslims, the Chamber does not find the evidence of Defence witnesses that this demonstrated that the authorities were simply respecting the wishes of the Bosnian Muslims who voluntarily wanted to leave the municipality to be reliable. D3126 (Witness statement of Jovan Nikolić dated 10 March 2013), para. 41; D3852 (Witness statement of Mirko Perić dated 1 July 2013), para. 8. See also D3690 (Witness statement of Neđo Nikolić dated 8 June 2013), para. 6; D3852 (Witness statement of Mirko Perić dated 1 July 2013), para. 12; D3174 (Witness statement of Vujadin Stević dated 23 March 2013), paras. 25-27; Vujadin Stević, T. 36043-36045 (26 March 2013). In reaching that conclusion, the Chamber refers to its credibility assessment in fns. 2236, 2256, and 2342 and also refers to its findings with respect to the overall circumstances created in the municipality.

2558 P4374 (Witness statement of Milenko Katanić dated 11 October 2011), para. 22; D2061 (List of decisions and orders issued by the Crisis Staff, War Staff, and Wartime Presidency of Bratunac Municipality, 29 August 1992), p. 3; Milenko Katanić, T. 24542 (10 February 2012). 
houses were broken into and the head of police was criticised for failing to prevent these property crimes. $^{2559}$

788. In late May or early June 1992 the Bratunac Brigade called on Bosnian Muslims who did not want to fight a war to return to their homes and live normally. ${ }^{2560}$ However, by June 1992, with the exception of a few individuals there were no Bosnian Muslims in Bratunac. ${ }^{2561}$

789. On 6 June 1992, the Accused, Mladić, and Koljević were informed by Ostojić that there were "no Muslims in Bratunac municipality". ${ }^{2562}$ The Accused was at a meeting in Zvornik on 30 June 1992 when Simić said that only two Muslims remained in Bratunac. ${ }^{2563}$

790. As discussed in more detail in Section IV.C.1.a., while Serb Forces were successful in taking over and holding town centres in municipalities including Bratunac, pockets in the surrounding countryside, which had a Bosnian Muslim majority population, remained under the control of Bosnian Muslim forces. ${ }^{2564}$ Bosnian Muslim forces in the second half of 1992 and early 1993 launched an offensive in which they took control of territory in Bratunac. ${ }^{2565}$ The counteroffensive by the VRS in spring 1993 prompted the movement of the vast majority of the Bosnian Muslim civilians who remained in Konjević Polje and thousands fled towards Srebrenica. ${ }^{2566}$

791. Having considered the totality of the evidence and assessed the circumstances in which departures occurred, the Chamber finds that Bosnian Muslims were forced to leave Bratunac.

\footnotetext{
2559 Srbislav Davidović, T. 24392 (9 February 2012); P4374 (Witness statement of Milenko Katanić dated 11 October 2011), para. 22.

2560 D3398 (Witness statement of Ljubisav Simić dated 7 April 2013), para. 55.

2561 P4374 (Witness statement of Milenko Katanić dated 11 October 2011), para. 44; P4994 (Addendum to Ewa Tabeau's expert report entitled "Ethnic Composition in Internally Displaced Persons and Refugees from 27 Municipalities of BiH 1991 to 1997”, 3 February 2009), p. 30.

2562 P1478 (Ratko Mladić's notebook, 27 May-31 July 1992), pp. 93, 98, 101.

2563 P1478 (Ratko Mladić's notebook, 27 May-31 July 1992), pp. 246, 258. See also Ljubisav Simić, T. $37302-$ 37303, 37310-37311 (16 April 2013) (testifying that he was referring only to Muslims who remained in Bratunac town).

2564 See para. 4946.

2565 See para. 4946. The Chamber received evidence that by the end of 1992, following a counter-offensive by Bosnian Muslim forces, many Bosnian Serbs from Bratunac fled across the Drina River to Serbia. See D1504 (Report of humanitarian organisation, 21 December 1992), paras. 2-6 (under seal). However, the Chamber considers that such evidence does not negate its findings with respect to the displacement of the Bosnian Muslim population by Serb Forces.

2566 See paras. 4947-4949, 4954-4956, 4962.
} 
(A) Charges

792. In relation to Brčko, the Prosecution has limited the allegations in the Indictment to crimes associated with Luka camp. ${ }^{2567}$

793. Under Count 3, the Prosecution alleges that persecution, a crime against humanity, was committed in Luka camp as part of the objective to permanently remove Bosnian Muslims and/or Bosnian Croats from the Municipalities. ${ }^{2568}$ Acts of persecution alleged to have been committed at Luka camp by Serb Forces and Bosnian Serb Political and Governmental Organs include killings related to the detention facility as well as killings committed during, and deaths resulting from, cruel and inhumane treatment. ${ }^{2569}$ The Prosecution also characterises these killings as extermination, a crime against humanity, under Count 4; murder, a crime against humanity, under Count 5; and murder, a violation of the laws or customs of war, under Count $6^{2570}$

794. Other acts of persecution alleged to have been committed in Luka camp by Serb Forces and Bosnian Serb Political and Governmental Organs include (i) torture, beatings, and physical and psychological abuse as cruel or inhumane treatment; ${ }^{2571}$ (ii) rape and other acts of sexual violence as cruel and inhumane treatment; ${ }^{2572}$ (iii) the establishment and perpetuation of inhumane living conditions, including the failure to provide adequate accommodation, shelter, food, water, medical care, or hygienic sanitation facilities, as cruel or inhumane treatment; ${ }^{2573}$ (iv) unlawful detention; ${ }^{2574}$ and (v) forced labour at the frontline and the use of Bosnian Muslims and Bosnian Croats as human shields. 2575

2567 See Prosecution Submission Pursuant to Rule 73 bis(D), 31 August 2009, fn. 14; Pre-Trial Conference, T. 467 (6 October 2009); Rule 73 bis Decision, para. 6; Decision on Fourth Adjudicated Facts Motion, para. 28; Hearing, T. 16607, 14 July 2011 (recalling that while the Prosecution may lead general evidence relating to the take-over of Brčko, it should not present evidence pertaining to incidents alleged to have occurred in Brčko during the take-over and in detention facilities which were struck out of the Indictment after the Rule 73 bis Decision and noting that with respect to the alleged Municipalities JCE, given the large number of municipalities remaining in the Indictment and the number of crimes alleged to have occurred therein, there is no need for the Prosecution to present evidence relating to crimes struck out under Rule 73 bis in order to present its case on the pattern of events across the municipalities).

2568 Indictment, paras. 48-49.

2569 Indictment, para. 60(a)(ii). See Scheduled Incident B.5.1.

2570 Indictment, para. 63(b).

2571 Indictment, para. 60(b). See Scheduled Detention Facility C.7.2.

2572 Indictment, para. 60(c). See Scheduled Detention Facility C.7.2.

2573 Indictment, para. 60(d). See Scheduled Detention Facility C.7.2.

2574 Indictment, para. 60(g). See Scheduled Detention Facility C.7.2.

2575 Indictment, para. 60(h). The Chamber notes that in footnote 8 of paragraph 60(i) of the Indictment, the Prosecution specifies that it will not allege criminal responsibility for plunder of property in municipalities including Brčko. The Chamber further recalls that the Prosecution in its closing arguments clarified that with respect to footnote 8 of the Indictment, it did not allege criminal responsibility for both appropriation and 


\section{(B) Lead-up}

795. Brčko is a municipality in northeastern $\mathrm{BiH}$ on the border with Croatia along the Sava River. $^{2576}$ In 1991, the population of Brčko consisted of approximately $45 \%$ Bosnian Muslims, $25 \%$ Bosnian Croats, and 20\% Bosnian Serbs. ${ }^{2577}$ Inter-ethnic relations deteriorated in Brčko after the formation of national parties, the organisation of political rallies in Brčko, ${ }^{2578}$ the outbreak of war in Croatia and Slovenia and the referendum on the secession of $\mathrm{BiH}^{2579}$ From the autumn of 1991 there was an increasing militarisation of Brčko with weapons distributed to residents of all ethnicities $^{2580}$ and the arrival of paramilitary units. ${ }^{2581}$

796. In December 1991 the President of the SDS in Brčko, Milenko Vojinović received and read out the Variant A/B Instructions ${ }^{2582}$ after which (i) the Serb Municipal Assembly of Brčko was formed and Đorde Ristanić was appointed as President; ${ }^{2583}$ and (ii) a Crisis Staff was formed with Boško Maričić as its president. ${ }^{2584}$

plunder in certain municipalities, even though the footnote only referred to plunder. Prosecution Closing Argument, T. 47694 (30 September 2014). The Chamber further notes that the Prosecution does not allege criminal responsibility for forcible transfer or deportation in Brčko. Indictment, fn. 6.

2576 D484 (Map of BiH); P3009 (Map of BiH and Brčko); Isak Gaši, P3002 (Transcript from Prosecutor v. Krajišnik), T. 389, 410; Herbert Okun, P776 (Transcript from Prosecutor v. Krajišnik), T. 4278.

2577 P2888 (Brčko's War Presidency Summary of events in Brčko Municipality), p. 1; P3023 (Witness statement of Đorđe Ristanić dated 15 June 2011), para. 2; Isak Gaši, P3002 (Transcript from Prosecutor v. Krajišnik), T. 392-393. See also Pero Marković, T. 34722 (4 March 2013). The town of Brčko consisted of approximately 56\% Bosnian Muslims, 20\% Bosnian Serbs and 7\% Bosnian Croats. P2888 (Brčko’s War Presidency Summary of events in Brčko Municipality), p. 1; Isak Gaši, P3002 (Transcript from Prosecutor v. Krajišnik), T. 410. Isak Gaši, P3002 (Transcript from Prosecutor v. Krajišnik), T. 400, 402, 538-539.

2579 D3003 (Witness statement of Petar Kaurinović 17 February 2013), paras. 3-6; D3073 (Witness statement of Obren Marković dated 2 March 2013), paras. 3-4, 9; D3072 (Witness statement of Pero Marković dated 1 March 2013), paras. 7, 9. The Chamber also heard evidence that SDS representatives began being outvoted on the Executive Board. D3072 (Witness statement of Pero Marković dated 1 March 2013), para. 6.

2580 P58 (Witness statement of Sakib Husrefović dated 27 May 1995), p. 3; P3023 (Witness statement of Đorđe Ristanić dated 15 June 2011), paras. 8-12, 87-88; Isak Gaši, P3002 (Transcript from Prosecutor v. Krajišnik), T. 404-406, 535; D1563 (Letter signed by Isak Gaši), p. 2; Adjudicated Facts 2335-2336; P2888 (Brčko's War Presidency Summary of events in Brčko Municipality), pp. 1-2; D3073 (Witness statement of Obren Marković dated 2 March 2013), paras. 9, 13; Obren Marković, T. 34774, 34777 (5 March 2013).

2581 P2888 (Brčko's War Presidency Summary of events in Brčko Municipality), p. 3; P3023 (Witness statement of Đorđe Ristanić dated 15 June 2011), paras. 98-100, 102; Isak Gaši, P3002 (Transcript from Prosecutor v. Krajišnik), T. 406; D1412 (Report of Republic of Serbia MUP, 8 August 1992), p. 7.

2582 P3023 (Witness statement of Đorđe Ristanić dated 15 June 2011), paras. 13, 32-37, 65-66. See also Đorđe Ristanić, T. 16732 (15 July 2011) (testifying that Vojinović was in contact with and received instructions on behalf of the Brčko SDS from republican-level leaders, particularly Krajišnik by telephone).

2583 P3023 (Witness statement of Đorđe Ristanić dated 15 June 2011), paras. 1, 41-44. See also Pero Marković, T. 34721-34722 (4 March 2013).

2584 P3023 (Witness statement of Đorđe Ristanić dated 15 June 2011), paras. 39-40. Other members of the Crisis Staff were Vojinović, Pero Marković, and Miodrag Pajić. See also P2761 (RS MUP report on work for period April to December 1992), p. 5. The Chamber received Defence evidence that while the Crisis Staff was formed it did not have any role. See D3072 (Witness statement of Pero Marković dated 1 March 2013), para. 19. However, in light of the evidence received about the existence and role of the Crisis Staff in Brčko, discussed for example in paras. 829 and 833 , the Chamber does not accept this evidence. 
797. In the lead-up to April 1992, preparations were made for the establishment of a Bosnian Serb SJB in Brčko. ${ }^{2585}$ There were also discussions and an agreement between the SDS and SDA on the physical division of Brčko following an SDS proposal. ${ }^{2586}$

798. On 30 April 1992, the pedestrian and railroad bridges that connected Brčko with Croatia were blown up in twin explosions. ${ }^{2587}$ On or about 1 May 1992 Serb Forces numbering approximately 1,000 men launched an attack on Brčko. ${ }^{2588}$ The Serb Forces involved in this attack included Serb units of the JNA, over 500 men from Bijeljina consisting of uniformed units, active and reserve police officers, soldiers, military reserves, a TO battalion, Ljubiša Savić's ("Mauzer") Serbian National Guard, Arkan's men, the White Eagles and the Radicals commanded by Mirko Blagojević. ${ }^{2589}$ The Serb Forces initially met with armed resistance from groups using light infantry weapons but they quickly took control of the town. ${ }^{2590}$

2585 P2761 (RS MUP report on work for period April to December 1992), p. 5; Đorđe Ristanić, T. 16781 (18 July 2011). For evidence on the divisions between police see D3003 (Witness statement of Petar Kaurinović 17 February 2013), paras. 7-8, 20; D3073 (Witness statement of Obren Marković dated 2 March 2013), para. 10. See also D3072 (Witness statement of Pero Marković dated 1 March 2013), para. 8. Other municipal structures including the War Presidency (which was replaced by the War Commission) and the War Executive Board were formed in April and May 1992. P3023 (Witness statement of Đorđe Ristanić dated 15 June 2011), paras. 17-19, 21-25, 29, 144-145, 149; P2888 (Brčko's War Presidency Summary of events in Brčko Municipality), p. 1; D3072 (Witness statement of Pero Marković dated 1 March 2013), para. 30; P2888 (Brčko's War Presidency Summary of events in Brčko Municipality), p. 6; P3023 (Witness statement of Đorđe Ristanić dated 15 June 2011), paras. 30-31. See also Pero Marković, T. 34721-34722, 34727 (4 March 2013); P6172 (Brčko War Presidency travel pass, 8 May 1992).

2586 Isak Gaši, P3002 (Transcript from Prosecutor v. Krajišnik), T. 407-408. The Chamber received Defence evidence which suggested that the division of the municipality was a joint proposal from all three parties in power. See D3072 (Witness statement of Pero Marković dated 1 March 2013), para. 33. The Chamber does not find this evidence reliable in light of Marković's equivocal answers when questioned about whether it was an SDS proposal. In addition the Chamber finds that Marković's evidence was marked by insincerity and evasiveness.

2587 KDZ057, P66 (Transcript from Prosecutor v. Krajišnik), T. 564-565 (under seal); P2888 (Brčko’s War Presidency Summary of events in Brčko Municipality), p. 2; D1574 (Report of Brčko SJB, undated), p. 1; Isak Gaši, P3002 (Transcript from Prosecutor v. Krajišnik) T. 411-412; P3010 (Photograph of bridge in Brčko); P3018 (Map of Brčko marked by Isak Gaši); P3020 (BiHTV report entitled "Dossier Brčko", with transcript), pp. 1, 6; D1563 (Letter signed by Isak Gaši), p. 6; Pero Marković, T. 34724 (4 March 2013). The Chamber received evidence about the circumstances in which the bridges were blown up and who was supposedly responsible for this incident. However, given the limited allegations with respect to Brčko, the Chamber will not enter findings with respect to who was responsible for these explosions and the number or identity of the people killed or injured in this incident. See P58 (Witness statement of Sakib Husrefović dated 27 May 1995), p. 3; D3073 (Witness statement of Obren Marković dated 2 March 2013), paras. 18-19; Obren Marković, T. 34778 (5 March 2013); Isak Gaši, P3002 (Transcript from Prosecutor v. Krajišnik) T. 496-497; Isak Gaši, T. 16671 (15 July 2011); KDZ010, P416 (Transcript from Prosecutor v. Jelisić), T. 59-60, 103; P3023 (Witness statement of Đorđe Ristanić dated 15 June 2011), paras. 111-116; Đorđe Ristanić, T. 16741 (18 July 2011).

2588 Adjudicated Fact 2340.

2589 Milorad Davidović, T. 15541 (28 June 2011); P2848 (Witness statement of Milorad Davidović dated 22 June 2011), para. 123; P2888 (Brčko’s War Presidency Summary of events in Brčko Municipality), pp. 2-4; D3144 (Witness statement of Dragomir Ljubojević dated 18 March 2013), para. 8; Dragomir Ljubojević, T. 35905 (22 March 2013); P2889 (Report of the Eastern Bosnia Corps, 29 September 1992), p. 1; P3020 (BiHTV report entitled "Dossier Brčko", with transcript), p. 7; P2901 (SRT video footage of interview of Mirko Blagojević), p. 9; P58 (Witness statement of Sakib Husrefović dated 27 May 1995), p. 4; KDZ010, P416 (Transcript from Prosecutor v. Jelisić), T. 136-137. See also Adjudicated Facts 2340, 2341, 2343; Đorđe Ristanić, T. 16709, 16711, 16720-16721 (15 July 2011); P3023 (Witness statement of Đorđe Ristanić dated 15 June 2011), paras. 


\section{(C) Scheduled Detention facility C.7.2}

799. The Indictment refers to the use of the Luka camp as a detention facility at least from 7 May 1992 until mid July 1992. ${ }^{2591}$

\section{(1) Establishment and control of camp}

800. Luka Camp was located in the vicinity of the Brčko SJB building ${ }^{2592}$ and consisted of hangars or warehouses which had been previously used for the storage of goods. ${ }^{2593}$ From early May 1992, many military-aged non-Serb men from Brčko municipality were taken to Luka Camp and detained in a hangar, after having been separated from women, children and the elderly. ${ }^{2594}$ The men were brought to the camp from various locations in Brčko including the barracks, ${ }^{2595}$ the Laser Company, ${ }^{2596}$ the mosque,${ }^{2597}$ the Brčko hospital, ${ }^{2598}$ and the police station. ${ }^{2599}$ Bosnian

Muslims were taken to the mosque from their homes during searches for weapons which were conducted by armed men who had disguised their faces with paint or black stockings. ${ }^{2600}$ This

131, 174; KDZ057, P66 (Transcript from Prosecutor v. Krajišnik), T. 567-568, 570 (under seal); P2763 (Bijeljina CSB report, 7 May 1992); D3003 (Witness statement of Petar Kaurinović 17 February 2013), para. 18; Obren Marković, T. 34785 (5 March 2013); D3072 (Witness statement of Pero Marković dated 1 March 2013), para. 17; Pero Marković, T. 34735 (4 March 2013). On 19 May 1992, the Bijeljina CJB reported to the MUP that the Serb TO of SAO Semberija and Majevica had "liberated and holds three quarters of the Brčko town territory" and that combat operations were being carried out in the neighbourhood of Klanac where the forces of the "TO of former BH" had concentrated. P5489 (Report of Bijeljina SJB, 19 May 1992), p. 1. 
operation was commanded by Mauzer. ${ }^{2601}$ Between May and June 1992 groups of people were brought in and out of the hangar at Luka Camp with the number of people detained ranging from 100 to 200 people, approximately $90 \%$ of whom were Bosnian Muslims with the remainder Bosnian Croats and Albanians. ${ }^{2602}$

801. Members of the Brčko SJB and others in police uniforms were present at Luka Camp or visited there. $^{2603}$ In addition, soldiers in JNA uniforms, other men in camouflage uniforms, including those with the insignia of Arkan, as well as members of the Serbian SUP would also come to the camp. ${ }^{2604}$ Goran Jelisić was in charge of the camp ${ }^{2605}$ and introduced himself to the detainees as the "Serbian Adolf Hitler". ${ }^{2606}$ Jelisić wore a blue police uniform and later wore a military camouflage uniform. ${ }^{2607}$ Towards the end of May 1992, Jelisić was replaced by a new director named Konstantin Simonović who was a policeman from the Brčko SJB. ${ }^{2608}$

802. In early May 1992, the Brčko War Presidency was informed by the Chief of the Brčko SJB and Brčko residents that people were being detained at Luka Camp with no legal grounds and that they were mostly Bosnian Muslims from Brčko who were brought there by Serb Forces. ${ }^{2609}$ Veselić in agreement with the War Presidency sent police inspectors to Luka Camp to identify what

stop against a tree, and was beaten with rifle butts by five or six soldiers and when detained in the mosque the detainees were guarded by five to ten Bosnian Serb soldiers dressed in grey olive colour uniforms).

2601 P58 (Witness statement of Sakib Husrefović dated 27 May 1995), pp. 4-6.

2602 Isak Gaši, P3002 (Transcript from Prosecutor v. Krajišnik) T. 450-454. The people detained with Gaši were all men who were in civilian clothes with the exception of one woman and her son and nearly all of them were from Brčko. Gaši testified that the people ranged in age from 20 to 75. See also Adjudicated Fact 2358.

2603 Isak Gaši, T. 16613-16615, $16617-16618$ (14 July 2011); P3005 (Brčko SJB payroll sheet, September 1992), pp. 1, 4-6; Đorđe Ristanić, T. 16817 (18 July 2011). See also Petar Kaurinović, T. 34129-34131 (20 February 2013); Obren Marković, T. 34795 (5 March 2013); P6177 (Brčko District Police information, 11 September 1999).

2604 Isak Gaši, P3002 (Transcript from Prosecutor v. Krajišnik), T. 455-456.

2605 KDZ010, P416 (Transcript from Prosecutor v. Jelisić), T. 58. See also Adjudicated Fact 2355.

2606 KDZ057, P66 (Transcript from Prosecutor v. Krajišnik), T. 604, 649-650 (under seal); Adjudicated Fact 2365. See also Dragomir Andan, D3774 (Transcript from Prosecutor v. Stanišić), T. 21428.

2607 KDZ010, P416 (Transcript from Prosecutor v. Jelisić), T. 76; Isak Gaši, T. 16638-16639 (14 July 2011). Gaši identified Jelisić and the uniform he wore in this photograph. P3008 (Photograph of an execution outside Brčko SJB). See also P3028 (Photograph of Goran Jelisić outside Brčko SJB); Isak Gaši, P3002 (Transcript from Prosecutor v. Krajišnik) T. 458. While Jelisić dressed in police uniform the Chamber received evidence that he was not a regular policeman and that at the time individuals wore uniforms and put on ranks and insignia and gave themselves titles. D3003 (Witness statement of Petar Kaurinović 17 February 2013), para. 26; Đorđe Ristanić, T. 16794-16795 (18 July 2011); Dragomir Andan, D3774 (Transcript from Prosecutor v. Stanišić), T. 21650-21651, 21815-21816.

2608 Adjudicated Fact 2355; Isak Gaši, T. 16615-16616 (14 July 2011); Isak Gaši, P3002 (Transcript from Prosecutor v. Krajišnik), T. 456-457; Obren Marković, T. 34795 (5 March 2013); KDZ010, P416 (Transcript from Prosecutor v. Jelisić), T. 129-130. The Chamber finds that Kaurinović was contradicted with respect to his evidence that Simonović was never an employee of the MUP. D3003 (Witness statement of Petar Kaurinović 17 February 2013), para. 32; Petar Kaurinović, T. 34132-34133 (20 February 2013); P3005 (Brčko SJB payroll sheet, September 1992), p. 1.

2609 Đorđe Ristanić, T. 16712-16715 (15 July 2011). See also P3023 (Witness statement of Đorđe Ristanić dated 15 June 2011), paras. 192-193. 
was happening there and to officially question people about the reason for their detention; some detainees were then released and some were issued with passes to leave the camp. ${ }^{2610}$ Some of the detainees were also released when Bosnian Serb acquaintances came and asked for their release, but this did not happen very often and, in some cases, they were re-arrested and detained after their release. $^{2611}$ This demonstrates that detainees were released in a selective manner, based on personal connections and that there still remained a significant number of Bosnian Muslims who were detained at Luka Camp. Ristanić visited Luka Camp on one occasion to secure the release of some detainees, but he did not visit the camp again. ${ }^{2612}$

803. From around June 1992 some detainees from Luka Camp were taken to Batković camp in Bijeljina. $^{2613}$ When Davidović and his team arrived in Brčko in July 1992 he went to Luka Camp and found approximately 60 to 70 Bosnian Muslims, including children detained, in a hangar. ${ }^{2614}$ These detainees were released. ${ }^{2615}$

2610 P3023 (Witness statement of Đorđe Ristanić dated 15 June 2011), paras. 194-195, 198-199; Đorđe Ristanić, T. 16715-16719, 16722 (15 July 2011), T. 16793, 16809-16812 (18 July 2011); P3027 (Aerial photograph of Luka Camp marked by Đorđe Ristanić), marked with B; P3025 (Travel permit issued by Brčko's War Presidency, 9 May 1992); P3026 (Travel pass issued by Brčko's War Presidency, 14 May 1992). One of these passes was signed by Jelisić as “Adolf” with the notation “100\% clean and vouched for!”. Between 80 to 100 people were selected by Ristanić for release when he visited the administration building of Luka Camp. D3003 (Witness statement of Petar Kaurinović 17 February 2013), paras. 25-26. See also Pero Marković, T. 34730, 34733 (4 March 2013); P6173 (Brčko garrison travel pass, 13 July 1992); D1577 (Brčko garrison travel pass, 8 July 1992); D1578 (Certificate of Brčko MUP, July 4 1992); D1579 (Brčko War Presidency travel pass, 23 May 1992); D1580 (Brčko War Presidency travel pass, 8 May 1992).

2611 KDZ010, P416 (Transcript from Prosecutor v. Jelisić), T. 122-124. See also Isak Gaši, P3002 (Transcript from Prosecutor v. Krajišnik), T. 454, 490-493, 495, 497-499, 519. Gaši was detained at the camp until 7 June 1992 when he was released by a man in the uniform of the JNA military police who introduced himself as Rade Bozić and was informed that Captain Dragan of the Red Berets had issued the order for his release. See KDZ057, P66 (Transcript from Prosecutor v. Krajišnik), T. 619 (under seal).

2612 Đorđe Ristanić, T. 16722-16723 (15 July 2011). The Chamber received contrary evidence which suggested that Ristanić was angry when Kaurinović reported that some of the detainees had been released and that he ordered that the detainees be kept in detention for the purposes of exchange. Petar Kaurinović, T. 34138-34140 (20 February 2013); P6147 (Excerpt from record of interview with Petar Kaurinović, undated), pp. 2-3. However, the Chamber does not find this evidence to be reliable. In reaching that conclusion the Chamber observed that Kaurinović's evidence was marked with contradictions and evasiveness and it was of the view that he was not a frank and forthcoming witness.

2613 Đorđe Ristanić, T. 16805 (18 July 2011).

2614 P2848 (Witness statement of Milorad Davidović dated 22 June 2011), para. 111; Milorad Davidović, T. 15544 (28 June 2011).

2615 P2848 (Witness statement of Milorad Davidović dated 22 June 2011), para. 111. 
804. The detainees were held in a hangar in crowded, unsanitary conditions. ${ }^{2617}$ Some detainees were lying on cardboard and on the concrete floor on both sides of the hangar. ${ }^{2618}$ Their personal documents and valuables were seized by the guards on arrival. ${ }^{2619}$ Detainees were not allowed to leave the camp and had to ask for permission from the guards each time they wanted to go outside to use the toilet or drink water. ${ }^{2620}$ When detainees were given permission to go to the toilet and take some water they were beaten. ${ }^{2621}$ Gaši was told that he would be given one tablet to treat the diarrhoea he was suffering from, for each Muslim "extremist" he named. ${ }^{2622}$

805. The detainees were told by Jelisić that they would be interrogated, that those who were found to be "guilty" would be killed and the others would be released. ${ }^{2623}$ Jelisić boasted to the detainees that he had killed many people at Luka Camp thus far and that he would continue to do so. ${ }^{2624} \mathrm{He}$ also told the detainees that he had been given the green light to do whatever he wanted to the Bosnian Muslim detainees and that it was his duty to hate and "eradicate the Muslim people" as there were too many of them. ${ }^{2625}$ The Chamber received evidence that Jelisić was unpredictable and not of sound mind. ${ }^{2626}$ However, this is not medical evidence and simply reflects an observation about the nature of Jelisić's conduct; it does not amount to a medical diagnosis which the Chamber could rely on to make a finding in this regard.

2616 The Chamber received evidence about the nature and conditions of detention and mistreatment of detainees at other locations in Brčko. P58 (Witness statement of Sakib Husrefović dated 27 May 1995), pp. 5-7; Milorad Šehovac, T. 31353-31355, 31361-31363 (12 and 13 December 2012); P6043 (Map of Bosanski Samac marked by Milorad Šehovac); Adjudicated Fact 2347. The Chamber will not enter findings in this regard given that the allegations in the Indictment are limited to mistreatment and detention at Luka camp.

2617 See Adjudicated Fact 2354.

2618 Isak Gaši, P3002 (Transcript from Prosecutor v. Krajišnik), T. 445, 451. See also KDZ010, P416 (Transcript from Prosecutor v. Jelisić), T. 63-64.

2619 KDZ010, P416 (Transcript from Prosecutor v. Jelisić), T. 64, 85.

2620 Isak Gaši, P3002 (Transcript from Prosecutor v. Krajišnik) T. 455.

2621 KDZ010, P416 (Transcript from Prosecutor v. Jelisić), T. 83-84.

2622 Isak Gaši, T. 16616 (14 July 2011).

2623 KDZ010, P416 (Transcript from Prosecutor v. Jelisić), T. 58-59 (testifying that Jelisić had stated that in his view there was not "a single balija who was not guilty").

2624 KDZ010, P416 (Transcript from Prosecutor v. Jelisić), T. 60. See also Isak Gaši, P3002 (Transcript from Prosecutor v. Krajišnik), T. 458; Isak Gaši, T. 16616-16617 (14 July 2011); D1436 (Report of SerBiH MUP, 17 June 1992), p. 3.

2625 KDZ057, P66 (Transcript from Prosecutor v. Krajišnik), T. 604 (under seal); Adjudicated Facts $2347,2365$. See also Dragomir Andan, D3774 (Transcript from Prosecutor v. Stanišić), T. 21428. The Chamber received evidence which suggested that Jelisić was given instructions by Mauzer's and Arkan's men to carry out killings in Brčko. P2848 (Witness statement of Milorad Davidović dated 22 June 2011), para. 115. However, the Chamber does not accept this evidence in the absence of further corroboration as it is not clear on what basis Davidović reached his conclusion in this regard.

2626 Dragomir Andan, D3774 (Transcript from Prosecutor v. Stanišić), T. 21642-21643. See also D1436 (Report of SerBiH MUP, 17 June 1992), p. 3. 
806. Detainees were frequently verbally abused, threatened, and beaten by the guards at the camp, sometimes with mace like weapons or wrenches. ${ }^{2627}$ Two of the detainees, were nicknamed the "Muslims snipers" and were taken outside and beaten daily. One of these detainees was a mentally disabled man named "Jovo". ${ }^{2628}$ Some of these detainees were beaten by a man named Enver who introduced himself as a "Chetnik". ${ }^{2629}$ On one occasion Enver grabbed a man by the neck and kicked him, ${ }^{2630}$ Enver then carved a cross on his forehead with a knife and the man fell to the ground bleeding. ${ }^{2631}$ On one occasion, a man was brought into the middle of the room where newly arrived detainees were present and beaten fiercely until his screams stopped. ${ }^{2632}$ Jelisić told the detainees that this "is just an example of what could happen to you" ${ }^{2633}$ Detainees were also ordered to beat each other. ${ }^{2634}$ The detainees were called "balijas", a "Turkish gang, a fictitious people, a non-existent people" and told that they would all be killed or exterminated. ${ }^{2635}$ They were also forced to sing "Chetnik" songs which were played. ${ }^{2636}$ Jelisić and Ranko Češić took part in the beating of detainees. ${ }^{2637}$

807. Petar Kaurinović (a.k.a. Pero), a member of the Brčko SJB, carried out interrogations at the camp and asked detainees about weapons and "Bosnian Muslim extremists". ${ }^{2638}$ Gaši was not

2627 KDZ010, P416 (Transcript from Prosecutor v. Jelisić), T. 56, 63-64, 98, 128-129, 152-153; P417 (Photograph of hangar marked by KDZ010); P58 (Witness statement of Sakib Husrefović dated 27 May 1995), pp. 7-8; KDZ057, P66 (Transcript from Prosecutor v. Krajišnik), T. 585, 611 (under seal); Isak Gaši, P3002 (Transcript from Prosecutor v. Krajišnik), T. 468-469 (testifying that he was beaten by a man named Zivan who wore a camouflage uniform with the insignia of Arkan's men and who was accompanied by two men in JNA reserve uniforms); Adjudicated Facts 2359-2360.

2628 Isak Gaši, P3002 (Transcript from Prosecutor v. Krajišnik) T. 552.

2629 Isak Gaši, P3002 (Transcript from Prosecutor v. Krajišnik) T. 464. See also KDZ010, P416 (Transcript from Prosecutor v. Jelisić), T. 127.

2630 Isak Gaši, P3002 (Transcript from Prosecutor v. Krajišnik) T. 464.

2631 Isak Gaši, P3002 (Transcript from Prosecutor v. Krajišnik) T. 464.

2632 KDZ057, P66 (Transcript from Prosecutor v. Krajišnik), T. 605-608 (under seal).

2633 KDZ057, P66 (Transcript from Prosecutor v. Krajišnik), T. 605-608 (under seal).

2634 KDZ057, P66 (Transcript from Prosecutor v. Krajišnik), T. 587 (under seal).

2635 KDZ010, P416 (Transcript from Prosecutor v. Jelisić), T. 56, 64, 98, 152-153. See also KDZ057, P66 (Transcript from Prosecutor v. Krajišnik), T. 585 (under seal).

2636 KDZ010, P416 (Transcript from Prosecutor v. Jelisić), T. 64, 152-153. See also Isak Gaši, P3002 (Transcript from Prosecutor v. Krajišnik) T. 456, 487 (testifying that on one occasion soldiers in camouflage uniforms, including the old and new JNA uniforms, and carrying flash lights arrived at the camp at around 2 a.m. and started beating and kicking the detainees and forced them to sing a "Serbian song" as loud as they could for 40 minutes while beating them and pointing the flashlights in their faces).

2637 Adjudicated Facts 2359-2360. On one occasion, a woman identified as "Monika", arrived with Jelisić, poured a bottle of cola over one of the detainees, and broke the bottle over his head. Isak Gaši, P3002 (Transcript from Prosecutor v. Krajišnik) T. 457-458. Češić was at the time a member of the police reserve corps of the war station of the Brčko SJB. Isak Gaši, T. 16612-16613 (14 July 2011); P3004 (Brčko SJB certificate re Ranko Ćešić, 28 October 1992); Obren Marković, T. 34792 (5 March 2013); P6177 (Brčko District Police information, 11 September 1999). See also Petar Kaurinović, T. 34132 (20 February 2013). Češić was a member of the Brčko SJB from 15 May until 26 June 1992 and then continued to serve in the VRS in Brčko till October 1992. P6176 (Certificate of RS Ministry of Defence, Brčko Department, 5 July 2002); Obren Marković, T. 3479234793, 34801-34802 (5 March 2013).

2638 Isak Gaši, P3002 (Transcript from Prosecutor v. Krajišnik) T. 470-472; P3005 (Brčko SJB payroll sheet, September 1992); Isak Gaši, T. 16611-16613 (14 July 2011), T. 16698 (15 July 2011). 
mistreated when he was interrogated by Kaurinović and was asked whether he had been ill-treated and why he had bruises on his head. ${ }^{2639}$ Gaši for fear of repercussions decided to say he had not been ill-treated. ${ }^{2640}$

808. On one occasion Češić interrogated a female detainee and intimidated her by firing an automatic rifle in her direction. ${ }^{2641}$ Češić then drove her out of the camp and raped her at knife point in a vehicle. ${ }^{2642}$ After this Češić said he would take her to the bridge, cut her throat and throw her into the river. ${ }^{2643}$ Češić was then stopped by a man who identified himself as "Dragan", who berated Češić for taking out a detainee without permission. ${ }^{2644}$ The female detainee was then taken by Dragan to the SUP where she was interrogated by Veselić, taken to the Brčko hospital and then driven back to Luka Camp with three other detainees. ${ }^{2645}$ The female detainee was taken to a room and raped again by two soldiers. ${ }^{2646}$ When in this room, she saw a woman lying on the floor undressed and heard the screams of another woman. ${ }^{2647}$ From 5 to 19 May 1992 while detained at the camp, the female detainee was raped on a continuous basis. ${ }^{2648}$ On 19 May 1992, some detainees outlined the nature of their rape and mistreatment to a military officer who visited the camp with Veselić, after which the mistreatment stopped with a guard posted at the entrance to the detainees' rooms. ${ }^{2649}$

809. As detailed below, the mistreatment and beating of the detainees continued even after Jelisić told them about receiving an order to prohibit such acts. ${ }^{2650}$

2639 Isak Gaši, P3002 (Transcript from Prosecutor v. Krajišnik) T. 471-472. Seven or eight days after Gaši’s arrival at Luka Camp he was also questioned by Pero Zarić and Branko Gajić who were assistants to the commander of the Brčko SJB. Isak Gaši, T. 16611-16612 (14 July 2011); P3003 (Minutes of Brčko SJB, 2 June 1992), p. 1. But see Petar Kaurinović, T. 34141 (20 February 2013) (stating that he did not recall having a conversation with Gaši).

2640 Isak Gaši, P3002 (Transcript from Prosecutor v. Krajišnik) T. 471.

2641 [REDACTED].

2642 [REDACTED]. The witness testified that while being raped he said words to the effect of "it was a pleasure to have one more balija woman to rape". [REDACTED].

2643 [REDACTED].

2644 [REDACTED].

2645 [REDACTED].

2646 [REDACTED].

2647 [REDACTED].

2648 [REDACTED].

2649 [REDACTED].

2650 See para. 822. The Chamber received evidence that Kaurinović in the few days he was at the camp only heard about one incident of mistreatment which he passed on to Veselić and that Veselić said they would try to do everything to prevent such incidents and restore order in Luka but that the paramilitaries had absolute power and could do what they wanted. Petar Kaurinović, T. 34136-34137, 34146 (20 February 2013). The Chamber does not find this evidence to be reliable. In reaching this conclusion the Chamber observed that Kaurinović's evidence was marked with contradictions and evasiveness and concluded that he was not a frank and forthcoming witness. 
810. Some detainees were forced to serve soldiers food, clean their offices and toilets with their bare hands and were also taken from the camp to clean Bosnian Muslim houses in the town for the use of Bosnian Serb families who would return. ${ }^{2651}$ Detainees were also forced to carry bodies, and were beaten and taunted when doing so. ${ }^{2652}$

(3) Conclusion on conditions of detention and treatment of detainees

811. Based on the above, the Chamber finds that Serb Forces brought to and detained non Serbs, including women, children, and the elderly at Luka camp from May to June 1992. The Chamber further finds that the detainees were held in poor conditions. These included lack of space, adequate bedding, and poor sanitary conditions. The Chamber also finds that detainees were regularly and viciously subjected to beatings by Serb Forces at Luka camp. Finally, the Chamber finds that female detainees were raped while at the camp.

\section{(4) Scheduled Killing Incident - B.5.1}

812. The Prosecution alleges that a number of men were killed at Luka camp between 8 May and 6 June $1992 .^{2653}$

813. On numerous occasions, groups of detainees at Luka camp were taken out of the hangar and summarily executed. ${ }^{2654}$ While at the camp, one detainee saw a document entitled "People to be executed", which listed approximately 50 prominent, educated, or wealthy Muslims and Croats. ${ }^{2655}$ On 9 May 1992, Jelisić brought Stjepo Glavočević, a Bosnian Muslim, into the hangar, while he was holding the man's severed ear, he then struck Glavočević with a sabre, killing him. ${ }^{2656}$ Jelisić $^{2}$ also took two Bosnian Muslim men from Bijeljina out of the hangar and later ordered two other

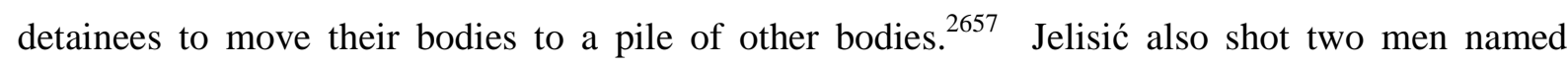
Jasminko and Cita. ${ }^{2658}$

\footnotetext{
2651 KDZ057, P66 (Transcript from Prosecutor v. Krajišnik), T. 613-614 (under seal). See also Isak Gaši, T. 16614-16615 (14 July 2011). While Gaši uses the phrase "collected volunteers" to sweep the streets and do other jobs in town, in light of the other evidence, and the circumstances of their detention, the Chamber does not accept that the detainees performed this work voluntarily. However, the Chamber notes that this type of forced labour is not charged in the Indictment, which only covers forced labour at the frontlines. See para. 816.

The Prosecution submits that the evidence shows that these killings occurred between 4 May 1992 and 7 June 1992. Prosecution Final Brief, Appendix B.

See Adjudicated Fact 2362.

Adjudicated Fact 2366; KDZ057, P66 (Transcript from Prosecutor v. Krajišnik), T. 612-613 (under seal).

See Adjudicated Fact 2363.

P58 (Witness statement of Sakib Husrefović dated 27 May 1995), pp. 8-9.

P58 (Witness statement of Sakib Husrefović dated 27 May 1995), pp. 8-9.
} 
814. During the night of 11 May 1992, four detainees were called out of the hangar, and other detainees could hear the blows, the detainees moaning and begging as they were beaten and cursed outside the hangar. ${ }^{2659}$ One of the detainees was instructed to lie down and lean his head against a grate, after which a "silenced shot" was heard, followed by the "blunt sound of a blow against the concrete". 2660 This was repeated in the following days, with groups of four detainees taken out approximately 25 to 30 times with only one or two detainees returning from each group. ${ }^{2661}$

815. The guards would yell that the detainees should come out by themselves and on the second or third day of his detention, KDZ010 "volunteered" to go out, after about ten groups of four "volunteers" had left the hangar. ${ }^{2662}$ Outside they were beaten and cursed, after which they were lined up against the wall with their heads bent down and hands behind their backs. ${ }^{2663}$ One man was pulled out of the group of four by a man identified as "Ivan" who was also known as "Repić" and ordered to lie on the asphalt and place his head on a grate after which he was shot by Jelisić. ${ }^{2664}$ On one occasion the guards entered the hangar and asked if any of the detainees were married to Serb women, and when one man stood up and was taken outside, the detainees could hear that he was verbally abused, beaten and then ordered by Jelisić to lie down and put his head against the grate; a gun shot was then heard. ${ }^{2665}$ On another occasion Gaši saw "four civilians" being taken out of an office at Luka Camp and saw Češić shooting at their backs after which two men fell to the ground. ${ }^{2666}$ On yet another day, a detainee dropped a bottle of water, soldiers beat him fiercely, and Jelisić took him to a grate where he was killed in the same way as the other detainees. ${ }^{2667}$

816. At the end of every night a group of seven or eight detainees were called out to clean the blood outside the hangar. ${ }^{2668}$ Detainees were also ordered to carry bodies into a refrigerated

2659 KDZ010, P416 (Transcript from Prosecutor v. Jelisić), T. 65.

2660 KDZ010, P416 (Transcript from Prosecutor v. Jelisić), T. 65-66. See also Isak Gaši, P3002 (Transcript from Prosecutor v. Krajišnik), T. 460; P3016 (Photograph of Luka Camp).

2661 KDZ010, P416 (Transcript from Prosecutor v. Jelisić), T. 70, 81, 113-114.

2662 KDZ010, P416 (Transcript from Prosecutor v. Jelisić), T. 66.

2663 KDZ010, P416 (Transcript from Prosecutor v. Jelisić), T. 67; P417 (Photograph of hangar marked by KDZ010) (the detainees were lined up at the spot marked 1).

2664 KDZ010, P416 (Transcript from Prosecutor v. Jelisić), T. 67-70, 81, 156-157 (testifying that after killing one of the detainees in this manner Jelisić said:“Another balija less"); P417 (Photograph of hangar marked by KDZ010). See also Isak Gaši, P3002 (Transcript from Prosecutor v. Krajišnik), T. 459 (stating that he heard about Jelisić killing detainees from another detainee present during the execution and that Gaši was also told that 80 detainees had been killed in this way and that this detainee had helped load the bodies onto a truck).

2665 KDZ010, P416 (Transcript from Prosecutor v. Jelisić), T. 82-83.

2666 Isak Gaši, P3002 (Transcript from Prosecutor v. Krajišnik), T. 461 (testifying that he could not confirm whether the people were killed on the spot and that a man in camouflage uniform identified as Mišo Cajević and a man in police uniform who Gaši believed was Pudić were at the scene when the shooting occurred). See also P3017 (Photograph of Ranko Češić).

2667 KDZ010, P416 (Transcript from Prosecutor v. Jelisić), T. 84-85. KDZ010 could only see him beaten but was taken out of sight when he heard the shot.

2668 KDZ010, P416 (Transcript from Prosecutor v. Jelisić), T. 70. 
lorry ${ }^{2669}$ which was used to transport the bodies elsewhere; other bodies were thrown into the Sava River. $^{2670}$ When Gaši returned to the hangar after helping with the disposal of the bodies a soldier told them: "You'd better keep quiet about what you had done and what you had seen". ${ }^{2671}$ After detainees returned from carrying bodies they were beaten and taunted by threats that they would face the same fate in a few days. ${ }^{2672}$

817. On one occasion, approximately 50 civilians were lined up near the entrance to the warehouse after which a blast of gunfire, moans and the sound of bodies falling onto the concrete could be heard. ${ }^{2673}$

818. There was an agreement between the War Presidency and Veselić, the Chief of the Brčko SJB, under which the bodies collected from Luka Camp would be identified. ${ }^{2674}$

819. While the Chamber received evidence which suggested that the Bosnian Serb authorities in Brčko were not aware of events or killings at Luka Camp until much later, the Chamber is not satisfied that Kaurinović was able to adequately explain a prior inconsistent statement which suggested that the Crisis Staff was in charge of the town and would have known about events at the camp. $^{2675}$ Kaurinović was also confronted with and did not adequately explain evidence that tended

2669 KDZ010, P416 (Transcript from Prosecutor v. Jelisić), T. 69, 79-80, 155-156. The witness identified the truck in this photograph as the one used for the purpose of storing the bodies. P420 (Photograph of mass grave in Brčko); Adjudicated Fact 2364.

2670 KDZ010, P416 (Transcript from Prosecutor v. Jelisić), T. 155-156; Adjudicated Fact 2364. Gaši and three or four detainees were taken by a man in camouflage uniform and two guards in JNA reserve uniforms to throw a group of 15 to 20 bodies into the river. The bodies were in civilian clothes and had bloodstains on their backs and bullet holes in the back or in the back of their heads and necks. Gaši recognised two of the bodies and they were Bosnian Muslims. Gaši was not sure whether the bodies thrown into the river were shot at Luka Camp or at another location. Isak Gaši, P3002 (Transcript from Prosecutor v. Krajišnik), T. 464-466; Isak Gaši, T. 16626 (14 July 2011).

2671 Isak Gaši, P3002 (Transcript from Prosecutor v. Krajišnik) T. 467-468.

2672 KDZ010, P416 (Transcript from Prosecutor v. Jelisić), T. 69-70, 81, 156-157, Adjudicated Fact 2364.

2673 KDZ057, P66 (Transcript from Prosecutor v. Krajišnik), T. 591-593 (under seal).

2674 Đorđe Ristanić, T. 16816 (18 July 2011). The Chamber also received evidence about steps taken by Bosnian Serb authorities for the identification of 60 Bosnian Muslims killed by paramilitaries. However, it is not clear whether or not these killings relate to Luka Camp, therefore the Chamber will not make any findings in this regard. Petar Kaurinović, T. 34115-34116, 34125-34129 (20 February 2013). The Chamber received other evidence about disappereances, killings and burials of victims in mass graves in Brčko. See P1607 (RS Ministry of Justice report on prisons and camps on the RS territory, 22 October 1992), p. 3; D3105 (Witness statement of Slobodan Avlijaš dated 9 March 2013), para. 27; Slobodan Avlijaš, T. 35196 (11 March 2013); P3023 (Witness statement of Đorđe Ristanić dated 15 June 2011), paras. 189-191, 202-205, 214-217, 220-223; Đorđe Ristanić, T. 16726, 16730, 16736 (15 July 2011); P4854 (Updated Table 1 to the Report of Amor Mašović), p. 1; P4852 (Report of Amor Mašović, 20-21 October 2009), pp. 3, 11. See also P87 (List of Commissions for Exchange, 1992) (under seal). However, this evidence cannot be directly connected to events at Luka Camp, and so the Chamber will not be making findings in this regard.

2675 D3003 (Witness statement of Petar Kaurinović 17 February 2013), paras. 22-23; Petar Kaurinović, T. 3411634117, 34120-34121 (20 February 2013). Ristanić was also unclear about whether and when he received information about the killings which were reported to have occurred at Luka Camp; he claimed that he only heard rumours and later through stories reported in the media and from people who had been in the camp about what happened there. Given his equivocal answers in an attempt to distance himself from knowledge of these 
to contradict his evidence that the police were unable to control the activities of paramilitaries in the camp. ${ }^{2676}$ This contradictory evidence revealed that the police themselves were actually involved in the killing and mistreatment of detainees. ${ }^{2677}$ The evidence about lack of knowledge about events at Luka Camp on the part of the Bosnian Serb authorities is also not consistent with evidence that in June or July 1992, Dr. Milan Novaković who was the President of the Bijeljina Municipal Board of the SDS “announced on radio that the Jelisić 'factory' was the most productive (at expulsion and murder of Muslims) at the time". ${ }^{2678}$

820. Ristanic testified that with respect to the Bosnian Serb municipal authorities "we either didn't have [the] strength or willingness" to stop Jelisić. ${ }^{2679}$ While the Chamber accepts that the Bosnian Serb authorities were not willing to stop Jelisić it does not accept the suggestion that they did not have the power to do so. ${ }^{2680}$ In this regard the Chamber notes that Jelisić was eventually removed from the police, but there was no investigation of the alleged crimes and he was simply transferred to a military unit. ${ }^{2681}$ In addition the Chamber received evidence of an Eastern Bosnia Corps report which suggested that Ristanić himself was aware about murders which had been committed in the municipality and did not care about preventing the information from leaking "because there were much larger graves in Prijedor". ${ }^{262}$ While Ristanić denied the specific detail contained in this report, the Chamber accepts that it supports the other evidence received which suggests a level of awareness by the Bosnian Serb authorities about crimes committed in the municipality and attempts to cover them up. ${ }^{2683}$

821. In this regard it was also reported that the commander of the Brčko barracks, Colonel Đurđević and the Corps Staff were informed of these events "in order to prevent leakage of information" but that they responded that this was a matter for the civilian authorities. ${ }^{2684}$ This report also noted that organs from the Army and SUP and Simo Radovanović, who was one of Captain Dragan's instructors, suggested that the civilian authorities "do this properly to prevent

events, the Chamber does not accept Ristanić's evidence in this regard. See P3023 (Witness statement of Đorđe Ristanić dated 15 June 2011), paras. 185-187; Đorđe Ristanić, T. 16726 (15 July 2011); Đorđe Ristanić, T. 16796 (18 July 2011).

2676 D3003 (Witness statement of Petar Kaurinović 17 February 2013), paras. 22-23; Petar Kaurinović, T. 3411634117, 34120-34121, 34134 (20 February 2013), T. 34134 (20 February 2013).

2677 D3003 (Witness statement of Petar Kaurinović 17 February 2013), paras. 22-23; Petar Kaurinović, T. 3411634117, 34120-34121, 34134 (20 February 2013), T. 34134 (20 February 2013). P2848 (Witness statement of Milorad Davidović dated 22 June 2011), para. 116.

2679 P3023 (Witness statement of Đorđe Ristanić dated 15 June 2011), para. 210.

2680 P3023 (Witness statement of Đorđe Ristanić dated 15 June 2011), paras. 209-211.

2681 P3023 (Witness statement of Đorđe Ristanić dated 15 June 2011), paras. 209-211.

2682 P2889 (Report of the Eastern Bosnia Corps, 29 September 1992), p. 1.

2683 P2889 (Report of the Eastern Bosnia Corps, 29 September 1992), p. 1. Đorđe Ristanić, T. 16731-16732 (15 July 2011), T. 16746 (18 July 2011). See also Adjudicated Fact 2367.

2684 P2889 (Report of the Eastern Bosnia Corps, 29 September 1992), pp. 1-2. 
information leakage". ${ }^{2685}$ This report also observed that the next action was to "officially admit in front of the international community that a certain number of Muslims and Croats for whom we would have to prove that they had been working on ethnic cleansing of Serbs from these areas". ${ }^{2686}$ The report stressed that "absolutely correct documentation" had to be established for these Bosnian Muslims and Bosnian Croats for presentation to representatives of the international community who were expected to visit Brčko very soon. ${ }^{2687}$ The report mentioned that the "next phase would be public trial of two or three extremists with all possible publicity" for the international reporters. $^{2688}$

822. The killings at Luka Camp continued until on or about 16 May 1992 when Jelisić entered the hangar with Major Džurković and a captain wearing a JNA uniform and said that they had received an order that the killing and mistreatment of detainees were prohibited after which the names and personal details of the detainees were recorded. ${ }^{2689}$ However, contrary to this order, the mistreatment and beating of the detainees continued. ${ }^{2690}$

823. In light of the evidence above, the Chamber finds that a large number of non-Serb men were killed by Serb Forces at the Luka Camp between at least 9 May 1992 and 16 May 1992.

(D) Problems with paramilitaries and law and order

824. The Bosnian Serb local authorities had difficulties in controlling paramilitary groups which entered and operated in Brčko; these paramilitaries attacked or mistreated police, army officers, soldiers and civilians and placed pressure on the SJB and other municipal structures. ${ }^{2691}$ The

P2889 (Report of the Eastern Bosnia Corps, 29 September 1992), p. 2.

P2889 (Report of the Eastern Bosnia Corps, 29 September 1992), p. 2.

P2889 (Report of the Eastern Bosnia Corps, 29 September 1992), p. 2.

P2889 (Report of the Eastern Bosnia Corps, 29 September 1992), p. 2.

KDZ010, P416 (Transcript from Prosecutor v. Jelisić), T. 70-71, 85, 143-145. The Chamber notes that contrary to this order the mistreatment and beating of the detainees continued. KDZ010, P416 (Transcript from Prosecutor v. Jelisić), T. 130-131, 145-146.

2690 KDZ010, P416 (Transcript from Prosecutor v. Jelisić), T. 130-131, 145-146.

2691 Živan Filipović, T. 35813 (21 March 2013); P2888 (Brčko’s War Presidency Summary of events in Brčko Municipality), pp. 3-6; D3003 (Witness statement of Petar Kaurinović 17 February 2013), para. 23; D1412 (Report of Republic of Serbia MUP, 8 August 1992), pp. 7-8, 10; P2889 (Report of the Eastern Bosnia Corps, 29 September 1992), p. 1; D3073 (Witness statement of Obren Marković dated 2 March 2013), para. 29; D3072 (Witness statement of Pero Marković dated 1 March 2013), para. 20; P2853 (Report of Bijeljina CSB, 21 May 1992), p. 1; Milorad Davidović, T. 15474-15475 (28 June 2011); Dragomir Andan, T. 40835-40836 (5 July 2013); D1436 (Report of SerBiH MUP, 17 June 1992), pp. 3-4; Milorad Davidović, T. 15748-15749 (30 June 2011). See also P58 (Witness statement of Sakib Husrefović dated 27 May 1995), p. 2; Pero Marković, T. 34738 (4 March 2013); D3003 (Witness statement of Petar Kaurinović 17 February 2013), paras. 21, 23-24; Isak Gaši, P3002 (Transcript from Prosecutor v. Krajišnik), T. 506-507; Dragomir Andan, D3774 (Transcript from Prosecutor v. Stanišić \& Župljanin), T. 21411; P3023 (Witness statement of Đorđe Ristanić dated 15 June 2011), para. 25; D3003 (Witness statement of Petar Kaurinović 17 February 2013), paras. 13, 18, 21; D3073 (Witness statement of Obren Marković dated 2 March 2013), para. 29; Obren Marković, T. 34788-34789, 34800 (5 March 2013); D3072 (Witness statement of Pero Marković dated 1 March 2013), paras. 14, 15, 16-17,
} 
paramilitaries issued an ultimatum for the "removal of the entire management team of the Brčko SJB" which was complied with by the local authorities out of fear. ${ }^{2692}$

825. The Brčko SJB faced structural problems in carrying out investigations and had shortages in vehicles, equipment and communication facilities. ${ }^{2693}$ Proposals were made to recruit new personnel, re-organise management, and remove individuals from reserve police units who had been charged with criminal acts, to cancel all unauthorised positions, and to improve co-operation with the military security, neighbouring SJB's and the Serbian MUP. ${ }^{2694}$ The Brčko War Presidency leadership sent a summary of the situation in Brčko to the RS Presidency to identify the results achieved and the problems that needed to be resolved. ${ }^{2695}$

826. Between 29 May and 12 June 1992, employees of the Serbian MUP inspected and offered professional assistance to the Brčko SJB with respect to the failure to perform its basic functions. $^{2696}$ Dragan Andan was sent to Brčko to rebuild the SJB structures and organisation; he also attempted to eliminate the operations of paramilitary groups such as the Red Berets in Brčko and in doing so had ongoing struggles with the local political structures and paramilitary groups. ${ }^{2697}$

827. On 2 June 1992, the Brčko SJB established an organisational structure for the police station, appointed commanders and assistant commanders and outlined the tasks and obligations of personnel in preserving public law and order and protecting property. ${ }^{2698}$ An agreement was reached that all detention measures "be recommended and submitted in writing" to the head of the

19. The paramilitary groups identified as operating in Brčko included the units affilitated with Arkan, Mauzer, Captain Dragan, Šešelj, "Zika the Montenegrin", "the Obilić men from Kosoco", Živojin Ivanović, who was also known as "Crnogorac".

2692 D1412 (Report of Republic of Serbia MUP, 8 August 1992), p. 8; D3003 (Witness statement of Petar Kaurinović 17 February 2013), para. 22. Paramilitaries also threatened officials of the local authorities. Milorad Šehovac, T. 31381 (13 December 2012)

D1574 (Report of Brčko SJB, undated), p. 4; Đorđe Ristanić, T. 16799 (18 July 2011).

D1574 (Report of Brčko SJB, undated), p. 4; Đorđe Ristanić, T. 16800 (18 July 2011).

P2888 (Brčko's War Presidency Summary of events in Brčko Municipality), p. 6. See also Đorđe Ristanić, T. 16728-16729 (15 July 2011); P3023 (Witness statement of Đorđe Ristanić dated 15 June 2011), paras. 224225.

2696 D1436 (Report of SerBiH MUP, 17 June 1992), p. 1.

2697 Dragomir Andan, D3774 (Transcript from Prosecutor v. Stanišić \& Župljanin), T. 21402-21403, 21406-21421, 21426-21427, 21629-21631; D3779 (Minutes from meeting of Brčko SJB specialist board, 2 June 1992), pp. 34; D3780 (Brčko SJB information, undated); D3810 (Bijeljina CSB dispatch to SerBiH MUP, 23 July 1992); D3811 (Bijeljina CSB dispatch to SerBiH MUP, 24 July 1992); Dragomir Andan, T. 40819-40822, 40836 (5 July 2013); D3789 (Dragomir Andan's notes), pp. 3-4; D3778 (CSB Bijeljina authorisation, 28 May 1992); D3788 (Bijeljina CSB report to SerBiH MUP, 20 July 1992). Andan acknowledged that in the few weeks he was in Brčko his first task was to set up the police station but he did not have time to investigate mass graves, murders and rapes. Dragomir Andan, T. 40897 (5 July 2013).

2698 
Brčko SJB by the head of the Crime department and that a depot be established in which stolen items could be stored. $^{2699}$

828. Over 150 policemen from the frontlines were withdrawn to form a functioning patrol in the town of Brčko and other measures were taken to gather information on crimes committed including property offences, violent and sex crimes. ${ }^{2700}$ Given that a large number of crimes had also been committed by members of the SJB, it was agreed that the gathering of information would continue once the armed conflict was over and necessary measures would be taken against the persons in question at that time. ${ }^{2701}$

829. In the summer of 1992, given the increasing security problems in northeast $\mathrm{BiH}$ including in Brčko, the SerBiH MUP requested the Federal SUP to send the police and Milorad Davidović to the area to stabilise the security situation and establish the normal functioning of organs of internal affairs. ${ }^{2702}$ Davidović was asked by the leaders of the Crisis Staff in Brčko to come to Brčko to reestablish law and order. ${ }^{2703}$ This followed a request from the Accused that a special unit be sent to Brčko to address the problems with paramilitaries. ${ }^{2704}$

830. Davidović located, disarmed and arrested the Red Berets including their leader "Žika" and the Božić brothers who had identification from the Serbian MUP. ${ }^{2705}$ After he arrested some of the Red Berets, Frenki Simatović phoned Davidović twice, cursed him and asked how he had the right to act in that way. ${ }^{2706}$ The Chief of the SJB was arrested and beaten by members of a paramilitary unit and Ristanić himself was detained by paramilitaries wearing red berets in late July or early

\footnotetext{
2699 P3003 (Minutes of Brčko SJB, 2 June 1992), p. 3.

2700 D1436 (Report of SerBiH MUP, 17 June 1992), pp. 1-2; Milorad Davidović, T. 15747 (30 June 2011 ); Dragomir Andan, D3774 (Transcript from Prosecutor v. Stanišić \& Župljanin), T. 21410, 21422, 21639-21640.

2701 D1436 (Report of SerBiH MUP, 17 June 1992), p. 2.

2702 D1412 (Report of Republic of Serbia MUP, 8 August 1992), p. 1. See also Petar Kaurinović, T. 34135 (20 February 2013); D3072 (Witness statement of Pero Marković dated 1 March 2013), para. 21; Pero Marković, T. 34752 (4 March 2013); D1632 (Report of Bijeljina SJB, 23 July 1992), p. 2.

2703 P2848 (Witness statement of Milorad Davidović dated 22 June 2011), paras. 102, 105. The delegation that came to Bijeljina to request assistance from Davidović were Đorđe Ristanić, Dr. "Beli" and Pavle Milinković. See also D3003 (Witness statement of Petar Kaurinović 17 February 2013), para. 24; D3073 (Witness statement of Obren Marković dated 2 March 2013), para. 30.

2704 Đorđe Ristanić, T. 16796 (18 July 2011). See also D3072 (Witness statement of Pero Marković dated 1 March 2013), para. 21; Pero Marković, T. 34752 (4 March 2013); Milorad Šehovac, T. 31381-31382 (13 December 2012); Dragomir Andan, D3774 (Transcript from Prosecutor v. Stanišić \& Župljanin), T. 21456-21457.

2705 P2848 (Witness statement of Milorad Davidović dated 22 June 2011), paras. 103, 106; Đorđe Ristanić, T. 16801-16802 (18 July 2011); D1412 (Report of Republic of Serbia MUP, 8 August 1992), pp. 6, 9-10. See also Dragomir Andan, D3774 (Transcript from Prosecutor v. Stanišić \& Župljanin), T. 21456-21457; D3073 (Witness statement of Obren Marković dated 2 March 2013), para. 30.

2706 P2848 (Witness statement of Milorad Davidović dated 22 June 2011), paras. 80, 112.
} 
August 1992 for bringing people from Bijeljina to Brčko to introduce order. ${ }^{2707}$ The paramilitaries expressed their anger and threatened Ristanić because their men had been arrested. ${ }^{2708}$

831. Davidović was transporting the arrested paramilitaries to Bijeljina when he received a radio call which demanded the immediate release of the Red Berets and informed him that the members of the Crisis Staff were being held hostage and one person would be killed every half an hour if the demand was not complied with. ${ }^{2709}$ VRS Lieutenant Colonel Milinković, also pleaded with Davidović to release the arrested men or otherwise the Red Berets would kill him. ${ }^{2710}$ Davidović refused to comply with these demands and took the arrested persons to Bijeljina. ${ }^{2711}$

832. Davidović returned to Brčko the next morning and was informed that the members of the Crisis Staff had been released, after which 90 Red Berets were arrested, of which 80 were from Serbia. ${ }^{2712}$ The arrested individuals were placed on buses and transported across the border to Sremska Rača and handed to representatives of the Serbian MUP. ${ }^{2713}$

833. Davidović established curfews and check-points in Brčko with the support of the Crisis Staff, engaged the active duty policemen and was able to restore some law and order within three days of taking control of the Brčko SJB. ${ }^{2714}$ An agreement was reached between the VRS and the SDS regarding the command of the area which allowed Davidović and his team to move back and forth between Bijeljina and Brčko to maintain stability. ${ }^{2715}$

\footnotetext{
2707 P3023 (Witness statement of Đorđe Ristanić dated 15 June 2011), paras. 25-26; Đorđe Ristanić, T. 16786, 16802-16804 (18 July 2011).

2708 Đorđe Ristanić, T. 16803-16804 (18 July 2011).

2709 P2848 (Witness statement of Milorad Davidović dated 22 June 2011), para. 108; D1412 (Report of Republic of Serbia MUP, 8 August 1992), p. 8; Milorad Davidović, T. 15799 (30 June 2011).

2710 P2848 (Witness statement of Milorad Davidović dated 22 June 2011), para. 109.

2711 P2848 (Witness statement of Milorad Davidović dated 22 June 2011), paras. 108-109; Milorad Davidović, T. 15800 (30 June 2011).

2712 P2848 (Witness statement of Milorad Davidović dated 22 June 2011), para. 110. See also Đorđe Ristanić, T. 16804 (18 July 2011). While Ristanić's version of events is slightly different in terms of timing, the Chamber accepts that Davidović's direct evidence to be more reliable.

2713 P2848 (Witness statement of Milorad Davidović dated 22 June 2011), para. 110; Milorad Davidović, T. 15676 (29 June 2011).

2714 P2848 (Witness statement of Milorad Davidović dated 22 June 2011), paras. 111; Milorad Davidović, T. 15544 (28 June 2011); Milorad Davidović, T. 15765-15766 (30 June 2011); Dragomir Andan, D3774 (Transcript from Prosecutor v. Stanišić \& Župljanin), T. 21419-21421, 21639-21640. See also D3003 (Witness statement of Petar Kaurinović 17 February 2013), para. 24; Petar Kaurinović, T. 34117 (20 February 2013).

2715 P2848 (Witness statement of Milorad Davidović dated 22 June 2011), para. 124.
} 


\section{(A) Charges}

834. Under Count 3, the Prosecution alleges that persecution, a crime against humanity, was committed in Foča as part of the objective to permanently remove Bosnian Muslims and/or Bosnian Croats from the Municipalities. ${ }^{2716}$ Under Count 1, the Prosecution further alleges that in certain municipalities, including Foča, this persecutory campaign included or escalated to include conduct that manifested an intent to destroy in part the national, ethnical and/or religious groups of Bosnian Muslims and/or Bosnian Croats as such. ${ }^{2717}$

835. Acts alleged to have been committed in Foča by Serb Forces and Bosnian Serb Political and Governmental Organs include killings during and after the take-over of Foča; ${ }^{2718}$ killings related to detention facilities; and killings committed during and deaths resulting from, cruel and inhumane treatment at scheduled detention facilities. ${ }^{2719}$ The Prosecution characterises these acts as killing, an underlying act of genocide, under Count 1; persecution, a crime against humanity, under Count 3; extermination, a crime against humanity, under Count 4; murder, a crime against humanity, under Count 5; and murder, a violation of the laws or customs of war, under Count $6 .{ }^{2720}$

836. Other acts alleged to have been committed in Foča by Serb Forces and Bosnian Serb Political and Governmental Organs include torture, beatings, and physical and psychological abuse, rape and other acts of sexual violence during and after the take-over and in scheduled detention facilities, as well as the establishment and perpetuation of inhumane living conditions in detention facilities, as cruel or inhumane treatment, an act of persecution under Count $3 .^{2721}$ In relation to Count 1, the Prosecution alleges that in scheduled detention facilities in Foča thousands of Bosnian Muslims and Bosnian Croats were subjected to cruel and inhumane treatment, including torture, physical and psychological abuse, rape, other acts of sexual violence, and beatings by Serb Forces and Bosnian Serb Political and Governmental Organs; the Prosecution characterises this inhumane

\footnotetext{
2716 Indictment, paras. 48-49.

2717 Indictment, paras. 37-38.

2718 Indictment, para. 60(a)(i). See Scheduled Incidents A.5.2 and A.5.4. The Chamber notes that Scheduled Incident A.5.1 was withdrawn by the Prosecution pursuant to the "Notice of Withdrawal of Incident A.5.1." filed on 18 August 2014.

2719 Indictment, para. 60(a)(ii). See Scheduled Incident B.8.1. The Prosecution does not allege criminal responsibility for killings resulting from cruel and inhumane treatment at Scheduled Detention Facilities C.10.2, C.10.5, C.10.6, C.10.7. Indictment, fn. 4.

2720 Indictment, paras. 40(a)(i), 40(a)(ii), 63(a), 63(b).

2721 Indictment, para. 60(b), 60(c), 60(d) (specifying that the conditions included the failure to provide adequate accommodation, shelter, food, water, medical care, or hygienic sanitation facilities). See Scheduled Detention Facilities C.10.1. C10.2, C10.4, C.10.5, C10.6, and C10.7. The Prosecution does not allege criminal responsibility for rape and other acts of sexual violence in Scheduled Detention Facilities C.10.1 and C.10.6. Indictment, fn. 5.
} 
treatment as causing serious bodily or mental harm to members of the Bosnian Muslim and Bosnian Croat groups, an underlying act of genocide. ${ }^{2722}$ In addition, under Count 1, the Prosecution alleges that members of the Bosnian Muslim and Bosnian Croat groups were detained under conditions of life calculated to bring about physical destruction, namely through cruel and inhumane treatment, including torture, physical and psychological abuse, rape, other acts of sexual violence, inhumane living conditions, forced labour and the failure to provide adequate accommodation, shelter, food, water, medical care or hygienic sanitation facilities. ${ }^{2723}$

837. Under Count 3, other acts of persecution alleged to have been committed in Foča by Serb Forces and Bosnian Serb Political and Governmental Organs, include (i) forcible transfer or deportation of Bosnian Muslims and Bosnian Croats from their homes; ${ }^{2724}$ (ii) unlawful detention in scheduled detention facilities; ${ }^{2725}$ (iii) forced labour at the frontline and the use of human shields; ${ }^{2726}$ (iv) appropriation or plunder of property, during and after the take-over of Foča, during arrests and detention and in the course of or following acts of deportation or forcible transfer; ${ }^{2727}$ (v) the wanton destruction of private property including homes and business premises and public property including cultural monuments and sacred sites; ${ }^{2728}$ and (vi) the imposition and maintenance of restrictive and discriminatory measures. ${ }^{2729}$

838. Under Counts 7 and 8, the Prosecution alleges deportation and inhumane acts (forcible transfer), respectively, as crimes against humanity. ${ }^{2730}$ In this regard, the Prosecution alleges that, by the end of 1992, Serb Forces, Bosnian Serb Political and Governmental Organs had forcibly displaced Bosnian Muslims and Bosnian Croats from areas in Foča in which they had been lawfully present. $^{2731}$ It is alleged that from March 1992, restrictive and discriminatory measures, arbitrary arrest and detention, harassment, torture, rape and other acts of sexual violence, killing, destruction

\footnotetext{
2722 Indictment, para. 40(b).

2723 Indictment, para. 40(c). See Scheduled Detention Facilities C.10.1, C.10.2, C.10.4, C.10.5, C.10.6, C.10.7.

2724 Indictment, para. 60(f).

2725 Indictment, para. 60(g). See Scheduled Detention Facilities C.10.1, C.10.2, C10.4, C.10.5, C.10.6, C.10.7.

2726 Indictment, para. 60(h).

2727 Indictment, para. 60(i).

2728 Indictment, para. 60(j). See Scheduled Incident D.10.

2729 Indictment, para. 60(k). The restrictive and discriminatory measures alleged include the denial of freedom of movement; the removal from positions of authority; the invasion of privacy through arbitrary searches of homes; unlawful arrest and/or the denial of the right to judicial process; and/or the denial of equal access to public services.

2730 Indictment, paras. 68-75.

2731 Indictment, paras. 69, 72.
} 
of houses, cultural monuments and sacred sites, as well as the threat of further such acts caused Bosnian Muslims and Bosnian Croats to flee in fear while others were physically driven out. ${ }^{2732}$

(B) Lead-up

839. Foča is a large municipality in eastern $\mathrm{BiH}$ located to the southeast of Sarajevo in the region of Podrinje. ${ }^{2733}$ Prior to the war the population of Foča was approximately 40,000 and consisted of about 52\% Bosnian Muslims, 45\% Bosnian Serbs, and about 3\% who were Montenegrin. ${ }^{2734}$ While Foča was ethnically mixed, there were neighbourhoods in Foča town and villages in the municipality which could be identified as predominantly Bosnian Muslim or Bosnian Serb. ${ }^{2735}$

840. Inter-ethnic relations in Foča deteriorated following the formation of national parties and after the multi-party elections with increasing divisions and suspicion on all sides. ${ }^{2736}$ Petko Čančar was elected President of the SDS, but was later replaced by Miroslav Stanić. ${ }^{2737}$ Rallies were held by both the SDS and SDA; ${ }^{2738}$ this disrupted inter-ethnic relations further and led to rumours that the territory of the municipality, the companies, and institutions would be split along ethnic lines. ${ }^{2739}$ Relations further deteriorated after war broke out in Slovenia and Croatia ${ }^{2740}$ and the two

$2732 \quad$ Indictment, para. 71.

2733 D484 (Map of BiH); Momčilo Mandić, T. 5279-5280 (15 July 2010); Trifko Pljevaljčić, T. 32289 (21 January 2013); P1367 (Transcript of $26^{\text {th }}$ session of RS Assembly, 2 April 1993), p. 25; P1371 (Transcript of $30^{\text {th }}$ session of RS Assembly, 5-6 May 1993), p. 78.

2734 KDZ239, P3336 (Transcript from Prosecutor v. Krnojelac), T. 1296-1301; KDZ239, T. 18937 (16 September 2011); D4002 (Letter from Neđžad Ugljen to Vasvija Vidović, 4 July 1995), p. 23. See also P1480 (Ratko Mladić's notebook, 10-30 September 1992), p. 66.

2735 See Adjudicated Fact 724. See also Radojica Mlađenović, T. 36605 (4 April 2013).

2736 KDZ239, P3336 (Transcript from Prosecutor v. Krnojelac), T. 1182-1183; see Adjudicated Fact 725; Milorad Krnojelac, D2716 (Transcript from Prosecutor v. Krnojelac), T. 7601. See also Trifko Pljevaljčić, T. 3228933290 (21 January 2013).

2737 D3314 (Witness statement of Radojica Mlađenović dated 1 April 2013), para. 14. Radojica Mlađenović was Vice President of the SDS.

2738 For evidence on SDA rallies, publications and the strike of Bosnian Muslims workers at the Fočatrans company which also disrupted inter-ethnic relations, see Milutin Vujičić, T. 32095, 32103-32104, 32106-32111, 3211532121, 32141 (17 January 2013); D2767 (Witness statement of Milutin Vujičić dated 14 January 2013), paras. 2, 4; Trifko Pljevaljčić, T. 32293-32295, 32321, 32333-32334 (21 January 2013); D3314 (Witness statement of Radojica Mlađenović dated 1 April 2013), paras. 5-6, 9, 15; Radojica Mlađenović, T. 36689, 36709-36710 (5 April 2013); D3133 (Witness statement of Cvijetin Simić dated 16 March 2013), para. 37; P6079 (Foča SJB statement, 12 September 1990); KDZ017, T. 19881-19882 (4 October 2011); Robert Donia, T. 3223 (2 June 2010); Mitar Rašević, T. 46768-46769 (11 February 2014).

2739 KDZ239, P3336 (Transcript from Prosecutor v. Krnojelac), T. 1183-1185, 1294-1296; P6078 (Video clip re founding assembly of Foča SDA, with transcript); D2767 (Witness statement of Milutin Vujičić dated 14 January 2013), paras. 3, 5 (stating that the SDS was formed after the SDA); Milutin Vujičić, T. 32103-32109, 32112, 32114 (17 January 2013). See also Radojica Mlađenović, T. 36624-36625 (5 April 2013). According to Defence evidence and in the Accused's submission, the SDS rallies were directed towards respect for neighbourly relations and the preservation of peace. D3314 (Witness statement of Radojica Mlađenović dated 1 April 2013), paras. 15-16; D2767 (Witness statement of Milutin Vujičić dated 14 January 2013), para. 3; Defence Final Brief, para. 1758. However, the Chamber does not find the evidence adduced by the Accused to be reliable in this regard. In reaching that conclusion the Chamber noted that the evidence of the relevant witnesses was marked by multiple contradictions and extreme evasiveness.

2740 D3314 (Witness statement of Radojica Mlađenović dated 1 April 2013), para. 10. 
communities further separated with Bosnian Serbs and Bosnian Muslims having their own cafés. $^{2741}$

841. In 1991, Bosnian Serb leaders, including the Accused, Koljević, and Plavšić attended SDS rallies in Foča. ${ }^{2742}$ Other SDS leaders from the Republican level including Velibor Ostojić, the minister of information in $\mathrm{BiH}^{2743}$ and Vojislav Maksimović, the President of the SDS Deputies' Club would often visit Foča, while Plavšić also visited occasionally. ${ }^{2744}$ Maksimović, who was from Foča, made a statement at a public SDS rally in Goražde that "in the previous war the Drina flowed bloody, and in this war the Cehotina river would flow bloody too". ${ }^{2745}$

842. In June 1991, representatives of the SDA and SDS of Foča met to discuss issues, including an inter-party agreement for the appointment of personnel to official positions in the municipality including the SJB, the judiciary and the Municipal TO Staff. ${ }^{2746}$

\section{(1) Division of municipal structures}

843. In December 1991 the SDS decided to establish the Serb Assembly of Foča. ${ }^{2747}$ On 24 January 1992, the Serb Assembly of Foča established an Executive Board with Radojica Mlađenović as Chairman. ${ }^{2748}$

844. In an intercepted conversation between Stanić and the Accused in January 1992, the Accused asked Stanić about the situation in Foča. ${ }^{2749}$ Stanić proceeded to tell the Accused that they

\footnotetext{
$2741 \quad$ KDZ017, T. 19877 (4 October 2011).

2742 D3314 (Witness statement of Radojica Mlađenović dated 1 April 2013), para. 16; Radojica Mlađenović, T. 36624 (5 April 2013); KDZ239, P3336 (Transcript from Prosecutor v. Krnojelac), T. 1186; KDZ239, T. 1896118962 (16 September 2011). See also P5681 (Intercept of conversation between Biljana Plavšić and Radovan Karadžić, 23 May 1991), p. 1.

2743 KDZ379, P3332 (Transcript from Prosecutor v. Krnojelac), T. 3124.

2744 KDZ239, P3336 (Transcript from Prosecutor v. Krnojelac), T. 1186; KDZ239, T. 18961 (16 September 2011); KDZ017, P3568 (Transcript from Prosecutor v. Krnojelac), T. 2902, 2941; KDZ017, T. 19867-19868 (4 October 2011), 19868-19870 (4 October 2011) (private session); P90 (Witness statement of KDZ216 dated 8 June 1998), p. 16. (under seal).

2745 KDZ239, T. 18912, 18931 (15 September 2011); KDZ239, P3336 (Transcript from Prosecutor v. Krnojelac), T. 1186. The Chamber notes that the Cehotina River flows through Foča. D484 (Map of BiH).

2746 D1686 (Minutes of meeting between SDA and SDS, 20 June 1991), pp. 1-2; D1685 (Clarification of Foča Executive Board, 3 October 1991). See also D3314 (Witness statement of Radojica Mlađenović dated 1 April 2013), para. 2. The Chamber notes there were disagreements about the appointment of individuals to certain positions but the parties discussed the importance of avoiding conflict. D3314 (Witness statement of Radojica Mlađenović dated 1 April 2013), paras. 3, 12, 18, 29; D4872 (Letter from Vukosavljević to Foča Executive Board, 21 February 1992); D1686 (Minutes of meeting between SDA and SDS, 20 June 1991), p. 3; D2767 (Witness statement of Milutin Vujičić dated 14 January 2013), para. 28.

2747 P3333 (Official Gazette of Serbian Municipality of Foča, 17 September 1992), pp. 1-3; D3314 (Witness statement of Radojica Mlađenović dated 1 April 2013), paras. 14, 20. See also Adjudicated Fact 729.

2748 P3333 (Official Gazette of Serbian Municipality of Foča, 17 September 1992), p. 11; P6264 (Excerpt from transcript of extended session of SDS Main Board and Executive Board, 14 February 1992, with audio), pp. 1-2. See also D3314 (Witness statement of Radojica Mlađenović dated 1 April 2013), para. 20.
} 
had formed a "Serb municipality and you have that information" after which the Accused said: "Yes, yes, and take complete control over your affairs" to which Stanić agreed and said "everything as it is in the instructions". 2750

845. On 3 April 1992, the Statute of the Serb Municipality of Foča was promulgated and stated that the municipality was part of the SAO Herzegovina. ${ }^{2751}$ This statute provided that the boundaries in the municipality "may be modified only keeping with the will of the local Serbian people" and also stipulated that the Serb Municipality of Foča was to enforce the laws of the SerBiH and the SAO Herzegovina. ${ }^{2752}$ Pursuant to the terms of the statute, the Crisis Staff of the Serb Municipality of Foča ("Foča Crisis Staff”) was established on the same day ${ }^{2753}$ and Miroslav Stanić was appointed as its president. ${ }^{2754}$ Bosnian Muslims also established a crisis staff in Foča. $^{2755}$ The Foča Crisis Staff operated from the Bosnian Serb neighbourhood of Čerežluk ${ }^{2756}$ and was required to take over the duties of the Municipal Assembly during an imminent threat or state of war. ${ }^{2757}$

846. On 7 April 1992, following pressure from the SDS leadership, the police was divided along ethnic lines. $^{2758}$

2749 P3337 (Intercept of conversation between Miroslav Stanić and Radovan Karadžić, 6 January 1992), p. 2; KDZ239, T. 18909 (15 September 2011).

2750 P3337 (Intercept of conversation between Miroslav Stanić and Radovan Karadžić, 6 January 1992), p. 2. The Chamber finds that considering the timing of this conversation and the context, the reference to "the instructions" is a reference to the Variant A/B Instructions which were distributed in December 1991. P5 (SDS Instructions for Organisation of Organs of the Serbian People in BiH, 19 December 1991), pp. 6, 10.

2751 P3333 (Official Gazette of Serbian Municipality of Foča, 17 September 1992), p. 14; KDZ239, T. 18938 (16 September 2011).

2752 P3333 (Official Gazette of Serbian Municipality of Foča, 17 September 1992), pp. 14, 16.

2753 P3333 (Official Gazette of Serbian Municipality of Foča, 17 September 1992), pp. 39-40. See also D3314 (Witness statement of Radojica Mlađenović dated 1 April 2013), para. 20; D4002 (Letter from BiH MUP to Vasvija Vidović, 4 July 1995), p. 23.

2754 KDZ239, T. 18940 (16 September 2011). Members of the Foča Crisis Staff were not necessarily all SDS members. KDZ379, T. 18850-18851 (15 September 2011); Trifko Pljevaljčić, T. 32329 (21 January 2013). Other members of the Foča Crisis Staff included Vojislav Maksimović, Velibor Ostojić, Petko Čančar, Milum Milanović, Dragan Gagović, and Radojca Mlađenović. D4002 (Letter from BiH MUP to Vasvija Vidović, 4 July 1995), p. 23. See also D1684 (Order of Foča Crisis Staff).

2755 See Adjudicated Facts 729, 730; KDZ017, T. 19878 (4 October 2011); D3314 (Witness statement of Radojica Mlađenović dated 1 April 2013), paras. 4, 23.

$2756 \quad$ Adjudicated Fact 731.

2757 P3333 (Official Gazette of Serbian Municipality of Foča, 17 September 1992), pp. 31, 40-41; D3314 (Witness statement of Radojica Mlađenović dated 1 April 2013), paras. 20, 22. See also Trifko Pljevaljčić, T. 3234832349 (21 January 2013) (testifying that the Foča Crisis Staff was established when negotiations fell through).

2758 See Adjudicated Fact 732. See also Trifko Pljevaljčić, T. 32288 (21 January 2013); D3319 (Belgrade Radio news report, 8 April 1992). 


\section{(2) Militarisation of Foča}

847. By January 1992 all Bosnian Muslim reservists had left the JNA base at Ustikolina following orders of the SDA. ${ }^{2759}$ At that time, in addition to regular JNA troops a significant number of Serb reservists came to the JNA barracks and were provided with supplies. ${ }^{2760}$

848. In the months before the outbreak of the conflict in Foča, both Bosnian Serbs and Bosnian Muslims began to arm themselves, though Bosnian Serbs were better prepared. ${ }^{2761}$ Bosnian Serbs armed themselves surreptitiously at first, distributing weapons by truck in the evenings, or from local businesses. ${ }^{2762}$ Immediately prior to the outbreak of the conflict, the distribution of arms to Bosnian Serbs was done openly. ${ }^{2763}$ On 17 March 1992, the Executive Board of the Serb Assembly of Foča sent a letter to the JNA General Staff urgently requesting that a JNA garrison be stationed in Foča. ${ }^{2764}$

849. The SDS and Gojko Janković were involved in military preparations and formed several units in the municipality. ${ }^{2765}$ Stanić, who was also a member of the SDS Main Board, was the commander of the Tactical Group of Foča and became known as the "First War Commander" in the

2759 KDZ379, T. 18867-18868 (15 September 2011); KDZ379, P3332 (Transcript from Prosecutor v. Krnojelac), T. 3101, 3103.

2760 KDZ379, P3332 (Transcript from Prosecutor v. Krnojelac), T. 3098, 3100.

2761 KDZ239, P3336 (Transcript from Prosecutor v. Krnojelac), T. 1187, 1307; KDZ379, T. 18857-18858 (15 September 2011); P90 (Witness statement of KDZ216 dated 8 June 1998), p. 3 (under seal). See also Adjudicated Fact 727. Pljevaljčić disputed the extent to which the Bosnian Serbs were armed and testified that only one reserve complement of Bosnian Serbs was armed and that Bosnian Serbs had access to hunting weapons but only took infantry weapons from warehouses when the conflict broke out. Trifko Pljevaljčić, T. 32299-32300, 32333 (21 January 2013). However, the Chamber notes that when confronted with evidence which suggested that the Bosnian Serb population was being armed, Pljevaljčić maintained that Gojko Janković was not involved but denied all knowledge about the formation of four battalions under the organisation of the SDS in 1991 and claimed he was not aware of what the Foča Crisis Staff did in forming units. Trifko Pljevaljčić, T. 32335-32336 (21 January 2013); P6082 (Proposal of Foča Territorial Group, 13 August 1993), p. 1. In light of these equivocal answers and the other evidence received on this issue, the Chamber does not accept Pljevaljčić's evidence about the extent to which Bosnian Serbs were being armed in Foča. The Chamber is however, satisfied that Bosnian Muslims were also armed to some extent and that Bosnian Muslim paramilitary formations, such as the Patriotic League and Green Berets, were present in Foča before clashes broke out. D2767 (Witness statement of Milutin Vujičić dated 14 January 2013), paras. 3, 5, 19, 22-24; Milutin Vujičić, T. 32124-32126, 32141 (17 January 2013); Trifko Pljevaljčić, T. 32286, 32291-32292, 32324, 3233832339, 32342, (21 January 2013); D3065 (Witness statement of Aleksandar Vasiljević dated 26 February 2013), paras. 126, 222; D299 (ABiH Supreme Command Staff Special Report, 17 July 1993), p. 2; D246 (Article from Ljiljan, entitled "Inteview of the week: Halid Čengić", 18-25 May 1998), pp. 1, 6-7; D3128 (Witness statement of Veljko Marić dated 16 March 2013), para. 10; D3314 (Witness statement of Radojica Mlađenović dated 1 April 2013), paras. 9, 11-12, 14, 45; D2739 (4 ${ }^{\text {th }}$ Corps security organ report, 1 December 1991), p. 3.

2762 See Adjudicated Fact 728

2763 See Adjudicated Fact 728.

2764 P5481 (Request of Foča Municipal Assembly, 17 March 1992).

2765 P6081 (Video clips re interview and speech of Miroslav Stanić, with transcript). See also KDZ239, T. 18933 (15 September 2011); P6082 (Proposal of Foča Tactical Group, 13 August 1993), p. 1. 
municipality. ${ }^{2766}$ Another significant leader in Foča was Marko Kovač, a former JNA officer ${ }^{2767}$ who subsequently took over from Stanić as the commander of the Tactical Group. ${ }^{2768}$ Stanić and Kovač reported on behalf of the Tactical Group to Mladić ${ }^{2769}$ and this unit was transformed into a unit of the VRS in May 1992. ${ }^{2770}$ The Tactical Group reported to the Herzegovina Corps, ${ }^{2771}$ which in turn reported on the activities of the Tactical Group to the VRS Main Staff. ${ }^{2772}$

\section{(C) Take-over of Foča}

850. On 2 March 1992, the SDS Municipal Board of Foča sent a letter addressed to the office of the President of the SDS Crisis Staff in Sarajevo indicating that they were "ready to carry out any order". 2773

851. On 4 March 1992, at a meeting between representatives of the SDA and SDS, negotiations concluded with an agreement to lift blockades which had been erected by both Bosnian Muslims and Bosnian Serbs and to hold an extraordinary session of the Municipal Assembly to discuss the political and security situation. ${ }^{2774}$ There were also discussions between Bosnian Serb and Bosnian Muslim representatives about the division of Foča into two municipalities and the division of power. $^{2775}$

852. In early April 1992, Stanić, was heard on Radio Foča saying that it was no longer possible for Bosnian Serbs to live with their Bosnian Muslim neighbours, that they could not be woken

\footnotetext{
2766 KDZ379, T. 18832-18833, 18836-18837 (15 September 2011); see Adjudicated Fact 731; P3476 (Video clip of interview with Miroslav Stanić, with transcript), pp. 2-3; P6081 (Video clips re interview and speech of Miroslav Stanić, with transcript); Radojica Mlađenović, T. 36645-36646 (5 April 2013).

2767 P90 (Witness statement of KDZ216 dated 8 June 1998), p. 15 (under seal); KDZ216, P69 (Transcript from Prosecutor v. Kunarac), T. 3386 (under seal).

2768 Trifko Pljevaljčić, T. 32327 (21 January 2013); Radojica Mlađenović, T. 36645-36646 (5 April 2013). See also P3476 (Video clip of interview with Miroslav Stanić, with transcript), p. 3 (stating that the Tactical Group was the name given to the group previously commanded by Stanić and that Stanić had handed over command of the group to Kovač).

2769 P1480 (Ratko Mladić's notebook, 10-30 September 1992), pp. 60-71; P1478 (Ratko Mladić's notebook, 27 May-31 July 1992), p. 394 (showing that Pero Elez also met with Mladić and requested supplies).

2770 KDZ239, T. 18932-18934 (15 September 2011), T. 19006 (16 September 2011).

2771 See P3355 (Combat report of Foča's Tactical Group, 21 July 1992); P6080 (Report of Foča Military Post, 10 October 1992).

2772 P3356 (Combat report of the Herzegovina Corps, 31 July 1992); P6659 (List of prisoners in Foča prison, 27 October 1993).

2773 P5515 (Letter from SDS Municipal Board of Foča to SDS Crisis Staff in Sarajevo, 2 March 1992).

2774 Trifko Pljevaljčić, T. 32286-32287, 32300, 32305 (21 January 2013); D3314 (Witness statement of Radojica Mlađenović dated 1 April 2013), para. 22; D3315 (Protocol of inter-party meeting between SDS and SDA on 4 March 1992).

2775 D1690 (Announcement of Foča Municipal Assembly, 7 April 1992); D3317 (Agreement re Foča, 8 April 1992), p. 1; Radojica Mlađenović, T. 36604-36607 (4 April 2013); Trifko Pljevaljčić, T. 32288-32289 (21 January 2013); D3314 (Witness statement of Radojica Mlađenović dated 1 April 2013), para. 50. See also D3317 (Agreement re Foča, 8 April 1992) which pertains to an agreement reached between Bosnian Muslim and
} 
every morning by the hodža from the mosque, and that there was a danger that the Bosnian Serb population would be circumcised. ${ }^{2776}$ Stanić also stated the Bosnian Serb position that "the Drina would never become a border but a windpipe between two lungs", which was a reference to the RS and Serbia. ${ }^{2777}$ Other messages were broadcast by radio to the effect that "the time had come for the Serbs to settle accounts with the balijas once and for all, and that the Serbs would no longer allow their ribs to be broken. They will no longer allow their children to be circumcised". ${ }^{2778}$ These radio broadcasts created further divisions in Foča. ${ }^{2779}$

853. Despite these negotiations, armed clashes began in Foča on 6 April 1992 when the results of the referendum on the independence of $\mathrm{BiH}$ were published. ${ }^{2780}$ By 7 April 1992, there was a presence of Serb Forces on the streets, and some people failed to report for work, fearful of the rising tensions in the town. ${ }^{2781}$ After the conflict broke out there were calls by the military authorities for mobilisation of the Bosnian Serb population from loudspeakers. ${ }^{2782}$ A number of Bosnian Serbs were mobilised on 7 April 1992 and issued with weapons and that night, Bosnian Serbs took over the Foča radio station, the warehouse of the regional medical centre, and the TO warehouse where weapons were stored. ${ }^{2783}$

854. On 7 April 1992, the President of the Serb Municipality of Foča made a public announcement that in accordance with decisions made by the Bosnian Serb Assembly, all organs of the Serb municipality would become operational. ${ }^{2784}$ This same announcement called "upon the Serbian people and other civilians to maintain composure and common sense" and observed that TO units and the SJB would maintain public law and order, protect people and property, and prevent the presence of paramilitary formations in the Serb Municipality of Foča. ${ }^{2785}$ It also

Bosnian Serb representatives for the removal of barricades, the expulsion of armed people who had entered from outside, the introduction of a curfew, and a ban on the movement of units. KDZ239, P3336 (Transcript from Prosecutor v. Krnojelac), T. 1185.

KDZ379, T. 18832-18834 (15 September 2011); P3476 (Video clip of interview with Miroslav Stanić, with transcript), p. 2.

KDZ239, T. 18929 (15 September 2011).

KDZ239, P3336 (Transcript from Prosecutor v. Krnojelac), T. 1185.

KDZ239, P3336 (Transcript from Prosecutor v. Krnojelac), T. 1187-1188; see Adjudicated Facts 488, 491.

See Adjudicated Fact 738. Mlađenović disputed that the army was visibly present on the streets on 7 April 1992. D3314 (Witness statement of Radojica Mlađenović dated 1 April 2013), para. 54. However, the Chamber does not consider that Mlađenović's evidence can be relied on in this regard. In reaching that conclusion, the Chamber noted that his evidence was marked by contradictions, evasiveness, and bias.

Milorad Krnojelac, D2716 (Transcript from Prosecutor v. Krnojelac), T. 7596, 7767-7768. This message was also broadcast on radio. KDZ239, P3336 (Transcript from Prosecutor v. Krnojelac), T. 1336.

See Adjudicated Fact 738. See also KDZ239, P3336 (Transcript from Prosecutor v. Krnojelac), T. 1336.

D1690 (Announcement of Foča Municipal Assembly, 7 April 1992).

D1690 (Announcement of Foča Municipal Assembly, 7 April 1992). 
appealed to all citizens, including Bosnian Muslims and Bosnian Serbs, not to move out of Foča and for those who had left to return. ${ }^{2786}$

855. Serb Forces deployed heavy artillery weapons on elevated sites around Foča. ${ }^{2787}$ On the morning of 8 April 1992, Serb Forces commenced the main attack on the town of Foča, with a combination of infantry fire and shelling from artillery weapons directed primarily at predominantly Muslim neighbourhoods. ${ }^{2788}$ They proceeded to take over Foča area by area, including the areas of Donje Polje and Šukovac where there was resistance by Bosnian Muslim forces. $^{2789}$ The Foča Crisis Staff issued orders for the taking of certain positions, which were implemented by Serbs Forces. ${ }^{2790}$ The Serb Forces that took part in the attack included local soldiers as well as soldiers from Serbia and Montenegro, the Foča Tactical Group and paramilitaries, including the White Eagles. ${ }^{2791}$ The attack continued for six or seven days, although the worst shelling and damage took place in the first few days. ${ }^{2792}$ The attack resulted in large numbers of wounded civilians, most of whom were Bosnian Muslims. ${ }^{2793}$

2786 KDZ239, T. 18983, 18985 (16 September 2011). KDZ239 testified further that this was just a trap and the announcement was made "to increase the number of those who were caught" and those Bosnian Muslims who returned believing it to be safe "fared badly". However, the Chamber does not rely on KDZ239's assessment, which is based on his speculation.

2787 KDZ239, P3336 (Transcript from Prosecutor v. Krnojelac), T. 1190-1191; KDZ017, T. 19877 (4 October 2011). See also Adjudicated Fact 728.

2788 See Adjudicated Facts 741, 742. See also KDZ239, P3336 (Transcript from Prosecutor v. Krnojelac), T. 11901191; Trifko Pljevaljčić, T. 32304, 32321 (21 January 2013). Adjudicated Fact 741 indicates that the shelling was from Kalinovik and Miljevina. However, Vujičić testified that this was not possible given that Kalinovik was 40 kilometres away and thus out of range. Milutin Vujičić, T. 32145 (17 January 2013). While Vujičić's evidence was marked by evasiveness and some aspects were unreliable, the Chamber considers that his evidence does cast some doubt as to the precise origin of fire. However, this does not undermine the evidence that Serb Forces launched the artillery attacks in question.

2789 See Adjudicated Fact 743. Donje Polje was also the location of the Bosnian Muslim crisis staff in Foča. KDZ017, T. 19878 (4 October 2011); Adjudicated Fact 730. See also D3128 (Witness statement of Veljko Marić dated 16 March 2013), para. 24 (stating that the Serb Forces did not occupy the hospital but that the Bosnian Muslim forces retreated as they lost their position).

2790 KDZ379, T. 18834, 18836 (15 September 2011); P3476 (Video clip of interview with Miroslav Stanić, with transcript). Mlađenović testified that the goal of the Foča Crisis Staff was simply to "save the people" and deal with resources, supply and production. D3314 (Witness statement of Radojica Mlađenović dated 1 April 2013), paras. 20, 26; Radojica Mlađenović, T. 36626-36627, 36684 (5 April 2013). The Chamber does not consider that it can rely on Mlađenović's evidence in this regard given that his evidence was marked by significant contradictions and evasiveness which undermined his credibility and showed bias.

2791 D4002 (Letter from BiH MUP to Vasvija Vidović, 4 July 1995), p. 23; see Adjudicated Fact 741. See also KDZ379, P3332 (Transcript from Prosecutor v. Krnojelac), T. 3111; KDZ379, T. 18880-18881 (15 September 2011); KDZ216, P69 (Transcript from Prosecutor v. Kunarac), T. 3316 (under seal); KDZ017, T. 19892 (4 October 2011) (testifying that some of the soldiers also wore the five pointed star of the JNA); KDZ239, T. 18993 (16 September 2011) (testifying that Arkan's men and Šešelj's men and a "Guard” from Užice took part in the attack but he could not remember the insignia they wore).

2792 See Adjudicated Fact 747.

2793 See Adjudicated Fact 744. Defence witnesses testified that (i) Serb Forces were able to "liberate" Foča with few casualties on both sides; (ii) the White Eagles and JNA never took part in the conflict; (iii) civilians were not killed in the first few days; (iv) there was no heavy artillery fire at Foča; (v) Bosnian Serbs only fought with light arms until June 1992; (vi) the shelling by Bosnian Muslims caused panic and prompted large numbers of both Bosnian Serbs and Bosnian Muslims to head towards Montenegro and Serbia; and (vii) Serb Forces were 
856. The Chamber finds that there were clashes between Serb Forces and Bosnian Muslim forces but before long Serb Forces had control of the town. ${ }^{2794}$ During the conflict, many civilians hid in their homes, basements, or with relatives while others left Foča altogether for their safety. ${ }^{2795}$

857. During the attack, some neighbourhoods were destroyed and Bosnian Muslim homes were set on fire by Serb Forces. ${ }^{2796}$ Bosnian Muslim homes were also set on fire by Serb Forces at that time as well as after the town had been secured. ${ }^{2797}$ Some of these houses were looted before being set on fire. ${ }^{2798}$ Some Bosnian Muslim houses were destroyed and were beside an untouched Serb apartment identified with a note saying "Serb apartment — do not torch". ${ }^{2799}$ Fire engines protected Bosnian Serb houses while Bosnian Muslim houses burned. ${ }^{2800}$ Other Bosnian Muslim

able to take control of Foča with no assistance from the SDS leadership or the JNA. D2767 (Witness statement of Milutin Vujičić dated 14 January 2013), paras. 5-6, 12, 26-27, 29; Milutin Vujičić, T. 32122-32125 (17 January 2013); Trifko Pljevaljčić, T. 32301, 32303-32304, 32306, 32321-32322, 32327-32328, 32342, 32347-32348, 32350-32351 (21 January 2013); D3314 (Witness statement of Radojica Mlađenović dated 1 April 2013), para. 55; Radojica Mlađenović, T. 36612 (4 April 2013), T. 36617, 36690-36691 (5 April 2013). However, the Chamber does not find this evidence to be reliable. In reaching that conclusion, the Chamber noted that the evidence of the relevant witnesses was either based on speculation alone, or marked by evasiveness, contradictions, negative demeanour and indicators that they were trying to mislead the Chamber. These factors undermined their credibility and in light of the other evidence received, the Chamber does not consider this evidence to be reliable.

2794 KDZ017, T. 19869 (4 October 2011) (private session); T. 19876-19877 (4 October 2011); Adjudicated Fact 743; KDZ239, P3336 (Transcript from Prosecutor v. Krnojelac), T. 1188; D2767 (Witness statement of Milutin Vujičić dated 14 January 2013), para. 1; Milorad Krnojelac, D2716 (Transcript from Prosecutor v. Krnojelac), T. 7589. See also D3314 (Witness statement of Radojica Mlađenović dated 1 April 2013), paras. 30-31, 33; Trifko Pljevaljčić, T. 32305 (21 January 2013).

2795 Adjudicated Fact 746. Vujičić testified that both Bosnian Serbs and Bosnian Muslims left Foča during the fighting. D2767 (Witness statement of Milutin Vujičić dated 14 January 2013), para. 7. While the Chamber is satisfied that some Bosnian Serbs may have left, the remaining evidence indicates that this did not happen on the scale at which Bosnian Muslims left the municipality. See paras. 929-934.

2796 See Adjudicated Fact 902. See also Adjudicated Fact 813.

2797 See Adjudicated Fact 902; KDZ239, P3336 (Transcript from Prosecutor v. Krnojelac), T. 1188-1189. For example Donje Polje, the largely Muslim neighbourhood of Šukovać, and Bosnian Muslim houses in Kamerici and in Granovski Sokak were burned as was the old town neighbourhood of Prijeka Čaršija with its orientalIslamic style market and Muslim houses in Pilipovići and the neighbouring village of Paunci. Adjudicated Facts 903, 904, 909. See also P90 (Witness statement of KDZ216 dated 8 June 1998), p. 12 (under seal); KDZ216, P69 (Transcript from Prosecutor v. Kunarac), T. 3367-3368 (under seal); P502 (Video clip of a man and destroyed houses). While KDZ239 testified that Bosnian Muslim homes were set on fire in order "to frighten the local population to flee the town", the Chamber does not rely on his opinion in this regard. The Chamber notes that the evidence adduced by the Defence does not dispute the destruction of Bosnian Muslim homes, but challenges the systematic nature of the destruction and seeks to blame Bosnian Muslim Forces for instigating these events. Mlađenović testified that (i) Bosnian Muslim houses were not systematically torched during the attack on the town; (ii) the torching of houses was started by Bosnian Muslim units; (iii) the military command issued an order which involved sealing abandoned properties and prohibiting destruction and looting of property; and that (iv) the burning of houses by both sides got out of control when Bosnian Muslim forces started burning houses. D3314 (Witness statement of Radojica Mlađenović dated 1 April 2013), paras. 46, 56; Radojica Mlađenović, T. 36615-36616, 36679, 36697 (5 April 2013). While the Chamber finds that some Bosnian Serb homes may have been burnt (see KDZ239, P3336 (Transcript from Prosecutor v. Krnojelac), T. 1188-1189), it does not consider Mlađenović's evidence to be reliable. In reaching that conclusion the Chamber noted that Mlađenović's evidence was marked by contradictions, extreme evasiveness and bias which undermined his credibility.

2798 KDZ239, P3336 (Transcript from Prosecutor v. Krnojelac), T. 1189.

2799 See Adjudicated Fact 905.

2800 See Adjudicated Fact 906. 
houses were dismantled for materials or re-allocated to Bosnian Serbs who had lost their own homes. ${ }^{2801}$ Bosnian Muslim businesses were looted or burned, or had equipment confiscated. ${ }^{2802}$

858. On 8 April 1992, roadblocks were set up throughout the town, ${ }^{2803}$ but the Foča Crisis Staff called on citizens of all nationalities to remain calm and informed the population that the Bosnian Serb TO and SJB were controlling the town. ${ }^{2804}$ By around mid-April 1992, Serb Forces had taken control of the town of Foča. ${ }^{2805}$ Many of the Bosnian Muslims who had remained during the fighting fled Foča when Serb Forces took control of the town. ${ }^{2806}$ After the Bosnian Serb civilian authorities returned to the municipality, ${ }^{2807}$ it was announced on the radio during the second half of April 1992 that the administration of the entire municipality of Foča would be run by the Serbs. ${ }^{2808}$ Ostojić reported that the Bosnian Serbs had "established state and executive authority in the Serbian commune of Foča". ${ }^{2809}$ On or about 26 April 1992, Bosnian Serb officials including Maksimović, Stanić, Čančar and Ostojić, met at the Foča Crisis Staff headquarters. ${ }^{2810}$

859. After Serb Forces took control of Foča town, attacks against the non-Serb civilian population continued, including attacks against Bosnian Muslim villages which were taken over

\footnotetext{
$2801 \quad$ Adjudicated Fact 907.

2802 See Adjudicated Fact 779.

2803 Adjudicated Fact 740.

2804 D3319 (Belgrade Radio news report, 8 April 1992); Radojica Mlađenović, T. 36704 (5 April 2013).

2805 KDZ017, T. 19890 (4 October 2011); KDZ017, T. 19909-19910 (5 October 2011); P3338 (TANJUG news report, 14 April 1992) (in which Ostojić reported that the Bosnian Serb TO was controlling a "huge part of the town" and that the entire Bosnian Serb TO "is on its feet"); see Adjudicated Fact 748.

2806 See Adjudicated Fact 748. Vujičić testified that by the end of April, (i) Foča was freed and the remaining Bosnian Muslim civilian population and their homes were not touched; and (ii) civilians who had not left the villages remained in their homes. D2767 (Witness statement of Milutin Vujičić dated 14 January 2013), paras. 30-31. The Chamber does not consider Vujičić's evidence to be reliable on this issue. In reaching that conclusion the Chamber noted that his evidence was marked by evasiveness and other indicators which undermined his credibility.

2807 Radojica Mlađenović, T. 36636 (5 April 2013).

2808 Adjudicated Fact 769.

2809 D3319 (Belgrade Radio news report, 8 April 1992); Radojica Mlađenović, T. 36704 (5 April 2013). Ostojić was the state commissioner for Foča Municipality until this authority was transferred to Vojislav Maksimović on 4 June 1992 by a certificate signed on behalf of the Accused. P3339 (Certificate of appointment signed by Radovan Karadžić, 4 June 1992); KDZ239, T. 18911-18912 (15 September 2011).

2810 KDZ379, P3332 (Transcript from Prosecutor v. Krnojelac), T. 3118-3120; KDZ379, T. 18885-18886 (15 September 2011). See also P90 (Witness statement of KDZ216 dated 8 June 1998), p. 16 (under seal). [REDACTED]. In addition the Chamber received hearsay evidence that Velibor Ostojić attended meetings in Foča during the attack in April 1992 and said that there should be no negotiations, that "they should all be killed" and that they should "slaughter anything that is human". KDZ017, T. 19868-19870, (4 October 2011) (private session), T. 19872 (4 October 2011). See also Radojica Mlađenović, T. 36636-36638 (5 April 2013) (acknowledging that Ostojić was present at some time during the take-over of Foča); KDZ379, P3332 (Transcript from Prosecutor v. Krnojelac), T. 3118-3121. But see Velibor Ostojić, D2361 (Transcript from Prosecutor v. Krajišnik), T. 26732-26734, 26738-26739; D2362 (Witness statement of Velibor Ostojić dated 6 June 2006), para. 36. However, having weighed the relevant evidence, the Chamber, while satisfied that Ostojić did attend some meetings during the conflict in Foča, is not satisfied that it can make a finding about what Ostojić said at those meetings based on this hearsay evidence.
} 
and destroyed. ${ }^{2811}$ For example, the village of Brod was attacked on 20 April 1992, after the village authorities did not respond to a Foča Crisis Staff demand that the village surrender. ${ }^{2812}$ Similarly around 28 April 1992, Serb Forces attacked Ustikolina where Bosnian Muslims had tried to form resistance, after which the Serb Forces set fire to Bosnian Muslim houses there. ${ }^{2813}$

860. On 30 April 1992, Ostojić reported to the Bosnian Serb government that Ustikolina was "liberated" and that the civilian authorities had "control over the overall situation". ${ }^{2814}$ Thereafter, Serb Forces continued attacking and destroying Muslim villages along the Drina while the population fled. ${ }^{2815}$ Ostojić continued to report on progress of the military action in Foča to republican level organs. ${ }^{2816}$ By around the end of April 1992, Serb Forces had control of the municipality. $^{2817}$

861. In June 1992, Serb Forces continued to attack, loot, and burn down Bosnian Muslim villages in Foča. ${ }^{2818}$ During these attacks Bosnian Muslim villagers were rounded up or captured, and sometimes beaten. ${ }^{2819}$ For example, in Miljevina, Serb Forces set the surrounding Muslim villages on fire and arrested Bosnian Muslim civilian males. ${ }^{2820}$

(D) Events after the take-over of Foča

862. After the take-over, the municipality was run by the Foča Crisis Staff until the municipal assembly was able to function. ${ }^{2821}$ Immediately after the take-over, restrictions were imposed on

\footnotetext{
$2811 \quad$ See Adjudicated Facts 749, 750.

2812 See Adjudicated Fact 753.

2813 See Adjudicated Facts 910, 755.

2814 P4986 (Report of SerBiH Government, 30 April 1992), p. 1.
}

2815 See Adjudicated Fact 756. While the Adjudicated Fact also refers to the killing of Bosnian Muslims, the Chamber notes that these killings are not charged pursuant to Schedules A or B of the Indictment. See fn. 13.

2816 P3476 (Video clip of interview with Miroslav Stanić, with transcript), p. 3.

2817 Adjudicated Fact 745; KDZ379, T. 18834-18835 (15 September 2011); P3476 (Video clip of interview with Miroslav Stanić, with transcript). See also Trifko Pljevaljčić, T. 32307 (21 January 2013).

2818 See Adjudicated Facts 751, 752.

2819 See Adjudicated Fact 752. While the Adjudicated Fact also refers to the killing of Bosnian Muslims, the Chamber notes that that these killings are not charged pursuant to Schedules A or B of the Indictment. See fn. 13. See also Milorad Krnojelac, D2716 (Transcript from Prosecutor v. Krnojelac), T. 7888.

2820 See Adjudicated Fact 754. According to Defence witnesses, when soldiers were mobilised into the Serb Forces they were informed about provisions of Geneva Conventions which were contained in the rules of conduct and an official announcement was read out to soldiers informing them that when mopping up villages the civilian population, homes and property were "completely off limits and that every transgression of these units would be strictly punished". D2767 (Witness statement of Milutin Vujičić dated 14 January 2013), paras. 14-15; Milutin Vujičić, T. 32133, 32145-32146 (17 January 2013). Considering that Vujičić's evidence was marked by indicators of evasiveness and attempts to mislead the Chamber, the Chamber does not find that this evidence is reliable.

2821 P6265 (Video footage of interview with Velibor Ostojić, with transcript), p. 6; Radojica Mlađenović, T. 36642 (5 April 2013). 
the non-Serb inhabitants. ${ }^{2822}$ Between 10 April 1992 and the beginning of June 1992, large-scale arrests of non-Serb civilian men, mostly of Muslim ethnicity, were carried out throughout Foča. ${ }^{2823}$ Non-Serbs were arrested throughout the municipality. Bosnian Muslim men were rounded up in the streets, separated from the women and children and from the Bosnian Serb population. ${ }^{2824}$ Others were arrested in their apartments or in the houses of friends and relatives, taken away from their workplaces, or dragged from their hospital beds and detained at multiple detention facilities. ${ }^{2825}$ Upon arrest and during transportation to detention facilities, they were referred to by Serb soldiers by the derogatory term "balija", cursed, and beaten. ${ }^{2826}$

863. The Foča hospital continued to function and treated both Bosnian Muslims and Bosnian Serbs and civilians of all ethnicities who sought shelter there at the start of the conflict. ${ }^{2827}$ On one occasion, a Bosnian Serb soldier severely kicked three patients in Foča hospital and beat them with a chair after learning that they were Muslim and the beating stopped only when a doctor intervened and called the police. ${ }^{2828}$

864. In April and May 1992, Bosnian Muslim households were searched by the Bosnian Serb MP or soldiers, including for weapons and money. ${ }^{2829}$ Bosnian Serb houses were not searched, or at most were searched superficially. ${ }^{2830}$ Bosnian Muslims were ordered to surrender their weapons while Serbs were allowed to keep theirs. ${ }^{2831}$ Many of the Bosnian Muslims gave up their personal weapons so that they would not be accused of participating in the conflict. ${ }^{2832}$

\footnotetext{
2822 See Adjudicated Fact 766.

2823 See Adjudicated Fact 822.

2824 See Adjudicated Fact 767.

2825 KDZ239, T. 18946, 18984 (16 September 2011). See Adjudicated Fact 768.

2826 See Adjudicated Facts 766, 780.

2827 D3128 (Witness statement of Veljko Marić dated 16 March 2013), paras. 5, 8-13, 21-23; Veljko Marić, T. 35570-35574, 35578, 35580-35582, 35607-35613, 35621-35622 (19 March 2013); D3129 (Record of patients in pediatric ward of Foča Hospital March - December 1992); D3130 (Record of patients in Foča Hospital); D3131 (Excerpt from Foča Hospital patients log); D3132 (Excerpt from list of patients transferred from Goražde to Pljevlja, 1992). See also D3314 (Witness statement of Radojica Mlađenović dated 1 April 2013), para. 22; P6080 (Report of Foča Military Post, 10 October 1992).

2828 Adjudicated Fact 781. Veljko Marić testified that he had never heard about this incident. D3128 (Witness statement of Veljko Marić dated 16 March 2013), para. 26. The Chamber does not consider that Marić's lack of knowledge about this incident is inconsistent with it having occurred.

2829 See Adjudicated Fact 776. See also Milorad Krnojelac, D2716 (Transcript from Prosecutor v. Krnojelac), T. 7888. The Chamber notes that D1684 (Order of Foča Crisis Staff) is an order by the Foča Crisis Staff to the MP to disarm and take into custody any person involved in theft in the town and to "prohibit any misuse and conduct unbecoming a soldier". However, given that the order is undated, this limits its probative value. 
865. From April 1992, Bosnian Muslims were laid off from their jobs or were prevented or discouraged from reporting to work. ${ }^{2833}$ Restrictions were placed on the movement of non-Serbs and announcements were made over the radio and with a loudspeaker on a police car that Bosnian Muslims were not allowed to move about. ${ }^{2834}$ At the same time, the Bosnian Serb population could move around freely, with the exception of a night curfew from 8 p.m. to 6 a.m. imposed on all inhabitants. $^{2835}$ Bosnian Muslims were forbidden to meet with each other, and had their phone lines cut off. ${ }^{2836}$ Restrictions imposed resulted in them being under virtual house arrest. ${ }^{2837}$ Military check-points were established, controlling access in and out of Foča and its surrounding villages. $^{2838}$

866. Paramilitary formations were present in Foča, including units known as Tuta's Group, Pero's group, Brane Ćosović's group, Gojko Janković's group, and Zaga's unit which was led by Dragan Kunarac, a.k.a. Zaga. ${ }^{2839}$ Paramilitaries were involved in looting gold, jewellery, and money from homes. ${ }^{2840}$ Commanders of these units would visit Kovač. ${ }^{2841}$ However, by May 1992

$2833 \quad$ See Adjudicated Facts 770, 771.

2834 See Adjudicated Fact 772. Defence witnesses disputed this adjudicated fact and testified that it was dangerous for all citizens to walk around and that there were no restrictions on the movement of the non-Serb population except during the curfew when all citizens were subject to movement restrictions. D3314 (Witness statement of Radojica Mlađenović dated 1 April 2013), paras. 25, 57; D3128 (Witness statement of Veljko Marić dated 16 March 2013), para. 25. The Chamber does not consider that this evidence is reliable. In reaching that conclusion, the Chamber noted that Mlađenović's evidence was marked by multiple contradictions and extreme evasiveness. With respect to Marić, the Chamber notes that he simply states that Adjudicated Fact 772 is not correct and that it was dangerous for all citizens to walk around but does not expressly address whether or not there were additional restrictions imposed on Bosnian Muslims.

2835 See Adjudicated Fact 772.

2836 See Adjudicated Fact 773. Radojica Mlađenović disputed this adjudicated fact and testified that it was not possible to selectively disconnect phone lines. D3314 (Witness statement of Radojica Mlađenović dated 1 April 2013), para. 58. The Chamber does not consider that it can rely on this evidence as it was marked by multiple contradictions and extreme evasiveness which undermined his credibility.

2837 See Adjudicated Fact 774.

$2838 \quad$ Adjudicated Fact 775.

2839 P90 (Witness statement of KDZ216 dated 8 June 1998), pp. 6, 13, 15 (under seal); D4002 (Letter from BiH MUP to Vasvija Vidović, 4 July 1995), p. 23; P69 (Transcript from Prosecutor v. Kunarac), T. 3330, 3378, 3385-3386 (under seal); Milutin Vujičić, T. 32127-32128 (17 January 2013); Trifko Pljevaljčić, T. 3233132332 (21 January 2013). See also P3354 (Order of Foča Tactical Group, 7 July 1992), p. 3 (identifying the involvement of Zaga's unit in mopping up operations).

2840 P90 (Witness statement of KDZ216 dated 8 June 1998), p. 15 (under seal).

2841 P69 (Transcript from Prosecutor v. Kunarac), T. 3386 (under seal); P90 (Witness statement of KDZ216 dated 8 June 1998), p. 15 (under seal). See also Radojica Mlađenović, T. 36673 (5 April 2013) (testifying that these units "acted in concert with regular units of the army"). Defence witnesses testified that paramilitary groups (i) came to the municipality randomly for the purposes of plunder; (ii) were not considered welcome by the civilian and military authorities; and (iii) killed both Bosnian Serbs and Bosnian Muslims. D3314 (Witness statement of Radojica Mlađenović dated 1 April 2013), paras. 42-43; Mitar Rašević, T. 46813-46815 (11 February 2014); Trifko Pljevaljčić, T. 32332-32333 (21 January 2013); D2767 (Witness statement of Milutin Vujičić dated 14 January 2013), para. 10; Milutin Vujičić, T. 32124 (17 January 2013). The Chamber does not find this evidence to be reliable. In this regard, with respect to Vujičić the Chamber notes a contradiction in his evidence. On the one hand, Vujičić states that the paramilitary formations were completely unknown to him, but he knew that they killed people regardless of ethnicity. Similarly, the evidence of Mlađenovic that these groups came randomly is contradicted by his evidence that some of the units "acted in concert with the regular units of the 
the authorities attempted to expel paramilitary formations from the municipality. ${ }^{2842}$ In July 1992, Mićo Stanišić instructed the special unit led by Davidović and Andan to establish law and order in Foča and to take measures against paramilitaries who were disrupting the functioning of the legal authorities. $^{2843}$

\section{(1) Scheduled Incident A.5.2}

867. The Prosecution alleges that a number of civilians from the village of Jeleč were killed between 1 and 5 May 1992.

868. Jeleč is a village about 22 kilometres from Foča near Miljevina. Jeleč was shelled, attacked by infantry, and taken over by Serb Forces on 4 or 5 May 1992. ${ }^{2844}$ Serb Forces set Jeleč on fire after which the population fled to a nearby forest. Muslims who stayed in their homes or who tried to escape were killed. ${ }^{2845}$ Other male Bosnian Muslim villagers were captured and detained before being transferred to the KP Dom Foča. ${ }^{2846}$

869. The Chamber therefore finds that a number of civilians from the village of Jeleč were killed by Serb Forces between 1 and 5 May 1992.

\section{(2) $\underline{\text { Scheduled Incident A.5.4 }}$}

870. The Prosecution alleges that a number of people hiding in the woods near Mješaja/Trošanj were killed in early July 1992.

army". In addition the evidence of these witnesses is marked by multiple other contradictions and extreme evasiveness, which undermine their credibility.

2842 KDZ379, T. 18889 (15 September 2011); D2767 (Witness statement of Milutin Vujičić dated 14 January 2013), para. 9; Trifko Pljevaljčić, T. 32332 (21 January 2013).

2843 Dragomir Andan, D3774 (Transcript from Prosecutor v. Stanišić \& Župljanin), T. 21493-21494, $21503,21505$. See also D4312 (Report of RS MUP, 14 September 1992), p. 1; D1675 (Report re Foča police station, 1 December 1992), pp. 1-4; D3314 (Witness statement of Radojica Mlađenović dated 1 April 2013), para. 47.

2844 See Adjudicated Fact 760.

2845 See Adjudicated Fact 761. See also Adjudicated Fact 752. The Prosecution refers to Mašović's evidence with respect to the exhumation of one individual who it links to this incident. Prosecution Final Brief, Appendix G, Foča, Scheduled Incident A.5.2. Mašović refers to one individual from Jeleč who went missing on 4 May 1992 and who was exhumed from a grave. P4853 (Updated Table 2 to the Report of Amor Mašović), p. 6. However, the Chamber is not satisfied that, in the absence of further evidence it can link the named individual with this scheduled incident based on Mašović's evidence and will therefore not rely on this exhumation evidence for the purposes of entering findings with respect to this incident. Mlađenović testified that Jeleč was a stronghold of the Patriotic League and Serb Forces "liberated" the village after previous failed attempts to negotiate for the return of weapons and to avoid clashes. D3314 (Witness statement of Radojica Mlađenović dated 1 April 2013), para. 41. Similarly the Accused made a submission that the casualties in Jeleč were collateral damage in a military operation. Defence Final Brief, para. 1771. However, the Chamber does not consider that Mlađenović's evidence or the Accused's unsupported submission contradicts the evidence which relates to the conduct of the members of Serb Forces who entered Jeleč, burnt down the village, forced villagers to flee, and killed those who remained in their houses or who tried to escape.

2846 See Adjudicated Fact 761. See Scheduled Detention Facility C.10.1 for evidence relating to detention and treatment at KP Dom Foča. 
871. On 3 July 1992, the Bosnian Muslim village of Mješaja/Trošanj, situated between Foča and Tjienstište, was attacked by Serb Forces including units led by Gojko Janković and Radomir Kovač. $^{2847}$ Kovač was a member of Ćosović's group. ${ }^{2848}$

872. At the time of the attack, some Bosnian Muslim villagers in Trošanj continued living in their houses but would sleep in the woods at night and only return to their homes during the daytime. $^{2849}$ They were afraid because they saw other Muslim villages burning and felt targeted as Muslims. ${ }^{2850}$ The Chamber also took judicial notice that three villagers in Mješaja/Trošanj were killed during the initial attack. ${ }^{2851}$ However, the Chamber does not have sufficient evidence as to the circumstances surrounding the deaths of these three individuals during the attack on the village to make a finding in this regard.

873. After capturing a group of about 50 Muslim villagers, Serb Forces separated the men from the women. The women were chased down a hill towards the village and seven detained men were beaten and then killed. ${ }^{2852}$ Serb soldiers hit the villagers with rifle butts and tree branches, kicking them, and calling them "Ustashas" and one of the Muslims lost an eye as a result of the beating. ${ }^{2853}$

2847 See Adjudicated Facts 763, 2398. The Chamber received evidence that Janković went to villages to identify how Bosnian Muslims and Bosnian Serbs could be rescued and that there had been previous attempts to negotiate the surrender of weapons in the village of Trošanj and assurances given to Bosnian Muslims who surrendered their weapons. Milutin Vujičić, T. 32128 (17 January 2013); D3316 (Agreement between Trošanj Muslim representatives and Foča authorities, 24 April 1992), p. 1. However, the Chamber does not accept that this evidence is reliable or can be connected with this incident. In reaching that conclusion the Chamber noted that Vujičić's evidence was marked by evasiveness and indicators that he was attempting to mislead the Chamber, which resulted in his credibility being undermined. In addition, the Chamber notes that Mlađenović acknowledged that he may have not been properly informed about all events in the village and denied any knowledge of evidence which suggested that Bosnian Muslims did in fact hand over weapons. Radojica Mlađenović, T. 36655-36656 (5 April 2013). The Chamber therefore does not consider that Mlađenović's evidence casts any doubt on the evidence received which relates to the conduct of Serb Forces during the attack.

KDZ216, P69 (Transcript from Prosecutor v. Kunarac), T. 3385 (under seal).

Adjudicated Fact 764.

See Adjudicated Fact 764. See also Adjudicated Fact 752.

See Adjudicated Facts 765, 2398, 2399.

See Adjudicated Facts 765, 2398, 2399, 2401. The Prosecution refers to Mašović's evidence with respect to the exhumation of one individual who it links to this incident. Prosecution Final Brief, Appendix G, Foča Scheduled Incident A.5.4. Mašović's evidence is that ten bodies which were exhumed from a mass grave at Trošanj are linked to individuals who went missing on 1 May 1992. P4853 (Updated Table 2 to the Report of Amor Mašović), p. 6. The Chamber notes that this date is not consistent with the evidence which suggested that these killings occurred in July 1992. In addition, in the absence of further evidence, the Chamber cannot link the named individual with this scheduled incident based on Mašović's evidence and will therefore not rely on this exhumation evidence for the purposes of entering findings with respect to this incident.

See Adjudicated Fact 2400. 
Some Bosnian Muslims from the village were taken to detention facilities including KP Dom ${ }^{2854}$ and the Worker's Huts at Buk Bijela. ${ }^{2855}$

874. The Chamber therefore finds that Serb Forces killed at least seven Bosnian Muslim civilians from the village of Mješaja/Trošanj in July 1992.

\section{(E) Detention Facilities in Foča}

\section{(1) Scheduled Detention Facility C.10.6}

875. The Indictment refers to the use of the TO military warehouses at Livade as a detention facility between 14 and 17 April 1992.

876. In mid-April 1992, many Bosnian Muslim civilians who were arrested in the centre of Foča or other areas of the town were taken and detained at the TO military warehouses at Livade. ${ }^{2856}$ Those detained included several doctors and medical staff from Foča hospital and members of the SDA who were arrested by soldiers, including members of the TO and soldiers in camouflage JNA uniforms. $^{2857}$ During the arrests, several of the detainees were severely beaten and injured while others had their hands tied before being taken away. ${ }^{2858}$ In mid April 1992, approximately 80 to 100 men were detained in hangars at the facility. ${ }^{2859}$ This figure did not include the women and children who were separated and taken to other hangars. ${ }^{2860}$ Most the people detained were Bosnian Muslims and one was a Bosnian Croat. ${ }^{2861}$

877. Some detainees who arrived at the facility had already been severely beaten. ${ }^{2862}$ Veselin Čančar was the commander of Livade and was heard cursing and threatening the detainees. ${ }^{2863} \mathrm{~A}$

2854 Trifko Pljevaljčić, T. 32346 (21 January 2013). See Scheduled Detention Facility C.10.1 for evidence relating to detention and treatment at KP Dom Foča.

2855 See Adjudicated Fact 2407. See Scheduled Detention Facility C.10.4 for evidence relating to detention and treatment at the Worker's Huts at Buk Bijela.

2856 See Adjudicated Facts 782, 783, 784, 785.

2857 KDZ239, P3335 (Transcript from Prosecutor v. Krnojelac), T. 1195-1200, 1198-1199 (under seal). See also Adjudicated Fact 785. Mlađenović stated that Bosnian Muslim civilians were brought to this facility for a short time as they were suspected of being involved in the arming of the Bosnian Muslim population. D3314 (Witness statement of Radojica Mlađenović dated 1 April 2013), para. 36. The Chamber does not find this evidence to be reliable. In reaching that conclusion the Chamber noted that Mlađenović's evidence was marked by multiple contradictions and extreme evasiveness.

2858 Adjudicated Fact 786. See also KDZ239, P3335 (Transcript from Prosecutor v. Krnojelac), T. 1197 (under seal).

2859 KDZ239, P3336 (Transcript from Prosecutor v. Krnojelac), T. 1200. See also Milorad Krnojelac, D2716 (Transcript from Prosecutor v. Krnojelac) T. 7887-7888.

2860 KDZ239, P3336 (Transcript from Prosecutor v. Krnojelac), T. 1200.

2861 KDZ239, P3336 (Transcript from Prosecutor v. Krnojelac), T. 1200, 1202. The Bosnian Croat was identified as Krunoslav Marinović.

2862 KDZ239, P3336 (Transcript from Prosecutor v. Krnojelac), T. 1200, 1202.

2863 KDZ239, P3336 (Transcript from Prosecutor v. Krnojelac), T. 1201-1202. 
boy who was captured in the town of Foča and brought to Livade, was tied to a fence and beaten with ropes. ${ }^{2864}$ While the detainees could not see the beating, they could hear the blows, his screams and the "rope piercing the air". 2865

878. KDZ239 testified that the conditions at the facility were very poor, there "was a lot of humidity there. Hygienic conditions were poor, also food was not good, and this was not a good place to stay either. Conditions were poor". ${ }^{2866}$ The Chamber does not consider that KDZ239's evidence in this regard provides sufficient detail to allow the Chamber to make a finding as to the conditions of detention at this facility. On 17 April 1992, all the male Bosnian Muslim civilians detained at Livade were transferred to the KP Dom Foča. ${ }^{2867}$

879. Based on the above, the Chamber finds that non-Serbs were brought to and detained at the TO military warehouses in Livade in mid-April 1992 and that some of the detainees were beaten there.

\section{(2) Scheduled Detention Facility C.10.1}

880. The Indictment refers to the use of the KP Dom Foča as a detention facility from 18 April 1992 until at least 31 December $1992 .^{2868}$

(a) Arrival of detainees and control over the detention facility

881. Before the war KP Dom functioned as a prison with a capacity of between 600 and 800 detainees. $^{2869}$ However, many of these detainees were released or escaped in the lead-up to the war. $^{2870}$ Bosnian Muslims who had been arrested were transferred to the KP Dom Foča from midApril 1992. ${ }^{2871}$ For example, all Bosnian Muslim civilians detained at Livade were transferred to

\footnotetext{
2864 KDZ239, P3336 (Transcript from Prosecutor v. Krnojelac), T. 1202.

2865 KDZ239, P3336 (Transcript from Prosecutor v. Krnojelac), T. 1202.

2866 KDZ239, P3336 (Transcript from Prosecutor v. Krnojelac), T. 1202.

2867 See Adjudicated Fact 823; KDZ239, P3336 (Transcript from Prosecutor v. Krnojelac), T. 1204; Radojica Mlađenović, T. 36657 (5 April 2013). See also Milorad Krnojelac, D2716 (Transcript from Prosecutor v. Krnojelac) T. 7887-7888.

2868 The Prosecution submits that the evidence shows that the facility operated from 18 April 1992 until 4 October 1994. Prosecution Final Brief, Appendix B.

2869 D4307 (Witness statement of Mitar Rašević dated 2 February 2014), paras. 3-5. See also P6657 (Sketch of KP Dom marked by Mitar Rasević); Adjudicated Fact 823; Milorad Krnojelac, D2716 (Transcript from Prosecutor v. Krnojelac), T. 7669 (testifying that to his knowledge the facility could house between 1,000 and 1,200 people); KDZ017, P3568 (Transcript from Prosecutor v. Krnojelac), T. 2894-2895; D3314 (Witness statement of Radojica Mlađenović dated 1 April 2013), para. 48; Radojica Mlađenović, T. 36657, 36667 (5 April 2013); D3105 (Witness statement of Slobodan Avlijaš dated 9 March 2013), paras. 34-35; P5527 (Decision of Radovan Karadžić to establish Correctional Facility in Foča), p. 1.

2870 D4307 (Witness statement of Mitar Rašević dated 2 February 2014), para. 5.

2871 See Adjudicated Facts 822, 823; KDZ239, T. 18914-18915 (15 September 2011).
} 
the KP Dom in mid April 1992. ${ }^{2872}$ When this group arrived there were already between 40 and 60 detainees in one room. ${ }^{2873}$ After a few days the names and professions of the detainees were recorded by one of the guards. ${ }^{2874}$ Towards the end of April 1992, detainees were taken from the Velečevo prison to KP Dom. At the entrance of the KP Dom there was a bus filled with women and children. ${ }^{2875}$ A group of about 20 Bosnian Muslims from Foča who had fled were arrested in Montenegro and brought to KP Dom in May 1992 under the escort of police from Foča. ${ }^{2876}$ After a few days, 50 to 60 other Bosnian Muslims civilians were brought from Foča and surrounding villages to the facility. ${ }^{2877}$ More non-Serb detainees were brought to the facility in June $1992 .^{2878}$ Some Bosnian Serbs were also detained at the facility primarily for breaches of military discipline. $^{2879}$

882. Even though Bosnian Muslims had been transferred to the facility from mid-April 1992, it was only on 4 July 1992 that the KP Dom Foča was formally established following a decision by the government of the SerBiH. ${ }^{2880}$ Members of the municipal level military and civilian authorities visited the facility. ${ }^{2881}$ Both the Ministry of Justice and the military authorities in Foča had responsibility and exercised control over the facility. ${ }^{2882}$ However, it was the military authorities at

2872 See Adjudicated Fact 823; KDZ239, T. 18914-18915 (15 September 2011) (testifying that none of the detainees had been on the frontline). On arrival, detainees from Livade were met by soldiers and police. KDZ239, P3336 (Transcript from Prosecutor v. Krnojelac), T. 1204. See also Radojica Mlađenović, T. 36657 (5 April 2013); Milorad Krnojelac, D2716 (Transcript from Prosecutor v. Krnojelac), T. 7887-7888.

2873 KDZ239, P3336 (Transcript from Prosecutor v. Krnojelac), T. 1217.

2874 KDZ239, P3336 (Transcript from Prosecutor v. Krnojelac), T. 1204.

2875 KDZ379, P3332 (Transcript from Prosecutor v. Krnojelac), T. 3127, 3129.

2876 KDZ017, P3568 (Transcript from Prosecutor v. Krnojelac), T. 2774-2778, 2781-2782, 2789, 2793; KDZ017, T. 19894-19896 (4 October 2011); Momir Bulatović, T. 34569-34571 (1 March 2013). Miodrag Stevanović an official from Foča was involved in this arrest and transfer. The group of detainees brought from Montenegro included Bosnian Serb soldiers who had deserted but they were only detained at the KP Dom for a few days. This transfer occurred at the request of the Foča SUP. D1746 (Excerpt from report), pp. 1-4.

2877 KDZ017, P3568 (Transcript from Prosecutor v. Krnojelac), T. 2789.

2878 KDZ017, P3568 (Transcript from Prosecutor v. Krnojelac), T. 2792, 2799, 2820-2821 (testifying that those detained with him included men in their 60s and 70s and two of the 72 detainees held in his room were Bosnian Croats while the remainder were Bosnian Muslims).

2879 D2767 (Witness statement of Milutin Vujičić dated 14 January 2013), para. 31; KDZ017, P3568 (Transcript from Prosecutor v. Krnojelac), T. 2793; see Adjudicated Fact 826; P5545 (Report of Foča Penal and Correctional Facility, 11 July 1992), p. 3; D2722 (Report of KP Dom Foča to RS Ministry of Justice, undated), pp. 16-17; KDZ379, T. 18858 (15 September 2011).

2880 P1098 (Minutes of $36^{\text {th }}$ session of SerBiH Government, 4 July 1992), pp. 2, 4; Slobodan Avlijaš, T. 35153 (11 March 2013); P6195 (Report on organising judiciary institutions in Foča); D3105 (Witness statement of Slobodan Avlijaš dated 9 March 2013), para. 8.

2881 D4307 (Witness statement of Mitar Rašević dated 2 February 2014), para. 16. Rašević identified Marko Kovač as one of the individuals who visited the facility.

2882 See Adjudicated Facts 836, 837, 838, 839, 840; D3314 (Witness statement of Radojica Mlađenović dated 1 April 2013), para. 48; D4307 (Witness statement of Mitar Rašević dated 2 February 2014), paras. 11-16; Milorad Krnojelac, D2716 (Transcript from Prosecutor v. Krnojelac), T. 7599, 7944, 8175-8176; P6195 (Report on organising judiciary institutions in Foča), p. 2; P3343 (Ruling of RS Ministry of Justice and Administration, 16 December 1992), p. 1; P5545 (Report of Foča Penal and Correctional Facility, 11 July 1992), p. 1. While the Chamber accepts that there may have been difficulties in communication, Rašević's evidence that there was no contact between the KP Dom on the one hand and the Minister of Justice and the Republican 
KP Dom that had the power to make decisions concerning which non-Serb detainees would be detained in, and released from, the facility. ${ }^{2883}$ The military authorities at KP Dom could also make decisions about which persons would be permitted to enter the facility, and had some power over the appointment of persons to work assignments at the facility. ${ }^{2884}$ Krnojelac was kept informed about who was to be detained by the military authorities and who was to be released ${ }^{285}$ and was obliged to forward requests for release of these detainees to the Foča Crisis Staff or the Foča Tactical Group. ${ }^{2886}$ Krnojelac did forward some requests for release of Bosnian Muslim detainees to the Foča Crisis Staff and to the Foča Tactical Group and some requests were approved after the detainees had been processed. ${ }^{2887}$

883. Bosnian Muslim civilians who were arrested by Serb Forces were detained at KP Dom for periods lasting from four months to more than two and a half years. ${ }^{2888}$ They were not detained on any legal grounds and their continued detention was not subject to review by Serb authorities. ${ }^{2889}$

government on the other for a period for several months is not credible and in any event does not rule out the possibility of communication between other organs of the local authorities and the Republican government. See D4307 (Witness statement of Mitar Rašević dated 2 February 2014), para. 40.

2883 See Adjudicated Fact 837; P3347 (Order of Foča's Military Post, 7 September 1992); KDZ239, T. 18921 (15 September 2011). See also Milorad Krnojelac, D2716 (Transcript from Prosecutor v. Krnojelac), T. 8138; Milorad Krnojelac, D2715 (Testimony of Milorad Krnojelac in Prosecutor v. Krnojelac), T. 7687-7689, 7691 (under seal).

$2884 \quad$ See Adjudicated Fact 839.

2885 See Adjudicated Fact 838.

2886 See Adjudicated Fact 837; Milorad Krnojelac, D2716 (Transcript from Prosecutor v. Krnojelac), T. 7645-7648; D2723 (Request for release from KP Dom Foča, 30 July 1992); D2724 (Request for release from KP Dom Foča, 30 July 1992); D2725 (Request for release from KP Dom Foča, 14 May 1992).

2887 Milorad Krnojelac, D2716 (Transcript from Prosecutor v. Krnojelac), T. 7936-7938, 7940-7943; P3344 (Letter from KP Dom Foča's Acting Warden to Foča Crisis Staff, 15 May 1992); KDZ239, T. 18917 (15 September 2011), T. 18986-18987 (16 September 2011); D1688 (Report of Foča Tactical Group “A”, 18 July 1992); P5540 (Discharge letter of Foča Crisis Staff re the release of Dževad Dedović, 7 May 1992); P5539 (Discharge letter of Foča Crisis Staff re the release of Enes Zuko, 21 May 1992); P5526 (Certificate of the Foča Crisis Staff, 7 July 1992); D1691 (Travel permit of Foča SJB, 26 June 1992); D1687 (List of men released from KP Dom Foča, 8 December 1992).

2888 See Adjudicated Fact 825; KDZ017, P3568 (Transcript from Prosecutor v. Krnojelac), T. 2818, 2820. Defence witnesses testified that the KP Dom Foča and other detention facilities (i) were "reception facilities" which were used by the Bosnian Serb authorities to protect and guarantee the security of these civilians from uncontrolled paramilitary and criminal elements; (ii) Bosnian Muslims who were held at these centres could ask for permission from the guards to either leave the municipality or to return to their villages to care for livestock or buy food from the shops. D2767 (Witness statement of Milutin Vujičić dated 14 January 2013), paras. 31, 33; Milutin Vujičić, T. 32097, 32133 (17 January 2013); Trifko Pljevaljčić, T. 32313-32316, 32344 (21 January 2013). The Chamber does not find this evidence to be reliable. In reaching that conclusion, the Chamber noted that Vujičić's evidence was marked by evasiveness and indicators that he was seeking to mislead the Chamber which undermined his credibility in this regard. With respect to Pljevaljčić's evidence on this issue, he testified in general terms and the Chamber is not satisfied that it pertains specifically to those detained at KP Dom Foča.

2889 See Adjudicated Facts 826, 827. Mitar Rašević testified that no detainee was brought to the facility without being referred by the army command with appropriate documentation which listed the grounds for detention. D4307 (Witness statement of Mitar Rašević dated 2 February 2014), paras. 29, 43; Mitar Rašević, T. 46816 (11 February 2014). The Chamber does not find this evidence to be reliable. In reaching that conclusion, the Chamber noted contradictions in the testimony of Rašević in this regard and his denial of knowledge that documentation used for the detention of individuals contained standard wording which suggested that they were captured in war operations, when they were actually civilians. Mitar Rašević, T. 46777-46780 
Investigators from the MUP came to the KP Dom to interrogate detainees. ${ }^{2890}$ The Chamber also received evidence that in February 1993, Slobodan Avlijaš sent a letter to penal and correctional facilities, including the KP Dom Foča, noting that the Ministry of Justice had been informed that people were detained without detention orders from a competent court. Avlijaš requested these correctional facilities to inform the Ministry about the number of detainees and those who did not have detention orders and to release the latter. ${ }^{2891}$ However, ultimately, the Bosnian Muslim detainees were not suspected, charged, tried, or convicted for any crime before being detained or while detained at the KP Dom ${ }^{2892}$ nor were they advised of their rights before or during their detention. ${ }^{2893}$ After the conflict started, the overwhelming majority of those detained at the facility were Bosnian Muslims, these included doctors and medical health workers, journalists, former KP Dom employees, managers, police officers, and other civilians. ${ }^{2894}$ No consideration was given to age, state of health or civilian status. The detainees ranged from 15 to almost 80 years of age. ${ }^{2895}$ In addition to the mainly civilian population at the KP Dom, there was a small number of Bosnian Muslim soldiers kept in isolation cells separately from the civilian detainees. ${ }^{2896}$

884. In mid-April-1992, the facility was run by the Užice Corps of the JNA. ${ }^{289}$ Apart from members of the Užice Corps, the civilian police, and people from Serbia were also present at the

(11 February 2014); P6656 (Excerpt from Mitar Rašević's testimony before BiH State Court, 11 December 2007), pp. 5-6. Similarly, the Chamber notes contradictions in Krnojelac's evidence on this issue. He initially testified that he was told people were detained there because they were Bosnian Muslims but later retracted this statement. Milorad Krnojelac, D2716 (Transcript from Prosecutor v. Krnojelac), T. 7844-7845. 
KP Dom. ${ }^{2898}$ When the Užice Corps left, a unit known as the Livade Company consisting of local Bosnian Serbs, including the police, took responsibility for detained Bosnian Muslims. ${ }^{2899}$

885. On 18 April 1992, Milorad Krnojelac was appointed by the Foča Crisis Staff as the warden of KP Dom. ${ }^{2900}$ Krnojelac was associated with members of the SDS and wore a military uniform at the facility. ${ }^{2901}$ Savo Todović was the deputy warden and issued orders to detainees regarding work obligations. $^{2902}$ Bosnian Muslim detainees could not be taken away from the facility without prior authorisation by Todovic ${ }^{2903}$ or Krnojelac. ${ }^{2904}$ Mitar Rašević was the commander of the guards at the facility. ${ }^{2905}$ The guards included the former guards of KP Dom and wore military uniforms, the old KP Dom uniform, while others wore standard police, military, camouflage and multicoloured

2898 KDZ239, P3336 (Transcript from Prosecutor v. Krnojelac), T. 1211. See also D4307 (Witness statement of Mitar Rašević dated 2 February 2014), para. 13.

2899 See Adjudicated Fact 823; Milorad Krnojelac, D2716 (Transcript from Prosecutor v. Krnojelac), T. 7610-7611, 7615, 7618-7619, 8217-8218.

2900 KDZ239, P3336 (Transcript from Prosecutor v. Krnojelac), T. 1213; D4307 (Witness statement of Mitar Rašević dated 2 February 2014), para. 11; Mitar Rašević, T. 46774-46775 (11 February 2014); D3314 (Witness statement of Radojica Mlađenović dated 1 April 2013), para. 48; D2729 (Letter from RS Ministry of Justice and Administration re Krnojelac's employment status, 3 June 1994). See also Milorad Krnojelac, D2716 (Transcript from Prosecutor v. Krnojelac), T. 7600, 7638-7639, 7710-7711, 7768, 7775-7777 (testifying that he only received formal appointment to this role from the Ministry of Justice in July or August 1992). See P1141 (Decision of Ministry of Justice of SerBiH appointing Milorad Krnojelac, 17 July 1992). The Chamber notes Krnojelac's testimony that he was appointed to this post by the president of the Executive Board of the municipal assembly of Foča and denied knowledge that the Foča Crisis Staff appointed him to the post of warden of the facility or that he had the Foča Crisis Staff phone number. However, the Chamber does not consider his evidence to be reliable given that he was directly contradicted during his prior cross-examination which showed that he did have the Foča Crisis Staff number. Milorad Krnojelac, D2716 (Transcript from Prosecutor v. Krnojelac), T. 7604, 7781, 7784, 7844-7845. See also P3349 (List of persons working at Srbinje Penal and Correctional Facility between April 1992 and October 1994), p. 1, where Milorad Krnojelac is listed as a temporary acting warden from 18 April 1992 to 17 July 1992.

2901 KDZ017, P3568 (Transcript from Prosecutor v. Krnojelac), T. 2900-2901, 2905.

2902 KDZ017, P3568 (Transcript from Prosecutor v. Krnojelac), T. 2911-2912, 2927; KDZ239, P3336 (Transcript from Prosecutor v. Krnojelac), T. 1280; D4307 (Witness statement of Mitar Rašević dated 2 February 2014), paras. 11, 15; Milorad Krnojelac, D2715 (Transcript from Prosecutor v. Krnojelac), T. 7691 (under seal). Todović was appointed acting deputy warden of KP Dom on 16 December 1992 by a ruling signed by Momčilo Mandić. P3343 (Ruling of RS Ministry of Justice and Administration, 16 December 1992), p. 1; KDZ239, T. 18916 (15 September 2011)

2903 D4307 (Witness statement of Mitar Rašević dated 2 February 2014), para. 15.

2904 See Adjudicated Fact 840. The Chamber does not accept Krnojelac's evidence on this point which sought to minimise his involvement in the facility and which sought to distance himself from anything to do with detainees and his claims that he raised concerns about the detainees. Milorad Krnojelac, D2716 (Transcript from Prosecutor v. Krnojelac), T. 7605-7606, 7614, 7618, 7623-7626, 7639, 7654, 7855. The Chamber finds that his testimony is contradicted by other evidence received including Krnojelac's own reports regarding the use of the facility for the accommodation of Bosnian Muslim detainees and the request for personnel and funds. D2732 (Report of KP Dom Foča, 6 May 1993); P5545 (Report of Foča Penal and Correctional Facility, 11 July 1992).

2905 KDZ017, P3568 (Transcript from Prosecutor v. Krnojelac), T. 2915; Milorad Krnojelac, D2716 (Transcript from Prosecutor v. Krnojelac), T. 8070; Milorad Krnojelac, D2715 (Transcript from Prosecutor v. Krnojelac), T. 7691 (under seal); D4307 (Witness statement of Mitar Rašević dated 2 February 2014), para. 1; Mitar Rašević, T. 46752-46754 (11 February 2014); D4308 (Excerpt of rules governing the internal organisation of KP Dom Foča, August 1992). See also KDZ239, P3336 (Transcript from Prosecutor v. Krnojelac), T. 12801281. 
uniforms. ${ }^{2906}$ During the first few weeks of detention, military units were responsible at KP Dom. $^{2907}$ Members of the military would enter the KP Dom, although they needed the prior permission of the military authorities. ${ }^{2908}$ Towards the end of April 1992, pursuant to an order of the Executive Board of the Serb Municipality of Foča, approximately 40 people who had worked as policemen were assigned by the Foča Crisis Staff to work at the KP Dom. ${ }^{2909}$ The Foča Crisis Staff also appointed authorised persons for the purposes of interrogations at the facility. ${ }^{2910}$

886. In May 1992, the Command of the Foča Tactical Group requested the allocation of rooms within the KP Dom for "accommodation of prisoners of war". ${ }^{2911}$ This request was approved by Krnojelac. $^{2912}$ In August 1992, the Bosnian Serb Government established commissions for the inspection of "collection centres and other facilities for prisoners". 2913 These commissions were instructed to look into the status of people held at these facilities in accordance with international conventions, to speed up the processing of these individuals, and to report on their inspection. ${ }^{2914}$ Avlijaš was a member of a commission which visited Foča and was informed by the commander of the Foča Tactical Group that the "prisoners of war in the facility" were his business and it was a military matter for him to handle. ${ }^{2915}$ In November 1992, Krnojelac reported to the Ministry of Justice that the KP Dom was used for the accommodation of Bosnian Muslim "prisoners of war" and requested a resolution about the legal status of the KP Dom. ${ }^{2916}$

887. Some detainees were released after interrogation on the condition that they report daily to the police or were released for the purposes of exchange. ${ }^{2917}$ Groups of detainees were transferred

2906 KDZ239, P3336 (Transcript from Prosecutor v. Krnojelac), T. 1281; KDZ017, P3568 (Transcript from Prosecutor v. Krnojelac), T. 2916; D4307 (Witness statement of Mitar Rašević dated 2 February 2014), para. 13. See also Adjudicated Fact 835; P3349 (List of persons working at Srbinje Penal and Correctional Facility between April 1992 and October 1994); D2730 (Decision of SerBiH Presidency published in Official Gazette, 12 May 1992), pp. 1-2.

2907 See Adjudicated Facts 834, 833.

2908 Adjudicated Fact 840.

2909 KDZ239, T. 18910-18914 (15 September 2011); P3340 (Decision of Foča Executive Board, 26 April 1992); Radojica Mlađenović, T. 36661 (5 April 2013).

2910 P6268 (Request of KP Dom Foča to Foča Crisis Staff, 20 May 1992); Radojica Mlađenović, T. 36661-36662 (5 April 2013); P3349 (List of persons working at Srbinje Penal and Correctional Facility between April 1992 and October 1994).

2911 P3341 (Request by Foča's Tactical Group, 8 May 1992).

2912 P3342 (Decision of KP Dom Foča Temporary Warden, May 1992); Milorad Krnojelac, D2716 (Transcript from Prosecutor v. Krnojelac), T. 8168-8169 (testifying that this decision was based on the approval of Mlađenović).

2913 D466 (Decision of Government of SerBiH on establishment of Commission for Inspection of Collection Centres and other facilities for prisoners, 9 August 1992), p. 2.

2914 D466 (Decision of Government of SerBiH on establishment of Commission for Inspection of Collection Centres and other facilities for prisoners, 9 August 1992), pp. 2-3.

2915 D3105 (Witness statement of Slobodan Avlijaš dated 9 March 2013), paras. 33-35.

2916 D2722 (Report of KP Dom Foča to RS Ministry of Justice, undated), pp. 16-17.

2917 D3318 (Foča Crisis Staff certificate of release, 26 April 1992); D4779 (List of POWs released from KP Dom, 12 July 1993); P3345 (List of people to be released from KP Dom Foča, 7 May 1992); KDZ239, T. 18918 
from the KP Dom to other camps in $\mathrm{BiH}$, including the Kula camp before eventually being exchanged. $^{2918}$ On at least one occasion, detainees were taken across a national border (to Montenegro) in these exchanges. ${ }^{2919}$

888. At its peak in the summer of 1992, there were about 500 to 600 detainees at the KP Dom. $^{2920}$ This number decreased from the autumn of 1992 until 1993 when about 200 to 300 detainees remained. $^{2921}$ The last detainees were only released from the facility in October 1994. ${ }^{2922}$ However, given that the Indictment only alleges detention until at least 31 December 1992 at KP Dom, the Chamber will not make findings with respect to detention after this date.

\section{(b) Conditions of detention}

889. The detainees were forced to endure inadequate living conditions while being detained at the KP Dom, as a result of which numerous individuals have suffered lasting physical and psychological problems. ${ }^{2923}$ Defence witness Rašević referring to KP Dom expressed regret for the "fate that befell all of these people" and acknowledged that "evil [...] was done to these

(15 September 2011); P5540 (Discharge Letter of Foča Crisis Staff re the release of Dževad Dedović, 7 May 1992); D3105 (Witness statement of Slobodan Avlijaš dated 9 March 2013), para. 60; D1689 (List of men to be released from KP Dom Foča on 21 October 1992); P6206 (Order of Foča Tactical Group, 4 July 1993). See also KDZ379, P3332 (Transcript from Prosecutor v. Krnojelac), T. 3152, 3175-3176; Radojica Mlađenović, T. 36668-36669 (5 April 2013); Milorad Krnojelac, D2716 (Transcript from Prosecutor v. Krnojelac), T. 79287932. Avlijaš testified that one of these exchanges was done independently of the central authorities which did not have knowledge of events in Foča until December 1992. D3105 (Witness statement of Slobodan Avlijaš dated 9 March 2013), para. 60. However, the witness when cross-examined acknowledged that he was not in a position to know what kind of information was being reported by representatives of Foča to the Bosnian Serb leadership. Slobodan Avlijaš, T. 35150-35151 (11 March 2013); P6194 (SerBiH Government request to Foča Crisis Staff, 23 May 1992). In light of this qualification the Chamber does not rely on Avlijaš's assessment in this regard.

2918 Soniboj Škiljević, T. 36925 (10 April 2013), T. 36926-36927, 36929-36930 (10 April 2013) (private session); see Adjudicated Fact 876; KDZ239, P3336 (Transcript from Prosecutor v. Krnojelac), T. 1204, 1283 ; P3348 (ICRC Certificate re KDZ239, 1 July 1994) (under seal); P3350 (Certificate of BiH's State Commission for the Exchange of POWs, 11 November 1994) (under seal); KDZ017, P3568 (Transcript from Prosecutor $v$. Krnojelac), T. 2917-2918.

2919 See Adjudicated Fact 901. In August, a group of approximately 55 detainees were taken for exchange to Montenegro, but the bus was intercepted by a Bosnian Serb soldier who separated 20 younger men and took them away and the remaining 35 men were exchanged in Montenegro. The 20 younger men were not seen again.

2920 Adjudicated Fact 824; KDZ239, P3336 (Transcript from Prosecutor v. Krnojelac), T. 1218, 1225; KDZ239, T. 18935, (15 September 2011), T. 18946, 18973 (16 September 2011) (private session) (testifying that the number of detainees at KP Dom was the largest at the end of May and beginning of June 1992 and he estimated that there were between 600 and 650 detainees). KDZ017 counted a total of 570 detainees at KP Dom and during his detention this figure reached 752 and in his estimation more than 1,000 men were detained at some point in time at the facility. KDZ017, P3568 (Transcript from Prosecutor v. Krnojelac), T. 2893-2895, 2916; KDZ017, T. 19899-19900 (4 October 2011). See also P5545 (Report of Foča Penal and Correctional Facility, 11 July 1992), p. 3.

2921 See Adjudicated Fact 824.

2922 KDZ017, P3568 (Transcript from Prosecutor v. Krnojelac), T. 2893-2894, 2916. See also Adjudicated Fact 824; D4307 (Witness statement of Mitar Rašević dated 2 February 2014), para. 39.

2923 See Adjudicated Fact 841; KDZ017, P3568 (Transcript from Prosecutor v. Krnojelac), T. 2806, 2918-2919, 2931-2932. 
people". ${ }^{2924}$ Detainees were locked in their rooms except for meals and work duty. ${ }^{2925}$ The detainees were deliberately housed in cramped conditions. Even though the KP Dom had the capacity to house more than the maximum number of non-Serbs detained at the facility, the detainees were crowded into a small number of rooms. ${ }^{2926}$ Solitary confinement cells designed to hold one person were packed with up to 18 people at a time, making it impossible for the detainees to move around the cell, or to sleep lying down. ${ }^{2927}$ Because of the overcrowding, not everyone had a bed or even a mattress, and there were insufficient blankets. ${ }^{2928}$ Bedding was insufficient or non-existent. ${ }^{2929}$ The only bed linen provided was that left-over from former convicts, and these items were never washed or changed throughout $1992 .^{2930}$

890. Hygienic conditions were deplorable and washing facilities minimal. ${ }^{2931}$ Detainees only occasionally were given soap to wash their clothes in cold water. ${ }^{2932}$ Access to baths or showers, with no hot water, was irregular at best. ${ }^{2933}$ There were insufficient hygienic products and

2924 P6655 (Excerpt of Mitar Rašević's interview with OTP), p. 5; Mitar Rašević, T. 46768-46769 (11 February 2014).

2925 See Adjudicated Fact 844.

2926 See Adjudicated Facts 842, 844. Defence witnesses testified that overcrowding was only an issue during the first month after which almost every detainee had their own bed. D4307 (Witness statement of Mitar Rašević dated 2 February 2014), para. 17. The Chamber does not find Rašević's evidence in this regard to be credible. In reaching that conclusion the Chamber noted that the witness was evasive and contradicted by reference to his prior testimony. The witness was also very defensive about the conduct of his guards and the Chamber found his lack of knowledge about mistreatment at the facility to be incredible, especially since, as noted in para. 889 , he acknowledged that "evil" was done to the detainees.

2927 Adjudicated Fact 843. Rašević also testified that the solitary confinement cells were small but contained a bed, toilet and sink and it was not possible for 18 people to be placed in these rooms and detainees were only placed in solitary confinement for misdemeanours. D4307 (Witness statement of Mitar Rašević dated 2 February 2014), paras. 8, 21-22. The Chamber does not find Rašević's evidence in this regard to be credible. In reaching that conclusion the Chamber refers to its earlier assessment in fn. 2926 regarding the credibility of Rašević's evidence.

2928 Adjudicated Fact 844; KDZ239, P3336 (Transcript from Prosecutor v. Krnojelac), T. 1212-1213; KDZ017, P3568 (Transcript from Prosecutor v. Krnojelac), T. 2805, 2813. Krnojelac testified that there was sufficient bedding and blankets and that he gave instructions for their use by detainees. Milorad Krnojelac, D2716 (Transcript from Prosecutor v. Krnojelac), T. 7669-7670. The Chamber does not find Krnojelac's evidence to be reliable in this regard. In reaching that conclusion the Chamber noted that in his prior testimony in his own case, Krnojelac's evidence was marked by evasiveness, contradictions, and attempts to minimise his own involvement.

2929 Adjudicated Fact 846; KDZ239, P3336 (Transcript from Prosecutor v. Krnojelac), T. 1212-1213.

2930 Adjudicated Fact 846.

2931 Adjudicated Fact 845.

2932 KDZ017, P3568 (Transcript from Prosecutor v. Krnojelac), T. 2979.

2933 Adjudicated Fact 845. Defence witnesses testified that water problems were fixed and measures were taken to allow for the heating of water to allow detainees to bathe. D4307 (Witness statement of Mitar Rašević dated 2 February 2014), para. 17; Milorad Krnojelac, D2716 (Transcript from Prosecutor v. Krnojelac), T. 76687669. The Chamber does not consider this evidence to be reliable. In reaching that conclusion, the Chamber notes the equivocal nature of these requests and the unreliability of evidence given by Krnojelac considering his interest in minimising his own responsibility for the conditions of detention at the facility as he claimed to have not actually entered the premises where people were detained. The Chamber also refers to its earlier assessment in fn. 2926 regarding the credibility of Rašević's evidence. 
toiletries. $^{2934}$ Due to the poor hygienic conditions and since the detainees did not have an opportunity to bathe or change clothes there was a major problem with lice. ${ }^{2935}$

891. Non-Serb detainees were held in rooms with insufficient heating during the harsh winter of 1992, no heaters were placed in the rooms, windowpanes were left broken and clothes made from blankets to combat the cold were confiscated. ${ }^{2936}$ Stoves and furnaces had been produced to heat the offices in the administration building, and there was sufficient raw material for such furnaces to have been provided for the non-Serb detainees. ${ }^{2937}$

892. Any attempts made by non-Serb detainees to improve their living conditions in the camp were punished with solitary confinement. ${ }^{2938}$ Acts which resulted in beatings or periods in the isolation cells included efforts to get additional food or access to warm water, and attempts to communicate with each other, the guards, or the outside world. ${ }^{2939}$

893. The effect of the cold on the detainees was exacerbated by the fact that while they received two meals a day, the food was poor. ${ }^{2940}$ A large number of the Bosnian Muslim detainees experienced severe weight loss and saw their medical condition deteriorate. ${ }^{2941}$ While non-Serb detainees were fed starvation rations leading to severe weight loss and other health problems, ${ }^{2942}$

2934 Adjudicated Fact 845. The Chamber finds that hygienic conditions did improve to some extent by 1993 but the allegations with respect to KP Dom are limited to the end of 1992. KDZ017, P3568 (Transcript from Prosecutor v. Krnojelac), T. 2979.

2935 KDZ239, P3336 (Transcript from Prosecutor v. Krnojelac), T. 1227-1228. See also Milorad Krnojelac, D2716 (Transcript from Prosecutor v. Krnojelac), T. 7676; Adjudicated Fact 847.

2936 See Adjudicated Fact 848; KDZ239, P3336 (Transcript from Prosecutor v. Krnojelac), T. 1212-1213, 1226. See also Adjudicated Fact 850. The Chamber also received evidence that furnaces were only provided to nonSerb detainees by the ICRC in October 1993. Adjudicated Fact 849. However, given that this falls outside the period of alleged detention at KP Dom, the Chamber does not consider this to be of significance. For other evidence on the improvements of conditions after Krnojelac left the facility in 1993, see KDZ017, P3568 (Transcript from Prosecutor v. Krnojelac), T. 2910-2911, 2947. See also D4307 (Witness statement of Mitar Rašević dated 2 February 2014), para. 23.

2937 Adjudicated Fact 849. See also Adjudicated Fact 850. Mitar Rašević testified that the first winter was the worst, the heating did not work, there were not enough furnaces, and they were unable to supply firewood because of the war. D4307 (Witness statement of Mitar Rašević dated 2 February 2014), para. 19. The Chamber does not find Rašević's evidence in this regard to be reliable. In reaching that conclusion the Chamber refers to its earlier assessment in fn. 2926 regarding the credibility of Rašević's evidence.

2938 Adjudicated Fact 865.

2939 Adjudicated Fact 866; KDZ017, P3568 (Transcript from Prosecutor v. Krnojelac), T. 2805, 2810-2813, 28152816, 2979.

2940 KDZ239, P3336 (Transcript from Prosecutor v. Krnojelac), T. 1226; KDZ239, T. 18968 (16 September 2011).

2941 KDZ239, P3336 (Transcript from Prosecutor v. Krnojelac), T. 1226, 1299, 1287, 1311-1312; KDZ017, P3568 (Transcript from Prosecutor v. Krnojelac), T. 2805-2806 (testifying that he lost approximately 25 kilograms while in detention).

2942 See Adjudicated Fact 851. 
Bosnian Serb detainees received army rations with extra meat and vegetables and did not suffer the extreme weight loss of non-Serb detainees. ${ }^{2943}$

894. Apart from a short period at the beginning of their detention at the KP Dom, Bosnian Muslim detainees were denied any contact with the outside world or with their families, and (for a long time) with the ICRC. ${ }^{2944}$ By April 1992, detainees were not allowed to receive visits and therefore could not supplement their meagre food rations and hygienic supplies. ${ }^{2945}$ From mid-July 1992, the conditions of detention deteriorated even further. ${ }^{2946}$ On one occasion after Krnojelac's son was wounded in June or July 1992, the guards and staff at KP Dom were angry and as a result the detainees received the bare minimum of food. ${ }^{2947}$ While there was a general shortage of food in Foča during the conflict, there was a deliberate policy to feed the non-Serb detainees barely enough for their survival while the Bosnian Serbs in the facility received normal meals. ${ }^{2948}$ Left-over food from the Bosnian Serb detainees, if any, would occasionally be given to the non-Serb detainees. ${ }^{2949}$

2943 KDZ017, P3568 (Transcript from Prosecutor v. Krnojelac), T. 2952-2953; see Adjudicated Facts $852,853$. Defence evidence was adduced to suggest that (i) the military command provided for food for the detainees in general and there was no distinction made in the food prepared for Bosnian Muslim detainees; (ii) the Bosnian Serb authorities provided extra food and supplies when requested; and (iii) there were no complaints regarding lack of food. Milorad Krnojelac, D2716 (Transcript from Prosecutor v. Krnojelac), T. 7629-7631, 7633-7634, 7651-7652, 7664-7665, 7903-7904, 8096-8101; D2720 (Request from KP Dom Foča to Foča Red Cross, 21 October 1992); D2721 (Request from KP Dom Foča to Foča garrison, 3 March 1993); D2726 (Report of KP Dom Foča to RS Ministry of Finance and Ministry of Justice, 15 November 1992); D2727 (Request from KP Dom Foča to RS Ministry of Economy, 7 December 1992); D2735 (Request from KP Dom Foča to Foča Executive Board, 19 February 1993); D2736 (Request from KP Dom Foča to Foča Executive Board, 30 March 1993); D4309 (Letter from KP Dom to Foča Red Cross, 21 October 1992); D4310 (Letter from Milorad Krnojelac to Foča Garrison Military Post, 3 March 1993); D4311 (Order of Foča Tactical Group, date illegible); D3314 (Witness statement of Radojica Mlađenović dated 1 April 2013), para. 48; D4307 (Witness statement of Mitar Rašević dated 2 February 2014), para. 20; Mitar Rašević, T. 46757-46761, 46794-46795 (11 February 2014). While the Chamber accepts that some requests for supplies were made, this does not cast doubt about the credible evidence received as to the discrimination between the food received by Bosnian Muslim and Bosnian Serb detainees. In reaching that conclusion, the Chamber notes the equivocal nature of these requests and the unreliability of evidence given by Krnojelac considering his interest in minimising his own responsibility for the conditions of detention at the facility. The Chamber also notes that Rašević's evidence was highly qualified and he admitted that he did not know whether some people received more or less food when distributed. Mitar Rašević, T. 46794-46795 (11 February 2014).

2944 See Adjudicated Fact 827. Milorad Krnojelac testified that Bosnian Muslim detainees had visitors, that visitors were only prohibited for a few days when there was lice outbreak, and that it was the military command which authorised these visits. Milorad Krnojelac, D2716 (Transcript from Prosecutor v. Krnojelac), T. $7676,8109$. However, the Chamber does not consider Krnojelac evidence to be reliable in this regard given his interest in minimising his own responsibility for the conditions of detention at the facility.

2945 See Adjudicated Fact 851 See also Mitar Rašević, T. 46810 (11 February 2014).

2946 KDZ239, T. 18916 (15 September 2011).

2947 KDZ239, P3336 (Transcript from Prosecutor v. Krnojelac), T. 1270.

2948 See Adjudicated Fact 852; KDZ017, P3568 (Transcript from Prosecutor v. Krnojelac), T. 2799-2801, 29442945; KDZ239, P3336 (Transcript from Prosecutor v. Krnojelac), T. 1229.

2949 KDZ239, P3336 (Transcript from Prosecutor v. Krnojelac), T. 1229. 
895. While the KP Dom had its own medical clinic and detainees had access to a physician, ${ }^{2950}$ medical care was inadequate and medicine was in very short supply. ${ }^{2951}$ A basic medical service was provided but those in need of urgent medical attention were left unattended or given insufficient treatment. $^{2952}$ At least one detainee died as a result of poor medical care. ${ }^{2953}$ Detainees who were kept in isolation cells and solitary confinement were denied all access to medical care. ${ }^{2954}$ Non-Serb detainees who arrived at the KP Dom with injuries sustained prior to or in the course of their arrest were not given access to medical treatment, nor were non-Serb detainees who were severely beaten during interrogations at the KP Dom. ${ }^{2955}$ KDZ017 asked for medical treatment but was not taken to the clinic until he met with Rašević. ${ }^{2956}$ The Chamber finds that while detainees had access to some basic medical treatment not all detainees were treated. Further, the treatment in many cases was inadequate.

896. The shortage of food, basic hygienic conditions, and medicine in KP Dom had a significant impact on detainees who were sick. ${ }^{2957}$ The condition of the sick detainees, including those who had heart conditions, deteriorated while they were detained at KP Dom. ${ }^{2958}$ Poor living conditions and lack of medication also contributed to detainees suffering multiple bouts of pneumonia. ${ }^{2959}$ The authorities in the facility received complaints from detainees regarding the food, the poor

$2950 \quad$ KDZ239, T. 18968 (16 September 2011); KDZ017, P3568 (Transcript from Prosecutor v. Krnojelac), T. 2949. See also Milorad Krnojelac, D2716 (Transcript from Prosecutor v. Krnojelac), T. 7665-7666.

2951 Adjudicated Fact 854; KDZ017, P3568 (Transcript from Prosecutor v. Krnojelac), T. 2949-2950. Krnojelac testified that (i) the medical facilities at KP Dom were adequate and detainees had regular access to doctors and nurses; (ii) there was no distinction between the treatment of Bosnian Serb and Bosnian Muslim detainees; and (iii) detainees were taken to hospital if necessary. Milorad Krnojelac, D2716 (Transcript from Prosecutor v. Krnojelac), T. 7665-7668, 8116. The Chamber does not find Krnojelac's evidence to be reliable given that he disclaimed knowledge of most matters related to detainees and then claimed that he knew about the provision of medical care. Krnojelac's evidence in his own case also demonstrated a clear interest in minimising his involvement and downplaying the poor conditions of detention at the facility.

2952 See Adjudicated Fact 854. See also KDZ239, P3336 (Transcript from Prosecutor v. Krnojelac), T. 1219, 1231, 1266.

2953 See Adjudicated Fact 854; KDZ017, P3568 (Transcript from Prosecutor v. Krnojelac), T. 2789-2792; KDZ239, P3336 (Transcript from Prosecutor v. Krnojelac), T. 1230. KD017 and KDZ239 testified about the death of Ešad Hadžić who died from internal bleeding after his medication finished and that threats were made by the guards who were asked to help. Veljko Marić testified that he did not believe any detainee died at the KP Dom because of lack of medical treatment but acknowledged that he did not know what was happening at the facility as he did not have occasion to see it. D3128 (Witness statement of Veljko Marić dated 16 March 2013), paras. 17-20; Veljko Marić, T. 35599-35601 (19 March 2013). In light of Marić's qualification that he did not always know what was happening at the facility, the Chamber does not consider that it can rely on his evidence in this regard.

2954 Adjudicated Fact 855.

2955 Adjudicated Fact 856.

2956 KDZ017, P3568 (Transcript from Prosecutor v. Krnojelac), T. 2817.

2957 KDZ017, P3568 (Transcript from Prosecutor v. Krnojelac), T. 2797-2798. The detainees identified included Hamdija Mandzo and Ismet Pasović.

2958 KDZ239, P3336 (Transcript from Prosecutor v. Krnojelac), T. 1220-1221.

2959 KDZ017, P3568 (Transcript from Prosecutor v. Krnojelac), T. 2805-2806. 
living and hygienic conditions, and the deficient provision of medical care but claimed that nothing could be done due to the war conditions. ${ }^{2960}$

897. In July 1992, to prevent detainees from escaping, the inner compound of KP Dom was mined by a group of soldiers under the orders of Foča Crisis Staff member Milun Milanović who was accompanied by Krnojelac. ${ }^{2961}$

898. Whenever the ICRC arrived at KP Dom, a group of detainees, which included prominent men from Foča, was taken away and hidden in a cellar until the ICRC left. ${ }^{2962}$ In October 1992, the ICRC demanded that it be allowed to have private conversations and examine prisoners at KP Dom without the presence of official organs from the facility, but this request was rejected until they were able to do the same for Serb prisoners in Goražde. ${ }^{2963}$ Conditions in the facility would improve for a day or so after the ICRC visited. ${ }^{2964}$ When a film crew accompanied by Rašević visited, the detainees were given meals which were "a bit more plentiful" and when another film crew visited, the detainees were ordered to clean all the premises in the facility in the days leading up to the visit. ${ }^{2965}$

\section{(c) Mistreatment of detainees}

899. On arrival, one group of detainees was met by a group of uniformed soldiers who cursed, kicked, and hit them with rifle butts. ${ }^{2966}$ On entry into the KP Dom the detainees were searched and had their identity cards, money, jewellery and watches seized. ${ }^{2967}$ Individuals or groups of armed soldiers were allowed into KP Dom during the first months of the detention of non-Serb

2960 KDZ239, P3336 (Transcript from Prosecutor v. Krnojelac), T. 1275, 1277, 1280; KDZ017, P3568 (Transcript from Prosecutor v. Krnojelac), T. 2915.

2961 KDZ017, P3568 (Transcript from Prosecutor v. Krnojelac), T. 2910, 2941. See also Milorad Krnojelac, D2716 (Transcript from Prosecutor v. Krnojelac), T. 8183-8184, 8186-8188. Krnojelac testified that the reason the mines were laid was to protect property and not to prevent detainees from escaping and that the order was simply given to him by Todović to sign. The Chamber notes contradictions in Krnojelac's evidence as to the reason why the mines were laid and who was responsible. The Chamber does not find his evidence in this regard to be credible.

2962 KDZ017, P3568 (Transcript from Prosecutor v. Krnojelac), T. 2897; KDZ239, P3336 (Transcript from Prosecutor v. Krnojelac), T. 1267-1268; KDZ239, T. 18992(16 September 2011). Mitar Rašević denied knowledge that detainees were hidden during ICRC visits. Milorad Krnojelac, D2716 (Transcript from Prosecutor v. Krnojelac), T. 7707-7708; Mitar Rašević, T. 46801-46802 (11 February 2014). However, the Chamber notes that when confronted with his prior statement Rašević acknowledged that detainees were taken away by the army before the ICRC visits but claimed the staff at the KP Dom were not involved. In light of this contradiction, the Chamber finds Rašević's evidence on this issue to be unreliable. Similarly the Chamber noted that Krnojelac attempted to distance himself from all knowledge of mistreatment of detainees or conditions of detention.

2963 P6080 (Report of Foča Military Post, 10 October 1992), pp. 1-2.

2964 KDZ017, P3568 (Transcript from Prosecutor v. Krnojelac), T. 2948.

2965 KDZ017, P3568 (Transcript from Prosecutor v. Krnojelac), T. 2804.

2966 KDZ017, P3568 (Transcript from Prosecutor v. Krnojelac), T. 2783-2786.

2967 KDZ017, P3568 (Transcript from Prosecutor v. Krnojelac), T. 2786. 
civilians. $^{2968}$ The guards were also involved in the beating of non-Serb detainees. ${ }^{2969}$ The MP was also allowed to enter the facility, remove detainees, and beat them. ${ }^{2970}$

900. From April until July 1992, beatings took place on a frequent and systematic basis. ${ }^{2971}$ The guards called out the names of detainees on a list and took them to other rooms or buildings where they were beaten. ${ }^{2972}$ Detainees were also regularly interrogated by guards, soldiers or police officers and would often be beaten or mistreated during this process. ${ }^{2973}$ For example, eight detainees from the Marinkovići area in Foča were beaten and ill-treated after their arrival at the facility. ${ }^{2974}$ They were taken out three or four days after their arrival to give statements and when they returned, they could not stand as they had been badly beaten "on the orders of the investigators". 2975 Detainees were punched, kicked, and beaten with batons. ${ }^{2976}$ Some beatings

2968

2969

Adjudicated Facts 857, 868, 877. KP Dom guards identified as involved in these beatings, included Dragomir Obrenovnić, Milenko Burilo, Zoran Matović, Vlatko Pljevaljčić, Predrag Stefanović, Jovo Savić, Radovan Vuković, Milovan Vuković, Milivoj Milić and Milenko Elčić. See Adjudicated Fact 858. Rašević testified he was not aware that these guards were involved in mistreating detainees and he was therefore not able to launch an investigation, all the more because there was no organised or systematic mistreatment. See also Mitar Rašević, T. 46766, 46788-46791, 46807 (11 February 2014); P6657 (Sketch of KP Dom marked by Mitar Rasević); D4307 (Witness statement of Mitar Rašević dated 2 February 2014), paras. 25-27, 30, $35 . \quad$ The Chamber does not find Rašević's evidence in this regard to be reliable. In reaching that conclusion the Chamber refers to its earlier assessment in fn. 2926 regarding the credibility of Rašević's evidence. The Chamber also notes that on cross-examination Rašević acknowledged that he had no information about the conduct of others during interrogations and detainees may not have dared to report it and that there was some mistreatment by military police during interrogations but that he took measures to stop night time interrogations unless ordered by the army commander. Mitar Rašević, T. 46766-46767 (11 February 2014); D4307 (Witness statement of Mitar Rašević dated 2 February 2014), para. 26; Mitar Rašević, T. 46792 (11 February 2014). Rašević himself testified that he intervened during the interrogation of a detainee after which the beating stopped and he saw that he was bleeding which is in conflict with his testimony that he never saw detainees being beaten. Mitar Rašević, T. 46796 (11 February 2014). In light of these contradictions and indicators of bias, the Chamber does not consider Rašević's evidence to be reliable in this regard.

KDZ017, P3568 (Transcript from Prosecutor v. Krnojelac), T. 2956; KDZ239, P3336 (Transcript from Prosecutor v. Krnojelac), T. 1238, 1324; see Adjudicated Fact 868. See also Mitar Rašević, T. 46766-46767 (11 February 2014). Rašević himself testified he could not do his job efficiently in maintaining security over the facility because he was often away from the KP Dom and that there was some mistreatment. D4307 (Witness statement of Mitar Rašević dated 2 February 2014), para. 23; P6655 (Excerpt of Mitar Rasević's interview with OTP), p. 5; Mitar Rašević, T. 46768-46769 (11 February 2014). The Chamber does not find Rašević's evidence about his inability to maintain security in the facility seeking, to minimise his own involvement, to be reliable. In reaching that conclusion the Chamber refers to its earlier assessment in fn. 2926 regarding the credibility of Rašević's evidence.

2971 Adjudicated Fact 867.

2972 See Adjudicated Facts 858, 867, 878, 879; KDZ239, P3336 (Transcript from Prosecutor v. Krnojelac), T. 12351240, 1253, 1256; KDZ017, P3568 (Transcript from Prosecutor v. Krnojelac), T. 2830, 2836. See also KDZ239, P3336 (Transcript from Prosecutor v. Krnojelac), T. 1281, 1283 (who was not himself physically mistreated during his detention); KDZ379, P3332 (Transcript from Prosecutor v. Krnojelac), T. 3148-3150 [REDACTED]. Detainees who were severely beaten by guards of the KP Dom and military policemen, and who were then kept in solitary confinement for several days included Vahida Džemal, Enes Uzunović, Aziz Šahinović, and Elvedin Čedić. See Adjudicated Fact 868.

2973 See Adjudicated Facts 863, 878, 888.

2974 KDZ017, P3568 (Transcript from Prosecutor v. Krnojelac), T. 2820-2821. These men included men in their 60s and 70s.

2975 KDZ017, P3568 (Transcript from Prosecutor v. Krnojelac), T. 2822. 
lasted for several hours ${ }^{2977}$ and detainees were beaten all over their bodies, including on the soles of their feet with a baseball bat. ${ }^{2978}$ Detainees were tied by chains and belts while they were beaten ${ }^{2979}$ and in one case a detainee was cut on his neck and ear with a knife. ${ }^{2980}$ Many were returned to their rooms with visible wounds and bruises resulting from the beating. ${ }^{2981}$ Some were unable to walk, stand or talk for days after the beatings. ${ }^{2982}$ Detainees were also beaten while lining up for lunch or while being taken back and forth through the compound. ${ }^{2983}$ One of the detainees hanged himself in the premises of KP Dom. ${ }^{2984}$ Apart from the physical effects of detention at KP Dom, detainees continued to suffer ongoing psychological effects which required psychiatric treatment. ${ }^{2985}$

2976 See Adjudicated Facts 860, 874; KDZ017, P3568 (Transcript from Prosecutor v. Krnojelac), T. 2807-2808; KDZ239, P3336 (Transcript from Prosecutor v. Krnojelac), T. 1209-1211. For example Emir Mandžo was restrained in a chair before being beaten and kicked until he fainted while KDZ017 was slapped and kicked in the chest and around the kidneys. Rašević testified that he visited detainees in solitary confinement on a daily basis, and was never told that the guards had beaten them. On cross-examination, he acknowledged that he did see injured people in the isolation cells but the detainees told him the injuries were not inflicted by the guards and if they had medical problems he would refer them to the nurse. When confronted with his prior testimony Rašević acknowledged that it was possible that the detainees told him that the military police officers beat them but he claimed to have reported it to the warden but that they did not have the power to enter and be present during interrogations by the military. In addition Rašević's suggestion that the guards were not involved in mistreatment of detainees is inconsistent with his evidence that he felt threatened even by his own guards because he treated Bosnian Muslims well. The Chamber finds that the contradictions in this regard cast doubt on the reliability of Rašević's evidence that guards were not involved in mistreatment. See D4307 (Witness statement of Mitar Rašević dated 2 February 2014), paras. 21, 31-32; Mitar Rašević, T. 46775-46776, 4680446806 (11 February 2014); P6656 (Excerpt from Mitar Rašević's testimony before BiH State Court, 11 December 2007), p. 8.

See Adjudicated Fact 870 . Krnojelac testified that he never saw any detainees who had visible signs of beatings nor did he ever hear any moans, screams or cries of pain and that he was never told about any beating. Milorad Krnojelac, D2716 (Transcript from Prosecutor v. Krnojelac), T. 7677-7678. The Chamber notes that Krnojelac's evidence is directly contradicted by evidence that detainees met with him and complained about their treatment. KDZ239, P3336 (Transcript from Prosecutor v. Krnojelac), T. 1271-1280. In addition the Chamber does not consider Krnojelac's evidence to be credible in this regard given his evidence is marked by indicators that he was seeking to minimise his own involvement in the mistreatment at the facility.

See Adjudicated Fact 871. Other detainees who in the summer of 1992 were called out and severely beaten by KP Dom guards or soldiers included Ramo Džendušić, Nail Hodžić, Emir Frašto, Husko or Husein Rikalo, Nurko Nisić, Esad Kiselica, Latif Hasanbegović, Aziz Hasković, Halim Seljanci, Kemo or Kemal Isanović, a young man by the last name of Čedić, and Emir Mandžo. See Adjudicated Facts 869, 870, 871, 872, 873, 874. Ekrem Zeković was beaten following his re-capture after escaping from the facility. Mitar Rašević, T. 4679646797 (11 February 2014).

KDZ239, P3336 (Transcript from Prosecutor v. Krnojelac), T. 1246. KDZ239, P3336 (Transcript from Prosecutor v. Krnojelac), T. 1247; KDZ239, T. 18993 (16 September 2011). Adjudicated Facts 864, 872; KDZ239, P3336 (Transcript from Prosecutor v. Krnojelac), T. 1237-1240, 1256; KDZ017, P3568 (Transcript from Prosecutor v. Krnojelac), T. 2826.

See Adjudicated Facts 864, 871.

See Adjudicated Fact 861; KDZ239, P3336 (Transcript from Prosecutor v. Krnojelac), T. 1264-1265; KDZ017, P3568 (Transcript from Prosecutor v. Krnojelac), T. 2889, 2891.

KDZ017, P3568 (Transcript from Prosecutor v. Krnojelac), T. 2888; KDZ239, P3336 (Transcript from Prosecutor v. Krnojelac), T. 1233, 1252; Milorad Krnojelac, D2716 (Transcript from Prosecutor v. Krnojelac), T. 7678. The detainee was Juso Džamalja who was exhumed from an individual grave in 2001. P4853 (Updated Table 2 to the Report of Amor Mašović), p. 82.

KDZ017, P3568 (Transcript from Prosecutor v. Krnojelac), T. 2919. 
901. Detainees heard the groans and screams of those who were being beaten and physically abused and this lasted until mid-July 1992, thus creating fear among them. ${ }^{2986}$ The beating began at dusk and would continue into the night and sometimes till daylight. ${ }^{2987}$ When the beating stopped, victims were sometimes taken to an isolation cell. ${ }^{2988}$ On one occasion in October 1991 when soldiers from outside the facility beat detainees and ordered them to lie on the ground, this was watched by Rašević and the guards did not intervene. ${ }^{2989}$

902. Detainees were forced to work while detained at KP Dom and were engaged in work at the farm, bakery, furniture factory, or in gardening and selling wood. ${ }^{2990}$ Detainees were placed on lists to be taken under guard to work in hospitals, mines, hotels, and sometimes the MP would escort them to work. ${ }^{2991}$ Todović, who was in charge of labour affairs, gave guards the list of work assignments to be carried out by the detainees. ${ }^{2992}$ On a couple of occasions, a detainee who refused to work was beaten and taken to an isolation cell. ${ }^{2993}$ However, some detainees were not required to work at the facility. ${ }^{2994}$ Two detainees were ordered to drive vehicles to detect landmines. $^{2995}$

2986 KDZ239, P3336 (Transcript from Prosecutor v. Krnojelac), T. 1235, 1264; see Adjudicated Facts 864, 869, 872, 880; KDZ017, P3568 (Transcript from Prosecutor v. Krnojelac), T. 2839-2840.

2987 KDZ239, P3336 (Transcript from Prosecutor v. Krnojelac), T. 1248; see Adjudicated Fact 880.

2988 Adjudicated Fact 881

2989 KDZ017, P3568 (Transcript from Prosecutor v. Krnojelac), T. 2891-2892; see Adjudicated Fact 862. Rašević testified that he never saw this incident and that if he received information about it, it was only in verbal form otherwise it would have been documented. D4307 (Witness statement of Mitar Rašević dated 2 February 2014), para. 42. The Chamber does not find Rašević's evidence in this regard to be credible given his attempt to distance himself from mistreatment and knowledge of mistreatment of detainees.

2990 KDZ017, P3568 (Transcript from Prosecutor v. Krnojelac), T. 2896; KDZ239, T. 18992 (16 September 2011). Krnojelac testified that (i) some Bosnian Muslim detainees were taken out to do work but he was told that these detainees wanted to work voluntarily as they preferred this to spending time in the detention facility; (ii) they worked regular hours and received food; and (iii) he was not aware of detainees being used for trench digging on the frontline or used to search for mines. Milorad Krnojelac, D2716 (Transcript from Prosecutor v. Krnojelac), T. 7692-7696, 7698-7699, 7914. The Chamber does not find Krnojelac's evidence to be reliable in this regard, given that he qualifies this evidence based on what he was told. The Chamber notes that this is also contrary to his evidence relating to his lack of knowledge or involvement in affairs relating to detainees and also notes that Krnojelac acknowledged that some detainees were involved in working on his house which had burnt down during the conflict. Krnojelac was also unable to adequately explain why Bosnian Muslim detainees were engaged in the economic unit given that there was no reform element required for this category of detainees, see Milorad Krnojelac, D2716 (Transcript from Prosecutor v. Krnojelac), T. 7821-7822; D2730 (Decision of SerBiH Presidency published in Official Gazette, 12 May 1992), p. 3. In any event, the Chamber will only enter findings on the type of forced labour charged in the Indictment. See Indictment, para. 60(h).

2991 D4307 (Witness statement of Mitar Rašević dated 2 February 2014), para. 24.

2992 KDZ017, P3568 (Transcript from Prosecutor v. Krnojelac), T. 2911-2912.

2993 KDZ017, P3568 (Transcript from Prosecutor v. Krnojelac), T. 2915.

2994 KDZ239, P3336 (Transcript from Prosecutor v. Krnojelac), T. 1267.

2995 See Adjudicated Fact 875. 
$\underline{\text { detainees }}$

(d) Conclusion on conditions of detention and treatment of

903. Based on the above, the Chamber finds that non-Serbs from multiple locations were brought to and detained at KP Dom Foča by Serb Forces from mid-April 1992 until at least 31 December 1992. The detainees were held in poor conditions. These included lack of space, inadequate bedding, poor sanitary conditions, insufficient heating, lack of food, and inadequate medical care. Detainees were subjected to regular beatings, and were forced to work at a number of locations. The Chamber finds that at least one detainee died as a result of the inadequate medical care at the facility. ${ }^{2996}$

(e) Scheduled Incident B.8.1

904. The Indictment refers to the killing of over 200 detainees at KP Dom Foča between June and December 1992.

905. In some instances after detainees had been taken out to be beaten, other detainees heard the sound of pistol shots, as well as the sound of vehicles moving. ${ }^{2997}$

906. Groups of detainees, generally young people, were taken out of the KP Dom by either regular police or MP and disappeared. ${ }^{2998}$ This included one group consisting of 35 detainees, another group of 23 detainees, ${ }^{2999}$ and a group of detainees suffering from untreated mental

2996 This finding does not include the persons alleged to have been killed in Scheduled Incident B.8.1, which is discussed below. Further, witnesses also testified about the death of detainees after 31 December 1992 but this falls outside the alleged period of detention charged in the Indictment with respect to this facility. KDZ239, P3336 (Transcript from Prosecutor v. Krnojelac), T. 1230-1231, 1233-1235, 1313-1314; KDZ017, P3568 (Transcript from Prosecutor v. Krnojelac), T. 2824-2825.

2997 KDZ239, P3336 (Transcript from Prosecutor v. Krnojelac), T. 1248; KDZ239, T. 19000-19001 (16 September 2011); see Adjudicated Fact 881.

2998 KDZ239, P3336 (Transcript from Prosecutor v. Krnojelac), T. 1212, 1230, 1238-1243, 1245-1246, 1253-1255, 1256, 1259, 1314-1315; KDZ017, P3568 (Transcript from Prosecutor v. Krnojelac), T. 2790-2792, 2798, 2823, 2836-2837, 2862, 2889, 2956-2958. Krnojelac testified that he heard that Halim Konjo had committed suicide and that a commission came to carry out an investigation and that he was never told about or aware of detainees disappearing overnight. Milorad Krnojelac, D2716 (Transcript from Prosecutor v. Krnojelac), T. 8114-8115. The Chamber does not consider Krnojelac's evidence in this regard to be reliable given that he sought to minimise his involvement in the facility and distance himself from anything to do with detainees.

2999 KDZ239, P3336 (Transcript from Prosecutor v. Krnojelac), T. 1212, 1230, 1238-1243, 1245-1246, 1253-1255, 1256, 1259, 1314-1315; KDZ017, P3568 (Transcript from Prosecutor v. Krnojelac), T. 2790-2792, 2798, 2823, 2836-2837, 2862, 2889, 2956-2958. KDZ017 knew that these individuals were missing after having spoken to the relatives of some of them who told him that they were never seen alive again. See Adjudicated Fact 900. The group of 23 detainees who were taken out and disappeared included Ismet Pasović, Nurko Kušić, Hamdo Bićo (who was exhumed from an individual grave), Halim Konjo, Halid Konjo, three brothers named Rikalo, Karabegović, Adil Granov, Zulfo Veiz, Krunoslav Marinović, Asim Mezbur (who was exhumed from a mass grave), Hajro Sabanović, Dr. Aziz Torlak (who was brought to the facility by the Užice Corps), Esad Kiselica, and Ismet Deleut. P4853 (Updated Table 2 to the Report of Amor Mašović), pp. 80, 82; see Adjudicated Facts $889,893$. 
conditions. ${ }^{3000}$ When the detainees spoke to the guards about the disappearances, they would claim that they knew nothing and that others were making the decisions. ${ }^{3001}$ Some of the detainees were called out from lists and taken out on the pretext that they were going to be exchanged, but these were not exchanges and with a few exceptions, they were not seen again. ${ }^{3002}$ These disappearances were confirmed through contact with families, other detainees, or the ICRC. ${ }^{3003}$ Witnesses testified that approximately 400 to 450 men "disappeared" in these exchanges. Only approximately 200 detainees who remained at KP Dom survived. ${ }^{3004}$ For example, in September 1992, between 35 to 60 detainees were selected by KP Dom guards from a list and taken out of the facility in two groups but never returned and were never seen again. ${ }^{3005}$

907. Four groups, each consisting of nine detainees, were taken to the main building for interrogation. ${ }^{3006}$ The first group of detainees was taken out three or four days after 12 June 1992

3000 KDZ017, P3568 (Transcript from Prosecutor v. Krnojelac), T. 2794, 2888; KDZ239, P3336 (Transcript from Prosecutor v. Krnojelac), T. 1218-1219 (testifying that some of the detainees with mental conditions who were detained separately started mutilating themselves). See also P3351 (Schedule C of List of Indictment against Milorad Krnojelac). Mujo Murguz, Ibrahim Ovcina, Babić were identified as having been in a group of detainees with mental conditions who disappeared and Omer Muježinović, Hakan Hajdarević, Edhem Bunda and "Culum" were detainees with mental conditions who were separated and detained separately.

$3001 \quad$ KDZ239, P3336 (Transcript from Prosecutor v. Krnojelac), T. 1260.

3002 KDZ239, P3336 (Transcript from Prosecutor v. Krnojelac), T. 1265; see Adjudicated Facts 877, 884, 900. Mitar Rašević, T. 46778, 46793 (11 February 2014); D4307 (Witness statement of Mitar Rašević dated 2 February 2014), paras. 32-35, 37-38; P6655 (Excerpt of Mitar Rašević's interview with OTP), e-court pp. 2-3. While Rašević stated that detainees were taken away for exchange according to lists provided by the army and he did not notice large groups of detainees going missing, he acknowledged on cross-examination that some detainees disappeared in these "exchanges" and sometimes that detainees were taken away without permission. The Chamber finds that Rašević's evidence only serves to confirm that some detainees did disappear in these apparent exchanges and that the Military Police was involved in taking away detainees but in light of the credibility assessment of Rašević in fn. 2926, the Chamber does not place any weight on his testimony that they were taken away without permission and that he did not notice large groups of detainees going missing.

3003 See Adjudicated Fact 900.

3004 KDZ017, P3568 (Transcript from Prosecutor v. Krnojelac), T. 2894-2895; KDZ239, P3336 (Transcript from Prosecutor v. Krnojelac), T. 1265-1266, 1315. Krnojelac testified that he was never told about any killings except for two suicides in the facility. Milorad Krnojelac, D2716 (Transcript from Prosecutor v. Krnojelac), T. 7677-7678. The Chamber does not consider Krnojelac's evidence to be credible in this regard. In reaching that conclusion the Chamber refers to its earlier assessment in fns. 2889, 2900, and 2928 regarding the credibility of Krnojelac. Radojica Mlađenović testified that nobody from the military or civilian leadership asked or ordered that any crime be committed and they actually required compliance with international conventions and that it was possible that some paramilitary units did not comply and that any killings in Foča were isolated cases and the authorities tried to prevent them and carried out on-site investigations into specific cases. D3314 (Witness statement of Radojica Mlađenović dated 1 April 2013), para. 40; Radojica Mlađenović, T. 36612 (4 April 2013). The Chamber does not find this evidence or shifting of responsibility to be reliable. In reaching that conclusion the Chamber noted that Mlađenović's evidence was marked by multiple contradictions and extreme evasiveness. In addition, the Chamber notes that when confronted with evidence of killings at KP Dom Foča, the witness qualified his answer and claimed that he was not a witness to what happened at the KP Dom. Radojica Mlađenović, T. 36663-36664 (5 April 2013).

3005 See Adjudicated Facts 896, 897, 898. Two of those detainees, Murat Crneta and Halid Konjo were found in a mass grave. P4853 (Updated Table 2 to the Report of Amor Mašović), p. 82. Other detainees who were identified as having been taken out of the facility on other occasions and never returned included Mensud Pašović, Haso Selimović, Rasim Kajgana, Azim Mezbur. See Adjudicated Facts 892, 894, 890, 891.

3006 KDZ017, T. 19900 (4 October 2011). See also KDZ017, P3568 (Transcript from Prosecutor v. Krnojelac), T. 2828-2829. 
and the last group was taken out towards the end of June 1992. ${ }^{3007}$ The detainees of the first group were lined up and taken inside a building one by one. As each detainee was taken in, the sounds of beating and screaming were heard, followed by a single pistol shot. ${ }^{3008}$ In a similar manner, the second, ${ }^{3009}$ third $^{3010}$ and fourth group ${ }^{3011}$ of detainees were taken out with an intervening period of a few days between each group. The sequence of events was the same for these groups as it was for each of the detainees in the first group, viz. nine detainees were taken out, the sound of beatings,

3007 KDZ017, P3568 (Transcript from Prosecutor v. Krnojelac), T. 2831-2832, 2887, 2957, 2972; KDZ239, P3336 (Transcript from Prosecutor v. Krnojelac), T. 1249-1250, 1252. Detainees who were identified as having been taken out and disappeared included Kemo Dželilović and Munib Veiz. See also Adjudicated Fact 886.

3008 KDZ017, P3568 (Transcript from Prosecutor v. Krnojelac), T. 2837-2839, 2842, 2852, 2866, 2971, 2990; KDZ017, T. 19902 (4 October 2011); P3569 (Series of photographs of Foča), pp. 1, 3; see Adjudicated Facts 886, 899, 887 (which listed Kemo Dželilović, Halim Konjo, Mustafa Kuloglija, Mithat and Zaim Rikalo and Munib Veiz as being in the group of detaineed taken out and severely beaten by guards before shots were heard).

3009 KDZ017, P3568 (Transcript from Prosecutor v. Krnojelac), T. 2862, 2864-2865, 2875, 2956-2958; KDZ017, T. 19901-19904 (4 October 2011); KDZ239, P3336 (Transcript from Prosecutor v. Krnojelac), T. 1251, 1253, 1258. The detainees who were identified as having disappeared in this group included Ševal Šoro, Mate Ivancić (who was a Bosnian Croat), Zulfo Veiz, Ekrem Tulek, Refik Čankusić, and Salem Bičo. See also Adjudicated Fact 895 (referring to the disappearance of Ševal Šoro).

3010 KDZ017, P3568 (Transcript from Prosecutor v. Krnojelac), T. 2793-2796, 2798, 2821-2823, 2830-2833, 2862-2868, 2875-2879, 2883, 2885, 2888-2889, 2895-2896, 2956, 2958-2960; KDZ239, P3336 (Transcript from Prosecutor v. Krnojelac), T. 1220, 1240-1242, 1249-1250, 1252, 1255-1259, 1262; KDZ239, T. 1892018921 (15 September 2011), T. 18979-18980 (16 September 2011). The names of individuals who these witnesses identified as having being taken out of KP Dom in groups and who disappeared included Džemal Vahida, Fuad Mandzo, Alija Altoka, Miralem Altoka, Nermin Hadžimusić (only identified by KDZ017), Adil Krajčin, Enes Uzunović, Enko Čedić, Adnan Pasalić (only identified by KDZ017), Adil Granov, Abdurahman Cankušić; Fuad Mandzo, Hamid Ramović, Džemal Vahida, Gordan Huković (a Bosnian Croat only identified by KDZ239), Zaim Rikalo, Husein Rikalo, Mithat Rikalo, Seval Šoro, Mate Ivancić, Zulfo Veiz; Ekrem Tulek, Kemal Tulek (Rašević also testified that Tulek went missing. Mitar Rašević, T. 46788 (11 February 2014)), Refik Čankušić, Zulfo Veiz, Munib Veiz, Zaim Čedić (only identified by KDZ017), Edhem Bunda, Culum FNU (only identified by KDZ017), Elmedin Džanko, Eldin Džanko, Ismet Deleut (only identified by KDZ017), Gradisic FNU (only identified by KDZ239), Hajdarević FNU (KDZ017 identified him as Hakan Hajdarević), Latif Hasanbegović (only identified by KDZ017), Azid Hasković (only identified by KDZ017), Nail Hodžić (only identified by KDZ017), Abdulah Kamerić (who was exhumed from a mass grave. P4853 (Updated Table 2 to the Report of Amor Mašović), p. 80), Omer Mujezinović (only identified by KDZ017), Samir Mujezinović (only identified by KDZ239), Mujo Murguz (only identified by KDZ017), Ibrahim Ovcina (only identified by KDZ017) (the Chamber notes that an Ibro Ovcina is listed in Mašović's table but his name is not listed by Mašović as associated with Scheduled Incident B.8.1 even though the name is listed in Appendix G of the Prosecution Final Brief. P4853 (Updated Table 2 to the Report of Amor Mašović), p. 80), Ismet Pašović (only identified by KDZ017), Halim Seljanci (only identified by KDZ017), Mirsad Subašić (only identified by KDZ239). See also Adjudicated Fact 885 (which lists the names of 26 detainees who were killed by KP Dom guards or members of the military who came from outside of the facility). Of those on the list Mašović identified that Abdurahman Cankušić, Salem Bičo, Halim Konjo were exhumed from an individual graves, while Adil Krajčin, Fuad Mandžo, Ekrem Tulek, Kemal Tulek were exhumed from mass graves. P4853 (Updated Table 2 to the Report of Amor Mašović), pp. 81-83, 107.

3011 KDZ017, P3568 (Transcript from Prosecutor v. Krnojelac), T. 2864-2866, 2868, 2877, 2883, 2886-2887, 2960; KDZ017, T. 19904 (4 October 2011). KDZ017 could identify Ismet Karahasnović (who was exhumed from a mass grave. P4853 (Updated Table 2 to the Report of Amor Mašović), p. 80). The Chamber notes that this name is not listed as a Schedule B.8.1 victim on Mašović's table), Suad Islambasić, Zaim Čedić, Ismet Pačo (who was exhumed from a mass grave. P4853 (Updated Table 2 to the Report of Amor Mašović), p. 80), Mehmed Sofradzija (who was exhumed from a mass grave. P4853 (Updated Table 2 to the Report of Amor Mašović), p. 83. The Chamber notes that this name is not listed as a Scheduled Incident B.8.1 victim on Mašović's table), Hasan Džano, Ramo Džendušić, Alija Dželil, Rasim Kajgana in this group. The Chamber notes that the Prosecution lists both Ramo Džendusic and Ramo Djendušić as separate victims of Scheduled Incident B.8.1. Prosecution Final Brief, Appendix G. However, the Chamber is not satisfied that the evidence cited supports that these are two different victims. 
followed by a single shot. ${ }^{3012}$ None of those taken away in groups as described above returned or were seen alive again. ${ }^{3013}$

908. During and after the beating of detainees, guards of the KP Dom were seen carrying blankets into the administration building and removing what appeared to be bodies in those blankets. ${ }^{3014}$ A vehicle also left the facility and returned 10 to 15 minutes later and was cleaned by men in green-grey uniforms. ${ }^{3015}$ Detainees who were sent to clean, saw blood and bloodied instruments in the rooms where the beatings occurred. ${ }^{3016}$

909. The Chamber took judicial notice of the exhumation of 62 male bodies from a mass grave on Maluša Mountain at a site called Jama Piljak. ${ }^{3017}$ However, with the exception of one body which had a name card indicating that the individual was last seen at the KP Dom, the Chamber has insufficient evidence to link these bodies with this scheduled incident. ${ }^{3018}$ Mašović's evidence regarding the exhumation of bodies from mass or individual graves corroborates the evidence of witnesses who identified 16 individuals who were taken from the facility and disappeared and whose names also appear on Mašović's list of exhumed bodies. ${ }^{3019}$

910. In assessing the overall number of persons killed at KP Dom Foča, the Chamber has considered the (i) witness testimony that between 400 and 450 detainees were taken from KP Dom Foča for purported exchanges but disappeared; (ii) witness testimony that multiple groups of

3012 KDZ017, P3568 (Transcript from Prosecutor v. Krnojelac), T. 2838, 2883, 2886; KDZ017, T. 19903-19904 (4 October 2011) (testifying that he was told by a detainee that bodies were transferred to banks of the Drina and buried by stones); see Adjudicated Fact 887. Rašević testified that he never saw any bodies being moved from the KP Dom and that to his knowledge nobody was ever killed at the KP Dom but he acknowledged that he was not aware of whether there was mistreatment during interrogations or whether people were killed outside the facility. In light of these qualifications, the Chamber does not attribute any weight to Rašević's evidence on this issue. See D4307 (Witness statement of Mitar Rašević dated 2 February 2014), paras. 31, 35; Mitar Rašević, T. 46783-46785 (11 February 2014)

3013 KDZ017, P3568 (Transcript from Prosecutor v. Krnojelac), T. 2858, 2866, 2886. KDZ017 having contacted the families of Nurko Nišić, Halim Konjo, Ešad Kiselića, Salem Bičo, Adil Granov (from the third group) was told that they were never seen alive again. Mašović identified that Salem Bičo was exhumed from an individual grave, while Ramo Đendušić, Alija Dželil were exhumed from mass graves. P4853 (Updated Table 2 to the Report of Amor Mašović), pp. 81-82, 107. See Adjudicated Facts 887, 899. Mašović as a member of the State Commission of $\mathrm{BiH}$ received information about prisoners being killed in camps in municipalities including Foča. P4850 (Witness statement of Amor Mašović dated 23 March 2012), para. 54. See also P3346 (Order of Foča's Crisis Staff, 9 May 1992); KDZ239, T. 18920-18921 (15 September 2011); KDZ239, T. 18979-18981 (16 September 2011).

3014 See Adjudicated Facts 882, 887.

3015 See Adjudicated Fact 887.

3016 See Adjudicated Fact 883; KDZ017, P3568 (Transcript from Prosecutor v. Krnojelac), T. $2858,2973$.

3017 P4876 (Sarajevo Cantonal Court record of exhumation of Piljak mass grave in Foča, 2001). See also Adjudicated Facts 2402, 2403

3018 P4850 (Witness statement of Amor Mašović dated 23 March 2012), Annex A, pp. 2-3.

3019 P4853 (Updated Table 2 to the Report of Amor Mašović), pp. 81-82, 107. Mašović identifies the names of 159 individuals who went missing from KP Dom Foča who were exhumed from mass graves or individual graves. However, the Chamber is not satisfied that in the absence of further evidence it can rely on Mašović's evidence to link the exhumed bodies to Scheduled Incident B.8.1. 
detainees were taken out of the facility and shot; (iii) exhumation records which confirm that some of the identified individuals who went missing from KP Dom Foča were exhumed from mass graves or individuals graves.

911. The Chamber therefore finds that, over 200 detainees, as alleged were killed at KP Dom Foča by Serb Forces between June and December 1992.

\section{(3) Scheduled Detention Facility C.10.4}

912. The Prosecution refers to the use of worker's huts at Buk Bijela as a detention facility in July $1992 .^{3020}$

913. Some women from the village of Mješaja/Trošanj were taken by Serb soldiers to a detention centre at Buk Bijela, where Gojko Janković was in charge. ${ }^{3021}$ There, Serb soldiers repeatedly raped Muslim women and girls. ${ }^{3022}$ Girls, women, and some elderly men who were at Buk Bijela were transported by bus to Foča and kept in the Foča High School. ${ }^{3023}$ During this transfer, some Bosnian Muslim women tried to complain to the police, including the police chief Dragan Gagović, but no action was taken. ${ }^{3024}$

\section{(4) Scheduled Detention Facilities C.10.5 and C.10.7}

914. The Prosecution refers to the use of the Partizan Hall ${ }^{3025}$ and Srednja škola - Foča High School $^{3026}$ as detention facilities during 1992.

915. The Muslim civilians held at the Partizan Sports Hall and Foča High School were kept in unhygienic conditions, without hot water, and were provided with insufficient food. ${ }^{3027}$ Their freedom of movement was curtailed; they were not allowed to go to any other territory or to go back to their houses. ${ }^{3028}$ They were guarded and lived in an atmosphere of intimidation. ${ }^{3029}$ All

\footnotetext{
3020 The Indictment refers to the use of this detention facility in both June and July 1992, as per the Prosecution's 73 bis Submission, Appendix B, p. 27. However, the Prosecution now limits the allegations with respect to this facility to July 1992. Prosecution Final Brief, Appendix B, fn. 231.

3021 Adjudicated Fact 2407.

3022 See Adjudicated Fact 787.

3023 Adjudicated Fact 788.

3024 See Adjudicated Facts 789, 790. A woman who tried to escape and sought refuge with the police was hit by a policeman with a rifle butt.

3025 Indictment, Scheduled Detention Facility C.10.5.

3026 Indictment, Scheduled Detention Facility C.10.7.

3027 See Adjudicated Fact 813. See also KDZ239, T. 18946-18947 (15 September 2011).

3028 Adjudicated Fact 813.
} 
this was done in full view, in complete knowledge and sometimes with the direct involvement of the local authorities, particularly the police forces. ${ }^{3030}$

916. Mitar Šipčić, a member of the Foča Crisis Staff, ${ }^{3031}$ was in charge of the guards at the Foča High School. ${ }^{3032}$ Guards worked in shifts to prevent the detainees from escaping, but they did not prevent soldiers from entering the facility. ${ }^{3033}$ Soldiers and policemen would come constantly, sometimes several times a day; they would point at women and girls or call them by their names, take them out and rape them. ${ }^{3034}$ The women had no choice but to obey those men and those who tried to resist were beaten in front of the other women. ${ }^{3035}$ At Foča High School, the girls and women were generally taken for a few hours and returned, sometimes overnight, and some of them were taken away every day. ${ }^{3036}$ After about 10 to 15 days, most of the women from Foča High School were transferred to the Partizan Hall. ${ }^{3037}$

917. The Partizan Hall was guarded by police officers. ${ }^{3038}$ At Partizan Hall, some women were taken out of the facility on multiple occasions and raped by soldiers. ${ }^{3039}$ One woman estimated that during the 40 days of detention at both Foča High School and Partizan Hall, she was raped approximately 150 times. $^{3040}$ The guards at Partizan Hall and Foča High School did not try to prevent soldiers from entering. ${ }^{3041}$ The chief of Foča police, Dragan Gagović, was seen at Foča High School and Partizan Hall. ${ }^{3042}$ Gagović, was one of the men who came to detention facilities,

3029 Adjudicated Fact 813. Mitar Rašević testified that the Partizan Hall was a reception centre from where people could be transported in the direction they wanted to go. Mitar Rašević, T. 46815-46816 (11 February 2014). The Chamber does not consider this evidence to be reliable. In reaching that conclusion the Chamber noted that the witness was evasive and contradicted by reference to his prior testimony.

$3030 \quad$ Adjudicated Fact 813.

3031 P3333 (Official Gazette of Serbian Municipality of Foča, 17 September 1992), p. 40.

3032 See Adjudicated Fact 2409.

3033 SeeAdjudicated Facts 791, 796.

3034 See Adjudicated Facts 792, 787.

3035 Adjudicated Fact 792.

3036 Adjudicated Fact 793.

3037 Adjudicated Fact 793.

3038 Adjudicated Fact 2408.

3039 See Adjudicated Facts 794, 787. See also KDZ239, T. 18946-18947 (16 September 2011); P90 (Witness statement of KDZ216 dated 8 June 1998), p. 14 (under seal); KDZ216, P69 (Transcript from Prosecutor v. Kunarac), T. 3370-3371 (under seal). The witness testified that it was "generally known that soldiers were coming [to Partizan] and taking them away and forcing them to have sexual relations with them". See also D3314 (Witness statement of Radojica Mlađenović dated 1 April 2013), para. 49 who acknowledged that "disgraceful and disgusting things" were committed in this facility. However, the Chamber does not find Mlađenović's unsubstantiated assertion that the perpetrators were processed and punished or that the Bosnian Serb authorities resolved the problem at the facility to be credible. In reaching that conclusion the Chamber also noted that Mlađenović's evidence was marked by multiple contradictions and extreme evasiveness.

$3040 \quad$ See Adjudicated Fact 794.

3041 See Adjudicated Fact 796.

3042 See Adjudicated Fact 795. Milutin Vujičić who was engaged as a guard at the Partizan Hall in late April or early May 1992, testified that (i) guards were ordered to strictly guard the facility and to prevent anyone from being taken out of the facility particularly at night; (ii) it was recommended that civilians go to the Partizan Hall 
including Partizan Hall and the Foča High School, to take women out and rape them. ${ }^{3043}$ On 23 October 1992, a group of women and children who had been detained for a month at Partizan Hall, were transported by bus to Goražde. ${ }^{3044}$

(5) Scheduled Detention Facility C.10.2 and other evidence of rape and other acts of sexual violence during and after the take-over of Foča

918. The Indictment refers to the use of Karaman's house in Miljevina as a detention facility at least between August and October 1992.

919. Dragoljub Kunarac's unit also known as the Zaga Detachment received orders from the Foča Tactical Group. ${ }^{3045}$ Other members of this group included Dragomir "Gaga" Vuković, and Jagos Kontić. ${ }^{3046}$ Kunarac removed many Bosnian Muslim women and girls from various detention centres, including the Partizan Hall. ${ }^{3047}$

920. The girls and women, who were selected by Kunarac or by his men in August 1992, were systematically taken to the soldiers' base in a house in Ulica Osmana Đikića where girls and women were repeatedly raped by Kunarac's men and Kunarac himself during the night. ${ }^{3048}$ Some women were gang-raped in the same house by soldiers while another woman was taken to a separate room by "Gaga" who ordered her to have sex with a 16 year old boy. ${ }^{3049}$ Kunarac was fully aware that the women were raped by other soldiers. ${ }^{3050}$ Some of the women were taken out

for their own safety; (iii) women were allowed to leave facilities during the day and were guarded at night; and (iv) nobody was taken away from the facility while he was at the facility. D2767 (Witness statement of Milutin Vujičić dated 14 January 2013), para. 11; Milutin Vujičić, T. 32095-32096, 32131-32132 (17 January 2013). The Chamber does not find Vujičić's evidence to be of much significance given that he was only at the facility for four days and he did not know who took over the guarding of the facility or what happened after he left. The Chamber finds that his evidence that those who took over the facility also had to obey the order which he received is pure speculation and has no basis or foundation.

See Adjudicated Facts 814, 795. Mlađenović expressed his view that he did not believe that Gagović would have acted in this way. Radojica Mlađenović, T. 36651 (5 April 2013). The Chamber does not consider this evidence to be of much weight given that it is simply the witness's opinion but does note that Mlađenović did acknowledge that crimes did occur.

3044 See Adjudicated Fact 915.

3045 P3354 (Order of Foča Tactical Group, 7 July 1992), p. 3. See also Radojica Mlađenović, T. 36649 (5 April 2013).

3046 See Adjudicated Fact 799.

3047 See Adjudicated Facts 800, 797, 808, 811. See also KDZ216, P69 (Transcript from Prosecutor v. Kunarac), T. 3376, 3439-3440 (under seal).

3048 See Adjudicated Facts 801, 797, 808. Radojica Mlađenović testified that this house was never a headquarters or base for any unit of the regular army. D3314 (Witness statement of Radojica Mlađenović dated 1 April 2013), para. 53; Radojica Mlađenović, T. 36647-36648 (5 April 2013). However, the Chamber does not find this evidence to be reliable. In reaching that conclusion the Chamber noted that Mlađenović's evidence was marked by multiple contradictions and extreme evasiveness.

$3050 \quad$ Adjudicated Fact 811. 
and raped in an abandoned house in Trnovače by Kunarac and another soldier. ${ }^{3051}$ Kunarac also took a girl from the Kalinovik High School, and raped her in a house in an area known as Aladža. ${ }^{3052}$

921. Some of the women from Partizan Hall and Kalinovik High School were at some point moved to different houses and apartments where they continued to be raped and mistreated. ${ }^{3053}$

922. Girls under the age of 20 from the village of Partizan were detained in an apartment which was under the control of Zaga and his men. ${ }^{3054}$ Zaga's men raped the girls and women in the apartment in front of each other. ${ }^{3055}$ Some girls were raped by several of Zaga's men at the same time and this was watched by Zaga. ${ }^{3056}$ Ranko Radulović, who was from Montenegro under the command of Zaga, also violently raped a 16 year old girl. ${ }^{3057}$ One victim was taken to the basement, stripped, threatened with a knife and then raped by one of Zaga's men. ${ }^{3058}$ The girls who had been raped heard that they had to be given to Pero Elez and were taken to Karaman's house in Miljevina. $^{3059}$ At Karaman's house, soldiers had easy access to women and girls whom they raped. $^{3060}$ Radovan Stanković was in charge at the Karaman's house. ${ }^{3061}$ On 3 August 1992, Kunarac went to Ulica Osmana Đikića where he took four women, and drove them to Miljevina. ${ }^{3062}$ There, the women and girls were handed over to soldiers who brought them to Karaman's house where they were constantly raped. ${ }^{3063}$ Some women were detained at Karaman's house for several months to over a year. ${ }^{3064}$ Girls who were brought to Karaman's house were "divided between the men, like property", with Pero Elez deciding which girl went with which soldier. ${ }^{3065}$ There were

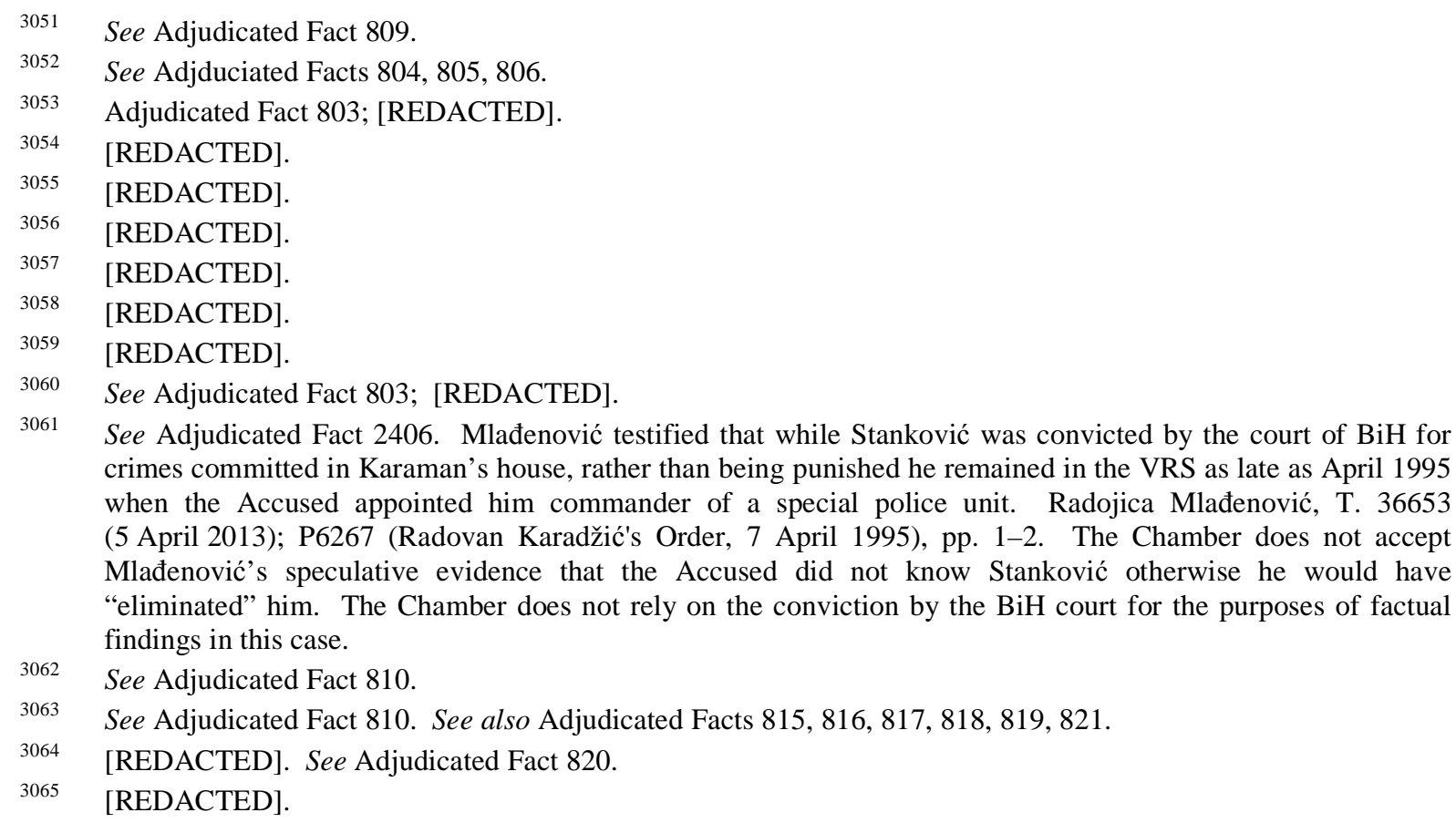

3061 See Adjudicated Fact 2406. Mlađenović testified that while Stanković was convicted by the court of BiH for crimes committed in Karaman's house, rather than being punished he remained in the VRS as late as April 1995 when the Accused appointed him commander of a special police unit. Radojica Mlađenović, T. 36653 (5 April 2013); P6267 (Radovan Karadžić's Order, 7 April 1995), pp. 1-2. The Chamber does not accept Mlađenović's speculative evidence that the Accused did not know Stanković otherwise he would have "eliminated" him. The Chamber does not rely on the conviction by the BiH court for the purposes of factual findings in this case. See Adjudicated Fact 810.

See Adjudicated Fact 810. See also Adjudicated Facts 815, 816, 817, 818, 819, 821.

[REDACTED]. See Adjudicated Fact 820.

[REDACTED]. 
about five or six women in Karaman's house who cooked and cleaned for the soldiers. ${ }^{3066}$ The women did not feel free to leave the house due to the presence of many soldiers. ${ }^{3067}$ Women were also taken to a house in Trnovaca and raped openly by soldiers including Zaga. ${ }^{3068}$

923. Considering the above, the Chamber finds that women and girls were brought to, detained and subjected to acts of sexual violence by members of Serb Forces at multiple locations in Foča, including at Scheduled Detention Facilities C.10.2, C.10.4, C.10.5 and C.10.7.

\section{(F) Scheduled Incident D.10}

924. The Indictment refers to the destruction of two mosques in Foča at least between April and August 1992. ${ }^{3069}$

925. Several mosques in Foča town and municipality were burned or otherwise destroyed. ${ }^{3070}$ Bosnian Serb fire brigades stood by and watched as mosques burned. ${ }^{3071}$ The Aladža mosque dating from 1555 and under UNESCO protection was blown up and the rubble was removed from the site by the end of the war. ${ }^{3072}$ In August 1992, KDZ216 heard a huge detonation at night and she was told that this was the mosque being destroyed. ${ }^{3073}$ The blast broke the windows of the house and KDZ216 heard that it was "Zaga again". ${ }^{3074}$ KDZ216 later saw that the mosque was demolished. ${ }^{3075}$

926. Riedlmayer reported that the Aladža mosque was completely destroyed. ${ }^{3076}$ It was destroyed by explosives, and only traces of the foundations remained and the site had been levelled by a bulldozer with all building materials removed but the adjacent buildings were only lightly

\footnotetext{
3066 [REDACTED].

3067 [REDACTED].

3068 [REDACTED]. The Chamber notes that Stanić praised a number of commanders who were involved in the war in Foča including Gojko Janković and there was proposal to honour Janković for his contribution to the war. P6081 (Video clips re interview and speech of Miroslav Stanić, with transcript); P6082 (Proposal of Foča Tactical Group, 13 August 1993), p. 1.

3069 These are the Aladža mosque and the Jeleč mosque.

3070 Adjudicated Fact 908. See also KDZ379, T. 18837 (15 September 2011) (who was told that the mosques in Foča were shelled and that most mosques were either destroyed or had their minarets destroyed).

3071 See Adjudicated Fact 913; P90 (Witness statement of KDZ216 dated 8 June 1998), pp. 6, 12 (under seal); Milorad Krnojelac, D2716 (Transcript from Prosecutor v. Krnojelac), T. 7887; KDZ216, P69 (Transcript from Prosecutor v. Kunarac), T. 3368 (under seal).

3072 Adjudicated Fact 911; András Riedlmayer, T. 22541 (9 December 2011).

3073 P90 (Witness statement of KDZ216 dated 8 June 1998), p. 6 (under seal); KDZ216, P69 (Transcript from Prosecutor v. Kunarac), T. 3344, 3400-3401 (under seal).

3074 P90 (Witness statement of KDZ216 dated 8 June 1998), p. 6 (under seal); KDZ216, P69 (Transcript from Prosecutor v. Kunarac), T. 3344, 3400-3401 (under seal).

3075 KDZ216, P69 (Transcript from Prosecutor v. Kunarac), T. 3422 (under seal).
} 
damaged. ${ }^{3077}$ Since the end of the conflict, the site of the Aladža mosque was used as a parking lot for buses and littered with rubbish. The house adjacent to the mosque site was burned and fragments of the razed mosque were found dumped in the Cehotina river and buried under rubble and refuse at sites near the Drina river. ${ }^{3078}$ The mosque in Jeleč was burned and its minaret destroyed and only parts of the perimeter walls and rubble remained at the end of the war. ${ }^{3079}$

927. Vujičić acknowledged that Serb Forces attacked the mosques but claimed that they were attacked because Bosnian Muslims, including snipers, were fighting from the mosques which were also used to store weapons and for training. ${ }^{3080}$ However, the Chamber notes that when Vujičić was challenged on cross-examination and presented with Riedlemayer's report which suggested that the Aladža mosque was destroyed in August 1992 and was razed to the ground when there was no fighting, Vujičić's answers were evasive and unconvincing. ${ }^{3081}$ In addition Vujičić's evidence was marked by evasiveness and other indicators which undermined his credibility. The Chamber therefore does not consider his evidence to be reliable with respect to the reason why the Serb Forces attacked the mosques in Foča.

928. Considering the above evidence the Chamber finds that Serb Forces destroyed the Aladža mosque and the Jeleč mosque between April and August 1992.

\section{(G) Movement of the population from Foča}

929. Following the attack on Foča in April 1992, Bosnian Muslims left their homes and made their way through the surrounding woods and neighbouring villages searching for shelter. ${ }^{3082}$ Many

\footnotetext{
3076 P4069 (Cultural destruction database), record 133; P4070 (Attachment to the expert report of András J. Riedlmayer, entitled "Destruction of Cultural Heritage in $\mathrm{BiH}$ " prepared for the Karadžić case, formatted records), pp. 127-134; P4071 (Slide images of damaged religious sites in $\mathrm{BiH}$ ), p. 12.

3077 P4069 (Cultural destruction database), record 133; P4070 (Attachment to the expert report of András J. Riedlmayer, entitled "Destruction of Cultural Heritage in BiH" prepared for the Karadžić case, formatted records), pp. 127-131.

3078 P4069 (Cultural destruction database), record 133; P4070 (Attachment to the expert report of András J. Riedlmayer, entitled "Destruction of Cultural Heritage in $\mathrm{BiH}^{\prime}$ prepared for the Karadžić case, formatted records), pp. 127-131.

3079 Adjudicated Fact 912; P4069 (Cultural destruction database), record 156; P4070 (Attachment to the expert report of András J. Riedlmayer, entitled "Destruction of Cultural Heritage in BiH" prepared for the Karadžić case, formatted records), pp. 132-134. Riedlmayer also reported on damage to other cultural monuments and sacred sites in Foča however, these sites are not charged in Schedule D of the Indictment. P4069 (Cultural destruction database), records 131-165.

3080 D2767 (Witness statement of Milutin Vujičić dated 14 January 2013), paras. 22, 24; Milutin Vujičić, T. 32123 (17 January 2013); Trifko Pljevaljčić, T. 32296-32297, 32304, 32357 (21 January 2013); D3314 (Witness statement of Radojica Mlađenović dated 1 April 2013), para. 37.

3081 Milutin Vujičić, T. 32123 (17 January 2013).

3082 D299 (ABiH Supreme Command Staff Special Report, 17 July 1993), pp. 2-3.
} 
left out of fear for their safety after Serb Forces took over parts of Foča where they lived. ${ }^{3083}$ In order to leave they had to arrange for certificates from the local police and sign a form transferring their property to the "Bosnian-Serb Republic". 3084

930. Following the fall of Foča, a large number of civilians moved from Foča towards Ustikolina and a group of between 300 to 500 people consisting almost exclusively of Bosnian Muslims sought shelter in the JNA depot. ${ }^{3085}$ However, Pero Mihajlović who was the SDS representative in Ustikolina, instructed the personnel at the JNA depot that they should not receive Bosnian Muslims and if they continued to house Bosnian Muslims at the compound "he would send people who were paid to cleanse that area". ${ }^{3086}$ On the night of 25 April 1992 there were clashes in the vicinity of the depot after which most of the Bosnian Muslims left towards Goražde before Serb Forces captured the depot. ${ }^{3087}$

931. In May 1992, buses were organised to take civilians out of Foča. ${ }^{3088}$ The Chamber finds that some Bosnian Muslims did request to leave the municipality after which the Bosnian Serb authorities arranged for their transportation out of the municipality. ${ }^{3089}$ However, the Chamber also finds that even if Bosnian Muslims signed documents which indicated that they wished to leave,

3083 See Adjudicated Fact 2410; KDZ017, P3568 (Transcript from Prosecutor v. Krnojelac), T. $2770,2773-2774$. The Chamber also received evidence of both Bosnian Muslims and Bosnian Serbs leaving Foča before the outbreak of hostilities, but does not consider this evidence to be relevant to the charges in the Indictment. See Adjudicated Facts 733, 734, 735; Trifko Pljevaljčić, T. 32286, 32324 (21 January 2013). See also KDZ017, T. 19893 (4 October 2011); Momir Bulatović, T. 34569-34571 (1 March 2013).

3084 See Adjudicated Fact 2410. Radojica Mlađenović testified that no statements were signed by Bosnian Muslims and that they would leave their property to friends or neighbours for protection. D3314 (Witness statement of Radojica Mlađenović dated 1 April 2013), para. 51. See also Radojica Mlađenović, T. 36616, 36698 (5 April 2013). However, the Chamber does not consider this to be reliable evidence. In reaching that conclusion, the Chamber noted that Mlađenović was contradicted and evasive on a number of occasions during his testimony. Similarly the Chamber does not accept the speculative and unsubstantiated evidence that it was Bosnian Muslim propaganda about the threat faced by the Bosnian Muslim population which caused panic and prompted Bosnian Muslims to leave the municipality. D3314 (Witness statement of Radojica Mlađenović dated 1 April 2013), para. 34; Radojica Mlađenović, T. 36693 (5 April 2013); Veljko Marić, T. 35625 (19 March 2013).

3085 KDZ379, P3332 (Transcript from Prosecutor v. Krnojelac), T. 3103-3104, 3108, 3160-3161 (testifying that there were between 300 and 500 people who sought shelter); KDZ379, T. 18855, 18871-18872, 18874, 1889618897 (15 September 2011); D3065 (Witness statement of Aleksandar Vasiljević dated 26 February 2013), para. 189 (referring to 200 "Muslim refugees"); Aleksandar Vasiljević, T. 34703-34704, 34706-34707 (4 March 2013), 34705-34706 (4 March 2013) (private session).

3086 KDZ379, P3332 (Transcript from Prosecutor v. Krnojelac), T. 3107-3108.

3087 KDZ379, P3332 (Transcript from Prosecutor v. Krnojelac), T. 3104, 3109-3111, 3114; KDZ379, T. 18877, 18879-18881 (15 September 2011) (testifying that approximately 50 women, children, and the disabled or sick who could not leave remained when the depot was taken over by Serb Forces). See also Adjudicated Fact 757. The Chamber also received contrasting evidence about whether or not there were armed members of the SDA in this group of Bosnian Muslims and the reason why Serb Forces took control of the depot. However, the Chamber does not consider that this affects the predominantly civilian character of the Bosnian Muslims who had taken shelter in the depot. See D1683 (Report of JNA 744 ${ }^{\text {th }}$ Logistics Base, 27 April 1992), pp. 1-2 (under seal); KDZ379, T. 18878, 18883 (15 September 2011).

3088 See Adjudicated Fact 914. See also Milorad Krnojelac, D2716 (Transcript from Prosecutor v. Krnojelac), T. 7889. 
this was a product of pressures put on them and the surrounding circumstances in the municipality, including attacks against Bosnian Muslims and their homes. ${ }^{3090}$

932. Defence witnesses testified that Bosnian Muslims who left by convoy left voluntarily, that they were not expelled, and did not flee from the Serb Forces. In addition, according to these witnesses, the Bosnian Muslims who remained were given shelter and the civilian authorities treated them fairly, in the same way as Bosnian Serb citizens, and did not confiscate their property. ${ }^{3091}$ However, the Chamber does not consider this evidence to be reliable in light of the other evidence received as to the surrounding circumstances in Foča. The Chamber also notes that Pljevaljčić was challenged on cross-examination and it was suggested that his evidence about whether the people left voluntarily was hearsay. ${ }^{3092}$ While Pljevaljčić adhered to the content of his evidence, the Chamber considers his evidence to be purely speculative and does not rely on his assessment as to the voluntariness of these departures. Similarly the Chamber does not consider Vujičić's evidence pertaining to the voluntariness of the departure of Bosnian Muslims and the treatment of those who remained to be credible. In reaching that conclusion, the Chamber noted that Vujičić's evidence was marked by evasiveness and indicators that he was trying to mislead the Chamber and lacked forthrightness. In addition, there were contradictions in his evidence which on the one hand suggested that Bosnian Muslims left voluntarily and on the other that the municipality became almost exclusively Serb after the break-out of clashes. While the Chamber received evidence which suggested that Bosnian Serb authorities issued a public statement inviting those who had left Foča to return, it does not have sufficient detail as to the circumstances or timing of this invitation for it to be considered of any significance. ${ }^{3093}$

933. At the session of the Bosnian Serb Assembly held from 24 to 26 July 1992, greetings were extended to "liberated Foča". 3094 At this same session Vojo Kuprešanin spoke about the danger of losing Foča which would allow the establishment of the "green transversal". 3095 In August 1992, the remaining Bosnian Muslims in Foča, mostly women and children, were taken to Montenegro ${ }^{3096}$

\footnotetext{
3089 P2642 (Report of Foča War Commission, 18 June 1992), p. 1; Radojica Mlađenović, T. 36697 (5 April 2013 ).

3090 See also Colm Doyle, T. 2946, 2951-2952 (28 May 2010); Colm Doyle, P918 (Transcript from Prosecutor v. S. Milošević), T. 25281-25282.

3091 Trifko Pljevaljčić, T. 32303-32304, 32315-32317, 32319-32320, 32343-32346, 32352-32353 (21 January 2013); D2767 (Witness statement of Milutin Vujičić dated 14 January 2013), paras. 8, 16, 30, 32; Milutin Vujičić, T. 32134-32135, 32142 (17 January 2013). See also P6080 (Report of Foča Military Post, 10 October 1992).

3092 Trifko Pljevaljčić, T. 32346 (21 January 2013).

3093 KDZ379, T. 18874 (15 September 2011).

3094 D92 (Transcript of $17^{\text {th }}$ session of SerBiH Assembly, 24-26 July 1992), p. 5.

3095 D92 (Transcript of $17^{\text {th }}$ session of SerBiH Assembly, 24-26 July 1992), p. 41.

3096 See Adjudicated Fact 914. See also Milorad Krnojelac, D2716 (Transcript from Prosecutor v. Krnojelac), T. 7889-7890.
} 
and by mid-August 1992 there were almost no Bosnian Muslims in Foča. ${ }^{3097}$ In April and May 1993, Petko Čančar reported to the Bosnian Serb Assembly that not a single Bosnian Muslim was in Foča, that every part of the municipality was controlled by Bosnian Serbs, and that there was "only one people" living in Foča and "one religion" being practised there. ${ }^{3098}$

934. Having considered the totality of the evidence and assessed the circumstances in which departures occurred, the Chamber finds that Bosnian Muslims were forced to leave Foča.

\section{v. Rogatica}

\section{(A) Charges}

935. Under Count 3, the Prosecution alleges that persecution, a crime against humanity, was committed in Rogatica as part of the objective to permanently remove Bosnian Muslims and/or Bosnian Croats from the Municipalities. ${ }^{3099}$ Acts of persecution alleged to have been committed in Rogatica by Serb Forces and Bosnian Serb Political and Governmental Organs include killings related to detention facilities and killings committed during, and deaths resulting from, cruel and inhumane treatment at scheduled detention facilities. ${ }^{3100}$ The Prosecution also characterises these killings as extermination, a crime against humanity, under Count 4; murder, a crime against humanity, under Count 5; and as murder, a violation of the laws or customs of war, under Count $6 . .^{3101}$

936. Other acts of persecution alleged to have been committed by Serb Forces and Bosnian Serb Political and Governmental Organs include (i) torture, beatings, and physical and psychological abuse, during and after the take-over and in scheduled detention facilities, as cruel or inhumane treatment; ${ }^{3102}$ (ii) rape and other acts of sexual violence, during and after the take-over and in

3097 P90 (Witness statement of KDZ216 dated 8 June 1998), p. 12 (under seal); KDZ216, P69 (Transcript from Prosecutor v. Kunarac), T. 3367-3368 (under seal); P502 (Video clip of a man and destroyed houses); P1480 (Ratko Mladić's notebook, 10-30 September 1992), p. 66. See also Milorad Krnojelac, D2716 (Transcript from Prosecutor v. Krnojelac), T. 7889-7890; Adjudicated Fact 917 (which suggested that Foča had become an almost purely Serb town by the end of 1995).

3098 P1371 (Transcript of 30 ${ }^{\text {th }}$ session of RS Assembly, 5-6 May 1993), p. 78; P1367 (Transcript of $26^{\text {th }}$ session of RS Assembly, 2 April 1993), p. 25. See also D4002 (Letter from BiH MUP to Vasvija Vidović, 4 July 1995), p. 24 (reporting that no non-Serbs lived in Foča). After the war, Foča was referred to as Srbinje. KDZ379, T. 18831-18832 (15 September 2011).

3099 Indictment, paras. 48-49.

3100 Indictment, para. 60(a)(ii). The acts of murder and extermination in Rogatica are restricted to killings related to detention facilities, including those resulting from cruel and inhumane treatment. See Scheduled Incidents B.16.1 and B.16.2. The Chamber notes that a scheduled incident pertaining to killings which allegedly occurred during and after the take-over of Rogatica was withdrawn from the Indictment. Rule 73 bis Decision, Schedule B, p. 65 .

3101 Indictment, para. 63(b).

3102 Indictment, para. 60(b). See Scheduled Detention Facilities C.21.1, C.21.2, C.21.3. 
scheduled detention facilities, as cruel and inhumane treatment; ${ }^{3103}$ (iii) the establishment and perpetuation of inhumane living conditions in detention facilities in Rogatica, including the failure to provide adequate accommodation, shelter, food, water, medical care, or hygienic sanitation facilities, as cruel or inhumane treatment; ${ }^{3104}$ (iv) forcible transfer or deportation of Bosnian Muslims and Bosnian Croats from their homes; ${ }^{3105}$ (v) unlawful detention in scheduled detention facilities; $;^{3106}$ (vi) forced labour at frontlines and the use of Bosnian Muslims and Bosnian Croats as human shields $;^{3107}$ (vii) the appropriation or plunder of property, during and after the take-over, during arrests and detention and in the course of or following acts of deportation or forcible transfer; ${ }^{3108}$ (viii) the wanton destruction of private property including homes, business premises, and public property including cultural monuments and sacred sites; ${ }^{3109}$ and (ix) the imposition and maintenance of restrictive and discriminatory measures. ${ }^{3110}$

937. Under Counts 7 and 8, the Prosecution alleges deportation and inhumane acts (forcible transfer), respectively, as crimes against humanity. ${ }^{311}$ In this regard, the Prosecution alleges that, by the end of 1992, Serb Forces and Bosnian Serb Political and Governmental Organs had forcibly displaced Bosnian Muslims and Bosnian Croats from areas in Rogatica in which they were lawfully present. $^{3112}$ It is alleged that from March 1992 restrictive and discriminatory measures, arbitrary arrest and detention, harassment, torture, rape and other acts of sexual violence, killing, destruction of houses, cultural monuments and sacred sites, as well as the threat of further such acts caused Bosnian Muslims and Bosnian Croats to flee in fear while others were physically driven out. ${ }^{3113}$

\section{(B) Lead-up}

938. Rogatica is a municipality in eastern $\mathrm{BiH}$ located between the municipalities of Sarajevo to the west, Višegrad to the east, Goražde to the south, and Srebrenica to the northeast. ${ }^{314}$ Main road

Indictment, para. 60(j). See Scheduled Incident D.18.

Indictment, para. 60(c). See Scheduled Detention Facilities C.21.1, C.21.2, C.21.3.

Indictment, para. 60(d). See Scheduled Detention Facilities C.21.1, C.21.2, C.21.3.

Indictment, para. 60(f).

Indictment, para. 60(g). See Scheduled Detention Facilities C.21.1, C.21.2, C.21.3.

Indictment, para. 60(h).

Indictment, para. 60(i).

Indictment, para. $60(\mathrm{k})$. The restrictive and discriminatory measures alleged include the denial of freedom of movement; the removal from positions of authority; the invasion of privacy through arbitrary searches of homes; unlawful arrest and/or the denial of the right to judicial process; and/or the denial of equal access to public services.

3111 Indictment, paras. 68-75.

3112 Indictment, paras. 69, 72.

3113 Indictment, para. 71.

3114 D484 (Map of $\mathrm{BiH}$ ).
} 
connections from Serbia to Sarajevo traversed Rogatica. ${ }^{3115}$ Prior to the war, the majority of the population in Rogatica was Bosnian Muslim, making up approximately $60 \%$ of the population, while Bosnian Serbs accounted for approximately $38 \%$ of the population with a few other nationalities making up the remainder. ${ }^{316}$ In Rogatica town Bosnian Muslims constituted 64\% of the population while $33 \%$ were Bosnian Serbs with very few Bosnian Croats. ${ }^{3117}$

939. Inter-ethnic conflict arose in Rogatica following the creation of national parties. ${ }^{3118}$ In Rogatica, the SDA and the SDS were formed in the first half of 1990 and in early September 1990 respectively. ${ }^{3119}$ Sveto Veselinović was elected president of the SDS in Rogatica and was also the president of the SDS Romanija Regional Board. ${ }^{3120}$ The SDA won the most seats in the 1990 elections; ${ }^{3121}$ however, an agreement was reached in 1991 between the SDA and SDS as to how specific posts in the municipality should be filled. ${ }^{3122}$ A multi-party government was formed under which Adil Lutvić, a Bosnian Muslim, was elected President of the municipality and the President of the Executive Board was a Bosnian Serb named Mile Ujić. ${ }^{3123}$ Tomislav Batinić was elected Vice President of the Municipal Assembly. ${ }^{3124}$ Ismet Osmanović, a Bosnian Muslim, became Chief

3115 P3279 (Witness statement of KDZ606 dated 1 September 2011), para. 4 (under seal). See also D232 (Directive 1, 6 June 1992), p. 4.

3116 P4994 (Addendum to Ewa Tabeau's expert report entitled "Ethnic Composition in Internally Displaced Persons and Refugees from 27 Municipalities of BiH 1991 to 1997”, 3 February 2009), pp. 21, 31, 34, 37, 40; P3405 (Witness statement of KDZ051 dated 17 September 2011), para. 3; D2930 (Witness statement of Tomislav Batinić dated 11 February 2013), para. 5; P3289 (Witness statement of KDZ607 dated 1 September 2011), para. 4 (under seal); P3279 (Witness statement of KDZ606 dated 1 September 2011), para. 5 (under seal); D2351 (Witness statement of Stevan Veljović dated 19 October 2012), para. 6; Elvir Pašić, P59 (Transcript from Prosecutor v. Tadić), T. 838. See also P3281 (Map of Rogatica showing ethnic composition); P2829 (Map of Rogatica municipality marked by Asim Džambasović); Momčilo Mandić, T. 5299 (16 July 2010).

3117 D2351 (Witness statement of Stevan Veljović dated 19 October 2012), para. 6. See also P2828 (Witness statement of Asim Džambasović dated 18 June 2011), para. 12; P3405 (Witness statement of KDZ051 dated 17 September 2011), paras. 3-4.

3118 D2930 (Witness statement of Tomislav Batinić dated 11 February 2013), para. 3.

3119 D3038 (Witness statement of Novica Andrić dated 23 February 2013), para. 3; D2930 (Witness statement of Tomislav Batinić dated 11 February 2013), para. 4; D2950 (Witness statement of Sveto Veselinović dated 15 February 2013), para. 3.

3120 D2950 (Witness statement of Sveto Veselinović dated 15 February 2013), paras. 3, 9; D2958 (Press statement of SDS Romanija Regional Board, 11 May 1991); P3405 (Witness statement of KDZ051 dated 17 September 2011), para. 5; P3289 (Witness statement of KDZ607 dated 1 September 2011), para. 5 (under seal); P3279 (Witness statement of KDZ606 dated 1 September 2011), paras. 8, 10-11 (under seal). Other senior members of the SDS included Veljko Bojović, Rajko Kušić, Tomo Pavlović, Dušan Planojević and Mile Ujić. P3405 (Witness statement of KDZ051 dated 17 September 2011), para. 5.

3121 P3289 (Witness statement of KDZ607 dated 1 September 2011), para. 5 (under seal). See also Elvir Pašić, P59 (Transcript from Prosecutor v. Tadić), T. 837-838, 890-891; Momčilo Mandić, T. 5299 (16 July 2010); P2829 (Map of Rogatica municipality marked by Asim Džambasović); P3405 (Witness statement of KDZ051 dated 17 September 2011), paras. 3-4.

3122 D2957 (Minutes of meeting in Rogatica, 4 January 1991); D2950 (Witness statement of Sveto Veselinović dated 15 February 2013), para. 5; Sveto Veselinović, T. 33873-33874 (18 February 2013).

3123 P3405 (Witness statement of KDZ051 dated 17 September 2011), para. 8; P3289 (Witness statement of KDZ607 dated 1 September 2011), para. 5 (under seal); D2930 (Witness statement of Tomislav Batinić dated 11 February 2013), para. 6; D2909 (Witness statement of Mile Ujić dated 9 February 2013), para. 4; P6104 (Record of interview with Mile Ujić, 6 June 2004), p. 2. See also Sveto Veselinović, T. 33874 (18 February 2013).

3124 D2930 (Witness statement of Tomislav Batinić dated 11 February 2013), para. 6. 
of the SJB, the Commander of the SJB was Ramiz Alajbegović, and the deputy Chief of the SJB was a Bosnian Serb, Mladen Vasiljević. ${ }^{3125}$

940. Disagreements arose between the SDS and the SDA about the division of functions and there were protests that the SDA had violated the inter-party agreement on the division of power. $^{3126}$ A joint government continued to function until as late as mid-1991; however, cooperation deteriorated after the SDA municipal leadership started supporting the secession of BiH. $^{3127}$ Police, coffee shops, restaurants, bars, businesses, and clubs became divided along ethnic lines. $^{3128}$

941. In mid-1991, during political rallies that were held and attended by thousands, Bosnian Serbs delivered nationalist speeches. ${ }^{3129}$ This sentiment was reflected in the speeches of SDS officials who said that the time had come for the Serbian people to unite and create an "integral state", that they would not allow the secession of $\mathrm{BiH}$, that Serbs and Muslims could no longer live together, and that they wanted to "create a Serbian state, once and for all". 3130 Veselinović stated that the Bosnian Serbs were "ready and [...] 1941 will never be repeated". 3131 These rallies and speeches created insecurity amongst the Bosnian Muslim population. ${ }^{3132}$ Inflammatory statements were also made by Bosnian Muslim leaders. ${ }^{3133}$

3125 P3405 (Witness statement of KDZ051 dated 17 September 2011), para. 8; P3289 (Witness statement of KDZ607 dated 1 September 2011), para. 5 (under seal); D2909 (Witness statement of Mile Ujić dated 9 February 2013), para. 12.

3126 D2950 (Witness statement of Sveto Veselinović dated 15 February 2013), para. 7; Sveto Veselinović, T. 33875 (18 February 2013); D2909 (Witness statement of Mile Ujić dated 9 February 2013), para. 12; D2951 (Article entitled "Barricades in Front of the Municipal Assembly"). See also P3279 (Witness statement of KDZ606 dated 1 September 2011), para. 9 (under seal); KDZ606, T. 18292-18293 (5 September 2011) (closed session).

3127 D2950 (Witness statement of Sveto Veselinović dated 15 February 2013), paras. 8-9; Sveto Veselinović, T. 33875 (18 February 2013).

3128 P3405 (Witness statement of KDZ051 dated 17 September 2011), paras. 4, 7; KDZ051, T. 19367-19368 (22 September 2011); D2930 (Witness statement of Tomislav Batinić dated 11 February 2013), para. 8. See also D3031 (Witness statement of Milovan Lelek dated 23 February 2013), para. 6; D2909 (Witness statement of Mile Ujić dated 9 February 2013), para. 13.

3129 P3279 (Witness statement of KDZ606 dated 1 September 2011), paras. 14, 18-19 (under seal). Sveto Veselinović stated that the rhetoric at the majority of pre-election gatherings was not inflammatory and that the need for maximum co-operation between the SDS, the SDA, and other parties was stressed. D2950 (Witness statement of Sveto Veselinović dated 15 February 2013), para. 3. The Chamber finds that Veselinović's evidence that the majority of pre-election gatherings were not inflammatory is not inconsistent with inter-ethnic hatred being fueled at some rallies.

3130 P3279 (Witness statement of KDZ606 dated 1 September 2011), paras. 15-16, 18 (under seal); P3409 (Video footage of statement by Serbian Mayor of Rogatica); KDZ051, T. 19360 (22 September 2011). See also P3286 (Witness statement of Armin Baždar dated 23 January 1999), p. 2.

3131 D2953 (Article from Politika entitled "SDA Causing Crisis"), p. 1; D2950 (Witness statement of Sveto Veselinović dated 15 February 2013), para. 9; Sveto Veselinović, T. 33901-33902 (18 February 2013).

3132 P3279 (Witness statement of KDZ606 dated 1 September 2011), paras. 17, 19 (under seal).

3133 D2909 (Witness statement of Mile Ujić dated 9 February 2013), paras. 15-16; D2950 (Witness statement of Sveto Veselinović dated 15 February 2013), para. 9; D2952 (SDS Romanija Regional Board communiqué, 6 May 1991); D2958 (Press statement of SDS Romanija Regional Board, 11 May 1991); Sveto Veselinović, T. 
942. Inter-ethnic relations further deteriorated when war broke out in Croatia and Bosnian Muslims refused to fight in the TO but went to Croatia for training. ${ }^{3134}$ At a gathering at a stadium in Rogatica, JNA officers made an announcement that Bosnian Muslim reservists were no longer needed and that Bosnian Muslims who did not want to fight in Croatia were not to come back. ${ }^{3135}$ From January to February 1992, members of the SDS travelled to Bosnian Serb villages and informed the Bosnian Serbs that there was "a Muslim threat" and they should be prepared to protect themselves; this encouraged Serb nationalism. ${ }^{3136}$

\section{(1) Militarisation of Rogatica}

943. As early as 1990 the weapons stored in the TO headquarters in Rogatica were moved to the barracks in Han Pijesak and placed under the control of the JNA. ${ }^{3137}$ Towards the end of 1991, there was an increased presence of JNA troops in Rogatica. ${ }^{3138}$ From this time, the $1^{\text {st }}$ Mountain Battalion of the JNA was deployed to Bosnian Serb areas of Rogatica. At night, they armed local Bosnian Serbs with the assistance of the Bosnian Serb political and military officials. ${ }^{3139}$ Bosnian Serbs also started organising village guards at night in the second half of $1991 .^{3140}$

33876 (18 February 2013); Mile Ujić, T. 33440-33441 (12 February 2013). The Chamber also received evidence about increasing Bosnian Muslim nationalism after the referendum on the secession of BiH. D3038 (Witness statement of Novica Andrić dated 23 February 2013), para. 5; D2930 (Witness statement of Tomislav Batinić dated 11 February 2013), para. 4; D2351 (Witness statement of Stevan Veljović dated 19 October 2012), para. 8. See also D1374 (Report of JNA $4^{\text {th }}$ Corps command, 30 October 1991).

3134 P3405 (Witness statement of KDZ051 dated 17 September 2011), para. 10; P3279 (Witness statement of KDZ606 dated 1 September 2011), para. 6 (under seal); P127 (Witness statement of Alija Isaković dated 22 January 1999), pp. 2-3; D2909 (Witness statement of Mile Ujić dated 9 February 2013), para. 20 ; D3031 (Witness statement of Milovan Lelek dated 23 February 2013), para. 5. See also P3286 (Witness statement of Armin Baždar dated 23 January 1999), p. 2 (testifying that relations between Bosnian Serbs and Bosnian Muslims further deteriorated in March 1992).

3135 P3405 (Witness statement of KDZ051 dated 17 September 2011), para. 10; KDZ051, T. 19375-19376 (22 September 2011).

3136 P3279 (Witness statement of KDZ606 dated 1 September 2011), para. 21 (under seal).

3137 P3279 (Witness statement of KDZ606 dated 1 September 2011), para. 22 (under seal); KDZ606, T. 18302 (5 September 2011) (closed session) (confirming that these weapons were moved by the previous government before the elections); D3038 (Witness statement of Novica Andrić dated 23 February 2013), paras. 7-8.

3138 Elvir Pašić, P59 (Transcript from Prosecutor v. Tadić), T. 844.

3139 P2828 (Witness statement of Asim Džambasović dated 18 June 2011), paras. 39, 43, 46-47, 49, 53; P3404 (Witness statement of KDZ051 dated 17 September 2011), paras. 17-18 (under seal); P3405 (Witness statement of KDZ051 dated 17 September 2011), paras. 19-22; P128 (Alija Isaković's statement to BiH authorities, 30 March 1993), p. 2; P3279 (Witness statement of KDZ606 dated 1 September 2011), paras. 23, 25-28 (under seal); KDZ606, T. 18311-18312 (5 September 2011) (closed session); P3281 (Map of Rogatica showing ethnic composition). Džambasović stated that the removal and distribution of JNA weapons was "very well planned and organised by senior Serb political and military officials" given the normal strict controls on the distribution of JNA weapons and ammunition. P2828 (Witness statement of Asim Džambasović dated 18 June 2011), paras. 46, 49, 53; P2831 (Diary of Asim Džambasović), pp. 10, 27. In support of the observation that this was organised, Džambasović testified that the JNA had powerful security and military judicial structures which "would not tolerate such weapons diversions" and yet despite the serious transgressions the headquarters, security organs and military prosecutors did nothing. P2828 (Witness statement of Asim Džambasović dated 18 June 2011), para. 53-54; P2831 (Diary of Asim Džambasović), pp. 10, 18, 27-28; P3286 (Witness statement of Armin Baždar dated 23 January 1999, p. 3; P2830 (Report of $1^{\text {st }}$ Podrinje Light Infantry Brigade, 25 February 
944. Members of the SDS were also involved in transporting weapons to local communes, where they were distributed to surrounding villages. ${ }^{3141}$ This distribution of weapons continued in the spring of $1992,{ }^{3142}$ and local Bosnian Serbs also started wearing military uniforms. ${ }^{3143}$ Mladen Vasiljević was involved in these arming operations ${ }^{3144}$ as was Rajko Kušić who was a member of the SDS Main Board. ${ }^{3145}$

945. The SDA was also involved in arming the Bosnian Muslim population and in forming Bosnian Muslim units from late $1990 .{ }^{3146}$ There was also a mobilisation of the police reserve

1993), pp. 1, 3. See also P1383 (Transcript of $36^{\text {th }}$ session of RS Assembly, 30-31 December 1993), p. 164; P5844 (Intercept of conversation between Jovan Tintor and Ratko Adžić, 14 October 1991), p. 2; D4002 (Letter from BiH MUP to Vasvija Vidović, 4 July 1995), p. 28. D3038 (Witness statement of Novica Andrić dated 23 February 2013), para. 6. See also D2930 (Witness statement of Tomislav Batinić dated 11 February 2013), para. 14; D2950 (Witness statement of Sveto Veselinović dated 15 February 2013), para. 12.

3141 P3279 (Witness statement of KDZ606 dated 1 September 2011), paras. 31-32 (under seal).

3142 Elvir Pašić, P59 (Transcript from Prosecutor v. Tadić), T. 848-850; Adjudicated Fact 1972; P127 (Witness statement of Alija Isaković dated 22 January 1999), p. 2. Defence witnesses testified that the JNA did not arm Bosnian Serbs in Rogatica and only supplied weapons to those who joined the JNA. D3038 (Witness statement of Novica Andrić dated 23 February 2013), para. 8; D2930 (Witness statement of Tomislav Batinić dated 11 February 2013), para. 17; Sveto Veselinović, T. 33898-33899 (18 February 2013). See also D3031 (Witness statement of Milovan Lelek dated 23 February 2013), para. 15. However, the Chamber does not find this evidence to be reliable. In reaching that conclusion, the Chamber found that the evidence of Andric was marked by evasiveness and indicators that he was not completely forthright in his testimony in this regard. With respect to Batinić, the Chamber noted that he simply stated that he did not know about the arming of Bosnian Serbs by the JNA and claimed that given his position he "would probably have known if something like that had happened". D2930 (Witness statement of Tomislav Batinić dated 11 February 2013), para. 17. The Chamber finds this to be purely speculative and is not convinced that it can rely on this evidence. With respect to Veselinović, the Chamber noted conflicting statements which undermined the reliability of his evidence on this issue.

3143 P3286 (Witness statement of Armin Baždar dated 23 January 1999), p. 2.

3144 P3279 (Witness statement of KDZ606 dated 1 September 2011), paras. 31-33 (under seal). Other members of the SDS identified by KDZ606 as involved in the arming of Bosnian Serbs included Radan Bojović, Miloš Rajak, and Mićo Andrić.

3145 Elvir Pašić, P59 (Transcript from Prosecutor v. Tadić), T. 849-850. Kušić was responsible for contact with the JNA and was "heavily involved" in the effort to arm local Bosnian Serbs. P2828 (Witness statement of Asim Džambasović dated 18 June 2011), paras. 28, 39. See also P3408 (List of members of SDS' Main Board), p. 2 (which confirms that Kušić was a member of the SDS Main Board).

3146 D2909 (Witness statement of Mile Ujić dated 9 February 2013), paras. 10-11, 17, 30; D3038 (Witness statement of Novica Andrić dated 23 February 2013), para. 4; D3031 (Witness statement of Milovan Lelek dated 23 February 2013), paras. 6-7; Milovan Lelek, T. 34374 (27 February 2013); D2950 (Witness statement of Sveto Veselinović dated 15 February 2013), paras. 11, 21; P2832 (Article from Srpska Vojska article entitled “They Saved Serbian Land", 15 July 1993), p. 2; D2351 (Witness statement of Stevan Veljović dated 19 October 2012), paras. 4-5, 35; P3267 (Witness statement of Šefik Hurko dated 1 September 2011), para. 2 (stating that Bosnian Muslim villages organised night watches but were poorly armed). But see Asim Džambasović, T. 15156 (22 June 2011); P3405 (Witness statement of KDZ051 dated 17 September 2011), para. 23; P127 (Witness statement of Alija Isaković dated 22 January 1999), p. 2; KDZ051, T. 19388-19390 (22 September 2011); Elvir Pašić, P59 (Transcript from Prosecutor v. Tadić), T. 859-860, 884; P3279 (Witness statement of KDZ606 dated 1 September 2011), para. 57 (under seal). 
which primarily included Bosnian Muslims. ${ }^{3147}$ The Chamber also received evidence about actions by Bosnian Muslims, including attacks against Bosnian Serbs. ${ }^{3148}$

946. There was a close relationship between the Bosnian Serb officers in the $216^{\text {th }}$ Mountain Brigade of the JNA and members of the SDS leadership. The latter would often come to the brigade's barracks and meet its Commander Dragomir Milošević. ${ }^{3149}$ As Chief of Staff of the $216^{\text {th }}$ Mountain Brigade, Asim Džambasović discussed these visits and irregularities relating to the control of weapons with Dragomir Milošević and the Commander of the $4^{\text {th }}$ Corps of the JNA, but no action was taken. ${ }^{3150}$ As early as January 1992 Bosnian Serbs started refusing to take orders from non-Serb officers in the JNA. ${ }^{3151}$

947. In March 1992, volunteers were mobilised but given the Bosnian Muslim boycott of the mobilisation, Bosnian Serbs became predominant in the JNA. ${ }^{3152}$ Following this mobilisation, two Bosnian Serb battalions of the $216^{\text {th }}$ Mountain Brigade were formed and members of the SDS assisted in this mobilisation. ${ }^{3153}$ A Bosnian Serb TO was formed in March 1992 after the Rogatica

3147 D2930 (Witness statement of Tomislav Batinić dated 11 February 2013), paras. 11-12; Tomislav Batinić, T. 33676 (14 February 2013); D2909 (Witness statement of Mile Ujić dated 9 February 2013), paras. 12.

3148 D2909 (Witness statement of Mile Ujić dated 9 February 2013), paras. 17, 30-31; D2351 (Witness statement of Stevan Veljović dated 19 October 2012), para. 9; P2832 (Article from Srpska Vojska entitled "They Saved Serbian Land", 15 July 1993), p. 3; Milovan Lelek, T. 34429-34430 (27 February 2013). KDZ606 testified that Kušić had feigned attacks against Bosnian Serb villages and used that as pretext to enter these villages and instil fear about attacks by Bosnian Muslim paramilitaries which created support to conduct clearing operations in the area. P3279 (Witness statement of KDZ606 dated 1 September 2011), para. 57 (under seal). However, the Chamber finds this evidence to be too speculative and will not rely on it in this regard.

3149 P2828 (Witness statement of Asim Džambasović dated 18 June 2011), paras. 2, 76-78, 80; Asim Džambasović, T. 15156-15157, 15168-15169 (22 June 2011). The SDS leaders who visited Dragomir Milošević between January and March 1992 included Rajko Dukić. Adjudicated Fact 1974.

3150 Asim Džambasović, T. 15157 (22 June 2011); P2828 (Witness statement of Asim Džambasović dated 18 June 2011), paras. 53-54, 90-91; P2831 (Diary of Asim Džambasović), pp. 21, 28.

3151 P2828 (Witness statement of Asim Džambasović dated 18 June 2011), para. 91; P2831 (Diary of Asim Džambasović), pp. 4, 8, 21. See also Asim Džambasović, T. 15178 (22 June 2011).

3152 P2828 (Witness statement of Asim Džambasović dated 18 June 2011), paras. 55-56; P2831 (Diary of Asim Džambasović), p. 22. See also D2930 (Witness statement of Tomislav Batinić dated 11 February 2013), para. 7; Tomislav Batinić, T. 33676 (14 February 2013); D2351 (Witness statement of Stevan Veljović dated 19 October 2012), para. 10; D2950 (Witness statement of Sveto Veselinović dated 15 February 2013), para. 10; D2954 (SDS Rogatica Municipal Board information, undated); Sveto Veselinović, T. 33898, 33900 (18 February 2013), T. 45093-45094 (16 December 2013); D2909 (Witness statement of Mile Ujić dated 9 February 2013), para. 8; D2953 (Article from Politika entitled "SDA Causing Crisis"); P127 (Witness statement of Alija Isaković dated 22 January 1999), p. 3; Dragomir Milošević, T. 32495-32497 (23 January 2013). The Chamber received evidence about attempts by Bosnian Muslims to move conscript files to prevent disciplinary action against those who failed to respond to the call-up for mobilisation but finds this to be of limited relevance. See D2930 (Witness statement of Tomislav Batinić dated 11 February 2013), paras. 9-10; D2909 (Witness statement of Mile Ujić dated 9 February 2013), para. 37.

3153 See Adjudicated Fact 1971; P3270 (Letter to SRBiH Presidency, Government and Ministry of National Defence re formation of Serb forces in Rogatica, not dated), p. 2; KDZ606, T. 18257-18258 (2 September 2011) (closed session) (indicating that this document reflected the situation in Rogatica). See also D2930 (Witness statement of Tomislav Batinić dated 11 February 2013), para. 7; D2950 (Witness statement of Sveto Veselinović dated 15 February 2013), para. 10. 
TO split by agreement into Bosnian Muslim and Bosnian Serb parts. ${ }^{3154}$ The Bosnian Serb TO had access to weapons from the former Rogatica $\mathrm{TO}^{3155}$ and was subsequently integrated into the Army of the SerBiH pursuant to a decision of the Presidency of SerBiH on 19 May 1992. ${ }^{3156}$ In March 1992, volunteers arrived from Serbia in military and civilian vehicles, and were housed, fed, and supplied in the JNA barracks. ${ }^{3157}$ In the spring of 1992, there was an increase in JNA equipment such as artillery, canons, tanks, armed vehicles, and columns of infantry passing through Rogatica. $^{3158}$

948. Kušić was described as the "commander of all military matters in Rogatica". ${ }^{3159}$ In late February or early March 1992 a military formation was organised in the predominantly Bosnian Serb village of Borike under the command of Kušić ${ }^{3160}$ who had close connections with both the Accused and Krajišnik. ${ }^{3161}$ Even though Kušić's unit was not formally listed in the JNA records it operated under the auspices of Dragomir Milošević ${ }^{3162}$ and was formed within the $1^{\text {st }}$ Battalion, which was commanded by Radomir Furtula. ${ }^{3163}$

\footnotetext{
3154 Milovan Lelek, T. 34373-34374 (27 February 2013).

3155 D3038 (Witness statement of Novica Andrić dated 23 February 2013), para. 7.

3156 P2835 (Report of Rogatica Crisis Staff, April-June 1992), pp. 6-7. See also D3031 (Witness statement of Milovan Lelek dated 23 February 2013), paras. 9-10.

3157 P2828 (Witness statement of Asim Džambasović dated 18 June 2011), para. 72; P2831 (Diary of Asim Džambasović), p. 34. Džambasović testified that the term 'volunteer' was used to describe groups of people from Serbia and Vojvodina, who came through the municipality. P2828 (Witness statement of Asim Džambasović dated 18 June 2011), para. 72. See also P6104 (Record of interview with Mile Ujić, 6 June 2004), p. 5.
}

3158 Elvir Pašić, P59 (Transcript from Prosecutor v. Tadić), T. 844-845, 891 (testifying that the soldiers wore the grey olive uniforms). See also P3289 (Witness statement of KDZ607 dated 1 September 2011), para. 8 (under seal).

3159 P3267 (Witness statement of Šefik Hurko dated 1 September 2011), para. 53; P3279 (Witness statement of KDZ606 dated 1 September 2011), para. 7 (under seal). See also P2828 (Witness statement of Asim Džambasović dated 18 June 2011), para. 66.

3160 P2834 (Report of $1^{\text {st }}$ Podrinje Light Infantry Brigade, 18 December 1994), p. 1 (indicating that this military formation was formed on 24 February 1992); Asim Džambasović, T. 15152-15153 (22 June 2011), T. 15296 (23 June 2011); P3279 (Witness statement of KDZ606 dated 1 September 2011), paras. 7, 63 (under seal); P128 (Alija Isaković's statement to BiH authorities, 30 March 1993), p. 2; D568 (Speech of Dragomir Milošević, 30 March 1996), p. 2; KDZ606, T. 18255-18258 (2 September 2011) (closed session); KDZ051, T. 19356 (22 September 2011). Džambasović confirmed that this report was generally consistent with his knowledge on the issue, but that he thought the unit had been formed on 4 March 1992. P2828 (Witness statement of Asim Džambasović dated 18 June 2011), paras. 56, 58, 66, 121; Asim Džambasović, T. 15154 (22 June 2011); Elvir Pašić, P59 (Transcript from Prosecutor v. Tadić), T. 846-847. See also Adjudicated Fact 1973. Džambasović marked the location of Borike on P2829 (Map of Rogatica municipality marked by Asim Džambasović). The unit also operated in the predominantly Bosnian Serb village of Gučevo. Elvir Pašić, P59 (Transcript from Prosecutor v. Tadić), T. 846-847. See also P3279 (Witness statement of KDZ606 dated 1 September 2011), para. 63 (under seal).

3161 P1154 (Witness statement of KDZ088 dated 27-29 April 2010), pp. 158-159 (under seal). As mentioned above, Kušić was also a member of the SDS Main Board. P3408 (List of members of the SDS' Main Board), p. 2.

3162 P3279 (Witness statement of KDZ606 dated 1 September 2011), para. 49 (under seal); P2831 (Diary of Asim Džambasović), p. 27; see Adjudicated Fact 1973. See also Sveto Veselinović, T. 33912 (18 February 2013).

3163 P2828 (Witness statement of Asim Džambasović dated 18 June 2011), paras. 56, 58. See also P3405 (Witness statement of KDZ051 dated 17 September 2011), para. 26; KDZ606, T. 18257-18258 (2 September 2011) 
949. In April 1992, Kušić stated that "he and the JNA had to defend Serbian people and Serbian land". 3164 At first Kušić's unit consisted of approximately 40 to 50 men, described as "SDS activists". ${ }^{3165}$ Members of this unit wore camouflage uniforms and carried automatic weapons, and included members of the reserve police. ${ }^{3166}$ Kušić's unit was initially known as the Rogatica Brigade and, when the VRS was formed, it became part of the SRK. ${ }^{3167}$ On 22 May 1992, the Command of the SRK issued an order which acknowledged the formation of the Rogatica Brigade under the command of Kušić and provided for its restructure. ${ }^{3168}$ Kušić was able to arm the Rogatica Brigade from JNA weaponry of the $1^{\text {st }}$ Battalion. ${ }^{3169}$ The Rogatica Brigade consisted of three infantry battalions and smaller support units for communications, logistics, medical care, and MP. ${ }^{3170}$ Kušić also formed units in Seljani, Mesići and Pešurići, which included SDS supporters and individuals brought from Serbia, including the White Eagles. ${ }^{3171}$ Later, when the Drina Corps was formed in November 1992, the Rogatica Brigade became the $1^{\text {st }}$ Podrinje Light Infantry Brigade of the Drina Corps. ${ }^{3172}$

(closed session); P3289 (Witness statement of KDZ607 dated 1 September 2011), para. 8 (under seal); D4002 (Letter from BiH MUP to Vasvija Vidović, 4 July 1995), p. 28.

P3405 (Witness statement of KDZ051 dated 17 September 2011), para. 25.

P2830 (Report of $1^{\text {st }}$ Podrinje Light Infantry Brigade, 25 February 1993), p. 2; see Adjudicated Facts 2494, 2500; P3279 (Witness statement of KDZ606 dated 1 September 2011), para. 53 (under seal); P3270 (Letter to SRBiH Presidency, Government and Ministry of National Defence re formation of Serb forces in Rogatica, not dated), p. 2 (indicating that "30 armed Serbs" were brought to Borike); KDZ606, T. 18257-18258 (2 September 2011) (closed session) (indicating that P3270 reflected the situation in Rogatica).

See Adjudicated Fact 2500. The insignia of this unit stated "With the trust in God, Freedom or Death" and members had a skull and the word SDS written on their caps. P3405 (Witness statement of KDZ051 dated 17 September 2011), para. 24. See also D2930 (Witness statement of Tomislav Batinić dated 11 February 2013), para. 14; Tomislav Batinić, T. 33676 (14 February 2013); D3031 (Witness statement of Milovan Lelek dated 23 February 2013), para. 7; Milovan Lelek, T. 34373-34375 (27 February 2013); D2950 (Witness statement of Sveto Veselinović dated 15 February 2013), para. 13; Sveto Veselinović, T. 33877,33896 (18 February 2013); P2828 (Witness statement of Asim Džambasović dated 18 June 2011), para. 119 (referring to P2830 (Report of $1^{\text {st }}$ Podrinje Light Infantry Brigade, 25 February 1993), p. 2).

P2834 (Report of $1^{\text {st }}$ Podrinje Light Infantry Brigade, 18 December 1994), p. 1; P2830 (Report of $1^{\text {st }}$ Podrinje Light Infantry Brigade, 25 February 1993), pp. 4, 15; D308 (SRK Order, 22 May 1992), p. 2; P2835 (Report of Rogatica Crisis Staff, April - June 1992), pp. 6-7. See also D3031 (Witness statement of Milovan Lelek dated 23 February 2013), para. 15. The Chamber shall thus refer to the Rogatica Brigade up until 1 November 1992.

P1505 (SRK Order, 22 May 1992), e-court pp. 1-2.

P2828 (Witness statement of Asim Džambasović dated 18 June 2011), para. 65; Sveto Veselinović, T. 33912 (18 February 2013).

D3031 (Witness statement of Milovan Lelek dated 23 February 2013), para. 16. By June 1992, the Rogatica Brigade grew to over 1,400 men who were trained for combat, wore uniforms and carried automatic weapons and had also formed one intervention company. P5485 (Report of Rogatica Brigade, 15 June 1992). By December 1992 the strength of the $1^{\text {st }}$ Podrinje Light Infantry Brigade was reported to be in excess of 2,700. P2955 (Report of the Drina Corps, 17 December 1992), p. 6.

P3279 (Witness statement of KDZ606 dated 1 September 2011), paras. 40, 54, 63 (under seal); KDZ606, T. 18313 (5 September 2011) (closed session).

P2834 (Report of $1^{\text {st }}$ Podrinje Light Infantry Brigade, 18 December 1994), p. 1. 
950. Members of the Rogatica Brigade mistreated and terrorised the Bosnian Muslim population and conducted patrols on roads. ${ }^{3173}$ They also entered villages and fired weapons into the air in order to threaten Bosnian Muslims. ${ }^{3174}$ In addition there were incidents of shooting at Bosnian Muslim houses and mosques which, together with the arming of the Bosnian Serbs, intimidated local Bosnian Muslims. ${ }^{3175}$ Members of the Rogatica Brigade also entered villages, sang nationalist songs, carried out searches of Bosnian Muslims, and seized vehicles. ${ }^{3176}$ Bosnian Serb soldiers also harassed Bosnian Muslims by making derogatory remarks. ${ }^{3177}$ Džambasović complained on a number of occasions to higher commanders about these incidents, but no action was taken, and he was actually warned by Furtula that he should not enforce discipline. ${ }^{3178}$ With time, Džambasović was progressively stripped of his duties and authority; on 6 April 1992, he was told that his safety could not be guaranteed and he left the JNA. ${ }^{3179}$

951. The presence of the Rogatica Brigade forced the Bosnian Muslim police to withdraw from Borike and caused further anxiety amongst the Bosnian Muslim population. ${ }^{3180}$ The Bosnian Serb police and the Rogatica Brigade also engaged in looting from Bosnian Muslims. ${ }^{3181}$ The Accused, as President of the Presidency of the SerBiH, was informed in March 1992 that due to the actions of the Rogatica Brigade, Bosnian Muslims sought protection from the Rogatica SJB. ${ }^{3182}$

952. On 23 March 1992, a Bosnian Muslim was stopped and maltreated by a group of four armed persons in camouflage uniforms. These men were under the leadership of Kušić. ${ }^{3183}$ Following

\footnotetext{
3173 P3405 (Witness statement of KDZ051 dated 17 September 2011), paras. 14, 24; P2828 (Witness statement of Asim Džambasović dated 18 June 2011), para. 66. See also P2831 (Diary of Asim Džambasović), p. 27.

3174 See Adjudicated Fact 2500. See also P3270 (Letter to SRBiH Presidency, Government and Ministry of National Defence re formation of Serb forces in Rogatica, undated), p. 2.

3175 P127 (Witness statement of Alija Isaković dated 22 January 1999), p. 2. Volunteers also showed the threefinger Serb sign and shot in the direction of Bosnian Muslims. P2828 (Witness statement of Asim Džambasović dated 18 June 2011), para. 72.

3176 P2828 (Witness statement of Asim Džambasović dated 18 June 2011), paras. 67-68.

3177 P2828 (Witness statement of Asim Džambasović dated 18 June 2011), para. 43.

3178 P2828 (Witness statement of Asim Džambasović dated 18 June 2011), paras. 43-45.

3179 P2828 (Witness statement of Asim Džambasović dated 18 June 2011), paras. 82, 113.

3180 P3270 (Letter to SRBiH Presidency, Government and Ministry of National Defence re formation of Serb forces in Rogatica, not dated), p. 2; KDZ606 testified that this document reflected the situation in Rogatica. KDZ606, T. 18255-18258 (2 September 2011) (closed session); P3279 (Witness statement of KDZ606 dated 1 September 2011), paras. 65, 74 (under seal); P3269 (Report of SRBiH MUP re BiH security situation on 6-7 March 1992), p. 3.

3181 P127 (Witness statement of Alija Isaković dated 22 January 1999), p. 3; P3407 (Report on the work of the Rogatica Municipal Assembly and Executive Board from July 1992 to September 1993), pp. 31-32. See also P2828 (Witness statement of Asim Džambasović dated 18 June 2011), para. 66 (stating that Dragomir Milošević did not do anything to stop this).

3182 P3269 (Report of SRBiH MUP re BiH security situation on 6-7 March 1992), p. 3; KDZ606, T. 18255-18256 (2 September 2011) (closed session); P3279 (Witness statement of KDZ606 dated 1 September 2011), para. 65 (under seal).

3183 P2838 (SerBiH MUP Bulletin on daily events, 24 March 1992), p. 2; P2828 (Witness statement of Asim Džambasović dated 18 June 2011), para. 118.
} 
this incident, Bosnian Muslims set up barricades in Rogatica and demanded the withdrawal of the Rogatica Brigade. $^{3184}$ On 24 March 1992, the Bosnian Serbs also erected barricades. ${ }^{3185}$ Serb Forces sealed off the town of Rogatica using armoured vehicles and tanks, blocked all roads, prevented the movement of the Bosnian Muslim population and cut their phone lines and utilities. ${ }^{3186}$ The Rogatica Brigade manned the check-points at the entrance to most Bosnian Serb villages and Bosnian Muslims who tried to pass through the check-points faced difficulties. ${ }^{3187}$ The erection of barricades on both sides and the media in $\mathrm{BiH}$ contributed to the instillation of fear and anxiety in the population. ${ }^{3188}$

953. From the latter half of May 1992, the citizens of Rogatica could no longer receive BiH television and were thus limited to Serbian-based television and radio broadcasts. ${ }^{3189}$ Certain broadcasts emphasised that Bosnian Serbs who were threatened in $\mathrm{BiH}$ should join together, mobilise and join the Army of the SerBiH. ${ }^{3190}$ These calls to mobilise were made "in the name of the Serb Republic and the presidency" and the Accused. ${ }^{3191}$

\section{(2) Creation of Bosnian Serb Institutions}

954. As discussed above, ${ }^{3192}$ the SAO Romanija (comprising the municipalities of Pale, Sokolac, Han Pijesak and Rogatica) was unilaterally proclaimed in September 1991 with the assistance of

3184 P2838 (SerBiH MUP Bulletin on daily events, 24 March 1992), p. 2; D2930 (Witness statement of Tomislav Batinić dated 11 February 2013), para. 15. See also D2909 (Witness statement of Mile Ujić dated 9 February 2013), para. 17.

3185 P3271 (Report of Rogatica's Executive Board, 24 March 1992), p. 1; KDZ606, T. 18259-18262 (2 September 2011) (closed session); P3279 (Witness statement of KDZ606 dated 1 September 2011), para.75 (under seal); P128 (Alija Isaković's statement to BiH authorities, 30 March 1993), p. 2; D2930 (Witness statement of Tomislav Batinić dated 11 February 2013), para. 15. See also KDZ607, T. 18495-18497 (6 September 2011). For location of the roadblocks, see D2912 (Map of Rogatica). But see P2828 (Witness statement of Asim Džambasović dated 18 June 2011), para. 68 (according to whom it is not clear who set up the barricades first). The Chamber also received evidence that roadblocks had already been established by Bosnian Serbs in mid1991 after the formation of Bosnian Muslim paramilitary units. D2909 (Witness statement of Mile Ujić dated 9 February 2013), para. 17.

3186 P3279 (Witness statement of KDZ606 dated 1 September 2011), para. 45 (under seal).

3187 Elvir Pašić, P59 (Transcript from Prosecutor v. Tadić), T. 846-848; P2838 (SerBiH MUP Bulletin on daily events, 24 March 1992), p. 2; P2828 (Witness statement of Asim Džambasović dated 18 June 2011), para. 118 (indicating that the information in the MUP bulletin is consistent with the information he possessed at the time).

3188 D2930 (Witness statement of Tomislav Batinić dated 11 February 2013), para. 15. See also KDZ051, T. 19381, 19383 (22 September 2011). The Chamber also received evidence about attacks against Bosnian Serbs. D2909 (Witness statement of Mile Ujić dated 9 February 2013), paras. 18-19, 30.

3189 Elvir Pašić, P59 (Transcript from Prosecutor v. Tadić), T. 856.

3190 Elvir Pašić, P59 (Transcript from Prosecutor v. Tadić), T. 856.

3191 Elvir Pašić, P59 (Transcript from Prosecutor v. Tadić), T. 856.

3192 See political structures section para. 130. 
the SDS. ${ }^{3193}$ Mile Ujić was nominated as the representative from Rogatica. ${ }^{3194}$ Ujić was also the President of the SDS Executive Board in Rogatica. ${ }^{3195}$

955. The Assembly of the Serb Municipality of Rogatica was established in on December $1991^{3196}$ in accordance with the Variant A/B Instructions. ${ }^{3197}$ At the inaugural session of the Rogatica Serb Municipal Assembly held on 26 December 1991, Batinić, an SDS leader, was proclaimed President of the municipality. ${ }^{3198}$

956. Towards the end of 1991, following a request of the SDS Main Board, an SDS Crisis Staff was formed in Rogatica to monitor the situation and inform the party leadership "if there was a dramatic turn of events". 3199 The Rogatica Crisis Staff was established at a session of the SDS Main Board on 8 April 1992 and Milorad Sokolović was appointed its president. ${ }^{3200}$ The Rogatica Crisis Staff was composed of Bosnian Serb members of the joint municipal organs and included

3193 Elvir Pašić, P59 (Transcript from Prosecutor v. Tadić), T. 892, 896 (testifying that Rogatica was included in the SAO Romanija even though it was ethnically mixed); see Adjudicated Fact 1923; D2930 (Witness statement of Tomislav Batinić dated 11 February 2013), para. 13.

3194 D2930 (Witness statement of Tomislav Batinić dated 11 February 2013), para. 13.

3195 P2828 (Witness statement of Asim Džambasović dated 18 June 2011), para. 79.

3196 P3407 (Report on the work of the Rogatica Municipal Assembly and Executive Board from July 1992 to September 1993), e-court p. 5; see Adjudicated Fact 2498; D2930 (Witness statement of Tomislav Batinić dated 11 February 2013), para. 14. See also P3289 (Witness statement of KDZ607 dated 1 September 2011), para. 6 (under seal); KDZ607, T. 18493 (6 September 2011); Elvir Pašić, P59 (Transcript from Prosecutor v. Tadić), T. 855. The Rogatica Serb Municipal Assembly was composed of all Serb Council Members who were elected at the multi-party elections and following the instructions of the SDS Main Board, it also included the presidents of the SDS local boards from the municipality. P3407 (Report on the work of the Rogatica Municipal Assembly and Executive Board from July 1992 to September 1993), e-court p. 5.

3197 P5 (SDS Instructions for Organisation of Organs of the Serbian People in BiH, 19 December 1991), p. 7; P3407 (Report on the work of the Rogatica Municipal Assembly and Executive Board from July 1992 to September 1993), e-court p. 5; Tomislav Batinić, T. 33669-33670 (14 February 2013).

3198 P3407 (Report on the work of the Rogatica Municipal Assembly and Executive Board, from July 1992 to September 1993), e-court p. 8; P2828 (Witness statement of Asim Džambasović dated 18 June 2011), para. 79; P3279 (Witness statement of KDZ606 dated 1 September 2011), para. 12 (under seal); D2930 (Witness statement of Tomislav Batinić dated 11 February 2013), paras. 14, 19. See also KDZ051, T. 19357-19358 (22 September 2011). Batinić testified that while the Serb assembly was formed it never started functioning and only existed on paper and faced difficulties due to the absence of communication with the Presidency and the SDS Main Board. D2930 (Witness statement of Tomislav Batinić dated 11 February 2013), para. 14; Tomislav Batinić, T. 33670-33671-33672, 33712-33713 (14 February 2013). However, the Chamber does not consider this evidence to be reliable. In reaching that conclusion the Chamber noted that Batinic was contradicted on cross-examination about his evidence that there were no assembly sessions but then claimed that it only sat twice. Tomislav Batinić, T. 33671-33673 (14 February 2013).

3199 D2950 (Witness statement of Sveto Veselinović dated 15 February 2013), para. 13; Sveto Veselinović, T. 33877 (18 February 2013).

3200 Sveto Veselinović, T. 33877 (18 February 2013); P2828 (Witness statement of Asim Džambasović dated 18 June 2011), para. 122; P3279 (Witness statement of KDZ606 dated 1 September 2011), para. 13 (under seal); Mile Ujić, T. 33450-33451 (12 February 2013); P2835 (Report of Rogatica Crisis Staff, April-June 1992), pp. 1-2; P3289 (Witness statement of KDZ607 dated 1 September 2011), para. 7 (under seal). 
prominent Bosnian Serbs who were not members of the SDS. ${ }^{3201}$ As such, it was an expansion of the SDS Crisis Staff. ${ }^{3202}$

957. The Rogatica Crisis Staff operated from the beginning of the war and was authorised to adopt decisions falling under the jurisdiction of the Rogatica Serb Municipal Assembly. ${ }^{3203}$ The Rogatica Crisis Staff was tasked with co-ordinating the work of all municipal administrative organs during a state of war or when under threat of imminent war. ${ }^{3204}$ The Rogatica Crisis Staff had direct oral and written contact with the Presidency and ministries of the SerBiH, the Bosnian Serb Government, the army, and the police. ${ }^{3205}$ There was co-operation between the Rogatica Crisis Staff and the Bosnian Serb TO, and later with the VRS. ${ }^{3206}$ In August 1992, the Executive Board was formed and the Crisis Staff ceased to exist. ${ }^{3207}$

958. On 24 March 1992 approximately 3,000 armed Serb soldiers under the leadership of Kušić threatened to open fire on the town of Rogatica unless the municipality and the SJB were divided along ethnic lines that night. ${ }^{3208}$ These soldiers wore different uniforms, including the uniforms of

3201 D2950 (Witness statement of Sveto Veselinović dated 15 February 2013), para. 13; Sveto Veselinović, T. 33877 (18 February 2013); see Adjudicated Fact 2497. See also Elvir Pašić, P59 (Transcript from Prosecutor v. Tadić), T. 855, 894 (testifying that prominent Bosnian Serb citizens were members of the Crisis Staff).

3202 Tomislav Batinić, T. 33673-33674, 33712-33713 (14 February 2013).

3203 P2835 (Report of Rogatica Crisis Staff, April-June 1992), p. 3-4; P3407 (Report on the work of the Rogatica Municipal Assembly and Executive Board from July 1992 to September 1993), e-court p. 5. See also D2930 (Witness statement of Tomislav Batinić dated 11 February 2013), paras. 18, 26-27; D2950 (Witness statement of Sveto Veselinović dated 15 February 2013), paras. 15, 17; Sveto Veselinović, T. 33881, 33892 (18 February 2013) (testifying that the Crisis Staff made all significant decisions during the war).

3204 P2835 (Report of Rogatica Crisis Staff, April-June 1992), p. 3-4. See also D2930 (Witness statement of Tomislav Batinić dated 11 February 2013), para. 18.

3205 P2835 (Report of Rogatica Crisis Staff, April-June 1992), pp. 5-6. Defence witnesses testified that there was no contact with the leadership in Pale between April and June 1992. D2909 (Witness statement of Mile Ujić dated 9 February 2013), para. 39. See also Tomislav Batinić, T. 33677 (14 February 2013). However, the Chamber does not find this evidence to be of much weight given that the witness's evidence was qualified by what was known to him. In addition when challenged on cross-examination Ujić acknowledged that it would have been the President of the Crisis Staff who had contact if any, and he did not know whether there was such contact. Mile Ujić, T. 33451 (12 February 2013). The Accused also cited to the loss of electricity in Rogatica for five months as a factor which exacerbated the problems with communication. Defence Final Brief, para. 2950, referring to D2909 (Witness statement of Mile Ujić dated 9 February 2013), para. 35; D2930 (Witness statement of Tomislav Batinić dated 11 February 2013), para. 25; Sveto Veselinović, T. 33912 (18 February 2013). The Chamber does not consider that the evidence presented supports the conclusion that communication problems were exacerbated by this loss of electricity particularly in light of the other evidence received regarding communication between municipal and higher authorities.

3206 P2835 (Report of Rogatica Crisis Staff, April-June 1992), pp. 6-7.

3207 D2930 (Witness statement of Tomislav Batinić dated 11 February 2013), paras. 26-27; D2950 (Witness statement of Sveto Veselinović dated 15 February 2013), para. 15; D2961 (Decision of Rogatica Executive Board, 30 June 1992); Sveto Veselinović, T. 33881 (18 February 2013).

3208 P3271 (Report of Rogatica's Executive Board, 24 March 1992); KDZ606, T. 18261 (2 September 2011) (closed session); P3279 (Witness statement of KDZ606 dated 1 September 2011), para. 75 (under seal); P6105 (Notice of resignation, 25 March 1992), p. 1. Mile Ujić testified that both Bosnian Serb and Bosnian Muslim troops threatened to attack the town if it was not divided. Mile Ujić, T. 33451-33452 (12 February 2013). However, the Chamber does not find this evidence to be reliable. In reaching that conclusion the Chamber noted that when Ujić was shown a document where he wrote to the Accused only about the threat of the Serb TO to attack 
the JNA, the TO, and included paramilitary formations from Serbia such as the White Eagles. ${ }^{3209}$ The town was blocked from all sides and there was sporadic firing which continued until morning when it eased. ${ }^{3210}$ The Deputy Prime Ministers and the Bosnian Serb MUP were informed about the developments and were immediately requested to come to the municipality in order to reach a negotiated solution to the conflict. ${ }^{3211}$ Džambasović, along with the commander of the JNA $4^{\text {th }}$ Corps, General Đurđevac, and Dragomir Milošević went to Rogatica and after speaking to both sides, secured the removal of most of the barricades. ${ }^{3212}$

959. In April and May 1992, the Rogatica Crisis Staff was involved in negotiations with the Bosnian Muslim leadership, and formed commissions for the demarcation of territory and division of power within the municipality. ${ }^{3213}$ In these negotiations even communes with mixed populations were delineated as Serb territories with the agreement from the Bosnian Muslims who sought to avoid conflict. ${ }^{3214}$ During negotiations, the SDS representatives said they would report to the Main Board of the SDS in Pale. ${ }^{3215}$

960. Some reserve police officers who had been brought into the SJB by the SDS insisted that it was impossible to work together with Bosnian Muslims, that there could be no co-existence and that the Bosnian Serbs would get their own institutions. ${ }^{3216}$ These police officers threatened to join the JNA, which they said would be on their side, and stated that if the Bosnian Muslims offered resistance they would have no chance and would be expelled. ${ }^{3217}$ SDS representatives sought to divide the SJB and the TO and by March 1992, Bosnian Muslim representatives agreed to this

the town, he avoided answering the question directly. The Chamber also noted that his evidence was marked by contradictions and evasiveness and could not rely on his testimony in this regard.

KDZ606, T. 18261 (2 September 2011) (closed session); P3279 (Witness statement of KDZ606 dated 1 September 2011), para. 75 (under seal).

3210 P3272 (Report of Rogatica Monitoring and Early Warning Center, 25 March 1992), p. 1. [REDACTED].

3211 P3271 (Report of Rogatica's Executive Board, 24 March 1992). See also P3279 (Witness statement of KDZ606 dated 1 September 2011), para. 75 (under seal).

3212 P2828 (Witness statement of Asim Džambasović dated 18 June 2011), para. 68; Asim Džambasović, T. 15176 (22 June 2011); P3279 (Witness statement of KDZ606 dated 1 September 2011), paras. 46-47, 49, 52 (under seal); [REDACTED].

3213 P2835 (Report of Rogatica Crisis Staff, April - June 1992), p. 2; KDZ606, T. 18264-18266 (2 September 2011) (closed session); P3279 (Witness statement of KDZ606 dated 1 September 2011), para. 71 (under seal); D2950 (Witness statement of Sveto Veselinović dated 15 February 2013), para. 14. The Chamber received Defence evidence that the Bosnian Serb authorities wanted to avoid the conflicts which had already broken out in the neighbouring municipalities and continued with negotiations until 22 May 1992. Mile Ujić, T. 33438-33439 (12 February 2013). See also KDZ606, T. 18317 (5 September 2011) (closed session).

3214 KDZ606, T. 18267-18268 (2 September 2011) (closed session) referring to P3273 (Map of Rogatica municipality); P3279 (Witness statement of KDZ606 dated 1 September 2011), para. 81 (under seal).

3215 P3279 (Witness statement of KDZ606 dated 1 September 2011), para. 84 (under seal).

3216 P3279 (Witness statement of KDZ606 dated 1 September 2011), para. 73 (under seal).

3217 P3279 (Witness statement of KDZ606 dated 1 September 2011), para. 73 (under seal). While the witness testified that these police officers claimed that this was the position taken by the Main Board of the SDS, the Chamber is not convinced that they would be in a position to know this information. P3279 (Witness statement of KDZ606 dated 1 September 2011), para. 73 (under seal). 
partition. ${ }^{3218}$ The division of the police was implemented by Mladen Vasiljević in accordance with orders from the SAO Romanija and with orders issued by the Serb Municipality of Rogatica, and the Rogatica Crisis Staff. ${ }^{3219}$

961. The SJB in Rogatica was divided along ethnic lines in April 1992, with the Bosnian Serbs forming their own SJB and moving into a different building. ${ }^{320}$ The Bosnian Muslim police remained in the same premises. ${ }^{3221}$ The Bosnian Serb police also made changes to their uniform including the use of Cyrillic script and adding a reference to the SDS on their insignia. ${ }^{3222}$ Vasiljević became commander of the Bosnian Serb SJB in Rogatica. ${ }^{3223}$

962. Kušić wanted to attack Rogatica and this brought him into conflict with the Bosnian Serb civilian authorities; as a consequence, as representatives of the civilian authorities, Veselinović, Ujić, and Batinić, tendered their joint resignation to the Accused on 25 March 1992. ${ }^{3224}$ Bosnian Serbs were alarmed by these resignations and left the city centre out of fear, a new government was

3218 See Adjudicated Fact 2495; P3279 (Witness statement of KDZ606 dated 1 September 2011), paras. 72,77 (under seal). See also D3038 (Witness statement of Novica Andrić dated 23 February 2013), para. 6; Milovan Lelek, T. 34373-34374 (27 February 2013). Defence witnesses testified that both Bosnian Serbs and Bosnian Muslims realised that the division of the municipality was the best solution in order to avoid an armed conflict and that this division was consensual. D2930 (Witness statement of Tomislav Batinić dated 11 February 2013), para. 16; Milovan Lelek, T. 34375 (27 February 2013); D2950 (Witness statement of Sveto Veselinović dated 15 February 2013), para. 12. See also D2909 (Witness statement of Mile Ujić dated 9 February 2013), para. 21; Mile Ujić, T. 33437 (12 February 2013); P6104 (Record of interview with Mile Ujić, 6 June 2004), p. 2; P128 (Alija Isaković's statement to $\mathrm{BiH}$ authorities, 30 March 1993), p. 2. However, the Chamber finds that the consensual nature of the division is undermined by credible evidence that during these negotiations, Bosnian Muslim negotiators agreed to the division of the municipality in order to avoid war and to gain time to prevent an attack and that Bosnian Muslims were intimidated and from late 1991, Kušić threatened that if Bosnian Muslims did not agree to the division of the territory they would have no future in the area and would be attacked if they did not leave or pledge loyalty to the Bosnian Serb authorities. [REDACTED].

3219 Elvir Pašić, P59 (Transcript from Prosecutor v. Tadić), T. 852-855, 893. Pašić left duty as police officer on the day the police was divided out of fear of being a Muslim in the regular police force "in a town where there were a number of armed Serbs". Elvir Pašić, P59 (Transcript from Prosecutor v. Tadić), T. 854-855, 881, 893.

3220 Elvir Pašić, P59 (Transcript from Prosecutor v. Tadić), T. 853-854; Adjudicated Fact 2496; P3279 (Witness statement of KDZ606 dated 1 September 2011), para. 73 (under seal); P3405 (Witness statement of KDZ051 dated 17 September 2011), para. 9; P2761 (RS MUP report on work for period April to December 1992), p. 7; D2930 (Witness statement of Tomislav Batinić dated 11 February 2013), para. 20; D2909 (Witness statement of Mile Ujić dated 9 February 2013), para. 23; P6104 (Record of interview with Mile Ujić, 6 June 2004), pp. 2-3. See also KDZ607, T. 18494 (6 September 2011); KDZ051, T. 19373-19374 (22 September 2011).

3221 D2930 (Witness statement of Tomislav Batinić dated 11 February 2013), para. 20. See also D2909 (Witness statement of Mile Ujić dated 9 February 2013), para. 23.

3222 P3405 (Witness statement of KDZ051 dated 17 September 2011), para. 9; Elvir Pašić, P59 (Transcript from Prosecutor v. Tadić), T. 853-854.

3223 P3279 (Witness statement of KDZ606 dated 1 September 2011) (under seal), para. 9; KDZ606, T. 18292 (5 September 2011) (closed session).

3224 D2930 (Witness statement of Tomislav Batinić dated 11 February 2013), para. 16; Tomislav Batinić, T. 3367433678 (14 February 2013); Sveto Veselinović, T. 33878, 33892 (18 February 2013); P6105 (Notice of resignation, 25 March 1992), p. 1; Mile Ujić, T. 33456 (12 February 2013). See also P2832 (Article from Srpska Vojska entitled “They Saved Serbian Land”, 15 July 1993), p. 3. 
formed with the agreement of Kušić and the appointments were confirmed by a Municipal Board meeting of the SDS. ${ }^{3225}$

963. In negotiations between Bosnian Serb and Bosnian Muslim representatives at the beginning of May 1992, local SDS leaders, including Batinić and Milorad Sokolović, demanded that control of the whole municipality be handed over to the SDS. ${ }^{3226}$ Bosnian Muslim representatives objected to this demand. ${ }^{3227}$ On 2 May 1992, an agreement on the division of Rogatica into Serb and Muslim municipalities was reached and adopted at a joint session of the Municipal Assembly. ${ }^{3228}$ This agreement did not cover Rogatica town and such a decision was never adopted given the events which unfolded in the municipality. ${ }^{3229}$ On 18 May 1992, the Rogatica Serb Municipal Assembly abrogated the original agreement on the division of the municipality alleging that the Bosnian Muslim side had avoided attempts to implement that agreement. ${ }^{3230}$ This occurred one day after the Accused, Mladić, and Krajišnik held a meeting with representatives of municipalities, including Rogatica, and discussed the creation of a Bosnian Serb state in $\mathrm{BiH}$, stating that the time had come for the demarcation of areas between the national groups. ${ }^{3231}$

964. The Rogatica Crisis Staff, in agreement with the TO command, adopted a decision which provided for inhabitants of Bosnian Muslim settlements to hand over their weapons after which their safety and security would be guaranteed. ${ }^{3232}$ Kušić and the SDS issued ultimatums to Bosnian

3225 D2950 (Witness statement of Sveto Veselinović dated 15 February 2013), para. 14; Sveto Veselinović, T. 33878 (18 February 2013).

3226 P3279 (Witness statement of KDZ606 dated 1 September 2011), paras. 79-80 (under seal). See also Adjudicated Fact 2502.

3227 P3279 (Witness statement of KDZ606 dated 1 September 2011), para. 88 (under seal). See also Adjudicated Fact 2502.

3228 P2835 (Report of Rogatica Crisis Staff, April - June 1992), p. 2; KDZ606, T. 18264 (2 September 2011) (closed session); D2930 (Witness statement of Tomislav Batinić dated 11 February 2013), para. 16; D2909 (Witness statement of Mile Ujić dated 9 February 2013), para. 22; Mile Ujić, T. 33437 (12 February 2013); P6104 (Record of interview with Mile Ujić, 6 June 2004), p. 3. See also Sveto Veselinović, T. $45112-45113$ (16 December 2013). Ujić testified that the division of the municipality was designed to ensure the Bosnian Serbs and Bosnian Muslims could live next to one another and they did not have a plan of expelling Bosnian Muslims. Mile Ujić, T. 33439 (12 February 2013). However, the Chamber does not consider that Ujić's evidence to be reliable in this regard. In reaching that conclusion the Chamber noted that the witness's testimony was marked by inconsistencies, contradictions, and evasiveness.

3229 P2835 (Report of Rogatica Crisis Staff, April-June 1992), p. 2; D2930 (Witness statement of Tomislav Batinić dated 11 February 2013), para. 16; D2909 (Witness statement of Mile Ujić dated 9 February 2013), para. 22.

$3230 \quad$ P2835 (Report of Rogatica Crisis Staff, April-June 1992), p. 3.

3231 P1477 (Ratko Mladić's notebook, 14 February-28 May 1992), pp. 349-351; P6254 (Article from TANJUG entitled "Serb Leaders Promote Ethnic Demarcation", 17 May 1992).

3232 D2909 (Witness statement of Mile Ujić dated 9 February 2013), paras. 27, 30; P3279 (Witness statement of KDZ606 dated 1 September 2011), paras. 66-68, 70, 80, 88 (under seal) (stating that Milorad Sokolović offered to bring in the Užice Corps to take control of Rogatica and provide security for the Bosnian Muslim population if they handed over power and weapons but this was not accepted). Bosnian Muslim representatives did not believe these assurances as they had been receiving media reports of events which had been unfolding in other areas in $\mathrm{BiH}$ and feared that they would face the same fate in Rogatica. P3279 (Witness statement of KDZ606 dated 1 September 2011), paras. 77, 80 (under seal). See also KDZ606, T. 18318 (5 September 2011) (closed session). 
Muslim villages to hand over any weapons and express loyalty in return for their safety and security. ${ }^{3233}$ Those who did not comply were threatened with expulsion, arrest or the "worst consequences". ${ }^{3234}$ Following these ultimatums, people in some villages handed over weapons. ${ }^{3235}$ Batinić observed that "enormous pressure" was being exerted by the SDS Main Board and military command to "get the job done". ${ }^{3236}$ The final ultimatum from Bosnian Serb representatives was made after 10 May 1992 and called on all people to pledge loyalty to the SDS and return all weapons or face the possibility of operations in Rogatica municipality. ${ }^{3237}$ On 19 May 1992, the Bosnian Muslim village of Kukavice was disarmed which led the Bosnian Muslim population to withdraw from the village. ${ }^{3238}$ In some villages, Bosnian Muslims were told that they may come under attack which prompted them to hide in the woods. ${ }^{3239}$

\section{(C) Take-over of Rogatica}

965. The killing of Dražen Mihajlović in an ambush on 22 May 1992 and the refusal of the Bosnian Muslim forces to return his body resulted in clashes. ${ }^{3240}$ Following this incident, both Bosnian Serbs and Bosnian Muslims moved their families out of the town as did the Bosnian Muslim leadership to areas where they were a majority. ${ }^{3241}$ In addition, the Rogatica Crisis Staff was expanded to approximately 15 people and Sokolović was elected President. ${ }^{3242}$

\footnotetext{
3233 P3279 (Witness statement of KDZ606 dated 1 September 2011), paras. 66,-68, 70, 80 (under seal); D2909 (Witness statement of Mile Ujić dated 9 February 2013), para. 27.

3234 P3279 (Witness statement of KDZ606 dated 1 September 2011), para. 70 (under seal); see Adjudicated Fact 2499. See also P3279 (Witness statement of KDZ606 dated 1 September 2011), paras. 55, 85 (under seal).

3235 P3279 (Witness statement of KDZ606 dated 1 September 2011), paras. 66-68 (under seal). See also D2909 (Witness statement of Mile Ujić dated 9 February 2013), para. 32.

3236 [REDACTED].

3237 P3279 (Witness statement of KDZ606 dated 1 September 2011), para. 86 (under seal).

3238 P3279 (Witness statement of KDZ606 dated 1 September 2011), para. 89 (under seal). The Chamber also received evidence that in the lead-up to the attack on Rogatica, several Bosnian Muslims were killed in the nearby villages, which caused panic amongst the Bosnian Muslim population. P3405 (Witness statement of KDZ051 dated 17 September 2011), para. 13; KDZ051, T. 19385-19386 (22 September 2011). The Chamber notes that these that these killings are not charged pursuant to Schedules A or B of the Indictment. See fn. 13.

3239 P3267 (Witness statement of Šefik Hurko dated 1 September 2011), para. 3.

3240 D2930 (Witness statement of Tomislav Batinić dated 11 February 2013), para. 23; Tomislav Batinić, T. 33680, 33696-33698 (14 February 2013); D3031 (Witness statement of Milovan Lelek dated 23 February 2013), para. 14; Milovan Lelek, T. 34383 (27 February 2013); D2909 (Witness statement of Mile Ujić dated 9 February 2013), para. 24; Mile Ujić, T. 33437-33439, 33459 (12 February 2013). See also D2351 (Witness statement of Stevan Veljović dated 19 October 2012), para. 9; D2950 (Witness statement of Sveto Veselinović dated 15 February 2013), para. 15 (stating that after this attack negotiations between the parties were suspended); Sveto Veselinović, T. 33904, 33910-33911 (18 February 2013), T. 45104 (16 December 2013); D2965 (Rogatica Brigade report, 29 May 1992).

3241 D2909 (Witness statement of Mile Ujić dated 9 February 2013), para. 25.

3242 D2950 (Witness statement of Sveto Veselinović dated 15 February 2013), para. 14; D2959 (Decision of Rogatica Crisis Staff, 24 May 1992); Sveto Veselinović, T. 33879 (18 February 2013). Veselinović was also appointed as a member of the Rogatica Crisis Staff. D2950 (Witness statement of Sveto Veselinović dated 15 February 2013), para. 14.
} 
966. The town of Rogatica was in a valley and was surrounded by artillery positions manned by Bosnian Serbs; a road was built approximately a month before the attack, which encircled the town and allowed for artillery and weapons to be transported. ${ }^{3243}$

967. The town of Rogatica was attacked on or about 22 May 1992 for seven continuous days by artillery, anti-aircraft, and infantry weapons, with the artillery primarily hitting the centre of town and Bosnian Muslim neighbourhoods, while Bosnian Serb areas of the town were not shelled. ${ }^{3244}$ A large part of the town centre was destroyed in this attack. ${ }^{3245}$ By the date of the attack, the Bosnian Serb population had left Muslim-majority areas and moved to Serb parts of the town and Bosnian Serb women and children had been evacuated to Serbia. ${ }^{3246}$

968. The shelling began at noon and came from the direction of surrounding hills and villages. ${ }^{3247}$ On the first day, the shelling lasted three or four hours, which forced Bosnian Muslims to take shelter in their cellars and in neighbouring houses when their houses were damaged. ${ }^{3248}$ The first attack consisted of mortars, anti-aircraft guns, tanks, artillery and heavy machine guns. ${ }^{3249}$ There were clashes with Bosnian Muslim forces, which put up armed resistance in the town in the days following the first shelling. ${ }^{3250}$ As discussed above, the town had been blockaded. ${ }^{3251}$

3243 P3405 (Witness statement of KDZ051 dated 17 September 2011), paras. 27-28. According to KDZ051 the closest artillery position was 50 to 60 metres from his house and he could recognise the people manning the weapons from the closest positions as his Serb neighbours and former classmates. P3405 (Witness statement of KDZ051 dated 17 September 2011), para. 28.

3244 Elvir Pašić, P59 (Transcript from Prosecutor v. Tadić), T. 857, 887, 889; P3405 (Witness statement of KDZ051 dated 17 September 2011), paras. 30, 33-34; KDZ606, T. 18269 (2 September 2011) (closed session); P3279 (Witness statement of KDZ606 dated 1 September 2011), para. 90 (under seal); P128 (Alija Isaković's statement to BiH authorities, 30 March 1993), pp. 2-3.

3245 Elvir Pašić, P59 (Transcript from Prosecutor v. Tadić), T. 885.

3246 Elvir Pašić, P59 (Transcript from Prosecutor v. Tadić), T. 889; P3405 (Witness statement of KDZ051 dated 17 September 2011), para. 29; KDZ051, T. 19363 (22 September 2011).

3247 P3405 (Witness statement of KDZ051 dated 17 September 2011), para. 30. The Chamber does not consider that the Accused's challenge to KDZ051's evidence about identifying the direction of fire succeeded in casting doubt as to the veracity of his evidence on this point. KDZ051, T. 19393 (22 September 2011).

3248 P3405 (Witness statement of KDZ051 dated 17 September 2011), paras. 32-33; P127 (Witness statement of Alija Isaković dated 22 January 1999), p. 4; P128 (Alija Isaković's statement to BiH authorities, 30 March 1993), p. 3.

3249 P127 (Witness statement of Alija Isaković dated 22 January 1999), p. 3.

3250 P3279 (Witness statement of KDZ606 dated 1 September 2011), para. 95 (under seal); D2930 (Witness statement of Tomislav Batinić dated 11 February 2013), para. 25; D3037 (Rogatica Brigade report, 9 June 1992), p. 2; Milovan Lelek, T. 34436-34437 (27 February 2013); D2965 (Rogatica Brigade report, 29 May 1992). See also Sveto Veselinović, T. 33883, 33885-33886, 33912 (18 February 2013); D2909 (Witness statement of Mile Ujić dated 9 February 2013), para. 35; D2950 (Witness statement of Sveto Veselinović dated 15 February 2013), para. 18; D2966 (Rogatica Brigade report, 23 June 1992); P3414 (Report of the Rogatica Brigade, 11 June 1992), pp. 1-2; P5485 (Report of Rogatica Brigade, 15 June 1992) (reporting that there was no significant enemy activity); D2963 (Video footage of Rogatica). But see KDZ051, T. 19394-19396 (22 September 2011) (testifying that the population of Rogatica was completely unarmed).

$3251 \quad$ See para. 958. 
Following the clashes on 22 May 1992, Serb Forces took control of some areas of the town while the larger part of the town remained under Bosnian Muslim control. ${ }^{3252}$

969. After Rogatica was shelled, members of the $5^{\text {th }}$ Užice Corps were posted in Mesići and a group of 300 Arkan's men and White Eagles was posted in Borike, ready to start operations as soon as Kušić so ordered. ${ }^{3253}$ Šešelj's men were also involved in the attack on Rogatica and had arrived at the JNA barracks a few weeks before the attack. ${ }^{3254}$ Members of the active and reserve police were also involved in this operation. ${ }^{3255}$ All armed groups which arrived in Rogatica were placed under the command of the Rogatica Brigade. ${ }^{3256}$

970. In the days following the initial attack on Rogatica, Serb Forces entered the town, going from street to street; tanks and APCs would come to the town on a daily basis and fire at the mosques, at Bosnian Muslim houses and into the cellars where Bosnian Muslims were hiding. ${ }^{3257}$ Serb Forces also threw hand grenades before making forceful entry into houses, firing automatic weapons as they did so, ordering out groups of Bosnian Muslims who were in hiding, and detaining them. $^{3258}$ Serb Forces also sprayed chemicals into buildings and fired incendiary rounds which ignited the chemicals; this forced Bosnian Muslims out of the cellars. ${ }^{3259}$ Men were separated from the women and forced to lie down as they were kicked and beaten by the soldiers who demanded

3252 D2909 (Witness statement of Mile Ujić dated 9 February 2013), para. 24; D3031 (Witness statement of Milovan Lelek dated 23 February 2013), para. 14; D2912 (Map of Rogatica); Sveto Veselinović, T. 33911 (18 February 2013) (testifying that Rogatica was actually taken over by Bosnian Muslims).

3253 [REDACTED].

3254 P127 (Witness statement of Alija Isaković dated 22 January 1999), p. 5.

3255 P3275 (Report of Rogatica SJB, 14 August 1992), p. 1. [REDACTED].

3256 P3275 (Report of Rogatica SJB, 14 August 1992), p. 1. Batinić testified that paramilitaries did not stay long in Rogatica because "no one accepted them". D2930 (Witness statement of Tomislav Batinić dated 11 February 2013), para. 31. The Chamber does not consider that Batinić's evidence is reliable in this regard given that in his own testimony he claimed to have never seen or had contact with paramilitaries.

3257 P127 (Witness statement of Alija Isaković dated 22 January 1999), p. 4; Elvir Pašić, P59 (Transcript from Prosecutor v. Tadić), T. 857-858; P3405 (Witness statement of KDZ051 dated 17 September 2011), para. 36; KDZ051, T. 19363-19364 (22 September 2011).

3258 P3405 (Witness statement of KDZ051 dated 17 September 2011), paras. 37-38; Elvir Pašić, P59 (Transcript from Prosecutor v. Tadić), T. 860-863. Pašić testified that he could recognise the voices and/or faces of the men who ordered the group of Bosnian Muslims out of the shelter even though some were wearing masks and they were Serbs in olive green and light and dark blue camouflage uniforms. One of the men identified was Vlado Marković who was previously an active duty policeman in Rogatica. Elvir Pašić, P59 (Transcript from Prosecutor v. Tadić), T. 862-864; P3291 (List of policemen working at Rogatica SJB in May 1992), p. 1. The Chamber received evidence about the killing of Bosnian Muslims during and after the take-over of Rogatica. P3405 (Witness statement of KDZ051 dated 17 September 2011), paras. 35, 42, 79-82; P3410 (List of bodies exhumed in Višegrad during 2000-2001); D2950 (Witness statement of Sveto Veselinović dated 15 February 2013), para. 20; KDZ051, T. 19405-19406 (22 September 2011); P3279 (Witness statement of KDZ606 dated 1 September 2011) (under seal), paras. 98, 101; P127 (Witness statement of Alija Isaković dated 22 January 1999), p. 3; P128 (Alija Isaković's statement to BiH authorities, 30 March 1993), pp. 3-4; P3283 (List of Bosnian Muslim civilians killed in Rogatica). The Chamber notes that the Prosecution cites to these killings and the bodies found in the streets of Rogatica in its Final Brief. Prosecution Final Brief, Appendix A, Rogatica, para. 14. However, the Chamber notes that there are no killings charged in Schedule A of the Indictment with respect to Rogatica. 
that they hand over any weapons. ${ }^{3260}$ Serb Forces entered the town and used flame throwers to set houses on fire; this process continued house by house, until large parts of the town were destroyed and Bosnian Muslim houses were burned. ${ }^{3261}$ This pattern continued until Serb Forces took full control of the town. ${ }^{3262}$ By the end of July 1992, Rogatica was under the control of the Rogatica Brigade. $^{3263}$ Many Bosnian Muslims fled and took refuge in the square. ${ }^{3264}$

971. The take-over of Rogatica was planned and executed by the SRK and Mladic was informed of it. ${ }^{3265}$ The Main Staff issued a directive which gave the corps commanders "a broad opportunity for self-initiative" and directed them to "establish lines", leaving it to the "corps commander, the commanders of brigades, and lower-ranking units, to make corrections in the lines of defence"; Rogatica was taken because it "was deep within the territory that was under the control of the Serbs". 3266

\section{(D) Attacks on surrounding villages}

972. On or about 22 May 1992 and the following days, many of the Bosnian Muslim villages in Rogatica Municipality were attacked and came under fire. ${ }^{3267}$ For example, the Bosnian Muslim

3259 P127 (Witness statement of Alija Isaković dated 22 January 1999), p. 4.

3260 Elvir Pašić, P59 (Transcript from Prosecutor v. Tadić), T. 861, 863 (testifying that during this process one soldier threatened to kill him and held a knife to his throat; the soldiers also threw a grenade into a shelter which injured a man when he refused to leave).

3261 P3405 (Witness statement of KDZ051 dated 17 September 2011), paras. 37-38; P3289 (Witness statement of KDZ607 dated 1 September 2011), para. 59 (under seal); P3404 (Witness statement of KDZ051 dated 17 September 2011), para. 40 (under seal); P3411 (Photograph of KDZ051's house) (under seal). See also Elvir Pašić, P59 (Transcript from Prosecutor v. Tadić), T. 866 (testifying that he heard that one third of the town consisting of the predominantly Bosnian Muslim areas was burned down).

3262 P3405 (Witness statement of KDZ051 dated 17 September 2011), para. 36; KDZ051, T. 19363-19364 (22 September 2011).

3263 P3407 (Report on the work of the Rogatica Municipal Assembly and Executive Board from July 1992 to September 1993), p. 14.

3264 P3405 (Witness statement of KDZ051 dated 17 September 2011), para. 42; KDZ051, T. $19405-19406$ (22 September 2011).

3265 [REDACTED]. Hurko testified that Furtula commanded the attack on Rogatica. P3267 (Witness statement of Šefik Hurko dated 1 September 2011), para. 56. However, it is not clear to the Chamber on what basis the witness knew who commanded the attack and therefore the Chamber will not rely on this evidence to make a finding in this regard.

3266 [REDACTED].

3267 P3267 (Witness statement of Šefik Hurko dated 1 September 2011), para. 5; Šefik Hurko, T. 18223 (2 September 2011); P3279 (Witness statement of KDZ606 dated 1 September 2011), paras. 90-91 (under seal). See also D4002 (Letter from BiH MUP to Vasvija Vidović, 4 July 1995), pp. 27-28; David Harland, T. 2118 (7 May 2010). The Chamber also received evidence that the village of Živaljevina was shelled as early as 12 or 13 May 1992. See Adjudicated Fact 2503. However, the Chamber has no evidence as to who carried out this shelling and is therefore not satisfied that it can make a finding in this regard. Lelek testified that Serb Forces did not fire at a populated area and that they were seeking to liberate the road to retrieve Mihajlović's body. Milovan Lelek, T. 34384, 34400-34401, 34403, 34433-34435 (27 February 2013). The Chamber does not find this evidence to be reliable. In reaching that conclusion the Chamber found that Lelek's evidence was marked by contradictions and indicators that he was misleading the Chamber. 
village of Mađer, which is six kilometres from Rogatica, ${ }^{3268}$ came under heavy small arms fire from the surrounding hills. ${ }^{3269}$ The surrounding villages of Kovalj, Vragolovi, Kopljevići, Orahovo, Šljedovići, and Čubrići were also attacked. ${ }^{3270}$ Following these attacks, Bosnian Muslims started leaving their villages out of fear, ${ }^{3271}$ with some escaping to Žepa and Kozići. ${ }^{3272}$

973. Two or three days after the shelling of the villages, infantry attacks were also launched against some of these villages. ${ }^{3273}$ Kušic reported to the "Supreme Command" of the SerBiH that on 22 May 1992 villages in Rogatica which were described as "enemy strongholds" were attacked and that the enemy was "crushed with losses and casualties". 3274 Villages from which weapons had been handed over were not shelled. ${ }^{3275}$ On 23 May 1992, Kušić ordered units to hold positions and to conduct "čišćenje" or "mopping up" operations in villages with mixed populations, ${ }^{3276}$ and for all units "to carry out destruction of personnel without hesitation" and "to open fire from all available weapons". 3277

974. When Bosnian Muslim representatives asked that the attacks against Bosnian Muslim settlements be stopped, they were told that the only way to stop the attacks was if weapons were surrendered by a set deadline. ${ }^{3278}$ Following these discussions the attacks intensified and Bosnian

Šefik Hurko, T. 18223 (2 September 2011).

P3267 (Witness statement of Šefik Hurko dated 1 September 2011), para. 3; Šefik Hurko, T. 18344 (5 September 2011).

Šefik Hurko, T. 18223 (2 September 2011); Šefik Hurko, T. 18344 (5 September 2011).

P3289 (Witness statement of KDZ607 dated 1 September 2011), para. 11 (under seal).

KDZ606, T. 18271 (2 September 2011) (closed session); P3279 (Witness statement of KDZ606 dated 1 September 2011), paras. 91-92 (under seal). KDZ606 also testified about the killing of villagers during these attacks. The Chamber notes that these killings are not charged pursuant to Schedules A or B of the Indictment. See fn. 13

P3279 (Witness statement of KDZ606 dated 1 September 2011), para. 92 (under seal).

P3265 (Report of Rogatica Batallion, 23 May 1992), p. 1. [REDACTED]; D3031 (Witness statement of Milovan Lelek dated 23 February 2013), para. 14. See also Mile Ujić, T. 33460 (12 February 2013); Sveto Veselinović, T. 45106-45107 (16 December 2013) (testifying that the army attacked villages with Bosnian Muslim forces); P2832 (Article from Srpska Vojska entitled "They Saved Serbian Land", 15 July 1993), p. 3. Prosecution witnesses disputed this report and testified that there were no enemy strongholds in these villages but that there were only civilians there; nonetheless, they acknowledged that there were some armed civilians who were defending their homes. P3267 (Witness statement of Šefik Hurko dated 1 September 2011), para. 4; Šefik Hurko, T. 18224 (2 September 2011), T. 18343-18344, 18358 (5 September 2011); KDZ606, T. 18270 (2 September 2011) (closed session) (testifying that there were also individual members of the reserve police forces in these villages); P3405 (Witness statement of KDZ051 dated 17 September 2011), paras. 31, 38-39; P3289 (Witness statement of KDZ607 dated 1 September 2011), para. 59 (under seal). The Chamber, having regard to the totality of the circumstances, in particular the length of time it took for Serb Forces to take over Rogatica, does not consider the evidence that there was no armed resistance to be credible.

[REDACTED].

[REDACTED].

P3274 (Order of Rajko Kušić, 23 May 1992), p. 1. [REDACTED].

P3279 (Witness statement of KDZ606 dated 1 September 2011), para. 97 (under seal). Defence witnesses testified that (i) villages were only attacked following provocations and attacks against Bosnian Serb villages; (ii) were considered military targets if there was fire coming from them; (iii) Bosnian Muslim villages were first asked to surrender their weapons, and it was only when they refused that they were attacked and taken over by Serb Forces; (iv) villagers were warned about the possible attack and only a very small number of people 
Muslim homes were burnt down in villages including Bjelogorci, Pašić Kula, Šljedovići, Ovlagije, Seljani, Živaljevići, Kovanj, Lepenica, Kramer, Tičijak, Mala Žepa, and Biljino Polje. ${ }^{3279}$

975. There was a Bosnian Muslim minority in the village of Seljani, where the local recreation hall was converted into barracks used by local Bosnian Serbs and members of the White Eagles. ${ }^{3280}$ Bosnian Muslim houses were targeted by infantry fire. ${ }^{3281}$ During the shelling, Armin Baždar and his family took shelter in the woods; his father was told by a Bosnian Serb friend that Bosnian Muslim men and women had been arrested and that Bosnian Muslim men had been taken in the direction of Pješevica. ${ }^{3282}$ There were no military facilities in the village. ${ }^{3283}$

976. In the few days following the attack on Seljani, Serb Forces wearing camouflage uniforms, red berets, and SDS insignia and carrying automatic weapons went from house to house and ordered Bosnian Muslims to move in together to allow for greater control of the Bosnian Muslim population. $^{3284}$ As a result, four or five families numbering about 20 people were living together; Serb Forces patrolled the area and kept them "under control". 3285 Until August 1992, they were "placed under a sort of house arrest", were not allowed to go to work or buy food, and could only

remained in specific villages. D2909 (Witness statement of Mile Ujić dated 9 February 2013), para. 30; Mile Ujić, T. 33461, 33466-33467 (12 February 2013); D3038 (Witness statement of Novica Andrić dated 23 February 2013), para. 9; D3031 (Witness statement of Milovan Lelek dated 23 February 2013), paras. 6, 14. While the Chamber accepts that there had been requests for villages to disarm prior to attacks by Serb Forces, the Chamber does not consider the remainder of this evidence to be reliable. In reaching that conclusion the Chamber notes that evidence of the relevant witnesses was marked by inconsistencies, contradictions, and evasiveness and indicators that some were not forthright in their testimony in this regard.

P128 (Alija Isaković's statement to BiH authorities, 30 March 1993), p. 3; P3279 (Witness statement of KDZ606 dated 1 September 2011), para. 97 (under seal); P3286 (Witness statement of Armin Baždar dated 23 January 1999), p. 3; Armin Baždar, T. 18381 (5 September 2011); P3267 (Witness statement of Šefik Hurko dated 1 September 2011), para. 55 (stating that he overheard soldiers saying that the attacks on some villages were led by Mile Ujić). The Chamber also received evidence about the killing of civilians during these attacks but these that these killings are not charged pursuant to Schedules A or B of the Indictment. See fn. 13. See P3279 (Witness statement of KDZ606 dated 1 September 2011), para. 97 (under seal); P3289 (Witness statement of KDZ607 dated 1 September 2011), para. 11 (under seal); P128 (Alija Isaković's statement to BiH authorities, 30 March 1993), p. 3; P3283 (List of Bosnian Muslim civilians killed in Rogatica). See Prosecution Final Brief, Appendix A, Rogatica, para. 14.

3280 P3286 (Witness statement of Armin Baždar dated 23 January 1999), p. 3.

3281 P3286 (Witness statement of Armin Baždar dated 23 January 1999), p. 3 (further testifying that a Bosnian Muslim was killed in the attack); Armin Baždar, T. 18381 (5 September 2011). The Chamber notes that these killings are not charged pursuant to Schedules A or B of the Indictment. See fn. 13. Lelek testified that the village of Seljani was a majority Bosnian Serb village and that it was not attacked. Milovan Lelek, T. 34428 (27 February 2013). While the Chamber accepts that Seljani had a majority Bosnian Serb population, the Chamber is not satisfied that Lelek's evidence that the village was not attacked is reliable. In reaching this conclusion the Chamber had regard to the credible testimony of Baždar about the attack against the village and also considered that Lelek's evidence was marked by contradictions and indicators that he was misleading the Chamber.

3282 P3286 (Witness statement of Armin Baždar dated 23 January 1999), p. 3.

3283 P3286 (Witness statement of Armin Baždar dated 23 January 1999), p. 3.

3284 P3286 (Witness statement of Armin Baždar dated 23 January 1999), p. 3.

3285 P3286 (Witness statement of Armin Baždar dated 23 January 1999), p. 4; Armin Baždar, T. 18392 (5 September 2011). 
tend to their animals. ${ }^{3286}$ White Eagles were seen in the village and from their accents were identified as being from Serbia. ${ }^{3287}$ Some Bosnian Muslim houses were set on fire between May and August 1992. ${ }^{3288}$

977. The villages of Kramer Selo, Kozarde, Dobrašina and Borovsko were shelled on 2 August 1992 by Serb Forces, which prompted Bosnian Muslims to flee. ${ }^{3289}$

(E) Events after the take-over of Rogatica

978. Veselinović entered Rogatica five or six days after the take-over of the town and headed a commission which was formed by the Rogatica Crisis Staff to accommodate and help refugees and to ensure the safety and security of abandoned properties. ${ }^{3290}$ The commission took measures to regulate unauthorised movement into abandoned homes. However, groups of Serb refugees arrived in August 1992, and after Plavšić arrived in Rogatica and asked refugees to be accommodated in the town, people moved into abandoned homes and took away household items. ${ }^{3291}$

979. On 1 August 1992, Kušić as commander of the Rogatica Brigade issued an order to combat the illegal use and destruction of "war booty" and required the submission of criminal reports against individuals who failed to respect the order. ${ }^{3292}$ At a Rogatica Serb Municipal Assembly meeting on 19 August 1992, the further distribution of these abandoned homes as temporary

\footnotetext{
3286 P3286 (Witness statement of Armin Baždar dated 23 January 1999), p. 4; Armin Baždar, T. 18392-18393 (5 September 2011).

3287 P3286 (Witness statement of Armin Baždar dated 23 January 1999), p. 3; Armin Baždar, T. 18393-18394 (5 September 2011).

3288 P3286 (Witness statement of Armin Baždar dated 23 January 1999), p. 4.

3289 P3289 (Witness statement of KDZ607 dated 1 September 2011), paras. 12, 55 (under seal); KDZ607, T. 18493 (6 September 2011); P3292 (SRK Command report, 3 August 1992), p. 1; Mile Ujić, T. 33466-33467 (12 February 2013); D2909 (Witness statement of Mile Ujić dated 9 February 2013), para. 30. While the Chamber received evidence about killings at Kramer Selo. P3289 (Witness statement of KDZ607 dated 1 September 2011), para. 55 (under seal); KDZ607, T. 18510 (7 September 2011); P3283 (List of Bosnian Muslim civilians killed in Rogatica), pp. 3-4. The Chamber notes that these that these killings are not charged pursuant to Schedules A or B of the Indictment. See fn. 13.

3290 D2950 (Witness statement of Sveto Veselinović dated 15 February 2013), paras. 15-16; D2960 (Decision of Rogatica Crisis Staff, 30 May 1992); D2962 (Decision of Rogatica Executive Board, 11 July 1992); D2956 (Report of Rogatica Executive Board, April 1993); Sveto Veselinović, T. 33880, 33882-33884 (18 February 2013).

3291 D2950 (Witness statement of Sveto Veselinović dated 15 February 2013), para. 16; D2956 (Report of Rogatica Executive Board, April 1993); Sveto Veselinović, T. 33887-33889 (18 February 2013). See also P3407 (Report on the work of the Rogatica Municipal Assembly and Executive Board, from July 1992 to September 1993), ecourt p. 27; D2964 (Video footage of refugees in Rogatica).

3292 P3282 (Order of SRK, 1 August 1992), pp. 1-2.
} 
accommodation was prohibited. ${ }^{3293}$ The Executive Board also took measures to address the unauthorised use of abandoned homes. ${ }^{3294}$

980. On 23 November 1992, Batinić wrote a letter to the SJB in Rogatica requesting their full engagement in ensuring public law and order to create conditions for the normal life and work of the organs of authority, including the prevention of misappropriation of property, unlawful seizure of apartments, and businesses and the personal safety of citizens. ${ }^{3295}$

(F) Detention facilities in Rogatica

(1) Scheduled Detention Facility C.21.1

981. The Indictment refers to the use of the Veljko Vlahović Secondary School as a detention facility at least between 1 May and 31 September $1992 .^{3296}$

(a) Arrival of detainees and control over detention facility

982. The Veljko Vlahović Secondary School was located in the Bosnian Serb part of Rogatica. ${ }^{3297}$ After the shelling of Rogatica, which started on 22 May 1992, Bosnian Muslims were detained at the school for periods of up to three and a half months. ${ }^{3298}$ In the first month the school held approximately 400 people, and of this group, only 70 to 90 were men. ${ }^{3299}$ Thereafter, many new detainees arrived at the school and the number of people held grew to $1,100{ }^{3300}$ All the detainees in the school were Bosnian Muslims except for two Bosnian Serb women who were married to Bosnian Muslims and one Bosnian Serb family whose sons did not want to fight in the $\operatorname{army.}^{3301}$

\footnotetext{
3293 P3407 (Report on the work of the Rogatica Municipal Assembly and Executive Board from July 1992 to September 1993), e-court pp. 28, 31-32. See also P3282 (Order of SRK, 1 August 1992), pp. 1-2.

3294 D2930 (Witness statement of Tomislav Batinić dated 11 February 2013), para. 27. See also P3407 (Report on the work of the Rogatica Municipal Assembly and Executive Board from July 1992 to September 1993), e-court pp. 11-12, 14, 17-18, 24, 31-32; KDZ051, T. 19357-19358 (22 September 2011).

3295 D2930 (Witness statement of Tomislav Batinić dated 11 February 2013), paras. 27-28; D2931 (Warning of Rogatica Municipal Assembly, 23 November 1992); Tomislav Batinić, T. 33684 (14 February 2013).

3296 The Indictment originally referred to detention until at least 31 August 1992 but this period was extended to at least September 1992. See Prosecution Rule 73 bis Submission, Appendix B, p. 65

3297 P3405 (Witness statement of KDZ051 dated 17 September 2011), paras. 52-53; P3412 (Two photographs of Veljko Vlahović secondary school); P6157 (Map of Rogatica).

3298 See Adjudicated Facts 2506, 2508, 2510. See also P3405 (Witness statement of KDZ051 dated 17 September 2011), para. 41; P3283 (List of Bosnian Muslim civilians killed in Rogatica), p. 12-20; P3286 (Witness statement of Armin Baždar dated 23 January 1999), p. 4; D2914 (Response of $1^{\text {st }}$ Podrinje Light Infantry Brigade, 30 November 1992).

3299 P3405 (Witness statement of KDZ051 dated 17 September 2011), para. 65.

3300 P3405 (Witness statement of KDZ051 dated 17 September 2011), para. 65.

3301 P3405 (Witness statement of KDZ051 dated 17 September 2011), paras. 54, 58.
} 
983. A few days following the attack on Rogatica on 22 May 1992, loudspeakers were used to order the Bosnian Muslim population of the town to gather in the central square, where a group of armed Bosnian Serb soldiers demanded that they sign loyalty oaths or surrender documents to the Bosnian Serb authorities and move to the school for their personal security. ${ }^{3302}$ The group of soldiers included a captain wearing a regular JNA uniform and seven or eight other uniformed persons wearing camouflage uniforms ${ }^{3303}$ Following these announcements at least 200 to 300 unarmed Bosnian Muslims gathered in the town square. ${ }^{3304}$

984. Živojin Novaković, a VRS soldier, was told that the Veljko Vlahović Secondary School was too small to accommodate this large group of people and was asked to release the Bosnian Muslims since the Serb Forces already had control of the town. ${ }^{3305}$ After making a radio call, Novaković said that this was not possible and that "the town would be cleansed", that the Bosnian Muslims would all have to proceed to the school, that "anyone found in the town would be killed", and that he had received an order that all Bosnian Muslims should be taken to the school. ${ }^{3306}$ Novaković told the Bosnian Muslims that they would only have to stay a few days in the school until the situation calmed down and that they all had to go to there "to avoid the cleansing". 3307

985. Following this, Bosnian Serb police and soldiers in olive-green camouflage uniform entered homes and removed those who did not comply with the orders to go to the school. ${ }^{3308}$ During this process men were beaten ${ }^{3309}$ and Bosnian Muslims, including women and children who had been

3302 Elvir Pašić, P59 (Transcript from Prosecutor v. Tadić), T. 858-860, 884, 896; P3405 (Witness statement of KDZ051 dated 17 September 2011), paras. 43, 50; P3279 (Witness statement of KDZ606 dated 1 September 2011), para. 42 (under seal) (stating that Rajko Kušić himself used a megaphone and called on the people to surrender before they were taken to the Veljko Vlahović Secondary School); P127 (Witness statement of Alija Isaković dated 22 January 1999), p. 4; P128 (Alija Isaković's statement to BiH authorities, 30 March 1993), p. 3 (identifying Žika Novaković as one of the people who used a megaphone to call on the Bosnian Muslims to come out). See also Adjudicated Fact 2504.

3303 Elvir Pašić, P59 (Transcript from Prosecutor v. Tadić), T. 859-860, 884; P3405 (Witness statement of KDZ051 dated 17 September 2011), paras. 43, 46 (stating that Živojin Novaković who represented the VRS called upon the Bosnian Muslims to surrender and proceed to the school). See also Adjudicated Fact 2504.

3304 P3405 (Witness statement of KDZ051 dated 17 September 2011), para. 64. The Chamber received other evidence that between 2,000 and 3,000 Bosnian Muslims gathered in the town square. See also KDZ051, T. 19404 (22 September 2011); Adjudicated Fact 2504; D2909 (Witness statement of Mile Ujić dated 9 February 2013), para. 40. However, the Chamber does not find this figure to be consistent with the evidence regarding the initial number of Bosnian Muslims who were gathered and detained at the Veljko Vlahović Secondary School.

3305 P3405 (Witness statement of KDZ051 dated 17 September 2011), para. 46; KDZ051, T. 19404 (22 September 2011).

3306 P3405 (Witness statement of KDZ051 dated 17 September 2011), para. 46. See also Adjudicated Fact 2504.

3307 P3405 (Witness statement of KDZ051 dated 17 September 2011), para. 46; KDZ051, T. 19404-19405 (22 September 2011).

3308 See Adjudicated Fact 2505.

3309 See Adjudicated Fact 2505. 
captured in shelters, were taken to the school and detained there for a few days. ${ }^{3310}$ At the beginning of June 1992, 200 to 300 people surrendered at the school when the area they were in was shelled. ${ }^{3311}$ Upon their arrival, they discovered that there were already 100 people at the school and that two detainees were drawing up a list of detainees. ${ }^{3312}$ On 11 June 1992, the command of the Rogatica Brigade reported that large numbers of Bosnian Muslim civilians were arriving every day and were "finding shelter" in the school. ${ }^{3313}$ The Chamber finds that the reference to Bosnian Muslim civilians seeking "shelter" at the school is a mischaracterisation and that those who were at the facility were detained there. ${ }^{3314}$ In early August 1992, local Bosnian Serb soldiers continued to enter Bosnian Muslim houses and transfer groups of Bosnian Muslims to

3310 Elvir Pašić, P59 (Transcript from Prosecutor v. Tadić), T. 864 (testifying that apart from two Muslim families, he also knew one Serb family and "one from a mixed marriage" who were already present at the school).

3311 P3405 (Witness statement of KDZ051 dated 17 September 2011), paras. 48-49.

3312 P3405 (Witness statement of KDZ051 dated 17 September 2011), para. 51.

3313 P3414 (Report of the Rogatica Brigade, 11 June 1992), p. 1. The Rogatica Brigade also reported to the command of the SRK on 15 June 1992 that a large number of Bosnian Muslims (mainly women and children) were arriving in the town daily and they were being moved to the secondary school. P5485 (Report of Rogatica Brigade, 15 June 1992).

3314 P3405 (Witness statement of KDZ051 dated 17 September 2011), para. 39; KDZ051, T. 19397-19398 (22 September 2011). Defence witnesses testified that (i) no more than 200 to 250 people passed through the school until August 1992; (ii) the people in the school were not treated as detainees; (iii) the people were not brought to the school by force and the Bosnian Muslim population who stayed behind in the town and expressed loyalty and were not willing to fight were asked to move to the school; (iv) the school was a shelter or a safe house used to protect people from murder and mistreatment which could accommodate 1,100 people; (v) the school was used as a collection centre until August 1992 when the people were asked whether they wanted to remain in Rogatica or whether they wanted to change their place of residence after which they were sent to their desired location; (vi) the civilian authorities asked the Brigade to act in accordance with international conventions; (vii) after Rogatica was "liberated" at the end of July 1992, the Bosnian Muslims at the school were able to go to their houses and take things that were left there, but they did not dare to go when there was still fighting because of the Bosnian Muslim forces; and (viii) the civilian police was at the school and would prevent anyone from entering the compound and mistreating the civilian population. Milovan Lelek, T. 34384 34390, 34428-34429 (27 February 2013); D3035 (Rogatica Brigade combat report, 12 June 1992); D2909 (Witness statement of Mile Ujić dated 9 February 2013), paras. 25, 27, 41-43; Mile Ujić, T. 33461-33462, 33465, 33468, 33476-33480 (12 February 2013); D2914 (Response of $1^{\text {st }}$ Podrinje Light Infantry Brigade, 30 November 1992), p. 1; D3038 (Witness statement of Novica Andrić dated 23 February 2013), para. 16; D2950 (Witness statement of Sveto Veselinović dated 15 February 2013), para. 18; D2930 (Witness statement of Tomislav Batinić dated 11 February 2013), paras. 24-25, 31; Tomislav Batinić, T. 33682-33684, 33702-33703 (14 February 2013). However, the Chamber does not find this evidence to be credible considering the reliable first-hand accounts of detainees. In reaching this conclusion the Chamber noted that the evidence of the relevant witnesses was marked by inconsistencies, contradictions, evasiveness and indicators that some were not forthright in their testimony. More specifically the Chamber observed that it was not clear how Lelek could testify about these issues given that in his own admission he never entered the facility during the relevant period. Milovan Lelek, T. 34389 (27 February 2013). The Chamber also found that Lelek's evidence was marked by contradictions and indicators that he was misleading the Chamber. The Chamber also noted inconsistencies in the evidence of Ujić with respect to the school and cannot rely on his evidence in this regard. The Chamber also noted that Batinić side-stepped questions with respect to the school and does not find his evidence to be reliable in this regard. 
the school. ${ }^{3315}$ In mid-August 1992, Serb Forces entered the village of Mađer and Bosnian Muslims were arrested and taken to detention facilities, including the school. ${ }^{3316}$

986. The guards at the school included Bosnian Serb police, paramilitaries, and soldiers. ${ }^{3317}$ The school operated under Kušić's command. ${ }^{3318}$ Kušić visited the school on a number of occasions and the detainees had to address him as "Vojvoda". 3319 Kušić taunted some of the young male detainees that he would mobilise them to "defend Serbdom". ${ }^{332}$ During one of his visits, Kušić addressed approximately 200 detainees and told them they were not co-operating sufficiently, that he was facing a deadline from Pale, and that he was "running late with the cleansing of Rogatica", which could cause problems when he was required to report to the leadership in Pale. ${ }^{3321}$

987. The paramilitaries in the school included a man nicknamed "Noka" who was one of Arkan's men, and others who spoke the Ekavian dialect. ${ }^{3322}$ The Rogatica SJB reported in August 1992 that there were problems with the treatment of those at the school and that neither the military nor the civilian authorities wanted to take responsibility. ${ }^{3323}$ The detainees were not free to leave, as guards were posted on the perimeter of the school compound and soldiers manned a sniper's nest near the building. ${ }^{3324}$ The doors of the school were "fastened with a thick chain" and the detainees had been

3315 P3286 (Witness statement of Armin Baždar dated 23 January 1999), p. 4; Armin Baždar, T. 18394 (5 September 2011).

3316 P3267 (Witness statement of Šefik Hurko dated 1 September 2011), paras. 6-7, 14 (stating that on his arrival he was detained with 35 to 40 Bosnian Muslim men, women and children); Šefik Hurko, T. 18226 (2 September 2011), T. 18347-18350, 18356 (5 September 2011) (testifying that he was not part of any military unit but instead was part of a work platoon that was digging trenches and roads and that on the certificate he received at the end of the war he was categorised as a civilian victim of the war). See also P3266 (Report of $2^{\text {nd }}$ Romanija Motorised Brigade, 15 August 1992) (reporting on combat operations in the vicinity of Mađer on the day).

3317 P3405 (Witness statement of KDZ051 dated 17 September 2011), paras. 54, 56; see Adjudicated Fact 2508. This included Bosnian Serb soldiers wearing camouflage uniforms and SDS insignia. P3286 (Witness statement of Armin Baždar dated 23 January 1999), p. 4; Armin Baždar, T. 18382, 18393-18394 (5 September 2011).

3318 P3405 (Witness statement of KDZ051 dated 17 September 2011), paras. 56, 62, 68, 89; P3279 (Witness statement of KDZ606 dated 1 September 2011), para. 42 (under seal).

3319 P3405 (Witness statement of KDZ051 dated 17 September 2011), para. 89; KDZ051, T. 19358,19402 (22 September 2011)

3320 P3405 (Witness statement of KDZ051 dated 17 September 2011), para. 89; KDZ051, T. 19415-19416 (22 September 2011).

3321 P3405 (Witness statement of KDZ051 dated 17 September 2011), paras. 90-91; KDZ051, T. 19415 (22 September 2011).

3322 P3405 (Witness statement of KDZ051 dated 17 September 2011), para. 56. While KDZ051 also testified that these persons were under the direct control of Kušić and that the regular police and military worked together with the paramilitaries it is not clear on what basis the witness reached this conclusion. P3405 (Witness statement of KDZ051 dated 17 September 2011), para. 56. The Chamber is not satisfied that it can rely on this evidence alone to make a finding in this regard.

3323 P3275 (Report of Rogatica SJB, 14 August 1992), p. 1.

3324 P3405 (Witness statement of KDZ051 dated 17 September 2011), para. 54. See also Adjudicated Fact 2507. Lelek disputed this Adjudicated Fact. Milovan Lelek, T. 34390-34391 (27 February 2013). However, the Chamber does not find this evidence to be reliable given that Lelek acknowledged that he had not entered the school and never talked to any Bosnian Muslims who had been at the school even though he gave evidence about conditions in the facility. He was also confronted with a prior statement where he denied any knowledge 
warned that the whole area around the school had been mined in the event that anyone tried to escape through a window. ${ }^{3325}$ Nobody could enter the school unless the soldiers or paramilitaries brought them in. 3326

988. Batinić visited the school once, and when asked by a detainee what would happen to them, he said that it was too late, that everything would be destroyed, and that all the detainees would be killed. 3327

\section{(b) Conditions of detention and treatment of detainees}

989. People were detained in the classrooms in terrible conditions. ${ }^{3328}$ Some detainees did not have anything to eat for days and when food was provided it was very limited. ${ }^{3329}$ The food and washing facilities were "grossly inadequate" and the sleeping facilities were non-existent with over 40 people, including women and children sleeping in one room. ${ }^{330}$ Detainees had limited access to water; for example one detainee was only able to wash himself once in the three and a half months he was detained at the school. ${ }^{3331}$ The jewellery of the detainees was taken. ${ }^{3332}$ The guards also forced detainees to sign papers stating that they had "voluntarily joined the Serbian Orthodox religion". 3333 Detainees were subjected to "serious mental and physical abuse" by Bosnian Serb

about the facility. See Milovan Lelek, T. 34391, 34405-34409 (27 February 2013); P6151 (Official record of Sarajevo CJB, 17 June 2004), p. 2.

3325 P3405 (Witness statement of KDZ051 dated 17 September 2011), para. 54. See also Adjudicated Fact 2507.

3326 KDZ051, T. 19409 (22 September 2011).

3327 P3405 (Witness statement of KDZ051 dated 17 September 2011), para. 93; KDZ051, T. 19358,19416 (22 September 2011).

3328 P127 (Witness statement of Alija Isaković dated 22 January 1999), p. 4. In contrast, Batinić himself testified that after he returned to the town, his priority was to visit the school and that when he visited, he spoke to the people and distributed cigarettes to them and he heard that they were provided food and were safe there. D2930 (Witness statement of Tomislav Batinić dated 11 February 2013), para. 26; Tomislav Batinić, T. 33682 (14 February 2013). The Chamber finds that Batinić's evidence with respect to the school is marked by contradictions in that he first claimed that he never heard that Bosnian Muslim civilians were taken from their villages by the Brigade Command and taken to the school but when confronted with documents which showed that the Brigade Command did inform him he acknowledged that he remembered these letters but denied that the civilian authorities ordered them to do so. Batinić's attempt to distance the civilian authorities from these events is contrary to the document which suggests that civilians were separated from "extreme combatants" and gathered at the school with the approval of the Municipal Assembly of Rogatica. Tomislav Batinić, T. 3368333685 (14 February 2013); D2914 (Response of $1^{\text {st }}$ Podrinje Light Infantry Brigade, 30 November 1992). Having regard to these contradictions, the Chamber cannot rely on Batinić's evidence with respect to events at the school.

3329 P3405 (Witness statement of KDZ051 dated 17 September 2011), para. 59. Ujić testified that detainees received three meals a day which were prepared at a central location for the army, refugees and people at the school. D2909 (Witness statement of Mile Ujić dated 9 February 2013), paras. 27-28. The Chamber does not find this evidence to be reliable given that the witness only visited the school once and that there were inconsistencies in his evidence with respect to the nature of the school.

3330 P3405 (Witness statement of KDZ051 dated 17 September 2011), para. 59.

3331 P3405 (Witness statement of KDZ051 dated 17 September 2011), para. 59.

3332 P3405 (Witness statement of KDZ051 dated 17 September 2011), para. 57.

3333 P3405 (Witness statement of KDZ051 dated 17 September 2011), para. 57. 
police and armed individuals in uniforms who entered the facility. ${ }^{334}$ Detainees were taken to the third floor and the cellar where they were questioned and where pliers were used to mistreat them. $^{3335}$

990. At night soldiers would bang on the walls and open the doors violently, flash their flashlights onto the faces of detainees, choose women and girls at random, say they were being taken for questioning but they would take them away to be raped. ${ }^{336}$ The other detainees could hear the women and girls screaming for help. ${ }^{337}$ Women and girls as young as seven, as well as a 13 year old boy were taken out of the classrooms almost every night for a period of two and a half months and raped by the police and soldiers who guarded the camp. ${ }^{3338}$ Some of the women were also taken from the school to flats and apartments in other parts of town, where they were also raped. ${ }^{3339}$

991. When one of his female relatives was taken away, a male detainee tried to follow her but could not; he was later taken by two men to the cellar and shown where she had been raped. ${ }^{3340}$ This detainee was taken to the cellar almost every day and he could see chains that were for leading cattle, as well as traces of blood and could smell the "stench of sperm and sweat". ${ }^{3341}$ He was also raped two and a half weeks after being detained; he was brought to the basement at least 30 times

3334 P3405 (Witness statement of KDZ051 dated 17 September 2011), paras. 51, 67; see Adjudicated Facts 2509 , 2510. Ujić testified that when he visited the school and talked to detainees he received no complaints about the conduct of the police or that people were being taken away and killed. D2909 (Witness statement of Mile Ujić dated 9 February 2013), para. 28. The Chamber does not find this evidence to be reliable or of significance given that Ujić visited the school only on one occasion and it is unclear when he went and to how many people he spoke about their treatment. The Chamber also found inconsistencies in his evidence with respect to the school.

3335 P3405 (Witness statement of KDZ051 dated 17 September 2011), paras. 67, 76 (testifying that one of Arkan's men beat him); see Adjudicated Fact 2509; Elvir Pašić, P59 (Transcript from Prosecutor v. Tadić), T. 865 (testifying that the soldiers wore uniforms which were olive green in colour and the "uniforms worn by the Serb police").

3336 P3405 (Witness statement of KDZ051 dated 17 September 2011), paras. 70-71 (identifying the soldiers who took women out of the facility). This group included members of the SJB such as Mladen Kojić and Vlado Marković. P3291 (List of policemen working at Rogatica SJB in May 1992); Adjudicated Facts 2509 (identifying the guards as those responsible for the rape of Bosnian Muslim detainees), 2510.

3337 P3405 (Witness statement of KDZ051 dated 17 September 2011), para. 70; P3404 (Witness statement of KDZ051 dated 17 September 2011), para. 77 (under seal); P3286 (Witness statement of Armin Baždar dated 23 January 1999), p. 4.

3338 P3405 (Witness statement of KDZ051 dated 17 September 2011), paras. 69-71; P3404 (Witness statement of KDZ051 dated 17 September 2011), paras. 73, 77 (under seal); Adjudicated Fact 2509; P3286 (Witness statement of Armin Baždar dated 23 January 1999), p. 4. See also Elvir Pašić, P59 (Transcript from Prosecutor v. Tadić), T. 865; KDZ051, T. 19364, 19417-19418 (22 September 2011).

3339 P3405 (Witness statement of KDZ051 dated 17 September 2011), paras. 69-70. See also Adjudicated Fact 2509.

3340 [REDACTED].

3341 [REDACTED]. 
and raped on almost every occasion. ${ }^{3342}$ He was tied to a desk, he was verbally abused, pliers were used to mistreat him, and he was raped by police truncheons and similar objects. ${ }^{3343}$

992. Some of the detainees at the school were ordered to work; they dug trenches, collected garbage, carried ammunition, made machine-gun nests, and buried corpses. ${ }^{3344}$ Detainees who did not work fast enough or do exactly as they were instructed were beaten, insulted, and threatened. ${ }^{3345}$ When a Bosnian Serb tank was hit by an anti-tank mine which killed the driver and injured other soldiers, Kušić came to the school with soldiers and collected four to five Bosnian Muslim men who "were taken to be a sort of human shield for the Serb soldiers so they could pull out their dead and wounded from the tank". 3346

993. At the end of June 1992, a group of between 200 and 300 people were taken from the school, placed on buses and trucks, and told that they were being taken to Bosnian Muslim territory. ${ }^{3347}$ They were escorted by Bosnian Serb police. ${ }^{3348}$ The convoy was stopped by local Bosnian Serbs and members of the White Eagles who separated men between the ages of 16 and 65 from the women and children. ${ }^{334}$ The women and children were transported out of the municipality while the men were eventually taken to other detention facilities in other municipalities including the Sušica camp in Vlasenica, ${ }^{3350}$ the Batković camp in Bijeljina, ${ }^{3351}$ and the Kula Prison in Ilidža. ${ }^{3352}$ The women and children were loaded onto buses and trucks "like cattle" and taken to Hreša where they were later exchanged. ${ }^{3353}$ On 16 August 1992, a person named Kojić from the Bosnian Serb MUP came to the school and ordered that all "loyal" Muslims

3353 P3286 (Witness statement of Armin Baždar dated 23 January 1999), p. 4; Armin Baždar, T. 18382 (5 September 2011); P128 (Alija Isaković's statement to BiH authorities, 30 March 1993), p. 4. See also P3289 (Witness statement of KDZ607 dated 1 September 2011) (under seal), para. 13.
} 
be released and that everyone else should be taken to the Rasadnik camp after which some families were released. ${ }^{3354}$

$\underline{\text { detainees }}$

(c) Conclusion on conditions of detention and treatment of

994. Based on the above, the Chamber finds that non-Serb civilians including women and children from Rogatica were brought to and detained at the Veljko Vlahović Secondary School from at least May 1992 until August 1992. The detainees were held in poor conditions which included inadequate food, overcrowding, and limited access to water. Detainees were subjected to beatings and mental abuse and were forced to work at the frontlines. Both male and female detainees were also subjected to acts of sexual violence.

\section{(d) $\underline{\text { Scheduled Incident B.16.1 }}$}

995. The Indictment refers to the killing of a number of men taken from the Veljko Vlahović Secondary School between June and September 1992.

996. Between June and September 1992, groups of male detainees were taken out of the school to a location behind the school, after which shooting was heard and the detainees did not return. ${ }^{3355}$ After many detainees disappeared from the school those who remained were told that they would all be killed and that they would all disappear. ${ }^{3356}$

997. The Chamber therefore finds that a number of men taken from the Veljko Vlahović Secondary School between June and September 1992 were killed by Serb Forces.

\section{(2) Scheduled Detention Facility C.21.2}

998. The Indictment refers to the use of the garage of Novica Andrić as a detention facility on or about 14 August 1992.

\footnotetext{
3354 P3267 (Witness statement of Šefik Hurko dated 1 September 2011), para. 21; Šefik Hurko, T. 18233-18234 (2 September 2011), T. 18368 (5 September 2011). See also P3404 (Witness statement of KDZ051 dated 17 September 2011) (under seal), para. 99.

3355 See Adjudicated Fact 2511; P3405 (Witness statement of KDZ051 dated 17 September 2011), paras. 87-88 (testifying inter alia that he was told that Mujo Bešlija was killed by one of Arkan's men); KDZ051, T. 1941319414 (22 September 2011). See also P3283 (List of Bosnian Muslim civilians killed in Rogatica), pp. 4, 10 (which lists the names of five people who were killed on the premises of the school and also identifies that Mujo Bešlija was "detained and killed" but does not specify a date). The Chamber is not satisfied with the provenance of this document and will not rely on it for the purposes of a finding in this regard.

3356 P3405 (Witness statement of KDZ051 dated 17 September 2011), para. 93
} 
999. The garage of Novica Andrić was located in the village of Kosovo, approximately four kilometres from the village of Mađer, and was used as a place of detention. ${ }^{3357}$ On 14 August 1992, Šefik Hurko, his mother, father, and cousin were arrested by four Bosnian Serb soldiers in the village of Mađer and brought to the garage of Novica Andrić. ${ }^{3358}$ There was a large group of armed men in uniforms who were identified as "Chetniks". 3359 These men wore beards and cockades, as well as skull and cross-bone insignias. ${ }^{3360}$ Šefik Hurko and his family were ordered by four soldiers to go into the garage. ${ }^{3361}$ These four soldiers behaved in a professional manner and did not beat or mistreat the detainees. ${ }^{3362}$ Hurko testified that when he and his family entered the garage they sat on a bench and other soldiers entered, including a man with a moustache who introduced himself as Rajko Kušić. ${ }^{3363}$ Hurko was beaten on arrival in the garage. ${ }^{3364}$ Kušić ordered Stojan Perković and Brane Krsmanović to search them. ${ }^{3365}$ After a packet of bullets and a pistol was found, Perković and Krsmanović beat Hurko and his father. ${ }^{3366}$ Krsmanović told Hurko's father to "stick his tongue out", took a knife to cut his tongue off, and then started to cut his ears. ${ }^{3367}$ Perković hit Hurko on the head with the packet of bullets, cursed him, and forced him to eat three or four of the bullets. ${ }^{3368}$

3357 P3267 (Witness statement of Šefik Hurko dated 1 September 2011), para. 8; Šefik Hurko, T. 18226-18227 (2 September 2011); P6157 (Map of Rogatica).

3358 P3267 (Witness statement of Šefik Hurko dated 1 September 2011), paras. 6, 8; Šefik Hurko, T. 18226-18227 (2 September 2011); Šefik Hurko, T. 18364 (5 September 2011).

3359 P3267 (Witness statement of Šefik Hurko dated 1 September 2011), para. 8.

3360 P3267 (Witness statement of Šefik Hurko dated 1 September 2011), para. 8.

3361 Šefik Hurko, T. 18227 (2 September 2011).

3362 Šefik Hurko, T. 18364, 18365-18366 (5 September 2011); P3267 (Witness statement of Šefik Hurko dated 1 September 2011), para. 7.

3363 Šefik Hurko, T. 18364-18365 (5 September 2011). The Accused tried to suggest that other people introduced themselves as Rajko Kušić but the witness did not know anything about this and only knew that the person introduced himself as Kušić. Šefik Hurko, T. 18363-18364 (5 September 2011). Given that Andrić himself acknowledged that Kušić was there the Chamber places no weight on the Accused's suggestion that this could have been a misidentifcation. Novica Andrić, T. 34454 (28 February 2013).

3364 Šefik Hurko, T. 18367 (5 September 2011). Andrić testified that his garage was used as a shelter to protect Bosnian Muslims from acts of revenge by Bosnian Serb soldiers and that the Hurko family only stayed in the garage for a short time, they were not mistreated or abused and were allowed to leave but had nowhere safer to go. D3038 (Witness statement of Novica Andrić dated 23 February 2013), paras. 10-11, 13; Novica Andrić, T. 34447, 34453-34457 (28 February 2013); D3039 (Photograph of a garage); D3040 (Photograph of a garage). See also D3041 (Photograph of a house); D3042 (Photograph of a house). The Chamber does not consider Andrić's evidence to be reliable in this regard. In reaching this conclusion the Chamber noted inconsistencies in Andrić's evidence and found that his evidence was marked by evasiveness as well as indicators that he was not candid with the Chamber. More specifically Andrić denied any knowledge that Perković had pled guilty and was convicted for the crimes committed in the garage; the Chamber also noted an inconsistency between his evidence that the Hurko family members were not detained and his testimony that they were in military detention and prisoners of the army.

3365 Šefik Hurko, T. 18364 (5 September 2011).

3366 P3267 (Witness statement of Šefik Hurko dated 1 September 2011), paras. 9, 12; Šefik Hurko, T. 18228 (2 September 2011), T. 18356 (5 September 2011).

3367 Šefik Hurko, T. 18228 (2 September 2011).

3368 P3267 (Witness statement of Šefik Hurko dated 1 September 2011), para. 12; Šefik Hurko, T. 18227-18228 (2 September 2011); Šefik Hurko, T. 18364-18365 (5 September 2011). 
1000. Hurko was singled out by Kušić and taken out of the garage with a gun pointed at his back; he could still hear them beating his father when he went outside. ${ }^{3369}$ Hurko was questioned by Kušić about Bosnian Muslim forces before being taken back into the garage. ${ }^{3370}$ When he was taken back inside Hurko saw his father on the floor, covered in blood with both his ears cut. ${ }^{3371}$ Perković stabbed Hurko in the hand with a knife and attempted to slash his throat. ${ }^{3372}$ Kušić watched this whole incident ${ }^{3373}$ and ordered that Hurko and his family be taken to Rogatica, ${ }^{3374}$ after which they were taken to the Veljko Vlahović Secondary School. ${ }^{3375}$ Perković received an award during the first anniversary of the "liberation" of Rogatica. 3376

1001. Based on the above, the Chamber finds that a Bosnian Muslim family was detained at the garage of Novica Andrić on or about 14 August 1992 and that the male members of the family were beaten, stabbed, and mistreated by Serb Forces.

\section{(3) $\underline{\text { Scheduled Detention Facility C.21.3 }}$}

1002. The Indictment refers to the use of Rasadnik as a detention facility at least between August 1992 and October 1994.

\section{(a) Arrival of detainees and control over detention facility}

1003. The Rasadnik detention facility was located at a factory farm which had been used before the war to house farm animals. ${ }^{3377}$ The building where people were detained had been previously used for cattle exhibitions. ${ }^{3378}$

\footnotetext{
3369 P3267 (Witness statement of Šefik Hurko dated 1 September 2011), para. 11; Šefik Hurko, T. 18366-18367 (5 September 2011).

3370 P3267 (Witness statement of Šefik Hurko dated 1 September 2011), para. 11.

3371 P3267 (Witness statement of Šefik Hurko dated 1 September 2011), para. 10; Šefik Hurko, T. 18228 (2 September 2011), T. 18367 (5 September 2011).

3372 P3267 (Witness statement of Šefik Hurko dated 1 September 2011), paras. 9, 60; Šefik Hurko, T. 18228 (2 September 2011). The Chamber also received evidence with respect to a killing which occurred at Novica Andrić's garage. The Chamber notes that this killings is not charged pursuant to Schedules A or B of the Indictment. See fn. 13.

3373 P3267 (Witness statement of Šefik Hurko dated 1 September 2011), paras. 10, 12; Šefik Hurko, T. 18227-18229 (2 September 2011).

3374 Šefik Hurko, T. 18229-18230 (2 September 2011); P3267 (Witness statement of Šefik Hurko dated 1 September 2011), para. 11.

3375 Šefik Hurko, T. 18230 (2 September 2011).

3376 P2832 (Article from Srpska Vojska entitled "They Saved Serbian Land”, 15 July 1993), p. 4.

3377 P3289 (Witness statement of KDZ607 dated 1 September 2011), para. 16 (under seal); P3290 (Aerial photograph of Rasadnik farm); P6157 (Map of Rogatica). See also P3286 (Witness statement of Armin Baždar dated 23 January 1999), p. 4.

3378 P3286 (Witness statement of Armin Baždar dated 23 January 1999), p. 4; Armin Baždar, T. 18382-18383 (5 September 2011); P127 (Witness statement of Alija Isaković dated 22 January 1999), pp. 4-5; P128 (Alija
} 
1004. On 5 August 1992, approximately 20 Bosnian Muslim men and one boy aged 14 who had been separated from the women and children at the Veljko Vlahović Secondary School were taken to Rasadnik. ${ }^{3379}$ They were detained in two rooms with boarded up windows. ${ }^{3380}$

1005. Other Bosnian Muslims who fled Rogatica in early August 1992 were arrested by Serb Forces and taken to Sokolac before some were brought to Rasadnik. ${ }^{3381}$ On 10 August 1992, Serb Forces separated men from the women; the women and children were taken by mini-bus to Hreša. ${ }^{3382} 13$ of the men were lined up and a Bosnian Serb soldier took down their names before they were put into a van and transported to Rasadnik, where they were all put into one small room. ${ }^{3383}$ In addition to these 13 men, there were approximately 22 other detainees held in two other rooms and other detainees held in another room. ${ }^{3384}$

1006. On the evening of 16 August 1992, detainees who had been previously held at the Veljko Vlahović Secondary School were brought to Rasadnik. ${ }^{3385}$ The men were separated from the women. ${ }^{3386}$ Some detainees received better treatment because they were friends of Kušić's or because they co-operated with the Bosnian Serbs. ${ }^{3387}$ Detainees were also brought to the facility in October $1992^{3388}$ and there were reports that Bosnian Muslims were still being held at the facility in 1995. ${ }^{3389}$ However, given that the Indictment only alleges detention until October 1994 at Rasadnik, the Chamber will not make findings with respect to detention after this date.

Isaković's statement to BiH authorities, 30 March 1993), p. 4. See also P3283 (List of Bosnian Muslim civilians killed in Rogatica), pp. 12-20; P3405 (Witness statement of KDZ051 dated 17 September 2011), para. 41. P3286 (Witness statement of Armin Baždar dated 23 January 1999), p. 4; P127 (Witness statement of Alija Isaković dated 22 January 1999), pp. 4-5; P128 (Alija Isaković's statement to BiH authorities, 30 March 1993), p. 4; Elvir Pašić, P59 (Transcript from Prosecutor v. Tadić), T. 869. See Scheduled Detention Facility C.21.1 where the detention at the Veljko Vlahović Secondary School is described. See also D2909 (Witness statement of Mile Ujić dated 9 February 2013), para. 29; P6104 (Record of interview with Mile Ujić, 6 June 2004), p. 5. P3286 (Witness statement of Armin Baždar dated 23 January 1999), p. 4; Armin Baždar, T. 18382-18383 (5 September 2011).

3381 P3289 (Witness statement of KDZ607 dated 1 September 2011), paras. 12-13 (under seal). The Chamber received evidence about the mistreatment of this group when detained at other locations. The Chamber notes that these facilities are not charged pursuant to Schedule C of the Indictment. P3289 (Witness statement of KDZ607 dated 1 September 2011), para. 13 (under seal).

3382 P3289 (Witness statement of KDZ607 dated 1 September 2011), para. 13 (under seal).

3383 P3289 (Witness statement of KDZ607 dated 1 September 2011), paras. 14, 16 (under seal).

3384 P3289 (Witness statement of KDZ607 dated 1 September 2011), paras. 17, 20-21 (under seal). KDZ607 was detained at Rasadnik for a period of six days from 10 to 15 August 1992. P3289 (Witness statement of KDZ607 dated 1 September 2011), para. 23 (under seal).

3385 P3267 (Witness statement of Šefik Hurko dated 1 September 2011), para. 21.

3386 P3267 (Witness statement of Šefik Hurko dated 1 September 2011), para. 22.

3387 P3267 (Witness statement of Šefik Hurko dated 1 September 2011), para. 31. See also P128 (Alija Isaković's statement to BiH authorities, 30 March 1993), pp. 5-6; D3038 (Witness statement of Novica Andrić dated 23 February 2013), paras. 12, 17.

3388 P3267 (Witness statement of Šefik Hurko dated 1 September 2011), para. 34.

3389 D2133 (1 $1^{\text {st }}$ Mountain Brigade Report, 30 July 1995); Andrić, T. 34468-34469 (28 February 2013). 
1007. Rasadnik was guarded by the civilian police of Rogatica and the warden of the facility was Miloš Vojanović. ${ }^{3390}$ The guards wore camouflage or olive grey uniforms and automatic weapons of the JNA. ${ }^{3391}$ After 1 November 1992, the guards at the detention facility were replaced by soldiers who called themselves "Chetniks", and JNA officers from Serbia would also visit the facility. ${ }^{3392}$ Kušić visited the camp on several occasions in 1992 and 1993 and gave the impression that he had " $100 \%$ control" over the facility. ${ }^{3393}$ The Eastern Bosnia Corps command and the command of the $4^{\text {th }}$ Podrinje Light Infantry Brigade were informed about the capture and detention of Bosnian Muslims in Rogatica, including at Rasadnik. ${ }^{3394}$

1008. Defence witnesses testified that (i) Rasadnik was a military detention facility where both Bosnian Muslims and Bosnian Serbs were detained and questioned; (ii) the Bosnian Muslims detained at this facility were suspects who had weapons when their villages were searched or had fired at Bosnian Serb villages; (iii) some civilians may have moved to the camp when the Veljko Vlahović Secondary School closed; (iv) there was no mistreatment of detainees; and (v) the facility was a reception centre. ${ }^{3395}$ The Chamber does not find this evidence to be reliable. In reaching that conclusion the Chamber refers to refers to its discussion above relating to the credibility assessment of the relevant witnesses. ${ }^{3396}$ More specifically, the Chamber notes that Lelek was shown a list of captured Bosnian Muslims from Rogatica and asked whether they were prisoners, but Lelek maintained that they were placed in Rasadnik because the Veljko Vlahović Secondary School was closed. $^{3397}$ Lelek was confronted with evidence that civilians including elderly women were detained and died at Rasadnik, and Lelek confirmed that there were civilians detained there but

\footnotetext{
3390 P3267 (Witness statement of Šefik Hurko dated 1 September 2011), para. 23 (stating that two of the guards were nicknamed Šolaja and Buco); P3289 (Witness statement of KDZ607 dated 1 September 2011), paras. 19, 22 (under seal). See also Milovan Lelek, T. 34386 (27 February 2013).

3391 P3289 (Witness statement of KDZ607 dated 1 September 2011), paras. 19, 22 (under seal).

3392 P127 (Witness statement of Alija Isaković dated 22 January 1999), p. 5; P128 (Alija Isaković's statement to BiH authorities, 30 March 1993), pp. 4-5.

3393 P3267 (Witness statement of Šefik Hurko dated 1 September 2011), para. 44; Šefik Hurko, T. 18238-18239 (2 September 2011). See also P128 (Alija Isaković's statement to BiH authorities, 30 March 1993), p. 5.

3394 P6153 (Drina Corps list of captured persons, 10 April 1993), pp. 1-2; P6155 (List of prisoners in Rogatica Vili camp, 1 February 1993).

3395 D2930 (Witness statement of Tomislav Batinić dated 11 February 2013), para. 32; D2909 (Witness statement of Mile Ujić dated 9 February 2013), para. 29; D2950 (Witness statement of Sveto Veselinović dated 15 February 2013), para. 19; D3038 (Witness statement of Novica Andrić dated 23 February 2013), paras. 16-17; Novica Andrić, T. 34457-34458 (28 February 2013); D3031 (Witness statement of Milovan Lelek dated 23 February 2013), para. 19; Milovan Lelek, T. 34413-34419, 34426-34427 (27 February 2013).

$3396 \quad$ See fns. 3142, 3208.

3397 P6153 (Drina Corps list of captured persons, 10 April 1993).
} 
insisted that he did not understand why elderly civilians would be killed there. ${ }^{3398}$ In light of these inconsistencies the Chamber does not consider Lelek's evidence to be reliable in this regard.

\section{(b) Conditions of detention and treatment of detainees}

1009. While the detainees were held at the facility, the windows were boarded up. ${ }^{3399}$ The detainees had no running water and their access to the water which was kept in containers outside was at the discretion of the guards; they also had no toilet and had to be escorted outside by guards. ${ }^{3400}$

1010. All the newly arrived detainees were beaten by a guard called Šolaja. ${ }^{3401}$ Severe beating of detainees was common place at the facility. ${ }^{3402}$ Detainees were interrogated in a small room and in the course of the interrogations were beaten on their heads and stomachs with rifle butts; the room was left bloody from the beatings. ${ }^{3403}$ Dragomir Kanostrevac was among those involved in the interrogations and beatings. ${ }^{3404}$ Later, interrogations were carried out by Novak Džida who was dressed in civilian clothes. ${ }^{3405}$ Kanostrevac and Džida were on the list of active policemen working at the Rogatica SJB in May 1992. ${ }^{3406}$

3398 Milovan Lelek, T. 34413-34421 (27 February 2013); P6152 (Sarajevo Cantonal Court record of Rogatica exhumation, 4 November 1998), pp. 10-13. See also P6155 (List of prisoners in Rogatica Vili camp, 1 February 1993); P6153 (Drina Corps list of captured persons, 10 April 1993) (which suggests that detainees included elderly men, women and children). P3289 (Witness statement of KDZ607 dated 1 September 2011), para. 17 (under seal); P3286 (Witness statement of Armin Baždar dated 23 January 1999), p. 4; Armin Baždar, T. 18382-18383 (5 September 2011).

3400 P3289 (Witness statement of KDZ607 dated 1 September 2011), para. 18 (under seal). In contrast Ujić testified that detainees at Rasadnik had access to toilets and warm water. D2909 (Witness statement of Mile Ujić dated 9 February 2013), para. 29. Having reviewed this evidence, the Chamber is not convinced that Ujic was in a position to know about the specific conditions of detention at Rasadnik. The Chamber is therefore not convinced that it can rely on his evidence in this regard. In addition, the Chamber noted contradictions in the evidence of Lelek with respect to the Rasadnik facility and therefore does not accept his evidence with respect to the conditions of detention and treatment of detainees. Milovan Lelek, T. 34386 (27 February 2013). Similarly, on cross-examination, Andrić could not confirm whether or not Bosnian Muslim women, including a 101 year old, was detained at Rasadnik because his job did not involve going into the buildings but he acknowledged that Bosnian Muslim civilians were detained at the facility. Andrić denied knowledge of old women who died after a year of detention at Rasadnik on the basis that he only came there rarely and was not aware of all things that happened there. Novica Andrić, T. 34460-34464, 34479-34481 (28 February 2013); D3038 (Witness statement of Novica Andrić dated 23 February 2013), para. 17 (stating further that the detainees received the same food as the staff and soldiers at the facility). Having regard to the inconsistencies and evasiveness in Andrić's evidence, the Chamber does not consider that Andrić's evidence is of much weight in this regard particularly given his claim when questioned that he was not aware of many things which happened in the facility.

3401 P3267 (Witness statement of Šefik Hurko dated 1 September 2011), para. 33.

3402 P127 (Witness statement of Alija Isaković dated 22 January 1999), p. 5; P3267 (Witness statement of Šefik Hurko dated 1 September 2011), paras. 36, 38-40.

3403 P3289 (Witness statement of KDZ607 dated 1 September 2011), para. 16 (under seal). See also P3267 (Witness statement of Šefik Hurko dated 1 September 2011), para. 22.

3404 P3289 (Witness statement of KDZ607 dated 1 September 2011), para. 16 (under seal).

3405 P3289 (Witness statement of KDZ607 dated 1 September 2011), para. 16 (under seal).

3406 P3291 (List of policemen working at Rogatica SJB in May 1992); KDZ607, T. 18483 (6 September 2011) (private session). While the Chamber received evidence that Radisav Ljubinac (a.k.a. "Pjano") was found guilty 
1011. From 16 August to 1 September 1992, Hurko was not beaten, but around 2 a.m. on 1 September, his father was taken to the warden's office for questioning and he could hear his father being beaten through the wall. ${ }^{3407}$ When Hurko saw his father the next day, he could see that his father's face was swollen from the blows. ${ }^{3408}$ After half an hour, Hurko was taken to a room and was threatened by Vojinović to answer all questions truthfully if he wanted to keep his "head on his shoulders". ${ }^{3409}$ When Hurko was questioned about the location of trenches and mines and denied any knowledge about the matter he was beaten as the question was repeated. ${ }^{3410}$ Hurko was beaten on the back with a baton and when he fell down a guard nicknamed "Buco" jumped on him. When he lost consciousness, a bucket of water was poured on him and the beating stopped. ${ }^{3411}$

1012. Both Hurko and his father were taken away from the camp by Bosnian Serb police to the Rogatica SJB. Hurko arrived at the Rogatica SJB after his father and saw his father covered in blood. $^{3412}$ At the Rogatica SJB, Hurko was threatened before being forced to sign a statement about his father's involvement in organising specific meetings in Rogatica. ${ }^{3413}$ Hurko was then returned to Rasadnik where his mother told him that his father had been seriously beaten. As a result of the beating, his father could not move for the next 15 days. ${ }^{3414}$

1013. Although Mile Bojat, who was the warden at Rasadnik for a month, ${ }^{3415}$ told the detainees that there would be no more maltreatment under his command, the mistreatment continued. ${ }^{3416}$ Bojat was replaced by Vinko Bojić in October $1992 .{ }^{3417}$ Bojić, who wore a MP uniform took over command of the facility and was involved in the severe beating of detainees. ${ }^{3418}$ During beatings, Bojić would order the detainee to lie on the floor and would jump on him. ${ }^{3419}$ In beating Alija Isaković Bojić broke six of Isaković's ribs. He also carved a cross on Isaković's chest with a

of kicking and punching detained civilians at the Rasadnik camp the Chamber will not rely on this judgement to support findings in this case. P6106 (Verdict of BiH Court against Ljubinac Radisav, 8 March 2007), pp. 1-2.

P3267 (Witness statement of Šefik Hurko dated 1 September 2011), para. 25.

P3267 (Witness statement of Šefik Hurko dated 1 September 2011), para. 27.

P3267 (Witness statement of Šefik Hurko dated 1 September 2011), para. 26.

P3267 (Witness statement of Šefik Hurko dated 1 September 2011), para. 26.

P3267 (Witness statement of Šefik Hurko dated 1 September 2011), para. 26.

P3267 (Witness statement of Šefik Hurko dated 1 September 2011), paras. 28-29.

P3267 (Witness statement of Šefik Hurko dated 1 September 2011), paras. 28, 30.

P3267 (Witness statement of Šefik Hurko dated 1 September 2011), paras. 30-31.

P3267 (Witness statement of Šefik Hurko dated 1 September 2011), para. 34.

P128 (Alija Isaković's statement to BiH authorities, 30 March 1993), p. 5.

P3267 (Witness statement of Šefik Hurko dated 1 September 2011), para. 34. See also Šefik Hurko, T. 18236 (2 September 2011) (private session) (testifying that Bojić was appointed by Kušić). It is not clear to the Chamber how Hurko knew that Bojić was appointed by Kušić and therefore the Chamber is not satisfied it can rely on this evidence.

P128 (Alija Isaković's statement to BiH authorities, 30 March 1993), p. 6.

P128 (Alija Isaković's statement to BiH authorities, 30 March 1993), p. 6. 
hunting knife, pushed lit cigarettes into his ears and cursed Isaković and called him a "Turk". 3420 Bojić carved 30 crosses on the body of Bećir Ćutarija, burned him with cigarettes, pulled his teeth, jumped on him, and forced him to swallow two bullets. ${ }^{3421}$ Bojić also allowed other "Chetniks" to beat the detainees; the maltreatment of the detainees worsened when Bosnian Serb soldiers were killed in clashes with Bosnian Muslims. ${ }^{3422}$

1014. Isaković was beaten on another occasion for two days and two nights by two men known as Brđanin and Šolaja and on other occasions by Mišo Vojinović, Rajak and Ikonić. ${ }^{3423}$ Other guards who beat the detainees included Bojić's brother, Branko Planojević, and Sorak. ${ }^{3424}$ In July 1993, Hurko heard the beating of a captured member of the ABiH; Hurko himself was beaten around 10 July 1993, when the chief of the SJB in Rogatica and his deputy visited the camp. ${ }^{3425}$ Some detainees died following the beatings. ${ }^{3426}$ Other detainees were taken away, after which the sound of beating followed by a gun shot were heard. ${ }^{3427}$

1015. The ICRC visited Rasadnik on 28 July 1993 and after being assured that the detainees could speak frankly and in confidence, Hurko told the representatives that their situation was difficult, that they had been taken to the frontlines, that they did not have enough food, and were being sexually mistreated. ${ }^{3428}$ After about three days, Hurko was beaten by Bojić in a manner which he describes as "bestial", stating: "He put his pistol in my mouth. He pulled hair from my armpits and inserted it in my mouth. He extinguished cigarettes on me and ordered me to eat the extinguished cigarettes. He ordered me to remove my clothes. He then hit me in my ribs with a knife handle." 3429 One of Hurko's ribs was broken while Bojić asked him about everything he had complained about to the ICRC. ${ }^{3430}$ Bojić then brought in Hurko's father and asked him if he

\footnotetext{
$3420 \quad$ P128 (Alija Isaković's statement to BiH authorities, 30 March 1993), p. 6; P127 (Witness statement of Alija Isaković dated 22 January 1999), p. 5.

3421 P128 (Alija Isaković's statement to BiH authorities, 30 March 1993), p. 6.

3422 P128 (Alija Isaković's statement to BiH authorities, 30 March 1993), p. 6.

3423 P128 (Alija Isaković's statement to BiH authorities, 30 March 1993), p. 5.

3424 P128 (Alija Isaković's statement to BiH authorities, 30 March 1993), p. 6; P3267 (Witness statement of Šefik Hurko dated 1 September 2011), para. 35.

3425 P3267 (Witness statement of Šefik Hurko dated 1 September 2011), para. 41.

3426 P127 (Witness statement of Alija Isaković dated 22 January 1999), pp. 4-5; P128 (Alija Isaković's statement to BiH authorities, 30 March 1993), pp. 4-6. See also P3283 (List of Bosnian Muslim civilians killed in Rogatica), p. 8; P6152 (Sarajevo Cantonal Court record of Rogatica exhumation, 4 November 1998), pp. 9-14.

3427 P3267 (Witness statement of Šefik Hurko dated 1 September 2011), paras. 38-40. See also P3267 (Witness statement of Šefik Hurko dated 1 September 2011), paras. 33, 47-48; P128 (Alija Isaković's statement to BiH authorities, 30 March 1993), p. 6.

3428 P3267 (Witness statement of Šefik Hurko dated 1 September 2011), para. 45; Šefik Hurko, T. 18241-18242 (2 September 2011).

3429 P3267 (Witness statement of Šefik Hurko dated 1 September 2011), para. 45.

3430 P3267 (Witness statement of Šefik Hurko dated 1 September 2011), para. 45; Šefik Hurko, T. 18244 (2 September 2011).
} 
wanted to go to a third country, which reflected what he had told the ICRC, and then ordered Hurko to beat his father. ${ }^{3431}$ Hurko could only hit his father five or six times as he was out of strength after which Bojić said: "If you don't want to, I will” and continued to hit his father 15 to 16 times until he fell down. ${ }^{3432}$ Two 65 year old men were also beaten badly. ${ }^{3433}$

1016. Women were also taken out at night and were forced by Bojić to strip and perform sexual acts with elderly detainees, ${ }^{3434}$ after which Bojić would take the women to another room. ${ }^{3435}$ Several Bosnian Muslim women who had been detained at Rasadnik told Hurko that Bojić had raped them. ${ }^{3436}$

1017. Bojić also forced "male prisoners to perform unnatural sexual acts". ${ }^{3437}$ This included an incident in or around February 1993 where Bosnian Muslim men and women detainees were ordered to undress, dance and perform sexual acts in front of Bosnian Serb soldiers who wore ammunition belts and "skull insignia". ${ }^{3438}$ Over the course of one or two hours, the Bosnian Soldiers took the naked women one by one to another room for a period of approximately 20 minutes. $^{3439}$ Four women were taken away that day while other women were taken away in the following days. ${ }^{3440}$

1018. Bosnian Muslim detainees were taken to the town of Rogatica each day and forced to clean up broken glass and construction material work in places that had been shelled. ${ }^{3441}$ Detainees were also forced to clean and paint Bosnian Muslim apartments to prepare them for Serbs who would be moving into them, as well as to move furniture and belongings out of Bosnian Muslim homes into

\footnotetext{
3431 P3267 (Witness statement of Šefik Hurko dated 1 September 2011), para. 46; Šefik Hurko, T. 18243-18244 (2 September 2011).

3432 P3267 (Witness statement of Šefik Hurko dated 1 September 2011), para. 46.

3433 Šefik Hurko, T. 18242-18243 (2 September 2011).

3434 P3267 (Witness statement of Šefik Hurko dated 1 September 2011), para. 35.

3435 P3267 (Witness statement of Šefik Hurko dated 1 September 2011), para. 35.

3436 P3267 (Witness statement of Šefik Hurko dated 1 September 2011), para. 35. See also Šefik Hurko, T. 18236 (2 September 2011) (private session).

3437 P3267 (Witness statement of Šefik Hurko dated 1 September 2011), para. 35.

3438 P3267 (Witness statement of Šefik Hurko dated 1 September 2011), paras. 36-37; Šefik Hurko, T. 18236 (2 September 2011) (private session).

3439 [REDACTED].

3440 [REDACTED]. While the Chamber received a report which listed 12 women who were taken away from the Rasadnik camp and raped, it is not satisfied as to the provenance of this document and the basis on which it reached this conclusion and thus will not rely on it in making a finding. P3283 (List of Bosnian Muslim civilians killed in Rogatica), p. 12.

3441 P3289 (Witness statement of KDZ607 dated 1 September 2011), para. 18 (under seal). The Chamber notes that the type of forced labour charged in the Indictment is limited to work at the frontlines and the use of human shields.
} 
"new Serb occupied residences". 3442 Some detainees were also taken from the camp to dig trenches ${ }^{3443}$ while others were taken to unload lorries at the Sladara barley factory. ${ }^{3444}$

1019. In mid-July 1993, ten detainees and two captured ABiH soldiers were taken from the camp by truck to the village of Starčići. ${ }^{3445}$ The detainees were instructed to recover the bodies of 17 soldiers in an area which was mined. ${ }^{3446}$ A Bosnian Muslim named Mirsad Omanović who was meant to know the positions of the mines, was told to lead them. ${ }^{3447}$ When one man hit a land mine and lost a leg, Bojić stabbed Omanović, cursed the detainees' "Balija mothers", and shot Osmanović. ${ }^{3448}$ Hurko and another detainee were ordered to bury the body in a shallow grave. ${ }^{3449}$ After this incident the detainees spent three days in the area and found the 17 bodies and buried them there. ${ }^{3450}$

1020. Some detainees were exchanged from the facility ${ }^{3451}$ while others were transported to Batković camp. ${ }^{3452}$ In July 1993, 30 detainees were selected for a proposed exchange and taken towards Bijeljina. ${ }^{3453}$ However, this exchange did not occur and the detainees were returned to Rasadnik, after which Kušić came to the facility, cursed the detainees and said “Alija doesn't want you, I don't know what to do with you, I'll invite the International Red Cross to send you where you want, and if they don't want you, I'll kill you all." ${ }^{3454}$ On 30 April 1994, 12 male detainees

\footnotetext{
3442 P3286 (Witness statement of Armin Baždar dated 23 January 1999), p. 5. The Chamber notes that the type of forced labour charged in the Indictment is limited to work at the frontlines and the use of human shields.

3443 P3267 (Witness statement of Šefik Hurko dated 1 September 2011), para. 38. While the Chamber received a report which listed four people who were taken from Rasadnik camp and killed when used as human shields in August 1992, it s not satisfied as to the provenance of this document and the basis on which it reached this conclusion and thus will not rely on it in making a finding. P3283 (List of Bosnian Muslim civilians killed in Rogatica), p. 9.

3444 P3289 (Witness statement of KDZ607 dated 1 September 2011), para. 25 (under seal). Ujić testified that all detainees who had committed a crime were put on trial and subject to work obligation. Mile Ujić, T. 33470 (12 February 2013). The Chamber refers to its credibility assessment in fn. 3208 as to why it does not consider Ujić's evidence in this regard to be reliable.

3445 P3267 (Witness statement of Šefik Hurko dated 1 September 2011), para. 42.

3446 P3267 (Witness statement of Šefik Hurko dated 1 September 2011), para. 42.

3447 P3267 (Witness statement of Šefik Hurko dated 1 September 2011), para. 42.

3448 P3267 (Witness statement of Šefik Hurko dated 1 September 2011), para. 43.

3449 P3267 (Witness statement of Šefik Hurko dated 1 September 2011), para. 43 (stating that Omanović's body was covered with blood, his neck had been cut with a knife, and his chest was "riddled with bullets").

3450 P3267 (Witness statement of Šefik Hurko dated 1 September 2011), para. 43.

3451 P127 (Witness statement of Alija Isaković dated 22 January 1999), p. 5; P128 (Alija Isaković's statement to BiH authorities, 30 March 1993), p. 8.

3452 P3267 (Witness statement of Šefik Hurko dated 1 September 2011), para. 44; Šefik Hurko, T. 18239-18241 (2 September 2011). Refer to Scheduled Detention Facility C.2.1 for evidence on detention at Batković camp.

3453 P3267 (Witness statement of Šefik Hurko dated 1 September 2011), para. 44.

3454 P3267 (Witness statement of Šefik Hurko dated 1 September 2011), para. 44; Šefik Hurko, T. 18239, 18241, 18243-18244 (2 September 2011).
} 
and a large number of women and children were transported by bus from Rasadnik to Kula by Dragan Bulajić, the president of the Serbian Commission for Prisoner Exchange. ${ }^{3455}$

$\underline{\text { detainees }}$

(c) Conclusion on conditions of detention and treatment of

1021. Based on the above, the Chamber finds that non-Serbs from Rogatica, including civilians and some $\mathrm{ABiH}$ soldiers, were brought to and detained at Rasadnik from at least August 1992 to October 1994. The detainees were held in poor conditions which included limited access to water. Detainees were subjected to mental abuse and beatings and some detainees died following those beatings. ${ }^{3456}$ Detainees were forced to work on the frontline. Both male and female detainees were also subjected to acts of sexual violence.

\section{(d) Scheduled Incident B.16.2}

1022. The Indictment refers to the killing of at least 27 men taken from detention facilities at Rasadnik on 15 August 1992. ${ }^{3457}$

1023. On 15 August 1992 Radisav Ljubinac (a.k.a. "Pjano") went to a work site and told Bosnian Muslim detainees who were working at the site that under the orders of Kušić they were to leave their work and would be taken "to where the action was". ${ }^{3458}$ Pjano drove a mini-bus carrying approximately 27 Bosnian Muslim detainees and was accompanied by other Bosnian Serb soldiers. ${ }^{3459}$ Some of these detainees had been asked to declare their loyalty to a Serb state. ${ }^{3460}$

\footnotetext{
3455 P3267 (Witness statement of Šefik Hurko dated 1 September 2011), para. 49.

3456 This finding does not include the persons alleged to have been killed in Scheduled Incident B.16.2, which is discussed below.

3457 The Chamber notes however, that the Prosecution only refers to the names of 24 victims with respect to this incident in its final brief. Prosecution Final Brief, Appendix G.

3458 P3286 (Witness statement of Armin Baždar dated 23 January 1999), p. 5; Armin Baždar, T. 18414 (6 September 2011)

3459 P3289 (Witness statement of KDZ607 dated 1 September 2011), paras. 27-28 (under seal). The people KDZ607 identified on the van were Ago Kapo, Armin Baždar, Edis Čatić, Midhat Čatić, Mehmed Delija, Halil Halilović, Eldin Hodžić, Faruk Isaković, Hamdija Jašarević, Huso Jašarević, Suljo Jašarević, Fuad Kazić, Sulejman Kazić, Nedžad Kazić, Besim Kurčehaić, Asim Kapo, Šukrija Omeragić, Derviš Pašić, Mujo Pašić, Zaljko Salihović, Osman Solak, Fuad Šetić, Mustafa Tanković. See also Armin Baždar, T. 18388 (5 September 2011) (testifying that Mustafa Tanković and Hamdija Jasarević were in this group of men).

3460 P3289 (Witness statement of KDZ607 dated 1 September 2011), para. 24 (under seal). Money and valuables were taken from them after being ordered to undress.
} 
1024. The detainees were driven to a meadow and were met by Miša Krsmanović a.k.a "Pipa". 3461 When they arrived Pjano swore and asked where Kušić was. ${ }^{3462}$ The detainees were driven to the frontline at Duljevac and stopped at a spot where there was a group of "Chetniks" who had beards, long hair, and were wearing caps with Serb insignia. ${ }^{3463}$ The detainees were ordered to get out of the mini-bus one by one. ${ }^{3464}$ As the detainees got off the bus, one of the Bosnian Serbs said: "[T]hese should be immediately slaughtered" and one who was wearing a yellow headband and was named Dragoje Paunović who was called Špiro, ${ }^{3465}$ said that he would decide. ${ }^{3466}$

1025. Špiro was commander of a unit of the Rogatica Brigade. ${ }^{3467}$ The 10 to 15 Bosnian Serb soldiers were wearing grey, olive, and camouflage uniforms. ${ }^{3468}$ Špiro ordered the soldiers to tie the men's hands behind their backs and to have them walk down a fenced alley towards the frontline. ${ }^{3469}$ Špiro ordered the Bosnian Serb soldiers to advance towards the frontlines with the detainees. ${ }^{3470}$ Two or three Bosnian Muslim men were ordered to walk in front of the Bosnian Serb soldiers towards the frontline. ${ }^{3471}$ When shooting started two of the Bosnian Muslim detainees

3461 P3289 (Witness statement of KDZ607 dated 1 September 2011), para. 28 (under seal). While the Accused on cross-examination tried to show an inconsistency between the witness's statement and his court testimony on this issue, the Chamber found that the Accused did not accurately quote the witness's statement and that conflicting statements were not established to any degree. The Chamber is therefore satisfied with the witness's evidence in this regard. See KDZ607, T. 18517 (7 September 2011) (private session).

3462 P3289 (Witness statement of KDZ607 dated 1 September 2011), para. 28 (under seal); P3286 (Witness statement of Armin Baždar dated 23 January 1999), p. 5; Armin Baždar, T. 18396-18397 (5 September 2011).

3463 P3286 (Witness statement of Armin Baždar dated 23 January 1999), p. 5; Armin Baždar, T. 18396-18397 (5 September 2011). See also P3289 (Witness statement of KDZ607 dated 1 September 2011), para. 34 (under seal); KDZ607, T. 18482 (6 September 2011) (private session) (testifying that they were behind the frontline controlled by the VRS); P3267 (Witness statement of Šefik Hurko dated 1 September 2011), paras. 15-17; Šefik Hurko, T. 18226, 18231-18233 (2 September 2011).

3464 P3286 (Witness statement of Armin Baždar dated 23 January 1999), p. 5; Armin Baždar, T. 18396-18397 (5 September 2011).

3465 P3286 (Witness statement of Armin Baždar dated 23 January 1999), p. 6; Armin Baždar, T. 18383 (5 September 2011); Armin Baždar, T. 18409 (6 September 2011).

3466 P3289 (Witness statement of KDZ607 dated 1 September 2011), para. 29 (under seal); KDZ607, T. 18520_ 18521 (7 September 2011) (private session).

3467 Mile Ujić, T. 33471 (12 February 2013).

3468 P3289 (Witness statement of KDZ607 dated 1 September 2011), paras. 29-32 (under seal). The witness recognised Zoran Rajak, Duško Štica, Ratko Nešković, Vojo Nešković, Dragan Bojević and Uglješa Pećenica. Vojo Nešković and Zlatko Nešković were on the list of active policemen working at the Rogatica SJB in May 1992. P3291 (List of policemen working at Rogatica SJB in May 1992); KDZ607, T. 18484 (6 September 2011) (private session); P3286 (Witness statement of Armin Baždar dated 23 January 1999), p. 6; Armin Baždar, T. 18383 (5 September 2011); Armin Baždar, T. 18409 (6 September 2011).

3469 P3289 (Witness statement of KDZ607 dated 1 September 2011), paras. 29 32-34 (under seal); KDZ607, T. 18519, 18521 (7 September 2011) (private session). P3286 (Witness statement of Armin Baždar dated 23 January 1999), p. 5. The witness identified some of the soldiers in the group as Mladen LNU, Mitar Ljubinać (a.k.a. Grof), and Boban Planojević; Armin Baždar, T. 18411 (6 September 2011).

3470 P3286 (Witness statement of Armin Baždar dated 23 January 1999), p. 6; Armin Baždar, T. 18383 (5 September 2011); Armin Baždar, T. 18409 (6 September 2011).

3471 P3286 (Witness statement of Armin Baždar dated 23 January 1999), p. 5-6. 
were wounded. ${ }^{3472}$ Thereafter, the Bosnian Muslim men were led along a dirt road for 50 metres and then towards a field and ordered to stop. ${ }^{3473}$ When they crossed a meadow three Bosnian Serb soldiers with automatic rifles faced them; Špiro asked how many were wounded and when he was told that some were wounded, he said "I have a lot more" and then ordered a Bosnian Serb soldier to kill them. ${ }^{3474}$ The Bosnian Serb soldier then shot at the front of the line of detainees. ${ }^{3475}$ When some of the younger people in the group pleaded for mercy Špiro cocked his automatic rifle and shot bursts of fire at the group of men and three other soldiers also opened fire. ${ }^{3476}$

1026. After the shooting, those who survived were moaning, after which Špiro ordered that all those who were still alive should be finished off. ${ }^{3477}$ The Bosnian Serb soldiers walked around and shot potential survivors. ${ }^{3478}$ After Bosnian Serb soldiers spotted one detainee sitting up, they opened a burst of gunfire and killed him. ${ }^{3479}$ Baždar, who was among the Bosnian Muslim men who were shot at, survived. While Baždar was laying face down under the body of his dead uncle, he heard a radio conversation where a person who identified himself as Rajko Kušić asked Špiro "who's shooting?" ${ }^{3480}$ Ujić also found out about this incident either on the same day or the day after. $^{3481}$

3472 P3289 (Witness statement of KDZ607 dated 1 September 2011), paras. 35-36, 38 (under seal); KDZ607, T. 18523 (7 September 2011) (private session).

3473 P3286 (Witness statement of Armin Baždar dated 23 January 1999), p. 6; Armin Baždar, T. 18389 (5 September 2011); P3289 (Witness statement of KDZ607 dated 1 September 2011), para. 39 (under seal).

3474 P3289 (Witness statement of KDZ607 dated 1 September 2011), para. 39 (under seal); P3286 (Witness statement of Armin Baždar dated 23 January 1999), p. 6; Armin Baždar, T. 18389 (5 September 2011), T. 18411-18412 (6 September 2011). The Chamber notes that Bazdar testified that two and not three detainees said that they were injured.

3475 P3286 (Witness statement of Armin Baždar dated 23 January 1999), p. 6; Armin Baždar, T. 18389 (5 September 2011).

3476 P3286 (Witness statement of Armin Baždar dated 23 January 1999), p. 6; Armin Baždar, T. 18389 (5 September 2011); P3289 (Witness statement of KDZ607 dated 1 September 2011), para. 41 (under seal); KDZ607, T. 18524 (7 September 2011) (private session). Ujić testified that this execution was carried out by Špiro on his own accord, but that nobody approved of this incident at the Brigade Command, Corps Command or Supreme Command levels. He also testified that he did not report the incident to the Accused nor was he aware of whether anyone else reported the incident to the Accused. Mile Ujić, T. 33470, 33473-33477 (12 February 2013). However, the Chamber does not consider Ujić's evidence to be reliable in this regard. The Chamber noted that Ujić's evidence was marked by contradictions and inconsistencies and his evidence demonstrated a clear interest in minimising the awareness and involvement of the Bosnian Serb authorities in the incident.

3477 P3289 (Witness statement of KDZ607 dated 1 September 2011), para. 44 (under seal).

3478 P3286 (Witness statement of Armin Baždar dated 23 January 1999), p. 6; Armin Baždar, T. 18389-18390 (5 September 2011); P3289 (Witness statement of KDZ607 dated 1 September 2011), para. 44 (under seal). When Baždar was shot in the arm he fell down and his uncle who had been shot in the chest fell over him. Baždar lay face down and pretended to be dead, and while he was there the Bosnian Serbs walked towards them to see if anyone was still alive they shot his uncle in the head and the bullet went through his uncle's head into Baždar's arm. P3286 (Witness statement of Armin Baždar dated 23 January 1999), p. 6

3479 P3286 (Witness statement of Armin Baždar dated 23 January 1999), p. 6.

3480 P3286 (Witness statement of Armin Baždar dated 23 January 1999), p. 6; Armin Baždar, T. 18390-18391 (5 September 2011).

3481 Mile Ujić, T. 33472-33476 (12 February 2013); P6107 (Verdict of BiH Court against Dragoje Paunović, 26 May 2006), p. 3. 
1027. The BiH Research and Document Agency reported on the exhumation of 24 bodies from a mass grave site at Duljevac, Rogatica, in September 1998 which was carried out pursuant to a decision of the Sarajevo Cantonal Court. ${ }^{3482}$ Bullet cases were retrieved from the mass grave and in the vicinity of the grave. ${ }^{3483}$ The 24 bodies were identified following a post-mortem examination. ${ }^{3484}$ KDZ607 confirmed that the names listed in the exhumation report corresponded to the names of the people he identified as the victims of this incident. ${ }^{3485}$ The bodies were returned to families for burial after they identified the exhumed bodies. ${ }^{3486}$

1028. The Chamber therefore finds that 24 Bosnian Muslims who had been taken from Rasadnik were killed by Serb Forces on 15 August $1992 .{ }^{3487}$

\section{(G) Scheduled Incident D.18}

1029. The Indictment refers to the destruction of five mosques in Rogatica at least between June and December $1992 .{ }^{3488}$

1030. In the days following the initial attack on Rogatica on 22 May 1992, tanks and APCs came to the town on a daily basis and fired at targets including the mosques. ${ }^{3489}$ While KDZ051 was

3482 P3276 (Report of BiH Research and Documentation Agency on Rogatica mass grave, 13 October 1998), pp. 23, 5-6, 64. KDZ606 recognised the names of almost everyone on this list. P3279 (Witness statement of KDZ606 dated 1 September 2011), paras. 99-100 (under seal); P4850 (Witness statement of Amor Mašović dated 23 March 2012), Annex A, p. 10; P4895 (Sarajevo MUP record of Duljevac exhumation and identification, 10 September 1992). See also P4853 (Updated Table 2 to the Report of Amor Mašović), pp. 9394. P3276 (Report of BiH Research and Documentation Agency on Rogatica mass grave, 13 October 1998), pp. 34.

3484 P3276 (Report of BiH Research and Documentation Agency on Rogatica mass grave, 13 October 1998), p. 7.

3485 KDZ607, T. 18479-18480 (6 September 2011); P3276 (Report of BiH Research and Documentation Agency on Rogatica mass grave, 13 October 1998). KDZ606 also confirmed that the list was an accurate list of the bodies exhumed from the grave. KDZ606, T. 18275-18276 (2 September 2011) (closed session).

3486 P3276 (Report of BiH Research and Documentation Agency on Rogatica mass grave, 13 October 1998), p. 3. The names of the bodies identified by family members were Edis Ćatić, Sulejman Kazić, Eldin Hodžić, Asim Kapo, Mujo Pašić, Mesud Pašić, Mevludin Ćatić, Faruk Isaković, Šukrija Omeragić, Fuad Šetić, Nedžad Kazić, Hamdija Jašarević, Midhat Ćatić, Husein Jašarević, Vahudin Ćatić, Mehmed Delija, Mustafa Tanković, Sulejman Jašarević, Osman Solak, Fuad Kazić, Besim Kurčehajić, Halil Halilović, Zajko Salihović, and Derviš Pašić. P3276 (Report of BiH Research and Documentation Agency on Rogatica mass grave, 13 October 1998), pp. 7-62; 64-69. The Chamber notes that it received another report which listed 26 people who were killed in this incident. P3283 (List of Bosnian Muslim civilians killed in Rogatica), p. 7. The Chamber is not satisfied with the provenance of this document and will not rely on it for the purposes of a finding in this regard.

3487 Armin Baždar, T. 18385-18387 (5 September 2011); P3286 (Witness statement of Armin Baždar dated 23 January 1999), p. 7; P3289 (Witness statement of KDZ607 dated 1 September 2011), paras. 42-43, 45-53 (under seal). Baždar managed to escape into the woods while Bosnian Serb soldiers chased and opened fire on him. See also P127 (Witness statement of Alija Isaković dated 22 January 1999), p. 5; P128 (Alija Isaković's statement to $\mathrm{BiH}$ authorities, 30 March 1993), p. 4; D3038 (Witness statement of Novica Andrić dated 23 February 2013), para. 17; P3267 (Witness statement of Šefik Hurko dated 1 September 2011), paras. 15-17, 2324; Šefik Hurko, T. 18231-18233 (2 September 2011) (testifying that he heard Bosnian Serb soldiers talking about this incident and that they had "killed all the balijas" and that he had seen the Bosnian Muslims being driven at Duljevac.) 
detained at the Veljko Vlahović Secondary School, he saw Bosnian Serb soldiers go past in a tank carrying a black flag with the skull and bone insignia and the tricolour flag of the RS heading in the direction of a mosque in town. ${ }^{3490}$ After some time, KDZ051 heard "a couple of blows or knocks", and then ten minutes later, the tank returned. ${ }^{3491}$ That same afternoon, KDZ051 heard that the mosque had been partially destroyed; on the next day, the tank returned with others and destroyed it completely. ${ }^{3492}$

1031. By the end of 1992 the two mosques in Rogatica, named Čaršijska and Arnaudija, ${ }^{3493}$ were completely destroyed. ${ }^{3494}$ The buildings adjacent to the mosques remained in good condition. ${ }^{3495}$

Bosnian Muslims were taken to sites and forced to clear the rubble of both mosques which had been "razed to the ground". ${ }^{4496}$ The Chamber therefore finds that Serb Forces destroyed the Arnaudija and Čaršijska mosques in the town of Rogatica between June and December 1992.

3488 Arnaudija mosque, Čaršijska mosque (the Chamber notes that the Indictment refers to the Čaršija mosque but considers this to be a reference to the same mosque), three mosques in the area of Vragolovi.

3489 P127 (Witness statement of Alija Isaković dated 22 January 1999), p. 4.

3490 P3405 (Witness statement of KDZ051 dated 17 September 2011), para. 84.

3491 P3405 (Witness statement of KDZ051 dated 17 September 2011), para. 84.

3492 P3405 (Witness statement of KDZ051 dated 17 September 2011), para. 84. Defence witnesses testified that (i) the Green Berets assembled around the mosques; (ii) the mosques were used by Bosnian Muslim forces for the storage of anti-tank mines; (iii) sniper nests were located near the mosques; (iv) the mosques may have been hit during clashes; and (v) Serb Forces were instructed not to destroy any religious facilities. Milovan Lelek, T. 34391-34393 (27 February 2013) (testifying further that there were major enemy concentrations in the area of Vragolovi); D2950 (Witness statement of Sveto Veselinović dated 15 February 2013), para. 18; Sveto Veselinović, T. 33886-33887 (18 February 2013); D2909 (Witness statement of Mile Ujić dated 9 February 2013), para. 38; D2930 (Witness statement of Tomislav Batinić dated 11 February 2013), para. 33. See also D2963 (Video footage of Rogatica), 16:32:00-17:00:00, 21:34:00-22:10:00 (which shows a machine gun nest and what appears to be a destroyed mosque. The Chamber notes that it is unclear when this video was taken and is not satisfied that it can be used to support a finding that machine gun nests were near mosques but does suggest damage to a mosque in Rogatica). The Chamber does not find this evidence to be reliable. In reaching that conclusion the Chamber noted that the evidence the some of the mosques were completely destroyed while adjacent buildings remained in good condition undermined the testimony of the witnesses that they were destroyed in clashes. In addition the Chamber refers to the credibility assessment of the relevant witnesses in fns. 3142 and 3208 as to why the evidence of these witnesses is unreliable in this regard.

3493 P3405 (Witness statement of KDZ051 dated 17 September 2011), para. 83; P4069 (Cultural destruction database), record 263; see Adjudicated Fact 2513.

3494 P3267 (Witness statement of Šefik Hurko dated 1 September 2011), para. 61; Šefik Hurko, T. 18375 (5 September 2011); P3289 (Witness statement of KDZ607 dated 1 September 2011), paras. 59-63 (under seal); P3278 (Photograph of Carsijska mosque in Rogatica); P3294 (Photograph of field in Rogatica); P3277 (Photograph of Arnaudija mosque in Rogatica); P3293 (Photograph of field in Rogatica); KDZ606, T. 1827618278 (2 September 2011) (closed session); P3279 (Witness statement of KDZ606 dated 1 September 2011), paras. 105-109 (under seal); P127 (Witness statement of Alija Isaković dated 22 January 1999), p. 5; P4070 (Attachment to the expert report of András J. Riedlmayer, entitled "Destruction of Cultural Heritage in BiH" prepared for the Karadžić case, formatted records), pp. 259-263; P3286 (Witness statement of Armin Baždar dated 23 January 1999), p. 4; P6157 (Map of Rogatica); P3405 (Witness statement of KDZ051 dated 17 September 2011), para. 83. See also David Harland, T. 2118 (7 May 2010) (testifying that when he travelled through Rogatica he could see the minarets of mosques lying on the ground). P4069 (Cultural destruction database), records 263-264.

3496 P3267 (Witness statement of Šefik Hurko dated 1 September 2011), para. 61; Šefik Hurko, T. 18375 (5 September 2011). 
1032. Three mosques in the Vragolovi area were also destroyed. ${ }^{3497}$ While the Chamber relies on Riedlmayer for the purposes of finding that the mosques were destroyed, and the nature and extent of the damage to the mosques and surrounding buildings, it does not rely on his evidence as to when and who was responsible for the destruction of the mosques which fall outside his expertise and are based on informant statements which he received. Therefore, while the Chamber further finds that three mosques in the Vragolovi area were also destroyed, it has insufficient evidence to determine when they were destroyed and who was responsible for their destruction.

\section{(H) Movement of the population from Rogatica}

1033. In the period leading up to the attack on Rogatica, Bosnian Muslims were harassed, searched, and "insulted on religious and ethnic grounds"; thereafter most of them stopped going to work. ${ }^{3498}$ The security situation became more complicated in April 1992. ${ }^{3499}$ The shortages in food and necessities caused panic and prompted people to take refuge outside the municipality, including in Serbia. ${ }^{3500}$ Both Bosnian Muslims and Bosnian Serbs left because of fear, which was exacerbated in May 1992 due to increasing insecurity and shooting incidents. ${ }^{3501}$ Bosnian Serbs left the town en masse and found accommodation with relatives on the outskirts of town or in houses in Bosnian Serb villages or hamlets outside town. ${ }^{3502}$ Since the majority of the Bosnian Serb inhabitants had moved out of the town, the organs of the Serb Municipality of Rogatica also relocated. ${ }^{3503}$ When the Bosnian Serb families started moving out of the town, this made the

3497 See Adjudicated Fact 2513. Riedlmayer's report, which is based on his visits to the sites in 2002 and on information he received from the Islamic Community of $\mathrm{BiH}$ and other sources, identifies the following mosques and the level of damage: Arnaudija mosque (completely destroyed), Čaršijska mosque (completely destroyed), Vragolovi mosque (heavily damaged): P4070 (Attachment to the expert report of András J. Riedlmayer, entitled "Destruction of Cultural Heritage in $\mathrm{BiH}^{\prime}$ prepared for the Karadžić case, formatted records), pp. 259- 265; P4069 (Cultural destruction database), records 258-262, 265-266, 268-269; P4071 (Slide images of damaged religious sites in BiH), p. 8; András Riedlmayer, T. 22534 (8 December 2011) referring to the Čaršijska mosque. The Chamber also received evidence on damage to other cultural monuments and sacred sites in Rogatica however, these sites are not charged in Schedule D of the Indictment. P3279 (Witness statement of KDZ606 dated 1 September 2011), para. 105 (under seal); P3289 (Witness statement of KDZ607 dated 1 September 2011), para. 59 (under seal); see Adjudicated Fact 2513; P4070 (Attachment to the expert report of András J. Riedlmayer, entitled "Destruction of Cultural Heritage in BiH" prepared for the Karadžić case, formatted records), pp. 266-268; P4069 (Cultural destruction database), records 258-262, 266, 268; András Riedlmayer, T. 22527 (8 December 2011). (6 September 2011).

3499 P3407 (Report on the work of the Rogatica Municipal Assembly and Executive Board from July 1992 to September 1993), p. 14.

3500 P3407 (Report on the work of the Rogatica Municipal Assembly and Executive Board from July 1992 to September 1993), p. 14.

3501 KDZ051, T. 19380-19381 (22 September 2011); D2950 (Witness statement of Sveto Veselinović dated 15 February 2013), para. 16.

3502 D2930 (Witness statement of Tomislav Batinić dated 11 February 2013), para. 21.

3503 D2930 (Witness statement of Tomislav Batinić dated 11 February 2013), para. 22. See also D3031 (Witness statement of Milovan Lelek dated 23 February 2013), para. 10. 
Bosnian Muslim population nervous about what would happen to them. ${ }^{3504}$ A significant number of Bosnian Muslims left the town. ${ }^{3505}$

1034. Prior to the attack on Rogatica, Bosnian Serb men had already taken their military positions outside Rogatica and Bosnian Serb women and children had moved out of the area; as a result the only people remaining were Bosnian Muslims and a few Bosnian Serbs. ${ }^{3506}$ Some Bosnian Muslims who tried to escape their villages were arrested by Serb Forces and taken to Sokolac. ${ }^{3507}$

1035. The shelling of downtown Rogatica, which had a majority Muslim population, prompted Bosnian Muslims to move out from the town centre and columns of people began moving through Kozarde. ${ }^{3508}$ The Chamber has also described above the number of Bosnian Muslims who gathered in Rogatica town and who were taken to Veljko Vlahović Secondary School. ${ }^{3509}$ A group of between 1,500 and 2,000 Bosnian Muslims left following the shelling of the town and arrived in the Bosnian Muslim village of Vragolovi where there were approximately 5,000 to 6,000 displaced Bosnian Muslims. ${ }^{3510}$ Bosnian Muslims from the villages around Rogatica also went to Vragolovi while others continued towards Goražde. ${ }^{3511}$ Bosnian Muslims were threatened and warned of forthcoming "cleansing". 3512 They were told that they would be allowed to leave the area and that buses to Visoko and Zenica would be provided, as this was where Bosnian Muslims were "supposed to live". ${ }^{3513}$ When he visited Rogatica in August 1992, Bowen was told that the expulsion of Bosnian Muslims was led by Kušić. ${ }^{3514}$ Bowen also interviewed Bosnian Muslims who were former residents of Rogatica who spoke to him about killing, forcible evacuation and the rape of young women. ${ }^{3515}$

\footnotetext{
3504 P127 (Witness statement of Alija Isaković dated 22 January 1999), p. 3.

3505 D2930 (Witness statement of Tomislav Batinić dated 11 February 2013), para. 22.

3506 P3405 (Witness statement of KDZ051 dated 17 September 2011), para. 13.

3507 P3289 (Witness statement of KDZ607 dated 1 September 2011), paras. 12-13 (under seal); KDZ607, T. 1850818509 (7 September 2011).

3508 P3289 (Witness statement of KDZ607 dated 1 September 2011), para. 11 (under seal).

3509 See paras. 982-985.

3510 See Adjudicated Fact 2512. In light of other accepted evidence, the Chamber does not attribute weight to an article which suggested that Bosnian Serb authorities arranged for the transport of Bosnian Muslims to Sarajevo upon their request. P2832 (Article from Srpska Vojska entitled "They Saved Serbian Land", 15 July 1993), p. 4. See also P3404 (Witness statement of KDZ051 dated 17 September 2011), paras. 101-102 (under seal) [REDACTED].

3511 Milovan Lelek, T. 34394 (27 February 2013).

3512 P3279 (Witness statement of KDZ606 dated 1 September 2011), para. 102 (under seal).

3513 P3279 (Witness statement of KDZ606 dated 1 September 2011), para. 102 (under seal).

3514 P2068 (Witness statement of Jeremy Bowen dated 10 August 2009), para. 53.

3515 Jeremy Bowen, T. 10254-10255 (14 January 2011). See also Milan Tupajić, P5238 (Transcript from Prosecutor v. Krajišnik), T. 15376-15377 (testifying that columns of Bosnian Muslim refugees from Rogatica and Višegrad passed through Sokolac in late May, June and July 1992 and related that "very ugly things were happening" including murders).
} 
1036. Some Bosnian Muslims were moved out of Rogatica in an organised way. ${ }^{3516}$ At the end of November 1992 Kušić stated that the Municipal Assembly had lists of "loyal Muslims" in Rogatica and also lists of "the ones who were sent away from Rogatica in the previous months during combat activities". ${ }^{3517}$ There was also an increasing number of Serb refugees arriving from other areas of $\mathrm{BiH}$ who were accommodated in the abandoned homes of Bosnian Muslims and Bosnian Serbs. ${ }^{3518}$ By the end of June 1992, more Bosnian Muslims left Rogatica given that the Bosnian Serbs "were terrorising the people" and creating conditions in which "it was impossible for the Muslims to continue to live in the area."3519 The Bosnian Muslim civilian authorities and police from Rogatica withdrew from the town. ${ }^{3520}$

1037. On 26 June 1992, Tomislav Šipčić, as Commander of the SRK, issued a written warning to the Rogatica Brigade Command in which he said: "Kušić, I strictly forbid you to take any action on your own unless I personally approve, particularly any form of mopping up of anybody's villages. For the last time, I am warning you to refrain from massacre, rampaging, abusing the innocent population of any nationality." 3521 Despite this order, Kušić retained his position in the Rogatica Brigade, but the order did result in some improvement in his conduct. ${ }^{3522}$

3516 KDZ051, T. 19380 (22 September 2011). Batinić denied that the Rogatica Crisis Staff or the Bosnian Serb leadership adopted a position, rendered a decision on the forcible moving out of the Bosnian Muslim population. or incited any other institution to do so. D2930 (Witness statement of Tomislav Batinić dated 11 February 2013), paras. 18, 35 referring to P2835 (Report of Rogatica Crisis Staff, April - June 1992); Tomislav Batinić, T. 33673 (14 February 2013). However, the Chamber does not find Batinić's evidence to be reliable in this regard. In reaching this conclusion the Chamber noted Batinić had an interest in minimising his own involvement in events in Rogatica and that the witness was evasive and his evidence was marked by contradictions.

3517 D2914 (Response of $1^{\text {st }}$ Podrinje Light Infantry Brigade, 30 November 1992), p. 1. Defence witnesses testified that Bosnian Muslim villages which expressed loyalty to the Bosnian Serb authorities and handed over their weapons were protected. D2930 (Witness statement of Tomislav Batinić dated 11 February 2013), paras. 27, 29-30; Tomislav Batinić, T. 33689, 33711 (14 February 2013); D2909 (Witness statement of Mile Ujić dated 9 February 2013), para. 32; Mile Ujić, T. 33462-33463 (12 February 2013); Milovan Lelek, T. 34377-34379 (27 February 2013). The Chamber does not find this evidence that Bosnian Muslim villages were protected to be reliable. In reaching that conclusion, the Chamber noted that Batinić acknowledged on cross-examination that Bosnian Muslims did not remain in these villages throughout the war and that in October 1994 the last remaining Bosnian Muslims left the municipality but he claimed that that they left at their own request. When Batinić was confronted with documents which suggested that these last remaining Bosnian Muslims were forcibly expelled by Bosnian Serb soldiers who came to their homes he claimed he did not know that this was happening. The Chamber found a contradiction in Batinić's evidence that Bosnian Muslims were leaving at their own request and his denial of any knowledge about how they were moved from their homes and his acknowledgement that they lived in fear and the authorities were unable to keep everything under control. Tomislav Batinić, T. 33691-33695 (14 February 2013). The Chamber also refers to its credibility assessment in fns. 3142 and 3208 as to why the evidence of the relevant witnesses are unreliable in this regard. D2950 (Witness statement of Sveto Veselinović dated 15 February 2013), para. 16. P3289 (Witness statement of KDZ607 dated 1 September 2011), para. 58 (under seal). P3279 (Witness statement of KDZ606 dated 1 September 2011), paras. 89, 96 (under seal); P128 (Alija Isaković's statement to BiH authorities, 30 March 1993), pp. 2-3.

P1001 (Warning of SRK Commander to Rogatica Brigade, 26 June 1992), pp. 1-2; [REDACTED]. [REDACTED]. 
1038. In July 1992, 1,500 Bosnian Muslims escaped from Vragolovi to Goražde after the former was shelled by Serb Forces. ${ }^{3523}$ In August 1992, almost all Bosnian Muslims who had taken refuge in Vragolovi left the village after they received a warning about another attack. ${ }^{3524}$

1039. The Chamber finds that the Bosnian Muslim population were forced to leave Rogatica following immense pressure put on them, given the surrounding circumstances in the municipality including inter alia (i) attacks against their homes; (ii) shelling of villages; (iii) destruction of mosques and other property; (iv) forcible arrest and removal from their homes; (v) detention in multiple detention facilities; as well as (vi) mistreatment and killings. While the Chamber received evidence that orders were issued which called for the protection of members of the population who handed over weapons, this does not undermine the evidence received with respect to lack of voluntariness in the departure of the Bosnian Muslim population. ${ }^{3525}$

1040. Bosnian Muslim women, children and elderly continued to be expelled from Rogatica even until October 1994 when the last remaining Bosnian Muslims left the municipality. ${ }^{3526}$ By the time the Accused delivered a speech at the RS Assembly on 28 August 1995 there were almost no Bosnian Muslims in Rogatica. ${ }^{3527}$

vi. Sokolac

(A) Charges

1041. Under Count 3, the Prosecution alleges that persecution, a crime against humanity, was committed in Sokolac as part of the objective to permanently remove Bosnian Muslims and/or Bosnian Croats from the Municipalities. ${ }^{3528}$ Acts of persecution alleged to have been committed by Serb Forces and Bosnian Serb Political and Governmental Organs include killings during and after

\footnotetext{
$3523 \quad$ See Adjudicated Fact 2512.

$3524 \quad$ See Adjudicated Fact 2512.

3525 D2910 (SRK Order, 22 October 1992), p. 1; D2911 (SRK Order, 12 July 1992); D95 (Instructions from RS Presidency to presidents of municipalities in Goražde area, 14 July 1992). The Chamber received evidence that in a UNCHR memorandum dated 17 August 1994, General Soubirou expressed his belief that the "forced eviction of civilians in Rogatica which was covered by the media as ethnic cleansing" was part of an agreement between the parties. D950 (UN report re meeting with General Soubirou, 17 August 1994), p. 2. The Chamber does not consider that the opinion of General Soubirou in this context is of much weight given that he simply states that this was his belief without any indication of the basis of his opinion. It is also not clear whether his observation relates to the whole course of the conflict in Rogatica or a specific incident in 1994. The Chamber also notes that when Bowen was shown this document, he testified that when he interviewed those who left Rogatica, they told him about the difficulties they faced including killing, forced evacuation, and rapes. Jeremy Bowen, T. 10254-10255 (14 January 2011). The Chamber also refers to its finding in paras. 1033-1035 regarding the lack of voluntariness in the departure of the Bosnian Muslim population.

3526 P4867 (BiH State Commission for Exchange of POWs report, 15 October 1994), p. 4.

3527 Sveto Veselinović, T. 45110 (16 December 2013).

3528 Indictment, paras. 48-49.
} 
the take-over of Sokolac, ${ }^{3529}$ and killings committed during, and deaths resulting from, cruel and inhumane treatment at scheduled detention facilities. ${ }^{3530}$ The Prosecution also characterises these killings as extermination, a crime against humanity, under Count 4; murder, a crime against humanity, under Count 5; and murder, a violation of the laws or customs of war, under Count $6 .{ }^{3531}$

1042. Other acts of persecution alleged to have been committed by Bosnian Serb Forces and Bosnian Serb Political and Governmental Organs in Sokolac include (i) torture, beatings, and physical and psychological abuse, during and after the take-over and in scheduled detention facilities, as cruel or inhumane treatment; ${ }^{3532}$ (ii) rape and other acts of sexual violence, during and after the take-over and in scheduled detention facilities as cruel and inhumane treatment; ${ }^{3533}$ (iii) the establishment and perpetuation of inhumane living conditions in detention facilities, including the failure to provide adequate accommodation, shelter, food, water, medical care, or hygienic sanitation facilities, as cruel or inhumane treatment; ${ }^{3534}$ (iv) forcible transfer or deportation of Bosnian Muslims and Bosnian Croats from their homes; ${ }^{3535}$ (v) unlawful detention in scheduled detention facilities; ${ }^{3536}$ (vi) forced labour at the frontline and the use of Bosnian Muslims and Bosnian Croats as human shields ${ }^{3537}$ (vii) the appropriation or plunder of property, during and after the take-over, during arrests and detention and in the course of or following acts of deportation or forcible transfer; ${ }^{3538}$ (viii) the wanton destruction of private property including homes and business premises and public property, including cultural monuments and sacred sites; ${ }^{3539}$ and (ix) the imposition and maintenance of restrictive and discriminatory measures. ${ }^{3540}$

1043. Under Counts 7 and 8, the Prosecution alleges deportation and inhumane acts (forcible transfer), respectively, as crimes against humanity. ${ }^{3541}$ In this regard, the Prosecution alleges that Bosnian Serb Forces and Bosnian Serb Political and Governmental Organs forcibly displaced Bosnian Muslims and Bosnian Croats from areas in Sokolac in which they were lawfully present by

Indictment, para. 60(a)(i). See Scheduled Incident A.13.1.

3530 Indictment, para. 60(a)(ii). See Scheduled Detention Facilities C.23.1, C.23.2.

3531 Indictment, paras. 63(a), 63(b).

3532 Indictment, para. 60(b). See Scheduled Detention Facilities C.23.1, C.23.2.

3533 Indictment, para. 60(c). See Scheduled Detention Facilities C.23.1, C.23.2.

3534 Indictment, para. 60(d). See Scheduled Detention Facilities C.23.1, C.23.2.

3535 Indictment, para. 60(f).

3536 Indictment, para. 60(g). See Scheduled Detention Facilities C.23.1, C.23.2.

3537 Indictment, para. 60(h).

3538 Indictment, para. 60(i).

3539 Indictment, para. 60(j). See Destruction of Cultural Monuments and Sacred Sites: Scheduled Incident D.20.

3540 Indictment, para. 60(k). The restrictive and discriminatory measures alleged include the denial of freedom of movement; the removal from positions of authority; the invasion of privacy through arbitrary searches of homes; unlawful arrest and/or the denial of the right to judicial process; and/or the denial of equal access to public services.

3541 Indictment, paras. 68-75.
} 
the end of $1992 .{ }^{3542}$ It is alleged that from March 1992, restrictive and discriminatory measures, arbitrary arrest and detention, harassment, torture, rape and other acts of sexual violence, killing, destruction of houses, cultural monuments and sacred sites, as well as the threat of further such acts caused Bosnian Muslims and Bosnian Croats to flee in fear while others were physically driven out. $^{3543}$

\section{(B) Lead-up}

1044. Sokolac is a municipality in eastern $\mathrm{BiH}$ located to the east of Sarajevo and to the west of Rogatica. ${ }^{3544}$ According to the 1991 census, the municipality of Sokolac had approximately 15,000 inhabitants, of whom around 66\% were Bosnian Serbs and 33\% were Bosnian Muslims. ${ }^{3545}$

1045. Following the multi-party elections in late 1990, the SDS won 29 of the 50 seats in Sokolac and an inter-party agreement was reached with the SDA under which positions of authority were divided between Bosnian Serbs and Bosnian Muslims. ${ }^{3546}$ The agreement on the distribution of posts in the SJB was confirmed at a meeting of the MUP. ${ }^{3547}$ Multi-ethnic patrols of reserve army and police were also formed at that time. ${ }^{3548}$

1046. From the beginning of 1991, there were increasing inter-ethnic tensions and fear amongst Bosnian Muslims and Bosnian Serbs. ${ }^{3549}$ In January 1992, a meeting was held between SDS and SDA representatives to discuss the deterioration of the political and security situation. ${ }^{3550}$ Tensions were further exacerbated at the beginning of $1992 .{ }^{3551}$

\footnotetext{
3542 Indictment, paras. 68, 69, 72 .

3543 Indictment, para. 71.

3544 D484 (Map of $\mathrm{BiH})$.

3545 D3206 (Witness statement of Milovan Bjelica dated 30 March 2013), para. 20; Milan Tupajić, P5238 (Transcript from Prosecutor v. Krajišnik), T. 15322; D3175 (Witness statement of Dragomir Obradović dated 24 March 2013), para. 2.

3546 D3175 (Witness statement of Dragomir Obradović dated 24 March 2013), paras. 2-3; D3206 (Witness statement of Milovan Bjelica dated 30 March 2013), paras. 20-21.

3547 D3206 (Witness statement of Milovan Bjelica dated 30 March 2013), para. 21.

3548 D3206 (Witness statement of Milovan Bjelica dated 30 March 2013), para. 23.

3549 D3175 (Witness statement of Dragomir Obradović dated 24 March 2013), para. 4. See also D3206 (Witness statement of Milovan Bjelica dated 30 March 2013), para. 24.

3550 P5246 (Excerpt from Milan Tupajić's diary, 23 December 1991-20 January 1992), p. 10.

3551 D3206 (Witness statement of Milovan Bjelica dated 30 March 2013), paras. 31-32, 70; D3226 (Minutes from $4^{\text {th }}$ session of Sokolac Crisis Staff, 4 May 1992), p. 2; P5246 (Excerpt from Milan Tupajić's diary, 23 December 1991-20 January 1992), p. 10. Examples heard by the Chamber included the fact that the inter-party agreements started to fall apart when the Bosnian Serbs in Sokolac refused to agree to the referendum on $\mathrm{BiH}$ independence. D3206 (Witness statement of Milovan Bjelica dated 30 March 2013), para. 22; D3175 (Witness statement of Dragomir Obradović dated 24 March 2013), para. 5. The Chamber also heard evidence about increasing fear among Bosnian Serbs given information that Bosnian Muslims from the region had volunteered to fight in Croatia and were returning with weapons and that Bosnian Muslim paramilitary formations had received training there. D3206 (Witness statement of Milovan Bjelica dated 30 March 2013), paras. 24, 39. The
} 
1047. From 1991 to spring 1992, both Bosnian Serbs and Bosnian Muslims were being armed in Sokolac. ${ }^{3552}$ The $2^{\text {nd }}$ Romanija Motorised Brigade of the Army of SerBiH was established on 21 May 1992 and was made up of local conscripts from Sokolac, Han Pijesak, and the surrounding area and all members of the TO were mobilised into the brigade. ${ }^{3553}$ Radislav Krstic was the commander of this brigade. ${ }^{3554}$

1048. Around March 1992, check-points were erected in Sokolac on important roads or at locations leading to the direction of Olovo and armed Bosnian Serbs in uniforms were placed at those check-points. ${ }^{3555}$ Bosnian Muslims were stopped, taken away or mistreated at these checkpoints. ${ }^{3556}$

1049. During April 1992, several paramilitary units were based in Sokolac town and its surrounding villages. ${ }^{3557}$ These units included Arkan's men, the White Eagles, and some local groups. ${ }^{3558}$ Other informal groups were also present in the municipality. ${ }^{3559}$

Chamber also received evidence about attacks against Bosnian Serb villages by Bosnian Muslims. D3206 (Witness statement of Milovan Bjelica dated 30 March 2013), para. 44; D3175 (Witness statement of Dragomir Obradović dated 24 March 2013), para. 7; Dragomir Obradović, T. 36079-36082 (26 March 2013); D3186 (Photograph of Slavko Batinić's house); D3187 (Photograph of Slavko Batinić's house); D3188 (Photograph of Slavko Batinić's house).

3552 The Chamber heard evidence that (i) the SDS and JNA were involved in the distribution of weapons and uniforms to Bosnian Serbs; (ii) the SDA was involved in the arming of the Bosnian Muslim population; (iii) units of the Patriotic League and the Green Berets were formed in Sokolac; and (iv) the reserve forces of the TO and the $216^{\text {th }}$ Mountain Brigade of the JNA were mobilised and a JNA rocket unit was moved to Sokolac. P131 (Witness statement of Asim Hamzić dated 25 March 1996), pp. 3-6; D3175 (Witness statement of Dragomir Obradović dated 24 March 2013), paras. 5-6, 8; D3206 (Witness statement of Milovan Bjelica dated 30 March 2013), paras. 23, 38-39; Milovan Bjelica, T. 36411-36414 (3 April 2013); P2828 (Witness statement of Asim Džambasović dated 18 June 2011), para. 108; D3219 (Report of RS MUP National Security Service, undated). See also P1113 (Interview with Momčilo Mandić in Slobodna Bosna, 10 April 1998), p. 2 ; D3224 (Article from Oslobođenje entitled "We Knew What to Do", 24 September 1992).

3553 Milan Tupajić, P5238 (Transcript from Prosecutor v. Krajišnik), T. 15384; D3175 (Witness statement of Dragomir Obradović dated 24 March 2013), para. 14.

3554 Milan Tupajić, P5238 (Transcript from Prosecutor v. Krajišnik), T. 15432.

3555 P131 (Witness statement of Asim Hamzić dated 25 March 1996), p. 5; Adjudicated Fact 2673. The Chamber received Defence evidence which suggested that there were no barricades in Sokolac at all and that the only armed formations in March 1992 were members of the TO. D3175 (Witness statement of Dragomir Obradović dated 24 March 2013), para. 27. The Chamber does not accept this evidence and in reaching this conclusion, the Chamber considered that Obradović's evidence was marked by deliberate evasiveness and was contradictory on a number of occasions. Furthermore, the Chamber noted that this point was contradicted by other Defence evidence which suggested that there were reserve police check-points manned by a special purpose unit of the SJB that was removed from the police after complaints were made about its actions, and which therefore corroborates the existence of such check-points. D3206 (Witness statement of Milovan Bjelica dated 30 March 2013), paras. 61, 67; D3222 (Minutes from session of Sokolac Crisis Staff, 20 April 1992), p. 8.

3556 P131 (Witness statement of Asim Hamzić dated 25 March 1996), p. 8.

3557 See Adjudicated Fact 2675. The Chamber is not satisfied that there were no paramilitary formations in Sokolac, as suggested by the evidence led by the Defence. D3206 (Witness statement of Milovan Bjelica dated 30 March 2013), paras. 53, 63. In reaching this conclusion, the Chamber considered that in this respect, the evidence of Bjelica was marked with partisanship and bias and could not be relied on in relation thereto.

3558 Adjudicated Fact 2675. 
1050. Measures for the creation of a separate Bosnian Serb police in Sokolac started in early 1992. In February 1992, two days after the establishment of a "Serbian collegium" of the MUP to be managed by Momčilo Mandić, ${ }^{3560}$ Mandić instructed Zoran Cvijetić, Chief of the Sokolac SJB, and other heads of security centres to have a meeting with all senior executives of the MUP in their area of responsibility and report back to him. ${ }^{3561}$ Some time in March or April 1992, Cvijetić dismissed all Bosnian Muslim members of the police force and established a separate Bosnian Serb police. ${ }^{3562}$ By April 1992 only Bosnian Serbs remained on the payroll of the Sokolac SJB. ${ }^{3563}$

1051. The Sokolac Crisis Staff was established in April 1992, and its first session was held on 6 April 1992. ${ }^{3564}$ At this first session, Milan Tupajić, an SDS member and president of the municipal assembly, was appointed as its president. ${ }^{3565}$ The Crisis Staff consisted of the President of the Municipality, the President of the SDS Municipal Board, the chief of police, and other members of the SDS and the SDP and was designed to take over the functions of the municipal assembly when it was unable to convene due to emergency situations. ${ }^{3566}$ The Crisis Staff was tasked with maintaining the functioning of authority, commercial, and social life at the municipality level, collaborating with the police in Sokolac, the command of the army and the Bosnian Serb government on all vital issues. ${ }^{3567}$ All important decisions of the SDS Main Board that needed to

3559 D3206 (Witness statement of Milovan Bjelica dated 30 March 2013), paras. 53, 63. See also D3175 (Witness statement of Dragomir Obradović dated 24 March 2013), paras. 10, 29.

3560 P1083 (Minutes of meeting of representatives of SerBiH MUP, 11 February 1992), p. 4. For the establishment, and creation of the Bosnian Serb MUP, see Section II.C.3: Bosnian Serb MUP.

3561 Momčilo Mandić, C2 (Transcript from Prosecutor v. Krajišnik), T. 8649-8650; P1112 (Order of SRBiH MUP to all CSBs and SJBs, 13 February 1992).

3562 P2831 (Diary of Asim Džambasović), p. 34; P6089 (BiH MUP report, 24 March 1992), p. 2; P2828 (Witness statement of Asim Džambasović dated 18 June 2011), para. 87; P131 (Witness statement of Asim Hamzić dated 25 March 1996), p. 5; Momčilo Mandić, T. 4888-4889 (8 July 2010); P6234 (List of employees of Sokolac Police Station in April 1992). See also Adjudicated Fact 2674. The Chamber does not accept the Defence evidence that Bosnian Muslim police were temporarily removed for their own safety or as a temporary measure pending the resolution of structural issues in the police. D3206 (Witness statement of Milovan Bjelica dated 30 March 2013), paras. 42, 62; D3175 (Witness statement of Dragomir Obradović dated 24 March 2013), para. 28; Dragomir Obradović, T. 36088, 36090 (26 March 2013). In this regard, the Chamber notes Bjelica's own admission that the employees of the Sokolac SJB could not return to their jobs until the end of the war and that Obradović's evidence was marked by deliberate evasiveness and was contradictory on a number of occasions.

3563 P6234 (List of employees of Sokolac Police Station in April 1992).

3564 Milan Tupajić, P5238 (Transcript from Prosecutor v. Krajišnik), T. 15321, 15323, 15508-15509. See also P5242 (Minutes of meeting of Sokolac Crisis Staff, 15 May 1992), p. 1; P131 (Witness statement of Asim Hamzić dated 25 March 1996), p. 3; D3206 (Witness statement of Milovan Bjelica dated 30 March 2013), para. 28.

3565 Milan Tupajić, P5238 (Transcript from Prosecutor v. Krajišnik), T. 15321, 15323, 15508-15509. See also P5242 (Minutes of meeting of Sokolac Crisis Staff, 15 May 1992), p. 1; P131 (Witness statement of Asim Hamzić dated 25 March 1996), p. 3; D3206 (Witness statement of Milovan Bjelica dated 30 March 2013), para. 28.

3566 D3206 (Witness statement of Milovan Bjelica dated 30 March 2013), para. 28; Milovan Bjelica, T. 36394 (2 April 2013).

3567 Milan Tupajić, P5238 (Transcript from Prosecutor v. Krajišnik), T. 15330; P5243 (Sokolac Crisis Staff decision, 29 May 1992), p. 1; D3206 (Witness statement of Milovan Bjelica dated 30 March 2013), para. 30. For examples of the issues the Crisis Staff was dealing with see P5250 (Minutes of meeting of Sokolac Crisis Staff, 
be implemented in Sokolac were sent to the SDS Municipal Board of Sokolac ${ }^{3568}$ and the Crisis Staff was informed of these decisions. ${ }^{3569}$ Around June 1992, a War Commission was created in Sokolac consisting of SDS members to communicate developments at the municipality level to the republican level. ${ }^{3570}$ The Sokolac Crisis Staff operated until some time in July 1992 when the Executive Board took over its functions. 3571

1052. From 10 April 1992, the Crisis Staff took measures to preserve or restore public law and order in Sokolac and these measures included restrictions on the entry and movement of armed formations without approval, ordering investigation and taking measures against theft in the municipality regardless of the ethnic background of the victim. ${ }^{3572}$ The presidents of local communes were instructed to inform the relevant authorities and the Sokolac SJB in the event that

10 April 1992); P5240 (Sokolac Crisis Staff conclusions, 20 April 1992); P5247 (Sokolac Crisis Staff conclusions, 5 May 1992); P5241 (Request of SerBiH Government to the Sokolac Crisis Staff, 9 May 1992); P5239 (Request of SerBiH Government to the Sokolac Crisis Staff, 11 May 1992); P5242 (Minutes of meeting of Sokolac Crisis Staff, 15 May 1992); P5244 (Minutes of meeting of Sokolac Crisis Staff, 22 June 1992).

3568 Milovan Bjelica replaced Mirko Malović at the beginning of 1992 as the president of the SDS Municipal Board. Milan Tupajić, P5238 (Transcript from Prosecutor v. Krajišnik), T. 15349-15350, 15462-15463; D3206 (Witness statement of Milovan Bjelica dated 30 March 2013), para. 18.

3569 Milan Tupajić, P5238 (Transcript from Prosecutor v. Krajišnik), T. 15349. In light of the equivocal answers on cross-examination and the fact that Bjelica's evidence was marked by partisanship and bias, the Chamber does not accept his evidence that the municipal authorities never received nor implemented the Variant A/B Instructions. See D3206 (Witness statement of Milovan Bjelica dated 30 March 2013), paras. 18, 28; Milovan Bjelica, T. 36434, 36438-36442 (3 April 2013); P6253 (Letter from OTP to RS liaison officer, 30 July 2001).

3570 Milan Tupajić, P5238 (Transcript from Prosecutor v. Krajišnik), T. 15402-15403, 15492-15495.

3571 D3206 (Witness statement of Milovan Bjelica dated 30 March 2013), para. 29; Milan Tupajić, P5238 (Transcript from Prosecutor v. Krajišnik), T. 15493. But see Milan Tupajić, P5238 (Transcript from Prosecutor v. Krajišnik), T. 15376-15377, 15381-15382, 15384-15385 (claiming that after 21 May 1992 when the $2^{\text {nd }}$ Romanija Motorised Brigade was established the Crisis Staff lost influence over the security of citizens in the municipality and there were many disagreements between the command of the brigade and the civilian authorities).

3572 P5250 (Minutes of meeting of Sokolac Crisis Staff, 10 April 1992), p. 5; D3176 (Sokolac Crisis Staff order, 10 April 1992); D3177 (Sokolac Crisis Staff order, 20 April 1992); D3206 (Witness statement of Milovan Bjelica dated 30 March 2013), para. 66; D3175 (Witness statement of Dragomir Obradović dated 24 March 2013), para. 12; P5245 (Order of Sokolac Crisis Staff, 20 April 1992); Milan Tupajić, P5238 (Transcript from Prosecutor v. Krajišnik), T. 15344-15345. The Crisis Staff also decided to disband the Special Purposes Unit of the SJB and redeploy its members to the TO following reports that it had contravened regulations. D3206 (Witness statement of Milovan Bjelica dated 30 March 2013), paras. 33, 67; D3178 (Sokolac Crisis Staff order, 21 April 1992); D3222 (Minutes from session of Sokolac Crisis Staff, 20 April 1992), p. 8; D3175 (Witness statement of Dragomir Obradović dated 24 March 2013), para. 9. The Crisis Staff also imposed restrictions on the service and sale of alcohol. D3206 (Witness statement of Milovan Bjelica dated 30 March 2013), para. 75; D3211 (Sokolac Crisis Staff decision, 18 May 1992); Milovan Bjelica, T. 36394 (2 April 2013); D3181 (Sokolac Crisis Staff order, 10 April 1992); D3225 (Minutes from session of Sokolac Crisis Staff, 27 April 1992), p. 1; D3175 (Witness statement of Dragomir Obradović dated 24 March 2013), para. 11. For investigations on disturbances to public law and order when the victims were Bosnian Muslims, see D3206 (Witness statement of Milovan Bjelica dated 30 March 2013), paras. 46, 70; D3226 (Minutes from $4^{\text {th }}$ session of Sokolac Crisis Staff, 4 May 1992), p. 3; D3230 (Sokolac Crisis Staff conclusions, 5 May 1992); D3175 (Witness statement of Dragomir Obradović dated 24 March 2013), para. 22; D3221 (Sokolac SJB criminal report, 17 September 1992); D3180 (Sokolac SJB dispatch, 1 October 1994); D613 (2 ${ }^{\text {nd }}$ Romanija Motorised Brigade report re looting, 6 August 1992), p. 1. See also Dragomir Obradović, T. 36137 (26 March 2013); D3193 (Investigation report of Sokolac Lower Court, 20 July 1992). 
individuals or organised groups attempted to enter the municipality. ${ }^{3573}$ Despite these measures there was evidence that orders of the Crisis Staff were not being respected, ${ }^{3574}$ and that the SJB was not functioning adequately and was either unable or unwilling to control increasing lawlessness against civilians notably by unofficial groups. ${ }^{3575}$

1053. On 20 April 1992, the TO was mobilised. ${ }^{3576}$ On 21 April 1992, the Crisis Staff ordered that measures be taken against individuals who did not respond to the call for mobilisation and for individuals who deserted their TO and JNA units. ${ }^{3577}$ Around that period, there were discussions between the Sokolac Crisis Staff and Bosnian Muslim representatives on how to resolve important issues with respect to the establishment of authority and order and resolve problems in the municipality. ${ }^{3578}$ The Crisis Staff adopted conclusions which called (i) on individuals who had temporarily left the municipality to return to their homes without fear; (ii) on Bosnian Muslims to return to their jobs; and (iii) for good inter-ethnic relations to be maintained. ${ }^{3579}$ Apart from conscripts who required approval from the Secretariat of National Defence, other citizens were able to move freely without passes. ${ }^{3580}$ On 7 May 1992, the Crisis Staff concluded that Bosnian Muslim workers should be allowed to engage in their regular jobs but that in the event of provocation the workers would be suspended in accordance with the law. ${ }^{3581}$ The Crisis Staff decided on 15 May

3573 D3223 (Minutes from meeting between Sokolac Crisis Staff and presidents of local communes, 23 April 1992), p. 6; D3185 (Conclusions of Sokolac Crisis Staff, 23 April 1992), p. 1; D3175 (Witness statement of Dragomir Obradović dated 24 March 2013), paras. 10, 29.

3574 D3206 (Witness statement of Milovan Bjelica dated 30 March 2013), paras. 78-79; D3229 (Sokolac Crisis Staff conclusions, 4 June 1992). See also Milovan Bjelica, T. 36394 (2 April 2013); D3233 (Decision of Sokolac Crisis Staff, 22 June 1992).

3575 D3206 (Witness statement of Milovan Bjelica dated 30 March 2013), para. 81; D3234 (Conclusions of Sokolac Executive Board, 24 September 1992); Milovan Bjelica, T. 36396-36398 (2 April 2013). See also Dragomir Obradović, T. 36134 (26 March 2013).

3576 D3222 (Minutes from session of Sokolac Crisis Staff, 20 April 1992), pp. 4-5.

3577 P5248 (Order of Sokolac Crisis Staff, 21 April 1992); Milan Tupajić, P5238 (Transcript from Prosecutor v. Krajišnik), T. 15340-15343. See also D3222 (Minutes from session of Sokolac Crisis Staff, 20 April 1992), p. 9.

3578 P5240 (Sokolac Crisis Staff conclusions, 20 April 1992), p. 2; D3206 (Witness statement of Milovan Bjelica dated 30 March 2013), paras. 33-34; D3179 (Sokolac Municipal Assembly notification, 21 April 1992); D3175 (Witness statement of Dragomir Obradović dated 24 March 2013), para. 11. See also P131 (Witness statement of Asim Hamzić dated 25 March 1996), pp. 5-6.

3579 D3206 (Witness statement of Milovan Bjelica dated 30 March 2013), para. 34; D3223 (Minutes from meeting between Sokolac Crisis Staff and presidents of local communes, 23 April 1992), pp. 4, 6; D3175 (Witness statement of Dragomir Obradović dated 24 March 2013), paras. 11, 13; D3185 (Conclusions of Sokolac Crisis Staff, 23 April 1992), p. 1; Dragomir Obradović, T. 36070-36071 (26 March 2013). In addition, the Crisis Staff appealed to Bosnian Muslims to send their children to school until war broke out in surrounding municipalities. D3206 (Witness statement of Milovan Bjelica dated 30 March 2013), paras. 68-69, 72-74; D3207 (Sokolac Crisis Staff conclusions, 27 April 1992); D3225 (Minutes from session of Sokolac Crisis Staff, 27 April 1992), p. 2; D3210 (Sokolac Crisis Staff decision, 18 May 1992). See also D3208 (Sokolac Crisis Staff conclusions, 5 May 1992); D3209 (Sokolac Crisis Staff decision, 7 May 1992).

3580 D3206 (Witness statement of Milovan Bjelica dated 30 March 2013), para. 77 . See also D3175 (Witness statement of Dragomir Obradović dated 24 March 2013), para. 22.

3581 D3227 (Minutes from $5^{\text {th }}$ session of Sokolac Crisis Staff, 7 May 1992), pp. 1-3; D3231 (Sokolac Crisis Staff conclusions, 7 May 1992), p. 1; D3206 (Witness statement of Milovan Bjelica dated 30 March 2013), paras. 35- 
1992 that a public call would be made for citizens who had been "exiled" to return to Sokolac and that those who did not return before 22 May 1992 would be prohibited from returning. ${ }^{3582}$

1054. By mid-May 1992, there were approximately 4,000 Bosnian Serb refugees in the Sokolac area which added to the atmosphere of "fear and uncertainty" with minor incidents involving Bosnian Serb refugees targeting Bosnian Muslims who remained in Sokolac. ${ }^{3583}$ Initially, some of the Bosnian Serb refugees moved into abandoned homes without permission and on 22 April 1992, the Crisis Staff prohibited the unlawful and unauthorised occupation of premises, save in the event of "justifiable need" when approval of the use of premises could be granted by the Crisis Staff following an inventory of their contents. ${ }^{3584}$ On 22 May 1992, the Crisis Staff allocated all vacant premises for the temporary use by refugees according to criteria set by the Red Cross of Sokolac after an inventory of the contents carried out by a committee created for this purpose. ${ }^{3585}$

(C) Attacks against Bosnian Muslim villages

1055. At a meeting of the Sokolac Crisis Staff on 15 May 1992, Drago Mačar, as Chief of Staff of the TO, indicated that plans for disarming certain villages had been made. ${ }^{3586}$ Following its formation the $2^{\text {nd }}$ Romanija Motorised Brigade took over all the activities and assignments of the TO Staff and was involved in disarming Bosnian Muslim villages. ${ }^{3587}$ There was not a positive response to calls for the voluntary surrender of weapons and there was armed resistance to attempts to disarm Bosnian Muslim villages. ${ }^{3588}$

36; D3228 (Sokolac Crisis Staff conclusions, 15 May 1992). The Chamber also received evidence that the Municipal Board of the SDS formed a Personnel Commission for the nomination of candidates to managerial positions and decided that Bosnian Muslims workers may work and receive tasks. P5242 (Minutes of meeting of Sokolac Crisis Staff, 15 May 1992), p. 1; Milan Tupajić, P5238 (Transcript from Prosecutor v. Krajišnik), T. 15363.

3582 P5242 (Minutes of meeting of Sokolac Crisis Staff, 15 May 1992), p. 7. See also Dragomir Obradović, T. 36069 (26 March 2013).

3583 Milan Tupajić, P5238 (Transcript from Prosecutor v. Krajišnik), T. 15383-15384. See also D3206 (Witness statement of Milovan Bjelica dated 30 March 2013), paras. 43, 76; D3212 (Sokolac Crisis Staff conclusions, 22 May 1992); Milovan Bjelica, T. 36401 (2 April 2013). These Bosnian Serb refugees arrived from central $\mathrm{BiH}$, Goražde, Olovo, Kladanj and municipalities in Sarajevo which were under Bosnian Muslim control.

3584 D3206 (Witness statement of Milovan Bjelica dated 30 March 2013), paras. 43, 67; D3177 (Sokolac Crisis Staff order, 20 April 1992).

3585 D3216 (Sokolac Crisis Staff decision, 22 May 1992); D3215 (Sokolac Crisis Staff decision, 22 May 1992); D3214 (Sokolac Crisis Staff conclusions, 22 May 1992). See also D3217 (Sokolac Crisis Staff conclusions, 22 June 1992) for the proposed relocation of these refugees to other municipalities.

3586 Milan Tupajić, P5238 (Transcript from Prosecutor v. Krajišnik), T. 15373-15374; P5242 (Minutes of meeting of Sokolac Crisis Staff, 15 May 1992), item 16.

3587 Milan Tupajić, P5238 (Transcript from Prosecutor v. Krajišnik), T. 15374, 15385-15387, 15403.

3588 D3175 (Witness statement of Dragomir Obradović dated 24 March 2013), paras. 16-17; D3206 (Witness statement of Milovan Bjelica dated 30 March 2013), paras. 41, 48. The villages which put up resistance included Šahbegovići, Kaljina, Knežina, Meljine, Šaševci, Žulj, Šahbegovići, Pediše, Išerić Brdo, Rakitnica, Novoseoci, Kuti, Mičivode and Kalimanići. See also Milan Tupajić, P5238 (Transcript from Prosecutor v. Krajišnik), T. 15375-15378 (testifying that he advised Bosnian Muslims that, should they be asked to hand over 
1056. During the period from the end of July to the end of September 1992, the $2^{\text {nd }}$ Romanija Motorised Brigade attacked and destroyed several Muslim villages in Sokolac municipality, including Pihlice, Kaljina, Sahbegovići, Mangurići, and Meljine. ${ }^{3589}$ The village of Meljine was attacked by Serb Forces using tanks and howitzers from the village of Knežina. ${ }^{3590}$ Attacks began with artillery fire, followed by infantry incursions. ${ }^{3591}$ As soon as the first actions commenced, the Bosnian Muslim women, children and elderly started withdrawing from their villages towards Olovo after facing verbal abuse and harassment. ${ }^{3592}$

\section{(1) Scheduled Incident A 13.1}

1057. The Prosecution alleges that at least 40 men were killed in the village of Novoseoci on or about 22 September 1992.

1058. The village of Novoseoci is roughly eight to nine kilometres away from the town of Sokolac and four to five kilometres from the Rogatica-Sokolac cross-road. ${ }^{3593}$ It consisted of 60 to 70 houses inhabited by Bosnian Muslims. ${ }^{3594}$

1059. In the spring of 1992, Mačar came to Novoseoci and asked the men in the village to turn in any weapons they might have, whereupon the men handed over hunting rifles and other weapons including pistols. ${ }^{3595}$ The disarming of villagers continued on 27 July 1992, as Momčilo Pajić, a Bosnian Serb from Sokolac and Velemir Elez, a journalist, came to Novoseoci to request the handover of weapons, ${ }^{3596}$ and told the Bosnian Muslim men of the village that they should go on with

their weapons, they should comply because they could not resist the VRS forces and that he could not offer them protection from events which were occurring in other municipalities). See also D3206 (Witness statement of Milovan Bjelica dated 30 March 2013), paras. 44, 64; D3175 (Witness statement of Dragomir Obradović dated 24 March 2013), paras. 7, 14, 30; Dragomir Obradović, T. 36080-36082, 36111 (26 March 2013).

3589 Adjudicated Fact 2684; Milan Tupajić, P5238 (Transcript from Prosecutor v. Krajišnik), T. 15403-15404, 15408-15409, 15412-15414, 15416-15417. Tupajić also identified a number of other villages attacked in this manner.

3590 P131 (Witness statement of Asim Hamzić dated 25 March 1996), p. 9.

3591 Milan Tupajić, P5238 (Transcript from Prosecutor v. Krajišnik), T. 15403-15404, 15408-15409, 15412-15414; P131 (Witness statement of Asim Hamzić dated 25 March 1996), p. 9; Adjudicated Fact 2684.

3592 Milan Tupajić, P5238 (Transcript from Prosecutor v. Krajišnik), T. 15414, 15417-15418; D3175 (Witness statement of Dragomir Obradović dated 24 March 2013), para. 17.

3593 Milan Tupajić, P5238 (Transcript from Prosecutor v. Krajišnik), T. 15429.

3594 P3295 (Witness statement of Munira Selmanović dated 23 January 2009), para. 2.

3595 P3295 (Witness statement of Munira Selmanović dated 23 January 2009), para. 3; P3296 (2 ${ }^{\text {nd }}$ Romanija Motorised Brigade's Record of confiscation of weapons in Novoseoci, 27 July 1992); Munira Selmanović, T. 18550-18551 (7 September 2011); D1667 (SRK combat report, 27 July 1992).

3596 Munira Selmanović, T. 18552 (7 September 2011); P3295 (Witness statement of Munira Selmanović dated 23 January 2009), para. 4. 
their work and should not be concerned about their safety. ${ }^{3597}$ The SRK reported that it did not believe that the villagers had surrendered all of their weapons. ${ }^{3598}$

1060. On 19 September 1992, Krstić reported to the Main Staff that active combat operations would be conducted aimed at liberating Bosnian Serb villages and surrounding areas from Bosnian Muslim “extremists". 3599 On 22 September 1992, members of the $2^{\text {nd }}$ Romanija Motorised Brigade surrounded Novoseoci. ${ }^{3600}$ Munira Selmanović was among the Bosnian Muslim villagers who were instructed to gather in a nearby valley and told they would be transferred soon to "Metaljka", which was a meadow above the village. ${ }^{3601}$ Instructions were given by soldiers to some of the gathered Bosnian Muslims to go to the village and inform everyone to go to "Metaljka". ${ }^{3602}$ When Selmanović was sent back to her house, she saw soldiers looting property including furniture from her home. ${ }^{3603}$ Approximately 100 women and children and about 44 men from Novoseoci ultimately gathered at "Metaljka" and were surrounded by approximately 100 Bosnian Serb soldiers in military uniforms, who pointed their weapons at the villagers. ${ }^{3604}$ The soldiers read out the names of the villagers to identify whether everyone was present. ${ }^{3605}$

1061. Momčilo Pajić appeared to be in charge and asked the villagers whether they still had any weapons and said that the houses of the village were going to be searched. ${ }^{3606}$ Pajic then said he was awaiting orders from Sokolac, and he told the villagers to remain still while he went there. ${ }^{3607}$ Pajić, after returning, read out an order, saying that women and children, as well as the elderly were

3597 Munira Selmanović, T. 18537, 18549-18550 (7 September 2011); P3295 (Witness statement of Munira Selmanović dated 23 January 2009), para. 6 (referring to a Bosnian Serb named Rade Dubovina from the village of Kula frequently visiting Novoseoci and assuring the population that it was safe and there was no reason to leave).

3598 D1667 (SRK combat report, 27 July 1992), para. 1.

3599 D3191 (Report of $2^{\text {nd }}$ Romanija Motorised Brigade, 19 September 1992), p. 1.

$3600 \quad$ Adjudicated Fact 2676.

3601 P3295 (Witness statement of Munira Selmanović dated 23 January 2009), para. 8; Munira Selmanović, T. 18556-18557 (7 September 2011).

3602 P3295 (Witness statement of Munira Selmanović dated 23 January 2009), paras. 8, 14-15; Munira Selmanović, T. 18560 (7 September 2011). Munira Selmanović testified that when she fetched her father, he was covered in blood and told her that soldiers had beaten him with a rifle butt after asking him why he was still in the house and where he had put his weapons. P3295 (Witness statement of Munira Selmanović dated 23 January 2009), para. 15; Munira Selmanović, T. 18538, 18542 (7 September 2011).

3603 P3295 (Witness statement of Munira Selmanović dated 23 January 2009), para. 15; Munira Selmanović, T. 18538, 18540, 18542, 18561-18562 (7 September 2011). See also P5480 (Approval to move furniture from Novoseoci to Sokolac signed by Radislav Krstić, 26 September 1992) (wherein Krstić approves that a conscript transport furniture from Novoseoci to Sokolac until the individual moved into a house in Novoseoci which he had chosen).

3604 P3295 (Witness statement of Munira Selmanović dated 23 January 2009), paras. 9-10, 13.

3605 Munira Selmanović, T. 18557 (7 September 2011).

3606 P3295 (Witness statement of Munira Selmanović dated 23 January 2009), paras. 11-13. Besides Pajić, Selmanović also recognised some other soldiers there from Sokolac, including a policeman named Milenko Krsmanović.

3607 P3295 (Witness statement of Munira Selmanović dated 23 January 2009), para. 12. 
to be sent to Sarajevo by bus, while able-bodied men were to remain and undertake mandatory work. ${ }^{3608}$ The former were assembled and walked from "Metaljka" to the entrance of Novoseoci where they were ordered to get on a bus parked near the mosque. ${ }^{3609}$ Pajić entered the bus to check if any of the men had also got in, after which the bus was driven to Hreša, where the passengers were ordered to walk to Sarajevo. ${ }^{3610}$ After this incident no Bosnian Muslims remained in the village of Novoseoci. ${ }^{3611}$ KDZ607 was told that all the houses in Novoseoci had been destroyed. ${ }^{3612}$

1062. Krstić informed the Main Staff on 22 September 1992 that "[d]uring the day, the village of Novoseoci was cleansed". ${ }^{3613}$ On the following day, Krstić reported that units were searching for and destroying straggling groups which had escaped the villages that had been "mopped up", including Novoseoci. ${ }^{3614}$

1063. Members of the $2^{\text {nd }}$ Romanija Motorised Brigade killed 40 to 45 Bosnian Muslim civilian men from Novoseoci, as well as a few from Rogatica who happened to be in Novoseoci on or about 22 September $1992 .^{3615}$

1064. On the evening of 22 September 1992, Tupajić learned that the bodies of the Bosnian Muslim men from Novoseoci who had been killed, had been found at a land fill garbage dump in

3608 P3295 (Witness statement of Munira Selmanović dated 23 January 2009), paras. 17-18; Munira Selmanović, T. 18558 (7 September 2011); Adjudicated Fact 2676.

3609 P3295 (Witness statement of Munira Selmanović dated 23 January 2009), paras. 18, 20; Munira Selmanović, T. 18542 (7 September 2011).

3610 P3295 (Witness statement of Munira Selmanović dated 23 January 2009), para. 20.

3611 Milovan Bjelica, T. 36460 (3 April 2013).

3612 P3289 (Witness statement of KDZ607 dated 1 September 2011), para. 55(c) (under seal).

3613 P5438 (Report of $2^{\text {nd }}$ Romanija Motorised Brigade, 22 September 1992), p. 1; Adjudicated Fact $2677 . \quad$ The Chamber notes that P5438 uses the term "čišćenje", which is translated as either cleansed or mopped up. The Chamber received evidence which suggested there was no police investigation of this incident as it had no jurisdiction over the army. See Dragomir Obradović, T. 36096, 36102-36103 (26 March 2013); D3175 (Witness statement of Dragomir Obradović dated 24 March 2013), para. 20. However, Obradović was unable to adequately explain why the police in this case did not carry out an investigation into this serious incident when it did carry out initial investigations of misdemeanours perpetrated by VRS members. In addition while Obradović testified that the civilian authorities did not inform higher organs about this incident, given that the witness merely expressed his own opinion, the Chamber is not satisfied that the witness would have known whether or not the higher organs had been informed.

3614 D3192 (Report of $2^{\text {nd }}$ Romanija Motorised Brigade, 23 September 1992), p. 2. The Chamber received evidence to suggest that Krstić issued the order to kill these civilians. D3206 (Witness statement of Milovan Bjelica dated 30 March 2013), para. 57; Milovan Bjelica, T. 36454-36455 (3 April 2013). However, this evidence is based on Bjelica's assumption following a conversation with a third person. The Chamber does not accept this conclusion given the absence of any further corroborating evidence.

3615 P3295 (Witness statement of Munira Selmanović dated 23 January 2009), paras. 19, 21; P131 (Witness statement of Asim Hamzić dated 25 March 1996), p. 7; Munira Selmanović, T. 18509 (7 September 2011); P3289 (Witness statement of KDZ607 dated 1 September 2011), para.55(b) (under seal); Milan Tupajić, P5238 (Transcript from Prosecutor v. Krajišnik), T. 15428-15429. See also Adjudicated Fact 2676; D3206 (Witness statement of Milovan Bjelica dated 30 March 2013), para. 57; D3175 (Witness statement of Dragomir Obradović dated 24 March 2013), para. 20; Dragomir Obradović, T. 36094 (26 March 2013). 
Ivan Polje. ${ }^{3616}$ Following exhumation of the Ivan Polje site, 42 male bodies were received for postmortem examinations and it was estimated that the age of the bodies ranged from 12 to 85, with the majority aged between 30 and $60 .^{3617} 36$ of the 38 Bosnian Muslim men identified by Selmanović who remained in Novoseoci were found among the remains of 42 bodies exhumed from the gravesite at Ivan Polje. ${ }^{3618}$ No military clothing was found. ${ }^{3619}$ Personal belongings were found, and one body carried a miniature Koran. ${ }^{3620}$ Evidence of gunshot injuries were found in all of the 42 bodies, 38 having been shot multiple times. ${ }^{3621}$ With the exception of one case where the skull was missing, all of the other 41 men died from gunshot injuries. ${ }^{3622}$ The exhumation report conclusions are consistent with the majority of the bodies being shot from behind with high velocity weapons. ${ }^{3623}$

1065. The Chamber therefore finds that approximately 40 Bosnian Muslim men were killed by Serb Forces in the village of Novoseoci on or around 22 September 1992.

3616 Milan Tupajić, P5238 (Transcript from Prosecutor v. Krajišnik), T. 15428-15430; Munira Selmanović, T. 18547-18548 (7 September 2011). See also D3206 (Witness statement of Milovan Bjelica dated 30 March 2013), para. 57. Following this incident at Novoseoci, Tupajić tendered his resignation as president of the municipality. However, members of the Municipal Board asked him to withdraw his resignation as it could have a detrimental effect or be viewed as condemnation of the policies at the time. After Tupajić's car was blown up he decided to continue performing his duties. P5249 (Letter from Milan Tupajić to Sokolac SDS Municipal Board, 9 October 1992); Milan Tupajić, P5238 (Transcript from Prosecutor v. Krajišnik), T. 1543215435; P5251 (Insurance company report on damage to Milan Tupajić's car, 13 October 1992). In light of (i) the evidence about Tupajić's knowledge of events in Novoseoci, and steps taken to prevent his resignation; and (ii) the internal inconsistencies in the evidence of the relevant Defence witnesses, the Chamber does not accept Defence evidence that nobody from the municipal authorities knew about this incident and that when they did find out they all condemned it. See D3206 (Witness statement of Milovan Bjelica dated 30 March 2013), para. 57; Milovan Bjelica, T. 36455-36456 (3 April 2013); D3175 (Witness statement of Dragomir Obradović dated 24 March 2013), para. 20; Dragomir Obradović, T. 36074, 36094-36095 (26 March 2013).

3617 P4106 (John Clark's expert report entitled "Report of the Chief Pathologist, Paklenik Cave and Ivan Polje Grave-Sites (2000)”, 30 July 2002), p. 14; P3297 (Exhumation report of mass grave in Ivan Polje, 4 September 2000).

3618 P3295 (Witness statement of Munira Selmanović dated 23 January 2009), paras. 21, 23; Munira Selmanović, T. 18544-18545 (7 September 2011). See also P3297 (Exhumation report of mass grave in Ivan Polje, 4 September 2000); P4853 (Updated Table 2 to the Report of Amor Mašović), p. 49. While Selmanović testified in court that she herself saw and recognised her son's remains, however, in the exhumation report it is recorded that her son's remains were recognised by her sister, Amra Korman. Munira Selmanović, T. 18545, 18548-18549 (7 September 2011); P3297 (Exhumation report of mass grave in Ivan Polje, 4 September 2000), p. 8. While the Chamber notes this inconsistency, it is not of such significance to affect the credibility of Selmanović's evidence.

3619 P4106 (John Clark's expert report entitled "Report of the Chief Pathologist, Paklenik Cave and Ivan Polje Grave-Sites (2000)", 30 July 2002), p. 14.

3620 P4106 (John Clark's expert report entitled "Report of the Chief Pathologist, Paklenik Cave and Ivan Polje Grave-Sites (2000)", 30 July 2002), p. 14.

3621 P4106 (John Clark's expert report entitled "Report of the Chief Pathologist, Paklenik Cave and Ivan Polje Grave-Sites (2000)", 30 July 2002), p. 15.

3622 P4106 (John Clark's expert report entitled "Report of the Chief Pathologist, Paklenik Cave and Ivan Polje Grave-Sites (2000)", 30 July 2002), p. 15.

3623 P4106 (John Clark's expert report entitled "Report of the Chief Pathologist, Paklenik Cave and Ivan Polje Grave-Sites (2000)", 30 July 2002), p. 16. 
1066. The Indictment refers to the destruction of five mosques in Sokolac at least between August and September 1992. ${ }^{3624}$

1067. All five mosques in Sokolac municipality, namely in Knežina, Kruševci, Kaljina, Novoseoci, and Košutica, were blown up or destroyed during attacks on these villages. ${ }^{3625}$ The destruction of the mosques was seen by Bosnian Serbs as a way in which Bosnian Muslims would "lose a motive to return to their villages". ${ }^{3626}$

1068. More specifically, the mosque in Novoseoci was blown up by the $2^{\text {nd }}$ Motorised Romanija Brigade. $^{3627}$ Bogdan Jovanović together with some other Bosnian Serbs was seen placing explosives around the mosque known as 'Selimija' in Knežina which was completely destroyed in a large explosion and four other mosques were destroyed at about the same time. ${ }^{3628}$ Remains of a destroyed mosque were found at the Ivan Polje garbage dump. ${ }^{3629}$

1069. Therefore the Chamber finds that five mosques were destroyed by Serb Forces between August and September 1992.

3624 Specifically, the mosques are the Kruševci mosque, Knežina mosque, Kaljina mosque, Novoseoci mosque, Koštica mosque.

3625 Adjudicated Fact 2684. See also Milan Tupajić, P5238 (Transcript from Prosecutor v. Krajišnik), T. 15431; P4070 (Attachment to the expert report of András J. Riedlmayer, entitled "Destruction of Cultural Heritage in BiH” prepared for the Karadžić case, formatted records), pp. 312-322; P4069 (Cultural destruction database), records 332-335. While Asim Hamzić stated that Aleska Krsmanović was among the individuals responsible for the destruction of the mosques, the Chamber considers that it is uncorroborated hearsay evidence and is not satisfied that it can rely on this alone to make a findings that Krsmanović was responsible. P131 (Witness statement of Asim Hamzić dated 25 March 1996), p. 8. The Chamber does not accept Defence evidence that (i) mosques in border villages of Sokolac were used for combat operations; (ii) that members of the Patriotic League hid and distributed weapons from these facilities; (iii) these mosques were destroyed during the war, in an environment of chaos in remote villages by individuals and informal groups; or (iv) that the municipal authorities did not know or approve of their destruction and had no control over the territory where these mosques were located. D3206 (Witness statement of Milovan Bjelica dated 30 March 2013), paras. 55, 64; D3175 (Witness statement of Dragomir Obradović dated 24 March 2013), paras. 26, 30. In reaching this conclusion, the Chamber considered the evidence of the two relevant defence witnesses was unreliable given their evidence was marked by inconsistencies and indications of partisanship and bias. In addition the evidence received with respect to the attack on Novoseoci contradicts the Defence evidence that mosques were destroyed in an environment of chaos or by individuals or informal groups. Adjudicated Facts 2676, 2684; Milan Tupajić, P5238 (Transcript from Prosecutor v. Krajišnik), T. 15431.

3626 Milan Tupajić, P5238 (Transcript from Prosecutor v. Krajišnik), T. 15431.

3627 Milan Tupajić, P5238 (Transcript from Prosecutor v. Krajišnik), T. 15431. See also András Riedlmayer, T. 22548 (9 December 2011); P4068 (András Riedlmayer's expert report on Destruction of Cultural Heritage in Bosnia and Herzegovina during 1992-1995, 7 May 2009), p. 9; P4070 (Attachment to the expert report of András J. Riedlmayer, entitled "Destruction of Cultural Heritage in BiH" prepared for the Karadžić case, formatted records), p. 316.

3628 P131 (Witness statement of Asim Hamzić dated 25 March 1996), p. 8; P4070 (Attachment to the expert report of András J. Riedlmayer, entitled "Destruction of Cultural Heritage in BiH" prepared for the Karadžić case, formatted records), pp. 312-314.

3629 P3297 (Exhumation report of mass grave in Ivan Polje, 4 September 2000), p. 2. 


\section{(D) Detention Facilities in Sokolac}

\section{(1) Scheduled Detention Facility C.23.2}

1070. Around 20 July 1992, four Bosnian Serbs dressed in MP uniforms and travelling an APC arrested a Bosnian Muslim teacher named Gagula, and brought him to barracks in Knežina where he was interrogated and beaten by one of the officers. ${ }^{3630}$ Gagula was then transported to the Slaviša Vajner Čiča Elementary School by local Bosnian Serb soldiers where he was detained with 13 other detainees until 3 October 1992. ${ }^{3631}$ On his arrival at the school, Gagula was again interrogated and beaten by Bosnian Serb soldiers. ${ }^{3632}$

\section{(2) Scheduled Detention Facility C.23.1}

1071. On 3 October 1992, detainees, including Gagula, were transferred to the former elementary school in Čavarine. ${ }^{3633}$ The facility was under the responsibility of the $2^{\text {nd }}$ Romanija Motorised Brigade. ${ }^{3634}$ Bosnian Muslims were arrested and detained there by the $2^{\text {nd }}$ Romanija Motorised Brigade without any charges or legal grounds. ${ }^{3635}$ Conditions were harsh with insufficient food and

$3630 \quad$ See Adjudicated Fact 2678.

3631 Adjudicated Fact 2679; Milan Tupajić, P5238 (Transcript from Prosecutor v. Krajišnik), T. 15410. But see D3206 (Witness statement of Milovan Bjelica dated 30 March 2013), para. 54. The Chamber does not accept this evidence that there were no camps or prisons during the war.

3632 See Adjudicated Fact 2679. Obradović testified that a military detention unit was set up at the Sokolac primary school at the beginning of October 1992 for approximately 10 days after which it was relocated to Čavarine; however, on cross-examination, he acknowledged that he had not been to the facility, that he simply heard about it and did not know what the conditions were and could not say how long the facility operated. D3175 (Witness statement of Dragomir Obradović dated 24 March 2013), para. 25; Dragomir Obradović, T. 36113-36115 (26 March 2013). Similarly, the Chamber does not accept Bjelica's evidence that the school was used for the questioning of Bosnian Muslims suspected of involvement in sabotage or terrorist actions, that the detainees were treated humanely, and that conditions were satisfactory. In reaching this conclusion, the Chamber considered that Bijelica's evidence was unreliable given that it was marked by indications of partisanship and bias. In addition Bijelica acknowledged on cross-examination that he did not know why a 62 year old woman was detained and that he assumed that the facilities did not have the required hygienic and other facilities. The witnesss was also contradicted on cross-examination and acknowledged that hygiene conditions were not satisfactory. In addition, the witness's evidence with respect to the conditions in these facilities was qualified and he acknowledged on cross-examination that he never visited these facilities. See D3206 (Witness statement of Milovan Bjelica dated 30 March 2013), paras. 54, 65; Milovan Bjelica, T. 36448-36450, 36452-36454 (3 April 2013); P6255 (Letter from Sokolac POW Exchange Committee to VRS Lukavica Committee for Exchange and Release of POW, 9 November 1992); Milovan Bjelica, P6256 (Excerpt from transcript from Prosecutor v. Krajišnik), T. 22721.

3633 See Adjudicated Fact 2680; Milan Tupajić, P5238 (Transcript from Prosecutor v. Krajišnik), T. 15410.

3634 D3206 (Witness statement of Milovan Bjelica dated 30 March 2013), para. 65.

3635 Milan Tupajić, P5238 (Transcript from Prosecutor v. Krajišnik), T. 15387-15388. 
hygiene facilities. ${ }^{3636}$ Detainees were beaten by Bosnian Serb paramilitaries coming from Ilijaš. ${ }^{3637}$ On 15 March 1993, Gagula was transferred to the Batković camp in Bijeljina. ${ }^{3638}$

(E) Movement of the population from Sokolac

1072. By the end of 1992, the majority of Bosnian Muslims had left the municipality with as few as 30 to 40 families remaining. ${ }^{3639}$ The departure of some Bosnian Muslims in Sokolac followed attacks on Bosnian Muslim villages and verbal abuse and harassment. ${ }^{3640}$ In some cases Bosnian Muslim women, children and elderly were separated and ordered to board buses taking them away from their villages. ${ }^{3641}$ Bosnian Muslim men were not allowed to leave with their families. ${ }^{3642}$ Milan Tupajić also advised a Bosnian Muslim to find a safe place to hide as he was afraid that he might be harmed due to the "ethnic cleansing" which had already begun in many of the surrounding villages; Bosnian Muslims then started to move mainly to the areas of Olovo, Tuzla, Visoko, Vareš, Kladanj, and Kakanj. ${ }^{3643}$

1073. The Chamber does not accept Defence evidence which suggests that Bosnian Muslims voluntarily left the municipality on a temporary basis and returned after the war was over. ${ }^{3644}$ In reaching that conclusion the Chamber notes that by 1997 very few Bosnian Muslims had in fact returned to Sokolac. ${ }^{3645}$ In addition the Chamber considered that in this respect, the evidence of Bjelica and Obradović was unreliable due to inconsistencies in their evidence and some degree of evasiveness in their testimony; there were also indications of partisanship and bias. The Chamber also finds inconsistencies in Obradović's evidence received about when, why and the circumstances in which Bosnian Muslims from the village of Vrhbarje left and does not accept that this is an

\footnotetext{
3636 Adjudicated Fact 2681; Milan Tupajić, P5238 (Transcript from Prosecutor v. Krajišnik), T. 15410-15411; D3206 (Witness statement of Milovan Bjelica dated 30 March 2013), para. 54.

3637 See Adjudicated Fact 2682.

3638 See Adjudicated Fact 2683.

3639 Milovan Bjelica, T. 36457-36459 (3 April 2013).

3640 See para. 1056 above referring to Milan Tupajić, P5238 (Transcript from Prosecutor v. Krajišnik), T. 15414, 15417-15418; D3175 (Witness statement of Dragomir Obradović dated 24 March 2013), para. 17.

3641 See paras. 1060-1061 referring to P3295 (Witness statement of Munira Selmanović dated 23 January 2009), paras. 17-18, 20; Munira Selmanović, T. 18542, 18558 (7 September 2011); Adjudicated Fact 2676.

3642 P131 (Witness statement of Asim Hamzić dated 25 March 1996), p. 6.

3643 P131 (Witness statement of Asim Hamzić dated 25 March 1996), pp. 5-6.

3644 Milovan Bjelica, T. 36399-36400, 36402, 36405 (2 April 2013), 36464, 36474 (3 April 2013); D3206 (Witness statement of Milovan Bjelica dated 30 March 2013), para. 37; D3175 (Witness statement of Dragomir Obradović dated 24 March 2013), paras. 18-19; Dragomir Obradović, T. 36069-36070, 36083 (26 March 2013).

3645 P4994 (Addendum to Ewa Tabeau's expert report entitled "Ethnic Composition in Internally Displaced Persons and Refugees from 27 Municipalities of BiH 1991 to 1997”, 3 February 2009), p. 32.
} 
example of Bosnian Muslims remaining in their homes until the end of the war and requesting to leave by mutual agreement. ${ }^{3646}$

1074. Having considered the totality of the evidence and assessed the circumstances in which departures occurred, the Chamber finds that Bosnian Muslims were forced to leave Sokolac.

vii. Višegrad

\section{(A) Charges}

1075. The Chamber notes that although for the purpose of the Indictment, the Prosecution lists Scheduled Incident A.14.2 under Višegrad Municipality, the killing incident charged therein is alleged to have occurred in the municipality of Sokolac. ${ }^{3647}$ There are no other charges in relation to Višegrad municipality. ${ }^{3648}$

1076. With respect to Scheduled Incident A.14.2, the Prosecution alleges that on 15 June 1992, following their expulsion from Višegrad, approximately 48 civilians were killed at a place near Paklenik near the village of Kalimanići, in Sokolac municipality. The Prosecution charges Scheduled Incident A.14.2 as persecution, a crime against humanity, under Count 3; extermination, a crime against humanity, under Count 4 ; murder, a crime against humanity, under Count 5; and murder, a violation of the laws or customs of war, under Count $6 .^{3649}$

\section{(B) Lead-up}

1077. Višegrad is a municipality in eastern $\mathrm{BiH},{ }^{3650}$ which had a predominantly Muslim population before the war. $^{3651}$ In the spring of 1992, tensions increased in Višegrad and militarisation of the municipality ensued where both Bosnian Muslims and Bosnian Serbs organised themselves militarily. ${ }^{3652}$ The security situation in Višegrad on 24 March 1992 was described as "complex and dramatical". ${ }^{3653}$ At the beginning of April 1992, barricades were set up

\footnotetext{
3646 See D3175 (Witness statement of Dragomir Obradović dated 24 March 2013), paras. 18-19; D3206 (Witness statement of Milovan Bjelica dated 30 March 2013), para. 37; Milovan Bjelica, T. 36399-36402, 36405, 36460, 36463-36464 (2 and 3 April 2013); Dragomir Obradović, T. 36069-36070, 36083, 36108-36111 (26 March 2013); D3189 (Sokolac SJB dispatch, 31 October 1994); P6235 (Statement of Avdija Katica, 3 January 1995), p. 3.

3647 See Prosecution Rule 73 bis Submission, fn. 14; Indictment, para. 48, fn. 3; Scheduled Incident A.14.2, fn. 1.

3648 See Indictment, para. 48, fn. 3; Prosecution Rule 73 bis Submission, fn. 14.

3649 Indictment, paras. 60(a), 63(a).

3650 D484 (Map of $\mathrm{BiH})$.

3651 Momčilo Mandić, T. 5299 (16 July 2010).

3652 D3065 (Witness statement of Aleksandar Vasiljević dated 26 February 2013), para. 169.

3653 P2838 (SerBiH MUP Bulletin on daily events, 24 March 1992), p. 2.
} 
by both Bosnian Serbs and Bosnian Muslims. ${ }^{3654}$ At the time, many Bosnian Muslim villagers fled to Višegrad town and later from there to Goražde; Bosnian Muslim men then organised a defence group for Višegrad. ${ }^{3655}$ Around the same time, a paramilitary unit from Serbia arrived in the village of Dobrun. ${ }^{3656}$

1078. By 10 April 1992, it was reported that the situation in the Višegrad sector was "extremely serious" and "[l]awlessness and anarchy reign[ed]". ${ }^{3657}$ Threats were made by Bosnian Muslims to blow up the hydro-electric dam if the JNA did not prevent attacks by paramilitary formations against Bosnian Muslims. ${ }^{3658}$ On 11 April 1992, there was an armed attack allegedly by "Serbian armed formations" on Višegrad with 30 mortar bombs launched at the town; individuals evacuated to surrounding slopes and to the army barracks in Uzamnica. ${ }^{3659}$

1079. By 20 April 1992, the Užice Corps of the JNA had entered Višegrad and taken control of all important positions; ${ }^{3660}$ thereafter the situation started returning to normal for a while and the population which had left began returning to their homes. ${ }^{3661}$ The Užice Corp left Višegrad on or about 18 May 1992. Following the departure of the Užice Corps, paramilitary formations arrived in the municipality, including the unit known as the "White Eagles" led by Milan Lukić, and joined those which had come earlier. ${ }^{3662}$ The paramilitaries held power in the municipality. ${ }^{3663}$

3654 Ferid Spahić, P61 (Transcript from Prosecutor v. Vasiljević), T. 351, 353, 405.

3655 P60 (Witness statement of Ferid Spahić dated 4 November 1997), p. 2; Ferid Spahić, P61 (Transcript from Prosecutor v. Vasiljević), T. 407.

3656 Ferid Spahić, P61 (Transcript from Prosecutor v. Vasiljević), T. 351. See also Ferid Spahić, P61 (Transcript from Prosecutor v. Vasiljević), T. 405.

3657 P925 (JNA $2^{\text {nd }}$ Military District combat report, 10 April 1992), p. 5.

3658 P925 (JNA $2^{\text {nd }}$ Military District combat report, 10 April 1992), p. 5. See also D218 (Green Berets Staff telegraph, 12 April 1992).

3659 D1493 (Transcript of broadcast of Sarajevo, Zagreb, and Belgrade Radio, 11 April 1992). See also Ferid Spahić, P61 (Transcript from Prosecutor v. Vasiljević), T. 407.

3660 Ferid Spahić, P61 (Transcript from Prosecutor v. Vasiljević), T. 355-356, 409; P60 (Witness statement of Ferid Spahić dated 4 November 1997), p. 2; D1694 (Intercept of conversation between Ješirić and Čedo Kljajić, 16 April 1992), p. 4; P2039 (BBC news report re Višegrad, with transcript), 00:00:00-00:00:29.

3661 D1694 (Intercept of conversation between Ješirić and Čedo Kljajić, 16 April 1992), p. 3; P60 (Witness statement of Ferid Spahić dated 4 November 1997), p. 2; Ferid Spahić, P61 (Transcript from Prosecutor v. Vasiljević), T. 353, 356, 406. See also D1694 (Intercept of conversation between Ješirić and Čedo Kljajić, 16 April 1992), p. 4.

3662 Ferid Spahić, P61 (Transcript from Prosecutor v. Vasiljević), T. 356-357; P60 (Witness statement of Ferid Spahić dated 4 November 1997), p. 3 (testifying that although he did not have contact with these groups, he heard that they included Šešelj's men, Arkan's men, the "Black Shirts", Milan Lukić, and the White Eagles). Those who had come with the Užice Corps and remained in Višegrad after its departure wore black uniforms and the traditional "šubara". See Ferid Spahić, P61 (Transcript from Prosecutor v. Vasiljević), T. 357 ; P60 (Witness statement of Ferid Spahić, dated 4 November 1997), pp. 2-3.

3663 Ferid Spahić, P61 (Transcript from Prosecutor v. Lukić and Lukić), T. 548. 


\section{(C) Scheduled Incident A.14.2}

1080. After the withdrawal of the Užice Corps, the situation changed and became more dangerous for local Bosnian Muslim men. ${ }^{3664}$ The Chamber heard evidence about attacks against Bosnian Muslim hamlets and the killing of Bosnian Muslims in Višegrad in May and June 1992 but since they are not charged in Schedules A or B of the Indictment, the Chamber will not enter findings with respect to these incidents. ${ }^{3665}$

1081. Ferid Spahić attended a meeting on 13 June 1992 in Bosanska Jagodina with local Bosnian Serbs and Bosnian Muslims from other villages. ${ }^{3666}$ At that meeting, the Bosnian Muslims were informed that the "ethnic cleansing of the Muslims was already going on" and they were encouraged to leave for their own safety with a convoy departing the next day. ${ }^{3667}$ Ljupko Tašić, who wore a camouflage uniform at the meeting, seemed to be in charge of the organisation of the convoy. ${ }^{3668}$ Tašić stated that the convoy had been announced officially on Radio Višegrad, that the "Red Cross" was also involved, and that the convoy would be escorted by Bosnian Serbs from the region whom the Bosnian Muslims knew and trusted. ${ }^{3669}$ This message was subsequently conveyed from hamlet to hamlet in the surrounding area. ${ }^{3670}$

1082. On the morning of 14 June 1992, approximately 100 to 150 Bosnian Muslims from the surrounding area gathered at the bus station in Bosanska Jagodina and left in a convoy of two buses and a truck towards Višegrad where approximately three other buses and two trucks joined the convoy. ${ }^{3671}$ Other Bosnian Muslims joined the convoy as it made its way to Višegrad. ${ }^{3672}$ They were allowed to take identification documents, clothing, money, and limited personal belongings. ${ }^{3673}$

\footnotetext{
P60 (Witness statement of Ferid Spahić dated 4 November 1997), p. 3.

3665 P60 (Witness statement of Ferid Spahić dated 4 November 1997), p. 3; Ferid Spahić, P61 (Transcript from Prosecutor v. Vasiljević) T. 357-360.

3666 P60 (Witness statement of Ferid Spahić dated 4 November 1997), p. 4; Ferid Spahić, P61 (Transcript from Prosecutor v. Vasiljević) T. 361-362, 409.

3667 P60 (Witness statement of Ferid Spahić dated 4 November 1997), p. 4; Ferid Spahić, P61 (Transcript from Prosecutor v. Vasiljević) T. 361-362, 409.

3668 Ferid Spahić, P61 (Transcript from Prosecutor v. Vasiljević), T. 362; Ferid Spahić, P61 (Transcript from Prosecutor v. Lukić and Lukić), T. 540-541, 546, 564-565.

3669 P60 (Witness statement of Ferid Spahić dated 4 November 1997), p. 4; Ferid Spahić, P61 (Transcript from Prosecutor v. Vasiljević), T. 362-365.

3670 Ferid Spahić, P61 (Transcript from Prosecutor v. Vasiljević) T. 365.

3671 P60 (Witness statement of Ferid Spahić dated 4 November 1997), p. 4; Ferid Spahić, P61 (Transcript from Prosecutor v. Vasiljević), T. 366-367, 382.

3672 Ferid Spahić, P61 (Transcript from Prosecutor v. Vasiljević), T. 366-367, 382.

3673 Ferid Spahić, P61 (Transcript from Prosecutorv. Vasiljević), T. 375.
} 
1083. In Višegrad, in front of the Višegrad Hotel by the old bridge, the buses and trucks were parked and those on the convoy were registered and given the option of choosing whether they wanted to head in the direction of Skopje, Olovo or Kladanj, and they all chose Skopje. ${ }^{3674}$ Three other buses and two trucks joined the convoy while a number of soldiers in different uniforms were walking around. ${ }^{3675}$ Milan Lukić attempted to get Esad Kustura, also known as "Zenga", 3676 off one of the buses, but Ljupko Tašić talked Lukić out of it. ${ }^{3677}$

1084. The convoy of buses and trucks left Višegrad before 11.00 a.m. on 14 June 1992 and there were escorts armed with automatic weapons on each bus. ${ }^{3678}$ Željko Tašić, a policeman who served in the Višegrad SJB in June and July 1992, followed the convoy in his car. ${ }^{3679}$ The convoy did not head in the requested direction of Skopje and the Bosnian Muslims were told by guards at a checkpoint and by the driver of the bus that they had to bypass Rogatica and were going to Olovo through Sokolac. ${ }^{3680}$ A journalist who stopped the convoy was told by the drivers that there were about 700 to 800 Bosnian Muslims in the convoy. ${ }^{3681}$

1085. The convoy drove through Seljane, near Rogatica, and Sokolac before arriving in Išarića Brdo in the municipality of Olovo. ${ }^{3682}$ At Išarića Brdo, the convoy was surrounded by armed soldiers dressed in camouflage uniforms who said that the younger men could not continue and had

3674 P60 (Witness statement of Ferid Spahić dated 4 November 1997), p. 4; Ferid Spahić, P61 (Transcript from Prosecutor v. Vasiljević), T. 362, 367, 371, 382; Ferid Spahić, P61 (Transcript from Prosecutor v. Lukić and Lukić), T. 527-528; P501 (Addendum to witness statement of Ferid Spahić dated 24 August 2008), para. 4 (specifying that he was in charge of drawing up the list of those on his bus).

3675 P60 (Witness statement of Ferid Spahić dated 4 November 1997), p. 4; Ferid Spahić, P61 (Transcript from Prosecutor v. Vasiljević) T. 367-368; Ferid Spahić, P61 (Transcript from Prosecutor v. Lukić and Lukić), T. 527-528.

3676 Ferid Spahić, P60 (witness statement dated 4 November 1997), p. 4; Ferid Spahić, P61 (Transcript from Prosecutor v. Vasiljević), T. 368-369. The Accused submits that Spahić's identification of Milan Lukić is speculative and groundless. See Defence Final Brief, para. 1809. However the Chamber is satisfied that Milan Lukić was positively identified by a person who passed this information on to Spahić.

3677 P60 (Witness statement of Ferid Spahić dated 4 November 1997), p. 4; Ferid Spahić, P61 (Transcript from Prosecutor v. Vasiljević), T. 368-369; Ferid Spahić, P61 (Transcript from Prosecutor v. Lukić and Lukić), T. 529-530, 542, 544-545; P501 (Addendum to witness statement of Ferid Spahić dated 24 August 2008); paras. 6, 17.

Ferid Spahić, P61 (Transcript from Prosecutor v. Vasiljević), T. 367, 373, 411; Ferid Spahić, P61 (Transcript from Prosecutor v. Lukić and Lukić), T. 527-528.

3679 P60 (Witness statement of Ferid Spahić dated 4 November 1997), p. 5; P5508 (Report of Višegrad SJB, 1 August 1992).

3680 P60 (Witness statement of Ferid Spahić dated 4 November 1997), p. 5; Ferid Spahić, P61 (Transcript from Prosecutor v. Vasiljević), T. 371, 373-374; Ferid Spahić, P61 (Transcript from Prosecutor v. Lukić and Lukić), T. 527-528.

3681 P61 (Transcript from Prosecutor v. Vasiljević), T. 374, 411; P60 (Witness statement of Ferid Spahić dated 4 November 1997), p. 5; P501 (Addendum to witness statement of Ferid Spahić dated 24 August 2008), para. 8.

3682 P60 (Witness statement of Ferid Spahić dated 4 November 1997), p. 5; P501 (Addendum to witness statement of Ferid Spahić dated 24 August 2008), para. 22; Ferid Spahić, P61 (Transcript from Prosecutor v. Vasiljević), T. 374 (specifying that it was still daytime on 14 June 1992 when they arrived in Išarića Brdo); Ferid Spahić, P61 (Transcript from Prosecutor v. Lukić and Lukić), T. 531-532; P80 (Map marked by Ferid Spahić). The map shows the route taken by the convoy from Višegrad. 
to return. ${ }^{3683}$ Željko Tašić told those in the convoy not to worry and that their return was only for the purpose of a prisoner exchange. ${ }^{3684}$ Approximately 49 Bosnian Muslim males were thus separated and left on the buses, while the women, children and some of the older men in the convoy were asked to leave the buses and go to Olovo on foot. ${ }^{3685}$ The separated Bosnian Muslim men were then driven back to Sokolac, where they were gathered in one bus parked outside the police station and spent the night on the bus watched by two guards. ${ }^{3686}$

1086. On the morning of 15 June 1992, the Bosnian Muslim men were driven in the direction of Rogatica. ${ }^{3687}$ On the way, a soldier wearing a Montenegrin Serbian Guard cap entered the bus, called the Bosnian Muslim men "Ustaša", asked which of them was "Zenga", and cursed him. ${ }^{3688}$ He told the driver of the bus to leave "Zenga" to him, but left. 3689

1087. The bus stopped in front of a factory in Rogatica, two soldiers entered and ordered those on the bus to hand over their documents, valuables, and money. ${ }^{3690}$ Another bus was parked close by. ${ }^{3691}$ An APC stopped in front of the bus holding the Bosnian Muslim men and there were approximately 10 soldiers standing around. ${ }^{3692}$ Slaviša Vukojičić, a blonde man in civilian clothes, arrived in a small car, followed by the soldier in the Montenegrin Serbian Guard cap mentioned earlier. ${ }^{3693}$ A young blindfolded man whose hands were tied behind his back was pulled out of the car, hit in the stomach, and pushed onto another bus. ${ }^{3694}$ When "Zenga" was identified, the soldiers

3683 P60 (Witness statement of Ferid Spahić dated 4 November 1997), p. 5; Ferid Spahić, P61 (Transcript from Prosecutor v. Vasiljević), T. 375.

3684 P60 (Witness statement of Ferid Spahić dated 4 November 1997), p. 5; Ferid Spahić, P61 (Transcript from Prosecutor v. Vasiljević), T. 377-378.

3685 P60 (Witness statement of Ferid Spahić dated 4 November 1997), p. 5. Ferid Spahić, P61 (Transcript from Prosecutor v. Vasiljević), T. 375-376. See also Ferid Spahić, P61 (Transcript from Prosecutor v. Lukić and Lukić), T. 532.

3686 P60 Witness statement of Ferid Spahić dated 4 November 1997), p. 5. Ferid Spahić, P61 (Transcript from Prosecutor v. Vasiljević), T. 375-376; Ferid Spahić, P61 (Transcript from Prosecutor v. Lukić and Lukić), T. 532.

3687 P60 (Witness statement of Ferid Spahić dated 4 November 1997), p. 5. Ferid Spahić, P61 (Transcript from Prosecutor v. Vasiljević), T. 376.

3688 P60 (Witness statement of Ferid Spahić dated 4 November 1997), p. 5.

3689 P60 (Witness statement of Ferid Spahić dated 4 November 1997), p. 5.

3690 P60 (Witness statement of Ferid Spahić dated 4 November 1997), pp. 5-7; Ferid Spahić, P61 (Transcript from Prosecutor v. Vasiljević), T. 377.

3691 P60 (Witness statement of Ferid Spahić dated 4 November 1997), p. 6.

3692 P60 (Witness statement of Ferid Spahić dated 4 November 1997), p. 6; Ferid Spahić, P61 (Transcript from Prosecutor v. Vasiljević), T. 384-385.

3693 P60 (Witness statement of Ferid Spahić dated 4 November 1997), p. 6; Ferid Spahić, P61 (Transcript from Prosecutor v. Vasiljević), T. 384-385. Slaviša Vukojičić was a member of the Rogatica SJB. P3291 (List of policemen working at Rogatica SJB in May 1992)s, p.1. The Chamber notes a minor discrepancy in the spelling of his name but is satisfied that it is the same person.

3694 P60 (Witness statement of Ferid Spahić dated 4 November 1997), p. 6; Ferid Spahić, P61 (Transcript from Prosecutor v. Vasiljević), T. 384. 
took him off the bus, kicked, and beat him. ${ }^{3695}$ Other Bosnian Muslim men were ordered off the bus and beaten by Vukojičić, ${ }^{3696}$ All this was done in the presence of Željko Tašić. ${ }^{3697}$ After asking who the Bosnian Muslims were, Vukojičić shouted: "You cattle come out" and ordered them to run onto the bus where the young man had been taken. ${ }^{3698}$ The detainees were taken off the bus one by one and their hands were tied behind their backs with "half steel wire" so tightly that every movement caused pain. ${ }^{3699}$ Some of the Bosnian Muslims were randomly beaten by Vukojičić during this process. ${ }^{3700}$ After each Bosnian Muslim was tied they were returned to the bus; the bus then headed back in the direction of Sokolac with three Bosnian Serb soldiers onboard and an additional car driven by Vukojičić escorting the bus. ${ }^{3701}$ One of the soldiers said they were going to exchange 50 Muslim men for 10 Serb men. ${ }^{3702}$ There were approximately 50 to 52 men on the bus at that time. ${ }^{3703}$

1088. The bus reached a forest location called Paklenik, in Sokolac municipality, on the border with Rogatica. ${ }^{3704}$ It stopped near a hill close to a small clearing and Vukojičić drove away in his car for a while before returning. ${ }^{3705}$ The Bosnian Muslims were forced to sing a "Chetnik" song and were told that "thanks to Alija" they could not live together any longer. ${ }^{3706}$ After Vukojičić returned and talked with the soldiers, the bus drove off again with approximately 11 soldiers

3695 P60 (Witness statement of Ferid Spahić dated 4 November 1997), p. 6; Ferid Spahić, P61 (Transcript from Prosecutor v. Vasiljević), T. 386-387.

3696 P60 (Witness statement of Ferid Spahić dated 4 November 1997), p. 6; Ferid Spahić, P61 (Transcript from Prosecutor v. Vasiljević), T. 386-387; Ferid Spahić, P61 (Transcript from Prosecutor v. Lukić and Lukić), T. 568.

3697 P60 (Witness statement of Ferid Spahić dated 4 November 1997), p. 6; Ferid Spahić, P61 (Transcript from Prosecutor v. Vasiljević), T. 386.

3698 P60 (Witness statement of Ferid Spahić dated 4 November 1997), p. 6; Ferid Spahić, P61 (Transcript from Prosecutor v. Vasiljević), T. 384-386.

3699 Ferid Spahić, P61 (Transcript from Prosecutor v. Vasiljević), T. 386.

$3700 \quad$ P60 (Witness statement of Ferid Spahić dated 4 November 1997), p. 6; Ferid Spahić, P61 (Transcript from Prosecutor v. Vasiljević), T. 385.

3701 P60 (Witness statement of Ferid Spahić dated 4 November 1997), p. 6; Ferid Spahić, P61 (Transcript from Prosecutor v. Vasiljević), T. 385.

3702 P60 (Witness statement of Ferid Spahić dated 4 November 1997), p. 6; Ferid Spahić, P61 (Transcript from Prosecutor v. Vasiljević), T. 388.

3703 P60 (Witness statement of Ferid Spahić dated 4 November 1997), p. 7. See also Ferid Spahić, P61 (Transcript from Prosecutor v. Vasiljević), T. 387-388 (identifying 23 names which correspond to the list of named victims for this incident, see Prosecution Pre-Trial Brief, Confidential Appendix B. 19 of those names correspond to the bodies identified during the exhumation of the site, see P4902 (Sarajevo Cantonal Court record of Jama Paklenik exhumation, 15 August 2000), pp. 7-42).

3704 Ferid Spahić, P61 (Transcript from Prosecutor v. Lukić and Lukić), T. 529; P78 (Sketch drawn by Ferid Spahić). See also D3206 (Witness statement of Milovan Bjelica dated 30 March 2013), para. 58. Dragomir Obradović identified the location as Arbinjska Propast located seven kilometres from the village of Kalimanići in Sokolac. D3175 (Witness statement of Dragomir Obradović dated 24 March 2013), para. 21.

3705 P60 (Witness statement of Ferid Spahić dated 4 November 1997), p. 7; Ferid Spahić, P61 (Transcript from Prosecutor v. Vasiljević), T. 388-389.

3706 P60 (Witness statement of Ferid Spahić dated 4 November 1997), p. 7; Ferid Spahić, P61 (Transcript from Prosecutor v. Vasiljević), T. 388-389. 
walking in two columns next to the bus. ${ }^{3707}$ The bus stopped after about 100 metres, and the Bosnian Muslim men were ordered to get out of the bus, line up two-by-two, and walk on a forest path leading up to a hill. ${ }^{3708}$ One soldier asked "Zenga" and Spahić how many "Serb soldiers" they had killed and beat "Zenga". ${ }^{3709}$ When other soldiers told him not to beat "Zenga" that hard, he said that they would discuss this after seeing what conditions those Serbs waiting to be exchanged were in. ${ }^{3710}$

1089. After being ordered to walk in a line with their heads bent down for approximately 100 to 200 metres, the Bosnian Muslims were ordered to stop as they reached a clearing. ${ }^{3711}$ About nine soldiers lined up in two half circles around a bush. ${ }^{3712}$ In addition to Predrag Milisavljević, Spahić also identified Boriša Čeho, who was wearing a blue reserve police uniform, standing close to the site. ${ }^{3713}$ The first 10 Bosnian Muslim men from the column were ordered to step up "towards" the soldiers standing around the bush and Predrag Milisavljević started shooting at the first two Bosnian Muslims in the column with an automatic rifle. ${ }^{3714}$ The Bosnian Muslim men fell into a pit after being shot. ${ }^{3715}$ After the first 10 Bosnian Muslims from the column were shot, the two soldiers at the end of the column were called over by Vukojičić to join the other soldiers in the front. $^{3716}$ When the second group of ten men was being lined up to be shot, Spahić managed to

3707 P60 (Witness statement of Ferid Spahić dated 4 November 1997), pp. 7-8. The soldiers were in different clothes, including olive green and camouflage uniforms, civilian clothes, and one in "blue working suit".

3708 P60 (Witness statement of Ferid Spahić dated 4 November 1997), p. 8; Ferid Spahić, P61 (Transcript from Prosecutor v. Vasiljević), T. 389, 391-392; P78 (Sketch drawn by Ferid Spahić).

3709 P60 (Witness statement of Ferid Spahić dated 4 November 1997), p. 8; Ferid Spahić, P61 (Transcript from Prosecutor v. Vasiljević), T. 391-392; Ferid Spahić, P61 (Transcript from Prosecutor v. Lukić and Lukić), T. 529; Spahić had seen this soldier before in his hamlet when the Užice Corps was still there.

3710 P60 (Witness statement of Ferid Spahić dated 4 November 1997), p. 8; Ferid Spahić, P61 (Transcript from Prosecutor v. Vasiljević), T. 392.

3711 P60 (Witness statement of Ferid Spahić dated 4 November 1997), p. 8; Ferid Spahić, P61 (Transcript from Prosecutor v. Vasiljević), T. 392-393.

3712 P60 (Witness statement of Ferid Spahić dated 4 November 1997), p. 8; Ferid Spahić, P61 (Transcript from Prosecutor v. Vasiljević), T. 393-394; P79 (Sketch drawn by Ferid Spahić).

3713 Ferid Spahić, P61 (Transcript from Prosecutor v. Lukić and Lukić), T. 553; P60 (Witness statement of Ferid Spahić dated 4 November 1997), p. 8.

3714 P60 (Witness statement of Ferid Spahić dated 4 November 1997), p. 8; Ferid Spahić, P61 (Transcript from Prosecutor v. Vasiljević), T. 393-394; Ferid Spahić, P61 (Transcript from Prosecutor v. Lukić and Lukić), p. 553; P79 (Sketch drawn by Ferid Spahić).

3715 P60 (Witness statement of Ferid Spahić dated 4 November 1997), pp. 8-9; Ferid Spahić, P61 (Transcript from Prosecutor v. Vasiljević), T. 394, 397-398 (noting that he could not actually see the pit at the time but saw it when he returned at a later date).

3716 P60 (Witness statement of Ferid Spahić dated 4 November 1997), pp. 8-9; Ferid Spahić, P61 (Transcript from Prosecutor v. Lukić and Lukić), T. 553; Ferid Spahić, P61 (Transcript from Prosecutor v. Vasiljević), T. 395396; P79 (Sketch drawn by Ferid Spahić). 
escape and was shot at before taking shelter in the Bosnian Muslim village of Mrči. ${ }^{3717}$ As he was escaping, Spahić could hear the shooting continuing. ${ }^{3718}$

\section{(1) Forensic and documentary evidence regarding Scheduled Incident}

\section{$\underline{\text { A.14.2 }}$}

1090. John Clark reported on the exhumations carried out with respect to the Paklenik Cave. ${ }^{3719}$ The Chamber finds that the Paklenik cave site was located in a forest in the area near the village of Kalimanići in Sokolac municipality and is the same location referred to by Ferid Spahić as the pit into which the Bosnian Muslim men fell after being shot. ${ }^{3720}$ The post-mortem examination team received 73 whole male bodies. ${ }^{3721}$ They estimated that the ages of the bodies exhumed ranged from 15 to 75, with $74 \%$ aged between 30 and $55 .{ }^{3722}$ Of the 73 whole bodies found at Paklenik, 66 were identified, and 19 of the 66 identified bodies matched with the names of the 23 Bosnian Muslims on the bus who were identified by Ferid Spahić. ${ }^{3723}$ In addition to the 23 Bosnian Muslims who Spahić named, he also identified without naming them, the two sons of Musa Omerović and the two sons of Ismet Kustura and two of these bodies were also identified in the exhumation. $^{3724}$ At least 21 of the bodies exhumed from the Paklenik cave site are not linked to Scheduled Incident A.14.2. ${ }^{3725}$

3717 P60 (Witness statement of Ferid Spahić dated 4 November 1997), p. 9; Ferid Spahić, P61 (Transcript from Prosecutor v. Vasiljević), T. 403-404.

3718 P60 (Witness statement of Ferid Spahić dated 4 November 1997), p. 9; Ferid Spahić, P61 (Transcript from Prosecutor v. Vasiljević), T. 395-396, 398; Ferid Spahić, P61 (Transcript from Prosecutor v. Lukić and Lukić), T. 529.

3719 P4106 (John Clark's expert report entitled "Report of the Chief Pathologist, Paklenik Cave and Ivan Polje Grave-Sites (2000)", 30 July 2002), p. 5, Figure 1; P4107 (John Clark's expert report entitled “Supplementary Report of the Chief Pathologist, Paklenik Cave and Ivan Polje Grave-Sites (2000)", 30 September 2002).

3720 P4902 (Sarajevo Cantonal Court record of Jama Paklenik exhumation, 15 August 2000), p. 3; P4850 (Witness statement of Amor Mašović dated 23 March 2012), Annex A, p. 13; P4106 (John Clark's expert report entitled "Report of the Chief Pathologist, Paklenik Cave and Ivan Polje Grave-Sites (2000)", 30 July 2002), p. 5, Figure 1; P78 (Sketch drawn by Ferid Spahić); P79 (Sketch drawn by Ferid Spahić).

3721 P4106 (John Clark's expert report entitled "Report of the Chief Pathologist, Paklenik Cave and Ivan Polje Grave-Sites (2000)", 30 July 2002), pp. 5-6. Clark noted in his report that among the 75 bodies they received from the exhumation team, only 73 were whole bodies, while the remaining two turned out to be large body parts. See also P3410 (List of bodies exhumed in Višegrad during 2000-2001), p. 5.

3722 P4106 (John Clark's expert report entitled "Report of the Chief Pathologist, Paklenik Cave and Ivan Polje Grave-Sites (2000)", 30 July 2002), p. 6.

3723 P60 (Witness statement of Ferid Spahić dated 4 November 1997), p. 7; P3410 (List of bodies exhumed in Višegrad during 2000-2001); P4902 (Sarajevo Cantonal Court record of Jama Paklenik exhumation, 15 August 2000), pp. 7-42; P4853 (Updated Table 2 to the Report of Amor Mašović), pp. 49-51. Of the identified bodies exhumed, 39 names correspond to the list of named victims attached to the Prosecution's pre-trial brief. Prosecution Pre-Trial Brief, Confidential Appendix B. These 39 identified bodies include 19 of the 23 individuals named by Ferid Spahić.

3724 P60 (Witness statement of Ferid Spahić dated 4 November 1997), p. 7; P4902 (Sarajevo Cantonal Court record of Jama Paklenik exhumation, 15 August 2000), pp. 10, 33.

3725 P4106 (John Clark's expert report entitled "Report of the Chief Pathologist, Paklenik Cave and Ivan Polje Grave-Sites (2000)", 30 July 2002), p. 5. 
1091. Clothing that was not military was still present on all of the exhumed bodies. ${ }^{3726}$ Personal items were found on many of the victims, including watches, spectacles, combs, keys, money, cigarette lighters, and four miniature Korans. ${ }^{3727}$ A large number of the bodies exhumed from the cave were found with their hands tied behind their backs with wire. ${ }^{3728}$ None of the bodies were blindfolded and there were no other obvious objects of restraint. ${ }^{3729}$

1092. Gunshot injuries were found in 57 out of the 73 bodies. ${ }^{3730}$ Bullet casings were found and other injuries resulted from shotguns and shrapnel. ${ }^{3731}$ Evidence of blunt trauma was found in some of the bodies which had probably occurred before death. ${ }^{3732}$ There was also evidence that some of the men were still alive when thrown in the cave and died from the resulting injuries. ${ }^{3733}$ For 11 of the 73 bodies, it was not possible to determine the cause of death. ${ }^{3734}$ The Chamber is satisfied based on the large percentage of the shots fired which struck the trunk or head of the bodies that the shots were not random. ${ }^{3735}$ The Chamber is also satisfied that the pathological evidence suggests that many of the victims had been shot from behind which is consistent with

3726 P4106 (John Clark's expert report entitled "Report of the Chief Pathologist, Paklenik Cave and Ivan Polje Grave-Sites (2000)", 30 July 2002), p. 6.

3727 P4106 (John Clark's expert report entitled "Report of the Chief Pathologist, Paklenik Cave and Ivan Polje Grave-Sites (2000)", 30 July 2002), p. 6.

3728 P4902 (Sarajevo Cantonal Court record of Jama Paklenik exhumation, 15 August 2000), p. 6; P4106 (John Clark's expert report entitled "Report of the Chief Pathologist, Paklenik Cave and Ivan Polje Grave-Sites (2000)", 30 July 2002), p. 6.

3729 P4106 (John Clark's expert report entitled "Report of the Chief Pathologist, Paklenik Cave and Ivan Polje Grave-Sites (2000)", 30 July 2002), p. 6.

3730 P4106 (John Clark's expert report entitled "Report of the Chief Pathologist, Paklenik Cave and Ivan Polje Grave-Sites (2000)", 30 July 2002), p. 7. Among the 57 bodies where "convincing gunshots injuries" were found, 45 were shot only once or twice ( 29 of them were only shot once), while the other 12 were shot three to five times.

3731 P4106 (John Clark's expert report entitled "Report of the Chief Pathologist, Paklenik Cave and Ivan Polje Grave-Sites (2000)", 30 July 2002), pp. 8-9; P4902 (Sarajevo Cantonal Court record of Jama Paklenik exhumation, 15 August 2000), p. 3.

3732 P4106 (John Clark's expert report entitled "Report of the Chief Pathologist, Paklenik Cave and Ivan Polje Grave-Sites (2000)", 30 July 2002), p. 7.

3733 P4106 (John Clark's expert report entitled "Report of the Chief Pathologist, Paklenik Cave and Ivan Polje Grave-Sites (2000)", 30 July 2002), pp. 9-10.

3734 P4106 (John Clark's expert report entitled "Report of the Chief Pathologist, Paklenik Cave and Ivan Polje Grave-Sites (2000)", 30 July 2002), p. 7; P4107 (John Clark's expert report entitled "Supplementary Report of the Chief Pathologist, Paklenik Cave and Ivan Polje Grave-Sites (2000)", 30 September 2002), p. 2. In the original Report, it was stated that it was not possible to determine the cause of death for 15 men. In the Supplementary Report, however, 4 originally unascertained cases were also determined to have died from gunshot to the head ( 3 of the 4 ) or to the chest ( 1 of the 4 ). Note that during his testimony Clark also indicated that the cause of death of 15 people was unascertained. John Clark, T. 22702-22704 (10 January 2012).

3735 P4106 (John Clark's expert report entitled "Report of the Chief Pathologist, Paklenik Cave and Ivan Polje Grave-Sites (2000)", 30 July 2002), pp. 5-10; P4107 (John Clark's expert report entitled "Supplementary Report of the Chief Pathologist, Paklenik Cave and Ivan Polje Grave-Sites (2000)", 30 September 2002), p. 2. The Chamber notes that due to the badly decomposed state of the bodies an estimate of the distance of fire was not possible but that it was estimated that $85 \%$ of identifiable shots struck the trunk or the head of the bodies. 
Ferid Spahić's evidence about this incident and the way in which the victims were lined up before being shot. ${ }^{3736}$

\section{(2) $\underline{\text { Conclusion }}$}

1093. Considering (i) Spahić's evidence that the number of Bosnian Muslims taken to the execution site was between 50 to 52; (ii) that Spahić survived the execution; (iii) that 66 of the whole bodies exhumed from the mass grave were identified but that at least 21 of those identified bodies are not linked to Scheduled Incident A14.2; and (iv) that there were seven bodies exhumed from the mass grave which were not identified, the Chamber finds that approximately 45 Bosnian Muslim civilians were killed near Paklenik, close to the village of Kalimanići, in Sokolac municipality by Serb Forces on 15 June 1992.

viii. Vlasenica

\section{(A) Charges}

1094. Under Count 3, the Prosecution alleges that persecution, a crime against humanity was committed in Vlasenica as part of the objective to permanently remove Bosnian Muslims and/or Bosnian Croats from the Municipalities. ${ }^{3737}$ Under Count 1, the Prosecution further alleges that in certain municipalities, including Vlasenica, this persecutory campaign included or escalated to include conduct that manifested an intent to destroy in part the national, ethnical and/or religious groups of Bosnian Muslims and/or Bosnian Croats as such. ${ }^{3738}$

1095. Acts alleged to have been committed by Serb Forces and Bosnian Serb Political and Governmental Organs in Vlasenica include killings during and after the take-over, ${ }^{3739}$ killings related to detention facilities and killings committed during, and deaths resulting from, cruel and inhumane treatment at scheduled detention facilities. ${ }^{3740}$ The Prosecution characterises these acts as killing, an underlying act of genocide, under Count 1; persecution, a crime against humanity,

\footnotetext{
3736 P4106 (John Clark's expert report entitled "Report of the Chief Pathologist, Paklenik Cave and Ivan Polje Grave-Sites (2000)", 30 July 2002), p. 8. According to the report 42 were shot from behind, 9 from the side, 8 from the front, and 28 from an unknown direction. See P60 (Witness statement of Ferid Spahić dated 4 November 1997), p. 8; Ferid Spahić, P61 (Transcript from Prosecutor v. Vasiljević), T. 393-394; Ferid Spahić, P61 (Transcript from Prosecutor v. Lukić and Lukić), p. 553; P79 (Sketch drawn by Ferid Spahić). 
under Count 3; extermination, a crime against humanity, under Count 4; murder, a crime against humanity, under Count 5; and murder, a violation of the laws or customs of war, under Count $6 .{ }^{3741}$

1096. Other acts alleged to have been committed in Vlasenica by Serb Forces and Bosnian Serb Political and Governmental Organs include torture, beatings, and physical and psychological abuse, rape and other acts of sexual violence, during and after the take-over and in scheduled detention facilities, as well as the establishment and perpetuation of inhumane living conditions in detention facilities, as cruel or inhumane treatment, an act of persecution under Count $3 .{ }^{3742}$ In relation to Count 1, the Prosecution alleges that in scheduled detention facilities in Vlasenica thousands of Bosnian Muslims and Bosnian Croats were subjected to cruel and inhumane treatment, including torture, physical and psychological abuse, rape, other acts of sexual violence, and beatings by Serb Forces and Bosnian Serb Political and Governmental Organs; the Prosecution characterises this inhumane treatment as causing serious bodily or mental harm to members of the Bosnian Muslim and Bosnian Croat groups, an underlying act of genocide. ${ }^{3743}$ In addition, under Count 1 , the Prosecution alleges that members of the Bosnian Muslim and Bosnian Croat groups were detained under conditions of life calculated to bring about physical destruction, namely through cruel and inhumane treatment, including torture, physical and psychological abuse, rape, other acts of sexual violence, inhumane living conditions, forced labour, and the failure to provide adequate accommodation, shelter, food, water, medical care or hygienic sanitation facilities. ${ }^{3744}$

1097. Under Count 3, other acts of persecution alleged to have been committed in Vlasenica by Serb Forces and Bosnian Serb Political and Governmental Organs include (i) forcible transfer or deportation of Bosnian Muslims and Bosnian Croats from their homes; ${ }^{3745}$ (ii) unlawful detention in scheduled detention facilities, ${ }^{3746}$ (iii) forced labour at the frontline and the use of human shields; (iv) the appropriation or plunder of property, during and after the take-over, during arrests and detention and in the course of or following acts of deportation or forcible transfer; ${ }^{3747}$ (v) the wanton destruction of private property including homes and business premises and public

\footnotetext{
3741 Indictment, paras. 40(a)(i), 40(a)(ii), 63(a), 63(b).

3742 Indictment, para. 60(b), 60(c). See Scheduled Detention Facilities C.25.1, C.25.2, C.25.3. With respect to C.25.4, on 22 August 2014, the Prosecution filed the Notice of Withdrawal of Incident C.25.4 on the basis that it had not led evidence in relation to this detention facility.

3743 Indictment, para. 40(b).

3744 Indictment, paras. 40(c), 60(d), 60(h). See Scheduled Detention Facilities C.25.1, C25.2, C.25.3.

3745 Indictment, paras. 56, 60(f).

3746 Indictment, para. 60(g). See Scheduled Detention Facilities C.25, C.25.2, C.25.3.

3747 Indictment, para. 60(i).
} 
property; ${ }^{3748}$ and (vi) the imposition and maintenance of restrictive and discriminatory measures. $^{3749}$

1098. Under Counts 7 and 8, the Prosecution alleges deportation and inhumane acts (forcible transfer, respectively, as crimes against humanity. ${ }^{3750}$ The Prosecution alleges that, by the end of 1992, Serb Forces and Bosnian Serb Political and Governmental Organs had forcibly displaced Bosnian Muslims and Bosnian Croats from areas in Vlasenica in which they had been lawfully present. $^{3751}$ It is alleged that from March 1992, restrictive and discriminatory measures, arbitrary arrest and detention, harassment, torture, rape and other acts of sexual violence, killing, destruction of houses, as well as the threat of further such acts caused Bosnian Muslims and Bosnian Croats to flee in fear while others were physically driven out. ${ }^{3752}$ It is further alleged that acts of forcible displacement continued in Vlasenica between January and March 1993 when Serb Forces attacked the Cerska area of the Vlasenica municipality. ${ }^{3753}$

\section{(B) Lead-up}

1099. Vlasenica is a municipality in eastern BiH located to the south of Zvornik and to the west of Bratunac and Srebrenica. ${ }^{3754}$ Prior to the war the population of Vlasenica was approximately 34,000 and consisted of about 55\% Bosnian Muslims, 42\% Bosnian Serbs, and 0.1\% Bosnian Croats. $^{3755}$ The town of Vlasenica itself had a population of between 6,000 and $7,000 .{ }^{3756}$

\footnotetext{
3748 Indictment, para. 60(j). The Chamber notes that there are no cultural monuments and sacred sites with respect to Vlasenica in Schedule D of the Indictment.

3749 Indictment, para. 60(k). The restrictive and discriminatory measures alleged include the denial of freedom of movement; the removal from positions of authority; the invasion of privacy through arbitrary searches of homes; unlawful arrest and/or the denial of the right to judicial process; and/or the denial of equal access to public services.

3750 Indictment, paras. 68-75.

3751 Indictment, paras. 69, 72.

3752 Indictment, para. 71.

3753 Indictment, para. 72.

3754 D484 (Map of BiH); Izet Redžić, T. 17677 (23 August 2011).

3755 Izet Redžić, P3189 (Transcript from Prosecutor v. Krajišnik), T. 5005; Izet Redžić, T. 17674 (23 August 2011); D3093 (Witness statement of Mane Đurić dated 3 March 2013), para. 4; D3098 (Vlasenica Executive Board request, 17 January 1992), p. 3; P6200 (Excerpt from census records of 1991), p. 4; P6199 (Excerpt from censuses records of 1971, 1981 and 1991), p. 2; P4994 (Addendum to Ewa Tabeau's expert report entitled "Ethnic Composition in Internally Displaced Persons and Refugees from 27 Municipalities of BiH 1991 to 1997", 3 February 2009), pp. 31, 34, 40. For differing testimony as to the ethnic composition of the municipality, see D3007 (Witness statement of Zoran Jovanović dated 18 February 2013), para. 4; Zoran Jovanović, T. 34204-34205 (21 February 2013); P3212 (Witness statement of Ibro Osmanović dated 23 August 2011), para. 6.

3756 P3212 (Witness statement of Ibro Osmanović dated 23 August 2011), para. 7.
} 
Vlasenica formed part of the geographic link to Serbia, ${ }^{3757}$ which was part of the third Strategic Goal. $^{3758}$

1100. In the multi-party elections in 1990, for the Vlasenica Municipal Assembly, the SDS won 27 seats, the SDA won 26 seats, and seven seats were won by other parties. ${ }^{3759}$ After this election, the SDS and SDA divided leadership posts between them. ${ }^{3760}$ For example, the SDS selected Milenko Stanić as President of the Assembly ${ }^{3761}$ and Izet Redžić was selected by the SDA as President of the Executive Board. ${ }^{3762}$ The chief of the SJB was a Serb named Rade Bjelanović while the second in command was a Bosnian Muslim, Fadil Turković. ${ }^{3763}$ With time, there was increasing disagreement between Bosnian Serb and Bosnian Muslim representatives in the Assembly. ${ }^{3764}$

1101. Inter-ethnic relations in Vlasenica deteriorated after conflict broke out in Croatia. ${ }^{3765}$ Tomislav Savkić, the president of the Vlasenica SDS, ${ }^{3766}$ delivered speeches which emphasised that

3757 P921 (Transcript of $24^{\text {th }}$ session of RS Assembly, 8 January 1993), p. 46; D115 (Transcript of $25^{\text {th }}$ session of RS Assembly, 19-20 January 1993), p. 42; P972 (Robert Donia's expert report entitled "Thematic Excerpts from the Assembly or Republika Srpska, 1991-1996", 17 March 2008), p. 131.

3758 P956 (Transcript of $16^{\text {th }}$ session of SerBiH Assembly, 12 May 1992), e-court p. 9; P781 (Decision on six strategic goals for Bosnian Serb people, 12 May 1992); P1478 (Ratko Mladić's notebook, 27 May-31 July 1992), pp. 102-103.

3759 Izet Redžić, P3189 (Transcript from Prosecutor v. Krajišnik), T. 5006; Izet Redžić, T. 17685 (23 August 2011); D1645 (Report of Vlasenica Municipal Electoral Commission, 27 November 1990); Milenko Stanić, T. 33989 (19 February 2013); D4661 (Letter from the SDS Vlasenica Municipal Council to Radovan Karadžić, 6 November 1991) (informing the Accused of the election results).

3760 Izet Redžić, P3189 (Transcript from Prosecutor v. Krajišnik), T. 5006; Izet Redžić, T. 17695-17696 (23 August 2011); D1645 (Report of Vlasenica Municipal Electoral Commission, 27 November 1990). See also D2982 (Witness statement of Milenko Stanić dated 16 February 2013), para. 5; D4661 (Letter from the SDS Vlasenica Municipal Council to Radovan Karadžić, 6 November 1991); P3212 (Witness statement of Ibro Osmanović dated 23 August 2011), para. 11.

3761 Izet Redžić, P3189 (Transcript from Prosecutor v. Krajišnik), T. 5006; Izet Redžić, T. 17688 (23 August 2011); D2982 (Witness statement of Milenko Stanić dated 16 February 2013), para. 5. See also D2932 (Witness statement of Tomislav Savkić dated 11 February 2013), para. 9.

3762 Izet Redžić, P3189 (Transcript from Prosecutor v. Krajišnik), T. 5007; Izet Redžić, T. 17688 (23 August 2011); D2982 (Witness statement of Milenko Stanić dated 16 February 2013), para. 5. See also D2932 (Witness statement of Tomislav Savkić dated 11 February 2013), para. 9.

3763 Izet Redžić, T. 17694-17695 (23 August 2011); D3093 (Witness statement of Mane Đurić dated 3 March 2013), para. 5. See also D2932 (Witness statement of Tomislav Savkić dated 11 February 2013), para. 8; D4661 (Letter from the SDS Vlasenica Municipal Council to Radovan Karadžić, 6 November 1991); D3007 (Witness statement of Zoran Jovanović dated 18 February 2013), para. 5. Other parties including the SDP shared power with the SDA and SDS. D3007 (Witness statement of Zoran Jovanović dated 18 February 2013), para. 5.

3764 D2922 (Witness statement of Savo Čeliković dated 10 February 2013), para. 6; D2982 (Witness statement of Milenko Stanić dated 16 February 2013), para. 6; D3007 (Witness statement of Zoran Jovanović dated 18 February 2013), para. 5. See also D2932 (Witness statement of Tomislav Savkić dated 11 February 2013), paras. $10-11,32$.

3765 Izet Redžić, P3189 (Transcript from Prosecutor v. Krajišnik), T. 5008; Izet Redžić, T. 17698-17699 (23 August 2011); D2967 (Witness statement of Momir Deurić dated 16 February 2013), paras. 7-8, 10; D3093 (Witness statement of Mane Đurić dated 3 March 2013), para. 6; D2982 (Witness statement of Milenko Stanić dated 16 February 2013), para. 4; D3007 (Witness statement of Zoran Jovanović dated 18 February 2013), para. 7; D2932 (Witness statement of Tomislav Savkić dated 11 February 2013), para. 4. See also P3285 (Witness 
Serbs were under threat as they would be killed and eliminated from $\mathrm{BiH}$ when an Islamic state was formed. These speeches instilled fear amongst the Bosnian Serb population. ${ }^{3767}$ Redžić attended a meeting with Milenko Stanić where Stanić declared: "The moment $[\mathrm{BiH}]$ is proclaimed a sovereign state, we will draw up our borders in blood". ${ }^{3768}$ Inflammatory speeches were also delivered at SDA rallies. ${ }^{3769}$

\section{(1) Militarisation of Vlasenica}

1102. In 1991 Bosnian Muslims started leaving the JNA and boycotted the mobilisation upon instructions of the SDA leadership. ${ }^{3770}$ After this boycott, there was a mobilisation of local Bosnian Serbs. ${ }^{3771}$ In the spring of 1991, military units were formed in Bosnian Serb villages and there was an increased presence of uniformed men, including those wearing cockades and carrying automatic weapons. ${ }^{3772}$ For example, after the outbreak of war in Croatia in 1991, units were formed by the SDS in Vlasenica with between 1,200 and 1,500 troops located at a garrison formed in the Bosnian Serb settlement of Milići. ${ }^{3773}$ These units erected barricades, wore "Chetnik insignia" and cockades, maltreated people, and "instilled fear among the Muslim population”. 3774

statement of Sead Hodžić dated 24 May 2000), paras. 5, 10; Sead Hodžić, T. 18438-18439 (6 September 2011); D3048 (Witness statement of Božidar Trišić dated 24 February 2013), paras. 4-5.

Izet Redžić, P3189 (Transcript from Prosecutor v. Krajišnik), T. 5048; Tomislav Savkić, T. 33751 (15 February 2013).

Izet Redžić, P3189 (Transcript from Prosecutor v. Krajišnik), T. 5049.

Izet Redžić, P3189 (Transcript from Prosecutor v. Krajišnik), T. 5040-5041.

D2967 (Witness statement of Momir Deurić dated 16 February 2013), para. 9. See also D3007 (Witness statement of Zoran Jovanović dated 18 February 2013), para. 7; D2932 (Witness statement of Tomislav Savkić dated 11 February 2013), paras. 5-7.

Izet Redžić, P3189 (Transcript from Prosecutor v. Krajišnik), T. 5112-5113, 5151; Izet Redžić, T. 17732 (23 August 2011); D2932 (Witness statement of Tomislav Savkić dated 11 February 2013), paras. 12-14; D2922 (Witness statement of Savo Čeliković dated 10 February 2013), paras. 8-11; KDZ033, T. 18042-18043 (29 August 2011) (closed session). See also D2967 (Witness statement of Momir Deurić dated 16 February 2013), para. 13; Mane Đurić, T. 35076 (7 March 2013); D3007 (Witness statement of Zoran Jovanović dated 18 February 2013), paras. 9-13; D2982 (Witness statement of Milenko Stanić dated 16 February 2013), paras. 7 10; D1373 (Report of Vlasenica Municipal Assembly to SRBiH Presidency, 8 July 1991), p. 1.

P3212 (Witness statement of Ibro Osmanović dated 23 August 2011), paras. 12-13; Ibro Osmanović, T. 17971 (29 August 2011).

P3212 (Witness statement of Ibro Osmanović dated 23 August 2011), paras. 12-13; Ibro Osmanović, T. 17971 (29 August 2011); Izet Redžić, P3189 (Transcript from Prosecutor v. Krajišnik), T. 5017-5019, 5029-5030.

Izet Redžić, P3189 (Transcript from Prosecutor v. Krajišnik), T. 5008, 5140; Izet Redžić, T. 17727 (23 August 2011); P3212 (Witness statement of Ibro Osmanović dated 23 August 2011), para. 14. See also P2828 (Witness statement of Asim Džambasović dated 18 June 2011), paras. 55-56. Stanić testified that the SDS was not involved in the formation of these units. Milenko Stanić, T. 34021 (19 February 2013). However, the Chamber does not find Stanić's evidence to be reliable in this regard. In reaching that conclusion the Chamber found that Stanić's evidence was marked by evasiveness and indicators that he was witholding information from the Chamber.

Izet Redžić, P3189 (Transcript from Prosecutor v. Krajišnik), T. 5008, 5010. 
1103. In the autumn of 1991, both Bosnian Serbs and Bosnian Muslims were arming themselves. ${ }^{3775}$ In the second half of 1991, night watches were organised in villages and while they were initially mixed, they separated with time due to growing distrust between Bosnian Muslims and Bosnian Serbs. ${ }^{3776}$

1104. Weapons were brought to and stored in the Bosnian Serb village of Tišća and then taken by SDS members to Vlasenica town and secretly distributed to the local Bosnian Serb population to ensure that every Bosnian Serb home had a weapon. ${ }^{3777}$ Milenko Stanić was informed of which villages had to be provided with weapons and SDS members in Bosnian Serb villages were provided with weapons by Bjelanović. ${ }^{3778}$

1105. Starting in the summer of 1991, Redžić made contact with Dragomir Milošević, Commander of the JNA barracks in Han Pijesak. He discussed the situation in Vlasenica and the possibility of mobilising the TO, composed of both Bosnian Muslims and Bosnian Serbs, which could protect all citizens. ${ }^{3779}$ Dragomir Milošević in response said that "a Muslim cannot be given

3775 P3227 (Witness statement of KDZ033 dated 7 April 2010), para. 18 (under seal); KDZ033, T. 18026 (29 August 2011) (closed session). The Chamber finds that there were Bosnian Muslim armed formations in Vlasenica and that the SDA and TO Chief were involved in the arming of Bosnian Muslims. D2967 (Witness statement of Momir Deurić dated 16 February 2013), paras. 13; D3093 (Witness statement of Mane Đurić dated 3 March 2013), paras. 15-16; Mane Đurić, T. 35058-35059 (7 March 2013) (private session); D1646 (Report of Vlasenica SJB, 8 May 1992), pp. 1-3; D1648 (Official note of Vlasenica SJB, 17 June 1991), pp. 1-2; D1649 (Basic plan of engagement of Vlasenica SJB, 24 June 1991), pp. 1-2; D1651 (Order of ABiH Tuzla Main Staff, 9 August 1992), p. 2; D2922 (Witness statement of Savo Čeliković dated 10 February 2013), paras. 28, 31; D2982 (Witness statement of Milenko Stanić dated 16 February 2013), para. 11; D3007 (Witness statement of Zoran Jovanović dated 18 February 2013), paras. 14-16, 20; D2932 (Witness statement of Tomislav Savkić dated 11 February 2013), paras. 15-20, 22-24. See also D3008 (Video still of four armed men); D3012 (Video still of a letter "U”); Zoran Jovanović, T. 34176-34177 (21 February 2013); D1657 (Excerpt from book entitled "The Truth about Bratunac"), p. 2; D2944 (Witness statement of Zoran Durmić dated 12 February 2013), para. 19. Other witnesses testified that they were not aware of the existence or formation of the Patriotic League in Vlasenica. Izet Redžić, P3189 (Transcript from Prosecutor v. Krajišnik), T. 5113; Izet Redžić, T. 17702-17703, 17705, 17715, 17722-17723 (23 August 2011); Ibro Osmanović, T. 17958 (29 August 2011). However, the Chamber notes that Redžić's evidence on this issue was equivocal and he could not comment on the content of documents which related to Bosnian Muslim military formations in the municipality. Similarly, Osmanović simply testified that he was not aware of Bosnian Muslim military formations but did not rule out the possibility that they existed. The Chamber therefore does not rely on their evidence in this regard.

3776 D2922 (Witness statement of Savo Čeliković dated 10 February 2013), para. 7. See also D2932 (Witness statement of Tomislav Savkić dated 11 February 2013), para. 26. In July 1991 the Executive Board instructed the TO to place a guard outside the Municipal Assembly. D1654 (Conclusions from session of Vlasenica's Executive Board, 10 July 1991), p. 1.

3777 P3227 (Witness statement of KDZ033 dated 7 April 2010), para. 18 (under seal). See also Mane Đurić, T. 35058 (7 March 2013) (private session).

3778 Izet Redžić, P3189 (Transcript from Prosecutor v. Krajišnik), T. 5020-5021, 5141; Izet Redžić, T. 17702 (23 August 2011).

3779 Izet Redžić, P3189 (Transcript from Prosecutor v. Krajišnik), T. 5010-5013; Izet Redžić, T. 17678 (23 August 2011). Redžić contacted Dragomir Milošević because the JNA had taken all weapons that should have been available to the TO, and in the event of war, while the civilian authorities could mobilise the TO it would be subordinated to the military. See also P3201 (Order of SFRY Federal Secretariat for National Defence, 14 May 1990) (in which General Adžić issued an order for the JNA to take-over TO weapons depots in May 1990). 
a rifle, because that rifle would be turned against the Serbs". ${ }^{3780}$ In the first days of April 1992, a large number of soldiers and reservists were present in Vlasenica. Tanks, artillery, and armed vehicles from Milići, Han Pijesak, and Šekovići, were deployed, which created concern among the Bosnian Muslim population. ${ }^{3781}$ There was also shooting during the day and night. ${ }^{3782}$

1106. On 21 April 1992, the Bosnian Serb authorities mobilised the Bosnian Serb population of Vlasenica through the Vlasenica TO. Additional JNA units also arrived in the municipality from Šekovići, and volunteers were also deployed. ${ }^{3783}$ Dragomir Milošević visited the units deployed in Milići. He explained the presence of this unit, by saying that the "Serbs should have the military that would protect them". ${ }^{3784}$ Other leaders, including the Accused, Biljana Plavšić, Nikola Koljević and other high level SDS leaders visited the units located in Milići. ${ }^{3785}$

1107. The reserve police force in Vlasenica consisted of 70 to $80 \%$ Bosnian Serbs. ${ }^{3786}$ An order of the Presidency of SRBiH which directed police chiefs to ensure ethnic balance in the reserve police force at the municipal level was not respected by Bjelanović in Vlasenica. ${ }^{3787}$

\section{(2) Division of municipal structures}

1108. On 26 December 1991, despite the opposition of Bosnian Muslim representatives, ${ }^{3788}$ the Vlasenica Municipal Assembly issued a decision to join the SAO Birač. ${ }^{3789}$ On 18 February 1992,

Izet Redžić, P3189 (Transcript from Prosecutor v. Krajišnik), T. 5014.

Izet Redžić, P3189 (Transcript from Prosecutor v. Krajišnik), T. 5039-5040; see Adjudicated Fact 2687.

Izet Redžić, P3189 (Transcript from Prosecutor v. Krajišnik), T. 5040. There were also Bosnian Muslim attacks against Bosnian Serb villages. D3007 (Witness statement of Zoran Jovanović dated 18 February 2013), paras. 30-35; D3014 (Video clip of Neđelišta village); Zoran Jovanović, T. 34177-34189 (21 February 2013); D3009 (Excerpt from a notebook found in Neđeljišta village).

3783 D2922 (Witness statement of Savo Čeliković dated 10 February 2013), para. 22. See also D2967 (Witness statement of Momir Deurić dated 16 February 2013), para. 15; D3093 (Witness statement of Mane Đurić dated 3 March 2013), para. 14.

3784 Izet Redžić, P3189 (Transcript from Prosecutor v. Krajišnik), T. 5014-5015.

3785 Izet Redžić, P3189 (Transcript from Prosecutor v. Krajišnik), T. 5016-5017; Izet Redžić, T. 17679, 17727 (23 August 2011). Redžić further testified that the purpose of these visits was for the Accused, in co-operation with SDS officials, to prepare the Bosnian Serb people to fight their neighbours. However, it is not clear on what basis Redžić knew this information and the Chamber will not rely on Redžić's assessment in this regard.

3786 Izet Redžić, T. 17709 (23 August 2011). The Accused tendered a document which suggested that less than 10\% of police candidates nominated for a training course in March 1992 were Serb. D1647 (Order of SerBiH MUP, 12 March 1992). The Chamber notes that the document only refers to two names which relate to Vlasenica and does not consider that this undermines the credible evidence of Redžić regarding the composition of the reserve police force.

3787 Izet Redžić, P3189 (Transcript from Prosecutor v. Krajišnik), T. 5023-5025.

3788 The Chamber notes that some Bosnian Muslims did vote in favour of this decision. D2932 (Witness statement of Tomislav Savkić dated 11 February 2013), para. 28.

3789 D2932 (Witness statement of Tomislav Savkić dated 11 February 2013), para. 28; D2922 (Witness statement of Savo Čeliković dated 10 February 2013), paras. 18-19. Izet Redžić as President of the Executive Board of Vlasenica objected to the implementation of the decision on Vlasenica joining the SAO Birač. Mane Đurić, T. 35008-35010 (7 March 2013); D3098 (Vlasenica Executive Board request, 17 January 1992); D3007 (Witness statement of Zoran Jovanović dated 18 February 2013), para. 17.
} 
the Executive Council of the SAO Birač reached a conclusion that "[i]n order to take over power in the area of the Birač SAO as efficiently as possible" it was necessary to take stock of the situation, including with respect to infrastructure and the economic situation in the region. ${ }^{3790}$ After the formation of the SAO Birač, the municipalities in the region, including Vlasenica, established their own crisis staffs. ${ }^{3791}$

1109. On 4 April 1992, following the instructions of the SDS Main Board, the Municipal Board of the SDS in Vlasenica passed a decision establishing a crisis staff of the Serb Municipality of Vlasenica ("Vlasenica Crisis Staff”) and Milenko Stanić was appointed President. ${ }^{3792}$

1110. Negotiations between Bosnian Serb and Bosnian Muslim representatives took place from 30 March until 11 April 1992. ${ }^{3793}$ The SDS representatives prepared a proposal and placed

3790 P6113 (Minutes from $1^{\text {st }}$ session of Executive Council of SAO Birač, 18 February 1992), p. 3. Savkić acknowledged that in his position within the SAO he worked on political and ethnic issues. Tomislav Savkić, T. 33756 (15 February 2013). Milenko Stanić was the President of the Executive Council of the SAO Birač. D2932 (Witness statement of Tomislav Savkić dated 11 February 2013), paras. 28-29; D3007 (Witness statement of Zoran Jovanović dated 18 February 2013), para. 17.

3791 P3227 (Witness statement of KDZ033 dated 7 April 2010), para. 19 (under seal). Defence witnesses testified that while the SAO was constituted it never became operational and had no influence on the municipalities. D2922 (Witness statement of Savo Čeliković dated 10 February 2013), para. 18; Savo Čeliković, T. 3356033561 (13 February 2013); D3093 (Witness statement of Mane Đurić dated 3 March 2013), paras. 7-8; D2982 (Witness statement of Milenko Stanić dated 16 February 2013), para. 13; Milenko Stanić, T. 33996, 3400034002, 34041 (19 February 2013); P6112 (Excerpt from Naser Orić's book entitled "Srebrenica"), pp. 2, 5. The Chamber does not find the evidence of these witnesses as to whether the SAO was operational to be reliable and considers that it is contradicted by reliable evidence to the contrary. In addition the Chamber notes that the evidence of the relevant witnesses was marked by inconsistencies, evasiveness, and other indicators that the witnesses were not forthright in this regard.

3792 P6121 (Decision of Vlasenica's SDS Municipal Board, 4 April 1992), p. 1; P3212 (Witness statement of Ibro Osmanović dated 23 August 2011), para. 40. See also P3227 (Witness statement of KDZ033 dated 7 April 2010), para. 19 (under seal); D3093 (Witness statement of Mane Đurić dated 3 March 2013), paras. 9-10. The SJB Chief of Vlasenica and the Commander of the TO were also members of the Vlasenica Crisis Staff. But see D2932 (Witness statement of Tomislav Savkić dated 11 February 2013), para. 34; Tomislav Savkić, T. $33777-$ 33779 (15 February 2013). The Chamber notes that Savkić disputed the date on which the Vlasenica Crisis Staff was created. However, the Chamber finds his evidence in this regard to be equivocal and marked by contradictions. Similarly Stanić did not recall that the Vlasenica Crisis Staff met before 21 April 1992 and testified that it did not function in its full capacity as some members moved to the newly formed Milići municipality. Stanić was confronted with documents which suggested that the Vlasenica Crisis Staff was functioning and issued decisions before that date but he maintained it only started sitting after 21 April 1992 and that some of the documents produced by the Crisis Staff were drafted in the secretariat of the Municipal Assembly. He also drew into question the authenticity of the stamps used on the documents. D2982 (Witness statement of Milenko Stanić dated 16 February 2013), paras. 29-30; Milenko Stanić, T. 34007-34011, 3404734048 (19 February 2013); P6137 (Decision of Vlasenica Crisis Staff, 19 April 1992); P6138 (Decision of Vlasenica Crisis Staff, 19 April 1992); P3214 (Decision of Vlasenica Crisis Staff, 19 April 1992). Having regard to the weight of evidence received, and the equivocal nature of Stanić's evidence, the Chamber is satisfied that the documents issued by the Vlasenica Crisis Staff are authentic. Defence witnesses also testified that the Vlasenica Crisis Staff only operated for a short period of time. D3093 (Witness statement of Mane Đurić dated 3 March 2013), paras. 12-13; D2982 (Witness statement of Milenko Stanić dated 16 February 2013), paras. 30, 32. However, considering credible evidence about the actions of the Vlasenica Crisis Staff, and considering the credibility assessment of the relevant witnesses in fn. 3791, the Chamber does not find their evidence to be reliable with respect to the dissolution of the Vlasenica Crisis Staff. The Chamber does find however, that by 17 June 1992 a War Commission for Vlasenica was established. P5486 (RS Presidency Confirmation of Appointment of Members of the War Commission in Vlasenica, 17 June 1992). 
pressure on Bosnian Muslims to agree to a division of Vlasenica into three parts: Serbian Vlasenica, Muslim Vlasenica, and Milići municipality. ${ }^{3794}$ Redžić was instructed by Alija Izetbegović to prolong the negotiations to allow as many Bosnian Muslims as possible to evacuate from Vlasenica to Bosnian Muslim majority areas. ${ }^{3795}$ Savkić threatened that, if the Bosnian Muslims refused the partition or stalled the negotiations, armed intervention would follow and that there were "tanks ready to shed blood". 3796 Bosnian Muslims were also asked to return their weapons. ${ }^{3797}$ During these negotiations, Milenko Stanić told Redžić that there "were no more possibilities" and that he had orders which had come from "higher up", which he was simply obeying. ${ }^{3798}$

1111. In an attempt to protect the Bosnian Muslim population from possible attacks, the Bosnian Muslim representatives eventually agreed to the proposed division of the municipality. ${ }^{3799}$ The

3793 Izet Redžić, P3189 (Transcript from Prosecutor v. Krajišnik), T. 5042-5043, 5084. See also D2932 (Witness statement of Tomislav Savkić dated 11 February 2013), para. 34.

3794 Izet Redžić, P3189 (Transcript from Prosecutor v. Krajišnik), T. 5040, 5042-5043, 5050-5051. See also D2922 (Witness statement of Savo Čeliković dated 10 February 2013), para. 20; D2932 (Witness statement of Tomislav Savkić dated 11 February 2013), para. 34; D1286 (Agreement on division of Vlasenica, 11 April 1992).

3795 Izet Redžić, P3189 (Transcript from Prosecutor v. Krajišnik), T. 5043-5044, 5051-5052; Izet Redžić, T. 17739 (23 August 2011). See also Mane Đurić, T. 35062 (7 March 2013); D2982 (Witness statement of Milenko Stanić dated 16 February 2013), para. 20; D2932 (Witness statement of Tomislav Savkić dated 11 February 2013), para. 35; Tomislav Savkić, T. 33749 (15 February 2013). Savkić testified that this demonstrated that the SDA leadership was probably planning to attack Vlasenica. D2932 (Witness statement of Tomislav Savkić dated 11 February 2013), para. 36; Tomislav Savkić, T. 33749-33750 (15 February 2013). However, the Chamber finds that Savkić's evidence in this regard is purely speculative and does not rely on his evidence in this regard. The Chamber also received a note handwritten by Redžić, which referred to organising Bosnian Muslim defence. The document also included a typewritten addition which suggested that the note confirmed that the SDA "had a plan ready for taking over power in nearly all segments of life". D1656 (Handwritten document by Izet Redžić), p. 1. See also Decision on Accused's Motion to Admit Documents Previously Marked for Identification, 4 November 2011, para. 14. While Redžić acknowledged that the handwriting on the document was his, he testified that the type written addition was used to create a "false picture" and that the date was a forgery. Izet Redžić, T. 17742-17743 (23 August 2011). Having regard to Redžić's evidence in this regard and the uncertain provenance of the type-written additions, the Chamber does not rely on the typewritten additions to support the suggestion that the SDA had a plan to take-over power in Vlasenica but finds that there were preparations for Bosnian Muslim defence in Vlasenica. The Chamber further finds that there were rumours about the possibility of a forceful take-over of Vlasenica by Bosnian Muslims. KDZ033, T. 18031 (29 August 2011) (closed session).

3796 Izet Redžić, P3189 (Transcript from Prosecutor v. Krajišnik), T. 5047. See also Adjudicated Fact 2689. Defence witnesses testified that (i) there was no such threat; (ii) the decision to divide the municipality was adopted without any pressure; (iii) the division did not form part of a goal to establish Serb control over territory; and (iv) the proposed division was to avoid war given increasing tensions. D2922 (Witness statement of Savo Čeliković dated 10 February 2013), para. 21; Savo Čeliković, T. 33559-33560 (13 February 2013); D2982 (Witness statement of Milenko Stanić dated 16 February 2013), para. 14. The Chamber does not find this evidence to be reliable. In reaching that conclusion the Chamber noted that the testimony of Čeliković was marked by inconsistencies and the testimony of Stanić was marked by evasiveness and other indicators that the witness was not forthright nor candid in this regard.

3797 Izet Redžić, P3189 (Transcript from Prosecutor v. Krajišnik), T. 5050-5051; Izet Redžić, T. 17702 (23 August 2011).

3798 Izet Redžić, P3189 (Transcript from Prosecutor v. Krajišnik), T. 5057, 5070.

3799 Izet Redžić, T. 17736-17737 (23 August 2011). 
agreement on the division of the municipality was signed on 11 April $1992 .^{3800}$ Notwithstanding this agreement, Bosnian Muslim leaders, including Redžić, left the municipality a few days later. $^{3801}$

1112. On 13 April 1992, Milenko Stanić reported to the Bosnian Serb Assembly that the Vlasenica Municipal Assembly would adopt the protocol on the agreement for the territorial delineation of the municipality and urged all citizens who had fled Vlasenica to return to their homes; negotiating teams were urged to pay special attention to the balance of urban settlement and to "enable each member of a particular nation to become part of his or her ethnic community". 3802

While the decision on the division of the municipality was adopted, only the decision on the establishment of the Milići municipality was verified as Bosnian Muslim representatives did not want to implement the agreement. ${ }^{3803}$ In a briefing attended by Mladić in June 1992, Milenko Stanić reported there were still problems with the delineation of the municipalities of Vlasenica and Milići. $^{3804}$

(C) Take-over of Vlasenica

1113. On 19 April 1992 the Vlasenica Crisis Staff adopted a decision to take-over power in the territory of the Serb Municipality of Vlasenica. ${ }^{3805}$ On the same day, the Vlasenica Crisis Staff proclaimed that there was an imminent threat of war and that it would assume the functions of the

3800 Izet Redžić, P3189 (Transcript from Prosecutor v. Krajišnik), T. 5053, 5084; Izet Redžić, T. 17739 (23 August 2011); see Adjudicated Fact 2688. See also D2967 (Witness statement of Momir Deurić dated 16 February 2013), para. 14; Mane Đurić, T. 35014-35015 (7 March 2013); D1286 (Agreement on division of Vlasenica, 11 April 1992).

3801 Izet Redžić, P3189 (Transcript from Prosecutor v. Krajišnik), T. 5053. See also D2967 (Witness statement of Momir Deurić dated 16 February 2013), para. 14.

3802 D1655 (Conclusions from extraordinary session of Vlasenica Municipal Assembly, 13 April 1992), p. 1.

3803 D2982 (Witness statement of Milenko Stanić dated 16 February 2013), para. 15; Milenko Stanić, T. 34042 (19 February 2013); P961 (Shorthand Record of 12 ${ }^{\text {th }}$ session of SerBiH Assembly, 24 March 1992), pp. $23-24$. See also D3007 (Witness statement of Zoran Jovanović dated 18 February 2013), para. 25; D2932 (Witness statement of Tomislav Savkić dated 11 February 2013), para. 34; Tomislav Savkić, T. 33751, 33760 (15 February 2013).

3804 P1478 (Ratko Mladić's notebook, 27 May-31 July 1992), p. 233.

3805 P3214 (Decision of Vlasenica Crisis Staff, 19 April 1992); P3212 (Witness statement of Ibro Osmanović dated 23 August 2011), para. 26. Đurić testified that these decisions were adopted by the Vlasenica Crisis Staff because of (i) the departure of Bosnian Muslims from the municipality; (ii) poor inter-ethnic relations and the large quantity of weapons which were held by citizens; and (iii) the fact that the joint assembly could not function. D3093 (Witness statement of Mane Đurić dated 3 March 2013), paras. 18-21. Stanić also testified that the creation of the Serb Municipality of Vlasenica was not intended to mean an ethnically pure municipality. Milenko Stanić, T. 34041-34042 (19 February 2013). The Chamber does not consider this evidence, so far as it relates to the motivation or reasons behind these decisions, to be reliable. In reaching that conclusion the Chamber noted that evidence of the relevant witnesses was marked by contradictions, evasiveness and indicators that they were witholding information from the Chamber. For the Chamber's analysis and conclusion with respect to the reason for the take-over of Vlasenica, see Section IV.A.3: Overarching JCE and the Accused's responsibility. 
Municipal Assembly. ${ }^{3806}$ It also passed a decision establishing the TO Staff ${ }^{3807}$ and a Serbian Assembly. ${ }^{3808}$ Milenko Stanić was appointed president of the Serb Municipality of Vlasenica. ${ }^{3809}$

1114. On or about 21 April 1992, the Bosnian Serb police, the $\mathrm{TO}^{3810}$ and 200 JNA soldiers from the Novi Sad Corps with the assistance of armed local Serbs took control of Vlasenica. ${ }^{3811}$ The White Eagles also came to Vlasenica at the beginning of the conflict but their operations were limited to the vicinity of the bauxite mine in Milići. ${ }^{3812}$ The Serb Forces took control of the municipality premises, the police station, the post office, the bank, the court, factories, and the medical centre. ${ }^{3813}$ Serb flags were "hoisted around town, and very loud Serbian nationalist music was playing through the public address system". ${ }^{3814}$ The Vlasenica Crisis Staff was involved in the co-ordination of the take-over with the JNA and continued to command and control units in the

3806 P6137 (Decision of Vlasenica Crisis Staff, 19 April 1992); D3093 (Witness statement of Mane Đurić dated 3 March 2013), paras. 18-19. The SAO Birač on 29 April 1992 proclaimed a state of war in the entire SAO. P2615 (Decision of Birač Crisis Staff, 29 April 1992). P6140 (Decision of Vlasenica Crisis Staff, 19 April 1992).

P3214 (Decision of Vlasenica Crisis Staff, 19 April 1992). But see Milenko Stanić, T. 34010 (19 February 2013). The Chamber refers to its assessment in fn. 3792 relating to Stanić's evidence about the date when the Vlasenica Crisis Staff was established.

P6139 (Decision of Vlasenica Municipal Assembly, 30 March 1992). But see Milenko Stanić, T. 34014 (19 February 2013) (disputing the veracity of this document).

The TO included Bosnian Serb reservists from Vlasenica, Milići and Šekovići, and later became part of the Vlasenica Brigade of the VRS. P3227 (Witness statement of KDZ033 dated 7 April 2010), para. 20 (under seal).

P3227 (Witness statement of KDZ033 dated 7 April 2010), para. 20 (under seal); KDZ033, T. 18029 (29 August 2011) (closed session); P3285 (Witness statement of Sead Hodžić dated 24 May 2000), para. 13; P2761 (RS MUP report on work for period April to December 1992), p. 7. See also D3093 (Witness statement of Mane Đurić dated 3 March 2013), paras. 27-28; D2982 (Witness statement of Milenko Stanić dated 16 February 2013), para. 22; D3007 (Witness statement of Zoran Jovanović dated 18 February 2013), paras. 2122; D2932 (Witness statement of Tomislav Savkić dated 11 February 2013), para. 37; D4002 (Letter from BiH MUP to Vasvija Vidović, 4 July 1995), p. 34; P1478 (Ratko Mladić's notebook, 27 May-31 July 1992), p. 232 (Stanić reported that they launched an operation in Vlasenica on 21 April 1992). P62 (Witness statement of Nedžad Hadžiefendić dated 3 October 1997), p. 3. Before the take-over some Bosnian Serb locals had already been mobilised into the police and on the day of the take-over were standing outside of and took control of the enterprises and institutions in the town of Vlasenica. P3227 (Witness statement of KDZ033 dated 7 April 2010), paras. 20-21 (under seal).

KDZ033, T. 18033, 18038 (29 August 2011) (closed session).

P3212 (Witness statement of Ibro Osmanović dated 23 August 2011), paras. 18-19, 23-25. See also Adjudicated Fact 2690; D2932 (Witness statement of Tomislav Savkić dated 11 February 2013), para. 37; Ibro Osmanović, T. 17961 (29 August 2011). Defence witnesses also testified that the role of the JNA was to separate "warring sides in case of an armed clash" and that Serb Forces entered Vlasenica to pre-empt a Bosnian Muslim operation to attack Vlasenica. D3007 (Witness statement of Zoran Jovanović dated 18 February 2013), para. 22; D2932 (Witness statement of Tomislav Savkić dated 11 February 2013), para. 37. However, the Chamber does not find this evidence to be reliable. In reaching that conclusion, the Chamber noted that the testimony of the relevant witnesses was marked by evasiveness, bias, insincerity and indicators that they were witholding information from the Chamber.

P3227 (Witness statement of KDZ033 dated 7 April 2010), para. 21 (under seal). 
field until 28 June 1992 when units became part of the $1^{\text {st }}$ Birčani Brigade which later became part of the Vlasenica Brigade. ${ }^{3815}$

1115. There was no armed Bosnian Muslim resistance to the take-over of Vlasenica and no casualties. $^{3816}$ Members of the Novi Sad Corps came to Vlasenica following reports that Bosnian Serbs had been killed but found these reports to be false and treated the Bosnian Muslim population fairly. ${ }^{3817}$ The "liberation" of the town of Vlasenica on 21 April 1992 marked the start of combat operations in the area and; a number of villages in the municipality were also "liberated". 3818

1116. Members of the SDA leadership had already left Vlasenica before the take-over, ${ }^{3819}$ but after the take-over SDA members were brought into custody and asked for weapons; other Bosnian Muslims were also arrested. ${ }^{3820}$

(D) Developments in Vlasenica after take-over

1117. After the take-over, the seat of the Serb Municipality of Vlasenica was moved to the Boskit office building in Vlasenica town. ${ }^{3821}$ Thereafter, the Vlasenica Crisis Staff took control of life in Vlasenica. ${ }^{3822}$

3815 P2636 (Report of $1^{\text {st }}$ Vlasenica Light Infantry Brigade, 19 December 1994), p. 1. Defence witnesses disputed the veracity of this report and testified that the Vlasenica Crisis Staff did not co-ordinate the take-over and that the author of this report was not in Vlasenica at the time. Tomislav Savkić, T. 33774-33777 (15 February 2013); Milenko Stanić, T. 34017-34019 (19 February 2013). However, the Chamber does not consider the testimony of the witnesses to be reliable in this regard. In reaching that conclusion the Chamber noted that their testimony was marked by contradictions, evasiveness, and indicators that they were not completely forthright in their evidence. The Chamber thus has no reason to doubt the veracity of this report. P3227 (Witness statement of KDZ033 dated 7 April 2010), para. 20 (under seal); Sead Hodžić, T. 18431-18432 (6 September 2011); D2982 (Witness statement of Milenko Stanić dated 16 February 2013), para. 22; D3007 (Witness statement of Zoran Jovanović dated 18 February 2013), para. 21; D2932 (Witness statement of Tomislav Savkić dated 11 February 2013), para. 37; Tomislav Savkić, T. 33774 (15 February 2013) (testifying that this operation was not co-ordinated by the SDS Crisis Staff); D2922 (Witness statement of Savo Čeliković dated 10 February 2013), para. 22; P3212 (Witness statement of Ibro Osmanović dated 23 August 2011), paras. 28, 59. See also D3093 (Witness statement of Mane Đurić dated 3 March 2013), para. 14; D1652 (Report of ABiH's Vlasenica municipal staff, 19 July 1992), p. 1.

3817 P3212 (Witness statement of Ibro Osmanović dated 23 August 2011), paras. 17, 21; Ibro Osmanović, T. 17960, 17962 (29 August 2011); Izet Redžić, P3189 (Transcript from Prosecutor v. Krajišnik), T. 5060-5062; Izet Redžić, T. 17679 (23 August 2011); Sead Hodžić, T. 18432 (6 September 2011).

3818 P6458 (Report of $1^{\text {st }}$ Birač Infantry Brigade, 30 October 1993), pp. 3, 7. The report names over 15 villages and other strategic points.

3819 KDZ033, T. 18030 (29 August 2011) (closed session). See also D1652 (Report of ABiH's Vlasenica municipal staff, 19 July 1992), p. 1.

3820 P3212 (Witness statement of Ibro Osmanović dated 23 August 2011), paras. 35-36; P3216 (Vlasenica SJB crime register, April-December 1992), p. 3. No Bosnian Serbs were prosecuted for the illegal possession of weapons. Mane Đurić, T. 35059-35060 (7 March 2013).

3821 D3093 (Witness statement of Mane Đurić dated 3 March 2013), para. 63. See also Adjudicated Fact 2690. The Chamber notes that the Adjudicated Fact also refers to the setting up of a "Serb Crisis Staff" after the take-over. However, the Chamber notes that this is not consistent with evidence cited in para. 1109 about the formation of the Vlasenica Crisis Staff before this date. 


\section{(1) Control of movement and other restrictions}

1118. From April 1992, Bosnian Serb police, acting under the authorisation of an SDS member, ${ }^{3823}$ established check-points on all access roads towards Vlasenica and on local roads to villages. $^{3824}$ The Vlasenica Crisis Staff issued passes for people to move around town and introduced a curfew. ${ }^{3825}$ In order for Bosnian Muslims to pass check-points, move around or leave the municipality they had to be issued a travel pass by the Bosnian Serb municipal authorities. ${ }^{3826}$ Even if they did have such passes, they were often arrested and detained. On the other hand, Bosnian Serb citizens did not have to obtain movement passes. ${ }^{3827}$ Bosnian Muslims who were involved with the SDA or other Muslim organisations were not issued such passes. ${ }^{3828}$ Transit passes were usually only issued to women, children and the elderly with able bodied men only able to secure such passes if they had connections or had substantial amounts of money to pay for such passes, particularly if they wanted to leave the municipality. ${ }^{3829}$

1119. Graffiti appeared on the houses of eminent Muslims with the words "Ustasha", "Muslims out", "We will slaughter", "Out", and "This is Serb, this is Serbia". 3830 Following the take-over, three houses belonging to Bosnian Muslims, including the commander of the police, were torched

3822 P3227 (Witness statement of KDZ033 dated 7 April 2010), para. 44 (under seal). See also P3212 (Witness statement of Ibro Osmanović dated 23 August 2011), para. 48.

3823 See Adjudicated Fact 2692. Đurić testified that check-points were not erected by the SDS but by the TO and were later taken over by the police. D3093 (Witness statement of Mane Đurić dated 3 March 2013), para. 65. The Chamber refers to its credibility assessment in fn. 3791 in concluding that it does not find his evidence with respect to the lack of involvement of the SDS in this regard to be reliable.

P3227 (Witness statement of KDZ033 dated 7 April 2010), para. 22 (under seal).

P3212 (Witness statement of Ibro Osmanović dated 23 August 2011), paras. 33, 48; Ibro Osmanović, T. 17977 (29 August 2011). See also P3217 (Travel pass issued by Vlasenica Crisis Staff, undated).

P3212 (Witness statement of Ibro Osmanović dated 23 August 2011), paras. 43-44, 46-48; Ibro Osmanović, T. 17972 (29 August 2011); P3217 (Travel pass issued by Vlasenica Crisis Staff, undated); P3227 (Witness statement of KDZ033 dated 7 April 2010), para. 22 (under seal). See also Adjudicated Fact 2691.

P3227 (Witness statement of KDZ033 dated 7 April 2010), para. 22 (under seal). The Chamber does find however, that Bosnian Serb conscripts also needed a military pass in order to leave the municipality. KDZ033, T. 18062-18064 (31 August 2011) (closed session). The Chamber notes that Stanić himself was issued passes. D2984 (Travel passes issued to Milenko Stanić). One of the passes issued to Stanić was in his capacity as a military conscript. The Chamber finds that the issuance of passes to Bosnian Serb military conscripts does not undermine the evidence that there were additional restrictions faced by Bosnian Muslim civilians which did not apply to Bosnian Serbs. Defence witnesses testified that passes were issued on request to everyone regardless of ethnicity to allow them to move around freely due to war operations. D3093 (Witness statement of Mane Đurić dated 3 March 2013), para. 64; D2982 (Witness statement of Milenko Stanić dated 16 February 2013), para. 33; D2983 (Vlasenica Crisis Staff travel pass); Milenko Stanić, T. 33990-33991 (19 February 2013). The Chamber does not find the evidence to be reliable in this regard and refers to its credibility assessment of the relevant witnesses in fn. 3791 in reaching that conclusion.

P3227 (Witness statement of KDZ033 dated 7 April 2010), para. 22 (under seal); KDZ033, T. 18064 (31 August 2011) (closed session).

P3212 (Witness statement of Ibro Osmanović dated 23 August 2011), para. 45; P3227 (Witness statement of KDZ033 dated 7 April 2010), paras. 11, 22, 55 (under seal); KDZ033, T. 18064, 18095 (31 August 2011) (closed session).

P3212 (Witness statement of Ibro Osmanović dated 23 August 2011), para. 39. 
in broad daylight and the fire brigade was prevented from taking action. ${ }^{3831}$ Bosnian Muslims unlike Bosnian Serbs had limitations on the amount of money they could withdraw from the bank. $^{3832}$ Bosnian Serbs started boycotting Bosnian Muslim cafés and shops, there was gun fire at night and increasing intimidation; altogether this created fear among the Bosnian Muslim population. ${ }^{3833}$ The intimidation included the beating, arrest and questioning of Bosnian Muslim men, including Bosnian Muslim intellectuals and people of influence. In addition, television broadcasts from Sarajevo were cut and Bosnian Muslims were threatened that they should not go to work. $^{3834}$ Members of the Bosnian Serb police selected the houses of wealthy Bosnian Muslims and took away their property. ${ }^{3835}$ The cars of some Bosnian Muslim detainees were also confiscated by the Bosnian Serb police. ${ }^{3836}$ Non-Serb intellectuals, political leaders and the wealthy who had not fled before the conflict began were the first to be "forcibly removed" from Vlasenica. ${ }^{3837}$

1120. Muslims working in state-owned companies and other public services in Vlasenica municipality were dismissed from their jobs. ${ }^{3838}$ Muslim shop-keepers feared keeping their

3831 P3212 (Witness statement of Ibro Osmanović dated 23 August 2011), para. 37.

3832 Ibro Osmanović, T. 18006 (29 August 2011).

3833 P3285 (Witness statement of Sead Hodžić dated 24 May 2000), paras. 7-12. There were also incidents of shooting in Bosnian Serb villages. D2932 (Witness statement of Tomislav Savkić dated 11 February 2013), para. 25. See also P3212 (Witness statement of Ibro Osmanović dated 23 August 2011), para. 38 (stating that immediately following the take-over of Vlasenica, Bosnian Serb businesses re-opened while Bosnian Muslim shops remained closed).

3834 P3285 (Witness statement of Sead Hodžić dated 24 May 2000), paras. 14-15, 19, 21; Sead Hodžić, T. 1844618447 (6 September 2011); P418 (Witness statement of Mersudina Saim-Hodžić dated 24 May 2002), p. 4. The Chamber received evidence of killings by Serb Forces of Bosnian Muslims after the take-over of Vlasenica between May and October 1992 but these killings are not charged pursuant to Schedules A or B of the Indictment. See fn. 13. P3227 (Witness statement of KDZ033 dated 7 April 2010), paras. 61-64, 66, 79 (under seal); KDZ033, T. 18098-18099 (31 August 2011) (closed session); P3242 (Map of Vlasenica showing locations of exhumation sites); P3260 (List of missing civilians in Vlasenica in 1992), pp. 3, 12 (under seal); P3212 (Witness statement of Ibro Osmanović dated 23 August 2011), para. 193; Ibro Osmanović, T. 17948 (25 August 2011). The Chamber received evidence from Mašović and Tabeau about a large number of other individuals who went missing from Vlasenica and who were later exhumed. However, in the absence of other evidence linking these to scheduled incidents, the Chamber has not relied on this evidence in this regard. P4854 (Updated Table 1 to the Report of Amor Mašović), p. 2; P4852 (Report of Amor Mašović, 20-21 October 2009), p. 3; P4856 (Appendix B to the Prosecution Pre-Trial Brief filed on 18 May 2009 marked by Amor Mašović), pp. 29-30; P4853 (Updated Table 2 to the Report of Amor Mašović), pp. 51-55; D2250 (Ewa Tabeau's report entitled "Deaths and Disappearance of BiH Muslims 1992-1995," 25 April 2012); Ewa Tabeau, T. 28411-28412 (2 May 2012). The Chamber also received evidence about the destruction of the Vlasenica mosque but Schedule D of the Indictment does not charge the destruction of cultural monuments and sacred sites in Vlasenica. P3227 (Witness statement of KDZ033 dated 7 April 2010), para. 57 (under seal); KDZ033, T. 18095-18096 (31 August 2011) (closed session). See also Mane Đurić, T. 35055-35056 (7 March 2013); Zoran Jovanović, T. 34195-34196, 34212-34213 (21 February 2013); D2932 (Witness statement of Tomislav Savkić dated 11 February 2013), para. 99; Tomislav Savkić, T. 33719-33720 (14 February 2013), T. 33744 (15 February 2013).

3835 P3227 (Witness statement of KDZ033 dated 7 April 2010), para. 51 (under seal).

3836 P3227 (Witness statement of KDZ033 dated 7 April 2010), para. 81 (under seal).

3837 P3227 (Witness statement of KDZ033 dated 7 April 2010), para. 53 (under seal).

3838 See Adjudicated Fact 2686; P3227 (Witness statement of KDZ033 dated 7 April 2010), para. 24 (under seal). Defence witnesses testified that (i) Bosnian Muslim were not dismissed from their jobs; (ii) some workers no 
businesses open, and the salaries of the Bosnian Muslim workers of the local bauxite mine were stopped. Their Serb colleagues on the other hand, continued to receive salaries. ${ }^{3839}$ On 14 May 1992, the local bauxite mine announced that "not a single Muslim should return to work". 3840 In August 1992, at one company, an announcement was made that the Vlasenica Crisis Staff had ordered Bosnian Muslims to return to work and that those who were absent would lose their jobs and property. ${ }^{3841}$

\section{(2) Confiscation of weapons and interrogations}

1121. The Vlasenica Crisis Staff issued an ultimatum for the surrender of weapons by 21 April 1992 and guaranteed the security of citizens who complied with this deadline. ${ }^{3842}$ Bosnian Muslims were ordered to surrender their weapons to the Serb authorities or face arrest. ${ }^{3843}$ The Bosnian Serb police went through town and called for the surrender of all weapons and stated that while the army was there for protection, force would be used against those who did not comply. ${ }^{3844}$ Following this announcement, groups of Bosnian Muslims handed over their hunting and personal weapons to the SJB. ${ }^{3845}$ Following this hand over, the Bosnian Serb police began arresting Bosnian Muslims who were suspected of still possessing weapons. ${ }^{3846}$ From 27 to 30 April 1992, orders

longer reported for work; and (iii) companies started operating at reduced capacity and cancelled work arrangements for workers who did not show up at work and such notices were also given to Bosnian Serbs. D2982 (Witness statement of Milenko Stanić dated 16 February 2013), para. 18; D3093 (Witness statement of Mane Đurić dated 3 March 2013), para. 62; D2922 (Witness statement of Savo Čeliković dated 10 February 2013), para. 4; Savo Čeliković, T. 33550-33551 (13 February 2013). However, the Chamber does not consider this evidence to be reliable. In reaching that conclusion the Chamber refers to its credibility assessment of the relevant witnesses in fns. 3791 and 3796.

3839 See Adjudicated Fact 2686.

3840 Izet Redžić, P3189 (Transcript from Prosecutor v. Krajišnik), T. 5028-5029; Izet Redžić, T. 17681 (23 August 2011). Redžić further testified that not a single Bosnian Muslim was working in any company or institution in Vlasenica by mid-May 1992. Izet Redžić, P3189 (Transcript from Prosecutor v. Krajišnik), T. 5028. However, the Chamber accepted the evidence of KDZ033 that even in June 1992, some Bosnian Muslims continued to work in the municipality and thus does not accept Redžić's contrary evidence in this regard. KDZ033, T. 18061 (31 August 2011) (closed session).

3841 P3212 (Witness statement of Ibro Osmanović dated 23 August 2011), para. 41. See also Adjudicated Fact 2693.

3842 P3215 (Decision of Vlasenica Crisis Staff, 19 April 1992), p. 1; P3212 (Witness statement of Ibro Osmanović dated 23 August 2011), paras. 30-32; Ibro Osmanović, T. 17962 (29 August 2011); D3093 (Witness statement of Mane Đurić dated 3 March 2013), para. 22. See also D3093 (Witness statement of Mane Đurić dated 3 March 2013), para. 22 (stating that the decision applied to all citizens regardless of nationality).

3843 See Adjudicated Fact 2693; P3227 (Witness statement of KDZ033 dated 7 April 2010), para. 20 (under seal); KDZ033, T. 18039-18040 (29 August 2011) (closed session). Bosnian Serbs were not expected to hand over their weapons. See also D3007 (Witness statement of Zoran Jovanović dated 18 February 2013), para. 21 (stating that it was the Bosnian Serb TO which called for the surrender of weapons and that many Bosnian Muslims complied); D3010 (Photograph of weapons); D3011 (Photograph of weapons). See also Ibro Osmanović, T. 17988 (29 August 2011).

3844 P3212 (Witness statement of Ibro Osmanović dated 23 August 2011), paras. 27, 31; Ibro Osmanović, T. 17964, 17968, 17999 (29 August 2011).

3845 P3212 (Witness statement of Ibro Osmanović dated 23 August 2011), paras. 28-29; P3227 (Witness statement of KDZ033 dated 7 April 2010), paras. 20-21 (under seal).

3846 P3227 (Witness statement of KDZ033 dated 7 April 2010), para. 20 (under seal). KDZ033 also stated that many of these arrests were a pretext for gaining information including where money had been hidden. However, the 
were issued by the TO which noted that Bosnian Muslims still possessed illegal firearms in a number of villages and the Vlasenica TO decided in co-operation with the SJB to "mop up the terrain" to seize these weapons. The Vlasenica TO commander ordered that in carrying out this operation, measures should be taken to "prevent unnecessary casualties and wounding". 3847

1122. On 19 May 1992, the Vlasenica Crisis Staff issued an instruction to the Commander of the TO and the Chief of the SJB to control the entry of armed persons into the town. ${ }^{3848}$ All Bosnian Serb members of the Vlasenica TO Staff moved to the Serb Municipality of Vlasenica. ${ }^{3849}$

1123. By mid May 1992, the JNA had withdrawn but left behind its equipment, armoured vehicles, tanks and weapons, which were given to local Bosnian Serbs. ${ }^{3850}$ While the JNA was in Vlasenica, the focus was in forcing the Bosnian Muslims to surrender their weapons, but when the JNA left there was a shift towards rounding up, detaining and interrogating Bosnian Muslims. ${ }^{3851}$ Bosnian Muslims were arrested in their homes and taken for interrogation. ${ }^{3852}$ At first those taken for interrogation were on lists which identified people suspected of being involved in the arming of Bosnian Muslims or owning weapons. ${ }^{3853}$ Over time however, "for all practical purposes almost every single Muslim was brought in for interrogation"; some were released while others were not. $^{3854}$

\section{(3) Establishment of Bosnian Serb SJB}

1124. The Vlasenica Crisis Staff decided to disarm the active duty and reserve members of the joint police force, the reserve police was mobilised, and a new Bosnian Serb SJB was formed. ${ }^{3855}$ In May 1992, Mane Đurić replaced Bjelanović as the Chief of the Vlasenica SJB, and Bjelanović

Chamber does not know on what basis KDZ033 formed this conclusion and does not rely on his evidence in this regard.

3847 D3100 (Reports of Vlasenica TO, 27-30 April 1992); Mane Đurić, T. 35012-35015 (7 March 2013).

3848 P3218 (Letter from Vlasenica Crisis Staff to TO commander and SJB chief, 19 May 1992).

3849 D1652 (Report of ABiH's Vlasenica municipal staff, 19 July 1992), p. 1.

3850 P3212 (Witness statement of Ibro Osmanović dated 23 August 2011), paras. 52, 59; Ibro Osmanović, T. 1796217963, 17982 (29 August 2011). See also P3227 (Witness statement of KDZ033 dated 7 April 2010), para. 25 (under seal); Izet Redžić, P3189 (Transcript from Prosecutor v. Krajišnik), T. 5114.

3851 P3227 (Witness statement of KDZ033 dated 7 April 2010), para. 25 (under seal).

3852 KDZ033, T. 18062 (31 August 2011) (closed session).

3853 KDZ033, T. 18064-18065 (31 August 2011) (closed session); P3212 (Witness statement of Ibro Osmanović dated 23 August 2011), paras. 34, 51; Ibro Osmanović, T. 17989-17990, 17994 (29 August 2011).

3854 KDZ033, T. 18065 (31 August 2011) (closed session).

3855 D3093 (Witness statement of Mane Đurić dated 3 March 2013), paras. 23-25, 30. While Đurić also refers to an attempt by a paramilitary formation to take-over the SJB, the evidence on this point is equivocal and it is unclear whether this refers to a Bosnian Serb or Bosnian Muslim paramilitary formation and the Chamber does not rely on his evidence in this regard. See also P2761 (RS MUP report on work for period April to December 1992), p. 7; P6138 (Decision of Vlasenica Crisis Staff, 19 April 1992). 
became the SJB Chief in Milići municipality. ${ }^{3856}$ Radenko Stanić was the Commander of the SJB and the Assistant Commander was Dragomir Šargić. ${ }^{3857}$ While the Vlasenica Crisis Staff informed Bosnian Muslims that they could continue their employment, in practice, Bosnian Muslims were dismissed from their positions in the municipal authorities and the police. ${ }^{3858}$ After these dismissals the police became a "Serb only body" with police officers wearing a white patch with an eagle and a white ribbon on their sleeves. ${ }^{3859}$ Joint police or joint security organs were no longer organised. $^{3860}$ Đurić, in a briefing attended by Mladić in June 1992, reported that an SJB had been set up and was involved in confiscating weapons. ${ }^{3861}$

\section{(4) Formation of Special Platoon}

1125. Bosnian Serbs received summons for mobilisation and a platoon was formed, which was named the Special Police Platoon. ${ }^{3862}$ This platoon, which consisted of between 20 to 30 men who had no previous police experience; they had criminal records ${ }^{3863}$ and refused to place themselves under the command of the Vlasenica TO. ${ }^{3864}$ The Special Police Platoon was commanded by

3856 Rade Bjelanović was identified as the "right-hand man” of the SDS Main Board member, Rajko Đukić. P3227 (Witness statement of KDZ033 dated 7 April 2010), para. 15 (under seal).

3857 P3227 (Witness statement of KDZ033 dated 7 April 2010), para. 15 (under seal); P3226 (List of Vlasenica SJB active workers in May 1992); Zoran Durmić, T. 33857 (18 February 2013). See also D3093 (Witness statement of Mane Đurić dated 3 March 2013), para. 29.

3858 P3227 (Witness statement of KDZ033 dated 7 April 2010), paras. 15, 24 (under seal); P3212 (Witness statement of Ibro Osmanović dated 23 August 2011), paras. 49, 69; P3226 (List of Vlasenica SJB active workers in May 1992). See also P3285 (Witness statement of Sead Hodžić dated 24 May 2000), para. 13. Deurić stated that people continued to work until mid-April 1992 but then Bosnian Muslims stopped coming to work at the TO out of fear. D2967 (Witness statement of Momir Deurić dated 16 February 2013), para. 11. The Chamber does not consider that evidence that some Bosnian Muslims stopped coming to work out of fear is inconsistent with others being dismissed from their jobs. Đurić testified that Bosnian Muslim police decided of their own accord not to return to work and were not given decisions on termination of employment or sent on forced leave. However, he was confronted and contradicted by reference to his prior testimony where he testified that all Bosnian Serb police officers were re-employed while Bosnian Muslims were laid off or told to take annual leave and it was done to change the ethnic composition of the police. D3093 (Witness statement of Mane Đurić dated 3 March 2013), para. 25; Mane Đurić, T. 35063-35065 (7 March 2013) (private session). In light of these contradictions, the Chamber does not consider Đurić's evidence to be reliable in this regard. See also KDZ033, T. 18044 (29 August 2011) (closed session). While KDZ033 testified that to his knowledge Bosnian Muslims left the MUP of their own accord, the Chamber finds his answers in this regard to be equivocal.

3859 P3285 (Witness statement of Sead Hodžić dated 24 May 2000), para. 13; Sead Hodžić, T. 18444 (6 September 2011).

3860 Ibro Osmanović, T. 17977 (29 August 2011).

$3861 \quad$ P1478 (Ratko Mladić's notebook, 27 May-31 July 1992), p. 233.

3862 P3227 (Witness statement of KDZ033 dated 7 April 2010), paras. 6-8 (under seal); P3234 (Mobilisation order, 26 April 1992) (under seal); P3235 (Mobilisation order) (under seal); KDZ033, T. 18041 (29 August 2011) (closed session).

3863 KDZ033, T. 18045 (29 August 2011) (closed session); KDZ033, T. 18047-18048 (31 August 2011) (closed session); P3227 (Witness statement of KDZ033 dated 7 April 2010), para. 64 (under seal).

3864 D3093 (Witness statement of Mane Đurić dated 3 March 2013), paras. 31-33, 35; Mane Đurić, T. 35065-35066, 35067 (7 March 2013) (private session); P3227 (Witness statement of KDZ033 dated 7 April 2010), para. 64 (under seal). 
Miroslav Kraljević and was within the organisational structure of the SJB. ${ }^{3865}$ Members of the Special Police Platoon received payment from the SJB and reported daily to Kraljević at the SJB. $^{3866}$ They were under the command of the Vlasenica Crisis Staff. ${ }^{3867}$

1126. The Special Police Platoon engaged in illegal activities and mistreated Bosnian Muslims. ${ }^{3868}$ For example, members of the Special Police Platoon would beat Bosnian Muslims during interrogations. ${ }^{3869}$ In mid-June 1992, they looted goods from Bosnian Muslim homes while conducting searches and in one case moved into an abandoned Bosnian Muslim house. ${ }^{3870}$ Bosnian Muslims who remained in their homes were interrogated to identify people considered to be Muslim leaders in the municipality ${ }^{3871}$ and were also harassed by members of the police who came to their homes at night and demanded money. ${ }^{3872}$ The Special Police Platoon conducted these operations on a daily basis and sometimes at night. ${ }^{3873}$ Đurić and Radenko Stanić initially permitted members of the Special Police Platoon and reserve police to loot non-Serb property and misappropriate non-Serb houses. ${ }^{3874}$ The Special Police Platoon was disbanded in August $1992 .{ }^{3875}$

3865 P3227 (Witness statement of KDZ033 dated 7 April 2010), paras. 8, 14, 16-17 (under seal); KDZ033, T. 18050 (31 August 2011) (closed session); P3225 (List of Vlasenica SJB reserve workers in September 1992); P3244 (Payroll list of reserve police force in Vlasenica).

3866 P3227 (Witness statement of KDZ033 dated 7 April 2010), paras. 10, 13 (under seal).

$3867 \quad$ See Adjudicated Fact 2694.

3868 Mane Đurić, T. 35066 (7 March 2013), 35067 (7 March 2013) (private session); P3227 (Witness statement of KDZ033 dated 7 April 2010), para. 64 (under seal). Đurić testified that whenever the SJB received reports about the illegal behaviour of members of the Special Police Platoon, the commander was called, reports were made against the individuals who were removed from the unit but the SJB did not have the time to control this unit. D3093 (Witness statement of Mane Đurić dated 3 March 2013), paras. 34-36. However, having noted the contradictions and evasiveness in Đurić's testimony, the Chamber does not consider his evidence in this regard is reliable.

3869 KDZ033, T. 18065 (31 August 2011) (closed session).

3870 P3227 (Witness statement of KDZ033 dated 7 April 2010), para. 26 (under seal).

3871 P3227 (Witness statement of KDZ033 dated 7 April 2010), para. 26 (under seal).

3872 P3227 (Witness statement of KDZ033 dated 7 April 2010), para. 27 (under seal).

3873 P3227 (Witness statement of KDZ033 dated 7 April 2010), para. 25 (under seal).

3874 P3227 (Witness statement of KDZ033 dated 7 April 2010), para. 51 (under seal).

3875 The Special Police Platoon was disbanded following an order of the MUP Minister, which disbanded all special units attached to the SJB and placed them under the command of the VRS. P6192 (Vlasenica SJB report, 10 August 1992); D3094 (Romanija-Birač CSB instructions, 28 July 1992); Mane Đurić, T. 35068-35071 (7 March 2013); D3093 (Witness statement of Mane Đurić dated 3 March 2013), para. 38 ; P6193 (List of reserve police force of Vlasenica SJB). While this platoon was disbanded, its commander and his deputy remained employed by the MUP. This order also required that individuals who committed crimes be dismissed from the MUP and be put at the disposal of the VRS. The Vlasenica SJB did dismiss members of the reserve police for crimes they had committed. D3094 (Romanija-Birač CSB instructions, 28 July 1992), pp. 1-2; D3095 (Romanija-Birač CSB instructions, 25 July 1992); D3096 (Vlasenica SJB report, 6 August 1992); D3097 (Vlasenica SJB report, 25 September 1992). 


\section{(5) Take-over of surrounding villages}

1127. After the take-over of Vlasenica, representatives of the Bosnian Serb authorities drove from village to village and used megaphones to call on all Bosnian Muslims to hand over their weapons. $^{3876}$

1128. The Special Police Platoon first took-over "several villages" on the road from Vlasenica to Milići. ${ }^{3877}$ Kraljević received orders for operations against Bosnian Muslim villages from Radenko Stanić. ${ }^{3878}$ The aim was to "cleanse" the area of Bosnian Muslims and Kraljević instructed the Special Police Platoon that the "territory had to be 100 percent clean and that none of the Muslims should remain in the area". 3879

1129. In May and June 1992, the Special Police Platoon, led by Kraljević, conducted two operations, one in Sušica, and another in Gradina and other Muslim hamlets in the municipality, occasionally encountering armed resistance. ${ }^{3800}$ In accordance with Kraljević's instruction, the Special Police Platoon set Bosnian Muslim houses on fire. ${ }^{3881}$ In the village of Piskavice only the homes belonging to Bosnian Muslims were torched while the Bosnian Serbs continued to live in their houses. 3882

1130. In early May 1992, Kraljević ordered the Special Police Platoon to conduct an operation in Turalići, during which the village was "burnt almost entirely to the ground". ${ }^{3883}$ In late May 1992, Kraljević ordered the Special Police Platoon to take-over the village of Gradina and the surrounding area. ${ }^{3884}$ The Gradina operation was discussed in an informal meeting at the SJB building attended by officials, including Đurić and Radenko Stanić. ${ }^{3885}$ On the morning of the operation, inhabitants were instructed by loudspeaker to surrender their weapons and warned that if

\footnotetext{
3876 P3285 (Witness statement of Sead Hodžić dated 24 May 2000), para. 17; Sead Hodžić, T. 18449 (6 September 2011); D3007 (Witness statement of Zoran Jovanović dated 18 February 2013), para. 21.

3877 [REDACTED].

3878 [REDACTED].

3879 [REDACTED].

$3880 \quad$ See Adjudicated Fact 2694.

3881 [REDACTED]; see Adjudicated Fact 2694.

3882 [REDACTED].

3883 [REDACTED].

3884 [REDACTED]. See also Adjudicated Fact 2694; [REDACTED].

3885 [REDACTED]. Some of these individuals were listed as employees of the SJB in August 1992. P6382 (Public Auditing Service confirmation of debit; Payroll of Vlasenica SJB, August 1992).
} 
they failed to do so, military action would be taken. ${ }^{3886}$ The Special Police Platoon was supported by police officers from the Vlasenica SJB and a VRS unit with a tank and two APCs. ${ }^{3887}$

1131. The members of the Special Police Platoon were ordered by Kraljević to search for weapons, detain men who surrendered for questioning, kill those men who tried to escape, and send women and children to Vlasenica town. ${ }^{3888}$ After the escape of a Bosnian Muslim man, Kraljević instructed the Special Police Platoon not to take any more male Muslim prisoners alive. ${ }^{3889}$ There were armed clashes with Bosnian Muslims during the take-over of Gradina. ${ }^{3890}$ After Bosnian Muslims fled, Serb Forces torched many Bosnian Muslim homes in Gradina and surrounding villages. ${ }^{3891}$ Some men were arrested, detained and then transferred to Sušica camp. ${ }^{3892}$ Following the attack on Gradina, Serb Forces took part in operations in the villages of Borići, Barice and Hrastovac. ${ }^{3893}$

1132. On 7 June 1992, the Command of the Eastern Bosnia Corps issued an order to secure Milići, protect the Milići-Vlasenica route, and "mop up" the Birač territory of remaining enemy forces. ${ }^{3894}$

1133. In early June 1992, the Special Police Platoon was ordered to return to Gradina where they burnt down the remaining non-Serb houses and then almost all Bosnian Muslim houses in the area were destroyed. $^{3895}$ This second operation covered a larger area, including the Bosnian Muslim villages from Drum to the north. ${ }^{3896}$ The Special Police Platoon, members of the TO, SJB Milići, members of the VRS and local Bosnian Serbs took part in the operation. ${ }^{3897}$ Kraljević explicitly ordered the units to torch all Bosnian Muslim houses because "you can see for yourselves that if we don't set fire to these houses, they'll return later on". ${ }^{3898}$ After this operation, the area of Gradina

\footnotetext{
3886 [REDACTED].

3887 [REDACTED]. The Chamber places no weight on Svetozar Andrić's testimony that he did not believe that the army participated in this operation given that he himself had not heard of the operation. Svetozar Andrić, T. 41673-41674 (22 July 2013).

3888 [REDACTED]. See also Adjudicated Fact 2694.

3889 [REDACTED].

3890 [REDACTED]; D2932 (Witness statement of Tomislav Savkić dated 11 February 2013), paras. 60-61.

3891 [REDACTED].

3892 See Adjudicated Fact 2694. [REDACTED].

3893 [REDACTED].

3894 P5400 (Order of Eastern Bosnia Corps, 7 June 1992), pp. 1-2. But see Svetozar Andrić, T. 41669-41670 (22 July 2013) (testifying that "cleansing" involved dealing with both Bosnian Muslim and Bosnian Serb paramilitaries). The Chamber notes that Andrić's evidence was marked by contradictions and indicators of insincerety which undermine the reliability of his evidence in this regard.

3895 [REDACTED]. See also Adjudicated Fact 2694.

3896 [REDACTED]. See also P6458 (Report of $1^{\text {st }}$ Birač Infantry Brigade, 30 October 1993), pp. 3. For evidence specific to the village of Drum, see Scheduled Incident A.15.1.

3897 [REDACTED].

3898 [REDACTED]. See also Adjudicated Fact 2694.
} 
was "ethnically pure" with nobody living in the Bosnian Muslim villages. ${ }^{3899}$ Thereafter, approximately 500 Bosnian Muslims, including many women and children, were captured and transported to Sušica camp or sent to the bus station or football field in Vlasenica for transportation to Kladanj. ${ }^{3900}$

1134. The Special Police Platoon proceeded to "cleanse" the villages of Drum, Piškavica, Alihodžići and Pustoše. ${ }^{3901}$ Local Bosnian Serbs were involved in the looting of Bosnian Muslim villages. $^{3902}$ During these operations, Serb Forces, including the Special Police Platoon, took-over the Bosnian Muslim villages of Dragaši, Dzemat, Drum, Alihadžić, Piskavice, Pijuć, Gradina, Turalići, Zaklopača, Kašaha, Nedeljište, Peševina, Hodžići, Mršići, Smajići, and Kuljančić. ${ }^{3903}$ Following these take-overs the non-Serb inhabitants escaped to Kladanj, Cerska and other villages while the others were captured and taken to Sušica camp. ${ }^{3904}$ Some Bosnian Muslim men who were captured were interrogated and beaten. ${ }^{3905}$

(a) Scheduled Incident A.15.2

1135. The Prosecution alleges that at least 60 people were killed in the village of Zaklopača on 16 May 1992.

1136. Zaklopača was a Bosnian Muslim village located approximately six kilometres from Vlasenica. ${ }^{3906}$ The village was the only Bosnian Muslim village in the area and was surrounded by Bosnian Serb villages. $^{3907}$

\footnotetext{
3899 [REDACTED].

3900 [REDACTED]. For evidence on detention at Sušica camp, see Scheduled Detention Facility C.25.3.

3901 [REDACTED].

3902 [REDACTED].

3903 [REDACTED]. See also P6459 (Map of Vlasenica); P6458 (Report of $1^{\text {st }}$ Birač Infantry Brigade, 30 October 1993), p. 7.

3904 [REDACTED].

3905 [REDACTED]. While the Chamber also received evidence that Bosnian Muslims were killed during the attacks on Bosnian Muslim villages, with the exception of the alleged killings in the villages of Drum and Zaklopača, it notes that these killings are not charged pursuant to Schedules A or B of the Indictment. See fn. 13. [REDACTED]; P3242 (Map of Vlasenica showing locations of exhumation sites); P3212 (Witness statement of Ibro Osmanović dated 23 August 2011), paras. 54-55; [REDACTED].

3906 P3285 (Witness statement of Sead Hodžić dated 24 May 2000), para. 2; P418 (Witness statement of Mersudina Saim-Hodžić dated 24 May 2002), p. 2; P6459 (Map of Vlasenica). See also D3048 (Witness statement of Božidar Trišić dated 24 February 2013), para. 3; D3050 (Map of Zaklopača marked by Božidar Trišić). There were a few Bosnian Serb houses on the outskirts of the village and overlooking hills.

3907 P3285 (Witness statement of Sead Hodžić dated 24 May 2000), para. 3; P3212 (Witness statement of Ibro Osmanović dated 23 August 2011), para. 56; P3227 (Witness statement of KDZ033 dated 7 April 2010), para. 50 (under seal); KDZ033, T. 18088 (31 August 2011) (closed session); P418 (Witness statement of Mersudina Saim-Hodžić dated 24 May 2002), p. 2; Zoran Jovanović, T. 34206 (21 February 2013).
} 
1137. In the lead-up to the attack on the village, reserve soldiers gathered and there was a large number of soldiers in the area; they initially wore the regular JNA uniforms but later added "Četnik insignias" and cockades. ${ }^{3908}$ Out of fear, Bosnian Muslims left their homes and started hiding in the woods at night. ${ }^{3909}$

1138. Approximately 10 to 15 days before the attack on Zaklopača, the village was visited by a delegation of Bosnian Serb leaders who demanded the surrender of weapons and assured the population of their security if the weapons were surrendered. ${ }^{3910}$ The licensed weapons held by Bosnian Muslims in the village were also confiscated by Bosnian Serb police..$^{3911}$

1139. On 3 May 1992, the nearby Bosnian Muslim village of Žutica was burned down and a bus full of people who had been expelled from the village following the attack by Serb Forces was brought to Zaklopača. ${ }^{3912}$ Many of the men from Žutica had been severely beaten. They described how Serb Forces had attacked the village, arrested men, and raped women, which caused fear. ${ }^{3913}$

1140. On 15 May 1992, the Birač Brigade issued an order for its units to take co-ordinated action with the Birač TO to "restore control over the territory". 3914 On 16 May 1992, Serb Forces entered in four or five army vehicles and one police car and attacked the village. ${ }^{3915}$ Some of the soldiers

3908 P418 (Witness statement of Mersudina Saim-Hodžić dated 24 May 2002), p. 2. See also D3007 (Witness statement of Zoran Jovanović dated 18 February 2013), para. 22; P3285 (Witness statement of Sead Hodžić dated 24 May 2000), para. 26; Sead Hodžić, T. 18428 (6 September 2011).

3909 Izet Redžić, P3189 (Transcript from Prosecutor v. Krajišnik), T. 5062; P3285 (Witness statement of Sead Hodžić dated 24 May 2000), para. 23.

3910 P418 (Witness statement of Mersudina Saim-Hodžić dated 24 May 2002), pp. 2-3; see Adjudicated Fact 2697. See also P3227 (Witness statement of KDZ033 dated 7 April 2010), para. 50 (under seal).

3911 P3285 (Witness statement of Sead Hodžić dated 24 May 2000), paras. 16-18. But see D3048 (Witness statement of Božidar Trišić dated 24 February 2013), para. 30 (stating that both Bosnian Serbs and Bosnian Muslims were asked for their weapons).

3912 P3285 (Witness statement of Sead Hodžić dated 24 May 2000), para. 24; Sead Hodžić, T. 18433, 18450 (6 September 2011). But see D3048 (Witness statement of Božidar Trišić dated 24 February 2013), paras. 6-7 (stating that the Bosnian Muslims from Žutica were fleeing from Bosnian Muslim forces, who were attempting to mobilise them). The Chamber notes that Trišić was contradicted during his cross-examination on this issue and does not rely on his evidence in this regard. Božidar Trišić, T. 34494-34496, 34509 (28 February 2013).

3913 P3285 (Witness statement of Sead Hodžić dated 24 May 2000), para. 24; Sead Hodžić, T. 18433 (6 September 2011). While the witness also testified about reports of killings in this village, these killings are not charged pursuant to Schedules A or B of the Indictment. See fn. 13.

3914 D3890 (Order of Birač Brigade, 15 May 1992), pp. 1, 3; D3886 (Witness statement of Svetozar Andrić dated 16 July 2013), para. 2.

3915 P3285 (Witness statement of Sead Hodžić dated 24 May 2000), paras. 27-28; P418 (Witness statement of Mersudina Saim-Hodžić dated 24 May 2002), p. 3; see Adjudicated Fact 2698. See also P3227 (Witness statement of KDZ033 dated 7 April 2010), para. 49 (under seal). The Serb Forces included members of the police, men wearing JNA uniforms, camouflage uniforms and civilian clothes. Defence witnesses testified that this incident was not a planned operation and was an example of both sides taking revenge, that it must have been an attack by "outsiders", and that both Bosnian Serb and Bosnian Muslim houses were shot at. D2932 (Witness statement of Tomislav Savkić dated 11 February 2013), paras. 63-65, 99. See also D2944 (Witness statement of Zoran Durmić dated 12 February 2013), paras. 30-32. The Chamber does not find the evidence of these witnesses to be of any weight in this regard given that it is based on unfounded speculation. For example Durmić acknowledged that he did not see the incident himself and he heard rumours. Zoran Durmić, T. 33863 
had long beards and wore cockades on their uniforms; others covered their faces with masks. ${ }^{3916}$ After a soldier fired a signal flare, the attack on the village commenced with extensive automatic gun-fire. ${ }^{3917}$ There was no organised defence in the village to this attack. ${ }^{3918}$

1141. Sead Hodžić passed the house of Murat Hreljić and saw a body with multiple bullet wounds lying in a pool of blood and another body in the garden. ${ }^{3919}$ Hodžić saw five other Bosnian Muslims being shot and killed. ${ }^{3920}$ Hodžić saw other bodies as he passed through the village and was warned by Elvira Hreljić to run away because the Serb Forces were going through the village and killing all the men. ${ }^{3921}$ Sead Hodžić was shot at as he ran away. ${ }^{3922}$ Haso Hodžić was caught by two soldiers and brought back to his home, questioned about whether he had any weapons, and when he denied having any weapons he was shot and killed by a soldier. ${ }^{3923}$ Sporadic gunfire continued from different places in the village. Serb Forces then stole some cars and withdrew. ${ }^{3924}$

(18 February 2013). Savkić refused to explain how no Bosnian Serbs were killed in Zaklopača if it was an attack on both ethnicities, see Tomislav Savkić, T. 33787-33791 (15 February 2013). P418 (Witness statement of Mersudina Saim-Hodžić dated 24 May 2002), p. 3.

3917 P3285 (Witness statement of Sead Hodžić dated 24 May 2000), paras. 28-30.

3918 Sead Hodžić, T. 18435 (6 September 2011). Trišić testified that there was confusion as to who was attacking the village and he saw Bosnian Serbs firing into the woods from their houses. He also stated that it was a spontaneous attack. He testified that the police did not participate in the attack, the authorities did not know about the incident, and he heard that there was an investigation into the incident. D3048 (Witness statement of Božidar Trišić dated 24 February 2013), paras. 12, 14-15, 23, 26; Božidar Trišić, T. 34511 (28 February 2013). However, the Chamber does not find his evidence to be reliable in this regard. In reaching that conclusion the Chamber noted that Trišić's evidence was marked by inconsistencies, which undermined his evidence in this respect. For example on cross-examination, he acknowledged that this was his guess and did not know who the attackers were and acknowledged that while he did not see police participating in the attack it could have happened. Božidar Trišić, T. 34505-34508 (28 February 2013). P3285 (Witness statement of Sead Hodžić dated 24 May 2000), para. 36. Hodžić stated that he learned that the body was Salim Avdić's. However, there is no indication of how the witness found out and the Chamber does not place any weight on this aspect of his evidence.

3920 P3285 (Witness statement of Sead Hodžić dated 24 May 2000), para. 22. The people identified as having been shot were Rifet Hodžić, Mujo Hodžić, Salko Salihović, Bajro Salihović, and Becir Hodžić; Sead Hodžić, T. 18462 (6 September 2011). See also P418 (Witness statement of Mersudina Saim-Hodžić dated 24 May 2002), p. 3.

3921 P3285 (Witness statement of Sead Hodžić dated 24 May 2000), para. 36; Sead Hodžić, T. 18453 (6 September 2011). Trišić testified that (i) no Bosnian Muslims who stayed in their homes were killed and that only those who were outside or tried to flee were killed; (ii) he did not see police cars during the attack. D3048 (Witness statement of Božidar Trišić dated 24 February 2013), para. 29; Božidar Trišić, T. 34505-34507, 34513 (28 February 2013). The Chamber does not consider that Trišić's evidence pertaining to whether he saw police cars to be significant. However, the Chamber does note his admission that Bosnian Muslims who were outside or tried to flee were killed. Savkić also testified that this incident was not a planned operation but acknowledged on cross-examination that this was his guess and did not know who the attackers were.

3922 P3284 (Witness statement of Sead Hodžić dated 24 May 2000), paras. 37, 39 (under seal); P3285 (Witness statement of Sead Hodžić dated 24 May 2000), para. 38; Sead Hodžić, T. 18453 (6 September 2011) (private session).

3923 P418 (Witness statement of Mersudina Saim-Hodžić dated 24 May 2002), p. 3; Sead Hodžić, T. 18454 (6 September 2011).

3924 P3285 (Witness statement of Sead Hodžić dated 24 May 2000), para. 41; Sead Hodžić, T. 18454 (6 September 2011). See also D3048 (Witness statement of Božidar Trišić dated 24 February 2013), para. 18. 
1142. Mersudina Saim-Hodžić saw many bodies lying around the village and estimated that approximately 80 people were killed that day. ${ }^{3925}$ When the survivors returned they saw the bodies of at least 58 men and those of some women and children; they were all from Zaklopača. ${ }^{3926}$ Scattered in groups around the village, most of the bodies bore gunshot wounds through the mouth. ${ }^{3927}$ The Chamber notes at least two of those killed were members of an ABiH unit. ${ }^{3928}$

1143. After the incident, men wearing gas masks and protective equipment arrived in the village and used a mechanical digger, tractor, and trailer to dig a mass grave; they then wrapped the bodies in sheets and threw them into the grave. ${ }^{3929}$ The bodies were moved from the first grave to another location after Bosnian Serbs moved into the village. ${ }^{3930}$

1144. Very few males from the village survived the attack. ${ }^{3931}$ The villagers who had survived gathered together and left in trucks to Gradina with two of the wounded women taken to Vlasenica hospital. 3932 One of the trucks was stopped at a Bosnian Serb check-point where three Bosnian

3925 P418 (Witness statement of Mersudina Saim-Hodžić dated 24 May 2002), p. 4; see Adjudicated Fact 2698. See also Izet Redžić, P3189 (Transcript from Prosecutor v. Krajišnik), T. 5062, 5104; Izet Redžić, T. 17681 (23 August 2011) (testifying that 83 civilians were killed); P3285 (Witness statement of Sead Hodžić dated 24 May 2000), para. 43; Božidar Trišić, T. 34496 (28 February 2013) (testifying that over 60 of his Bosnian Muslim neighbours in the village were killed by gun-fire). [REDACTED]. Osmanović was told that approximately 80 people were killed in Zaklopača and that four houses had been burned. P3212 (Witness statement of Ibro Osmanović dated 23 August 2011), para. 55; Ibro Osmanović, T. 17995 (29 August 2011).

P3285 (Witness statement of Sead Hodžić dated 24 May 2000), paras. 43, 45 (stating that 28 members of his family were killed in this attack). The bodies Sead Hodžić saw and identified included Ibrahim Hodžić, Huso Hodžić, Mersudin Hodžić (16 years old), Hamdija Hodžić, Haso Hodžić, Bećir Hodžić, Ibro Hodžić, Safet Hodžić, Muhamed Hodžić, Ibiš Hodžić, Đulsuma Hodžić (a woman), Behadil Hodžić, Fadil Hodžić, Ismeta Hodžić (a woman), Sedin Hodžić (16 years old), Sadmir Hodžić (12 years old), Admir Hodžić (9 years old), Admira Hodžić (4 or 5 years old), Fail Hodžić's wife, Mujo Hodžić, Salih Hodžić (10 years old), Enisa Hodžić (a woman), Ismet Hodžić, Rifet Hodžić, Meho Hodžić, Admira Hodžić (12 years old), Asim Hodžić (3 years old), Anesa Hodžić (7 years old), Alija Hamidović, Osman Hamidović, Bego Hamidović, Hašim Hamidović, Asim Hamidović, Senaid Hamidović, Hamed Hamidović, Fata Hamidović (a woman), Zada Hamidović (a woman), Murat Hreljić, Muradif Hreljić, Salko Salihović, Bajro Salihović, Mujaga Salihović, Osman Salihović, Fatima Salihović, Edin Salihović (13 years old), Edina Salihović (10 years old), Nedžad Salihović (13 years old), Mustafa Mahmutović, Šaban Avdić, Mustafa Avdić, Salim Avdić, Raif Dugalić, Šaha Dugalić, Mustafa Berbić, Fatima Berbić, Junuz Selimović, Adem Selimović, and Salih Selimović. Mersudina Saim-Hodžić also identified 59 people who were killed. P418 (Witness statement of Mersudina Saim-Hodžić dated 24 May 2002), pp. 5-6. In addition to some of those listed above she also identified the following individuals: Makbula Hodžić, Velida Hodžić, Ades Hodžić, Adesa Hodžić, Sajma Hodžić, Senahid Hamidović, Asko Hamidović, Edina Hamidović, and a female named Hamidović. Of these named individuals, 50 were identified by Mašović as having been exhumed from a mass grave. P4853 (Updated Table 2 to the Report of Amor Mašović), pp. 5557. See also P4856 (Appendix B to the Prosecution Pre-Trial Brief filed on 18 May 2009 marked by Amor Mašović), pp. 8-9. P3285 (Witness statement of Sead Hodžić dated 24 May 2000), para. 44.

3928 D2942 (Request of ABiH $1^{\text {st }}$ Žepa Brigade, 13 February 1995). The Chamber notes that Savkić's evidence with respect to whether those who were killed in the village were members of an armed Bosnian Muslim group is equivocal and thus not of much weight. See also Tomislav Savkić, T. 33823-33831 (15 February 2013); D2943 (Recommendation sent to Alija Izetbegović, 23 June 1995), p. 6.

3929 P3285 (Witness statement of Sead Hodžić dated 24 May 2000), paras. 51-54.

3930 Sead Hodžić, T. 18435 (6 September 2011). [REDACTED].

3931 P418 (Witness statement of Mersudina Saim-Hodžić dated 24 May 2002), p. 4.

3932 P3285 (Witness statement of Sead Hodžić dated 24 May 2000), para. 46; P418 (Witness statement of Mersudina Saim-Hodžić dated 24 May 2002), p. 6. 
Muslims were arrested, taken away, and never seen again while the women were allowed to head to Gradina. ${ }^{3933}$ The Chamber has insufficient evidence to conclude whether or not Serb Forces killed the three Bosnian Muslims who disappeared during the transportation.

1145. Bosnian Muslim survivors from Zaklopača stayed in Gradina until it was also attacked by Serb Forces. ${ }^{3934}$ They then took shelter for a few days in the woods; a large number of women and children surrendered to Bosnian Serbs and were taken to Sušica camp before being transferred to Cerska and Kladanj. ${ }^{3935}$

1146. Considering the above, the Chamber finds that at least 60 people, including women and children, were killed in the village of Zaklopača by Serb Forces on or about 16 May 1992. While at least two of those killed were $\mathrm{ABiH}$ soldiers, the Chamber found that (i) many of the victims were women and young children; (ii) some of the victims were shot while trying to escape or after they had been captured by Serb Forces; and (iii) most of those killed had gun shot wounds through the mouth. The Chamber therefore finds beyond reasonable doubt that those killed by Serb Forces were civilians or had been rendered hors de combat.

\section{(b) Scheduled Incident A.15.1}

1147. The Prosecution alleges that at least 20 men were killed in the village of Drum on or about 2 June 1992.

1148. Drum was a Bosnian Muslim village in the commune of Piskavica ${ }^{3936}$ and was surrounded by a number of Bosnian Serb villages. ${ }^{3937}$ Armed Bosnian Muslims had established a check-point in the village at the beginning of 1992 and there was shooting from the village. ${ }^{3938}$

3933 P3285 (Witness statement of Sead Hodžić dated 24 May 2000), para. 47. The people who were taken away were identified as Meho Hamidović, Edin Hamidović (10 years old), and Pašan Selimović. See also P418 (Witness statement of Mersudina Saim-Hodžić dated 24 May 2002), p. 5 (stating that Meho Hamidović and Edin Hamidović were killed).

3934 For evidence relating to the attack on Gradina, see paras. 1129-1130.

3935 P3285 (Witness statement of Sead Hodžić dated 24 May 2000), paras. 53-55; Sead Hodžić, T. 18433-18434 (6 September 2011); P418 (Witness statement of Mersudina Saim-Hodžić dated 24 May 2002), p. 4.

3936 P3227 (Witness statement of KDZ033 dated 7 April 2010), para. 34 (under seal); P3262 (Witness statement of KDZ603 dated 30 August 2011), para. 2 (under seal); KDZ603, T. 18136 (1 September 2011); P6459 (Map of Vlasenica); P3212 (Witness statement of Ibro Osmanović dated 23 August 2011), para. 93; Ibro Osmanović, T. 17994-17995 (29 August 2011). There were only two Bosnian Serb houses on the outskirts of the village.

3937 P3262 (Witness statement of KDZ603 dated 30 August 2011), para. 2 (under seal); KDZ603, T. 18136 (1 September 2011). See also Zoran Jovanović, T. 34206 (21 February 2013).

3938 Ibro Osmanović, T. 17994-17996 (29 August 2011). See also Mane Đurić, T. 35005-35007 (7 March 2013); D2932 (Witness statement of Tomislav Savkić dated 11 February 2013), paras. 58-59; D2982 (Witness statement of Milenko Stanić dated 16 February 2013), para. 43; Milenko Stanić, T. 34020 (19 February 2013); KDZ033, T. 18083 (31 August 2011) (closed session); Svetozar Andrić, T. 41671-41672 (22 July 2013). In the Accused's submission, the village of Drum was a legitimate military target. Defence Final Brief, para. 1436. 
1149. In late May 1992, Bosnian Serb police confiscated a few hunting weapons held by Bosnian Muslims in the village. ${ }^{3939}$ Houses of Bosnian Muslims were searched multiple times by Bosnian Serbs who claimed to be searching for weapons, but the searches had the effect of intimidating the population. ${ }^{3940}$ Bosnian Serb police went through the village and used a megaphone to tell the Bosnian Muslims that they had to hand over all their weapons or else their homes would be burned down and the men would be arrested. ${ }^{3941}$

1150. On 2 June 1992, Serb Forces attacked Drum. ${ }^{3942}$ Serb Forces first entered the village and, at approximately 7 a.m., when an APC with a heavy calibre machine gun opened fire, the soldiers attacked the village. ${ }^{3943}$ While some Bosnian Muslim villagers may have had weapons, there was no armed resistance to the attack by Serb Forces on Drum. ${ }^{3944}$ The Special Police Platoon patrolled the village in search of Bosnian Muslim men who may have hidden in houses and shot at them whether or not they were armed. ${ }^{3945}$

1151. Soldiers dragged people out of their homes and killed them in plain sight with machine guns. ${ }^{3946}$ More than 20 Bosnian Muslim males were killed in a few minutes with only three male residents surviving the attack. ${ }^{3947}$ The women and children were gathered and held at gunpoint

While the Chamber finds that there were armed Bosnian Muslims in Drum, the evidence accepted by the Chamber does not support the conclusion that the whole village was a legitimate military target or justifies the manner in which the attack against the village was carried out. In this regard the Chamber does not find the evidence of witnesses Đurić, Savkić, Stanić, and Andrić about the extent to which Bosnian Muslims were armed to be reliable. In reaching that conclusion the Chamber refers to its credibility assessment in fns. 3791, 3813, and 3894 with respect to the relevant witnesses. 
before being sent by bus to Sušica. ${ }^{3948}$ As the villagers were ordered onto the bus they faced a "barrage of insults" as to their "Muslim ethnicity". ${ }^{3949}$ The villagers were taken to Sušica under the guard of the reserve police. ${ }^{3950}$ After this date there were no Bosnian Muslims left in Drum. ${ }^{3951}$

1152. While Osmanović was detained at the prison building in Vlasenica he was taken with three other Bosnian Muslim detainees to Drum to bury 22 bodies. ${ }^{3952}$ Osmanović knew four of the deceased men personally ${ }^{3953}$ and observed that all but one of the bodies had a single gunshot wound between the eyes. ${ }^{3954}$ Osmo Hodžić had been shot in the chest. ${ }^{3955}$ All the victims were Bosnian Muslims between the ages of 18 to 65 and were wearing civilian clothes. ${ }^{3956}$ The bodies had been arranged next to each other in front of the local bar, which was owned by a Bosnian Muslim. ${ }^{3957}$ The guards instructed Osmanović to search the bodies for valuables and documents before they were loaded onto a tractor and taken to the Muslim cemetery near the Boksit stadium and buried in a hole. ${ }^{3958}$ Lime was poured over the bodies before they were covered. ${ }^{3959}$

even if they had heard about the incident they were unsure whether the Bosnian Muslims were armed or had provoked the attack. Svetozar Andrić, T. 41672 (22 July 2013); D2982 (Witness statement of Milenko Stanić dated 16 February 2013), para. 37; Mane Đurić, T. 35082 (7 March 2013); D3853 (Witness statement of Zvonko Bajagić dated 5 July 2013), para. 26. The Chamber does not find the evidence of these witnesses to be reliable in this regard. In reaching that conclusion the Chamber refers to its credibility assessments for the relevant witnesses in fns. 3791 and 3894. In addition the Chamber notes that the evidence of Bajagić was also marked by contadictions, evasiveness and indicators that he was not forthright in his testimony in this regard.

3948 See Adjudicated Fact 2696. The surviving three male villagers were also transferred to Sušica. See also P3262 (Witness statement of KDZ603 dated 30 August 2011), paras. 12, 14-16 (under seal); KDZ603, T. 18148 (1 September 2011). P3262 (Witness statement of KDZ603 dated 30 August 2011), para. 21 (under seal); KDZ603, T. 18147 (1 September 2011).

3950 P3262 (Witness statement of KDZ603 dated 30 August 2011), paras. 19-21 (under seal); P3262 (Witness statement of KDZ603 dated 30 August 2011), para. 24 (under seal); KDZ603, T. 18159 (1 September 2011).

3951 KDZ603, T. 18158 (1 September 2011).

3952 P3212 (Witness statement of Ibro Osmanović dated 23 August 2011), paras. 93-95. For evidence on detention at the Vlasenica prison building, see Scheduled Detention Facility C.25.2.

3953 P3212 (Witness statement of Ibro Osmanović dated 23 August 2011), para. 93.

3954 P3212 (Witness statement of Ibro Osmanović dated 23 August 2011), para. 93. KDZ603 saw approximately 20 bodies in Drum and was able to positively identify the bodies of Goro Salihović, Braco Salihović, Osmo Hodžić, Nedžad Hodžić, Jasmin Kičić, the brother of Jasmin Kičić, Huso Aličević, Meho Jahić, Ekrem Jahić, Hadžo Malešević, Fadil Salihović. P3262 (Witness statement of KDZ603 dated 30 August 2011), paras. 22-23 (under seal); KDZ603, T. 18132, 18138, 18152 (1 September 2011). The bodies of Osmo Hodžić, Huso Aličević, Meho Jahić, Ekrem Jahić and Fadil Salihović were identified by Mašović as having been exhumed from a mass grave, while Nedžad Hodžić was exhumed from an individual grave. P4853 (Updated Table 2 to the Report of Amor Mašović), pp. 51, 53-55. See also P4856 (Appendix B to the Prosecution Pre-Trial Brief filed on 18 May 2009 marked by Amor Mašović), p. 8.

3955 P3212 (Witness statement of Ibro Osmanović dated 23 August 2011), para. 93.

3956 P3212 (Witness statement of Ibro Osmanović dated 23 August 2011), para. 96.

3957 P3212 (Witness statement of Ibro Osmanović dated 23 August 2011), para. 93.

3958 P3212 (Witness statement of Ibro Osmanović dated 23 August 2011), para. 93. The Chamber does not accept Đurić's evidence that the Bosnian Serb police were requested to provide protection and ensured the proper burial of Bosnian Muslims killed in Drum. The Chamber refers to its credibility assessment in fn. 3791 as to why Đurić's evidence is not reliable in this regard. D3093 (Witness statement of Mane Đurić dated 3 March 2013), para. 44; Mane Đurić, T. 35006, 35030-35031 (7 March 2013). The Chamber does note however, that Đurić himself acknowledged that some of the victims were Bosnian Muslim civilians. 
1153. Considering the above, the Chamber finds that at least 20 Bosnian Muslim men in the village of Drum were killed by Serb Forces on or about 2 June 1992.

\section{(6) Scheduled Incident B.18.4}

1154. The Prosecution alleges that at least 29 men were taken away from the Civil Defence Building and killed on the side of the road near the village of Nova Kasaba between May and June 1992. ${ }^{3960}$

1155. On 17 May 1992, Bosnian Muslims were taken from villages surrounding Bratunac and, in three full buses, were brought to Bratunac town. They were then transferred to Vlasenica. ${ }^{3961}$ They were loaded onto buses by Bosnian Serb police and accompanied by an armed guard in each bus and a police car. ${ }^{3962}$ After their arrival in Vlasenica, a group of Bosnian Serb soldiers approached the buses; they wore camouflage uniforms with balaclavas or stockings over their faces, ${ }^{3963}$ they also wore patches, including those of Arkan's men and of the White Eagles. The soldiers ordered

all the men to line up in front of the buses. ${ }^{3964}$ The men were made to sing "Serbian nationalist songs" and to give the three-fingered Serbian salute and those who refused were beaten. ${ }^{3965}$ One of the detainees was kicked and beaten when questioned about a military backpack he was wearing. 3966

1156. The elderly men in the group were sent back to the buses while approximately 34 men of military age and five minors were taken to the MUP prison and detained for several days. ${ }^{3967}$ On arrival, the group was held in a small room and severely beaten. ${ }^{3968}$ Two of the men were taken back to the buses with the women, children and elderly who were taken to Kladanj. ${ }^{3969}$ The remaining Bosnian Muslims were beaten during the day and night with batons, tubes, and rifle butts

\footnotetext{
3959 P3212 (Witness statement of Ibro Osmanović dated 23 August 2011), para. 93.

3960 The Prosecution submits that the evidence shows that these individuals were taken from the Vlasenica SJB building. Prosecution Final Brief, Appendix B, fn. 807.

3961 P3263 (Witness statement of Suad Džafić dated 31 August 2011), paras. 15, 19-21, 24. For evidence on the transfer from Bratunac, see para. 763.

3962 P3263 (Witness statement of Suad Džafić dated 31 August 2011), paras. 19, 24.

3963 P3263 (Witness statement of Suad Džafić dated 31 August 2011), para. 26.

3964 P3263 (Witness statement of Suad Džafić dated 31 August 2011), para. 26.

3965 P3227 (Witness statement of KDZ033 dated 7 April 2010), paras. 29, 160 (under seal).

3966 P3263 (Witness statement of Suad Džafić dated 31 August 2011), para. 26; Suad Džafić, T. 18197 (1 September 2011).

3967 P3263 (Witness statement of Suad Džafić dated 31 August 2011), paras. 27-28. See also P3227 (Witness statement of KDZ033 dated 7 April 2010), para. 29 (under seal).

3968 P3263 (Witness statement of Suad Džafić dated 31 August 2011), para. 29; Suad Džafić, T. 18197-18198 (1 September 2011).

3969 P3263 (Witness statement of Suad Džafić dated 31 August 2011), para. 29.
} 
by Bosnian Serb soldiers. ${ }^{3970}$ They were not provided with any food or water until the second day. $^{3971}$

1157. On 21 May 1992, this group of Bosnian Muslims, with the exception of the five minors, was taken out by two policemen and told they would be exchanged. ${ }^{3972}$ The detainees were asked to hand over all their personal belongings before being loaded onto a bus to be taken towards Nova Kasaba. ${ }^{3973}$ One detainee was cursed and beaten "wildly" by a soldier called "Makedonac" when he was found to have not handed over a wristwatch. ${ }^{3974}$ As the Bosnian Muslims were waiting to leave, four cars with the insignia of a skull on their doors arrived and uniformed men, including a man named Pero Mitrović, got out. ${ }^{3975}$ There was also an armoured vehicle with soldiers parked near the bus, the soldiers entered the bus and made the Bosnian Muslims sing "Chetnik" songs. ${ }^{3976}$ The bus was then led by the armoured vehicle and followed by the cars towards Bratunac. ${ }^{3977}$

1158. The column of vehicles stopped at the entrance to Nova Kasaba, and the soldiers got out of their vehicles; Makedonac told the detainees to get off the bus in groups of four or five. ${ }^{3978}$ The detainees in the first group were killed on the spot as they got off the bus. ${ }^{3979}$ The other groups of detainees were ordered to get off the bus and run across the fields where they were then shot with automatic rifles and a machine gun mounted on the armoured vehicle. ${ }^{3980}$ Suad Džafić was in the last group; he was hit by gunfire and wounded in four different parts of his body but survived. ${ }^{3981}$ Mitrović and Makedonac shot any survivors they found in the head. ${ }^{3982}$ As Mitrović and Makedonac got closer to Suad Džafić he could hear an argument which suggested that the execution should not have taken place on the main road. The soldiers were then ordered to leave

\footnotetext{
3970 P3263 (Witness statement of Suad Džafić dated 31 August 2011), paras. 31, 68. P3263 (Witness statement of Suad Džafić dated 31 August 2011), para. 31. P3263 (Witness statement of Suad Džafić dated 31 August 2011), paras. 33-34. One of the guards recognised by Suad Džafić was a Bosnian Serb from Bratunac named Nešo Zivanović. Suad Džafić, T. 18173, 18202 (1 September 2011). See also Adjudicated Fact 2701.

3973 P3263 (Witness statement of Suad Džafić dated 31 August 2011), paras. 35-36. See also Adjudicated Fact 2701.

3974 P3263 (Witness statement of Suad Džafić dated 31 August 2011), para. 38; Suad Džafić, T. 18173, 1820218203 (1 September 2011).

3975 P3263 (Witness statement of Suad Džafić dated 31 August 2011), paras. 39-40.

3976 P3263 (Witness statement of Suad Džafić dated 31 August 2011), paras. 41-42.

3977 P3263 (Witness statement of Suad Džafić dated 31 August 2011), para. 43. See also Adjudicated Fact 2701.

3978 P3263 (Witness statement of Suad Džafić dated 31 August 2011), paras. 47-48; Suad Džafić, T. 18174-18175 (1 September 2011). See also Adjudicated Fact 2702.

3979 P3263 (Witness statement of Suad Džafić dated 31 August 2011), paras. 48-50. [REDACTED].

3980 P3263 (Witness statement of Suad Džafić dated 31 August 2011), paras. 49-51. See also Adjudicated Fact 2702.

3981 P3263 (Witness statement of Suad Džafić dated 31 August 2011), para. 50, 52.

3982 P3263 (Witness statement of Suad Džafić dated 31 August 2011), para. 53. See also Adjudicated Fact 2702.
} 
immediately; this allowed Suad Džafić to escape. ${ }^{3983}$ Of the 29 Bosnian Muslim men who were killed, Suad Džafić was able to identify 21 relatives and neighbours. ${ }^{3984}$ The Milići SJB reported to CSB Sarajevo on 3 August 1992 about this incident and stated that the summary execution was carried out by the Vukovar Detachment, which was a paramilitary group. ${ }^{3985}$

1159. The Chamber therefore finds that approximately 29 Bosnian Muslim men were taken from Vlasenica, on or about 21 May 1992 and killed by Serb Forces.

(E) Detention Facilities in Vlasenica

(1) Scheduled Detention Facility C.25.1

1160. The Indictment refers to the use of SJB building in Vlasenica as a detention facility at least between May and July 1992. ${ }^{3986}$

(a) Arrival of detainees and control over the detention facility

1161. The SJB building was located in the centre of Vlasenica. ${ }^{3987}$ The police officers who worked at the SJB building went from door to door, interrogating non-Serbs, bringing them to the SJB building and demanding money. ${ }^{3988}$ Bosnian Muslims were arrested in their homes by reserve police officers and taken to the SJB building with no explanation as to the reason for their arrest. ${ }^{3989}$

3983 P3263 (Witness statement of Suad Džafić dated 31 August 2011), paras. 55-58, 66 (stating that Rahman Karić and Sado Muhić also survived).

3984 P3263 (Witness statement of Suad Džafić dated 31 August 2011), paras. 60-63, 65; Suad Džafić, T. 18204 (1 September 2011) (testifying that of the 32 men taken for execution, 29 were killed). The identified individuals are Mehmed Džafić, Ibro Džafić, Hamed Džafić, Osman Džafić, Fahrudin Džafić, Fejzo Džafić, Mirsad Džafić, Huso Džafić, Samir Džafić, Šahin Suljić, Himzo Suljić, Izo Suljić, Suljo Suljić, Ramiz Karić, Arif Karić, Ismet Salihović, Ragib Salihović, Galib Ahmetović, Hidajet Alic, Ibro Suljagić, Alija Suljagić. Each of these 21 named individuals was identified as having been exhumed from a mass grave. P4853 (Updated Table 2 to the Report of Amor Mašović), pp. 95-96. See also P4856 (Appendix B to the Prosecution Pre-Trial Brief filed on 18 May 2009 marked by Amor Mašović), pp. 29-30; P3264 (Report of Milići SJB, 3 August 1992), pp. 1-2.

3985 P3263 (Witness statement of Suad Džafić dated 31 August 2011), para. 67; P3264 (Report of Milići SJB, 3 August 1992), pp. 1-2. While the report also suggested that the Milići SJB was unable to protect these people from the execution as the Vukovar Detachment was heavily armed, the Chamber places no weight on this attempt by the SJB to distance itself from the incident. In reaching that conclusion the Chamber noted the testimony of Džafić that he saw no attempts by the police to protect the detainees and in fact one policeman had said "[1]et me kill them all now."

3986 The Prosecution submits that the evidence shows that the facility operated in May and June 1992. Prosecution Final Brief, Appendix B.

3987 P3212 (Witness statement of Ibro Osmanović dated 23 August 2011), para. 99; P3219 (Aerial photograph of Vlasenica marked by Ibro Osmanović); P3227 (Witness statement of KDZ033 dated 7 April 2010), para. 163 (under seal); P3258 (Photograph of Vlasenica SJB); P6459 (Map of Vlasenica).

3988 P3227 (Witness statement of KDZ033 dated 7 April 2010), para. 166 (under seal); P3212 (Witness statement of Ibro Osmanović dated 23 August 2011), para. 189.

3989 P3212 (Witness statement of Ibro Osmanović dated 23 August 2011), paras. 60-64, 189, 191; Ibro Osmanović, T. 17984, 17992 (29 August 2011); P3225 (List of Vlasenica SJB reserve workers in September 1992). 
1162. The first non-Serbs who were detained and interrogated at the SJB building were intellectuals, SDA members, and wealthy individuals. While some were detained for a couple of days, others were detained longer. Some were released and re-arrested. ${ }^{3990}$ Members of the Vlasenica SJB were involved in interrogations including members of the Special Police Platoon. ${ }^{3991}$

1163. In May 1992, members of the Special Police Platoon were ordered by Kraljević to take all able-bodied men from the predominantly Bosnian Muslim suburb of Sušica to the SJB building to be questioned about weapons. ${ }^{3992}$ A total of 50 Bosnian Muslim men, including some elderly and underage boys were rounded up in this operation. ${ }^{3993}$

\section{(b) Conditions of detention and treatment of detainees}

1164. Bosnian Muslims were detained and mistreated in a small cell of the SJB building by the Bosnian Serb police for several days. ${ }^{3994}$ When Osmanović was detained in this cell, there were over 20 Bosnian Muslims, including some children, who were locked in these cramped conditions for three to four hours. 10 men were then taken to another room. ${ }^{3995}$ None of these individuals had taken part in military activities. ${ }^{3996}$

1165. A number of reserve police officers were also involved in the mistreatment of Bosnian Muslim detainees at the SJB building. ${ }^{3997}$ Members of the Special Police Platoon were also allowed to enter the SJB building and were involved in the beating of the detainees. ${ }^{3998}$ Detainees were taken out either in groups or individually for interrogations during which time they were beaten. $^{3999}$ They had their arms and legs tied and were beaten over the course of about 10 days

\footnotetext{
3990 P3227 (Witness statement of KDZ033 dated 7 April 2010), para. 165 (under seal).

3991 [REDACTED]. See also P3262 (Witness statement of KDZ603 dated 30 August 2011), para. 33 (under seal).

3992 [REDACTED].

3993 [REDACTED].

3994 P3227 (Witness statement of KDZ033 dated 7 April 2010), paras. 20, 163 (under seal); P3255 (Photograph inside of Vlasenica SJB); see Adjudicated Fact 2699. With respect to Adjudicated Fact 2699, Đurić testified that it was only in mid-May 1992 that effective control was established over the SJB building and that before then the SJB was unable to prevent paramilitary groups from entering the building. D3093 (Witness statement of Mane Đurić dated 3 March 2013), para. 67. The Chamber does not consider Đurić's evidence to be reliable in this regard. In reaching that conclusion the Chamber refers to its credibility assessment in fn. 3791. P3212 (Witness statement of Ibro Osmanović dated 23 August 2011), paras. 65-68 (naming the other detainees as including Hasan Kuljančić and Dževad Topalović); Ibro Osmanović, T. 17986-17987 (29 August 2011).

3996 P3212 (Witness statement of Ibro Osmanović dated 23 August 2011), para. 67.

3997 P3212 (Witness statement of Ibro Osmanović dated 23 August 2011), paras. 184-186, 189-191; P3224 (List of members of Vlasenica SJB reserve forces, 25 June 1992); P3225 (List of Vlasenica SJB reserve workers in September 1992); P3226 (List of Vlasenica SJB active workers in May 1992); P3227 (Witness statement of KDZ033 dated 7 April 2010), para. 164 (under seal).

3998 P3227 (Witness statement of KDZ033 dated 7 April 2010), para. 28 (under seal); P3212 (Witness statement of Ibro Osmanović dated 23 August 2011), para. 71.

3999 P3212 (Witness statement of Ibro Osmanović dated 23 August 2011), paras. 68, 70.
} 
with police batons, metal pipes, grips of guns, and metal chains. ${ }^{4000}$ Detainees were also cut on multiple places of their body with knives and in one case a detainee had salt rubbed into those wounds. $^{4001}$

1166. While occasionally, the detainees were allowed to have food from their homes, they were frequently hungry. ${ }^{4002}$ On one occasion the detainees were given food and it was spoiled. ${ }^{4003}$ The detainees did not have any access to any medical care and the conditions of detention were poor. ${ }^{4004}$ While the detainees had access to water in the basement of the building, they were beaten en route. ${ }^{4005}$ The detainees did not have beds and slept on concrete tiles. ${ }^{4006}$ Osmanović described the atmosphere as one of "suffering, misery, of pain". 4007

$\underline{\text { detainees }}$

(c) Conclusion on conditions of detention and treatment of

1167. Based on the above, the Chamber finds that Bosnian Muslim civilian men as well as some children and elderly, were arrested in their homes and detained at the Vlasenica SJB building in May 1992 by Serb Forces. The detainees were held in poor conditions which included lack of food, bedding, no medical care, and over-crowding. Detainees were subjected to beatings with batons, metal pipes, chains and other objects. Some detainees were cut with knives during their detention.

\section{(d) Scheduled Incident B.18.3}

1168. The Indictment refers to the killing of one man in SJB building on or about 22 May 1992.

1169. On or about 22 May 1992, Džemal Ambešković, an ex-policeman who had helped organise the referendum for an independent $\mathrm{BiH}$ in Vlasenica, ${ }^{4008}$ was pushed into a room, and other detainees saw his face and stomach were bruised. ${ }^{4009}$ After some time, Stevan Mumović, who wore

4000 P3212 (Witness statement of Ibro Osmanović dated 23 August 2011), paras. 70, 78; see Adjudicated Fact 2699. The Chamber places no weight on Đurić's evidence that some detainees assaulted inspectors during interviews and thus had to be "physically overpowered". D3093 (Witness statement of Mane Đurić dated 3 March 2013), paras. 45-47. The Chamber does not find this evidence to be plausible. The Chamber also refers to its credibility assessment in fn. 3791 in concluding that Đurić's evidence in this regard was unreliable.

4001 P3212 (Witness statement of Ibro Osmanović dated 23 August 2011), paras. 77-78.

4002 P3212 (Witness statement of Ibro Osmanović dated 23 August 2011), para. 79.

4003 P3212 (Witness statement of Ibro Osmanović dated 23 August 2011), para. 79.

4004 P3212 (Witness statement of Ibro Osmanović dated 23 August 2011), para. 79; see Adjudicated Fact 2699.

4005 P3212 (Witness statement of Ibro Osmanović dated 23 August 2011), para. 79.

4006 P3212 (Witness statement of Ibro Osmanović dated 23 August 2011), para. 79.

4007 P3212 (Witness statement of Ibro Osmanović dated 23 August 2011), para. 79.

4008 P3212 (Witness statement of Ibro Osmanović dated 23 August 2011), para. 72. See also Adjudicated Fact 2700; P4856 (Appendix B to the Prosecution Pre-Trial Brief filed on 18 May 2009 marked by Amor Mašović), p. 29; P4853 (Updated Table 2 to the Report of Amor Mašović), p. 95 (identifying Džemal Ambešković as having been exhumed from an individual grave).

4009 P3212 (Witness statement of Ibro Osmanović dated 23 August 2011), para. 72. 
a "war police" patch, told Ambešković to get out of the room. As Ambešković stepped out of the room he was struck on the back of his head, he fell to the floor, and then a single pistol shot was heard. $^{4010}$ After he was killed three of the detainees were ordered by a member of the reserve police force to "get out and load this shit", given a plastic bag, and ordered to load the body onto a van. $^{4011}$ After the body was loaded onto the van, the detainees were beaten as they went up the stairs. $^{4012}$

1170. The Chamber therefore finds that on or about 22 May 1992 a Bosnian Muslim man was killed by a member of the Serb Forces at the Vlasenica SJB building.

\section{(2) Scheduled Detention Facility C.25.2}

1171. The Indictment refers to the use of the Prison building in Vlasenica as a detention facility at least between June and July $1992 .^{4013}$

(a) Arrival of detainees and control over detention facility

1172. The prison in Vlasenica was close to the SJB building and the commander of the prison was a man named Branislav Sokanović; he was a police officer of the Vlasenica SJB ${ }^{4014}$ The guards at the prison were Bosnian Serb police and included reserve police officers. ${ }^{4015}$

1173. Beginning in May 1992, Bosnian Muslims were arrested and detained for several days at the Vlasenica prison by Bosnian Serb police. ${ }^{4016}$ These included a group of approximately 30 non-Serb men from Bratunac and a significant number of other non-Serbs from Vlasenica. ${ }^{4017}$

4010 P3212 (Witness statement of Ibro Osmanović dated 23 August 2011), paras. 73-74. See also Adjudicated Fact 2700; [REDACTED]; P3260 (List of missing civilians in Vlasenica in 1992) (under seal). But see D3093 (Witness statement of Mane Đurić dated 3 March 2013), para. 68 (stating that nobody was killed at the SJB building). The Accused himself acknowledges that the evidence presented confirms that a man was killed at this facility on or about 22 May 1992 but asserts that no evidence was introduced to link this killing with anyone at the Republican level. Defence Final Brief, para. 1439.

4011 P3212 (Witness statement of Ibro Osmanović dated 23 August 2011), paras. 75-76; P3226 (List of Vlasenica SJB active workers in May 1992).

4012 P3212 (Witness statement of Ibro Osmanović dated 23 August 2011), para. 76. The Chamber received evidence of other killings of individuals who had been detained at the facility. P3227 (Witness statement of KDZ033 dated 7 April 2010), paras. 164, 166 (under seal). The Chamber notes that these killings are not charged pursuant to Schedules A or B of the Indictment. See fn. 13.

4013 The Prosecution submits that the evidence shows that the facility operated in May and June 1992. Prosecution Final Brief, Appendix B, p. 56.

4014 P3212 (Witness statement of Ibro Osmanović dated 23 August 2011), paras. 81-82, 99, 191; P3226 (List of Vlasenica SJB active workers in May 1992); P3219 (Aerial photograph of Vlasenica marked by Ibro Osmanović); P3227 (Witness statement of KDZ033 dated 7 April 2010), paras. 85, 158 (under seal).

4015 P3212 (Witness statement of Ibro Osmanović dated 23 August 2011), para. 190; P3225 (List of Vlasenica SJB reserve workers in September 1992); P3227 (Witness statement of KDZ033 dated 7 April 2010), para. 159 (under seal). See also D3093 (Witness statement of Mane Đurić dated 3 March 2013), para. 49.

4016 P3227 (Witness statement of KDZ033 dated 7 April 2010), paras. 20, 28-29, 159 (under seal). 


\section{(b) Conditions of detention and treatment of detainees}

1174. The Vlasenica prison was designed to hold approximately 20 to 50 detainees. ${ }^{4018}$ Despite this capacity, about 150 Bosnian Muslim men were held in very poor conditions in five rooms of the Vlasenica prison. ${ }^{4019}$ Osmanović was transferred to the Vlasenica prison on 2 June 1992 and was detained there until 18 June $1992 .^{4020}$ On his arrival Osmanović was searched, stripped of his valuables, and placed in a cell with other Bosnian Muslim men. ${ }^{4021}$

1175. The Bosnian Muslim detainees had to sleep on wooden pallets on the floor or on shelves as there were no beds. ${ }^{4022}$ They received food from their homes and from acquaintances and once received left-over food in the prison. ${ }^{4023}$ While at the Vlasenica prison the detainees did not have access to medical care or medication. ${ }^{4024}$

1176. Detainees were taken out of the Vlasenica prison by Bosnian Serbs in camouflage uniforms to loot valuables from Bosnian Muslim homes. ${ }^{4025}$ The detainees were also taken out to bury bodies and dig trenches on the frontline between Vlasenica and Kladanj ${ }^{4026}$ and also to carry out other work such as chopping wood. ${ }^{4027}$

1177. Detainees were either interrogated at the prison or taken to the nearby SJB building. ${ }^{4028}$ Some detainees in the prison were subjected to prolonged and severe beatings. They were also

4017 P3227 (Witness statement of KDZ033 dated 7 April 2010), para. 160 (under seal). For evidence on the arrest of these detainees in Bratunac, see para. 763. Đurić testified that the facility was used because there were people under investigation who had to be imprisoned. D3093 (Witness statement of Mane Đurić dated 3 March 2013), para. 49. The Chamber refers to its credibility assessment in fn. 3791 as to why Đurić's evidence is not reliable in this regard.

4018 P3227 (Witness statement of KDZ033 dated 7 April 2010), paras. 90, 158 (under seal); P3212 (Witness statement of Ibro Osmanović dated 23 August 2011), para. 83.

4019 P3212 (Witness statement of Ibro Osmanović dated 23 August 2011), para. 83. See also Adjudicated Fact 2703.

4020 P3212 (Witness statement of Ibro Osmanović dated 23 August 2011), para. 80.

4021 P3212 (Witness statement of Ibro Osmanović dated 23 August 2011), para. 83.

4022 P3227 (Witness statement of KDZ033 dated 7 April 2010), para. 162 (under seal); P3212 (Witness statement of Ibro Osmanović dated 23 August 2011), para. 84.

4023 P3212 (Witness statement of Ibro Osmanović dated 23 August 2011), para. 84.

4024 P3212 (Witness statement of Ibro Osmanović dated 23 August 2011), para. 84.

4025 P3212 (Witness statement of Ibro Osmanović dated 23 August 2011), paras. 91-92. See also Adjudicated Fact 2704.

4026 P3212 (Witness statement of Ibro Osmanović dated 23 August 2011), paras. 89, 93-98. See also Adjudicated Fact 2704. Detainees were taken away in JNA military trucks by Bosnian Serbs in olive grey uniforms. The Chamber notes that there was no fighting at the time when detainees were taken to dig trenches. P3227 (Witness statement of KDZ033 dated 7 April 2010), para. 61 (under seal).

4027 P3227 (Witness statement of KDZ033 dated 7 April 2010), para. 162 (under seal). The Chamber notes that this type of forced labour is not charged in the Indictment, which only covers forced labour at the frontlines.

4028 P3227 (Witness statement of KDZ033 dated 7 April 2010), para. 163 (under seal). For evidence on treatment at the Vlasenica SJB building, see Scheduled Detention Facility C.25.1. 
threatened and subjected to intimidation. ${ }^{4029}$ When the commander of the Vlasenica prison, Sokanović, was present, the detainees were treated fairly but when he was not there conditions worsened and the detainees were beaten. ${ }^{4030}$ When Sokanović was absent, the detainees were only allowed to use the toilet once or twice a day and were beaten en route. ${ }^{4031}$ Detainees were kicked and beaten with batons, rifle butts, machine guns, metal bars, sticks, and thick plastic pipes. ${ }^{4032}$

1178. After the death of Kraljević's brother, uniformed individuals came to the prison and proceeded to take revenge on the detainees and subjected them to further mistreatment. ${ }^{4033}$ In addition civilians and uniformed individuals, were brought to or allowed to enter, the facility to beat the detainees and the guards did not provide the detainees with any protection. ${ }^{4034}$

\section{(c) $\underline{\text { Conclusion }}$}

1179. Based on the above, the Chamber finds that Bosnian Muslim men were arrested and detained at the Vlasenica prison from May to June 1992 by Serb Forces. The detainees were held in poor conditions which included over-crowding, inadequate medical care and bedding. Detainees were forced to work at a number of locations and, for example, were used to bury bodies, and dig trenches. Detainees were subjected to beatings with batons, metal bars, guns, pipes, and other objects.

\section{(3) Scheduled Detention Facility C.25.3}

1180. The Indictment refers to the use of the Sušica camp as a detention facility at least between May and about 30 September 1992.

\footnotetext{
4029 P84 (Witness statement of Mirsad Kuralić dated 27 June 1996), p. 7 (stating that he was not beaten after the intervention by an individual who knew his family).

4030 P3212 (Witness statement of Ibro Osmanović dated 23 August 2011), paras. 83, 89, 191 (stating that he lost five teeth during these beatings). See also Adjudicated Fact 2705.

4031 P3212 (Witness statement of Ibro Osmanović dated 23 August 2011), para. 84.

4032 P3212 (Witness statement of Ibro Osmanović dated 23 August 2011), para. 88.

4033 P3212 (Witness statement of Ibro Osmanović dated 23 August 2011), paras. 89-90.

4034 P3212 (Witness statement of Ibro Osmanović dated 23 August 2011), para. 90. The Chamber also received evidence about the killing and disappearance of detainees taken from the Vlasenica prison. P3227 (Witness statement of KDZ033 dated 7 April 2010), paras. 44, 159-160 (under seal); KDZ033, T. 18090-18091 (31 August 2011) (closed session); P3212 (Witness statement of Ibro Osmanović dated 23 August 2011), paras. 55, 85-89, 185; Ibro Osmanović, T. 17943-17945 (25 August 2011). The Chamber notes that the above killings are not charged pursuant to Schedules A or B of the Indictment. See fn. 13.
} 
(a) Arrival of detainees and control over the detention facility

1181. Sušica camp was close to the town of Vlasenica on the road from Sarajevo to Belgrade and consisted of sheds owned by a forestry company prior to the war. ${ }^{4035}$ The facility was taken over and used for the storage of TO weapons and a hangar was then used to detain persons brought to the camp. ${ }^{4036}$ The camp was established on 31 May 1992 by an order issued by the VRS $1^{\text {st }}$ Infantry Brigade Commander, acting pursuant to a decision of the SAO Birač on regulating the "moving out of the Muslim population". 4037

1182. Both the VRS and the Vlasenica SJB brought Bosnian Muslims to the camp and had responsibility over the facility, and the SJB determined in practice how the camp functioned. ${ }^{4038}$ The camp warden was Veljko Bašić and the facility was guarded by members of the police, the Special Police Platoon, and the VRS. ${ }^{4039}$ Bašić and his deputy would visit the camp almost every morning and update a list which recorded the personal details of any new detainees who had arrived

4035 P3212 (Witness statement of Ibro Osmanović dated 23 August 2011), paras. 104-105, 144; P3223 (Aerial photograph of Sušica camp marked by Ibro Osmanović); KDZ033, T. 18071 (31 August 2011) (closed session); P6459 (Map of Vlasenica); P6130 (Photographs of Sušica camp); Momir Deurić, T. 33922-33923 (18 February2013); P3227 (Witness statement of KDZ033 dated 7 April 2010), para. 70 (under seal); P3231 (Aerial photograph of Vlasenica marked by KDZ033) (under seal).

4036 P3212 (Witness statement of Ibro Osmanović dated 23 August 2011), para. 105, 144; P3223 (Aerial photograph of Sušica camp marked by Ibro Osmanović); KDZ044, P107 (Transcript from KDZ044's testimony), T. 465 (under seal). The facility was first used to house Serb refugees who arrived in the municipality and was then taken over by the army. See D2967 (Witness statement of Momir Deurić dated 16 February 2013), para. 17; Momir Deurić, T. 33919-33920 (18 February 2013); P3245 (Assessment report on Sušica camp), pp. 2-3.

4037 P3240 (Order of Birač Brigade, 31 May 1992); [REDACTED]. See also Adjudicated Fact $2706 ;$ D3886 (Witness statement of Svetozar Andrić dated 16 July 2013), para. 7. Defence witnesses testified that this order related to the organisation of the camp and the maintenance of law and order rather than to its establishment and that the SAO Birač was not involved in the moving out of the non-Serb population and there was no such decision. Svetozar Andrić, T. 41681-41684 (22 July 2013); Milenko Stanić, T. 34022-34024 (19 February 2013). Stanić maintained this position even when confronted with a magazine article which referred to the Government of the SAO Birač passing a decision on the movement of Bosnian Muslims from the area, see P6030 (Article from Javnost entitled "Serbian Region of Birač: Borders Determined”, 6 June 1992). See also Tomislav Savkić, T. 33786-33787 (15 February 2013) (testifying that the author of the article was not properly informed). The Chamber refers to its credibility assessment in fns. 3796, 3813, and 3894 in concluding that the evidence of the relevant witnesses is not reliable in this regard.

4038 P3227 (Witness statement of KDZ033 dated 7 April 2010), para. 69 (under seal); KDZ033, T. 18071 (31 August 2011) (closed session). Defence witnesses testified that (i) it was only the army which brought Bosnian Muslims to the camp; (ii) the police only occasionally visited the facility; and (iii) the municipal authorities did not receive any information nor could they influence what happened at the facility. D2967 (Witness statement of Momir Deurić dated 16 February 2013), para. 19; Momir Deurić, T. 33921-33922 (18 February 2013); D2982 (Witness statement of Milenko Stanić dated 16 February 2013), para. 28. The Chamber refers to its credibility assessment in fns. 3791 and 3858 as to why it does not find the evidence of the relevant witnesses to be reliable in this regard.

4039 P3227 (Witness statement of KDZ033 dated 7 April 2010), paras. 71-72, 75-76 (under seal); P3245 (Assessment report on Sušica camp), pp. 7, 9. See also Adjudicated Fact 2707; D2967 (Witness statement of Momir Deurić dated 16 February 2013), para. 17; P3212 (Witness statement of Ibro Osmanović dated 23 August 2011), para. 110 (stating that the guards wore JNA uniforms and were mostly Bosnian Serbs from Vlasenica and nearby villages). 
at the camp and would then deliver those updated lists to the Vlasenica SJB. ${ }^{4040}$ The Sušica camp was equipped with a telephone and radio used for communicating with the Vlasenica Crisis Staff, the Vlasenica Battalion command, and the Vlasenica SJB. ${ }^{4041}$ The SJB and the Vlasenica Crisis Staff received regular reports on the situation at the Sušica camp. ${ }^{4042}$ The Vlasenica Crisis Staff also made decisions concerning the camp and detainees, such as decisions on release, visits by international representatives, and exchanges. ${ }^{4043}$

1183. In June 1992, Dragan Nikolić was put in charge of Sušica camp; he introduced himself to the detainees as the camp commander and said that he was "god and the law". 4044 Dragan Nikolić was a member of the Special Police Platoon and reported to Kraljević. ${ }^{4045}$ Other members of the Special Police Platoon would also come to the camp and were involved in questioning the detainees. $^{4046}$

1184. The Chamber took judicial notice that the camp operated for four months until September 1992. ${ }^{4047}$ The first group of detainees which was brought to the facility included 300 male and female Bosnian Muslims from Šekovići municipality who had been detained by members of the MP and brought to Sušica in late May or early June 1992. ${ }^{4048}$ The VRS and Bosnian Serb police, including members of the Special Police Platoon, then brought other Bosnian Muslims from

4040 P3227 (Witness statement of KDZ033 dated 7 April 2010), paras. 75, 92 (under seal). The Chamber places no weight on KDZ033's speculation that the detainee list would most probably have been provided to the Vlasenica Crisis Staff.

4041 P3227 (Witness statement of KDZ033 dated 7 April 2010), para. 83 (under seal).

4042 See Adjudicated Fact 2708; P3227 (Witness statement of KDZ033 dated 7 April 2010), paras. 17, 75, 83-84 (under seal). But see D3093 (Witness statement of Mane Đurić dated 3 March 2013), para. 70 (stating that if reports were submitted they would have been submitted to the TO command and the brigade command after the VRS was established). Members of the Vlasenica Crisis Staff only infrequently visited the camp and thus relied on the reports received. P3227 (Witness statement of KDZ033 dated 7 April 2010), para. 86 (under seal).

4043 P3227 (Witness statement of KDZ033 dated 7 April 2010), para. 84 (under seal). See also Adjudicated Fact 2709. But see D3093 (Witness statement of Mane Đurić dated 3 March 2013), para. 71 (stating that the Vlasenica Crisis Staff had been disbanded by 31 May 1992). The Chamber refers to its credibility assessment in fn. 3858 as to why it considers the evidence of Đurić to be unreliable in this regard.

4044 P3212 (Witness statement of Ibro Osmanović dated 23 August 2011), paras. 106-107, 111; Ibro Osmanović, T. 17998 (29 August 2011); P84 (Witness statement of Mirsad Kuralić dated 27 June 1996), p. 6; KDZ044, P107 (Transcript from KDZ044's testimony), T. 465 (under seal); KDZ044, P109 (Transcript from Prosecutor v. Nikolić), T. 267-269 (under seal); P111 (Witness statement of KDZ044 dated 28 September 1994), p. 2 (under seal); see Adjudicated Fact 2715. See also D2967 (Witness statement of Momir Deurić dated 16 February 2013), para. 18.

4045 [REDACTED]; P3212 (Witness statement of Ibro Osmanović dated 23 August 2011), paras. 108-109, 112-113, $142,183$.

4046 P3212 (Witness statement of Ibro Osmanović dated 23 August 2011), paras. 183, 192; P3225 (List of Vlasenica SJB reserve workers in September 1992). See also P3227 (Witness statement of KDZ033 dated 7 April 2010), paras. 10, 12, 82 (under seal); P3257 (Annotated photograph of members of Vlasenica special police platoon) (under seal)

$4047 \quad$ See Adjudicated Fact 2711.

4048 P3227 (Witness statement of KDZ033 dated 7 April 2010), paras. 67, 112(under seal). See also P3212 (Witness statement of Ibro Osmanović dated 23 August 2011), para. 114; P3227 (Witness statement of KDZ033 dated 
Vlasenica to the camp. ${ }^{4049}$ These included large numbers of Bosnian Muslims who were arrested in their homes in Vlasenica and taken to the camp with their families and who had been told they would be exchanged for Bosnian Serbs who had been taken prisoner in Tuzla. ${ }^{4050}$ In addition, inhabitants of villages who were captured after their villages were encircled and attacked by Serb Forces were also brought to Sušica. ${ }^{4051}$ Other detainees were transferred from the Vlasenica prison and SJB building to the camp. ${ }^{4052}$ Finally, people were also transported by Serb Forces to the Sušica camp from Rogatica ${ }^{4053}$ and Kalesija. ${ }^{4054}$

7 April 2010), para. 88 (under seal). The military police were formed by a decision of the Vlasenica Crisis Staff. P3227 (Witness statement of KDZ033 dated 7 April 2010), para. 7 (under seal).

4049 P3227 (Witness statement of KDZ033 dated 7 April 2010), paras. 67, 80 (under seal). Defence witnesses testified that (i) the municipal authorities decided to convert the TO facilities into a reception centre where Bosnian Muslims who had not left the municipality could be housed for their own protection; (ii) most Bosnian Muslims accepted the offer made by the municipal authorities for their temporary accommodation in the Sušica camp, until they could be transported to their location of choice; (iii) Sušica was not a camp but a reception centre which also housed Bosnian Serbs and Bosnian Croats; (iv) some Bosnian Muslim families would go to Sušica at night and return to their homes during the day. D2922 (Witness statement of Savo Čeliković dated 10 February 2013), paras. 26-27; Savo Čeliković, T. 33565 (13 February 2013); D3093 (Witness statement of Mane Đurić dated 3 March 2013), paras. 50-54; Mane Đurić, T. 35023-35028 (7 March 2013); D2967 (Witness statement of Momir Deurić dated 16 February 2013), para. 18; D3101 (Vlasenica SJB report, 6 August 1992); D3102 (Vlasenica SJB report, 1 September 1992); D3007 (Witness statement of Zoran Jovanović dated 18 February 2013), para. 29; D2932 (Witness statement of Tomislav Savkić dated 11 February 2013), paras. 42-44. See also Svetozar Andrić, T. 41684 (22 July 2013); D2982 (Witness statement of Milenko Stanić dated 16 February 2013), paras. 26, 28. Having regard to the weight of evidence, including the surrounding circumstances in the municipality and considering the credibility assessments of the relevant witnesses in fn. 3791, 3813, 3858, and 3894, the Chamber does not consider this evidence to be reliable. The Chamber also received a report which described Sušica camp as a "holding centre" to receive both Bosnian Muslims and Bosnian Serbs who had voluntarily expressed a desire to leave the municipality and stated that the camp met the basic conditions for their temporary accommodation. P3250 (Report of Vlasenica SJB, 1 September 1992). In light of the weight of evidence and also considering KDZ033's testimony as to the accuracy of P3250, the Chamber does not rely on this report's characterisation of the nature, purpose of, and conditions at the Sušica camp. P3227 (Witness statement of KDZ033 dated 7 April 2010), para. 91 (under seal). However, the Chamber finds that there were some people who came voluntarily to the camp as they expected faster transport from there out of Vlasenica to Bosnian Muslim controlled territory. KDZ033, T. 18074-18076 (31 August 2011) (closed session).

4050 KDZ044, P107 (Transcript from KDZ044's testimony), T. 461-463 (under seal); KDZ044, P109 (Transcript from Prosecutor v. Nikolić), T. 263-266 (under seal); P111 (Witness statement of KDZ044 dated 28 September 1994), p. 2 (under seal).

4051 Izet Redžić, P3189 (Transcript from Prosecutor v. Krajišnik), T. 5146; P3227 (Witness statement of KDZ033 dated 7 April 2010), para. 59 (under seal). See also KDZ044, P107 (Transcript from KDZ044's testimony), T. 464 (under seal); KDZ044, P109 (Transcript from Prosecutor v. Nikolić), T. 266 (under seal). These detainees include Bosnian Muslim women, children and the elderly who were brought to the camp following the attack on the village of Drum on or about 2 June 1992. P3262 (Witness statement of KDZ603 dated 30 August 2011), paras. 21, 24 (under seal); KDZ603, T. 18159 (1 September 2011). On the arrival of this group from Drum, soldiers discussed and confirmed that Vlasenica "had been cleaned". P3262 (Witness statement of KDZ603 dated 30 August 2011), paras. 25-26 (under seal).

4052 P3212 (Witness statement of Ibro Osmanović dated 23 August 2011), paras. 100-101; Ibro Osmanović, T. 17999 (29 August 2011); P3227 (Witness statement of KDZ033 dated 7 April 2010), para. 80 (under seal).

4053 Elvir Pašić, P59 (Transcript from Prosecutor v. Tadić), T. 870-872; KDZ033, T. 18073 (31 August 2011) (closed session).

4054 P84 (Witness statement of Mirsad Kuralić dated 27 June 1996), pp. 2, 6; Mirsad Kuralić, P63 (Transcript from Prosecutor v. Krajišnik), T. 12562-12564. See also D2982 (Witness statement of Milenko Stanić dated 16 February 2013), para. 28; P3212 (Witness statement of Ibro Osmanović dated 23 August 2011), para. 114. 
1185. Approximately 1,000 Bosnian Muslims were brought to the Sušica camp in the space of a few days. ${ }^{4055}$ During their transportation to the camp, Bosnian Muslims were threatened and subjected to racial slurs. ${ }^{4056}$ On arrival at the camp, the details of the detainees were recorded in a notebook. $^{4057}$

1186. The vast majority of the detainees were civilians. ${ }^{4058}$ The women, children and elderly men were separated from the men and transported towards Kladanj while the men were detained in a hangar after being searched. ${ }^{4059}$ The identification papers and valuables of the detainees were confiscated. $^{4060}$ The women were asked to sign a document saying that they were leaving Vlasenica of their own free will and those who refused to sign were threatened with being beaten or killed. $^{4061}$ Thereafter, only approximately 20 women remained at the camp, with approximately 800 women and children transported in buses, trucks and lorries from the camp over two days. ${ }^{4062}$

4055 P3262 (Witness statement of KDZ603 dated 30 August 2011), para. 28 (under seal); KDZ603, T. 18159 (1 September 2011); see Adjudicated Fact 2712. See also P84 (Witness statement of Mirsad Kuralić dated 27 June 1996), p. 6; Mirsad Kuralić, P63 (Transcript from Prosecutor v. Krajišnik), T. 12563-12564.

4056 Elvir Pašić, P59 (Transcript from Prosecutor v. Tadić), T. 870-872.

4057 P3227 (Witness statement of KDZ033 dated 7 April 2010), paras. 92-95 (under seal); P3251 (Handwritten document related to detainees) (under seal); P3252 (Handwritten document related to detainees) (under seal); P3253 (Handwritten list of non-Serbs brought to Sušica camp, 18 July 1992) (under seal).

4058 P3227 (Witness statement of KDZ033 dated 7 April 2010), paras. 53, 88 (under seal). See also P84 (Witness statement of Mirsad Kuralić dated 27 June 1996), p. 6; Mirsad Kuralić, P63 (Transcript from Prosecutor v. Krajišnik), T. 12563-12564; P3212 (Witness statement of Ibro Osmanović dated 23 August 2011), paras. 116117. Contrary to this finding that the vast majority of the detainees were civilians, the Accused submits that only those who had been "involved in activities against the Bosnian Serbs" were involuntarily detained at the camp. Defence Final Brief, confidential, para. 1437, [REDACTED]. However, the evidence cited by the Accused does not support this proposition. For example [REDACTED] testified that some men were released "after it was probably established that they had not been involved in any activities against the Serb authorities"; the Chamber finds this to be pure speculation. With respect to the evidence of [REDACTED] cited by the Accused, there is no reference to this issue in the witness's evidence.

4059 Izet Redžić, P3189 (Transcript from Prosecutor v. Krajišnik), T. 5067-5069, 5145-5146; P3227 (Witness statement of KDZ033 dated 7 April 2010), para. 74 (under seal); KDZ044, P107 (Transcript from KDZ044's testimony), T. 463-464 (under seal); KDZ044, P109 (Transcript from Prosecutor v. Nikolić), T. 266 (under seal); P111 (Witness statement of KDZ044 dated 28 September 1994), p. 2 (under seal); P3212 (Witness statement of Ibro Osmanović dated 23 August 2011), para. 115.

4060 KDZ044, P109 (Transcript from Prosecutor v. Nikolić), T. 266 (under seal); P111 (Witness statement of KDZ044 dated 28 September 1994), p. 2 (under seal); KDZ044, P107 (Transcript from KDZ044's testimony), T. 467-468 (under seal); see Adjudicated Fact 2712.

4061 KDZ044, P107 (Transcript from KDZ044's testimony), T. 466-467 (under seal); P111 (Witness statement of KDZ044 dated 28 September 1994), p. 2 (under seal); see Adjudicated Fact 2712. But see D3093 (Witness statement of Mane Đurić dated 3 March 2013), para. 72 (stating that the Bosnian Serb authorities did not force anyone to leave the municipality and did not confiscate valuables from Bosnian Muslims).

4062 P3262 (Witness statement of KDZ603 dated 30 August 2011), paras. 31-32 (under seal); see Adjudicated Fact 2712; KDZ044, P107 (Transcript from KDZ044's testimony), T. 467, 497 (under seal); KDZ603, T. 1816418165 (1 September 2011). KDZ044 also testified that detainees died during transportation, but the Chamber notes that these killings are not charged pursuant to Schedules A or B of the Indictment. See fn. 13. 
Women were detained in a separate building near the hangar and with time there were fewer and fewer women detained there. ${ }^{4063}$

1187. On 7 June 1992, the Command of the Eastern Bosnia Corps reported to the Main Staff of the VRS, that in the area of Vlasenica they held around 800 prisoners. ${ }^{4064}$ In mid June 1992, the Birač Brigade Command reported to the Command of the Eastern Bosnia Corps that it was "necessary to urgently resolve the issue of prisoner camps" given the large number of detainees which endangered the safety situation in the town. ${ }^{4065}$ By mid June 1992 there were between 500 and 600 detainees at the camp. ${ }^{4066}$ The number of detainees fluctuated with detainees brought in and others taken away, with on average between 150 and 200 detainees at the camp, reaching a peak towards the end of June and the beginning of July 1992. Approximately 400 detainees were then transferred to the Batković camp in Bijeljina. ${ }^{4067}$ In total, approximately 2,000 to 2,500 Bosnian Muslim men, women, children and the elderly passed through the camp. ${ }^{4068}$

\section{(b) Conditions of detention and treatment of detainees}

1188. While Bašić and his deputy delivered updated lists of detainees to the company which prepared the food for camp detainees, ${ }^{4069}$ detainees at the camp were insufficiently fed. Water was very scarce, sanitary conditions were poor, and medical care was not provided. ${ }^{4070}$ In the first two or three days after his arrival, Osmanović and the detainees were brought food from their homes but this depended on the good will of the guards and the warden; if Nikolic was not in a good mood

4063 P3212 (Witness statement of Ibro Osmanović dated 23 August 2011), para. 144; P3223 (Aerial photograph of Sušica camp marked by Ibro Osmanović); P3227 (Witness statement of KDZ033 dated 7 April 2010), paras. 88, 96 (under seal).

4064 P3237 (Report of the Eastern Bosnian Corps, 7 June 1992), p. 2; P3227 (Witness statement of KDZ033 dated 7 April 2010), para. 90 (under seal). See also Svetozar Andrić, T. 41668 (22 July 2013).

4065 P3220 (Report of Birač Brigade, 14 June 1992); P3221 (Request of Birač Brigade, 17 June 1992). Ibro Osmanović observed that while these figures were not exactly the same as his estimates, they were overall the same given that detainees would come and go from the facility. P3212 (Witness statement of Ibro Osmanović dated 23 August 2011), para. 115; P3227 (Witness statement of KDZ033 dated 7 April 2010), para. 90 (under seal).

4066 P3227 (Witness statement of KDZ033 dated 7 April 2010), para. 87 (under seal). See also P3262 (Witness statement of KDZ603 dated 30 August 2011), para. 27 (under seal).

4067 P3227 (Witness statement of KDZ033 dated 7 April 2010), paras. 87, 143 (under seal); P3262 (Witness statement of KDZ603 dated 30 August 2011), para. 35 (under seal). See also Adjudicated Fact 2251; P3212 (Witness statement of Ibro Osmanović dated 23 August 2011), para. 115; KDZ044, P109 (Transcript from Prosecutor v. Nikolić), T. 266 (under seal). For evidence on detention at Batković, see Scheduled Detention Facility C.2.1.

4068 P3227 (Witness statement of KDZ033 dated 7 April 2010), paras. 87-88 (under seal); KDZ033, T. 1807318074 (31 August 2011) (closed session). See also Adjudicated Fact 2710.

4069 [REDACTED].

4070 See Adjudicated Fact 2714; P3262 (Witness statement of KDZ603 dated 30 August 2011), para. 30 (under seal); KDZ603, T. 18163 (1 September 2011). See also P3227 (Witness statement of KDZ033 dated 7 April 2010), para. 74 (under seal); P3228 (Excerpt from CSCE's report on Sušica camp), e-court pp. 1-2. 
they would not get any food. ${ }^{4071}$ The detainees were provided with one meal a day which was served on 10 plates and the over 500 detainees had to eat from these plates which were not washed. $^{4072}$ The food was left-over from what the soldiers had eaten, ${ }^{4073}$ which was sour. ${ }^{4074}$ One cup of drinking water was distributed twice a day to the detainees. ${ }^{4075}$

1189. The detainees were held in a big hangar and slept on the concrete with planks ${ }^{4076}$ with no heating in the camp. ${ }^{4077}$ There were no beds in the camp ${ }^{4078}$ and the detainees were forced to sit on the concrete floor. ${ }^{4079}$ Some of the detainees had a blanket on which they slept. ${ }^{4080}$ In mid-June there was a terrible stench due to the inadequate toilet facilities. ${ }^{4081}$ In the morning the detainees were taken in groups, ordered by the guards to line up and run to urinate in the Sušica river and to defecate behind an improvised shelter of two blankets. ${ }^{4082}$ Detainees were sometimes beaten so they could not relieve themselves. ${ }^{4083}$ If detainees wanted to relieve themselves during the night they had to use a pot, which quickly filled which meant that the detainees simply relieved themselves in their pants and had no place to clean themselves. ${ }^{4084}$ Over time the detainees were engaged in the construction of toilets, were given sponges and blankets and provided with food supplies. $^{4085}$

1190. Dragan Nikolić subjected the detainees to all kinds of mistreatment, including frequent beatings. $^{4086}$ Some detainees would be beaten every day by Dragan Nikolić because they were

\footnotetext{
4071 P3212 (Witness statement of Ibro Osmanović dated 23 August 2011), paras. 119, 137. See also KDZ603, T. 18163 (1 September 2011); P3228 (Excerpt from CSCE's report on Sušica camp), pp. 1-2. [REDACTED].

4072 P3212 (Witness statement of Ibro Osmanović dated 23 August 2011), para. 119. See also KDZ044, P107 (Transcript from KDZ044's testimony), T. 487 (under seal); P111 (Witness statement of KDZ044 dated 28 September 1994), p. 5 (under seal).

4073 KDZ603, T. 18163 (1 September 2011).

4074 KDZ044, P109 (Transcript from Prosecutor v. Nikolić), T. 267, 273 (under seal).

4075 P3212 (Witness statement of Ibro Osmanović dated 23 August 2011), para. 120

4076 P74 (Supplemental information sheet for Mirsad Kuralić), p. 2.

4077 P3227 (Witness statement of KDZ033 dated 7 April 2010), para. 120 (under seal).

4078 P3227 (Witness statement of KDZ033 dated 7 April 2010), para. 74 (under seal).

4079 KDZ603, T. 18159-18160 (1 September 2011); P3212 (Witness statement of Ibro Osmanović dated 23 August 2011), para. 118.

$4080 \quad$ P3212 (Witness statement of Ibro Osmanović dated 23 August 2011), para. 123.

4081 P3227 (Witness statement of KDZ033 dated 7 April 2010), para. 71 (under seal). See also P3228 (Excerpt from CSCE's report on Sušica camp), pp. 1-2.

4082 P3212 (Witness statement of Ibro Osmanović dated 23 August 2011), para. 122; P3262 (Witness statement of KDZ603 dated 30 August 2011), para. 30 (under seal).

4083 P3212 (Witness statement of Ibro Osmanović dated 23 August 2011), para. 122. See also P111 (Witness statement of KDZ044 dated 28 September 1994), p. 6 (under seal).

4084 P3212 (Witness statement of Ibro Osmanović dated 23 August 2011), para. 122.

4085 KDZ033, T. 18073 (31 August 2011) (closed session).

4086 See Adjudicated Fact 2715; P3262 (Witness statement of KDZ603 dated 30 August 2011) (under seal), para. 34; KDZ603, T. 18165-18166 (1 September 2011) (private session); P111 (Witness statement of KDZ044 dated 28 September 1994), p. 2 (under seal). Jovanović testified that he visited the facility on one occasion to give supplies to some friends and was told that the conditions were not bad and nobody was "disturbing" the
} 
accused of being members of the SDA and having weapons. Dragan Nikolić also threatened to kill them if they did not reveal the location of weapons. ${ }^{4087} \mathrm{He}$ would beat the detainees with a truncheon, a pistol butt or kick them with his army boots. In one case he broke the ribs of a detainee. $^{4088}$ On other occasions, Nikolić would force detainees to kneel on the floor and put his knife or a bayonet into their mouths to scare them during interrogations. ${ }^{4089}$

1191. Galib Smajlović and Dževad Šarić were taken out on several occasions from the hangar and beaten. $^{4090}$ On or about 25 June 1992, Smajlović and Šarić were taken out by multiple guards including Dragan Nikolić, and then screaming was heard. ${ }^{4091}$ Smaljović was dragged back into the hangar unconscious after being beaten outside. ${ }^{4092}$ There were dark bruises on Smajlović's body and Šarić was very pale and was holding his stomach. ${ }^{4093}$ On another occasion in June 1992, Reuf Rasidagić was questioned by Nikolić and told "you will piss blood if you don't talk". ${ }^{4094}$ Rasidagić was beaten by Nikolić over four of five days and began to urinate blood and he begged Nikolić to kill him, but was told that one bullet cost money. ${ }^{4095}$

1192. Some detainees were also tied to a drain outside the hangar and had to kneel on sharp stones with their hands tied above their heads until they fainted. ${ }^{4096}$ Some were ordered by Nikolić to sit for 40 hours in a puddle of water with their hands behind their heads and legs spread on the ground as they were kicked and beaten. ${ }^{4097}$ On other occasions, Nikolić would cock an empty pistol, point

detainees. D3007 (Witness statement of Zoran Jovanović dated 18 February 2013), para. 29; Zoran Jovanović, T. 34207-34209 (21 February 2013). Jovanović on cross-examination maintained that he was not told about the murder, torture and sexual assault of detainees and that he did not witness the rape of a woman contrary to the statement of a victim who identified a Zoran Jovanović at the scene. In light of this cross-examination and considering its credibility assessment in fn. 3813 , the Chamber does not find Jovanović's evidence to be reliable in this regard. KDZ044, P107 (Transcript from KDZ044's testimony), T. 485 (under seal); P111 (Witness statement of KDZ044 dated 28 September 1994), p. 5 (under seal). KDZ044, P107 (Transcript from KDZ044's testimony), T. 485 (under seal); P111 (Witness statement of KDZ044 dated 28 September 1994), p. 5 (under seal); P3212 (Witness statement of Ibro Osmanović dated 23 August 2011), paras. 100, 130; P3227 (Witness statement of KDZ033 dated 7 April 2010), para. 108 (under seal).

P3212 (Witness statement of Ibro Osmanović dated 23 August 2011), para. 130; KDZ044, P109 (Transcript from Prosecutor v. Nikolić), T. 272 (under seal); KDZ044, P107 (Transcript from KDZ044's testimony), T. 485-486 (under seal); P111 (Witness statement of KDZ044 dated 28 September 1994), p. 5 (under seal). P3212 (Witness statement of Ibro Osmanović dated 23 August 2011), para. 135.

4091 P3212 (Witness statement of Ibro Osmanović dated 23 August 2011), para. 135; KDZ044, P107 (Transcript from KDZ044's testimony), T. 475 (under seal).

4092 P3212 (Witness statement of Ibro Osmanović dated 23 August 2011), para. 135.

4093 P3212 (Witness statement of Ibro Osmanović dated 23 August 2011), para. 136.

4094 P3212 (Witness statement of Ibro Osmanović dated 23 August 2011), para. 125.

4095 P3212 (Witness statement of Ibro Osmanović dated 23 August 2011), para. 125; Ibro Osmanović, T. 1794517946 (25 August 2011). Rasidagić and Osmanović were transferred to Batković on 30 June 1992. For evidence on detention at Batković, see Scheduled Detention Facility C.2.1.

4096 KDZ044, P107 (Transcript from KDZ044's testimony), T. 486 (under seal); P111 (Witness statement of KDZ044 dated 28 September 1994), p. 5 (under seal).

4097 P3212 (Witness statement of Ibro Osmanović dated 23 August 2011), paras. 131-132. 
the gun at detainees or put it into their mouths and pull the trigger; he once shot an automatic weapon at the wall above the heads of the detainees. ${ }^{4098}$

1193. Some detainees were interrogated at the camp itself while others were taken for interrogation to the Vlasenica SJB or other locations and some returned severely bruised after being beaten. ${ }^{4099}$ The interrogations were for the most part conducted by members of the Special Police Platoon $^{4100}$ while members of the Vlasenica SJB would take notes. ${ }^{4101}$ Some detainees were questioned about military operations and security issues while others were simply subjected to mistreatment for the purpose of obtaining their money. ${ }^{4102}$ The group of detainees from the area of Šekovići were frequently interrogated and physically abused by members of the Šekovići unit. ${ }^{4103}$

1194. Between June and September 1992, Bosnian Serb guards, soldiers, and other men who had been given access to the camp raped and committed other acts of sexual violence against non-Serb women. ${ }^{4104}$ Young women would be taken out in the evening and brought back in the morning in tears, with "their hair tousled and their clothes torn". ${ }^{4105}$

1195. The Vlasenica SJB issued orders for detainees at the camp to be taken out to perform work or to be released, ${ }^{4106}$ which then required the approval of Dragan Nikolić. ${ }^{4107}$ By the second half of

4098 P3212 (Witness statement of Ibro Osmanović dated 23 August 2011), para. 138; KDZ044, P109 (Transcript from Prosecutor v. Nikolić), T. 273-274 (under seal). Deurić denied seeing Nikolić mistreating a detainee despite being confronted with the statements of detainees who saw Deurić at the scene. Momir Deurić, T. 33926-33929 (18 February 2013). In light of Deurić's credibility assessment in fn. 3858, the Chamber does not find Deurić's denial and attempt to distance himself from the mistreatment to be reliable.

4099 P3227 (Witness statement of KDZ033 dated 7 April 2010), paras. 80, 111 (under seal); P3262 (Witness statement of KDZ603 dated 30 August 2011), para. 33 (under seal). See also P84 (Witness statement of Mirsad Kuralić dated 27 June 1996), p. 6. The Chamber also received evidence about detainees who were taken from the camp for interrogation or for purported exchanges but disappeared or were killed. P3227 (Witness statement of KDZ033 dated 7 April 2010), paras. 97, 110, 113, 119, 145-147 (under seal); P3260 (List of missing civilians in Vlasenica in 1992) (under seal); KDZ033, T. 18086 (31 August 2011) (closed session); P111 (Witness statement of KDZ044 dated 28 September 1994), p. 6 (under seal); KDZ044, P107 (Transcript from KDZ044's testimony), T. 484-485 (under seal); P3262 (Witness statement of KDZ603 dated 30 August 2011), paras. 27, 29 (under seal); P3212 (Witness statement of Ibro Osmanović dated 23 August 2011), paras. 143, 148, 193; Ibro Osmanović, T. 17948-17950 (25 August 2011); Izet Redžić, P3189 (Transcript from Prosecutor v. Krajišnik), T. 5069. The Chamber notes that the above killings are not charged pursuant to Schedules A or B of the Indictment. See fn. 13.

4100 [REDACTED]. See also P3212 (Witness statement of Ibro Osmanović dated 23 August 2011), para. 71.

4101 P3251 (Handwritten document related to detainees) (under seal); P3227 (Witness statement of KDZ033 dated 7 April 2010), para. 93 (under seal).

4102 [REDACTED].

4103 P3227 (Witness statement of KDZ033 dated 7 April 2010), paras. 82, 112 (under seal).

4104 P3227 (Witness statement of KDZ033 dated 7 April 2010), para. 108 (under seal). See also P3212 (Witness statement of Ibro Osmanović dated 23 August 2011), para. 114.

4105 KDZ044, P107 (Transcript from KDZ044's testimony), T. 498 (under seal); KDZ044, P109 (Transcript from Prosecutor v. Nikolić), T. 273 (under seal).

4106 P3227 (Witness statement of KDZ033 dated 7 April 2010), para. 85 (under seal); P3249 (Handwritten order, 18 August 1992) (under seal). 
July 1992 most of the detainees were engaged in physical labour. ${ }^{4108}$ The detainees who were taken for work left the camp at 7 a.m. and returned at about 5 p.m. or 6 p.m. in the evening. ${ }^{4109}$ They performed several types of labour, including burial of bodies, digging of trenches, and carrying of munitions at frontlines. 4110

1196. Further, each day a group of detainees was taken to the VRS barracks to work on renovations ${ }^{4111}$ while others were sent for physical labour at factories, businesses and roads or were engaged in agricultural work while others were used to clean the houses abandoned by nonSerbs. $^{4112}$ These houses were looted and cleaned before Bosnian Serb refugees moved into them. ${ }^{4113}$ On one occasion detainees were ordered to set fire to the goods which had been looted from a Bosnian Muslim house $\mathrm{H}^{414}$ and on another occasion were forced to load onto a truck the rubble from the Vlasenica mosque which had been destroyed. ${ }^{4115}$ The detainees were afraid for their lives and of being beaten if they refused to work. ${ }^{4116}$ Some detainees taken for work

4107 KDZ044, P107 (Transcript from KDZ044's testimony), T. 488 (under seal); P3227 (Witness statement of KDZ033 dated 7 April 2010), paras. 73, 92 (under seal); P3212 (Witness statement of Ibro Osmanović dated 23 August 2011), para. 107; P3251 (Handwritten document related to detainees) (under seal).

4108 P3227 (Witness statement of KDZ033 dated 7 April 2010), para. 99 (under seal).

4109 KDZ044, P107 (Transcript from KDZ044's testimony), T. 487 (under seal).

$4110 \quad$ See Adjudicated Fact 2713.

4111 P3227 (Witness statement of KDZ033 dated 7 April 2010), paras. 99, 103 (under seal); P3259 (Aerial photograph of Vlasenica). See also P3247 (Handwritten list of men working at Sušica camp, 8-12 September 1992) (under seal); KDZ033, T. 18080 (31 August 2011) (closed session); KDZ044, P107 (Transcript from KDZ044's testimony), T. 487 (under seal).

4112 P3227 (Witness statement of KDZ033 dated 7 April 2010), paras. 79, 93, 99, 103, 105-106 (under seal); P3212 (Witness statement of Ibro Osmanović dated 23 August 2011), para. 124; P3247 (Handwritten list of men working at Sušica camp, 8-12 September 1992) (under seal); P3253 (Handwritten list of non-Serbs brought to Sušica camp, 18 July 1992), pp. 2-3 (under seal); P3248 (Handwritten list of people who worked or visited Sušica camp) (under seal); P3251 (Handwritten document related to detainees) (under seal), p. 5; P3254 (Handwritten list of men 10-11 August 1992) (under seal); KDZ044, P107 (Transcript from KDZ044's testimony), T. 486-487 (under seal); P111 (Witness statement of KDZ044 dated 28 September 1994), pp. 2,6 (under seal). The detainees were taken away by police and military commanders and members of the reserve police. P3227 (Witness statement of KDZ033 dated 7 April 2010), paras. 79, 93, 100, 107 (under seal); P3248 (Handwritten list of people who worked or visited Sušica camp) (under seal); P3251 (Handwritten document related to detainees), p. 5 (under seal). The Chamber notes that this type of forced labour is not charged in the Indictment, which only covers forced labour at the frontlines.

4113 P3227 (Witness statement of KDZ033 dated 7 April 2010), para. 99 (under seal).

4114 P3212 (Witness statement of Ibro Osmanović dated 23 August 2011), para. 124.

4115 P3227 (Witness statement of KDZ033 dated 7 April 2010), para. 57 (under seal). The Chamber notes that the destruction of the mosque is not charged in Schedule D of the Indictment.

4116 P3212 (Witness statement of Ibro Osmanović dated 23 August 2011), para. 124. See also P111 (Witness statement of KDZ044 dated 28 September 1994), p. 2 (under seal). But see KDZ033, T. 18081-18082, 18101 (31 August 2011) (closed session); KDZ603, T. 18166-18167 (1 September 2011), who testified that (i) detainees were asked to volunteer for work assignments; (ii) those who could not work for example for health reasons were not subject to any punishment or penalty; and (iii) detainees would often receive better food and provisions when taken for work assignments and were treated fairly. While the Chamber finds that detainees may have received better provisions while on work assignment, in light of the circumstances of detention including the beating and mistreatment, and the direct evidence of Osmanović that detainees were afraid to refuse work, the Chamber does not consider that the detainees from the camp voluntarily performed the work assignments. KDZ033 himself was equivocal and could not confirm whether or not the labour was forced or not. 
assignments were insulted and called "Balija's mother" and some were beaten with tree branches. $^{4117}$

1197. Every day a list was drawn up indicating the number of detainees needed on a given day for work. ${ }^{4118}$ When the detainees returned, the detainees list would be checked to confirm that all the detainees had returned; if a detainee was missing, the camp would inform the Vlasenica SJB and the person who took the detainees away would then explain whether the detainee had been released, taken to the SJB or killed. ${ }^{4119}$

\section{(c) Transfer of detainees and inspection of camp}

1198. In June 1992 the VRS prepared a strictly confidential report on the security at Sušica camp. $^{4120}$ This report also indicated that it was "impossible to apply any disinformation or coverup measures because it is a public place" and that everyone was practically informed about the "number and structure of prisoners". 4121 In this regard, the report suggested that in order to "prevent informing the public about the prisoners' appearance and the conditions they live in", any attempts to take in recording devices or conduct interviews must be prevented and "extensive movement must be prohibited". ${ }^{422}$ In addition, the report indicated that visits of any type and the bringing of food and other material to the prisoners "must be prohibited" and recommended relocation of the camp. ${ }^{4123}$

1199. Detainees were only released after receipt of written orders from officials, including the VRS security officer, the SJB chief, the Special Police Platoon commander. ${ }^{4124}$ Despite being told they would be exchanged, ${ }^{4125}$ able-bodied men were transferred to the Batković camp in three

\footnotetext{
4117 P111 (Witness statement of KDZ044 dated 28 September 1994), p. 6 (under seal).

4118 P3227 (Witness statement of KDZ033 dated 7 April 2010), paras. 101-104 (under seal). See also P3247 (Handwritten list of men working at Sušica camp, 8-12 September 1992) (under seal). Deurić denied being involved in making a list of detainees who would be forced to be taken for work. Momir Deurić, T. 3392833932 (18 February 2013). Having considered its credibility assessment in fn. 3858, and given Deurić's attempts to distance himself from the mistreatment of detainees, the Chamber does not find his evidence in this regard to be reliable.

4119 P3227 (Witness statement of KDZ033 dated 7 April 2010), para. 101 (under seal).

4120 [REDACTED]; P3245 (Assessment report on Sušica camp).

4121 P3245 (Assessment report on Sušica camp), p. 4.

4122 P3245 (Assessment report on Sušica camp), p. 4.

4123 P3245 (Assessment report on Sušica camp), pp. 4-5.

4124 [REDACTED].

4125 P3227 (Witness statement of KDZ033 dated 7 April 2010), para. 142 (under seal); P3212 (Witness statement of Ibro Osmanović dated 23 August 2011), paras. 145-146, 149; Ibro Osmanović, T. 17999 (29 August 2011); KDZ044, P107 (Transcript from KDZ044's testimony), T. 491 (under seal).
} 
groups at the end of June $1992^{4126}$ while women, children and elderly were taken to the frontlines at Kladanj or Cerska and released or taken to the Pelemiš camp in Šekovići. ${ }^{4127}$

1200. When representatives of an international organisation were scheduled to visit the Sušica camp, the Vlasenica SJB instructed those responsible for the camp that the detainees should be moved to another location urgently. ${ }^{4128}$ In July 1992, representatives of international organisations visited Sušica camp. ${ }^{4129}$ During these two visits, Nikolić managed to conceal many detainees and the true state of the conditions of detention. ${ }^{4130}$ Before the arrival of international representatives, the detainees who remained in the camp were instructed to hide their belongings and were hidden in the forest. ${ }^{4131}$ A similar visit was carried out on 2 September 1992 by the CSCE, but the guards at the camp did not have enough time to hide the detainees before the international representatives accompanied by a Bosnian Serb delegation arrived. ${ }^{4132}$ However, there were only 30 or 40 detainees in the camp at the time and when questioned by the international representatives the detainees stated that they were just waiting for transport and had received fine treatment at the camp. ${ }^{4133}$ However, the CSCE reported, inter alia, that the detainees had been held for more than two months, that they were fearful and reluctant to speak openly in front of the guards and seemed "haggard, pale and thin" but their state of nourishment could not be assessed as they were dressed in heavier clothing. ${ }^{4134}$ After the visit Velibor Ostojić said that they would no longer have to hide

4126 For evidence of detention at Batković, see Scheduled Detention Facility C.2.1.

4127 P3227 (Witness statement of KDZ033 dated 7 April 2010), paras. 140-144 (under seal); P3262 (Witness statement of KDZ603 dated 30 August 2011), para. 35 (under seal); KDZ044, P107 (Transcript from KDZ044's testimony), T. 488-489 (under seal) (testifying that he was told by a guard that being transferred to Batković was their only hope as they would all be killed if they remained at Sušica); P3212 (Witness statement of Ibro Osmanović dated 23 August 2011), paras. 145-146, 148-149, 193; Ibro Osmanović, T. 17948-17949 (25 August 2001), 17999 (29 August 2011). See also P3241 (Report of Šekovići Military Post, 3 July 1992); P3213 (List of persons detained at Batković camp) where KDZ033 was able to identify a number of detainees at the Batković camp who had previously been detained at Sušica but who were transported on 30 June 1992. D3093 (Witness statement of Mane Đurić dated 3 March 2013), para. 55.

4128 [REDACTED].

4129 P3227 (Witness statement of KDZ033 dated 7 April 2010), para. 151 (under seal). See also Adjudicated Fact 2716.

$4130 \quad$ See Adjudicated Fact 2716.

4131 P3227 (Witness statement of KDZ033 dated 7 April 2010), para. 151 (under seal). See also Adjudicated Fact 2716. But see D2967 (Witness statement of Momir Deurić dated 16 February 2013), para. 21; Momir Deurić, T. 33924 (18 February 2013).

4132 P3227 (Witness statement of KDZ033 dated 7 April 2010), para. 154 (under seal); KDZ033, T. 18020 (29 August 2011) (closed session)

4133 P3227 (Witness statement of KDZ033 dated 7 April 2010), para. 155 (under seal). See also P3239 (Two photographs of a man) (under seal); P3243 (Photograph of man at hangar in Sušica camp); KDZ033, T. 18020 (29 August 2011) (closed session); P3228 (Excerpt from CSCE's report on Sušica camp), p. 1.

4134 P3228 (Excerpt from CSCE's report on Sušica camp), pp. 1-2; P6131 (Photographs of CSCE visit to Sušica camp). 
evidence of the camp, and that it would soon be closed down. ${ }^{4135}$ The camp was shut down by the end of September 1992. ${ }^{4136}$

$\underline{\text { detainees }}$

(d) Conclusion on conditions of detention and treatment of

1201. Based on the above, the Chamber finds that from late May until the end of September 1992, large numbers of Bosnian Muslim civilians, including women, children and the elderly, were brought to and detained at Sušica camp by Serb Forces. At one point, women, children and the elderly were transported out of the municipality while the men continued to be detained. Their identification papers, money, and valuables were confiscated. The detainees were held in poor conditions which included lack of food, limited access to water, no bedding, poor sanitary and hygienic facilities, and no medical care. Detainees were subjected to frequent beatings with truncheons, guns, knives and were also subjected to other mistreatment and threats. Women at the camp were raped. Detainees were also forced to dig trenches and to carry munitions at the frontlines.

(e) Scheduled Incident B.18.1

1202. The Prosecution alleges that approximately nine men from Sušica camp were killed between June and August 1992. ${ }^{4137}$

1203. The Chamber took judicial notice that nine detainees in the Sušica camp were killed by camp guards or died from mistreatment and that these deaths were reported to warden Bašić with no consequences. ${ }^{4138}$ After these killings, the detainees were simply removed from the list of

4135 [REDACTED]. But see Velibor Ostojić, D2361 (Transcript from Prosecutor v. Krajišnik), T. 26682-26683, 26726-26728; D2362 (Witness statement of Velibor Ostojić dated 6 June 2006), para. 43. Ostojić denied that he ever visited the facility. P1607 (RS Ministry of Justice report on prisons and camps on the RS territory, 22 October 1992), pp. 2; Slobodan Avlijaš, T. 35174, 35196 (11 March 2013); D3105 (Witness statement of Slobodan Avlijaš dated 9 March 2013), para. 26 (stating that by the time of his inspection in October 1992 the detainees had already been exchanged or transferred).

4136 P3227 (Witness statement of KDZ033 dated 7 April 2010), paras. 136, 138 (under seal); KDZ033, T. 1810818109 (31 August 2011) (closed session). See also D1660 (Annex B, “Admitted, undisputed and contested facts"), (under seal), p. 2.

4137 The Prosecution submits that that the evidence shows that these killings occurred in June and July 1992. Prosecution Final Brief, Appendix B.

4138 See Adjudicated Fact 2717. See also P3227 (Witness statement of KDZ033 dated 7 April 2010), para. 115 (under seal); P4856 (Appendix B to the Prosecution Pre-Trial Brief filed on 18 May 2009 marked by Amor Mašović), p. 29. The order which established the Sušica camp forbade the arbitrary "liquidation" of detainees. P3240 (Order of Birač Brigade, 31 May 1992); D3886 (Witness statement of Svetozar Andrić dated 16 July 2013), para. 7; Svetozar Andrić, T. 41684-41685 (22 July 2013). See also D3093 (Witness statement of Mane Đurić dated 3 March 2013), para. 53. However, this order was not followed in practice. P3227 (Witness statement of KDZ033 dated 7 April 2010), para. 68 (under seal); KDZ033, T. 18100 (31 August 2011) (closed session). 
detainees and recorded as deceased with no report. ${ }^{4139}$ The nine detainees who were killed were buried in the Vlasenica town cemetery. ${ }^{4140}$

1204. During one of the nights on or about of 21 June 1992, Dragan Nikolić and Goran Tešić entered the hangar and took out a pensioner named Durmo Handžić and another detainee named Asim Zildžić, and then screaming was heard. ${ }^{414}$ Handžić was questioned about the location of his son. The two detainees were then beaten with a spade and a pipe and kicked while they were lying on the ground. ${ }^{4142}$ Detainees were ordered to pour water over Handžić and Zildžić for them to regain consciousness. They were then carried back to the hangar. ${ }^{4143}$ Zildžić's face was severely beaten, his eye was coming out of the socket, and he was spitting blood. ${ }^{4144}$ Other detainees helped to wipe blood from Handžić's body as he moaned and sobbed. ${ }^{4145}$ Zildžić and Handžić died shortly after being brought back to the hangar and other detainees were ordered to bury their bodies in unmarked graves. ${ }^{4146}$

1205. On or about 25 June 1992, Dževad Šarić was taken out and killed with a sub-machine gun $^{4147}$ and detainees were ordered to take away his body and wash and cover the traces of

4139 P3227 (Witness statement of KDZ033 dated 7 April 2010), para. 115 (under seal). But see D2967 (Witness statement of Momir Deurić dated 16 February 2013), paras. 19-20; Momir Deurić, T. 33926-33927, 3393133932 (18 February 2013). See P6132 (Verdict of BiH Court against Predrag Bastah and Goran Višković, 4 February 2010). Deurić testified that he was not aware of any killings, but then admitted he would go home at night, and that even when he was there during the day he tried to avoid seeing the detainees. He then acknowledged that he heard stories about crimes against detainees in the camp but that some were convicted for those crimes. The Chamber does not find Deurić's evidence in this regard to be consistent or reliable

4140 P3227 (Witness statement of KDZ033 dated 7 April 2010), para. 114 (under seal); KDZ033, T. 18106 (31 August 2011) (closed session).

4141 P3212 (Witness statement of Ibro Osmanović dated 23 August 2011), para. 126; KDZ044, P107 (Transcript from KDZ044's testimony), T. 469 (under seal); P111 (Witness statement of KDZ044 dated 28 September 1994), p. 3 (under seal).

4142 KDZ044, P107 (Transcript from KDZ044's testimony), T. 469-470 (under seal); P111 (Witness statement of KDZ044 dated 28 September 1994), p. 3 (under seal); P3227 (Witness statement of KDZ033 dated 7 April 2010) (under seal), paras. 108, 114.

4143 P3212 (Witness statement of Ibro Osmanović dated 23 August 2011), para. 127; KDZ044, P107 (Transcript from KDZ044's testimony), T. 470-471 (under seal); KDZ044, P109 (Transcript from Prosecutor v. Nikolić), T. 270 (under seal).

4144 KDZ044, P107 (Transcript from KDZ044's testimony), T. 471 (under seal).

4145 KDZ044, P107 (Transcript from KDZ044's testimony), T. 471 (under seal); P111 (Witness statement of KDZ044 dated 28 September 1994), p. 3 (under seal).

4146 P3212 (Witness statement of Ibro Osmanović dated 23 August 2011), para. 127; KDZ044, P107 (Transcript from KDZ044's testimony), T. 471-472, 474 (under seal); KDZ044, P109 (Transcript from Prosecutor v. Nikolić), T. 269-270 (under seal); P111 (Witness statement of KDZ044 dated 28 September 1994), pp. 3-4 (under seal). Both Zildžić and Handžić were exhumed from individual graves. P4853 (Updated Table 2 to the Report of Amor Mašović), pp. 94-95. Detainees were also ordered to tell Zildžić's wife that he had died of a heart attack. A false report was also drawn up to suggest that both Handžić and Zildžić had died of heart attacks. P3212 (Witness statement of Ibro Osmanović dated 23 August 2011), para. 128; P3222 (Report of Sušica Military Prison, 22 June 1992); [REDACTED]. The Accused cites to this evidence to suggest that [REDACTED] was concealing the truth about the deaths from his superiors. Defence Final Brief, confidential, para. 1437.

4147 P3227 (Witness statement of KDZ033 dated 7 April 2010), paras. 108, 114 (under seal); KDZ044, P107 (Transcript from KDZ044's testimony), T. 475 (under seal); P113 (Witness statement of KDZ044 dated 7 
blood. ${ }^{4148}$ Muharem Kolarević was also taken out of the hangar and badly beaten but was still alive when the detainees moved his body. ${ }^{4149}$ Kolarević's body was later discovered entangled on a wire fence. ${ }^{4150}$ Tešić then took a sub machine gun and shot him. ${ }^{4151}$ On or about 26 June 1992, "Musa" Zekić, who was accused of killing a Bosnian Serb, was taken out of the hangar and interrogated in a chair before Goran Tešić shot him with a machine gun. ${ }^{4152}$ Rašid Ferhatbegović who was about 60 years old was accused of attempting to escape; he was taken out of the hangar and shot. ${ }^{4153}$ Detainees were ordered to bury the bodies of Šarić, Kolarević and Ferhatbegović in a forest. ${ }^{4154}$

1206. In June 1992, Ismet Dedić was repeatedly beaten over a number of days before he died and his body was taken by a car sent by the Vlasenica SJB and buried at the Muslim cemetery. ${ }^{4155}$ In the first half of July 1992, Mevludin Hatunić was taken out of the hangar, beaten, and kicked by Dragan Nikolić and fell to the ground. ${ }^{4156}$ Hatunić was carried back to the hangar as he could not walk on his own and later died. Nikolić then ordered that the body be removed from the hangar,

October 1997), p. 2 (under seal); P3227 (Witness statement of KDZ033 dated 7 April 2010), paras. 108, 114 (under seal); P3212 (Witness statement of Ibro Osmanović dated 23 August 2011), para. 139; Ibro Osmanović, T. 17945 (25 August 2011).

4148 KDZ044, P107 (Transcript from KDZ044's testimony), T. 476 (under seal); P113 (Witness statement of KDZ044 dated 7 October 1997), p. 2 (under seal).

4149 P3212 (Witness statement of Ibro Osmanović dated 23 August 2011), para. 139; Ibro Osmanović, T. 17945 (25 August 2011); KDZ044, P107 (Transcript from KDZ044's testimony), T. 475-476 (under seal); P111 (Witness statement of KDZ044 dated 28 September 1994), p. 4 (under seal); P113 (Witness statement of KDZ044 dated 7 October 1997), p. 2 (under seal).

4150 KDZ044, P107 (Transcript from KDZ044's testimony), T. 480-481 (under seal); P111 (Witness statement of KDZ044 dated 28 September 1994), p. 5 (under seal).

4151 KDZ044, P107 (Transcript from KDZ044's testimony), T. 481 (under seal); P111 (Witness statement of KDZ044 dated 28 September 1994), p. 5 (under seal); P3227 (Witness statement of KDZ033 dated 7 April 2010) (under seal), para. 108.

4152 P3212 (Witness statement of Ibro Osmanović dated 23 August 2011), para. 139; Ibro Osmanović, T. 17998 (29 August 2011); P111 (Witness statement of KDZ044 dated 28 September 1994), p. 5 (under seal); KDZ044, P107 (Transcript from KDZ044's testimony), T. 476-477 (under seal); KDZ044, P109 (Transcript from Prosecutor v. Nikolić), T. 271 (under seal); P113 (Witness statement of KDZ044 dated 7 October 1997), p. 2 (under seal); P3227 (Witness statement of KDZ033 dated 7 April 2010) (under seal), para. 108.

4153 P3212 (Witness statement of Ibro Osmanović dated 23 August 2011), para. 140; KDZ044, P107 (Transcript from KDZ044's testimony), T. 479-481 (under seal); P111 (Witness statement of KDZ044 dated 28 September 1994), p. 5 (under seal); P113 (Witness statement of KDZ044 dated 7 October 1997), p. 3 (under seal); P3227 (Witness statement of KDZ033 dated 7 April 2010), paras. 108, 114 (under seal). The three bodies were exhumed from individual graves. P4853 (Updated Table 2 to the Report of Amor Mašović), pp. 94-95; P4109 (John Clark's expert report entitled "Report of the Chief Pathologist, Vlasenica Grave-Site (2000)", 30 September 2002), pp. 1-5.

4154 KDZ044, P107 (Transcript from KDZ044's testimony), T. 482-483 (under seal); P111 (Witness statement of KDZ044 dated 28 September 1994), p. 5 (under seal); P113 (Witness statement of KDZ044 dated 7 October 1997), p. 3 (under seal).

4155 P3227 (Witness statement of KDZ033 dated 7 April 2010), para. 117 (under seal).

4156 P3227 (Witness statement of KDZ033 dated 7 April 2010), paras. 108, 118 (under seal). 
the SJB was informed and the body was buried at the Muslim cemetery. ${ }^{4157}$ Galib Musić was also beaten to death in the first half of July $1992 .^{4158}$

1207. Based on the above, the Chamber therefore finds that nine men from Sušica camp were killed by Serb Forces in June and July 1992.

\section{(f) Scheduled Incident B.18.2}

1208. The Prosecution alleges that up to 140 detainees were killed in Sušica camp on or about 30 September 1992.

1209. By way of background to this incident, the Chamber notes that on 29 September 1992, the funeral for 29 Bosnian Serb soldiers killed by $\mathrm{ABiH}$ forces, was held at the Orthodox church in Vlasenica. ${ }^{4159}$ Over 1,000 people attended the funeral, including the Bosnian Serb leadership from the municipality and from Pale, namely the Accused, Velibor Ostojić, Nikola Koljević and Svetozar Andrić, amongst others. ${ }^{4160}$ Speeches were given at the funeral; the speakers and the crowd "were very agitated and embittered" by the death of the Bosnian Serb soldiers. ${ }^{4161}$ The Accused in his speech said: "Nor must we forget their executioners and attackers. I do not know if I am allowed to say that we must not forgive either. Who knows how many times this century our brothers, who are no brothers at all, have been at our throats. They assault our good men. But the Lords sees that and has given us strength to resist [...]". 4162

1210. The Accused gave an interview on the day of the funeral and said "We are concerned about Muslims, we want them to have their own territory. Since we wanted to separate from them, since we see that we can't live together any longer. But, if they do not proclaim a realistic objective concerning territories, they may lose everything."4163

\footnotetext{
4157 P3227 (Witness statement of KDZ033 dated 7 April 2010), para. 118 (under seal).

4158 P3227 (Witness statement of KDZ033 dated 7 April 2010), para. 108 (under seal).

4159 P3227 (Witness statement of KDZ033 dated 7 April 2010), para. 121 (under seal); D1662 (Article from SRNA entitled "Vlasenica: Serbs- victims of moslem terrorists vandal crime buried today", 29 September 1992); KDZ033, T. 18121 (29 August 2011) (closed session); P810 (Sky news report re Vlasenica, with transcript). See Adjudicated Fact 2718.

4160 P3227 (Witness statement of KDZ033 dated 7 April 2010), para. 121, 125-126 (under seal); P810 (Sky news report re Vlasenica, with transcript). See also D2967 (Witness statement of Momir Deurić dated 16 February 2013), paras. 24, 27.

4161 P3227 (Witness statement of KDZ033 dated 7 April 2010), paras. 122-124, 126 (under seal); KDZ033, T. 18124, 18134 (31 August 2011) (closed session).

4162 P3261 (Excerpt of video footage of Radovan Karadžić's speech, with transcript); P3227 (Witness statement of KDZ033 dated 7 April 2010), para. 123 (under seal).

4163 P3230 (Video footage re excerpt of interview with Radovan Karadžić, with transcript); KDZ033, T. 18024 (29 August 2011) (closed session)
} 
1211. After the funeral at around 9 or 10 p.m., Bosnian Serb police officers carrying automatic rifles arrived at the Sušica camp with a truck. ${ }^{4164}$ At that time, approximately 140 to 150 non-Serb detainees remained at Sušica camp. ${ }^{4165}$ The police officers said that they had been instructed by Mane Đurić to remove the detainees as soon as possible, that they should pack their belongings and that they would probably be transported to the frontline where they would be released. ${ }^{4166}$ The police officers also presented a written order from the SJB Chief to the guards instructing them to hand over the detainees. ${ }^{4167}$ The detainees were hurried to gather their belongings as quickly as possible and were loaded onto the truck in groups of 30 to 40 persons and taken towards Vlasenica town. ${ }^{4168}$ The detainees who were taken in the first group were called out from a list of names. ${ }^{4169}$ Approximately one and a half or two hours later the police officers returned with the empty truck and called out the names of the next group of detainees who were also loaded onto the truck. ${ }^{4170}$ This process repeated itself with three or four groups of detainees taken away in the truck in this manner with the last group taken away in a small bus accompanied by a group of Bosnian Serbs wearing police and military uniforms. ${ }^{4171}$

1212. The Chamber took judicial notice that three MUP officers arrived at the Sušica camp, removed all 140 to 150 inmates in four loads, and killed them. ${ }^{4172}$ This included 41 non-Serb detainees who were taken away and killed by the Bosnian Serb police at Debelo Brdo. ${ }^{4173}$ This

4164 P3227 (Witness statement of KDZ033 dated 7 April 2010), para. 129 (under seal); KDZ033, T. 18122 (29 August 2011) (closed session).

4165 P3227 (Witness statement of KDZ033 dated 7 April 2010), para. 120 (under seal).

4166 P3227 (Witness statement of KDZ033 dated 7 April 2010), para. 128 (under seal).

4167 P3227 (Witness statement of KDZ033 dated 7 April 2010), para. 128 (under seal). But see D2967 (Witness statement of Momir Deurić dated 16 February 2013), para. 25; Momir Deurić, T. 33933-33934 (18 February 2013) who denied knowledge of what happened to the detainees. See also D3886 (Witness statement of Svetozar Andrić dated 16 July 2013), para. 7, who also denied knowledge about the incident but then testified that the Brigade did not have the responsibility or strength to protect the detainees. The Chamber refers to its credibility assessment in fns. 3858 and 3894 as to why the evidence of the relevant witnesses is not reliable in this regard.

4168 P3227 (Witness statement of KDZ033 dated 7 April 2010), para. 129 (under seal).

4169 P3227 (Witness statement of KDZ033 dated 7 April 2010), para. 129 (under seal).

4170 P3227 (Witness statement of KDZ033 dated 7 April 2010), para. 130 (under seal).

4171 P3227 (Witness statement of KDZ033 dated 7 April 2010), paras. 130-132 (under seal).

4172 P3227 (Witness statement of KDZ033 dated 7 April 2010), paras. 135, 137 (under seal). See Adjudicated Fact 2719 (the Chamber notes that the Adjudicated Fact refers to the night of 30 September 1992 while the evidence received in this case indicates that they were taken away on the night of 29 September 1992). But see D3093 (Witness statement of Mane Đurić dated 3 March 2013), para. 73 (stating that to his knowledge no police officer was involved in the murder of detainees). The Chamber refers to its credibility assessment in fn. 3858 as to why Đurić's evidence in this regard is found to be unreliable. The Accused acknowledged that 140 to 150 people were taken from Sušica and killed but submitted that this was an impulsive act of revenge which was not the result of his visit or speech. Defence Final Brief, confidential, para. 1438.

4173 P3227 (Witness statement of KDZ033 dated 7 April 2010), paras. 97, 103-104, 106, 134, 137, 157 (under seal); P3260 (List of missing civilians in Vlasenica in 1992) (under seal). See also P3253 (Handwritten list of nonSerbs brought to Sušica camp, 18 July 1992) (under seal). The individuals identified by KDZ033 as having been removed by the police from the Sušica camp that night were Nedžmin Aganović, Amir Alihodžić, Jakub Alihodžić, Salko Arifhodžić, Naser Atalov, Šaban Durmanović, Osmo Efendić, Salko Efendić, Jasmin 
incident was reported to members of the Vlasenica Crisis Staff, who took no action except to order the dismantling of the camp, the destruction of any documents, and the concealment of any traces of the existence of the camp. ${ }^{4174}$

1213. The Chamber therefore finds that approximately 140 detainees were taken from Sušica camp on or about 30 September 1992 and killed by Serb Forces.

(F) Movement of the population from Vlasenica and appropriation of property

1214. A large number of both Bosnian Muslims and Bosnian Serbs left Vlasenica in the lead-up to 21 April 1992. ${ }^{4175}$ The departure of both Bosnian Serbs and Bosnian Muslims increased when conflict began in Bijeljina and Zvornik. ${ }^{4176}$ The mass departure of the Bosnian Muslim population from Vlasenica started at the beginning of April 1992 with most people leaving for Kladanj, Tuzla, and Živinice. ${ }^{4177}$ Bosnian Serb and Bosnian Muslim representatives went to Tuzla and appealed to the population to return, but when this failed the Bosnian Muslim leadership also left Vlasenica. ${ }^{4178}$

Ferhatbegović, Ragib Ferhatbegović, Jusuf Gruhonjić, Bernes Hadžić, Enes Hadžić, Namko Hadžić, Suljo Handžić, Armin Hasanbegović, Mensur Hasanbegović, Mevludin Hasanbegović, Šemsudin Hasanbegović, Mevludin Hodžić, Sead Mehanović, Seid Mehanović, Sejfo Mehanović, Mehmed Mlačo, Hasan Parić, Osman Saračević, Alija Smajlović, Hazim Smaljović, Mujo Smaljović, Edhem Šahbegović, Esad Šahinpašić, Mersudin Šahinpašić, Nedim Šahinpašić, Senahid Šahinpašić, Ahmet Taljić, Muhamed Telalović, Sejfo Telalović, Bego Topčić, Enver Topčić, Mensur Tutić, Ibrahim Zlatić, and Suljo Hajdarević (this name was added by the witness during direct examination). KDZ033, T. 18016 (29 August 2011) (closed session). Of these named individuals, 18 were identified as having been exhumed from a mass grave. P4853 (Updated Table 2 to the Report of Amor Mašović), pp. 52-55, 95. See also P4856 (Appendix B to the Prosecution Pre-Trial Brief filed on 18 May 2009 marked by Amor Mašović), p. 29.

4174 [REDACTED]. See also Adjudicated Fact 2720. But see D3093 (Witness statement of Mane Đurić dated 3 March 2013), para. 74 (stating that the municipal authorities were not involved in hiding this incident and that the Vlasenica Crisis Staff has already ceased to exist). The Chamber refers to its credibility assessment in fn. 3858 as to why Đurić's evidence in this regard is found to be unreliable.

4175 Ibro Osmanović, T. 17959 (29 August 2011); D2922 (Witness statement of Savo Čeliković dated 10 February 2013), paras. 4, 23; Savo Čeliković, T. 33550 (13 February 2013); D3093 (Witness statement of Mane Đurić dated 3 March 2013), paras. 19, 41; Mane Đurić, T. 35023-35024 (7 March 2013); D2982 (Witness statement of Milenko Stanić dated 16 February 2013), paras. 16-17; D3007 (Witness statement of Zoran Jovanović dated 18 February 2013), para. 27; D2932 (Witness statement of Tomislav Savkić dated 11 February 2013), paras. $26,45$.

4176 D2982 (Witness statement of Milenko Stanić dated 16 February 2013), para. 17; Izet Redžić, P3189 (Transcript from Prosecutor v. Krajišnik), T. 5111-5112; Izet Redžić, T. 17739-17740 (23 August 2011); KDZ033, T. 18031 (29 August 2011) (closed session); P3262 (Witness statement of KDZ603 dated 30 August 2011), para. 5 (under seal); KDZ603, T. 18142 (1 September 2011). See also P3212 (Witness statement of Ibro Osmanović dated 23 August 2011), para. 16; D2967 (Witness statement of Momir Deurić dated 16 February 2013), para. 12.

4177 Izet Redžić, P3189 (Transcript from Prosecutor v. Krajišnik), T. 5105. See also D2967 (Witness statement of Momir Deurić dated 16 February 2013), para. 14; D3093 (Witness statement of Mane Đurić dated 3 March 2013), para. 19; D2982 (Witness statement of Milenko Stanić dated 16 February 2013), para. 17. Defence witnesses testified that Bosnian Muslims took their families to areas where there was a Bosnian Muslim majority and then military aged men returned to the villages around Vlasenica. D2922 (Witness statement of Savo Čeliković dated 10 February 2013), para. 32. See also D3093 (Witness statement of Mane Đurić dated 3 March 2013), para. 19. The Chamber does not consider this to be inconsistent with the evidence regarding the movement of the population. Similarly the Chamber places no weight on the assessment that Bosnian Serb and Bosnian Muslim populations relocated of their own initiative to villages where they were a majority and that this 
1215. Redžić had contact with Izetbegović about allowing Bosnian Muslims a chance to flee Vlasenica. ${ }^{4179}$ After the Bosnian Serb TO entered Vlasenica on 21 April 1992, some of the Bosnian Muslim population left for Kladanj and Tuzla. ${ }^{4180}$ The Bosnian Serb authorities were asked for help in providing transport for people who were requesting to leave the municipality. Many inhabitants were then transported in the direction of Kladanj while others left in their own vehicles or by bus. ${ }^{4181}$

1216. The day after the JNA left Vlasenica in May 1992, local Bosnian Serbs fired mortar shells at the Bosnian Muslim villages of Pijuci, Džamdžići and Bare. ${ }^{4182}$ Following these attacks the Bosnian Muslims from these villages headed in the direction of Kladanj, Živinice and Cerska. ${ }^{4183}$ Paramilitaries also used force which placed pressure on Bosnian Muslims to leave the municipality. ${ }^{4184}$ Before being transferred from Vlasenica in May 1992, women from Zaklopača were made to sign statements that they would give their houses and property to the Bosnian Serbs. ${ }^{4185}$

1217. On 19 May 1992, the Vlasenica Crisis Staff instructed the Commander of the TO and the Chief of the SJB that those who wanted to leave Vlasenica and who are "of no interest" to the SJB could do so after obtaining a permit. ${ }^{4186}$ In order to be issued a pass to leave an individual had to sign a statement saying that they were leaving of their own free will. ${ }^{4187}$ In accordance with this instruction, Bosnian Muslims queued outside the municipality building and before being issued a pass to leave the municipality had to sign a statement saying they were leaving of their own free

demonstrated that war in Vlasenica was defensive. D2922 (Witness statement of Savo Čeliković dated 10 February 2013), para. 29

(Witness statement of Savo Čeliković dated 10 February 2013), para. 33; D2982 (Witness statement of Milenko Stanić dated 16 February 2013), paras. 19, 21, 36. See also D2932 (Witness statement of Tomislav Savkić dated 11 February 2013), paras. 29, 39.

4179 Izet Redžić, P3189 (Transcript from Prosecutor v. Krajišnik), T. 5107-5111.

4180 D2932 (Witness statement of Tomislav Savkić dated 11 February 2013), para. 40 (testifying that by this date at least $50 \%$ of the Bosnian Muslim population had already left Vlasenica).

4181 Izet Redžić, P3189 (Transcript from Prosecutor v. Krajišnik), T. 5058, 5060, 5148; D2982 (Witness statement of Milenko Stanić dated 16 February 2013), paras. 23, 27; D2932 (Witness statement of Tomislav Savkić dated 11 February 2013), para. 40; P3212 (Witness statement of Ibro Osmanović dated 23 August 2011), para. 57 (stating that the Bosnian Muslim population left after they heard about the attack on the village of Zaklopača). For evidence on the attack on Zaklopača, see Scheduled Incident A.15.2.

4182 P3212 (Witness statement of Ibro Osmanović dated 23 August 2011), paras. 53, 56. The Chamber places no weight on Osmanović's speculation that the shells possibly contained "white phosphorous type compound".

4183 P3212 (Witness statement of Ibro Osmanović dated 23 August 2011), para. 56.

4184 Izet Redžić, P3189 (Transcript from Prosecutor v. Krajišnik), T. 5043. Stanić testified that the Bosnian Muslim population left because of the tense situation and not because they were expelled. D2982 (Witness statement of Milenko Stanić dated 16 February 2013), para. 19. The Chamber refers to its credibility assessment in fn. 3791 above as to why it does not consider Stanić's evidence to be reliable in this regard.

4185 P418 (Witness statement of Mersudina Saim-Hodžić dated 24 May 2002), p. 6. For further evidence on events in Zaklopača, see Scheduled Incident A.15.2.

4186 P3218 (Letter from Vlasenica Crisis Staff to TO commander and SJB chief, 19 May 1992). 
will and that they were voluntarily surrendering their rights to their property. ${ }^{4188}$ Osmanović's mother, who refused to sign this document, was denied permission to leave the municipality, was forcibly moved out of her house, and taken to Sušica. ${ }^{4189}$

1218. From May to October 1992, non-Serbs moved from Vlasenica and this movement related mainly to the town of Vlasenica and the central and central-northern parts of the municipality which had a majority Bosnian Muslim population. ${ }^{4190}$

1219. Bosnian Muslims from villages that were taken over Serb Forces in May 1992 gathered at the Vlasenica bus station or football stadium with their belongings waiting for an opportunity to leave the municipality. ${ }^{4191}$ While the Bosnian Serb authorities referred to this as "voluntary departure", these people were fleeing the municipality out of fear for their lives. ${ }^{4192}$ At some point the Bosnian Serb authorities did allow some Bosnian Muslims to return to their villages, but their homes had already been burnt down and almost destroyed. ${ }^{4193}$

1220. In October 1992 there were very few non-Serbs, ${ }^{4194}$ who had married Bosnian Serbs, who remained in Vlasenica town and by the end of 1992 there were approximately 150 Bosnian

4187 P3218 (Letter from Vlasenica Crisis Staff to TO commander and SJB chief, 19 May 1992).

4188 P3227 (Witness statement of KDZ033 dated 7 April 2010), para. 23 (under seal); P3212 (Witness statement of Ibro Osmanović dated 23 August 2011), para. 58. Đurić acknowledged that Bosnian Muslims left fearing for their safety but they did so voluntarily and did not have any pressure put on them and that both Bosnian Serbs and Bosnian Muslims had to sign documents saying they were leaving voluntarily. D3093 (Witness statement of Mane Đurić dated 3 March 2013), paras. 40-41. The Chamber does not find Đurić's evidence in this regard to be reliable. In reaching that conclusion, the Chamber refers to its credibility assessment in fn. 3858 . Defence witnesses testified that (i) a commission was formed which sealed and subsequently assigned abandoned Bosnian Muslim homes for the temporary accommodation of Serb refugees to prevent property from being stolen; (ii) citizens could request that their houses be exchanged and the municipal authorities would approve such exchanges after checking to see that such contracts were done properly and not under coercicion; and (iii) when the conditions were right, properties were returned to their original occupants. D2982 (Witness statement of Milenko Stanić dated 16 February 2013), paras. 23-25; Milenko Stanić, T. 33992-33993 (19 February 2013); D2985 (List of persons for the exchange of houses and apartments); D2922 (Witness statement of Savo Čeliković dated 10 February 2013), paras. 24-25; Savo Čeliković, T. 33563-33564. 33569-33570 (13 February 2013); D3007 (Witness statement of Zoran Jovanović dated 18 February 2013), para. 28. The Chamber refers to its credibility assessment in fn. 3791 and 3813 as to why it does not find the evidence of these witnesses to be reliable to the extent that this suggests that these measures were taken to prevent property from being stolen, to prevent coercion, and to facilitate the return of property.

4189 P3212 (Witness statement of Ibro Osmanović dated 23 August 2011), para. 58. She only managed to leave for Tuzla in February 1993.

4190 P3227 (Witness statement of KDZ033 dated 7 April 2010), para. 52 (under seal). [REDACTED] testified about the involvement of Savo Bačić in "cleansing" operations against Bosnian Muslim villages. However, the Chamber finds that the evidence about his involvement is somewhat equivocal and does not consider this evidence to be of sufficient specificity to make findings in this regard. [REDACTED].

4191 P3227 (Witness statement of KDZ033 dated 7 April 2010), para. 54 (under seal); KDZ033, T. 18077, 1809418095 (31 August 2011) (closed session).

4192 P3227 (Witness statement of KDZ033 dated 7 April 2010), para. 54 (under seal).

4193 P3227 (Witness statement of KDZ033 dated 7 April 2010), para. 54 (under seal).

4194 For evidence on the mass departure of the Bosnian Muslim population, see para. 1214. 
Muslims left in Vlasenica ${ }^{4195}$ who had not been taken into detention. ${ }^{4196}$ The Chamber has discussed above the detention of Bosnian Muslims in Vlasenica. ${ }^{4197}$

1221. As discussed in more detail in Section IV.C.1.a, while Serb Forces were successful in taking over and holding town centres in municipalities including Vlasenica, pockets in the surrounding countryside, which had a Bosnian Muslim majority population, remained under the control of Bosnian Muslim forces. $^{4198}$ Bosnian Muslim forces in the second half of 1992 and early 1993 launched an offensive in which they took control of territory in Vlasenica and tried to link with Bosnian Muslim forces in Cerska. ${ }^{4199}$ The counter-offensive by the VRS in spring 1993, prompted the movement of the vast majority of the Bosnian Muslim civilians who remained in Cerska and thousands fled towards Srebrenica. ${ }^{4200}$

1222. The Chamber finds that Bosnian Muslims were forced to leave the municipality, albeit in some cases, they may have left out of fear following the arrival of Bosnian Serb refugees or even requested to leave the municipality. ${ }^{4201}$ Even if the Bosnian Muslims requested to leave the municipality the Chamber finds that this was still involuntary considering the surrounding circumstances in which they left the municipality.

ix. Zvornik

(A) Charges

1223. Under Count 3, the Prosecution alleges that persecution, a crime against humanity, was committed in Zvornik as part of the objective to permanently remove Bosnian Muslims and/or Bosnian Croats from the Municipalities. ${ }^{4202}$ Under Count 1, the Prosecution further alleges that in certain municipalities, including Zvornik, this persecutory campaign included or escalated to

\footnotetext{
4195 P3227 (Witness statement of KDZ033 dated 7 April 2010), paras. 56, 58 (under seal). See also P4994 (Addendum to Ewa Tabeau's expert report entitled "Ethnic Composition in Internally Displaced Persons and Refugees from 27 Municipalities of BiH 1991 to 1997”, 3 February 2009), p. 31 (reporting that by 1997 the Bosnian Muslim population in Vlasenica had dropped to $0.2 \%$ of the total population); D4002 (Letter from BiH MUP to Vasvija Vidović, 4 July 1995), p. 34 (referring to the expulsion of 15,000 non-Serbs from Vlasenica and surrounding villages).

4196 P3212 (Witness statement of Ibro Osmanović dated 23 August 2011), para. 181. See also P3227 (Witness statement of KDZ033 dated 7 April 2010), para. 56 (under seal).

4197 See Section IV.A.1.a.viii.E: Detention facilities in Vlasenica.

4198 See para. 4946.

4199 See para. 4946

4200 See paras. 4947-4949, 4954-4956, 4962.

4201 D3093 (Witness statement of Mane Đurić dated 3 March 2013), paras. 42-43; D2932 (Witness statement of Tomislav Savkić dated 11 February 2013), paras. 32-42, 45.

4202 Indictment, paras. 48-49.
} 
include conduct that manifested an intent to destroy in part the national, ethnical and/or religious groups of Bosnian Muslims and/or Bosnian Croats as such. ${ }^{4203}$

1224. Acts alleged to have been committed in Zvornik by Serb Forces and Bosnian Serb Political and Governmental Organs include killings during and after the take-over; ${ }^{4204}$ killings related to detention facilities; and killings committed during, and deaths resulting from, cruel and inhumane treatment at scheduled detention facilities. ${ }^{4205}$ The Prosecution characterises these acts as killing, an underlying act of genocide, under Count 1; persecution, a crime against humanity, under Count 3; extermination, a crime against humanity, under Count 4, murder, a crime against humanity, under Count 5; and murder, a violation of the laws or customs of war, under Count $6 .{ }^{4206}$

1225. Other acts alleged to have been committed in Zvornik by Serb Forces and Bosnian Serb Political and Governmental Organs include torture, beatings, and physical and psychological abuse, rape and other acts of sexual violence, during and after the take-over and in scheduled detention facilities, as well as the establishment and perpetuation of inhumane living conditions in detention facilities, as cruel or inhumane treatment, an act of persecution under Count $3{ }^{4207}$. In relation to Count 1, the Prosecution alleges that in scheduled detention facilities in Zvornik thousands of Bosnian Muslims and Bosnian Croats were subjected to cruel or inhumane treatment, including torture, physical and psychological abuse, rape, other acts of sexual violence, and beatings by Serb Forces and Bosnian Serb Political and Governmental Organs; the Prosecution characterises this inhumane treatment as causing serious bodily or mental harm to members of the Bosnian Muslim and Bosnian Croat groups, an underlying act of genocide. ${ }^{4208}$ In addition, under Count 1 , the Prosecution alleges that members of the Bosnian Muslim and Bosnian Croat groups were detained under conditions of life calculated to bring about physical destruction, namely through cruel and inhumane treatment, including torture, physical and psychological abuse, rape, other acts of sexual violence, inhumane living conditions, forced labour and the failure to provide adequate accommodation, shelter, food, water, medical care or hygienic sanitation facilities. ${ }^{4209}$

\footnotetext{
4203 Indictment, paras. 37-38.

4204 Indictment, para. 60(a)(i). See Scheduled Incidents A.16.1, A.16.3.

4205 Indictment, para. 60(b). See Scheduled Detention Facilities C.27.1, C.27.2, C.27.3, C.27.4, C.27.5, C.27.6, C.27.7.

4206 Indictment, paras. 40(a)(i), 40(a)(ii), 63(a), 63(b).

4207 Indictment, para. 60(b), 60(c). See Scheduled Detention Facilities C.27.1, C.27.2, C.27.3, C.27.4, C.27.5, C.27.6, C.27.7.

4208 Indictment, para. 40(b).

4209 Indictment, paras. 40(c), 60(d), 60(h). See Scheduled Detention Facilities C.27.1, C.27.2, C.27.3, C.27.4, C.27.5, C.27.6, C.27.7.
} 
1226. Under Count 3, other acts of persecution alleged to have been committed in Zvornik by Serb Forces and Bosnian Serb Political and Governmental Organs, include (i) forcible transfer or deportation of Bosnian Muslims and Bosnian Croats from their homes; ${ }^{4210}$ (ii) unlawful detention in scheduled detention facilities; ${ }^{4211}$ (iii) appropriation or plunder of property, during and after the take-over, during arrests and detention and in the course of or following acts of deportation or forcible transfer; ${ }^{4212}$ (iv) the wanton destruction of private property including homes and business premises and public property including cultural monuments and sacred sites; ${ }^{4213}$ and (v) the imposition and maintenance of restrictive and discriminatory measures. ${ }^{4214}$

1227. Under Counts 7 and 8, the Prosecution alleges deportation and inhumane acts (forcible transfer), respectively, as crimes against humanity. ${ }^{4215}$ The Prosecution alleges that, by the end of 1992, Serb Forces as well as Bosnian Serb Political and Governmental Organs forcibly displaced Bosnian Muslims and Bosnian Croats from areas in Zvornik in which they were lawfully present. $^{4216}$ It is alleged that from March 1992, restrictive and discriminatory measures, arbitrary arrest and detention, harassment, torture, rape and other acts of sexual violence, killing, destruction of houses, cultural monuments and sacred sites, as well as the threat of further such acts caused Bosnian Muslims and Bosnian Croats to flee in fear while others were physically driven out. ${ }^{4217}$

(B) Lead-up

1228. Zvornik is a municipality in eastern $\mathrm{BiH}^{4218}$ It is located on the Drina river, which marks the boundary between $\mathrm{BiH}$ and Serbia. ${ }^{4219}$ Prior to the war approximately $60 \%$ of the population in the municipality were Bosnian Muslims and approximately $38 \%$ were Bosnian Serbs. ${ }^{422}$

\footnotetext{
$4210 \quad$ Indictment, para. 60(f).

4211 Indictment, para. 60(g). See Scheduled Detention Facilities C27.1, C.27.2, C.27.3, C.27.4, C.27.5, C.27.6, C.27.7.

4212 Indictment, para. 60(i).

4213 Indictment, para. 60(j). See Scheduled Incident D.22.

4214 Indictment, para. 60(k). The restrictive and discriminatory measures alleged include the denial of freedom of movement; the removal from positions of authority; the invasion of privacy through arbitrary searches of homes; unlawful arrest and/or the denial of the right to judicial process; and/or the denial of equal access to public services.

4215 Indictment, paras. 68-75.

4216 Indictment, paras. 69, 72

4217 Indictment, para. 71.

4218 D484 (Map of BiH); P3175 (Map of Zvornik).

4219 P2919 (Witness statement of KDZ023 dated 29 September 1996), p. 2; P96 (Witness statement of KDZ059 dated 5 December 1998), p. 2. (under seal); D1627 (Video footage re view of Zvornik from Kula); P3165 (Witness statement of KDZ340 undated), p. 51 (under seal); P3175 (Map of Zvornik).

4220 P6199 (Excerpt from censuses records of 1971, 1981 and 1991), p. 2; P62 (Witness statement of Nedžad Hadžiefendić dated 3 October 1997), p. 2; Momčilo Mandić, T. 5299 (16 July 2010); KDZ555, T. 17221 (16 August 2011); D3693 (Witness statement of Marinko Vasilić dated 9 June 2013), para. 5; Marinko Vasilić, T. 39923 (13 June 2013); D3723 (Witness statement of Čedomir Zelenović dated 22 June 2013), para. 3 ; D3724
} 
1229. Prior to the formation of national parties in mid-1990 inter-ethnic relations in Zvornik were good. $^{4221}$ The SDS in Zvornik was formed in September 1990 and Branko Grujić was elected president. $^{4222}$ Following the multi-party elections, in November 1990, the SDA won an absolute majority of the votes in Zvornik but a coalition government was formed between the SDA and the SDS. $^{4223}$ Official positions were divided between Bosnian Muslims and Bosnian Serbs in accordance with the election results. For example, Abdulah Pašić was appointed president of the municipality, Jovan Ivanović was appointed chairman of the Executive Board of the Municipal Assembly, Osman Mustafić was appointed chief of the SJB while Dragan Spasojević was appointed commander of the SJB. ${ }^{4224}$

1230. In the summer of 1991, the Accused attended an SDS rally in Zvornik, ${ }^{4225}$ after which the SDS and SDA issued a joint declaration which expressed the need to maintain peace in the municipality and called for greater tolerance between ethnic groups there. ${ }^{426}$ However, tensions in Zvornik increased from then on, caused by a number of factors including (i) SDA political rallies calling for the secession of $\mathrm{BiH}^{4}{ }^{427}$ (ii) disputes about the SDA outvoting the SDS and personnel

(Witness statement of Branko Grujić dated 22 June 2013), para. 5; D3692 (Witness statement of Jovan Ivanović dated 9 June 2013), para. 8; P6370 (Excerpt from 1991 census re Zvornik). See also P4994 (Addendum to Ewa Tabeau's expert report entitled "Ethnic Composition, Internally Displaced Persons and Refugees from 27 Municipalities of BiH 1991 to 1997", 3 February 2009), pp. 32. Similarly, approximately 64\% of the population in the town of Zvornik were Bosnian Muslims with the remainder Bosnian Serbs. Petko Panić, P3380 (Transcript from Prosecutor v. Stanišić \& Župljanin), T. 2869.

4221 P62 (Witness statement of Nedžad Hadžiefendić dated 3 October 1997), p. 2; KDZ555, T. 17222 (16 August 2011); D3693 (Witness statement of Marinko Vasilić dated 9 June 2013), para. 6; D3723 (Witness statement of Čedomir Zelenović dated 22 June 2013), para. 5; D3724 (Witness statement of Branko Grujić dated 22 June 2013), para. 4; D3692 (Witness statement of Jovan Ivanović dated 9 June 2013), para. 7; KDZ072, P425 (Transcript from Prosecutor v. Šě̌elj), T. 8691-8692.

4222 D3724 (Witness statement of Branko Grujić dated 22 June 2013), paras. 3, 6; D3692 (Witness statement of Jovan Ivanović dated 9 June 2013), para. 4; P96 (Witness statement of KDZ059 dated 5 December 1998), p. 3 (under seal); KDZ228, P324 (Transcript from Prosecutor v. Popović et al.), T. 14935; D3654 (Witness statement of KW317 dated 26 September 2012), paras. 5-8 (under seal). The Chamber notes that Branko Grujić is also referred to as Brano Grujić.

4223 D3693 (Witness statement of Marinko Vasilić dated 9 June 2013), para. 5; D3724 (Witness statement of Branko Grujić dated 22 June 2013), paras. 5, 7; D3692 (Witness statement of Jovan Ivanović dated 9 June 2013), paras. 3, 9; D3654 (Witness statement of KW317 dated 26 September 2012), para. 12 (under seal); D3723 (Witness statement of Čedomir Zelenović dated 22 June 2013), para. 4.

4224 D3692 (Witness statement of Jovan Ivanović dated 9 June 2013), para. 9; D3724 (Witness statement of Branko Grujić dated 22 June 2013), paras. 7-8; KDZ059, P67 (Transcript from Prosecutor v. S. Milošević), T. 29094; D3723 (Witness statement of Čedomir Zelenović dated 22 June 2013), para. 6; D3654 (Witness statement of KW317 dated 26 September 2012), para. 20 (under seal); D3693 (Witness statement of Marinko Vasilić dated 9 June 2013), para. 7; P34 (Structure of Serbian SDB and Zvornik/Bijeljina MUP) (under seal).

4225 D3693 (Witness statement of Marinko Vasilić dated 9 June 2013), paras. 17-18; D3723 (Witness statement of Čedomir Zelenović dated 22 June 2013), para. 18; KDZ320, T. 28092 (25 April 2012).

4226 D3724 (Witness statement of Branko Grujić dated 22 June 2013), para. 15; D3725 (Joint declaration of Zvornik SDS and SDA, undated).

4227 D3693 (Witness statement of Marinko Vasilić dated 9 June 2013), para. 7; D3724 (Witness statement of Branko Grujić dated 22 June 2013), paras. 6, 22; D3692 (Witness statement of Jovan Ivanović dated 9 June 2013), paras. 4-6, 11. See also D3723 (Witness statement of Čedomir Zelenović dated 22 June 2013), paras. 6, 8-9, 16-17; D3654 (Witness statement of KW317 dated 26 September 2012), para. 6 (under seal); D3693 (Witness statement of Marinko Vasilić dated 9 June 2013), paras. 8-10. 
changes in enterprises and organisations; ${ }^{4228}$ (iii) the outbreak of war in Slovenia and Croatia and the Bosnian Muslim boycott of JNA mobilisation; ${ }^{422}$ (iv) acts of violence against Bosnian Serbs and Bosnian Serb villages; ${ }^{4230}$ and (v) sporadic shooting in the centre of town and around Zvornik. $^{4231}$ This led to violent incidents and greater divisions and ill-feeling between Bosnian Muslims and Bosnian Serbs. ${ }^{4232}$ Some Bosnian Serb women and children chose to cross-over the Drina to Serbia to sleep at night. ${ }^{4233}$

\section{(1) Division of municipal structures}

1231. In December 1991 at an SDS meeting in Sarajevo attended by SDS officials including the Accused, representatives of municipal authorities, including Zvornik, received the Variant A/B Instructions. ${ }^{4234}$ These instructions were also discussed by the Accused at a meeting of the SDS Deputies Club, which was also attended by representatives from Zvornik. ${ }^{4235}$ Given that Zvornik had a majority Muslim population, the Variant B instructions were to be implemented. ${ }^{4236}$

4228 D3693 (Witness statement of Marinko Vasilić dated 9 June 2013), para. 11. See also D3723 (Witness statement of Čedomir Zelenović dated 22 June 2013), paras. 6, 8-9; D3724 (Witness statement of Branko Grujić dated 22 June 2013), paras. 8-9; D3692 (Witness statement of Jovan Ivanović dated 9 June 2013), paras. 10-11; D3654 (Witness statement of KW317 dated 26 September 2012), paras. 21-22 (under seal).

4229 D3723 (Witness statement of Čedomir Zelenović dated 22 June 2013), para. 10; D3724 (Witness statement of Branko Grujić dated 22 June 2013), paras. 10, 13; D3654 (Witness statement of KW317 dated 26 September 2012), para. 13 (under seal); KDZ072, P425 (Transcript from Prosecutor v. Šešelj), T. 8692. See also D3693 (Witness statement of Marinko Vasilić dated 9 June 2013), para. 20; D3723 (Witness statement of Čedomir Zelenović dated 22 June 2013), paras. 11-12; P925 (JNA $2^{\text {nd }}$ Military District combat report, 10 April 1992), p. 2.

4230 D3654 (Witness statement of KW317 dated 26 September 2012), para. 27 (under seal); D3693 (Witness statement of Marinko Vasilić dated 9 June 2013), paras. 12, 19. See also D3723 (Witness statement of Čedomir Zelenović dated 22 June 2013), para. 15; D3724 (Witness statement of Branko Grujić dated 22 June 2013), paras. 13-14, 45 referring for example to D48 (Zvornik Lower Court's on-site investigation report); Branko Grujić, T. 40378 (25 June 2013); D3692 (Witness statement of Jovan Ivanović dated 9 June 2013), para. 15; D2944 (Witness statement of Zoran Durmić dated 12 February 2013), paras. 7-9, 12-17, 25-26.

$4231 \quad$ KDZ059, P67 (Transcript from Prosecutor v. S. Milošević), T. 29085-29087.

4232 P133 (Witness statement of Matija Bošković dated 20 November 2003), para. 10; P96 (Witness statement of KDZ059 dated 5 December 1998), p. 3 (under seal); KDZ059, P67 (Transcript from Prosecutor v. S. Milošević), T. 29085-29086. See also Petko Panić, T. 19160 (20 September 2011).

4233 P4837 (Witness statement of KDZ610 dated 27 March 2012), para. 4 (under seal); P4838 (Map of ethnic composition of Zvornik); KDZ610, T. 27180, 27184 (29 March 2012); D3723 (Witness statement of Čedomir Zelenović dated 22 June 2013), para. 17; KDZ240, P2935 (Transcript from Prosecutor v. Krajišnik), T. 67556756, 6913 (under seal); KDZ240, T. 16083-16084 (5 July 2011) (closed session).

4234 KDZ555, T. 17223, 17227 (16 August 2011); P5 (SDS Instructions for Organisation of Organs of the Serbian People in BiH, 19 December 1991); Branko Grujić, T. 40448-40449 (26 June 2013); Jovan Ivanović, T. 39844 39845 (12 June 2013); P6402 (Excerpt from Jovan Ivanović's statement to OTP, 27 March 2002), p. 2; P6403 (Excerpt from Jovan Ivanović's testimony before Belgrade District Court, 29 September 2006), p. 3. See also KW317, T. 39329 (5 June 2013); P6369 (Excerpts from KW317's statement to OTP, 14 June 2002), e-court p. 2 (under seal).

4235 P6369 (Excerpts from KW317's statement to OTP, 14 June 2002), p. 2 (under seal); KW317, T. 39337 (5 June 2013).

4236 P104 (Witness statement of Fadil Banjanović dated 30 March 2002), paras. 10-11. 
1232. On 22 December 1991, a crisis staff was formed in Zvornik and Branko Grujić was appointed as its President. ${ }^{4237}$ The Zvornik Crisis Staff consisted of leading SDS officials from the municipality and the municipal command staff of the JNA. ${ }^{4238}$

1233. The Variant A/B Instructions were implemented by the Zvornik Crisis Staff. ${ }^{4239}$ On 26 December 1991, the Zvornik SDS issued a statement that a decision would be adopted the following day to form the Serb Municipality of Zvornik and that a team of negotiators should be formed to decide on partitions. ${ }^{4240}$ The decision to form the Serb Municipality of Zvornik directly cited to the Variant $\mathrm{A} / \mathrm{B}$ Instructions and included the separation of certain parts of the municipality. ${ }^{4241}$ On 27 December 1991, the Serb Assembly of Zvornik was formed along with all

4237 D3654 (Witness statement of KW317 dated 26 September 2012), para. 25 (under seal); P2590 (Conclusions of Zvornik's SDS Municipal Board, 22 December 1991); P3165 (Witness statement of KDZ340 undated) (under seal), p. 35. Bosnian Muslims also created a crisis staff in Zvornik. D3724 (Witness statement of Branko Grujić dated 22 June 2013), para. 20; KW317, T. 39411 (6 June 2013). Defence witnesses disputed the date when the Zvornik Crisis Staff was created and testified that the purpose of its creation was to find a peaceful solution and to normalise relations through political discussions and to prepare for the danger that elected bodies could be blocked from discharging their functions. D3724 (Witness statement of Branko Grujić dated 22 June 2013), paras. 18, 20, 28; D3692 (Witness statement of Jovan Ivanović dated 9 June 2013), para. 15; D3654 (Witness statement of KW317 dated 26 September 2012), paras. 26, 33 (under seal); D3723 (Witness statement of Čedomir Zelenović dated 22 June 2013), para. 13; Čedomir Zelenović, T. 40317-40321 (24 June 2013). Having analysed this evidence, the Chamber does not find it to be reliable in this regard. In reaching that conclusion, the Chamber noted that the evidence of Grujić, Ivanović and Zelenović was marked by indicators of bias, evasiveness, insincerity and extensive contradictions.

4238 See Adjudicated Fact 2210; D3654 (Witness statement of KW317 dated 26 September 2012) (under seal), para. 25; P2590 (Conclusions of Zvornik's SDS Municipal Board, 22 December 1991).

4239 KDZ555, T. 17227 (16 August 2011); KW317, T. 39333-39334 (5 June 2013). However, witnesses also testified that there was no monitoring of the implementation of these instructions from a higher level, and that it was only selectively implemented in Zvornik after identifying elements which suited the municipality and excluding those aspects which could not be implemented in the municipality. KDZ555, T. 17234-17235 (16 August 2011) (private session), T. 17280 (16 August 2011), T. 17339 (17 August 2011); D3724 (Witness statement of Branko Grujić dated 22 June 2013), para. 18; Branko Grujić, T. 40367 (25 June 2013); KW317, T. 39333-39334 (5 June 2013). The Chamber does not find the evidence of these witnesses to be reliable with respect to the manner in which the Variant A/B Instructions were implemented in Zvornik. In reaching that conclusion the Chamber noted that the testimony of the relevant witnesses was marked by extreme evasiveness, attempts to distance themselves from prior statements, and indicators of bias. For example Grujić was contradicted on cross-examination by reference to his prior testimony and interview where he suggested that the Variant A/B Instructions were mandatory and that the Zvornik Crisis Staff reported back, received, and implemented additional instructions from the republic level. Grujić ultimately acknowledged that Jovo Mijatović was tasked with conveying all conclusions and decisions of the Zvornik Crisis Staff to the appropriate levels and would convey all instructions from the republic level. Branko Grujić, T. 40371-40373 (25 June 2013); P6415 (Excerpt from Branko Grujić's testimony before Belgrade District Court, 30 November 2005), pp. 2-3.

4240 D3726 (Letter from Zvornik SDS, 26 December 1991); D3724 (Witness statement of Branko Grujić dated 22 June 2013), para. 19. See also P104 (Witness statement of Fadil Banjanović dated 30 March 2002), paras. $10-11$.

4241 P2591 (Decision regarding the formation of the Serbian Municipality of Zvornik, 27 December 1991), pp. 1-2. Witnesses testified the establishment of the Serbian Municipality of Zvornik and its Assembly was not for the purpose of creating a Serbian state or to take-over Bosnian Muslim territory, but to assist with negotiations, to allow the municipality to function in a crisis situation, and to ensure the protection of Bosnian Serbs. They also testified that while preparations were made, individuals were appointed to their positions and Serb institutions were created, they were not activated until 1992 when the conflict broke out. D3724 (Witness statement of Branko Grujić dated 22 June 2013), paras. 19, 21; KDZ555, T. 17344 (17 August 2011); D3654 (Witness statement of KW317 dated 26 September 2012), paras. 23-24, 26 (under seal); KW317, T. 39409-39410 (6 June 2013); Jovan Ivanović, T. 39844-39845 (12 June 2013); D3692 (Witness statement of Jovan Ivanović dated 9 
organs and it identified the territory that would belong to the Serb Municipality of Zvornik. ${ }^{4242}$ Jovo Mijatović was elected President of the Serb Municipality of Zvornik ${ }^{4243}$ and appointed coordinator for discussions with the SDA. ${ }^{4244}$

1234. From early January 1992, employees of the SJB were in regular contact with the Steering Committee of the SDS and were instructed to gather support and prepare for the formation of a Serb SJB. ${ }^{4245}$

1235. The SDS took the position that the municipality and town should be divided geographically between Bosnian Serbs and Bosnian Muslims but could not reach an agreement with the SDA. ${ }^{4246}$ On 15 March 1992, the Assembly of the Serb Municipality of Zvornik proclaimed the Serb Municipality of Zvornik, consisting of parts of the town, villages and communes where Bosnian Serbs were in the majority. ${ }^{4247}$ On the same date the Serb Assembly of Zvornik decided to join the SAO Majevica-Semberija. ${ }^{4248}$ These decisions were made in accordance with the second level of the Variant A/B Instructions, which had been activated by the Accused at a meeting attended by a representative from Zvornik. ${ }^{4249}$

1236. Also on 15 March 1992, the Assembly of the Serb Municipality of Zvornik passed a decision banning the sale or trade of real estate within the municipality unless it was between

June 2013), para. 15; P6402 (Excerpt from Jovan Ivanović's statement to OTP, 27 March 2002), p. 2; P6403 (Excerpt from Jovan Ivanović's testimony before Belgrade District Court, 29 September 2006), p. 3. The Chamber refers to its assessment in fns. 4237 and 4239 as to why it cannot rely on the evidence of these witnesses with respect to the purpose of creating the Serb Municipality of Zvornik and when the Serb institutions were activated. Similarly the evidence of KW317 in this respect was also marked by attempts to distance himself from prior statements and contradictions which undermined his evidence in this regard.

4242 D3724 (Witness statement of Branko Grujić dated 22 June 2013), para. 19.

4243 Branko Grujić, T. 40367, 40370, 40372 (25 June 2013); P2590 (Conclusions of Zvornik's SDS Municipal Board, 22 December 1991), p. 1-2; KDZ555, T. 17228-17230 (16 August 2011) (private session).

4244 D3655 (Decision of Zvornik Municipal Assembly, 27 December 1991); D3654 (Witness statement of KW317 dated 26 September 2012), para. 24 (under seal).

4245 P3390 (Report on activities of Zvornik SJB for 1993), p. 20; P3183 (Excerpt from Report on the work of the Zvornik SJB for the year 1992), p. 2; P2761 (RS MUP report on work for period April to December 1992), p. 5. See also P104 (Witness statement of Fadil Banjanović dated 30 March 2002), paras. 10-11.

4246 KDZ320, T. 28093 (25 April 2012). See also D3723 (Witness statement of Čedomir Zelenović dated 22 June 2013), para. 19. The Chamber notes that when Vasilić was cross-examined about the percentage of the territory of Zvornik which was identified as being Serb he distanced himself from his prior interview where he estimated that it was 80\%. Marinko Vasilić, T. 39920-39924 (13 June 2013); P6405 (Excerpt from Marinko Vasilić's interview with OTP, 21 October 2002), p. 2. The Chamber notes that Vasilić was extremely evasive when questioned and claimed he was not aware of the decision to form the Serb Municipality of Zvornik which listed the territories which it would comprise even though he had previously stated that he heard about the decision. In light of these contradicitons and evasiveness the Chamber does not find Vasilić's evidence to be reliable in this regard.

4247 D1693 (Decision of Zvornik Assembly, 15 March 1992), p. 1. See also Marinko Vasilić, T. 39920-39922 (13 June 2013); D3654 (Witness statement of KW317 dated 26 September 2012), para. 28 (under seal).

4248 D3654 (Witness statement of KW317 dated 26 September 2012), para. 29 (under seal); D3656 (Decision of Zvornik Municipal Assembly, 15 March 1992).

4249 KW317, T. 39334-39337 (5 June 2013). 
"ethnic Serbs". ${ }^{4250}$ In late March 1992, local youth were given assignments by Bosnian Serb police to erect barricades at specific locations, secure important facilities in Karakaj, and seize bridges. ${ }^{4251}$

1237. At the end of March 1992, a decision was adopted by the Bosnian Serb Assembly, calling on the Bosnian Serb police to separate by 1 April 1992. ${ }^{4252}$ On 4 April 1992, Bosnian Muslim forces attacked a column of JNA soldiers in Sapna, Zvornik municipality. ${ }^{4253}$ Following this incident, the Bosnian Serb authorities decided barricades would be erected in Karakaj and active and reserve SJB personnel who were Bosnian Serbs would be called up. ${ }^{4254}$ On 5 April 1992 , Mandić sent a dispatch to Zvornik, noting that the MUP was being divided into Serb and Muslim components and ordered the movement of the Bosnian Serb institutions to Karakaj. ${ }^{4255}$ Karakaj was an industrial settlement located to the northeast of Zvornik. ${ }^{4256}$ Following this instruction, the police stations in the municipality, were divided into Serb and Muslim parts. ${ }^{4257}$

4250 P3151 (Decision of Zvornik's Assembly, 15 March 1992), pp. 1-2. KDZ555 testified that this was a local measure that was not connected with the Variant B instructions. KDZ555, T. 17237-17239 (16 August 2011); KDZ555, T. 17344 (17 August 2011). However, the Chamber does not find KDZ555's evidence to be reliable with respect to this issue. In reaching that conclusion the Chamber noted that the evidence of KDZ555 was marked by indicators of extreme evasiveness, bias and contradictions.

$4251 \quad$ P3390 (Report on activities of Zvornik SJB for 1993), p. 21.

4252 Petko Panić, P3380 (Transcript from Prosecutor v. Stanišić \& Župljanin), T. 2869-2870; P1116 (Letter from Momčilo Mandić to SRBiH MUP re division of MUP, 31 March 1992); see Adjudicated Fact 2729. See also KDZ555, T. 17263-17264 (16 August 2011) (private session); KDZ555, T. 17346-17347 (17 August 2011).

4253 P3390 (Report on activities of Zvornik SJB for 1993), pp. 21-22; KDZ555, T. 17266 (16 August 2011) (private session); D3723 (Witness statement of Čedomir Zelenović dated 22 June 2013), paras. 19-20; D3654 (Witness statement of KW317 dated 26 September 2012), para. 35 (under seal); D3693 (Witness statement of Marinko Vasilić dated 9 June 2013), para. 21; D3724 (Witness statement of Branko Grujić dated 22 June 2013), para. 24; D3692 (Witness statement of Jovan Ivanović dated 9 June 2013), para. 15.

4254 P3390 (Report on activities of Zvornik SJB for 1993), p. 22.

4255 P104 (Witness statement of Fadil Banjanović dated 30 March 2002), para. 11. Grujić testified that he did not know about the dispatch from Mandic about the division of the police but was presented with his prior testimony where he said that the dispatch is what caused the police to separate and move. Branko Grujić, T. 40381-40383 (25 June 2013); P6415 (Excerpt from Branko Grujić's testimony before Belgrade District Court, 30 November 2005), p. 6. The Chamber finds that Grujić was contradicted with respect to his evidence pertaining to this dispatch and does not find his evidence with respect to this issue to be credible. The Chamber finds however, that in the lead-up to the split of the police force, there had been increasing divisions and disputes between Bosnian Serb and Bosnian Muslim police including on issues relating to training in Croatia and moblisation of reserve police stations. Petko Panić, T. 19151-19155 (20 September 2011); Petko Panić, P3380 (Transcript from Prosecutor v. Stanišić \& Župljanin), T. 2971-2974; P3390 (Report on activities of Zvornik SJB for 1993), pp. 20-21; P2761 (RS MUP report on work for period April to December 1992), p. 5. See also D3724 (Witness statement of Branko Grujić dated 22 June 2013), para. 12; D3692 (Witness statement of Jovan Ivanović dated 9 June 2013), para. 12; D3693 (Witness statement of Marinko Vasilić dated 9 June 2013), paras. 13, 18; D3723 (Witness statement of Čedomir Zelenović dated 22 June 2013), para. 19; P1154 (Witness statement of KDZ088 dated 27-29 April 2010), pp. 152-153 (under seal); P4848 (Map of Zvornik marked by KDZ610); P4837 (Witness statement of KDZ610 dated 27 March 2012), para. 81 (under seal).

4256 Petko Panić, P3380 (Transcript from Prosecutor v. Stanišić \& Župljanin), T. 2871; D1613 (Map of Zvornik marked by KDZ555); KDZ555, T. 17418 (18 August 2011).

4257 P104 (Witness statement of Fadil Banjanović dated 9 February 1998), paras. 2-13, 2-14; Fadil Banjanović, P57 (Transcript from Prosecutor v S. Milošević), T. 20675; see Adjudicated Facts 2729, 2738. KDZ555 testified that before the conflict there was agreement within the MUP on the division of assets and premises to transform the MUP. KDZ555, T. 17347 (17 August 2011). However, in light of its credibility assessment in fn. 4239, the Chamber does not consider that it can rely on KDZ555's evidence in this regard. 
1238. At a meeting of the SDS on 5 April 1992, Mile Mijić was appointed as chief of the SJB and Spasojević as its commander. ${ }^{4258}$ By 6 April 1992, following the orders of Spasojević who ordered the withdrawal of all Bosnian Serb police with their vehicles and equipment, ${ }^{4259}$ the Bosnian Serb MUP, the TO and the Zvornik Crisis Staff relocated to the Alhos building in Karakaj. ${ }^{4260}$ The Zvornik Crisis Staff met every day starting from 4 or 5 April 1992 and discussed how to take control of Zvornik, how to restore organs and authorities and how to organise armed formations. ${ }^{4261}$

1239. On 10 April 1992, following the suggestion of Marko Pavlović, ${ }^{4262}$ the Zvornik Crisis Staff formed the Interim Government of the Serb Municipality of Zvornik, after which the Zvornik Crisis Staff ceased operating and the other bodies of government were disbanded. ${ }^{4263}$ Grujić was chosen as acting chairman of the Interim Government which consisted of members of the SDS. ${ }^{4264}$

4258 Petko Panić, P3380 (Transcript from Prosecutor v. Stanišić \& Župljanin), T. 2872-2875, 2930, 2978, 29982999. Mijić was replaced by Miloš Pantelić and Spasojević was replaced by Marinko Vasilić. In mid-June 1992, Pantelić was replaced by Vasilić and Momčilo Marić became the new commander. In turn, Vasilić was replaced by Milorad Lokanjcević at the end of July 1992.

4259 Petko Panić, P3380 (Transcript from Prosecutor v. Stanišić \& Župljanin), T. 2870, 2977; P2764 (Bijeljina CSB report), p. 2; P104 (Witness statement of Fadil Banjanović dated 9 February 1998), para. 2-14; Fadil Banjanović, P57 (Transcript from Prosecutor v S. Milošević), T. 20675; P3390 (Report on activities of Zvornik SJB for 1993), p. 22. Defence witnesses testified, inter alia, that the Bosnian Serb police only moved to Alhos after they had been disarmed by the Bosnian Muslim police and the Bosnian Serb police only withdrew their personal weapons, communications equipment and two or three cars while the Bosnian Muslims retained the arms depot. D3654 (Witness statement of KW317 dated 26 September 2012) (under seal), para. 40; D3693 (Witness statement of Marinko Vasilić dated 9 June 2013), para. 22; KDZ555, T. 17349-17350 (17 August 2011). The Chamber refers to its assessment in fns. 4237 and 4239 as to why it cannot rely on the evidence of these witnesses in this regard. Vasilić's evidence was also marked by contradictions and inconsistencies which undermined the reliability of his evidence in this regard.

4260 P3165 (Witness statement of KDZ340 undated), p. 3 (under seal); see Adjudicated Fact 2729; P2761 (RS MUP report on work for period April to December 1992), p. 5. See also KDZ555, T. 17235, 17264 (16 August 2011) (private session); D3692 (Witness statement of Jovan Ivanović dated 9 June 2013), para. 16; KDZ446, P28 (Transcript from Prosecutor v. S. Milošević), T. 21020-21021 (under seal).

4261 KDZ555, T. 17234 (16 August 2011) (private session).

4262 KW317, T. 39343-39344 (5 June 2013). Marko Pavlović's real name was Branko Popović; he was a security official of the federal organs of the SFRY and came to Zvornik from Serbia. Petko Panić, P3380 (Transcript from Prosecutor v. Stanišić \& Župljanin), T. 2887-2888; KW317, T. 39342 (5 June 2013); P2848 (Witness statement of Milorad Davidović dated 22 June 2011), para. 128. See also KDZ446, P28 (Transcript from Prosecutor v. S. Milošević), T. 23620, 23626, 23634 (under seal); D3724 (Witness statement of Branko Grujić dated 22 June 2013), paras. 48, 51; Branko Grujić, T. 40361 (25 June 2013).

4263 P3381 (Decision of the Zvornik Crisis Staff, 10 April 1992), pp. 2-3; D3723 (Witness statement of Čedomir Zelenović dated 22 June 2013), paras. 13-14; D3692 (Witness statement of Jovan Ivanović dated 9 June 2013), para. 24; D3654 (Witness statement of KW317 dated 26 September 2012) (under seal), para. 47; KW317, T. 39402 (6 June 2013). See also KDZ555, T. 17219, 17233, 17235-17236 (16 August 2011) (private session). For more detail on the actions taken by the Interim Government, see P3381 (Decision of the Zvornik Crisis Staff, 10 April 1992), pp. 2-3; D3692 (Witness statement of Jovan Ivanović dated 9 June 2013), para. 24; D1714 (Conclusion of Zvornik Interim Government, 25 June 1992), p. 1; Petko Panić, T. 19208-19209 (20 September 2011); D1709 (Decision of Zvornik Interim Government, 18 May 1992), pp. 3-4; P314 (Decision of interim Zvornik government, 20 May 1992); Milorad Davidović, T. 15650 (29 June 2011); P3393 (Decision of Zvornik Interim Government, 14 April 1992), p. 1. The Accused acknowledged that a Bosnian Serb Crisis Staff was formed but that it was only operational from 6 to 10 April 1992 until the Interim Government was formed. Defence Final Brief, confidential, para. 1444.

4264 D3724 (Witness statement of Branko Grujić dated 22 June 2013), para. 36; KW317, T. 39343 (5 June 2013 ); KDZ555, T. 17282-17283 (16 August 2011). 


\section{(2) Militarisation of Zvornik}

1240. From early 1992, both Bosnian Serbs and Bosnian Muslims were arming themselves, but the Bosnian Serbs were better armed as they received support from the JNA. ${ }^{4265}$ The Bosnian Serb police also enabled the transport of weapons, ammunition and other material. ${ }^{4266}$ Towards the end of February 1992, at a meeting chaired by Grujić and attended by JNA officers and the military commander for Zvornik, Zoran Jovanović, there was a discussion about the formation of a military unit for the area of Zvornik. ${ }^{4267}$ Grujić also discussed the possibility of a Bosnian Serb attack on the town. ${ }^{4268}$ After this meeting, weapons were distributed by Jovanović to the homes of Bosnian Serb managers of businesses, factories, and municipal organs. ${ }^{4269}$ In early spring 1992, Bosnian Serb officials from Zvornik received weapons from Croatia and Serbia, which were distributed to the villages around Zvornik. ${ }^{4270}$

4265 KDZ059, P67 (Transcript from Prosecutor v. S. Milošević), T. 29088-29089, 29101; P4837 (Witness statement of KDZ610 dated 27 March 2012), para. 4 (under seal); KDZ610, T. 27179 (29 March 2012). See also Marinko Vasilić, T. 39918-39919 (13 June 2013); KDZ555, T. 17238, 17246-17247 (16 August 2011). The Chamber finds that the level of military organisation by Bosnian Muslims in Zvornik was limited. KDZ610, T. 27179 (29 March 2012). See also P1996 (Witness statement of Martin Bell dated 8 March 2010), para. 24 (testifying that Bosnian Muslims in Zvornik had no defence). However, it finds that there were armed Bosnian Muslim formations and that the SDA was involved in arming of the Bosnian Muslim population. Petko Panić, P3380 (Transcript from Prosecutor v. Stanišić \& Župljanin), T. 2974-2976; Petko Panić, T. 19156-19157 (20 September 2011); KDZ555, T. 17246 (16 August 2011), T. 17331-17332, 17334-17335. 17363 (17 August 2011), T. 17402 (18 August 2011); D3693 (Witness statement of Marinko Vasilić dated 9 June 2013), paras. 13 15, 20; D3724 (Witness statement of Branko Grujić dated 22 June 2013), paras. 11-12, 26; Branko Grujić, T. 40352-40354 (25 June 2013); D2944 (Witness statement of Zoran Durmić dated 12 February 2013), para. 10; D3692 (Witness statement of Jovan Ivanović dated 9 June 2013), para. 13; KDZ059, P67 (Transcript from Prosecutor v. S. Milošević), T. 29089-29090. See also D1657 (Excerpt from book entitled "The Truth about Bratunac"); D3729 (Photograph of a board); D38 (ABiH Report on units in Zvornik, 5 November 1992), pp. 3, 5-6; D1607 (List of paramilitary groups operating in support of BiH), p. 11; KDZ320, T. 28093 (25 April 2012); KDZ340, T. 17500-17501 (19 August 2011) (private session).

4266 P3390 (Report on activities of Zvornik SJB for 1993), p. 20; P3183 (Excerpt from Report on the work of the Zvornik SJB for the year 1992), p. 2.

4267 P96 (Witness statement of KDZ059 dated 5 December 1998), pp. 3-4 (under seal); KDZ059, P67 (Transcript from Prosecutor v. S. Milošević), T. 29107-29108.

4268 P96 (Witness statement of KDZ059 dated 5 December 1998), p. 4 (under seal).

4269 P96 (Witness statement of KDZ059 dated 5 December 1998), p. 4 (under seal).

4270 KDZ555, T. 17248-17250, 17254-17255, 17257, 17259, 17261-17262 (16 August 2011) (private session) (testifying that Pavlović provided logistical support in bringing arms into BiH from Serbia); KDZ555, T. 1737517377 (17 August 2011); KDZ555, T. 17397 (18 August 2011); KDZ555, T. 17248-17250, 17254-17255, 17257 (16 August 2011) (private session); KDZ446, P28 (Transcript from Prosecutor v. S. Milošević), T. 21007, 21025-21026 (under seal). See also Jovan Ivanović, T. 39854-39855 (12 June 2013). The Chamber notes evasiveness and contradictions in Grujić's testimony about the extent to which the SDS and he were involved in the arming of Bosnian Serbs and does not consider his evidence to be reliable in this regard. P6414 (Excerpt from Branko Grujić's interview with OTP, 15 July 2002), pp. 1-3; Branko Grujić, T. 40356-40360 (25 June 2013). 
1241. On 4 April 1992, the Command of the $17^{\text {th }}$ Corps of the JNA reported that in municipalities, including Zvornik, there was a real danger of deterioration in the security situation and there was a threat of inter-ethnic conflict. ${ }^{4271}$

1242. Following the attack against the JNA column on 4 April 1992, ${ }^{4272}$ Arkan's men were asked to come urgently to the municipality. ${ }^{4273}$ On the night between 5 and 6 April 1992, Arkan's men, other paramilitaries, soldiers from Serbia, and local Bosnian Serb police constructed barricades and check-points. ${ }^{4274}$ These check-points were manned by Serbs wearing camouflage uniforms ${ }^{4275}$ and some Bosnian Muslims were stopped at check-points, searched, and beaten. ${ }^{4276}$ Bosnian Muslims also erected barricades on the bridge from Zvornik to Serbia. ${ }^{4277}$ Bosnian Serbs also formed village guards in areas where they lived and set up barricades around their villages. ${ }^{4278}$

1243. On 5 April 1992, the Zvornik Crisis Staff ordered that all TO units in the Serb Municipality of Zvornik be mobilised. ${ }^{4279}$ On 10 April 1992, the Interim Government decided to form the

\footnotetext{
$4271 \quad$ P5474 (Report of JNA $17^{\text {th }}$ Corps, 4 April 1992), p. 2.

4272 See para. 1237.
}

4273 Petko Panić, P3380 (Transcript from Prosecutor v. Stanišić \& Župljanin), T. 2878-2879; KDZ555, T. 17266, 17269 (16 August 2011) (private session); KDZ446, P28 (Transcript from Prosecutor v. S. Milošević), T. 23675-23676 (under seal); D1612 (Video footage of Arkan in "My Guest, His Truth", July/August 1994), transcript, p. 13. On or about 5 April 1992, Arkan appointed his deputy Marko Pejić (a.k.a "Peja") as the person in charge of the municipality. KDZ446, P28 (Transcript from Prosecutor v. S. Milošević), T. 21006 (under seal). See also KDZ555, T. 17266-17267, 17269 (16 August 2011) (private session). Peja went to the Alhos factory on 6 April 1992 and met with the Bosnian Serb leadership. D3693 (Witness statement of Marinko Vasilić dated 9 June 2013), para. 25; D3692 (Witness statement of Jovan Ivanović dated 9 June 2013), para. 19. See also D3654 (Witness statement of KW317 dated 26 September 2012), paras. 38-39 (under seal); D3723 (Witness statement of Čedomir Zelenović dated 22 June 2013), para. 24; Čedomir Zelenović, T. 40315 (24 June 2013).

4274 P96 (Witness statement of KDZ059 dated 5 December 1998), p. 5 (under seal); KDZ059, P67 (Transcript from Prosecutor v. S. Milošević), T. 29112; P62 (Witness statement of Nedžad Hadžiefendić dated 3 October 1997), p. 2; see Adjudicated Fact 2729; Petko Panić, P3380 (Transcript from Prosecutor v. Stanišić \& Župljanin), T. 2870-2871. See also P62 (Witness statement of Nedžad Hadžiefendić dated 3 October 1997), p. 2; D3693 (Witness statement of Marinko Vasilić dated 9 June 2013), para. 42.

4275 P70 (Witness statement of Jusuf Avdispahić dated 22 October 1997), p. 3; P133 (Witness statement of Matija Bošković dated 20 November 2003), para. 11.

4276 P70 (Witness statement of Jusuf Avdispahić dated 22 October 1997), p. 3.

4277 See Adjudicated Fact 2730. The Chamber finds that Bosnian Muslims also erected barricades. D3724 (Witness statement of Branko Grujić dated 22 June 2013), paras. 23, 56-57; D3723 (Witness statement of Čedomir Zelenović dated 22 June 2013), paras. 20-24; Čedomir Zelenović, T. 40340-40341 (25 June 2013); D3693 (Witness statement of Marinko Vasilić dated 9 June 2013), paras. 19, 21; D3692 (Witness statement of Jovan Ivanović dated 9 June 2013), paras. 15-16, 18.

4278 D3693 (Witness statement of Marinko Vasilić dated 9 June 2013), para. 21. See also Jovan Ivanović, T. 39854 39855 (12 June 2013); P6404 (Excerpt from Jovan Ivanović's statement to OTP, 23 October 2002), p. 2 ; D3692 (Witness statement of Jovan Ivanović dated 9 June 2013), para. 15.

4279 P5505 (Order of the Zvornik Municipality Crisis Staff, 5 April 1992); see Adjudicated Fact 2728. See also D3654 (Witness statement of KW317 dated 26 September 2012), para. 41 (under seal). Grujić testified that he issued this decision on his own without waiting for a decision of the Crisis Staff. Branko Grujić, T. 40379 (25 June 2013); P6415 (Excerpt from Branko Grujić's testimony before Belgrade District Court, 30 November 2005), pp. 4-5. Having regard to the extensive contradictions and indications of bias, the Chamber does not find that Grujić's evidence to be reliable in this regard. 
Zvornik TO with Pavlović as its commander. ${ }^{4280}$ Pavlović worked closely with Grujić, had close ties with Arkan, ${ }^{4281}$ and implemented the policies of the Zvornik Crisis Staff. ${ }^{4282}$

1244. Grujić and Spasojević were among the Bosnian Serb officials who invited and paid for paramilitaries to come to Zvornik. ${ }^{4283}$ Between 5 and 8 April 1992, paramilitary units from Serbia arrived in Zvornik. These included the White Eagles led by Aždaja; ${ }^{4284}$ the unit led by Vojin Vučoković, known as Žućo, and his brother Dušan Vučković (a.k.a. Repić); ${ }^{4285}$ the Red Berets led

4280 P3155 (Decision of Zvornik Interim Government, 10 April 1992), p. 1; KDZ446, P28 (Transcript from Prosecutor v. S. Milošević), T. 21004 (under seal); KDZ228, P323 (Transcript from Prosecutor v. Popović et al.), T. 14934, 14940 (under seal); Petko Panić, P3380 (Transcript from Prosecutor v. Stanišić \& Župljanin), T. 2887-2888; P2860 (Zvornik TO's payroll, May 1992), p. 3; P1478 (Ratko Mladić's notebook, 27 May-31 July 1992), p. 250; Petko Panić, T. 19136 (19 September 2011); KDZ555, T. 17244, 17259 (16 August 2011) (private session), T. 17284 (16 August 2011); P2955 (Report of the Drina Corps, 17 December 1992), p. 2; P3165 (Witness statement of KDZ340 undated) (under seal), pp. 11-12, 16; P4837 (Witness statement of KDZ610 dated 27 March 2012), para. 17 (under seal); KW317, T. 39341-39342 (5 June 2013); P6434 (Excerpt from Dragomir Andan's interview with OTP), p. 2. See also P34 (Structure of Serbian SDB and Zvornik/Bijeljina MUP) (under seal); D3724 (Witness statement of Branko Grujić dated 22 June 2013), paras. 48, 51; Branko Grujić, T. 40361 (25 June 2013).

4281 KW317, T. 39341-39343, 39350-39351 (5 June 2013); D3724 (Witness statement of Branko Grujić dated 22 June 2013), paras. 48, 51; Branko Grujić, T. 40361 (25 June 2013).

4282 Milorad Davidović, T. 15536 (28 June 2011).

4283 KDZ320, T. 28106-28107 (25 April 2012); KDZ446, P28 (Transcript from Prosecutor v. S. Milošević), T. 21016 (under seal); P31 (List of names referred to during testimony of KDZ446) (under seal); KDZ555, T. 17266, 17269 (16 August 2011) (private session); P6414 (Excerpt from Branko Grujić's interview with OTP, 15 July 2002), p. 5; Petko Panić, T. 19130, 19147 (19 September 2011); Vojislav Šešelj, T. 39576 (10 June 2013); P3178 (Indictment from Bijeljina Lower Court, 13 September 1999), p. 7 (under seal); see Adjudicated Fact 2728. See also Jovan Ivanović, T. 39865 (12 June 2013) (testifying that while officially the local leaders did not call the paramilitaries, they were probably aware or unofficially involved in the operation and it was unlikely that they came uninvited). Defence witnesses testified that (i) they had never heard about such an invitation by the Crisis Staff; (ii) Grujić did not invite the paramilitary formations into Zvornik; and (iii) they did not know who called these units. D3724 (Witness statement of Branko Grujić dated 22 June 2013), para. 55; Branko Grujić, T. 40363-406364, 40383-40384 (25 June 2013); P6414 (Excerpt from Branko Grujić's interview with OTP, 15 July 2002), pp. 4-5; D3723 (Witness statement of Čedomir Zelenović dated 22 June 2013), para. 35; Čedomir Zelenović, T. 40321-40325 (24 June 2013), T. 40338 (25 June 2013). The Chamber does not find the evidence of Grujić and Zelenović to be reliable in this regard. In reaching that conclusion the Chamber noted that Grujić had an interest in downplaying his own role and involvement with the paramilitaries and his testimony in this regard was marked by inconsistencies and contradictions. Zelenović simply stated that he had not heard of such an invitation and when cross-examined on the issue of support to paramilitaries by local authorities he was evasive.

4284 Milorad Davidović, T. 15494 (28 June 2011); P2865 (White Eagles' payroll, June 1992); P133 (Witness statement of Matija Bošković dated 20 November 2003), para. 17; P2880 (Official Note of Valjevo State Security Centre, 2 July 1992). The White Eagles (Beli Orlovi) were transferred in October 1992 from the Zvornik to the Birač Brigade. P5404 (Order of Dragan Petković, 13 October 1992); KDZ340, T. 17490 (19 August 2011).

4285 As discussed in para. 1280, this unit was initially known as the special TO unit, then the Igor Marković unit and later the Yellow Wasps. This unit was organised in Zvornik in April 1992 and controlled by Žućo who was from Belgrade, his brother Repić, and a journalist named Milan Timotić. Bosnian Serb locals including those with criminal backgrounds joined this unit. KDZ446, P28 (Transcript from Prosecutor v. S. Milošević), T. 21006-21007 (under seal); Petko Panić, P3380 (Transcript from Prosecutor v. Stanišić \& Župljanin), T. 2888, 3007; P2880 (Official Note of Valjevo State Security Centre, 2 July 1992); P2855 (VRS Main Staff report on paramilitary formations, 28 July 1992), p. 3; P3165 (Witness statement of KDZ340 undated), pp. 18, 28-33, 36, 41, 69, 72 (under seal); P3173 (Statement of Nenad Simić to Bijeljina SJB, 6 August 1992), p. 1 (under seal); KDZ340, T. 17525 (19 August 2011); KDZ340, T. 17535, 17560-17561 (19 August 2011) (private session); P2848 (Witness statement of Milorad Davidović dated 22 June 2011), paras. 126, 141; P2904 (Report of SerBiH MUP, 4 August 1992), p. 1; D1412 (Report of Republic of Serbia MUP, 8 August 1992), p. 9; D1417 (Report of Republic of Serbia MUP, 6 November 1993), p. 3. Žućo often visited Stevo Radić who a member of the 
by Captain Dragan; ${ }^{4286}$ Niški’s group and Pivarski's group; ${ }^{4287}$ as well as the "Simo Chetnik" group. ${ }^{4288}$ Other groups which arrived or operated in Zvornik included Mauzer's unit, ${ }^{4289}$ Šešelj's men, ${ }^{4290}$ Bošković's unit, ${ }^{4291}$ the Birčani Brigade under the command of Svetozar Andrić, ${ }^{4292}$ Mile Petrović's unit, ${ }^{4293}$ Gogić's unit, ${ }^{4294}$ and Crni's unit. ${ }^{4295}$

1245. A meeting was arranged in Mali Zvornik on 7 April 1992 between SDS, SDA, and JNA representatives to discuss how to "avoid an attack on the city" and divide the municipality into Serb and Muslim parts. $^{4296}$ When Arkan heard these negotiations were taking place without his knowledge or approval he arrived at the meeting with his men, took the Bosnian Serb representatives to the municipal assembly building, called them traitors, and beat them. ${ }^{4297}$ Arkan

Zvornik Crisis Staff. Branko Grujić, T. 40391 (25 June 2013); P3165 (Witness statement of KDZ340 undated), p. 5 (under seal).

4286 Petko Panić, P3380 (Transcript from Prosecutor v. Stanišić \& Župljanin), T. 2923 (testifying that this unit arrived in Zvornik some time after 25 May 1992).

4287 D1632 (Report of Bijeljina SJB, 23 July 1992), p. 1; Petko Panić, P3380 (Transcript from Prosecutor v. Stanišić \& Župljanin), T. 2876, 2925; D3789 (Dragomir Andan's notes), p. 1; P3165 (Witness statement of KDZ340 undated), pp. 17-18 (under seal); P36 (Report by CSB Bijeljina re security situation in the Zvornik Municipality, 20 July 1992) (under seal). These two groups were independent and later joined the TO. Pivarski's Group was later placed under the command of the Yellow Wasps. Milorad Davidović, T. 15493 (28 June 2011); P2864 (Pivarski unit's payroll, June 1992); KDZ340, T. 17523 (19 August 2011).

4288 Petko Panić, P3380 (Transcript from Prosecutor v. Stanišić \& Župljanin), T. 2888.

4289 P2848 (Witness statement of Milorad Davidović dated 22 June 2011), pp. 43-44.

4290 Petko Panić, P3380 (Transcript from Prosecutor v. Stanišić \& Župljanin), T. 2879; P2238 (Intercept of conversation between Radomir Pejičić and unknown, June 1992), p. 2; P4849 (Excerpt from video entitled "The Death of Yugoslavia"), 01:27-01:37.

4291 P133 (Witness statement of Matija Bošković dated 20 November 2003), paras. 13-14; P158 (Payroll list of reserve soldiers); P159 (Payroll list of volunteers). Bošković was an SRS member from Zvornik and the rest of his unit were from Mali Zvornik and were supporters of Šešelj.

4292 P3165 (Witness statement of KDZ340 undated), p. 25 (under seal).

4293 P2855 (VRS Main Staff report on paramilitary formations, 28 July 1992), p. 5. This unit was based in the village of Rastošnica.

4294 P133 (Witness statement of Matija Bošković dated 20 November 2003), para. 20; Marinko Vasilić, T. 3994539947 (13 June 2013). Members of this unit came from Serbia, wore police uniforms, and were paid by the municipality and included individuals who had been released from prison and consisted of members of the SRS. Petko Panić, P3380 (Transcript from Prosecutor v. Stanišić \& Župljanin), T. 2906, 2984-2986; Petko Panić, T. 19130-19131 (19 September 2011); P3382 (List of members of Loznica TO in April 1992), pp. 1-2. This unit was tasked with trying to control the other paramilitary groups. KDZ555, T. 17289-17290 (16 August 2011), T. 17291 (16 August 2011) (private session).

4295 Petko Panić, P3380 (Transcript from Prosecutor v. Stanišić \& Župljanin), T. 2908-2909 (testifying that Crni’s unit operated as an independent group in Zvornik even though they were given police uniforms and received the same salary); Petko Panić, T. 19135 (19 September 2011).

4296 D3724 (Witness statement of Branko Grujić dated 22 June 2013), paras. 31-32; D3692 (Witness statement of Jovan Ivanović dated 9 June 2013), para. 20; D3654 (Witness statement of KW317 dated 26 September 2012), para. 41 (under seal); P70 (Witness statement of Jusuf Avdispahić dated 22 October 1997), p. 4; Petko Panić, P3380 (Transcript from Prosecutor v. Stanišić \& Župljanin), T. 2877-2878; KDZ555, T. 17232, 17268-17269, 17271-17272 (16 August 2011) (private session); D3693 (Witness statement of Marinko Vasilić dated 9 June 2013), para. 27.

4297 D3724 (Witness statement of Branko Grujić dated 22 June 2013), para. 34. See also P104 (Witness statement of Fadil Banjanović dated 30 March 2002), para. 15; P70 (Witness statement of Jusuf Avdispahić dated 22 October 1997), p. 4; Petko Panić, P3380 (Transcript from Prosecutor v. Stanišić \& Župljanin), T. 2877-2878; KDZ555, T. 17267 (16 August 2011) (private session); D1612 (Video footage of Arkan in "My Guest, His Truth", July/August 1994), transcript, p. 13; D3692 (Witness statement of Jovan Ivanović dated 9 June 2013), paras. 21- 
told the Bosnian Serb representatives that instead of negotiating with the Bosnian Muslims, they should give them an ultimatum. ${ }^{4298}$ He asked who had authorised them "to sell the Serbian land". 4299

1246. Arkan resumed the meeting but prevented negotiations from proceeding any further. ${ }^{4300} \mathrm{He}$ gave the Bosnian Muslim negotiators an ultimatum that if they did not surrender all their weapons by the next morning, there would be a military attack and he would destroy the town. ${ }^{4301}$ On 8 April 1992, after this meeting, an urgent telegram was sent to the Commander of the JNA Tuzla Corps appealing for the JNA to deploy their units to protect the population of Zvornik. ${ }^{4302}$ Arkan and his men subsequently took command of military operations in Zvornik. ${ }^{4303}$

1247. In the days leading up to the attack on Zvornik in April 1992, most of the Bosnian Serbs, especially the women and children left Zvornik for Serbia or predominantly Bosnian Serb villages. $^{4304}$

22; Jovan Ivanović, T. 39864 (12 June 2013); D3654 (Witness statement of KW317 dated 26 September 2012), para. 42 (under seal); Petko Panić, P3380 (Transcript from Prosecutor v. Stanišić \& Župljanin), T. 2877; Petko Panić, T. 19163 (20 September 2011); D1605 (Telegram of Izet Mehinagić to JNA Tuzla Corps Commander, 8 April 1992).

4298 D3654 (Witness statement of KW317 dated 26 September 2012), para. 43 (under seal). See also Petko Panić, P3380 (Transcript from Prosecutor v. Stanišić \& Župljanin), T. 2877; Petko Panić, T. 19163 (20 September 2011); D1605 (Telegram of Izet Mehinagić to JNA Tuzla Corps Commander, 8 April 1992), p. 1. After this incident Jovo Mijatović and Jovan Ivanović resigned from the Zvornik Crisis Staff. KDZ555, T. 17285 (16 August 2011); D3692 (Witness statement of Jovan Ivanović dated 9 June 2013), para. 24.

4299 KDZ555, T. 17269, 17272 (16 August 2011) (private session); KDZ555, T. 17355, 17387 (17 August 2011); D1611 (Video footage depicting Arkan's pre-election campaign in Zvornik, 8 September 1996), transcript p. 1; D1612 (Video footage of Arkan in "My Guest, His Truth", July/August 1994), transcript, p. 13; D3723 (Witness statement of Čedomir Zelenović dated 22 June 2013), paras. 25-26; Branko Grujić, T. 40460 (26 June 2013); D3692 (Witness statement of Jovan Ivanović dated 9 June 2013), para. 22.

4300 D3723 (Witness statement of Čedomir Zelenović dated 22 June 2013), para. 26.

4301 D1612 (Video footage of Arkan in "My Guest, His Truth", July/August 1994), transcript, p. 13; KDZ555, T. 17269, 17272 (16 August 2011) (private session); KDZ555, T. 17355, 17387 (17 August 2011); D3654 (Witness statement of KW317 dated 26 September 2012), para. 44 (under seal). See also D3692 (Witness statement of Jovan Ivanović dated 9 June 2013), para. 22; D1605 (Telegram of Izet Mehinagić to JNA Tuzla Corps Commander, 8 April 1992), p. 1; P2919 (Witness statement of KDZ023 dated 29 September 1996), p. 3; KDZ023, P65 (Transcript from Prosecutor v. S. Milošević), T. 26125; P104 (Witness statement of Fadil Banjanović dated 30 March 2002), pp. 3-4; D1611 (Video footage depicting Arkan's pre-election campaign in Zvornik, 8 September 1996), transcript p. 1; D3723 (Witness statement of Čedomir Zelenović dated 22 June 2013), para. 25; Branko Grujić, T. 40460 (26 June 2013).

4302 D1605 (Telegram of Izet Mehinagić to JNA Tuzla Corps Commander, 8 April 1992), p. 1; KDZ555, T. 17355 (17 August 2011).

4303 D3693 (Witness statement of Marinko Vasilić dated 9 June 2013), para. 28. See also D3723 (Witness statement of Čedomir Zelenović dated 22 June 2013), para. 26; D3724 (Witness statement of Branko Grujić dated 22 June 2013), paras. 33-34; Branko Grujić, T. 40363 (25 June 2013); D3692 (Witness statement of Jovan Ivanović dated 9 June 2013), paras. 23-24.

4304 P70 (Witness statement of Jusuf Avdispahić dated 22 October 1997), p. 4; D3723 (Witness statement of Čedomir Zelenović dated 22 June 2013), paras. 21, 24. See also Adjudicated Fact 2727; D3724 (Witness statement of Branko Grujić dated 22 June 2013), paras. 30, 54; KDZ555, T. 17267 (16 August 2011) (private session), T. 17349, 17386 (17 August 2011); KDZ340, T. 17498-17500, 17503-17504 (19 August 2011) (private session); D3692 (Witness statement of Jovan Ivanović dated 9 June 2013), para. 18; D3693 (Witness statement of Marinko Vasilić dated 9 June 2013), para. 22. 


\section{(C) Events in early April 1992}

\section{(1) $\underline{\text { Take-over }}$}

1248. On 6 April 1992, the Zvornik Crisis Staff issued a decision declaring a state of war in the territory of the Serb Municipality of Zvornik, temporarily taking over the responsibilities of the municipal organs, and assigning defence duties to the Zvornik TO and parts of the reserve SJB. ${ }^{4305}$

1249. The attack on Zvornik began on or about 8 April 1992. ${ }^{4306}$ The units which took part in the attack included Arkan's men, SRS volunteers, ${ }^{4307}$ members of the police, Zvornik TO and the JNA, and men from groups belonging to Niški, Pivarski, Žućo, Gogić, as well as the White Eagles. ${ }^{4308}$ Pavlović and Peja were involved in planning and commanding the attack. ${ }^{4309}$ The Bosnian Serb police were ordered by Spasojević to follow Arkan's men during the attack and to patrol, occupy,

4305 P3154 (Decision of Zvornik's Crisis Staff, 6 April 1992); Petko Panić, P3380 (Transcript from Prosecutor v. Stanišić \& Župljanin), T. 2875; D3654 (Witness statement of KW317 dated 26 September 2012), para. 37 (under seal). The Chamber does not consider the evidence of KDZ555 and Ivanović with respect to manner and reason why this decision was made to be reliable. KDZ555, T. 17273-17274 (16 August 2011) (private session); D3692 (Witness statement of Jovan Ivanović dated 9 June 2013), para. 17. In reaching that conclusion the Chamber noted that the evidence of Ivanović and KDZ555 was marked by contradictions, evasiveness and indicators of insincerity and bias. [REDACTED].

4306 Marinko Vasilić, T. 39928-39929 (13 June 2013); P3390 (Report on activities of Zvornik SJB for 1993), p. 22; Petko Panić, T. 19164 (20 September 2011); Čedomir Zelenović, T. 40326-40327 (24 June 2013); KDZ228, P324 (Transcript from Prosecutor v. Popović et al.), T. 14934-14935. See also P3263 (Witness statement of Suad Džafić dated 31 August 2011), para. 5; Branko Grujić, T. 40400-40403 (25 June 2013); D3692 (Witness statement of Jovan Ivanović dated 9 June 2013), paras. 23, 25; KDZ555, T. 17275-17276 (16 August 2011).

4307 Šešelj in an interview said that he was asked for volunteers by Slobodan Milošević, that the Zvornik operation was planned in Belgrade, and that special units were sent from the Serbian State Security Service. Vojislav Šešelj, T. 39575 (10 June 2013); P6388 (Excerpt from video of interview with Vojislav Šešelj for "Death of Yugoslavia" documentary, with transcript), pp. 3-4. However, the Chamber does not consider that it can rely on this evidence given that on cross-examination Šešelj acknowledged that he could have made this statement in the interview in order to annoy Milošević. Vojislav Šešelj, T. 39571-39572 (10 June 2013).

4308 KDZ228, P323 (Transcript from Prosecutor v. Popović et al.), T. 14934 (under seal); P4837 (Witness statement of KDZ610 dated 27 March 2012), para. 7 (under seal); P133 (Witness statement of Matija Bošković dated 20 November 2003), paras. 12, 21, 34; D3665 (Witness statement of Vojislav Šešelj dated 1 June 2013), paras. 50, 70-71; P6388 (Excerpt from video of interview with Vojislav Šešelj for "Death of Yugoslavia" documentary, with transcript), p. 3; Vojislav Šešelj, T. 39575-39577 (10 June 2013); see Adjudicated Fact 2741; KDZ555, T. 17276 (16 August 2011); P2882 (Report of Bijeljina SJB, 8 August 1992), p. 3 ; P3178 (Indictment from Bijeljina Lower Court, 13 September 1999), p. 7 (under seal). Witnesses testified that only a small number of Karakaj TO members helped in the lifting of the blockade, that the JNA was not involved at all, that Arkan's men launched the attack to lift the blockade of Zvornik but nobody in the municipal government, including the Zvornik Crisis Staff, had requested or authorised the attack. D3724 (Witness statement of Branko Grujić dated 22 June 2013), para. 58; D3654 (Witness statement of KW317 dated 26 September 2012) (under seal), para. 46. The Chamber finds the evidence of Grujić and KW317 about who was involved in authorising or conducting the attack on Zvornik to be unreliable. In reaching that conclusion the Chamber refers to its credibility assessment in fns. 4237 and 4239 . The Chamber also notes that it is contradicted by other credible evidence about the involvement of Pavlović and Spasojević in the operation as well as the participation of the Bosnian Serb police and the Zvornik TO in the attack. It is also not consistent with measures taken by the Zvornik Crisis Staff in the lead-up to the attack.

4309 P104 (Witness statement of Fadil Banjanović dated 30 March 2002), paras. 15, 17. See also P133 (Witness statement of Matija Bošković dated 20 November 2003), para. 21; Petko Panić, T. 19130 (19 September 2011). 
and secure important facilities in the town. ${ }^{4310}$ Arkan's men entered the SUP building, took all documents and equipment and destroyed everything else. ${ }^{4311}$ After the initial attack, about half of Zvornik was under the control of Serb Forces and over the following 20 odd days, almost all of the remaining territory of the town also came under their control. ${ }^{4312}$ A Bosnian Muslim part of the municipality remained around Sapna. ${ }^{4313}$

1250. There were clashes between Serb Forces and Bosnian Muslim forces on 8 April 1992 and Serb Forces launched an artillery attack; they shelled the town, including with heavy mortars. ${ }^{4314}$ The town of Zvornik fell quickly following the attack by Serb Forces. ${ }^{4315}$ Bosnian Muslims who were hiding in their homes heard on radio that the Patriotic League defence lines had been broken but initially were unable to leave Zvornik because of shelling. ${ }^{4316}$ However, on the evening of 8 April 1992, when there was a lull in the shooting, approximately 10,000 people, the majority of whom were Bosnian Muslims, managed to leave Zvornik with most crossing to Mali Zvornik. ${ }^{4317}$

1251. Buildings in the town of Zvornik were burnt, windows were broken and there were traces of shooting on the walls. ${ }^{4318}$ Armed soldiers wearing black uniforms were seen entering buildings; houses were either hit with mortars or set on fire. ${ }^{4319}$ During the attack, paramilitaries, including Arkan's men, were involved in looting. ${ }^{4320}$ By the morning of 9 April 1992, Zvornik was under the

4310 Petko Panić, P3380 (Transcript from Prosecutor v. Stanišić \& Župljanin), T. 2876, 2879-2881, 2979; D1631 (Report of Zvornik SJB, 29 June 1992), pp. 2-3; Petko Panić, T. 19129 (19 September 2011); P2001 (BBC news report re Zvornik, with transcript), 00:00:00-00:00.21, 00:00:38-00:00:42; P3390 (Report on activities of Zvornik SJB for 1993), p. 22; P2761 (RS MUP report on work for period April to December 1992), p. 5; D3693 (Witness statement of Marinko Vasilić dated 9 June 2013), paras. 31-32; Marinko Vasilić, T. 39948 (13 June 2013). See also D1625 (Report on activities of Zvornik SJB, July-September 1992), p. 5.

4311 Petko Panić, P3380 (Transcript from Prosecutor v. Stanišić \& Župljanin), T. 2881.

4312 KDZ555, T. 17276 (16 August 2011). See also P2886 (Interview with Marko Pavlović, 30 June 1992), p. 1.

4313 KW317, T. 39407 (6 June 2013).

4314 P96 (Witness statement of KDZ059 dated 5 December 1998), pp. 6-7 (under seal) (stating that the shelling started from an elevated area above Mali Zvornik and that shells were "falling in Zvornik like rain. The targeting was not precise"); P70 (Witness statement of Jusuf Avdispahić dated 22 October 1997), pp. 4-5; P62 (Witness statement of Nedžad Hadžiefendić dated 3 October 1997), pp. 2-3; P2919 (Witness statement of KDZ023 dated 29 September 1996), p. 3; KDZ240, P2935 (Transcript from Prosecutor v. Krajišnik), T. 6759, 6910 (under seal); KDZ240, T. 16081-16082 (5 July 2011) (closed session); P2936 (Excerpt of video "The Death of Yugoslavia”, with transcript) (under seal).

4315 Petko Panić, T. 19164 (20 September 2011); Petko Panić, P3380 (Transcript from Prosecutor v. Stanišić \& Župljanin), T. 2885; D1617 (Report of Zvornik Municipal Staff, 5 November 1992), p. 2; D1614 (Report of the Armed Forces of Tuzla District, 10 July 1992), p. 2; D1611 (Video footage depicting Arkan's pre-election campaign in Zvornik, 8 September 1996), transcript, pp. 1-2; D1612 (Video footage of Arkan in "My Guest, His Truth", July/August 1994), transcript, p. 13; D38 (ABiH Report on units in Zvornik, 5 November 1992), p. 2.

4316 P70 (Witness statement of Jusuf Avdispahić dated 22 October 1997), p. 5.

4317 P70 (Witness statement of Jusuf Avdispahić dated 22 October 1997), p. 5.

4318 KDZ240, P2935 (Transcript from Prosecutor v. Krajišnik), T. 6759 (under seal).

4319 P96 (Witness statement of KDZ059 dated 5 December 1998), p. 8 (under seal).

4320 KDZ059, P67 (Transcript from Prosecutor v. S. Milošević), T. 29117 ; P4837 (Witness statement of KDZ610 dated 27 March 2012), para. 65 (under seal). See also P3338 (TANJUG news report, 14 April 1992); Petko Panić, P3380 (Transcript from Prosecutor v. Stanišić \& Župljanin), T. 2907. 
control of Serb Forces; a Serbian flag was flying over the main mosque and Serbian music was played through the loudspeakers on the minarets. ${ }^{4321}$ In the following days, the Chief of the CSB in Bijeljina, ${ }^{4322}$ and the Bosnian Serb municipal leadership and military commanders ${ }^{4323}$ were informed that Zvornik was under the control of Serb Forces and "had been liberated". Grujić reported on the situation in the municipality to the SDS Main Board. ${ }^{4324}$ Milorad Davidović was told by Mićo Stanišić that Arkan's forces were in Zvornik and Bijeljina and "helping to liberate territory [that] they believed should become part of [the RS]". ${ }^{4325}$

1252. After the take-over of Zvornik, Arkan's men, members of the JNA, and SRS volunteers withdrew ${ }^{4326}$ but other groups lead by Žućo, Pivarski, Niški, and Crni remained in town. ${ }^{4327}$ After Arkan's departure Pavlović took on a commanding role with the paramilitaries. ${ }^{4328}$

1253. In mid April 1992, Biljana Plavšić visited the Alhos factory and met with Bosnian Serb leaders including the Zvornik Crisis Staff. ${ }^{432}$ Mićo Stanišić in a daily report on 22 April 1992, reported that life in Zvornik was returning to normal and that the town was being cleared of Green Berets. ${ }^{430}$ On 29 April 1992, the Chief of the Bijeljina CSB visited the Zvornik SJB and discussed

4321 P96 (Witness statement of KDZ059 dated 5 December 1998), pp. 7-8 (under seal); P70 (Witness statement of Jusuf Avdispahić dated 22 October 1997), p. 5; P3165 (Witness statement of KDZ340 undated), pp. 2-3 (under seal); P4837 (Witness statement of KDZ610 dated 27 March 2012), para. 11 (under seal); see Adjudicated Fact 2742.

4322 P5490 (Report of Bijeljina CSB, 16 April 1992), p. 2; P3392 (Report of Bijeljina SJB, 21 April 1992), p. 1. See also P2849 (Intercept of conversation between Goran Sarić and Mićo Davidović, 21 April 1992), p. 4; Milorad Davidović, T. 15459 (24 June 2011). In the 21 April 1992 report, the Bijeljina CSB was also informed that the town was "being cleaned".

4323 KDZ446, P28 (Transcript from Prosecutor v. S. Milošević), T. 21029-21031 (under seal).

4324 KW513, T. 39328 (5 June 2013). The Bosnian Serb authorities in Zvornik were also in contact with the Bosnian Serb MUP in Sarajevo. P5717 (Intercept of conversation between Radmila LNU and an unidentified male, 18 April 1992).

4325 P2848 (Witness statement of Milorad Davidović dated 22 June 2011), para. 66. See also D1611 (Video footage depicting Arkan's pre-election campaign in Zvornik, 8 September 1996), transcript, p. 2; KDZ555, T. 1738317384 (17 August 2011); D1612 (Video footage of Arkan in "My Guest, His Truth”, July/August 1994), transcript, p. 13.

4326 Petko Panić, P3380 (Transcript from Prosecutor v. Stanišić \& Župljanin), T. 2881-2882; P1478 (Ratko Mladić's notebook, 27 May-31 July 1992), pp. 251-252; P1109 (Intercept of conversation between Arkan and Radmila Kalaban, 16 April 1992), p. 6; Vojislav Šešelj, T. 39593-39594 (10 June 2013); D3665 (Witness statement of Vojislav Šešelj dated 1 June 2013), para. 50; KDZ320, T. 28105-28107 (25 April 2012).

4327 P104 (Witness statement of Fadil Banjanović dated 30 March 2002), paras. 19, 21, 24; KDZ555, T. 17276 (16 August 2011) (private session); P4837 (Witness statement of KDZ610 dated 27 March 2012), para. 38 (under seal); KDZ610, T. 27197 (29 March 2012) (private session). See also D3724 (Witness statement of Branko Grujić dated 22 June 2013), para. 37 (stating that while Arkan left some of his men remained).

4328 Jovan Ivanović, T. 39866-39867 (12 June 2013).

4329 P3165 (Witness statement of KDZ340 undated), pp. 6-7 (under seal); KDZ555, T. 17277-17279 (16 August 2011) (private session).

4330 P2748 (SerBiH MUP daily report, 22 and 23 April 1992), pp. 3-4; P5490 (Report of Bijeljina CSB, 16 April 1992), p. 2. See also D1711 (Decision of Zvornik Interim Government, 22 April 1992); Petko Panić, T. $19205-$ 19206 (20 September 2011); P6170 (Transcript of conversation between Branko Kostić, Alija Izetbegović, and Blagoje Adžić, 26 April 1992), p. 9. For evidence on sporadic clashes in the area until May 1992, see P5489 (Report of Bijeljina SJB, 19 May 1992), p. 1; P2753 (SerBiH MUP daily report, 22 May 1992), p. 2; D3886 (Witness statement of Svetozar Andrić dated 16 July 2013), para. 3. 
steps to return the situation in Zvornik back to normal. ${ }^{4331}$ Between April and December 1992 police from the Zvornik SJB participated in combat and mopping up operations and the SJB acknowledged that there were "cases of individuals whose method of operation was unskilled, unprofessional and illegal". 4332

(2) $\underline{\text { Scheduled Incident A.16.1 }}$

1254. The Prosecution alleges that at least 15 people were killed in the town of Zvornik between 9 and 10 April 1992.

1255. During the attack on Zvornik, Arkan's men "piled dozens of dead bodies", including the bodies of children, women, and elderly persons onto four or five trucks while other bodies remained in the streets and outside houses. ${ }^{433}$ Among those killed was Fehim Kujundžić, the director of the Karakaj Technical School, ${ }^{434}$ Muhamed Zaimović, a municipal judge, ${ }^{435}$ and the three sons of Rasim Karaosmanović. ${ }^{4336}$

4331 P2850 (Fax of Bijeljina CSB, 29 April 1992). Measures included prohibiting or restricting the service and sale of alcohol. D1698 (Order of Zvornik Interim Government, 12 May 1992), p. 1; D1699 (Order of Zvornik Interim Government, 1 June 1992), p. 1; Petko Panić, T. 19195-19196 (20 September 2011).

4332 D1631 (Report of Zvornik SJB, 29 June 1992), p. 4; D1625 (Report on activities of Zvornik SJB, JulySeptember 1992), p. 1; P3390 (Report on activities of Zvornik SJB for 1993), pp. 22, 35, 38, 40, 47.

4333 See Adjudicated Facts 2742, 2743; P4849 (Excerpt from video entitled "The Death of Yugoslavia"), 01:3702:23, 01:49-02:17; P2936 (Excerpt of video "The Death of Yugoslavia", with transcript) (under seal); P4837 (Witness statement of KDZ610 dated 27 March 2012), paras. 65, 82 (under seal); KDZ240, P2935 (Transcript from Prosecutor v. Krajišnik), T. 6758-6759, 6910 (under seal); KDZ240, T. 15966-15967 (4 July 2011) (closed session). See also Petko Panić, P3380 (Transcript from Prosecutor v. Stanišić \& Župljanin), T. 28802881; KDZ240, P2935 (Transcript from Prosecutor v. Krajišnik), T. 6759, 6990-6991 (under seal); KDZ059, P67 (Transcript from Prosecutor v. S. Milošević), T. 2911; P3338 (TANJUG news report, 14 April 1992); Martin Bell, T. 9783, 9803 (14 December 2010); P1996 (Witness statement of Martin Bell dated 8 March 2010), paras. 23-24; Jovan Ivanović, T. 39866 (12 June 2013) (testifying that the people killed were not killed in combat as there was no fighting and the people were killed to "sow fear, to create chaos"); P96 (Witness statement of KDZ059 dated 5 December 1998), p. 8 (under seal); Martin Bell, T. 9783-9786, 9803 (14 December 2010); P2001 (BBC news report re Zvornik, with transcript), 00:01.50-00:02.20; P2002 (BBC news report re Zvornik, with transcript), 00:00.21-00:00.31, 00:00.43-00:01.10, 00:01.51-00:02.09, 00:02.2400:02.37; P2003 (BBC news report re Zvornik, with transcript), 00:00.29-00:00.38. Grujić in his testimony acknowledged that he did not personally take part in the take-over and was in Mali Zvornik at the time. Branko Grujić, T. 40400-40401 (25 June 2013); D3724 (Witness statement of Branko Grujić dated 22 June 2013), paras. 35, 46, 59, 61. Given this qualification, the Chamber does not consider Grujić's evidence with respect to the nature and number of casualties in Zvornik to be of much weight. In addition considering that Grujić's evidence was marked by multiple contradictions and evasiveness, the Chamber does not consider Grujić's evidence to be reliable in this regard.

4334 P4837 (Witness statement of KDZ610 dated 27 March 2012), para. 65 (under seal); KDZ023, P65 (Transcript from Prosecutor v. S. Milošević), T. 26131; P4837 (Witness statement of KDZ610 dated 27 March 2012), para. 65 (under seal). The body of Fehim Kujundžić was exhumed from a mass grave. P4853 (Updated Table 2 to the Report of Amor Mašović), p. 57.

4335 P4849 (Excerpt from video entitled "The Death of Yugoslavia"), 00:52-01:26, 01:22-01:26; P4837 (Witness statement of KDZ610 dated 27 March 2012), para. 82(c) (under seal).

4336 P70 (Witness statement of Jusuf Avdispahić dated 22 October 1997), p. 6. The Chamber notes that the bodies of the sons of Rasim Karaosmanović were exhumed from a mass grave. P4853 (Updated Table 2 to the Report of Amor Mašović), p. 58. 
1256. On the morning of 9 April 1992, approximately 10 Serb soldiers in camouflage uniforms, masks and fingerless black gloves detonated the door leading to a basement in a building on Filipa Kljajića street. ${ }^{4337}$ A group of over 30 men, women and children were sheltering at this location, and the soldiers ordered them to surrender any weapons and then forced them out to the street at gun point. ${ }^{4338}$ During this process, men and women were separated and 15 men were lined up against the wall of the apartment building after which a burst of gunfire was heard. ${ }^{4339}$ The women were forced to walk away from the scene by the soldiers. ${ }^{4340}$ KDZ023 was later told by other women that they had seen the dead bodies of the men who had been taken out of the cellar in front of the apartment building. ${ }^{4341}$ KDZ059 also heard that many men had been killed on Filipa Kljajića street, including Taib Futović and his son. ${ }^{4342}$

1257. When KDZ023 sought information from Branko Grujić about the men who had been separated, she was told that there was no longer a place for them in Zvornik. ${ }^{4343}$ When she returned to the scene a week later she found her husband's hat and son's sports shoes, which were covered in blood, and saw that there was blood on the wall, which was also "peppered with bullet holes". ${ }^{434}$ Bosnian Serb authorities were involved in organising the collection of civilian bodies for burial. ${ }^{4345}$

4337 P2919 (Witness statement of KDZ023 dated 29 September 1996), pp. 2-3.

4338 P2919 (Witness statement of KDZ023 dated 29 September 1996), p. 3; KDZ023, P65 (Transcript from Prosecutor v. S. Milošević), T. 26130, 26141-26142.

4339 P2919 (Witness statement of KDZ023 dated 29 September 1996), pp. 3-4. The witness identified 15 men as part of this group (including one Bosnian Croat) and named 12 of them (Hajrudin Delić, Sead Hidić, Senad Hidić, Šemsudin Ahmetović, Nusret Ahmetović, a man known as "Dedo", Samir Bilalić, Senad Bilalić, Sabit Bilalić, Ivo Kojić, Fahrudin Alajbegović, Edhem Hadžić. Of these named individuals, 10 were identified by Mašović as having been exhumed from mass graves. P4853 (Updated Table 2 to the Report of Amor Mašović), pp. 57-58.

4340 P2919 (Witness statement of KDZ023 dated 29 September 1996), p. 3 (under seal).

4341 P2919 (Witness statement of KDZ023 dated 29 September 1996), pp. 4-5. The Chamber notes the Accused's acknowledgement that men were separated from women and children and killed by Arkan's men and Šešelj's men. Defence Final Brief, confidential, para. 1450.

4342 P96 (Witness statement of KDZ059 dated 5 December 1998), p. 8 (under seal); KDZ059, P67 (Transcript from Prosecutor v. S. Milošević), T. 29092. The Chamber notes that the Prosecution connects these two individuals to Taib Hudović and Asim Hudović whose bodies were exhumed from a mass grave according to Mašović. Prosecution Final Brief, Appendix G referring to P4853 (Updated Table 2 to the Report of Amor Mašović), p. 57. The Chamber is not satisfied that these bodies can be linked to the evidence of KDZ059.

4343 P2919 (Witness statement of KDZ023 dated 29 September 1996), p. 5.

4344 P2919 (Witness statement of KDZ023 dated 29 September 1996), pp. 4-5.

4345 P4839 (Decision of the Serb Municipality of Zvornik, 28 April 1992); P4840 (Order of the Zvornik TO Staff, 19 May 1992); P4837 (Witness statement of KDZ610 dated 27 March 2012), paras. 18-19, 21 (under seal); KDZ610, T. 27194-27195 (29 March 2012) (private session). The Chamber also received evidence that approximately 120 bodies of those killed between 8 and 23 April 1992, were stored in a warehouse at the Alhos building until they were buried in a mass grave. KDZ610, T. 27190 (29 March 2012) (private session); P4837 (Witness statement of KDZ610 dated 27 March 2012), paras. 22-27, 31 (under seal); P4841 (Letter from FBiH Commission for Missing Persons, 30 July 2007). However, the Chamber notes that this period extends beyond the allegations in the Indictment for the purposes of this scheduled incident and that it has insufficient evidence to link these bodies with this incident. The Chamber also received evidence about the disappearance and killing of non-Serbs and the exhumation of mass graves in Zvornik. P4841 (Letter from FBiH Commission for Missing Persons, 30 July 2007); P4903 (Crni Vrh Exhumation Report by Derek Congram, 14 November 2003); D2250 
1258. The Chamber therefore finds that at least 15 people were killed by Serb Forces on or about 9 April 1992 in the town of Zvornik.

\section{(D) Events in other villages in Zvornik municipality}

1259. As mentioned above, ${ }^{4346}$ after the attack on Zvornik, many Bosnian Muslims left Zvornik and headed to other villages in the municipality. From then on, paramilitary units were involved in operations against Bosnian Muslims in these villages in which they arrested individuals and detained them in facilities, which were then taken over by the police. ${ }^{4347}$

\section{(1) $\underline{\text { Kula Grad }}$}

1260. Kula Grad is a town located to the southwest of Zvornik. ${ }^{4348}$ On 8 April 1992, there were between 5,000 and 6,000 Bosnian Muslims from Zvornik town in Kula Grad when an attack was launched. ${ }^{4349}$ Kula Grad was shelled from a JNA tank unit causing casualties in the town which prompted some of the Bosnian Muslims to flee towards Tuzla. ${ }^{4350}$ Bosnian Muslim forces in Kula Grad resisted a number of attacks by Arkan's men on the village. ${ }^{431}$ On 26 April 1992, Serb Forces, including paramilitaries, and local police, launched an early morning attack on Kula Grad

(Ewa Tabeau's report entitled "Deaths and Disappearance of BiH Muslims 1992 - 1995," 25 April 2012), p. 1; Ewa Tabeau, T. 28411-28412 (2 May 2012); P4841 (Letter from FBiH Commission for Missing Persons, 30 July 2007); P4850 (Witness statement of Amor Mašović dated 23 March 2012), para. 54; P4852 (Report of Amor Mašović, 20-21 October 2009), p. 13; P4854 (Updated Table 1 to the Report of Amor Mašović), p. 2. The Chamber will not rely on this evidence in the absence of a positive connection with a scheduled killing incident charged in the Indictment.

$4346 \quad$ See paras. 1250, 1261, 1269.

4347 Petko Panić, P3380 (Transcript from Prosecutor v. Stanišić \& Župljanin), T. 2896; P104 (Witness statement of Fadil Banjanović dated 9 February 1998), paras. 2-18; D3654 (Witness statement of KW317 dated 26 September 2012), paras. 49-50 (under seal).

4348 P4838 (Map of ethnic composition of Zvornik); P4848 (Map of Zvornik marked by KDZ610); P4837 (Witness statement of KDZ610 dated 27 March 2012), para. 81 (under seal) (marking the location of Kula Grad in relation to Zvornik with number 1).

4349 P4837 (Witness statement of KDZ610 dated 27 March 2012), para. 8 (under seal).

4350 P4837 (Witness statement of KDZ610 dated 27 March 2012), paras. 9-10 (under seal); KDZ610, T. 27198 (29 March 2012).

4351 P4837 (Witness statement of KDZ610 dated 27 March 2012), para. 10 (under seal); P62 (Witness statement of Nedžad Hadžiefendić dated 3 October 1997), p. 3 See also KDZ610, T. 27199 (29 March 2012); D38 (ABiH Report on units in Zvornik, 5 November 1992), p. 2; KDZ555, T. 17452-17454 (18 August 2011); D1627 (Video footage re view of Zvornik from Kula); D1628 (Video footage re view of Zvornik and Mali Zvornik from Kula); D1629 (Video footage re view of Divič from Kula); D1630 (Video footage re view of Kula from Zvornik); D1617 (Report of Zvornik Municipal Staff, 5 November 1992), p. 2 
and took control of the village. ${ }^{4352}$ Some houses were set on fire during the attack. ${ }^{4353}$ This attack forced the remaining Bosnian Muslims in the village to flee towards Tuzla and Kamenica. ${ }^{4354}$

\section{(2) Kozluk}

1261. Kozluk is a town approximately 20 kilometres from Zvornik ${ }^{4355}$ which had a majority Bosnian Muslim population before the war. ${ }^{4356}$ Bosnian Muslims from the neighbouring Bosnian Muslim villages of Šepak and Skočić had fled to Kozluk on account of their fear of Serb Forces who had been demanding the surrender of weapons. ${ }^{4357}$ Following the take-over of Zvornik, Kozluk was completely surrounded by Serb Forces, who set up barricades in surrounding villages and cut off exit routes. ${ }^{4358}$

1262. The Bosnian Muslim population of Kozluk handed over their hunting weapons and hand guns. $^{4359}$ Bosnian Serb municipal leaders visited Kozluk and reassured the Bosnian Muslims that they would not be harmed or arrested and that they should return to their villages. ${ }^{4360}$ From April to

$4352 \quad$ See Adjudicated Fact 2732; P133 (Witness statement of Matija Bošković dated 20 November 2003), para. 26; P62 (Witness statement of Nedžad Hadžiefendić dated 3 October 1997), p. 3. See also KDZ555, T. 17276 (16 August 2011).

4353 P133 (Witness statement of Matija Bošković dated 20 November 2003), para. 26.

4354 P133 (Witness statement of Matija Bošković dated 20 November 2003), para. 26; P62 (Witness statement of Nedžad Hadžiefendić dated 3 October 1997), p. 3. Some members of this group were apprehended in Orahovac, taken to the local Crisis Staff Headquarters, had their money and valuables confiscated, and were taken back to the SUP in Zvornik. KDZ072, P425 (Transcript from Prosecutor v. Šě̌elj), T. 8697.

4355 Fadil Banjanović, P57 (Transcript from Prosecutor v S. Milošević), T. 20615; D1613 (Map of Zvornik marked by KDZ555); P4838 (Map of ethnic composition of Zvornik).

4356 Fadil Banjanović, P57 (Transcript from Prosecutor v S. Milošević), T. 20615, 20668; KDZ555, T. 17308-17309 (17 August 2011).

4357 P104 (Witness statement of Fadil Banjanović dated 9 February 1998), paras. 2-3, 2-24. As a result, at the time, there were 10,000 to 12,000 people in Kozluk. See Adjudicated Fact 2736; D3654 (Witness statement of KW317 dated 26 September 2012), para. 60 (under seal). Grujić testified that Peja insisted that Bosnian Muslims remain in their homes and he guaranteed them security. D3724 (Witness statement of Branko Grujić dated 22 June 2013), para. 66. Having regard to the extensive contradictions and indications of bias, the Chamber does not find that Grujić's evidence to be reliable in this regard. For the same reasons the Chamber does not consider Grujić's evidence reliable with respect to other events in Kozluk, including the treatment of the Bosnian Muslim population, the voluntariness of their departure from Kozluk, and the attack on Kozluk. D3724 (Witness statement of Branko Grujić dated 22 June 2013), paras. 48, 64-68. See also Branko Grujić, T. 40404-40405, 40412-40416, 40452 (25 June 2013). For further contradictions in Grujić's evidence on this point and his attempt to minimise his own involvement in events in Kozluk, see Branko Grujić, T. 40410-40412 (25 June 2013); P6416 (Excerpt from Serbia Appeals Court judgement against Branko Grujić, 3 October 2011), pp. 5, 9-16; P6417 (Article from New York Times entitled "Serbian Mayor Displays the Wares of 'Ethnic Cleansing', 7 March 1994").

4358 Kozluk was surrounded by the Serb villages of Ugljar, Malešići, Tabanci, Riči, Kiseljak and Tršić, see P104 (Witness statement of Fadil Banjanović dated 9 February 1998), paras. 2-4, 2-14, 2-18, 2-40; Fadil Banjanović, P57 (Transcript from Prosecutor v S. Milošević), T. 20619, 20693, 20672; see Adjudicated Fact 2737.

4359 P104 (Witness statement of Fadil Banjanović dated 9 February 1998), para. 2-15; Fadil Banjanović, P57 (Transcript from Prosecutor v S. Milošević), T. 20617, 20665, 20677-20678; D1695 (List of Kozluk residents who surrendered weapons, 16 April 1992)

4360 P104 (Witness statement of Fadil Banjanović dated 9 February 1998), para. 2-29; Fadil Banjanović, P57 (Transcript from Prosecutor v S. Milošević), T. 20676-20677; KDZ555, T. 17402 (18 August 2011). See also D3654 (Witness statement of KW317 dated 26 September 2012), para. 51 (under seal). Pejić also made similar 
mid-June 1992, the citizens of Kozluk were subjected to acts of intimidation, which included shooting and throwing of grenades. ${ }^{4361}$

1263. The Bosnian Serb authorities tried to prevent the Bosnian Muslim population from leaving towards Tuzla; ${ }^{4362}$ however, by the end of May 1992 a large number of Bosnian Muslims had managed to leave Kozluk, including 5,000 to 6,000 people who returned to their homes in Šepak and Skočić and approximately 3,000 people who left for foreign countries. ${ }^{4363}$

1264. In June 1992, Bosnian Muslim police officers in Kozluk were forced to surrender their weapons and uniforms, ${ }^{4364}$ after which there was extensive shooting near the town. ${ }^{4365}$ In the leadup to the attack on Kozluk, Bosnian Serb paramilitary units started training local Serbs. ${ }^{4366}$ The local Serbs were told by Pavlović to mark all Serb houses so they would not be shot at. ${ }^{4367}$ Pavlović organised and ordered an attack on Kozluk on the morning of 21 June $1992 .{ }^{4368}$ Between 20 and 25 June 1992, a large number of Bosnian Serb soldiers, TO and paramilitary units entered Kozluk in military vehicles; during this period some Bosnian Muslims were beaten and their goods were looted. ${ }^{4369}$ The strong military presence including tanks, the attacks on local citizens, and the burning of property, increased the pressure on the Bosnian Muslim population to leave. ${ }^{4370}$

1265. Fadil Banjanović was summoned to meet with Grujić and Jovo Mijatović on or about 26 June 1992 at the Kozluk police station. ${ }^{4371}$ He was informed that the authorities could no longer guarantee the safety of the Bosnian Muslim population. He was told that the Bosnian Muslims had

assurances. P104 (Witness statement of Fadil Banjanović dated 9 February 1998), para. 2-38; Fadil Banjanović, P57 (Transcript from Prosecutor v S. Milošević), T. 20692-20693, 20695.

4361 Fadil Banjanović, P57 (Transcript from Prosecutor v S. Milošević), T. 20618; KDZ555, T. 17407-17408 (18 August 2011). But see P2886 (Interview with Marko Pavlović, 30 June 1992), p. 1.

4362 P104 (Witness statement of Fadil Banjanović dated 9 February 1998), paras. 2-26, 2-40; Fadil Banjanović, P57 (Transcript from Prosecutor v S. Milošević), T. 20693.

4363 P104 (Witness statement of Fadil Banjanović dated 9 February 1998), para. 2-45; Fadil Banjanović, P57 (Transcript from Prosecutor v S. Milošević), T. 20678, 20706; Milorad Davidović, T. 15534-15535 (28 June 2011); KDZ555, T. 17309 (17 August 2011). See also D3654 (Witness statement of KW317 dated 26 September 2012), para. 61 (under seal).

4364 P104 (Witness statement of Fadil Banjanović dated 9 February 1998), para. 2-47; see Adjudicated Fact 2739.

4365 P104 (Witness statement of Fadil Banjanović dated 9 February 1998), para. 2-47.

4366 P104 (Witness statement of Fadil Banjanović dated 9 February 1998), para. 2-7; Fadil Banjanović, P57 (Transcript from Prosecutor v S. Milošević), T. 20673.

4367 P104 (Witness statement of Fadil Banjanović dated 30 March 2002), para. 2-23.

4368 P104 (Witness statement of Fadil Banjanović dated 30 March 2002), para. 2-23; Fadil Banjanović, P57 (Transcript from Prosecutor v S. Milošević), T. 20618. See also Adjudicated Fact 2740.

4369 P104 (Witness statement of Fadil Banjanović dated 30 March 2002), paras. 24-25; P104 (Witness statement of Fadil Banjanović dated 9 February 1998), para. 2-48; Fadil Banjanović, P57 (Transcript from Prosecutor v S. Milošević), T. 20621-20622, 20655. See also Adjudicated Fact 2774.

4370 P104 (Witness statement of Fadil Banjanović dated 9 February 1998), para. 48; Fadil Banjanović, P57 (Transcript from Prosecutor v S. Milošević), T. 20620, 20624, 20655, 20664.

4371 P104 (Witness statement of Fadil Banjanović dated 9 February 1998), para. 2-48; Fadil Banjanović, P57 (Transcript from Prosecutor v S. Milošević), T. 20621-20622, 20628, 20655. 
to leave the town within an hour and that everything, including transportation, had been organised. ${ }^{4372}$ Mijatović told Banjanović that "an all-out attack was being prepared on Kozluk", that there "could be a massacre", and all Muslims would be killed if they did not move out. ${ }^{4373}$

1266. The operation to move out the Bosnian Muslim population was ordered by Pavlovic ${ }^{4374}$ and carried out by the commander of the MP known as "Studeni". ${ }^{4375}$ Soldiers forced Bosnian Muslims to gather in the centre of town, while beating and opening fire at them. ${ }^{4376}$ People from the nearby locality of Skočić were also ordered to assemble in the centre of Kozluk. ${ }^{4377}$ Bosnian Serb soldiers registered the names of the Bosnian Muslims who had gathered, told them that they could not take any personal belongings, and forced them to sign statements that they gave up their property. ${ }^{4378}$

1267. After this, a convoy ${ }^{4379}$ of buses, trucks, trailers and cars took almost 2,000 villagers from over 500 households from Kozluk to Šabac in Serbia, where they were transferred to trains to the Serbian-Hungarian border. From then on, Serbs who had fled other locations were settled in Kozluk. $^{4380}$

4372 P104 (Witness statement of Fadil Banjanović dated 30 March 2002), para. 33; P104 (Witness statement of Fadil Banjanović dated 9 February 1998), para. 2-48; Fadil Banjanović, P57 (Transcript from Prosecutor $v$ S. Milošević), T. 20621-20622, 20628, 20655; Milorad Davidović, T. 15538 (28 June 2011).

4373 Fadil Banjanović, P57 (Transcript from Prosecutor v S. Milošević), T. 20627-20628, 20696.

4374 P104 (Witness statement of Fadil Banjanović dated 30 March 2002), para. 33. See also D3724 (Witness statement of Branko Grujić dated 22 June 2013), para. 48. But see P2886 (Interview with Marko Pavlović, 30 June 1992), p. 1.

4375 Fadil Banjanović, P57 (Transcript from Prosecutor v S. Milošević), T. 20666.

4376 Fadil Banjanović, P57 (Transcript from Prosecutor v S. Milošević), T. 20629, 20655.

4377 Fadil Banjanović, P57 (Transcript from Prosecutor v S. Milošević), T. 20630.

4378 P104 (Witness statement of Fadil Banjanović dated 9 February 1998), para. 2-49; Fadil Banjanović, P57 (Transcript from Prosecutor v S. Milošević), T. 20705. See also Adjudicated Fact 2774; Milorad Davidović, T. 15535-15536 (28 June 2011).

4379 During transportation, those on the convoy, which was under police escort, were not free to leave. Fadil Banjanović, P57 (Transcript from Prosecutor v S. Milošević), T. 20643, 20651, 20709-20710. The Chamber received evidence about the killing of people who remained in Kozluk. Fadil Banjanović, P57 (Transcript from Prosecutor v S. Milošević), T. 20694. The Chamber notes that these killings are not charged pursuant to Schedules A or B of the Indictment. See fn. 13.

4380 P104 (Witness statement of Fadil Banjanović dated 9 February 1998), para. 50; Fadil Banjanović, P57 (Transcript from Prosecutor v S. Milošević), T. 20632-20633, 20641, 20660, 20662-20663, 20667; P72 (Letter regarding people leaving Kozluk, 26 June 1992); P162 (List of persons leaving Kozluk, 26 June 1992); P73 (List of persons leaving Skočić, 26 June 1992); P2887 (Article from The Independent entitled "Refugees board a nightmare train", 19 July 1992), pp. 1-2; Petko Panić, T. 19137 (19 September 2011); P76 (Map marked by Fadil Banjanović). See Adjudicated Fact 2775. But see D3654 (Witness statement of KW317 dated 26 September 2012) (under seal), paras. 57-59; P6369 (Excerpts from KW317's statement to OTP, 14 June 2002) (under seal), pp. 3-4. The Chamber refers to fns. 4237 and 4239 as to why it does not consider KW317's evidence as to the circumstances in which the Bosnian Muslim population left Kozluk to be reliable. Further, the Chamber notes specific contradictions, attempts to minimise his own involvement and his acknowledgement on cross-examination that Bosnian Muslims did not move of their own free will. KW317, T. 39362-39365 (6 June 2013). 
1268. Documents and statements were provided which stated that Bosnian Muslims from Kozluk had explicitly, and without any duress, requested resettlement. ${ }^{4381}$ However, Banjanović stated that these documents did not reflect the actual situation and that while"[t]hey wrote this letter saying that we were doing everything voluntarily, but in fact, they expelled us. We left in trucks, in buses. The stoning, the beating, the killings [were] not an act of benevolence but an act of expulsion. Why would 5,000 people leave their homes?". ${ }^{432}$ Having reviewed the evidence, the Chamber finds that the Bosnian Muslims did not leave voluntarily, and even if some had provided statements which indicated that they left voluntarily, these statements were given in intimidating and violent circumstances, which negated the voluntariness of these departures.

\section{(3) $\underline{\text { Other villages }}$}

1269. From April 1992, Serb Forces attacked or took over a number of villages including Dugi Dio, ${ }^{4383}$ Snagovo, ${ }^{4384}$ Divič,${ }^{4385}$ Đulići which was also known as Bijeli Potok, ${ }^{4386}$ and Liplje. ${ }^{4387}$ Women and girls from the village of Liplje were raped by Serb Forces. ${ }^{438}$ During some of these attacks Serb Forces set fire to houses, destroyed mosques and cut the electricity supply. ${ }^{4389}$ These

4381 Fadil Banjanović, P57 (Transcript from Prosecutor v S. Milošević), T. 20632, 20657, 20704. See also P106 (Document of Serbian Commission for Refugees, 26 June 1992).

4382 Fadil Banjanović, P57 (Transcript from Prosecutor v S. Milošević), T. 20650, 20698; P72 (Letter regarding people leaving Kozluk, 26 June 1992); P73 (List of persons leaving Skočić, 26 June 1992. See also P2887 (Article from The Independent entitled "Refugees board a nightmare train", 19 July 1992), p. 2; KDZ240, P2935 (Transcript from Prosecutor v. Krajišnik), T. 6761-6763 (under seal).

4383 P133 (Witness statement of Matija Bošković dated 20 November 2003), para. 27 (identifying Bošković’s unit as taking over the village with the presence of JNA units). See also P3195 (Witness statement of KDZ029 dated 28 June 2011), para. 13 (under seal).

4384 P64 (Witness statement of Osman Krupinac dated 29 May 2000), pp. 2-3.

4385 The attack on Divič was carried out by forces including Arkan's men, the White Eagles, and the reserve police. In late April or early May 1992, Serb Forces demanded that the villagers of Divič surrender but attacked the village before the deadline for surrender had expired. See Adjudicated Fact 2735.

4386 Petko Panić, P3380 (Transcript from Prosecutor v. Stanišić \& Župljanin), T. 2898. See Adjudicated Fact 2733; P4838 (Map of ethnic composition of Zvornik).

4387 P71 (Witness statement of Safeta Hamzić dated 17 July 1996), p. 2. See also KDZ064, T. 1316, 1318-1319 (21 April 2010), T. 1404 (22 April 2010) (testifying about attacks against Kamenica). Gornja Kamenica and Donja Kamenica are located to the south west of Zvornik. P4838 (Map of ethnic composition of Zvornik).

4388 P71 (Witness statement of Safeta Hamzić dated 17 July 1996), pp. 2-7. The Chamber also received evidence about the detention and killing of Bosnian Muslims in Liplje. The Chamber notes that these killings and detention facilities are not charged pursuant to Schedules A, B or C of the Indictment. See fn. 13.

4389 KDZ064, T. 1316, 1318-1319 (21 April 2010), T. 1404 (22 April 2010) (testifying that Serb Forces destroyed the four mosques in Kamenica); P133 (Witness statement of Matija Bošković dated 20 November 2003), para. 27. For the Chamber's findings with respect to the destruction of mosques, see Scheduled Incident D.22. See also P3195 (Witness statement of KDZ029 dated 28 June 2011), para. 13 (under seal). The Chamber also received evidence about the killing of Bosnian Muslims from Kamenica and Snagovo. KDZ064, T. 1311 (21 April 2010); KDZ064, T. 1404 (22 April 2010); P64 (Witness statement of Osman Krupinac dated 29 May 2000), p. 2-3; P6372 (Excerpt from SFRY Federal Secretariat for National Defence information, 26 May 1992), p. 2. The Chamber notes that these killings are not charged pursuant to Schedules A or B of the Indictment. See fn. 13. 
attacks prompted the Bosnian Muslim population to flee their villages, ${ }^{4390}$ after which Bosnian Serbs moved into Bosnian Muslim homes. ${ }^{4391}$ When some Bosnian Muslims who had fled Divič tried to return they were turned away by Serb Forces. ${ }^{4392}$

1270. In late April 1992, Bosnian Muslims of Kostijerevo, following a demand by Serb Forces handed over weapons. ${ }^{4393}$ Similarly, in the second half of May 1992, the Zvornik Crisis Staff called for the surrender of weapons which was complied with by villages, including Đulići, Šetići, Klisa, Kaldrane, Sjenokos, Drina, Kučić-Kula, Mrakonci, Durakovići, Lupe, Tršić, and Petkovci. ${ }^{4394}$

1271. Some villages were attacked multiple times until they fell to Serb Forces. ${ }^{4395}$ In late May 1992, between 400 and 500 Bosnian Muslims from Divič, including women, children and the elderly, were forced onto buses by Yellow Wasps and taken to Crni Vrh where they were allowed to leave for Bosnian Muslim territory on foot. ${ }^{4396}$

1272. On or about 28 May 1992, the Bosnian Serb Crisis Staff in Sapna, announced that all residents of Šetići and 13 other hamlets should gather in Klisa to be moved to Živinice. ${ }^{4397}$ After this announcement Serbs warned their Bosnian Muslim neighbours, that they would be killed and that they should flee towards Klisa. ${ }^{4398}$ As a result more than 4,000 people, including women and children, gathered at Klisa and some headed towards Međeđa and Tuzla. ${ }^{4399}$

1273. On the morning of 1 June 1992, Klisa was surrounded by Serb soldiers wearing the uniform of the JNA and heavily armed paramilitaries. ${ }^{4400}$ Bosnian Muslims were instructed by the Bosnian

4390 KDZ064, T. 1316, 1318-1319, 1334 (21 April 2010), T. 1404 (22 April 2010); P64 (Witness statement of Osman Krupinac dated 29 May 2000), pp. 2-3; see Adjudicated Fact 2735 (1,000 Bosnian Muslims fled from Divič to Jošanica). The Chamber also received evidence about the burning of six Bosnian Muslims from Kamenica. KDZ064, T. 1311 (21 April 2010), T. 1404 (22 April 2010). The Chamber notes that these killings are not charged pursuant to Schedules A or B of the Indictment. See fn. 13.

4391 P3195 (Witness statement of KDZ029 dated 28 June 2011), para. 13 (under seal).

4392 See Adjudicated Fact 2735.

4393 KDZ072, P425 (Transcript from Prosecutor v. Šešelj), T. 8696-8697.

4394 D1639 (Statement of KDZ029 to Tuzla SDB, 17 June 1992), p. 1 (under seal); KDZ029, T. 17588 (22 August 2011) (closed session).

4395 P64 (Witness statement of Osman Krupinac dated 29 May 2000), p. 5.

4396 See Adjudicated Fact 2771. But see D3724 (Witness statement of Branko Grujić dated 22 June 2013), paras. 49, 63. The Chamber refers to fns. 4237 and 4239 as to why it does not find Grujić's evidence with respect to the departure of Bosnian Muslims from Divič to be reliable.

4397 D1639 (Statement of KDZ029 to Tuzla SDB, 17 June 1992), p. 1 (under seal).

4398 P3195 (Witness statement of KDZ029 dated 28 June 2011), para. 6 (under seal); KDZ029, T. 17598-17599, 17608-17609 (22 August 2011) (closed session).

4399 P3195 (Witness statement of KDZ029 dated 28 June 2011), para. 7 (under seal); KDZ029, T. 17614 (22 August 2011) (closed session).

4400 P3195 (Witness statement of KDZ029 dated 28 June 2011), paras. 8-9 (under seal); KDZ029, T. 17609 (22 August 2011) (closed session). 
Serb soldiers that they could only take their bags and leave for Đulići. ${ }^{4401}$ After this, 4,000 people walked towards Đulići under the escort of armed Bosnian Serbs; ${ }^{4402}$ they were intimidated and searched at a check-point for weapons, and had their vehicles confiscated. ${ }^{4403}$ On arrival in Đulići, Bosnian Serbs, in regular police uniforms, camouflage uniforms and JNA uniforms, with some wearing masks ordered the separation of the men from the women and children. ${ }^{4404}$ Between 5,000 and 6,000 women and children were moved out from Bijeli Potok and Đulići. ${ }^{4405}$ Approximately 700 men from 13 Bosnian Muslims villages were separated, had their hands tied behind their backs, and were transported to the Karakaj Technical School. ${ }^{4406}$ The police assisted in loading people onto buses while VRS units were responsible for the transportation. ${ }^{4407}$

1274. On 30 May 1992, Serbian Radio Zvornik, informed all citizens of the Drinjača-Kostijerevo commune to stay in their homes and co-operate with the "army" which would arrive. ${ }^{4408}$ Then, soldiers dressed in the JNA reserve uniform arrived, firing shots. ${ }^{4409}$ About 150 people, including women and children, were gathered and ordered to form a column before being escorted to the cultural centre in Drinjača. ${ }^{4410}$

\footnotetext{
4401 P3195 (Witness statement of KDZ029 dated 28 June 2011), para. 10 (under seal); P3184 (Record of Belgrade's District Court, War Crime Chamber Investigating Judge, 14 February 2007), p. 4 (under seal); KDZ029, T. 17616 (22 August 2011) (closed session).

4402 P3195 (Witness statement of KDZ029 dated 28 June 2011), para. 10 (under seal); KDZ029, T. 17620 (22 August 2011) (closed session).

4403 P3195 (Witness statement of KDZ029 dated 28 June 2011), para. 11 (under seal).

4404 P3195 (Witness statement of KDZ029 dated 28 June 2011), para. 12 (under seal); KDZ029, T. 17618-17619 (22 August 2011) (closed session); P64 (Witness statement of Osman Krupinac dated 29 May 2000), pp. 2-3. The Chamber also received evidence about the killing of Bosnian Muslim men in this incident. Petko Panić, P3380 (Transcript from Prosecutor v. Stanišić \& Župljanin), T. 2899-2901. The Chamber notes that the above killings are not charged pursuant to Schedules A or B of the Indictment. See fn. 13.

4405 Petko Panić, P3380 (Transcript from Prosecutor v. Stanišić \& Župljanin), T. 2896, 2900, 2989-2990. See also D3654 (Witness statement of KW317 dated 26 September 2012), paras. 53-55 (under seal); Petko Panić, T. 19188 (20 September 2011).

4406 P3195 (Witness statement of KDZ029 dated 28 June 2011), para. 13 (under seal); P3184 (Record of Belgrade's District Court, War Crime Chamber Investigating Judge, 14 February 2007) (under seal), pp. 4-5; KDZ029, T. 17620-17621 (22 August 2011) (closed session); Petko Panić, P3380 (Transcript from Prosecutor v. Stanišić \& Župljanin), T. 2896, 2899-2901, 2989-2990.

4407 Petko Panić, P3380 (Transcript from Prosecutor v. Stanišić \& Župljanin), T. 2898, 2900-2902; KDZ555, T. 17304-17305 (17 August 2011) (private session).

4408 KDZ072, P425 (Transcript from Prosecutor v. Šešelj), T. 8698.

4409 KDZ072, P425 (Transcript from Prosecutor v. Šěselj), T. 8699.

4410 KDZ072, P425 (Transcript from Prosecutor v. Šešelj), T. 8699-8701.
} 


\section{(E) Developments in Zvornik after take-over}

\section{(1) Measures imposed in Zvornik}

1275. On 8 April 1992, the Zvornik Crisis Staff imposed a curfew on all civilians ${ }^{4411}$ and issued an order for the general mobilisation of all adults in the Serb Municipality of Zvornik. ${ }^{4412}$ Both Bosnian Muslims and Bosnian Serbs were issued with passes by the military authorities allowing free movement and all citizens were required to have these passes. Paramilitaries would stop people to check these passes. ${ }^{4413}$

1276. Some Bosnian Muslims were prevented from going to work, and those who attempted to do so, were stopped at a barricade in Karakaj, slapped, insulted, and sent home. ${ }^{4414}$ After the conflict broke out, some Bosnian Muslims were fired from their jobs ${ }^{4415}$ and Bosnian Muslim judges were expelled from the municipality. ${ }^{4416}$ In April 1992, Bosnian Serb authorities called on both Bosnian Serbs and Bosnian Muslims to return to work and live in Zvornik, declaring it was safe to do so. ${ }^{4417}$ However, Bosnian Muslims who did return were taken in for interviewing, ${ }^{4418}$ had to register, ${ }^{4419}$ and in order to remain employed, had to sign a pledge of loyalty to the Bosnian Serb authorities. ${ }^{4420}$ Some Bosnian Muslims after being questioned by the police were kept effectively under house arrest, and in one case in May 1992, Serb Forces called out the names of Bosnian Muslims who

\footnotetext{
4411 P3381 (Decision of the Zvornik Crisis Staff, 8 April 1992), pp. 1-2; Petko Panić, T. 19127 (19 September 2010).

4412 P3381 (Decision of the Zvornik Crisis Staff, 8 April 1992), p. 5; KDZ555, T. 17351 (17 August 2011). See also Marinko Vasilić, T. 39926-39927 (13 June 2013); Petko Panić, T. 19127 (19 September 2011), T. 19174 (20 September 2011) (testifying that the municipality did not have the authority to declare mobilisation or to declare a state of war unless it was cut off from the state).

4413 P4837 (Witness statement of KDZ610 dated 27 March 2012), paras. 14, 16 (under seal); KDZ610, T. 27193, 27202 (29 March 2012) (private session).

4414 KDZ072, P425 (Transcript from Prosecutor v. Šě̌elj), T. 8697.

4415 KDZ610, T. 27188 (29 March 2012) (private session).

4416 D92 (Transcript of $17^{\text {th }}$ session of SerBiH Assembly, 24-26 July 1992), pp. 71-72. The Chamber finds that some Bosnian Serbs were also relieved from their duties in the Zvornik lower Court by the Interim Government. D1712 (Decision of Zvornik Interim Government, 27 April 1992); Petko Panić, T. 19207 (20 September 2011).

4417 KDZ555, T. 17441 (18 August 2011); P70 (Witness statement of Jusuf Avdispahić dated 22 October 1997 ), p. 6.

4418 KDZ555, T. 17242-17243 (16 August 2011) (private session).

4419 P70 (Witness statement of Jusuf Avdispahić dated 22 October 1997), p. 7; KDZ023, P65 (Transcript from Prosecutor v. S. Milošević), T. 26138-26139. KDZ023 testified that the registration was only a pretext and those who returned and registered were killed. However, the Chamber considers KDZ023's evidence in this regard to be speculative. KDZ023, P65 (Transcript from Prosecutor v. S. Milošević), T. 26138-26139.

$4420 \quad$ See Adjudicated Fact 2734. But see D3724 (Witness statement of Branko Grujić dated 22 June 2013), para. 62; KDZ555, T. 17354 (17 August 2011). The Chamber refers to its credibility assessment in fns. 4237 and 4239 as to why it does not find the evidence of Grujić and KDZ555 to be reliable with respect to the pledge of loyalty and the issue of discriminatation against Bosnian Muslims.
} 
were still living in a building in Zvornik. ${ }^{4421}$ White Eagles also searched Bosnian Muslim apartments, at times using violence. ${ }^{4422}$

1277. In May 1992, an agency was established which was authorised to execute exchanges of real estate between residents of Zvornik and other municipalities. ${ }^{4423}$ Through this commission the abandoned property of Bosnian Muslims was seized and distributed to Bosnian Serbs who had moved to Zvornik. ${ }^{4424}$ By August 1992, Bosnian Serb authorities in Zvornik did take measures to move out individuals who unlawfully moved into property and to investigate cases of plunder of property. $^{4425}$

1278. On 6 June 1992, Mladić issued an urgent directive to secure communications from Sarajevo to Zvornik and mop up or cleanse the zone of "remaining enemy groups". ${ }^{4426}$ More specifically the Eastern Bosnia Corps was directed to secure road access and to mop up or cleanse Birač of remaining "enemy forces". 4427 This directive also stated that "maltreating of civilian unarmed population is strictly forbidden and prisoners must be treated pursuant to [the] Geneva Convention[s]". ${ }^{4428}$ The Command of the Eastern Bosnia Corps issued an order to the Zvornik Brigade on 7 June 1992, which reflected this directive and also strictly prohibited the maltreatment of the unarmed civilian population. ${ }^{4429}$

1279. On 17 June 1992, the Accused confirmed the appointment of five members of the War Commission of the Serb Municipality of Zvornik, which was to disband the Interim Government

\footnotetext{
4421 P70 (Witness statement of Jusuf Avdispahić dated 22 October 1997), pp. 3, 8-9. The Serb Forces included those wearing the insignia of Šešelj's men.

4422 P70 (Witness statement of Jusuf Avdispahić dated 22 October 1997), p. 14.

4423 Adjudicated Fact 2770; P2734 (Decision of Zvornik municipality on establishment of Agency for Exchange of Real Estate Properties, 11 May 1992). See also D3724 (Witness statement of Branko Grujić dated 22 June 2013), para. 70.

4424 Petko Panić, T. 19139 (19 September 2011), T. 19151, 19200-19201 (20 September 2011); P3385 (Decision of Zvornik's Temporary Government, 15 May 1992), p. 1; D1705 (Order of Zvornik Interim Government, 21 May 1992), p. 1; see Adjudicated Fact 2773. See also D1710 (Decision of Zvornik Interim Government, 22 June 1992), p. 1; Branko Grujić, T. 40456 (26 June 2013); D3732 (Decision of Zvornik Interim Government, 30 May 1992). But see D3724 (Witness statement of Branko Grujić dated 22 June 2013), para. 72; Branko Grujić, T. 40454-40456 (26 June 2013). The Chamber refers to its credibility assessment in fns. 4237 and 4239 as to why it does not find the evidence of Grujić to be reliable with respect to the occupation of Bosnian Muslim homes by Serb refugees.

4425 D1624 (Minutes of $2^{\text {nd }}$ meeting of Zvornik Assembly, 19 August 1992), pp. 4-5. See also D1708 (Order of Zvornik Interim Government, 2 July 1992), p. 3; D1709 (Decision of Zvornik Provisional Government, 18 May 1992), p. 1; Petko Panić, T. 19201, 19203-19204 (20 September 2011).

4426 D232 (Directive 1, 6 June 1992), pp. 1-2.

4427 D232 (Directive 1, 6 June 1992), p. 4. Birač was one of the SAOs which included the municipality of Zvornik. Momčilo Mandić, T. 5088 (14 July 2010)

4428 D232 (Directive 1, 6 June 1992), p. 5.

4429 P5400 (Order of Eastern Bosnia Corps, 7 June 1992), pp. 1-2, 5-6.
} 
and restore the Municipal Assembly. ${ }^{4430}$ On the same day, the Serb Municipality of Zvornik ordered the back pay of pensions for Serbs. ${ }^{4431}$

\section{(2) Actions of paramilitaries}

1280. On 18 April 1992, the Interim Government issued an order to form a special unit tasked with securing the territory of the Serb Municipality of Zvornik. ${ }^{4432}$ This special unit was referred to as the Igor Marković unit and was later known as the Yellow Wasps. ${ }^{443}$ Members of the Yellow Wasps would regularly report to the Zvornik Crisis Staff. ${ }^{4434}$ The Yellow Wasps had close cooperation with, and were issued arms by, the $\mathrm{TO}^{4435}$ and were subsequently under the command of the Zvornik Brigade. ${ }^{4436}$ In May 1992, the Zvornik TO was transformed into the Zvornik Brigade, which formed part of the Eastern Bosnia Corps. ${ }^{4437}$ Žućo reported to, and received orders from, the Brigade command. ${ }^{4438}$ Pivarski's Group received orders from Pavlović although it was under the command of the Zvornik Brigade as was Niški's Group. ${ }^{4439}$ When volunteers and paramilitaries arrived in Zvornik they reported to the Zvornik Crisis Staff and were sent to the TO to be deployed. ${ }^{440}$ Members of paramilitary and volunteer units were on the payroll of the Zvornik TO or Zvornik Brigade and were paid by municipal bodies, including the TO Staff and Zvornik Crisis Staff, which also paid for their transportation to Zvornik. ${ }^{4441}$ Pavlović had a major role in arming

4430 P5479 (RS Presidency confirmation of appointment of Zvornik War Commission members, 17 June 1992); D3654 (Witness statement of KW317 dated 26 September 2012), paras. 67-68, 73 (under seal) [REDACTED]. See also D1716 (Decision of Zvornik Interim Government, 28 July 1992); Petko Panić, T. 19210 (20 September 2011); D4694 (Zvornik Wartime Commission Decisions, 1 July 1992).

4431 P3152 (Request of Investbank to Zvornik's temporary Government, 17 June 1992) p. 2; KDZ555, T. 17241 (16 August 2011).

4432 D1719 (Order of Zvornik Interim Government, 18 April 1992), p. 1; Petko Panić, T. 19216 (20 September 2011). Branko Grujić delayed the implementation of this decision. D1720 (Conclusion of Zvornik Interim Government, 9 May 1992), pp. 1-2; Petko Panić, T. 19217 (20 September 2011).

4433 P2867 (Decision of Zvornik Interim Government, 27 April 1992); Milorad Davidović, 15497 (28 June 2011 ).

$4434 \quad$ KDZ340, T. 17479 (18 August 2011).

4435 See Adjudicated Fact 2108; P3165 (Witness statement of KDZ340 undated), pp. 17, 19, 49 (under seal). See also Reynaud Theunens, T. 17090-17092 (21 July 2011); Milorad Davidović, T. 15491 (28 June 2011).

4436 P3165 (Witness statement of KDZ340 undated), pp. 16, 19, 22-23, 26-27 (under seal); P3169 (Letter from Zvornik Brigade, 17 June 1992), p. 1; P3170 (Duty book of Zvornik Brigade, 9 June - 9 July 1992).

4437 P3167 (Order of the Eastern Bosnia Corps, 30 May 1992); D1457 (Order of Eastern Bosnia Corps, 6 June 1992 ), p. 1.

4438 P3165 (Witness statement of KDZ340 undated), pp. 25-31 (under seal); P3171 (Combat Report of the Eastern Bosnia Corps, 6 July 1992), p. 2; P3170 (Duty book of Zvornik Brigade, 9 June - 9 July 1992), p. 7.

4439 P3165 (Witness statement of KDZ340 undated), pp. 17, 23-24 (under seal) (stating that Niški's full name was Svetozar Mitrović and first came to Zvornik under Arkan's command and returned on 26 April 1992 under the command of Žućo and then Pavlović). See also P3169 (Letter from Zvornik Brigade, 17 June 1992), p. 1.

4440 Branko Grujić, T. 40384-40385 (25 June 2013), T. 40444-40445 (26 June 2013); D3692 (Witness statement of Jovan Ivanović dated 9 June 2013), para. 26; D3654 (Witness statement of KW317 dated 26 September 2012), para. 39 (under seal); KDZ340, T. 17518 -17519 (19 August 2011); KDZ555, T. 17293 (16 August 2011).

4441 Petko Panić, P3380 (Transcript from Prosecutor v. Stanišić \& Župljanin), T. 2893-2894, 2906, 2984-2985; Petko Panić, T. 19130-19131 (19 September 2011); P2866 (Declaration of Milorad Davidović, 22 June 2011), pp. 2-3; Milorad Davidović, T. 15489, 15491-15495, 15497 (28 June 2011); P2867 (Decision of Zvornik Interim Government, 27 April 1992); P2862 (Yellow Wasps payroll, 1 May 1992); P2863 (Yellow Wasps' 
Serb paramilitary units in the region. ${ }^{442}$ Some of the paramilitary groups which came from Serbia later joined the TO or the VRS but mostly worked independently. ${ }^{443}$ There were difficulties in attempts to place them under a unified command. ${ }^{444}$

1281. Before being integrated into the Eastern Bosnia Corps, the Zvornik TO worked in parallel and in co-operation with the Zvornik Brigade, which allowed both Pavlović and the Zvornik Brigade commander to issue orders to military units in Zvornik. ${ }^{4445}$ In June 1992, Pavlović was appointed commander of "the single military and territorial command" of the Serb Municipality of Zvornik. $^{4446}$

1282. Paramilitaries were involved in looting goods and vehicles, which were then smuggled to Serbia. ${ }^{4477}$ The actions of paramilitaries created fear among the Bosnian Muslim population. ${ }^{4448}$

payroll, June 1992); P2869 (Zvornik Brigade's payroll, June 1992); P2871 (Zvornik TO's payroll, April 1992); P2865 (White Eagles' payroll, June 1992); P2872 (Zvornik TO's payroll, May 1992); P2873 (List of volunteers in Zvornik Municipality, 7 May 1992); P2634 (Order of Zvornik's interim government, 4 May 1992), p. 1; P3156 (Approval for payment of Zvornik Municipal Assembly, 30 April 1992); P3157 (Payroll of unemployed reservists, May 1992), p. 4 (referring to entry 41 which is a payment made to Žuća); P3159 (Zvornik Brigade's payroll for June 1992) (under seal); P158 (Payroll list of reserve soldiers); P159 (Payroll list of volunteers); P3382 (List of members of Loznica TO in April 1992), pp. 1-2; P3165 (Witness statement of KDZ340 undated), pp. 7-9, 16-17, 19-20, 31, 84-86 (under seal); P2870 (TO's payroll of reserve soldiers, May 1992); KDZ340, T. 17526-17527 (19 August 2011) (private session); KDZ555, T. 17270-17271, (16 August 2011) (private session), T. 17287-17289, 17293 (16 August 2011); KW317, T. 39357-39358 (6 June 2013); P3173 (Statement of Nenad Simić to Bijeljina SJB, 6 August 1992), p. 1 (under seal); P133 (Witness statement of Matija Bošković dated 20 November 2003), paras. 13, 31, 56; P160 (Receipts of confiscated vehicles, 23 June 1992); P5434 (Payroll sheet for members of the Zvornik TO, May 1992); P5435 (List of soldiers in the White Eagles Unit, 16 June 1992); P5542 (Permission of the Zvornik Municipality, 10 June 1992); Marinko Vasilić, T. 3994539947 (13 June 2013); P3383 (Payment list for Zoran Aleksić's unit), pp. 1-5; P2859 (Zvornik TO's payroll, April 1992), pp. 6-7; see Adjudicated Fact 2108. Defence witnesses testified that the local authorities did not dare enter into a more detailed analysis of who was on payment lists because of fear and that they were forced to provide logistical support by the paramilitaries. Branko Grujić, T. 40390 (25 June 2013); P6415 (Excerpt from Branko Grujić's testimony before Belgrade District Court, 30 November 2005), pp. 9-10; Čedomir Zelenović, T. 40329-40332 (24 June 2013). However, the Chamber notes that on cross-examination Grujić was challenged about this testimony and did not adequately explain why he had not previously mentioned this theory that payments were made under coercion. Branko Grujić, T. 40390 (25 June 2013); P6415 (Excerpt from Branko Grujić's testimony before Belgrade District Court, 30 November 2005), pp. 9-10. The Chamber further notes that Grujić's evidence was marked by multiple contradictions and evasiveness and does not consider it to be reliable in this regard. Zelenović was shown P2913, which showed Grujić requesting payment from the republican authorities for members of the TO without mentioning any coercion. The Chamber does not consider Zelenović's evidence to be reliable in this regard considering that his testimony was marked by evasiveness.

4442 P104 (Witness statement of Fadil Banjanović dated 30 March 2002), paras. 5-6, 9; P3165 (Witness statement of KDZ340 undated), p. 17 (under seal).

4443 Petko Panić, P3380 (Transcript from Prosecutor v. Stanišić \& Župljanin), T. 2888; Petko Panić, T. 1916619167 (20 September 2011). See also Marinko Vasilić, T. 39947, 39970 (13 June 2013); D3663 (Witness statement of Goran Mačar dated 3 May 2013), para. 28.

4444 D3724 (Witness statement of Branko Grujić dated 22 June 2013), para. 37.

4445 P3165 (Witness statement of KDZ340 undated), pp. 12-15 (under seal); KDZ340, T. 17519-17521 (19 August 2011).

4446 P313 (Decision of interim Zvornik government, 16 June 1992), p. 1.

4447 KDZ446, P28 (Transcript from Prosecutor v. S. Milošević), T. 23634-23636 (under seal).

4448 D3654 (Witness statement of KW317 dated 26 September 2012), paras. 49-50 (under seal); P2764 (Bijeljina CSB report), pp. 2-3. 
These actions included the formation of check-points around town, the seizure of cars, buildings and apartments, the looting of private houses and factories, maltreatment, killings, and rape. ${ }^{4449}$

1283. The local authorities faced difficulties in controlling the actions of the paramilitaries. ${ }^{4450}$ However, in some cases the paramilitary formations "carried out their illegal activities with the knowledge and consent" of members of the Bosnian Serb authorities in Zvornik. ${ }^{4451}$ More specifically, paramilitaries such as Žućo had close contact with Pavlović. ${ }^{4452}$ With respect to one incident, in which two Bosnian Muslim men were killed and two Bosnian Muslim women were

4449 D1436 (Report of SerBiH MUP, 17 June 1992), p. 5; D3693 (Witness statement of Marinko Vasilić dated 9 June 2013), para. 37; P3165 (Witness statement of KDZ340 undated), pp. 50-51 (under seal); P3181 (Statement of KDZ340 to Bijeljina SJB, 6 August 1992), p. 1 (under seal); P3173 (Statement of Nenad Simić to Bijeljina SJB, 6 August 1992), pp. 1, 3 (under seal); KDZ340, T. 17535-17536, 17538, 17543 (19 August 2011) (private session); P3176 (Map of area around Zvornik marked by KDZ340) (under seal); P3178 (Indictment from Bijeljina Lower Court, 13 September 1999) (under seal), p. 7. See also P6372 (Excerpt from SFRY Federal Secretariat for National Defence information, 26 May 1992), p. 2; P70 (Witness statement of Jusuf Avdispahić dated 22 October 1997), p. 3; KDZ555, T. 17286-17287 (16 August 2011) (private session); D1450 (Milorad Davidović's statement to Belgrade District Court, 26 December 2007), pp. 5, 31; P2764 (Bijeljina CSB report), pp. 2-3. The Chamber will not enter a finding with respect to killings which are not connected to scheduled killing incidents.

4450 Dragan Vidović, T. 17762 (23 August 2011); D1696 (List of active policemen in Zvornik SJB, 21 April 1992), pp. 1-2; Petko Panić, T. 19172-19173 (20 September 2011); D3654 (Witness statement of KW317 dated 26 September 2012), paras. 49-50 (under seal); P3390 (Report on activities of Zvornik SJB for 1993), p. 23, 38; D1450 (Milorad Davidović's statement to Belgrade District Court, 26 December 2007), pp. 5, 31 ; D1436 (Report of SerBiH MUP, 17 June 1992), p. 5; D1631 (Report of Zvornik SJB, 29 June 1992), p. 3; D1625 (Report on activities of Zvornik SJB, July-September 1992), p. 1; P2764 (Bijeljina CSB report), pp. 2-3; Dragomir Andan, T. 40836 (5 July 2013); P2880 (Official Note of Valjevo State Security Centre, 2 July 1992), p. 4. See also P1478 (Ratko Mladić's notebook, 27 May-31 July 1992), pp. 264-265; P2743 (Witness statement of Dragan Kezunović dated 14 June 2011), pp. 62-63; D3724 (Witness statement of Branko Grujić dated 22 June 2013), paras. 37, 53; D3693 (Witness statement of Marinko Vasilić dated 9 June 2013), para. 35 ; D3692 (Witness statement of Jovan Ivanović dated 9 June 2013), para. 27; D3960 (Witness Statement of Tomislav Kovač dated 28 October 2013), para. 79; D3723 (Witness statement of Čedomir Zelenović dated 22 June 2013), para. 28; D3692 (Witness statement of Jovan Ivanović dated 9 June 2013), para. 27; Petko Panić, T. 1918819190 (20 September 2011); Mićo Stanišić, T. 46553-46554 (5 February 2014).

4451 P3390 (Report on activities of Zvornik SJB for 1993), p. 23; P36 (Report by CSB Bijeljina re security situation in the Zvornik Municipality, 20 July 1992), p. 5 (under seal); D1450 (Milorad Davidović's statement to Belgrade District Court, 26 December 2007), p. 8. As a result of dissatisfaction with the legalisation of the stay of "criminally inclined persons" and the actions of the military authorities, the Chief of the Zvornik SJB requested to be released from his duties. D1436 (Report of SerBiH MUP, 17 June 1992), p. 5; Petko Panić, P3380 (Transcript from Prosecutor v. Stanišić \& Župljanin), T. 2923. But see KDZ555, T. 17286-17287 (16 August 2011) (private session); D3693 (Witness statement of Marinko Vasilić dated 9 June 2013), paras. 32-34, 36; Marinko Vasilić, T. 39945-39946, 39950, 39962-39963 (13 June 2013); D3723 (Witness statement of Čedomir Zelenović dated 22 June 2013), paras. 28-30; Čedomir Zelenović, T. 40329, 40332 (24 June 2013 ), T. 40337 (25 June 2013); D3692 (Witness statement of Jovan Ivanović dated 9 June 2013), paras. 25-27; Jovan Ivanović, T. 39866-39867 (12 June 2013), T. 39873-39874, 39897 (13 June 2013); D3663 (Witness statement of Goran Mačar dated 3 May 2013), para. 29; D3654 (Witness statement of KW317 dated 26 September 2012) (under seal), para. 71; KW317, T. 39402 (6 June 2013); D3724 (Witness statement of Branko Grujić dated 22 June 2013), paras. 37-39. The Chamber does not find the evidence of these witnesses that local authorities could not control or punish paramilitaries to be reliable. In reaching that conclusion the Chamber refers to its credibility asessment in fns. 4237 and 4239 . Vasilić, for example, qualified his evidence and acknowledged that he did not know if the military authorities were supporting paramilitaries. Similarly the Chamber notes that the evidence of Mačar was also marked by contradictions and extreme evasiveness which undermined his credibility in this regard.

4452 Dragomir Andan, T. 40893-40895 (5 July 2013). There were attempts to hide the contacts and connections between members of the local government and paramilitary groups. KDZ446, P28 (Transcript from Prosecutor v. S. Milošević), T. 23634-23636, 23661 (under seal). 
raped by members of the Zvornik TO under the command of Žućo, the SFRY Secretariat for National Defence reported that that the leadership of Zvornik did not want to uncover the identity of the perpetrators. ${ }^{4453}$ The SJB protested against the Interim Government which had engaged paramilitary formations and was aware of and consented to their illegal activities. ${ }^{4454}$

1284. At the end of May 1992, Bosnian Serb leaders from Zvornik informed Mandić and Mićo Stanišić about the situation in the municipality, including the actions of the paramilitaries. ${ }^{4455}$ In response, they were told that the local police should attempt to control these groups given that the SerBiH government and the VRS were still in the process of being established and did not have the resources to assist the municipalities in controlling the paramilitaries at the time. ${ }^{4456}$

1285. When paramilitaries felt that their activities, including looting, were interfered with and their presence was not supported, they also threatened and mistreated Bosnian Serb officials, threatened to attack the Zvornik SJB, blocked government buildings, and issued demands. ${ }^{4457}$ It was only following these incidents that the local authorities took some steps to get rid of them. ${ }^{4458}$

1286. In another incident in June 1992, the Government and Zvornik Crisis Staff building was encircled by paramilitary formations and a member of Captain Dragan's unit threatened the President of the Municipality. ${ }^{449}$ The Accused and Mladić visited Zvornik the following day. ${ }^{4460}$

\footnotetext{
4453 P6372 (Excerpt from SFRY Federal Secretariat for National Defence information, 26 May 1992), p. 2.

4454 P3389 (Report of Zvornik SJB, 28 July 1992), p. 1; P3390 (Report on activities of Zvornik SJB for 1993 ), p. 23.

4455 D3654 (Witness statement of KW317 dated 26 September 2012), para. 65 (under seal).

4456 D3654 (Witness statement of KW317 dated 26 September 2012), paras. 66, 70 (under seal).

4457 P2880 (Official Note of Valjevo State Security Centre, 2 July 1992), pp. 1-4; D1436 (Report of SerBiH MUP, 17 June 1992), p. 5; D3723 (Witness statement of Čedomir Zelenović dated 22 June 2013), paras. 28-29; Čedomir Zelenović, T. 40329 (24 June 2013), T. 40337 (25 June 2013); P1478 (Ratko Mladić's notebook, 27 May-31 July 1992), p. 250. See also D3724 (Witness statement of Branko Grujić dated 22 June 2013), paras. 37-38; D3692 (Witness statement of Jovan Ivanović dated 9 June 2013), para. 27; D3693 (Witness statement of Marinko Vasilić dated 9 June 2013), para. 38; Vojislav Šešelj, T. 39577 (10 June 2013); KDZ555, T. 1728917290 (16 August 2011); Marinko Vasilić, T. 39948, 39967-39968 (13 June 2013).

4458 P2848 (Witness statement of Milorad Davidović dated 22 June 2011), p. 28; D1450 (Milorad Davidović's statement to Belgrade District Court, 26 December 2007), p. 68; Milorad Davidović, T. 15778 (30 June 2011). See also P3165 (Witness statement of KDZ340 undated), pp. 53-54 (under seal); D1450 (Milorad Davidović's statement to Belgrade District Court, 26 December 2007), p. 6; Dragomir Andan, D3774 (Transcript from Prosecutor v. Stanišić \& Župljanin), T. 21799; P6434 (Excerpt from Dragomir Andan's interview with OTP), p. 1. When cross-examined, Andan maintained that the mistreatment of Ostojić was not the direct cause of the operation but this incident could have accelerated the process and that approval for the operation was received a day or two after the incident. Dragomir Andan, T. 40885-40887, 40905-40907 (5 July 2013); P6435 (Article entitled "The Sting of the 'Yellow Wasp"”, 10 December 2002), p. 2; P6434 (Excerpt from Dragomir Andan's interview with OTP), p. 1. See also KW317, T. 39415-39416 (6 June 2013). But see Mićo Stanišić, T. 4665346554 (5 February 2014). The Chamber does not consider Stanišić's evidence that this was already planned to be reliable. In reaching that conclusion the Chamber noted that his testimony was marked by contradictions, evasiveness and indicators that the witness was not being forthright in his evidence to the Chamber.
}

4459 D1436 (Report of SerBiH MUP, 17 June 1992), p. 5; P1478 (Ratko Mladić's notebook, 27 May-31 July 1992), pp. 250, 264; KDZ555, T. 17289-17290 (16 August 2011); Marinko Vasilić, T. 39967-39968 (13 June 2013 ). See also P2880 (Official Note of Valjevo State Security Centre, 2 July 1992), pp. 3-4. 
Grujić reported to the Accused and Mladić that in addition to "major accomplishments" there were also many problems from paramilitary formations which broke free after Arkan's withdrawal and called for their removal. ${ }^{4461}$ At this meeting, the Accused stated that it would be a shame to abolish Captain Dragan's training centre at Divič and that it would be easiest to "put the incident behind us". ${ }^{4462}$ Mladić said he had not approved the establishment of the training centre and that Captain Dragan was "no more than an ordinary mobster" and insisted that Captain Dragan leave the municipality. ${ }^{4463}$ Mladić also expressed strong disapproval of the paramilitaries and threatened to arrest anyone who did not place themselves under the command of the Army. ${ }^{4464}$

1287. After June 1992, the Yellow Wasps did not place themselves under the joint military command of the VRS. ${ }^{4465}$ In July 1992, members of the Yellow Wasps went to Pale and received weapons from the Pale SJB after which Žućo met with Biljana Plavšić. ${ }^{4466}$ Žućo also spoke to the Minister of Defence about the status of his group and Bogdan Subotić confirmed that all those who received orders from VRS officers were part of the VRS whether they were reservists, volunteers or paramilitaries. ${ }^{4467}$ Subotic alerted these units that they needed to fully comply with the rules and regulations of the VRS, including those relating to uniforms, insignia and command structures. ${ }^{4468}$

1288. Reports submitted to the MUP in June and July 1992, indicated that the situation with respect to paramilitary forces in Zvornik had yet to be resolved ${ }^{4469}$ and that the Yellow Wasps had

P2880 (Official Note of Valjevo State Security Centre, 2 July 1992), p. 3; Marinko Vasilić, T. 39960 (13 June 2013). See also Petko Panić, T. 19187-19188 (20 September 2011).

4461 P1478 (Ratko Mladić's notebook, 27 May-31 July 1992), pp. 249-250, 252, 266.

4462 P1478 (Ratko Mladić's notebook, 27 May-31 July 1992), pp. 250, 270.

4463 P2880 (Official Note of Valjevo State Security Centre, 2 July 1992), pp. 1, 3; Marinko Vasilić, T. 39960 (13 June 2013); D1436 (Report of SerBiH MUP, 17 June 1992), p. 5; Petko Panić, T. 19133, 19135 (19 September 2011), T. 19187-19188 (20 September 2011); P3384 (Report of Eastern Bosnia Corps, 7 June 1992), p. 1; P1478 (Ratko Mladić's notebook, 27 May-31 July 1992), pp. 266-269. See also Marinko Vasilić, T. 3995139952 (13 June 2013).

4464 D3654 (Witness statement of KW317 dated 26 September 2012), para. 69 (under seal).

4465 P2882 (Report of Bijeljina SJB, 8 August 1992), p. 3; D1412 (Report of Republic of Serbia MUP, 8 August 1992), p. 9; D3724 (Witness statement of Branko Grujić dated 22 June 2013), para. 53. The Chamber refers to para. 1281 above explaining that Pavlović was in June 1992 appointed commander of the single military command in Zvornik.

4466 Dragomir Andan, D3774 (Transcript from Prosecutor v. Stanišić \& Župljanin), T. 21712-21713; P3174 (Certificate of Pale SJB, 11 July 1992); see Adjudicated Fact 2109; Mićo Stanišić, T. 46524 (5 February 2014); [REDACTED]. The Chamber has considered the Accused's submissions with respect to P3174 and the issuance of weapons. Defence Final Brief, paras. 1108-1109. The Chamber does not consider that these submissions affect the conclusion that the Yellow Wasps received weapons through the Pale SJB.

4467 See Adjudicated Fact 2109; [REDACTED]; D3695 (Witness statement of Bogdan Subotić dated 16 June 2013), paras. 205-206. See also D3695 (Witness statement of Bogdan Subotić dated 16 June 2013), para. 293; D3705 (Letter from RS Ministry of Defence to Zvornik Municipality Executive Board, 16 October 1992); Adjudicated Fact 2110.

4468 D3695 (Witness statement of Bogdan Subotić dated 16 June 2013), para. 293; D3705 (Letter from RS Ministry of Defence to Zvornik Municipality Executive Board, 16 October 1992).

4469 D3810 (Bijeljina CSB dispatch to SerBiH MUP, 23 July 1992); D1632 (Report of Bijeljina SJB, 23 July 1992), pp. 1-2; P36 (Report by CSB Bijeljina re security situation in the Zvornik Municipality, 20 July 1992), p. 1 
attempted to influence the municipal authorities to appoint Žućo’s men to certain positions and had taken control of check-points. ${ }^{4470}$ Measures taken from June to July 1992 to control paramilitaries included controlling the issuance of VRS uniforms, ${ }^{4471}$ placing controls on weapons, ${ }^{4472}$ and restricting the presence of armed individuals in the town. ${ }^{4473}$ The local authorities also took steps to expel police employees who had engaged "in inappropriate conduct" or had joined paramilitary units; a large number of police were then sent to the VRS. ${ }^{4474}$ Vasilić and Grujić went to Pale in mid-June or July 1992 to inform the Bosnian Serb leadership about the situation in Zvornik and to ask for help in dealing with paramilitaries. ${ }^{445}$ Two days after Grujić and Vasilić returned from Pale they were taken prisoner by the Yellow Wasps and threatened. ${ }^{4476}$ They were released the next day but Grujić and Vasilić resigned from their positions. ${ }^{4477}$

1289. On 25 July 1992, Milorad Davidović reported on the threat to the security situation posed by Žućo and the killings perpetrated by Repić at Čelopek after which steps were taken to arrest him. ${ }^{4478}$ The Bijeljina CSB chief in a report delivered, inter alios, to the Minister of Internal Affairs recommended that a special unit of the MUP be sent to Zvornik to eliminate the paramilitary formations to improve the security situation in the region, and noted that Žućo was operating with the assistance of members of the local governmental authorities. ${ }^{449}$ The MUP

(under seal); Dragomir Andan, T. 40819-40820 (5 July 2013); Dragomir Andan, D3774 (Transcript from Prosecutor v. Stanišić \& Župljanin), T. 21402, 21439 21465, 21629.

4470 D1632 (Report of Bijeljina SJB, 23 July 1992), p. 2; Petko Panić, P3380 (Transcript from Prosecutor v. Stanišić \& Župljanin), T. 2925; P36 (Report by CSB Bijeljina re security situation in the Zvornik Municipality, 20 July 1992), p. 3 (under seal); Milorad Davidović, T. 15491 (28 June 2011). See also D1436 (Report of SerBiH MUP, 17 June 1992), p. 5.

4471 D1703 (Conclusion of Zvornik Interim Government, 29 June 1992); Petko Panić, T. 19199 (20 September 2011).

4472 D1700 (Order of Zvornik Interim Government, 2 July 1992); D1701 (Order of Zvornik Interim Government, 2 July 1992); Petko Panić, T. 19197-19198 (20 September 2011). A similar order was issued by the Executive Board on 24 September 1992. D1702 (Order of Zvornik Executive Board, 24 September 1992).

4473 D1623 (Order of Zvornik's War Commission, 1 July 1992); KDZ555, T. 17443 (18 August 2011)

4474 D1704 (Recommendation of Zvornik Executive Board, 12 November 1992), p. 1; Petko Panić, T. 19200 (20 September 2011).

4475 D3693 (Witness statement of Marinko Vasilić dated 9 June 2013), para. 40; Marinko Vasilić, T. 39948, 3995339955, 39970-39971 (13 June 2013); D3724 (Witness statement of Branko Grujić dated 22 June 2013), paras. 39, 41. See also P2848 (Witness statement of Milorad Davidović dated 22 June 2011), para. 126; Milorad Davidović, T. 15777-15778 (30 June 2011); D1450 (Milorad Davidović's statement to Belgrade District Court, 26 December 2007), p. 4; P104 (Witness statement of Fadil Banjanović dated 30 March 2002), paras. 21-22.

4476 D3724 (Witness statement of Branko Grujić dated 22 June 2013), para. 42.

4477 D3724 (Witness statement of Branko Grujić dated 22 June 2013), para. 42.

4478 D3789 (Dragomir Andan's notes), pp. 5-6; Dragomir Andan, D3774 (Transcript from Prosecutor v. Stanišić \& Župljanin), T. 21489-21490, 21683; D3724 (Witness statement of Branko Grujić dated 22 June 2013), para. 39; P2879 (Official Note of Valjevo State Security Centre, 2 July 1992), p. 5 (under seal); P2880 (Official Note of Valjevo State Security Centre, 2 July 1992); Petko Panić, P3380 (Transcript from Prosecutor v. Stanišić \& Župljanin), T. 2903-2905, 3013. For evidence on these killings, see Scheduled Incident B.20.2.

4479 P36 (Report by CSB Bijeljina re security situation in the Zvornik Municipality, 20 July 1992), p. 5 (under seal). 
concluded that paramilitary formations from Serbia should be banned in Zvornik and that members of Captain Dragan's unit should return to regular units of the VRS. ${ }^{4480}$

1290. As instructed, Davidović planned the operation to arrest the paramilitary groups in Zvornik in co-operation with Andan and special units of the MUP. ${ }^{4481}$ On 27 July 1992, the police expelled Gojić's group to Mali Zvornik and took back control of check-points. ${ }^{442}$ On 29 July 1992, Žućo was arrested and brought to Bijeljina. ${ }^{483}$ During this operation, other leaders and members of the Yellow Wasps were arrested ${ }^{4484}$ as were municipal leaders, who had links with or collaborated with the Yellow Wasps, including Pavlović. ${ }^{4485}$ During this operation a large quantity of gold, jewellery, cars, weapons, ammunition, alcohol, and other goods were found at the premises of those

4480 D1436 (Report of SerBiH MUP, 17 June 1992), p. 5.

4481 P2848 (Witness statement of Milorad Davidović dated 22 June 2011), paras. 126, 130-132; Milorad Davidović, T. 15766, 15779 (30 June 2011); D1412 (Report of Republic of Serbia MUP, 8 August 1992), pp. 6-7; D1450 (Milorad Davidović's statement to Belgrade District Court, 26 December 2007), pp. 6-7; D3918 (Witness statement of Milomir Savčić dated 21 July 2013), para. 33. See also Mićo Stanišić, T. 46380 (3 February 2014); Momčilo Mandić, T. 5289-5290 (16 July 2010); Dragomir Andan, T. 40827-40828, 40891-40893, 4090640907 (5 July 2013); Dragomir Andan, D3774 (Transcript from Prosecutor v. Stanišić \& Župljanin), T. $21473-$ 21474, 21478-21479, 21489-21490, 21678, 21680, 21693.

4482 Petko Panić, P3380 (Transcript from Prosecutor v. Stanišić \& Župljanin), T. 2907-2908, 2925-2926; P3389 (Report of Zvornik SJB, 28 July 1992), p.1; Petko Panić, T. 19144 (19 September 2011), T. 19191, 19211 (20 September 2011); P3390 (Report on activities of Zvornik SJB for 1993), p. 23.

4483 P2848 (Witness statement of Milorad Davidović dated 22 June 2011), para. 134; D1450 (Milorad Davidović's statement to Belgrade District Court, 26 December 2007), p. 17; Dragomir Andan, D3774 (Transcript from Prosecutor v. Stanišić \& Župljanin), T. 21506-21510, 21693; P6435 (Article entitled "The Sting of the 'Yellow Wasp"”, 10 December 2002), p. 3. See also Mićo Stanišić, T. 46380 (3 February 2014).

4484 P2848 (Witness statement of Milorad Davidović dated 22 June 2011), paras. 126, 136-137, 139 141; Milorad Davidović, T. 15493 (28 June 2011) (testifying that Pivarski who had joined the Yellow Wasps was also arrested), T. 15794 (30 June 2011); Petko Panić, P3380 (Transcript from Prosecutor v. Stanišić \& Župljanin), T. 2908, 2926-2928, 2937, 3006, 3008; D1625 (Report on activities of Zvornik SJB, July-September 1992), p. 2; Petko Panić, T. 19144-19145 (19 September 2011), T. 19191-19193, 19211 (20 September 2011); P3390 (Report on activities of Zvornik SJB for 1993), pp. 23, 38; P2904 (Report of SerBiH MUP, 4 August 1992), p. 1; KDZ555, T. 17311-17312 (17 August 2011); D1612 (Video footage of Arkan in "My Guest, His Truth", July/August 1994), transcript, p. 13; P3165 (Witness statement of KDZ340 undated), p. 63 (under seal); P133 (Witness statement of Matija Bošković dated 20 November 2003), para. 33; D1633 (Report of SerBiH MUP, 29 July 1992), p. 1; P2903 (Report of SerBiH MUP, 31 July 1992), p. 1; D1635 (Report of SerBiH MUP Pale's Crime Prevention Department, 10 August 1992), p.1; KDZ340, T. 17535 (19 August 2011) (private session); D3693 (Witness statement of Marinko Vasilić dated 9 June 2013), para. 44; D3724 (Witness statement of Branko Grujić dated 22 June 2013), para. 42; Jovan Ivanović, T. 39899 (13 June 2013). See also Dragomir Ljubojević, T. 35913 (22 March 2013).

4485 KDZ555, T. 17311-17312 (17 August 2011); Dragomir Andan, T. 40894 (5 July 2013); P2848 (Witness statement of Milorad Davidović dated 22 June 2011), paras. 140-141; D1412 (Report of Republic of Serbia MUP, 8 August 1992), p. 3; D1450 (Milorad Davidović's statement to Belgrade District Court, 26 December 2007), p. 69. The Chamber received differing evidence about the number of paramilitaries arrested in this operation, ranging from 30 to 180. D3694 (Bijeljina CSB report, 29 July 1992); KDZ340, T. 17567 (19 August 2011) (private session); P2904 (Report of SerBiH MUP, 4 August 1992), p. 1; D480 (SerBiH MUP information on paramilitaries in Zvornik, 31 July 1992); P2848 (Witness statement of Milorad Davidović dated 22 June 2011), paras. 140-141; D1412 (Report of Republic of Serbia MUP, 8 August 1992), p. 3; D1450 (Milorad Davidović's statement to Belgrade District Court, 26 December 2007), p. 69; D3693 (Witness statement of Marinko Vasilić dated 9 June 2013), para. 44; Marinko Vasilić, T. 39971 (13 June 2013); D3724 (Witness statement of Branko Grujić dated 22 June 2013), para. 42; D3692 (Witness statement of Jovan Ivanović dated 9 June 2013), para. 28. See also Dragomir Andan, D3774 (Transcript from Prosecutor v. Stanišić \& Župljanin), T. $21461,21680$. 
arrested. ${ }^{4486}$ All items found during the arrests were confiscated, ${ }^{4487}$ and Andan instructed the Zvornik SJB to return the personal belongings of those who resided in the municipality. ${ }^{4488}$

1291. On the day of the arrests, Davidović met with the Zvornik Crisis Staff and the municipal leadership and informed them that they had arrested and disarmed the paramilitaries; this was met with relief and gratitude by Grujić. ${ }^{4489}$ Mićo Stanišić and the MUP were informed about the successful operation in Zvornik to arrest the paramilitaries after which Stanišić paid tribute to their efforts. ${ }^{4400}$ Stanišić was also informed that some of the leading officers, including the police station commander, had taken part in criminal activities, after which Stanišić said that everyone involved in any criminal activity that could be documented should be processed and criminal reports submitted for prosecution. ${ }^{4491}$

1292. Davidović prepared the documentation and submitted a criminal report to the Military Prosecutor in Bijeljina but, after his men withdrew, the proceedings were suspended and all the men were released by August $1992 ;{ }^{4492}$ some returned to Serbia. ${ }^{4493}$ A number of paramilitaries

4486 P2904 (Report of SerBiH MUP, 4 August 1992), pp. 2-3; D1412 (Report of Republic of Serbia MUP, 8 August 1992), p. 9; D1417 (Report of Republic of Serbia MUP, 6 November 1993), pp. 4-5; P2848 (Witness statement of Milorad Davidović dated 22 June 2011), para. 136; P2903 (Report of SerBiH MUP, 31 July 1992), p. 1; D1634 (Official record of Zvornik SJB re search of KDZ340's appartment, 31 July 1992) (under seal); KDZ340, T. 17564 (19 August 2011) (private session); P3179 (Certificate on entering KDZ340's apartment, 3 August 1992) (under seal). See also P3181 (Statement of KDZ340 to Bijeljina SJB, 6 August 1992), p. 6 (under seal); KDZ340, T. 17533-17535 (19 August 2011) (private session); P3180 (Letter from Milisav Simić, 21 August 1992), pp. 1-2.

4487 Dragomir Andan, T. 40828, 40858-40860 (5 July 2013).

4488 Dragomir Andan, T. 40828-40830 (5 July 2013); D3793 (Letter from Bijeljina SJB to Zvornik SJB, 13 August 1992); D3816 (Letter from Bijeljina SJB to Zvornik SJB, 13 August 1992); P6435 (Article entitled "The Sting of the 'Yellow Wasp"”, 10 December 2002), p. 3.

4489 D1450 (Milorad Davidović's statement to Belgrade District Court, 26 December 2007), pp. 12-13, 33.

4490 Dragomir Andan, D3774 (Transcript from Prosecutor v. Stanišić \& Župljanin), T. 21493, 21512; D3791 (Bijeljina CSB dispatch to SerBiH MUP, 1 August 1992); P6386 (Letter from Goran Mačar to SerBiH MUP forwarding a report, 4 August 1992); Goran Mačar, T. 39499 (7 June 2013). See also Mićo Stanišić, T. 46382 (3 February 2014); D4275 (Order of RS MUP, 27 October 1992).

4491 Dragomir Andan, D3774 (Transcript from Prosecutor v. Stanišić \& Župljanin), T. 21494-21495. See also Dragomir Andan, D3774 (Transcript from Prosecutor v. Stanišić \& Župljanin), T. 21498, 21513-21514, 21525, 21711; D3792 (Bijeljina SJB dispatch to SerBiH MUP, 31 July 1992); Dragomir Andan, T. 40828 (5 July 2013); D3663 (Witness statement of Goran Mačar dated 3 May 2013), para. 29; Goran Mačar, T. 39493, 3950739509 (7 June 2013). Mićo Stanišić testified that criminal reports with respect to Serbians were handed over to the authorities of the FRY because the RS judicial system did not have adequate courts to try them. Mićo Stanišić, T. 46380-46381 (3 February 2014). The Chamber refers to its credibility assessment in fn. 4458 as to why it cannot rely on Mićo Stanišić's evidence with respect to the submission of criminal reports and processing of cases.

4492 P2848 (Witness statement of Milorad Davidović dated 22 June 2011), paras. 142, 168; Milorad Davidović, T. 15523 (28 June 2011), 15652, 15655-15656 (29 June 2011); D1450 (Milorad Davidović's statement to Belgrade District Court, 26 December 2007), pp. 7, 11, 52; P3165 (Witness statement of KDZ340 undated), pp. 55-56, 59 (under seal); KDZ340, T. 17490-17491, 17556 (19 August 2011) (private session); Dragomir Andan, D3774 (Transcript from Prosecutor v. Stanišić \& Župljanin), T. 21524-21525, 21688; Dragomir Andan, T. 40859 (5 July 2013); P2882 (Report of Bijeljina SJB, 8 August 1992); P3178 (Indictment from Bijeljina Lower Court, 13 September 1999), pp. 1-3 (under seal); P2904 (Report of SerBiH MUP, 4 August 1992); D1412 (Report of Republic of Serbia MUP, 8 August 1992), p. 9; D1625 (Report on activities of Zvornik SJB, July-September 1992), pp. 1-2; P2905 (Decision of Bijeljina Lower Court, 28 August 1992); D1413 (Request of 
were banned from entering RS while locals returned to regular units after the paramilitaries were disbanded. ${ }^{4494}$ The MUP special unit returned intermittently to try and prevent paramilitaries from returning to Zvornik. ${ }^{4495}$ In September 1992, after being released from detention, Žućo attempted to return to Zvornik and threatened to take revenge. ${ }^{4496}$

1293. The Chamber also notes that the paramilitaries were primarily detained for petty theft of property and vehicles at check-points and not for serious crimes committed against Bosnian Muslims. ${ }^{4497}$ While a criminal report was filed against Repić and Žućo on the basis of suspicions that they had committed war crimes, the proceedings were never completed in $\mathrm{BiH}$ and proceedings

Prosecutor in Bijeljina, 14 September 1992); D1626 (Official Note of SerBiH MUP's Crime Prevention Administration, 4 August 1992); D3790 (Decision of Bijeljina SJB, 29 July 1992). See also P3177 (Bijeljina SJB's Ruling on detention of KDZ340, 29 July 1992) (under seal); P3165 (Witness statement of KDZ340 undated), p. 55 (under seal); D3794 (Report of Zvornik SJB, 11 August 1992). The Chamber does not place any weight on Andan's opinion as to why these cases were not processed. Dragomir Andan, D3774 (Transcript from Prosecutor v. Stanišić \& Župljanin), T. 21688; Dragomir Andan, T. 40887-40888 (5 July 2013). KDZ446, P28 (Transcript from Prosecutor v. S. Milošević), T. 23634-23636 (under seal); Petko Panić, P3380 (Transcript from Prosecutor v. Stanišić \& Župljanin), T. 2923, 3052; D1450 (Milorad Davidović's statement to Belgrade District Court, 26 December 2007), p. 8; D3724 (Witness statement of Branko Grujić dated 22 June 2013), para. 39.

4493 Dragomir Andan, D3774 (Transcript from Prosecutor v. Stanišić \& Župljanin), T. 21686-21688. But see D3693 (Witness statement of Marinko Vasilić dated 9 June 2013), para. 45; Marinko Vasilić, T. 39971 (13 June 2013); D3723 (Witness statement of Čedomir Zelenović dated 22 June 2013), para. 34; D3724 (Witness statement of Branko Grujić dated 22 June 2013), paras. 42, 52; Branko Grujić, T. $40443-40444$ (26 June 2013); D3692 (Witness statement of Jovan Ivanović dated 9 June 2013), para. 28; Momčilo Mandić, T. 5292 (16 July 2010); D2269 (Šabac District Court Indictment against Duško Vučković, 28 April 1994), pp. 1-2, 4-7; D3727 (Letter from Bijeljina SJB to Republic of Serbia MUP, 9 August 1992); D1415 (Request of Bijeljina Lower Court, 24 December 1993); D3728 (Letter from Bijeljina SJB to Republic of Serbia MUP, 9 August 1992); D482 (Belgrade Supreme Court Judgement against Duško Vučković and others). The Accused points to D481 and D482 to support his proposition that when the authorities learned about the crimes at Čelopek Dom Culture, the perpetrators were arrested, prosecuted and punished. See Defence Final Brief, para. 1455. See also D3665 (Witness statement of Vojislav Šešelj dated 1 June 2013), para. 70. However, the Chamber does not consider the evidence of the relevant witnesses as to the proceedings initiated against those arrested to be reliable. In reaching that conclusion the Chamber noted that the testimony of the relevant witnesses was marked by evasiveness, contradictions, and inconsistencies. For example, Zelenović testified that he was not aware that the paramilitaries were released shortly after their arrest or whether people were convicted or not. Čedomir Zelenović, T. 40336-40337 (25 June 2013). Grujić also acknowledged that the paramilitaries were released soon after their arrest and acknowledged that this did happen and that he himself was afraid because he thought "serious proceedings should be initiated against them but that did not happen". Branko Grujić, T. 40391-40392 (25 June 2013). In light of these contradictions the Chamber does not consider their evidence in this regard to be reliable.

4494 KDZ555, T. 17313 (17 August 2011); D1418 (List of persons bannned from entering RS), p. 1; KDZ340, T. 17528 (19 August 2011).

4495 Petko Panić, P3380 (Transcript from Prosecutor v. Stanišić \& Župljanin), T. 3013-3014. See also D3664 (Report of Zvornik SJB, 22 November 1992); Goran Mačar, T. 39530-39531 (7 June 2013).

4496 P3387 (Report of Birač SNB, 5 September 1992), p. 1; Petko Panić, P3380 (Transcript from Prosecutor v. Stanišić \& Župljanin), T. 2935; Petko Panić, T. 19145 (19 September 2011); D1638 (Report of RS MUP National Security Service, Sarajevo, 22 September 1992), p. 1; D1450 (Milorad Davidović's statement to Belgrade District Court, 26 December 2007), p. 46; Milorad Davidović, T. 15612-15613 (29 June 2011); Dragomir Andan, D3774 (Transcript from Prosecutor v. Stanišić \& Župljanin), T. 21526-21527; D1637 (Report of RS MUP National Security Service, Sarajevo, 10 September 1992).

4497 P2882 (Report of Bijeljina SJB, 8 August 1992); P3178 (Indictment from Bijeljina Lower Court, 13 September 1999), pp. 1-3 (under seal); P3165 (Witness statement of KDZ340 undated), pp. 55-56 (under seal); KDZ340, T. 17490-17491 (19 August 2011) (private session). P2904 (Report of SerBiH MUP, 4 August 1992); D1412 
were instituted much later in Serbia. ${ }^{4498}$ In contrast the Zvornik SJB was instructed by Goran Mačar in November 1995 to intensify their activities and file criminal reports against perpetrators of war crimes against "the Serbian people" in municipalities including Zvornik. ${ }^{4499}$

1294. Overall conditions did improve somewhat after the arrest of paramilitaries and the local authorities were able to exercise more control over the functioning of the municipality. ${ }^{4500}$

(F) Detention Facilities in Zvornik

1295. On 7 June 1992, the Eastern Bosnia Corps reported that in the area of Zvornik, approximately "500 prisoners" were being held. ${ }^{4501}$ The Birač Brigade reported on 17 June 1992 that it had close to "600 prisoners" and the Eastern Bosnia Corps had failed to establish a camp for prisoners of war at the corps level. ${ }^{4502}$ Accordingly Mladić ordered the Eastern Bosnia Corps to set up a camp for prisoners of war and for the Birač brigade to be relieved of guarding those prisoners. $^{4503}$

(1) Scheduled Detention Facility C.27.1 and Scheduled Incident B.20.2

1296. The Indictment refers to the use of the Čelopek Dom Kulture as a detention facility at least between May and June 1992. ${ }^{4504}$ The Prosecution alleges that a number of men were killed there between 10 and 28 June 1992.

(Report of Republic of Serbia MUP, 8 August 1992), p. 9; D1625 (Report on activities of Zvornik SJB, JulySeptember 1992), pp. 1-2. See also Dragomir Andan, T. 40857-40860 (5 July 2013). (Request of Bijeljina Lower Court, 24 December 1993); Milorad Davidović, T. 15657 (29 June 2011); KDZ446, P28 (Transcript from Prosecutor v. S. Milošević), T. 23662 (under seal); D1417 (Report of Republic of Serbia MUP, 6 November 1993), pp. 1-2. See also Momčilo Mandić, T. 5289-5291 (16 July 2010), T. 5147-5148 (14 July 2010).

4499 P6385 (Letter from Bijeljina SJB to Zvornik CJB, 17 November 1995); Goran Mačar, T. 39489-39490 (7 June 2013).

4500 D3723 (Witness statement of Čedomir Zelenović dated 22 June 2013), para. 34; D3724 (Witness statement of Branko Grujić dated 22 June 2013), para. 43; D3692 (Witness statement of Jovan Ivanović dated 9 June 2013), para. 30; D3654 (Witness statement of KW317 dated 26 September 2012), paras. 71-72 (under seal); KW317, T. 39414 (6 June 2013). See also Petko Panić, T. 19211 (20 September 2011); D1717 (Decision of Zvornik Assembly, 19 August 1992), p. 3; D1718 (Decision of Zvornik Executive Board, 10 September 1992), p. 1; D3654 (Witness statement of KW317 dated 26 September 2012), para. 72 (under seal). P3237 (Report of the Eastern Bosnia Corps, 7 June 1992), p. 2.

4502 P3238 (Order of the VRS Main Staff, 17 June 1992), p. 1.

4503 P3238 (Order of the VRS Main Staff, 17 June 1992), p. 2.

4504 The Prosecution submits that the evidence presented shows that the facility was operational between May and July 1992. Prosecution Final Brief, Appendix B, p. 61. 


\section{(a) Events}

1297. The Čelopek Dom Kulture was located in the industrial area of Karakaj. ${ }^{4505}$ Bosnian Muslims were detained at this facility from late May 1992 onwards. ${ }^{4506}$ Bosnian Muslims were taken to the Čelopek Dom on buses under the orders of either the TO Staff or the Interim Government and were escorted there by Miko Miljanović who was a police official. ${ }^{4507}$ The Yellow Wasps also took Bosnian Muslims from settlements and brought them to Čelopek Dom where they were detained. ${ }^{4508}$ Reserve police officers were involved in guarding the facility. ${ }^{4509}$ The non-Serbs detained in Zvornik were not arrested following normal police procedure and were detained without being informed of the allegations against them or handed over for prosecution. ${ }^{4510}$

1298. On or about 10 June 1992, detainees were forced to sing songs and then forced to beat each other with the promise that the winner would be spared from being killed. ${ }^{4511}$ After this, Repić shot and killed 17 detainees, he also cut off the body parts of some detainees and stabbed others in the chest. ${ }^{4512}$ Detainees were forced to eat the severed body parts and Repić's men killed two detainees

4505 P4847 (Map of Karakaj marked by KDZ610); P4837 (Witness statement of KDZ610 dated 27 March 2012), para. 80 (under seal); P4845 (Photograph of Čelopek Dom Kulture); KDZ228, P323 (Transcript from Prosecutor v. Popović et al.), T. 14942 (under seal); P3187 (Map of Zvornik municipality).

4506 See Adjudicated Fact 2745. See also KDZ555, T. 17299 (17 August 2011); Petko Panić, P3380 (Transcript from Prosecutor v. Stanišić \& Župljanin), T. 2897, 3057-3058.

4507 Marinko Vasilić, T. 39944-39945, 39969 (13 June 2013). See also P3390 (Report on activities of Zvornik SJB for 1993), pp. 24, 35.

4508 Milorad Davidović, T. 15518 (28 June 2011). See also Svetozar Andrić, T. 41682 (22 July 2013).

4509 Marinko Vasilić, T. 39944 (13 June 2013); P4837 (Witness statement of KDZ610 dated 27 March 2012), para. 62 (under seal). See also Petko Panić, P3380 (Transcript from Prosecutor v. Stanišić \& Župljanin), T. 2897, 2933, 2953, 3004, 3016-3018; Petko Panić, T. 19152-19153, 19175 (20 September 2011). While Panić also testified that the police were not strong enough to prevent the entry of paramilitaries into detention facilities, the Chamber does not find this evidence to be of much weight given that Panić makes this observation without further context as to whether it applies to a specific facility or particularly period of time. See also P3388 (Payroll of men working at Zvornik's prison, August 1992), p. 2; Petko Panić, T. 19143 (19 September 2011).

4510 Petko Panić, P3380 (Transcript from Prosecutor v. Stanišić \& Župljanin), T. 3057. However, the Zvornik SJB did conduct a number of interviews to identify "Muslim extremists". D1631 (Report of Zvornik SJB, 29 June 1992), pp. 1-2; Petko Panić, P3380 (Transcript from Prosecutor v. Stanišić \& Župljanin), T. 2939; P3390 (Report on activities of Zvornik SJB for 1993), p. 41-42, 50.

4511 D1417 (Report of Republic of Serbia MUP, 6 November 1993), p. 2; see Adjudicated Facts $2745,2747$. KDZ340 testified that Vučković was against the killing or mistreatment of detainees. P3165 (Witness statement of KDZ340 undated), p. 74 (under seal). However, the Chamber does not consider that KDZ340's evidence is reliable in this regard. In reaching that conclusion the Chamber noted that his evidence was marked by indicators that he was testifying with a lack of candour and frankness [REDACTED].

4512 D1417 (Report of Republic of Serbia MUP, 6 November 1993), p. 2; Adjudicated Fact 2749. See also P4417 (Death certificate for Zaim Pezerović); P3173 (Statement of Nenad Simić to Bijeljina SJB, 6 August 1992), p. 4 (under seal); P3165 (Witness statement of KDZ340 undated), pp. 34-36, 45-46, 73-78, 80 (under seal); P2848 (Witness statement of Milorad Davidović dated 22 June 2011), para. 133; Milorad Davidović, T. 15535 (28 June 2011). 
who could not bring themselves to do so. ${ }^{4513}$ Four detainees were forced to unload the dead bodies in a gravel pit after which they were also killed by Repić. ${ }^{4514}$

1299. On 10 and 14 June 1992, Repić took away two groups of people for questioning and they never returned to the facility. There were 19 detainees in the first group and four detainees in the second group. ${ }^{4515}$ Having regard to the manner in which Repic treated the detainees in the facility and the threats he made to kill detainees, the Chamber is satisfied that these 23 detainees were also killed. Repić returned on a few other occasions, beat the detainees with batons, punched and kicked them, and forced them to sing. On or about 27 June 1992, he lined up a group of detainees and opened fire with an automatic rifle and pistol, killing approximately 19 and wounding approximately 13 detainees. ${ }^{4516}$ After these killings, surviving detainees were moved to Novi Izvor. $^{4517}$

1300. One of the detainees was told by Kosta Erić about the killing and maltreatment of detainees at Čelopek. He was instructed to clean the facility and found traces of human blood; he was also involved in transporting bodies and burying them in mass graves. ${ }^{4518}$ In mid-July 1992, the

$4513 \quad$ See Adjudicated Fact 2749

4514 D1417 (Report of Republic of Serbia MUP, 6 November 1993), p. 2.

4515 D1417 (Report of Republic of Serbia MUP, 6 November 1993), p. 2; P2880 (Official Note of Valjevo State Security Centre, 2 July 1992). This same report indicated that Repić was prone to taking drugs. Panić testified that even though the guards had a written order not to allow anyone into the facility they did not dare confront Repić and did not report any incidents. Petko Panić, P3380 (Transcript from Prosecutor v. Stanišić \& Župljanin), T. 2903-2904, 3015-3016, 3056; Petko Panić, T. 19184-19186 (20 September 2011). However, the Chamber notes that Panić's evidence with respect to shifting blame for actions to paramilitaries lacked balance and was marked by indicators of partiality. Considering inconsistencies and indicators of bias the Chamber does not find his evidence with respect to the specific issue of the inability to prevent the abuses of paramilitaries to be credible.

4516 D1417 (Report of Republic of Serbia MUP, 6 November 1993), pp. 2-3; see Adjudicated Fact 2750. According to the Adjudicated Fact, Repić returned to the detention facility on 27 June 1992 and killed 20 detainees and wounded 22. Davidović was informed by Jekić about this incident where around 20 Bosnian Muslim civilians were killed in Čelopek. D1450 (Milorad Davidović's statement to Belgrade District Court, 26 December 2007), pp. 8, 21, 30. See also P4837 (Witness statement of KDZ610 dated 27 March 2012), para. 62 (under seal); Jovan Ivanović, T. 39877-39878 (13 June 2013); KDZ340, T. 17475-17476 (18 August 2011) (private session). The Serbian State Security Department was also informed about these incidents. P2880 (Official Note of Valjevo State Security Centre, 2 July 1992).

4517 P4837 (Witness statement of KDZ610 dated 27 March 2012), para. 63 (under seal). See also Petko Panić, P3380 (Transcript from Prosecutor v. Stanišić \& Župljanin), T. 3033-3034; Petko Panić, T. 19187 (20 September 2011) (wherein Panić testified that the remaining detainees were transferred to Novi Izvor in order to be protected and to receive medical treatment). While the Chamber considers that Panić's evidence corroborates the movement of the remaining detainees to Novi Izvor, his evidence was marked by indicators that he lacked balance and in addition he sought to shift the blame for events in Zvornik.

4518 [REDACTED]. The Chamber received evidence that 15 men were identified after exhumation of the mass graves at Crni Vrh and Grbavci-Hajdarev as people who had disappeared in Čelopek in May or June 1992. However, the Chamber notes that there is insufficient evidence to link these individuals to this scheduled incident, which is limited to killings between 10 and 28 June 1992. In addition [REDACTED] simply states that he knew some of these individuals but does not clarify whether he knew they went missing from Čelopek or when they disappeared. [REDACTED]; P4841 (Letter from FBiH Commission for Missing Persons, 30 July 2007). These 15 individuals are also named by Mašović as having been exhumed from mass graves. P4853 (Updated Table 2 to the Report of Amor Mašović), pp. 61-73, 105, 107. The Chamber notes that Mašović 
detainees who remained at Čelopek were transferred with the assistance of the Bosnian Serb municipal authorities to the Batković camp in Bijeljina. ${ }^{4519}$

\section{(b) Conclusion}

1301. The Chamber therefore finds that Bosnian Muslim men were detained at Čelopek Dom Kulture from late May until July 1992. The detainees were forced to beat each, some were stabbed and mistreated, and at least 60 men were killed by Serb Forces.

\section{(2) $\underline{\text { Scheduled Detention Facility C.27.2 }}$}

1302. The Indictment refers to the use of the Karakaj Technical School as a detention facility at least between May and June 1992. ${ }^{4520}$

\section{(a) Arrival of detainees and control of facility}

1303. The Karakaj Technical School was located in the Karakaj industrial area, close to the Alhos factory. ${ }^{4521}$ The Karakaj Technical School was guarded by Bosnian Serb soldiers, ${ }^{4522}$ which included the Karakaj TO (a.k.a Karakaj Company) that later became part of the VRS. ${ }^{4523}$ Dragan Ristanović, the commander of the Karakaj TO, and paramilitaries including Topola, Mrski, Crni

identifies additional individuals who were exhumed from mass graves but there is no other evidence to link them to this incident. The Chamber will therefore not rely on Mašović's evidence in that regard.

4519 See Adjudicated Fact 2748. The Chamber also received evidence about the inspection of detention facilities in Zvornik in October 1992 but is not satisfied that this evidence pertains to any of the scheduled detention facilities. P1607 (RS Ministry of Justice report on prisons and camps on the RS territory, 22 October 1992), pp. 3, 7; D3105 (Witness statement of Slobodan Avlijaš dated 9 March 2013), para. 26. The Accused's refers to this report and submits that it does not identify the Čelopek Dom as a detention facility. Defence Final Brief, para. 1455. The Chamber does not consider this submission or the absence of a reference to this facility in this report to be of any significance.

4520 The Prosecution submits that the evidence presented shows that the facility was operational from 1 June 1992. Prosecution Final Brief, Appendix B, fn. 902.

4521 Petko Panić, P3380 (Transcript from Prosecutor v. Stanišić \& Župljanin), T. 2883; P3187 (Map of Zvornik municipality); P4847 (Map of Karakaj marked by KDZ610) (marking the location of Karakaj Technical School with a number 4); P4837 (Witness statement of KDZ610 dated 27 March 2012), para. 80 (under seal); P3195 (Witness statement of KDZ029 dated 28 June 2011), para. 18 (under seal); P3185 (Photograph of Karakaj Technical School); P3184 (Record of Belgrade's District Court, War Crime Chamber Investigating Judge, 14 February 2007), p. 5 (under seal).

$4522 \quad$ See Adjudicated Fact 2753.

4523 Petko Panić, P3380 (Transcript from Prosecutor v. Stanišić \& Župljanin), T. 2897-2898; P3192 (Dragan Vidović's interview with Prosecution), pp. 4-5, 18, 20; Guards identified were Ljubiša Pejić, Zdravko Blagojević, Mile Savić, Dušan Stevanović, Ivan Arapović, Mile Blagojević, Kosta Pejić, Drgan Pejić, Željko Pejić, Steva Vasiljević (a.k.a. Koružnjak), Dušan Mitrović, Božo Radić, Milan Arapović, Branko Pejić. See also P3194 (Payroll of the Karakaj unit of the Zvornik Brigade, undated); P3192 (Dragan Vidović's interview with Prosecution), pp. 5-6. 
and Pivarski were present at the facility. ${ }^{4524}$ The guards worked in shifts and were under the command of Pivarski. ${ }^{4525}$

1304. When people from 13 Bosnian Muslim villages arrived in Đulići on 1 June 1992, approximately 750 men were separated from women and children and taken to the Karakaj Technical School. ${ }^{4526}$ Before being loaded onto trucks organised by the Zvornik TO, ${ }^{4527}$ Bosnian Serb soldiers took away money and ID papers from the men ${ }^{4528}$ who were packed on three trucks "like sardines" and beaten. ${ }^{4529}$ Bosnian Serb soldiers accompanied the detainees. ${ }^{4530}$ Apart from Đulići, the detainees were also from Lupe and Klisa. ${ }^{4531}$

\section{(b) Conditions of detention}

1305. Approximately 750 men were brought to the workshop building and kept in a room which was too small. However, the detainees were able to break down the iron sheet which separated it from another room. ${ }^{4532}$ The only water available was in this second room. ${ }^{4533}$ Approximately 20 detainees died from suffocation during this first night. ${ }^{4534}$ Only a few loaves of bread were thrown

4524 P3192 (Dragan Vidović's interview with Prosecution), p. 6. While Vidović also testified that the facility was under the control of the paramilitaries despite the presence of the Karakaj TO, the Chamber has treated this conclusion with caution. In making that assessment the Chamber noted that Vidović's evidence was marked by indicators that he was trying to remove himself from any responsibility and to place all blame on Pivarski. His evidence in this regard was marked by indicators of insincerity and partiality and the Chamber cannot rely on it for this purpose.

4525 P3192 (Dragan Vidović's interview with Prosecution), pp. 6-7, 23; Dragan Vidović, T. 17759, 17761, 17763 (23 August 2011) (testifying that guards who did not comply with orders from Pivarski to beat detainees were threatened). Panić testified that the guards were unable to stop the paramilitaries from entering the facility as they pleased. Petko Panić, T. 19183 (20 September 2011). However, the Chamber refers to its credibility assessment in fn. 4517 as to why it cannot rely on Panić's evidence with respect to this issue.

4526 P3195 (Witness statement of KDZ029 dated 28 June 2011), para. 13 (under seal); KDZ029, T. 17620 (22 August 2011) (closed session); see Adjudicated Fact 2752; Petko Panić, P3380 (Transcript from Prosecutor $v$. Stanišić \& Župljanin), T. 2896. See also KDZ555, T. 17302-17304 (17 August 2011) (private session). The Accused acknowledged that detainees were held at the Karakaj Technical School between May and June 1992. Defence Final Brief, para. 1453.

4527 KDZ555, T. 17302 (17 August 2011) (private session).

4528 P3195 (Witness statement of KDZ029 dated 28 June 2011), para. 14 (under seal); KDZ029, T. 17619 (22 August 2011) (closed session).

4529 P3195 (Witness statement of KDZ029 dated 28 June 2011), para. 15 (under seal); KDZ029, T. 17621 (22 August 2011) (closed session).

4530 P3195 (Witness statement of KDZ029 dated 28 June 2011), para. 16 (under seal).

4531 P3192 (Dragan Vidović's interview with Prosecution), pp. 8, 24-25.

4532 P3195 (Witness statement of KDZ029 dated 28 June 2011), paras. 13, 18, Sketch B (under seal). KDZ029 was able to identify 38 men [REDACTED] who were detained with him in the workshop building. KDZ029 stated that the bodies of 14 of these 38 men were recovered mostly in the Crni Vrh area and buried [REDACTED]; KDZ029 stated that he only approximated the size of the room. KDZ029, T. 17622-17623 (22 August 2011) (closed session); P3192 (Dragan Vidović's interview with Prosecution), pp. 8-9, 24-25. See also P62 (Witness statement of Nedžad Hadžiefendić dated 3 October 1997), p. 12.

4533 P3195 (Witness statement of KDZ029 dated 28 June 2011), para. 18 (under seal).

4534 P3195 (Witness statement of KDZ029 dated 28 June 2011), para. 20 (under seal). KDZ029 was told that two of the detainees who died of suffocation were Hrustan Avdić and Nešad Hamzić. These two individuals were later 
into the building where detainees were held and those who could not get a piece remained without food. $^{4535}$

\section{(c) Treatment of detainees}

1306. On arrival at the Karakaj Technical School, the men were ordered to jump from the truck and run past a large number of Bosnian Serb soldiers ${ }^{4536}$ who hit them with rifle butts, punched, kicked, swore, and cursed at them. ${ }^{4537}$ As the men ran into the building, Bosnian Serb women were on the other side of the road and could be heard screaming and telling the soldiers to "kill the Balijas". ${ }^{4538}$ On the morning after their arrival, the detainees were ordered to hand over all money, watches and documentation, which were collected by Pivarski. They were then made to walk to another area and were beaten severely by soldiers upon Pivarski's orders. ${ }^{4539}$

$\underline{\text { detainees }}$

\section{(d) Conclusion on conditions of detention and treatment of}

1307. The Chamber therefore finds that from June 1992, Bosnian Muslim men were brought to and detained at the Karakaj Technical School by Serb Forces. The detainees were held in poor conditions characterised by lack of space on the first night, which resulted in the suffocation of approximately 20 men. The detainees were also beaten. They received inadequate food and had their valuables taken away from them.

\section{(e) Scheduled Incident B.20.3}

1308. The Prosecution alleges that approximately 160 men were killed at the Karakaj Technical School between 1 and 5 June 1992.

1309. Bosnian Serb soldiers would select "rich or prominent people" and take them to another room; thereafter the other detainees would hear, moaning, screaming and gun bursts. ${ }^{4540}$ Captain

exhumed from mass graves. P4853 (Updated Table 2 to the Report of Amor Mašović), pp. 105-106; see Adjudicated Fact 2754.

4535 P3195 (Witness statement of KDZ029 dated 28 June 2011), para. 24 (under seal). See also P62 (Witness statement of Nedžad Hadžiefendić dated 3 October 1997), p. 12.

4536 P3195 (Witness statement of KDZ029 dated 28 June 2011), para. 16 and sketch A (under seal); P3184 (Record of Belgrade's District Court, War Crime Chamber Investigating Judge, 14 February 2007), p. 6 (under seal); see Adjudicated Fact 2752. See also KDZ555, T. 17304 (17 August 2011) (private session).

4537 P3195 (Witness statement of KDZ029 dated 28 June 2011), para. 17 (under seal).

4538 P3195 (Witness statement of KDZ029 dated 28 June 2011), para. 17 (under seal).

4539 P3195 (Witness statement of KDZ029 dated 28 June 2011), para. 21 and sketch B (under seal); see Adjudicated Fact 2755; P3192 (Dragan Vidović's interview with Prosecution), pp. 10, 12. See also Petko Panić, T. 19142 (19 September 2011); P62 (Witness statement of Nedžad Hadžiefendić dated 3 October 1997), p. 12.

4540 P3195 (Witness statement of KDZ029 dated 28 June 2011), paras. 22-23 (under seal). But see Dragan Vidović, T. 17752-17754, 17759-17762 (23 August 2011); P3192 (Dragan Vidović's interview with Prosecution), pp. 9, 
Mijo, who wore a cockade, called out detainees from Tršić, and those who were taken away were never seen again. ${ }^{4541}$ Other detainees were then selected to carry out the bodies and would often not come back themselves. ${ }^{4542}$ Approximately 160 people were selected, taken out and killed in this manner by the guards in the facility. ${ }^{4543}$ Vasilic acknowledged that nothing was done to investigate the killings at the Karakaj Technical School. ${ }^{4544}$

1310. The Chamber also received evidence about the disappearance of detainees who were taken away for prisoner exchange and who remain unaccounted for. ${ }^{4545}$ However, the Chamber will not make findings in this regard given that it is not satisfied that these disappearances are linked to Scheduled Killing Incident B.20.3, which relates to a very specific date range in June 1992.

11-12, 14, 24-25. The Chamber notes its credibility assessment in fn. 4524 in concluding that Vidović's evidence that there was no mistreatment or killing of detainees at the facility, was not reliable. The Chamber further notes that when specifically questioned about the killings at the facility, Vidović attempted to avoid the question and then distanced himself from a previous inconsistent statement. Similarly, there was a major inconsistency in Vasilić's evicence who also sought to distance himself from his previous interview in which he stated that he heard rumours about the killings at the Karakaj Technical School. Marinko Vasilić, T. 3994039943 (13 June 2013); P6405 (Excerpt from Marinko Vasilić's interview with OTP, 21 October 2002), pp. 4-5. In light of these inconsistencies, the Chamber does not rely on Vasilić's denial of contemporaneous knowledge of the killings.

4541 P3195 (Witness statement of KDZ029 dated 28 June 2011), para. 26 (under seal); KDZ029, T. 17623-17625 (22 August 2011) (closed session). [REDACTED].

4542 P3195 (Witness statement of KDZ029 dated 28 June 2011), para. 22 (under seal).

4543 P3195 (Witness statement of KDZ029 dated 28 June 2011), paras. 23, 26 (under seal) (identifying the names of five of the detainees who were killed in this way: Ramiz Sinanović, Soman Smajlović, Hasan Avdić, Nurija Jašarević and Avdo Jašarević); see Adjudicated Fact 2756. See P4853 (Updated Table 2 to the Report of Amor Mašović), p. 60, 63-65, 67, 71, 105-106 for list of victims exhumed from mass graves linked to this scheduled incident (of the named individuals identified by KDZ029, Hasan Avdić, Nurija Jašarević and Avdo Jašarević were exhumed from mass graves as per Mašović's table). See also Jovan Ivanović, T. 39875-39877 (13 June 2013); P4837 (Witness statement of KDZ610 dated 27 March 2012), para. 66 (under seal); KDZ446, P29 (Transcript from Prosecutor v. S. Milošević), T. 21036-21037. Mašović identified a number of individuals who were exhumed from mass graves which he linked to Scheduled Incident B.20.3, however, there is no other evidence which links these specific individuals to the scheduled incident. See P4853 (Updated Table 2 to the Report of Amor Mašović), pp. 63-64, 71, Prosecution Final Brief, Appendix G. Similarly the Chamber received the death certificates of nine people who are reported to have died on 1 June 1992 at Bijeli Potok which are referred to in the Prosecution's Final Brief as being linked to this scheduled incident. See P4418 (Death certificates for Himzo Dedić, Zijad Gojkić and Nijaz Gojkić); P4419 (Death certificates for individuals killed in Zvornik); P4420 (Death certificate for Ibro Gojkić). However, in the absence of further evidence linking these named individuals the Chamber will not rely on this evidence in this regard. The Chamber therefore does not rely on these death certificates or the forensic evidence of Mašović (with the exception of the three named individuals mentioned above) for the purposes of making a finding with respect to this scheduled incident.

4544 Marinko Vasilić, T. 39944 (13 June 2013). See also D3654 (Witness statement of KW317 dated 26 September 2012), para. 56 (under seal); KW317, T. 39367 (6 June 2013) (testifying that he was informed by Pavlović that he had ordered the separation of approximately 170 men and their detention at Karakaj for the purposes of exchange but that the paramilitaries later killed many of the men who had been detained there). The Chamber also received hearsay evidence that Grujić was aware of what happened to the detainees but claimed that it was done without his knowledge. KDZ446, P28 (Transcript from Prosecutor v. S. Milošević), T. 21087-21088 (under seal). The Chamber places no weight on this hearsay denial by Grujić who also sought to distance himself from this incident.

4545 P3195 (Witness statement of KDZ029 dated 28 June 2011), para. 24 (under seal). Ismet Ahmetović was exhumed from a mass grave. P4853 (Updated Table 2 to the Report of Amor Mašović), p. 60. See also P3191 (Dragan Vidović's interview with Prosecution), p. 7 (under seal). 
1311. The Chamber therefore finds that approximately 160 men were killed by Serb Forces at the Karakaj Technical School in early June 1992.

\section{(f) $\underline{\text { Scheduled Incident A.16.3 }}$}

1312. The Prosecution alleges that approximately 190 men were killed at Gero's Slaughterhouse between 5 and 8 June 1992.

1313. On 5 June 1992, the 550 detainees who remained at the Karakaj Technical School were placed on buses and told they were being taken for exchange; however, they were taken to Pilica. ${ }^{4546}$ The convoy consisted of five or six buses each carrying between 50 and 60 people. ${ }^{4547}$ Dragan Spasojević ordered the police to escort the convoy of buses to the Pilica Cultural Centre ${ }^{4548}$ where many soldiers in JNA uniforms were waiting for them. ${ }^{459}$ The guards shot above the detainees' heads and ordered them to hand over money and gold. ${ }^{450}$ After three days, the men who were being held at Pilica were told they were being taken to Živinice for prisoner exchange. ${ }^{4551}$

1314. [REDACTED] was in a group of 64 detainees who were taken and forced onto a truck; Bosnian Serb soldiers then pulled down a tarpaulin. ${ }^{4552}$ The truck was led by a police car and was taken to Gero's slaughterhouse located in the Karakaj industrial area near the Drina River. ${ }^{4553}$ The detainees were taken off the truck, placed in separate rooms, and told to face the wall. ${ }^{4554}$ There

\footnotetext{
4546 [REDACTED]. The transport of prisoners on 5 June 1992 is noted in a Drinatrans document which observes that the orders for transport came from the Interim Government and the Zvornik TO. P3186 (Drina Trans invoice re transport of refugees from Zvornik municipality, 8 June 1992), pp. 1-2; [REDACTED]; P3192 (Dragan Vidović's interview with Prosecution), pp. 8, 14-15; Dragan Vidović, T. 17761 (23 August 2011). See also Adjudicated Fact 2744.

4547 Dragan Vidović, T. 17761 (23 August 2011).

4548 The Chamber notes that this location has been referred to by witnesses as either the "Cultural Center", the "Pilica Dom", the "Dom Kultur(e)", the "Dom of Culture", a house or hall of culture, and a cinema hall. See inter alia Dražen Erdemović, P332 (Transcript from Prosecutor v. Popović et al.), T. 10982; D3993 (Witness Statement of Vujadin Popović dated 2 November 2013), para. 71; Milenko Tomić, P390 (Transcript from Prosecutor v. Popović et al.), T. 21001; P3192 (Dragan Vidović's interview with Prosecution), pp. 16, 26; P3195 (Witness statement of KDZ029 dated 28 June 2011), para. 29 (under seal); D3927 (Witness statement of Franc Kos dated 26 July 2013), pp. 26-27; Jevto Bogdanović, P385 (Transcript from Prosecutor v. Popović et al.), T. 11323; Jean-René Ruez, T. 23850, 23852 (30 January 2012). The Chamber finds that all of these witnesses refer to the same building and, for sake of consistency, will refer to it as the "Pilica Cultural Centre" throughout this Judgement.

4549 P3192 (Dragan Vidović's interview with Prosecution), pp. 15-16, 26-27, 30.

4550 [REDACTED].

4551 [REDACTED].

4552 [REDACTED]. See also Adjudicated Fact 2744. [REDACTED]: Sejdo Hasanović, Muradif Hasanović, Smajo Smailović, and Asim Hamzić. These four bodies were exhumed from a mass grave. P4853 (Updated Table 2 to the Report of Amor Mašović), pp. 66, 72. See also P4903 (Crni Vrh Exhumation Report by Derek Congram, 14 November 2003).

4553 [REDACTED]; P3193 (Photograph of Gero's slaughterhouse).

4554 [REDACTED].
} 
were two guards wearing JNA uniforms and who were carrying machine guns. ${ }^{4555}$ When the detainees had their backs turned, the guards started shooting at them; [REDACTED]. ${ }^{4556}$ Once the shooting ended in the first room, the guards moved to the second room and also fired at the detainees. ${ }^{4557}$ When one detainee who had been injured begged to be killed, the guards said that since he was a "Balija" they would let him suffer. ${ }^{458}$ After the guards left, [REDACTED] was able to escape to the Drina river, which was close to the building, and observed that trucks returned to the site on two additional occasions; after their return he could hear gun bursts. ${ }^{4559}$ While [REDACTED] estimated that about 190 people were brought there and executed in three groups, the Chamber is not satisfied that it can rely on his estimation in this regard given the evidence is unclear as to whether or not he could have seen the people getting off the trucks. ${ }^{450}$

1315. The Chamber therefore finds that a large number of Bosnian Muslim men were brought to and killed at Gero's slaughterhouse between 5 and 8 June 1992 by Serb Forces. ${ }^{4561}$

\section{(3) Scheduled Detention Facility C.27.3}

1316. The Indictment refers to the use of the Alhos Factory as a detention facility on or about 9 April 1992.

(a) Arrival of detainees and control of facility

1317. The Alhos Factory was a former textile manufacturing facility located in Karakaj. ${ }^{4562}$ The police, Arkan's men and the White Eagles detained Bosnian Muslims at this facility. ${ }^{4563}$ Other

4555 [REDACTED]. See also Adjudicated Fact 2744.

4556 [REDACTED]. See also Jovan Ivanović, T. 39878 (13 June 2013).

4557 [REDACTED].

4558 [REDACTED]. The Accused acknowledged that 50 to 70 Bosnian Muslim men were brought to Gero's slaughterhouse in June 1992 and that they were killed by paramilitaries. Defence Final Brief, confidential, para. 1458. The Accused further submits that there was no evidence that high level municipal officers were present and that the evidence does not disclose the origin of any orders with respect to the burials.

4559 [REDACTED]. See also Adjudicated Fact 2744.

4560 [REDACTED]. See also Adjudicated Fact 2744.

4561 The Chamber received evidence that in May 1992, hundreds of bodies were unloaded at Gero's slaughterhouse and subsequently buried in mass graves. The Chamber also received evidence of other killings committed at, and burial of bodies taken from, Gero's slaughterhouse but these events fall outside the period charged in the Indictment with respect to this scheduled incident. P4837 (Witness statement of KDZ610 dated 27 March 2012) (under seal), paras. 32, 34-47, 53, 67-74; KDZ610, T. 27196 (29 March 2012) (private session); P4842 (Photograph of Gero's slaughterhouse marked by KDZ610); P4846 (Map drawn by KDZ610) (under seal); Petko Panić, P3380 (Transcript from Prosecutor v. Stanišić \& Župljanin), T. 2902-2903, 2991; KDZ555, T. 17307 (17 August 2011) (private session). See also KW317, T. 39365-39366 (6 June 2013).

4562 P70 (Witness statement of Jusuf Avdispahić dated 22 October 1997), p. 2; Petko Panić, P3380 (Transcript from Prosecutor v. Stanišić \& Župljanin), T. 2871, 2940; P3187 (Map of Zvornik municipality); P3166 (Map of Karakaj industrial area).

4563 See Adjudicated Fact 2757. See also P96 (Witness statement of KDZ059 dated 5 December 1998), pp. 8, 10 (under seal). But see KDZ555, T. 17309-17310 (17 August 2011) (private session) (testifying that Arkan's men controlled the facility and did not give access to anyone else). Some Bosnian Serbs were also arrested for issues 
paramilitaries including those affiliated with Žućo, Pivarski, Crni and Niski were present at the Alhos Factory. ${ }^{4564}$ One of Arkan's men said that they would bring in every Bosnian Muslim found in town. ${ }^{4565}$

\section{(b) Treatment of detainees}

1318. 20 Bosnian Muslims from Zvornik and a few people from Buković, a settlement just outside Zvornik, were held in the men's cloakroom at the Alhos factory. ${ }^{4566}$ Each person was taken one at a time for interrogation to another room, from where the sound of dull blows and loud screams could be heard. ${ }^{4567}$ When they were brought back, they were thrown to the floor and some were "unconscious in a pool of blood, some had obviously broken arms or broken jaw or an eye knocked out. Some younger, fitter men were lying on the floor seemingly unconscious with their limbs twitching". ${ }^{4} 68$ There were 15 men lying on the floor and occasionally the guards would open the door, throw some tear gas into the room and stand outside laughing. ${ }^{4569}$

1319. The men were taken out for interrogation by the guards but the interrogations themselves were conducted by Arkan's men. ${ }^{4570}$ The white tiles in the interrogation room had blood splattered all over them and the floor was covered in broken glass which KDZ059 had heard the detainees had been forced to swallow. ${ }^{4571}$ On or about 9 April 1992, Branko Grujić interrogated and beat a detainee. ${ }^{4572}$ After speaking to Pejić over the phone, Banjanović was allowed to come to the Alhos

relating to military discipline and detained at the facility. P96 (Witness statement of KDZ059 dated 5 December 1998), p. 8 (under seal); KDZ059, P67 (Transcript from Prosecutor v. S. Milošević), T. 29115.

4564 P4837 (Witness statement of KDZ610 dated 27 March 2012), para. 33 (under seal).

4565 P96 (Witness statement of KDZ059 dated 5 December 1998), p. 9 (under seal).

4566 P96 (Witness statement of KDZ059 dated 5 December 1998), pp. 9-10 (under seal).

4567 P96 (Witness statement of KDZ059 dated 5 December 1998), p. 10 (under seal).

4568 P96 (Witness statement of KDZ059 dated 5 December 1998), p. 10 (under seal).

4569 P96 (Witness statement of KDZ059 dated 5 December 1998), p. 10 (under seal).

4570 P96 (Witness statement of KDZ059 dated 5 December 1998), p. 10 (under seal). [REDACTED].

4571 P96 (Witness statement of KDZ059 dated 5 December 1998), p. 10 (under seal). The Chamber also received evidence about the maltreatment of a Bosnian Serb at the facility who was to be used as an example to other Serbs. P96 (Witness statement of KDZ059 dated 5 December 1998), pp. 8-9 (under seal). The Chamber does not find Grujić's evidence and speculation as to who was responsible for the abuses in the Alhos factory to be reliable. D3724 (Witness statement of Branko Grujić dated 22 June 2013), para. 50. In reaching that conclusion the Chamber also refers to its credibility assessment in fns. 4237 and 4239.

4572 See Adjudicated Fact 2758. But see D3724 (Witness statement of Branko Grujić dated 22 June 2013), para. 60; Branko Grujić, T. 40401-40402 (25 June 2013). The Chamber notes specific inconsistencies in Grujić's testimony in this regard and clear indicators that he was seeking to minimise his own involvement. The Chamber does not consider his evidence to be reliable in this regard. Adjudicated Fact 2758 also refers to the killing of 18 Bosnian Muslim detainees by Arkan's men on or soon after 9 April 1992, however there are no Schedule B killing incidents charged in the Indictment with respect to this facility. 
factory and managed to secure the release of people from Kozluk who had been detained there and observed that these "people were beaten black and blue". 4573

\section{(c) $\underline{\text { Conclusion }}$}

1320. The Chamber therefore finds that Bosnian Muslims were detained at the Alhos factory in April 1992. The detainees were subjected to severe beatings and mistreatment by Serb Forces.

\section{(4) Scheduled Detention Facility C.27.4}

1321. The Indictment refers to the use of the Novi Izvor company also known as Ciglana as a detention facility at least between 29 May 1992 and 30 July $1992 .{ }^{4574}$

\section{(a) Arrival of detainees and control of facility}

1322. The Ciglana factory was located in the area of Karakaj. ${ }^{4575}$ On or about 18 May 1992, the Ciglana factory was taken over by Major Toro and his group, known as the Kobras, including men known as Pufta and Zoks. ${ }^{4576}$ Five or six guards, including Žućo, ${ }^{4577}$ guarded the Ciglana factory. ${ }^{4578}$ The reserve police also guarded this detention facility. ${ }^{4579}$

1323. On 27 May 1992, 186 Bosnian Muslims from Divič were detained at the facility. ${ }^{4580}$ In addition, approximately 20 detainees from Ekonomija farm were transported to Ciglana factory where they were all detained in a small room that had boarded up windows. ${ }^{4581}$ The detainees included 12 men who had been identified in a Belgrade television broadcast as Green Berets. ${ }^{4582}$

4573 P104 (Witness statement of Fadil Banjanović dated 9 February 1998), para. 2-41; Fadil Banjanović, P57 (Transcript from Prosecutor v S. Milošević), T. 20695.

4574 The Prosecution submits that the evidence led shows that Ciglana operated as a detention facility from 27 May to 15 July 1992. Prosecution Final Brief, Appendix B, fn. 914.

4575 Petko Panić, T. 19139-19141 (19 September 2011). See also KDZ228, P323 (Transcript from Prosecutor v. Popović et al.), T. 14942 (under seal); P3187 (Map of Zvornik municipality).

4576 P70 (Witness statement of Jusuf Avdispahić dated 22 October 1997), pp. 13, 19. See also Petko Panić, T. 19139-19141 (19 September 2011). The Accused's acknowledges this take-over. Defence Final Brief, para. 1457.

4577 P70 (Witness statement of Jusuf Avdispahić dated 22 October 1997), p. 19.

4578 P70 (Witness statement of Jusuf Avdispahić dated 22 October 1997), p. 18.

4579 See Adjudicated Fact 2759. See also Petko Panić, P3380 (Transcript from Prosecutor v. Stanišić \& Župljanin), T. 2897, 2953, 2933, 3004, 3016-3018; Petko Panić, T. 19152-19153, 19175 (20 September 2011).

4580 See Adjudicated Fact 2760. See also Petko Panić, P3380 (Transcript from Prosecutor v. Stanišić \& Župljanin), T. 2897, 3057-3058.

4581 P62 (Witness statement of Nedžad Hadžiefendić dated 3 October 1997), pp. 9-10; P70 (Witness statement of Jusuf Avdispahić dated 22 October 1997), p. 17. See P75 (Sketches made by Nedžad Hadžiefendić), Sketch C for the witness's evidence as to the location of the Novi Izvor factory. See also P70 (Witness statement of Jusuf Avdispahić dated 22 October 1997), p. 11.

4582 P70 (Witness statement of Jusuf Avdispahić dated 22 October 1997), pp. 6, 18. The men identified by the witness included Ismet Čirka, Fikret LNU, Nedžad Hadziefendić, Muhamed Redžić, Bego LNU, Besim LNU, 
On 15 July 1992, with the exception of one detainee who was taken to the Zvornik SUP, the detainees at Ciglana were taken to Batković camp before being exchanged in January $1993 .{ }^{4583}$

\section{(b) Treatment of detainees}

1324. Detainees were made to work, loading and unloading blocks onto trucks and cleaning the yard; other groups were taken daily to help with looting abandoned homes in Zvornik, Kozluk, and Kula Grad. ${ }^{4584}$ The detainees were woken at 5 a.m. and taken to work. ${ }^{4585}$ Given the amount of work that had to be done, another group of detainees from Čelopek and other detention camps, including ten people who had been detained by Captain Dragan's unit were brought to the Ciglana factory. ${ }^{4586}$

1325. Paramilitaries from Serbia frequently visited the facility and "severely mistreated" the detainees. $^{4587}$ A group of five White Eagles from Loznica entered the building and beat the detainees for one or two hours and ordered them to sing "Chetnik" songs. ${ }^{4588}$ Detainees were beaten with a thick wooden stick and some were also ordered to beat other detainees. ${ }^{4589}$ Men from Niški's group also brought detainees to the facility from Ekonomija farm and beat them. ${ }^{4590}$ Members of the White Eagles, a man addressed as "Vojvoda" and Žućo took detainees out and beat them; on one occasion with a cable. ${ }^{4591}$ One detainee, who was identified as an SDA leader was beaten until he passed out. ${ }^{4592}$ During this mistreatment detainees were also humiliated by being

Safet LNU, Kemal Korkutović, Sead Feriz, Smajo LNU, a barber from Zvornik nicknamed Brico and Ciciban, Nermin LNU, Ibrahim Subašić, Admir Hadžiavdić, Sejfudin Džihić, Edib Omerović, Senaid Avdić, Mirsad Salihović.

P70 (Witness statement of Jusuf Avdispahić dated 22 October 1997), p. 23. The Prosecution refers to P2916 to support the proposition that the buses were paid for by the Interim Government. Prosecution Final Brief, Appendix B, fn. 922. However, the Chamber notes that P2916 was only admitted as a source document for reference purposes and does not rely on it in this regard.

P70 (Witness statement of Jusuf Avdispahić dated 22 October 1997), pp. 11, 20-21; P62 (Witness statement of Nedžad Hadžiefendić dated 3 October 1997), p. 13 . The Chamber notes that the only type of forced labour charged in the Indictment is forced labour at the frontlines.

4585 P70 (Witness statement of Jusuf Avdispahić dated 22 October 1997), p. 18.

4586 P70 (Witness statement of Jusuf Avdispahić dated 22 October 1997), p. 22.

4587 See Adjudicated Fact 2761. See also P62 (Witness statement of Nedžad Hadžiefendić dated 3 October 1997), p. $12-15$.

4588 P70 (Witness statement of Jusuf Avdispahić dated 22 October 1997), pp. 17-19.

4589 P70 (Witness statement of Jusuf Avdispahić dated 22 October 1997), p. 19.

4590 P70 (Witness statement of Jusuf Avdispahić dated 22 October 1997), pp. 17-18; P62 (Witness statement of Nedžad Hadžiefendić dated 3 October 1997), pp. 9, 11-12. The witness testified that Niški himself never beat them.

4591 P70 (Witness statement of Jusuf Avdispahić dated 22 October 1997), pp. 19-20.

4592 P70 (Witness statement of Jusuf Avdispahić dated 22 October 1997), p. 20. 
forced to make the sign of the cross, to use the greeting "God help your hero" and to eat carbonised bread without dropping anything. ${ }^{4593}$

1326. In June 1992, Pufta and his group started searching the detainees for money and he used a knife to carve out a detainee's tattoo which depicted a crescent and star. ${ }^{4594}$ The White Eagles came to the facility on another occasion and beat the detainees but, that night, the guards told the detainees that they had received instructions not to allow any other outsiders in without permission after which the detainees were not mistreated for several days. ${ }^{4595}$ Similarly, after another incident in which detainees were beaten, Niški slapped Žućo; thereafter the detainees were not beaten for five or six days. ${ }^{4596}$

1327. After three detainees hit one of the guards and escaped from the facility, Kobra and Žućo said that all the detainees should be killed. ${ }^{4597}$ That evening, detainees were questioned and suffered injuries including a cut ear, a fractured head, and a cut cheek. ${ }^{4598}$ The next morning the detainees were lined up outside the building and made to stand for three hours. ${ }^{4599}$ After that day Pufta was never seen again and the detainees were not mistreated. ${ }^{460}$

\section{(c) Conclusion}

1328. Based on the above, the Chamber finds that Bosnian Muslims were detained at Ciglana by Serb Forces from late May 1992 until July 1992. The detainees were subjected to beatings, humiliation and were forced to work at the facility and in other locations in Zvornik. ${ }^{4601}$

\section{(5) Scheduled Detention Facility C.27.5}

1329. The Indictment refers to the use of the Drinjaća building (Dom Kulture) as a detention facility at least between May and June 1992.

4593 P70 (Witness statement of Jusuf Avdispahić dated 22 October 1997), pp. 19-20. The Accused acknowledged that paramilitary groups beat detainees at the facility but submitted that this indicated that this was arbitrary action by paramilitaries without any co-ordination or communication from the legal authorities. Defence Final Brief, para. 1457. The Chamber will address the Accused's submissions in this regard in Section IV.A.3.a.iii.D: Paramilitary units.

4594 P70 (Witness statement of Jusuf Avdispahić dated 22 October 1997), p. 22.

4595 P70 (Witness statement of Jusuf Avdispahić dated 22 October 1997), p. 21.

4596 P70 (Witness statement of Jusuf Avdispahić dated 22 October 1997), p. 20.

4597 P70 (Witness statement of Jusuf Avdispahić dated 22 October 1997), p. 22.

4598 P70 (Witness statement of Jusuf Avdispahić dated 22 October 1997), pp. 22-23.

4599 P70 (Witness statement of Jusuf Avdispahić dated 22 October 1997), pp. 22-23.

4600 P70 (Witness statement of Jusuf Avdispahić dated 22 October 1997), pp. 22-23.

4601 The Chamber also received evidence about the killing or disappearance of detainees at the facility. P70 (Witness statement of Jusuf Avdispahić dated 22 October 1997), pp. 12, 21-22. However, the Chamber notes that there are no scheduled killing incidents charged in Schedule B of the Indictment with respect to this facility. 
(a) Arrival of detainees and control of facility

1330. Drinjača is located south of Zvornik. ${ }^{4602}$ On 30 May 1992, about 150 Bosnian Muslim men, women, and children from Kostijerevo were taken to and detained in the Drinjača cultural centre, ${ }^{4603}$ which was very close to the Drinjača School playground. ${ }^{4604}$ Other detainees arrived from another part of Kostijerevo, as well as from Drinjača, Sopotnik and Đevanje. ${ }^{4605}$ In total, approximately 300 Muslim men, women and children, were detained at the Drinjača cultural centre. $^{4606}$

1331. The detainees were guarded by Bosnian Serb soldiers wearing the JNA reserve uniform. ${ }^{4607}$ The detainees were informed by one of the soldiers that there was nothing to fear and that they would be transferred to some villages near Zenica while Bosnian Serbs would come to live in their villages. ${ }^{4608}$ The women and children were separated from the men, "crammed" into a bus, driven to Čelopek, and held in barns and sheds for three days before being allowed to go to Bosnian Muslim held territory. ${ }^{4609}$

\section{(b) Treatment of detainees}

1332. A group of men wearing camouflage uniforms entered the Drinjača cultural centre, and verbally abused the male detainees and forced them to sing "Chetnik" songs. ${ }^{4610}$ These soldiers took individual detainees from the group onto a stage and severely beat them. ${ }^{4611}$ In one case, a man was beaten until he was unconscious and then stabbed three times. ${ }^{4612}$ Between 25 and 30 detainees were beaten and threatened. ${ }^{4613}$ The Bosnian Serb soldiers present in the cultural centre

\footnotetext{
4602 P3187 (Map of Zvornik municipality); D1613 (Map of Zvornik marked by KDZ555).

4603 KDZ072, P425 (Transcript from Prosecutor v. Šešelj), T. 8699-8701; P99 (Photograph showing Dom Kulture Drinjača).

4604 P4837 (Witness statement of KDZ610 dated 27 March 2012), paras. 55, 59 (under seal); P99 (Photograph showing Dom Kulture Drinjača).

4605 KDZ072, P425 (Transcript from Prosecutor v. Šě̌elj), T. 8702.

4606 KDZ072, P425 (Transcript from Prosecutor v. Šešelj), T. 8702. The Accused acknowledges that between May and June 1992 a number of people were detained at Drinjača. Defence Final Brief, para. 1452.

4607 KDZ072, P425 (Transcript from Prosecutor v. Šešelj), T. 8701; P99 (Photograph showing Dom Kulture Drinjača).

4608 KDZ072, P425 (Transcript from Prosecutor v. Šešelj), T. 8702-8703.

4609 KDZ072, P425 (Transcript from Prosecutor v. Šě̌elj), T. 8703, 8726.

4610 KDZ072, P425 (Transcript from Prosecutor v. Šě̌elj), T. 8704, 8708-8709.

4611 KDZ072, P425 (Transcript from Prosecutor v. Šě̌elj), T. 8705.

4612 KDZ072, P425 (Transcript from Prosecutor v. Šěselj), T. 8705-8706. The Accused acknowledged that detainees were severely beaten and forced to sing by soldiers identified as Arkan's men but that no official reports were submitted regarding this incident. Defence Final Brief, confidential, para. 1452.

4613 KDZ072, P425 (Transcript from Prosecutor v. Šešelj), T. 8706-8708 (testifying that detainees were beaten with wooden batons, pieces of iron, police batons and electrical wire).
} 
observed what was happening but did nothing to prevent or stop the beatings which continued till around 9 p.m. when the group of men left. ${ }^{4614}$

$\underline{\text { detainees }}$

(c) Conclusion on conditions of detention and treatment of

1333. Based on the above, the Chamber finds that Bosnian Muslims, including women and children, were detained at the Drinjača cultural centre from the end of May 1992 by Serb Forces. The women and children were separated from the men before being transferred to Bosnian Muslim held territory. The male detainees were subjected to threats, severe beatings, and were stabbed by Serb Forces.

\section{(d) Scheduled Incident B.20.1}

1334. The Prosecution alleges that approximately 88 men were killed at Drinjača on or about 30 May 1992.

1335. On the night of 30 May 1992, a group of men wearing olive-green uniforms, and some wearing cockades, entered the Drinjača cultural centre. ${ }^{4615}$ This group of men ordered the detainees to put their heads down and asked for ten volunteers to step forward. ${ }^{4616}$ When none of the detainees volunteered, ten people were selected and taken outside, which was followed by the sound of a burst of gunfire. ${ }^{4617}$ This process was repeated every five minutes. ${ }^{4618}$

1336. The fifth group of detainees taken out. One of the detainees was shot at by the soldiers who were lined up in a row but; managed to escape. ${ }^{4619}$ When he fled the scene, he saw a large group of people dead on the concrete. ${ }^{4620}$ This detainee provided a list of 88 people from the villages of Kostijerevo, Drinjača, Sopotnik and Đevanje who were captured, detained at the Drinjača Cultural Centre and shot on the evening of 30 May 1992. He identified five other people who were killed

\footnotetext{
4614 KDZ072, P425 (Transcript from Prosecutor v. Šešelj), T. 8708-8709.

4615 KDZ072, P425 (Transcript from Prosecutor v. Šešelj), T. 8710-8711, 8717, 8736-8740.

4616 KDZ072, P425 (Transcript from Prosecutor v. Šešelj), T. 8711 (under seal).

4617 [REDACTED].

4618 [REDACTED].

4619 [REDACTED].

4620 [REDACTED]. The Accused acknowledged that 83 Bosnian Muslim men were executed in this incident but that the police were afraid of the paramilitaries who were responsible and no official reports were made about this incident. Defence Final Brief, confidential, para. 1451. The Accused also cites to the evidence of Panić to suggest that it was impossible to reach Drinjača because the tunnels were laid with explosives. Petko Panić, T. 19182-19183 (20 September 2011). The Chamber does not consider that this evidence supports a conclusion that it was impossible to reach Drinjača.
} 
while trying to escape arrest during the course of the day. ${ }^{4621}$ The Chamber took judicial notice that White Eagles took out groups of ten detainees from the Drinjača cultural centre and shot and killed 88 people. $^{4622}$

1337. On the morning of 31 May 1992, members of the Zvornik Public Utility Service were ordered to pick up bodies at Drinjača; they saw that the women and children had boarded three buses. $^{4623}$ At the Drinjača School playground, which was 50 metres away from the Drinjača cultural centre, there were "dead bodies and blood everywhere". ${ }^{4624}$ The men had been shot in the back of the head and the bodies which were of Bosnian Muslim civilians were scattered at the location. ${ }^{4625}$ Given the volume of blood, those who were transporting the bodies had to return twice to the Drinjača playground to wash the location. ${ }^{4626}$ The bodies were loaded onto a truck, covered with a tarpaulin and taken towards Gero's slaughterhouse; the bodies were then moved from this location and buried at Ramin Grob Muslim cemetery. ${ }^{4627}$ Of the 155 bodies exhumed from this mass grave KDZ610 was able to recognise some people who he had seen killed in Drinjača. $^{4628}$

1338. The Chamber therefore finds that approximately 88 men were killed by Serb Forces at Drinjača on or about 30 May 1992.

\footnotetext{
4621 P95 (List of persons captured or killed on 30 May 1992) (under seal); [REDACTED]. The witness also participated in the identification process and identified his father and brothers following the exhumation of the bodies in September 1998. P101 (Exhumation report from "Ramin Grob" - Glumina) (under seal). Of the 88 individuals named by [REDACTED], 73 were exhumed from mass graves. P4853 (Updated Table 2 to the Report of Amor Mašović), pp. 98-107. In addition 52 of the 88 individuals named by KDZ072 were listed in P101 (Exhumation report from "Ramin Grob" - Glumina) (under seal).

4622 See Adjudicated Fact 2762. The Chamber finds that Vasilić was informed about the execution of detainees in this incident by a TO unit commanded by Lieutenant Matić. Marinko Vasilić, T. 39930-39933 (13 June 2013). Vasilić testified however, that the reserve police could not prevent this incident. The Chamber notes that Vasilić, when confronted with his prior statement, testified that the police would most probably have seen what happened. Vasilić was also confronted with his prior statement that he spoke to leading politicians and members of the TO Staff about this incident and nothing was done which was contrary to his testimony that he discussed the issue with TO Staff Chief Marko Pavlović who promised to investigate the case. Marinko Vasilić, T. 39933-39938 (13 June 2013); P6405 (Excerpt from Marinko Vasilić's interview with OTP, 21 October 2002), pp. 6-7. In light of these contradictions, the Chamber does not consider Vasilić's assessment that the reserve police could not to prevent this incident to be reliable. The Chamber also refers to its credibility assessment in fn. 4259 in reaching that conclusion.

4623

4624

4625

4626

4627

4628

[REDACTED].

[REDACTED] (stating that he saw that approximately 83 Bosnian Muslim men were killed, with some as young as 17); P99 (Photograph showing Dom Kulture Drinjača).

[REDACTED].

[REDACTED].

[REDACTED].

[REDACTED]; P101 (Exhumation report from "Ramin Grob" - Glumina) (under seal).
} 
(6) $\underline{\text { Scheduled Detention Facility C.27.6 }}$

1339. The Indictment refers to the use of the Ekonomija farm as a detention facility between April and December $1992 .{ }^{4629}$

\section{(a) Arrival of detainees and control of facility}

1340. Ekonomija farm is located four kilometres from Zvornik in the industrial area of Karakaj. ${ }^{4630}$ Detainees were held in a building in the centre of the farm. ${ }^{4631}$ The detainees at this facility included Bosnian Muslims from the villages of Divič and Đulići. ${ }^{4632}$ On or about 11 May 1992, eight men detained at Karakaj were transported to this facility by Bosnian Serb police. ${ }^{4633}$ Other detainees were taken to the facility from their apartments by soldiers, including a group from Loznica in Serbia and men with White Eagle patches and bearing MP inscriptions. These detainees were hit and searched before their transportation to the Ekonomija farm. ${ }^{4634}$ A unit of the Zvornik TO commanded by Miladin Mijatović was stationed at the Ekonomija farm. ${ }^{4635}$

\section{(b) Treatment of detainees}

1341. 15 men were detained in a room previously used for the storage of fertiliser and were beaten. ${ }^{4636}$ An old man who was detained at the Ekonomija farm died after a series of beatings. ${ }^{4637}$

\footnotetext{
4629 The Prosecution submits that the evidence led demonstrates that it operated as a detention facility during May 1992. Prosecution Final Brief, Appendix B, fn. 927.

4630 P70 (Witness statement of Jusuf Avdispahić dated 22 October 1997), p. 11; P3187 (Map of Zvornik municipality); P4847 (Map of Karakaj marked by KDZ610) (showing the location of Ekonomija Farm with number 2); P4837 (Witness statement of KDZ610 dated 27 March 2012), para. 80 (under seal).

4631 P4837 (Witness statement of KDZ610 dated 27 March 2012), para. 51 (under seal); P4843 (Photograph of Ekonomija Farm marked by KDZ610). See also Petko Panić, P3380 (Transcript from Prosecutor v. Stanišić \& Župljanin), T. 2897, 3057-3058.

4632 KW317, T. 39366 (6 June 2013).

4633 P62 (Witness statement of Nedžad Hadžiefendić dated 3 October 1997), pp. 7, 9-10; see P75 (Sketches made by Nedžad Hadžiefendić). See also Adjudicated Fact 2763.

4634 P70 (Witness statement of Jusuf Avdispahić dated 22 October 1997), pp. 10-11.

4635 Petko Panić, T. 19136 (19 September 2011); P3386 (List of men working at the Ekonomija Farm, 15 May 1992), pp. 1-4. The members of the Zvornik TO being paid for their work at the Ekonomija Farm included Branko Mićić, Pero Mićić, Petko Nikolić, Branko Đokić, Dobrinko Đokić, Mirko Jokić, Mile Mićić, Slobodan Stevanović, Milan Filipović, and Zdravko Simić.

4636 P62 (Witness statement of Nedžad Hadžiefendić dated 3 October 1997), p. 8.

4637 P62 (Witness statement of Nedžad Hadžiefendić dated 3 October 1997), pp. 9-10; P70 (Witness statement of Jusuf Avdispahić dated 22 October 1997), p. 12 (who identified the old man as the father of Fehim Dautović). See also Adjudicated Fact 2765. The Accused acknowledged that detainees were beaten by soldiers wearing White Eagle and Kobra insignia and that an old man died as a result of injuries sustained during beatings but that the death was not reported to the Bosnian Serb authorities. Defence Final Brief, para. 1456.
} 
A police inspector from Zvornik asked the detainees to give statements that the old man had died of natural causes. ${ }^{4638}$ Bosnian Muslims were also taken from Ekonomija farm and forced to work. ${ }^{4639}$

1342. The belongings of detainees were taken away and soldiers threatened that they would all be killed if they did not provide statements about the location of weapons. ${ }^{4640}$ At least ten detainees were severely beaten. ${ }^{4641}$ Avdispahić for example was told that his statement did not match the statement of another detainee; five or six soldiers then came into the room, beat him for almost half an hour, made him stand against the wall and make the three fingered Serbian sign. ${ }^{4642}$ As they beat Avidspahic the soldiers swore at him. ${ }^{4643}$ After one or two hours, a group of four or five soldiers arrived, threatened Avdispahić and beat him for two hours with a stake, a thick electric cable, and a rubber hose. ${ }^{4644}$ Approximately every two hours this group of soldiers would enter and beat the detainees for as long as they could and this lasted the whole day. ${ }^{4645}$

1343. On 12 or 13 May 1992, Bego Bukvić was taken outside, beaten, and when he was brought back inside he was "half dead". ${ }^{4646}$ The arms of some detainees were broken during these beatings. ${ }^{4647}$ That same night, another group of soldiers, entered and told all men who did not vote for a sovereign $\mathrm{BiH}$ to sit down. ${ }^{4648}$ When Avdispahić did not sit as his legs were too swollen, he was ordered to turn towards the wall and was beaten. ${ }^{4649}$ Avdispahic then hit the wall and fainted before waking up "on the floor in blood and water". ${ }^{4650}$

1344. On the morning of 13 May 1992, a man in JNA uniform, with a Serbian accent, by the name of Učo, questioned the detainees, and beat one of them who he accused of smuggling weapons. ${ }^{4651}$ After Učo left, another group of soldiers came in and immediately started beating the detainees. ${ }^{4652}$ Two men were ordered to get down on all fours after which a pointed stake was pushed into their

4638 P62 (Witness statement of Nedžad Hadžiefendić dated 3 October 1997), pp. 9-10. Avdispahić also testified that he was ordered to sit on an old man and he could not tell if he was already dead. P70 (Witness statement of Jusuf Avdispahić dated 22 October 1997), p. 11. It is not clear to the Chamber if this refers to the same man.

4639 P4837 (Witness statement of KDZ610 dated 27 March 2012), para. 49 (under seal). The Chamber notes that only forced labour at the frontlines is charged in the Indictment.

4640 P70 (Witness statement of Jusuf Avdispahić dated 22 October 1997), pp. 11-12.

4641 P70 (Witness statement of Jusuf Avdispahić dated 22 October 1997), pp. 12-13

4642 P70 (Witness statement of Jusuf Avdispahić dated 22 October 1997), pp. 12-13.

4643 P70 (Witness statement of Jusuf Avdispahić dated 22 October 1997), p. 13.

4644 P70 (Witness statement of Jusuf Avdispahić dated 22 October 1997), p. 13.

4645 P70 (Witness statement of Jusuf Avdispahić dated 22 October 1997), p. 13.

4646 P70 (Witness statement of Jusuf Avdispahić dated 22 October 1997), pp. 13-14.

4647 P70 (Witness statement of Jusuf Avdispahić dated 22 October 1997), p. 14.

4648 P70 (Witness statement of Jusuf Avdispahić dated 22 October 1997), p. 14.

4649 P70 (Witness statement of Jusuf Avdispahić dated 22 October 1997), p. 14.

4650 P70 (Witness statement of Jusuf Avdispahić dated 22 October 1997), p. 14.

4651 P70 (Witness statement of Jusuf Avdispahić dated 22 October 1997), p. 15.

4652 P70 (Witness statement of Jusuf Avdispahić dated 22 October 1997), p. 15. 
anuses up to 30 centimetres during which the detainees screamed and howled. ${ }^{4653}$ Once the beating and abuse ended the detainees were ordered to wipe the blood with their clothes. ${ }^{4654}$

1345. During this incident the soldiers shouted at the detainees. ${ }^{4655}$ Zoran Jovanović came in and was told by Brko "here are your birds from Glinica"; Jovanović laughed and left. ${ }^{4656}$ After Jovanović left, Brko hit Avdispahić on the head and the other detainees were ordered to beat each other, remove their underwear and bite each others penises while the soldiers stood by and laughed. ${ }^{4657}$

$\underline{\text { detainees }}$

(c) Conclusion on conditions of detention and treatment of

1346. Based on the above, the Chamber finds that Bosnian Muslims were transferred to and detained at Ekonomija by Serb Forces in May 1992. The detainees were subjected to severe beatings and sexual violence. The Chamber finds that one detainee died following a severe beating. ${ }^{4658}$

\section{(d) Scheduled Incident B.20.4}

1347. The Prosecution alleges that one man was killed at Ekonomija Farm between April and May 1992.4659

1348. A soldier ordered Bego Bukvić to come out of the room where he was detained and after he left there was the sound of two short machine gun bursts. ${ }^{4660}$ Avdispahić was also ordered out and told to put Bukvić's body into a bag and noticed that there were gun shots in the shape of a cross on Bukvić's back. ${ }^{4661}$ After one or two hours another group entered the room, beat everyone, and took Sead Omerović out. ${ }^{4662}$ Once Sead was taken out, detainees could hear screaming and blows

\footnotetext{
4653 P70 (Witness statement of Jusuf Avdispahić dated 22 October 1997), p. 15.

4654 P70 (Witness statement of Jusuf Avdispahić dated 22 October 1997), p. 15.

4655 P70 (Witness statement of Jusuf Avdispahić dated 22 October 1997), p. 15. The Chamber refers to para. 1240 as to Jovanović's position.

4656 P70 (Witness statement of Jusuf Avdispahić dated 22 October 1997), p. 15.

4657 P70 (Witness statement of Jusuf Avdispahić dated 22 October 1997), pp. 15-16.

4658 This finding does not include the persons alleged to have been killed in Scheduled Incident B.20.4, which is discussed below.

4659 While the Indictment refers to the killing of one man, the Prosecution Final Brief lists five individuals linked to this incident. The Chamber notes that the death of one of these individuals is addressed in para. 1341, which addresses the death of a detainee after he was beaten. The Prosecution also limits the period of the killings to May 1992. Prosecution Final Brief, Appendix B.

4660 P70 (Witness statement of Jusuf Avdispahić dated 22 October 1997), p. 16.

4661 P70 (Witness statement of Jusuf Avdispahić dated 22 October 1997), p. 16.

4662 P70 (Witness statement of Jusuf Avdispahić dated 22 October 1997), p. 16.
} 
followed by the sound of two short machine gun bursts; they were then called out to put Sead's body in a body bag. ${ }^{463}$

1349. The Chamber therefore finds that at least two men were killed at Ekonomija Farm by Serb Forces in May 1992. ${ }^{4664}$

\section{(7) Scheduled Detention Facility C.27.7}

1350. The Indictment refers to the use of the Standard Factory as a detention facility at least between April and the end of June 1992. ${ }^{4665}$

1351. The Standard Factory was located in Karakaj on the road from Zvornik to Bijeljina. ${ }^{4666}$ It was a building constructed for the Standard Company and was then used as a barracks. ${ }^{4667}$ It was used to detain Bosnian Muslim men from April 1992 and was guarded by local Bosnian Serbs. ${ }^{4668}$ The facility was also used by the TO, the Zvornik Brigade, the MUP, the police, and by the Interim Government. $^{4669}$ On or about 3 or 4 May 1992, following interrogations at the SUP in Zvornik, groups of Bosnian Muslim men were transported by policemen to the Standard Factory. ${ }^{4670}$ The guards at the Standard Factory wore JNA uniforms and were men from Čelopek. ${ }^{4671}$ While the Bosnian Muslim men were detained at the facility, separate groups of men wearing camouflage uniforms with cockades would arrive and ask them questions. ${ }^{4672}$

\footnotetext{
4663 P70 (Witness statement of Jusuf Avdispahić dated 22 October 1997), pp. 16-17.

4664 The Chamber also received evidence about the disappearance of a detainee but has insufficient evidence to make a finding in this regard or to link it to this scheduled incident. P4837 (Witness statement of KDZ610 dated 27 March 2012), para. 50 (under seal).

4665 The Prosecution submits that the evidence presented shows that the facility was operational in April and May 1992. Prosecution Final Brief, Appendix B, fn. 936.

4666 P62 (Witness statement of Nedžad Hadžiefendić dated 3 October 1997), pp. 4-5; Petko Panić, P3380 (Transcript from Prosecutor v. Stanišić \& Župljanin), T. 2883; P3187 (Map of Zvornik municipality); P3166 (Map of Karakaj industrial area).

4667 Petko Panić, P3380 (Transcript from Prosecutor v. Stanišić \& Župljanin), T. 2883.

4668 See Adjudicated Fact 2766.

4669 KDZ555, T. 17235-17236 (16 August 2011) (private session); P4837 (Witness statement of KDZ610 dated 27 March 2012), paras. 42, 69 (under seal); KDZ610, T. 27175 (29 March 2012); P3165 (Witness statement of KDZ340 undated), pp. 9-10 (under seal). The Accused submits that with respect to this scheduled detention facility, the "presence of several armed soldiers" indicated that there was no cohesion or co-operation and that there was an unclear chain of command. Defence Final Brief, para. 1459. The Chamber will address the Accused's submissions in this regard in Section IV.A.3.a.iii: Authority over military and police forces acting in $\mathrm{BiH}$

4670 P62 (Witness statement of Nedžad Hadžiefendić dated 3 October 1997), pp. 4-5; P75 (Sketches made by Nedžad Hadžiefendić), Sketch D.

4671 P62 (Witness statement of Nedžad Hadžiefendić dated 3 October 1997), p. 5.

4672 P62 (Witness statement of Nedžad Hadžiefendić dated 3 October 1997), p. 6.
} 
1352. Armed groups, including paramilitaries from Serbia, frequently visited the detention facility and "severely mistreated the detainees". 4673 One of these groups from Loznica, entered and started punching and kicking the detainees and beating them with sticks, bent cables, and wires. ${ }^{4674}$

1353. Based on the above, the Chamber finds that Bosnian Muslim men were transported to and detained at Standard Factory by Serb Forces in April and May 1992. The detainees were subjected to severe beatings during their detention at this facility. ${ }^{4675}$

\section{(G) Scheduled Incident D.22}

1354. The Indictment refers to the destruction of at least 28 mosques in Zvornik between April and November 1992.4676

1355. By the morning of 9 April 1992, a Serbian flag was flying "over the main Mosque at the market place in Zvornik" and Serbian music was played through the loudspeakers on the minarets. ${ }^{4677}$ The minarets from two other mosques were destroyed in the shelling of the previous day. ${ }^{4678}$ In April 1992, Serb Forces also entered Kamenica and destroyed four mosques. ${ }^{4679}$

1356. On or about 18 July 1992, some of the mosques in the surrounding area of Zvornik and the mosque in the centre of Zvornik were demolished by a group of men described as "saboteurs" from Pančevo; they loaded the copper from the demolished mosques and took it in vehicles to Serbia under the escort of army commandos. 4680

\footnotetext{
4673 See Adjudicated Fact 2767.

4674

Witness statement of Nedžad Hadžiefendić dated 3 October 1997), pp. 6-7.

The Chamber also received evidence about the killing of Bosnian Muslims at the Standard Factory and their burial but there are no killing incidents charged in Schedule B of the Indictment with respect to this facility. KDZ555, T. 17310-17311 (17 August 2011) (private session); Petko Panić, P3380 (Transcript from Prosecutor v. Stanišić \& Župljanin), T. 2940; Petko Panić, T. $19178-19179$ (20 September 2011); P4837 (Witness statement of KDZ610 dated 27 March 2012), para. 69 (under seal).

4676 Indictment, Schedule D.22. The Indictment refers to the destruction of at lease 28 mosques but only names 16 mosques.

4677 P96 (Witness statement of KDZ059 dated 5 December 1998), p. 7 (under seal); P70 (Witness statement of Jusuf Avdispahić dated 22 October 1997), p. 5; P3165 (Witness statement of KDZ340 undated), pp. 2-3 (under seal); P4837 (Witness statement of KDZ610 dated 27 March 2012), para. 11 (under seal).

4678 P70 (Witness statement of Jusuf Avdispahić dated 22 October 1997), p. 5.

4679 KDZ064, T. 1316 (21 April 2010). See also P4070 (Attachment to the expert report of András J. Riedlmayer, entitled "Destruction of Cultural Heritage in BiH" prepared for the Karadžić case, formatted records), pp. 352354, 378-380 (identifying the damage to the Donja Kamenica mosque, Gornja Kamenica mosque, Donja Kamenica -Redžići mosque).

4680 P3173 (Statement of Nenad Simić to Bijeljina SJB, 6 August 1992), pp. 4-5 (under seal); KDZ340, T. 17496, 17532 (19 August 2011) (private session); P3181 (Statement of KDZ340 to Bijeljina SJB, 6 August 1992), p. 6 (under seal). Grujić testified that the Bosnian Muslim monuments were damaged by the paramilitaries. However, on cross-examination Grujić was challenged about this evidence and referred to his prior interview where he had stated that the mosques in Zvornik had been destroyed by a military unit since they were in possession of the explosives and materials necessary to carry this out and he acknolwedged that he could not be
} 
1357. According to Riedlmayer's report, a total of 29 mosques and two Muslim shrines were damaged in Zvornik during the course of the war. ${ }^{4681}$ The Chamber notes that with respect to three of these mosques, Riedlmayer describes them as "lightly damaged". 4682 The Chamber therefore finds that at least 26 mosques in Zvornik were heavily damaged, almost destroyed, or completely destroyed. Riedlmayer identified a number of mosques in Zvornik municipality which have now been razed and used as dumping sites for garbage or other constructions. ${ }^{4683}$ With respect to the Divič mosque, a Serbian Orthodox church was built on the site of the destroyed mosque. ${ }^{4684}$

1358. The Chamber has considered the evidence it has received which identified Serb Forces as responsible for the destruction of specific mosques in Zvornik town and surrounding villages. ${ }^{4685}$ It

sure whether it was the regular army or the volunteers who had done this. D3724 (Witness statement of Branko Grujić dated 22 June 2013), para. 71; Branko Grujić, T. $40392-40393$ (25 June 2013). See also KDZ555, T. 17319-17320 (17 August 2011) (testifying that all mosques were destroyed after Zvornik was taken over by Bosnian Serbs and this did not happen during the war operations). KDZ555 also testified that [REDACTED]. KDZ555, T. 17359, 17361 (17 August 2011) (private session). However, the Chamber does not consider KDZ555's evidence to be reliable in this regard. In reaching that conclusion the Chamber noted that KDZ555's evidence was marked by indicators of extreme evasiveness, bias and contradictions.

P4070 (Attachment to the expert report of András J. Riedlmayer, entitled "Destruction of Cultural Heritage in $\mathrm{BiH}$ ” prepared for the Karadžić case, formatted records), pp. 328-400. Riedlmayer identifies the level of damage with respect to each of the mosques listed by name in the Indictment: Đulići mosque (completely destroyed), Kula Grad mosque (completely destroyed), Kozluk mosque (completely destroyed), Divič mosque (completely destroyed), Snagovo mosque (heavily damaged), Novo Selo mosque (almost destroyed), Skočić mosque (almost destroyed), Svrake mosque (lightly damaged), Drinjača mosque (heavily damaged), Glumina mosque (completely destroyed), Donja Kamenica mosque (almost destroyed), Gornja Kamenica mosque (heavily damaged), Klisa mosque (heavily damaged), Kovačevići mosque (heavily damaged), Rijeka mosque (completely destroyed), Selimovići mosque (heavily damaged); P4071 (Slide images of damaged religious sites in $\mathrm{BiH}$ ), pp. 1, 10, 13-15, 18, 20-23. Riedlmayer identified that the buildings adjacent to the Divič mosque, Drinjača mosque, Kozluk mosque, Rijeka mosque were in good condition, while the buildings adjacent to the Kovačevići mosque, Kula Grad mosque were also heavily damaged. In addition to these 16 mosques, Riedlmayer identified the level of damage with respect to another 13 mosques as follows: Beksuja mosque (completely destroyed), Zamlaz mosque (completely destroyed), Kušlat mosque (almost destroyed), Donja Kamenica -Redžići mosque (heavily damaged), Gornja Sapna mosque (heavily damaged), Jošanica mosque (completely destroyed), Hasići mosque (completely destroyed), Vitinica mosque (lightly damaged), Gornji Šepak mosque (completely destroyed), Donji Križevići mosque (lightly damaged), Glodi mosque (heavily damaged), Seferovići mosque (almost destroyed), Avdo Tucić mosque - Kula Grad (completely destroyed). Riedlmayer also refers to the damage to two other Islamic sites (Turbe of Hasan Kaimija - Kula Grad, Dervish lodge and shrine - Divič), which are not mosques and thus not charged in the Indictment. See also P4518 (Excerpts from Robert Đurđević's diary, 7-25 September 1993), p. 2. See also P4068 (András Riedlmayer's expert report on Destruction of Cultural Heritage in Bosnia and Herzegovina during 1992-1995, 7 May 2009), paras. 15-16, 24; András Riedlmayer, T. 22530-22531, 22536-22537 (8 December 2011), 22541-22547 (9 December 2011); P4069 (Cultural destruction database), records 337, 339, 340, 345, 346, 359, 360, 362, 363, 366, 369, 370, 372, 374, 378, 380; Adjudicated Fact 2768.

4682 Svrake mosque, Vitinica mosque, and Donji Križevići mosque. See also P4068 (András Riedlmayer's expert report on Destruction of Cultural Heritage in Bosnia and Herzegovina during 1992-1995, 7 May 2009), paras. 24-25 (stating that of the 30 mosques which were in the part of Zvornik municipality controlled by Serb Forces during the war only one survived without significant damage).

4683 P4068 (András Riedlmayer's expert report on Destruction of Cultural Heritage in Bosnia and Herzegovina during 1992-1995, 7 May 2009), paras. 42-43.

4684 P4068 (András Riedlmayer's expert report on Destruction of Cultural Heritage in Bosnia and Herzegovina during 1992-1995, 7 May 2009), para. 43.

4685 See P70 (Witness statement of Jusuf Avdispahić dated 22 October 1997), p. 5; KDZ064, T. 1316 (21 April 2010); P3173 (Statement of Nenad Simić to Bijeljina SJB, 6 August 1992), pp. 4-5 (under seal); KDZ340, 
has also had regard to the fact that with very few exceptions, almost all mosques in the municipality sustained serious damage or were completely destroyed after Serb Forces took over power. Finally, the Chamber has assessed the evidence received with respect to the surrounding circumstances in Zvornik, including the attacks on and take-over of multiple Bosnian Muslim villages by Serb Forces in the relevant time frame. Having weighed these factors, the Chamber is satisfied beyond reasonable doubt that Serb Forces were responsible for the attacks on and destruction of mosques in Zvornik.

1359. Therefore, the Chamber finds that at least 26 mosques were heavily damaged, almost destroyed or completely destroyed by Serb Forces from April 1992.

\section{(H) Movement of the population from Zvornik}

1360. As discussed above ${ }^{4686}$ following the attack on Zvornik approximately 10,000 people, the majority of whom were Bosnian Muslims, left Zvornik with most crossing to Mali Zvornik. ${ }^{4687}$ Other people took shelter in the municipality of Kalesija, ${ }^{4688}$ the town of Snagovo, ${ }^{4689}$ and Kula Grad. $^{4690}$ Bosnian Muslims who headed in the direction of Tuzla tried to cross into Bosnian Muslim controlled territory and those who managed to cross into Serbia travelled to third countries from there. ${ }^{4691}$

1361. Bosnian Muslim women who had been separated from men were verbally abused by the soldiers who identified themselves as "Šešelj's men". ${ }^{4692}$ After being addressed by Arkan, these

T. 17496, 17532 (19 August 2011) (private session); P3181 (Statement of KDZ340 to Bijeljina SJB, 6 August 1992), p. 6 (under seal).

4686 See para. 1250.

4687 P96 (Witness statement of KDZ059 dated 5 December 1998), p. 7 (under seal); KDZ059, P67 (Transcript from Prosecutor v. S. Milošević), T. 29113-29114; see Adjudicated Fact 2730; KDZ240, P2935 (Transcript from Prosecutor v. Krajišnik), T. 6760 (under seal); KDZ240, T. 15967 (4 July 2011) (closed session), T. 1607816079 (5 July 2011) (closed session); KDZ446, P28 (Transcript from Prosecutor v. S. Milošević), T. 21019 (under seal). See also P62 (Witness statement of Nedžad Hadžiefendić dated 3 October 1997), p. 3; Martin Bell, T. 9783, 9803 (14 December 2010); P1996 (Witness statement of Martin Bell dated 8 March 2010), paras. 23 24; Colm Doyle, T. 2932-2933 (28 May 2010); Colm Doyle, P918 (Transcript from Prosecutor v. S. Milošević), T. 25275; D1694 (Intercept of conversation between Ješirić and Čedo Kljajić, 16 April 1992), p. 3 (which suggests that the figure was between 15,000 to 25,000 people). But see Čedomir Kljajić, T. 42208-42210 (30 July 2013) (testifying that the figure of 15,000 was blown out of proportion). P84 (Witness statement of Mirsad Kuralić dated 27 June 1996), p. 2; Mirsad Kuralić, P63 (Transcript from Prosecutor v. Krajišnik), T. 12560.

4689 P64 (Witness statement of Osman Krupinac dated 29 May 2000), pp. 1-2.

4690 See Adjudicated Fact 2732; P4837 (Witness statement of KDZ610 dated 27 March 2012), paras. 7-8 (under seal). See also KDZ059, P67 (Transcript from Prosecutor v. S. Milošević), T. 29115-29116.

4691 P4837 (Witness statement of KDZ610 dated 27 March 2012), para. 82 (under seal); P4849 (Excerpt from video entitled "The Death of Yugoslavia"), 02:47-03:02.

4692 P89 (Witness statement of KDZ023 dated 29 September 1996), pp. 4-5 (under seal); KDZ023, P65 (Transcript from Prosecutor v. S. Milošević), T. 26136; P92 (Addendum to witness statement of KDZ023), pp. 1-2, 4 (under seal). 
women were put on buses and taken to Serbia, and "saw many more dead bodies lying in the gardens of houses" as they were driven through Zvornik. ${ }^{4693}$

1362. On 10 April 1992, the Interim Government instructed residents to return to Zvornik and lay claim to their properties by 15 May 1992 or face loss of title. ${ }^{4694}$ On 20 April 1992, the Interim Government appointed a commission to negotiate with the SDA. Items to negotiate included the situation of a large group of Bosnian Muslims who wanted to move. ${ }^{4695}$ Mićo Stanišić reported that "inhabitants of the Muslim villages around Zvornik are being evacuated". 4696 The SUP issued permits for Bosnian Muslims to cross into Serbia ${ }^{4697}$ and Grujić was involved in transporting Bosnian Muslims from Zvornik to Serbia. ${ }^{4698}$ Peja instructed Bošković to take all the women, children and men over the age of 50 and allow them to cross to Mali Zvornik. ${ }^{4699}$ Bošković then took groups of 200 to 300 people across the bridge on several occasions, but men of combat age were not allowed to cross. ${ }^{4700}$ The money and gold of Bosnian Muslims were taken away before they crossed the bridge to Serbia. ${ }^{4701}$

1363. In late May 1992, Bosnian Muslim representatives met with local Serbs, including a member of the Interim Government to discuss the removal of Bosnian Muslims from the municipality. ${ }^{4702}$ On or about 28 May 1992, the commander of the VRS $1^{\text {st }}$ Birač Brigade, Svetozar Andrić, ordered the Zvornik TO to organise and co-ordinate the movement out of the Bosnian Muslim population, with only women and children to be moved out and men fit for military service placed in camps for exchange. ${ }^{4703}$

1364. Having considered the totality of the evidence and assessed the circumstances in which departures occurred, the Chamber finds that Bosnian Muslims were forced to leave Zvornik.

\footnotetext{
4693 P89 (Witness statement of KDZ023 dated 29 September 1996), p. 4 (under seal).

$4694 \quad$ See Adjudicated Fact 2769.

4695 P2883 (Conclusions of Zvornik Municipality's Interim Government, 20 April 1992); Milorad Davidović, T. 15525-15526 (28 June 2011).

4696 P2749 (SerBiH MUP daily report, 25 April 1992), p. 4.

4697 Petko Panić, T. 19166 (20 September 2011).

4698 P3173 (Statement of Nenad Simić to Bijeljina SJB, 6 August 1992), p. 5 (under seal).

4699 P133 (Witness statement of Matija Bošković dated 20 November 2003), para. 21.

$4700 \quad$ P133 (Witness statement of Matija Bošković dated 20 November 2003), para. 21.

4701 P4849 (Excerpt from video entitled "The Death of Yugoslavia"), 00:00-00:22; P4837 (Witness statement of KDZ610 dated 27 March 2012), para. 82 (under seal). Members of the Zvornik MUP were identified as being involved in this search process.

4702 See Adjudicated Fact 2751. But see KW317, T. 39405-39406 (6 June 2013).

4703 P3055 (Order of Birač Brigade, 28 May 1992), p. 1; see Adjudicated Fact 2772. But see D3886 (Witness statement of Svetozar Andrić dated 16 July 2013), para. 5; Svetozar Andrić, T. 41666-41667 (22 July 2013). The Chamber does not consider that Andrić's evidence as to the reason why the Bosnian Muslim population was moved out and that their departure was voluntary to be reliable. In reaching that conclusion the Chamber noted that during his testimony he had an interest in minimising his own involvement in events in Zvornik and that his evidence was marked by contradictions and evasiveness and indicators of lack of sincerity in this regard.
} 
1365. The Drina Corps Command reported that with "the arrival of paramilitary organisations to the Zvornik municipality, particularly the arrival of Arkan and his people, this territory was liberated from the Turks. Turks made up $60 \%$ of the municipality's population and it has now been cleansed and replaced with an ethnically pure Serb population". ${ }^{4704}$ The ECMM also reported that "people were being forcibly removed" from where they lived in Zvornik. ${ }^{4705}$ Towards the end of June 1992 very few Bosnian Muslims remained in the town. ${ }^{4706}$

4704 P2955 (Report of the Drina Corps, 17 December 1992), p. 1. See also KDZ240, T. 16224-16225 (6 July 2011$)$ (closed session). But see P2886 (Interview with Marko Pavlović, 30 June 1992), p.1 (stating that the movement of populations was a voluntary and temporary measure). The Chamber does not consider this interview where Pavlović had a clear interest in presenting the actions of the Bosnian Serb authorities in a positive light to be reliable. Davidović also testified that Pavlović in this interview was simply stating what the Zvornik Crisis Staff and politicians expected him to say. Milorad Davidović, T. 15536 (28 June 2011).

4705 Colm Doyle, T. 2932 (28 May 2010). See also P1029 (Witness statement of John Wilson dated 4 November 2008), paras. 36, 94, 99. See also Milan Babić, P741 (Transcript from Prosecutor v. S. Milošević), T. 13081.

4706 Petko Panić, T. 19139 (19 September 2011); P4837 (Witness statement of KDZ610 dated 27 March 2012), para. 79 (under seal). Pašalić challenged the evidence on the change in the Bosnian Muslim population in Zvornik. D3125 (Stevo Pašalić's expert report entitled "Ethnic Composition, Displaced Persons and Refugees from 27 Municipalities in the Territory of BiH, 1991-1997”, August 2012), p. 35; Stevo Pašalić, T. 35379-35380 (13 March 2013). However, the Chamber does not consider Pašalić's evidence to be reliable in this regard. In reaching this conclusion the Chamber noted that his evidence was marked by extreme evasiveness and indicators of partiality and bias which undermined the credibility of his evidence in this regard. But see Branko Grujić, T. 40453 (26 June 2013) (testifying that after the war there was a general call for all citizens of Zvornik, both Muslim and Serb, who had left their homes to return to the municipality and that these people returned and were treated fairly by all organs of the municipality). The Chamber refers to its credibility assessment in fn. 4237 as to why it does not find Grujić's evidence about the return of citizens to Zvornik to be reliable. The Chamber does find, however, that in Kozluk, one or two years after the end of the war most of the Bosnian Muslims returned and moved back into their homes with the co-operation of Banjanović. Petko Panić, T. 19170 (20 September 2011); KDZ555, T. 17410 (18 August 2011); Dragan Vidović, T. 17771 (23 August 2011). 


\section{b. Autonomous Region of Krajina ("ARK”)}

\section{i. Municipal level}

(A) Banja Luka

\section{(1) $\underline{\text { Charges }}$}

1366. In relation to Banja Luka municipality, the Prosecution has limited the allegations in the Indictment to crimes associated with the Manjača camp ("Manjača”). ${ }^{4707}$

1367. Under Count 3, the Prosecution alleges that persecution, a crime against humanity, was committed in Banja Luka as part of the objective to permanently remove Bosnian Muslims and/or Bosnian Croats from the Municipalities. ${ }^{4708}$ Acts of persecution alleged to have been committed by Serb Forces and Bosnian Serb Political and Governmental Organs in Banja Luka include killings related to Manjača, as well as killings committed during, and deaths resulting from, cruel and inhumane treatment at that facility. ${ }^{4709}$ The Prosecution also characterises these killings as extermination, a crime against humanity, under Count 4; murder, a crime against humanity, under Count 5 ; and murder, a violation of the laws or customs of war, under Count $6 .{ }^{4710}$

1368. Other acts of persecution alleged to have been committed in Banja Luka by Serb Forces and Bosnian Serb Political and Governmental Organs include (i) torture, beatings, and physical and psychological abuse in Manjača as cruel or inhumane treatment, ${ }^{4711}$ (ii) the establishment and perpetuation of inhumane living conditions in Manjača, including the failure to provide adequate accommodation, shelter, food, water, medical care, or hygienic sanitation facilities, as cruel or inhumane treatment; ${ }^{4712}$ iii) unlawful detention in Manjača; ${ }^{4713}$ as well as iv) forced labour at the frontline and the use of Bosnian Muslims and Bosnian Croats as human shields. ${ }^{4714}$

\footnotetext{
4707 Indictment, fn. 1; Prosecution Rule 73 bis Submission, fn. 14; Pre-Trial Conference, T. 467 (6 October 2009 ); Rule 73 bis Decision, para. 6; Decision on Fourth Adjudicated Facts Motion, para. 28.

4708 Indictment, paras. 48-49.

4709 Indictment, para. 60(a)(ii). See Scheduled Incidents B.1.1, B.1.2, B.1.3, B.1.4; Scheduled Detention Facility C.1.2.

4710 Indictment, para. 63(b).

4711 Indictment, para. 60(b). See Scheduled Detention Facility C.1.2.

4712 Indictment, para. 60(d). See Scheduled Detention Facility C.1.2.

4713 Indictment, para. 60(g). See Scheduled Detention Facility C.1.2.

4714 Indictment, para. 60(h). See Scheduled Detention Facility C.1.2. The Chamber notes that the Prosecution does not allege criminal responsibility for rape and other acts of sexual violence; forcible transfer or deportation; or appropriation or plunder of property in Banja Luka. Indictment, fn. 5, 6, 8.
} 


\section{(2) Lead-up}

1369. Banja Luka is the largest municipality in $\mathrm{BiH}$ and is located to the east of Prijedor and Sanski Most and to the south of Bosanska Gradiška. ${ }^{4715}$ According to the 1991 census, Banja Luka municipality had 195,139 inhabitants, of whom about 55\% were Bosnian Serbs, $15 \%$ were Bosnian Muslims, and $15 \%$ were Bosnian Croats. ${ }^{4716}$

1370. In the multi-party elections of November 1990, the SDS won 64 seats of the 130 seats in the Municipal Assembly while the SDA secured 13 seats only. ${ }^{4717}$ Predrag Radić, a member of the SDS Main Board, was appointed as the President of Banja Luka Municipal Assembly. ${ }^{4718}$ Rajko Kasagić was appointed as President of the Executive Board. ${ }^{4719}$ In 1991, Župljanin was appointed the Chief of Banja Luka CSB. ${ }^{4720}$

\section{On 22 January 1992, the Banja Luka SDS established a Crisis Staff. ${ }^{4721}$}

1372. The Banja Luka Crisis Staff was established in May 1992 and Radić was appointed as the President of the Crisis Staff. ${ }^{4722}$ By 15 May 1992, the Serbian Defence Forces ("SOS") and at least three other Serb armed formations led by Nikodin Čavić, Vlado Jotanović, and Brane Palačković respectively operated in Banja Luka. ${ }^{4723}$

\footnotetext{
4715 P6135 (Map of BiH); D287 (SDA decision on proclamation of municipality Banja Luka-Stari Grad, September 1991).

4716 D4002 (Letter from BiH MUP to Vasvija Vidović, 4 July 1995), pp. 1-2; P5449 (Report of the MUP, Banja Luka RDB, February 1995), p. 2; P783 (Ethnic map of BiH). But see P4994 (Addendum to Ewa Tabeau's expert report entitled "Ethnic Composition in Internally Displaced Persons and Refugees from 27 Municipalities of BiH 1991 to 1997", 3 February 2009), pp. 21, 23-24, 29, 32, 35, 38 (reporting that in 1991, Banja Luka had 165,140 inhabitants).

4717 D4110 (Article from Bosanska Krajina entitled "Second Round on 9 December", 27 November 1990), p. 1; D4259 (Witness statement of Duško Jakšić dated 25 January 2014), para. 10 (stating that the SDS won 62 of 130 seats).

4718 D4002 (Letter from BiH MUP to Vasvija Vidović, 4 July 1995), p. 3; Predrag Radić, P1 (Transcript from Prosecutor v. Krajišnik), T. 7364, 7373; D4036 (Report on Situation in the ARK and Banja Luka, 15 May 1992), p. 2.

4719 P6523 (Excerpt of Minutes of the $69^{\text {th }}$ Banja Luka Executive Board Session, 8 May 1992), p. 1; D4064 (Excerpt of minutes of the $2^{\text {nd }}$ Banja Luka Municipal Assembly session, 31 January 1992), pp. 3, 9; D4036 (Report on Situation in the ARK and Banja Luka, 15 May 1992), p. 1.

4720 Christian Nielsen, T. 16301 (7 July 2011); P3773 (Witness statement of KDZ532 dated 31 October 2011), para. 11 (under seal); P1097 (CSB Banja Luka dispatch to SerBiH MUP, 20 July 1992); P2746 (Dispatch of Banja Luka CSB, 10 April 1992); D4071 (Summary of $15^{\text {th }}$ session of ARK Assembly, 4 March 1992), p. 2 ; D4036 (Report on Situation in the ARK and Banja Luka, 15 May 1992), p. 1.

4721 P2553 (Intercept of conversation between Radovan Karadžić and Jovan Čizmović, 22 January 1992), p. 7.

4722 Predrag Radić, P1 (Transcript from Prosecutor v. Krajišnik), T. 7379, 7384; P6524 (Excerpt of Minutes of the $19^{\text {th }}$ Banja Luka Municipal Assembly Session, 23 June 1992), p. 1; D4077 (Witness statement of Anđelko Grahovac dated 23 November 2013), para. 8; D4086 (Witness statement of Nikola Erceg dated 24 November 2013), para. 2.

4723 D4036 (Report on Situation in the ARK and Banja Luka, 15 May 1992), pp. 1-2. See also Adjudicated Fact 2223.
} 
1373. During the republican referendum on independence on 29 February and 1 March 1992, the SOS blockaded the municipality building. ${ }^{4724}$ The SOS in Banja Luka was under the command of Nenad Stevandić and included many well-known criminals from Banja Luka. ${ }^{4725}$ On 3 April 1992, they erected check-points around town and issued a press statement calling on the president of the municipality to establish a crisis staff in order to pursue several goals of the SOS, including the dismissal of JNA Banja Luka Corps officers and public utility managers who voted "against Yugoslavia". ${ }^{4726}$ The demands of the SOS were adopted by the SDS. ${ }^{4727}$

1374. Upon the establishment of a municipal Serb Crisis Staff in the spring of 1992, Radic announced several measures, including that CSB employees had to pledge loyalty to the SerBiH or lose their jobs; the presidency of the SFRY would be requested to reinforce the JNA Banja Luka Corps and dismiss or transfer JNA officers who had not voted "for Yugoslavia"; and the directors of several public enterprises who pursued "an anti-Serbian policy" would be dismissed. ${ }^{4728}$ Employers in Banja Luka were told to evict non-Serbs from employer-owned apartments in order to make space for families of fallen Serb soldiers. ${ }^{4729}$ Those who attempted to protect non-Serbs in Banja Luka were reprimanded or even replaced. ${ }^{4730}$ To enforce compliance with these orders, mixed patrols of the police, the TO, and the JNA were to take-over control of the roads from the SOS. $^{4731}$

\section{(3) Scheduled Detention Facility C.1.2}

1375. The Indictment refers to the use of Manjača as a detention facility in Banja Luka municipality between 21 April and 18 December $1992 .{ }^{4732}$

\footnotetext{
$4724 \quad$ See Adjudicated Fact 2224.

4725 P2855 (VRS Main Staff report on paramilitary formations, 28 July 1992), p. 4. See also Adjudicated Fact 2223.

4726 See Adjudicated Fact 2225.

4727 P6522 (Article from Glas entitled "SOS is not an illegal organisation”, 4 April 1992), p. 1. See also Adjudicated Fact 2226.

4728 Predrag Radić, P1 (Transcript from Prosecutor v. Krajišnik), T. 7379, 7384; P6524 (Excerpt of Minutes of the $19^{\text {th }}$ Banja Luka Municipal Assembly Session, 23 June 1992), p. 1; D4077 (Witness statement of Anđelko Grahovac dated 23 November 2013), para. 8; D4086 (Witness statement of Nikola Erceg dated 24 November 2013), para. 2; Adjudicated Fact 2226.

$4729 \quad$ Adjudicated Fact 2228.

$4730 \quad$ Adjudicated Fact 2228.

4731 Adjudicated Fact 2226.

4732 In its Final Brief, the Prosecution notes that the evidence led in relation to Manjača shows that it operated as a detention facility from 15 May 1992 until December 1992. See Prosecution Final Brief, Appendix B, p. 2, fn. 23.
} 
(a) Establishment and control

1376. Manjača was located approximately 35 kilometres to the southwest of the town of Banja Luka and about 15 to 20 kilometres to the east of Ključ. ${ }^{4733}$ Manjača was part of a large JNA installation called Mika Bosnić Barracks and had previously served as a military exercise field. ${ }^{4734}$ Manjača consisted of farmland, six large stables, called "pavilions" by the guards, and a number of warehouses. ${ }^{4735}$ There were mines, a fence, and several guard towers around Manjača. ${ }^{4736}$

1377. Around 15 September 1991, the Command of the $5^{\text {th }}$ Corps of the JNA began using Manjača as a camp to hold POWs from the conflict in Croatia. ${ }^{4737}$ In mid-May 1992, the $1^{\text {st }}$ Krajina Corps assumed control of Manjača and from this point until its closure, Manjača remained under VRS control. ${ }^{4738}$ In June 1992, the Command of $1^{\text {st }}$ Krajina Corps was entrusted with the task of establishing a POW camp and assessing the needs for prisoner exchanges. ${ }^{4739}$ In July 1992, Colonel Božidar Popović was appointed as commander of Manjača. ${ }^{4740}$ Predrag

4733 KDZ163, P3717 (Transcript from Prosecutor v. Stanišić \& Župljanin), T. 5258-5260, 5333-5334; P3729 (Pictures and routes of Manjača camp); P3639 (Map entitled "Betornika-Manjača”). See also Adjudicated Fact 562.

4734 P3488 (Witness statement of Atif Džafić undated), para. 100; KDZ026, T. 10392 (17 January 2011) (closed session); P718 (Witness statement of Ahmet Zulić dated 22 February 2010), para. 107; D1846 (Order of the $5^{\text {th }}$ Corps, 13 September 1991), p. 1.

4735 P3488 (Witness statement of Atif Džafić undated), para. 100; P3499 (Drawing of Manjača); P3729 (Pictures and routes of Manjača camp); P3730 (Excerpt of video footage of Manjača camp); P701 (Witness statement of Sakib Muhić dated 11 April 2000), p. 7; KDZ163, P3717 (Transcript from Prosecutor v. Stanišić \& Župljanin), T. 5261-5262; P718 (Witness statement of Ahmet Zulić dated 22 February 2010), para. 107.

4736 Charles McLeod, P712 (Transcript from Prosecutor v. Brđanin), T. 7314; Faik Biščević, P135 (Transcript from Prosecutor v. Brđanin), T. 7081; KDZ163, P3717 (Transcript from Prosecutor v. Stanišić \& Župljanin), T. 5258, 5261-5263, 5332; P3499 (Drawing of Manjača); P3488 (Witness statement of Atif Džafić undated), paras. 100, 103; Mirzet Karabeg, P3303 (Transcript from Prosecutor v. Brđanin), T. 6184-6185; P3549 (Report of the Commission for Inspecting Collection Centres and Other Facilities for Captives in the ARK, 17 August 1992), p. 5; D1846 (Order of the $5^{\text {th }}$ Corps, 13 September 1991), p. 1; P701 (Witness statement of Sakib Muhić dated 11 April 2000), p. 7; D4204 (Witness statement of Radomir Radinković dated 8 December 2013), p. 2; P718 (Witness statement of Ahmet Zulić dated 22 February 2010), para. 107; P3755 (Manjača camp daily report to the $1^{\text {st }}$ Krajina Corps, 9 November 1992), p. 1 (under seal).

4737 P534 (ECMM Report, 3 September 1992), p. 5; KDZ026, T. 10392 (17 January 2011) (closed session); KDZ163, P3717 (Transcript from Prosecutor v. Stanišić \& Župljanin), T. 5257, 5264; D1846 (Order of the $5^{\text {th }}$ Corps, 13 September 1991), p. 1; D1847 (Order of the $5^{\text {th }}$ Corps, 7 January 1992), p. 2; D4204 (Witness statement of Radomir Radinković dated 8 December 2013), p. 1.

4738 P534 (ECMM Report, 3 September 1992), p. 5; Predrag Radić, P1 (Transcript from Prosecutor v. Krajišnik), T. 7614; KDZ163, P3717 (Transcript from Prosecutor v. Stanišić \& Župljanin), T. 5350; Edward Vulliamy, P3777 (Transcript from Prosecutor v. Stakić), T. 8084-8085; Petar Skrbić, P4523 (Transcript from Prosecutor v. Popović et al.), T. 15584; Dragomir Keserović, T. 40993 (8 July 2013); KW540, D4449 (Transcript from Prosecutor v. Stanišić \& Župljanin), T. 3375, 3461 (under seal). See also Adjudicated Fact 562.

4739 D1848 (Order of the $1^{\text {st }}$ Krajina Corps, 15 June 1992), pp. 1-3.

4740 KDZ024, P713 (Transcripts from Prosecutor v. S. Milošević), T. 30084 (under seal); P3491 (Excerpt of Tode Gajić's diary), p. 1; P5472 (Daily Report of Manjača Camp Operational Team, 18-20 August 1992), p. 1; D4204 (Witness statement of Radomir Radinković dated 8 December 2013), p. 2; P3724 (Manjača camp report to the $1^{\text {st }}$ Krajina Corps, 8 August 1992), p. 2; KDZ163, P3717 (Transcript from Prosecutor v. Stanišić \& Župljanin), T. 5261, 5264-5266; P718 (Witness statement of Ahmet Zulić dated 22 February 2010), p. 26; Sakib Muhić, P700 (Transcript from Prosecutor v. Brđanin), T. 8144; P534 (ECMM Report, 3 September 1992), p. 1; D4077 (Witness statement of Anđelko Grahovac dated 23 November 2013), para. 39. See also Adjudicated Fact 564. 
Kovačević, nicknamed Špaga, was Popović’s personal assistant; Kovačević was also in charge of the prison guards. ${ }^{4741}$ Generally, military policemen guarded the detainees inside the camp whereas members of the MUP protected the external boundaries of the camp. ${ }^{4742}$ However, the $1^{\text {st }}$ Krajina Corps Commander and the Ključ and Sanski Most SJBs also agreed that members of the MUP be sent inside Manjača for short periods to assist. ${ }^{473}$ MUP members who were in Manjača were placed under the command of Popović. ${ }^{474}$

1378. The authorities in Manjača drafted reports for the superior command on a weekly basis or more frequently when necessary. ${ }^{4745}$

1379. The number of detainees held at Manjača ranged from approximately 140 to 3,600 at a given time. ${ }^{4746}$ In total, 4,403 detainees passed through the camp. ${ }^{4747}$ The majority of the detainees

4741 Mirzet Karabeg, P3303 (Transcript from Prosecutor v. Brđanin), T. 6188; KDZ074, P709 (Transcript from Prosecutor v. Stakić), T. 2386-2388; P711 (Witness statement of KDZ074 dated 23 September 1994 and 16 May 2001), p. 10; P701 (Witness statement of Sakib Muhić dated 11 April 2000), p. 10; P718 (Witness statement of Ahmet Zulić dated 22 February 2010), p. 31; D4204 (Witness statement of Radomir Radinković dated 8 December 2013), p. 11; Asim Egrlić, P6586 (Transcript from Prosecutor v. Krajišnik), T. 4798.

4742 KDZ163, P3717 (Transcript from Prosecutor v. Stanišić \& Župljanin), T. 5265; P718 (Witness statement of Ahmet Zulić dated 22 February 2010), p. 32; Faik Biščević, P135 (Transcript from Prosecutor v. Brđanin), T. 7081-7082; KDZ492, P3596 (Transcript from Prosecutor v. Krajišnik), T. 3878 (under seal); KDZ024, P713 (Transcript from Prosecutor v. S. Milošević), T. 30085 (under seal).

4743 P3734 (Report of Ključ SJB, 24 June 1992); KDZ163, P3717 (Transcript from Prosecutor v. Stanišić \& Župljanin), T. 5267; KDZ163, P3716 (Transcript from Prosecutor v. Stanišić \& Župljanin), T. 5274 (under seal). These civilian police officers would spend two or three days at Manjača and then return to their SJBs. KDZ163, P3716 (Transcript from Prosecutor v. Stanišić \& Župljanin), T. 5274 (under seal). [REDACTED]. Likewise, Radomir Radinković stated that the civilian police was not allowed inside the camp. However, Radinković, later in his statement, conceded that members of civilian police interrogated the detainees in the camp. See D4204 (Witness statement of Radomir Radinković dated 8 December 2013), pp. 2, 4. The Chamber notes the reliable documentary evidence which indicates that inspectors from Ključ SJB and Sanski Most SJB were sent to Manjača in order to "process" the detainees. See P3734 (Report of Ključ SJB, 24 June 1992); P3736 (Manjača camp daily report to the $1^{\text {st }}$ Krajina Corps, 27 June 1992) (under seal); D3912 (Manjača camp daily report to $1^{\text {st }}$ Krajina Corps, 2 July 1992); D4170 (Witness statement of Mile Dobrijević dated 2 December 2013), para. 14. The Chamber also notes that according to a report compiled by the authorities in Manjača, Radenko Kaurin, who was a policeman, slapped two detainees because they had taken bread from the bread baskets which they had been forced to carry. See P3754 (Manjača camp daily report to the $1^{\text {st }}$ Krajina Corps, 1 November 1992) (under seal). Given this evidence and in light of the inconsistencies displayed by [REDACTED] and Radinković during their respective testimonies, the Chamber rejects their assertion that the civilian police only entered the camp in situations of emergency.

4744 [REDACTED].

4745 D4204 (Witness statement of Radomir Radinković dated 8 December 2013), p. 3.

4746 P534 (ECMM Report, 3 September 1992), p. 2; KDZ048, P678 (Transcript from Prosecutor v. Stakić), T. 3374; Radomir Radinković, T. 45312 (18 December 2013); P701 (Witness statement of Sakib Muhić dated 11 April 2000), pp. 6-8, 10; P3735 (Manjača camp daily report to the $1^{\text {st }}$ Krajina Corps, 26 June 1992), p. 1 (under seal); P3736 (Manjača camp daily report to the $1^{\text {st }}$ Krajina Corps, 27 June 1992) (under seal); P3737 (Manjača camp daily report to the $1^{\text {st }}$ Krajina Corps, 1 July 1992), p. 1 (under seal); P3746 (Manjača camp daily report to the $1^{\text {st }}$ Krajina Corps, 22 July 1992), p. 2 (under seal); P3751 (Manjača camp daily report to the $1^{\text {st }}$ Krajina Corps, 10 August 1992), p. 1 (under seal); P3755 (Manjača camp daily report to the $1^{\text {st }}$ Krajina Corps, 9 November 1992) (under seal); P3725 (ICRC Communication to the Press, 14 November 1992); P3723 (Manjača camp report to $1^{\text {st }}$ Krajina Corps, 14 November 1992), p. 2 (under seal); P3726 (List of detainees at Manjača, 23 November 1992); P3727 (Manjača camp daily report to $1^{\text {st }}$ Krajina Corps, 14 December 1992), e-court p. 2; see Adjudicated Fact 2229. 
at Manjača were Bosnian Muslims, though some Bosnian Croats and very few Bosnian Serbs were also held there. ${ }^{4748}$ For the most part, the detainees were aged between 18 and 60, but there were also a number of minors and elderly individuals. ${ }^{474}$ On several occasions, those in charge of the security and intelligence at the camp proposed that individuals under 18 and over 60 as well as the seriously ill be released; these proposals, however, were largely ignored. ${ }^{4750}$ Several Imams as well as a Catholic priest were also detained in Manjača. ${ }^{4751}$

1380. During mop-up operations in Bosnian Muslim villages, VRS detained the male population and handed them over to the Serb civilian authorities; the majority of such detainees were later brought to Manjača by Serb policemen. ${ }^{4752}$ In some instances detainees were brought to the camp by the MP. ${ }^{4753}$ Often, detainees were taken and held at Manjača without any reason for their detention having been recorded. ${ }^{4754}$ The camp authorities distributed old JNA uniforms to some of

4747 KDZ163, P3717 (Transcript from Prosecutor v. Stanišić \& Župljanin), T. 5345, 5353; KDZ163, T. 20748 (1 November 2011), T. 20769 (2 November 2011).

4748 P534 (ECMM Report, 3 September 1992), para. 21; D4204 (Witness statement of Radomir Radinković dated 8 December 2013), para. 22; P3755 (Manjača camp daily report to the $1^{\text {st }}$ Krajina Corps, 9 November 1992), p. 1 (under seal); see Adjudicated Facts 563, 566.

4749 Radomir Radinković, T. 45317-45319 (18 December 2013); P3750 (Manjača camp daily report to the $1^{\text {st }}$ Krajina Corps, 7 August 1992), p. 2 (under seal); P3549 (Report of the Commission for Inspecting Collection Centres and Other Facilities for Captives in the ARK, 17 August 1992), p. 5; KDZ163, P3717 (Transcript from Prosecutor v. Stanišić \& Župljanin), T. 5282, 5289, 5298, 5357, 5387; KDZ474, P3395 (Transcript from Prosecutor v. Brđanin), T. 7761, 7808 (under seal). P718 (Witness statement of Ahmet Zulić dated 22 February 2010), para. 116; P3733 (Manjača camp daily report to the $1^{\text {st }}$ Krajina Corps, 22 June 1992), p. 1 (under seal); P3737 (Manjača camp daily report to the $1^{\text {st }}$ Krajina Corps, 1 July 1992), p. 2 (under seal); P3739 (Manjača camp daily report to the $1^{\text {st }}$ Krajina Corps, 5 July 1992), p. 1 (under seal).

4750 P3740 (Manjača camp daily report to the $1^{\text {st }}$ Krajina Corps, 8 July 1992), p. 1 (under seal); P3739 (Manjača camp daily report to the $1^{\text {st }}$ Krajina Corps, 5 July 1992) (under seal); P3733 (Manjača camp daily report to the $1^{\text {st }}$ Krajina Corps, 22 June 1992), p. 1 (under seal); P3737 (Manjača camp daily report to the $1^{\text {st }}$ Krajina Corps, 1 July 1992), p. 2 (under seal); KDZ163, P3717 (Transcript from Prosecutor v. Stanišić \& Župljanin), T. 5289, 5291; P3738 (Manjača camp daily report to the $1^{\text {st }}$ Krajina Corps, 4 July 1992), p. 1 (under seal); P3751 (Manjača camp daily report to the $1^{\text {st }}$ Krajina Corps, 10 August 1992) (under seal); D1852 (Report of Manjača camp sent to $1^{\text {st }}$ Krajina Corps, 12 August 1992) (under seal); D1862 (Manjača camp daily report to $1^{\text {st }}$ Krajina Corps, 3 July 1992) (under seal).

4751 Radomir Radinković, T. 45329 (18 December 2013); KDZ026, P2089 (Transcript from Prosecutor v. Stakić), T. 1905 (under seal); KDZ163, P3717 (Transcript from Prosecutor v. Stanišić \& Župljanin), T. 5360; P3738 (Manjača camp daily report to the $1^{\text {st }}$ Krajina Corps, 4 July 1992) (under seal); P3751 (Manjača camp daily report to the $1^{\text {st }}$ Krajina Corps, 10 August 1992), p. 1 (under seal).

4752 KDZ163, P3717 (Transcript from Prosecutor v. Stanišić \& Župljanin), T. 5275; D4204 (Witness statement of Radomir Radinković dated 8 December 2013), p. 7; KW545, T. 46955-46957 (12 February 2014) (closed session); KW540, D4449 (Transcript from Prosecutor v. Stanišić \& Župljanin), T. 3377-3378, 3386, 3388, 3392-3393 (under seal).

4753 KDZ163, P3717 (Transcript from Prosecutor v. Stanišić \& Župljanin), T. 5335; D4204 (Witness statement of Radomir Radinković dated 8 December 2013), p. 7.

4754 KDZ163, P3717 (Transcript from Prosecutor v. Stanišić \& Župljanin), T. 5276, 5311, 5354; KDZ163, T. 20737-20738 (1 November 2011) (private session); P3723 (Manjača camp report to $1^{\text {st }}$ Krajina Corps, 14 November 1992), p. 2 (under seal); Christian Nielsen, T. 16285 (7 July 2011). Colonel Stevilović, a military police officer at Manjača, attempted to stop the influx of undocumented detainees from Ključ. [REDACTED]. On 19 August 1992, Župljanin ordered SJBs to create a file on every individual that had been transferred to Manjača by the police. D1864 (Order of Banja Luka CSB, 19 August 1992). On 23 August 1992, the Chief of the Prijedor SJB reported that the documentation for the detainees transferred from Omarska to Manjača had been forwarded to the commander of Manjača . D1866 (Prijedor SJB dispatch to Banja Luka CSB, 23 August 
the detainees. ${ }^{4755}$ While both the VRS and the Bosnian Serb civilian authorities described Manjača as a camp for POWs, ${ }^{4756}$ documents sent from Manjača to the Command of $1^{\text {st }}$ Krajina Corps do not refer to the detainees as combatants. ${ }^{4757}$

1381. In mid-1992, detention facilities such as Omarska were closed and the detainees were sent to Manjača. ${ }^{4758}$

1382. Sometime during the first week of June 1992, members of the Sanski Most SJB and around ten SOS members transported a group of approximately 140 male detainees from Hasan Kikić sports hall, in Sanski Most municipality, to Manjača. ${ }^{4759}$ On or about 7 June 1992, Serb members of the reserve police took approximately 400 detainees from Sitnica School, in Ključ municipality, to Manjača on foot. ${ }^{4760}$ Sometime before 13 June 1992, the VRS transferred about 900 individuals, most of them Bosnian Muslims, from a prison in Stara Gradiška, in Croatia, to Manjača. ${ }^{4761}$ On or about 25 June 1992, Bosnian Serb policemen from Ključ, took a number of detainees from Ključ SJB to Manjača. ${ }^{4762}$

1992). On 27 August 1992, the Chief of the Sanski Most SJB sent to Manjača a list of detainees as well as official notes in relation to some of them. D1867 (Sanski Most SJB dispatch, 27 August 1992).

4755 KDZ163, P3717 (Transcript from Prosecutor v. Stanišić \& Župljanin), T. 5318-5319; P3500 (Photograph of detainees at Manjača); P3488 (Witness statement of Atif Džafić undated), para. 113; P3756 (Excerpt from video clip from Banja Luka TV, with transcript), p. 1. Džafić who had been detained in Manjača, stated that the distribution of old JNA uniforms was a ploy by the camp authorities to make the detainees look as if they had been Bosnian Muslim soldiers. P3488 (Witness statement of Atif Džafić undated), para. 113.

4756 Edward Vulliamy, P3777 (Transcript from Prosecutor v. Stakić), T. 7923; KDZ474, T. 19335 (21 September 2011) (closed session); P534 (ECMM Report, 3 September 1992), p. 1; Dragomir Keserović, T. 42158 (29 July 2013); D4077 (Witness statement of Anđelko Grahovac dated 23 November 2013), para. 39; KW545, D4328 (Transcript from Prosecutor v. Stanišić \& Župljanin) T. 26203 (under seal).

4757 P3747 (Manjača camp daily report to the $1^{\text {st }}$ Krajina Corps, 23 July 1992), p. 1 (under seal); P3741 (Manjača camp daily report to the $1^{\text {st }}$ Krajina Corps, 9 July 1992), p. 1 (under seal); P3740 (Manjača camp daily report to the $1^{\text {st }}$ Krajina Corps, 8 July 1992), p. 1 (under seal); P3746 (Manjača camp daily report to the $1^{\text {st }}$ Krajina Corps, 22 July 1992), p. 1 (under seal); P3753 (Manjača camp daily report to the $1^{\text {st }}$ Krajina Corps, 22 August 1992), p. 1 (under seal).

4758 Christian Nielsen, T. 16285 (7 July 2011); Atif Džafić, T. 19747 (30 September 2011).

4759 Mirzet Karabeg, P3303 (Transcript from Prosecutor v. Brđanin), T. 6164, 6252-6253; P701 (Witness statement of Sakib Muhić dated 11 April 2000), pp. 5-6; Sakib Muhić, P700 (Transcript from Prosecutor v. Brđanin), T. 8105, 8122-8123, 8131-8132; P3327 (Order of Sanski Most Crisis Staff, 6 June 1992); Faik Biščević, P122 (Transcript from Prosecutor v. Krajišnik), T. 5537; Faik Biščević, P135 (Transcript from Prosecutor v. Brđanin), T. 7095; D4363 (Witness statement of Slobodan Jurišić dated 8 February 2014), para. 39; Dušan Mudrinić, T. 47393 (19 February 2014); D470 (CSB Banja Luka Report concerning collection centres, undated), e-court pp. 8, 16. See also Adjudicated Fact 583. See para. 2003.

4760 P3488 (Witness statement of Atif Džafić undated), paras. 95-96; KDZ056, P686 (Transcript from Prosecutor v. Brđanin), T. 10354-10355; KDZ163, P3717 (Transcript from Prosecutor v. Stanišić \& Župljanin), T. 5259, 5333-5334. It took the detainees seven or eight hours to reach Manjača from Sitnica school. P3488 (Witness statement of Atif Džafić undated), paras. 96-101.

4761 KDZ163, P3717 (Transcript from Prosecutor v. Staniš̌ić \& Župljanin), T. 5279; P3718 (1 ${ }^{\text {st }}$ Krajina Corps combat report, 13 June 1992), p. 2; Asim Egrlić, P6586 (Transcript from Prosecutor v. Krajišnik), T. 47954796.

4762 KDZ024, P713 (Transcript from Prosecutor v. Brđanin), T. 9158, 9162-9163, 9216 (under seal); KDZ024, P713 (Transcript from Prosecutor v. S. Milošević), T. 30084-30085 (under seal). 
1383. On 7 July 1992, under the escort of the civilian police from Sanski Most, a convoy of trucks with approximately 500 detainees from Betonirka factory garage, Krings Hall, and Hasan Kikić sports hall, arrived at Manjača. ${ }^{4763}$

1384. On 6 August 1992, the $1^{\text {st }}$ Krajina Corps received reports that up to 1,000 detainees were going to be transferred from Omarska, in Prijedor municipality, to Manjača and that they were expected to arrive in the afternoon. ${ }^{4764}$ That same day, at around 10 p.m., about 20 Autoprevoz buses, transporting approximately 1,300 detainees arrived at the gates of Manjača; they were escorted by two armoured personnel carriers. ${ }^{4765}$ During their transportation from Omarska to Manjača, the prisoners had been guarded by members of the intervention squad from Prijedor SJB. ${ }^{4766}$ However, Popović did not allow the detainees to enter the camp and instead ordered that they stay on the buses for the night. ${ }^{4767}$ That same day, Lieutenant Colonel Stevan Bogojević, the Chief of Intelligence and Security at Manjača, complained that a great number of the detainees from Omarska could not be characterised as "prisoners of war" and requested that such individuals be selected and eventually released. ${ }^{4768}$ In the morning of 7 August 1992, the detainees from

4763 Faik Biščević, P135 (Transcript from Prosecutor v. Brđanin), T. 7096; Faik Biščević, P122 (Transcript from Prosecutor v. Krajišnik), T. 5537; Mirzet Karabeg, P3303 (Transcript from Prosecutor v. Brđanin), T. 6175; P3747 (Manjača camp daily report to the $1^{\text {st }}$ Krajina Corps, 23 July 1992), p. 1 (under seal); P3740 (Manjača camp daily report to the $1^{\text {st }}$ Krajina Corps, 8 July 1992) (under seal); KDZ163, P3717 (Transcript from Prosecutor v. Stanišić \& Župljanin), T. 5293-5294; P3773 (Witness statement of KDZ532 dated 31 October 2011), para. 28 (under seal); Rajif Begić, P691 (Transcript from Prosecutor v. Krajišnik), T. 2999, 3019 ; P692 (Witness statements of Rajif Begić dated 15 March 2000), e-court p. 7; Ahmet Zulić, T. 1030 (13 April 2010); KW545, D4328 (Transcript from Prosecutor v. Stanišić \& Župljanin) T. 26130 (under seal); D4170 (Witness statement of Mile Dobrijević dated 2 December 2013), para. 14. [REDACTED].

4764 P3757 (Official note from the Security Centre in Banja Luka, 10 August 1992), p. 1 (under seal).

4765 KDZ392, P707 (Transcript from Prosecutor v. Kvočka), T. 2749-2750 (under seal); KDZ048, P678 (Transcript from Prosecutor v. Stakić), T. 3370, 3376, 3500; KDZ024, P713 (Transcript from Prosecutor v. Brđanin), T. 9218 (under seal); KDZ074, P709 (Transcript from Prosecutor v. Stakić), T. 2340-2341; P711 (Witness statement of KDZ074 dated 23 September 1994 and 16 May 2001), p. 9; P3757 (Official note from the Security Centre in Banja Luka, 10 August 1992), p. 1 (under seal); KDZ026, P2089 (Transcript from Prosecutor v. Stakić), T. 1839, 1928, 1940 (under seal); KDZ026, T. 10323, 10391, 10393, 10421 (17 January 2011) (closed session); P3719 ( $1^{\text {st }}$ Krajina Corps combat report, 7 August 1992), p. 2; P2 (Predrag Radić's interview with OTP, 16 July 2001), p. 28; D4204 (Witness statement of Radomir Radinković dated 8 December 2013), p. 6; P3502 (Photograph of Manjača's main entrance); Mevludin Sejmenović, T. 20496 (27 October 2011); P636 (ECMM Report, 3 September 1992), p. 2; KW609, D4246 (Transcript from Prosecutor v. Stanišić \& Župljanin), T. 16770-16771; D4086 (Witness statement of Nikola Erceg dated 24 November 2013), para. 90; Željko Mejakić, T. 44216, 44259, 44273, 44281 (29 November 2013). See also Adjudicated Fact 2489.

4766 KDZ048, P678 (Transcript from Prosecutor v. Stakić), T. 3370; KDZ026, T. 10322, 10329 (17 January 2011) (closed session); KDZ163, P3717 (Transcript from Prosecutor v. Stanišić \& Župljanin), T. 5309; D4204 (Witness statement of Radomir Radinković dated 8 December 2013), p. 12. For further detail on the intervention squad, see para. 1587.

4767 KDZ048, P678 (Transcript from Prosecutor v. Stakić), T. 3373; P711 (Witness statement of KDZ074 dated 23 September 1994 and 16 May 2001), p. 9; KDZ026, P2089 (Transcript from Prosecutor v. Stakić), T. 1932 (under seal); KDZ026, T. 10322-10323 (17 January 2011) (closed session).

4768 P3773 (Witness statement of KDZ532 dated 31 October 2011), para. 27 (under seal); P3720 ( $1^{\text {st }}$ Krajina Corps report re selection of war prisoners in Manjača camp, 6 August 1992); KDZ163, T. 20737, 20739-20740 (1 November 2011) (private session). On 17 August 1992, the Chief of Prijedor SJB forwarded the personal details of 402 detainees and promised that the details of the remaining detainees would be sent to Manjača within a week. See P3752 (Report of Prijedor SJB, 17 August 1992). 
Omarska were taken from the buses, and made to sit in a nearby field. ${ }^{4769}$ Subsequently a roll call of the detainees was made and they were taken inside Manjača and registered. ${ }^{470}$ Two weeks later, between 170 and 180 additional individuals were transferred from Omarska to Manjača. ${ }^{4771}$

1385. On or about 28 August 1992, policemen in blue uniforms transferred 13 detainees from the SJB building and prison in Sanski Most and 36 detainees from Krings Hall to Manjača. ${ }^{4772}$

1386. Apart from these instances, detainees continued to be brought to Manjača from detention facilities in Sanski Most and Ključ; detainees were also brought to Manjača from detention facilities in Bosanska Dubica, Doboj, Derventa, Glamoč, Kotor Varoš, and Jajce. ${ }^{4773}$

\section{(b) Conditions of detention and treatment of detainees}

1387. The food provided to the detainees in Manjača was insufficient and consisted for the most part of a thin broth and a slice of bread twice a day. ${ }^{4774}$ As a result, many detainees lost a

4769 KDZ026, P2089 (Transcript from Prosecutor v. Stakić), T. 1932, 1940 (under seal).

4770 KDZ048, P678 (Transcript from Prosecutor v. Stakić), T. 3498; KDZ026, P2089 (Transcript from Prosecutor v. Stakić), T. 1932 (under seal); D4204 (Witness statement of Radomir Radinković dated 8 December 2013), p. 7.

4771 KDZ048, P678 (Transcript from Prosecutor v. Stakić), T. 3371; P711 (Witness statement of KDZ074 dated 23 September 1994 and 16 May 2001), p. 10; KDZ026, T. 10421 (17 January 2011) (closed session); Željko Mejakić, T. 44281-44282 (29 November 2013). But see KDZ163's assertion that after 7 August 1992, no more detainees were transferred from Omarska to Manjača. KDZ163, T. 20736 (1 November 2011).

4772 Mirzet Karabeg, P3303 (Transcript from Prosecutor v. Brđanin), T. 6182-6183, 6258; Faik Biščević, P122 (Transcript from Prosecutor v. Krajišnik), T. 5536; Faik Biščević, P135 (Transcript from Prosecutor v. Brđanin), T. 7077-7081; KDZ492, P3596 (Transcript from Prosecutor v. Krajišnik), T. 3858 (under seal).

4773 D3911 (Report on the work of Sanski Most SJB, July 1992), p. 7; P3507 (List of Ključ SJB of persons being sent to Manjača, 22 July 1992); Radomir Radinković, T. 45312-45313 (18 December 2013); P3753 (Manjača camp daily report to the $1^{\text {st }}$ Krajina Corps, 22 August 1992), p. 1 (under seal); P3749 (Manjača camp daily report to the $1^{\text {st }}$ Krajina Corps, 29 July 1992), p. 2 (under seal); P3740 (Manjača camp daily report to the $1^{\text {st }}$ Krajina Corps, 8 July 1992), p. 1 (under seal); P3739 (Manjača camp daily report to the $1^{\text {st }}$ Krajina Corps, 5 July 1992) (under seal); P3736 (Manjača camp daily report to the $1^{\text {st }}$ Krajina Corps, 27 June 1992) (under seal); P3732 (List of detainees from Ključ Municipality, 19 June 1992); P3735 (Manjača camp daily report to the $1^{\text {st }}$ Krajina Corps, 26 June 1992), p. 1 (under seal); P3737 (Manjača camp daily report to the $1^{\text {st }}$ Krajina Corps, 1 July 1992), p. 1 (under seal); P3549 (Report of the Commission for Inspecting Collection Centres and Other Facilities for Captives in the ARK, 17 August 1992), p. 5; Sakib Muhić, P700 (Transcript from Prosecutor v. Brđanin), T. 8138; D3105 (Witness statement of Slobodan Avlijaš dated 9 March 2013), para. 28; KDZ163, P3717 (Transcript from Prosecutor v. Stanišić \& Župljanin), T. 5279; P3718 (1 ${ }^{\text {st }}$ Krajina Corps combat report, 13 June 1992), p. 2; P4258 (Map of ARK); P722 (Third book of Ahmet Zulić's diary), p. 18; D1868 (Report of Kotor Varoš Military Post to Manjača camp, 10 December 1992); P3723 (Manjača camp report to $1^{\text {st }}$ Krajina Corps, 14 November 1992), p. 2 (under seal); D1861 (Manjača camp daily report to $1^{\text {st }}$ Krajina Corps, 24 June 1992), p. 2; D1863 (List of persons sent to the Manjača camp, 20 July 1992); Dragomir Keserović, T. 42015 (25 July 2013). See also Adjudicated Fact 565.

4774 KDZ024, P713 (Transcript from Prosecutor v. Brđanin), T. 9166 (under seal); P3488 (Witness statement of Atif Džafić undated), para. 102; P3758 (Letter from Radovan Karadžić to Branko Đerić, attaching an ICRC report, 7 August 1992), e-court p. 5; Sakib Muhić, P700 (Transcript from Prosecutor v. Brđanin), T. 8142; P692 (Witness statements of Rajif Begić dated 15 March 2000), e-court p. 7; Ahmet Zulić, T. 1032 (13 April 2010); KDZ163, P3717 (Transcript from Prosecutor v. Stanišić \& Župljanin), T. 5400, 5402; D1858 (Manjača camp daily report to $1^{\text {st }}$ Krajina Corps, 18 June 1992), p. 2; Faik Biščević, P135 (Transcript from Prosecutor v. Brđanin), T. 7084-7086; Dragomir Keserović, T. 42015 (25 July 2013); see Adjudicated Fact 569. But see Radinković's claim that adequate food was provided to the detainees. D4204 (Witness statement of Radomir Radinković dated 8 December 2013), pp. 7, 10, 11; Radomir Radinković, T. 45316 (18 December 2013). 
substantial amount of weight. ${ }^{4775}$ Some became so thin that they were unable to walk or even stand. ${ }^{4776}$ Some detainees resorted to eating grass. ${ }^{4777}$ With assistance from the ICRC and Merhamet, a local Bosnian Muslim humanitarian organisation, the food and the general situation improved slightly sometime after August 1992. ${ }^{4778}$

1388. There was also insufficient potable water at Manjača. ${ }^{479}$ During July and August 1992 , twice each day, cups of water were provided; however, four detainees would have to divide one cup among themselves. ${ }^{4780}$ There was no water for the purposes of personal hygiene. ${ }^{4781}$ If they tried to collect rain water, the camp guards would beat them. ${ }^{4782}$ At one point, camp authorities refused to provide diesel for trucks that pumped water and transported it to the camp. ${ }^{4783}$ From this point on,

4775 KDZ024, P713 (Transcript from Prosecutor v. Brđanin), T. 9166, 9169 (under seal); P3488 (Witness statement of Atif Džafić undated), para. 123; P3758 (Letter from Radovan Karadžić to Branko Đerić, attaching an ICRC report, 7 August 1992), e-court p. 6; Sakib Muhić, P700 (Transcript from Prosecutor v. Brđanin), T. 8144; P701 (Witness statement of Sakib Muhić dated 11 April 2000), pp. 8-9; KDZ163, P3717 (Transcript from Prosecutor v. Stanišić \& Župljanin), T. 5400; P3695 (Excerpt from video clip of Manjača camp and interview with Radovan Karadžić); see Adjudicated Fact 569. One detainee lost approximately 50 kilograms. Sakib Muhić, P700 (Transcript from Prosecutor v. Brđanin), T. 8144; P701 (Witness statement of Sakib Muhić dated 11 April 2000), pp. 8-9. On 23 September 1992, the ICRC reported that in Manjača there were 300 detainees whose body mass index was below 17. D1874 (ICRC Work Report, 23 September 1992), p. 3.

4776 Mirzet Karabeg, P3303 (Transcript from Prosecutor v. Brđanin), T. 6186.

4777 P701 (Witness statement of Sakib Muhić dated 11 April 2000), p. 9; P718 (Witness statement of Ahmet Zulić dated 22 February 2010), p. 32; P722 (Third book of Ahmet Zulić's diary), pp. 6, 10; see Adjudicated Fact 569. According to a report drawn up by the authorities in Manjača, a prisoner suffered from mushroom poisoning. P3755 (Manjača camp daily report to the $1^{\text {st }}$ Krajina Corps, 9 November 1992) (under seal).

4778 Charles McLeod, P712 (Transcript from Prosecutor v. Brđanin), T. 7316; Mirzet Karabeg, P3303 (Transcript from Prosecutor v. Brđanin), T. 6189; KDZ163, P3717 (Transcript from Prosecutor v. Stanišić \& Župljanin), T. 5346, 5350; Sakib Muhić, P700 (Transcript from Prosecutor v. Brđanin), T. 8141; Faik Biščević, P135 (Transcript from Prosecutor v. Brđanin), T. 7083-7084; Predrag Radić, P1 (Transcript from Prosecutor v. Krajišnik), T. 7615; KDZ024, P713 (Transcript from Prosecutor v. Brđanin), T. 9166 (under seal). On several occasions, Merhamet delivered meat to the camp but the guards took the meat home. Faik Biščević, P135 (Transcript from Prosecutor v. Brđanin), T. 7085. If the camp guards at Manjača wanted to demonstrate to a delegation that the detainees were well-fed, they would slaughter calves and present them as meals for the detainees; however, the detainees would not actually receive such meals, which would instead be served to the command staff. Sakib Muhić, P700 (Transcript from Prosecutor v. Brđanin), T. 8143.

4779 P692 (Witness statements of Rajif Begić dated 15 March 2000), e-court p. 7; P721 (Second book of Ahmet Zulić's diary), p. 8; P722 (Third book of Ahmet Zulić's diary), p. 9; Dragomir Keserović, T. 42015 (25 July 2013). But see D4204 (Witness statement of Radomir Radinković dated 8 December 2013), p. 7. Given the large body of accepted evidence to the contrary, the Chamber rejects Radinković's assertion that "sufficient quantities of drinking water were provided" to the detainees.

4780 Ahmet Zulić, T. 1032 (13 April 2010); P692 (Witness statements of Rajif Begić dated 15 March 2000), e-court p. 7; P721 (Second book of Ahmet Zulić's diary), p. 8; P722 (Third book of Ahmet Zulić's diary), p. 9; P718 (Witness statement of Ahmet Zulić dated 22 February 2010), p. 30; P3488 (Witness statement of Atif Džafić undated), para. 102.

4781 P3488 (Witness statement of Atif Džafić undated), para. 102; Mirzet Karabeg, P3303 (Transcript from Prosecutor v. Brđanin), T. 6186; P692 (Witness statements of Rajif Begić dated 15 March 2000), e-court p. 7.

4782 Mirzet Karabeg, P3303 (Transcript from Prosecutor v. Brđanin), T. 6187; P692 (Witness statements of Rajif Begić dated 15 March 2000), e-court p. 7.

4783 D1876 (ICRC Work Report, 5-18 November 1992), p. 1. 
the only available water originated from a nearby lake, and its poor quality caused intestinal and stomach problems among the detainees. ${ }^{4784}$

1389. Initially, there were a number of barrels in each stable which served as toilets; later, however, the detainees dug holes outside and used them as toilets. ${ }^{4785}$

1390. Faik Biščević who was a dentist and three detainees who were doctors by profession, namely, Emir Kapetanović, Enis Šabanović and Mehmed Derviškadić, as well as a Serb nurse, staffed a medical clinic; this clinic, however, suffered from a severe shortage of medicine and supplies and could not provide adequate medical care to the detainees. ${ }^{4786}$ At times, the guards refused to allow the sick detainees to go to the clinic for up to a week. ${ }^{4787}$ Some detainees did not receive any medical treatment for their pre-existing conditions or the injuries they sustained from the beatings. ${ }^{4788}$

1391. Initially, the detainees were unable to contact their families; later however, the ICRC facilitated the sending and receiving of messages between the detainees and their family members. $^{4789}$

4784 Asim Egrlić, P6586 (Transcript from Prosecutor v. Krajišnik), T. 4799; D1876 (ICRC Work Report, 518 November 1992), p. 1; P722 (Third book of Ahmet Zulić's diary), pp. 8, 16; D4204 (Witness statement of Radomir Radinković dated 8 December 2013), p. 11; Radomir Radinković, T. 45316-45317 (18 December 2013); Faik Biščević, P135 (Transcript from Prosecutor v. Brđanin), T. 7086-7087. See Adjudicated Facts 570, 571. Diarrhoea and constipation were rife in the camp. P722 (Third book of Ahmet Zulić's diary), pp. 8, 16. On 27 July 1992, the $1^{\text {st }}$ Krajina Corps Assistant Commander for Logistics was informed that the bacteriological tests of water in Manjača had shown unsatisfactory results and that repairs needed to be conducted. P3748 (Request of $1^{\text {st }}$ Krajina Corps, 27 July 1992).

4785 P3488 (Witness statement of Atif Džafić undated), para. 102.

4786 P534 (ECMM Report, 3 September 1992), p. 3; KDZ024, P713 (Transcript from Prosecutor v. Brđanin), T. 9163, 9167 (under seal); P3488 (Witness statement of Atif Džafić undated), para. 104; Asim Egrlić, P6586 (Transcript from Prosecutor v. Krajišnik), T. 4826; Mirzet Karabeg, P3303 (Transcript from Prosecutor v. Brđanin), T. 6184; D1874 (ICRC Work Report, 23 September 1992), p. 4; KDZ163, P3717 (Transcript from Prosecutor v. Stanišić \& Župljanin), T. 5276-5277; P3758 (Letter from Radovan Karadžić to Branko Đerić, attaching an ICRC report, 7 August 1992), e-court p. 7; D4204 (Witness statement of Radomir Radinković dated 8 December 2013), p. 7; Faik Biščević, P135 (Transcript from Prosecutor v. Brđanin), T. 7087-7088; see Adjudicated Fact 572 .

4787 P3488 (Witness statement of Atif Džafić undated), para. 105.

4788 Sakib Muhić, P700 (Transcript from Prosecutor v. Brđanin), T. 8137-8138; P534 (ECMM Report, 3 September 1992), p. 4; KDZ024, P713 (Transcript from Prosecutor v. Brđanin), T. 9166 (under seal); P3488 (Witness statement of Atif Džafić undated), para. 105; KDZ163, P3717 (Transcript from Prosecutor v. Stanišić \& Župljanin), T. 5400; D1862 (Manjača camp daily report to $1^{\text {st }}$ Krajina Corps, 3 July 1992) (under seal); P3758 (Letter from Radovan Karadžić to Branko Đerić, attaching an ICRC report, 7 August 1992), e-court pp. 6-7; D1869 (Logbook of patients at the Manjača camp, 11 June-23 August 1992).

4789 D1858 (Manjača camp daily report to $1^{\text {st }}$ Krajina Corps, 18 June 1992), p. 2; P5472 (Daily Report of Manjača Camp Operational Team, 18-20 August 1992), p. 1 (reporting that ICRC delegates were informed that "in the future we would not allow messages to be received or sent, only when they are carrying out their regular camp inspection."). 
1392. The detainees were kept in large, crowded stables meant for livestock, where they sat or laid down for most of the day. ${ }^{4790}$ Generally, detainees could not leave the stables freely, and the stable doors were kept closed. ${ }^{4791}$

1393. During the initial period after the establishment of the camp, there were not enough blankets in the stables for all of the detainees and some had to sleep on concrete; however, ICRC provided everyone with blankets in August 1992. ${ }^{4792}$ Except for some old JNA uniforms referred to above, the camp authorities at Manjača did not provide clothing; detainees normally wore the same clothes they arrived in throughout their detention. ${ }^{4793}$ Furthermore, Manjača had insufficient hygiene and was infested with lice. ${ }^{4794}$ Leaking roofs, wet blankets, and persistent cold became part of the detainees' lives in the later months of $1992 .{ }^{4795}$

1394. Detainees were also forced to work. ${ }^{4796}$ They usually worked for eight to ten hours daily. $^{4797}$

4790 Faik Biščević, P135 (Transcript from Prosecutor v. Brđanin), T. 7082-7083; Charles McLeod, P712 (Transcript from Prosecutor v. Brđanin), T. 7314, 7317; KDZ163, P3717 (Transcript from Prosecutor v. Stanišić \& Župljanin), T. 5262; KDZ026, T. 10325 (17 January 2011) (closed session); P3322 (Photograph of interior of Manjača); Radomir Radinković, T. 45313-45314 (18 December 2013); P3488 (Witness statement of Atif Džafić undated), para. 129; Atif Džafić, T. 19743 (30 September 2011); P604 (Photograph of detainees in Manjača); P701 (Witness statement of Sakib Muhić dated 11 April 2000), pp. 7-8; Ahmet Zulić, T. 1031 (13 April 2010); Adjudicated Fact 567.

4791 P701 (Witness statement of Sakib Muhić dated 11 April 2000), p. 9.

4792 P5472 (Daily Report of Manjača Camp Operational Team, 18-20 August 1992), p. 1; Mirzet Karabeg, P3303 (Transcript from Prosecutor v. Brđanin), T. 6186, 6259; KDZ074, P709 (Transcript from Prosecutor v. Stakić), T. 2395; P692 (Witness statements of Rajif Begić dated 15 March 2000), e-court p. 7; Sakib Muhić, P700 (Transcript from Prosecutor v. Brđanin), T. 8169; P3549 (Report of the Commission for Inspecting Collection Centres and Other Facilities for Captives in the ARK, 17 August 1992), p. 5; Predrag Radić, P1 (Transcript from Prosecutor v. Krajišnik), T. 7615. See also Adjudicated Fact 567.

4793 Charles McLeod, P712 (Transcript from Prosecutor v. Brđanin), T. 7317, 7335; KDZ163, P3717 (Transcript from Prosecutor v. Stanišić \& Župljanin), T. 5319, 5400; P3758 (Letter from Radovan Karadžić to Branko Đerić re ICRC visit, 7 August 1992), e-court p. 6. Between 17 September and 5 October 1992, the ICRC provided socks, shoes, hats, and underwear for all the detainees. D1875 (ICRC Work Report, 6 October 1992), p. 4.

4794 P3488 (Witness statement of Atif Džafić undated), para. 106; Mirzet Karabeg, P3303 (Transcript from Prosecutor v. Brđanin), T. 6186; KDZ163, P3717 (Transcript from Prosecutor v. Stanišić \& Župljanin), T. 5402; P3758 (Letter from Radovan Karadžić to Branko Đerić, attaching an ICRC report, 7 August 1992), ecourt p. 5. See also Adjudicated Fact 568.

4795 D1876 (ICRC Work Report, 5-18 November 1992), p. 1.

4796 P5549 (Request of $1^{\text {st }}$ Krajina Corps for POW's from Manjača camp, 24 September 1992); P534 (ECMM Report, 3 September 1992), p. 2; KDZ024, P713 (Transcript from Prosecutor v. Brđanin), T. 9167, 9228 (under seal); Faik Biščević, P135 (Transcript from Prosecutor v. Brđanin), T. 7093; P3488 (Witness statement of Atif Džafić undated), paras. 111, 128; P718 (Witness statement of Ahmet Zulić dated 22 February 2010), para. 127; P722 (Third book of Ahmet Zulić's diary), pp. 5-6, 9, 11, 17-18; D4204 (Witness statement of Radomir Radinković dated 8 December 2013), p. 6; D4205 (Order of $1^{\text {st }}$ Krajina Corps, 10 October 1992); KDZ163, P3717 (Transcript from Prosecutor v. Stanišić \& Župljanin), T. 5263-5264, 5305, 5351. On 22 September 1992, Colonel Vukelić authorised the daily use of 60 detainees in Manjača for work on a co-operative farm in Banja Luka. See D1873 (Order of the $1^{\text {st }}$ Krajina Corps to the Manjača camp command, 22 September 1992). Though the Chamber received evidence that the detainees in Manjača were forced to work, this work is not covered by the Indictment as it was not conducted at the frontlines and did not include the digging of trenches. 
1395. On arrival at Manjača, the detainees were ordered to lower their heads and keep their arms behind their backs with hands clasped, a camp rule that remained in effect throughout their detention. ${ }^{4798}$ The detainees were also made to hand in their money, gold, and other valuables. ${ }^{4799}$ The guards searched the stables and detainees frequently, appropriating any valuables they found while beating the detainees. ${ }^{4800}$

1396. The detainees were required to stand up whenever Kovačević entered the stables; these visits at times lasted a few hours and caused the weaker detainees to faint and fall to the ground. ${ }^{4801}$

1397. During the transfer of approximately 1,300 detainees from Omarska to Manjača on 6 August 1992, some of those detainees were severely beaten and humiliated by the guards who had accompanied them on the buses. ${ }^{4802}$ On one occasion, one of the buses stopped in front of a café at which point a number of drunken soldiers boarded the bus and beat the detainees inside. ${ }^{4803}$ The detainees were forced to sing "Chetnik songs". ${ }^{4804}$ They were also prevented from opening the windows of the buses. ${ }^{4805}$ Due to the intense heat, an elderly detainee died on the way to Manjača. ${ }^{4806}$ Upon arriving at Manjača, the detainees were forced to stay on the buses; despite the high temperature outside, the guards kept the heating on and closed the doors of the buses. ${ }^{4807}$ During the entire night, the guards called out the names of detainees, took them outside and

4797 P718 (Witness statement of Ahmet Zulić dated 22 February 2010), para. 127; D4205 (Order of $1^{\text {st }}$ Krajina Corps, 10 October 1992).

4798 KDZ024, P713 (Transcript from Prosecutor v. Brđanin), T. 9163 (under seal); P3488 (Witness statement of Atif Džafić undated), para. 124; KDZ026, P2089 (Transcript from Prosecutor v. Stakić), T. 1940 (under seal); Rajif Begić, P691 (Transcript from Prosecutor v. Krajišnik), T. 3000; KDZ163, P3717 (Transcript from Prosecutor v. Stanišić \& Župljanin), T. 5317-5318; P718 (Witness statement of Ahmet Zulić dated 22 February 2010), para. 97; Charles McLeod, P712 (Transcript from Prosecutor v. Brđanin), T. 7317-7318; P3756 (Excerpt from video clip from Banja Luka TV, with transcript).

4799 Mirzet Karabeg, P3303 (Transcript from Prosecutor v. Brđanin), T. 6184-6185.

4800 Faik Biščević, P135 (Transcript from Prosecutor v. Brđanin), T. 7081; P3488 (Witness statement of Atif Džafić undated), para. 101; Mirzet Karabeg, P3303 (Transcript from Prosecutor v. Brđanin), T. 6188; KDZ074, P709 (Transcript from Prosecutor v. Stakić), T. 2387.

$4801 \quad$ KDZ074, P709 (Transcript from Prosecutor v. Stakić), T. 2386-2387.

4802 KDZ074, P709 (Transcript from Prosecutor v. Stakić), T. 2342; P711 (Witness statement of KDZ074 dated 23 September 1994 and 16 May 2001), p. 9; KDZ026, P2089 (Transcript from Prosecutor v. Stakić), T. 1930-1931, 1941 (under seal); KDZ026, T. 10323 (17 January 2011) (closed session); P692 (Witness statements of Rajif Begić dated 15 March 2000), e-court p. 7; P701 (Witness statement of Sakib Muhić dated 11 April 2000), p. 8; KDZ026, P2089 (Transcript from Prosecutor v. Stakić), T. 1930-1932 (under seal); see Adjudicated Fact 574.

4803 KDZ048, P678 (Transcript from Prosecutor v. Stakić), T. 3490.

$4804 \quad$ KDZ074, P709 (Transcript from Prosecutor v. Stakić), T. 2381.

4805 KDZ048, P678 (Transcript from Prosecutor v. Stakić), T. 3375; P711 (Witness statement of KDZ074 dated 23 September 1994 and 16 May 2001), p. 9; KDZ074, P709 (Transcript from Prosecutor v. Stakić), T. 2341.

4806 KDZ048, P678 (Transcript from Prosecutor v. Stakić), T. 3375. This killing is not charged in Schedule B of the Indictment. See fn. 13.

4807 KDZ026, P2089 (Transcript from Prosecutor v. Stakić), T. 1932, 1941 (under seal); KDZ026, T. 10322-10324 (17 January 2011) (closed session). 
severely beat them. ${ }^{4808}$ The beating of KDZ026 stopped only when Popović, upon hearing KDZ026's cries after he was stabbed in the stomach, came outside and shouted at the guards to stop. $^{4809}$

1398. On another occasion, an officer from the security service of the $1^{\text {st }}$ Krajina Corps went outside the camp and saw that policemen were beating two detainees "sadistically". 4810

1399. The detainees were forced to run the gauntlet on arrival into the camp. ${ }^{4811}$ Once inside, they were regularly beaten by members of the MP and the MUP. ${ }^{4812}$ Detainees were beaten with bare hands, batons, wooden poles, rifle butts, and electric cables. ${ }^{4813}$ They were regularly interrogated about their involvement in military matters. ${ }^{4814}$ During the interrogations, the guards beat the detainees, sometimes to the point that the detainees could no longer move. ${ }^{4815}$ During the night, detainees were called out and beaten; at least five to ten detainees were called out every night. ${ }^{4816}$

4808 P711 (Witness statement of KDZ074 dated 23 September 1994 and 16 May 2001), p. 9; KDZ026, P2089 (Transcript from Prosecutor v. Stakić), T. 1931, 1941 (under seal); KDZ026, T. 10323-10324, 10329 (17 January 2011) (closed session). According to KDZ163, the members of the MP inside Manjača were unable to stop the beatings carried out directly outside of Manjača by those who brought the detainees to the camp. KDZ163, P3717 (Transcript from Prosecutor v. Stanišić \& Župljanin), T. 5300.

4809 KDZ026, P2089 (Transcript from Prosecutor v. Stakić), T. 1932 (under seal); KDZ026, T. 10308, 10324, 10405 (17 January 2011) (closed session).

$4810 \quad$ KDZ163, P3717 (Transcript from Prosecutor v. Stanišić \& Župljanin), T. 5308; P3757 (Official note from the Security Centre in Banja Luka, 10 August 1992) (under seal), p. 2; P3750 (Manjača camp daily report to the $1^{\text {st }}$ Krajina Corps, 7 August 1992), p. 1 (under seal).

4811 Radomir Radinković, T. 45331-45332 (18 December 2013).

4812 KDZ024, P713 (Transcript from Prosecutor v. Brđanin), T. 9163-9165, 9219-9220, 9222 (under seal); Faik Biščević, P135 (Transcript from Prosecutor v. Brđanin), T. 7091-7092; P3488 (Witness statement of Atif Džafić undated), paras. 103, 108-109, 128; Asim Egrlić, P6586 (Transcript from Prosecutor v. Krajišnik), T. 4796; Mirzet Karabeg, P3303 (Transcript from Prosecutor v. Brđanin), T. 6187; D1862 (Manjača camp daily report to $1^{\text {st }}$ Krajina Corps, 3 July 1992) (under seal); P3754 (Manjača camp daily report to the $1^{\text {st }}$ Krajina Corps, 1 November 1992) (under seal); P3747 (Manjača camp daily report to the $1^{\text {st }}$ Krajina Corps, 23 July 1992), p. 1 (under seal); KDZ163, P3717 (Transcript from Prosecutor v. Stanišić \& Župljanin), T. 5300, 5400; P692 (Witness statements of Rajif Begić dated 15 March 2000), e-court p. 7; P718 (Witness statement of Ahmet Zulić dated 22 February 2010), paras. 123-126; D4204 (Witness statement of Radomir Radinković dated 8 December 2013), p. 3; Dragomir Keserović, T. 42015 (25 July 2013); Radomir Radinković, T. 45331-45332 (18 December 2013) (testifying that beatings and mistreatments occurred only during the initial period after the establishment of the camp); see Adjudicated Fact 573.

4813 P718 (Witness statement of Ahmet Zulić dated 22 February 2010), paras. 123-126; see Adjudicated Fact 576.

4814 P534 (ECMM Report, 3 September 1992), p. 4; P3488 (Witness statement of Atif Džafić undated), paras. 103, 107; P692 (Witness statements of Rajif Begić dated 15 March 2000), e-court p. 7; P718 (Witness statement of Ahmet Zulić dated 22 February 2010), paras. 118-119; P3733 (Manjača camp daily report to the $1^{\text {st }}$ Krajina Corps, 22 June 1992) (under seal); P3735 (Manjača camp daily report to the $1^{\text {st }}$ Krajina Corps, 26 June 1992), p. 1 (under seal); P3736 (Manjača camp daily report to the $1^{\text {st }}$ Krajina Corps, 27 June 1992) (under seal); D1855 (Report of Manjača camp sent to $1^{\text {st }}$ Krajina Corps), p. 1; D1856 (Manjača camp daily report to $1^{\text {st }}$ Krajina Corps, 15 June 1992); D1857 (Manjača camp daily report to $1^{\text {st }}$ Krajina Corps, 16 June 1992); D1859 (Manjača camp daily report to $1^{\text {st }}$ Krajina Corps, 20 June 1992). [REDACTED].

4815 Mirzet Karabeg, P3303 (Transcript from Prosecutor v. Brđanin), T. 6188; P692 (Witness statements of Rajif Begić dated 15 March 2000), e-court p. 7; P718 (Witness statement of Ahmet Zulić dated 22 February 2010), para. 119. [REDACTED].

4816 KDZ024, P713 (Transcript from Prosecutor v. Brđanin), T. 9168 (under seal); P3488 (Witness statement of Atif Džafić undated), para. 104; Sakib Muhić, P700 (Transcript from Prosecutor v. Brđanin), T. 8139; P721 (Second 
Detainees were also placed in isolation cells and on one occasion, the ICRC observed the traces of fresh human blood in one of those cells. ${ }^{4817}$

1400. Kovačević was in charge of the beatings; he was present and many times personally beat the detainees. $^{4818}$ He prepared lists of detainees to be beaten-a detainee could not be beaten until Kovačević ordered it. ${ }^{4819}$ Because of his brutality, both the guards and the detainees feared Kovačević. ${ }^{4820}$ Popović and Talić were aware of the mistreatment. ${ }^{4821}$ On one occasion, Popović came to the scene and angrily dispersed the military policemen who had been beating the detainees. $^{4822}$

1401. On 3 July 1992, the Command of the $1^{\text {st }}$ Krajina Corps was informed that efforts to stamp out the wilful mistreatment of prisoners at the hands of MP were proving increasingly difficult. ${ }^{4823}$ On 11 July 1992, during a meeting with senior MUP officials, Stojan Župljanin, Chief of Banja Luka CSB, stated that the conditions in Manjača were bad and that something had to be done. ${ }^{4824}$ On 16 July 1992, one of the camp authorities complained to the $1^{\text {st }}$ Krajina Corps Command that the MP and the security commander, Staff Sergeant Mesar, “just don't understand that the prisoners are humans and that they are protected by international regulations while in the camp". ${ }^{4825}$ In a separate report filed a week later, the same individual warned the VRS MP commander that Manjača was "not a torture house but a camp of war prisoners". ${ }^{826}$ Furthermore, the ICRC reported that the beating of two detainees by the guards during a visit by the ICRC on 16 July 1992 resulted in the ICRC prematurely terminating its visit to the camp and that there were "frequent and widespread traces of recent and often severe beatings". ${ }^{4827}$ In the same report, the ICRC criticised the living conditions in Manjača and recommended that Manjača be closed down. ${ }^{4828}$ This report

book of Ahmet Zulić's diary), p. 10; Faik Biščević, P135 (Transcript from Prosecutor v. Brđanin), T. 70907091.

4817 P3744 (Manjača camp daily report to the $1^{\text {st }}$ Krajina Corps, 16 July 1992), p. 1 (under seal); P3745 (Report of $1^{\text {st }}$ Krajina Corps, 16 July 1992), p. 1.

4818 P701 (Witness statement of Sakib Muhić dated 11 April 2000), p. 10; P692 (Witness statements of Rajif Begić to Sanski Most Court, 16 April 1995), e-court p. 21.

4819 P701 (Witness statement of Sakib Muhić dated 11 April 2000), p. 10.

4820 KDZ074, P709 (Transcript from Prosecutor v. Stakić), T. 2386; P711 (Witness statement of KDZ074 dated 23 September 1994 and 16 May 2001), p. 10.

4821 See Adjudicated Facts 578-580.

4822 KDZ024, P713 (Transcript from Prosecutor v. Brđanin), T. 9221 (under seal).

4823 D1862 (Manjača camp daily report to $1^{\text {st }}$ Krajina Corps, 3 July 1992) (under seal).

4824 Čedomir Kljajić, T. 42212-42213 (30 July 2013).

4825 P3744 (Manjača camp daily report to the $1^{\text {st }}$ Krajina Corps, 16 July 1992), p. 1 (under seal).

4826 P3747 (Manjača camp daily report to the $1^{\text {st }}$ Krajina Corps, 23 July 1992), pp. 1-2 (under seal).

4827 P3758 (Letter from Radovan Karadžić to Branko Đerić, attaching an ICRC report, 7 August 1992), e-court p. 5.

4828 P3758 (Letter from Radovan Karadžić to Branko Đerić, attaching an ICRC report, 7 August 1992), e-court pp. $5-6$. 
was provided to the Accused on 25 July 1992. ${ }^{4829}$ On 7 August 1992, the Accused forwarded to Branko Đerić, the RS Prime Minister at the time, a copy of the ICRC's report; the Accused also requested that Đerić take prompt action with a view to improving the living conditions in prisons on RS held territory. ${ }^{4830}$

(c) Visits to Manjača and transfer of detainees

1402. On 18 June 1992, representatives from Merhamet, the VRS and the MUP as well as SDS officials from Banja Luka visited Manjača. ${ }^{4831}$ Omer Filipović, a Bosnian Muslim detainee, told the visitors that the detainees had been taken from their homes and described the poor living conditions in the camp. ${ }^{4832}$ On 24 June 1992, representatives of Merhamet delivered food and medical supplies to Manjača but were barred from having contact with the detainees. ${ }^{4833}$ On 6 July 1992, the Presidents of municipal, district and military courts in Banja Luka, together with prosecutors and the Military Legal Officer of the $1^{\text {st }}$ Krajina Corps visited Manjača and discussed the possibility of instituting judicial proceedings against the detainees. ${ }^{4834}$ In response to a written request to the command of the $1^{\text {st }}$ Krajina Corps by Merhamet, approximately 100 minors, elderly, and sick detainees were released around 10 July $1992 .{ }^{4835}$

1403. In mid-July 1992, representatives from the ICRC, accompanied by medical personnel, visited Manjača. ${ }^{4836}$ All of the detainees were registered and weighed by the ICRC. ${ }^{4837}$ The process lasted a number of days. ${ }^{4838}$ At the end of July 1992, Vojo Kuprešanin, the President of the ARK Assembly, visited Manjača and promised the detainees that the majority of them would be

\footnotetext{
4829 P3758 (Letter from Radovan Karadžić to Branko Đerić, attaching an ICRC report, 7 August 1992), e-court p. 4.

4830 P3758 (Letter from Radovan Karadžić to Branko Đerić, attaching an ICRC report, 7 August 1992), e-court p. 1.

4831 D1858 (Manjača camp daily report to $1^{\text {st }}$ Krajina Corps, 18 June 1992).

4832 P3488 (Witness statement of Atif Džafić undated), para. 112.

4833 D1861 (Manjača camp daily report to $1^{\text {st }}$ Krajina Corps, 24 June 1992), p. 1; D1870 (Record of medical supplies and medicines received at the Manjača camp, 24 June 1992); D1871 (Logbook of patients at the Manjača camp, 23 August 1992).

4834 P3740 (Manjača camp daily report to the $1^{\text {st }}$ Krajina Corps, 8 July 1992), p. 2 (under seal).

4835 P3743 (List of detainees to be released from the Manjača camp, 10 July 1992); P3741 (Manjača camp daily report to the 1 st Krajina Corps, 9 July 1992), p. 1 (under seal); P3742 ( $1^{\text {st }}$ Krajina Corps combat report, 10 July 1992), p. 1; KDZ163, P3717 (Transcript from Prosecutor v. Stanišić \& Župljanin), T. 5297-5298; see Adjudicated Fact 582.

4836 P3758 (Letter from Radovan Karadžić to Branko Đerić, attaching an ICRC report, 7 August 1992), e-court p. 4; P3488 (Witness statement of Atif Džafić undated), para. 113; P718 (Witness statement of Ahmet Zulić dated 22 February 2010), paras. 121-122; P701 (Witness statement of Sakib Muhić dated 11 April 2000), p. 8; KDZ163, P3717 (Transcript from Prosecutor v. Stanišić \& Župljanin), T. 5299, 5306; P3744 (Manjača camp daily report to the $1^{\text {st }}$ Krajina Corps, 16 July 1992), pp. 1-2 (under seal); P3745 (Report of $1^{\text {st }}$ Krajina Corps, 16 July 1992), p. 1; KDZ024, P713 (Transcript from Prosecutor v. Brđanin), T. 9221 (under seal).

4837 P3488 (Witness statement of Atif Džafić undated), para. 118; P701 (Witness statement of Sakib Muhić dated 11 April 2000), p. 8; P718 (Witness statement of Ahmet Zulić dated 22 February 2010), para. 121; P3746 (Manjača camp daily report to the $1^{\text {st }}$ Krajina Corps, 22 July 1992), p. 2 (under seal).

4838 P701 (Witness statement of Sakib Muhić dated 11 April 2000), p. 8.
} 
released promptly; this did not materialise and it caused unrest and anxiety amongst the detainees. $^{4839}$ Sometime at the end of July or in early August, Župljanin and a number of other Serb officials visited Manjača and went to the stables, where they talked with some of the detainees. $^{4840}$

1404. The ICRC representatives again visited Manjača on 28 July 1992; during this visit, they distributed mail and cigarettes to the detainees and conducted a number of interviews. ${ }^{4841}$ In early August, the ICRC once again visited Manjača and this time demanded that more water be provided to the detainees. ${ }^{4842}$ Prior to this visit, pursuant to an order issued by Mladić on 3 August 1992, Major General Talić had ordered the authorities in Manjača to, inter alia (i) ensure cleanliness and medical care for the detainees; (ii) prepare accurate records of the detainees' arrival and release as well as records of deaths and findings on their causes; and (iii) select a number of prisoner representatives. $^{4843}$ On 8 August 1992, journalists, including members of foreign news agencies, were allowed to visit Manjača. ${ }^{4844}$ During this visit, the journalists requested to see the detainees who had arrived from Omarska two days prior but were not allowed to see them. ${ }^{4845}$ On 12 and 19 August 1992, foreign journalists again visited Manjača. ${ }^{4846}$ On 22 August 1992, the Prijedor SJB reported the transfer of a number of individuals from Manjača to Trnopolje. ${ }^{4847}$ On 24 August 1992, Milovanović ordered the authorities in Manjača to provide a list of the detainees and their places of residence so that such information could be forwarded to the ICRC. ${ }^{4848}$ On 31 August, a delegation from CSCE visited the camp and the ICRC brought food from Zagreb. ${ }^{4849}$

\footnotetext{
4839 P3488 (Witness statement of Atif Džafić undated), para. 125; Asim Egrlić, P6586 (Transcript from Prosecutor v. Krajišnik), T. 4806; P3724 (Manjača camp report to $1^{\text {st }}$ Krajina Corps, 8 August 1992), p. 2; KDZ163, P3717 (Transcript from Prosecutor v. Stanišić \& Župljanin), T. 5310; KDZ163, T. 20740-20741 (1 November 2011); P3751 (Manjača camp daily report to the $1^{\text {st }}$ Krajina Corps, 10 August 1992), p. 1 (under seal); D4204 (Witness statement of Radomir Radinković dated 8 December 2013), p. 10; Dragomir Keserović, T. 40992-40994 (8 July 2013).

4840 P3488 (Witness statement of Atif Džafić undated), paras. 121-124.

4841 P3749 (Manjača camp daily report to the $1^{\text {st }}$ Krajina Corps, 29 July 1992), p. 1 (under seal).

4842 P692 (Witness statements of Rajif Begić dated 15 March 2000), e-court p. 7; P5460 (Order of $1^{\text {st }}$ Krajina Corps, 3 August 1992), p. 1.

4843 P5461 (VRS Main Staff Order, 3 August 1992); P5460 (Order of $1^{\text {st }}$ Krajina Corps, 3 August 1992), p. 1; KDZ163, T. 20735-20736 (1 November 2011).

4844 P3724 (Manjača camp report to $1^{\text {st }}$ Krajina Corps, 8 August 1992); D4204 (Witness statement of Radomir Radinković dated 8 December 2013), p. 8; P3488 (Witness statement of Atif Džafić undated), para. 127.

4845 P3724 (Manjača camp report to $1^{\text {st }}$ Krajina Corps, 8 August 1992), p. 2.

4846 D1852 (Report of Manjača camp sent to $1^{\text {st }}$ Krajina Corps, 12 August 1992) (under seal); D4204 (Witness statement of Radomir Radinković dated 8 December 2013), p. 8; P5472 (Daily Report of Manjača Camp Operational Team, 18-20 August 1992), pp. 2-3; P3488 (Witness statement of Atif Džafić undated), para. 127.

4847 D1865 (Prijedor SJB dispatch to Banja Luka CSB, 22 August 1992).

4848 D1853 (Request for information on prisons from Manojlo Milovanović, 24 August 1992). The requested list was forwarded to the VRS Main Staff the following day. See D1854 (1 ${ }^{\text {st }}$ Krajina Corps dispatch, 25 August 1992).

4849 P5577 (Note to RS MUP and Radovan Karadžić, 31 August 1992); P722 (Third book of Ahmet Zulić's diary), p. 14.
} 
On the same day, a group of RS government representatives who had approval from Đerić took a tour of the camp in order to compile a report. ${ }^{4850}$ In late August 1992, representatives from the Bosanska Dubica, Ključ, Banja Luka, Prijedor, and Mrkonjić Grad CSBs came to Manjača in order to discuss "tasks and instructions for joint work". ${ }^{4851}$ In August and September 1992, more minors and elderly were released. ${ }^{4852}$

1405. On or about 1 September 1992, the ECMM visited Manjača. ${ }^{4853}$ During this visit, Popović insisted that the camp authorities adhered to all provisions of the Geneva Conventions while the detainees told the visitors that they were entirely civilians and that all soldiers had already been shot. $^{4854}$ In early September 1992, RS civilian and military officials and ICRC representatives discussed the steps needed for the exchange of the detainees and the closure of Manjača. ${ }^{4855}$ On 11 September 1992, the Accused issued a decree, "granting amnesty from criminal prosecution" to 69 detainees at Manjača and Trnopolje. ${ }^{4856}$ On 16 September 1992, the ICRC visited Manjača for the seventh time; during this visit, Popović stated that the camp administration had taken steps to guarantee the mental and physical integrity of the detainees. ${ }^{4857}$ ICRC representatives, however, were of the view that Manjača should be closed as soon as possible, its civilian detainees released and the imprisoned soldiers transferred to suitable prisons. ${ }^{4858}$ On 19 September 1992, detainees were aken out of Manjača and exchanged. ${ }^{4859}$ Additional visits by the ICRC took place on 23 September and 30 September $1992 .^{4860}$

\footnotetext{
4850 D1852 (Report of Manjača camp sent to $1^{\text {st }}$ Krajina Corps, 12 August 1992) (under seal). On one occasion, KDZ026 saw the Chief of Prijedor SJB, Simo Drljača, in Manjača. KDZ026, P2089 (Transcript from Prosecutor v. Stakić), T. 2047 (under seal).

4851 P5472 (Daily Report of Manjača Camp Operational Team, 18-20 August 1992), p. 4.

4852 Faik Biščević, P135 (Transcript from Prosecutor v. Brđanin), T. 7080; Mirzet Karabeg, P3303 (Transcript from Prosecutor v. Brđanin), T. 6259; P718 (Witness statement of Ahmet Zulić dated 22 February 2010), para. 133; P534 (ECMM Report, 3 September 1992), p. 4; see Adjudicated Fact 582. In late August 1992, camp authorities compiled a list of 92 ill or underage detainees whose imprisonment they believed was attracting attention from the media and humanitarian organisations. P3491 (Excerpt of Tode Gajić's diary); Radomir Radinković, T. 45328 (18 December 2013). Report, 3 September 1992), p. 1; P534 (ECMM Report, 3 September 1992), p. 1.

Charles McLeod, P712 (Transcript from Prosecutor v. Brđanin), T. 7316; P534 (ECMM Report, 3 September 1992), p. 7.

4855 D1872 (Report of $1^{\text {st }}$ Krajina Corps, 2 September 1992).

4856 P3721 (Report of $1^{\text {st }}$ Krajina Corps re decision by Radovan Karadžić, 11 September 1992); D456 (Transcript of $20^{\text {th }}$ session of RS Assembly, 14-15 September 1992), p. 55; KDZ163, T. 20741-20742 (1 November 2011) (private session).

4857 D1874 (ICRC Work Report, 23 September 1992), p. 1.

4858 D1874 (ICRC Work Report, 23 September 1992), p. 2. ICRC reiterated its position again on 6 October 1992. See D1875 (ICRC Work Report, 6 October 1992), p. 3.

4859 KDZ392, P707 (Transcript from Prosecutor v. Kvočka), T. 2750, 2766 (under seal).

4860 D1875 (ICRC Work Report, 6 October 1992), p. 1.
} 
1406. On 1 October 1992, Kuprešanin wrote to the RS Presidency, requesting the pardon and release of 13 detainees held at Manjača. ${ }^{4861}$ On 3 and 4 October 1992, the ICRC visited Manjača and brought letters for the detainees, and visited again on 7 October in order to obtain a list of sick detainees. ${ }^{4862}$ On 12 October 1992, the ICRC arrived with a list of sick persons; these detainees were released and taken abroad for treatment. ${ }^{483}$ On 30 October 1992, the ICRC started working in the camp every day. ${ }^{4864}$ In addition to the ICRC, other organisations and renowned individuals such as Bernard Kouchner and Elie Wiesel visited the detainees. ${ }^{4865}$

1407. On 31 October 1992, about 60 detainees were exchanged. ${ }^{4866}$ Starting in November, preparatory measures were taken for the release and eventual transfer of all the detainees to third countries. ${ }^{4867}$ On 13 November, the Accused ordered the release of approximately 700 individuals from Manjača. ${ }^{4868}$ In the early hours of 14 November 1992, minors, elderly detainees, as well as those who were not considered to be "extremists" or "war criminals" by the camp authorities, were lined up; these detainees were told to sign a document which barred them from the territory of $\mathrm{BiH}$ and placed them under the authority of UNHCR for the purpose of their relocation to a Western European country. ${ }^{4869}$ Prior to this, Popović told the detainees that if they were ever captured in the territory of $\mathrm{BiH}$, they would be killed instantly. ${ }^{4870}$ With the assistance of the ICRC, these detainees were released and taken to Karlovac in Croatia. ${ }^{4871}$

4861 P3722 (Request sent from Vojo Kuprešanin to Radovan Karadžić, 1 October 1992); D4204 (Witness statement of Radomir Radinković dated 8 December 2013), p. 10.

4862 P722 (Third book of Ahmet Zulić's diary), pp. 15-17; P718 (Witness statement of Ahmet Zulić dated 22 February 2010), para. 135.

4863 P722 (Third book of Ahmet Zulić's diary), pp. 17-18; D4204 (Witness statement of Radomir Radinković dated 8 December 2013), p. 9; Radomir Radinković, T. 45318 (18 December 2013).

4864 P722 (Third book of Ahmet Zulić's diary), p. 18.

4865 P3488 (Witness statement of Atif Džafić undated), para. 127; KDZ474, P3395 (Transcript from Prosecutor v. Brđanin), T. 7766 (under seal); P722 (Third book of Ahmet Zulić's diary), p. 10; D1877 (Manjača camp report to $1^{\text {st }}$ Krajina Corps, 29 November 1992), p. 1; D4204 (Witness statement of Radomir Radinković dated 8 December 2013), p. 8.

4866 Mirzet Karabeg, P3303 (Transcript from Prosecutor v. Brđanin), T. 6260; Mirzet Karabeg, T. 18700 (13 September 2011).

4867 KDZ163, P3717 (Transcript from Prosecutor v. Stanišić \& Župljanin), T. 5316, 5362; P3723 (Manjača camp report to $1^{\text {st }}$ Krajina Corps, 14 November 1992), p. 1 (under seal). According to KDZ163, many detainees relocated to Belgium and Germany. KDZ163, P3717 (Transcript from Prosecutor v. Stanišić \& Župljanin), T. 5362. See also P692 (Witness statement of Rajif Begić to Sanski Most Court, 16 April 1996), e-court p. 21 (stating that he was resettled in Germany).

4868 D956 (RS President's Decision on Amnesty, 13 November 1992) (under seal); D4204 (Witness statement of Radomir Radinković dated 8 December 2013), p. 9.

4869 KDZ048, P678 (Transcript from Prosecutor v. Stakić), T. 3377; KDZ026, P2089 (Transcript from Prosecutor v. Stakić), T. 1934-1935, 1951 (under seal); KDZ026, T. 10392-10393 (17 January 2011) (closed session); KDZ163, T. 2074420745 (1 November 2011) (closed session).

4870 KDZ074, P709 (Transcript from Prosecutor v. Stakić), T. 2343; Faik Biščević, P122 (Transcript from Prosecutor v. Krajišnik), T. 5539-5540.

4871 KDZ048, P678 (Transcript from Prosecutor v. Stakić), T. 3376-3378; D1876 (ICRC Work Report, 5-18 November 1992), p. 1; Faik Biščević, P122 (Transcript from Prosecutor v. Krajišnik), T. 5539-5540; Faik 
1408. On 4 December 1992, the Accused indicated that he would order the release of all detainees held in Manjača provided that they be transferred to third countries. ${ }^{4872}$

1409. On 13 December 1992, a group of 532 detainees was transferred from Manjača to Batković camp. ${ }^{4873}$ From Batković camp, some of these detainees were transferred to Kula Prison. ${ }^{4874}$ On 14 December 1992, a number of local journalists visited Manjača. ${ }^{4875}$ However, the detainees had been warned not to speak to the visitors for their own safety. ${ }^{4876}$ The remainder of the detainees in Manjača, after signing documents which required them to leave for third countries, were released on 14,16 , or 18 December 1992 and taken to Karlovac. ${ }^{4877}$ Manjača was then closed down. ${ }^{4878}$

\section{(d) $\underline{\text { Conclusion }}$}

1410. Based on the above, the Chamber finds that during the period between 15 May and 18 December 1992, Serb Forces detained a large number of Bosnian Muslim and Bosnian Croat men, including minors, sick, and elderly, at Manjača and regularly subjected them to beatings and mistreatment. The Chamber further finds that the detainees were held in poor conditions. These included lack of food and water, insufficient sanitary facilities and inadequate medical care.

Biščević, P135 (Transcript from Prosecutor v. Brđanin), T. 7004, 7093-7094; KDZ024, P713 (Transcript from Prosecutor v. S. Milošević), T. 30084-30085 (under seal); KDZ024, P713 (Transcript from Prosecutor v. Brđanin), T. 9165, 9169-9170 (under seal); Charles McLeod, P712 (Transcript from Prosecutor v. Brđanin), T. 7334; P3726 (List of detainees at Manjača, 23 November 1992).

4872 D1851 (Letter from Radovan Karadžić to Daniel Shiffer, 4 December 1992).

4873 P3727 (Manjača camp daily report to $1^{\text {st }}$ Krajina Corps, 14 December 1992), e-court p. 3; KDZ163, T. 20749 (1 November 2011); D4204 (Witness statement of Radomir Radinković dated 8 December 2013), p. 9; Asim Egrlić, T. 19980 (5 October 2011); Asim Egrlić, P6586 (Transcript from Prosecutor v. Krajišnik), T. 4796; Dragomir Keserović, T. 42026 (25 July 2013).

4874 Dragomir Keserović, T. 42026 (25 July 2013).

4875 P3727 (Manjača camp daily report to the $1^{\text {st }}$ Krajina Corps, 14 December 1992), e-court p. 1.

4876 P722 (Third book of Ahmet Zulić's diary), p. 11; P718 (Witness statement of Ahmet Zulić dated 22 February 2010), para. 131.

4877 The ICRC assisted detainees in transferring from Manjača to Karlovac, Croatia, where they were handed over to UNHCR officials. P3725 (ICRC Communication to the Press, 14 November 1992); P692 (Witness statements of Rajif Begić dated 15 March 2000), e-court p. 8; Ahmet Zulić, T. 1035-1036 (13 April 2010); KDZ026, T. 10329 (17 January 2011) (closed session); KDZ163, P3717 (Transcript from Prosecutor v. Stanišić \& Župljanin), T. 5362; Rajif Begić, P691 (Transcript from Prosecutor v. Krajišnik), T. 3001; P3727 (Manjača camp report to $1^{\text {st }}$ Krajina Corps, 14 December 1992), e-court pp. 1-2; KDZ074, P709 (Transcript from Prosecutor v. Stakić), T. 2343, 2371, 2396; Rajif Begić, P691 (Transcript from Prosecutor v. Krajišnik), T. 3000-3001; P3488 (Witness statement of Atif Džafić undated), para. 128; P3931 (Report of $1^{\text {st }}$ Krajina Corps, 16 December 1992), p. 1; Dragomir Keserović, T. 42026 (25 July 2013); P5468 (ICRC press release, 18 December 1992).

4878 P3914 (Ewan Brown's expert report entitled "Military Developments in the Bosanska Krajina - 1992", 27 November 2002), p. 109; KDZ048, P678 (Transcript from Prosecutor v. Stakić), T. 3374; P5468 (ICRC press release, 18 December 1992); see Adjudicated Fact 582. 
(e) Scheduled Incident B.1.1

1411. The Indictment refers to the killing of at least six men in front of Manjača after their transportation from Hasan Kikić Elementary School in Sanski Most on or about 3 June 1992. 4879

1412. As mentioned earlier, sometime in the first week of June 1992, members of Sanski Most SJB and SOS loaded approximately 140 non-Serb detainees held at Hasan Kikić School, in Sanski Most municipality, onto two trucks and departed for Manjača. The trucks were extremely crowded with approximately 70 detainees standing in each truck. ${ }^{4880}$

1413. Approximately six to seven hours later, the trucks stopped on the road next to the entrance gate of Manjača but the detainees were not allowed to exit. ${ }^{4881}$ After waiting for 30 to 60 minutes standing beneath tarpaulins, the detainees were ordered to exit the trucks one by one. ${ }^{4882}$ A group of 20 armed men in mixed and camouflage military uniforms, including Daniluško Kajtez, waited outside the trucks as the detainees exited. ${ }^{4883}$ The armed men beat the detainees with batons, wooden handles of shovels, and wooden planks as they exited the truck. ${ }^{4884}$ Six of the detainees, all Bosnian Muslim men, were subsequently separated from the rest. ${ }^{485}$ Two of these six detainees were handcuffed and taken near a small truck. ${ }^{4886}$ The other four detainees were taken to different points approximately 15 metres away. ${ }^{4887}$ Subsequently, three to five armed men surrounded each of the detainees and beat them for approximately 20 minutes with multiple objects; all six detainees

4879 Indictment, Scheduled Incident B.1.1. In Annex B to its Final Trial Brief, p. 1, the Prosecution refers to 6 June 1992 as the date of Scheduled Incident B.1.1.

4880 Sakib Muhić, P700 (Transcript from Prosecutor v. Brđanin), T. 8122-8123; P701 (Witness statement of Sakib Muhić dated 11 April 2000), p. 6; see Adjudicated Fact 583.

4881 P701 (Witness statement of Sakib Muhić dated 11 April 2000), p. 6.

4882 P701 (Witness statement of Sakib Muhić dated 11 April 2000), p. 6; Sakib Muhić, P700 (Transcript from Prosecutor v. Brđanin), T. 8124.

4883 Sakib Muhić, P700 (Transcript from Prosecutor v. Brđanin), T. 8127-8128, 8130; P701 (Witness statement of Sakib Muhić dated 11 April 2000), p. 7. Daniluško Kajtez was a member of the SOS. Members of the SOS, including Daniluško Kajtez, were later integrated into the $6^{\text {th }}$ Krajina Brigade. See P3634 (Witness statement of KDZ490, undated) (under seal), pp. 20-22, 27, 30; KW540, D4449 (Transcript from Prosecutor v. Stanišić \& Župljanin), T. 3315-3317 (under seal); P3519 (Indictment of the $1^{\text {st }}$ Krajina Corps Military Prosecutor's Office, 2 June 1993), p. 1; P6542 (Report of Sanski Most SDS Municipal Board, 10 September 1993); P3520 (Decision of Banja Luka Military Court, 9 July 1993), p. 1. In a letter to Vlado Vrkeš, the President of Sanski Most SDS, Kajtez admitted to killing 12 individuals from Manjača on two separate occasions. See P6556 (Letter from Daniluško Kajtez to "Vlado"), p. 1.

4884 P701 (Witness statement of Sakib Muhić dated 11 April 2000), p. 6.

4885 P701 (Witness statement of Sakib Muhić dated 11 April 2000), pp. 6-7; Sakib Muhić, P700 (Transcript from Prosecutor v. Brđanin), T. 8124, 8126. According to Muhić, the six detainees were: Ermin Bahtić, Jasmin Jelečević, Medin Hadžiahmetović (a.k.a. Hapač), Neron Mehadžić, Haris Biščević, and Fajko Pašić. P701 (Witness statement of Sakib Muhić dated 11 April 2000), pp. 6-7; Sakib Muhić, P700 (Transcript from Prosecutor v. Brđanin), T. 8125-8126.

4886 Sakib Muhić, P700 (Transcript from Prosecutor v. Brđanin), T. 8125-8126; P701 (Witness statement of Sakib Muhić dated 11 April 2000), p. 7.

4887 P701 (Witness statement of Sakib Muhić dated 11 April 2000), p. 7; Sakib Muhić, P700 (Transcript from Prosecutor v. Brđanin), T. 8129. 
were killed. ${ }^{4888}$ The six bodies were then thrown into the small truck, and the rest of the detainees were taken to Manjača. ${ }^{4889}$

1414. The Chamber received forensic evidence which identifies six bodies as related to this incident. $^{4890}$

1415. Based on the above, the Chamber finds that on 6 June 1992, Serb Forces killed six Bosnian Muslim men in front of the gates of Manjača.

\section{(f) $\underline{\text { Scheduled Incident B.1.2 }}$}

1416. The Indictment refers to the deaths of a number of prisoners who suffocated in trucks while being transported from Betonirka detention facility in Sanski Most to Manjača on 7 July 1992.

1417. In the morning of 7 July 1992, Serb policemen took approximately 64 detainees, most of them Bosnian Muslims, from the Betonirka factory garage, in Sanski Most municipality, and loaded them into a truck with tarpaulin cover. ${ }^{4891}$ The detainees were crammed. ${ }^{4892}$ The Serb policemen then pulled down and locked the tarpaulin cover, hermetically sealing the back of the truck. $^{4893}$ Under escort of the Sanski Most civilian police, the truck joined a convoy of trucks transporting several hundred detainees from Krings Hall and Hasan Kikić sports hall, and together they headed for Manjača. ${ }^{4894}$

4888 P701 (Witness statement of Sakib Muhić dated 11 April 2000), pp. 5, 7; Sakib Muhić, P700 (Transcript from Prosecutor v. Brđanin), T. 8125, 8127; KW540, D4449 (Transcript from Prosecutor v. Stanišić \& Župljanin), T. 3408-3409 (under seal); see Adjudicated Fact 584.

4889 P701 (Witness statement of Sakib Muhić dated 11 April 2000), pp. 7-8; Sakib Muhić, P700 (Transcript from Prosecutor v. Brđanin), T. 8125, 8136.

4890 These individuals were exhumed from the mass grave at Stričići-Manj, in Banja Luka municipality on 23 May 2007. P4853 (Updated Table 2 to the Report of Amor Mašović), p. 73.

4891 Faik Biščević, P122 (Transcript from Prosecutor v. Krajišnik), T. 5537-5538; P718 (Witness statement of Ahmet Zulić dated 22 February 2010), paras. 86-88, 96; P721 (Second book of Ahmet Zulić's diary), p. 5; KDZ163, P3717 (Transcript from Prosecutor v. Stanišić \& Župljanin), T. 5294; KW545, D4328 (Transcript from Prosecutor v. Stanišić \& Župljanin) T. 26131 (under seal); see Adjudicated Fact 585. [REDACTED].

4892 P718 (Witness statement of Ahmet Zulić dated 22 February 2010), para. 88; P721 (Second book of Ahmet Zulić's diary), p. 5; KDZ163, P3717 (Transcript from Prosecutor v. Stanišić \& Župljanin), T. 5294; see Adjudicated Fact 587.

4893 P718 (Witness statement of Ahmet Zulić dated 22 February 2010), para. 88.

4894 Faik Biščević, P135 (Transcript from Prosecutor v. Brđanin), T. 7096; Faik Biščević, P122 (Transcript from Prosecutor v. Krajišnik), T. 5537; Mirzet Karabeg, P3303 (Transcript from Prosecutor v. Brđanin), T. 6175; P3747 (Manjača camp daily report to the $1^{\text {st }}$ Krajina Corps, 23 July 1992), p. 1 (under seal); P3740 (Manjača camp daily report to the $1^{\text {st }}$ Krajina Corps, 8 July 1992) (under seal); KDZ163, P3717 (Transcript from Prosecutor v. Stanišić \& Župljanin), T. 5293-5294; P3773 (Witness statement of KDZ532 dated 31 October 2011), para. 28 (under seal); Rajif Begić, P691 (Transcript from Prosecutor v. Krajišnik), T. 2999, 3019 ; P692 (Witness statement of Rajif Begić dated 15 March 2000), e-court p. 7; Ahmet Zulić, T. 1030 (13 April 2010); KW545, D4328 (Transcript from Prosecutor v. Stanišić \& Župljanin) T. 26130 (under seal); D4170 (Witness statement of Mile Dobrijević dated 2 December 2013), para. 14. [REDACTED]. 
1418. The journey to Manjača lasted approximately 10 or 11 hours. ${ }^{4895}$ It was very hot that day, and there was no ventilation for the detainees beneath the sealed canvas tarpaulin of the truck from Betonirka factory garage. ${ }^{4896}$ During the journey, fumes from the exhaust pipe of the truck flowed in, making it difficult for the detainees to breathe. ${ }^{497}$ The detainees squeezed their shoes in between the tarpaulin and the truck frame in order to allow air in, but the policemen hit the shoes back inside the truck at the check-points. ${ }^{4898}$ By the time the truck stopped a second time at a check-point in Vrhpolje, the detainees had finished the six litres of water given to them at the beginning of the journey, and the guards refused to provide them additional water. ${ }^{4899}$ A detainee resorted to drinking his own urine. ${ }^{4900}$ As the journey continued, a number of detainees began to faint and die. ${ }^{4901}$ When the truck finally reached Manjača around sunset, the detainees were called out one by one by name. ${ }^{4902}$ Of the detainees, 24 did not respond and remained lying on the floor of the truck. ${ }^{4903}$ As the camp officials refused to take the dead and unwell detainees, they were taken back to Sanski Most along with Edin Biščević, a detained Bosnian Muslim doctor who had

4895 Faik Biščević, P122 (Transcript from Prosecutor v. Krajišnik), T. 5538; P692 (Witness statement of Rajif Begić dated 15 March 2000), e-court p. 7; Ahmet Zulić, T. 1030-1031 (13 April 2010) (testifying that the journey from Betonirka to Manjača should normally last two hours).

4896 P3634 (Witness statement of KDZ490, undated), p. 118 (under seal); P718 (Witness statement of Ahmet Zulić dated 22 February 2010), paras. 87-88; P721 (Second book of Ahmet Zulić's diary), p. 5; KDZ163, P3717 (Transcript from Prosecutor v. Stanišić \& Župljanin), T. 5294; Radomir Radinković, T. 45334 (18 December 2013); KW540, D4449 (Transcript from Prosecutor v. Stanišić \& Župljanin), T. 3419 (under seal). See also Adjudicated Fact 587.

4897 Ahmet Zulić, T. 1031 (13 April 2010).

4898 P718 (Witness statement of Ahmet Zulić dated 22 February 2010), paras. 88-91; see KDZ163, P3717 (Transcript from Prosecutor v. Stanišić \& Župljanin), T. 5294.

4899 Faik Biščević, P122 (Transcript from Prosecutor v. Krajišnik), T. 5538; P718 (Witness statement of Ahmet Zulić dated 22 February 2010), para. 89; P721 (Second book of Ahmet Zulić's diary), p. 5. See also Adjudicated Fact 587. An unknown woman tried to give the detainees water, but the guards prevented her from doing so. P718 (Witness statement of Ahmet Zulić dated 22 February 2010), para. 89.

$4900 \quad$ P718 (Witness statement of Ahmet Zulić dated 22 February 2010), para. 92.

4901 P721 (Second book of Ahmet Zulić's diary), p. 6; Faik Biščević, P122 (Transcript from Prosecutor v. Krajišnik), T. 5538; Dragomir Keserović, T. 41999 (25 July 2013).

4902 Rajif Begić, P691 (Transcript from Prosecutor v. Krajišnik), T. 3000; P718 (Witness statement of Ahmet Zulić dated 22 February 2010), para. 94; P721 (Second book of Ahmet Zulić's diary), p. 6.

4903 Rajif Begić, P691 (Transcript from Prosecutor v. Krajišnik), T. 3000; P718 (Witness statement of Ahmet Zulić dated 22 February 2010), para. 94; P721 (Second book of Ahmet Zulić's diary), p. 6; P3740 (Manjača camp daily report to the $1^{\text {st }}$ Krajina Corps, 8 July 1992), pp. 1-2 (under seal); P3744 (Manjača camp daily report to the $1^{\text {st }}$ Krajina Corps, 16 July 1992), p. 2 (under seal); KDZ163, P3717 (Transcript from Prosecutor v. Stanišić \& Župljanin), T. 5294, 5336-5337; D4204 (Witness statement of Radomir Radinković dated 8 December 2013), p. 5; Radomir Radinković, T. 45334 (18 December 2013); P3773 (Witness statement of KDZ532 dated 31 October 2011), para. 28 (under seal). See also Adjudicated Fact 588. According to a report compiled by two Bosnian Serb doctors, 20 detainees died from asphyxia during the transfer from Betonirka to Manjača. P724 (List of civilians killed during transport to Manjača), pp. 1-2. In light of this evidence, the Chamber finds that four of the detainees did not suffocate in the tarpaulin covered truck and were taken back to Sanski Most alive. The Indictment limits the victims of Scheduled Incident B.1.2 to "prisoners who suffocated in trucks while being transported from Betornika detention facility to Manjača”. 
volunteered to resuscitate those who were unwell. ${ }^{4904}$ Edin Biščević and the unwell detainees who were taken back to Sanski Most have never been seen alive again. ${ }^{4905}$

1419. The Chamber received forensic evidence which identifies a number of bodies as being related to this incident. ${ }^{4906}$ Furthermore, the Manjača authorities reported to the $1^{\text {st }}$ Krajina Corps Command on 8 and 9 July 1992 that 24 individuals had died during transportation to Manjača. 4907

1420. Based on the above, the Chamber finds that on 7 July 1992, Serb Forces forced a number of Bosnian Muslim and Bosnian Croat men detained at Betonirka factory garage to board a tarpaulin covered truck which was bound for Manjača and that due to the lack of sufficient ventilation, 20 detainees suffocated during transportation.

4904 KDZ492, P3596 (Transcript from Prosecutor v. Krajišnik), T. 3861 (under seal); D4214 (Witness statement of Vinko Nikolić dated 13 January 2014), para. 23; P3740 (Manjača camp daily report to the $1^{\text {st }}$ Krajina Corps, 8 July 1992), p. 1 (under seal); P3741 (Manjača camp daily report to the $1^{\text {st }}$ Krajina Corps, 9 July 1992), p. 1 (under seal); KDZ163, P3717 (Transcript from Prosecutor v. Stanišić \& Župljanin), T. 5293-5295; P724 (List of civilians killed during transport to Manjača); P718 (Witness statement of Ahmet Zulić dated 22 February 2010), paras. 94-105; P692 (Witness statement of Rajif Begić dated 15 March 2000), e-court p. 7; D4204 (Witness statement of Radomir Radinković dated 8 December 2013), p. 5; Radomir Radinković, T. 45334 (18 December 2013); P3634 (Witness statement of KDZ490, undated), p. 118 (under seal); P6466 (Article from Sanski Most Online entitled "Nedim Caressed the Bones of His Twin Brother Edin", 20 April 2007); KW545, D4328 (Transcript from Prosecutor v. Stanišić \& Župljanin) T. 26287 (under seal); D4170 (Witness statement of Mile Dobrijević dated 2 December 2013), para. 14; KW540, D4449 (Transcript from Prosecutor v. Stanišić \& Župljanin), T. 3418-3419 (under seal); Dragomir Keserović, T. 41996-41999 (25 July 2013); D4387 (Witness statement of Dušan Mudrinić dated 15 February 2014), para. 20. According to a report compiled by two Bosnian Serb doctors, the detainees who died from asphyxia during the transfer from Betonirka to Manjača were Sevdaga Hukanović, Josip Mlinar, Vinko Matanović, Hivzo Hodžić, Ismet Memić, Fadil Kamić, Mirsad Halimović, Kemo Talić, Nedžad Muhić, Dževad Muhić, Ibro Mušić, Mustafa Hodžić, Mirhad Delić, Ramo Jusić, Atif Kerić, Nenad Čorak, Ivan Tutić, Ismet Hidžić, Muharem Pršić, and Zijad Mujadžić. P724 (List of civilians killed during transport to Manjača), pp. 1-2. [REDACTED].

4905 Faik Biščević, P122 (Transcript from Prosecutor v. Krajišnik), T. 5538; Faik Biščević, P135 (Transcript from Prosecutor v. Brđanin), T. 7098. As noted above, the Indictment limits the scope of Scheduled Incident B.1.2 to "prisoners who suffocated in trucks while being transported from Betornika detention facility to Manjača".

4906 According to Mašović, the remains of 21 victims of Scheduled Incident B.1.2 have been identified. These victims are Jasmin Bajrektarević, Adam Delić, Mirsad Halimović, Hivzo Hodžić, Ismet Hodžić, Sevdaga Hukanović, Adem Jakupović, Ramo Jusić, Fadil Kamić, Vinko Matanović, Izet Mehić, Josip Mlinar, Dževad Muhić, Nedžad Muhić, Zijad Mujadžić, Kelo Talić, Edin Bišćević, Enver Burnić, Mirhad Delić, Ibrahim Mušić, and Ivica Tutić. The first 16 victims were exhumed from the Ušće Dabra mass grave, in Sanski Most municipality, on 17 July 2001 whereas the last five victims were exhumed from the Dragoraj mass grave, in Mrkonjić Grad municipality on 19 April 2000. P4853 (Updated Table 2 to the Report of Amor Mašović), pp. 48, 73. See also P6690 (Addendum to Nicolas Sébire's report, 16 May 2003), pp. 71-73; P6689 (Excerpts from report on exhumations in Prijedor municipality, 28 August 2002), e-court p. 206; P4408 (Death certificate for Zijad Mujadžić); P6466 (Article from Sanski Most Online entitled "Nedim Caressed the Bones of His Twin Brother Edin", 20 April 2007). The Chamber, however, notes that from the 21 victims referred to by Mašović, only 15 are included in P724 (List of civilians killed during transport to Manjača). These individuals are Sevdaga Hukanović, Josip Mlinar, Vinko Matanović, Hivzo Hodžić, Fadil Kamić, Mirsad Halimović, Kemo Talić, Nedžad Muhić, Dževad Muhić, Ibrahim Mušić, Mirhad Delić, Ramo Jusić, Ivica Tutić, Ismet Hodžić, and Zijad Mujadžić.

4907 P3740 (Manjača camp daily report to the $1^{\text {st }}$ Krajina Corps, 8 July 1992), p. 1 (under seal); P3741 (Manjača camp daily report to the $1^{\text {st }}$ Krajina Corps, 9 July 1992), p. 1 (under seal). 
(g) Scheduled Incident B.1.3

1421. The Indictment refers to the killings of a number of men in front of Manjača upon their arrival from Omarska camp on or about 6 August 1992.

1422. As mentioned earlier, on the night of 6 August 1992, approximately 1,300 detainees were brought to the gates of Manjača from Omarska and made to spend the night in the buses in which they had travelled. ${ }^{4908}$ At one point, members of the Prijedor SJB's intervention squad took out a number of detainees, including Dedo Crnalić and Jasko Alisić, from the buses, took them behind some agricultural machines nearby and slit their throats. ${ }^{4909}$ One of the guards who killed Crnalić wiped his bloody knife on Crnalić's shirt. ${ }^{4910}$ The next day, during the roll call of the detainees, Dedo Crnalić's name was called first. ${ }^{4911}$ Members of the intervention squad who at that time were standing next to the bus began laughing and said: "There he is on top of that pile."4912 Later, the detainees heard that in addition to Crnalić and Alisić, the members of the intervention squad had killed six or seven detainees in front of the gates of Manjača, including Nezir Krak, Nihad Basić, and a man by the name Djuzin. ${ }^{4913}$ After Popović refused to accept the dead bodies into the camp, members of the Prijedor SJB loaded them on the buses and drove off in the direction of Banja Luka. ${ }^{4914}$

1423. The Chamber has received forensic evidence which identifies a number of bodies as related to this incident. ${ }^{4915}$

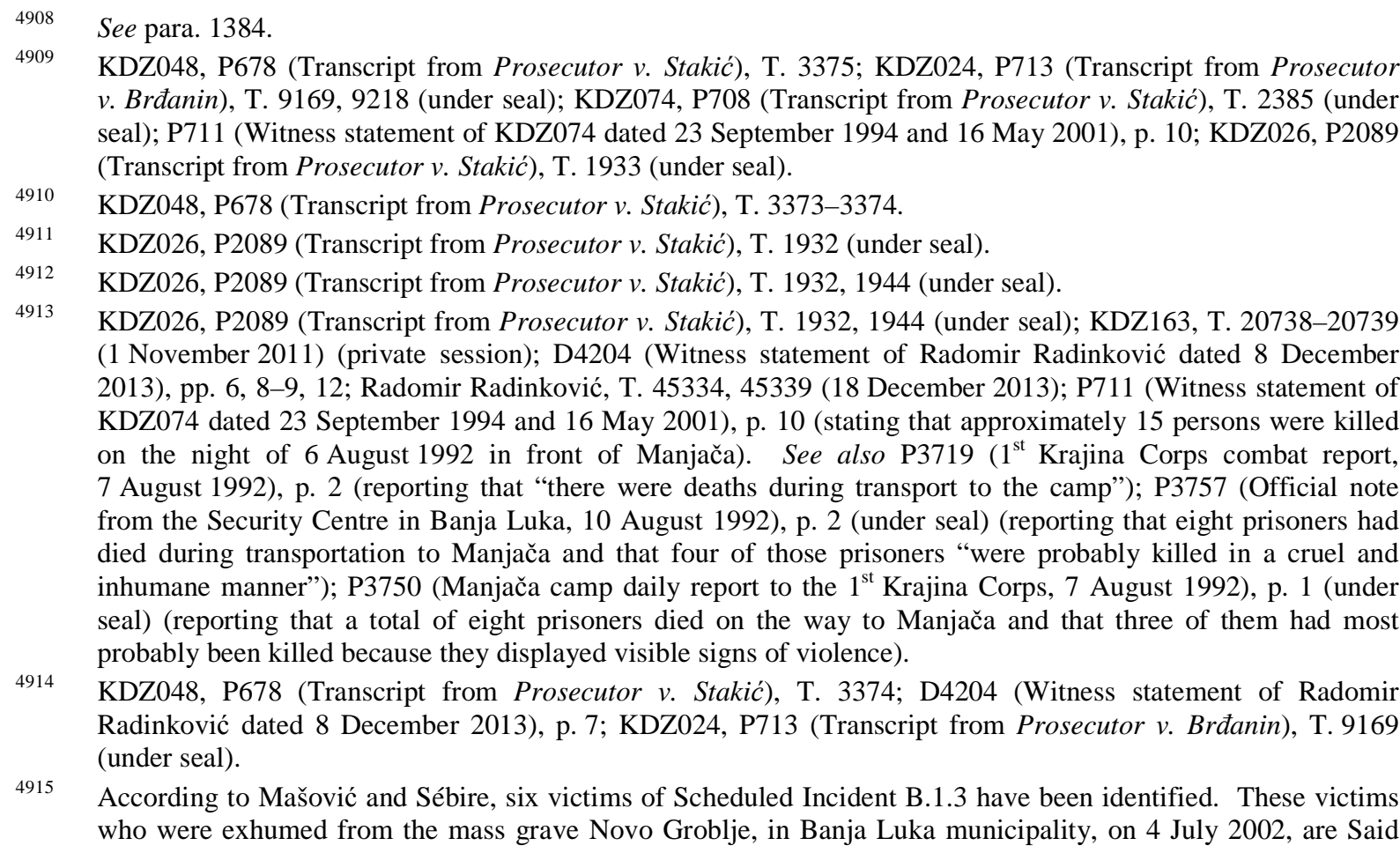


1424. Based on the above, the Chamber finds that on 6 August 1992, Serb Forces separated at least eight or nine Bosnian Muslims and Bosnian Croats from the group of detainees who had arrived at the gates of Manjača from Omarska and killed them.

\section{(h) $\underline{\text { Scheduled Incident B.1.4 }}$}

1425. The Indictment refers to the killings of at least 10 men in Manjača between 1 June and 18 December 1992.

1426. On 10 July 1992, the guards at Manjača beat Emir Mulalić to death. ${ }^{4916}$ The guards then called in a detainee who was also a doctor. ${ }^{4917}$ Since Popović had ordered that the cause of death of the detainees who died from beatings be falsified, the doctor confirmed Mulalić's death but reported that he had died from a heart attack. ${ }^{4918}$

1427. On 24 June 1992, Zlatan Miškić was taken to Manjača and died some hours later. ${ }^{4919}$ On the night of 29 July 1992, Željko Bulatović called out Omer Filipović and Esad Bender to the isolation rooms where they were severely beaten. ${ }^{4920}$ Filipović died as a result of the beatings that night, but Bender was brought back around midnight. He crawled into the stable, bleeding and crying for help; no one assisted him out of fear of the guards. ${ }^{4921}$ Around 7 a.m. the next morning,

Babić, Dedo Crnalić, Nezir Krak, Nihad Bašić, Kemal Jakupović, and Zvonko Tokmadžić. P4853, (Updated Table 2 to the Report of Amor Mašović), p. 73; P646 (Excerpts from report on exhumations in Prijedor municipality, 28 August 2002) (under seal), pp. 79, 94. See also P4850 (Witness statement of Amor Mašović dated 23 March 2012), para. 111, Annex A, pp. 1-2; P4869 (Record of identification for Kemal Jakupović and Nezir Krak, 29 July 2003); P4873 (Letter from BiH Commission for Missing Persons to the OTP re exhumations at Novo Groblje, 11 September 2006); P4874 (Bihać Cantonal Court record of Novo Groblje exhumation, 4 October 2002); P4875 (Autopsy reports of persons exhumed at Novo Groblje, 22 July 2002).

4916 P692 (Witness statement of Rajif Begić dated 15 March 2000), e-court p. 7; P718 (Witness statement of Ahmet Zulić dated 22 February 2010), para. 118.

4917 P692 (Witness statement of Rajif Begić dated 15 March 2000), e-court p. 7.

4918 P692 (Witness statement of Rajif Begić dated 15 March 2000), e-court p. 7; see Adjudicated Fact 593.

4919 D1861 (Manjača camp daily report to $1^{\text {st }}$ Krajina Corps, 24 June 1992), p. 3. The Chamber has not received sufficient evidence as to the circumstances of the death of Zlatan Miškić to make a finding in relation thereto.

4920 P3749 (Manjača camp daily report to the $1^{\text {st }}$ Krajina Corps, 29 July 1992) (under seal); Asim Egrlić, P6586 (Transcript from Prosecutor v. Krajišnik), T. 4800; P701 (Witness statement of Sakib Muhić dated 11 April 2000), pp. 8-10; Sakib Muhić, P700 (Transcript from Prosecutor v. Brđanin), T. 8139; P718 (Witness statement of Ahmet Zulić dated 22 February 2010), pp. 31-32; D4204 (Witness statement of Radomir Radinković dated 8 December 2013), pp. 6, 12; D4235 (Witness statement of Jevto Janković dated 24 January 2014), para. 7. The camp officials considered Filipovic to be the leader of SDA in Ključ and an organiser of "armed rebellion". See D4204 (Witness statement of Radomir Radinković dated 8 December 2013), p. 5.

4921 P3488 (Witness statement of Atif Džafić undated), para. 126; Asim Egrlić, T. 19969 (5 October 2011); Asim Egrlić, P6586 (Transcript from Prosecutor v. Krajišnik), T. 4800; Sakib Muhić, P700 (Transcript from Prosecutor v. Brđanin), T. 8139-8140, 8168; P701 (Witness statement of Sakib Muhić dated 11 April 2000), p. 9; P718 (Witness statement of Ahmet Zulić dated 22 February 2010), p. 32; Ahmet Zulić, T. 1034 (13 April 2010); KDZ163, P3717 (Transcript from Prosecutor v. Stanišić \& Župljanin), T. 5348; D4204 (Witness statement of Radomir Radinković dated 8 December 2013), p. 12; D4235 (Witness statement of Jevto Janković dated 24 January 2014), para. 7. 
Dr. Eniz Šabanović checked Bender's pulse and confirmed he was dead. ${ }^{4922}$ Later that morning, the bodies of Filipović and Bender were wrapped in blankets and loaded into a vehicle with a JNA license plate. ${ }^{4923}$ The guards called out at least eleven other detainees, including a minor, at night and beat them to death. ${ }^{4924}$

1428. Around 10 p.m. on 3 August 1992, guards began beating a detainee named Stipo. ${ }^{4925}$ Stipo fought back and Bulatović subsequently shot him dead. ${ }^{4926}$

1429. The Chamber took judicial notice between June and November 1992, at least 10 detainees died inside Manjača as a result of beatings or of sporadic killings. ${ }^{4927}$ The Chamber also took judicial notice of the fact that Popović ordered that death certificates, giving a false account of the cause of death of detainees who were killed as a result of beatings inside Manjača, be issued. ${ }^{4928}$ In addition, the Chamber received forensic evidence which identifies two bodies as related to this incident. $^{4929}$

1430. Based on the above, the Chamber finds that between 1 June and 18 December 1992, Serb Forces killed at minimum 15 Bosnian Muslim men detained in Manjača.

\footnotetext{
4922 Atif Džafić, T. 19698 (30 September 2011); P3488 (Witness statement of Atif Džafić undated), para. 126; Asim Egrlić, T. 19968-19969 (5 October 2011); P701 (Witness statement of Sakib Muhić dated 11 April 2000), p. 9; Sakib Muhić, P700 (Transcript from Prosecutor v. Brđanin), T. 8168; P718 (Witness statement of Ahmet Zulić dated 22 February 2010), p. 32; Ahmet Zulić, T. 1034 (13 April 2010); D4204 (Witness statement of Radomir Radinković dated 8 December 2013), p. 12; D4235 (Witness statement of Jevto Janković dated 24 January 2014), para. 7.

4923 P701 (Witness statement of Sakib Muhić dated 11 April 2000), pp. 9-10; Sakib Muhić, P700 (Transcript from Prosecutor v. Brđanin), T. 8169.

4924 According to Zulić and Muhić, these detainees were Zijo Avdić, Fadil Kamić, Hukanović, Adem Jakupović, Ivo Mlinar, Milić, Mirso Hlimović, Zikrija Talić, Senad, Supuk, and Ruski. P721 (Second book of Ahmet Zulić's diary), p. 10; Sakib Muhić, P700 (Transcript from Prosecutor v. Brđanin), T. 8139-8140, 8168. P722 (Third book of Ahmet Zulić's diary), p. 1. P722 (Third book of Ahmet Zulić's diary), p. 1.

4927 See Adjudicated Fact 592. But see KDZ163's claim that only five detainees died in Manjača and that of these deaths, only two were caused by violence. KDZ163, P3717 (Transcript from Prosecutor v. Stanišić \& Župljanin), T. 5348, 5353.

4928 See Adjudicated Fact 593.

4929 P4853 (Updated Table 2 to the Report of Amor Mašović), p. 73; P533 (Autopsy reports for Esad Bender and Omer Filipović); P4872 (Ključ Municipal Court's record of exhumation of Kazaferija cemetery, 17 November 1998); P6690 (Addendum to Nicolas Sébire's report, 16 May 2003), pp. 41-42; Nicolas Sébire, P694 (Transcripts from Prosecutor v. Brđanin), T. 16718-16719.
} 


\section{(B) Bosanski Novi}

\section{(1) Charges}

1431. Under Count 3, the Prosecution alleges that persecution, a crime against humanity, was committed in Bosanski Novi as part of the objective to permanently remove Bosnian Muslims and/or Bosnian Croats from the Municipalities. ${ }^{4930}$

1432. Acts of persecution alleged to have been committed in Bosanski Novi by Serb Forces and Bosnian Serb Political and Governmental Organs include (i) torture, beatings, and physical and psychological abuse, during and after the take-over as well as in the Mlakve football stadium, as cruel or inhumane treatment; ${ }^{4931}$ (ii) the establishment and perpetuation of inhumane living conditions in the Mlakve football stadium, including the failure to provide adequate accommodation, shelter, food, water, medical care, or hygienic sanitation facilities, as cruel or inhumane treatment; ${ }^{4932}$ (iii) forcible transfer or deportation of Bosnian Muslims and Bosnian Croats from their homes, ${ }^{4933}$ (iv) unlawful detention in the Mlakve football stadium; ${ }^{4934}$ (v) the appropriation or plunder of property, during and after the take-over in Bosanski Novi, during arrests and detention, and in the course of or following acts of deportation or forcible transfer; ${ }^{4935}$ (vi) the wanton destruction of private property, including homes and business premises, and public property, including cultural monuments and sacred sites; ${ }^{4936}$ and (vii) the imposition and maintenance of restrictive and discriminatory measures. ${ }^{4937}$

1433. Under Counts 7 and 8, the Prosecution alleges deportation and inhumane acts (forcible transfer), respectively, as crimes against humanity. ${ }^{4938}$ In this regard, the Prosecution alleges that by the end of 1992, Serb Forces and Bosnian Serb Political and Governmental Organs had forcibly displaced Bosnian Muslims and Bosnian Croats from areas in Bosanski Novi in which they had been lawfully present. ${ }^{4939}$ It is alleged that from March 1992, restrictive and discriminatory

\footnotetext{
$4930 \quad$ Indictment, paras. 48-49.

4931 Indictment, para. 60(b). See Scheduled Detention Facility C.4.1

4932 Indictment, para. 60(d). See Scheduled Detention Facility C.4.1.

4933 Indictment, para. 60(f).

4934 Indictment, para. 60(g). See Scheduled Detention Facility C.4.1.

4935 Indictment, para. 60(i).

4936 Indictment, para. 60(j). See Scheduled Incident D.4.

4937 Indictment, para. 60(k). The restrictive and discriminatory measures alleged include the denial of freedom of movement; the removal from positions of authority; the invasion of privacy through arbitrary searches of homes; unlawful arrest and/or the denial of the right to judicial process; and/or the denial of equal access to public services. The Chamber notes that the Prosecution does not allege criminal responsibility for rape and other acts of sexual violence or for forced labour at the frontlines in Bosanski Novi. Indictment, fns. 5, 7.

4938 Indictment, paras. 68-75

Indictment, paras. 69,72 .
} 
measures, arbitrary arrest and detention, harassment, torture, killing, destruction of houses, cultural monuments and sacred sites, as well as the threat of further such acts caused Bosnian Muslims and Bosnian Croats to flee in fear, while others were physically driven out. ${ }^{4940}$

\section{(2) Lead-up}

1434. Bosanski Novi is a municipality in northwest $\mathrm{BiH}$ bordered by the municipalities of Bosanski Krupa, Sanski Most, Prijedor, and Bosanski Dubica. ${ }^{4941}$ The Una River runs along the northwestern edge of the municipality, also forming part of the border between $\mathrm{BiH}$ and Croatia. ${ }^{4942}$ In 1991, the population of Bosanski Novi was approximately 42,000, consisting of $33.7 \%$ Muslims, $60.2 \%$ Serbs, and approximately $6 \%$ other ethnicities. ${ }^{4943}$ The Japra valley area in particular, including Suhača and Blagaj, was inhabited predominantly by Bosnian Muslims, while the villages of Maslovare, Gvozdeni, Vitasovci, and Radomirovac had large Serb populations, and the village of Jošava was exclusively a Serb village. ${ }^{4944}$ The village of Blagaj is divided by the Sana River into Blagaj Japra and Blagaj Rijeka. ${ }^{4945}$

1435. Following the multi-party elections in 1990, the SDS won the majority of seats in Bosanski Novi. ${ }^{4946}$ Gavro Bogić was elected as President of the SDS and Radomir Pašić was elected as President of the Municipal Assembly. ${ }^{4947}$

1436. Prior to the 1990 elections and the start of the war in Croatia, inter-ethnic relations between Bosnian Serbs and Bosnian Muslims in Bosanski Novi were generally good. ${ }^{4948}$ However, following the start of the war in Croatia, there were increasing inter-ethnic tensions between

\footnotetext{
$4940 \quad$ Indictment, para. 71.

4941 D484 (Map of BiH).

4942 D484 (Map of BiH).

4943 P4994 (Addendum to Ewa Tabeau's expert report entitled "Ethnic Composition in Internally Displaced Persons and Refugees from 27 Municipalities of BiH 1991 to 1997”, 3 February 2009), pp. 23, 104 (citing to the 1991 RS Population Census). See also P5449 (Report of the MUP, Banja Luka RDB, February 1995), pp. 8-9 (referring to Bosanski Novi as Novi Grad); D4002 (Letter from BiH MUP to Vasvija Vidović, 4 July 1995), p. 6. But see D1913 (Intelligence report re review of security in Bosanski Novi municipality, undated), p. 1. The Chamber shall rely on the statistics for the ethnic composition of Bosanski Novi in 1991 from Tabeau's report which are based on the 1991 RS Population Census.

4944 KDZ011, P3800 (Transcript from Prosecutor v. Brđanin), T. 13959; P687 (Witness statement of Hasan Alić dated 21 August 1999), e-court p. 9; P687 (Witness statement of Hasan Alić to AID, 9 July 1998), e-court p. 18; P3802 (Map of Bosanski Novi with photographs).

4945 See Adjudicated Fact 657.

4946 D3849 (Witness statement of Radomir Pašić dated 5 July 2013), p. 2.

4947 P687 (Witness statement of Hasan Alić dated 21 August 1999), e-court p. 9; D3849 (Witness statement of Radomir Pašić dated 5 July 2013), pp. 2-3.

4948 P687 (Witness statement of Hasan Alić dated 21 August 1999), e-court p. 9; KDZ011, P3800 (Transcript from Prosecutor v. Brđanin), T. 13959.
} 
them. ${ }^{4949}$ When the war broke out in Croatia, border points were closed in Bosanski Novi, among other areas, and movement was restricted. ${ }^{4950}$

1437. As early as 1991 and at the beginning of 1992, Bosnian Muslims began to be dismissed from their employment. ${ }^{4951}$ In mid-April 1992, the newly appointed Serb police chief dismissed all Muslim police officers in Bosanski Novi because they refused to sign an oath of loyalty to the Serb authorities; however, even the Muslims who signed this paper were fired and sent home as well. ${ }^{4952}$ The remaining police officers were issued with a new camouflage uniform with a Serb flag on the epaulette. $^{4953}$ Bosnian Muslims who worked in companies, administrative organs, and institutions in Bosanski Novi were required to sign an oath and were also dismissed from their jobs. ${ }^{4954}$

1438. In April 1992, check-points manned by Bosnian Serb soldiers wearing JNA uniforms were established, including between Hozići and Donji Agići and between Suhača and Jošava. ${ }^{4955}$ Movement was also restricted. ${ }^{4956}$ The soldiers at these specific check-points only checked the papers of Bosnian Muslims. ${ }^{4957}$

1439. Pašić received the Variant A/B Instructions from the SDS Main Board, ${ }^{4958}$ pursuant to which the SDS formed the Bosanski Novi Crisis Staff in April 1992. ${ }^{4959}$ Bosanski Novi was a Variant A municipality as Bosnian Serbs were the majority in the municipality. ${ }^{4960}$ After receiving the RS government instructions on the work of the Crisis Staffs, the Bosanski Novi Crisis Staff re-

\section{9}

KDZ011, P3800 (Transcript from Prosecutor v. Brđanin), T. 13959; KDZ011, T. 21214 (10 November 2011). P687 (Witness statement of Hasan Alić dated 21 August 1999), e-court p. 10; KDZ011, T. 21199-21201 (10 November 2011). See also D1911 (Report of Banja Luka CSB, 11 July 1991).

KDZ011, P3800 (Transcript from Prosecutor v. Brđanin), T. 13961. See also KDZ011, T. 21215-21216 (10 November 2011).

Adjudicated Fact 2279; P687 (Witness statement of Hasan Alić dated 21 August 1999), e-court pp. 9-10. See also P3804 (Witness statement of Charles Kirudja dated 17 November 2010), para. 50.

Adjudicated Fact 2279.

KDZ011, P3800 (Transcript from Prosecutor v. Brđanin), T. 13961, 14025; P2632 (Report of Bosanski Novi's Crisis Staff, undated), pp. 3-4. See Adjudicated Fact 2279. The Chamber received contrary evidence from Radomir Pašić that Muslims were not dismissed from employment and that such ultimatum did not occur and that moreover, it was still relatively peaceful in April 1992. He also testified that Bosnian Muslims "refused to work at the police station, although we asked them to". D3849 (Witness statement of Radomir Pašić dated 5 July 2013), p. 20; Radomir Pašić, T. 41020 (9 July 2013). However, the Chamber does not find this evidence to be reliable. In reaching that conclusion, the Chamber considered that Pašić's evidence in this regard was marked with contradictions.

KDZ011, P3800 (Transcript from Prosecutor v. Brđanin), T. 13961-13962, 13966; KDZ011, T. 21200 (10 November 2011).

KDZ011, P3800 (Transcript from Prosecutor v. Brđanin), T. 13961-13962, 13966; KDZ011, T. 21200 (10 November 2011).

KDZ011, P3800 (Transcript from Prosecutor v. Brđanin), T. 13962.

Radomir Pašić, T. 41011-41014 (9 July 2013).

Radomir Pašić, T. 41014 (9 July 2013); P687 (Witness statement of Hasan Alić dated 21 August 1999), e-court p. 9; KDZ011, T. 21202 (10 November 2011). See also P2632 (Report of Bosanski Novi's Crisis Staff, undated), p. 1.

Radomir Pašić, T. 41014 (9 July 2013). 
organised itself on 20 May 1992 to "take over the prerogatives and functions" of the Municipal Assembly. ${ }^{4961}$ As a result, Pašić, who was President of the Bosanski Novi Municipal Assembly, became President of the Bosanski Novi Crisis Staff. ${ }^{4962}$

1440. In the Muslim village of Suhača, in particular, discussions with SDS representatives from the village of Jošava about the handover of Muslim weapons began in late March $1992 .{ }^{4963}$ At the end of April 1992, the SDA President in Suhača informed the villagers that he had reached an agreement with the SDS members in Bosanski Novi, including Ranko Balaban, President of the SDS in Jošava, that if they surrendered their weapons to the Serbs, they would be allowed to go on living as before. ${ }^{4964}$ The next day, the Bosnian Muslims of Suhača surrendered their weapons to the Serb MP at a check-point between Suhača and Jošava. ${ }^{495}$ Following the surrender of weapons, the villagers were instructed to go to a field in Jošava while they waited for all of the houses in Suhača to be searched by Serb soldiers, accompanied by two Bosnian Muslim civilians. ${ }^{4966}$

1441. On 4 May 1992, the SDS in Bosanski Novi held talks with representatives from the SDA in an attempt to find a compromise that would compel all citizens, Serbs, Muslims, and Croats, in Bosanski Novi to hand in illegally held weapons to the TO or to the Bosanski Novi SJB; on the same day, the ARK government issued an order for mobilisation, instructing the surrender of weapons by 11 May 1992, and imposed a curfew for all citizens in the ARK. ${ }^{4967}$ In line with this order, on or around 9 May 1992, the Bosanski Novi Crisis Staff under Radomir Pašić issued an ultimatum over Bosanski Novi radio for Bosnian Muslims in the municipality to hand in their

\footnotetext{
4961 P2717 (SerBiH Government instructions for Crisis Staffs, 26 April 1992); P2632 (Report of Bosanski Novi’s Crisis Staff, undated), p. 7.

4962 Radomir Pašić, T. 41021-41023 (9 July 2013); P2632 (Report of Bosanski Novi's Crisis Staff, undated), p. 7.

4963 See Adjudicated Fact 2280.

4964 KDZ011, P3800 (Transcript from Prosecutor v. Brđanin), T. 13962-13964.

4965 KDZ011, P3800 (Transcript from Prosecutor v. Brđanin), T. 13962-13966; see Adjudicated Fact 2281. Sifet Barjaktarević organised the surrender of weapons in Suhača, which included approximately 300 weapons in total and were primarily hunting rifles, and pistols. KDZ011, T. 21228-21229 (10 November 2011). See also P3804 (Witness statement of Charles Kirudja dated 17 November 2010), para. 61; P3817 (Memo re 5,000 Muslims from Bosanski Novi, 5 June 1992), p. 1.

4966 KDZ011, P3800 (Transcript from Prosecutor v. Brđanin), T. 13967-13968, 14025-14026; KDZ011, T. 2123921240 (10 November 2011); see Adjudicated Fact 2281. See also P3804 (Witness statement of Charles Kirudja dated 17 November 2010), para. 61; P3817 (Memo re 5,000 Muslims from Bosanski Novi, 5 June 1992), p. 1.

4967 D3849 (Witness statement of Radomir Pašić dated 5 July 2013), pp. 4-5, 19; P2818 (Decision of ARK Regional Secretariat for National Defence, 4 May 1992). See also P2819 (Dispatch from Banja Luka CSB to all SJBs, 4 May 1992); P2632 (Report of Bosanski Novi's Crisis Staff, undated), pp. 3-5; Ewan Brown, T. 21598-21599 (18 November 2011); D1921 (Report of Bosanski Novi SJB, 15 August 1992), p. 1.
} 
weapons within 24 hours. ${ }^{4968}$ However, according to Pašić, a number of citizens ignored these orders and refused to turn in weapons and military equipment. ${ }^{4969}$

\section{(3) Attacks against Bosnian Muslim villages}

(a) Blagaj village

1442. After the deadline for the surrender of weapons expired on 11 May 1992, conflict started in the Blagaj area. ${ }^{4970}$ At 1 a.m. on 14 May 1992, pursuant to orders from Pašić, Serb soldiers fired 13 shells on Blagaj from Izba, a hill overlooking Bosanski Novi. ${ }^{4971}$ Shells were fired into the village for two days, wounding civilians. ${ }^{4972}$ The shelling caused damage to houses of Bosnian Muslims but did not kill anyone. ${ }^{4973}$

1443. On 14 May 1992, a Bosnian Muslim delegation went to speak with Drago Ninić, the SDS president of the neighbouring village of Petkovac, to tell the Bosnian Serbs that Bosnian Muslims in Blagaj did not have weapons. ${ }^{4974}$ The meeting with Ninić also included Bogić, Bosanski Novi SDS President. ${ }^{4975}$ The Serbs did not want to speak to this delegation and demanded that three Bosnian Muslim men in particular be brought to them because they had weapons. ${ }^{4976}$ These men went to talk to the Bosnian Serbs again, when they were also told that "Serbs and Muslims could

\footnotetext{
4968 D1921 (Report of Bosanski Novi SJB, 15 August 1992), p. 1; Milorad Sajić, T. 44134-44135 (27 November 2013); Adjudicated Fact 2283. See also P687 (Witness statement of Hasan Alić dated 21 August 1999), e-court p. 11

4969 D3849 (Witness statement of Radomir Pašić dated 5 July 2013), p. 6. See also P3819 (UNPROFOR Memo, 29 May 1992), p. 4; D1921 (Report of Bosanski Novi SJB, 15 August 1992), pp. 1, 5.

4970 P2632 (Report of Bosanski Novi's Crisis Staff, undated), pp. 4-5. See also P3819 (UNPROFOR Memo, 29 May 1992), p. 4; P6440 (Banja Luka CSB report, 12 May 1992), p. 2.

4971 P687 (Witness statement of Hasan Alić dated 21 August 1999), e-court p. 11; P687 (Witness statement of Hasan Alić to AID, 9 July 1998), e-court p. 19; P6436 (Summary of intercepted conversation, 11 May 1992); D3849 (Witness statement of Radomir Pašić dated 5 July 2013), pp. 20-21; Radomir Pašić, T. 41031-41038 (9 July 2013); see Adjudicated Facts 658, 2284. Despite an intercepted conversation between Major Željaja and Colonel Dević stating that Pašić ordered the attack on Blagaj, Pašić denied that the attack on Blagaj was carried out pursuant to his orders; according to Pašić, as the President of the Municipal Assembly and the President of the Crisis Staff, he did not have the authority to issue such orders or to activate anything in a military sense. Radomir Pašić, T. 41038-41043 (9 July 2013). See P6436 (Summary of intercepted conversation, 11 May 1992). However, the Chamber does not find Pašić's evidence on this issue to be reliable. In reaching this conclusion, the Chamber considered that Pašić's evidence in this regard was contradictory and concluded that he was evasive and lacked sincerity.

$4972 \quad$ See Adjudicated Fact 2284.

4973 P687 (Witness statement of Hasan Alić dated 21 August 1999), e-court p. 11; P687 (Witness statement of Hasan Alić to AID, 9 July 1998), e-court p. 19; P2632 (Report of Bosanski Novi's Crisis Staff, undated), pp. 4-5. See also Adjudicated Fact 2290.

4974 P687 (Witness statement of Hasan Alić dated 21 August 1999), e-court p. 11.

4975 P687 (Witness statement of Hasan Alić to AID, 9 July 1998), e-court p. 19.

4976 P687 (Witness statement of Hasan Alić dated 21 August 1999), e-court p. 11.
} 
not live together any longer". 4977 They reached an agreement that the Bosnian Muslims would gather all of the weapons into the school. ${ }^{4978}$

1444. However, the shelling of Blagaj resumed at around 2 p.m., hours before the delegation had even returned from Petkovac. ${ }^{4979}$ The shells originated from Huzeirovica Brda. ${ }^{4980}$ That evening, a group of 500 villagers, including women and children, formed a column walking to a house of a Bosnian Serb, who had previously been on good terms with Bosnian Muslims, in Maslovare. ${ }^{4981}$ They were stopped on the road by a group of 50 armed men led by Mićo Karlica; these armed men wore green camouflage uniforms with badges showing the four "S" insignia, and cockades on their hats. $^{4982}$ The villagers were told, at gun point, to surrender all weapons; they handed over all of their hunting weapons and were then allowed to continue to the house. ${ }^{4983}$ Later, the same soldiers who confiscated their weapons came to the house and shot at the villagers; one Bosnian Muslim man was wounded, and another was shot dead. ${ }^{4984}$

1445. The next day, 15 May 1992, Captain Bogdan Grab, wearing camouflage and a red beret, arrived in Maslovare with a group of approximately 20 soldiers, and started insulting the villagers. $^{4985}$ Later, Grab's soldiers took 15 Bosnian Muslim men and made them walk in front of the Serbs to "clear" the village of Blagaj but did not find anything. ${ }^{4986}$ There, the Bosnian Serbs placed flags depicting the four Cyrillic "S" symbols around the village. 4987 On the same day, the villagers were allowed to return to the village. ${ }^{4988}$ The shooting continued all around Blagaj and the villagers were surrounded and could not leave. ${ }^{4989}$ On the same day, the mosque and houses of Bosnian Muslims were set on fire. ${ }^{4990}$

P687 (Witness statement of Hasan Alić dated 21 August 1999), e-court p. 11.

P687 (Witness statement of Hasan Alić dated 21 August 1999), e-court p. 11.

P687 (Witness statement of Hasan Alić dated 21 August 1999), e-court p. 11; P687 (Witness statement of Hasan Alić to AID, 9 July 1998), e-court p. 19.

4980 P687 (Witness statement of Hasan Alić to AID, 9 July 1998), e-court p. 19.

4981 P687 (Witness statement of Hasan Alić dated 21 August 1999), e-court p. 11; P687 (Witness statement of Hasan Alić to AID, 9 July 1998), e-court p. 19.

4982 P687 (Witness statement of Hasan Alić dated 21 August 1999), e-court p. 11.

4983 P687 (Witness statement of Hasan Alić dated 21 August 1999), e-court pp. 10-12.

4984 P687 (Witness statement of Hasan Alić dated 21 August 1999), e-court p. 12. The Chamber notes that these killings are not charged pursuant to Schedules A or B of the Indictment. See fn. 13.

4985 P687 (Witness statement of Hasan Alić dated 21 August 1999), e-court p. 12. See also P687 (Witness statement of Hasan Alić dated 29 April 2003), e-court p. 6.

4986 P687 (Witness statement of Hasan Alić dated 21 August 1999), e-court p. 12. The Chamber notes that forced labour, including the use of Bosnian Muslims and Bosnian Croats as human shields, is not charged in Bosanski Novi pursuant to the Indictment. See Indictment, para. 60(h), fn. 7.

4987 P687 (Witness statement of Hasan Alić dated 21 August 1999), e-court p. 12.

4988 P687 (Witness statement of Hasan Alić dated 21 August 1999), e-court p. 12.

4989 P687 (Witness statement of Hasan Alić dated 21 August 1999), e-court p. 12.

4990 P687 (Witness statement of Hasan Alić dated 21 August 1999), e-court p. 12.
} 
1446. According to Alić, after 15 May 1992, Bosnian Muslims from Blagaj Japra were "taken away in droves for questioning" in Bosanski Novi by MP wearing red berets. ${ }^{4991}$

1447. On 24 May 1992, Bosnian Serb soldiers took valuables and money from Bosnian Muslims in Blagaj Rijeka and Blagaj Japra, and houses in Blagaj Rijeka were looted and set on fire. ${ }^{4992}$

\section{(b) Suhača village}

1448. Three days after the villagers surrendered their weapons in May 1992, Suhača was shelled beginning at 6:30 a.m. and continued for the next seven days. ${ }^{4993}$ The shells were fired from the hills surrounding Suhača, from the direction of the villages of Jošava and Krslje, both Serb villages, mainly targeting areas of the village where the mosques were located. ${ }^{4994}$ During the shelling of Suhača, its inhabitants took shelter in the basements of houses. ${ }^{4995}$

1449. One day when there was no shelling, soldiers came to Suhača and told the villagers that the town would be attacked and that they could not protect the villagers. ${ }^{4996}$ They were therefore told to leave and retreat towards Bosanski Novi where it would be decided where they would go. ${ }^{4997}$ After the shelling of Suhača, Bosnian Serb soldiers entered the village and looted the houses. ${ }^{4998}$

(c) Other villages in the Japra valley

1450. The Chamber took judicial notice that on 11 May 1992, Bosnian Serb forces shelled the Bosnian Muslim village of Gornji Agići. ${ }^{4999}$ On 23 May 1992, Muslim villages in the Japra valley,

\footnotetext{
4991 P687 (Witness statement of Hasan Alić to AID, 9 July 1998), e-court p. 20.

$4992 \quad$ Adjudicated Fact 658

4993 KDZ011, P3800 (Transcript from Prosecutor v. Brđanin), T. 13967-13969; KDZ011, T. 21186-21187 (10 November 2011); Adjudicated Fact 660.

4994 KDZ011, P3800 (Transcript from Prosecutor v. Brđanin), T. 13959, 13968-13969; KDZ011, T. 21187, 21240 (10 November 2011).

4995 KDZ011, P3800 (Transcript from Prosecutor v. Brđanin), T. 13969. The Chamber notes that KDZ011 gave evidence in the Brđanin case that houses close to the mosques in Suhača were damaged during the shelling of the village; see KDZ011, P3800 (Transcript from Prosecutor v. Brđanin), T. 13969. However, on crossexamination in this case, KDZ011 confirmed his testimony in the Krajišnik case, stating that houses in Suhača remained intact after the shelling, except for abandoned houses on the hills around the village. KDZ011, T. 21241 (10 November 2011). Based on KDZ011's conflicting evidence on this issue, the Chamber is not satisfied that houses in Suhača were damaged during the shelling of the village.

KDZ011, P3800 (Transcript from Prosecutor v. Brđanin), T. 13969-13970. See also Adjudicated Fact 668.

KDZ011, P3800 (Transcript from Prosecutor v. Brđanin), T. 13970. See also Adjudicated Fact 668.

4998 See Adjudicated Fact 660. See also P2632 (Report of Bosanski Novi's Crisis Staff, undated), pp. 8-9. According to Pašić, there were no orders to do so from the official authorities and it was difficult to monitor "uncontrolled groups" who entered towns and Muslim houses for their own enrichment. D3849 (Witness statement of Radomir Pašić dated 5 July 2013), pp. 23-24. However, the Chamber does not find this evidence to be reliable. In reaching that conclusion, the Chamber observed that Pašić's evidence was marked with contradictions and concluded that he was not a reliable witness.

4999 See Adjudicated Fact 661.
} 
including Gornji Agići and Donji Agići, were attacked and houses were set alight; in Donji Agići, Bosnian Muslim property was looted and set on fire by Serb Forces. 5000

\section{(4) $\underline{\text { Scheduled Incident D.4 }}$}

1451. The Indictment refers to the destruction of nine mosques in Bosanski Novi which occurred at least between March and June 1992. ${ }^{5001}$

1452. In May 1992, the old wooden mosque in Blagaj Rijeka and the mosque in Blagaj Japra were shelled and set on fire by soldiers, destroying their minarets. ${ }^{5002}$ During the shelling of Suhača, the two mosques in the village, the Stara Suhača and the Suhača mosques, were also badly damaged. 5003

1453. In early May or June 1992, the town mosque in Bosanski Novi, Gradska Džamija, was shelled, set on fire by Bosnian Serb soldiers, and destroyed. ${ }^{5004}$ The walls were badly damaged but the minaret remained standing. ${ }^{5005}$ Heavy machinery was brought from Prijedor in order to knock down the minaret. ${ }^{5006}$ When the mosque was destroyed, trucks arrived to remove the rubble from the mosque and the site was then flattened and used as a parking lot; the tombs of the cemetery

5000 P3804 (Witness statement of Charles Kirudja dated 17 November 2010), para. 61; P3817 (Memo re 5,000 Muslims from Bosanski Novi, 5 June 1992), p. 2; Adjudicated Facts 661, 2285. See also D470 (CSB Banja Luka Report concerning collection centres, undated), e-court p. 17; P2632 (Report of Bosanski Novi's Crisis Staff, undated), pp. 8-9. Pašić maintains that there was no shelling of these villages "to his knowledge" with heavy weaponry and that only searches for illegal weapons occurred; furthermore, Pašić testified that the authorities did not order or give instructions to destroy or burn property "just because it is Muslim". D3849 (Witness statement of Radomir Pašić dated 5 July 2013), pp. 6, 22-23; Radomir Pašić, T. 41043-41046 (9 July 2013). However, the Chamber does not find this evidence to be reliable based on the Chamber's observations about his contradictory evidence and low credibility.

5001 The Indictment refers to the following nine mosques: Stara Suhača mosque, the Suhača mosque, the mosque in Blagaj Japra, the mosques in Prekosanje, Urije, and Gornji Agići, the old wooden mosque in Blagaj Rijeka, the town mosque in Bosanski Novi (Gradska Džamija), and the Vidorije mosque. Indictment, Schedule D.4.

5002 P687 (Witness statement of Hasan Alić dated 21 August 1999), e-court pp. 11-12, 16; P687 (Witness statement of Hasan Alić to AID, 9 July 1998), e-court p. 20 (testifying further that on 15 May 1992, two men, including Veljko Lazarević from Blagaj Japra, first fired bullets at the mosque in Blagaj Japra and then set fire to it, including the wood minaret); KDZ011, T. 21195-21196 (10 November 2011). See Adjudicated Facts 662, 663, 2290. See also P4070 (Attachment to the expert report of András J. Riedlmayer, entitled "Destruction of Cultural Heritage in BiH” prepared for the Karadžić case, formatted records), pp. 35-36, 44-46; P4069 (Cultural destruction database), records 58-59. See also paras. 1444-1445.

5003 KDZ011, P3800 (Transcript from Prosecutor v. Brđanin), T. 14012-14013; KDZ011, T. 21187-21188, 21196 (10 November 2011). See Adjudicated Fact 664. See also P3803 (Photograph of destroyed mosque in Suhača); P4070 (Attachment to the expert report of András J. Riedlmayer, entitled "Destruction of Cultural Heritage in BiH” prepared for the Karadžić case, formatted records), pp. 31-34; P4069 (Cultural destruction database), records 74-75. See also paras. 1448-1449.

5004 See Adjudicated Fact 666. As KDZ011 was leaving Bosanski Novi from Mlavke stadium in an open truck, he saw that both mosques in Bosanski Novi, the Gradska Džamija and Vidorije mosques, were destroyed; however he saw that an Orthodox church in Bosanski Novi was still standing. KDZ011, T. 21196, 21214 (10 November 2011); KDZ011, P3800 (Transcript from Prosecutor v. Brđanin), T. 14018. See also P4070 (Attachment to the expert report of András J. Riedlmayer, entitled "Destruction of Cultural Heritage in BiH" prepared for the Karadžić case, formatted records), pp. 47-51; P4069 (Cultural destruction database), record 64.

5005 Adjudicated Fact 666. 
were also removed. ${ }^{5007}$ The Vidorije mosque was burned down in May 1992 and its minaret was destroyed. ${ }^{5008}$ The mosques in Prekosanje, Urije, and Gornji Agići were also destroyed during the summer months of $1992 .{ }^{5009}$

1454. The Chamber has considered the evidence it has received which identified Serb Forces as responsible for the destruction of mosques in Bosanski Novi in May and June 1992. ${ }^{5010}$ It also had regard to the fact that almost all mosques in the municipality sustained heavy damage or were completely destroyed after Serb Forces took over the municipality. Having weighed these factors, the Chamber is satisfied beyond reasonable doubt that Serb Forces were responsible for the attacks on and destruction of mosques in Bosanski Novi.

1455. The Chamber therefore finds that nine mosques in Bosanski Novi municipality were destroyed or heavily damaged by Serb Forces in May and June 1992.

\section{(5) Movement of the population within and from Bosanski Novi}

1456. On 20 May 1992, the SDS Municipal Board adopted three decisions regarding the situation in Bosanski Novi: (i) all citizens who wanted to leave Bosanski Novi were "enabled to do so peacefully"; (ii) all measures and activities that could be aimed at driving out residents were strictly prohibited; and (iii) all citizens who wanted to remain were required to be loyal to RS. ${ }^{5011}$ In line with these decisions, Pašić began to look for solutions, including negotiating with UNPROFOR and other representatives, "to enable Muslims who wished to leave Bosanski Novi". 5012

\footnotetext{
$5006 \quad$ Adjudicated Fact 666.

5007 See Adjudicated Fact 666.

5008 KDZ011, T. 21196 (10 November 2011); KDZ011, P3800 (Transcript from Prosecutor v. Brđanin), T. 14018; Adjudicated Fact 667. See also P4070 (Attachment to the expert report of András J. Riedlmayer, entitled "Destruction of Cultural Heritage in BiH" prepared for the Karadžić case, formatted records), pp. 52-56; P4069 (Cultural destruction database), record 63.

5009 Adjudicated Fact 665. KDZ011 also testified he saw that the minarets of the mosques in Prekosanje and Urije had been destroyed when he passed the towns on the train heading to Mlavke stadium in June 1992. KDZ011, T. 21195 (10 November 2011). See also P4070 (Attachment to the expert report of András J. Riedlmayer, entitled "Destruction of Cultural Heritage in BiH" prepared for the Karadžić case, formatted records), pp. 3743; P4069 (Cultural destruction database), records 71, 73, 76.

5010 See paras. 1444-1445, 1448-1449. In his final brief, the Accused argues that there is no evidence that official authorities in Bosanski Novi ordered or otherwise participated in the destruction of the mosques there. See Defence Final Brief, para. 1503. Furthermore, according to Pašić, there was no organised destruction of mosques and all mosques were set on fire by paramilitaries, or "unknown perpetrators". D3849 (Witness statement of Radomir Pašić dated 5 July 2013), pp. 18, 27. However, the Chamber has considered the evidence before it and given its findings on the destructions of mosques in Bosanski Novi as well as its assessment of Pašić's credibility, the Chamber does not find his evidence to be reliable in this regard. See fn. 4971.

5011 D3849 (Witness statement of Radomir Pašić dated 5 July 2013), pp. 7-8.

5012 D3849 (Witness statement of Radomir Pašić dated 5 July 2013), pp. 8-9.
} 
1457. On 24 May 1992, between 8,000 and 10,000 Bosnian Muslim men, women, and children from various villages in the Japra valley, including 1,200 Bosnian Muslims from Suhača, left the valley in a convoy of cars, tractors, and horse-drawn carts. ${ }^{5013}$ They headed to Blagaj Japra. ${ }^{5014}$

1458. Meanwhile, SDA President and representative of Suhača, Sifet Barjaktarević, negotiated with Bosanski Novi municipal authorities regarding the safe passage of this convoy to Croatia. ${ }^{5015}$ An MP patrol sent the convoy towards Bosanski Novi, accompanied by two military trucks with Bosnian Serb soldiers. ${ }^{5016}$ Bosnian Serb soldiers wearing JNA uniforms intercepted the convoy at Blagaj Japra bridge $\mathrm{e}^{5017}$ and demanded that they leave their property and board a train headed towards Banja Luka. ${ }^{5018}$ When they refused, the convoy was forced to return to Blagaj where it remained guarded by armed Bosnian Serb soldiers until 9 June 1992. ${ }^{5019}$ Freedom of movement was limited and special permission was required to leave the village, making it feel "like a prison camp". 5020

1459. On 26 May 1992, Charles Kirudja, the Chief Civil Affairs Officer and Civil Affairs Coordinator for UNPROFOR in UN Protected Area Sector North, a UN protected area in Croatia adjacent to the northwestern boarder of $\mathrm{BiH}$, met with Jugoslav Borojević, Mayor of Dvor in Croatia. ${ }^{5021}$ Borojević told Kirudja that Pašić had requested the passage of 5,000 Bosnian Muslims from Bosanski Novi who were leaving the municipality "voluntarily" and would travel through Krajina to Austria and Slovenia. ${ }^{5022}$ Kirudja asked how Serb authorities could speak about the

5013 KDZ011, P3800 (Transcript from Prosecutor v. Brđanin), T. 13971-13972; P687 (Witness statement of Hasan Alić to AID, 9 July 1998), e-court p. 21; P3804 (Witness statement of Charles Kirudja dated 17 November 2010), para. 61; P3817 (Memo re 5,000 Muslims from Bosanski Novi, 5 June 1992), p. 2. See also KDZ011, T. 21204, 21207 (10 November 2011); P2632 (Report of Bosanski Novi's Crisis Staff, undated), pp. 8-9; Adjudicated Facts 669, 2286.

5014 KDZ011, P3800 (Transcript from Prosecutor v. Brđanin), T. 13971-13972; P687 (Witness statement of Hasan Alić to AID, 9 July 1998), e-court p. 21. See also Adjudicated Fact 659.

5015 KDZ011, P3800 (Transcript from Prosecutor v. Brđanin), T. 13972, 13975-13976; see Adjudicated Fact 669. See also D3849 (Witness statement of Radomir Pašić dated 5 July 2013), p. 21.

5016 See Adjudicated Fact 669.

5017 KDZ011, P3800 (Transcript from Prosecutor v. Brđanin), T. 13973. According to Kirudja, the soldiers were "persons in Serbian military uniforms and Serb paramilitary groups" and from the symbols on their uniforms, "it was deduced they were under the control of the SDS and Mayor Pasić". P3804 (Witness statement of Charles Kirudja dated 17 November 2010), para. 61.

5018 KDZ011, P3800 (Transcript from Prosecutor v. Brđanin), T. 13973; P3804 (Witness statement of Charles Kirudja dated 17 November 2010), para. 61; P3817 (Memo re 5,000 Muslims from Bosanski Novi, 5 June 1992), p. 2. See Adjudicated Facts 669, 2286.

5019 KDZ011, P3800 (Transcript from Prosecutor v. Brđanin), T. 13973-13975; P687 (Witness statement of Hasan Alić dated 21 August 1999), e-court p. 13; P687 (Witness statement of Hasan Alić to AID, 9 July 1998), e-court p. 21; P3817 (Memo re 5,000 Muslims from Bosanski Novi, 5 June 1992), p. 2. See Adjudicated Fact 669.

5020 P687 (Witness statement of Hasan Alić dated 21 August 1999), e-court p. 13; P687 (Witness statement of Hasan Alić to AID, 9 July 1998), e-court p. 21.

5021 P3804 (Witness statement of Charles Kirudja dated 17 November 2010), paras. 2, 40.

5022 P3804 (Witness statement of Charles Kirudja dated 17 November 2010), paras. 40-42; Charles Kirudja, T. 21259-21260, 21278-21280 (11 November 2011) (testifying further that when asked why a mayor in Croatia 
desires of a group of Muslims without a single Bosnian Muslim representative being present, but he was only told to speak with Pašić on the phone, which he refused to do. ${ }^{5023}$

1460. The next day, a delegation from Bosanski Novi, including Pašić, arrived unannounced at Kirudja's office to discuss the request. ${ }^{5024}$ Pašić admitted to Kirudja that Bosnian Muslims in Bosanski Novi had been put under pressure from "armed Serbian irregulars" to leave the area after refusing to sign loyalty oaths to the new SerBiH government or to disarm. ${ }^{5025}$ According to Pašić, the 5,000 Muslims had asked the authorities in Bosanski Novi for protection and conveyed their desire to travel in a convoy to Austria and Germany where they had relatives. ${ }^{5026}$ Given that the Bosnian Muslims had refused to go to other parts of $\mathrm{BiH}$ because they were afraid of being mobilised, Pašić informed Kirudja that the Bosanski Novi authorities "wanted to do everything possible to accommodate their wishes" and to provide a peaceful and secure departure for the Muslim population from Bosanski Novi. ${ }^{5027}$ Determining that the Bosnian Muslims were not leaving Bosanski Novi voluntarily, Kirudja refused to provide UN assistance "to make refugees out of people still in their own homes". 5028

1461. In the beginning of June 1992, there were many rounds of negotiations between Muslim representatives, the Serb municipal authorities, and international representatives, to discuss the

was speaking on behalf of the mayor of Bosanski Novi, Borojević told Kirudja that Bosanski Novi was now part of a "new reality", or the new reality of the "Serbian Republic of BiH", and the Bosnian Muslims did not want to accept this new Serb authority in Bosanski Novi). See also P3815 (UNPROFOR Memo, 8 June 1992), p. 2.

5023 P3804 (Witness statement of Charles Kirudja dated 17 November 2010), para. 43; Charles Kirudja, T. 2126021262 (11 November 2011). See also P3816 (UNPROFOR Memo, 26 May 1992).

5024 P3804 (Witness statement of Charles Kirudja dated 17 November 2010), para. 45; D3849 (Witness statement of Radomir Pašić dated 5 July 2013), p. 9. See also P3815 (UNPROFOR Memo, 8 June 1992), pp. 2-3.

5025 P3804 (Witness statement of Charles Kirudja dated 17 November 2010), paras. 46-48, 50-51; Charles Kirudja, T. 21280-21281, 21283-21284 (11 November 2011); D3849 (Witness statement of Radomir Pašić dated 5 July 2013), p. 9; Radomir Pašić, T. 41047 (9 July 2013). See also P3815 (UNPROFOR Memo, 8 June 1992), p. 3; P3818 (UNPROFOR daily report, 11 May 1992).

5026 P3804 (Witness statement of Charles Kirudja dated 17 November 2010), paras. 45, 49. See also P3819 (UNPROFOR Memo, 29 May 1992), pp. 3-4; Charles Kirudja, T. 21292-21294 (11 November 2011). Pašić also informed Kirudja that two Muslim spokespersons from Bosanski Novi had been identified, Barjaktarević and Fikret Hamzagić, a member of the SDA and member of the Bosanski Novi municipal government, respectively; Kirudja later received information that they had been imprisoned in a school in Blagaj. P3804 (Witness statement of Charles Kirudja dated 17 November 2010), paras. 46, 61; P3817 (Memo re 5,000 Muslims from Bosanski Novi, 5 June 1992), p. 2.

5027 P3804 (Witness statement of Charles Kirudja dated 17 November 2010), para. 45; D3849 (Witness statement of Radomir Pašić dated 5 July 2013), p. 9; P2918 (Order of Bosanski Novi's Crisis Staff, 8 June 1992). See also D1916 (Conclusion of Bosanski Novi Municipal Assembly, 18 June 1992) (referring inter alia to the decisions adopted by the SDS Municipal Board on 20 May 1992 referred to in paragraph 1456); D1917 (Bosanski Novi Red Cross announcement, 7 June 1992); Radomir Pašić, T. 41048-41050, 41057-41058, 41073-41076, 4109041092 (9 July 2013) (testifying further that Bosnian Muslims wanted to leave voluntarily and the Serb authorities did not threaten anyone or forcibly remove anyone from their homes, nor did they have an objective to do so).

5028 P3804 (Witness statement of Charles Kirudja dated 17 November 2010), para. 52; Charles Kirudja, T. 2128221283, 21298-21299 (11 November 2011); P3819 (UNPROFOR Memo, 29 May 1992), p. 5; P3815 (UNPROFOR Memo, 8 June 1992), p. 3. See also KDZ240, P2935 (Transcript from Prosecutor v. Krajišnik), T. 6789-6791 (under seal); D1918 (Letter to Radomir Pašić, 20 June 1992). 
departure of Croats and Muslims in a convoy from Bosanski Novi. ${ }^{5029}$ The negotiations took place in Pašić's office, in Dvor, in Emin Purić's house, and on the bridge over the Una River. ${ }^{5030}$ There was no discussion regarding the possibility for people to return. ${ }^{5031}$

1462. On 8 June 1992, the villagers in Blagaj were told by Bosnian Serbs to move out of the village. $^{5032}$ On the morning of 9 June 1992, a bus full of Bosnian Serb soldiers, a truck, and a tank drove through Blagaj from the direction of Svodna. ${ }^{5033}$ In Troske village, the soldiers got off the bus and the tank turned around and stopped 500 metres from Blagaj, and pointed its cannon toward the village. ${ }^{5034}$ The soldiers began firing infantry weapons at civilians in the village and there were explosions from houses and houses were shot at and burned. ${ }^{5035}$ The attack lasted about two hours, and those staying in the village fled towards the bridge in the direction of Blagaj Rijeka in order to escape. $^{5036}$ However, at the bridge, the Bosnian Muslim men, women, and children were stopped by masked Bosnian Serb soldiers from neighbouring villages, some of whom wore civilian clothing while the rest were wearing green camouflage uniforms. ${ }^{5037}$ The soldiers instructed them to hand over all of their personal belongings, including money, gold, jewellery, identification cards, photographs, and papers and keys for cars. ${ }^{5038}$ The soldiers threatened to kill anyone if they were later found with money or gold. ${ }^{5039}$

1463. A man named "Zoran", nicknamed "Red Beret", wearing a JNA uniform, arrived and started separating the men from the women before they crossed the bridge. ${ }^{5040}$ Soldiers wearing JNA uniforms waited on the other side of the bridge and searched the Bosnian Muslims again and

\footnotetext{
5029 See Adjudicated Fact 2291. See also D3849 (Witness statement of Radomir Pašić dated 5 July 2013), pp. 2425.

5030 See Adjudicated Fact 2291. See also D3849 (Witness statement of Radomir Pašić dated 5 July 2013), pp. 2425.

$5031 \quad$ Adjudicated Fact 2291.

5032 P687 (Witness statement of Hasan Alić dated 21 August 1999), e-court p. 13; P687 (Witness statement of Hasan Alić to AID, 9 July 1998), e-court p. 21.

5033 KDZ011, P3800 (Transcript from Prosecutor v. Brđanin), T. 13976; P687 (Witness statement of Hasan Alić dated 21 August 1999), e-court p. 13.

5034 KDZ011, P3800 (Transcript from Prosecutor v. Brđanin), T. 13976-13977; P687 (Witness statement of Hasan Alić dated 21 August 1999), e-court p. 13.

5035 KDZ011, P3800 (Transcript from Prosecutor v. Brđanin), T. 13977; P687 (Witness statement of Hasan Alić dated 21 August 1999), p. 13; P687 (Witness statement of Hasan Alić to AID, 9 July 1998), e-court p. 21.

$5036 \quad$ KDZ011, P3800 (Transcript from Prosecutor v. Brđanin), T. 13977-13978.

5037 P687 (Witness statement of Hasan Alić dated 21 August 1999), e-court p. 13. See also KDZ011, T. 21209 (10 November 2011).

5038 KDZ011, P3800 (Transcript from Prosecutor v. Brđanin), T. 13978; P687 (Witness statement of Hasan Alić dated 21 August 1999), e-court p. 13; P687 (Witness statement of Hasan Alić to AID, 9 July 1998), e-court p. 21.

5039 P687 (Witness statement of Hasan Alić to AID, 9 July 1998), e-court p. 21.

5040 KDZ011, P3800 (Transcript from Prosecutor v. Brđanin), T. 13978-13980.
} 
separated some of the men from the group, while women and children were sent inside the Japra Company compound, which was surrounded by barbed wire. ${ }^{5041}$

1464. A group of the Bosnian Muslim men was instructed by soldiers to lie down in the road in two rows 50 metres away from the tank pointing at them and their pockets were searched again. ${ }^{5042}$ A Bosnian Serb from Jošava, nicknamed "Trnka", ordered Alić's brother and two other men to leave the formation, and led them away and shot them. ${ }^{5043}$ While the remaining men were lying on the road, the tank was ordered to drive over them by a bearded man called "Vojvoda". 5044 The tank began driving towards them but was stopped by an officer who came from the direction of the bridge and ordered that the people be removed from the road, stating that no one should be killed that way. ${ }^{5045}$ The men lying on the road were taken to the Japra Company compound. ${ }^{5046}$ Later, the Bosnian Serbs soldiers called five men to step forward; however, only three of the five men were still alive and stepped forward. ${ }^{5047}$ The remaining men were loaded onto train cars waiting at the compound by the soldiers. 5048

1465. In total, approximately 4,000 to 8,000 Bosnian Muslims were loaded onto 22 train cars, used to transport cattle, at Blagaj Japra by members of the Municipal TO Staff and the MP. ${ }^{5049}$ Women and children were loaded onto the train cars first and the men were loaded on after; the cars were tightly packed with people with no space left. ${ }^{5050}$ Alić was one of the last ones to board and

5041 KDZ011, P3800 (Transcript from Prosecutor v. Brđanin), T. 13980-13981. See also KDZ011, T. 21209 (10 November 2011); Adjudicated Fact 631.

5042 P687 (Witness statement of Hasan Alić dated 21 August 1999), e-court p. 13.

5043 P687 (Witness statement of Hasan Alić dated 21 August 1999), e-court pp. 13-14; P687 (Witness statement of Hasan Alić to AID, 9 July 1998), e-court pp. 21-22.

5044 P687 (Witness statement of Hasan Alić dated 21 August 1999), e-court p. 14.

5045 P687 (Witness statement of Hasan Alić dated 21 August 1999), e-court p. 14; P687 (Witness statement of Hasan Alić to AID, 9 July 1998), e-court p. 22.

5046 P687 (Witness statement of Hasan Alić dated 21 August 1999), e-court p. 14.

5047 P687 (Witness statement of Hasan Alić dated 21 August 1999), e-court p. 14 (stating that the five men called to step forward were Husein Ekić, Hasan Ekić, Saim Sumić, Kemal Alić, and Ismet Selimagić; however, Kemal Alić and Ismet Selimagić had already been killed by this point); P687 (Witness statement of Hasan Alić to AID, 9 July 1998), e-court p. 22; KDZ011, P3800 (Transcript from Prosecutor v. Brđanin), T. 13994-13995.

5048 KDZ011, P3800 (Transcript from Prosecutor v. Brđanin), T. 13994-13995; P687 (Witness statement of Hasan Alić dated 21 August 1999), e-court p. 14; P687 (Witness statement of Hasan Alić to AID, 9 July 1998), e-court p. 23. The Chamber notes that the above killings are not charged pursuant to Schedules A or B of the Indictment. See fn. 13.

5049 KDZ011, P3800 (Transcript from Prosecutor v. Brđanin), T. 13995-13996; KDZ011, T. 21209-21212 (10 November 2011); P687 (Witness statement of Hasan Alić dated 21 August 1999), e-court p. 14; Ewan Brown, T. 21599-21600 (18 November 2011); D1921 (Report of Bosanski Novi SJB, 15 August 1992), pp. 2-3. See also D470 (CSB Banja Luka Report concerning collection centres, undated), e-court p. 10; Adjudicated Fact 631.

5050 KDZ011, P3800 (Transcript from Prosecutor v. Brđanin), T. 13995-13997; P687 (Witness statement of Hasan Alić dated 21 August 1999), e-court p. 14. See Adjudicated Facts 632, 633. 
witnessed two individuals taken off the train and shot by a Bosnian Serb man. ${ }^{5051}$ Guarded by the members of the Bosanski Novi SJB, the train left in the direction of Banja Luka and stopped in Ostruzna, a village near Doboj, the next morning. ${ }^{5052}$ In Ostruzna, the men were separated from the women and children by a soldier, nicknamed "Jovo" or "Joja". 5053 The women, children, and men above 60 years old were put in the front part of the train and the remaining carriages were filled with men between 15 and 60 years old. ${ }^{5054}$ The carriages were separated and the women and children were taken to Doboj, while the men, numbering approximately 700 to 750 , were loaded onto four train cars and sent to Banja Luka. ${ }^{5055}$

1466. The men spent the night on the train in Banja Luka, where they were mistreated and cursed at by Bosnian Serb soldiers. ${ }^{5056}$ On the morning of 11 June 1992, the train continued to Bosanski Novi, stopping once in Blagaj where men on the train had water for the first time in two days. ${ }^{5057}$ While in Blagaj, Alić saw Bosnian Serbs taking possessions from their houses. ${ }^{5058}$ The men were then loaded back into the train cars and taken to Mlakve Football Stadium. ${ }^{5059}$ No food was given to them during the entire period spent in the railway carriages and there were no hygienic facilities aboard. ${ }^{5060}$

5051 P687 (Witness statement of Hasan Alić dated 21 August 1999), e-court p. 14. The Chamber notes that these killings are not charged pursuant to Schedules A or B of the Indictment. See fn. 13.

5052 KDZ011, P3800 (Transcript from Prosecutor v. Brđanin), T. 13991, 13994-13995, 14031; P687 (Witness statement of Hasan Alić dated 21 August 1999), e-court p. 14; D1921 (Report of Bosanski Novi SJB, 15 August 1992), p. 3. See also Adjudicated Fact 633; KDZ011, T. 21209-21210 (10 November 2011).

5053 KDZ011, P3800 (Transcript from Prosecutor v. Brđanin), T. 13995; P687 (Witness statement of Hasan Alić dated 21 August 1999), e-court pp. 14-15; P687 (Witness statement of Hasan Alić to AID, 9 July 1998), e-court p. 23.

5054 KDZ011, P3800 (Transcript from Prosecutor v. Brđanin), T. 13995-13997; P687 (Witness statement of Hasan Alić dated 21 August 1999), e-court pp. 14-15; P687 (Witness statement of Hasan Alić to AID, 9 July 1998), ecourt p. 23.

5055 KDZ011, P3800 (Transcript from Prosecutor v. Brđanin), T. 13997; KDZ011, T. 21210-21212 (10 November 2011); Ewan Brown, T. 21599-21600 (18 November 2011); P687 (Witness statement of Hasan Alić dated 21 August 1999), e-court pp. 14-15; P687 (Witness statement of Hasan Alić to AID, 9 July 1998), e-court p. 23. See Adjudicated Fact 633; D1921 (Report of Bosanski Novi SJB, 15 August 1992), pp. 3-4. See also D3849 (Witness statement of Radomir Pašić dated 5 July 2013), p. 22 (stating that there was a convoy of Bosnian Muslims travelling by train from Blagaj to Prijedor, Banja Luka, and Doboj, but that the number of people in the convoy was between 400-600).

5056 KDZ011, P3800 (Transcript from Prosecutor v. Brđanin), T. 13997-13998, 14032; P687 (Witness statement of Hasan Alić dated 21 August 1999), e-court p. 15. See Adjudicated Fact 633.

5057 KDZ011, P3800 (Transcript from Prosecutor v. Brđanin), T. 13998; P687 (Witness statement of Hasan Alić dated 21 August 1999), e-court p. 15.

5058 P687 (Witness statement of Hasan Alić dated 21 August 1999), e-court p. 15.

5059 P687 (Witness statement of Hasan Alić dated 21 August 1999), e-court p. 15; KDZ011, P3800 (Transcript from Prosecutor v. Brđanin), T. 13998-13999. The Chamber notes that it will deal with the detention of people at Mlakve Football Stadium at the end of this section of the judgement.

$5060 \quad$ See Adjudicated Facts 634, 635. 
1467. At the end of June or beginning of July 1992, the Bosanski Novi Crisis Staff issued instructions regulating the conditions for people to be allowed to leave the municipality. ${ }^{5061}$ On 6 July 1992, Pašić sent a letter to Kirudja repeating his claim that Bosnian Muslims from Bosanski Novi were leaving the municipality voluntarily, and stating that Bosnian Serb authorities had offered to provide buses and security for them. ${ }^{5062}$ Between 7 and 10 July 1992, Kirudja met with officials from Dvor and Bosanski Novi and they informed Kirudja that Bosnian Muslims leaving Bosanski Novi were required to sign a statement indicating that they left voluntarily, and to prove that they had either sold, exchanged, or donated their houses and all other immovable property. ${ }^{5063}$ Persons who did not own property had to obtain an official document from the municipal land registry office certifying this and those who owned property were required to draft a contract either leaving the property to the Serbs or the Serb state, or simply renouncing it. ${ }^{5064}$ Persons wishing to leave also had to provide a list of all the members of the household, obtain a certificate showing that they had no previous convictions, obtain a certificate showing that all utility bills were paid; obtain documentation from the municipal secretariat for national defence stating that they had completed military service; and obtain a document from the SJB allowing them to leave. ${ }^{5065}$ All documents had to state that the action taken was on a voluntary basis. ${ }^{5066}$

1468. The Bosanski Novi authorities informed Kirudja that they had processed applications from 3,000 to 5,000 people who fulfilled the criteria. ${ }^{5067}$ On the basis of this information, Kirudja

5061 Adjudicated Fact 2292. See also D1916 (Conclusion of Bosanski Novi Municipal Assembly, 18 June 1992); P3835 (Letter from Bosanski Novi Crisis Staff, 6 July 1992).

5062 P3804 (Witness statement of Charles Kirudja dated 17 November 2010), paras. 77-78; P3835 (Letter from Bosanski Novi Crisis Staff, 6 July 1992). See also P3836 (Order of Dvor na Uni Municipal Crisis Staff, 8 July 1992). However, according to Pašić, a number of Muslims who did not possess the requisite documentation also left the municipality. D3849 (Witness statement of Radomir Pašić dated 5 July 2013), pp. 25-26; Radomir Pašić, T. 41079-41082 (9 July 2013).

5063 P3804 (Witness statement of Charles Kirudja dated 17 November 2010), paras. 83-85; P3840 (Fax re Bosanski Novi: Dvor Issue and Refugee Flood, 12 July 1992), pp. 2-3; P3837 (UNPROFOR Memo, 9 July 1992); P3838 (UNPROFOR Memo, 8 July 1992), p. 1. See P6439 (Official record of Bosanski Novi Secretariat for Administrative and Social Affairs, 9 July 1992); P3841 (UNPROFOR Memo, 13 July 1992), p. 2; P3842 (UNPROFOR Memo, 13 July 1992), pp. 2-3. See also para. 1481.

Adjudicated Fact 2292. See also KDZ240, P2935 (Transcript from Prosecutor v. Krajišnik), T. 7008-7009 (under seal).

5065 Adjudicated Fact 2292.

5066 Adjudicated Fact 2292. According to Pašić, Bosnian Muslims leaving Bosanski Novi were allowed to make their own decisions regarding their property, including that they could take all of their personal property, including vehicles, with them. With regard to real estate, they were allowed to sell it, swap it, give it for safekeeping, or cede it to other refugees, and made decisions in this regard without any duress and influence from the municipal authorities. Moreover, according to Pašić, a majority of the property referred to in the certificates was "completely legally replaced" with Serbian assets from Croatia and the contracts signed by Muslims were only "temporary" until the situation calmed down. D3849 (Witness statement of Radomir Pašić dated 5 July 2013), pp. 10-11, 25-26; Radomir Pašić, T. 41079-41086 (9 July 2013). However, the Chamber does not find this evidence to be reliable. In reaching that conclusion, the Chamber considered the significant body of evidence supporting that Bosnian Muslims were forced to sign over their property and finds that Pašić gave inconsistent and evasive evidence in this regard. 
concluded that the Bosnian Muslims were not leaving Bosanski Novi voluntarily and he informed the Serb authorities that UNPROFOR did not wish their departure if they did not want to leave. ${ }^{5068}$ Moreover, Kirudja concluded that there was a strategy to ethnically cleanse the area by the Serb authorities and they were using the UN Protected Area in Sector North as an exit point. ${ }^{5069}$

1469. However, between 20 and 21 July 1992, Kirudja and other international authorities became increasingly concerned about the safety of the convoy and ultimately, the Croatian authorities agreed to accept the Bosnian Muslims and UNHCR agreed to organise the transportation with UNPROFOR's assistance, stating they "preferred 4,000 more refugees than 4,000 more bodies". 5070

1470. Although originally intended to be 4,000 people, on 23 July 1992, a convoy of between 9,000 and 11,000 Bosnian Muslims and some Bosnian Croats, including between 600 and 700 detainees from Mlakve Football Stadium and a large number from Prijedor, Bosanska Kostajnica, and Bosanska Dubica, were ultimately transported to Karlovac, and later to third countries. ${ }^{5071}$

1471. The Bosanski Novi SJB reported that by 23 July 1992, it had "de-registered" 5,629 Muslims who had applied to leave the municipality "voluntarily". 5072 Of the approximately 14,000 Bosnian Muslims living in Bosanski Novi prior to the conflict, roughly 1,000 Muslims remained behind following the departure of the convoy to Karlovac on 23 July $1992 .^{5073}$ In sum, by the end of 1992 , the majority of Bosnian Muslims had left Bosanski Novi. ${ }^{5074}$ According to KDZ011, not a single

5068 P3804 (Witness statement of Charles Kirudja dated 17 November 2010), paras. 80, 83

5069 P3804 (Witness statement of Charles Kirudja dated 17 November 2010), para. 80. See also KDZ240, P2935 (Transcript from Prosecutor v. Krajišnik), T. 6789-6791 (under seal).

5070 [REDACTED]; P3804 (Witness statement of Charles Kirudja dated 17 November 2010), paras. 94-98; P3847 (UNPROFOR Memo, 21 July 1992), pp. 2-3. See also P2940 (Reuters report, 27 July 1992), p. 1 (under seal); Adjudicated Fact 673.

5071 P3804 (Witness statement of Charles Kirudja dated 17 November 2010), para. 99 (testifying that although the original number of Bosnian Muslims to be transported was 4,000, the actual number exceeded 9,000, and as a result, the transportation took the entire day); KDZ240, P2935 (Transcript from Prosecutor v. Krajišnik), T. 6785-6787 (under seal); P2951 (Press release of Republic of Croatia Ministry of Information, 24 July 1992) (under seal); P2940 (Reuters report, 27 July 1992), p. 1 (under seal). See Adjudicated Fact 671. See also P687 (Witness statement of Hasan Alić dated 21 August 1999), e-court p. 16; KDZ011, P3800 (Transcript from Prosecutor v. Brđanin), T. 14018. See also para. 1482.

5072 D1921 (Report of Bosanski Novi SJB, 15 August 1992), p. 4. See also Adjudicated Fact 2293.

5073 See Adjudicated Fact 672. In August 1992, Kirudja and other international authorities were pressed by Serb authorities to assist in the evacuation of thousands more refugees, primarily Bosnian Muslims, from Sanski Most, Prijedor, Bosanska Krupa, and Bosanska Kostajnica through Sector North, claiming that if they did not assist, "the Muslims will suffer". Pašić warned Kirudja that "[i]f we are left to resolve the matter by ourselves, we will resolve it very quickly". However, the international authorities responded that they would not succumb to further "blackmail" and refused to assist in any further "evacuations" of non-Serbs out of BiH. P3804 (Witness statement of Charles Kirudja dated 17 November 2010), paras. 101-118; P2941 (Article from The Associated Press, 11 August 1992) (under seal); P3856 (UNPROFOR report, 5 September 1992), pp. 3-5.

5074 In reaching that conclusion, the Chamber noted that by 1997 , very few Bosnian Muslims had returned to Bosanski Novi. In 1991, approximately 33.7\% of the population of Bosanski Novi was Muslim and in 1995, $4.8 \%$ of the population was Muslim and in 1997, Muslims only comprised $2.7 \%$ of the population. P4994 (Addendum to Ewa Tabeau's expert report entitled "Ethnic Composition in Internally Displaced Persons and Refugees from 27 Municipalities of BiH 1991 to 1997”, 3 February 2009), pp. 23-24, 104. See also P10 
Bosnian Muslim remained in the town of Suhača by the end of $1992 .^{5075}$ When Alić returned to Blagaj after the war, he found Bosnian Serbs living in his house, after being given permission by authorities. ${ }^{5076}$ He observed that there were only 64 houses still in good condition after the war and they were all occupied by Bosnian Serbs. ${ }^{5077}$

1472. Having considered the totality of the evidence and assessed the circumstances in which departures occurred, the Chamber finds that Bosnian Muslims were forced to leave Bosanski Novi.

\section{(6) Scheduled Detention Facility C.4.1}

1473. The Indictment refers to a detention facility at the Mlakve football stadium which operated at least between May and July 1992.

1474. On 2 June 1992, members of the Bosanski Novi TO and MP brought between 300 and 350 non-Serbs to the Mlakve football stadium ("Mlakve Football Stadium") and detained them there for four days. ${ }^{5078}$ On 6 June 1992, Kirudja was informed by members of the Danish UNPROFOR team in Sector North that they had seen 350 men gathered at the stadium; they were then seen being loaded onto buses and driven off to an unknown destination in $\mathrm{BiH}^{5079}$ The observers also saw that approximately 100 women and children, with their heads covered in clothes and carrying plastic bags, had been brought into the stadium with ten armed guards; Kirudja later learned that the women and children had likely been delivering provisions to the men held in the stadium. ${ }^{5080}$

1475. On 11 June 1992, the train coming from Banja Luka arrived at the stadium, where soldiers with machine guns ordered the men off the train and instructed them to go inside the empty stadium. ${ }^{5081}$ From early June until the end of August 1992, at least 700 Bosnian Muslim civilian men, some elderly, from Bosanski Novi municipality were confined at the Mlakve Football

(Report of the MUP, Banja Luka SNB, May 1993), p. 2 (referring to Bosanski Novi as Novi Grad); P5449 (Report of the MUP, Banja Luka RDB, February 1995), pp. 8-9 (referring to Bosanski Novi as Novi Grad); D4002 (Letter from BiH MUP to Vasvija Vidović, 4 July 1995), p. 7 (estimating that 500 non-Serbs remained in Bosanski Novi in 1995).

5075 KDZ011, P3800 (Transcript from Prosecutor v. Brđanin), T. 14018.

5076 P687 (Witness statement of Hasan Alić dated 21 August 1999), e-court p. 16.

5077 P687 (Witness statement of Hasan Alić dated 21 August 1999), e-court p. 16.

5078 D1921 (Report of Bosanski Novi SJB, 15 August 1992), pp. 1-2.

5079 P3804 (Witness statement of Charles Kirudja dated 17 November 2010), paras. 55-57, 59. See also P3821 (UNPROFOR Memo, 6 June 1992), p. 2; P3815 (UNPROFOR Memo, 8 June 1992), p. 3; P3823 (UNPROFOR report, 20 July 1992), p. 7.

5080 P3804 (Witness statement of Charles Kirudja dated 17 November 2010), paras. 58-59; P3822 (Fax from UNPROFOR, 6 June 1992); P3815 (UNPROFOR Memo, 8 June 1992), p. 2. See also P3823 (UNPROFOR report, 20 July 1992), p. 7.

5081 KDZ011, P3800 (Transcript from Prosecutor v. Brđanin), T. 13998-13999; P687 (Witness statement of Hasan Alić dated 21 August 1999), e-court p. 15. See Adjudicated Fact 634. See also paras. 1465-1466. 
Stadium; some of these men were transferred from the Omarska, Trnopolje, and Keraterm camps. $^{5082}$

1476. The detainees at Mlakve Football Stadium were guarded by Bosnian Serb soldiers, as well as reservists, including Ranko Balaban, former SDS President in Jošava, and Momčilo Kenjalo. ${ }^{5083}$ Once a week on Wednesdays, the guards would change shifts. ${ }^{5084}$

1477. For the duration of their detention, the stadium was fenced in and the detainees were not allowed to leave. ${ }^{5085}$ Although no detainees were killed during their detention at the stadium, ${ }^{5086}$ beatings did take place, ${ }^{5087}$ and this included beatings when drunk Bosnian Serb soldiers returned from the front. ${ }^{5088}$ As a result of the beating inflicted by a Bosnian Serb soldier, a detainee was blinded in one eye. ${ }^{5089}$ Detainees were also verbally mistreated; the guards cursed, taunted and threatened the detainees with death, and subjected them to ethnic slurs. ${ }^{5090}$ A Bosnian Serb soldier with a gun forced detainees to graze grass like animals, for the purposes of humiliating them. ${ }^{5091}$

1478. The quantity of food was not sufficient and detainees received at most two small meals a day; access to water was also limited to twice a day. ${ }^{5092}$ Detainees lost considerable weight-Alić lost 18 kilograms and KDZ011 lost 11 kilograms-during their detention. ${ }^{5093}$

5082 See Adjudicated Facts 628, 629. According to Pašić, Mlakve Football Stadium was not a "camp", but a reception centre where "some non-Serbs, who possessed weapons and military equipment, were processed". D3849 (Witness statement of Radomir Pašić dated 5 July 2013), pp. 15, 27. However, the Chamber does not find this evidence to be reliable based upon its consideration that Pašić provided insincere and ultimately unsatisfactory evidence.

5083 P687 (Witness statement of Hasan Alić dated 21 August 1999), e-court p. 15; KDZ011, P3800 (Transcript from Prosecutor v. Brđanin), T. 13999, 14004-14005, 14013. See Adjudicated Fact 630.

5084 P687 (Witness statement of Hasan Alić dated 21 August 1999), e-court p. 15; KDZ011, P3800 (Transcript from Prosecutor v. Brđanin), T. 13999.

5085 KDZ011, P3800 (Transcript from Prosecutor v. Brđanin), T. 13999-14000; P687 (Witness statement of Hasan Alić dated 21 August 1999), e-court p. 15.

5086 KDZ011, T. 21212 (10 November 2011).

5087 See Adjudicated Fact 636. While KDZ011 and Alić testified that there were no beatings and that they were not physically mistreated or beaten while detained at Mlakve Football Stadium, in light of the conditions at the stadium as described by these witnesses, including verbal and psychological abuse, as well as the fact that hundreds of other detainees were held there, the Chamber is of the view that the evidence of KDZ011 and Alic does not rebut the presumption created by Adjudicated Facts 636, 637, and 638. See also para. 1481; KDZ011, P3800 (Transcript from Prosecutor v. Brđanin), T. 14016-14017; P687 (Witness statement of Hasan Alić dated 21 August 1999), e-court pp. 15-16).

5088 Adjudicated Fact 638

5089 Adjudicated Fact 637

$5090 \quad$ KDZ011, P3800 (Transcript from Prosecutor v. Brđanin), T. 14002; P687 (Witness statement of Hasan Alić to AID, 9 July 1998), e-court p. 24; see Adjudicated Fact 639.

5091 See Adjudicated Fact 640.

5092 KDZ011, T. 21192 (10 November 2011); P687 (Witness statement of Hasan Alić to AID, 9 July 1998), e-court p. 24; see Adjudicated Fact 644 According to Pašić, detainees at Mlakve Football Stadium received three meals per day and that it was the same food given to the military and TO staff. D3849 (Witness statement of Radomir Pašić dated 5 July 2013), pp. 26-27. However, the Chamber does not find Pašić's evidence in this regard to be reliable given that his evidence was marked with contradictions and insincerity. 
1479. The detainees were confined to one part of the stadium, as a result there was a shortage of space for approximately 700 men. ${ }^{5094}$ They slept on the floor with no blankets. ${ }^{5095}$ Although the detainees could wash themselves, they did not have any facilities to wash clothes. ${ }^{5096}$ Toilet facilities were also inadequate. ${ }^{5097}$ Some of the detainees were ill and were not provided with medical care at any point; one man died of asthma while detained. ${ }^{5098}$ Detainees were not allowed to move around the stadium but they had to perform labour to smooth the path around the stadium. ${ }^{5099}$ Later, visits to the stadium were not permitted, letters and parcels were not allowed to be sent or received, and the detainees were not allowed to notify anyone of their location or detention. $^{5100}$

1480. From one side of the stadium, the detainees could see UNPROFOR vehicles across the Una River on the Croatian side and tried to signal for help with white flags; the UNPROFOR soldiers noticed them, however, the guards at Mlakve Football Stadium realised and forbade the detainees from further use of that section of the stadium. ${ }^{5101}$ During their detention, the soldiers called out names of the detainees and brought them to the police station, the fire department, or Hotel Una for interrogation. ${ }^{5102}$

1481. On or around 22 July 1992, after approximately 45 days of detention, the detainees at the Mlakve Football Stadium were told by members of the Bosnian Serb MP that they would be released. ${ }^{5103}$ For approximately 80 detainees who had family in the town of Bosanski Novi, close to the stadium, their family members could sign certificates to release them earlier than the other

\footnotetext{
5093 P687 (Witness statement of Hasan Alić to AID, 9 July 1998), e-court p. 24; KDZ011, P3800 (Transcript from Prosecutor v. Brđanin), T. 13999-14000. See also Adjudicated Fact 644.

5094 Adjudicated Fact 642.

5095 KDZ011, P3800 (Transcript from Prosecutor v. Brđanin), T. 13999; see Adjudicated Fact 643.

5096 KDZ011, P3800 (Transcript from Prosecutor v. Brđanin), T. 14002; Adjudicated Fact 645.

5097 Adjudicated Fact 645.

5098 KDZ011, P3800 (Transcript from Prosecutor v. Brđanin), T. 14000; see Adjudicated Fact 646. The Chamber notes that killings resulting from cruel and inhumane treatment at Mlakve Football Stadium are not charged pursuant to Schedule C of the Indictment. See Indictment, para. 60(a), fn. 4. See also fn. 13 of this Judgement. KDZ011, T. 21192 (10 November 2011); KDZ011, P3800 (Transcript from Prosecutor v. Brđanin), T. 1400014002. The Chamber notes that forced labour at the frontlines, including the use of Bosnian Muslims and Bosnian Croats as human shields, is not charged in Bosanski Novi pursuant to the Indictment. See Indictment, para. 60(h), fn. 7.

5100 KDZ011, T. 21191 (10 November 2011); P687 (Witness statement of Hasan Alić to AID, 9 July 1998), e-court p. 24.

5101 KDZ011, P3800 (Transcript from Prosecutor v. Brđanin), T. 14003; P687 (Witness statement of Hasan Alić dated 21 August 1999), e-court p. 15; P3804 (Witness statement of Charles Kirudja dated 17 November 2010), para. 71. See also P3829 (UNPROFOR Memo, 22 June 1992), p. 2; P3830 (UNPROFOR Memo, 22 June 1992), p. 3; Charles Kirudja, T. 21344-21348 (11 November 2011).

$5102 \quad$ See Adjudicated Fact 2287.

5103 KDZ011, P3800 (Transcript from Prosecutor v. Brđanin), T. 14014; P687 (Witness statement of Hasan Alić dated 21 August 1999), e-court p. 15; P687 (Witness statement of Hasan Alić to AID, 9 July 1998), e-court p. 24. See Adjudicated Fact 641 (stating that detainees were held at Mlakve Football Stadium for about 45 days).
} 
detainees. ${ }^{5104}$ The remaining detainees were forced to sign certificates to be released, confirming that they would voluntarily surrender all of their movable and immovable property to the RS in Bosanski Novi. ${ }^{5105}$ After the certificates were signed, 15 detainees, all members of the SDA party, were singled out of the group and taken to the "fire house", where they were beaten. ${ }^{5106}$ According to Alić, about nine men were killed. ${ }^{5107}$

1482. On 23 July 1992, the detainees at Mlakve Football Stadium were released pursuant to an order by the Bosanski Novi Municipal Executive Board. ${ }^{5108}$ An UNPROFOR vehicle arrived at the stadium; all of the detainees were then loaded onto buses and trucks and taken across the bridge to Dvor, Croatia. ${ }^{5109}$ During this process, there were no soldiers around the detainees and they were guarded by UNPROFOR soldiers. ${ }^{5110}$

1483. The Chamber therefore finds that during the period between 2 June and 23 July 1992 , members of the Serb Forces detained Bosnian Muslim men at the Mlakve Football Stadium, and subjected them to beatings and verbal mistreatment, including threats and ethnic slurs. The Chamber also finds that detainees held at Mlakve Football Stadium were not provided with adequate food or water, resulting in malnutrition, and that there was no medical care available to the detainees during this period.

\section{(C) Ključ}

\section{(1) $\underline{\text { Charges }}$}

1484. Under Count 3, the Prosecution alleges that persecution, a crime against humanity, was committed in Ključ as part of the objective to permanently remove Bosnian Muslims and/or Bosnian Croats from the Municipalities. ${ }^{511}$ Under Count 1, the Prosecution further alleges that in

\footnotetext{
$5104 \quad$ KDZ011, P3800 (Transcript from Prosecutor v. Brđanin), T. 14014.

5105 KDZ011, P3800 (Transcript from Prosecutor v. Brđanin), T. 14014-14016; KDZ011, T. 21194 (10 November 2011); P687 (Witness statement of Hasan Alić dated 21 August 1999), e-court p. 15.

5106 KDZ011, P3800 (Transcript from Prosecutor v. Brđanin), T. 14016-14017; P687 (Witness statement of Hasan Alić dated 21 August 1999), e-court pp. 15-16.

5107 P687 (Witness statement of Hasan Alić dated 21 August 1999), e-court p. 16. The Chamber received evidence that nine detainees died in the Mlakve Football Stadium; however, the Chamber notes that killings at Mlakve Football Stadium are not charged pursuant to Schedule B of the Indictment, nor resulting from cruel and inhumane treatment pursuant to Schedule C of the Indictment. See Indictment, para. 60(a), fn. 4. See also fn. 13 of this Judgement.

5108 D1921 (Report of Bosanski Novi SJB, 15 August 1992), p. 2 (stating that Mlakve Football Stadium was closed after the detainees were released).

5109 KDZ011, P3800 (Transcript from Prosecutor v. Brđanin), T. 14014, 14017-14018; KDZ011, T. 21194 (10 November 2011); P687 (Witness statement of Hasan Alić dated 21 August 1999), e-court p. 16.

5110 KDZ011, P3800 (Transcript from Prosecutor v. Brđanin), T. 14017; P687 (Witness statement of Hasan Alić dated 21 August 1999), e-court p. 16.

5111 Indictment, paras. 48-49.
} 
certain municipalities, including Ključ, this persecutory campaign included or escalated to include conduct that manifested an intent to destroy in part the national, ethnical, and/or religious groups of Bosnian Muslims and/or Bosnian Croats as such. ${ }^{5112}$

1485. Acts alleged to have been committed in Ključ by Serb Forces and Bosnian Serb Political and Governmental Organs include killings during and after the take-over; ${ }^{5113}$ killings related to detention facilities, ${ }^{5114}$ and killings committed during, and deaths resulting from, cruel and inhumane treatment at scheduled detention facilities. ${ }^{515}$ The Prosecution characterises these acts as killing, an underlying act of genocide, under Count 1; persecution, a crime against humanity, under Count 3; extermination, a crime against humanity, under Count 4; murder, a crime against humanity, under Count 5; and murder, a violation of the laws or customs of war, under Count $6 .^{5116}$

1486. Other acts alleged to have been committed in Ključ by Serb Forces and Bosnian Serb Political and Governmental Organs include torture, beatings, and physical and psychological abuse, rape and other acts of sexual violence, during and after the take-over and in scheduled detention facilities, as well as the establishment and perpetuation of inhumane living conditions in detention facilities, as cruel or inhumane treatment, an act of persecution under Count $3 .^{5117}$ In relation to Count 1, the Prosecution alleges that in scheduled detention facilities in Ključ thousands of Bosnian Muslims and Bosnian Croats were subjected to cruel or inhumane treatment, including torture, physical and psychological abuse, rape, other acts of sexual violence, and beatings by Serb Forces and Bosnian Serb Political and Governmental Organs; the Prosecution characterises this inhumane treatment as causing serious bodily or mental harm to members of the Bosnian Muslim and Bosnian Croat groups, an underlying act of genocide. ${ }^{5118}$ In addition, under Count 1, the Prosecution alleges that members of the Bosnian Muslim and Bosnian Croat groups were detained under conditions of life calculated to bring about physical destruction, namely through cruel and inhumane treatment, including torture, physical and psychological abuse, rape, other acts of sexual violence, inhumane living conditions, forced labour and the failure to provide adequate accommodation, shelter, food, water, medical care or hygienic sanitation facilities. ${ }^{5119}$

\footnotetext{
$5112 \quad$ Indictment, para. 38.

5113 Indictment, para. 60(a)(i). See Scheduled Incidents A.7.1, A.7.2, A.7.3.

5114 Indictment, para. 60(a)(ii). Scheduled Incident B.10.

5115 Indictment, para. 60(a)(ii). Scheduled Detention Facilities C.15.1, C.15.2, C.15.3.

5116 Indictment, paras. 40(a), 60(a), 63(a), 63(b).

5117 Indictment, para. 60(b), 60(c), 60(d) (specifying that the conditions included the failure to provide adequate accommodation, shelter, food, water, medical care, or hygienic sanitation facilities). See Scheduled Detention Facilities C.15.1, C.15.2, C.15.3.

5118 Indictment, para. 40(b).

5119 Indictment, para. 40(c). See Scheduled Detention Facilities C.15.1, C.15.2, C.15.3.
} 
1487. Under Count 3, other acts of persecution alleged to have been committed in Ključ by Serb Forces and Bosnian Serb Political and Governmental Organs include: (i) forcible transfer or deportation of Bosnian Muslims and Bosnian Croats from their homes; ${ }^{5120}$ (ii) unlawful detention in scheduled detention facilities; ${ }^{.121}$ (iii) forced labour at the frontline and the use of Bosnian Muslims and Bosnian Croats as human shields; ${ }^{5122}$ (iv) appropriation or plunder of property during and after the take-over, during arrests and detention, and in the course of or following acts of deportation or forcible transfer, ${ }^{5123}$ (v) the wanton destruction of private property including homes and business premises and public property including cultural monuments and sacred sites; ${ }^{5124}$ and (vi) the imposition and maintenance of restrictive and discriminatory measures. ${ }^{5125}$

1488. Under Counts 7 and 8, the Prosecution alleges deportation and inhumane acts (forcible transfer), respectively, as crimes against humanity. ${ }^{5126}$ In this regard, the Prosecution alleges that by the end of 1992, Serb Forces and Bosnian Serb Political and Governmental Organs had forcibly displaced Bosnian Muslims and Bosnian Croats from areas in Ključ in which they had been lawfully present. ${ }^{5127}$ It is alleged that from March 1992, restrictive and discriminatory measures, arbitrary arrest and detention, harassment, torture, rape and other acts of sexual violence, killings, destruction of houses, cultural monuments, and sacred sites, as well as the threat of further such acts caused Bosnian Muslims and Bosnian Croats to flee in fear, while others were physically driven out. ${ }^{5128}$

\section{(2) Lead-up}

1489. The municipality of Ključ lies within northwestern BiH south of Sanski Most and southwest of Banja Luka. ${ }^{5129}$ In 1991, the municipality included eight villages that were then inhabited primarily by non-Serbs: Velagići, Krasulje, Biljani, Prhovo, Crljeni, Pudin Han, Ramići, and

\footnotetext{
5120 Indictment, para. 60(f).

5121 Indictment, para. 60(g).

5122 Indictment, para. 60(h)

5123 Indictment, para. 60(i).

5124 Indictment, para. 60(j). See Scheduled Incident D.13.

5125 Indictment, para. 60(k). The restrictive and discriminatory measures alleged include the denial of freedom of movement, the removal from positions of authority in local government institutions and the police and the general dismissal from employment, the invasion of privacy through arbitrary searches of homes, unlawful arrest and/or denial of the right to judicial process, and/or the denial of equal access to public services.

5126 Indictment, paras. 68-75.

5127 Indictment, paras. 69, 72.

5128 Indictment, para. 71.

5129 Asim Egrlić, T. 19926-19927, 19940 (5 October 2011); P3574 (Map of BiH, highlighted); D1729 (Map of BiH marked by KDZ192); P3855 (Map of Croatia and BiH marked by Charles Kirudja); P3492 (Map of ethnic composition of Ključ); D1352 (Report of Ključ SJB to Banja Luka CSB, July 1992), p. 1; D1738 (Report of the Assistant Commander for Civilian Affairs of the Military Post 7286, 16 February 1993), p. 2.
} 
Sanica, which each contained several hamlets. ${ }^{5130}$ The population of Ključ numbered approximately 37,300 people in 1991, among which $49.6 \%$ were Serb, $47.3 \%$ were Muslim, and $0.9 \%$ were Croat. $^{5131}$

1490. Ethnic relations in Ključ were "quite harmonious" before the war. ${ }^{5132}$ In November 1990, the SDS achieved a majority by winning $50.8 \%$ of the votes in the Ključ municipal elections, while the SDA won $32.8 \% .^{5133}$ In accordance with the principle of "equal representation", positions within the municipal administration were allocated according to an agreement between the SDS, the SDA, and the MBO. ${ }^{5134}$ Jovo Banjac of the SDS was appointed President of the Municipality; while Omer Filipović, the leader of the Ključ MBO, was made Vice President of the Municipal Assembly as well as Banjac's deputy; Asim Egrlić, the President of the Ključ SDA, and Tihomir Dakić of the SDS became Chairman and Vice Chairman of the Executive Board of the Ključ Municipal Assembly, respectively. ${ }^{5135}$ The rest of the municipal executive positions were evenly distributed to both SDA and SDS members. ${ }^{5136}$ Vinko Kondic of the SDS became Chief of the SJB, while Atif Džafić, who was nominated by the SDA but was not affiliated with any party, became acting commander of the police. ${ }^{5137}$

1491. Once the war in Croatia began during the summer of 1991, the Ključ Secretariat for People's Defence began to issue mobilisation orders to Ključ's male population. ${ }^{5138}$ However, both

5130 P3488 (Witness statement of Atif Džafić undated), paras. 7-8; Atif Džafić, T. 19657-19658 (30 September 2011); D1738 (Report of the Assistant Commander for Civilian Affairs of the Military Post 7286, 16 February 1993), p. 2. See also P3575 (Map of Ključ).

5131 D1352 (Report of Ključ SJB to Banja Luka CSB, July 1992), p. 1; P3488 (Witness statement of Atif Džafić undated), para. 7; P3492 (Map of ethnic composition of Ključ); D1738 (Report of the Assistant Commander for Civilian Affairs of the Military Post 7286, 16 February 1993), p. 2. See also P1476 (Ratko Mladić's notebook, 30 December 1991-14 February 1992), e-court pp. 64-65.

5132 Asim Egrlić, P6586 (Transcript from Prosecutor v. Krajišnik), T. 4638; Asim Egrlić, T. 19938 (5 October 2011); D4169 (Witness statement of Rajko Kalabić dated 1 December 2013), para. 5; KDZ024, P713 (Transcript from Prosecutor v. Brđanin), T. 9100-9101 (under seal).

5133 P3488 (Witness statement of Atif Džafić undated), paras. 4, 10; Asim Egrlić, P6586 (Transcript from Prosecutor v. Krajišnik), T. 4637; KDZ192, T. 19430 (22 September 2011) (closed session). See also D4169 (Witness statement of Rajko Kalabić dated 1 December 2013), para. 4.

5134 KDZ192, P3416 (Transcript from Prosecutor v. Brđanin), T. 11658 (under seal); KDZ192, T. 19430-19431, 19433 (22 September 2011) (closed session).

5135 P3488 (Witness statement of Atif Džafić undated), paras. 4, 10, 11; Atif Džafić, T. 19673-19674 (30 September 2011); Asim Egrlić, P6586 (Transcript from Prosecutor v. Krajišnik), T. 4635, 4637, 4638, 4681-4682; Asim Egrlić, T. 19939 (5 October 2011); D4169 (Witness statement of Rajko Kalabić dated 1 December 2013), para. 4; KDZ192, T. 19431 (22 September 2011) (closed session).

5136 D4169 (Witness statement of Rajko Kalabić dated 1 December 2013), paras. 4-5; P3488 (Witness statement of Atif Džafić undated), paras. 10-11.

5137 P3488 (Witness statement of Atif Džafić undated), paras. 4-5 (differentiating but not explaining the difference between the positions of SJB chief and police commander), 10; D4169 (Witness statement of Rajko Kalabić dated 1 December 2013), para. 4. See also Adjudicated Fact 933.

5138 P3488 (Witness statement of Atif Džafić undated), para. 38; Atif Džafić, T. 19694 (30 September 2011); Asim Egrlić, P6586 (Transcript from Prosecutor v. Krajišnik), T. 4646; Asim Egrlić, T. 19954-19955 (5 October 
local and national leaders of the SDA and MBO discouraged Bosnian Muslims from responding. ${ }^{5139}$ Thus, Bosnian Muslims and Bosnian Croats generally did not respond to mobilisation into the JNA and for the frontline in Croatia, whereas Bosnian Serbs did. ${ }^{5140}$ The lack of Bosnian Muslim response to the mobilisation led to the composition of the JNA becoming primarily Bosnian Serb. ${ }^{5141}$

1492. The Bosnian Serb population of Ključ obtained arms through this mobilisation process, as those returning from the frontline in Croatia retained possession of their weapons. ${ }^{5142}$ The SDS was also involved in distributing weapons to Bosnian Serbs in Ključ. ${ }^{5143}$ The SDS Executive Board discussed the distribution of weapons multiple times between October 1991 and March 1992, ${ }^{5144}$ when Veljko Kondić remarked that "we will undertake to get additional weapons". 5145 Thereafter, the SDS Executive Board established record-keeping reflecting the weapons kept. ${ }^{5146}$

2011); P3422 (Minutes of the $2^{\text {nd }}$ session of Ključ SDS Municipal Board Executive Board, 20 September 1991), p. 1; P3424 (Minutes of the $3^{\text {rd }}$ session of Ključ Municipal Board Executive Board, 2 October 1991), pp. 1-2.

5139 Asim Egrlić, P6586 (Transcript from Prosecutor v. Krajišnik), T. 4936-4942; Asim Egrlić, T. 19956-19957 (5 October 2011); P3488 (Witness statement of Atif Džafić undated), para. 38; P3576 (Announcement of Ključ's MBO Municipal Board, 21 September 1991), p. 1.

5140 KDZ192, T. 19437 (22 September 2011) (closed session); Asim Egrlić, P6586 (Transcript from Prosecutor v. Krajišnik), T. 4638, 4846; Asim Egrlić, T. 19955, 19957-19958, 19961 (5 October 2011); P3488 (Witness statement of Atif Džafić undated), para. 39. See e.g. P3422 (Minutes of the $2^{\text {nd }}$ session of Ključ Municipal Board Executive Board, 20 September 1991), p. 1; KDZ192, P3416 (Transcript from Prosecutor v. Brđanin), T. 11368 (under seal).

5141 Asim Egrlić, P6586 (Transcript from Prosecutor v. Krajišnik), T. 4641, 4844; KDZ192, T. 19439 (22 September 2011) (closed session).

5142 Asim Egrlić, P6586 (Transcript from Prosecutor v. Krajišnik), T. 4641-4642, 4663-4664; Atif Džafić, T. 19688 (30 September 2011); KDZ024, P713 (Transcript from Prosecutor v. Brđanin), T. 9109 (under seal). Members of the reserve police force, who had been mobilised at the same time as the TO, were also issued weapons. P3493 (List of Ključ SJB of persons who were issued weapons, undated); Atif Džafić, P3488 (Witness statement of Atif Džafić undated), para. 37. Several witnesses also testified that they had heard that weapons were delivered via military helicopter. KDZ075, P3359 (Transcript from Prosecutor v. Krajišnik), T. 4956-4957; KDZ075, T. 19015-19016 (16 September 2011). See also P3488 (Witness statement of Atif Džafić undated), para. 36; Asim Egrlić, P6586 (Transcript from Prosecutor v. Krajišnik), T. 4663-4664; KDZ024, P713 (Transcript from Prosecutor v. Brđanin), T. 9109, 9200 (under seal); P3580 (Official Statement of Ključ's MBO Municipal Board, 21 September 1991), p. 1.

5143 See KDZ192, P3416 (Transcript from Prosecutor v. Brđanin), T. 11489 (under seal).

5144 P3424 (Minutes of the $3^{\text {rd }}$ session of Ključ SDS Municipal Board Executive Board, 2 October 1991), pp. 1-2; P3428 (Minutes of $6^{\text {th }}$ Session of Ključ SDS Municipal Board Executive Board, 23 December 1991), pp. 3-4 (reflecting that Jovan Kevac and Boško Bajić suggested to the "Crisis Staff" that Bosnian Serbs acquire arms).

5145 P3435 (Minutes of the $9^{\text {th }}$ session of Ključ SDS Municipal Board Executive Board, 12 March 1992). See also P3433 (Minutes of the $8^{\text {th }}$ session of Ključ SDS Municipal Board Executive Board, 6 March 1992), p. 1 (recording that Ljuban Bajić had suggested that a training should be held).

5146 P3436 (Minutes of the $10^{\text {th }}$ session of Ključ SDS Municipal Board Executive Board, 23 March 1992), p. 1; P3493 (List of Ključ SJB of persons who were issued weapons, undated). The Chamber thus does not accept the testimony of Rajko Kalabić, who testified that the procurement of weapons was done by individuals rather than by the SDS. D4169 (Witness statement of Rajko Kalabić dated 1 December 2013), para. 14. For a discussion of the armament of Bosnian Muslims, see para. 1508. 
1493. Between late 1991 and the spring of 1992, soldiers returning from the frontlines in Croatia often became inebriated and committed drive-by shootings, firing at local mosques in Ključ. ${ }^{5147}$ While the SDS discussed these problems and made statements denouncing the use of firearms in public, ${ }^{5148}$ Vinko Kondić ultimately returned weapons that had been seized from soldiers "engag[ing] in illegal acts". 5149 Additionally, during the latter half of 1991, Serb Forces established check-points at the various entrances to Ključ. ${ }^{5150}$ Ethnic relations in Ključ deteriorated, compromising both the functioning of municipal organs as well as security in general. ${ }^{5151}$

1494. Throughout the fall of 1991, the SDA and MBO opposed the growing signs of regionalisation in Ključ. In late September, the SDA released a public statement rejecting the proclamation of the ARK as a "para-state" successor organisation to the ZOBK and warning that if "such an illegal decision" were implemented, the SDA would organise a referendum to establish a "separate Muslim commune". 5152

1495. At the end of October 1991, the Ključ SDS received a telex message from Radoslav Brđanin which contained an "Order of the SDS Sarajevo" and outlined a number of instructions

5147 P3488 (Witness statement of Atif Džafić undated), paras. 40-41; Atif Džafić, T. 19687-19688 (30 September 2011). See also Asim Egrlić, P6586 (Transcript from Prosecutor v. Krajišnik), T. 4641-4642, 4661-4662, 4700; KDZ075, P3359 (Transcript from Prosecutor v. Krajišnik), T. 4956; KDZ075, T. 19035, 19037, 19039 (16 September 2011); P3584 (Joint Official Announcement of Ključ's MBO Municipal Board and SDA Town Board, 24 December 1991), p. 1.

5148 P3431 (Handwritten diary of KDZ192) (under seal), pp. 7-8; KDZ192, P3416 (Transcript from Prosecutor v. Brđanin), T. 11461 (under seal). See also P3580 (Official Statement of Ključ's MBO Municipal Board, 21 September 1991), pp. 1-2 (stating its opposition to "uncontrolled arming"and proposing inter-party talks).

5149 P3488 (Witness statement of Atif Džafić undated), para. 41; Atif Džafić, T. 19688 (30 September 2011). When asked about what action might be taken to curb such excesses, Vinko Kondić told Džafić that he was too busy and had "bigger fish to fry"”. P3488 (Witness statement of Atif Džafić undated), para. 41.

5150 P3488 (Witness statement of Atif Džafić undated), paras. 32-33; Atif Džafić, T. 19687 (30 September 2011). See also Atif Džafić, T. 19687-19688 (30 September 2011) (acknowledging that known arms smuggling routes, as well as routes taken by army deserters and sabotage groups transversed Ključ). Additionally, Bosnian Serb and Bosnian Muslim officers began to prefer working with members of their own ethnicity rather than with mixed patrols and with mixed personnel at check-points. P3488 (Witness statement of Atif Džafić undated), para. 28; Atif Džafić, T. 19690-19691 (30 September 2011).

5151 Asim Egrlić, P6586 (Transcript from Prosecutor v. Krajišnik), T. 4641, 4701, 4703; P3488 (Witness statement of Atif Džafić undated), para. 35; Atif Džafić, T. 19692-19693 (30 September 2011). See also P3422 (Minutes of the $2^{\text {nd }}$ session of Ključ SDS Municipal Board Executive Board, 20 September 1991), p. 1; KDZ075, P3359 (Transcript from Prosecutor v. Krajišnik), T. 4955.

5152 P3577 (Public Statement of Ključ's SDA Town Board, 21 September 1991), pp. 1-2. See also P3578 (Information of Ključ's MBO Municipal Board, 17 September 1991) (negatively characterising the proclamation of the ARK by the SDS). The Ključ SDS Municipal Board had already voted to join the ZOBK at the beginning of 1991, but the matter had not been put to a vote at the Ključ Municipal Assembly. Asim Egrlić, P6586 (Transcript from Prosecutor v. Krajišnik), T. 4654-4655; P3577 (Public Statement of Ključ's SDA Town Board, 21 September 1991), p. 2; P3579 (Decision of Ključ Municipal Assembly, undated) (referring to a decision taken on 10 April 1991 to remain within the "Banja Luka Community of Municipalities"); D1889 (Decision of Skender Vakuf Municipal Assembly, 12 April 1991) (listing Ključ as a member of the 'Bosanska Krajina' Association of Municipalities). 
which had been subsequently adopted by the ARK government. ${ }^{5153}$ These instructions included directions to, inter alia, (i) form a command of the town and establish round-the-clock duty; (ii) fully mobilise the TO; (iii) reassign all men under the age of 40 from Civilian Protection to the TO; (iv) re-subordinate the TO to "the Corps"; (v) take over management in public enterprises, including the banks, judiciary, and media; (vi) proclaim a wartime programme schedule on radio stations; (vii) ban the employment of able-bodied persons from war regions and fire any such persons employed at the date of the order's issuance; (viii) collect all weapons and equipment from deserters; and (ix) disband all existing paramilitary formations and reassign them to the TO. ${ }^{5154}$ The SDA and MBO released a joint statement publicising and denouncing the above order. ${ }^{5155}$ When Asim Egrlić, who was then the president of the Ključ Executive Board and had erroneously received the telex, asked Jovo Banjac about the propriety of such instructions, Banjac minimised their importance and suggested that Brđanin "was mad".5156 Nevertheless, Egrlić observed that most of these items were eventually implemented. ${ }^{5157}$

1496. When the decision to join the ARK was confirmed by the SDS delegates of the Ključ Municipal Assembly on 26 December 1991, ${ }^{5158}$ the SDA representatives at the Municipal Assembly walked out rather than vote on the issue. ${ }^{5159}$ Sometime in January or February 1992, Bosnian Muslim leaders formed a separate Assembly of Bosnian Ključ, headed by Omer Filipović. $^{5160}$

\footnotetext{
5153 P2548 (Telex entitled "The Sarajevo SDS Order", 29 October 1991); Asim Egrlić, P6586 (Transcript from Prosecutor v. Krajišnik), T. 4668, 4943-4944.

5154 P2548 (Telex entitled "The Sarajevo SDS Order", 29 October 1991).

5155 P3582 (Joint Statement of Ključ MBO and SDA, 31 October 1991), p. 1 (strongly objecting that the telex contained instructions to "organise life in the conditions of war").

5156 Asim Egrlić, P6586 (Transcript from Prosecutor v. Krajišnik), T. 4668, 4943-4944.

5157 Asim Egrlić, P6586 (Transcript from Prosecutor v. Krajišnik), T. 4668-4669, 4877.

5158 Asim Egrlić, P6586 (Transcript from Prosecutor v. Krajišnik), T. 4655; Asim Egrlić, T. 19947 (5 October 2011); P3430 (Decision of Ključ Municipal Assembly, 16 January 1992) (referring to the decision taken on 26 December 1991); P3579 (Decision of Ključ Municipal Assembly, undated).

5159 Asim Egrlić, T. 19962 (5 October 2011); KDZ192, P3416 (Transcript from Prosecutor v. Brđanin), T. 1166411665 (under seal); KDZ192, T. 19464 (27 September 2011) (closed session). The MBO and SDA also objected to the plebiscite held by the SerBiH Assembly on 9 and 10 November 1991, contending that it was "tantamount to breaking up the common State", which violated the Constitution of BiH. P3419 (Handwritten diary), p. 12 (under seal); KDZ192, P3416 (Transcript from Prosecutor v. Brđanin), T. 11398 (under seal); Asim Egrlić, P6586 (Transcript from Prosecutor v. Krajišnik), T. 4695-4696; P3583 (Joint Official Announcement of Ključ's MBO Municipal Board and SDA Town Board, 7 November 1991).

5160 P3458 (Announcement of Bosanski Ključ Municipal Assembly, 31 January 1992); KDZ192, P3416 (Transcript from Prosecutor v. Brđanin), T. 11406-11407 (under seal). See also D1352 (Report of Ključ SJB to Banja Luka CSB, July 1992), p. 3 (referring to the declaration of a Bosnian Muslim municipality in December 1991); P1476 (Ratko Mladić's notebook, 30 December 1991-14 February 1992), e-court p. 66 (referring to intense work on forming a Bosnian Muslim municipality).
} 
1497. Meanwhile, the Ključ SDS received the Variant A/B Instructions from the SDS Main Board. ${ }^{5161}$ On 23 December 1991, the Ključ SDS Executive Board established a Crisis Staff. ${ }^{5162}$ Jovo Banjac became President of the Crisis Staff; other original members included the Chief of the Ključ SJB, Vinko Kondić; the Secretary of the National Defence Secretariat, Slobodan Jurišić; the TO Staff Commander, Boško Lukić; the President of the SDS Municipal Board, Veljko Kondić; the Deputy in the SerBiH Assembly, Rajko Kalabić; the Vice President of the Executive Board of the Municipal Assembly, Tihomir Dakić; Ljuban Bajić; and Dragan Smiljanić. ${ }^{5163}$ In mid-May 1992, the Crisis Staff was expanded to include a number of new members and was transformed into a Crisis Staff of the Ključ Municipal Assembly. ${ }^{5164}$

1498. The frequency of mobilisation calls became constant at the beginning of 1992, increasing the number of soldiers present in the municipality. ${ }^{5165}$ Some paramilitaries, including the Red Berets, arrived in Ključ around November 1991, while other groups such as the White Eagles arrived in Ključ around February 1992. ${ }^{5166}$ During the same month, over the objection of SDA representatives to the National Defence Council, ${ }^{5167}$ JNA units withdrawing from Knin were

5161 P3428 (Minutes of $6^{\text {th }}$ Session of the Ključ SDS Municipal Board Executive Board, 23 December 1991) (recording that Veljko Kondić advised the attendees on the Instructions for the organisation and activities of the Serbian people in BiH). But see KDZ192, P3416 (Transcript from Prosecutor v. Brđanin), T. 11416 (under seal) [REDACTED]. Moreover, the Chamber notes that Ključ SDS members took action pursuant to instructions 3 and 4 of the "first stage" of Option A within four days of the dissemination of the Variant A/B Instructions. P3470 (SDS Instructions for Organisation of Organs of the Serbian People in $\mathrm{BiH}$, 19 December 1991), pp. 2-3 (calling for the SDS Municipal Board to immediately establish a "Crisis Staff of the Serbian People" and to proclaim an "Assembly of the Serbian people" in the municipality).

5162 P2592 (Minutes of $6^{\text {th }}$ Session of the Executive Board of the Ključ SDS Municipal Board, 23 December 1991), p. 1; P2643 (Ključ Crisis Staff Report, 15 May - 29 July 1992), p. 2; KDZ192, P3416 (Transcript from Prosecutor v. Brđanin), T. 11671-11672 (under seal). At the same meeting, Milan Jovičić proposed that the Assembly of the Serbian Municipality of Ključ be proclaimed at the assembly session. P3428 (Minutes of $6^{\text {th }}$ Session of the Executive Board of the Ključ SDS Municipal Board Executive Board, 23 December 1991), p. 2.

5163 P3488 (Witness statement of Atif Džafić undated), paras. 4, 10, 54; Asim Egrlić, P6586 (Transcript from Prosecutor v. Krajišnik), T. 4637, 4681-4682; D4169 (Witness statement of Rajko Kalabić dated 1 December 2013), para. 4; KDZ192, T. 19431 (22 September 2011) (closed session); P3428 (Minutes of $6^{\text {th }}$ Session of the Ključ SDS Municipal Board Executive Board, 23 December 1991), pp. 1-2; P3419 (Handwritten diary), p. 17 (under seal). See also Adjudicated Fact 2192.

5164 P2643 (Ključ Crisis Staff Report, 15 May - 29 July 1992), p. 2.

5165 Asim Egrlić, P6586 (Transcript from Prosecutor v. Krajišnik), T. 4738.

5166 Asim Egrlić, P6586 (Transcript from Prosecutor v. Krajišnik), T. 4888-4889; P3488 (Witness statement of Atif Džafić undated), paras. 52-53 (stating that the Red Berets were well trained and assisted in conducting regular police activities); Atif Džafić, T. 19722 (30 September 2011). Atif Džafić was told that one "Dragan" was the commander of the Red Berets, and inferred that the Red Berets were under the control of the TO or had been summoned by the commander of the TO because they were regularly on duty at the TO premises. P3488 (Witness statement of Atif Džafić undated), paras. 51, 53. See also Adjudicated Fact 2426. The Chamber notes that although Marko Adamović denied that any paramilitary units, including the White Eagles, operated in the Ključ territory, Adamović did not state the basis for his knowledge. D4165 (Witness statement of Marko Adamović dated 1 December 2013), para. 24. Furthermore, as set out in more detail in fn. 5274, the Chamber is of the view that Adamović was often less than forthright with the Chamber and shall only rely on his evidence where it is corroborated by other reliable evidence.

5167 Asim Egrlić, P6586 (Transcript from Prosecutor v. Krajišnik), T. 4736; Asim Egrlić, T. 20009-20010 (6 October 2011); P3432 (Minutes of the $6^{\text {th }}$ session of Ključ SDS Municipal Board, 18 February 1992), p. 3; 
stationed in a compound in Lanište. ${ }^{5168}$ The JNA's arrival at Lanište led to an increase in anxiety amongst the Bosnian Muslim population of Ključ, ${ }^{5169}$ and, along with the arming of the Bosnian Serb population, contributed to the perception that a "war policy" was escalating in Ključ. 5170

1499. In February 1992, a special reserve unit of the Ključ police called the "Manoeuvring Unit" was sent to Manjača camp for special training. ${ }^{5171}$ There only the Bosnian Serb members of the unit received training on the use of mortars, Zoljas, heavy machine guns, hand to hand combat, mines, and cannons. This training had never previously been offered to the Manoeuvring Unit. ${ }^{5172}$ In early March 1992, in order to prevent Bosnian Muslims from accessing TO weapons, ${ }^{5173}$ the TO armoury was transferred to the Kula military depot in Mrkonjić Grad. ${ }^{5174}$ The weapons were later used to arm the Ključ Battalion. ${ }^{5175}$

1500. The violence in the villages surrounding Ključ town intensified during March and April 1992. ${ }^{5176}$ Inebriated Bosnian Serb soldiers who had returned from the Croatian front continued to fire rifles in Bosnian Muslim villages. ${ }^{5177}$ Bosnian Muslim settlements began to form "loose defence night patrols" at the entrance and exit to the villages to guard against the occurrence of violent incidents, ${ }^{5178}$ and Bosnian Serbs demanded that mixed ethnicity patrols be conducted in the

KDZ192, P3416 (Transcript from Prosecutor v. Brđanin), T. 11458-11460 (under seal); P3431 (Handwritten diary of KDZ192), p. 6 (under seal).

5168 Asim Egrlić, P6586 (Transcript from Prosecutor v. Krajišnik), T. 4733, 4736-4737; Asim Egrlić, T. 20009 (6 October 2011). See also KDZ024, P713 (Transcript from Prosecutor v. Brđanin), T. 9202 (under seal); KDZ075, T. 19035-19036 (16 September 2011).

5169 Asim Egrlić, P6586 (Transcript from Prosecutor v. Krajišnik), T. 4738.

5170 Asim Egrlić, P6586 (Transcript from Prosecutor v. Krajišnik), T. 4733.

5171 P3488 (Witness statement of Atif Džafić undated), para. 64. Manoeuvring units were usually used to prevent large scale disturbances of law and order, and thus their usual training covered crowd control techniques, riot control, and the use of chemical agents and firearms. P3488 (Witness statement of Atif Džafić undated), para. 64.

5172 P3488 (Witness statement of Atif Džafić undated), para. 65. When Atif Džafić visited the training in late February 1992, a Bosnian Muslim officer told Džafić that at night, the Bosnian Serb officers had been drunk and had sung Serbian nationalistic songs while sharpening their knives, firing from their rifles, and making derogatory remarks about Bosnian Muslims. P3488 (Witness statement of Atif Džafić undated), para. 66.

5173 KDZ192, P3416 (Transcript from Prosecutor v. Brđanin), T. 11499-11500 (under seal); P3494 (Report of Miloš Group, 24 April 1992).

5174 P3433 (Minutes of the $8^{\text {th }}$ session of Ključ SDS Municipal Board Executive Board, 6 March 1992), p. 1; P3488 (Witness statement of Atif Džafić undated), paras. 48-49; Atif Džafić, T. 19719 (30 September 2011); P3436 (Minutes of the $10^{\text {th }}$ session of Ključ SDS Municipal Board Executive Board, 23 March 1992), p. 1 (reflecting that the transfer of weapons was complete and that only 'a small amount was left for [the SDS's] needs'); P3437 (Minutes of the $11^{\text {th }}$ session of Ključ SDS Municipal Board Executive Board, 30 March 1992), p. 1; KDZ192, P3416 (Transcript from Prosecutor v. Brđanin), T. 11499 (under seal); KDZ192, T. 19461 (27 September 2011) (closed session).

$5175 \quad$ See fn. 5237.

5176 P3488 (Witness statement of Atif Džafić undated), para. 71.

5177 P3488 (Witness statement of Atif Džafić undated), para. 71.

5178 P3488 (Witness statement of Atif Džafić undated), paras. 71-72; Atif Džafić, T. 19729 (30 September 2011); Asim Egrlić, P6586 (Transcript from Prosecutor v. Krajišnik), T. 4784; Asim Egrlić, T. 19971 (5 October 2011). 
mixed ethnicity villages. ${ }^{5179}$ This was done for one or two nights, before conflicts arose and the process was halted. ${ }^{5180}$ One day during March or April 1992, several buildings in Pudin Han burst into flames. ${ }^{5181}$ Bosnian Serbs and Bosnian Muslims began to leave Ključ due to the escalating tensions. $^{5182}$

\section{(3) $\underline{\text { Take-over }}$}

1501. By 29 April 1992, Bosnian Serbs had consolidated power within the municipality. ${ }^{5183}$ That day, the SDS Municipal Board adopted a conclusion to "first prepare everything and coordinate with the army and, when everything is prepared, implement the change in insignia/loyalty of the police". ${ }^{5184}$ In accordance with a decision of the ARK government taken on 4 May, ${ }^{5185}$ on the following day the President of the Ključ National Defence Council, Jovo Banjac, imposed a curfew in Ključ municipality. ${ }^{5186}$ Throughout May, the Ključ Crisis Staff announced deadlines for citizens to surrender unlicensed weapons or face arrest. ${ }^{5187}$ Meanwhile, on 7 May 1992, units from the JNA $9^{\text {th }}$ Corps based at Lanište and the $5^{\text {th }}$ Corps (comprised of a battalion of the $6^{\text {th }}$ Partisan Brigade and the $3^{\text {rd }}$ Battalion of the $1^{\text {st }}$ Partisan Brigade) secured the town before responsibility for security was taken over by the Serb TO and the reserve police. ${ }^{5188}$ Serb Forces completed the military take-

5179 P3488 (Witness statement of Atif Džafić undated), para. 71.

5180 P3488 (Witness statement of Atif Džafić undated), para. 71. See also KDZ024, P713 (Transcript from Prosecutor v. Brđanin), T. 9102, 9198-9199 (under seal).

5181 P3488 (Witness statement of Atif Džafić undated), para. 72 (referring to stables, garages, and a house). Although one person was arrested afterward, Džafić was suspicious that one person could have started all of the fires in such a short time. P3488 (Witness statement of Atif Džafić undated), para. 72. Additionally, the police had information that shots were fired into the spires of mosques and at the homes of veterans, but investigations were not carried out. Atif Džafić, T. 19729 (30 September 2011).

5182 KDZ192, P3416 (Transcript from Prosecutor v. Brđanin), T. 11538 (under seal); KDZ192, T. 19474 (27 September 2011) (closed session). See also Asim Egrlić, T. 20000 (5 October 2011) (conceding that individuals of all ethnicities left the municipality before the war broke out); D4165 (Witness statement of Marko Adamović dated 1 December 2013), para. 3 (stating that 2,500 Bosnian Muslims moved away from Velagići prior to the outbreak of the conflict).

5183 P3438 (Minutes of the $8^{\text {th }}$ session of Ključ SDS Municipal Board Executive Board, 29 April 1992) pp. 1-2. See also P3592 (Handwritten notes re organisation of Ključ Civil Defence), e-court pp. 9-10; Asim Egrlić, P6586 (Transcript from Prosecutor v. Krajišnik), T. 4792-4793 (identifying the handwriting in P3592 as Vinko Kondić's and explaining his familiarity with the same).

5184 P3438 (Minutes of the $8^{\text {th }}$ session of Ključ SDS Municipal Board Executive Board, 29 April 1992) p. 4 (emphasis added).

5185 P2818 (Decision of ARK Regional Secretariat for National Defence, 4 May 1992).

5186 P3460 (Order of President of the Council for National Defence of Ključ Municipal Assembly, 5 May 1992) (providing an exception to the curfew for persons with official authorisation from the police, military police, or TO). See also Adjudicated Fact 2427. See also Slobodan Jurišić, D4363 (Witness statement of Slobodan Jurišić dated 8 February 2014), para. 33; Slobodan Jurišić, T. 47093-47094 (14 February 2014).

5187 [REDACTED]; D3901 (Public announcement of Ključ Crisis Staff, 9 May 1992), p. 2; P3439 (Minutes of meeting of Ključ Crisis Staff, 13-14 May 1992), pp. 1-2.

5188 Asim Egrlić, P6586 (Transcript from Prosecutor v. Krajišnik), T. 4756-4757 (testifying that in addition to securing the roads, the JNA units had already established control over strategic positions and institutions in town). See also P3586 (Order of the $6^{\text {th }}$ Partisan Brigade, 18 May 1992); P3488 (Witness statement of Atif Džafić undated), para.76; P3590 (Minutes of meeting of presidents of municipalities in the zone of responsibility of the $1^{\text {st }}$ Partisan Brigade, 14 May 1992), p. 2; P3663 (Report on the $6^{\text {th }}$ Brigade in the period 
over swiftly, between 7 and 10 May, and without sustaining any losses, ${ }^{5189}$ and the Serbian flag was hoisted on the municipal building and the local police station. ${ }^{5190}$

organs and work force

(a) Expulsion of Bosnian Muslims from police, administrative

1502. On 7 May, Vinko Kondić called a meeting of all non-Serb officers in the SJB building, where the officers were asked to sign an oath of loyalty to the RS government as required by the law on internal affairs. ${ }^{5191}$ They were also asked to accept changes incorporating Serbian insignia into their uniforms. ${ }^{5192}$ None of the non-Serb officers wished to sign the oath. ${ }^{5193}$ After consulting with two Bosnian Serb inspectors from the Banja Luka CSB who were also present, ${ }^{5194}$ Kondić told the non-Serb officers to go on leave and to "think carefully" about their decision. ${ }^{5195}$ The nonSerb officers were recalled to the SJB building approximately two weeks later, but since none of them had changed their minds about signing the oath, they were immediately relieved of their duties. ${ }^{5196}$ Although the Ključ Crisis Staff publicly announced that the change in insignia would

between 8 October 1991 and 28 August 1992), p. 5. When the JNA withdrew from the territory of BiH, the $6^{\text {th }}$ Partisan Brigade was integrated into the VRS as part of the $1^{\text {st }}$ Krajina Corps. P3663 (Report on the $6^{\text {th }}$ Brigade in the period between 8 October 1991 and 28 August 1992), p. 5; P3660 (Handwritten "War Record" of the $6^{\text {th }}$ Krajina Infantry Brigade, undated), p. 3. See also Adjudicated Fact 2428.

5189 P3663 (Report on the $6^{\text {th }}$ Brigade in the period between 8 October 1991 and 28 August 1992), p. 5.

5190 P3488 (Witness statement of Atif Džafić undated), para. 76; D1724 (Public announcement of Ključ Crisis Staff, 8 May 1992), p. 1. See Adjudicated Fact 2428.

5191 P3488 (Witness statement of Atif Džafić undated), paras. 74, 75, 78 (testifying inter alia that P3498 is an example of such an oath); P3498 (Solemn declaration of SerBiH official, 6 April 1992); P3468 (Excerpt from SerBiH's Official Gazette, 23 March 1992); KDZ192, P3416 (Transcript from Prosecutor v. Brđanin), T. 11714 (under seal); KDZ024, P713 (Transcript from Prosecutor v. Brđanin), T. 9102-9103 (under seal). See also Adjudicated Fact 2429. After returning from a meeting in Banja Luka in March 1992, Vinko Kondić had warned his staff that he had signed a pledge of allegiance to the CSB in Banja Luka and that they too would soon have to pledge loyalty to the "Serbian authorities and the Serbian Republic". P3488 (Witness statement of Atif Džafić undated), para. 63; Atif Džafić, T. 19724 (30 September 2011) (stating that after signing the oath, Vinko Kondić had stopped carrying out orders from Sarajevo and began acting on orders from Banja Luka instead). The Chamber understands Kondić's reference to the "Serbian authorities" to refer to the authorities of the SerBiH.

5192 P3497 (Public Announcement of Ključ Crisis Staff) (informing citizens of changes made to police uniforms on 7 May 1992); P3438 (Minutes of the $8^{\text {th }}$ session of Ključ SDS Municipal Board Executive Board, 29 April 1992), p. 3.

5193 P3488 (Witness statement of Atif Džafić undated), para. 75; Asim Egrlić, P6586 (Transcript from Prosecutor v. Krajišnik), T. 4745-4746; KDZ024, P713 (Transcript from Prosecutor v. Brđanin), T. 9102, 9199, 9251 (under seal).

5194 Several weeks earlier, on 8 April 1992, Stojan Župljanin, as Chief of the Banja Luka CSB, had held a press conference in which he stated that all MUP employees were required to sign a loyalty oath by 15 April 1992; if they did not, their employment would be terminated. KDZ192, P3416 (Transcript from Prosecutor v. Brđanin), T. 11715 (under seal); P3469 (News bulletin, 8 April 1992).

5195 P3488 (Witness statement of Atif Džafić undated), paras. 74-76, 78, 81. See also Atif Džafić, T. 19691-19692 (30 September 2011).

5196 P3488 (Witness statement of Atif Džafić undated), paras. 78, 79, 81; Atif Džafić, T. 19691-19692, 19730, 19749 (30 September 2011); KDZ024, P713 (Transcript from Prosecutor v. Brđanin), T. 9102,9199 (under seal); P3489 (Report of Banja Luka CSB, 28 May 1992) (order to all SJB Chiefs in the Banja Luka CSB stating that all SJB employees who had not signed the loyalty oath were considered dismissed as of 15 April 1992 and that their insurance and entitlements should be cancelled). 
"not threaten the livelihood of those workers who did not sign the solemn oath [...] because attempts will be made to create conditions for their further work", ${ }^{5197}$ these words were not honoured. $^{5198}$

1503. Between late 1991 and early March 1992, the SDS had formed a personnel committee which was tasked with carrying out an analysis of the personnel structures in the municipality area. $^{5199}$ At an SDS Executive Board meeting on 6 March 1992, the structure of the Public Auditing Service ("SDK") in Ključ was characterised as "unfavourable", which referred to the fact that a Bosnian Muslim was employed there. ${ }^{5200}$ In the weeks preceding 7 May 1992, a Bosnian Muslim member of the SDK and the Bosnian Muslim editor-in-chief of the radio station were replaced by members of the SDS. ${ }^{5201}$ Both men were told that "since there had been a take-over in Ključ, they had to be replaced by individuals from the SDS". 5202

1504. By the end of May 1992, most Bosnian Muslims in Ključ had lost or would soon lose their jobs. $^{5203}$ On 7 May 1992, Bosnian Muslim municipal employees had been told to leave the municipality building with the proviso that they would be called back if needed. ${ }^{5204}$ Between midMay and early June, the Ključ Crisis Staff concluded that "all management positions in enterprises must be filled by people absolutely loyal to" the SerBiH and that the replacement of all non- Serbs who were then employed in posts which encompassed the "protection of properties" was to be carried out by 1 June 1992. ${ }^{5205}$ These principles were later recorded in the 21 July 1992 decision of

5197 D1724 (Public announcement of Ključ Crisis Staff, 8 May 1992), p. 1; KDZ192, T. 19471 (27 September 2011) (closed session) (interpreting the announcement to mean that even those who did not sign the loyalty oath would be able to retain employment with the MUP).

5198 Asim Egrlić, P6586 (Transcript from Prosecutor v. Krajišnik), T. 4761; KDZ024, P713 (Transcript from Prosecutor v. Brđanin), T. 9102,9199 (under seal).

5199 KDZ192, P3416 (Transcript from Prosecutor v. Brđanin), T. 11433-11435, 11693 (under seal); P3419 (Handwritten diary), p. 22 (under seal); P3436 (Minutes of the $10^{\text {th }}$ session of Ključ SDS Municipal Board Executive Board, 23 March 1992), p. 2 (including discussion of the activities of the Personnel Commission).

5200 P3433 (Minutes of the $8^{\text {th }}$ session of Ključ SDS Municipal Board Executive Board, 6 March 1992), p. 1; KDZ192, P3416 (Transcript from Prosecutor v. Brđanin), T. 11463 (under seal).

5201 Asim Egrlić, P6586 (Transcript from Prosecutor v. Krajišnik), T. 4738, 4756; Asim Egrlić, T. 19994 (5 October 2011). See also Adjudicated Fact 2430.

5202 Asim Egrlić, P6586 (Transcript from Prosecutor v. Krajišnik), T. 4756.

5203 Asim Egrlić, T. 19935 (5 October 2011); Asim Egrlić, P6586 (Transcript from Prosecutor v. Krajišnik), T. 4756, 4762, 4765, 4885-4886; P3587 (List of employees of Ključ Municipal Assembly, 26 June 1992).

5204 Asim Egrlić, P6586 (Transcript from Prosecutor v. Krajišnik), T. 4744, 4756; Asim Egrlić, T. 19965 (5 October 2011)

5205 P2606 (Minutes from sessions of Ključ's Crisis Staff, 27 May-10 July 1992), pp. 2, 15 (referring to the conclusions of the ARK Crisis Staff), 18 (referring to a working group reviewing the managerial vacancies left by Bosnian Muslims); P3431 (Handwritten diary of KDZ192), p. 26 (under seal). As a result, several Bosnian Muslim members of the National Defence Council were suspended immediately and SDS members were tasked with identifying suitable replacements to fill the vacancies created. P2606 (Minutes from sessions of Ključ's Crisis Staff, 27 May - 10 July 1992), p. 3; KDZ192, P3416 (Transcript from Prosecutor v. Brđanin), T. 11555 (under seal) (identifying two Bosnian Muslims listed on p. 3 of P2606). 
the Ključ Crisis Staff, which had since been renamed the War Presidency, ${ }^{5206}$ when it held that, in accordance with a prior decision of the ARK Crisis Staff, ${ }^{5207}$ only Bosnian Serb officials could occupy managerial posts, posts that could provide access to information or involve the protection of public property, and posts that were important for the functioning of the economy. ${ }^{5208}$ On the same day, the Ključ War Presidency also issued a decision terminating the employment of "all employees who ha[d] failed to respond to the general mobilisation". ${ }^{5209}$ Following these decisions, the War Presidency ordered the dismissal of several non-Serbs from municipal positions, including the positions of president and vice president of the executive board of the municipality. ${ }^{5210}$ By 31 July, Vinko Kondić reported that only Serb workers were employed in business enterprises. ${ }^{5211}$

1505. Rajko Kalabić testified that Bosnian Muslims reported to their jobs without interference until late May 1992 and asserted that this timing suggested that they left their jobs of their own free will rather than under duress. ${ }^{5212}$ However, while Asim Egrlić acknowledged that his employer had been entitled to terminate his employment after he failed to report to work for five days, he explained that the same persons who terminated his employment for failing to report to work also imprisoned him in a camp, and that this termination occurred long after he ceased reporting for work as a result of the security conditions in Ključ. ${ }^{5213}$ In light of the security situation prevailing in Ključ at the time, as well as the retroactive Crisis Staff decisions, the Chamber finds that, contrary to Kalabić's assertion, Bosnian Muslims were dismissed from their jobs on account of their ethnicity.

5206 P2643 (Ključ Crisis Staff Report, 15 May - 29 July 1992), p. 2.

5207 P7 (Decision of ARK Crisis Staff, 22 June 1992); KDZ192, P3416 (Transcript from Prosecutor v. Brđanin), T. 11734 (under seal) (conceding that the wording ARK Crisis Staff's decision was similar to that used by the Ključ War Presidency in their decision taken in July).

5208 P3464 (Decision of Ključ War Presidency, 21 July 1992); Asim Egrlić, T. 19921-19922 (5 October 2011 ) (describing P3514 as "retroactively" covering "what had already been effected"); P3488 (Witness statement of Atif Džafić undated), paras. 76, 79; Atif Džafić, T. 19662-19663, 19749 (30 September 2011).

5209 P3514 (Decision of Ključ War Presidency, 21 July 1992).

$5210 \quad$ Adjudicated Fact 2431.

5211 P5411 (Minutes of the $13^{\text {th }}$ session of the Ključ Municipal Assembly, 31 July 1992). See also KDZ192, P3416 (Transcript from Prosecutor v. Brđanin), T. 11696-11697 (under seal) [REDACTED]. The Chamber notes that although in his witness statement, Slobodan Jurišić claimed that all individuals left their jobs of their own free will, he later admitted that he had heard that disloyal individuals had been removed from executive positions pursuant to an ARK order. D4363 (Witness statement of Slobodan Jurišić dated 8 February 2014), para. 35; Slobodan Jurišić, T. 47071 (13 February 2014). The Chamber therefore will not place weight on that part of Jurišić's witness statement.

5212 D4169 (Witness statement of Rajko Kalabić dated 1 December 2013), para. 7.

5213 Asim Egrlić, T. 19936-19938 (5 October 2011); P3588 (Ruling of Ključ War Presidency, 21 July 1992) (terminating Egrlić's services as chairman of the Executive Board); D1348 (Decision of Ključ War Presidency, 21 July 1992) (same); D1349 (Decision of Ključ War Presidency, 21 July 1992) (terminating the duties of Omer Filipović as Vice President of the Municipal Assembly). See also P3572 (Decision on termination of employment by Veledprodaja enterprise in Ključ, 28 October 1992); Asim Egrlić, T. 19922, 19935 (5 October 2011) (testifying that P3572 reflected a decision that had already been taken in May or June). 
(b) Outbreak of armed conflict in Ključ

1506. After 7 May 1992, Bosnian Muslims' freedom of movement was restricted both temporally and geographically, and Bosnian Muslims were required to identify themselves and to explain their movements at check-points. ${ }^{5214}$ On 25 May 1992, Banjac, as President of the Ključ Crisis Staff, issued an order to bring the TO units in Ključ municipality up to strength and to set up civilian protection units in all local communes, including Bosnian Muslim ones. ${ }^{5215}$

1507. Armed operations in Ključ began with several incidents between Bosnian Muslims and Bosnian Serbs on 27 May 1992. ${ }^{5216}$ Around 11 a.m., while responding to a report that a barricade had been erected on the road near Krasulje, the Assistant Commander of the Ključ SJB, Dušan Stojaković, was fatally wounded during an "armed clash" with Bosnian Muslims; ${ }^{5217}$ a military and a regular policeman were also wounded during the incident. ${ }^{5218}$ Around 2 p.m. on the same day, a bus carrying members of the JNA who were returning from Knin to Banja Luka came under fire near Pudin Han, resulting in the deaths of four or five individuals. ${ }^{5219}$ During the course of the day, a check-point at the intersection of the Ključ-Sanica road came under fire, and in the evening, a "squa[d] of extremists" attempted to blow up a road above Velagići. ${ }^{522}$ In addition to the incidents

5214 Asim Egrlić, P6586 (Transcript from Prosecutor v. Krajišnik), T. 4761; KDZ075, P3358 (Transcript from Prosecutor v. Krajišnik) T. 4961 (under seal) (stating that after the establishment of the check-point between Sanica and Biljani, the residents of Biljani could no longer reach Ključ or Sanica). See also Adjudicated Fact 2432.

5215 D1726 (Order of Ključ Crisis Staff, 25 May 1992).

5216 Asim Egrlić, T. 19938 (5 October 2011); D1352 (Report of Ključ SJB to Banja Luka CSB, July 1992), p. 6; KDZ192, T. 19476 (27 September 2011) (closed session). During the days preceding 27 May, Bosnian Muslims destroyed a television relay station near Krasulje. P3594 (Report of Ključ SJB, 25 September 1992), p. 1; KDZ192, T. 19477 (27 September 2011) (closed session); KDZ192, P3416 (Transcript from Prosecutor v. Brđanin), T. 11525-11526 (under seal); D4363 (Witness statement of Slobodan Jurišić dated 8 February 2014), para. 11; Slobodan Jurišić, T. 47075 (13 February 2014); D4268 (Witness statement of Jovo Kevac dated 25 January 2014), para. 5.

5217 See Adjudicated Fact 2433; D1352 (Report of Ključ SJB to Banja Luka CSB, July 1992), p. 6; D4169 (Witness statement of Rajko Kalabić dated 1 December 2013), paras. 6, 17; D4165 (Witness statement of Marko Adamović dated 1 December 2013), paras. 3, 7a-b; D4268 (Witness statement of Jovo Kevac dated 25 January 2014), para. 6; D4363 (Witness statement of Slobodan Jurišić dated 8 February 2014), para. 12.

5218 KDZ192, T. 19476, 19480 (27 September 2011) (closed session); D1352 (Report of Ključ SJB to Banja Luka CSB, July 1992), pp. 6-7; Asim Egrlić, P6586 (Transcript from Prosecutor v. Krajišnik), T. 4857; Asim Egrlić, T. 19989-19990 (5 October 2011); D4169 (Witness statement of Rajko Kalabić dated 1 December 2013), paras. 6, 17; D4165 (Witness statement of Marko Adamović dated 1 December 2013), paras. 3, 7a; D4268 (Witness statement of Jovo Kevac dated 25 January 2014), para. 6; D4363 (Witness statement of Slobodan Jurišić dated 8 February 2014), para. 12; KDZ024, P713 (Transcript from Prosecutor v. Brđanin), T. 9206-9207 (under seal).

5219 D1352 (Report of Ključ SJB to Banja Luka CSB, July 1992), p. 7; KDZ192, T. 19476 (27 September 2011) (closed session); D4268 (Witness statement of Jovo Kevac dated 25 January 2014), para. 7; D4363 (Witness statement of Slobodan Jurišić dated 8 February 2014), para. 12.

5220 D1352 (Report of Ključ SJB to Banja Luka CSB, July 1992), p. 7. After the incidents, the "commander of these Muslim formations" surrendered at the invitation of Colonel Galić and was taken to the military remand prison in Banja Luka. D4363 (Witness statement of Slobodan Jurišić dated 8 February 2014), para. 15. 
that occurred that day, the Ključ SJB discovered that seven members of Serb Forces had been captured in Crljeni two days before. ${ }^{5221}$

1508. The Chamber received conflicting evidence regarding the establishment and level of organisation of a Bosnian Muslim TO, as well as its involvement in the events of 27 May 1992. According to a Ključ SJB dispatch dated 25 September 1992, Bosnian Muslim forces began to obtain weapons through individual purchases in early 1992, and established a "Bosanski Ključ TO" in April 1992. ${ }^{5222}$ Asim Egrlić acknowledged that guards had been assigned to various Bosnian Muslim settlements located north of Ključ since early 1992, but suggested that they lacked any military organisation. ${ }^{523}$ Although he initially denied that a Bosnian Muslim TO existed and suggested that Bosnian Serbs considered the entire Bosnian Muslim population to be members of the TO, Egrlić later conceded (i) that after Bosnian Muslim representatives were expelled from the Ključ Municipal Assembly around 10 May, they had established an office in Pudin Han in order to communicate with the population, and (ii) that Omer Filipović was appointed TO Commander. ${ }^{5224}$ Even when shown an SJB report from July 1992 which estimated the numerical strength of Muslim forces in Ključ at the outbreak of the conflict as being approximately 1,300 to 1,500 men, ${ }^{5225}$ and an official note of the $2^{\text {nd }}$ Krajina Corps Command's Intelligence Department dated 11 July 1992 which described a fully-functioning staff, ${ }^{5226}$ Egrlić maintained that the Bosnian Muslim TO staff had not had time to set up any units. ${ }^{5227}$ However, the Chamber finds that, in light of

5221 D1352 (Report of Ključ SJB to Banja Luka CSB, July 1992), p. 7; P3488 (Witness statement of Atif Džafić undated), para. 90; Asim Egrlić, P6586 (Transcript from Prosecutor v. Krajišnik), T. 4787, 4862; D4268 (Witness statement of Jovo Kevac dated 25 January 2014), para. 4; D4165 (Witness statement of Marko Adamović dated 1 December 2013), para. 3.

5222 P3594 (Report of Ključ SJB, 25 September 1992), p. 1. See also D1731 (Report of Ključ SJB, 3 June 1992), p. 1 (referring to the establishment of a Bosnian Muslim TO following the issuance of an order by Izetbegović); D1352 (Report of Ključ SJB to Banja Luka CSB, July 1992), p. 11 (referring to SJB employees acquiring and distributing arms to Bosnian Muslims).

5223 Asim Egrlić, P6586 (Transcript from Prosecutor v. Krajišnik), T. 4784; Asim Egrlić, T. 19971 (5 October 2011). But see D1352 (Report of Ključ SJB to Banja Luka CSB, July 1992), p. 5 (referring to an efficient system of command and control).

5224 Asim Egrlić, P6586 (Transcript from Prosecutor v. Krajišnik), T. 4784-4786, 4866-4867; Asim Egrlić, T. 19965-19967, 19970-19971 (5 October 2011). Other members of the Bosnian Muslim TO included Amir Avdić and Mevzad Đerić as field co-ordinators, and Egrlić as responsible for political affairs. D1350 (Lists of Muslim people in Ključ, 10 June 1992); P3594 (Report of Ključ SJB, 25 September 1992); Asim Egrlić, P6586 (Transcript from Prosecutor v. Krajišnik), T. 4790 (confirming that D1350 contains an accurate list of the Bosnian Muslim TO staff) and 4808 (confirming that he was a member of the TO); Asim Egrlić, T. 19967 (5 October 2011). See also D1730 (Official note of Ključ SJB, 31 May 1992), p. 1. By contrast, the Bosnian Muslim "Crisis Staff" described in D1350 was never established because it was never confirmed by the deputies who were members of the Ključ Municipal Assembly. Asim Egrlić, P6586 (Transcript from Prosecutor v. Krajišnik), T. 4790.

5225 D1352 (Report of Ključ SJB to Banja Luka CSB, July 1992), pp. 9-10. See also Jovo Kevac, T. 46273 (30 January 2014) (testifying that a Bosnian Muslim TO of approximately 2,000 men was formed in 1992).

5226 D1748 (Official note of $2^{\text {nd }}$ Krajina Corps Command, 11 July 1992).

5227 Asim Egrlić, T. 19964-19967, 19970-19972 (5 October 2011); Asim Egrlić, P6586 (Transcript from Prosecutor v. Krajišnik), T. 4784-4786, 4819, 4855-4856, 4866-4867. See also Asim Egrlić, T. 19973-19974 (5 October 2011) (observed that the statements comprising D1748 had been obtained from persons detained in 
contemporaneous documents of the Banja Luka CSB and the Ključ SJB, the events of 27 May 1992 were carried out by Bosnian Muslim forces. ${ }^{522}$

1509. Beginning at 8 a.m. on 28 May 1992 and continuing throughout the day, the Ključ Crisis Staff and the Ključ Defence Command ${ }^{5229}$ issued orders to Bosnian Muslims to hand in their weapons and to hand over Stojaković's body, as well as those responsible for firing on the JNA convoy on the previous day. ${ }^{5230}$ At 4 p.m., the Ključ Defence Command accepted Omer Filipović's request for an extension of the deadline to surrender weapons until $10 \mathrm{a} . \mathrm{m}$. the following day in exchange for handing over the seven captured soldiers and Stojaković's body by 5 p.m. on 28 May 1992. ${ }^{5231}$ Filipović was also taken into custody. ${ }^{5232}$ However, after the 4 p.m. announcement, the Ključ Defence Command issued a further statement at 8 p.m. ordering the residents of Pudin Han and Velagići to surrender their weapons by 9 p.m. that evening. ${ }^{5233}$ Failure to comply with the provisions of the statement would result in a state of armed conflict. ${ }^{5234}$

Manjača who may have been under duress); D1352 (Report of Ključ SJB to Banja Luka CSB, July 1992), pp. 56 (describing a TO that was "primarily organised for defence operations"). p. 6 (suggesting that despite being primarily organised for defence purposes, a decision was taken to "change the concept from defensive to offensive operations").

5229 On 31 May 1992, Colonel Stanislav Galić, the Commander of the $30^{\text {th }}$ Partisan Division, issued an order forming the "Ključ Defence Command", which was to consist, inter alia, of the Commander of the $3^{\text {rd }}$ Battalion of the $1^{\text {st }}$ Partisan Brigade, the Commander of the newly-formed $4^{\text {th }}$ Battalion of the $1^{\text {st }}$ Partisan Brigade, the Commander of the Ključ Territorial Defence Staff, the Chief of the Ključ SJB, the President of Ključ Municipality and two or three members of the Ključ Crisis Staff. P3445 (Order of the $30^{\text {th }}$ Partisan Division, 31 May 1992), p. 1; P3914 (Ewan Brown's expert report entitled "Military Developments in the Bosanska Krajina - 1992", 27 November 2002), para. 2.46; D4169 (Witness statement of Rajko Kalabić dated 1 December 2013), para. 9. The primary task of the Ključ Defence Command was "the protection of the Serbian people in the greater area of the municipality" by, inter alia, deploying "in the areas where combat activities were conducted until recently (the areas populated by the [Bosnian] Muslims)", controlling the routes of approach and points of entrance to the municipality, establishing the SerBiH Army on the entirety of the territory, and facilitating the functioning of the municipal authorities. P3445 (Order of the $30^{\text {th }}$ Partisan Division, 31 May 1992), p. 1.

5230 P3444 (Order of Ključ Crisis Staff, 28 May 1992); KDZ192, P3416 (Transcript from Prosecutor v. Brđanin), T. 11666-11667 (under seal). Anyone who did not comply would face "thorough measures [...] to disarm them", which the Crisis Staff warned could have "disastrous consequences for their personal security and that of their property". P3444 (Order of Ključ Crisis Staff, 28 May 1992). See also Adjudicated Fact 919.

5231 D1728 (Order of Ključ Defence Command, 28 May 1992); P3591 (Order of Ključ Crisis Staff, 28 May 1992); D1352 (Report of Ključ SJB to Banja Luka CSB, July 1992), p. 7.

5232 KDZ192, T. 19484 (27 September 2011) (closed session) [REDACTED]; KDZ192, P3416 (Transcript from Prosecutor v. Brđanin), T. 11725-11727 (under seal) [REDACTED]. See also D4169 (Witness statement of Rajko Kalabić dated 1 December 2013), para. 8 (describing talks between Galić and Filipović and suggesting that, at the latter's request, Filipović was "escorted" to Ključ by the Chief of the SJB). See also para. 1508 (discussing the Bosnian Muslim TO in Ključ).

5233 D4678 (Statement from the Ključ Defence Command, 28 May 1992). The deadline for residents of Krasulje and Gorni Ramići to surrender their weapons was also brought forward to 7 a.m. on 29 May. D4678 (Statement from the Ključ Defence Command, 28 May 1992).

5234 D4678 (Statement from the Ključ Defence Command, 28 May 1992). 
1510. As a result of this "new security situation", ${ }^{5235}$ Banjac, as President of the Ključ Crisis Staff, issued an order prohibiting citizens from moving from one area to another within the municipality without special permission from the Ključ SJB. ${ }^{5236}$ Additionally, the Ključ Battalion ${ }^{5237}$ was deployed to "mop up" the town and surrounding settlements by disarming "all paramilitary formations in the direction of the attacks and to arrest members of these formations", ${ }^{5238}$ while the $1^{\text {st }}$ Brigade of the $30^{\text {th }}$ Partisan Division was also deployed in the area. ${ }^{5239}$

1511. At the same time, beginning on 27 May, the Serb Forces attacked Bosnian Muslim areas of Ključ, including Pudin Han. ${ }^{5240}$ As these operations ensued, members of Serb Forces collected weapons from Bosnian Muslim villages including Pudin Han, Velagići, Krasulje, Biljani, Sanica, and Kamičak. ${ }^{5241}$ Bosnian Serbs were not required to turn in their weapons. ${ }^{5242}$ In the morning of 30 May 1992, members of the Serb Forces, including the White Eagles, ${ }^{5243}$ went from village to village, instructing villagers to hang white sheets from the houses to signal their loyalty and forcing military-aged men to walk in front of the Serb Forces to shield them from fire until the Serb Forces

5235 KDZ192, P3416 (Transcript from Prosecutor v. Brđanin), T. 11557-11558 (under seal); KDZ192, T. 19479_ 19480 (27 September 2011) (closed session).

5236 P3443 (Order of Ključ Crisis Staff, 27 May 1992).

5237 The Ključ Battalion had been formed at the end of April 1992 and was integrated into the $1^{\text {st }}$ Light Infantry Brigade of the $1^{\text {st }}$ Krajina Corps as its $3^{\text {rd }}$ Infantry Battalion, quartered in Sitnica. P6543 (Report of $1^{\text {st }}$ Krajina Corps, 2 November 1993), p. 2. See also D4363 (Witness statement of Slobodan Jurišić dated 8 February 2014), paras. 6-7; Slobodan Jurišić, T. 47125 (14 February 2014). Branko Ribić and Marko Adamović were appointed commander and deputy commander, repectively. P6543 (Report of $1^{\text {st }}$ Krajina Corps, 2 November 1993), p. 2. After the $4^{\text {th }}$ Infantry Battalion of the $1^{\text {st }}$ Light Infantry Brigade was created on or around 1 June 1992, the Ključ Battalion joined the $17^{\text {th }}$ Light Infantry Brigade, which was a unit of the $2^{\text {nd }}$ Krajina Corps. P6543 (Report of $1^{\text {st }}$ Krajina Corps, 2 November 1993), p. 3; P3914 (Ewan Brown's expert report entitled "Military Developments in the Bosanska Krajina - 1992", 27 November 2002), para. 1.99.

5238 P6543 (Report of $1^{\text {st }}$ Krajina Corps, 2 November 1993), p. 3; P2606 (Minutes from sessions of Ključ's Crisis Staff, 27 May - 10 July 1992), p. 2.

5239 P1171 (1 $1^{\text {st }}$ Krajina Corps combat report, 28 May 1992), p. 1; D4169 (Witness statement of Rajko Kalabić dated 1 December 2013), para. 8 (stating that "Galić's unit" from Mrkonjić Grad arrived in Ključ and set up checkpoints on the routes leading to Ključ); Stanislav Galić, T. 37154 (15 April 2013) (testifying that he was the commander of the $30^{\text {th }}$ Infantry Division at Mrkonjić Grad). See also D4363 (Witness statement of Slobodan Jurišić dated 8 February 2014), para. 14 (stating that a company was brought from the direction of Petrovac to control the Ključ-Petrovac road).

5240 KDZ192, P3416 (Transcript from Prosecutor v. Brđanin), T. 11559-11560, 11667, 11725-11727, 11729 (under seal); D1352 (Report of Ključ SJB to Banja Luka CSB, July 1992), p. 7; P6543 (Report of $1^{\text {st }}$ Krajina Corps, 2 November 1993), p. 3.

5241 D4169 (Witness statement of Rajko Kalabić dated 1 December 2013), para. 10. Zgon, Velečovo, and Dubočani, were not subjected to weapons collection. D4169 (Witness statement of Rajko Kalabić dated 1 December 2013), para. 10; KDZ024, P713 (Transcripts from Prosecutor v. S. Milošević), T. 9105-9106 (under seal); KDZ024, P713 (Transcript from Prosecutor v. Brđanin), T. 30069-30071, 30074-30075 (under seal); KDZ075, P3359 (Transcript from Prosecutor v. Krajišnik), T. 4957; D4363 (Witness statement of Slobodan Jurišić dated 8 February 2014), para. 15.

5242 KDZ024, P713 (Transcript from Prosecutor v. Brđanin), T. 9107 (under seal).

5243 KDZ075, P3359 (Transcript from Prosecutor v. Krajišnik), T. 4960, 4985. On 28 May 1992, the White Eagles had been ordered to place themselves under the command of the "Ključ operations group". P3444 (Order of Ključ Crisis Staff, 28 May 1992), p. 2; D4363 (Witness statement of Slobodan Jurišić dated 8 February 2014), para. 37 (commenting that every individual and group had to be part of either the VRS or the civilian police). See also Adjudicated Fact 2434. The Chamber therefore finds that the White Eagles were acting under the direction of the Ključ Defence Command as of 28 May 1992. 
reached the next village. ${ }^{5244}$ From there, the men were allowed to return home and the process was repeated with the men from that village. ${ }^{5245}$ In Biljani, where Serb Forces searched the houses for weapons, their search yielded none. ${ }^{5246}$

(c) Destruction of houses and looting of movable property

1512. Beginning while the combat operations were underway and continuing throughout 1992 some 3,500 houses in Bosnian Muslim villages including Pudin Han, Velagići, Biljani, and Prhovo were razed to the ground and burned. ${ }^{5247}$ Furthermore, during the same period, members of the Serb Forces “illegally appropriat[ed]” Bosnian Muslims' movable property, such as cattle, housing materials, and vehicles. ${ }^{5248}$ Although the Ključ Crisis Staff explained to Bosnian Serb citizens in June 1992 that property was considered "inviolable [and] should be protected from the wilfulness of individuals", ${ }^{249}$ and the Ključ Executive Board passed a decision on 29 September 1992 transferring the ownership of movable and immovable property from those who had left the municipality to the state, ${ }^{5250}$ a later military report stated that "illegal acts of appropriation of state property continued [...] [and] nothing was done to prevent further acts of unlawful appropriation". 5251 The $1^{\text {st }}$ Krajina Assistant Corps Commander for Civilian Affairs reported that as late as 1 February 1993, such acts were occurring in "full co-ordinated action and co-operation of the Military and civilian police". ${ }^{5252}$ The Chamber is therefore satisfied that such crimes

5244 KDZ075, P3359 (Transcript from Prosecutor v. Krajišnik), T. 4958-4961.

5245 KDZ075, P3359 (Transcript from Prosecutor v. Krajišnik), T. 4958-4961.

5246 KDZ075, P3359 (Transcript from Prosecutor v. Krajišnik), T. 4961. See also Adjudicated Fact 2435.

5247 Asim Egrlić, P6586 (Transcript from Prosecutor v. Krajišnik), T. 4820; D1352 (Report of Ključ SJB to Banja Luka CSB, July 1992), p. 11; see Adjudicated Facts 948, 949, 2448. See also P3662 (1 ${ }^{\text {st }}$ Krajina Corps report, 31 May 1992), p. 2; P2972 (Report of Ključ SJB, 28 September 1992), p. 1.

5248 D1738 (Report of the Assistant Commander for Civilian Affairs of the Military Post 7286, 16 February 1993), p. 2 (attributing such actions to military personnel as well as police and local Serbs); D1352 (Report of Ključ SJB to Banja Luka CSB, July 1992), p. 11; P2972 (Report of Ključ SJB, 28 September 1992), p. 1. See also Adjudicated Fact 950; KDZ192, T. 19514 (27 September 2011) (closed session) (attributing the looting to "paramilitary individuals"). But see D4363 (Witness statement of Slobodan Jurišić dated 8 February 2014), para. 16 (attributing the looting to "renegade individuals" who were not under the control of the army and police).

5249 KDZ192, T. 19514-19515 (27 September 2011) (closed session) [REDACTED]. See also D1739 (Decisions of Ključ Crisis Staff, 30 June 1992), p. 1 (calling on all persons who had appropriated cars or valuables to return them to the army within a five day grace period or risk sanction); P3452 (Extract from Minutes of Ključ War Presidency, 10 July 1992), p. 1 (forming a commission to take in "war booty); KDZ192, P3416 (Transcript from Prosecutor v. Brđanin), T. 11634-11635 (under seal) (stating that "war booty" referred to movable property that had been taken from Bosnian Muslims although some had stayed in Ključ without their property being disturbed).

5250 D1738 (Report of the Assistant Commander for Civilian Affairs of the Military Post 7286, 16 February 1993), pp. 2-3.

5251 D1738 (Report of the Assistant Commander for Civilian Affairs of the Military Post 7286, 16 February 1993), p. 3 (describing the appropriation of livestock, as well as any usable building materials that remained in Bosnian Muslim villages, by people who were "armed and dressed in military uniforms").

5252 D1738 (Report of the Assistant Commander for Civilian Affairs of the Military Post 7286, 16 February 1993), p. 3. 
continued to be perpetrated by members of Serb Forces even after the measures taken by the Ključ Crisis Staff and Ključ Executive Board in June and September 1992.

(4) Killings on or around 1 June 1992

(a) $\underline{\text { Scheduled Incident A.7.1 }}$

1513. The Indictment refers to the killing of "a number" of people in Pudin Han on or about 28 May 1992.

1514. As the Chamber has previously noted, a Bosnian Muslim TO was headquartered in Pudin Han. $^{5253}$ At the time, Pudin Han was almost exclusively a Bosnian Muslim village located approximately three kilometres north of Ključ town. ${ }^{5254}$ Even as the Ključ Crisis Staff issued its ultimatum on 28 May 1992, ${ }^{5255}$ Pudin Han had already begun to be shelled from locations controlled by Serb Forces on the previous day. ${ }^{5256}$ Many people were hit by the shells as they tried to flee. ${ }^{5257}$ While at his house on 28 May, KDZ024 could see smoke coming from the houses in Pudin Han. ${ }^{5258}$ During the attack on Pudin Han, the mosque in Pudin Han was blown up and leveled. ${ }^{525}$ KDZ024 visited Pudin Han after it was shelled, and found everything burned,

\footnotetext{
$5253 \quad$ See para. 1508.

5254 Asim Egrlić, P6586 (Transcript from Prosecutor v. Krajišnik), T. 4767. See Adjudicated Fact 918. See also P3488 (Witness statement of Atif Džafić undated), para. 8; Atif Džafić, T. 19657-19658 (30 September 2011) (describing Pudin Han as one of eight villages in Ključ municipality which was populated predominantly by non-Serbs). See para.1509. During a meeting at the youth centre in Pudin Han, the vast majority of inhabitants of Pudin Han were in favour of surrendering their weapons, and those who disagreed left for Bihać. Adjudicated Fact 920.

5256 KDZ024, P713 (Transcript from Prosecutor v. Brđanin), T. 9117, 9209 (under seal); P6543 (Report of $1^{\text {st }}$ Krajina Corps, 2 November 1993), p. 3. See also para. 1511; Adjudicated Fact 921; P3488 (Witness statement of Atif Džafić undated), para. 82. KDZ192 gave conflicting evidence as to whether Pudin Han was fired upon in order to induce the leader of the Bosnian Muslim TO to surrender. KDZ192, P3416 (Transcript from Prosecutor v. Brđanin), T. 11559-11560, 11726-11727, 11729 (under seal); KDZ192 T. 19484 (27 September 2011) (closed session) (acknowledging that Bosnian Muslims maintained that Filipović had surrendered prior to the commencement of fire but testifying that the Serb Forces only fired to induce Filipović to surrender). See also P3450 (Video footage of TV Banja Luka depicting events in Ključ), at 00:02:27-00:06:41 (showing Vinko Kondić stating that Bosnian Muslim “extremists" in Pudin Han had refused to surrender their weapons). The Chamber notes that the Accused concedes that Pudin Han was shelled even prior to the expiration of the Crisis Staff's ultimatum, and that at least three civilians died, but suggests that the shelling was not carried out by Serb Forces, who "had no interest in shelling since they had information that the Bosnian Muslim extremists who remained armed had left for Bihać". Defence Final Brief, para. 1517. However, the Chamber is satisfied beyond reasonable doubt that, as stated in the main text above, the shelling was carried out by Serb Forces, not by any other armed group.

5257 KDZ024, P713 (Transcript from Prosecutor v. Brđanin), T. 9117 (under seal).

5258 KDZ024, P713 (Transcript from Prosecutor v. Brđanin), T. 9117 (under seal); Adjudicated Fact 2451.

5259 Adjudicated Fact 2451; KDZ024, P713 (Transcript from Prosecutor v. Brđanin), T. 9117 (under seal). See also paras. $1557-1558$.
} 
destroyed, and in ruins. ${ }^{5260}$ Electricity poles had fallen down, and dead livestock littered the roads. ${ }^{5261}$

1515. The Chamber notes that the Prosecution alleges that "a number" of people were killed in Pudin Han on or about 28 May 1992. ${ }^{5262}$ The Chamber took judicial notice of the fact that, at a minimum, three civilians from Pudin Han died as a consequence of the shelling. ${ }^{5263}$ Additionally, KDZ024 testified that on 30 May 1992, [REDACTED] found and buried the bodies of more than ten people, including children, who had been killed by the shelling. ${ }^{5264}$ The bodies of eight Bosnian Muslims killed during the shelling of Pudin Han were exhumed from graves in Velagići in $1996,{ }^{5265}$ but the Chamber notes that five of those eight were last reported alive on 1 June $1992 .{ }^{5266}$ Accordingly, the Chamber concludes that, at a minimum, three civilians were killed by Serb Forces during the attack in Pudin Han and that the village_including the mosque ${ }^{5267}$ — was destroyed on or about 28 May 1992.

(b) Scheduled Incident A.7.2

1516. The Indictment refers to the killing of at least 38 people in Prhovo village and further on the road to Peći on or about 1 June 1992.

5260 KDZ024, P713 (Transcript from Prosecutor v. Brđanin), T. 9118 (under seal).

5261 KDZ024, P713 (Transcript from Prosecutor v. Brđanin), T. 9118 (under seal).

5262 Indictment, Scheduled Incident A.7.1. See also Confidential Appendix B to Prosecution Pre-Trial Brief [Scheduled Incident A7.1] (listing 11 persons).

5263 Adjudicated Fact 921. See also KDZ192, P3416 (Transcript from Prosecutor v. Brđanin), T. 11725 (under seal) (testifying that Bosnian Muslims had made statements that five or six civilians had been killed in Pudin Han).

5264 KDZ024, P713 (Transcript from Prosecutor v. Brđanin), T. 9118-9119 (under seal).

5265 P6690 (Addendum to Nicolas Sébire's report, 16 May 2003), e-court pp. 74-75 (naming eight persons listed in Scheduled Incident A.7.1 of Appendix G to the Prosecution's Final Trial Brief as having been exhumed from a grave in Velagići that was linked to the Pudin Han incident in 1996); P4878 (List of mass graves and bodies exhumed in Ključ Municipality, 1996), p. 10 (listing the same eight); P4880 (Ključ Court record of autopsy and identification of victims exhumed from graves in Velagići and Ključ, 10-11 November 1996), pp. 5, 8-14 (giving details regarding the clothing found on and injuries sustained by the persons listed in P4878); P4853 (Updated Table 2 to the Report of Amor Mašović), pp. 6-7 (identifying these eight persons as Bosnian Muslims). The bodies of an additional four Bosnian Muslims who went missing from the Pudin Han area on 27 May 1992 were exhumed from graves in the same area, but the evidence before the Chamber is insufficient to conclude that they were killed by Serb Forces during this attack. P4853, p. 7 (identifying these four persons as Bosnian Muslims); P4878 (List of mass graves and bodies exhumed in Ključ Municipality, 1996), pp. 10-11 (listing the additional four); P4880 (Ključ Court record of autopsy and identification of victims exhumed from graves in Velagići and Ključ, 10-11 November 1996), pp. 8-9, 18.

5266 P4853 (Updated Table 2 to the Report of Amor Mašović), pp. 6-7.

5267 See paras. 1556-1558. 
1517. Around 1 June 1992, approximately 100 members of the Serb Forces armed with automatic weapons arrived in Prhovo, ${ }^{5268}$ a village located northeast of Ključ town and southeast of the village of Peći which was then inhabited primarily by Bosnian Muslims. ${ }^{5269}$

1518. The Serb Forces ordered approximately 40 unarmed male residents of Prhovo, as well as a number of unarmed women and children, to line up facing the wall of Karanfil Osmanović's house, and then began to beat some of them. ${ }^{5270}$ Four Bosnian Muslim men were called out by name, told to run away, and then shot dead. ${ }^{5271}$

1519. The Serb Forces ordered the approximately 30 remaining Bosnian Muslim men from Prhovo to form a column and walk to the nearby village of Peći. ${ }^{5272}$ On the way to Peći, three Bosnian Muslim men from the column were killed after they failed to drag a military vehicle out of the mud. ${ }^{5273}$ The commander of the unit, Marko Adamović, ${ }^{5274}$ ordered that the village be set on

5268 See Adjudicated Facts 2437, 922. Some of the Bosnian Serbs wore JNA camouflage uniforms, but there were also masked armed civilians. Adjudicated Fact 922.

5269 P645 (Map of Prhovo marked by KDZ056); KDZ056, P686 (Transcript from Prosecutor v. Brđanin), T. 10334 (8 October 2002) (stating that Prhovo contained approximately 60 houses that were home to about 200 villagers); see Adjudicated Fact 2437.

5270 Adjudicated Fact 2437; KDZ056, P686 (Transcript from Prosecutor v. Brđanin), T. 10341-10342. See also Adjudicated Fact 923.

5271 Adjudicated Fact 923; KDZ056, P686 (Transcript from Prosecutor v. Brđanin), T. 10341-10342. See also Adjudicated Facts 924, 2437.

5272 Adjudicated Fact 925; KDZ056, P686 (Transcript from Prosecutor v. Brđanin), T. 10343-10344.

5273 See Adjudicated Fact 925; KDZ056, P686 (Transcript from Prosecutor v. Brđanin), T. 10344. The group left the bodies of the three dead men behind while the rest of the men continued the walk toward Peći. KDZ056, P686 (Transcript from Prosecutor v. Brđanin), T. 10344.

5274 While testifying in this case, Marko Adamović denied that he was the commander of the operation in Prhovo and claimed that he only learned what took place there when a military officer who was crying arrived at the Crisis Staff meeting on the same day. D4165 (Witness statement of Marko Adamović dated 1 December 2013), para. 23; Marko Adamović, T. 44458-44459, 44464-44466, 44470 (4 December 2013). The Chamber notes that at the time of his testimony, Adamović was awaiting judgement in the re-trial of his case in $\mathrm{BiH}$, which related to the events in Prhovo. Marko Adamović, T. 44457-44458 (4 December 2013). The Chamber thus considers that Adamović had an incentive to be less than forthcoming about his role in those events. Moreover, Adamović was evasive throughout his testimony, particularly when questioned about how he had come to know about what had happened in Prhovo. D4165 (Witness statement of Marko Adamović dated 1 December 2013), para. 23; Marko Adamović, T. 44459-44464, 44467-44473, 44478-44479, 44485-44487, 44489 (4 December 2013) (denying involvement but conceding that the minutes of the Crisis Staff meeting did not reflect that he was present); P2606 (Minutes from sessions of Ključ's Crisis Staff, 27 May-10 July 1992), pp. 7-8. The Chamber therefore shall not rely on Adamović's evidence in relation to this incident. Although Rajko Kalabić corroborated Adamović's testimony that a tearful military officer informed the Crisis Staff about the events in Prhovo on 1 June 1992, Kalabić, who was himself evasive throughout his testimony, was inconsistent regarding Adamović's presence at the meeting. Compare Rajko Kalabić, T. 44578-44580 (5 December 2013) (explaining that he had only disclosed that Adamović was present at the Crisis Staff meeting during the appellate phase of a case in $\mathrm{BiH}$ and not before because the Prosecutor had not asked about Adamović's presence during the trial) with Rajko Kalabić, T. 44582-44583 (5 December 2013) (accepting the possibility that the Crisis Staff had actually only learned about the events in Prhovo two or three days later, as Kalabic had testified in the Brđanin case). Accordingly, the Chamber finds that Adamović was present and in command of the Serb Forces in Prhovo. 
fire and the women and children be killed. ${ }^{5275}$ KDZ056 then heard shooting and an explosion from the village. ${ }^{5276}$

1520. Only 12 men from the column survived the trek to Peći. ${ }^{5277}$ Sulejman Medanović, having survived the walk, died during the following night as a result of beatings he sustained while the group was detained overnight in a co-operative centre called "Dom". 5278 In the morning, the 11 survivors were taken to the Nikola Mačkić Elementary School, arriving around 11:00 a.m. ${ }^{5279}$

1521. A total of 51 bodies identified as those of Bosnian Muslims who were killed in Prhovo on or around 1 June 1992 by Serb Forces were exhumed from two mass graves located in Prhovo. ${ }^{5280}$

5275 Adjudicated Fact 2438; KDZ056, P686 (Transcript from Prosecutor v. Brđanin), T. 10346 (testifying that the commander ordered that no one be left alive in the village).

5276 KDZ056, P686 (Transcript from Prosecutor v. Brđanin), T. 10346. KDZ056 later learned that the Serb Forces in the village had killed the people who had remained behind. KDZ056, P686 (Transcript from Prosecutor v. Brđanin), T. 10346.

5277 See Adjudicated Fact 926. The Serb Forces killed two or three more Bosnian Muslim men when the group reached the crossroad junction for Sokolovo and Peći, and, after having ordered the remaining men to take off their shoes and clothing from the waist up, opened fire on them in a field, leaving only 12 survivors. KDZ056, P686 (Transcript from Prosecutor v. Brđanin), T. 10349-10351 (testifying that although 14 men originally survived, the soldiers shot the two youngest survivors after stating that 14 survivors were two too many for the soldiers to be able to exact "[their] revenge"). But see D4165 (Witness statement of Marko Adamović dated 1 December 2013), para. 8b (stating that he heard that Bosnian Muslims had opened fire on the Bosnian Serb unit from a small forest and that the unit had reacted by firing randomly in the direction of the forest). In light of the fact that the Bosnian Serb unit's acts could bear on Adamović's culpability in relation to this incident, the Chamber declines to rely on Adamović's evidence in this regard.

5278 KDZ056, P686 (Transcript from Prosecutor v. Brđanin), T. 10352-10353; P6690 (Addendum to Nicolas Sébire's report, 16 May 2003), pp. 79-80 (stating that a post mortem examination of Medanović's body revealed that the cause of death was force trauma to the head and chest, including brain injury). See also Adjudicated Fact 927. The Serb Forces tied the surviving men's hands with wires and strings, beat them, and ordered them to lie down near an electricity pole, where the survivors were held overnight without access to food or water, and told them that they would all be killed in the morning. KDZ056, P686 (Transcript from Prosecutor v. Brđanin), T. 10352-10353.

5279 KDZ056, P686 (Transcript from Prosecutor v. Brđanin), T. 10353. See also Scheduled Detention Facility C.15.2.

5280 KDZ056 testified that the 27 persons listed in P531 were killed in Prhovo village, as well as on the road and in the field on the way to Peći. P531 (List of persons captured/killed in Prhovo), p. 1; KDZ056, P686 (Transcript from Prosecutor v. Brđanin), T. 10346, 10357-10359. Autopsy reports and exhumation reports demonstrate that the bodies of these 27 persons, as well as the bodies of 24 others, were exhumed from two graves associated with the Serb Forces' attack on Prhovo on 1 June 1992; all of these persons died as a result of gunshot injuries to the head, thoracic cavity, and/or limbs. P622 (Record of autopsies of bodies from Prhovo, 13 May 1997) (recording the autopsy results for 36 persons killed by Serb Forces in Prhovo on 1 June 1992 who were wearing civilian clothing and who died of gunshot injuries to the head, thoracic cavity, and/or spine); P4882 (Bihać Cantonal Court record of Prhovo exhumation, 7 May 1997) (relating to the autopsies compiled in P622); P623 (Record of autopsies of bodies from Prhovo, 25 September 1999) (recording the exhumation of 15 bodies from a mass grave at Ciganska Dolina, 13 of whom were listed in P531). In light of the similarity in the causes of death and having cross-referenced P531 with P22 and P623, the Chamber concludes that all 51 persons included in P622 and P623 were killed by Serb Forces in Prhovo on or around 1 June 1992. See also P6690 (Addendum to Nicolas Sébire's report, 16 May 2003), pp. 76-79; Asim Egrlić, P6586 (Transcript from Prosecutor v. Krajišnik), T. 4810-4812 (testifying that he attended the exhumation of a Prhovo gravesite); Adjudicated Fact 928. In addition to the exhumations of the 51 persons mentioned above, Amor Mašović recorded the exhumation of the body of one additional person who went missing from Prhovo on 1 June 1992 from the Ciganska Dolina grave. P4853 (Updated Table 2 to the Report of Amor Mašović), pp. 7-8; P4850 (Witness statement of Amor Mašović dated 23 March 2012), Annex A, p. 5. However, this individual is not listed in P623 and no evidence in the record provides either an explanation for this omission or forensic information regarding 
The Chamber also received forensic evidence that Sulejman Medanović died as a result of injuries consistent with the beatings he received while the group was detained en route to the Nikola Mačkić School, ${ }^{5281}$ bringing the total number of bodies linked to the attack on Prhovo to $52 .{ }^{5282}$

1522. The Chamber therefore finds that Serb Forces killed 52 Bosnian Muslims in Prhovo and on the road to Peći on or about 1 June 1992.

(5) Arrests, detentions, and killings associated with detention facilities

\section{$\underline{\text { B.10.1 }}$}

(a) Scheduled Detention Facility C.15.3 and Scheduled Incident

1523. The Indictment refers to the use of the Velagići School as a detention facility at least between 30 May and June $1992,{ }^{5283}$ and to the killing of at least 77 men at the school on or about 1 June 1992. ${ }^{5284}$

1524. On the evening of 1 June 1992, approximately 100 unarmed Bosnian Muslim men who had surrendered to members of Serb Forces at the check-point in Velagići, a majority Bosnian Muslim village, ${ }^{5285}$ arrived at the Velagići School, ${ }^{5286}$ which was guarded by soldiers. ${ }^{5287}$ The men's names

the death. Accordingly, the Chamber cannot be satisfied that this person was killed by Serb Forces in Prhovo on or around 1 June 1992.

5281 See para. 1520, fn. 5278.

5282 The Chamber notes that the Accused concedes that the local authorities were informed that "a number of civilians" were killed during fighting in Prhovo. Defence Final Brief, para. 1518 (citing the witness statement of Slobodan Jurišić). Jurišić testified that the Crisis Staff was informed on 1 June 1992 that "a number of Muslim civilians" were killed in Prhovo, although he did not mention any fighting. D4363 (Witness statement of Slobodan Jurišić dated 8 February 2014), para. 23.

5283 Indictment, Scheduled Detention Facility C.15.3. In Appendix B to the Prosecution Final Brief, however, the Prosecution only refers to men being detained at the school on 1 June 1992.

5284 Indictment, Scheduled Incident B.10.1. The Chamber also notes that the Accused appears to characterise this event as two separate killing incidents, but observes that the evidence he cites, which the Chamber has analysed below, does not support this theory. Defence Final Brief, paras. 1519-1520.

5285 KDZ192, P3416 (Transcript from Prosecutor v. Brđanin), T. 11368 (under seal).

5286 P1170 (Map of Velagići marked by KDZ024) (showing the location of the school marked with an "S"); KDZ024, P713 (Transcript from Prosecutor v. Brđanin), T. 9127, 9146 (under seal). Some 80 persons who remained at the check-point were placed in an abandoned, windowless schoolhouse. See also P1155 (Excerpts from Banja Luka Military Court file), e-court p. 4.

5287 KDZ024, P713 (Transcript from Prosecutor v. Brđanin), T. 9121, 9125-9126 (under seal); P3488 (Witness statement of Atif Džafić undated), para. 138 (stating that he heard from a fellow inmate at Manjača that approximately 100 men were detained by Serb Forces, including the police and army, at Velagići school). See also Adjudicated Fact 946; Slobodan Jurišić, D4363 (Witness statement of Slobodan Jurišić dated 8 February 2014), para. 16 (suggesting that civilians were brought to the school to give statements in connection with the possession of weapons); Rajko Kalabić, T. 44585 (5 December 2013) (suggesting that "paramilitary members" in Pudin Han and Velagići had been "invited" to the school to surrender their weapons). On their way to the school, the group had encountered Željko Radojicić as well as one or two soldiers wearing olive grey uniforms, and Radojicić had told the soldiers: "Kill them all. They're not going to form a džamahirija here". KDZ024, P713 (Transcript from Prosecutor v. Brđanin), T. 9123 (under seal). Radojicić went from one man to the next, swearing at them and cursing their mothers. KDZ024, P713 (Transcript from Prosecutor v. Brđanin), T. 9123 (under seal). 
and dates of birth were recorded. ${ }^{5288}$ Two soldiers ordered the group to line up, raise their hands, and empty their pockets, and collected any documents or money that had been discarded in the process. $^{5289}$

1525. The two soldiers then ordered the group of Bosnian Muslim men to enter a small room on the first floor, where they were crowded in so tightly that they "literally had to sit in each other's laps". 5290 The Bosnian Muslim men were cursed and told to "bow down. You'll never again have the opportunity." 5291 At one point, the Bosnian Muslim men heard several men who were being held downstairs being told to stand up, and when they could not, the Bosnian Muslim men upstairs heard three to four bursts of fire and the men crying out. ${ }^{5292}$

1526. The Bosnian Muslim men remained in the classroom at the Velagici School while the soldiers cursed and maltreated them, until approximately 11:30 p.m. ${ }^{529}$ At that point, the soldiers ordered the detainees to stand and line up in a single file; as they exited the school, they were ordered to form a column, two by two. ${ }^{5294}$ Once the entire column had exited and lined up against the building, two soldiers who had been crouching in the nearby grass and pointing their automatic rifles began to fire at the column. ${ }^{5295}$ When the shooting stopped, the soldiers approached the fallen detainees and shot any apparent survivors, ${ }^{5296}$ [REDACTED]. ${ }^{5297}$ The soldiers began to drink

5288 KDZ024, P713 (Transcript from Prosecutor v. Brđanin), T. 9123-9125 (under seal); KDZ024, P713 (Transcript from Prosecutor v. S. Milošević), T. 30077-30078 (under seal).

5289 KDZ024, P713 (Transcript from Prosecutor v. Brđanin), T. 9123-9124, 9125 (under seal); KDZ024, P713 (Transcript from Prosecutor v. S. Milošević), T. 30077 (under seal).

5290 KDZ024, P713 (Transcript from Prosecutor v. Brđanin), T. 9123-9126, 9128 (under seal).

5291 KDZ024, P713 (Transcript from Prosecutor v. Brđanin), T. 9128 (under seal).

5292 KDZ024, P713 (Transcript from Prosecutor v. Brđanin), T. 9128 (under seal). See also P1155 (Excerpts from Banja Luka Military Court file), e-court p. 7.

5293 KDZ024, P713 (Transcript from Prosecutor v. Brđanin), T. 9128-9129 (under seal). When one man repeatedly asked for a telephone in order to "phone Vinko", a soldier put a rifle barrel in the man's mouth, and the man became covered in blood. KDZ024, P713 (Transcript from Prosecutor v. Brđanin), T. 9128 (under seal).

5294 KDZ024, P713 (Transcript from Prosecutor v. Brđanin), T. 9129, 9138 (under seal); KDZ024, P713 (Transcript from Prosecutor v. S. Milošević), T. 30078 (under seal).

5295 KDZ024, P713 (Transcript from Prosecutor v. Brđanin), T. 9129 (under seal); P1155 (Excerpts from Banja Luka Military Court file), e-court pp. 7-8. See also Adjudicated Fact 947.

5296 KDZ024, P713 (Transcript from Prosecutor v. Brđanin), T. 9129 (under seal); P1155 (Excerpts from Banja Luka Military Court file), e-court p. 9. The Chamber received evidence suggesting that the soldiers had only opened fire when some of the detainees attempted to escape. See P3614 (Handwritten letter of complaint to Lanište-Ključ Military Post, 12 June 1992), pp. 2-3 (suggesting that the soldiers had only opened fire when some of the detainees started to escape); P3513 (Request for investigation by the $1^{\text {st }}$ Krajina Corps Military Prosecutor's Office, 8 March 1993 (requesting an investigation into the suspects named in P1155); P1155 (Excerpts from Banja Luka Military Court file), e-court p. 5; D4165 (Witness statement of Marko Adamović dated 1 December 2013), para. 11.

5297 [REDACTED]. See also para. 1526. 
rakija and sing "Chetnik songs about Draza Mihajlović and about the establishment of an empire". 5298

1527. An excavator and lorries from the army base at Lanište were used to bury the bodies at Lanište, where they were discovered in $1998 .^{5299}$ On 3 June 1992, an investigating judge from the Ključ Municipal Court went to the Velagići School to conduct an on-site investigation. ${ }^{5300}$ On 5 June 1992, a criminal report was filed by the Banja Luka Military Prosecutor's Office against 12 members of the MP and intervention platoons affiliated with the VRS engineering unit based at Lanište. ${ }^{5301}$ However, the soldiers were never fully investigated and were only in custody for a month. ${ }^{5302}$

1528. Seventy seven bodies linked to the killings at Velagići School on 1 June 1992 were exhumed from the Lanište II "Babina Dolina" mass grave in Ključ in the autumn of $1996 .{ }^{5303}$ Although three of the bodies were so skeletonised as to preclude the establishment of a cause of

5298 KDZ024, P713 (Transcript from Prosecutor v. Brđanin), T. 9130 (under seal).

5299 KDZ024, P713 (Transcript from Prosecutor v. Brđanin), T. 9130, 9146 (under seal); P1155 (Excerpts from Banja Luka Military Court file), p. 6; D1751 (Official record of Banja Luka's Military Post 4627, Military Police Official, 3 June 1992) (stating that the traces of removal by an engineering machine were found and that it was determined that bodies of the victims were transported by trucks five kilometres away from the crime scene in the direction of Gorni Budelj, and buried by an engineering machine); P3488 (Witness statement of Atif Džafić undated), para. 138; Atif Džafić, T. 19745 (30 September 2011). See also Adjudicated Fact 2446.

5300 D1751 (Official record of Banja Luka's Military Post 4627, Military Police Official, 3 June 1992); Adjudicated Fact 2447.

5301 P1155 (Excerpts from Banja Luka Military Court file), e-court p. 4; KDZ024, P713 (Transcript from Prosecutor v. Brđanin), T. 9215-9216 (under seal); Adjudicated Fact 2447.

5302 P3614 (Handwritten letter of complaint to Lanište-Ključ Military Post, 12 June 1992) (in which 11 of the 12 suspects stated that they had been in custody since 1 June 1992 and threatened to go on hunger strike if not released immediately); P3513 (Request for investigation by the $1^{\text {st }}$ Krajina Corps Military Prosecutor's Office, 8 March 1993 (requesting an investigation into the suspects named in P1155); P3616 (Proposal of the Military Prosecutor's Office attached to the $1^{\text {st }}$ Krajina Corps, 29 July 1993) (suggesting that two suspects then in custody be released due to the inability to bring the remainder into custody and because both the deputy prime minister of the RS and the chairman of the Ključ Executive Board had recommended halting the proceedings); P6143 (Excerpt from ruling of Banja Luka Military Court, 29 July 1993) pp. 1-2 (stating that two of the suspects were released pursuant to the suggestion of the prosecutor contained in P3616); Asim Egrlić, T. 19991-19992 (5 October 2011) (testifying that although Bosnian Serb investigating bodies had carried out an investigation in relation to the incident, the suspects were held in prison for 18 days and then released); Adjudicated Fact 2447. But see D4363 (Witness statement of Slobodan Jurišić dated 8 February 2014), para. 17; Slobodan Jurišić, T. 47080 (14 February 2014).

5303 P3512 (Report on Lanište II mass grave, 4 October 1996) (describing the autopsies performed on 77 Bosnian Muslim males exhumed from Lanište II, 71 of whom were identified); P4850 (Witness statement of Amor Mašović dated 23 March 2012), para. 108 (describing P3512 as a court record which includes autopsy and exhumation reports). [REDACTED]; P618 (Photograph of Velagići cemetery). See also P4878 (List of mass graves and bodies exhumed in Ključ Municipality, 1996) (listing 70 Bosnian Muslim males who had been exhumed from Lanište II, in addition to seven who were not identified, all of whom were found upon examination to have been civilians who had been shot at point-blank range), pp. 11-13; P3637 (Report of BiH Federal Ministry of the Interior, 22 October 1996) (same); P4853 (Updated Table 2 to the Report of Amor Mašović), pp. 7, 84-86 (showing that 77 Bosnian Muslim males who were reported missing from Velagići on or around 1 June 1992 were found in the Lanište II grave); P6690 (Addendum to Nicolas Sébire's report, 16 May 2003), p. 83; Adjudicated Facts 2446, 947. 
death, the remainder all bore signs of fatal gunshot wounds, mostly to the head or trunk, and all were found in civilian clothing. ${ }^{5304}$

1529. The Chamber therefore finds that Bosnian Muslim men were detained, subjected to verbal and mental abuse, and that 77 Bosnian Muslim men were ultimately killed at Velagići School by Serb Forces on 1 June 1992.

\section{(b) Scheduled Detention Facility C.15.1}

1530. The Indictment refers to the use of the Ključ SJB Building as a detention facility at least between May and August 1992. ${ }^{5305}$

1531. On the morning of 28 May 1992, Asim Egrlić was arrested at a check-point just outside Ključ; he was then escorted to the SJB building in Ključ, ${ }^{5306}$ which was staffed and operated by the Bosnian Serb police. ${ }^{5307}$ While detained at the SJB building, Egrlić was beaten and sustained extensive injuries to his head and body before being transferred to the hospital, where he remained for approximately one hour. ${ }^{5308}$ While in the hospital, Veljko Kondić and Tihomir Dakić came to see Egrlić. ${ }^{5309}$ On the same day, Muhamed Filipović, a Bosnian Muslim member of the Ključ

5304 P3512 (Report on Lanište II mass grave, 4 October 1996) (describing the autopsies performed on 77 individuals exhumed from Lanište II, 71 of whom were identified); P4881 (Autopsy reports for victims exhumed at Lanište II, 6 October 1996). See also Adjudicated Fact 2447.

5305 Indictment, Scheduled Detention Facility C.15.1. In Appendix B to the Prosecution's Final Brief, however, the Prosecution only referred to the period "following attacks in May and June [19]92". The Chamber received evidence referring to the building housing the Ključ SJB as the "SJB building", the "SUP building", and the "police station". For clarity, the Chamber will use the term "SJB building" throughout this section to denote this building.

5306 Asim Egrlić, P6586 (Transcript from Prosecutor v. Krajišnik), T. 4789, 4795, 4945; Asim Egrlić, T. 19985 (5 October 2011); KDZ192, T. 19493-19494 (27 September 2011) (closed session); D1737 (Official note of Ključ War Department, 16 February 1993), pp. 1-2. See also Adjudicated Fact 2440. The Chamber received evidence suggesting that Egrlić was wounded during the attack on the JNA convoy discussed above. See para. 1509. D1748 (Official note of $2^{\text {nd }}$ Krajina Corps Command, 11 July 1992), p. 3 (naming Egrlić as one of the attackers); D4169 (Witness statement of Rajko Kalabić dated 1 December 2013), paras. 6, 20. Egrlić contested the veracity of the narrative contained in D1748, suggesting that the statements on which it was based were obtained from persons detained in Manjača who may have been under duress and that he had actually wounded himself by shooting himself in the foot. Asim Egrlić, T. 19971-19974 (5 October 2011); Asim Egrlić, P6586 (Transcript from Prosecutor v. Krajišnik), T. 4788-4789, 4795, 4945. Although the Chamber considers Egrlić's account of his wounding implausible, the Chamber does not consider that Egrlić's involvement in this event, if any, would have any impact on the credibility of his testimony regarding the treatment he received during his subsequent detention.

5307 See Adjudicated Fact 933. The Accused acknowledges that the Ključ SJB building was staffed and operated by Bosnian Serb police, who, along with local civilians subjected detainees to beatings and verbal abuse. Defence Final Brief, para. 1523. See also Adjudicated Fact 932 (stating that the SJB building was located in the town of Ključ).

5308 Asim Egrlić, P6586 (Transcript from Prosecutor v. Krajišnik), T. 4795, 4945, 4949-4950; Asim Egrlić, T. 19985 (5 October 2011) (stating that he was admitted to the Ključ hospital). See also Adjudicated Fact 2440; D4169 (Witness statement of Rajko Kalabić dated 1 December 2013), para. 6 (stating that Egrlić was administered first aid at the Ključ Health Centre but transferred to Banja Luka for further treatment).

5309 Asim Egrlić, T. 19985 (5 October 2011). [REDACTED]. 
Municipal Assembly, ${ }^{5310}$ was arrested by two Bosnian Serbs in military uniforms and taken to the SJB building, where he was subjected to beatings by Bosnian Serb soldiers. ${ }^{5311}$ At the time, at least 22 other Bosnian Muslims were held at the SJB building. ${ }^{5312}$

1532. Those arrested were beaten in a gauntlet at the steps of the entrance to the SJB building with feet, fists, batons, rifle-butts and chair legs, and were subjected to ethnic slurs. ${ }^{5313}$ They were then beaten inside the SJB building, including during interrogations. ${ }^{5314}$ The perpetrators of these beatings were Bosnian Serb police officers and local civilians. ${ }^{5315}$

1533. A prominent Bosnian Muslim was thrown down the stairs, and was carried into the SJB building unconscious, whilst another suffered a cut lip and broken ribs. ${ }^{5316}$ As a result of the severity of the beatings, the former suffered a serious, lasting injury with continuing effects to date. $^{5317}$
1534. [REDACTED]. ${ }^{5318}$
[REDACTED]. ${ }^{5319}$
[REDACTED]. ${ }^{5320}$
[REDACTED]. ${ }^{5321}$
[REDACTED.$^{5322}$ [REDACTED.$^{5323}$ [REDACTED.$^{5324}$ [REDACTED.$^{5325}$ [REDACTED $] .{ }^{5326}$

1535. Other detainees, including Egrlić and Filipović, were later taken to the prison in Stara Gradiška and subsequently to Manjača. ${ }^{5327}$

1536. The Chamber finds that during the period between late May and late June 1992, members of Serb Forces detained Bosnian Muslim men at the Ključ SJB building and subjected them to ethnic

5327 Asim Egrlić, P6586 (Transcript from Prosecutor v. Krajišnik), T. 4795-4796 (stating that he was taken from the hospital via the SJB building and was beaten until unconscious and bloody while en route to the Stara Gradiška prison); Adjudicated Fact 2442.
} 
slurs as well as beatings with fists, batons, rifle-butts and chair legs, which were sufficiently severe as to cause permanent injury.

\section{(c) Scheduled Detention Facility C.15.2}

1537. The Indictment refers to the use of the Nikola Mačkić Elementary School as a detention facility at least between 1 May and July 1992. ${ }^{5328}$

1538. From 2 June $1992,^{5329}$ approximately 300 Muslim men were detained and guarded by Bosnian Serb regular and reserve civilian police in the Nikola Mačkić Elementary School in Ključ. ${ }^{5330}$ When the detainees arrived at the Nikola Mačkić Elementary School, they were forced to run through a gauntlet of Bosnian Serb civilians armed with cables, bats, clubs, and other objects, while being beaten, spat on, and verbally degraded. ${ }^{531}$ Before entering the gym, all detainees were searched by Bosnian Serbs, who seized the detainees' valuables and documents. ${ }^{532}$ Some detainees were also interrogated about whether they had weapons and whether they were combatants. ${ }^{5333}$

1539. Two Bosnian Serb police officers stood in the corridor, beating the detainees at random as they entered the gym, where approximately 100 civilian men of all ages were sitting on the floor with their hands behind their backs, ${ }^{5334}$ facing the walls, which were stained with blood. ${ }^{535}$ Some detainees were crying, while others were bleeding and injured from the beatings. ${ }^{5336}$ Detainees were forced to extend the three fingers in the Serbian salute. ${ }^{5337}$ One detainee was forced to lick his own blood off the floor after having been beaten severely. ${ }^{5338}$ Beatings took place both during and outside interrogations, including the beating of a boy who was 16 and still attending high school, despite the fact that his age was known to the interrogators. ${ }^{5339}$

\footnotetext{
5328 Indictment, Scheduled Detention Facility C.15.2. In Appendix B to the Prosecution Final Brief, however, the Prosecution only refers to the period "from 27 and during early Jun[e 19]92".

5329 P3488 (Witness statement of Atif Džafić undated), paras. 87, 139; KDZ056, P686 (Transcript from Prosecutor v. Brđanin), T. 10353.

5330 See Adjudicated Facts 2444, 938; Slobodan Jurišić, D4363 (Witness statement of Slobodan Jurišić dated 8 February 2014), para. 25 (testifying that the school was guarded by civilian police). The Accused concedes that the Nikola Mačkić School was staffed by civilian police, who, along with Bosnian Serb civilians, took part in the beatings that occurred at the school. Defence Final Brief, para. 1524.

5331 P3488 (Witness statement of Atif Džafić undated), para. 87; see Adjudicated Fact 939.

5332 P3488 (Witness statement of Atif Džafić undated), para. 87.

5333 KDZ056, P686 (Transcript from Prosecutor v. Brđanin), T. 10353.

5334 P3488 (Witness statement of Atif Džafić undated), para. 88.

5335 KDZ056, P686 (Transcript from Prosecutor v. Brđanin), T. 10354.

5336 P3488 (Witness statement of Atif Džafić undated), para. 88.

5337 Adjudicated Fact 943.

5338 P3488 (Witness statement of Atif Džafić undated), para. 94.

5339 Adjudicated Fact 940.
} 
1540. Former Bosnian Muslim police officers were the object of particularly severe physical abuse and humiliation. ${ }^{5340}$ Atif Džafić was taken from the gym to a classroom, ${ }^{531}$ where he was interrogated by a Bosnian Serb police officer, Nedeljko Vasić. ${ }^{5342}$ Džafić was then returned to the gym and "put on display" in the middle of the gym floor with his hands behind his back, where his former subordinates beat him. ${ }^{5343}$ After one hour, Džafić was again taken to the corridor by two masked policemen wearing camouflage uniforms. These policemen beat him and took him for further interrogation by Duško Miličević, who was an inspector from the Banja Luka CSB and dressed in the uniform of a military captain, and another military captain. Miličević and the other military captain beat Džafić with desk legs, cables, and bats. ${ }^{534}$ The other military captain asked Džafić what Džafić knew about who had killed Dušan Stojaković and why Džafić had not signed the SJB loyalty oath. ${ }^{534}$ Džafić denied involvement in Stojaković's death, ${ }^{5346}$ but was given a piece of paper and asked to "write everything down" before being returned to the gym, where he was again placed in the middle of the floor. ${ }^{5347}$

1541. The municipal authorities were aware that Bosnian Muslims were beaten by Bosnian Serbs in the Nikola Mačkić School. ${ }^{5348}$

1542. The detainees were held at the Nikola Mačkić School until at least 7 p.m. on 2 June 1992 without being given any food or water. ${ }^{5349}$

\footnotetext{
5340 Adjudicated Fact 941. Atif Džafić recognised two or three of his former police colleagues among the detainees in civilian clothes. P3488 (Witness statement of Atif Džafić undated), para. 88.

5341 While en route to and from this classroom, Džafić was beaten with school desk legs and cables. P3488 (Witness statement of Atif Džafić undated), para. 88.

5342 P3488 (Witness statement of Atif Džafić undated), para. 88

5343 P3488 (Witness statement of Atif Džafić undated), para. 88.

5344 P3488 (Witness statement of Atif Džafić undated), para. 89. See also Adjudicated Fact 941. Miličević beat another Bosnian Muslim police officer, Atif Dedić. P3488 (Witness statement of Atif Džafić undated), para. 89. See also Adjudicated Fact 941.

5345 P3488 (Witness statement of Atif Džafić undated), para. 91; Atif Džafić, T. 19741 (30 September 2011).

5346 Džafić asserted that there was "no reason to arrest him", but suggested that the interrogators might have thought that as police commander, he would have known more and therefore focused their investigations on him. Atif Džafić, T. 19743 (30 September 2011).

5347 P3488 (Witness statement of Atif Džafić undated), paras. 91, 93, 94; Atif Džafić, T. 19741 (30 September 2011).

5348 Adjudicated Fact 944. Slobodan Jurišić testified that he did not know or hear that Muslims were being beaten at Nikola Mačkić School, nor was this discussed at the Crisis Staff. D4363 (Witness statement of Slobodan Jurišić dated 8 February 2014), para. 26. Considering, however, that Jurišić was a member of the Crisis Staff, and that whether the Crisis Staff was informed of the beatings at the Nikola Mačkić's school could bear on Jurišić's responsibility in relation to those events, the Chamber shall not rely on Jurišić's evidence on this point. The Chamber notes that the Accused relied on Jovo Kevac's evidence to support his assertion that "all reported incidents of abuse were dealt with" by the Ključ authorities. Defence Final Brief, para. 1524. However, Kevac merely stated his belief that the Crisis Staff was not aware of the beatings, and even admitted a lack of knowledge in this regard. D4268 (Witness statement of Jovo Kevac dated 25 January 2014), para. 33. The Chamber will therefore not rely on Kevac's opinion.
} 
1543. On 5 June 1992, other detainees were transferred directly from the Nikola Mačkić School to Manjača. ${ }^{550}$ On approximately 7 June 1992, the detainees in Sitnica were also transferred to Manjača. ${ }^{5351}$

1544. The Chamber therefore finds that during the period between 2 and 5 June 1992, members of Serb Forces detained Bosnian Muslim men at the Nikola Mačkić School, and subjected them to severe beatings with such objects as cables, bats, and clubs, as well as verbal abuse and other forms of humiliation.

\section{(6) Killings after June 1992: Scheduled Incident A.7.3}

1545. The Indictment refers to the killing of at least 144 people in Biljani on or about 10 July 1992.

1546. Around 6:15 a.m. on 10 July 1992, all men in Biljani between the ages of 18 and 60 were told to gather at a field near the village ${ }^{5352}$ while the women and children were allowed to remain at home. ${ }^{5353}$ Approximately 20 or 30 soldiers were visible on the elevations surrounding the village, which was consequently completely surrounded and cut off. ${ }^{5354}$ Between 50 and 70 men arrived at the field, where they found Marko Samardžija, a captain in the reserve forces, ${ }^{535}$ waiting with Mladjo Tesić and ten other soldiers. ${ }^{5356}$ The soldiers ordered the men to line up so they could be questioned. ${ }^{537}$ The Bosnian Muslim men remained there for approximately one hour while the

\footnotetext{
5349 P3488 (Witness statement of Atif Džafić undated), para. 95; KDZ056, P686 (Transcript from Prosecutor v. Brđanin), T. 10354.

$5350 \quad$ See Adjudicated Fact 2445.

5351 P3488 (Witness statement of Atif Džafić undated), para. 95; KDZ056, P686 (Transcript from Prosecutor v. Brđanin), T. 10354. See also para. 1382.

5352 The village of Biljani is located north-west of the town of Ključ between Krasulje and Sanica, and contained the hamlets of Brkići, Džaferagići, Botonići and Jakubovac, which were almost exclusively inhabited by Bosnian Muslims. P3365 (Map of area around Biljani); Adjudicated Fact 929. See also P3488 (Witness statement of Atif Džafić undated), para. 140; KDZ075, P3359 (Transcript from Prosecutor v. Krajišnik), T. 4954 (commenting on P3365); KDZ075, T. 19033 (16 September 2011).

5353 KDZ075, P3359 (Transcript from Prosecutor v. Krajišnik), T. 4965-4966.

5354 KDZ075, P3359 (Transcript from Prosecutor v. Krajišnik), T. 4966.

5355 KDZ075, P3359 (Transcript from Prosecutor v. Krajišnik), T. 4967-4968. KDZ075 knew Samardžija because he had been KDZ075's primary school teacher in Biljani. KDZ075, P3359 (Transcript from Prosecutor v. Krajišnik), T. 4967.

5356 KDZ075, P3359 (Transcript from Prosecutor v. Krajišnik), T. 4966.

5357 KDZ075, P3359 (Transcript from Prosecutor v. Krajišnik), T. 4966-4967. The soldiers told them not to be afraid, that nothing would happen to them, that they had a list of people who should be questioned, while those who were not on the list would be "sent back". KDZ075, P3359 (Transcript from Prosecutor v. Krajišnik), T. 4966.
} 
village was being searched; they were then marched in a column to the Biljani Primary School, approximately one kilometre away. ${ }^{5358}$

1547. When the men arrived at the Biljani Primary School, a van was parked under a tree with about ten military policemen from Ključ wearing white belts. ${ }^{5359}$ Many soldiers stood around the school and approximately ten were in front of a shop, guarding women and children brought from another hamlet. ${ }^{5360}$ Samardžija greeted Mile Tomić, a police commander in Sanica, ${ }^{5361}$ and his deputy, Mihić, along with several other men before the detained men were told to enter the school. ${ }^{5362}$ Soldiers were arriving from all directions, bringing people from the seven or eight hamlets in the village. ${ }^{5363}$

1548. Between 120 and 150 men were confined in two classrooms inside the Biljani Primary School. ${ }^{5364}$ Before entering the classrooms, the group of men from KDZ075's hamlet, were made to empty their pockets and their documents in the corridor. ${ }^{5365}$ Mihić and another reserve policeman spent approximately 45 minutes writing down the detainees' names before leaving the classroom. ${ }^{5366}$

5358 KDZ075, P3359 (Transcript from Prosecutor v. Krajišnik), T. 4966. See also P3360 (List of detainees from Biljani). The Chamber shall not rely on Rajko Kalabić's testimony that those detained at Biljani were not detained on account of their ethnicity or age, but because they were suspected of being members of paramilitary forces or of possessing illegal weapons, as Kalabić later denied knowing anything about the incident in Biljani, and ultimately admitted that he had previously testified that he had heard that a "massacre" had occurred there on 10 July 1992. D4169 (Witness statement of Rajko Kalabić dated 1 December 2013), para. 19; Rajko Kalabić, T. 44588-44589 (5 December 2013). See also P3488 (Witness statement of Atif Džafić undated), para. 141 (noting that he had talked to Bosnian Muslim survivors of the Biljani incident and that they were all civilians).

5359 KDZ075, P3359 (Transcript from Prosecutor v. Krajišnik), T. 4967, 4968; KDZ075, T. 19017 (16 September 2011). See also P3366 (Official note of Ključ SJB, 10 July 1992); KDZ075, P3359 (Transcript from Prosecutor v. Krajišnik), T. 4969 (testifying that this was consistent with what he saw in the Biljani school gym). See also Adjudicated Facts 930, 939; P3488 (Witness statement of Atif Džafić undated), para. 140; Atif Džafić, T. 19740 (30 September 2011) (testifying that he later learned that Bosnian Serb military and civilian police had attacked Biljani on the morning of 10 July and had rounded up the entire village population and taken them to the elementary school).

5360 KDZ075, P3359 (Transcript from Prosecutor v. Krajišnik), T. 4968.

5361 KDZ075, P3359 (Transcript from Prosecutor v. Krajišnik), T. 4967 (testifying that he knew Tomić personally).

5362 KDZ075, P3359 (Transcript from Prosecutor v. Krajišnik), T. 4967-4968.

5363 KDZ075, P3359 (Transcript from Prosecutor v. Krajišnik), T. 4968. When shown P3367, an order of Ključ Military Post dated 9 July 1992 which described the assignment of the $2^{\text {nd }}$ Battalion of the $17^{\text {th }}$ Light Infantry Brigade, a reconnaissance platoon, a military police squad, and a police platoon to block, search, and mop up the Donji Biljani, Domazeti, Botonjići, Jabukovac, Osmanovići, and Brkići sectors on 10 July 1992, KDZ075 confirmed that this was consistent with what transpired on 10 July 1992, as various different units had brought the residents of Botonjići, Jabukovac Polje, and Domezeti to the school. KDZ075, P3359 (Transcript from Prosecutor v. Krajišnik), T. 4971 (commenting on P3367).

5364 See Adjudicated Fact 930.

5365 KDZ075, P3359 (Transcript from Prosecutor v. Krajišnik), T. 4968.

5366 KDZ075, P3359 (Transcript from Prosecutor v. Krajišnik), T. 4969, 4972; KDZ075, T. 19019 (16 September 2011) (private session); P3361 (List of 76 persons). See also KDZ075, T. 19018 (16 September 2011). 
1549. After 20 to 30 minutes, Mihić returned and began to call out ten names, and one by one, the men left the classroom and the detainees heard a burst of fire each time. ${ }^{5367}$ After another five or ten minutes, the men began to be called out in groups of five. ${ }^{5368}$ When the first group exited, the shooting and screams of men outside intensified. ${ }^{5369}$ The policemen guarding the detainees told them that the Green Berets were attacking and that the guards would drive them away. ${ }^{5370}$ When one detainee remarked that they were all going to be killed, panic ensued. ${ }^{5371}$ A soldier told the men to calm down and that they would all "be going", but that the elderly men should gather on one side of the classroom because only the younger men would be travelling. ${ }^{5372}$

1550. After leaving the classroom, the groups of five detainees were lined up in the corridor and let out of the building one by one. ${ }^{5373}$ Some were beaten while passing through a line of 20 to 30 Bosnian Serb soldiers on the way to two buses parked near the school, ${ }^{5374}$ while others were taken away to the road below. ${ }^{5375}$ Detainees continued to be loaded onto the buses until they were packed with approximately 70 people. ${ }^{5376}$ When the buses were full, the detainees who had not yet boarded the buses were shot. ${ }^{5377}$

5367 KDZ075, P3359 (Transcript from Prosecutor v. Krajišnik), T. 4972; KDZ075, T. 19069 (19 September 2011) When KDZ075's relative was called out but tried to return for his jacket, which he had forgotten, a policeman told the relative to leave the jacket because he would not need it anymore. KDZ075, P3359 (Transcript from Prosecutor v. Krajišnik), T. 4972-4973; KDZ075, P3358 (Transcript from Prosecutor v. Krajišnik), T. 49794980 (under seal). After KDZ075's relative left, the men remaining in the gym heard a burst of fire. KDZ075, P3359 (Transcript from Prosecutor v. Krajišnik), T. 4973; KDZ075, P3358 (Transcript from Prosecutor v. Krajišnik), T. 4979-4980 (under seal). [REDACTED]. See also P3362 (List of persons detained in Biljani Elementary School); KDZ075, T. 19025-19026 (16 September 2011) (private session).

5368 Adjudicated Fact 930; KDZ075, P3359 (Transcript from Prosecutor v. Krajišnik), T. 4973.

5369 KDZ075, P3359 (Transcript from Prosecutor v. Krajišnik), T. 4973.

5370 KDZ075, P3359 (Transcript from Prosecutor v. Krajišnik), T. 4973. The detainees did not believe this because "not a single bullet was fired from [the Bosnian Muslim] side in Biljani" and because most of the Bosnian Muslim men had already been brought to the school building. KDZ075, T. 19023 (16 September 2011). See also KDZ075, T. 19054-19055, 19057-19058 (private session) (19 September 2011); T. 19067-19068 (19 September 2011) (asserting that Bosnian Muslims had been surrendered, that there were no Bosnian Muslim soldiers in Biljani in 1992, and that there was no combat in Biljani in 1992). The detainees only later realised that the individuals who were being taken out were being killed. KDZ075, T. 19023 (16 September 2011).

5371 KDZ075, P3359 (Transcript from Prosecutor v. Krajišnik), T. 4973.

5372 KDZ075, P3359 (Transcript from Prosecutor v. Krajišnik), T. 4973-4975.

5373 KDZ075, P3359 (Transcript from Prosecutor v. Krajišnik), T. 4974.

5374 KDZ075, P3359 (Transcript from Prosecutor v. Krajišnik), T. 4973-4974. Dragan Cvijić, a special purpose policeman, was standing at the bottom of the steps, and kicked KDZ075 in the stomach as the latter passed by. KDZ075, P3359 (Transcript from Prosecutor v. Krajišnik), T. 4974 . Once on board the bus, KDZ075 heard soldiers say, in relations to detainees who fell down while en route to the bus, "take him away. This man is good for nothing. Kill him.” KDZ075, P3359 (Transcript from Prosecutor v. Krajišnik), T. $4975 . \quad$ KDZ075 also recalled a specific instance when "another man came along who worked in Ključ, and he said 'give this one to me. This one is not getting on the bus." KDZ075, P3359 (Transcript from Prosecutor v. Krajišnik), T. 4975.

5375 KDZ075, P3359 (Transcript from Prosecutor v. Krajišnik), T. 4973-4974.

5376 KDZ075, P3359 (Transcript from Prosecutor v. Krajišnik), T. 4975; KDZ075, T. 19058 (private session) (19 September 2011).

5377 KDZ075, P3359 (Transcript from Prosecutor v. Krajišnik), T. 4975; KDZ075, T. 19069 (19 September 2011) (recalling that one man who appeared to be in charge yelled 'we don't need the rest of them, kill them all'). 
1551. As the bus departed, four men were taken off the bus and killed. ${ }^{5378}$ After the bus had gone approximately 100 metres, an additional five men, including KDZ075, Fikret Balagić, Alija Avdić, Besim Avdić, and a man whose first name was Rufad were also removed from the bus by military policemen wearing camouflage uniforms and white belts. ${ }^{5379}$

1552. The men were led to a ditch behind a house, where KDZ075 saw the other men who had been taken off the bus earlier lying dead. ${ }^{5380}$ When KDZ075 and two of the men with him tried to escape, the soldiers called after them, "stop, fuck your balija mothers!"5381 KDZ075 heard a burst of fire, and one of the men fell to the ground with "two or three huge holes in his back" ${ }^{5382}$ When a soldier indicated that a third man was still alive, another soldier fired a burst of fire at the third man. ${ }^{5383}$ Soldiers from the bus yelled at the shooters to hurry up, but the shooters waited for the men to stop breathing before eventually running back to the buses. ${ }^{5384}$

1553. After the bus left, KDZ075 fled and hid in the cornfields nearby. ${ }^{5385}$ From there, he could hear trucks and bulldozers coming to collect the bodies and houses being set on fire. ${ }^{5386}$ The collection of bodies continued into the night of 10 July $1992 .{ }^{5387}$

1554. The bodies of 184 Bosnian Muslims, most of whom had been shot in the head, were exhumed from graves associated with the events at Biljani Primary School on 10 July 1992. ${ }^{5388}$

5378 KDZ075, P3359 (Transcript from Prosecutor v. Krajišnik), T. 4975-4976; KDZ075, T. 19064 (19 September 2011).

5379 KDZ075, P3359 (Transcript from Prosecutor v. Krajišnik), T. 4976, 4984; KDZ075, T. 19060 (19 September 2011).

$5380 \quad$ KDZ075, P3359 (Transcript from Prosecutor v. Krajišnik), T. 4976.

5381 KDZ075, T. 19061-19062 (19 September 2011); KDZ075, P3359 (Transcript from Prosecutor v. Krajišnik), T. 4977.

5382 KDZ075, P3359 (Transcript from Prosecutor v. Krajišnik), T. 4977; KDZ075, T. 19062 (19 September 2011).

5383 KDZ075, P3359 (Transcript from Prosecutor v. Krajišnik), T. 4977.

5384 KDZ075, P3359 (Transcript from Prosecutor v. Krajišnik), T. 4977. See also KDZ075, T. 19063 (19 September 2011). The Chamber notes that while Jovo Kevac attributed responsibility for these killings to criminal groups that "broke free of control and burst into the area at some point", he could not definitively state that such groups had been present at Biljani school. Jovo Kevac, T. 46230-46231 (30 January 2014). Kevac also suggested that the perpetrators had been apprehended and proceedings conducted against them, but could not recall any names or produce documents associated with the alleged investigation. D4268 (Witness statement of Jovo Kevac dated 25 January 2014), para. 9; Jovo Kevac, T. 46233, 46235 (30 January 2014).

5385 KDZ075, T. 19025 (16 September 2011). After the shooting, KDZ075 lay where he had fallen for approximately 1.5 hours, after which he fled to the woods and then to a cornfield nearby. KDZ075, T. 19025 (16 September 2011); KDZ075, T. 19065 (19 September 2011).

5386 KDZ075, T. 19025, 19034 (16 September 2011).

5387 KDZ075, T. 19035 (16 September 2011).

5388 KDZ075 testified that P3361 and P3362 contained the names of persons detained in the classroom with him at the Biljani primary school. KDZ075, T. 19019-19020, 19026 (16 September 2011); P3361 (List of 76 persons); P3362 (List of persons detained in Biljani Elementary School). The bodies of the vast majority of the persons listed in P3361 and P3362 were exhumed from the Lanište I and Crvena Zemlja mass graves in 1996. P3363 (Report on Lanište I mass grave, 3 October 1996) (containing the autopsies of persons listed in P3361 and P3362); P4879 (Ključ Court record of Crvena Zemlja II exhumation, 4-15 November 1996) (containing the autopsies of persons listed in P3361 and P3362); P4853 (Updated Table 2 to the Report of Amor Mašović), pp. 
The bodies of 15 additional Bosnian Muslims, the majority of whom bore signs of fatal gunshot wounds to the head, were exhumed from graves located in and around Biljani and were identified as containing the remains of persons killed by Serb Forces on or around 10 July 1992. 5389

1555. The Chamber therefore finds that 199 Bosnian Muslims were killed by Serb Forces on or around 10 July 1992 in Biljani.

\section{(7) Scheduled Incident D.13}

1556. The Indictment refers to the destruction of eight mosques and a Catholic church between at least May and August 1992. 5390

1557. Eight mosques in Ključ municipality were destroyed during the period between May 1992 and August 1992. ${ }^{5391}$ With regard to the destruction of specific sites and the identities of those responsible, the Chamber received evidence indicating that the Velagići-Pudin Han mosque was blown up by Serb Forces during the attack on Pudin Han on 28 May $1992,{ }^{5392}$ and that the Biljani Mosque was set on fire in the morning of 10 July 1992 when the village was attacked by Serb Forces. ${ }^{5393}$ The Ključ mosque was blown up at approximately 3:05 a.m. on 30 July 1992. ${ }^{5394}$ According to a report issued the following day, although the perpetrators were unknown, an

8-13; P6690 (Addendum to Nicolas Sébire's report, 16 May 2003), pp. 84, 90-93. See also P4878 (List of mass graves and bodies exhumed in Ključ Municipality, 1996), pp. 2-5 (containing a partial list of persons exhumed from Lanište I); P3637 (Report of BiH Federal Ministry of the Interior, 22 October 1996), pp. 9-10 (containing a partial list of persons exhumed from Lanište I); Adjudicated Fact 930; P3488 (Witness statement of Atif Džafić undated), para. 140.

5389 P4877 (Ključ Court record in relation to Biljani exhumation, 14 October 1996); P4878 (List of mass graves and bodies exhumed in Ključ Municipality, 1996), pp. 6-7; P4853 (Updated Table 2 to the Report of Amor Mašović), p. 13; P6690 (Addendum to Nicolas Sébire's report, 16 May 2003), pp. 84-89.

5390 The religious sites identified in Scheduled Incident D.13 are the Ključ Town mosque, Biljani-Džaferagići mosque, Pudin Han-Velagići mosque, Donji Budelj mosque, Humići mosque, Krasulje mosque, Sanica mosque, Tićevići mosque,and the Town Catholic church. See also Prosecution Pre-Trial Brief, Confidential Appendix A, p. 32 (asserting that Pudin Han mosque and Velagići mosque are one and the same). The Chamber has treated them accordingly.

5391 P4070 (Attachment to the expert report of András Riedlmayer, entitled "Destruction of Cultural Heritage in BiH" prepared for the Karadžić case, formatted records), pp. 149-172 (including photographic evidence of destruction). See also KDZ075, T. 19025 (16 September 2011) (recalling that he observed an attempt to blow up a mosque in late July or early August). According to Riedlmayer's report, the Catholic church in Ključ was destroyed in January or February 1993. P4070 (Attachment to the expert report of András Riedlmayer, entitled "Destruction of Cultural Heritage in BiH" prepared for the Karadžić case, formatted records), pp. 173-175. The destruction of the church thus falls outside the time period specified in Scheduled Incident D.13.

5392 See Adjudicated Fact 2451. See also KDZ024, P713 (Transcript from Prosecutor v. Brđanin), T. 9117 (under seal).

5393 See Adjudicated Fact 952. The Chamber notes that Slobodan Jurišić testified that the municipal authorities' position was to "do everything to preserve these buildings", and suggested that the fact that the explosives were set "unprofessionally" suggested that they were perpetrated by "riotous groups". Slobodan Jurišić, T. 47113, 47117 (14 February 2014).

5394 D1735 (Investigation report of Ključ Lower Court, 30 July 1992); D1736 (Journalist report regarding Ključ SJB, undated), p. 1. See also Adjudicated Fact 951. 
investigation was underway to uncover their identities. ${ }^{5395}$ The Chamber also took judicial notice of the fact that following the Crisis Staff's order, at least four Muslim monuments in Ključ municipality, including the Atik mosque in the town of Ključ, were either completely destroyed or heavily damaged by fire and explosives set by Serb Forces during 1992. 5396

1558. In light of the evidence described above and noting the pattern of destruction of the mosques in Ključ municipality, particularly the temporal proximity of the destruction of the Velagići-Pudin Han Mosque and the Biljani Mosque to the attacks by Serb Forces on those villages, ${ }^{5397}$ the Chamber finds that eight mosques in Ključ municipality were destroyed by Serb Forces between May and August 1992.

\section{(8) Movement of the population from Ključ}

1559. At a meeting on 20 May 1992, the ARK Crisis Staff adopted several conclusions which were later endorsed in Ključ, ${ }^{5398}$ including that there was "no reason for the population of any nationality to move out of the territory of the [ARK]". ${ }^{539}$ However, one week later, the Ključ Crisis Staff established an Agency for the Reception and Removal of Refugees, adopted a Decision on the Organisation of Departure from the Area of the Municipality, and decided that the National Defence Council would be responsible for organising departures from the municipality. ${ }^{5400}$ Over the next several days, during its meetings, the Ključ Crisis Staff considered the resettlement of the Bosnian Muslim population. ${ }^{5401}$

1560. On the morning of 29 May, the Ključ Defence Command and Crisis Staff jointly issued an order for "all citizens of Muslim ethnicity, women, children, and men loyal to the Serbian Republic of Bosnia and Herzegovina" to gather at various points in Ključ, including the football grounds in Ključ, the Social Centre in Šehići, the factory grounds in Hanlovsko Vrelo, and the ŠIPAD warehouse in Ključ, by 11 a.m. that day. ${ }^{5402}$

\footnotetext{
5395 KDZ192, T. 19507-19508 (27 September 2011) (closed session); D1736 (Journalist report regarding Ključ SJB, undated), pp. 1-2.

5396 See Adjudicated Fact 2450.

5397 Asim Egrlić testified that the Bosnian Serb assertion that "extremists" were located in mosques was merely a pretext. Asim Egrlić, P6586 (Transcript from Prosecutor v. Krajišnik), T. 4820; P3450 (Video footage of TV Banja Luka depicting events in Ključ), at 00:07:02-00:07:25.

5398 [REDACTED].

5399 D1309 (Conclusions of the ARK Crisis Staff, 20 May 1992).

5400 P2606 (Minutes from sessions of Ključ's Crisis Staff, 27 May-10 July 1992), p. 3 (inter alia prohibiting the return of families who departed "without appropriate reasons"); Adjudicated Fact 2452.

5401 [REDACTED]; P2606 (Minutes from sessions of Ključ's Crisis Staff, 27 May-10 July 1992), p. 10 (recording "the question of the removal of the population" as an agenda item on 3 June); [REDACTED]. See also D4165 (Witness statement of Marko Adamović dated 1 December 2013), para. 12.

5402 P3473 (Order of Ključ Defence Command and Crisis Staff, 29 May 1992); [REDACTED].
} 
1561. The Ključ War Presidency adopted a decision pursuant to which "all citizens", regardless of ethnicity, would be allowed to leave the municipality if they gave a statement to the relevant organ that they wished to do so. ${ }^{5403}$ People who wished to move out of the municipality were required to obtain permission to do so from the municipal authorities. ${ }^{5404}$ Anyone who wished to leave was required to state that their departure was voluntary as well as permanent. ${ }^{5405}$ Moreover, those who owned real property were required to make a declaration renouncing that property by either exchanging it or placing it at the disposal of the municipality. ${ }^{5406}$ For at least a month, such housing was reassigned to Bosnian Serb refugees. ${ }^{5407}$ While these declarations were ostensibly made voluntarily, Asim Egrlić testified that they were made under duress and that the people decided to relinquish their property in order to save their lives, irrespective of the words contained therein. $^{5408}$ In accordance with the ARK decision of 4 August 1992, individuals leaving the ARK could take with them no more than 300 German marks. ${ }^{5409}$

1562. The Accused contends that the renunciations and reassignments only pertained to temporary use, and not to ownership of such property. ${ }^{5410}$ The Chamber received evidence that the municipal authorities did not pass any decision which would have collectively converted abandoned

5403 P3472 (Report re Ključ War Presidency, undated). In accordance with the decision of the ARK Crisis Staff on 29 May, departure would be permanent. See P3461 (Conclusions of ARK Crisis Staff, 29 May 1992).

5404 KDZ075, T. 19047-19048 (19 September 2011); P3462 (Decision of Ključ War Presidency, 30 July 1992) (permitting persons who had given a statement to the Commission for Collecting Data on Moving Away to leave the territory voluntarily and permanently); P3472 (Report re Ključ War Presidency, undated). See also Adjudicated Facts 953, 954, 2452; Slobodan Jurišić, T. 47095 (14 February 2014). For an example of such a statement, see e.g. P3463 (Record of the Commission for Gathering Information Relating to the Departure of Population from Ključ, 31 July 1992). The Chamber notes that although in their statements, Marko Adamović and Rajko Kalabić denied that permits were required in order to leave the municipality, see D4165 (Witness statement of Marko Adamović dated 1 December 2013), para. 15 (suggesting that people were not required to obtain permits); D4169 (Witness statement of Rajko Kalabić dated 1 December 2013), para. 23 (denying that any permits were required in order to leave the municipality), the Accused conceded that those leaving were required to make statements. Defence Final Brief, para. 1514.

5405 P3462 (Decision of Ključ War Presidency, 30 July 1992); P3573 (Record of declaration of individuals leaving Ključ, 10 August 1992), pp. 2-10; Asim Egrlić, P6586 (Transcript from Prosecutor v. Krajišnik), T. 4766; Asim Egrlić, T. 19933-19935 (5 October 2011). See also Adjudicated Fact 2453.

5406 P3462 (Decision of Ključ War Presidency, 30 July 1992), p. 1; P3472 (Report re Ključ War Presidency, undated); [REDACTED]. See e.g. P3573 (Record of declaration of individuals leaving Ključ, 10 August 1992), pp. 2-10; Asim Egrlić, P6586 (Transcript from Prosecutor v. Krajišnik), T. 4766; Asim Egrlić, T. 19933-19935 (5 October 2011). But see Slobodan Jurišić, T. 47095-47098 (14 February 2014); D4363 (Witness statement of Slobodan Jurišić dated 8 February 2014), paras. 18, 43 (denying that people were required to sign such documents).

5407 [REDACTED]; P3472 (Report re Ključ War Presidency, undated). But see P3463 (Record of the Commission for Gathering Information Relating to the Departure of Population from Ključ, 31 July 1992) (which does not mention the abandonment of property to the municipality); [REDACTED]. See further P3453 (Decision of Ključ War Presidency, 13 July 1992) (deciding to "stop further flat allotment on any basis until criteria for allotment at the regional level [could be] created").

5408 Asim Egrlić, T. 19925, 19930 (5 October 2011) (commenting on P3573); P3573 (Record of declaration of individuals leaving Ključ, 10 August 1992). Egrlić further explained that despite what was stated on such declarations, in practice, property was forcefully confiscated before being disposed of by the administrative organ of Bosnian Serb Ključ municipality. Asim Egrlić, T. 19933 (5 October 2011).

5409 Adjudicated Fact 2454. 
properties into state property, and that no changes were made to the land registry books such as would indicate a permanent change in property ownership. ${ }^{5411}$ However, the Chamber notes that on 19 June, the ARK Crisis Staff took a decision that all "abandoned" property would be proclaimed property of the state and placed at the disposal of the municipal assemblies. ${ }^{5412}$ The Chamber is therefore satisfied that such real property was effectively seized by the Bosnian Serb Political and Governmental Organs on a permanent basis.

1563. Mass departures began to take place as of 1 June $1992 .^{5413}$ On 4 June, the President of the Ključ Crisis Staff made a statement indicating that all citizens who wished to leave Ključ permanently would be allowed to do so in an organised manner, assisted by international humanitarian organisations and the competent organs of the Ključ Municipal Assembly. ${ }^{5414}$ Those who wished to leave were to report to the Civilian Protection Department of the Municipal Assembly or to the local committees in local communes. ${ }^{5415}$

1564. A number of convoys of Bosnian Muslims and Bosnian Croats were first organised by the police prior to a convoy of approximately 1,000 people, the majority of whom included Bosnian Muslim women and children, leaving Ključ for Travnik in late July $1992 .{ }^{5416}$ Very few able-bodied men left in this convoy. ${ }^{5417}$

1565. On 11 September 1992, approximately 500 Bosnian Muslims were transported to Travnik. ${ }^{5418}$ At least two other Travnik-bound convoys left in September, including one in which

5410 Defence Final Brief, confidential, para. 1514.

5411 [REDACTED]; Slobodan Jurišić, T. 47127 (14 February 2014).

5412 P3451 (Decisions of the ARK Crisis Staff, June 1992), p. 13; [REDACTED]. See also Asim Egrlić, T. 1993019931, 19935 (5 October 2011) (conceding that such declarations pertained to use and that no property ownership changes were effected but equating the declarations coupled with departure as permanent relinquishment under the circumstances).

5413 Asim Egrlić, T. 20000 (5 October 2011).

5414 P3448 (Statement of Ključ Crisis Staff, 4 June 1992). See also D4169 (Witness statement of Rajko Kalabić dated 1 December 2013), para. 22; D4363 (Witness statement of Slobodan Jurišić dated 8 February 2014), para. 18.

5415 P3448 (Statement of Ključ Crisis Staff, 4 June 1992).

5416 See Adjudicated Facts 953, 954. The Chamber notes that Marko Adamović testified that the ROPS transport company and privately owned transport companies, rather than the police, organised the convoys and that the police merely escorted the convoys for security reasons. D4165 (Witness statement of Marko Adamović dated 1 December 2013), para. 13. See also D4169 (Witness statement of Rajko Kalabić dated 1 December 2013), para. 27 (testifying that the police escorted the convoys for security reasons and that "Civilian Protection" organised and kept certain records). However, the Chamber considers that neither Adamović nor Kalabić established the basis for their knowledge in this regard. Moreover, the Chamber observed that both appeared evasive throughout their testimonies, and that their evidence on other points was contradicted in such a way as to cast doubt on the overall credibility of each. The Chamber therefore declines to place weight on their evidence on this point.

5417 Adjudicated Fact 953.

5418 Adjudicated Fact 955. The Chamber notes that the Accused concedes that the Ključ Crisis Staff organised these convoys, although he suggests that that this was done at the request of Bosnian Muslims. Defence Final Brief, para. 1515 (citing the witness statement of Slobodan Jurišić). 
an over-crowded convoy transported 1,000 Bosnian Muslims and Bosnian Croats, whose names were called prior to their boarding from a list of people who had paid a fare. ${ }^{5419}$ At a meeting in September 1992, Jovo Banjac informed Mladić that only 5,000 Bosnian Muslims remained in Ključ as of the date of their meeting, and that another 1,500 left on the same day. ${ }^{5420}$

1566. Approximately 2,500 Bosnian Muslims and Bosnian Croats, the majority of whom were women, children and elderly, were also transported from Ključ towards Travnik on 1 October 1992. ${ }^{5421}$ Bosnian Serb local police and the Bosnian Serb army were at the departure point with a list of those who had paid what was asked of them and signed over their property. ${ }^{5422}$ Bosnian Serbs escorted the convoy to a location 25 kilometres away from Travnik, whereupon they demanded money and valuables from the passengers, who then walked to Travnik. ${ }^{5423}$

1567. Numerous Defence witnesses testified that many Bosnian Muslims remained in the municipality throughout the war. ${ }^{5424}$ However, other evidence indicates that between May 1992 and January 1993, 4,154 of the 4,200 residents of Sanica, 3,429 of the 3,649 residents of Velagići, 2,655 of the 2,815 residents of Peći, 1,250 of the 1,732 residents of Humići, all of the 778 residents of Sokolovo, and all 24 residents of Gornji Ribnik left Ključ municipality. ${ }^{5425}$ By 1995, only about 1,200 of Ključ's original 17,000 Bosnian Muslims remained. ${ }^{5426}$

1568. Having considered the totality of the evidence and assessed the circumstances in which departures occurred, the Chamber finds that Bosnian Muslims and Bosnian Croats were forced to leave Ključ.

\footnotetext{
5419 Adjudicated Fact 955. See also D4165 (Witness statement of Marko Adamović dated 1 December 2013), para. 14 (stating that people who wanted to leave Ključ voluntarily had to pay the normal fare).

$5420 \quad$ P1480 (Ratko Mladić's notebook, 10-30 September 1992), p. 26.

$5421 \quad$ Adjudicated Fact 956.

5422 Adjudicated Fact 956.

$5423 \quad$ Adjudicated Fact 956.

5424 D4165 (Witness statement of Marko Adamović dated 1 December 2013), para. 6; Marko Adamović, T. 44491 (4 December 2013) (referring to 3,500 Bosnian Muslims who remained and stating that only those who were "arrested, disarmed, and responsible for some offences" were expelled); D4268 (Witness statement of Jovo Kevac dated 25 January 2014), para. 13 (stating that "a number" of Bosnian Muslims remained in Ključ during 1992 and 1993 and were not mistreated and that some voluntarily joined the VRS and the police); Slobodan Jurišić, T. 47101-47102 (14 February 2014) (testifying that some "particularly prominent" Bosnian Muslims remained in Ključ throughout the war and even into 1995). See also KDZ192, T. 19498 (27 September 2011) (closed session).

5425 D1738 (Report of the Assistant Commander for Civilian Affairs of the Military Post 7286, 16 February 1993), pp. 4-5. See also KDZ075, P3359 (Transcript from Prosecutor v. Krajišnik), T. 4984-4985; Adjudicated Fact 2457; para. 1489.

5426 P5449 (Report of the MUP, Banja Luka RDB, February 1995), pp. 12-13. See also P10 (Report of the MUP, Banja Luka SNB, May 1993); P1481 (Ratko Mladić's notebook, 5 October-27 December 1992), pp. $123-124$.
} 


\section{(D) Prijedor}

\section{(1) $\underline{\text { Charges }}$}

1569. Under Count 3, the Prosecution alleges that persecution, a crime against humanity, was committed in Prijedor as part of the objective to permanently remove Bosnian Muslims and/or Bosnian Croats from the Municipalities. ${ }^{5427}$ Under Count 1, the Prosecution further alleges that in certain municipalities, including Prijedor, this persecutory campaign included or escalated to include conduct that manifested an intent to destroy in part the national, ethnical and/or religious groups of Bosnian Muslims and/or Bosnian Croats as such. ${ }^{5428}$

1570. Acts alleged to have been committed in Prijedor by Serb Forces and Bosnian Serb Political and Governmental Organs include killings during and after the take-over; ${ }^{5429}$ killings related to detention facilities; ${ }^{5430}$ and killings committed during, and deaths resulting from, cruel and inhumane treatment at scheduled detention facilities. ${ }^{531}$ The Prosecution characterises these acts as killing, an underlying act of genocide, under Count 1; persecution, a crime against humanity, under Count 3; extermination, a crime against humanity, under Count 4; murder, a crime against humanity, under Count 5; and murder, a violation of the laws or customs of war, under Count $6 .{ }^{5432}$

1571. Other acts alleged to have been committed in Prijedor by Serb Forces and Bosnian Serb Political and Governmental Organs include torture, beatings, physical and psychological abuse, rape and other acts of sexual violence during and after the take-over and in scheduled detention facilities, as well as the establishment and perpetuation of inhumane living conditions in detention facilities, as cruel or inhumane treatment, an act of persecution under Count $3 .^{5433}$ In relation to Count 1 , the Prosecution alleges that in scheduled detention facilities in Prijedor, thousands of Bosnian Muslims and Bosnian Croats were subjected to cruel or inhumane treatment, including torture, physical and psychological abuse, rape, other acts of sexual violence, and beatings by the Serb Forces and Bosnian Serb Political and Governmental Organs; the Prosecution characterises

\footnotetext{
$5427 \quad$ Indictment, paras. 48-49.

5428 Indictment, paras. 37-38.

5429 Indictment, para. 60(a)(i). See Scheduled Incidents A.10.1; A.10.2; A.10.3; A.10.4; A.10.5; A.10.6; A.10.7; A.10.8; A.10.9.

5430 Indictment, para. 60(a)(ii). See Scheduled Incidents B.15.1; B.15.2; B.15.3; B.15.4; B.15.5; B.15.6.

5431 Indictment, para. 60(a)(ii). See Scheduled Detention Facilities C.20.1; C.20.2; C.20.3; C.20.4; C.20.5; C.20.6; C.20.7.

5432 Indictment, paras. 40(a), 60(a), 63(a), 63(b).

5433 Indictment, para. 60(b), 60(c), 60(d) (specifying that the conditions included the failure to provide adequate accommodation, shelter, food, water, medical care, or hygienic sanitation facilities). See Scheduled Detention Facilities C.20.1; C.20.2; C.20.4; C.20.5; C.20.6; C.20.7.
} 
this inhumane treatment as causing serious bodily or mental harm to members of the Bosnian Muslim and Bosnian Croat groups, an underlying act of genocide. ${ }^{5434}$ In addition, under Count 1, the Prosecution alleges that members of the Bosnian Muslim and Bosnian Croat groups were detained under conditions of life calculated to bring about physical destruction, namely through cruel and inhumane treatment, including torture, physical and psychological abuse, rape, other acts of sexual violence, inhumane living conditions, forced labour, and the failure to provide adequate accommodation, shelter, food, water, medical care, or hygienic sanitation facilities. ${ }^{5435}$

1572. Under Count 3, other acts of persecution alleged to have been committed in Prijedor by Serb Forces and Bosnian Serb Political and Governmental Organs, include (i) forcible transfer or deportation of Bosnian Muslims and Bosnian Croats from their homes within Prijedor; ${ }^{5436}$ (ii) unlawful detention in scheduled detention facilities; ${ }^{5437}$ (iii) forced labour at the frontline and the use of Bosnian Muslims and Bosnian Croats as human shields; ${ }^{5438}$ (iv) the appropriation or plunder of property during and after the take-over, during arrests and detention, and in the course of or following acts of deportation or forcible transfer, ${ }^{5439}$ (v) the wanton destruction of private property, including homes and business premises, and public property, including cultural monuments and sacred sites; ${ }^{5440}$ and (v) the imposition and maintenance of restrictive and discriminatory measures. ${ }^{5441}$

1573. Under Counts 7 and 8, the Prosecution alleges deportation and inhumane acts (forcible transfer), respectively, as crimes against humanity. ${ }^{542}$ In this regard, the Prosecution alleges that by the end of 1992, Serb Forces and Bosnian Serb Political and Governmental Organs had forcibly displaced Bosnian Muslims and Bosnian Croats from areas in Prijedor in which they had been lawfully present. ${ }^{543}$ It is alleged that from March 1992, restrictive and discriminatory measures, arbitrary arrest and detention, harassment, torture, rape and other acts of sexual violence, killings, destruction of houses, cultural monuments and sacred sites, as well as the threat

Indictment, paras. 40(c). See Scheduled Detention Facilities C.20.1; C.20.2; C.20.3; C.20.4; C.20.5; C.20.6; C.20.7.

5436 Indictment, para. 60(f).

5437 Indictment, para. 60(g). See Scheduled Detention Facilities C.20.1; C.20.2; C.20.3; C.20.4; C.20.5; C.20.6; C.20.7.

5438 Indictment, para. 60(h).

5439 Indictment, para. 60(i).

$5440 \quad$ Indictment, para. 60(j). See Scheduled Incident D.17.

5441 Indictment, para. 60(k). The restrictive and discriminatory measures alleged include the denial of freedom of movement; the removal from positions of authority; the invasion of privacy through arbitrary searches of homes; unlawful arrest and/or the denial of the right to judicial process; and/or the denial of equal access to public services.

5442 Indictment, paras. 68-75.

5443 Indictment, paras. 69, 72.
} 
of further such acts caused Bosnian Muslims and Bosnian Croats to flee in fear, while others were physically driven out. ${ }^{5444}$

\section{(2) Background}

1574. Prijedor is a municipality in northwest $\mathrm{BiH}$ in the ARK and is surrounded by Bosanski Novi, Bosanska Dubica, Bosanski Gradiška, Banja Luka, and Sanski Most. ${ }^{5445}$ In 1991, the population of Prijedor was approximately 112,543, among whom 43.9\% were Bosnian Muslims, $42.3 \%$ were Bosnian Serbs, and 5.6\% were Bosnian Croats. ${ }^{546}$

\section{$\underline{\text { Bosnian Serb institutions }}$}

(a) Division of municipal structures and establishment of

1575. Inter-ethnic relations in Prijedor were good before the 1990 election campaign; however, the events in Croatia and at the republican level in $\mathrm{BiH}$ began to influence the relationships between the groups. ${ }^{547}$ Relations started to change and people stopped trusting each other and socialising. ${ }^{5448}$

1576. In 1990, multi-party elections were held in Prijedor, resulting in the SDA taking 30 of the 90 seats in the Municipal Assembly, the SDS taking 28 seats, the HDZ taking two seats, and the remaining seats going to smaller parties. ${ }^{5449}$ Subsequently, and on the basis of a prior agreement between the national parties concerning the division of powers, it was agreed amongst the elected Assembly members that the SDA should nominate the president of the municipality and the SDS would nominate the vice president. ${ }^{5450}$ The SDS would also nominate the president of the Executive Board and the SDA would nominate the vice president. ${ }^{5451}$

1577. As a result, Muhamed Čehajić was nominated as President of the Prijedor Municipal Assembly, Milomir Stakić was nominated as the Vice President, and Milan Kovačević was

\footnotetext{
$5444 \quad$ Indictment, para. 71.

5445 P569 (Map of Prijedor municipality); P4258 (Map of ARK). See Adjudicated Fact 1002.

5446 P6684 (Excerpt from census records of 1991), p. 2; P3701 (Map of Prijedor from 1991 census); D4002 (Letter from BiH MUP to Vasvija Vidović, 4 July 1995), p. 15; Mevludin Sejmenović, T. 20613 (28 October 2011); Mirsad Mujadžić, P3703 (Transcript from Prosecutor v. Stakić), T. 3580. See also Adjudicated Fact 1006.

5447 Idriz Merdžanić, P3881 (Transcript from Prosecutor v. Stakić), T. 7719.

5448 Ivo Atlija, P3672 (Transcript from Prosecutor v. Stakić), T. 5544-5545, 5549.

5449 KDZ026, P2089 (Transcript from Prosecutor v. Stakić), T. 1815 (under seal). See also Mevludin Sejmenović, T. 20455 (27 October 2011); Adjudicated Fact 1005.

5450 Mirsad Mujadžić, P3703 (Transcript from Prosecutor v. Stakić), T. 3595.

5451 KDZ026, P2089 (Transcript from Prosecutor v. Stakić), T. 1816 (under seal). See also Mevludin Sejmenović, T. 20455 (27 October 2011).
} 
nominated as President of the Executive Board. ${ }^{5452}$ There was disagreement between the SDS, SDA, and HDZ over other appointments to public office in Prijedor. ${ }^{5453}$

1578. In 1991, SDS representatives proposed to other parties and local politicians that Prijedor be divided into two municipalities and that the municipal institutions be divided along ethnic lines. ${ }^{544}$ In September 1991, the Accused intervened to replace the local SDS President in Prijedor, Srdo Srdić, with Simo Mišković, who promised to follow the policies of the SDS Main Board. $^{5455}$ In December 1991, Mišković received the Variant A/B Instructions at a meeting of the SDS Main Board, over which the Accused presided. ${ }^{5456}$ Mišković then conveyed the Variant A/B Instructions to the Prijedor SDS leadership. ${ }^{5457}$ On 7 January 1992, the SDS members left the Prijedor Municipal Assembly and formed their own assembly, proclaimed as the Assembly of the Serbian People of the Municipality of Prijedor ("Prijedor Serb Assembly"); Milomir Stakić was appointed as its President, and Milan Kovačević was appointed as President of the Executive Board. ${ }^{5458}$ A Crisis Staff, later renamed the War Presidency, ${ }^{545}$ was also formed by the SDS

5452 Mirsad Mujadžić, P3703 (Transcript from Prosecutor v. Stakić), T. 3596; D4195 (Witness statement of Milomir Stakić dated 16 November 2013), para. 2 (stating further that between 11 September 1991 and 7 January 1992, he was also Vice Chairman of the SDS Municipal Board); KDZ026, P2089 (Transcript from Prosecutor $v$. Stakić), T. 1816-1817 (under seal).

5453 KDZ074, P709 (Transcript from Prosecutor v. Stakić), T. 2375; Mevludin Sejmenović, T. 20529-20531 (28 October 2011); Mirsad Mujadžić, P3703 (Transcript from Prosecutor v. Stakić), T. 3594-3595, 3599-3602, 3618-3624 (testifying further that in February 1992, the SDA sent its proposal to the SDS regarding the division of power in Prijedor between the SDS, SDA, and HDZ, including the division of appointments to significant positions in public office). See P3704 (Letter from Prijedor SDA Executive Board to Prijedor SDS, 16 February 1992).

5454 Mevludin Sejmenović, T. 20457-20459 (27 October 2011).

5455 P3706 (Minutes of meeting of Prijedor Municipal Assembly, 11 September 1991), pp. 3-4; P2571 (Intercepts of conversations between (i) Radovan Karadžić and Radomir Nešković; (ii) Radovan Karadžić and Mišković; and (iii) Radovan Karadžić and Srdo Srdić, 20 December 1991), pp. 4-15; Mirsad Mujadžić, P3703 (Transcript from Prosecutor v. Stakić), T. 3599-3601. See P12 (Extended session of Main and Executive Boards of the SDS, 14 February 1992), p. 18; Simo Mišković, T. 45351-45361 (18 December 2013).

5456 D4206 (Witness statement of Simo Mišković dated 6 December 2013), para. 10; Milomir Stakić, T. 4522745228 (17 December 2013). See P5 (SDS Instructions for Organisation of Organs of the Serbian People in BiH, 19 December 1991), pp. 6-7; Simo Mišković, T. 45363 (18 December 2013).

5457 P2595 (Minutes of meeting of Prijedor SDS Municipal Board, 27 December 1991), p. 1; P5517 (Summary of meeting of the Representatives of the Prijedor Municipality Sector for Military Matters, undated), p. 1; P6610 (Excerpt of book of minutes of Prijedor's SDS Municipal Board meetings, 1991), p. 1. See Simo Mišković, T. 45363 (18 December 2013); P6587 (Excerpts from Simo Mišković's testimony from Prosecutor v. Stanišić \& Župljanin), T. 15178. See also Adjudicated Fact 1007.

5458 Mirsad Mujadžić, P3703 (Transcript from Prosecutor v. Stakić), T. 3634, 3641; Simo Mišković, T. 45365 (18 December 2013); Milomir Stakić, T. 45227-45228 (17 December 2013); D4195 (Witness statement of Milomir Stakić dated 16 November 2013), paras. 2, 11; KDZ026, P2089 (Transcript from Prosecutor v. Stakić), T. 1820 (under seal); P2099 (Article from Kozarski Vjesnik entitled "Serbs Live in This Municipality As Well", 31 January 1992); P6581 (Article from Kozarski Vjesnik entitled "How Dr. Milomir Stakic...saw events of $30^{\text {th }}$ April...”, 28 April 1994), p. 1. See Adjudicated Fact 1008.

5459 P2104 (Video footage of interview with Milomir Stakić and Vladimir Arsić), p. 2; P2608 (Report of the SDS Executive Board on the formation of war presidencies, 31 May 1992), p. 1; P2607 (SerBiH Presidency decision on constituting war presidencies in municipalities at a time of imminent threat of war or state of war, 31 May 1992); D411 (Minutes of $17^{\text {th }}$ session of Government of the SerBiH, 31 May 1992), p. 2; P11 (Article from Kozarski Vjesnik, entitled "Krajina Representatives in Prijedor", 17 July 1992), p. 3; D4195 (Witness statement of Milomir Stakić dated 16 November 2013), para. 2. See Adjudicated Fact 1032. 
Municipal Board in line with the Variant A/B Instructions, to act as a 24 hour information and communication centre. ${ }^{5460}$

1579. On 17 January 1992, the Prijedor Serb Assembly unanimously voted to join the ARK. ${ }^{5461}$ Stakić, Mišković, Drljača, and Kovačević were elected as ARK Assembly representatives on 26 March 1992. ${ }^{5462}$ In February 1992, Mišković attended another meeting with the Accused in Sarajevo; at the meeting, the Accused ordered the implementation of stage two of the Variant A/B Instructions. ${ }^{5463}$ Mišković later passed this instruction on to the SDS Municipal Board. ${ }^{5464}$

1580. On 16 April 1992, the Prijedor Serb Assembly elected individuals to different positions amongst whom were Boško Mandić, elected Deputy Chairman of the Executive Board, and Drljača, elected Chief of the SJB. ${ }^{5465}$ Drljača only assumed the position on 30 April 1992 once Prijedor was taken over. ${ }^{5466}$ On 23 April 1992, the SDS Municipal Board decided, inter alia, to reinforce the Crisis Staff, to subordinate "all units and staff in management posts" to the Crisis Staff, and "to immediately start working on the takeover, the co-ordination with JNA notwithstanding". 5467 Up until 30 April 1992, the SDA and HDZ continued to engage in talks with the SDS. ${ }^{5468}$ On 30 April 1992, Stakić was appointed President of the Prijedor

5460 D4195 (Witness statement of Milomir Stakić dated 16 November 2013), para. 11; P6610 (Excerpt of book of minutes of Prijedor's SDS Municipal Board meetings, 1991), p. 1; P2630 (Transcript of broadcast of Radio Prijedor), p. 7; Slavko Budimir, D4463 (Transcript from Prosecutor v. Stakić), T. 12971. See Simo Mišković, T. 45365-45366 (18 December 2013); Dragan Kezunović, T. 14943-14946 (20 June 2011); P2744 (Excerpt from SJB Prijedor's log book); Dusan Janković, T, 47340-47341 (18 February 2014). See also P5 (SDS Instructions for Organisation of Organs of the Serbian People in BiH, 19 December 1991), pp. 6-7.

5461 P3728 (Decision of Prijedor Municipal Assembly, 17 January 1992); D4195 (Witness statement of Milomir Stakić dated 16 November 2013), para. 13. See also Adjudicated Fact 1009.

5462 P5566 (Minutes of the $4^{\text {th }}$ session of the Assembly of the Serbian People in Prijedor Municipality, 26 March 1992).

5463 P12 (Extended session of Main and Executive Boards of the SDS, 14 February 1992), pp. 5-7; P5516 (Minutes of Meeting of SDS Prijedor Municipal Board, 17 February 1992), p. 1. See P6588 (Receipt of Holiday Inn Hotel, 14-15 February 1992); Adjudicated Fact 1010.

5464 P5516 (Minutes of Meeting of SDS Prijedor Municipal Board, 17 February 1992), p. 1; see Simo Mišković, T. 45373-45375 (18 December 2013).

5465 P2097 (Article from Kozarski Vjesnik, entitled "Government of the Serbian Municipality Elected", 24 April 1992), p. 1; P2630 (Transcript of broadcast of Radio Prijedor), p. 7; Dušan Janković, T. 47269 (18 February 2014). See also Adjudicated Fact 1011. At the time Drljača was elected, a member of the SDA, Hasan Talundžić, held the position of Chief of the SJB in Prijedor. See Mirsad Mujadžić, P3703 (Transcript from Prosecutor v. Stakić), T. 3595, 3619-3624; Nusret Sivac, P3478 (Transcript from Prosecutor v. Stakić), T. 6558-6559; Dušan Janković, T. 47269 (18 February 2014).

5466 Mevludin Sejmenović, T. 20540 (28 October 2011); Dušan Janković, T. 47269 (18 February 2014); P2630 (Transcript of broadcast of Radio Prijedor), p. 7 (stating that Drljača informed Kovačević on 30 April 1992 that all the individuals appointed on 16 April assumed their posts and were functioning from that moment forward); Nusret Sivac, P3478 (Transcript from Prosecutor v. Stakić), T. 6559. See also para. 1597. Drljača was formally appointed as Chief of the SJB on 30 July 1992. P6379 (Decision of SerBiH MUP, 25 April 1992; Request of Banja Luka CSB, 4 May 1992; Decision of Banja Luka CSB, 30 July 1992; Decision of Banja Luka CSB, 13 June 1992), e-court pp. 5-6.

5467 D1830 (Minutes of session of Prijedor SDS Municipal Board, 23 April 1992), p. 1. See also Adjudicated Fact 1012.

5468 Mevludin Sejmenović, T. 20465 (27 October 2011). 
Municipality. ${ }^{5469}$ At this time, the Prijedor SDS was regularly receiving instructions from the central SDS and the Prijedor Crisis Staff received and implemented decisions from the Bosnian Serb Assembly. ${ }^{5470}$

1581. On 20 May 1992, the Prijedor Serb Assembly formally adopted a Prijedor Crisis Staff decision of 1 May 1992, which implemented the 26 April 1992 Instructions issued by the Bosnian Serb Government, reorganising the Prijedor Crisis Staff, and creating a unified command of Crisis Staff, TO, police, and military. ${ }^{541}$ On the same day, the Prijedor Serb Assembly also appointed Stakić as President of the Crisis Staff and Dragan Savanović as Vice President; other members appointed to the Crisis Staff included Kovačević, Slobodan Kuruzović, Boško Mandić, Drljača, and Slavko Budimir. ${ }^{5472}$

\section{(b) Propaganda and militarisation of Prijedor}

1582. When the conflict in Croatia began in 1991, the residents of Prijedor began to feel insecure. ${ }^{5473}$ When the mobilisation of conscripts to be sent to Croatia with the JNA started, many Bosnian Muslims and Bosnian Croats chose not to respond to the call-up; this lack of response by non-Serbs resulted in Bosnian Serbs constituting the majority of JNA conscripts who went to fight in Croatia. ${ }^{544}$ At the same time there was a rise in propaganda designed to instil fear among the population. ${ }^{545}$ In late 1991 or early 1992, the SDS obtained a "repeater" at Mrkovica, from which only Serb programmes were emitted. ${ }^{5476}$ In February 1992, the JNA took over the TV relay at the Kozara mountain, blocking TV broadcasts from Croatia and Sarajevo and

\footnotetext{
5469 D4195 (Witness statement of Milomir Stakić dated 16 November 2013), para. 2.

5470 P2560 (Letter from Radovan Karadžić to presidents of municipalities, 23 March 1992); P3536 (Decisions and orders of Prijedor Municipal Assembly and Prijedor Crisis Staff, published in Prijedor Official Gazette on 25 June 1992), pp. 49, 80-81; D4468 (Confirmation of decisions adopted by Crisis Staff by Prijedor Municipal Assembly, 24 July 1992), e-court p. 2; P956 (Transcript of $16^{\text {th }}$ session of SerBiH Assembly, 12 May 1992), pp. 53-54. See also P5414 (Letter from SDS President's Office, 20 April 1992).

5471 P2605 (Decision of Prijedor Assembly on the organisation and work of Prijedor Crisis Staff, May 1992), pp. 25; P3536 (Decisions and orders of Prijedor Municipal Assembly and Prijedor Crisis Staff, published in Prijedor Official Gazette on 25 June 1992), pp. 1-9; D4195 (Witness statement of Milomir Stakić dated 16 November 2013), para. 20; Mirsad Mujadžić, P3703 (Transcript from Prosecutor v. Stakić), T. 3677-3679; P3529 (Minutes of $4^{\text {th }}$ meeting of Prijedor's Council for National Defence, 15 May 1992), p. 2; D4468 (Confirmation of decisions adopted by Crisis Staff by Prijedor Municipal Assembly, 24 July 1992), e-court p. 2. See also P2717 (SerBiH Government instructions for Crisis Staffs, 26 April 1992); P2966 (Order of SerBiH MUP, 15 May 1992), pp. 1-2; Adjudicated Fact 1026. See paras. 142-144.

5472 P3536 (Decisions and orders of Prijedor Municipal Assembly and Prijedor Crisis Staff, published in Prijedor Official Gazette on 25 June 1992), pp. 7-9. See Adjudicated Fact 1027.

5473 KDZ026, P2089 (Transcript from Prosecutor v. Stakić), T. 1817-1818 (under seal); KDZ026, T. 10363 (17 January 2011) (closed session).

5474 KDZ026, P2089 (Transcript from Prosecutor v. Stakić), T. 1818 (under seal); Idriz Merdžanić, P3881 (Transcript from Prosecutor v. Stakić), T. 7719. See also Ivo Atlija, P3672 (Transcript from Prosecutor v. Stakić), T. 5658.

5475 KDZ026, P2089 (Transcript from Prosecutor v. Stakić), T. 1819 (under seal).

5476 Ivo Atlija, P3672 (Transcript from Prosecutor v. Stakić), T. 5550.
} 
only permitting broadcasts from Belgrade and Banja Luka. ${ }^{547}$ Radio and TV broadcasts relayed propaganda and used derogatory names for non-Serbs. ${ }^{5478}$ Announcements were made on Radio Prijedor that Bosnian Muslim doctors were trying to reduce the birth rate among Serbs in that part of $\mathrm{BiH}$, either by sterilising Serb women or giving pregnant Serb women injections so that they could only give birth to female children; these allegations caused great fear among the Serb population of Prijedor, and negatively impacted inter-ethnic relations in the municipality. ${ }^{5479}$ Propaganda was also used to encourage Serbs to accept a policy of discrimination against nonSerbs; those Serbs who refused to comply with this policy of discrimination against non-Serbs were branded "traitors". 5480

1583. Starting in 1991 and lasting until spring 1992, weapons were distributed in Prijedor from JNA storage facilities to Prijedor TO units and then to local communes. ${ }^{5481}$ Check-points were also established throughout the Prijedor area during this time. ${ }^{5482}$ By late 1991, Prijedor contained the largest concentration of former JNA weapons. ${ }^{5483}$ The weapons given to Bosnian Muslim communes were antiquated and were matched with the wrong type of ammunition, whereas Bosnian Serb communes were given more weapons which did not have these problems. ${ }^{5484}$ By late 1991, JNA military helicopters landed several times a day in Serb areas of Prijedor distributing weapons. ${ }^{5485}$ In early 1992, the SDA Municipal Board received reports from

5477 P5633 (Intercept of conversation between Radovan Karadžić and Nenad Stanić, 5 November 1991), p. 6; Jusuf Arifagić, P689 (Transcript from Prosecutor v. Stakić), T. 7058.

5478 Nusret Sivac, P3478 (Transcript from Prosecutor v. Stakić), T. 6618.

5479 Ivo Atlija, P3672 (Transcript from Prosecutor v. Stakić), T. 5550-5551; KDZ523, T. 23349-23350 (19 January 2012) (closed session) (testifying that information was released that Esad Sadiković, a prominent Bosnian Muslim physician who had worked for UNHCR, was working on sterilisation of Serb women so that less Serbs would be born). See Adjudicated Fact 1188. Sadiković was later taken to Omarska and was killed. See paras. 1766, 1776-1778.

$5480 \quad$ See Adjudicated Fact 1094.

5481 D2265 (Srđo Srdić's interview with OTP), p. 26; Mirsad Mujadžić, P3703 (Transcript from Prosecutor v. Stakić), T. 3605-3606; Mevludin Sejmenović, T. 20459-20460 (27 October 2011) (testifying that he witnessed the arming of Serbs in Prijedor and heard about it, including through reports of army helicopters transporting weapons to Serbs in certain villages); Idriz Merdžanić, P3881 (Transcript from Prosecutor v. Stakić), T. 77197720; KDZ392, P707 (Transcript from Prosecutor v. Kvočka), T. 2617 (under seal).

5482 KDZ074, P709 (Transcript from Prosecutor v. Stakić), T. 2296-2297, 2360; KDZ026, P2089 (Transcript from Prosecutor v. Stakić), T. 1832 (under seal); KDZ094, P706 (Transcript from Prosecutor v. Stakić), T. 5878 (under seal); P4101 (Witness statement of KDZ611 dated 27 February 1999), e-court p. 6; P711 (Witness statement of KDZ074 dated 23 September 1994), e-court p. 6. See also KDZ092, P703 (Transcript from Prosecutor v. Stakić), T. 3917.

5483 Nusret Sivac, P3478 (Transcript from Prosecutor v. Stakić), T. 6770; Mirsad Mujadžić, P3703 (Transcript from Prosecutor v. Stakić), T. 3605-3607.

5484 Mirsad Mujadžić, P3703 (Transcript from Prosecutor v. Stakić), T. 3605-3607; Nusret Sivac, P3478 (Transcript from Prosecutor v. Stakić), T. 6779-6780 (testifying further that the Croatian villages in Ljubija were very poorly armed and that the Bosnian Muslims and Croats of Prijedor "stood no chance" as any weapons they had received or collected were "very meager").

5485 KDZ074, P709 (Transcript from Prosecutor v. Stakić), T. 2328-2331, 2367, 2381; P711 (Witness statement of KDZ074 dated 23 September 1994), e-court p. 8; P4101 (Witness statement of KDZ611 dated 27 February 1999), e-court pp. 5-6; Jusuf Arifagić, P689 (Transcript from Prosecutor v. Stakić), T. 7059. 
people who saw JNA lorries with JNA soldiers distributing weapons in Serb villages, as well as reports of training groups run by the JNA for Serbs. ${ }^{5486}$

1584. In August 1991, 300 to 400 Serbs from Prijedor and the Krajina region were sent to Podgradci for a secret, advanced police training course by instructors from Serbia under Captain Dragan. ${ }^{5487}$ Radoslav Brđanin, Stojan Župljanin, and Drljača visited the course. ${ }^{5488}$

1585. By the end of April 1992, a number of clandestine Serb police stations were created in Prijedor and more than 1,500 Serb policemen were mobilised. ${ }^{5489}$

1586. In early May 1992, the Prijedor Serb Assembly ordered mobilisation pursuant to orders from the ARK and the RS Defence Ministry, requiring all men liable for military service in the ARK to mobilise for the TO. ${ }^{5490}$ On 22 May, the Crisis Staff ordered a further mobilisation pursuant to the 20 May $1992 \mathrm{SerBiH}$ Presidency order, requiring conscripts to report to their war unit, and only Serbs were mobilised. ${ }^{5491}$ The JNA withdrew from BiH around 20 May 1992, a few days before the attack on Hambarine; however, according to Sejmenović, the JNA did not really withdraw, rather "[t]hey just changed their name" and "[t]he officers started calling themselves the Serb army". ${ }^{5492}$ In fact, the number of troops increased in the Prijedor area after the JNA pulled out of $\mathrm{BiH} .{ }^{5493}$ Radmilo Željaja, commander of the $43^{\text {rd }}$ Motorised Brigade, which was later called the $343^{\text {rd }}$ Motorised Brigade, fully co-operated with Drljača and the SJB during this period. ${ }^{5494}$

5486 Mirsad Mujadžić, P3703 (Transcript from Prosecutor v. Stakić), T. 3608-3610. See P4262 (Request of Municipal Assembly Executive Board of Banja Luka, 19 August 1994), p. 1; P4263 (Video footage of award ceremony of the Red Berets, with transcript), e-court pp. 2-3 (stating that 26 training camps for special police units of the RS and RSK were established in 1991 or 1992).

5487 [REDACTED]. The instructors all wore traditional military camouflage uniforms with a "militia of Krajina" insignia on their sleeves. See P3813 (Insignia of Krajina Police "Wolves" group). See also P4258 (Map of ARK).

5488 KDZ523, P4257 (Transcript from Prosecutor v. Brđanin), T. 21061-21062, 21065 (under seal).

5489 P5518 (Report of Prijedor SJB to Banja Luka CSB, 30 April 1992). See P5528 (Report of Prijedor SJB, June 1992), p. 2 (describing the creation of shadow police stations); Adjudicated Fact 1013.

5490 P2818 (Decision of ARK Regional Secretariat for National Defence, 4 May 1992), pp. 1-2; P3535 (Minutes of $2^{\text {nd }}$ session of Prijedor's Council for National Defence, 5 May 1992), pp. 1-2; P3530 (Minutes of Prijedor SDS Municipal Board, 9 May 1992), p. 2.

5491 P3537 (Decision of Prijedor Crisis Staff, 22 May 1992), pp. 1-2; P3919 (Radovan Karadžić's Decision, 20 May 1992); P3528 (Witness statement of Kerim Mešanović, undated), pp. 7-8.

5492 Mevludin Sejmenović, T. 20478-20749 (27 October 2011).

5493 Mevludin Sejmenović, T. 20479 (27 October 2011). See also Mevludin Sejmenović, T. $20588-20590$ (28 October 2011).

5494 KDZ523, P4257 (Transcript from Prosecutor v. Brđanin), T. 21070, 21073-21074 (under seal); Nusret Sivac, P3478 (Transcript from Prosecutor v. Stakić), T. 6559 (testifying that at this time it was not possible to be Chief of the SJB without approval from Stakić). 
1587. A civilian police unit—later called the "intervention squad"-was formed in Prijedor in June 1992 by conscripting members of the civilian police in Prijedor; Captain Jović, head of the MP in Prijedor, placed Milutin Čađo in charge of its establishment. ${ }^{5495}$ The intervention squad was established by order of the Prijedor Crisis Staff. ${ }^{5496}$ It was headed by Miroslav Paras and was comprised of two squads; one of the squads was headed by Pero Čivčić and the other was headed by Dragoljub Gligić. ${ }^{5497}$ The duties of the intervention squad included the prevention and deterrence of crime, arresting and detaining individuals from Bosnian Muslim groups who were allegedly involved in the "attacks on Prijedor" from 30 May 1992, and "[normalising] life in Prijedor town and in the whole of the municipality". ${ }^{5498}$ Furthermore, the intervention squad was ordered by its commanders to arrest certain Bosnian Muslims based on lists compiled by the commanders; these lists included prominent Bosnian Muslims, such as doctors, lawyers, professors, and religious leaders, and Bosnian Muslims linked to World War II through their predecessors. ${ }^{5499}$ During operations against Bosnian Muslims, the intervention squad co-operated with and was under the command of the military. ${ }^{5500}$

\section{(3) Take-over of Prijedor town}

1588. Prijedor town is located in the centre of Prijedor municipality. ${ }^{5501}$ The town of Prijedor itself had a mixed population, although the Stari Grad area in the centre of the town was a predominantly Bosnian Muslim neighbourhood. ${ }^{5502}$ There was an old mosque in the centre of Stari Grad, surrounded by a Muslim cemetery called Mezar. ${ }^{5503}$ The Municipal Assembly, the

5495 KDZ523, P4257 (Transcript from Prosecutor v. Brđanin), T. 21067-21068, 21070, 21073 (under seal); KDZ523, T. 23345-23346, 23376-23377 (19 January 2012) (closed session). See also Nusret Sivac, P3478 (Transcript from Prosecutor v. Stakić), T. 6625.

5496 D2039 (Prijedor Crisis Staff Order, 17 June 1992). See P2637 (Report of Prijedor SJB, 1 July 1992), p. 2. See also Adjudicated Facts 1256, 2487. Although the intervention squad was established by the order of the Prijedor Crisis Staff, Stakić maintained that he never learned of its establishment; furthermore, although Drljača, as head of the Prijedor SJB, reported directly to the Crisis Staff on the implementation of a number of Crisis Staff decisions, including the establishment of the intervention squad, Stakić stated that Drljača did not inform the Crisis Staff as to everything he was doing and moreover, that "what he wrote was one thing and his actions were different". Milomir Stakić, T. 45244-45248 (17 December 2013).

5497 KDZ523, P4257 (Transcript from Prosecutor v. Brđanin), T. 21071 (under seal).

5498 P2637 (Report of Prijedor SJB, 1 July 1992), p. 2; KDZ523, P4257 (Transcript from Prosecutor v. Brđanin), T. 21072 (under seal).

5499 KDZ523, P4257 (Transcript from Prosecutor v. Brđanin), T. 21120-21122 (under seal); KDZ523, T. 2335223353 (19 January 2012) (closed session).

$5500 \quad$ KDZ523, P4257 (Transcript from Prosecutor v. Brđanin), T. 21072-21073 (under seal).

5501 P569 (Map of Prijedor municipality). See Adjudicated Fact 1003; P2096 (Map of Prijedor town).

5502 KDZ026, P2089 (Transcript from Prosecutor v. Stakić), T. 1794-1795, 1801 (under seal).

5503 KDZ026, P2089 (Transcript from Prosecutor v. Stakić), T. 1802 (under seal). 
seat of the local government in Prijedor municipality, was located in the centre of town, as was the Executive Council and other executive bodies. ${ }^{5504}$

1589. In the beginning of April 1992, there was an increase in the number of armed Serbs in the streets and cafes in the town of Prijedor; ${ }^{5505}$ many of them wore JNA uniforms and insignia while others wore police uniforms. ${ }^{5506}$

1590. On 29 April 1992, the Prijedor SDS received a fax, which appeared to be from Alija Delimustafić and the BiH Presidency, ordering police stations in $\mathrm{BiH}$ to "commence operations" and secure the surrender of the JNA. ${ }^{5507}$ On 29 April, Mirsad Mujadžić, President of the SDA Municipal Board, was invited to meet with Colonel Arsić, of the $5^{\text {th }}$ Corps of the JNA, and Mišković at the Prijedor barracks at Urije, where he was shown the fax; Mujadžić immediately believed it to be forged and conveyed this belief to Colonel Arsić and Mišković. ${ }^{5508}$ At dinner that evening, Mujadžić repeated to Arsić and Mišković that the SDA had no intentions to attack the SDS or Bosnian Serbs in Prijedor. ${ }^{5509}$

1591. Defence witnesses have testified that on 23 April 1992, at a meeting of the Prijedor SDS Municipal Board, the SDS was still not certain how it would act in the event of a conflict, and that the take-over of Prijedor was an unplanned response to the fax from Alija Delimustafić. ${ }^{5510}$ The Chamber has considered the following evidence which confirms that the take-over of Prijedor was planned in advance of receiving the 29 April fax: (i) according to Mandić, the Prijedor SDS had organised themselves well in advance of receiving the fax on 29 April; (ii) Kovačević stated on Radio Prijedor that well before 30 April, "it was all neatly prepared and done and we waited for the moment which we had set and then on [29 April 1992] at 0400 hrs [...] we did it" and that "it

\footnotetext{
5504 KDZ026, P2089 (Transcript from Prosecutor v. Stakić), T. 1795 (under seal); P2096 (Map of Prijedor town).

5505 Ivo Atlija, P3672 (Transcript from Prosecutor v. Stakić), T. 5551, 5553.

5506 Ivo Atlija, P3672 (Transcript from Prosecutor v. Stakić), T. 5551, 5553, 5554 (testifying further that one of the armed Serbs in Prijedor told him during this time that they only wanted to defend Yugoslavia and for all Serbs to live in one state, and that they would never allow that "part of $[\mathrm{BiH}]$ to become Croatian, Ustasha soil, or a dzemaharija", a derogatory name for a state in which Muslims would live and be in power).

5507 D400 (BiH MUP Order, 29 April 1992); Mirsad Mujadžić, P3703 (Transcript from Prosecutor v. Stakić), T. 3665-3666; P6587 (Excerpts from Simo Mišković's testimony from Prosecutor v. Stanišić \& Župljanin), T. 15223.

5508 Mirsad Mujadžić, P3703 (Transcript from Prosecutor v. Stakić), T. 3662-3667 (testifying further that it was later established that the document had probably been sent by the counterintelligence service of the JNA in order to provide the army with a "pretext" for the intervention). Mujadžić also served as President of the SDA in Banja Luka during the conflict, and as deputy of the BiH Parliament. Mirsad Mujadžić, P3703 (Transcript from Prosecutor v. Stakić), T. 3575-3576, 3578.

5509 Mirsad Mujadžić, P3703 (Transcript from Prosecutor v. Stakić), T. 3667-3668.

5510 See D4195 (Witness statement of Milomir Stakić dated 16 November 2013), para. 16; D4229 (Witness statement of Boško Mandić dated 18 January 2014), para. 23; D4228 (Witness statement of Zdravko Torbica dated 18 January 2014), para. 9; D400 (BiH MUP Order, 29 April 1992), p. 1. The Accused also presented his case on this issue during his cross-examination of Mevludin Sejmenović, T. 20588 (28 October 2011).
} 
really went the way we had planned"; (iii) according to Sejmenović, the Prijedor SDS in fact "had well-laid plans" by 23 April; (iv) Mišković considered the take-over of Prijedor town on 30 April 1992 to be part of the implementation of Variant B and that "preparations had to be made [...] in order to take over power"; and finally, (v) Dušan Janković testified that a decision was made on 16 April to install Drljača as Chief of the SJB on 30 April. ${ }^{5511}$ The Chamber also took judicial notice of the fact that the forcible take-over of the municipal authorities in Prijedor was prepared well in advance of 1 May 1992 and that a transmission by BiH leaders was used as a pretext for the take-over of Prijedor municipality. ${ }^{5512}$ The Chamber therefore finds that the take-over of Prijedor was planned well in advance of 30 April 1992, and was not an unplanned act in response to threats to Bosnian Serbs in Prijedor.

1592. On 30 April 1992, a take-over of the town of Prijedor was organised by the Prijedor Serb Assembly and the Prijedor SDS and executed by JNA forces, including the $5^{\text {th }}$ Kozara Brigade, and members of the Prijedor SJB and other clandestine Serb police stations. ${ }^{5513}$ During the night between 29 and 30 April 1992, members of the SJB and reserve police stations, some of whom were wearing military uniforms, gathered in Čirkin Polje, an area of Prijedor town. ${ }^{5514}$ Between 1 and 5 a.m., Serb Forces set-up patrols, sniper nests, machine-gun nests, sandbags, and checkpoints throughout Prijedor town in several locations; there was no resistance from the non-Serb population. ${ }^{5515}$

5511 See Boško Mandić, T. 45757-45758 (21 January 2014); P2630 (Transcript of broadcast of Radio Prijedor), p. 7; Mevludin Sejmenović, T. 20588 (28 October 2011); Simo Mišković, T. 45381, 45408 (18 December 2013); P6587 (Excerpts from Simo Mišković's testimony from Prosecutor v. Stanišić \& Župljanin), T. 15223; Dušan Janković, T. 47268-47270 (18 February 2014). See also P2968 (Report of Prijedor SJB, January 1993), p. 2; P5528 (Report of Prijedor SJB, June 1992), p. 2; D1830 (Minutes of session of Prijedor SDS Municipal Board, 23 April 1992), p. 1; Zdravo Torbica, T. 45732-45733 (21 January 2014). See para. 1580.

5512 See Adjudicated Facts 1015, 1020.

5513 Mevludin Sejmenović, T. $20465-20466$ (27 October 2011), T. 20589 (28 October 2011); Nusret Sivac, P3478 (Transcript from Prosecutor v. Stakić), T. 6568; D4219 (Witness statement of Miroslav Kvočka dated 17 January 2014), para. 12; P2968 (Report of Prijedor SJB, January 1993), p. 2; D4195 (Witness statement of Milomir Stakić dated 16 November 2013), para. 16; Mirsad Mujadžić, P3703 (Transcript from Prosecutor v. Stakić), T. 3668-3669; P3528 (Witness statement of Kerim Mešanović, undated), p. 15; P3691 (Witness statement of Nusreta Sivac dated 22 October 2011), p. 3 (under seal); Nusreta Sivac, T. 20387 (26 October 2011); Edward Vulliamy, T. 21079 (9 November 2011); P2630 (Transcript of broadcast of Radio Prijedor), pp. 1-6 (describing preparations for the take-over and the events on 30 April 1992); D470 (CSB Banja Luka Report concerning collection centres, undated), e-court pp. 6, 32; P5518 (Report of Prijedor SJB to Banja Luka CSB, 30 April 1992); D4002 (Letter from BiH MUP to Vasvija Vidović, 4 July 1995), pp. 15-16. See D1838 (Regular Combat Report from JNA $5^{\text {th }}$ Corps Command to $2^{\text {nd }}$ Military District Command, 1 May 1992 ), p. 1. See also Adjudicated Facts 1014, 1015, 1016; P6611 (Bulletin of the $4^{\text {th }}$ Tactical Group, May 1994), pp. 1-2.

5514 P2968 (Report of Prijedor SJB, January 1993), p. 2; see Adjudicated Fact 1016.

5515 Mevludin Sejmenović, T. $20465-20466$ (27 October 2011); Nusret Sivac, P3478 (Transcript from Prosecutor v. Stakić), T. 6568; D4219 (Witness statement of Miroslav Kvočka dated 17 January 2014), para. 12; Mirsad Mujadžić, P3703 (Transcript from Prosecutor v. Stakić), T. 3668-3669; Idriz Merdžanić, P3881 (Transcript from Prosecutor v. Stakić), T. 7720; P3528 (Witness statement of Kerim Mešanović, undated), p. 15; P3691 (Witness statement of Nusreta Sivac dated 22 October 2011), p. 3 (under seal); KDZ026, P2089 (Transcript 
1593. By the morning of 30 April, soldiers occupied all of the most important institutions and buildings in Prijedor, such as the Municipal Assembly building, the police station, medical centre, court building, bank, post office, and radio station. ${ }^{5516}$ Later that day, flags on municipal buildings in Prijedor town were also changed to Serb flags with the four Cyrillic letter "Cs". 5517

1594. A declaration on the take-over prepared by the SDS was read out on Radio Prijedor the day after the take-over and was repeated throughout the day. ${ }^{5518}$ That morning, a group of armed soldiers surrounded the Radio Prijedor building. ${ }^{5519}$ Stakić came to Radio Prijedor and was introduced to employees as the President of the Serb municipality of Prijedor. ${ }^{5520}$ A press release was read out on-air, and Stakić was interviewed. ${ }^{5521}$ During that interview, Stakić stated that he represented the Serb municipality of Prijedor, as its President, and that the leadership of the Serb municipality could no longer wait for an agreement with the SDA, which was the reason for the take-over of territory which rightly belonged to them. When Stakić was asked what would happen with the Bosnian Muslim residents of Prijedor, he stated: "We have nothing to do with them. On their portion of the municipal territory, they are free to organise themselves as they please, as they see fit and best for their interests." 5522 Stakić mentioned several areas of the municipality that were considered to be Muslim, including Kozarac, Brdo, and the Stari Grad neighbourhood of Prijedor town. ${ }^{5523}$

1595. After the take-over, movement outside of Prijedor municipality was initially prohibited for both Serbs and non-Serbs, and later movement towards Prijedor town from non-Serb areas inside the municipality was also prohibited. ${ }^{5524}$

judicial organs, and work force

(a) Expulsion of non-Serbs from police, administrative and

1596. On 30 April, non-Serbs were refused entrance into their work places and other institutions and were dismissed from management positions. ${ }^{5525}$ Nusreta Sivac, a Bosnian Muslim municipal

from Prosecutor v. Stakić), T. 1823 (under seal); P2630 (Transcript of broadcast of Radio Prijedor), pp. 1-6. See also Adjudicated Facts 1014, 1017. KDZ026, P2089 (Transcript from Prosecutor v. Stakić), T. 1822-1823, 1828 (under seal); P3691 (Witness statement of Nusreta Sivac dated 22 October 2011), p. 3 (under seal); Nusreta Sivac, T. 20387 (26 October 2011). See Adjudicated Facts 1016, 1017, 1018, 1019.

5517 KDZ026, P2089 (Transcript from Prosecutor v. Stakić), T. 1823 (under seal); Ivo Atlija, P3672 (Transcript from Prosecutor v. Stakić), T. 5553.

5518 Adjudicated Fact 1022.

5519 [REDACTED]. See also Adjudicated Fact 1018.

5520 [REDACTED].

5521 [REDACTED]. See D4195 (Witness statement of Milomir Stakić dated 16 November 2013), para. 16.

5522 [REDACTED]; Nusret Sivac, P3478 (Transcript from Prosecutor v. Stakić), T. 6568-6570.

5523 [REDACTED]. 
court judge in Prijedor town, went to work on 30 April and found armed Serb military and paramilitary units at the court building. ${ }^{5526}$ She tried to enter the building and one of the soldiers asked her name and informed her that she no longer worked there. ${ }^{527}$ The majority of Bosnian Muslim judges, prosecutors, and public attorneys were similarly dismissed in the first few days after the take-over and were replaced by Serbs. ${ }^{5528}$ Nusreta Sivac identified several Bosnian Muslim court officials who were dismissed and taken to Omarska camp where they were singled out as Bosnian Muslim intellectuals. ${ }^{5529}$

1597. Non-Serb members of the police were disarmed and dismissed or forced to sign a statement of loyalty if they wanted to stay employed. ${ }^{5530}$ Non-Serb commanders in the police were replaced with Serbs-Drljača assumed the position of Chief of the Prijedor SJB to which he was elected two weeks prior, Dušan Janković became Commander of the Prijedor Police Station, and Željko Mejakić became squad commander of the police. ${ }^{5531}$ A few days after the take-over, most non-Serb teachers were also dismissed from schools. ${ }^{5532}$

1598. Also on 30 April, KDZ094 found that the vehicle he drove for work had been moved from the depot to the Urije headquarters of the company, where the main gate was closed, and an armed Serb guard in a green military uniform tried to search him for weapons, but he refused; KDZ094 then went home and did not return to work again, and neither did other non-Serbs who worked for the company. ${ }^{5533}$

1599. After the take-over, Atlija went to work at the Ljubija mines and his manager told him that the SDS had taken power in Prijedor and that he should go home; Atlija returned to his home town of Briševo. ${ }^{5534}$ He was told later that a Serb had moved into his apartment in Prijedor. ${ }^{5535}$ Furthermore, one day after the take-over, KDZ611 was stopped on his way to work at a check-

\footnotetext{
5524 Mevludin Sejmenović, T. 20468 (27 October 2011).

5525 Mevludin Sejmenović, T. $20468-20469$ (27 October 2011); KDZ026, P2089 (Transcript from Prosecutor v. Stakić), T. 1835-1836 (under seal). See also P3694 (Conclusions of ARK Crisis Staff sent to municipality presidents, 11 May 1992), p. 1; Adjudicated Fact 1096.

5526 P3691 (Witness statement of Nusreta Sivac dated 22 October 2011), pp. 2-3 (under seal).

5527 P3691 (Witness statement of Nusreta Sivac dated 22 October 2011), p. 3 (under seal). See also Nusreta Sivac, T. 20387 (26 October 2011).

5528 P3691 (Witness statement of Nusreta Sivac dated 22 October 2011), pp. 3-4 (under seal).

5529 P3691 (Witness statement of Nusreta Sivac dated 22 October 2011), pp. 3-4 (under seal). See P3553 (Decision of Prijedor Executive Board, 4 May 1992). See also paras. 1749, 1766.

5530 Mevludin Sejmenović, T. 20467-20468 (27 October 2011).

5531 D4219 (Witness statement of Miroslav Kvočka dated 17 January 2014), para. 6. See Adjudicated Fact 1023; para. 1580.

5532 Mevludin Sejmenović, T. 20468 (27 October 2011).

5533 KDZ094, P706 (Transcript from Prosecutor v. Stakić), T. 5875-5878, 5982 (under seal).

5534 Ivo Atlija, P3672 (Transcript from Prosecutor v. Stakić), T. 5553-5555.

5535 Ivo Atlija, P3672 (Transcript from Prosecutor v. Stakić), T. 5554-5555, 5659-5660.
} 
point manned by armed Serbs in JNA uniforms; they forced all of the non-Serbs to get off the bus KDZ611 was on and told him that he should no longer report for work. ${ }^{5536}$

1600. For several days following the take-over, employees at Radio Prijedor were given several announcements to read out, such as one concerning a curfew imposed by the Serb authorities in Prijedor. ${ }^{537}$ On one of these days, two Bosnian Muslim men, one of whom was Bećir Medunjanin, a local SDA leader, came to the radio station asking that an announcement be made that the people of Kozarac wished to live in peace and that there was no threat or danger coming from them. ${ }^{5538}$ However, soldiers inside the studio building prevented this announcement from being made on air, stating that police permission was required. When the men returned to the studio an hour later, they said that they had been denied permission by a police officer for the announcement to be made. ${ }^{5539}$ Employees at Radio Prijedor were later fired pursuant to a decision of the ARK Crisis Staff. ${ }^{5540}$

1601. On 22 June 1992, the ARK Crisis Staff issued a decision stating that all posts important for the functioning of the economy may only be held by "personnel of Serbian ethnicity"; 5541 this was then forwarded by Župljanin to all SJBs for its immediate implementation within the ARK. ${ }^{5542}$ In July 1992, the Prijedor Crisis Staff and the Prijedor SJB reported that the ARK Crisis Staff decision was implemented in the municipality. ${ }^{5543}$

\section{(b) House searches and surrender of weapons}

1602. Following the take-over, there was a military presence on the streets of Prijedor town. ${ }^{5544}$ On 8 May 1992, Vahid Cerić, who worked for the TO, was arrested. ${ }^{5545}$ In accordance with a decision of the ARK government on 4 May 1992, ${ }^{5546}$ there were announcements on the radio that Bosnian Muslims and Bosnian Croats had to hand in their weapons by a certain deadline, and that

\footnotetext{
5536 KDZ611, P698 (Transcript from Prosecutor v. Kvočka), T. 5814-5815 (under seal); KDZ611, P698 (Transcript from Prosecutor v. Brđanin), T. 12452-12453 (under seal); P4101 (Witness statement of KDZ611 dated 27 February 1999), e-court p. 6.

5537 [REDACTED].

5538 [REDACTED].

5539 [REDACTED].

5540 [REDACTED].

5541 P7 (Decision of ARK Crisis Staff, 22 June 1992).

5542 P6533 (Decision of ARK Crisis Staff forwarded by Banja Luka CSB, 1 July 1992). See also Adjudicated Fact 534. See para. 2061.

5543 P9 (Prijedor Municipal Assembly Report, 13 July 1992), p. 2; P2637 (Report of Prijedor SJB, 1 July 1992). See, e.g., P3709 (Decision of Prijedor Executive Board, 7 May 1992).

5544 KDZ026, P2089 (Transcript from Prosecutor v. Stakić), T. 1832 (under seal).

5545 KDZ026, P2089 (Transcript from Prosecutor v. Stakić), T. 1833 (under seal) (testifying further that he later saw Vahic Cerić in Manjača).

5546 P2818 (Decision of ARK Regional Secretariat for National Defence, 4 May 1992).
} 
white flags should be hung from the front of houses as a sign of loyalty to the authorities. ${ }^{5547}$ Prominent non-Serbs in the community, amongst whom were Dr. Esad Sadiković and Dedo Crnalić, went around to houses of non-Serbs encouraging them to hand in any weapons that they had in order to avoid conflict. ${ }^{5548}$ The Serb residents of Prijedor town were allowed to keep weapons and local Serbs were given weapons. ${ }^{5549}$

1603. In addition, houses of Bosnian Muslims and Bosnian Croats were frequently searched and looted. $^{5550}$ On 12 May 1992, two men from the CSB came to see Nusret Sivac, a journalist for Sarajevo TV, at his apartment and informed him they had orders to bring him to the CSB to meet with the chief, Ranko Mijić. ${ }^{5551}$ Mijić told Nusret Sivac that he had orders from the "new Serb authorities" and the Crisis Staff to seize all of his camera equipment. ${ }^{5552}$ They confiscated all of his equipment, including a large van equipped with cameras and his private tapes. ${ }^{553}$ Nusret Sivac was held at the CSB for a while longer and then was allowed to go home after Mijić warned him not to leave Prijedor in case they needed to ask him further questions. ${ }^{554}$

1604. During May 1992, continuous references were made by Serbs on the police radio about destroying mosques and everything that belonged to the "balijas", as well as the need to destroy the "balijas" themselves. 5555

\section{(c) Clashes in Prijedor town}

1605. On 30 May 1992, a group of around 20 Bosnian Muslims led by Slavko Ećimović attacked Prijedor town. ${ }^{556}$ Announcements were made on the radio that Ećimović, a Bosnian Muslim who had been the target of threats by Serb police officers following the SDS take-over, was attacking

\footnotetext{
5547 KDZ026, P2089 (Transcript from Prosecutor v. Stakić), T. 1833 (under seal); P3691 (Witness statement of Nusreta Sivac dated 22 October 2011), pp. 5-6 (under seal); Nusret Sivac, P3478 (Transcript from Prosecutor v. Stakić), T. 6576; D470 (CSB Banja Luka Report concerning collection centres, undated), e-court p. 27. See also KDZ523, P4257 (Transcript from Prosecutor v. Brđanin), T. 21119-21120 (under seal); Adjudicated Fact 1021.

5548 KDZ026, P2089 (Transcript from Prosecutor v. Stakić), T. 1837-1838 (under seal).

5549 KDZ026, P2089 (Transcript from Prosecutor v. Stakić), T. 1854-1855 (under seal).

5550 KDZ026, P2089 (Transcript from Prosecutor v. Stakić), T. 1834 (under seal); P3691 (Witness statement of Nusreta Sivac dated 22 October 2011), p. 6 (under seal). See Adjudicated Fact 1097.

5551 Nusret Sivac, P3478 (Transcript from Prosecutor v. Stakić), T. 6570.

5552 Nusret Sivac, P3478 (Transcript from Prosecutor v. Stakić), T. 6570-6571.

5553 Nusret Sivac, P3478 (Transcript from Prosecutor v. Stakić), T. 6571-6572.

$5554 \quad$ Nusret Sivac, P3478 (Transcript from Prosecutor v. Stakić), T. 6571.

$5555 \quad$ See Adjudicated Fact 1024.

5556 Nusret Sivac, T. 19585, 19598-19599 (28 September 2011); Nusret Sivac, P3478 (Transcript from Prosecutor $v$. Stakić), T. 6572-6573; KDZ026, P2089 (Transcript from Prosecutor v. Stakić), T. 1846-1847, 2012-2014 (under seal); KDZ026, T. 10376 (17 January 2011) (closed session). See also KDZ523, P4257 (Transcript from Prosecutor v. Brđanin), T. 21067 (under seal) (testifying that Prijedor town was attacked by Bosnian Muslim paramilitaries). Stakić testified that early in the morning on 30 May 1992, gun-fire and shooting could be heard in Prijedor town and explosions around the MUP building. Milomir Stakić, T. 45232 (17 December 2013).
} 
Prijedor town in an attempt to "liberate" it. ${ }^{5557}$ According to Nusreta Sivac, however, the group was too small to successfully take-over the buildings belonging to the radio station, MUP, or other important institutions. ${ }^{5558}$

1606. Around 9 a.m., a Serb tank and troops moved from the area around the Municipal Assembly Building towards the Stari Grad neighbourhood of Prijedor town. ${ }^{559}$ Radical "Chetnik" songs also played on the radio calling for the killing of "Turks and other non-Serb people" and radio announcements called on all armed Serbs to defend the town and destroy the extremists. ${ }^{550}$ Sometime that day, there was a confrontation between Ećimović and his group on one side and the Serb Forces on the other; Ećimović's group ultimately retreated towards the Sana River, but Ećimović was captured. ${ }^{5561}$ After Ećimović's group retreated, Serb Forces, with APCs, heavy artillery weapons, and tanks, encircled Prijedor town, section by section. ${ }^{5562}$ From the morning until the late afternoon, a tank and several grenade launchers fired at the old town of Prijedor from the bank of the Bereg, setting parts of the area ablaze for several hours. ${ }^{5563}$ At around 6 p.m. that day, Serb Forces set fire to the main mosque in the centre of Prijedor town, called the Čaršijska mosque. ${ }^{5564}$ The Zagrad mosque in Prijedor town was also burned and

5557 Nusret Sivac, P3478 (Transcript from Prosecutor v. Stakić), T. 6572-6573. See also P2630 (Transcript of broadcast of Radio Prijedor), p. 6. According to Nusreta Sivac, allegations on the radio stated that the small armed group of non-Serbs did not agree with Prijedor becoming a Serb town. Nusreta Sivac, T. 20398 (26 October 2011).

5558 Nusreta Sivac, T. 20398-20399 (26 October 2011).

5559 Milomir Stakić, T. 45232 (17 December 2013).

5560 Nusret Sivac, P3478 (Transcript from Prosecutor v. Stakić), T. 6572-6573.

5561 Nusret Sivac, P3478 (Transcript from Prosecutor v. Stakić), T. 6574; Nusret Sivac, T. 19593 (28 September 2011). Ećimović was later taken to Omarska and killed; furthermore, his whole family was killed and his godfather was singled out and beaten at Omarska once their relationship was discovered. See Nusret Sivac, T. 19593 (28 September 2011); Ivo Atlija, T. 20349 (26 October 2011); KDZ026, P2089 (Transcript from Prosecutor v. Stakić), T. 1878 (under seal); Željko Mejakić T. 44255-44256, (29 November 2013). See also para. 1766.

5562 Nusret Sivac, P3478 (Transcript from Prosecutor v. Stakić), T. 6574.

5563 Nusret Sivac, P3478 (Transcript from Prosecutor v. Stakić), T. 6575.

5564 Nusret Sivac, P3478 (Transcript from Prosecutor v. Stakić), T. 6575-6576, 6606-6607 (testifying further that later in August 1992, the Catholic Church in Prijedor town and the mosque in the Puharska neighbourhood were destroyed); Idriz Merdžanić, P3881 (Transcript from Prosecutor v. Stakić), T. 7800-7801. The individuals involved in setting fire to the mosque were Milenko Milić, a member of Milan Andzić's paramilitary group, as well as his commander, Momčilo Radanović, and Milorad Vokić, a police officer and personal bodyguard to Drljača. See also Adjudicated Facts 1282, 1284, 1285; P4070 (Attachment to the expert report of András J. Riedlmayer, entitled "Destruction of Cultural Heritage in $\mathrm{BiH}^{\prime}$ prepared for the Karadžić case, formatted records), pp. 222-224. 
destroyed. $^{5565}$ The majority of Stari Grad was destroyed or left in ruins during the attack; the mosque in Stari Grad was torn down by Serb Forces using tanks. ${ }^{5566}$

1607. Throughout the day on 30 May, soldiers wearing red berets with red straps, and various different insignia, searched apartments, including that of Nusret Sivac, for weapons and alcohol and removed what they wanted. ${ }^{5567}$ Serb Forces also escorted columns of people, amongst whom were elderly people and children with white armbands; each column was led by a man carrying a white flag to different locations in Prijedor town, where buses arrived to take them to Trnopolje, Omarska, and Keraterm camps. ${ }^{5568}$ Non-Serbs who remained outside the detention facilities were required to wear white armbands to distinguish themselves and were subjected to harassment and beatings. 5569

1608. There was no large-scale fighting the following day, but there was intermittent shooting and explosions. ${ }^{5570}$ Serb Forces continued to loot the homes of non-Serbs in the days after the attack. ${ }^{5571}$ Furthermore, soldiers wearing olive-green colour uniforms with the Serbian four "S" insignia and "kokarda" caps, formerly worn by the JNA, stormed into houses and arrested people; non-Serbs in Prijedor town lived in fear of being attacked or taken away to Omarska and other camps. ${ }^{5572}$ The movement of non-Serbs was restricted by means of a curfew and check-points; registers in apartment buildings were also used to record their movements. ${ }^{5573}$

5565 Nusret Sivac, P3478 (Transcript from Prosecutor v. Stakić), T. 6575. See also Adjudicated Fact 1283; P4070 (Attachment to the expert report of András J. Riedlmayer, entitled "Destruction of Cultural Heritage in BiH" prepared for the Karadžić case, formatted records), pp. 225-226. See para. 1887.

5566 P3536 (Decisions and orders of Prijedor Municipal Assembly and Prijedor Crisis Staff, published in Prijedor Official Gazette on 25 June 1992), pp. 24-29, 40-41, 44-45, 61-62; P3528 (Witness statement of Kerim Mešanović, undated), pp. 78-81; D4468 (Confirmation of decisions adopted by Crisis Staff by Prijedor Municipal Assembly, 24 July 1992), e-court pp. 5, 7, 9; Nusret Sivac, P3478 (Transcript from Prosecutor v. Stakić), T. 6604, 6692-6693; Milomir Stakić, T. 45232 (17 December 2013). See also Adjudicated Fact 1268. Serb soldiers came back to Stari Grad in June 1992 and cleared the rubble from 30 May with tanks and cranes, tearing down the remains of the Stari Grad mosque first. P3528 (Witness statement of Kerim Mešanović, undated), p. 81; Nusret Sivac, P3478 (Transcript from Prosecutor v. Stakić), T. 6607-6608. See also P4070 (Attachment to the expert report of András J. Riedlmayer, entitled "Destruction of Cultural Heritage in BiH" prepared for the Karadžić case, formatted records), pp. 213-215.

5567 Nusret Sivac, P3478 (Transcript from Prosecutor v. Stakić), T. 6576.

5568 Nusret Sivac, P3478 (Transcript from Prosecutor v. Stakić), T. 6574-6575.

5569 Nusret Sivac, P3478 (Transcript from Prosecutor v. Stakić), T. 6576; P3691 (Witness statement of Nusreta Sivac dated 22 October 2011), p. 5 (under seal). See Adjudicated Fact 1092.

5570 P3691 (Witness statement of Nusreta Sivac dated 22 October 2011), p. 6 (under seal); KDZ026, P2089 (Transcript from Prosecutor v. Stakić), T. 1847 (under seal).

5571 P3691 (Witness statement of Nusreta Sivac dated 22 October 2011), p. 6 (under seal).

5572 P3691 (Witness statement of Nusreta Sivac dated 22 October 2011), p. 5 (under seal); KDZ026, P2089 (Transcript from Prosecutor v. Stakić), T. 1853-1854 (under seal).

5573 Nusret Sivac, P3478 (Transcript from Prosecutor v. Stakić), T. 6576; P3691 (Witness statement of Nusreta Sivac dated 22 October 2011), pp. 5-6 (under seal). See Adjudicated Facts 1097, 1100. 
1609. In the days after the 30 May attack, Radio Prijedor broadcast reports stating that Serbs had taken over Prijedor town and were "controlling all power and authority" there. ${ }^{5574}$ Propaganda against non-Serbs later intensified on the radio, including appeals to Serbs to "lynch" all nonSerbs. ${ }^{5575}$

1610. From 10 June 1992 on, Prijedor town was in a terrible state; there was no electricity or water and soldiers frequently searched apartments and evicted people from them. ${ }^{5576}$ The homes of non-Serbs were searched by the police and military, allegedly looking for weapons; however during those searches, valuables were taken. ${ }^{5577}$ Non-Serbs were evicted from their houses and apartments and Serbs moved in. ${ }^{5578}$ Serb families were protected and lived a normal life; they went to work, shopped, and walked around town. ${ }^{5579}$ Non-Serbs were taken away "in an unknown direction" and rumours started spreading about the existence of "concentration camps" in Prijedor municipality. ${ }^{5580}$

\section{(4) Attacks on surrounding villages}

1611. Prior to the 30 May attack on Prijedor town, Serb Forces had launched attacks on other villages and areas in Prijedor municipality, starting with the villages of Hambarine and Ljubija on 23 May, Kozarac on 24 May, and Kamičani on 26 May 1992. ${ }^{5581}$

\section{(a) Kozarac area}

1612. The area of Kozarac is located approximately 12 kilometres to the east of Prijedor town, with Kozarac town lying on the main road from Prijedor to Banja Luka, beneath Mount Kozara. ${ }^{5582}$ Before the events of 1992, Kozarac town and the surrounding villages were inhabited by Bosnian Serbs and Bosnian Muslims alike; however some of the villages in the area were almost entirely inhabited by Bosnian Muslims (such as Garibi, Kamičani, Kevljani, Babići, and Hrnići), and other villages had a majority Bosnian Serb population (such as Vidovići, Balte, Lamovita, Omarska,

\footnotetext{
5574 P3691 (Witness statement of Nusreta Sivac dated 22 October 2011), p. 6 (under seal).

5575 Nusret Sivac, P3478 (Transcript from Prosecutor v. Stakić), T. 6618.

5576 Nusret Sivac, P3478 (Transcript from Prosecutor v. Stakić), T. 6617. See Adjudicated Fact 1098.

5577 Nusret Sivac, P3478 (Transcript from Prosecutor v. Stakić), T. 6603.

5578 P3691 (Witness statement of Nusreta Sivac dated 22 October 2011), p. 6 (under seal).

5579 P3691 (Witness statement of Nusreta Sivac dated 22 October 2011), p. 6 (under seal); Nusret Sivac, P3478 (Transcript from Prosecutor v. Stakić), T. 6603. See also Nusreta Sivac, T. 20387-20388 (26 October 2011).

5580 P3691 (Witness statement of Nusreta Sivac dated 22 October 2011), p. 5 (under seal).

5581 P2968 (Report of Prijedor SJB, January 1993), p. 4 (stating that combat operations commenced in Prijedor municipality on 22 May 1992); D470 (CSB Banja Luka Report concerning collection centres, undated), e-court pp. 28-29. See also Adjudicated Fact 1034.

5582 KDZ048, P678 (Transcript from Prosecutor v. Stakić), T. 3314; KDZ026, P2089 (Transcript from Prosecutor v. Stakić), T. 1796 (under seal); P569 (Map of Prijedor municipality); P621 (Map and photographs of Kozarac). See also P3891 (Map of Kozarac and Omarska); Adjudicated Fact 1003.
} 
Jelicka, Maricka, Tomašica, Jaruge, Orlovći, and Garevći). ${ }^{553}$ As of 1991, 27,000 people lived in the whole area and in Kozarac town alone, over 90\% of the population was Bosnian Muslim; Bosnian Serbs comprised 3\% of the population and there were very few Croats. ${ }^{5584}$

1613. Beginning in March 1992, tensions increased among the population in the Kozarac area and military troops and equipment were brought in by the JNA. ${ }^{555}$ Local Serbs in Kozarac began openly carrying weapons, which they had brought home from fighting in Croatia. ${ }^{556}$ As a result of these tensions, in April 1992 in various locations in Kozarac, some joint check-points were supplemented with, and eventually replaced by, Serb check-points. ${ }^{557}$ By early May 1992, there was a Serb check-point at the main entrance to Kozarac and a tank was posted there. ${ }^{5588}$

1614. In October 1991, the President of the local board of the SDA of Kozarac mobilised around 120 men for the TO in Kozarac. ${ }^{559}$ Beginning in the period before the take-over of Prijedor, ${ }^{5590}$ members of the TO, the Green Berets, and other armed Bosnian Muslim groups were active in the Kozarac area. ${ }^{5591}$

1615. Immediately following the take-over of Prijedor, there were also efforts on the part of the local non-Serb population to organise themselves to defend their homes from the attacks they anticipated, but they were poorly armed and equipped with no artillery or heavy equipment. ${ }^{5592}$

5583 KDZ048, P678 (Transcript from Prosecutor v. Stakić), T. 3315; Jusuf Arifagić, P689 (Transcript from Prosecutor v. Stakić), T. 7055-7056; KDZ611, P698 (Transcript from Prosecutor v. Brđanin), T. 12454 (under seal); P699 (Witness statement of KDZ611 dated 27 February 1999), e-court p. 6 (under seal); Idriz Merdžanić, P3881 (Transcript from Prosecutor v. Stakić), T. 7722 . See also KDZ392, P707 (Transcript from Prosecutor v. Kvočka), T. 2611, 2639-2640 (under seal); Adjudicated Fact 1034.

5584 KDZ392, P707 (Transcript from Prosecutor v. Kvočka), T. 2639-2640 (under seal); Nusret Sivac, P3478 (Transcript from Prosecutor v. Stakić), T. 6764; Idriz Merdžanić, P3881 (Transcript from Prosecutor v. Stakić), T. 7722. See also Adjudicated Fact 1041.

5585 KDZ392, P707 (Transcript from Prosecutor v. Kvočka), T. 2617-2618 (under seal); Jusuf Arifagić, P689 (Transcript from Prosecutor v. Stakić), T. 7056-7059.

5586 Jusuf Arifagić, P689 (Transcript from Prosecutor v. Stakić), T. 7057-7059, 7063.

5587 Idriz Merdžanić, P3881 (Transcript from Prosecutor v. Stakić), T. 7720-7722; see Adjudicated Fact 1041.

5588 Idriz Merdžanić, P3881 (Transcript from Prosecutor v. Stakić), T. 7720-7722; D1922 (Witness statement of Idriz Merdžanić dated 28 August 2000), e-court p. 2.

5589 KDZ392, P707 (Transcript from Prosecutor v. Kvočka), T. 2614-2619, 2641 (under seal).

5590 See Section IV.A.1.b.i.D.3: Take-over of Prijedor.

5591 KDZ048, P678 (Transcript from Prosecutor v. Stakić), T. 3323-3325, 3456-3459; KDZ392, P707 (Transcript from Prosecutor v. Kvočka), T. 2614-2619, 2641 (under seal); D1743 (Report of $1^{\text {st }}$ Krajina Corps Command, 27 May 1992) (stating that the total strength of the Green Berets was 1,500 to 2,000 men in the area and that they did not have heavy weapons and furthemore that between 25 and 27 May, 80 to 100 Green Berets were killed, and approximately 1,500 more were captured, in Kozarac town and the surrounding villages); P5405 (Report of $1^{\text {st }}$ Krajina Corps, 26 May 1992), p. 1; D4138 (Witness statement of Željko Mejakić dated 26 November 2013), para. 3. See also Ewan Brown, T. 21585-21586 (18 November 2011).

5592 Jusuf Arifagić, P689 (Transcript from Prosecutor v. Stakić), T. 7070-7071; KDZ048, P678 (Transcript from Prosecutor v. Stakić), T. 3326-3328; KDZ392, P707 (Transcript from Prosecutor v. Kvočka), T. 2615-2617 (under seal). 
Members of the TO patrolled Kozarac on night duty. ${ }^{5593}$ Other local Bosnian Muslims set up armed guard posts at various places around Kozarac. ${ }^{5594}$ In Javori, five to ten Bosnian Muslims, including Sead Čirkin, a former JNA officer, participated in guard duty to protect the outer border of Kozarac; they were armed with hunting rifles. ${ }^{5595}$

1616. After the take-over in Prijedor, the town of Kozarac was cut off. ${ }^{5596}$ On 22 May 1992, the telephone lines were disconnected and entry to and exit from the area, as well as medical supplies, were controlled. ${ }^{597}$ This instilled a feeling of insecurity in the local residents. ${ }^{5598}$ The local radio and television stations broadcast announcements that the local population and members of the police and TO should sign an oath of loyalty to the SDS and the authorities in Prijedor, including to Drljača, Željaja, and Kovačević, and only upon such signature would members of the police and TO be allowed to keep their jobs. ${ }^{5599}$ The majority of the population of Kozarac, however, refused to sign the oath. ${ }^{5600}$ Local non-Serb leaders, Čirkin and Medunjanin, sought to negotiate with the new SDS authorities in Prijedor, amongst whom was Župljanin, and to reassure them that the population had no intention of attacking them. ${ }^{5601}$ The local TO and police of Kozarac were ordered to surrender all of their weapons and if they did not, Kozarac would be attacked; the TO and police did not obey and the attack on Kozarac began shortly after the ultimatum expired. ${ }^{5602}$

(i) $\underline{\text { Scheduled Incident A.10.1 }}$

1617. The Prosecution alleges that a number of people were killed in Kozarac and the surrounding areas between 24 May and June 1992.

\footnotetext{
5593 KDZ392, P707 (Transcript from Prosecutor v. Kvočka), T. 2618-2619, 2641 (under seal).

5594 Jusuf Arifagić, P689 (Transcript from Prosecutor v. Stakić), T. 7070-7071, 7129-7131. See Adjudicated Fact 1041.

5595 Jusuf Arifagić, P689 (Transcript from Prosecutor v. Stakić), T. 7070-7073, 7118-7119.

5596 KDZ048, P678 (Transcript from Prosecutor v. Stakić), T. 3321-3322; Idriz Merdžanić, P3881 (Transcript from Prosecutor v. Stakić), T. 7724; see Adjudicated Fact 1042.

5597 KDZ048, P678 (Transcript from Prosecutor v. Stakić), T. 3321-3322; Idriz Merdžanić, P3881 (Transcript from Prosecutor v. Stakić), T. 7724; see Adjudicated Fact 1042.

5598 KDZ048, P678 (Transcript from Prosecutor v. Stakić), T. 3321-3322.

5599 Jusuf Arifagić, P689 (Transcript from Prosecutor v. Stakić), T. 7065-7066; KDZ048, P678 (Transcript from Prosecutor v. Stakić), T. 3323; Idriz Merdžanić, P3881 (Transcript from Prosecutor v. Stakić), T. 7722; Idriz Merdžanić, T. 21430-21431 (16 November 2011); D2265 (Srđo Srdić's interview with OTP), p. 28. See also Adjudicated Fact 1043.

5600 Jusuf Arifagić, P689 (Transcript from Prosecutor v. Stakić), T. 7067-7068; D1922 (Witness statement of Idriz Merdžanić dated 28 August 2000), e-court p. 2.

5601 Jusuf Arifagić, P689 (Transcript from Prosecutor v. Stakić), T. 7067-7068; Idriz Merdžanić, P3881 (Transcript from Prosecutor v. Stakić), T. 7722; D1922 (Witness statement of Idriz Merdžanić dated 28 August 2000), ecourt p. 2.

5602 Nusret Sivac, P3478 (Transcript from Prosecutor v. Stakić), T. 6765; KDZ392, P707 (Transcript from Prosecutor v. Kvočka), T. 2620 (under seal); Idriz Merdžanić, P3881 (Transcript from Prosecutor v. Stakić), T. 7722; D4219 (Witness statement of Miroslav Kvočka dated 17 January 2014), para. 19; D4138 (Witness
} 
1618. On 24 May 1992, Kozarac was attacked. ${ }^{5603}$ Around 12 p.m., shells were fired from the direction of Mount Kozara in the north. ${ }^{5604}$ A column of military vehicles, mounted with heavy machine guns and anti-aircraft guns, advanced on Kozarac from the directions of Prijedor and Banja Luka. ${ }^{5605}$ The column was followed by infantry soldiers who fired towards the civilian areas in Kozarac, including on houses and religious buildings, as well as at the Bosnian Muslim manned check-points. ${ }^{5606}$ They were supported by artillery fire and shelling from the surrounding hills. ${ }^{5607}$ After the shelling started, the population of Kozarac town and the surrounding villages retreated towards the centre of Kozarac. ${ }^{5608}$

1619. Also on 24 May 1992, after inhabitants had been told to hand over their weapons, several shells were fired at the Bosnian Muslim inhabited hamlet of Garibi; Garibi was in Trnopolje, seven kilometres from Kozarac. ${ }^{5609}$ At least four Bosnian Muslims from Garibi, including two women and an invalid elderly man, were killed during the attack. ${ }^{5610}$ The local inhabitants of Garibi fled towards Sivći, Huskići, and other nearby villages. ${ }^{5611}$ In the evening, the other Muslim villages in the area, including Huskići, Kevljani, Hadžići, Jakupovići, Kamičani, Softići, Brdjani, Kozaruša, and Mujkanovići, were shelled. ${ }^{5612}$ The village of Kozaruša was destroyed and only Serb houses remained, for the most part, untouched. ${ }^{5613}$

1620. The units involved in the attack on Kozarac and the operation following the attack included units of the $1^{\text {st }}$ Krajina Corps, such as the Banja Luka Corps, the $343^{\text {rd }}$ Motorised Brigade, and the

statement of Željko Mejakić dated 26 November 2013), para. 3; D2265 (Srđo Srdić's interview with OTP), pp. 27-28. See Adjudicated Facts 1035, 1043.

KDZ048, P678 (Transcript from Prosecutor v. Stakić), T. 3322; Jusuf Arifagić, P689 (Transcript from Prosecutor v. Stakić), T. 7070; Idriz Merdžanić, P3881 (Transcript from Prosecutor v. Stakić), T. 7724, 77297732; KDZ611, P698 (Transcript from Prosecutor v. Kvočka), T. 5815 (under seal); Mevludin Sejmenović, T. 20479 (27 October 2011); D4219 (Witness statement of Miroslav Kvočka dated 17 January 2014), para. 19; D4138 (Witness statement of Željko Mejakić dated 26 November 2013), para. 3; P684 (Witness statement of KDZ054 dated 14 March 2000), e-court p. 6. See also KDZ026, P2089 (Transcript from Prosecutor v. Stakić), T. 1846 (under seal); Senija Elkasović, P690 (Transcript from Prosecutor v. Tadić), T. 4600-4601; Adjudicated Fact 1044.

Idriz Merdžanić, P3881 (Transcript from Prosecutor v. Stakić), T. 7728-7732 (testifying that the attack started at 12 p.m. on 24 May and continued for two days with brief lulls). Cf. Jusuf Arifagić, P689 (Transcript from Prosecutor v. Stakić), T. 7071-7073 (testifying that fire was opened on Kozarac from Orlovći for about ten minutes, and then nothing further happened until the following morning when the shelling continued for 48 hours). KDZ048, P678 (Transcript from Prosecutor v. Stakić), T. 3328-3331; see Adjudicated Fact 1045.

5606 KDZ048, P678 (Transcript from Prosecutor v. Stakić), T. 3329-3331; Mevludin Sejmenović, T. 20480 (27 October 2011). See Adjudicated Facts 1036, 1045.

5607 KDZ048, P678 (Transcript from Prosecutor v. Stakić), T. 3329, 3331-3333.

5608 Jusuf Arifagić, P689 (Transcript from Prosecutor v. Stakić), T. 7073-7074.

5609 [REDACTED].

5610 [REDACTED].

5611 [REDACTED].

5612 KDZ611, P698 (Transcript from Prosecutor v. Kvočka), T. 5815 (under seal); see Adjudicated Fact 1279.

5613 See Adjudicated Fact 1279. 
$6^{\text {th }}$ Krajina Brigade, ${ }^{5614}$ as well as units of the Prijedor TO, Serb paramilitaries, and members of the Prijedor SJB. ${ }^{5615}$ The commander of all of the units involved in this attack, including the paramilitary units, was Željaja. ${ }^{5616}$

1621. The shelling and firing lasted for two to three days and caused panic amongst the local population. ${ }^{5617}$ Houses and buildings in Kozarac and the surrounding villages were damaged by the shelling and shooting, and some were destroyed. ${ }^{5618}$ The Serb infantry soldiers also set houses on fire; in some areas, such as Jakupovići and Končari, entire villages were "razed". 5619 Sejmenović witnessed the Serb infantry set fire to houses with people still inside; those who were able to escape said that special bombs were used to set the houses on fire in a second. ${ }^{5620}$ Organised looting also occurred; looted property, including refrigerators and stoves, was collected in a large truck and every three or four days, the truck would take it all away to Kozarac and then come back for more. $^{5621}$

1622. The majority of the Bosnian Muslim employees of the Kozarac police station were killed during the take-over of Kozarac; a small number was taken to Omarska and Keraterm. ${ }^{5622}$

5614 D1743 (Report of $1^{\text {st }}$ Krajina Corps Command, 27 May 1992) (stating that components of the $343^{\text {rd }}$ Motorised Brigade, supported by two $105 \mathrm{~mm}$ howitzer batteries and one M-84 tank squadron, participated in the attack); P3660 (Handwritten "War Record" of the $6^{\text {th }}$ Krajina Infantry Brigade, undated), p. 3; Mevludin Sejmenović, T. 20481-20482 (27 October 2011). See Adjudicated Facts 1050, 1056, 1057 (stating inter alia that LieutenantGeneral Talić was the Commander of the Banja Luka Corps), 1059; P5405 (Report of $1^{\text {st }}$ Krajina Corps, 26 May 1992), p. 1. See also Ewan Brown, T. 21585-21586 (18 November 2011); P3914 (Ewan Brown's expert report entitled "Military Developments in the Bosanska Krajina - 1992", 27 November 2002), paras. 2.45, 2.74, fn. 391; P5407 (Report of $1^{\text {st }}$ Krajina Corps, 1 June 1992); P3317 (Report of $1^{\text {st }}$ Krajina Corps, 29 May 1992).

5615 P2968 (Report of Prijedor SJB, January 1993), p. 4; Nusret Sivac, P3478 (Transcript from Prosecutor v. Stakić), T. 6764-6765. See Mevludin Sejmenović, T. 20481-20482 (27 October 2011). See also P3914 (Ewan Brown's expert report entitled "Military Developments in the Bosanska Krajina - 1992", 27 November 2002), paras. 2.5, fn. 240, 2.42-2.45, 2.71-2.72; D470 (CSB Banja Luka Report concerning collection centres, undated), e-court pp. 6, 32 .

5616 Nusret Sivac, P3478 (Transcript from Prosecutor v. Stakić), T. 6765. See Adjudicated Fact 1058.

5617 Jusuf Arifagić, P689 (Transcript from Prosecutor v. Stakić), T. 7073; Idriz Merdžanić, P3881 (Transcript from Prosecutor v. Stakić), T. 7734-7735; KDZ048, P678 (Transcript from Prosecutor v. Stakić), T. 3329-3331; Mevludin Sejmenović, T. 20479 (27 October 2011); P684 (Witness statement of KDZ054 dated 14 March 2000), e-court p. 6; Ivo Atlija, P3672 (Transcript from Prosecutor v. Stakić), T. 5558-5559; Ivo Atlija, T. 20341-20343 (26 October 2011). See Adjudicated Facts 1036, 1044.

5618 Jusuf Arifagić, P689 (Transcript from Prosecutor v. Stakić), T. 7073; Idriz Merdžanić, P3881 (Transcript from Prosecutor v. Stakić), T. 7728-7732, 7741; P3890 (Photograph of clinic in Kozarac); P3892 (Photograph of clinic in Kozarac); Mevludin Sejmenović, T. 20479 (27 October 2011); Ivo Atlija, P3672 (Transcript from Prosecutor v. Stakić), T. 5558-5559; Ivo Atlija, T. 20341-20343 (26 October 2011). See Adjudicated Fact 1046.

5619 KDZ048, P678 (Transcript from Prosecutor v. Stakić), T. 3329-3334. See also Ivo Atlija, P3672 (Transcript from Prosecutor v. Stakić), T. 5558-5559; Ivo Atlija, T. 20341-20343 (26 October 2011). See Adjudicated Facts 1037, 1045.

5620 Mevludin Sejmenović, T. 20479-20480 (27 October 2011).

5621 Mevludin Sejmenović, T. $20483-20484$ (27 October 2011); Jusuf Arifagić, P689 (Transcript from Prosecutor v. Stakić), T. 7079; Idriz Merdžanić, P3881 (Transcript from Prosecutor v. Stakić), T. 7741. See also Adjudicated Fact 1271.

5622 Nusret Sivac, P3478 (Transcript from Prosecutor v. Stakić), T. 6764. See Adjudicated Fact 1049. 
However, the Chamber does not have sufficient evidence as to the circumstances surrounding the deaths of these policemen to make a finding on these killings.

1623. Arifagić was on guard duty in Javori during the attack and he saw six men killed as a result of the shelling. ${ }^{5623}$ At least three individuals were killed in Duračci, a village outside of Trnopolje in the Kozarac area. ${ }^{562}$ However, the Chamber does not have sufficient evidence as to the circumstances surrounding the deaths of these three individuals, or as to their status at the time of their deaths, to make a finding on these killings.

1624. During the shelling, Idriz Merdžanić, a doctor in charge of the local outpatient clinic in Kozarac town, treated women, children, and other individuals who were injured during the shelling. ${ }^{5625}$ Patients at the clinic died there as a result of shelling wounds and other injuries when the clinic was shelled. ${ }^{5626}$ One civilian was brought into the clinic dead. ${ }^{5627}$ The Chamber, however, does not have sufficient evidence as to the circumstances surrounding the death of this individual to make a finding on this killing.

1625. On 25 May 1992, Merdžanić decided to move the clinic to a location more accessible to the population on the outskirts of the town. ${ }^{5628}$ When he tried to negotiate through a police radio in order to obtain the safe passage of the wounded, including two children, one of whom had her legs completely shattered, he was told over the radio: "Let all of you balija [...] die there. We'll kill you all anyway". 5629

1626. On the morning of 26 May 1992, the terms of surrender for the population of Kozarac were agreed upon, after which the shelling stopped. ${ }^{5630}$ A convoy was organised to leave the town. ${ }^{5631}$ The wounded were allowed to leave first, followed by police officers, and then the remaining civilian population. ${ }^{5632}$ A convoy of primarily Bosnian Muslim villagers formed and moved

\footnotetext{
5623 Jusuf Arifagić, P689 (Transcript from Prosecutor v. Stakić), T. 7070-7073. Arifagić testified further that the men at his guard post fired shots as well. Jusuf Arifagić, P689 (Transcript from Prosecutor v. Stakić), T. 7128, 7146-7147. See also KDZ048, P678 (Transcript from Prosecutor v. Stakić), T. 3333-3334 (testifying that there may have been some firing on the part of the Kozarac inhabitants towards the attacking forces).

5624

5625

5626

5627

5628

5629

5630

5631

Idriz Merdžanić, P3881 (Transcript from Prosecutor v. Stakić), T. 7716-7717, 7733-7734.

See Adjudicated Fact 1047.

Idriz Merdžanić, P3881 (Transcript from Prosecutor v. Stakić), T. 7734.

Idriz Merdžanić, P3881 (Transcript from Prosecutor v. Stakić), T. 7734-7735.

Idriz Merdžanić, P3881 (Transcript from Prosecutor v. Stakić), T. 7735-7738. See also Adjudicated Fact 1047.

Idriz Merdžanić, P3881 (Transcript from Prosecutor v. Stakić), T. 7738. See also KDZ048, P678 (Transcript from Prosecutor v. Stakić), T. 3334-3335.

Idriz Merdžanić, P3881 (Transcript from Prosecutor v. Stakić), T. 7738. See Mevludin Sejmenović, T. 20480 (27 October 2011).

Idriz Merdžanić, P3881 (Transcript from Prosecutor v. Stakić), T. 7738.
} 
towards Kozarac town. ${ }^{5633}$ They travelled through Kozarac town, which was completely destroyed, and by the time they reached the intersection at the main Prijedor-Banja Luka road, their group had been augmented by many others moving in the same direction. ${ }^{5634}$

1627. KDZ048 and his family had travelled in the convoy in their car and at the intersection, they encountered a tank and a lot of troops in various uniforms, who first told them to leave their vehicles behind, but then permitted them to continue on their way towards Prijedor town. ${ }^{5635}$ At the intersection, KDZ048 also saw at least ten dead bodies in police uniforms, one of whom he recognised as a local Bosnian Muslim police officer. ${ }^{5636}$ However, the Chamber does not have sufficient evidence as to the circumstances surrounding the deaths of these ten individuals during the attack on Kozarac to make a finding on these killings.

1628. At the same intersection, the men were separated from the women and children by Serb soldiers; the men were taken to Keraterm and Omarska primarily, though some were sent to Trnopolje, and the women and children were put on separate buses and taken to Trnopolje. ${ }^{5637}$

1629. After the convoy set off, Merdžanić and the other staff members of the clinic went back to the original location of the clinic to check if there were any wounded. ${ }^{5638}$ When they arrived they were captured by Serb soldiers wearing camouflage uniforms, red berets, and armbands. ${ }^{5639}$ After a few minutes, a JNA truck arrived and the soldiers loaded it with all the medical supplies of the clinic and the truck left; Merdžanić and the other staff were taken to the centre of Kozarac. ${ }^{5640}$ While in the centre, Merdžanić saw one of the soldiers single out Nihad Bahonjić, the ambulance driver from the Kozarac clinic, and take him away; it was confirmed later that Bahonjić was

\footnotetext{
5633 KDZ048, P678 (Transcript from Prosecutor v. Stakić), T. 3329-3331, 3336-3341 (testifying that they were told to leave the area and go towards Prijedor town, so that the Serbs could "mop up the terrain"); KDZ611, P698 (Transcript from Prosecutor v. Kvočka), T. 5815-5818 (under seal); KDZ611, P698 (Transcript from Prosecutor v. Brdanin), T. 12458, 12460-12461 (under seal); P4101 (Witness statement of KDZ611 dated 27 February 1999 and 28 February 1999), e-court p. 7. See Mevludin Sejmenović, T. 20480 (27 October 2011).

5634 KDZ048, P678 (Transcript from Prosecutor v. Stakić), T. 3338-3341; KDZ611, P698 (Transcript from Prosecutor v. Brđanin), T. 12459 (under seal); P4101 (Witness statement of KDZ611 dated 27 February 1999), e-court p. 7. See Jusuf Arifagić, P689 (Transcript from Prosecutor v. Stakić), T. 7074-7075. KDZ048, P678 (Transcript from Prosecutor v. Stakić), T. 3341. KDZ048, P678 (Transcript from Prosecutor v. Stakić), T. 3342-3343.

5637 KDZ048, P678 (Transcript from Prosecutor v. Stakić), T. 3345-3347; KDZ611, P698 (Transcript from Prosecutor v. Kvočka), T. 5817-5818 (under seal); KDZ611, P698 (Transcript from Prosecutor v. Brđanin), T. 12460-12461 (under seal); P4101 (Witness statement of KDZ611 dated 27 February 1999), e-court p. 7; Mevludin Sejmenović, T. 20480 (27 October 2011); Jusuf Arifagić, P689 (Transcript from Prosecutor v. Stakić), T. 7074-7075. See also Adjudicated Fact 1103.

5638 Idriz Merdžanić, P3881 (Transcript from Prosecutor v. Stakić), T. 7738-7739.

5639 Idriz Merdžanić, P3881 (Transcript from Prosecutor v. Stakić), T. 7739-7740

5640 Idriz Merdžanić, P3881 (Transcript from Prosecutor v. Stakić), T. 7739-7746; see P3893 (Sketch drawn by Idriz Merdžanić of Kozarac).
} 
killed. ${ }^{5641}$ Shortly after, the group was forced to enter a jeep and taken in the direction of Prijedor, where they were put on to a bus full of women and children and were transferred to Trnopolje. ${ }^{5642}$

1630. By 26 May 1992, most of the population of Kozarac had surrendered; however, those who had not surrendered, amongst whom were armed members of the Bosnian Muslim TO and SDA leaders, retreated to Mount Kozara. ${ }^{5643}$ One group, which included Arifagić, came under fire at a place called Zeciji Kamen and a fight ensued. ${ }^{5644}$

1631. Another group of approximately 100 Bosnian Muslims and Bosnian Croats from the Kevljani area was arrested by armed Bosnian Serbs wearing different kinds of uniforms; one man was shot dead after they found a Croatian passport on him. ${ }^{5645}$ This group was taken to the Benkovac training grounds, which had been used for military purposes before the conflict, but had been turned into a detention camp run by the military. ${ }^{5646}$ At the Benkovac training grounds, the detained group was ordered to line up in front of a building, and a Bosnian Serb soldier with the last name of Romanić singled out four individuals. ${ }^{5647}$ They were taken to one of the rooms inside the building and shot dead. ${ }^{5648}$ The "hodža" was also beaten to death by the soldiers. ${ }^{5649}$ In the course of the day, 60 individuals were taken to the woods in groups, from where bursts of gunfire could be heard; all of these individuals were killed. ${ }^{5650}$

1632. Arifagić was not captured with the group taken to Benkovac, but he stayed in the forest with a group of people who then made contact with Čirkin and Medunjanin. ${ }^{5651}$

5641 Idriz Merdžanić, P3881 (Transcript from Prosecutor v. Stakić), T. 7743-7746; Idriz Merdžanić, T. 21446,21449 (16 November 2011). See also P646 (Excerpts from report on exhumations in Prijedor municipality, 28 August 2002) (under seal), p. 15

5642 Idriz Merdžanić, P3881 (Transcript from Prosecutor v. Stakić), T. 7744-7748.

5643 Jusuf Arifagić, P689 (Transcript from Prosecutor v. Stakić), T. 7074, 7078; KDZ392, P707 (Transcript from Prosecutor v. Kvočka), T. 2621-2623 (under seal). See also Adjudicated Fact 1053; D4138 (Witness statement of Željko Mejakić dated 26 November 2013), para. 3; D4229 (Witness statement of Boško Mandić dated 18 January 2014), pp. 4-6. 
1633. Another group of approximately 35 to 40 people left Kozarac after the attack and moved towards Kozarački Kamen to reach the Sava River in order to cross over to Croatia. ${ }^{5652}$ After the group passed Kozarački Kamen, they were noticed by "uniformed reconnaissance men" who opened fire on them and a member of the group was killed. ${ }^{5653}$ The Chamber, however, does not have sufficient evidence as to the circumstances surrounding the death of this individual, or regarding his status at the time, to make a finding about this killing. The remainder of the group fled and returned to a suburb of Kozarac; they were later captured and brought to the Prijedor barracks on or around 9 June $1992 .{ }^{5654}$

1634. On 14 June 1992, Arifagić was captured by Serb soldiers at Mujkanovići, a village close to Trnopolje, where he had gone in the hope of seeing his mother. ${ }^{5655}$ He was in a group of about 40 men, who had all been captured at the same time and were ordered to march towards Kamičani. ${ }^{5656}$ The men in the group were beaten and forced to sing "Serbian songs" along the way. Upon arriving at a check-point in Kamičani, they were further beaten and mistreated. ${ }^{5657}$ This group of men was then put on a bus from the "Prijedor Autotransport" company and they were taken to Omarska, and then on to Keraterm. ${ }^{5658}$

1635. While the Chamber took judicial notice of two adjudicated facts which state that as a result of the shelling of Kozarac on 24 May 1992, over 800 of its inhabitants were killed, ${ }^{5659}$ the Chamber cannot be satisfied beyond reasonable doubt as to the precise circumstances surrounding these deaths, nor about the status of these individuals in light of the other evidence before it. The Chamber is therefore unable to include these deaths in its findings on the killings for this Scheduled Incident.

\footnotetext{
$5652 \quad$ KDZ392, P707 (Transcript from Prosecutor v. Kvočka), T. 2622-2623 (under seal) [REDACTED].

5653 KDZ392, P707 (Transcript from Prosecutor v. Kvočka), T. 2623-2624 (under seal); see P4853 (Updated Table 2 to the Report of Amor Mašović), p. 23. See also P646 (Excerpts from report on exhumations in Prijedor municipality, 28 August 2002), pp. 174, 238 (under seal).

5654 KDZ392, P707 (Transcript from Prosecutor v. Kvočka), T. 2624-2628 (under seal).

5655 Jusuf Arifagić, P689 (Transcript from Prosecutor v. Stakić), T. 7078-7079.

5656 Jusuf Arifagić, P689 (Transcript from Prosecutor v. Stakić), T. 7080.

5657 Jusuf Arifagić, P689 (Transcript from Prosecutor v. Stakić), T. 7080-7081 (testifying further that they were then taken to a nearby house where they were told to unload household appliances from a truck).

5658 Jusuf Arifagić, P689 (Transcript from Prosecutor v. Stakić), T. 7081.

5659 See Adjudicated Facts 1046 (stating inter alia that as a result of the shelling in Kozarac, over 800 of its inhabitants were killed and that the remainder, including those from surrounding Muslim villages, were expelled), 1057 (stating that: "On 27 May 1992 senior military officers met to be briefed on the attack on Kozarac: Lieutenant-General Talić, as Commander of the Banja Luka Corps, the $5^{\text {th }}$ Corps of the old JNA, was informed that 800 people had been killed in the attack on Kozarac and an additional 1,200 had been captured; casualties on the part of the units of the Corps were four soldiers killed and fifteen injured.").
} 
1636. The Chamber also took judicial notice of the fact that at least 80 Bosnian Muslim civilians were killed when Bosnian Serb soldiers and police entered the villages of the Kozarac area. ${ }^{5660}$ The Chamber has made findings above in respect of approximately 80 individuals who were killed during the attack on Kozarac and the surrounding areas. ${ }^{5661}$ In addition, the Chamber received forensic evidence to support the deaths of some identified individuals from Kozarac and the surrounding areas between 24 May and June $1992 .^{5662}$

1637. In light of the above, the Chamber is therefore satisfied that at least 80 Bosnian Muslims, including civilians, were killed by Serb Forces in Kozarac and the surrounding areas between 24 May and June 1992.

\section{(ii) Aftermath of the attack}

1638. By 28 May 1992, 50\% of Kozarac was destroyed, with the remaining damage occurring between June and August 1992. ${ }^{5663}$ By the end of summer 1992, the area of Kozarac was desolate; many of the buildings which had survived the attack undamaged were subsequently looted and destroyed. ${ }^{5664}$ During the attack on Kozarac, however, care was taken to try to avoid damage to Serb houses and property. ${ }^{5655}$ After the take-over, Kozarac was occupied by Serb Forces under the control of the Serb authorities. ${ }^{5666}$

\footnotetext{
$5660 \quad$ See Adjudicated Fact 1048.

5661 See paras. 1619, 1623-1624, 1629, 1631. See also D1743 (Report of $1^{\text {st }}$ Krajina Corps Command, 27 May 1992) (reporting that between 25 and 27 May 1992, 80 to 100 Green Berets were killed and approximately 1,500 more were captured in Kozarac town and the surrounding villages).

5662 P4853 (Updated Table 2 to the Report of Amor Mašović), pp. 15-16, 20, 23 (confirming the deaths of 11 identified individuals from Kozarac and the surrounding areas who were exhumed from graves in TrnopoljeRedži, Huskići, Jakarina Kosa, Dera-Bešići, and Kamičani in 2000, 2001, 2003, 2006, 2007, 2009); P4888 (Bihać Cantonal Court record of Huskići-Kamičani and Prijedor exhumations, 16 June 2000), p. 3 (confirming the exhumation of two of the same individuals identified by Mašović, Enver Huskić and Šerif Huskić, in June 2000). The Chamber notes that there is a discrepancy between the forensic reports regarding the name of one of the victims of this Scheduled Incident. More specifically, Mašović contains a reference to Edhem Huskić, son of Sulejman born on 15 August 1929, while the Bihać Cantonal Court record contains a reference to Šerif Huskić, son of Sulejman born on 15 August 1929. The Chamber considers this inconsistency to be minor. Accordingly, the Chamber concludes that this is in fact the same individual. See also P4850 (Witness statement of Amor Mašović dated 23 March 2012), Annex A, p. 8; P646 (Excerpts from report on exhumations in Prijedor municipality, 28 August 2002), pp. 16, 19, 84, 113-114, 238 (under seal) (confirming the deaths of nine identified individuals, including eight of the same individuals identified by Mašović, as having been killed in Kozarac and the surrounding areas in May and June 1992).

5663 See Adjudicated Fact 1270.

5664 Edward Vulliamy, P3777 (Transcript from Prosecutor v. Stakić), T. 7911. See Adjudicated Fact 1274.

5665 See Adjudicated Facts 1272, 1273.

5666 P3483 (Video clip of interviews in Prijedor, including with Milomir Stakić, with transcript), pp. 7-8. See also D4219 (Witness statement of Miroslav Kvočka dated 17 January 2014), para. 19; Adjudicated Fact 1046.
} 
1639. In early June 1992, KDZ392 saw that the Mutnik mosque in Kozarac was burnt; it was later destroyed. ${ }^{567}$ Unlike the mosque, the Serbian Orthodox church in Kozarac was not damaged during the attack. ${ }^{5668}$ When KDZ048 returned to Kozarac in 1997, none of the 16 mosques that had previously been there remained intact. ${ }^{5669}$

1640. During his journey on 5 August, Edward Vulliamy, a British journalist covering the conflict in $\mathrm{BiH}$ in 1992, was escorted by Major Milutinović, who told Vulliamy that the only remaining inhabitants were the local Serbs and that "some 40,000 Muslims" had left the area by this time. ${ }^{5670}$ When KDZ048 returned in 1997, he found Serb refugees from Croatia living in his house. ${ }^{5671}$

(iii) $\underline{\text { Scheduled Incident A.10.3 }}$

1641. The Prosecution alleges that a number of people were killed in Kamičani on or about 26 May 1992.

1642. Kamičani is a village located approximately two kilometres to the southeast of Kozarac; in 1992, Kamičani was predominantly Bosnian Muslim with 2,000 to 3,000 inhabitants. ${ }^{5672}$

1643. Between 24 and 26 May 1992, Kamičani was shelled by Serb Forces. ${ }^{5673}$ Houses in Kamičani were damaged by the shelling. ${ }^{5674}$ Additionally, the mosque in Kamičani was set alight

5667 KDZ392, P707 (Transcript from Prosecutor v. Kvočka), T. 2621 (under seal); KDZ048, P678 (Transcript from Prosecutor v. Stakić), T. 3333, 3406; P548 (Photograph of Mutnik mosque in Kozarac). See also Adjudicated Facts 1272, 1287; Idriz Merdžanić, P3881 (Transcript from Prosecutor v. Stakić), T. 7836; P4070 (Attachment to the expert report of András J. Riedlmayer, entitled "Destruction of Cultural Heritage in BiH" prepared for the Karadžić case, formatted records), pp. 248-250.

5668 KDZ392, P707 (Transcript from Prosecutor v. Kvočka), T. 2621 (under seal); P621 (Map and photographs of Kozarac); P550 (Photograph of orthodox church in Kozarac); see Adjudicated Fact 1272.

5669 KDZ048, P678 (Transcript from Prosecutor v. Stakić), T. 3382, 3405-3407. See P549 (Photograph of Kalata mosque in Kozarac). See also para.1888.

5670 Edward Vulliamy, P3777 (Transcript from Prosecutor v. Stakić), T. 7910-7912. See Section IV.A.1.b.i.D.7: Movement of the population from Prijedor and appropriation of property.

5671 KDZ048, P678 (Transcript from Prosecutor v. Stakić), T. 3379-3382.

5672 KDZ054, P682 (Transcript from Prosecutor v. Stakić), T. 6208-6209; P684 (Witness statement of KDZ054 dated 14 March 2000), e-court p. 6; P3891 (Map of Kozarac and Omarska); P569 (Map of Prijedor municipality).

5673 P684 (Witness statement of KDZ054 dated 14 March 2000), e-court p. 6; KDZ611, P698 (Transcript from Prosecutor v. Kvočka), T. 5815 (under seal); P4101 (Witness statement of KDZ611 dated 27 February 1999), ecourt pp. 6-7. See para.1888. See also Adjudicated Facts 1034, 1063.

5674 P4101 (Witness statement of KDZ611 dated 27 February 1999), e-court p. 7. 
by Serb Forces. ${ }^{5675}$ During the attack, at least eight Bosnian Muslims took refuge $\left[\right.$ REDACTED] ${ }^{5676}$ in Kamičani. ${ }^{5677}$

1644. [REDACTED]. ${ }^{5678}$ [REDACTED.${ }^{5679}$ [REDACTED.${ }^{5680}$ [REDACTED]. ${ }^{5681}$

1645. [REDACTED]. ${ }^{5682}\left[\right.$ REDACTED]. ${ }^{5683}$

1646. [REDACTED]. ${ }^{5684}$ [REDACTED]. ${ }^{5685}$ [REDACTED]. ${ }^{5686}$ [REDACTED]. ${ }^{5687}$

1647. [REDACTED].$^{5688}\left[\right.$ REDACTED].$^{5689}$ [REDACTED].${ }^{5690}$

1648. [REDACTED]. ${ }^{5691}\left[\right.$ REDACTED]. ${ }^{5692}$ [REDACTED]. ${ }^{5693}$

1649. Based on the above, the Chamber therefore finds that at least nine Bosnian Muslim men and women were killed by Serb Forces in the village of Kamičani on or about 26 May 1992.

(iv) Scheduled Incident A.10.4

1650. The Prosecution alleges that a number of men were killed in the village of Jaskići on or about 14 June 1992.

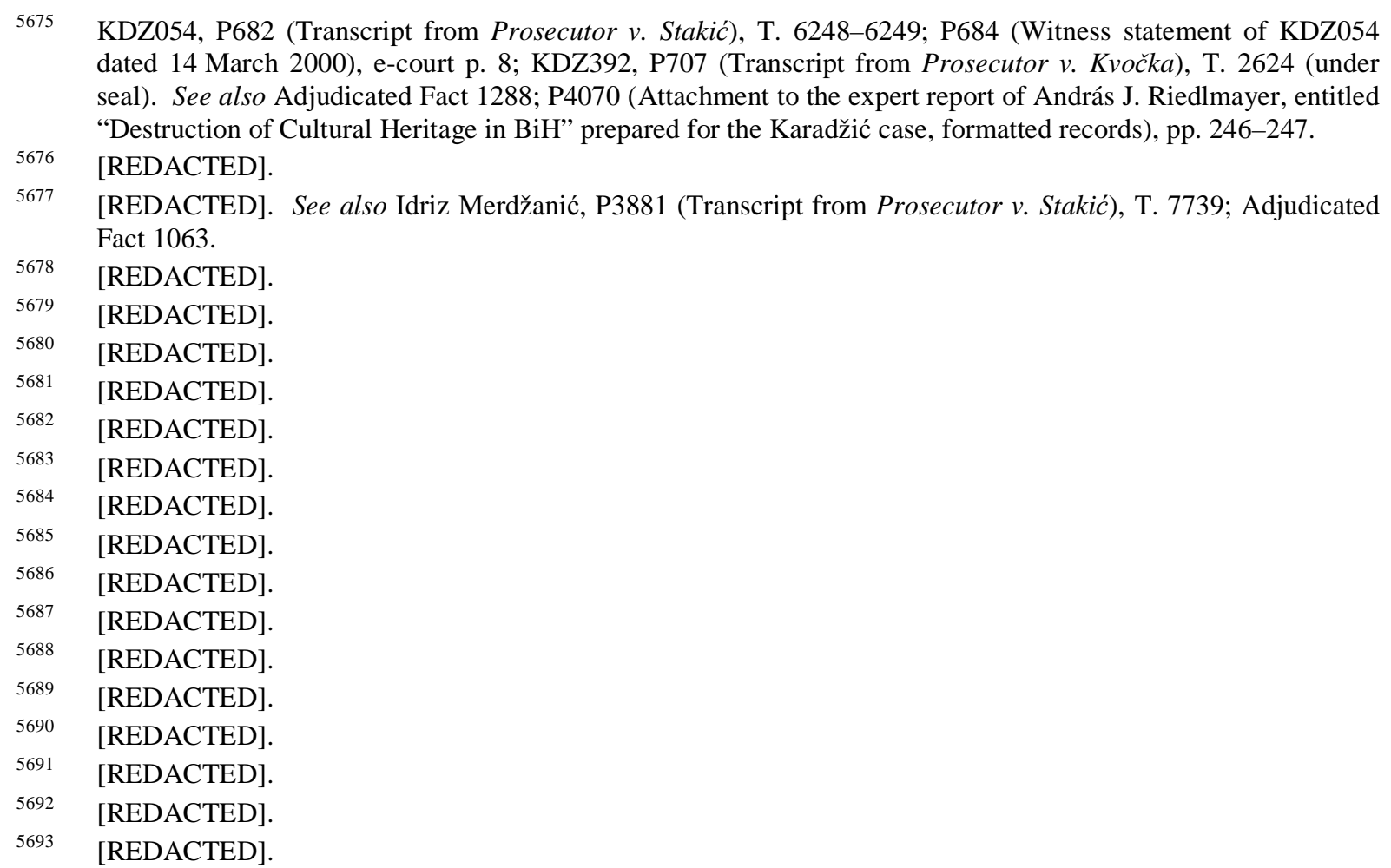


1651. Jaskići is a Bosnian Muslim village located to the south of Kozarac, near Trnopolje. ${ }^{5694}$ During the attack on Kozarac, Bosnian Muslim refugees from all over, including from Brdjani, Jakupovići, Kamičani, Kozaruša, and Bešići, travelled to Jaskići to seek shelter. ${ }^{5695}$

1652. On 14 June 1992, soldiers arrived in Jaskići between 2 and 3 p.m. ${ }^{5696}$ Senija Elkasović, a Bosnian Muslim woman, heard shots behind her house, two soldiers then came to the entrance of her house, pointed rifles through the front door, and ordered the women and children to step back and for the men to step forward. ${ }^{5697}$ Elkasović's husband, brother, and brother-in-law were taken from the house while one of the soldiers ordered Elkasović and eight other family members, all women and children, to lie down in the kitchen. ${ }^{568}$ Before lying down, she saw Duško Tadić, wearing a multi-coloured camouflage military uniform, standing in her yard. ${ }^{569}$ The soldier who remained in the house searched the house for money and jewellery, as well as for anyone hiding; he opened closets, emptied drawers, shouted threats and cursed their mothers and insulted them, saying that they would be sent to Turkey. ${ }^{5700}$ Elkasović heard voices and shouts coming from outside and then she heard shots. ${ }^{5701}$ The soldier left her house and Elkasović looked out of the window to see soldiers leaving towards Kozarac. ${ }^{5702}$

1653. Elkasović then left her house and saw two dead men in her vegetable garden who she later identified; both men had been shot in the back of the head. ${ }^{5703}$ She continued alongside a hedge towards the house of her father-in-law, and found two more dead men from her village; one had been shot in the back of the head and the other had been shot in the forehead. ${ }^{5704}$ According to Elkasović, only three elderly men, including her father-in-law, were left in Jaskići after the soldiers left that day. 5705

\footnotetext{
5694 P3891 (Map of Kozarac and Omarska); P569 (Map of Prijedor municipality); Senija Elkasović, P690 (Transcript from Prosecutor v. Tadić), T. 4601.

5695 Senija Elkasović, P690 (Transcript from Prosecutor v. Tadić), T. 4601.

5696 Senija Elkasović, P690 (Transcript from Prosecutor v. Tadić), T. 4602, 4623.

5697 Senija Elkasović, P690 (Transcript from Prosecutor v. Tadić), T. 4602-4605, 4623. See P561 (Photograph of Senija Elkasović's house); P559 (Photographs of Jaskići).

5698 Senija Elkasović, P690 (Transcript from Prosecutor v. Tadić), T. 4605, 4623. See P561 (Photograph of Senija Elkasović's house). Senija Elkasović, P690 (Transcript from Prosecutor v. Tadić), T. 4597-4599, 4605-4608, 4609-4610, 46244625 .

5700 Senija Elkasović, P690 (Transcript from Prosecutor v. Tadić), T. 4608-4610.

5701 Senija Elkasović, P690 (Transcript from Prosecutor v. Tadić), T. 4610.

5702 Senija Elkasović, P690 (Transcript from Prosecutor v. Tadić), T. 4610-4611.

5703 Senija Elkasović, P690 (Transcript from Prosecutor v. Tadić), T. 4612-4613.

5704 Senija Elkasović, P690 (Transcript from Prosecutor v. Tadić), T. 4612-4613.

5705 Senija Elkasović, P690 (Transcript from Prosecutor v. Tadić), T. 4613-4615.
} 
1654. Three days later, Elkasović, her father-in-law, and another man, Huse Jaskić, went to Trnopolje camp to ask permission to bury the bodies of the men killed in Jaskići. ${ }^{5706}$ They were told by soldiers guarding the camp to speak to Kuruzović; he then gave them permission. ${ }^{5707}$ They returned and buried the bodies in a common grave. ${ }^{5708}$ Thereafter, soldiers came through Jaskići, and into Elkasović's home, on a daily basis, as they searched for cars, tractors, fuel, livestock, brandy, and other items. ${ }^{5709}$

1655. After 14 June 1992, only a small number of families and Huse Jaskić remained in Jaskići. ${ }^{5710}$ Elkasović stayed in Jaskići for another month and then she and her children were forced to leave by members of the police and were taken to Trnopolje camp. ${ }^{5711}$

1656. Elkasović confirmed the names of the four men whose bodies she found outside of her house, as well as that of one additional Bosnian Muslim man who was killed on 14 June 1992. ${ }^{5712}$ In addition, Elkasović never saw or heard from her husband, brother, or her brother-in-law after they were taken out of her house by soldiers on 14 June $1992 .{ }^{5713}$ The Chamber has also received forensic evidence to support the deaths of the five men identified by Elkasović as having been killed and of her husband, brother, and her brother-in-law who went missing from Jaskići on 14 June 1992. ${ }^{5714}$ Further, the Chamber took judicial notice of the fact that at least eight Bosnian Muslim men were shot and killed when Bosnian Serb soldiers entered the village of Jaskići on 14 June $1992 .^{5715}$

1657. In light of the above evidence, the Chamber is satisfied that at least eight Bosnian Muslim men were killed by Serb Forces in the village of Jaskići on or about 14 June 1992.

\footnotetext{
5706 Senija Elkasović, P690 (Transcript from Prosecutor v. Tadić), T. 4615-4616.

5707 Senija Elkasović, P690 (Transcript from Prosecutor v. Tadić), T. 4616.

5708 Senija Elkasović, P690 (Transcript from Prosecutor v. Tadić), T. 4616-4617.

5709 Senija Elkasović, P690 (Transcript from Prosecutor v. Tadić), T. 4617-4618.

5710 Senija Elkasović, P690 (Transcript from Prosecutor v. Tadić), T. 4618.

5711 Senija Elkasović, P690 (Transcript from Prosecutor v. Tadić), T. 4618-4619.

5712 Senija Elkasović, P690 (Transcript from Prosecutor v. Tadić), T. 4614-4615. See P573 (List of men killed or taken from Jaskići on 14 June 1992) (under seal) (referring to the names of Elkasović's husband, brother, and her brother-in-law as missing on 14 June 1992).

5713 Senija Elkasović, P690 (Transcript from Prosecutor v. Tadić), T. 4622.

5714 P4853 (Updated Table 2 to the Report of Amor Mašović), pp. 15-16, 18, 21, 23, 32 (confirming that the eight individuals identified by Elkasović as having been killed or taken away from Jaskići on 14 June 1992, as well as five additional bodies, were exhumed from individual or mass graves in the area). See also P646 (Excerpts from report on exhumations in Prijedor municipality, 28 August 2002), pp. 16, 18-19 (under seal).

5715 See Adjudicated Fact 1064.
} 


\section{(b) Brdo area}

1658. The area of Brdo is located to the southwest and west of Prijedor town and comprises the villages of Bišćani, Rizvanovići, Rakovćani, Hambarine, Čarakovo, and Zecovi. ${ }^{5716}$ In 1992, the village of Hambarine was inhabited solely by Bosnian Muslims and was the highest elevation point in Brdo. ${ }^{5717}$ The village of Bišćani itself had a number of hamlets, namely Mrkalji, Hegići, Ravine, Sredići, Duratovići, and Kadići. ${ }^{5718}$ Prior to the conflict, Čarakovo was a predominantly Bosnian Muslim village with about 800 to 900 houses and Rizvanovići was a Bosnian Muslim village with one Croat. ${ }^{5719}$ The Brdo area was surrounded by predominantly Serb villages. ${ }^{5720}$

1659. After the take-over of Prijedor, the village of Bišćani was cut off; all of the Bosnian Muslims there were dismissed from their jobs, and they could not go into Prijedor town because of the check-points that had been set-up. ${ }^{5721}$

1660. There was a check-point manned by Serb soldiers in camouflage uniforms in the village of Gomjenica, and another on the main road between Prijedor town and Sanski Most, in Tukovi. ${ }^{5722}$ After 30 April 1992, Bosnian Muslims also established check-points at the entrance to the villages of Hambarine and Rizvanovići. ${ }^{5723}$ Nermin Karagić, a Bosnian Muslim 17 year old boy from Rizvanovići, participated in guarding the Rizvanovići check-point with about nine other local men; between them, they only had one M48 rifle. ${ }^{5724}$

1661. Bosnian Muslims in Bišćani set up a crisis staff there, which operated starting at the end of April 1992 until 22 May 1992 before the attack on Hambarine. ${ }^{5725}$ In Čarakovo, villagers had no electricity starting on at least 7 May 1992 while the surrounding Serb villages across the Sana

\footnotetext{
5716 P562 (Map of the Brdo region in Prijedor); P569 (Map of Prijedor municipality); KDZ038, P676 (Transcript from Prosecutor v. Stakić), T. 6854-6855, 6857; KDZ014, P674 (Transcript from Prosecutor v. Stakić), T. 5720. See also Adjudicated Fact 1065.

5717 KDZ074, P708 (Transcript from Prosecutor v. Stakić), T. 2292 (under seal); KDZ050, P680 (Transcript from Prosecutor v. Sikirica), T. 2498; KDZ038, P676 (Transcript from Prosecutor v. Stakić), T. 6854-6855, 6857; KDZ026, P2089 (Transcript from Prosecutor v. Stakić), T. 1795 (under seal).

5718 KDZ094, P706 (Transcript from Prosecutor v. Stakić), T. 5879 (under seal). See also Adjudicated Fact 1072.

5719 KDZ014, P674 (Transcript from Prosecutor v. Stakić), T. 5720. See also Adjudicated Facts 1066, 1280.

$5720 \quad$ KDZ038, P676 (Transcript from Prosecutor v. Stakić), T. 6857.

5721 KDZ038, P676 (Transcript from Prosecutor v. Stakić), T. 6853. Non-Serbs living in Hambarine, and in Prijedor municipality generally, lost their jobs on or around 23 May 1992. KDZ092, P703 (Transcript from Prosecutor v. Stakić), T. 3917.

5722 KDZ014, P674 (Transcript from Prosecutor v. Stakić), T. 5721-5722; KDZ014, P674 (Transcript from Prosecutor v. Brđanin), T. 12538.

5723 KDZ038, P676 (Transcript from Prosecutor v. Stakić), T. 6853-6854; KDZ074, P708 (Transcript from Prosecutor v. Stakić), T. 2297 (under seal); KDZ050, P680 (Transcript from Prosecutor v. Sikirica), T. 24972498; Nermin Karagić, P651 (Transcript from Prosecutor v. Stakić), T. 5205.

5724 Nermin Karagić, P651 (Transcript from Prosecutor v. Stakić), T. 5205, 5209-5210.

5725 KDZ038, P676 (Transcript from Prosecutor v. Stakić), T. 6969-6973.
} 
River, as well as Prijedor town, continued to have electricity. ${ }^{5726}$ Sometime in May it became necessary to obtain a permit from the MUP to be allowed to go to Prijedor. ${ }^{5727}$

1662. Prior to the beginning of the conflict, Bosnian Muslim paramilitary groups were active in the Prijedor area and the TO had a presence in Hambarine, although they had no anti-armour weapons. ${ }^{5728}$ Some weapons had been brought to Hambarine and were stored in the community centre for use in case of an attack; however, these weapons were very old and not functional. ${ }^{5729}$

1663. On 22 May 1992, there was a shooting incident involving five to six Serb soldiers at a Bosnian Muslim check-point near Hambarine. ${ }^{5730}$ Later that day, Serb soldiers arrived in Hambarine in a tank and presented an ultimatum to the villagers, namely that Aziz Ališković and Ferid Sikirić, the Bosnian Muslim policemen believed to have been involved in the incident at the

\footnotetext{
$5726 \quad$ KDZ014, P674 (Transcript from Prosecutor v. Stakić), T. 5765.

5727 KDZ014, P674 (Transcript from Prosecutor v. Stakić), T. 5719, 5721-5722, 5753, 5759, 5765.
}

5728 D4229 (Witness statement of Boško Mandić dated 18 January 2014), para. 14; Mirsad Mujadžić, P3703 (Transcript from Prosecutor v. Stakić), T. 3718; Elvedin Nasić, P696 (Transcript from Prosecutor v. Brđanin), T. 12685-12686. See also P3483 (Video clip of interviews in Prijedor, including with Milomir Stakić, with transcript).

5729 KDZ092, P702 (Transcript from Prosecutor v. Stakić), T. 4054-4055 (under seal).

5730 Mirsad Mujadžić, P3703 (Transcript from Prosecutor v. Stakić), T. 3696-3701 (testifying that at 7 p.m. on 22 May, he heard shooting at the Hambarine check-point, 300 metres from his parents' house, and ran to the scene, where eyewitnesses and individuals involved in the incident on both sides told him that a vehicle with men wearing the White Eagles uniform started shooting at the TO members manning the check-point after their shift commander, Aziz Ališković, stopped the vehicle and asked the men to turn in their weapons; the incident ended when a TO member who was passing by grabbed a gun and shot at the Serbs, killing two and injuring at least two); KDZ074, P708 (Transcript from Prosecutor v. Stakić), T. 2298 (under seal); P711 (Witness statement of KDZ074 dated 23 September 1994), e-court p. 10; KDZ050, P680 (Transcript from Prosecutor v. Sikirica), T. 2497-2498; Elvedin Nasić, P696 (Transcript from Prosecutor v. Brđanin), T. 12686; P697 (Witness statement of Elvedin Nasić dated 15 January 1995), e-court p. 2; KDZ092, P702 (Transcript from Prosecutor v. Stakić), T. 4035-4038 (under seal); Nermin Karagić, P651 (Transcript from Prosecutor v. Stakić), T. 5204, 5289-5290; KDZ038, P676 (Transcript from Prosecutor v. Stakić), T. 6854; KDZ026, P2089 (Transcript from Prosecutor v. Stakić), T. 1842 (under seal). Cf. D4269 (Witness statement of Ratko Milojica dated 27 January 2014), paras. 3-4 (testifying that he and four other VRS soldiers were stopped at the Hambarine check-point and all of a sudden, Bosnian Muslims manning the check-point opened fire at his vehicle with machine guns for over five minutes, killing two of the soldiers); D470 (CSB Banja Luka Report concerning collection centres, undated), e-court p. 28; D4882 (Witness statement of Dušan Đenadija undated), para. 7; D4195 (Witness statement of Milomir Stakić dated 16 November 2013), para. 18; Dusan Jankovic, T. 47271-47272 (18 February 2014). See also Adjudicated Fact 1060; Ivo Atlija, P3672 (Transcript from Prosecutor v. Stakić), T. 5555-5556; KDZ050, P680 (Transcript from Prosecutor v. Sikirica), T. 2497-2498; D4219 (Witness statement of Miroslav Kvočka dated 17 January 2014), para. 17; Mevludin Sejmenović, T. 20478 (27 October 2011); D4222 (Report of Prijedor SJB to Banja Luka CSB, 5 July 1992), p. 1; D4010 (Report of Prijedor SJB, September 1993), p. 2; D4230 (Witness statement of Čedo Šipovac dated 18 January 2014), para. 11; P3483 (Video clip of interviews in Prijedor, including with Milomir Stakić, with transcript); D4228 (Witness statement of Zdravko Torbica dated 18 January 2014), para. 5. 
Hambarine check-point, should surrender, or the village would be attacked. ${ }^{5731}$ The tank fired four shells at the village that night. ${ }^{5732}$

(i) Scheduled Incident A.10.2

1664. The Prosecution alleges that a number of people were killed in the Hambarine and Ljubija area between 23 May and 1 July 1992.

1665. On 23 May 1992, a broadcast was issued over Radio Prijedor calling for a number of identified people, including Aziz Alisković, to surrender and warning that all weapons in the possession of non-Serbs should be handed in to the authorities or Hambarine would be attacked. ${ }^{5733}$

1666. Around noon that day, Hambarine was shelled from different directions for several hours. ${ }^{5734}$ Ivo Atlija witnessed the attack on Hambarine from Briševo and saw two or three tanks firing at the town; he later saw smoke, houses burning, and a large number of soldiers moving around the village. ${ }^{5735}$ All of the houses in Hambarine were shelled and the old mosque in Hambarine was targeted and shelled. ${ }^{5736}$

5731 KDZ074, P709 (Transcript from Prosecutor v. Stakić), T. 2298-2299, 2347-2350, 2358-2359, 2361; P711 (Witness statement of KDZ074 dated 23 September 1994), e-court p. 10; KDZ050, P680 (Transcript from Prosecutor v. Sikirica), T. 2497; Nermin Karagić, P651 (Transcript from Prosecutor v. Stakić), T. 5290; Ivo Atlija, P3672 (Transcript from Prosecutor v. Stakić), T. 5556; Ivo Atlija, T. 20339-20341 (26 October 2011).

5732 KDZ074, P709 (Transcript from Prosecutor v. Stakić), T. 2299. See also KDZ092, P703 (Transcript from Prosecutor v. Stakić), T. 3918; KDZ092, P702 (Transcript from Prosecutor v. Brđanin), T. 12648 (under seal).

5733 Ivo Atlija, P3672 (Transcript from Prosecutor v. Stakić), T. 5556; Ivo Atlija, T. 20339-20341 (26 October 2011); KDZ092, P702 (Transcript from Prosecutor v. Stakić), T. 4037, 4043, 4051 (under seal); KDZ038, P676 (Transcript from Prosecutor v. Stakić), T. 6855-6856, 6977-6978; KDZ026, P2089 (Transcript from Prosecutor v. Stakić), T. 1842-1843 (under seal); Elvedin Nasić, P696 (Transcript from Prosecutor v. Brđanin), T. 12686; P3485 (Article from Kozarski Vjesnik, entitled "Public Statements", 29 May 1992), pp. 1-3; D4219 (Witness statement of Miroslav Kvočka dated 17 January 2014), para. 18. See Adjudicated Facts 1035, 1060. See also P3483 (Video clip of interviews in Prijedor, including with Milomir Stakić, with transcript).

5734 KDZ074, P709 (Transcript from Prosecutor v. Stakić), T. 2299; KDZ048, P678 (Transcript from Prosecutor v. Stakić), T. 3322; KDZ611, P698 (Transcript from Prosecutor v. Brđanin), T. 12455; KDZ050, P680 (Transcript from Prosecutor v. Sikirica), T. 2497; KDZ092, P703 (Transcript from Prosecutor v. Stakić), T. 3918-3919; Nermin Karagić, P651 (Transcript from Prosecutor v. Stakić), T. 5290; KDZ038, P676 (Transcript from Prosecutor v. Stakić), T. 6856-6857; Mirsad Mujadžić, P3703 (Transcript from Prosecutor v. Stakić), T. 3718; KDZ092, P702 (Transcript from Prosecutor v. Brđanin), T. 12648-12649 (under seal); Elvedin Nasić, P696 (Transcript from Prosecutor v. Brđanin), T. 12686-12687. See also Adjudicated Facts 1034, 1060, 1061.

5735 Ivo Atlija, P3672 (Transcript from Prosecutor v. Stakić), T. 5555-5557; Mirsad Mujadžić, P3703 (Transcript from Prosecutor v. Stakić), T. 3718 (stating that the entire area of Brdo and especially Hambarine came under shelling from mortars and other artillery before being joined by two or three tanks). See Mevludin Sejmenović, T. 20478 (27 October 2011). See also Ivo Atlija, T. 20340-20341 (26 October 2011); Adjudicated Facts 1036, 1061; P3914 (Ewan Brown's expert report entitled "Military Developments in the Bosanska Krajina - 1992", 27 November 2002), para. 2.5 (stating that tanks, howitzers, and anti-armour artillery were deployed to the $43^{\text {rd }}$ Motorised Brigade prior to the attack on Hambarine in spring 1992).

5736 KDZ074, P709 (Transcript from Prosecutor v. Stakić), T. 2303; Elvedin Nasić, P696 (Transcript from Prosecutor v. Brđanin), T. 12687. See also Adjudicated Fact 1286; P4070 (Attachment to the expert report of András J. Riedlmayer, entitled "Destruction of Cultural Heritage in BiH" prepared for the Karadžić case, formatted records), pp. 219-221. 
1667. After several hours of artillery shelling, armed Serb Forces entered the area supported by one or two tanks. ${ }^{5737}$ After a brief period of intermittent fighting, local Bosnian Muslim leaders collected any remaining weapons from villagers and surrendered these, as well as most of the weapons that had belonged to the TO and the local police force, to the Serb Forces. ${ }^{5738}$

1668. The units that took part in the 23 May attack on Hambarine included units of the $1^{\text {st }}$ Krajina Corps, including the $6^{\text {th }}$ Krajina Brigade and the $43^{\text {rd }}$ Motorised Brigade, ${ }^{5739}$ the Prijedor SJB, including the intervention squad, joined by members of Bosnian Serb paramilitary groups. ${ }^{5740}$

1669. During the attack, villagers fled south to the Kurevo woods; ${ }^{5741}$ some were pursued by tanks, which opened fire towards the woods. ${ }^{5742}$ KDZ092 testified that as she fled her home, she saw a lot of soldiers in multi-coloured uniforms, armed with automatic rifles, passing by and shooting at the villagers, accompanied by tanks firing at the houses. ${ }^{5743}$ She saw houses burning as a result. ${ }^{5744}$ In addition, at least 50 houses along the Hambarine-Prijedor road were damaged or destroyed by Serb Forces. ${ }^{5745}$

5737 Elvedin Nasić, P696 (Transcript from Prosecutor v. Brđanin), T. 12688; Ivo Atlija, P3672 (Transcript from Prosecutor v. Stakić), T. 5557; Mirsad Mujadžić, P3703 (Transcript from Prosecutor v. Stakić), T. 3718-3719. See Adjudicated Fact 1062.

5738 Ivo Atlija, P3672 (Transcript from Prosecutor v. Stakić), T. 5557; Elvedin Nasić, P696 (Transcript from Prosecutor v. Brđanin), T. 12688; Mirsad Mujadžić, P3703 (Transcript from Prosecutor v. Stakić), T. 37183719; D4222 (Report of Prijedor SJB to Banja Luka CSB, 5 July 1992), p. 1. See Adjudicated Fact 1062. In his final brief, the Accused argues that Serbian forces were met with "strong resistance" in Hambarine when they attempted to dismantle the check-point there. See Defence Final Brief, para. 1547. However, the Chamber has received credible and mutually corroborative evidence that the fighting in Hambarine on 23 May 1992 was brief, and that the armament on the Bosnian Muslim side was poor. See Adjudicated Facts 1035, 1038, 1062, 1294; KDZ074, P709 (Transcript from Prosecutor v. Stakić), T. 2303, 2305; Elvedin Nasić, P696 (Transcript from Prosecutor v. Brđanin), T. 12687; KDZ026, P2089 (Transcript from Prosecutor v. Stakić), T. 2017-2018 (under seal).

5739 P5405 (Report of $1^{\text {st }}$ Krajina Corps, 26 May 1992), p. 1; P3656 ( $1^{\text {st }}$ Krajina Corps report, 1 June 1992) pp. 1-2; P6611 (Bulletin of the $4^{\text {th }}$ Tactical Group, May 1994), p. 2. See also P3660 (Handwritten "War Record" of the $6^{\text {th }}$ Krajina Infantry Brigade, undated), p. 3; D4226 (Witness statement of Dragan Radetić dated 17 January 2014), para. 17; P3914 (Ewan Brown's expert report entitled "Military Developments in the Bosanska Krajina 1992”, 27 November 2002), paras. 2.5, 2.71-2.72.

5740 P5555 (Report of Prijedor SJB, 29 September 1992), p. 3; P2968 (Report of Prijedor SJB, January 1993), p. 4; D4219 (Witness statement of Miroslav Kvočka dated 17 January 2014), para. 18; D4226 (Witness statement of Dragan Radetić dated 17 January 2014), para. 17; KDZ523, P4257 (Transcript from Prosecutor v. Brđanin), T. 21081-21082 (under seal). See also Adjudicated Facts 1034, 1061.

5741 KDZ074, P709 (Transcript from Prosecutor v. Stakić), T. 2302; KDZ092, P703 (Transcript from Prosecutor v. Stakić), T. 3919; Elvedin Nasić, P696 (Transcript from Prosecutor v. Brđanin), T. 12688; P697 (Witness statement of Elvedin Nasić dated 15 January 1995), e-court p. 2; KDZ050, P680 (Transcript from Prosecutor v. Sikirica), T. 2498. See also Adjudicated Facts 1036, 1294.

$5742 \quad$ KDZ092, P703 (Transcript from Prosecutor v. Stakić), T. 3927.

5743 KDZ092, P703 (Transcript from Prosecutor v. Stakić), T. 3919-3920. See also Adjudicated Fact 1036.

5744 KDZ092, P703 (Transcript from Prosecutor v. Stakić), T. 3920; [REDACTED]; P551 (Photograph of Hambarine); P552 (Photograph of Hambarine).

$5745 \quad$ See Adjudicated Fact 1281. 
1670. No one in the group she was with was returning fire, although she conceded that some people had pistols. ${ }^{5746}$ KDZ092 also saw the dead body of a woman she knew lying at the entrance to her house with her head severed from her body, and the dead body of another woman she knew who was lying in the entrance to her house with blood surrounding her body. ${ }^{5747}$ KDZ092 further testified that her best friend's husband and son were killed in Rizvanovići after having fled Hambarine during the attack. ${ }^{5748}$ Her son's throat was slit and her husband was shot and killed as he ran out of the house to his son; his wife buried both men in a shallow grave in Rizvanovicii. ${ }^{5749}$

1671. Also on 23 May, about 400 refugees from the Hambarine area, mostly women, children, and elderly men, but also some young men, went to Briševo. ${ }^{5750}$

1672. On 24 May, KDZ092 and her family went to Ljubija, where they stayed until it was attacked. ${ }^{5751}$ During this period, Serb soldiers came and took some people away from Ljubija, including a former police officer who KDZ092 knew. ${ }^{5752}$ One day, very early in the morning, soldiers in camouflage uniforms came to the house where KDZ092 was staying and told the 38 occupants, all Bosnian Muslim men, women, and children, to go outside. ${ }^{5753}$ The men were separated from the women and children and the men were then taken away to the Ljubija stadium. ${ }^{5754}$ However, one of the men, [REDACTED], had a kidney condition and his family called an ambulance to take him to the hospital to receive treatment; a military ambulance with two soldiers took him and on the way home, the soldiers took him out of the ambulance and killed him. ${ }^{5755}$ The women and children were returned to the cellar, verbally abused, and robbed of their valuables. ${ }^{5756}$

\footnotetext{
5746 KDZ092, P702 (Transcript from Prosecutor v. Stakić), T. 4024-4025, 4053-4054 (under seal); Mirsad Mujadžić, P3703 (Transcript from Prosecutor v. Stakić), T. 3720.

5747 KDZ092, P702 (Transcript from Prosecutor v. Stakić), T. 3920-3921, 3925-3926 (under seal); KDZ092, P702 (Transcript from Prosecutor v. Brđanin), T. 12648-12649 (under seal); P4853 (Updated Table 2 to the Report of Amor Mašović), p. 32. See also P646 (Excerpts from report on exhumations in Prijedor municipality, 28 August 2000), pp. 18, 126 (under seal); Adjudicated Fact 1061.

5748 KDZ092, P702 (Transcript from Prosecutor v. Stakić), T. $4008-4009$ (under seal).

5749 KDZ092, P702 (Transcript from Prosecutor v. Stakić), T. $4008-4009$ (under seal).

$5750 \quad$ Ivo Atlija, P3672 (Transcript from Prosecutor v. Stakić), T. 5558, 5660-5661. See Scheduled Incident A.10.9.

5751 KDZ092, P702 (Transcript from Prosecutor v. Stakić), T. 3927-3928, 4056-4057 (under seal); P522 (Sketch drawn by KDZ092) (under seal).

5752 KDZ092, P703 (Transcript from Prosecutor v. Stakić), T. 3928.

5753 KDZ092, P703 (Transcript from Prosecutor v. Stakić), T. 3929-3930; KDZ092, P702 (Transcript from Prosecutor v. Stakić), 3991-3993 (under seal).

5754 KDZ092, P703 (Transcript from Prosecutor v. Stakić), T. 3930; KDZ092, P702 (Transcript from Prosecutor v. Brđanin), T. 12650 (under seal).

5755 KDZ092, P702 (Transcript from Prosecutor v. Stakić), T. 3991-3992 (under seal).

5756 KDZ092, P703 (Transcript from Prosecutor v. Stakić), T. 3929-3931.
} 
1673. During May and June 1992, announcements calling for weapons to be turned in and for certain individuals to surrender were made on Radio Prijedor. ${ }^{5757}$ In particular, the local population of Bišćani was instructed to hand in their weapons and any uniforms they had from previous reserve service in the army. ${ }^{5758}$ They did as instructed. ${ }^{5759}$ During the attacks on the villages in the Brdo area, Radio Prijedor broadcast that "an Ustasha fundamentalist stronghold" had fallen, and that it had been a great success of the Serb army. ${ }^{5760}$

1674. During June 1992, Serb soldiers came to Čarakovo, demanding fuel, vehicles, and livestock, and looking for local men. ${ }^{5761}$ KDZ014 was aware that some of the local leaders in Čarakovo had a meeting with Serb officials around this time, but that they had not been able to agree on anything except that the Bosnian Muslims should put up white sheets or flags on their houses. ${ }^{5762}$ This they did. ${ }^{5763}$ After the attack on Hambarine, life in the area, including in Bišćani, was difficult, as the Brdo area remained isolated.

1675. On 9 June 1992, soldiers wearing drab olive uniforms and helmets arrived at a shop and café in Hambarine, which they looted and subsequently set on fire. ${ }^{5764}$ On 11 June 1992, KDZ074 took shelter in his cousin's garage nearby, along with members of his family, who were all unarmed civilians. ${ }^{5765}$ He then departed with two male relatives, and subsequently was told by his mother that one of his brothers had been shot and killed in the garage by four Serb police officers; KDZ074's wife was also shot in the leg and wounded. ${ }^{5766}$ After the survivors escaped, the garage was then set on fire by one of the Serb police officers. ${ }^{5767}$

1676. In addition to the deaths of the six individuals confirmed by witnesses above, ${ }^{5768}$ the Chamber also received forensic evidence to support the deaths of at least six additional victims who

\footnotetext{
$5757 \quad$ KDZ014, P674 (Transcript from Prosecutor v. Stakić), T. 5723-5725.

$5758 \quad$ KDZ038, P676 (Transcript from Prosecutor v. Stakić), T. 6857-6858.

5759 KDZ038, P676 (Transcript from Prosecutor v. Stakić), T. 6858.

$5760 \quad$ Ivo Atlija, P3672 (Transcript from Prosecutor v. Stakić), T. 5559.

5761 KDZ014, P674 (Transcript from Prosecutor v. Stakić), T. 5724-5725.

5762 KDZ014, P674 (Transcript from Prosecutor v. Brđanin), T. 12541-12543.

5763 KDZ014, P674 (Transcript from Prosecutor v. Brđanin), T. 12541-12543.

5764 KDZ074, P709 (Transcript from Prosecutor v. Stakić), T. 2306; P711 (Witness statement of KDZ074 dated 23 September 1994), e-court pp. 10-11.

5765 KDZ074, P709 (Transcript from Prosecutor v. Stakić), T. 2308-2310; P711 (Witness statement of KDZ074 dated 23 September 1994), e-court p. 11.

5766 KDZ074, P709 (Transcript from Prosecutor v. Stakić), T. 2309-2310, 2323-2327; P711 (Witness statement of KDZ074 dated 23 September 1994), e-court p. 11. See also P646 (Excerpts from report on exhumations in Prijedor municipality, 28 August 2002), p. 18.

5767 KDZ074, P709 (Transcript from Prosecutor v. Stakić), T. 2323-2327; P711 (Witness statement of KDZ074 dated 23 September 1994), e-court p. 11.

5768 See paras. $1670,1672,1675$.
} 
were killed in the areas of Hambarine and Ljubija between 23 May and 1 July 1992. ${ }^{5769}$ However, the Chamber does not have sufficient evidence as to the circumstances surrounding the deaths of these six latter individuals to make a finding in this regard.

1677. Based on the above, the Chamber therefore finds that at least six Bosnian Muslims were killed by Serb Forces in the areas of Hambarine and Ljubija between 23 May and 1 July 1992.

\section{(ii) $\underline{\text { Scheduled Incident A.10.5 }}$}

1678. The Prosecution alleges that a number of people were killed in the villages of the Brdo area between 1 and 23 July 1992.

1679. Beginning on 20 July 1992, Serb Forces, including units of the $1^{\text {st }}$ Krajina Corps, such as the $6^{\text {th }}$ Krajina Brigade, as well as the Reconnaissance and Sabotage Company and members of the intervention squad, attacked villages around the entire region of Brdo. ${ }^{5770}$

1680. On 21 and 22 July 1992, the villages of Rakovćani and Rizvanovići were also attacked. ${ }^{5771}$ Karagić saw an APC open fire towards Rizvanovići. ${ }^{572}$ Soldiers patrolled the village and some of the villagers took shelter in the basement of one of the houses there. ${ }^{573}$ The next day, Karagic saw soldiers wearing olive-grey military uniforms throwing hand grenades and shooting; he ran to a vantage point from where he could see the whole area and saw these soldiers taking up positions around the village. ${ }^{5774}$ After the attack on Rizvanovići, Karagić saw houses on fire in the area. ${ }^{5775}$ During this attack, homes were destroyed and personal belongings were looted. ${ }^{576}$

\footnotetext{
5769 P4853 (Updated Table 2 to the Report of Amor Mašović), p. 32 (confirming that the bodies of seven identified individuals, including Mevla Čaušević, were exhumed from individual and mass graves in Hambarine and other areas of Prijedor in 1998, 2000, and 2001); P4892 (BiH State Commission for Tracing Missing Persons list of exhumed persons from Prijedor, Čelinac, Bosanski Novi, 29 October 2002), p. 4 (confirming that the body of one of the same individuals identified by Mašović was exhumed from a mass grave in Hrnići, Prijedor in 2001). See also P4850 (Witness statement of Amor Mašović dated 23 March 2012), Annex A, p. 9; P646 (Excerpts from report on exhumations in Prijedor municipality, 28 August 2002), pp. 18, 240 (under seal) (confirming that the bodies of five of the same individuals identified by Mašović were exhumed from graves in Hambarine and other areas of Prijedor with injuries indicating that they died from gunshot wounds).

5770 KDZ038, P676 (Transcript from Prosecutor v. Stakić), T. 6858; Nermin Karagić, P651 (Transcript from Prosecutor v. Stakić), T. 5291; P697 (Witness statement of Elvedin Nasić dated 15 January 1995), e-court p. 2; KDZ074, P709 (Transcript from Prosecutor v. Stakić), T. 2344; P5437 (Report of $1^{\text {st }}$ Krajina Corps, 22 August 1992); D1817 (Order of $6^{\text {th }}$ Partisan Brigade, 18 June 1992), pp. 1-3. [REDACTED]; Adjudicated Facts 1068, 1073, 1295.

5771 Elvedin Nasić, P696 (Transcript from Prosecutor v. Brđanin), T. 12689; Nermin Karagić, P651 (Transcript from Prosecutor v. Stakić), T. 5206-5207.

5772 Nermin Karagić, P651 (Transcript from Prosecutor v. Stakić), T. 5206-5207.

5773 Nermin Karagić, P651 (Transcript from Prosecutor v. Stakić), T. 5209-5210.

5774 Nermin Karagić, P651 (Transcript from Prosecutor v. Stakić), T. 5291-5292.

5775 Nermin Karagić, P651 (Transcript from Prosecutor v. Stakić), T. 5270.

5776 See Adjudicated Fact 1280.
} 
1681. Karagić also saw a tank fire about 20 shells towards the mosque in Hambarine. ${ }^{5777}$ The mosque in Rajkovac was also shelled. ${ }^{5778}$ According to Nasić, three young men were taken away from Rizvanovići in late July 1992; they were never seen again. ${ }^{579}$

1682. The village of Čarakovo was attacked on 23 July 1992, after several demands that residents should hand in their weapons. ${ }^{5780}$ According to KDZ014, all rifles, pistols, and other weapons in Čarakovo were handed in by residents to Serb Forces by June 1992. ${ }^{5781}$ Based on the evidence before it, the Chamber finds that the TO and other Bosnian Muslim units were not active in Čarakovo at this time and that there was no armed resistance to the attack on the village by Serb Forces on 23 July.

1683. That day, KDZ014 was hiding in a corn field, trying to get to her children in her house, when she heard the sounds of tanks and shooting and women and children screaming. ${ }^{5782}$ She saw houses burning and soldiers in camouflage uniforms moving through the woods nearby. ${ }^{5783}$ During the attack, Čarakovo suffered extensive damage and destruction and houses were looted. ${ }^{5784}$

1684. The mosque in Čarakovo, including the minaret, was destroyed by Serb soldiers on 23 July 1992, and 17 people, including the "hodža", were killed outside. ${ }^{5785}$

1685. After the initial attack on Čarakovo, soldiers mistreated and killed some of the villagers. ${ }^{5786}$ For instance, on or around 23 July 1992, Besim Musić was approached by Serb soldiers while he was shredding corn; they took him into a car, beat him, and then threw him out on the road. ${ }^{5787}$ The

\footnotetext{
5777 Nermin Karagić, P651 (Transcript from Prosecutor v. Stakić), T. 5207. The Chamber notes that the Hambarine mosque had already been shelled and damaged during the attack on Hambarine in May 1992 by Serb Forces. See paras. 1666-1668. See also para. 1889.

5778 Nermin Karagić, P651 (Transcript from Prosecutor v. Stakić), T. 5207.

5779 Elvedin Nasić, P696 (Transcript from Prosecutor v. Brđanin), T. 12724. However, the Chamber does not have sufficient evidence as to the circumstances surrounding these events to make a finding that these three individuals were killed in relation to this Scheduled Incident.

5780 KDZ014, P674 (Transcript from Prosecutor v. Stakić), T. 5727, 5730; KDZ014, P674 (Transcript from Prosecutor v. Brđanin), T. 12543-12545. See also Adjudicated Fact 1069; KDZ523, P4257 (Transcript from Prosecutor v. Brđanin), T. 21087-21090 (under seal). In his final brief, the Accused concedes that following several demands for disarmament of the village, Bosnian Serb tanks attacked Čarakovo on 23 July 1992. See Defence Final Brief, para. 1550.

$5781 \quad$ KDZ014, P674 (Transcript from Prosecutor v. Stakić), T. 5724.

5782 KDZ014, P674 (Transcript from Prosecutor v. Stakić), T. 5727-5729; KDZ014, P674 (Transcript from Prosecutor v. Brđanin), T. 12543.

5783 KDZ014, P674 (Transcript from Prosecutor v. Stakić), T. 5729.

5784 See Adjudicated Fact 1278; KDZ014, P674 (Transcript from Prosecutor v. Stakić), T. 5739-5740.

5785 KDZ014, P674 (Transcript from Prosecutor v. Brđanin), T. 12547. See also KDZ523, P4257 (Transcript from Prosecutor v. Brđanin), T. 21090 (under seal); P4070 (Attachment to the expert report of András J. Riedlmayer, entitled "Destruction of Cultural Heritage in BiH" prepared for the Karadžić case, formatted records), pp. 216218. See para. 1889.

5786 KDZ014, P674 (Transcript from Prosecutor v. Stakić), T. 5740-5741.

5787 KDZ014, P674 (Transcript from Prosecutor v. Stakić), T. 5740.
} 
soldiers also shot around Musić, causing the bullets to rip skin on his head, arms, and legs, while not actually hitting him. ${ }^{5788}$ Another villager told KDZ014 that Musić's wife had been killed, along with another man, by soldiers who questioned them about the whereabouts of hideouts used by the Green Berets. 5789

1686. Also in Čarakovo, KDZ014 saw the dead bodies of Rubija Redžić, a local Bosnian Muslim woman, Fehim Karupović, a local Bosnian Muslim man, and her neighbour, Adem Hopovac. They were all unarmed, wearing civilian clothes, and had been shot. ${ }^{5790}$ In the swampy area known as Bare, between Zecovi and Čarakovo, KDZ014 also saw eight dead bodies of Bosnian Muslims in civilian clothes. ${ }^{5791}$ She and her brothers then collected and buried these bodies. ${ }^{5792}$ KDZ014 also assisted in burying the bodies of two Bosnian Muslim men found in a field on 24 July $1992 .{ }^{5793}$ On 27 July 1992, she saw the body of another Bosnian Muslim man as it was buried by his son. ${ }^{5794}$

1687. In the days following the attack, KDZ014 and the other local residents sometimes slept in the woods and returned to their homes in the mornings to collect food; they were afraid that if they were found they would be killed. ${ }^{5795}$ The Serb soldiers stole vehicles, farm machinery, money, and gold from the local residents in Čarakovo; household items were also stolen and loaded on to vehicles. ${ }^{5796}$ KDZ014 also saw men, women, and children from the area being forced on to buses

5788 KDZ014, P674 (Transcript from Prosecutor v. Stakić), T. 5740-5741 (testifying that she took Musić to a hospital in Prijedor on 25 July 1992, after she had taken care of him for a day or two in her house).

5789 KDZ014, P674 (Transcript from Prosecutor v. Stakić), T. 5741. See also P6689 (Excerpts from report on exhumations in Prijedor municipality, 28 August 2002), p. 25 (confirming that Badema Musić was officially declared dead by Sanski Most municipal court and given a date of death of 23 July 1992).

5790 KDZ014, P674 (Transcript from Prosecutor v. Stakić), T. 5732-5734; KDZ014, P674 (Transcript from Prosecutor v. Brđanin), T. 12544-12545. See also Adjudicated Fact 1069 (stating that during the raid of Carakovo, at least 16 civilians were killed and that three of them were shot dead in front of their houses).

5791 KDZ014, P674 (Transcript from Prosecutor v. Stakić), T. 5735-5737; KDZ014, P674 (Transcript from Prosecutor v. Brđanin), T. 12545-12546 (identifying the bodies she found in Bare as Asim Redžić, Huse Hopovac, Suad Hopovac, Fadil Malovcić, Velid Hopovac, Nijaz Hopovac, Mirhad Hopovac, and Nijaz Redžić); P4853 (Updated Table 2 to the Report of Amor Mašović), pp. 34, 36 (confirming that the bodies of Asim Redžić, Huse Hopovac, and Suad Hopovac were exhumed from graves in Čarakovo-Baćuša in 1998 and 1999). See also P6689 (Excerpts from report on exhumations in Prijedor municipality, 28 August 2002), pp. 21-22 (confirming that the bodies of Huse Hopovac, Nijaz Hopovac, and Asim Redžić were exhumed from mass graves in Čarakovo, Baćuša and Zecovi-Kosa in October 1998 and August 1998, respectively, and that Huse Hopovac and Asim Redžić had been killed by gun shot wounds).

5792 KDZ014, P674 (Transcript from Prosecutor v. Stakić), T. 5738.

5793 KDZ014, P674 (Transcript from Prosecutor v. Stakić), T. 5741-5742 (identifying the bodies as Ermin Sijacić and Huse Salihović); P4853 (Updated Table 2 to the Report of Amor Mašović), pp. 34-36 (confirming that the body of Huse Salihović was exhumed from a grave in Brdo in 1998). See also Adjudicated Fact 1069.

5794 KDZ014, P674 (Transcript from Prosecutor v. Stakić), T. 5742-5743 (identifying the body of Nasif Dizdarević and testifying that his son told her that he had found his father's body with numerous bullet holes in the kitchen of his house).

5795 KDZ014, P674 (Transcript from Prosecutor v. Stakić), T. 5743; KDZ014, P674 (Transcript from Prosecutor v. Brđanin), T. 12547-12548.

5796 KDZ014, P674 (Transcript from Prosecutor v. Stakić), T. 5729, 5740, 5769; KDZ014, P674 (Transcript from Prosecutor v. Brđanin), T. 12544, 12547-12548. 
by Serb soldiers and driven away. Other groups of villagers left on foot in the days after the attack; KDZ014 did not know where buses or groups of villagers were going. ${ }^{5797}$

1688. In late July 1992, KDZ014 decided to leave Čarakovo; she and approximately 100 other people, primarily women, children, and elderly, assembled and went to the village "dom" carrying a white flag; they were kept there for three hours and verbally abused by Serb soldiers. ${ }^{5798}$ They were then escorted by the Serb soldiers to an area of Čarakovo known as Žeger, where the road to Čarakovo meets the main road from Prijedor to Sanski Most. ${ }^{5799}$

1689. Bosnian Muslim and Bosnian Croat men were stopped and killed at a bridge in Žeger. ${ }^{5800}$ KDZ092 testified that she saw buses from Prijedor with men from Čarakovo stop and unload the men at Žeger Bridge. ${ }^{5801}$ KDZ014 also testified that she saw men stripped down to their waists and detained at Žeger Bridge. ${ }^{5802}$ Soldiers in camouflage uniforms, with white ribbons on the shoulders, and camouflage caps shot the men who were dressed in civilian clothes at the bridge and threw their bodies into the Sana River. ${ }^{583}$ Other Bosnian Muslim and Bosnian Croat men were put on to buses at Žeger Bridge and taken away. ${ }^{5804}$

1690. At Žeger Bridge, women, children, and elderly, including KDZ014, were loaded onto "Autotransport Prijedor" buses driven by Serb soldiers. ${ }^{505}$ She saw one of her neighbours, Hasib Simbegović, try to board one of the buses, but he was prevented from doing so by Dragan Tintar, a

5797 KDZ014, P674 (Transcript from Prosecutor v. Stakić), T. 5729-5730; KDZ014, P674 (Transcript from Prosecutor v. Brđanin), T. 12544, 12547-12548. See also KDZ523, P4257 (Transcript from Prosecutor v. Brđanin), T. 21076, 21090 (under seal).

5798 KDZ014, P674 (Transcript from Prosecutor v. Stakić), T. 5745-5746.

5799 KDZ014, P674 (Transcript from Prosecutor v. Stakić), T. 5746-5747; KDZ014, P674 (Transcript from Prosecutor v. Brđanin), T. 12537. See also KDZ523, P4257 (Transcript from Prosecutor v. Brđanin), T. 21076-21077 (under seal); Adjudicated Fact 1070.

5800 KDZ092, P703 (Transcript from Prosecutor v. Stakić), T. 3947-3949; KDZ092, P702 (Transcript from Prosecutor v. Stakić), T. 3950-3954, 3656 (under seal); KDZ014, P674 (Transcript from Prosecutor v. Stakić), T. 5746-5747. See also Adjudicated Fact 1070. The Chamber notes the discrepancy surrounding the date of the killings at Žeger Bridge. Adjudicated Fact 1070 states that the date of the killings was 23 July 1992. This adjudicated fact is based on KDZ092's evidence in the Stakić case, as admitted in the Brđanin case, and KDZ092 confirmed in the Stakić case that this incident occurred on the same day as the attack on the village of Carakovo, which was 23 July. However, KDZ014 testified that she saw men at Žeger Bridge on 28 July 1992 , the day on which she left Carakovo. Based on the evidence before it, the Chamber considers that the killings at Žeger Bridge occurred on or around 23 July 1992 following, and as a part of, the attack on Carakovo and thus finds that they occurred within the period of the Indictment for this incident.

5801 KDZ092, P702 (Transcript from Prosecutor v. Stakić), T. 3950-3954, 3656 (under seal).

$5802 \quad$ KDZ014, P674 (Transcript from Prosecutor v. Stakić), T. 5743, 5747.

5803 KDZ092, P702 (Transcript from Prosecutor v. Stakić), T. 3951-3955, 3994 (under seal). See also Adjudicated Fact 1070.

5804 KDZ092, P702 (Transcript from Prosecutor v. Stakić), T. 3937, 3947, 3950, 3956, 3994 (under seal); KDZ092, P702 (Transcript from Prosecutor v. Brđanin), T. 12655 (under seal). [REDACTED].

5805 KDZ014, P674 (Transcript from Prosecutor v. Stakić), T. 5747-5748. See also KDZ523, P4257 (Transcript from Prosecutor v. Brđanin), T. 21076-21077 (under seal). 
local Serb from Tukovi wearing a camouflage uniform, who then shot him in the head. ${ }^{5806}$ After they were loaded onto the buses, the women, children, and elderly were driven to Trnopolje, where they spent one night before being transported by trucks and buses to Vlasić. ${ }^{587}$ At Vlasić, they got off of the buses and were told to walk to "their country" and were received by Bosnian Muslim soldiers, who took them to Travnik. ${ }^{5808}$

1691. The Chamber took judicial notice that a large number of killings of Bosnian Muslims and Bosnian Croats occurred in the Brdo area around 20 July 1992 as a result of the campaign conducted by Bosnian Serb forces. ${ }^{5809}$ In addition, the Chamber has received forensic evidence to support the deaths of some identified individuals who were killed in the Brdo region between 1 and 23 July $1992 .^{5810}$

1692. Based on the above, the Chamber therefore finds that a number of Bosnian Muslims and Bosnian Croats, including civilians, were killed by Serb Forces in the Brdo area on or around 23 July 1992.

(iii) $\underline{\text { Scheduled Incident A.10.6 }}$

1693. The Prosecution alleges that a number of men were killed in the village of Bišćani and in the surrounding hamlets of Hegići, Mrkalji, Ravine, Duratovići, Kadići, Lagići, and Čemernica on or about 20 July 1992.

1694. On 20 July 1992, the village of Bisćani and the surrounding hamlets were attacked by Serb Forces, including the $6^{\text {th }}$ Krajina Brigade and members of the police and the intervention squad. ${ }^{5811}$

1695. Starting around 10 a.m. on 20 July, the village of Bišćani was attacked by Serb Forces from the direction of Tukovi. ${ }^{5812}$

\footnotetext{
$5806 \quad$ KDZ014, P674 (Transcript from Prosecutor v. Stakić), T. 5748, 5771.

5807 KDZ014, P674 (Transcript from Prosecutor v. Stakić), T. 5749-5750.

5808 KDZ014, P674 (Transcript from Prosecutor v. Stakić), T. 5749-5750; Senija Elkasović, P690 (Transcript from Prosecutor v. Tadić), T. 4620-4622. [REDACTED]. See paras. 1834, 1837.

5809 See Adjudicated Fact 1068.

5810 P4853 (Updated Table 2 to the Report of Amor Mašović), pp. 34-36 (confirming that at least 16 bodies were exhumed from graves in Čarakovo, Baćuša, Pašinac, Kosa and Brdo in 1998, 1999, and 2000). See also P6689 (Excerpts from report on exhumations in Prijedor municipality, 28 August 2002), pp. 21-26, 46, 253, 254 (confirming that the bodies of Huse Hopovac, Nijaz Hopovac, Asim Redžić, Hamdija Hopovac, Aziz Behlić, Naila Redžić, Namir Redžić, and Vahid Redžić were exhumed from mass graves in Čarakovo, Baćuša and Zecovi-Kosa in 1998 and 2000); see fn. 5791.

5811 KDZ094, P706 (Transcript from Prosecutor v. Stakić), T. 5881-5882 (under seal); KDZ094, P706 (Transcript from Prosecutor v. Brđanin), T. 11849 (under seal); P5437 (Report of $1^{\text {st }}$ Krajina Corps, 22 August 1992), p. 2; D1817 (Order of 6th Partisan Brigade, 18 June 1992); [REDACTED]. See also Adjudicated Fact 1073. [REDACTED].
} 
1696. On 20 July 1992, Bosnian Muslim males in Bišćani as young as 16 years old were told to gather at various collection points manned by Serb soldiers throughout the village; the women stayed in their homes and were eventually taken away to Trnopolje or other places. ${ }^{5813}$ Several people were beaten and killed at these collection points in Bišćani. ${ }^{5814}$ For instance, one of the collection points was a coffee bar; at that location, a uniformed soldier instructed two men, Mirhad Mrkalj and Ferid Sabanović, to carry the dead body of Hamdija Fikić behind a house. ${ }^{5815}$ KDZ038 saw the soldier fire "into" Mrkalj and Sabanović and they did not come back. ${ }^{5816}$ Additionally, KDZ038 saw three other men killed at the coffee bar collection point-Mirsad Medić and another colleague who worked with Medić at the petrol station, as well a former policeman, Saša Karagić. ${ }^{5817}$ The Chamber is therefore satisfied that in total six men were killed by Bosnian Serb soldiers at the coffee bar collection point on 20 July 1992.

1697. A while later, a "Prijedor Autotransport" bus arrived at the coffee bar collection point and soldiers instructed some of the men in the group, including KDZ038, to get on the bus, while other men were instructed to stay behind. ${ }^{5818}$ In Prijedor town, they stopped and changed to another Autotransport bus, which drove them on the main Prijedor-Banja Luka road and stopped near Keraterm for awhile. ${ }^{5819}$ They then went to Omarska, where the bus waited outside, before continuing on to Trnopolje. ${ }^{5820}$

1698. Sometime later in the afternoon on 20 July, a second bus arrived at Trnopolje with the other group of men who had stayed behind at the coffee bar collection point; however, KDZ038 noticed that a number of men who had been in this second group were not in the group that arrived at Trnopolje. ${ }^{5821}$ KDZ038 later heard from a survivor that the whole second group of men had been

5812 KDZ038, P676 (Transcript from Prosecutor v. Stakić), T. 6859; P697 (Witness statement of Elvedin Nasić dated 15 January 1995), e-court p. 3 (stating that when he went into Bišćani some time after the attack he found the entire village empty and all the villagers were gone).

5813 KDZ038, P676 (Transcript from Prosecutor v. Stakić), T. 6859-6861 (testifying that the soldiers he saw throughout Bišćani on and after 20 July wore different uniforms-olive drab in colour, camouflage, as well as police uniforms). See also Adjudicated Fact 1074.

5814 KDZ038, P676 (Transcript from Prosecutor v. Stakić), T. 6861; P697 (Witness statement of Elvedin Nasić dated 15 January 1995), e-court p. 2; Elvedin Nasić, P696 (Transcript from Prosecutor v. Brđanin), T. 12715 (testifying that his brother told him that his father, who was unarmed, was killed by an armed soldier in front of his brother on the day Bišćani was attacked). See also Adjudicated Fact 1074.

5815 KDZ038, P676 (Transcript from Prosecutor v. Stakić), T. 6861-6862.

5816 KDZ038, P676 (Transcript from Prosecutor v. Stakić), T. 6861-6862. See para. 1708. See also P646 (Excerpts from report on exhumations in Prijedor municipality, 28 August 2002), pp. 22-23, 177 (under seal).

5817 KDZ038, P676 (Transcript from Prosecutor v. Stakić), T. 6862-6863. See also Adjudicated Fact 1074.

5818 KDZ038, P676 (Transcript from Prosecutor v. Stakić), T. 6865.

5819 KDZ038, P676 (Transcript from Prosecutor v. Stakic), T. 6866.

5820 KDZ038, P676 (Transcript from Prosecutor v. Stakić), T. 6866-6867.

5821 KDZ038, P676 (Transcript from Prosecutor v. Stakić), T. 6868, 6870 (identifying the names of seven men, Nurija Kekić, Halid Kekić, Sabahudin Kekić, Asmir Kekić, Muhamed Tedić, Ferid Risvanović, and Elvir Vojniković, who KDZ038 had seen at the coffee bar collection point and who did not ultimately arrive at 
put on to a bus but that, at a sand pit along the road towards Prijedor, some of the men were taken off the bus, lined up, and shot with an automatic rifle by a soldier wearing an olive drab uniform and helmet. ${ }^{5822}$ When the remaining villagers from Bišćani were later taken to Trnopolje along that road, they saw the bodies of these men. ${ }^{5823}$

1699. Two of the brothers of KDZ074 were also killed on 20 July 1992, while taking shelter in the basement of a house in Bišćani with their families. ${ }^{5824}$ They were taken from the basement along with other men by Serb police officers wearing blue uniforms, led to the yard of another house nearby, shot, and killed with automatic rifles; all of the men were unarmed and in civilian clothes. ${ }^{5825}$ Their bodies were later collected. ${ }^{5826}$

1700. On 20 July, the hamlet of Duratovići was attacked; it was one of the first hamlets in the area around Bišćani targeted and there were few survivors. ${ }^{5827}$ Karagić later heard that there were 20 to 30 dead bodies outside a shop in Duratovići and a number of dead bodies lying across the street from the shop. ${ }^{5828}$ Two of Karagić's uncles were killed in Duratovići. ${ }^{5829}$

1701. Between 2 p.m. and 2:30 p.m. on 20 July, Hegići was attacked by Serb Forces. ${ }^{5830}$ Hegići was on a hill about 300 to 350 metres in a straight line from Mrkalji, which was also on a hill. ${ }^{5831}$ A group of villagers from Hegići watched what was happening in Mrkalji and heard screams from women and children there. ${ }^{5832}$ Approximately 30 to 40 men from Mrkalji, including 12 and 13 year old boys and elderly men between 60 and 65 years old, dressed in civilian clothes and unarmed, were surrounded by APCs and about 20 to 30 soldiers in military camouflage uniforms at a clay pit;

Trnopolje); see P4853 (Updated Table 2 to the Report of Amor Mašović), p. 37 (confirming that the body of Elvir Vojniković was exhumed from a grave in Rizvanovići in 2005).

5822 KDZ038, P676 (Transcript from Prosecutor v. Stakić), T. 6864, 6868-6869, 6872; KDZ094, P706 (Transcript from Prosecutor v. Stakić), T. 5950 (under seal) (testifying that he retrieved 15 to 25 bodies from the side of the road near the Sredicko Polje sand pits and was told later that these people had been on a bus and that half of the occupants of the bus had been killed in that spot).

5823 KDZ038, P676 (Transcript from Prosecutor v. Stakić), T. 6871.

5824 KDZ074, P709 (Transcript from Prosecutor v. Stakić), T. 2344.

5825 KDZ074, P709 (Transcript from Prosecutor v. Stakić), T. 2310, 2344-2345.

5826 KDZ074, P709 (Transcript from Prosecutor v. Stakić), T. 2345; P711 (Witness statement of KDZ074 dated 23 September 1994), e-court pp. 13-14.

5827 Nermin Karagić, P651 (Transcript from Prosecutor v. Stakić), T. 5293-5294.

5828 Nermin Karagić, P651 (Transcript from Prosecutor v. Stakić), T. 5294; KDZ094, P706 (Transcript from Prosecutor v. Brđanin), T. 11851 (under seal). See para. 1708.

5829 Nermin Karagić, P651 (Transcript from Prosecutor v. Stakić), T. 5294.

5830 KDZ094, P706 (Transcript from Prosecutor v. Stakić), T. 5881-5882, 5912-5913 (under seal) [REDACTED]; KDZ094, P706 (Transcript from Prosecutor v. Brđanin), T. 11849 (under seal).

5831 KDZ094, P706 (Transcript from Prosecutor v. Stakić), T. 5882-5883 (under seal).

5832 KDZ094, P706 (Transcript from Prosecutor v. Stakić), T. 5882 (under seal); KDZ094, P706 (Transcript from Prosecutor v. Brđanin), T. 11849 (under seal). 
they were lined up, told to run, and then shot and killed. ${ }^{533}$ The mosque in Mrkalji was also on fire. $^{5834}$

1702. The hamlet of Čermernica was also attacked on 20 July $1992 .{ }^{5835}$ Soldiers in blue uniforms, along with a few others in green and olive-grey camouflage uniforms, arrived on foot in Čemernica, followed by military vehicles and APCs. ${ }^{5836}$ Around 35 to 40 residents of Čemernica assembled at the village cemetery and were lined up by the soldiers. ${ }^{5837}$ Two soldiers approached one of the men, Muhamed Hazdić, and asked him his name; when he responded, one of the soldiers said "are you a pejgamber?", referring to a Muslim word about God, and then shot and killed him. ${ }^{5838}$ KDZ094 noticed that elderly people in the line had been beaten and their clothes were cut; [REDACTED]. ${ }^{5839}$ Two other soldiers arrived, Rade Bilbija and Miodrag Glusac, also known as "Tosa", dressed in camouflage uniforms; Bilbija, seemed to be in charge and upon his instructions, the soldiers then left. ${ }^{5840}$ KDZ094 buried Muhamed Hazdic the next morning. ${ }^{5841}$

1703. Around 20 July 1992, 12 persons were lined up in an orchard in Hegići and shot dead. ${ }^{5842}$ Also on or around 20 July, between 20 to 30 people were killed at a bus stop at a crossroads between Alagići, Čemernica, and Jugovći; an elderly woman, went looking for her three sons who had gone missing and saw heaps of bodies at this location. ${ }^{5843}$

1704. On 21 July, soldiers returned to Čemernica in small groups and stole television sets, valuables, and gold items. ${ }^{5844}$ They took away several of the villagers to collect the bodies of

5833 KDZ094, P706 (Transcript from Prosecutor v. Stakić), T. 5882, 5885, 5887, 5890-5893 (under seal); KDZ094, P706 (Transcript from Prosecutor v. Brđanin), T. 11849 (under seal). See P1164 (Photograph of Hegići hamlet in Bišćani marked by KDZ094); P583 (Photograph of Mrkalji hamlet in Bišćani); P1162 (Photograph of house of Smail Mrkalj in Bišćani marked by KDZ094). See also Adjudicated Fact 1075; para. 1705.

5834 KDZ094, P706 (Transcript from Prosecutor v. Stakić), T. 5882 (under seal). See also KDZ523, P4257 (Transcript from Prosecutor v. Brđanin), T. 21090 (under seal).

5835 KDZ094, P706 (Transcript from Prosecutor v. Stakic), T. 5897, 5906 (under seal) (testifying that he saw that "everything had burned" in Čemernica and that "everyone had been killed").

5836 KDZ094, P706 (Transcript from Prosecutor v. Stakić), T. 5906 (under seal); KDZ094, P706 (Transcript from Prosecutor v. Brđanin), T. 11850 (under seal).

5837 KDZ094, P706 (Transcript from Prosecutor v. Stakić), T. 5893, 5906-5907 (under seal); KDZ094, P706 (Transcript from Prosecutor v. Brđanin), T. 11850 (under seal).

5838 KDZ094, P706 (Transcript from Prosecutor v. Stakić), T. 5906-5907 (under seal); KDZ094, P706 (Transcript from Prosecutor v. Brđanin), T. 11850 (under seal).

5839 KDZ094, P706 (Transcript from Prosecutor v. Stakić), T. 5907 (under seal).

5840 KDZ094, P706 (Transcript from Prosecutor v. Stakić), T. 5908-5910 (under seal).

5841 KDZ094, P706 (Transcript from Prosecutor v. Stakić), T. 5910 (under seal).

5842 KDZ094, P706 (Transcript from Prosecutor v. Stakić), T. 5922 (under seal); KDZ094, P706 (Transcript from Prosecutor v. Brđanin), T. 11851 (under seal); P576 (Photograph of orchard in Bišćani). See also Adjudicated Fact 1076.

5843 KDZ094, P706 (Transcript from Prosecutor v. Stakić), T. 5925 (under seal); KDZ094, P706 (Transcript from Prosecutor v. Brđanin), T. 11851-11852 (under seal). See also Adjudicated Fact 1077.

5844 KDZ094, P706 (Transcript from Prosecutor v. Stakić), T. 5910-5911 (under seal); KDZ094, P706 (Transcript from Prosecutor v. Brđanin), T. 11850 (under seal). 
people who had been killed in the area, and two of those men, Husnija Hadzić and Hare Pelak, never returned. ${ }^{5845}$

1705. Serb soldiers continued to take away several villagers from Čemernica each day to collect bodies and load them into trucks in the surrounding villages. ${ }^{5846}$ On 23 July around 8 or 9 a.m., two Serbs in camouflage uniforms, Ranko Došen and Slavko Petrović, arrived in Čemernica in green military trucks and instructed KDZ094 to go with eight to ten other Bosnian Muslim men to collect bodies from the Bišćani area and load them onto trucks. ${ }^{5847}$ They were accompanied by armed escorts, Serb soldiers in green, olive-grey military uniforms with rifles. ${ }^{5848}$ They first went to Hegići, where they found the badly decomposing bodies of Salih Hegić and Esef Avdić, both with gunshot wounds, and loaded them into the truck using blankets which they collected from nearby houses. ${ }^{584}$ KDZ094 then went to the clay pit in Mrkalji and saw a number of bodies lying face down, which had been shot in the back. ${ }^{5850}$

1706. After Mrkalji, KDZ094 and the other men with the truck went to the neighbouring hamlet of Kadići, where they picked up the bodies of Sead and Kemal Kadić, which had gunshot wounds in the chest. ${ }^{5851}$ They then went towards Ravine, and KDZ094 observed that the Bišćani mosque no longer had a roof or munara and had been damaged by fire, as had nearby houses. ${ }^{5852}$ He stated that he had last seen part of the munara on 23 July 1992, from his house, before it was burned. ${ }^{5853}$ The Chamber received evidence that throughout the whole area of Bišćani, Rizvanovići, and Rakovčani, "all the mosques were burned and looted". ${ }^{584}$ These mosques had been intact in April 1992. ${ }^{5855}$ The mosque in Bišćani was destroyed on 20 July 1992 and the Rizvanovići mosque and other mosques in the area were destroyed in the summer months, and by August $1992 .{ }^{5856}$

\footnotetext{
5845 KDZ094, P706 (Transcript from Prosecutor v. Stakić), T. 5911-5912 (under seal); KDZ094, P706 (Transcript from Prosecutor v. Brđanin), T. 11850-11851 (under seal).

5846 KDZ094, P706 (Transcript from Prosecutor v. Stakić), T. 5911-5915 (under seal).

5847 KDZ094, P706 (Transcript from Prosecutor v. Stakić), T. 5913-5915 (under seal).

5848 KDZ094, P706 (Transcript from Prosecutor v. Stakić), T. 5916-5917 (under seal).

5849 KDZ094, P706 (Transcript from Prosecutor v. Stakić), T. 5917-5920, 5922 (under seal); P1164 (Photograph of Hegići hamlet in Bišćani marked by KDZ094). See also P646 (Excerpts from report on exhumations in Prijedor municipality, 28 August 2002), pp. 20, 22, 24 (under seal).

5850 KDZ094, P706 (Transcript from Prosecutor v. Stakić), T. 5923 (under seal). See para. 1701.

5851 KDZ094, P706 (Transcript from Prosecutor v. Stakić), T. 5927 (under seal).

5852 KDZ094, P706 (Transcript from Prosecutor v. Stakić), T. 5927-5929 (under seal); P574 (Photograph of mosque in Bišćani); P575 (Photograph of mosque in Bišćani); P590 (Photograph of interior of mosque in Bišćani).

5853 KDZ094, P706 (Transcript from Prosecutor v. Stakić), T. 5882, 5928-5929 (under seal).

5854 KDZ094, P706 (Transcript from Prosecutor v. Stakić), T. 5929 (under seal).

5855 KDZ094, P706 (Transcript from Prosecutor v. Stakić), T. 5929-5930 (under seal).

5856 KDZ094, P706 (Transcript from Prosecutor v. Stakić), T. 5928-5930 (under seal). See also Adjudicated Fact 1289; KDZ523, P4257 (Transcript from Prosecutor v. Brđanin), T. 21090 (under seal); P4070 (Attachment to the expert report of András J. Riedlmayer, entitled "Destruction of Cultural Heritage in BiH" prepared for the Karadžić case, formatted records), pp. 227-228, 233-235. See para. 1889.
} 
1707. At some point on 23 July, KDZ094 was ordered by Došen to drive a second truck and they continued to Ravine; they collected a few more bodies along the road and then five or six more in a field about 50 metres from the turn-off to Ravine, all of which had gunshot injuries. ${ }^{557}$ In a forest in Ravine, they picked up another 25 to 30 bodies near the woods and outside of houses; [REDACTED]. ${ }^{5858}$ One of the bodies was a young female [REDACTED] found naked, lying on a couch inside a house with a bullet hole in her head. ${ }^{5859}$

1708. Near a place called Bijela Zemlja, KDZ094 picked up the body of Mirhad Mrkalj and a few other unidentified people. ${ }^{5860}$ Further along, they picked up another 15 to 20 bodies close to the main road between Ravine and Bišćani. ${ }^{5861}$ Near the "Diskont" shop in Bijela Zemlja, an area near the hamlet of Duratovići, they found the largest number of bodies and spent some time there collecting them. ${ }^{5862}$

1709. The group continued on towards Tukovi, and at the coffee production plant near the junction leading to Sredice, they picked up another 10 to 15 bodies. ${ }^{5863}$ Further along the road, at the Sredicko Polje sand pit, they retrieved another 15 to 25 bodies from the right hand side of the road, also with gunshot wounds. ${ }^{5864}$ Close to the turnpike at Tukovi, they found another two groups of bodies with gunshot wounds, including some women and children, who were 12, 13, and 14 years old. $^{5865}$

1710. At the check-point in Tukovi, KDZ094 parked the truck and got out, and some soldiers drove two of the three trucks, which were full of bodies, off in the direction of Sanski Most; KDZ094 heard Došen and Petrović complaining that they did not want to drive much further and that they would go somewhere "closer", which he interpreted to mean that they did not want to drive all the way to Tomašica, but would rather find somewhere closer to take the bodies. ${ }^{5866}$ The

\footnotetext{
5857 KDZ094, P706 (Transcript from Prosecutor v. Stakić), T. 5930, 5932-5933 (under seal); P592 (Photograph of orchard in Bišćani).

5858 KDZ094, P706 (Transcript from Prosecutor v. Stakić), T. 5882, 5936-5939 (under seal) [REDACTED]; see P593 (Photograph of a path).

5859 KDZ094, P706 (Transcript from Prosecutor v. Stakić), T. 5938-5939 (under seal).

5860 KDZ094, P706 (Transcript from Prosecutor v. Stakić), T. 5942 (under seal); KDZ038, P676 (Transcript from Prosecutor v. Stakić), T. 6862; see para. 1696.

5861 KDZ094, P706 (Transcript from Prosecutor v. Stakić), T. 5943 (under seal).

5862 KDZ094, P706 (Transcript from Prosecutor v. Stakić), T. 5944-5948 (under seal) [REDACTED]. See P1166 (Photograph of Diskont store marked by KDZ094); P1169 (Photograph of Diskont store marked by KDZ094). See para. 1700.

5863 KDZ094, P706 (Transcript from Prosecutor v. Stakić), T. 5948 (under seal) [REDACTED].

5864 KDZ094, P706 (Transcript from Prosecutor v. Stakić), T. 5948-5951 (under seal); see para. 1698. See also KDZ038, P676 (Transcript from Prosecutor v. Stakić), T. 6864, 6868-6869, 6872.

5865 KDZ094, P706 (Transcript from Prosecutor v. Stakić), T. 5951-5952 (under seal).

5866 KDZ094, P706 (Transcript from Prosecutor v. Stakić), T. 5934-5935, 5953-5956 (under seal); KDZ094, P706 (Transcript from Prosecutor v. Brđanin), T. 11854 (under seal) (further testifying that he noticed a "trip order"
} 
third truck was used to return the other Bosnian Muslim villagers, and the two armed Serbs, to the Hegići area. $^{5867}$

1711. On 24 July, six to eight young men who had been captured were brought to the check-point in Tukovi to help KDZ094 collect bodies; they went to the area of Sredicko Polje to resume collecting bodies. ${ }^{5868}$

1712. KDZ094 estimated that in two days, he collected between 300 to 350 bodies, all of which were Bosnian Muslims, as well as a few Bosnian Croats, who had been unarmed and wearing civilian clothes. ${ }^{5869}$ While many were from the Brdo area, there were also others who had been displaced from other areas and had taken shelter there. ${ }^{5870}$ The women, children, and elderly people who had remained in Bišćani and other villages went to Tukovi and were then transported to Travnik. 5871

1713. The Chamber considers that while it does not have specific evidence about the circumstances of each of the deaths of the 300 to 350 individuals whose bodies KDZ094 collected on 23 and 24 July 1992 in Bišćani and the surrounding villages, ${ }^{5872}$ the evidence before it establishes a pattern of killings on or around 20 July throughout this area. Furthermore, the Chamber finds that there was no armed activity in the area of Bišćani during this period. ${ }^{5873}$ Accordingly, the Chamber finds beyond reasonable doubt that most of these 300 to 350 individuals were non-Serb civilians who were deliberately killed by Serb Forces after the attack on the village of Bisćani and the surrounding hamlets.

1714. The Chamber also received forensic evidence to support the deaths of some identified individuals who were killed in the village of Bišćani and in the surrounding hamlets on or about 20 July $1992 .^{5874}$

in the truck which indicated the start point of the trip as the Zarko Zgonjanin barracks and the destination to be the area of Brdo and Tomašica).

5867 KDZ094, P706 (Transcript from Prosecutor v. Stakić), T. 5959 (under seal).

5868 KDZ094, P706 (Transcript from Prosecutor v. Stakić), T. 5959-5961 (under seal).

5869 KDZ094, P706 (Transcript from Prosecutor v. Brđanin), T. 11850-11852, 11864 (under seal); KDZ094, P706 (Transcript from Prosecutor v. Stakić), T. 5968-5972 (under seal) (providing a list with the names of 34 people who he recognised as among those whose bodies he collected); P587 (List of persons from Bišćani killed around 20 July 1992, identified by KDZ094). See also Adjudicated Fact 1071.

5870 KDZ094, P706 (Transcript from Prosecutor v. Stakić), T. 5966 (under seal).

5871 KDZ074, P709 (Transcript from Prosecutor v. Stakić), T. 2345.

5872 See paras. 1700, 1703, 1706-1709.

5873 See KDZ523, P4257 (Transcript from Prosecutor v. Brđanin), T. 21076, 21081-21082 (under seal).

5874 P4853 (Updated Table 2 to the Report of Amor Mašović), pp. 19, 22, 34, 36-37 (confirming the bodies of 34 men, and one body of an unknown gender, were exhumed from graves in Šurakovac, Čarakovo-Brđani, Bišćani, Rizvanovići, Redak-Ljubija, Sredice-Garaža, and Jakarina Kosa in 1998, 2000, 2001, and 2005); P4892 (BiH 
1715. Based on the above, the Chamber therefore finds that at least 300 non-Serbs, including civilians, were killed by Serb Forces in the village of Bišćani and in the surrounding hamlets of Hegići, Mrkalji, Ravine, Duratovići, Kadići, Lagići, and Čemernica on or about 20 July 1992.

\section{(c) Briševo}

1716. Briševo is a village in the local commune of Ljubija and is located to the south of Prijedor town. ${ }^{5875}$ Prior to the conflict, Briševo was inhabited mainly by Bosnian Croats. ${ }^{5876}$ The villages in the Ljubija commune were primarily comprised of Bosnian Croats, while within the town of Ljubija itself, Gornji Ljubija was almost purely Croat, and the other part, Donja Ljubija, was predominantly Bosnian Muslim. ${ }^{5877}$

1717. Briševo was first shelled on 27 May 1992 from the direction of the Serb villages of Rasavci and Oštra Luka; the shelling lasted the entire day but there was no physical damage to the village during this attack. ${ }^{5878}$ After the attack, Atlija, together with other men in the village, decided to send a delegation of five men to Rasavci and Oštra Luka to ask why they were being attacked. ${ }^{5879}$ When the delegation returned, they informed the villagers that the Serbs had issued an ultimatum requesting them to surrender their arms, and that if they failed to do so, the Serbs would search their houses. ${ }^{5880}$ The residents of Briševo only had five or six hunting rifles and a few pistols among them which they handed over to the Serbs; however, the Serb representatives demanded more weapons and said that houses would be searched and people would be killed. ${ }^{5881}$

State Commission for Tracing Missing Persons list of exhumed persons from Prijedor, Čelinac, Bosanski Novi, 29 October 2002), p. 2. See also P4850 (Witness statement of Amor Mašović dated 23 March 2012), Annex A, p. 9; P6689 (Excerpts from report on exhumations in Prijedor municipality, 28 August 2002), e-court pp. 20-24, 61, 72, 104, 108-111, 130-131, 139, 150, 152, 154, 157-158, 163, 166, 175-177, 189, 243-246, 249, 253; P6690 (Addendum to Nicolas Sébire's report, 16 May 2003), e-court p. 31 (identifying bodies exhumed from Jakarina Kosa in 2009).

P569 (Map of Prijedor municipality); Ivo Atlija, P3672 (Transcript from Prosecutor v. Stakić), T. 5547 (testifying that according to the 1991 census, Briševo was comprised of 120 houses). See also Adjudicated Fact 1086.

5876 Ivo Atlija, P3672 (Transcript from Prosecutor v. Stakić), T. 5546-5547. See also Adjudicated Fact 1086.

5877 Ivo Atlija, P3672 (Transcript from Prosecutor v. Stakić), T. 5544-5547.

5878 Ivo Atlija, P3672 (Transcript from Prosecutor v. Stakić), T. 5559-5561; Ivo Atlija, T. 20310 (20 October 2011), 20347 (26 October 2011). See also Adjudicated Fact 1087.

5879 Ivo Atlija, P3672 (Transcript from Prosecutor v. Stakić), T. 5561-5562.

5880 Ivo Atlija, P3672 (Transcript from Prosecutor v. Stakić), T. 5562; Ivo Atlija, T. 20347 (26 October 2011). See also Adjudicated Fact 1087.

5881 Ivo Atlija, P3672 (Transcript from Prosecutor v. Stakić), T. 5562-5565. See also Ivo Atlija, T. 20345-20346 (26 October 2011) (testifying further that all of the villagers' weapons had been handed over to the Serb authorities in Rasavci before the second attack and that "only when the Serb forces were absolutely sure that there's not a single rifle, not a single pistol, not a single bullet in our village, that's when we were attacked"); Adjudicated Fact 1087. 
1718. No one came to search houses in Briševo following the hand-over and the following weeks were relatively peaceful, although the village was completely blocked by Serb-manned checkpoints and no one could enter or leave for food or medicine. ${ }^{5882}$

1719. On 24 June 1992, a police van from Ljubija came to Briševo and three or four police officers took at least six male villagers from Briševo to be interviewed at the police station in Ljubija. $^{583}$ These men never returned to Briševo and Atlija later found out that they had been questioned and beaten in Ljubija, taken to Keraterm camp, then to Omarska, and finally to Manjača. ${ }^{5884}$

\section{(i) Scheduled Incident A.10.9}

1720. The Prosecution alleges that at least 68 people were killed in the village of Briševo between 23 July and 26 July 1992.

1721. On 23 July 1992, a Serb from Oštra Luka told Atlija and his cousin to leave Briševo because it would be "cleansed" the following day. ${ }^{585}$ However, they chose not to leave and Atlija was awoken by explosions at around 3:30 a.m. on 24 July 1992; Atlija ran to hide in a neighbours' cellar. ${ }^{5886}$ Infantry fire increased during the early hours; some people were killed, and the shelling continued until the evening of 25 July. ${ }^{587}$ That evening, Bosnian Serb infantry entered the village. ${ }^{5888}$ The soldiers wore JNA uniforms with red ribbons around their arms and some had red ribbons tied around their helmets. ${ }^{589}$ They identified themselves as "Serb soldiers" and told some of the inhabitants that if they went to their homes, nothing would happen to them. ${ }^{580}$ As a result, Atlija and the others who were hiding in the cellar dispersed. ${ }^{5891}$

1722. After 10 minutes, Atlija heard shouts from the Dimač house and ran towards it, seeing two soldiers engaged in discussion with Pero Dimač, a 65 year old man, and Atlija's mother. ${ }^{5892}$ The

\footnotetext{
5882 Ivo Atlija, P3672 (Transcript from Prosecutor v. Stakić), T. 5565-5566, 5659 (testifying that permits were necessary for non-Serbs to move around Prijedor and movement was very restricted).

5883 Ivo Atlija, P3672 (Transcript from Prosecutor v. Stakić), T. 5566-5568.

5884 Ivo Atlija, P3672 (Transcript from Prosecutor v. Stakić), T. 5568-5569 (testifying further that, as far as he knew, none of these men were actively involved in politics or leaders in the village).

5885 Ivo Atlija, P3672 (Transcript from Prosecutor v. Stakić), T. 5570-5571.

5886 Ivo Atlija, P3672 (Transcript from Prosecutor v. Stakić), T. 5571-5573. See also Ivo Atlija, T. 20310 (20 October 2011).

5887 Ivo Atlija, P3672 (Transcript from Prosecutor v. Stakić), T. 5573.

5888 Ivo Atlija, P3672 (Transcript from Prosecutor v. Stakić), T. 5573-5574. See also Adjudicated Fact 1089.

5889 Ivo Atlija, P3672 (Transcript from Prosecutor v. Stakić), T. 5573-5575. See also Adjudicated Fact 1089.

5890 Ivo Atlija, P3672 (Transcript from Prosecutor v. Stakić), T. 5575; Ivo Atlija, T. 20351-20352 (26 October 2011).

$5891 \quad$ Ivo Atlija, P3672 (Transcript from Prosecutor v. Stakić), T. 5577.

5892 Ivo Atlija, P3672 (Transcript from Prosecutor v. Stakić), T. 5577.
} 
soldiers wore JNA uniforms, as well as "Subara" hats with cockades, and carried different hunting knives than those weapons carried by regular JNA soldiers. ${ }^{5893}$ Atlija approached his mother, who was crying and shouting, and she told him that his father had been killed and that he should leave. ${ }^{5894}$ Atlija left his mother and ran to the woods from where he saw several hundreds of soldiers arrive in the village. ${ }^{585}$ The soldiers then locked his mother in the pigsty, threw Dimač to the ground, beat him with a bible they had found inside his house, shouted "let the Catholic Jesus help him now", and asked "why Tudjman wasn't helping him". ${ }^{896}$ They then set fire to the house and made Dimač take off his clothes and pray "according to the Catholic ritual"; they continued to beat and taunt him. ${ }^{5897}$ The soldiers eventually forced him to run between them and shot him in the head. ${ }^{5898}$

1723. From his hiding position in the woods, Atlija saw houses in the village burning and groups of soldiers, both JNA soldiers in uniforms with the JNA insignia and "Chetniks", passing by, shooting, and taking away looted property; over 100 houses in Briševo were destroyed during the attack. $^{5899}$

1724. The units involved in the attack on Briševo were units of the $1^{\text {st }}$ Krajina Corps, including the $6^{\text {th }}$ Krajina Brigade ${ }^{5900}$ and $5^{\text {th }}$ Kozara Brigade, as well as paramilitary units. ${ }^{5901}$ There were no

5893 Ivo Atlija, P3672 (Transcript from Prosecutor v. Stakić), T. 5577-5578 (testifying further that he could not tell if they were JNA soldiers, but it was quite usual for soldiers wearing this type of insignia to be "Chetniks", referring to paramilitary units from World War II). See also Adjudicated Fact 1089.

5894 Ivo Atlija, P3672 (Transcript from Prosecutor v. Stakić), T. 5578. See para. 1726.

5895 Ivo Atlija, P3672 (Transcript from Prosecutor v. Stakić), T. 5578-5579.

5896 Ivo Atlija, P3672 (Transcript from Prosecutor v. Stakić), T. 5579-5580.

5897 Ivo Atlija, P3672 (Transcript from Prosecutor v. Stakić), T. 5579-5580. See also Adjudicated Fact 1090.

5898 Ivo Atlija, P3672 (Transcript from Prosecutor v. Stakić), T. 5579-5581; Ivo Atlija, T. 20358-20363 (26 October 2011); D1818 (Excerpt of transcript from testimony of Ivo Atlija in Prosecutor v. Brđanin), T. 11967. See also Adjudicated Fact 1090; P3674 (Sketch drawn by Ivo Atlija) (showing Atlija's position in the woods in relation to Pero Dimač's house).

5899 Ivo Atlija, P3672 (Transcript from Prosecutor v. Stakić), T. 5582-5583; Vojislav Kuprešanin, T. 43531-43533 (14 November 2013), T. 43575 (15 November 2013). See also Adjudicated Facts 1275, 1276.

$5900 \quad$ See para. 1926.

5901 Ivo Atlija, P3672 (Transcript from Prosecutor v. Stakić), T. 5584-5587, 5637-5638; D1817 (Order of 6th Partisan Brigade, 18 June 1992), pp. 2-3; P3914 (Ewan Brown's expert report entitled "Military Developments in the Bosanska Krajina - 1992", 27 November 2002), paras. 1.100, 2.5; P3660 (Handwritten "War Record" of the $6^{\text {th }}$ Krajina Infantry Brigade, undated), p. 3; D1816 (Prijedor SJB dispatch to Banja Luka CSB, 18 May 1992); P2855 (VRS Main Staff report on paramilitary formations, 28 July 1992), p. 4. See also P3675 (Sketch drawn by Ivo Atlija); P3688 (Excerpt from video clip of aerial flyover of Prijedor); Vojislav Kuprešanin, T. 43532-43533 (14 November 2013). But see Ivo Atlija, P3672 (Transcript from Prosecutor v. Stakić), T. 56435644 (stating that Kuprešanin told Atlija after the attack that "a renegade group had committed" the killings in Briševo). The Chamber notes that in his final brief, the Accused argues that the soldiers involved in the attack on Briševo were not wearing the regular JNA uniforms and that Kuprešanin described the soldiers as a renegade group of the $6^{\text {th }}$ Sana Brigade, referring to Atlija's testimony which repeated Kuprešanin's statement in this regard. See Defence Final Brief, para. 1554, fn. 3528. However, the Chamber finds that members of at least the $6^{\text {th }}$ Krajina Brigade and the $5^{\text {th }}$ Kozara Brigade took part in the attack on the village of Briševo. In reaching that conclusion, the Chamber has considered the evidence before it. It also considered that the Accused only refers to evidence from Atlija recounting that Kuprešanin said the soldiers were a renegade group, whereas Kuprešanin 
announcements or warnings made on Radio Prijedor for villagers to surrender, or do otherwise, before the 24 July attack on Briševo, unlike in Hambarine and other villages. ${ }^{5902}$ Furthermore, there were no military units in Briševo and none of the residents were armed when the village was attacked on 24 July $1992 .{ }^{5903}$

1725. The majority of the Serb soldiers left Briševo the evening after the attack, taking with them 36 men. ${ }^{5904}$ Atlija later found out that this group of men was taken to Krings Hall in Sanski Most and that, after bribing someone, they were released from the camp alive after two months. ${ }^{5905}$

1726. The evening after the attack Atlija found his father's body, with three gunshot wounds to his back, about 15 to 20 metres away from his house. ${ }^{5906}$ Atlija buried his father and Dimač that evening in Mustanica. ${ }^{5907}$

1727. The following day, Atlija returned to the village and found 68 houses, out of 120 houses in the village, burnt to the ground. ${ }^{5908}$ In addition, the Catholic church in Briševo was burnt. ${ }^{5909}$

1728. In the weeks after the attack, Atlija went around Briševo and neighbouring hamlets and found piles of bodies, including in the Kurevo hills. ${ }^{5910}$ Atlija testified that, in total, 68 people were

in fact testified that the "army" was the perpetrator of the attack and of the killings in Briševo. See Vojislav Kuprešanin, T. 43532-43533 (14 November 2013).

5902 Ivo Atlija, P3672 (Transcript from Prosecutor v. Stakić), T. 5587.

5903 Ivo Atlija, T. 20351 (26 October 2011); Ivo Atlija, P3672 (Transcript from Prosecutor v. Stakić), T. 5562 (testifying further that the only weapons in Briševo were a few hunting rifles for which people had legal permits); Vojislav Kuprešanin, T. 43575 (15 November 2013). But see D1817 (Order of $6^{\text {th }}$ Partisan Brigade, 18 June 1992), p. 1. The Chamber notes that the Accused acknowledges in his final brief that in May 1992, "the Serbs received misinformation that the village of Briševo was armed" and that on 24 July 1992, Serb Forces entered Briševo and 68 people were killed during the attack. Defence Final Brief, para. 1554.

5904 Ivo Atlija, P3672 (Transcript from Prosecutor v. Stakić), T. 5589, 5597.

5905 Ivo Atlija, P3672 (Transcript from Prosecutor v. Stakić), T. 5597-5598. See also Defence Final Brief, para. 1554 (conceding that 36 people were taken to Krings in Sanski Most after the attack on Briševo).

5906 Ivo Atlija, P3672 (Transcript from Prosecutor v. Stakić), T. 5598, 5616.

5907 Ivo Atlija, P3672 (Transcript from Prosecutor v. Stakić), T. 5598. See P4853 (Updated Table 2 to the Report of Amor Mašović), p. 40; P3686 (Photograph of graves) (showing a gravestone with the name of Atlija's father).

5908 Ivo Atlija, P3672 (Transcript from Prosecutor v. Stakić), T. 5589-5592. Atlija confirmed the damage to the houses in Briševo in a number of photographs taken by someone else after the attack on the village. See P3677 (Photograph of destroyed house); P3678 (Photograph of destroyed house); P3680 (Photograph of destroyed house); P3682 (Photograph of destroyed house); P3688 (Excerpt from video clip of aerial flyover of Prijedor).

5909 Ivo Atlija, P3672 (Transcript from Prosecutor v. Stakić), T. 5589-5591, 5594-5595, 5635, 5638-5639. See P3676 (Photograph of church); P3689 (Video footage of destroyed buildings and monuments in Prijedor), 4:047:10; P3688 (Excerpt from video clip of aerial flyover of Prijedor). See also Adjudicated Fact 1290; P4070 (Attachment to the expert report of András J. Riedlmayer, entitled "Destruction of Cultural Heritage in BiH" prepared for the Karadžić case, formatted records), e-court pp. 255-258 (reporting also that the interior walls were defaced with Serbian graffiti reading "Šešelj"). See para. 1893.

5910 Ivo Atlija, P3672 (Transcript from Prosecutor v. Stakić), T. 5597-5599. 
killed during the course of the attack on Briševo, including 14 women, two males under 16 years old, and four invalids, and that in the days after, their bodies were lying around. ${ }^{5911}$

1729. Specifically, Atlija first found the remains of Stipo Dimač, an elderly man around 76 or 78 years old, as well as the bodies of Franjo Marijan and Mara Marijan, in a house in Dimanci. ${ }^{5912}$ Atlija then found at least six more bodies in a pile in Mlinari, who he helped bury. ${ }^{5913}$ Also in Mlinari and nearby the other pile, Atlija found a grave with at least six more bodies, including an invalid, and another grave with the body of Mara Mlinar, a 74 year old woman. ${ }^{5914}$

1730. In Buzuci, Atlija then found at least three more bodies, Milan Buzuk, Mate Buzuk, and Ivica Buzuk, an invalid, in front of a house. ${ }^{5915}$ Atlija next found in Jezerce the bodies with bullet wounds of Srećo Buzuk, Ivo Lovrić, Miroslav Buzuk, and Vlatko Buzuk, an invalid. ${ }^{5916}$ In Cengije, Atlija found the body of Marko Buzuk, which was badly burned from the waist down, and another grave with several bodies, including women. ${ }^{5917}$

5911 Ivo Atlija, P3672 (Transcript from Prosecutor v. Stakić), T. 5589, 5597; Vojislav Kuprešanin, T. 43531-43532, 43575 (14 November 2013) (testifying that between 63 and 88 people were killed in Briševo). See also Adjudicated Fact 1091. In his final brief, the Accused concedes that 68 people were killed after Serb Forces entered Briševo on 24 July 1992. See Defence Final Brief, para. 1554.

5912 Ivo Atlija, P3672 (Transcript from Prosecutor v. Stakić), T. 5602-5603; P4853 (Updated Table 2 to the Report of Amor Mašović), p. 39 (confirming that the bodies of Stipan Dimač, born in 1911, Franjo Marijan, and Mara Marijan were exhumed from a grave in Mlinari in 1998). The Chamber notes that Atlija refers to an individual named "Stipo Dimač", while Mašovic's report identifies a "Stipan Dimač". The Chamber considers this inconsistency to be minor and concludes that this is in fact the same individual.

5913 Ivo Atlija, P3672 (Transcript from Prosecutor v. Stakić), T. 5603-5605 (testifying further that he heard from eyewitnesses that these individuals had been made to dig their own graves).

5914 Ivo Atlija, P3672 (Transcript from Prosecutor v. Stakić), T. 5604-5605, 5611; P4853 (Updated Table 2 to the Report of Amor Mašović), p. 39 (confirming that, in total, the bodies of 12 people were exhumed from graves in Mlinari in 1998, including the body of Mara Mlinar).

5915 Ivo Atlija, P3672 (Transcript from Prosecutor v. Stakić), T. 5605-5606; Ivo Atlija, T. $20312-20313$ (20 October 2011); P4853 (Updated Table 2 to the Report of Amor Mašović), pp. 39-40, 44 (confirming that the bodies of Milan Buzuk, Mato Buzuk, and Ivo Buzuk were exhumed from graves in Briševo in 1998). The Chamber notes that there are some discrepancies between the forensic evidence and the evidence of Atlija regarding the names of some of the victims of Scheduled Incident A.10.9. More specifically, Atlija's testimony contains references to "Mate Buzuk" and "Ivica Buzuk", whereas Mašovic's report identifies the bodies of "Mato Buzuk" and "Ivo Buzuk". The Chamber considers these inconsistencies to be minor. Accordingly, the Chamber concludes that these are in fact the same individuals. The Chamber also notes that the report of Amor Mašović confirms that the bodies of two men named Mato Buzuk, born in different years, were exhumed from graves in Prijedor, one from Briševo in 1998 and one from Stara Rijeka in 1997. Although it is unclear to which "Mato Buzuk" Atlija is referring as being found in Buzuci, the Chamber is satisfied that the body of one man named Mato Buzuk was found in Buzuci by Atlija after the attack on Briševo on 24 July 1992.

5916 Ivo Atlija, P3672 (Transcript from Prosecutor v. Stakić), T. 5606; Ivo Atlija, T. 20313 (20 October 2011); P4853 (Updated Table 2 to the Report of Amor Mašović), p. 39 (confirming that the bodies of Srećo Buzuk, Ivo Lovrić, Miroslav Buzuk, and Vlatko Buzuk were exhumed from graves in Mlinari in 1998).

5917 Ivo Atlija, P3672 (Transcript from Prosecutor v. Stakić), T. 5606-5607, 5609-5610 (stating that eyewitnesses told him that one woman in Cengije had been raped and beaten until she died); P4853 (Updated Table 2 to the Report of Amor Mašović), p. 39 (confirming that the body of Marko Buzuk was exhumed from a grave in Raljaš in 1998). 
1731. In Mustanica, Atlija found and buried the body of Ante Matanović, another invalid, who had a bullet wound to the back. ${ }^{5918}$ Also in Mustanica, Atlija saw the body of Jozo Jakara lying near a church, but Atlja did not go close enough to the body to see how he died; Atlija was later told by an eyewitness that Jakara's throat had been slit with glass. ${ }^{5919}$ In Ivandići, Atlija next found several graves and the bodies of "practically the whole Ivandić family" with bullet wounds, including the bodies of Bato Ivandić, Sreto and Danica Ivandić, an elderly couple, Mara Ivandić, and several more women. ${ }^{5920}$ Atlija also testified that several members of the Komljen family were killed in Ivandići, including Luka Komljen, Ivo Komljen, Kaja Komljen, and another son. ${ }^{5921}$ On Raljaš Hill, Atlija found two individual graves, one with the body of Luka Mlinar, a 14 year old boy, and another with the body of Mirsad Švraka, a 14 or 15 year old boy. ${ }^{5922}$

1732. Finally, Atlija also saw a pile of 10 to 12 bodies under a tree in Stara Rijeka, all of whom seemed to be men around 20 years old. ${ }^{5923}$ The bodies appeared to have bullet holes in them. ${ }^{5924}$

1733. Atlija was able to bury some of the bodies he found in Briševo and the surrounding area after the attack with the help of other villagers who survived. ${ }^{525}$

5918 Ivo Atlija, P3672 (Transcript from Prosecutor v. Stakić), T. 5607-5608; Ivo Atlija, T. $20313-20314$ (20 October 2011); P4853 (Updated Table 2 to the Report of Amor Mašović), p. 40 (confirming that the body of Ante Matanović was exhumed from a grave in Begine Glavice in 1998).

5919 Ivo Atlija, P3672 (Transcript from Prosecutor v. Stakić), T. 5608; P4853 (Updated Table 2 to the Report of Amor Mašović), p. 40 (confirming that the body of Jozo Jakara was exhumed from a grave in Briševo in 1998).

5920 Ivo Atlija, P3672 (Transcript from Prosecutor v. Stakić), T. 5609; Ivo Atlija, T. 20315-20316 (20 October 2011); P4853 (Updated Table 2 to the Report of Amor Mašović), p. 40 (confirming that the bodies of Srećko Ivandić, Danica Ivandić, and Mara Ivandić were exhumed from graves in Prijedor and Zecovi in 1998). The Chamber notes that Atlija refers to an individual named "Sreto Ivandić" who he found in Ivandići, while Mašovic's report identifies a "Srećko Ivandić". The Chamber considers this inconsistency to be minor and concludes that this is in fact the same individual.

5921 Ivo Atlija, P3672 (Transcript from Prosecutor v. Stakić), T. 5610; Ivo Atlija, T. 20316-20317 (20 October 2011), T. 20363 (26 October 2011); P4853 (Updated Table 2 to the Report of Amor Mašović), p. 40 (confirming that the bodies of Luka Komljen, Ivo Komljen, Kata Komljen, and Ante Komljen were exhumed from graves in Zecovi and Rasavci in 1998). The Chamber notes that Atlija did not refer to the second Komljen son by name, while Mašovic's report identifies "Ante Komljen", who was born in 1956. The Chamber is satisfied that Ante Komljen is the second Komljen son listed by Atlija. The Chamber also notes that Atlija refers to "Kaja Komljen" as being killed in Ivandići, while Mašovic's report identifies a "Kata Komljen". The Chamber considers this inconsistency to be minor and concludes that this is in fact the same individual.

5922 Ivo Atlija, P3672 (Transcript from Prosecutor v. Stakić), T. 5610-5611; P4853 (Updated Table 2 to the Report of Amor Mašović), pp. 39-40 (confirming that the bodies of Luka Mlinar and Mirsad Švraka were exhumed from graves in Raljaš and Briševo in 1998). See Ivo Atlija, T. 20311 (20 October 2011); P3685 (Photograph of graves) (showing graves of Briševo victims buried at the Raljaš Catholic Church).

5923 Ivo Atlija, P3672 (Transcript from Prosecutor v. Stakić), T. 5601 (testifying that shortly after the attack on Briševo, Atlija heard from other villagers that a group of about 12 Bosnian Muslims passed through Briševo, and later Stara Rijeka, in the direction of Stari Majdan); P4853 (Updated Table 2 to the Report of Amor Mašović), p. 44 (confirming that the bodies of nine men between the ages of 16 and 46 years old were exhumed from a grave in Stara Rijeka in 1997).

5924 Ivo Atlija, P3672 (Transcript from Prosecutor v. Stakić), T. 5601-5602.

5925 Ivo Atlija, P3672 (Transcript from Prosecutor v. Stakić), T. 5598-5599. 
1734. The Chamber also received forensic evidence to support the deaths of at least 57 identified individuals who were killed in the village of Briševo and the surrounding areas between 24 and 26 July $1992 .^{5926}$

1735. Based on the above, the Chamber therefore finds that at least 68 people were killed by Serb Forces in the village of Briševo between 24 and 26 July 1992.

\section{(ii) $\underline{\text { Visit of ARK authorities to Stara Rijeka }}$}

1736. At the beginning of August 1992, representatives of the authorities of the ARK, including Kuprešanin and Nedeljko Rašula, President of the Sanski Most Municipal Assembly, visited Stara Rijeka accompanied by a bishop, Bishop Komarica, to attend an open meeting with several hundred villagers from the village of Stara Rijeka and surrounding villages, including Atlija. ${ }^{5927}$ Kuprešanin said that he had come, at the request of Bishop Komarica, to find out about the situation in the Sanski Most and Prijedor areas. ${ }^{5928}$ Kuprešanin stated that he had heard about some incidents in the area, but before that, he did not know that Croats lived in the area; furthermore, he said that everything was going to be fine as soon as they established a "Serb state" in BiH. ${ }^{5929}$ When Atlija challenged him during the meeting, informing him about what happened in Briševo, Kuprešanin replied that "such things occurred in wars", and that unfortunately the attack on Briševo and all of the killings had been carried out by a renegade group from the $6^{\text {th }}$ Brigade and were not directed against the Croats in the area, but rather against the Muslims in the area. ${ }^{5930}$ Bishop Komarica promised the villagers that they would receive humanitarian aid and encouraged them to stay in their villages. 5931

1737. One month later, Atlija had another meeting at the Ljubija church with Bishop Komarica and Kuprešanin. ${ }^{5932}$ Kuprešanin asked him if the situation in Briševo had improved and asked him

\footnotetext{
5926 P4853 (Updated Table 2 to the Report of Amor Mašović), pp. 39-40, 44 (confirming that 57 bodies of Bosnian Croat men and women from Briševo were exhumed from individual and mass graves in the areas of Briševo, Mlinari, Gravorac, Raljaš, Begine Glavice, Gornji Rasavci, Buzuci, Zecovi, Stara Rijeka, and Stari Majdan in 1997 and 1998); P3673 (Exhumation Report of Stari Majdan-Stara Rijeka mass graves, 16 June 1997), pp. 1-18 (confirming that the 16 bodies of individuals from Stara Rijeka and Moštanica were exhumed from several mass graves in Stari Majdan and Stara Rijeka and identified in 1997). Ivo Atlija, P3672 (Transcript from Prosecutor v. Stakić), T. 5641-5642, 5646-5647; Vojislav Kuprešanin, T. 43531-43533 (14 November 2013), T. 43575 (15 November 2013).

5928 Ivo Atlija, P3672 (Transcript from Prosecutor v. Stakić), T. 5643. The Chamber notes that Atlija was interpreted as saying "Sanska" during his testimony, but this most likely refers to "Sanski Most".

5929 Ivo Atlija, P3672 (Transcript from Prosecutor v. Stakić), T. 5643.

5930 Ivo Atlija, P3672 (Transcript from Prosecutor v. Stakić), T. 5643-5644. But see Vojislav Kuprešanin, T. 43532-43533 (14 November 2013) (testifying that the perpetrator of the mass killings in Briševo was the "army"). See also para. 1724.

5931 Ivo Atlija, P3672 (Transcript from Prosecutor v. Stakić), T. 5644-5646, 5648-5649, 5662.

5932 Ivo Atlija, P3672 (Transcript from Prosecutor v. Stakić), T. 5647.
} 
to present the issues to Milomir Stakić. ${ }^{533}$ Thus, a couple of days later, Atlija and two others went to Prijedor town and met with Stakić, and asked him for his help to leave the area. ${ }^{534}$ Stakić suggested that people from Briševo should move to abandoned houses in Bišćani but that he could not help them to leave the area because "they were being accused of ethnic cleansing already at that point". 5935 Atlija informed him they were not inclined to accept his offer and would continue to try to leave the area. ${ }^{5936}$

\section{(5) Detention facilities in Prijedor}

1738. From about 24 May 1992 until at least the end of September 1992, Bosnian Muslims and Bosnian Croats were detained at the Prijedor SJB Building, Omarska camp (“Omarska”), Keraterm camp ("Keraterm"), Trnopolje camp ("Trnopolje”), the Miška Glava community centre or "Dom" ("Miška Glava Dom”), the Ljubija football stadium ("Ljubija Football Stadium”), and the Prijedor JNA barracks ("Prijedor Barracks"). ${ }^{5937}$ The detention facilities in Prijedor were established by the Prijedor Crisis Staff, which was presided over by Stakić. ${ }^{5938}$ There was co-ordinated co-operation between the Crisis Staff and members of the Serb Forces in operating the detention facilities. ${ }^{5939}$ The Crisis Staff participated in overseeing security at the facilities, took decisions on the continuing detention of non-Serbs in Prijedor, provided transport, as well as the necessary fuel, for the transfer of detainees between the various detention facilities, and co-ordinated the provision of food for

\footnotetext{
5933 Ivo Atlija, P3672 (Transcript from Prosecutor v. Stakić), T. 5647-5648.

5934

5935

5936 Fact 1105. Defence witnesses Milomir Stakić and Slavko Budimir testified that the Crisis Staff did not participate in the establishment of Omarska, Keraterm, or Trnopolje and had no authority over the facility. D4195 (Witness statement of Milomir Stakić dated 16 November 2013), paras. 22-23, 48-49; Milomir Stakić, T. 45238-45240, 45242-45246, 45254 (17 December 2013); Slavko Budimir, D4463 (Transcript from Prosecutor v. Stakić), T. 12947-12958, 12964. However, the Chamber does not find this evidence to be convincing based on the credible evidence before the Chamber to the contrary which confirms that the Prijedor Crisis Staff was involved in the establishment of these detention facilities and in their operations.

See Scheduled Detention Facilities C.20.1, C.20.2, C.20.3, C.20.4, C.20.5, C.20.6, C.20.7. See also Adjudicated Facts 553, 1106. Stakić also testified that the Crisis Staff did not co-operate with members of the police and army in operating the camps; rather the police was in charge of Omarska and Keraterm, and the army was in charge of Tronopolje. Furthermore, Stakić stated that the police and army "turned to the [C]risis [S]taff for aid in food and medicines, just like the Red Cross". D4195 (Witness statement of Milomir Stakić dated 16 November 2013), para. 49. See also Slavko Budimir, D4463 (Transcript from Prosecutor v. Stakić), T. 12947-12958, 12964. However, the Chamber does not find this evidence to be convincing based on the credible evidence before the Chamber to the contrary which confirms that the Prijedor Crisis Staff was involved in the operations of the detention facilities in the municipality.
} 
detainees. ${ }^{5940}$ The Crisis Staff also prohibited the release of detainees from the detention facilities and prevented them from returning to their homes in Prijedor. ${ }^{5941}$

(a) Scheduled Detention Facility C.20.1

1739. The Indictment refers to the use of the Prijedor SJB Building as a detention facility in Prijedor municipality between 24 May and September $1992 .{ }^{5942}$

$\underline{\text { facility }}$

(i) Arrival of detainees and control over the detention

1740. Located in the town of Prijedor, the Prijedor SJB Building was used as a detention facility beginning on or around 26 May 1992 until approximately 24 June $1992 .{ }^{5943}$ During this period, Bosnian Muslims and Bosnian Croats, including many prominent men of the Prijedor community, as well as two women and a 13 or 14 year old boy, were detained there. ${ }^{5944}$

1741. The Prijedor SJB Building had two wings; two floors were on one side and three floors on the other, and a courtyard was at the back of the building. ${ }^{5945}$ The detention cell where detainees were held was located in an auxiliary building across the courtyard from the main building. ${ }^{5946}$

5940 See Scheduled Detention Facilities C.20.1, C.20.2, C.20.3, C.20.4, C.20.5, C.20.6, C.20.7; see Adjudicated Fact 1107.

5941 See Scheduled Detention Facilities C.20.1, C.20.2, C.20.3, C.20.4, C.20.5, C.20.6, C.20.7; see Adjudicated Fact 1108.

5942 In its Final Brief, the Prosecution notes that the evidence led in relation to the Prijedor SJB Building shows that it operated as a detention facility from approximately 26 May 1992 until around the end of June 1992. See Prosecution Final Brief, Appendix B, p. 38, fn. 548.

5943 P2095 (Map and photographs of Prijedor); Nusret Sivac, P3478 (Transcript from Prosecutor v. Stakić), T. 6619_ 6620, 6721; Nusret Sivac, T. 19610 (28 September 2011); KDZ026, T. 10313-10314 (17 January 2011) (closed session); KDZ026, P2089 (Transcript from Prosecutor v. Stakić), T. 1799-1800, 1847-1848 (under seal); P3528 (Witness statement of Kerim Mešanović, undated), pp. 23-25; Mevludin Sejmenović, T. 20491-20492 (27 October 2011); KW609, D4246 (Transcript from Prosecutor v. Stanišić \& Župljanin), T. 16726-16727.

5944 Nusret Sivac, P3478 (Transcript from Prosecutor v. Stakić), T. 6619-6620, 6623, 6723; KDZ026, P2089 (Transcript from Prosecutor v. Stakić), T. 1849 (under seal); P3528 (Witness statement of Kerim Mešanović, undated), pp. 4-5, 24; Mevludin Sejmenović, T. 20454-20455, 20491-20492 (27 October 2011); KW609, D4246 (Transcript from Prosecutor v. Stanišić \& Župljanin), T. 16727; P5528 (Report of Prijedor SJB, June 1992), p. 6. See also Adjudicated Fact 1109. However, Defence witnesses Dušan Janković and Zdravko Torbica testified that women and minors were never taken into custody at the Prijedor SJB Building. D4228 (Witness statement of Zdravko Torbica dated 18 January 2014), para. 11; Dušan Janković, T. 47283-47284 (18 February 2014). The Chamber, however, does not rely on their evidence on this issue. In reaching that conclusion, the Chamber considers that Janković and Torbica contradicted themselves on several occasions. The Chamber further considers the body of credible evidence before it which demonstrates that women and a minor were detained at the Prijedor SJB Building.

5945 Nusret Sivac, T. 19609 (28 September 2011); P3528 (Witness statement of Kerim Mešanović, undated), p. 14. See also P2090 (Photograph of Prijedor SJB Building).

5946 KW609, D4246 (Transcript from Prosecutor v. Stanišić \& Župljanin), T. 16727; P3528 (Witness statement of Kerim Mešanović, undated), p. 14; KDZ026, P2089 (Transcript from Prosecutor v. Stakić), T. 1848-1849 (under seal). Before its use as a detention facility, the detention cell was used by the SJB to hold prisoners before they attended misdemeanour court, as there was no prison in Prijedor. Nusret Sivac, T. 19610 (28 September 2011); Slavko Budimir, D4463 (Transcript from Prosecutor v. Stakić), T. 12947. 
1742. Before being brought to the Prijedor SJB Building, detainees were arrested by members of the Prijedor SJB, including Ranko "Bato" Kovačević. 5947 Once there, they were held in the detention cell and guarded by members of the intervention squad. ${ }^{5948}$

(ii) Conditions of detention and treatment of detainees

1743. The cell in which detainees were held was small, and there were no windows; the only source of light was a tiny hole in the wall. ${ }^{5949}$ In that cell, there was a bed frame and a couple of blankets. ${ }^{5950}$ There were no toilet facilities; there was only a bag which was used in place of a toilet. $^{5951}$

1744. Detainees were generally held at the Prijedor SJB Building for a short period and were mistreated during their detention. ${ }^{5952}$ Nusret Sivac was arrested on 20 June 1992 and taken to the Prijedor SJB Building. ${ }^{5953} \mathrm{He}$ and a group of other detainees, including two women, a 13 or 14 year old boy and a prominent Muslim doctor, Osman Mahmuljin, were forced to gather in the courtyard. ${ }^{5954}$ Members of the intervention squad, including Rade Strika, ordered the detainees to remove their belts and the laces from their shoes. ${ }^{5955}$ The detainees were then forced to run a gauntlet formed by members of the intervention squad who proceeded to savagely beat the

5947 Nusret Sivac, P3478 (Transcript from Prosecutor v. Stakić), T. 6619; KDZ026, T. 10313 (17 January 2011) (closed session); P3528 (Witness statement of Kerim Mešanović, undated), p. 23. According to KW609, these arrests were for the purpose of interrogating people suspected of illegally procuring fire-arms, in order to prevent large-scale disturbances to law and order. KW609, D4246 (Transcript from Prosecutor v. Stanišić \& Župljanin), T. 16726-16727. However, Nusret Sivac testified that while he was held at the Prijedor SJB Building, no interviews were conducted or statements taken from detainees; moreover, according to him, people were just arrested in the street if they ran into a Serb patrol or were recognised as Muslim. Nusret Sivac, T. 19640 (30 September 2011).

5948 KDZ026, P2089 (Transcript from Prosecutor v. Stakić), T. 1849-1850 (under seal).

5949 Nusret Sivac, T. 19610 (28 September 2011); Kerim Mešanović, T. 19837 (4 October 2011); KDZ026, T. 10385 (17 January 2011) (closed session).

5950 Kerim Mešanović, T. 19837 (4 October 2011); KDZ026, T. 10385 (17 January 2011) (closed session).

5951 Kerim Mešanović, T. 19837 (4 October 2011); KDZ026, T. 10385 (17 January 2011) (closed session).

5952 Nusret Sivac, P3478 (Transcript from Prosecutor v. Stakić), T. 6619-6621, 6626, 6721-6723; KDZ026, P2089 (Transcript from Prosecutor v. Stakić), T. 1847-1848, 1850-1851 (under seal); KDZ026, T. 10314-10315 (17 January 2011) (closed session); P3528 (Witness statement of Kerim Mešanović, undated), pp. 24-26; Mevludin Sejmenović, T. 20492 (27 October 2011). See also Adjudicated Fact 1110.

5953 Nusret Sivac, P3478 (Transcript from Prosecutor v. Stakić), T. 6619, 6721; Nusret Sivac, T. 19610 (28 September 2011). Sivac was first arrested on 10 June 1992 and taken to Omarska due to an administrative error because, in fact, his sister, Nusreta Sivac's, name was on the list instead of his. When the mistake was discovered, he was transported back to the Prijedor SJB Building and he returned home. Nusret Sivac, P3478 (Transcript from Prosecutor v. Stakić), T. 6608-6609, 6614, 6721; Nusret Sivac, T. 19610 (28 September 2011). Nusreta Sivac turned herself in to the Prijedor SJB Building after being told to report there, but she never entered the building and was transported to Omarska the same day. Nusreta Sivac, T. 20401-20402 (26 October 2011); Nusreta Sivac, T. 20405 (26 October 2011) (private session).

5954 Nusret Sivac, P3478 (Transcript from Prosecutor v. Stakić), T. 6619-6620, 6623, 6626 (further explaining that Mahmuljin had been falsely accused of trying to kill a patient on Radio Prijedor prior to his arrest).

5955 Nusret Sivac, P3478 (Transcript from Prosecutor v. Stakić), T. 6620. 
detainees with metal rods. ${ }^{5956}$ Following these beatings, the detainees were locked in the detention cell until they heard members of the intervention squad shout: "The doctor didn't get enough". ${ }^{5957}$ Members of the intervention squad then rushed into the cell and again beat the detainees. ${ }^{5958}$ One of the detainees was struck on the head with a metal rod. ${ }^{595}$ Members of the intervention squad threatened to kill Mahmuljin and they beat him the worst. ${ }^{5960}$ At one point, he fainted and later it was confirmed that his left arm had been fractured in several places. ${ }^{5961}$ That evening, the detainees were forced to board a police van and were taken to Omarska. ${ }^{5962}$ Sivac and two other detainees had to drag Mahmuljin into the vehicle as he could not move after the beatings. ${ }^{5963}$

1745. Kerim Mešanović was arrested on the morning of 24 June 1992 and held in the detention cell with seven other detainees. ${ }^{5964}$ Later that day, one of the detainees, Nihad Basić, was taken out by the intervention squad, subjected to ethnic slurs, and beaten. ${ }^{5965}$ When he returned, he was covered in blood. ${ }^{596}$ In the evening, the detainees were removed from the cell and lined up against the wall outside where they were searched again and forced to make a three-finger salute. ${ }^{5967}$ The detainees were then ordered to run a gauntlet formed by the intervention squad towards the police van. $^{5968}$ Members of the intervention squad yelled ethnic slurs and beat the detainees as they

5956 Nusret Sivac, P3478 (Transcript from Prosecutor v. Stakić), T. 6620. The members of the intervention squad included Darko Mrđa and Zoran Babić. Nusret Sivac, P3478 (Transcript from Prosecutor v. Stakić), T. 6620. See also Adjudicated Facts 1110, 1113. However, Defence witness Dušan Janković testified that there was no gauntlet at the Prijedor SJB Building. Dušan Janković, T. 47286-47287 (18 February 2014). The Chamber does not find this evidence to be convincing. In reaching that conclusion, the Chamber considers that Janković contradicted himself and evaded questions on several occasions and that there is significant evidence before the Chamber which confirms that detainees were forced to run a gauntlet while held at the Prijedor SJB Building. Nusret Sivac, P3478 (Transcript from Prosecutor v. Stakić), T. 6620-6621.

Nusret Sivac, P3478 (Transcript from Prosecutor v. Stakić), T. 6620-6621.

Nusret Sivac, P3478 (Transcript from Prosecutor v. Stakić), T. 6621.

Nusret Sivac, P3478 (Transcript from Prosecutor v. Stakić), T. 6621 (testifying that they threatened to kill Mahmuljin so that he would "never get a chance to kill Serb children again").

Nusret Sivac, P3478 (Transcript from Prosecutor v. Stakić), T. 6621 (testifying that Mahmuljin's arm fracture was confirmed later by Dr. Sadiković when Sivac and Mahmuljin met him at Omarska).

Nusret Sivac, P3478 (Transcript from Prosecutor v. Stakić), T. 6621. See also Adjudicated Fact 1112.

Nusret Sivac, P3478 (Transcript from Prosecutor v. Stakić), T. 6621.

P3528 (Witness statement of Kerim Mešanović, undated), pp. 14, 23-26; KDZ026, T. 10313-10315 (17 January 2011) (closed session); KDZ026, P2089 (Transcript from Prosecutor v. Stakić), T. 1847-1849, 1851-1852 (under seal).

KDZ026, T. 10314 (17 January 2011) (closed session); KDZ026, P2089 (Transcript from Prosecutor v. Stakić), T. 1850-1851 (under seal). However, Mešanović stated that no one was touched or called out of the cell until the evening. P3528 (Witness statement of Kerim Mešanović, undated), p. 24. See also Defence Final Brief, confidential, para. 1556. [REDACTED].

KDZ026, T. 10314 (17 January 2011) (closed session); KDZ026, P2089 (Transcript from Prosecutor v. Stakić), T. 1850-1851 (under seal).

P3528 (Witness statement of Kerim Mešanović, undated), pp. 24-25; KDZ026, T. 10314-10315 (17 January 2011) (closed session); KDZ026, P2089 (Transcript from Prosecutor v. Stakić), T. 1851 (under seal).

KDZ026, T. 10314-10315 (17 January 2011) (closed session); KDZ026, P2089 (Transcript from Prosecutor v. Stakić), T. 1851 (under seal); P3528 (Witness statement of Kerim Mešanović, undated), p. 25. 
ran. ${ }^{5969}$ Mešanović fell and was kicked in the head, losing four teeth from the blows. ${ }^{5970}$ Once the detainees were seated in the van, they were so afraid that they held hands. ${ }^{5971}$ This group of detainees was then transferred to Omarska on 24 June 1992 around 10 p.m. ${ }^{5972}$

1746. All of the non-Serb male detainees held at the Prijedor SJB Building were transferred either to Omarska or Keraterm camps. ${ }^{5973}$

\section{(iii) $\underline{\text { Conclusion }}$}

1747. Based on the above, the Chamber finds that non-Serb civilians, including women and a minor, were detained at the Prijedor SJB Building by Bosnian Serb Forces between around 26 May and 24 June 1992. Detainees were held in a small cell for up to two days in poor conditions before being transferred to Omarska or Keraterm camps. The Chamber also finds that detainees were subjected to severe beatings by Bosnian Serb Forces.

\section{B.15.2}

(b) Scheduled Detention Facility C.20.2 and Scheduled Incident

1748. The Indictment refers to the use of Omarska as a detention facility in Prijedor municipality between 15 May and 21 August 1992. The Prosecution alleges that a number of people were killed at Omarska and at various places after they were taken from the camp between 27 May and 21 August 1992.

facility

(i) Arrival of detainees and control over detention

1749. The village of Omarska is located to the southeast of Prijedor town, on the train line to Banja Luka. ${ }^{574}$ Omarska was located at the Ljubija iron-ore mine, about two kilometres to the south of Omarska village. ${ }^{5975}$ Omarska operated as a detention facility from 25 May 1992 until

\footnotetext{
5969 P3528 (Witness statement of Kerim Mešanović, undated), p. 25; KDZ026, T. 10315 (17 January 2011) (closed session); KDZ026, P2089 (Transcript from Prosecutor v. Stakić), T. 1851 (under seal).

5970 P3528 (Witness statement of Kerim Mešanović, undated), p. 25; KDZ026, T. 10315 (17 January 2011) (closed session); KDZ026, P2089 (Transcript from Prosecutor v. Stakić), T. 1851 (under seal).

5971 KDZ026, T. 10315 (17 January 2011) (closed session); KDZ026, P2089 (Transcript from Prosecutor v. Stakić), T. 1851-1852 (under seal).

5972 P3528 (Witness statement of Kerim Mešanović, undated), p. 26; KDZ026, T. 10314-10315 (17 January 2011$)$ (closed session); KDZ026, P2089 (Transcript from Prosecutor v. Stakić), T. 1852 (under seal).

5973 Nusret Sivac, P3478 (Transcript from Prosecutor v. Stakić), T. 6608-6609 (testifying that on his first arrest, he was brought to the Prijedor SJB Building courtyard and then was transported to the Keraterm administration building); Mevludin Sejmenović, T. 20491-20492 (27 October 2011); KW609, D4246 (Transcript from Prosecutor v. Stanišić \& Župljanin), T. 16727-16728 [REDACTED]. See Adjudicated Facts 1111, 1112.

5974 P569 (Map of Prijedor municipality).

5975 See Adjudicated Fact 1116; KDZ048, P678 (Transcript from Prosecutor v. Stakić), T. 3355 ; P536 (Photograph of model of Omarska); P543 (Aerial photograph of Omarska).
} 
21 August 1992, ${ }^{5976}$ holding as many as 3,000 detainees at one time, primarily Bosnian Muslim and Bosnian Croat men. ${ }^{5977}$ Boys as young as 15 were detained at Omarska, as well as some elderly and physically and/or mentally impaired individuals. ${ }^{5978}$ In addition, approximately 40 women were held at Omarska; they were kept in the canteen during the day to help with the preparation of the food. ${ }^{5979}$ Prominent members of the Bosnian Muslim and Bosnian Croat local communities, including women involved in local affairs, were detained at Omarska. ${ }^{5980}$

1750. Detainees at Omarska were either transferred from other camps, such as Trnopolje or Keraterm, or were arrested in different areas of Prijedor municipality. ${ }^{591}$ Various buildings in the mine complex were used to house detainees, including a hangar, the largest of four buildings at the camp, the administration building, and two smaller structures, known as the "white house" and the "red house", which was at the edge of the compound. ${ }^{5982}$ To the north of the hangar and separated by an open concrete area, known as the "pista", was the administration building, which contained a kitchen, an eating area, as well as sleeping quarters for female detainees, and offices upstairs used,

5976 D470 (CSB Banja Luka Report concerning collection centres, undated), e-court pp. 4, 30; P6585 (SRNA press release, 22 August 1992); see Adjudicated Facts 1116, 1124.

5977 D470 (CSB Banja Luka Report concerning collection centres, undated), e-court pp. 4, 30-31 (reporting that between 27 May and 16 August 1992, a total of 3,334 people were brought to Omarska); P5528 (Report of Prijedor SJB, June 1992), p. 5; Nusreta Sivac, T. 20406 (26 October 2011); KDZ026, P2089 (Transcript from Prosecutor v. Stakić), T. 1897, 1902, 1904 (under seal); KDZ026, T. 10378 (17 January 2011) (closed session). See Adjudicated Facts 1117, 1118 (stating that the only Serb prisoners held at Omarska were said to have been there because they were "on the side of the Muslims"); KW609, D4246 (Transcript from Prosecutor v. Stanišic \& Župljanin), T. 16751. But see Željko Mejakić, T. 44280 (29 November 2013) (testifying that the total number of people held at Omarska was 3,400, but that there was never a time when it held 3,000 people at one time).

5978 Nusret Sivac, P3478 (Transcript from Prosecutor v. Stakić), T. 6630-6633; KDZ026, P2089 (Transcript from Prosecutor v. Stakić), T. 1904, 1908 (under seal). See also Adjudicated Facts 1119, 1122, 1182.

5979 Nusreta Sivac, T. 20406 (26 October 2011); see Adjudicated Facts 1117, 1119, 1167; KDZ026, P2089 (Transcript from Prosecutor v. Stakić), T. 1899-1900 (under seal); KDZ026, T. 10319 (17 January 2011) (closed session). See also Miroslav Kvočka, T. 45601-45602 (20 January 2014); KW609, D4246 (Transcript from Prosecutor v. Stanišić \& Župljanin), T. 16920.

5980 KDZ026, P2089 (Transcript from Prosecutor v. Stakić), T. 1903-1905 (under seal); P3528 (Witness statement of Kerim Mešanović, undated), pp. 40-41. See Adjudicated Facts 1119, 1120, 1121, 1188. Prominent Bosnian Muslims and Bosnian Croats detained at Omarska included political leaders, such as Professor Muhamed Čehajić, the mayor of Prijedor prior to the take-over, members of the police, doctors, lawyers and judges, professors, and businessmen. KDZ026, P2089 (Transcript from Prosecutor v. Stakić), T. 1903-1905, 19091921 (under seal); Nusret Sivac, P3478 (Transcript from Prosecutor v. Stakić), T. 6630, 6633-6634, 6680, 6684-6687; P3691 (Witness statement of Nusreta Sivac dated 22 October 2011), pp. 38-39, 57-58 (under seal); P3528 (Witness statement of Kerim Mešanović, undated), p. 31; KDZ048, P678 (Transcript from Prosecutor v. Stakić), T. 3365-3370; Mirsad Mujadžić, P3703 (Transcript from Prosecutor v. Stakić), T. 3736-3737.

5981 P3691 (Witness statement of Nusreta Sivac dated 22 October 2011), p. 9 (under seal); KDZ392, P707 (Transcript from Prosecutor v. Kvočka), T. 2648 (under seal); Mevludin Sejmenović, T. 20492-20493 (27 October 2011); KDZ074, P709 (Transcript from Prosecutor v. Stakić), T. 2316; P711 (Witness statement of KDZ074 dated 23 September 1994), e-court p. 12; KDZ026, P2089 (Transcript from Prosecutor v. Stakić), T. 1848-1852 (under seal).

5982 KDZ048, P678 (Transcript from Prosecutor v. Stakić), T. 3410-3412; P543 (Aerial photograph of Omarska); P2091 (Video footage of Omarska and the white house); KDZ093, P705 (Transcript from Prosecutor v. Kvočka), T. 6232; KDZ026, T. 10315-10317 (17 January 2011) (closed session); P2101 (Excerpt of documentary re Prijedor, with transcript) (under seal); KDZ026, P2089 (Transcript from Prosecutor v. Stakić), T. 1926-1928 (under seal); P6593 (Aerial photograph of Omarska marked by Miroslav Kvočka); Miroslav Kvočka, T. 45603-45605 (20 January 2014). See Adjudicated Facts 1159, 1160. 
inter alia, for interrogation. ${ }^{5983}$ There was also a small garage to the far north of the administration building and a grassy area to the west of the hangar. ${ }^{5984}$

1751. Omarska was established by the Prijedor Crisis Staff through a written order issued by Drljača on 31 May 1992. ${ }^{5985}$ As Chief of the SJB in Prijedor, Drljača ordered that security at the camp be provided by the Omarska SJB under the command of Omarska SJB commander Mejakić. ${ }^{5986}$ Dušan Janković was Mejakić's superior and was directly subordinated to Drljača and supervised the implementation of Drljača's 31 May 1992 order in Omarska. ${ }^{5987}$ Miroslav Kvočka, patrol sector leader in the Omarska SJB, was delegated the authority to activate the reserve police force in order to serve as guards in the camps. ${ }^{5988}$ Members of the VRS formed an external security ring around Omarska and members of the TO staffed posts in a second ring and were tasked with preventing unauthorised persons from entering the camp and ensuring that detainees did not escape. ${ }^{5989}$

5983 KDZ048, P678 (Transcript from Prosecutor v. Stakić), T. 3410; KDZ026, P2089 (Transcript from Prosecutor v. Stakić), T. 1876-1877 (under seal); P543 (Aerial photograph of Omarska); D4413 (Diagram of administration building in Omarska); KDZ093, P705 (Transcript from Prosecutor v. Kvočka), T. 6201, 6206-6208 (stating that female detainees were detained on the first floor of the "restaurant building" in the former offices). See P611 (Plan of first floor of restaurant building in Omarska marked by KDZ093) (on which KDZ093 marked with a "U" the room in which she slept in the restaurant building); Adjudicated Facts 1161, 1162 1163, 1166. KDZ048, P678 (Transcript from Prosecutor v. Stakić), T. 3410; P543 (Aerial photograph of Omarska); see Adjudicated Facts 1163, 1166.

5985 P2640 (Prijedor SJB report, 31 May 1992); D470 (CSB Banja Luka Report concerning collection centres, undated), e-court pp. 3-4, 29, 32; P2637 (Report of Prijedor SJB, 1 July 1992); D4138 (Witness statement of Željko Mejakić dated 26 November 2013), pp. 3, 4; D4219 (Witness statement of Miroslav Kvočka dated 17 January 2014), para. 38; see Adjudicated Facts 1105, 1115, 1124, 1126, 1131. [REDACTED].

5986 P2640 (Prijedor SJB report, 31 May 1992), pp. 1-2; D4138 (Witness statement of Željko Mejakić dated 26 November 2013), pp. 1, 6; D4219 (Witness statement of Miroslav Kvočka dated 17 January 2014), paras. 6, 9, 38; KW609, D4246 (Transcript from Prosecutor v. Stanišić \& Župljanin), T. 16730-16731; Nusret Sivac, P3478 (Transcript from Prosecutor v. Stakić), T. 6616-6617; P3691 (Witness statement of Nusreta Sivac dated 22 October 2011), p. 10 (under seal); D470 (CSB Banja Luka Report concerning collection centres, undated), ecourt pp. 4, 29-30, 32; see Adjudicated Facts 1115, 1125, 1128, 1129, 1132, 1133. See also Željko Mejakić, T. 44215, 44232-44233 (29 November 2013); P5520 (List of individuals providing security at Omarska, 21 June 1992).

5987 D4219 (Witness statement of Miroslav Kvočka dated 17 January 2014), paras. 6, 9; Miroslav Kvočka, T. 45580 (20 January 2014); Dušan Janković, T. 47280-47282 (18 February 2014); KW609, D4246 (Transcript from Prosecutor v. Stanišić \& Župljanin), T. 16745-16746. See also Adjudicated Fact 1130 (stating that Janković's duties in regard to implementing Drljača's order were to be carried out "in collaboration with the Banja Luka [CSB]"), 1131, 1132. But see Dušan Janković, T. 47275-47278 (18 February 2014) (testifying that the security of Omarska could not have been overseen by the police station in Omarska because there was no such police station, only a reserve police station; moreover, the administration at Omarska could only receive orders from the Crisis Staff or someone higher up than Drljača; and finally that he never visited Omarska personally and did not have any connection to Drljača's order). However, the Chamber does not find Janković's evidence on this issue to be reliable, in light of the accepted testimony of Kvočka, who was stationed at Omarska during the relevant period. In reaching this conclusion, the Chamber also considered that Janković's evidence in this regard was contradictory; he was also evasive and lacked sincerity.

5988 D4219 (Witness statement of Miroslav Kvočka dated 17 January 2014), para. 9; see Adjudicated Facts 1133, 1134. See also D4219 (Witness statement of Miroslav Kvočka dated 17 January 2014), paras. 21-26.

5989 Željko Mejakić, T. 44232 (29 November 2013); D4219 (Witness statement of Miroslav Kvočka dated 17 January 2014), para. 38; see Adjudicated Fact 1137. 
1752. Drljača further ordered mixed teams of investigators, comprised of representatives from civilian public security, state security, and military security, to interrogate and categorise detainees at Omarska. ${ }^{590}$ Mejakić and the heads of the interrogation teams reported to Drljača every day pursuant to his order. ${ }^{5991}$

1753. Following interrogation, detainees were grouped into three categories. ${ }^{5992}$ The first category was to be comprised of individuals who were suspected of "the gravest crimes" and who had directly organised or participated in "armed rebellion". ${ }^{5993}$ However in practice, the first category also included intellectuals and political leaders from the Bosnian Muslim and Bosnian Croat communities. $^{5994}$ The second category included individuals who had supported or assisted detainees in the first category in the armed rebellion, while the third category encompassed detainees who were of "no security interest", or the "least guilty", including women and children, and who were to be eventually released. ${ }^{5995}$

\section{(ii) $\underline{\text { Conditions of detention }}$}

1754. Conditions at Omarska were appalling. The food was grossly insufficient, the medical care was inadequate, and the hygiene facilities were poor. ${ }^{5996}$ Some days, the detainees received no

5990 P2640 (Prijedor SJB report, 31 May 1992), p. 1; see Adjudicated Facts 1126, 1128, 1162; D470 (CSB Banja Luka Report concerning collection centres, undated), e-court pp. 3, 6, 29, 32. See also KDZ026, P2089 (Transcript from Prosecutor v. Stakić), T. 2049 (under seal); KDZ026, T. 10386 (17 January 2011) (closed session). Drljača's order assigned responsibility to co-ordinate the work of the investigators to Ranko Mijić, Mirko Ješić, and Lieutenant Colonel Majstorović. P2640 (Prijedor SJB report, 31 May 1992), p. 1; see Adjudicated Fact 1127.

5991 D4138 (Witness statement of Željko Mejakić dated 26 November 2013), paras. 18-19; Željko Mejakić, T. 44231-44232 (29 November 2013); see P2640 (Prijedor SJB report, 31 May 1992), p. 3.

5992 D470 (CSB Banja Luka Report concerning collection centres, undated), e-court pp. 4, 30; P3549 (Report of the Commission for Inspecting Collection Centres and Other Facilities for Captives in the ARK, 17 August 1992), p. 4; see Adjudicated Fact 1120; Željko Mejakić, T. 44229 (29 November 2013); KDZ523, P4257 (Transcript from Prosecutor v. Brđanin), T. $21106-21109$ (under seal).

5993 D470 (CSB Banja Luka Report concerning collection centres, undated), e-court pp. 4, 30; P3549 (Report of the Commission for Inspecting Collection Centres and Other Facilities for Captives in the ARK, 17 August 1992), p. 4; [REDACTED].

5994 P3528 (Witness statement of Kerim Mešanović, undated), pp. 40-41, 54; Kerim Mešanović, T. 19852 (4 October 2011). See also Adjudicated Fact 1120; D4251 (List of persons detained at Omarska, 23 July 1992).

5995 D470 (CSB Banja Luka Report concerning collection centres, undated), e-court pp. 4, 30; P3549 (Report of the Commission for Inspecting Collection Centres and Other Facilities for Captives in the ARK, 17 August 1992), p. 4; P3528 (Witness statement of Kerim Mešanović, undated), pp. 40-41; [REDACTED]. See also Adjudicated Fact 1120; KDZ523, P4257 (Transcript from Prosecutor v. Brđanin), T. 21107, 21119 (under seal).

5996 P3528 (Witness statement of Kerim Mešanović, undated), pp. 27, 49-50, 70-71; Mevludin Sejmenović, T. 20494-20495 (27 October 2011); KDZ074, P709 (Transcript from Prosecutor v. Stakić), T. 2338-2339; KDZ048, P678 (Transcript from Prosecutor v. Stakić), T. 3370. See also Željko Mejakić, T. 44223-44224 (29 November 2013); Miroslav Kvočka, T. 45586, 45613-45614 (20 January 2014); D4138 (Witness statement of Željko Mejakić dated 26 November 2013), para. 14; D3645 (Witness statement of Nenad Kecmanović dated 27 May 2013), para. 54. But see Željko Mejakić, T. 44285-44286 (29 November 2013) (testifying that some medical care was offered at Omarska by one of the detainees, as well as another doctor who visited Omarska every day); D4388 (Witness statement of Momčilo Gruban dated 31 January 2014), para. 23 (stating that medical staff came to Omarska in order to disinfect detainees' rooms); Momčilo Gruban, T. 47486 (20 February 
food at all. ${ }^{5997}$ Groups of about 30 men at a time were taken to the canteen to receive their daily meal, and had to eat in under two minutes to avoid being beaten. ${ }^{5998}$ Nevertheless, detainees were often beaten in the canteen, to the point they could not walk and had to be carried. ${ }^{599}$ Detainees often chose to skip meals in order to avoid the beatings that accompanied them. ${ }^{6000}$ Sejmenović recounted how the arms of a 13 year old boy were broken so badly that he had to be carried into the canteen and fed by other detainees. ${ }^{6001}$ Many detainees lost between 20 to 30 kilograms during their detention, others lost considerably more. ${ }^{602}$ Serb nationalist songs were loudly and continuously played over speakers. ${ }^{6003}$ Detainees were denied drinking water for long periods and when water was provided, it was not potable. ${ }^{6004}$ This caused the detainees intestinal problems. ${ }^{6005}$

1755. The detainees had only occasional access to water for washing, and were given no soap or toothpaste, or any change of clothing. ${ }^{6006}$ Their access to toilet facilities was also limited, depending on which room they were held in; detainees had to wait hours before being allowed to use them, and sometimes risked being beaten if they asked. ${ }^{6007}$ Detainees were often forced to excrete and urinate in their rooms. ${ }^{6008}$ Skin diseases were prevalent as well as acute cases of diarrhoea and dysentery. ${ }^{6009}$ Some detainees were able to receive personal items from their families outside the camp, through individual guards, but these cases were rare. ${ }^{6010}$

2014) (testifying that there was a physician and nurse available at Omarska and medical assistance was provided when people requested it).

5997 KDZ074, P709 (Transcript from Prosecutor v. Stakić), T. 2338-2339; Edward Vulliamy, P3777 (Transcript from Prosecutor v. Stakić), T. 7940; see Adjudicated Fact 1143.

5998 P3528 (Witness statement of Kerim Mešanović, undated), pp. 27, 49-50, 70-71; KDZ026, T. 10317-10318, 10378-10380 (17 January 2011) (closed session); P3691 (Witness statement of Nusreta Sivac dated 22 October 2011), pp. 60-61 (under seal); Nusreta Sivac, T. 20429 (27 October 2011); P3779 (Excerpt from ITN video clip of canteen at Omarska); P3543 (Excerpt from video clip of visits to Omarska and Trnopolje, with transcript); see Adjudicated Facts 1141, 1142; Nusret Sivac, P3478 (Transcript from Prosecutor v. Stakić), T. 6680-6681. Mevludin Sejmenović, T. 20495 (27 October 2011). KDZ026, P2089 (Transcript from Prosecutor v. Stakić), T. 1897 (under seal); see Adjudicated Fact 1144. Mevludin Sejmenović, T. 20495 (27 October 2011).

6002 KDZ048, P678 (Transcript from Prosecutor v. Stakić), T. 3370; KDZ026, P2089 (Transcript from Prosecutor v. Stakić), T. 1881 (under seal); KDZ392, P707 (Transcript from Prosecutor v. Kvočka), T. 2750 (under seal); see Adjudicated Fact 1145.

6003 Mevludin Sejmenović, T. 20495 (27 October 2011).

6004 Nusret Sivac, P3478 (Transcript from Prosecutor v. Stakić), T. 6642; P3691 (Witness statement of Nusreta Sivac dated 22 October 2011), p. 58 (under seal). See also Adjudicated Facts 1146, 1147.

6005 Nusret Sivac, P3478 (Transcript from Prosecutor v. Stakić), T. 6642. See also Adjudicated Fact 1147.

6006 KDZ026, P2089 (Transcript from Prosecutor v. Stakić), T. 1886 (under seal); KDZ026, T. 10318 (17 January 2011) (closed session).

6007 KDZ026, P2089 (Transcript from Prosecutor v. Stakić), T. 1877, 1886 (under seal); P3528 (Witness statement of Kerim Mešanović, undated), pp. 27, 70; Željko Mejakić, T. 44223, 44230 (29 November 2013); Miroslav Kvočka, T. 45586, (20 January 2014); see Adjudicated Fact 1148.

6008 Adjudicated Fact 1148.

6009 Nusret Sivac, P3478 (Transcript from Prosecutor v. Stakić), T. 6642. See Adjudicated Fact 1149.

6010 KDZ026, P2089 (Transcript from Prosecutor v. Stakić), T. 1886 (under seal). 
1756. The rooms at Omarska were extremely crowded; sometimes 200 to 300 detainees were confined in rooms that were too small. ${ }^{6011}$ Around 29 May 1992, 120 detainees were transferred to the camp from the Benkovac military barracks and crammed into a garage for several days; two young men suffocated to death as a result. ${ }^{6012}$ Detainees were also crowded together in the lavatories where they were packed one on top of the other and often had to lie in the midst of excrement. ${ }^{6013}$ The crowded and overflowing rooms at Omarska were stifling in the summer heat and guards often refused to open windows or demanded that detainees pay them with one of their possessions in exchange for opening a window or obtaining a glass of water. ${ }^{6014}$

\section{(iii) Treatment of detainees}

\section{Beatings and killings}

1757. Upon arriving at Omarska in buses, the guards on duty approached the detainees, demanded all of their belongings, verbally abused them, and then beat them, sometimes to death. ${ }^{6015}$ On one occasion, the guards who escorted one of the arriving buses formed a gauntlet through which the detainees had to pass while being beaten and forced to sing nationalist songs. ${ }^{6016}$ The detainees were then escorted to the "pista", to rooms in the hangar, or in the majority of cases, to the white house, and were often beaten on the way. ${ }^{6017}$ Kvočka, Drago Prcać, Mladen Radić, or "Krkan”, a

6011 P3528 (Witness statement of Kerim Mešanović, undated), p. 26; KDZ026, P2089 (Transcript from Prosecutor v. Stakić), T. 1875-1877 (under seal); see Adjudicated Fact 1139.

6012 See Adjudicated Fact 1172.

6013 See Adjudicated Fact 1139.

6014 See Adjudicated Fact 1140. However, Momčilo Gruban testified that (i) the conditions at Omarska were humane under the circumstances; (ii) the detainees had access to water, toilets, and showers; (iii) they received sufficient food, including the same food eaten by the guards; and (iv) detainees did not fear ill-treatment. D4388 (Witness statement of Momčilo Gruban dated 31 January 2014), paras. 8, 16-23. The Chamber does not find Gruban's evidence to be credible in this regard. In reaching that conclusion, the Chamber considers that he was not forthright with the Chamber on several occasions and that due to his involvement at Omarska, he had an interest in distancing himself from any knowledge of conditions there.

6015 P3528 (Witness statement of Kerim Mešanović, undated), pp. 51-52; P3691 (Witness statement of Nusreta Sivac dated 22 October 2011), pp. 37-40 (under seal); Mevludin Sejmenović, T. 20492-20493 (27 October 2011); KDZ093, P705 (Transcript from Prosecutor v. Kvočka), T. 6201. See also Nusret Sivac, P3478 (Transcript from Prosecutor v. Stakić), T. 6612-6614; Miroslav Kvočka, T. 45584-45585 (20 January 2014); Adjudicated Fact 1138.

6016 P3528 (Witness statement of Kerim Mešanović, undated), pp. 51-52; D4219 (Witness statement of Miroslav Kvočka dated 17 January 2014), para. 64 (stating that it was members of the MP who accompanied the detainees on the buses and later formed the gauntlet); see Adjudicated Fact 1156 (stating that Krkan in fact organised the gauntlet of guards who beat detainees on one occasion).

6017 P3691 (Witness statement of Nusreta Sivac dated 22 October 2011), pp. 37-38 (under seal); P3528 (Witness statement of Kerim Mešanović, undated), pp. 51-52; KDZ392, P707 (Transcript from Prosecutor v. Kvočka), T. 2649-2651, 2653, 2655 (under seal). 
shift commander at Omarska, and Milojica Kos, or "Krle", a shift leader, were often present during these beatings. ${ }^{6018}$ They did nothing to prevent them. ${ }^{6019}$

1758. Several non-Serb detainees arrived at Omarska after being held in the same cell at the Prijedor SJB Building earlier that day. When they arrived, they were made to line up against a wall, where they were beaten and insulted. ${ }^{6020}$ They were then taken to the white house and put in a small room, which was already crowded with about 60 to 70 men. ${ }^{6021}$ All the men were extremely frightened and were not allowed to speak. ${ }^{6022}$

1759. Other detainees were immediately brought to an office in the administration building and interrogated upon arrival. ${ }^{6023}$ For example, upon Sejmenović's arrival at Omarska from Trnopolje, an inspector from the Prijedor SJB, Dragan Radaković, interrogated him. ${ }^{6024}$ On the third day of questioning, two inspectors from Banja Luka arrived and questioned him for about an hour. ${ }^{6025}$ When Nusreta Sivac arrived at Omarska, she was immediately taken to the reception office of the administration building where Mejakić, Kvočka, Krle, and others were waiting. ${ }^{6026}$ She was then interrogated by Nenad Babić and Nenad Tomčić about her involvement in implementing the referendum for a sovereign $\mathrm{BiH} .{ }^{6027}$

1760. While in detention, beatings of detainees were frequent. ${ }^{6028}$ It was commonplace for detainees to be called out during the night by the guards. ${ }^{6029}$ Indeed, it was the nights that were most feared by the detainees for this reason. ${ }^{6030}$ In addition, detainees were beaten constantly by

\footnotetext{
6018 P3691 (Witness statement of Nusreta Sivac dated 22 October 2011), pp. 37-39, 43 (under seal); P3528 (Witness statement of Kerim Mešanović, undated), p. 51. See also Adjudicated Fact 1156.

6019 P3691 (Witness statement of Nusreta Sivac dated 22 October 2011), pp. 37-39, 43 (under seal); P3528 (Witness statement of Kerim Mešanović, undated), p. 51. See also Adjudicated Fact 1156.

6020 KDZ026, P2089 (Transcript from Prosecutor v. Stakić), T. 1869 (under seal).

6021 KDZ026, P2089 (Transcript from Prosecutor v. Stakić), T. 1869-1870, 1875 (under seal). See also KDZ074, P709 (Transcript from Prosecutor v. Stakić), T. 2316; P711 (Witness statement of KDZ074 dated 23 September 1994), e-court p. 12.

6022 KDZ026, P2089 (Transcript from Prosecutor v. Stakić), T. 1870 (under seal).

6023 P3691 (Witness statement of Nusreta Sivac dated 22 October 2011), pp. 9-10 (under seal). See also Nusret Sivac, P3478 (Transcript from Prosecutor v. Stakić), T. 6612, 6614.

6024 Mevludin Sejmenović, T. 20492-20494 (27 October 2011).

6025 Mevludin Sejmenović, T. 20493 (27 October 2011).

6026 P3691 (Witness statement of Nusreta Sivac dated 22 October 2011), pp. 9-10, 26 (under seal).

6027 P3691 (Witness statement of Nusreta Sivac dated 22 October 2011), pp. 32-33 (under seal).

6028 P3528 (Witness statement of Kerim Mešanović, undated), pp. 27-28; KDZ392, P707 (Transcript from Prosecutor v. Kvočka), T. 2657-2663, 2744-2749 (under seal); Nusret Sivac, P3478 (Transcript from Prosecutor v. Stakić), T. 6680-6682; KDZ093, P705 (Transcript from Prosecutor v. Kvočka), T. 6201-6203; P3691 (Witness statement of Nusreta Sivac dated 22 October 2011), pp. 28-30, 32 (under seal); Željko Mejakić, T. 44225-44226, 44240-44241 (29 November 2013). See also Adjudicated Facts 1150, 1151, 1154, 1155.

6029 KDZ026, P2089 (Transcript from Prosecutor v. Stakić), T. 1873 (under seal); KDZ392, P707 (Transcript from Prosecutor v. Kvočka), T. 2744-2749 (under seal).

6030 KDZ026, P2089 (Transcript from Prosecutor v. Stakić), T. 1887-1888, 1906 (under seal); P3528 (Witness statement of Kerim Mešanović, undated), pp. 27-28.
} 
the guards, at the slightest perceived provocation, and some were beaten to death. ${ }^{6031}$ KDZ392 was beaten on numerous occasions during his detention at Omarska. ${ }^{6032}$ At one point, KDZ392 and his father were beaten two days in a row by Dušan Knežević, a.k.a "Duca", and Zoran Žigić. Afterwards, his father was singled out and beaten more severely. ${ }^{6033}$ KDZ392's father was left deformed and in severe pain and as a result of the beatings, he died the next morning. ${ }^{6034}$ His body was taken away in a dark blue police van. ${ }^{6035}$

1761. One room in the white house was reserved for brutal assaults on prisoners, who were often stripped, beaten, kicked, and otherwise abused; many detainees died as a result of these repeated assaults on them in the white house. ${ }^{6036}$

1762. Between 600 and 700 detainees at a time were held outside in the "pista" area of Omarska for prolonged periods. ${ }^{6037}$ The detainees had to sit, and sometimes lie, on the ground, with machine-guns pointed at them. ${ }^{6038}$ While on the "pista", KDZ026 witnessed the guards forcing a young mentally handicapped detainee by the name of Crnalić to drink motor oil. He then heard gunfire and the young man was not seen again. ${ }^{6039}$ The Chamber is satisfied that this detainee was killed in this incident. On 10 June 1992, Nusreta Sivac saw Žigić call out the names of three male detainees on the "pista"; when these three men finally returned, they were swollen, covered in bruises, and their "faces were completely distorted". 6040

1763. Detainees were also severely beaten during interrogations. ${ }^{6041}$ Detainees brought to the red house for interrogation were often killed. ${ }^{6042}$ KDZ093 testified that in July 1992, she saw men,

6031 KDZ026, P2089 (Transcript from Prosecutor v. Stakić), T. 1883-1884 (under seal). See also KDZ392, P707 (Transcript from Prosecutor v. Kvočka), T. 2728-2729, 2744-2749 (under seal); Adjudicated Fact 1155 (stating that on religious holidays or if the relative of a guard was killed in the battlefield, beatings intensified).

6032 
including a Muslim or Croat doctor and a Muslim teacher she recognised, being called out from an area in the restaurant building in Omarska called the "glass house". ${ }^{6043}$ They were taken to the red house and later that night, KDZ093 heard gunfire and guards cursing, using the words "Ustashas" and "balijas". 6044

1764. After their interrogation, detainees were often made to sign false statements regarding their involvement in acts against Serbs. ${ }^{6045}$ Detainees were also ordered to beat other detainees. ${ }^{6046}$ They were humiliated in front of other detainees, forced to sing Serbian nationalist songs, make the three fingered Serbian sign, and were subjected to ethnic slurs by the camp guards. ${ }^{6047}$ On one occasion, on a Serb holiday, guards at the camp got drunk, set fire to rubber tires, and threw Smail Duratović, a well-known Bosnian Muslim athlete, into the fire, along with at least nine other detainees. ${ }^{6048}$ Detainees, including female detainees, were regularly threatened with death. ${ }^{6049}$ At one point during his detention in Omarska, KDZ026 was told by two guards that his name was on a list of detainees to be "liquidated", but that he would be saved if he gave them money. ${ }^{6050}$

1765. The beatings were administered by camp guards at Omarska, including Milutin Popović, a.k.a. "Pop", and Žarko Marmat, ${ }^{6051}$ as well as by individuals from outside the camp who were permitted to enter and mistreat detainees, including Žigić and Knežević. ${ }^{6052}$ Detainees feared these

\footnotetext{
$6042 \quad$ See Adjudicated Fact 1179.

6043 KDZ093, P705 (Transcript from Prosecutor v. Kvočka), T. 6230-6232.

6044 KDZ093, P705 (Transcript from Prosecutor v. Kvočka), T. 6232.

6045 See Adjudicated Fact 1152.

6046 KDZ392, P707 (Transcript from Prosecutor v. Kvočka), T. 2733, 2771 (under seal).

6047 KDZ392, P707 (Transcript from Prosecutor v. Kvočka), T. 2737 (under seal) (testifying that after being beaten, his father was forced to lick his own blood); Nusret Sivac, P3478 (Transcript from Prosecutor v. Stakić), T. 6640-6641, 6644; P3691 (Witness statement of Nusreta Sivac dated 22 October 2011), pp. 11, 19-21, 30 (under seal); Željko Mejakić, T. 44224-44225 (29 November 2013). See also Adjudicated Facts 1135, 1169, 1171, 1182. But see Milorad Sajić, T. $44162-44164$ (27 November 2013) (testifying that Radić told him that detainees at Omarska raised three fingers and sang songs about Serbia during a delegation visit at the camp, but that the detainees did these things spontaneously and he was not told that they were forced to do so); D4114 (Witness statement of Milorad Sajić dated 24 November 2013), para. 57.

6048 Nusret Sivac, P3478 (Transcript from Prosecutor v. Stakić), T. 6682-6683 (testifying that Duratović managed to escape the fire, but was badly burned); KDZ048, P678 (Transcript from Prosecutor v. Stakić), T. 3357-3359 (testifying that one man who was thrown into the fire was never seen after this incident).

6049 P3691 (Witness statement of Nusreta Sivac dated 22 October 2011), p. 30 (under seal); KDZ026, T. 1032010321 (17 January 2011) (closed session). See also Adjudicated Fact 1170.

6050 KDZ026, T. 10320-10321 (17 January 2011) (closed session) (testifying that the guards demanded 10,000 German marks but when KDZ026 protested that he did not have access to that amount of money, they suggested the sum of 3,000 marks and KDZ026 managed to send letters to his wife asking her to try to get the money; however, she was unable to raise enough money). See also P2094 (KDZ026's letters from Omarska) (under seal).

6051 P3528 (Witness statement of Kerim Mešanović, undated), pp. 34-35, 49-52; P3691 (Witness statement of Nusreta Sivac dated 22 October 2011), pp. 28, 38-40 (under seal); KDZ026, P2089 (Transcript from Prosecutor v. Stakić), T. 1883-1884 (under seal). See Adjudicated Fact 1154.

6052 KDZ392, P707 (Transcript from Prosecutor v. Kvočka), T. 2728-2729, 2731-2737 (under seal); P3691 (Witness statement of Nusreta Sivac dated 22 October 2011), pp. 40-41, 52-53 (under seal); KDZ026, P2089 (Transcript from Prosecutor v. Stakić), T. 1885 (under seal); D4138 (Witness statement of Željko Mejakić dated
} 
outside individuals even more than the camp guards, as the beatings were worse when they appeared; the detainees were beaten with a variety of sticks, iron bars, and lengths of heavy electric cable, sometimes with nails embedded in them to pierce the detainees' skin. ${ }^{6053}$ They were also attacked with knives. ${ }^{6054}$ Members of the intervention squad also mistreated detainees at Omarska. ${ }^{6055}$

1766. Prominent Bosnian Muslim and Bosnian Croat political leaders, including SDA officials and members, as well as doctors, professionals, and police, were among the individuals most often mistreated and killed at Omarska. ${ }^{6056}$ Detainees frequently saw dead bodies on the lawn in front of or near the white house. ${ }^{657}$ The detainees witnessed bodies being taken away by truck and they could also hear the sounds of earth-moving equipment in the vicinity of the camp. ${ }^{6058}$ Detainees were required to clean the white house and the red house and they often found hair, teeth, skin, blood, clothes, footwear and empty pistol cartridges. ${ }^{6059}$ Camp guards also forced detainees to load 26 November 2013), para. 15; Željko Mejakić, T. $44233-44235$ (29 November 2013); D4219 (Witness statement of Miroslav Kvočka dated 17 January 2014), para. 57. See Adjudicated Facts 1153, 1157, $1158,1173$. But see D4388 (Witness statement of Momčilo Gruban dated 31 January 2014, paras. 25, 31 (stating that although no such beatings occurred in his presence, there were some cases of individual armed groups from the outside getting in to the camp and mistreating the detainees; however, these groups were armed and the guards at Omarska were not able to resist them because of low numbers). See Adjudicated Facts 1153, 1173.

See Adjudicated Fact 1173.

D4139 (Report of Prijedor SJB, 13 June 1992); D4138 (Witness statement of Željko Mejakić dated 26 November 2013), para. 15; Željko Mejakić, T. 44218-44220 (29 November 2013). See also Adjudicated Fact 2487.

KDZ026, P2089 (Transcript from Prosecutor v. Stakić), T. 1909-1915, 1917-1921 (under seal); Nusret Sivac, P3478 (Transcript from Prosecutor v. Stakić), T. 6629-6630; P3691 (Witness statement of Nusreta Sivac dated 22 October 2011), pp. 24-25 (under seal) (stating that Prcać and other guards called people, usually highranking members of the SDA or HDZ, out from lists and they were never seen again); P3528 (Witness statement of Kerim Mešanović, undated), pp. 40-41, 54; Kerim Mešanović, T. 19852 (4 October 2011); KDZ048, P678 (Transcript from Prosecutor v. Stakić), T. 3365-3368. See also Adjudicated Fact 1120. On 27 July 1992, Professor Muhamed Cehajić, an SDA official and the former mayor and president of the Prijedor Municipal Assembly, was humiliated, mistreated, and disappeared. Zlatan Besirević, the director of the Bosna Montaza company in Prijedor, was called out one day and never returned; Dr. Sadiković was also called out one night and taken away by bus with detainees who had been held in Keraterm, none of whom were seen again. Fikret Mujidzić and Camil Pezo were severely beaten and both subsequently died from their injuries. Similarly, Idriz Jakupović was severely beaten and then taken out and disappeared one night. Mustafa Crnalić, Burhurudin Kapetanović, Abdulah Puskar, Ziko Crnalić and his son, Zijad Mahmuljin, Osman Mahmuljin, Alessanda Komsić, Esref Crnkić, Nedzad Serić, Omere Kerenović, Esad Mehmedagić, Mustafa Tadzić, Mehmedalija Kapetanović, Asaf Kapetanović, Rufat Suljanović, Ibrahim Okanović, Bajram Zgog, Senad Mujkanović, Kadir Mujkaonović, Fikret Mujakić, Islam Bahonjić, Meho Tursić, Hamdija Balić, and Huseain Crnkić were called out at night and never returned. [REDACTED].

P3691 (Witness statement of Nusreta Sivac dated 22 October 2011), pp. 41-42 (under seal); KDZ026, P2089 (Transcript from Prosecutor v. Stakić), T. 1902 (under seal); KDZ093, P705 (Transcript from Prosecutor v. Kvočka), T. 6204-6205. See P610 (Photograph of model of Omarska marked by KDZ093) (on which KDZ093 marked the areas where she saw the bodies outside of the white house); Adjudicated Fact 1178.

P3691 (Witness statement of Nusreta Sivac dated 22 October 2011), pp. $42-43$ (under seal); KDZ026, P2089 (Transcript from Prosecutor v. Stakić), T. 1902 (under seal); KDZ093, P705 (Transcript from Prosecutor v. Kvočka), T. 6232-6233; KDZ048, P678 (Transcript from Prosecutor v. Stakić), T. 3370-3371.

See Adjudicated Facts 1176, 1180. 
onto trucks dead bodies of detainees who had been killed in the white and red houses. ${ }^{6060}$

result, the detainees constantly lived in fear of being killed at any time. ${ }^{6061}$

1767. Detainees were also taken from Omarska and killed outside the camp. ${ }^{6062}$ In late July 1992 , 46 detainees, including two female detainees, were taken out of Omarska, put on a bus, and told that they would be exchanged in the direction of Bosanska Krupa. ${ }^{6063}$ They were never seen again. ${ }^{6064}$ The Chamber finds that these 46 detainees were killed after being taken out of Omarska in late July 1992.

1768. In addition, the Chamber received forensic evidence to support the deaths of some identified individuals who were detained at Omarska between 25 May 1992 and 21 August 1992. ${ }^{6065}$

$6060 \quad$ See Adjudicated Facts 1178, 1181.

6061 KDZ026, P2089 (Transcript from Prosecutor v. Stakić), T. 1905 (under seal).

6062 [REDACTED].

6063 KDZ392, P707 (Transcript from Prosecutor v. Kvočka), T. 2741, 2743-2744 (under seal); P3691 (Witness statement of Nusreta Sivac dated 22 October 2011), pp. 46-47 (under seal) (stating that two female detainees, Edna Dautović and Sadeta Medunjanin, were called out one day by Mejakić and informed that they were going to be exchanged; they boarded a bus with other people which said "Šešelj Private Driving School" and had Bihać plates, and were never seen again until their bodies were exhumed in 2000 from a mass grave in Bosanska Krupa municipality); Željko Mejakić, T. 44257-44258 (29 November 2013) (confirming that he was present when 44 men and two women were called out from a list brought to the camp by Drljača's driver and put on a bus and that the bodies of all of these detainees were exhumed from a mass grave in Jama Lisac in Bosanska Krupa). See also Adjudicated Fact 1186.

6064 KDZ392, P707 (Transcript from Prosecutor v. Kvočka), T. 2741, 2743-2744 (under seal); P3691 (Witness statement of Nusreta Sivac dated 22 October 2011), pp. 46-47 (under seal). See also Adjudicated Fact 1186.

6065 P4410 (Death certificates from Prijedor) (confirming the deaths of 21 identified individuals at Omarska between 3 June and 20 August 1992); P4853 (Updated Table 2 to the Report of Amor Mašović), pp. 14-15, 18-20, 2232, 37-41; P5909 (Bihać MUP identification reports concerning Stari Kevljani mass grave, 30 June 2005), pp. 5, 7, 10-18, 20, 22-24, 29-36, 38-42, 45, 47-57, 59, 61-67 (confirming that 73 identified individuals who went missing from Omarska were exhumed from the Stari Kevljani mass grave); P4892 (BiH State Commission for Tracing Missing Persons list of exhumed persons from Prijedor, Čelinac, Bosanski Novi, 29 October 2002) (confirming two individuals who went missing from Omarska and were exhumed from Jakarina Kosa mass grave). See also P4850 (Witness statement of Amor Mašović dated 23 March 2012), Annex A, pp. 8-9; P4893 (Bihać MUP report on Stari Kevljani exhumation, 18 January 2004); P4890 (BiH State Commission for Tracing Missing Persons report on Jama Lisac exhumation, 20-28 June 2000); P4891 (Bihać Cantonal Court record of exhumation at Jama Lisac, 11 July 2000); P646 (Excerpts from report on exhumations in Prijedor municipality, 28 August 2002), pp. 34-43 (under seal); Nicolas Sébire, P694 (Transcript from Prosecutor v. Stakić), T. 73707371; Nicolas Sébire, P694 (Transcript from Prosecutor v. Brđanin), T. 16699; Adjudicated Fact 1186 (stating that during the exhumation in Jama Lisac, 56 bodies were found and most of them died from gunshot injuries; DNA analysis allowed the investigators to identify the bodies of Sureta Medunjanin, the wife of Bećir Medunjanin, and Ekrem Alić and Smail Alić, who were last seen in Omarska). The Chamber notes that Adjudicated Fact 1186, which is based on Sébire's testimony in the Stakić case, refers to the name "Sureta" Medunjanin as the wife of Bećir Medunjanin and one of the individuals who was exhumed in Jama Lisac; however based on the other evidence before it, including Sébire's subsequent testimony in the Brđanin case, the Chamber considers that this was an error and is satisfied that the individual's name is "Sadeta" Medunjanin. See Nicolas Sébire, P694 (Transcript from Prosecutor v. Brđanin), T. 16699; P646 (Excerpts from report on exhumations in Prijedor municipality, 28 August 2002), p. 37 (under seal). 


\section{Sexual violence}

1769. At Omarska, there were frequent incidents of female detainees who were called out of their rooms by different guards, as well as the camp commander, and were raped or sexually assaulted. ${ }^{6066}$ On one occasion, Krkan called a female detainee into his office and told her that he knew high-ranking military officials and could help her if she had sexual intercourse with him. ${ }^{6067}$ Nedeljko Grabovac, a.k.a. "Kapitan", who stayed at Omarska for only a short period and wore an olive uniform similar to the former JNA uniform, also sexually assaulted female detainees. ${ }^{6068}$

1770. KDZ093 testified that several times during her detention at Omarska, she was called out at night and during the day, by the same guard, and taken to another room in the restaurant building where she was raped by this guard; afterwards, several other men entered the room and raped her repeatedly. ${ }^{6069}$

1771. Guards at Omarska also attempted to force a male detainee to rape another female detainee. $^{6070}$ On the night of 26 June 1992, a detainee heard some guards laughing, the voice of a young woman crying, and a man he recognised as Mehmedalija Sarajlić pleading with the guards. ${ }^{6071}$ Sarajlić was told by the guards to rape the young woman and when he refused he was beaten. ${ }^{6072}$ The next morning, the detainee saw Sarajlić's body lying outside, not far from the white house. ${ }^{6073}$

1772. Female detainees were also physically assaulted at Omarska. On one occasion, a man, wearing a camouflage uniform and a cap with a cockade symbol on it, entered the restaurant and started shouting and hitting a Bosnian Muslim female prisoner sitting at a table; he then carved a cross on her cheek and she started to bleed. ${ }^{6074}$ On another occasion, a guard approached a female

6066 P3691 (Witness statement of Nusreta Sivac dated 22 October 2011), pp. 34, 47-51 (under seal); KDZ093, P705 (Transcript from Prosecutor v. Kvočka), T. 6226, 6228-6230. See also Adjudicated Fact 1168. But see D4388 (Witness statement of Momčilo Gruban dated 31 January 2014), para. 29 (stating that there were no such cases of rape or sexual assault of female detainees during his shifts and he did not hear that such things took place during other shifts). The Chamber does not find Gruban's evidence to be credible in this regard. In reaching that conclusion, the Chamber refers to its earlier assessment in fn. 6014 regarding the credibility of Gruban.

6067 P3691 (Witness statement of Nusreta Sivac dated 22 October 2011), pp. 34, 47-49 (under seal).

6068 P3691 (Witness statement of Nusreta Sivac dated 22 October 2011), pp. 49-51 (under seal).

6069 KDZ093, P705 (Transcript from Prosecutor v. Kvočka), T. 6226, 6228-6229 (testifying that she did not know the name of the guard); see P611 (Plan of first floor of restaurant building in Omarska marked by KDZ093) (on which KDZ093 marked with a "U" the room in which she was raped at night, number B1).

6070 [REDACTED]. See also Adjudicated Fact 1183.

6071 [REDACTED]. See also Adjudicated Fact 1183.

6072 [REDACTED]. See also Adjudicated Fact 1183.

6073 [REDACTED]. See also Adjudicated Fact 1183.

6074 P3691 (Witness statement of Nusreta Sivac dated 22 October 2011), pp. 40-41 (under seal); Nusreta Sivac, T. 20413-20414 (26 October 2011) (private session). 
detainee in the restaurant, uncovered her breast and took out a knife and went over her breast with it for several minutes, while other guards watched laughing. ${ }^{6075}$

1773. Female detainees were made to work in the canteen at Omarska. ${ }^{6076}$ On one occasion, Milorad Tadić, a.k.a. "Brk", Mejakić's driver and bodyguard, entered the kitchen and shouted at the women for giving prisoners more bread than permitted; he ordered them to face the wall with their hands up for 40 minutes, then laughed, and said it was a "warning" and he would shoot them if they gave out too much bread again. ${ }^{6077}$ After completing their work duty during the day, the women would clean the interrogation rooms in the evening; they found blood on the floors and walls, traces of torn clothing, and various devices, such as batons, with traces of blood as well. ${ }^{6078}$

\section{Conclusion on conditions of detention and treatment of detainees}

1774. Based on the above, the Chamber finds that non-Serbs, including civilians, were transferred to and detained at Omarska by Serb Forces between 25 May 1992 and 21 August 1992. The detainees were held in poor conditions characterised by lack of space, poor sanitary conditions, inadequate medical care, and insufficient food. The Chamber finds that the male detainees at Omarska were subjected to severe beatings by Serb Forces. The Chamber also finds that a number of Bosnian Muslim women detained at Omarska were subjected to acts of sexual violence by Serb Forces and were forced to work. ${ }^{6079}$ Finally, the Chamber finds that a large number of non-Serbs were killed by Serb Forces at Omarska, or after they were taken from the camp, between 25 May 1992 and 21 August 1992. ${ }^{6080}$

\section{(iv) $\underline{\text { Scheduled Incident B.15.3 }}$}

1775. The Indictment refers to the killing of a number of men and women taken from Omarska in the area called Hrastova Glavica on or about 5 August $1992 .{ }^{6081}$

1776. On 5 August 1992, two bus loads of approximately 120 detainees from Keraterm were brought to Omarska. ${ }^{6082}$ Dr. Esad Sadiković, who was regarded by other detainees as a "moral and

\footnotetext{
6075 P3691 (Witness statement of Nusreta Sivac dated 22 October 2011), p. 41 (under seal).

6076 Nusreta Sivac, T. 20429 (27 October 2011).

6077 P3691 (Witness statement of Nusreta Sivac dated 22 October 2011), pp. 30-31 (under seal).

6078 P3691 (Witness statement of Nusreta Sivac dated 22 October 2011), pp. 31-32 (under seal).

6079 However, the Chamber notes that this type of forced labour is not charged in the Indictment, which only covers forced labour at the frontlines.

6080 This finding does not include the persons alleged to have been killed in Scheduled Incidents B.15.3 and B.15.4, which are discussed below.

6081 See Indictment, Scheduled Incident B.15.3, fn. 5 (wherein the Prosecution alleges that detainees from Keraterm were among the victims of Scheduled Incident B.15.3).
} 
spiritual authority" at the camp, was called out by Prcać that night and he was made to board one of the buses along with the other detainees from Keraterm already on the buses; they left Omarska in the direction of Sanski Most. ${ }^{6083}$

1777. The Chamber took judicial notice that on the way to Sanski Most, unidentified Bosnian Serbs shot dead a number of the detainees being transported on the buses. ${ }^{6084}$ The bodies of 126 individuals were later found in an area called Hrastova Glavica and 46 individuals were identified. ${ }^{6085}$ For 121 of the 126 bodies, the forensic experts determined that the cause of death was a gunshot wound. ${ }^{6086}$

1778. Based on the above, the Chamber finds that approximately 120 non-Serb civilians taken from Keraterm and Omarska were killed by Serb Forces on or about 5 August 1992 in the area of Hrastova Glavica.

\section{(v) Scheduled Incident B.15.4}

1779. The Indictment refers to the execution of over 150 men from the Brdo region of Prijedor at Omarska on or about 20 July 1992.

1780. On 16 July 1992, a group of about 200 people from the Brdo area, including Hambarine, were brought to Omarska in buses and detained in the white house. ${ }^{6087}$ In the middle of the night, KDZ048 heard gunshots and saw a number of dead and wounded people lying in front of the white

6082 KDZ050, P680 (Transcript from Prosecutor v. Sikirica), T. 2522-2523, 2527, 2531-2532; P1949 (Excerpt from KDZ050's witness statement dated 19 November 2000) (providing a list of about 60 names of men he knew who were taken from Keraterm on two buses and stating that he heard from other detainees that these men were first taken to Omarska); Željko Mejakić, T. 44258 (29 November 2013) (confirming that two busloads of detainees from Keraterm were brought to Omarska on the afternoon of 5 August 1992). See also Adjudicated Fact 1220.

6083 Nusret Sivac, P3478 (Transcript from Prosecutor v. Stakić), T. 6686-6687; KDZ026, P2089 (Transcript from Prosecutor v. Stakić), T. 1837-1838 (under seal); KDZ050, P680 (Transcript from Prosecutor v. Sikirica), T. 2522; Željko Mejakić, T. 44258 (29 November 2013). See also Adjudicated Facts 1188, 1220; fn. 6056.

6084 See Adjudicated Fact 1220. See also P4887 (Bihać Cantonal Court record of Hrastova Glavica exhumation, 7 December 1998), p. 2.

6085 P4887 (Bihać Cantonal Court record of Hrastova Glavica exhumation, 7 December 1998), pp. 2, 8-9; P646 (Excerpts from report on exhumations in Prijedor municipality, 28 August 2002), pp. 32-33 (under seal); P4850 (Witness statement of Amor Mašović dated 23 March 2012), Annex A, pp. 7-8; P4853 (Updated Table 2 to the Report of Amor Mašović), pp. 42-44; P4414 (Death certificate for Ismet Avdić). KDZ050 subsequently identified the bodies of some of the 120 men who were taken away in the two buses on 5 August 1992, which were recovered from Hrastova Glavica in Sanski Most. KDZ050, P680 (Transcript from Prosecutor v. Sikirica), T. 2522-2523, 2527-2528, 2531-2532; P1949 (Excerpt from KDZ050's witness statement dated 19 November 2000). See also Željko Mejakić, T. $44258-44259$ (29 November 2013); Adjudicated Facts 1220, 1221.

6086 P646 (Excerpts from report on exhumations in Prijedor municipality, 28 August 2002), pp. 32-33 (under seal). See also Adjudicated Fact 1222.

6087 KDZ048, P678 (Transcript from Prosecutor v. Stakić), T. 3359-3361; P3528 (Witness statement of Kerim Mešanović, undated), p. 56; Nusret Sivac, T. 19529-19530 (28 September 2011). See also Adjudicated Facts $1185,1191$. 
house. ${ }^{6088}$ He then saw camp guards, including Zivko Marmat, firing one additional shot into the heads of each of these people. ${ }^{6089}$ A truck arrived, and detainees held in the hangar were given the task of loading the bodies on to the truck, which was then driven away. ${ }^{6090}$ The truck returned several times to be re-loaded and KDZ048 estimated that there were about 180 bodies in total. ${ }^{6091}$ All of the detainees held in the white house were killed that night and it was empty the following day. $^{6092}$

1781. Based on the totality of the evidence before it, the Chamber therefore finds that at least 150 non-Serb detainees from the Brdo region were killed by Serb Forces on or around 20 July 1992 at Omarska.

\section{(vi) Visits to Omarska and transfer of detainees}

1782. On or around 15 July 1992, a high-ranking delegation from Banja Luka and Prijedor, including Brđanin, Kuprešanin, Župljanin, Stakić, Radoslav Vujić, Predrag Radić, and Talić, visited Omarska and were received by Drljača and Mejakić. ${ }^{6093}$ Nusreta Sivac and other women watched the delegation arrive through the glass walls of the canteen at Omarska; a choir of detainees-“living skeletons"- had been lined up outside the canteen and they sang Chetnik songs and gave the three finger Serbian salute as the delegation passed by. ${ }^{6094}$

1783. According to Mejakić, Drljača then met with the delegation in the administration building without Mejakić present, where Župljanin denounced the camp and asked that it be dismantled

KDZ048, P678 (Transcript from Prosecutor v. Stakić), T. 3360-3361. See also Adjudicated Fact 1185.

KDZ048, P678 (Transcript from Prosecutor v. Stakić), T. 3360. See also Adjudicated Fact 1185.

KDZ048, P678 (Transcript from Prosecutor v. Stakić), T. 3360-3362; P3528 (Witness statement of Kerim Mešanović, undated), pp. 55-56. See also Adjudicated Fact 1185.

6091 KDZ048, P678 (Transcript from Prosecutor v. Stakić), T. 3362; P3528 (Witness statement of Kerim Mešanović, undated), p. 56. See also Adjudicated Fact 1185.

6092 P3528 (Witness statement of Kerim Mešanović, undated), p. 56. However, Mejakić gave evidence that crimes in Prijedor were "fabricated and attributed to Serbs under RS leadership". According to him, this includes the killing of 3,500 civilians at Omarska and, in particular, the killing of a group of 250 detainees brought in from the Brdo area; he stated that this incident was fabricated and is not supported by evidence. D4138 (Witness statement of Željko Mejakić dated 26 November 2013), pp. 3-4. However, the Chamber does not find Mejakić's evidence to be reliable on this issue in light of the other evidence before the Chamber regarding this incident.

6093 P3691 (Witness statement of Nusreta Sivac dated 22 October 2011), pp. 10-22 (under seal); Nusret Sivac, P3478 (Transcript from Prosecutor v. Stakić), T. 6639-6641; D4138 (Witness statement of Željko Mejakić dated 26 November 2013), p. 10; Predrag Radić, P1 (Transcript from Prosecutor v. Krajišnik), T. 7437-7438; [REDACTED]. See also P6465 (Photograph of model of Omarska marked by Nusreta Sivac); P11 (Article from Kozarski Vjesnik, entitled "Krajina Representatives in Prijedor", 17 July 1992), p. 1; P3482 (Article from Kozarski Vjesnik, entitled "It's Difficult for Everyone", 17 July 1992); Adjudicated Fact 1135.

6094 P3691 (Witness statement of Nusreta Sivac dated 22 October 2011), pp. 10-11, 12-21 (under seal); Nusret Sivac, P3478 (Transcript from Prosecutor v. Stakić), T. 6640-6641; Predrag Radić, P1 (Transcript from Prosecutor v. Krajišnik), T. 7437-7438 (testifying that it amounted to pyschological abuse to force the detainees to sing these kind of songs). See P6465 (Photograph of model of Omarska marked by Nusreta Sivac); Adjudicated Fact 1135.
} 
immediately. ${ }^{6095}$ However, the camp was not closed immediately after this visit and, in fact, on 20 July 1992, Župljanin sought the view of RS officials regarding the status of detainees of no security interest being held in ARK detention facilities and recommended that they be treated as "hostages" to exchange for Serb detainees. ${ }^{6096}$ Furthermore, following the visit, Brđanin publicly stated that: "What we have seen in Prijedor is an example of a job well done". 6097 According to Kuprešanin, following the delegation visit, the Accused called Kuprešanin to suggest that he influence the municipal authorities in Prijedor to close the "investigation centres" in the municipality. ${ }^{6098}$ Kuprešanin subsequently asked the authorities of Omarska and Keraterm to close the facilities and to improve the living conditions for the detainees until their disbandment. ${ }^{6099}$

1784. As mentioned above, pursuant to an order issued by Mladić on 3 August 1992, Talić ordered the authorities at Omarska, Trnopolje, and Manjača to urgently prepare for visits by the ICRC and teams of reporters. ${ }^{6100}$

1785. In early August 1992, the majority of detainees remaining at Omarska were transferred to either Trnopolje or Manjača camps. ${ }^{6101}$ On 3 August 1992, Dragoljub Prcać came to the restaurant building at Omarska and read out a list of women's names, including the names of KDZ093 and Nusreta Sivac. ${ }^{6102}$ Although Prćac said they were "going home", that day a bus came to pick up this group of women and took them to Trnopolje. ${ }^{6103}$

1786. On 5 August 1992, Vulliamy and two television reporting teams from ITN, including Penny Marshall and Ian Williams, visited Omarska and met with Drljača, Stakić, Kovačević, and an

6095 D4138 (Witness statement of Željko Mejakić dated 26 November 2013), p. 10. See Željko Mejakić, T. 4426444267 (29 November 2013).

6096 P1097 (Banja Luka CSB dispatch to SerBiH MUP, 20 July 1992).

6097 P11 (Article from Kozarski Vjesnik, entitled “Krajina Representatives in Prijedor”, 17 July 1992), p. 2.

6098 D4011 (Witness statement of Vojislav Kuprešanin dated 11 November 2013), para. 46; Vojislav Kuprešanin, T. 43530, 43543-43545 (14 November 2013). See also P6510 (Excerpt of Vojo Kuprešanin's interview with OTP), e-court p. 11.

6099 D4011 (Witness statement of Vojislav Kuprešanin dated 11 November 2013), para. 46; Vojislav Kuprešanin, T. 43543-43545 (14 November 2013).

6100 P5461 (VRS Main Staff Order, 3 August 1992); P5460 (Order of $1^{\text {st }}$ Krajina Corps, 3 August 1992). See para. 1404. See also 1849.

6101 KDZ093, P705 (Transcript from Prosecutor v. Kvočka), T. 6211-6213; Željko Mejakić, T. 44280-44281 (29 November 2013); KDZ026, P2089 (Transcript from Prosecutor v. Stakić), T. 1928 (under seal); KDZ026, T. 10391 (17 January 2011) (closed session); KDZ392, P707 (Transcript from Prosecutor v. Kvočka), T. 27492750, 2766 (under seal); see Adjudicated Fact 2489.

6102 KDZ093, P705 (Transcript from Prosecutor v. Kvočka), T. 6211-6212; P3691 (Witness statement of Nusreta Sivac dated 22 October 2011), pp. 53-54 (under seal).

6103 KDZ093, P705 (Transcript from Prosecutor v. Kvočka), T. 6211-6213; Željko Mejakić, T. 44281 (29 November 2013) (confirming that on 3 August 1992, a group of approximately 140 or 150 detainees were transferred to Trnopolje). 
interpreter, Nada Balaban, upon their arrival. ${ }^{6104}$ The journalists interviewed detainees; however, the detainees were told not to complain about the conditions of detention. ${ }^{6105}$ The journalists were not allowed to see anything beyond the cafeteria, despite informing Drljača and Mejakić that they had approval from the Accused to visit the whole camp. ${ }^{6106}$ On or around 12 August 1992, representatives from the ICRC, as well as international and Serbian journalists, visited Omarska. ${ }^{6107}$ The ICRC delegation was given access to visit the whole camp. ${ }^{6108}$

1787. Sejmenović was present when international journalists arrived at Omarska and was brought out to speak to them; however they did not interview him. ${ }^{6109}$ He had been interviewed by Serbian journalists earlier, but he did not tell the truth; rather he answered in the manner he was told in order to save his life. ${ }^{6110}$ The day after the international journalists visited Omarska, Sejmenović met with Kuprešanin who informed him that he would be leaving Omarska for Banja Luka that day. ${ }^{6111}$ Later Sejmenović learned Kuprešanin's intentions for taking him out of Omarska when he overheard a phone conversation between Kuprešanin and the Accused. ${ }^{6112}$ Kuprešanin "received instructions" and responded that he was planning to get a suit for Sejmenović and allow him time to recuperate, and then he was planning round-table discussions for Sejmenović to speak publicly about the situation in Bosnian Krajina. ${ }^{613}$ At his own request, Sejmenović was then taken to his sister's house in Vrbanja, where Kuprešanin visited him three times. ${ }^{6114}$ On the third visit, Kuprešanin informed Sejmenović he was going to Banja Luka to meet with the Accused and

\footnotetext{
6104 Edward Vulliamy, P3777 (Transcript from Prosecutor v. Stakić), T. 7937-7946, 7948-7953. See Adjudicated Facts 1136, 2488.

6105 Mevludin Sejmenović, T. 20499-20501 (27 October 2011); see Adjudicated Fact 2488.

6106 Edward Vulliamy, P3777 (Transcript from Prosecutor v. Stakić), T. 7939-7946, 7948-7953; Edward Vulliamy, T. 21043-21048 (9 November 2011); P3543 (Excerpt from video clip of visits to Omarska and Trnopolje, with transcript); P3797 (Excerpt of ITN video clip of journalist visit to Omarska and Trnopolje); P3785 (Excerpt of ITN video clip of journalist visits to Omarska and Trnopolje, with transcript); D4138 (Witness statement of Željko Mejakić dated 26 November 2013), p. 10; Željko Mejakić, T. 44271-44273 (29 November 2013).

6107 D4138 (Witness statement of Željko Mejakić dated 26 November 2013), p. 10; Željko Mejakić, T. 44274 (29 November 2013).

6108 D4138 (Witness statement of Željko Mejakić dated 26 November 2013), p. 10.

6109 Mevludin Sejmenović, T. 20498-20499 (27 October 2011).

6110 Mevludin Sejmenović, T. 20499-20501 (27 October 2011). See P3696 (Video footage of Mevludin Sejmenović in Omarska).

6111 Mevludin Sejmenović, T. 20503-20504 (27 October 2011).

6112 Mevludin Sejmenović, T. 20504-20505 (27 October 2011), T. 20578-20579, 20586 (28 October 2011) (testifying that he learned that Kuprešanin wanted Sejmenović to "fatten up" and get better for upcoming public appearances). Sejmenović recognised the Accused's voice, which was "very familiar" to him, on the phone and later Kuprešanin confirmed it was the Accused. See also Vojislav Kuprešanin, T. 43546-43547 (14 November 2013). Sejmenović further confirmed that communication by telephone, "certainly [...] between Prijedor and Banja Luka" was possible in August 1992, despite the Accused suggesting that communication was restored only in September 1992. Mevludin Sejmenović, T. 20586-20587 (28 October 2011). See D1357 (Report of Prijedor SDS Municipal Board, 11 September 1991-26 December 1992), p. 6.

6113 Mevludin Sejmenović, T. 20504-20505 (27 October 2011). See also Vojislav Kuprešanin, T. 43546-43547 (14 November 2013).

6114 Mevludin Sejmenović, T. 20506-20507 (27 October 2011).
} 
others. ${ }^{6115}$ Sejmenović was brought by Kuprešanin as one of the two official SDA functionaries to meet with the Accused, Vance, and Owen. ${ }^{6116}$ Following the meeting, Sejmenović confirmed Vance's public statement that Vance did not agree with the Accused that "no ethnic cleansing was taking place" in $\mathrm{BiH}$, and stated that this was consistent with his own observations of what was occurring in the region. ${ }^{6117}$ Sejmenović left Vrbanja on 15 January 1993 after obtaining the proper documents to present to international agencies and officials to be able to leave. ${ }^{6118}$ Kuprešanin wrote an accompanying letter, confirming Sejmenović's identity, which referred to the fact that he was released from Omarska at the request of the Accused. ${ }^{6119}$

1788. On 6 August 1992, around 600 of the Omarska detainees were called out as being "not dangerous" and were sent to Trnopolje. ${ }^{6120}$ On the same day, a second group of approximately 1,300 detainees, including KDZ026, were taken to Manjača. ${ }^{6121}$ The men in this second group were put on to buses by members of the intervention squad and the buses departed Omarska; there were approximately 100 to 120 men on KDZ026's bus. ${ }^{6122}$ Between 170 and 180 detainees remained at Omarska after these transfers. ${ }^{6123}$

1789. That evening, approximately 200 military beds were delivered to Omarska and thereafter, detainees received two meals a day and conditions improved. ${ }^{6124}$ A delegation of ICRC representatives and journalists visited the camp again a week later, on or around 12 August 1992. ${ }^{6125}$ By mid-August 1992, a total of 1,773 detainees were transferred from

\footnotetext{
6115 Mevludin Sejmenović, T. 20507 (27 October 2011).

6116 Mevludin Sejmenović, T. 20507-20510 (27 October 2011), testifying about P3698 (STV video footage of interview with Radovan Karadžić).

6117 Mevludin Sejmenović, T. 20511-20512 (27 October 2011), testifying about P3699 (Video of NTV news re Vance's statements in Banja Luka).

6118 Mevludin Sejmenović, T. 20512 (27 October 2011).

6119 P3700 (Letter from Vojislav Kuprešanin to Banja Luka CSB, 12 January 1993). The Chamber notes that the letter is dated 12 January 1992; however given Sejmenović's evidence regarding when he left Vrbanja and the context of the surrounding evidence, the Chamber considers that this is a typographical error and the letter should in fact be dated 12 January 1993.

6120 KDZ026, P2089 (Transcript from Prosecutor v. Stakić), T. 1928 (under seal).

6121 KDZ026, P2089 (Transcript from Prosecutor v. Stakić), T. 1928 (under seal); KDZ026, T. 10391 (17 January 2011) (closed session); KDZ392, P707 (Transcript from Prosecutor v. Kvočka), T. 2749-2750, 2766 (under seal). See Adjudicated Fact 2489.

6122 KDZ026, T. 10322 (17 January 2011) (closed session).

6123 Željko Mejakić, T. 44273, 44280 (29 November 2013); P3549 (Report of the Commission for Inspecting Collection Centres and Other Facilities for Captives in the ARK, 17 August 1992), p. 4.

6124 Željko Mejakić, T. 44273-44274, 44280 (29 November 2013).

6125 Željko Mejakić, T. 44273-44274, 44280 (29 November 2013); P3543 (Excerpt from video clip of visits to Omarska and Trnopolje, with transcript).
} 
Omarska to Trnopolje. ${ }^{6126}$ On 21 August 1992, the last group of detainees was transferred to Manjača, on buses escorted by Mejakić, and Omarska was closed. ${ }^{6127}$

(c) Scheduled Detention Facility C.20.3

1790. The Indictment refers to the use of Keraterm as a detention facility in Prijedor municipality between 15 May and 6 August 1992.

(i) Establishment of camp and arrival of detainees

1791. A former ceramic tile factory located on the eastern outskirts of Prijedor, Keraterm operated as a detention facility between 24 May and 21 August $1992 .{ }^{6128}$ Keraterm was clearly visible from the main road from Prijedor to Banja Luka. ${ }^{6129}$

1792. Keraterm was established by the Prijedor Crisis Staff. ${ }^{6130}$ The camp operated under camp commander, Duško Sikirica, and security at the camp was provided by members of the Prijedor SJB and MP. ${ }^{6131}$

1793. Approximately 4,000 detainees, primarily Bosnian Muslim and Bosnian Croat men, were held at Keraterm throughout its operation as a camp. ${ }^{6132}$ Some of the detainees brought to

6126 See Adjudicated Fact 2489; Željko Mejakić, T. 44280-44281 (29 November 2013). But see Željko Mejakić, T. 44281 (29 November 2013) (testifying that transfers of detainees to Trnopolje started in early June 1992 and that the total number of detainees transferred there was much lower than 1,700).

6127 Željko Mejakić, T. 44281-44282 (29 November 2013); P6585 (SRNA press release, 22 August 1992) (reporting that Omarska had been closed down in the course of the day and that authority over Trnopolje had been handed over to the Red Cross). See also Milomir Stakić, T. 45278-45281 (17 December 2013) (testifying that once Manjača camp opened, there was no longer a reason to keep Omarska and Keraterm open and those who were "found to be guilty of war crimes" were transferred to Manjača).

6128 KDZ074, P709 (Transcript from Prosecutor v. Stakić), T. 2312; Jusuf Arifagić, P689 (Transcript from Prosecutor v. Stakić), T. 7081-7083; P541 (Photograph of Keraterm); P542 (Photograph of Keraterm); P3549 (Report of the Commission for Inspecting Collection Centres and Other Facilities for Captives in the ARK, 17 August 1992), p. 4; P2968 (Report of Prijedor SJB January 1993), p. 5; P5555 (Report of Prijedor SJB, 29 September 1992), p. 4. See Adjudicated Facts 1102, 1103, 1192, 1196.

6129 Jusuf Arifagić, P689 (Transcript from Prosecutor v. Stakić), T. 7083. See also P6594 (Aerial photograph of Keraterm marked by Dragan Radetić); D4254 (Aerial photograph of Keraterm marked by KW609); D470 (CSB Banja Luka Report concerning collection centres, undated), e-court p. 3.

6130 See Adjudicated Facts 1105, 1193; D470 (CSB Banja Luka Report concerning collection centres, undated), ecourt pp. 2-3, 6, 11, 29, 32. See also P2741 (Decision of Prijedor Crisis Staff, 2 June 1992); P2637 (Report of Prijedor SJB, 1 July 1992). Defence witnesses Milomir Stakić and Slavko Budimir testified that the Crisis Staff did not participate in the formation of Keraterm and had no authority over the facility; rather that only the police was in charge of the facility. D4195 (Witness statement of Milomir Stakić dated 16 November 2013) paras. 23, 48-49; Milomir Stakić, T. 45242-45246, 45254 (17 December 2013); Slavko Budimir, D4463 (Transcript from Prosecutor v. Stakić), T. 12947-12958, 12964. However, the Chamber does not find this evidence to be credible based on the accepted evidence before the Chamber to the contrary which confirms that the Prijedor Crisis Staff was involved in the establishment of Keraterm and in its operations.

6131 See Adjudicated Facts 1193, 1194; D470 (CSB Banja Luka Report concerning collection centres, undated), ecourt pp. 3, 6, 11, 29, 32. See also P2915 (Summary of conclusions of Prijedor's Executive Board, 29 April-17 August 1992), p. 3; P2741 (Decision of Prijedor Crisis Staff, 2 June 1992); P2637 (Report of Prijedor SJB, 1 
Keraterm were originally detained at the Prijedor SJB Building, but were brought to Keraterm when the SJB was unable to accommodate the increased number of detainees. ${ }^{6133}$

1794. Keraterm held up to as many as 1,500 prisoners at one time, crowded into a number of large rooms or halls. ${ }^{6134}$ Between 200 and 500 Bosnian Muslim and Croat men, between the ages of 17 and 55, were detained in Room 2 at Keraterm. ${ }^{6135}$ There were other rooms used to house detainees, known as Rooms 1, 3, and 4. ${ }^{6136}$ Between 250 and 270 men were initially held in Room 3 but later two more groups arrived and the number grew to $570 .{ }^{6137}$ There were machine guns placed near the entrance to the camp. ${ }^{6138}$

1795. Interrogation teams were sent to Keraterm to interview and investigate detainees there; ${ }^{6139}$ the teams were comprised of representatives from civilian public security, state security, and military security. ${ }^{6140}$ Dragan Radetić, a Serb military prosecutor appointed as a member of one of the commissions investigating detainees at Keraterm, testified that over a period of 15 days, his

July 1992). Damir Došen, a.k.a "Kajin", was one of the shift commanders at Keraterm. See Adjudicated Fact 1195.

6132 P3549 (Report of the Commission for Inspecting Collection Centres and Other Facilities for Captives in the ARK, 17 August 1992), p. 4. See Adjudicated Fact 1197 (stating that "[t]here were a couple of Albanians, and a Bosnian Serb accused of not being a loyal Serb" detained at Keraterm).

6133 KW609, D4246 (Transcript from Prosecutor v. Staniš̌ić \& Župljanin), T. 16727-16728. See also Dušan Janković, T. 47285 (18 February 2014) (stating that people held at the Prijedor SJB who were under investigation or interrogation were taken to the Keraterm or Omarska detention facilities).

6134 See Adjudicated Fact 1196. See also P572 (Sketches of Keraterm drawn by Jusuf Arifagić).

6135 Safet Tači, P693 (Transcript from Prosecutor v. Kvočka), T. 3757-3758 (stating that approximately 500 men were being held in Room 2 when he arrived). Cf. Jusuf Arifagić, P689 (Transcript from Prosecutor v. Stakić), T. 7086-7087 (estimating that there were approximately 200 to 300 people in Room 2 when he arrived); KDZ074, P709 (Transcript from Prosecutor v. Stakić), T. 2315; P711 (Witness statement of KDZ074 dated 23 September 1994), p. 8 (stating that about 200 other Bosnian Muslim male prisoners were being held in Room 2).

${ }_{6136}$ Jusuf Arifagić, P689 (Transcript from Prosecutor v. Stakić), T. 7106-7108; P572 (Sketches of Keraterm drawn by Jusuf Arifagić).

6137 KDZ050, P680 (Transcript from Prosecutor v. Sikirica), T. 2503; see Adjudicated Fact 1198. However, Dragan Radetić testified that (i) the number of Bosnian Muslims held at Keraterm was much lower than 4,000, and he had never heard of any Serbs or Albanians being held there; (ii) Keraterm camp could not have possibly held 1,500 prisoners at once; (iii) the number of 570 being detainees held in Room 3 is exaggerated. D4226 (Witness statement of Dragan Radetić dated 17 January 2014), paras. 36-38. The Chamber does not find Radetić's evidence to be credible in this regard. In reaching that conclusion, the Chamber considers that he was not forthright with the Chamber on several occasions and that due to his involvement in interrogating detainees at Keraterm, he had an interest in distancing himself from any knowledge of conditions there.

6138 Jusuf Arifagić, P689 (Transcript from Prosecutor v. Stakić), T. 7084-7086, 7108; see P572 (Sketches of Keraterm drawn by Jusuf Arifagić).

6139 Defence witnesses testified that Keraterm was used as an investigation centre for those individuals who refused to mobilise and were considered armed and dangerous, or for those who had participated in armed rebellion, such as members of the Green Berets. D4882 (Witness statement of Dušan Đenadija undated), para. 6; Vojislav Kuprešanin, T. 43454-43455 (14 November 2013); D4010 (Report of Prijedor SJB, September 1993), p. 2.

6140 D4226 (Witness statement of Dragan Radetić dated 17 January 2014), paras. 28, 30, 35; Dragan Radetić, T. 45677 (20 January 2014); KW609, D4246 (Transcript from Prosecutor v. Stanišić \& Župljanin), T. 1691116913; D470 (CSB Banja Luka Report concerning collection centres, undated), e-court pp. 3, 6, 29, 32 . See Adjudicated Fact 1207 (stating that interrogators at Keraterm "consisted of members of the Banja Luka CSB and of the Banja Luka Corps"). See also Adjudicated Fact 1204 (stating that "most of the detainees in Keraterm 
commission interviewed 50 detainees, all adult men who denied having been involved in the conflict or with the armed forces. ${ }^{6141}$

\section{(ii) $\underline{\text { Conditions of detention }}$}

1796. Conditions in Keraterm were atrocious. ${ }^{6142}$ Detainees were crowded into unlit, windowless rooms, with barely enough space to lie down on concrete floors. ${ }^{6143}$ In Room 3, the floor was wet and the walls were stained. ${ }^{6144}$ The rooms in Keraterm were intensely hot in the summer with no ventilation and the detainees were kept locked in these rooms for days on end, crowded together. $^{6145}$

1797. There were few toilet facilities and the detainees were allowed to go to the toilet only once a day, five men at a time, and escorted by guards. ${ }^{6146}$ Initially, one lavatory was available for all of the detainees but it became blocked and barrels were supplied instead which leaked, causing an overpowering stench. ${ }^{6147}$ Detainees were not able to bathe, but they could occasionally wash a little. ${ }^{6148}$ The detainees received no soap or toothpaste. ${ }^{6149}$ Infestations of lice appeared. ${ }^{6150}$ Dysentery was rife and there was no medical care. ${ }^{6151}$

were interrogated in an attempt to identify opponents of the new Serb regime"); KDZ026, P2089 (Transcript from Prosecutor v. Stakić), T. 1840-1841 (under seal).

6141 D4226 (Witness statement of Dragan Radetić dated 17 January 2014), paras. 28, 30, 31, 35. See also KDZ026, P2089 (Transcript from Prosecutor v. Stakić), T. 1840-1841 (under seal); KDZ026, T. 10308, 10381-10382 (17 January 2011) (closed session).

6142 Adjudicated Fact 1198; P3661 (UNPROFOR Memo, 4 July 1992), p. 2 (reporting that "100-200 Muslims believed to be [held at Keraterm] under extremely bad conditions"). See also D3645 (Witness statement of Nenad Kecmanović dated 27 May 2013), para. 54.

6143 KDZ050, P680 (Transcript from Prosecutor v. Sikirica), T. 2502-2503; see Adjudicated Facts 1198, 1199.

6144 KDZ050, P680 (Transcript from Prosecutor v. Sikirica), T. 2502-2503.

6145 KDZ050, P680 (Transcript from Prosecutor v. Sikirica), T. 2503, 2505; see Adjudicated Fact 1199.

6146 See Adjudicated Fact 1200.

6147 KDZ050, P680 (Transcript from Prosecutor v. Sikirica), T. 2505-2506; see Adjudicated Fact 1199. KDZ050 testified that in the first two days at Keraterm, they were not allowed to leave Room 3 for any reason, including to use the toilet, and they had to use a blue plastic barrel which had been placed inside the room. KDZ050, P680 (Transcript from Prosecutor v. Sikirica), T. 2505-2506.

${ }_{6148}$ See Adjudicated Fact 1200. In addition, Radetić testified that the lack of hygienic care at Keraterm was due to a general shortage of water, and that the guards also suffered from this shortage. D4226 (Witness statement of Dragan Radetić dated 17 January 2014), para. 39 (referring to D4227 (Notification re water supply in Prijedor, 29 September 2000), p. 1).

6149 Adjudicated Fact 1200.

6150 Adjudicated Fact 1200.

6151 Adjudicated Fact 1201. But see D4226 (Witness statement of Dragan Radetić dated 17 January 2014), para. 40 (stating that he "did not know there were problems like this" at Keraterm). The Chamber does not find Radetić's evidence to be credible in this regard. In reaching that conclusion, the Chamber refers to its earlier assessment in fn. 6137 regarding the credibility of Radetić. 
1798. At Keraterm, both the quality and quantity of food provided to the detainees were totally inadequate, and they suffered from malnutrition and, in some instances, starvation. ${ }^{6152}$ The detainees received two pieces of bread that they had to eat very quickly or they would be beaten. ${ }^{6153}$ Furthermore, the food was not delivered regularly and sometimes there was no food provided at all. ${ }^{6154}$ To supplement the meagre camp provisions, detainees were sometimes allowed to receive food brought to the camp by their families, although these occasional supplements were not sufficient to alleviate their hunger and malnutrition. ${ }^{6155}$

\section{(iii) Treatment of detainees}

1799. Detainees were beaten upon arrival at Keraterm. ${ }^{6156}$ Jusuf Arifagić was brought to Keraterm on 14 June 1992, by bus, along with a group of about 40 other men captured with him in Mujkanovići. ${ }^{6157}$ When his group arrived at the camp, two "Serb soldiers" entered the bus, ordered the men to get off in small groups, and began beating and kicking them as they lay on the ground. ${ }^{6158}$ Safet Tači, a young Bosnian Muslim man who resided in Kozarac with his family until 1992, was also taken to Keraterm by "Serb forces" in mid-June 1992. ${ }^{6159}$ Arifagić and Tači were put in Room 2, where other men from villages in the Prijedor region, who had also been physically mistreated, were being held. ${ }^{6160}$ On the evening of their arrival, Arifagić and the men who had

\footnotetext{
6152 See Adjudicated Facts 1200, 1202. KDZ050 testified that he was given no food or water for two days after arriving at Keraterm. KDZ050, P680 (Transcript from Prosecutor v. Sikirica), T. 2505.

6153 Adjudicated Fact 1202.

$6154 \quad$ Adjudicated Fact 1202.

6155 See Adjudicated Fact 1203. KDZ093 visited her husband in Keraterm for the first time in mid-June 1992 and brought him food and clothes, but a guard took the bag at the gate and said he would give it to him; she saw her husband from far away and he looked very thin and exhausted. KDZ093 visited him a second time around the end of June 1992 and as she approached the gate, Zoran Žigić recognised her and brought her husband to the fence and said to her: "Here. Take a good look at your husband. He's going to fall first for the freedom of this town." Her husband was very thin and exhausted; he did not say anything to her at the fence, but tears ran down his face. KDZ093 never saw her husband again after that day; she heard later from more than a hundred witnesses that her husband was beaten and killed in broad daylight in Omarska camp. KDZ093, P705 (Transcript from Prosecutor v. Kvočka), T. 6191-6194, 6236, 6244. But see D4226 (Witness statement of Dragan Radetić dated 17 January 2014), para. 41 (stating that the guards also suffered from malnutrition due to wartime shortages of food).

6156 Jusuf Arifagić, P689 (Transcript from Prosecutor v. Stakić), T. 7084, 7089; KDZ074, P709 (Transcript from Prosecutor v. Stakić), T. 2314-2315; P711 (Witness statement of KDZ074 dated 23 September 1994), p. 8; KDZ050, P680 (Transcript from Prosecutor v. Sikirica), T. 2501-2502. See also Adjudicated Fact 1205.

6157 Jusuf Arifagić, P689 (Transcript from Prosecutor v. Stakić), T. 7080, 7083-7084. KDZ093 testified that her husband was detained by "Serb forces" in mid-June 1992 and taken to Keraterm. KDZ093, P705 (Transcript from Prosecutor v. Kvočka), T. 6189, 6191.

6158 Jusuf Arifagić, P689 (Transcript from Prosecutor v. Stakić), T. 7084.

6159 Safet Tači, P693 (Transcript from Prosecutor v. Kvočka), T. 3755-3756.

6160 Safet Tači, P693 (Transcript from Prosecutor v. Kvočka), T. 3755-3757; Jusuf Arifagić, P689 (Transcript from Prosecutor v. Stakić), T. 7084-7086, 7107; KDZ074, P709 (Transcript from Prosecutor v. Stakić), T. 2315. See also P572 (Sketches of Keraterm drawn by Jusuf Arifagić).
} 
been brought in with him were ordered to leave Room 2 and to lie down on the ground outside, where they were severely beaten and told to confess to being members of the Green Berets. ${ }^{6161}$

1800. KDZ074 was captured in the woods between Čarakovo and Hambarine by armed men in camouflage uniforms and taken to Keraterm on 8 July $1992{ }^{6162}$ Upon his arrival, he was interrogated and beaten, and then taken to Room $2 .{ }^{6163}$

1801. While in detention, beatings were very frequent at Keraterm. ${ }^{6164}$ The guards called out the names of detainees, often at night, and they were taken outside and beaten. ${ }^{6165}$ Those who returned were bloody and bruised all over; some died of their injuries. ${ }^{6166}$ Some detainees who were called out never returned, and the other detainees assumed that they had died as a result of the beatings. ${ }^{6167}$ Arifagic testified that the bodies of the men who died after being taken out at night were deposited in a part of the camp referred to as the "garbage dump". 6168

1802. Detainees were beaten with bars and batons, and made to beat each other. ${ }^{6169}$ Detainees were often beaten and humiliated in front of other detainees. ${ }^{6170}$ Two former Bosnian Muslim policemen were severely beaten with chains and metal rods, one of whom died as a consequence of this beating. ${ }^{6171}$ Detainees were also beaten during interrogations at Keraterm. ${ }^{6172}$ The beatings were administered by the guards at Keraterm, in particular by Nenad Banović, a.k.a. "Čupo", and

6161 Jusuf Arifagić, P689 (Transcript from Prosecutor v. Stakić), T. 7087-7090 (further stating that he sustained a number of injuries as a consequence and the next day was taken to a hospital in a van, along with some other detainees, accompanied by Žigić, where his wounds were dressed, and then he was returned to Keraterm). One of the detainees who was with Arifagić-Emsud Bahonjić-later died as a result of his injuries and Arifagić assisted in carrying his body to the guards' cabin in the camp. Jusuf Arifagić, P689 (Transcript from Prosecutor v. Stakić), T. 7090. Dušan Janković testified that members of the Green Berets were captured during the attack on the Prijedor municipal building on 30 May 1992 and were taken to the Keraterm and Omarska detention facilities to be investigated. Dušan Janković, T. 47272, 47274 (18 February 2014).

6162 KDZ074, P709 (Transcript from Prosecutor v. Stakić), T. 2304-2305, 2312 (stating that he was unarmed and in civilian clothes at the time of his capture).

6163 KDZ074, P709 (Transcript from Prosecutor v. Stakić), T. 2314-2315; P711 (Witness statement of KDZ074 dated 23 September 1994), p. 8.

6164 See Adjudicated Fact 1208.

6165 See Adjudicated Facts 1208, 1209; Jusuf Arifagić, P689 (Transcript from Prosecutor v. Stakić), T. 7090-7091; KDZ050, P680 (Transcript from Prosecutor v. Sikirica), T. 2506-2507; Safet Tači, P693 (Transcript from Prosecutor v. Kvočka), T. 3758.

6166 Jusuf Arifagić, P689 (Transcript from Prosecutor v. Stakić), T. 7090-7091; KDZ050, P680 (Transcript from Prosecutor v. Sikirica), T. 2506-2507; see Adjudicated Fact 1209.

6167 Jusuf Arifagić, P689 (Transcript from Prosecutor v. Stakić), T. 7090-7091; KDZ050, P680 (Transcript from Prosecutor v. Sikirica), T. 2506-2507; see Adjudicated Fact 1209. [REDACTED].

6168 Jusuf Arifagić, P689 (Transcript from Prosecutor v. Stakić), T. 7091.

6169 See Adjudicated Fact 1208.

6170 See Adjudicated Fact 1212.

6171 Jusuf Arifagić, P689 (Transcript from Prosecutor v. Stakić), T. 7093-7094 (stating that the two men were wearing police uniforms when they arrived at Keraterm and said that although they had signed the oath of loyalty and had continued to work as policemen, they had nonetheless been disarmed and brought to the camp). See also Adjudicated Fact 1210.

6172 See Adjudicated Fact 1206. 
Zoran Žigić, ${ }^{6173}$ as well as by people from outside the camp allowed in by the guards, such as Duško Knežević. ${ }^{6174}$ Additionally, some prisoners were questioned about money and taken to their homes and were made to search for money, which was handed over to the guards if found. ${ }^{6175}$

1803. Women detained in Keraterm were also raped. ${ }^{6176}$ KDZ093, a Bosnian Muslim woman from Prijedor, was arrested with others from her apartment building on 14 July 1992 by "Serb forces" wearing police uniforms-light blue shirts and grey-blue trousers-and brought to Keraterm. ${ }^{6177}$ They were immediately brought to a room and Sikirica, who introduced himself as the commander of the camp, ordered them to take off their jewellery and everything they had on. ${ }^{6178}$ That night, Neđeljko Timarac took KDZ093 and another Muslim woman who was her

6173 See Adjudicated Facts 1195, 1211; KDZ050, P680 (Transcript from Prosecutor v. Sikirica), T. 2501-2502, 2507, 2520-2521, 2536-2538 (stating that when "Čupo Banović's shift was on duty, they took out people" to be beaten more often, and that he sometimes visited the camp when he was not on duty in order to "torture" the detainees); Jusuf Arifagić, P689 (Transcript from Prosecutor v. Stakić), T. 7089, 7091; Safet Tači, P693 (Transcript from Prosecutor v. Kvočka), T. 3758-3763 (stating that Žigić wore a camouflage uniform, often wore sunglasses, and always had a bandage on his hand, and that he was often involved in beatings and the detainees were all in fear of him; on one occasion, he was beaten by Žigić as he returned to Room 2 from the toilet); KDZ093, P705 (Transcript from Prosecutor v. Kvočka), T. 6192-6194, 6244 (stating that she knew Žigić well from attending elementary school together and that he was wearing a military uniform and a red "beret" when she saw him at Keraterm at the end of June 1992); Dragan Radetić, T. 45681-45684 (20 January 2014), T. 45689-45691 (21 January 2014) (stating that Žigić was a member of the civilian police). However, the Chamber also received evidence that Žigić was an "armed uniformed person" who entered the camp in the evenings and beat detainees, despite warnings from officials of the camp not to enter, suggesting that Žigić was not a guard at Keraterm. D4140 (Official note of Prijedor SJB, 4 July 1992).

6174 See Adjudicated Fact 1211; Jusuf Arifagić, P689 (Transcript from Prosecutor v. Stakić), T. 7089; D4140 (Official note of Prijedor SJB, 4 July 1992). See also Dragan Radetić, T. 45681-45684 (20 January 2014), T. 45689-45690 (21 January 2014). Stakić also testified that at Keraterm, "people would be taken away by armed individuals", but he did not know who these individuals were. Milomir Stakić, T. 45250-45251 (17 December 2013).

6175 See Adjudicated Fact 1214. See also D1925 (Prijedor SJB criminal report, 2 July 1992) (stating that Zoran Žigić was under suspicion of having received a bribe from Esad Marošlić, a detainee held at Keraterm, on 9 June 1992); D1926 (Order of Banja Luka CSB, 1 July 1992) (ordering that Žigić be detained for three days for accepting the bribe from Marošlić). However, Radetić stated that (i) he never noticed that the persons he interviewed had any signs of physical abuse; (ii) beatings did not occur during interrogations while he worked at Keraterm; (iii) beatings never occurred in his presence; (iv) "Muslim members of the security structures, including the police, were not kept together with the civilians held at Keraterm" and he believed they were interviewed separately; and (v) he never heard of any cases of detainees being made to search for money in their homes by guards and he is convinced it was not done by anyone participating in the commissions interviewing detainees. D4226 (Witness statement of Dragan Radetić dated 17 January 2014), paras. 32, 43-46, 48; Dragan Radetić, T. 45680 (20 January 2014). However, Radetić also admitted that he received information and was aware that Žigić, Knežević, and others beat prisoners at Keraterm, after which the detainees died. Dragan Radetić, T. 45681-45684 (20 January 2014), T. 45689-45690 (21 January 2014). See also D4140 (Official note of Prijedor SJB, 4 July 1992). Based on these internal inconsistencies in Radetić's evidence, as well as the Chamber's observation that he was not forthright on several occasions, the Chamber does not find Radetić's evidence that beatings did not occur at Keraterm to be reliable. The Chamber also notes that during his testimony, as demonstrated by these statements, Radetić attempted to distance himself from any knowledge of mistreatment of detainees or conditions of detention.

6176 See Adjudicated Fact 1213.

6177 KDZ093, P705 (Transcript from Prosecutor v. Kvočka), T. 6194-6195.

6178 KDZ093, P705 (Transcript from Prosecutor v. Kvočka), T. 6196. 
neighbour, to two separate offices inside the Keraterm building. ${ }^{6179}$ KDZ093 was then repeatedly raped by Timarac and "other men" throughout the night on a table. ${ }^{6180}$ A guard found her in the morning in a pool of blood and ordered her to wash up and brought her out to the yard where she sat for two to three hours in bloodstained clothes. ${ }^{6181}$ The same guard brought KDZ093's neighbour out that morning; she looked frightened and was crying. ${ }^{6182}$ That afternoon, KDZ093, her neighbour, and a group of six or seven men were taken to Omarska camp in a "police van". ${ }^{6183}$

1804. Detainees at Keraterm were eventually transferred to Omarska or Trnopolje. ${ }^{6184}$ Arifagić was transferred by bus from Keraterm to Trnopolje on 1 August 1992, along with many others. ${ }^{6185}$ On 5 August 1992, a soldier read out a list of names of detainees, numbering about 120 men in total, and they were put on to two buses and drove away. ${ }^{6186}$ After those two buses were driven away, new buses arrived and the remaining detainees in Keraterm, including KDZ050, were put on these buses and taken to Trnopolje. ${ }^{6187}$

\section{$\underline{\text { treatment of detainees }}$}

(iv) Conclusion on conditions of detention and

1805. Based on the above, the Chamber finds that non-Serb civilians from multiple locations were brought to and detained at Keraterm by Serb Forces from 24 May 1992 until at least 5 August 1992. The detainees were held in poor conditions which included lack of space, inadequate bedding, poor sanitary conditions, lack of food, and inadequate medical care. The Chamber finds that detainees were subjected to regular beatings by Serb Forces at Keraterm. The Chamber finds that at least one

6179 KDZ093, P705 (Transcript from Prosecutor v. Kvočka), T. 6197-6198 (further stating that she knew Neđeljko Timarac well from primary school; he wore a military uniform with a grey military "cap").

6180 KDZ093, P705 (Transcript from Prosecutor v. Kvočka), T. 6198-6199. See also Adjudicated Fact 1213.

6181 KDZ093, P705 (Transcript from Prosecutor v. Kvočka), T. 6199-6200. See also Adjudicated Fact 1213.

6182 KDZ093, P705 (Transcript from Prosecutor v. Kvočka), T. 6200. Radetić stated there was no mention of such cases of rape during the time he was at Keraterm. D4226 (Witness statement of Dragan Radetić dated 17 January 2014), para. 47. The Chamber does not find Radetić's evidence in this regard to be credible given his attempt to distance himself from any knowledge of mistreatment of detainees at Keraterm.

6183 KDZ093, P705 (Transcript from Prosecutor v. Kvočka), T. 6200-6201.

6184 Adjudicated Fact 1197.

6185 Jusuf Arifagić, P689 (Transcript from Prosecutor v. Stakić), T. 7105.

6186 KDZ050, P680 (Transcript from Prosecutor v. Sikirica), T. 2522. KDZ050 provided a list of about 60 men, who he stated were "men who were taken away before, who were killed. That is, people that I used to know personally. And this shows also people who were taken out before and those men who were put on those two buses". KDZ050, P680 (Transcript from Prosecutor v. Sikirica), T. 2523; P1949 (Excerpt from KDZ050's witness statement dated 19 November 2000). KDZ050 subsequently identified the bodies of some of the 120 men who were taken away in the first two buses on 5 August 1992, which were recovered from Hrastova Glavica in Sanski Most; though he confirmed that he had heard from other detainees that these men were first taken to Omarska. KDZ050, P680 (Transcript from Prosecutor v. Sikirica), T. 2527, 2531-2532. See Schedule Incident B.15.3. See also Indictment, Scheduled Incident B.15.3, fn. 5 (wherein the Prosecution alleges that detainees from Keraterm were among the victims of Scheduled Incident B.15.3).

6187 KDZ050, P680 (Transcript from Prosecutor v. Sikirica), T. 2524. 
detainee died as a result of beatings. ${ }^{6188}$ The Chamber also finds that a number of Bosnian Muslim women were raped by Serb Forces at Keraterm.

\section{(v) Scheduled Incident B.15.1}

1806. The Indictment refers to the killing of approximately 150 people in Room 3 at Keraterm on or about 24 and 25 July 1992.

1807. On 20 or 21 July 1992, the detainees held in Room 3 were relocated to Rooms 2 and $4 .{ }^{6189}$ Room 3 was then filled with groups of Bosnian Muslim men who arrived in buses from the Brdo area. ${ }^{6190}$ A few days later, on or around 24 July 1992, the detainees held in Room 3 were allowed to leave the room to lie on the grass outside for two or three hours. ${ }^{6191}$ On that day, there was a noticeable increase in activity at the camp, with more vehicles and more "soldiers" present, who were singing. ${ }^{6192}$ Early that evening, the detainees were brought back to Room 3, and the door was locked. ${ }^{6193}$ The detainees in Room 2 were also told to go into their room early, just before nightfall, face the wall, and stay calm. ${ }^{6194}$

1808. Later that night, around 9 or 10 p.m., the detainees heard a lot of commotion outside, including trucks and members of the army entering the camp. ${ }^{6195}$ A table was set up opposite Room 3, with a chair beside it and the area was lit up with strong lights; later, a heavy machine gun was placed on the table, pointed towards Room $3 .^{6196}$

\footnotetext{
6188 This finding does not include the persons alleged to have been killed in Scheduled Incident B.15.1, which is discussed below.

6189 Jusuf Arifagić, P689 (Transcript from Prosecutor v. Stakić), T. 7095; Safet Tači, P693 (Transcript from Prosecutor v. Kvočka), T. 3766. See also Adjudicated Fact 1215.

6190 KDZ050, P680 (Transcript from Prosecutor v. Sikirica), T. 2498-2503 (testifying that he surrendered to "Serb troops" on 23 July 1992 at a check-point in the hamlet of Brkić and was transported to Keraterm camp in two buses with approximately 120 to 130 other Bosnian Muslim men who had surrendered or been captured in the Brdo area); Jusuf Arifagić, P689 (Transcript from Prosecutor v. Stakić), T. 7096-7097 (testifying that he saw their documents being taken away from them upon their arrival in the camp and after their arrival, this group of people were not permitted to leave Room 3 or to mix with the other detainees); Safet Tači, P693 (Transcript from Prosecutor v. Kvočka), T. 3766. See also Adjudicated Fact 1215. Upon arriving at the camp, the men on the buses were searched, their valuables and personal documents taken, and their names recorded. They were then made to lie on the grass, and some of them were beaten; an hour or so later, they were moved into Room 3. KDZ050, P680 (Transcript from Prosecutor v. Sikirica), T. 2501-2502.

6191 KDZ050, P680 (Transcript from Prosecutor v. Sikirica), T. 2507-2508.

6192 KDZ050, P680 (Transcript from Prosecutor v. Sikirica), T. 2509, 2535; Safet Tači, P693 (Transcript from Prosecutor v. Kvočka), T. 3764-3765; P572 (Sketches of Keraterm drawn by Jusuf Arifagić).

6193 KDZ050, P680 (Transcript from Prosecutor v. Sikirica), T. 2510.

6194 Jusuf Arifagić, P689 (Transcript from Prosecutor v. Stakić), T. 7097. See also Adjudicated Fact 1216.

6195 Jusuf Arifagić, P689 (Transcript from Prosecutor v. Stakić), T. 7097. See also Adjudicated Fact 1217.

6196 Safet Tači, P693 (Transcript from Prosecutor v. Kvočka), T. 3764-3766; Jusuf Arifagić, P689 (Transcript from Prosecutor v. Stakić), T. 7097, 7101. See also Adjudicated Fact 1217.
} 
1809. At around 11 p.m. or midnight, there was a short burst of gunfire towards the window of Room 3, and later pebbles were thrown at the windows and on the roof. ${ }^{6197}$ The detainees inside began to behave strangely, their eyes stinging, and KDZ050, who was at the back of the room, began to feel faint. ${ }^{6198}$ He concluded that some kind of tear gas or other poisonous gas must have been thrown in the room. ${ }^{6199}$ The detainees began to push against one another, and then broke the door down in an effort to escape, at which point KDZ050 heard the first burst of machine-gun fire from outside. ${ }^{6200}$ The shooting lasted for four or five minutes, and then there was a lull, before it started again. ${ }^{6201}$ KDZ050 passed out briefly, but counted three such bursts of machine-gun fire in total. $^{6202}$ He heard men crying out for help, as well as the sound of the soldiers outside trying to prevent people from escaping. ${ }^{6203}$ Afterwards, he also heard infantry weapons being fired outside a couple of times. ${ }^{6204}$

1810. Detainees in Room 2 heard a burst of gunfire from automatic rifles, the sounds of metal and glass breaking, and men crying out from Room 3. ${ }^{6205}$ One of the detainees in Room 2 heard one of the "Serb soldiers" swearing and saying: "Don't come out or we'll shoot. There they are. They're fleeing" and then the sound of gunfire. ${ }^{6206}$

1811. The next morning, KDZ050 saw blood all over the inside of Room 3, as well as the bodies of injured and killed men lying around. ${ }^{6207}$ He estimated that there were around 200 dead bodies piled inside and outside the room. ${ }^{6208}$ The survivors were then told to come outside, where they stayed on the grass for three or four hours. ${ }^{6209}$ Also that morning, a large truck arrived in the camp

\footnotetext{
6197

6198

KDZ050, P680 (Transcript from Prosecutor v. Sikirica), T. 2510.

KDZ050, P680 (Transcript from Prosecutor v. Sikirica), T. 2511.

6199 KDZ050, P680 (Transcript from Prosecutor v. Sikirica), T. 2511. See also Safet Tači, P693 (Transcript from Prosecutor v. Kvočka), T. 3780 (testifying that he subsequently learned from a survivor from Room 3 that some kind of poisonous gas had been thrown into the room, which meant the occupants could not breathe and had to try to break out of the room); [REDACTED].

6200 KDZ050, P680 (Transcript from Prosecutor v. Sikirica), T. 2511, 2531. See also Adjudicated Fact 1217.

6201 KDZ050, P680 (Transcript from Prosecutor v. Sikirica), T. 2512-2514; Safet Tači, P693 (Transcript from Prosecutor v. Kvočka), T. 3767; Jusuf Arifagić, P689 (Transcript from Prosecutor v. Stakić), T. 7098 (stating that the shooting lasted for about half an hour in total, or even an hour).

6202 KDZ050, P680 (Transcript from Prosecutor v. Sikirica), T. 2512-2514.

6203 KDZ050, P680 (Transcript from Prosecutor v. Sikirica), T. 2512. See also Safet Tači, P693 (Transcript from Prosecutor v. Kvočka), T. 3766-3767.

6204 KDZ050, P680 (Transcript from Prosecutor v. Sikirica), T. 2516. See also Safet Tači, P693 (Transcript from Prosecutor v. Kvočka), T. 3767.

6205 Jusuf Arifagić, P689 (Transcript from Prosecutor v. Stakić), T. 7097-7098; Safet Tači, P693 (Transcript from Prosecutor v. Kvočka), T. 3766-3767. See also Adjudicated Fact 1217.

6206 Safet Tači, P693 (Transcript from Prosecutor v. Kvočka), T. 3767.

6207 KDZ050, P680 (Transcript from Prosecutor v. Sikirica), T. 2516. See also Jusuf Arifagić, P689 (Transcript from Prosecutor v. Stakić), T. 7098-7099; Adjudicated Fact 1218.

6208 KDZ050, P680 (Transcript from Prosecutor v. Sikirica), T. 2516-2517. See also Adjudicated Fact 1218

6209 KDZ050, P680 (Transcript from Prosecutor v. Sikirica), T. 2516-2517.
} 
and was parked in front of Room 3. ${ }^{6210}$ All the detainees were told to come out of their rooms, and those who looked strongest, including Tači and Arifagić, were directed to load bodies from Room 3 into the truck. ${ }^{6211}$ It took about an hour to load all of the bodies, and then the truck drove away. ${ }^{6212}$ In addition, those who had survived but were injured were also taken away in the truck. ${ }^{6213}$ Blood dripped from the truck as it left. ${ }^{6214}$ A fire engine, or some type of truck equipped with water and a hose, arrived and was used to wash the blood from the ground of Room 3 and the surrounding area. $^{6215}$

1812. Those who survived were returned to Room 3 after it was cleaned. ${ }^{6216}$ The following night, Arifagić heard shooting again from Room 3, although it did not last as long as the first time. ${ }^{6217}$ At one point he heard someone shouting: "What are we going to do? There are survivors here", and he then heard about 40 individual shots. ${ }^{6218}$ Once again, the next morning, a truck arrived and bodies were loaded on to it. ${ }^{6219}$ In addition, the occupants of Rooms 1, 2, and 4 were ordered to go outside, and those who had injuries were told to board the truck, as were the six men who had been involved in loading the bodies, and it drove away. ${ }^{620}$ A day or two after the shootings, Arifagić saw Simo Drljača in the camp, near Room 1. ${ }^{6221}$ Some of the detainees approached him, and he said that "this" should not have happened and they had his assurances that they would not be harmed again. ${ }^{6222}$

\footnotetext{
6210 Safet Tači, P693 (Transcript from Prosecutor v. Kvočka), T. 3768-3769; KDZ050, P680 (Transcript from Prosecutor v. Sikirica), T. 2517. See also Adjudicated Fact 1218; KDZ092, P702 (Transcript from Prosecutor v. Stakić), T. 3974 (under seal).

6211 Safet Tači, P693 (Transcript from Prosecutor v. Kvočka), T. 3768-3769; Jusuf Arifagić, P689 (Transcript from Prosecutor v. Stakić), T. 7098-7099 (stating that the guards were looking for volunteers who "were not afraid of the dead"); KDZ050, P680 (Transcript from Prosecutor v. Sikirica), T. 2517-2518. See Edward Vulliamy, P3777 (Transcript from Prosecutor v. Stakić), T. 7947 (testifying that a detainee told him that he had to clear the bodies from a hangar in Keraterm after about 200 people had been killed in one night); Edward Vulliamy, T. 21050-21051 (9 November 2011). See also KDZ092, P702 (Transcript from Prosecutor v. Stakić), T. 3974 (under seal).

6212 Safet Tači, P693 (Transcript from Prosecutor v. Kvočka), T. 3770; Jusuf Arifagić, P689 (Transcript from Prosecutor v. Stakić), T. 7098-7099; KDZ050, P680 (Transcript from Prosecutor v. Sikirica), T. 2517-2518.

6213 KDZ050, P680 (Transcript from Prosecutor v. Sikirica), T. 2517-2518; Safet Tači, P693 (Transcript from Prosecutor v. Kvočka), T. 3769. See also KDZ092, P702 (Transcript from Prosecutor v. Stakić), T. 3974,4066 [REDACTED].

6214 Jusuf Arifagić, P689 (Transcript from Prosecutor v. Stakić), T. 7098-7099. See also Adjudicated Fact 1218.

6215 Safet Tači, P693 (Transcript from Prosecutor v. Kvočka), T. 3770; Jusuf Arifagić, P689 (Transcript from Prosecutor v. Stakić), T. 7099. See also Adjudicated Fact 1219.

6216 KDZ050, P680 (Transcript from Prosecutor v. Sikirica), T. 2518 (testifying that out of approximately 570 Bosnian Muslim men who were detained in Room 3, about half of them survived the killings in Room 3).

6217 Jusuf Arifagić, P689 (Transcript from Prosecutor v. Stakić), T. 7100.

6218 Jusuf Arifagić, P689 (Transcript from Prosecutor v. Stakić), T. 7100.

6219 Jusuf Arifagić, P689 (Transcript from Prosecutor v. Stakić), T. 7100.

6220 Jusuf Arifagić, P689 (Transcript from Prosecutor v. Stakić), T. 7100.

6221 Jusuf Arifagić, P689 (Transcript from Prosecutor v. Stakić), T. 7104.

6222 Jusuf Arifagić, P689 (Transcript from Prosecutor v. Stakić), T. 7104.
} 
1813. Defence witnesses testified that the killing incident which occurred in Room 3 at Keraterm (i) resulted from a rebellion or an escape attempt by the detainees; ${ }^{6223}$ or (ii) were spontaneous killings by local battalions or reservists, committed in revenge for Serbian soldiers killed at the frontline. ${ }^{6224}$ The Chamber considers that these claims are speculative and hearsay; therefore, the Chamber does not find the evidence of these witnesses to be reliable.

1814. The Chamber took judicial notice that a minimum of 190 persons were killed in Room 3 at Keraterm. ${ }^{625}$ Furthermore, in assessing the overall number of persons killed during this incident, the Chamber has considered witness testimony that (i) there were approximately 200 dead bodies piled inside and outside of Room 3 the morning after the killings there; ${ }^{626}$ and (ii) out of approximately 570 Bosnian Muslim men who were detained in Room 3, about half of them survived the killings in Room 3 on or around 24 July 1992. ${ }^{6227}$ In addition, the Chamber received forensic evidence to support the deaths of some identified individuals at Keraterm in connection with the killings in Room 3 on or around 24 July $1992 .{ }^{6228}$

1815. In weighing the totality of the evidence before it, the Chamber is therefore satisfied that at least 190 Bosnian Muslim men were killed in Room 3 at Keraterm by Serb Forces on or about 24 and 25 July 1992.

6223 D4242 (Witness statement of Draško Vujić dated 24 January 2014), para. 8 (stating that he received information that there had been a "rebellion" of detainees at Keraterm and that firearms were used and many people killed as a result); Dušan Janković, T. 47282-47283 (18 February 2014) (testifying that he heard there was a mutiny by the detainees at Keraterm and in the process, the mutineers were killed); D4226 (Witness statement of Dragan Radetić dated 17 January 2014), para. 49 (stating that he heard that some of the detainees attempted to escape from Keraterm and that some of them were killed as a result).

6224 D4195 (Witness statement of Milomir Stakić dated 16 November 2013), para. 24; Milomir Stakić, T. 45286 (17 December 2013) (testifying that according to his intelligence at the time, as well as information from Drljača, after several Serbian soldiers were killed at the frontline, members of their unit "raided Keraterm and killed several dozens of prisoners out of revenge").

6225 See Adjudicated Fact 1219.

6226 See KDZ050, P680 (Transcript from Prosecutor v. Sikirica), T. 2516. [REDACTED]. See also P4853 (Updated Table 2 to the Report of Amor Mašović), p. 26 [REDACTED]; P646 (Excerpts from report on exhumations in Prijedor municipality, 28 August 2002, pp. 173, 266 (under seal) [REDACTED].

6227 See KDZ050, P680 (Transcript from Prosecutor v. Sikirica), T. 2518.

6228 See P4409 (Death certificates from Prijedor), e-court pp. 1-14, 17-24, 27-32, 35-38, 41-46, 58-63 (confirming the deaths of 22 identified individuals at Keraterm camp between 23 July and 28 July 1992); P4853 (Updated Table 2 to the Report of Amor Mašović), pp. 16-20, 23-31, 34, 41 (wherein Mašović identifies the names of 76 identified individuals who went missing from Keraterm on or around 24 July 1992 and who were later exhumed from various mass graves, including the Stari Kevljani mass grave, who he links to the killings in Room 3); P5909 (Bihać MUP identification reports concerning Stari Kevljani mass grave, 30 June 2005), pp. 1, 3-4, 8-12, 16, 19-20, 22-23, 31, 35-36, 43, 49-51, 57-58 (confirming that 21 identified individuals who went missing from Keraterm, and were linked to the killings in Room 3, were exhumed from the Stari Kevljani mass grave). See also P4850 (Witness statement of Amor Mašović dated 23 March 2012), Annex A, pp. 8-10; P4893 (Bihać MUP report on Stari Kevljani exhumation, 18 January 2004); [REDACTED]; P646 (Excerpts from report on exhumations in Prijedor municipality, 28 August 2002), pp. 29-30, 259-268 (under seal) (stating that, at the time of the creation of his report, none of the bodies of the victims of the incident in Room 3 at Keraterm had been exhumed, but finding that 69 identified individuals died during the incident based on witness testimony and court rulings declaring individuals as officially dead in connection with this incident); Nicolas Sébire, P694 (Transcript from Prosecutor v. Stakić), T. 7358-7359. 


\section{$\underline{\text { B. } 15.5}$}

(d) Scheduled Detention Facility C.20.4 and Scheduled Incident

1816. The Indictment refers to the use of Trnopolje as a detention facility in Prijedor municipality between at least 15 May and 30 September 1992. The Prosecution alleges that a number of people were killed at Trnopolje and at various places after they were taken from the camp between 28 May and October 1992.

facility

(i) Arrival of detainees and control over detention

1817. Trnopolje is located in the village of Trnopolje, which lies to the southeast of Prijedor town and on the train line from Prijedor to Banja Luka. ${ }^{629}$ The camp was established in a former elementary school and its surrounding buildings, which included a gymnasium, shop, the former municipal centre, and an attached theatre, known as the "dom". 6230

1818. Trnopolje became operational on or around 24 May 1992 during the attacks on Hambarine and Kozarac when residents of those areas who had been displaced from their homes were brought there. ${ }^{6231}$ Initially, primarily Bosnian Muslim and Bosnian Croat women, children, and elderly were brought to Trnopolje; however, later Bosnian Muslim and Bosnian Croat men of military age were transferred there from Keraterm and Omarska. ${ }^{6232}$

6229 P569 (Map of Prijedor municipality). See Adjudicated Fact 1223.

6230 KDZ038, P676 (Transcript from Prosecutor v. Stakić), T. 6867, 6873; KDZ048, P678 (Transcript from Prosecutor v. Stakić), T. 3407-3409; P535 (Aerial photograph of Trnopolje); P537 (Photograph of Trnopolje school); P538 (Photograph of Trnopolje); P539 (Photograph of Trnopolje); P540 (Photograph of Trnopolje); Idriz Merdžanić, P3881 (Transcript from Prosecutor v. Stakić), T. 7747-7748; P3894 (Sketch drawn by Idriz Merdžanić of Trnopolje); Idriz Merdžanić, T. 21455-21457 (16 November 2011); D1924 (Aerial photo of Trnopolje camp annotated by Idriz Merdžanić); P3528 (Witness statement of Kerim Mešanović, undated), pp. 65-68; P3543 (Excerpt from video clip of visits to Omarska and Trnopolje, with transcript); KDZ054, P682 (Transcript from Prosecutor v. Stakić), T. 6222-6223. See Adjudicated Fact 1226; D470 (CSB Banja Luka Report concerning collection centres, undated), e-court p. 2.

6231 Idriz Merdžanić, P3881 (Transcript from Prosecutor v. Stakić), T. 7755, 7759 (testifying that he arrived at Trnopolje on 26 May 1992); P684 (Witness statement of KDZ054 dated 14 March 2000), e-court p. 8; Jusuf Arifagić, P689 (Transcript from Prosecutor v. Stakić), T. 7105; KDZ038, P676 (Transcript from Prosecutor v. Stakić), T. 6867, 6873-6874; Nusret Sivac, P3478 (Transcript from Prosecutor v. Stakić), T. 6688-6690; D470 (CSB Banja Luka Report concerning collection centres, undated), e-court pp. 2-3, 28; P2968 (Report of Prijedor SJB, January 1993), p. 5; D4195 (Witness statement of Milomir Stakić dated 16 November 2013), para. 22; Milomir Stakić, T. 45239 (17 December 2013). See also KDZ092, P702 (Transcript from Prosecutor v. Stakić), T. 3997 (under seal); Adjudicated Facts 1102, 1224, 1225; P3898 (Photograph of detainees at Trnopolje); P3899 (Photograph of detainees at Trnopolje); P3900 (Photograph of detainees at Trnopolje).

6232 Idriz Merdžanić, P3881 (Transcript from Prosecutor v. Stakić), T. 7756, 7787-7788; KDZ611, P698 (Transcript from Prosecutor v. Brđanin), T. 12468-12469 (under seal); KDZ038, P676 (Transcript from Prosecutor v. Stakić), T. 6876-6877; P4101 (Witness statement of KDZ611 dated 27 February 1999), e-court pp. 8, 12-13; KDZ014, P674 (Transcript from Prosecutor v. Stakić), T. 5748-5750; P5555 (Report of Prijedor SJB, 29 September 1992), p. 4; P2968 (Report of Prijedor SJB, January 1993), p. 5; P3785 (Excerpt of ITN video clip of journalist visits to Omarska and Trnopolje, with transcript), pp. 7-15; P3780 (Excerpt from ITN video clip of 
1819. The Accused presented evidence that Trnopolje was an "open reception centre" where Bosnian Muslim and Bosnian Croat refugees went voluntarily and stayed for their own protection and shelter during the conflict. ${ }^{6233}$ The Accused argues that due to its "civilian nature", Trnopolje was only partially enclosed by a fence. ${ }^{6234}$ The Chamber considers that although Trnopolje was not entirely fenced in, a barbed wire fence surrounded parts of the compound. ${ }^{6235}$ Further, the Chamber considers that despite Trnopolje being "open" in certain areas, detainees were not allowed to leave unless under certain circumstances. ${ }^{6236}$ For instance, some people were allowed to leave the camp to collect food from nearby villages, as long as they left their identification documents at the camp

men at Trnopolje). See also Adjudicated Facts 1103, 1225, 1296; D470 (CSB Banja Luka Report concerning collection centres, undated), e-court pp. 2-4, 28-29.

6233 D470 (CSB Banja Luka Report concerning collection centres, undated), e-court pp. 2-3, 28-29 (describing Trnopolje as an "Open Reception Centre" established to house citizens who did not want to participate in the fighting, to ensure their safety and protect them from attacks by "extremists"); P3549 (Report of the Commission for Inspecting Collection Centres and Other Facilities for Captives in the ARK, 17 August 1992), p. 3; D4195 (Witness statement of Milomir Stakić dated 16 November 2013), para. 22; D4008 (Witness statement of Slavko Puhalić dated 11 November 2013), paras. 6-7, 18-19; Slavko Puhalić, T. 43397-43399, 43402-43405 (13 November 2013), T. 43452, 43454-43455 (14 November 2013); D4009 (Video footage of Trnopolje); D3968 (Report of Prijedor SJB, 9 August 1992); P3784 (Video clip of interview with Radovan Karadžić) (in which the Accused states that Trnopolje is a "place for people who have no place to stay"). See also D3105 (Witness statement of Slobodan Avlijaš dated 9 March 2013), para. 38; D4230 (Witness statement of Čedo Šipovac dated 18 January 2014), para. 16; Charles McLeod, P712 (Transcript from Prosecutor v. Brđanin), T. 7326-7327; P636 (ECMM Report, 3 September 1992), pp. 1-2. Mevlujdin Sejmenović testified that he entered Trnopolje twice unobserved. Mevludin Sejmenović, T. 20487-20488 (27 October 2011).

6234 See Defence Final Brief, paras. 1596-1597. The Accused further submits that Penny Marshall and her team of journalists chose to set up her camera and interview detainees inside the tool shed area at Trnopolje which was surrounded by barbed wire, but in fact all of the people they filmed were "free". See Accused Opening Statement, T. 845-847 (1 March 2010).

6235 Idriz Merdžanić, P3881 (Transcript from Prosecutor v. Stakić), T. 7750-7751, 7838-7851 (testifying that a barbed wire fence was erected when Keraterm and Omarska were disbanded to contain the detainees transferred to Trnopolje from those camps and that Penny Marshall filmed detainees behind the fence surrounding the shop building at Trnopolje, but that this was not the same fence erected temporarily to contain the detainees transferred from Keraterm and Omarska); P3909 (Sketch of Trnopolje marked by Idriz Merdžanić); P3910 (Excerpt of video clip of Trnopolje); Edward Vulliamy, P3777 (Transcript from Prosecutor v. Stakić), T. 7946, 7963, 8141-8144 (testifying that on 5 August 1992, he and Penny Marshall interviewed detainees at Trnopolje who had been transferred from Keraterm and Omarska and were detained behind a barbed wire fence and in a "serious state of decay", but there seemed to be two barbed wire fences at Trnopolje—one that was older and one newer); P3780 (Excerpt from ITN video clip of men at Trnopolje); P3781 (Excerpt from ITN video clip of men at Trnopolje); P3697 (Video footage of visit of foreign journalists to Trnopolje); Edward Vulliamy, T. 21051 (9 November 2011); Mevludin Sejmenović, T. 20491 (27 October 2011), T. 20581 (28 October 2011) (testifying that there was a fenced-in area used for agricultural equipment, but also that detainees transferred from Keraterm were specifically placed inside a wired area, called the "quarantine" by camp authorities, and were strictly prohibited from leaving the area); KDZ038, P676 (Transcript from Prosecutor v. Stakić), T. 69836984; KDZ611, P698 (Transcript from Prosecutor v. Brđanin), T. 12464-12465 (under seal); KDZ054, P682 (Transcript from Prosecutor v. Stakić), T. 6306-6309. See also Adjudicated Fact 1230.

6236 Idriz Merdžanić, P3881 (Transcript from Prosecutor v. Stakić), T. 7748, 7750-7751; KDZ048, P678 (Transcript from Prosecutor v. Stakić), T. 3350-3352; KDZ611, P698 (Transcript from Prosecutor v. Brđanin), T. 12464 12465 (under seal); KDZ092, P702 (Transcript from Prosecutor v. Stakić), T. 3997 (under seal); Milomir Stakić, T. 45239 (17 December 2013); Charles McLeod, P712 (Transcript from Prosecutor v. Brđanin), T. 7326-7327. See P2637 (Report of Prijedor SJB, 1 July 1992); P2741 (Decision of Prijedor Crisis Staff, 2 June 1992); P2915 (Summary of conclusions of Prijedor's Executive Board, 29 April-17 August 1992), p. 3; [REDACTED]. See also Adjudicated Fact 1230 . 
or were escorted by guards. ${ }^{6237}$ Others could leave only if they were authorised for release by Drljača or the camp commander, Slobodan Kuruzović, or if they were transferred to another camp. $^{6238}$ Furthermore, Trnopolje was otherwise surrounded on all sides by guards, machine-gun nests, and armed posts pointing guns towards the camp. ${ }^{6239}$ Idriz Merdžanić, a physician brought to Trnopolje, testified that "apart from the checkpoints and the guards, even if only a simple line had been drawn on the ground, nobody would dare cross that line". ${ }^{240}$ Stakić further testified that people were not brought to Trnopolje, or held there, voluntarily. ${ }^{6241}$ The Chamber considers that in light of evidence of the security conditions surrounding the camp, the poor conditions and mistreatment which occurred there, and the testimony of witnesses who were held there, ${ }^{6242}$ it finds that Trnopolje was a detention facility for the duration of its existence.

1820. Trnopolje was established by the Prijedor Crisis Staff. ${ }^{6243}$ The camp commander was Slobodan Kuruzović, a former TO commander and member of the Prijedor Crisis Staff; he was

6237 KDZ038, P676 (Transcript from Prosecutor v. Stakić), T. 6875; Idriz Merdžanić, P3881 (Transcript from Prosecutor v. Stakić), T. 7757-7758; Mevludin Sejmenović, T. 20489-20490 (27 October 2011), T. 20580 (28 October 2011).

6238 KDZ038, P676 (Transcript from Prosecutor v. Stakić), T. 6875, 6984; Idriz Merdžanić, P3881 (Transcript from Prosecutor v. Stakić), T. 7750; Nusret Sivac, P3478 (Transcript from Prosecutor v. Stakić), T. 6691; P2741 (Decision of Prijedor Crisis Staff, 2 June 1992); [REDACTED].

6239 Idriz Merdžanić, P3881 (Transcript from Prosecutor v. Stakić), T. 7751-7755; P3909 (Sketch of Trnopolje marked by Idriz Merdžanić); Mevludin Sejmenović, T. 20491 (27 October 2011), T. 20581-20582 (28 October 2011); KDZ048, P678 (Transcript from Prosecutor v. Stakić), T. 3351-3352; KDZ611, P698 (Transcript from Prosecutor v. Brđanin), T. 12464-12465 (under seal); Charles McLeod, P712 (Transcript from Prosecutor v. Brđanin), T. 7327. See also Adjudicated Fact 1230. However, Puhalić testified that Trnopolje was not surrounded by soldiers, nor were there machine-gun nests or armed positions with guns pointed at the camp. D4008 (Witness statement of Slavko Puhalić dated 11 November 2013), para. 21. The Chamber does not find Puhalić's evidence to be credible in this regard. In reaching that conclusion, the Chamber considers that he was not forthright with the Chamber on several occasions and that due to his involvement at Trnopolje, he had an interest in distancing himself from knowledge of conditions there.

6240 Idriz Merdžanić, P3881 (Transcript from Prosecutor v. Stakić), T. 7751. See also KDZ611, P698 (Transcript from Prosecutor v. Brđanin), T. 12464-12465 (under seal) (stating that he did not feel free to leave Trnopolje at any time and people did not leave the camp); KDZ092, P702 (Transcript from Prosecutor v. Stakić), T. 3997 (under seal) (testifying that "[i]t was not a place for refugees. It was a camp. There was no freedom there at all”); KDZ048, P678 (Transcript from Prosecutor v. Stakić), T. 3351-3352 (testifying that he felt imprisoned and was not there of his own free will).

6241 Milomir Stakić, T. 45239 (17 December 2013). The Accused argues that people came to Trnopolje voluntarily and that Stakić did not suggest that they were brought in forcibly. See Accused Closing Argument, T. 4788147882 (1 October 2014). The Chamber considers Stakić to be clear that everyone did not go to Trnopolje voluntarily.

6242 Idriz Merdžanić, P3881 (Transcript from Prosecutor v. Stakić), T. 7751; KDZ611, P698 (Transcript from Prosecutor v. Brđanin), T. 12464-12465 (under seal); KDZ092, P702 (Transcript from Prosecutor v. Stakić), T. 3997 (under seal); KDZ048, P678 (Transcript from Prosecutor v. Stakić), T. 3351-3352. See also Edward Vulliamy, T. 21114-21116 (9 November 2011); Charles McLeod, P712 (Transcript from Prosecutor v. Brđanin), T. 7326-7327.

6243 D470 (CSB Banja Luka Report concerning collection centres, undated), e-court pp. 2, 28-29; P2772 (Report of Prijedor SJB, 5 August 1992); D4468 (Confirmation of decisions adopted by Crisis Staff by Prijedor Municipal Assembly, 24 July 1992), e-court p. 6. See Adjudicated Fact 1105. However, Stakić stated that Trnopolje was not established by the Crisis Staff. D4195 (Witness statement of Milomir Stakić dated 16 November 2013), paras. 22, 48; Milomir Stakić, T. 45238-45240 (17 December 2013). The Chamber does not find this evidence to be credible based on the accepted evidence before the Chamber to the contrary which confirms that the Prijedor Crisis Staff was involved in the establishment of Trnopolje. 
referred to in the camp as "Major". ${ }^{6244}$ Kuruzović and all of the camp guards at Trnopolje wore military uniforms. ${ }^{6245}$ Kuruzović stayed in a house on the camp premises and was often seen by the detainees with his body guards, the Balaban twin brothers. ${ }^{6246}$ Slavko Puhalić assisted Kuruzović in the operation of the camp early on. ${ }^{6247}$

1821. Trnopolje was officially closed at the end of September 1992 but some people remained there until December $1992 .{ }^{6248}$

(ii) Conditions of detention

1822. Detainees were held in poor conditions at Trnopolje. ${ }^{649}$ Early on, the buildings at Trnopolje could not house all of the detainees, so detainees were forced to sleep outdoors in makeshift shelters of plastic bags, sticks, and blankets. ${ }^{6250}$ Only after the majority of the women

6244 P3710 (Decision of Prijedor Crisis Staff, 29 May 1992) (in which Stakić orders that Kuruzović be placed under the "Regional Command"); Milomir Stakić, T. 45239 (17 December 2013) (testifying that Kuruzović was appointed as commander on behalf of the "army"); D4008 (Witness statement of Slavko Puhalić dated 11 November 2013), para. 3; D4468 (Confirmation of decisions adopted by Crisis Staff by Prijedor Municipal Assembly, 24 July 1992), e-court p. 6 (assigning the duty of providing security for Trnopolje to the "Regional Command"); P3536 (Decisions and orders of Prijedor Municipal Assembly and Prijedor Crisis Staff, published in Prijedor Official Gazette on 25 June 1992), p. 8; Idriz Merdžanić, P3881 (Transcript from Prosecutor v. Stakić), T. 7759-7760; KDZ611, P698 (Transcript from Prosecutor v. Kvočka), T. 5823 (under seal); KDZ611, P698 (Transcript from Prosecutor v. Brđanin), T. 12513-12515 (under seal); P4101 (Witness statement of KDZ611 dated 27 February 1999), e-court p. 8; KDZ048, P678 (Transcript from Prosecutor v. Stakić), T. 3352; Jusuf Arifagić, P689 (Transcript from Prosecutor v. Stakić), T. 7105; KDZ092, P702 (Transcript from Prosecutor v. Stakić), T. 3959 (under seal); KDZ038, P676 (Transcript from Prosecutor v. Stakić), T. 68746875; KDZ054, P682 (Transcript from Prosecutor v. Stakić), T. 6224. See also Adjudicated Fact 1227.

6245 KDZ611, P698 (Transcript from Prosecutor v. Brđanin), T. 12513-12515 (under seal); KDZ048, P678 (Transcript from Prosecutor v. Stakić), T. 3352; KDZ092, P702 (Transcript from Prosecutor v. Stakić), T. 3998 (under seal); D3968 (Report of Prijedor SJB, 9 August 1992) (reporting that Trnopolje was secured by the SerBiH Army). See also Adjudicated Facts 1227, 1228.

6246 KDZ038, P676 (Transcript from Prosecutor v. Stakić), T. 6874-6875; Idriz Merdžanić, P3881 (Transcript from Prosecutor v. Stakić), T. 7830-7832; D4008 (Witness statement of Slavko Puhalić dated 11 November 2013), para. 3; P4101 (Witness statement of KDZ611 dated 27 February 1999), e-court p. 8; KDZ092, P702 (Transcript from Prosecutor v. Stakić), T. 3959-3960 (under seal). See also Adjudicated Fact 1229 (stating that the Balaban brothers were "well known for their brutality").

6247 D4008 (Witness statement of Slavko Puhalić dated 11 November 2013), paras. 3-4; Slavko Puhalić, T. 43409 (13 November 2013) (testifying that he was at Trnopolje until 11 June 1992 and then went for a spa treatment until 17 July 1992, after which he returned to Trnopolje until around 15 August 1992).

6248 Idriz Merdžanić, P3881 (Transcript from Prosecutor v. Stakić), T. 7800; D3110 (ICRC press release, 2 October 1992); P6504 (Report of Prijedor Red Cross, 30 September 1992), pp. 9-10; P2948 (Report of humanitarian organisation, 8 October 1992) (under seal), p. 2; P2968 (Report of Prijedor SJB, January 1993) (stating that Trnopolje remained in operation until November 1992). See also Adjudicated Fact 1224. The Chamber will address the date on which Trnopolje closed in further details below in this section.

6249 Idriz Merdžanić, P3881 (Transcript from Prosecutor v. Stakić), T. 7756-7760; KDZ611, P698 (Transcript from Prosecutor v. Brđanin), T. 12462 (under seal); Nusret Sivac, P3478 (Transcript from Prosecutor v. Stakić), T. 6783-6784; KDZ038, P676 (Transcript from Prosecutor v. Stakić), T. 6875-6878; KDZ092, P702 (Transcript from Prosecutor v. Stakić), T. 3958-3960 (under seal); P3528 (Witness statement of Kerim Mešanović, undated), pp. 65-68; P3543 (Excerpt from video clip of visits to Omarska and Trnopolje, with transcript); P3797 (Excerpt of ITN video clip of journalist visit to Omarska and Trnopolje); P6503 (Video footage of Penny Marshall's visit to Trnopolje). See also Slavko Puhalić, T. 43403-43404 (13 November 2013).

6250 KDZ038, P676 (Transcript from Prosecutor v. Stakić), T. 6877-6878; KDZ014, P674 (Transcript from Prosecutor v. Stakić), T. 5749; KDZ014, P674 (Transcript from Prosecutor v. Brđanin), T. 12556; Idriz 
and children were transferred out of Trnopolje were male detainees able to sleep inside in the sports hall of the school or elsewhere. ${ }^{6251}$ Even then, there was little space to sleep, no beds or blankets, and detainees had to sleep on the floor. ${ }^{6252}$

1823. Little or no food was supplied to the detainees by the camp authorities; ${ }^{653}$ detainees received some food which was brought to them by relatives or local residents in the area, but it was insufficient. ${ }^{6254}$ Detainees who had money were able to buy bread, but the remaining detainees had to rely upon others sharing food with them. ${ }^{6255}$ There was almost no potable water at Trnopolje, as only one pump existed for the whole camp. ${ }^{6256}$ There was no running water and only limited lavatory facilities. ${ }^{6257}$ Furthermore, there were no facilities to wash and the heat and flies made the situation unbearable. ${ }^{658}$ Due to the lack of food and unsanitary conditions, lice and scabies were rampant, and the majority of detainees suffered from dysentery. ${ }^{6259}$ There was no organised

Merdžanić, P3881 (Transcript from Prosecutor v. Stakić), T. 7756-7757; Nusret Sivac, P3478 (Transcript from Prosecutor v. Stakić), T. 6783-6784; P684 (Witness statement of KDZ054 dated 14 March 2000), e-court p. 8; KDZ054, P682 (Transcript from Prosecutor v. Stakić), T. 6223-6224; Charles McLeod, P712 (Transcript from Prosecutor v. Brđanin), T. 7327; P3797 (Excerpt of ITN video clip of journalist visit to Omarska and Trnopolje). See also D4008 (Witness statement of Slavko Puhalić dated 11 November 2013), para. 11; Slavko Puhalić, T. 43418 (13 November 2013); see Adjudicated Facts 1231, 1236.

6251 KDZ038, P676 (Transcript from Prosecutor v. Stakić), T. 6877-6878.

6252 Idriz Merdžanić, P3881 (Transcript from Prosecutor v. Stakić), T. 7757; KDZ038, P676 (Transcript from Prosecutor v. Stakić), T. 6877-6878; P684 (Witness statement of KDZ054 dated 14 March 2000), e-court p. 8; P3885 (Photographs at Trnopolje). See also Adjudicated Fact 1236.

6253 P684 (Witness statement of KDZ054 dated 14 March 2000), e-court p. 8; KDZ054, P682 (Transcript from Prosecutor v. Stakić), T. 6249, 6309-6311; KDZ611, P698 (Transcript from Prosecutor v. Brđanin), T. 12462 (under seal); P4101 (Statement of KDZ611 to investigators dated 26 June 1995), e-court p. 30; Idriz Merdžanić, P3881 (Transcript from Prosecutor v. Stakić), T. 7757-7758. See Adjudicated Fact 1234; P684 (Witness statement of KDZ054 dated 13 June 2002), e-court p. 3.

6254 Idriz Merdžanić, P3881 (Transcript from Prosecutor v. Stakić), T. 7757-7758; KDZ611, P698 (Transcript from Prosecutor v. Brđanin), T. 12462 (under seal); KDZ038, P676 (Transcript from Prosecutor v. Stakić), T. 68756876; KDZ054, P682 (Transcript from Prosecutor v. Stakić), T. 6311-6312; Mevludin Sejmenović, T. 20489_ 20490 (27 October 2011); P3797 (Excerpt of ITN video clip of journalist visit to Omarska and Trnopolje); D4008 (Witness statement of Slavko Puhalić dated 11 November 2013), para. 11.

6255 KDZ038, P676 (Transcript from Prosecutor v. Stakić), T. 6876; KDZ611, P698 (Transcript from Prosecutor v. Brđanin), T. 12462 (under seal); Idriz Merdžanić, P3881 (Transcript from Prosecutor v. Stakić), T. 77577758; KDZ014, P674 (Transcript from Prosecutor v. Stakić), T. 5749; KDZ014, P674 (Transcript from Prosecutor v. Brđanin), T. 12556.

6256 Adjudicated Fact 1233.

6257 KDZ038, P676 (Transcript from Prosecutor v. Stakić), T. 6876; Idriz Merdžanić, P3881 (Transcript from Prosecutor v. Stakić), T. 7759; P684 (Witness statement of KDZ054 dated 14 March 2000), e-court p. 8; KDZ092, P702 (Transcript from Prosecutor v. Stakić), T. 3959-3960 (under seal). See Adjudicated Fact 1232.

6258 KDZ038, P676 (Transcript from Prosecutor v. Stakić), T. 6876.

6259 Idriz Merdžanić, P3881 (Transcript from Prosecutor v. Stakić), T. 7759, 7778; P684 (Witness statement of KDZ054 dated 14 March 2000), e-court p. 8; KDZ092, P702 (Transcript from Prosecutor v. Stakić), T. 3959 (under seal); P3797 (Excerpt of ITN video clip of journalist visit to Omarska and Trnopolje); P3903 (Photograph of a detainee at Trnopolje); P3904 (Photograph of a detainee at Trnopolje); see Adjudicated Fact 1235 (stating that as many as $95 \%$ of the detainees at Trnopolje suffered from dysentery). Detainees also noted that the condition of people who arrived at Trnopolje from the Omarska and Keraterm camps was much worse. They had all lost a lot of weight, were dirty, unshaven, had dysentery, and many of them had been severely beaten and could not even walk. KDZ611, P698 (Transcript from Prosecutor v. Brđanin), T. 12468 (under seal). But see D4008 (Witness statement of Slavko Puhalić dated 11 November 2013), para. 23 (stating that he 
medical care at Trnopolje but some medical assistance was provided by non-Serb detainees held in the camp, including Merdžanić and Azra Blazević, a veterinarian. ${ }^{6260}$ They worked out of a clinic at the camp but were not provided with any medical supplies by the camp authorities until the International Red Cross arrived. ${ }^{6261}$

\section{(iii) Treatment of detainees}

\section{Beatings and killings}

1824. Although the scale of abuse at Trnopolje was less than that at Omarska, mistreatment was common there. ${ }^{6262}$ Camp guards cut male detainees with knives and beat them with baseball bats, iron bars, rifle butts, or whatever they had at their disposal. ${ }^{6263}$ Detainees who were taken out for questioning would often return badly beaten and covered with blood. ${ }^{6264}$

1825. A laboratory inside the clinic at Trnopolje was used for interrogations and beatings. ${ }^{6265}$ Merdžanić could hear the sounds of camp guards beating and verbally abusing the detainees there. ${ }^{6266}$ Merdžanić treated some of the detainees after they were beaten there and photographed them without anyone knowing. ${ }^{6267}$ Beatings also occurred outside and in a boiler room in the

did not witness these issues and given that he sat with the "people in the camp [...] he would have caught these diseases as well" if they had existed there).

6260 Idriz Merdžanić, P3881 (Transcript from Prosecutor v. Stakić), T. 7730-7731, 7747-7748; Mevludin Sejmenović, T. 20489 (27 October 2011); P3528 (Witness statement of Kerim Mešanović, undated), p. 66; P3797 (Excerpt of ITN video clip of journalist visit to Omarska and Trnopolje); P684 (Witness statement of KDZ054 dated 14 March 2000), e-court p. 8; KDZ054, P682 (Transcript from Prosecutor v. Stakić), T. 62496252. See also D4008 (Witness statement of Slavko Puhalić dated 11 November 2013), para. 11.

6261 Idriz Merdžanić, P3881 (Transcript from Prosecutor v. Stakić), T. 7747-7748, 7785-7786; Idriz Merdžanić, T. 21473-21474 (17 November 2011); P3797 (Excerpt of ITN video clip of journalist visit to Omarska and Trnopolje); KDZ054, P682 (Transcript from Prosecutor v. Stakić), T. 6249-6250.

6262 See Adjudicated Fact 1237.

6263 Idriz Merdžanić, P3881 (Transcript from Prosecutor v. Stakić), T. 7766-7768; P684 (Witness statement of KDZ054 dated 14 March 2000), e-court p. 9; KDZ092, P702 (Transcript from Prosecutor v. Stakić), T. 3958 (under seal). See also Adjudicated Fact 1237.

6264 KDZ054, P682 (Transcript from Prosecutor v. Stakić), T. 6250; P4101 (Statement of KDZ611 to investigators dated 26 June 1995), e-court p. 30; P684 (Witness statement of KDZ054 dated 14 March 2000), e-court p. 9. See also Adjudicated Fact 1237. Further, Puhalić stated that there were some individual incidents of mistreatment at Trnopolje in the beginning before military security was introduced there; however, Puhalić reported these incidents to Kuruzović who went to the police and asked that these incidents be investigated. According to him, after military security was introduced, these incidents no longer occurred. D4008 (Witness statement of Slavko Puhalić dated 11 November 2013), para. 25.

6265 Idriz Merdžanić, P3881 (Transcript from Prosecutor v. Stakić), T. 7766, 7780-7785; P3905 (Sketch drawn by Idriz Merdžanić of clinic in Trnopolje); P3906 (Photograph of interrogation room in Trnopolje) (showing blood stains on the walls from the beatings); P3907 (Photograph of interrogation room in Trnopolje); Mevludin Sejmenović, T. 20491 (27 October 2011).

6266 Idriz Merdžanić, P3881 (Transcript from Prosecutor v. Stakić), T. 7766, 7780-7785.

6267 Idriz Merdžanić, P3881 (Transcript from Prosecutor v. Stakić), T. 7766-7767, 7769-7774, 7780-7785; P3896 (Photograph of a detainee at Trnopolje); P3897 (Photograph of a detainee at Trnopolje). 
school building. ${ }^{6268}$ On one occasion, Žigić beat and kicked one of the detainees who had arrived from Keraterm and no one tried to stop him. ${ }^{6269}$

1826. Detainees, including female detainees, at Trnopolje were verbally abused, insulted with ethnic slurs, and threatened with death. ${ }^{6270}$ Detainees were forced to fight each other in the camp. $^{6271}$ Detainees were selected to bury dead bodies in nearby villages and in the camp. ${ }^{6272}$ They were also taken out to perform forced labour. ${ }^{6273}$

1827. Detainees at Trnopolje were killed inside and outside the camp. ${ }^{6274}$ A number of detainees died as a result of the beatings by the guards during interrogations. ${ }^{6275}$ At least two detainees died in Trnopolje as a result of lack of medical care. ${ }^{6276}$ Others were killed by camp guards or other soldiers who entered the camp. ${ }^{677}$ For instance, on the first night of KDZ038's detention in the shop building at Trnopolje, a uniformed Serb he knew took out an elderly man, Sulejman Kekić, and beat him. ${ }^{6278}$ Later that night, the same man was taken away, KDZ038 heard two shots, and the man did not return. ${ }^{6279}$ The Chamber is satisfied that this individual was killed. KDZ054 recalled one night during his detention when soldiers from a reserve unit came into the camp and called out

\footnotetext{
6268 Idriz Merdžanić, P3881 (Transcript from Prosecutor v. Stakić), T. 7768.

6269 Safet Tači, P693 (Transcript from Prosecutor v. Kvočka), T. 3770-3773; Idriz Merdžanić, P3881 (Transcript from Prosecutor v. Stakić), T. 7768-7769.

6270 KDZ092, P702 (Transcript from Prosecutor v. Stakić), T. 3995-3997 (under seal); Idriz Merdžanić, P3881 (Transcript from Prosecutor v. Stakić), T. 7760-7761; P684 (Witness statement of KDZ054 dated 14 March 2000), e-court p. 9.

6271 P684 (Witness statement of KDZ054 dated 14 March 2000), e-court p. 9.

6272 KDZ611, P698 (Transcript from Prosecutor v. Brđanin), T. 12466 (under seal); P4101 (Witness statement of KDZ611 dated 27 February 1999), e-court p. 9; Idriz Merdžanić, P3881 (Transcript from Prosecutor v. Stakić), T. 7786-7787; P684 (Witness statement of KDZ054 dated 14 March 2000), e-court p. 9; Mevludin Sejmenović, T. 20489 (27 October 2011).

6273 Idriz Merdžanić, P3881 (Transcript from Prosecutor v. Stakić), T. 7786-7787, 7838. However, the Chamber notes that the Indictment only covers forced labour at the frontlines.

6274 Idriz Merdžanić, P3881 (Transcript from Prosecutor v. Stakić), T. 7785-7787, 7804; P4101 (Witness statement of KDZ611 dated 27 February 1999), e-court p. 9; P684 (Witness statement of KDZ054 dated 14 March 2000), e-court p. 9; KDZ054, P682 (Transcript from Prosecutor v. Stakić), T. 6253-6254; KDZ050, P680 (Transcript from Prosecutor v. Sikirica), T. 2524-2525, 2532; KDZ038, P676 (Transcript from Prosecutor v. Stakić), T. 6870-6873; P3908 (Excerpt of video clip of Trnopolje, with transcript), p. 2. See also P646 (Excerpts from report on exhumations in Prijedor municipality, 28 August 2002) (under seal), p. 313; see Adjudicated Fact 1242.

6275 Idriz Merdžanić, P3881 (Transcript from Prosecutor v. Stakić), T. 7773-7774, 7785; P3908 (Excerpt of video clip of Trnopolje, with transcript), p. 2. See also Adjudicated Fact 1242.

6276 Idriz Merdžanić, P3881 (Transcript from Prosecutor v. Stakić), T. 7785-7786; P684 (Witness statement of KDZ054 dated 14 March 2000), e-court p. 8; P3908 (Excerpt of video clip of Trnopolje, with transcript), p. 2.

6277 KDZ092, P702 (Transcript from Prosecutor v. Stakić), T. 3998-3999 (under seal); KDZ038, P676 (Transcript from Prosecutor v. Stakić), T. 6880; P684 (Witness statement of KDZ054 dated 14 March 2000), e-court p. 9; KDZ054, P682 (Transcript from Prosecutor v. Stakić), T. 6253-6254. See also Adjudicated Fact 1242.

6278 KDZ038, P676 (Transcript from Prosecutor v. Stakić), T. 6867, 6880 (testifying that he was in a group of men taken by bus from Bišćani to Trnopolje on 20 July 1992, and put into a shop building at Trnopolje).

6279 KDZ038, P676 (Transcript from Prosecutor v. Stakić), T. 6880.
} 
six detainees from the Foric family. ${ }^{6280}$ They took them behind the corner of the building and about 10 to 20 minutes later, KDZ054 heard shooting. ${ }^{6281}$ Later, the detainees who were selected to bury the bodies confirmed that the six detainees who had been taken out earlier were shot dead. ${ }^{6282}$

1828. Shortly after KDZ038 arrived at Trnopolje on 20 July 1992, a group of men from Bišćani arrived at the camp on a bus; KDZ038 saw that 12 of the men were called out and sent back to the bus, which drove them away. ${ }^{6283}$ Later, he was told by people who had walked some of the way from the Brdo area to Trnopolje that they had seen the dead bodies of these men in an area called Kratalj. ${ }^{6284}$ KDZ038 later spoke to a man who had been in this group of 12, who told him that the bus drove them back towards Bišćani, but that it stopped along the way and the men were lined up and shot with some kind of automatic rifle. ${ }^{6285} \mathrm{He}$ and one other man survived the incident. ${ }^{6286}$

1829. Furthermore, on or around 8 September 1992, KDZ050 saw some of the detainees taken out to a nearby fish pond. ${ }^{6287}$ Shortly afterwards, KDZ050 heard rounds of fire from that direction, and those detainees never returned. ${ }^{6288}$ The Chamber is satisfied that these individuals were killed in this incident.

\section{Sexual violence}

1830. There were many incidents of rape at Trnopolje between May and October $1992 .{ }^{6289}$ During one of these incidents, the perpetrator told the victim: "Muslim women should give birth to

\footnotetext{
6280 P684 (Witness statement of KDZ054 dated 14 March 2000), e-court p. 9; KDZ054, P682 (Transcript from Prosecutor v. Stakić), T. 6253-6254; P4101 (Witness statement of KDZ611 dated 27 February 1999), e-court p. 9; Idriz Merdžanić, P3881 (Transcript from Prosecutor v. Stakić), T. 7786, 7804; Mevludin Sejmenović, T. 20488-20489 (27 October 2011).

6281 P684 (Witness statement of KDZ054 dated 14 March 2000), e-court p. 9; KDZ054, P682 (Transcript from Prosecutor v. Stakić), T. 6253-6254.

6282 P684 (Witness statement of KDZ054 dated 14 March 2000), e-court p. 9; KDZ054, P682 (Transcript from Prosecutor v. Stakić), T. 6253-6254.

6283 KDZ038, P676 (Transcript from Prosecutor v. Stakić), T. 6870.

6284 KDZ038, P676 (Transcript from Prosecutor v. Stakić), T. 6871.

6285 KDZ038, P676 (Transcript from Prosecutor v. Stakić), T. 6872-6873.

6286 KDZ038, P676 (Transcript from Prosecutor v. Stakić), T. 6871-6873.

6287 KDZ050, P680 (Transcript from Prosecutor v. Sikirica), T. 2524-2525, 2532.

6288 KDZ050, P680 (Transcript from Prosecutor v. Sikirica), T. 2524-2525.

6289 P684 (Witness statement of KDZ054 dated 14 March 2000), p. 8; Mevludin Sejmenović, T. 20490 (27 October 2011) (testifying that he heard from other detainees that rapes of women, including younger women and children, were taking place in the former cinema in the camp); Idriz Merdžanić, P3881 (Transcript from Prosecutor v. Stakić), T. 7759-7764; Nusret Sivac, P3478 (Transcript from Prosecutor v. Stakić), T. 6690. See also Adjudicated Fact 1238. Puhalić also testified that he was aware of rapes committed at Trnopolje in the beginning before the military guard was established by "unknown people who were outside any control" who broke into the camp. He stated that he reported the incidents to Kuruzović and some of the individuals who committed the rapes were arrested by the military police, but he did not know if any of them were prosecuted. However, Puhalić stated that it was not true that people were allowed to visit the camp from the outside. D4008 (Witness statement of Slavko Puhalić dated 11 November 2013), paras. 18, 26; Slavko Puhalić, T. 43408, 43421-43423 (13 November 2013)
} 
Serb children", and he also told her earlier that "Muslims were not human beings". ${ }^{6290}$ [REDACTED]. ${ }^{6291}$ [REDACTED]. ${ }^{6292}$ [REDACTED]. ${ }^{6293}$ [REDACTED ]. ${ }^{6294}$ [REDACTED]. ${ }^{6295}$ [REDACTED $].{ }^{6296}$ [REDACTED $] .{ }^{6297}$ [REDACTED.${ }^{6298}$ [REDACTED.${ }^{6299}$ [REDACTED $] .{ }^{6300}$

1831. Camp guards at Trnopolje allowed men from outside the camp, including Serb soldiers and other Serbs, to enter the camp and rape women and girls. ${ }^{6301}$ Detainees assigned to work in the clinic at Trnopolje, including Merdžanić and Vasif Gutić, treated and counselled many victims of rape there, including a 12 year old girl. ${ }^{6302}$ The incidents of rape at Trnopolje caused terrible fear and mental trauma among all of the detainees. ${ }^{6303}$

\section{$\underline{\text { treatment of detainees }}$}

(iv) Conclusion on conditions of detention and

1832. Based on the above, the Chamber finds that non-Serbs, including women and children, were transferred to and detained at Trnopolje by Serb Forces beginning on or around 24 May 1992 until at least 30 September 1992. The detainees were held in poor conditions, including lack of space, poor sanitary conditions, inadequate medical care, and insufficient food. The Chamber finds that male detainees at Trnopolje were subjected to beatings by Serb Forces and were forced to work. ${ }^{6304}$ The Chamber also finds that a number of women detained at Trnopolje were raped by Serb Forces, including by the camp commander, Kuruzović. Finally, the Chamber finds that a number of non-

\begin{tabular}{ll}
\hline 6290 & [REDACTED $].$ \\
6291 & [REDACTED $].$ \\
6292 & [REDACTED $]$ \\
6293 & [REDACTED $]$ \\
6294 & [REDACTED $]$ \\
6295 & [REDACTED $]$ \\
6296 & [REDACTED $]$ \\
6297 & [REDACTED $].$ \\
6298 & [REDACTED $]$ \\
6299 & [REDACTED $].$ \\
6300 & [REDACTED $]$
\end{tabular}

6301 P684 (Witness statement of KDZ054 dated 14 March 2000), p. 8; Idriz Merdžanić, P3881 (Transcript from Prosecutor v. Stakić), T. 7761-7764. See also Adjudicated Fact 1238. However, on one occasion, on 3 August 1992, Žigić came to Trnopolje and a guard at the entrance of a room where women from Omarska were being held ordered the women to lie down because "Žigić is coming". Žigić asked the guard where the women were, but the guard cocked his weapon at Žigić and told him that there were no women there and forbid him to enter the room. P3691 (Witness statement of Nusreta Sivac dated 22 October 2011), pp. 54-55 (under seal); KDZ093, P705 (Transcript from Prosecutor v. Kvočka), T. 6234-6236. Idriz Merdžanić, P3881 (Transcript from Prosecutor v. Stakić), T. 7760-7764; see Adjudicated Fact 1239. See Adjudicated Fact 1241.

6304 However, as noted above, the Chamber notes that the Indictment only covers forced labour at the frontlines. 
Serbs were killed by Serb Forces in Trnopolje and at various places after they were taken from the camp between 28 May 1992 and approximately 8 September $1992 .{ }^{6305}$

\section{(v) $\underline{\text { Scheduled Incident B.15.6 }}$}

1833. The Indictment refers to the killing on or about 21 August 1992 of approximately 200 men taken from Trnopolje to Vlašić mountain in Skender Vakuf.

1834. On 21 August 1992, a convoy of four buses marked "Autotransport Prijedor", organised by the Prijedor Crisis Staff and the Prijedor Red Cross to transport people out of Prijedor into Muslimheld territory, arrived at Trnopolje. ${ }^{6306}$ Primarily male detainees, including witnesses KDZ038 and KDZ611, as well as some women and children, were loaded onto them. ${ }^{6307}$ Kuruzović and members of the intervention squad were present as the detainees boarded the buses. ${ }^{6308}$ When the buses were full, they left in the direction of Kozarac, accompanied by members of the intervention squad and escorted by police and military vehicles. ${ }^{6309}$ Near Kozarac, the convoy stopped and was joined by four other buses and eight trucks, which had been loaded in Tukovi with Bosnian Muslim men, women, and children under orders from intervention squad commander, Miroslav Paraš. ${ }^{6310}$ Paraš and Kuruzović spoke to each other during this stop. ${ }^{6311}$ At this point, the convoy included eight buses and eight trucks, accompanied by a number of police vehicles. ${ }^{6312}$ The convoy

6305 This finding does not include the persons alleged to have been killed in Scheduled Incident B.15.6 which is discussed below.

6306 KDZ038, P676 (Transcript from Prosecutor v. Stakić), T. 6883; KDZ611, P698 (Transcript from Prosecutor v. Kvočka), T. 5823-5824 (under seal); KDZ611, P698 (Transcript from Prosecutor v. Brđanin), T. 12472 (under seal); P4101 (Witness statement of KDZ611 dated 27 February 1999), e-court pp. 13-14; Idriz Merdžanić, P3881 (Transcript from Prosecutor v. Stakić), T. 7789-7790; Dušan Janković, T. 47299-47301 (18 February 2014). See also Adjudicated Fact 1243; [REDACTED]; P4259 (Photograph of Autotransport Prijedor Bus).

6307 KDZ038, P676 (Transcript from Prosecutor v. Stakić), T. 6883; KDZ611, P698 (Transcript from Prosecutor v. Kvočka), T. 5823-5824 (under seal); KDZ611, P698 (Transcript from Prosecutor v. Brđanin), T. 12473 (under seal) (testifying that the drivers of the bus were regular civilian drivers and that the bus he was on also carried two armed men in former JNA uniforms); P4101 (Witness statement of KDZ611 dated 27 February 1999), ecourt pp. 13-14; Idriz Merdžanić, P3881 (Transcript from Prosecutor v. Stakić), T. 7829; Senija Elkasović, P690 (Transcript from Prosecutor v. Tadić), T. 4619-4620. See also Adjudicated Fact 1243.

6308 KDZ038, P676 (Transcript from Prosecutor v. Stakić), T. 6884; P4101 (Witness statement of KDZ611 dated 27 February 1999), e-court p. 14. See also Adjudicated Fact 1243.

6309 KDZ038, P676 (Transcript from Prosecutor v. Stakić), T. 6887; KDZ611, P698 (Transcript from Prosecutor v. Brđanin), T. 12473 (under seal) (testifying that the convoy escorts included men in camouflaged blue police unforms); P699 (Witness statement of KDZ611 dated 27 February 1999), e-court pp. 14-15 (under seal); Dušan Janković, T. 47300-47301 (18 February 2014); P2969 (Report of Prijedor SJB, 15 September 1992). See also Adjudicated Facts 1243, 1244; P697 (Witness statement of Elvedin Nasić dated 15 January 1995), e-court p. 6; P697 (Witness statement of Elvedin Nasić dated 15 March 2000), e-court p. 10.

6310 KDZ038, P676 (Transcript from Prosecutor v. Stakić), T. 6887, 6896; KDZ611, P698 (Transcript from Prosecutor v. Brđanin), T. 12472-12473 (under seal); P699 (Witness statement of KDZ611 dated 27 February 1999), e-court p. 15 (under seal); [REDACTED]; Elvedin Nasić, P696 (Transcript from Prosecutor v. Brđanin), T. 12711-12713; Senija Elkasović, P690 (Transcript from Prosecutor v. Tadić), T. 4619-4620. See also Adjudicated Fact 1243.

6311 [REDACTED].

6312 KDZ038, P676 (Transcript from Prosecutor v. Stakić), T. 6896. 
continued through Banja Luka and on to Skender Vakuf, moving towards their final destination, which was the line of separation between Serb and Muslim controlled territory near Travnik. ${ }^{6313}$

1835. The convoy stopped a number of additional times on the way. ${ }^{6314}$ At one stop, one of the guards on the bus ordered KDZ038 to collect money and valuables from the men on his bus. ${ }^{6315}$ Members of the intervention squad also collected money and other valuables from the detainees and placed them in plastic bags. ${ }^{6316}$ At another stop, soldiers in olive drab uniforms boarded the buses and remained for the rest of the journey. ${ }^{6317}$

1836. Shortly after Skender Vakuf, the convoy stopped again near a stream; young men of military age were then pulled out of the convoy by members of the intervention squad at Paraš's orders and loaded into two empty buses. ${ }^{6318}$ The men on KDZ038's bus were ordered to line up outside of the bus. ${ }^{6319}$ They were then told to board one of two empty buses and to lie on the floor. ${ }^{6320}$ KDZ038 estimated that there were 100 men packed on to the first bus. ${ }^{6321}$

1837. The men of military age on the bus of KDZ611 were separated and loaded into the other empty bus; some women and older men were allowed to stay on one of the original buses. ${ }^{6322}$

6313 KDZ038, P676 (Transcript from Prosecutor v. Stakić), T. 6897; P599 (Map of Trnopolje-Vlašić route); KDZ611, P698 (Transcript from Prosecutor v. Brđanin), T. 12473-12474 (under seal); P699 (Witness statement of KDZ611 dated 27 February 1999), e-court pp. 15-16 (under seal); P4101 (Statement of KDZ611 to investigators dated 26 June 1995), e-court pp. 30-31, 49; Senija Elkasović, P690 (Transcript from Prosecutor v. Tadić), T. 4619-4620. See also Adjudicated Fact 1245.

6314 KDZ038, P676 (Transcript from Prosecutor v. Stakić), T. 6898; KDZ611, P698 (Transcript from Prosecutor v. Brđanin), T. 12474 (under seal).

6315 KDZ038, P676 (Transcript from Prosecutor v. Stakić), T. 6898.

6316 Elvedin Nasić, P696 (Transcript from Prosecutor v. Brđanin), T. 12713; P697 (Witness statement of Elvedin Nasić dated 15 January 1995), e-court p. 6; P699 (Witness statement of KDZ611 dated 27 February 1999), ecourt p. 18 (under seal); [REDACTED]; KDZ038, P676 (Transcript from Prosecutor v. Stakić), T. 6903; Senija Elkasović, P690 (Transcript from Prosecutor v. Tadić), T. 4619-4620.

6317 KDZ038, P676 (Transcript from Prosecutor v. Stakić), T. 6899-6900; P699 (Witness statement of KDZ611 dated 27 February 1999), e-court p. 16 (under seal). KDZ611 noticed a man in an olive-grey uniform with a red beret on his head, carrying a walkie-talkie. KDZ611, P698 (Transcript from Prosecutor v. Kvočka), T. 58265827 (under seal); KDZ611, P698 (Transcript from Prosecutor v. Brđanin), T. 12474 (under seal).

6318 [REDACTED]; KDZ611, P698 (Transcript from Prosecutor v. Brđanin), T. 12475-12476 (under seal); P699 (Witness statement of KDZ611 dated 27 February 1999), e-court pp. 17-18 (under seal); P699 (Statement of KDZ611 to investigators dated 26 June 1995), e-court p. 50 (under seal); KDZ038, P676 (Transcript from Prosecutor v. Stakić), T. 6900-6901. See also Adjudicated Fact 1246.

6319 KDZ038, P676 (Transcript from Prosecutor v. Stakić), T. 6900. See also Adjudicated Fact 1246.

6320 KDZ038, P676 (Transcript from Prosecutor v. Stakić), T. 6900-6901. See also Adjudicated Facts 1248, 1249.

6321 KDZ038, P676 (Transcript from Prosecutor v. Stakić), T. 6902. See also Adjudicated Fact 1248.

6322 KDZ611, P698 (Transcript from Prosecutor v. Brđanin), T. 12475-12476 (under seal); P699 (Witness statement of KDZ611 dated 27 February 1999), e-court p. 17 (under seal); P699 (Statement of KDZ611 to investigators dated 26 June 1995), e-court p. 50 (under seal). See Adjudicated Fact 1247 (stating that a truck appeared and the women and children were told to board it; another truck arrived and departed with more detainees but left behind a number of people who had been at Trnopolje and some residents of Kozarac). 
KDZ611 estimated that there were "well over 100 people" on his bus, which proceeded, behind the first bus while the rest of the convoy carried on ahead of them, towards Travnik. ${ }^{6323}$

1838. The buses continued for another 10 to 15 minutes before stopping again on a road flanked on one side by a steep cliff and on the other by a deep gorge; an area referred to as Korićanske Stijene. ${ }^{6324}$ Members of the intervention squad directed the detainees on the bus KDZ038 was on to disembark, form a column two by two, and walk down the road. ${ }^{6325}$ After they walked for about 100 metres, the men were ordered to stop, turn left, take three steps forward, and kneel down facing the abyss. ${ }^{6326}$ KDZ038 heard a man in police uniform in charge say: "Here we exchange the dead for the dead and the living for the living" and then shots were fired towards the line of men at the edge of the gorge. ${ }^{6327}$ KDZ038 saw people falling down and shouted at his father to throw himself into the abyss; his father then pushed him into the gorge. ${ }^{6328}$ KDZ038 then found himself at the bottom, his ankle broken, and his foot hanging by a tendon. ${ }^{6329}$ Two men came down into the abyss and shot anyone who tried to escape in the head; KDZ038 pretended to be dead. ${ }^{6330} \mathrm{He}$ then heard more shooting and saw dead bodies around him. ${ }^{6331}$

1839. Once the second bus stopped, the men on board, including KDZ611, were told to disembark by a soldier in a red beret. ${ }^{632}$ KDZ611 saw the other bus parked ten metres away. ${ }^{6333}$ They were

6323 P699 (Witness statement of KDZ611 dated 27 February 1999), e-court pp. 17-18 (under seal); see KDZ611, P698 (Transcript from Prosecutor v. Brđanin), T. 12475-12476 (under seal) (testifying that there were "around 150 " men on his bus). Nasić testified that he was on this convoy but when it stopped and some of the men were told to get off, he stayed on it. At a place near Vlašić, the convoy stopped again and the remaining people were told to disembark and they walked from there to Travnik. According to Nasić, about 150 to 200 men who started out on the convoy did not make it to Travnik. Elvedin Nasić, P696 (Transcript from Prosecutor v. Brđanin), T. 12714. See also Senija Elkasović, P690 (Transcript from Prosecutor v. Tadić), T. 4620-4622 (testifying that after leaving on one of the organised buses from Trnopolje, her bus stopped at a big stone barricade and the passengers were told to get off and walk; she walked 40 or 50 kilometres to a school in Travnik while others who could not walk remained on the road and somehow were transported to Travnik).

6324 KDZ038, P676 (Transcript from Prosecutor v. Stakić), T. 6903-6905; KDZ611, P698 (Transcript from Prosecutor v. Kvočka), T. 5829, 5836 (under seal); KDZ611, P698 (Transcript from Prosecutor v. Brđanin), T. 12479-12480 (under seal); P564 (Photograph of road at Mount Vlašić); P565 (Photograph of road at Mount Vlašić); P566 (Photograph of road at Mount Vlašić); P567 (Photograph of Mount Vlašić); P568 (Photograph of Mount Vlašić). See also Adjudicated Facts 1250, 1251.

6325 KDZ038, P676 (Transcript from Prosecutor v. Stakić), T. 6904-6905; KDZ523, P4257 (Transcript from Prosecutor v. Brđanin), T. 21142 (under seal). See also Adjudicated Fact 1252.

6326 KDZ038, P676 (Transcript from Prosecutor v. Stakić), T. 6905; KDZ611, P698 (Transcript from Prosecutor v. Brđanin), T. 12481 (under seal); P699 (Witness statement of KDZ611 dated 27 February 1999), e-court p. 19 (under seal). See also Adjudicated Fact 1252.

6327 KDZ038, P676 (Transcript from Prosecutor v. Stakić), T. 6905-6906; [REDACTED]. See also Adjudicated Fact 1253.

6328 KDZ038, P676 (Transcript from Prosecutor v. Stakić), T. 6906. See also Adjudicated Fact 1255.

6329 KDZ038, P676 (Transcript from Prosecutor v. Stakić), T. 6907.

6330 KDZ038, P676 (Transcript from Prosecutor v. Stakić), T. 6907-6909.

6331 KDZ038, P676 (Transcript from Prosecutor v. Stakić), T. 6908-6909.

6332 KDZ611, P698 (Transcript from Prosecutor v. Brđanin), T. 12479-12480 (under seal).

6333 KDZ611, P698 (Transcript from Prosecutor v. Brđanin), T. 12480 (under seal); P699 (Witness statement of KDZ611 dated 27 February 1999), e-court p. 18 (under seal). 
ordered to form a column two abreast and to walk for several minutes until they reached a wooded area with a steep slope on one side of the road and a steep drop on the other side. ${ }^{6334}$ The men were ordered to face the drop, to step forward to the edge, and to kneel down, at which point gunfire was directed at them by members of the intervention squad. ${ }^{635}$ KDZ611 was pushed by the man beside him down the slope. ${ }^{636}$ He fell to the bottom uninjured, and continued to hear the sounds of gunfire for a number of minutes. ${ }^{6337}$ He saw many other men falling down the slope to the bottom. ${ }^{6338}$ Individuals who did not fall into the abyss were pushed into it by the men shooting at them. ${ }^{6339}$ Grenades were also thrown into the gorge. ${ }^{6340}$

1840. When night fell, KDZ038 crawled to the river at the bottom of the gorge and spent the night there. He roughly bandaged his foot and the next day began to crawl along the river until he came to a derelict mill where he took shelter. ${ }^{6341}$ He was later found by some soldiers who took him to Skender Vakuf, where he was given medical attention and a statement was taken from him about the killings at Korićanske Stijene; he was then taken by ambulance to a hospital in Banja Luka. ${ }^{6342}$

1841. KDZ611 and another man who had survived the shooting ${ }^{6343}$ remained hidden in the woods for two or three days, after which they surrendered to a group of Serb soldiers at a place called Galica. ${ }^{634}$ They were then taken to Skender Vakuf and held with three other wounded survivors of

\footnotetext{
6334 KDZ611, P698 (Transcript from Prosecutor v. Kvočka), T. 5829 (under seal); KDZ611, P698 (Transcript from Prosecutor v. Brđanin), T. 12480-12481 (under seal); [REDACTED].

6335 KDZ611, P698 (Transcript from Prosecutor v. Brđanin), T. 12490 (under seal); P699 (Witness statement of KDZ611 dated 27 February 1999), e-court p. 20 (under seal); [REDACTED]. See also Adjudicated Fact 1256 (stating that the primary perpetrators of the killings at Korićanske Stijene were members of the Prijedor intervention squad).

6336 KDZ611, P698 (Transcript from Prosecutor v. Brđanin), T. 12490 (under seal); P699 (Witness statement of KDZ611 dated 27 February 1999), e-court p. 20 (under seal).

6337 KDZ611, P698 (Transcript from Prosecutor v. Brđanin), T. 12490-12491 (under seal); P699 (Witness statement of KDZ611 dated 27 February 1999), e-court p. 20 (under seal).

6338 KDZ611, P698 (Transcript from Prosecutor v. Brđanin), T. 12490 (under seal); P699 (Witness statement of KDZ611 dated 27 February 1999), e-court p. 20 (under seal).

6339 [REDACTED]. See also Adjudicated Fact 1255.

6340 [REDACTED]; KDZ038, P676 (Transcript from Prosecutor v. Stakić), T. 6908. See also Adjudicated Fact 1255.

6341 KDZ038, P676 (Transcript from Prosecutor v. Stakić), T. 6910-6913.

6342 KDZ038, P676 (Transcript from Prosecutor v. Stakić), T. 6913-6918.

6343 KDZ611, P698 (Transcript from Prosecutor v. Kvočka), T. 5833 (under seal); P699 (Witness statement of KDZ611 dated 27 February 1999), e-court pp. 20-21 (under seal) (stating that at one point the other survivor he was with, Bahrija Jakupović, went back for a look and told KDZ611 that people from the other bus were being killed in small groups, rather than lining them up all at once).

6344 KDZ611, P698 (Transcript from Prosecutor v. Kvočka), T. 5833-5834 (under seal). See P699 (Witness statement of KDZ611 dated 27 February 1999), e-court p. 21 (under seal).
} 
the incident, and interrogated about what had happened at Korićanske Stijene by both an army officer and the police. ${ }^{6345}$ They were then transferred to a hospital in Banja Luka. ${ }^{646}$

1842. In the hospital, KDZ038, KDZ611, and other survivors were beaten and mistreated by other patients and by local civilians, police, and soldiers, with the permission of the guards who were watching them. ${ }^{6347}$ Later, they were transferred to another hospital at Paprikovac, near Banja Luka, where they and other non-Serbs were also mistreated. ${ }^{6348}$ Following his release from the hospital, and after being interviewed by a judge in Banja Luka about the incident at Korićanske Stijene, KDZ611 was housed by a Muslim charity in Banja Luka called Merhamet. ${ }^{639}$ Later, an international organisation took him back to Trnopolje to get the necessary papers to permit him to leave RS, and then on to Karlovac, from where he travelled to a third country. ${ }^{6350}$ KDZ038 remained in the Paprikovac hospital until 15 October 1992, when he was told that he was free to leave and, with the assistance of Merhamet, he went to stay at the mosque. ${ }^{651}$ The wound on KDZ038's ankle festered badly and his foot was finally amputated. ${ }^{6352}$

1843. On 22 August 1992, a meeting was held with Paraš, Župljanin, Bogdan Subotić, Drljača, and other high level officials at the Prijedor SJB to discuss the incident at Korićanske Stijene. ${ }^{6353}$ That day, members of the intervention squad who had been told to go into hiding after the incident

6345 KDZ611, P698 (Transcript from Prosecutor v. Brđanin), T. 12501-12503 (under seal); P699 (Witness statement of KDZ611 dated 27 February 1999), e-court p. 21 (under seal) (providing the names of the other survivors: Midhet Mujkanović, Mehmed Sivac, and Sulejman Kahrimanović and noting that they also gave a statement to a judge in Banja Luka after they had been released from the hospital).

6346 KDZ611, P698 (Transcript from Prosecutor v. Kvočka), T. 5835 (under seal).

6347 KDZ038, P676 (Transcript from Prosecutor v. Stakić), T. 6920; KDZ611, P698 (Transcript from Prosecutor v. Brđanin), T. 12503-12504 (under seal).

6348 KDZ038, P676 (Transcript from Prosecutor v. Stakić), T. 6922-6924; KDZ611, P698 (Transcript from Prosecutor v. Brđanin), T. 12503-12505 (under seal); KDZ611, P698 (Transcript from Prosecutor v. Kvočka), T. 5835 (under seal) (testifying that there they also met another survivor of the incident at Korićanske Stijene, Sanimir Kljajić).

6349 KDZ611, P698 (Transcript from Prosecutor v. Brđanin), T. 12509 (under seal). See D4236 (Report of Banja Luka Lower Court, 24 September 1992); D2044 (Report of Banja Luka Public Prosecutor's Office, 14 September 1992).

6350 KDZ611, P698 (Transcript from Prosecutor v. Kvočka), T. 5835-5836 (under seal); KDZ611, P698 (Transcript from Prosecutor v. Brđanin), T. 12510 (under seal); P699 (Witness statement of KDZ611 dated 11 September 1995), e-court p. 37 (under seal).

$6351 \quad$ KDZ038, P676 (Transcript from Prosecutor v. Stakić), T. 6923.

6352 KDZ038, P676 (Transcript from Prosecutor v. Stakić), T. 6922-6924, 6956, 6959 (testifying that during his time in Paprikovac, he met other survivors of the killings at Korićanske Stijene and gave a statement to the ICRC which he said was not a true statement; he stated that he was constantly watched by guards when he gave it and they told him not to tell the truth).

6353 [REDACTED]; Dušan Janković, T. $47302-47303$ (18 February 2014). See also [REDACTED]; D2041 (1 Krajina Corps combat report, 22 August 1992), p. 2 (wherein the $1^{\text {st }}$ Krajina Corps Command reported to the VRS Main Staff about the Mount Vlašić incident, including that "a massacre against civilians—Muslim menwas committed on 21 August between 1830 and 1900 hours [...] by a group of policemen escorting a convoy of refugees to Travnik"). 
returned to Prijedor and resumed their duties. ${ }^{634}$ On 23 or 24 August 1992, members of the intervention squad were taken back to Korićanske Stijene to attempt to recover bodies from the abyss; Drljača and Župljanin were both present. ${ }^{655}$ Approximately 150 to 200 dead bodies were seen at Korićanske Stijene after the incident. ${ }^{636}$ The attempt to extract the bodies failed as they did not have the heavy machinery required for such an operation. ${ }^{6357}$ A second attempt was made to extract the bodies with a crane but it also failed, as did their attempt to burn the bodies. ${ }^{6358}$ During the second attempt, some of the bodies were destroyed; members of the intervention squad then tried to cover the remaining bodies with stones and branches, under the supervision of Drljača, Paraš, and two other commanders. ${ }^{6359}$

1844. Shortly after the incident, the intervention squad was disbanded and its 40 members were sent on a combat mission to Han Pijesak. ${ }^{6360}$ On 3 September 1992, the $1^{\text {st }}$ Krajina Corps reported to the VRS Main Staff that Drljača was responsible for the incident at Korićanske Stijene and that it had caused indignation among citizens and members of the $1^{\text {st }}$ Krajina Corps, creating a "dark stain", but that it was fortunate that the "international community did not find out about it in more detail". 6361

1845. On 14 September 1992, in response to a request by Mićo Stanišić to initiate an investigation into the incident, ${ }^{6362}$ Drljača stated that an investigation could not be carried out because the officers who had participated in the convoy and incident were currently deployed in the battlefield. ${ }^{6363}$ Although an investigation into the incident was initiated, ${ }^{6364}$ none of the policemen

\footnotetext{
$6354 \quad$ [REDACTED].

6355 [REDACTED].

6356 Nenad Krejić, P3760 (Transcript from Prosecutor v. Stanišić \& Župljanin), T. 14037-14039; P3767 (Aerial photograph marked by Nenad Krejić); P3768 (Witness statement of Milan Komljenović dated 28 October 2011), pp. 6-7; [REDACTED].

6357 [REDACTED]. See also D4379 (Witness statement of Vladimir Glamočić dated 10 February 2014), paras. 1924.

6358 [REDACTED]; Vladimir Glamočić, T. 47240-47241 (17 February 2014); P6673 (Video footage re Korićanske Stijene). See also D4379 (Witness statement of Vladimir Glamočić dated 10 February 2014), para. 33.

6359 Nenad Krejić, P3760 (Transcript from Prosecutor v. Stanišić \& Župljanin), T. 14049-14050, 14055; Milan Komljenović, T. 20916-20919 (3 November 2011); P3768 (Witness statement of Milan Komljenović dated 28 October 2011), pp. 9-10, 21-22, 24-25; [REDACTED]. See P3929 (Report of $1^{\text {st }}$ Krajina Corps, 3 September 1992), p. 4.

6360 Dušan Janković, T. 47303-47304 (18 February 2014) (testifying that disbanding the unit and sending them to the frontline was a compromise as if Drljača had arrested them, they would have resisted and "it could not be done without bloodshed"); [REDACTED]. See D1882 (Letter from Simo Drljača, 14 September 1992); D1885 (Dispatch from Simo Drljača to Stojan Župljanin, 13 October 1992).

6361 P3929 (Report of $1^{\text {st }}$ Krajina Corps, 3 September 1992), p. 4.

6362 P3763 (Order of Banja Luka CSB forwarding order of RS MUP, 11 September 1992); Mićo Stanišić, T. $46411-$ 46413 (4 February 2014).

6363 D1882 (Letter from Simo Drljača, 14 September 1992); D1885 (Dispatch from Simo Drljača to Stojan Župljanin, 13 October 1992). See also Adjudicated Fact 2492.
} 
involved in the incident were held accountable for their involvement. ${ }^{6365}$ Furthermore, in November 1993 and June 1994, members of the intervention squad, as well as high officials involved in the incident, such as Drljača, Paraš, Milutin Čađo, and others in the Prijedor SJB, were promoted and awarded medals of bravery by the Accused. ${ }^{6366}$

1846. The Chamber took judicial notice of the fact that on 21 August 1992, approximately 200 men travelling in a convoy over Mount Vlašić were killed by Serb armed men at Korićanske Stijene. ${ }^{6367}$ Furthermore, in assessing the overall number of persons killed during this incident, the Chamber has considered witness testimony that there were two buses with approximately 100 men or more on each bus. ${ }^{6368}$ In addition, the Chamber received forensic evidence to support the deaths of some identified individuals in connection with the killings at Korićanske Stijene. ${ }^{6369}$

6364 D2040 (Special report of the $22^{\text {nd }}$ Light Infantry Brigade, 21 August 1992); D2042 (Miloš’s report re Korićanske Stijene incident, 22 August 1992); D2043 (Record of forensic examination at Korićanske Stijene, 31 August 1992); D2044 (Report of Banja Luka Public Prosecutor's Office, 14 September 1992); D4236 (Report of Banja Luka Lower Court, 24 September 1992); D1883 (Letter from Banja Luka Prosecutor's Office to Banja Luka CJB, 30 September 1992); P6644 (Letter from Banja Luka CJB to Banja Luka Prosecutor's Office, 1999); Mićo Stanišíc, T. 46411-46413 (4 February 2014), T. 46542-46548 (5 February 2014); D4235 (Witness statement of Jevto Janković dated 24 January 2014), paras. 9-10, 12. See P3768 (Witness statement of Milan Komljenović dated 28 October 2011), para. 4; D4195 (Witness statement of Milomir Stakić dated 16 November 2013), para. 30.

6365 [REDACTED]; P3768 (Witness statement of Milan Komljenović dated 28 October 2011), pp. 6-7. See also P2958 (Christian Nielsen's expert report entitled "The Bosnian Serb Ministry of Internal Affairs: Genesis, Performance and Command and Control 1990-1992", 19 May 2011), paras. 327-328.

6366 [REDACTED]; P4261 (Article in the Kozarski Vesnik entitled "Shoulder to Shoulder with the Army", 26 November 1993); P4265 (Compilation of video footage from various Serbian TV stations, undated, with transcript). The Chamber will discuss in further detail the Accused's knowledge of this incident and subsequent actions in Section IV.A.3.a.v: Accused's knowledge of crimes and measures he took to prevent them. See paras. 3346, 3418, 3432. Furthermore, rather than being treated as a "rogue police chief", as alleged by the Accused during his case, Drljača was rewarded as a hero for his actions in Prijedor and given more appointments in Banja Luka and Prijedor over the subsequent years. For instance, Drljača was appointed as assistant Chief of the Banja Luka CSB on 17 January 1994, and later, he was again appointed as Chief of the Prijedor SJB on 27 April 1994. P6638 (Decisions of RS MUP, 17 January 1994 and 27 April 1994); Mićo Stanišić, T. $46517-$ 46518 (5 February 2014); Miroslav Kvočka, T. 45631 (20 January 2014); P4261 (Article in the Kozarski Vesnik entitled "Shoulder to Shoulder with the Army", 26 November 1993); P4265 (Compilation of video footage from various Serbian TV stations, undated, with transcript); [REDACTED].

See Adjudicated Fact 1254.

See paras. 1836-1837.

6369 P4437 (Death certificates for 16 individuals reported missing on Mount Vlašić) (under seal); P4421 (Death certificate for Bećir Bešić) (under seal); P4422 (Death certificate for Rasim Bašić) (under seal); P4423 (Death certificate for Almir Fazlić) (under seal); P4424 (Death certificate for Nedžad Čaušević) (under seal); P4425 (Death certificate for Samir Garibović) (under seal); P4426 (Death certificate for Šefik Garibović) (under seal); P4427 (Death certificate for Zijad Huskanović) (under seal); P4428 (Death certificate for Fehret Jaskić) (under seal); P4429 (Death certificate for Hasan Kararić) (under seal); P4430 (Death certificate for Fahrudin Mujkanović) (under seal); P4431 (Death certificate for Sejad Avdić) (under seal); P4432 (Death certificate for Zijad Tadžić) (under seal); P4433 (Death certificate for Suad Zulić) (under seal); P4434 (Death certificate for Mesud Zulić) (under seal); P4435 (Death certificate for Sejad Kadirić) (under seal); P4438 (Death certificate for Midhet Hodžić) (under seal); P4853 (Updated Table 2 to the Report of Amor Mašović), pp. 91-93 (wherein Mašović identifies the names of 55 identified individuals who went missing Korićanske Stijene on 21 August 1992 and who were later exhumed from Korićanske Stijene); P4640 (DNA reports of persons exhumed from Korićanske Stijene on 3 October 2003); P5911 (DNA reports of persons exhumed from Korićanske Stijene on 21 July-26 August 2006); P5912 (DNA reports of persons exhumed from Korićanske Stijene on 15-21 May 2003). KDZ611 identified Jasim Fazlić, his brother, eight neighbours with the last name Garibović, Kadir 
1847. Based on the above, the Chamber finds that approximately 200 non-Serb men, some of whom were taken from Trnopolje, were killed on 21 August 1992 by Serb Forces at Korićanske Stijene.

\section{(vi) Transfer of detainees out of Trnopolje}

1848. Women and children were taken away in convoys from Trnopolje early on until there were primarily only men left in the camp. ${ }^{6370}$

1849. As mentioned above, pursuant to an order issued by Mladić on 3 August 1992, Talić ordered the authorities at Omarska, Trnopolje, and Manjača to urgently prepare for visits by the ICRC and teams of reporters. ${ }^{6371}$

1850. When journalists and foreign delegations visited Trnopolje, camp officials would take down the barbed wire fence and sometimes a sign would be put up saying that it was a "collection centre". ${ }^{672}$ On 18 August 1992, ICRC representatives were denied access to Trnopolje for a week. ${ }^{6373}$ In that week, officials prepared the camp for subsequent visits by journalists and ICRC representatives by organising numerous convoys, including the convoy to Mount Vlasić on 21 August 1992, to transfer Bosnian Muslims and Bosnian Croats out of Trnopolje in order to empty the camp. ${ }^{6374}$ The convoys transferring detainees out of Trnopolje were organised and secured by the Prijedor Crisis Staff, Prijedor SJB, Banja Luka SJB, and the VRS. ${ }^{6375}$ ICRC regained access to Trnopolje on 26 August 1992 and began registering detainees for the first time. ${ }^{6376}$

Kararić, and Elvir Kararić as individuals who were with him on the convoy and were killed at Korićanske Stijene). KDZ611, P698 (Transcript from Prosecutor v. Kvočka), T. 5830 (under seal); KDZ611, P698 (Transcript from Prosecutor v. Brđanin), T. 12511 (under seal); P699 (Witness statement of KDZ611 dated 27 February 1999), e-court pp. 14-15, 19 (under seal). See also P4851 (Witness statement of Amor Mašović dated 23 March 2012), Confidential Appendix B, pp. 16-19 (under seal); P646 (Excerpts from report on exhumations in Prijedor municipality, 28 August 2002), pp. 63, 68-69, 72-73, 76-78, 84, 86, 95-96, 113-116, 123-124, 142, 148, 169, 176, 181-184, 201, 204-206, 210-213 (under seal).

6370 KDZ038, P676 (Transcript from Prosecutor v. Stakić), T. 6876-6877 (testifying that he watched the convoys of buses and trucks leaving from the camp, carrying women and children, and sometimes tried to get on board, but was unable to board).

6371 P5461 (VRS Main Staff Order, 3 August 1992); P5460 (Order of $1^{\text {st }}$ Krajina Corps, 3 August 1992). See also paras. 1404, 1784.

6372 Idriz Merdžanić, P3881 (Transcript from Prosecutor v. Stakić), T. 7793; KDZ038, P676 (Transcript from Prosecutor v. Stakić), T. 6879.

6373 P807 (Address by ICRC President at the London Conference, 26 August 1992), p. 3.

6374 Idriz Merdžanić, P3881 (Transcript from Prosecutor v. Stakić), T. 7789-7791; Idriz Merdžanić, T. 21395-21398 (16 November 2011); P3901 (Photograph of detainees at Trnopolje); P3902 (Photograph of detainees waiting to board a truck at Trnopolje); KDZ014, P674 (Transcript from Prosecutor v. Stakić), T. 5748-5750; KDZ611, P698 (Transcript from Prosecutor v. Brđanin), T. 12517-12518 (under seal); Dušan Janković, T. 47301 (18 February 2014). See also Adjudicated Fact 1296.

6375 P5503 (Report of Prijedor SJB, 18 July 1992); KDZ038, P676 (Transcript from Prosecutor v. Stakić), T. 68816882 (testifying that an intervention squad known as "Sarenci" would come to Trnopolje whenever one of the convoys was leaving to guard the convoys as the people were being loaded on to the buses and trucks and 
1851. Trnopolje was officially closed at the end of September 1992, but some detainees stayed there longer so that they could be registered and leave. ${ }^{677}$ A large convoy from Trnopolje was organised by the ICRC on 1 October 1992; 1,560 people were transferred from Trnopolje to a reception centre in Karlovac. ${ }^{678}$ All of the detainees transferred in this convoy were required to sign documents relinquishing their property rights in Prijedor to Serbs. ${ }^{6379}$ It was only after signing these documents that they were permitted to leave. ${ }^{630}$ According to the Prijedor Red Cross, over 23,000 people had been "housed" at Trnopolje by the end of September $1992 .{ }^{6381}$

1852. Some detainees remained at Trnopolje until the end of 1992. ${ }^{6382}$ On 2 December 1992 , Kirudja co-ordinated a convoy of 600 to 800 people out of Trnopolje to Dvor, in Croatia. ${ }^{6383}$

\section{(e) Scheduled Detention Facility C.20.5}

1853. The Indictment refers to the use of the Miška Glava Dom as a detention facility in Prijedor municipality between 21 and 25 July 1992.

facility

(i) Arrival of detainees and control over the detention

1854. Located in the village of Miška Glava, the Miška Glava Dom was used as a detention facility in Prijedor from around 21 to 25 July 1992. ${ }^{6384}$ Miška Glava Dom was a cultural club

describing that the unit wore a police combat uniform of blue and yellow camouflage with the word "Milicija" in Cyrillic); [REDACTED]. See also Adjudicated Fact 1296.

6376 P807 (Address by ICRC President at the London Conference, 26 August 1992), p. 3; KDZ038, P676 (Transcript from Prosecutor v. Stakić), T. 6882-6883; Idriz Merdžanić, P3881 (Transcript from Prosecutor v. Stakić), T. 7799. See D4253 (Video footage of interviews at Omarska, with transcript), p. 9. See also P6585 (SRNA press release, 22 August 1992) (reporting that authority over Trnopolje had been handed over to the Red Cross in the course of the day pursuant to a decision by the RS President).

6377 Idriz Merdžanić, P3881 (Transcript from Prosecutor v. Stakić), T. 7791, 7800; D3110 (ICRC press release, 2 October 1992); P6504 (Report of Prijedor Red Cross, 30 September 1992), pp. 9-10; P2948 (Report of humanitarian organisation, 8 October 1992) (under seal), p. 2. See also Adjudicated Fact 1224.

6378 D3110 (ICRC press release, 2 October 1992); Idriz Merdžanić, P3881 (Transcript from Prosecutor v. Stakić), T. 7791, 7800, 7834-7835; P684 (Witness statement of KDZ054 dated 14 March 2000), e-court p. 9; P6504 (Report of Prijedor Red Cross, 30 September 1992), pp. 9-10. See P786 (Third notebook of Herbert Okun's ICFY diary), e-court p. 13.

6379 Idriz Merdžanić, P3881 (Transcript from Prosecutor v. Stakić), T. 7800, 7834-7835; Jusuf Arifagić, P689 (Transcript from Prosecutor v. Stakić), T. 7106, 7133-7134.

6380 Idriz Merdžanić, P3881 (Transcript from Prosecutor v. Stakić), T. 7800, 7834-7835; Jusuf Arifagić, P689 (Transcript from Prosecutor v. Stakić), T. 7106.

6381 P6504 (Report of Prijedor Red Cross, 30 September 1992), p. 9.

6382 P2968 (Report of Prijedor SJB, January 1993), p. 5 (stating that Trnopolje remained in operation until November 1992). See also Adjudicated Fact 1224. In a meeting with international representatives on 3 October 1992, it was brought to the attention of Okun and other ICFY representatives that more than 1,000 people entered Trnopolje "voluntarily" after it "had been emptied" a few days prior with the departure of the large convoy on 1 October. P786 (Third notebook of Herbert Okun's ICFY diary), e-court p. 20.

6383 P3804 (Witness statement of Charles Kirudja dated 17 November 2010), para. 74, fn. 187; P3833 (UNPROFOR Memo, 8 December 1992). 
which had been transformed into a command post staffed and guarded by members of the Miška Glava TO. ${ }^{6385}$

1855. Around 21 July 1992, a group of approximately 114 Bosnian Muslim men and boys were captured by Serb soldiers and transported in buses to Miška Glava Dom. ${ }^{6386}$ This group had been part of a column of between 200 and 300 men and boys walking in the direction of Bihać. ${ }^{6387}$ The column was attacked by Serb soldiers in the Kalejevo woods and it broke apart. ${ }^{6388}$ A group from the column, including Nermin Karagić and Elvedin Nasić, ran into the woods near Miška Glava and were surrounded by about 20 soldiers dressed in olive-grey JNA uniforms and blue reserve police uniforms. ${ }^{6389}$ The group was lined up in four columns, searched, and ordered to throw all of their possessions in a pile on the ground. ${ }^{6390}$ They were then led to the road, where a van was brought to take them in groups to Miška Glava Dom. ${ }^{631}$ Three men tried to escape on the way to the van, one of whom was shot. ${ }^{6392}$

1856. When they arrived at Miška Glava Dom, the detainees were locked in a room that had served as a café. ${ }^{6393}$ Their names were recorded by an officer. ${ }^{6394}$

6384 P598 (Map of Prijedor area); Nermin Karagić, P651 (Transcript from Prosecutor v. Stakić), T. 5215, 52175218, 5226; Elvedin Nasić, P696 (Transcript from Prosecutor v. Brđanin), T. 12693-12695, 12698; P697 (Witness statement of Elvedin Nasić dated 15 January 1995), e-court p. 3. See also Adjudicated Fact 1102.

6385 P697 (Witness statement of Elvedin Nasić dated 15 January 1995), e-court p. 3; Nermin Karagić, P651 (Transcript from Prosecutor v. Stakić), T. 5219-5220. See also Adjudicated Facts 1257, 1258. The secretary of the local commune had his office at Miška Glava Dom and local commune meetings were held there. Nermin Karagić, P651 (Transcript from Prosecutor v. Stakić), T. 5215, 5217, 5219.

6386 Nermin Karagić, P651 (Transcript from Prosecutor v. Stakić), T. 5213-5215, 5223; Elvedin Nasić, P696 (Transcript from Prosecutor v. Brđanin), T. 12691, 12693. See also Adjudicated Fact 1259.

6387 Nermin Karagić, P651 (Transcript from Prosecutor v. Stakić), T. 5211-5212 (testifying that the column consisted of adult men and boys his age (17 years old)); Elvedin Nasić, P696 (Transcript from Prosecutor $v$. Brđanin), T. 12690, 12723.

6388 Nermin Karagić, P651 (Transcript from Prosecutor v. Stakić), T. 5213; Elvedin Nasić, P696 (Transcript from Prosecutor v. Brđanin), T. 12690; P697 (Witness statement of Elvedin Nasić dated 15 January 1995), e-court p. 3.

6389 Elvedin Nasić, P696 (Transcript from Prosecutor v. Brđanin), T. 12690-12691; Nermin Karagić, P651 (Transcript from Prosecutor v. Stakić), T. 5213-5214, 5219-5220; P697 (Witness statement of Elvedin Nasić dated 15 January 1995), e-court p. 3.

6390 Nermin Karagić, P651 (Transcript from Prosecutor v. Stakić), T. 5214; Elvedin Nasić, P696 (Transcript from Prosecutor v. Brđanin), T. 12691; P697 (Witness statement of Elvedin Nasić dated 15 January 1995), e-court p. 3.

6391 Nermin Karagić, P651 (Transcript from Prosecutor v. Stakić), T. 5214-5215; Elvedin Nasić, P696 (Transcript from Prosecutor v. Brđanin), T. 12691.

6392 Nermin Karagić, P651 (Transcript from Prosecutor v. Stakić), T. 5215 (testifying further that he heard later that the other two men were killed in Sanski Most); Elvedin Nasić, P696 (Transcript from Prosecutor v. Brđanin), T. 12691, 12700; P697 (Witness statement of Elvedin Nasić dated 15 January 1995), e-court p. 3. The Chamber notes these killings are not charged pursuant to Schedule A or Schedule B of the Indictment. See fn. 13.

6393 Elvedin Nasić, P696 (Transcript from Prosecutor v. Brđanin), T. 12693; Nermin Karagić, P651 (Transcript from Prosecutor v. Stakić), T. 5215, 5218; P697 (Witness statement of Elvedin Nasić dated 15 January 1995), e-court p. 3. 
(ii) Conditions of detention and treatment of detainees

1857. Detainees were held in the café at Miška Glava Dom for between three to five days. ${ }^{6395}$ The room was small and so overcrowded that detainees had to sit in a crouching position, with their knees to their chests and their arms around their legs. ${ }^{6396}$ It was stiflingly hot. ${ }^{6397}$ While at Miška Glava Dom, detainees received little to no food and they had to "earn" drinking water by singing songs about Greater Serbia. ${ }^{6398}$

1858. Detainees were regularly called out of the café to a smaller room to be interrogated and were beaten by soldiers with their fists and rifle butts. ${ }^{6399}$ They suffered concussions, bleeding, and heavy bruising. ${ }^{6400}$ Karagic heard the moaning of his father as he was being beaten and when his father returned, he was covered in bruises. ${ }^{6401}$ Karagić also saw a man named Islam Hopovac beaten until he was "black and blue". ${ }^{6402}$ Detainees were also beaten when they went outside to go to the bathroom. ${ }^{6403}$

1859. At one point, a man whose son was allegedly killed by Muslims in Rizvanovići entered the room and called out ten men from Rizvanovići, including Ismet Hamulić, and said he would "do

6394 Nermin Karagić, P651 (Transcript from Prosecutor v. Stakić), T. 5218; Elvedin Nasić, P696 (Transcript from Prosecutor v. Brđanin), T. 12693; P697 (Witness statement of Elvedin Nasić dated 15 January 1995), e-court p. 3. See also Adjudicated Fact 1259.

6395 Nermin Karagić, P651 (Transcript from Prosecutor v. Stakić), T. 5218; Elvedin Nasić, P696 (Transcript from Prosecutor v. Brđanin), T. 12694; P697 (Witness statement of Elvedin Nasić dated 15 January 1995), e-court p. 3.

6396 Nermin Karagić, P651 (Transcript from Prosecutor v. Stakić), T. 5220, 5225; P697 (Witness statement of Elvedin Nasić dated 15 January 1995), e-court p. 3.

6397 Nermin Karagić, P651 (Transcript from Prosecutor v. Stakić), T. 5220.

6398 Nermin Karagić, P651 (Transcript from Prosecutor v. Stakić), T. 5219-5220 (stating that the detainees were given a single loaf of bread and a packet of sweets to share amongst all of them); Elvedin Nasić, P696 (Transcript from Prosecutor v. Brđanin), T. 12709-12710 (testifying that he was given nothing to eat during his detention at Miška Glava Dom).

6399 Elvedin Nasić, P696 (Transcript from Prosecutor v. Brđanin), T. 12694; Nermin Karagić, P651 (Transcript from Prosecutor v. Stakić), T. 5220-5221; P697 (Witness statement of Elvedin Nasić dated 15 January 1995), e-court p. 3. See also Adjudicated Facts 1258, 1259, 1260.

6400 Nermin Karagić, P651 (Transcript from Prosecutor v. Stakić), T. 5220-5221, 5223. See also Adjudicated Fact 1260.

6401 Nermin Karagić, P651 (Transcript from Prosecutor v. Stakić), T. 5220-5221.

6402 Nermin Karagić, P651 (Transcript from Prosecutor v. Stakić), T. 5223.

6403 Elvedin Nasić, P696 (Transcript from Prosecutor v. Brđanin), T. 12693. 
the same" to them; these men were never seen again. ${ }^{6404}$ In addition, at least three men were taken out of the room by soldiers and did not return. ${ }^{6405}$

1860. On around 25 July 1992, the remaining detainees were put on to two buses and transferred to the Ljubija football stadium. ${ }^{6406}$

\section{(iii) $\underline{\text { Conclusion }}$}

1861. Based on the above, the Chamber finds that Bosnian Muslims, including minors, were detained at Miška Glava Dom by Serb Forces from around 21 July to 25 July 1992. The Chamber also finds that detainees were held in poor conditions characterised by lack of space and insufficient food and were subjected to severe beatings by Serb Forces.

\section{$\underline{\text { A. } 10.8}$}

(f) $\underline{\text { Scheduled Detention Facility C.20.6 and Scheduled Incident }}$

1862. The Indictment refers to the use of the Ljubija Football Stadium as a detention facility in Prijedor municipality on or about 25 July $1992 .{ }^{6407}$ The Prosecution alleges that a number of men were killed at the Ljubija Football Stadium and surrounding areas on or about 25 July $1992 .{ }^{6408}$

$\underline{\text { facility }}$

(i) Arrival of detainees and control over the detention

1863. On or around 25 July 1992 in the afternoon, Bosnian Muslim civilians who had been detained at Miška Glava Dom were transferred by bus to the Ljubija Football Stadium. ${ }^{6409}$ Ljubija

6404 Nermin Karagić, P651 (Transcript from Prosecutor v. Stakić), T. 5221-5225 (further testifying that he could not recall if the man was wearing a uniform or civilian clothing); Elvedin Nasić, P696 (Transcript from Prosecutor v. Brđanin), T. 12695, 12723-12724; P697 (Witness statement of Elvedin Nasić dated 15 January 1995), e-court p. 3. The Chamber notes these killings are not charged pursuant to Schedule B of the Indictment with respect to this detention facility. See fn. 13.

6405 P697 (Witness statement of Elvedin Nasić dated 15 January 1995), e-court p. 3; Elvedin Nasić, P696 (Transcript from Prosecutor v. Brđanin), T. 12723-12724 (testifying that three men were taken out of the room by soldiers from Banja Luka and were never seen again); Nermin Karagić, P651 (Transcript from Prosecutor v. Stakić), T. 5221-5225 (testifying that a man from Cazin and a man from Višegrad were taken from the room and that he heard the sounds of these two men being killed outside and saw a soldier in an olive-grey uniform take three other detainees from the café one by one, and each time, the soldier returned to the café alone with blood on his knife and glove). The Chamber notes these killings are not charged pursuant to Schedule B of the Indictment with respect to this detention facility. See fn. 13.

6406 Nermin Karagić, P651 (Transcript from Prosecutor v. Stakić), T. 5225-5226; P697 (Witness statement of Elvedin Nasić dated 15 January 1995), e-court p. 3; Elvedin Nasić, P696 (Transcript from Prosecutor v. Brđanin), T. 12695. See also Adjudicated Fact 1261; Scheduled Detention Facility C.20.6.

6407 In its Final Brief, the Prosecution notes a typographical error in the Indictment for Scheduled Detention Facility C.20.6, namely that it omitted to allege the year as 1992. See Prosecution Final Brief, Appendix B, p. 43, fn. 642.

6408 The Chamber notes that these killings are alleged under Schedule A of the Indictment. However, they are killings related directly to the Ljubija Football Stadium listed as Scheduled Detention Facility C.20.6 in the Indictment. 
Football Stadium was located at the entrance to Gornja Ljubija. ${ }^{6410}$ On the way to the stadium, one of the buses stopped at the entrance to an iron ore mine near Gornja Ljubija. ${ }^{6411}$ A policeman named "Simo", soldiers wearing dark blue and black camouflage overalls, and members of a "Special Forces intervention squad" boarded the bus and began to beat and kick the detainees. ${ }^{6412}$ The bus then continued on to the stadium, and the detainees were ordered off. ${ }^{6413}$

1864. Upon arriving at the stadium, children were separated from the other detainees and held in a building that served as a changing room for athletes. ${ }^{6414}$

1865. Ljubija Football Stadium was guarded by Bosnian Serb policemen, members of the military, and members of the intervention squad who accompanied the buses. ${ }^{6415}$ A guard in civilian clothes, who was called "vojvoda", was also present at the stadium. ${ }^{6416}$

\section{(ii) Treatment of detainees}

1866. As they exited the bus, the detainees were beaten by civilians who had assembled at the stadium, as well as by soldiers and members of the intervention squad and police, with metal rods, rifle butts, baseball bats, and other implements. ${ }^{6417}$

Elvedin Nasić, P696 (Transcript from Prosecutor v. Brđanin), T. 12695-12696; P697 (Witness statement of Elvedin Nasić dated 15 January 1995), e-court p. 3; Nermin Karagić, P651 (Transcript from Prosecutor v. Stakić), T. 5226-5227. See also Adjudicated Facts 1102, 1261.

6410 P569 (Map of Prijedor municipality); Elvedin Nasić, P696 (Transcript from Prosecutor v. Brđanin), T. 1269612697; Nermin Karagić, P651 (Transcript from Prosecutor v. Stakić), T. 5227; P563 (Map of Ljubija-Briševo) (on which Karagić identified the stadium as photograph number 2). See also Ivo Atlija, P3672 (Transcript from Prosecutor v. Stakić), T. 5634; P3688 (Excerpt from video clip of aerial flyover of Prijedor).

Elvedin Nasić, P696 (Transcript from Prosecutor v. Brđanin), T. 12695-12697 (testifying that the mine was located at "Ljubija Zeljezne Rude", a different location than the "Kipe" mine); P569 (Map of Prijedor municipality).

6412 Elvedin Nasić, P696 (Transcript from Prosecutor v. Brđanin), T. 12695-12696; P697 (Witness statement of Elvedin Nasić dated 15 January 1995), e-court p. 3; P697 (Witness statement of Elvedin Nasić dated 15 March 2000), e-court p. 9.

6413 Elvedin Nasić, P696 (Transcript from Prosecutor v. Brđanin), T. 12696.

6414 Nermin Karagić, P651 (Transcript from Prosecutor v. Stakić), T. 5228, 5234, 5236 (testifying that he only heard children had been separated later from the children themselves and that although he was only 17 years old, he was not sent to the changing room; in addition, one Serb detainee was allowed to go to the changing room later and survived); P563 (Map of Ljubija-Briševo) (on which Karagić identifies a white two-story building that served as the changing room in photograph number two).

6415 Elvedin Nasić, P696 (Transcript from Prosecutor v. Brđanin), T. 12698-12700, 12702 (testifying that he recognised a local reserve policeman called "Stiven" and a soldier named Predrag Vasiljević); P697 (Witness statement of Elvedin Nasić dated 15 January 1995), e-court p. 4; Nermin Karagić, P651 (Transcript from Prosecutor v. Stakić), T. 5231 (testifying that there was a "Major" in an olive-grey uniform and a military police officer in a camouflage uniform with a white belt). See also Adjudicated Facts 1078, 1262.

6416 Nermin Karagić, P651 (Transcript from Prosecutor v. Stakić), T. 5231.

6417 Elvedin Nasić, P696 (Transcript from Prosecutor v. Brđanin), T. 12698-12699 (testifying that there were civilians assembled at the entrance to the stadium who helped beat the detainees when they arrived); P697 (Witness statement of Elvedin Nasić dated 15 January 1995), e-court p. 4; Nermin Karagić, P651 (Transcript from Prosecutor v. Stakić), T. 5228, 5230 (testifying that detainees on his bus were ordered to run into the stadium past the bus driver as he beat them). See also Adjudicated Fact 1263. 
1867. Some detainees were ordered to bend forward against a brick wall surrounding the stadium and were kicked until there was a stream of blood running along the wall. ${ }^{6418}$ Karagic was kicked in the face and from behind; he sustained a broken nose and hit his head against the wall. ${ }^{6419}$ Detainees were made to raise their arms so that their hands were positioned on top of the wall; the driver of the bus then walked on top of the wall, stepping on their fingers. ${ }^{6420}$ While being beaten, the detainees were forced to sing songs about Greater Serbia. ${ }^{6421}$ For several hours, the soldiers beat the detainees until some of them died. ${ }^{6422}$

1868. A group of men were singled out from the detainees at the wall and taken to a wire fence surrounding the stadium to be killed. ${ }^{6423}$ Karagić witnessed at least one detainee being shot. ${ }^{6424}$ Furthermore, Nasić's cousin, Irfan Nasić, was singled out, sent to the fence, and shot by Stiven with a pistol at close range. ${ }^{6425}$ Nasić saw a guard nicknamed "Duča" fire at Muharem Petrovac, splitting his head in two. ${ }^{6426}$ Nasić also saw a third man shot and killed. ${ }^{6427}$ Nasić was then beaten on the head with a metal baton by a soldier and lost consciousness. When he regained consciousness, he was ordered to move the bodies of the three men who had been killed. ${ }^{6428}$

1869. The surviving detainees were then lined up in columns, with their hands behind their necks, and forced to board a bus as they were beaten further by soldiers with baseball bats. ${ }^{6429}$ Some detainees were ordered to load the dead bodies on to the bus. ${ }^{6430}$ Karagic thought that one of the

\footnotetext{
6418 Nermin Karagić, P651 (Transcript from Prosecutor v. Stakić), T. 5228, 5230-5231, 5233.

6419 Nermin Karagić, P651 (Transcript from Prosecutor v. Stakić), T. 5233, 5235.

6420 Nermin Karagić, P651 (Transcript from Prosecutor v. Stakić), T. 5235, 5241-5242.

6421 Nermin Karagić, P651 (Transcript from Prosecutor v. Stakić), T. 5235, 5241.

6422 Nermin Karagić, P651 (Transcript from Prosecutor v. Stakić), T. 5236.

6423 Nermin Karagić, P651 (Transcript from Prosecutor v. Stakić), T. 5227, 5233-5234 (testifying that he saw two or three men, including Ismet Avdić and Ferid Kadirić or Kadić taken to the fence; Karagić could not say how many men were singled out and taken to the fence but estimated that there were "a lot of people there"); P563 (Map of Ljubija-Briševo). See also Elvedin Nasić, P696 (Transcript from Prosecutor v. Brđanin), T. 12699; KDZ092, P702 (Transcript from Prosecutor v. Stakić), T. 3930-3931 (under seal) [REDACTED]; Adjudicated Fact 1079

6424 Nermin Karagić, P651 (Transcript from Prosecutor v. Stakić), T. 5233-5235 (testifying that the detainees were ordered to look towards the wall, but Karagic looked up and saw a member of the military police wearing a multi-coloured uniform and white belt shoot three bullets into one man at the fence). See also Adjudicated Fact 1079.

6425 Elvedin Nasić, P696 (Transcript from Prosecutor v. Brđanin), T. 12695, 12698-12699 (testifying that Stiven had asked if any of the men had weapons and someone said that Irfan Nasić had a "zolja", however Irfan Nasić did not have any weapons); P697 (Witness statement of Elvedin Nasić dated 15 January 1995), e-court p. 4. See also Adjudicated Fact 1078.

6426 Elvedin Nasić, P696 (Transcript from Prosecutor v. Brđanin), T. 12699-12700; P697 (Witness statement of Elvedin Nasić dated 15 January 1995), e-court p. 4. See also Adjudicated Fact 1078.

6427 Elvedin Nasić, P696 (Transcript from Prosecutor v. Brđanin), T. 12700; P697 (Witness statement of Elvedin Nasić dated 15 January 1995), e-court p. 4.

6428 Elvedin Nasić, P696 (Transcript from Prosecutor v. Brđanin), T. 12701; P697 (Witness statement of Elvedin Nasić dated 15 January 1995), e-court p. 4.

6429 Elvedin Nasić, P696 (Transcript from Prosecutor v. Brđanin), T. 12701-12702.

6430 Nermin Karagić, P651 (Transcript from Prosecutor v. Stakić), T. 5237. See also Adjudicated Fact 1080.
} 
bodies he was made to carry was his father's, but he was not sure as the body was missing half of the skull. ${ }^{6431}$ As Karagic was carrying the bodies, he saw a pile of between 15 and 20 bodies that were already in the back of the bus. ${ }^{6432}$ After loading the dead bodies on to the bus, the detainees had to sit in the bus with their heads down, while the soldiers shouted ethnic slurs at them. ${ }^{6433}$ The detainees were then transported to the "Kipe" mine. ${ }^{6434}$

1870. The Chamber took judicial notice of the fact that at least 15 detainees were killed at Ljubija Football Stadium. ${ }^{6435}$ The Chamber also received forensic evidence to support the deaths of three identified individuals who were detained at Ljubija Football Stadium on or around 25 July $1992 .{ }^{6436}$ Furthermore in assessing the total number of detainees killed at the stadium, the Chamber has considered witness testimony that there were between 15 to 20 dead bodies loaded on to the bus before the detainees were transferred out of the stadium.

\section{(iii) $\underline{\text { Conclusion }}$}

1871. Based on the above, the Chamber finds that on or around 25 July 1992, Bosnian Muslims, including minors, were transferred to and detained at Ljubija Football Stadium for several hours by Serb Forces, and that while held there, the detainees were subjected to severe beatings by Serb Forces. The Chamber also finds that at least 15 detainees were killed by Serb Forces at Ljubija Football Stadium on or around 25 July 1992.

\section{(iv) Scheduled Incident A.10.7}

1872. The Indictment refers to the killing of a number of men in the Ljubija iron ore mine Kipe on or about 25 July $1992 .^{6437}$

\footnotetext{
6431 Nermin Karagić, P651 (Transcript from Prosecutor v. Stakić), T. 5238-5239 (testifying that he recognised his father's pale blue jumper on the torso, and that the body had the same build as his father).

6432 Nermin Karagić, P651 (Transcript from Prosecutor v. Stakić), T. 5237.

6433 Nermin Karagić, P651 (Transcript from Prosecutor v. Stakić), T. 5239.

6434 P697 (Witness statement of Elvedin Nasić dated 15 January 1995), e-court p. 4; Nermin Karagić, P651 (Transcript from Prosecutor v. Stakić), T. 5244. See also Adjudicated Fact 1082.

6435 See Adjudicated Fact 1081.

6436 P4853 (Updated Table 2 to the Report of Amor Mašović), pp. 34-35 (confirming that the bodies of Ismet Avdić and Muharem Petrovac were exhumed from a mass grave in Redak in 2000); Nermin Karagić, P651 (Transcript from Prosecutor v. Stakić), T. 5247-5249 (testifying that a year and a half later, he identified his father's body at the exhumation in Redak and that a DNA analysis later confirmed that it was his father). See also P646 (Excerpts from report on exhumations in Prijedor municipality, 28 August 2002), pp. 26-29 (under seal); Nicolas Sébire, P694 (Transcript from Prosecutor v. Stakić), T. 7356.

6437 The Chamber notes that these killings are alleged under Schedule A of the Indictment. However, they are killings related to the Ljubija Football Stadium listed as Scheduled Detention Facility C.20.6 in the Indictment.
} 
1873. On or around 25 July 1992, at least 50 detainees from Ljubija Football Stadium were put on a bus, provided by a local public transport company and guarded by numerous armed soldiers. ${ }^{6438}$ They were taken to an iron ore mine southwest of Ljubija referred to as "Kipe" ("Kipe mine"). ${ }^{6439}$

1874. The bus stopped at Kipe mine between 8 p.m. and 10 p.m. and the soldiers called the detainees off the bus in groups of three and shot them. ${ }^{6440}$ The dead bodies were thrown into a hole in the ground. ${ }^{6441}$ As Nasić and two other men were getting off the bus, four other detainees broke a window and tried to escape, distracting the soldiers. ${ }^{6442}$ In the confusion, Nasić and the other two men were not shot, and Nasić hid in the hole between the bodies and pretended to be dead. ${ }^{6443}$ While this was going on, Karagić jumped through the broken bus window. ${ }^{6444}$ He managed to run away without being shot because the soldier guarding the bus was changing his ammunition clip. ${ }^{645}$ As he was fleeing, Karagić recognised two other detainees from the bus who had also managed to escape. ${ }^{6446}$

1875. After the commotion, one of the soldiers said that some of the men were still alive so they illuminated the area with flashlights to ensure that everyone was dead. ${ }^{6447}$ If they noticed any survivors or heard moaning, the soldiers shot them again while cursing their "Muslim mothers". ${ }^{6448}$

6438 Elvedin Nasić, P696 (Transcript from Prosecutor v. Brđanin), T. 12701-12702; Nermin Karagić, P651 (Transcript from Prosecutor v. Stakić), T. 5241, 5245 (testifying that the bus was a local "Autotransport" or "Autoservice" bus with approximately 50 seats and all the seats and aisle were full); P697 (Witness statement of Elvedin Nasić dated 15 January 1995), e-court p. 4 (stating that about 90 detainees were put on a "double bus"). See also Adjudicated Fact 1082.

6439 P697 (Witness statement of Elvedin Nasić dated 15 January 1995), e-court p. 4; Nermin Karagić, P651 (Transcript from Prosecutor v. Stakić), T. 5242-5245; P563 (Map of Ljubija-Briševo); Elvedin Nasić, P696 (Transcript from Prosecutor v. Brđanin), T. 12697. See also Adjudicated Fact 1082; P569 (Map of Prijedor municipality); Ivo Atlija, P3672 (Transcript from Prosecutor v. Stakić), T. 5592-5594 (noting the location of the mine on a video clip); P3689 (Video footage of destroyed buildings and monuments in Prijedor).

6440 Elvedin Nasić, P696 (Transcript from Prosecutor v. Brđanin), T. 12702-12703; P697 (Witness statement of Elvedin Nasić dated 15 January 1995), e-court p. 4; Nermin Karagić, P651 (Transcript from Prosecutor v. Stakić), T. 5243-5246. See also Adjudicated Fact 1083.

${ }^{6441}$ Elvedin Nasić, P696 (Transcript from Prosecutor v. Brđanin), T. 12703, 12705-12706; P697 (Witness statement of Elvedin Nasić dated 15 January 1995), e-court pp. 4-5. See also Adjudicated Fact 1085.

6442 Elvedin Nasić, P696 (Transcript from Prosecutor v. Brđanin), T. 12703 (testifying further that of the four men who managed to escape the Kipe mine, "only two are currently alive"); P697 (Witness statement of Elvedin Nasić dated 15 January 1995), e-court p. 4; Nermin Karagić, P651 (Transcript from Prosecutor v. Stakić), T. 5246.

6443 Elvedin Nasić, P696 (Transcript from Prosecutor v. Brđanin), T. 12703; P697 (Witness statement of Elvedin Nasić dated 15 January 1995), e-court pp. 4-5.

6444 Nermin Karagić, P651 (Transcript from Prosecutor v. Stakić), T. 5246.

6445 Nermin Karagić, P651 (Transcript from Prosecutor v. Stakić), T. 5246. See also Ivo Atlija, P3672 (Transcript from Prosecutor v. Stakić), T. 5614.

6446 Nermin Karagić, P651 (Transcript from Prosecutor v. Stakić), T. 5246-5247 (testifying further that he heard later that other detainees had managed to escape).

6447 Elvedin Nasić, P696 (Transcript from Prosecutor v. Brđanin), T. 12703-12706 (stating that the soldiers also used the headlights of a car to illuminate the area); P697 (Witness statement of Elvedin Nasić dated 15 January 1995), e-court p. 5.

6448 Elvedin Nasić, P696 (Transcript from Prosecutor v. Brđanin), T. 12705-12706. 
Nasić was still lying in the hole but he was not hit by any bullets. ${ }^{6449}$ Once the soldiers were certain that everyone had been killed, they left. ${ }^{6450}$ Nasić returned to the site a few days later and the hole had been covered with dirt and he saw blood and pieces of clothing and shoes. ${ }^{6451}$

1876. The Chamber took judicial notice of the fact that all of the detainees on the bus, save Nasic and Karagić, were killed. ${ }^{6452}$ The Chamber also received forensic evidence to support the deaths of some identified individuals who were executed at Kipe mine on or around 25 July $1992 .{ }^{6453}$

1877. Based on the above, the Chamber finds that about 50 non-Serbs were killed by Serb Forces on or about 25 July 1992 at Kipe mine.

(g) Scheduled Detention Facility C.20.7

1878. The Indictment refers to the use of the Prijedor barracks as a detention facility in Prijedor municipality between at least May and June 1992.

\section{(i) Arrival of detainees}

1879. Located in Urije, the Prijedor Barracks, also known as the Žarko Zgonjanin barracks, was used as a transition detention facility in Prijedor in June 1992. ${ }^{6454}$ Prijedor Barracks was one of the

6449 Elvedin Nasić, P696 (Transcript from Prosecutor v. Brđanin), T. 12705-12706; P697 (Witness statement of Elvedin Nasić dated 15 January 1995), e-court p. 5.

6450 Elvedin Nasić, P696 (Transcript from Prosecutor v. Brđanin), T. 12706; P697 (Witness statement of Elvedin Nasić dated 15 January 1995), e-court p. 5.

6451 Elvedin Nasić, P696 (Transcript from Prosecutor v. Brđanin), T. 12710; P697 (Witness statement of Elvedin Nasić dated 15 January 1995), e-court pp. 5-6. Ivo Atlija testified that "just after the attack on Briševo" he came across a heap of bodies, possibly as many as 200, at Kipe mine. He knew about the killings there because he met Karagić after he escaped. Ivo Atlija, P3672 (Transcript from Prosecutor v. Stakić), T. 5611-5614. See also P3684 (Photograph of mass grave in Redak).

6452 See Adjudicated Fact 1084. The Chamber however notes the evidence before it in this case establishing that there were additional survivors to Nasić and Karagić in this incident. See para. 1874.

6453 P646 (Excerpts from report on exhumations in Prijedor municipality, 28 August 2002), pp. 28-29 (confirming that in 2000, the bodies of 64 individuals were exhumed from the Kipe mine site and 21 individuals were identified; for 63 of the 64 bodies, the forensic experts determined that the cause of death was a gunshot wound) (under seal); Nicolas Sébire, P694 (Transcript from Prosecutor v. Stakić), T. 7355-7358; P4853 (Updated Table 2 to the Report of Amor Mašović), pp. 34-36; P4415 (Death certificate for Sabahudin Kadirić). See also Elvedin Nasić, P696 (Transcript from Prosecutor v. Brđanin), T. 12706-12707; P697 (Witness statement of Elvedin Nasić dated 15 January 1995), e-court pp. 4-5 (testifying that the following men were detained with him and killed that night: Reuf Fikić; Abdulah ("Dule") Muhić; Rasid Medić; Suad Mulalić, Islam Hopovac; Besim Hegić; and others with the surnames Muhić, Hamulić, Jamastagić, Kadirić, and Kekić); Nermin Karagić, P651 (Transcript from Prosecutor v. Stakić), T. 5247 (testifying further that a year and a half after the executions at Kipe mine, he identified the exhumed body of Islam Hopovac at the Redak grave).

6454 P3528 (Witness statement of Kerim Mešanović, undated), pp. 2-4; P3532 (Map of Prijedor with photographs); P3533 (Photograph of barracks in Prijedor); P3534 (Photograph of barracks in Prijedor); KDZ392, P707 (Transcript from Prosecutor v. Kvočka), T. 2633, 2648 (under seal); P608 (Map of Prijedor town); KDZ026, P2089 (Transcript from Prosecutor v. Stakić), T. 1840 (under seal). See also Adjudicated Facts 1102, 1264. Defence witnesses testified that the Prijedor Barracks was not set up as a "prison" and that no civilians were detained there. D4226 (Witness statement of Dragan Radetić dated 17 January 2014), para. 27 (stating further that Prijedor Barracks was only used for holding suspects); Slavko Budimir, D4463 (Transcript from Prosecutor 
locations in Prijedor used by the military and civilian police to investigate and interrogate suspects. $^{6455}$

1880. In early June 1992, KDZ026 was arrested and detained at Prijedor Barracks for a few hours; while there, he recognised another man detained there. ${ }^{6456}$

1881. Around 9 June 1992, KDZ392 and his mother and father were captured in Bešići by soldiers wearing camouflage uniforms. ${ }^{6457}$ They had been trying to reach the Sava River in order to cross over to Croatia. ${ }^{6458}$ At the time, the father of KDZ392 had a pistol with him but KDZ392 and his mother were not armed. ${ }^{6459}$ After being captured, KDZ392 and his parents were taken to Prijedor Barracks. ${ }^{6460}$ On the way, the soldiers captured two other men, a father and son named Suad and Fehid Trnjanin. ${ }^{6461}$ En route, KDZ392 also observed traces of burning in all of the villages inhabited by Bosnian Muslims along the main road leading from Prijedor to Banja Luka; while the villages approaching Omarska and at the exit of Prijedor inhabited by Serbs were not burned. ${ }^{6462}$

\section{(ii) Treatment of detainees}

1882. While held at Prijedor Barracks, detainees were interrogated and mistreated by soldiers and military and civilian police. ${ }^{6463}$

1883. When KDZ392 and his parents arrived at the barracks, they were hit and made to kneel down in the field outside of the barracks with their hands behind their heads. ${ }^{6464}$ KDZ392 was taken to a building while his mother and father remained in the field. ${ }^{6465}$ He could hear the soldiers shouting ethnic slurs outside, and when his father entered the building, he was covered in blood and

v. Stakić), T. 12946 (testifying that he did not see any civilians being detained at Prijedor Barracks when he visited from time to time). However, the Chamber does not find this evidence to be reliable based on the evidence before the Chamber to the contrary which suggests that non-Serb civilians were brought to the Prijedor Barracks and detained there for a short period before being transferred to other detention facilities. In reaching this conclusion, the Chamber also considered that Radetic was not forthright with the Chamber on several occasions.

KDZ523, P4257 (Transcript from Prosecutor v. Brđanin), T. 21108-21109 (under seal).

KDZ026, P2089 (Transcript from Prosecutor v. Stakić), T. 1840 (under seal).

KDZ392, P707 (Transcript from Prosecutor v. Kvočka), T. 2628-2629, 2632, 2648 (under seal); P607 (Map of Prijedor).

KDZ392, P707 (Transcript from Prosecutor v. Kvočka), T. 2622, 2642 (under seal).

KDZ392, P707 (Transcript from Prosecutor v. Kvočka), T. 2627, 2630-2631 (under seal).

KDZ392, P707 (Transcript from Prosecutor v. Kvočka), T. 2629-2630, 2632 (under seal).

KDZ392, P707 (Transcript from Prosecutor v. Kvočka), T. 2629-2630 (under seal).

KDZ392, P707 (Transcript from Prosecutor v. Kvočka), T. 2646-2647 (under seal).

KDZ523, P4257 (Transcript from Prosecutor v. Brđanin), T. 21108-21109 (under seal); KDZ392, P707

(Transcript from Prosecutor v. Kvočka), T. 2633-2635 (under seal).

KDZ392, P707 (Transcript from Prosecutor v. Kvočka), T. 2633-2634 (under seal).

KDZ392, P707 (Transcript from Prosecutor v. Kvočka), T. 2634 (under seal). 
one side of his nose had been slit. ${ }^{6466}$ KDZ392 and his parents were then taken to the prison building in the barracks. ${ }^{6467}$ Despite being injured and physically exhausted, they did not receive medical treatment. ${ }^{6468}$

1884. Detainees were held at Prijedor Barracks for a short period before being transferred to Keraterm or Omarska. ${ }^{6469}$

\section{(iii) $\underline{\text { Conclusion }}$}

1885. Based on the above, the Chamber finds that non-Serb civilians were detained at Prijedor Barracks by Serb Forces in June 1992. The Chamber also finds that detainees at Prijedor Barracks were subjected to beatings and deprived of medical treatment.

\section{(6) Scheduled Incident D.17}

1886. The Indictment refers to the destruction of 18 mosques and two Catholic churches in Prijedor between at least May and December $1992 .{ }^{6470}$

1887. The Chamber recalls its finding that Serb Forces burned and destroyed the Čaršijska mosque in Prijedor town on 30 May 1992 during the attack. ${ }^{641}$ As it was damaged beyond repair, in July 1992, pursuant to orders from the Prijedor Executive Board, Serb engineers and architects demolished the remainder of the Čaršijska mosque, as well as houses in the area, and removed the rubble. ${ }^{6472}$ The Chamber recalls that the Zagrad mosque in Prijedor town was also burned and destroyed on 30 May by Serb Forces. ${ }^{6473}$

1888. The Chamber recalls that the Mutnik mosque, as well as other mosques in Kozarac, were destroyed during the attack on the area by Serb Forces at the end of May and June $1992 .^{6474}$ The

\footnotetext{
6466 KDZ392, P707 (Transcript from Prosecutor v. Kvočka), T. 2634-2635, 2638-2639, 2645 (under seal) [REDACTED].

6467 KDZ392, P707 (Transcript from Prosecutor v. Kvočka), T. 2638 (under seal).

6468 KDZ392, P707 (Transcript from Prosecutor v. Kvočka), T. 2625-2627, 2638 (under seal) [REDACTED].

6469 KDZ392, P707 (Transcript from Prosecutor v. Kvočka), T. 2645, 2647-2648 (under seal) [REDACTED].

6470 The religious sites identified in Schedule D.17 are the (1) Kozaruša mosque, (2) Stari Grad mosque, (3) Čarakovo mosque, (4) Hambarine old mosque, (5) Čaršijska mosque in Prijedor town, (6) Zagrad mosque in Prijedor town, (7) Bišćani mosque, (8) Gornja Puharska mosque, (9) Donja Puharska mosque, (10) Rizvanovići mosque, (11) Brezičani mosque, (12) Ališići mosque, (13) Zecovi mosque, (14) Čejreci mosque, (15) Gomjenica mosque, (16) Kevljani mosque, (17) Kamičani mosque, (18) Kozarac-Mutnik mosque; as well as the Prijedor town Catholic church and the Briševo church. Indictment, Schedule D.17.

$6471 \quad$ See para. 1606.

6472 P3484 (Decision of Prijedor Executive Board, 21 July 1992), pp. 1-3; Nusret Sivac, P3478 (Transcript from Prosecutor v. Stakić), T. 6692-6694.

6473 See para. 1606.

$6474 \quad$ See para. 1639.
} 
Chamber further recalls that the mosque in Kamičani was set alight by Serb Forces between 24 and 26 May $1992 .^{6475}$

1889. Additionally, the Chamber recalls that the mosque in Hambarine was shelled during the attack on Hambarine in May 1992, and again during the attack on the village in July 1992, by Serb Forces. ${ }^{6476}$ The Chamber also recalls that the Rajkovac mosque was shelled in late July $1992 .{ }^{6477}$ The Chamber further recalls that the mosque in Bišćani was destroyed on 20 July 1992, and that the mosque in Rizvanovići was destroyed in the summer months, before August 1992. ${ }^{6478}$ The Chamber also recalls that the mosque in Čarakovo was destroyed on 23 July 1992 by Serb soldiers. ${ }^{6479}$

1890. In addition, the Donja Puharska mosque in Prijedor was blown up and destroyed on 28 August 1992 by Serb Forces; the explosion occurred within ten minutes of the explosion that destroyed the Catholic church in Prijedor town. ${ }^{6480}$

1891. The Chamber took judicial notice of the facts that within the summer months of 1992, the mosque in Gornja Puharska was razed to the ground, ${ }^{6481}$ the minaret of the mosque in Kozaruša was badly damaged, ${ }^{6482}$ and that the new mosque in Kevljani was completely destroyed by mines. ${ }^{6483}$

1892. The Prijedor SJB reported that by September 1993, not a single Bosnian Muslim place of worship remained in Prijedor. ${ }^{6484}$

1893. In regard to the Catholic churches, the Chamber further recalls that on 29 July 1992, the Catholic church in Briševo was destroyed. ${ }^{6485}$ Furthermore, the Catholic church in Prijedor town

\footnotetext{
6475 See para. 1643.

6476 See paras. 1666, 1681.

6477 See para. 1681.

6478 See para. 1706.

6479 See para. 1684.

6480 Nusret Sivac, P3478 (Transcript from Prosecutor v. Stakić), T. 6606-6608; P3528 (Witness statement of Kerim Mešanović, undated), pp. 81-82; Drasko Vujić, T. 46079-46080, 46082-46083 (28 January 2014); P3564 (Photograph of destroyed mosque in Prijedor); P3565 (Photograph of destroyed mosque in Prijedor); P6613 (Photographs of destroyed mosque in Donja Puharska, Prijedor); D4381 (Prijedor Basic Court's on-site investigation report, 29 August 1992). See also P4070 (Attachment to the expert report of András J. Riedlmayer, entitled "Destruction of Cultural Heritage in BiH" prepared for the Karadžić case, formatted records), e-court pp. 231-232; Adjudicated Fact 1284.

6481 See Adjudicated Fact 1292. See also P4070 (Attachment to the expert report of András J. Riedlmayer, entitled "Destruction of Cultural Heritage in BiH" prepared for the Karadžić case, formatted records), e-court pp. 229230 .

6482 See Adjudicated Fact 1291. See also P4070 (Attachment to the expert report of András J. Riedlmayer, entitled "Destruction of Cultural Heritage in BiH" prepared for the Karadžić case, formatted records), pp. 211-212 (stating that the minaret of the Kozaruša mosque had been destroyed down to its base by a blast).

6483 See Adjudicated Fact 1293. See also P4070 (Attachment to the expert report of András J. Riedlmayer, entitled "Destruction of Cultural Heritage in BiH" prepared for the Karadžić case, formatted records), pp. 244-245
} 
was destroyed on 28 August 1992 when Bosnian Serb soldiers broke into it and planted explosives which later detonated and destroyed the church. ${ }^{6486}$ Serb engineers and architects later toppled the bell of the Catholic church and used heavy machinery to remove the rubble. ${ }^{6487}$

1894. According to Riedlmayer's reports, a total of 18 mosques and two Catholic churches in Prijedor were damaged or destroyed during the war. ${ }^{6488}$ The Chamber notes that with respect to one mosque, the Gomjenica mosque, Riedlmayer describes it as "lightly damaged" and that it was the only mosque in the Prijedor region that still had a roof at the end of the war. ${ }^{6489}$ Riedlmayer states that all of the remaining 17 mosques and two Catholic churches were heavily damaged, almost destroyed, or completely destroyed. The Chamber therefore finds that 17 mosques and two Catholic churches were heavily damaged, almost destroyed, or completely destroyed.

1895. The Chamber has considered the evidence it has received which identified Serb Forces as responsible for the destruction of mosques in Prijedor between May and December $1992 .{ }^{6490}$ It also had regard to the fact that almost all mosques in the municipality sustained heavy damage or were completely destroyed after Serb Forces took over the municipality. Having weighed these factors, the Chamber is satisfied beyond reasonable doubt that Serb Forces were responsible for the attacks on and destruction of mosques and Catholic churches in Prijedor.

D4010 (Report of Prijedor SJB, September 1993), p. 3. See P586 (Map of destroyed mosques in Prijedor).

See para. 1727.

Nusret Sivac, P3478 (Transcript from Prosecutor v. Stakić), T. 6606-6607; P3528 (Witness statement of Kerim Mešanović, undated), pp. 81-82; Drasko Vujić, T. 46082 (28 January 2014); P3563 (Photograph of destroyed church in Prijedor); D4381 (Prijedor Basic Court's on-site investigation report, 29 August 1992). See also P4070 (Attachment to the expert report of András J. Riedlmayer, entitled "Destruction of Cultural Heritage in BiH” prepared for the Karadžić case, formatted records), e-court pp. 251-254; Adjudicated Fact 1285.

6487 Nusret Sivac, P3478 (Transcript from Prosecutor v. Stakić), T. 6693-6694, 6756-6757.

6488 Riedlmayer identified the level of damage with respect to each of the mosques and Catholic churches listed by name in the Indictment: (i) completely destroyed: Stari Grad mosque, Čaršijska mosque, Zagrad mosque, Donja Puharska mosque, Rizvanovići mosque, Brezičani mosque, Ališići mosque, and Prijedor Catholic church; (ii) almost destroyed: Čarakovo mosque; (iii) heavily damaged: Kozaruša mosque, Bišćani mosque, Hambarine mosque, Gornja Puharska mosque, Zecovi mosque, Čejreci mosque, Kevljani mosque, Kamičani mosque, Kozarac mosque, and Briševo Catholic church; (iv) lightly damaged: Gomjenica mosque. P4070 (Attachment to the expert report of András J. Riedlmayer, entitled "Destruction of Cultural Heritage in BiH" prepared for the Karadžić case, formatted records), e-court pp. 211, 213, 216, 219, 222, 225, 227, 229, 231, 233, 236-238, 240, 243-244, 246, 248, 251, 255. See also P4069 (Cultural destruction database), records 214-215, 217-220, 224, 228, 232, 236-237, 239, 241, 245, 247-249, 251, 256-257.

6489 P4070 (Attachment to the expert report of András J. Riedlmayer, entitled "Destruction of Cultural Heritage in BiH” prepared for the Karadžić case, formatted records), e-court p. 243.

6490 In his final brief, the Accused argues that some of the cultural sites in Prijedor were destroyed by forces outside the control of the legal authorities in Prijedor. See Defence Final Brief, para. 1612. However, the Chamber considers that in support of this argument, the Accused only refers to testimony from Drasko Vujić, who recounted that his soldiers told him that the explosion which destroyed the Donja Puharska mosque was "a total surprise". See D4242 (Witness statement of Draško Vujić dated 24 January 2014), para. 11. The Chamber does not consider that Vujić's evidence in this regard contradicts the evidence which relates to the conduct of Serb Forces in the destruction of the mosques and Catholic churches during the attacks on villages throughout Prijedor.
} 
1896. Therefore, the Chamber finds that 17 mosques and two Catholic churches were heavily damaged, almost destroyed, or completely destroyed by Serb Forces in Prijedor between May and December 1992.

property

(7) $\underline{\text { Movement of the population from Prijedor and appropriation of }}$

1897. Following the attacks on towns and villages in Prijedor between late May and end of July 1992, the non-Serb population was expelled from the municipality. ${ }^{6491}$

1898. At a meeting on 20 May 1992, the ARK Crisis Staff adopted several conclusions, including that there was "no reason for the population of any nationality to move out of the territory of the [ARK]". ${ }^{6492}$ However, on 29 May 1992, the ARK Crisis Staff decided that Bosnian Muslims and Bosnian Croats would be allowed to leave Prijedor and other municipalities in the ARK, as part of an organised resettlement of non-Serbs in central BiH and Serbs in Krajina. ${ }^{6493}$ On 1 June 1992 , Kuprešanin informed the Civil Affairs Office in Sector North that 15,000 Bosnian Muslim refugees from municipalities in the ARK, including Prijedor, were moving across the border towards Dvor, Croatia, and that another 15,000 would likely follow. ${ }^{6494}$

1899. On 7 June 1992, Prijedor municipal authorities decided, along with six other municipalities in the region, that "Muslims and Croats should move out to a level at which all the municipalities can maintain Serbian power on their territories". 6495

1900. Mass departures from Prijedor began to take place after the attack on Hambarine in late May 1992 and gained momentum through June and July 1992. ${ }^{6496}$ The Prijedor SJB estimated that 20,000 citizens, primarily non-Serbs, had moved out of Prijedor by mid-1992. ${ }^{6497}$

6491 KDZ240, P2935 (Transcript from Prosecutor v. Krajišnik), T. 6802 (under seal). See Sections IV.A.1.b.i.D.3: Take-over of Prijedor town; IV.A.1.b.i.D.4: Attacks on surrounding villages.

6492 D1309 (Conclusions of the ARK Crisis Staff, 20 May 1992); D4086 (Witness statement of Nikola Erceg dated 24 November 2013), para. 95.

6493 P3461 (Conclusions of meeting of ARK Crisis Staff, 29 May 1992), p. 1.

6494 P3804 (Witness statement of Charles Kirudja dated 17 November 2010), para. 53.

6495 P2641 (Conclusions of sub-regional meeting of municipalities sent to ARK Crisis Staff, 7 June 1992), p. 2 (stating that if the leadership of the ARK fails to solve this issue "our seven municipalities will take all Muslims and Croats under military escort from our municipalities to the centre of Banja Luka").

6496 P3852 (Banja Luka CSB Security Assessment for Prijedor Municipality, 23 October 1992), p. 2 (stating that since the security situation deteriorated in May 1992 Bosnian Muslims and Croats have started a "mass exodus" from Prijedor); Edward Vulliamy, P3777 (Transcript from Prosecutor v. Stakić), T. 7910-7912 (testifying that approximately "40,000 Muslims” had left the Kozarac area by 5 August 1992). See Scheduled Incidents A.10.1, A.10.2, A.10.5. See also Section IV.A.1.b.i.D.4.a.ii: Aftermath of the attack. See also Adjudicated Fact 1295 (stating that on 20 July 1992, 20,000 non-Serbs were expelled from the areas of Hambarine and Ljubija which were under Serb control).

6497 D470 (CSB Banja Luka Report concerning collection centres, undated), e-court p. 31. 
1901. The Prijedor Crisis Staff and civilian authorities facilitated the movement of the non-Serb population of Prijedor out of the municipality through the use of buses, trucks, and other vehicles, and by negotiating with the ICRC and the Prijedor Red Cross regarding the movement of convoys. $^{6498}$

1902. The Chamber recalls that thousands of non-Serbs were transferred to, and detained at, detention facilities in Prijedor municipality in 1992. ${ }^{6499}$ As detention facilities were closed in Prijedor, detainees held there were transferred around the municipality as well as to camps outside of the municipality and ultimately often to third countries. ${ }^{6500}$

1903. Non-Serb residents of Prijedor who left the municipality during the conflict had to sign over their property to the Serb authorities in Prijedor, either to the ARK or to the RS; ${ }^{6501}$ at first, real property certificates were issued in order to justify the confiscation, but later on certificates were no longer issued. ${ }^{6502}$ In contrast, Bosnian Serb residents did not have their property confiscated. ${ }^{6503}$

1904. Property left behind by non-Serbs was appropriated by the Prijedor Crisis Staff as "municipal property", and was often redistributed to Bosnian Serbs ${ }^{6504}$ and, in some cases, to

6498 Idriz Merdžanić, P3881 (Transcript from Prosecutor v. Stakić), T. 7834-7835; D4247 (Letter from Prijedor Municipal Secretariat for the Economy and Public Services, undated), p. 1 (stating that in the month of July 1992 alone, the Prijedor Crisis Staff rented 31 buses from Autotransport, a bus company from Prijedor town, which together travelled a total of 1,300 kilometres); P6614 (Record of Autotransport Prijedor, July 1992), pp. 1-3; P3852 (Banja Luka CSB Security Assessment for Prijedor Municipality, 23 October 1992), p. 2; D470 (CSB Banja Luka Report concerning collection centres, undated), e-court p. 31.

6499 See Scheduled Detention Facilities C.20.1, C.20.2, C.20.3, C.20.4, C.20.5, C.20.6, C.20.7.

6500 P2772 (Report of Prijedor SJB, 5 August 1992), p. 1; D470 (CSB Banja Luka Report concerning collection centres, undated), e-court pp. 3-4, 6, 11; D1551 (Order of Banja Luka CSB, 21 August 1992), p. 1; D1864 (Order of Banja Luka CSB, 19 August 1992), p. 1; D1865 (Prijedor SJB dispatch to Banja Luka CSB, 22 August 1992), p. 1; D4464 (Minutes of Prijedor Municipal Assembly National Defence Council session, 29 September 1992), p. 1; P3757 (Official note from the Security Centre in Banja Luka, 10 August 1992), pp. 12 (under seal); P3753 (Manjača camp daily report to the 1st Krajina Corps, 22 August 1992), p. 1 (under seal). See paras. 1746, 1785, 1788-1789, 1804, 1848, 1850-1852, 1860, 1884.

6501 P3691 (Witness statement of Nusreta Sivac dated 22 October 2011), pp. 56-57 (under seal) (stating that the documents were signed by Budimir); KDZ092, P702 (Transcript from Prosecutor v. Stakić), T. 4003 (under seal) [REDACTED]; Ivo Atlija, P3672 (Transcript from Prosecutor v. Stakić), T. 5655; Idriz Merdžanić, P3881 (Transcript from Prosecutor v. Stakić), T. 7800, 7834-7835; Jusuf Arifagić, P689 (Transcript from Prosecutor v. Stakić), T. 7106, 7133-7134; KDZ611, P698 (Transcript from Prosecutor v. Brđanin), T. 12510 (under seal); Nusret Sivac, P3478 (Transcript from Prosecutor v. Stakić), T. 6696. See Adjudicated Fact 1101. See also para. 1851.

6502 See Adjudicated Fact 1101.

6503 Adjudicated Fact 1101

6504 D4178 (Decision of the ARK Secretariat of National Defence, 5 June 1992), p. 26 (stating that flats left empty for more than 15 days would be used to house the homeless and particularly participants in the war); P3536 (Decisions and orders of Prijedor Municipal Assembly and Prijedor Crisis Staff, published in Prijedor Official Gazette on 25 June 1992), pp. 16-17; Bosko Mandić, T. 45775 (21 January 2014); KDZ048, P678 (Transcript from Prosecutor v. Stakić), T. 3379-3382; Idriz Merdžanić, P3881 (Transcript from Prosecutor v. Stakić), T. 7800 . 
Bosnian Croats. ${ }^{6505}$ On 19 June 1992 the ARK Crisis Staff decided that all "abandoned" property would be proclaimed property of the state and placed at the disposal of the municipal assemblies. $^{6506}$

1905. On 16 August 1992, the Prijedor SJB issued termination of residence notices to 13,180 residents, in exchange for the residents receiving permits to leave the municipality. ${ }^{6507}$ By the end of September 1992, the Prijedor SJB reported that due to the "increasing migration of the population, especially of the Muslim and Croat population", it had received and processed 15,280 applications for departure. ${ }^{6508}$ Those who desired to leave the municipality were first required to unregister their official residences with the local Serb authorities as a condition to receive an exit permit. $^{6509}$

1906. On 19 August 1992, representatives from Prijedor, including both Bosnian Muslims and Bosnian Serbs, met with UNHCR and the UN Civil Affairs Office to discuss, inter alia, whether the UN would assist in evacuating thousands of Bosnian Muslim "applicants". ${ }^{6510}$ The Prijedor delegation wanted a convoy to go through Sector North, and the applicants included 8,000 Bosnian Muslims from Prijedor who, according to the delegation, wanted to leave the municipality "voluntarily". ${ }^{6511}$ The UNHCR representative responded that UNHCR would not assist with the removal of people. ${ }^{6512}$ Kirudja did not believe that these people wanted to leave voluntarily and furthermore, thought that the detailed lists of applicants prepared by the delegation demonstrated the "meticulous" system used to remove people from the area. ${ }^{6513}$

\footnotetext{
6505 Ivo Atlija, P3672 (Transcript from Prosecutor v. Stakić), T. 5651-5653 (testifying that he was offered abandoned property in the Bosnian Muslim village of Bišćani directly from Stakić in late August 1992). See para. 1737.

6506 P3451 (Decisions of the ARK Crisis Staff, June 1992), p. 13.

6507 D470 (CSB Banja Luka Report concerning collection centres, undated), e-court p. 31. See P3691 (Witness statement of Nusreta Sivac dated 22 October 2011), pp. 56-57 (under seal); P3693 (Decision of SerBiH's Ministry of Defence, Prijedor Section, 18 August 1992); Slavko Budimir, D4463 (Transcript from Prosecutor v. Stakić), T. 13142.

6508 P5555 (Report of Prijedor SJB, 29 September 1992), p. 8. See Jusuf Arifagić, P689 (Transcript from Prosecutor v. Stakić), T. 7133-7134. See also P2958 (Christian Nielsen's expert report entitled "The Bosnian Serb Ministry of Internal Affairs: Genesis, Performance and Command and Control 1990-1992”, 19 May 2011), para. 325.

6509 D470 (CSB Banja Luka Report concerning collection centres, undated), e-court pp. 6-7, 31.

6510 P3804 (Witness statement of Charles Kirudja dated 17 November 2010), para. 111.

6511 P3804 (Witness statement of Charles Kirudja dated 17 November 2010), para. 112.

6512 P3804 (Witness statement of Charles Kirudja dated 17 November 2010), para. 115.

6513 P3804 (Witness statement of Charles Kirudja dated 17 November 2010), paras. 112, 114.
} 
1907. According to Serb assessments, by October 1992, about 38,000 Bosnian Muslims and Bosnian Croats had left the municipality of Prijedor. ${ }^{6514}$ Approximately 3,600 of these individuals left the area with the help of the ICRC and the Prijedor Red Cross. ${ }^{6515}$

1908. By 1993, the vast majority of non-Serb towns and villages in Prijedor were uninhabited and destroyed. ${ }^{6516}$ In September 1993, the Prijedor SJB estimated that $80 \%$ of Bosnian Muslim houses in Prijedor had been destroyed. ${ }^{6517}$ The Chamber also recalls that by mid-1993, most of the Bosnian Muslim places of worship in Prijedor had been almost or completely destroyed. ${ }^{6518}$

1909. In May 1993, the Bosnian Serb MUP estimated that 42,000 Bosnian Muslims and 2,000 Bosnian Croats had moved out of Prijedor, while 14,000 Bosnian Serbs had moved in. ${ }^{6519}$ Some of the Bosnian Muslims and Bosnian Croats who had moved out of Prijedor had been "deported in cattle cars". ${ }^{6520}$ Bosnian Muslims and Bosnian Croats continued to move out of Prijedor into $1994 .^{6521}$

1910. Slobodan Kuruzović, the commander of Trnopolje, confirmed that the plan of the Serb authorities was to reduce the number of Bosnian Muslims in Prijedor to $10 \%$ or less, and then later to reduce this to $2 \%$ or less. ${ }^{6522}$

1911. The Accused contends that Bosnian Muslims, and to a lesser extent, Bosnian Serbs and Bosnian Croats, left Prijedor voluntarily and without external pressure, and that non-Serbs were not forced to sign over their possessions in order to receive permits to leave the municipality. ${ }^{6523}$ Furthermore, Budimir testified that everyone who applied to him for permission to leave Prijedor

\footnotetext{
6514 P3852 (Banja Luka CSB Security Assessment for Prijedor Municipality, 23 October 1992), p. 2. See P2948 (Report of humanitarian organisation, 8 October 1992) (under seal), p. 2.

6515 P3852 (Banja Luka CSB Security Assessment for Prijedor Municipality, 23 October 1992), p. 2; Slavko Budimir, D4463 (Transcript from Prosecutor v. Stakić), T. 13142. See P6504 (Report of Prijedor Red Cross, 30 September 1992), p. 9.

6516 P3852 (Banja Luka CSB Security Assessment for Prijedor Municipality, 23 October 1992), p. 2 (stating that Čarakovo, Zecovi, Hambarine, Rizvanovići, Bišćani, Rakovčani, Kozarruša, Kozarac, Kamičani, Babići, and Kevljani had been completely destroyed, while Gornji Garevici, Ćela, Čejreci, Donja Puharska, Trnopolje, Donja Ljubija, Gornji and Donja Ravska, Šurkovac, Briševo, Žune, Gornji Volar, and the old part of Prijedor were partly destroyed).

6517 D4010 (Report of Prijedor SJB, September 1993), p. 3.

6518 D4010 (Report of Prijedor SJB, September 1993), p. 3. See Scheduled Incident D.17.

6519 P10 (Report of the MUP, Banja Luka SNB, May 1993), p. 2.

6520 Predrag Radić, P1 (Transcript from Prosecutor v. Krajišnik), T. 7436.

6521 D705 (UNPROFOR report re meetings with Radovan Karadžić and Alija Izetbegović, 7 April 1994), pp. 3-4; D1138 (Radovan Karadžić's Order, 3 April 1994); D4213 (Radovan Karadžić's Order, 4 July 1994).

6522 See Adjudicated Fact 1093.

6523 Defence Final Brief, paras. 1537, 1539. In support, the Accused refers to the following evidence: D1357 (Report of Prijedor SDS Municipal Board, 11 September 1991-26 December 1992), p. 3; D4195 (Witness statement of Milomir Stakić dated 16 November 2013), paras. 25-26; D4229 (Witness statement of Boško Mandić dated 18 January 2014), para. 9; D4226 (Witness statement of Dragan Radetić dated 17 January 2014), para. 6; Slavko Budimir, D4463 (Transcript from Prosecutor v. Stakić), T. 13037, 13142.
} 
received it, but that many people left on their own in their personal vehicles without approval from the municipality. ${ }^{6524}$

1912. However, the Chamber recalls the movement on a mass scale of non-Serbs within and out of Prijedor and the fact that non-Serbs in Prijedor were forced to sign over their property to Serb authorities. The Chamber has had regard to the immense pressure put on Bosnian Muslims and Bosnian Croats, given the surrounding circumstances in the municipality, including inter alia: (i) armed attacks against their towns, villages, and homes; (ii) destruction of religious and cultural property; (iii) forcible arrest and removal from their homes; (iv) detention in multiple detention facilities; as well as (v) mistreatment and killings.

1913. For these reasons, the Chamber finds that Bosnian Muslims and Bosnian Croats were forced to leave Prijedor. By 1995, the population of Prijedor municipality consisted of approximately $92 \%$ Bosnian Serbs, $5 \%$ Bosnian Muslims, and 1\% Bosnian Croats. ${ }^{6525}$

\section{(E) Sanski Most}

\section{(1) $\underline{\text { Charges }}$}

1914. Under Count 3, the Prosecution alleges that persecution, a crime against humanity, was committed in Sanski Most as part of the objective to permanently remove Bosnian Muslims and/or Bosnian Croats from the Municipalities. ${ }^{6526}$ Under Count 1, the Prosecution further alleges that in certain municipalities, including Sanski Most, this persecutory campaign included or escalated to include conduct that manifested an intent to destroy in part the national, ethnical, and/or religious groups of Bosnian Muslims and/or Bosnian Croats as such. ${ }^{6527}$

1915. Acts alleged to have been committed in Sanski Most by Serb Forces and Bosnian Serb Political and Governmental Organs include killings during and after the take-over, ${ }^{6528}$ killings related to one detention facility, ${ }^{6529}$ as well as killings committed during, and deaths resulting from,

\footnotetext{
6524 Slavko Budimir, D4463 (Transcript from Prosecutor v. Stakić), T. 13144 (testifying further, however, that although some people left voluntarily, "Muslims and Croats were worse off than Serbs"). But see KDZ026, T. 10407 (17 January 2011) (closed session) (testifying that he did not have the money to "pay for [his] exit out of that hell").

6525 P5449 (Report of the MUP, Banja Luka RDB, February 1995), pp. 6-7. See D4002 (Letter from BiH MUP to Vasvija Vidović, 4 July 1995), p. 16 (reporting that approximately 2,000 non-Serbs remained in Prijedor in 1995).

6526 Indictment, paras. 48-49.

6527 Indictment, para. 38.

6528 Indictment, para. 60(a)(i). See Scheduled Incidents A.12.1, A.12.2, A.12.3, A.12.4, A.12.5.

6529 Indictment, para. 60(a)(ii). See Scheduled Incident B.17.
} 
cruel and inhumane treatment at scheduled detention facilities. ${ }^{6530}$ The Prosecution characterises these acts as killing, an underlying act of genocide, under Count 1; persecution, a crime against humanity, under Count 3; extermination, a crime against humanity, under Count 4; murder, a crime against humanity, under Count 5; and murder, a violation of the laws or customs of war, under Count $6 .{ }^{6531}$

1916. Other acts alleged to have been committed in Sanski Most by Serb Forces and Bosnian Serb Political and Governmental Organs include torture, beatings, and physical and psychological abuse, rape and other acts of sexual violence, during and after the take-over and in scheduled detention facilities, as well as the establishment and perpetuation of inhumane living conditions in detention facilities, as cruel or inhumane treatment, an act of persecution under Count $3 .{ }^{6532}$ In relation to Count 1, the Prosecution alleges that in scheduled detention facilities in Sanski Most thousands of Bosnian Muslims and Bosnian Croats were subjected to cruel or inhumane treatment, including torture, physical and psychological abuse, rape, other acts of sexual violence, and beatings by Serb Forces and Bosnian Serb Political and Governmental Organs; the Prosecution characterises this inhumane treatment as causing serious bodily or mental harm to members of the Bosnian Muslim and Bosnian Croat groups, an underlying act of genocide. ${ }^{633}$ In addition, under Count 1 , the Prosecution alleges that members of the Bosnian Muslim and Bosnian Croat groups were detained under conditions of life calculated to bring about physical destruction, namely through cruel and inhumane treatment, including torture, physical and psychological abuse, rape, other acts of sexual violence, inhumane living conditions, forced labour and the failure to provide adequate accommodation, shelter, food, water, medical care or hygienic sanitation facilities. ${ }^{6534}$

1917. Under Count 3, other acts of persecution alleged to have been committed in Sanski Most by Serb Forces and Bosnian Serb Political and Governmental Organs include: (i) forcible transfer or deportation of Bosnian Muslims and Bosnian Croats from their homes; ${ }^{6535}$ (ii) unlawful detention in scheduled detention facilities; ${ }^{6536}$ (iii) forced labour at the frontlines and the use of Bosnian Muslims and Bosnian Croats as human shields; ${ }^{6537}$ (iv) appropriation or plunder of property during and after the take-over, during arrests and detention, and in the course of or following acts of

\footnotetext{
6530 Indictment, para. 60(a)(ii). See Scheduled Detention Facilities C.22.1, C.22.2, C.22., C.22.4, C.22.5.

6531 Indictment, paras. 40(a), 60(a), 63(a), 63(b).

6532 Indictment, para. 60(b), 60(c), 60(d) (specifying that the conditions included the failure to provide adequate accommodation, shelter, food, water, medical care, or hygienic sanitation facilities). See Scheduled Detention Facilities C.22.1, C.22.2, C.22.3, C.22.4.

6533 Indictment, para. 40(b).

6534 Indictment, para. 40(c). See Scheduled Detention Facilities C.22.1, C.22.2, C.22.3, C.22.4, C.22.5.

6535 Indictment, para. 60(f).

6536 Indictment, para. 60(g). See Scheduled Detention Facilities C.22.1, C.22.2, C.22.3, C.22.4, C.22.5.

6537 Indictment, para. 60(h).
} 
deportation or forcible transfer; ${ }^{6538}(\mathrm{v})$ the wanton destruction of private property including homes and business premises and public property including cultural monuments and sacred sites; ${ }^{6539}$ and (vi) the imposition and maintenance of restrictive and discriminatory measures. ${ }^{6540}$

1918. Under Counts 7 and 8, the Prosecution alleges deportation and inhumane acts (forcible transfer), respectively, as crimes against humanity. ${ }^{651}$ In this regard, the Prosecution alleges that by the end of 1992, Serb Forces and Bosnian Serb Political and Governmental Organs had forcibly displaced Bosnian Muslims and Bosnian Croats from areas in Sanski Most in which they had been lawfully present. ${ }^{652}$ It is alleged that from March 1992, restrictive and discriminatory measures, arbitrary arrest and detention, harassment, torture, rape and other acts of sexual violence, killings, destruction of houses, cultural monuments, and sacred sites, as well as the threat of further such acts caused Bosnian Muslims and Bosnian Croats to flee in fear, while others were physically driven out. $^{6543}$

\section{(2) Lead-up}

1919. Sanski Most is a municipality centrally located in the ARK and is surrounded by Bosanski Novi, Bosanska Krupa, Bosanski Petrovac, Prijedor, Banja Luka, and Ključ. ${ }^{654}$ In 1991, the population of Sanski Most was approximately 28,000 Bosnian Muslims, 25,000 Bosnian Serbs, and 4,000 Bosnian Croats. ${ }^{6545}$ Villages with a predominantly Bosnian Muslim population included Vrhopolje, Hrustovo, Sehovći, Begići, and Kenjari. ${ }^{654}$ Škrljevita was a village with a predominantly Bosnian Croat population. ${ }^{6547}$

\footnotetext{
6538 Indictment, para. 60(i).

6539 Indictment, para. 60(j). See Scheduled Incident D.19. The Indictment refers to the Hrustovo-Kukavice mosque as being two different mosques (the old and new mosque) situated next to each other. Indictment, fn. 17.

6540 Indictment, para. 60(k). The restrictive and discriminatory measures alleged include the denial of freedom of movement; the removal from positions of authority; the invasion of privacy through arbitrary searches of homes; unlawful arrest and/or the denial of the right to judicial process; and/or the denial of equal access to public services.

6541 Indictment, paras. 68-75.

6542 Indictment, paras. 69, 72.

6543 Indictment, para. 71.

6544 P3638 (Map of Sanski Most municipality).

6545 P6548 (Conclusions of the Sanski Most Municipal Assembly, 4 October 1993), p. 6; D4452 (Map of ethnic composition of Sanski Most); KW540, D4449 (Transcript from Prosecutor v. Stanišić \& Župljanin), T. 33023303 (under seal). See also P3310 (Map of Sanski Most's ethnic composition); Faik Biščević, P122 (Transcript from Prosecutor v. Krajišnik), T. 5486; P3634 (Witness statement of KDZ490, undated), p. 3 (under seal); P4994 (Addendum to Ewa Tabeau's expert report entitled "Ethnic Composition in Internally Displaced Persons and Refugees from 27 Municipalities of BiH 1991 to 1997”, 3 February 2009), pp. 30, 33, 39 (listing the 1991 population as approximately 22,830 Bosnian Muslims, 21,746 Bosnian Serbs, and 3,688 Bosnian Croats).

6546 P3634 (Witness statement of KDZ490, undated), p. 3 (under seal); P532 (Map of Sanski Most). For locations of these villages, see P3638 (Map of Sanski Most municipality); P3310 (Map of Sanski Most's ethnic composition).

6547 P532 (Map of Sanski Most).
} 
1920. The SDS, SDA, and HDZ parties were formed in Sanski Most in $1990 .^{6548}$ The Accused and Krajišnik came to Lušci Palanka, a Bosnian Serb village in Sanski Most, on the occasion of the formation of the SDS in Sanski Most. ${ }^{6549}$ As a result of the multi-party elections in November 1990, the SDS won 23 seats, the SDA won 22 seats, the HDZ won 4 seats, and the reform party won 11 seats in the 60 seat Municipal Assembly. ${ }^{650}$ Nedeljko Rašula, who was then the president of the Sanski Most SDS, became the president of the Municipal Assembly. ${ }^{651}$ Vlado Vrkeš was the secretary of the Sanski Most SDS and he later became its president. ${ }^{6552}$ Mirzet Karabeg, a Bosnian Muslim, was appointed as the president of the Executive Board. ${ }^{6553}$

\section{(a) Militarisation of Sanski Most}

1921. The arming of the Bosnian Serb population in Sanski Most began in late 1990, with the distribution of JNA weapons to SDS members. ${ }^{6554}$

1922. As in other municipalities in $\mathrm{BiH}$, the armed conflict in Croatia led to a mobilisation call in Sanski Most for volunteers to fight in Croatia with the JNA. ${ }^{655}$ Those who did not respond to the call-up were ordered to return their uniforms and weapons and were to be deleted from the mobilisation lists. ${ }^{6556}$

\footnotetext{
6548 Faik Biščević, P122 (Transcript from Prosecutor v. Krajišnik), T. 5486-5487. See also D4653 (Certificate of Sanski Most SJB, 7 May 1991).

6549 Faik Biščević, P122 (Transcript from Prosecutor v. Krajišnik), T. 5488-5490, 7643-7645; P142 (Photograph of Radovan Karadžić and Momčilo Krajišnik).

6550 Mirzet Karabeg, P3303 (Transcript from Prosecutor v. Brđanin), T. 6069; P3304 (Decision of Serb people of Sanski Most, 25 March 1992), p. 3. See also Faik Biščević, P122 (Transcript from Prosecutor v. Krajišnik), T. 5492; D4233 (Witness statement of Branko Davidović dated 20 January 2014), para. 4.

6551 Mirzet Karabeg, P3303 (Transcript from Prosecutor v. Brđanin), T. 6070; Mirzet Karabeg, T. 18686, 18690 (13 September 2011); KDZ474, P3395 (Transcript from Prosecutor v. Brđanin), T. 7630 (under seal); KW545, D4328 (Transcript from Prosecutor v. Stanišić \& Župljanin) T. 26141 (under seal); KDZ474, T. 19243 (21 September 2011) (closed session). See also Faik Biščević, P122 (Transcript from Prosecutor v. Krajišnik), T. 5487, 5492; Faik Biščević, P135 (Transcript from Prosecutor v. Brđanin), T. 7023; P3634 (Witness statement of KDZ490, undated), pp. 5, 18 (under seal); P3396 (Photographs depicting Radovan Karadžić, Ratko Mladić, Biljana Plavšić, Momčilo Krajišnik and others), p. 1; KDZ474, T. 19243 (21 September 2011) (closed session).

6552 Faik Biščević, P122 (Transcript from Prosecutor v. Krajišnik), T. 5487; KDZ474, P3395 (Transcript from Prosecutor v. Brđanin), T. 7642,7654 (under seal); KW545, D4328 (Transcript from Prosecutor v. Stanišić \& Župljanin), T. 26302-26303 (under seal); Faik Biščević, P135 (Transcript from Prosecutor v. Brđanin), T. 1797.

6553 Mirzet Karabeg, P3303 (Transcript from Prosecutor v. Brđanin), T. 6066; Mirzet Karabeg, T. 18690 (13 September 2011). Karabeg held the position of president of the Executive Board until 17 April 1992. Mirzet Karabeg, P3303 (Transcript from Prosecutor v. Brđanin), T. 6066.

6554 P3634 (Witness statement of KDZ490, undated), pp. 38-42 (under seal); KDZ490, T. 20207 (19 October 2011) (closed session).

6555 Faik Biščević, P122 (Transcript from Prosecutor v. Krajišnik), T. 5497.

6556 Faik Biščević, P122 (Transcript from Prosecutor v. Krajišnik), T. 5497.
} 
1923. At the end of 1991, Mladić attended a meeting in Sanski Most and, afterwards, JNA weapons were distributed to Bosnian Serbs in the area. ${ }^{657}$

1924. In November 1991, weapons owned by the staff of the TO were transferred to the goods reserve of the TO. ${ }^{6558}$ This order came from the $5^{\text {th }}$ corps of the JNA to the local TO staff. ${ }^{659}$ In 1992, the weapons were taken by Colonel Branko Basara and distributed to the Bosnian Serbs in Sanski Most. ${ }^{6560}$

1925. At the end of 1991, the Serbian Defence Forces ("SOS") an armed group, was formed. ${ }^{6561}$ They were commanded by Duško Šaović, a.k.a. Njunja. ${ }^{6562}$ The SOS received orders from the SDS in Sanski Most. ${ }^{6563}$ On 28 February 1992, members of the SDS and the SOS broke into the premises of the Public Auditing Service and tried to physically remove the head of the institution. ${ }^{6564}$ Karabeg and the Executive Board condemned this action. ${ }^{6565}$ Soon after, the SOS started targeting buildings and businesses belonging to Bosnian Croats and Bosnian Muslims and blew them up with explosives. ${ }^{6566}$

\footnotetext{
6557 P3634 (Witness statement of KDZ490, undated), p. 39 (under seal).

6558 P3634 (Witness statement of KDZ490, undated), p. 42 (under seal); P3643 (Order of Sanski Most TO, 6 November 1991).

6559 P3634 (Witness statement of KDZ490, undated), p. 42 (under seal); P3643 (Order of Sanski Most TO, 6 November 1991).

6560 P3634 (Witness statement of KDZ490, undated), p. 43 (under seal).

6561 P3634 (Witness statement of KDZ490, undated), p. 20 (under seal); KW540, D4449 (Transcript from Prosecutor v. Stanišić \& Župljanin), T. 3314-3315 (under seal).

6562 P3634 (Witness statement of KDZ490, undated), p. 20 (under seal). Duško Šaović was also Vrkeš’s bodyguard. P3634 (Witness statement of KDZ490, undated), p. 20 (under seal); D4387 (Witness statement of Dušan Mudrinić dated 15 February 2014), para. 4; Dušan Mudrinić, T. 47365 (19 February 2014); see, e.g., KDZ474, P3395 (Transcript from Prosecutor v. Brđanin), T. 7829 (under seal).

6563 P3634 (Witness statement of KDZ490, undated), pp. 22, 25, 30 (under seal); KW540, D4449 (Transcript from Prosecutor v. Stanišić \& Župljanin), T. 3316-3317, 3555 (under seal); Vinko Nikolić, T. 45439-45441 (16 January 2014).

6564 Mirzet Karabeg, P3303 (Transcript from Prosecutor v. Brđanin), T. 6082-6083; P3309 (Minutes of meeting of Sanski Most's Executive Board, 5 March 1992).

6565 P3309 (Minutes of meeting of Sanski Most's Executive Board, 5 March 1992). See also Mirzet Karabeg, P3303 (Transcript from Prosecutor v. Brđanin), T. 6083; Mirzet Karabeg, T. 18767-18768 (14 September 2011) (testifying that it was an attempt to channel the taxes from Sanski Most to Banja Luka, instead of Sarajevo).

6566 Mirzet Karabeg, P3303 (Transcript from Prosecutor v. Brđanin), T. 6076-6077; P3634 (Witness statement of KDZ490, undated), pp. 31-32 (under seal); P3397 (Report of Sanski Most SOS Intervention Platoon, 16 September 1992), p. 2. See also KDZ474, P3395 (Transcript from Prosecutor v. Brđanin), T. 7634-7635 (under seal) (testifying that from late 1991 through the beginning of 1992, businesses in Sanski Most were blown up); see Adjudicated Fact 2523. Dušan Mudrinić testified that he was not aware of such explosions blowing up buildings and denied that the SOS was involved in these acts. Dušan Mudrinić, T. 47377-47378, 47385 (19 February 2014). The Chamber does not find his evidence on this point to be reliable. In reaching this conclusion, the Chamber found that the evidence of Mudrinić was evasive, contradicted on numerous occasions by other accepted evidence, including P3397 (Report of Sanski Most SOS Intervention Platoon, 16 September 1992), and was overall unconvincing.
} 
1926. Soldiers of the JNA's $6^{\text {th }}$ Partisan Brigade arrived in Sanski Most in early April $1992 .{ }^{6567}$

This brigade initially consisted of three battalions but later expanded. ${ }^{658}$ It was commanded by Basara. ${ }^{6569}$ Rašula invited the SDA leaders to a meeting with Basara where Basara introduced himself and stated that he had brought the $6^{\text {th }}$ Krajina Brigade to Sanski Most because they were on leave from fighting in Croatia and that they were "guarantors of peace" ${ }^{6570}$ The $6^{\text {th }}$ Krajina Brigade was later subordinated to the $1^{\text {st }}$ Krajina Corps. ${ }^{671}$ By the end of May 1992, the $6^{\text {th }}$ Krajina Brigade was comprised of 3,907 soldiers, making up 11 battalions and artillery units. ${ }^{6572}$

1927. After the arrival of the $6^{\text {th }}$ Krajina Brigade, check-points were set up throughout the municipality and soldiers from the $6^{\text {th }}$ Krajina Brigade asked residents to stop and show their identity cards. $^{6573}$

1928. On 22 April 1992, the Crisis Staff decided to integrate the SOS as a special unit of the TO. ${ }^{6574}$ The Crisis Staff also provided financial assistance to the SOS. ${ }^{6575}$

6567 P148 (Order of $5^{\text {th }}$ Corps, 1 April 1992); P149 (5 $5^{\text {th }}$ Corps combat report, 2 April 1992); P3634 (Witness statement of KDZ490, undated), p. 35 (under seal); P3663 (Report on the $6^{\text {th }}$ Brigade in the period between 8 October 1991 and 28 August 1992), p. 2; P3640 (Document entitled "Informator of the Serbian Democratic Party Sanski Most”, 1992), pp. 38-39 (referring to it as the $6^{\text {th }}$ Krajina Brigade); Faik Biščević, P122 (Transcript from Prosecutor v. Krajišnik), T. 5498-5499; Mirzet Karabeg, P3303 (Transcript from Prosecutor v. Brđanin), T. 6099; P3660 (Handwritten "War Record" of the $6^{\text {th }}$ Krajina Infantry Brigade, undated), p. 2 (referring to it as the $6^{\text {th }}$ Infantry Brigade); KDZ490, T. 20181-20182 (19 October 2011) (closed session). As seen in the documents cited above, the $6^{\text {th }}$ Partisan Brigade was also referred to as the $6^{\text {th }}$ Krajina Brigade or another name. For ease of reference, the Chamber will refer to it as the $6^{\text {th }}$ Krajina Brigade throughout this Judgement. KDZ490 stated that later when it grew to 12 battalions, it changed its name to the $6^{\text {th }}$ Sana Brigade but "[ $\left.t\right]$ his brigade, whether called Partisan/Krajina/Sana brigade was subordinated and under the command of General Momir Talić, Commander of the $5^{\text {th }}$ JNA Corps, later the $1^{\text {st }}$ Krajina Corps during 1992". P3634 (Witness statement of KDZ490, undated), pp. 34-35 (under seal).

6568 P3634 (Witness statement of KDZ490, undated), p. 34 (under seal).

6569 P3634 (Witness statement of KDZ490, undated), pp. 34, 37 (under seal); Mirzet Karabeg, P3303 (Transcript from Prosecutor v. Brđanin), T. 6100; P3663 (Report on the $6^{\text {th }}$ Brigade in the period between 8 October 1991 and 28 August 1992). p. 1; Faik Biščević, P135 (Transcript from Prosecutor v. Brđanin), T. 7017; P2614 (Conclusions of Sanski Most's Crisis Staff, 30 May 1992).

6570 Faik Biščević, P135 (Transcript from Prosecutor v. Brđanin), T. 7020-7021; Faik Biščević, P122 (Transcript from Prosecutor v. Krajišnik), T. 5499-5500; Mirzet Karabeg, P3303 (Transcript from Prosecutor v. Brđanin), T. 6101-6102.

6571 P3634 (Witness statement of KDZ490, undated) (under seal), p. 34.

6572 P3663 (Report on the $6^{\text {th }}$ Brigade in the period between 8 October 1991 and 28 August 1992), p. 4. See also P3660 (Handwritten "War Record" of the $6^{\text {th }}$ Krajina Infantry Brigade, undated). Members of the SOS were later integrated into the $6^{\text {th }}$ Krajina Brigade. P3634 (Witness statement of KDZ490, undated), pp. 27, 30 (under seal); KW540, D4449 (Transcript from Prosecutor v. Stanišić \& Župljanin), T. 3315-3317 (under seal). See also P6681 (Report of Sanski Most SOS, 4 September 1992).

6573 Mirzet Karabeg, P3303 (Transcript from Prosecutor v. Brđanin), T. 6099; see Adjudicated Fact 2525. See also Grgo Stojić, P3515 (Transcript from Prosecutor v. Brđanin), T. 6766-6767.

6574 KW540, D4449 (Transcript from Prosecutor v. Stanišić \& Župljanin), T. 3325-3326 (under seal); D1679 (Conclusions of meeting of Sanski Most Crisis Staff. 22 April 1992), p. 1. See also Adjudicated Fact 2107.

6575 P6682 (Conclusions of Sanski Most Crisis Staff, 18 June 1992), p. 1 (showing that Aničić, the TO commander, submitted a report on the work of the SOS and the Crisis Staff approved giving the SOS financial assistance). 
1929. On 28 April 1992, the Crisis Staff decided that Basara would meet with the Crisis Staff and "start regulating the relationship" between the TO forces and the JNA. ${ }^{6576}$ On 7 May 1992, the Crisis Staff held a meeting where Mladen Lukić and Mirko Vrućinić were ordered to hold talks with Basara to involve him in transforming the JNA into the "Serbian TO". 6577 The TO was ordered to set up a MP platoon. ${ }^{6578}$ All "able-bodied persons" were required to report to the Red Cross, the list would be forwarded to the TO staff, and those who were not registered would be "detained and sent to the municipalities of their residence". 6579

\section{(b) Establishment of Bosnian Serb institutions}

1930. The regionalisation process with the formation of the ZOBK led to increasing disagreements between members of the SDS, SDA, and HDZ in Sanski Most. ${ }^{6500}$ Faik Biščević, the president of the SDA, stated that the SDA could not agree with this regionalisation process. ${ }^{6581}$

1931. In February 1992, the SDS encouraged "all the Serbs of [BiH]" to abstain from voting in the upcoming referendum on the independence of $\mathrm{BiH}$, claiming that it was against the interests of the "Serbian people". ${ }^{6582}$

1932. In March 1992, the main issue that the SDS raised for discussions in the Municipal Assembly was whether Sanski Most should declare itself as "Serbian Sanski Most", a part of the ARK. ${ }^{6583}$ Sanski Most was the only municipality (out of the 17 municipalities in the Bosnian Krajina) whose assembly had not yet decided on this matter. ${ }^{6584}$ On 25 March 1992, Rašula and Vrkeš signed a proclamation declaring that all Bosnian Serb territories in Sanski Most were part of the SerBiH, "as a unique Serb municipality of Sanski Most". ${ }^{6585}$

1933. On 3 April 1992, Rašula issued a decision on behalf of the "Serbian People's Assembly" that the "Serbian Municipality" of Sanski Most would become part of the ARK. ${ }^{6586}$ This decision

\footnotetext{
6576 P3328 (Conclusions of meeting of Sanski Most Crisis Staff, 28 April 1992), para. 4.

6577 P3645 (Conclusions of the Sanski Most Crisis Staff, 7 May 1992), p. 1.

6578 P3645 (Conclusions of the Sanski Most Crisis Staff, 7 May 1992), p. 1.

6579 P3645 (Conclusions of the Sanski Most Crisis Staff, 7 May 1992), p. 1.

6580 Faik Biščević, P122 (Transcript from Prosecutor v. Krajišnik), T. 5495-5496.

6581 Faik Biščević, P122 (Transcript from Prosecutor v. Krajišnik), T. 5496.

6582 P3308 (SDS Leaflet); P3329 (Excerpt from handwritten diary of Nedeljko Rašula), p. 6; Mirzet Karabeg, P3303 (Transcript from Prosecutor v. Brđanin), T. 6077-6078.

6583 Mirzet Karabeg, P3303 (Transcript from Prosecutor v. Brđanin), T. 6095. See also Adjudicated Fact 2514.

6584 Mirzet Karabeg, P3303 (Transcript from Prosecutor v. Brđanin), T. 6096-6097.

6585 P3304 (Decision of Serb people of Sanski Most, 25 March 1992) (listing 25 "local communities and Serb settlement" which formed a "unique Serb municipality" in Sanski Most); Mirzet Karabeg, T. 18688-18689 (13 September 2011). See also Adjudicated Fact 2515.

6586 P3325 (Decision of Sanski Most Municipal Assembly, 3 April 1992); Mirzet Karabeg, P3303 (Transcript from Prosecutor v. Brđanin), T. 6102. See also Adjudicated Fact 2516.
} 
was made by the Sanski Most SDS deputies only. ${ }^{657}$ By 6 or 7 April 1992, the Sanski Most Municipal Assembly stopped meeting altogether. ${ }^{6588}$

1934. On 14 April 1992, the Crisis Staff of Sanski Most was established at a session of the Municipal Board of the Sanski Most SDS. ${ }^{6589}$ Rašula was appointed as president. ${ }^{6590}$ The Crisis Staff was the "centre of power" in Sanski Most and had, for instance, authority over the police. ${ }^{6591}$

1935. On 16 April 1992, the "Serbian Municipality" of Sanski Most was formed. ${ }^{6592}$

1936. On 17 April 1992, Stojan Župljanin, head of the Banja Luka CSB, ordered that all police employees must sign a statement of loyalty to the Serb Municipality of Sanski Most. ${ }^{6593}$ The police then became effectively divided along ethnic lines: all of the Bosnian Serbs signed the statement, only one Bosnian Croat signed it, and none of the Bosnian Muslims did. ${ }^{6594}$ Those who did not sign the loyalty oath left the police. ${ }^{6595}$ The chief of the SJB ordered all police members to change the emblems on their caps to the Serbian tricolour to show loyalty as Serbs. ${ }^{6596}$ This was done in accordance with the order from Župljanin that police employees should wear new uniforms with sleeve insignias of the word "milicija" written in Cyrillic and blue berets with the tricolour

6587 Mirzet Karabeg, P3303 (Transcript from Prosecutor v. Brđanin), T. 6102-6103.

6588 Mirzet Karabeg, P3303 (Transcript from Prosecutor v. Brđanin), T. 6098.

6589 P3329 (Excerpt from handwritten diary of Nedeljko Rašula), pp. 19-21.

6590 P3634 (Witness statement of KDZ490, undated), p. 6 (under seal) (stating that the Secretariat of the SDS evolved into the Crisis Staff); P3329 (Excerpt from handwritten diary of Nedeljko Rašula), p. 20 (listing as other members: Colonel Nedeljko Ančić, Nemanja Tripković, Boro Savanović, Mirko Vrućinić, Dragan Majkić, Mladen Lukić, Vlado Vrkeš, and Zvonko Nikolić). See also KW540, D4449 (Transcript from Prosecutor v. Stanišić \& Župljanin), T. 3340-3342 (under seal). By 30 May 1992, the Crisis Staff of Sanski Most consisted of 12 persons, namely: (1) Rašula, (2) Vrkeš, (3) Mladen Lukić, economic affairs, (4) Boro Savanović, president of the club of SDS deputies, (5) Boro Tadić, secretary of the People's Defence Secretariat, (6) Vrućinić, (7) Aničić, TO commander, (8) Milenko Stojinović, commander of the municipal civilian protection staff, (9) Nenad Davidović, medical services, (10) Basara, (11) Vinko Nikolić, in charge of vehicles, and (12) Nemanja Tripković, integrating and co-ordinating humanitarian associations. P2614 (Conclusions of Sanski Most's Crisis Staff, 30 May 1992), p. 1

6591 KW545, D4328 (Transcript from Prosecutor v. Stanišić \& Župljanin) T. 26300-26302, 26325-26326, 2633026331 (under seal); KW540, D4449 (Transcript from Prosecutor v. Stanišić \& Župljanin), T. 3328, 3342 (under seal). See, e.g., P2613 (Conclusions of Sanski Most's Crisis Staff, 22 May 1992); P2614 (Conclusions of Sanski Most's Crisis Staff, 30 May 1992).

6592 KDZ474, P3395 (Transcript from Prosecutor v. Brđanin), T. 7652 (under seal).

6593 KDZ474, P3395 (Transcript from Prosecutor v. Brđanin), T. 7652 (under seal); KW545, D4328 (Transcript from Prosecutor v. Stanišić \& Župljanin), T. 26338 (under seal); KW540, D4449 (Transcript from Prosecutor v. Stanišić \& Župljanin), T. 3311 (under seal). See also Adjudicated Fact 2520.

6594 KDZ474, P3395 (Transcript from Prosecutor v. Brđanin), T. 7652 (under seal); KW540, D4449 (Transcript from Prosecutor v. Stanišić \& Župljanin), T. 3311 (under seal).

6595 KW540, D4449 (Transcript from Prosecutor v. Stanišić \& Župljanin), T. 3311-3312 (under seal).

6596 P3634 (Witness statement of KDZ490, undated), pp. 46-47 (under seal); Mirzet Karabeg, P3303 (Transcript from Prosecutor v. Brđanin), T. 6104. 
badge. ${ }^{6597}$ Rašula enforced this order by stating that all police members who accepted this would retain their jobs and those who refused would be transferred. ${ }^{6598}$

1937. After refusing to sign the loyalty oath, the Bosnian Muslim and Bosnian Croat policemen who had left the police went to the fire brigade building on the other bank of the Sana River to establish their own police force. ${ }^{659}$ Karabeg and other Bosnian Muslim and Bosnian Croat leaders then went to the municipality building in Sanski Most both as a sign of protest and in order to organise their own administration. ${ }^{6600}$ In discussions on 18 April 1992, the SDA, SDS, and HDZ agreed that the municipality should be divided; however, the Executive Board of the SDS later rejected the agreement. ${ }^{6601}$

1938. On 30 April 1992, the Crisis Staff appointed Vrućinić as acting chief of the SJB and Mladen Lukić as president of the Executive Board. ${ }^{662}$ Rašula maintained his power as the president of the Crisis Staff. ${ }^{6603}$

\section{(3) $\underline{\text { Take-over of Sanski Most }}$}

1939. At approximately 9:30 p.m. on 19 April 1992, Rašula issued an ultimatum to the Bosnian Muslims and Bosnian Croats inside the municipality building to surrender by 10 p.m. or the Crisis Staff would not be responsible for the consequences - the $6^{\text {th }}$ Krajina Brigade, which had been in Sanski Most since early April, was deployed close by. ${ }^{6604}$ In response, the Bosnian Muslims and

6597 P3330 (Conclusions of session of Banja Luka CSB Enlarged Centre Council, 6 April 1992), para. 4.

6598 KW545, D4328 (Transcript from Prosecutor v. Stanišić \& Župljanin), T. 26338 (under seal).

6599 KDZ474, P3395 (Transcript from Prosecutor v. Brđanin), T. 7659-7660 (under seal); KW540, D4449 (Transcript from Prosecutor v. Stanišić \& Župljanin), T. 3311-3312 (under seal); Mirzet Karabeg, P3303 (Transcript from Prosecutor v. Brđanin), T. 6106-6107.

6600 KDZ474, P3395 (Transcript from Prosecutor v. Brđanin), T. 7660-7662 (under seal); Mirzet Karabeg, P3303 (Transcript from Prosecutor v. Brđanin), T. 6107; P3634 (Witness statement of KDZ490, undated), p. 47 (under seal). See also Adjudicated Fact 2521.

6601 KDZ474, P3395 (Transcript from Prosecutor v. Brđanin), T. 7661-7663 (under seal). KDZ474 specifies that the agreement from the SDA was coerced as the Bosnian Muslims were in a position of weakness. KDZ474, P3395 (Transcript from Prosecutor v. Brđanin), T. 7665 (under seal).

6602 P3306 (Conclusions of meeting of Sanski Most Crisis Staff, 30 April 1992); P3634 (Witness statement of KDZ490, undated), pp. 10-11, 45 (under seal); D4347 (Decision of Sanski Most Crisis Staff, 1 May 1992). See also P6670 (List of Sanski Most SJB employees for advance on salary for April 1992), p. 3. Vrućinić was formally appointed as chief of the SJB on 13 June 1992. P6379 (Decision of Banja Luka CSB, 13 June 1992); KW540, D4449 (Transcript from Prosecutor v. Stanišić \& Župljanin), T. 3410 (under seal).

6603 KDZ474, P3395 (Transcript from Prosecutor v. Brđanin), T. 7651 (under seal). See also P2614 (Conclusions of Sanski Most's Crisis Staff, 30 May 1992), p. 1.

6604 KDZ474, P3395 (Transcript from Prosecutor v. Brđanin), T. 7666-7668, 7671-7677, 7862-7863 (under seal); KW540, D4449 (Transcript from Prosecutor v. Stanišić \& Župljanin), T. 3312-3313 (under seal); Mirzet Karabeg, P3303 (Transcript from Prosecutor v. Brđanin), T. 6110, 6113-6116; P3634 (Witness statement of KDZ490, undated), pp. 47-48 (under seal); Faik Biščević, P135 (Transcript from Prosecutor v. Brđanin), T. 7023-7024. See also Adjudicated Facts 1299, 2521, 2522; Mirzet Karabeg, T. 18692 (13 September 2011); P3305 ( $5^{\text {th }}$ Corps combat report, 20 April 1992), p. 1. Rašula did not offer any guarantees of safety for those who surrendered. KDZ474, P3395 (Transcript from Prosecutor v. Brđanin), T. 7671 (under seal). 
Bosnian Croats exited through the back of the municipality building and escaped to Sehovći. ${ }^{6605}$ The building was subsequently attacked by the $6^{\text {th }}$ Krajina Brigade and members of the SOS and TO. ${ }^{6606}$

1940. The following day, on 20 April 1992, representatives of the SDS, SDA, and HDZ met with military representatives, including Talić, Commander of the $1^{\text {st }}$ Krajina Corps, and Basara, Commander of the $6^{\text {th }}$ Krajina Brigade. ${ }^{6607}$ The SDA presented six requests, which the SDS rejected. $^{6608}$ Talić ended the meeting by threatening that the SDA should not call anyone for help. ${ }^{6609}$ On the same day, the Crisis Staff held a meeting in which it concluded that it only recognised the "Serbian Municipality" of Sanski Most, including the "Serbian TO" and the "Serbian SJB". ${ }^{6} 10$ The Crisis Staff also declared that the "former Municipal Assembly of Sanski Most" was illegal and that only the laws of the SerBiH would be in effect in Sanski Most. ${ }^{6611}$

1941. On 28 April 1992, the Crisis Staff concluded that all citizens in Sanski Most must surrender their weapons. ${ }^{6612}$ Radio Sana then broadcast a message that all citizens in Sanski Most must turn in their weapons to the SJB or the TO by 3 May 1992 and that their security would be protected. ${ }^{6613}$

\footnotetext{
6605 KDZ474, P3395 (Transcript from Prosecutor v. Brđanin), T. 7672-7673 (under seal); KW540, D4449 (Transcript from Prosecutor v. Stanišić \& Župljanin), T. 3312-3313 (under seal).

6606 P3634 (Witness statement of KDZ490, undated) (under seal), pp. 48-49; Mirzet Karabeg, P3303 (Transcript from Prosecutor v. Brđanin), T. 6116-6118; KW540, D4449 (Transcript from Prosecutor v. Stanišić \& Župljanin), T. 3317, 3322 (under seal). See also Adjudicated Facts 1299, 2523.

6607 KDZ474, P3395 (Transcript from Prosecutor v. Brđanin), T. 7700 (under seal); KDZ474, T. 19336 (21 September 2011) (closed session). See also P3663 (Report on the $6^{\text {th }}$ Brigade in the period between 8 October 1991 and 28 August 1992); P3929 (Report of $1^{\text {st }}$ Krajina Corps, 3 September 1992), p. 8.

6608 KDZ474, P3395 (Transcript from Prosecutor v. Brđanin), T. 7701-7702, 7706 (under seal); KDZ474, T. 19339 (21 September 2011) (closed session). The requests included: (i) guarantee of the public safety of citizens and their property; (ii) establishment of the organisation and the functioning of the legal public security service and police station by finding the appropriate facilities and dividing resources; (iii) functioning of the legitimate municipal assembly and its organs; (iv) functioning of the economy and payment of transactions in keeping with the agreement in Bosanski Novi of 17 April 1992; (v) establishment of activity by all public institutions and companies with special emphasis on the work of the radio station with parity programming; and (vi) determination of the sequence of events on 18 and 19 April 1992 through the work of a mixed committee with the presence of European Community observers and representatives of the regular army. KDZ474, P3395 (Transcript from Prosecutor v. Brđanin), T. 7702 (under seal); P3329 (Excerpt from handwritten diary of Nedeljko Rašula), p. 23.

6609 KDZ474, P3395 (Transcript from Prosecutor v. Brđanin), T. 7708 (under seal).

6610 P3399 (Conclusions of meeting of Sanski Most Crisis Staff, 20 April 1992), para. 4.

6611 P3399 (Conclusions of meeting of Sanski Most Crisis Staff, 20 April 1992), para. 4. See also Adjudicated Fact 2517.

6612 P3328 (Conclusions of meeting of Sanski Most Crisis Staff, 28 April 1992), para. 1; P3634 (Witness statement of KDZ490, undated), pp. 55-56 (under seal); Mirzet Karabeg, P3303 (Transcript from Prosecutor v. Brđanin), T. 6133-6134. See also KW545, D4328 (Transcript from Prosecutor v. Stanišić \& Župljanin), T. 26173 (under seal).

6613 P3634 (Witness statement of KDZ490, undated), pp. 55-57 (under seal); Faik Biščević, P122 (Transcript from Prosecutor v. Krajišnik), T. 5507-5508, 5510, 5513; Faik Biščević, P135 (Transcript from Prosecutor v. Brđanin), T. 7021, 7054; P692 (Witness statement of Rajif Begić dated 15 March 2000), e-court pp. 5-6; Rajif Begić, P691 (Transcript from Prosecutor v. Krajišnik), T. 2967-2969; KDZ052, P3370 (Transcript from Prosecutor v. Brđanin), T. 8052-8054. See also Adjudicated Fact 1307; Grgo Stojić, P3515 (Transcript from Prosecutor v. Brđanin), T. 6768.
} 
Operations were carried out to disarm the citizens in predominantly Bosnian Muslim and Bosnian Croat villages. ${ }^{6614}$ There were never any efforts made to disarm the Bosnian Serb population. ${ }^{6615}$

1942. On 11 May 1992, the ARK Crisis Staff issued a decision to the presidents of the municipalities in the ARK that the deadline for the voluntary surrender of "illegally acquired" weapons, as ordered in a decision issued by the ARK government on 4 May 1992, ${ }^{6616}$ was extended to " $24: 00$ on 14 May 1992 ". 6617

1943. Beginning on 20 May 1992, the Crisis Staff ordered the disarmament of "paramilitary formations" in Sanski Most in accordance with the decision from the ARK government. ${ }^{6618}$

1944. By 25 May 1992, soldiers from the $6^{\text {th }}$ Krajina Brigade searched the houses of Bosnian Muslims and Bosnian Croats in Sanski Most in order to disarm them. ${ }^{6619}$ The Sanski Most SJB reported on the total number of weapons seized from Muslim villages. ${ }^{620}$ In Mahala, an announcement was made on the radio that people should hand over weapons to check-points. ${ }^{6621}$ In addition, an announcement was made that all Bosnian Muslims who were loyal to the Serbian state should fly white flags in front of their houses. ${ }^{6622}$

1945. On 25 May 1992, the $6^{\text {th }}$ Krajina Brigade attacked the Bosnian Muslim neighbourhoods of Mahala, Muhići, and Otoka in Sanski Most town. ${ }^{6623}$ The attack started with shelling, followed by

6614 P3648 (Report of Sanski Most SJB, 10 July 1992); KW545, T. 46963 (12 February 2014) (closed session).

6615 P3634 (Witness statement of KDZ490, undated) (under seal), pp. 58-60.

6616 P2818 (Decision of ARK Regional Secretariat for National Defence, 4 May 1992).

6617 P3694 (Conclusions of ARK Crisis Staff, 11 May 1992), para. 1; Mirzet Karabeg, T. 18801-18802 (14 September 2011); KW540, D4449 (Transcript from Prosecutor v. Stanišić \& Župljanin), T. 3351 (under seal).

6618 P3647 (Order of Sanski Most Crisis Staff, 20 May 1992); P2613 (Conclusions of Sanski Most Crisis Staff, 22 May 1992), p. 2; P3402 (Conclusions of Sanski Most Crisis Staff, 22 May 1992).

6619 D4233 (Witness statement of Branko Davidović dated 20 January 2014), para. 21. The Sanski Most SJB report states that the disarming and surrendering of weapons was carried out until 25 May 1992. P3928 (Report of Sanski Most SJB, 15 June 1992), p. 1; Mile Dobrijević, T. 44632 (6 December 2013).

6620 P3648 (Report of Sanski Most SJB, 10 July 1992), p. 1 (stating that "[a] special group was established for these jobs that went to Muslim villages seising weapons, based on orders from the SJB and that the military police were also engaged in the operations).

6621 Faik Biščević, P122 (Transcript from Prosecutor v. Krajišnik), T. 5512-5513.

6622 Faik Biščević, P122 (Transcript from Prosecutor v. Krajišnik), T. 5514. Biščević stated that it was used as a sign to identify houses belonging to the Bosnian Muslims and Bosnian Croats, differentiating them from the Bosnian Serb-owned houses when the houses were destroyed later. Faik Biščević, P122 (Transcript from Prosecutor v. Krajišnik), T. 5515.

6623 P3928 (Report of Sanski Most SJB, 15 June 1992); Faik Biščević, P122 (Transcript from Prosecutor v. Krajišnik), T. 5513; KW545, D4328 (Transcript from Prosecutor v. Stanišić \& Župljanin), T. 26198 (under seal); Sakib Muhić, P700 (Transcript from Prosecutor v. Brđanin), T. 8105-8106; KDZ474, T. 19247 (21 September 2011) (closed session). See also Adjudicated Facts 2527, 2528. KDZ490 states that the attack occurred on 26 May 1992. P3634 (Witness statement of KDZ490, undated), pp. 69-70 (under seal). Given the volume of consistent and accepted documentary evidence, witness testimony, and adjudicated facts in this regard, the Chamber finds that the attack occurred on 25 May 1992. 
soldiers entering the area. ${ }^{624}$ The soldiers set houses on fire. ${ }^{6625}$ According to a Sanski Most SJB report, the attack against Mahala resulted in the "capture of 2,000 civilians" but no significant amount of weapons was found. ${ }^{6626}$

1946. Attacks continued the following day. ${ }^{6627}$ Neđeljko Aničić ordered "upon completion of the task, [to] take the prisoners to the sports hall" and "hand over the war booty" to the "Sanski Most Serbian TO Staff". ${ }^{6628}$ Other villages in Sanski Most were subsequently attacked, including Hrustovo, Vrhpolje, Lukavica, and Trnovo. ${ }^{6629}$ According to a military report, there was a "comprehensive operation" undertaken between 25 May and 4 June 1992 to "mop up the terrain and disarm Muslim extremists" in Sanski Most. ${ }^{6630}$

1947. Meetings of the Crisis Staff were to be held daily to discuss a "long-term solution" for the "problem of refugees from the Mahala area, as well as the Muslims and Croats who are not loyal to the Constitution and laws of the $[\mathrm{SerBiH}] "{ }^{6631}$ The Crisis Staff concluded that all "those who have not taken up arms and want to change their municipality" should be allowed to move out. ${ }^{6632}$

1948. Pursuant to an order from the Crisis Staff, the "displaced population" from the Mahala, Muhići, and Otoka areas was to be transferred by a Sanatrans bus to the sports hall for "care and

6624 KW540, D4449 (Transcript from Prosecutor v. Stanišić \& Župljanin), T. 3365 (under seal); P718 (Witness statement of Ahmet Zulić dated 22 February 2010), para. 31. See also Sakib Muhić, P700 (Transcript from Prosecutor v. Brđanin), T. 8106.

6625 KW540, D4449 (Transcript from Prosecutor v. Stanišić \& Župljanin), T. 3365 (under seal); Faik Biščević, P122 (Transcript from Prosecutor v. Krajišnik), T. 5513 (testifying that 192 houses were set on fire, destroyed, and looted, namely "the entire Gornji Mahala was destroyed"). Mihajlo Orlović testified that he passed through Mahala two or three years later and did not see houses burned. He also refuted the shelling of Mahala. Mihaljo Orlović, T. 46643-46645 (6 February 2014). The Chamber does not find this evidence to be reliable. In reaching this conclusion, the Chamber found that Orlović was not completely forthright with the Chamber and his evidence was contradicted on numerous occasions by other accepted evidence, including P3928 (Report of Sanski Most SJB, 15 June 1992), witnesses Faik Biščević, KW545, Sakib Muhić, KDZ474, and Adjudicated Fact 2528.

6626 P3928 (Report of Sanski Most SJB, 15 June 1992), p. 1.

6627 P3313 (Order of Sanski Most TO, undated), pp. 1-2; P718 (Witness statement of Ahmet Zulić dated 22 February 2010), para. 31; P3634 (Witness statement of KDZ490, undated), p. 70 (under seal).

6628 P3313 (Order of Sanski Most TO, undated), p. 3. See Scheduled Detention Facility C.22.3.

6629 P718 (Witness statement of Ahmet Zulić dated 22 February 2010), paras. 36, 41-42; P3928 (Report of Sanski Most SJB, 15 June 1992), p. 1. See also KDZ052, P3370 (Transcript from Prosecutor v. Brđanin), T. 8052 8053; P3318 (Order of Sanski Most Crisis Staff, 2 June 1992) (ordering the machinery and manpower for the burial of persons killed in combat operations in Vrhpolje and Hrustovo); Adjudicated Fact 2529. See, e.g., Scheduled Incidents A.12.1, A.12.2, A.12.4. KW540 testified that in Vrhpolje, there were approximately 400 Bosnian Muslim men who were "the best armed and the best organised" by the SDA and this was why the $6^{\text {th }}$ Krajina Brigade attacked Vrhopolje. KW540, D4449 (Transcript from Prosecutor v. Stanišić \& Župljanin), T. 3485-3486 (under seal).

6630 P3663 (Report on the $6^{\text {th }}$ Brigade in the period between 8 October 1991 and 28 August 1992), p. 5.

6631 P2614 (Conclusions of Sanski Most's Crisis Staff, 30 May 1992), p. 1.

6632 P2614 (Conclusions of Sanski Most's Crisis Staff, 30 May 1992), p. 1. 
accommodation". ${ }^{6633}$ The following day, the TO ordered the "clean up" of the terrain in Mahala, Otoka, and Mahići and the search, identification, and burial of dead bodies. ${ }^{6634}$

1949. On 27 May 1992, Biščević was arrested, beaten, and taken to Radio Sana, which was by then controlled by the SDS. ${ }^{6635}$ He was forced to read a statement on the radio. ${ }^{6636}$ The statement announced that the VRS had taken over the municipality and all Bosnian Muslims and Bosnian Croats must unconditionally surrender their weapons in order to prevent the destruction of the town. ${ }^{6637}$ After making this statement, Biščević was taken to Magarice village. ${ }^{6638}$ An additional announcement was broadcast on the radio stating that residents who wished to leave Sanski Most would be allowed to and those who wished to stay were required to submit a request for a permanent residence permit. ${ }^{6639}$

\section{(4) Events after the take-over of Sanski Most}

1950. Following the take-over, Bosnian Serbs were appointed to positions in the municipality of Sanski Most while Bosnian Muslims and Bosnian Croats employees of the municipality were removed from their jobs. ${ }^{640}$ This included judges and employees of the municipal court, directors

6633 P3315 (Order of Sanski Most TO Municipal Staff, 26 May 1992) (also ordering that medical treatment shall be provided); Mirzet Karabeg, P3303 (Transcript from Prosecutor v. Brđanin), T. 6149-6151; KW540, D4449 (Transcript from Prosecutor v. Stanišić \& Župljanin), T. 3453-3454 (under seal). Karabeg testified that members of the SDS executive board, Boro Savanović, Tomo Delić, and Nemanja Tripković, visited him in the SJB prison and told him that Mahala and Otoka had been "liberated" and set on fire. Mirzet Karabeg, P3303 (Transcript from Prosecutor v. Brđanin), T. 6150-6151. See para. 2006.

6634 P3316 (Order of Sanski Most TO Municipal Staff, 27 May 1992); Mirzet Karabeg, P3303 (Transcript from Prosecutor v. Brđanin), T. 6151-6152.

6635 Faik Biščević, P122 (Transcript from Prosecutor v. Krajišnik), T. 5520-5524; Faik Biščević, P135 (Transcript from Prosecutor v. Brđanin), T. 7030-7036. See also P3634 (Witness statement of KDZ490, undated) (under seal), pp. 17, 69; P3644 (Conclusions of the Sanski Most Crisis Staff, 12 May 1992), p. 1; see Adjudicated Fact 2530.

6636 Faik Biščević, P122 (Transcript from Prosecutor v. Krajišnik), T. 5520-5524; Faik Biščević, P135 (Transcript from Prosecutor v. Brđanin), T. 7030-7036; P725 (Audio recording of radio announcement); Mirzet Karabeg, P3303 (Transcript from Prosecutor v. Brđanin), T. 6156-6159; Grgo Stojić, P3515 (Transcript from Prosecutor v. Brđanin), T. 6770; KDZ474, P3395 (Transcript from Prosecutor v. Brđanin), T. 7449-7750 (under seal). See also P3634 (Witness statement of KDZ490, undated), pp. 17, 69 (under seal); P3644 (Conclusions of the Sanski Most Crisis Staff, 12 May 1992), p. 1. Mihaljo Orlović testified that he asked Faik Biščević about this radio statement and that Biščević had read it out of his own free will and was not coerced. Mihaljo Orlović, T. 46651-46652 (6 February 2014). The Chamber does not find his evidence to be reliable. In reaching this conclusion, the Chamber found that the evidence of Orlović was contradicted by other accepted evidence, including that of witnesses KDZ474, Mirzet Karabeg, and Faik Biščević, and that he was not completely forthright with the Chamber.

6637 Faik Biščević, P122 (Transcript from Prosecutor v. Krajišnik), T. 5522; Faik Biščević, P135 (Transcript from Prosecutor v. Brđanin), T. 7037-7038.

6638 Faik Biščević, P135 (Transcript from Prosecutor v. Brđanin), T. 7042. See para. 2021.

6639 Grgo Stojić, P3515 (Transcript from Prosecutor v. Brđanin), T. 6771-6772.

6640 Faik Biščević, P122 (Transcript from Prosecutor v. Krajišnik), T. 5512; P3634 (Witness statement of KDZ490, undated), pp. 49, 53-55, 61-62 (under seal). See also P2740 (Decision of ARK Crisis Staff, 22 June 1992); P3646 (Conclusion of the Sanski Most Crisis Staff, 20 May 1992); see Adjudicated Fact 2518. Mikan Davidović testified that non-Serbs did not show up for work, rather than being dismissed from employment in May 1992. However, he confirmed that Bosnian Muslims and Bosnian Croats in top positions, such as directors 
of public companies, and employees of the local radio and health centre. ${ }^{6641}$ Bosnian Muslim and Bosnian Croat political leaders were arrested. ${ }^{6642}$

1951. On 8 June 1992, the TO was dismantled, the $6^{\text {th }}$ Krajina Brigade set up a forward command post in Sanski Most, and Aničić was appointed Commander. ${ }^{6643}$ All the former TO units in Sanski Most were integrated into the $6^{\text {th }}$ Krajina Brigade. ${ }^{644}$ Throughout June, July, and August 1992, armed attacks on villages throughout the municipality continued. ${ }^{6645}$

(a) Scheduled Incident A.12.1

1952. The Prosecution alleges that about 28 men were killed between Begići and Vrhpolje Bridge on or about 31 May 1992.

1953. Begići is a hamlet in the village of Kljevci with approximately 80 inhabitants. ${ }^{6646}$ Begići is divided into two halves: Gornji Begići and Donji Begići, which were several 100 metres apart. ${ }^{6647}$ In 1992, the majority of the population in Begići was Bosnian Muslim. ${ }^{6648}$

1954. On 25 May 1992, soldiers from the $6^{\text {th }}$ Krajina Brigade entered Gornji Begići and Donji Begići. ${ }^{6649}$ They damaged property and beat some of the residents. ${ }^{6650}$ The soldiers then returned to their check-point near Stojanovići. ${ }^{6651}$

1955. On 31 May 1992, soldiers from the $6^{\text {th }}$ Krajina Brigade entered Donji Begići and ordered the residents to come out of their houses and to go towards Gornji Begići. ${ }^{6652}$ Once they arrived

and judges, were replaced by Bosnian Serbs. Mikan Davidović, T. 44521-44522 (5 December 2013). Vinko Nikolic testified that all citizens were allowed to maintain their employement if they respected the RS constitution. Vinko Nikolić, T. 45446-45451 (16 January 2014). However, his testimony was contradicted by evidence showing that Bosnian Croat and Bosnian Muslim employees were removed from their jobs. The Chamber notes that this was one of many contradictions in his evidence which magnified his lack of credibility on the stand.

6641 P3634 (Witness statement of KDZ490, undated) (under seal), pp. 61-62. See Adjudicated Fact 2518.

6642 Faik Biščević, P135 (Transcript from Prosecutor v. Brđanin), T. 7027-7030.

6643 P3663 (Report on the $6^{\text {th }}$ Brigade in the period between 8 October 1991 and 28 August 1992), p. 6.

6644 P3663 (Report on the $6^{\text {th }}$ Brigade in the period between 8 October 1991 and 28 August 1992), p. 6.

6645 P3663 (Report on the $6^{\text {th }}$ Brigade in the period between 8 October 1991 and 28 August 1992), pp. 6-7.

6646 P692 (Witness statement of Rajif Begić dated 15 March 2000), e-court p. 5; Rajif Begić, P691 (Transcript from Prosecutor v. Krajišnik), T. 2962-2963. For the location of Kljevci and Begići, see P3638 (Map of Sanski Most municipality); P1159 (Map of Hrstovo-Vrhpolje marked by Rajif Begić).

6647 Rajif Begić, P691 (Transcript from Prosecutor v. Krajišnik), T. 2971, 2975.

6648 Rajif Begić, P691 (Transcript from Prosecutor v. Krajišnik), T. 2963.

6649 Rajif Begić, P691 (Transcript from Prosecutor v. Krajišnik), T. 2969-2971; P692 (Witness statement of Rajif Begić dated 15 March 2000), e-court p. 6.

6650 Rajif Begić, P691 (Transcript from Prosecutor v. Krajišnik), T. 2970; P692 (Witness statement of Rajif Begić Sanski Most Court dated 16 April 1995), e-court p. 13.

6651 Rajif Begić, P691 (Transcript from Prosecutor v. Krajišnik), T. 2970; P692 (Witness statement of Rajif Begić to Sanski Most Court dated 16 April 1995), e-court pp. 13-14. 
there, they saw that the men from Gornji Begići had gathered outside. ${ }^{653}$ The women and children were separated from the men and taken away. ${ }^{6654}$ The soldiers ordered the men, approximately 20 in the group, to go towards the Vrhpolje Bridge where they were told there would be buses waiting to transport them to Sanski Most. ${ }^{655}$ The men walked, two-by-two, in a column through the fields towards the Vrhpolje Bridge. ${ }^{656}$ According to Rajif Begić, there were 20 Bosnian Muslim men in this column, including himself, and they were escorted by eight armed soldiers. ${ }^{6657}$

1956. Jadranko Palija, a soldier from the $6^{\text {th }}$ Krajina Brigade, was in charge of leading the column of men from Begići to the Vrhpolje Bridge. ${ }^{6658}$ During the walk to the bridge, two of the Bosnian Muslim men were taken out of the column by Palija, shot, and killed near a slaughterhouse. ${ }^{6659}$ As the group continued towards the bridge, Palija shot and killed another man near the crossroads of the main road connecting Sanski Most and Ključ. ${ }^{6600}$ Before the group reached the bridge, approximately 50 metres away, a military van pulled up and Palija got in to speak to the driver. ${ }^{6661}$ Palija ordered another man, Ismet Kurbegović, from the column to come to the passenger side of the van, which he did. ${ }^{6662}$ Palija shot and killed Kurbegović. ${ }^{6663}$

\footnotetext{
6652 Rajif Begić, P691 (Transcript from Prosecutor v. Krajišnik), T. 2973-2975; P692 (Witness statement of Rajif Begić dated 15 March 2000), e-court p. 6. See also Adjudicated Fact 1303.

6653 Rajif Begić, P691 (Transcript from Prosecutor v. Krajišnik), T. 2979.

6654 Rajif Begić, P691 (Transcript from Prosecutor v. Krajišnik), T. 2979. See also Adjudicated Fact 1303.

6655 Rajif Begić, P691 (Transcript from Prosecutor v. Krajišnik), T. 2979. See also Adjudicated Fact 1304 (which states that "between 20-30 men" were in this group. For the location of the Vrhpolje Bridge, see P1159 (Map of Hrstovo-Vrhpolje marked by Rajif Begić).

6656 Rajif Begić, P691 (Transcript from Prosecutor v. Krajišnik), T. 2980; P1159 (Map of Hrstovo-Vrhpolje marked by Rajif Begić).

6657 Rajif Begić, P691 (Transcript from Prosecutor v. Krajišnik), T. 2980; P692 (Witness statement of Rajif Begić to Sanski Most Court dated 16 April 1995), e-court pp. 13, 15; P1159 (Map of Hrstovo-Vrhpolje marked by Rajif Begić). Begić named the 19 other men who were taken with him, namely Miralem Cerić, Enes Cerić, Midhet Cerić, Hakija Begić, Muharem Begić, Šaćir Begić, Safet Begić, Muhamed Begić, Irfan Begić, Fuad Begić, Elmedin Begić, Najil Begić, Ismet Kurbegović, Munib Begić, Nedžad Begić, Ismet Dizdarević, Muhamed Dizdarević, Mirsad Dizdarević, and Enes Dizdarević. Rajif Begić, P691 (Transcript from Prosecutor v. Krajišnik), T. 2981, 2984; P692 (Witness statement of Rajif Begić to Sanski Most Court dated 16 April 1995), e-court p. 16.

${ }^{6658}$ P692 (Witness statement of Rajif Begić to Sanski Most Court dated 16 April 1995), e-court pp. 15-16; Rajif Begić, P691 (Transcript from Prosecutor v. Krajišnik), T. 2973-2974, 2980. See also Adjudicated Fact 1305; D4387 (Witness statement of Dušan Mudrinić dated 15 February 2014), para. 21. Mudrinić confirmed that it was Jadranko Palija who was in charge and responsible because "the incident was investigated and an on-site investigation was conducted”. D4387 (Witness statement of Dušan Mudrinić dated 15 February 2014), para. 21.

6659 Rajif Begić, P691 (Transcript from Prosecutor v. Krajišnik), T. 2982-2983 (Begić identifies these men as Miralem Cerić and Enes Cerić); P692 (Witness statement of Rajif Begić dated 16 April 1995), e-court p. 16; P1159 (Map of Hrstovo-Vrhpolje marked by Rajif Begić). See also Adjudicated Fact 1306.

6660 Rajif Begić, P691 (Transcript from Prosecutor v. Krajišnik), T. 2983 (Begić identifies this man as Ismet Kurbegović); P692 (Witness statement of Rajif Begić dated 16 April 1995), e-court p. 16. See also Adjudicated Fact 1306.

6661 Rajif Begić, P691 (Transcript from Prosecutor v. Krajišnik), T. 2984.

6662 Rajif Begić, P691 (Transcript from Prosecutor v. Krajišnik), T. 2984; P692 (Witness statement of Rajif Begić dated 16 April 1995), e-court pp. 16-17.
} 
1957. When the remaining men reached the bridge, armed soldiers were waiting for them. ${ }^{664}$ The men were ordered to line up along the bridge and told that they would be killed because VRS soldiers had been killed. ${ }^{665}$ They were ordered to take off their clothes and shoes. ${ }^{6666}$ One of the men was ordered to jump into the river. ${ }^{6667} \mathrm{He}$ did and as he was swimming in the river, the soldiers leaned over the bridge, shot, and killed him. ${ }^{6668}$ The soldiers repeated this with every man. ${ }^{6669}$ Begić was the sixth man who was ordered to jump off the bridge. ${ }^{6670}$ He did so and instead of swimming to the surface, he dived under the water and swam towards the left bank where he hid under trees and shrubbery. ${ }^{6671}$ The soldiers continued in this manner with each man on the bridge. ${ }^{672}$ Begić was the only survivor. $^{6673}$

1958. Begić identified 19 Bosnian Muslim men who were killed in relation to this incident. ${ }^{6674}$ The Chamber also received evidence that in July 1992, the bodies of 13 males were found buried under the Vrhpolje Bridge on the right bank of the Sana River, the bodies of 11 other males were taken out of the Sana River, and Irfan Begić was found dead by the road near the bridge. ${ }^{6675}$ Of the

6663 Rajif Begić, P691 (Transcript from Prosecutor v. Krajišnik), T. 2984 (Begić identifies this man as Irfan Begić); P692 (Witness statement of Rajif Begić dated 16 April 1995), e-court pp. 16-17. See also Adjudicated Fact 1306.

6664 Rajif Begić, P691 (Transcript from Prosecutor v. Krajišnik), T. 2985-2986; P692 (Witness statement of Rajif Begić to Sanski Most Court dated 16 April 1995), e-court p. 18. See also Adjudicated Fact 1306.

6665 Rajif Begić, P691 (Transcript from Prosecutor v. Krajišnik), T. 2986-2987; P692 (Witness statement of Rajif Begić to Sanski Most Court dated 16 April 1995), e-court p. 18.

6666 Rajif Begić, P691 (Transcript from Prosecutor v. Krajišnik), T. 2987; P692 (Witness statement of Rajif Begić to Sanski Most Court dated 16 April 1995), e-court p. 18. See also Adjudicated Fact 1306.

6667 Rajif Begić, P691 (Transcript from Prosecutor v. Krajišnik), T. 2987; P692 (Witness statement of Rajif Begić to Sanski Most Court dated 16 April 1995), e-court p. 18. Begić identifies this man as Midhet Cerić. P692 (Witness statement of Rajif Begić to Sanski Most Court dated 16 April 1995), e-court p. 18.

6668 Rajif Begić, P691 (Transcript from Prosecutor v. Krajišnik), T. 2987; P692 (Witness statement of Rajif Begić to Sanski Most Court dated 16 April 1995), e-court p. 18.

6669 Rajif Begić, P691 (Transcript from Prosecutor v. Krajišnik), T. 2988-2990; P1158 (Photograph of Vrhpolje bridge marked by Rajif Begić); P692 (Witness statement of Rajif Begić to Sanski Most Court dated 16 April 1995), e-court p. 18. Begić identifies other men who were killed as Munib Begić, Mirsad Dizdarević, Enes Dizdarević, and Elmedin Begić. Enes Dizdarević was shot on the bridge before he could jump off. Rajif Begić, P691 (Transcript from Prosecutor v. Krajišnik), T. 2989-2990. See also Adjudicated Facts 1304, 1306; P3634 (Witness statement of KDZ490, undated), p. 77 (under seal).

6670 Rajif Begić, P691 (Transcript from Prosecutor v. Krajišnik), T. 2991; P692 (Witness statement of Rajif Begić dated 15 March 2000), e-court p. 6; P692 (Witness statement of Rajif Begić to Sanski Most Court dated 16 April 1995), e-court p. 19.

6671 Rajif Begić, P691 (Transcript from Prosecutor v. Krajišnik), T. 2991; P692 (Witness statement of Rajif Begić to Sanski Most Court dated 16 April 1995), e-court p. 18.

6672 Rajif Begić, P691 (Transcript from Prosecutor v. Krajišnik), T. 2992. See also Adjudicated Fact 1306. KDZ492 testified that he had heard from soldiers of the $6^{\text {th }}$ Krajina Brigade that Bosnian Muslim civilians were killed and thrown off the bridge into the Sana River. KDZ492, P3596 (Transcript from Prosecutor v. Krajišnik), T. 3861-3862 (under seal).

6673 Rajif Begić, P691 (Transcript from Prosecutor v. Krajišnik), T. 2992-2993; P692 (Witness statement of Rajif Begić dated 15 March 2000), e-court p. 6; P692 (Witness statement of Rajif Begić to Sanski Most Court dated 16 April 1995), e-court p. 19. Begić states that "more than 20" Bosnian Muslims were killed on 31 May 1992. P692 (Witness statement of Rajif Begić to Sanski Most Court dated 18 April 1996), e-court p. 11.

6674 P692 (Witness statement of Rajif Begić to Sanski Most Court dated 16 April 1995), e-court pp. 15-17.

6675 P557 (Report on bodies found in Vrhpolje, 10 July 1992). 
11 bodies taken out of the river, five of them match the names of men that were identified as having been with Begić's group. ${ }^{6676}$ Further, the Chamber received evidence that in May 1996, the bodies of 28 males were exhumed from mass graves connected to this incident. ${ }^{6677}$ Of those 28 males, seven were identified as having been with Begić's group and four were also named in the July 1992 report as bodies taken from the Sana River. ${ }^{6678}$ Injuries noted by the forensic report include gunshot wounds and fractured bones, mainly of the skull and ribs. ${ }^{6679}$ Some of the bodies in one part of the mass grave were in civilian clothing and another section of the mass grave contained a large quantity of civilian clothing. ${ }^{6680}$ The Chamber also received evidence that the body of Ismet Kurbegović was discovered in a mass grave in Prijedor. ${ }^{6681}$

1959. The Chamber took judicial notice of the fact that at least 28 Bosnian Muslim men were killed in this event. ${ }^{6682}$

1960. The Chamber therefore finds that approximately 20 men were killed by Serb Forces between Begići and Vrhpolje Bridge on or about 31 May 1992.

(b) $\underline{\text { Scheduled Incident A.12.2 }}$

1961. The Prosecution alleges that a number of people in the village of Hrustovo were killed on or about 31 May 1992.

1962. Hrustovo is a village in Sanski Most. ${ }^{663}$ It has six hamlets: Merdanovići, Keranovići, Jelečevići, Kukavice, Handanovići, and Zukići. ${ }^{664}$ In 1992, the population of these hamlets was primarily Bosnian Muslim. ${ }^{665}$

\footnotetext{
6676 P557 (Report on bodies found in Vrhpolje, 10 July 1992), pp. 3-4.

6677 P4901 (Sanski Most Court record on the investigation and exhumation of mass graves by the Vrhpolje Bridge in Sanski Most, 7 May 1996). See also P4853 (Updated Table 2 to the Report of Amor Mašović), pp. 44-45 (listing 22 individuals connected to this scheduled incident); P6690 (Addendum to Nicolas Sébire's report, 16 May 2003), e-court pp. 51-52 (listing 28 bodies exhumed from three gravesites near the Vrhpolje Bridge); P4850 (Witness statement of Amor Mašović dated 23 March 2012), Annex A, pp. 12-13. See P4870 (DNA report for Najil Begić, 25 June 2007); P4871 (Record of identification for Najil Begić, 25 June 2007).

P4901 (Sanski Most Court record on the investigation and exhumation of mass graves by the Vrhpolje Bridge in Sanski Most, 7 May 1996), pp. 20-21 (reporting that only 15 of the 28 bodies were positively identified by relatives). The men who were also identified in P557 (Report on bodies found in Vrhpolje, 10 July 1992) include Muhamed Dizdarević, Fuad Begić, Irfan Begić, and possibly Mirsad Dizdarević.

6679 P4901 (Sanski Most Court record on the investigation and exhumation of mass graves by the Vrhpolje Bridge, Sanski Most, 7 May 1996), pp. 5-20.

6680 P4901 (Sanski Most Court record on the investigation and exhumation of mass graves by the Vrhpolje Bridge, Sanski Most, 7 May 1996), pp. 3-4.

6681 P6689 (Excerpts from report on exhumations in Prijedor municipality, 28 August 2002), p. 111.

6682 See Adjudicated Fact 1306.

6683 KDZ097, P714 (Transcript from Prosecutor v. Brđanin), T. 7206 (under seal); P616 (Map of Hrustovo-Vrhpolje marked by KDZ097).

6684 P715 (Witness statement of KDZ097 dated 21 April 2001), e-court p. 4 (under seal).
} 
1963. On the morning of 31 May 1992, in Jelečevići, approximately 20 to 25 Bosnian Muslim civilians, mainly women and children, were ordered by soldiers wearing JNA uniforms to go to Kukavice. ${ }^{6686}$ The reason given was that the soldiers were going to search houses for weapons and it would be easier if there were fewer people in the village. ${ }^{667}$ In Kukavice, the group grew to about 30 individuals who were gathered in the garage of a house. ${ }^{6688}$ Shortly afterwards, soldiers came to the garage and opened fire at the garage door. ${ }^{6689}$ The soldiers yelled for everyone to come out of the garage. ${ }^{6690}$ Husein Merdanović went outside and told the soldiers to stop shooting and that there were only women and children inside the garage. ${ }^{6691}$ The soldiers shot and killed him. ${ }^{6692}$ The soldiers opened fire on the garage a second time. ${ }^{6693}$ As the civilians panicked, they came out of the garage and started running away, the soldiers fired at them. ${ }^{694}$ Only eight people survived the attack. ${ }^{6695}$

6685 P715 (Witness statement of KDZ097 dated 21 April 2001), e-court p. 4 (under seal); KDZ052, P3370 (Transcript from Prosecutor v. Brđanin), T. 8047.

6686 KDZ097, P714 (Transcript from Prosecutor v. Brđanin), T. 7208-7209, 7213, 7222-7223 (under seal); P715 (Witness statement of KDZ097 dated 21 April 2001), e-court pp. 4-6 (under seal). See also Adjudicated Facts 1307, 1308.

6687 KDZ097, P714 (Transcript from Prosecutor v. Brđanin), T. 7209 (under seal).

6688 P715 (Witness statements\ of KDZ097 dated 21 April 2001), e-court p. 4 (under seal); KDZ097, P714 (Transcript from Prosecutor v. Brdanin), T. 7212 (under seal) (testifying that a number of people from Keranovići had joined). Merdanović was the only "able bodied man" in the garage; he was "50-60" years old. The other males in the garage were under the age of 14 years old. Of the 30 people in the garage, the following 22 individuals were identified by name: Muharema Keranović, Almadina Keranović, Sabina Keranović, Sabra Merdanović, Jasmin Merdanović, Besima Merdanović, Edita Merdanović, Husein Merdanović (age 4-5 years) (listed twice), Zumra Merdanović, Fatima Zukić, Senija Keranović, Sejida Keranović, Čama Jelečević, Razija Jelečević, Sead Jelečević, Asim Jelečević, Elvira Jelečević, Edina Jelečević, Jasmina Merdanović, Dino Keranović, Ernes Keranović, and Husein Merdanović (age 50-60 years). [REDACTED]. See also Adjudicated Fact 1308.

6689 P715 (Witness statement of KDZ097 dated 21 April 2001), e-court p. 6 (under seal). See also Adjudicated Facts 1309, 1310.

6690 KDZ097, P714 (Transcript from Prosecutor v. Brđanin), T. 7215-7216 (under seal); P715 (Witness statements of KDZ097 dated 21 April 2001 and 11 December 2001), p. 4 (under seal).

6691 P715 (Witness statement of KDZ097 dated 21 April 2001), e-court p. 6 (under seal). See also Adjudicated Fact 1311.

6692 P715 (Witness statement of KDZ097 dated 21 April 2001), e-court p. 6 (under seal); KDZ097, P714 (Transcript from Prosecutor v. Brđanin), T. 7214 (under seal). See also Adjudicated Fact 1311.

6693 P715 (Witness statement of KDZ097 dated 21 April 2001), e-court p. 6 (under seal). See also Adjudicated Fact 1312.

6694 P715 (Witness statement of KDZ097 dated 21 April 2001), e-court p. 6 (under seal); KDZ097, P714 (Transcript from Prosecutor v. Brđanin), T. 7233 (under seal). See also Adjudicated Fact 1312.

6695 P715 (Witness statement of KDZ097 dated 21 April 2001), e-court p. 8 (under seal). The survivors were Čama Jelečević, Edina Jelečević, Razija Jelečević, Sead Jelečević, Ernes Keranović, Senija Keranović, Dino Keranović, and KDZ097. P715 (Witness statement of KDZ097 dated 21 April 2001), e-court p. 8 (under seal). On cross-examination, Boro Tadić testified that with respect to this scheduled incident, he could not confirm what had happened, nor could he confirm that a prosecution for those responsible had been conducted. Boro Tadić, T. 44414-44415 (3 December 2013). Mihaljo Orlović testified that he did not believe this killing incident happened and that it may have been a rumour or propaganda. Mihaljo Orlović, T. 46646 (6 February 2014). The Chamber does not find his evidence on this point to be reliable as it amounted to mere speculation. The Chamber also found that the evidence of Orlović was marked with numerous contradictions and that he was not completely forthright with the Chamber. 
1964. The Chamber took judicial notice of the fact that at a minimum, 15 people were killed in this incident. ${ }^{6696}$ The Chamber received evidence that bodies were found in a mass grave in Hrustovo in relation to this incident. ${ }^{6697}$

1965. Accordingly, the Chamber finds that a number of people were killed by Serb Forces in Hrustovo village on or about 31 May 1992.

\section{(c) Scheduled Incident A.12.3}

1966. The Prosecution alleges that about 18 men from Kenjari were killed on or about 27 June 1992 in the hamlet of Blaževići.

1967. Kenjari is a hamlet located north of Begići. ${ }^{6698}$ In 1992, the population of Kenjari was primarily Bosnian Muslim. ${ }^{669}$ Around 27 or 28 June 1992, Bosnian Serb soldiers, led by Milorad Mijatović, entered Kenjari and started searching houses for weapons. ${ }^{6700}$ The Bosnian Muslims in the hamlet were ordered to leave their houses and wait outside at the crossroads. ${ }^{6701}$ After the soldiers were finished searching the houses, they ordered that all the men be taken elsewhere for interrogation, while the women and children could return to their homes. ${ }^{6702}$ KDZ052 testified that about 18 or 20 men were with him when they were taken to a house to be interrogated. ${ }^{6703}$ They were kept at the house in Kenjari until the following day when Vrkeš, the president of the SDS in Sanski Most, came to see the men and told them they would be exchanged for Bosnian Serbs in eastern $\mathrm{BiH}^{6704}$ The men were then taken to a house in Blaževići. ${ }^{6705}$ While they were in the house, there was an explosion inside. ${ }^{6706}$ KDZ052 managed to jump out of the window and hide. ${ }^{6707} \mathrm{He}$ and others were shot at while they attempted to escape out of the house. ${ }^{6708}$ The

\footnotetext{
6696 See Adjudicated Fact 1313.

6697 P4898 (Sanski Most Municipal Court record of Hrustovo I exhumation, 15 April 1997), pp. 3-20 (listing 30 bodies found in the mass grave Hrustovo I, of which eight are also named by KDZ097); P3637 (Report of BiH Federal Ministry of the Interior, 22 October 1996), p. 6 (listing 31 bodies found in the mass grave Hrustovo I, of which seven are also named by KDZ097); P4853 (Updated Table 2 to the Report of Amor Mašović), pp. 45-47 (which names 13 individuals in relation to this scheduled incident); P6690 (Addendum to Nicolas Sébire's report, 16 May 2003), e-court pp. 53-54, 56 (which identifies 31 bodies recovered from two mass graves, of which nine were also named by KDZ097).

6698

6699

6700

6701

6702

6703

6704

6705

6706

6707
} 
bodies of the men who were killed were taken by the soldiers back to the house and the house was set on fire. ${ }^{6709}$ KDZ052 survived and made his way to Tomina. ${ }^{6710}$

1968. The Chamber received evidence that the bodies of 18 men were identified in a mass grave and linked to this scheduled incident. ${ }^{6711}$

1969. Based on the evidence presented above, the Chamber finds that approximately 18 men from Kenjari in the hamlet of Blaževići were killed by Serb Forces on or about 27 June 1992.

\section{(d) Scheduled Incident A.12.4}

1970. The Prosecution alleges that a number of people from the hamlet of Budim in Lukavice village were killed on or about 1 August 1992.

1971. Lukavice is a village in the northwestern region of Sanski Most municipality. ${ }^{6712}$ The population of Lukavice was primarily Bosnian Muslim. ${ }^{6713}$ The Chamber took judicial notice of the fact that on 1 August 1992, Bosnian Serb Forces attacked Budim and killed 14 members of the Alibegović family, all of whom were unarmed civilians. ${ }^{6714}$ The Chamber also took judicial notice of the fact that the victims were shot from a close distance with automatic weapons. ${ }^{6715}$

6708 KDZ052, P3370 (Transcript from Prosecutor v. Brđanin), T. 8063-8064. See also Adjudicated Fact 2532.

6709 KDZ052, P3370 (Transcript from Prosecutor v. Brđanin), T. 8065-8066. See also Adjudicated Fact 2532.

6710 KDZ052, P3370 (Transcript from Prosecutor v. Brđanin), T. 8067-8068. See also P3377 (Map of HrustovoVrhpolje marked by KDZ052) (under seal).

6711 P3373 (Excerpt of exhumation report on Hrustovo and Vrhpolje mass grave) (under seal) (stating that charred remains were found in the house and in a nearby mass grave, and information from KDZ052 and others identified 19 persons who were executed and whose bodies were set on fire); P3376 (Excerpt of exhumation report on Hrustovo and Vrhpolje mass grave) (under seal) (listing the 18 names as identified by KDZ052); KDZ052, T. 19082-19083 (19 September 2011); KDZ052, P3370 (Transcript from Prosecutor v. Brđanin), T. 8075; P3637 (Report of BiH Federal Ministry of the Interior, 22 October 1996), p. 2. See also P6690 (Addendum to Nicolas Sébire's report, 16 May 2003), e-court pp. 58-59.

6712 P532 (Map of Sanski Most); P3638 (Map of Sanski Most municipality).

6713 P532 (Map of Sanski Most); P3638 (Map of Sanski Most municipality).

6714 See Adjudicated Fact 1315.

6715 See Adjudicated Fact 1315. In his Final Brief, the Accused acknowledges that "[o]n 1 August 1992, Serb soldiers attacked Budin[sic] and killed 14 unarmed members of the Alibegovic family". However, the Accused also submits that "KDZ097 testified that large numbers of people roamed his area in uniform". The Accused therefore argues that there was "no plan to perpetrate killings by official Serb authorities." Defence Final Trial Brief, p. 437 (section on Persecution), para. 1623. The Accused also submits that the crimes committed in Sanski Most cannot be attributed to him because they were acts committed without his knowledge, against his policies, and by people outside of his control. He also submits that there was no plan to permanently remove non-Serbs from Sanski Most. Defence Final Brief, paras. 2894-2900. This submission will be dealt with in Section IV.A.3.iii: Authority over military and police forces acting in $\mathrm{BiH}$. 
1972. The Chamber also received evidence that 14 bodies were exhumed in a mass grave in relation to this incident. ${ }^{6716}$ These bodies were determined to be Bosnian Muslim male civilians. $^{6717}$

1973. The Chamber finds that approximately 14 people from the hamlet of Budim in Lukavice village were killed by Serb Forces on or about 1 August 1992.

\section{(e) $\underline{\text { Scheduled Incident A.12.5 }}$}

1974. The Prosecution alleges that approximately seven men were killed near the village of Škrljevita on or about 2 November 1992.

1975. Škrljevita is a village in eastern Sanski Most. ${ }^{6718}$ In 1992, the majority of the population in Škrljevita was Bosnian Croat. ${ }^{6719}$ On 2 November 1992, Grgo Stojić and his cousin were walking from Sanski Most town to Škrljevita when they encountered two soldiers from the $6^{\text {th }}$ Krajina Brigade on the road near the Glamošnica forest. ${ }^{6720}$ The soldiers asked them for identification. ${ }^{6721}$ After looking at their identity cards, the soldiers asked Stojić and his cousin to follow them. ${ }^{6722}$ They were led through the forest and to the Glamošnica River, where four of Stojić's neighbours were already lined up. ${ }^{6723}$ A soldier was pointing a machine gun at the four men. ${ }^{6724}$ Stojić and his cousin were told to line up next to his neighbours. ${ }^{6725}$ They were searched, their personal

6716 P4853 (Updated Table 2 to the Report of Amor Mašović), pp. 47-48; P4899 (Bihać Cantonal Court record of Lukavice postmortem examination, 11 June 1997); P4900 (Bihać Cantonal Court record of Lukavice exhumation, 2 June 1997). See also P6690 (Addendum to Nicolas Sébire's report, 16 May 2003), e-court pp. $60-61$.

6717 P4900 (Bihać Cantonal Court record of Lukavice exhumation, 2 June 1997); P4899 (Bihać Cantonal Court record of Lukavice postmortem examination, 11 June 1997).

6718 P3638 (Map of Sanski Most municipality).

6719 Grgo Stojić, P3515 (Transcript from Prosecutor v. Brđanin), T. 6764. See also Adjudicated Fact 1316. There was also a Bosnian Serb minority. Grgo Stojić, P3515 (Transcript from Prosecutor v. Brđanin), T. 6764.

6720 Grgo Stojić, P3515 (Transcript from Prosecutor v. Brđanin), T. 6773-6774. The soldiers were identified as members of the $6^{\text {th }}$ Krajina Brigade. P3519 (Indictment of the $1^{\text {st }}$ Krajina Corps Military Prosecutor's Office, 2 June 1993); p. 1; P3520 (Decision of Banja Luka Military Court, 9 July 1993, p. 1; P3521 (Ruling of Banja Luka Military Court, 14 March 1995, p. 1. The name of Stojić's cousin was Dragan Tadić. Grgo Stojić, P3515 (Transcript from Prosecutor v. Brđanin), T. 6774. See also Adjudicated Fact 1317.

6721 Grgo Stojić, P3515 (Transcript from Prosecutor v. Brđanin), T. 6775.

6722 Grgo Stojić, P3515 (Transcript from Prosecutor v. Brđanin), T. 6775-6776.

6723 Grgo Stojić, P3515 (Transcript from Prosecutor v. Brđanin), T. 6776. See also Adjudicated Fact 1317. The neighbours detained by the armed men were Ante Tutić, Petar Nikić, Žarko Nikić, and Josip Banović. Grgo Stojić, P3515 (Transcript from Prosecutor v. Brđanin), T. 6776. All of the men detained were Bosnian Croats. See Adjudicated Fact 1317.

6724 Grgo Stojić, P3515 (Transcript from Prosecutor v. Brđanin), T. 6776. Stojić and his cousin met these neighbours earlier that day as they were walking to Skrljevita, but the neighbours had walked ahead of them. Grgo Stojić, P3515 (Transcript from Prosecutor v. Brđanin), T. 6774.

6725 Grgo Stojić, P3515 (Transcript from Prosecutor v. Brđanin), T. 6776. 
belongings were taken, and they were questioned. ${ }^{6726}$ The soldiers declared: "We are Šešelj army," and shot Stojić, his cousin, and his neighbours, killing five of them. ${ }^{6727}$ Stojić was the only survivor. $^{6728}$

1976. Stojić was shot in his left arm and hip. ${ }^{6729}$ He continued heading through the forest towards Škrljevita. ${ }^{6730}$ While in the forest, Stojić heard strong bursts of gunfire. ${ }^{6731} \mathrm{He}$ later learned that this gunfire came from VRS soldiers killing four other men from Škrljevita. ${ }^{6732}$

1977. The Chamber took judicial notice of the fact that seven Bosnian Croats were killed in relation to this incident. ${ }^{6733}$ The Chamber received evidence from Stojić, an eye-witness to the incident that five men were killed and he learned after he escaped that an additional four men were killed soon after. The Chamber also received evidence that nine bodies were recovered in a mass grave and in relation to this incident, the identities of which are corroborated by Stojić's evidence. $^{6734}$

1978. The Chamber finds that nine men were killed by Serb Forces near the village of Škrljevita on or about 2 November 1992.

${ }^{6726}$ Grgo Stojić, P3515 (Transcript from Prosecutor v. Brđanin), T. 6777. In addition to the two armed men Stojić encountered, there were two more armed men by the river who wore camouflage military uniforms, had light machine guns with the four S's carved into the rifle butts, and carried two clips of ammunition. Grgo Stojić, P3515 (Transcript from Prosecutor v. Brđanin), T. 6776-6777. On cross-examination, Stojić stated that the armed men were part of Šešelj's men. Grgo Stojić, P3515 (Transcript from Prosecutor v. Brđanin), T. 6797. Grgo Stojić, P3515 (Transcript from Prosecutor v. Brđanin), T. 6777-6778. See also P3518 (Report of Sanski Most's Lower Court Investigating Judge, 9 November 1992), pp. 1-2; P3519 (Indictment of the $1^{\text {st }}$ Krajina Corps Military Prosecutor's Office, 2 June 1993), pp. 1-2. According to Stojić, the victims killed within his line of sight were Ante Tutić, Petar (Pero) Nikić, Žarko Nikić, Josip Banović, and Dragan Tadić. Grgo Stojić, P3515 (Transcript from Prosecutor v. Brđanin), T. 6778, 6780. See also Adjudicated Facts 1318, 1319.

6728 Grgo Stojić, P3515 (Transcript from Prosecutor v. Brđanin), T. 6778. See also P3518 (Report of Sanski Most's Lower Court Investigating Judge, 9 November 1992), pp. 1-2.

6729 Grgo Stojić, P3515 (Transcript from Prosecutor v. Brđanin), T. 6777-6778.

6730 Grgo Stojić, P3515 (Transcript from Prosecutor v. Brđanin), T. 6779. He reached Škrljevita, where he received assistance and first aid. He was subsequently brought to the Sanski Most Health Centre, then transferred to Prijedor, and ultimately transported to the Banja Luka Hospital. Grgo Stojić, P3515 (Transcript from Prosecutor v. Brđanin), T. 6780-6781. See also P3516 (Photographs of Grgo Stojić); P3522 (Recommendation for medical treatment of Grgo Stojić, 14 December 1992); P3527 (Letter of discharge of Grgo Stojić from Banja Luka Clinical Hospital Centre, 2 December 1992). While recovering in the Banja Luka hospital, Stojic was visited by a VRS soldier who ordered him to raise the three-finger salute and said, "[n]ow you are a Serb". He was also called "ustasha" by the nurses and other patients. Grgo Stojić, P3515 (Transcript from Prosecutor v. Brđanin), T. 6782-6786.

6731 Grgo Stojić, P3515 (Transcript from Prosecutor v. Brđanin), T. 6779.

6732 Grgo Stojić, P3515 (Transcript from Prosecutor v. Brđanin), T. 6779, 6791. A sister of one of the victims informed Stojić of the killings while he was at the Banja Luka Hospital. She told him that the victims were Ivo Tutić, Bone Tutić, "Adlo Tatić [phone], and Josip Fertalac [phone]”. Grgo Stojić, P3515 (Transcript from Prosecutor v. Brđanin), T. 6779.

6733 See Adjudicated Fact 1319.

6734 P3518 (Report of Sanski Most's Lower Court Investigating Judge, 9 November 1992) (listing nine men killed in relation to this scheduled incident). See also P4853 (Updated Table 2 to the Report of Amor Mašović), p. 48 (listing eight individuals in relation to this scheduled incident); P6690 (Addendum to Nicolas Sébire's report, 16 May 2003), e-court pp. 64-65 (listing nine bodies exhumed in relation to this scheduled incident). 


\section{(5) Detention Facilities in Sanski Most}

1979. Detention facilities in Sanski Most were established by the Crisis Staff. ${ }^{6735}$ After military operations against Bosnian Muslim and Bosnian Croat villages in Sanski Most, soldiers collected the able-bodied military-aged men from the village and transferred them by bus to Sanski Most town. ${ }^{6736}$ In town, they were handed over to the civilian authorities. ${ }^{6737}$ An inspector from the SJB and an inspector from the CSB interrogated the men believed to be "military prisoners". 6738 KW540 estimated that 1,600 "military prisoners" were handed over to the civilian authorities in Sanski Most in 1992. ${ }^{6739}$ The majority of detainees in Sanski Most were transferred to Manjača camp. $^{6740}$ They would be labelled into three categories of "prisoners": (i) politicians, (ii) nationalist extremists, and (iii) people unwelcome in Sanski Most municipality. ${ }^{6741}$ The majority of detainees in Sanski Most were civilians, as will be addressed below.

\section{(a) Scheduled Detention Facility C.22.1}

1980. The Indictment refers to the use of the SJB building and prison in Sanski Most as a detention facility at least between 26 May and August 1992.

\section{(i) Establishment and control}

1981. The SJB building and prison were located in the centre of Sanski Most town, near the Betonirka Factory Garage. ${ }^{6742}$ The prison facility was located behind the SJB police building. ${ }^{6743}$

\footnotetext{
6735 KW540, D4449 (Transcript from Prosecutor v. Stanišić \& Župljanin), T. 3453 (under seal); D470 (CSB Banja Luka Report concerning collection centres, undated), e-court pp. 7-8.

6736 KW540, D4449 (Transcript from Prosecutor v. Stanišić \& Župljanin), T. 3377, 3386 (under seal).

6737 KW540, D4449 (Transcript from Prosecutor v. Stanišić \& Župljanin), T. 3377, 3386 (under seal).

6738 KW540, D4449 (Transcript from Prosecutor v. Stanišić \& Župljanin), T. 3377, 3500-3501 (under seal).

6739 KW540, D4449 (Transcript from Prosecutor v. Stanišić \& Župljanin), T. 3392 (under seal).

$6740 \quad$ See paras. 1987, 1990, 2009, 2017.

6741 P2639 (Conclusions of Sanski Most Crisis Staff, 4 June 1992); see Adjudicated Fact 2558. Mile Dobrijević testified that he had no knowledge of the three categories of detainees and when presented with P2639, he insisted that he made no decisions on categorisation. Mile Dobrijević, T. 44636-44639 (6 December 2013). The Chamber does not accept his evidence on this point given that he was an SJB employee at Betonirka Factory Garage and the Hasan Kikić school and his claim to be unaware of these categories defy credibility.

6742 P3667 (Map of Sanski Most with photos of various buildings); P3314 (Photograph of Sanski Most police station); D4335 (Map of Sanski Most with photographs).

6743 Mirzet Karabeg, P3303 (Transcript from Prosecutor v. Brđanin), T. 6139-6140; D4339 (Photograph of Sanski Most SJB). See also D4341 (Photograph of Sanski Most SJB).
} 
The chief of the police station was Vručinić. ${ }^{674}$ Miladin Paprić was in charge of the SJB prison until 4 June 1992, when he was dismissed and replaced by Drago Vujanić. ${ }^{6745}$

1982. Detainees started arriving at the SJB building and prison on 25 May 1992, after the attack on Sanski Most town. ${ }^{6746}$ The majority of the detainees at the SJB building were prominent civilians who held important positions in the community. ${ }^{6747}$ There was one underage detainee. ${ }^{6748}$

\section{(ii) Conditions of detention and treatment of detainees}

1983. The detainees were held in small cells in the SJB prison and guarded by the police. ${ }^{6749}$ Due to the size of the cell, it was not possible for detainees to lie down to sleep and they had to sit very closely to each other. ${ }^{6750}$ The cells had a concrete roof, a metal door, and a metal plate with holes over the window. ${ }^{6751}$ During the summer months, the strong heat caused the room to be very hot and damp, with a terrible stench, making it very difficult to breathe. ${ }^{6752}$ There was no fresh air until someone removed the metal plate covering the window after approximately 40 days into the detention. ${ }^{6753}$ Furthermore, the guards did not permit the cells to be aired out. ${ }^{6754}$ There were blankets and an old mat for bedding. ${ }^{6755}$

\footnotetext{
6744 Mirzet Karabeg, P3303 (Transcript from Prosecutor v. Brđanin), T. 6145; P3319 (Report of Sanski Most SJB, 6 June 1992).

6745 Mirzet Karabeg, P3303 (Transcript from Prosecutor v. Brđanin), T. 6145, 6162; P2639 (Conclusions of Sanski Most Crisis Staff, 4 June 1992); KW545, D4328 (Transcript from Prosecutor v. Stanišić \& Župljanin), T. 26104, 26318-26319, 26322 (under seal); Mile Dobrijević, T. 44635-44636 (6 December 2013).

6746 Mirzet Karabeg was arrested on 25 May 1992 and taken to the SJB prison. Mirzet Karabeg, P3303 (Transcript from Prosecutor v. Brđanin), T. 6139-6140.

6747 Faik Biščević, P122 (Transcript from Prosecutor v. Krajišnik), T. 5530-5532; KDZ474, P3395 (Transcript from Prosecutor v. Brđanin), T. 7768 (under seal). See also Adjudicated Fact 1321.

6748 See Adjudicated Fact 1321.

6749 KDZ474, P3395 (Transcript from Prosecutor v. Brđanin), T. 7743 (under seal); Mirzet Karabeg, P3303 (Transcript from Prosecutor v. Brđanin), T. 6139, 6300-6301; D4340 (Photograph of Sanski Most SJB); D4342 (Photograph of Sanski Most SJB). See also Adjudicated Fact 1323.

6750 KDZ474, P3395 (Transcript from Prosecutor v. Brđanin), T. 7751 (under seal); Faik Biščević, P135 (Transcript from Prosecutor v. Brđanin), T. 7067 . KW545 admitted that conditions in the prison were inhumane, the facility and rooms did not meet the minimum requirements for holding people for long periods of time, and it was very difficult to maintain order. KW545, D4328 (Transcript from Prosecutor v. Stanišić \& Župljanin), T. 26114, 26239, 26241-26243 (under seal).

6751 KDZ474, P3395 (Transcript from Prosecutor v. Brđanin), T. 7746 (under seal); D4342 (Photograph of Sanski Most SJB); D4343 (Photograph of Sanski Most SJB); Mirzet Karabeg, P3303 (Transcript from Prosecutor v. Brđanin), T. 6301.

6752 KDZ474, P3395 (Transcript from Prosecutor v. Brđanin), T. 7753-7754 (under seal); Faik Biščević, P135 (Transcript from Prosecutor v. Brđanin), T. 7067-7068; KW545, D4328 (Transcript from Prosecutor v. Stanišić \& Župljanin), T. 26239 (under seal).

6753 KDZ474, P3395 (Transcript from Prosecutor v. Brđanin), T. 7753 (under seal).

6754 KDZ474, P3395 (Transcript from Prosecutor v. Brđanin), T. 7753 (under seal).

6755 KDZ474, P3395 (Transcript from Prosecutor v. Brđanin), T. 7751-7752 (under seal).
} 
1984. The detainees were not provided with sufficient food and water. ${ }^{6756}$ After the first 15 days, the detainees' meals were reduced from three to two meals per day; these meals were insufficient and resulted in the detainees suffering substantial weight loss. ${ }^{6757}$ Meals consisted of a piece of bread, a cup of something to drink and, if available, left-over food from the soldiers. ${ }^{6758}$ For water, the detainees were occasionally allowed to fill up bottles, but only when there was enough water for the toilets in the detention facility. ${ }^{6759}$ There were no toilets in the cells of the prison. ${ }^{6760}$ The detainees had access to two toilets but they became blocked. ${ }^{6761}$ The detainees were allowed five minutes in the morning and five minutes in the evening to use the toilets. ${ }^{6762}$ They subsequently dug a hole behind the building, which they were only permitted to use during lunchtime. ${ }^{6763}$ Save for a couple of exceptions, it was not possible to shower given the lack of water. ${ }^{6764}$

1985. The guards took the detainees out of the cells only for about 20 minutes per day, including for meals and for work they had to carry out. ${ }^{6765}$ On leaving the cell for work, the detainees were frequently beaten and mistreated. ${ }^{6766}$ Despite these conditions, Rašula told a detainee at the SJB: "[y]ou're safest where you are. If we release you, you will be killed either by your people or by mine". 6767

KDZ474, P3395 (Transcript from Prosecutor v. Brđanin), T. 7751 (under seal).

KDZ474, P3395 (Transcript from Prosecutor v. Brđanin), T. 7751, 7754 (under seal). The lunches contained pork with hair still on it. KDZ474, P3395 (Transcript from Prosecutor v. Brđanin), T. 7751 (under seal).

6758 Faik Biščević, P135 (Transcript from Prosecutor v. Brđanin), T. 7068. Biščević testified that he lost 32 kilograms while in detention. Faik Bǐčević, P135 (Transcript from Prosecutor v. Brđanin), T. 7067-7068.

6759 KDZ474, P3395 (Transcript from Prosecutor v. Brđanin), T. 7751 (under seal); Faik Biščević, P135 (Transcript from Prosecutor v. Brđanin), T. 7065.

6760 Faik Biščević, P135 (Transcript from Prosecutor v. Brđanin), T. 7065.

6761 KDZ474, P3395 (Transcript from Prosecutor v. Brđanin), T. 7752 (under seal); Faik Biščević, P135 (Transcript from Prosecutor v. Brđanin), T. 7064.

6762 Faik Biščević, P135 (Transcript from Prosecutor v. Brđanin), T. 7064-7065.

6763 KDZ474, P3395 (Transcript from Prosecutor v. Brđanin), T. 7752 (under seal).

6764 KDZ474, P3395 (Transcript from Prosecutor v. Brđanin), T. 7752 (under seal); Faik Biščević, P135 (Transcript from Prosecutor v. Brđanin), T. 7065. Biščević testified that he was allowed to shower and wash his clothing twice during his 95 days of detention. Faik Biščević, P135 (Transcript from Prosecutor v. Brđanin), T. 70657066.

6765 KDZ474, P3395 (Transcript from Prosecutor v. Brđanin), T. 7754 (under seal). Work included digging a makeshift toilet behind the building, washing dishes, and cleaning the SJB complex. KDZ474, P3395 (Transcript from Prosecutor v. Brđanin), T. 7752,7757 (under seal). The Chamber notes that only forced labour at the frontlines is charged in the Indictment.

6766 KDZ474, P3395 (Transcript from Prosecutor v. Brđanin), T. 7757 (under seal). In addition to being beaten, one detainee had his hands burned with hot water. KDZ474, P3395 (Transcript from Prosecutor v. Brđanin), T. 7757 (under seal).

6767 KDZ474, P3395 (Transcript from Prosecutor v. Brđanin), T. 7651, 7761 (under seal). See also P3396 (Photographs depicting Radovan Karadžić, Ratko Mladić, Biljana Plavšić, Momčilo Krajišnik and others). Basara, also visited the SJB building and made speeches to VRS soldiers there. See Adjudicated Fact 1325; KDZ474, P3395 (Transcript from Prosecutor v. Brđanin), T. 7899 (under seal).
} 
1986. The guards, regular police officers, and VRS soldiers beat the detainees. ${ }^{6768}$ Sometimes the guards would hand over the keys to the cells to the VRS soldiers, and according to Biščević, "[a]nyone could come in and beat us if they so pleased". ${ }^{6769}$ Some of the detainees were taken from their cells to the SJB building and interrogated. ${ }^{670}$ During interrogations, regular police officers and VRS soldiers beat the detainees, using rifle-butts, electric cables, poles, and wooden planks. ${ }^{6771}$ Detainees were also beaten in their cells, and some were forced to beat each other. ${ }^{6772}$ The detainees did not receive any medical treatment for injuries sustained in SJB custody. ${ }^{6773}$ As a result of the severe beatings, Karabeg suffered severe injuries to his body and head and lost all of his teeth. ${ }^{674}$ Two men were beaten at the SJB prison and subsequently killed. ${ }^{6775}$

1987. In early June 1992, detainees in the SJB prison were transferred to Manjača camp pursuant to an order from the Crisis Staff. ${ }^{6776}$

1988. The frequency of the beatings decreased after a visit from the ICRC in July $1992 .{ }^{6777}$ Furthermore, visits by family members were allowed after the ICRC visit. ${ }^{6778}$

6768 KDZ474, P3395 (Transcript from Prosecutor v. Brđanin), T. 7756, 7758 (under seal). See also P3519 (Indictment of the $1^{\text {st }}$ Krajina Corps Military Prosecutor's Office, 2 June 1993), p. 1; Adjudicated Facts 1328, 1329; Faik Biščević, P135 (Transcript from Prosecutor v. Brđanin), T. 7064 . A soldier from the $6^{\text {th }}$ Krajina Brigade was known for beating several detainees. KDZ474, P3395 (Transcript from Prosecutor v. Brđanin), T. 7758 (under seal); P3519 (Indictment of the $1^{\text {st }}$ Krajina Corps Military Prosecutor's Office, 2 June 1993 ), p. 1. Members of the VRS, including the military police, and regular police ran the SJB prison together. Mirzet Karabeg, P3303 (Transcript from Prosecutor v. Brđanin), T. 6154-6155.

6769 Faik Biščević, P135 (Transcript from Prosecutor v. Brđanin), T. 7073. See also Adjudicated Fact 1329.

$6770 \quad$ See Adjudicated Fact 1321.

6771 Faik Biščević, P135 (Transcript from Prosecutor v. Brđanin), T. 7068-7073; Mirzet Karabeg, P3303 (Transcript from Prosecutor v. Brđanin), T. 6166-6168; Adjudicated Facts 1326; 1327.

6772 KDZ474, T. 19334 (21 September 2011) (closed session); KDZ474, P3395 (Transcript from Prosecutor v. Brđanin), T. 7757 (under seal).

6773 KDZ474, P3395 (Transcript from Prosecutor v. Brđanin), T. 7759-7760 (under seal); Faik Biščević, P135 (Transcript from Prosecutor v. Brđanin), T. 7064. For example, a detainee had two ribs broken during a beating. He was taken to a hospital, where he waited for three hours and then was returned to his cell. KDZ474, P3395 (Transcript from Prosecutor v. Brđanin), T. 7754, 7759 (under seal). See also KDZ474, T. 19334 (21 September 2011) (closed session).

6774 Mirzet Karabeg, P3303 (Transcript from Prosecutor v. Brđanin), T. 6180-6182.

6775 Mirzet Karabeg, P3303 (Transcript from Prosecutor v. Brđanin), T. 6182-6183. Karabeg and Biščević identifies these two men as Hasib Kamber and Emir Seferović. Mirzet Karabeg, P3303 (Transcript from Prosecutor v. Brđanin), T. 6182; Faik Biščević, P122 (Transcript from Prosecutor v. Krajišnik), T. 5535; P146 (Record of identification of Emir Seferović's body, 2 June 1992). See also Adjudicated Fact 1330. With respect to the two men who were beaten and subsequently killed, without more evidence as to their deaths, the Chamber cannot find that they died as a result of the beating they were subjected to. These killings are therefore not covered by the charges in the Indictment under paragraph 60(a)(ii). Further, the Chamber notes that there is no Schedule B killing incident charged with respect to this detention facility.

6776 P3327 (Order of Sanski Most Crisis Staff, 6 June 1992); Mirzet Karabeg, P3303 (Transcript from Prosecutor v. Brđanin), T. 6164, 6252-6253 (Karabeg estimated that 152 people were transferred from the Hasan Kikić school on 3 June 1992 to Manjača camp and 172 persons were transferred on 6 June 1992 from the SJB prison, the Betonirka Factory Garage, and the sports hall).

6777 Mirzet Karabeg, P3303 (Transcript from Prosecutor v. Brđanin), T. 6176-6177, 6256-6257, 6324. See also Adjudicated Fact 1332. 
1989. By 27 July 1992, the Crisis Staff estimated that some 1,245 people had been questioned in the SJB. ${ }^{6779}$

1990. On 28 August 1992, the detainees were called out of their cells and told to take their belongings. ${ }^{6780}$ Some of the detainees were placed on a bus for transfer to Manjača camp. ${ }^{6781}$ Other detainees were transferred to different detention facilities in Sanski Most, including the Betonirka Factory Garage, the Hasan Kikić School, and a military facility at Magarice. ${ }^{6782}$

\section{(iii) Conclusion}

1991. Based on the above, the Chamber finds that Serb Forces detained non-Serb civilians, including prominent political leaders and an underage boy, at the SJB prison from 25 May until August 1992. The Chamber finds that the detainees were held in poor conditions, including lack of adequate food, accommodation, medical care, and sanitary facilities. The Chamber also finds that detainees were subjected to interrogations and beatings.

\section{(b) Scheduled Detention Facility C.22.2}

1992. The Indictment refers to the use of the Betonirka Factory Garage as a detention facility at least between 27 May and 7 June 1992.

\section{(i) Establishment and control}

1993. The Betonirka Factory was located approximately 100 to 150 metres behind the SJB building in Sanski Most town. ${ }^{6783}$ The factory had a main building and three garages attached. ${ }^{6784}$ Each garage was five to six metres long and four metres wide. ${ }^{6785}$

\footnotetext{
6778 See Adjudicated Fact 1332.

6779 P3657 (Minutes of $9^{\text {th }}$ session of Sanski Most Executive Board, 27 July 1992), p. 3

6780 KDZ474, P3395 (Transcript from Prosecutor v. Brđanin), T. 7760 (under seal).

6781 Mirzet Karabeg, P3303 (Transcript from Prosecutor v. Brđanin), T. 6176, 6182, 6258; KDZ474, P3395 (Transcript from Prosecutor v. Brđanin), T. 7742-7747, 7760 (under seal); KDZ474, T. 19335 (21 September 2011) (closed session).

6782 See Adjudicated Fact 1331. See also paras. 1995, 2007.

6783 P718 (Witness statement of Ahmet Zulić dated 22 February 2010), paras. 49-50; P726 (Map of Sanski Most town); P3667 (Map of Sanski Most with photos of various buildings); D4335 (Map of Sanski Most with photographs); KW540, D4449 (Transcript from Prosecutor v. Stanišić \& Župljanin), T. 3397 (under seal).

6784 P718 (Witness statement of Ahmet Zulić dated 22 February 2010), para. 50; P726 (Map of Sanski Most town); P719 (Photograph of Betonirka Factory Garage); D4335 (Map of Sanski Most with photographs). See also D4336 (Photograph of Betonirka Factory Garage). The three garages together will be referred to in the singular as the Betonirka Factory Garage.

6785 P718 (Witness statement of Ahmet Zulić dated 22 February 2010), para. 55; P732 (Photograph of the interior of Betonirka Factory Garage). See also D4336 (Photograph of Betonirka Factory Garage); D4337 (Photograph of Betonirka Factory Garage); D4338 (Photograph of Betonirka Factory Garage); P719 (Photograph of Betonirka Factory Garage).
} 
1994. In May 1992, the Betonirka Factory Garage was set up as a detention centre by the Crisis Staff. ${ }^{6786}$ On 25 May 1992, Paprić, who was also in charge of the SJB prison, was appointed as the head of the detention facility but was later replaced by Vujanić, a member of the police. ${ }^{6787}$ Vujanić was the warden of both the SJB prison and Betonirka Factory Garage. ${ }^{6788}$ The guards at the Betonirka Factory Garage were members of the Bosnian Serb police and reserve soldiers. ${ }^{6789}$ Rade Martić was the chief of the guards. ${ }^{6790}$

1995. Approximately 120 detainees, all males, were held at the Betonirka Factory Garage. ${ }^{6791}$ Members of the core leadership of the SDA were detained at Betonirka. ${ }^{6792}$ Detainees were held at Betonirka Factory Garage up to one month. ${ }^{6793}$ In June and July 1992, the detainees were transferred to Manjača camp. ${ }^{6794}$

(ii) Conditions of detention and treatment of detainees

1996. The detainees were kept inside the cramped and over-heated garage with little water. ${ }^{6795}$ The detainees were given two meals per day, which usually were the left-over food from the staff. $^{6796}$ Sometimes family members were allowed to visit the detainees and bring them food. ${ }^{6797}$ The sanitary conditions were inadequate as the detainees were only allowed out of their cells for

6786 D470 (CSB Banja Luka Report concerning collection centres, undated), e-court p. 7; P3634 (Witness statement of KDZ490, undated), p. 113 (under seal); see Adjudicated Fact 2537. See also KW540, D4449 (Transcript from Prosecutor v. Stanišić \& Župljanin), T. 3399-3400 (under seal); KW545, D4328 (Transcript from Prosecutor v. Stanišić \& Župljanin) T. 26112 (under seal).

6787 KDZ490, T. 20184 (19 October 2011) (closed session); P3635 (Handwritten diary of Nenad Davidović), e-court p. 4; KW545, D4328 (Transcript from Prosecutor v. Stanišić \& Župljanin) T. 26112 (under seal); see Adjudicated Fact 1345.

6788 P718 (Witness statement of Ahmet Zulić dated 22 February 2010), para. 66; KW545, D4328 (Transcript from Prosecutor v. Stanišić \& Župljanin), T. 26115, 26323 (under seal); Mirzet Karabeg, P3303 (Transcript from Prosecutor v. Brđanin), T. 6254. See Adjudicated Fact 1344.

6789 See Adjudicated Fact 1344; KW540, D4449 (Transcript from Prosecutor v. Stanišić \& Župljanin), T. 3399-3400 (under seal); P718 (Witness statement of Ahmet Zulić dated 22 February 2010), para. 51.

6790 P2639 (Conclusions of Sanski Most Crisis Staff, 4 June 1992); P3634 (Witness statement of KDZ490, undated), p. 113 (under seal).

6791 See Adjudicated Fact 1333; KW545, D4328 (Transcript from Prosecutor v. Staniš̌ić \& Župljanin), T. 2612926130 (under seal).

6792 KW540, D4449 (Transcript from Prosecutor v. Stanišić \& Župljanin), T. 3403 (under seal).

6793 See Adjudicated Fact 1334.

6794 Mirzet Karabeg, P3303 (Transcript from Prosecutor v. Brđanin), T. 6164, 6175; P718 (Witness statement of Ahmet Zulić dated 22 February 2010), paras. 86-87. See also KW545, D4328 (Transcript from Prosecutor v. Stanišić \& Župljanin), T. 26130 (under seal). On 6 or 7 July 1992, all the remaining detainees at Betonirka were transferred to Manjača camp, except for Karabeg and six others, who were transferred back to the SJB prison. Mirzet Karabeg, P3303 (Transcript from Prosecutor v. Brđanin), T. 6175-6176.

6795 P718 (Witness statement of Ahmet Zulić dated 22 February 2010), paras. 54, 57-64, 68-71 (Zulić identified some of the men who were held in his cell, including a Bosnian Croat); P3634 (Witness statement of KDZ490, undated), p. 113 (under seal); KW545, D4328 (Transcript from Prosecutor v. Stanišić \& Župljanin), T. 2611926120 (under seal); Mirzet Karabeg, P3303 (Transcript from Prosecutor v. Brđanin), T. 6169-6171; P3320 (Photograph of building).

6796 Mirzet Karabeg, P3303 (Transcript from Prosecutor v. Brđanin), T. 6169-6170; see Adjudicated Fact 1337.

6797 KW545, D4328 (Transcript from Prosecutor v. Stanišić \& Župljanin), T. 26133 (under seal). 
five minutes in the morning and five minutes in the evening to use the toilet. ${ }^{6798}$ There were no toilets inside the garage. ${ }^{6799}$ There was only one small window in each garage that was open for ventilation, which was inadequate. ${ }^{6800}$ One of the garages was so overcrowded that the detainees were forced to sleep standing up. ${ }^{6801}$

1997. The detainees were interrogated and beaten regularly. ${ }^{6802}$ Ahmet Zulić testified that out of the 21 nights he spent at Betonirka, he was not subjected to beatings on only three of those nights. ${ }^{6803}$ The beatings caused serious injuries to the detainees. ${ }^{684}$ There were no medical facilities available onsite. ${ }^{6805}$

\section{(iii) $\underline{\text { Conclusion }}$}

1998. Based on the above, the Chamber finds that Serb Forces detained Bosnian Muslim and Bosnian Croat male civilians, including some political leaders, from Sanski Most in the Betonirka Factory Garage from May until June 1992. The Chamber finds that the detainees were held in poor conditions, including lack of adequate food and sanitary facilities. The Chamber also finds that the detainees were subjected to beatings.

(iv) $\underline{\text { Scheduled Incident B.17.1 }}$

1999. The Prosecution alleges that approximately 17 men were taken from the Betonirka Factory Garage to Kriva Cesta near the Partisan cemetery and killed on or about 22 June 1992.

2000. On 22 June 1992, Zulić was taken from the Betonirka Factory Garage, where he had been detained, and driven to Kriva Cesta. ${ }^{606}$ He was taken down to the stream, given a hoe, and ordered

6798 Mirzet Karabeg, P3303 (Transcript from Prosecutor v. Brđanin), T. 6170; see Adjudicated Fact 1338 . See also KW545, D4328 (Transcript from Prosecutor v. Stanišić \& Župljanin), T. 26119-26121 (under seal).

6799 Mirzet Karabeg, P3303 (Transcript from Prosecutor v. Brđanin), T. 6170; see Adjudicated Fact 1338.

6800 Mirzet Karabeg, P3303 (Transcript from Prosecutor v. Brđanin), T. 6170-6175; KW545, D4328 (Transcript from Prosecutor v. Stanišić \& Župljanin), T. 26239 (under seal); see Adjudicated Fact 1336; KW540, D4449 (Transcript from Prosecutor v. Stanišić \& Župljanin), T. 3397, 3399 (under seal).

6801 See Adjudicated Fact 1335.

6802 P718 (Witness statement of Ahmet Zulić dated 22 February 2010), paras. 60-64, 68-71; P3634 (Witness statement of KDZ490, undated), p. 113 (under seal); Mirzet Karabeg, T. 18698-18699 (13 September 2011); Mirzet Karabeg, P3303 (Transcript from Prosecutor v. Brđanin), T. 6171-6175; see Adjudicated Fact 1339. KW545 testified that except for two specific cases, he had no knowledge of regular beatings and that he never heard screams or saw injuries on detainees. KW545, T. $47003-47004$ (13 February 2014) (closed session). KW540 testified that he also found out after the war that detainees at Betonirka had been beaten. KW540, D4449 (Transcript from Prosecutor v. Stanišić \& Župljanin), T. 3401 (under seal).

6803 P718 (Witness statement of Ahmet Zulić dated 22 February 2010), para. 63.

6804 See Adjudicated Facts 1340, 1341.

6805 See Adjudicated Fact 1343.

6806 P718 (Witness statement of Ahmet Zulić dated 22 February 2010), paras. 75-76; P726 (Map of Sanski Most town). Kriva Cesta is an area near the Partisan cemetery; P730 (Sketch drawn by Ahmet Zulić). See also Adjudicated Facts 1346, 1347, 2541. 
to dig his own grave. ${ }^{6807}$ He saw 20 to 25 other men there doing the same thing. ${ }^{6808}$ The men were being watched by Bosnian Serb soldiers wearing JNA uniforms. ${ }^{689}$ Rašula was also present. ${ }^{6810}$ During the operation, the soldiers pointed their guns at the men. ${ }^{6811}$ When the men had finished digging the holes, they were killed; their throats were either slit or they were shot to death. ${ }^{6812}$ Zulić was spared by Rašula, who stated that he should be kept alive in order to tell them where weapons were being hidden in Pobriježje. ${ }^{6813}$ Zulić was taken back to the Betonirka Factory Garage. ${ }^{6814}$ In total, three men survived. ${ }^{6815}$

2001. The Chamber took judicial notice of the fact that 17 men were killed in relation to this incident. ${ }^{6816}$ The Chamber also received evidence that bodies of civilians were recovered in a mass grave in relation to this incident. ${ }^{6817}$

2002. The Chamber finds that approximately 17 men were taken by Serb Forces from the Betonirka Factory Garage to Kriva Cesta near the Partisan cemetery and killed on or about 22 June 1992.

P718 (Witness statement of Ahmet Zulić dated 22 February 2010), para. 77.

P718 (Witness statement of Ahmet Zulić dated 22 February 2010), paras. 77-78. Zulić identified three men by their surnames only: Cerić, Džafić, and Velić. He identified one man as the brother-in-law of Ikan Smailović. The others were Ibro Eminić, "Lolo or Smail" Pašić, and Muhamed Hakić. P718 (Witness statement of Ahmet Zulić dated 22 February 2010), paras. 77-78, 84.

6809 P718 (Witness statement of Ahmet Zulić dated 22 February 2010), para. 79.

6810 P718 (Witness statement of Ahmet Zulić dated 22 February 2010), para. 79; Ahmet Zulić, T. $1029-1030$ (13 April 2010), T. 1129 (14 April 2010). See also Adjudicated Fact 2542.

6811 See Adjudicated Fact 1349.

6812 P718 (Witness statement of Ahmet Zulić dated 22 February 2010), para. 80; Ahmet Zulić, T. 1130 (14 April 2010). See also Adjudicated Fact 1348.

6813 P718 (Witness statement of Ahmet Zulić dated 22 February 2010), paras. 81-83.

6814 P718 (Witness statement of Ahmet Zulić dated 22 February 2010), para. 81.

6815 P718 (Witness statement of Ahmet Zulić dated 22 February 2010), para. 84. The other survivors were Muhamed Halkić and another man whose surname was Cerić. P718 (Witness statement of Ahmet Zulić dated 22 February 2010), para. 84.

$6816 \quad$ Adjudicated Facts 1347, 1348.

6817 P5442 (Decision of Sanski Most Crisis Staff, 23 May 1992) (a decision of the Crisis Staff determining that persons killed at the Greda Muslim cemetery shall be buried in a common grave); P4896 (Bihać Cantonal Court record of Greda, Kruhari exhumation, 28 May 1997) (describing the location of the Greda I mass grave and that 36 bodies were recovered from it. No names are included in this report); P4897 (Bihać Cantonal Court record of autopsy and identification of victims exhumed from graves in Greda, Kruhari, 9 June 1997) (listing 36 bodies exhumed from the Greda I-Kruhari mass grave. Eight were unidentified males, seven were females, and 21 were males identified by name. Of the males identified by name, Ibro Eminić was also named by Zulić). See also P4853 (Updated Table 2 to the Report of Amor Mašović), p. 94 (listing three individuals in relation to this scheduled incident); P6690 (Addendum to Nicolas Sébire's report, 16 May 2003), e-court pp. 66-70 (listing that at least two bodies exhumed from the mass grave are victims of the scheduled incident, but recovering 36 bodies total. Of those 36 bodies, there were 29 males and 7 females.).
} 
(c) Scheduled Detention Facility C.22.3

2003. The Indictment refers to the use of the "Hasan Kikić School sports halls" as a detention facility at least between May and July 1992. The Prosecution submits that Hasan Kikić School and the sports hall are two separate detention facilities. ${ }^{6818}$ The Prosecution submits that while civilians were detained in both facilities, it proceeds on the basis that Scheduled Detention Facility C.22.3 relates only to the sports hall. ${ }^{6819}$ The Chamber will also proceed on the basis that the detention facility referred to in Schedule C.22.3 is the sports hall.

\section{(i) Establishment and control}

2004. The sports hall was located in the northeastern part of Sanski Most town. ${ }^{620}$ On 26 May 1992, the Crisis Staff converted the sports hall into a detention centre. ${ }^{6821}$ The sports hall was staffed by guards in police and camouflage uniforms, under the command of Martić. ${ }^{6822}$ Milorad Krunić was appointed as the head of the detention centre. ${ }^{6823}$

2005. On 27 May 1992, an announcement on the radio ordered all Bosnian Muslims in Sanski Most town to gather at the training grounds of a driving school. ${ }^{6824}$ Sakib Muhić went there. ${ }^{6825}$ He estimated that 1,800 people had gathered there, including women and children. ${ }^{626}$ There were armed soldiers outside the driving school, and they shouted, "we will slaughter you all" at the people gathered there. ${ }^{6827}$ After an hour, the soldiers ordered everyone to go to the Krkojevći

\footnotetext{
6818 Prosecution Final Brief, Appendix B, fn. 750. See P3667 (Map of Sanski Most with photos of various buildings).

6819 Prosecution Final Brief, Appendix B, fn. 750.

6820 P726 (Map of Sanski Most town); P3667 (Map of Sanski Most with photos of various buildings); D4335 (Map of Sanski Most with photographs). The sports hall was also referred to as the sports complex. The Chamber will use the term "sports hall" to refer to this alleged detention facility.

6821 D470 (CSB Banja Luka Report concerning collection centres, undated), e-court p. 7; P3315 (Order of Sanski Most TO Municipal Staff, 26 May 1992); D1813 (Report of Sanski Most Crisis Staff, 30 May 1992); P3634 (Witness statement of KDZ490, undated), p. 75 (under seal). See also D4345 (Photograph of Hasan Kikić building); KW545, D4328 (Transcript from Prosecutor v. Stanišić \& Župljanin), T. 26112 (under seal); Adjudicated Facts 2537, 2538.

6822 Sakib Muhić, P700 (Transcript from Prosecutor v. Brđanin), T. 8114; see Adjudicated Fact 1351.

6823 KDZ490, T. 20184 (19 October 2011) (closed session). See also P3635 (Handwritten diary of Nenad Davidović), e-court p. 4.

6824 Sakib Muhić, P700 (Transcript from Prosecutor v. Brđanin), T. 8106-8108; P701 (Witness statement of Sakib Muhić dated 11 April 2000), p. 4; P718 (Witness statement of Ahmet Zulić dated 22 February 2010), para. 32.

6825 P701 (Witness statement of Sakib Muhić dated 11 April 2000), p. 4; Sakib Muhić, P700 (Transcript from Prosecutor v. Brđanin), T. 8106-8107.

6826 P701 (Witness statement of Sakib Muhić dated 11 April 2000), p. 4; Sakib Muhić, P700 (Transcript from Prosecutor v. Brđanin), T. 8111. See P639 (List of persons captured in Sanski Most municipality), p. 2.

6827 P701 (Witness statement of Sakib Muhić dated 11 April 2000), p. 4; Sakib Muhić, P700 (Transcript from Prosecutor v. Brđanin), T. 8113. See P639 (List of persons captured in Sanski Most municipality), p. 2.
} 
football stadium. ${ }^{6828}$ Around dusk, approximately 80 soldiers arrived at the stadium and began ordering people onto buses, which took them to the sports hall—the men left around midnight after the women and children. ${ }^{6829}$

2006. The next day at the sports hall women and children were separated from the men and sent to neighbouring villages. ${ }^{6830}$ Approximately 900-1,000 men remained in the sports hall for approximately five days. ${ }^{6831}$ The detainees included 200 men brought in from Ključ. ${ }^{6832}$ People who were detained at the sports hall were also from Mahala, Muhići, and Otoka. ${ }^{633}$

2007. The sports hall was guarded by men in both military and police uniforms. ${ }^{6834}$ After approximately five days, Muhić and four other men were taken to the SJB and interrogated. ${ }^{6835}$ Afterwards, they were transported back to the sports hall. ${ }^{6836}$

(ii) Conditions of detention and treatment of detainees

2008. The conditions in the sports hall were extremely overcrowded and lacked basic sanitation. ${ }^{637}$ The temperature was very hot due to the summer heat wave, which made the conditions worse. ${ }^{638}$ Some detainees were not provided with food for a few days but family members were allowed to visit and bring some food. ${ }^{6839}$ There was no bedding available for

\footnotetext{
6828 Sakib Muhić, P700 (Transcript from Prosecutor v. Brđanin), T. 8110-8111; P701 (Witness statement of Sakib Muhić dated 11 April 2000), p. 5.

6829 Sakib Muhić, P700 (Transcript from Prosecutor v. Brđanin), T. 8113; P701 (Witness statement of Sakib Muhić dated 11 April 2000), p. 5.

6830 Sakib Muhić, P700 (Transcript from Prosecutor v. Brđanin), T. 8113; P701 (Witness statement of Sakib Muhić dated 11 April 2000), p. 5.

6831 P701 (Witness statement of Sakib Muhić dated 11 April 2000), p. 5; Sakib Muhić, P700 (Transcript from Prosecutor v. Brđanin), T. 8117; P3634 (Witness statement of KDZ490, undated) (under seal), p. 115.

6832 See Adjudicated Fact 1350.

6833 KW545, D4328 (Transcript from Prosecutor v. Stanišić \& Župljanin), T. 26135 (under seal). See para. 1945.

6834 Sakib Muhić, P700 (Transcript from Prosecutor v. Brđanin), T. 8114; P701 (Witness statement of Sakib Muhić dated 11 April 2000), p. 5.

6835 Sakib Muhić, P700 (Transcript from Prosecutor v. Brđanin), T. 8119-8120.

6836 Sakib Muhić, P700 (Transcript from Prosecutor v. Brđanin), T. 8121.

6837 P3634 (Witness statement of KDZ490, undated) (under seal), p. 114; KDZ490, T. 20280-20281 (20 October 2011) (closed session); see Adjudicated Fact 2544. KW545 testified that the conditions in the sports hall were "all right" and that there were enough bathrooms, running water, and an outdoor area for walking. KW545, D4328 (Transcript from Prosecutor v. Stanišić \& Župljanin), T. 26162 (under seal). In weighing the totality of the evidence, the Chamber is not satisfied that it can rely on KW545's evidence on this particular point.

6838 P3634 (Witness statement of KDZ490, undated), p. 114 (under seal).

6839 P701 (Witness statement of Sakib Muhić dated 11 April 2000), p. 5; Sakib Muhić, P700 (Transcript from Prosecutor v. Brđanin), T. 8119.
} 
sleeping and no medical attention for the sick. ${ }^{640}$ Some men were taken to the SJB, interrogated, and transported back to the sports hall. ${ }^{6841}$

2009. The detainees were beaten. ${ }^{6842}$ In particular, on 6 June 1992, detainees were beaten severely before being forced to board trucks. ${ }^{6843}$ Two trucks transported approximately 150 detainees to Manjača camp. ${ }^{6844}$

2010. On 8 June 1992, pursuant to an order from the Crisis Staff, detainees at the sports hall were screened and those who were "brought in accidentally from other areas, persons from mixed marriages, persons in poor health, and persons who have fought on the front with the JNA" were to be released. ${ }^{6845}$ Again on 18 June 1992, certain detainees were screened and released. ${ }^{646}$ By 1 August 1992, the remaining detainees had been transferred elsewhere. ${ }^{6847}$

\section{(iii) Conclusion}

2011. Based on the above, the Chamber finds that Serb Forces detained non-Serb civilians in the sports hall in Sanski Most from May until August 1992. The Chamber finds that some of the detainees were subjected to beatings. The Chamber further finds that the conditions of detention were poor, including a lack of adequate food and sanitary facilities.

\section{(d) Scheduled Detention Facility C.22.4}

2012. The Indictment refers to the use of Krings Hall as a detention facility at least between May and July 1992.

\footnotetext{
6840 P701 (Witness statement of Sakib Muhić dated 11 April 2000), p. 5.

6841 Sakib Muhić, P700 (Transcript from Prosecutor v. Brđanin), T. 8120.

6842 Sakib Muhić, P700 (Transcript from Prosecutor v. Brđanin), T. 8121-8122; P701 (Witness statement of Sakib Muhić dated 11 April 2000), pp. 5-6. See also Adjudicated Fact 1352; KW545, D4328 (Transcript from Prosecutor v. Stanišić \& Župljanin), T. 26268 (under seal).

6843 Adjudicated Fact 1353. See also Sakib Muhić, P700 (Transcript from Prosecutor v. Brđanin), T. 8122.

6844 Sakib Muhić, P700 (Transcript from Prosecutor v. Brđanin), T. 8122-8123; P701 (Witness statement of Sakib Muhić dated 11 April 2000), p. 6; Mirzet Karabeg, P3303 (Transcript from Prosecutor v. Brđanin), T. 6164. See also Adjudicated Facts 583, 1353.

6845 P5444 (Conclusions of Sanski Most Crisis Staff, 8 June 1992).

6846 D4108 (Order of Sanski Most Crisis Staff, 18 June 1992); D4329 (Order of Sanski Most Crisis Staff, 18 June 1992).

6847 D470 (CSB Banja Luka Report concerning collection centres, undated), e-court p. 14. This report notes that 1,655 people were brought to the "collection centres" (the sports hall, Krings Hall, and Betonirka Factory Garage). It also notes that 1,528 were Bosnian Muslims and 122 were Bosnian Croats. D470 (CSB Banja Luka Report concerning collection centres, undated), e-court p. 14.
} 
(i) Establishment and control

2013. Krings Hall is located on the eastern edge of Sanski Most town. ${ }^{6848}$ It was a large, empty hall situated next to an office building, that was formerly used to manufacture equipment for the Famos company. ${ }^{6849}$ In May 1992, Krings Hall was set up as a detention centre by the Crisis Staff. $^{6850}$ Initially, when detainees were brought to Krings Hall, they were guarded by soldiers and after one week, the soldiers were replaced by the police. ${ }^{6851}$

2014. In early July 1992, VRS soldiers drove into Tomina and ordered all of the "refugees" who were hiding in the town to come out of the houses. ${ }^{6852}$ People from Kamicak and Vrhpolje had fled to Tomina. ${ }^{653}$ People came out of their houses and saw buses lined up on the main street. ${ }^{6854}$ Approximately 500 to 600 individuals were boarded onto buses and taken to Krings Hall. ${ }^{6855}$ The women and children spend one night there and were transferred out the following day to eastern or central BiH. ${ }^{6856}$ The men stayed behind in Krings Hall. ${ }^{6857}$

\section{(ii) Conditions of detention and treatment of detainees}

2015. In the beginning, when the VRS soldiers were guarding the detainees, there were no beatings or mistreatment. ${ }^{6858}$ However, when the police took control of Krings Hall, things changed. ${ }^{659}$ The police regularly interrogated and beat the detainees, sometimes with batons and

\footnotetext{
6848 P3667 (Map of Sanski Most with photos of various buildings); D4335 (Map of Sanski Most with photographs).

6849 KDZ052, P3370 (Transcript from Prosecutor v. Brđanin), T. 8069; KW545, D4328 (Transcript from Prosecutor v. Stanišić \& Župljanin), T. 26235 (under seal); P3371 (Photograph of exterior of Krings Hall); P3372 (Photograph of interior Krings Hall); P3375 (Photograph of exterior of Krings Hall); KDZ052, T. 19078-19079, 19082 (19 September 2011); D4344 (Photograph of Krings); D4335 (Map of Sanski Most with photographs). D470 (CSB Banja Luka Report concerning collection centres, undated), e-court p. 7; P3667 (Map of Sanski Most with photos of various buildings); P3634 (Witness statement of KDZ490, undated), p. 115 (under seal). See also Adjudicated Fact 2537.

6851 KDZ052, P3370 (Transcript from Prosecutor v. Brđanin), T. 8069-8070; KDZ052, T. 19075-19076 (19 September 2011).

6852 KDZ052, P3370 (Transcript from Prosecutor v. Brđanin), T. 8068; KDZ097, P714 (Transcript from Prosecutor v. Brđanin), T. 7227 (under seal); Rajif Begić, P691 (Transcript from Prosecutor v. Krajišnik), T. 2997-2998, 3015-3019; P692 (Witness statement of Rajif Begić dated 15 March 2000), e-court pp. 6-7. See also Adjudicated Fact 2543; KW545, D4328 (Transcript from Prosecutor v. Stanišić \& Župljanin), T. 26135 (under seal).

6853 KDZ052, P3370 (Transcript from Prosecutor v. Brđanin), T. 8068.

6854 Rajif Begić, P691 (Transcript from Prosecutor v. Krajišnik), T. 2998.

6855 KDZ052, P3370 (Transcript from Prosecutor v. Brđanin), T. 8068-8069; Rajif Begić, P691 (Transcript from Prosecutor v. Krajišnik), T. 2998. See also Adjudicated Fact 2543.

6856 KDZ052, P3370 (Transcript from Prosecutor v. Brđanin), T. 8068-8069.

6857 Rajif Begić, P691 (Transcript from Prosecutor v. Krajišnik), T. 2998. See also P3657 (Minutes of $9^{\text {th }}$ session of Sanski Most Executive Board, 27 July 1992), p. 3.

6858 Rajif Begić, P691 (Transcript from Prosecutor v. Krajišnik), T. 2098-2099; KDZ052, P3370 (Transcript from Prosecutor v. Brđanin), T. 8070.

6859 KDZ052, P3370 (Transcript from Prosecutor v. Brđanin), T. 8070.
} 
rifles. ${ }^{6800}$ While KDZ052 was detained there, he witnessed one man who died as a result of a beating. $^{6861}$

2016. The detention facility had running water and a sink but no working toilets. ${ }^{682}$ The hygiene conditions were extremely poor. ${ }^{6863}$ There was inadequate bedding for the detainees. ${ }^{6864}$ In the beginning, relatives of the detainees were allowed to bring food to Krings Hall but later this was not allowed. $^{6865}$

2017. In August 1992, the detainees from Krings Hall were transferred to Manjača camp. ${ }^{6866}$

\section{(iii) $\underline{\text { Conclusion }}$}

2018. Based on the above, the Chamber finds that Serb Forces detained Bosnian Muslim and Bosnian Croat civilians, mainly males, from Sanski Most at Krings Hall from May to August 1992. The Chamber further finds that the detainees were held in poor conditions, including lack of sanitary facilities. The Chamber also finds that the detainees were subjected to beatings and that one person died as a result of the beatings.

\section{(e) Scheduled Detention Facility C.22.5}

2019. The Indictment refers to the use of the "Magarica military facility" as a detention facility at least between May and June 1992. In its Final Brief, the Prosecution alleges that the "evidence led shows Magarice military facility operated as a detention facility” in May $1992 .{ }^{6867}$

2020. Magarice is a village located on the outskirts of Sanski Most town. ${ }^{6868}$ The Magarice military facility consisted of a house and a barn in the village of Magarice that was used by Basara and the $6^{\text {th }}$ Krajina Brigade for operations and the storage of weapons. ${ }^{6869}$

\footnotetext{
6860 KDZ052, P3370 (Transcript from Prosecutor v. Brđanin), T. 8069-8070. See also Adjudicated Fact 2545.

6861 KDZ052, P3370 (Transcript from Prosecutor v. Brđanin), T. 8070-8071.

6862 KDZ052, P3370 (Transcript from Prosecutor v. Brđanin), T. 8069. See also P3372 (Photograph of interior Krings Hall); KDZ052, T. 19079 (19 September 2011).

6863 See Adjudicated Fact 2544.

6864 KDZ052, P3370 (Transcript from Prosecutor v. Brđanin), T. 8069.

6865 KDZ052, P3370 (Transcript from Prosecutor v. Brđanin), T. 8069.

6866 Faik Biščević, P122 (Transcript from Prosecutor v. Krajišnik), T. 5536, 5539; Mirzet Karabeg, P3303 (Transcript from Prosecutor v. Brđanin), T. 6183; Faik Biščević, P135 (Transcript from Prosecutor v. Brđanin), T. 7076-7079. Approximately 50 Bosnian Muslim and Bosnian Croat men who were also detained with Biščević at the SJB prison were transported to Manjača camp with him. Faik Biščević, P135 (Transcript from Prosecutor v. Brđanin), T. 7079-7080. Mirzet Karabeg, P3303 (Transcript from Prosecutor v. Brđanin), T. 6183. Karabeg was placed on a bus with men from the SJB prison and Krings Hall and they were transported to Manjača camp. Mirzet Karabeg, P3303 (Transcript from Prosecutor v. Brđanin), T. 6183.

6867 Prosecution Final Brief, Appendix B, fn. 761.

6868 Faik Biščević, P135 (Transcript from Prosecutor v. Brđanin), T. 7030.
} 
2021. On 27 May 1992, Biščević was arrested at his home and taken to Magarice village. ${ }^{670} \mathrm{He}$ saw Basara there, along with other VRS soldiers. ${ }^{6871}$ He was taken to an orchard where one of the soldiers cursed at him about his "balija God". ${ }^{672}$ Biščević was then taken to a meadow where he was handcuffed, searched, and his pockets were emptied. ${ }^{6873}$ The soldiers took his money and driving license. ${ }^{6874}$ They beat him severely with their truncheons and sticks. ${ }^{6875}$ He was then taken to the Sanski Most radio station. ${ }^{6876}$ After being forced to make a statement on the radio, Biščević was brought back to Magarice. ${ }^{677}$

2022. Biščević was detained in the "curing room, hut" in the Magarice military facility for 30 hours. ${ }^{6878}$ This was a wooden room with pebble stones on the floor and was two metres by two metres. ${ }^{679}$ There was no toilet in the room. ${ }^{680}$ He was alone on the first day but two other Bosnian Muslim men were brought in the following day. ${ }^{681}$ They were beaten and their personal effects were taken from them. ${ }^{6882}$ During the time Biščević was detained, he was not given any food or water. ${ }^{6883}$

2023. Biščević and the two other men were then taken to the soldiers' canteen, given food, and transferred to the SJB prison. ${ }^{684}$

\footnotetext{
6869 Faik Biščević, P135 (Transcript from Prosecutor v. Brđanin), T. 7030, 7043; Faik Biščević, P122 (Transcript from Prosecutor v. Krajišnik), T. 5527; KDZ474, P3395 (Transcript from Prosecutor v. Brđanin), T. 7749 (under seal).

6870 Faik Biščević, P135 (Transcript from Prosecutor v. Brđanin), T. 7029-7030. See also Adjudicated Fact 2546.

6871 Faik Biščević, P135 (Transcript from Prosecutor v. Brđanin), T. 7031.

6872 Faik Biščević, P135 (Transcript from Prosecutor v. Brđanin), T. 7031.

6873 Faik Biščević, P135 (Transcript from Prosecutor v. Brđanin), T. 7032-7033.

6874 Faik Biščević, P135 (Transcript from Prosecutor v. Brđanin), T. 7033.

6875 Faik Biščević, P135 (Transcript from Prosecutor v. Brđanin), T. 7033-7034. See also KDZ474, P3395 (Transcript from Prosecutor v. Brđanin), T. 7748-7750 (under seal).

6876 See para. 1949.

6877 Faik Biščević, P135 (Transcript from Prosecutor v. Brđanin), T. 7042; see para. 1949.

6878 Faik Biščević, P135 (Transcript from Prosecutor v. Brđanin), T. 7042; Faik Biščević, P122 (Transcript from Prosecutor v. Krajišnik), T. 5528; KDZ474, P3395 (Transcript from Prosecutor v. Brđanin), T. 7749 (under seal). See also Adjudicated Fact 2546.

6879 Faik Biščević, P135 (Transcript from Prosecutor v. Brđanin), T. 7042-7043; Faik Biščević, P122 (Transcript from Prosecutor v. Krajišnik), T. 5528.

6880 Faik Biščević, P122 (Transcript from Prosecutor v. Krajišnik), T. 5528.

6881 Faik Biščević, P135 (Transcript from Prosecutor v. Brđanin), T. 7042; KDZ474, P3395 (Transcript from Prosecutor v. Brđanin), T. 7749 (under seal).

6882 Faik Biščević, P135 (Transcript from Prosecutor v. Brđanin), T. 7042.

6883 Faik Biščević, P122 (Transcript from Prosecutor v. Krajišnik), T. 5528. See also Adjudicated Fact 2546.

6884 Faik Biščević, P135 (Transcript from Prosecutor v. Brđanin), T. 7044; Faik Biščević, P122 (Transcript from Prosecutor v. Krajišnik), T. 5528. See also Mirzet Karabeg, P3303 (Transcript from Prosecutor v. Brđanin), T. 6158-6159.
} 
2024. Based on the above, the Chamber finds that Biščević and two other Bosnian Muslim men were detained in a room at the Magarice military facility on or about 27 May 1992. The Chamber also finds that during their detention, these men were beaten and mistreated by Serb Forces.

\section{(6) Scheduled Incident D.19}

2025. The Indictment refers to the destruction of 17 mosques and one Catholic church in Sanski Most between at least between May and December 1992. ${ }^{685}$

2026. The Chamber took judicial notice of the fact that the mosques in Sanski Most were subjected to major damage by Bosnian Serb forces. ${ }^{686}$ The Chamber also took judicial notice of the fact that in mid-1992, the SDS ordered the destruction of the Donji Kamengrad mosque and that Mladen Majkić, a military engineer, was ordered by a member of the SDS to set explosives in the mosque. ${ }^{6887}$

2027. Biščević testified that there were 26 mosques and four Catholic churches in Sanski Most municipality, and that all of them were destroyed. ${ }^{6888}$ KDZ490 testified that by the end of 1992, all of the mosques in Sanski Most had been destroyed. ${ }^{689}$ According to KDZ490, the mosques were destroyed pursuant to orders from the Crisis Staff and were destroyed so that Bosnian Muslims would not return. ${ }^{6890}$

2028. By the end of May 1992, the Trnova mosque and the Hrustovo-Kukavice mosque had been destroyed. ${ }^{6891}$ In 1992, the mosque in Vrhpolje and the mosque in Stari Majdan were destroyed. ${ }^{6892}$

\footnotetext{
6885 The religious sites identified in Scheduled Incident D.19 are the (1) Sanski Most town mosque, (2) Probiježje mosque, (3) Hrustovo-Kukavice mosque, (4) Hrustovo-Kerani mosque, (5) Vrhpolje mosque, (6) Šehovci mosque, (7) Trnova mosque, (8) Stari Majdan (Palanka) mosque, (9) Stari Majdan (Utriška) mosque, (10) Novo Naselje (Dževar) mosque, (11) Husimovci mosque, (12) Donji Kamengrad mosque, (13) Skucani Vakuf mosque, (14) Lukavice mosque, (15) Tomina mosque, (16) Čaplje mosque, and the Town Catholic church. The Indictment refers to the Hrustovo-Kukavice mosque as being two different mosques (the old and new mosque) situated next to each other. Indictment, Schedule D.19, fns. 17-19.

6886 See Adjudicated Fact 1358.

6887 Adjudicated Fact 2548.

6888 Faik Biščević, P122 (Transcript from Prosecutor v. Krajišnik), T. 5541. He further testified that none of the Serb religious institutions were destroyed. Faik Biščević, P122 (Transcript from Prosecutor v. Krajišnik), T. 5541.

6889 P3634 (Witness statement of KDZ490, undated), p. 120 (under seal).

6890 P3634 (Witness statement of KDZ490, undated), pp. 120-121, 123-124 (under seal).

6891 Faik Biščević, P122 (Transcript from Prosecutor v. Krajišnik), T. 5541, 5543; KDZ490, T. 20180 (19 October 2011) (closed session); KDZ097, P714 (Transcript from Prosecutor v. Brđanin), T. 7225 (under seal); P715 (Witness statement of KDZ097 dated 21 April 2001), e-court p. 7 (under seal). See also P4070 (Attachment to the expert report of András J. Riedlmayer, entitled "Destruction of Cultural Heritage in BiH" prepared for the Karadžić case, formatted records), e-court pp. 276-280, 289-290 (identifying damage to the old and new Hrustovo-Kukavice mosques and the Trnova mosque); P4069 (Cultural destruction database), records 278-279, 300; P716 (Witness statement of KDZ097 dated 21 April 2001), e-court p. 15. The old Hrustovo-Kukavice mosque was also referred to as the Hrustovo mosque. P715 (Witness statement of KDZ097 dated 21 April 2001), e-court p. 4 (under seal).
} 
The Pobriježje mosque was destroyed in mid-1992. ${ }^{6893}$

The town mosque in Sanski Most was destroyed by October 1992. ${ }^{689}$ The Šehovci mosque was blown up with explosives. ${ }^{695}$ The mosques in Donji Kamengrad, Čaplje, Hrustovo, Lukavice, Šehovci, Stari Majdan, and Tomina were destroyed. ${ }^{6896}$ The Catholic church in Sanski Most was also damaged. ${ }^{6897}$

2029. According to Riedlmayer's reports, a total of 17 mosques and the town Catholic church in Sanski Most were damaged or destroyed during the war. ${ }^{688}$ However, the Chamber notes that included in these 17 mosques is the Vrhpolje mosque, which Riedlmayer describes as only "lightly damaged" and as one of three mosques in Sanski Most that survived the war without structural damage. ${ }^{6899}$ The Chamber therefore finds that 16 mosques and the town Catholic church were heavily damaged, almost destroyed, or completely destroyed.

6892 KDZ490, T. 20180 (19 October 2011) (closed session); P3634 (Witness statement of KDZ490, undated), p. 123 (under seal). There were two mosques in Hrustovo, one in Kukavice and the other in Karavići. The mosque in Kukavice was the largest mosque and known as the Hrustovo mosque. P715 (Witness statement of KDZ097 dated 21 April 2001), e-court p. 4 (under seal); KDZ097, P714 (Transcript from Prosecutor v. Brđanin), T. 7206-7207 (under seal); P616 (Map of Hrustovo-Vrhpolje marked by KDZ097). See also P4070 (Attachment to the expert report of András J. Riedlmayer, entitled "Destruction of Cultural Heritage in BiH" prepared for the Karadžić case, formatted records), e-court pp. 283-285, 291-294; P4069 (Cultural destruction database), records 297-298, 301.

6893 P3634 (Witness statement of KDZ490, undated), p. 121 (under seal); P3670 (Report on the work of Sanski Most Municipal Civilian Protection Staff, 15 July-15 October 1992), p. 3. See also P4070 (Attachment to the expert report of András J. Riedlmayer, entitled "Destruction of Cultural Heritage in BiH" prepared for the Karadžić case, formatted records), e-court pp. 273-275; P4069 (Cultural destruction database), record 289.

6894 P3670 (Report on the work of Sanski Most Municipal Civilian Protection Staff, 15 July-15 October 1992); P3634 (Witness statement of KDZ490, undated), p. 121 (under seal). See also P4070 (Attachment to the expert report of András J. Riedlmayer, entitled "Destruction of Cultural Heritage in BiH" prepared for the Karadžić case, formatted records), e-court pp. 269-272; P4069 (Cultural destruction database), record 290.

6895 P3634 (Witness statement of KDZ490, undated), p. 122 (under seal). See also P4070 (Attachment to the expert report of András J. Riedlmayer, entitled "Destruction of Cultural Heritage in BiH" prepared for the Karadžić case, formatted records), e-court pp. 286-288; P4069 (Cultural destruction database), record 294.

6896 P3634 (Witness statement of KDZ490, undated), pp. 122-123 (under seal); P692 (Statements to Sanski Most Court, 18 April 1996), e-court p. 12; KDZ490, T. 20180 (19 October 2011) (closed session). See also P4070 (Attachment to the expert report of András J. Riedlmayer, entitled "Destruction of Cultural Heritage in BiH" prepared for the Karadžić case, formatted records), e-court pp. 286-288, 291-294, 303-304, 305-307, 308-309; P4069 (Cultural destruction database), records 270, 273, 284, 294, 297-299; see Adjudicated Fact 1358.

6897 P3634 (Witness statement of KDZ490, undated) (under seal), p. 123.

6898 Riedlmayer identifies the level of damage with respect to each of the mosques listed by name in the Indictment: Town mosque (completely destroyed), Pobriježje mosque (completely destroyed), Hrustovo-Kukavice new mosque (completely destroyed), Hrustovo-Kukavice old mosque (heavily damaged), Hrustovo-Kerani mosque (heavily damaged), Vrhpolje mosque (lightly damaged), Šehovci mosque (heavily damaged), Trnova mosque (heavily damaged), Stari Majdan (Palanka) mosque (completely destroyed), Dževar mosque (heavily damaged), Husimovci mosque (heavily damaged), Donji Kamengrad new mosque (almost destroyed), Skucani Vakuf mosque (heavily damaged), Lukavice mosque (heavily damaged), Tomina mosque (almost destroyed), Čaplje mosque (heavily damaged), the town Catholic church (completely destroyed). P4070 (Attachment to the expert report of András J. Riedlmayer, entitled "Destruction of Cultural Heritage in BiH" prepared for the Karadžić case, formatted records), e-court pp. 269-311. See also P4069 (Cultural destruction database), records 270, 273, 275, 278-281, 284, 287, 289, 290, 292, 294-295, 297-301; P4068 (András Riedlmayer's expert report on Destruction of Cultural Heritage in Bosnia and Herzegovina during 1992-1995, 7 May 2009), paras. 40-46; P4071 (Slide images of damaged religious sites in BiH), e-court pp. 4, 16-17.

6899 P4070 (Attachment to the expert report of András J. Riedlmayer, entitled "Destruction of Cultural Heritage in $\mathrm{BiH}$ " prepared for the Karadžić case, formatted records), e-court pp. 283-285. 
2030. The Chamber has considered the evidence it has received which identified Serb Forces as responsible for the destruction of mosques in Sanski Most. ${ }^{690}$ It also had regard to the fact that almost all mosques in the municipality sustained heavy damage or were completely destroyed after Serb Forces took over the municipality. Having weighed these factors, the Chamber is satisfied beyond reasonable doubt that Serb Forces were responsible for the attacks on and destruction of mosques and the Catholic church in Sanski Most.

2031. Therefore, the Chamber finds that at least 16 mosques and the town Catholic church were heavily damaged, almost destroyed or completely destroyed by Serb Forces between May and December 1992.

property

(7) Movement of the population from Sanski Most and appropriation of

2032. Following the attack on Sanski Most on 25 May 1992, the non-Serb population was expelled from the municipality. ${ }^{6901}$

2033. On 2 July 1992, the Crisis Staff adopted a decision on the criteria for voluntary departure from Sanski Most. ${ }^{6902}$ It ordered that those citizens who wish to permanently leave Sanski Most must hand over their real property to the Sanski Most municipal authorities. ${ }^{6903}$ People were allowed to take their movable property on the condition that they made a list of all of the property to be verified by an "authorised municipal administration organ". ${ }^{694}$ People who wished to stay were required to sign a loyalty oath and those who refused were threatened and often left under duress. $^{6905}$

2034. On 23 June 1992, the Crisis Staff formed a committee to deal with the "migration" of the population. ${ }^{6906}$ Vrkeš was appointed as the person responsible for matters relating to the removal

\footnotetext{
$6900 \quad$ See paras. 2026-2028.

6901 P3634 (Witness statement of KDZ490, undated), pp. 80-81 (under seal). See paras. 1945-1946.

6902 P3307 (Decision of Sanski Most Crisis Staff, 2 July 1992); Mirzet Karabeg, T. 18703-18706 (13 September 2011). See also Adjudicated Facts 2550, 2556.

6903 P3307 (Decision of Sanski Most Crisis Staff, 2 July 1992). See also Mirzet Karabeg, T. 18701 (13 September 2011). See also Adjudicated Fact 2556.

6904 P3307 (Decision of Sanski Most Crisis Staff, 2 July 1992), p. 1.

6905 Mirzet Karabeg, T. 18701, 18706-18707 (13 September 2011); P3330 (Conclusions of session of Banja Luka CSB Enlarged Centre Council, 6 April 1992), para. 3; see Adjudicated Fact 2552.

6906 P3636 (Order of Sanski Most Crisis Staff, 23 June 1992); P3634 (Witness statement of KDZ490, undated) (under seal), p. 85. See also Adjudicated Fact 2555.
} 
and exchange of the population and prisoners and was to report to Vojo Kuprešanin of the ARK Crisis Staff. ${ }^{6907}$

2035. By 27 July 1992, the Crisis Staff estimated that approximately 18,000 Bosnian Muslims and Bosnian Croats remained in Sanski Most and that approximately 6,000 to 7,000 had moved away. ${ }^{6908}$ It stated that Bosnian Muslims were requesting to move and noted that it should be made possible for them to do so by organising their voluntary resettlement. ${ }^{6909}$

2036. On 1 August 1992, the SJB reported that 12,000 individuals, mainly Bosnian Muslims but also some Bosnian Croats, had applied to the SJB to unregister their permanent residences in order to leave the municipality. ${ }^{6910}$

2037. On 14 August 1992, the Sanski Most Municipal Assembly granted permission to transfer the ownership of movable and immovable property based on exchange contracts and gift contracts. ${ }^{6911}$ It also noted that the first group of 3,000 people would be "resettled" from the municipality and transported by bus. ${ }^{6912}$ It was decided that while Bosnian Muslims were voluntarily going into exile, their property would be taken over for "safe keeping and use". ${ }^{6913}$

2038. On 19 August 1992, Vrkeš and representatives of the Sanki Most Bosnian Muslims and Croats met with UNHCR and Civil Affairs to discuss, inter alia, whether the UN would assist in evacuating up to 11,000 Bosnian Muslim "applicants" for evacuation. ${ }^{6914}$ Vrkeš explained that all those who wished to leave, should be able to do so. ${ }^{6915}$ In addition, Vrkeš stated that those who

6907 See Adjudicated Fact 2555. KDZ490 stated that the ARK Crisis Staff had great influence over the municipalities and that the Sanski Most Crisis Staff implemented decisions from the ARK Crisis Staff. P3634 (Witness statement of KDZ490, undated), pp. 11, 86-87 (under seal). See also P3804 (Witness statement of Charles Kirudja dated 17 November 2010), para. 111.

6908 P3657 (Minutes of $9^{\text {th }}$ session of Sanski Most Executive Board, 27 July 1992), p. 4. See also P3851 (Conclusion of the Executive Board of Sanski Most Municipal Assembly, 30 July 1992).

6909 P3657 (Minutes of $9^{\text {th }}$ session of Sanski Most Executive Board, 27 July 1992), pp. 3-4. See also P3851 (Conclusion of the Executive Board, of Sanski Most's Municipal Assembly, 30 July 1992). Boro Tadić testified that Bosnian Muslims voluntarily wanted to leave Sanski Most and that Vrkeš and others were trying to make it possible for the Bosnian Muslims to leave safely. Boro Tadić, T. 44424-44425 (4 December 2013). The Chamber does not accept Tadić's evidence. The Chamber found that Tadić's testimony was ambiguous, misleading, and often resorted to tu quoque. The Chamber finds that Tadić's reliability was compromised to such an extent that the Chamber could not accept his evidence.

6910 D470 (CSB Banja Luka Report concerning collection centres, undated), e-court p. 15. See also Adjudicated Fact 2557. By 11 August 1992, it was reported that 28,000 people, mainly Bosnian Muslims from Bosanski Novi, Sanski Most, Bosanska Kostajnica, and Bosanski Petrovac, were being forced to move from their homes. P2941 (Article from The Associated Press, 11 August 1992) (under seal).

6911 P3659 (Minutes of $11^{\text {th }}$ session of Sanski Most Executive Board, 14 August 1992), p. 12.

6912 P3659 (Minutes of $11^{\text {th }}$ session of Sanski Most Executive Board, 14 August 1992), p. 9; P3634 (Witness statement of KDZ490, undated), pp. 89-90 (under seal).

6913 P3659 (Minutes of $11^{\text {th }}$ session of Sanski Most Executive Board, 14 August 1992), p. 14.

6914 P3804 (Witness statement of Charles Kirudja dated 17 November 2010), paras. 111-112.

6915 P3804 (Witness statement of Charles Kirudja dated 17 November 2010), para. 114 
were leaving would sign a declaration stating they were leaving voluntarily, they had no wish to return, and they were leaving their properties to the authorities. ${ }^{6916}$ The UNHCR representative responded that UNHCR would not assist with the removal of people. ${ }^{6917}$

2039. The Chamber finds that Bosnian Muslims and Bosnian Croats were forced to leave Sanski Most following immense pressure put on them, given the surrounding circumstances in the municipality, including, inter alia, (i) armed attacks against their villages and homes; (ii) destruction of religious and cultural property; (iii) forcible arrest and removal from their homes; (iv) detention in multiple detention facilities; as well as (v) mistreatment and killings.

2040. By February 1995, the population of Sanski Most municipality was approximately 3,350 Bosnian Muslims, 1,050 Bosnian Croats, and 33,600 Bosnian Serbs. ${ }^{6918}$

\section{ii. Regional level}

2041. As stated earlier, the Serb-majority community of municipalities called the ZOBK was transformed into the ARK on 16 September $1991 .^{6919}$ This community of municipalities included the following municipalities relevant to the Indictment: Banja Luka, Bosanski Novi, Ključ, Prijedor, and Sanski Most (“ARK Municipalities”). ${ }^{6920}$ The ARK was vested with both executive and legislative powers within its area of jurisdiction and acted as an intermediate level of authority between the SerBiH and the municipalities. ${ }^{6921}$

2042. According to the ARK Statute, the ARK was a voluntary association. ${ }^{622}$ The statute provided that other municipalities could join the ARK. ${ }^{623}$ In this context, in the municipalities where the Bosnian Serbs were a majority, the respective decision to join the ARK was in fact taken only by the Bosnian Serb municipal delegates of these municipalities, with the SDA and the HDZ delegates either opposed to this idea or unaware that such a decision was being taken. ${ }^{6924}$ In the municipalities where the Bosnian Serbs were in a minority, the decision by the respective municipalities to join the ARK was taken either only by the Bosnian Serb delegates in the

\footnotetext{
6916 P3804 (Witness statement of Charles Kirudja dated 17 November 2010), para. 114.

6917 P3804 (Witness statement of Charles Kirudja dated 17 November 2010), para. 115.

6918 P5449 (Report of the MUP, Banja Luka RDB, February 1995), p. 8. In terms of percentages, in 1995, the population was $8 \%$ Bosnian Muslim, 2\% Bosnian Croat, and 88\% Bosnian Serb. P5449 (Report of the MUP, Banja Luka RDB, February 1995), p. 8. See paras. 42, 75. On 16 September 1991, the ZOBK Assembly transformed the ZOBK into the ARK. P2536 (Patrick Treanor's expert report entitled “The Bosnian Serb Leadership 1990-1992”, 30 July 2002), para. 136.

6920 P4258 (Map of ARK). See Indictment, para. 48.

6921 See Adjudicated Fact 520.

6922 D4014 (Statute of the ARK, September 1991), Articles 1, 10, 11. See Adjudicated Fact 521.

6923 D4014 (Statute of the ARK, September 1991), Articles 10, 11.

6924 See Adjudicated Fact 521.
} 
municipality or by the assemblies of the newly established Bosnian Serb municipalities. ${ }^{6925}$ Despite provisions of the ARK Statute which established the ARK as a multi-ethnic institution, ${ }^{6926}$ the ARK was in practice a Serb body. ${ }^{6927}$ Out of the 189 delegates to the ARK Assembly, only a negligible number were Bosnian Croats or Bosnian Muslims. ${ }^{6928}$

2043. The ARK Assembly had the power to enact decisions in accordance with the constitution and the law. ${ }^{6929}$ Upon the creation of the ARK, Vojo Kuprešanin was elected President of the ARK Assembly, and Radoslav Brđanin became First Vice President. ${ }^{630}$

2044. On 4 March 1992, during its $15^{\text {th }}$ Session, the ARK Assembly adopted a decision to form the CSB of the ARK; its seat was in Banja Luka and Stojan Župljanin was appointed as Chief of the CSB. ${ }^{6931}$ Furthermore, on 27 April 1992, the ARK Assembly established a "special purpose police detachment" within the Banja Luka CSB. ${ }^{6932}$

6925 See Adjudicated Fact 521. For example, in Ključ, when the decision to join the ARK was confirmed by the SDS delegates of the Ključ Municipal Assembly on 26 December 1991, the SDA representatives at the Municipal Assembly walked out and did not vote on the issue. In Prijedor, the Prijedor Serb Assembly unanimously voted to join the ARK on 17 January 1992. In Sanski Most, Rašula issued a decision on behalf of the "Serbian People's Assembly" that Sanski Most would become part of the ARK on 3 April 1992; the decision was only made by the Sanski Most SDS deputies. See paras. 1496, 1579, 1932-1933.

6926 D4014 (Statute of the ARK, September 1991), Article 4 (stating: "In performing tasks within the jurisdiction of the $[\mathrm{ARK}]$, all peoples and nationalities of the [ARK] shall have equal rights and duties [...]"; Article 5, stating: "The official language of the [ARK] organs shall be Serbo-Croatian and Croato-Serbian, using the Cyrillic or Latin alphabets.”).

6927 See Adjudicated Fact 522.

6928 See Adjudicated Fact 522.

6929 D4014 (Statute of the ARK, September 1991), Article 18; P2536 (Patrick Treanor's expert report entitled "The Bosnian Serb Leadership 1990-1992”, 30 July 2002), para. 142.

6930 D4011 (Witness statement of Vojislav Kuprešanin dated 11 November 2013), para. 1; D4034 (Witness statement of Radoslav Brđanin dated 8 November 2013), para. 1. See also Adjudicated Fact 523; P2536 (Patrick Treanor's expert report entitled “The Bosnian Serb Leadership 1990-1992”, 30 July 2002), paras. 142143; D4014 (Statute of the ARK, September 1991), Articles 18, 28, 31. In October 1991, Brđanin also became a member of the Bosnian Serb Assembly. See Adjudicated Fact 523. Anđelko Grahovac was appointed as President of the ZOBK in May 1991 and subsequently was the Prime Minister of the ARK until January 1992, when he was dismissed from the post because of his desire to establish strong links with the "Knin Krajina". D4077 (Witness statement of Anđelko Grahovac dated 23 November 2013), paras. 14, 35; Anđelko Grahovac, T. 44035-44036 (26 November 2013).

6931 D4075 (Excerpt of Minutes of $15^{\text {th }}$ session of ARK Assembly, 4 March 1992); D4071 (Summary of $15^{\text {th }}$ session of ARK Assembly, 4 March 1992); D4023 (Decision of ARK Assembly, 4 March 1992) (wherein the ARK Assembly also established funds for the ARK). See also Adjudicated Facts 530, 531. See para. 218.

6932 P5454 (Decision of ARK Assembly, 27 April 1992). See D4086 (Witness statement of Nikola Erceg dated 24 November 2013), para. 59; D4300 (Witness statement of KW426 dated 31 January 2014), para. 8; D4138 (Witness statement of Željko Mejakić dated 26 November 2013), para. 15; Željko Mejakić, T. 44218-44220 (29 November 2013); D4075 (Excerpt of Minutes of $15^{\text {th }}$ session of ARK Assembly, 4 March 1992); D4306 (Report of Banja Luka CSB, 5 August 1992), p. 1. See also Adjudicated Fact 530. The unit consisted of 140150 men and while it was formed as a police unit, it had three army platoons and one police platoon. Members of this unit provided security at Omarska but after ten days, Župljanin withdrew the unit from Omarska after he was informed of "terrible problems" they were causing there. The unit was disbanded in July 1992 pursuant to an order from Mićo Stanišić. D4300 (Witness statement of KW426 dated 31 January 2014), paras. 9-11; Željko Mejakić, T. 44218-44220 (29 November 2013); D4139 (Report of Prijedor SJB, 13 June 1992); D4273 (Order of RS MUP, 27 July 1992); D4306 (Report of Banja Luka CSB, 5 August 1992), p. 2; P3761 (Payroll of Banja 


\section{(A) Establishment of ARK Crisis Staff}

2045. The ARK Crisis Staff was formally established on 5 May 1992 by a decision of the ARK Executive Council; ${ }^{6933}$ however, it had been functioning since January 1992. ${ }^{6934}$ Brđanin was appointed as President of the newly created ARK Crisis Staff, which was later renamed the ARK War Presidency on 9 July 1992. ${ }^{6935}$ The Accused supported Brđanin to lead the ARK. ${ }^{6936}$ Brđanin retained this position until the abolition of the ARK on 15 September $1992 .{ }^{6937}$ The ARK War Presidency continued to meet at least until 8 September 1992, one week prior to the adoption of the SerBiH constitutional amendment that abolished the ARK as a territorial unit of SerBiH. ${ }^{6938}$

2046. Other members of the ARK Crisis Staff included Milorad Sajić, Secretary of the Regional Secretariat for National Defence, who was appointed Vice President of the ARK Crisis Staff; Vojo Kuprešanin, Deputy of the Bosnian Serb Assembly and President of the ARK Assembly; Milovan Milanović, Deputy of the Bosnian Serb Assembly; Nikola Erceg, President of the ARK Executive Council; Predrag Radić, President of the Banja Luka Municipal Assembly and Banja Luka Crisis Staff; Radislav Vukić; Talić; Župljanin; and Nenad Stevandić, head of the SOS. ${ }^{6939}$

2047. The ARK Crisis Staff acted as an intermediary regional body between the republican-level authorities and the ARK Municipalities by co-ordinating the implementation of instructions sent by the republic-level authorities in the ARK Municipalities. ${ }^{640}$ Municipal Crisis Staff presidents in

Luka's CSB Special Police Detachment, August 1992). See KW426, T. 46715-46718, 46732-46737 (6 February 2014).

6933 P6 (Decision on the formation of ARK Crisis Staff, 5 May 1992).

6934 P2553 (Intercept of conversation between Radovan Karadžić and Jovan Čizmović, 22 January 1992), p. 7. The Chamber recalls that Čizmović was appointed as the co-ordinator of activities of the executive bodies of the SAOs. See para. 130. See also Patrick Treanor, T. 14033-14035 (1 June 2011); Adjudicated Fact 524. But see D4011 (Witness statement of Vojislav Kuprešanin dated 11 November 2013), para. 53; D4034 (Witness statement of Radoslav Brđanin dated 8 November 2013), para. 37; D4114 (Witness statement of Milorad Sajić dated 24 November 2013), para. 63 (all stating that they had no knowledge of the ARK Crisis Staff being formed in January 1992).

6935 P6 (Decision on the formation of ARK Crisis Staff, 5 May 1992); D4034 (Witness statement of Radoslav Brđanin dated 8 November 2013), paras. 1, 12. See Adjudicated Fact 526.

6936 P2596 (Intercept of conversation between Radovan Karadžić and "Miroslav", 7 January 1992), pp. 3-6. See Milorad Dodik, T. 36885-36886 (9 April 2013).

6937 Adjudicated Fact 526.

6938 See Adjudicated Fact 529; P2536 (Patrick Treanor's expert report entitled “The Bosnian Serb Leadership 19901992", 30 July 2002), paras. 158-161.

6939 P6 (Decision on the formation of ARK Crisis Staff, 5 May 1992); D4011 (Witness statement of Vojislav Kuprešanin dated 11 November 2013), para. 1; Predrag Radić, P1 (Transcript from Prosecutor v. Krajišnik), T. 7364, 7378-7379, 7387-7388; D4114 (Witness statement of Milorad Sajić dated 24 November 2013), paras. 2, 33; D4086 (Witness statement of Nikola Erceg dated 24 November 2013), para. 2. See Adjudicated Facts 527, 528, 531. See also paras. 75, 179.

6940 Predrag Radić, P1 (Transcript from Prosecutor v. Krajišnik), T. 7401-7404, 7409-7410, 7419-7421 (testifying further that not all of the instructions communicated to the municipal Crisis Staffs by the ARK Crisis Staff emanated from the republican authorities; there were maybe one or two instructions which arrived from the "very top" in Pale); Branko Đerić, T. 28057-28058 (25 April 2012). See P2824 (RS Communication Centre 
the ARK regularly gave reports to the ARK Crisis Staff on events within their area of responsibility ${ }^{6941}$ and took actions in response to directives from the ARK Crisis Staff. ${ }^{6942}$ In some municipalities, for example in Prijedor, Srdić reported directly to Pale. ${ }^{6943}$ When authorities in the ARK Municipalities disobeyed instructions from Pale, some were replaced immediately, while others were subjected to disciplinary procedures, or "ironed", and would subsequently change their views. ${ }^{6944}$

2048. Decisions and conclusions of the ARK Crisis Staff were binding on the ARK Municipalities and were abided and implemented by the municipal Crisis Staffs. ${ }^{6945}$ Whenever the ARK Crisis

telegram logbook, June and July 1992), p. 4 (referring to a 5 June 1992 order from the Bosnian Serb Government which was implemented by the ARK Assembly on 6 June 1992); P6532 (Public announcement of ARK Assembly, 6 June 1992). See also P3645 (Conclusions of the Sanski Most Crisis Staff, 7 May 1992), p. 2. However, according to Kuprešanin, Erceg, and Sajić, the ARK operated independently from Pale as a "state within a state". D4011 (Witness statement of Vojislav Kuprešanin dated 11 November 2013), paras. 37-38; D4086 (Witness statement of Nikola Erceg dated 24 November 2013), para. 71; D4114 (Witness statement of Milorad Sajić dated 24 November 2013), paras. 51-53. Furthermore, according to Brđanin, the ARK Crisis Staff was not supported by the central republican authorities in Pale, primarily due to a rift between the ARK leadership and the RS leadership over what city should be the capital of the RS, Banja Luka or Pale; in addition, according to Brđanin, Kuprešanin, Erceg, and Sajić, until a corridor was opened on 28 June 1992, there was limited communication with the central authorities in Pale and Brđanin did not receive instructions from Pale or the Accused while the ARK Crisis Staff existed. D4034 (Witness statement of Radoslav Brđanin dated 8 November 2013), paras. 6-7, 9; Vojislav Kuprešanin, T. 43553-43554 (14 November 2013); D4086 (Witness statement of Nikola Erceg dated 24 November 2013), paras. 22-23, 29, 32, 34, 36, 42, 45-46, 57; D4114 (Witness statement of Milorad Sajić dated 24 November 2013), paras. 12, 47-52. See D4088 (Letter from President of ARK Executive Board, 18 June 1992). See also D4195 (Witness statement of Milomir Stakić dated 16 November 2013), para. 14. The Chamber considers that while there may have been limited communication at times between the authorities in Pale and the ARK authorities, the Chamber finds that instructions were indeed sent from Pale to the ARK and that, as such, the ARK Crisis Staff did not operate entirely independently as a "state within a state" as alleged by the Accused. The Chamber will discuss in further detail the relationship between the ARK Crisis Staff and the Bosnian Serb leadership and the impact of these lines of communication on the Accused's responsibility. See Section IV.A.3.a.ii.B: Regionalisation and creation of SAOs.

6941 Predrag Radić, P1 (Transcript from Prosecutor v. Krajišnik), T. 7404. See also Adjudicated Fact 2182.

6942 Predrag Radić, P1 (Transcript from Prosecutor v. Krajišnik), T. 7404-7409; P7 (Decision of ARK Crisis Staff, 22 June 1992); P8 (Communication from Petrovac Municipal Assembly Crisis Staff to ARK Crisis Staff, 25 June 1992).

6943 Predrag Radić, P1 (Transcript from Prosecutor v. Krajišnik), T. 7422-7424.

6944 Predrag Radić, P1 (Transcript from Prosecutor v. Krajišnik), T. 7456-7457.

6945 P5415 (Decision of ARK Crisis Staff, 9 May 1992); Milorad Dodik, T. 36886-36887 (9 April 2013); P1478 (Ratko Mladić's notebook, 27 May-31 July 1992), e-court p. 54 (in which at a 2 June 1992 meeting with the Accused, Brđanin stated that "everything in the ARK is done at [the crisis staff] level"). See paras. 2051-2053, 2056, 2058-2061, 2874. See, e.g., P3536 (Decisions and orders of Prijedor Municipal Assembly and Prijedor Crisis Staff, published in Prijedor Official Gazette on 25 June 1992), pp. 5-6; P3708 (Decision of Prijedor Crisis Staff, 22 May 1992) (stating that in accordance with the decision of the ARK Crisis Staff, "permanent operational duty" shall be introduced in all municipalities of the ARK); P2606 (Minutes from sessions of Ključ Crisis Staff, 27 May-10 July 1992), p. 2; P2614 (Conclusions of Sanski Most Crisis Staff, 30 May 1992). However, Brđanin, Kuprešanin, and Grahovac testified that there was no subordination and hierarchy in the relationship between the ARK Crisis Staff and municipal crisis staffs and they were independent of each other, in particular because the functioning of the ARK was dependent on funds provided by the municipalities and ultimately, the municipalities stopped earmarking funds for the ARK. Further, according to Brđanin, Erceg, Stakić, Mišković, and Sajić, although the ARK Crisis Staff tried to impose its decisions on the municipal crisis staffs, the ultimate implementation rested with the ARK Municipalities themselves and some chose to implement them while others did not. D4034 (Witness statement of Radoslav Brđanin dated 8 November 2013), paras. 20-22; Radoslav Brđanin, T. 43655-43656 (18 November 2013); D4011 (Witness statement of Vojislav Kuprešanin dated 11 November 2013), paras. 40, 49; Vojislav Kuprešanin, T. $43512-43517$ (14 November 
Staff wanted to implement a decision in the ARK Municipalities, the deputies would say that the order came from Pale, whether or not it was in fact the truth. ${ }^{6946}$ Municipal Crisis Staff presidents attended ARK Crisis Staff meetings. ${ }^{6947}$

2049. On 11 June 1992, the ARK Crisis Staff issued a statement setting forth the composition of municipal Crisis Staffs/War Presidencies in the ARK, which stated:

The War Presidency, that is the Crisis Staff, shall lead all-people's resistance on the territory of the municipality, ensure unity in implementing the policy of the [...] All People's Defence, repair war damage, coordinate the work of municipal administrative organs, adopt regulations within the competence of the Municipal Assembly if it is unable to convene and establish cooperation with the competent organs of other municipalities and the commands of armed forces units. ${ }^{6948}$

2050. Republican level ministers from Pale attended an ARK Assembly session on 17 July 1992 to receive reports on the situation in the ARK. ${ }^{6949}$ Furthermore, General Talić briefed the ARK

2013); D4077 (Witness statement of Anđelko Grahovac dated 23 November 2013), para. 16; D4086 (Witness statement of Nikola Erceg dated 24 November 2013), paras. 14, 77, 81-82, 84, 86, 94 (stating that some municipalities, such as Prijedor, demonstrated a high degree of independence because they were economically strong and the ARK was therefore unable to control them); D4206 (Witness statement of Simo Mišković dated 6 December 2013), para. 12 (stating that Prijedor was independent in relation to ARK policy, as well as independent from the republican authorities in Pale); D4114 (Witness statement of Milorad Sajić dated 24 November 2013), para. 55 (stating that Banja Luka municipality ignored the conclusions of the ARK Crisis Staff and considered them invalid); D4195 (Witness statement of Milomir Stakić dated 16 November 2013), para. 13 (stating that although the municipal authorities in Prijedor used the ARK for inter-municipal cooperation, they never considered that ARK decisions or documents were binding on the municipal government in Prijedor); D4057 (Prijedor Crisis Staff conclusions, published in Official Gazette, 23 June 1992) (concluding that the Prijedor Crisis Staff does not accept, and deems invalid, all decisions of the ARK Crisis Staff adopted before 22 June 1992, but shall "give effect" to all documents of the ARK Crisis Staff adopted after 22 June 1992); Nikola Erceg, T. 44095 (27 November 2013). See P6437 (Minutes from inter-municipality talks, 14 June 1992), p. 3. However, the Chamber does not find this evidence to be convincing in light of other accepted evidence, in particular documentary evidence, demonstrating that the orders and decisions issued by the ARK Crisis Staff were implemented in the majority, if not all, of the ARK Municipalities. For example, the Chamber refers to the implementation of the orders related to the (i) disarmament of the non-Serb population; (ii) policy to "resettle" the non-Serb population; and (iii) dismissals of non-Serbs from management and other positions in the ARK. In addition, the Chamber considers that the evidence provided by these witnesses was marked with contradictions and evasiveness on this issue; they had a clear incentive to distance themselves from events in the ARK Municipalities and the Chamber did not find them forthright when they claimed the ARK Municipalities were acting independently and could not be controlled. The Chamber will therefore not rely on their evidence in this regard.

6946 Predrag Radić, P1 (Transcript from Prosecutor v. Krajišnik), T. 7419-7421, 7428-7431 (testifying further that the deputies, such as Brđanin or Krajišnik, would come back from Assembly sessions or government meetings where decisions were made, and would inform the municipality-level authorities what took place at the republican level of the government).

6947 Radoslav Brđanin, T. 43649-43651 (18 November 2013); D4114 (Witness statement of Milorad Sajić dated 24 November 2013), para. 37. See P6512 (Excerpt of video from Banja Luka news broadcast, with transcript); P6437 (Minutes from inter-municipality talks, 14 June 1992), p. 2; P6564 (Excerpt of Miloš Milinčić's testimony from Prosecutor v. Krajišnik), T. 18443-18444; Miloš Milinčić, T. 44987-44988 (11 December 2013). However, according to Sajić, leaders from Pale never attended any of the ARK Crisis Staff meetings. D4114 (Witness statement of Milorad Sajić dated 24 November 2013), para. 47.

6948 P2620 (Order of ARK Crisis Staff, 11 June 1992).

6949 P5513 (Extract of Minutes from $18^{\text {th }}$ session of ARK Assembly, 17 July 1992). The following ministers attended the session: Generals Talić and Ninković, Goran Hadžić, Milan Martić, Minister of Defence Bogdan 
Assembly on military operations and, in turn, informed his subordinate officers within the $1^{\text {st }}$ Krajina Corps of decisions of the ARK Crisis Staff. ${ }^{650}$ ARK Crisis Staff members, particularly Brđanin, visited the frontlines regularly, where they were briefed by military personnel in order to gain an understanding of the situation and they, in turn, informed the ARK Crisis Staff about the military campaign. ${ }^{6951}$

(B) ARK Crisis Staff decisions

\section{(1) Disarmament of non-Serbs}

2051. As discussed above, an imminent threat of war was declared by the SerBiH Presidency on 15 April 1992, and the following day, the mobilisation of the TO was ordered. ${ }^{652}$ Minister of Defence Bogdan Subotić forwarded this decision for implementation to all Serb assemblies, including in the ARK, ${ }^{6953}$ and on 29 April 1992, the decision was then forwarded by Erceg to the President of Banja Luka Municipal Assembly also for implementation. ${ }^{6954}$ On 4 May 1992, the decision was implemented by the ARK Regional Secretariat for National Defence in an order issued by Milorad Sajić, the Secretary of the Regional Secretariat for National Defence, and forwarded to the ARK Municipalities, providing for the following measures: (i) general mobilisation of the territory of the ARK; (ii) imposition of a curfew; and (iii) disarmament of "[a]ll paramilitary formations and individuals who illegally possess weapons" by 11 May $1992 .{ }^{6955}$ Also on 4 May 1992, Župljanin ordered the SJB chiefs to implement the ARK decision of the same day. ${ }^{6956}$ In a decision issued on 11 May 1992, the ARK Crisis Staff reiterated the same measures as in the 4 May decision and extended the disarmament deadline to 14 May 1992 at 12 a.m. in response to the request of citizens to "return the weapons in a peaceful way and without the intervention of the police". 6957

Subotić, Velibor Ostojić, and Dragan Kalinić. P5513 (Extract of Minutes from $18^{\text {th }}$ session of ARK Assembly, 17 July 1992), p. 1.

6950 P5513 (Extract of Minutes from $18^{\text {th }}$ session of ARK Assembly, 17 July 1992), p. 1; see Adjudicated Fact 547.

6951 See Adjudicated Fact 548. See also D4034 (Witness statement of Radoslav Brđanin dated 8 November 2013), para. 38.

6952 P3922 (Decision of SerBiH Presidency, 15 April 1992). See para. 212.

6953 P2412 (Decision of SerBiH Ministry of Defence, 16 April 1992).

6954 P6531 (Information of ARK Executive Council, 29 April 1992). See Nikola Erceg, T. 44080 (27 November 2013).

6955 P2818 (Decision of ARK Regional Secretariat for National Defence, 4 May 1992); D4114 (Witness statement of Milorad Sajić dated 24 November 2013), paras. 14, 18-20. See Adjudicated Fact 2160.

6956 P2819 (Dispatch from Banja Luka CSB to all SJBs, 4 May 1992). See D4049 (Dispatch of Banja Luka CSB to all SJBs, 14 May 1992); Adjudicated Fact 536.

6957 P3694 (Conclusions of ARK Crisis Staff sent to municipality presidents, 11 May 1992). See P3925 (Report of $5^{\text {th }}$ Corps, 12 May 1992), p. 1 (wherein Talić reports the extension of the deadline); D4453 (Banja Luka CSB dispatch to all SJBs, 11 May 1992) (wherein Župljanin informs the local SJB chiefs of the extension of the 
2052. On 18 May 1992, the ARK Crisis Staff further decided that all individuals in the ARK who were "not part of the armed forces of the $[\mathrm{SerBiH}]$ or its police must hand in their weapons". ${ }^{6958}$ In accordance with the 18 May 1992 decision, Župljanin ordered all SJBs to report back to the CSB on the disarmament operations. ${ }^{6959}$ The municipal SJBs, as ordered, reported back to the CSB on the operations implemented in their respective areas of control. ${ }^{6960}$

2053. The measures ordered in the 4 May 1992 decision were implemented in the ARK Municipalities through public announcements and ultimatums to hand in illegally owned weapons. ${ }^{6961}$ Although the calls for disarmament in the ARK were directed to all "paramilitary units and individuals who illegally possess weapons", they were selectively enforced against nonSerbs. ${ }^{6962}$

\section{(2) Resettlement of non-Serbs and appropriation of property}

2054. In the same 11 May 1992 decision discussed above, the ARK Crisis Staff instructed that the property of all able-bodied men between 18 and 55 years old who failed to return to their municipalities in response to the mobilisation calls would be confiscated. ${ }^{693}$ At a meeting on 20 May 1992, the ARK Crisis Staff adopted several conclusions, including that there was "no reason for the population of any nationality to move out of the territory of the [ARK]". ${ }^{6} 64$

deadline to implement the measures ordered in the 4 May ARK decision). See also D4035 (Conclusions of ARK Crisis Staff, 14 May 1992) (reiterating that the CSB of the ARK shall "consistently carry out" the ARK Crisis Staff decision on the disarming of paramilitary units and individuals who are illegally in possession of weapons and ammunition).

6958 D4038 (Conclusions of ARK Crisis Staff, 18 May 1992).

6959 Adjudicated Fact 537. See D4456 (Dispatch from Banja Luka CSB to all SJBs, 18 August 1992); Adjudicated Fact 2161.

6960 See, e.g., P3648 (Report of Sanski Most SJB, 10 July 1992). See Adjudicated Fact 537.

6961 See paras. 1441 (Bosanski Novi), 1501, 1509 (Ključ), 1586, 1602, 1616, 1665, 1673, 1682 (Prijedor), 1942 1944, 1949 (Sanski Most). See also Adjudicated Fact 535.

6962 Adjudicated Fact 538. See fn. 6961. See also Milorad Sajić, T. 44137-44138 (27 November 2013); Adjudicated Facts 539, 540. However, Brđanin, Erceg, and Sajić testifed that the ARK Crisis Staff demanded the disarmament of all paramilitary formations, regardless of their nationality, though they were aimed first at Serb paramilitary units and individuals who possessed weapons illegally; its aim was to ensure the safety of all citizens of the ARK. Furthermore, they testified that a hierarchical relationship between the municipal authorities, the CSB, and the SJBs did not exist and it was purely upon the initiative of the municipalities themselves whether to implement these decisions or not. D4034 (Witness statement of Radoslav Brđanin dated 8 November 2013), paras. 24, 42-47; D4086 (Witness statement of Nikola Erceg dated 24 November 2013), para. 108; D4114 (Witness statement of Milorad Sajić dated 24 November 2013), paras. 40, 65-66; Milorad Sajić, T. 44135-44138 (27 November 2013). However, the Chamber does not find this evidence to be convincing in light of the other accepted evidence before the Chamber demonstrating that the ARK Crisis Staff decision ordering the disarmament of non-Serbs exclusively was implemented throughout the ARK Municipalities.

6963 P3694 (Conclusions of ARK Crisis Staff sent to municipality presidents, 11 May 1992). See Adjudicated Fact 2227; D4047 (Conclusions of ARK Crisis Staff, 27 May 1992) (stating that "[s]pecial records are to be kept" on all persons between 18 and 60 who may obtain permission to leave the ARK).

6964 D1309 (Conclusions of ARK Crisis Staff, 20 May 1992). See D4086 (Witness statement of Nikola Erceg dated 24 November 2013), para. 95. 
However, on 29 May 1992, the ARK Crisis Staff issued a decision stating that "all Muslims and Croats, who so wish, should be able to move out of the area of the [ARK]" and based on a concern that "several thousand Muslims from Prijedor, Sanski Most and Bosanski Novi wish to move to Central Bosnia, of their own free will", the ARK Crisis Staff provided for an organised "resettlement" of the population. ${ }^{6965}$

2055. On 3 June 1992, the ARK War Presidency issued a decision stating that individuals leaving the ARK could take with them no more than 300 German marks; ${ }^{6966}$ in turn, the Banja Luka CSB instructed its subordinate SJBs to implement this decision by seizing any larger amount of money from anyone leaving the ARK. ${ }^{6967}$

2056. On June 7 1992, municipal authorities from the ARK Municipalities decided at a subregional meeting that "Muslims and Croats should move out of our municipalities until a level is reached where Serbian authority can be maintained and implemented on its own territory in each of these municipalities" and requested that the ARK Crisis Staff provide a corridor for the resettlement of non-Serbs. ${ }^{6968}$

2057. On 12 June 1992, the ARK Crisis Staff established an Agency for Population Movement and Exchange of Material Wealth for the ARK (“ARK Agency”), appointing Miloš Bojinović as its Chief, to aid in the implementation of the resettlement policy. ${ }^{699}$ At the municipal level, other

6965 P3461 (Conclusions of ARK Crisis Staff, 29 May 1992). See Adjudicated Fact 541. Later on 10 June, the ARK Crisis Staff decided that only women, children, and the elderly could be moved from the ARK if they so wish, in co-operation with humanitarian organisations. D4046 (Decision of ARK Crisis Staff, 10 June 1992). See D4034 (Witness statement of Radoslav Brđanin dated 8 November 2013), para. 23(f) (stating that he does not remember the 10 June decision but that the police would have wanted to check able-bodied male non-Serbs before they left the ARK). Furthermore, the ARK Crisis Staff provided that there should be "reciprocity" with regard to the relocation of people throughout the $\mathrm{SerBiH}$, including that Serbs should be given the freedom to choose their place of residence. D4038 (Conclusions of ARK Crisis Staff, 18 May 1992); D4044 (Conclusions of ARK Crisis Staff, 28 May 1992), p. 2. See D4034 (Witness statement of Radoslav Brđanin dated 8 November 2013), para. 23(b), (d).

6966 P3447 (Report of the Banja Luka CJB, undated). See para. 1561. See also Adjudicated Fact 2454.

6967 D1307 (Order of Banja Luka CSB to all ARK SJBs, 31 July 1992). But see Miloš Bojinović, D4176 (Testimony from Prosecutor v. Brđanin), T. 22801-22802, 22893-22896 (testifying that as Chief of the Agency for Population Movement and Exchange of Material Wealth for the ARK, he never received any instructions to limit the amount of money people leaving the ARK could take with them and he was not aware of any searches for money or valuables on the convoys organised by his agency). See para. 2057.

6968 P2641 (Conclusions of sub-regional meeting of municipalities sent to ARK Crisis Staff, 7 June 1992), p. 2 (further stating that if the leadership of the ARK fails to solve this issue "our seven municipalities will take all Muslims and Croats under military escort from our municipalities to the centre of Banja Luka"). See also para. 1899. According to Brđanin, the ARK Crisis Staff held a meeting the following day, at which it rejected the request of the municipal authorities as it was "contrary to our policy". D4034 (Witness statement of Radoslav Brđanin dated 8 November 2013), para. 23(e). However, the Chamber considers that based on the events and specific actions taken by the ARK Crisis Staff following the request from the municipal authorities, it does not find reliable Brđanin's evidence that the ARK Crisis Staff rejected their request outright. See e.g. para. 2057.

6969 P2718 (Decision of ARK Crisis Staff, 12 June 1992); P2719 (Decision of ARK Crisis Staff, 12 June 1992); Miloš Bojinović, D4176 (Testimony from Prosecutor v. Brđanin), T. 22765-22768 (testifying that the ARK 
agencies were established throughout the ARK and, along with other competent institutions, were charged with establishing the resettlement procedures. ${ }^{6970}$ Departures of non-Serbs from the ARK had to be authorised by these competent institutions. ${ }^{6971}$ In order to obtain permits to leave the territory of the ARK, non-Serbs usually had to "de-register" from their places of residence and either relinquish their property to the SerBiH or the ARK without compensation or, in other cases, exchange their property for property located outside of the ARK. ${ }^{672}$ The ARK Agency organised convoys, on a bi-weekly basis or more often, to transport non-Serbs to the Muslim or Croatcontrolled lines near Travnik and Zagreb; passengers were required to buy tickets from the ARK Agency in order to leave on the convoys. ${ }^{6973}$ On 19 June 1992, the ARK Crisis Staff issued a decision declaring that all abandoned property will be declared state property and placed at the disposal of the municipal authorities. ${ }^{6974}$

Agency operated until the end of 1992). See D4034 (Witness statement of Radoslav Brđanin dated 8 November 2013), para. 23(g). See also Adjudicated Facts 542, 552.

6970 See Adjudicated Facts 542, 543. See, e.g., paras. 1559 (Ključ), 2034 (Sanski Most).

6971 Adjudicated Fact 543.

6972 See Section IV.A.1.b.i.B.5: Movement of the population within and from Bosanski Novi; Section IV.A.1.b.i.C.8: Movement of the population from Ključ; Section IV.A.1.b.i.D.7: Movement of the population from Prijedor and appropriation of property; Section IV.A.1.b.i.E.7: Movement of the population from Sanski Most and appropriation of property. See also Miloš Bojinović, D4176 (Testimony from Prosecutor v. Brđanin), T. 22790-22792; Adjudicated Fact 544. However, Brđanin, Kuprešanin, Sajić, Erceg, and Bojinović testified that the ARK authorities never engaged in forcible displacement and that the positions of the ARK Crisis Staff in this regard developed depending on the "situation on the ground". The ARK Agency was established to oversee the exchange of property and departure of people of all ethnicities, including Serbs, and furthermore, at the request of non-Serbs who were interested in having such services provided to them and was thus aimed at providing a humanitarian way to exchange property and secure transport. Finally, Brđanin stated that "had we wanted to expel non-Serbs, we would not have set any requirements and conditions for their leaving the ARK". Kuprešanin further stated he was not aware of the establishment of any agency to implement a policy of resettlement, nor that any such policy was co-ordinated at the regional level by the ARK. D4034 (Witness statement of Radoslav Brđanin dated 8 November 2013), paras. 23, 49, 55, 57; Radoslav Brđanin, T. 4366643667 (18 November 2013) (testifying further that there was no "strategic plan ever about forcible relocation", instead they "followed the situation which dictated for people to be relocated rather than to be killed or to perish"); D4011 (Witness statement of Vojislav Kuprešanin dated 11 November 2013), paras. 56-57, 60-61; D4114 (Witness statement of Milorad Sajić dated 24 November 2013), paras. 54, 67-69; D4086 (Witness statement of Nikola Erceg dated 24 November 2013), para. 95; Miloš Bojinović, D4176 (Testimony from Prosecutor v. Brđanin), T. 22776-22777, 22783-22784. However, as further expanded upon above in relation to each of the ARK Municipalities, the Chamber does not find this evidence to be convincing in light of the accepted evidence before the Chamber demonstrating that the resettlement policy promulgated by the ARK Crisis Staff was in fact implemented in the ARK Municipalities, resulting in the movement of the majority of the non-Serb population out of the ARK. The Chamber also does not find the evidence of Brđanin, Kuprešanin, Sajić, Erceg, and Bojinović to be reliable on this issue based on their close involvement in this policy and its implementation, creating an incentive to distance themselves from these events. Therefore, the Chamber will not rely on their evidence in this regard.

6973 Miloš Bojinović, D4176 (Testimony from Prosecutor v. Brđanin), T. 22786-22790, 22794-22795 (testifying further that tickets were purchased in dinars-a ticket cost 14,000 dinars in October 1992-though German marks were also used). See Miloš Bojinović, T. 44710-44716 (9 December 2013).

6974 D4054 (Decision of ARK Crisis Staff, 19 June 1992). See D4034 (Witness statement of Radoslav Brđanin dated 8 November 2013), para. 29 (stating that this policy was adopted in order to protect abandoned property from being unlawfully usurped by the influx of refugees); Radoslav Brđanin, T. 43726 (18 November 2013). 
2058. The municipal Crisis Staffs of the ARK Municipalities implemented this ARK policy. ${ }^{6975}$ For example, on 30 May 1992, the day following the ARK Crisis Staff decision setting out the policy, the Sanski Most Crisis Staff concluded that it would liaise with the ARK leadership regarding the "implementation of the idea on resettlement of the population". ${ }^{6976}$ On 4 June 1992, the Ključ Crisis Staff issued a statement regarding the resettlement of "all citizens who wish to permanently move out of the [m]unicipality of Ključ in an organized manner". ${ }^{6977}$ In August 1992, the Bosanski Novi SJB reported that following the ARK decision on "voluntary resettlement", it de-registered 5,680 individuals, 5,629 of whom were Bosnian Muslim who had applied to leave the municipality "voluntarily". ${ }^{6978}$ Immediately following the issuance of the decision, the $1^{\text {st }}$ Krajina Corps also reported on the implementation of the policy, reporting that the ARK had issued a decision to facilitate the departures of the non-Serb population and that those departing "will not be allowed to return" and referring to "public statements made in the media by SDS [ARK] leaders who advocate moving and expelling all Muslims and Croats from these areas". ${ }^{6979}$

2059. On 1 June 1992, Kirudja was informed that Kuprešanin had called the Civil Affairs Office in Sector North to report the concerns of mayors from Bosanski Novi, Prijedor, Ključ, Dubica, Sanski Most, and Banja Luka in relation to the situation of the Bosnian Muslim population in those areas. $^{6980}$ Kuprešanin informed the office that 15,000 Bosnian Muslim refugees from these municipalities were moving across the border towards Dvor, Croatia, and that another 15,000 would likely follow, appealing to UNPROFOR to "find a way to protect the civilian Muslim population". 6981

2060. The detention facilities in the ARK were also discussed at ARK Crisis Staff meetings; for example, representatives from Prijedor, Stakić, Drljača, and Kuruzović, attended one meeting and reported a shortage of food, clothing, and accommodation in the detention facilities in Prijedor. ${ }^{6982}$

\footnotetext{
6975 See, e.g., P2614 (Conclusions of Sanski Most Crisis Staff, 30 May 1992), p. 1; P3448 (Statement of Ključ Crisis Staff, 4 June 1992); D1921 (Report of Bosanski Novi SJB, 15 August 1992), p. 4. See also paras. 1467-1471, 1559-1561, 1563 (Ključ), 1898-1901 (Prijedor), 2033-2035 (Sanski Most).

6976 P2614 (Conclusions of Sanski Most Crisis Staff, 30 May 1992), p. 1.

6977 P3448 (Statement of Ključ Crisis Staff, 4 June 1992).

6978 D1921 (Report of Bosanski Novi SJB, 15 August 1992), p. 4.

6979 P3662 (1 $1^{\text {st }}$ Krajina Corps report, 31 May 1992), p. 2; P3656 (1 $1^{\text {st }}$ Krajina Corps report, 1 June 1992), p. 1. See also P5459 (Report of $1^{\text {st }}$ Krajina Corps, 2 August 1992), p. 2 (reporting that "[m]ethods of exercising pressure are increasing, as are organised expulsions of the Muslim and Croat population from the area of Bosnian Krajina and further afield").

6980 P3804 (Witness statement of Charles Kirudja dated 17 November 2010), para. 53.

6981 P3804 (Witness statement of Charles Kirudja dated 17 November 2010), para. 53.

6982 D4114 (Witness statement of Milorad Sajić dated 24 November 2013), paras. 56-58; Milorad Sajić, T. 4414644147 (27 November 2013). However, Brđanin and Erceg testified that detention facilities in the ARK were not discussed at meetings of the ARK Crisis Staff and that ARK authorities had nothing to do with the facilities. D4034 (Witness statement of Radoslav Brđanin dated 8 November 2013), para. 52; D4086 (Witness statement
} 


\section{(3) Dismissals of non-Serbs}

2061. On 8 May 1992, 11 May 1992, and 13 May 1992, the ARK Crisis Staff issued decisions stating that all management positions in $\mathrm{SerBiH}$ must be filled by "people who are absolutely loyal". ${ }^{693}$ Later, in a decision adopted on 22 June 1992 and directed to all municipal Crisis Staff presidents, the ARK Crisis Staff stated that all posts important for the functioning of the economy may only be held by "personnel of Serbian ethnicity". ${ }^{6984}$ The 22 June 1992 decision was forwarded by Župljanin to all SJBs on 1 July 1992 for its immediate implementation within the ARK. ${ }^{6985}$ In accordance with this decision, numerous municipalities dismissed non-Serb personnel; by the end of 1992, the majority of Bosnian Muslims and Bosnian Croats in the ARK had been dismissed from their jobs and were replaced by Bosnian Serbs. ${ }^{696}$ ARK Crisis Staff member Radić confirmed that the policy of dismissals of non-Serbs originated in Pale at the republic level. ${ }^{697}$

of Nikola Erceg dated 24 November 2013), para. 89. The Chamber considers that the evidence given by Sajić regarding the discussion of the detention facilities in the ARK Municipalities at the ARK Crisis Staff meeting is reliable given the detail he provides regarding at least this one particular meeting. The Chamber shall not rely on the evidence given by Brđanin and Erceg in this regard given their potential interest in distancing themselves from any knowledge of conditions at ARK detention facilities or invoking their lack of recollection of such a discussion at the meetings.

6983 D4043 (Conclusions of ARK Crisis Staff, 8 May 1992), p. 2; P3694 (Conclusions of ARK Crisis Staff sent to municipality presidents, 11 May 1992); D4041 (Conclusions of ARK Crisis Staff, 13 May 1992), p. 1; P5470 (Excerpts of conclusions of ARK Crisis Staff of 13 May 1992 sent to enterprises, 10 June 1992). See Mevludin Sejmenović, T. 20468-20469 (27 October 2011).

6984 P7 (Decision of ARK Crisis Staff, 22 June 1992) (further stating that the personnel were expected to confirm their "Serbian ethnicity" in the plebiscite and to express their loyalty to the SDS). See also Adjudicated Facts 532, 533.

6985 P6533 (Decision of ARK Crisis Staff forwarded by Banja Luka CSB, 1 July 1992). See also Adjudicated Fact 534.

6986 See paras. 1374 (Banja Luka), 1437 (Bosanski Novi), 1504 (Ključ), 1596-1601 (Prijedor), 1950 (Sanski Most). See Adjudicated Fact 532 (stating that the replacement of Bosnian Muslims and Bosnian Croats personnel by Bosnian Serbs guaranteed "an overall Bosnian Serb control over public and private enterprises and institutions throughout the ARK"). See also P2637 (Report of Prijedor SJB, 1 July 1992) (reporting that the 22 June 1992 ARK Crisis Staff decision "has been implemented in this [SJB]"); Adjudicated Fact 534. However, Brđanin testified that a leak of sensitive information about the movements of the $1^{\text {st }}$ Krajina Corps resulted in these measures being "temporarily" adopted by the ARK Crisis Staff and its decision involved the removal of executive positions of people that could misuse such positions and threaten the security of Krajina. Furthermore, the non-Serbs were not fired, but only removed from positions considered to be important due to security, and were given different jobs. D4034 (Witness statement of Radoslav Brđanin dated 8 November 2013), paras. 15-17, 39-41. According to Sajić and Erceg, although the 22 June 1992 decision provided for the dismissals of non-Serbs, it was implemented to "some extent", but was not put into practice in all cases. Furthermore, Sajić did not believe that Brđanin personally called for the dismissal of non-Serbs despite what the decision states. D4114 (Witness statement of Milorad Sajić dated 24 November 2013), para. 41; Milorad Sajić, T. 44139-44142 (27 November 2013); D4086 (Witness statement of Nikola Erceg dated 24 November 2013), paras. 98-101, 107. See Defence Final Brief, paras. 1172-1175 (wherein the Accused submits that he does not dispute that there may have been individual incidents of people being dismissed from their employment, but "this had nothing to do with alleged persecutions"). However, the Chamber does not find this evidence to be convincing based on the considerable evidence before the Chamber demonstrating that this policy of dismissals of non-Serb personnel as ordered by the ARK Crisis Staff was, in turn, implemented throughout the ARK Municipalities. 
c. Sarajevo Area

\section{i. Hadžići}

(A) Charges

2062. Under Count 3, the Prosecution alleges that persecution, a crime against humanity, was committed in Hadžići as part of the objective to permanently remove Bosnian Muslims and/or Bosnian Croats from the Municipalities. ${ }^{6988}$

2063. Acts of persecution alleged to have been committed by Serb Forces and Bosnian Serb Political and Governmental Organs in Hadžići include (i) torture, beatings, and physical and psychological abuse, during and after the take-over and in scheduled detention facilities, as cruel or inhumane treatment; ${ }^{6989}$ (ii) rape and other acts of sexual violence, during and after the take-over and in the Hadžići Culture and Sport Centre, as cruel and inhumane treatment; ${ }^{690}$ (iii) the establishment and perpetuation of inhumane living conditions in scheduled detention facilities, including the failure to provide adequate accommodation, shelter, food, water, medical care, or hygienic sanitation facilities, as cruel or inhumane treatment; ${ }^{6991}$ (iv) forcible transfer or deportation of Bosnian Muslims and Bosnian Croats from their homes within Hadžići; ${ }^{6992}$ (v) unlawful detention in scheduled detention facilities; ${ }^{6993}$ (vi) forced labour at the frontline and the use of Bosnian Muslims and Bosnian Croats as human shields; ${ }^{6994}$ (vii) the appropriation or plunder of property, during and after the take-over of Hadžići, during arrests and detention and in the course of or following acts of deportation or forcible transfer; ${ }^{6995}$ and (viii) the imposition and maintenance of restrictive and discriminatory measures. ${ }^{6996}$

2064. Under Counts 7 and 8, the Prosecution alleges deportation and inhumane acts (forcible transfer), respectively, as crimes against humanity. ${ }^{697}$ In this regard, the Prosecution alleges that, by the end of 1992, Serb Forces and Bosnian Serb Political and Governmental Organs had forcibly

\footnotetext{
$6988 \quad$ Indictment, paras. 48-49.

6989 Indictment, para. 60(b). See Scheduled Detention Facilities C.11.1, C.11.2.

6990 Indictment, para. 60(c). See Scheduled Detention Facility C.11.2.

6991 Indictment, para. 60(d). See Scheduled Detention Facilities C.11.1, C.11.2.

6992 Indictment, para. 60(f).

6993 Indictment, para. 60(g). See Scheduled Detention Facilities C.11.1, C.11.2.

6994 Indictment, para. 60(h)

6995 Indictment, para. 60(i).

6996 Indictment, para. 60(k). The restrictive and discriminatory measures alleged include the denial of freedom of movement; the removal from positions of authority; the invasion of privacy through arbitrary searches of homes; unlawful arrest and/or the denial of the right to judicial process; and/or the denial of equal access to public services. The Chamber notes that the Prosecution does not allege criminal responsibility for wanton destruction of private property in Hadžići. Indictment, fn. 9.

6997 Indictment, paras. 68-75.
} 
displaced most Bosnian Muslims and Bosnian Croats from areas in Hadžići in which they were lawfully present. ${ }^{6998}$ It is alleged that from March 1992, restrictive and discriminatory measures, arbitrary arrest and detention, harassment, torture, rape and other acts of sexual violence, killing, as well as the threat of further such acts caused Bosnian Muslims and Bosnian Croats to flee in fear while others were physically driven out. ${ }^{6999}$

(B) Lead-up

2065. Hadžići is a municipality in central $\mathrm{BiH}$, located about 12 kilometres southwest of Sarajevo. ${ }^{7000}$ The municipality is bordered to the northeast by Ilidža; to the north by Kiseljak; to the northwest by Kreševo; to the west and southwest by Konjic; and to the south and southeast by Trnovo. $^{7001}$

2066. Before the conflict, the population of Hadžići municipality was about 24,000 inhabitants with the demographic breakdown of approximately 63.6\% Bosnian Muslim, 26.3\% Serb, and 3.1\% Croat. $^{7002}$ The town of Hadžići, however, had a Serb majority. ${ }^{7003}$ Tarčin, ${ }^{7004}$ Binježevo, and Pazarić were large settlements within the Hadžići municipality, each of which was composed of a number of villages. ${ }^{7005}$

2067. The municipality was strategically important because of its geographical position, as well as the fact that it contained a large engineering factory run by the JNA, called the TRZ, ${ }^{7006}$ and a

\footnotetext{
6998 Indictment, paras. 69, 72.
}

6999 Indictment, para. 71.

7000 D1064 (Map of Sarajevo marked by Tihomir Glavaš) (showing the town of Hadžići and the surrounding Serbheld areas at " 1 " and the Serb villages in majority-Muslim territory at " 2 ").

7001 D1087 (Map of Hadžići municipality marked by Tihomir Glavaš). Kiseljak, Kreševo, and Busovača all had predominantly Croat populations. D2915 (Witness statement of Vidomir Banduka dated 9 February 2013), para. 22.

7002 P5964 (Census data for BiH by municipality in 1971, 1981, and 1991, April 1995). See also D225 (Ethnic map of BiH based on 1991 census); P41 (Witness statement of Ramiz Dupovac dated 16 January 1998), p. 3; P2296 (Witness statement of Tihomir Glavaš dated 13 February 2011), para. 22, p. 3; D3062 (Witness statement of Nevenko Samouković dated 26 February 1993), para. 2; D2915 (Witness statement of Vidomir Banduka dated 9 February 2013), para. 4.

7003 P2296 (Witness statement of Tihomir Glavaš dated 13 February 2011), para. 22.

7004 D1087 (Map of Hadžići municipality marked by Tihomir Glavaš). Tarčin had a majority Croat population. D2915 (Witness statement of Vidomir Banduka dated 9 February 2013), para. 12.

7005 Tihomir Glavaš, T. 11818 (14 February 2011). Both Bare in Drozgometva community and Miševići in Binježevo community had large Serb populations. P134 (Witness statement of Adem Balić dated 25 June 1997), p. 3.

7006 P1494 (ABiH map of Sarajevo, 15 June-20 July 1992) (showing the location of the repair and maintenance depot marked as "TRZ" in Hadžići municipality). The TRZ employed 1,500 workers and held tanks, Pragas, artillery weapons, and mortars. P124 (Witness statement of Zijad Okić dated 24 June 1997), e-court p. 2 ; P41 (Witness statement of Ramiz Dupovac dated 16 January 1998), pp. 3-4. See also D3062 (Witness statement of Nevenko Samouković dated 26 February 1993), para. 8. 
sizeable weapons depot at Žunovnica. ${ }^{7007}$ JNA military barracks were also situated in Žunovnica, as well as in Ušivak ${ }^{7008}$ and Pazarić. ${ }^{7009}$

2068. Following the 1990 elections, the SDA won $60 \%$ of the vote, the SDP won $12.5 \%$, and the SDS won $11 \% .^{7010}$ The parties came to an agreement whereby the President of the Municipal Assembly would be a member of the SDA, the President of the Executive Board of the Municipal Assembly would be a member of the SDS, ${ }^{7011}$ the head of the police would be a member of the SDA, ${ }^{7012}$ and the head of the Secretariat for Peoples Defence would be a member of the SDS. ${ }^{7013}$ In accordance with this agreement, SDA member Mustafa Dželilović, was made President of the Municipality. ${ }^{7014}$

\section{(1) Militarisation of Hadžići}

2069. During the course of 1991, the number of military personnel and the amount of weapons in the municipality increased. Around mid-1991, tanks appeared in the hills around Hadžići, and

7007 P2296 (Witness statement of Tihomir Glavaš dated 13 February 2011), para. 22; P124 (Witness statement of Zijad Okić dated 24 June 1997), e-court p. 2; D583 (SRK combat report, 31 May 1992), para. 1; Vidomir Banduka, T. 33503 (12 February 2013); D2915 (Witness statement of Vidomir Banduka dated 9 February 2013), para. 32. The Žunovnica complex" held "extremely large quantities of all sorts of ammunition". D317 (TO Hadžići report on combat readiness, 29 May 1992), p. 1. Prior to the 1990 elections, the Hadžići TO had its own supply of weapons which was controlled by the TO headquarters but stored in the JNA barracks at Žunovnica. P41 (Witness statement of Ramiz Dupovac dated 16 January 1998), p. 3. These arms included rifles, automatic and semi-automatic rifles, sniper rifles, $82 \mathrm{~mm}$ mortars, anti-tank rockets, and recoilless guns. P41 (Witness statement of Ramiz Dupovac dated 16 January 1998), p. 3.

7008 Vidomir Banduka testified that Serbs were the majority in Ušivak and thus these barracks were the only ones in a Serb-majority area. D2915 (Witness statement of Vidomir Banduka dated 9 February 2013), para. 35.

7009 P41 (Witness statement of Ramiz Dupovac dated 16 January 1998), pp. 3-4; P2405 (Map of Hadžići marked by Mehmed Musić); D2915 (Witness statement of Vidomir Banduka dated 9 February 2013), para. 34. Vidomir Banduka also mentioned army barracks in Krupska Rijeka, where a large quantity of weapons was stored. D2915 (Witness statement of Vidomir Banduka dated 9 February 2013), para. 33.

7010 P134 (Witness statement of Adem Balić dated 25 June 1997), p. 3; P41 (Witness statement of Ramiz Dupovac dated 16 January 1998), p. 3 (stating that the SDS was the second party). Of the 50 municipal assemblymen, the SDA had 23, the SDP 12, the SDS had 11, and two smaller parties had two deputies each. D2915 (Witness statement of Vidomir Banduka dated 9 February 2013), para. 17. The HDZ did not have any assemblymen. D2915 (Witness statement of Vidomir Banduka dated 9 February 2013), para. 17.

7011 SDS member Nevenko Samouković was appointed President of the Executive Board of Hadžići after the multiparty elections. D3062 (Witness statement of Nevenko Samouković dated 26 February 1993), paras. 3, 3a; D2915 (Witness statement of Vidomir Banduka dated 9 February 2013), para. 18. By mutual agreement between the parties, the Executive Board of Hadžići was composed of three Serbs and three Muslims. D3062 (Witness statement of Nevenko Samouković dated 26 February 1993), para. 4; D2915 (Witness statement of Vidomir Banduka dated 9 February 2013), para. 18.

7012 The Chief of the SJB was Bosnian Muslim Fadil Čović and the Commander was a Bosnian Serb, Tihomir Glavaš. D2915 (Witness statement of Vidomir Banduka dated 9 February 2013), para. 18.

7013 P41 (Witness statement of Ramiz Dupovac dated 16 January 1998), p. 3. Other positions, such as the President of the Magistrate's Court and the Secretary of the Assembly, were filled by the SDA, while others, such as the Administration for Income and the Land Registration and Real Estate were filled by the SDS. P41 (Witness statement of Ramiz Dupovac dated 16 January 1998), p. 3.

7014 P134 (Witness statement of Adem Balić dated 25 June 1997), p. 3. D2915 (Witness statement of Vidomir Banduka dated 9 February 2013), para. 11 (stating that he had been president of the SDA municipal board); D3062 (Witness statement of Nevenko Samouković dated 26 February 1993), para. 3a. Dželilović remained in this position until April 1992. See P134 (Witness statement of Adem Balić dated 25 June 1997), p. 3. 
mortar positions were established around the village of Bare. ${ }^{7015}$ Several tanks were also positioned in Binježevo. ${ }^{7016}$ During the last week of August and the first week of September, Bosnian Serb reserve soldiers in JNA uniforms who appeared to be mapping the area arrived at a barracks located in the village of Blažuj. ${ }^{7017}$ Around the same time, Mehmed Musić saw men unloading boxes of ammunition, ${ }^{7018}$ and Zijad Okić noticed weapons were taken up to trenches built on Tinovo Hill. ${ }^{7019}$

2070. From its founding until the commencement of the war, the SDS provided Serbs with weapons taken from the JNA military warehouses in Žunovnica. ${ }^{7020}$ Serbs also obtained weapons from the TRZ, which was controlled by the Serbs. ${ }^{7021}$ In particular, Marinko Đukanović, who had been a warehouse clerk at the TO (and thus had access to the weapons), ${ }^{7022}$ as well as Ratko Radić, the President of the Hadžići SDS, ${ }^{7023}$ distributed weapons to the Serb population in Hadžići. ${ }^{7024}$

2071. At the end of September and beginning of October, Croats in western BiH began to organise militarily, which contributed to incipient instability in Hadžići. ${ }^{7025}$ During the course of 1991,

7015 P124 (Witness statement of Zijad Okić dated 24 June 1997), e-court p. 2 (further specifying that Pragas and APCs appeared on Tinovo Hill).

7016 P124 (Witness statement of Zijad Okić dated 24 June 1997), e-court p. 2.

7017 P2403 (Witness statement of Mehmed Musić dated 28 February 2011), paras. 8-9; Mehmed Musić, T. 1284012841 (3 March 2011) (referring to the soldiers as unshaven "Chetniks dressed in JNA uniforms" estimating that he saw this happening between 30 August and 6 September 1991); P2405 (Map of Hadžići marked by Mehmed Musić) (showing the Ćatina Bara barracks located at Point 2 on the map).

7018 Mehmed Musić, T. 12849 (3 March 2011).

7019 P124 (Witness statement of Zijad Okić dated 24 June 1997), e-court p. 4.

7020 P2403 (Witness statement of Mehmed Musić dated 28 February 2011), para. 39; Tihomir Glavaš, T. 11954 (16 February 2011); P124 (Witness statement of Zijad Okić dated 24 June 1997), e-court p. 2. See also P41 (Witness statement of Ramiz Dupovac dated 16 January 1998), p. 5. The Chamber notes that Vidomir Banduka originally professed that he was unaware that Serbs obtained arms from the JNA, but when presented with his testimony in the Krajišnik case, wherein he had stated that the Serbs obtained weapons through the mobilisation of the reserve police, as well as the JNA reserves and the TO, Banduka clarified that reservists had obtained weapons through these channels but maintained that Serb civilians had not. Vidomir Banduka, T. 33499-33500 (12 February 2013). See also D2490 (Witness statement of Radojka Pandurević dated 27 November 2012), para. 62. However, the Chamber observes that according to a JNA report dated 19 March 1992, by that date, 1,500 "volunteers" who were not part of the JNA or the TO had been armed by the JNA or the SDS in Hadžići. P979 (Report from JNA $2^{\text {nd }}$ Military District to JNA General Staff, 20 March 1992), pp. 1, 6, 11. The Chamber therefore finds that in addition to arms provided during the mobilisation process, arms from JNA sources were also provided to Serbs outside the JNA, TO, and police mobilisation processes.

7021 P2296 (Witness statement of Tihomir Glavaš dated 13 February 2011), para. 22. In order to consolidate control over these barracks, troops, and equipment, the SDS—including Ratko Radić-spread rumours that units from Croatia were present in the municipality with the aim of committing crimes against Serbs. P41 (Witness statement of Ramiz Dupovac dated 16 January 1998), p. 4. The TRZ remained under Bosnian Serb control throughout the conflict. Vidomir Banduka, T 33503 (12 February 2013). See also D312 (SRK analysis of combat readiness of artillery rocket units, July 1994), p. 8.

7022 P2403 (Witness statement of Mehmed Musić dated 28 February 2011), para. 39.

7023 P134 (Witness statement of Adem Balić dated 25 June 1997), p. 3; P41 (Witness statement of Ramiz Dupovac dated 16 January 1998), p. 4; D3062 (Witness statement of Nevenko Samouković dated 26 February 1993), para. 9; D3063 (Witness statement of Mladen Tolj dated 25 February 2013), para. 17; D2915 (Witness statement of Vidomir Banduka dated 9 February 2013), para. 13.

7024 P2296 (Witness statement of Tihomir Glavaš dated 13 February 2011), para. 27.

7025 P41 (Witness statement of Ramiz Dupovac dated 16 January 1998), p. 4. See also D2915 (Witness statement of Vidomir Banduka dated 9 February 2013), para. 22. 
troops from the JNA engineering unit stationed at the TRZ began to return from Knin and Slavonia and spoke of having seen JNA units fighting in Croatia wearing Chetnik insignia. Thereafter, Muslims began to avoid JNA conscription and training. ${ }^{7026}$

2072. In the interim, Bosnian Muslims had obtained arms. On 15 October 1991, pursuant to an order of the SRBiH Presidency, ${ }^{7027}$ the Hadžići MUP mobilised 480 members of the reserve police force $;^{7028}$ this enabled members of the reserve police to obtain arms. ${ }^{7029}$ Meanwhile, the SDA was distributing weapons in municipalities within the city of Sarajevo, including Hadžići. ${ }^{7030}$ Some wealthier Bosnian Muslims bought weapons for themselves. ${ }^{7031}$

2073. By the beginning of February 1992, residents of the Hadžići municipality had begun to organise nightly patrols and guards in the local areas where each ethnic group was prominent. ${ }^{7032}$ Around the same time, Bosnian Serbs began to leave the regular and reserve police units, ${ }^{7033}$ and the JNA began distributing firearms to the Serb population at night. ${ }^{7034}$

2074. In late March 1992, the police warehouse in Rakovica, which was full of weapons, was broken into during a time when Bosnian Muslim officers were on duty. ${ }^{7035}$ Machine-guns, police

7026 P41 (Witness statement of Ramiz Dupovac dated 16 January 1998), pp. 3-4. See also D2915 (Witness statement of Vidomir Banduka dated 9 February 2013), para. 34.

7027 P41 (Witness statement of Ramiz Dupovac dated 16 January 1998), p. 4; D2491 (Report of Tarčin police station, 6 August 1992), p. 3.

7028 P41 (Witness statement of Ramiz Dupovac dated 16 January 1998), p. 4; Tihomir Glavaš, T. 11815, 1181811819, 11822-11823 (14 February 2011).

7029 The number of reserve police forces was reduced pursuant to a SRBiH MUP order of 21 December 1991 before being re-mobilised in January 1992. D2491 (Report of Tarčin police station, 6 August 1992), p. 3. Bosnian Muslims began to obtain arms through this mobilisation of the reserve police force, which was primarily made up of Bosnian Muslims. D2915 (Witness statement of Vidomir Banduka dated 9 February 2013), paras. 23, 29; D2490 (Witness statement of Radojka Pandurević dated 27 November 2012), para. 5.

7030 Tihomir Glavaš, T. 11812 (14 February 2011). The police were also aware that SDA leader Hasan Čengić had sent Bosnian Muslim policemen to Croatia to receive training and that he had obtained weapons by forging MUP IDs. Tihomir Glavaš, T. 11814 (14 February 2011). See also D2915 (Witness statement of Vidomir Banduka dated 9 February 2013), para. 30. In February 1992, Serb policemen attempted to stop a vehicle carrying weapons from entering Hadžići municipality but were prevented by Bosnian Muslim police. Tihomir Glavaš, T. 11815 (14 February 2011). The vehicle escaped in the direction of Mokrin, a predominantly Muslim village in the northern part of the municipality. Tihomir Glavaš, T. 11815 (14 February 2011); D1087 (Map of Hadžići municipality marked by Tihomir Glavaš) (showing Mokrin as being located northwest of the town of Hadžići, near the border with the Kiseljak municipality).

7031 P124 (Witness statement of Zijad Okić dated 24 June 1997), e-court p. 3.

7032 P41 (Witness statement of Ramiz Dupovac dated 16 January 1998), p. 5; P2403 (Witness statement of Mehmed Musić dated 28 February 2011), para. 13.

7033 P41 (Witness statement of Ramiz Dupovac dated 16 January 1998), p. 5. At the same time Bosnian Muslims heard that a separate Serb MUP was established in the local community of Drozgometva. P41 (Witness statement of Ramiz Dupovac dated 16 January 1998), p. 5.

7034 P41 (Witness statement of Ramiz Dupovac dated 16 January 1998), p. 5.

7035 P2296 (Witness statement of Tihomir Glavaš dated 13 February 2011), para. 59; Tihomir Glavaš, T. 11821 (14 February 2011). 
gear, and some transportation devices all went missing. ${ }^{7036}$ By the end of the month, Bosnian Muslim formations in Hadžići were "well-organised and armed". 7037

\section{(2) Division of municipal organs}

2075. In the meantime, the work of municipal organs had ground to a halt; shortly after the first mobilisation of the reserve police in October 1991, the SDS delegates had stopped co-operating in the joint Hadžići Municipal Assembly and the Municipal Assembly Executive Board. ${ }^{7038}$ Eventually, only the Municipal Defence Council remained functional. ${ }^{7039}$ Beginning in January 1992, at meetings of the Municipal Defence Council, Ratko Radić called for the establishment of a Serb assembly in Hadžići, an idea which had already been discussed by the Bosnian Serb Assembly in December $1991,{ }^{7040}$ and which was later reiterated by other SDS delegates at successive meetings of the Hadžići Municipal Defence Council. ${ }^{7041}$

2076. In early to mid-April $1992,{ }^{7042}$ the SDS stopped participating in the Municipal Defence Council, ${ }^{7043}$ and the Bosnian Serbs attended a meeting of the Municipal Assembly for the last

7036 P2296 (Witness statement of Tihomir Glavaš dated 13 February 2011), para. 59; Tihomir Glavaš, T. 11821 (14 February 2011). Glavaš, who was commander of the joint police station at the time, was criticised for having allowed this to happen. P2296 (Witness statement of Tihomir Glavaš dated 13 February 2011), para. 59. D3856 (Witness statement of Dragan Kapetina dated 13 July 2013), para. 30.

7038 P41 (Witness statement of Ramiz Dupovac dated 16 January 1998), p. 4. Ostensibly, this lack of co-operation originated when Bosnian Muslims refused to place the mobilisation of the reserve police on the Municipal Assembly's agenda. D3062 (Witness statement of Nevenko Samouković dated 26 February 1993), para. 7; D2490 (Witness statement of Radojka Pandurević dated 27 November 2012), para. 7; Radojka Pandurević, T. 30667-30668 (29 November 2012); D2915 (Witness statement of Vidomir Banduka dated 9 February 2013), paras. 20-21, 24-28. See also D2917 (Statement of Hadžići SDS Municipal Board, 10 October 1991). According to Radojka Pandurević, the mobilisation of the reserve police sparked a "fierce argument" because the mobilisation was done without the knowledge of the "then commander", Tihomir Glavaš. D2490 (Witness statement of Radojka Pandurević dated 27 November 2012), paras. 5-6.

7039 P41 (Witness statement of Ramiz Dupovac dated 16 January 1998), p. 4. The municipal Defence Council included a representative of the Army, the Police, the TO, the Administration Services and the Secretary of the Secretariat for People's Defence. P41 (Witness statement of Ramiz Dupovac dated 16 January 1998), p. 4. See also D2915 (Witness statement of Vidomir Banduka dated 9 February 2013), para. 28; Vidomir Banduka, T. 33496-33497 (12 February 2013).

7040 D84 (Shorthand Record of $3^{\text {rd }}$ Session of Assembly of SerBiH, 11 December 1991), pp. 16-17. See also para. 131.

7041 P41 (Witness statement of Ramiz Dupovac dated 16 January 1998), p. 4. Radic further stated that the Serb people did not want to be a part of a sovereign $\mathrm{BiH}$ and that Muslims should establish their own bodies of government. P41 (Witness statement of Ramiz Dupovac dated 16 January 1998), p. 4. Finally, Radić demanded that a Serb be assigned as the director of the primary school in Tarčin, stating, "if we cannot do it by goodwill we will do it by force". P134 (Witness statement of Adem Balić dated 25 June 1997), p. 3. The President of the Municipality warned Radić not to make threats, and ultimately a Bosnian Muslim was assigned as the director of the Tarčin primary school. P134 (Witness statement of Adem Balić dated 25 June 1997), p. 3.

7042 Balić testified that this meeting occurred "about 20 days before the shooting on Hadžići”. P134 (Witness statement of Adem Balić dated 25 June 1997), p. 3.

7043 P41 (Witness statement of Ramiz Dupovac dated 16 January 1998), pp. 4-5. 
time. ${ }^{7044}$ There, Ratko Radić called for the abolition of "joint policing" and the establishment of a Serb police. ${ }^{7045}$

2077. On 11 April 1992, citing the "extremely difficult political and security situation", 7046 the SDS held a Serb Assembly session at the Hadžići Culture and Sport Centre, ${ }^{7047}$ where the Serb Municipality of Hadžići was proclaimed. ${ }^{7048}$ At the same session, Nevenko Samouković was "given a mandate to form the municipal government". ${ }^{7049}$ The SDS selected Drago Milošević as President of the Serb Municipality of Hadžići as well as President of the Hadžići Assembly of the Serbian People, ${ }^{7050}$ but he was soon replaced by Ratko Radić, ${ }^{7051}$ who remained President of the Municipality until the end of the war. ${ }^{7052}$

2078. The SDS also decided to create a Serb SJB and appointed Tihomir Glavaš as Chief and Branislav Mijatović as Commander. ${ }^{7053}$ The Serb police wore the same uniforms as the previous

7044 P134 (Witness statement of Adem Balić dated 25 June 1997), p. 3.

7045 P134 (Witness statement of Adem Balić dated 25 June 1997), p. 3.

7046 The SDS claimed that the proclamation was made "in order to protect the Serbian people and preserve peace in the Territory of Hadžići municipality”. D1066 (Proclamation of the Hadžići Municipal Assembly, undated), p. 1; D2916 (Announcement of Hadžići Municipal Assembly, undated), p. 1; D3856 (Witness statement of Dragan Kapetina dated 13 July 2013), para. 34; D2915 (Witness statement of Vidomir Banduka dated 9 February 2013), para. 37. According to Vidomir Banduka, Bosnian Muslims' refusal to be mobilised into the JNA, combined with the simultaneous mobilisation of Bosnian Muslims into the reserve police force and the mobilisation of the Bosnian Muslim TO, also informed the SDS decision to establish the Serb Municipality of Hadžići. D2915 (Witness statement of Vidomir Banduka dated 9 February 2013), para. 36.

7047 P134 (Witness statement of Adem Balić dated 25 June 1997), p. 3 (stating that the proclamation session was held in the "Dom building" about 10 days before the war); P2298 (Photograph of Hadžići Radnički Dom); Tihomir Glavaš, T. 11777-11779 (14 February 2011) (identifying P2298 as the Culture and Sport Centre).

7048 P2296 (Witness statement of Tihomir Glavaš dated 13 February 2011), para. 6; D1066 (Proclamation of the Hadžići Municipal Assembly, undated), p. 1; P134 (Witness statement of Adem Balić dated 25 June 1997), p. 3; D3856 (Witness statement of Dragan Kapetina dated 13 July 2013), para. 31. See also Adjudicated Fact 2563; P2306 (Report on the work of the Hadžići Municipal Assembly in 1992), p. 1; P41 (Witness statement of Ramiz Dupovac dated 16 January 1998), p. 5. But see D2915 (Witness statement of Vidomir Banduka dated 9 February 2013), para. 37.

7049 D1066 (Proclamation of the Hadžići Municipal Assembly, undated), p. 1; D2916 (Announcement of Hadžići Municipal Assembly, undated), p. 1; Nevenko Samouković, T. 34600 (1 March 2013).

7050 P2296 (Witness statement of Tihomir Glavaš dated 13 February 2011), para. 6; D1066 (Proclamation of the Hadžići Municipal Assembly, undated), p. 1; D2916 (Announcement of Hadžići Municipal Assembly, undated), p. 1.

7051 P2296 (Witness statement of Tihomir Glavaš dated 13 February 2011), paras. 6, 21, 23. Dragan Kapetina and Ratko Gengo were chosen as Vice President and Secretary of the Assembly, respectively. D1066 (Proclamation of the Hadžići Municipal Assembly, undated), p. 1; D2916 (Announcement of Hadžići Municipal Assembly, undated), p. 1; D3856 (Witness statement of Dragan Kapetina dated 13 July 2013), para. 31; D2915 (Witness statement of Vidomir Banduka dated 9 February 2013), para. 39. See also P41 (Witness statement of Ramiz Dupovac dated 16 January 1998), p. 5.

7052 P2296 (Witness statement of Tihomir Glavaš dated 13 February 2011), para. 25. Radislav Petrić, Vidomir Banduka, and Nevenko Samouković, all functioned as President of the Executive Board of the Serbian Municipality of Hadžići at different times throughout the war. P2296 (Witness statement of Tihomir Glavaš dated 13 February 2011), para. 25; D3063 (Witness statement of Mladen Tolj dated 25 February 2013), para. 17.

7053 D1066 (Proclamation of the Hadžići Municipal Assembly, undated), p. 1; D2916 (Announcement of Hadžići Municipal Assembly, undated), p. 1; D2491 (Report of Tarčin police station, 6 August 1992), p. 4; P2296 (Witness statement of Tihomir Glavaš dated 13 February 2011), paras. 6, 21; Tihomir Glavaš, T. 11830-11831 (14 February 2011); D1068 (List of employees of Hadžići SJB, April 1992), p. 1; D1070 (List of employees of 
joint police, but replaced the star badge on their caps with a tricolour Serb badge. ${ }^{7054}$ Initially stationed at the Culture and Sport Centre where the proclamation session was held, ${ }^{7055}$ the Serb police later relocated to the ground floor of the Hadžići Municipal Assembly Building. ${ }^{7056}$ The SDS further called on Serbs of military age to register in the Serb TO, which was to be commanded by Mile Bratić, ${ }^{7057}$ or in the reserve police formation. ${ }^{7058}$

2079. The Serb Municipality of Hadžići covered the parts of Hadžići municipality where the Serbs were the majority population, ${ }^{7059}$ and the Serb police confined their public security tasks within that territory. ${ }^{7060}$ During the period immediately after the Serb police force was established in Hadžići, certain small groups of armed "free agents" who committed theft were present in the municipality. ${ }^{7061}$ Some members of the Serb police were also involved in crime. ${ }^{7062}$ The Serb police carried out mobilisation for the VRS and provided uniforms to "citizens of Serb nationality", 7063 which led to a reduction in "the number of groups and individuals forming paramilitary formations". ${ }^{7064}$

Hadžići SJB, July 1992); D3063 (Witness statement of Mladen Tolj dated 25 February 2013), para. 6; P41 (Witness statement of Ramiz Dupovac dated 16 January 1998), p. 5.

7054 P124 (Witness statement of Zijad Okić dated 24 June 1997), e-court p. 3.

7055 P134 (Witness statement of Adem Balić dated 25 June 1997), p. 3. The headquarters of the Serbian Assembly were also on the ground floor of the Hadžići Culture and Sport Centre throughout the period of April through August 1992. Tihomir Glavaš, T. 11778 (14 February 2011). But see D3063 (Witness statement of Mladen Tolj dated 25 February 2013), para. 6.

7056 Tihomir Glavaš, T. 11779 (14 February 2011).

7057 D1066 (Proclamation of the Hadžići Municipal Assembly, undated), p. 1; D2916 (Announcement of Hadžići Municipal Assembly, undated), p. 1; D2915 (Witness statement of Vidomir Banduka dated 9 February 2013), para. 38. See also P41 (Witness statement of Ramiz Dupovac dated 16 January 1998), p. 5; D3856 (Witness statement of Dragan Kapetina dated 13 July 2013), para. 33.

7058 D1066 (Proclamation of the Hadžići Municipal Assembly, undated), p. 1; D2916 (Announcement of Hadžići Municipal Assembly, undated), pp. 1-2; D3856 (Witness statement of Dragan Kapetina dated 13 July 2013), para. 33. See also P134 (Witness statement of Adem Balić dated 25 June 1997), p. 3 (stating that the TO split into separate Serb and Muslim branches approximately one month before the conflict).

7059 P2296 (Witness statement of Tihomir Glavaš dated 13 February 2011), para. 22; Tihomir Glavaš, T. 11934 (15 February 2011), T. 12038-12039 (16 February 2011); D1087 (Map of Hadžići municipality marked by Tihomir Glavaš) (showing the areas controlled by Serbs marked by an "S"); D3856 (Witness statement of Dragan Kapetina dated 13 July 2013), para. 32; D3063 (Witness statement of Mladen Tolj dated 25 February 2013), para. 20; Vidomir Banduka, T. 33494 (12 February 2013). See also Nevenko Samouković, T. 3461534616 (1 March 2013). D3856 (Witness statement of Dragan Kapetina dated 13 July 2013), para. 32.

7061 Tihomir Glavaš, T. 11982-11983 (16 February 2011); D1074 (Correspondence from Hadžići Police Station to Sarajevo CSB, 9 August 1992), pp. 1-2. Vidomir Banduka testified that the term "free agent" in BCS denotes a person who is not "part of the system". Vidomir Banduka, T. 33524 (12 February 2013).

7062 Tihomir Glavaš, T. 11984 (16 February 2011); D1074 (Correspondence from Hadžići Police Station to Sarajevo CSB, 9 August 1992), p. 2. See also Vidomir Banduka, T. 33523-33524 (12 February 2013) (stating that the Serb Hadžići municipal authorities "had problems with such individuals and small groups").

7063 See also P134 (Witness statement of Adem Balić dated 25 June 1997), p. 2 (stating that the SDS began to distribute JNA uniforms and mobilisation papers to local Serbs about 15 days before the conflict).

7064 D1074 (Correspondence from Hadžići Police Station to Sarajevo CSB, 9 August 1992), p. 2. 
2080. Immediately after the proclamation session, the Hadžići Crisis Staff was established as the highest organ of authority for the Serb municipality, taking over the functions of the Serb Municipal Assembly. ${ }^{7065}$ The members of the Hadžići Crisis Staff included the President of the Serb Municipality, the president of the Executive Board of the Serb Municipality, one member of the military, representatives of the management of the TRZ, and the Chief of the Serb police. ${ }^{7066}$ The first task of the Crisis Staff was to "organise the defence of the Serb territory of Hadžići and to take care of, feed and organise the citizens as much as war circumstances allow". ${ }^{7067}$ The Crisis Staff authorised security actions, which were then carried out by the military and/or the police. ${ }^{7068}$

\section{(3) Continued militarisation of Hadžići}

2081. From about 10 April, the co-operation between the SDS and the JNA commanders at the barracks located throughout Hadžići became more overt, ${ }^{7069}$ and reserve units from Serbia and Montenegro began to arrive in the municipality to be deployed at the TRZ. ${ }^{7070}$ Military preparations also began in the Serb-majority villages of Bare and Miševići. ${ }^{7071}$

7065 P2306 (Report on the work of the Hadžići Municipal Assembly in 1992), p. 1; P2296 (Witness statement of Tihomir Glavaš dated 13 February 2011), paras. 23, 26, 61; Nevenko Samouković, T. 34602 (1 March 2013); D2915 (Witness statement of Vidomir Banduka dated 9 February 2013), para. 42. See also Tihomir Glavaš, T. 11780-11781 (14 February 2011); D3062 (Witness statement of Nevenko Samouković dated 26 February 1993), para. 12.

7066 P2296 (Witness statement of Tihomir Glavaš dated 13 February 2011), para. 23; Tihomir Glavaš, T. 11780 (14 February 2011); D2915 (Witness statement of Vidomir Banduka dated 9 February 2013), para. 43. See also D3062 (Witness statement of Nevenko Samouković dated 26 February 1993), para. 14; Nevenko Samouković, T. 34616 (1 March 2013. Although as Chief of the police station, Glavaš was technically a member of the Crisis Staff, he rarely attended the meetings and sent the commander of the police station, Brane Mijatović, as a representative to report back to him on the topics covered. P2296 (Witness statement of Tihomir Glavaš dated 13 February 2011), paras. 23, 61; Tihomir Glavaš, T. 11782 (14 February 2011).

7067 P2306 (Report on the work of the Hadžići Municipal Assembly in 1992), p. 1; D3062 (Witness statement of Nevenko Samouković dated 26 February 1993), para. 13. The Serb Municipal Assembly did not convene again until approximately July 1992. Nevenko Samouković, T. 34621 (1 March 2013). See also D2915 (Witness statement of Vidomir Banduka dated 9 February 2013), para. 43. The Crisis Staff met every morning in a conference room in the Hadžići Municipal Assembly building. Tihomir Glavaš, T. 11781 (14 February 2011); P2301 (Photograph of Hadžići municipal building marked by Tihomir Glavaš).

P2296 (Witness statement of Tihomir Glavaš dated 13 February 2011), para. 61. Because Radić was both President of the municipality as well as President of the Crisis Staff, all units in the territory of Hadžićiincluding those stationed at the TRZ - as well as the regular and reserve police units were under the control of the Crisis Staff. P2296 (Witness statement of Tihomir Glavaš dated 13 February 2011), para. 24. Glavaš explained that the Crisis Staff obtained intelligence that was of interest for both the security service and the military; depending on the content of the information, decisions related to "domestic issues and the rear of the territory" would be taken by the Chief of the SJB or otherwise by the army. Tihomir Glavaš, T. 11782-11783 (14 February 2011).

7069 See Adjudicated Fact 2562.

7070 P41 (Witness statement of Ramiz Dupovac dated 16 January 1998), pp. 5-6.

7071 P134 (Witness statement of Adem Balić dated 25 June 1997), p. 3; D1087 (Map of Hadžići municipality marked by Tihomir Glavaš) (showing Miševići located at the northernmost tip of the Hadžići municipality). See also D313 (Excerpt from Igman Brigade's analysis of rocket units, undated), p. 1 (stating that in April 1992 the VRS Igman Brigade formed two howitzer batteries with $122 \mathrm{~mm}$ and $155 \mathrm{~mm}$ guns and its first fire-support groups); P2296 (Witness statement of Tihomir Glavaš dated 13 February 2011), para. 22 (referring to Serb defence lines being established in the areas of Kasatići, Tinovo Hill, and in the direction of the TRZ). 
2082. Also in April 1992, Serb soldiers began to capture and occupy significant buildings and positions in the town of Hadžići. ${ }^{7072}$ During the proclamation session, ${ }^{7073}$ an anti-aircraft artillery weapon was positioned outside of the Culture and Sport Centre and was manned by members of the Serb TO. ${ }^{7074}$ Thereafter, the Serb police began arresting "Muslim terrorists" who were transporting arms. $^{7075}$

2083. Between the morning of 16 April and the afternoon of 17 April, approximately 2,200 people reported to the SRBiH TO in Hadžići, which had been mobilised during the preceding days after fighting broke out in Zvornik and Bijeljina. ${ }^{7076}$ Most of those who reported were non-Serbs, ${ }^{7077}$ thereby rendering the SRBiH TO a de facto Bosnian Muslim organ. Because the Bosnian Muslim TO lacked arms, however, the leadership sent the men home, telling them that they would be invited to report again later. ${ }^{7078}$

\section{(C) Take-over}

\section{(1) Hadžići town}

2084. On 7 May 1992, a group of armed Serb reservists and policemen took over the municipal building in Hadžići and expelled all the workers. ${ }^{7079}$ The building was then locked and guarded. ${ }^{7080}$ On the following day, "small hostilities" broke out between the Bosnian Serb and Bosnian Muslim police. ${ }^{7081}$ After negotiations between the SDS and SDA, the Serbs took control of the health centre next to the municipal building and took positions in the hills. ${ }^{7082}$ At about 3 p.m., "key persons and parties of the Municipality" on both sides met to discuss the security situation. ${ }^{7083}$ Radić concluded the meeting by stating that if they did not "finish this work, the others would

\footnotetext{
7072 P41 (Witness statement of Ramiz Dupovac dated 16 January 1998), p. 6. See also Adjudicated Fact 2562.

7073 See para. 2071.

7074 P134 (Witness statement of Adem Balić dated 25 June 1997), p. 3. At the initial Assembly meeting, Ratko Radić had stressed that it was important for the Serb TO and the army to act together in order to protect the Serb population from "all possible attacks". P2297 (Minutes of meeting of Hadžići Municipal Assembly, 11 April 1992), p. 2.

7075 D1067 (SRNA news report, 20 April 1992), p. 1. See also D2919 (Report of ABiH $9^{\text {th }}$ Mountain Brigade, 5 January 1993) (stating that before the war a truck carrying 280 Kalashnikov rifles had been diverted to Ljubovčići in order to avoid interception by "Serbian extremists" and that these rifles were later distributed by the SDA in various villages including Pazarić, Tarčin, and Hadžići).

7076 P41 (Witness statement of Ramiz Dupovac dated 16 January 1998), p. 6.

7077 P41 (Witness statement of Ramiz Dupovac dated 16 January 1998), p. 6.

7078 P41 (Witness statement of Ramiz Dupovac dated 16 January 1998), p. 6.

7079 P134 (Witness statement of Adem Balić dated 25 June 1997), p. 4; see Adjudicated Fact 2564.

7080 P134 (Witness statement of Adem Balić dated 25 June 1997), p. 4.

7081 P124 (Witness statement of Zijad Okić dated 24 June 1997), e-court p. 3. According to Vidomir Banduka, on 8 May 1992, Bosnian Muslim forces put up a blockade in front of the entrance to the TRZ. D2915 (Witness statement of Vidomir Banduka dated 9 February 2013), paras. 45, 71. 
come" and they "would have blood [...] deep up to the knees". 7084 Approximately 30 minutes later, the police station came under artillery attack. ${ }^{7085}$

2085. Meanwhile, the SDS had issued an order demanding that the Muslim members of the police, TO Headquarters, and other municipal authorities leave Hadžići by 6 p.m. on 8 May. ${ }^{7086}$ The SDS provided residents with a map and indicated that they should leave in the direction of Pazarić. ${ }^{7087}$ That night, between roughly 2,000 and 3,000 Muslim and Croat men, women, and children withdrew from Hadžići town, leaving only 200 or 300 behind. $^{7088}$ By 9 May, the Serbs had taken control of parts of the municipality of Hadžici and had encircled the TRZ. ${ }^{7089}$

2086. Over the following few days, Serb reservists began setting up check-points around Hadžići town, thereby restricting residents' movements. ${ }^{7090}$ Serb women and children were put on buses headed toward Montenegro, ${ }^{7091}$ and the Serb Forces began to arrest, expel, or kill people who remained in the municipality. ${ }^{7092}$ The Serb police went around to homes, instructing people to stay inside. $^{7093}$ Police officers were placed in front of buildings in Hadžići, thus preventing any movement by the residents. ${ }^{7094}$ Many houses were searched. ${ }^{7095}$

2087. Between 10 and 12 May 1992, Serb Forces and the Bosnian Muslim TO engaged in a "heavy exchange of fire" in Hadžići. ${ }^{7096}$ By 12 May, Serb Forces in the Krupačka Rijeka area, near

\footnotetext{
$7084 \quad$ P41 (Witness statement of Ramiz Dupovac dated 16 January 1998), p. 6.

7085 P41 (Witness statement of Ramiz Dupovac dated 16 January 1998), p. 6. See also P134 (Witness statement of Adem Balić dated 25 June 1997), p. 4; Adjudicated Fact 2566.

7086 P41 (Witness statement of Ramiz Dupovac dated 16 January 1998), p. 6. See also Adjudicated Facts 2565, 2570.

7087 P41 (Witness statement of Ramiz Dupovac dated 16 January 1998), p. 6; D1087 (Map of Hadžići municipality marked by Tihomir Glavaš).

7088 P41 (Witness statement of Ramiz Dupovac dated 16 January 1998), p. 7 (further testifying that according to official records, 186 of those people were later listed as missing). See also Adjudicated Fact 2567; D2915 (Witness statement of Vidomir Banduka dated 9 February 2013), para. 46. Bosnian Muslim forces set up a check-point near the quarry on the road to Pazarić just outside town, which became and remained the frontline until the end of the war. P41 (Witness statement of Ramiz Dupovac dated 16 January 1998), p. 7.

7089 P41 (Witness statement of Ramiz Dupovac dated 16 January 1998), p. 7; P1477 (Ratko Mladić's notebook, 14 February-28 May 1992), p. 269. See also Adjudicated Fact 2566.

7090 P134 (Witness statement of Adem Balić dated 25 June 1997), p. 4. See also Adjudicated Fact 2568.

7091 P134 (Witness statement of Adem Balić dated 25 June 1997), p. 4. See also Adjudicated Fact 2567.

7092 P41 (Witness statement of Ramiz Dupovac dated 16 January 1998), p. 7. The Chamber notes these killings are not charged pursuant to either Schedule A or Schedule B of the Indictment. See fn. 13.

7093 P134 (Witness statement of Adem Balić dated 25 June 1997), p. 4; P161 (Adem Balić's statement to BiH authorities dated 7 February 1993), p. 1.

7094 P161 (Adem Balić's statement to BiH authorities dated 7 February 1993), p. 1.

7095 P124 (Witness statement of Zijad Okić dated 24 June 1997), e-court p. 4; P125 (Zijad Okić's statement to BiH authorities, 3 February 1993), p. 1; P161 (Adem Balić's statement to BiH authorities dated 7 February 1993), p. 1.

7096 D1073 (SerBiH MUP report on daily activities, 12 May 1992), p. 1. At the break of dawn on 11 May, Bosnian Muslim forces attacked locations in Hadžići town, including the Serb police station. D2921 (RS MUP information, 11 May 1992), p. 1; D2915 (Witness statement of Vidomir Banduka dated 9 February 2013), paras.
} 
Tinovo Hill, and the JNA complex at Žunovnica were all surrounded by Bosnian Muslim forces; however, the Serb Forces maintained control over the situation and the area. ${ }^{7097}$ Fighting in and around Hadžići town continued throughout May and into June $1992 .^{7098}$

\section{(2) Attacks against surrounding villages}

2088. Meanwhile, villages surrounding Hadžići had also come under attack. On 7 or 8 May 1992, using weapons stationed in front of the Culture and Sport Centre, Serb Forces opened fire on the village of Kovačevići. ${ }^{7099}$ On 8 May 1992, some Kovačevići residents were killed by a Serbian paramilitary group. ${ }^{7100}$ During the following two days, a peace commission was set up to calm the situation. $^{7101}$ The Serb Forces took control of Kovačevići on 11 May $1992 .^{7102}$

2089. After the attack on Kovačevići, the residents of Musići, a Muslim settlement within the Serb village of Ušivak, ${ }^{7103}$ came under fire from the Serb Forces. ${ }^{7104}$ On 8 May 1992, tanks approached

46, 47. See also P124 (Witness statement of Zijad Okić dated 24 June 1997), e-court pp. 3-4; D2491 (Report of Tarčin police station, 6 August 1992), p. 5; Vidomir Banduka, T 33531, 33529 (13 February 2013). Small arms fire continued after the shelling. P124 (Witness statement of Zijad Okić dated 24 June 1997), e-court p. 4.

D1073 (SerBiH MUP report on daily activities, 12 May 1992), p. 1; P2790 (SerBiH MUP daily report, 12 May 1992), p. 1. On 25 May 1992, Bosnian Muslim forces attacked the Serb-held Žunovnica complex and took control of over half of the storage premises, but Serb Forces had regained control by the following evening. D317 (TO Hadžići report on combat readiness, 29 May 1992), p. 1; P133 (Witness statement of Matija Bošković dated 20 November 2003), p. 8. See also D1211 (Ilidža Crisis Staff letter, 13 May 1992) (suggesting that the Muslim forces were intent on taking over the TRZ).

7098 D2915 (Witness statement of Vidomir Banduka dated 9 February 2013), paras. 49-51; Vidomir Banduka, T 33531 (13 February 2013). See also D1212 (Intercept of conversation between Neđeljko Prstojević and Milosav Gagović, 13 May 1992), p. 2; Mladen Tolj, T. 34649 (1 March 2013). Hadžići continued to come under heavy fire from the $\mathrm{ABiH}$ throughout the remainder of 1992 and into early 1993. D2451 (Witness statement of Velimir Dunjić dated 12 November 2012), para. 17; D2453 (Report of Igman Brigade, 2 October 1992); D2454 (Report of Igman Brigade, 24 September 1992); D2456 (Report of Igman Brigade, 8 December 1992); D2457 (Report of Igman Brigade, 7 December 1992); D2458 (Report of Igman Brigade, 6 December 1992); D2459 (Report of Igman Brigade, 4 December 1992); D2460 (Report of Igman Brigade, 27 November 1992); D2461 (Report of Igman Brigade, 23 November 1992); D2462 (Report of Igman Brigade, 21 November 1992); D2463 (Report of Igman Brigade, 18 November 1992); D2468 (Report of Igman Brigade, 22 December 1992); P4228 (UNPROFOR report re meeting with Radovan Karadžić and Alija Izetbegović, 16 February 1993), para. 6.

7099 P134 (Witness statement of Adem Balić dated 25 June 1997), p. 4. The firing only lasted for the day, but the situation was very tense afterwards. P134 (Witness statement of Adem Balić dated 25 June 1997), p. 4. The Serb village of Bare began shooting with rifles as well as light and heavy machine guns at the nearby Muslim village of Grivići. P124 (Witness statement of Zijad Okić dated 24 June 1997), e-court p. 3. See also P2296 (Witness statement of Tihomir Glavaš dated 13 February 2011), para. 67 (recalling a weapons seizing operation which occurred in Grivići).

7100 P2403 (Witness statement of Mehmed Musić dated 28 February 2011), para. 19; Mehmed Musić, T. 12831 (3 March 2011). The Chamber notes these killings are not charged pursuant to either Schedule A or B of the Indictment. See fn. 13.

7101 P134 (Witness statement of Adem Balić dated 25 June 1997), p. 4.

7102 P2403 (Witness statement of Mehmed Musić dated 28 February 2011), para. 21.

7103 P2403 (Witness statement of Mehmed Musić dated 28 February 2011), paras. 6-7; P2405 (Map of Hadžići marked by Mehmed Musić) (showing Musići at Point 1).

7104 P2403 (Witness statement of Mehmed Musić dated 28 February 2011), paras. 19, 21. The Serb police were "[one] hundred percent certain" that the residents of Musići settlement had illegal weapons. P2296 (Witness statement of Tihomir Glavaš dated 13 February 2011), paras. 33, 34, 39. See also P2403 (Witness statement of 
Musići from Tinovo Hill. ${ }^{7105}$ Realising that they would not be able to "offer resistance to the Chetniks", the residents of Musići organised buses and had already begun taking the women and children out of Musići between 7 and 9 May. ${ }^{7106}$

2090. Around 15 May, Serb Forces shelled houses and other buildings in Musići from positions located in Ušivak. ${ }^{7107}$ After about two days, two Bosnian Serbs came to Musići and called on the residents to surrender. ${ }^{7108}$ They refused, so the shelling resumed that evening and continued for three days. $^{7109}$

2091. On 20 May, pursuant to a decision of the Crisis Staff, ${ }^{7110}$ approximately 50 to 60 members of the Serb Forces entered Musići from all sides, supported by two Praga tanks. ${ }^{711}$ The Serb Forces announced through a loudspeaker that all weapons should be handed over. ${ }^{712}$ The soldiers then went from house to house to conduct searches and seize weapons. ${ }^{7113}$

Mehmed Musić dated 28 February 2011), paras. 15, 25; Mehmed Musić, T. 12830-12831, 12847 (3 March 2011). Glavaš acknowledged that the Serb police was aware that some people had permits allowing them to keep weapons, but suggested that the Serb police still sought out the owners of such weapons because they were being used illegally. P2296 (Witness statement of Tihomir Glavaš dated 13 February 2011), para. 67.

12

$$
\text { P2296 }
$$
settlement over weapons in a certain location. P2296 (Witness statement of Tihomir Glavaš dated 13 February 2011), para. 35.

7113 P2296 (Witness statement of Tihomir Glavaš dated 13 February 2011), para. 68. The Serbs seized illegally owned weapons, including approximately 20 or $30 \mathrm{M}-48$ rifles, explosives, and machine guns, from the settlement and took them to the police station. P2296 (Witness statement of Tihomir Glavaš dated 13 February 2011), paras. 37, 40-41, 43. The weapons were then distributed to either the Serb police or the military pursuant to a decision of the Crisis Staff. P2296 (Witness statement of Tihomir Glavaš dated 13 February 2011), paras. 40-41; Tihomir Glavaš, T. 11787-11788 (14 February 2011). 
2092. Mehmed Musić was arrested in his home by two members of the Serb MP and was taken along with 14 other men from Musići to Alija Musić's house, ${ }^{711}$ where he saw three dead bodies. $^{7115}$ Dragan Pušara sent a man to fetch the Musići residents who were still hiding, threatening to kill all of the 14 men if those in hiding refused to surrender. ${ }^{7116}$

2093. Eventually, the Serb soldiers led the 14 men away to the primary school in Hadžići, ${ }^{7117}$ which was guarded by men wearing olive-grey uniforms. ${ }^{718}$ Once the men had arrived inside a classroom on the first floor, the guards threatened to kill them and began to curse at them, stating, "there would be no balija state soon". 7119 The guards spat on the detainees and told them that they were finished. $^{7120}$ After approximately 30 minutes, the detainees were taken out of the school and marched to the garage of the Municipal Assembly building, which was located approximately 150 metres away. $^{7121}$

\section{(D) Detention facilities in Hadžići}

2094. In the meantime, the Hadžići Crisis Staff had decided to arrest and detain all Bosnian Muslim men of military age from areas in the municipality such as Binježevo, Žunovnica, and Kučice. $^{7122}$ According to Tihomir Glavaš, this decision was taken because the Serbs had

7114 P2403 (Witness statement of Mehmed Musić dated 28 February 2011), paras. 36, 38.

7115 P2403 (Witness statement of Mehmed Musić dated 28 February 2011), para. 38 (identifying the dead as Alija, Derviš, and Fadil Musić). See also P2296 (Witness statement of Tihomir Glavaš dated 13 February 2011), paras. 37, 62 (stating that three Bosnian Muslims were killed during the 20 May 1992 incident in Musići). The Chamber notes these killings are not charged pursuant to either Schedule A or B of the Indictment. See fn. 13.

7116 P2403 (Witness statement of Mehmed Musić dated 28 February 2011), para. 38. Rade Veselinović also suggested "liquidat[ing]" all 14 of the men lined up outside of Alija Musić's house, but Pušara opposed that. P2403 (Witness statement of Mehmed Musić dated 28 February 2011), paras. 38, 40 (describing Veselinović as singing "Chetnik" songs). See also P2296 (Witness statement of Tihomir Glavaš dated 13 February 2011), paras. 36, 44 (stating that Veselinović, who was a member of the reserve police before moving to the military police, was often tasked with disarmament operations and that he took part in the operation in Musići).

7117 P2403 (Witness statement of Mehmed Musić dated 28 February 2011), para. 41. According to Tihomir Glavaš, the men were arrested because long-barrelled weapons were found on them. P2296 (Witness statement of Tihomir Glavaš dated 13 February 2011), para. 45.

7118 P2403 (Witness statement of Mehmed Musić dated 28 February 2011), para. 42. The school was closed so the detainees were told to climb through a window and go up to a classroom on the first floor. P2403 (Witness statement of Mehmed Musić dated 28 February 2011), para. 42.

7119 P2403 (Witness statement of Mehmed Musić dated 28 February 2011), para. 42. The guards appeared to Musić to be in some kind of hurry or panic. P2403 (Witness statement of Mehmed Musić dated 28 February 2011), para. 43.

$7120 \quad$ P2403 (Witness statement of Mehmed Musić dated 28 February 2011), para. 43.

7121 P2403 (Witness statement of Mehmed Musić dated 28 February 2011), para. 44. See also Adjudicated Fact 2611; paras. 2095-2100.

7122 Tihomir Glavaš, T. 11784 (14 February 2011); P2296 (Witness statement of Tihomir Glavaš dated 13 February 2011), para. 26. The Chamber notes the testimony of Nevenko Samouković, who stated that, as far as he knew, "no one in the territory of Hadžići municipality made a decision to designate certain facilities as camps for detaining Muslims". Nevenko Samouković, T. 34614, 34624 (1 March 2013). Samouković also stated that this was consistent with a report from the Serb police in Hadžići dated 9 August 1992, which asserted that "in the area of Hadžići municipality, we do not have collection camps used by the army to bring in the Muslim population without documents on the reasons for detention”. D1074 (Correspondence from Hadžići Police 
information that Muslims were arresting military-aged Serbs and were preparing to attack; ${ }^{7123}$ the Serbs also claimed to be arresting Bosnian Muslims for possession of illegal weapons. ${ }^{7124}$ The arrests were carried out by the Serb police and the Serb TO. ${ }^{7125}$

\section{(1) Scheduled Detention Facility C.11.1}

2095. The Indictment refers to the use of the garage of the Hadžići Municipal Assembly Building as a detention facility from 20 May 1992 until at least June 1992.

2096. After the Hadžići SJB building was shelled around 10 May, ${ }^{7126}$ the Serb police moved into the Hadžići Municipal Assembly Building. ${ }^{7127}$ From 12 May until 1 June, Bosnian Muslims were arrested and held in the garage under the building "for interrogation". 7128

Station to Sarajevo CSB, 9 August 1992), p. 5. However, the Chamber observes that Samouković qualified his own testimony by referring to the extent of his own knowledge, which was itself questionable, and that he acknowledged that both the Culture and Sport Centre and the garage of the Municipal Building had been used to house "the remaining Muslim population" and as a holding centre, respectively. D3062 (Witness statement of Nevenko Samouković dated 26 February 1993), paras. 17, 22. The Chamber further notes that the correspondence from the Hadžići Serb police pertained to the situation in August 1992, several months after the arrests and detentions in Hadžići began. The Chamber therefore shall not place weight on either Samouković's testimony or D1074 in relation to whether there was a decision to arrest and detain Bosnian Muslim men.

P2296 (Witness statement of Tihomir Glavaš dated 13 February 2011), para. 45; Tihomir Glavaš, T. 11784 (14 February 2011). See also D3063 (Witness statement of Mladen Tolj dated 25 February 2013), para. 14 (suggesting that the records of detention reflected bona fide reasons for taking each person into custody). According to Tolj, the prevailing security conditions in Hadžići precluded compliance with the requirement that civilians be brought before an investigative judge within three days of their detention. Mladen Tolj, T. 34647 (1 March 2013). See also para. 305, fn. 935; D2915 (Witness statement of Vidomir Banduka dated 9 February 2013), para. 58 (stating that the Law on Criminal Procedure prevented anyone from being held for more than a month). According to Banduka, if there was a need to hold someone for a period that exceeded the three days prescribed by law, they were transferred to Kula prison. D2915 (Witness statement of Vidomir Banduka dated 9 February 2013), para. 58; Vidomir Banduka, T. 33520 (12 February 2013). Banduka also noted that the transport to Kula Prison would have required permission to transit through the airport, which was held at the time by international forces and thus would have required their consent. Vidomir Banduka, T. 33520-33521 (12 February 2013).

Tihomir Glavaš, T. 11784 (14 February 2011); P2296 (Witness statement of Tihomir Glavaš dated 13 February 2011), para. 47 (stating that he as Chief of the Serb police was aware that the Serb TO and the Serb police were taking people out of their homes). Defence witnesses Nevenko Samouković and Vidomir Banduka suggested that Bosnian Muslims had gone voluntarily to the collection centres but when presented with the testimonies of Mehmed Musić, Adem Balić, and Tihomir Glavaš, all of whom acknowledged that the Serb police and Serb TO had taken people from their houses, Banduka admitted that he was not in a position to answer whether they were taken voluntarily or not, while Samouković speculated that the police "probably had some operative intelligence" or that the arrests had been the result of incompetence or abuses of power. Nevenko Samouković, T. 34613-34614 (1 March 2013); Vidomir Banduka, T. 33512-33513 (12 February 2013). The Chamber thus considers the evidence of Samouković and Banduka to be speculative and shall not rely upon it relation to whether Bosnian Muslims were taken "voluntarily" to detention centres.

7126 See para. 2084, fn. 7096.

7127 D2915 (Witness statement of Vidomir Banduka dated 9 February 2013), para. 57; P2403 (Witness statement of Mehmed Musić dated 28 February 2011), para. 45; P2406 (Photograph of Hadžići municipal building); P2301 (Photograph of Hadžići municipal building marked by Tihomir Glavaš); Tihomir Glavaš, T. 11789-11790 (14 February 2011).

7128 P124 (Witness statement of Zijad Okić dated 24 June 1997), e-court p. 4. P2300 (Photograph of garage underneath Hadžići municipal building); Tihomir Glavaš, T. 11784, 11788-11789 (14 February 2011); P2403 
2097. When the 14 men from Musići arrived on 20 May, one Croat and one Muslim prisoner were already inside the garage. ${ }^{7129}$ Mehmed Musić spent six days in the garage with about 47 other men. ${ }^{7130}$ The detainees were only fed one slice of bread once or twice a day, as well as some watery soup, and were given only one or two bottles of water for the entire group. ${ }^{7131}$

2098. One by one, each detainee was called out and taken up into the Hadžići Municipal Assembly Building to be interrogated by members of the Serb Forces about the supply of weapons to Bosnian Muslims. ${ }^{7132}$ On their third day in the garage, the group of men from Musići were taken to the weapons storage facility in Žunovnica to load ammunition. ${ }^{7133}$

2099. On 25 May 1992, all but three of the men from Musići were moved to the Culture and Sport Centre. ${ }^{7134}$ The other detainees remained behind in the Municipal Assembly Building garage until 22 June, ${ }^{7135}$ when they were transferred to the "Slaviša Čiča" Barracks in Lukavica. ${ }^{7136}$

(Witness statement of Mehmed Musić dated 28 February 2011), paras. 47, 51-52. See also D2915 (Witness statement of Vidomir Banduka dated 9 February 2013), para. 57; Vidomir Banduka, T. 33538-33539 (13 February 2013) (stating that the detainees in the garage included Serbs and that all had been brought into custody for having committed crimes).

7129 P2403 (Witness statement of Mehmed Musić dated 28 February 2011), para. 46. See also Mladen Tolj, T. 34633 (1 March 2013).

7130 P2403 (Witness statement of Mehmed Musić dated 28 February 2011), para. 48; Mladen Tolj, T. 34634-34635 (1 March 2013). See also Adjudicated Fact 2611; Tihomir Glavaš, T. 11793 (14 February 2011) (estimating that 30 people, mostly from Muslić, Visasoci, Binježevo, and Kučiste were detained in the garage).

7131 P2403 (Witness statement of Mehmed Musić dated 28 February 2011), para. 48; Mehmed Musić, T. 12838 (3 March 2011). Mladen Tolj testified that "until 1994 there was no water in Hadžići”. Mladen Tolj, T. 34652 (1 March 2013); D3064 (Report of Hadžići Secretariat for Housing, Public Utilities, Transport and Communications, 1 December 1992), p. 3 (stating that after the outbreak of the war, the Serb municipality of Hadžići was affected by a water supply outage, forcing the use of an improvised pipeline to reroute the well located at the TRZ, which enabled the water supply to the immediate centre of Hadžići to be re-established; however, other parts were supplied via water from cisterns); D2915 (Witness statement of Vidomir Banduka dated 9 February 2013), para. 64 (stating that because the water supplies were in territory held by Bosnian Muslims, the water supply was cut at the beginning of the war).

7132 P2403 (Witness statement of Mehmed Musić dated 28 February 2011), para. 47.

7133 P2403 (Witness statement of Mehmed Musić dated 28 February 2011), para. 49; Mehmed Musić, T. 12834 (3 March 2011); P2405 (Map of Hadžići marked by Mehmed Musić) (showing Žunovnica at Point 3).

7134 P2403 (Witness statement of Mehmed Musić dated 28 February 2011), paras. 51-52. See also D3063 (Witness statement of Mladen Tolj dated 25 February 2013), para. 13; Mladen Tolj, T. 34635-34636 (1 March 2013) (stating that people on whom no weapons were found were taken to the Culture and Sport Centre). See para. 2102.

7135 Tihomir Glavaš estimated that by mid-June, approximately 30 Bosnian Muslims were being held in the garage of the Municipal Assembly Building. Tihomir Glavaš, T. 11793 (14 February 2011) (referring to the number of people being held when he prevented the White Eagles from entering the garage). See also fn. 7158.

7136 P2403 (Witness statement of Mehmed Musić dated 28 February 2011), para. 65. See also Scheduled Detention Facility C.18.1. The detainees from the garage smelled badly and told Musić that they had spent 33 days in the garage without being able to bathe. P2403 (Witness statement of Mehmed Musić dated 28 February 2011), para. 66; Mehmed Musić, T. 12838 (3 March 2011). See also P161 (Adem Balić's statement to BiH authorities dated 7 February 1993), p. 1. Around 25 June 1992, a woman and her sister were moved to the garage of the Municipal Assembly Building from the Hadzići civil defence headquarters. Adjudicated Fact 2613. The Chamber further notes that in early June, Arkan's men also removed a man from the Culture and Sport Centre and took him to the garage of the Municipal Assembly Building, where he was detained for 40 days. P161 (Adem Balić's statement to BiH authorities dated 7 February 1993), p. 1. The Chamber therefore concludes that 
2100. Based on the above, the Chamber finds that between 20 May and at least late June 1992, approximately 50 Bosnian Muslims, some of whom were civilians and two of whom were women, were detained in the garage under the Hadžici Municipal Assembly Building by members of Serb Forces and that while held there, the detainees were given inadequate food and water and on one occasion were forced to work.

\section{(2) Scheduled Detention Facility C.11.2}

2101. The Indictment refers to the use of the Hadžići Culture and Sport Centre as a detention facility from at least 25 May until September 1992.

(a) Establishment and control of detention facility

2102. Sometime prior to 25 May $1992,{ }^{7137}$ the Crisis Staff decided to detain military-aged Bosnian Muslims in the Culture and Sport Centre and to place the facility under military control. ${ }^{7138}$ As mentioned above, ${ }^{7139}$ on 25 May 1992, 12 men from Musići were moved from the garage of the Municipal Assembly Building to the Culture and Sport Centre. ${ }^{7140}$ By that time, about 60 men-as

people continued to be detained in the garage even after the group of men was transferred to the "Slaviša Čiča" Barracks in Lukavica on 22 June 1992.

The Chamber notes that Vidomir Banduka testified that the Crisis Staff only decided that the Culture and Sport Centre would be used as a "holding centre to accommodate people" after approximately 16 June 1992. D2915 (Witness statement of Vidomir Banduka dated 9 February 2013), paras. 53-54. However, Banduka conceded that he never visited the Culture and Sport Centre. Vidomir Banduka, T. 33510 (12 February 2013). The Chamber therefore considers that, even if taken as true, Banduka's testimony does not preclude the possibility that the decision to use the Culture and Sport Centre to accommodate Bosnian Muslims was taken earlier than 16 June 1992, and recalls that Adem Balić testified that Serb Forces had taken him from his home in Hadžići to the Culture and Sport Centre already on 16 May 1992. P134 (Witness statement of Adem Balić dated 25 June 1997), p. 4; P161 (Adem Balić's statement to BiH authorities, 7 February 1993), p. 1. The Chamber is therefore satisfied that the detention facility at the Culture and Sport Centre was established prior to 25 May 1992.

7138 P2296 (Witness statement of Tihomir Glavaš dated 13 February 2011), paras. 26, 46, 48; Tihomir Glavaš, T. 11784 (14 February 2011). See also Adjudicated Fact 2615. The Chamber notes that Vidomir Banduka and Mladen Tolj both testified that Muslims had chosen to be accommodated in the Culture and Sport Centre. D2915 (Witness statement of Vidomir Banduka dated 9 February 2013), para. 56; D3063 (Witness statement of Mladen Tolj dated 25 February 2013), paras. 9, 13. When presented with his testimony in the Krajišnik case, wherein he had conceded that Bosnian Muslims had been held against their will but stated that such detention "was for their own protection", Banduka denied that he had so testified and suggested that his testimony had been misinterpreted. Vidomir Banduka, T. 33516 (12 February 2013); P6110 (Excerpt from Vidomir Banduka's testimony in Prosecutor v. Krajišnik), p. 3. Having reviewed his prior testimony, the Chamber is of the view that the credibility of Banduka's testimony in this case on this point is undermined. The Chamber also observes that Tolj conceded that "very few went voluntarily", stating that "[m]ost were brought there and kept with the best of intentions because that's where it was the safest for them". Mladen Tolj, T. 34636-34637 (1 March 2013). The Chamber further notes that Banduka admitted that the guards would have had to give prior approval in order for anyone to leave. Vidomir Banduka, T. 33514-33515 (12 February 2013). The Chamber therefore finds that the people in the Culture and Sport Centre were indeed detained and not accommodated pursuant to mutual agreement. See further P2296 (Witness statement of Tihomir Glavaš dated 13 February 2011), paras. 46, 49 (stating that people were "brought in [...] for their safety" and that men were detained because the Serbs needed people for exchange) (emphasis added).

7139 Scheduled Detention Facility. C.11.2.

7140 P2403 (Witness statement of Mehmed Musić dated 28 February 2011), paras. 51-52; P2404 (Photograph of Hadžići Culture and Sport Centre); P2299 (Photograph of Hadžići Culture and Sport Centre). 
well as a woman ${ }^{7141}$ — were already being detained in two locker rooms of the Culture and Sport Centre. ${ }^{7142}$ The facility was first guarded by members of the Serb TO; ${ }^{7143}$ although the Serb police began to provide security along with members of the military after approximately August $1992 .^{7144}$

\section{(b) Conditions of detention and treatment of detainees}

2103. Since the men from Musići could not fit in the locker rooms, they were taken to the main gym area, where they slept on the floor without blankets. ${ }^{7145}$ The detainees were fed one slice of bread each day and some rice or soup in the morning and afternoon. ${ }^{7146}$ Only two toilets were available to the detainees. ${ }^{7147}$

2104. While in detention in the Culture and Sport Centre, the detainees were often beaten and sexually abused by members of paramilitary units. ${ }^{7148}$ On or before 25 May, ${ }^{7149}$ three of Arkan's

7141 P2403 (Witness statement of Mehmed Musić dated 28 February 2011), para. 55. See also Adjudicated Fact 2614.

7142 P2403 (Witness statement of Mehmed Musić dated 28 February 2011), para. 56; P161 (Adem Balić's statement to $\mathrm{BiH}$ authorities dated 7 February 1993), p. 1.

7143 The members of the TO who served as guards included Trifko Ignjatović, Rade Milović, Momo Vujović, Simo Kuzman, Marinko Djokić, Keko Krajišnik, and Radovan Duka. P2403 (Witness statement of Mehmed Musić dated 28 February 2011), para. 54; P2296 (Witness statement of Tihomir Glavaš dated 13 February 2011), para. 50; Tihomir Glavaš, T. 11785 (14 February 2011). Momo Vujović and, occasionally, Sretan Krajišnik (a.k.a. Kekan) were in charge of the facility. P2403 (Witness statement of Mehmed Musić dated 28 February 2011), para. 54.

7144 Mladen Tolj, T. 34637, 34639-34640, 34561 (1 March 2013); D1074 (Correspondence from Hadžići Police Station to Sarajevo CSB, 9 August 1992), p. 2 (stating that between April and July 1992, police officers of the Serb police were "included in all combat activities" but since 1 August 1992 had returned from the frontlines and were put back on regular MUP activities). Tihomir Glavaš denied that the Culture and Sport Centre was under the control of the Serb police. P2296 (Witness statement of Tihomir Glavaš dated 13 February 2011), paras. 48, 50, 51 (suggesting that the Culture and Sport Centre was under military control). However, the Chamber also observes that Glavaš himself qualified his evidence in this regard, stating, "at least for as long as I was in Hadžići”, and conceded that he never personally visited the Culture and Sport Centre. Tihomir Glavaš, T. 11785 (14 February 2011); P2296 (Witness statement of Tihomir Glavaš dated 13 February 2011), para. 53. The Chamber further notes that Glavaš testified that by 9 August 1992 he had already been transferred to Ilidža. P2296 (Witness statement of Tihomir Glavaš dated 13 February 2011), para. 82. The Chamber is therefore of the view that Glavaš's personal knowledge would therefore necessarily be limited and considers that Glavaš's testimony does not conflict with further evidence indicating that the Serb police were involved in the guarding and organisation of the detention facility at the Culture and Sport Centre from August 1992. See also P1607 (RS Ministry of Justice report on prisons and camps on the RS territory, 22 October 1992), e-court p. 7 (stating that organisation and security were being provided by the Hadžići SJB).

7145 P2403 (Witness statement of Mehmed Musić dated 28 February 2011), para. 56.

7146 P2403 (Witness statement of Mehmed Musić dated 28 February 2011), para. 56. See also P2296 (Witness statement of Tihomir Glavaš dated 13 February 2011), para. 64 (testifying that at the beginning of their detention, detainees were fed the same as the Serbs but that they were then fed poorly after it was discovered that Serbs were being mistreated in Tarčin and Pazarić); P804 (Sky news report re Kula prison, with transcript), $1: 20-1: 47$.

7147 P2403 (Witness statement of Mehmed Musić dated 28 February 2011), para. 56.

7148 See Adjudicated Fact 2616. See also P2403 (Witness statement of Mehmed Musić dated 28 February 2011), para. 57; P804 (SKY news report re Kula prison, with transcript), 1:20-1:47.

7149 Adem Balić estimated that Arkan's men arrived "around 1 June 1992". P161 (Adem Balić's statement to BiH authorities dated 7 February 1993), p. 1. However, Mehmed Musić was told that Arkan's men had been present at the Culture and Sport Centre on 25 May 1992 before he arrived from the Municipal Assembly Building garage. P2403 (Witness statement of Mehmed Musić dated 28 February 2011), para. 63. In light of Musić's 
men, who were dressed in black uniforms, arrived and beat and humiliated the prisoners. ${ }^{7150}$ On approximately 15 June, Šešelj's men arrived at the Culture and Sport Centre. ${ }^{7151}$ The men wore gloves with the fingertips cut off, painted their faces black, wore camouflage uniforms, and carried big knives. ${ }^{7152}$ A woman with dyed blond hair named Ljiljia who was with Šešelj's men removed one man's pants and told another man to "suck the first man's sexual organ". ${ }^{7153}$ She then removed her own pants and told the second man to lick her buttocks, threatening to slit the men's throats if they did not comply. ${ }^{7154}$

2105. Šešelj's men singled out certain detainees and beat them severely, ${ }^{7155}$ while forcing other detainees to fight each other. ${ }^{7156}$ These beatings took place in the presence of the Serb TO guards. ${ }^{7157}$ Later that day, when ten or fifteen people from Žunovnica arrived, Šešelj's men forced

further testimony that the second group of paramilitaries arrived on the second day of Bajram, which was 12 June 1992, Balić's testimony that the second group arrived 15 days after the first, and the fact that Musić had not yet been transferred when Arkan's men first arrived, the Chamber concludes that Arkan's men came to the Sport and Culture Centre on or before 25 May, and considers that this is not inconsistent with Balić's estimate of this date.

7150 P161 (Adem Balić's statement to BiH authorities dated 7 February 1993), p. 1; P134 (Witness statement of Adem Balić dated 25 June 1997), p. 4 (stating that the guards revealed that the men were Arkan's men). See also D3063 (Witness statement of Mladen Tolj dated 25 February 2013), paras. 9-10. Arkan's men also removed a man from the Culture and Sport Centre and took him to the garage of the Municipal Assembly Building. See fn. 7136.

7151 P161 (Adem Balić's statement to BiH authorities dated 7 February 1993), p. 1. Mehmed Musić referred to this second group as Arkan's men, stating that one of the men had identified himself and the group as such. P2403 (Witness statement of Mehmed Musić dated 28 February 2011), para. 57. However, Musić also testified that this group arrived on the second day of Bajram, which was 12 June 1992. Mehmed Musić, T. 12833, 12866 (3 March 2011). Adem Balić identified the group that arrived 15 days after Arkan's men, which would have been around 12 June, as Šešelj's men. P161 (Adem Balić's statement to BiH authorities dated 7 February 1993), p. 1. This identification is corroborated by the testimony of Tihomir Glavaš, who testified that he heard that Šešelj's men had sexually abused the detainees in the Culture and Sport Centre. P2296 (Witness statement of Tihomir Glavaš dated 13 February 2011), paras. 53-54. The Chamber therefore concludes that the paramilitaries in the second group were Šešelj's men rather than Arkan's men.

7152 P2403 (Witness statement of Mehmed Musić dated 28 February 2011), para. 57.

7153 P2403 (Witness statement of Mehmed Musić dated 28 February 2011), para. 58 (stating that he could identify her because she had taught his daughters at the technical school in Ilidža); P161 (Adem Balić's statement to BiH authorities dated 7 February 1993), p. 2. See also P2296 (Witness statement of Tihomir Glavaš dated 13 February 2011), para. 54; P804 (Sky news report re Kula prison, with transcript), 1:20-1:47. Musić explained that he had not mentioned this event in past statements because he did not want to embarrass these men, but did so once they passed away. P2403 (Witness statement of Mehmed Musić dated 28 February 2011), para. 59; Mehmed Musić, T. 12867 (3 March 2011).

7154 P2403 (Witness statement of Mehmed Musić dated 28 February 2011), paras. 58-59.

7155 P161 (Adem Balić's statement to BiH authorities dated 7 February 1993), pp. 1-2. See also P2296 (Witness statement of Tihomir Glavaš dated 13 February 2011), para. 54. Even in February 1993, Balić could still feel pain in his left kidney area from this beating. P161 (Adem Balić's statement to BiH authorities dated 7 February 1993), p. 1. Balić's brother was beaten with a flagpole and sustained a broken arm and leg. P161 (Adem Balić's statement to BiH authorities dated 7 February 1993), p. 2. See also P2403 (Witness statement of Mehmed Musić dated 28 February 2011), paras. 59-60 (recalling how after sexually abusing two men, Ljiljia then began to jump on a 70 year old man, causing him to cry).

7156 P161 (Adem Balić's statement to BiH authorities dated 7 February 1993), pp. 1-2; P2403 (Witness statement of Mehmed Musić dated 28 February 2011), paras. 60-62.

7157 P161 (Adem Balić's statement to BiH authorities dated 7 February 1993), pp. 1-2. 
one of the arrivals to run around the Culture and Sport Centre and swear at the detainees' "balija mother". 7158

\section{Centre}

\section{(c) Transfer and exchange of detainees at the Culture and Sport}

2106. By 22 June, 282 people had been detained in the Hadžići Culture and Sport Centre. ${ }^{7159}$ On approximately 22 June 1992, "a rather large group” of men, women, and children from Kučice, a settlement located nearby, arrived at the Culture and Sport Centre. ${ }^{7160}$ Soon thereafter, the guards told the detainees that they were going to be exchanged. ${ }^{7161}$ Around 10 p.m. that evening, in accordance with a decision of the Crisis Staff, ${ }^{7162}$ the male detainees in the Culture and Sport Centre were loaded onto several buses. ${ }^{7163}$ While en route, one bus stopped first in front of the garage of the Hadžići Municipal Assembly Building, ${ }^{7164}$ where it picked up detainees before proceeding to Kula Prison. ${ }^{7165}$ There, "Chetniks" boarded the bus, beat the detainees with rifle butts, and extinguished cigarettes on their faces. ${ }^{7166}$ Ultimately, the detainees were taken to the Slaviša Vajner Čiča Barracks in Lukavica. ${ }^{7167}$

7158 P2403 (Witness statement of Mehmed Musić dated 28 February 2011), para. 61. After leaving the Culture and Sport Centre, Šešelj's men tried to go to the Municipal Assembly Building garage and do the same thing to the detainees there, but were prevented from doing so by Tihomir Glavaš. P2296 (Witness statement of Tihomir Glavaš dated 13 February 2011), paras. 53-54; Tihomir Glavaš, T. 11993 (16 February 2011). See also D2915 (Witness statement of Vidomir Banduka dated 9 February 2013), para. 55 (testifying that in mid-June 1992, the Crisis Staff was made aware that "a group of hooligans [had] entered the sports hall where the Muslims were held, [and had] abused and physically molested them", and that the Crisis Staff condemned the incident and asked the Chief of Police to increase security at the facility and to "remove all those who might be expected to do something of the kind").

7159 P2403 (Witness statement of Mehmed Musić dated 28 February 2011), para. 64.

7160 P2403 (Witness statement of Mehmed Musić dated 28 February 2011), para. 64; P161 (Adem Balić's statement to $\mathrm{BiH}$ authorities dated 7 February 1993), p. 2 (stating that the people from Kučice arrived on 20 June); Momčilo Mandić, C2 (Transcript from Prosecutor v. Krajišnik), e-court pp. 261-262.

7161 P2403 (Witness statement of Mehmed Musić dated 28 February 2011), para. 65. Mehmed Musić testified that the women, children, and three men were allowed to remain behind. P2403 (Witness statement of Mehmed Musić dated 28 February 2011), para. 65.

7162 P2296 (Witness statement of Tihomir Glavaš dated 13 February 2011), para. 50; Tihomir Glavaš, T. 11784, 11786 (14 February 2011); P1478 (Ratko Mladić's notebook, 27 May-31 July 1992), e-court p. 219. Glavaš explained that this group was exchanged in return for the release of Serbs who were in detention in Tarčin and Pazarić, and that the authorities had been under "enormous pressure" from Serb citizens to facilitate such an exchange. Tihomir Glavaš, T. 11785-11786 (14 February 2011). See also Mladen Tolj, T. 34640-34641 (1 March 2013) (referring to a large-scale exchange of prisoners that had been agreed at the level of state organs between the Muslim and Serb sides).

7163 P2403 (Witness statement of Mehmed Musić dated 28 February 2011), paras. 65-69; P161 (Adem Balić's statement to $\mathrm{BiH}$ authorities dated 7 February 1993), p. 2.

7164 See para. 2102.

7165 See Scheduled Detention Facilities C.18.1, C.18.2.

7166 P2403 (Witness statement of Mehmed Musić dated 28 February 2011), paras. 67-69; P161 (Adem Balić's statement to $\mathrm{BiH}$ authorities dated 7 February 1993), p. 2.

7167 P161 (Adem Balić's statement to BiH authorities dated 7 February 1993), p. 2; P2403 (Witness statement of Mehmed Musić dated 28 February 2011), paras. 65-69. See also paras. 2276-2278; KDZ088, T. 6315-6316 (7 September 2010) (closed session); Adjudicated Fact 2617. 
2107. On the morning of 7 September, approximately 200 Bosnian Muslims from Binježevo, Garovići, Žunovnica, and Grivići-including men women, children, and elderly who had been under "house arrest" in Hadžići since the outbreak of armed conflict ${ }^{7168}$-boarded five buses, which took them to the check-point at Kobiljaća for an exchange. ${ }^{7169}$ The group remained at the check-point until approximately 8 p.m., ${ }^{710}$ but the exchange fell through when the Serbs brought women and children to the exchange instead of the captured Bosnian Muslim men from Hadžići and Ilidža as had been previously agreed. ${ }^{7171}$

2108. Thus, around 8 p.m., the convoy returned to the Culture and Sport Centre, where the detainees were placed under the guard of TRZ employees. ${ }^{7172}$ At 9 a.m. on 8 September, the detainees were transported back to the check-point at Kobiljača, but again, no exchange took place. ${ }^{7173}$ The convoy, which now numbered eight buses filled with approximately 500 people, returned to the Culture and Sport Centre by 10:30 p.m. that evening. ${ }^{717}$ When the detainees

7168 P124 (Witness statement of Zijad Okić dated 24 June 1997), e-court p. 5 (further stating that Zoran Gašević and a girl nicknamed "Beba", both of whom were wearing camouflage uniforms, had arrived at his house and given him, his wife, and their children 30 minutes to dress, gather belongings, and meet in front of the kindergarden); P2403 (Witness statement of Mehmed Musić dated 28 February 2011), para. 113 (stating that his father, brother, and brother's family had been among this group and had been given 30 minutes to gather their belongings and assemble near the Municipal Assembly Building). But see Mladen Tolj, T. 34643, 34649 (1 March 2013) (testifying that in such situations, people already knew in advance that they would be ready, but had only learned their exact departure time 30 minutes beforehand). See also Vidomir Banduka, T. 33526 (12 February 2013) (testifying that he thought that all civilians had left the Culture and Sport Centre by August 1992, but later conceding that the centre was used as a "staging area" prior to exchanges of civilians at Kobiljaća), T. 33539 (13 February 2013).

7169 P124 (Witness statement of Zijad Okić dated 24 June 1997), e-court p. 5.

7170 P124 (Witness statement of Zijad Okić dated 24 June 1997), e-court p. 5. Each bus was driven by a policeman, and one police guard was aboard each bus. P124 (Witness statement of Zijad Okić dated 24 June 1997), e-court p. 5. While at Kobiljaća the Bosnian Muslims were not provided with food or water. P124 (Witness statement of Zijad Okić dated 24 June 1997), e-court p. 5.

7171 D1075 (Report of Committee for Exchange of POWS, 21 December 1992), p. 1; P4850 (Witness statement of Amor Mašović dated 23 March 2012), paras. 33-34. See also P2403 (Witness statement of Mehmed Musić dated 28 February 2011), para. 114; Mladen Tolj, T. 34643 (1 March 2013).

7172 P124 (Witness statement of Zijad Okić dated 24 June 1997), e-court p. 5; P125 (Zijad Okić's statement to BiH authorities, 3 February 1993), p. 1.

7173 P124 (Witness statement of Zijad Okić dated 24 June 1997), e-court p. 5. As a member of the Missing Persons Institute of $\mathrm{BiH}$, Amor Mašović attended the exchange which had been scheduled to take place at Kobiljača on 8 September. P4850 (Witness statement of Amor Mašović dated 23 March 2012), paras. 33-34. After the failed exchange, Mašović, his deputy, and his bus driver were arrested by Serbs and taken first to the Hadžići Culture and Sport Centre, then to the Hadžići Serb police station, and then to spend the night at Brane Mijatović's house. P4850 (Witness statement of Amor Mašović dated 23 March 2012), paras. 35-37. On the following day, Mašović, his deputy, and the bus driver were taken to Ratko Radić's office, where Mašović promised Radić that he would organise another exchange once he returned to Sarajevo and said that no one was to blame for the failure of the exchange on the previous day. P4850 (Witness statement of Amor Mašović dated 23 March 2012), para. 37. Thereafter, Mašović and the two others were taken to the Red Cross premises in Ilidža and later crossed the confrontation line back into Sarajevo. P4850 (Witness statement of Amor Mašović dated 23 March 2012), paras. 37-38.

7174 P2403 (Witness statement of Mehmed Musić dated 28 February 2011), para. 117; P124 (Witness statement of Zijad Okić dated 24 June 1997), e-court p. 5. See also Adjudicated Fact 2618. The Chamber notes that Okić stated that the extra buses joined the convoy on 7 September rather than on 8 September, but notes that Okić returned to the check-point on the day after the first failed exchange, while Musić, who testified that he was bussed in from Ilidža on 8 September, did not. P2403 (Witness statement of Mehmed Musić dated 28 February 
arrived, they were given some food for the children, who at that point had not eaten for two days. $^{7175}$ Thereafter, the group spent approximately 12 days in the Culture and Sport Centre, receiving food every third day. ${ }^{7176}$ On about 18 September, the Serb Forces released all the women and children "to go home", leaving about 100 male detainees out of the original $500 .^{7177}$

2109. Between 9 and 23 September, detainees at the Culture and Sport Centre were engaged in a work platoon that dug trenches near Oštrik and at a mountain pass above the reservoir in Dupovci. ${ }^{7178}$ While there, the detainees were exposed to sporadic crossfire. ${ }^{7179}$ The work platoon also built "machine-gun nests" in some buildings and "were taken by a certain Miki Šarenac to loot houses". 7180

2110. During his second detention at the Culture and Sport Centre, Mehmed Musić was interrogated twice by Rade Veselinović. ${ }^{7181}$ Zijad Okić gave conflicting evidence regarding whether or not the prisoners were abused, first stating that the detainees were beaten and abused most by Zoran Gašević, Nemanja Jovičić, and Rade Veselinović. ${ }^{7182}$ However, Okić later stated that the detainees were not beaten or hurt during the 12 days in the Culture and Sport Centre. ${ }^{7183}$ The Chamber considers this evidence insufficient to establish that the detainees were beaten during this period.

2011), paras. 115-117. The Chamber therefore concludes that the additional buses joined the convoy on 8 September 1992.

P124 (Witness statement of Zijad Okić dated 24 June 1997), e-court p. 5.

P124 (Witness statement of Zijad Okić dated 24 June 1997), e-court p. 5; P2403 (Witness statement of Mehmed Musić dated 28 February 2011), para. 118. After three days, some women were allowed to go home to get food, and some women from the town also brought food to the Culture and Sport Centre. P2403 (Witness statement of Mehmed Musić dated 28 February 2011), para. 118; P124 (Witness statement of Zijad Okić dated 24 June 1997), e-court pp. 5-6.

P2403 (Witness statement of Mehmed Musić dated 28 February 2011), para. 119; P124 (Witness statement of Zijad Okić dated 24 June 1997), e-court p. 6.

P125 (Zijad Okić's statement to BiH authorities, 3 February 1993), pp. 1-2; P2403 (Witness statement of Mehmed Musić dated 28 February 2011), para. 121. See also P2296 (Witness statement of Tihomir Glavaš dated 13 February 2011), paras. 57-58. While Okić described the work platoon as "voluntary", Musić stated that although some prisoners volunteered to work in exchange for cigarettes, Vujović would come in with a list of names and have the men escorted out by police in camouflage uniforms. P124 (Witness statement of Zijad Okić dated 24 June 1997), e-court p. 6; P2403 (Witness statement of Mehmed Musić dated 28 February 2011), paras. 121-122. The Chamber therefore finds that at least some men were forced to work.

P124 (Witness statement of Zijad Okić dated 24 June 1997), e-court p. 7. See also P2296 (Witness statement of Tihomir Glavaš dated 13 February 2011), para. 58 (stating that he believed that some detainees were killed and wounded while at the frontline).

P125 (Zijad Okić's statement to BiH authorities, 3 February 1993), p. 2.

P2403 (Witness statement of Mehmed Musić dated 28 February 2011), para. 122. Brane Mijatović and Zoran Gašević were present at the second interrogation. P2403 (Witness statement of Mehmed Musić dated 28 February 2011), para. 122. Musić did not mention any beatings during either interrogation.

P125 (Zijad Okić's statement to the BiH authorities, 3 February 1993), p. 2.

P124 (Witness statement of Zijad Okić dated 24 June 1997), e-court p. 6, he states that "noone [sic] was beaten or hurt during this period". 
2111. On 22 October 1992, RS Ministry of Justice representative Slobodan Avlijaš submitted a report to the RS Minister of Justice, Momčilo Mandić, stating that at the time, 90 Muslim "prisoners of war" were being held in the Culture and Sport Centre, which was being secured by the Hadžići SJB. ${ }^{7184}$ The report also stated that the Hadžići SJB did not have the authority to keep people in custody for longer than three days, and therefore was acting "without any authorisation or justification in law". ${ }^{7185}$ On the same day, Mandić ordered the Serb Municipality of Hadžići to transfer all of its detainees to the Butmir KPD Investigations Department in Svrake. ${ }^{7186}$ On the following day, all but 14 of the remaining men were transferred to Planjo's house in Svrake. ${ }^{7187}$

\section{(d) Conclusion}

2112. Based on the above, the Chamber finds that Bosnian Muslims, including women and children, were detained at the Hadžići Culture and Sport Centre between at least 25 May and approximately 18 September 1992. In particular, during a first period lasting from at least 25 May to approximately 22 June, Bosnian Muslims were subjected to beatings by Arkan's men, as well as to beatings and sexual abuse by Šešelj's men, who each visited the premises once during the first half of June. The Chamber finds that throughout this period, the group was detained in poor conditions that included a lack of food and water. Additionally, the Chamber finds that between 7 September and approximately 18 September, when the women and children were released, Bosnian Muslims were held under conditions which included lack of food and poor sanitation and hygiene. The Chamber finds that after the women and children were released on 18 September, the men were forced to work by digging trenches near the frontlines.

property

(E) Movement of the population from Hadžići and appropriation of 2113. On 24 May 1992, President of the Hadžići Crisis Staff appointed a commission charged with listing all abandoned flats and other property within the territory of the Hadžići Serb

\footnotetext{
7184 P1607 (RS Ministry of Justice report on prisons and camps on the RS territory, 22 October 1992), e-court pp. 67, 28.

7185 P1607 (RS Ministry of Justice report on prisons and camps on the RS territory, 22 October 1992), e-court p. 7.

7186 P1607 (RS Ministry of Justice report on prisons and camps on the RS territory, 22 October 1992), e-court p. 28; P2307 (RS Ministry of Justice order to Hadžići and Ilidža municipalities, 22 October 1992).

7187 P2403 (Witness statement of Mehmed Musić dated 28 February 2011), paras. 123-125; P124 (Witness statement of Zijad Okić dated 24 June 1997), e-court p. 6; P125 (Zijad Okić's statement to BiH authorities, 3 February 1993), p. 1 (estimating that he was transferred on 23 September but was unsure of the date). See also Scheduled Detention Faciltiy C.26.1. The Chamber recalls that Mladen Tolj testified that the men who were transferred to Planjo's House had been captured in combat and were not civilians. Mladen Tolj, T. 34652 (1 March 2013). However, the Chamber notes that Tolj did not mention the basis for his knowledge in this regard, and in light of the extensive evidence of Okić and Musić regarding their prior periods of detention, the Chamber shall not rely on Tolj's testimony in this regard.
} 
Municipality, ${ }^{7188}$ the "vast majority" of which belonged to Muslims. ${ }^{7189}$ Radić ordered that the flats be sealed, registered, and placed at the disposal of the Serb municipality. ${ }^{7190}$ This was done immediately upon Radić's order. ${ }^{7191}$ On 19 July 1992, the Accused sent a memorandum to the municipality of Hadžići requesting an inventory of all vacant housing facilities following the "voluntary departure of Muslims", explaining that vacant homes would be used to house Serb residents of the Muslim part of Sarajevo, who would soon be leaving the city. ${ }^{7192}$

2114. On 15 December 1992, the $4^{\text {th }}$ session of the Serbian Hadžići Municipal Assembly adopted the "Statute of the Serbian municipality of Hadžići", the "Rules of Procedure for the Serbian municipality of Hadžići", and the "Decision on Law and Order". 7193 At the same meeting, the Assembly issued the "Decision to Rescind Rights Obtained on the Basis of Tenancy Rights or Employment", which stated that "all persons who were formerly resident on the territory of the Serbian Municipality of Hadžići” who had not returned to the municipality and had not provided an explanation for their absence would be labelled "displaced persons" and would not have the right to citizenship in the RS. ${ }^{7194}$ However, the minutes of the session indicate that the decision did not receive sufficient votes to be adopted. ${ }^{7195}$ Accordingly, the Chamber cannot conclude that the aforementioned decision was implemented in Hadžići.

2115. The Chamber recalls that, as described above, a group of male detainees was transferred to the Slaviša Vajner Čiča Barracks in Lukavica on approximately 22 June $1992,{ }^{7196}$ and that another group was transferred to Planjo's house in Svrake on 23 October 1992. ${ }^{7197}$ Defence witnesses testified that Bosnian Muslims left these areas of Hadžići of their own volition in order to move to

\footnotetext{
7188 D1084 (Hadžići Crisis Staff Decision, 26 May 1992); D3062 (Witness statement of Nevenko Samouković dated 26 February 1993), para. 12 (stating that this task was delegated to him and that he took an inventory of all abandoned apartments and sealed them in order to prevent subsequent intrusion).

7189

D1084 (Hadžići Crisis Staff Decision, 26 May 1992). Samouković testified that the language referring to "placing these apartments at the disposal of the municipality" was added in order to lend credence to the idea that the municipal authorities would not permit looting. Nevenko Samouković, T. 34610 (1 March 2013).

Nevenko Samouković, T. 34610-34611 (1 March 2013) (suggesting that the Hadžići commission took action in this regard pursuant to Radić's order and not the Accused's order of 19 July 1992 [P739]). But see P6167 (Request of Hadžići Secretariat for Housing and Public Utilities, 27 July 1992) (ordering the commissioners to inventory all abandoned and vacant dwellings that could be lived in; bearing a signature for Samouković).

P739 (RS Presidency request to various municipalities, 19 July 1992).

D1085 (Minutes of meeting of Hadžići Municipal Assembly, 15 December 1992), pp. 2-3, 5; P2306 (Report on the work of the Hadžići Municipal Assembly in 1992), p. 2.

D1083 (Decision of Hadžići Municipal Assembly, 15 December 1992). See also Adjudicated Fact 2571. In addition, the displaced persons would forfeit their property for the defence of the municipality and would no longer be entitled to any rights obtained on the basis of employment. Tihomir Glavaš, T. 12022-12023 (16 February 2011); D1083 (Decision of Hadžići Municipal Assembly, 15 December 1992).

D1085 (Minutes of meeting of Hadžići Municipal Assembly, 15 December 1992), pp. 4-5.

See para. 2106

See para. 2111.
} 
areas with a Bosnian Muslim majority. ${ }^{7198}$ As a result, a Bosnian Muslim commission based in Tarčin and a Bosnian Serb commission based in Hadžići were formed to visit Bosnian Muslims and Bosnian Serbs held in opposing territories and to interview them about their wishes to leave or stay. ${ }^{7199}$ Defence witnesses also testified that "many" Bosnian Muslims remained in Hadžići until the end of the war. ${ }^{7200}$ Having considered this evidence, however, the Chamber observes that these assertions do not directly contradict the evidence indicating that the groups described above were transferred out of the municipality. The Chamber therefore finds that the two groups of male detainees held at the Hadžići Culture and Sport Centre were forced to leave and transferred out of the municipality on approximately 22 June 1992 and 23 October 1992, respectively.

\section{ii. Ilidža}

\section{(A) Charges}

2116. Under Count 3, the Prosecution alleges that persecution, a crime against humanity was committed in Ilidža as part of the objective to permanently remove Bosnian Muslims and/or Bosnian Croats from the Municipalities. ${ }^{7201}$ Acts of persecution alleged to have been committed by Serb Forces and Bosnian Serb Political and Governmental Organs in Ilidža include killings related to the KP Dom Butmir (Kula Prison) (hereinafter referred to as "Kula Prison"). ${ }^{7202}$ The Prosecution also characterises these killings as extermination, a crime against humanity, under

7198 D3062 (Witness statement of Nevenko Samouković dated 26 February 1993), para. 15 (stating that he heard this from their friends and neighbours, as he "was ill during this period"), 18; Mladen Tolj, T. 34648-34649 (1 March 2013); D2915 (Witness statement of Vidomir Banduka dated 9 February 2013), para. 85. See also Tihomir Glavaš, T. 11926-11929, 11933 (15 February 2011); D1064 (Map of Sarajevo marked by Tihomir Glavaš) (referring to Bosnian Muslims being evacuated from majority Bosnian Muslim villages-denoted in green - within the circle marked "1"). Vidomir Banduka referred to a decision of the Bosanski Hadžići War Presidency dated 23 October 1993 authorising an exchange of Serb civilians from Pazarić and Tarčin for "Muslim civilians who are currently in the area of Hadžići, on the principle of "all for all and on a voluntary basis". D2920 (Decision of Bosanski Hadžići War Presidency, 23 October 1993). Banduka opined that this document showed that "people were moving by themselves to areas where their nation was the majority". D2915 (Witness statement of Vidomir Banduka dated 9 February 2013), paras. 80-81. However, the Chamber observes that this document only relates to the populations present in the respective territories at that time and as such, is not relevant to any movement of population that occurred in 1992.

7199 D2915 (Witness statement of Vidomir Banduka dated 9 February 2013), para. 85. See also Vidomir Banduka, T. 33541-33542 (13 February 2013); Mladen Tolj, T. 34648 (1 March 2013).

7200 D3062 (Witness statement of Nevenko Samouković dated 26 February 1993), para. 15; Mladen Tolj, T 34649 (1 March 2013); Vidomir Banduka, T 33542 (13 February 2013). Radojka Pandurević stated that she heard that Bosnian Muslims who stayed in Hadžići eventually left because "they were afraid about a Serbian revenge". D2490 (Witness statement of Radojka Pandurević dated 27 November 2012), para. 65; Radojka Pandurević, T. 30669 (29 November 2012). See also D3063 (Witness statement of Mladen Tolj dated 25 February 2013), para. 12 (stating that Muslims left because of fear of reprisals for the abuses in the Silos camp).

7201 Indictment, paras. 48-49.

7202 Indictment, para. 60(a). See Scheduled Incidents B.13.1, B.13.3. 
Count 4; murder, a crime against humanity, under Count 5; and murder, a violation of the laws or customs or war, under Count $6 .^{7203}$

2117. Other acts of persecution alleged to have been committed in Ilidža by Serb Forces and Bosnian Serb Political and Governmental Organs include (i) torture, beatings, and physical and psychological abuse, during and after the take-over as well as in Kula Prison as cruel or inhumane treatment; ${ }^{7204}$ (ii) rape and other acts of sexual violence during and after the take-over as well as in Kula Prison as cruel and inhumane treatment; ${ }^{7205}$ (iii) the establishment and perpetuation of inhumane living conditions in Kula Prison, including the failure to provide adequate accommodation, shelter, food, water, medical care, or hygienic sanitation facilities, as cruel or inhumane treatment; ${ }^{7206}$ (iv) forcible transfer or deportation of Bosnian Muslims and Bosnian Croats from their homes within Ilidža; ${ }^{7207}$ (v) unlawful detention in Kula Prison; ${ }^{7208}$ (vi) forced labour at the frontline and the use of Bosnian Muslims and Bosnian Croats as human shields; ${ }^{7209}$ (vii) the appropriation or plunder of property, during and after the take-over, during arrests and detention, and in the course of or following acts of deportation or forcible transfer; ${ }^{7210}$ and (viii) the imposition and maintenance of restrictive and discriminatory measures. ${ }^{7211}$

2118. Under Counts 7 and 8, the Prosecution alleges deportation and inhumane acts (forcible transfer), respectively, as crimes against humanity. ${ }^{7212}$ In this regard, the Prosecution alleges that by the end of 1992, Serb Forces and Bosnian Serb Political and Governmental Organs had forcibly displaced Bosnian Muslims and Bosnian Croats from areas in Ilidža in which they had been lawfully present. ${ }^{7213}$ It is alleged that from March 1992, restrictive and discriminatory measures, arbitrary arrest and detention, harassment, torture, rape and other acts of sexual

\footnotetext{
7203 Indictment, para. 63(a), 63(b).

Indictment, para. 60(b). See Scheduled Detention Facility C.18.2

Indictment, para. 60(c). See Scheduled Detention Facility C.18.2

Indictment, para. 60(d). See Scheduled Detention Facility C.18.2.

Indictment, para. 60(f).

Indictment, para. 60(g). See Scheduled Detention Facility C.18.2.

Indictment, para. 60(h).

Indictment, para. 60(i).

Indictment, para. $60(\mathrm{k})$. The restrictive and discriminatory measures alleged include the denial of freedom of movement; the removal from positions of authority; the invasion of privacy through arbitrary searches of homes; unlawful arrest and/or the denial of the right to judicial process; and/or the denial of equal access to public services. The Chamber notes that there are no cultural monuments and sacred sites with respect to Vlasenica in Schedule D of the Indictment. In addition the Prosecution does not allege criminal responsibility for wanton destruction of private property in Ilidža. Indictment, fn. 9.

7213 Indictment, paras. 69, 72.
} 
violence, killing, as well as the threat of further such acts caused Bosnian Muslims and Bosnian Croats to flee in fear, while others were physically driven out. ${ }^{7214}$

\section{(B) Background}

2119. Ilidža is one of the ten constitutive municipalities of Sarajevo and is located to the west of Novo Sarajevo, southwest of Novi Grad, and to the northeast of Hadžići. ${ }^{7215}$ According to the 1991 census, the population of Ilidža municipality was 43.2\% Muslim, 36.8\% Serb, 10.2\% Croat, 7.6\% Yugoslav, and $2.1 \%$ identified themselves as other. ${ }^{7216}$ Prior to the conflict, the populations of the local communes of Hrasnica, Butmir, Stupsko Brdo, part of Donji Kotorac, and Sokolović Kolonija were predominantly Muslim and those of Otes, Bare, and Stup were predominantly Croat. The populations of the other local communes were predominantly Serb. ${ }^{7217}$

2120. The territory of Ilidža municipality was strategically important because of its roads and railway that link Sarajevo town with eastern and central $\mathrm{BiH}$ and because the Sarajevo Airport is located there. ${ }^{7218}$

2121. After the first multi-party elections held in November 1990, in which the SDA won the highest number of seats in the municipal assembly, there was an inter-party agreement on the division of power in Ilidža. ${ }^{7219}$ Husein Mahmutović, of the SDA, became the President of the municipality and Radomir Kezunović, of the SDS, became the President of the Executive Board. $^{7220}$ Momčilo Čeklić of the SDS became the Secretary of the Assembly. ${ }^{7221}$ Neđeljko Prstojević became the Secretary for Communal Inspections and the SDS President for Ilidža municipality. ${ }^{7222}$ Of a total of 13 official posts, Bosnian Serbs and Muslims each held six and one post was held by a Bosnian Croat. ${ }^{7223}$

\footnotetext{
7214 Indictment, para. 71.

7215 P973 (Robert Donia's expert report entitled "Bosnian Serb Leadership and the Siege of Sarajevo, 1990-1995", January 2010), p. 8; Appendix B, Map 1; P2526 (Witness statement of Radomir Kezunović dated 21 May 2011), para. 17; Radomir Kezunović, T. 13908 (31 May 2011).

7216 P5964 (Census data for BiH by municipality in 1971, 1981, and 1991, April 1995), p. 2 of original and English versions. See also D3112 (Witness statement of Momčilo Čeklić dated 8 March 2013), para. 6.

7217 Radomir Kezunović, T. 13942-13943 (31 May 2011); Neđeljko Prstojević, T. 13264-13265 (11 March 2011), T. 13834 (21 March 2011); D1249 (Ethnic map of Sarajevo).

7218 D1218 (Ilidža National Security Service report, 17 May 1992), p. 2; P2308 (SJB Ilidža report, 20 September 1993), p. 2. See also D2479 (Witness statement of Mile Sladoje dated 25 November 2012), para. 8; Nikola Mijatović, T. 30701 (30 November 2012).

7219 D3112 (Witness statement of Momčilo Čeklić dated 8 March 2013), para. 6.

7220 P2526 (Witness statement of Radomir Kezunović dated 21 May 2011), para. 14; D3112 (Witness statement of Momčilo Čeklić dated 8 March 2013), para. 6.

7221 D3112 (Witness statement of Momčilo Čeklić dated 8 March 2013), para. 6.

7222 P2526 (Witness statement of Radomir Kezunović dated 21 May 2011), para. 15.

7223 D3112 (Witness statement of Momčilo Čeklić dated 8 March 2013), para. 6.
} 
2122. Inter-ethnic tensions were rising in Ilidža from at least May 1991; however, Kezunović and Mahmutović made efforts to work together in the joint-Assembly. ${ }^{7224}$ Despite these efforts, each side created separate institutions. The SDA formed a crisis staff for the Muslim part of Ilidža in July or August 1991, ${ }^{7225}$ and starting that autumn, Muslim populations in majority Muslim settlements were arming themselves and organising military formations. ${ }^{726}$

2123. In accordance with the Variant A/B Instructions, the SDS established a Crisis Staff in Ilidža on 2 January 1992, ${ }^{7227}$ and Radomir Kezunović declared the Assembly of the Serb Municipality of Ildiža ("Ilidža Serb Assembly") the following day. ${ }^{7228}$ However, the joint Assembly of the Municipality of Ilidža made efforts to work together until the beginning of April 1992. ${ }^{7229}$

2124. On 3 January 1992, the Ilidža Serb Assembly made a proposal to the Bosnian Serb Assembly to regulate, inter alia, the status of members of TO units and military-aged men as well as to take measures for the protection of the interests of Serbs in the territory of the Ilidža municipality. ${ }^{7230}$ Starting around the beginning of March 1992, local Serbs organised themselves and held neighbourhood watches in front of their houses. ${ }^{7231}$ In March and April 1992, Serb Forces distributed weapons seized from MUP storage units to Bosnian Serb civilians and

7224 P2526 (Witness statement of Radomir Kezunović dated 21 May 2011), paras. 42, 59, 61. See also Radomir Kezunović, T. 13936-13937, 13960-13963, 13989 (31 May 2011); D1252 (Supplemental Information Sheet for Radomir Kezunović, 29 May 2011), para. 14. See also Neđeljko Prstojević, T. 13591 (17 March 2011); D1178 (Minutes of meeting between SDA, SDS, and HDZ in Ilidža, 23 July 1991), pp 1-2.

7225 Neđeljko Prstojević, T. 13614 (17 March 2011); D3112 (Witness statement of Momčilo Čeklić dated 8 March 2013), para. 13.

7226 D3960 (Witness statement of Tomislav Kovač dated 28 October 2013), paras. 39- 40; D2553 (Witness statement of Svetozar Guzina dated 3 December 2012), paras. 3-5; D2479 (Witness statement of Mile Sladoje dated 25 November 2012), para. 3.

7227 Neđeljko Prstojević, T. 12942-12943 (3 March 2011), T. 12952-12953 (8 March 2011), T. 13615 (17 March 2011); Momčilo Čeklić, T. 35210-35212 (12 March 2013); D3112 (Witness statement of Momčilo Čeklić dated 8 March 2013), para. 11; P5 (SDS Instructions for Organisation of Organs of the Serbian People in BiH, 19 December 1991), p. 3.

7228 P2526 (Witness statement of Radomir Kezunović dated 21 May 2011), paras. 41-44, 48; Radomir Kezunović, T. 13901, 13946 (31 May 2011); Momčilo Čeklić, T. 35210-35212 (12 March 2013); D3112 (Witness statement of Momčilo Čeklić dated 8 March 2013), para. 12; P2408 (Decision on proclaiming Serb Municipal Assembly of Ilidža, 3 January 1992), Neđeljko Prstojević, T. 12953-12954 (8 March 2011), T. 13628-13629 (17 March 2015), T. 13645 (18 March 2011); P5 (SDS Instructions for Organisation of Organs of the Serbian People in BiH, 19 December 1991), p. 4; P2531 (TANJUG news report, 11 January); D1184 (Article from Javnost entitled "Serbian Municipality Proclaimed," 11 January 1992).

7229 Neđeljko Prstojević, T. 12957-12359 (8 March 2011), T. 13630 (17 March 2011), T. 13645 (18 March 2011); P2526 (Witness statement of Radomir Kezunović dated 21 May 2011), paras. 14, 46, 49, 54, 66; Radomir Kezunović, T. 13946, 13965-13966 (31 May 2011); D3112 (Witness statement of Momčilo Čeklić dated 8 March 2013), paras. 11-12; Momčilo Čeklić, T. 35210 (12 March 2013).

7230 P2409 (Ilidža Municipal Assembly proposal of decision, 3 January 1992); Neđeljko Prstojević, T. 12956-12957 (8 March 2011).

7231 D2479 (Witness statement of Mile Sladoje dated 25 November 2012), para. 4; D3112 (Witness statement of Momčilo Čeklić dated 8 March 2013), paras. 17-18. 
members of the Serb TO. ${ }^{7232}$ Bosnian Serbs in Ilidža were also armed with weapons from JNA warehouses. $^{7233}$

2125. The Ilidža MUP was divided in March 1992, after Bosnian Muslim police officers were dismissed from the SJBs; the Bosnian Serbs stayed in the Ilidža police station. ${ }^{7234}$ Edin Mlivić, then Chief of the Ilidža SJB, and Tomislav Kovač, then Ilidža police commander, ${ }^{7235}$ agreed that the Bosnian Serb police would function in the parts of Ilidža that had a Serb majority and the Bosnian Muslim police would function in those parts with a Muslim majority. ${ }^{7236}$ Initially, they continued to share the same building. ${ }^{7237}$ On 6 April 1992, the Bosnian Muslims stationed their MUP in Stup, with Mlivić as its chief, and established their "War Presidency". ${ }^{7238}$ Kovač was Chief of the Ilidža SJB from 1 April to 6 August 1992, ${ }^{7239}$ when Tihomir Glavaš succeeded him. $^{7240}$

2126. On 5 April 1992, the Ilidža Serb Assembly declared the Serb Municipality of Ilidža, to include the territory of settlements with a majority Serbian population in Ilidža and parts of Novi Grad, Kiseljak, and Trnovo. ${ }^{7241}$ The Serb Municipality of Ilidža excluded the communities where Muslims and Croats were a majority. ${ }^{7242}$ After 6 April 1992, the Ilidža Serb Assembly became a War Presidency, pursuant to an instruction from the Bosnian Serb Assembly. ${ }^{7243}$ On 6 April 1992,

7232 P2308 (SJB Ilidža report, 20 September 1993), p. 2; Momčilo Čeklić, T. 35214 (12 March 2013); D3960 (Witness statement of Tomislav Kovač dated 28 October 2013), para. 60. See also P2976 (Ilidža SJB proposal for decorations, 11 September 1993), p. 3.

7233 P2314 (Witness statement of Ramiz Mujkić dated 4 February 2011), para. 8; Momčilo Čeklić, T. 35214 (12 March 2013). At the beginning of April 1992, the procedure for the distribution of weapons was through the SDS (P2526 (Witness statement of Radomir Kezunović dated 21 May 2011), para. 67).

7234 P2308 (SJB Ilidža report, 20 September 1993), p. 3; D3960 (Witness statement of Tomislav Kovač dated 28 October 2013), para. 49. See also Adjudicated Fact 2572; Mirsad Kučanin, P16 (Transcript from Prosecutor v. Galić), T. 4500; Mirsad Kučanin, P17 (Transcript from Prosecutor v. S. Milošević), T. 28935; P2977 (Report of Ilidža SJB), p. 1.

7235 D3960 (Witness statement of Tomislav Kovač dated 28 October 2013), paras. 4, 48; Radomir Kezunović, T. 13936-13937 (31 May 2011); Tihomir Glavaš, T. 11825 (14 February 2011).

7236 D3960 (Witness statement of Tomislav Kovač dated 28 October 2013), para. 49; Tihomir Glavaš, T. 11825 (14 February 2011).

7237 P2526 (Witness statement of Radomir Kezunović dated 21 May 2011), para. 62; D3960 (Witness statement of Tomislav Kovač dated 28 October 2013), para. 49.

7238 Neđeljko Prstojević, T. 13705 (18 March 2011); D1208 (SerBiH MUP Daily Report, 4 May 1992), p. 3.

7239 D3960 (Witness statement of Tomislav Kovač dated 28 October 2013), para. 4.

7240 Tihomir Glavaš, T. 11804 (14 February 2011); D3112 (Witness statement of Momčilo Čeklić dated 8 March 2013), para. 19.

7241 D1190 (Ilidža Crisis Staff announcement, 11 April 1992); D1191 (SRNA news report, 11 April 1992); D3112 (Witness statement of Momčilo Čeklić dated 8 March 2013), para. 19. In addition, the Serbian Municipality of Ilidža incorporated part of Mojmila, Dobrinja, Nedžariće, and Vojničko Polje. See also P973 (Robert Donia's expert report entitled "Bosnian Serb Leadership and the Siege of Sarajevo, 1990-1995", January 2010), p. 35; Robert Donia, T. 3134 (1 June 2010).

7242 Neđeljko Prstojević, T. 13264-13265 (11 March 2011); Radomir Kezunović, T. 13989-13990 (31 May 2011).

7243 P2526 (Witness statement of Radomir Kezunović dated 21 May 2011), para. 68. 
the Ilidža Crisis Staff ordered general mobilisation. ${ }^{7244}$ A new Serb Crisis Staff was established by the Serbian Municipality of Ilidža and was publicly announced on 10 April $1992 .^{7245}$ Prstojević became the commander of the Crisis Staff but Kezunović remained as its President for about 15 to 20 days until he passed over his responsibilities to Prstojević. ${ }^{7246}$

2127. Until 19 May 1992, when the VRS was formed, the Serb TO staff organised defence in Ilidža. ${ }^{7247}$ At that point, the TO defence units became part of the VRS, first as part of the Ilidža Brigade and then as part of the Igman Brigade. ${ }^{7248}$

\section{(C) Armed conflict in Ilidža}

2128. Around 3 or 4 April 1992, barricades were erected around Ilidža. ${ }^{7249}$ From April 1992, there was an escalation in combat activity, ${ }^{7250}$ and Ilidža was constantly under fire. ${ }^{7251}$ The eastern and western parts of Ilidža were controlled by the Serbs but were divided by Muslim held territory in the middle. ${ }^{7252}$ The eastern and western parts of Ilidža were shelled by Bosnian Muslim forces from Mt. Mojmilo and Mt. Igman, respectively. ${ }^{7253}$ By the end of April 1992,

7244 D3112 (Witness statement of Momčilo Čeklić dated 8 March 2013), paras. 19-20; Neđeljko Prstojević, T. 12968 (8 March 2011); D3113 (Ilidža Crisis Staff order, 6 April 1992), p. 1; P2410 (Ilidža Crisis Staff Order on implementation of general mobilisation, 6 April 1992); Neđeljko Prstojević, T. 12968 (8 March 2011).

7245 P2526 (Witness statement of Radomir Kezunović dated 21 May 2011), paras. 54, 56; Radomir Kezunović, T. 13901 (31 May 2011); D1193 (Ilidža Crisis Staff members, 10 April 1992).

7246 P2526 (Witness statement of Radomir Kezunović dated 21 May 2011), paras. 54, 57-58, 73; Radomir Kezunović, T. 13901 (31 May 2011); Neđeljko Prstojević, T. 12961 (8 March 2011); D1193 (Ilidža Crisis Staff members, 10 April 1992).

7247 Neđeljko Prstojević, T. 12970-12971 (8 March 2011), T. 13757 (21 March 2011). See also D1218 (Ilidža National Security Service report, 17 May 1992), p. 2.

7248 Neđeljko Prstojević, T. 12975 (8 March 2011), T. 13799 (21 March 2011); Milomir Šoja, P1633 (Transcript from Prosecutor v. D. Milošević), T. 5160, 5162; Milomir Šoja, T. 7206-7207 (30 September 2010). The Ilidža Brigade was established on 20 May 1992. Neđeljko Prstojević, T. 13799 (21 March 2011).

7249 P2526 (Witness statement of Radomir Kezunović dated 21 May 2011), para. 66; Radomir Kezunović, T. 1396513966 (31 May 2011).

7250 Neđeljko Prstojević, T. 13646-13647, 13665, 13683-13687, 13691-13692, 13699, 13703 (18 March 2011); D3112 (Witness statement of Momčilo Čeklić dated 8 March 2013), paras. 25-32; Momčilo Čeklić T. 3521435220 (12 March 2013); P2526 (Witness statement of Radomir Kezunović dated 21 May 2011), para. 73; Radomir Kezunović, T. 13965-13966 (31 May 2011); D3960 (Witness statement of Tomislav Kovač dated 28 October 2013), paras. 50-53; D1196 (Public announcement from Ilidža Crisis Staff Information Service, 13 April 1992); D1200 (Protocol from meeting between SDS and SDA in Ilidža, 23 April 1992); D1201 (Intercept of conversation between Čedo Klajić and Tomislav Kovač, 20 April 1992); D1203 (Radovan Karadžić's announcement, 22 April 1992); D2479 (Witness statement of Mile Sladoje dated 25 November 2012), para. 4; D2553 (Witness statement of Svetozar Guzina dated 3 December 2012), para. 28; P1996 (Witness statement of Martin Bell dated 8 March 2010), para. 61; P2025 (BBC news report re Ilidža, with transcript).

7251 Neđeljko Prstojević, T. 13660 (18 March 2011); P2526 (Witness statement of Radomir Kezunović dated 21 May 2011), para. 66; Radomir Kezunović, T. 13965-13966 (31 May 2011).

7252 Radomir Kezunović, T. 13915 (31 May 2011); Neđeljko Prstojević, T. 13760 (21 March 2011).

7253 Radomir Kezunović, T. 13982-13984 (31 May 2011); D1255 (Ilidža Wartime Commission Statement, 29 October 1992. See also D2479 (Witness statement of Mile Sladoje dated 25 November 2012), paras. 9-10; Neđeljko Prstojević, T. 13660 (18 March 2011); D1076 (MUP Administration for the Police Duties and Affairs report, 3 August 1992), p. 5. 
Bosnian Serbs shelled various neighbourhoods in Sarajevo, including Butmir and Hrasnica in Ilidža municipality. ${ }^{7254}$

2129. In April 1992, Prstojević issued orders which resulted in various aspects of daily life being blocked. First, on 14 April, he ordered the suspension of activities of almost all enterprises in Ilidža. ${ }^{7255}$ Then, on 19 April, he ordered that all access to roads be blocked, with the exception of emergency medical assistance, local food supply, water control and electrical power enterprises. $^{7256}$

2130. On 22 April 1992, the Bosnian Muslim forces attacked the western and central parts of Ilidža. ${ }^{7257}$ After this attack, a confrontation line was established. Bosnian Serb and Muslim forces established positions along the roads leading from Sarajevo. ${ }^{7258}$ Combat activity continued in May 1992. ${ }^{7259}$ By 8 May 1992, Serb Forces were in control of the territories composing the Serb Municipality of Ilidža and some areas of life could return to normal. ${ }^{7260}$

7254 See Adjudicated Fact 2573 (stating that the Serb SJB also took part in the attacks). See Section IV.B.1.a: Chronology of events in Sarajevo.

7255 Neđeljko Prstojević, T. 13666-13667, 13669 (18 March 2011); D1197 (Ilidža Crisis Staff order, 14 April 1992); D3112 (Witness statement of Momčilo Čeklić dated 8 March 2013), para. 21. See also D1206 (Ilidža Crisis Staff announcement, 1 May 1992).

7256 Neđeljko Prstojević, T. 13679-13680 (18 May 2011), T. 13796-13797 (21 March 2011); D1199 (Ilidža Crisis Staff decision, 19 April 1992); D1238 (Intercept of conversation between Ratko Mladić and Neđeljko Prstojević, 24 May 1992); Momčilo Mandić, C2 (Transcript from Prosecutor v. Krajišnik), T. 9003-9004; Momčilo Mandić, T. 4684-4689 (6 July 2010); Momčilo Mandić, C3 (Transcript from Prosecutor v. Stanišić \& Župljanin), T. 9484-9485; P1147 (Intercept of conversation between Momčilo Mandić and Tomislav Kovač, 20 April 1992), p. 1-2; P5712 (Intercept of conversation between Momčilo Mandić and Branko Đerić, 20 April 1992), p. 2.

7257 D3960 (Witness statement of Tomislav Kovač dated 28 October 2013), para. 51-52; Tihomir Glavaš, T. 1194711948, 12005-12006 (16 February 2011); D3112 (Witness statement of Momčilo Čeklić dated 8 March 2013), para. 25; Momčilo Čeklić T. 35215 (12 March 2013); Neđeljko Prstojević, T. 13646-13647, 13683-136884, 13692 (18 March 2011); P2526 (Witness statement of Radomir Kezunović dated 21 May 2011), para. 73; Radomir Kezunović, T. 13965-13966 (31 May 2011); Martin Bell, T. 9818-9819 (14 December 2010); D918 (BBC news report re Sarajevo, with transcript). See also D2538 (Witness statement of Milan Pejić dated 2 December 2012), para. 15; P2308 (SJB Ilidža report, 20 September 1993, p. 4; Colm Doyle, T. 2775-2778 (26 May 2010); D221 (RS MUP report re attack on Ilidža, 28 April 1992), p. 2; D1200 (Protocol from meeting between SDS and SDA in Ilidža, 23 April 1992); D223 (SRNA news report, 23 April 1992); P5713 (Intercept of conversation between Rade Ristić and "Ilija", 20 April 1992), pp. 1-2.

7258 D3960 (Witness statement of Tomislav Kovač dated 28 October 2013), para. 55.

7259 Radomir Kezunović, T. 13967, 13968, 13970 (31 May 2011); Neđeljko Prstojević, T. 13677-13678, 13704, 13717, 13724-13728 (18 March 2011); D3112 (Witness statement of Momčilo Čeklić dated 8 March 2013), para. 33; D1208 (SerBiH MUP Daily Report, 4 May 1992), D1211 (Ilidža Crisis Staff information, 13 May 1992); D1212 (Intercept of conversation between Neđeljko Prstojević and Milosav Gagović, 13 May 1992), D1213 (Intercept of conversation between Neđeljko Prstojević and Tadija, 14 May 1992); ); D1214 (Ilidža Crisis Staff information, 14 May 1992); D1215 (Intercept of conversation between Đogo and Neđeljko Prstojević, and between Neđeljko Prstojević and Radivoje Grković, 14 May 1992), pp. 1-2; D1216 (Intercept of conversation between Đogo and Mandrić, 14 May 1992), p. 1; D1218 (Ilidža National Security Service report, 17 May 1992), p. 1; P5667 (Intercept of conversation between Milosav Gagović and Neđeljko Prstojević, 15 May 1992). See also D1210 (Intercept of conversation between Neđeljko Prstojević and Grandić, 12 May 1992); John Wilson, T. 3918 (21 June 2010); D1214 (Ilidža Crisis Staff information, 14 May 1992).

7260 D1209 (SerBiH MUP Daily Report, 8 May 1992), p. 2; Neđeljko Prstojević, T. 13706-13707 (18 March 2011 ); P2790 (SerBiH MUP daily report, 12 May 1992), p. 2. See Adjudicated Fact 2574. See also D2773 (Witness 
2131. Several armed groups were present in Ilidža during 1992. ${ }^{7261}$ Most notably, Brne Gavrilović and his group of Šešelj's men, ${ }^{7262}$ arrived in Ilidža on 9 July $1992 .{ }^{7263}$ On several occasions in 1992 and 1993, members of Gavrilović's group looted and expelled Bosnian Muslims from their homes. ${ }^{7264}$ Other armed groups also engaged in looting. ${ }^{7265}$ When confronted by security forces, members of these groups sometimes issued threats. ${ }^{7266}$ However, at times, members of the MUP tolerated the looting and even participated themselves. ${ }^{7267}$

statement of Slavko Mijanović dated 19 January 2013), para. 5; D1248 (Intercept of conversation between unkown male person and Legija, 15 May 1992), p. 4; D1254 (Decision on the Formation of the Serbian Municipality of Ilidža, 8 May 1992), p. 1; P1103 (Intercept of conversation between Momčilo Mandić and Branko Kvesić/Bruno Stojić/Mićo Stanišić, 5 May 1992), p. 9.

7261 Neđeljko Prstojević, T. 12976-12980, 12983-12986, 12988 (8 March 2011), T. 13825-13826, 13829-13832 (21 March 2011); Radomir Kezunović, T. 13912-13913 (31 May 2011); P2229 (Intercept of conversation between Mićo Stanišić and Nedjelko Žugić, 15 May 1992); P2411 (Intercept of conversation between Neđeljko Prstojević and Milosav Gagović, 14 May 1992); D1248 (Intercept of conversation between Željko Ražnatović and Legija, 15 May 1992), pp 4, 12-14; Tihomir Glavaš, T. 12041-12043 (16 February 2011); Ratomir Maksimović, D2667 (Witness statement of Ratomir Maksimović dated 14 December 2012), para. 56; KDZ088, T. 6309-6310 (7 September 2010) (closed session); P1499 (SRK report to VRS Main Staff re Dobrinja, 19 June 1992), p. 1; D3960 (Witness statement of Tomislav Kovač dated 28 October 2013), paras. 71, 73; P5690 (Intercept of conversation between Neđeljko Prstojević and "Đogo", 14 May 1992), p. 2; P133 (Witness statement of Matija Bošković dated 20 November 2003, paras. 35-36, 52; P1107 (SerBiH MUP report to the Minister of Interior re inspection of Romanija-Birač CSB and SJB, 10 August 1992), pp. 2-3; D541 (SRK combat report, 3 November 1992); P5691 (Intercept of conversation between Legija and Milosav Gagović, 14 May 1992).

7262 D2562 (Witness statement of Vladimir Radojčić dated 8 December 2012), para. 60; P2296 (Witness statement of Tihomir Glavaš dated 13 February 2011), para. 74; Neđeljko Prstojević, T. 12977-12979 (8 March 2011) (testifying that Šešelj visited the Serbian Municipality of Ilidža and was received by Prstojević at the Municipal Assembly Building on one occasion and that on another occasion, he toured Gavrilovć's unit); D3665 (Witness statement of Vojislav Šešelj dated 1 June 2013), paras. 58-61.

7263 Neđeljko Prstojević, T. 13853-13855 (21 March 2011); Radomir Kezunović, T. 13913-13914 (31 May 2011 ). See also P2228 (Intercept of conversation between Vojislav Šešelj and Branislav Gavrilović, April 1992), pp. 13. Prstojević gave Gavrilović permission to stay at a motel facility and deserted summer houses in Gladno Polje to conduct admission and training of volunteer units arriving to the area. See P2302 (Approval of the War Board of Commissioners of Ilidža Municipality, 9 July 1992). See also para. 234.

7264 Reports of incidents involving Gavrilović's men include D1080 (Ilidža SJB information, 4 June 1992), p. 3; P2303 (SRK combat report, 18 November 1992), p. 1; D1078 (Romanija-Birčani CSB report, 23 November 1992; P2304 (Report of the MUP, Sarajevo SNB, 9 January 1993); P2305 (Official note of the Ilidža War Department of the SNB, 12 February 1993); Neđeljko Prstojević, T. 13823-1384 (21 March 2011); P2296 (Witness statement of Tihomir Glavaš dated 13 February 2011), para. 74; D1080 (Ilidža SJB information, 4 June 1992), p. 3. See also D2562 (Witness statement of Vladimir Radojčić dated 8 December 2012), para. 60.

7265 P2526 (Witness statement of Radomir Kezunović dated 21 May 2011), para. 74; Radomir Kezunović, T. 1391113912 (31 May 2011); D3112 (Witness statement of Momčilo Čeklić dated 8 March 2013), para. 45 . See also P1154 (Witness statement of KDZ088 dated 27-29 April 2010), pp. 131-132 (under seal).

7266 Tihomir Glavaš, T. 11806 (14 February 2011); P2296 (Witness statement of Tihomir Glavaš dated 13 February 2011), paras. 74-75. One example of this occurred on 20 November 1992. The Ilidža SJB asked the military police for help to disarm paramilitary groups which had set up an illegal check-point. When the military police disarmed the group, around 20 armed men showed up and forced the retreat of the military police. D1081 (Ilidža SJB report, 21 November 1992). See also Momčilo Čeklić, T. 35231-35232 (12 March 2013); KDZ088, T. 6255-6256 (7 September 2010) (closed session).

7267 KDZ088, T. 6260-6262 (7 September 2010) (closed session); P1478 (Ratko Mladić's notebook, 27 May-31 July 1992), p. 388; P1110 (Intercept of conversation between Momčilo Mandić and Neđeljko Prstojević, 2 July 1992), p. 5. See also Neđeljko Prstojević, T. 13805 (21 March 2011). 
2132. Prstojević introduced irregular forces into the municipality, and allowed some groups to loot behind the frontline and expel Bosnian Muslims from their homes. ${ }^{7268}$ In a conversation with Dragan Despotović regarding combat activity in Kasindolsko Polje on 14 June 1992, Prstojević asked: "What shall we do? Would it be good if we gave it a thought and if we organised people from aside/outside to expel them all. Nobody needs to be shot or killed. Everyone expelled". Despotović responded: "That would be the right move."7269 In June 1992, Tomislav Šipčić, the then SRK Commander, revoked Prstojević's military command responsibilities; however Prstojević remained as President of the Crisis Staff and the SDS in Ilidža. ${ }^{7270}$ Prstojević subsequently met with the Accused in Pale and when he returned to Ilidža, "things started to go wrong again.,"7271

2133. From mid-April 1992, there was intense fighting around Dobrinja where the territories controlled by the Serbs were severed from Lukavica, Pale, and Kotorac on one side and Ilidža, Rajlovac, and Vogošća on the other. ${ }^{7272}$ While the Bosnian Serbs tried to establish a corridor to connect these neighbourhoods, the Bosnian Muslims sought to link up the old centre of Sarajevo with neighbourhoods such as Hrasnica and Sokolović Kolonija. ${ }^{7273}$ In addition, there were rumours that the SRK wanted to take over Dobrinja because it was predominantly populated by Serbs. ${ }^{7274}$ On 21 May 1992, Prstojević had a telephone conversation with Colonel Gagović about Bosnian Muslims fleeing Dobrinja and Gagović advised him that he had ordered a press centre to release information that they were only allowing Muslims to leave Dobrinja as entire families because they did not want the men to be left behind. ${ }^{7275}$ Around 14 June 1992, the Serb Forces

7268 KDZ088, T. 6255 (7 September 2010) (closed session); P1154 (Witness statement of KDZ088 dated 2729 April 2010), pp 134-135, 137, 154-155 (under seal). See also para. 2159.

7269 P1492 (Intercept of conversation between (i) Neđeljko Prstojević and Radomir and (ii) Neđeljko Prstojević and Dragan, 14 June 1992), p. 3. The Chamber notes that Prstojević testified that he did not say that outside groups should be organised to expel people. Neđeljko Prstojević, T. 13295-13298 (11 March 2011), T. 13547-13550 (17 March 2011). However, in his interview with the Prosecution, Prstojević stated that by "outside" groups, he was referring to Arkan's, Gavrilović's, and Boban's groups. P2512 (Excerpt from transcript and video of Neđeljko Prstojević's interview), pp. 2-3. Having reviewed the video and transcript of Prstojević's interview, the Chamber rejects Prstojević's testimony that he was not referring to those groups in the intercepted conversation.

7270 [REDACTED]. See also P1516 (Intercept of conversation between Neđeljko Prstojević and Tomislav Šipčić, 27 May 1992).

7271 [REDACTED].

7272 D1196 (Public announcement from Ilidža Crisis Staff Information Service, 13 April 1992); Neđeljko Prstojević, T. 13665 (18 March 2011); D2553 (Witness statement of Svetozar Guzina dated 3 December 2012), paras. 32 33; Momčilo Mandić, C2 (Transcript from Prosecutor v. Krajišnik), T. 9377-9378; John Wilson, T. 3918, 3994 (21 June 2010); KDZ088, T. 6492 (10 September 2010) (closed session). See also D577 (SRK combat report, 6 June 1992); P998 (SRK instructions, 7 June 1992), p. 3; P2019 (BBC news report Dobrinja, with transcript).

7273 D2553 (Witness statement of Svetozar Guzina dated 3 December 2012), para. 32; Momčilo Mandić, C2 (Transcript from Prosecutor v. Krajišnik), T. 9377-9378.

7274 P1154 (Witness statement of KDZ088 dated 27-29 April 2010), p. 142 (under seal); Svetozar Guzina, D2553 (Witness statement of Svetozar Guzina dated 3 December 2012), para. 32.

7275 D1236 (Intercept of conversation between Neđeljko Prstojević and Milosav Gagović, 21 May 1992), pp. 2-3. 
took Dobrinja 1 and Dobrinja 4 under their control. ${ }^{7276}$ Prstojević had a meeting with the Accused, Mladić, and other members of the Bosnian Serb leadership on 15 June 1992, in which it was concluded that they would "clear the Serbian territory", starting with Mojmilo and Dobrinja. $^{7277}$ Around 17 June 1992, SRK units took civilians out of Dobrinja to Lukavica barracks. ${ }^{7278}$ At Lukavica barracks, the MUP separated and classified them according to their ethnicities and the Bosnian Muslims were then sent to Kula Prison. ${ }^{7279}$

2134. On 25 June 1992, Prstojević spoke with Rade Ristić, a member of the Crisis Staff, and gave him permission to transfer Bosnian Muslim apartments in Dobrinja to Serbs who were involved in the fighting there and advised Ristic that he had printed the requisite forms for such transfer. $^{7280}$ During this conversation, Prstojević learned that Serbs Forces were holding their ground in the Kasindol area and told Ristić: "All right. But have them hold on to it tightly and have them all killed there, please. [...] All that is Muslim to be killed, like Alija [...] I don't want to see one military aged Muslim alive there". 7281

2135. From September 1992, there was a confrontation line on the eastern side of Dobrinja, separating the SRK-controlled areas of Dobrinja 1 and 4 from ABiH-controlled areas of Dobrinja 2 and $3 \mathrm{~B}^{7282}$ There was combat activity in Ilidža for the duration of the war. ${ }^{7283}$ Discussions continued among municipal leaders in Ilidža as to expanding control over a broader territory. ${ }^{7284}$

Neđeljko Prstojević, T. 13561-13562 (17 March 2011).

7277 P1478 (Ratko Mladić's notebook, 27 May-31 July 1992), e-court pp 171-172.

7278 [REDACTED]; P991 (SRK combat report re Dobrinja, 17 June 1992), p. 2.

7279 [REDACTED]; P991 (SRK combat report re Dobrinja, 17 June 1992), p. 2. See also Slobodan Avlijaš, T. 35185-35186 (11 March 2013); P1126 (SJB Ilidža information re KPD Butmir, 20 May 1992), p. 1.

7280 P1515 (Intercept of conversation between Neđeljko Prstojević and Radomir Ristić, 25 June 1992), p. 2. See also Adjudicated Fact 2666.

7281 P1515 (Intercept of conversation between Neđeljko Prstojević and Radomir Ristić, 25 June 1992), p. 2. See also Adjudicated Fact 2665.

7282 See Adjudicated Fact 91.

7283 Neđeljko Prstojević, T. 13276-13277 (11 March 2011), T. 13562-13563, 13571-13572, 13578-13582 (17 March 2011), T. 13697, 13714 (18 March 2011), T. 13800-13801, T. 13820-13822, 13827 (21 March 2011); P5638 (Intercept of conversation between Neđeljko Prstojević and Radomir Ristić, 16 June 1995); P2518 (Intercept of conversation between Neđeljko Prstojević and Velibor Veselinović, 29 June 1995); D1240 (Ilidža SJB Daily Situation Report, 2-3 June 1992), p. 2; D1246 (Ilidža War Committee Decision, 4 August 1992), p. 1; Radomir Kezunović, T. 13983-13985 (31 May 2011); D1255 (Ilidža Wartime Commission Statement, 29 October 1992); D2819 (SRK combat report, 10 July 1993); D564 (SRK combat report, 23 July 1992); D599 (SRK combat report, 24 July 1992); D591 (SRK combat report, 25 July 1992); D597 (SRK combat report, 20 July 1992); P1107 (SerBiH MUP report to the Minister of Interior re inspection of Romanija-Birač CSB and SJB, 10 August 1992), p. 2; P1006 (SRK Order, 12 September 1992), p. 1; D1255 (Ilidža Wartime Commission Statement, 29 October 1992); D534 (Article from AFP entitled "Fierce Fighting Raging Around Sarajevo", 3 December 1992); D536 (Article from AFP entitled "Serbs Cut Airport Road", 8 December 1992); P1435 (UNMO report, 11 December 1992), paras. 13-30; D2452 (Report of Ilidža Brigade, 25 December 1992), p. 1; D3405 (SRK combat report, 15 March 1993), p. 1; D3406 (SRK combat report, 18 March 1993); D2820 (SRK combat report, 16 July 1993); D4631 (Letter from Manojlo Milovanović to UNPROFOR, 2 August 1993); D2821 (SRK combat report, 3 August 1993); D2822 (SRK combat report, 10 August 1993); D2827 (SRK combat report, 19 August 1993); P1017 (SRK combat report,
} 


\section{(D) Scheduled Detention Facility C.18.2}

2136. The Indictment refers to the use of Kula Prison as a detention facility from May 1992 until at least 28 October $1994 .^{7285}$

\section{(1) Establishment and control}

2137. Kula Prison was located close to the Sarajevo airport, ${ }^{7286}$ on a compound with other buildings, including a police station, the Ministry of Justice, and the military prosecutor's office. $^{7287}$ The compound had a large warehouse for goods and food supplies. ${ }^{7288}$ It also had its own farming facilities. ${ }^{7289}$

2138. Prior to the war, Kula Prison served as a medium security prison for persons serving sentences of less than six months. ${ }^{7290}$ On 6 April 1992, all convicts were released on the orders of

27 September 1993); D4621 (SRK Report, 11 December 1993); P2667 (SRK combat report, 20 January 1994), pp. 1-2; D1515 (SRK combat report, 4 February 1994), p. 1; D838 (SRK combat report, 2 August 1994), pp. 12; D2823 (SRK combat report, 6 November 1994); P5132 (VRS Main Staff Report to Radovan Karadžić, 21 July 1995), p. 2.

7284 P1006 (SRK Order, 12 September 1992), p. 1 (ordering, following a meeting in Jahorina with municipal, military, and republican leaders, that it was necessary to "liberate and take control of important parts of the city, features close to it (Mojmilo, Stup junction) and estates (Donji Kotorac, Hrasnica, Butmir, and Sokolović Kolonija); Neđeljko Prstojević, T. 13267-13269, 13282 (11 March 2011); P2450 (Ilidža SDS Declaration for working in wartime, 6 February 1993, p. 2) (reporting that legal authority of the Serbian Municipality of Ilidža is to be established as soon as possible on, inter alia, Butmir, Hrasnica, and Sokolović Kolonija); P1483 (Ratko Mladić's notebook, 2 April-24 October 1993), pp. 276-277 (stating that a meeting held on 17 August 1993, Velibor Veselinović, then president of the Ilidža Serb Assembly, said that their goal was to strike Hrasnica and Sokolović Kolinija when tensions have lowered).

7285 Indictment, Scheduled Detention Facility C.18.2, fn. 12. The Indictment originally included the KP Dom Butimir detention facility (hereinafter referred to as "Kula Prison") as being located in Novo Sarajevo municipality; however it was subsequently corrected to include Kula Prison as falling within Ilidža municipality. See Indictment, Schedule C, fn. 11.

7286 KDZ239, P3336 (Transcript from Prosecutor v Krnojelac), T. 1283. See also KDZ017, P3567 (Transcript from Prosecutorv Krnojelac), T. 2916. Kula Prison was approximately 200 or 300 metres from the confrontation line between Gornji and Donji Kotorac and 500 or 600 metres from confrontation line in Dobrinja. KDZ601, T. 18617 (8 September 2011).

7287 Momčilo Mandić, C2 (Transcript from Prosecutor v. Krajišnik), T. 8730-8731, 8876; KDZ601, T. 1857818579, 18616 (8 September 2011); KDZ017, P3567 (Transcript from Prosecutor v Krnojelac), T. 2917; P3299 (Record of interview with KDZ601, 18 April 2005), p. 46 (under seal). See also P3300 (Sketch of KPD Kula prepared by KDZ601) (under seal); P3301 (Sketch of KPD Kula prepared by KDZ601) (under seal); D1076 (MUP Administration for the Police Duties and Affairs report, 3 August 1992), p. 5. The police station was the headquarters for the areas of Dobrinja, Lukavica, and Vojkovići. See P5698 (Intercept of conversation between Branko Đerić and Mićo Stanišić, 1 May 1992), pp. 3-4.

7288 P3299 (Record of interview with KDZ601, 18 April 2005), p. 46 (under seal); KDZ601, T. 18616 (8 September 2011).

7289 Soniboj Škiljević, T. 36783 (8 April 2013); D3331 (Witness statement of Soniboj Škiljević dated 5 April 2013), para. 4; KDZ601, T. 18616 (8 September 2011). See also Momčilo Mandić, C2 (Transcript from Prosecutor v. Krajišnik), T. 9106.

7290 KDZ601, T. 18614-18615 (8 September 2011). See also KDZ239, P3336 (Transcript from Prosecutor v. Krnojelac), T. 1283; P3299 (Record of interview with KDZ601, 18 April 2005), p. 8 (under seal); Momčilo Mandić, C2 (Transcript from Prosecutor v. Krajišnik), T. 8730-8732, 8876; Slobodan Avlijaš, D3105 (Witness Statement of Slobodan Avlijaš, dated 9 March 2013), para. 7. 
the then warden. ${ }^{7291}$ Kula Prison was under the jurisdiction of the MUP from at least May 1992 until the beginning of August 1992, when it was taken over by the RS Ministry of Justice. ${ }^{7292}$ Under the Ministry of Justice, it was converted into an investigating unit of the district court of Sarajevo. $^{7293}$

2139. As of 1 August 1992, Radoje Lalović was appointed as the first warden of Kula Prison and Soniboj Škiljević served as the acting warden from 16 December 1992 until 1 January $1994 .^{7294}$ The commander of the guards was Neđo Pandurević. ${ }^{7295}$ The police chief at Kula was Milenko Tepavčević and the police commander was Radenko Vujičić. ${ }^{7296}$

2140. After August 1992, Kula Prison continued to be secured by the MUP, with a police officer guarding the entrance to the premises. ${ }^{7297}$ The guards were responsible for the administration of the premises and were regulated by Tepavčević. ${ }^{7298}$ The JNA and later the VRS were present at Kula Prison, controlling, such matters as bringing and taking detainees, and the military commission for exchanges at the SRK. ${ }^{7299}$ The military prosecutor's office also had jurisdiction over the prisoners. ${ }^{7300}$

2141. Detainees began arriving at Kula Prison from May 1992 onwards. ${ }^{7301}$ Many detainees were transported from other detention facilities, ${ }^{7302}$ and others were transported directly from their

7291 D3331 (Witness statement of Soniboj Škiljević dated 5 April 2013), para. 3.

7292 D3112 (Witness statement of Momčilo Čeklić dated 8 March 2013), para. 44; D3105 (Witness statement of Slobodan Avlijaš dated 9 March 2013), para. 8; D3331 (Witness statement of Soniboj Škiljević dated 5 April 2013), para. 5; Adjudicated Fact 2635. See also D3340 (Decision on the forming of KPD Butmir, 16 June 1992), pp. 8-9; D3333 (Rules on the internal organisation of Butmir KPD); P1089 (Ministry of Justice Report on the Ministry's Activities in May-October 1992 Period, 16 November 1992), p. 2.

7293 Momčilo Mandić, C2 (Transcript from Prosecutor v. Krajišnik), T. 8732, 8876. See also D3105 (Witness Statement of Slobodan Avlijaš, dated 9 March 2013), paras. 3, 9.

7294 D3331 (Witness statement of Soniboj Škiljević dated 5 April 2013), paras. 2, 5; D3341 (Decision on appointment of Soniboj Škiljević; 16 December 1992). See also P3267 (Witness statement of Šefik Hurko dated 1 September 2011), para. 49.

7295 P3267 (Witness statement of Šefik Hurko dated 1 September 2011), para. 49.

7296 D3331 (Witness statement of Soniboj Škiljević dated 5 April 2013), para. 5.

7297 Slobodan Avlijaš, T. 35182-35183 (11 March 2013); KDZ601, T. 18579 (8 September 2011).

7298 Momčilo Mandić, C2 (Transcript from Prosecutor v. Krajišnik), T. 8733, 8749; D3105 (Witness Statement of Slobodan Avlijaš, dated 9 March 2013), para. 16. See also D3331 (Witness statement of Soniboj Škiljević dated 5 April 2013), paras. 5-6; D3105 (Witness statement of Slobodan Avlijaš dated 9 March 2013), para. 9; D3333 (Rules on the internal organisation of Butmir KPD).

7299 P3299 (Record of interview with KDZ601, 18 April 2005), p. 46 (under seal); KDZ601, T. 18616, 18579 (8 September 2011); D3105 (Witness Statement of Slobodan Avlijaš, dated 9 March 2013), para. 16. See also Momčilo Mandić, C2 (Transcript from Prosecutor v. Krajišnik), T. 8749; D3331 (Witness statement of Soniboj Škiljević dated 5 April 2013), paras. 5, 7; D3105 (Witness statement of Slobodan Avlijaš dated 9 March 2013), para. 9.

$7300 \quad$ D3331 (Witness statement of Soniboj Škiljević dated 5 April 2013), para. 7.

7301 See D1243 (Kula's Police Station book of duty transfer, 1 May-29 July 1992), p. 2; P43 (Witness statement of Mirsad Smajš dated 14 January 1998), e-court p. 9.

7302 Approximately 233 detainees from Hadžići were transferred from Lukavica to Kula Prison on 23 June 1992. P2403 (Witness statement of Mehmed Musić dated 28 February 2011), paras. 89, 92; Mehmed Musić, T. 12879 
homes or conflict zones. ${ }^{7303}$ The detainees held at Kula Prison included civilians, persons who had not violated any law, and persons held without official detention orders. ${ }^{7304}$ Mentally ill persons $^{7305}$ and several elderly persons were detained in Kula Prison. ${ }^{7306}$ Bosnian Muslims, Bosnian Croats, as well as Bosnian Serbs were detained there. ${ }^{7307}$

2142. Detainees were brought to Kula by soldiers, members of the police, paramilitary forces, as well as special purpose units of the JNA. ${ }^{7308}$ Members of paramilitary units, including the White Eagles, Arkan's men, ${ }^{7309}$ and Oljača's Chetniks ate their meals at Kula Prison. ${ }^{7310}$

(3 March 2011); P161 (Adem Balić's statement to BiH authorities, 7 February 1993), p. 3; P2296 (Witness statement of Tihomir Glavaš dated 13 February 2011), para. 81; D3063 (Witness statement of Mladen Tolj dated 25 February 2013), para. 10; Mladen Tolj, T. 34637-34638 (1 March 2013). See also Adjudicated Fact 2638; para. 2276. Approximately 34 detainees were transferred from the Pale Gym to Kula Prison on 11 July 1992. P2839 (Witness statement of Hajrudin Karić dated 13 May 2011), paras. 24, 44. See also para. 2346. In midDecember 1992, 130 detainees were transferred to Kula Prison from the Manjača camp. D3331 (Witness statement of Soniboj Škiljević dated 5 April 2013), para. 15. On 22 October 1992 the Ministry of Justice ordered that 90 Bosnian Muslims detained at the Sports Centre in Hadžići and 30 Bosnian Muslims detained at a school in Ilidža were to be transferred to Kula Prison. P1607 (RS Ministry of Justice report on prisons and camps on the RS territory, 22 October 1992), e-court pp. 6-7, 28; Momčilo Mandić, C2 (Transcript from Prosecutor v. Krajišnik), T. 9554. On 5 July 1993, KDZ239 was transferred from the KP Dom Foča to Kula Prison. KDZ239, P3336 (Transcript from Prosecutor v. Krnojelac), T. 1283. See also KDZ239, P3336 (Transcript from Prosecutor v. Krnojelac), T. 1278 (testifying that detainees from camps in Batković and Rogatica were present at Kula Prison).

7303 P1126 (SJB Ilidža information re KPD Butmir, 20 May 1992), p. 1 (stating that between 12 and 20 May 1992, the following persons were present at Kula Prison: (i) 38 persons from the Kasindolska Street area, (ii) 47 persons from the Gornji Kotorac area, (iii) 31 persons from Dobrinja, and (iv) 40 persons from Nedžarići, Vrace, Lukavica, Vojkovići, and elsewhere in Ilidža); KDZ239, T. 18922-18924 (15 September 2011) (testifying that a group from Rogatica which was brought on two or three buses included elderly people, women and about five or six children); Dragomir Obradović, T. 36110-36111 (26 March 2013); P6235 (Statement of Avdija Katica, 3 January 1995), pp. 3-4; D3189 (Sokolac SJB dispatch, 31 October 1994) (stating that on 29 October 1994, 61 Bosnian Muslim civilians were moved out of the village of Vrhbarje, Sokolac municipality through the RS Commission for Exchange and transported to Kula Prison); D3112 (Witness statement of Momčilo Čeklić dated 8 March 2013), para. 30; Momčilo Čeklić, T. 35219-35220 (12 March 2013). See also D2910 (SRK Order, 22 October 1992); Adjudicated Fact 2634.

7304 Mladen Tolj, T. 34637-34638 (1 March 2013); P5544 (Instructions on Detention of the RS Ministry of Justice and Administration, 23 February 1993). See also P2839 (Witness statement of Hajrudin Karić dated 13 May 2011), paras. 18, 21, 44, 54; Hajrudin Karić, T. 15348, 15350-15353, 15365 (23 June 2011), T. 15376 (24 June 2011) (testifying that at the time of his arrest, he was a civilian); KDZ239, P3336 (Transcript from Prosecutor v. Krnojelac), T. 1188, 1283 (testifying that at the time of his arrest, he was a civilian); KDZ239, P3335 (Transcript from Prosecutor v. Krnojelac), T. 1195 (under seal); Vitomir Žepinić, T. 33609 (13 February 2013); P1152 (Intercept of conversation between Momčilo Mandić and Ninković, 18 June 1992), pp. $3-4$.

7305 KDZ239, P3336 (Transcript from Prosecutor v. Krnojelac), T. 1284.

7306 P2403 (Witness statement of Mehmed Musić dated 28 February 2011), para. 96. See also KDZ239, T. 1892218924 (15 September 2011).

7307 See D3331 (Witness statement of Soniboj Škiljević dated 5 April 2013), paras. 22, 26; D3338 (List of detainees at KP Dom Butmir); D2923 (Witness statement of Vitomir Žepinić dated 11 February 2013), para. 75; Vitomir Žepinić, T. 33609 (13 February 2013); KDZ601, T. 18586-18588, 18619-18620 (8 September 2011); P3299 (Record of interview with KDZ601, 18 April 2005), p. 41 (under seal); P2839 (Witness statement of Hajrudin Karić dated 13 May 2011), para. 48.

7308 P3299 (Record of interview with KDZ601, 18 April 2005), pp. 13-14 (under seal); KDZ601, T. 18580-18581, 18585-18586 (8 September 2011); D2910 (SRK Order, 22 October 1992).

7309 In May 1992, two members of Arkan's group met with Tepavčević and advised him that they wanted to take over Kula Prison and the SJB. Tepavčević refused and sent them to speak with Tomislav Kovač which they did 
2143. Interrogations were carried out in two small rooms by operatives from all levels of the MUP, as well as by JNA and VRS soldiers. ${ }^{7311}$

2144. During the war, the Kula Prison compound also housed civilians from the surrounding areas while they awaited transfer to Muslim held territory. ${ }^{7312}$ They stayed in a separate part of the prison from the detainees. ${ }^{7313}$ At least 10,000 Bosnian Muslim civilians were accommodated at Kula Prison for periods ranging from a few days to several months. ${ }^{7314}$

\section{(2) Conditions of detention and treatment of detainees}

2145. At various times, some rooms in Kula Prison were so crowded that there was barely enough room for detainees to sit or lie down, and toilet access was so limited that detainees defecated and urinated in the room; the stench was over-powering. ${ }^{7315}$ The ground floor was damp; there was no heating and lice infestation was widespread. ${ }^{7316}$ Other rooms provided slightly better accommodation with mattresses on the floor or beds; the detainees also had access to the toilet at least three times per day, and access to water. ${ }^{7317}$

and subsequently did not return to Kula Prison. P3299 (Record of interview with KDZ601, 18 April 2005), p. 45 (under seal), KDZ601, T. 18593 (8 September 2011), T. 18650 (13 September 2011).

7310 P3299 (Record of interview with KDZ601, 18 April 2005), p. 46 (under seal); KDZ601, T. 18616 (8 September 2011).

7311 P3299 (Record of interview with KDZ601, 18 April 2005), p. 14 (under seal); KDZ601, T. 18581-18582 (8 September 2011), T. 18651 (13 September 2011); ; P3300 (Sketch of KPD Kula prepared by KDZ601) (under seal). See also Mehmed Musić, P2403 (Witness statement of Mehmed Musić dated 28 February 2011), para. 97.

7312 D3331 (Witness statement of Soniboj Škiljević dated 5 April 2013), paras. 19, 28; D3335 (Request of Butmir KPD to High Commissioner for Refugees and Humanitarian Aid, 5 September 1994); D3344 (Request of individual Croats to RS Government, 7 March 1994); D3343 (Report of RS Central Commission for Exchange, 28 October 1994); Soniboj Škilijević, T. 36782-36783, 36824-36826 (8 April 2013), T. 36932-36934 (10 April 2013); D3105 (Witness statement of Slobodan Avlijaš dated 9 March 2013), para. 7; P3267 (Witness statement of Šefik Hurko dated 1 September 2011), para. 49; P1127 (Letter from Central Commission for Exchange of Detained Persons re KPD Butmir, 28 October 1994); KDZ601, T. 18649 (13 September 2011).

7313 D3331 (Witness statement of Soniboj Škiljević dated 5 April 2013), para. 19; Soniboj Škiljević, T. 36783 (8 April 2013); P2839 (Witness statement of Hajrudin Karić, dated 13 May 2011), para. 47 (testifying that about 200 women and children from Hadžići were in two other rooms).

7314 P1127 (Letter from Central Commission for Exchange of Detained Persons re KPD Butmir, 28 October 1994); Momčilo Mandić, C2 (Transcript from Prosecutor v. Krajišnik), T. 8741-8742; Momčilo Mandić, T. 4414-4415 (30 June 2010); P4850 (Witness statement of Amor Mašović dated 23 March 2012), para. 31. See also Adjudicated Fact 2633. The Prosecution submits that the 10,000 Bosnian Muslim civilians accommodated at Kula Prison were detained. Prosecution Final Brief, Appendix B, pp. 20-21. Having reviewed all the evidence, the Chamber finds that the evidence is insufficient to determine whether these civilians were deprived of freedom of movement such that they were detained, as opposed to being merely accommodated due to the combat activity in the area.

7315 P2403 (Witness statement of Mehmed Musić dated 28 February 2011), para. 94; P161 (Adem Balić's statement to BiH authorities, 7 February 1993), p. 3.

7316 KDZ239, P3336 (Transcript from Prosecutor v. Krnojelac), T. 1284.

7317 P2403 (Witness statement of Mehmed Musić dated 28 February 2011), para. 98; P2839 (Witness statement of Hajrudin Karić dated 13 May 2011), para. 46. 
2146. The food was insufficient. ${ }^{7318}$ Several detainees were initially kept in crowded cells from which they were not permitted to leave; they were subsequently moved into more spacious cells and given access to the cafeteria. ${ }^{7319}$ In the former scenario they were only given one meal per day, which was brought to that cell. ${ }^{7320}$ However, in the cafeteria, detainees were given two meals per day. ${ }^{7321}$ On 20 May 1992, Tepavčević wrote to the MUP and Ministry of Justice advising of the inadequate conditions of accommodation, food, hygiene, and health of 156 detainees who had been present at Kula Prison since 12 May $1992 .^{7322}$

2147. On 7 May 1992, at least five detainees were badly beaten while detained at Kula Prison. ${ }^{7323}$ The Chamber also recalls that it found that detainees from Hadžići were beaten on a bus in front of Kula when it stopped there on its way to the Lukavica Barracks. ${ }^{7324}$ Several detainees testified that they were not beaten or mistreated during their detention at Kula Prison, ${ }^{7325}$ however others were beaten. ${ }^{7326}$ In addition, local Serbs and armed groups frequently gathered around the prison compound attempting to gain access and on occasion made it through. ${ }^{7327}$

2148. Detainees at Kula Prison were detailed to perform work on the frontlines of the conflict, including de-mining, transporting material for barricades, digging trenches and retrieving the

${ }_{7318}$ See e.g. P43 (Witness statement of Mirsad Smajš dated 14 January 1998), e-court p. 10.

7319 P161 (Adem Balić's statement to BiH authorities, 7 February 1993), p. 3; P2403 (Witness statement of Mehmed Musić dated 28 February 2011), para. 98.

$7320 \quad$ P161 (Adem Balić's statement to BiH authorities, 7 February 1993), p. 3.

7321 P2839 (Witness statement of Hajrudin Karić dated 13 May 2011), para. 46; P161 (Adem Balić's statement to BiH authorities, 7 February 1993), pp. 3-4; P2403 (Witness statement of Mehmed Musić dated 28 February 2011), para. 98; P46 (Witness statement of Bego Selimović dated 21 June 1997), para. 41; P47 (Statement of Bego Selimović to Ilijaš Municipality Commission for Crime Investigation, 5 April 1993), para. 34. For example, Mušić received tea and bread in the morning as well as "some cooked food", such as pea soup, in the afternoon. P2403 (Witness statement of Mehmed Musić dated 28 February 2011), para. 98. The Chamber notes that Defence witnesses testified that detainees received three meals per day, the food served at Kula Prison was normal for wartime conditions, and the accommodation provided was very good. D3331 (Witness statement of Soniboj Škiljević dated 5 April 2013), para. 8; Slobodan Avlijaš, T. 35184 (11 March 2013), (testifying that before August 1992 when Kula Prison was under the jurisdiction of the police, prisoners were mostly given dry rations in their rooms but after the establishment of Kula Prison, daily meals were provided to prisoners in the dining room); D3105 (Witness Statement of Slobodan Avlijaš, dated 9 March 2013), para. 17. Having considered all the evidence and taken into account the fact that these Defence witnesses had an incentive to distance themselves from the poor conditions at Kula Prison, and that the witnesses who were detained there were better placed to report on the conditions in which they were detained, the Chamber does not rely on the evidence of these Defence witnesses in this regard. [REDACTED].

7322 P1126 (SJB Ilidža information re KPD Butmir, 20 May 1992), p. 2.

7323 P43 (Witness statements of Mirsad Smajš dated 18 December 1993 and 14 January 1998), e-court pp. 5, 10. See also para. 2154.

$7324 \quad$ See para. 2276.

7325 Mehmed Musić, T. 12880 (3 March 2011); P2839 (Witness statement of Hajrudin Karić dated 13 May 2011), para. 49; D2923 (Witness statement of Vitomir Žepinić dated 11 February 2013), para. 76.

7326 See Adjudicated Fact 2636.

7327 D3105 (Witness Statement of Slobodan Avlijaš, dated 9 March 2013), paras. 17-18; KDZ601, T. 18652-18653 (13 September 2011); KDZ601, T. 18654 (13 September 2011); P1154 (Witness statement of KDZ088 dated 27-29 April 2010), p. 142 (under seal). See also Momčilo Mandić, T. 5241 (15 July 2010). 
bodies of fallen Serb combatants. ${ }^{7328}$ Several prisoners who were deployed to work were killed or injured by sniping or shells. ${ }^{7329}$ Detainees were also engaged in work, such as farm work, around the prison, close to the confrontation line. ${ }^{730}$ Shells frequently landed on the plantation where detainees were made to work and a few detainees were killed. ${ }^{7331}$

2149. The VRS decided which detainees would perform work outside of Kula Prison. ${ }^{7332}$ Mandić was also involved in providing detainees to perform forced labour. ${ }^{7333}$ The detainees could not refuse to work, ${ }^{7334}$ however some were not forced to work if they were unwell. ${ }^{7335}$

Detainees in work platoons were provided additional food by the prison staff and were sometimes

7328 P3299 (Record of interview with KDZ601, 18 April 2005), pp. 37, 65 (under seal); KDZ239, P3336 (Transcript from Prosecutor v. Krnojelac), T. 1284-1285; Hajrudin Karić, T. 15307 (23 June 2011); P2403 (Witness statement of Mehmed Musić dated 28 February 2011), paras. 99-100; Mehmed Musić, T. 12879-12880 (3 March 2011); P161 (Adem Balić's statement to BiH authorities, 7 February 1993), p. 3; P1938 (Witness Statement of KDZ310 dated 28 November 2010), para. 46; P3267 (Witness statement of Šefik Hurko dated 1 September 2011), para. 49; D2418 (Witness statement of Božo Tomić dated 5 November 2012), para. 15; Božo Tomić, T. 30200-30202 (13 November 2012); Dragan Maletić, T. 30866-30867 (4 December 2012); P5987 (Special report of the $2^{\text {nd }}$ Infantry Battalion re the escape of two prisoners, 21 May 1993), p. 1; P6280 (Worksite list of Kula prison, 24 September 1992 to 2 January 1993); P6281 (Notebook re Kula Prison, 1993); Željko Bambarez, T. 31324-31328 (12 December 2012); P6042 (Statement of Željko Bambarez, undated); P804 (Sky news report re Kula prison, with transcript); P926 (Witness statement of Aernout Van Lynden dated 26 February 2010), para. 63; D3331 (Witness statement of Soniboj Škiljević dated 5 April 2013), paras. 51-52; D3351 (Request of SRK Military Post to Kula KPD, 1 February 1993); D3352 (Requests of SRK units to Kula KPD); D3362 (Tables re work assignment of POWs and convicted persons). See also Adjudicated Fact 2640; para. 2267.

7329 P1938 (Witness statement of KDZ310 dated 28 November 2010), para. 46; KDZ239, T. 18922 (15 September 2011), 19004 (16 September 2011); P161 (Adem Balić's statement to BiH authorities, 7 February 1993), p. 3; D3331 (Witness statement of Soniboj Škiljević dated 5 April 2013); paras. 55-57; Soniboje Škiljević, T. 36952-36953 (10 April 2013); D3363 (Reports of person on duty at Butmir KPD). See also Adjudicated Fact 2640; P804 (Sky news report re Kula prison, with transcript), p. 2; P6282 (RS Central Exchange Committee list of persons); P6281 (Notebook re Kula Prison, 1993), pp. 3-4. The Chamber notes that save for Scheduled Incident B.13.3, killings of detainees who were forced to work were not charged pursuant to Schedule A or B of the Indictment. See fn. 13.

7330 Hajrudin Karić, T. 15307 (23 June 2011); P3267 (Witness Statement of Šefik Hurko, dated 1 September 2011), para. 49; Šefik Hurko, T. 18245 (2 September 2011). See also D3331 (Witness statement of Soniboj Škiljević dated 5 April 2013), para. 50; Soniboj Śkilijević, T. 36805 (8 April 2013); D3362 (Tables re work assignment of POWs and convicted persons); D3363 (Reports of person on duty at Butmir KPD). Hurko described the farm work as “extremely hard” and exhausting. P3267 (Witness Statement of Šefik Hurko, dated 1 September 2011), para. 49).

7331 P3299 (Record of interview with KDZ601, 18 April 2005) (under seal), pp. $46-47$ (testifying that a couple of Bosnian Muslim detainees were sent to work at the plantation where "shells were landing"); KDZ239, T. 19004 (16 September 2011) (testifying that he witnessed the fall of one shell). See also D3331 (Witness statement of Soniboj Škiljević dated 5 April 2013); paras. 53-54; D3405 (SRK combat report, 15 March 1993), p. 2 (documenting that shells from the Butmir and Igman directions fell on Kula Prison, killing one Serb detainee and wounding 14 others). The Chamber notes that save for Scheduled Incident B.13.3, killings of detainees who were forced to work were not charged pursuant to Schedule A or B of the Indictment. See fn. 13.

7332 D3331 (Witness statement of Soniboj Škiljević dated 5 April 2013), paras. 5-7.

7333 P1140 (Order of Ministry of Justice of SerBiH re KPD Butmir, 22 September 1992); P1143 (Intercept of conversation between Momčilo Mandić and Radivoje Grković, 3 July 1992), pp. 2-5; Momčilo Mandić, C2 (Transcript from Prosecutor v. Krajišnik), T. 8979-8973, 8983.

7334 Momčilo Mandič, C2 (Transcript from Prosecutor v. Krajišnik), T. 9106. See also KDZ239, T. 19004-19005 (16 September 2011). See also P47 (Statement of Bego Selimović to Ilijaš Municipality Commission for Crime Investigation, 5 April 1993), para. 34.

7335 Bego Selimović, P44 (Transcript from Prosecutor v. Krajišnik), T. 10905; P46 (Witness statement of Bego Selimović dated 21 June 1997), paras. 39, 45. 
given food or cigarettes by soldiers and locals in the locations where they worked. ${ }^{7336}$ However, they were not remunerated for their work. ${ }^{7337}$

2150. Detainees were registered with the ICRC. ${ }^{7338}$ Around 9 August 1992, Karadžić visited Kula prison with representatives of the media and the ICRC. ${ }^{7339}$ That day the food was better and only clean rooms were shown. ${ }^{7340}$

2151. On 3 October 1994, Bulajić, President of the State Commission was given permission to transfer all remaining detainees at Kula Prison to Bosnian Muslim held territory and until at least the end of October 1994, Kula Prison continued to be used to facilitate exchanges of civilians. ${ }^{7341}$

detainees

(3) Conclusion in relation to conditions of detention and treatment of

2152. Based on the foregoing, the Chamber finds that Serb Forces detained non-Serbs from Ilidža and neighbouring municipalities, including civilians, from May 1992 until at least 28 October 1994 in Kula Prison. The Chamber further finds that the detainees were held in poor conditions characterised by inadequate space, bedding, and sanitary facilities. The Chamber also finds that detainees were provided insufficient food. The Chamber further finds that male detainees were subjected to forced labour and beatings while detained at Kula Prison.

7336 P2403 (Witness statement of Mehmed Musić dated 28 February 2011), paras. 99-100; P161 (Adem Balić's statement to $\mathrm{BiH}$ authorities, 7 February 1993), p. 3; Hajrudin Karić, T. 15307 (23 June 2011); KDZ239, T. 19004-19005 (16 September 2011); D3331 (Witness statement of Soniboj Škiljević dated 5 April 2013), para. 7; D2418 (Witness statement of Božo Tomić dated 5 November 2012), para. 15. See also P6283 (Report on inspection and monitoring of Butmir KPD, April 1994), p. 4. The Accused argues that detainees requested to work voluntarily to receive cigarettes and pass the time. Defence Final Brief, para. 1675. In light of all the evidence, the Chamber finds that most detainees assigned to work while detained at Kula Prison, had no choice but to perform work.

7337 Momčilo Mandič, C2 (Transcript from Prosecutor v. Krajišnik), T. 9106.

7338 See e.g. KDZ239, T. 18992 (16 September 2011); P2839 (Witness statement of Hajrudin Karić dated 13 May 2011), para. 49; P46 (Witness statement of Bego Selimović dated 21 June 1997), paras. 42, 44-45; P47 (Statement of Bego Selimović to Ilijaš Municipality Commission for Crime Investigation, 5 April 1993), paras. 32, 35. See also D3331 (Witness statement of Soniboj Škiljević dated 5 April 2013), paras. 20, 37. On 13 May 1993, Mladić issued an order allowing ICRC delegates to interview prisoners in the absence of prison officials on the written approval of the VRS Main Staff. D3345 (VRS Main Staff Order, 13 May 1993); D3331 (Witness statement of Soniboj Škiljević dated 5 April 2013), para. 30.

7339 D3331 (Witness statement of Soniboj Škiljević dated 5 April 2013), paras. 13-14; Soniboje Škiljević, T. 36779_ 36780 (8 April 2013), T. 36932 (10 April 2013); P2839 (Witness statement of Hajrudin Karić dated 13 May 2011), para. 51. See also P2840 (Video footage of Radovan Karadžić's visit to Kula prison).

7340 P2839 (Witness statement of Hajrudin Karić dated 13 May 2011), para. 52; Hajrudin Karić, T. 15308 (23 June 2011).

7341 P2684 (VRS order, 3 October 1994); P1127 (Letter from Central Commission for Exchange of Detained Persons re KPD Butmir, 28 October 1994); D3189 (Sokolac SJB dispatch, 31 October 1994). 


\section{(4) Scheduled Incident B.13.1}

2153. The Indictment refers to the killing of at least two detainees in Kula Prison on or about 7 May 1992.

2154. On 7 May 1992, five detainees who had just arrived at Kula Prison from Grbavica were beaten so badly that one died immediately and another detainee, Zlatan Salčinović, died the next morning. ${ }^{7342}$ Mirsad Smajš and at least one other detainee took the bodies of these individuals to a van after which they were transported elsewhere. ${ }^{7343}$ The Chamber received forensic evidence that the body of an individual identified as Zlatan "Salčin" was discovered in a grave in Sarajevo. $^{7344}$

2155. The Trial Chamber therefore finds that on or about 7 May 1992 two detainees were beaten to death at Kula Prison by Serb Forces.

\section{(5) Scheduled Incident B.13.3}

2156. The Indictment refers to the killing of three detainees while performing forced labour at Kula Prison between 23 July and 24 November 1992.

2157. Adem Balić was detained at Kula Prison from 23 June to 24 November $1992 .^{7345}$ After approximately a month in detention there, he was detailed to a work platoon and witnessed the death and wounding of detainees who were forced to work on or near the frontlines. ${ }^{7346}$ Vahid Gačanović was killed by incoming fire at Ozrenska Street; Ramic Smajić and Zido Nizić were killed by incoming fire in the Kula Prison agricultural complex. ${ }^{7347}$ The Chamber also received forensic evidence that the bodies of Gačanović and Smajić were found in a mass grave at Vrangeš, which was a wartime cemetery located close to Kula Prison. ${ }^{7348}$

\footnotetext{
7342 P43 (Witness statement of Mirsad Smajš dated 18 December 1993); P43 (Witness statement of Mirsad Smajš dated 14 January 1998), p. 3.

7343 P43 (Witness statement of Mirsad Smajš dated 18 December 1993), p. 2.

7344 P4853 (Updated Table 2 to the Report of Amor Mašović), p. 89 (noting that the body of Zlatan "Salčin was discovered in the Miljevići III grave in Sarajevo).

7345 P161 (Adem Balić's statement to BiH authorities, 7 February 1993), pp. 3-4.

7346 P161 (Adem Balić's statement to BiH authorities, 7 February 1993), p. 3. The Chamber notes that KDZ310 gave evidence that he saw detainees from Kula Prison working at Ozrenska street and knew of several cases of them being killed by snipers. P1938 (Witness statement of KDZ310 dated 28 November 2010), para. 46).

7347 P161 (Adem Balić's statement to BiH authorities, 7 February 1993), p. 3. See also Adjudicated Fact 2640.

7348 P4853 (Updated Table 2 to the Report of Amor Mašović), p. 90; P4850 (Witness statement of Amor Mašović dated 23 March 2012), Annex A, p. 7; P4886 (Sarajevo Cantonal Court records relating to Vranješ exhumation, 30 August 1999), p. 26
} 
2158. Based on this evidence, the Chamber is satisfied that at least three detainees of Kula Prison were killed while performing forced labour between 23 July and 24 November 1992.

\section{(E) Movement of the population from Ilidža}

2159. There was much movement both into and out of Ilidža, with the most intense period being from April to June $1992,{ }^{7349}$ when large numbers of Serb refugees arrived in Ilidža. ${ }^{7350}$ Bosnian Muslims left their homes in Ilidža. ${ }^{7351}$ Prstojević participated in expelling Bosnian Muslim civilians from their homes with threats; people were terrified and had no choice but to leave. ${ }^{7352}$ On 26 May 1992, Tomislav Kovač advised Mandić that he was unable to prevent people from driving Bosnian Muslims from Ilidža. ${ }^{7353}$ On 2 June 1992, Mandić told Prstojević that he was aware that Prstojević was issuing ultimatums to Bosnian Muslims and evicting them from settlements. ${ }^{7354}$ Prstojević did not deny this; rather he stated that he had not given such ultimatums in public. $^{7355}$

\section{9}

(Witness statement of Slavko Mijanović dated 19 January 2013), para. 6.

D3112 (Witness statement of Momčilo Čeklić dated 8 March 2013), para. 27; Radomir Kezunović, T. 13968 (31 May 2011); Neđelko Prstojević, T. 13764-13767, 13815 (21 March 2011); D2852 (Witness statement of Srđan Śehovac dated 27 January 2013), para. 47; D2773 (Witness statement of Slavko Mijanović dated 19 January 2013), para. 6. See also D1226 (Intercept of conversation between Neđeljko Prstojević and Jovo Božić, 27 July 1992), pp. 4-5.

7351 KDZ088, T. 6261-6262 (7 September 2010) (closed session). See also D4002 (Letter from BiH MUP to Vasvija Vidović, 4 July 1995), pp. 59-60.

7352 P1154 (Witness statement of KDZ088 dated 27-29 April 2010), pp. 137-140 (under seal); KDZ088, T. 6263 (7 September 2010) (closed session); P1086 (Intercept of conversations between (i) Neđeljko Prstojević and Milenko LNU and (ii) Neđeljko Prstojević and FNU Novaković, 14 May 1992), pp 2-3; P1492 (Intercept of conversation between (i) Neđeljko Prstojević and Radomir and (ii) Neđeljko Prstojević and Dragan, 14 June 1992), p. 3. See also fn. 7269, para. 2134; P1515 (Intercept of conversation between Neđeljko Prstojević and Radomir Ristić, 25 June 1992), pp 1-2; Momčilo Mandić, C3 (Transcript from Prosecutor v. Stanišić \& Župljanin), T. 9484. At the $17^{\text {th }}$ session of the Bosnian Serb Assembly, Prstojević said that when the Accused "visited [them] in Ilidža and encouraged [them], the Serbs from Sarajevo retained control over the territory, and even extended their territory in some areas, driving the Muslims out of the territories where they had actually been majority." D92 (Transcript of $17^{\text {th }}$ session of SerBiH Assembly, 24-26 July 1992), p. 66. The Chamber notes that Prstojević objected to the translation of "driving the Muslims out" and said that he did not say that Muslims were expelled, but rather that they were "pushed back". P2513 (Excerpt from Neđeljko Prstojević's transcript from Prosecutor v. Krajišnik), T. 14664-14665; Neđeljko Prstojević, T. 13017-13021 (8 March 2011). The Chamber notes that the BCS version of the transcript of the $17^{\text {th }}$ session of the Bosnian Serb Assembly uses the word potjerali which means "to chase away". The Chamber considers this to be synonymous with "driving away". P2513 (Excerpt from Neđeljko Prstojević's transcript from Prosecutor v. Krajišnik), T. 14673. However, Prstojević also denied that he would have used the term "potjerali" and testified that he used a BCS word that means to push back (potisnuli). P2513 Neđeljko Prstojević, T. 13554 (17 March 2011); (Excerpt from Neđeljko Prstojević's transcript from Prosecutor v. Krajišnik), T. 14674. Given the plain text of the BCS version of the $17^{\text {th }}$ Session of the SerBiH Assembly, the Chamber rejects his evidence in this regard. The Chamber further notes that Prstojević stated that he did not mean that civilians were expelled, rather that combatants were pushed back after armed combat, however, he admitted that the majority of the civilian population left with the combatants gradually. P2513 (Excerpt from Neđeljko Prstojević's transcript from Prosecutor v. Krajišnik), T. 14665-14666.

7353 D1239 (Intercept of conversation between Momčilo Mandić and Tomo Kovač, 26 May 1992), p. 2.

7354 P1110 (Intercept of conversation between Momčilo Mandić and Neđeljko Prstojević, 2 July 1992 ), pp. 3-4. Prstojević testified that he had not been saying such things, that no ultimatums were issued, and that Mandić was incorrect. Neđeljko Prstojević, T. 13804, 13842 (21 March 2011). The Prosecution suggested that in the 
2160. On or about 26 June 1992, approximately 400 Bosnian Muslim women and children from Dobrinja who were at Kula Prison were transferred to the border between Serb and Muslim controlled Sarajevo; Mandić assisted in the transfer. ${ }^{7356}$

2161. For the duration of the war, not only Bosnian Muslim and Bosnian Croat prisoners of war but also refugees and unlawfully detained civilians were transferred to non-Serb controlled territory from Kula Prison pursuant to agreements reached with UNHCR and the Central Commission for Exchange of Prisoners and Civilians or pursuant to private agreements. ${ }^{7357}$ Insofar as these exchanges related to refugees or unlawfully detained civilians, the Chamber finds that these individuals were forced to leave the municipality.

2162. On 5 June 1992, the Ilidža Crisis Staff received permission from the Bosnian Serb Government to assign abandoned houses to persons whose apartments had been destroyed. ${ }^{7358}$ On 19 July 1992, the Accused requested that Ilidža prepare an inventory of housing facilities vacated

intercepted conversation, Prstojević only denied that he issued such ultimatums in public. See Neđeljko Prstojević, T. 13839-13842 (21 March 2011). In his testimony in the Krajišnik proceedings, Prstojević testified that: "With the exception of Kotorac, we did not have a policy of expelling civilians in any of the areas except where the circumstances required the population to leave the area because of the combat activities or where the population wanted to leave on their own inititiative." P2513 (Excerpt from Neđeljko Prstojević's transcript from Prosecutor v. Krajišnik), T. 14649. In light of this qualification pertaining to Kotorac, the Chamber is satisfied that there was some truth to Mandić's comments in the intercepted conversation.

7355 P1110 (Intercept of conversation between Momčilo Mandić and Neđeljko Prstojević, 2 July 1992), p. 4. The Chamber notes that Prstojević testified that he had not issued such ultimatums at all and that Mandić was incorrect. Neđeljko Prstojević, T. 13804, 13842 (21 March 2011). In his testimony in the Krajišnik proceedings, Prstojević said that he denied to Mandić that he issued such ultimatums at all and questioned where he said such things. P2513 (Excerpt from Neđeljko Prstojević's transcript from Prosecutor v. Krajišnik), T. 14645-14646. However, the Chamber considers that a plain reading of the text of the intercepted conversation indicates that Prstojević merely denied giving such ultimatums in public. P1110 (Intercept of conversation between Momčilo Mandić and Neđeljko Prstojević, 2 July 1992), p. 4.

7356 Momčilo Mandić, C2 (Transcript from Prosecutor v. Krajišnik), T. 8868-8870, 8886-8889; P1101 (Intercept of conversation between Momčilo Krajišnik and Momčilo Mandić, 26 June 1992), p. 3. Mandić and Avlijaš testified that civilians from Dobrinja left on their own accord to flee the fighting. Momčilo Mandić, C2 (Transcript from Prosecutor v. Krajišnik), T. 8869-8870, 8886-8889; P1101 (Intercept of conversation between Momčilo Krajišnik and Momčilo Mandić, 26 June 1992), p. 3; Slobodan Avlijaš, T. 35193-35194 (11 March 2013). However, in light of the evidence, discussed at paragraph 2133 that the Serb Forces took measures to clear the area, discussed giving Muslim owned apartments to Serbs, and that once the SRK took custody of the civilians, they separated the Bosnian Muslim civilians from the Serbs and Croats, the Chamber finds that the Bosnian Muslim civilians had no choice but to leave Dobrinja.

7357 D3331 (Witness statement of Soniboj Škiljević dated 5 April 2013), paras. 12, 15, 18-19, 46-48; Soniboj Škiljević, T. 36782-36783, 36824-36826 36791 (8 April 2013); D3332 (Certificate of KP Dom Butmir, 4 January 1994); D3350 (Notifications of RS Central Commission for Exchange, May 1994-January 1995); D3349 (Notification of RS Central Commission for Exchange, 7 July 1994); D3358 (Notification of RS Central Commission for Exchange, 13 April 1993; List of persons exchanged from Tarčin on 20 February 1993); Momčilo Mandić, C2 (Transcript from Prosecutor v. Krajišnik), T. 8894-8900; Momčilo Mandić, T. 4604 (5 July 2010); P2403 (Witness statement of Mehmed Musić dated 28 February 2011), para. 96; P3267 (Witness statement of Šefik Hurko dated 1 September 2011), paras. 49-50; P1151 (Letter from SJB Novi Grad to the Ministry of Justice of SerBiH, 25 May 1992); P1102 (Intercept of conversation between Radovan Karadžić and Momčilo Mandić, 1 July 1992); D3350 (Notifications of RS Central Commission for Exchange, May 1994January 1995); P2684 (VRS order, 3 October 1994), p. 1; P1127 (Letter from Central Commission for Exchange of Detained Persons re KPD Butmir, 28 October 1994). 
by Muslims for temporary use by Bosnian Serb refugees. ${ }^{7359}$ Also in July 1992, the Wartime Commission for the municipality founded a commission to implement the temporary distribution of flats. $^{7360}$ The commission encountered difficulties in carrying out its work. ${ }^{7361}$ By the summer of 1993, it made over 3,000 decisions to assign temporary flats. ${ }^{7362}$ The Accused argues that after the war, everyone's tenancy rights were recognised and people were permitted to buy and sell the flats in accordance with the law. ${ }^{7363}$ However, having considered all the evidence before it, the Chamber finds that the main purpose of the regulation was to facilitate the use of the vacant property in question by Serbs who had just arrived in the municipality. In turn, this ensured that those non-Serbs who left Ilidža would not return. Furthermore, on 4 April 1993, Prstojević issued a decision forbidding the return of Bosnian Muslims and Croats to the Serb Municipality of Ilidža for purported security reasons, unless they had written authorisation from the proper authorities. ${ }^{7364}$

2163. According to Bosnian Muslim SDB Chief Nedžad Ugljen, by July 1995, the Serb-held territory in Ilidža was almost devoid of non-Serbs. ${ }^{7365}$

2164. According to several witnesses, there was no organised campaign for the expulsion of Bosnian Muslims in Ilidža by the local authorities. ${ }^{7366}$ In light of the accepted evidence that the Ilidža Crisis Staff led by Prstojević expelled Bosnian Muslim civilians from their homes and redistributed vacant Bosnian Muslim property to Bosnian Serbs, the Chamber rejects this evidence. The Chamber also notes that while several witnesses testified that (i) several Bosnian Muslims left voluntarily; ${ }^{7367}$ (ii) civilians of all ethnicities left Ilidža due to the conflict; ${ }^{7368}$ and (iii) Bosnian Neđeljko Prstojević, T. 13806-13807 (21 March 2011); D416 (Letter from Government of SerBiH to Ilidža Municipal Assembly, 5 June 1992). [REDACTED].

7359 P739 (RS Presidency request to various municipalities, 19 July 1992).

7360 D2773 (Witness statement of Slavko Mijanović dated 19 January 2013), paras. 6-10.

7361 D2773 (Witness statement of Slavko Mijanović dated 19 January 2013), para. 9.

7362 D2773 (Witness statement of Slavko Mijanović dated 19 January 2013), para.10. See e.g. D1241 (Ilidža Crisis Staff ruling, 19 July 1992). In addition, the Chamber notes that on 25 June 1992, Prstojević gave Rade Ristić permission to give Muslim apartments in Dobrinja to Serbs and advised him that they had already reassigned 30 apartments in Nedžarići. P1515 (Intercept of conversation between Neđeljko Prstojević and Radomir Ristić, 25 June 1992), p. 2. See also Adjudicated Fact 2666.

D3960 (Witness statement of Tomislav Kovač dated 28 October 2013), paras. 57-58; Momčilo Mandić, C2 (Transcript from Prosecutor v. Krajišnik), T. 8709; Momčilo Čeklić, D3112 (Witness statement of Momčilo Čeklić dated 8 March 2013), para. 27; Momčilo Čeklić, T. 35218 (12 March 2013); Radomir Kezunović, T. 13972 (31 May 2011); D2773 (Witness statement of Slavko Mijanović dated 19 January 2013), para. 6.

7367 Čeklić maintained that civilians left the eastern parts of Ilidža around 23 April 1992 on their own accord because weapons were found in their homes. Momčilo Čeklić, T. 35219-35226 (12 March 2013). According to Kovač, after the attack on Ilidža of 22 April 1992, civilians, including Serbs, left due to the proximity of their homes to the front. D3960 (Witness statement of Tomislav Kovač dated 28 October 2013), para. 58.

7368 D3960 (Witness statement of Tomislav Kovač dated 28 October 2013), para. 57; Neđeljko Prstojević, T. 13784 (21 March 2011); D1232 (Program for the return of Serbs from SR Yugoslavia, 21 June 1992), p. 2 ; D3112
} 
Muslims who wanted to stay could do so and that many Bosnian Muslims and Croats remained in Ilidža during the conflict, ${ }^{7369}$ this evidence bears limited weight in light of the accepted evidence that Serb Forces participated in the expulsion of Bosnian Muslim civilians in Serb held parts of Ilidža and prevented their return.

2165. In light of the foregoing, the Chamber finds that members of the non-Serb population from the Serb-controlled parts of Ilidža were forced to leave.

iii. Novi Grad

(A) Charges

2166. Under Count 3, the Prosecution alleges that persecution, a crime against humanity, was committed in Novi Grad as part of the objective to permanently remove Bosnian Muslims and/or Bosnian Croats from the Municipalities. ${ }^{7370}$ Acts of persecution alleged to have been committed by Serb Forces and Bosnian Serb Political and Governmental Organs in Novi Grad include killings during the take-over of Novi Grad, ${ }^{7371}$ killings related to a detention facility as well as killings committed during, and deaths resulting from, cruel and inhumane treatment at this detention facility. ${ }^{7372}$ The Prosecution also characterises these killings as extermination, a crime against humanity, under Count 4; murder, a crime against humanity, under Count 5; and murder, a violation of the laws or customs of war, under Count $6 .^{7373}$

2167. Other acts of persecution alleged to have been committed in Novi Grad by Serb Forces and Bosnian Serb Political and Governmental Organs include (i) torture, beatings, and physical and psychological abuse, during and after the take-over and in a detention facility, as cruel or inhumane treatment; ${ }^{7374}$ (ii) rape and other acts of sexual violence, during and after the take-over and in a detention facility, as cruel and inhumane treatment; ${ }^{7375}$ (iii) the establishment and perpetuation of inhumane living conditions in a detention facility in Novi Grad, including the failure to provide adequate accommodation, shelter, food, water, medical care, or hygienic sanitation facilities, as

(Witness statement of Momčilo Čeklić dated 8 March 2013), para. 27; Momčilo Čeklić, T. 35218, 35226-35227 (12 March 2013); Radomir Kezunović, T. 13972 (31 May 2011) (testifying that he moved his family to Pale to stay in their holiday house during the war); D2773 (Witness statement of Slavko Mijanović dated 19 January 2013), para. 6 .

Momčilo Čeklić, T. 35220 (12 March 2013); Radomir Kezunović, T. 13973-13974 (31 May 2011); D2773 (Witness statement of Slavko Mijanović dated 19 January 2013), para. 6.

Indictment, paras. 48-49.

Indictment, para. 60(a)(i). See Scheduled Incident A.9.1.

Indictment, para. 60(a)(ii). See Scheduled Incidents B.12.1, B.12.2.

Indictment, para. 63(a), 63(b).

Indictment, para. 60(b). See Scheduled Detention Facility C.17.1.

Indictment, para. 60(c). 
cruel or inhumane treatment; ${ }^{7376}$ (iv) forcible transfer or deportation of Bosnian Muslims and Bosnian Croats from their homes; ${ }^{7377}$ (v) unlawful detention in a detention facility; ${ }^{7378}$ (vi) forced labour at the frontline and the use of Bosnian Muslims and Bosnian Croats as human shields; ${ }^{7379}$ (vii) the appropriation or plunder of property, during and after the take-over, during arrests and detention, and in the course of or following acts of deportation or forcible transfer; ${ }^{7380}$ (viii) the wanton destruction of private property including homes, business premises, and public property including cultural monuments and sacred sites; ${ }^{7381}$ and (ix) the imposition and maintenance of restrictive and discriminatory measures. ${ }^{7382}$

2168. Under Counts 7 and 8, the Prosecution alleges deportation and inhumane acts (forcible transfer), respectively, as crimes against humanity. ${ }^{7383}$ In this regard, the Prosecution alleges that by the end of 1992, Serb Forces and Bosnian Serb Political and Governmental Organs had forcibly displaced Bosnian Muslims and Bosnian Croats from areas in Novi Grad in which they were lawfully present. ${ }^{7384}$ It is alleged that from March 1992, restrictive and discriminatory measures, arbitrary arrest and detention, harassment, torture, rape and other acts of sexual violence, killing, destruction of houses, cultural monuments and sacred sites, as well as the threat of further such acts caused Bosnian Muslims and Bosnian Croats to flee in fear, while others were physically driven out. $^{7385}$

(B) Lead-up

(1) The municipality of Novi Grad

2169. The municipality of Novi Grad, one of the ten constitutive municipalities of Sarajevo, is bordered in the south and in the west by Ilidža, in the north by Vogošća and Ilijaš, and in the east by Novo Sarajevo. ${ }^{7386}$ It was established in 1977, encompassing the areas which had hitherto

\footnotetext{
7376 Indictment, para. 60(d). See Scheduled Detention Facility C.17.1.

7377 Indictment, para. 60(f).

7378 Indictment, para. 60(g). See Scheduled Detention Facility C.17.1.

7379 Indictment, para. 60(h).

7380 Indictment, para. 60(i).

7381 Indictment, para. 60(j). See Scheduled Incident D.15.

7382 Indictment, para. 60(k). The restrictive and discriminatory measures alleged include the denial of freedom of movement; the removal from positions of authority; the invasion of privacy through arbitrary searches of homes; unlawful arrest and/or the denial of the right to judicial process; and/or the denial of equal access to public services.

7383 Indictment, paras. 68-75.

7384 Indictment, paras. 69, 72.

7385 Indictment, para. 71.

7386 P973 (Robert Donia's expert report entitled "Bosnian Serb Leadership and the Siege of Sarajevo, 1990-1995", January 2010), p. 8; Appendix B, Map 1; P815 (Map of Sarajevo showing confrontation lines). See also Adjudicated Fact 2.
} 
constituted the western parts of Novo Sarajevo. ${ }^{7387}$ These areas included, inter alia, the local commune of Dobroševići which was comprised of the villages of Ahatovići, Bojnik, Dobroševići, and Mihaljevići, the local commune of Rajlovac, and Dobrinja, a set of large, high-rise residential complexes which housed around 40.000 people before the war. ${ }^{7388}$ According to the 1991 census, Novi Grad's population was 136,616 of which $50.8 \%$ were Muslim, $27.5 \%$ were Serb, and $6.5 \%$ were Croat. ${ }^{7389}$ The village of Ahatovići was inhabited mainly by Bosnian Muslims, while those living in Rajlovac and Dobroševići were mostly Bosnian Serbs. ${ }^{7390}$ Inhabitants of Novi Grad municipality generally lived together peacefully until the beginning of $1992 .^{7391}$

2170. Novi Grad was host to a number of important commercial, industrial and military installations, including the Rajlovac Barracks, the Butile Barracks, and Orao (a military industrial factory dedicated to the overhaul of aircraft engines). ${ }^{7392}$

2171. Before the start of the conflict, the president of the Municipal Assembly of Novi Grad was Ismet Čengić, a Bosnian Muslim. ${ }^{7393}$ Momčilo Krajišnik, Nikola Stanišić, Jovan Tintor, ${ }^{7394}$ and

7387 Robert Donia, T. 3089 (31 May 2010); P973 (Robert Donia’s expert report entitled “Bosnian Serb Leadership and the Siege of Sarajevo, 1990-1995”, January 2010), pp. 9-10, 30.

7388 D1101 (Excerpts from witness statements of Ramiz Mujkić, undated), e-court p. 3; P2314 (Witness statement of Ramiz Mujkić dated 4 February 2011), para. 16; P2343 (Information report of Ramiz Mujkić, 4 July 2004), pp. 1-3 (a number of photographs showing Ahatovići, Dobroševići, the Bojnik area and the Rajlovac area); Ramiz Mujkić, T. $12138-12139$ (17 February 2011), 12425, 12440 (25 February 2011); P2310 (Witness statement of KDZ041 dated 14 February 2011), para. 2 (under seal); D2387 (Witness statement of Stojan Džino dated 4 November 2012), para. 5; P973 (Robert Donia's expert report entitled "Bosnian Serb Leadership and the Siege of Sarajevo, 1990-1995”, January 2010), pp. 33, 35-36; Robert Donia, T. 3134, 3141 (1 June 2010); P2577 (Press release of Novo Sarajevo municipality, 1 April 1992), p. 1; P1866 (Witness statement of Youssef Hajir dated 25 February 2010), para. 8; Youssef Hajir, T. 8836-8837 (2 November 2010).

7389 P5964 (Census data for BiH by municipality in 1971, 1981, and 1991, April 1995), e-court p. 2; D4002 (Letter from BiH MUP to Vasvija Vidović, 4 July 1995), p. 60. But see P4994 (Addendum to Ewa Tabeau's expert report entitled "Ethnic Composition in Internally Displaced Persons and Refugees from 27 Municipalities of BiH 1991 to 1997", 3 February 2009), pp. 21, 30, 33, 36, 39 (indicating that in 1991, Novi Grad had 112,618 inhabitants of whom, approximately $49.5 \%$ were Bosnian Muslims, 28.3\% were Bosnian Serbs and 7.1\% Bosnian Croats). While the Chamber has found Tabeau's evidence to be generally reliable, for the purpose of determining the population of Novi Grad and the ethnic composition thereof in 1991, it relies on other evidence before it, such as the direct source document, P5964, which contains the raw data from the 1991 census in $\mathrm{BiH}$.

7390 P2310 (Witness statement of KDZ041 dated 14 February 2011), para. 2 (under seal); KDZ041, T. 12130 (17 February 2011); P2314 (Witness statement of Ramiz Mujkić dated 4 February 2011), paras. 16, 29; Ramiz Mujkić, T. 12139-12140 (17 February 2011); D1101 (Excerpts from witness statements of Ramiz Mujkić, undated), e-court p. 3; D2387 (Witness statement of Stojan Džino dated 4 November 2012), para. 7.

7391 P2310 (Witness statement of KDZ041 dated 14 February 2011), para. 5 (under seal); P2314 (Witness statement of Ramiz Mujkić dated 4 February 2011), para. 3; D2387 (Witness statement of Stojan Džino dated 4 November 2012), para. 9.

7392 Robert Donia, T. 3702 (10 June 2010); P2314 (Witness statement of Ramiz Mujkić dated 4 February 2011), para. 2; P2343 (Information report of Ramiz Mujkić, 4 July 2004), p. 4; D4002 (Letter from BiH MUP to Vasvija Vidović, 4 July 1995), p. 61.

7393 P2577 (Press release of Novo Sarajevo municipality, 1 April 1992), p. 2; P973 (Robert Donia's expert report entitled "Bosnian Serb Leadership and the Siege of Sarajevo, 1990-1995", January 2010), p. 34.

7394 Jovan Tintor was formally associated with the Vogošća municipality and was officially appointed to the post of the commander of the Vogošća TO Brigade on 22 May 1992. See P1505 (SRK Order, 22 May 1992), e-court p. 2; P3033 (Reynaud Theunens's expert report entitled "Radovan Karadžić and the SRBiH TO-VRS (19921995)"), e-court pp. 441-442. 
Ranko Torbica were prominent SDS leaders in the area. ${ }^{7395}$ Bakir Alispahić, Hasan Čengić, and Jusuf Pušina were SDA leaders in the municipality. ${ }^{7396}$

\section{(2) Establishment of Rajlovac municipality ${ }^{7397}$}

2172. Near the end of 1991, members of the SDS municipal board from Novi Grad began contemplating the creation of the Serb municipality of Rajlovac on territory which belonged, in large parts, to the municipality of Novi Grad, in order to prevent Serbs being outvoted in the Novi Grad government and the Novi Grad Municipal Assembly. ${ }^{7398}$ On 26 December 1991, Krajišnik informed the Accused that he had been to a Novi Grad Municipal Assembly session in which voting had been blocked. ${ }^{7399}$ In addition, on 9 February 1992, Krajišnik informed the Accused of the meeting he had recently attended in Reljevo, a village in Novi Grad municipality, and the discussions he had had about forming the Rajlovac municipality. ${ }^{7400}$ A few days later, on 11 February, Jovan Tintor told a certain Prodanović that a new municipality called Rajlovac was being created. ${ }^{7401}$

2173. On or about 23 February 1992, SDS leaders proclaimed the Serb municipality of Rajlovac on some of the territories which had hitherto belonged to the municipality of Novi Grad. ${ }^{7402}$ On 26 March 1992, Dobrinja was incorporated into the Serb municipality of Ilidža, while remaining parts of Novi Grad were incorporated in the Serb municipality of Novo Sarajevo. ${ }^{7403}$ On 11 May

7395 P2310 (Witness statement of KDZ041 dated 14 February 2011), paras. 2-3 (under seal). Krajišnik was born and owned a family house in Zabrđe, to the southeast of Ahatovići, near the Butile Barracks. Momčilo Krajišnik, T. 43153 (7 November 2013); P2314 (Witness statement of Ramiz Mujkić dated 4 February 2011), paras. 6061; P2327 (Map marked by Ramiz Mujkić), pp. 1-2; P2343 (Information report of Ramiz Mujkić, 4 July 2004), pp. 6-7; Robert Donia, T. 3132 (1 June 2010).

7396 P2310 (Witness statement of KDZ041 dated 14 February 2011), para. 2 (under seal); D2387 (Witness statement of Stojan Džino dated 4 November 2012), para. 8.

7397 The Prosecution alleges that in furtherance of the First and Fifth Strategic Goals, the Accused and the Bosnian Serb Leadership established the Serb municipality of Rajlovac in certain areas of Novi Grad, which included the Muslim village of Ahatovići. Prosecution Final Brief, Appendix A (Novi Grad section), para. 1.

7398 D84 (Shorthand Record of $3^{\text {rd }}$ session of SerBiH Assembly, 11 December 1991), pp. 20-22.

7399 P5785 (Intercept of conversation between Radovan Karadžić and Momčilo Krajišnik, 26 December 1991), p. 1.

7400 P5753 (Intercept of conversation between Radovan Karadžić and Momčilo Krajišnik, February 1992), p. 1. Also, sometime in February 1992, Krajišnik informed Nikola Koljević about a meeting he was going to attend in Rajlovac "in connection with this one municipality." P5758 (Intercept of conversation between Momčilo Krajišnik and Nikola Koljević, February 1992), p. 1.

7401 P965 (Intercept of conversation between Jovan Tintor and FNU Prodanović, 11 February 1992), p. 5.

7402 P973 (Robert Donia's expert report entitled "Bosnian Serb Leadership and the Siege of Sarajevo, 1990-1995", January 2010), p. 32; Stojan Džino, T. 29871 (7 November 2012); P967 (Intercept of conversation between Radovan Karadžić and Ljubo Grković, 22 February 1992), pp. 1-2. See also Adjudicated Fact 2580. On 24 March 1992, the Bosnian Serb Assembly unanimously verified the decision to establish the municipality of Rajlovac along with 34 other Serb municipalities. P961 (Shorthand Record of $12^{\text {th }}$ session of SerBiH Assembly, 24 March 1992), pp. 23-24.

7403 P2577 (Press release of Novo Sarajevo municipality, 1 April 1992), p. 1; P973 (Robert Donia's expert report entitled "Bosnian Serb Leadership and the Siege of Sarajevo, 1990-1995", January 2010), pp. 31, 35; Robert Donia, T. 3134 (1 June 2010); P966 (Map of Sarajevo marked by Robert Donia). 
1992, the Bosnian Serb Assembly adopted a law according to which the municipality of Rajlovac included, inter alia, Ahatovići, Bojnik, Dobroševići, Rajlovac, Reljevo-Dvor, Zabrđe, and Žuč. ${ }^{7404}$ Jovo Božić assumed the role of the President of the Rajlovac municipality. ${ }^{7405}$ Sometime after the proclamation of Rajlovac as a new municipality, the Rajlovac municipality Crisis Staff was established and Jovo Božić was appointed as its President. ${ }^{7406}$

\section{(3) The arming and mobilisation of Bosnian Serbs in Novi Grad}

2174. By 14 October 1991, Tintor and Ratko Adžić, who later became the President of the Serb Municipality of Ilijaš, ${ }^{7407}$ had already discussed the issue of arming and mobilisation and noted the inadequate response to the call for mobilisation of Serbs in Novi Grad and surrounding municipalities. Adžić specifically complained that despite a meeting during which he had announced that there was a unique opportunity for Serbs to come and take firearms, nobody from Novi Grad had shown up to collect such weaponry. ${ }^{7408}$

2175. In February 1992, civilian trucks with Serbian and Montenegrin number plates removed equipment and supplies, including a number of guns, from the Butile Barracks and two of those trucks were driven to Pale. ${ }^{7409}$ In March or April 1992, a MP company, headed by Nikola Šuput, was relocated from Kiseljak municipality to Butile Barracks, bringing a number of APCs, antiaircraft guns, and other weaponry. ${ }^{7410}$ From March 1992 onwards, local Serbs came to the Butile and Rajlovac Barracks in order to be issued uniforms and weapons, including sniper rifles, and to undergo military training. ${ }^{7411}$ Two Bosnian Serbs employed at the Orao factory, Stevo Petričević and Mirko Mirković, established and maintained connections between local Serbs and the officers in the Rajlovac Barracks, and were involved in the distribution of arms to the local Serbs. ${ }^{7412}$ At the same time, reserve troops, including Serbs from surrounding areas started arriving at the Butile

\footnotetext{
7404 P2315 (Decree on promulgation of Law on Establishment of Rajlovac Municipality, 11 May 1992), p. 1; Stojan Džino, T. 29865, 29901 (7 November 2012). See also Adjudicated Fact 2580.

7405 D2387 (Witness statement of Stojan Džino dated 4 November 2012), para. 14.

7406 See P2329 (Rajlovac Crisis Staff Order, 9 April 1992); P2628 (Report of Rajlovac's Crisis Staff, 28 May 1992).

7407 P2623 (Ilijaš list of revenues and expenses, 11 May to 30 June 1992), p. 4.

7408 P5844 (Intercept of conversation between Jovan Tintor and Ratko Adžić, 14 October 1991), pp. 1-3.

7409 P2314 (Witness statement of Ramiz Mujkić dated 4 February 2011), para. 4.

7410 P2314 (Witness statement of Ramiz Mujkić dated 4 February 2011), paras. 6-7; D1103 (Supplemental witness statement of Ramiz Mujkić dated 28 April 2000), p. 1.

7411 P2314 (Witness statement of Ramiz Mujkić dated 4 February 2011), para. 8; P2343 (Information report of Ramiz Mujkić, 4 July 2004), p. 4 (photograph showing the Rajlovac Barracks); D1101 (Excerpts from witness statements of Ramiz Mujkić, undated), e-court p. 2; P2310 (Witness statement of KDZ041 dated 14 February 2011), para. 4 (under seal).

7412 P2314 (Witness statement of Ramiz Mujkić dated 4 February 2011), paras. 12-13; D1101 (Excerpts from witness statements of Ramiz Mujkić, undated), e-court p. 2.
} 
Barracks. ${ }^{7413}$ They wore uniforms and were taught by Šuput's men how to operate mortars and other types of weapons. ${ }^{7414}$ In addition, Orao accommodated a Serb "paramilitary unit" which consisted of SDS members from the surrounding villages. ${ }^{7415}$ The insignias on the uniforms worn by this unit bore four Cyrillic "S" symbols and some of its members wore "kokarda" caps. ${ }^{7416}$

2176. On 3 March 1992, a certain Gvozden informed the Accused that he had mobilised Serbs from Pale and would do the same in other municipalities, including Novi Grad. ${ }^{7417}$ The Accused then demanded that efforts be made to show that Muslim mobilisation preceded Serb mobilisation by a number of hours. ${ }^{7418}$

2177. By March 1992, Bosnian Serbs established a check-point on the bridge across the Bosna river in the Reljevo settlement and near the Butile Barracks, and gradually blocked the passage of Bosnian Muslims. ${ }^{7419}$ On 9 April 1992, the Rajlovac municipality Crisis Staff ordered the "active observation" of the entire territory of Rajlovac municipality by means of controlling all vehicles and people moving in the direction of the "Distribution Centre". ${ }^{7420}$ The Rajlovac municipality Crisis Staff also ordered that one policeman and two TO members should be present at all times at the check-point towards the Distribution Centre. ${ }^{7421}$

2178. By early May 1992, almost all non-Serb soldiers and officers of the JNA had abandoned their posts and left the Butile Barracks. ${ }^{7422}$ However, pursuant to the instructions of Hasan Mujkić who was at the time the commander of the local Muslim TO, Ramiz Mujkić stayed in his post at the

\footnotetext{
7413 P2314 (Witness statement of Ramiz Mujkić dated 4 February 2011), para. 9.

7414 P2314 (Witness statement of Ramiz Mujkić dated 4 February 2011), para. 9; D1101 (Excerpts from witness statements of Ramiz Mujkić, undated), e-court p. 2.

7415 P2310 (Witness statement of KDZ041 dated 14 February 2011), para. 4 (under seal).

7416 P2310 (Witness statement of KDZ041 dated 14 February 2011), para. 4 (under seal).

7417 P5604 (Intercept of conversation between Gvozden and Radovan Karadžić, 3 March 1992), p. 3.

7418 P5604 (Intercept of conversation between Gvozden and Radovan Karadžić, 3 March 1992), pp. 2, 5.

7419 Ramiz Mujkić, T. 12427, 12433-12434 (25 February 2011); P2314 (Witness statement of Ramiz Mujkić dated 4 February 2011), paras. 17-18; P2327 (Map marked by Ramiz Mujkić); P2329 (Rajlovac Crisis Staff Order, 9 April 1992); KDZ041, T. 12083-12086 (17 February 2011); D2387 (Witness statement of Stojan Džino dated 4 November 2012), para. 12. Mujkić testified that the check-point was erected in January 1992. See Ramiz Mujkić, T. 12427, 12433 (25 February 2011); D1101 (Excerpts from witness statements of Ramiz Mujkić, undated), e-court p. 3. By contrast, Stojan Džino, testified that it was after the murder of the wedding guest in Sarajevo in March 1992 that Bosnian Serbs erected the first barricades. See D2387 (Witness statement of Stojan Džino dated 4 November 2012), paras. 9, 70. KDZ041 could only recall that the Serb barricades were erected sometime by the end of February or the beginning of March 1992. See P2310 (Witness statement of KDZ041 dated 14 February 2011), para. 4 (under seal). But see KDZ041, T. 12083 (17 February 2011) (indicating that the barricades were erected in the period of 20 to 25 May 1992). See paras. 3533-3539.

7420 P2329 (Rajlovac Crisis Staff Order, 9 April 1992).

$7421 \quad$ P2329 (Rajlovac Crisis Staff Order, 9 April 1992).

7422 P2314 (Witness statement of Ramiz Mujkić dated 4 February 2011), para. 14.
} 
Barracks in order to monitor the situation and report back to the TO command. ${ }^{7423}$ On or about 10 May 1992, the JNA handed over the Rajlovac Barracks and the Rajlovac airport to the Rajlovac TO. $^{7424}$

2179. Sometime after 20 May 1992, Ramiz Mujkić met a group of Albanian JNA soldiers who were in charge of the security of the Butile Barracks and who told him that they would help the Bosnian Muslim TO take over the barracks. ${ }^{7425}$ Ramiz Mujkić subsequently informed Hasan Mujkić of this proposal but was shown a written message from Alija Delimustafić, the Minister of BiH MUP, ${ }^{7426}$ prohibiting any such take-over. ${ }^{7427}$ Three or four days later, Delimustafić reversed his position but the take-over of the Butile Barracks could not be carried out as a number of White Eagles had arrived there in the meantime. ${ }^{7428}$

2180. On 22 May 1992, the SRK commander, Tomislav Šipčić, ordered the formation of the Rajlovac TO Brigade, thus subordinating the Rajlovac TO to the SRK, and appointed the Rajlovac Crisis Staff president, who at that time was Jovo Božić, to the post of the commander of the Brigade. $^{7429}$ On 28 May 1992, Božić reported to the Bosnian Serb government that the "Serbian Army of the Serbian Municipality of Rajlovac" included 1,280 conscripts. ${ }^{7430}$

2181. In May 1992, during talks between local SDA and SDS representatives in the village of Ahatovići, the Bosnian Serbs threatened to attack the village if the villagers did not leave. ${ }^{7431}$ The

7423 P2314 (Witness statement of Ramiz Mujkić dated 4 February 2011), para. 15; Ramiz Mujkić, T. 12413, 12431 (25 February 2011); D1 101 (Excerpts from witness statements of Ramiz Mujkić, undated), e-court p. 5.

7424 D2686 (Witness statement of Mihajlo Vujasin dated 16 December 2012), para. 10; P3033 (Reynaud Theunens's expert report entitled "Radovan Karadžić and the SRBiH TO-VRS (1992-1995)"), e-court p. 441.

7425 Ramiz Mujkić, T. 12415-12416 (25 February 2011); D1101 (Excerpts from witness statements of Ramiz Mujkić, undated), e-court p. 6.

7426 P1117 (Letter from SRBiH Minister of Interior to all MUP administrations, 31 March 1992), p. 2; P1121 (SRBiH Minister of Interior's letter to all CSBs, SJBs, and SUP Sarajevo, 8 April 1992).

7427 Ramiz Mujkić, T. 12416 (25 February 2011); D1101 (Excerpts from witness statements of Ramiz Mujkić, undated), e-court p. 6; Ramiz Mujkić, D1104 (Excerpts from transcript from Prosecutor v. Krajišnik), T. 9240.

7428 Ramiz Mujkić, T. 12416 (25 February 2011); D1101 (Excerpts from witness statements of Ramiz Mujkić, undated), e-court p. 6; D1104 (Excerpts from transcript from Prosecutor v. Krajišnik), T. 9240.

7429 P1505 (SRK Order, 22 May 1992), e-court pp. 1-2; P2628 (Report of Rajlovac's Crisis Staff, 28 May 1992).

7430 P2628 (Report of Rajlovac's Crisis Staff, 28 May 1992). Also, on 17 June 1992, during the $122^{\text {nd }}$ Session of the $\mathrm{BiH}$ Presidency, Sefer Halilović reported that in the territory of Novi Grad, the enemy forces numbered 1,200 and had in their possession, inter alia, ten tanks, 26 APCs, 129 Mortars, 12 PEA guns, eight PEA machineguns, 22 hand-held rocket launchers, nine pieces of $82 \mathrm{~mm}$ mortar guns, four pieces of $82 \mathrm{~mm}$ recoilless guns, five cannons and several sniper nests. D192 (Transcript of $17^{\text {th }}$ June 1992 session of the BiH Presidency), p. 4.

7431 KDZ041, T. 12081-12083 (17 February 2011); P2310 (Witness statement of KDZ041 dated 14 February 2011), para. 5 (under seal). See also Adjudicated Fact 2607. The Chamber is cognisant of the fact that in his statement, Witness KDZ041 referred to the beginning of March 1992 as the period during which Serbs requested that the inhabitants of Ahatovići leave the area whereas during his testimony, he asserted that the request was in fact made at the end of May 1992, that is, after the outbreak of war in Sarajevo. The Chamber is also mindful that according to Adjudicated Fact 2607, this request was conveyed to the inhabitants of Ahatovići in March 1992. The Chamber considers, however, that the meeting in question took place around the end of May 1992 as stated by KDZ041 during his testimony. First, that period roughly coincides with the outbreak of hostilities in 
Bosnian Muslims refused to comply with the demand and the local crisis staff of the Bosnian Muslims led by Hasan Mujkić set up barricades, ${ }^{7432}$ organised village guards, and armed them with infantry weapons. ${ }^{7433}$ The Muslim TO numbered some 200 men. $^{7434}$

2182. By mid-May 1992, all Serbs living in the villages of Dobroševići, Bojnik, Mihaljevići, and Brod left their houses for locations close to Rajlovac and Butile Barracks. ${ }^{7435}$ During the same period, the telephone and electricity lines to Ahatovići were disconnected. ${ }^{7436}$ By the end of May, Serbs had set up barricades on all the roads leading from Rajlovac and Bojnik to Sarajevo. ${ }^{7437}$ The individuals who manned these check-points stopped buses and vehicles and subjected the Bosnian Muslim passengers to searches, before refusing them passage to Sarajevo. ${ }^{7438}$

Sarajevo, as well as the alleged attack on the village of Ahatovići. Second, in his statement, Stojan Džino stated that the last meeting between Muslims from Ahatovići and Serbs took place on 27 May 1992. D2387 (Witness statement of Stojan Džino dated 4 November 2012), paras. 12-13. The Chamber notes, however, that this inconsistency in the evidence of KDZ041 is not so grave that it would affect his overall credibility.

7432 The Chamber notes that during his testimony before the Chamber, KDZ041 denied that there was a crisis staff in Ahatovići and instead referred to the existence of a group of village elders. See KDZ041, T. 12080, 1208712089 (17 February 2011). The Chamber, however, does not accept this part of KDZ041's testimony since in his witness statement, he stated that a crisis staff headed by Hasan Mujkić was formed in Ahatovići, and then proceeded to list its members. P2310 (Witness statement of KDZ041 dated 14 February 2011), para. 10 (under seal). Moreover, Ramiz Mujkić also indirectly confirmed the existence of the said crisis staff. See P2314 (Witness statement of Ramiz Mujkić dated 4 February 2011), para. 32. With respect to the existence of Muslim's barricades, the Chamber notes that in one of his written statements, Ramiz Mujkić stated that Muslims had set up barricades in Dobroševići and Ahatovići. See D1101 (Excerpts from witness statements of Ramiz Mujkić, undated), e-court p. 5. However, during his testimony, he denied that there were such barricades. See Ramiz Mujkić, T. 12417-12420, 12432 (25 February 2011). In assessing this inconsistency, the Chamber considered the following: First, KDZ041 stated that after the Serbs had established barricades, the Muslims erected barricades of their own around Ahatovići. P2310 (Witness statement of KDZ041 dated 14 February 2011), para. 6 (under seal). Second, Ramiz Mujkić did in fact concede that the Muslim TO had a number of permanent positions, such as dugouts, around Ahatovići village. See P2314 (Witness statement of Ramiz Mujkić dated 4 February 2011), para. 25. The Chamber therefore does not rely on Ramiz Mujkić's testimony that there were no Muslim barricades in Dobroševići and Ahatovići.

7433 P2310 (Witness statement of KDZ041 dated 14 February 2011), para. 10 (under seal); Ramiz Mujkić, T. 12417, 12432, 12436-12437 (25 February 2011); P2314 (Witness statement of Ramiz Mujkić dated 4 February 2011), paras. 25, 32. See also Adjudicated Fact 2607.

7434 P2314 (Witness statement of Ramiz Mujkić dated 4 February 2011), para. 25; D1101 (Excerpts from witness statements of Ramiz Mujkić, undated), e-court p. 3.

7435 According to KDZ041, the Serbs were ordered to leave their houses so that the paramilitary units could establish their positions. P2310 (Witness statement of KDZ041 dated 14 February 2011), para. 8 (under seal); KDZ041, T. 12090 (17 February 2011).

7436 P2310 (Witness statement of KDZ041 dated 14 February 2011), para. 13 (under seal); P2314 (Witness statement of Ramiz Mujkić dated 4 February 2011), para. 33.

7437 KDZ041, T. 12083 (17 February 2011); P2310 (Witness statement of KDZ041 dated 14 February 2011), paras. 6-7 (under seal). The Chamber is mindful that in his statement, KDZ041 stated that the barricades were erected in March whereas during his testimony he indicated that the barricades were erected sometime between 20 May 1992 and 25 May 1992. The Chamber considers that KDZ041's live testimony is more credible on this particular issue.

7438 P2310 (Witness statement of KDZ041 dated 14 February 2011), para. 7 (under seal); KDZ041, T. 12084-12085 (17 February 2011); P2314 (Witness statement of Ramiz Mujkić dated 4 February 2011), para. 17; D1101 (Excerpts from witness statements of Ramiz Mujkić, undated), e-court p. 3. 


\section{(C) Attack on Ahatovići}

2183. On 25 May 1992, the inhabitants of the village of Ahatovići received an ultimatum from Serb Forces to surrender their men along with their weapons. ${ }^{7439}$ On 24 or 25 May 1992, women, children, and the elderly attempted to leave Ahatovići for the nearby municipality of Visoko, but were prevented from doing so by Bosnian Serbs who fired at them. ${ }^{7440}$

2184. On 27 May 1992, Serbs in both JNA and camouflage uniforms arrived on the hills around Ahatovići from the direction of Rajlovac with tanks and armoured vehicles. ${ }^{7441}$ Using megaphones, they urged the villagers to surrender. ${ }^{742}$ They threatened: "Balijas, surrender, or we kill your children." ${ }^{, 443}$ When the villagers refused, at around 11 p.m. Serb Forces launched an attack, which was eventually repelled. $^{7444}$ During this initial attack two Muslims were killed and ten were wounded. $^{7445}$

2185. On 29 May 1992, ${ }^{7446}$ a final attack was launched on Ahatovići and Dobroševići, with heavy artillery. ${ }^{747}$ The shells were fired from all directions, including the Butile and Rajlovac Barracks. $^{7448}$ At this time, the women, children, and the elderly were moved to basements of

7439 KDZ041, T. 12091-12092 (17 February 2011); P2310 (Witness statement of KDZ041 dated 14 February 2011), para. 11 (under seal).

7440 P2310 (Witness statement of KDZ041 dated 14 February 2011), paras. 12, 19 (under seal). See also Adjudicated Fact 2608. Stojan Džino testified that Hasan Mujkić requested, on 29 May 1992, that Jovo Božić allow the evacuation of the convoy containing women and children from Ahatovići to Sarajevo but this was not allowed because the Serbs suspected the evacuation to be a preparatory step for an attack on Bosnian Serb settlements. See D2387 (Witness statement of Stojan Džino dated 4 November 2012), para. 14.

7441 P2310 (Witness statement of KDZ041 dated 14 February 2011), para. 15 (under seal); KDZ041, T. 12092 (17 February 2011).

7442 P2310 (Witness statement of KDZ041 dated 14 February 2011), para. 15 (under seal). See also Adjudicated Fact 2609.

$7443 \quad$ Adjudicated Fact 2609.

7444 P2310 (Witness statement of KDZ041 dated 14 February 2011), para. 15 (under seal). See also Adjudicated Fact 2609.

7445 P2310 (Witness statement of KDZ041 dated 14 February 2011), para. 16 (under seal). The Chamber notes that these killings are not charged in either Schedule A or B of the Indictment. See fn. 13.

7446 The Chamber notes that according to KDZ041, the shelling of Ahatovići commenced sometime between 7 a.m. and 8 a.m. whereas according to the statement of Ramiz Mujkić, it began at 3 p.m.. P2310 (Witness statement of KDZ041 dated 14 February 2011), para. 17 (under seal); P2314 (Witness statement of Ramiz Mujkić dated 4 February 2011), para. 26. However, the Chamber finds that this discrepancy is not so serious that it would adversely affect the credibility and reliability of either witness.

7447 KDZ041, T. 12097 (17 February 2011); P2310 (Witness statement of KDZ041 dated 14 February 2011), paras. 17-18 (under seal); Ramiz Mujkić, T. 12438, 12449-12452 (25 February 2011); P2314 (Witness statement of Ramiz Mujkić dated 4 February 2011), paras. 26, 33; D1101 (Excerpts from witness statements of Ramiz Mujkić, undated), e-court pp. 3, 6. KDZ601 testified that the attack took place in late May and early June 1992 and that forces participating in the attack included the members of the "Oljača group of Chetniks", members of the Ilidža Battalion, and the members of the SJB Ilidža. KDZ601, T. 18588-18590 (8 September 2011). See also Adjudicated Fact 2610.

7448 KDZ041, T. 12097 (17 February 2011); P2310 (Witness statement of KDZ041 dated 14 February 2011), paras. 17, 20 (under seal); P2314 (Witness statement of Ramiz Mujkić dated 4 February 2011), para. 28; D1101 (Excerpts from witness statements of Ramiz Mujkić, undated), e-court pp. 3, 6. 
several houses in the centre of the village. ${ }^{7449}$ On 31 May, pursuant to the instructions of Fikret Mujkić, a member of the Ahatovići Crisis Staff, a group of villagers left for Bioča in order to meet two TO platoons from Visoko that were sent to facilitate the withdrawal of the villagers. ${ }^{7450}$ Ramiz Mujkić was chosen to be a part of this group but did not manage to meet up with them and instead returned to Ahatovići on 3 June. ${ }^{751}$ The shelling lasted until 1 or 2 June 1992, resulting in destruction of, and damage to, nearly 130 houses in Ahatovići and the death of 15 to 20 Bosnian Muslims. $^{7452}$

2186. After the shelling stopped, Tintor as well as the local Serbs and members of paramilitary groups ${ }^{7453}$ mounted an infantry attack against Ahatovići. ${ }^{7454}$ During this infantry attack, about 20 Bosnian Muslim men were killed. $^{7455}$ Subsequently, about 30 Bosnian Muslim villagers, including KDZ041, who had run out of ammunition decided to break through enemy lines and escape towards Visoko but were eventually hit by artillery fire. ${ }^{7456}$ In that instance, four Bosnian Muslim men were killed whereas a number of others, including KDZ041, were wounded. ${ }^{7457}$ Soon after, Tintor, the local Serbs, and paramilitaries entered Ahatovići with APCs and tanks. ${ }^{7458}$ Sometime during the shelling or the infantry attack, Ramiz Mujkić's younger sister and her daughter Elma

7449 KDZ041, T. 12095 (17 February 2011); P2310 (Witness statement of KDZ041 dated 14 February 2011), paras. 12, 19 (under seal); P2314 (Witness statement of Ramiz Mujkić dated 4 February 2011), para. 31; D1101 (Excerpts from witness statements of Ramiz Mujkić, undated), e-court p. 3.

7450 P2314 (Witness statement of Ramiz Mujkić dated 4 February 2011), paras. 32, 35; D1101 (Excerpts from witness statements of Ramiz Mujkić, undated), e-court pp. 3, 6.

7451 P2314 (Witness statement of Ramiz Mujkić dated 4 February 2011), paras. 32, 35-36.

7452 KDZ041, T. 12097 (17 February 2011); P2310 (Witness statement of KDZ041 dated 14 February 2011), paras. 18-19 (under seal); Ramiz Mujkić, T. 12452 (25 February 2011); P2314 (Witness statement of Ramiz Mujkić dated 4 February 2011), para. 26. See also Adjudicated Fact 2660. The Chamber notes that these killings are not charged in Schedule A of the Indictment. See fn. 13.

7453 While KDZ041 testified that he saw men in JNA uniforms with white armbands and headbands and that those were members of the White Eagles, KDZ601 testified that the attack involved members of the "Oljača group of Chetniks" and that they were reinforced by VRS and MUP forces. See P2310 (Witness statement of KDZ041 dated 14 February 2011), para. 23 (under seal); KDZ601, T. 18588-18589 (8 September 2011). The Chamber also notes that it has received other evidence showing the participation of paramilitaries in this attack. For example, on 5 August 1992, the head of Ilidža Serb SJB lamented that the commander of the Ilidža Brigade had excluded "militia" from joint meals even though those forces had partaken in many combat activities such as those in Hadžići, Rakovica, Ahatovići and Dobrinja. P6639 (SJB Ilidža information, 5 August 1992), p. $6 . \quad$ On the basis of the foregoing evidence, the Chamber finds that paramilitaries took part in the attack against Ahatovići.

7454 P2310 (Witness statement of KDZ041 dated 14 February 2011), paras. 19-20, 23 (under seal); KDZ041, T. 12066-12067, 12108 (17 February 2011); P2314 (Witness statement of Ramiz Mujkić dated 4 February 2011), para. 26; D1101 (Excerpts from witness statements of Ramiz Mujkić, undated), e-court p. 3. See also Adjudicated Fact 2610.

7455 P2310 (Witness statement of KDZ041 dated 14 February 2011), paras. 18, 23 (under seal). See also Adjudicated Fact 2610; D4002 (Letter from BiH MUP to Vasvija Vidović, 4 July 1995), p. 61

7456 KDZ041, T. 12065-12067 (17 February 2011); P2310 (Witness statement of KDZ041 dated 14 February 2011), paras. 18-19, 20-21 (under seal).

7457 P2310 (Witness statement of KDZ041 dated 14 February 2011), para. 21 (under seal). The Chamber notes that these killings are not charged in either Schedule A or B of the Indictment.

7458 P2310 (Witness statement of KDZ041 dated 14 February 2011), paras. 19-20 (under seal). 
Bešić who was only 15 years old at the time, were also killed. ${ }^{7459}$ Subsequently, houses belonging to Bosnian Muslims were looted and set ablaze. ${ }^{7460}$ The Serbs captured about 400 women and children and 80 men, in addition to the 150 women and children who had been captured in Dobroševići, Bojnik, and Mihaljevići prior to the attack on Ahatovići. ${ }^{7461}$ Those captured in Ahatovići were subsequently taken in the direction of Rajlovac. ${ }^{7462}$ The attack was completed and Ahatovići came under Bosnian Serb control by 3 June $1992 .^{7463}$

2187. On 5 June 1992, Mijatović, from the Rajlovac Municipal Assembly, informed Neđeljko Prstojević, the president of the Ilidža Crisis Staff ${ }^{7464}$ that Ahatovići was no longer a threat. ${ }^{7465}$ Following a request signed by the Accused and dated 19 July 1992, houses that were not destroyed in Ahatovići were provided to the Serb refugees from the Muslim part of Sarajevo. ${ }^{7466}$

2188. In a 1993 report, Tihomir Glavaš, the Chief of the SJB Hadžići referred to the success of the 1 June 1992 military attack against Ahatovići launched by forces under his command and stated that as a result of the attack, the territories of Butile and Rajlovac had been unified. ${ }^{7467}$

\section{(D) Scheduled Incident A.9.1}

2189. The Indictment alleges that on or about 29 May 1992 at least 15 men were killed after they were captured while fleeing from the village of Ahatovići.

2190. After the 30 Bosnian Muslims, who tried to break through enemy lines and escape towards Visoko, were hit by artillery fire as described above, ${ }^{7468}$ The Bosnian Muslims surrendered to Serbs. ${ }^{7469}$ Among the Serbs were Stevo Petričević, Dragan Koprivica, and Bato Arnautović. ${ }^{7470}$ After their surrender, 15 of the Bosnian Muslim villagers, mainly those who were able to walk,

\footnotetext{
7459 P2314 (Witness statement of Ramiz Mujkić dated 4 February 2011), para. 48. The Chamber notes that these killings are not charged in either Schedule A or B of the Indictment.

7460 P2310 (Witness statement of KDZ041 dated 14 February 2011), paras. 23, 63 (under seal); P2314 (Witness statement of Ramiz Mujkić dated 4 February 2011), para. 39.

7461 P2310 (Witness statement of KDZ041 dated 14 February 2011), para. 32 (under seal).

7462 P2310 (Witness statement of KDZ041 dated 14 February 2011), para. 33 (under seal); P2314 (Witness statement of Ramiz Mujkić dated 4 February 2011), para. 89; D4002 (Letter from BiH MUP to Vasvija Vidović, 4 July 1995), p. 62.

7463 P2333 (SerBiH MUP Report re Romanija-Birčani CSB, 3 June 1992), p. 1, reports that Ahatovići was "liberated" and placed under the "Serb Army control".

7464 Neđeljko Prstojević, T. 12961 (8 March 2011).

7465 P2239 (Intercept of conversation between Mijatović and Neđeljko Prstojević, 5 June 1992), pp. 1, 3.

7466 P739 (RS Presidency request to various municipalities, 19 July 1992). See also P2314 (Witness statement of Ramiz Mujkić dated 4 February 2011), para. 39.

7467 P2308 (SJB Ilidža report, 20 September 1993), p. 5.

$7468 \quad$ See para. 2186.

7469 P2310 (Witness statement of KDZ041 dated 14 February 2011), para. 21.

7470 P2310 (Witness statement of KDZ041 dated 14 February 2011), paras. 22, 24 (under seal).
} 
were taken to a nearby road and made to sit. ${ }^{7471}$ Koprivica and Arnautović then proceeded to shoot the 15 remaining men who were unable to walk, killing them all. ${ }^{7472}$ At that point, Tintor, armed with a pistol and an automatic rifle and wearing a JNA uniform, along with a number of paramilitaries, appeared on the scene. ${ }^{7473}$ Tintor then ordered that the men be lined up in pairs and taken to the Butile Barracks. ${ }^{7474}$

2191. Several days after the incident, Ramiz Mujkić, who was hiding in the forest above Ahatovići at the time, observed an excavator digging three holes in three different locations in the village and a number of Serb soldiers throwing bodies in these holes, which were then covered with soil. $^{7475}$ In 1996, authorities from CSB Sarajevo exhumed the mortal remains of 25 Bosnian Muslim men and women from three different locations in Ahatovići. ${ }^{7476}$ KDZ041 identified four of these individuals as victims of the above-described execution. ${ }^{7477}$

7471 KDZ041, T. 12065 (17 February 2011); P2310 (Witness statement of KDZ041 dated 14 February 2011), para. 21 (under seal).

7472 KDZ041, T. 12065 (17 February 2011); P2310 (Witness statement of KDZ041 dated 14 February 2011), paras. 22, 24 (under seal). See also Adjudicated Fact 2610. Those killed included Jusuf Suljić, Nihad Tokmo, Bećir Žiga, Meho Žiga, and a man who went by the name "Kriminalac". P2310 (Witness statement of KDZ041 dated 14 February 2011), paras. 22, 24 (under seal). Contrary to this evidence, Džino stated that the 15 Bosnian Muslim men were combatants who were killed during combat. D2387 (Witness statement of Stojan Džino dated 4 November 2012). The Chamber, however, does not accept Džino's evidence for the following reasons. First, KDZ041 gave reliable and detailed evidence of the executions of the 15 captured Bosnian Muslim men which he witnessed. Second, the Chamber found Džino's evidence to be generally marked with contradictions.

7473 KDZ041, T. 12066, 12108 (17 February 2011); P2310 (Witness statement of KDZ041 dated 14 February 2011), para. 25 (under seal).

7474 P2310 (Witness statement of KDZ041 dated 14 February 2011), para. 27 (under seal).

7475 P2314 (Witness statement of Ramiz Mujkić dated 4 February 2011), paras. 83, 85; P2327 (Map marked by Ramiz Mujkić), pp. 1-2. See also D1105 (Supplemental information sheet for Ramiz Mujkić, 1 November 2004). On 3 June 1992, Ramiz Mujkić returned to Ahatovići and while moving through the village, was shot at. He escaped to the woods where he met Huso Gačanović and the two of them proceeded towards the forest known as Ptičija Glava, where they stayed until they were captured on 6 August 1992. P2314 (Witness statement of Ramiz Mujkić dated 4 February 2011), paras. 39-42, 44.

7476 P2310 (Witness statement of KDZ041 dated 14 February 2011), para. 64 (under seal); P2314 (Witness statement of Ramiz Mujkić dated 4 February 2011), paras. 84-86; P2341 (CSB Sarajevo report re exhumations in Ahatovići, 15 October 1996), p. 1; D1105 (Supplemental information sheet for Ramiz Mujkić, 1 November 2004); P4853 (Updated Table 2 to the Report of Amor Mašović), pp. 13-14. These 25 individuals are Elma Bešić (female, 1976), Razija Bešić (male, 1953), Džemail Bukalo (male, 1959), Mesud Burić (male, 1965), Admir Čaušević (male, 1972), Osman Čaušević (male, 1948), Elvedin Đedović (male, 1975), Hamid Divolić (male, 1950), Osman Evendić (male, 1954), Avdo Gačanović (male, 1944), Hamid Gačanović (male, 1952), Šerifa Hrustanović (female, 1942), Ramiz Hrvačić (male, 1950), Vahid Ligata (male, 1966), Nihad Mešanović (male, 1970), Samir Mujkić (male, 1966), Ajša Novalija (female, 1951), Šaban Peljto (male, 1969), Meho Rizvanović (male, 1966), Jusuf Suljić (male, 1961), Nijaz Šehović (male, 1962), Nihad Tokmo (male, 1970), Ahmo Uhota (male, 1951), Bećir Žiga (male, 1953) and Meho Žiga (male, 1930). In P4853, the name Šerifa Hrustanović appears twice, once as the daughter of Meho with 1942 as the year of birth and once as son of Jusuf with 1950 as the year of birth. However, in P4883 (Data on exhumations in the Sarajevo region in the period of 1996-1998), p. 18, it is stated that Ramiz Hrvačić was born in 1950 and that his father's first name was Jusuf. Having had regard to the name of father and the year of birth, the Chamber is satisfied that the second entry in P4853 was intended for Ramiz Hrvačić and not Šerifa Hrustanović. What is more, in P4883, the first name of Nijaz Šehović (male, 1962) is recorded as Nihaz. Nevertheless, the Chamber finds that this discrepancy is so minor that it does not have a bearing on the Chamber's finding with respect to Scheduled Incident A.9.1. Also, in P4883 Džemail Bukalo's first name is recorded as Džemal. However, the Chamber finds that this 
2192. The Prosecution submits, based on Amor Mašović's evidence, that in addition to the above four individuals identified by KDZ041, a number of other individuals out of the 25 exhumed as well as three individuals whose remains were exhumed on 9 December 1994 by UNPROFOR from a separate place in Ahatovići are also victims of Scheduled Incident A.9.1. ${ }^{778}$ However, the Chamber, based on the evidence before it, cannot conclude whether or not each of these additional individuals is a victim of Scheduled Incident A.9.1.

2193. In light of the foregoing, the Chamber finds that, following the attack on Ahatovići, on or about 1 June 1992, the Serb Forces executed 15 Bosnian Muslim men who had surrendered.

\section{(E) Scheduled Incident D.15}

2194. The Indictment refers to the destruction of the Ahatovići mosque on or about 4 June $1992 .^{7479}$

2195. The Chamber received evidence that a detonation destroyed the Ahatovići mosque, leaving only the stump of its minaret standing. ${ }^{780}$ Stojan Džino testified that it happened on 4 June 1992, during the combat activities related to the attack on Ahatovići village, and that he observed the explosion from a distance. ${ }^{781}$ Džino heard rumours that the ammunitions and the explosives that had been stored in the mosque by Bosnian Muslims had been hit by a heavy-calibre weapon, thus causing a significant explosion which destroyed the entire mosque. ${ }^{7482}$ Ramiz Mujkić denied that explosives were stored in the mosque. ${ }^{7483}$ Mujkić, moreover, testified that he returned to Ahatovići in the morning of 3 June $1992 .^{7484}$ According to Mujkić, at that time, the Muslim houses were

discrepancy is very minor. In P4883 Mesud Burić's first name appears as Mensud. The Chamber finds that this inconsistency is also very minor.

The individuals identified by KDZ041 as victims of Scheduled Incident A.9.1 are Jusuf Suljić, Nihad Tokmo, Bećir Žiga and Meho Žiga. P2310 (Witness statement of KDZ041 dated 14 February 2011), paras. 13, 26.

7478 These three individuals are Ešref Mujkić (male, 1938), Amir Novalija (male, 1965) and Vejsil Novalija (male, 1936). P4853 (Updated Table 2 to the Report of Amor Mašović), pp. 13-14; Prosecution Final Brief, Appendix G (Schedule A.9.1 section). Indictment, Scheduled Incident D. 15 .

7480 Ramiz Mujkić, T. 12458-12459 (25 February 2011); P2314 (Witness statement of Ramiz Mujkić dated 4 February 2011), para. 45; P2310 (Witness statement of KDZ041 dated 14 February 2011), para. 63 (under seal); András J. Riedlmayer, T. 22532-22533 (8 December 2011); P4069 (Cultural destruction database), record 332; P4070 (Attachment to the expert report of András J. Riedlmayer, entitled "Destruction of Cultural Heritage in BiH" prepared for the Karadžić case, formatted records), e-court pp. 201-204; Stojan Džino, T. 2986629867, 29888 (7 November 2012). See also Adjudicated Fact 2662.

Stojan Džino, T. 29866-29867 (7 November 2012). However, contrary to Džino's assertion that there were combat activities in Ahatovići on 4 June 1992, the Chamber has received reliable documentary and testimonial evidence that on 3 June 1992, Serb Forces were in control of Ahatovići. See fn. 7484-7486.

7482 Stojan Džino, T. 29866-29867 (7 November 2012) (referred to in the Defence Final Brief, para. 1712, in support of the Accused's submission that if the mosque had been used for military purposes, it lost the protection given to it by Article 3(d) of the Statute).

7483 Ramiz Mujkić, T. 12458-12459 (25 February 2011).

7484 P2314 (Witness statement of Ramiz Mujkić dated 4 February 2011), para. 39. 
being guarded by local Serbs and that for this reason he had to travel through the village via Serb houses. ${ }^{7485}$ The Chamber also notes that contrary to Džino's assertion that combat activities were still ongoing on 4 June 1992, a SerBiH MUP Report indicates that by 3 June 1992, Serb Forces had assumed control of Ahatovići. ${ }^{7486}$

2196. On the basis of the foregoing, the Chamber finds that the mosque in Ahatovići was destroyed due to a detonation on 4 June 1992 and that Serb Forces were responsible for causing the detonation which destroyed the mosque.

(F) Scheduled Detention Facility C.17.1 and Scheduled Incident B.12.1

2197. The Indictment alleges that cisterns near the Rajlovac Army Barracks were used as a detention facility in June $1992,{ }^{7487}$ and that "a number" of men detained there were killed between 1 June 1992 and 14 June 1992. ${ }^{7488}$

2198. As noted above ${ }^{7889}$ Bosnian Muslim men were captured following the attack on Ahatovići, after which Tintor ordered that they be transferred to the Butile Barracks. On the way to the Barracks, the men were subjected to threats as well as physical and verbal abuse. ${ }^{7400}$ When they reached a supermarket, some 200 metres from the Butile Barracks, they encountered about 100 well-armed White Eagles mistreating a number of villagers who had been captured from Dobroševići and other neighbouring villages. ${ }^{7491}$ The White Eagles and some local Serbs then beat the detained men with iron bars, rifle butts, and wooden batons. ${ }^{7492}$ At one point, one of the men was told that Arkan's men would soon take custody of the detainees. ${ }^{7493}$ Soon afterwards, the Bosnian Muslim detainees were forced to run the gauntlet and board a military bus. ${ }^{7494}$ On the bus, they were forced to sing "Chetnik songs",7495 and, the Serbs cursed Alija Izetbegović and the detainees" "balija mothers". ${ }^{7496}$ The bus travelled to the "army fuel depot" in Rajlovac. ${ }^{7497}$ Once

P2314 (Witness statement of Ramiz Mujkić dated 4 February 2011), para. 40.

P2333 (SerBiH MUP Report re Romanija-Birčani CSB, 3 June 1992), p. 1.

Indictment, Scheduled Detention Facility C.17.1.

Indictment, Scheduled Incident B.12.1.

See para. 2190.

P2310 (Witness statement of KDZ041 dated 14 February 2011), para. 27 (under seal).

P2310 (Witness statement of KDZ041 dated 14 February 2011), para. 27 (under seal).

P2310 (Witness statement of KDZ041 dated 14 February 2011), paras. 27-30 (under seal).

KDZ041, T. 12104 (17 February 2011).

KDZ041, T. 12083 (17 February 2011); P2310 (Witness statement of KDZ041 dated 14 February 2011), para. 31 (under seal). A SerBiH MUP report indicates that after the attack on Ahatovići, some 50 Green Berets and HOS members were captured and sent for interrogation to the Rajlovac Barracks. P5425 (Report of RS MUP, 3 June 1992). See also Adjudicated Fact 2626.

7495 P2310 (Witness statement of KDZ041 dated 14 February 2011), para. 31 (under seal).

7496 See Adjudicated Fact 2626.
} 
there, the detainees were ordered to lie down on the grass where they were beaten with sticks and had a pair of dogs unleashed on them. ${ }^{7498}$ Some detainees were then put on a truck and taken to Orao where their wounds were bandaged. ${ }^{749}$ Afterwards, they were taken back to Rajlovac Barracks and placed in a cistern or reservoir, which by that time housed approximately 90 detainees. $^{7500}$ Adjoining this cistern was a bigger cistern, which housed approximately 130 Bosnian Muslims and Bosnian Croats from Dobroševići, Mihaljevići, Bojnik, Kobiljska, and Bioča. ${ }^{7501}$

2199. The two cisterns formerly belonged to "Energopetrol Company" and had not been used since $1985 .^{7502}$ They housed the male detainees. ${ }^{7503}$ Near the cisterns were two buildings which were the premises of "Tehnogas Company" and the Distribution Centre. 7504

2200. On the morning of 2 June 1992, Mile Stojanović arrived and introduced himself as the commander of the "camp". ${ }^{7505}$ He wore a blue uniform which, although very similar to the police uniform, did not have any insignia. ${ }^{7506}$ On that occasion, Stojanović was accompanied by an individual named Šok and four others. ${ }^{7507}$ Šok wore the same blue uniform and also had a Yugoslav flag sewn onto his shirt. ${ }^{7508}$ Stojanović then asked the detainees for their identification cards and made a list of their names, ${ }^{7509}$ while Šok asked them about the weapons they had used

\footnotetext{
7497 P2310 (Witness statement of KDZ041 dated 14 February 2011), para. 31; KDZ041, T. 12083 (17 February 2011).

7498 P2310 (Witness statement of KDZ041 dated 14 February 2011), para. 31 (under seal).

7499 P2310 (Witness statement of KDZ041 dated 14 February 2011), para. 31 (under seal); Ramiz Mujkić, T. 12428 (25 February 2011).

7500 KDZ041, T. 12068 (17 February 2011); P2310 (Witness statement of KDZ041 dated 14 February 2011), para. 31 (under seal).

7501 P2310 (Witness statement of KDZ041 dated 14 February 2011), para. 31 (under seal).

7502 KDZ041, T. 12067-12069 (17 February 2011); P2310 (Witness statement of KDZ041 dated 14 February 2011), paras. 31, 48 (under seal); P2311 (Photograph of cisterns); P2327 (Map marked by Ramiz Mujkić), pp. 1-2; P2343 (Information report of Ramiz Mujkić, 4 July 2004), pp. 8-10.

7503 P2314 (Witness statement of Ramiz Mujkić dated 4 February 2011), para. 49; D1105 (Supplemental information sheet for Ramiz Mujkić, 1 November 2004).

7504 P2310 (Witness statement of KDZ041 dated 14 February 2011), para. 33 (under seal); P2314 (Witness statement of Ramiz Mujkić dated 4 February 2011), paras. 46-47; P2327 (Map marked by Ramiz Mujkić), pp. 1-2; P2343 (Information report of Ramiz Mujkić, 4 July 2004), p. 5.

7505 KDZ041, T. 12081 (17 February 2011); P2310 (Witness statement of KDZ041 dated 14 February 2011), paras. 34-35 (under seal); D1 101 (Excerpts from witness statements of Ramiz Mujkić, undated), e-court p. 5. See also Adjudicated Fact 2627.

7506 P2310 (Witness statement of KDZ041 dated 14 February 2011), para. 34 (under seal). There is evidence that Mile Stojanović held the rank of Sergeant Major in the MP. See P2314 (Witness statement of Ramiz Mujkić dated 4 February 2011), paras. 53-54, 67-68; D1101 (Excerpts from witness statements of Ramiz Mujkić, undated), e-court pp. 4, 7; D1103 (Supplemental witness statement of Ramiz Mujkić dated 28 April 2000), p. 2; P2325 (Medical certificate re Ramiz Mujkić, 22 August 1992), p. 1; Ramiz Mujkić, T. 12382 (24 February 2011).

7507 P2310 (Witness statement of KDZ041 dated 14 February 2011), para. 34 (under seal).

7508 KDZ041, T. 12105, 12108-12109 (17 February 2011); P2310 (Witness statement of KDZ041 dated 14 February 2011), para. 34 (under seal).

7509 P2310 (Witness statement of KDZ041 dated 14 February 2011), para. 34 (under seal).
} 
and the nature of their duties. ${ }^{7510}$ Šok also inquired whether Hasan Mujkić, Husein Mujkić, and Meho Novalija, who were SDA political leaders, had been present during the attack on Ahatovići. ${ }^{7511}$ After the prisoners were registered, Šok and his four men took two Bosnian Muslim men out of the cistern and beat them while questioning them about the weapons they used. ${ }^{7512}$ When Stojanović returned on the same day, he saw the bruises on the men and promised that it would not happen again. ${ }^{7513}$ Stojanović then indicated that there would be two prisoner exchanges, one involving women and children and the other at Kobilja Glava, involving the prisoners from the smaller cistern. ${ }^{7514}$ Despite Stojanović's pledge, however, on a nearly daily basis Šok took two or three prisoners in front of the cisterns and subjected them to beatings. ${ }^{7515}$ On one occasion, he and his men took out two men, beat them and broke the latter's arms. ${ }^{7516}$

2201. Due to the deposit of rainwater in the cisterns, the detainees were forced to stand for the entire duration of their detention. ${ }^{7517}$ They received no food or water during the first three days of their detention and afterwards received very little food and water. ${ }^{7518}$ On or about 3 June 1992, Šok forced a number of prisoners who did not have visible signs of injury to appear before a Serb television crew and state that they were being treated well. ${ }^{7519}$

2202. During the first week of June 1992, three new prisoners, namely Hajro Delić, his son, and Džemail Sačić were brought to the smaller cistern. ${ }^{7520}$ A few days into his detention, Delić was taken away and brought back the following day, severely injured. ${ }^{7521}$ He told the other prisoners that he had been severely beaten and abused by Šok on orders from Nikola Stanišić and that during

\footnotetext{
7510 P2310 (Witness statement of KDZ041 dated 14 February 2011), para. 34 (under seal).

7511 P2310 (Witness statement of KDZ041 dated 14 February 2011), para. 34 (under seal).

7512 P2310 (Witness statement of KDZ041 dated 14 February 2011), para. 36 (under seal).

7513 P2310 (Witness statement of KDZ041 dated 14 February 2011), para. 36 (under seal).

7514 P2310 (Witness statement of KDZ041 dated 14 February 2011), para. 36 (under seal); KDZ041, T. 12122 (17 February 2011).

7515 KDZ041, T. 12105 (17 February 2011); P2310 (Witness statement of KDZ041 dated 14 February 2011), para. 37 (under seal).

7516 P2310 (Witness statement of KDZ041 dated 14 February 2011), para. 37 (under seal).

7517 KDZ041, T. 12069 (17 February 2011); P2310 (Witness statement of KDZ041 dated 14 February 2011), para. 31 (under seal).

7518 P2310 (Witness statement of KDZ041 dated 14 February 2011), para. 38 (under seal). See also Adjudicated Fact 2628

7519 KDZ041, T. 12100 (17 February 2011); P2310 (Witness statement of KDZ041 dated 14 February 2011), para. 39 (under seal).

7520 KDZ041, T. 12069 (17 February 2011); P2310 (Witness statement of KDZ041 dated 14 February 2011), para. 40 (under seal).

7521 KDZ041, T. 12069 (17 February 2011); P2310 (Witness statement of KDZ041 dated 14 February 2011), para. 40 (under seal).
} 
the questioning, Stanišić had asked for one million German Marks as the price for releasing him. ${ }^{7522}$ Soon after that, Delić succumbed to his injuries and died. ${ }^{7523}$

2203. On two occasions, a man by the name of Žuti who was rumoured to be Tintor's chauffeur and a former "member of the Special Forces of Dragan Vikić" came to the smaller cistern, called out the names of a number of prisoners, indicating that they were to be taken for exchange in Ilidža. ${ }^{7524}$ None of these individuals have since been seen alive and KDZ041 heard that the remains of some of them were found at the Vlakovo city cemetery. ${ }^{7525}$

2204. On one occasion, Žuti approached one of the cisterns and threw in a gas grenade. ${ }^{7526}$ Immediately after Žuti had left, one of the guards opened the door to the cistern so that the prisoners could come out for fresh air. ${ }^{7527}$

2205. Between 1 and 14 June 1992, Stojanović, Šok, and other members of the special unit accompanied a man to one of the cisterns; this man then pointed out Enver Čelik, alleging that Čelik had abused his sister. ${ }^{7528}$ Šok and the other men took Čelik behind the cisterns, hanged him by his arms and killed him by hitting him twice in the back with iron bars. ${ }^{7529}$

2206. On 12 June 1992, the prisoners from the smaller cistern were told that they would be taken to Kobilja Glava, in order to be exchanged. ${ }^{7530}$ The next day, Stojanović called the names of 56 individuals and instructed them to board two trucks. ${ }^{7531}$ The two trucks travelled to a police station in Sokolac, then to the Koran Barracks, on to Rogatica, and finally to Pale, where they stopped near

\footnotetext{
7522 KDZ041, T. 12069-12070, 12106 (17 February 2011); P2310 (Witness statement of KDZ041 dated 14 February 2011), para. 40 (under seal). KDZ041 testified that Stanišić and Delić had an argument even before the war. KDZ041, T. 12069-12070, 12106 (17 February 2011).

7523 After Delić's death, his son and an individual by the name of Edin were transferred to the other reservoir in order to be exchanged. KDZ041, T. 12070, 12129 (17 February 2011); P2310 (Witness statement of KDZ041 dated 14 February 2011), para. 40 (under seal).

7524 According to KDZ041, these individuals included Edin Brajlović, Zajko Brajlović, Zijo Brajlović, another person with the last name Brajlović, two persons with the last name Salkić, a man called Amir who was from Dobroševići, Rusmir Pašić and Kadrija Ramadani. KDZ041, T. 12070-12071, 12124-12125 (17 February 2011); P2310 (Witness statement of KDZ041 dated 14 February 2011), paras. 41-44 (under seal).

7525 KDZ041, T. 12071 (17 February 2011); P2310 (Witness statement of KDZ041 dated 14 February 2011), paras. 42-44 (under seal).

7526 KDZ041, T. 12106-12107 (17 February 2011); P2310 (Witness statement of KDZ041 dated 14 February 2011), paras. 41, 43 (under seal).

7527 KDZ041, T. 12106-12107 (17 February 2011); P2310 (Witness statement of KDZ041 dated 14 February 2011), para. 41 (under seal).

7528 KDZ041, T. 12070, 12128-12129 (17 February 2011).

7529 KDZ041, T. 12070, 12128-12129 (17 February 2011). When cross-examined as to why he never mentioned this incident before, KDZ041 testified that he did mention it but that it was never recorded for some reason.

7530 KDZ041, T. 12122 (17 February 2011); P2310 (Witness statement of KDZ041 dated 14 February 2011), para. 45 (under seal).

7531 KDZ041, T. 12122 (17 February 2011); P2310 (Witness statement of KDZ041 dated 14 February 2011), para. 45 (under seal).
} 
the Panorama Hotel. ${ }^{7532}$ At about 6 p.m., the trucks returned to Rajlovac. ${ }^{7533}$ At that point, the larger cistern was empty as the people detained there had been exchanged on that day so the 56 detainees were placed there. $^{7534}$ On 14 June 1992, Hamo Karić, whose injuries had become infected, was taken out of the cistern in order to be exchanged. ${ }^{7535}$

2207. During the course of their respective cross-examinations, Stojan Džino and Mihajlo Vujasin both conceded that the civilians from Ahatovići had been taken to the Rajlovac Barracks and detained. ${ }^{7536}$ Vujasin even admitted that a few of the Bosnian Muslims were subjected to beatings there and that he had risked his life when ensuring that the detainees were not harmed by "certain individuals". 7537

2208. Between 9 and 18 June 1997, the remains of nine Bosnian Muslim men were exhumed from the Vlakovo cemetery in Ilidža municipality. ${ }^{7538}$ Out of those, six were identified by KDZ041 as having been killed during their detention in the cisterns. ${ }^{7539}$ According to Amor Mašović, with the exception of Edin Brajlović who was recorded as last seen alive on 17 June 1992 in Ahatovići, all these individuals were last seen alive on 1 or 2 June 1992 in Ahatovići. ${ }^{7540}$ The forensic evidence establishes the cause of death of seven of the nine victims as either gunshot to the head, gunshot to

\footnotetext{
7532 KDZ041, T. 12122 (17 February 2011); P2310 (Witness statement of KDZ041 dated 14 February 2011), para. 46 (under seal).

7533 KDZ041, T. 12122 (17 February 2011); P2310 (Witness statement of KDZ041 dated 14 February 2011), para. 47 (under seal).

7534 KDZ041, T. 12122-12123 (17 February 2011); P2310 (Witness statement of KDZ041 dated 14 February 2011), para. 47 (under seal).

7535 P2310 (Witness statement of KDZ041 dated 14 February 2011), para. 49 (under seal).

7536 Stojan Džino, T. 29857-29858 (6 November 2012), 29872-29873 (7 November 2012); Mihajlo Vujasin, T. 31805 (20 December 2012).

7537 Mihajlo Vujasin, T. 31805-31806 (20 December 2012).

7538 These nine individuals are Imer Bajramović (male, 1950), Edin Brajlović (male, 1963), Zajko Brajlović (male, 1939), Zijad Brajlović (male, 1962), Refik Džaferović (male, 1955), Džemal Efendić (male, 1958), Amir Habibović (male, 1955), Rusmir Pašić (male, 1969) and Kadrija Ramadani (male, 1933). P4853 (Updated Table 2 to the Report of Amor Mašović), pp. 86-87; P4883 (Data on exhumations in the Sarajevo region in the period of 1996-1998), p. 45; P4884 (Sarajevo Cantonal Court records relating to the Vlakovo Exhumation, 17 June 1997), pp. 8-9, 19-20, 41-42; P4850 (Witness statement of Amor Mašović dated 23 March 2012), Annex A, pp. 5-7; P4885 (Sarajevo Cantonal Court record of post-mortem examination of victims exhumed at Vlakovo, 25 August 1997), pp. 33-39. As regards the death of Edin Brajlović whose date of disappearance is indicated as 17 June 1992 in P4853, the Chamber has given consideration to the following facts. First, Edin Brajlović's cause of death was established as gunshot wound to the head. Second, according to evidence, Žuti removed him and a number of individuals from the cisterns and none of these individuals ever returned. Third, the body of Edin Brajlović was discovered at the same location where the remains of the eight individuals killed by Serb Forces were found, that is, in the mass grave in Vlakovo cemetery in Ilidža municipality. Based on these considerations, the Chamber finds that the reference in P4853 to 17 June 1992 as the day Edin Brajlović was last seen alive must be erroneous.

7539 These six individuals are Edin Brajlović, Zajko Brajlović, Zijo Brajlović, Amir Habibović, Rusmir Pašić and Kadrija Ramadani. P2310 (Witness statement of KDZ041 dated 14 February 2011), para. 44 (under seal).

7540 P4853 (Updated Table 2 to the Report of Amor Mašović), pp. 86-87.
} 
the chest cavity or injury to the head. ${ }^{7541}$ In light of the foregoing evidence, the Chamber finds that all of these nine individuals were killed, while detained in two cisterns near the Rajlovac Army Barracks some time during the first half of June 1992.

2209. Based on the foregoing, the Chamber finds that two reservoirs or cisterns near the Rajlovac Barracks had been turned into makeshift prisons for the male detainees and that the men detained there were given very little food and water and were forced to stand for the duration of their captivity. Further, the Chamber finds that the guards at this makeshift detention facility routinely subjected the male detainees to interrogations and beatings. The Chamber notes that some of the men, including KDZ041, were combatants prior to their detention. ${ }^{7542}$

2210. The Chamber also finds that sometime during the first week of June 1992, Serb Forces killed two Bosnian Muslim detainees in or near the cisterns ${ }^{7543}$ and that sometime during the first half of June 1992, Serb Forces removed nine Bosnian Muslim men from the cisterns in the Rajlovac Barracks and subsequently killed them. ${ }^{7544}$

\section{(G) Scheduled Incident B.12.2}

2211. The Indictment alleges that at least 47 men were taken from the cisterns and killed near Srednje in Ilijaš municipality on or about 14 June 1992.

2212. On 14 June 1992, at about 7 p.m., heavily armed men dressed in black and white camouflage uniforms, black balaclavas, and red berets whom KDZ041 thought were "Special Police Forces", arrived at the cisterns and ordered the detainees, including KDZ041, to form a single line and board a civilian bus as they were to be exchanged in Kobilja Glava. ${ }^{7545}$ Upon entering the bus, a guard hit the prisoners and ordered them to lie down on the floor, face down with their hands behind their heads. ${ }^{7546}$ As they were many, they had to lie on top of one another in

\footnotetext{
7541 P4885 (Sarajevo Cantonal Court record of post-mortem examination of victims exhumed at Vlakovo, 25 August 1997), pp. 33-39. The forensic documentation does not indicate the cause of death of the remaining victim, namely Zajko Brajlović. In relation to Imer Bajramović, the Chamber notes that the cause of death was determined to be penetration of the body by harpoon. See P4885 (Sarajevo Cantonal Court record of postmortem examination of victims exhumed at Vlakovo, 25 August 1997), pp. 29-30.

7542 See paras. 2190, 2193.

7543 These two individuals are Hajro Delić and Enver Čelik. See paras. 2202, 2205.

7544 These individuals are Imer Bajramović, Edin Brajlović, Zajko Brajlović, Zijad Brajlović, Refik Džaferović, Džemal Efendić, Amir Habibović, Rusmir Pašić and Kadrija Ramadani. See paras. 2203, 2208.

7545 KDZ041, T. 12071-12073, 12109-12110 (17 February 2011); P2310 (Witness statement of KDZ041 dated 14 February 2011), paras. 50-51 (under seal). See also Adjudicated Fact 2629.

7546 KDZ041, T. 12071, 12109-12110 (17 February 2011); P2310 (Witness statement of KDZ041 dated 14 February 2011), para. 51 (under seal).
} 
order to fit into the bus. ${ }^{7547}$ Žuti drove the bus while two guards watched the detainees. ${ }^{7548}$ Four cars containing members of what KDZ041 referred to as "Special Police Forces" were escorting the bus, two in the front, and two behind the bus. ${ }^{7549}$ The bus then drove to a barricade near Srednje where Žuti asked for directions to the village of Sokolina. ${ }^{750}$ By this time, the two cars which had been travelling behind the bus had disappeared. ${ }^{7551}$ Žuti proceeded to drive the bus for another ten minutes before stopping near the separation line. ${ }^{7552}$

2213. At that point, Žuti informed the detainees that the radiator had overheated and that he needed to cool it down, while one of the guards told the detainees not to stand up. ${ }^{7533}$ About 10 to 15 seconds after Žuti and the guards had left the bus, KDZ041 heard a loud explosion, following which the bus was fired upon by automatic rifles, machineguns, and Zoljas from all directions for about 15 minutes, while hand grenades were thrown underneath it. ${ }^{7554}$ Some of the prisoners attempted to escape but were shot and killed. ${ }^{7555}$ Shortly after the shooting stopped, KDZ041 heard the cars in the escort start their engines and drive off. ${ }^{7556}$ After this, two vehicles pulled over alongside the bus, and KDZ041 heard two men discussing whether to check for survivors, but they did not do so. ${ }^{7557}$ Afterwards, six of the Bosnian Muslims who had survived the attack, including KDZ041, managed to get out and walk towards a nearby forest. ${ }^{7558}$ However, due to the serious

\footnotetext{
7547 KDZ041, T. 12071, 12109 (17 February 2011); P2310 (Witness statement of KDZ041 dated 14 February 2011), para. 51 (under seal).

7548 KDZ041, T. 12071-12072, 12110 (17 February 2011); P2310 (Witness statement of KDZ041 dated 14 February 2011), paras. 51-52 (under seal).

7549 KDZ041, T. 12072, 12111-12112 (17 February 2011); P2310 (Witness statement of KDZ041 dated 14 February 2011), para. 51 (under seal).

7550 KDZ041, T. 12110-12111 (17 February 2011); P2310 (Witness statement of KDZ041 dated 14 February 2011), para. 52 (under seal).

7551 KDZ041, T. 12111-12112, 12131 (17 February 2011); P2310 (Witness statement of KDZ041 dated 14 February 2011), para. 52 (under seal).

7552 KDZ041, T. 12073, 12113, 12115 (17 February 2011); P2310 (Witness statement of KDZ041 dated 14 February 2011), para. 53 (under seal); P2343 (Information report of Ramiz Mujkić, 4 July 2004), p. 13 (photograph showing both sides of the road). See also Adjudicated Fact 2629.

7553 KDZ041, T. 12073 (17 February 2011); P2310 (Witness statement of KDZ041 dated 14 February 2011), para. 53 (under seal).

7554 KDZ041, T. 12074-12075, 12112, 12120-12121, 12131-12132 (17 February 2011); P2310 (Witness statement of KDZ041 dated 14 February 2011), paras. 53, 57 (under seal); P2343 (Information report of Ramiz Mujkić, 4 July 2004), p. 15. See also Adjudicated Fact 2629.

7555 P2310 (Witness statement of KDZ041 dated 14 February 2011), para. 53 (under seal).

7556 P2310 (Witness statement of KDZ041 dated 14 February 2011), para. 53 (under seal).

7557 KDZ041, T. 12074, 12131 (17 February 2011); P2310 (Witness statement of KDZ041 dated 14 February 2011), para. 54 (under seal).

7558 KDZ041, T. 12075 (17 February 2011); P2310 (Witness statement of KDZ041 dated 14 February 2011), para. 55 (under seal); P2314 (Witness statement of Ramiz Mujkić dated 4 February 2011), para. 49.
} 
injuries which they had sustained, two of the survivors, namely Nedžib Gačanović and Safet Rizvanović, died shortly after. ${ }^{7559}$

2214. The four remaining survivors walked all night and eventually made their way to Vukašovići, a village under the control of Bosnian Muslim TO. ${ }^{7560}$ The residents of Vukašovići, along with the Bosnian Muslim TO, then went to the scene in order to pull the dead bodies from the bus and, while at the scene, discovered another two survivors. ${ }^{7561}$ In addition, two more survivors were later found in the village of Palanka. ${ }^{7562}$

2215. The dead bodies were eventually removed from the bus, while the burned and damaged bus was filmed by a certain Ibrahim. ${ }^{7563}$ Towards the end of the removal, a number of VRS members, headed by Dragan Ikanović, who was from Srednje and who was allegedly a commander of Serb police, ${ }^{7564}$ appeared at the scene accompanied by two trucks in order to tow the bus. ${ }^{7565}$ Ikanović and his men were told to leave. ${ }^{7566}$ Members of the Bosnian Muslim TO then used tractors to take the bodies to the village of Ravne, in Ilijaš municipality, and buried them in a mass grave near that village. $^{7567}$ Before the burial, the survivors of the attack managed to identify 40 out of the 47

7559 KDZ041, T. 12074-12075, 12114 (17 February 2011); P2310 (Witness statement of KDZ041 dated 14 February 2011), para. 55 (under seal).

7560 KDZ041, T. 12075, 12112, $12115-12116$ (17 February 2011); P2310 (Witness statement of KDZ041 dated 14 February 2011), para. 55 (under seal).

7561 KDZ041, T. 12114-12115 (17 February 2011); P2310 (Witness statement of KDZ041 dated 14 February 2011), paras. 55-56 (under seal); P2314 (Witness statement of Ramiz Mujkić dated 4 February 2011), para. 49.

7562 P2310 (Witness statement of KDZ041 dated 14 February 2011), para. 56 (under seal); P2314 (Witness statement of Ramiz Mujkić dated 4 February 2011), para. 49.

7563 KDZ041, T. 12076-12077, 12116, 12118 (17 February 2011); P2310 (Witness statement of KDZ041 dated 14 February 2011), para. 60 (under seal); P2312 (Video footage of burned bus); P2343 (Information report of Ramiz Mujkić, 4 July 2004), pp. 12-14.

7564 P2310 (Witness statement of KDZ041 dated 14 February 2011), para. 50 (under seal); P3629 (Report on the work of the VRS Military Prosecutor's Office for 1992), p. 9.

7565 KDZ041, T. 12116, 12118 (17 February 2011). The Chamber is mindful that in his witness statement, KDZ041 stated that "[w]hen the villagers of [Vukašovići] reached the spot where the massacre had occurred, they found a Chetnik patrol there with two trucks". P2310 (Witness statement of KDZ041 dated 14 February 2011), para. 55 (under seal). The Chamber however, does not find that this discrepancy is so acute that it would undermine the overall credibility of KDZ041's evidence with respect to Scheduled Incident B.12.2.

7566 P2310 (Witness statement of KDZ041 dated 14 February 2011), para. 55 (under seal).

7567 KDZ041, T. 12075, 12077-12078, 12117-12118 (17 February 2011); P2310 (Witness statement of KDZ041 dated 14 February 2011), para. 58 (under seal); P2313 (Video footage of burial); P2343 (Information report of Ramiz Mujkić, 4 July 2004), p. 16. 
individuals who had been killed on the bus. ${ }^{7568}$ A few days later, Ikanović and his men came back and set the bus on fire. ${ }^{7569}$

2216. The remains of 47 Bosnian Muslim men were exhumed from a mass grave in the village of Ravne on 24-26 June 1996. ${ }^{7570}$ According to Amor Mašović, each of these 47 individuals was recorded as last seen in either Ahatovići or Dobroševići on 1 June $1992 .^{7571}$

7568 KDZ041, T. 12078 (17 February 2011); P2310 (Witness statement of KDZ041 dated 14 February 2011), paras. 58-59 (under seal). According to Ramiz Mujkić, his sister's husband and her son who was almost 21 years old were both killed during the attack on the bus on or about 14 June 1992. Ramiz Mujkić stated, moreover, that 13 individuals with the last name Mujkić were killed in the incident. Mujkić added that Zaim Rizvanović who was the fifth son in his family survived the bus incident whereas his four brothers died. P2314 (Witness statement of Ramiz Mujkić dated 4 February 2011), para. 49.

7569 KDZ041, T. 12116 (17 February 2011).

7570 These 47 individuals are Hamid Adilović (male, 1951), Meho Bašić (male, 1944), Salem Bečić (male, 1945), Ahmilo Bečković (male, 1967), Fadil Bečković (male, 1968), Nusret Bečković (male, 1972), Edin Bešić (male, 1971), Šućrija Bešić (male, 1949), Ibrahim Boloban (male, 1929), Amir Duraković (male, 1960), Jusuf Džuho (male 1949), Alija Gačanović (male, 1949), Ćazim Gačanović (male, 1955), Mufid Gačanović (male 1968), Mujo Gačanović (male, 1929), Mustafa Gačanović (male, 1959), Nedžib Gačanović (male, 1952), Samir Hrustanović (male, 1966), Ejub Kalkan (male, 1935), Ale Mehmedović (male, 1956), Nedžad Mešanović (male, 1970), Midhat Muharemović (male 1958), Armin Mujkić (male, 1968), Eldin Mujkić (male, 1974), Emir Mujkić (male, 1973), Fikret Mujkić (male, 1956), Hemed Mujkić (male, 1936), Mirsad Mujkić (male, 1958), Muhamed Mujkić (male, 1949), Refik Mujkić (male, 1952), Salem Mujkić (male, 1952), Šaćir Mujkić (male, 1963), Uzeir Mujkić (male, 1935), Zijad Mujkić (male, 1973), Ramiz Novalija (male, 1946), Ramiz Peljto (male, 1968), Ismet Rizvanović (male, 1958), Izet Rizvanović (male, 1960), Mehmed Rizvanović (male, 1961), Nedžad Rizvanović (male, 1972), Sulejman Rizvanović (male, 1945), Enes Suljić (male, 1950), Enver Suljić (male, 1952), Muhamed Suljić (male, 1936), Salih Suljić (male, 1934), Suad Suljić (male, 1972), and Ramiz Ušto (male, 1972). P4853 (Updated Table 2 to the Report of Amor Mašović), pp. 87-89; P4883 (Data on exhumations in the Sarajevo region in the period of 1996-1998), pp. 32-34. In P4853 (Updated Table 2 to the Report of Amor Mašović), p. 88, reference is made to Midhat Muharemović, born on 1958 and son of Murat. However, in P4883 (Data on exhumations in the Sarajevo region in the period of 1996-1998), p. 32, reference is made to Fikret Muharemović, born in 1958 and son of Murat. Having had regard to the name of father and the year of birth, as well as the fact that KDZ041 mentions the name Midhat Muharemović, the Chamber is satisfied that the correct first name of the victim in question is in fact Midhat and not Fikret. P2310 (Witness statement of KDZ041 dated 14 February 2011), p. 59 (under seal).

7571 P4853 (Updated Table 2 to the Report of Amor Mašović), pp. 87-89. The Chamber notes that there are some discrepancies between the forensic evidence and the evidence of KDZ041 as regards the names of some of the victims of Scheduled Incident B.12.2. More specifically, KDZ041's witness statement contains references to Meho Pašić, Salem Bešić, Ahmed Bečković, Šućro Bečić, Samir Hrustenmović, Almir Mujkić, Edmir Mujkić, Mehmed Mujkić, Šaćir Mujić, Ismet Rizvan, Nedžad Rizvan, and Sulejman Rizvan. P2310 (Witness statement of KDZ041 dated 14 February 2011), para. 59 (under seal). By contrast, in the forensic reports of $\mathrm{BiH}$ authorities dealing with exhumation and identification of victims, the names of these individuals are recorded as Meho Bašić, Salem Bečić, Ahmilo Bečković, Šućrija Bešić, Samir Hrustemović, Armin Mujkić, Emir Mujkić, Hemed Mujkić, Šaćir Mujkić, Ismet Rizvanović, Nedžad Rizvanović and Sulejman Rizvanović. P4853 (Updated Table 2 to the Report of Amor Mašović), pp. 88-89; P4883 (Data on exhumations in the Sarajevo region in the period of 1996-1998), pp. 32-34. However, the Chamber considers these inconsistencies to be minor and accordingly concludes that these are in fact the same individuals. Further, KDZ041's witness statement contains references to four persons who are not listed in the above-mentioned forensic reports, i.e., Nazif Mujkić, Safet Rizvan, Vahid Rizvan, and Nijaz Tiro. P2310 (Witness statement of KDZ041 dated 14 February 2011), para. 59 (under seal). Similarly, the forensic reports refer to 11 individuals who are not mentioned in the witness statement of KDZ041, i.e., Hamid Adilović, Fadil Bečković, Nusret Bečković, Ibrahim Boloban, Jusuf Džuho, Ale Mehmedović, Nedžad Mešanović, Ramiz Peljto, Izet Rizvanović, Mehmed Rizvanović, and Ramiz Ušto. P4853 (Updated Table 2 to the Report of Amor Mašović), pp. 88-89; P4883 (Data on exhumations in the Sarajevo region in the period of 1996-1998), pp. 32-34. Having considered these inconsistencies, the Chamber does not consider them to be of significance, as it is satisfied, as will be seen below, that 47 men indeed died in this incident. 
2217. The Accused contends that due to conflicting evidence it is impossible to properly ascertain the identity of the perpetrators who carried out the attack on the bus. ${ }^{7572}$ He submits that there is evidence that tends to show, on the one hand, that Boro Radić-a man who frequently acted without orders and who was psychologically unstable — had organised the attack, and on the other hand, that the attack had been carried out by Brne's group - a paramilitary unit led by Branislav Gavrilović, which the Bosnian Serb authorities tried to disband or even liquidate because of their criminal activities and substance abuse. ${ }^{7573}$ Finally, the Accused argues that there is also evidence which indicates that the attack on the bus was carried out by Bosnian Muslims who erroneously thought that the bus was filled with Serbs. ${ }^{7574}$

2218. The Chamber will now identify and analyse the relevant evidence which implicates Bosnian Serb forces in the attack on the bus and examine whether there are inconsistencies in such evidence: (i) KDZ041 testified that he heard that the "main organisers" of the attack on the bus were Boro Radić, Dragan Ikanović, and Ratko Adžić, ${ }^{7575}$ (ii) Eset Muračević, a Bosnian Muslim who was detained in Vogošća municipality in the second half of 1992, stated that he had heard from a fellow detainee that a Serb prison guard by the name Predrag Žarković, alias Božur, was "[a]mong the group of Chetniks" who carried out the attack on the bus; ${ }^{7576}$ and (iii) KDZ601 testified that [REDACTED], he heard [REDACTED] that Branislav Gavrilović from Vučija Luka and his unit had "hit" the bus with Zoljas. ${ }^{7577}$

2219. The Chamber, Judge Morrison dissenting, does not consider that the evidence of KDZ041 contradicts the evidence of Muračević on this issue because Muračević simply stated that Žarković was among the group of Chetniks who carried out the attack on the bus; he did not claim that Žarković was a main organiser of the attack. The Chamber, Judge Morrison dissenting, is also satisfied that the evidence of KDZ601 is not in conflict with the evidence of KDZ041 on this question because KDZ601 did not testify that Gavrilović and his men were the main organisers of

\footnotetext{
$7572 \quad$ Defence Final Brief, para. 1710.

7573 Defence Final Brief, paras. 1707-1708.

7574 Defence Final Brief, para. 1709.

7575 KDZ041, T. 12075 (17 February 2011); P2310 (Witness statement of KDZ041 dated 14 February 2011), paras. 50, 61 (under seal). According to KDZ020, Boro Radić was a common criminal from Vogošća who had the support of the SDS and eventually was integrated into the VRS and given the rank of colonel. KDZ020, T. 12524 (28 February 2011) (private session).

7576 P2361 (Witness statement of Eset Muračević dated 24 February 2011), paras. 20, 60. On Eset Muračević's detention, see Scheduled Detention Facilities C.26.1, C.26.3.

7577 P3299 (Record of interview with KDZ601, 18 April 2005), pp. 38-42 (under seal); KDZ601, T. 18590-18592 (8 September 2011). The Chamber received evidence that Branislav Gavrilović was known and referred to by the municipal authorities of Ilidža as the commander of all SAO Romanija volunteer units. P2302 (Approval of the War Board of Commissioners of Ilidža Municipality, 9 July 1992); Neđeljko Prstojević, T. 12988 (8 March 2011). Witness Velimir Dunjić stated that the unit of Branislav Gavrilović was in the zone of responsibility of
} 
the attack. Similarly, the Chamber, Judge Morrison dissenting, is of opinion that the evidence of KDZ601 does not contradict the evidence of Eset Muračević because Muračević merely spoke of one of the participants in the attack. In light of the foregoing, the Chamber, Judge Morrison dissenting, is of the view that there is no conflict in the evidence of these witnesses on the question of the identity of the perpetrators of the bus attack.

2220. The Chamber will now assess the evidence in light of the Accused's argument that the bus was attacked by Bosnian Muslims who mistakenly thought that it was filled with Serbs. ${ }^{7578}$ There is indeed evidence that Mirko Krajišnik informed Momčilo Krajišnik that Muslims had intercepted a bus carrying detained Muslims and, mistaking the occupants of the bus for Serbs, had opened fire on the bus, killing all the detainees and heavily wounding two Serb guards. ${ }^{7579}$

2221. However, there is also evidence that Momčilo Krajišnik gave instructions to the Bosnian Serbs in Rajlovac that nothing should happen to the Bosnian Muslim men detained there. More specifically, on 8 June 1992, Momčilo Krajišnik informed a certain Mijatović in Rajlovac that his brother Mirko had told him "about problems with these captured men", and stated that nothing should be done which would be wrong or outside of the rules. ${ }^{7580}$ He also told Mijatović that he was ready to help find a solution. ${ }^{7581}$ Krajišnik reiterated his position to another interlocutor in the same conversation, emphasising that nothing should be done to the men. ${ }^{7582}$

2222. In this regard, the Chamber notes that Mirko Krajišnik himself was involved in dealing with the detainees at the Rajlovac Barracks. This was brought out by Ramiz Mujkić, who testified that, on the morning of 7 August 1992 while he was detained at the Rajlovac Barracks, Mirko Krajišnik and others visited him in his cell, and enquired about the whereabouts of Hasan Mujkić and his brother Husein, the witness's son Elvir Mujkić, and a person named Junuz Mujkić. ${ }^{7583}$ Ramiz

the Igman Brigade and that, after a while, it put itself under the command of the Igman Brigade. D2451 (Witness statement of Velimir Dunjić dated 12 November 2012), para. 13.

7578 See Defence Final Brief, para. 1709.

7579 D1088 (Intercept of conversation between Momčilo Krajišnik and Mirko Krajišnik, 15 June 1992), pp. 1, 5-6.

7580 P2334 (Intercept of conversation between Momčilo Krajišnik, Mijatović and Ljubiša Vladušić, 8 June 1992), pp. $1-2$.

7581 P2334 (Intercept of conversation between Momčilo Krajišnik, Mijatović and Ljubiša Vladušić, 8 June 1992), p. 1.

7582 P2334 (Intercept of conversation between Momčilo Krajišnik, Mijatović and Ljubiša Vladušić, 8 June 1992), p. 4.

7583 P2314 (Witness statement of Ramiz Mujkić dated 4 February 2011), para. 59; Ramiz Mujkić, T. 12400-12409 (25 February 2011); D1105 (Supplemental information sheet for Ramiz Mujkić, 1 November 2004). The Chamber does not accept the Accused's assertion that since witness Ramiz Mujkić had failed to mention the visit by Vlasto Apostolski, Nikola Poplašen, and Mirko Krajišnik in his previous statements, his evidence on the same should necessarily be ignored by this Chamber. The Chamber has received evidence which corroborates Mujkić's account of the visit by Mirko Krajišnik. On 20 August 1992, during an intercepted telephone conversation, Bakir Alispahić informed Mirko Krajišnik that a person by the name Nikola had paid a visit to Ramiz Mujkić and asked whether Krajišnik could arrange for Mujkić's release. Although Krajišnik did not 
Mujkić further testified that on 22 August 1992, Stojanović and two other members of the MP took him from the Žica Hospital in Blažuj to Planjo's House in Svrake. ${ }^{7584}$ According to Ramiz Mujkić, Mirko Krajišnik subsequently intervened in order to have him exchanged. ${ }^{7585}$

2223. The Chamber also notes that on 20 June 1992 in an intercepted conversation, Mirko Krajišnik informed two individuals with the names Ćamil and Šemso that 284 prisoners from the cisterns near the Rajlovac Barracks had been exchanged whereas 50 additional prisoners had been sent home. ${ }^{7586}$ During the same conversation, Mirko Krajišnik, referring to the group of 50 prisoners, told Šemso that there were people with the last name Gačanović amongst them and added "[y]ou heard that there were some casualties among them.",7587

2224. An engaging feature about this conversation, in which Mirko Krajišnik told Šemso, a Bosnian Muslim, that 50 detainees were sent home and that there were some casualties amongst them, was that at no stage did Mirko Krajišnik mention that Muslims were to blame for the casualties. The Chamber, Judge Morrison dissenting, is of the view that had Bosnian Muslims in fact been responsible for the attack on the bus, Mirko Krajišnik would have raised the matter with Šemso in that conversation which occurred less than a week after the bus attack.

2225. The evidence described in the foregoing paragraphs, when taken together, leads the Chamber, Judge Morrison dissenting, to conclude that Mirko Krajišnik deliberately provided Momčilo Krajišnik with misinformation on what had become of those Muslim detainees in respect of whose safety Momčilo Krajišnik had previously articulated his apprehensions.

2226. In addition, further analysis of evidence lead the Chamber, Judge Morrison dissenting, to be convinced that the above attack on the bus was carried out by the Serb Forces.

2227. First, KDZ041 stated that just before the attack, the two escort cars behind the bus left the scene; thereafter, Žuti claimed that the engine of the bus had overheated, and along with the guards left the bus. Merely 10 to 15 seconds after Žuti and the guards had left the bus, the attack on the

expressly acknowledge having seen Mujkić, he implied that he knew that Mujkić had been injured and subsequently told Alispahić that "[w]e agreed for some kind of exchange for him". P2337 (Intercept of conversation between Mirko Krajišnik and Bakir Alispahić, 20 August 1992), p. 3. P2314 (Witness statement of Ramiz Mujkić dated 4 February 2011), paras. 67-68. On Mujkić's detention at Planjo's House, see Scheduled Detention Facility C.26.1.

7585 P2314 (Witness statement of Ramiz Mujkić dated 4 February 2011), para. 58; D1 105 (Supplemental information sheet for Ramiz Mujkić, 1 November 2004).

7586 D1089 (Intercept of conversation between Ćamil and Mirko Krajišnik, 20 June 1992), pp. 1-2.

7587 D1089 (Intercept of conversation between Ćamil and Mirko Krajišnik, 20 June 1992), p. 2. The Chamber notes that the forensic documentation concerning Scheduled Incident B.12.2 refers to six people with the last name Gačanović. See fn. 7570. 
bus commenced. ${ }^{7588}$ The Chamber, Judge Morrison dissenting, is of the view that had the attack been carried out by Bosnian Muslims, it would have been stretching coincidence past breaking point for them to have anticipated the precise time that the engine of the bus would have overheated and to have been in the right place at that exact time so that they could have sprung their ambush. $^{7589}$

2228. Further, the evidence of KDZ041 is that he was face down in the bus and bodies were on top of him; he was therefore unable to see anything. KDZ041 testified that shortly after the shooting had stopped, he heard the engines of the escort cars start up and the cars drive off. He then heard two vehicles pull alongside the bus and two men discuss whether they should check for survivors. According to KDZ041, these two men did not enter the bus and instead got into their vehicles and left the scene. ${ }^{7590}$ It is clear to the Chamber, Judge Morrison dissenting, that notwithstanding his inability to see during and immediately after the attack, KDZ041 heard what was happening around him. The Chamber assessed KDZ041 to be a credible and reliable witness and accordingly, found no good reason to reject his evidence about the things he said he heard.

2229. The Chamber also heard from KDZ041 that the residents of the Muslim village of Vukašovići and the Bosnian Muslim TO went to the scene and removed the bodies from the bus; that towards the end of the removal process, a number of VRS soldiers headed by Dragan Ikanović appeared on the scene with two trucks in order to tow the bus away; and that they were told to leave. The Chamber also heard from KDZ041 that a few days later, Ikanović and his men returned and set the bus on fire. ${ }^{7591}$ The Chamber, Judge Morrison dissenting, cannot comprehend the inordinate interest displayed by Ikanović and the VRS members in that bus, although allegedly it had been attacked by Muslims, to the extent they were bent on towing it away; and after that attempt failed, they returned and destroyed it a few days later. The actions of Ikanović and the VRS members impel the Chamber, Judge Morrison dissenting, to the conclusion that they manifestly sought to destroy the important evidence of the large killing incident. Their actions would have made no sense if the attack had been carried out by the Bosnian Muslim forces.

2230. Finally, the Chamber must also address the evidence of KDZ601. In the opinion of the Chamber, KDZ601, [REDACTED], evinced pronounced bias in favour of the Accused during cross

\footnotetext{
7588 See paras. 2212-2213.

7589 For this reason, the Chamber finds that Žuti and the guards were involved in the attack on the bus, although it is possible that they were not the main organisers of the attack as they could have found easier ways to kill the Bosnian Muslim men.

$7590 \quad$ See paras. 2212-2213.

$7591 \quad$ See para. 2215.
} 
examination. ${ }^{7592}$ In the throes of this bias, however, he implicated Serb paramilitaries in the attack, leaving the Chamber, Judge Morrison dissenting, with the abiding impression that he was being forthright with the Chamber in this respect.

2231. In conclusion, having found (i) that there is no inconsistency in the evidence of witnesses on the question of the identity of the perpetrators of the bus attack; (ii) that the evidence of KDZ041 is reliable; (iii) that the initial attempt by Ikanović and the VRS members to tow the bus away and then their ultimate destruction of the bus is indicative of a determination on their part to destroy the evidence of the killing; (iv) that Mirko Krajišnik deliberately misinformed Momčilo Krajišnik; and (v) that KDZ061 testified with forthrightness when he described the involvement of Serb paramilitaries in the attack on the bus, the Chamber, Judge Morrison dissenting is satisfied beyond reasonable doubt that on 14 June 1992, Serb Forces, including Žuti, other guards, and paramilitaries, attacked a bus filled with Bosnian Muslim male detainees with grenades and automatic weapons, and killed 47 Bosnian Muslim men.

\section{(H) Movement of the population from Novi Grad}

2232. Bosnian Muslims and Croats left the Novi Grad municipality en masse during the conflict. During a conversation that took place on 21 May 1992 between Colonel Milosav Gagović, Acting Commander of the JNA $4^{\text {th }}$ Corps Sarajevo, ${ }^{7593}$ and Neđeljko Prstojević, the former informed the latter that Muslims were fleeing Dobrinja and that he had taken measures to ensure that they knew that only entire families would be allowed to leave the area. ${ }^{7594}$

2233. According to KDZ041 and Ramiz Mujkić, during the period 1 to 14 June 1992, about 400 women and children from Ahatovići and the surrounding villages, including Ramiz Mujkić's mother, wife, and sister, were detained at the adjoining premises of Tehnogas Company and the Distribution Centre. ${ }^{7595}$ The VRS also temporarily placed the Muslim women and children in the Gavrilo Princip primary school after the attack on Ahatovići. ${ }^{7596}$ Further, a memorandum from the Rajlovac municipality Executive Board, dated 2 June 1992, referring to "captives from Ahatovići,

\footnotetext{
7592

See e.g. KDZ601, T. 18597, 18603-18604, 18615-18616, 18634-18635 (8 September 2011). D2738 (Witness statement of Milosav Gagović dated 7 March 2014), para. 2.

7594 D1236 (Intercept of conversation between Neđeljko Prstojević and Milosav Gagović, 21 May 1992), pp. 2-3; Robert Donia, T. 3140-3141 (31 May-3 June, 7-10 June 2010).

7595 On 13 June 1992, the women, including Ramiz Mujkić's wife, sister, and mother, as well as the children who were detained in the Tehnogas Company premises and the Distribution Centre were exchanged. Ramiz Mujkić, T. 12455 (25 February 2011); P2314 (Witness statement of Ramiz Mujkić dated 4 February 2011), paras. 47-48, 89; D1105 (Supplemental information sheet for Ramiz Mujkić, 1 November 2004); P2310 (Witness statement of KDZ041 dated 14 February 2011), paras. 32, 47 (under seal).

7596 P5425 (Report of RS MUP, 3 June 1992).
} 
the women and children", reveals an intention on the part of the Executive Board to confine them in the new part of the Tehnogas-Kiskana building. ${ }^{7597}$

2234. Moreover, following the attack against Ahatovići, all the surviving Muslims in the village were either arrested or expelled, together with Serbs and Croats who were married to Muslims. ${ }^{7598}$ In a telephone conversation conducted on 25 June 1992, Petko Budiša who was the chief of Ilidža SJB from August to 20 September 1992 and who later became Chief of the CSB in Bijeljina, ${ }^{7599}$ informed Slavko Lazendić from the Rajlovac SJB that he should not allow the entry or exit of any Bosnian Muslims to and from the area via the Bojnik bridge. ${ }^{7600}$ During the same conversation, Lazendić claimed that the area had been "liberated" and that it was "ethnically clean". 7601

2235. According to another report compiled by the Red Cross in Rajlovac, dated 1 October 1993, there were no Bosnian Muslims present in the Serb municipality of Rajlovac. ${ }^{7602}$

2236. The Accused claims that after the take-over of Ahatovići, a number of Bosnian Muslim and Bosnian Croat families wished to be taken to Sarajevo whereas some individuals remained throughout the entire war and even joined the VRS on a voluntary basis. ${ }^{7603}$ The Accused brought Stojan Džino and Mihajlo Vujasin, the deputy commander of the Rajlovac Brigade, to testify that the movement of population was voluntary. ${ }^{7604}$ However, the Chamber found both witnesses to be evasive, biased and partisan. The Chamber notes, as it did earlier, ${ }^{7605}$ that despite their evasiveness, both Stojan Džino and Mihajlo Vujasin conceded that civilians from Ahatovići had been taken to the Rajlovac Barracks and kept there against their will. The Chamber also recalls the evidence of Vujasin about the beatings of the civilians from Ahatovići and the surrounding areas and the dangers that they were exposed to. ${ }^{7606}$ The Chamber, further, notes the evidence concerning lootings and destruction of property. ${ }^{7607}$ The Chamber also recalls its earlier findings regarding the

\footnotetext{
7597 P5484 (Memorandum of the Rajlovac Municipality Executive Board, 2 June 1992), p. 1.

7598 See Adjudicated Fact 2667.

7599 P2296 (Witness statement of Tihomir Glavaš dated 13 February 2011), para. 9; P2848 (Witness statement of Milorad Davidović dated 22 June 2011), para. 101.

7600 P2335 (Intercepts of conversations between (i) Miodrag Stupar and Petko Budiša and (ii) Slavko Lazendić and Petko Budiša, 25 June 1992), pp. 4-7.

7601 P2335 (Intercepts of conversations between (i) Miodrag Stupar and Petko Budiša and (ii) Slavko Lazendić and Petko Budiša, 25 June 1992), p. 5.

7602 P2340 (Rajlovac Red Cross report, 1 October 1993), p. 1. See also D4002 (Letter from BiH MUP to Vasvija Vidović, 4 July 1995), p. 63.

7603 Defence Final Brief, para. 1698.

7604 Stojan Džino, T. 29854-29856 (6 November 2012); Mihajlo Vujasin, T. 31804 (20 December 2012).

7605 See para. 2207.

7606 See para. 2207.

7607 See paras. 2185-2187.
} 
destruction of the mosque in Ahatovići, ${ }^{7608}$ the existence of detention facilities in Novi Grad municipality and the involuntary confinement of women, children and men therein ${ }^{7609}$ as well the evidence which indicates that some civilians detained in such facilities were eventually exchanged for Serbs. ${ }^{7610}$

2237. Consequently, the Chamber finds that Serb Forces forced the non-Serb population out of the Serb-controlled parts of Novi Grad.

\section{iv. Novo Sarajevo}

\section{(A) Charges}

2238. Under Count 3, the Prosecution alleges that persecution, a crime against humanity, was committed in Novo Sarajevo as part of the objective to permanently remove Bosnian Muslims and/or Bosnian Croats from the Municipalities. ${ }^{7611}$

2239. Acts of persecution alleged to have been committed in Novo Sarajevo by Serb Forces and Bosnian Serb Political and Governmental Organs include: (i) torture, beatings, and physical and psychological abuse, during and after the take-over as well as in the Slaviša Vajner Čiča Barracks in Lukavica, as cruel or inhumane treatment; ${ }^{7612}$ (ii) rape and other acts of sexual violence during and after the take-over as cruel and inhumane treatment; ${ }^{7613}$ (iii) the establishment and perpetuation of inhumane living conditions in the Slaviša Vajner Čiča Barracks, including the failure to provide adequate accommodation, shelter, food, water, medical care, or hygienic sanitation facilities, as cruel or inhumane treatment; ${ }^{7614}$ (iv) forcible transfer or deportation of Bosnian Muslims and Bosnian Croats from their homes; ${ }^{7615}$ (v) unlawful detention in the Slaviša Vajner Čiča Barracks ${ }^{7616}$ (vi) forced labour at the frontline and the use of Bosnian Muslims and Bosnian Croats as human shields ${ }^{7617}$ (vii) the appropriation or plunder of property, during and after the take-over, during arrests and detention, and in the course of or following acts of deportation or forcible transfer; ${ }^{7618}$ (viii) the wanton destruction of private property, including homes and business

\footnotetext{
$7608 \quad$ See para. 2196.

7609 See paras. 2209, 2234.

$7610 \quad$ See para. 2206.

7611 Indictment, paras. 48-49.

7612 Indictment, para. 60(b). See Scheduled Detention Facility C.18.1.

7613 Indictment, para. 60(c). The Prosecution does not allege criminal responsibility for rape and other acts of sexual violence at Scheduled Detention Facility C.18.1. Indictment, fn. 5.

7614 Indictment, para. 60(d). See Scheduled Detention Facility C.18.1.

7615 Indictment, para. 60(f).

7616 Indictment, para. 60(g). See Scheduled Detention Facility C.18.1.

7617 Indictment, para. 60(h).
} 
premises, and public property; ${ }^{7619}$ and (ix) the imposition and maintenance of restrictive and discriminatory measures. ${ }^{7620}$

2240. Under Counts 7 and 8, the Prosecution alleges deportation and inhumane acts (forcible transfer), respectively, as crimes against humanity. ${ }^{7621}$ In this regard, the Prosecution alleges that by the end of 1992, Serb Forces and Bosnian Serb Political and Governmental Organs had forcibly displaced Bosnian Muslims and Bosnian Croats from areas in Novo Sarajevo in which they had been lawfully present. $^{7622}$ It is alleged that from March 1992, restrictive and discriminatory measures, arbitrary arrest and detention, harassment, torture, rape and other acts of sexual violence, killing, destruction of houses, as well as the threat of further such acts caused Bosnian Muslims and Bosnian Croats to flee in fear, while others were physically driven out. ${ }^{7623}$

\section{(B) Lead-up}

2241. Novo Sarajevo, one of the ten Sarajevo municipalities, is located in the eastern part of Sarajevo city between Novi Grad and Ilidža on one side and Centar, Stari Grad, and Pale on the other. $^{7624}$ According to the 1991 census, the population of Novo Sarajevo comprised 95,089 people, among whom 35.7\% were Bosnian Muslims, 34.6\% were Bosnian Serbs, 15.9\% were "Yugoslavs", 9.3\% were Bosnian Croats, and 4.6\% were "others and unknown". 7625 The municipality included, inter alia, Grbavica, located south of the Miljacka River; Vraca, located 600 to 800 metres to the southwest of Grbavica; Pofalici in the north part of the municipality; and Lukavica in the southwest part of the municipality. ${ }^{7626}$

\footnotetext{
7618 Indictment, para. 60(i).

7619 Indictment, para. 60(j). The Chamber notes that there are no cultural monuments and sacred sites with respect to Novo Sarajevo in Schedule D.

7620 Indictment, para. 60(k). The restrictive and discriminatory measures alleged include the denial of freedom of movement; the removal from positions of authority; the invasion of privacy through arbitrary searches of homes; unlawful arrest and/or the denial of the right to judicial process; and/or the denial of equal access to public services.

7621 Indictment, paras. 68-75.

7622 Indictment, paras. 69, 72.

7623 Indictment, para. 71.

7624 P815 (Map of Sarajevo showing confrontation lines); P973 (Robert Donia's expert report entitled "Bosnian Serb Leadership and the Siege of Sarajevo, 1990-1995”, January 2010), p. 8; Appendix B, Map 1. See also Adjudicated Fact 2.

7625 P5964 (Census data for BiH by municipality in 1971, 1981, and 1991, April 1995), p. 2; P973 (Robert Donia's expert report entitled "Bosnian Serb Leadership and the Siege of Sarajevo, 1990-1995”, January 2010), p. 9. See also Adjudicated Fact 5; P2577 (Press release of Novo Sarajevo municipality, 1 April 1992), p. 2; Radomir Nešković, P2568 (Transcript from Prosecutor v. Krajišnik), T. 16662-16663, 16676.

7626 KDZ310, T. 9214, 9222, 9227-9229 (29 November 2010); D883 (Map of Sarajevo marked by KDZ310); P926 (Witness statement of Aernout Van Lynden dated 26 February 2010), para. 92. See also Adjudicated Facts 65, $67,68$.
} 
2242. After the formation of the SDS, SDA, and HDZ, a Novo Sarajevo SDS Steering Committee was appointed to establish local boards in the local communes and an SDS Municipal Board of Novo Sarajevo. ${ }^{7627}$

2243. As a result of the 1990 multi-party elections, the SDS won 24 assembly seats in Novo Sarajevo, the communist SDP won 23, the Reformist Party won 22, the SDA won 21, the HDZ won 7, and the Muslim Bosniak Organisation won 2. ${ }^{7628}$ Žarko Đurović, from the SDS, was appointed as president of the Executive Board. ${ }^{7629}$ Kasim Demirović, from the SDA, was appointed as president of the municipality. ${ }^{7630}$ The post of vice president of the municipal assembly went to the HDZ. $^{7631}$

2244. As in other parts of $\mathrm{BiH}$, already growing tensions between Bosnian Serbs, Muslims, and Croats further increased with the war in Croatia. ${ }^{7632}$ The Serbs demanded and established their own TV channel. ${ }^{7633}$

\section{(1) Creation of separate municipal institutions}

2245. The Novo Sarajevo Crisis Staff was created in December 1991 in accordance with the Variant A/B Instructions, and Đurovic was its president. ${ }^{7634}$ According to Nešković, it was mandatory for those who received the Variant A/B Instructions to implement the document, and the

7627 D2673 (Witness statement of Zdravko Šalipur dated 16 December 2012), para. 2. According to Šalipur, who was a member of the Steering Committee and the Municipal Board, Novo Sarajevo had about 16 local communes with local SDS boards but only half the boards, those of communes with a Serb majority, were active. D2673 (Witness statement of Zdravko Šalipur dated 16 December 2012), para. 2. Milivoje Prijić was the president of the SDS Municipal Board. P2576 (Minutes of $13^{\text {th }}$ session of Novo Sarajevo's SDS Municipal Board, 28 February 1992), p. 2; Branko Radan, T. 31092 (6 December 2012).

7628 D2673 (Witness statement of Zdravko Šalipur dated 16 December 2012), para. 3 (further stating that $50 \%$ of the Reformists and SDP were Serbs). See also Branko Radan, T. 31090 (6 December 2012).

7629 D2673 (Witness statement of Zdravko Šalipur dated 16 December 2012), para. 3; Radomir Nešković, P2568 (Transcript from Prosecutor v. Krajišnik), T. 16641; Radomir Nešković, T. 14276 (6 June 2011).

7630 D2673 (Witness statement of Zdravko Šalipur dated 16 December 2012), para. 3. Nešković referred to Đurović as, alternatively, "president of the municipal government in Novo Sarajevo", president of the Executive Board, and "president of the municipal authorities". Radomir Nešković, P2568 (Transcript from Prosecutor v. Krajišnik), T. 16640-16641, 16652, 16673.

7631 D2673 (Witness statement of Zdravko Šalipur dated 16 December 2012), para. 3.

7632 P1938 (Witness statement of KDZ310 dated 28 November 2010), para. 3. See also D2418 (Witness statement of Božo Tomić dated 5 November 2012), para. 4; Božo Tomić, T. 30154-30157 (13 November 2012).

7633 P1938 (Witness statement of KDZ310 dated 28 November 2010), para. 3.

7634 Radomir Nešković, T. 14275-14276 (6 June 2011), T. 14352-14354 (7 June 2011); Radomir Nešković, P2568 (Transcript from Prosecutor v. Krajišnik), T. 16660-16662, 16684; P2575 (Excerpt from session of Novo Sarajevo's Crisis Staff, 23 December 1991). See also P5 (SDS Instructions for Organisation of Organs of the Serbian People in BiH, 19 December 1991); P6055 (Minutes of the Crisis Staff meeting, 25 December 1991); P6066 (Minutes from meeting of SDS Grbavica Local Board, 27 January 1992), p. 1; P2583 (Minutes of Lukavica's Crisis Staff meeting, 29 January 1992); Zdravko Šalipur, T. 31627-31640, 31655 (18 December 2012); D2674 (List of Secretariat of Novo Sarajevo SDS Municipal Board, undated). Nešković attended the meeting of the SDS Main and Executive Boards on 20 December 1991 where the Variant A/B Instructions were 
recipients were Serb municipal presidents and representatives as well as possibly SDS municipal board officials. $^{7635}$ The Crisis Staff included SDS members of the municipal assembly of Novo Sarajevo. $^{7636}$

2246. Around February 1992 the Accused and Krajišnik were involved in resolving an internal conflict in Novo Sarajevo. ${ }^{7637}$ The Accused and Krajišnik attended at least one meeting of the Novo Sarajevo SDS Municipal Board. ${ }^{7638}$ The record of the 28 February 1992 meeting of the Novo Sarajevo SDS Municipal Board also indicates that the Accused and Krajišnik were to be notified of the decision taken at the meeting to designate the vice president of the Board to carry out the work of the president of the Board, from which Prijić had been relieved, until a new president was elected. ${ }^{7639}$

2247. On 26 March 1992, SDS deputies of Novo Sarajevo, the presidents of SDS town boards, and deputies of the Sarajevo SDS passed a decision to establish the Serb Municipal Assembly of

distributed. Radomir Nešković, P2568 (Transcript from Prosecutor v. Krajišnik), T. 16646-16653. See para. 133.

7635 Radomir Nešković, P2568 (Transcript from Prosecutor v. Krajišnik), T. 16655-16660. In the case of Novo Sarajevo, the document would have gone to Žarko Đurović as the president of the executive board. Radomir Nešković, P2568 (Transcript from Prosecutor v. Krajišnik), T. 16652-16653. As to whether Novo Sarajevo fell under Variant A or Variant B, Nešković initially thought that Variant B applied to Novo Sarajevo but later stated, based on the tasks assigned in P2575, that Variant A was implemented in the municipality. Radomir Nešković, P2568 (Transcript from Prosecutor v. Krajišnik), T. 16662-16666; Radomir Nešković, T. 1435214354 (7 June 2011). See P5 (SDS Instructions for Organisation of Organs of the Serbian People in BiH, 19 December 1991), pp. 2-5 (outlining tasks numbered between 1 and 11 under Variant A's first phase); P2575 (Excerpt from session of Novo Sarajevo's Crisis Staff, 23 December 1991). Some Defence witnesses from Novo Sarajevo stated that they were not familiar with the Variant A/B Instructions. D2651 (Witness statement of Milorad Katić dated 10 December 2012), para. 2; Branko Radan, T. 31104-31105, 31135-31136 (6 December 2012); Dragan Šojić, T. 31754 (19 December 2012); D2673 (Witness statement of Zdravko Šalipur dated 16 December 2012), para. 5; Zdravko Šalipur, T. 31628-31633 (18 December 2012) (nonetheless testifying that the Novo Sarajevo SDS Municipal Board received extracts of the Variant A/B Instructions). Considering other reliable evidence to the contrary, including Šalipur's admission above, as well as the witnesses' evasiveness and lack of forthrightness with respect to the existence and implementation of the Variant A/B Instructions in Novo Sarajevo, the Chamber does not find their evidence on this point to be reliable. Nešković testified that no one from the Government came to or contacted Novo Sarajevo to monitor the implementation of the Variant A/B Instructions in the municipality. Radomir Nešković, T. 14272-14273 (6 June 2011). While the Chamber considers Nešković's evidence generally with regard to the Variant A/B Instructions to be reliable, the Chamber does not consider this testimony to contradict his or other evidence that the Variant A/B Instructions were carried out in Novo Sarajevo.

7636 P2575 (Excerpt from session of Novo Sarajevo's Crisis Staff, 23 December 1991); P2583 (Minutes of Lukavica's Crisis Staff meeting, 29 January 1992); Momir Garić, T. 29653 (5 November 2012).

7637 There was a debate about the role of the SDS Municipal Board versus other municipal institutions, and a conflict emerged between Prijić, the president of the Municipal Board, and Đurović, the president of the Executive Board. D1276 (Minutes of meeting of Novo Sarajevo SDS local boards, 3 February 1992), pp. 1-3; Radomir Nešković, P2568 (Transcript from Prosecutor v. Krajišnik), T. 16641, 16672-16679. The Accused and Krajišnik used their authority to defuse the conflict and Đurović held onto his position as "president of the municipal authorities". Radomir Nešković, P2568 (Transcript from Prosecutor v. Krajišnik), T. 16641, 16673. See also Zdravko Šalipur, T. 31640 (18 December 2012).

7638 P2576 (Minutes of $13^{\text {th }}$ session of Novo Sarajevo's SDS Municipal Board, 28 February 1992), p. 3; Radomir Nešković, P2568 (Transcript from Prosecutor v. Krajišnik), T. 16641, 16675; Zdravko Šalipur, T. 31640, 31657 (18 December 2012); Branko Radan, T. 31092-31093 (6 December 2012).

7639 P2576 (Minutes of $13^{\text {th }}$ session of Novo Sarajevo's SDS Municipal Board, 28 February 1992), p. 6. 
the Novo Sarajevo Municipality "as the highest representative and legislative body of the Serbian people of Novo Sarajevo municipality". ${ }^{7640}$ The Serb Municipality of Novo Sarajevo was established as part of SAO Romanija around this time. ${ }^{7641}$

2248. Around 10 April 1992, Radomir Nešković and Mirko Šarović set up a new Crisis Staff. ${ }^{7642}$ The Crisis Staff had an executive organ to carry out its decisions. ${ }^{7643}$ Nešković was president of this new Crisis Staff until 5 June 1992. ${ }^{7644}$ This Crisis Staff included representatives of the TO. ${ }^{7645}$ A 5 June 1992 letter reporting on the activities of the Novo Sarajevo Crisis Staff, addressed to the President of the Bosnian Serb Presidency and signed by Nešković, stated: "The Crisis Staff has performed the function of Municipal Assembly in war conditions." ${ }^{, 7646}$ The letter also indicated that the Crisis Staff co-ordinated and organised a variety of municipal services, including accommodation for "all refugees from the occupied territory and people who were left homeless", mobilisation, and accommodation of fighters from other areas. ${ }^{7647}$ The letter stated that the Crisis Staff has not dealt with and does not intend to deal with police or military command-related matters

7640 D2675 (Decision on establishment of the Assembly of Serbian Novo Sarajevo Municipality, 26 March 1992).

7641 P2577 (Press release of Novo Sarajevo municipality, 1 April 1992), p. 1. See also Radomir Nešković, P2568 (Transcript from Prosecutor v. Krajišnik), T. 16679-16680; D2673 (Witness statement of Zdravko Šalipur dated 16 December 2012), para. 7; D2683 (Witness statement of Dragan Šojić dated 15 December 2012), para. 7; Dragan Šojić, T. 31736 (19 December 2012). The local communities that were to comprise the municipality were Tilava, Miljevići, Lukavica, Vraca, Gornji and Donji Kovačići, Bane Surbat, Rava Janković, Slobodan Princip Seljo, Ivan Krndelj, Pero Kosorić, Blagoje Parović, Danilo Djokić, Hrasno Brdo, Nikola Tesla, Avdo Hodžić, Omer Maslić, Bratstvo Jedinstvo, Donji and Gornji Pofalići, and the parts of the local communities Gornji and Donji Velešići inhabited by Serbs, as well as parts of Novi Grad municipality, namely Otoka, Staro Hrasno, Petar Dokić, a part of Ivo Lola Ribar, and Odžakovići. P2577 (Press release of Novo Sarajevo municipality, 1 April 1992), p. 1. Nešković stated that although the founding assembly took place toward the end of March 1992, the Serb Municipality of Novo Sarajevo was set up only by 10 June 1992. Radomir Nešković, P2568 (Transcript from Prosecutor v. Krajišnik), T. 16680.

7642 Radomir Nešković, P2568 (Transcript from Prosecutor v. Krajišnik), T. 16683-16685, 16706; Radomir Nešković, T. 14282-14283 (6 June 2011); D1278 (Transcript of Radomir Nešković's interview with Karadžić's legal associate, 8 October 2009), pp. 31-33. See also D885 (Letter from Novo Sarajevo Crisis Staff to Radovan Karadžić, 5 June 1992), pp. 1, 4. Nešković drafted this letter and submitted it to the Accused in response to his invitation in June 1992 to the representatives of "Crisis Staffs Jahorina" to report on their work, largely in oral presentations. Radomir Nešković, P2568 (Transcript from Prosecutor v. Krajišnik), T. 16685. The 5 June 1992 letter reported that a Crisis Staff had been set up and included, among others, representatives of the local communes of Petrovići, Miljevići, Gornji Kovačići, Grbavica, Vraca, Hrasno Brdo, Lukavica, and Tilava; army and police representatives; and the "Chairman of the Executive Board". D885 (Letter from Novo Sarajevo Crisis Staff to Radovan Karadžić, 5 June 1992), p. 1.

7643 D885 (Letter from Novo Sarajevo Crisis Staff to Radovan Karadžić, 5 June 1992), p. 1.

7644 Radomir Nešković, P2568 (Transcript from Prosecutor v. Krajišnik), T. 16707.

7645 Radomir Nešković, P2568 (Transcript from Prosecutor v. Krajišnik), T. 16707.

7646 D885 (Letter from Novo Sarajevo Crisis Staff to Radovan Karadžić, 5 June 1992), pp. 1, 4. Nešković testified that the police and TO and later the VRS were responsible for protecting the territory and defending the population. Radomir Nešković, T. 14277-14278 (6 June 2011).

7647 D885 (Letter from Novo Sarajevo Crisis Staff to Radovan Karadžić, 5 June 1992), pp. 1-3. See also Radomir Nešković, T. 14288-14290 (6 June 2011). 
and therefore had no report on those subjects. ${ }^{7648}$ 10 June $1992 .^{7649}$

The Crisis Staff ceased to exist on

2249. In July 1992, Branko Radan became the president of the Executive Board of the municipality, and he was succeeded in March 1993 by Budimir Obradović. ${ }^{7650}$ In March 1993, Milorad Katić, a former member of the SDS Municipal Board in Novo Sarajevo, became the president of the Novo Sarajevo Serb Assembly and the president of the municipality. ${ }^{7651}$

2250. With respect to police structures, after the outbreak of armed conflict in Sarajevo in April 1992, ${ }^{7652}$ Sarajevo's ten SJBs were divided between Bosnian Serbs and Bosnian Muslims. ${ }^{7653}$

The station in Novo Sarajevo was among the four that remained under the control of Bosnian Muslims. $^{7654}$ From around 4 April 1992, the MUP special forces operated at the premises of the BiH MUP school in Vraca. ${ }^{7655}$ On 6 April 1992, Serb Forces seized the police station in Novo Sarajevo. ${ }^{7656}$ Simo Sipčić was the head of the MP in Novo Sarajevo. ${ }^{7657}$ Milenko Jovanović was the head of the Novo Sarajevo SJB. ${ }^{7658}$

2251. On 21 July 1992, the Accused as President of the Presidency confirmed the appointment of the members of the War Commission for the Serb Municipality of Novo Sarajevo. ${ }^{7659}$ Dragan

\footnotetext{
7648 D885 (Letter from Novo Sarajevo Crisis Staff to Radovan Karadžić, 5 June 1992), p. 2. The Chamber notes that the Crisis Staff did, however, order and engage in mobilisation. See paras. 2259-2260.

7649 Radomir Nešković, P2568 (Transcript from Prosecutor v. Krajišnik), T. 16809.

7650 D2549 (Witness statement of Branko Radan dated 3 December 2012), para. 10; Branko Radan, T. 31097, 31100 31103 (6 December 2012).

7651 D2651 (Witness statement of Milorad Katić dated 10 December 2012), paras. 2, 6, 17-18. The minutes of a session of the Council of the Serb City of Sarajevo indicate Katić was also president of the Executive Board of the Serb Municipality of Novo Sarajevo. D2652 (Excerpt from minutes of RS City Council of Sarajevo meeting, 10 July 1993), p. 1.

7652 See para. 3541.

7653 Mirsad Kučanin, P16 (Transcript from Prosecutor v. Galić), T. 4499-4500; Mirsad Kučanin, P17 (Transcript from Prosecutor v. S. Milošević), T. 28934-28935; P27 (Witness statement of Mirsad Kučanin dated 4 September 2000), p. 2.

7654 Mirsad Kučanin, P16 (Transcript from Prosecutor v. Galić), T. 4500; Mirsad Kučanin, P17 (Transcript from Prosecutor v. S. Milošević), T. 28934-28935; P27 (Witness statement of Mirsad Kučanin dated 4 September 2000), p. 2. See also P2308 (SJB Ilidža report, 20 September 1993), pp. 1-2.

7655 D3749 (Witness statement of Milenko Karišik dated 23 June 2013), paras. 19, 23; Branko Radan, T. 31112 (6 December 2012); Božo Tomić, T. 30158 (13 November 2012); Radomir Nešković, P2568 (Transcript from Prosecutor v. Krajišnik), T. 16714.

7656 P5743 (Intercept of conversation between Jovan Tintor and Danilo Veselinović, 6 April 1992), p. 3. See also Radomir Nešković, P2568 (Transcript from Prosecutor v. Krajišnik), T. 16714.

7657 KDZ310, T. 9273 (29 November 2010).

7658 See Adjudicated Fact 2560; P2575 (Excerpt from session of Novo Sarajevo's Crisis Staff, 23 December 1991); Radomir Nešković, P2568 (Transcript from Prosecutor v. Krajišnik), T. 16668-16669.

7659 P5543 (Decision of Radovan Karadžić appointing a War Commission in Novo Sarajevo, 21 July 1992); Radomir Nešković, P2568 (Transcript from Prosecutor v. Krajišnik), T. 16592-16593. Nešković stated that he does not know to this day what the purpose of the War Commission was and that at the time it was set up, "legally elected municipal bodies", i.e., the municipal assembly and municipal executive board, were in existence. Radomir Nešković, P2568 (Transcript from Prosecutor v. Krajišnik), T. 16593.
} 
Đokanović, as the Republican Commissioner, was to serve as Chairman of the War Commission, whose members included Nešković, Milorad Katić, Danilo Škrba, and Milorad Šanjević. ${ }^{7660}$

\section{(2) Militarisation of Novo Sarajevo}

2252. The distribution of weapons started as the JNA withdrew from Slovenia and parts of Croatia in September 1991; weapons and ammunition were transported into $\mathrm{BiH}$ and delivered to places under SDS control, including former JNA barracks. ${ }^{7661}$

2253. On 1 or 2 March 1992, Serbs began to set up barricades at strategic points in Sarajevo and surrounding municipalities. ${ }^{7662}$ Those involved in organising the barricades included Serb employees of the BiH MUP such as then-assistant Minister of Interior Momčilo Mandić, Milenko Jovanović, and SDS officials such as Rajko Dukić, Jovan Tintor, and Ratko Adžić. ${ }^{7663}$ In the area of Grbavica, there were barricades at the Vrbanja Bridge and Bratstvo-Jedinstvo Bridge. ${ }^{7664}$ Men wearing black masks were manning the barricades, and vehicles without license plates arrived every half hour with armed men inside. ${ }^{7665}$

2254. Around the end of March and the beginning of April 1992, an increased number of armed individuals were present in Vraca and Grbavica; tanks were placed below the MUP school, mines were laid, and soldiers fired at people who went outside. ${ }^{7666}$ From 6 April to mid-May 1992, on

7660 P5543 (Decision of Radovan Karadžić appointing a War Commission in Novo Sarajevo, 21 July 1992); Radomir Nešković, P2568 (Transcript from Prosecutor v. Krajišnik), T. 16592-16593.

7661 P1938 (Witness statement of KDZ310 dated 28 November 2010), para. 10; KDZ310, T. 9201-9202 (29 November 2010). See also P5977 (BiH MUP daily bulletin, 16 October 1991), pp. 1-4; Predrag Trapara, T. 29915-29918 (7 November 2012).

7662 D3803 (List of SRBiH MUP employees, 13 March 1992), pp. 1, 2; P1938 (Witness statement of KDZ310 dated 28 November 2010), paras. 6, 8, 66; P2444 (Witness statement of KDZ354 dated 5 February 2011), para. 4 (under seal). See also Adjudicated Fact 2560. KDZ310 stated that the barricades were everywhere in Grbavica, so that people were not able to go to work that morning. P1937 (Witness statement of KDZ310 dated 28 November 2010), paras. 6-7 (under seal).

7663 D3803 (List of SRBiH MUP employees, 13 March 1992), pp. 2-3; P1938 (Witness statement of KDZ310 dated 28 November 2010), paras. 6, 8. See also Adjudicated Fact 2560.

7664 P1937 (Witness statement of KDZ310 dated 28 November 2010), para. 6 (under seal).

7665 P1938 (Witness statement of KDZ310 dated 28 November 2010), paras. 6-8. KDZ310 saw that Mandić, then Deputy Minister of Interior, was able to walk through the barricade at Vrbanja Bridge and cross the river. P1938 (Witness statement of KDZ310 dated 28 November 2010), para. 8.

7666 P43 (Witness statement of Mirsad Smajš dated 18 December 1993), e-court p. 4; P43 (Witness statement of Mirsad Smajš dated 14 January 1998), e-court p. 9; P1938 (Witness statement of KDZ310 dated 28 November 2010), paras. 11, 13; P2444 (Witness statement of KDZ354 dated 5 February 2011), para. 18 (under seal). Mirsad Smajš identified them as Serb soldiers, some wearing "the former Police uniform" and others "the camouflage uniforms". P43 (Witness statement of Mirsad Smajš 14 January 1998), e-court p. 9 (further stating that they called themselves the "White Eagles" and that there was no insignia on the uniforms but there were white ribbons on the sleeves). Witness KDZ354 stated that military trucks with JNA registration plates and reservists arrived in Grbavica in April 1992 and that there were armoured cars on patrol and soldiers wearing uniforms of the former JNA. P2444 (Witness statement of KDZ354 dated 5 February 2011), para. 18 (under seal) (further stating that the men on the trucks had longer hair and beards and carried weapons, including rifles, and that some wore helmets). The vehicles were usually heading toward or coming from the direction of Vrace. P2444 (Witness statement of KDZ354 dated 5 February 2011), paras. 18-19 (under seal). 
several occasions "JNA units" and armed SDS members would go to Grbavica during the night, stay for a while at the buildings, and return to their original positions before dawn. ${ }^{7667}$

2255. At the beginning of April 1992, TO staffs in the Sarajevo municipalities where Serbs lived were mobilised as the JNA was already "falling apart" ${ }^{7668}$ A unit of the Serb members of the Novo Sarajevo TO staff, previously of mixed composition, was organised. ${ }^{7669}$ The Serb TO set up a line of defence that ran in front of areas with a mainly Serb population. ${ }^{7670}$ Momir, a.k.a. "Momo", ${ }^{7671}$ Garić was the commander of the Serb TO in Grbavica. ${ }^{7672}$ Armed units-including Gavrilović and Aleksić's groups of Šešelj's men-were operating in the Sarajevo area in April 1992. ${ }^{7673}$

2256. Members of the Serb TO, amongst whom were Obradović and Garić, organised local Serbs and gave them weapons around the time the conflict began in Sarajevo in early April 1992. ${ }^{7674}$ A 20 March 1992 report of the Command of the $2^{\text {nd }}$ Military District of the JNA indicates that by

7667 P1938 (Witness statement of KDZ310 dated 28 November 2010), paras. 11, 13.

7668 D2379 (Witness statement of Momir Garić dated 2 November 2012), para. 12.

7669 D2379 (Witness statement of Momir Garić dated 2 November 2012), paras. 13; Momir Garić, T. 29656-29658 (5 November 2012). According to Garić, the neighbourhoods of Novo Sarajevo where Serbs were organised were Tilava, Lukavica, Vraca, Gornji Kovačići, Miljevići, and Petrovići, and these areas were considered to be inhabited by Serbs only. Momir Garić, T. 29656-29657, 29659-29660 (5 November 2012); D2379 (Witness statement of Momir Garić dated 2 November 2012), paras. 13, 22.

7670 D2379 (Witness statement of Momir Garić dated 2 November 2012), para. 13 (stating that the area of responsibility of this unit extended from the Slaviša Vajner Čiča Barracks in Lukavica "below Mojmilo hill and Ozrenska street in Vraca and the Sarajevo bypass to the Jewish cemetery and then towards Zlatište and the road to Trebević").

7671 Božo Tomić confirmed that "Momo" was a nickname for Momir Garić. Božo Tomić, T. 30163 (13 November 2012).

7672 Neđeljko Prstojević, T. 13689 (18 March 2011). See also P5958 (Intercept of conversation between Rade Milinković and Momo Garić, 21 April 1992), p. 1; P1478 (Ratko Mladić's notebook, 27 May-31 July 1992), pp. 28, 31. Garić, however, did not describe himself as the commander of the TO. According to Garić, he was merely a member of the TO and later the VRS, which he left in September 1992 to work at the RS Ministry of Defence in Pale. D2379 (Witness statement of Momir Garić dated 2 November 2012), paras. 12-14, 30; Momir Garić, T. 29644-29645 (5 November 2012).

7673 See P2228 (Intercept of conversation between Vojislav Šešelj and Branislav Gavrilović, April 1992); P2523 (Intercept of conversation between Kaća Dučić and Branislav Gavrilović, 21 April 1992); Neđeljko Prstojević, T. 13853-13855 (21 March 2011); P5707 (Intercept of conversation between Kaća Dučić and Radomir Ninković, 21 April 1992); P1148 (Intercept of conversation between Momčilo Mandić and Igor, 21 April 1992); Momčilo Mandić, C2 (Transcript from Prosecutor v. Krajišnik), T. 9025-9029; Momčilo Mandić, T. 4644-4645 (5 July 2010); D3197 (Witness statement of Dobrislav Planojević dated 23 March 2013), para. 29. Witness KDZ354 saw Šešelj in Grbavica standing among "a large group of soldiers in camouflage uniforms" and accompanied by Aleksić. P2444 (Witness statement of KDZ354 dated 5 February 2011), paras. 1, 101 (under seal); KDZ354, T. 13197-13198 (10 March 2011). Aleksić was a member of the SDS Municipal Board of Novo Sarajevo. Zdravko Šalipur, T. 31641-31642, 31644 (18 December 2012). He was a member of the Serbian Chetnik Movement and a "Chetnik" vojvoda, or military leader, as commander of the Novo Sarajevo Chetnik Detachment. P5035 (Order of Vojislav Šešelj, 13 May 1993), p. 1. See also P6057 (Ilidža SJB receipt for goods, 15 January 1994).

7674 D2418 (Witness statement of Božo Tomić dated 5 November 2012), paras. 7-8, 12; Božo Tomić, T. 3015930164, 30170-30171 (13 November 2012); D2379 (Witness statement of Momir Garić dated 2 November 2012), paras. 12-14, 26; Momir Garić, T. 29661 (5 November 2012). Tomić testified that he and his neighbours in Vrace were given weapons for protecting all of the local population but that he does not know if any Bosnian Muslims went to the Serb TO to be armed. Božo Tomić, T. 30159-30160 (13 November 2012). The TO would 
then, 2,800 "volunteer" men not from the JNA or the Serb TO had been recruited in Novo Sarajevo. ${ }^{7675}$

2257. Bosnian Muslims also armed themselves and organised militarily in Novo Sarajevo. ${ }^{7676}$ They started forming units in the first half of $1991 .^{7677}$

2258. On 4 April 1992, there were clashes between Serb and Muslim police forces at the $\mathrm{BiH}$ MUP school in Vraca. ${ }^{7678}$ After several hours of fighting Serb Forces placed the school under their control. $^{7679}$ A few hours after the clashes, in Miljevići village in Vraca, a vehicle arrived from the military barracks in Lukavica ${ }^{7680}$ with automatic and semi-automatic weapons, which were distributed to local members of the TO and other people from the surrounding area. ${ }^{7681}$ Weapons were also supplied from Pale. ${ }^{7682}$

2259. On 22 April 1992, on the basis of an SNB order, the Novo Sarajevo Crisis Staff ordered all able-bodied men between the ages of 18 and 60 residing in the area of the Serb Municipality of Novo Sarajevo to report for mobilisation within 24 hours at Lukavica. ${ }^{7683}$ The Crisis Staff's order

gather in local communes and discuss matters; one meeting location was the Pajaco facility across the road from the police station and school in Vrace. Momir Garić, T. 29661 (5 November 2012). P979 (Report from JNA $2^{\text {nd }}$ Military District to JNA General Staff, 20 March 1992), pp. 6, 11.

D2673 (Witness statement of Zdravko Šalipur dated 16 December 2012), para. 11; D2683 (Witness statement of Dragan Šojić dated 15 December 2012), para. 12; D2549 (Witness statement of Branko Radan dated 3 December 2012), para. 6; Branko Radan, T. 31103 (6 December 2012).

D2379 (Witness statement of Momir Garić dated 2 November 2012), para. 5; D2549 (Witness statement of Branko Radan dated 3 December 2012), para. 6; Branko Radan, T. 31103, 31107 (6 December 2012); D2673 (Witness statement of Zdravko Šalipur dated 16 December 2012), paras. 11, 13.

See Milorad Katić, T. 31400-31401 (13 December 2012); D2418 (Witness statement of Božo Tomić dated 5 November 2012), para. 6; Božo Tomić, T. 30158 (13 November 2012). According to Karišik and Dobrislav Planojević, pursuant to an agreement to divide the BiH MUP, the BiH MUP school in Vraca was to go to the Serbs. D3749 (Witness statement of Milenko Karišik dated 23 June 2013), para. 19; D3197 (Witness statement of Dobrislav Planojević dated 23 March 2013), para. 15.

D2379 (Witness statement of Momir Garić dated 2 November 2012), para. 9.

See para. 2275.

Milorad Katić, T. 31400-31403 (13 December 2012). Tomić and his neighbours in Vraca were organised around the same time. See para. 2256, fn. 7674.

Milorad Katić, T. 31403-31404 (13 December 2012).

D888 (Order of Novo Sarajevo Crisis Staff, 22 April 1992). But see KDZ310, T. 9271-9272 (29 November 2010) (testifying that he did not believe the 22 April 1992 order to be genuine or that it was ever implemented). According to KDZ310, in May 1992, a mobilisation of males from ages 18 up to 60 was carried out, which applied only to males of Serb ethnic origin, and men from other ethnic groups were not mobilised. P1938 (Witness statement of KDZ310 dated 28 November 2010), paras. 16-17. KDZ310 stated that this period was the only time that he knows of "when Mladić was present in Grbavica for an inspection of the troops". P1938 (Witness statement of KDZ310 dated 28 November 2010), para. 17. See also P1145 (Intercept of conversation between Momčilo Krajišnik and Ratko Mladić, 24 May 1992), p. 5 (indicating that Mladić was located "by Miljacka" at that time). KDZ310 heard that Mladić confirmed that the mobilisation applied only to Serbs "for the time being”. P1937 (Witness statement of KDZ310 dated 28 November 2010), para. 17 (under seal). 
also stated that those who did not report for mobilisation, in violation of the order, would be subject to the Law on Military Obligation and Military Court and their property would be confiscated. ${ }^{7684}$

2260. In a report of 5 June 1992, the Novo Sarajevo Crisis Staff informed the President of the Bosnian Serb Presidency that it had mobilised about 900 people over the previous two months, including about 700 in the Lukavica and Tilava area and about 200 in Grbavica. ${ }^{7685}$

2261. Pursuant to an order of the SRK Command on 22 May 1992, the Novo Sarajevo TO comprising locals of Grbavica, Hrasno, Vrace, and Kovačići was organised into the SRK. ${ }^{7686}$

\section{(C) Take-over}

2262. Combat activity increased in late April 1992. ${ }^{7687}$ The Serb TO was engaged in Grbavica on 21 April 1992. ${ }^{7688}$ Garić requested additional men, and Prstojević, from Ilidža, prepared a platoon from Kasindol to assist. ${ }^{7689}$ JNA forces shelled Novo Sarajevo at the end of April $1992 .^{7690}$ Fighting also took place in May 1992. ${ }^{7691}$

7684 D888 (Order of Novo Sarajevo Crisis Staff, 22 April 1992).

7685 D885 (Letter from Novo Sarajevo Crisis Staff to Radovan Karadžić, 5 June 1992), p. 3 (indicating that "mobilisation was carried out in various ways (personally and directly, through SDS [...] local boards and local communes, with the help of police, etc.)").

7686 P1505 (SRK Order, 22 May 1992), p. 1; Božo Tomić, T. 30163-30164 (13 November 2012). See also D2351 (Witness statement of Stevan Veljović dated 19 October 2012), paras. 12-13. The TO had earlier been incorporated into the JNA. D2379 (Witness statement of Momir Garić dated 2 November 2012), paras. 14, 22; Momir Garić, T. 29663-29667 (5 November 2012).

7687 P5703 (Intercept of conversation between Momo Garić and "Velibor", 21 April 1992); P5705 (Intercept of conversation between Neđeljko Prstojević and unidentified male, 21 April 1992); P5706 (Intercept of conversation between Milenko Karišik and Slobodan Škipina, 21 April 1992); P5708 (Intercept of conversation between Momčilo Krajišnik and unidentified male, 21 April 1992); P5709 (Intercept of conversation between Radomir Ninković, Milenko Karišik, Nikola Koljević, and Momčilo Krajišnik, 21 April 1992); P5710 (Intercept of conversation between Neđeljko Prstojević and Krstović, 21 April 1992); D1202 (Intercept of conversation between Momo Garić and Neđeljko Prstojević, 21 April 1992); P5959 (Intercept of conversation between "Ranko" and Momo Garić, 21 April 1992); D920 (Intercept of conversation between Radovan Karadžić and Radovan Pejić, 23 April 1992).

7688 P5705 (Intercept of conversation between Neđeljko Prstojević and unidentified male, 21 April 1992), pp. 1-2; P5709 (Intercept of conversation between Radomir Ninković, Milenko Karišik, Nikola Koljević, and Momčilo Krajišnik, 21 April 1992), p. 2.

7689 P5703 (Intercept of conversation between Momo Garić and "Velibor", 21 April 1992); D1202 (Intercept of conversation between Momo Garić and Neđeljko Prstojević, 21 April 1992), p. 3; P5959 (Intercept of conversation between "Ranko" and Momo Garić, 21 April 1992), p. 1; P5705 (Intercept of conversation between Neđeljko Prstojević and unidentified male, 21 April 1992), p. 1; Neđeljko Prstojević, T. 13687-13690 (18 March 2011). See also P5710 (Intercept of conversation between Neđeljko Prstojević and Krstović, 21 April 1992), pp. 1-2.

7690 See Adjudicated Fact 2582. See also P2444 (Witness statement of KDZ354 dated 5 February 2011), paras. 1213 (under seal).

7691 P2240 (Intercept of conversation between Momčilo Krajišnik, Branko Đerić, and Milenko Karišik, 7 May 1992), pp. 1-2; P2332 (Intercept of conversation between Čedo and Radovan Karadžić, 30 May 1992), pp. 5-6; D2379 (Witness statement of Momir Garić dated 2 November 2012), paras. 21, 23; D2519 (Witness statement of Dragan Maletić dated 9 November 2012), para. 7; Momir Garić, T. 29734-29735 (5 November 2012); Zdravko Šalipur, T. 31642 (18 December 2012). Defence witnesses stated that Muslim forces fired on Grbavica and Lukavica. D2651 (Witness statement of Milorad Katić dated 10 December 2012), para. 5; D2379 (Witness 
2263. By mid-May, Grbavica was occupied by the Serbs, after an initiative by Serb Forces to move the confrontation line. ${ }^{7692}$ The line was established on the bank of the Miljacka River, including by the Bratstvo-Jedinstvo Bridge and Vrbanja Bridge, extending west toward Hrasno and east toward Skenderija. ${ }^{7693}$ Serb Forces took Grbavica with little fighting. ${ }^{7694}$ After the Serb takeover of Grbavica, it became no longer possible to cross over the Miljacka River. ${ }^{7695}$

\section{(1) Searches of Bosnian Muslim and Bosnian Croat houses}

2264. During the take-over, members of the Serb Forces, including theVRS, the police, and Šešelj’s men, searched Bosnian Muslim and Croat houses in Grbavica for weapons. ${ }^{7696}$ In one such instance, on 7 May 1992, a group of seven or eight armed soldiers came to the house of Smajš, a Bosnian Muslim, in Vrace to search for weapons. ${ }^{7697}$ Although they did not find any, they ordered Smajš to go with them. ${ }^{7698}$ Outside, a soldier ordered him to walk, with his head down, toward the Golf Café, in front of which a group of ten soldiers stood. ${ }^{7699}$ He was ordered to strip to the waist

statement of Momir Garić dated 2 November 2012), paras. 14, 17, 20; D2418 (Witness statement of Božo Tomić dated 5 November 2012), paras. 9-10, 19; Božo Tomić, T. 30179-30182, 30227 (13 November 2012); D2519 (Witness statement of Dragan Maletić dated 9 November 2012), paras. 20, 32, 39.

7692 P1938 (Witness statement of KDZ310 dated 28 November 2010), paras. 11, 13-15; D2379 (Witness statement of Momir Garić dated 2 November 2012), para. 16. See also Momčilo Mandić, C2 (Transcript from Prosecutor v. Krajišnik), T. 8708-8709. KDZ310 identified JNA and VRS forces as taking Grbavica. P1938 (Witness statement of KDZ310 dated 28 November 2010), paras. 11, 13-14; KDZ310, T. 9228 (29 November 2010). See also P926 (Witness statement of Aernout van Lynden dated 26 February 2010), para. 99; D2379 (Witness statement of Momir Garić dated 2 November 2012), para. 16; Adjudicated Facts 66, 68. P1938 (Witness statement of KDZ310 dated 28 November 2010), paras. 11, 13, 15; D2379 (Witness statement of Momir Garić dated 2 November 2012), para. 16. See para. 3557.

7694 P1938 (Witness statement of KDZ310 dated 28 November 2010), para. 14; Witness KDZ310, T. 9213-9214, 9228 (29 November 2010); D2379 (Witness statement of Momir Garić dated 2 November 2012), para. 16; Momir Garić, T. 29718-29720 (5 November 2012); P5695 (Intercept of conversation between Branko Đerić and Milenko Karišik, 7 May 1992), p. 3. In an intercepted conversation on 5 May 1992, Mandić said to Branko Kvesić: "We came down and cleaned Grbavica". P1103 (Intercept of conversation between Momčilo Mandić and Branko Kvesić/Bruno Stojić/Mićo Stanišić, 5 May 1992), p. 4. Later in the conversation, Mandić said to Bruno Stojić: "We očistiti /cleansed or mopped up/ Novo Sarajevo." P1103 (Intercept of conversation between Momčilo Mandić and Branko Kvesić/Bruno Stojić/Mićo Stanišić, 5 May 1992), p. 9. Mandić testified that the participants in the conversation knew that it was being intercepted and that these statements were jokes and did not reflect the actual situation on the ground. Momčilo Mandić, T. 4609-4611 (5 July 2010). Considering Mandić's interest in minimising the significance of his statements in the intercepted conversation as well as his evasiveness and partiality on this point, the Chamber does not find Mandić's evidence to be reliable in this regard.

7695 KDZ310, T. 9255 (29 November 2010).

7696 See Adjudicated Fact 2584; P2444 (Witness statement of KDZ354 dated 5 February 2011), para. 24 (under seal); P43 (Witness statement of Mirsad Smajš dated 18 December 1993), e-court pp. 4-5; P43 (Witness statement of Mirsad Smajš dated 14 January 1998), e-court p. 9.

7697 P43 (Witness statement of Mirsad Smajš dated 18 December 1993), e-court p. 4; P43 (Witness statement of Mirsad Smajš dated 14 January 1998), e-court pp. 8-9. Smajš described the armed men who came to his home as wearing camouflage uniforms and stated that outside his house, there were also men "in the Police uniforms" and men not wearing any uniforms. P43 (Witness statement of Mirsad Smajš dated 18 December 1993), e-court p. 4; P43 (Witness statement of Mirsad Smajš dated 14 January 1998), e-court pp. 8-9. P43 (Witness statement of Mirsad Smajš dated 18 December 1993), e-court p. 4.

7699 P43 (Witness statement of Mirsad Smajš dated 18 December 1993), e-court p. 4; P43 (Witness statement of Mirsad Smajš dated 14 January 1998), e-court pp. 8-9. 
and was then beaten with rifle butts, punched, and kicked all over for about 15 to 20 minutes. ${ }^{7700}$ He was then transported, along with his neighbour Mirsad Dedić, in a military vehicle to the MUP school at Vrace. ${ }^{7701}$ During the ride they were both beaten and one of the soldiers fired his unloaded automatic rifle three times into his temple; they were beaten again at the MUP school. ${ }^{7702}$ Smajš, blindfolded and with his hands tied behind his back, was then transported, along with Dedić, to "Kula prison". 7703

2265. Other Bosnian Muslims in Grbavica were frequently subjected to house searches by members of Serb Forces. ${ }^{7704}$ All Muslims had been asked to voluntarily surrender their weapons and a Commander Major Petković had told those who did so that the VRS would not search their flats. $^{7705}$

2266. The 5 June 1992 report of the Novo Sarajevo Crisis Staff stated, in the section entitled "[t]reatment of Muslims and Croats":

Citizens of all nationalities assemble frequently, especially in Grbavica, and our public attitude is very correct, we appoint a head of every building who is responsible for the situation in his building and for all the information about the occupants. Secretly, the police apply the usual procedure to people who were engaged in military activities against us. We informed the Muslims that they would be safe if they were militarily neutral to us, and so far the situation has been good. ${ }^{7706}$

7700 P43 (Witness statement of Mirsad Smajš dated 18 December 1993), e-court pp. 4; P43 (Witness statement of Mirsad Smajš dated 14 January 1998), e-court pp. 8-9. With respect to the men who beat him, Smajš said that based on their accents they were not from Grbavica and were probably from somewhere in Serbia. P43 (Witness statements of Mirsad Smajš dated 18 December 1993), e-court p. 5 ; P43 (Witness statements of Mirsad Smajš dated 18 December 1993 and 14 January 1998), e-court p. 9.

7701 P43 (Witness statement of Mirsad Smajš dated 18 December 1993), e-court pp. 4-5; P43 (Witness statement of Mirsad Smajš dated 14 January 1998), e-court p. 9.

7702 P43 (Witness statement of Mirsad Smajš dated 18 December 1993), e-court p. 5; P43 (Witness statement of Mirsad Smajš dated 14 January 1998), e-court p. 9.

7703 P43 (Witness statement of Mirsad Smajš dated 18 December 1993), e-court p. 5; P43 (Witness statement of Mirsad Smajš dated 14 January 1998), e-court pp. 8-9. See Scheduled Detention Facility C.18.2.

7704 P2444 (Witness statement of KDZ354 dated 5 February 2011), paras. 1, 24, 39-46 (under seal); KDZ354, T. 13215-13216, 13221 (11 March 2011). One of the men who came to KDZ354's building asked if there were any "balijas" there. Some wore JNA uniforms and others wore "military uniforms" with a white belt as she had seen military policemen wear. P2444 (Witness statement of KDZ354 dated 5 February 2011), paras. 24, 39, 41 (under seal).

7705 Radomir Nešković, P2568 (Transcript from Prosecutor v. Krajišnik), T. 16715. See also Radomir Nešković, T. 14292-14293 (6 June 2011).

7706 D885 (Letter from Novo Sarajevo Crisis Staff to Radovan Karadžić, 5 June 1992), pp. 3-4. According to Nešković, who signed the report, if "any inhabitants" noticed, in their building, Muslims who did not surrender their weapons and acted against the VRS, they were required to report the fact to the civilian police and "then further police procedures would be implemented", including arrest of the individual concerned. Radomir Nešković, P2568 (Transcript from Prosecutor v. Krajišnik), T. 16715-16716. See also Radomir Nešković, T. 14288, 14292-14293 (6 June 2011). The Chamber accepts Nešković's evidence with respect to his statement that Muslims were arrested. However, considering Nešković's interest in casting the report and the actions of the Crisis Staff in a favourable light, the Chamber does not consider that Nešković was entirely forthright in his explanation of "the usual procedure", applied "[s]ecretly", to which the report refers. The Chamber will therefore not rely on this portion of Nešković's evidence. 


\section{(2) $\underline{\text { Other acts }}$}

2267. Bosnian Muslims and Croats were forced to perform labour under the responsibility of VRS platoon or company commanders in Novo Sarajevo. ${ }^{7707}$ There were prisoners from Kula Prison in Ozrenska; there they had to dig trenches between the confrontation lines. ${ }^{7708}$ Several men were killed by sniper fire while performing these work duties. ${ }^{7709}$ Before the winter of 1992, detainees from Kula Prison were no longer brought to Ozrenska and they were replaced by "people from Grbavica". 7710

2268. Bosnian Muslims and Croats were beaten during the course of searches for weapons. ${ }^{7711}$ They were sexually assaulted and raped by soldiers wearing former JNA uniforms. ${ }^{7712}$ Bosnian Muslims and Croats were also killed. ${ }^{7713}$ Members of the VRS, including the MP, and of the civilian police engaged in mass looting from the point the VRS entered Grbavica. ${ }^{7714}$ While the looting did not take place pursuant to an order, it went unchecked without the perpetrators being

7707 P1938 (Witness statement of KDZ310 dated 28 November 2010), para. 46; P1937 (Witness statement of KDZ310 dated 28 November 2010), para. 18 (under seal). See also P2444 (Witness statement of KDZ354 dated 5 February 2011), para. 81 (under seal).

7708 P1938 (Witness statement of KDZ310 dated 28 November 2010), para. 46; P161 (Adem Balić's statement to BiH authorities, 7 February 1993), p. 3. See para. 2157. KDZ310 stated that he knew they were prisoners from Kula Prison because he asked them. P1938 (Witness statement of KDZ310 dated 28 November 2010), para. 46. See also D2418 (Witness statement of Božo Tomić dated 5 November 2012), para. 15; Božo Tomić, T. 30200 30204 (13 November 2012) (stating that a "work detail" composed of Muslim detainees from Kula Prison was engaged to help fortify the confrontation line at Sanač by digging trenches and covering the trenches). Tomić testified that coming to the area was not safe for members of the VRS but denied that the work detail was in danger in carrying out the tasks of digging and covering trenches at the line. Božo Tomić, T. 30201-30205, 30208-30209 (13 November 2012). But see P5987 (Special report of the $2^{\text {nd }}$ Infantry Battalion, 21 May 1993), pp. 1-2 (reporting to the Kula Prison Administration the escape of two Muslim detainees who had been building bunkers with nine other detainees and stating that the area where they were working was constantly under enemy fire). Tomić stated that the area referred to in the report was about 1,500 metres from his position. Božo Tomić, T. 30205-30207 (13 November 2012).

7709 P1938 (Witness statement of KDZ310 dated 28 November 2010), para. 46; P161 (Adem Balić's statement to BiH authorities, 7 February 1993), p. 3. The Chamber has already discussed these killings in the Ilidža Section of this Judgement. See para. 2157.

7710 P1938 (Witness statement of KDZ310 dated 28 November 2010), para. 46.

7711 P43 (Witness statement of Mirsad Smajš dated 18 December 1993 and 14 January 1998), e-court pp. 4-5, 9; P1937 (Witness statement of KDZ310 dated 28 November 2010), paras. 18-19, 23 (under seal); P2444 (Witness statement of KDZ354 dated 5 February 2011), paras. 50, 52-54 (under seal); KDZ354, T. 13223 (11 March 2011).

7712 P2444 (Witness statement of KDZ354 dated 5 February 2011), paras. 39-40, 47-60, 74 (under seal); KDZ354, T. 13192-13193 (10 March 2011); P1937 (Witness statement of KDZ310 dated 28 November 2010), para. 18 (under seal).

7713 P1937 (Witness statement of KDZ310 dated 28 November 2010), para. 20 (under seal); KDZ310, 9274-9275 (29 November 2010); P43 (Witness statement of Mirsad Smajš dated 18 December 1993 and 14 January 1998), e-court p. 5. The Chamber notes that these killings are not charged in either Schedule A or B of the Indictment.

7714 KDZ310, T. 9249-9250 (29 November 2010). See also D885 (Letter from Novo Sarajevo Crisis Staff to Radovan Karadžić, 5 June 1992), p. 3 (reporting that robberies, especially car thefts, had been rife); P2444 (Witness statement of KDZ354 dated 5 February 2011), paras. 7-8 (under seal) (describing car thefts in Grbavica in April 1992). 
brought to account. ${ }^{7715}$ Non-Serbs experienced psychological pressure as they feared being taken away or beaten. ${ }^{7716}$

2269. Veselin Vlahović, known as Batko, committed numerous crimes in Novo Sarajevo. ${ }^{7717} \mathrm{He}$ looted in June to July 1992. ${ }^{7718}$ He targeted Muslims and Croats and "was involved in all sorts of violence". 7719 He killed a number of non-Serbs. ${ }^{7720}$ Batko raped Bosnian Muslim women during house searches for weapons in June to September 1992. ${ }^{7721}$ Other non-local Serbs, including Zoka, mistreated Bosnian Muslims and Croats in the area of Grbavica. ${ }^{7722}$

2270. Municipal authorities were aware of the crimes committed by Batko and others over a period of months. A note of the Novo Sarajevo SJB and Vraca Reserve Police Station dated 31 May 1992 identified "Veselin Vlaović" as among members of the MP formed as part of the Novo Sarajevo Battalion who were "undertaking certain operations on their own without any authority", including carrying out searches of apartments and vehicles and taking "private and socially-owned property, securities and gold coins". ${ }^{7723}$ From around July 1992, municipal authorities discussed the problems caused by these men, did not support them, and, around

7715 KDZ310, T. 9250, 9254, 9265, 9274 (29 November 2010).

7716 P1937 (Witness statement of KDZ310 dated 28 November 2010), para. 23 (under seal).

7717 Radomir Nešković, P2568 (Transcript from Prosecutor v. Krajišnik), T. 16699-16705; Branko Radan, T. 31095-31096 (6 December 2012); P1938 (Witness statement of KDZ310 dated 28 November 2010), para. 19. KDZ354 said that she saw Batko wearing "an olive-drab uniform" and carrying a rifle and, at a later time, a camouflage uniform with an insignia on his sleeve saying "The Army of Republika Srpska" and showing a flag. KDZ354, T. 13194 (10 March 2011), T. 13225 (11 March 2011); P2444 (Witness statement of KDZ354 dated 5 February 2011), para. 65 (under seal) (stating that Batko himself said that he was a Montenegrin). See also D1278 (Transcript of Radomir Nešković's interview with Karadžić's legal associate, 8 October 2009), pp. 4041. Radan testified that Batko wore an army uniform but that he was not connected to the army. Branko Radan, T. 31097, 31109 (6 December 2012). But see D3197 (Witness statement of Dobrislav Planojević dated 23 March 2013), para. 26 (stating that "Batko was supposedly a member of the army").

7718 Radomir Nešković, P2568 (Transcript from Prosecutor v. Krajišnik), T. 16701-16702, 16704 (stating that Batko would enter people's flats at night, steal property, and commit "other misdeeds" and that there were rumours that he committed murders); D1278 (Transcript of Radomir Nešković's interview with Karadžić's legal associate, 8 October 2009), p. 41; P2444 (Witness statement of KDZ354 dated 5 February 2011), paras. 61-62 (under seal); KDZ354, T. 13239-13240 (11 March 2011). See also Adjudicated Fact 2586.

7719 Radomir Nešković, P2568 (Transcript from Prosecutor v. Krajišnik), T. 16704. See also D3197 (Witness statement of Dobrislav Planojević dated 23 March 2013), para. 26.

7720 KDZ310, T. 9274-9275 (29 November 2010). The Chamber notes that these killings are not charged in either Schedule A or B of the Indictment.

7721 See Adjudicated Fact 2585. Radomir Nešković stated that Batko committed rapes in Grbavica. D1278 (Transcript of Radomir Nešković's interview with Karadžić's legal associate, 8 October 2009), p. 41.

7722 D2549 (Witness statement of Branko Radan dated 3 December 2012), para. 13; Branko Radan, T. 31095-31096, 31107-31110 (6 December 2012). Vladimir Lukić stated that there was "chaos" in Grbavica with the outbreak of conflict owing to "self-appointed individuals" like "Batak" mistreating individuals, regardless of their ethnicity. D3563 (Witness statement of Vladimir Lukić dated 18 May 2013), para. 7. In light of other evidence and considering the witness's lack of candour on this point, the Chamber does not consider as reliable Lukić's statement in relation thereto.

7723 P6017 (Official note of Novo Sarajevo SJB, 31 May 1992), p. 2 (further stating that they were armed and in uniform). See also P1938 (Witness statement of KDZ310 dated 28 November 2010), para. 63. 
September 1992, tried to remove Batko and the others from the municipality. ${ }^{7724}$ Radan testified that "something could have been done earlier" to stop Batko's crimes, before he was eventually removed from the municipality. ${ }^{7725}$ Nešković stated that he informed Šipčić about Batko and that Batko was arrested by Šipčić on several occasions but "somebody would always release him". 7726 Batko "terrorise[d]" the population for a period of months; the MP could have arrested him at any time and the prosecutor's office could have tried him. ${ }^{7727}$ KDZ310 stated that no action was taken against Batko and that at some point he "disappeared" from Grbavica. ${ }^{7728}$ KDZ354 testified that she reported crimes committed by Batko to the Bosnian Serb MP in July 1992 but was not approached at any time by Bosnian Serb authorities regarding any investigation into the incident she reported. ${ }^{7729}$

2271. Republic-level leaders were also aware of the ongoing crimes by Batko and others. Vladimir Lukić stated that he spoke about the situation in Grbavica, though not about "Batak" specifically, with Koljević. ${ }^{7730}$ Nešković also stated that "the top leadership at Pale was told about Batko by Biljana Plavsić and it never yielded any results [...]". 7731 Dobrislav Planojević, who worked in the MUP from 20 April 1992, stated that he heard about what Batko was doing and the absence of any reporting or investigation due to fear and that he informed Mićo Stanišić about this. ${ }^{7732} \mathrm{He}$ also informed Prime Minister Đerić in 1992 about problems with crime in the area and with Batko. ${ }^{7733}$

7724 D2549 (Witness statement of Branko Radan dated 3 December 2012), para. 13; Branko Radan, T. 31095-31096, 31109-31111 (6 December 2012).

7725 Branko Radan, T. 31112-31113 (6 December 2012).

7726 Radomir Nešković, P2568 (Transcript from Prosecutor v. Krajišnik), T. 16709-16710; Radomir Nešković, T. 14318-14319 (7 June 2011); D1278 (Transcript of Radomir Nešković's interview with Karadžić's legal associate, 8 October 2009), p. 41. Nešković's report of 5 June 1992 discussed ongoing looting but did not refer specifically to Batko or other perpetrators. Radomir Nešković, P2568 (Transcript from Prosecutor v. Krajišnik), T. 16712; D885 (Letter from Novo Sarajevo Crisis Staff to Radovan Karadžić, 5 June 1992), p. 3.

7727 Radomir Nešković, T. 14309, 14316-14318 (7 June 2011).

7728 KDZ310, T. 9275 (29 November 2010). See also D2651 (Witness statement of Milorad Katić dated 10 December 2012), para. 3. Planojević stated that Batko disappeared from Grbavica for about ten days but that on his return the army arrested and detained him. D3197 (Witness statement of Dobrislav Planojević dated 23 March 2013), para. 27.

7729 KDZ354, T. 13192-13193 (10 March 2011).

7730 D3563 (Witness statement of Vladimir Lukić dated 18 May 2013), paras. 7-8 (stating that he was appointed commissioner of Novo Sarajevo municipality around this time by a decision of the Accused as President).

7731 Radomir Nešković, P2568 (Transcript from Prosecutor v. Krajišnik), T. 16710.

7732 D3197 (Witness statement of Dobrislav Planojević dated 23 March 2013), paras. 2, 17, 26 (stating that he was chief of the Crime Prevention and Detection Administration until mid-July 1992, became a National Security Service inspector in September 1992, and was chief of the State Security Centre Sarajevo from July 1994 to June 1995).

7733 D3197 (Witness statement of Dobrislav Planojević dated 23 March 2013), para. 27. See also P4982 (Witness Statement of Branko Đerić dated 5 April 2012), para. 14 (stating that he had received information through "private channels" about problems with a man in Grbavica named "Batica" and issues with detaining him). 
2272. On 20 October 1992, Defence Minister Bogdan Subotić proposed to the Accused the introduction of military rule in parts of the territory of RS, including the municipality of Novo Sarajevo. ${ }^{7734}$ Subotić set out as the causes for introduction of military rule "the fact that the political and security situation in some [RS] municipalities has become more tense due to the increasingly active paramilitary formations, quasi-state organs and institutions", that legal state organs were not performing their duties in accordance with the Constitution and laws and with adopted defence goals, and that decisions by the Government and other state organs were not being respected. ${ }^{7735}$

2273. On 15 November 1992, at a meeting of the SRK Command where then-President of Novo Sarajevo Municipality, Milivoje Prijić, was present, it was noted that among the flaws of the operations was "genocide on other nations". ${ }^{7736}$ The meeting also noted: "[t]he understanding and practice of individuals and groups that they are masters of life and death to every individual of different ethnicity, resulting in cases of unnecessary mistreatment and killing of members of other ethnicities, especially Muslims. Such people see the Geneva and other conventions as obsolete and unnecessary in this war."7737 Prijić gave a speech about the situation in Novo Sarajevo in which he stated: “A great portion of soldiers is exercising unruly behaviour. Mass removals of property from the municipality, rape, expulsions from flats are going unpunished, affecting morale. Military police are consolidating but are still not strong enough." 7738

\section{(D) Scheduled Detention Facility C.18.1}

2274. The Indictment refers to the use of the Slaviša Vajner Čiča Barracks in Lukavica as a detention facility from 22 June 1992 until September $1992 .{ }^{7739}$

2275. Lukavica, about three kilometres from Kula, was an area held by the SRK. ${ }^{7740}$ The Slaviša Vajner Čiča Barracks in Lukavica served as the Forward Command Post of the SRK. ${ }^{7741}$

\footnotetext{
7734 D458 (RS Ministry of Defence letter to Radovan Karadžić, 20 October 1992).

7735 D458 (RS Ministry of Defence letter to Radovan Karadžić, 20 October 1992).

7736 P5065 (Minutes of SRK Command consultation meeting, 15 November 1992), pp. 1-2, 4.

7737 P5065 (Minutes of SRK Command consultation meeting, 15 November 1992), p. 9. See also Branko Radan, T. 31124 (6 December 2012).

7738 P5065 (Minutes of SRK Command consultation meeting, 15 November 1992), p. 12. According to Radan, municipal leaders wanted to stop the crimes by VRS soldiers but lacked the capacity to do so and that they would have required co-operation from the army and the civilian and military police. Branko Radan, T. 31127 (6 December 2012). The Chamber notes Radan's interest in distancing himself from responsibility for addressing the crimes and does not consider his evidence reliable in this regard. The Chamber also considered its broader assessment of the testimony that the witness was witholding information from the Chamber on certain points.

7739 Indictment, Scheduled Detention Facility C.18.1. However, the Prosecution in its Final Brief refers only to detention around 22 June 1992. Prosecution Final Brief, Appendix B, p. 29.
} 
2276. On 22 June 1992, around 9 p.m., approximately 280 men who had previously been detained in the garage of the Hadžići Municipal Assembly Building ${ }^{7742}$ and in the Hadžići Culture and Sport centre $^{7743}$ were placed on four buses and transferred to the Slaviša Vajner Čiča Barracks in Lukavica. ${ }^{7744}$ The driver of one of the buses was Milan Ačimović. ${ }^{7745}$ The buses first went to Kula prison, in front of which two Serb individuals in camouflage uniforms got on the buses and started beating the detainees badly; these beatings resulted in head injuries. ${ }^{776}$ One of the soldiers extinguished a cigarette butt on the face of one of the Bosnian Muslims. ${ }^{7747}$ The soldiers threw bullets among the detainees and said, “[h]ey, balija, you have ammunition!”; they then used that as "a pretext" to beat the detainees. ${ }^{7748}$ The detainees were then taken to the Slaviša Vajner Čiča Barracks in Lukavica. ${ }^{7749}$

2277. Upon arrival at the Slaviša Vajner Čiča Barracks, the detainees exited the buses and were beaten by Serbs in uniforms as they made their way to the barracks. ${ }^{7750}$ Inside, the detainees were beaten with rifles, batons, and various objects when they went to the toilet or to get a drink of water. ${ }^{7751}$ Some people chose not to go to the toilet because they did not want to be beaten on the way. ${ }^{7752}$ All 280 of them were put in two empty rooms; as a result the rooms were very crowded. $^{7753}$ During the first hours of detention, individual detainees were called out and

\footnotetext{
7740 Momčilo Mandić, C2 (Transcript from Prosecutor v. Krajišnik), T. 8879. See also Adjudicated Fact 2630.

7741 KDZ088, T. 6277-6278 (7 September 2010) (closed session); P989 (Witness statement of Richard Philipps dated 25 May 2010), pp. 11, 17; Desimir Šarenac, T. 34922 (6 March 2013). See also John Hamill, P1994 (Transcript from Prosecutor v. Galić), T. 6115-6116; Hussein Ali Abdel-Razek, T. 5501 (19 July 2010).

7742 See Scheduled Detention Facility C.11.1.

7743 See Scheduled Detention Facility C.11.2.

7744 P2403 (Witness statement of Mehmed Musić dated 28 February 2011), paras. 51, 64-72; Mehmed Musić, T. 12868-12869 (3 March 2011); see Adjudicated Facts 2617, 2630. See also P161 (Adem Balić's statement to BiH authorities, 7 February 1993), p. 2 (stating that people were taken from the Sport centre to Lukavica on the night of 20 June 1992). See paras. 2099, 2106.

7745 P161 (Adem Balić's statement to BiH authorities, 7 February 1993), p. 2.

7746 P2403 (Witness statement of Mehmed Musić dated 28 February 2011), paras. 67-69 (referring to the men as "Chetniks"); P161 (Adem Balić's statement to BiH authorities, 7 February 1993), p. 2.

7747 P2403 (Witness statement of Mehmed Musić dated 28 February 2011), para. 69; Mehmed Musić, T. 12870 (3 March 2011). See also P161 (Adem Balić's statement to BiH authorities, 7 February 1993), p. 2.

7748 P2403 (Witness statement of Mehmed Musić dated 28 February 2011), para. 69; Mehmed Musić, T. 12870 (3 March 2011).

7749 P2403 (Witness statement of Mehmed Musić dated 28 February 2011), para. 69-72; P161 (Adem Balić's statement to BiH authorities, 7 February 1993), p. 2.

$7750 \quad$ P2403 (Witness statement of Mehmed Musić dated 28 February 2011), para. 72.

7751 P2403 (Witness statement of Mehmed Musić dated 28 February 2011), paras. 75-76; P161 (Adem Balić’s statement to BiH authorities, 7 February 1993), p. 2. See also Adjudicated Fact 2631.

7752 P2403 (Witness statement of Mehmed Musić dated 28 February 2011), para. 76. The detainees were also given only a few minutes to go to the toilet or get water. P161 (Adem Balić's statement to BiH authorities, 7 February 1993), p. 2.

7753 P2403 (Witness statement of Mehmed Musić dated 28 February 2011), para. 72; Mehmed Musić, T. 12872 (3 March 2011); P161 (Adem Balić's statement to BiH authorities, 7 February 1993), p. 2.
} 
beaten. ${ }^{7754}$ All 280 detainees were then taken to one room in another part of the barracks. ${ }^{7755}$ Subsequently, a man in uniform called out a list of 48 men. ${ }^{7756}$ Each of these men had to walk through a corridor with guards lined up on both sides and was beaten with various objects and kicked. ${ }^{7757}$ The guards swore at the detainees' "balija" mothers. ${ }^{7758}$ One of the detainees, Mehmed Musić, saw his brother, covered in blood, lying on the ground and was told to carry him. ${ }^{7759}$ Musić carried his brother into the room at the end of the gauntlet as instructed and saw the other detainees who had been called out, lined up against three walls, and three officers at a desk in the middle of the room. ${ }^{7760}$ They asked Musić his name, his father's name, and where he worked and "swore on [his] balija mother", and one of them kicked him. ${ }^{7761}$ One of the officers hit him and told him to get out, and as he went through the hallway, he was hit again. ${ }^{7762}$ Musić returned to the previous room and has not seen any member of the group of 47 since. ${ }^{7763}$ Soldiers later came twice to beat the detainees. ${ }^{7764}$ They also made the detainees make the sign of the cross and sing Serb songs. ${ }^{7765}$

7754 P2403 (Witness statement of Mehmed Musić dated 28 February 2011), paras. 73-74 (stating that he saw black and blue marks on the individuals when they returned); P161 (Adem Balić's statement to BiH authorities, 7 February 1993), p. 2. According to Musić, one of the men called out during this time, Kardaš Alija, was taken out of the room, those in the room heard him screaming and a shot, and he was not brought back to the room. P2403 (Witness statement of Mehmed Musić dated 28 February 2011), para. 73. The Chamber notes that there is no killing charged in relation to this detention facility pursuant to either Schedule B or C of the Indictment. See fn. 13; Indictment, para. 60(a)(ii), fn. 4.

7755 P2403 (Witness statement of Mehmed Musić dated 28 February 2011), para. 77.

7756 P2403 (Witness statement of Mehmed Musić dated 28 February 2011), paras. 78-79; P161 (Adem Balić's statement to BiH authorities, 7 February 1993), p. 2. Musić later learned that the man was Vujo Vukotić. P2403 (Witness statement of Mehmed Musić dated 28 February 2011), para. 78; Mehmed Musić, T. 12873 (3 March 2011).

7757 P2403 (Witness statement of Mehmed Musić dated 28 February 2011), para. 80. See also P161 (Adem Balić's statement to $\mathrm{BiH}$ authorities, 7 February 1993), p. 2. According to Musić, the men in the corridor who beat him all wore red berets and camouflage uniforms and, based on their speech, seemed to be from Serbia. P2403 (Witness statement of Mehmed Musić dated 28 February 2011), paras. 81-82; Mehmed Musić, T. 12873-12875 (3 March 2011). See also KDZ216, P69 (Transcript from Prosecutor v. Kunarac), T. 3395 (under seal) (stating that there were "Serbian soldiers" at the barracks in Lukavica, where he stayed for about a month). Musić stated that members of the police were present and described them as Serb, "SDS police", as distinct from "the ordinary, regular police" and from "the military police who wore white waist belts". P2403 (Witness statement of Mehmed Musić dated 28 February 2011), para. 83.

7758 P2403 (Witness statement of Mehmed Musić dated 28 February 2011), para. 80.

7759 P2403 (Witness statement of Mehmed Musić dated 28 February 2011), para. 84.

7760 P2403 (Witness statement of Mehmed Musić dated 28 February 2011), para. 84. Musić said he knew that they were officers because they all wore uniforms with ranks. P2403 (Witness statement of Mehmed Musić dated 28 February 2011), para. 84.

7761 P2403 (Witness statement of Mehmed Musić dated 28 February 2011), paras. 84-85 (also stating that one of the officers wore a cap with the coat of arms from Lika, Serbia and another "spoke like he was a Montenegrin").

7762 P2403 (Witness statement of Mehmed Musić dated 28 February 2011), para. 85.

7763 P2403 (Witness statement of Mehmed Musić dated 28 February 2011), para. 89. The Chamber notes that there is no killing charged in relation to this detention facility pursuant to either Schedule B or C of the Indictment. See Indictment, para. 60(a)(ii), fn. 4.

7764 P2403 (Witness statement of Mehmed Musić dated 28 February 2011), paras. 85-86; Mehmed Musić, T. 12879 (3 March 2011); P161 (Adem Balić's statement to BiH authorities, 7 February 1993), p. 3. These men carried large knives and wore the same gloves as those who beat Musić and others in the Sport centre; some wore black uniforms while others wore camouflage uniforms. P2403 (Witness statement of Mehmed Musić dated 28 February 2011), para. 86; Mehmed Musić, T. 12870 (3 March 2011). 
Later "regular JNA soldiers" came in and told the detainees to stop singing, said no one would touch them anymore, and brought them some food. ${ }^{7766}$

2278. The next day, the remaining approximately 233 men went back to the buses and were taken to Kula Prison. ${ }^{7767}$

2279. The Chamber took judicial notice of the fact that at the Lukavica barracks, detainees were forced to perform manual labour such as digging trenches and graves. ${ }^{7768}$ However, the Prosecution, for the period charged, did not provide evidence on forced labour at this detention facility or on detention other than in relation to the 280 non-Serb men for a few days in June 1992 discussed above. ${ }^{7769}$ The Chamber notes that the Prosecution itself limited its discussion of Scheduled Incident C.18.1 in the Final Brief to the detention and beatings of men from 22 June 1992. ${ }^{7770}$ The Chamber concludes that it does not have sufficient evidence on which to make a finding that detainees were forced to perform labour at the Slaviša Vajner Čiča Barracks.

2280. Based on the above, the Chamber finds that individuals were detained at the Slaviša Vajner Čiča Barracks in Lukavica for a few days in June 1992. The Chamber further finds that detainees were beaten and that 48 detainees were forced to run through a gauntlet. The Chamber finds that the detainees were held in poor conditions, including a lack of adequate space and access to sanitation facilities and water.

property

(E) Movement of the population from Novo Sarajevo and appropriation of

2281. During 1992 Bosnian Muslims and Croats, including nuns, were expelled from their homes, which were then looted. ${ }^{771}$ From the time Grbavica was taken over by Serb Forces, Bosnian

\footnotetext{
7765 P2403 (Witness statement of Mehmed Musić dated 28 February 2011), para. 86; Mehmed Musić, T. 12879 (3 March 2011).

7766 P2403 (Witness statement of Mehmed Musić dated 28 February 2011), paras. 87-88; Mehmed Musić, T. 12870-12871 (3 March 2011).

7767 P2403 (Witness statement of Mehmed Musić dated 28 February 2011), paras. 89, 92; Mehmed Musić, T. 12879 (3 March 2011); P161 (Adem Balić's statement to BiH authorities, 7 February 1993), p. 3. See also Adjudicated Fact 2638. See para. 2141.

7768 See Adjudicated Fact 2632.

7769 The Chamber notes P6282, which identifies a number of detainees who were forced to carry out labour at frontlines, including digging trenches, and were held in the Lukavica Barracksin 1993. See P6282 (RS Central Exchange Committee list of persons). However, as these events fall outside of the temporal scope for the Lukavica Barrackscharged in the Indictment, the Chamber will not make a finding of forced labour at the Lukavica Barracksbased thereon.

7770 Prosecution Final Brief, Appendix B, p. 29.

7771 P1938 (Witness statement of KDZ310 dated 28 November 2010), paras. 45, 64; P1937 (Witness statement of KDZ310 dated 28 November 2010), para. 18 (under seal); KDZ310, T. 9179, 9248-9249, 9255-9259 (29 November 2010); P2444 (Witness statement of KDZ354 dated 5 February 2011), paras. 82-91 (under seal); Radomir Nešković, P2568 (Transcript from Prosecutor v. Krajišnik), T. 16698-16701; Radomir Nešković,
} 
Muslims and Croats were expelled and forced to the other side of the Miljacka River. ${ }^{7772}$ KDZ310 testified that he could see from the expressions of the people moving that they were not going of their own free will; people were crying and did not want to leave their property behind to be looted. ${ }^{7773}$ Serb soldiers were kicking and hitting the Bosnian Croats and Muslims. ${ }^{7774}$ Both soldiers and the civilian and MP took part in the expulsion of non-Serbs from Grbavica. ${ }^{7775}$

2282. Intimidation and threats were employed to impel people to leave. ${ }^{7776} \mathrm{KDZ} 079$ stated that in early 1992 Serb soldiers would come, sometimes several times in one day, to the apartment where she lived with her husband and children, which made her and her family fear for their lives. ${ }^{7777}$ After her husband left to obtain food, Serb soldiers repeatedly came to the apartment asking for him and a photograph of him and his identity card. ${ }^{7778}$ The soldiers said they would take the witness and her daughter if her husband did not return. ${ }^{7779}$ Because Bosnian Croats and Muslims could not get bread and Serb soldiers were breaking into apartments and taking private possessions, on 26 May 1992 the witness, with her children, left the apartment and all their belongings. ${ }^{7780}$

2283. Soldiers entered buildings and made statements such as, "[i]n 10 minutes all Ustašas and Balijas out!". 7781 In one instance where civilians were being expelled from Grbavica, KDZ310 talked to a platoon member who agreed to go to the MP headquarters to ask for an explanation for the expulsions but the member did not receive an answer. ${ }^{7782}$

T. 14294-14295 (6 June 2011); P43 (Witness statement of Mirsad Smajš dated 18 December 1993), e-court p. 7. See also P2922 (Witness statements of KDZ079 dated 17 May 2006 and 12 March 1995), e-court pp. 5, 14.

KDZ310, T. 9179, 9255-9256 (29 November 2010); Radomir Nešković, P2568 (Transcript from Prosecutor v. Krajišnik), T. 16699-16701.

KDZ310, T. 9255-9257 (29 November 2010).

KDZ310, T. 9257 (29 November 2010).

KDZ310, T. 9179 (29 November 2010); P1938 (Witness statement of KDZ310 dated 28 November 2010), para. 64.

P1938 (Witness statement of KDZ310 dated 28 November 2010), para. 64.

P2922 (Witness statements of KDZ079 dated 17 May 2006 and 12 March 1995), e-court pp. 5, 14.

P2922 (Witness statements of KDZ079 dated 17 May 2006 and 12 March 1995), e-court pp. 5, 14.

P2922 (Witness statements of KDZ079 dated 17 May 2006 and 12 March 1995), e-court pp. 5, 14.

P2922 (Witness statements of KDZ079 dated 17 May 2006 and 12 March 1995), e-court pp. 5, 14.

P1938 (Witness statement of KDZ310 dated 28 November 2010), para. 64.

P1938 (Witness statement of KDZ310 dated 28 November 2010), para. 65. KDZ310 also went to the military police to seek protection for a Muslim civilian who lived in his building, but the military policeman on duty he found dismissed the request, waving his hand aside. P1938 (Witness statement of KDZ310 dated 28 November 2010), para. 65; KDZ310, T. 9265 (29 November 2010). 
2284. The 5 June 1992 report of the Novo Sarajevo Crisis Staff to the Bosnian Serb Presidency stated that it had provided as accommodation "empty and deserted Croatian and Muslim flats" to fighters from other areas who had joined regular units. ${ }^{7783}$

2285. On 19 July 1992, the Accused sent a memorandum to several municipalities, including Novo Sarajevo, requesting an inventory of all housing facilities "that are vacant following the voluntary departure of Muslims", explaining that vacant homes would be used to temporarily house Bosnian Serbs from the Muslim part of Sarajevo. ${ }^{7784}$

2286. A UN report from 30 September 1992 reported as confirmed that approximately 300 Bosnian Muslim civilians were expelled by Serbs that day from the area of Grbavica and had travelled on foot using one of two bridges, Vrbanja Bridge and a bridge behind the Bristol Hotel. ${ }^{7785}$ People were seen carrying bags and bundles, and armed soldiers, with rifles pointed in the air, were standing beside them. ${ }^{7786}$ On 1 October 1992, UNPROFOR Acting Commander, Morillon, conveyed in a letter to the Accused that he had received news of "[the Accused's] forces hav[ing] proceeded with the forced expulsion of nearly three hundred persons from Grbavica". ${ }^{7787}$ The 30 September UN report was brought up by the UNPROFOR Sarajevo sector commander, Hussein Ali Abdel-Razek, during multiple meetings with Plavšić. ${ }^{7788}$

7783 D885 (Letter from Novo Sarajevo Crisis Staff to Radovan Karadžić, 5 June 1992), p. 3; Radomir Nešković, P2568 (Transcript from Prosecutor v. Krajišnik), T. 16716-16717 (explaining that this was a way to protect these flats from looting or damage and to provide temporary housing to the fighters). However, KDZ310 testified that permission to use flats was given to fighters but that they looted the apartments they were issued. KDZ310, T. 9251-9252 (29 November 2010). Considering this testimony, which the Chamber finds credible, and considering Nešković's interest in casting the report and the activities of the Crisis Staff in a favourable light, the Chamber does not accept Nešković's explanation that the flats of Croats and Muslims were provided to prevent looting or damage.

7784 P739 (RS Presidency request to various municipalities, 19 July 1992).

7785 P1266 (UN report re expulsion of civilians from Grbavica, 30 September 1992). See also Hussein Ali AbdelRazek, T. 5521 (20 July 2010); KDZ310, T. 9286-9287 (29 November 2010); P1938 (Witness statement of KDZ310 dated 28 November 2010), para. 64; P1951 (TV Belgrade news report re UNPROFOR conference); P2444 (Witness statement of KDZ354 dated 5 February 2011), paras. 82-88 (under seal); Radomir Nešković, P2568 (Transcript from Prosecutor v. Krajišnik), T. 16700-16701 (stating that expulsions increased from around August 1992)

7786 P2444 (Witness statement of KDZ354 dated 5 February 2011), paras. 83-84 (under seal). Branko Radan testified that he heard, though did not personally observe, that on 30 September 1992, an estimated 300 Muslim citizens crossed over to Muslim-controlled territory over the Vrbanja Bridge. Branko Radan, T. 31098-31099, 31127-31128, 31131-31135 (6 December 2012). According to Radan, "no pressure was exerted" on the people and they "decided to cross over to the other side" in an "organised" and "satisfactory" move, in order to be safer. Branko Radan, T. 31098-31099, 31132 (6 December 2012). He testified that there was daily shooting, fighting, and shelling in the area of the frontlines in Jevrejsko Groblje, Gornja Kovačići, and Donji Kovačići. Branko Radan, T. 31098 (6 December 2012). Having considered the totality of the evidence in record, the Chamber rejects Radan's testimony that the movement of the 300 Muslims on 30 September 1992 was voluntary.

7787 P5419 (UNPROFOR letter to Radovan Karadžić, 1 October 1992), p. 1.

7788 Hussein Ali Abdel-Razek, T. 5521 (20 July 2010); P1267 (UNPROFOR report re meeting with Biljana Plavšić, 2 October 1992), p. 2. 
2287. In relation to the movement of population, Defence witnesses testified that: (i) with the outbreak of war in $\mathrm{BiH}$, some Serbs and non-Serbs moved to where they thought they were safer, ${ }^{7789}$ (ii) Serb and non-Serb civilians alike lacked complete freedom of movement, particularly in Grbavica and Vraca, due to almost continual sniping and shelling from high-rise buildings and other facilities under the control of Muslim forces; ${ }^{7790}$ (iii) a significant number of non-Serbs remained in Novo Sarajevo throughout the war; ${ }^{7791}$ and (iv) some Bosnian Muslims requested to leave. $^{7792}$

2288. Having considered the totality of the evidence, however, the Chamber finds that many Bosnian Muslims and Croats were forced to leave the municipality. The Chamber notes that in some instances people requested to leave; however, the Chamber finds that this was still involuntary considering the surrounding circumstances in which the departures occurred. Consequently, the Chamber is satisfied that Bosnian Muslims and Croats were forced to leave the Serb-controlled parts of Novo Sarajevo municipality.

7789 D2673 (Witness statement of Zdravko Šalipur dated 16 December 2012), para. 30; D2683 (Witness statement of Dragan Šojić dated 15 December 2012), para. 26; D2418 (Witness statement of Božo Tomić dated 5 November 2012), paras. 13-14; Božo Tomić, T. 30193-30194 (13 November 2012); D3563 (Witness statement of Vladimir Lukić dated 18 May 2013), para. 8.

7790 D2673 (Witness statement of Zdravko Šalipur dated 16 December 2012), para. 30; D2683 (Witness statement of Dragan Šojić dated 15 December 2012), para. 26.

7791 Radomir Nešković, T. 14336 (7 June 2011); D2673 (Witness statement of Zdravko Šalipur dated 16 December 2012), para. 30 (stating that more than 1,200 Muslims and Croats stayed in Novo Sarajevo throughout the war); D2683 (Witness statement of Dragan Šojić dated 15 December 2012), para. 26; Branko Radan, T. 31099-31100 (6 December 2012) (testifying that, by some estimates, between 1,350 and 1,500 Muslims remained in Grbavica throughout the war); D2651 (Witness statement of Milorad Katić dated 10 December 2012), para. 13 (stating that 1,500 non-Serbs remained in Grbavica throughout the war); P1483 (Ratko Mladić's notebook, 2 April-24 October 1993), p. 190 (wherein the President of Novo Sarajevo reported that out of the 30,000 people in the municipality, there were 1,500 Bosnian Muslims and 200 Croats on 2 June 1993). See also D2424 (Report of Protection Officer's visit to Grbavica, 11 March 1993) (stating that there were approximately 1,200 Muslims still in Grbavica and indicating that Muslim males of a certain age were required to perform work and that the officer had not been able to meet with Muslims who wanted to leave or were displaced within Grbavica, pending clearance by the army headquarters in Lukavica for such a visit). Radan testified that the Muslims who stayed "enjoyed all the same rights in terms of humanitarian aid, medical assistance and security" as Serbs and Croats. Branko Radan, T. 31099-31100 (6 December 2012). See also D2673 (Witness statement of Zdravko Šalipur dated 16 December 2012), para. 30; D2683 (Witness statement of Dragan Šojić dated 15 December 2012), para. 26. Considering Radan's interest in distancing himself from the mistreatment that occurred as well as the lack of candour on this point of all three witnesses, the Chamber rejects the evidence that Muslims who stayed were provided for and protected equally as Serbs and Croats.

7792 Radomir Nešković, P2568 (Transcript from Prosecutor v. Krajišnik), T. 16700-16701 (stating that before August 1992, there were expulsions of Muslims but that some Muslims requested to cross over to the other side because they did not feel safe and that "secret exchanges" of Muslims and Serbs also took place). See also Branko Radan, T. 31101-31102 (6 December 2012) (testifying that non-Serbs from Grbavica seeking reunion with their families and better living conditions made efforts to cross to the other side with the assistance of "freelancers"). However, Radan recognised the possibility that non-Serbs sought to leave because they were being subjected to harassment. Branko Radan, T. 31126 (6 December 2012). 


\section{(A) Charges}

2289. Under Count 3, the Prosecution alleges that persecution, a crime against humanity, was committed in Pale as part of the objective to permanently remove Bosnian Muslims and/or Bosnian Croats from the Municipalities. ${ }^{7793}$ Acts of persecution alleged to have been committed by Serb Forces and Bosnian Serb Political and Governmental Organs in Pale include killings related to the "Former Culture Centre/Dom Culture in Pale (also referred to as a Gym)", 7794 as well as killings committed during, and deaths resulting from, cruel and inhumane treatment at that facility. ${ }^{7795}$ The Prosecution also characterises these killings as extermination, a crime against humanity, under Count 4; murder, a crime against humanity, under Count 5; and murder, a violation of the laws or customs of war, under Count $6 .^{7796}$

2290. Other acts of persecution alleged to have been committed in Pale by Serb Forces and Bosnian Serb Political and Governmental Organs include (i) torture, beatings, and physical and psychological abuse during and after the take-over and in Pale Gym as cruel or inhumane treatment; ${ }^{7797}$ (ii) the establishment and perpetuation of inhumane living conditions in Pale Gym, including the failure to provide adequate accommodation, shelter, food, water, medical care, or hygienic sanitation facilities, as cruel or inhumane treatment; ${ }^{7798}$ (iii) forcible transfer or deportation of Bosnian Muslims and Bosnian Croats from their homes within Pale; ${ }^{7799}$ (iv) unlawful detention in Pale Gym; ${ }^{7800}$ (v) the wanton destruction of public property, including cultural monuments and sacred sites; ${ }^{7801}$ and (vi) the imposition and maintenance of restrictive and discriminatory measures. ${ }^{7802}$

The Chamber notes that in the Indictment and in the evidence, this detention facility has been referred to by various names. See e.g. Indictment, Scheduled Incident B.14.1, Scheduled Detention Facility C.19.2 (referring to "Former Culture Centre", "Dom Culture", and "a Gym"); P2839 (Witness statement of Hajrudin Karić, dated 13 May 2011), para. 18 (referring to "Pale sports centre" and "old Cultural Centre"); D4368 (Witness statement of Jovan Šarac dated 10 February 2014), para. 55 (referring to "sport complex"). For the sake of clarity, the Chamber will use the term "Pale Gym" to refer to this alleged detention facility throughout this Judgement. Indictment, para. 60(a)(ii). See Scheduled Incident B.14.1; Scheduled Detention Facility C.19.2.

7796 Indictment, para. 63(b).

7797 Indictment, para. 60(b). See Scheduled Detention Facility C.19.2.

7798 Indictment, paras. 60(d). See Scheduled Detention Facility C.19.2.

7799 Indictment, para. 60(f).

7800 Indictment, para. 60(g). See Scheduled Detention Facility C.19.2.

7801 Indictment, para. 60(j). See Scheduled Incident D.16.

7802 Indictment, para. 60(k). The restrictive and discriminatory measures alleged include the denial of freedom of movement; the removal from positions of authority; the invasion of privacy through arbitrary searches of homes; unlawful arrest and/or the denial of the right to judicial process; and/or the denial of equal access to public services. The Prosecution does not allege criminal responsibility for rape and other acts of sexual violence;
} 
2291. Under Counts 7 and 8, the Prosecution alleges deportation and inhumane acts (forcible transfer), respectively, as crimes against humanity. ${ }^{7803}$ In this regard, the Prosecution alleges that by the end of 1992, Serb Forces and Bosnian Serb Political and Governmental Organs had forcibly displaced Bosnian Muslims and Bosnian Croats from areas in Pale in which they had been lawfully present. ${ }^{7804}$ It is alleged that from March 1992, restrictive and discriminatory measures, arbitrary arrest and detention, harassment, torture, killing, destruction of cultural monuments and sacred sites, as well as the threat of further such acts caused some Bosnian Muslims and Bosnian Croats to flee in fear, while others were physically driven out. ${ }^{7805}$

\section{(B) Background}

2292. Pale, one of the ten constitutive municipalities of Sarajevo, is located to the east of Novo Sarajevo and Stari Grad and to the west of Rogatica. ${ }^{7806}$ The municipality of Pale includes, inter alia, the Muslim settlements of Bare, Donja Vinča, Prača, Podgrab and Renovica, and the largely Serb inhabited settlements of Krivodoli, Lapišnica, Mokro, and Vrhpraća. ${ }^{7807}$ According to the 1991 census, Pale municipality had 16,119 inhabitants, of whom about 27\% were Bosnian Muslims and $69 \%$ were Bosnian Serbs. ${ }^{7808}$

2293. There were a number of military installations in Pale, including an army barracks located in the centre of Renovica, an army depot in Krivodoli, a depot in Jahorinski Potok and a radar

forced labour on the frontlines; the appropriation or plunder of property or the wanton destruction of private property in Pale. Indictment, fn. 5, 7, 8, 9 .

7803

7804

7805

7806

7807 P733 (Witness statement of Sulejman Crnčalo dated 1 November 2009), para. 19; Sulejman Crnčalo, T. 1197, 1223 (15 April 2010); D15 (SRNA news report, 22 June 1992); D29 (Article from Glas Current Affairs entitled "Agreement with the Muslims in Pale", 17 April 1992); Hajrudin Karić, T. 15335 (23 June 2011); D2850 (Witness statement of Tomislav Hršum dated 27 January 2013), para. 16; Zdravko Čvoro, T. 30962 (5 December 2012); D4368 (Witness statement of Jovan Šarac dated 10 February 2014), para. 39; see Adjudicated Fact 2591.

7808 P5964 (Census data for BiH by municipality in 1971, 1981, and 1991, April 1995), e-court p. 2 of BCS version. See also Adjudicated Fact 3. But see P4994 (Addendum to Ewa Tabeau's expert report entitled "Ethnic Composition in Internally Displaced Persons and Refugees from 27 Municipalities of BiH 1991 to 1997", 3 February 2009), pp. 30, 33, 36, 39, 73, 75, 77, 79 (indicating that Pale municipality had 12,433 inhabitants, of whom 21.4\% were Bosnian Muslims, 74\% were Bosnian Serbs, and 0.9\% were Bosnian Croats); D4002 (Letter from BiH MUP to Vasvija Vidović, 4 July 1995), p. 56 (indicating that in 1991, Pale municipality had 15,482 inhabitants of whom, $25.4 \%$ were Bosnian Muslims, $68 \%$ were Bosnian Serbs and $0.6 \%$ were Bosnian Croats). While the Chamber finds P4994 and D4002 to be generally reliable, for the purpose of determining the population of Pale and the ethnic composition thereof in 1991, it relies on P5964, which is a direct source document and which contains the raw data from the 1991 census in $\mathrm{BiH}$. 
installation at Mt. Jahorina. ${ }^{7809}$ In late March or April 1992, the Republic Communications Centre was established in Pale and began providing secure communication links in the territory of SerBiH. ${ }^{7810}$

2294. The founding assembly of the SDA Municipal Board was held in July 1990 in Renovica. ${ }^{7811}$ In August or September 1990, the SDS Municipal Board in Pale, headed by Svetislav Lučić, was founded. $^{7812}$ In April 1991, Jovan Šarac became the President of the Pale SDS Municipal Board. $^{7813}$

2295. From April 1992 onwards, Pale served as the seat of the government of the SerBiH and later of the RS. ${ }^{7814}$ Between 1992 and 1995, the Accused used the following three locations in Pale as his office: the Kikinda building, the Mali Dom building, situated in the Panorama Hotel complex, and the administrative building of the Famos factory. ${ }^{7815}$ From April 1992 onwards, the Accused and his family resided at a number of locations in Pale. ${ }^{7816}$ Momčilo Krajišnik and Biljana Plavšić stayed in the Panorama Hotel complex. ${ }^{7817}$

\section{(C) Lead-up}

2296. In the multi-party elections, the SDS and SDA respectively obtained $65 \%$ and $20 \%$ of the votes for the Pale Municipal Assembly; subsequently, the SDS and SDA formed a coalition and divided the positions of authority in the municipality between themselves. ${ }^{7818}$ Slobodan Kovačević became the president of the Municipal Assembly and Malko Koroman was appointed the Chief of

\footnotetext{
7809 D2850 (Witness statement of Tomislav Hršum dated 27 January 2013), para. 16; Jovan Šarac, T. 47151 (14 February 2014); P733 (Witness statement of Sulejman Crnčalo dated 1 November 2009), para. 20.

7810 P2560 (Letter from Radovan Karadžić to presidents of municipalities, 23 March 1992), p. 1; P2794 (Witness statement of Ranko Vuković dated 24 May 2011), para. 2; see Adjudicated Fact 2063.

7811 D4368 (Witness statement of Jovan Šarac dated 10 February 2014), para. 30.

7812 D2850 (Witness statement of Tomislav Hršum dated 27 January 2013), para. 7; Tomislav Hršum, T. 32917 (30 January 2013); D4368 (Witness statement of Jovan Šarac dated 10 February 2014), para. 30.

7813 Jovan Šarac, T. 47141 (14 February 2014).

7814 Neđeljko Prstojević, T. 12965 (8 March 2011); D4368 (Witness statement of Jovan Šarac dated 10 February 2014), para. 21; P820 (Witness statement of David Harland dated 4 September 2009), paras. 50-51; David Harland, T. 2064-2067 (7 May 2010); P5742 (Intercept of conversation between Radovan Karadžić and an unidentified male, 6 April 1992), p. 2; D3583 (RTV news report, 14 August 1993); Nebojša Ristić, T. 1538815389 (24 June 2011); Momčilo Mandić, T. 5099-5100 (14 July 2010). See also Adjudicated Fact 2052.

7815 Nebojša Ristić, T. 15380, 15384-15387, 15389-5392 (24 June 2011); P2841 (Photographs and sketches marked by Nebojša Ristić), e-court pp. 1-3, 7; P2842 (Map of Pale marked by Nebojša Ristić); P2794 (Witness statement of Ranko Vuković dated 24 May 2011), para. 14; Momčilo Mandić, T. 4648 (5 July 2010), T. 5011 (13 July 2010); Patrick Rechner, T. 11081 (2 February 2011).

7816 Nebojša Ristić, T. 15380, 15383 (24 June 2011); P2841 (Photographs and sketches marked by Nebojša Ristić), e-court pp. 8-9.

7817 Nebojša Ristić, T. 15382 (24 June 2011).

7818 P733 (Witness statement of Sulejman Crnčalo dated 1 November 2009), para. 12; D2850 (Witness statement of Tomislav Hršum dated 27 January 2013), para. 7; Zdravko Čvoro, T. 30937 (4 December 2012); D4002 (Letter
} 
the Pale SJB. ${ }^{7819}$ Idriz Efendić, a Bosnian Muslim, was appointed as the Commander of the Pale SJB. ${ }^{7820}$ Hamed Palo, a Bosnian Muslim, was named as Kovačević's deputy. ${ }^{7821}$ Kovačević was later replaced by Radislav Starčević. ${ }^{782}$ In January 1992, Zdravko Čvoro was appointed as President of the Executive Board in Pale. ${ }^{7823}$

2297. In the beginning of 1991, Bosnian Serbs in Pale organised large public rallies at which they waved Serb flags and shouted nationalist slogans. ${ }^{7824}$ In response to the increasing national sentiments amongst Serbs, the Bosnian Muslims in Pale organised night watches in order to guard their families and homes. ${ }^{7825}$ Bosnian Muslims in Pale owned hunting rifles and pistols. ${ }^{7826}$

2298. On 8 May 1991, at the initiative of the SDS Regional Board, the municipalities of Pale, Han Pijesak and Sokolac declared that they would join together in order to create the SAO Romanija. ${ }^{7827}$

2299. In November 1991, Serbs from several army installations began secretly distributing arms to the local Serb population at night. ${ }^{7828}$ Stjepan Koroman, a relative of the police chief, was in

from BiH MUP to Vasvija Vidović, 4 July 1995), p. 56; D4368 (Witness statement of Jovan Šarac dated 10 February 2014), para. 33.

7819 P733 (Witness statement of Sulejman Crnčalo dated 1 November 2009), para. 12; Sulejman Crnčalo, T. 1252 (15 April 2010); P2839 (Witness statement of Hajrudin Karić, dated 13 May 2011), paras. 19, 41; Hajrudin Karić, T. 15347 (23 June 2011); P6089 (BiH MUP report, 24 March 1992), p. 2; P6090 (Pale SJB record, 8 February 1993), p. 1; P6093 (List of employees of Pale CJB), p. 1; Tomislav Hršum, T. 32938 (30 January 2013); D4368 (Witness statement of Jovan Šarac dated 10 February 2014), para. 44; Jovan Šarac, T. 47143 (14 February 2014); P963 (Interview with Malko Koroman in RS MUP magazine "Policeman", November 1994), p. 1.

7820 D2850 (Witness statement of Tomislav Hršum dated 27 January 2013), para. 6; Tomislav Hršum, T. 32921 (30 January 2013).

7821 P733 (Witness statement of Sulejman Crnčalo dated 1 November 2009), para. 12; Sulejman Crnčalo, T. 1194 (15 April 2010).

7822 P733 (Witness statement of Sulejman Crnčalo dated 1 November 2009), paras. 12, 35; D31 (14 ${ }^{\text {th }}$ session of Pale Municipal Assembly, 18 June 1992), e-court p. 1; D2530 (Witness statement of Zdravko Čvoro dated 1 December 2012), para. 6.

7823 D2530 (Witness statement of Zdravko Čvoro dated 1 December 2012), para. 1.

7824 P733 (Witness statement of Sulejman Crnčalo dated 1 November 2009), para. 10; Sulejman Crnčalo, T. 1189 1191 (15 April 2010).

7825 P733 (Witness statement of Sulejman Crnčalo dated 1 November 2009), paras. 13-14.

7826 Sulejman Crnčalo, T. 1208-1209 (15 April 2010). In 1991, some JNA sergeants and Bosnian Muslims stole weapons, mines, and explosives from the Renovica Barracks. D4368 (Witness statement of Jovan Šarac dated 10 February 2014), para. 36.

7827 D1267 (Article from Javnost entitled "Municipalities join together into a community of municipalities", 11 May 1991), e-court p. 1; D4368 (Witness statement of Jovan Šarac dated 10 February 2014), para. 12; D4002 (Letter from BiH MUP to Vasvija Vidović, 4 July 1995), p. 56.

7828 P733 (Witness statement of Sulejman Crnčalo dated 1 November 2009), paras. 19-20. See also P979 (Report from JNA $2^{\text {nd }}$ Military District to JNA General Staff, 20 March 1992), pp. 6, 11 (indicating that by 20 March 1992, in Pale municipality, 2,000 men who were not part of the JNA or the TO had been armed by either the JNA or the SDS). 
charge of distributing weapons to the inhabitants of Vrhpraća and Podgrab. ${ }^{7829}$ From this point on, there was an increase in Serbs firing their weapons. ${ }^{7830}$

2300. In early 1992, the Bosnian Serb police officers who had been disarmed and expelled from the Stari Grad SJB, joined the Pale SJB to work on security tasks. ${ }^{7831}$ In January 1992, the Bosnian Serb population in Pale was mobilised by means of written call-ups that were issued to them. ${ }^{7832}$

2301. During this period, paramilitary groups, including a formation commanded by Radomir Kojić, a special unit commanded by Rajko Kušić as well as Šešelj’s men began operating in Pale. $^{7833}$ In late April or early May 1992, members of Arkan's men, led by a man nicknamed "Čarli", also entered Pale and moved into the Panorama Hotel complex. ${ }^{7834}$ During May and June 1992, a large amount of military equipment and many military personnel arrived in Pale. ${ }^{7835}$ In the same period, an additional number of paramilitaries arrived in Pale. ${ }^{7836}$ They were mainly young Serbs; they had red ribbons on their arms and heads, and carried automatic rifles and knives. ${ }^{7837}$ They often drove around in Pale and confiscated the cars and trucks that belonged to non-Serbs. ${ }^{7838}$

2302. In March 1992, subsequent to talks between the Chiefs of Pale and Stari Grad SJBs, police check-points were created by both sides at Lapišnica. ${ }^{7839}$ Bosnian Muslims and Bosnian Serbs also established check-points on various roads leading in and out of Pale. ${ }^{7840}$

\footnotetext{
7829 P733 (Witness statement of Sulejman Crnčalo dated 1 November 2009), para. 19.

7830 Sulejman Crnčalo, T. 1196 (15 April 2010); P733 (Witness statement of Sulejman Crnčalo dated 1 November 2009), para. 17.

7831 D2850 (Witness statement of Tomislav Hršum dated 27 January 2013), para. 11; Tomislav Hršum, T. 32952_ 32953, 32955 (30 January 2013); D4368 (Witness statement of Jovan Šarac dated 10 February 2014), para. 50.

7832 P733 (Witness statement of Sulejman Crnčalo dated 1 November 2009), paras. 21-22, 46, 58.

7833 P2839 (Witness statement of Hajrudin Karić, dated 13 May 2011), para. 16; Hajrudin Karić, T. 15343 (23 June 2011); D4002 (Letter from BiH MUP to Vasvija Vidović, 4 July 1995), p. 57. The Chamber notes that the individual by the name of Rajko Kušić who is referred to in this section of the Judgement on Pale is not the same individual as the man also named Rajko Kušić who is referred to in the Rogatica section of this Judgement. See Hajrudin Karić, T. 15343 (23 June 2011).

D1076 (MUP Administration for the Police Duties and Affairs report, 3 August 1992), p. 3; P1107 (SerBiH MUP report to the Minister of Interior re inspection of Romanija-Birač CSB and SJB, 10 August 1992), p. 3. According to Hršum and Šarac, this group engaged in criminal acts against private and public property and for this reason, it was eventually disarmed by the Pale SJB and escorted back towards Serbia in June 1992. D2850 (Witness statement of Tomislav Hršum dated 27 January 2013), para. 25; D4368 (Witness statement of Jovan Šarac dated 10 February 2014), para. 45; Jovan Šarac, T. 47158-47159 (14 February 2014).

7835 P733 (Witness statement of Sulejman Crnčalo dated 1 November 2009), para. 52. See also Adjudicated Fact 2590.

7836 P733 (Witness statement of Sulejman Crnčalo dated 1 November 2009), paras. 52, 54.

7837 P733 (Witness statement of Sulejman Crnčalo dated 1 November 2009), paras. 52, 54; Sulejman Crnčalo, T. 1159 (14 April 2010), T. 1255 (15 April 2010).

7838 P733 (Witness statement of Sulejman Crnčalo dated 1 November 2009), paras. 52-53, 55; Sulejman Crnčalo, T. 1255 (15 April 2010).

7839 D2850 (Witness statement of Tomislav Hršum dated 27 January 2013), para. 14; Tomislav Hršum, T. 32948 (30 January 2013); D4368 (Witness statement of Jovan Šarac dated 10 February 2014), para. 39.
} 
2303. The Crisis Staff in Pale was established in March or April 1992; its headquarters was located in Pale SJB. ${ }^{7841}$ Zdravko Čvoro, the President of the Executive Board, was appointed as the President of the Crisis Staff. ${ }^{7842}$ The Crisis Staff, which included Šarac and other SDS members in Pale municipality such as Koroman, and Slobodan Ninković, controlled all municipal activities. ${ }^{7843}$ According to Šarac, the Pale Crisis Staff was in essence an expanded version of the Executive Board. $^{7844}$

2304. The SDS enjoyed "absolute power" in the municipality and the Pale municipal authorities allocated funds to it. ${ }^{7845}$ They also allocated premises and material resources and contributed financially to the Bosnian Serb Press Agency, the SRNA. ${ }^{7846}$

2305. In early March 1992, the Bosnian Serb municipal authorities called on non-Serbs to hand in their personal weapons. ${ }^{7847}$ Subsequently, in local communes outside of Pale town, authorities designated special locations for the non-Serb population to bring in their weapons; the weapons

7840 D4368 (Witness statement of Jovan Šarac dated 10 February 2014), para. 52; D2850 (Witness statement of Tomislav Hršum dated 27 January 2013), para. 14; P733 (Witness statement of Sulejman Crnčalo dated 1 November 2009), para. 43; Sulejman Crnčalo, T. 1215-1216 (15 April 2010); P2839 (Witness statement of Hajrudin Karić, dated 13 May 2011), para. 7; Hajrudin Karić, T. 15316-15318 (23 June 2011). See also Adjudicated Fact 2589.

7841 P733 (Witness statement of Sulejman Crnčalo dated 1 November 2009), para. 42; P2839 (Witness statement of Hajrudin Karić, dated 13 May 2011), para. 9; D2530 (Witness statement of Zdravko Čvoro dated 1 December 2012), paras. 2, 11. See also P6089 (BiH MUP report, 24 March 1992), p. 2 (indicating that the Pale Crisis Staff was functional as of March 1992 and that it ordered the Bosnian Muslim policemen in Pale SJB to hand in their weapons). On 6 April 1992, the $2^{\text {nd }}$ Military District Reserve Command Post reported that it maintained constant contact and co-ordinated its operations with the Pale Crisis Staff. P5426 (Report of $2^{\text {nd }}$ Military District RKM, 6 April 1992).

7842 D4368 (Witness statement of Jovan Šarac dated 10 February 2014), paras. 38, 46; Zdravko Čvoro, T. 30929 , 30933, 30936, 30938 (4 December 2012).

7843 P733 (Witness statement of Sulejman Crnčalo dated 1 November 2009), para. 42; Jovan Šarac, T. 47141 (14 February 2014). In April 1992, the Crisis Staff began receiving the daily dividends generated by the various companies that were based in Pale, including the Pale branch of Centrotrans. The Pale Crisis Staff also took decisions about companies and determined the salaries of their staff. In the same period, the Pale Crisis Staff adopted a number of regulations concerning the purchase and sale of basic commodities and banned the sale of alcohol. P2839 (Witness statement of Hajrudin Karić, dated 13 May 2011), paras. 10-13; Hajrudin Karić, T. 15336 (23 June 2011); D21 (SRNA news report, 24 April 1992); D22 (SRNA news report, 2 May 1992); D26 (SRNA news report, 25 May 1992).

7844 D4368 (Witness statement of Jovan Šarac dated 10 February 2014), para. 38; Jovan Šarac, T. 47171 (14 February 2014).

7845 P6029 (Decision of Pale Executive Board, 25 May 1992), p. 3; Zdravko Čvoro, T. 30937 (4 December 2012).

7846 Zdravko Čvoro, T. 30960 (5 December 2012).

7847 P733 (Witness statement of Sulejman Crnčalo dated 1 November 2009), para. 28. According to Hršum, the reasons for disarming were threefold: (i) in the area of Renovica, there were armed persons in hitherto unseen military uniforms moving about; (ii) there were constant incursions into and attacks against Renovica Barracks; and (iii) two individuals who had been linked with an alleged murder dating back to before the start of the war had hidden in the Renovica area. Tomislav Hršum, T. 32955-32957 (30 January 2013). The Chamber rejects Hršum's evidence on this point in light of reliable documentary evidence originating from the chief of Pale SJB's Criminal Investigation Service which indicates that in mid-March, Pale SJB confiscated weapons that were in the possession of Bosnian Muslims, "irrespective of whether they had permits for them or not." See P6090 (Pale SJB record, 8 February 1993), p. 1. 
collected in such locations were then brought to the SJB building in Pale town. ${ }^{7848}$ At the same time, men in camouflage uniforms who were not from the JNA conducted searches of Bosnian Muslim houses for weapons. ${ }^{7849}$

2306. During the night of 3 March 1992, three Bosnian Serb reservists in dark police uniforms arrested Sulejman Crnčalo and his neighbour and took them both to the SJB in Pale; at the time of his arrest, Crnčalo was guarding his house with a hunting rifle. ${ }^{7850}$ At a certain point, Koroman arrived at the SJB and while questioning Crnčalo, stated that if any of his "policemen or soldiers" were wounded in Crnčalo's neighbourhood, he would completely destroy that neighbourhood. ${ }^{7851}$ Koroman added that "[a]s long as there is no Serb policeman in Stari Grad, there is not going to be one Muslim policeman in Pale."7852 In the early morning hours, Koroman indicated that he was going to escort Crnčalo and his neighbour back to their respective homes. ${ }^{7853}$ When exiting the SJB, Crnčalo noticed at least a hundred reserve policemen outside. ${ }^{7854}$ Near his home, Crnčalo saw many heavily-armed soldiers and policemen facing the Bosnian Muslim inhabited parts of Pale. ${ }^{7855}$

2307. On 23 March 1992, about 35 Bosnian Muslim active-duty and reserve policemen from Pale SJB met with Koroman at the Prača reserve SJB. ${ }^{7856}$ At the meeting, Koroman stated that Bosnian Muslim policemen were required to hand in their weapons and equipment. ${ }^{7857}$ Koroman added that this was a countermeasure against the move made by Stari Grad SJB and that the reinstatement of Muslim policemen depended on Serb policemen returning to their jobs in the Stari Grad SJB. ${ }^{7858}$ The Bosnian Muslim policemen complied and handed in their weapons. ${ }^{7859}$ Later that day, Bosnian Muslim reserve policemen in the Pale SJB were disarmed in a similar fashion. ${ }^{7860}$ From this point on, Pale SJB stayed under Bosnian Serb control. ${ }^{7861}$

P733 (Witness statement of Sulejman Crnčalo dated 1 November 2009), para. 29.

P733 (Witness statement of Sulejman Crnčalo dated 1 November 2009), para. 31.

7850 P733 (Witness statement of Sulejman Crnčalo dated 1 November 2009), paras. 23-24; Sulejman Crnčalo, T. 1199 (15 April 2010).

7851 P733 (Witness statement of Sulejman Crnčalo dated 1 November 2009), para. 24.

7852 Sulejman Crnčalo, T. 1252 (15 April 2010); P733 (Witness statement of Sulejman Crnčalo dated 1 November 2009), para. 25.

7853 P733 (Witness statement of Sulejman Crnčalo dated 1 November 2009), para. 26; Sulejman Crnčalo, T. 1199 (15 April 2010).

7854 P733 (Witness statement of Sulejman Crnčalo dated 1 November 2009), para. 26.

7855 P733 (Witness statement of Sulejman Crnčalo dated 1 November 2009), para. 26.

7856 P6089 (BiH MUP report, 24 March 1992), p. 2.

7857 P6089 (BiH MUP report, 24 March 1992), p. 2.

7858 P6089 (BiH MUP report, 24 March 1992), p. 2; D4368 (Witness statement of Jovan Šarac dated 10 February 2014), para. 50.

7859 P6089 (BiH MUP report, 24 March 1992), p. 2.

7860 P6089 (BiH MUP report, 24 March 1992), p. 2. On 8 February 1993, the Pale SJB reported that due to "security reasons", during mid-March 1992 it had "disarmed the non-Serb police employees and removed them from
} 
2308. Ethnic tensions increased further in April 1992, when a large number of Bosnian Serb refugees from Sarajevo began to pour into Pale. ${ }^{7862}$ On 4 April 1992, on the Pale-Sarajevo road, two Bosnian Serb bus drivers and some of the Bosnian Serb passengers who were travelling with them were beaten by Bosnian Muslims. ${ }^{7863}$ In the village of Lapišnica, a Serb was wounded by Muslim gunfire. ${ }^{7864}$ Around the same period, certain shops refused to sell products to nonSerbs. ${ }^{7865}$ Eventually, most shops in Pale closed down. ${ }^{7866}$ By April 1992, many Bosnian Muslims had been suspended from their jobs. ${ }^{7867}$

2309. On 11 April 1992, the Pale Crisis Staff promised to provide full security to all residents of Pale regardless of their ethnicity, decided that supplies shall be provided equally to all parts of the municipality, and proposed to hold discussions with SDA officials about supply and security issues. $^{7868}$ On or about 16 April, the Bosnian Muslims in the villages of Bare, Renovica, Prača and Podgrab recognised the "legal police" in the municipality and received guarantees of personal and material security as well as normal supplies and regular bus transport. ${ }^{7869}$

2310. During late April 1992, paramilitary forces dressed in camouflage uniforms and led by Zoran Škobo arrested a number of Bosnian Muslim men aged between 20 and $30{ }^{7870}$ These men

service”. See P6090 (Pale SJB record, 8 February 1993), p. 1. See also Adjudicated Fact 2587. But see Hršum's testimony that on 17 March 1992, all Bosnian Muslim policemen of the Pale SJB and most Bosnian Muslim policemen at the Prača SJB branch indicated that they wanted to temporarily stop coming to work because of problems that had arisen in Sarajevo, and accordingly, handed in their weapons and official badges. Tomislav Hršum, T. 32923-32926 (30 January 2013). In light of its inconsistency with the reliable documentary evidence contained in P6089 and P6090, the Chamber rejects Hršum's assertion.

7861 Mirsad Kučanin, P16 (Transcript from Prosecutor v. Galić), T. 4500. See also P963 (Interview with Malko Koroman in RS MUP magazine "Policeman", November 1994), p. 2.

7862 Sulejman Crnčalo, T. 1198, 1201-1202 (15 April 2010); D8 (SRNA news report, 10 April 1992); D9 (SRNA news report, 19 May 1992); D11 (SRNA news report, 17 April 1992); Hajrudin Karić, T. 15337-15338 (23 June 2011); D2850 (Witness statement of Tomislav Hršum dated 27 January 2013), para. 15; D2530 (Witness statement of Zdravko Čvoro dated 1 December 2012), para. 3. In the latter half of May 1992, the number of Bosnian Serb refugees in Pale reached 15,000, which was nearly as much as Pale's original population. D10 (SRNA news report, 20 May 1992); D12 (SRNA news report, 21 May 1992); Sulejman Crnčalo, T. 1257 (15 April 2010).

7863 D4368 (Witness statement of Jovan Šarac dated 10 February 2014), para. 39; Hajrudin Karić, T. 15319-15321 (23 June 2011).

7864 D4368 (Witness statement of Jovan Šarac dated 10 February 2014), para. 39.

7865 Sulejman Crnčalo, T. 1230 (15 April 2010).

7866 P2839 (Witness statement of Hajrudin Karić, dated 13 May 2011), para. 15; Hajrudin Karić, T. 15338-15339 (23 June 2011).

7867 P733 (Witness statement of Sulejman Crnčalo dated 1 November 2009), para. 46; P2839 (Witness statement of Hajrudin Karić, dated 13 May 2011), paras. 8-9; Hajrudin Karić, T. 15324-15327 (23 June 2011).

7868 D28 (Conclusions of the Crisis Staff of Pale Municipal Assembly, 11 April 1992).

7869 D29 (Article from Glas Current Affairs entitled “Agreement with the Muslims in Pale”, 17 April 1992).

7870 P733 (Witness statement of Sulejman Crnčalo dated 1 November 2009), para. 49. 
were kept in the SJB for a few hours and then released. ${ }^{7871}$ In May 1992, more Bosnian Muslims were randomly arrested. ${ }^{7872}$

2311. In the beginning of May 1992, pursuant to an order issued by the Pale Crisis Staff, the Post Office in Pale disconnected the telephone lines of Bosnian Muslims. ${ }^{7873}$ From this point onwards, Bosnian Muslims went to the Post Office in order to make calls or asked their Serb neighbours to allow them access to their telephones. ${ }^{7874}$

(D) Attack against Renovica and other villages

2312. On 22 May 1992, the Bosnian Muslims in Prača, Bogovići, Gornja Vinča, and Podgrab handed over their weapons to Bosnian Serb Forces. ${ }^{7875}$ Residents of Renovica, however, refused. $^{7876}$

2313. On the same day, members of the Pale MUP and the VRS conducted a military operation against Renovica. ${ }^{7877}$ Policemen from Pale SJB detained approximately 30 Bosnian Muslims and took them to the Pale Gym. ${ }^{7878}$ On that day, Serb Forces also attacked and shelled the predominantly Muslim village of Donja Vinča, setting houses on fire and forcing the villagers to leave. ${ }^{7879}$ SRNA reported on the operation against Renovica, stating that seven MUP members had

7871 P733 (Witness statement of Sulejman Crnčalo dated 1 November 2009), para. 49.

7872 P733 (Witness statement of Sulejman Crnčalo dated 1 November 2009), para. 49. But see Tomislav Hršum, T. 32968 (30 January 2013) (testifying that members of Pale SJB never considered ethnicity as a basis for remanding individuals in custody). The Chamber does not accept this evidence given that Hršum was himself a policeman in Pale and therefore has an interest in denying that employees of Pale SJB arrested individuals on the basis of their ethnicity.

7873 P734 (Order of Pale Crisis Staff, 7 May 1992); P733 (Witness statement of Sulejman Crnčalo dated 1 November 2009), paras. 50-51. Zdravko Čvoro testified that private resources and services were taken over or withheld to defend the territory, that many Serbs and even public institutions also had their telephone lines cut as there was a shortage of telephone lines, and that the lines which were cut belonged to Bosnian Muslims who had already departed. See D2530 (Witness statement of Zdravko Čvoro dated 1 December 2012), para. 13; Zdravko Čvoro, T. 30929-30931 (4 December 2012). The Chamber rejects Čvoro's evidence on this point given his lack of candour and evasiveness in his explanation of P734, a document which bears his name (although signed by someone else) and which orders that the telephone lines of 15 Bosnian Muslims be cut. P733 (Witness statement of Sulejman Crnčalo dated 1 November 2009), para. 50.

7875 D15 (SRNA news report, 22 May 1992); Hajrudin Karić, T. 15353 (23 June 2011), T. 15376 (24 June 2011 ); D2850 (Witness statement of Tomislav Hršum dated 27 January 2013), para. 19.

7876 Hajrudin Karić, T. 15353 (23 June 2011); D15 (SRNA news report, 22 May 1992).

7877 Sulejman Crnčalo, T. 1217, 1220, 1222, 1225 (15 April 2010); P2839 (Witness statement of Hajrudin Karić, dated 13 May 2011), paras. 17-19; Hajrudin Karić, T. 15342, 15346, 15348, 15350-15351 (23 June 2011), T. 15376 (24 June 2011); D19 (Letter from Serbian villagers of Renovica to Pale Municipal Assembly, 26 June 1992); D31 (14 ${ }^{\text {th }}$ session of Pale Municipal Assembly, 18 June 1992), e-court p. 3; D2850 (Witness statement of Tomislav Hršum dated 27 January 2013), para. 19; Tomislav Hršum, T. 32925, 32956-32957 (30 January 2013); D4368 (Witness statement of Jovan Šarac dated 10 February 2014), para. 43; Jovan Šarac, T. 47149 (14 February 2014); D16 (SRNA news report, 22 May 1992).

7878 P2839 (Witness statement of Hajrudin Karić, dated 13 May 2011), paras. 17-19, 24; Hajrudin Karić, T. 15312 , 15351, 15364-15365 (23 June 2011) T. 15376 (24 June 2011); D2850 (Witness statement of Tomislav Hršum dated 27 January 2013), para. 19; Sulejman Crnčalo, T. 1227 (15 April 2010).

7879 See Adjudicated Fact 2591. 
been killed or wounded. ${ }^{7880}$ SRNA also reported that although the casualty figure in relation to the Bosnian Muslims had not been established yet, it was estimated to be "substantially greater". ${ }^{7881}$ Furthermore, SRNA quoted the Pale MUP's instruction to Muslims in Pale to hand over their weapons peacefully in order to prevent more bloodshed. ${ }^{7882}$ Around the same period, the Pale SJB also took control of villages that were situated in the direction of Renovica and Goražde. ${ }^{7883}$

2314. On 23 May 1992, Koroman appeared on television and after announcing that war had finally come to Pale, issued an ultimatum to all non-Serbs to surrender their weapons to the SJB. ${ }^{7884}$ During the days that followed, Bosnian Muslims handed over hundreds of additional pieces of weaponry to the Pale SJB. ${ }^{7885}$ Koroman subsequently informed the Pale Crisis Staff of the attack against Renovica and was advised to transfer the Bosnian Muslims who had been detained there and who were "guilty" to Kula Prison, in Ilidža municipality, and to release the ones that were "not guilty". 7886

2315. Pale SJB's chief of Criminal Investigation Service reported that, amongst other things, forcible entry into weekend houses was widespread and that SJB operatives, instead of suppressing such acts, participated and continued to participate in their commission. ${ }^{7887}$

\section{(E) Movement of the population from Pale and appropriation of property}

2316. On or about 13 March 1992, policemen and paramilitaries started advising non-Serbs to leave Pale municipality. ${ }^{7888}$ For instance, Jovan Škobo and Novica Stanar, who were both

7880 D15 (SRNA news report, 22 May 1992).

7881 D15 (SRNA news report, 22 May 1992). The Chamber notes that killings during the course of the attack on Renovica are not charged in the Indictment.

7882 D15 (SRNA news report, 22 May 1992).

7883 P963 (Interview with Malko Koroman in RS MUP magazine "Policeman”, November 1994), p. 2.

7884 P733 (Witness statement of Sulejman Crnčalo dated 1 November 2009), para. 28; Sulejman Crnčalo, T. 1209, 1216-1217, 1220, 1258 (15 April 2010); D16 (SRNA news report, 22 May 1992); D17 (SRNA news report, 23 May 1992); D2850 (Witness statement of Tomislav Hršum dated 27 January 2013), para. 19; Tomislav Hršum, T. 32955-32956 (30 January 2013); D4368 (Witness statement of Jovan Šarac dated 10 February 2014), para. 43.

7885 Sulejman Crnčalo, T. 1258 (15 April 2010); D17 (SRNA news report, 23 May 1992); D18 (SRNA news report, 24 May 1992); D2850 (Witness statement of Tomislav Hršum dated 27 January 2013), para. 19; D4368 (Witness statement of Jovan Šarac dated 10 February 2014), para. 43.

7886 Jovan Šarac, T. 47153 (14 February 2014).

7887 P6091 (Report of Pale SJB, 31 December 1992), p. 2; P6092 (Report of Pale SJB, 12 May 1993), e-court p. 1.

7888 P733 (Witness statement of Sulejman Crnčalo dated 1 November 2009), paras. 33-34; Sulejman Crnčalo, T. 1247-1248, 1250 (15 April 2010). But see Čvoro's claim that Serb authorities went to Bosnian Muslim villages and neighbourhoods in Pale in order to persuade the population there to stay. D2530 (Witness statement of Zdravko Čvoro dated 1 December 2012), para. 6; Zdravko Čvoro, T. 30939 (4 December 2012). The Chamber rejects Čvoro's evidence on this point because of his evasiveness and his lack of candour as a witness. For example, Čvoro insisted that he had no knowledge about the Pale SJB's involvement in the expulsion of Bosnian Muslims from Pale despite being showing documentary evidence to that effect which bore his signature. See Zdravko Čvoro, T. 30963-30967 (5 December 2012); P6034 (Report of Pale Executive Board, 7 July 1992). 
policemen, as well as Kojić, a paramilitary, visited Crnčalo’s village and during this visit, Škobo told the residents that it was better for them to voluntarily go to an area where the Muslims were a majority now rather than being "chase[d] through the woods" later. ${ }^{7889}$ In response, Crnčalo, his brother and a number of neighbours went to see Starčević who assured them that if they had not done anything wrong, they had nothing to worry about. ${ }^{7890}$

2317. In May 1992, Crnčalo and his neighbours requested that Koroman organise a meeting at the SJB building and invite a high-ranking government official so that Bosnian Muslims in the Pale municipality could be given guarantees about their safety. ${ }^{7891}$ Shortly after the start of the meeting, Nikola Koljević arrived and when asked by Bosnian Muslims to give guarantees that they could stay in Pale, he replied that "Serbs don't want to continue living with you here.",7892 During the same meeting and in the presence of Koljević, Koroman told the Muslim delegates that he could no longer guarantee their safety because he was unable to hold back the Red Berets who had come from Knin. ${ }^{7893}$

2318. On 12 June 1992, Starčević asked the secretary of the Pale SDS to urgently call a meeting of the Pale SDS Main Board so that the SDS could adopt a general position on the departure of non-Serbs from the municipality. ${ }^{7894}$ On 18 June 1992, during a Pale Municipal Assembly session, the President of the Assembly, Starčević, and the President of the Executive Board, Čvoro, complained that the Pale SJB had taken measures to move the Bosnian Muslim population out of the municipality. ${ }^{7895}$ On 19 June 1992, Pale Municipal Assembly adopted a decision which required non-Serbs who wished to leave the municipality to obtain permission from the SJB. ${ }^{7896}$ Pursuant to the same decision, the Pale SJB, in co-ordination with municipal commissions, was to

7889 P733 (Witness statement of Sulejman Crnčalo dated 1 November 2009), para. 34. See also Adjudicated Fact 2588. But see Šarac's evidence that the SJB never applied pressure to Bosnian Muslims of Pale to leave the municipality. D4368 (Witness statement of Jovan Šarac dated 10 February 2014), paras. 44, 51.

$7890 \quad$ P733 (Witness statement of Sulejman Crnčalo dated 1 November 2009), para. 35.

7891 P733 (Witness statement of Sulejman Crnčalo dated 1 November 2009), paras. 36-37; Sulejman Crnčalo, T. 1164-1165 (14 April 2010), 1260-1261 (15 April 2010).

7892 P733 (Witness statement of Sulejman Crnčalo dated 1 November 2009), para. 38; Sulejman Crnčalo, T. 1164 (14 April 2010), T. 1247 (15 April 2010).

7893 P733 (Witness statement of Sulejman Crnčalo dated 1 November 2009), paras. 39-40; Sulejman Crnčalo, T. 1164 (14 April 2010). On 2 July 1992, Crnčalo saw two soldiers who were wearing red berets near the Panorama Hotel, behind a privately owned house. P733 (Witness statement of Sulejman Crnčalo dated 1 November 2009), para. 71.

7894 D30 (Letter from Pale Municipal Assembly to Pale SDS President, 12 June 1992); Zdravko Čvoro, T. 30936 (4 December 2012).

7895 D31 (14 ${ }^{\text {th }}$ session of Pale Municipal Assembly, 18 June 1992), e-court p. 4.

7896 P5090 (Decision of the Pale Assembly, 19 June 1992); Tomislav Hršum, T. 32961 (30 January 2013); D2530 (Witness statement of Zdravko Čvoro dated 1 December 2012), para. 6; D4368 (Witness statement of Jovan Šarac dated 10 February 2014), para. 48; Jovan Šarac, T. 47178 (14 February 2014). 
compile a list of all property owned by non-Serbs who were leaving the municipality. ${ }^{7897}$ The Pale Municipal Assembly also entrusted the Pale SJB with the task of organising the departure of nonSerbs and making sure that they crossed the separation line safely. ${ }^{7898}$

2319. In late June and early July 1992, Bosnian Serb authorities in Pale gave Bosnian Muslim property-owners contract forms which already contained their data. ${ }^{7899}$ By virtue of these contracts, which the Muslims had to sign before they could depart from Pale, Muslim property in Pale became Serb property in exchange for Serb-owned property in Sarajevo. ${ }^{7900}$ Those who refused to sign such contracts were forced to surrender the keys to their houses to the Pale SJB. ${ }^{7901}$

2320. During the same period, Serb authorities in Pale organised a number of convoys for the transportation of non-Serbs out of the area. ${ }^{7902}$ Prior to this, written notices were put up, informing the non-Serb population of the location and time at which they could board the buses. ${ }^{7903}$ Those boarding the buses were allowed to take only what they could carry. ${ }^{7904}$ The first convoy left Pale on or about 28 June $1992 .^{7905}$ On 2 July 1992, SerBiH MUP ordered the Pale SJB to grant permission to Bosnian Muslims and Bosnian Croats living in Pale centre to move out of the Pale municipality "of their own free will" and instructed "police and military patrols to enable the

7897 D32 (Decision of Pale Municipal Assembly, 18 June 1992); Zdravko Čvoro, T. 30951-30952 (4 December 2012).

7898 D32 (Decision of Pale Municipal Assembly, 18 June 1992); D2850 (Witness statement of Tomislav Hršum dated 27 January 2013), para. 22; Tomislav Hršum, T. 32928 (30 January 2013).

7899 P733 (Witness statement of Sulejman Crnčalo dated 1 November 2009), para. 61 ; P735 (List of contracts for exchange of houses).

7900 P733 (Witness statement of Sulejman Crnčalo dated 1 November 2009), paras. 61-62; P735 (List of contracts for exchange of houses); Sulejman Crnčalo, T. 1267 (15 April 2010); P5429 (Request for relocation to Pale Municipal Assembly, 22 June 1992); P5524 (Request of Muslim Citizens to Relocate from Pale to Sarajevo, 22 June 1992); D33 (Contract regarding a house exchange in Pale, 2 July 1992). But see Čvoro's assertion that many Muslims "protected their property by entering into various agreements" with their Serb neighbours, including agreements that left Muslim property in Serb hands for the purposes of "safe-keeping". D2530 (Witness statement of Zdravko Čvoro dated 1 December 2012), para. 6; Zdravko Čvoro, T. 30949-30950 (4 December 2012). However, the Chamber notes that during the war, Čvoro himself had lived in property that belonged to a Bosnian Muslim. See Zdravko Čvoro, T. 30982-30983 (5 December 2012). This leads the Chamber to conclude that there was an obvious underlying self-interest on the part of Čvoro for advancing the claim that Muslims placed their property in Serb hands for safe-keeping.

7901 Sulejman Crnčalo, T. 1268 (15 April 2010).

7902 P733 (Witness statement of Sulejman Crnčalo dated 1 November 2009), paras. 64, 71; P736 (Decision of Pale SJB, 2 July 1992); P737 (Decision of Pale SJB, 6 July 1992); D35 (SJB Pale report on change of residence of Croats and Muslims from Pale, 6 July 1992); Hajrudin Karić, T. 15365-15366 (23 June 2011); D4368 (Witness statement of Jovan Šarac dated 10 February 2014), para. 48. See also Adjudicated Fact 2671-2672.

7903 P733 (Witness statement of Sulejman Crnčalo dated 1 November 2009), para. 65. See also Adjudicated Fact 2671.

7904 P733 (Witness statement of Sulejman Crnčalo dated 1 November 2009), para. 71; Sulejman Crnčalo, T. 1262 (15 April 2010). See also Adjudicated Fact 2672. But see Čvoro's and Šarac's assertions that Muslims were able to take their private cars as well as all their belongings and documents with them. D2530 (Witness statement of Zdravko Čvoro dated 1 December 2012), para. 6; D4368 (Witness statement of Jovan Šarac dated 10 February 2014), para. 60.

7905 P733 (Witness statement of Sulejman Crnčalo dated 1 November 2009), para. 66; D35 (SJB Pale report on change of residence of Croats and Muslims from Pale, 6 July 1992). 
unobstructed passage of three buses transporting Muslim civilians". 7906 The third convoy left Pale on 2 July 1992 for Hreša, a small hamlet near Sarajevo. ${ }^{7907}$ From Hreša, non-Serbs from Pale went to a reception centre for refugees in Vratnik, which was operated by Bosnian Muslim authorities. $^{7908}$

2321. On 6 July 1992, the Bosnian Serb MUP issued a decision, granting the request by non-Serbs living in the inner parts of Pale to move out of the Pale municipality "of their own free will" and "under the escort of police officers" of the Pale SJB, and instructed "police and military patrols" to enable the unobstructed passage of 420 civilians aboard eight buses bound for Stari Grad municipality. ${ }^{7909}$

2322. On the same day, pursuant to the instructions of the SerBiH government, the Executive Board decided that non-Serb individuals or families must not be allowed to leave the territory of the municipality until "a list of their property is made and the property is taken over in accordance with the regulations in force."7910 The Executive Board also requested that the Pale SJB take immediate measures to protect the property left behind by the non-Serbs until such time that this property was taken over by an authorised municipal commission. ${ }^{7911}$

2323. Also on 6 July 1992, the Pale SJB reported that between 30 June and 3 July 1992, it had "organised change of the place of residence from the territory of Pale municipality to the territory of Stari Grad Sarajevo municipality" of 1,042 non-Serbs. ${ }^{7912}$ The SJB continued to organise the movement of Bosnian Muslims out of Pale municipality for another one or two months. ${ }^{7913}$

2324. In a letter dated 7 July 1992, the Executive Board informed Plavšić that despite the Assembly's decision of 19 June $1992,{ }^{7914}$ there had been "forced and wilful" efforts to move Bosnian Muslims out of the municipality, resulting in a large number of criminal acts. ${ }^{7915}$

\footnotetext{
7906 P736 (Decision of Pale SJB, 2 July 1992).

7907 P733 (Witness statement of Sulejman Crnčalo dated 1 November 2009), paras. 9, 66, 77; Sulejman Crnčalo, T. 1238 (15 April 2010); D35 (SJB Pale report on change of residence of Croats and Muslims from Pale, 6 July 1992).

7908 P733 (Witness statement of Sulejman Crnčalo dated 1 November 2009), para. 77.

7909 P737 (Decision of Pale MUP, 6 July 1992).

7910 P738 (Conclusions of Pale Executive Board, 6 July 1992); P6031 (SerBiH Decree published in SerBiH's Official Gazette, 8 June 1992); Zdravko Čvoro, T. 30953-30954 (4 December 2012).

7911 P738 (Conclusions of Pale Executive Board, 6 July 1992); D2530 (Witness statement of Zdravko Čvoro dated 1 December 2012), para. 7; Zdravko Čvoro, T. 30951 (4 December 2012).

7912 P5428 (Report of Pale SJB, 6 July 1992); D35 (SJB Pale report on change of residence of Croats and Muslims from Pale, 6 July 1992).

7913 D2850 (Witness statement of Tomislav Hršum dated 27 January 2013), para. 22.

$7914 \quad$ See para. 2318.

7915 P6034 (Report of Pale Executive Board, 7 July 1992).
} 
2325. On 14 July 1992, the Executive Board noted the theft and unlawful use of abandoned property in Pale which in its opinion was attributable to the failure of the commissions established earlier for the purpose of making an inventory of abandoned non-Serb property. The Executive Board then established a new audit commission to re-examine the situation and file a written report. $^{7916}$

2326. On 19 July 1992, the Accused requested that Pale municipal authorities make an inventory of all housing facilities that were vacant "following the voluntary departure of Muslims."7917 On 10 August 1992, the Municipal Assembly signed over non-Serb housing property to Serb refugees for "temporary use". 7918 The municipal authorities also concentrated the movable property left behind by Muslims in the premises of various military and non-military institutions. ${ }^{7919}$

2327. On or about 24 July 1992, the Accused informed the Bosnian Serb Assembly that the Bosnian Serb government was giving assurances to Bosnian Muslims in Pale that "they have nothing to fear.",7920

2328. On 20 October 1992, the Executive Board decided to seize all movable property belonging to persons who had been outside of Pale municipality for more than 30 days. $^{7921}$ The Executive Board then noted that temporary allocation of such property to Serb refugees in Pale may take place on the condition that such allocation is authorised and recorded by a competent municipal commission. ${ }^{7922}$

2329. Only a small number of Bosnian Muslims remained in Pale municipality during the war. ${ }^{7923}$

2330. The Accused argues that (i) through their elected representatives or by filing individual applications, Bosnian Muslims of Pale requested permission to leave the municipality; ${ }^{7924}$ (ii) the

\footnotetext{
7916 D34 (Conclusion by Pale Executive Board, 14 July 1992); D2530 (Witness statement of Zdravko Čvoro dated 1 December 2012), para. 8; Zdravko Čvoro, T. 30952, 30955 (4 December 2012).

7917 P739 (RS Presidency request to various municipalities, 19 July 1992).

7918 D2850 (Witness statement of Tomislav Hršum dated 27 January 2013), para. 22; D4368 (Witness statement of Jovan Šarac dated 10 February 2014), para. 48; D4369 (Decision of Pale Municipal Assembly, 10 August 1992).

7919 Zdravko Čvoro, T. 30952 (4 December 2012).

7920 D27 (Radovan Karadžić's speech from 17 $7^{\text {th }}$ session of RS Assembly, 24-26 July 1992), e-court p. 3.

7921 D4737 (Conclusion of Pale Executive Board, 21 October 1992).

7922 D4737 (Conclusion of Pale Executive Board, 21 October 1992).

7923 D2850 (Witness statement of Tomislav Hršum dated 27 January 2013), para. 22; D4002 (Letter from BiH MUP to Vasvija Vidović, 4 July 1995), p. 57; P4994 (Addendum to Ewa Tabeau's expert report entitled "Ethnic Composition in Internally Displaced Persons and Refugees from 27 Municipalities of BiH 1991 to 1997”, 3 February 2009), pp. 21, 30.

7924 Defence Final Brief, para. 1720. Witnesses testified that through their elected representatives and by signing individual requests, the Bosnian Muslims in Pale sought permission from the municipal authorities to leave the municipality. They testified further that despite the assurances repeatedly given by the municipal and RS authorities, including those given by Biljana Plavšić in Prača, the Bosnian Muslim population of Pale insisted on
} 
Bosnian Muslims of Pale asked to leave because the Bosnian Muslim authorities in Sarajevo had demanded such departure as part of their preparations for a planned military take-over of Pale ${ }^{7925}$ and (iii) in order to prevent the departure of Bosnian Muslims, Serb authorities guaranteed the civil rights of all people regardless of any ethnic or religious affiliation. ${ }^{7926}$

2331. Having considered the totality of the evidence and assessed the circumstances in which the departures occurred, the Chamber finds that Bosnian Muslims were forced to leave. The Chamber notes that in some instances, Bosnian Muslims requested to leave the municipality; however, the Chamber finds that even when the Bosnian Muslims did request to leave Pale, they were driven by the fear caused by all of the surrounding circumstances. Consequently, the Chamber is satisfied that Bosnian Muslims were forced to leave the Serb-controlled parts of Pale municipality.

(F) Scheduled Detention Facility C.19.2 and Scheduled Incident B.14.1

2332. The Indictment refers to the use of Pale Gym as a detention facility at least between May and August 1992, and alleges that between June and July 1992, a number of men died as a result of beatings which they sustained in there.

\section{(1) Establishment and control}

2333. Pale Gym was a large sports hall situated near the Pale SJB, in Pale Culture Centre. ${ }^{7927}$ There were windows only on one side of Pale Gym. ${ }^{7928}$

2334. On 10 May 1992, Mirsad Smajš and eight other detainees from the Sarajevo area were transferred from Kula Prison to Pale Gym; at that point Pale Gym already held approximately 100 detainees, including some Serbs and Croats, and was guarded by SJB members in blue uniforms with the Serb flag emblazoned on the shoulder. ${ }^{7929}$ Upon arrival, each detainee was given a sandwich and a bottle of water. ${ }^{7930}$

their demand to leave. See D2850 (Witness statement of Tomislav Hršum dated 27 January 2013), para. 22; Tomislav Hršum, T. 32960-32962 (30 January 2013); D2530 (Witness statement of Zdravko Čvoro dated 1 December 2012), paras. 5-6; D4368 (Witness statement of Jovan Šarac dated 10 February 2014), para. 47; Jovan Šarac, T. 47178-47179 (14 February 2014); D3671 (Witness statement of Dušan Kovačević dated 7 June 2013), para. 41.

7925 Defence Final Brief, para. 1720.

7926 Defence Final Brief, para. 1721. See also D2530 (Witness statement of Zdravko Čvoro dated 1 December 2012), para. 5; Jovan Šarac, T. 47173-47175, 47177-47179 (14 February 2014).

7927 P2839 (Witness statement of Hajrudin Karić, dated 13 May 2011), para. 24; P3205 (Witness statement of KDZ605 dated 22 August 2011), para. 115 (under seal). P43 (Witness statement of Mirsad Smajš dated 14 January 1998), e-court p. 10.

7928 P43 (Witness statements of Mirsad Smajš dated 14 January 1998), e-court p. 10.

7929 P43 (Witness statement of Mirsad Smajš dated 18 December 1993), e-court pp. 5-6; P43 (Witness statement of Mirsad Smajš dated 18 December 1993), e-court pp. 9-11; P3205 (Witness statement of KDZ605 dated 22 
2335. A few days later, a group of about 400 badly beaten Bosnian Muslim men who had previously been detained at Vuk Karadžić School in Bratunac, were brought to Pale Gym in several trucks. ${ }^{7931}$ One by one, the detainees were taken off the trucks, registered and placed in the gym. $^{7932}$

2336. As was mentioned earlier, on 22 May, after conducting a military operation in Renovica, Serb Forces detained about 30 Bosnian Muslim men and took them to Pale Gym. ${ }^{7933}$

2337. During the last week of May 1992, Hajrudin Karić was arrested by two policemen, who then took him to Pale Gym. ${ }^{7934}$ At the time of Karić's arrival, Pale Gym was guarded by a number of policemen, including Predrag Štrbac, a man with the last name Čvoro, and Neđelko Kovačević. ${ }^{7935}$ Upon entering Pale Gym, Karić saw that it was full of Bosnian Muslims, including a woman. ${ }^{7936}$

August 2011) (under seal), paras. 116-117. See also Adjudicated Fact 2641. See Scheduled Detention Facility C.18.2. The Chamber notes that Jovan Šarac denied that anyone other than the prisoners from Bratunac was detained at Pale Gym. D4368 (Witness statement of Jovan Šarac dated 10 February 2014), para. 55. The Chamber notes it received reliable evidence to the contrary, that detainees from the Sarajevo area and from within Pale municipality were in fact brought to Pale Gym. See paras. 2334, 2337. P43 (Witness statement of Mirsad Smajš dated 18 December 1993), e-court p. 6.

7931 KDZ605, T. 17923 (25 August 2011); P3205 (Witness statement of KDZ605 dated 22 August 2011), paras. 108-109, 115, 122 (under seal); P43 (Witness statement of Mirsad Smajš dated 18 December 1993), e-court p. 6; P43 (Witness statement of Mirsad Smajš dated 14 January 1998), e-court pp. 10-11; P3208 (List of men taken from Bratunac to Pale); D2850 (Witness statement of Tomislav Hršum dated 27 January 2013), para. 17; D4368 (Witness statement of Jovan Šarac dated 10 February 2014), para. 41; Jovan Šarac, T. 47148-47149 (14 February 2014). See also Adjudicated Fact 2642. Some of the detainees from Bratunac had serious injuries. P43 (Witness statement of Mirsad Smajš dated 14 January 1998), e-court pp. 10-11; P733 (Witness statement of Sulejman Crnčalo dated 1 November 2009), para. 56; P3206 (Video footage re people from Bratunac in Visoko sports hall, with transcript); Zdravko Čvoro, T. 30945-30946 (4 December 2012). The Chamber notes that Jovan Šarac qualified his assertion that the men from Bratunac bore "no visible injuries" by stating that he had not spent much time in Pale Gym. Jovan Šarac, T. 47149 (14 February 2014). See also D2850 (Witness statement of Tomislav Hršum dated 27 January 2013), para. 17 (stating that there was "no record or information" that these citizens were mistreated during their stay in Pale); Tomislav Hršum, T. 32939-32941 (30 January 2013) (asserting that the Pale SJB did not investigate whether the detainees from Bratunac had been mistreated prior to their arrival and that they had not been mistreated while in Pale).

7932 P3205 (Witness statement of KDZ605 dated 22 August 2011), para. 113 (under seal). Approximately 100 Serb civilians had gathered near the trucks while the detainees disembarked, and "a few" soldiers wearing camouflage uniforms were also present nearby. P3205 (Witness statement of KDZ605 dated 22 August 2011), para. 115 (under seal). [REDACTED]. See Scheduled Detention Facility C.6.2 and Scheduled Incident B.4.1.

7933 See para. 2313.

7934 Karić did not know the identities of the two officers, but noted that they were wearing regular police uniforms. Karić was later told that he had been detained because his brother-in-law had participated in fighting in Bukvice village. P2839 (Witness statement of Hajrudin Karić, dated 13 May 2011), paras. 21-23; Hajrudin Karić, T. 15354-15356, 15358-15361, 15363 (23 June 2011).

7935 P2839 (Witness statement of Hajrudin Karić, dated 13 May 2011), paras. $26-27$.

7936 P2839 (Witness statement of Hajrudin Karić, dated 13 May 2011), para. 24; Hajrudin Karić, T. 15366-15367 (23 June 2011). 
2338. On 4 June 1992, Azem Omerović and three other men were taken to Pale Gym by Serbs in camouflage uniforms using police cars. ${ }^{7937}$

\section{(2) Conditions of detention and treatment of detainees}

2339. The detainees were given sufficient water to drink but insufficient food, only receiving sandwiches with a little bologna once a day; they became weak from hunger and often fainted. ${ }^{7938}$ They slept on the floor and they could only use the toilet after having received permission from the guards. ${ }^{7939}$

2340. The detainees in Pale Gym were constantly subjected to maltreatment. ${ }^{7940}$ The guards told them that they would be killed unless they were exchanged. ${ }^{7941}$ The guards also warned them not to attempt to escape and indicated that guards had been posted near each window. ${ }^{7942}$ The detainees were severely beaten with whatever the guards could have put their hands on and had to run the gauntlet when they asked to go to the toilet. ${ }^{7943}$ Smajš observed a man in a police uniform use a curved knife to cut off the detainees' hair. ${ }^{7944}$

2341. At one point, a fair-haired man, approximately 40 years old and wearing a police uniform, entered Pale Gym and introduced himself as a police commander from Pale. ${ }^{7945}$ He then proceeded

7937 See Adjudicated Fact 2643. But see P2839 (Witness statement of Hajrudin Karić, dated 13 May 2011), para. 25 (asserting that while he was detained in Pale Gym-that is, between 30 May and 11 July 1992-no more prisoners were brought to the gym). See also D4368 (Witness statement of Jovan Šarac dated 10 February 2014), paras. 41, 58 (stating that no additional "POWs" were brought to Pale Gym after the departure of the Bratunac detainees).

7938 P3205 (Witness statement of KDZ605 dated 22 August 2011), para. 121 (under seal); P2839 (Witness statement of Hajrudin Karić, dated 13 May 2011), para. 25; Hajrudin Karić, T. 15307-15308 (23 June 2011). See also Adjudicated Fact 2644.

P43 (Witness statement of Mirsad Smajš dated 14 January 1998), e-court p. 10. See also Adjudicated Fact 2644.

7940 P43 (Witness statement of Mirsad Smajš dated 18 December 1993), e-court p. 6. See also Adjudicated Fact 2645. Jovan Šarac stated that he had not received any information about the beatings of the detainees held in Pale Gym. Jovan Šarac, T. 47154-47158 (14 February 2014); D4368 (Witness statement of Jovan Šarac dated 10 February 2014), para. 57. The Chamber notes that even if accepted as reliable, Šarac's testimony does not necessarily suggest that maltreatment and beatings did not occur at Pale Gym. Hršum stopped short of asserting that no Bosnian Muslims had ever been beaten while in the custody of the Pale SJB, and accepted that the police guards might have allowed entry to the gym by "certain individuals". Hršum, however, insisted that the police guards did not undertake any "repressive measures" themselves. Tomislav Hršum, T. 32942 (30 January 2013). The Chamber found that Hršum worked for SJB Pale and that SJB Pale was involved in the detention of Bosnian Muslims in Pale Gym. D2850 (Witness statement of Tomislav Hršum dated 27 January 2013), paras. 1, 16; Tomislav Hršum, T. 32939-32942 (30 January 2013). These facts, in addition to Hršum's general evasiveness and lack of candour as a witness, lead the Chamber to conclude that Hršum had an incentive to distance himself from the events at the Pale Gym. Accordingly, the Chamber places no weight on Hršum's assertion that the members of the Pale SJB were never involved in beatings of detainees in Pale Gym. P3205 (Witness statement of KDZ605 dated 22 August 2011), paras. 117-118 (under seal). P3205 (Witness statement of KDZ605 dated 22 August 2011), para. 118 (under seal).

P3205 (Witness statement of KDZ605 dated 22 August 2011), paras. 116, 119 (under seal); KDZ605, T. 17924 (25 August 2011); P43 (Witness statement of Mirsad Smajš dated 14 January 1998), e-court p. 10.

7944 P43 (Witness statement of Mirsad Smajš dated 18 December 1993), e-court p. 6.

7945 P3205 (Witness statement of KDZ605 dated 22 August 2011), para. 120 (under seal). 
to beat the detainees. ${ }^{7946}$ At the same time, a soldier entered Pale Gym and announced that everyone would be killed unless the soldier's brother, who had been captured by Bosnian Muslims, was released. $^{7947}$

2342. Sometime after the Bosnian Muslim men from Bratunac had arrived, the guards had a disagreement with "army troops" who were at the door and wanted to enter the gym to beat the detainees. ${ }^{7948}$ The guards installed bars on the windows as well as an iron door in order to prevent them from entering the gym. ${ }^{7949}$ However, later, during Karić's detention, the police guards allowed paramilitary members, including members of Rajko Kušić's and Srđan Knežević's units, to access Pale Gym multiple times each day and beat the detainees severely with sticks and rifle butts. ${ }^{7950}$ Members of these paramilitary groups also took detainees out of Pale Gym to be beaten and some of those detainees never returned to the gym. ${ }^{7951}$

2343. On 15 May 1992, Branko Đerić ordered Sokolac Crisis Staff to provide "three tow trucks with canvas cover" for transportation of detainees from Pale to Visoko; Nedeljko Lakić requested that the Ilijaš Crisis Staff approve and provide passage through Ilijaš municipality for a group of detainees who were at Pale and who were going to be transported to Visoko under the escort of Pale Crisis Staff. Lakić also requested that the approval be destroyed the moment the detainees left Ilijaš. ${ }^{7952}$ On the morning of 16 or 17 May, the guards told the detainees from Bratunac that they were going to be exchanged, took them out of the gym in groups of ten, tied them together, and forced them to sing Serb songs before loading them onto trucks. ${ }^{7953}$ The detainees were then transferred under VRS escort to Visoko where they were exchanged. ${ }^{7954}$

\footnotetext{
7946 P3205 (Witness statement of KDZ605 dated 22 August 2011), para. 120 (under seal).

7947 P3205 (Witness statement of KDZ605 dated 22 August 2011), paras. 120, 123 (under seal).

7948 P3205 (Witness statement of KDZ605 dated 22 August 2011), para. 117 (under seal).

7949 P3205 (Witness statement of KDZ605 dated 22 August 2011), para. 117 (under seal); KDZ605, T. 17924 (25 August 2011).

7950 P2839 (Witness statement of Hajrudin Karić, dated 13 May 2011), paras. 28-29, 31. On 6 July 1992, a soldier ordered Karić to help another prisoner, Fahrudin Sipović, who had been beaten and lay on the ground with a broken arm and covered in blood, to stand up. As Sipović attempted to stand, the soldier beat him with a piece of wood. P2839 (Witness statement of Hajrudin Karić, dated 13 May 2011), para. 36.

7951 P2839 (Witness statement of Hajrudin Karić, dated 13 May 2011), paras. 29-30, 42-43. On 28 June 1992, Karić was called out of the main gymnasium by two relations of Rajko Kušić, who swore at Karić and beat him with a wooden stick until he fainted. After approximately 10 minutes, another Bosnian Serb, Milomir Tepeš, arrived and said "it's not him". The paramilitaries then threw Karić back in the main gym while badly injured. P2839 (Witness statement of Hajrudin Karić, dated 13 May 2011), paras. 32-33; Hajrudin Karić, T. 15304 15305, 15367-15368 (23 June 2011), T. 15372 (24 June 2011).

7952 P1604 (Letter from Nedeljko Lakić to Ilijaš Crisis Staff, 15 May 1992); P2619 (SerBiH order, 15 May 1992). Lakić also requested that the approval be destroyed the moment the detainees left Ilijaš.

7953 P3205 (Witness statement of KDZ605 dated 22 August 2011), para. 122 (under seal); KDZ605, T. 17925 (25 August 2011); P43 (Witness statements of Mirsad Smajš dated 18 December 1993 and 14 January 1998), ecourt pp. 6, 11 .

7954 P3205 (Witness statement of KDZ605 dated 22 August 2011), paras. 126-127 (under seal).
} 
2344. On 18 May, Smajš and 64 other detainees were also called out of Pale Gym. ${ }^{7955}$ This group was placed on a military cargo truck and transported to Hreša to be exchanged. ${ }^{7956}$

2345. On 6 July 1992, approximately five men belonging to Kušić's unit entered the gym and beat three Bosnian Muslim detainees with wooden sticks and brass knuckles until they were unconscious. $^{7957}$ Two of the detainees died about thirty minutes after the end of the beatings, and the third died two days later, without having received any medical care. ${ }^{7958}$

2346. On 11 July 1992, Hajrudin Karić and 34 other detainees were transferred, under the escort of reserve police, to Kula Prison. ${ }^{7959}$

\section{(3) $\underline{\text { Conclusion }}$}

2347. Based on the above, the Chamber finds that Serb Forces brought to and detained non-Serbs, including at least one woman, at Pale Gym from approximately 10 May to 11 July 1992. The Chamber further finds that the detainees were held in poor conditions. These included lack of food and adequate medical care. The Chamber also finds that detainees were regularly subjected to beatings by Serb Forces at Pale Gym and that at least three detainees died as a result of such beatings.

\section{(G) Scheduled Incident D.16}

2348. The Indictment refers to the destruction of three mosques, namely the mosques at Prača, Podvitez, and Bogovići, between July and September 1992. ${ }^{7960}$

2349. There were at least three mosques in Pale municipality. ${ }^{7961}$ Crnčalo heard that all three mosques were destroyed between 2 July and September $1992 .{ }^{7962}$

\footnotetext{
7955 P43 (Witness statement of Mirsad Smajš dated 18 December 1993), e-court pp. 6-7; P43 (Witness statement of Mirsad Smajš dated 14 January 1998), e-court p. 11.

7956 P43 (Witness statement of Mirsad Smajš dated 18 December 1993), e-court pp. 6-7; P43 (Witness statement of Mirsad Smajš dated 14 January 1998), e-court p. 11. See also Adjudicated Fact 2641.

7957 P2839 (Witness statement of Hajrudin Karić, dated 13 May 2011), paras. 37-38.

7958 P2839 (Witness statement of Hajrudin Karić, dated 13 May 2011), paras. 39-41; Hajrudin Karić, T. 15305 (23 June 2011); Sulejman Crnčalo, T. 1227 (15 April 2010); P4416 (Death certificate for Selim Pandžić). See also Adjudicated Fact 2647.

7959 P2839 (Witness statement of Hajrudin Karić, dated 13 May 2011), paras. 30, 44-45; D2850 (Witness statement of Tomislav Hršum dated 27 January 2013), para. 19 (stating that the persons taken into custody after the operation in Renovica were ultimately transported to Kula Prison). See also Adjudicated Fact 2646. See Scheduled Detention Facility C.18.2.

7960 Indictment, Scheduled Incident D.16. In its Final Brief, the Prosecution notes that evidence showed that the Prača Mosque was destroyed in October 1992. See Prosecution Final Brief, Appendix B, p. 31, fn. 447.

7961 Zdravko Čvoro, T. 30958 (5 December 2012).

7962 P733 (Witness statement of Sulejman Crnčalo dated 1 November 2009), para. 79.
} 
2350. According to Riedlmayer, the Podvitez mosque and the Bogovići mosque were "completely destroyed" in "the first year of the war" 7963 and the Prača mosque was "completely destroyed" by mining on 10 October $1992 .^{7964}$

2351. While the Chamber relies on Riedlmayer for the purposes of finding that the mosques in question were destroyed, and determining the nature and extent of the damage to those sites, it does not rely on his evidence in order to determine who was responsible for the destruction as such matters fall outside Riedlmayer's expertise and are based on statements which he received from, amongst others, the Islamic Community of $\mathrm{BiH}$ and informants.

2352. Having received no other evidence concerning Scheduled Incident D.16, the Chamber is not satisfied, beyond reasonable doubt, that Serb Forces destroyed the Prača, Podvitez, and Bogovići mosques, between July and September 1992.

\section{vi. Vogošća}

(A) Charges

2353. Under Count 3, the Prosecution alleges that persecution, a crime against humanity, was committed in Vogošća as part of the objective to permanently remove Bosnian Muslims and/or Bosnian Croats from the Municipalities. ${ }^{7965}$ Acts of persecution alleged to have been committed by Serb Forces and Bosnian Serb Political and Governmental Organs in Vogošća include killings related to detention facilities, as well as killings committed during, and deaths resulting from, cruel and inhumane treatment at these detention facilities. ${ }^{7966}$ The Prosecution also characterises these killings as extermination, a crime against humanity, under Count 4; murder, a crime against humanity, under Count 5; and murder, a violation of the laws or customs of war, under Count $6 .^{7967}$

2354. Other acts of persecution alleged to have been committed in Vogošća by Serb Forces and Bosnian Serb Political and Governmental Organs include: (i) torture, beatings, and physical and psychological abuse during and after the take-over and in scheduled detention facilities as cruel or inhumane treatment; ${ }^{7968}$ (ii) rape and other acts of sexual violence, during and after the take-over

\footnotetext{
7963 P4070 (Attachment to the expert report of András J. Riedlmayer, entitled "Destruction of Cultural Heritage in BiH” prepared for the Karadžić case, formatted records), e-court pp. 208-210. See also P4069 (Cultural destruction database), records 209, 211.

7964 P4070 (Attachment to the expert report of András J. Riedlmayer, entitled "Destruction of Cultural Heritage in BiH” prepared for the Karadžić case, formatted records), e-court pp. 205-207. See also P4069 (Cultural destruction database), record 212.

7965 Indictment, paras. 48-49.

7966 Indictment, para. 60(a)(ii). See Scheduled Incident B.19.1; Scheduled Detention Facilities C.26.1, C.26.3.

7967 Indictment, para. 63(b).

7968 Indictment, para. 60(b). See Scheduled Detention Facilities C.26.1, C.26.3.
} 
and in scheduled detention facilities, as cruel and inhumane treatment; ${ }^{7969}$ (iii) the establishment and perpetuation of inhumane living conditions in scheduled detention facilities, including the failure to provide adequate accommodation, shelter, food, water, medical care, or hygienic sanitation facilities, as cruel or inhumane treatment; ${ }^{7970}$ (iv) forcible transfer or deportation of Bosnian Muslims and Bosnian Croats from their homes; ${ }^{7971}$ (v) unlawful detention in scheduled detention facilities, ${ }^{7972}$ (vi) forced labour at frontlines and the use of Bosnian Muslims and Bosnian Croats as human shields; ${ }^{7973}$ (vii) the wanton destruction of private property, including homes and business premises, and public property, including cultural monuments and sacred sites $;{ }^{7974}$ and (viii) the imposition and maintenance of restrictive and discriminatory measures. ${ }^{7975}$

2355. Under Counts 7 and 8, the Prosecution alleges deportation and inhumane acts (forcible transfer), respectively, as crimes against humanity. ${ }^{7976}$ In this regard, the Prosecution alleges that by the end of 1992, Serb Forces and Bosnian Serb Political and Governmental Organs forcibly displaced Bosnian Muslims and Bosnian Croats from areas in Vogošća in which they were lawfully present. ${ }^{7977}$ It is alleged that from March 1992, restrictive and discriminatory measures, arbitrary arrest and detention, harassment, torture, rape and other acts of sexual violence, killing, destruction of houses, cultural monuments, and sacred sites, as well as the threat of further such acts caused Bosnian Muslims and Bosnian Croats to flee in fear, while others were physically driven out. ${ }^{7978}$

\section{(B) Lead-up}

2356. Vogošća, one of the ten municipalities making up Sarajevo, is located to the north of the city of Sarajevo, between the municipalities of Novi Grad and Ilijaš. ${ }^{7979}$ It includes, inter alia, the largely Muslim inhabited villages or settlements of Barice, Kiše, Tihovići, Svrake, Hotonj, Kobilja

\footnotetext{
7969 Indictment, para. 60(c). See Scheduled Detention Facility C.26.3. The Prosecution does not allege criminal responsibility for rape and other acts of sexual violence at Scheduled Detention Facility C.26.1. Indictment, fn. 5.

7970 Indictment, para. 60(d). See Scheduled Detention Facilities C.26.1, C.26.3.

7971 Indictment, para. 60(f).

7972 Indictment, para. 60(g). See Scheduled Detention Facilities C.26.1, C.26.3.

7973 Indictment, para. 60(h)

7974 Indictment, para. 60(j). See Schedule D.21.

7975 Indictment, para. 60(k). The restrictive and discriminatory measures alleged include the denial of freedom of movement; the removal from positions of authority; the invasion of privacy through arbitrary searches of homes; unlawful arrest and/or the denial of the right to judicial process; and/or the denial of equal access to public services.

7976 Indictment, para. 68-75.

7977 Indictment, paras. 69, 72.

7978 Indictment, para. 71.

7979 P966 (Map of Sarajevo marked by Robert Donia); P2362 (Map of Vogošća municipality with photographs); P973 (Robert Donia's expert report entitled "Bosnian Serb Leadership and the Siege of Sarajevo, 1990-1995", January 2010), p. 8; Appendix B, Map 1; Robert Donia, T. 3130 (1 June 2010); P2345 (Witness statement of KDZ020 dated 17 February 2011), para. 3. See also Adjudicated Fact 2.
} 
Glava and Ugorsko as well as the mainly Serb inhabited villages of Krivoglavci, Kotorovići, Blagovac, Paljevo Brdo and Semizovac. ${ }^{7980}$ According to the 1991 census, Vogošća municipality had approximately 24,700 inhabitants, of whom 51\% were Bosnian Muslims, 36\% were Bosnian Serbs, and $4 \%$ were Bosnian Croats. ${ }^{7981}$

2357. Vogošća was one of the most industrialised municipalities in the territory of SFRY, hosting several large factories, including the Pretis factory which manufactured artillery and ammunition. ${ }^{7982}$ There was also a JNA installation called the Semizovac Barracks, which was used to store weaponry and equipment of the JNA, the Vogošća TO as well as the Ilijaš TO. ${ }^{7983}$

2358. During the 1990 elections, the SDA won 18 seats in the Municipal Assembly, the SDS 15 seats, and other parties secured 18 seats. $^{7984}$ Subsequently, the SDA and SDS formed a coalition and divided the positions of authority in Vogošća amongst themselves. ${ }^{7985}$ Thus, Bilal Hasanović from the SDA became the President of the Vogošća Municipal Assembly, and Rajko Koprivica, who was the President of the SDS in the municipality, became the President of the Executive Board. ${ }^{7986}$ Vehid Hodžić, a Bosnian Muslim, became the Chief of the Vogošća SJB. ${ }^{7987}$

7980 P2345 (Witness statement of KDZ020 dated 17 February 2011), paras. 34, 61; KDZ020, T. 12608, 12618 (1 March 2011); D4028 (Article from Naš Glas entitled "Vogošća has a future”, 13 June 1992), p. 1; P2361 (Witness statement of Eset Muračević dated 24 February 2011), paras. 3-4, 99; Eset Muračević, T. 12650, 12672-12673, (1 March 2011); P2402 (Table prepared by Eset Muračević), e-court pp. 1-4; Svetozar Stanić, T. 31678-31679 (18 December 2012); Miladin Trifunović, T. 30393 (15 November 2012); D4002 (Letter from BiH MUP to Vasvija Vidović, 4 July 1995), p. 55.

7981 P5964 (Census data for BiH by municipality in 1971, 1981, and 1991, April 1995), e-court p. 2 ; P2402 (Table prepared by Eset Muračević), e-court p. 5; D4002 (Letter from BiH MUP to Vasvija Vidović, 4 July 1995), p. 55; P2345 (Witness statement of KDZ020 dated 17 February 2011), para. 6; Svetozar Stanić, T. 31678-31679 (18 December 2012). But see P4994 (Addendum to Ewa Tabeau's expert report entitled "Ethnic Composition in Internally Displaced Persons and Refugees from 27 Municipalities of BiH 1991 to 1997”, 3 February 2009), pp. 21, 31, 34, 40, 74, 76, 80 (indicating that in 1991 Vogošća had 19,970 inhabitants of whom, approximately 49\% were Bosnian Muslims, 37\% were Bosnian Serbs and 4\% Bosnian Croats). While the Chamber has found Tabeau's evidence to be generally reliable, for the purpose of determining the population of Vogošća and the ethnic composition thereof in 1991, it relies on other evidence before it, such as the direct source document, P5964, which contains the raw data from the 1991 census in $\mathrm{BiH}$.

7982 P2345 (Witness statement of KDZ020 dated 17 February 2011), paras. 5, 34, 43; Svetozar Stanić, T. 31679 (18 December 2012); P2621 (Order of SerBiH Government, 17 June 1992), p. 1.

7983 P2345 (Witness statement of KDZ020 dated 17 February 2011), paras. 34, 39, 44; P2361 (Witness statement of Eset Muračević dated 24 February 2011), para. 9; Eset Muračević, T. 12735 (2 March 2011).

7984 P2345 (Witness statement of KDZ020 dated 17 February 2011), para. 6; KDZ020, T. 12470-12471 (25 February 2011).

7985 P2345 (Witness statement of KDZ020 dated 17 February 2011), para. 7.

7986 P2345 (Witness statement of KDZ020 dated 17 February 2011), paras. 7-8, 51; KDZ020, T. 12473 (25 February 2011); P2361 (Witness statement of Eset Muračević dated 24 February 2011), para. 10; Eset Muračević, T. 12697-12698 (1 March 2011).

7987 Eset Muračević, T. 12697 (1 March 2011). 
2359. At times, Koprivica and Jovan Tintor, a high-ranking SDS official in Vogošća, ${ }^{7988}$ met with Momčilo Krajišnik in Hotonj. ${ }^{7989}$ Before the war, the Accused also visited Vogošća municipality on one or two occasions. ${ }^{7990}$

(1) Creation of separate Bosnian Serb institutions

2360. Discussions at the municipal level for the creation of a Serb SJB started in September 1991. ${ }^{7991}$ In September or October 1991, there were changes in the personnel structure of the Vogošća SJB; Borislav Maksimović, a Serb, was appointed as Commander, and two high-ranking Serb officials were replaced by a Bosnian Croat and a Bosnian Muslim. ${ }^{7992}$ Neither Bosnian Muslims nor Bosnian Serbs in Vogošća welcomed these changes. ${ }^{7993}$ Hodžić was warned that the staffing situation could result in demonstrations. ${ }^{7994}$ As a result, the Vogošća SJB organised reinforcements at the Pretis gate and the Semizovac flyover. ${ }^{7995}$

2361. In early 1992, a Serb Crisis Staff was established and Tintor was appointed as its President. $^{7996}$

7988 P2361 (Witness statement of Eset Muračević dated 24 February 2011), para. 10; Eset Muračević, T. 1275012751 (2 March 2011). See also Adjudicated Fact 2593.

7989 P2345 (Witness statement of KDZ020 dated 17 February 2011), para. 83.

7990 P2345 (Witness statement of KDZ020 dated 17 February 2011), para. 83.

7991 In an intercepted conversation dated 7 September 1991, Tintor told Milan Plakalović that they no longer had a single man in SUP and that a Serb SUP was therefore going to be established. P2347 (Intercept of conversation between Jovan Tintor and Milan Plakalović, 7 September 1991), p. 8.

7992 P2344 (Witness statement of KDZ020 dated 17 February 2011), paras. $23-24$ (under seal); KDZ020, T. 12537, 12542 (28 February 2011) (private session).

7993 P2344 (Witness statement of KDZ020 dated 17 February 2011), paras. 25, 27-28, 30-31 (under seal); KDZ020, T. 12539 (28 February 2011) (private session). In an intercepted conversation with Milan Plakalović, Tintor warned that as a result of the dismissals, Vogošća will "flare up [...] on Monday" and that "[a]ll the people will go out here, all of them, ten thousand people, to block all the roads!" P2347 (Intercept of conversation between Jovan Tintor and Milan Plakalović, 7 September 1991), p. 6. On 11 September 1991, during a telephone conversation, Rajko Koprivica and Tintor discussed the outcome of a meeting Koprivica had with Hodžić, Kemo Šabović, the head of the CSB, and Mićo Stanišić with respect to the reinstatement of Serb officers. In the same conversation, Koprivica implied that he was unable to proceed further without consulting with Momčilo Krajišnik first whereas Tintor replied by saying "[w]e will not go forward until we get a Martić in each municipality.” P2348 (Intercept of conversation between Jovan Tintor and Rajko, 11 September 1991), pp. 2-3. On 12 September 1991, Tintor and Mićo Stanišić discussed the staffing changes that had taken place in Vogošća SJB and Tintor told Mićo Stanišić that the refusal to reinstate Serbs could entail "bloodshed" in Vogošća and that he would raise 10,000 people against "this injustice". P2219 (Intercept of conversation between Jovan Tintor and Mićo Stanišić, 12 September 1991), p. 4.

7994 P2344 (Witness statement of KDZ020 dated 17 February 2011), para. 33 (under seal); D1107 (Witness statement of KDZ020 dated 16 August 2007), para. 51 (under seal).

7995 P2344 (Witness statement of KDZ020 dated 17 February 2011), para. 33 (under seal); D1107 (Witness statement of KDZ020 dated 16 August 2007), para. 51 (under seal).

7996 KDZ020, T. 12473 (25 February 2011) (private session); Eset Muračević, T. 12750-12751 (2 March 2011); D2678 (Witness statement of Svetozar Stanić dated 16 December 2012), para. 8; Svetozar Stanić, T. 31672, 31676 (18 December 2012). See also Adjudicated Fact 2593. But see KDZ020, T. 12491-12492, 12497, 12510, (28 February 2011), 12634-12635 (1 March 2011); P2345 (Witness statement of KDZ020 dated 17 February 2011), paras. 45, 92. Later, in June 1992, the Vogošća Crisis Staff was disbanded and replaced by the Vogošća War Presidency, which in turn was superseded by the Vogošća War Commission. D2678 (Witness 
2362. In March 1992, the SDS delegates in the Municipal Assembly, led by Koprivica, announced at an assembly session that they were going to organise the Serb Municipality of Vogošća and threatened that those Bosnian Muslims who did not pledge loyalty to this new municipality would be expelled. ${ }^{7997}$ Koprivica then stated that "Muslims were simply going to disappear". 7998 After making this announcement, the SDS delegates walked out of the assembly session. ${ }^{7999}$ On 24 March 1992, the Bosnian Serb Assembly unanimously verified the decision to establish the Serb municipality of Vogošća along with 34 other Serb municipalities. ${ }^{8000}$ The Serb municipality of Vogošća was proclaimed in March or April 1992. ${ }^{8001}$ Svetozar Stanić was appointed as its President and he stayed in that position until November $1992 .{ }^{8002}$ Koprivica was appointed as the President of the Serb Municipal Assembly. ${ }^{8003}$

2363. However, in February 1992, even before the adoption of the above decision, there had already been discussions amongst Serb leaders as to the lay-out of the Serb municipality of Vogošća. For instance, during a telephone conversation with a certain Prodanović, Tintor stated that it "will include everything all the way to Krš" but not Barica or Kobilja Glava. ${ }^{8004}$ On 22 February 1992, the Accused asked Ljubo Grković, Chef de Cabinet of the SDS Executive Board, ${ }^{8005}$ whether the planned Serb municipality of Rajlovac would include the territory of the Serb municipality of Vogošća and was told that Vogošća would be a separate unit. ${ }^{8006}$

2364. On 31 March 1992, non-Serb members of the police were invited by Mandic to join the newly established the Bosnian Serb MUP but were warned that before any such engagement, they

statement of Svetozar Stanić dated 16 December 2012), para. 10; D4027 (Witness statement of Nikola Poplašen dated 11 November 2013), para. 7; Nikola Poplašen, T. 43583 (15 November 2013). See Section II.B.7: Regional and municipal bodies.

7997 P2345 (Witness statement of KDZ020 dated 17 February 2011), paras. 59, 63. See also Adjudicated Fact 2592.

7998 P2344 (Witness statement of KDZ020 dated 17 February 2011), para. 59 (under seal).

7999 P2345 (Witness statement of KDZ020 dated 17 February 2011), paras. 59, 61, 63. See also Adjudicated Fact 2592.

8000 P961 (Shorthand Record of $12^{\text {th }}$ session of SerBiH Assembly, 24 March 1992), pp. 23-24.

8001 D2444 (Witness statement of Miladin Trifunović dated 11 November 2012), para. 5; D2678 (Witness statement of Svetozar Stanić dated 16 December 2012), para. 4; P2345 (Witness statement of KDZ020 dated 17 February 2011), para. 61.

8002 D2678 (Witness statement of Svetozar Stanić dated 16 December 2012), paras. 5, 11; P2373 (Vogošća Executive Board request to SerBiH Ministry of Finance, 15 July 1992); Svetozar Stanić, T. 31711 (18 December 2012).

8003 Svetozar Stanić, T. 31677 (18 December 2012); D3105 (Witness statement of Slobodan Avlijaš dated 9 March 2013), para. 12; Slobodan Avlijaš, T. 35159 (11 March 2013).

8004 P965 (Intercept of conversation between Jovan Tintor and FNU Prodanović, 11 February 1992), p. 5.

8005 P2579 (Minutes of $7^{\text {th }}$ session of SDS Executive Board, 30 December 1991), p. 1.

8006 P967 (Intercept of conversation between Radovan Karadžić and Ljubo Grković, 22 February 1992). On the creation of the Serb municipality of Rajlovac, see paras. 2172-2173. 
had to declare their loyalty to SerBiH in writing. ${ }^{8007}$ In the Vogošća SJB, all Serb police officers agreed with Mandić's demand but non-Serbs did not. ${ }^{8008}$ Subsequently, a meeting was held and the police officers agreed that until further notice Serbs, Muslims, and Croats would stay at the station and work together "in order to prevent bloodshed". 8009 Despite this agreement, in the Semizovac station, Serb and non-Serb policemen carried out their duties separately, though they did coalesce for joint patrols or when there were anti-crime assignments. ${ }^{8010}$

2365. In April 1992, a number of meetings between SDS and SDA representatives were held in Vogošća. ${ }^{8011}$ During the meetings, Tintor advanced the thesis that Vogošća was Serb land and therefore had to be governed by Serb authority. ${ }^{8012}$ Tintor, Koprivica, Slavko Jovanović, Svetozar Stanić and other local SDS leaders then insisted on dividing Vogošća along ethnic lines. ${ }^{8013}$ The division, as envisaged by them, would have left the Serbs with the town centre, all the industry and all the villages and communes except for Gornje, Donje Ugorsko, Kobilja Glava, and Hotonj. ${ }^{8014}$ The Bosnian Muslims refused this proposal. ${ }^{8015}$

\section{(2) $\underline{\text { Militarisation }}$}

2366. From 1991 to spring 1992, both Bosnian Serbs and Bosnian Muslims engaged in the process of arming and organising themselves in Vogošća. ${ }^{8016}$

2367. On or about 5 January 1992, there was unusual movement around the Semizovac Barracks; trucks driven by Serbs in military uniforms towed artillery pieces from there towards Mt. Paljevo, a

\footnotetext{
8007 P1116 (Letter from Momčilo Mandić to SRBiH MUP re division of MUP, 31 March 1992); P2345 (Witness statement of KDZ020 dated 17 February 2011), para. 62; KDZ020, T. 12575-12576 (28 February 2011).

8008 P2345 (Witness statement of KDZ020 dated 17 February 2011), paras. 62, 64.

8009 P2345 (Witness statement of KDZ020 dated 17 February 2011), para. 64; KDZ020, T. 12472 (25 February 2011).

8010 KDZ020, T. 12472 (25 February 2011), T. 12573 (28 February 2011).

8011 P2345 (Witness statement of KDZ020 dated 17 February 2011), paras. 61, 63; D2678 (Witness statement of Svetozar Stanić dated 16 December 2012), para. 21.

8012 P2345 (Witness statement of KDZ020 dated 17 February 2011), para. 63.

8013 P2345 (Witness statement of KDZ020 dated 17 February 2011), paras. 61, 63. See also Adjudicated Fact 2593.

8014 P2345 (Witness statement of KDZ020 dated 17 February 2011), paras. 61, 63; KDZ020, T. 12580 (28 February 2011). See also Adjudicated Fact 2593.

8015 P2345 (Witness statement of KDZ020 dated 17 February 2011), para. 61. Svetozar Stanić testified that during these meetings, the Bosnian Serbs proposed to share power with the Bosnian Muslims and that no agreement was reached because the Muslims insisted on their demand for absolute power over the entire territory of Vogošća. See D2678 (Witness statement of Svetozar Stanić dated 16 December 2012), para. 21. The Chamber, however, does not consider his evidence to be reliable in this regard. In reaching this conclusion, the Chamber noted this his evidence was marked by indicators of bias and lack of candour.

8016 P2345 (Witness statement of KDZ020 dated 17 February 2011), para. 35; P2361 (Witness statement of Eset Muračević dated 24 February 2011), paras. 9, 11; D2444 (Witness statement of Miladin Trifunović dated 11 November 2012), para. 5; D2540 (Witness statement of Goran Sikiraš dated 2 December 2012), paras. 6, 9; P979 (Report from JNA $2^{\text {nd }}$ Military District to JNA General Staff, 20 March 1992), pp. 6, 11 (indicating that by
} 
location above Krivoglavci, which overlooked the residences of Tintor and Koprivica. ${ }^{8017}$ On 7 January 1992, heavy artillery fire was opened from Mt. Paljevo. ${ }^{8018}$

2368. In early March 1992, both Bosnian Muslims and Bosnian Serbs erected barricades in areas where they formed a majority. ${ }^{8019}$ After the erection of barricades around Svrake, the JNA began distributing to local Serbs large quantities of weapons, which belonged to the Vogošća TO and had been stored in the Semizovac Barracks. ${ }^{8020}$ The JNA also trained local Serbs to use the weapons. $^{8021}$ All the weapons from the Pretis Factory were also brought to the Semizovac Barracks. ${ }^{8022}$ On 14 May 1992, the Semizovac Barracks were placed under the command of Vogošća Crisis Staff. ${ }^{8023}$

2369. During the spring of 1992, in the predominantly Muslim village of Svrake, the villagers carried out night watches. ${ }^{8024}$

\section{(3) Increase in inter-ethnic tensions}

2370. From September 1991 onwards, inter-ethnic tensions and criminal acts increased dramatically. ${ }^{8025}$ The situation was exacerbated by the arrival of a large group of JNA reservists at the Semizovac Barracks and their involvement in looting and firing of weapons. ${ }^{8026}$ Given the dire security situation and the inability of the police forces to maintain order, Bosnian Muslim municipal representatives led discussions for the mobilisation of the Vogošća TO but the Bosnian

20 March 1992, in Vogošća municipality, 1,500 men who were not part of the JNA or the TO had been armed by either the JNA or the SDS).

$$
\text { P2 }
$$

\section{p}


Serbs opposed any such mobilisation. ${ }^{8027}$ On 23 September 1991, Koprivica discussed the issue with the Accused who made it clear that he fully supported Koprivica's opposition to the mobilisation of the TO. ${ }^{8028}$

2371. Sometime between 29 February and 1 March 1992, a Bosnian Muslim family was attacked in the predominantly Serb populated village of Krivoglavci. ${ }^{8029}$ On that same day, intense automatic weapon fire was directed at Svrake. ${ }^{8030}$

2372. In early March 1992, there were further acts of violence, including the destruction of Bosnian Muslim and Bosnian Croat property situated in predominantly Serb villages. ${ }^{8031}$ During the same period, Tintor, on behalf of the Vogošća Crisis Staff, sent a dispatch to the Vogošća SJB and Kemo Šabović, prohibiting the SJB from conducting any investigations in Serb villages in connection with the alleged killing of a young Bosnian Muslim by a Serb. ${ }^{8032}$

\section{(C) Take-over}

\section{(1) Take-over of Vogošća town}

2373. On 3 April 1992, a group of armed Serbs led by Boro Radić attacked the police station in Vogošća, disarmed the Bosnian Muslim officers, and took away all the weapons there. ${ }^{8033}$ Radić and his men then forced everybody out and sprayed the inside of the station with automatic gunfire. $^{8034}$

2374. On the day of the attack against the Vogošća SJB, Tintor ordered the deployment of "[a]ll available manpower" at the check-points in Vogošća. ${ }^{8035}$ On the same day, Tintor instructed a certain Pero Radović not to react until "an agreement is reached" and to open fire "if anybody

\footnotetext{
8027 P2345 (Witness statement of KDZ020 dated 17 February 2011), paras. 48, 51; KDZ020, T. 12549 (28 February 2011), T. 12639 (1 March 2011) (private session).

8028 P2360 (Intercept of conversation between Radovan Karadžić and Rajko Koprivica, 23 September 1991), pp. 12; P2345 (Witness statement of KDZ020 dated 17 February 2011), para. 51.

8029 P2361 (Witness statement of Eset Muračević dated 24 February 2011), para. 6.

8030 P2361 (Witness statement of Eset Muračević dated 24 February 2011), para. 6.

8031 P2345 (Witness statement of KDZ020 dated 17 February 2011), paras. 55, 57; P2361 (Witness statement of Eset Muračević dated 24 February 2011), para. 8.

8032 P2345 (Witness statement of KDZ020 dated 17 February 2011), paras. 55, 57-58. The Chamber notes that there are no killings charged in Schedule A of the Indictment in relation to Vogošća.

8033 P2344 (Witness statement of KDZ020 dated 17 February 2011), paras. 68-69 (under seal); KDZ020, T. 12471 (25 February 2011), T. 12524 (private session), 12576-12577 (28 February 2011); D2678 (Witness statement of Svetozar Stanić dated 16 December 2012), paras. 15, 18.

8034 P2345 (Witness statement of KDZ020 dated 17 February 2011), para. 68; KDZ020, T. 12524 (28 February 2011) (private session).

8035 P5737 (Intercept of conversation between Jovan Tintor, Mlado LNU and Pero Radović, 3 April 1992), p. 1.
} 
enters the police station uninvited". ${ }^{8036}$ Also on 3 April 1992, Momčilo Krajišnik instructed Tintor not to start a war. ${ }^{8037}$

2375. On 4 April 1992, Tintor informed Momčilo Krajišnik that Bosnian Muslims from Kobilja Glava were on their way towards Graovište and Žuč. ${ }^{8038}$ On the same day, Koprivica told General Đurđevac that hundreds of Muslim reservists who had fled Ilijaš and the police reserve force had mobilised in order to take over the Vogošća SJB; he then requested intervention by the JNA. ${ }^{8039}$ However, Đurđevac rejected Koprivica's request and advised him to "[a]ct according to the instructions on operation in the crisis situation, you have those instructions work". 8040

2376. Between 4 and 17 April 1992, Serb Forces took over major parts of Vogošća municipality. ${ }^{8041}$ The Municipality building was surrounded by members of the TO and Tintor raised the Serb flag on top of it. ${ }^{8042}$

2377. On or about 18 April 1992, a special unit of the BiH MUP under the command of Dragan Vikić entered a military plant in the Pretis factory and took possession of vehicles and military equipment, including a truckload of shells, and headed to Sarajevo. ${ }^{8043}$ The following day at around noon, Safet Hadžić and other members of the Novi Grad TO also went to the Pretis factory to take weapons but were intercepted by members of the Vogošća TO and the JNA. ${ }^{8044}$ During the ensuing gunfight, Hadžić and four other members of the Novi Grad TO were killed and others were

8036 P5737 (Intercept of conversation between Jovan Tintor, Mlado LNU and Pero Radović, 3 April 1992), p. 2.

8037 P5736 (Intercept of conversation between Jovan Tintor and Momčilo Krajišnik, 3 April 1992), p. 3. A few days later, Tintor reported that the Accused had tried to contact him. See P5743 (Intercept of conversation between Jovan Tintor and Danilo Veselinović, 6 April 1992), p. 4.

P2359 (Intercept of conversation between Jovan Tintor and Momčilo Krajišnik, 4 April 1992), p. 1.

D1109 (Intercept of conversation between Rajko Koprivica and Đurđevac, 3 April 1992), p. 2.

D1109 (Intercept of conversation between Rajko Koprivica and Đurđevac, 3 April 1992), p. 2.

P5512 (Report of RS MUP regarding Vogošća SJB, 12 November 1992), p. 1.

P2345 (Witness statement of KDZ020 dated 17 February 2011), para. 66. In an interview with journalists from Naš Glas and Serbian Radio, published on 13 July 1992, Koprivica boasted that "we set up a crisis staff and one morning, stormed the Assembly building and took control of it". See D4028 (Article from Naš Glas entitled "Vogošća has a future", 13 June 1992), p. 1.

8043 KDZ020, T. 12613-12614, 12621 (1 March 2011); D2678 (Witness statement of Svetozar Stanić dated 16 December 2012), paras. 7, 22; Svetozar Stanić, T. 31708, 31714 (18 December 2012); D2681 (Report of Vogošća Municipal Secretariat for National Defence, 18 April 1992); P5720 (Intercept of conversation between Milutin Kukanjac and Radovan Karadžić, 18 April 1992); D2444 (Witness statement of Miladin Trifunović dated 11 November 2012), para. 10; D3068 (Letter from Milutin Kukanjac to Alija Izetbegović, 19 April 1992), e-court p. 1; D3069 (JNA $2^{\text {nd }}$ Military District report, 20 April 1992), p. 1; D3065 (Witness statement of Aleksandar Vasiljević dated 26 February 2013), para. 187; P5721 (Intercept of conversation between Rajko Koprivica and Momčilo Mandić, 18 April 1992); P5718 (Intercept of conversation between Milutin Kukanjac and Momčilo Mandić, 18 April 1992), p. 2; P2226 (Intercept of conversation between Momčilo Mandić and Vukota Vuković, 18 April 1992).

8044 KDZ020, T. 12640-12641 (1 March 2011); D2444 (Witness statement of Miladin Trifunović dated 11 November 2012), para. 10. 
wounded. ${ }^{8045}$ In response to the Pretis attacks, Tintor ordered the mobilisation of the Vogošća TO. ${ }^{8046}$

2378. On 18 April 1992, the JNA deployed heavy weapons and tanks inside and around Vogošća town as well as on the main roads. ${ }^{8047}$

2379. Two or three weeks after the take-over of Vogošća, non-Serb policemen moved out and set up separate offices in Donji Hotonj and in Ugorsko, while all Serb reserve staff left the Hotonj station with their weapons and joined the Serb reserve station in Blagovac. ${ }^{8048}$ From this point onwards, the Vogošća SJB remained under the control of Bosnian Serb authorities. ${ }^{8049}$

\section{(2) Take-over of Svrake}

2380. In the evening of 2 May 1992, military formations organised by the SDS, in co-ordination with the JNA, launched an attack against Svrake from their positions in Krivoglavci, Paljevo, Nebočaj, and the Semizovac Barracks. ${ }^{8050}$ During this attack, which lasted two days, one villager was killed, four were wounded, and 36 houses were destroyed. ${ }^{8051}$

2381. On 4 May 1992, using a loudspeaker, local Serbs called on the villagers, announcing that nothing would happen to them if they left. ${ }^{8052}$ In accordance with an agreement subsequently reached between local Bosnian Serb and Muslim representatives, most of the Muslim population which numbered about 1,000 left Svrake in order to go to Breza and the surrounding areas via

8045 KDZ020, T. 12621-12622, 12641 (1 March 2011); D3069 (JNA 2nd Military District report, 20 April 1992), p. 1; D3065 (Witness statement of Aleksandar Vasiljević dated 26 February 2013), para. 187; P5714 (Intercept of conversation between Milenko Karišik and unidentified male, 19 April 1992). The Chamber notes that these killings are not charged in either Schedule A or B of the Indictment. See fn. 13.

8046 D2444 (Witness statement of Miladin Trifunović dated 11 November 2012), para. 6; P1505 (SRK Order, 22 May 1992), p. 2; P2624 (Vogošća Crisis Staff Announcement, 11 May 1992), p. 1.

8047 P2361 (Witness statement of Eset Muračević dated 24 February 2011), para. 10.

8048 P2345 (Witness statement of KDZ020 dated 17 February 2011), paras. 62, 65; KDZ020, T. 12473 (25 February 2011). However, Eset Muračević, the Bosnian Muslim Secretary of the local commune of Svrake until May 1992, testified that it was after an attack on a police patrol in Krivoglavci in early March 1992, that the employees of the Vogošća SJB effectively split on an ethnic basis, with Muslim and Croat policemen setting up a station in Svrake as well as a police check-point on the Sarajevo-Zenica main road. See P2361 (Witness statement of Eset Muračević dated 24 February 2011), paras. 1, 8; Eset Muračević, T. 12649, 12669, 12705 (1 March 2011). The Chamber finds that the evidence of KDZ020, a police officer in Vogošća at the material time, as to the timing of the event carries more weight.

8049 Mirsad Kučanin, P15 (Transcript from Prosecutor v. Galić), T. 4499-4500 (under seal); Mirsad Kučanin, P17 (Transcript from Prosecutor v. S. Milošević), T. 28934-28935.

8050 P2361 (Witness statement of Eset Muračević dated 24 February 2011), paras. 11, 13; Eset Muračević, T. 12687, 12702 (1 March 2011), T. 12736 (2 March 2011). See also Adjudicated Fact 2601.

8051 P2361 (Witness statement of Eset Muračević dated 24 February 2011), para. 13; Eset Muračević, T. 12740 12741 (2 March 2011). The Chamber notes that this killing is not charged in Schedule A of the Indictment.

8052 P2361 (Witness statement of Eset Muračević dated 24 February 2011), para. 15; Eset Muračević, T. 12746 (2 March 2011). 
Semizovac. ${ }^{8053}$ Despite the agreement, however, one part of the convoy, which consisted of 430 Bosnian Muslims, was stopped in Semizovac by a number of local Serbs in former JNA and camouflage uniforms and eventually taken to the Semizovac Barracks. ${ }^{8054}$

(D) Developments in Vogošća after the take-over of the municipality

2382. After the take-over of Svrake, Serbs Forces continued to expel non-Serbs from their homes throughout the municipality, in particular in Svrake and Bioča. ${ }^{8055}$ Non-Serb workers at the Vogošća Medical Centre were suspended from their jobs. ${ }^{8056}$ Several Serb paramilitary and volunteer groups, including Šešelj's men headed by Vaske Vidović, a paramilitary group led by Boro Radić, ${ }^{8057}$ and the Šoša Detachment under the command of Major Jovo Ostojić ${ }^{8058}$ took part in combat activities in Vogošća alongside the Bosnian Serb authorities. ${ }^{8059}$ Vogošća municipal authorities allocated resources to paramilitary formations, such as Radićs group, and even remunerated them for their services. ${ }^{8060}$

2383. In May 1992, Šešelj's men attacked the village of Tihovići and killed about 20 people, including a number of Bosnian Muslim reserve policemen. ${ }^{8061}$

2384. On 16 May 1992, the Vogošća Crisis Staff concluded that mopping up operations should be conducted in Semizovac and indicated that similar operations were already underway in Svrake. ${ }^{8062}$

8053 P2361 (Witness statement of Eset Muračević dated 24 February 2011), para. 15; Eset Muračević, T. 12714 12715 (1 March 2011), T. 12747 (2 March 2011).

8054 P2361 (Witness statement of Eset Muračević dated 24 February 2011), paras. 15-16; Eset Muračević, T. 12714 12716, 12722-12723 (1 March 2011), T. 12746-12748 (2 March 2011). See also Adjudicated Fact 2601.

8055 P2361 (Witness statement of Eset Muračević dated 24 February 2011), para. 14.

8056 P2635 (Conclusions of Vogošća's Crisis Staff, 16 May 1992).

8057 Radić had the support of the SDS and he eventually was integrated into the VRS and given a rank. See KDZ020, T. 12524 (28 February 2011) (private session); P2366 (List of members of special detachment, 25 May 1992).

8058 The Šoša Detachment which consisted of individuals from Sombor, Serbia, arrived in late May or early June 1992, and was immediately placed under the command of VRS. See D2678 (Witness statement of Svetozar Stanić dated 16 December 2012), para. 14.

8059 P2344 (Witness statement of KDZ020 dated 17 February 2011), para. 72 (under seal); KDZ020, T. 1262512626 (1 March 2011); P6003 (Article from Naš Glas entitled "Elevation 681 has fallen", 12 August 1992 ), p. 1.

8060 P6001 (Request of Vogošća Municipality War Commission, 27 June 1992); P2373 (Vogošća Executive Board request to SerBiH Ministry of Finance, 15 July 1992); P2377 (Vogošća Wartime Commission conclusions, 30 July 1992). See also Adjudicated Fact 2597. But see Miladin Trifunović, T. 30444 (27 November 2012)(testifying that there were many paramilitary units in Vogošća and that they acted independently); D4027 (Witness statement of Nikola Poplašen dated 11 November 2013), para. 12 (testifying that paramilitary formations refused to be placed under any military command, that they acted independently, and that Vogošća municipal authorities took the necessary measures with a view to removing them from the territory of Vogošća). The Chamber finds that the evidence of Trifunović and Poplašen in this regard to be unreliable and that it was marked by clear indicators of bias and partiality.

8061 P2344 (Witness statement of KDZ020 dated 17 February 2011), para. 72 (under seal). These killings are not charged in either Schedule A or B of the Indictment.

8062 P2635 (Conclusions of Vogošća's Crisis Staff, 16 May 1992). 
2385. Between mid-April and November 1992, police officers engaged in combat operations and many of them also participated in criminal activities. ${ }^{8063}$

2386. On 14 November 1992, Momčilo Krajišnik attended the Vogošća Serb Assembly session during which it was stated that the take-over of the municipality had been a success but that the area up to the predominantly Muslim village Kobilja Glava still had to be cleaned up. ${ }^{8064}$

\section{(E) Scheduled Incident D.21}

2387. The Indictment refers to the destruction of the Ugorsko mosque as well as the Semizovac Catholic church between April and September 1992. ${ }^{8065}$

2388. According to Riedlmayer, the Ugorsko mosque in the southern part of Vogošća was "heavily damaged" by Serb shelling on 1 September 1992, and the Catholic church in Semizovac was "completely destroyed" by Serb forces after they took control of the area at the beginning of May 1992. ${ }^{8066}$ While the Chamber relies on Riedlmayer for the purposes of finding that the mosque and the church in question were destroyed, and determining the nature and extent of the damage to those sites, it does not rely on his evidence in order to determine who was responsible for the destruction as such matters fall outside Riedlmayer's expertise and are based on statements which he received from informants. ${ }^{8067}$

2389. Having received no other evidence concerning Scheduled Incident D.21, the Chamber is not satisfied, beyond reasonable doubt, that Serb Forces heavily damaged and completely destroyed the Ugorsko mosque and the Catholic church in Semizovac between April and September 1992.

8063 P5512 (Report of RS MUP regarding Vogošća SJB, 12 November 1992), pp. 2-5. See also Adjudicated Facts 2598, 2599, 2600.

8064 P5511 (Minutes of the $3^{\text {rd }}$ meeting of the Vogošća Municipal Assembly, 14 November 1992), pp. $2,9$.

8065 Indictment, Scheduled Incident D.21. The Indictment initially also referred to the Karauka-Donja mosque under Scheduled Incident D.21. Subsequently, however, the Prosecution indicated that the Karauka-Donja mosque should refer to the Karaula mekteb which was located in Ilijaš Municipality. See Indictment, Scheduled Incident D.21, fn. 21. In its Final Brief, the Prosecution confirmed the exclusion of the Karauka-Donja mosque from the scope of Scheduled Incident D.21. See Prosecution Final Brief, Appendix B, p. 60, fn. 874.

8066 P4070 (Attachment to the expert report of András J. Riedlmayer, entitled "Destruction of Cultural Heritage in BiH” prepared for the Karadžić case, formatted records), e-court pp. 323-327; P4071 (Slide images of damaged religious sites in $\mathrm{BiH}$ ), e-court p. 2; András J. Riedlmayer, T. 22531 (8 December 2011). See also P4069 (Cultural destruction database), records 328-329; P2362 (Map of Vogošća municipality with photographs).

8067 The Chamber notes that it received evidence as to the destruction of the mosque in Svrake. See P2361 (Witness statement of Eset Muračević dated 24 February 2011), para. 58; Eset Muračević, T. 12652 (1 March 2011), T. 12737, 12739 (2 March 2011); P4069 (Cultural destruction database), record 331. However, this evidence is not relevant to Scheduled Incident D.21. 


\section{(F) Detention facilities in Vogošća}

2390. There were several detention facilities in Vogošća, including a World War II era bunker known as "the Bunker" and "Planjo's House". 8068

2391. All detention facilities in Vogošća were run by one reserve police unit under the command of Branko Vlačo. ${ }^{8069}$ Vlačo answered to the Crisis Staff and determined who entered or exited the Bunker and Planjo's House. ${ }^{8070}$ Nebojša Špirić was Vlačo's deputy and was formally appointed as commander of the guards for the Vogošća detention facilities. ${ }^{8071}$ Špirić later replaced Vlačo and became the warden of all detention facilities in Vogošća. ${ }^{8072}$

\section{(1) Scheduled Detention Facility C.26.3}

2392. The Indictment refers to the use of the Bunker in Vogošća as a detention facility at least between May and July 1992.

\section{(a) Establishment and control}

2393. The Bunker was a concrete structure of about 36 square metres that had been built during World War II. ${ }^{8073}$ It had concrete floors, one door and a small window with metal bars. ${ }^{8074}$ It was situated in close proximity to a river and a local restaurant and motel called "Kon Tiki", also known as "Kod Sonja". ${ }^{8075}$ Kod Sonja served as the headquarters of the Vogošća Crisis Staff. 8076

8068 P2345 (Witness statement of KDZ020 dated 17 February 2011), para. 73; P2361 (Witness statement of Eset Muračević dated 24 February 2011), paras. 17, 19, 21; Momčilo Mandić, C2 (Transcript from Prosecutor v. Krajišnik), T. 8973-8974; D3105 (Witness statement of Slobodan Avlijaš dated 9 March 2013), para. 12; Slobodan Avlijaš, T. 35141-35142 (11 March 2013); P2362 (Map of Vogošća municipality with photographs).

8069 P2345 (Witness statement of KDZ020 dated 17 February 2011), paras. 73, 76; P2372 (Vogošća municipality list of prisoners, 5 July 1992); P2361 (Witness statement of Eset Muračević dated 24 February 2011), paras. 19, 47, 73; Eset Muračević, T. 12653 (1 March 2011); P2374 (SerBiH Ministry of Justice decision, 21 July 1992); P2314 (Witness statement of Ramiz Mujkić dated 4 February 2011), para. 74; Ramiz Mujkić, T. 12384 (24 February 2011); Slobodan Avlijaš, T. 35165 (11 March 2013); P46 (Witness statement of Bego Selimović dated 21 June 1997), para. 24; P124 (Witness statement of Zijad Okić dated 24 June 1997), e-court pp. 6-7.

8070 Slobodan Avlijaš, T. 35198 (11 March 2013); P2361 (Witness statement of Eset Muračević dated 24 February 2011), para. 19, Eset Muračević, T. 12653 (1 March 2011).

8071 P2375 (SerBiH Ministry of Justice decision, 21 July 1992); P2314 (Witness statement of Ramiz Mujkić dated 4 February 2011), para. 74; Ramiz Mujkić, T. 12384 (24 February 2011); Bego Selimović, P44 (Transcript from Prosecutor v. Krajišnik), T. 10932.

8072 P2361 (Witness statement of Eset Muračević dated 24 February 2011), paras. 43, 73; P2393 (List of prisoners in KP Dom Butmir, 19 December 1992), p. 3; P124 (Witness statement of Zijad Okić dated 24 June 1997), e-court p. 7.

8073 P2345 (Witness statement of KDZ020 dated 17 February 2011), para. 73; P2361 (Witness statement of Eset Muračević dated 24 February 2011), para. 21; P2362 (Map of Vogošća municipality with photographs); Eset Muračević, T. 12650 (1 March 2011).

8074 P2361 (Witness statement of Eset Muračević dated 24 February 2011), para. 21.

8075 P2361 (Witness statement of Eset Muračević dated 24 February 2011), paras. 21, 38; Eset Muračević, T. 12650 (1 March 2011); P2353 (Photograph of house); P2354 (Aerial photograph marked by KDZ020); P2344 (Witness 
2394. On 2 May 1992, Slavko Jovanović, acting on behalf of Tintor, ordered Željka Beganović, the son of the owner of Kod Sonja, to provide suitable premises to the Vogošća SJB and TO for the purpose of questioning detained persons. ${ }^{8077}$ Individuals captured during combat in Vogošća, Svrake and Semizovac were transferred to the Bunker. ${ }^{8078}$

2395. There were on average 30 to 70 persons detained in the Bunker. ${ }^{8079}$ Initially, four women were held in the Bunker and the adjoining buildings. ${ }^{8080}$ Later on, more women were also brought to Kod Sonja. ${ }^{8081}$ Individuals in the Bunker were detained upon the orders of the Vogošća Crisis Staff and the VRS. ${ }^{8082}$ Vlačo gave specific instructions to Radić to arrest people and bring them in for questioning. ${ }^{8083}$

2396. A guard patrolled at the top of the Bunker and approximately ten guards secured its surroundings. ${ }^{8084}$ Some guards at the Bunker and Kod Sonja wore old JNA uniforms, ${ }^{8085}$ while soldiers there were seen usually wearing camouflage uniforms and cockades. ${ }^{8086}$ Some of them boasted that they were from Serbia or that they were Šešelj's men. ${ }^{8087}$

2397. As found above, on 4 May 1992, after the take-over of Svrake, a large group of Bosnian Muslim villagers was apprehended by Serb Forces and taken to the Semizovac Barracks. ${ }^{8088}$ There, the Bosnian Muslim men, women and children were placed in a hangar which had been previously

statement of KDZ020 dated 17 February 2011), para. 73 (under seal); P2314 (Witness statement of Ramiz Mujkić dated 4 February 2011), para. 68; P2327 (Map marked by Ramiz Mujkić); D2678 (Witness statement of Svetozar Stanić dated 16 December 2012), para. 13; Svetozar Stanić, T. 31687, 31721-31722 (18 December 2012); Slobodan Avlijaš, T. 35161 (11 March 2013). The Bunker itself was sometimes called Kon Tiki. See P2361 (Witness statement of Eset Muračević dated 24 February 2011), para. 21.

8076 Svetozar Stanić, T. 31686 (18 December 2012).

8077 P2398 (Vogošća Municipal Assembly order, 2 May 1992); Eset Muračević, T. 12800 (2 March 2011); Svetozar Stanić, T. 31686, 31721-31722 (18 December 2012). Svetozar Stanić testified that after its requisition, Kod Sonja served as a place where "prisoners of war" were temporarily detained until they could be transferred to Kula for further processing. See D2678 (Witness statement of Svetozar Stanić dated 16 December 2012), para. 13; Svetozar Stanić, T. 31686, 31690, 31723 (18 December 2012).

8078 D3105 (Witness statement of Slobodan Avlijaš dated 9 March 2013), para. 12.

8079 P2361 (Witness statement of Eset Muračević dated 24 February 2011), para. 23; P2372 (Vogošća municipality list of prisoners, 5 July 1992); P2376 (Vogošća municipality list of prisoners, 26 July 1992).

8080 P2361 (Witness statement of Eset Muračević dated 24 February 2011), paras. 23, 29.

8081 P2361 (Witness statement of Eset Muračević dated 24 February 2011), para. 29.

8082 Slobodan Avlijaš, T. 35161-35162 (11 March 2013).

8083 Many detainees told Muračević that they had been arrested by Radić's unit. See P2361 (Witness statement of Eset Muračević dated 24 February 2011), para. 47.

8084 P2361 (Witness statement of Eset Muračević dated 24 February 2011), para. 21; Eset Muračević, T. 12766 (2 March 2011).

8085 P2361 (Witness statement of Eset Muračević dated 24 February 2011), para. 43.

8086 P2361 (Witness statement of Eset Muračević dated 24 February 2011), para. 44; Eset Muračević, T. 12767 (2 March 2011).

8087 P2361 (Witness statement of Eset Muračević dated 24 February 2011), para. 44.

8088 See para. 2381. 
used for storing tanks. ${ }^{8089}$ After two days, the women and children were separated from the men and taken back to Svrake. ${ }^{8090}$ Approximately 150 able-bodied men were taken to a place called "Naka's Garage" whereas a few individuals, including Muračević, were taken to the Bunker by Predrag Žarković and Nebojša Lazić, a paramilitary from Serbia. ${ }^{8091}$

\section{(b) Conditions of detention and treatment of detainees}

2398. The roof of the Bunker had holes through which rainwater entered. ${ }^{8092}$ Inside the Bunker, it was very dark, cold and, wet. ${ }^{8093}$ Detainees slept on a dirty concrete floor. ${ }^{8094}$ On or about 16 May 1992, the guards brought gym mats but these mats became soaked with rainwater. ${ }^{8095}$ All the garbage and leftovers from Kod Sonja were thrown downhill and accumulated around the Bunker. $^{8096}$

2399. Little food was provided to the detainees and the guards decided who received food and who did not. ${ }^{8097}$ At times, the food which was intended for the detainees was given to dogs. ${ }^{8098}$ The guards sometimes used the same bowls they had used to feed the dogs to distribute food to the detainees. $^{8099}$

2400. During the initial period at the Bunker, the guards took the detainees outside so that they could use the toilet. ${ }^{8100}$ As the number of detainees increased later on, however, the guards placed a bucket inside and at times, this bucket was not emptied for days. ${ }^{8101}$ The Bunker did not have a water tap and Eset Muračević only managed to wash his face for the first time during his detention in early August. ${ }^{8102}$ Slobodan Avlijaš who became a member of the SerBiH Commission for the Inspection of Collection Centres in August 1992, ${ }^{8103}$ testified that during an official visit to the

\footnotetext{
8089 P2361 (Witness statement of Eset Muračević dated 24 February 2011), para. 15.

8090 P2361 (Witness statement of Eset Muračević dated 24 February 2011), para. 17; Eset Muračević, T. 1272312724 (1 March 2011), T. 12748 (2 March 2011). See also Adjudicated Fact 2601.

8091 P2361 (Witness statement of Eset Muračević dated 24 February 2011), paras. 17, 20; Eset Muračević, T. 12652 (1 March 2011), T. 12748 (2 March 2011); P2363 (Photograph of garage).

8092 P2361 (Witness statement of Eset Muračević dated 24 February 2011), para. 38.

8093 P2361 (Witness statement of Eset Muračević dated 24 February 2011), para. 38.

8094 P2361 (Witness statement of Eset Muračević dated 24 February 2011), para. 38; Eset Muračević, T. 12753 (2 March 2011).

8095 P2361 (Witness statement of Eset Muračević dated 24 February 2011), para. 38.

8096 P2361 (Witness statement of Eset Muračević dated 24 February 2011), para. 38.

8097 P2361 (Witness statement of Eset Muračević dated 24 February 2011), para. 39.

8098 P2361 (Witness statement of Eset Muračević dated 24 February 2011), para. 39.

8099 P2361 (Witness statement of Eset Muračević dated 24 February 2011), para. 39.

8100 P2361 (Witness statement of Eset Muračević dated 24 February 2011), para. 40.

8101 P2361 (Witness statement of Eset Muračević dated 24 February 2011), para. 40.

8102 P2361 (Witness statement of Eset Muračević dated 24 February 2011), para. 41.

8103 D466 (Decision of Government of SerBiH on establishment of Commission for Inspection of Collection Centres and other facilities for prisoners, 9 August 1992), p. 2.
} 
Bunker, he observed the detainees' conditions and found them to be so inhumane that he was left "feeling horror". 8104

2401. The women detained at the Bunker were subjected to sexual abuse at the Bunker, at its surrounding buildings, and at Serb frontline positions. ${ }^{8105}$

2402. During his first day in the Bunker, Muračević was forced to run the gauntlet. ${ }^{8106}$ Later that same day, he was taken, blindfolded, to a bridge where he was interrogated, threatened, and beaten by Predrag Jovanović, Lazić, and Žarković. ${ }^{8107}$

2403. In early May 1992, detainees at the Bunker were taken out on a daily basis for interrogation, during the course of which beatings occurred. ${ }^{8108}$ Later, interrogations continued but they were not always accompanied by beatings. ${ }^{8109}$ Those involved in the interrogations and beatings were guards and two inspectors by the names of Mile Renovica and Slaviša Mišić, as well as Vlačo and Živko Lazarević, a former inspector at the Vogošća SJB. ${ }^{8110}$

2404. From the Bunker, detainees were also brought to the Vogošća SJB for questioning. ${ }^{8111}$ Detainees were also taken out of the Bunker to work on trenches and perform other forms of labour. $^{8112}$

2405. The guards threatened the detainees, stole from them, or brought people from the outside to mistreat them in the absence of Vlačo. ${ }^{8113}$ The guards as well as members of Šešelj's men threw smoke grenades, tear gas grenades and stink bombs into the Bunker in the presence of Vlačo. ${ }^{8114}$

2406. On one occasion, six members of Šešelj's men, in the presence of Vlačo and other guards, took Ahmet Hido and Hasan Abaz, kicked them, and hit them with their fists and rifle butts. ${ }^{8115}$

Slobodan Avlijaš, T. 35158-35161 (11 March 2013).

P2361 (Witness statement of Eset Muračević dated 24 February 2011), para. 29-30; D4002 (Letter from BiH MUP to Vasvija Vidović, 4 July 1995), p. 56.

8106 P2361 (Witness statement of Eset Muračević dated 24 February 2011), para. 25.

8107 P2361 (Witness statement of Eset Muračević dated 24 February 2011), para. 25.

8108 P2361 (Witness statement of Eset Muračević dated 24 February 2011), paras. 26-27 (also testifying that during the interrogations, the detainees were accused of organising the resistance in Svrake and of harbouring the intention to create an Islamic state).

8109 P2361 (Witness statement of Eset Muračević dated 24 February 2011), para. 28.

8110 P2361 (Witness statement of Eset Muračević dated 24 February 2011), paras. 26-27.

8111 P2361 (Witness statement of Eset Muračević dated 24 February 2011), para. 28; P2344 (Witness statement of KDZ020 dated 17 February 2011), para. 74 (under seal); P2355 (Aerial photograph marked by KDZ020).

8112 P2361 (Witness statement of Eset Muračević dated 24 February 2011), paras. 34, 49, 54-57.

8113 Eset Muračević, T. 12767-12770 (2 March 2011); P2361 (Witness statement of Eset Muračević dated 24 February 2011), paras. 33, 44.

8114 P2361 (Witness statement of Eset Muračević dated 24 February 2011), para. 46; Eset Muračević, T. 1276712768 (2 March 2011).
} 
Afterwards, they forced the two Bosnian Muslim men to have oral sex and sexual intercourse. ${ }^{8116}$ The Šešelj's men then forced Hasan Abaz to jump off a three metre high wall with his bare chest first several times. ${ }^{8117}$ Abaz sustained severe injuries from these jumps and subsequently vomited blood. ${ }^{8118}$ Similarly, Nijaz Salkić and Taib Kodžaga were forced to jump off the upper level of the Bunker. $^{8119}$

2407. On 26 May 1992, the detainees were informed that UNPROFOR would visit the Bunker the following day. They were ordered to wash themselves with a hose beside Kod Sonja. ${ }^{8120}$ Muračević and four other detainees were selected as spokespersons in case UNPROFOR asked any questions. ${ }^{8121}$ The detainees were threatened with severe punishment in the event they complained. ${ }^{8122}$ The next day, UNPROFOR personnel came but did not enter the Bunker. ${ }^{8123}$

2408. Around the end of May 1992, Muračević was told that he would be sent back to Svrake in order to be killed there by Muslims. ${ }^{8124}$ He was then blindfolded and taken to Naka's Garage for one night where he saw 150 individuals, many of them from Svrake. ${ }^{8125}$

2409. On 25 May 1992, the Serb municipality of Vogošća Department for Judiciary, Administration and Regulations proposed the exchange of 15 "citizens of Muslim ethnicity" captured in the residential area of Svrake for a number of Serbs who had been detained in Visoko. ${ }^{8126}$ Pursuant to a decision made by the Head of the Department for Judiciary, on 25 May 1992, with the approval of the Vogošća Crisis Staff, 21 "[c]itizens of Muslim nationality who were captured in fights in Svrake" were to be exchanged in Lješevo for three Serbs who were detained in prisons in Visoko municipality. ${ }^{8127}$

\footnotetext{
8115 P2361 (Witness statement of Eset Muračević dated 24 February 2011), para. 45.

8116 P2361 (Witness statement of Eset Muračević dated 24 February 2011), para. 45; Eset Muračević, T. 12787 (2 March 2011).

8117 P2361 (Witness statement of Eset Muračević dated 24 February 2011), para. 45; Eset Muračević, T. 12787 (2 March 2011).

8118 P2361 (Witness statement of Eset Muračević dated 24 February 2011), para. 45.

8119 P2361 (Witness statement of Eset Muračević dated 24 February 2011), para. 45.

$8120 \quad$ P2361 (Witness statement of Eset Muračević dated 24 February 2011), para. 31.

8121 P2361 (Witness statement of Eset Muračević dated 24 February 2011), para. 32.

8122 P2361 (Witness statement of Eset Muračević dated 24 February 2011), para. 32.

8123 P2361 (Witness statement of Eset Muračević dated 24 February 2011), para. 33; Eset Muračević, T. 1275512757 (2 March 2011).

8124 P2361 (Witness statement of Eset Muračević dated 24 February 2011), para. 36.

8125 P2361 (Witness statement of Eset Muračević dated 24 February 2011), paras. 35-36; Eset Muračević, T. 1274812749 (2 March 2011). The Chamber notes that Naka's Garage is not a scheduled detention facility in the Indictment.

8126 P2367 (Decision of Vogošća Department for Judiciary, 25 May 1992), p. 1.

8127 P2356 (Vogošća municipality department for judiciary decision to release prisoners, 25 May 1992).
} 


\section{(c) Conclusion}

2410. Based on the foregoing, the Chamber finds that Serb Forces detained non-Serbs from Vogošća and surrounding areas, including civilian males and females, at the Bunker. The Chamber further finds that the detainees were held in poor conditions. These included a lack of adequate food, sanitary facilities and general hygiene. The Chamber also finds that the male detainees were subjected to beatings and forced labour and that both male and female detainees were subjected to acts of sexual violence.

\section{(2) Scheduled Detention Facility C.26.1}

2411. The Prosecution refers to the use of Planjo's House in Svrake as a detention facility from early July 1992 until at least February $1993 .^{8128}$

\section{(a) Establishment and control}

2412. Planjo's House was situated between Svrake and Semizovac, some 200 metres from the Sarajevo-Zenica road. ${ }^{8129}$ It had a garage, an attic, and three spacious floors. ${ }^{8130}$ Planjo's House was originally a private property owned by two Muslims, Almas Planjo and Miralem Planjo. ${ }^{8131}$

2413. In early July 1992, Avlijaš advised the authorities of the Serb municipality of Vogošća that Planjo's House should replace the Bunker as a detention facility. ${ }^{8132}$ According to Avlijaš, Planjo's House was chosen for two reasons: (i) it was further away from the frontlines and could therefore not be shelled by Muslim forces; (ii) it was more suitable to serve as a detention facility and conformed with the Accused's instructions concerning the treatment of captured persons. ${ }^{8133}$ On

8128 Indictment, Scheduled Detention Facility C.26.1. The Indictment originally referred to the period between August 1992 until December 1992. However, by virtue of the Prosecution Rule 73 bis Submission, Appendix B, p. 92, this period was extended to be from ealry July 1992 until at least February 1993.

8129 P2345 (Witness statement of KDZ020 dated 17 February 2011), para. 73; P2352 (Aerial photograph marked by KDZ020); P2361 (Witness statement of Eset Muračević dated 24 February 2011), para. 35; P2327 (Map marked by Ramiz Mujkić); P2362 (Map of Vogošća municipality with photographs); P2328 (Photograph of Planjo's house); P2403 (Witness statement of Mehmed Musić dated 28 February 2011), paras. 124-125.

8130 P2403 (Witness statement of Mehmed Musić dated 28 February 2011), paras. 124-125; P2314 (Witness statement of Ramiz Mujkić dated 4 February 2011), paras. 70, 72; P2328 (Photograph of Planjo's house); P2343 (Information report of Ramiz Mujkić, 4 July 2004), p. 16; Ramiz Mujkić, T. 12462-12463 (25 February 2011); P46 (Witness statement of Bego Selimović dated 21 June 1997), para. 22.

8131 P1605 (Decision of Vogošća Municipal Secretariat, 8 July 1992); P42 (Witness statement of Mustafa Fazlić dated 22 June 1997), p. 4; P2314 (Witness statement of Ramiz Mujkić dated 4 February 2011), para. 70; Ramiz Mujkić, T. 12383 (24 February 2011).

8132 D3105 (Witness statement of Slobodan Avlijaš dated 9 March 2013), para. 13; Slobodan Avlijaš, T. 35142 , 35198-35199 (11 March 2013).

8133 D3105 (Witness statement of Slobodan Avlijaš dated 9 March 2013), para. 13; Slobodan Avlijaš, T. 35198 (11 March 2013); P1134 (SerBiH Ministry of Defence Instructions on the Treatment of Captured Persons, 13 June 1992). 
8 July 1992, the Municipal Secretariat for Town Planning temporarily turned Planjo's House over to the Ministry of Justice, for the needs of the Prison Department of Vogošća. ${ }^{8134}$

2414. From August 1992, mainly non-Serbs, ${ }^{8135}$ including women and children, were detained in Planjo's House. ${ }^{8136}$ On 11 August 1992, Vlačo and a few guards transferred Muračević and about 30 of the 40 or so detainees who were left in the Bunker to Planjo's House which was at the time empty. ${ }^{8137}$ The detainees were placed in the cellar. ${ }^{8138}$ On 17 August 1992, the Ilijaš SJB brought 91 Bosnian Muslims who had been detained in Ilijaš. ${ }^{8139}$ On 22 August 1992, Ramiz Mujkić who had been detained in the Rajlovac Barracks, in Novi Grad municipality, was also transferred to Planjo's House. ${ }^{8140}$ In late September or October 1992, about 70 Bosnian Muslim men who had been detained in the Hadžići Culture and Sport Centre were transferred to Planjo's house. ${ }^{8141}$ Apart from these instances, detainees were brought from other places around the municipality of Vogošća, such as Visoko, Sokolac, Hadžići, Bioča, Doglodi, and Nahorevo. ${ }^{8142}$ In December 1992, four girls between the ages of 16 and 22 were brought to Planjo's House. ${ }^{8143}$

8134 P1605 (Decision of Vogošća Municipal Secretariat, 8 July 1992). See also Adjudicated Fact 2650. However, according to Avlijaš, the RS Ministry of Justice was only responsible for the security and well-being of the prisoners whereas the army was in charge of all other matters, including prisoner exchanges and prisoner labour. Slobodan Avlijaš, T. 35165-35166 (11 March 2013).

8135 One of the male detainees in Planjo's House was a Bosnian Serb but he was promptly transferred to Kula. A Bosnian Serb woman who had been married to a Muslim, and her young son were also detained in Planjo's House. See P2314 (Witness statement of Ramiz Mujkić dated 4 February 2011), para. 73; Bego Selimović, P44 (Transcript from Prosecutor v. Krajišnik), T. 10927. See also Adjudicated Fact 2652.

8136 Bego Selimović, P44 (Transcript from Prosecutor v. Krajišnik), T. 10924, 10926-10927; P124 (Witness statement of Zijad Okić dated 24 June 1997), e-court p. 9; P2361 (Witness statement of Eset Muračević dated 24 February 2011), para. 81. See also Adjudicated Fact 2652.

8137 P2361 (Witness statement of Eset Muračević dated 24 February 2011), paras. 63-64.

8138 P2361 (Witness statement of Eset Muračević dated 24 February 2011), para. 64.

8139 P42 (Witness statement of Mustafa Fazlić dated 22 June 1997), p. 4; P46 (Witness statement of Bego Selimović dated 21 June 1997), paras. 20-22; P47 (Statement of Bego Selimović to Ilijaš Municipality Commission for Crime Investigation, 5 April 1993), para. 23; P2379 (Vogošća prison bulletin, 17 August 1992); P2361 (Witness statement of Eset Muračević dated 24 February 2011), para. 64. See also Adjudicated Facts 2648, $2649,2651$.

8140 P2314 (Witness statement of Ramiz Mujkić dated 4 February 2011), paras. 68-69; P2326 (Vogošća municipality prison report re Ramiz Mujkić, 22 August 1992).

8141 P2403 (Witness statement of Mehmed Musić dated 28 February 2011), para. 123; P124 (Witness statement of Zijad Okić dated 24 June 1997), e-court p. 6; P125 (Zijad Okić's statement to BiH authorities, 3 February 1993), p. 2; P2361 (Witness statement of Eset Muračević dated 24 February 2011), para. 81; D3105 (Witness statement of Slobodan Avlijaš dated 9 March 2013), para. 32; P1607 (RS Ministry of Justice report on prisons and camps on the RS territory, 22 October 1992), e-court p. 28. During a visit to Hadžići Culture and Sport Centre, Avlijaš recommended the transfer of the detainees to Planjo's House because he was afraid that relatives of Bosnian Serbs held by the Muslim side in Tarčin would exact revenge on those detainees. See D3105 (Witness statement of Slobodan Avlijaš dated 9 March 2013), para. 32; Slobodan Avlijaš, T. 35143-35144 (11 March 2013).

8142 P2361 (Witness statement of Eset Muračević dated 24 February 2011), paras. 81, 84.

8143 P124 (Witness statement of Zijad Okić dated 24 June 1997), e-court p. 9. 
2415. From 22 August 1992 until mid October 1992, Planjo's House alone housed between 100 and 150 detainees. ${ }^{8144}$ This number later increased to $200 .^{8145}$ Women and children were held in separate quarters. ${ }^{8146}$

2416. Armed soldiers and policemen who were dressed in camouflage uniforms guarded Planjo's House at all times. ${ }^{8147}$

2417. Around mid August 1992, Momčilo Mandić and a Serb journalist visited Planjo’s House. ${ }^{8148}$ When queried by one of the detainees about possible exchanges, Mandić replied that there was no need for any exchanges as the detainees were at their "homes". 8149

2418. At some point, those detained in Naka's Garage were allowed to return to Svrake under the condition that they (i) report on a daily basis to the Serb authorities in order to be assigned and carry out work and (ii) go back to Planjo's House every night in order to spend the night there. ${ }^{8150}$ However, eventually, these individuals were confined to Planjo's House during day-time as well. $^{8151}$

2419. On 23 October 1992, ICRC representatives came to Planjo's House, registered the individuals held there. Some of the detainees were exchanged a few days later. ${ }^{8152}$

\section{(b) Conditions of detention and treatment of detainees}

2420. The food served in Planjo's House was of poor quality. ${ }^{8153}$ Some detainees slept in the beds that were available, others slept on the floor, and a number slept on the stairs. ${ }^{8154}$ Blankets were provided. ${ }^{8155}$ Detainees were allowed to use the bathroom, situated in the basement. ${ }^{8156}$

\footnotetext{
8144 P2314 (Witness statement of Ramiz Mujkić dated 4 February 2011), paras. 72-73; P46 (Witness statement of Bego Selimović dated 21 June 1997), para. 23; P2357 (List of prisoners in Vogošća prison, 30 August 1992); P2339 (List of prisoners in Vogošća prison, 3 September 1992). See also Adjudicated Fact 2653. P2361 (Witness statement of Eset Muračević dated 24 February 2011), para. 81; P2314 (Witness statement of Ramiz Mujkić dated 4 February 2011), para. 72.

8146 P2361 (Witness statement of Eset Muračević dated 24 February 2011), para. 81; Bego Selimović, P44 (Transcript from Prosecutor v. Krajišnik), T. 10924; P46 (Witness statement of Bego Selimović dated 21 June 1997), para. 23; P124 (Witness statement of Zijad Okić dated 24 June 1997), e-court p. 9. See also Adjudicated Fact 2652.

8147 P46 (Witness statement of Bego Selimović dated 21 June 1997), para. 24; Bego Selimović, P44 (Transcript from Prosecutor v. Krajišnik), T. 10928. See also Adjudicated Fact 2652.

8148 P2361 (Witness statement of Eset Muračević dated 24 February 2011), para. 62.

8149 P2361 (Witness statement of Eset Muračević dated 24 February 2011), para. 62.

8150 P2361 (Witness statement of Eset Muračević dated 24 February 2011), paras. 35, 37; Eset Muračević, T. $12723-$ 12724 (1 March 2011), T. 12748 (2 March 2011); P2368 (Vogošća Crisis Staff Order, 26 May 1992).

8151 Eset Muračević, T. 12724 (1 March 2011); T. 12748 (2 March 2011).

8152 P2314 (Witness statement of Ramiz Mujkić dated 4 February 2011), para. 82.

8153 P46 (Witness statement of Bego Selimović dated 21 June 1997), para. 25.
} 
2421. Muračević stated that although the conditions were slightly better in Planjo's House, the treatment was the same as that in the Bunker, if not worse. ${ }^{8157}$

2422. In Planjo's House, some detainees were placed in a small isolation room. ${ }^{8158}$ Siniša Đurđić and Nikola Jovanović, Tintor's personal driver, beat and abused the detainees and brought their friends to watch. ${ }^{8159}$ After one such beating as a result of which one of the detainees was left unconscious, one of Đurđić's friends drew out his gun and placed it in the mouths of several detainees, threatening to kill everybody. ${ }^{8160}$

2423. One of the guards, Dragan Damjanović, often forced detainees to beat one another with batons. ${ }^{8161} \mathrm{He}$ also accompanied them to their work duties and physically abused them there. ${ }^{8162}$ On one occasion, Damjanović forced Bego Selimović and another man to carry the body of someone who had been killed in the battlefield. ${ }^{8163}$ While Selimović and the man were carrying the body, Damjanović repeatedly hit them with a piece of wood, to a point that Selimović's back turned black. $^{8164}$ Musić dated 28 February 2011), para. 124.

8155 P46 (Witness statement of Bego Selimović dated 21 June 1997), para. 25.

8156 P2403 (Witness statement of Mehmed Musić dated 28 February 2011), para. 126; P46 (Witness statement of Bego Selimović dated 21 June 1997), para. 25. Trifunović who was the commander of the Vogošća Brigade at the time, testified that the conditions at Planjo's House were generally good, in particular, that the rooms had large windows with good light and heating, and that there were toilets, showers, and a kitchen available to the detainees. D2444 (Witness statement of Miladin Trifunović dated 11 November 2012), para. 1; Miladin Trifunović, T. 30373-20374 (15 November 2012). However, the Chamber rejects Trifunović's assertions in light of his lack of forthrightness as a witness and because of the consistent and reliable evidence which indicates that contrary to Trifunović's claim, the conditions at Planjo's House were poor.

8157 P2361 (Witness statement of Eset Muračević dated 24 February 2011), para. 65.

8158 P2361 (Witness statement of Eset Muračević dated 24 February 2011), para. 66.

8159 P2361 (Witness statement of Eset Muračević dated 24 February 2011), paras. 66, 68. Mujkić testified that the guards did not abuse the detainees. Ramiz Mujkić, T. 12386 (24 February 2011). The Chamber, however, does not find this part of Mujkić's testimony to be reliable and notes that Mujkić contradicted himself on this point on two occasions. In his statement, Mujkić stated that a mentally disabled individual was beaten unconscious by the guards and that a professor by the name of Zahid Baručija was mistreated by a guard who claimed to have been Baručija's former student. See P2314 (Witness statement of Ramiz Mujkić dated 4 February 2011), para. 75.

8160 P2361 (Witness statement of Eset Muračević dated 24 February 2011), para. 66.

8161 P2361 (Witness statement of Eset Muračević dated 24 February 2011), para. 87; Damjanović sometimes wore a black uniform and other times he wore a camouflage uniform. He sometimes wore a black hat with a cockade. Bego Selimović, P44 (Transcript from Prosecutor v. Krajišnik), T. 10931.

8162 P2361 (Witness statement of Eset Muračević dated 24 February 2011), para. 87; Bego Selimović, P44 (Transcript from Prosecutor v. Krajišnik), T. 10930-10931.

8163 P46 (Witness statement of Bego Selimović dated 21 June 1997), para. 28.

8164 P46 (Witness statement of Bego Selimović dated 21 June 1997), para. 28. 
2424. On 20 August 1992, Muračević and a group of approximately 50 prisoners were taken to Ravne Hill in order to clear a small forest which had been burnt during fighting the day before. ${ }^{8165}$ The prisoners spent the entire day working without any food or water. Some fell from exhaustion and were beaten with rifle butts. ${ }^{8166}$ On that same day, Muračević injured his hand while working. ${ }^{8167}$ Due to lack of adequate medical care, the injury eventually became infected. ${ }^{8168}$

2425. One day, a mentally disabled detainee by the name of Pinjo cursed the Serb guards who then beat him unconscious. ${ }^{8169}$ That same afternoon, Vlačo came to Planjo's House and after hearing from the guards about what Pinjo had said, hit him with his pistol, causing him to fall. ${ }^{8170}$

2426. Sometimes during the weekends, intoxicated volunteers from Serbia came to Planjo's House to beat and mistreat the detainees. ${ }^{8171}$ These individuals were called "weekend Chetniks" by the prison guards. ${ }^{8172}$ On one occasion, one of these "weekend Chetniks" entered Planjo's House and ordered Mirsad Šehić to eat cigarette butts. ${ }^{8173}$ Šehić proceeded to chew the cigarette butts but when he proved unable to swallow them, he was ordered to perform oral sex with another man in front of his own father. ${ }^{8174}$ According to Mujkić, in another instance, another "weekend Chetnik" forced a young detainee in Planjo's House to climb up a fence from the balcony and dive onto the ground, head first. ${ }^{8175}$

2427. On 18 June 1992, a compulsory work obligation was introduced for all citizens in Vogošća. ${ }^{8176}$ On 7 August 1992, Poplašen requested the approval of the SerBiH Ministry of Justice

\footnotetext{
8165 P2361 (Witness statement of Eset Muračević dated 24 February 2011), paras. 71-72 ; Eset Muračević, T. 12764 (2 March 2011).

8166 P2361 (Witness statement of Eset Muračević dated 24 February 2011), para. 71; Eset Muračević, T. 12764 (2 March 2011).

8167 P2361 (Witness statement of Eset Muračević dated 24 February 2011), para. 71; Eset Muračević, T. 1276412765 (2 March 2011).

8168 P2361 (Witness statement of Eset Muračević dated 24 February 2011), para. 71; Eset Muračević, T. 12765 (2 March 2011).

8169 P2314 (Witness statement of Ramiz Mujkić dated 4 February 2011), para. 75; Ramiz Mujkić, T. 12384-12385 (24 February 2011).

8170 P2314 (Witness statement of Ramiz Mujkić dated 4 February 2011), para. 75; Ramiz Mujkić, T. 12385 (24 February 2011).

8171 Ramiz Mujkić, T. 12385 (24 February 2011). See also Adjudicated Fact 2654.

8172 P2314 (Witness statement of Ramiz Mujkić dated 4 February 2011), para. 80; Ramiz Mujkić, T. 12385 (24 February 2011).

8173 P2314 (Witness statement of Ramiz Mujkić dated 4 February 2011), para. 80.

8174 P2314 (Witness statement of Ramiz Mujkić dated 4 February 2011), para. 80. See also Adjudicated Fact 2654.

8175 P2314 (Witness statement of Ramiz Mujkić dated 4 February 2011), para. 81; Ramiz Mujkić, T. 12411-12412 (25 February 2011).

8176 D4031 (Decision of Vogošća War Commission, 18 June 1992), p. 1; D4027 (Witness statement of Nikola Poplašen dated 11 November 2013), para. 24. According to a decision adopted by the Vogošća War Commission on 23 June 1992, individuals who carried out their compulsory work obligation were to be remunerated. See P2370 (Vogošća Wartime Commissariat Decision, 23 June 1992).
} 
for "occasional use of detainees for construction and other work" ${ }^{8177}$ Three days, later, Mandić gave Poplašen approval. ${ }^{8178}$

2428. From late August until late January 1993, Serb Forces took non-Serb detainees from Planjo's House to the frontlines and forced them to construct bunkers for Serb soldiers, dig trenches, carry ammunition, cut wood, search for land mines, carry dead bodies, dig graves, or serve as human shields. ${ }^{8179}$ The detainees who worked received more food and cigarettes from the guards. ${ }^{8180}$ Dušan Arnaut and a man with the last name Milošević, who were both soldiers, drove the detainees at Planjo's House to work and guarded them while they worked. ${ }^{8181}$ At times, Damjanović also took the detainees to work. ${ }^{8182}$

2429. On 16 July 1992, the War Commission of the Serb municipality of Vogošća ordered the exchange of a Bosnian Muslim "prisoner of war" for a member of the Koševo Brigade held by the

8177 P1606 (Request from Vogošća Municipality to Ministry of Justice of SerBiH, 6 August 1992).

8178 P1142 (Letter from Ministry of Justice of SerBiH to Vogošća War Presidency, 10 August 1992).

8179 P124 (Witness statement of Zijad Okić dated 24 June 1997), e-court pp. 6-7; P125 (Zijad Okić's statement to $\mathrm{BiH}$ authorities, 3 February 1993), p. 3; P2361 (Witness statement of Eset Muračević dated 24 February 2011), paras. 69, 71-72, 74-75, 77, 79, 87; Eset Muračević, T. 12763-12765 (2 March 2011); P2403 (Witness statement of Mehmed Musić dated 28 February 2011), paras. 127, 129; P45 (Vogošća prison report, 29 August 1992); P5999 (Order of Vogošća Brigade, 18 October 1992); P6000 (Order of Vogošća Brigade, 22 September 1992); P42 (Witness statement of Mustafa Fazlić dated 22 June 1997), pp. 4-6; Bego Selimović, P44 (Transcript from Prosecutor v. Krajišnik), T. 10929-10931; P46 (Witness statement of Bego Selimović dated 21 June 1997), paras. 25-30, 34-35, 37-38; P47 (Statement of Bego Selimović to Ilijaš Municipality Commission for Crime Investigation, 5 April 1993), para. 24; P2314 (Witness statement of Ramiz Mujkić dated 4 February 2011), paras. 76-79; P2381 (Vogošća prison report, 26 August 1992); P2382 (Vogošća prison report, 1 September 1992); P2338 (Request of Rajlovac $1^{\text {st }}$ Infantry Brigade, 24 August 1992); P2395 (Request of Rajlovac Light Infantry Brigade re prisoners, 26 December 1992); P2392 (Semizovac Battalion request re prisoners, 25 November 1992); P2386 (Ilijaš police station request re prisoners, 11 September 1992); P2384 (Vogošća SJB request re prisoners, 1 September 1992); P2383 (Semizovac Battalion request re prisoners, 12 September 1992); P2345 (Witness statement of KDZ020 dated 17 February 2011), para. 77; P2390 (Vogošća War Commission order, 6 November 1992); P2397 (List of people arrested in Vogošća during 1992-1995), p. 3. See also Adjudicated Fact 2655. But see Trifunović who testified that the detainees in Planjo's House were not used as human shields or trench diggers at the frontlines and that their task was merely to "fortify the lines". Trifunović also asserted that the detainees who were taken on compulsory work assignments were in no danger because VRS was always there with them. Miladin Trifunović, T. 30398, 30400, 30405-30407, 30412 (15 November 2012). The Chamber, however, does not find this evidence to be reliable for the following reasons. First, the Chamber found that Trifunović's testimony to be marked by indicators of lack of forthrightness. Second, the Chamber is not convinced that the presence of the VRS alongside the detainees at the frontlines would have assured the latter's safety. On the contrary, the Chamber is of the view that such presence would have further exacerbated the extremely precarious situation in which the detainees were already forced into by Serb Forces. Third, the Chamber received and found to be reliable the detailed evidence of a number of former detainees who personally experienced being forced to serve as human shields and who observed others get injured or killed while doing the same thing.

8180 Eset Muračević, T. 12763-12764 (2 March 2011); P42 (Witness statement of Mustafa Fazlić dated 22 June 1997), p. 4.

8181 Bego Selimović, P44 (Transcript from Prosecutor v. Krajišnik), T. 10930; P46 (Witness statement of Bego Selimović dated 21 June 1997), para. 26; P124 (Witness statement of Zijad Okić dated 24 June 1997), e-court p. 6.

8182 Bego Selimović, P44 (Transcript from Prosecutor v. Krajišnik), T. 10930-10931; P46 (Witness statement of Bego Selimović dated 21 June 1997), para. 26; P124 (Witness statement of Zijad Okić dated 24 June 1997), ecourt p. 8. 
Muslim side. ${ }^{8183}$ On 29 July 1992, the War Commission ordered the release of two Muslim "prisoners of war". ${ }^{8184}$ In mid-August 1992, Mirko Krajišnik and a Bosnian Muslim negotiated the exchange of several other individuals. ${ }^{8185}$ On 25 October 1992, 53 detainees, including Ramiz Mujkić and Mustafa Fazlić, were exchanged and later crossed into BiH-controlled territory. ${ }^{8186}$ On 6 November 1992, the War Presidency of the Serb municipality of Vogošća ordered that 14 Bosnian Muslims be exchanged with 14 Serbs. ${ }^{8187}$ On 25 December 1992, Špirić handed over 18 Bosnian Muslims from the detention facilities in Vogošća to Hadžići SJB officials so that they could be exchanged. ${ }^{8188}$

\section{(c) $\underline{\text { Conclusion }}$}

2430. Based on the foregoing, the Chamber finds that Serb Forces used Planjo's House as a detention facility at least from August 1992 until at least February 1993. The Chamber further finds that the detainees were held in poor conditions. These included a lack of adequate food, sanitary facilities, general hygiene and medical care. The Chamber also finds that non-Serbs, including women and children, were detained in Planjo's House and that the guards there routinely subjected the male detainees to beatings and maltreatment, including acts of a sexual nature. Furthermore, the Chamber finds that Serb Forces routinely took non-Serb males who were detained in Planjo's House in Svrake to the frontlines and forced them to carry out labour or to serve as human shields.

\section{(d) Scheduled Incident B.19.1}

2431. The indictment alleges the killing of "a number of detainees" who were taken out from Planjo's House in Svrake between August and September 1992 in order to carry out forced labour and to serve as human shields. ${ }^{8189}$

2432. On 29 August 1992, Vlačo reported that eight detainees were taken to work at Žuč and that one of them was "wounded by an enemy sniper while working". ${ }^{8190}$ In the second half of September 1992, pursuant to an order issued by Trifunović, 50 detainees, including Mustafa Fazlić

\footnotetext{
8183 P6058 (Order of Vogošća War Staff, 16 July 1992).

8184 P6059 (Order of Vogošća War Commission, 29 July 1992).

8185 P5652 (Intercept of conversation between Stojko and Mirko Krajišnik, 12 August 1992).

8186 P2314 (Witness statement of Ramiz Mujkić dated 4 February 2011), para. 82; P42 (Witness statement of Mustafa Fazlić dated 22 June 1997), p. 6.

8187 P2391 (Vogošća War Presidency order, 6 November 1992).

8188 P2394 (List of prisoners in KP Dom Butmir to be exchanged, 25 December 1992).

8189 Indictment, Scheduled Incident B.19.1. The Indictment originally referred to the period between 30 May and December 1992 as the time frame for Scheduled Incident B.19.1. However, as per the Prosecution Rule 73 bis Submission, Appendix B, p. 92, this time frame was reduced to August and September 1992.
} 
and Bego Selimović, were selected by Vlačo, divided in groups, and taken to Žuč in order to look for mines, dig trenches and serve as human shields. ${ }^{8191}$ Trifunović ordered that on 26 September 1992, 30 detainees be transported to Žuč by military vehicles in order to carry out construction work and be given food by the Vogošća Brigade Command. ${ }^{8192}$ Near the end of September, detainees were again taken to Žuč and at one point ordered to walk close by a Serb tank that was, together with a number Serb infantry troops, engaged in combat activities. As a result, a number of detainees were seriously wounded. ${ }^{8193}$ At one point, the tank lost control and slipped down a hill near the Bosnian Muslim positions. ${ }^{8194}$ Some of the remaining detainees were made to retrieve the ammunition from the tank. ${ }^{8195}$ During this operation, several detainees were killed by Muslim fire. ${ }^{8196}$

2433. At least 16 non-Serbs were killed at Žuč and other locations while carrying out work or serving as human shields during August and September 1992. ${ }^{8197}$

\footnotetext{
$8190 \quad$ P45 (Vogošća prison report, 29 August 1992).

8191 P42 (Witness statement of Mustafa Fazlić dated 22 June 1997), pp. 4-5; P46 (Witness statement of Bego Selimović dated 21 June 1997), paras. 28-29; P2361 (Witness statement of Eset Muračević dated 24 February 2011), para. 74-75; P2385 (Vogošća Brigade request re prisoners, 17 September 1992); P1144 (Vogošća municipality prison department bulletin re use of prisoners for manual labour, 19 September 1992).

8192 P6000 (Order of Vogošća Brigade, 22 September 1992).

8193 P42 (Witness statement of Mustafa Fazlić dated 22 June 1997), p. 5.

8194 P2361 (Witness statement of Eset Muračević dated 24 February 2011), para. 67; P42 (Witness statement of Mustafa Fazlić dated 22 June 1997), pp. 5-6.

8195 P2361 (Witness statement of Eset Muračević dated 24 February 2011), para. 67; P42 (Witness statement of Mustafa Fazlić dated 22 June 1997), p. 6.

8196 P2361 (Witness statement of Eset Muračević dated 24 February 2011), para. 67.

8197 P1144 (Vogošća municipality prison department bulletin re use of prisoners for manual labour, 19 September 1992); P2387 (Vogošća prison bulletin, 21 September 1992), P2388 (Vogošća prison bulletin, 24 September 1992), P47 (Statement of Bego Selimović to Ilijaš Municipality Commission for Crime Investigation, 5 April 1993), paras. 24-27; P42 (Witness statement of Mustafa Fazlić dated 22 June 1997), p. 5; P2361 (Witness statement of Eset Muračević dated 24 February 2011), paras. 67, 74-75. See also Miladin Trifunović, T. 30404 (15 November 2012). The Chamber heard additional evidence on incidents which occurred after September 1992 and which involved the use of human shields as well as forced labour and resulted in casualties. See P124 (Witness statement of Zijad Okić dated 24 June 1997), e-court p. 7, P46 (Witness statement of Bego Selimović dated 21 June 1997), paras. 34-35, 38, P124 (Witness statement of Zijad Okić dated 24 June 1997), e-court p. 9. The Chamber notes, however, that these incidents are not charged in the Indictment. The list of the killed and missing civilians in Vogošća, prepared by Muračević, refers to 10 individuals who died while performing forced labour or serving as human shields during September 1992. These individuals are Enver Činara, Azem Durmić, Nail Durmić, Bajro Holujić, Bajro Hujić, Safet Kruezi, Hamid Rizvo, Hasan Rizvo, Nermin Skando and Avdo Tirić. P2397 (List of people arrested in Vogošća during 1992-1995), pp. 5-6, 10, 14, 21, 23, 25. By contrast, Amor Mašović refers to 16 individuals, namely Azim Čović, Bajram Salkić, Avdo Tirić, Azem Durmić, Bajro Hujić, Džmail Šehić, Enver Činara, Ferid Šehić, Hamid Rizvo, Mehmed Šehić, Nail Durmić, Nermin Skando, Nusret Selimović, Ramiz Handžić, Rasim Avdukić and Safet Kruezi, as victims of Scheduled Incident B19.1. P4853 (Updated Table 2 to the Report of Amor Mašović), pp. 97-98. Having considered these inconsistencies, the Chamber does not consider them to be of relevance, as it is satisfied, that a number of men indeed died in Scheduled Incident B.19.1. Furthermore, the Chamber notes that there are some discrepancies in evidence as regards the names of some of the victims of Scheduled Incident B.19.1, but it considers these inconsistencies to be minor. Accordingly, the Chamber concludes that these are in fact the same individuals.
} 
2434. Based on the foregoing, the Chamber finds that as a result of the detainees in Planjo's House being forced by Serb Forces to carry out labour at the frontlines or to serve as human shields, at least 16 detainees were killed and a number were wounded during August and September 1992.

property

(G) Movement of the population from Vogošća and appropriation of

2435. According to Muračević, between May 1992 and mid-June 1993, approximately 13,000 individuals, of whom the greater majority were Bosnian Muslims, left the Serb-controlled parts of the municipality of Vogošća. ${ }^{8198}$ Muračević further stated that almost all the Bosnian Muslim inhabitants of Svrake and Tihovići left during the same period. ${ }^{8199}$ On 31 May 1993, the Executive Board of the Serb municipality of Vogošća established the municipal commission for the census of the population. ${ }^{8200}$ According to the census that was subsequently conducted, the villages of Svrake had not a single Muslim resident, the village of Hotonj had one, whereas Semizovac had $16 .^{8201}$ The same census indicates that the population of the 14 villages that were surveyed in the municipality of Vogošća was 93.5\% Bosnian Serb, 1.8\% Bosnian Muslim, and 2.6\% Bosnian Croat. ${ }^{8202}$

2436. Bosnian Muslims leaving Vogošća were required to obtain certificates of departure and were forced to either sign their property over to the municipal authorities or exchange it with Serb property in other municipalities in $\mathrm{BiH}^{8203}$ In an interview, published on 13 July 1992, Koprivica admitted that the distribution to Serb refugees of empty houses in the municipality of Vogošća had not been carried out appropriately and implied that there had been various cases where individuals had simply occupied houses without any form of registration whatsoever. ${ }^{8204}$

2437. By reference to the evidence of Nikola Poplašen, the Accused argues that (i) the intention behind the regulation requiring the departing non-Serbs to sign documents transferring ownership of property to the Bosnian Serb authorities was to preserve it and to prevent its misuse by organised armed groups, ${ }^{8205}$ (ii) the enactment of this regulation in itself suggests that there were no

\footnotetext{
8198 Eset Muračević, T. 12676-12678 (1 March 2011); P2402 (Table prepared by Eset Muračević), pp. 1-2.

8199 Eset Muračević, T. 12677-12678 (1 March 2011).

8200 P2400 (Vogošća Executive Board decision, 31 May 1993).

8201 P2401 (Results of 1993 census re Vogošća), pp. 1-2; Eset Muračević, T. 12812 (2 March 2011).

8202 P2401 (Results of 1993 census re Vogošća), p. 3.

8203 P2365 (Vogošća Crisis Staff Order, 20 May 1992); P2361 (Witness statement of Eset Muračević dated 24 February 2011), para. 88.

8204 D4028 (Article from Naš Glas entitled "Vogošća has a future", 13 June 1992), p. 2.

8205 Defence Final Brief, para. 1754 (referring to D4027 (Witness statement of Nikola Poplašen dated 11 November 2013), para. 14). In the same vein, the Accused asserts that the regulation created an inventory of
} 
expulsions, because non-Serbs could otherwise not leave the municipality, ${ }^{8206}$ and (iii) non-Serbs relocated on their own accord to the areas where they were in the majority and where they thought they would be safer. ${ }^{8207}$ The Chamber rejects these arguments. Poplašen himself conceded that the regulation did not provide for the return of ownership rights to the original owners and that it had to be annulled before such restoration could take place. ${ }^{8208}$ Furthermore, it is clear from the evidence before the Chamber that the main purpose of the regulation was to facilitate the use of the vacant property in question by Serbs who had just arrived in the municipality. In turn, this ensured that those non-Serbs who left Vogošća, due to the circumstances there, would not return.

2438. In light of the foregoing, and considering the surrounding circumstances in the municipality, the Chamber finds that the non-Serb population from the Serb-controlled parts of Vogošća was forced to leave.

\section{Legal findings on crimes}

a. Chapeau requirements for Articles 3 and 5 of the Statute

2439. In the Municipalities component of the case, in addition to a count of genocide under Article 4 of the Statute, the Accused is charged with a count of violations of the laws or customs of war under Article 3 of the Statute, namely murder, as well as with five counts of crimes against humanity under Article 5 of the Statute, namely persecution, murder, extermination, deportation, and forcible transfer as an inhumane act. ${ }^{8209}$ The Prosecution alleges that there was a state of armed conflict at all times relevant to the Indictment. ${ }^{8210}$ It further alleges that all acts and omissions charged as crimes against humanity, except those that formed part of the sniping and shelling campaign in Sarajevo, were part of a widespread or systematic attack directed against the Bosnian Muslim and Bosnian Croat civilian populations of $\mathrm{BiH}^{8211}$

all property which subsequently helped "immensely" in returning them to their rightful owners upon their return to Vogošća. Defence Final Brief, paras. 1747, 1754. The Chamber is unable to assign any weight to this assertion as there is no evidence in support of it. Defence Final Brief, para. 1754.

Defence Final Brief, para. 1745 (referring to D4027 (Witness statement of Nikola Poplašen dated 11 November 2013), para. 4).

See D4027 (Witness statement of Nikola Poplašen dated 11 November 2013), para. 14.

See para. 5.

Indictment, para. 89 .

Indictment, para. 88 . 


\section{i. Article 3 of the Statute}

2440. Based on the evidence set out in detail above regarding the events related to this case, the Chamber finds that there was an armed conflict in $\mathrm{BiH}$ throughout the period relevant to the crimes alleged in the Indictment. At the latest, the armed conflict in BiH started in early April 1992. In the wake of the referendum on the independence of BiH on 29 February and 1 March 1992, armed clashes between Serb Forces on the one hand and Bosnian Muslim and/or Bosnian Croat forces on the other ensued. ${ }^{8212}$ These armed clashes intensified and in early April 1992, municipalities starting with those in Eastern BiH were taken over by Serb Forces. ${ }^{8213}$

2441. For murder charged under Article 3 of the Statute, the Chamber has examined whether it was closely related to the armed conflict and made such findings where relevant in this Judgement. ${ }^{8214}$

2442. In relation to the four so called "Tadic Conditions", the Chamber refers to the applicable law sections of this Judgement, which expanded on the legal basis for each of the crimes charged in the Indictment under Article 3 of the Statute. ${ }^{8215}$ In relation to murder, the prohibition stems from Common Article 3 which is deemed to be part of customary international law. ${ }^{8216}$ Further, the Appeals Chamber has confirmed that violations of the provisions of Common Article 3 entail individual criminal responsibility. ${ }^{8217}$ The Chamber is therefore satisfied that the four Tadic Conditions are met, and consequently that the chapeau requirements for Article 3 of the Statute are fulfilled, in relation to murder.

\section{ii. Article 5 of the Statute}

2443. As found above, there was an armed conflict in $\mathrm{BiH}$ throughout the period of the Indictment. The evidence admitted at trial and explained in detail in the relevant factual sections of this Judgement, demonstrates that there also existed a widespread and systematic attack against the Bosnian Muslim and Bosnian Croat civilian populations of $\mathrm{BiH}$ at all times relevant to the crimes charged in the Indictment. The attack took many forms, as shown below in relation to each of the relevant components of the case. As reflected below, the Chamber is also satisfied that the crimes

\footnotetext{
8212 See paras. 609, 952, 958, 1242, 1500, 2258, 2306-2308, 2368-2369, 2373.

8213 See paras. 610-614, 711-714, 850-859, 1113-1115, 1248-1251, 1501, 2373, 1592-1593, 1939-1941.

8214 See para. 2455. The Chamber notes that in relation to the Municipalities component, murder is the only charged violation of the laws or customs of war pursuant to Article 3 of the Statute.

8215 See Section III.A.1: Article 3 of the Statute of the Tribunal.

8216 Čelebići Appeal Judgement, para. 143.

8217 Čelebići Appeal Judgement, paras. 167, 170, 173-174 (holding at para. 173: "It is universally acknowledged that the acts enumerated in common Article 3 are wrongful and shock the conscience of civilised people, and
} 
upon which the Chamber has entered findings formed part of that attack and that the perpetrators knew of the attack and that the crimes were part of it. ${ }^{8218}$

2444. In the Municipalities, at the time relevant to the Indictment, the Bosnian Muslim and Bosnian Croat civilian populations were the subject of a widespread and systematic campaign of violence, including through acts of murder, and forcible displacement. ${ }^{8219}$ The acts of violence and crimes committed against the Bosnian Muslim and Croat populations included killings, cruel and inhumane treatment such as torture and rape, the establishment and perpetuation of inhumane living conditions, unlawful detention, forced labour at the frontlines and the use of human shields, plunder of property, wanton destruction of private and public property, as well as the imposition of restrictive and discriminatory measures. ${ }^{8220}$ While the Chamber finds differences in each of the Municipalities, it is satisfied that there was a generally similar pattern of co-ordinated violence during and after the take-over of these Municipalities and in detention facilities throughout. Indeed, in twenty municipalities in Eastern BiH, the ARK, and the Sarajevo area, and in detention facilities therein, Serb Forces committed acts of murder, persecution, and forcible displacement, which resulted in a vast number of Bosnian Muslim and Bosnian Croat victims. The Chamber is therefore satisfied that this demonstrates the systematic and widespread nature of the attack.

2445. The Chamber is therefore satisfied that the chapeau requirements for the crimes charged under Article 5 of the Statute are met.

\section{b. Crimes}

\section{i. Murder: Counts 5 and 6}

(A) Killing incidents

2446. The Chamber recalls its factual findings in Section IV.A.1 above, that a large number of Bosnian Muslims and Bosnian Croats were killed by Serb Forces during and after the take-over ${ }^{8221}$

thus are, in the language of Article 15(2) of the ICCPR, 'criminal according to the general principles of law recognised by civilised nations'.”).

See paras. 2456, 2463, 2481-2482, 2517, 2521, 2529, 2537, 2546, 2558, 2569.

See Sections IV.A.2.b.i: Legal findings on crimes (Murder: Counts 5 and 6), IV.A.2.b.iii: Legal findings on crimes (Deportation and inhumane acts (forcible transfer): Counts 7 and 8).

See Section IV.A.2.b.iv: Legal findings on crimes (Persecution: Count 3).

The Chamber recalls that it did not enter factual findings with respect to killings committed by Serb Forces during and after the take-over of Banja Luka, Bosanki Novi, Brčko, Hadžići, Ilidža, Novo Sarajevo, Pale, Rogatica, and Vogošća as there were no Schedule A killing incidents charged with respect to these municipalities. 


$$
\begin{aligned}
& \text { of Bijeljina, }{ }^{8222} \text { Bratunac, }{ }^{8223} \text { Foča, }{ }^{8224} \text { Ključ }{ }^{8225} \text { Novi Grad, }{ }^{8226} \text { Prijedor, }{ }^{822} \text { Sanski Most },{ }^{8228} \\
& \text { Sokolac, }{ }^{8229} \text { Višegrad, }{ }^{8230} \text { Vlasenica, }{ }^{8231} \text { and Zvornik. }{ }^{8232}
\end{aligned}
$$

\section{The Chamber also recalls its findings in section IV.A.1 above, that many Bosnian Muslims}

and Bosnian Croats were killed by Serb Forces while detained at detention facilities ${ }^{8233}$ in Banja Luka, ${ }^{8234}$ Bijeljina, ${ }^{8235}$ Bratunac, ${ }^{8236}$ Brčko, ${ }^{8237}$ Foča,${ }^{8238}$ Ilidža, ${ }^{8239}$ Ključ,${ }^{8240}$ Novi Grad, ${ }^{8241}$
Pale,${ }^{8242}$ Prijedor, ${ }^{8243}$ Rogatica, ${ }^{8244}$ Sanski Most,${ }^{824}$ Vlasenica, ${ }^{8246}$ Vogošća, ${ }^{8247}$ and Zvornik. ${ }^{8248}$

8222 The killing of at least 45 civilians in the town of Bijeljina: Scheduled Incident A.1.1.

8223 The killing of at least four people in the village of Hranča and the killing of at least 65 Bosnian Muslims in the village of Glogova: Scheduled Incidents A.3.1, A.3.2. The Chamber recalls that it did not have sufficient evidence to make a finding beyond reasonable doubt as to the circumstances surrounding the death of some Bosnian Muslims killed in Hranča in the municipality of Bratunac.

8224 The killing of a number of civilians from the village of Jeleč and the killing of at least seven Bosnian Muslim civilians from the village of Mješaja/ Trošanj: Scheduled Incidents A.5.2, A.5.4. The Chamber recalls that it did not have sufficient evidence to make a finding beyond reasonable doubt as to the circumstances surrounding the death of three individuals during the initial attack on Mješaja/Trošanj in the municipality of Foča.

8225 The killing of at least three civilians in the village of Pudin Han, the killing of 52 Bosnian Muslims in Prhovo; and the killing of approximately 200 Bosnian Muslims in Biljani: Scheduled Incidents A.7.1, A.7.2, A.7.3. The killing of 15 Bosnian Muslim men following the attack on Ahatovići: Scheduled Incident A.9.1.

8227 The killing of 80 Bosnian Muslims in Kozarac, the killing of at least six Bosnian Muslims in Hambarine and Ljubija, the killing of at least nine Bosnian Muslim men and women in Kamičani, at least eight Bosnian Muslim men in Jaskići, the killing of a number of Bosnian Muslims and Bosnian Croats in the Brdo area, the killing of at least 300 non-Serbs in Bišcani and surrounding hamlets, the killing of about 50 persons at a mine in Kipe, and the killing of at least 68 people in the village of Briševo: Scheduled Incidents A.10.1, A.10.2, A.10.3, A.10.4, A.10.5, A.10.6, A.10.7, A.10.9.

The killing of approximately 20 men between Begići and Vrhpolje Bridge, the killing of a number of people in Hrustovo village, the killing of approximately 18 men from Kenjari in the hamlet of Blaževići, the killing of approximately 14 people from the hamlet of Budim in Lukavice village, and the killing of nine men near the village of Škrljevita: Scheduled Incidents A.12.1, A12.2, A.12.3, A.12.4, A.12.5.

The killing of approximately 45 Bosnian Muslim civilians near Paklenik, close to the village of Kalimanići in Sokolac municipality: Scheduled Incident A.14.2. While the killing incident charged in Scheduled Incident A.14.2 occurred in Sokolac, for ease of reference and as charged in paragraph 48 of the Indictment, the Chamber herein includes it under Višegrad since it occurred after the take-over of Višegrad and relates to Bosnian Muslims taken from this municipality. including women and children in the village of Zaklopača: Scheduled Incidents A.15.1, A.15.2.

The killing of at least 15 people in the town of Zvornik and the killing of a large number of Bosnian Muslim men at Gero's slaughterhouse: Scheduled Incidents A.16.1, A.16.3.

8233 The Chamber recalls that it did not enter factual findings with respect to killings of Bosnian Muslims and Bosnian Croats while detained at detention facilities in Bosanki Novi, Hadžići, Sokolac, and Višegrad as there were no Schedule B killing incidents charged with respect to these municipalities.

The killing of six Bosnian Muslim men in front of the gates of Manjača, the suffocation of 20 detainees during transportation to Manjača, Banja Luka, the killing of eight or nine Bosnian Muslims and Bosnian Croats on their arrival at Manjača, and the killing of at least 15 Bosnian Muslim men detained at Manjača: Scheduled Incidents B.1.1, B.1.2, B.1.3, B.1.4.

8235 The killing of at least six Bosnian Muslim men at Batković camp: Scheduled Incident B.2.1.

8236 The killing of at least 50 detainees at the Vuk Karadžić School: Scheduled Incident B.4.1.

8237 The killing of a large number of non-Serb men at the Luka Camp: Scheduled Incident B.5.1.

8238 The killing of over 200 detainees at KP Dom Foča: Scheduled Incident B.8.1.

8239 The beating to death of two detainees at Kula Prison and the killing of at least three detainees from Kula Prison while performing forced labour: Scheduled Incidents B.13.1, B.13.2. The Chamber notes that the Indictment originally included Kula Prison as being located in Novo Sarajevo municipality; however it was subsequently 
2448. The Chamber further recalls its findings in section IV.A.1 above, that some Bosnian Muslims and Bosnian Croats died as a result of cruel and inhumane treatment by Serb Forces at detention facilities in Banja Luka, ${ }^{8249}$ Bijeljina, ${ }^{8250}$ Bratunac, ${ }^{8251}$ Foča, ${ }^{8252}$ Prijedor, ${ }^{8253}$ Rogatica, ${ }^{8254}$ Sanski Most, ${ }^{8255}$ and Zvornik. ${ }^{8256}$

corrected to include Kula Prison as falling within Ilidža municipality. See fn. 7285 . The killing incidents related to this detention facility are therefore considered under Ilidža.

8240 The killing of 77 Bosnian Muslim men at Velagići School: Scheduled Incident B.10.1.

8241 The killing of 11 Bosnian Muslim detainees who were being held at the cisterns in the Rajlovac barracks and the killing of 47 Bosnian Muslim detainees who had been taken away from Rajlovac by bus: Scheduled Incidents B.12.1, B.12.2.

8242 The killing of at least three detainees who died as a result of beatings at Pale Gym: Scheduled Incident B.14.1.

8243 The killing of at least 190 persons in Room 3 at Keraterm camp; the killing of a large number of non-Serbs at Omarska or after they were taken from Omarska; the killing of at least 120 persons taken from Omarska in the area of Hrastova Glavica; the killing of at least 150 persons from the Brdo region who were detained at Omarska; the killing of a number of non-Serbs after they were taken from Trnopolje; the killing of approximately 200 men at Korićanske Stijene; and the killing of at least 15 detainees at Ljubija Football Stadium: Scheduled Incidents B.15.1, B.15.2, B.15.3, B.15.4, B.15.5, B.15.6, A.10.8.

8244 The killing of a number of men taken from the Veljko Vlahović Secondary School and the killing of 24 Bosnian Muslims who had been taken from Rasadnik: Scheduled Incidents B.16.1, B.16.2.

8245 The killing of approximately 17 men taken from the Betonirka Factory Garage: Scheduled Incident B.17.1.

8246 The killing of nine men from Sušica camp in June and July 1992; the killing of approximately 140 detainees taken from Sušica camp on or about 30 September 1992; the killing of a Bosnian Muslim man at the Vlasenica SJB building; and the killing of approximately 29 Bosnian Muslim men near Nova Kasaba who were taken from Vlasenica: Scheduled Incidents B.18.1, B.18.2, B.18.3, B.18.4. The Chamber notes that with respect to its finding that 29 Bosnian Muslim men were killed near Nova Kasaba, it is charged in the Indictment as a killing related to a detention facility: Scheduled Incident B.18.4. While the Prosecution filed a notice of withdrawal with respect to the relevant detention facility (Scheduled Detention Facility C.25.4), the Chamber has considered these killings as a Schedule B incident as charged in the Indictment.

8247 The killing of at least 16 detainees taken from Planjo's House in Svrake and killed while carrying out work on the front-lines or while being used as human shields: Scheduled Incident B.19.1.

8248 The killing of approximately 88 men at Drinjača; the killing of at least 60 men at Čelopek Dom Kulture; the killing of approximately 160 men at the Karakaj Technical School; and the killing of at least two men at the Ekonomija Farm: Scheduled Incidents B.20.1, B.20.2, B.20.3, B.20.4.

8249 The Chamber found that one elderly detainee died during transportation to Manjača due to intense heat: Scheduled Detention Facility C.1.2.

8250 The Chamber found that some detainees from the Batković camp died from starvation, exhaustion or while being forced to work on the front-lines: Scheduled Detention Facility C.2.1

8251 The Chamber found that one detainee died of suffocation after Serb Forces piled detainees on top of each other: Scheduled Detention Facility C.6.2.

${ }^{8252}$ The Chamber found that at least one detainee died as a result of poor medical care: Scheduled Detention Facility C.10.1.

8253 The Chamber found that at least one detainee died as a result of beatings: Scheduled Detention Facility C.20.3. The Chamber also found that at least two men died of suffocation after being crammed into a garage for several days: Scheduled Detention Facility C.20.2.

8254 The Chamber found that some detainees died following beatings: Scheduled Detention Facility C.21.3.

8255 The Chamber found that one detainee died as a result of a beating: Scheduled Detention Facility C.22.4.

8256 The Chamber found that approximately 20 detainees died from suffocation after being held in cramped conditions: Scheduled Detention Facility, C.27.2. The Chamber found that one detainee died following a severe beating: Scheduled Detention Facility C.27.6. 


\section{(B) Intent of perpetrators}

2449. The Chamber recalls its findings that the death of the victims for each of the incidents identified above was a result of the acts of Serb Forces. The Chamber finds that the perpetrators of each of these incidents acted with the intent to kill the victims or at least wilfully caused serious bodily harm, which they should reasonably have known might lead to death.

2450. In reaching that conclusion, the Chamber had regard to the circumstances and the manner in which the victims were killed. With respect to the Schedule A killing incidents, the Chamber found that many of the victims were deliberately shot. ${ }^{8257}$ In other incidents, while the Chamber did not have evidence that the victims were deliberately shot, the Chamber did find that they were killed during or after the take-over of towns or villages by Serb Forces ${ }^{8258}$ and is satisfied considering the surrounding circumstances that these killings were deliberate. ${ }^{8259}$

2451. With respect to killings in scheduled detention facilities under Schedule B of the Indictment, the Chamber found that the victims (i) were shot by Serb Forces during their detention; ${ }^{8260}$ (ii) died as a result of severe beatings by Serb Forces during their detention; ${ }^{8261}$ or (iii) were taken away from the detention facilities by Serb Forces and killed. ${ }^{8262}$

2452. The Chamber recalls its finding that in Vogošća and Ilidža a number of detainees were taken from their place of detention by Serb Forces and killed while carrying out work on the frontlines or while being used as human shields. ${ }^{8263}$ The victims died as a result of the actions of Serb Forces who used them for work on the front-lines or as human shields. In using the victims for work on the front-lines or as human shields, the members of the Serb Forces deliberately took the risk that they would be killed. The Chamber finds that in using them as human shields or in forcing

8257 Scheduled Incidents A.1.1, A.3.1, A.7.2, A.7.3, A.9.1, A.13.1, A.14.2, A.15.1, A.15.2, A.16.1, A.16.3, A.12.1, A.12.2, A.12.3, A.12.4, A.12.5, B.17.1 (includes victims whose throats were slit), A.10.1, A.10.2, A.10.3, A.10.4, A.10.5, A.10.6, A.10.7, A.10.8, A.10.9.

8258

8259

8261 Scheduled Incidents B.2.1, B.4.1, B.8.1, B.12.1, B.15.2, B.15.5, B.18.1, B.1.4, B.12.1, B.13.1. The Indictment refers to a separate category of killings committed during, and deaths resulting from, cruel and inhumane treatment and detention facilities. Indictment, para. 60(a)(ii). However, the Chamber notes that some of the Schedule B killing incidents pertain to deaths resulting from such cruel and inhumane treatement.

8262 Scheduled Incidents B.8.1, B.12.1, B.12.2, B.15.2, B.15.3, B.15.6, B.16.1, B.18.2, B.1.1, B.1.3, B.17.1.

8263 Scheduled Incidents B.19.1, B.13.3. 
them to work on the frontlines, the perpetrators wilfully caused the victims serious bodily harm, which they should reasonably have known might lead to death.

2453. With respect to victims who died as a result of cruel and inhumane treatment at detention facilities, the Chamber found that the victims died in circumstances which showed an intent by the perpetrators to kill or at least wilfully cause them serious bodily harm, which they should reasonably have known might lead to death. ${ }^{8264}$ For example the Chamber found that the detainees were severely beaten ${ }^{8265}$ inter alia with chains and metal rods. ${ }^{8266}$ Others were subjected to such conditions that they died from starvation, exhaustion, ${ }^{8267}$ lack of medical care, ${ }^{8268}$ intense heat, ${ }^{8269}$ or suffocation. ${ }^{8270}$

\section{(C) Status of victims}

2454. The Chamber also finds that the victims of each of these incidents were civilians ${ }^{8271}$ or had been rendered hors de combat at the time of their killing. Many of the victims were executed or killed after being captured by Serb Forces; ${ }^{8272}$ some were killed while trying to escape from Serb Forces ${ }^{8273}$ while others were killed after being detained by Serb Forces in scheduled detention facilities. $^{8274}$

\section{(D) Conclusion}

2455. The Chamber has found that there was an armed conflict in $\mathrm{BiH}$ throughout the period relevant to the Indictment. As demonstrated by the Chamber's factual findings explained above, the Chamber finds that the killings referred to in this section were closely related to that armed conflict and thus constitute murder as violation of the laws or customs of war.

\footnotetext{
$8264 \quad$ See para. 2448.

8265 Scheduled Detention Facility C.27.6.

8266 Scheduled Detention Facility C.20.3.

8267 Scheduled Detention Facility C.2.1.

8268 Scheduled Detention Facility C.10.1.

8269 Scheduled Detention Facility C.1.2.

8270 Scheduled Detention Facilities C.6.2, C.20.2, C.27.6. See also Scheduled Incident B.1.2.

8271 Scheduled Incidents A.1.1, A.3.2, A.7.1, A.13.1, A.14.2, A.15.2, A.7.1, A.12.2, A.12.4, A.10.1, A.10.3, A.10.4, A.10.5, A.10.6, B.15.3.

8272 Scheduled Incidents A.3.1, A.3.2, A.5.4, A.7.2, A.7.3, A.9.1, A.15.1, A.15.2, A.16.1, A.16.3, A.12.1, A.12.3, A.12.5, A.10.5, A.10.6.

8273 Scheduled Incidents A.5.2, A.15.2, A.12.2, A.12.3, A.10.3, A.10.2, A.10.7.

8274 Scheduled Incidents B.2.1, B.4.1, B.5.1, B.8.1, B.10.1, B.12.1, B.12.2, B.15.1, B.15.2, B.15.3, B.15.4, B.15.5, B.15.6, A.10.8, B.16.1, B.16.2, B.18.1, B.18.2, B.18.3, B.20.1 B.20.2, B.20.3, B.20.4, B.1.1, B.1.2, B.1.3, B.1.4, B.13.1.
} 
2456. The Chamber has also found that there was a widespread and systematic attack against the Bosnian Muslim and Bosnian Croat civilian populations of $\mathrm{BiH}$. The Chamber finds that the killings referred to above were part of this widespread and systematic attack and the perpretrators of these killings knew of the attack and that their crimes were part of it. In reaching that conclusion the Chamber considered the locations, time period, and the identity of the victims of these killings, which correspond with the scope of the widespread and systematic attack, as well as the magnitude and systematic nature of the attack on the Bosnian Muslim and Croat civilian populations of BiH. The Chamber therefore finds that these killings constitute murder as a crime against humanity.

\section{ii. Extermination: Count 4}

2457. The Chamber has also had regard to each of the killing incidents identified above to determine whether they amount to extermination. While the Chamber recalls that there is no minimum threshold of victims for the purposes of extermination, it still has to be satisfied that the killings occurred on a mass scale and needs to conduct a case-by-case assessment in that regard. ${ }^{8275}$

2458. As previously noted, extermination may be established based on the accumulation of separate incidents. ${ }^{8276}$ However, it has been found that "as a general matter, the element of killing on a large scale cannot be satisfied by a collective consideration of distinct events committed in different prefectures, in different circumstances, by different perpetrators, and over an extended period of time". 8277

2459. In this case, the Chamber noted that a large number of killing incidents charged in the Indictment with respect to the Municipalities were committed in different locations, in different circumstances, and by different perpetrators over an extended period of time. Having considered these factors, where the Chamber found that the incidents in question were distinct, the Chamber assessed on a case-by-case basis whether each incident amounts to a mass scale killing for the purposes of the actus reus of extermination. In making that assessment, the Chamber has had regard to the scale of each of the killing incidents and the circumstances in which the killings occurred. The Chamber has done so where the circumstances indicated that the killings were committed in geographically proximate locations, in similar circumstances, over a relatively short period of time and were thus considered to be part of the same operation.

\footnotetext{
8275 See Section III.A.2.c: Extermination as a crime against humanity.

8276 See Section III.A.2.c: Extermination as a crime against humanity.

8277 See Section III.A.2.c: Extermination as a crime against humanity.
} 
2460. On this basis, the Chamber finds that the element of killing on a mass scale is established with respect to each of the following incidents which occurred during and after the take-over of the Municipalities: (i) the killing of at least 45 civilians in the town of Bijeljina; ${ }^{8278}$ (ii) the killing of at least 65 Bosnian Muslims in the village of Glogova in Bratunac; ${ }^{8279}$ (iii) the killing of 52 Bosnian Muslims in Prhovo in Ključ; ${ }^{8280}$ (iv) the killing of approximately 200 Bosnian Muslims in Biljani in Ključ; ${ }^{8281}$ (v) the killing of 80 Bosnian Muslims in Kozarac in Prijedor; ${ }^{8282}$ (vi) the killing of at least 300 non-Serbs in the village of Bišćani and surrounding hamlets in Prijedor; ${ }^{823}$ (vii) the killing of about 50 persons at a mine in Kipe in Prijedor; ${ }^{8284}$ (viii) the killing of at least 68 people in the village of Briševo in Prijedor; ${ }^{8285}$ (ix) the killing of approximately 40 Bosnian Muslim men in the village of Novoseoci in Sokolac; ${ }^{8286}$ (x) the killing of approximately 45 Bosnian Muslim civilians near Paklenik after being taken from Višegrad; ${ }^{8287}$ (xi) the killing of at least 60 people, including women and children, in the village of Zaklopača in Vlasenica; ${ }^{8288}$ and (xii) the killing of a large number of Bosnian Muslim men at Gero's slaughterhouse in Zvornik. ${ }^{8289}$

2461. Similarly, the Chamber finds that the element of killing on a mass scale is established with respect to each of the following incidents which occurred in charged detention facilities: (i) the killing of at least 50 detainees at the Vuk Karadžić School in Bratunac; ${ }^{8290}$ (ii) the killing of a large number of non-Serb men at the Luka Camp in Brčko; ${ }^{8291}$ (iii) the killing of over 200 detainees at KP Dom Foča; ${ }^{8292}$ (iv) the killing of 77 Bosnian Muslim men at Velagići School in Ključ; ${ }^{8293}$ (v) the killing of 47 Bosnian Muslim detainees who had been taken away from Rajlovac in Novi Grad; ${ }^{8294}$ (vi) the killing of at least 190 persons in Room 3 at Keraterm camp in Prijedor; ${ }^{8295}$ (vii) the killing of a large number of non-Serbs at Omarska or after they were taken from Omarska in

\footnotetext{
$8278 \quad$ Scheduled Incident A.1.1.

8279 Scheduled Incident A.3.2.

8280 Scheduled Incident A.7.2.

8281 Scheduled Incident A.7.3.

8282 Scheduled Incident A.10.1.

8283 Scheduled Incident A.10.6.

8284 Scheduled Incident A.10.7.

8285 Scheduled Incident A.10.9.

8286 Scheduled Incident A.13.1.

8287 Scheduled Incident A.14.2.

8288 Scheduled Incident A.15.2.

8289 Scheduled Incident A. 16.3.

8290 Scheduled Incident B.4.1.

8291 Scheduled Incident B.5.1.

8292 Scheduled Incident B.8.1.

8293 Scheduled Incident B.10.1.

8294 Scheduled Incident B.12.2.

8295 Scheduled Incident B.15.1.
} 
Prijedor; ${ }^{8296}$ (viii) the killing of at least 120 persons taken from Omarska in the area of Hrastova Glavica in Prijedor; ${ }^{8297}$ (ix) the killing of at least 150 persons from the Brdo region who were detained at Omarska in Prijedor; ${ }^{8298}$ (x) the killing of approximately 200 non-Serb men at Korićanske Stijene including men taken from Trnopolje in Prijedor, ${ }^{829}$ (xi) the killing of approximately 140 detainees taken from Sušica camp in Vlasenica; ${ }^{8300}$ (xii) the killing of approximately 88 men at Drinjača in Zvornik; ${ }^{8301}$ (xiii) the killing of at least 60 men at Čelopek Dom Kulture in Zvornik; ${ }^{8302}$ and (xiv) the killing of approximately 160 men at the Karakaj Technical School in Zvornik. ${ }^{8303}$

2462. The Chamber recalls its finding that the perpetrators of each of the killing incidents identified above acted with the intent to kill the victims or at least wilfully caused serious bodily harm, which they should reasonably have known might lead to death. Having regard to the scale of the killings, the Chamber further finds that with respect to the killing incidents above, the perpetrators had intent to kill on a mass scale.

2463. The Chamber found there was a widespread and systematic attack against the Bosnian Muslim and Bosnian Croat civilian populations of $\mathrm{BiH}$. The Chamber finds that the killings above were part of this widespread and systematic attack and the perpretrators of these killings knew of the attack and that their crimes were part of it. In reaching that conclusion the Chamber considered the locations, time period, and the identity of the victims of these killings, which correspond with the scope of the widespread and systematic attack. Further, given the magnitude and systematic nature of the attack on the Bosnian Muslim and Croat civilian populations of $\mathrm{BiH}$, the Chamber further finds that the perpretrators knew of the attack and that the crimes were part of it. The Chamber therefore finds that these killings constitute extermination as a crime against humanity. ${ }^{8304}$

\footnotetext{
$8296 \quad$ Scheduled Incident B.15.2.

8297 Scheduled Incident B.15.3.

8298 Scheduled Incident B.15.4.

8299 Scheduled Incident B.15.6.

8300 Scheduled Incident B.18.2.

8301 Scheduled Incident B.20.1.

8302 Scheduled Incident B.20.2.

8303 Scheduled Incident B.20.3.

8304 For the remaining killing incidents the Chamber was not satisfied that the element of killing on a mass scale was established. The Chamber also found that these remaining incidents were distinct and that it was impermissible to aggregate them for the purposes of assessing the mass scale element of the killings for the actus reus of extermination.
} 
2464. The Chamber will deal with the issue of cumulative convictions later in this Judgement and the impermissibility of entering convictions for both extermination and murder under Article 5 of the Statute where the elements of both crimes have been established. ${ }^{8305}$

\section{iii. Deportation and inhumane acts (forcible transfer): Counts 7 and 8}

\section{(A) Actus reus}

\section{(1) Movement of population}

2465. The Chamber recalls its findings in Section IV.A.1 of this Judgement that a large number of Bosnian Muslims and Bosnian Croats in the Municipalities ${ }^{8306}$ were displaced. Bosnian Muslims and Bosnian Croats in Bijeljina, ${ }^{8307}$ Bratunac, ${ }^{8308}$ Foča, ${ }^{8309}$ Pale,${ }^{8310}$ Prijedor, ${ }^{8311}$ Rogatica, ${ }^{8312}$ Sanski Most, ${ }^{8313}$ Sokolac, ${ }^{8314}$ Vlasenica,${ }^{8315}$ Zvornik, ${ }^{8316}$ Bosanki Novi ${ }^{8317}$ Ilidža, ${ }^{8318}$ Novi Grad, ${ }^{8319}$ Novo, Sarajevo, ${ }^{8320}$ Ključ, ${ }^{8321}$ Hadžići, ${ }^{8322}$ and Vogošća ${ }^{8323}$ were displaced from their homes, villages and towns in which they were lawfully present to other locations in $\mathrm{BiH}$. The locations to which they moved were mostly under Bosnian Muslim control including Tuzla, Konjević Polje, Srebrenica, Goražde, Visoko, Zenica, and areas of Sarajevo. In the case of Bijeljina, the Chamber found that Bosnian Muslims were transferred to "no-man's land" before being able to cross to

The Prosecution does not allege criminal responsibility for forcible transfer or deportation in Banja Luka, Brčko and Višegrad as an underlying act of persecution under Count 3 of the Indictment. Indictment, fn. 6 . The Chamber notes that in fn. 13 of the Indictment, the Prosecution only states that with regard to deportation as a crime against humanity under Count 7 of the Indictment, it does not allege criminal responsibility for Višegrad. However, the Chamber has interpreted this restrictively in light of fn. 6 of the Indictment in favour of the Accused and will not make findings with respect to forcible transfer or deportation in Banja Luka, Brčko, and Višegrad under Counts 3, 7, or 8.

8307 See Section IV.A.1.a.i.H: Movement of the population from Bijeljina.

8308 See Section IV.A.1.a.ii.I: Movement of the population from Bratunac.

8309 See Section IV.A.1.a.iv.G: Movement of the population from Foča.

8310 See Section IV.A.1.c.v.E: Movement of the population from Pale and appropriation of property.

8311 See Section IV.A.1.b.i.D.7: Movement of the population from Prijedor and appropriation of property.

8312 See Section IV.A.1.a.v.H: Movement of the population from Rogatica.

8313 See Section IV.A.1.b.i.E.7: Movement of the population from Sanski Most and appropriation of property.

8314 See Section IV.A.1.a.vi.E: Movement of the population from Sokolac.

8315 See Section IV.A.1.a.viii.F: Movement of the population from Vlasenica and appropriation of property.

8316 See Section IV.A.1.a.ix.H: Movement of the population from Zvornik.

8317 See Section IV.A.1.b.i.B.5: Movement of the population within and from Bosanski Novi.

8318 See Section IV.A.1.c.ii.E: Movement of the population from Ilidža.

8319 See Section IV.A.1.c.iii.H: Movement of the population from Novi Grad.

8320 See Section IV.A.1.c.iv.E: Movement of the population from Novo Sarajevo and appropriation of property.

8321 See Section IV.A.1.b.i.C.8: Movement of the population from Ključ.

8322 See Section IV.A.1.c.i.E: Movement of the population from Hadžići and appropriation of property.

8323 See Section IV.A.1.c.vi.G: Movement of the population from Vogošća and appropriation of property.
} 
Bosnian Muslim controlled territory. ${ }^{8324}$ With respect to these incidents the Chamber finds that Bosnian Muslims and Bosnian Croats were displaced within the national boundaries of $\mathrm{BiH}$.

2466. The Chamber also found that Bosnian Muslims in Bijeljina, Zvornik and Bosanski Novi were displaced from their homes, villages and towns in which they were lawfully present to Serbia or Croatia. ${ }^{8325}$ In addition, the Chamber found that following the attack on Zvornik in April 1992 by Serb Forces, thousands of Bosnian Muslims fled to Mali Zvornik in Serbia. ${ }^{8326}$ The Chamber also found that some Bosnian Muslims from Foča were transferred to Montenegro. ${ }^{8327}$ The Chamber also recalls that Bosnian Muslim and Bosnian Croat detainees from Prijedor were transferred in convoys to locations in Croatia. ${ }^{8328}$ With respect to these incidents the Chamber finds that Bosnian Muslims and Bosnian Croats were displaced across a de jure or de facto border between states.

2467. The Chamber recalls that the scale and extent of the expulsions and movement of civilians from the Municipalities resulted in the displacement of a vast number of Bosnian Muslims and Bosnian Croats. ${ }^{8329}$

\section{(2) Forcible nature of movement}

2468. The Chamber finds that the Bosnian Muslims and Bosnian Croats referred to above were forcibly displaced. In reaching that conclusion, the Chamber had regard to the surrounding circumstances in the Municipalities and found that the Bosnian Muslims and Bosnian Croats were displaced as a result of physical force, ${ }^{8330}$ threat of force, ${ }^{8331}$ or coercion. ${ }^{8332}$ Others fled out of

\footnotetext{
8324 See para. 673.

8325 See paras. 673, 1360, 1458.

8326 See para. 1250.

$8327 \quad$ See para. 933.

8328 See para. 1852.

8329 See paras. 678 (the Chamber found that when the Dayton Accords were signed only 500 to 1,000 Bosnian Muslims remained in Bijeljina from the original 17,000); 788 (the Chamber found that with the exception of a few individuals there were no Bosnian Muslims left in Bratunac by June 1992); 933 (the Chamber found that by mid-August 1992 there were almost no Bosnian Muslims in Foča); 1040 (the Chamber found that by August 1995 there were almost no Bosnian Muslims in Rogatica); 1072 (the Chamber found that by the end of 1992 there were as few as 30 to 40 Bosnian Muslim families remaining in Sokolac); 1220 (the Chamber found that in June 1992 there were approximately 150 Bosnian Muslims in Vlasenica who had not been detained and very few non-Serbs remained by October 1992); 1365 (the Chamber found that by the end of June 1992 very few Bosnian Muslims remained in the town of Zvornik); 1471 (the Chamber found that by the end of 1992 the majority of Bosnian Muslims had left Bosanski Novi); 1567 (the Chamber found that by 1995 only 1,200 of the 17,000 Bosnian Muslims remained in Ključ); 2435 (the Chamber found that by May 1993 only 1.8 per cent of 14 villages in Vogošća were Bosnian Muslim); 2329 (the Chamber found that during the war only a small number of Bosnian Muslims remained in Pale).

8330 See Sections IV.A.1.a.i.H: Movement of the population from Bijeljina; IV.A.1.a.ii.I: Movement of the population from Bratunac; IV.A.1.a.v.H: Movement of the population from Rogatica; IV.A.1.a.viii.F: Movement of the population from Vlasenica and appropriation of property; IV.A.1.a.ix.H: Movement of the population from Zvornik; IV.A.1.c.iv.E: Movement of the population from Novo Sarajevo and appropriation of
} 
fear. $^{8333}$ This fear was caused by ongoing violence and various crimes committed against nonSerbs including inter alia, killings, cruel and inhumane treatment, unlawful detention, rape and other acts of sexual violence, discriminatory measures, and wanton destruction of villages, houses and cultural monuments. ${ }^{8334}$

2469. Bosnian Muslims were often given limited time to leave their homes before being loaded onto trucks, buses or trains and transported out of the Municipalities. ${ }^{835}$ Some Bosnian Muslims and Bosnian Croats, when expelled, were forced to sign statements which left their property to the Bosnian Serb authorities. ${ }^{8336}$ In some cases they had to sign statements saying that they were leaving a particular area and would never return again. ${ }^{8337}$ The Chamber also recalls its finding that in Vlasenica for example, some Bosnian Muslim women were forced to sign documents saying they were leaving the municipality of their own free will and those who refused to sign were subjected to threats to their lives and security. ${ }^{8338}$

2470. In many cases Bosnian Muslims and Bosnian Croats were forced to leave following attacks against their villages or after the take-over of towns by Serb Forces. ${ }^{8339}$ In other cases, Bosnian Muslims and Bosnian Croats were first arrested, and detained in detention facilities before being transported out of the municipality. ${ }^{8340}$ While the transfers of some detainees out of detention facilities were described as "exchanges", the Chamber finds that given that these "exchanges" were

property; IV.A.1.c.iii.H: Movement of the population from Novi Grad; IV.A.1.b.i.E.7: Movement of the population from Sanski Most and appropriation of property; IV.A.1.b.i.D.7: Movement of the population from Prijedor and appropriation of property.

8331 See, e.g., Sections IV.A.1.a.ii.I: Movement of the population from Bratunac; IV.A.1.a.v.H: Movement of the population from Rogatica; IV.A.1.a.ix.H: Movement of the population from Zvornik; IV.A.1.c.iv.E: Movement of the population from Novo Sarajevo and appropriation of property.

8332 See, e.g., Sections IV.A.1.a.i.H: Movement of the population from Bijeljina; IV.A.1.a.ii.I: Movement of the population from Bratunac; IV.A.1.a.viii.F: Movement of the population from Vlasenica and appropriation of property; IV.A.1.b.i.E.7: Movement of the population from Sanski Most and appropriation of property.

8333 See Sections IV.A.1.a.i.H: Movement of the population from Bijeljina; IV.A.1.a.ii.I: Movement of the population from Bratunac; IV.A.1.a.v.H: IV.A.1.a.iv.G: Movement of the population from Foča; Movement of the population from Rogatica; IV.A.1.a.viii.F: Movement of the population from Vlasenica and appropriation of property.

8334 The Chamber found in this section of the Judgement numerous examples of such acts directed against Bosnian Muslims and Bosnian Croats in the Municipalities.

8335 See paras. 672, 732, 931, 1035, 1060, 1072, 1144-1145, 1267, 1271, 1462, 2320.

8336 See paras. $675,929,1093,1216-1217,1266,1467,1561,1566,2033,2319,2322,2436-2438$. See also para. 2057.

$8337 \quad$ See para. 730.

$8338 \quad$ See paras. $1186,1217$.

8339 See paras. 728-732, 747, 858, 929, 972, 977, 1035, 1056, 1060, 1072, 1134, 1139, 1144-1145, 1151, 1216, 1219, 1250, 1260-1261, 1273, 1449, 1456, 1462-1463, 2089, 2313.

8340 See paras. 762-764, 888, 1152, 1186, 1202, 1479, 1850-1852, 1902, 2115, 2343-2344, 2161. 
predominantly in relation to unlawfully detained civilians, they also amount to forced displacement. $^{8341}$

2471. The Chamber recalls its findings that in some Municipalities Bosnian Muslims may have requested assistance or permission to leave, and in some cases they paid exorbitant fees to do so. However, these departures were not voluntary and occurred under circumstances in which they had no real choice but to leave. ${ }^{8342}$ Even when Bosnian Muslim leaders or other non-governmental organisations were involved in trying to evacuate Bosnian Muslims, this occurred in an environment of fear and threats which does not suggest that the population left voluntarily. ${ }^{8343}$ The Chamber finds that even though non-governmental organisations may have been involved in facilitating some of these displacements, this does not render lawful what were otherwise unlawful transfers. The Chamber found that in other municipalities while the Bosnian Serb authorities referred to movement of the population as "voluntary departure", in reality civilians were fleeing out of fear for their lives; this occurred in intimidating and violent circumstances which negated any suggestion of voluntariness in their departures. ${ }^{8344}$

2472. In addition the Chamber recalls its finding that even in municipalities where Bosnian Serb authorities did invite citizens to return, the number of those who returned was extremely limited, and the pattern of mistreatment, intimidation and expulsions continued. ${ }^{8345}$ In Vlasenica for example, Bosnian Muslims when they returned to their villages found that their homes had been burnt down. ${ }^{8346}$ In another incident the Chamber found that Serb Forces turned away Bosnian Muslims who tried to return after fleeing their village in Zvornik. ${ }^{8347}$

2473. The Chamber finds that there is no indication that the forcible displacement of the Bosnian Muslim and Bosnian Croat population was carried out on any grounds permitted under international law.

\section{(B) Mens rea}

2474. With respect to the incidents in paragraph 2465, the Chamber finds that members of the Serb Forces and Bosnian Serb Political and Governmental Organs intended to forcibly displace the

\footnotetext{
${ }^{8341}$ For the Chamber's findings with respect to unlawful detention, see Section IV.A.2.b.iv.D: Legal findings on crimes (Unlawful detention).

See paras. 673, 786, 931, 1215, 1222, 1362, 1459-1460, 1561, 1563, 1565-1566, 2039, 2318, $2320,2331,2288$. See also para. 2058.

8343 See paras. 1110, 1215, 1467-1469.

8344 See paras. 1219, 1268.

8345 See paras. 677, 720-721, 788-789, 1214.

$8346 \quad$ See para. 1219.
} 
population within a national border. In relation to the incidents in paragraph 2466, the Chamber finds that members of the Serb Forces and Bosnian Serb Political and Governmental Organs intended to forcibly displace the population across a de jure or de facto border.

2475. In reaching that conclusion, the Chamber had regard to the involvement of Serb Forces and Bosnian Serb Political and Governmental Organs in the systematic movement of Bosnian Muslims and Bosnian Croats from the Municipalities. The Chamber also considered the similar pattern in which Bosnian Muslims and Bosnian Croats were forcibly displaced and the involvement of Serb Forces and Bosnian Serb Political and Governmental Organs in creating an environment of fear in which Bosnian Muslims and Bosnian Croats had no choice but to leave the Municipalities. As found above, this environment of fear was caused by ongoing violence, killings, cruel and inhumane treatment, unlawful detention, rape and other acts of sexual violence, discriminatory measures, and wanton destruction of villages, houses, and cultural monuments. In many cases the population fled following attacks against their villages and homes by Serb Forces. The Chamber finds beyond reasonable doubt that these circumstances demonstrate the requisite intent to forcibly displace the population.

2476. In addition, the Chamber was able to infer intent from a number of explicit examples. In this regard the Chamber also recalls its finding that during attacks on Bosnian Muslim villages in Bratunac for example, members of Serb Forces said "this is a Serb country" and the Bosnian Muslims should be expelled. ${ }^{8348}$ The Chamber also recalls its finding that Bosnian Muslims were told that they would have to go to Tuzla because Bosnian Serbs were going to live in Bratunac. ${ }^{8349}$ In Pale, Bosnian Muslims were told it was better to go "voluntarily" to areas where they were a majority than to be "chase[d] through the woods" later. ${ }^{8350}$

2477. Bosnian Muslims in Rogatica were also threatened and warned about the forthcoming "cleansing" and were told they would be allowed to leave to Visoko and Zenica because this was where Bosnian Muslims were "supposed to live". ${ }^{8351}$ In Vlasenica, members of Serb Forces were instructed to "cleanse" specific areas of Bosnian Muslims and that the "territory had to be 100 percent clean and that none of the Muslims should remain in the area". ${ }^{832}$ In Zvornik, the Chamber recalls its finding that Bosnian Serb authorities met to discuss the removal of Bosnian

\begin{tabular}{ll}
\hline 8347 & See para. 1269. \\
8348 & See para. 744. \\
8349 & See para. 769. \\
8350 & See para. 2316. \\
8351 & See para. 1035. \\
8352 & See para. 1128.
\end{tabular}


Muslims and that the Zvornik TO was ordered to organise and co-ordinate the movement out of the Bosnian Muslim population. ${ }^{8353}$

2478. The Chamber found for example in Bijeljina, that there was a plan for the organised expulsion of Bosnian Muslims. ${ }^{8354}$ This involved multiple phases which created an atmosphere of fear, hardship, intimidation and humiliation where a large number of Bosnian Muslims were expelled or fled the municipality out of fear. ${ }^{8355}$ In Rogatica the Bosnian Serb authorities were involved in the organised displacement of the Bosnian Muslim population and maintained lists of Bosnian Muslims who had been sent away from the municipality. ${ }^{8356}$ In Pale, Bosnian Serb authorities convened meetings to discuss and take a position on the departure of non-Serbs from the municipality. They informed Bijljana Plavšić that there had been "forced and wilful" efforts to move Bosnian Muslims out of the municipality. ${ }^{8357}$

2479. The intent to forcibly displace the population was also demonstrated by statements from Bosnian Serb leaders that for example in Foča, not a single Bosnian Muslim was in Foča and that there was "only one people" living in the municipality and "one religion" being practised there. ${ }^{8358}$ With respect to Zvornik, the Drina Corps reported that “Turks made up 60\% of the municipality's population and it has now been cleansed and replaced with an ethnically pure Serb population". 8359

\section{(C) Conclusion}

2480. With respect to the incidents above, which relate to forcible displacement within national boundaries, the Chamber finds that those who were displaced left their homes, belongings and livelihoods, without any guarantee concerning the possibility to return in the future and this caused the victims serious mental suffering or injury. These acts were committed with the intent to inflict serious mental suffering, or with knowledge that these acts were likely to cause such suffering. These acts are of similar seriousness to deportation which is listed under Article 5(d) of the Statute. The Chamber therefore finds that these acts are sufficiently serious to amount to "other inhumane acts" pursuant to Article 5(i) of the Statute.

2481. The Chamber found that there was a widespread and systematic attack against the Bosnian Muslim and Bosnian Croat civilian populations of $\mathrm{BiH}$. The Chamber finds that these acts of

$\begin{array}{ll}8353 & \text { See para. 1363. } \\ 8354 & \text { See paras. 671-672. } \\ 8355 & \text { See paras. 670-673. } \\ 8356 & \text { See para. 1036. } \\ 8357 & \text { See } \text { para. 2324. } \\ 8358 & \text { See } \text { para. 933. } \\ 8359 & \text { See para. 1365. }\end{array}$


deportation and forcible transfer were part of this widespread and systematic attack and the perpretrators of these acts knew of the attack and that their crimes were part of it. In reaching that conclusion the Chamber considered the locations, time period, and the identity of the victims of these killings, which correspond with the scope of the widespread and systematic attack, as well as the magnitude and systematic nature of the attack on the Bosnian Muslim and Croat civilian populations of $\mathrm{BiH}$. The Chamber therefore finds that these incidents constitute deportation and other inhumane acts (forcible transfer) as crimes against humanity.

\section{iv. Persecution: Count 3}

\section{(A) Killings}

2482. The Chamber refers to its legal findings which address murder as a crime against humanity and a violation of the laws or customs of war charged under Counts 5 and 6 of the Indictment, respectively. The Chamber found above that many Bosnian Muslims and Bosnian Croats (i) were killed by Serb Forces during and after the take-over of the Municipalities; (ii) were killed by Serb Forces while detained at multiple detention facilities in the Municipalities; or (iii) died during and as a result of cruel and inhumane treatment by Serb Forces at a number of detention facilities in the Municipalities. The Chamber also also found that the perpetrators of each of these incidents acted with the intent to kill the victims or at least wilfully caused serious bodily harm, which they should reasonably have known might lead to death. The Chamber further found that the victims of each of these incidents were civilians or had been rendered hors de combat at the time of their killing.

2483. The Chamber also finds that the perpetrators of the killings mentioned above intentionally targeted their victims solely on the basis of their identity as Bosnian Muslims or Bosnian Croats; these killings were carried out on discriminatory grounds. In reaching that conclusion, the Chamber also had regard to the insults, taunts and threats directed at the victims by Serb Forces on the basis of their identity as Bosnian Muslims or Bosnian Croats. ${ }^{8360}$ As found earlier, these killings were part of a widespread and systematic attack against the Bosnian Muslim and Bosnian Croat civilian populations of $\mathrm{BiH}$ and the perpetrators knew of the attack and that their crimes were part of it.

2484. Therefore the Chamber finds that these killings constitute persecution as a crime against humanity.

8360 See, e.g., 743, 806, 873, 1019, 1151, 1314, 1552, 1625, 1702, 1722, 1763, 1869, 1875. 
(B) Cruel and/or inhumane treatment

(1) Torture, beatings, physical and psychological abuse

2485. The Chamber refers to its factual findings in Section IV.A.1 with respect to acts carried out by members of Serb Forces in the Municipalities. These factual findings demonstrate an egregious level of mistreatment suffered by Bosnian Muslims and Bosnian Croats throughout the Municipalities while in detention or during and after the take-over of the Municipalities.

2486. For example, the Chamber found that detainees were cut or stabbed with knives. ${ }^{8361}$ Some detainees had crosses carved with knives on their body including on their face, arm, and chest. ${ }^{8362}$ One detainee alone had 30 crosses carved onto his body with a hunting knife. ${ }^{8363}$ In one incident a detainee had salt rubbed into his wounds after being cut. ${ }^{8364}$ In another incident a knife was used to carve out a detainee's tattoo which depicted a crescent and star. ${ }^{8365}$ In another detention facility, detainees were forced to eat body parts which had been severed from other detainees. ${ }^{8366}$

2487. The Chamber also recalls its finding that detainees were severely beaten and mistreated during interrogations. ${ }^{8367}$ Some detainees were questioned about military operations and security issues and mistreated at the same time. ${ }^{8368}$ They had their arms and legs tied and were beaten over an extended period of time. ${ }^{8369}$ Detainees were tied with chains and belts and some were beaten for several hours including on the soles of their feet with a bat, ${ }^{8370}$ while others were physically mistreated with pliers during questioning. ${ }^{8371}$ In another incident, a boy was tied to a fence and beaten with a rope. ${ }^{8372}$ Some detainees were also forced to lie on the ground where they were severely beaten and told to confess about their involvement with Bosnian Muslim forces. ${ }^{8373}$ At another detention facility, a guard repeatedly beat a detainee after he could not answer questions; the detainee fell to the ground and the guard then jumped on him until the detainee lost

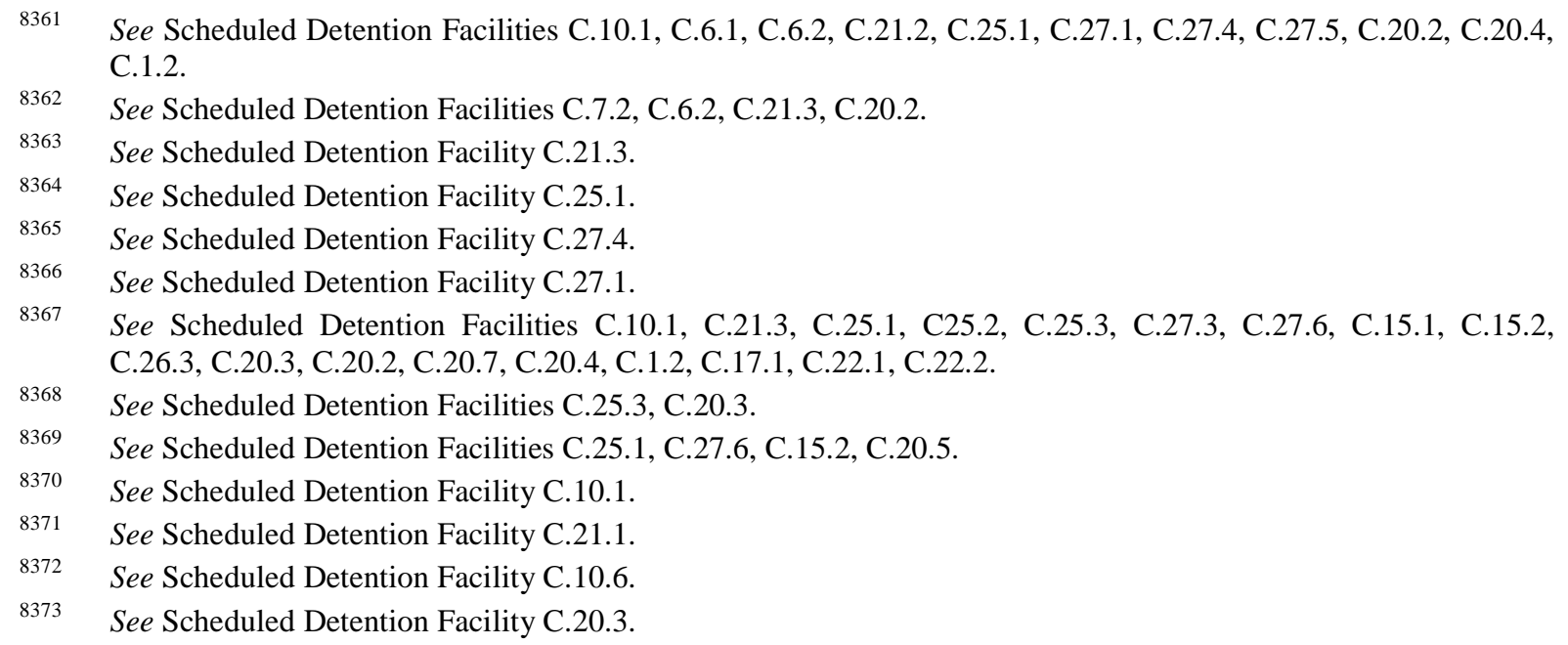


consciousness and was revived with water poured on him. ${ }^{8374}$ Detainees were also threatened or beaten before being forced to sign statements regarding their involvement in certain activities. ${ }^{8375}$

2488. In detention facilities, some detainees were forced to kneel on the floor, they had knives, bayonets, or guns put in their mouths as a scare tactic; ${ }^{8376}$ others were ordered to lie on the ground and then a guard jumped on them. ${ }^{8377}$ In one incident a detainee was forced to lick his own blood off the floor after being severely beaten. ${ }^{8378}$ Detainees were ordered to bend forward against a wall and kicked until there was a stream of blood running along the wall; their fingers were then stepped on as they were instructed to position them on top of the wall. ${ }^{8379}$ Members of the Serb Forces also threw smoke grenades, tear gas grenades, and stink bombs into areas where the detainees were held. $^{8380}$

2489. Other incidents of mistreatment included detainees being forced to swallow bullets, ${ }^{8381}$ hair which had been pulled from their armpits, ${ }^{8382}$ cigarettes, ${ }^{8383}$ broken glass, ${ }^{8384}$ and motor oil. ${ }^{8385}$ Detainees were also burnt with lit cigarettes ${ }^{8386}$ and had their teeth pulled out. ${ }^{838}$ Other detainees were ordered to sit for 40 hours in water, with their hands behind their heads and legs spread on the ground, as they were kicked and beaten. ${ }^{8388}$ Detainees were also forced to stand up for several hours which in one incident caused the weaker detainees to faint and fall to the ground. ${ }^{8389}$ The Chamber also recalls an incident where detainees were packed on top of each other in lavatories and forced to lie in the midst of excrement. ${ }^{8390}$

2490. In another incident a prominent Bosnian Muslim detainee was thrown down the stairs and had to be carried out of the detention facility unconscious. ${ }^{8391}$ Some detainees were forced to jump,

\footnotetext{
$8374 \quad$ See Scheduled Detention Facility C.21.3.

8375 See Scheduled Detention Facilities C.21.3, C.15.2, C.20.2.

8376 See Scheduled Detention Facilities C.25.3, C.15.3, C.26.1.

8377 See Scheduled Detention Facility C.21.3.

8378 See Scheduled Detention Facility C.15.2.

8379 See Scheduled Detention Facility C.20.6.

8380 See Scheduled Detention Facilities C.26.3, C.20.3, C.27.3, C.17.1.

8381 See Scheduled Detention Facilities C.21.2, C.21.3.

8382 See Scheduled Detention Facility C.21.3.

8383 See Scheduled Detention Facilities C.21.3, C.26.1.

8384 See Scheduled Detention Facility C.27.3.

8385 See Scheduled Detention Facility C.20.2.

8386 See Scheduled Detention Facilities C.21.3, C.11.2, C.18.1.

8387 See Scheduled Detention Facility C.21.3.

8388 See Scheduled Detention Facility C.25.3.

8389 See Scheduled Detention Facilities C.1.2, C.27.4, C.17.1.

8390 See Scheduled Detention Facility C.20.2.

8391 See Scheduled Detention Facility C.15.1.
} 
sometimes head first or chest first, from high points, and, as a result they sustained severe injuries. ${ }^{8392}$ In another incident, detainees were thrown into a fire made of rubber tires. ${ }^{8393}$

2491. Detainees were punched, kicked, and beaten often severely with whatever device could be found, including chains, batons, bats, clubs, rifle butts, machine guns, heavy wooden sticks, iron tubes, steel rods, wooden planks, poles, thick plastic pipes, cables, rubber hoses, stakes, chair legs, and brass knuckles. ${ }^{8394}$ Some of these beatings occurred while detainees were forced to run a gauntlet. ${ }^{8395}$ Detainees were sometimes taken out of the detention facilities and beaten. ${ }^{8396}$ Some detainees were also forced to beat or fight each other, ${ }^{8397}$ while others were severely beaten if they did not say what they were instructed to say to ICRC representatives. ${ }^{8398}$

2492. Detainees were also beaten when they were given permission to use the toilet or get water, ${ }^{8399}$ or while receiving food. ${ }^{8400}$ Some detainees were beaten when forced to carry dead bodies, ${ }^{8401}$ while others were beaten for any attempts they made to improve the conditions of their detention. $^{8402}$ Other detainees were severely beaten on arrival at detention facilities and when they were searched for valuables. ${ }^{8403}$

2493. Detainees were also subject to verbal and mental abuse, intimidation, and threats, including threats that they would be killed. ${ }^{8404}$ In addition, detainees were in constant fear as they were involved in moving dead bodies or could hear the screams of other detainees being beaten and physically abused during the night. ${ }^{8405}$ Some detainees were also forced to carry and bury dead bodies, clean toilets with their bare hands, clean traces of blood of detainees who had been beaten

\footnotetext{
8392 See Scheduled Detention Facilities C.26.1, C.26.3.

8393 See Scheduled Detention Facility C.20.2.

8394 See Scheduled Detention Facilities C.2.1, C.7.2, C.10.1, C.6.1, C.6.2, C.21.3, C.25.1, C.25.2, C.25.3, C.27.2, C.27.4, C27.5, C.27.6, C.27.7, C.11.2, C.15.1, C.15.2, C.26.1, C.26.3, C.20.3, C.20.2 (the Chamber found that in some cases there were nails embedded in the implements so that the skin of the detainees would be pierced), C.20.1, C.20.5, C.20.6, C.20.4, C.19.2, C.1.2, C.17.1, C.22.1, C.22.3, C.22.4, C.22.5. See also Scheduled Detention Facility C.18.1.

8395 See Scheduled Detention Facilities C.20.1, C.20.6, C.19.2, C.1.2, C.18.1, C.17.1.

8396 See Scheduled Detention Facilities C.10.1, C.21.2, C.21.3, C.23.2, C.23.1, C.25.3, C.27.4, C.4.1, C.17.1.

8397 See Scheduled Detention Facilities C.2.1, C.7.2, C.21.3, C.27.1, C.27.4, C.27.6, C.11.2, C.15.2, C.26.1, C.20.3, C.20.2, C.20.4, C.22.1.

8398 See Scheduled Detention Facilities C.2.1, C.21.3.

8399 See Scheduled Detention Facilities C.7.2, C.25.1, C.25.2, C.20.2, C.20.1, C.18.1.

8400 See Scheduled Detention Facilities C.10.1, C.20.2, C.20.3.

8401 See Scheduled Detention Facility C.7.2.

8402 See Scheduled Detention Facilities C.10.1, C.1.2.

8403 See Scheduled Detention Facilities C.1.2, C.18.1. See also See Scheduled Detention Facility C.18.2.

8404 See Scheduled Detention Facilities C.7.2, C.10.6, C.10.5, C.10.7, C.10.2, C.6.1, C.6.2, C.21.1, C.21.3, C.25.2, C.27.1 (the Chamber found that detainees were forced to beat each other with the promise that the one who won would not be killed), C.27.4, C.27.5, C.27.6, C.15.3, C.15.2, C.26.3, C.26.1, C.4.1, C.20.2, C.20.1, C20.4, C.19.2. See also paras. 2093, 2264.

8405 See Scheduled Detention Facilities C.20.2, C.10.1. See also Scheduled Detention Facility C.21.3.
} 
or killed, and were also taken to loot or clean Bosnian Muslim houses in the town for the use of Bosnian Serb families. ${ }^{8406}$

2494. Some detainees were singled out for severe beatings in front of other detainees as an example of what could happen to them. ${ }^{8407}$ Detainees were also taunted when forced to carry dead bodies. $^{8408}$ Detainees were subjected to humiliation; this included being forced to (i) make the "Serb three-finger sign", ${ }^{8409}$ (ii) make the sign of the cross, ${ }^{8410}$ (iii) walk or kneel with their heads bowed, ${ }^{8411}$ (iv) eat carbonised bread without dropping anything, ${ }^{8412}$ and (v) graze grass like animals at gun point. ${ }^{8413}$ Some detainees were spat at and verbally degraded. ${ }^{8414}$ In one case a Bosnian Muslim priest was targeted for humiliation; he was forced to drink beer, make the "Serb threefinger sign", and sing "Chetnik" songs. ${ }^{8415}$ Some Bosnian Muslim detainees were also forced to sign papers saying that they had "voluntarily joined the Serbian Orthodox religion". ${ }^{8416}$ The Chamber also found that Serb nationalist songs were played loudly and continuously in a detention facility. ${ }^{8417}$ In Pale, the Chamber found that detainees had their hair forcibly cut with a knife. ${ }^{8418}$ In another incident detainees in Novi Grad were forced to lie on the ground, beaten, and then subject to attacks by dogs. ${ }^{8419}$

2495. The Chamber also recalls its findings that Bosnian Muslims were beaten or abused during or after attacks on villages ${ }^{8420}$ or during and after their arrest. ${ }^{8421}$ Some Bosnian Muslim patients

8406 See Scheduled Detention Facilities C.7.2, C.21.3, C.25.3, C.20.2, C.20.4, C.27.4. The Chamber also found that other detainees were forced to work at Ekonomija farm but has insufficient evidence as to the nature of the work to determine whether it amounted to a denial of or infringement upon a fundamental right to reach the level of gravity of other Article 5 crimes. See Scheduled Detention Facility C.27.6.

8407 See Scheduled Detention Facilities C.7.2, C.26.1, C.15.2.

8408 See Scheduled Detention Facility C.7.2.

8409 See Scheduled Detention Facilities C.2.1, C.6.2, C.27.6, C.15.2, C.20.2, C.20.1.

$8410 \quad$ See Scheduled Detention Facilities C.27.4, C.18.1.

8411 See Scheduled Detention Facilities C.2.1, C.1.2.

8412 See Scheduled Detention Facility C.27.4.

8413 See Scheduled Detention Facility C.4.1.

8414 See Scheduled Detention Facility C.15.2.

8415 See Scheduled Detention Facility C.6.2.

8416 See Scheduled Detention Facility C.21.1.

8417 See Scheduled Detention Facility C.20.2.

8418 See Scheduled Detention Facility C.19.2.

8419 See Scheduled Detention Facility C.17.1.

8420 See paras. 861, 873, 1264, 1266. The Chamber recalls its finding that following the attack on Mješaja/Trošanj by Serb Forces, Bosnian Muslim villagers were kicked and hit with rifle butts and tree branches, and in one case a Bosnian Muslim lost an eye. See para. 1139.

8421 See paras. 862, 876-877, 970, 985, 1126, 1134, 1155-1156, 1464, 2093; Scheduled Detention Facilities C.27.2, C.27.6, C.20.6. 
were also severely kicked and beaten in hospitals when it was discovered that they were Bosnian Muslims. $^{8422}$

2496. The Chamber also recalls its finding that prominent Bosnian Muslims and Bosnian Croats, including professionals and leaders, were targeted, taken away, detained, and subjected to intimidation and beatings. ${ }^{8423}$ The Chamber also found that members of Serb Forces mistreated and intimidated Bosnian Muslims by making derogatory remarks, by shooting at their homes and mosques, and by stopping, beating, and mistreating Bosnian Muslims at check-points and barricades. $^{8424}$

2497. The Chamber recalls its finding that many detainees had visible wounds and bruises following this mistreatment and some were unable to walk or talk for days. ${ }^{8425}$ Some detainees were subjected to multiple beatings on a daily basis. ${ }^{8426}$ Injuries included broken and fractured bones, bleeding, severe bruises, swelling, and knocked-out teeth. ${ }^{8427}$ In one case a detainee began to urinate blood after being beaten severely, ${ }^{8428}$ and others had their eyes knocked out or were blinded. ${ }^{8429}$ Some detainees were beaten severely until they lost consciousness. ${ }^{8430}$ The Chamber also found that detainees continued to suffer ongoing physical and psychological effects. ${ }^{8431}$

2498. Having considered these incidents, the Chamber finds that Bosnian Muslims and Bosnian Croats were subjected to intentional acts which caused severe physical and mental pain or suffering. These acts were intentionally carried out by members of Serb Forces and were aimed at (i) obtaining information or a confession; (ii) punishing, intimidating, or coercing the victim or a third person, or (iii) discriminating against the victim or a third person. The Chamber therefore finds that acts of torture were carried out against Bosnian Muslims and Bosnian Croats in the Municipalities.

2499. In addition, these incidents establish that Bosnian Muslims and Bosnian Croats were also subjected to deliberate beatings, physical and psychological abuse, including harassment, constant humiliation, and degradation. The Chamber finds that these beatings and abuse caused serious

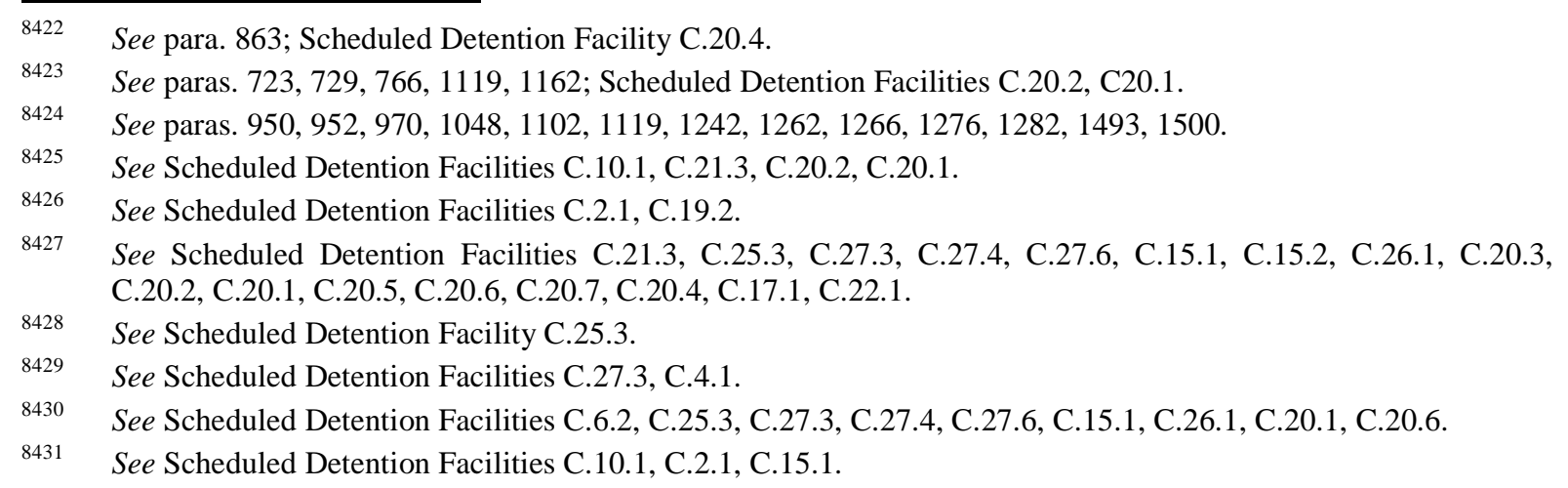


mental or physical suffering or injury or constituted a serious attack on human dignity and amounted to a denial of or infringement upon a fundamental right. The Chamber therefore finds that these acts of beatings, physical and psychological abuse are of equal gravity to the other crimes listed under Article 5 of the Statute.

\section{(2) Rape and other acts of sexual violence ${ }^{8432}$}

2500. The Chamber found in Section IV.A.1 above that Serb Forces committed rape against Bosnian Muslim and Bosnian Croat women and men in Bijeljina, ${ }^{8433}$ Brčko, ${ }^{8434}$ Foča, ${ }^{8435}$ Novo Sarajevo, ${ }^{8436}$ Prijedor, ${ }^{8437}$ Rogatica, ${ }^{8438}$ Vlasenica, ${ }^{8439}$ Vogošća,${ }^{840}$ and Zvornik. ${ }^{8411}$ Some Bosnian Muslim women and girls were raped on multiple occasions, sometimes on a continuous basis by members of Serb Forces while in detention facilities. ${ }^{842}$

2501. In one case a woman was raped approximately 150 times during her detention. ${ }^{8443}$ There were incidents where Bosnian Muslim women who had been detained were taken out of the facilities and raped by Serb Forces; in some incidents the rape was accompanied by additional threats or use of violence and sometimes involved gang rape. ${ }^{8444}$ Some Bosnian Muslim women were moved to houses and apartments where they were raped on some occasions in front of each other. ${ }^{8445}$ Other incidents included women being raped and further humiliated publicly by members of Serb Forces in villages which had been taken-over. ${ }^{846}$ The Chamber also found that some Bosnian Muslim male detainees, including a 13-year-old boy, were also raped by Serb Forces who used police truncheons and similar objects. ${ }^{8447}$

\footnotetext{
8432 The Prosecution does not allege criminal responsibility for rape and other acts of sexual violence in Banja Luka, Bosanski Novi, Bratunac, Pale, and Višegrad. Indictment, fn. 5.

8433 See para. 631 ; Scheduled Detention Facility C.2.1.

8434 See Scheduled Detention Facility C.7.2.

8435 See Scheduled Detention Facilities C.10.4, C.10.5, C.10.2.

8436 See paras. 2270-2271, 2274.

8437 See Scheduled Detention Facilities C.20.3, C.20.2, C.20.4.

8438 See Scheduled Detention Facility C.21.3.

8439 See Scheduled Detention Facility C.25.3.

8440 See Scheduled Detention Facility C.26.3.

8441 See Scheduled Detention Facility C.27.6.

8442 See Scheduled Detention Facilities C.7.2, C.10.4, C.10.2, C.21.1, C.21.3, C.20.3, C.20.2, C.20.4.

8443 See Scheduled Detention Facilities C.10.5, C.10.7.

8444 See Scheduled Detention Facilities C.7.2, C.10.5, C.10.2, C.21.1. See also Scheduled Detention Facilities C.20.3 (the Chamber found that a Bosnian Muslim woman was found in a pool of blood after being raped), C.20.2, C.20.4.

8445 See Scheduled Detention Facilities C.10.2, C.21.1.

8446 See paras. 631, 1269.

8447 See Scheduled Detention Facility C.21.1.
} 
2502. In one incident Bosnian Muslim detainees were ordered to get down on all fours, a pointed stake was introduced into their anuses causing them to scream in pain; they were then ordered to wipe the blood with their clothes. ${ }^{8448}$ In other incidents detainees were forced to have oral and sexual intercourse with each other, sometimes in front of other detainees. ${ }^{8449}$

2503. Other acts of sexual violence included male and female detainees who were ordered to undress, dance, and perform sexual acts in front of Bosnian Serb soldiers. ${ }^{8450}$ In other incidents detainees were forced to remove their underwear and bite or suck each others' penises while soldiers stood by and laughed. ${ }^{8451}$ In another incident detainees were forced to lick the buttocks of a Bosnian Serb woman, who threatened to slit their throats if they did not comply. ${ }^{8452}$ A female detainee had her breast exposed while a guard went over it with a knife and the other guards watched and laughed. ${ }^{8453}$

2504. The Chamber finds that each of these acts of rape and other acts of sexual violence were committed by members of Serb Forces without the consent of the victims, that the perpetrators intentionally committed these acts, and that the perpetrators were aware that the victims did not consent to such acts. In reaching that conclusion the Chamber has had regard to the circumstances in which they occurred and the horrific nature of the acts themselves. This includes the fact that the victims were often detained and subjected to threats of or actual violence and humiliation.

2505. With respect to the other acts of sexual violence referred to above, the Chamber finds that they involved serious abuses of a sexual nature which were inflicted upon the integrity of the victims by means of coercion, threat of force, or intimidation in a way that caused the utmost humiliation and degradation to the dignity of the victims. The Chamber finds that these acts of sexual violence amounted to denial of or infringement upon a fundamental right and were of equal gravity to the other crimes listed under Article 5 of the Statute.

2506. The Chamber therefore finds that Bosnian Muslim women, men, girls, and boys were subject to rape and other acts of sexual violence.

\footnotetext{
$8448 \quad$ See Scheduled Detention Facility C.27.6.

8449 See Scheduled Detention Facilities C.2.1, C.26.3, C.26.1, C.20.2.

8450 See Scheduled Detention Facility C.21.3.

8451 See Scheduled Detention Facilities C.27.6, C.11.2.

${ }_{8452}$ See Scheduled Detention Facility C.11.2.

${ }^{8453}$ See Scheduled Detention Facility C.20.2.
} 
(3) Establishment and perpetuation of inhumane living conditions

2507. The Chamber found in Section IV.A.1 above that Bosnian Muslims and Bosnian Croats were detained in multiple detention facilities. The Chamber recalls its findings that the detainees were held in terrible living conditions characterised by severe over-crowding; ${ }^{8454}$ poor sleeping conditions, including insufficient bedding and blankets; ${ }^{8455}$ insufficient or no heating; ${ }^{8456}$ lack of ventilation and light; stifling heat: ${ }^{8457}$ poor sanitation and hygiene, including inadequate washing and toilet facilities; ${ }^{8458}$ the provision of inadequate food and in some cases rotten food; ${ }^{8459}$ insufficient or restricted access to water; ${ }^{8460}$ and inadequate or non-existent medical care. ${ }^{8461}$

2508. At some detention facilities, the detainees were held in dark, cold, and wet conditions due to leaking roofs. ${ }^{8462}$ In one of these facilities, food was distributed in bowls which had been used to feed dogs and in some cases the detainees' food was given to the dogs. ${ }^{8463}$ The Chamber also recalls its finding that in some detention facilities, there was a terrible stench due to the inadequate and leaking toilet facilities and that at night detainees were forced to use a pot and when this filled, they relieved themselves in their pants or in their rooms. ${ }^{8464}$

2509. In some cases detainees experienced extreme weight loss, malnutrition, and a deterioration of their health during their detention as a result of the lack of food and medical attention. ${ }^{8465}$ The

8454 See Scheduled Detention Facilities C.2.1, C.7.2, C.10.1, C.25.1, C.25.2, C.27.2, C.15.3, C.4.1, C.20.3, C.20.2, C.20.5, C.20.4 (the Chamber found that due to the lack of space detainees were forced to sleep outdoors in makeshift shelters), C.18.1, C.18.2, C.22.1, C.22.2, C.22.3.

8455 See Scheduled Detention Facilities C.10.1, C.21.1, C.25.1, C.25.2, C.25.3, C.11.2, C.26.3, C.26.1, C.4.1, C.20.3, C.19.2, C.1.2, C.22.1, C.22.2, C.22.3, C.22.4.

8456 See Scheduled Detention Facilities C.10.1, C.18.2. The Chamber found that this was done deliberately, with no heaters in the rooms, windowpanes left broken, and clothes used to combat the cold confiscated from the detainees. See Scheduled Detention Facility C.25.3.

8457 See Scheduled Detention Facilities C.20.3, C.20.2, C.20.1, C.20.5, C.20.4, C.1.2, C.22.1, C.22.2, C.22.3

8458 See Scheduled Detention Facilities C.2.1, C.10.1, C.10.5, C.10.7, C.21.1, C.21.3, C.23.1, C.25.3, C.11.2, C.26.3 (the Chamber found that detainees were held in a location where garbage was disposed of and accumulated), C.26.1, C.4.1, C.20.3, C.20.2, C.20.1, C.20.4, C.19.2, C.1.2, C.18.2, C.22.1, C.22.2, C.22.4.

${ }^{8459}$ See Scheduled Detention Facilities C.2.1, C.10.1, C.10.5, C.10.7, C.6.2, C.21.1, C.23.1, C.25.1, C.25.3, C.27.2, C.11.2, C.11.1, C.26.3, C.26.1, C.4.1, C.20.3, C.20.2, C.20.5, C.20.4, C.19.2, C.1.2, C.17.1, C.18.2, C.22.1, C.22.2, C.22.3, C.22.4.

8460 See Scheduled Detention Facilities C.21.3, C.25.3, C.11.1, C.4.1, C.20.2 (the Chamber found that detainees were denied water for long periods and when it was provided it was not potable which caused intestinal problems), C.20.5 (the Chamber found that detainees had to "earn" drinking water by singing songs about Greater Serbia), C.20.4, C.1.2, C.18.1, C.17.1, C.22.1, C.22.2, C.22.5.

8461 See Scheduled Detention Facilities C.21.1, C.10.1, C.25.1, C.25.2, C.25.3, C.26.1, C.4.1, C.20.3, C.20.2, C.20.7, C.20.4, C.19.2, C.1.2, C.22.2, C.22.3.

8462 See Scheduled Detention Facilities C.26.3, C.1.2, C.17.1.

8463 See Scheduled Detention Facility C.26.3.

8464 See Scheduled Detention Facilities C.25.3, C.20.2, C.20.3

8465 See Scheduled Detention Facilities C.2.1, C.10.1 (finding that some detainees suffered multiple bouts of pneumonia due to the conditions in the facility), C.26.1, C.4.1, C.20.3, C.20.2. See also Scheduled Detention Facilities C.19.2, C.1.2. 
poor hygienic conditions also resulted in a major problem with lice, skin diseases, and dysentery at some facilities. ${ }^{8466}$ The Chamber also found that the living conditions in some detention facilities caused lasting physical and psychological problems for some detainees. ${ }^{8467}$ The Chamber also refers to its findings in Section IV.A.2.b.i regarding the detainees who died as a result of the conditions of detention.

2510. While the Chamber did find that the conditions improved in some facilities with time, this does not detract from the fact that prior to these modest improvements conditions were deplorable in the overwhelming majority of detention facilities referred to in the Indictment. ${ }^{8468}$ The Chamber also notes in this regard its findings that Bosnian Serb authorities and officials attempted to cover up and prevent the leakage of information regarding the conditions of detention and the condition of detainees. ${ }^{8469}$ These attempts included hiding detainees before the arrival of international representatives and threatening detainees with severe punishment if they complained about conditions and treatment. ${ }^{8470}$

2511. Having considered these factors the Chamber finds that members of the Bosnian Serb Political and Governmental Organs and Serb Forces deliberately established and perpetuated inhumane living conditions at a number of detention facilities in the Municipalities. ${ }^{841}$ Having considered the extent and the deplorable nature of these inhumane conditions in so many detention facilities, and the grave consequences for those detained, the Chamber concludes that these acts amount to a denial of or infringement upon a fundamental right and reach the level of seriousness of other crimes listed under Article 5 of the Statute.

\section{(4) Conclusion on cruel and inhumane treatment}

2512. As found above, Bosnian Muslims and Bosnian Croats in the Municipalities were subjected to (i) torture, beatings, and physical and psychological abuse; (ii) rape and other acts of sexual violence; and (iii) inhumane living conditions. These acts and/or omissions resulted in serious mental or physical suffering or injury for the victims; this amounts to a serious attack on human dignity. The perpetrators of these acts or omissions were members of Serb Forces. The Chamber finds that the perpetrators committed these acts or omissions (i) with intent to cause serious mental or physical suffering or injury; (ii) with intent to cause a serious attack on human dignity; or (iii)

\footnotetext{
8466 See Scheduled Detention Facilities C.10.1, C.20.3, C.20.2, C.20.4, C.1.2, C.18.2.

8467 See Scheduled Detention Facility C.10.1.

8468 See Scheduled Detention Facility C.25.3.

8469 See paras. 1198, 1200. See also para. 2150.

8470 See Scheduled Detention Facilities C.25.3, C.26.3. See also Scheduled Detention Facilities C.4.1, C.20.2.
} 
with knowledge that serious mental or physical suffering or injury or a serious attack on human dignity was a probable consequence of these acts or omissions.

2513. In addition, the Chamber finds that the perpetrators of these acts or omissions chose their victims on the basis of their identity as Bosnian Muslims or Bosnian Croats. The Chamber finds that these acts or omissions discriminated in fact and denied or infringed on fundamental rights. The Chamber also finds that these acts or omissions were carried out deliberately with the intent to discriminate on the basis of the identity of the victims as Bosnian Muslims or Bosnian Croats. ${ }^{8472}$ In reaching that conclusion, the Chamber infers intent from the fact that those targeted by these acts of cruel and inhumane treatment were almost exclusively Bosnian Muslims or Bosnian Croats. In addition, the Chamber also had regard to the insults, taunts, and threats directed at the victims on the basis of their identity as Bosnian Muslims or Bosnian Croats, which expressly demonstrated this discriminatory intent.

2514. Examples of such insults and taunts which the Chamber found were connected to these acts of cruel and inhumane treatment include the following. Detainees who were subject to beatings or mistreatment were called "balijas" and a "Turkish gang, a fictitious people, a non-existent people" and told that they would all be killed or exterminated. ${ }^{843}$ Other detainees were subject to similar ethnic slurs during the beating and mistreatment. ${ }^{847}$ In one incident a detainee was forced to run around the detention facility and swear at the detainees" "balija mother". ${ }^{8475}$ Some detainees were called "Ustasha" before or during their mistreatment. ${ }^{8476}$ Detainees were also forced to sing "Chetnik" songs ${ }^{8477}$ and to make the "Serb three-finger sign". ${ }^{8478}$ Detainees were also taunted with political comments such as "You wanted a state: here is a state for you", "where is now your Alija to save you?", and "Where is Naser, your liberator?". ${ }^{8479}$ Bosnian Muslims were told "there would be no balija state soon" and they were "finished". ${ }^{8480}$ The Chamber recalls that it found that during one rape, a Bosnian Muslim woman was told that "Muslim women should give birth to Serb children", and the perpetrator also said that Muslims were not human beings. ${ }^{8481}$ The

\footnotetext{
8471 The Chamber recalls that it did not have sufficient evidence to made a finding as to the conditions of detention at the TO military warehouses at Livade in Foča. See Scheduled Detention Facility C.10.6.

8472 The Chamber considers that discrimination on the grounds of the identity of the victims as Bosnian Muslims or Bosnian Croats falls within the prohibited grounds of discrimination under Article 5(h) of the Statute.

$8473 \quad$ See para. 806.

8474 See paras. 862, 1013, 1196, 1306, 1477, 1532, 1536, 1745, 1764, 1826, 2021, 2093, 2105, 2198, $2277-2278$.

8475 See para. 2105.

8476 See paras. $776,873,1763$.

8477 See Scheduled Detention Facilities C.7.2, C.6.2, C.27.4, C.27.5, C.20.2, C.1.2, C.18.1.

8478 See Scheduled Detention Facilities C.2.1, C.6.2.

8479 See para. 2514

$8480 \quad$ See para. 2093.

8481 See para. 1830.
} 
discriminatory nature of the conditions of detention was shown, for example, by the finding that in facilities where some Bosnian Serb detainees were also held, they received better food and did not suffer the extreme weight loss of non-Serb detainees. ${ }^{8482}$

2515. In finding discriminatory intent for these acts of cruel and inhumane treatment, the Chamber also had regard to the surrounding circumstances in the Municipalities in the lead-up to, during, and after the take-over of the Municipalities including specific statements directed against the Bosnian Muslim population. In Foča for example, Bosnian Serb leaders made radio announcements that it was no longer possible for Bosnian Serbs to live with their Bosnian Muslim neighbours, that they could not be woken every morning by the hodza from the mosque, and that the "the time had come for the Serbs to settle accounts with the balijas once and for all, and that the Serbs would no longer allow their ribs to be broken. They will no longer allow their children to be circumcised". ${ }^{8483}$ Similar radio broadcasts were made in Prijedor which referred to the destruction of the "balijas" and their property and mosques. ${ }^{8484}$

2516. In addition, the Chamber found in Bratunac, for instance, that in the lead-up to the conflict, SDS members wrote slogans on street and traffic signs as well as on public and private property, which were derogatory towards Bosnian Muslims, including messages to the effect: "Muslims, Balijas, Turks move out, you're going to be slaughtered". ${ }^{8485}$ In Vlasenica, Bosnian Serb leaders declared that when $\mathrm{BiH}$ "was proclaimed a sovereign state, we will draw up our borders in blood". ${ }^{8486}$ Similarly in Vlasenica, graffiti was written on the houses of prominent Bosnian Muslims saying "Ustasha", "Muslims out", "We will slaughter", "Out", and "This is Serb, this is Serbia". ${ }^{8487}$ Bosnian Serb leaders in Vogošca said that "Muslims were simply going to disappear". 8488

2517. Further, the Chamber found that there was a widespread and systematic attack against the Bosnian Muslim and Bosnian Croat civilian populations of $\mathrm{BiH}$. The Chamber finds that the acts or omissions referred to above were part of this widespread and systematic attack and the perpretrators knew of the attack and that their crimes were part of it. In reaching that conclusion the Chamber considered the locations, time period, and the identity of the victims, which

\footnotetext{
$8482 \quad$ See paras. 893-894.

8483 See para. 852.

8484 See paras. 1604, 1606, 1609. See also para. 688.

8485 See para. 688. See also para. 2184.

${ }_{8486} \quad$ See para. 1101.

$8487 \quad$ See para. 1119.

${ }^{8488} \quad$ See para. 2362.
} 
correspond with the scope of the widespread and systematic attack, as well as the magnitude and systematic nature of the attack on the Bosnian Muslim and Croat civilian populations of $\mathrm{BiH}$.

2518. The Chamber therefore finds that these incidents of cruel and inhumane treatment constitute acts of persecution as a crime against humanity.

\section{(C) Forcible transfer and deportation}

2519. The Chamber found above that deportation and inhumane acts (forcible transfer) were committed and these constituted crimes against humanity as charged under Counts 7 and 8 of the Indictment.

2520. The Chamber also finds that the perpetrators of these acts of forcible transfer and deportation chose their victims on the basis of their identity as Bosnian Muslims or Bosnian Croats. These acts were carried out on discriminatory grounds and with discriminatory intent. In reaching that conclusion, the Chamber recalled its finding that Bosnian Muslims who were removed from their villages were subjected to a "barrage of insults" with respect to their "Muslim ethnicity". ${ }^{8489}$ Similarly during expulsions in Novo Sarajevo Serb Forces made statements such as "all Ustašas

and Balijas out!" and in Prijedor victims were cursed and told they would be sent to Turkey. ${ }^{8490}$ The Chamber also refers to its findings above relating to mens rea which are also indicative of this discriminatory intent. ${ }^{8491}$ The Chamber also had regard to its finding that these acts of forcible transfer and deportation were discriminatory in fact given that the victims of these acts were almost exclusively Bosnian Muslims and Bosnian Croats.

2521. As the Chamber found above, these acts were part of a widespread and systematic attack against the Bosnian Muslim and Bosnian Croat civilian populations of $\mathrm{BiH}$ and the perpetrators knew of the attack and that their crimes were part of it. In addition the Chamber found that the acts of forcible displacement within national boundaries were sufficiently serious to amount to "other inhumane acts". Therefore the Chamber finds that these acts of forcible transfer and deportation constitute acts of persecution as a crime against humanity.

(D) Unlawful detention

2522. The Chamber found in Section IV.A.1 that a large number of Bosnian Muslim and Bosnian Croat civilians were detained by members of Serb Forces and Bosnian Serb Political and

$\begin{array}{ll}8489 & \text { See para. } 1151 . \\ 8490 & \text { See paras. 1652, } 2283 \\ 8491 & \text { See paras. 2474-2479. }\end{array}$


Governmental Organs in detention facilities in Banja Luka, ${ }^{8492}$ Bijeljina, ${ }^{8493}$ Bosanski Novi, ${ }^{8494}$ Bratunac, ${ }^{8495}$ Brčko, $^{8496}$ Foča, ${ }^{8497}$ Hadžići, ${ }^{8498}$ Ključ, ${ }^{8499}$ Ilidža, ${ }^{8500}$ Novi Grad, ${ }^{8501}$ Novo Sarajevo; ${ }^{8502}$ Pale, ${ }^{8503}$ Prijedor, ${ }^{8504}$ Rogatica, ${ }^{8505}$ Sanski Most, ${ }^{8506}$ Sokolac, ${ }^{8507}$ Vlasenica, ${ }^{8508}$ Vogošća, ${ }^{8509}$ and Zvornik. ${ }^{8510}$

2523. The arbitrary nature of this detention was shown by the Chamber's findings that in some detention facilities the detainees (i) were not detained on any legal grounds; (ii) were not informed as to why they were arrested and detained; (iii) were not suspected, charged, tried, or convicted for any crime before being detained or while detained; (iv) were not advised of their rights before or during their detention and (v) their detention was not subject to review. ${ }^{8511}$ The Chamber also recalls, for example, that the local authorities in Brčko were informed that people were being detained without any legal grounds, and while some detainees were released, this was done in a selective manner and based on personal connections. ${ }^{8512}$

2524. The arbitrary nature of the detention is also evidenced, for example, by the decision by the Bosnian Serb authorities in Hadžići to arrest and detain all Bosnian Muslim men of military age from certain areas in the municipality ${ }^{8513}$ and that in the Omarska camp the detainees were categorised, and included a category of detainees of "no security interest". 8514

\footnotetext{
8492 See Scheduled Detention Facility C.1.2.

8493 See Scheduled Detention Facility C.2.1.

8494 See Scheduled Detention Facility C.4.1.

8495 See Scheduled Detention Facilities C.6.1, C.6.2.

8496 See Scheduled Detention Facility C.7.2.

8497 See Scheduled Detention Facilities C.10.1, C.10.2, C.10.4, C.10.5, C.10.6, C.10.7.

8498 See Scheduled Detention Facilities C.11.1, C.11.2.

8499 See Scheduled Detention Facilities C.15.1, C.15.2, C.15.3.

8500 See Scheduled Detention Facility C.18.2.

8501 See Scheduled Detention Facility C.17.1.

8502 See Scheduled Detention Facility C.18.1.

8503 See Scheduled Detention Facility C.19.2

8504 See Scheduled Detention Facilities C.20.1, C.20.2, C.20.3, C.20.4, C.20.5, C.20.6, C.20.7.

8505 See Scheduled Detention Facilities C.21.1, C.21.2, C.21.3. While in Rogatica, some Bosnian Muslims surrendered themselves to Veljko Vlahović Secondary School, the Chamber recalls its finding that those individuals did not seek shelter but were detained at the facility. See Scheduled Detention Facility C.21.1.

8506 See Scheduled Detention Facilities C.22.1, C.22.2, C.22.3, C.22.4, C.22.5.

8507 See Scheduled Detention Facilities C.23.1, C.23.2.

8508 See Scheduled Detention Facilities C.25.1, C.25.2, C.25.3.

8509 See Scheduled Detention Facilities C.26.1, C.26.2.

8510 See Scheduled Detention Facilities C.27.1, C.27.2, C.27.3, C.27.4, C.27.5, C.27.6, C.27.7.

8511 See paras. 883, 1071, 1161, 1297, 1380, 2141.

8512 See para. 802.

8513 See para. 2094

$8514 \quad$ See para. 1753.
} 
2525. The Chamber found that these detainees were arrested and taken to these detention facilities from their homes, following attacks on villages or towns, or transferred from other detention facilities. ${ }^{8515}$ In some cases, the Bosnian Muslim population was ordered to gather en masse and then moved to detention facilities. ${ }^{8516}$ Most of those detained were civilians and included women, children, the sick, and the elderly. ${ }^{8517}$

2526. The Chamber noted that a small number of detainees in some facilities were Bosnian Muslim soldiers or combatants. ${ }^{8518}$ The Chamber is not satisfied that their detention was unlawful.

2527. The Chamber considered the circumstances in which detainees were brought to and detained at these facilities, the extended period of detention, the large number of individuals detained across multiple municipalities, and the status of the overwhelming majority as civilians including women, children, and the elderly. On this basis the Chamber finds that with the exception of the Bosnian Muslim soldiers referred to in the previous paragraph, the detainees at these facilities were arbitrarily deprived of their liberty with no legal basis and that the perpetrators intended to arbitrarily deprive these individuals of their liberty. The Chamber finds that this amounted to a denial of or infringement upon a fundamental right and was of equal gravity to the other crimes listed under Article 5 of the Statute. The Chamber therefore finds that there was unlawful detention of Bosnian Muslims and Bosnian Croats.

2528. In addition, the Chamber finds that the perpetrators of these acts of unlawful detention chose their victims on the basis of their identity as Bosnian Muslims or Bosnian Croats. The Chamber finds that these acts were carried out deliberately with the intent to discriminate on the basis of the identity of the victims as Bosnian Muslims or Bosnian Croats. ${ }^{8519}$ In concluding that these acts were carried out with discriminatory intent, the Chamber had regard to its finding that these acts of unlawful detention were discriminatory in fact given that the unlawful detention was almost exclusively directed against Bosnian Muslims and Bosnian Croats whereas the guards and those in charge of the detention facilities were Bosnian Serbs. In addition, the Chamber also had regard to the insults, taunts, and threats directed at the victims on the basis of their identity as

\footnotetext{
8515 See Scheduled Detention Facilities C.6.1, C.6.2, C.2.1, C.7.2, C.10.6, C.10.1, C.10.4, C.10.5, C.10.7, C.10.2, C.21.1, C.21.2, C.21.3, C.25.1, C.25.3, C.27.1, C.27.4, C.27.6, C.15.3, C.15.1, C.26.3, C.26.1, C.20.3, C.20.2, C.20.1, C.20.7, C.20.4, C.1.2, C.18.2.

8516 See paras. 983-984.

8517 See Scheduled Detention Facilities C.2.1, C.6.1, C.7.2, C.10.6, C.10.1, C.21.1, C.25.1, C.25.3, C.27.5, C.11.1, C.11.2, C.15.1, C.26.3, C.26.1, C.4.1, C.20.2, C.20.1, C.20.6, C.20.4, C.19.2, C.1.2, C.18.2, C.22.1, C.22.3.

8518 See paras. 883, 1021, 1323, 2209, 2336.

8519 The Chamber considers that discrimination on the grounds of the identity of the victims as Bosnian Muslims or Bosnian Croats falls within the prohibited grounds of discrimination under Article 5(h) of the Statute.
} 
Bosnian Muslims or Bosnian Croats, which expressly demonstrated this discriminatory intent. ${ }^{8520}$ For further evidence of discriminatory intent with respect to unlawful detention, the Chamber also recalls its finding that, for example, in Vlasenica, the Sušica camp was established pursuant to an order of the VRS, following a decision of the SAO Birač on regulating the "moving out of the Muslim population". 8521 In addition, the Chamber found that Bosnian Muslims during their transportation to the Sušica camp were subjected to threats and racial slurs. ${ }^{8522}$ In Zvornik, the Chamber found that a member of the Serb Forces said that they would bring in every Bosnian Muslim who was found in town. ${ }^{8523}$

2529. Further, the Chamber found that there was a widespread and systematic attack against the Bosnian Muslim and Bosnian Croat civilian populations of $\mathrm{BiH}$. The Chamber finds that the incidents of unlawful detention were part of this widespread and systematic attack and the perpretrators of these acts knew of the attack and that their crimes were part of it. In reaching that conclusion the Chamber considered the locations and time period of those acts, and the identity of the victims, which correspond with the scope of the widespread and systematic attack. Further, given the magnitude of the attack on the Bosnian Muslim and Bosnian Croat civilian populations of $\mathrm{BiH}$, the Chamber further finds that the perpretrators knew of the attack and that the crimes were part of it.

2530. The Chamber therefore finds that these incidents of unlawful detention constitute acts of persecution as a crime against humanity.

(E) Forced labour and the use of human shields ${ }^{8524}$

2531. The Chamber recalls its findings in Section IV.A.1 that detainees at a number of detention facilities in Bijeljina, ${ }^{8525}$ Foča, ${ }^{8526}$ Hadžići, ${ }^{8527}$ Ilidža, ${ }^{8528}$ Novo Sarajevo, ${ }^{8529}$ Rogatica, ${ }^{8530}$

\footnotetext{
8520 The Chamber has had regard to its findings with respect to the insults, taunts, and threats which were discussed in the context of cruel and inhumane treatment of these detainees.

$8521 \quad$ See para. 1181.

8522 See para. 1185.

8523 See para. 1317.

8524 The Prosecution does not allege criminal responsibility for forced labour in Bosanski Novi, Bratunac, Pale and Višegrad. Indictment, fn. 7.

8525 See Scheduled Detention Facility C.2.1.

8526 See Scheduled Detention Facility C.10.1.

8527 See Scheduled Detention Facilities C.11.1, C.11.2.

8528 See Scheduled Detention Facility C.18.2.

$8529 \quad$ See para. 2267.

8530 See Scheduled Detention Facilities C.21.1, C.21.3.
} 
Vlasenica, ${ }^{8531}$ and Vogošća. ${ }^{8532}$ were forced to perform labour on the front lines including, inter alia, digging trenches, clearing mines, burying bodies, and carrying munitions. ${ }^{8533}$

2532. By way of illustration, the Chamber found, that while undertaking work on the front lines the detainees were exposed to sporadic crossfire. ${ }^{8534}$ The Chamber found that some detainees were forced to work in all weather conditions which affected their health. ${ }^{8535}$ The Chamber further recalls that in some municipalities, detainees who did not work fast enough or do exactly as they were instructed were beaten, insulted, and threatened. ${ }^{8536}$ The Chamber found that Bosnian Muslims in Bijeljina were subject to a work obligation including on the front lines. ${ }^{8537}$ Those who did not comply with this work obligation were either sent to Batković camp or expelled from the municipality. ${ }^{8538}$

2533. The forcible nature of this work was demonstrated by the Chamber's finding that detainees were afraid for their lives and of being beaten if they refused to work. ${ }^{859}$ The Chamber also found that in one incident detainees were also severely beaten and did not receive any food or water while they worked. ${ }^{8540}$

2534. Bosnian Muslims in Rogatica, ${ }^{8541} \mathrm{Ključ}^{8542}{ }^{50 g o s ̌ c ́ a}{ }^{8543}$ were also used as human shields on front lines to protect Serb Forces. In one incident Bosnian Muslim detainees were instructed to lead Serb Forces through an area, which had been mined, to recover dead bodies. ${ }^{8544}$

2535. The Chamber also had regard to the nature of the forced work, the circumstances in which the detainees were held, and the vulnerable position of the detainees, including the cruel and inhumane treatment and unlawful detention discussed above. Having considered these factors, the Chamber finds that the acts of forced labour and use of human shields amounted to a denial of or

\footnotetext{
8531 See Scheduled Detention Facilities C.25.2, C.25.3.

8532 See Scheduled Detention Facilities C.26.3, C.26.1.

8533 The Chamber also received evidence about detainees being forced to perform other kinds of work not at the front lines. However, the Chamber has interpreted the allegations in paragraph $60(\mathrm{~h})$ of the Indictment to be limited to forced labour at the front lines.

8534 See Scheduled Detention Facility C.11.2.

8535 See para. 655.

8536 See Scheduled Detention Facilities C.21.1, C.25.3.

8537 See para. 670.

$8538 \quad$ See para. 671.

8539 See paras. 902, 1196.

8540 See paras. 2423-2424.

8541 See paras. 992, 1025.

8542 See para. 1511.

8543 See paras. 2432, 2434.

$8544 \quad$ See para. 1019.
} 
infringement upon a fundamental right and were of equal gravity to the other crimes listed under Article 5 of the Statute.

2536. In addition, the Chamber finds that the perpetrators of these acts of forced labour and use of human shields chose their victims on the basis of their identity as Bosnian Muslims or Bosnian Croats. The Chamber finds that these acts were carried out deliberately with the intent to discriminate on the basis of the identity of the victims as Bosnian Muslims or Bosnian Croats. ${ }^{8545}$ In reaching this conclusion, the Chamber had regard to its finding that these acts were discriminatory in fact given that only Bosnian Muslims and Bosnian Croats who had been detained were forced to work or used as human shields. The Chamber also had regard to its findings with respect to the insults, taunts, and threats which were discussed in the context of other underlying acts of persecution which expressly demonstrated this discriminatory intent. In addition, the Chamber recalls its finding that in Vlasenica some detainees who were taken away for forced labour were subject to insults such as references to "Balija's mother". ${ }^{8546}$ In another incident where Bosnian Muslims were used as human shields in Rogatica, when one person was hit by incoming fire, a member of the Serb Forces cursed the detainees by reference to their "Balija mothers". ${ }^{847}$

2537. Further, the Chamber found that there was a widespread and systematic attack against the Bosnian Muslim and Bosnian Croat civilian populations of BiH. The Chamber finds that the acts of forced labour and use of detainees as human shields were part of this widespread and systematic attack and the perpretrators of these acts knew of the attack and that their crimes were part of it. In reaching that conclusion the Chamber considered the locations, time period, and the identity of the victims of these acts, which correspond with the scope of the widespread and systematic attack, as well as the magnitude and systematic nature of the attack on the Bosnian Muslim and Bosnian Croat civilian populations of $\mathrm{BiH}$.

2538. The Chamber therefore finds that these incidents of forced labour and use of human shields constitute acts of persecution as a crime against humanity.

(F) Plunder of property ${ }^{8548}$

2539. The Chamber found in Section IV.A.1 that Bosnian Muslims were expelled from their homes, which were then seized by the local authorities and assigned to Serb refugees. ${ }^{854}$ Some

\footnotetext{
8545 The Chamber considers that discrimination on the grounds of the identity of the victims as Bosnian Muslims or Bosnian Croats falls within the prohibited grounds of discrimination under Article 5(h) of the Statute.

$8546 \quad$ See para. 1196.

8547 See para. 1019.
} 
Bosnian Muslims and Bosnian Croats were forced to sign statements leaving their property to the local authorities. ${ }^{850}$ The Chamber recalls its finding that in Ključ, for example, the Bosnian Serb Political and Governmental Organs effectively seized the abandoned property of Bosnian Muslims on a permanent basis. ${ }^{8551}$

2540. Serb Forces also looted property and homes belonging to Bosnian Muslims and Bosnian Croats during and after the take-over of towns and villages in Bijeljina, ${ }^{8552}$ Bosanski Novi, ${ }^{8553}$ Bratunac, ${ }^{8554}$ Foča, ${ }^{8555}$ Ključ ${ }^{8556}$ Ilidža, ${ }^{857}$ Novi Grad, ${ }^{8558}$ Novo Sarajevo, ${ }^{859}$ Prijedor, ${ }^{8560}$ Rogatica, ${ }^{8561}$ Vlasenica, ${ }^{8562}$ Zvornik. ${ }^{8563}$ The Chamber also recalls its finding that in some cases Serb Forces used Bosnian Muslim detainees to loot Bosnian Muslim homes and move furniture and belongings to Bosnian Serb residences. ${ }^{8564}$

2541. The Chamber found that Bosnian Serb authorities allocated premises left vacant by Bosnian Muslims for the use of refugees in Sokolac. ${ }^{8565}$ However, it has insufficient evidence to determine whether this amounted to an unlawful appropriation of property given that there was evidence that the Bosnian Serb authorities prohibited the unlawful and unauthorised occupation of premises, and that when property was allocated to refugees, these were temporary measures and followed a set criteria including the taking of an inventory of contents by a committee which was created for the allocation of this property. ${ }^{8566}$

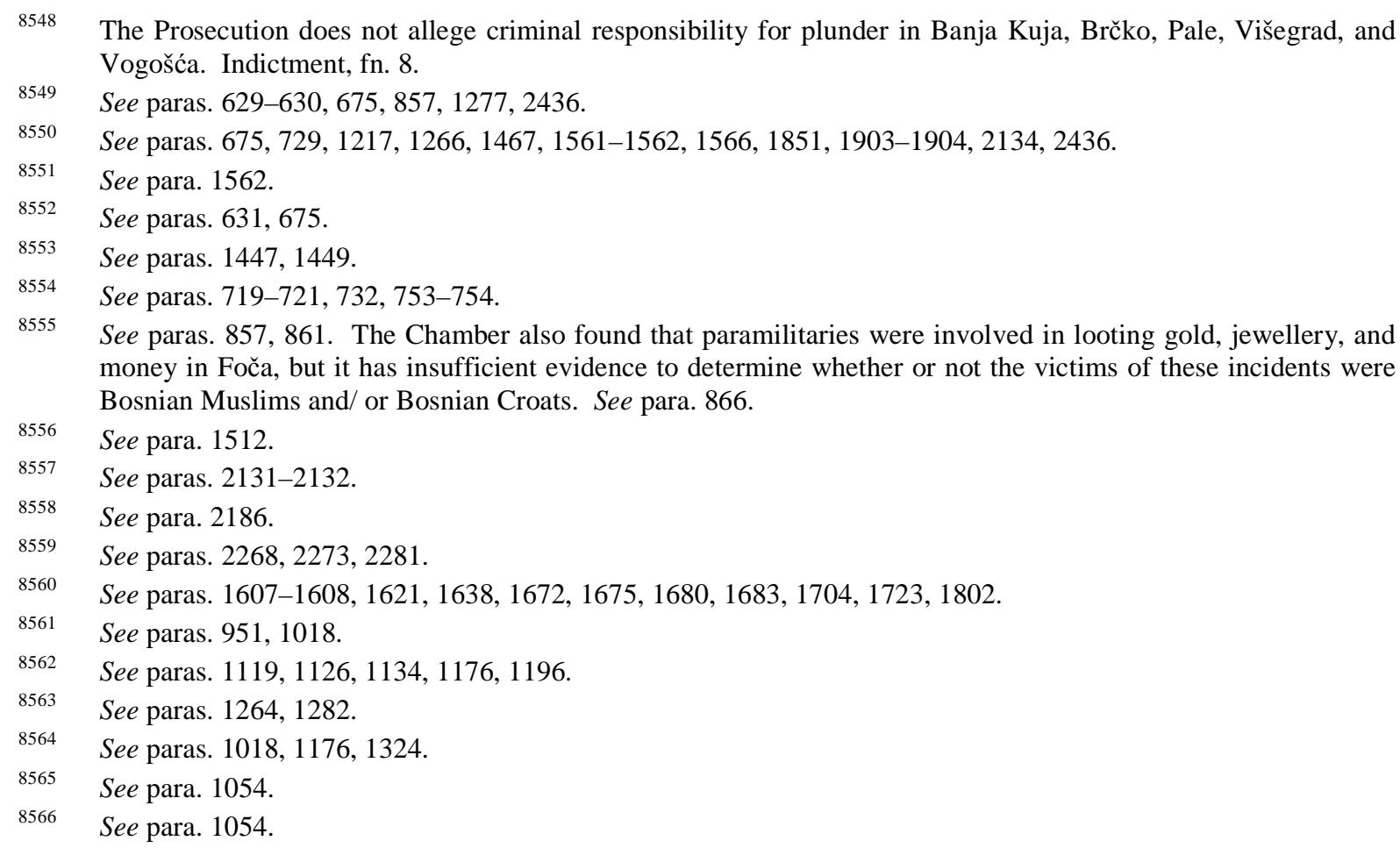
money in Foča, but it has insufficient evidence to determine whether or not the victims of these incidents were Bosnian Muslims and/ or Bosnian Croats. See para. 866.

$8556 \quad$ See para. 1512.

8557 See paras. 2131-2132.

8558 See para. 2186.

8559 See paras. 2268, 2273, 2281.

8560 See paras. 1607-1608, 1621, 1638, 1672, 1675, 1680, 1683, 1704, 1723, 1802.

8561 See paras. 951, 1018.

8562 See paras. 1119, 1126, 1134, 1176, 1196.

8563 See paras. $1264,1282$.

8564 See paras. 1018, 1176, 1324.

8565 See para. 1054.

$8566 \quad$ See para. 1054 
2542. Bosnian Muslims had their money, identification documents, jewellery, and valuables taken away from them before leaving the municipality, ${ }^{8567}$ on arrival at detention facilities, ${ }^{8568}$ or before their execution. ${ }^{8569}$ The Chamber found on one occasion that Serb Forces were also instructed to search the bodies of killed Bosnian Muslims for valuables before the bodies were taken away for burial. $^{8570}$ Serb Forces also seized the vehicles of Bosnian Muslims. ${ }^{8571}$

2543. The property of Bosnian Muslim businesses was also looted or confiscated. ${ }^{8572}$ The Chamber also found that Bosnian Croat companies were looted by Serb Forces in Bijeljina. ${ }^{8573}$

2544. The Chamber finds that these acts involved the unlawful appropriation of the private property of Bosnian Muslims and Bosnian Croats by Serb Forces and Bosnian Serb Political and Governmental Organs. Having considered the extent and scope of the unlawful appropriation of property owned by Bosnian Muslims and Bosnian Croats in multiple municipalities, the Chamber concludes that these acts had grave consequences and amounted to a denial of or infringement upon a fundamental right and are of equal gravity to the other crimes listed under Article 5 of the Statute.

2545. The perpetrators of these acts of plunder chose their victims on the basis of their identity as Bosnian Muslims or Bosnian Croats. The Chamber finds that these acts were carried out deliberately with the intent to discriminate on the basis of the identity of the victims as Bosnian Muslims or Bosnian Croats. ${ }^{8574}$ In concluding that these acts were carried out with discriminatory intent, the Chamber had regard to its finding that these acts were discriminatory in fact given that Bosnian Muslims and Bosnian Croats were systematically targeted by these acts of plunder which were directed at their homes and property. The Chamber also had regard to its findings with respect to the insults, taunts, and threats which were discussed in the context of other underlying acts of persecution which expressly demonstrated this discriminatory intent.

2546. Further, the Chamber found that there was a widespread and systematic attack against the Bosnian Muslim and Bosnian Croat civilian populations of $\mathrm{BiH}$. The Chamber finds that the acts of plunder were part of this widespread and systematic attack and the perpretrators of these acts

\footnotetext{
$8567 \quad$ See paras. $673,1157,1362,1458$.

8568 See Scheduled Detention Facilities C.6.1, C.7.2, C.10.1, C.21.1, C.25.2, C.25.3, C.27.2, C.27.6, C.15.3, C.15.2, C.20.2, C.20.5, C.1.2. See also Scheduled Detention Facilities C.26.3 (the Chamber found that guards stole from detainees), C.22.5.

8569 See para. 1835.

$8570 \quad$ See para. 1152.

$8571 \quad$ See paras. 950, 1282.

$8572 \quad$ See paras. 857, 1282.

$8573 \quad$ See para. 631.

8574 The Chamber considers that discrimination on the grounds of the identity of the victims as Bosnian Muslims or Bosnian Croats falls within the prohibited grounds of discrimination under Article 5(h) of the Statute.
} 
knew of the attack and that their crimes were part of it. In reaching that conclusion the Chamber considered the locations, time period, and the identity of the victims of these acts, which correspond with the scope of the widespread and systematic attack, as well as the magnitude and systematic nature of the attack on the Bosnian Muslim and Bosnian Croat civilian populations of $\mathrm{BiH}$.

2547. The Chamber therefore finds that these incidents of plunder constitute acts of persecution as a crime against humanity.

(G) Wanton destruction of private property and public property including cultural monuments and sacred sites ${ }^{8575}$

2548. The Chamber recalls its findings in Section IV.A.1 that during attacks by Serb Forces, Bosnian Muslim and Bosnian Croat homes and businesses were set on fire and Bosnian Muslim and Bosnian Croat villages were destroyed by Serb Forces in Bosanski Novi, ${ }^{8576}$ Bratunac, ${ }^{8577}$ Foča, ${ }^{8578}$ Ključ,${ }^{8579}$ Novi Grad ${ }^{8580}$ Pale,${ }^{8581}$ Prijedor, ${ }^{8582}$ Rogatica, ${ }^{8583}$ Sanski Most, ${ }^{8584}$ Sokolac, ${ }^{8585}$ Vlasenica, ${ }^{8586}$ Vogošća, ${ }^{8587}$ and Zvornik. ${ }^{8588}$ For example, in the municipality of Ključ alone, the Chamber found that approximately 3,500 houses were razed to the ground and burned in Bosnian Muslim villages. ${ }^{8589}$

2549. The Chamber also found that Bosnian Muslim neighbourhoods in the centre of Rogatica were extensively shelled by artillery, mortars, anti-aircraft guns, and tanks and, as a result, a large part of the town was destroyed. ${ }^{8590}$ The Chamber also recalls its finding that Bosnian Muslim

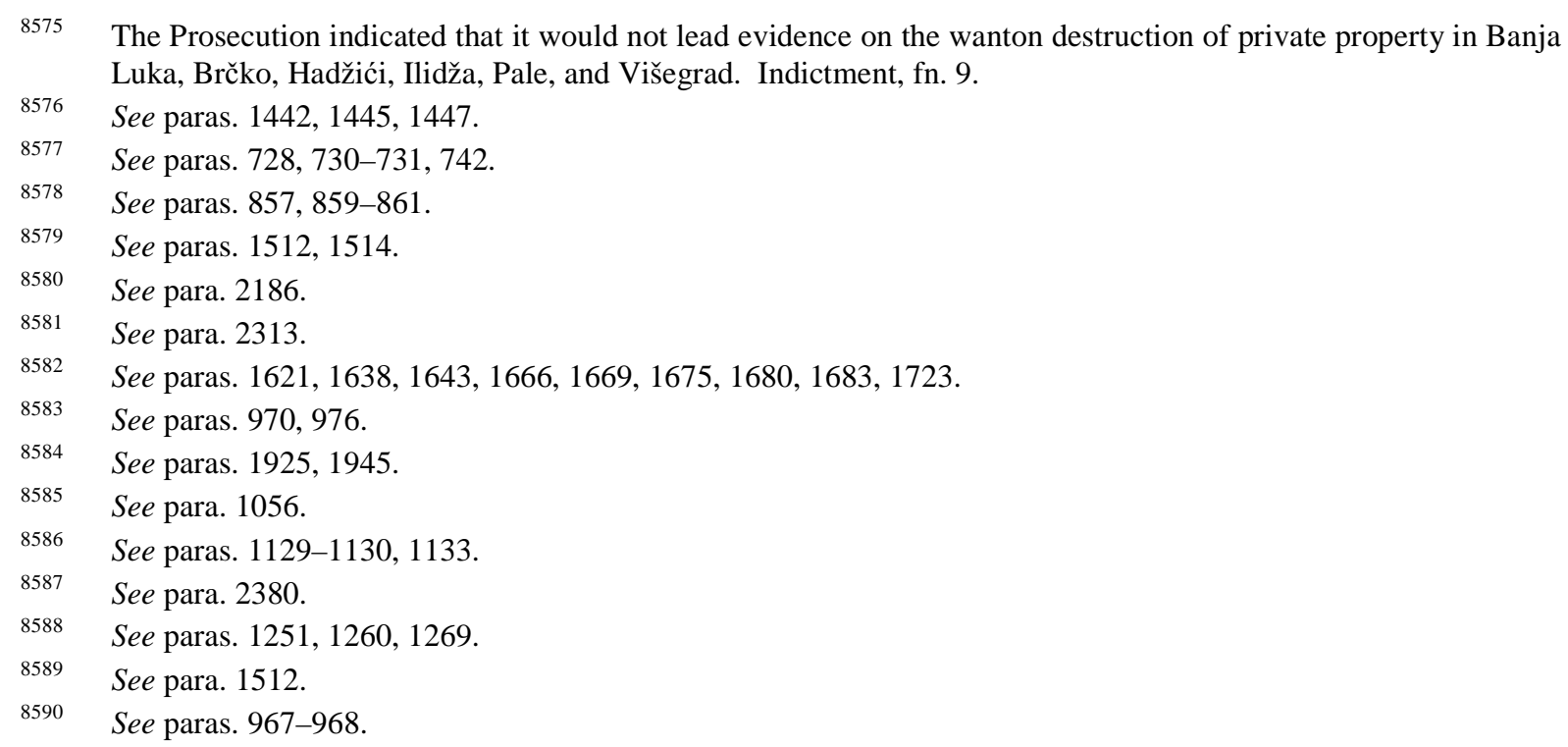


detainees were ordered to set fire to property which had been taken from a Bosnian Muslim house in Vlasenica. ${ }^{8591}$ Some Bosnian Muslim houses were dismantled for materials. ${ }^{8592}$

2550. The Chamber finds that the property referred to in paragraphs above was destroyed or damaged extensively and such destruction or damage was not justified by military necessity.

2551. While the Chamber also found that Serb Forces shelled Konjević Polje in Bratunac, ${ }^{8593}$ the villages of Kramer Selo, Kozarde, Dobrašina, and Borovsko in Rogatica, ${ }^{8594}$ the village of Musići in Hadžići, ${ }^{8595}$ the village of Blagaj in Bosanski Novi ${ }^{8596}$ it has insufficient evidence about the property destroyed or the extent of damage to conclude whether this amounts to wanton destruction of private property.

2552. The Chamber recalls its finding that Serb Forces completely destroyed, almost destroyed, or heavily damaged multiple mosques, Catholic churches and other cultural monuments and sacred sites in Bratunac, ${ }^{859}$ Bosanski Novi, ${ }^{8598}$ Foča, ${ }^{8599}$ Ključ, ${ }^{8600}$ Novi Grad, ${ }^{8601}$ Prijedor, ${ }^{8602}$ Rogatica, ${ }^{8603}$ Sanski Most, ${ }^{864}$ Sokolac, ${ }^{8605}$ and Zvornik. ${ }^{8606}$ The Chamber finds that the Serb Forces intended to destroy these monuments and sites. In reaching that conclusion the Chamber had regard to the nature and extent of the damage to these monuments and sites and the manner in which they were destroyed. For example, the Chamber notes evidence that Bosnian Serb fire brigades stood by and watched while mosques were burnt in Foča. ${ }^{8607}$ Many of the mosques were completely destroyed by explosives; the rubble was removed from the site and the location was later used for other purposes including as garbage dumps and parking lots. ${ }^{8608}$

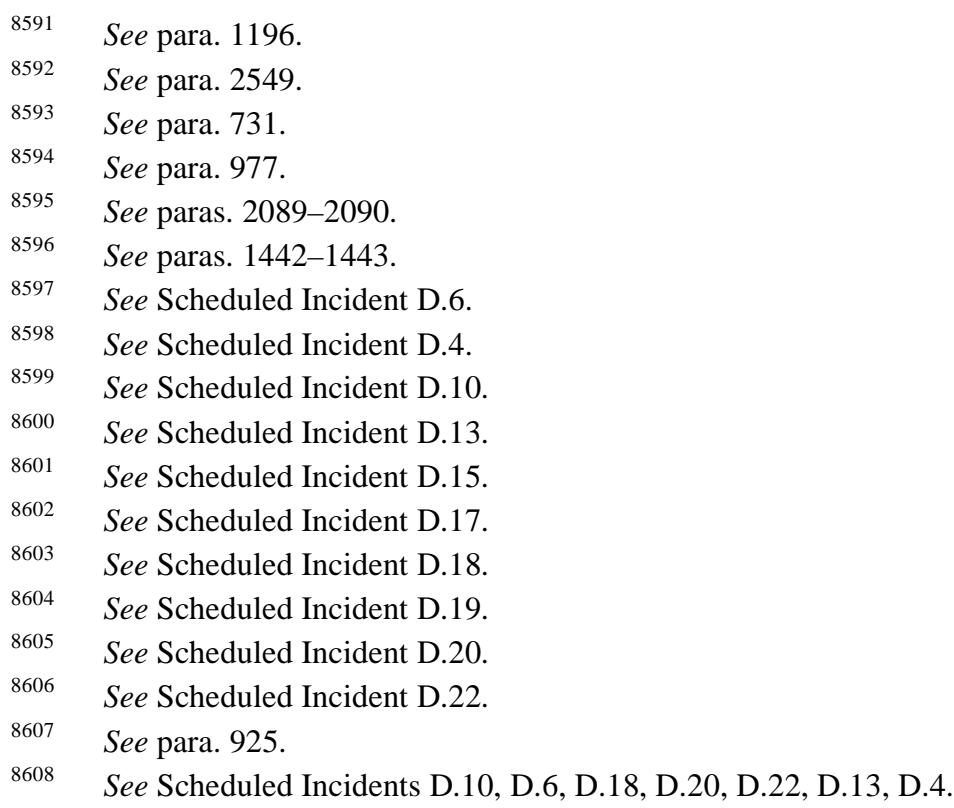


2553. The Chamber recalls its finding that the evidence presented with respect to Bijeljina, ${ }^{8609}$ Pale ${ }^{8610}$ and Vogošća ${ }^{8611}$ was insufficient to allow for an inference to be drawn that Serb Forces destroyed the cultural monuments and sacred sites in those municipalities. The Chamber did not enter a finding with respect to the destruction of the Catholic Church in Ključ. ${ }^{8612}$ The Chamber also found that three mosques in the Vragolovi area of Rogatica were destroyed but had insufficient evidence to determine when they were destroyed and who was responsible for their destruction. ${ }^{8613}$

2554. The Chamber finds that the destruction of these mosques, cultural monuments, and sacred sites was not justified by military necessity. For example, with regard to Foča, where the Accused argued that certain mosques were used for military purposes in Foča, the Chamber concluded that this evidence was unreliable and further that there was no other indication that the mosques were used for military purposes. ${ }^{8614}$

2555. The Chamber also finds that these acts of wanton destruction of private and public property, including cultural monuments and sacred sites, were carried out with discriminatory intent against Bosnian Muslims and Bosnian Croats. ${ }^{8615}$ In reaching that conclusion the Chamber noted that in some cases adjacent Bosnian Serb homes were untouched and there were notes which identified them as Serb property that should not be torched. ${ }^{8616}$ In addition, fire engines were used to protect Bosnian Serb houses while Bosnian Muslim houses burned. ${ }^{8617}$ In an attack on a Bosnian Muslim village in Vlasenica, Serb Forces were specifically ordered to torch all Bosnian Muslim houses and told "you can see for yourselves that if we don't set fire to these houses, they'll return later on". 8618

2556. With respect to the cultural monuments and sacred sites, the Chamber found that the sites destroyed were targeted given their significance to the Bosnian Muslim or Bosnian Croat people in those locations and were discriminatory in fact and were carried out with discriminatory intent.

2557. Having considered the nature and extent of the private and public property destroyed, the Chamber finds that the impact of the destruction was serious given that it affected indispensable

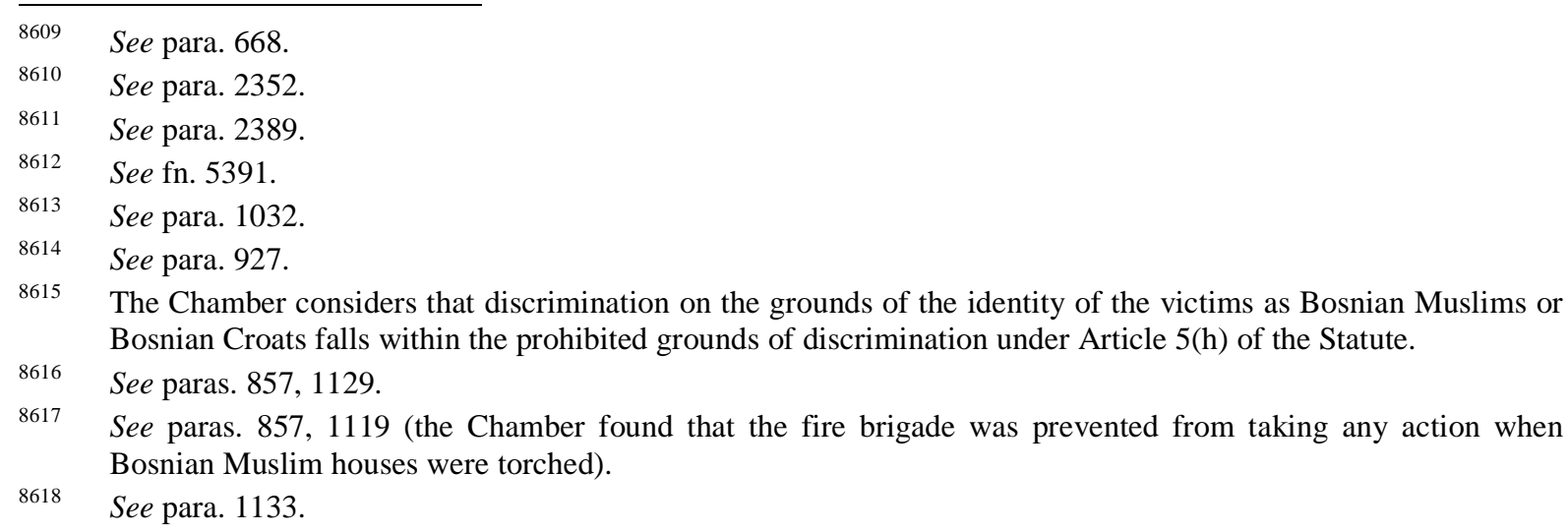

8615 The Chamber considers that discrimination on the grounds of the identity of the victims as Bosnian Muslims or Bosnian Croats falls within the prohibited grounds of discrimination under Article 5(h) of the Statute.

8616 See paras. 857, 1129.

8617 See paras. 857, 1119 (the Chamber found that the fire brigade was prevented from taking any action when Bosnian Muslim houses were torched).

8618 See para. 1133. 
and vital assets of the population, including homes and religious sites. The Chamber therefore finds that these acts of wanton destruction of private and public property amounted to a denial of or infringement upon a fundamental right and were of equal gravity to the other crimes listed under Article 5 of the Statute.

2558. Further, the Chamber found that there was a widespread and systematic attack against the Bosnian Muslim and Bosnian Croat civilian populations of BiH. The Chamber finds that the acts of wanton destruction were part of this widespread and systematic attack and the perpretrators of these acts knew of the attack and that their crimes were part of it. In reaching that conclusion the Chamber considered the locations, time period, and the identity of the victims of these acts, which correspond with the scope of the widespread and systematic attack, as well as the magnitude and systematic nature of the attack on the Bosnian Muslim and Bosnian Croat civilian populations of $\mathrm{BiH}$.

2559. The Chamber therefore finds that these incidents of wanton destruction of private and public property, including cultural monuments and sacred sites, constitute acts of persecution as a crime against humanity.

measures $^{8619}$

(H) Imposition and maintenance of restrictive and discriminatory

2560. The Chambers found in section IV.A.1 that Bosnian Muslims and Bosnian Croats were removed from positions of authority and dismissed from their employment in Bijeljina, ${ }^{8620}$ Bosanski Novi, ${ }^{8621}$ Bratunac, ${ }^{8622}$ Foča, ${ }^{8623}$ Ključ, ${ }^{8624}$ Pale, ${ }^{8625}$ Prijedor, ${ }^{8626}$ Sanski Most, ${ }^{8627}$ Vogošca, ${ }^{8628}$ Vlasenica, ${ }^{8629}$ and Zvornik. ${ }^{8630}$ In Foča for example, announcements were made that the administration of the entire municipality would be run by Bosnian Serbs. ${ }^{8631}$ In addition, after the dismissal of Bosnian Muslims in Bratunac, all key positions in local government were taken

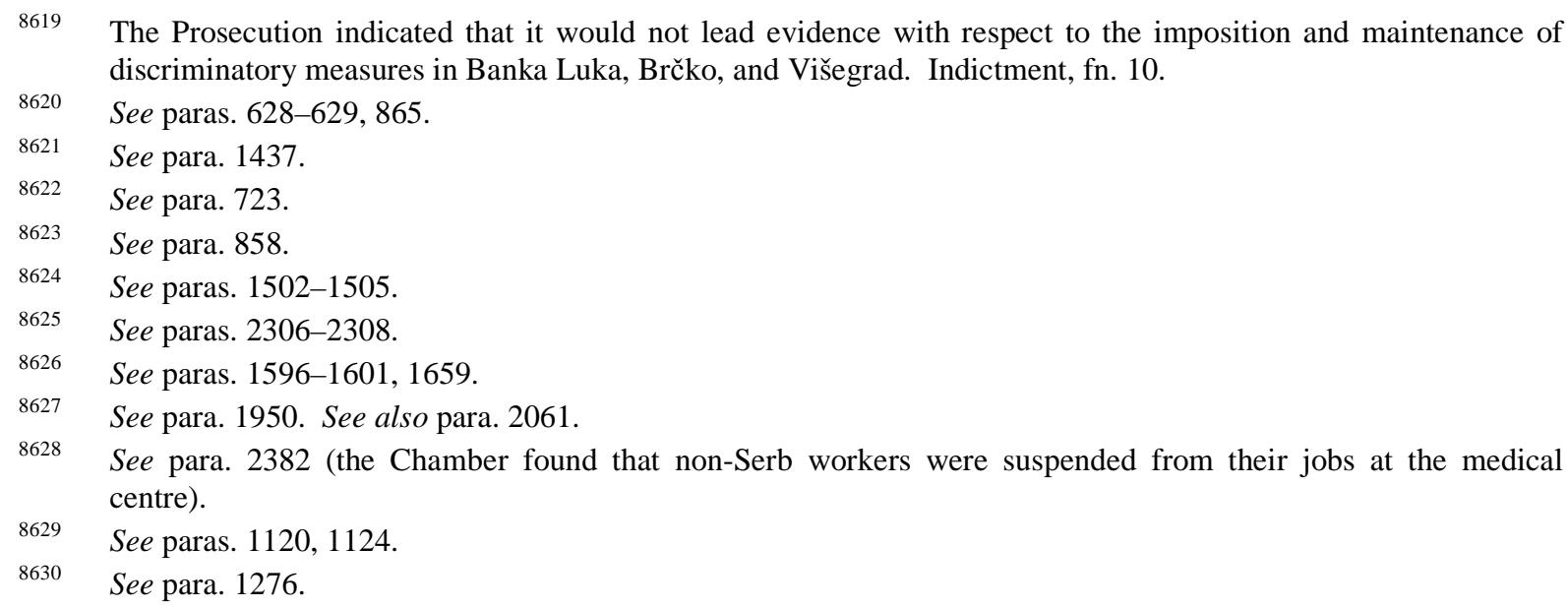


over by Bosnian Serbs. ${ }^{8632}$ In some municipalities, Bosnian Muslims were prevented or discouraged from reporting for work, ${ }^{8633}$ while others were subject to threats, harassment, and insults after which they stopped going to work. ${ }^{8634}$ In Vlasenica, the Chamber also found that the salaries of Bosnian Muslim workers were stopped while Bosnian Serb workers continued to be paid. $^{8635}$

2561. In Bratunac, Vlasenica, and Zvornik, Bosnian Muslim judges were expelled, ${ }^{8636}$ while in Pale ${ }^{8637}$ Sokolac, ${ }^{8638}$ and Vlasenica, ${ }^{8639}$ Bosnian Muslim members of the SJB were dismissed. The Chamber also recalls its finding that a Bosnian Muslim officer in the JNA was progressively stripped of his duties and authority until he was told that his safety could not be guaranteed and he left the JNA. ${ }^{8640}$

2562. Other discriminatory measures included forcing Bosnian Muslim police officers to pledge loyalty to the Bosnian Serb authorities and wear the Serb flag on their caps to retain their jobs. ${ }^{8641}$ Similarly in Bratunac, Bosnian Muslims were given a deadline to pledge loyalty to the Serbian Municipality of Bratunac but continued to be subject to searches of their homes and other intimidation. $^{8642}$ Bosnian Muslims in Zvornik who returned were required to register and sign a pledge of loyalty to the Bosnian Serb authorities in order to remain employed. ${ }^{8643}$

2563. The dismissal of Bosnian Muslims and Bosnian Croats from their employment was discriminatory in fact. In addition, the Chamber found in Ključ that the Bosnian Serb authorities expressly decided that only Bosnian Serb officials could occupy certain important posts in the municipality and that those dismissed from their jobs were so treated because of their ethnicity. ${ }^{8644}$

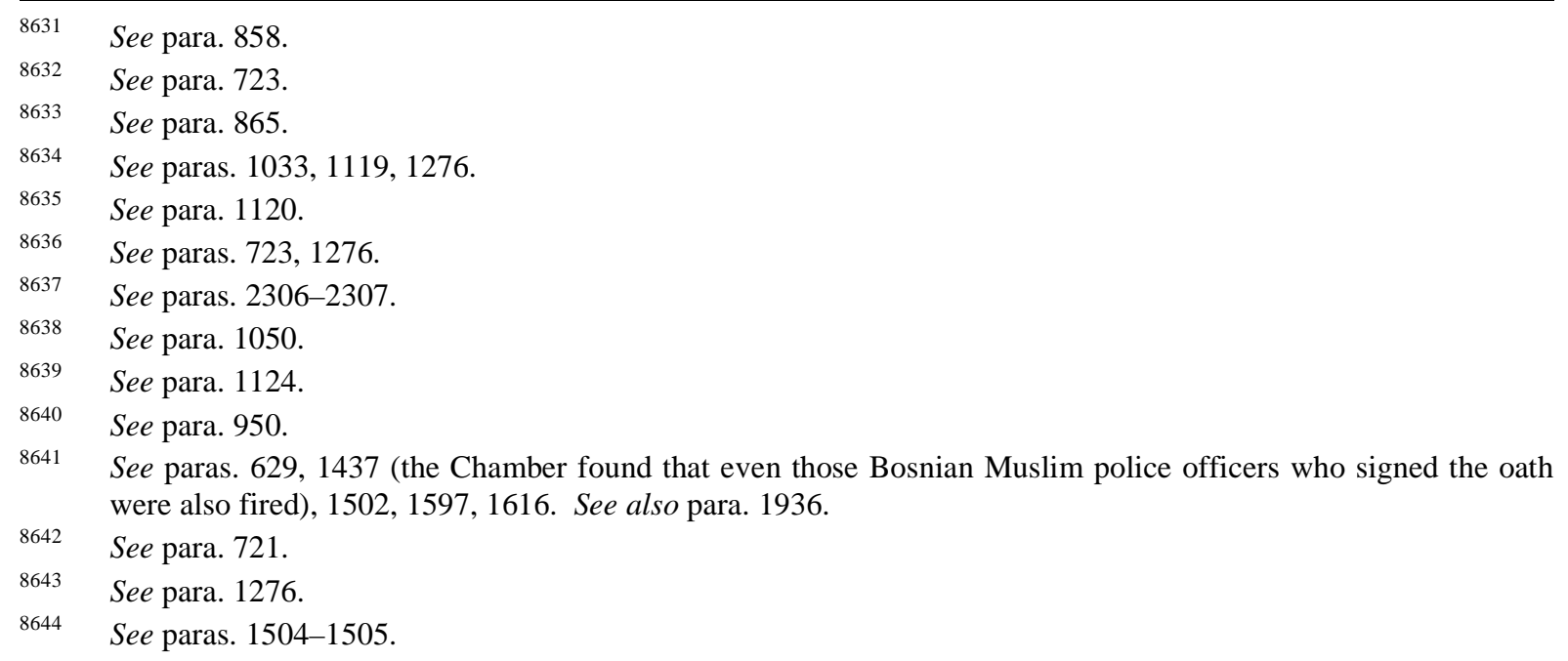


2564. In Foča there were widespread arrests of Bosnian Muslim male civilians who were rounded up and arrested in the streets or in their homes, workplaces, or hospitals. ${ }^{8645}$ Similarly the Chamber found that there were random arrests of Bosnian Muslims in Pale and Prijedor. ${ }^{8646}$ For further evidence on arbitrary arrests, the Chamber refers to its findings in Section IV.A.2.iv.D above regarding unlawful detention. During and after these arrests, Bosnian Muslims were referred to by Serb soldiers by the derogatory term "balija" and cursed. ${ }^{8647}$ Bosnian Muslim homes were also subject to arbitrary searches sometimes accompanied by violence or intimidation towards the occupants. $^{8648}$ On occasions those searches were on the pretext of searching for weapons but intimidated the Bosnian Muslim population. ${ }^{8649}$

2565. The Chamber also found that restrictions were placed on the movement of Bosnian Muslims, including the issuance of movement passes which did not apply to Bosnian Serbs. ${ }^{8650}$ Some Bosnian Muslims who were involved with the SDA were not issued with passes, and others who did have such passes were still often arrested and detained. ${ }^{8651}$ Some Bosnian Muslims were only able to secure transit passes if they had connections or they had to pay substantial amounts of money in order to leave the municipality. ${ }^{8652}$

2566. The Chamber also recalls that there were restrictions on Bosnian Muslims meeting each other, their phone lines and utilities were cut, and some were placed under virtual house arrest. ${ }^{8653}$ The Chamber found that in Zvornik, for example, Bosnian Serb authorities banned the sale or trade of real estate in the municipality unless it was between Bosnian Serbs and and only ordered the back pay of pensions for Bosnian Serbs. ${ }^{8654}$ In Vlasenica, the Chamber found that Bosnian Muslims had restrictions placed on the amount of money they could withdraw from the bank. ${ }^{8655}$

\footnotetext{
$8645 \quad$ See para. 862.

8646 See paras. 1587, 2310.

8647 See paras. 862, 1033.

8648 See paras. 864, 1126 (the Chamber found that Bosnian Muslim homes in Vlasenica were visited during the night by members of the Serb Forces who harassed them and demanded money), 1276, 1610. See also paras. 950 (pertaining to the searches of Bosnian Muslims), 2264-2266, 2268. The Chamber also found that Serb Forces searched houses in Hadžići but has insufficient evidence to determine if these searches were arbitrary or directed against Bosnian Muslims and/ or Bosnian Croats. See para. 2086.

8649 See para. 1149.

8650 See paras. $865,952,1118,1506,1609,1661$. See also paras. 2177,2182 . The Chamber also found that Serb Forces restricted the movement of the population in Hadžići but has insufficient evidence to determine if these restrictions were directed against Bosnian Muslims and/ or Bosnian Croats. See para. 2086.

$8651 \quad$ See para. 1118.

8652 See para. 1118

8653 See paras. 865, 952, 976, 1119 (relating to television broadcasts from Sarajevo), 1276, 2311. See also para. 1269 (the Chamber found that in some cases after the attack by Serb Forces on Bosnian Muslim villages they cut the electricity supply).

8654 See paras. 1236, 1279.

$8655 \quad$ See para. 1119.
} 
2567. The Chamber considered the circumstances and the environment in which Bosnian Muslims and Bosnian Croats were subjected to restrictive and discriminatory measures. The Chamber did not consider these measures in isolation, but also had regard to its findings that contemporaneously Bosnian Muslims and Bosnian Croats in the Municipalities were also subject to killings, torture, beatings, physical and psychological abuse, rape and other acts of sexual violence, cruel and inhumane living conditions, forcible displacement, unlawful detention, forced labour, plunder, and the wanton destruction of private and public property. ${ }^{865}$ When these restrictive and discriminatory measures are considered in conjunction with these other underlying acts of persecution which were perpetrated at the same time, against the same category of victims, the Chamber finds that this amounted to a denial of or infringement upon a fundamental right and was of equal gravity to the other crimes listed under Article 5 of the Statute.

2568. In addition, the Chamber finds that the perpetrators of these restrictive and discriminatory measures chose their victims on the basis of their identity as Bosnian Muslims or Bosnian Croats. The Chamber finds that these acts were carried out deliberately with the intent to discriminate on the basis of the identity of the victims as Bosnian Muslims or Bosnian Croats. ${ }^{8657}$ In concluding that these acts were carried out with discriminatory intent, the Chamber had regard to its finding that these acts were discriminatory in fact given that the restrictive and discriminatory measures were directed against Bosnian Muslims and Bosnian Croats whereas Bosnian Serbs were not subject to the same restrictions. In addition, the Chamber also had regard to the insults, taunts, and threats directed at the victims on the basis of their identity as Bosnian Muslims or Bosnian Croats in the Municipalities which expressly demonstrated this discriminatory intent with respect to other underlying acts of persecution. ${ }^{8658}$

2569. Further, the Chamber found that there was a widespread and systematic attack against the Bosnian Muslim and Bosnian Croat civilian populations in the Municipalities. The Chamber finds that the incidents of restrictive and discriminatory measures were part of this widespread and systematic attack and the perpretrators of these acts knew of the attack and that their crimes were part of it. In reaching that conclusion the Chamber considered the locations, time period, and the identity of the victims of these acts, which correspond with the scope of the widespread and

\footnotetext{
8656 For the Chamber's findings in this regard, see Section IV.A.2.iv: Legal findings on crimes (Persecution: Count 3).

8657 The Chamber considers that discrimination on the grounds of the identity of the victims as Bosnian Muslims or Bosnian Croats falls within the prohibited grounds of discrimination under Article 5(h) of the Statute.

8658 The Chamber has had regard to its findings with respect to the insults, taunts, and threats which were discussed in the context of cruel and inhumane treatment of these detainees.
} 
systematic attack, as well as the magnitude and systematic nature of the attack on the Bosnian Muslim and Bosnian Croat civilian populations of $\mathrm{BiH}$.

2570. The Chamber therefore finds that the imposition and maintenance of restrictive and discriminatory measures constitute acts of persecution as a crime against humanity.

\section{v. Genocide: Count 1}

2571. In Count 1 of the Indictment, the Prosecution charges the Accused with genocide pursuant to Article 4 of the Statute. It alleges that between 31 March and 31 December 1992, in seven of the Municipalities, namely Bratunac, Foča, Ključ, Prijedor, Sanski Most, Vlasenica, and Zvornik (“Count 1 Municipalities"), the alleged persecutory campaign included or escalated to include conduct that manifested an intent to destroy in part the national, ethnical and/or religious groups of Bosnian Muslims and/or Bosnian Croats as such. ${ }^{8659}$ It submits that the crimes charged in the Indictment were not aimed at the victims as individuals but as members of an "undesired community"; the Accused "intended the demographic restructuring of Bosnia to be accomplished by the destruction of substantial parts of the Bosnian Muslim and Bosnian Croat communities" in the Count 1 Municipalities. ${ }^{860}$ According to the Prosecution, the proper name for this crime is "genocide". 8661

2572. In his Final Brief, the Accused concentrates his argument in relation to Count 1 on the lack of genocidal intent from his part or from anyone in the Bosnian Serb leadership; this argument will be addressed below. The Chamber notes that at the end of the Prosecution's case, in his submissions pursuant to Rule 98 bis, the Accused argued that there was no genocide in the Municipalities in 1992 and that there was therefore no evidence upon which the Chamber could conclude that the Accused was guilty of genocide as charged in Count $1 .{ }^{8662}$ More specifically, he argued that "displacement does not equal destruction", 863 and referred to all of the previous Tribunal judgements in which genocide was not found to have been committed in the Municipalities, or at least in some of the Municipalities. ${ }^{8664}$

\footnotetext{
8659 Indictment, paras. 36, 38. The Chamber gives a restrictive interpretation to paragraph 38 of the Indictment, which states that the "most extreme manifestations of an intent to partially destroy these groups took place in [the Count 1 Municipalities]". This is in conformity with the Prosecution Final Brief focusing on the Count 1 Municipalities, by reference only to the "municipalities specified in Count 1". Prosecution Final Brief, para. 570 .

8660 Prosecution Final Brief, para. 570.

8661 Prosecution Final Brief, para. 570.

8662 Hearing, T. 28570 (11 June 2012).

8663 Hearing, T. 28571 (11 June 2012).

8664 Hearing, T. 28572-28579 (11 June 2012).
} 


\section{(A) The protected group}

2573. For the purpose of Count 1, the Prosecution alleges that the protected groups are the national, ethnical and/or religious groups of Bosnian Muslims and Bosnian Croats. ${ }^{8665}$

2574. The Chamber notes that other Chambers have concluded that both the Bosnian Muslims and the Bosnian Croats are protected groups within the meaning of Article 4 of the Statute. ${ }^{8666}$ The Chamber is satisfied for the purpose of Article 4 of the Statute that the protected groups were the Bosnian Muslims and the Bosnian Croats.

\section{(B) The actus reus}

2575. In relation to Count 1, the Prosecution charges three types of acts under Article 4(2) of the Statute: (i) the killing of Bosnian Muslims and Bosnian Croats, including leading members of these groups ${ }^{8667}$ (ii) the causing of serious bodily or mental harm to thousands of Bosnian Muslims and Bosnian Croats, including leading members of these groups, during their confinement in detention facilities; ${ }^{8668}$ and (iii) the detention of thousands of Bosnian Muslims and Bosnian Croats, including leading members of these groups, in detention facilities, under conditions of life calculated to bring about their physical destruction. ${ }^{8669}$ The Prosecution alleges that the evidence is overwhelming that these acts of genocide within the meaning of Article 4(2) of the Statute occurred on a massive scale. $^{8670}$

\footnotetext{
8665 See Indictment, para. 38; Prosecution Final Brief, fn. 2147 (making reference to the "national group of Bosnian Muslims and of Croats").

8666 In relation to the Bosnian Muslim group, see Krstić Appeal Judgement, para. 15 (holding that identifying "the protected group as the national group of Bosnian Muslims" comports with the guidelines in relation to the definition of the protected group pursuant to Article 4 of the Statute). See also Popović et al. Trial Judgement, para. 840; Krstić Trial Judgement, para. 560. In relation to both the Bosnian Muslim and Bosnian Croat groups, see Stakić Appeal Judgement, para. 36 (concluding that the Trial Chamber did not err in law either by defining the groups allegedly targeted for genocide as Bosnian Muslims and Bosnian Croats"). See also Brđanin Trial Judgement, para. 736.

8667 Indictment, para. 40(a) (referring to killings carried out during and after take-overs and in detention facilities, including those committed during, and deaths resulting from, cruel and inhumane treatment at detention facilities).

8668 Indictment, para. 40(b) (referring to cruel or inhumane treatment, including torture, physical and psychological abuse, rape, other acts of sexual violence and beatings).

8669 Indictment, para. 40(c) (referring to cruel and inhumane treatment, including torture, physical and psychological abuse, rape, other acts of sexual violence, inhumane living conditions, forced labour and the failure to provide adequate accommodation, shelter, food, water, medical care or hygienic sanitation facilities).

8670 Prosecution Final Brief, para. 572; Prosecution Closing Argument, T. 47577 (29 September 2014).
} 
2576. When presenting the Accused's closing arguments on genocide under Count 1 , the Accused's legal adviser acknowledged that "crimes such as murder and infliction of serious harm, were committed during the 1992 events in the municipalities in Bosnia". 8671

2577. The Chamber will examine below each of the categories of acts charged under Article 4(2) of the Statute.

\section{(1) Killing members of the group}

2578. The Chamber entered findings that a large number of Bosnian Muslims and Bosnian Croats were killed by Serb Forces throughout the Count 1 Municipalities. Victims were killed during and after the take-over of these municipalities. Victims were also killed while they were detained at detention facilities; some of them died as a result of cruel and inhumane treatment inflicted on them. $^{8672}$

2579. The Chamber is therefore satisfied for the purpose of Article 4(2)(a) of the Statute that members of the Bosnian Muslim and Bosnian Croat groups were killed.

\section{(2) Causing serious bodily or mental harm to members of the group}

2580. Throughout the Count 1 Municipalities, the Chamber found that a large number of Bosnian Muslims and Bosnian Croats were subjected to cruel treatment, including torture, beatings, as well as physical and psychological abuse. The Chamber described these acts in detail above in relation to Count 3 and provided vivid examples of the most egregious acts found to have been committed against the Bosnian Muslims and Bosnian Croats in detention facilities as well as during and after take-overs in the Count 1 Municipalities. The Chamber also found that prominent Bosnian Muslims and Bosnian Croats, including professionals and leaders, were targeted for such treatment. Following these acts, the Chamber found that many detainees bore serious injuries, had visible wounds, were unable to walk or talk for days, and suffered long-term psychological and physical effects. These acts were found to cause serious mental or physical suffering or injury.

2581. The Chamber also found that in some of the Count 1 Municipalities, namely Foča, Prijedor, Vlasenica, and Zvornik, Bosnian Muslim women, men, girls, and boys were subjected to rape and

\footnotetext{
8671 Accused Closing Argument, T. 47935-47936 (2 October 2014).

8672 See para. 2446. For Bratunac, see fn. 8223, 8236, 8251; for Foča, see fn. 8224, 8238, 8252; for Ključ, see fn. 8225, 8240; for Prijedor, see fn. 8227, 8243, 8253; for Sanski Most, see fn. 8228, 8245, 8255; for Vlasenica, see fn. 8231, 8246; and for Zvornik, see fns. 8232, 8248, 8256.
} 
other acts of sexual violence, involving serious abuses of a sexual nature. ${ }^{8673}$ These acts were found to cause serious mental or physical suffering or injury. ${ }^{8674}$

2582. The Chamber considers that these acts were of such a serious nature as to contribute or tend to contribute to the destruction of the Bosnian Muslims and Bosnian Croats in the Count 1 Municipalities. The Chamber is therefore satisfied for the purpose of Article 4(2)(b) of the Statute that members of the Bosnian Muslim and Bosnian Croat groups were subjected to serious bodily or mental harm in the Count 1 Municipalities.

(3) Deliberately inflicting on the group conditions calculated to bring about its physical destruction in whole or in part

2583. The Chamber recalls that when the same acts are charged under Articles 4(2)(b) and 4(2)(c), a chamber will consider whether these alleged acts amount to conditions calculated to bring about physical destruction only when it does not find them to amount to "causing serious bodily or mental harm". ${ }^{8675}$ The Chamber shall therefore limit its assessment to the acts which are not included above. These include the imposition of inhumane living conditions, forced labour and the failure to provide adequate accommodation, shelter, food, water, medical care or hygienic sanitation facilities. $^{8676}$

2584. In all of the Count 1 Municipalities, the Chamber found that Bosnian Muslim and Bosnian Croat detainees were held in terrible conditions. ${ }^{8677}$ For the purpose of Article 4(2)(c), the Chamber recalls its findings that the detainees faced severe over-crowding in the detention facilities. ${ }^{8678}$ This combined with stifling heat and lack of ventilation led to unbearable conditions for the detainees and some died. ${ }^{8679}$ In these detention facilities, medical care was non-existent or inadequate, at best. ${ }^{8680}$ Access to water and food was insufficient, which led to severe weight loss, malnutrition, and at times, starvation. ${ }^{8681}$ Hygienic conditions were poor and the lack of access to washing facilities led to dysentery, lice, and skin diseases spreading throughout the facilities. ${ }^{8682}$

\footnotetext{
8673 See paras. 2500-2505. In particular for Foča, see fn. 8435; for Prijedor, see fn. 8437; for Vlasenica, see fn. 8439; and for Zvornik, see fn. 8441.

8674 See paras. 2499, 2505, 2512.

8675 See Brđanin Trial Judgement, para. 905.

8676 Indictment, para. 40(c).

8677 See generally para. 2507.

8678 See para. 2507, fn. 8454. in relation to Foča, Ključ, Prijedor, Vlasenica, and Zvornik.

8679 See paras. 780, 1299, 1301, 1756.

8680 See para. 2507, fn. 8461.

8681 See paras. 2507, 2509; fns. 8459, 8460.

8682 See para. 2509.
} 
The Chamber further found that the living conditions in some of the detention facilities had serious effects on some of the detainees. ${ }^{8683}$

2585. Further, in Foča, Ključ, and Vlasenica, the Chamber found that a number of Bosnian Muslim and Bosnian Croat detainees were forced to perform labour at the frontline. ${ }^{8684}$ They were put in dangerous situations, were afraid for their lives and of being beaten if they refused to work. $^{8685}$

2586. However, the Chamber recalls that the "actus reus of Article 4(2)(c) of the Statute "covers methods of physical destruction, other than killing, whereby the perpetrator ultimately seeks the death of the members of the group"" ${ }^{8686}$ While Article 4(2)(a) and (b) in that Article 4(2)(a) and (b) proscribes acts causing a specific result, i.e.: death and serious bodily or mental harm, respectively, Article 4(2)(c) concerns "those methods of destruction that do not immediately kill the members of the groups, but which, ultimately, seek their physical destruction", i.e.: slow death. ${ }^{8687}$

2587. While the conditions in the detention facilities in the Count 1 Municipalities were dreadful and had serious effects on the detainees, the Chamber is not convinced that the evidence before it demonstrates that they ultimately sought the physical destruction of the Bosnian Muslims and Bosnian Croats. The Chamber is therefore not satisfied for the purpose of Article 4(2)(c) of the Statute that conditions of life calculated to bring about the physical destruction of the Bosnian Muslims and Bosnian Croats were deliberately inflicted on these groups in the Count 1 Municipalities.

\section{(C) The mens rea}

2588. The Prosecution first alleges that there is direct evidence that the Accused had genocidal intent. ${ }^{8688}$ This is exemplified, according to the Prosecution, through the statements the Accused made as to the fate of the Bosnian Muslims and Bosnian Croats if they persisted in pursuing independence. ${ }^{8689}$ The Prosecution also claims that by casting the conflict as existential and

\footnotetext{
$8683 \quad$ See para. 2509.

8684 See paras. 2531, 2534.

8685 See paras. 2532-2533.

8686 Tolimir Appeal Judgement, para. 233 (citing ICJ Croatia v. Serbia Judgement, para. 161).

8687 Tolimir Appeal Judgement, paras. 228, 233.

8688 Prosecution Final Brief, paras. 578-581.

8689 Prosecution Final Brief, para. 579.
} 
genocidal and by requiring the use of reciprocal force, the Accused "prepared his followers for the use of destructive forces". ${ }^{8690}$

2589. Second, the Prosecution alleges that the existence of genocidal intent is confirmed through indirect evidence. ${ }^{861}$ For the Prosecution, the pattern of crimes in the Count 1 Municipalities, taking Prijedor as the core example, ${ }^{8692}$ demonstrates the intent to destroy the very existence of the Bosnian Croat and Bosnian Muslim communities in the Count 1 Municipalities and to prevent their ability to reconstitute themselves. ${ }^{8693}$ The Prosecution submits that "[n]ot only can the paramount leader of the Bosnian Serbs' intent to destroy be inferred, it is compelled by the nature and extent of the underlying genocidal acts". ${ }^{8694}$ It further claims that other members of the Overarching JCE shared the Accused's genocidal intent, in particular Mladić, whom the Accused personally selected to command his military forces and continued to entrust with carrying out his policies, even when the VRS was perpetrating widespread acts of genocide. ${ }^{8695}$

2590. On the contrary, the Accused submits that there is no direct or indirect evidence that he or the Bosnian Serb leadership had genocidal intent with regard to the Count 1 Municipalities. ${ }^{8696}$

2591. The Chamber recalls that in the present case the required mens rea for genocide is the intent to destroy, in part, the Bosnian Muslim and the Bosnian Croat groups as such. ${ }^{8697}$ The Appeals Chamber held that given that the Accused is charged under Count 1 for his participation in the first form of JCE, "it is the genocidal intent of Karadžić and other alleged JCE members, not the physical perpetrators of the underlying alleged genocidal acts, that is determinative". 8698 The Chamber notes, however, that the Accused's responsibility under Count 1, is alleged in relation to all modes of responsibility under Articles 7(1) and 7(3) of the Statute and therefore at this stage the Chamber must examine whether there was genocidal intent present at any level from the physical perpetrators of the crimes to Bosnian Serb representatives not named as alleged Overarching JCE members, all the way up to the named alleged JCE members, including the Accused himself.

2592. In determining the existence of such specific intent, the Chamber has considered the evidence as a whole and examined whether there existed direct evidence or whether such inference

\footnotetext{
$8690 \quad$ Prosecution Final Brief, para. 580.

8691 Prosecution Final Brief, paras. 582-595.

8692 Prosecution Final Brief, paras. 589-594.

8693 Prosecution Final Brief, paras. 583-585.

8694 Prosecution Final Brief, para. 585 (further alleging that "[t]his intent is confirmed by [the Accused's] own statements anticipating, threatening, and embracing just such acts”.)

$8695 \quad$ Prosecution Final Brief, para. 586.

8696 Defence Final Brief, paras. 2767-2771; Closing Arguments, T. 47931-47935 (2 October 2014).

8697 See para. 549.
} 
could be drawn from all the facts and the circumstances in the case. In this regard, the Chamber recalls that such inference must be the only reasonable inference that could be made based on that evidence. ${ }^{8699}$ Given that the intent of the named alleged JCE members, including the Accused, is intrinsically connected to all of the evidence on the record pertaining to the existence and the scope of the Overarching JCE, the Chamber conducted a holistic and contextualised assessment of this evidence and will indicate below, where relevant, the appropriate cross-references to these sections.

\section{(1) Intent to destroy the group as such, in part}

2593. In the instant case, under Count 1 , the Prosecution refers to the intent to destroy a part of the protected groups of the Bosnian Muslims and Bosnian Croats, namely the Bosnian Muslims and Bosnian Croats in the Count 1 Municipalities. ${ }^{8700}$ It argues that the part of the Bosnian Muslim and Bosnian Croat groups in each of the Count 1 Municipalities satisfies the substantiality requirement when considering the numeric size and significance of the targeted parts as well as the areas of the perpetrators' activity and the possible extent of their reach. ${ }^{8701}$ Prijedor is taken as the primary example of the part of the Bosnian Muslim and Bosnian Croat groups that would meet the substantiality requirement with regard to numeric size and the significance of targeting these communities, given that Prijedor represented a symbol of "brotherhood and unity". 8702

2594. The Chamber will examine below whether it can be satisfied beyond reasonable doubt that there was intent to destroy a part of the Bosnian Muslim and/or Bosnian Croat groups, namely the Bosnian Muslims and Bosnian Croats in the Count 1 Municipalities.

\section{Overarching JCE members}

\section{(2) Evidence of genocidal intent of the Accused and named alleged}

2595. In assessing whether or not the Accused or any of the named members of the alleged Overarching JCE had genocidal intent for the purposes of Count 1, the Chamber relies on the findings in the section of the Judgement pertaining to the ideology and objectives of the Accused and the Bosnian Serb leadership, and in particular paragraphs 2634 to 2903 therein.

2596. The Chamber found that the speeches and statements made by the Accused and the Bosnian Serb leadership denigrated Bosnian Muslims and Bosnian Croats, portrayed them as their historic enemies, and exacerbated ethnic tensions in $\mathrm{BiH}$. This evidence also demonstrates an intent to

\footnotetext{
$8698 \quad$ Rule 98 bis Appeal Judgement, para. 79.

8699 See para. 10.

8700 See Indictment, paras. 36, 38.

8701 Prosecution Final Brief, paras. 589-594.

8702 Prosecution Final Brief, paras. 589-594.
} 
create an ethnically homogeneous Serb state in $\mathrm{BiH}$, to separate from Bosnian Muslims and Bosnian Croats, and remove them from Bosnian Serb controlled territory. It also shows that the Accused and the Bosnian Serb leadership advocated a position that co-existence with non-Serbs within Bosnian Serb-controlled territory in $\mathrm{BiH}$ was impossible. ${ }^{8703}$ However, the Chamber is not satisfied that the evidence which demonstrates this objective also shows an intent to physically destroy a part of either of those protected groups.

2597. Even where the Bosnian Serb leadership called into question the identity of the Bosnian Muslims as a nation or a people, ${ }^{8704}$ these speeches were delivered in the context that the Bosnian Muslim population residing in Bosnian Serb-claimed territory should be separated from the Serbs - by force if necessary—but did not suggest that a part of that group should be physically destroyed as such.

2598. The Chamber also found that the Accused and the Bosnian Serb leadership repeatedly referred to the historic grievances of the Serb people. ${ }^{8705}$ The Chamber found that these speeches were used by the Accused and the Bosnian Serb leadership to remind the Bosnian Serb population about crimes committed against Serbs by Muslims and Croats and emphasised the need to ensure that they would not be repeated. ${ }^{8706}$ The Chamber also found that these references were used as justification for renewing historical Bosnian Serb claims to land in $\mathrm{BiH}$ where they had once been a majority. ${ }^{8707}$ These speeches also had the effect of creating fear and inciting inter-ethnic hatred amongst the population. ${ }^{8708}$ This rhetoric then made it easier for the Accused and the Bosnian Serb leadership to promote their objectives of ethnic separation and the creation of an ethnically homogeneous state. However, the Chamber did not find any evidence to demonstrate that these constant references to the historic genocide against Serbs were used to call on the Bosnian Serbs to do the same. The Chamber therefore finds that while these statements had the effect of identifying the historic enemies of the Bosnian Serbs and furthering the objective of ethnic separation, they do not demonstrate that the only reasonable inference is that the Bosnian Serb leadership intended to physically destroy a part of the Bosnian Muslim and/or Bosnian Croat groups in order to achieve these aims.

2599. While there were certainly highly inflammatory speeches and statements in which the Accused and other alleged members of the Overarching JCE spoke about the "disappearance",

\footnotetext{
8703 See Section IV.A.3.a.i.D.2: Conclusion.

8704 See e.g. paras. 2664, 2773.

8705 See Section IV.A.3.a.i.B: Identification of historic enemies.

8706 See para. 2670.

8707 See para. 2671.
} 
"annihilation", "vanish[ing]", "elimination", and "extinction" of the Bosnian Muslims, the Chamber has considered these statements in the full context in which they were delivered and not in isolation. ${ }^{8709}$ The Chamber finds that the early speeches which contained this kind of rhetoric were delivered mainly as a warning that Bosnian Muslims should not pursue a path to independence which was contrary to the Bosnian Serb interests, and as a threat that if they did do so there would be war which would lead to severe bloodshed. The Chamber also recalls that some of the statements made by the Accused himself reflected how angry he was about the proposed moves towards the independence of $\mathrm{BiH}$, which would lead to violence if Bosnian Serb demands were not met. ${ }^{8710}$ The Chamber finds that when the Accused and the Bosnian Serb leadership issued these threats they envisaged that any attempt to circumvent the interests of the Bosnian Serbs would result in chaos and extreme violence. The record shows that the Bosnian Serbs were prepared to use force and violence against Bosnian Muslims and Bosnian Croats in order to achieve their objectives and assert their historic territorial claims. However, in light of the totality of the evidence, the Chamber is not convinced that the only reasonable inference to draw from these statements is that the respective speakers intended to physically destroy a part of the Bosnian Muslim and/or Bosnian Croat groups.

2600. For example, the Chamber recalls its finding that in the Accused's speech in October 1991 to the SRBiH Assembly in which he spoke about a "highway of hell", he issued very specific threats about what would happen if the Bosnian Muslims continued to pursue the path of independence and ignored the will of the Bosnian Serbs. ${ }^{871}$ The Chamber finds that the Accused was clearly threatening war if the Bosnian Serb interests were ignored, and that he also envisaged that such a war would be "hell" and that the Bosnian Muslims would be unable to defend themselves in such a scenario. The Chamber finds that through this speech the Accused intended to threaten the Bosnian Muslims against pursuing independence for $\mathrm{BiH}$ and that he was fully aware that a potential conflict would be extremely violent. However, the Chamber is not satisfied that the only reasonable inference is that this statement demonstrates that the Accused intended to physically destroy a part of the Bosnian Muslim group .

2601. Another example is the speech the Accused delivered in July 1992 before the Bosnian Serb Assembly where he said that the conflict had been "roused in order to eliminate the Muslims [...] They think they are being nationally established, but in fact they are vanishing" ${ }^{8712}$ The

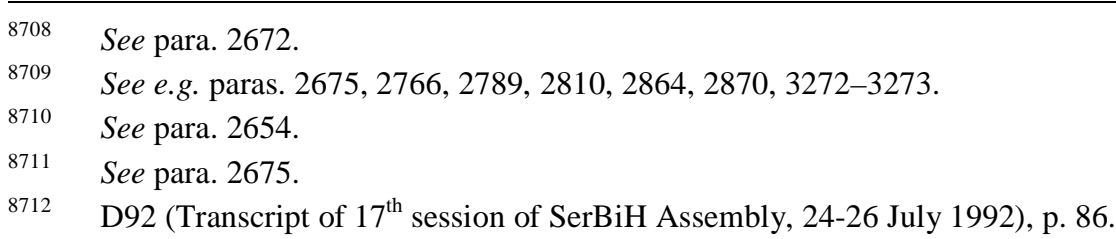


Prosecution refers to this statement as evidence that the Accused was preparing his followers for the use of destructive force. ${ }^{8713}$ However, the Chamber also notes that right after making this statement, the Accused went on to say: "I think we have to save the Serb people in their ethnic and also historical territories [...]. We'll have for sure, we'll have in the beginning so many Serbs, but I think that they will leave those states, both the Muslim and the Croat state. In the state that we are building, we have to ensure that they have all the rights that we have, under the condition that they are not hostile and that they leave the weapons". ${ }^{8714}$ When read in the full context, the Chamber is not satisfied that the Accused's statement at the Bosnian Serb Assembly demonstrates that he intended to physically destroy a part of the Bosnian Muslim and/or Bosnian Croat groups.

2602. Similarly, the Chamber considers that while Šešelj, Plavšić, and Koljević sometimes delivered highly inflammatory and violent statements, ${ }^{8715}$ the evidence before the Chamber does not lead to the conclusion that the only reasonable inference was that they intended to physically destroy a part of the Bosnian Muslim and/or Bosnian Croat groups.

2603. With respect to an order of 10 April 1994 in which Mladic is quoted as encouraging VRS operations because "The [t]urks must disappear from these areas", the Chamber notes that the area covered by this order is not related to the Count 1 Municipalities. ${ }^{8716}$ In any event, the Chamber also notes Michael Rose's testimony with regard to this order, namely that he and other international representatives had thought that the objective of the combat operations in Goražde was to move the Bosnian Muslims out of the right bank of the town and therefore he suspected the reference in the order to "[t]he Turks must disappear from these areas" to mean just that: the removal—not the destruction—of the Bosnian Muslim population in those areas. ${ }^{8717}$ The Chamber also noted statements made by Mladić at the Bosnian Serb Assembly where he stated that their enemies should be eliminated but later stated that there are ways of neutralising the Muslims which do not mean that they have to be expelled or drowned. ${ }^{8718}$ The Chamber therefore considers that, while the evidence clearly evinces the intent to separate and move Bosnian Muslims out of Bosnian Serb claimed territory, it is not satisfied that the only reasonable inference is that Mladic intended to destroy a part of that group in the process.

\footnotetext{
8713 Prosecution Final Brief, para. 580.

8714 D92 (Transcript of $17^{\text {th }}$ session of SerBiH Assembly, 24-26 July 1992), p. 86.

8715 See e.g. paras. 2657, 2663-2664, 2706, 2728, 2798.

8716 P1645 (Order of Višegrad Tactical Group, 11 April 1994).

8717 Michael Rose, T. 7424-7425 (5 October 2010).

8718 P956 (Transcript of $16^{\text {th }}$ session of SerBiH Assembly, 12 May 1992), pp. 33, 39.
} 
2604. In relation to the 20 September 1994 entry in Mladić's diary, in which Slobodan Milošević stated that he opposed the view of Krajišnik to "kill off all the Muslims and Croats", ${ }^{8719}$ the Chamber notes that it has very limited information about when or in which context Krajišnik expressed this sentiment, and therefore, that it is of low probative value. The Chamber is therefore not satisfied that the only reasonable inference is that this demonstrates intent to destroy a part of either of the protected groups.

2605. The Chamber has also analysed the totality of the evidence relating to the statements, speeches, and actions of the Accused and the named members of the alleged Overarching JCE. The Chamber has characterised each of these statements and reached a conclusion about what they meant and what they showed in terms of intent. In conducting that assessment, the Chamber did not simply look at these statements in isolation, but also had regard to their meaning in the context of the totality of the evidence on the record. As has been discussed in this section, the Chamber has found that these statements, speeches, and actions were consistent with the Bosnian Serb objective of ethnic separation and the forceful creation of an ethnically homogenous state. However, the Chamber is not satisfied that this evidence-even when considered in the context of the pattern of crimes found to have been committed in the Count 1 Municipalities as will be detailed belowallows the Chamber to conclude that the Accused or the named members of the alleged Overarching JCE had genocidal intent for the purposes of Count 1. In other words, the evidence does not support a conclusion that the only reasonable inference is that the Accused or any of the alleged members of the Overarching JCE had the intent to physically destroy the Bosnian Muslim and/or the Bosnian Croat groups in the Count 1 Municipalities as such.

(3) Evidence of genocidal intent of Bosnian Serbs not named as alleged members of the Overarching JCE

2606. In relation to the intent of the Accused's "followers", the Prosecution refers to what it coins as a threat by Miroslav Deronjić that the Muslims of Bratunac would disappear. ${ }^{8720}$ At a meeting between SDS and SDA representatives in early April 1992, Deronjić reiterated that the police should be divided into separate Bosnian Serb and Bosnian Muslim units and when the SDA representatives opposed the idea, fearing it would lead to further tensions, Deronjić threatened that if they did not comply, "Muslims would disappear". ${ }^{8721}$ He went on to say that the division would be the best way for the Bosnian Muslims to prevent violence breaking out. ${ }^{8722}$ In the context of

\footnotetext{
8719 See P1487 (Ratko Mladić's notebook, 4 September 1994-28 January 1995), p. 17.

8720 See Prosecution Final Brief, para. 580, referring to P3196 (Witness statement of Dževad Gušić undated), paras. 31-32.

8721 P3196 (Witness statement of Dževad Gušić undated), paras. 31-32.

8722 P3196 (Witness statement of Dževad Gušić undated), para. 32.
} 
negotiations at the republic and the municipal levels to divide the police into separate entities, ${ }^{8723}$ the Chamber considers that, in the statement above, Deronjić clearly intended to intimidate the SDA representatives and coerce them into accepting the division. However, the Chamber is not satisfied beyond reasonable doubt that the only reasonable inference to be drawn from this statement is that Deronjić possessed genocidal intent.

2607. The Prosecution also refers to a speech made before the Bosnian Serb Assembly in July 1992 by Miladin Nedić, member of the SDS Main Board and representative at the Bosnian Serb Assembly, which the Prosecution coins as "the executioners' speech". ${ }^{8724}$ The Accused, on the contrary, refers to Nedić's evidence that this particular statement must be understood in light of his later address during the same session. ${ }^{8725}$ During his first address to the $17^{\text {th }}$ Bosnian Serb Assembly session, Nedić stated the following

I am against solving the situation in Bosnia in haste, we must admit that the Muslims have been planted to us as a people whose executioners we are to be. I do not want the Serb people to be executioners but I am also against us giving up our state, our land and our territory.[...] Therefore we should not hurry, because we are a people who have been determined to be executioners and to do someone a favour. ${ }^{8726}$

2608. Nedić testified that the essence of his statement was that he was advocating a peaceful solution to avoid the war. ${ }^{8727}$ The Chamber notes that Nedić indeed described the Serb people as having been called upon to be the executioners of the Muslims. However, it also notes that he immediately stated: "I am against any defined borders while people are getting killed". ${ }^{8728}$ Furthermore, later in the session, during a second address, Nedic reiterated that he opposed any discussion on the definition of borders and advocated the following:

Let us leave the time to solve that, but I am not for waging a war in order to enslave some and us to become oppressors. Let us treat the soldiers in accordance with military codes, let us not kill women and children for wearing dimijas. [...] I told a colonel that I am for a knightly warfare and not for genocide. ${ }^{8729}$

2609. The Chamber notes that the Prosecution refers to later statements made by Nedić before the Bosnian Serb Assembly, which it claims contradicts Nedić's evidence that he was advocating

\footnotetext{
8723 See Section IV.A.3.a.ii.C: Split in the MUP and the creation of Bosnian Serb MUP.

8724 Prosecution Final Brief, fn. 2184. The Chamber notes that the Prosecution erroneously refers to D4332 and not to D4232 as the exhibit number for Nedić's witness statement.

8725 Defence Final Brief, para. 2769.

8726 D92 (Transcript of $17^{\text {th }}$ session of SerBiH Assembly, 24-26 July 1992), p. 41. See also Miladin Nedić, T. 45883 (22 January 2014) (testifying, in relation to this statement, that he never advocated the extermination of the Muslim people and that the "only thing I hold against the Muslims as a religious group or people, whatever you wish, is that they are forcing me to have to fire at them too").

8727 D4232 (Witness statement of Miladin Nedić dated 20 January 2014), para. 5.

8728 D92 (Transcript of $17^{\text {th }}$ session of SerBiH Assembly, 24-26 July 1992), p. 41.
} 
peace. ${ }^{8730}$ Having considered these statements, the Chamber finds that they show Nedićs exasperation with the position of the Bosnian Muslims during negotiations and his wish that peace be established; albeit solely under the conditions established by the Bosnian Serbs. ${ }^{8731}$

2610. In light of the above, the Chamber is not satisfied that the only reasonable inference that can be drawn from Nedić's statement at the $17^{\text {th }}$ session of the Bosnian Serb Assembly is that he possessed the intent to destroy a part of the Bosnian Muslim group as such.

2611. The Chamber notes that these are merely examples referred to by the Prosecution to show genocidal intent of the "Accused's followers" but that the Chamber conducted its own assesment of the remainder of the trial record to examine whether there was genocidal intent towards the Bosnian Muslim and/or Bosnian Croat groups in the Count 1 Municipalities as such, on the part of Bosnian Serbs not named as alleged Overarching JCE members.

2612. In light of the above and having assessed the entire trial record, including the pattern of crimes described below, ${ }^{8732}$ the Chamber is not satisfied beyond reasonable doubt that the only reasonable inference that can be drawn from the facts and circumstances is that Bosnian Serbs not named as alleged Overarching JCE members possessed the intent to destroy the Bosnian Muslim and/or the Bosnian Croat groups in the Count 1 Municipalities as such.

\section{(4) Evidence of genocidal intent of the physical perpetrators}

2613. The Chamber examined the record to assess whether there was evidence of genocidal intent by the perpetrators of the above acts in relation to the Count 1 Municipalities. In relation to Count 3 , the Chamber found that victims of crimes during the take-overs of the Count 1 Municipalities and in detention facilities in those municipalities were targeted solely on the basis that they were Bosnian Muslims and Bosnian Croats. ${ }^{8733}$ This led the Chamber to find that the said crimes were committed with discriminatory intent. ${ }^{8734}$ The Chamber is not satisfied, however, that there is evidence establishing, beyond reasonable doubt, that the perpetrators of these crimes possessed

\footnotetext{
8729 D92 (Transcript of $17^{\text {th }}$ session of SerBiH Assembly, 24-26 July 1992), p. 60.

8730 Prosecution Final Brief, fn. 2184.

8731 D115 (Transcript of $25^{\text {th }}$ session of RS Assembly, 19-20 January 1993), p. 25 (stating: "Everything that we offered them as a people they refused, and had they been a people, they would have accepted at least one option, for us to live like human beings and like peoples. They are to blame, not us. Let them fare as God sees fit."); P1394 (Transcript of $42^{\text {nd }}$ session of RS Assembly, 18-19 July 1994), ecourt p. 85 (stating:"I don't know what /they/ want from us, to go in front of a wall of pain to beg someone for peace. [...] I am not worried about the Muslims who have declared war on us, I am worried about Serbs."). The Chamber notes that the Prosecution erroneously refers to D1379 in fn. 2184, which is a map.

8732 See paras. 2614-2615.

8733 See paras. 2483, 2513-2516.

8734 See paras. 2483, 2513.
} 
intent to destroy the Bosnian Muslim and/or Bosnian Croat groups in the Count 1 Municipalities as such.

\section{(5) Evidence of genocidal intent through the pattern of crimes}

2614. The Chamber will now examine whether the pattern of crimes in the Count 1 Municipalities, as considered in light of the whole trial record, satisfies the Chamber that the only reasonable inference that could be drawn from the facts and circumstances was that the acts described above in the Count 1 Municipalities were committed with genocidal intent.

2615. The Chamber recalls a few key factual findings made above in relation to each of the Count 1 Municipalities, first in relation to eastern BiH (Zvornik, Foča, Bratunac, and Vlasenica) before turning to the ARK (Ključ, Prijedor, and Sanski Most).

2616. In Zvornik, preparations for the division of municipal organs and the creation of Serb institutions started at the end of $1991 .^{8735}$ The take-over of the town of Zvornik by Serb Forces started on or about 8 April 1992 and by the following morning, a Serbian flag was flying over the main mosque. ${ }^{8736}$ During the take-over, Bosnian Muslims were killed by Serb Forces. ${ }^{8737}$ Restrictive measures were imposed and Bosnian Muslims were dismissed from employment. ${ }^{8738}$ Paramilitaries looted, mistreated, raped, and killed inhabitants. ${ }^{8739}$ After the attack on the town, Serb Forces attacked surrounding villages; they set houses on fire, cut the electricity supply, and rounded up people who were then either transferred out of the municipality or detained in detention facilities there. ${ }^{8740}$ Hundreds of Bosnian Muslims were arrested and detained in detention facilities throughout Zvornik; there, they were held in appalling conditions, subjected to severe mistreatment, rape and other acts of sexual violence; some detainees were killed. ${ }^{8741}$ The Chamber also found that 26 mosques were heavily damaged, almost destroyed, or completely destroyed by Serb Forces from April 1992. ${ }^{8742}$ Finally, the Chamber found that Bosniam Muslims were forced to leave Zvornik and that towards the end of June 1992, there were very few Bosnian Muslims remaining in the town. ${ }^{8743}$

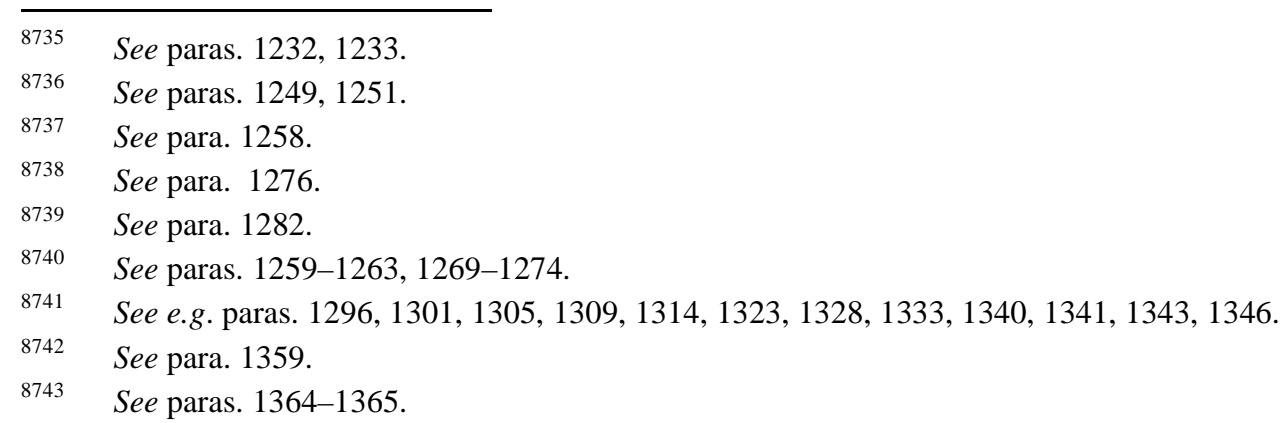


2617. In Foča, steps towards the creation of separate Serb institutions were taken starting at the end of $1991 .{ }^{8744}$ The town was taken over by Serb Forces in early April 1992. ${ }^{8745}$ During and after the take-over, Bosnian Muslim houses were looted and destroyed and Bosnian Muslim inhabitants left. ${ }^{8746}$ Then, ensued a period of large-scale arrests of non-Serb men who were taken to detention facilities throughout the municipality and of restrictions on the Bosnian Muslim population. ${ }^{8747}$ The Chamber found that Bosnian Muslim civilians were killed either during attacks on villages throughout the municipality or in detention facilities. ${ }^{8748}$ In the detention facilities, detainees were held in terrible conditions; they were also mistreated and subjected to rape and acts of sexual violence. ${ }^{8749}$ The Chamber also found that two mosques were destroyed by Serb Forces between April and August 1992. ${ }^{8750}$ Finally, the Chamber found that Bosnian Muslims were forced to leave Foča and that by mid-August 1992, there were almost no Bosnian Muslim left in Foča. ${ }^{8751}$

2618. In Bratunac, the Chamber made findings that at the end of 1991 and the beginning of 1992 , preparations were made to divide municipal structures and create separate Serb institutions. ${ }^{8752}$ On or about 17 April 1992, Serb Forces entered the town. ${ }^{8753}$ From then on, Bosnian Muslim houses were searched and looted, ${ }^{8754}$ Bosnian Muslims were dismissed from their jobs, ${ }^{8755}$ Bosnian Serb refugees settled in the homes of Bosnian Muslims who had left, ${ }^{8756}$ and mosques and other Muslim monuments were destroyed. ${ }^{8757}$ In the days following the attack on the town, surrounding Bosnian Muslim villages were attacked by Serb Forces; during the course of these attacks, houses were looted and burned, and villagers were told to leave. ${ }^{8758}$ Bosnian Muslims were also killed by Serb Forces in these villages. ${ }^{8759}$ From May 1992, hundreds of Bosnian Muslims and Bosnian Croats were rounded up from their homes and detained in facilities throughout Bratunac, where they were subjected to severe mistreatment and held in cramped condition; some detainees died. ${ }^{8760}$ In these

\footnotetext{
$8744 \quad$ See paras. $843-846$.

8745 See paras. $852-855$.

8746 See paras. $855-858$.

8747 See paras. 861-865.

8748 See paras. 869, 874, 911.

8749 See paras. 879, 889, 903, 923.

$8750 \quad$ See para. 928.

8751 See paras. 930-934.

8752 See paras. 697-710.

8753 See para. 714.

8754 See paras. 719, 721.

8755 See para. 723.

$8756 \quad$ See para. 725.

8757 See paras. 782-783.

8758 See paras. 728-732.

8759 See paras. 737, 749.

$8760 \quad$ See paras. 759, 766, 767, 780.
} 
detention facilities, prominent Bosnian Muslims intellectuals were targeted. ${ }^{8761}$ The Chamber found that Bosnian Muslims were forced to leave Bratunac and that by the end of June 1992, very few remained in the town. ${ }^{8762}$

2619. In Vlasenica, measures were adopted to divide municipal institutions and create Serb organs at the end of 1991 and the beginning of $1992 .^{8763}$ Serb Forces took over Vlasenica on or about 21 April 1992. ${ }^{8764}$ After the take-over, the movement of Bosnian Muslims was restricted and they were dismissed from their jobs. ${ }^{8765}$ They were arrested and interrogated. ${ }^{8766}$ During the course of the take-over of villages within the municipality, Bosnian Muslim houses were set on fire. ${ }^{8767}$ Bosnian Muslims were also killed during the course of these attacks. ${ }^{8768}$ There were a number of detention facilities in Vlasenica; there, Bosnian Muslims were detained, held in appalling conditions, beaten, raped, and some were killed. ${ }^{8769}$ The Chamber found that Bosnian Muslims were forced to leave Vlasenica in 1992 and early 1993 and that by then there were very few Bosnian Muslims left in Vlasenica town. ${ }^{870}$

2620. In Prijedor, measures were also taken for the division of municipal organs and the establishment of Serb institutions at the end of 1991 and the beginning of $1992 .{ }^{8771}$ At this time, propaganda in the municipality against Bosnian Muslims and Bosnian Croats was common. ${ }^{8772}$ The town of Prijedor was taken over on 30 April 1992 by Serb Forces. ${ }^{873}$ After the take-over, nonSerbs were dismissed from the workforce and their houses were searched and looted. ${ }^{874}$ About a month later, villages in the predominantly Muslim areas of Kozarac and Brdo, as well as in Briševo were attacked by Serb Forces; villages were shelled, set ablaze, and for the most part destroyed, ${ }^{8775}$ During the course of these attacks, Bosnian Muslims and Croats were killed. ${ }^{8776}$ Thousands of

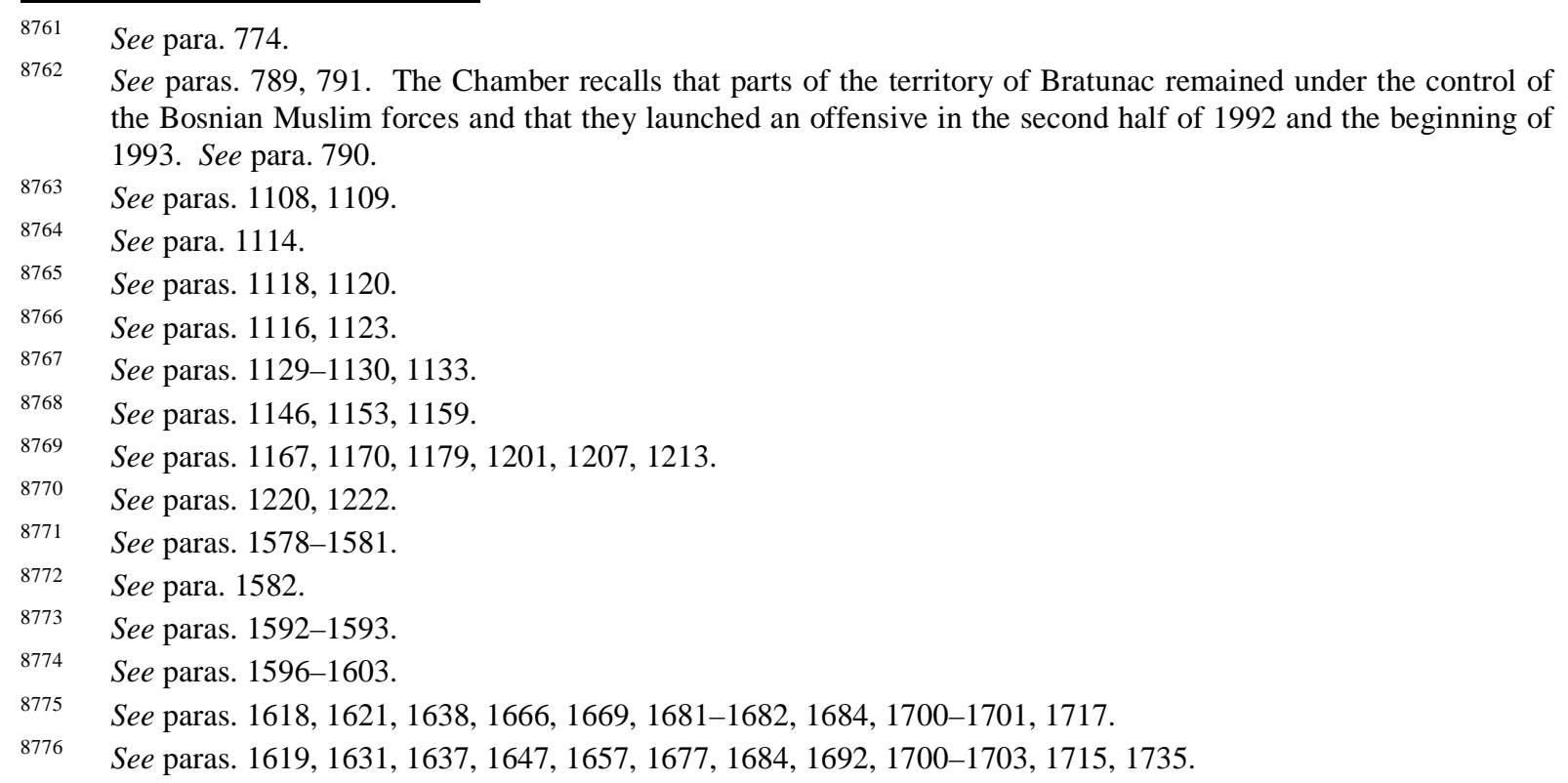


Bosnian Muslims and Bosnian Croats were detained in detention facilities in Prijedor. ${ }^{877}$ The Chambers has made findings that the conditions in these detention facilities were, in general, abysmal, that detainees were subjected to frequent and severe beatings, rape and other acts of sexual violence, and that some were killed. ${ }^{8778}$ In Prijedor, 17 mosques and two Catholic churches were heavily damaged, almost destroyed, or completely destroyed by Serb Forces. ${ }^{879}$ The Chamber found that following the attacks on towns and villages in Prijedor between late May and end of July 1992, the non-Serb population was expelled from the municipality. ${ }^{8780}$ As detention facilities were closed in Prijedor, detainees held there were transferred around the municipality as well as to camps outside of the municipality and ultimately often to third countries. ${ }^{8781}$ The Chamber found by 1995, the population of Prijedor municipality consisted of approximately $92 \%$ Bosnian Serbs, $5 \%$ Bosnian Muslims, and 1\% Bosnian Croats. ${ }^{8782}$

2621. In Sanski Most, Serb municipal organs were only established in early April $1992 .{ }^{8783}$ Bosnian Muslim neighbourhoods and villages were attacked on 25 May 1992. ${ }^{8784}$ Houses were destroyed and individuals were captured. ${ }^{8785}$ Thereafter, Bosnian Muslims were dismissed from their work and Bosnian Croat and Muslim political leaders were arrested. ${ }^{8786}$ Bosnian Muslims and Croats were killed. ${ }^{8787}$ After military operations against Bosnian Muslim and Bosnian Croat villages in Sanski Most, soldiers collected the able-bodied military-aged men from the village and transferred them by bus to Sanski Most town. ${ }^{8788}$ Over a thousand individuals were thus detained in detention facilities throughout the municipality in poor conditions; they were beaten and some were also killed. ${ }^{8789}$ The Chamber also found that at least 16 mosques and the town Catholic church were heavily damaged, almost destroyed or completely destroyed by Serb Forces between May and December 1992. ${ }^{8790}$ The Chamber also found that Bosnian Muslims and Bosnian Croats in Sanski Most were forced to leave and that by February 1995, the population of Sanski Most

\footnotetext{
$8777 \quad$ See paras. $1628,1738$.

8778 See paras. 1747, 1774, 1778, 1781, 1803, 1815, 1832, 1847, 1861, 1871, 1877, 1885.

$8779 \quad$ See para. 1896.

$8780 \quad$ See para. 1897.

$8781 \quad$ See para. 1902.

8782 See para. 1913.

8783 See paras. 1933-1934.

8784 See para. 1945.

8785 See para. 1945.

8786 See para. 1950.

8787 See paras. 1960, 1965, 1969, 1973, 1978.

8788 See para. 1979.

8789 See paras. 1991, 1998, 2002, 2011, 2018, 2024.

$8790 \quad$ See para. 2031.
} 
municipality was approximately 3,350 Bosnian Muslims, 1,050 Bosnian Croats, and 33,600 Bosnian Serbs. ${ }^{8791}$

2622. In Ključ, preparations to establish separate Serb institutions started at the end of $1991 .^{8792}$ Violence intensified in March 1992 and the town was taken over in early May 1992. ${ }^{8793}$ After the take-over, Bosnian Muslims were expelled from the police, administrative organs, and the workforce. ${ }^{8794}$ A large number of Bosnian Muslim houses were destroyed and Bosnian Muslims were killed during the course or after attacks on villages. ${ }^{8795}$ Other Bosnian Muslims from Ključ were rounded up and detained in facilities throughout the municipality, where they were subjected to mental abuse and physical mistreatment. ${ }^{8796}$ The Chamber found that eight mosques were destoyed by Serb Forces between May and August 1992. ${ }^{8797}$ The Chamber also found that Bosnian Muslims and Bosnian Croats were forced to leave Ključ and that by 1995, only 1,200 of Ključ's original 17,000 Bosnian Muslims remained. ${ }^{8798}$

2623. As summarised above, the Chamber's findings in relation to the Count 1 Municipalities show a clear pattern of widespread intimidation, violence, killings, and expulsions targeted at the Bosnian Muslims and Bosnian Croats, for the most part of 1992 and, in some instances, into 1993. The Chamber has already found that there was a widespread and systematic attack against the Bosnian Muslim and Bosnian Croat population of $\mathrm{BiH}$, demonstrated by the existence of a campaign of co-ordinated violence during the take-overs and in the detention facilities. ${ }^{8799}$ Further, the acts which the Chamber has determined herein to constitute acts under Article 4(2) of the Statute were found to have targeted their victims solely on the basis of their ethnicity and were therefore found to constitute persecution. ${ }^{8800}$ This campaign of violence resulted in the Serbclaimed territories of the Count 1 Municipalities being cleared of the overwhelming majority of their Bosnian Muslim and Bosnian Croat populations, as most had left by the end of 1992 and into 1993.

2624. This pattern of crimes in the Count 1 Municipalities is illustrated by the commission of dreadful crimes, namely crimes against humanity and violations of the law or customs of war,

\footnotetext{
8791 See paras. 2039-2040.

8792 See para. 1495-1497.

8793 See paras. 1500-1501.

8794 See paras. 1502-1505.

8795 See paras. 1512, 1515, 1522, 1555.

8796 See paras. 1529, 1536, 1544.

8797 See para. 1558.

8798 See paras. 1567, 1568.

8799 See para. 2444.

$8800 \quad$ See paras. 2513-2514, 2518.
} 
against the Bosnian Muslims and Bosnian Croats on a widespread scale. As a result, many Bosnian Muslims and Bosnian Croats in the Count 1 Municipalities, including some prominent members of that group, were subjected to the acts described above. The Chamber found that the scale and extent of the expulsions and movement of the civilians from the Municipalities, including the Count 1 Municipalities, resulted in the displacement of a vast number of Bosnian Muslims and Bosnian Croats and in drastic changes to the ethnic composition of towns with almost no Bosnian Muslim remaining there. ${ }^{8801}$ As recalled above, by early 1993, practically all of the Bosnian Muslims had been moved out of Serb held territory in the Count 1 Municipalities. The total number of Bosnian Muslims and Bosnian Croats displaced-especially when examined in light of the portion of the groups of Bosnian Muslims and Bosnian Croats allegedly targeted for destruction in the Count 1 Municipalities through the commission of the acts under Article 4(2) of the Statute identified above as well as the fact that Serb Forces exercised control over these territories-does not satisfy the Chamber that the only reasonable inference is that there existed an intent to destroy the Bosnian Muslim and/or Bosnian Croat groups in the Count 1 Municipalities as such. Rather, the Chamber considers that a reasonable inference to be drawn from the pattern described above is that the intent behind those crimes was to ensure the removal of members of the Bosnian Muslims and Bosnian Croats from the Count 1 Municipalities.

2625. In assessing this pattern of crimes also in the context of its findings on the objectives of the Bosnian Serb leadership, including the Accused, ${ }^{8802}$ the Chamber recalls that their objective was to create an ethnically pure Bosnian Serb state as well as contiguous Serb areas, which would require a redistribution-rather than the physical destruction-of the population. ${ }^{8803}$ Bosnian Serbs promoted the idea that they could not live with anyone else and therefore that $\mathrm{BiH}$ had to be divided along ethnic lines. ${ }^{8804}$ The results on the ground, including in the Count 1 Municipalities, were consistent with these goals. As an example that this pattern of crimes is consistent with the Bosnian Serb leadership's intent to create ethnically pure territories through the removal of the Bosnian Muslims and Bosnian Croats, the Chamber refers to the Accused's speech at the $37^{\text {th }}$ Bosnian Serb Assembly in 1994 where he congratulates Foča, then renamed as Srbinje, for being "a true Serbian town" as well as to the broadcast in which he announced that Bosnian Muslims have given up on Foča in their negotiations. ${ }^{8805}$ When seen in this context, the Chamber is not satisfied that the only reasonable inference that can be drawn from the pattern of crimes described above is

\footnotetext{
$8801 \quad$ See para. 2467.

8802 See Section IV.A.3.a.i: Objectives of the Accused and the Bosnian Serb leadership.

8803 See Section IV.A.3.a.i: Objectives of the Accused and the Bosnian Serb leadership; para. 2898.

8804 See para. 2841.

8805 See paras. 2810-2811.
} 
that there existed intent to destroy the parts of the Bosnian Muslim and/or Bosnian Croat groups in the Count 1 Municipalities as such.

\section{(6) $\underline{\text { Conclusion }}$}

2626. Having reviewed all of the evidence on the record, for the purpose of Count 1 , the Chamber is not satisfied beyond reasonable doubt that the acts under Article 4(2) identified above in the Count 1 Municipalities were committed with genocidal intent. Further, it is not convinced that the only reasonable inference to be drawn from the evidence is that named members of the alleged Overarching JCE, including the Accused, other Bosnian Serbs not named as alleged members of the Overarching JCE, or physical perpetrators possessed such intent to destroy the Bosnian Muslim and/or Bosnian Croat groups in the Count 1 Municipalities as such.

\section{Overarching JCE and the Accused's responsibility}

2627. The Chamber recalls that with respect to the Overarching JCE, the Prosecution alleges that from at least October 1991 to 30 November 1995, the Accused participated in an "overarching" JCE, the objective of which was to permanently remove Bosnian Muslims and Bosnian Croats from Bosnian Serb claimed territory in $\mathrm{BiH}^{8806}$

2628. The named individuals who are alleged to have been members of the Overarching JCE and to have acted in concert with the Accused are Krajišnik, Mladić, Slobodan Milošević, Plavšić, Koljević, Mićo Stanišić, Mandić, Jovica Stanišić, Franko Simatović, Arkan, and Šešelj. ${ }^{8807}$

2629. In addition, the Prosecution alleges that other members of the Overarching JCE included members and leaders of the Bosnian Serb Political and Governmental Organs and commanders, senior officers, chiefs of the Serbian MUP, JNA, VJ, VRS, RS MUP, Bosnian Serb TO, and leaders of Bosnian Serb paramilitary forces and volunteer units. ${ }^{808}$ In the alternative, the Prosecution alleges that some or all of these individuals were not members of the Overarching JCE, but were used by members of the Overarching JCE to carry out the crimes committed in furtherance of its objective. $^{8809}$

2630. The Prosecution alleges that the objective of the Overarching JCE was achieved through the commission of the crimes of genocide, persecution, extermination, murder, deportation, and

\footnotetext{
8806 See paras. 592-594; Indictment, paras. 9-14, 30-31.

8807 See Indictment, para. 11.

8808 See Indictment, para. 12.

8809 See Indictment, para. 12.
} 
inhumane acts (forcible transfer). ${ }^{8810}$ The Prosecution charges the Accused with the first and the third form of JCE in relation to the Overarching JCE. ${ }^{8811}$ It primarily argues that the Accused shared the intent for the commission of each of these crimes with other members of the Overarching JCE. ${ }^{8812}$ Alternatively, the Prosecution argues that the shared objective of the Overarching JCE included at least the crimes of deportation and inhumane acts (forcible transfer) and that for the remaining crimes the Accused is responsible as it was foreseeable that the remaining crimes might be perpetrated in order to carry out the actus reus of the crimes which formed part of the shared objective. ${ }^{8813}$

2631. The Prosecution alleges that members of the Overarching JCE implemented its objective by personally committing crimes, and/or by using others to carry out crimes in furtherance of its objective. ${ }^{8814}$ Those alleged to have been used by members of the Overarching JCE to carry out these crimes were members of the Bosnian Serb Political and Governmental Organs and members of the Serb Forces. ${ }^{8815}$

2632. The Prosecution lists ten ways in which it alleges the Accused significantly contributed to the objective of the Overarching JCE. ${ }^{8816}$

2633. The Chamber will consider the evidence presented with respect to (i) the objectives of the Accused and the Bosnian Serb leadership; (ii) the Accused's authority over Bosnian Serb political and governmental structures; (iii) the Accused's authority over Serb Forces; (iv) the knowledge and acts of named alleged members of the Overarching JCE; and (v) the Accused's knowledge of crimes and measures taken to prevent and punish crimes in the Municipalities. The Chamber will analyse this evidence to determine whether the Overarching JCE existed, and if so, when it came into existence, what was its common purpose, and whether a plurality of persons, including the Accused, shared and acted pursuant to that common purpose. The Chamber will then analyse whether or not the Accused significantly contributed to the alleged Overarching JCE and which crimes if any were intended or, alternatively, whether any of the alleged crimes were foreseeable in the implementation of the objective of the Overarching JCE.

\footnotetext{
$8810 \quad$ See Indictment, para. 9.

8811 See Indictment, paras. 9-10.

8812 See Indictment, para. 9.

8813 See Indictment, para. 10.

8814 See Indictment, para. 13.

8815 See Indictment, para. 13.

8816 See Indictment, para. 14.
} 


\section{a. Responsibility related facts}

\section{i. Objectives of the Accused and the Bosnian Serb leadership}

(A) Unity of the Serb people and promotion of Serb interests

\section{(1) Analysis of evidence}

2634. In the period leading up to the start of the conflict, the Accused made statements calling for the unity of the Serb people and the promotion of Serb interests. These are discussed below.

2635. The Chamber recalls that the SDS was established on 12 July 1990, and the Accused as president of the party stated that the objectives of the SDS included "a federative Yugoslavia, and in it an equal federal Bosnia and Herzegovina". ${ }^{8817}$ During this speech he also spoke about how decades of "single-party rule have intensely disturbed the natural development of the Serbian nation". 8818 In addition, he spoke about how "Serbian entities" in BiH had been broken down and had been left in an inferior "economic, demographic and political position". 8819

2636. On 13 October 1990, in a speech before Serb representatives in Banja Luka, the Accused expressed his view that the "Serbian nation" was united and spoke of his fear that BiH would set its course to separate from Yugoslavia and that the Serbs would be separated from Serbia and be a national minority. ${ }^{8820}$ The Accused also said "[w]hether a greater Croatia or greater Bosnia and Herzegovina as some kind of independent state, separate from Yugoslavia, they are equally unfavourable for us, the Serbs. [...] The Serbian people of Bosnia and Herzegovina will not abandon its demands to live in a state which also includes its main country, the country of Serbia". ${ }^{821}$ In the same speech, the Accused spoke about changes to "the essence of the borders, the quality and nature of our internal borders. So the administrative lines which are supposed to join us have been transformed, or will soon be transformed into firm state borders which separate us. [...] They would like to chop the Serbian nation up in pieces against its will." ${ }^{8822}$ The Accused

8817 See para. 58; D255 (Radovan Karadžić's speech at the constituent SDS Assembly), p. 2; P971 (Robert Donia's expert report entitled "The Origins of Republika Srpska, 1990-1992", 30 July 2002), p. 20; Patrick Treanor, T. 14001 (1 June 2011). See also Adjudicated Fact 1931.

8818 D255 (Radovan Karadžić's speech at the constituent SDS Assembly), p. 1.

8819 D255 (Radovan Karadžić's speech at the constituent SDS Assembly), p. 1.

8820 D1280 (Nikola Koljević and Radovan Karadžić's speeches at the All-Serb Council in Banja Luka, 13 October 1990), pp. 5-6.

8821 D1280 (Nikola Koljević and Radovan Karadžić's speeches at the All-Serb Council in Banja Luka, 13 October 1990), p. 6. See also D3015 (Witness statement of Vladislav Jovanović dated 22 February 2013), para. 38 .

8822 D1280 (Nikola Koljević and Radovan Karadžić's speeches at the All-Serb Council in Banja Luka, 13 October 1990), p. 4. 
also expressed his concern regarding the collapse of Yugoslavia "into the abyss" and warned that the Bosnian Serbs would take any threat of civil war seriously. ${ }^{8823}$

2637. At this same meeting, Koljević identified the purpose of establishing the SDS as a means of expressing the national objective of the Bosnian Serbs, which was "a federative Yugoslavia and for the Serbs to be able to survive [...] in that Yugoslavia and for all the other peoples to be able to survive together". ${ }^{824}$ Koljević also emphasised that the SDS was formed in "response to the new situation which has arisen and which we will not and must not tolerate" and that they should not remain unprepared. ${ }^{8825}$ In this same speech Koljević called on the other national parties in BiH to think about "what the partition of a confederal Yugoslavia means and for them not to push us into another civil war". 8826

2638. In an interview in November 1990, the Accused discussed the possibility of Serbs being outvoted in the $\mathrm{BiH}$ Assembly and predicted that if that happened "all conditions for a civil war would be in place, because the Serbs in $\mathrm{BiH}$ are no longer helpless, but very powerful and united". ${ }^{827}$ The Accused stated that he did not think civil war would happen "because the Serbs won't start the skirmish first and others are afraid to. No one has reason to fear the Serbs if they have no misdeeds against them". ${ }^{828}$ The Accused further stated that "under no circumstances will Serbs accept to live in several independent states, and to become a national minority everywhere outside Serbia. The Serbs will stay in one state - Federative Yugoslavia" and would not be separated from Serbia. ${ }^{8829}$

\footnotetext{
8823 D1280 (Nikola Koljević and Radovan Karadžić's speeches at the All-Serb Council in Banja Luka, 13 October 1990), p. 4. See also P5860 (Intercept of conversation between Radovan Karadžić and Momčilo Krajišnik, 23 September 1991).

8824 D1280 (Nikola Koljević and Radovan Karadžić's speeches at the All-Serb Council in Banja Luka, 13 October 1990), p. 8.

8825 D1280 (Nikola Koljević and Radovan Karadžić's speeches at the All-Serb Council in Banja Luka, 13 October 1990), p. 8.

8826 D1280 (Nikola Koljević and Radovan Karadžić's speeches at the All-Serb Council in Banja Luka, 13 October 1990), p. 9.

8827 P2539 (Radovan Karadžić's interview in NIN, 9 November 1990), p. 3.

8828 D1281 (Articles from Večernje Novine entitled "Karadžić shocked me" and "Šešelj is amiable", 9 May 1991), pp. 2-3. See also P6540 (Excerpt of video from Banja Luka, 3 March 1991, with transcript), p. 2 ; P6617 (Article entitled "Jovan Rašković on Shrink's Sofa"), p. 2. The Chamber places no weight on the opinions expressed by Jovan Rašković in this article, including his view that the Bosnian Serb leadership had "burnt the fuse of Serbian people".

8829 P2539 (Radovan Karadžić's interview in NIN, 9 November 1990), pp. 6-8. See also P2555 (Intercepts of conversations between (i) Radovan Karadžić and Anđelko Vukić; and (ii) Radovan Karadžić and Boro Sendić, 16 October 1991), p. 3; D269 (Radovan Karadžić's interview with NIN, 20 July 1990), p. 6; Radomir Nešković T. 14260 (6 June 2011). But see D3528 (Witness statement of Milan Martić dated 7 May 2013), para. 69; Milan Martić, T. 38106-38109 (13 May 2013) (testifying that contrary to what the Accused said in P2555, the Accused's position was not that he wanted to keep Serbian parts of $\mathrm{BiH}$ linked to other Serbian parts of the former Yugoslavia). The Chamber does not find Martić's evidence in this regard to be reliable. In reaching that
} 
2639. The Accused also indicated that the political life of Bosnian Serbs "had been fully revived and established", which was the main purpose of setting up the SDS, and that in all places where Serbs lived they had set up municipal organisations with municipal and local boards. ${ }^{8830}$ He spoke about how the SDS had become the party of all Serbs and there was now "only a unified Serbian people". 8831 These statements were made before the first multi-party elections, which the Chamber recalls were held in $\mathrm{BiH}$ on 18 November $1990 .{ }^{8832}$

2640. The Accused delivered a speech in 1990 in which he said that Bosnian Serbs did not agree to "sacrifice any Croat, any Muslim, and any human being in organizing a state" and that those who did not know how to organise their state "except with blood and corpses, they must go!" ${ }^{8833}$ In this speech the Accused also said they would act democratically and be benign so long as democracy was able to function but that the "moment anyone attacks us, we shall bring out the spear" ${ }^{8834}$ The Accused also stated that one of the objectives of the SDS was to improve multi-ethnic relations but that it would not co-operate with any parties which "have even the slightest trace of antiSerbism". 8835

2641. In May 1991, the Accused and Plavšić discussed preserving the common state of Yugoslavia, the danger of $\mathrm{BiH}$ "sliding into chaos and civil war", and the need to reach an agreement with Izetbegović in line with their interests. ${ }^{836}$ The Accused, in June 1991, repeated his position that $\mathrm{BiH}$ would never be independent and that it would not follow the footsteps of Croatia. ${ }^{8837} \mathrm{He}$ also said that if $\mathrm{BiH}$ were to collapse, there would be chaos but that they would not bow their heads. ${ }^{8838}$ The Accused warned Izetbegović out of frustration that they would form a

conclusion the Chamber found that his testimony was marked by contradictions, evasiveness, and indicators of bias.

8830 P2539 (Radovan Karadžić's interview in NIN, 9 November 1990), p. 1. See also P5643 (Intercept of conversation between Radovan Karadžić and an unidentified male, 8 July 1991).

8831 P2539 (Radovan Karadžić's interview in NIN, 9 November 1990), p. 1. See also P5063 (Video footage depicting interview of Radovan Karadžić on “Ask the President”, undated, with transcript), p. 47.

\section{$8832 \quad$ See para. 38.}

8833 D4185 (Radovan Karadžić's speech, 2 September 1990, with transcript), p. 2. Miloš Milinčić testified that the Accused in this speech called for good neighbourly relations, and that people lived best when they lived together in peace and harmony. Miloš Milinčić, T. 44937-44940 (11 December 2013). The Chamber notes that this is based on Milinčić's own interpretation of the Accused's speech and is thus of limited weight. In addition, Milinčić's evidence was marked by extreme evasiveness and indicators that he lacked candour. The Chamber therefore does not find his evidence in this regard to be reliable.

8834 P6563 (Excerpt of Radovan Karadzić's speech in Srbac, 2 September 1990, with transcript).

8835 D255 (Radovan Karadžić's speech at the constituent SDS Assembly), pp. 2-3.

8836 P5681 (Intercept of conversation between Biljana Plavšić and Radovan Karadžić, 23 May 1991), pp. 2-3. See also P5727 (Intercept of conversation between Biljana Plavšić and Radovan Karadžić, 2 March 1992), p. 2; P5605 (Intercept of conversation between Radovan Karadžić, Goran Milić, Alija Izetbegović, and an unidentified woman, 3 March 1992), p. 7.

8837 D270 (Intercept of conversation between Radovan Karadžić and Vitomir Žepinić, 17 June 1991), p. 7. See also P5896 (Intercept of conversation between Radovan Karadžić and an unidentified journalist, 24 June 1991).

8838 D270 (Intercept of conversation between Vitomir Žepinić and Radovan Karadžić, 17 June 1991), pp. 8-9. 
parallel government and parallel police if their people were excluded and that the Bosnian Serbs were all armed. ${ }^{8839}$ The Accused also said in a related conversation that they had "prepared an alternative, which will be atrocious. We prepared it and we'll fuck their mothers". ${ }^{8840}$ The Accused in another conversation also spoke about territories which would be integral to the Serb part of $\mathrm{BiH}$ in the event that there was a split and that they would have their own "army and militia". 8841

2642. On 23 July 1991, the Accused told Kuprešanin that the referendum for an independent Krajina would be a mistake for negotiations at that time because the Bosnian Muslims had prepared "all the evidence that the Serbs are creating the Greater Serbia. And now you are playing right into their hands, as if they are paying you. [...]. They have to make a mistake. They will definitely make a mistake we know that". 8842

2643. In an intercepted conversation on 4 September 1991, the Accused said that the army had been invited to Tuzla and that the Bosnian Muslims should be warned that the Serbs could defend themselves. ${ }^{8843}$ When informed about tensions in Bratunac, the Accused responded "we will arrest them and kill them. [...] Tell them that Serbs in Bosnia and Herzegovina [...] can defend themselves and defend themselves successfully. There are two hundred thousand armed men and they should not mess around". 844 On 13 September 1991, referring to a proposal by Izetbegović to resolve the question of the army in $\mathrm{BiH}$ and demilitarisation, the Accused said to Koljevic "we will put the army in all our areas, Serbian Bosnia, right? Down there, on Neretva..." ${ }^{845}$ The Accused also told international representatives that unless the Serb areas in $\mathrm{BiH}$ could remain tied to

8839 P5625 (Intercept of conversation between Radovan Karadžić and Vitomir Žepinić, 8 July 1991), p. 1; D364 (Intercept of conversation between Radovan Karadžić and Vitomir Žepinić, 24 July 1991), p. 6. See also D2925 (Intercept of conversation between Radovan Karadžić and Vitomir Žepinić, 9 September 1991), p. 2.

8840 D364 (Intercept of conversation between Radovan Karadžić and Vitomir Žepinić, 24 July 1991), p. 4. See also P962 (Intercept of conversation between Radovan Karadžić and Malko Koroman, 9 September 1991), pp. 2-3. Žepinić stated that he did not take the comments the Accused made during these intercepted phone conversations in this regard seriously as the Accused was "blowing off steam" and that he did not believe he meant them literally. D2923 (Witness statement of Vitomir Žepinić dated 11 February 2013), paras. 40, 43, 4849. While the Chamber accepts that Žepinić formed this impression during these conversations, the Chamber finds that these conversations show that the Accused was indeed angry about proposed moves towards the independence of $\mathrm{BiH}$ and was prepared to change their strategy if Bosnian Serb demands were not met and this would include violence.

8841 P5616 (Intercept of conversation between Radovan Karadžić and an unidentified male, 13 December 1991), pp. 4-5.

8842 P1084 (Intercept of conversation between Radovan Karadžić and Vojo Kuprešanin, 23 July 1991), pp. 3-4.

8843 D1643 (Intercept of conversation between Radovan Karadžić and Zvonko Bajagić, 4 September 1991), pp. 5-8.

8844 D1643 (Intercept of conversation between Radovan Karadžić and Zvonko Bajagić, 4 September 1991), p. 7.

8845 P5870 (Intercepts of conversations between (i) Radovan Karadžić and Mira; (ii) Radovan Karadžić and Nikola Koljević, 13 September 1991), pp. 2-3 
Yugoslavia war would result. ${ }^{8846}$ On 30 September 1991, the Accused stated that the "war goal" of the Serbian people was Yugoslavia. ${ }^{8847}$ The SDS was ready to have Serb territories secede from an independent $\mathrm{BiH}$ if that was the only way for Serbs to remain in Yugoslavia. ${ }^{8848}$

2644. In May 1991, Slobodan Milošević told the Accused that his position should be that they were against the secession and wanted $\mathrm{BiH}$ to remain in Yugoslavia, to which the Accused agreed. $^{8849}$ In another conversation in July 1991, Milošević told the Accused that their objective was to "have disintegration in [...] line with our inclinations" and that they "should take radical steps and speed the things up". 8850

2645. In other conversations, Slobodan Milošević told the Accused that the Serbs would not be divided into many states, and that this "should be the basic premise for your thinking". ${ }^{8851} \mathrm{He}$ also questioned who could "take the Serbian people out of Yugoslavia if it is against their will", to which the Accused responded that it was important to emphasise that the borders had been artificially created by Tito and did not follow an "ethnical [or] historical principle". 8852

2646. In July 1991, Milošević encouraged meetings between Serbs and Muslims because the population did not want war. ${ }^{8853}$ The Accused agreed but said that it was Izetbegović who was preparing for civil war and suggested to "let everybody identify themselves now, who does not want an agreement with the Serbs obviously wants a dispute with the Serbs". ${ }^{854}$ Milošević made it clear that they were "offering nothing else but an integral Bosnia, equal to other republics in Yugoslavia". ${ }^{8855}$ The Accused repeated that they wanted to have strong ties with Yugoslavia and if

8846 Herbert Okun, P776 (Transcript from Prosecutor v. Krajišnik), T. 4172-4173, 4400-4401. See also Herbert Okun, T. 1516-1517 (23 April 2010), T. 1698 (27 April 2010), T. 1843-1844 (28 April 2010); P780 (Seventh notebook of Herbert Okun's Vance Mission Diary), e-court p. 37; P777 (Fourth notebook of Herbert Okun's Vance Mission diary), e-court p. 23.

8847 P2543 (Minutes of meeting of SDS deputies' club, 30 September 1991). See also D3695 (Witness statement of Bogdan Subotić dated 16 June 2013), paras. 27-28 (stating the Bosnian Serbs wanted to preserve Yugoslavia); D3528 (Witness statement of Milan Martić dated 7 May 2013), paras. 13-14.

$8848 \quad$ See Adjudicated Fact 1932.

8849 D1282 (Intercept of conversation between Radovan Karadžić and Slobodan Milošević, 29 May 1991), p. 3. See also P5686 (Intercept of conversation between Radovan Karadžić and Slobodan Milošević, 11 June 1991), p. 2; P5687 (Intercepts of conversations between (i) Ljiljana Karadžić and Slobodan Milošević and (ii) Radovan Karadžić and Slobodan Milošević, 12 June 1991), p. 3.

8850 P5890 (Intercept of conversation between Radovan Karadžić and Slobodan Milošević, 1 July 1991), p. 2.

8851 P5881 (Intercept of conversation between Radovan Karadžić and Slobodan Milošević, 31 July 1991), p. 11.

8852 P5880 (Intercept of conversation between Radovan Karadžić and Slobodan Milošević, 6 August 1991), p. 5. See also P5877 (Intercept of conversation between Radovan Karadžić and Slobodan Milošević, 4 September 1991), p. 2; Herbert Okun, P776 (Transcript from Prosecutor v. Krajišnik), T. 4164; Herbert Okun, T. 1479 (22 April 2010); P786 (Third notebook of Herbert Okun's ICFY diary), e-court p. 34.

8853 P5881 (Intercept of conversation between Radovan Karadžić and Slobodan Milošević, 31 July 1991), p. 5. See also P5775 (Intercept of conversation between Radovan Karadžić and Slobodan Milošević, 5 January 1992), pp. 2-3.

8854 P5881 (Intercept of conversation between Radovan Karadžić and Slobodan Milošević, 31 July 1991), p. 5.

8855 P5881 (Intercept of conversation between Radovan Karadžić and Slobodan Milošević, 31 July 1991), p. 6. 
the Bosnian Muslims refused, the alternative would be war. ${ }^{885}$ This was confirmed in an intercepted conversation towards the end of the conflict, where the Accused and Krajišnik spoke about the fact that they had waged war because they did not accept $\mathrm{BiH}$ as "integral and separate from Yugoslavia". 8857

2647. On 2 October 1991, in an intercepted conversation with Krajišnik, the Accused alluded to there being "very concrete plans for transfer" and combat operations from Western Herzegovina to "that Ustasha's oasis in Goražde and further to the Drina River". ${ }^{858}$ In this conversation, the Accused and Krajišnik agreed upon and discussed the importance of unifying Serbs in a common state, and Krajišnik stated that they had a clear, unified vision of a "state over the state". ${ }^{859}$ At a joint meeting between the government of the SAO Krajina and the ARK Executive Council in Banja Luka on 20 October 1991, which was attended by the Accused and Krajišnik, a conclusion was reached to support and implement the objective that the Serb people would remain in a single joint state. ${ }^{8860}$ The Accused also spoke to Milošević and told him that Serbs had one third of the electorate in $\mathrm{BiH}$ and that they were "going to forcefully make some other moves and they can no longer keep up with us". ${ }^{8861}$

2648. In an intercepted conversation in January 1992, the Accused emphasised his ideology with municipal leaders and said that the policy of the SDS "is the unified Serbianhood" in $\mathrm{BiH}$ and that if anybody had a problem they could create their own party. ${ }^{8862}$ The Accused also spoke about working towards an option involving a "union of Serbian states" which would involve preparing a Serbian federation and defending "it with arms and at any cost". ${ }^{863}$ He also said that if they could not preserve Yugoslavia, the Serbs would find their own "place in the Sun" and that the "back up option" was to have all Serb territories in one state. ${ }^{8864}$ Similarly in February 1992, in the context

\footnotetext{
8856 P5877 (Intercept of conversation between Radovan Karadžić and Slobodan Milošević, 4 September 1991), pp. 1-2; P5795 (Intercept of conversation between Radovan Karadžić and Slobodan Milošević, 17 December 1991), p. 3.

8857 P5607 (Intercept of conversation between Todor Dutina, Momčilo Krajišnik and Radovan Karadžić, 30 May 1995), p. 9.

8858 P5856 (Intercept of conversation between Radovan Karadžić and Momčilo Krajišnik, 2 October 1991), p. 3.

8859 P5856 (Intercept of conversation between Radovan Karadžić and Momčilo Krajišnik, 2 October 1991), pp. 1-2.

8860 D4082 (Article from Glas entitled "Resolutely in a United State", 21 October 1991).

8861 P5822 (Intercept of conversation between Radovan Karadžić and Slobodan Milošević, 11 November 1991), pp. $1,3$.

8862 P2556 (Intercept of conversation between Radovan Karadžić and Nenad Stevandić, 11 January 1992), p. 3; P5821 (Intercept of conversation between Radovan Karadžić and Dobrica Ćosić, 11 November 1991), pp. 1-2, 9, 12. See also D300 (Article from Politika entitled "Transformation of BiH”, 17 January 1992), pp. 1-2.

8863 P5763 (Intercept of conversation between Radovan Karadžić and Dobrica Ćosić, 19 January 1992), pp. 4, 6-7; P5762 (Intercept of conversation between Radovan Karadžić and Dobrica Ćosić, 22 January 1992), p. 3.

8864 P5762 (Intercept of conversation between Radovan Karadžić and Dobrica Ćosić, 22 January 1992), pp. 7, 9-10; P5063 (Video footage depicting interview of Radovan Karadžić on "Ask the President" , undated, with transcript), pp. 5-7.
} 
of discussing their position at international negotiations, the Accused emphasised that: "Our optimum is a Greater Serbia, and if not that, then a Federal Yugoslavia" and that while they could settle for a cantonal structure he stated that " $[\mathrm{t}]$ here are no further concessions". 8865

2649. The Accused also spoke derisively of Serbs who did "not comply with the policy of the SDS, which advocates a single solution for the Serb people in Yugoslavia". ${ }^{8866}$ At a rally in February 1992, attended by Bosnian Serb leaders including Krajišnik, Plavšić, and Koljević, speeches were delivered, including by a minister from Serbia, who said that nobody had the right to separate the Serbian people from Serbia and that if the Bosnian Serbs did not get what they were asking for in $\mathrm{BiH}$ they could rely on the support of Serbia. ${ }^{8867}$

2650. On 29 February 1992, the Accused, Krajišnik, and Koljević attended the $14^{\text {th }}$ session of the ARK Assembly. ${ }^{8868}$ At the meeting, the Accused declared that if $\mathrm{BiH}$ changed its status in Yugoslavia then the Serbs would change their status as well. ${ }^{8869}$ In a March 1992 interview, the Accused stated: "I am convinced that the Serbs will never find peace until they have achieved their age-old aspiration of living in one state. Whether now or in a few years' time, I don't know. But they will achieve it." $" 8870$

\section{(2) Conclusion}

2651. Having considered the evidence above, the Chamber finds that from 1990 and into mid1991, the political objective of the Accused and the Bosnian Serb leadership was to preserve Yugoslavia and to prevent the separation or independence of $\mathrm{BiH}$, which would result in a separation of Bosnian Serbs from Serbia.

2652. The Chamber also finds that the Accused emphasised that the Bosnian Serbs did not want to be a minority in an independent $\mathrm{BiH}$ and would not accept separation from Serbia. In these speeches, the Accused also spoke about the marginalisation of the Serb people and the need to protect their interests. These speeches and statements also demonstrate that the Accused was passionate about a common Serb identity and working towards creating a unified Serbian nation, which was viewed as an age-old aspiration of all Serbs living in one state. The Accused continued to adhere to this ideology of Serb unity and the importance of creating a Serb state into 1992.

\footnotetext{
8865 P5748 (Intercept of conversation between Radovan Karadžić and Lukić, 13 February 1992), pp. 1-2.

8866 P2596 (Intercept of conversation between Radovan Karadžić and "Miroslav", 7 January 1992), p. 5.

8867 Isak Gaši, P3002 (Transcript from Prosecutor v. Krajišnik), T. 400-402, 538-539.

8868 P5452 (Extract from minutes of $14^{\text {th }}$ session of ARK Assembly, 29 February 1992), p. 1.

8869 P5452 (Extract from minutes of $14^{\text {th }}$ session of ARK Assembly, 29 February 1992), p. 2.

8870 P1940 (Interview with Radovan Karadžić from Naša Borba entitled "Yugoslavia or Three Bosnias", 16 March 1992), p. 1; KDZ310, T. 9175-9176 (29 November 2010).
} 
2653. The Chamber finds that this evidence demonstrates the central role which the Accused played in developing the ideology and role of the SDS after its formation in 1990. The Accused also promoted the SDS as the party which would address the political aspirations of Bosnian Serbs and spoke against Serbs who did not follow the policy of the SDS.

2654. In this period, the Accused also foreshadowed the prospect of civil war if the Bosnian Serbs were politically outvoted in the BiH Assembly or if Serb areas could not remain tied with Yugoslavia. He also warned that the Bosnian Serbs were prepared for such a threat of civil war and were powerful and united. It was clear that even in the speeches in which he spoke in favour of improving multi-ethnic relations and against violence, the Accused stressed that the Bosnian Serbs were ready to use violence if they considered that they had been attacked and would not co-operate with anyone seen to be against the Serbs. He also adumbrated chaos and violence if $\mathrm{BiH}$ followed the path towards independence. The Accused also spoke about alternative preparations Bosnian Serbs had made if their demands were not met, and it was clear that these alternatives envisaged violence.

(B) Identification of historic enemies

\section{(1) Analysis of evidence}

2655. At the founding assembly of the SDS in July 1990, the Accused called for the unity of the Serbs and also made reference to the genocide which had been carried out against them by their "enemies" and his opposition to a system in $\mathrm{BiH}$ "which seemed to have been established to ensure our national annihilation". ${ }^{871}$ At the founding meeting of the SDS in Brčko, the Accused delivered a speech in which he said that the "Serbian people for the first time in its history had a chance to set up its own party and that for the first time in history the Serbian people would have enough political strength to avoid the repetition of the bloody history". 8872

2656. In an interview in May 1991, the Accused stated:

We have today at play the Croat-Muslim party coalition, but we cannot be outvoted in the Assembly. The Serbs cannot allow the Muslims to declare themselves the majority people on the basis of the Ustasha genocide against the Serbs in World War II, before which the Serbs were the majority people in Bosnia. We are a state-building people even if we are just five, let alone $31 \% .^{8873}$

\footnotetext{
8871 D255 (Radovan Karadžić's speech at the constituent SDS Assembly), p. 1.

8872 Isak Gaši, T. 16621-16622, 16642-16643 (14 July 2011).

8873 D1281 (Articles from Večernje Novine entitled "Karadžić shocked me" and "Šešelj is amiable", 9 May 1991), p. 2.
} 
2657. Both Šešelj and the Accused spoke at a rally in May 1991, where Šešelj stated that in the Serbian part of $\mathrm{BiH}$, they had only one political party, the SDS, and its leadership had "saved the dignity of the all-Serbian brotherhood". ${ }^{874}$ Šešelj in this speech also spoke about the "traditional enemies" of the Serbian people and the need for Serbs to be united to prevent a "new genocide against the Serbian people". ${ }^{8875}$ He emphasised that they would avenge the current and historic Serb victims and that they would not "give an inch of the Serbian land". 8876 He also warned the Muslims not to "become a weapon of the Croatian Ustashas again" and that if they repeated history again it would be "fatal to the Muslims, because us Serbs shall no longer forget or forgive. Our revenge is going to be terrible", 8877

2658. In January 1991, at a commemoration ceremony, the Accused stated, "Serbs are the only people in the world who were persecuted and killed only because they exist. That is why we will no longer allow them to separate us and divide us in three states and gradually destroy us." ${ }^{, 878} \mathrm{He}$ also assured the population that the Bosnian Serb leadership would "not let you be slaughtered like in 1941". 8879 The Accused told Koljević in June 1991 that he had told Izetbegović that "nobody can form a state on a territory where there was genocide". ${ }^{8800}$ At a meeting with Bosnian Serb representatives on 10 June 1992, the Accused stated that the plan was to empty BiH of Serbs and that Bosnian Serbs should persist and defend their borders against attacks but not attack themselves. $^{8881}$

2659. The Accused in his speeches before the Bosnian Serb Assembly repeatedly referred to the threat faced by the Serb people and the historic threats they faced dating back to World War II and the need to protect themselves from their "enemies". 8882 In June 1992, the Accused signed the

\footnotetext{
8874 P2527 (Video footage of speeches of Vojislav Šešelj and Radovan Karadžić, 6 May 1991, with transcript), pp. 1-2. See also D1281 (Articles from Večernje Novine entitled "Karadžić shocked me" and "Šešelj is amiable", 9 May 1991), p. 1; D3665 (Witness statement of Vojislav Šešelj dated 1 June 2013), paras. 36-37.

8875

8881 P1478 (Ratko Mladić's notebook, 27 May-31 July 1992), pp. 132-133.

8882 P1343 (Transcript of $1^{\text {st }}$ session of SerBiH Assembly, 24 October 1991), pp. 56-60 (wherein the Accused spoke about the international Catholic and Islamic objective to "drive the Orthodox Slavs from the Mediterranean"). See also D86 (Shorthand Record of $4^{\text {th }}$ session of SerBiH Assembly, 21 December 1991), pp. 37, 42; D88 (Shorthand Record of $8^{\text {th }}$ session of SerBiH Assembly, 25 February 1992), pp. 16-17; P956 (Transcript of $16^{\text {th }}$ session of SerBiH Assembly, 12 May 1992), e-court p. 4; P1367 (Transcript of $26^{\text {th }}$ session of RS Assembly, 2 April 1993), pp. 3, 8; P1379 (Transcript of $34^{\text {th }}$ session of RS Assembly, 27-29 August, 9-11 September, 29 September to 1 October 1993), pp. 9, 11; P5492 (Record of speech by Radovan Karadžić, 9 January 1994), pp. P6391 (Excerpts from Vojislav Šešelj's speech).

P6389 (Vojislav Šešelj's interview with Pogledi, 31 May 1991), p. 2.

P1939 (Article from Javnost, entitled "Mind for the Souls of the Innocents", 26 January 1991).

P6540 (Excerpt of video from Banja Luka, 3 March 1991, with transcript), p. 3.

P5683 (Intercepts of conversations between (i) Radovan Karadžić and Slobodan Milošević and (ii) Radovan Karadžić and Nikola Koljević, 4 June 1991), p. 4.
} 
"political platform for the survival of the Serbian people in $\mathrm{BiH}^{\circ}$ which noted that a war to extinction had been imposed on the Serbs. ${ }^{883}$ This platform called for the Bosnian Muslims to end the war and negotiate and claimed that both Muslims and Serbs had a right to stay in the country. ${ }^{884}$ The Accused continued to make speeches which emphasised the historic suffering and victimisation of the Serbs. ${ }^{8885}$ For example, in September 1992, the Accused spoke about the continuation of the fascist policy of World War II in which one third of Serbs were to be expelled, one third converted to Catholicism, and one third were to be killed. ${ }^{886}$

2660. These constant references to World War II and the historic suffering and grievances of the Serbian people polarised the population in $\mathrm{BiH}$ and incited inter-ethnic hatred. ${ }^{8877}$ The media was also used as a propaganda tool to emphasise the historic suffering of the Serb people and to encourage people to fight for their "motherland" so that all Serbs would be together. ${ }^{888}$ In August 1992, VJ General Panić told Mladić that there should be "propagators among ordinary people", that is a person in every region instructed to say one thing but do another. ${ }^{8899}$ At a meeting with Sarajevo municipality presidents and commanders of SRK units on 14 January 1994, the Accused suggested to "give a little more thought to the propaganda war" and to create a small propaganda staff. $^{8890}$

2661. These messages of suspicion and hatred were also reflected at a municipal level where messages were broadcast on the radio in the lead-up to the conflict to the effect that "the time had come for the Serbs to settle accounts with the balijas once and for all, and that the Serbs would no longer allow their ribs to be broken. They will no longer allow their children to be circumcised". 8891

2662. International observers such as Okun noted the constant references to, and intensity with which the Accused spoke about, the genocide committed against the Serbs and warned him that if

3, 5; Milorad Dodik, T. 36896-36897 (9 April 2013); P6487 (Declaration of SDS Executive Board, undated); P6688 (Interview with Radovan Karadžić in Duga Magazine, 23 May 1992), pp. 1-2.

8883 D4686 (Article from SRNA entitled "Political platform for the survival of the Serbian People in BiH", 12 June 1992), p. 1.

8884 D4686 (Article from SRNA entitled "Political platform for the survival of the Serbian People in BiH", 12 June 1992), p. 4.

8885 See, e.g., D115 (Transcript of $25^{\text {th }}$ session of RS Assembly, 19-20 January 1993), pp. 3, 8.

8886 P809 (Video footage of Radovan Karadžić's Press Conference at ICFY, 18 September 1992, with transcript), pp. 1-2.

8887 KDZ310, T. 9170-9174 (29 November 2010); P3634 (Witness statement of KDZ490, undated) (under seal), p. 14.

8888 KDZ310, T. 9188-9189 (29 November 2010); KDZ240, P2935 (Transcript from Prosecutor v. Krajišnik), T. 6812-6813, 6913 (under seal); KDZ240, T. 16084 (5 July 2011) (closed session).

8889 P1479 (Ratko Mladić's notebook, 16 July-9 September 1992), pp. 29, 38.

8890 P1484 (Ratko Mladić's notebook, 28 October 1993-15 January 1994), pp. 133, 148-149. 
he kept "talking about the genocide of the Serbs so much, you will commit a pre-emptive genocide". ${ }^{8892}$ Okun made this statement to the Accused to express his shock at the argument that the genocide committed during World War II "justified all of Bosnian Serb behaviour". ${ }^{8893}$ Mladić in meeting with international representatives also spoke about the genocide committed against Serbs in World War II in areas including Srebrenica and Sarajevo. ${ }^{8894}$

2663. Other Bosnian Serb leaders including Biljana Plavšić, ${ }^{8895}$ Nikola Koljević, ${ }^{8896}$ and Momčilo Krajišnik $^{8897}$ delivered speeches about the historical and contemporary threats faced by Serbs, the importance of all Serbs living in one state, and the political decisions made by Muslim and Croat representatives which made it impossible to live together. This sentiment was also reflected in political rallies attended by other Bosnian Serb leaders; for example at a rally in Banja Luka in November 1991, Predrag Radić stated "[t]wice they slaughtered us. We have forgiven but not forgotten. If they try to do the same for the third time, we shall neither forgive nor forget, regardless of how non-Christian it may be" ${ }^{8898}$ At this same rally Krajišnik spoke about not allowing the "dark forces" to "destroy our common fatherland, to tear us into pieces". 8899 The Accused spoke and said that by voting to remain in a federal state "with all the Serbian lands and those who wish to stay with us, we hope to, once and for all, put a circle by state where there will be no traitors, a state that will not fall apart every 20 years or so". 8900

2664. In January 1993, other deputies such as Vlado Kovačević spoke in the Bosnian Serb Assembly about the threat faced by the Serb people, and described the Islamic and Catholic threat

8891 KDZ239, T. 18929 (15 September 2011). See para. 852.

8892 Herbert Okun, P776 (Transcript from Prosecutor v. Krajišnik), T. 4156, 4164-4165; Herbert Okun, T. 14891491 (22 April 2010); P779 (Sixth notebook of Herbert Okun's Vance Mission Diary), e-court p. 43 ; P778 (Fifth notebook of Herbert Okun's Vance Mission Diary), e-court p. 41.

8893

8894 P1347 (Shorthand record of $5^{\text {th }}$ session of SerBiH Assembly, 9 January 1992), pp. 51, 56-57; P1353 (Shorthand record of $10^{\text {th }}$ session of SerBiH Assembly, 11 March 1992), pp. 11, 13-14; Vitomir Žepinić, T. 33594-33595 (13 February 2013).

8897 D88 (Shorthand Record of $8^{\text {th }}$ session of SerBiH Assembly, 25 February 1992), pp. 30-31, 62, 64; P1353 (Shorthand record of $10^{\text {th }}$ session of SerBiH Assembly, 11 March 1992), pp. 15-16. See also P6306 (Letter from Momčilo Krajišnik to Government of SAO Krajina, 19 December 1991) (where Krajišnik wrote about the historical right of the Serbian people to live in one state); P6308 (Letters from Milan Martić to Radovan Karadžić, Momčilo Krajišnik, Slobodan Milošević, Jovica Stanišić, and Momčilo Perišić), pp. 1-5; P2448 (Excerpt of video depicting speech of Velibor Ostojić, with transcript).

8898 P13 (TV footage of plebiscite rally held in Banja Luka, with transcript), p. 1; Predrag Radić, P1 (Transcript from Prosecutor v. Krajišnik), T. 7370-7371, 7377-7378.

8899 P13 (TV footage of plebiscite rally held in Banja Luka, with transcript), p. 1; Predrag Radić, P1 (Transcript from Prosecutor v. Krajišnik), T. 7377-7378.

8900 P13 (TV footage of plebiscite rally held in Banja Luka, with transcript), p. 1; Predrag Radić, P1 (Transcript from Prosecutor v. Krajišnik), T. 7377-7378. 
as a "two-headed dragon" which wanted to destroy the Serb people and that Europe wanted to push them into being "imprisoned in the dark realm of Islam". 8901 Krajišnik thanked Kovačević for his speech and praised him, saying "you are the best when we have opponents". ${ }^{8902}$ Krajišnik went on to say that the Bosnian Muslims were not a nation or a people and called on the Bosnian Serb Assembly to take a position that Muslims were a group of unbelievers, a sect, "a communist creation and that they are a religious group of Turkish orientation". ${ }^{8903}$ Krajišnik also spoke about the need to "take the Muslims out of Serbism for ever". ${ }^{8904}$ Šešelj also did not recognise the Bosnian Muslims as a people but described them as "Muslim Serbs" and stated that there was no such thing as a Bosnian language and that the Croatian nation was an "artificial nation under the direct patronage of the Catholic church". 8905

2665. In addition to historic crimes committed against Serbs, there were also references made to the killing of Bosnian Serbs during the conflict. For example, when 29 Bosnian Serb soldiers were killed by $\mathrm{ABiH}$ forces, the funeral was held on 30 September 1992 at the Orthodox church in Vlasenica. ${ }^{8906}$ Over 1,000 people attended the funeral, including the Bosnian Serb leadership from Pale that consisted of the Accused, Ostojić, Koljević, and Svetozar Andrić. ${ }^{8907}$ The Accused and others gave speeches at the funeral and the speakers and the crowd "were very agitated and embittered" by the death of the Bosnian Serb soldiers. ${ }^{8908}$ The Accused delivered a speech in which he said:

Nor must we forget their executioners and attackers. I do not know if I am allowed to say that we must not forgive either. Who knows how many times this century our brothers, who are no brothers at all, have been at our throats. They assault our good men. But the Lords sees that and has given us strength to resist [...] I will keep telling the international powers that Serbs do not persecute anyone, that Serbs only defend their homes. And if they do not want to believe, it's up to them. The God believes, and he turned his face to us, and He will help us get out of the darkness of slavery, fears, lies, pretence, and to become what every nation in the world deserves. ${ }^{8909}$

\footnotetext{
$8901 \quad$ P921 (Transcript of $24^{\text {th }}$ session of RS Assembly, 8 January 1993), p. 38.

8902 P921 (Transcript of $24^{\text {th }}$ session of RS Assembly, 8 January 1993), p. 39.

8903 P921 (Transcript of $24^{\text {th }}$ session of RS Assembly, 8 January 1993), pp. 95-97. This conclusion about the status of the Bosnian Muslims was accepted unanimously.

8904 P921 (Transcript of $24^{\text {th }}$ session of RS Assembly, 8 January 1993), p. 96.

8905 D3665 (Witness statement of Vojislav Šešelj dated 1 June 2013), para. 15; Vojislav Šešelj, T. 39546-39548 (7 June 2013), T. 39558-39559 (10 June 2013); D3667 (Transcript of Vojislav Šešelj's press conference, 26 March-16 April 1992), p. 20. See also Herbert Okun, T. 1774-1775 (28 April 2010); D119 (Radovan Karadžić's speech re cessation of hostilities, May 1992), p. 2.

8906 P3227 (Witness statement of KDZ033 dated 7 April 2010), para. 121 (under seal).

8907 P3227 (Witness statement of KDZ033 dated 7 April 2010), para. 121 (under seal).

8908 P3227 (Witness statement of KDZ033 dated 7 April 2010), paras. 122, 124-125 (under seal).

8909 P3261 (Excerpt of video footage of Radovan Karadžić's speech, with transcript); P3227 (Witness statement of KDZ033 dated 7 April 2010), paras. 123, 125 (under seal); KDZ033, T. 18110-18114 (31 August 2011) (closed session).
} 
These speeches created a feeling that the Bosnian Serbs would be pardoned for whatever they did and created a fear that Bosnian Muslims who remained in Vlasenica would be killed. ${ }^{8910}$ The Chamber recalls its finding that following this funeral, approximately 140 detainees were taken from Sušica camp and killed by Serb Forces. ${ }^{8911}$ The Accused also gave an interview on the day of the funeral and said: "We are concerned about Muslims, we want them to have their own territory. Since we wanted to separate from them, since we see that we can't live together any longer. But, if they do not proclaim a realistic objective concerning territories, they may lose everything." 8912

2666. Such speeches were in contrast to statements the Accused made to international representatives. For example, in a meeting with General Morillon in February 1993, the Accused claimed that their army had discovered a mass grave containing more than 50 bodies in the recaptured territory south of Zvornik and that General Milovanović had requested that he not release this information as it would "inflame the local Serb population in the area" 8913

2667. At a meeting of Serb representatives on 8 January 1993 in Belgrade with the Accused in attendance, Vladislav Jovanović, who was the foreign minister of Serbia, stated that the destruction of the Serb people was a necessary condition of the plan to divide the FRY. ${ }^{8914}$

2668. In May 1993, the Accused described the situation as a "conflict between us and the greatest enemy". 8915 He also spoke of the Serbs' neighbours as those who "every 20 years, turn into our executioners". ${ }^{8916}$ In September 1993, the Accused said "[w]ho knows when we will settle our relations with Moslems? Most probably never if the fundamentalists keep coming from the East

8910 P3227 (Witness statement of KDZ033 dated 7 April 2010), paras. 122-123 (under seal). See also KDZ033, T. 18114 (31 August 2011) (closed session). But see D2932 (Witness statement of Tomislav Savkić dated 11 February 2013), para. 98 (stating that the Accused's speech did not incite anyone to hate or take revenge but seeing the bodies themselves would have created hatred and a desire for revenge). However, the Chamber notes that Savkić's evidence was marked by multiple contradictions and indicators that he was not forthright in his testimony and therefore does not rely on his evidence in this regard. In addition the Chamber has had regard to the text of the speech itself, and Savkić's evidence is in direct contradiction to the content of that speech.

8911 See Scheduled Incident B.18.2.

8912 P3230 (Video footage re excerpt of interview with Radovan Karadžić, with transcript); KDZ033, T. 1802318024 (29 August 2011) (closed session).

8913 P4228 (UNPROFOR report re meeting with Radovan Karadzic and Alija Izetbegović, 16 February 1993), p. 2; P4203 (Witness statement of Pyers Tucker dated 12 May 2010), para. 135.

8914 P1482 (Ratko Mladić's notebook, 2-28 January 1993), p. 40.

8915 P1373 (Transcript of $31^{\text {st }}$ session of RS Assembly, 9 May 1993), p. 18. See also P1379 (Transcript of $34^{\text {th }}$ session of RS Assembly, 27-29 August, 9-11 September, 29 September to 1 October 1993), pp. 9, 11 (where the Accused spoke about their "biggest enemy, our annihilators"). Other deputies spoke about the need to distance themselves from their "blood enemies". P1373 (Transcript of $31^{\text {st }}$ session of RS Assembly, 9 May 1993), p. 21.

8916 P939 (Video footage of Radovan Karadžić's speech at the $21^{\text {st }}$ session of RS Assembly, 30 October 1992, with transcript), p. 2. 
[...]. Under this kind of circumstances we must have a different kind of the Army". ${ }^{8917}$ He spoke about recognising the "ancient danger posed by the toxic, all-destructive Islamic octopus" which was "constant in its irreconcilable poisonousness towards the Serbian Orthodox being". 8918

2669. At a symposium of the VRS held on 15 January 1994, in the presence of the Accused, Mladić opened his speech with: "For three years now our people have been shedding blood, defending their country and infants from Ustasha and Islamic hordes which have, for decades, in secret and from within the bosom of our people, been preparing its extermination". 8919

\section{(2) $\underline{\text { Conclusion }}$}

2670. The evidence above demonstrates that the Accused and the Bosnian Serb leadership in their speeches repeatedly and consistently referred to the historic grievances of the Serb people and the crimes which were committed against them by Muslims and Croats. The Chamber finds that these speeches were used by the Accused and the Bosnian Serb leadership to remind the Bosnian Serb population about crimes committed against Serbs and emphasised the need to ensure they would not be repeated. In order to convey this message the Accused and the Bosnian Serb leadership often portrayed the Muslims and Croats as the historic enemies of the Serbs and stressed the importance of recognising this fact for the future survival of the Serb people. The Accused also used these historic references to emphasise the important role of the SDS in protecting the Serbs.

2671. The Accused also often referred to the genocide committed against Serbs during World War II which made them a minority in $\mathrm{BiH}$ and asserted that they could not allow the Bosnian Muslims to declare themselves a majority people in $\mathrm{BiH}$ on this basis. The references to the genocide committed against the Serbs was also used as justification for renewing the historical claims to land in $\mathrm{BiH}$ where they had once been a majority. ${ }^{8920}$ The Chamber finds that speeches and messages of this nature were delivered by the Accused and the Bosnian Serb leadership from as early as 1990 and continued throughout the conflict in $\mathrm{BiH}$.

2672. As these speeches demonstrate, the reference to the historical threats faced by the Serbs was used by the Accused to justify his position that the Serbs would not allow themselves to be separated or outvoted in $\mathrm{BiH}$. It was also used to promote the idea that the Bosnian Serbs could not live together with the Bosnian Muslims and Bosnian Croats and formed the foundation for the

\footnotetext{
8917 P1379 (Transcript of 34 ${ }^{\text {th }}$ session of RS Assembly, 27-29 August, 9-11 September, 29 September to 1 October 1993), pp. 427-428.

8918 P5492 (Record of speech by Radovan Karadžić, 9 January 1994), p. 6.

8919 P1484 (Ratko Mladić's notebook, 28 October 1993-15 January 1994), p. 150.

8920 See para. 55.
} 
separation of the three people and the creation of an ethnically homogeneous Serb state. The Chamber also finds that this rhetoric, which was amplified by the media, had the effect of adding to ethnic divisions and tension in $\mathrm{BiH}$ and incited inter-ethnic hatred. The Chamber further finds that it encouraged Serbs to fight for what was portrayed as their survival and to fight for the creation of a state were all Serbs would be united.

2673. These speeches also demonstrate that the Bosnian Serb leadership went so far as to suggest that the Bosnian Muslims were not a nation or a people at all and that Islam posed a threat to the Bosnian Serbs.

(C) Reaction to proposed independence of $\mathrm{BiH}$

(1) Analysis of evidence

2674. The Chamber took judicial notice that a confidential SDS document, dated 23 February 1991, considered specific actions to be taken should $\mathrm{BiH}$ move towards independence. $^{8921}$ This document provided that in this situation, municipal authorities were to ensure that only Yugoslav (federal) law would apply, suspending the implementation of republican regulations and thus creating a foundation for direct communication and co-operation between the municipalities and Yugoslavia and its organs. It also provided for the engagement of the JNA and the Federal Secretariat for National Defence. ${ }^{8922}$ This policy was adopted by the SDS Deputies' Club, the parliamentary caucus of the party, and was made public in a document dated 10 June 1991. ${ }^{8923}$ This document indicated the opposition of the Serbian deputies to unilateral action which would break up Yugoslavia. ${ }^{8924}$ They also expressed their opposition to the separation of the Bosnian Serbs from Yugoslavia. ${ }^{8925}$ At a meeting of the SDS Deputies' Club on 30 September 1991, the Accused stated: "We are politically most numerous in Yugoslavia and Bosnia. Nothing can be done in BiH without the Serbs and their will". ${ }^{8926}$

2675. The Chamber recalls that in October 1991, the coalition government in SRBiH broke down and during the night of 14 to 15 October 1991, the Accused addressed the SRBiH Assembly, stressing that the proposed secession of $\mathrm{BiH}$ from Yugoslavia was unconstitutional and was against

\footnotetext{
$8921 \quad$ See Adjudicated Fact 1917.

8922 See Adjudicated Fact 1918.

8923 Adjudicated Fact 1919.

8924 D4654 (Report of SDS Deputies Club, 10 June 1991), p. 2.

8925 D4654 (Report of SDS Deputies Club, 10 June 1991), pp. 4-5.

8926 P2543 (Minutes of meeting of SDS deputies' club, 30 September 1991).
} 
the will of the Bosnian Serb people. ${ }^{8927}$ While the Accused professed that he was not acting like the "God of war", he emphasised that the Serb people wanted to live in Yugoslavia and that if the same situation developed in $\mathrm{BiH}$ as it did in Slovenia and Croatia, "the hell would be one thousand times worse". ${ }^{828}$ He also stated that while he was not threatening the Bosnian Muslims, he was asking them one more time to take seriously the will of the Serbian people. He finished with a warning that " $[\mathrm{t}]$ his is the road that you want $[\mathrm{BiH}]$ to take, the same highway of hell and suffering that Slovenia and Croatia went through. Don't think you won't take $[\mathrm{BiH}]$ to hell and Muslim people in possible extinction. Because, Muslim people will not be able to defend itself if it comes to war here!". ${ }^{8929}$ Given that these speeches were broadcast, the sentiments and particularly the suggestion that a people would disappear created fear among the Bosnian Muslim population. ${ }^{8930}$

2676. This statement was greeted with a loud reaction from the $\mathrm{BiH}$ assembly to which the Accused responded "I know these are serious words. Serious situations call for serious words. How will you prevent that everybody start killing everybody in $[\mathrm{BiH}]$ " and he concluded that he wanted them to take the matter of the independence of $\mathrm{BiH}$ off the agenda. ${ }^{8931}$

2677. This was not the only occasion on which the Accused spoke in these terms about the inability of the Bosnian Muslims to survive if they insisted on independence which would lead to civil war. On 4 September 1991, he told Krajišnik: "We'll make our point, you see, that's where it leads, where your policies lead!!! [...] Do you realise that you will disappear in all this?! [...] Man, you will disappear. Many of us will also disappear, but you will be annihilated!". 8932 In response,

8927 See paras. 44, 47; D267 (Video footage of Radovan Karadžić's speech at the $8^{\text {th }}$ session of SR BiH Assembly, 15 October 1991, with transcript), pp. 1-2. See also Herbert Okun, P776 (Transcript from Prosecutor v. Krajišnik), T. 4163; D270 (Intercept of conversation between Radovan Karadžić and Vitomir Žepinić, 17 June 1991), pp. 8-9; Milorad Dodik, T. 36839-36840 (9 April 2013); P5843 (Intercept of conversation between Radovan Karadžić and Borisav Jović, 15 October 1991), pp. 2-3; P5842 (Intercept of conversation between Radovan Karadžić and Vukić, 15 October 1991).

8928 D267 (Video footage of Radovan Karadžić's speech at the $8^{\text {th }}$ session of SRBiH Assembly, 15 October 1991 , with transcript), pp. 2-3. See also Herbert Okun, T. 1626 (26 April 2010), T. 1669 (27 April 2010).

8929 D267 (Video footage of Radovan Karadžić's speech at the $8^{\text {th }}$ session of SRBiH Assembly, 15 October 1991 , with transcript), pp. 3-4. See also Eset Muračević, T. 12673-12674 (1 March 2011); Robert Donia, T. 31013105 (1 June 2010); P3405 (Witness statement of KDZ051 dated 17 September 2011), para. 96; KDZ310, T. 9176, 9186, 9191-9192 (29 November 2010).

8930 Izet Redžić, P3189 (Transcript from Prosecutor v. Krajišnik), T. 5022-5023; KDZ026, P2089 (Transcript from Prosecutor v. Stakić), T. 1993-1994 (under seal); KDZ026, T. 10414-10415 (18 January 2011) (closed session). See also KDZ029, T. 17613-17614 (22 August 2011) (closed session); Ramiz Mujkić, T. 12458 (25 February 2011); Mirsad Mujadžić, P3703 (Transcript from Prosecutor v. Stakić), T. 3648-3650; P3707 (Video footage of Radovan Karadžić's speech, with transcript), p. 4.

8931 D267 (Video footage of Radovan Karadžić's speech at the $8^{\text {th }}$ session of SRBiH Assembly, 15 October 1991 , with transcript), p. 4. See also Vitomir Žepinić, T. 33655 (14 February 2013).

8932 P3200 (Intercept of conversation between Radovan Karadžić and Momčilo Krajišnik, 4 September 1991), p. 2. See also P5862 (Intercept of conversation between Radovan Karadžić and Nikola Koljević, 22 September 1991), p. 2. 
Krajišnik suggested that they should deliberately say that both sides would disappear and the Accused agreed. ${ }^{8933}$

2678. The Accused made a similar observation in an intercepted conversation on 12 October 1991 where he said that if the Bosnian Muslims started a war "they should be thrashed" and that they would "disappear, that people will disappear from the face of the earth [...], if they start now. Our offer was their only chance". ${ }^{8934}$ The Accused continued and said that they did not understand that they would be "up to their necks in blood and that the Muslim people would disappear, the poor Muslims would disappear, who don't know where he is taking them" and that it would be a "real bloodbath". ${ }^{8935}$ In a similar vein in another conversation on the same day, the Accused repeated that the "Muslims know what it is, it is hell in which five-six hundreds of thousands of them will disappear, they will disappear". 8936

2679. The Accused echoed this sentiment in an intercepted conversation with Mandić on 13 October 1991 in which he also referred to what happened in Croatia. The Accused said that what would happen had nothing to do with his decision or anyone else's decision but they knew what was going to happen in $\mathrm{BiH}$ and that "[i]n just a couple of days, Sarajevo will be gone and there will be five hundred thousand dead, in one month Muslims will be annihilated in BiH". 8937

2680. In a telephone conversation on 15 October 1991, the Accused spoke about the attempt to create an independent $\mathrm{BiH}$, and said '[t]welve percent of Serbs made hell in Croatia, they didn't allow an Ustasha state to be introduced into their homes, and these here are trying to do this with thirty-five percent" and further stated: "[t]hat would mean war until their extinction. [...] The Serbs would never forgive them such a thing, it would destroy them completely. First, none of their leaders would survive, they'd all be killed in three to four hours. They'd stand no chance of surviving whatsoever". 8938

2681. The Accused also warned Izetbegović that if the Bosnian Muslims proceeded with a constitution and referendum for $\mathrm{BiH}$, the Serbs would not be able to recognise $\mathrm{BiH}$ since "events will overrun you" and that he would not be able to hold back the "extremists" who he had until then

\footnotetext{
8933 P3200 (Intercept of conversation between Radovan Karadžić and Momčilo Krajišnik, 4 September 1991), p. 2.

8934 D279 (Intercept of conversation between Radovan Karadžić and Gojko Đogo, 12 October 1991), pp. 3, 7.

8935 D279 (Intercept of conversation between Radovan Karadžić and Gojko Đogo, 12 October 1991), pp. 8-9. See also P5063 (Video footage depicting interview of Radovan Karadžić on "Ask the President", undated, with transcript), pp. 17-18.

8936 P5846 (Intercept of conversation between Radovan Karadžić and an unidentified male, 12 October 1991), p. 3. For further analysis of this speech, see Section IV.A.2.b.v: Genocide.

8937 D377 (Intercept of conversation between Radovan Karadžić and Momčilo Mandić, 13 October 1991), p. 2.

8938 P2540 (Intercept of conversation between Radovan Karadžić and Miodrag Davidović, 15 October 1991), pp. 56. See also Patrick Treanor, T. 14005-14006 (1 June 2011).
} 
restrained with "all [his] might". ${ }^{8939}$ In October 1991, the Accused told Milošević that the solution Izetbegović was pursuing could "trigger a long-lasting civil war" and that the Bosnian Serbs would not accept the $\mathrm{BiH}$ authorities "in 40 municipalities and all forces would be turned towards opposing this"; in short, the situation would be even worse than in Croatia. ${ }^{8940}$ Milošević responded that it would be better than in Croatia because the balance of forces was "vastly more favourable". 8941

2682. The Chamber recalls that after the SRBiH Assembly was adjourned on 15 October 1991 and the Bosnian Serb delegates walked out, the HDZ and SDA delegates reconvened without the Serb delegates and passed a declaration of sovereignty. ${ }^{8942}$ The SDS Political Council then met to assess the situation. ${ }^{8943}$ At this meeting it was noted that the Serbs had to "shed the illusion that a form of coexistence with the Muslims and Croats can be found". ${ }^{8944}$ The SDS leadership demanded that the declaration of sovereignty be repealed before 24 October $1991 .^{8945}$ The SDS position was that unless the declaration of sovereignty was withdrawn within seven days, the SDS would instruct its members to leave governmental institutions and start creating parallel institutions. ${ }^{8946}$ The Bosnian Serb leadership also objected to earlier violations by the Bosnian Muslims of the inter-party agreement on the sharing of power in $\mathrm{BiH} .{ }^{8947}$

2683. On 24 October 1991 the Accused complained to Slobodan Milošević about the steps which had been taken by Izetbegović towards the independence of $\mathrm{BiH}^{8948}$ The Accused indicated that they had given Izetbegović a deadline to abolish the decisions taken with respect to the independence of $\mathrm{BiH}$, but Izetbegović did not intend to abolish them. ${ }^{8949}$ The Accused explained that they would "respond with all means possible" and that they would "establish Yugoslavia in all the areas where we live". 8950 He continued and told Milošević that the Bosnian Muslims wanted "Europe, to give them a state in which we would be locked within these borders by international agreements, we can't allow that, we have to [...] prepare everything, and we have prepared

\footnotetext{
8939 P5877 (Intercept of conversation between Radovan Karadžić and Slobodan Milošević, 4 September 1991 ), p. 6.

8940 P5832 (Intercept of conversation between Radovan Karadžić and Slobodan Milošević, 29 October 1991), pp. 89.

8941 P5832 (Intercept of conversation between Radovan Karadžić and Slobodan Milošević, 29 October 1991), p. 9.

8942 See paras. 46, 76.

8943 See para. 76; Adjudicated Fact 1937; D294 (Minutes of SDS Council meeting, 15 October 1991); Robert Donia, T. 3107 (1 June 2010).

8944 D294 (Minutes of SDS Council meeting, 15 October 1991), p. 1.

8945 See para. 46.

8946 D294 (Minutes of SDS Council meeting, 15 October 1991), p. 1.

8947 Momčilo Mandić, T. 4750-4751 (6 July 2010); P1079 (Intercept of conversation between Radovan Karadžić and Momčilo Mandić, 22 July 1991), p. 4.

8948 P2546 (Intercept of conversation between Radovan Karadžić and Slobodan Milošević, 24 October 1991), p. 1.

8949 P2546 (Intercept of conversation between Radovan Karadžić and Slobodan Milošević, 24 October 1991), p. 1.
} 
everything to create a de facto situation [...] which they will break their teeth on, they simply have to break them, there is no way we will live in a country with them. No, no way at all, that's it". ${ }^{8951}$

2684. Slobodan Milošević encouraged the Accused to speak to Izetbegović to explain the position of the Bosnian Serbs but the Accused responded that Izetbegović was a religious fanatic who could not be talked to. ${ }^{8952}$ When Milošević asked whether he should speak to Izetbegović, the Accused responded that he could tell Izetbegović that "Karadžić and the others will not give up on establishing an Assembly and parallel organs of authority" and that the "Serbian Assembly" would decide on what was to be respected and not. ${ }^{8953}$ The Accused also suggested that Milošević tell Izetbegović "that the Serbs are moving on [...] that you can't exert influence over us to mellow things down. We are moving on. We will establish full authority over the Serbian territories in BiH [...]. He will not be able to exercise power. He will not have control over $65 \%$ of his territory. That is our goal". ${ }^{8954}$

2685. Milošević questioned whether it was wise to use "an illegitimate act in response to another illegitimate act" and questioned the legality of forming a Bosnian Serb Assembly. However, the Accused dismissed this and stressed the illegality of the measures taken by the Bosnian Muslims and the importance of the Bosnian Serb interests. ${ }^{8955}$ The Accused emphasised that they held power in 37 municipalities and had relative majority in about ten municipalities and that they would not implement "any of their decisions" given that they were leading them to secession from Yugoslavia. ${ }^{8956}$

2686. Milošević also suggested that they should not announce the Bosnian Serb Assembly but the Accused responded "[b]ut we have to announce it! There can be no discussion about it, this is an obligation of the Serbian people and the representatives of the Serbian people in [the] executive, because they will start arresting us, they'll start pacifying municipalities forcibly, forcibly, installing special forces, we will not allow that". ${ }^{8957}$ When Slobodan Milošević suggested that the

\footnotetext{
8950 P2546 (Intercept of conversation between Radovan Karadžić and Slobodan Milošević, 24 October 1991), p. 1.

8951 P2546 (Intercept of conversation between Radovan Karadžić and Slobodan Milošević, 24 October 1991), p. 1.

8952 P2546 (Intercept of conversation between Radovan Karadžić and Slobodan Milošević, 24 October 1991), pp. 1$2,6$.

8953 P2546 (Intercept of conversation between Radovan Karadžić and Slobodan Milošević, 24 October 1991), p. 6.

8954 P2546 (Intercept of conversation between Radovan Karadžić and Slobodan Milošević, 24 October 1991), p. 7. See also P5620 (Intercept of conversation between Radovan Karadžić and an unidentified male, 21 January 1992), pp. 2-4; P5621 (Intercept of conversation between Radovan Karadžić and Dobrica Ćosić, 25 January 1992), p. 8.

8955 P2546 (Intercept of conversation between Radovan Karadžić and Slobodan Milošević, 24 October 1991), pp. $4-$ 5.

8956 P2546 (Intercept of conversation between Radovan Karadžić and Slobodan Milošević, 24 October 1991), p. 5.

8957 P2546 (Intercept of conversation between Radovan Karadžić and Slobodan Milošević, 24 October 1991), pp. 56.
} 
Accused not call it an assembly, the Accused insisted: "No [...] we can't do that to the people. The people $[. .$.$] feel they have been robbed and destroyed". 8958$

2687. In this same conversation Slobodan Milošević expressed his reservations about how a Bosnian Serb Assembly could exclude the Muslims who were "for Yugoslavia", but the Accused replied: “There are none, President! Not even $10 \%$ [...] we can't take a risk for those $10 \%$ ! That's out of the question! The Serbian people want a clear situation. We cannot go on pretending anymore. They've destroyed us, we have to respond. We can't just mobilise the people for nothing". 8959

2688. The Accused also stated that "the army can no longer agree to cease-fires, it is out of the question. Tuđman has to be militarily crushed, the military might of Croatia has to be destroyed. I guarantee you that after Friday 500,000 Serbs must rise again, there can be no more discussion about it, this is destroying, exhausting, crippling, dragging us into the winter and we will all be ruined". 8960 When Slobodan Milošević suggested a more considered approach without getting excited, the Accused replied: "No, we're not excited at all. Our steps are calculated and we have to establish authority and control over our territories, so that he doesn't get his sovereign Bosnia. Croatia doesn't have control over $30 \%$ of its territory, and Bosnia will not have control over $60 \%$ of its territory!". 8961

2689. Despite these words of caution, Slobodan Milošević, in meetings with international representatives, did not accept the independence of $\mathrm{BiH}$ and spoke of the desire of all Serbian people to live together. ${ }^{8962}$ In September 1991, Milošević told the Accused that they should "get mobilised, acquire the arms and get going". ${ }^{8963}$ In November 1991, when the Accused informed Milošević that Izetbegović did not want BiH to be in Yugoslavia, Milošević asked him to "take care of this and nothing else". ${ }^{8964}$ The Accused responded that he would but that they should "prepare a

8958 P2546 (Intercept of conversation between Radovan Karadžić and Slobodan Milošević, 24 October 1991), p. 6. See also P5817 (Intercept of conversation between Radovan Karadžić and Božidar Vučurović, 14 November 1991), p. 2 (in which the Accused said that if he stood up in the Assembly and said that they accepted the independence and sovereignty of $\mathrm{BiH}$, the people would reject it and take up arms including against him). This conversation was referred to by the Accused in his final brief. Defence Final Brief, para. 266. The Chamber finds that in light of the weight of evidence, the Accused's observation was purely rhetorical and he had no intention of acknowledging the independence of $\mathrm{BiH}$ P2546 (Intercept of conversation between Radovan Karadžić and Slobodan Milošević, 24 October 1991), p. 7. P2546 (Intercept of conversation between Radovan Karadžić and Slobodan Milošević, 24 October 1991), p. 2. P2546 (Intercept of conversation between Radovan Karadžić and Slobodan Milošević, 24 October 1991), pp. 7 8.

8962 KDZ240, P2935 (Transcript from Prosecutor v. Krajišnik), T. 6747 (under seal).

8963 P5861 (Intercept of conversation between Radovan Karadžić and Slobodan Milošević, 23 September 1991), p. 5.

8964 P5897 (Intercept of conversation between Radovan Karadžić and Slobodan Milošević, 14 November 1991), p. 3. 
reserve variant" because he did not "know what will it be like tomorrow". ${ }^{8965}$ In a conversation with General Uzelac on 2 November 1991, the Accused discussed the mobilisation of the Serb population in $\mathrm{BiH}$, stating "I'll call all the presidents of the municipalities [...] to deploy the army". 8966

2690. The Chamber recalls that a plebiscite was held in November 1991 to determine whether Serbs in BiH wished to remain in a joint state of Yugoslavia, and the overwhelming majority voted in favour. ${ }^{8967}$ The Accused delivered a speech connected with the plebiscite where he said if there was a sovereign $\mathrm{BiH}$ it would be "without our areas" unless there was an exchange of population. ${ }^{8968}$ The Accused in this speech said that he had openly told Izetbegovic that "no Muslim foundation shall ever be laid in Serb areas and Serb villages whether or not you import Turks because we will instruct Serbs not to sell land to Muslims. [...] The first foundations that are laid will be blown up, and all foundations that are laid will be blown up" ${ }^{8969} \mathrm{He}$ also envisaged that there was a chance that they would fight, and they were prepared to "let the chips fall where they may" in the knowledge that the Serbs were better armed and that the war would be bloody. ${ }^{8970}$ He also emphasised that they would not give up on their territories and that it was "a fight to the finish, a battle for living space". 8971

2691. In December 1991, Milošević told the Accused that he should not give in to Izetbegović and that they had to stick to their line and that "if they want to fight, we'll fight" given that the Serbs were stronger. ${ }^{8972}$ They also spoke about the unconstitutional nature of the decision changing the status of $\mathrm{BiH}^{8973}$ In an intercepted conversation on 17 December 1991, the Accused affirmed his commitment to use force to ensure that the establishment of a sovereign and independent $\mathrm{BiH}$ did not result in the separation of Bosnian Serbs from other Serbs in the former Yugoslavia. ${ }^{8974}$ In relation to the possible secession of $\mathrm{BiH}$, the Accused stated "we will completely defend the

\footnotetext{
8965 P5897 (Intercept of conversation between Radovan Karadžić and Slobodan Milošević, 14 November 1991 ), p. 3.

8966 P5824 (Intercept of conversation between Radovan Karadžić and General Uzelac, 2 November 1991), pp. 1-2, 6-8.

8967 See para. 47. See also Robert Donia, T. 3107 (1 June 2010).

8968 P958 (Radovan Karadžić's speech at the Plebiscite of the Serb People, November 1991), p. 5.

8969 P958 (Radovan Karadžić's speech at the Plebiscite of the Serb People, November 1991), p. 6. See also Eset Muračević, T. 12673-12676, 12683 (1 March 2011); Eset Muračević, T. 12822 (2 March 2011).

8970 P958 (Radovan Karadžić's speech at the Plebiscite of the Serb People, November 1991), p. 6.

8971 P958 (Radovan Karadžić's speech at the Plebiscite of the Serb People, November 1991), p. 6.

8972 P5790 (Intercept of conversation between Radovan Karadžić and Slobodan Milošević, 20 December 1991), pp. 2-3.

8973 P5787 (Intercept of conversation between Radovan Karadžić and Slobodan Milošević, 25 December 1991), pp. 2-3.

8974 P5794 (Intercept of conversation between Radovan Karadžić and Branko Kostić, 17 December 1991), pp. 4-5 (wherein Kostić stated "nobody can make a decision on his own, er, each possible Bosnian request for
} 
country", including if necessary by war, "fuck them, if they fuck around, the country should be defended with all powers". 8975

2692. On 21 December 1991, at the Bosnian Serb Assembly, the Accused issued another warning about the hundreds of thousands of deaths, destruction, displacement of people and population homogenisation which would occur if there was a civil war in $\mathrm{BiH}^{8976}$

2693. In January 1992, the Accused spoke to Krajišnik and said "we have to realise our minimum aim, there's no other way. Nothing should and nothing can stop us. No way". 8977 The Accused was also angry about Izetbegović speaking openly about a sovereign and independent $\mathrm{BiH}$, and said: "Does he want someone to destroy Sarajevo? [...] he's really crazy [...] fuck him. We will release our tigers and let them do their job" ${ }^{8978}$ He went on to say that he had been calming the Serb people for a year, but that he "will not be calming anyone anymore, nor can I" and that they could no longer hold back their people anymore. ${ }^{8979}$

2694. As early as January 1992, Koljević warned of the danger of an Islamic republic being created. ${ }^{8980}$ In this regard, Koljević spoke with Tuđman and noted that they had a common interest of separating people, that an independent $\mathrm{BiH}$ did not suit them as it would separate them from their "mother lands", and that they advocated a sovereign Muslim, Serbian and Croatian Bosnia. ${ }^{8981}$

2695. At a meeting of the SRBiH Assembly on 24 January 1992, the issue of a national referendum was discussed and the speakers from the SDS opposed the holding of a referendum. ${ }^{8982}$ The Serb position was that they would not accept or allow themselves to become a minority in $\mathrm{BiH}$ and that they would not be forced to do something they did not want to do. The Serbs also expressed their concern that the SDA wanted to create an Islamic state in $\mathrm{BiH}$ and that the only

recognition and so on, leads directly into a conflict" and the Accused responded: "[d]irectly to war, a bloody, bloody and dangerous war".). 
guarantee for the Serbs was to have a separate state in $\mathrm{BiH}^{8983}$ The SDS under the leadership of the Accused withdrew from the session when no agreement could be reached and, following their withdrawal, the $\mathrm{BiH}$ Assembly supported a referendum being held between 29 February and 1 March regarding the sovereignty and independence of BiH. ${ }^{8984}$ On 19 February 1992, the Chairman of the SDS Executive Board ordered the municipal and regional boards of the SDS to hold immediate meetings and to draw up a plan of action to stop the referendum and to explain to "every adult Serb" that they should boycott the referendum which would be illegal after the adoption of the Constitution of the SerBiH. ${ }^{8985}$

2696. The Chamber recalls that on 23 February 1992, the Cutileiro Plan was proposed and called for an independent and geographically continuous $\mathrm{BiH}$, comprised of the three constituent units that represented the Bosnian Muslims, Bosnian Croats, and Bosnian Serbs. ${ }^{8986}$ The Cutileiro Plan included constitutional principles for $\mathrm{BiH}$ and proposed the structure of the Assembly and government of $\mathrm{BiH} .{ }^{8987}$ The Accused decided to accept the Cutileiro Plan notwithstanding the fact that it contemplated $\mathrm{BiH}$ as an independent state, with cantons where ethnic minorities would remain, even though this was less than what the Bosnian Serb leadership had wished for, namely to remain in Yugoslavia. ${ }^{8988}$ In a conversation with Kuprešanin on 23 February 1992, the Accused expressed satisfaction with the recent international negotiations where the Cutileiro Plan was discussed, stating:

We achieved maximum success because we achieved that Bosnia cannot be a single state anymore and that it will be composed of three republics. In one paper they even called them states. [...] Our police on our territory. Our national guard on our territory. Our national guard, and we're pushing further: our army on our territory, one that is placed under a single command in case of an external enemy. ${ }^{8989}$

2697. On 25 February 1992, the Accused summarised the outcome of the talks at a session of the Bosnian Serb Assembly and stated that the Bosnian Serbs had agreed to the three main principles of the Cutileiro Plan which stated that $\mathrm{BiH}$ would (i) be an independent state, (ii) maintain its present

\footnotetext{
8983 P942 (ECMM report re the BiH Assembly meeting held on 24-25 January 1992), p. 1; Colm Doyle, T. $2825-$ 2826 (27 May 2010).

8984 P942 (ECMM report re the BiH Assembly meeting held on 24-25 January 1992), p. 2; Colm Doyle, T. 28252826 (27 May 2010).

8985 P5475 (Letter from SDS Executive Board to SDS Municipal and Regional Boards BiH, 19 February 1992).

8986 See International Peace Negotiations Section, para. 14. The Chamber does not consider that Mandić's assertion that this plan demonstrated that the Bosnian Serb leadership did not intend to exchange populations in $\mathrm{BiH}$ to have a basis. Momčilo Mandić, T. 4895 (8 July 2010).

8987 See International Peace Negotiations Section, para. 14.

8988 D3015 (Witness statement of Vladislav Jovanović dated 22 February 2013), paras. 39, 50. See also D3645 (Witness statement of Nenad Kecmanović dated 27 May 2013), paras. 55-56; Milorad Dodik, T. 36849-36850 (9 April 2013).
} 
borders; and (iii) consist of three constituent parts. ${ }^{890}$ However, when war broke out the option of an independent $\mathrm{BiH}$ with cantons was dropped. ${ }^{8991}$

2698. The Chamber recalls that the referendum on the question of SRBiH independence was held on 29 February and 1 March 1992 and resulted in a vote in favour of independence. ${ }^{8992}$

2699. In February 1992, Jovanović spoke with the Accused and Koljević about the Cutileiro Plan; they discussed internal borders in $\mathrm{BiH}$ and the establishment of cantonal units in $\mathrm{BiH}$ based on ethnic principles. ${ }^{8993}$ Jovanović explained to the Accused that his priorities should be to synchronise the negotiations in order to provide the maximum protections for the Serbian people and to form cantons which were both economically and geographically sustainable. ${ }^{894}$ Jovanović warned the Accused that Europe could ask for a commitment towards an independent $\mathrm{BiH}$, and told the Accused not to mention state borders. ${ }^{8995}$ The Accused spoke about having three entities in BiH as a confederation "based on the national territories where national communities make a majority and they have their organs plus common organs". ${ }^{8996}$ Jovanović spoke with Koljević about maintaining the right to self-determination and to independently organise or integrate with "the mother country" but that in negotiations they did not have to mention directly integration with the mother countries. ${ }^{8997}$

2700. In February 1992, the Accused in meetings with international representatives expressed his view that the request of $\mathrm{BiH}$ for independence was a "very irresponsible move" and he had a tough time keeping Serbs quiet and that he was worried about deaths and disaster. ${ }^{8998} \mathrm{He}$ also stated that

\footnotetext{
8989 P5745 (Intercept of conversation between (i) Radovan Karadžić and an unidentified male; (ii) Radovan Karadžić and Vojo Kuprešanin, 23 February 1992), p. 3.

8990 See para. 325; D88 (Shorthand Record of $8^{\text {th }}$ session of SerBiH Assembly, 25 February 1992), pp. 11-12; P798 (Statement of Principles, Lisbon Agreement, 23 February 1992).

8991 Vladislav Jovanović, T. 34300-34305 (26 February 2013); D3015 (Witness statement of Vladislav Jovanović dated 22 February 2013), paras. 38-39, 41.

8992 See Adjudicated Fact 395; P5427 (Proclamation of the SDS Executive Board, undated); P5530 (Proclamation of the SDS Executive Board, 20 February 1992), p. 3.

8993 D3015 (Witness statement of Vladislav Jovanović dated 22 February 2013), para. 49.

8994 D3015 (Witness statement of Vladislav Jovanović dated 22 February 2013), para. 49; P5750 (Intercept of conversation between Radovan Karadžić, Nikola Koljević, and Vladislav Jovanović, 12 February 1992), pp. 34.

8995 P5750 (Intercept of conversation between Radovan Karadžić, Nikola Koljević, and Vladislav Jovanović, 12 February 1992), p. 6.

8996 P5750 (Intercept of conversation between Radovan Karadžić, Nikola Koljević, and Vladislav Jovanović, 12 February 1992), pp. 4-5. See also D2149 (Aide mémoire of Manojlo Milovanović), p. 9; P5063 (Video footage depicting interview of Radovan Karadžić on "Ask the President”, undated, with transcript), p. 4 ; P3119 (Minutes of meeting of the Club of Deputies from the SDS and SPO, 23 January 1992), p. 1.

8997 P5750 (Intercept of conversation between Radovan Karadžić, Nikola Koljević, and Vladislav Jovanović, 12 February 1992), p. 22.

8998 P778 (Fifth notebook of Herbert Okun's Vance Mission Diary), e-court p. 41.
} 
it was very hard to disarm the people in $\mathrm{BiH}$ because individuals held 500,000 weapons. ${ }^{8999} \mathrm{He}$ emphasised that any moves towards the independence of $\mathrm{BiH}$ would imply a very cruel war. ${ }^{9000}$ The Accused was described by international representatives as "very radical" and they observed that it was important that the Accused's "illusions" were overcome. ${ }^{9001}$ International representatives also identified that negotiations with the Accused, Koljević, and Krajišnik were the most difficult. ${ }^{9002}$

2701. The Accused also told international observers that Bosnian Serbs would not fight after the map of BiH was decided. ${ }^{9003}$ At an SDS Deputies' Club meeting on 28 February 1992, the Accused spoke about a confederal $\mathrm{BiH}$ with an "integral Serbian Bosnia and Herzegovina within it". ${ }^{9004}$ At this meeting the Accused also said:

Bosnia and Herzegovina will remain in Yugoslavia until we say it has left Yugoslavia. If Bosnia and Herzegovina is to leave Yugoslavia, then only three Bosnia and Herzegovinas will leave Yugoslavia. As Mr Krajišnik says, Muslims who used to be a religious sect, and have recently been given the status of a people, that's what I say, should now get their independence. For what? [...] If they want independence, then we want independence too! $!^{9005}$

2702. The Chamber recalls that the Cutileiro Plan was further refined through a Statement of Principles which was agreed upon by the parties to the conflict on 18 March 1992. ${ }^{9006}$ The Statement of Principles stated that $\mathrm{BiH}$ would be one state "composed of three constituent units, based on national principles and taking into account economic, geographic, and other criteria".9007 The Statement of Principles also provided for a working group to be established to define the territory of the constituent units. ${ }^{9008}$ Bosnian Serb negotiators reported back to the Bosnian Serb Assembly regarding this plan and noted that it aimed at a division of $\mathrm{BiH}$ into three constituent

KDZ240, P2935 (Transcript from Prosecutor v. Krajišnik), T. 6749-6750 (under seal).
P779 (Sixth notebook of Herbert Okun's Vance Mission Diary), e-court p. 24. Skoko

P778 (Fifth notebook of Herbert Okun's Vance Mission Diary), e-court p. 41.

P779 (Sixth notebook of Herbert Okun's Vance Mission Diary), e-court p. 24. Skoko stated that the Accused always looked for reasons to accept international peace plans and to make concessions during negotiations with respect to other ethnicities. D3321 (Witness statement of Milorad Skoko dated 1 April 2013), para. 30. The Chamber noted that Skoko's testimony was marked by multiple contradictions, evasiveness and indicators of partiality and bias and therefore does not find his evidence to be reliable in this regard.

9002 P779 (Sixth notebook of Herbert Okun's Vance Mission Diary), e-court p. 56.

9003 Herbert Okun, P776 (Transcript from Prosecutor v. Krajišnik), T. 4177-4178. Okun's assessment was that this meant that the Bosnian Serbs would stop fighting only when they acquired the territory they wanted.

9004 P938 (Minutes from SDS Deputies' Club meeting, 28 February 1992), pp. 33-34. Mandić testified that originally all three sides agreed that there should be three entities in BiH but the Croats and Muslims failed to adhere to this agreement. Momčilo Mandić, T. 5001 (13 July 2010).

9005 P938 (Minutes from SDS Deputies' Club meeting, 28 February 1992), p. 4.

9006 See para. 326.

9007 See para. 326.

9008 See para. 326. 
units based not only on nationality, but also on economic and geographic considerations and would be marked as a "basis for further negotiations". 9009

2703. In April 1992, the Accused in a meeting with international representatives agreed that all sides would lose if there was a conflict and complained about propaganda against the Serbs. ${ }^{9010} \mathrm{He}$ also said that they founded the TO because many troops were out of control. ${ }^{9011}$ Koljević at this meeting said that he and the Accused had agreed that they should divide Sarajevo. ${ }^{9012}$ During a discussion with international observers in September 1992, the Accused proposed constructing a wall in Sarajevo to separate the Serb controlled areas and the Muslim controlled areas. ${ }^{9013}$

2704. Krajišnik wrote to Cutileiro on 3 April 1992, suggesting a continuation of negotiations based on the Statement of Principles. ${ }^{9014}$ In June 1992, Izetbegović withdrew his agreement to the Cutileiro Plan. ${ }^{9015}$ By July 1992, Izetbegović stated that he could not agree to certain elements of the Statement of Principles. ${ }^{9016}$ The Accused stated that while he continued to agree with the Statement of Principles, the proposal of BiH being a unitary state was not satisfactory. ${ }^{9017}$

2705. The Chamber recalls that during a meeting in September 1992, the Accused and Koljević stated that the Bosnian Serbs and the Bosnian Croats would not accept a unitary BiH state; a state based on one-man, one-vote. ${ }^{9018}$ Koljević also stated that the Bosnian Serbs would not accept the internal borders of $\mathrm{BiH}$ without some form of cantonisation. ${ }^{9019}$ At international negotiations, the Accused also expressed the Bosnian Serb position that while they wanted a political resolution they would not abandon their sovereignty or accept a unitarian state or a "loss of national status on our land". 9020 The Accused also called for three units for the three constituent peoples in $\mathrm{BiH}$ and emphasised the security of the Serb people who he presented as the "principal victims". 9021

\footnotetext{
$9009 \quad$ See para. 327.

9010 P780 (Seventh notebook of Herbert Okun's Vance Mission Diary), e-court p. 36.

9011 P780 (Seventh notebook of Herbert Okun's Vance Mission Diary), e-court p. 36.

9012 P780 (Seventh notebook of Herbert Okun's Vance Mission Diary), e-court p. 36.

9013 Aernout van Lynden, T. 2563-2564 (20 May 2010).

$9014 \quad$ See para. 328.

$9015 \quad$ See para. 333.

$9016 \quad$ See para. 340.

$9017 \quad$ See para. 340.

$9018 \quad$ See para. 357.

$9019 \quad$ See para. 357.

9020 P789 (Sixth notebook of Herbert Okun's ICFY diary), e-court p. 9. See also P791 (Eighth notebook of Herbert Okun's ICFY diary), e-court pp. 38-39.

9021 P789 (Sixth notebook of Herbert Okun's ICFY diary), e-court p. 45; P790 (Seventh notebook of Herbert Okun's ICFY diary), e-court pp. 10-11.
} 
2706. At first the Accused expressed that he wanted to be loyal to Yugoslavia and for the Bosnian Serbs to stay in this joint state. ${ }^{9022}$ When the situation deteriorated and it became clear that BiH would not remain in Yugoslavia, the Accused adapted this goal. ${ }^{9023}$ In October 1992, Plavšić stated that the "establishment of a Muslim state without observing the interests of the Serbian people verges on insanity" and that Izetbegović had walked into that situation and "the consequences are now obvious". 9024

\section{(2) $\underline{\text { Conclusion }}$}

2707. The Chamber finds that the Accused's speech to the SRBiH Assembly in October 1991 in which he spoke about a "highway of hell" clearly shows the Accused's consistent opposition to the proposed independence of $\mathrm{BiH}$. While the Accused in the speech stated that he was not threatening the Bosnian Muslims, the Chamber finds that on the contrary, the speech contained very specific threats about what would happen if the Bosnian Muslims continued to pursue the path of independence and ignored the will of the Bosnian Serbs. The Chamber finds that the Accused was clearly threatening war if the Bosnian Serb interests were ignored, and he also envisaged that such a war would be "hell" and that the Bosnian Muslims would be unable to defend themselves in such a scenario.

2708. The Chamber also finds that these warnings by the Accused were not just an isolated aberration. The Chamber finds, by reference to multiple intercepted conversations in September and October 1991, that the Accused discussed how he would warn the Bosnian Muslims that if they persisted with their policies relating to the independence of $\mathrm{BiH}$, this course of action would lead to extreme bloodshed, annihilation and the disappearance or extinction of the Bosnian Muslims. These conversations, in addition to speeches made by the Accused in 1991, underscore that the Accused intended to threaten the Bosnian Muslims against pursuing independence for $\mathrm{BiH}$ and that he was fully aware that a potential conflict would be extremely violent and result in thousands of deaths, the destruction of property, and the displacement of people and that it would be particularly devastating for the Bosnian Muslim population.

\footnotetext{
9022 Vladislav Jovanović, T. $34268-34269$ (26 February 2013). See also Milorad Dodik, T. 36845 (9 April 2013 ); D3051 (Witness statement of Momir Bulatović dated 25 February 2013), paras. 8, 15. The Chamber does not rely on Bulatović's general opinion that everything that the Bosnian Serbs did was in response to acts and threats by Bosnian Muslims.

9023 Vladislav Jovanović, T. 34269 (26 February 2013); D3051 (Witness statement of Momir Bulatović dated 25 February 2013), para. 16. See also P1349 (Transcript of $6^{\text {th }}$ session of SerBiH Assembly, 26 January 1992), p. 8.

9024 P1360 (Transcript from Joint session (21 ${ }^{\text {st }}$ session) of RS Assembly and Assembly of Serbian Krajina, 31 October 1992), pp. 9-10.
} 
2709. The Chamber finds that the declaration of sovereignty by the SRBiH Assembly in the absence of the Bosnian Serb delegates on 15 October 1991, escalated the situation. The Bosnian Serb leadership made it clear once again that they would not accept a sovereign $\mathrm{BiH}$ and issued an ultimatum for the revocation of this declaration. However, it is clear from the conversation on 24 October 1991 between the Accused and Slobodan Milošević that the Accused did not expect the Bosnian Muslims to abolish the decisions they had taken with respect to the sovereignty of BiH.

2710. The conversation with Milošević in October 1991 is also instructive as it shows that the Accused envisaged responding in such a way that the Bosnian Serbs would establish full authority in Bosnian Serb territories, create a de facto situation to ensure that the Bosnian Serbs would never live in the same state as the Bosnian Muslims, and create their own parallel and separate institutions and structures. It is also clear from this conversation that Slobodan Milošević was attempting to take a more cautious approach while the Accused was adamant that their goal was to ensure that they would establish full authority in their territories, which would mean that Izetbegović would not have control of $65 \%$ of $\mathrm{BiH}$, and that they would announce their own Bosnian Serb Assembly.

2711. The Chamber also finds that while Milošević expressed reservations about excluding Bosnian Muslims, the Accused was adamant that there were not even 10\% of Bosnian Muslims who supported Yugoslavia and that they could not take such a risk. The Accused also spoke clearly about steps Bosnian Serbs would take to establish authority and control over territories which they claimed and that the Bosnian Serbs would be moving towards mobilisation. The Chamber finds that this demonstrates that the Accused from October 1991 vehemently opposed the independence of $\mathrm{BiH}$ and planned on taking over Bosnian Serb claimed territory. This conversation also demonstrates that the Accused envisaged a separation of the Bosnian Serbs from non-Serbs in $\mathrm{BiH}$ and that war in $\mathrm{BiH}$ would result in "population homogenisation". The Chamber also finds that the Accused supported the creation of ethnically based entities in $\mathrm{BiH}$. The Accused also encouraged the identification of Serb areas which would be to the exclusion of Bosnian Muslims.

2712. The Accused's conversation with Krajišnik in January 1992 also demonstrates the Accused's continuing anger with respect to the proposed independence of $\mathrm{BiH}$. In this regard the Accused said that he would not be calming the Bosnian Serb people any further and that he would "release [their] tigers and let them do their job". The Accused also spoke about the non-negotiable character of the Bosnian Serb objectives and his position that they would not allow anything to stop them. The Chamber finds that the Accused's position was that the Bosnian Serbs would not allow $\mathrm{BiH}$ to secede from Yugoslavia, and if $\mathrm{BiH}$ insisted on independence so would the Bosnian Serbs. 
2713. The Accused also described the Bosnian Muslims as a "religious sect" who had only recently been given the status of "people" and that they had no basis for their independence. The Chamber finds that this rhetoric when combined with the Accused's references to the Bosnian Muslims as their historic enemies, created an environment which sought to quash any claim to independence by $\mathrm{BiH}$ and to re-assert the Bosnian Serb interests in $\mathrm{BiH}$.

2714. In meetings with international representatives, the Accused repeated his warning about how the independence of $\mathrm{BiH}$ would result in a "cruel war" and his prediction that he would not be able to calm down the Bosnian Serbs in this scenario.

2715. The Chamber also finds that there was a disjuncture between what the Accused said in private conversations or before a Bosnian Serb audience and the tone he took in international negotiations where he was more conciliatory, spoke against conflict, and claimed that the Serbs were the victims of propaganda. The Accused took a leading role in portraying the Bosnian Serbs as the victims of the conflict and used this as justification for pursuing their territorial and political objectives of a separate Serb state in $\mathrm{BiH}$.

state

(D) Advocating separation of population and creation of a Bosnian Serb

\section{(1) Analysis of evidence}

(a) Separation of population-inability to co-exist

2716. On 27 August 1991, in an intercepted conversation with Koljević, the Accused expressed his opposition to $\mathrm{BiH}$ independence and indicated his willingness to divide $\mathrm{BiH}$ along ethnic lines by stating "[1]et us see what it is, what the solution for each ethnic group would be, and for everyone to agree to it $[\ldots]$. Because if there is no solution acceptable to us in $[\mathrm{BiH}]$, we will find our own solution". 9025

2717. In November 1991, the Accused spoke about the "principle of reciprocity" and that the Serbs alone would not move out of certain areas and then allow the Bosnian Muslims to "stay in our areas to settle and build their colonies". ${ }^{9026}$ The Accused called on the Bosnian Serbs to "get ready and establish your authority in your territories; in municipalities, regions, local communities, and to prepare yourselves for restructuring and regionalizing the municipalities" and for them to (Transcript of $53^{\text {rd }}$ session of RS Assembly, 28 August 1995), p. 29.
} 
control the process until the very last moment. ${ }^{9027}$ The Accused concluded that after and during the plebiscite it was important to "seize power wherever you can". 9028

2718. With respect to the "three national communities" in $\mathrm{BiH}$, the Accused suggested that "the more separate things there are the better it will be". ${ }^{9029}$

2719. The Accused in a speech in January 1992 stated that the Bosnian Serbs would "not impose anything on each other" and that they would work towards a form of state organisation to which Croats, Serbs and Muslims would agree. ${ }^{9030}$ The Accused also said that they had "no influence over the war or peace" and that if an inter-ethnic or religious war started in BiH, Serbs, Muslims, and Croats would run away and go to their own "fully homogeneous" areas and that there would be severe bloodshed and destruction of towns. ${ }^{9031}$ Similarly the Accused told Vance that BiH independence could lead to war and that there "will be great mass movements, homogenisation of territories, migrations from one area into another and, of course, accompanied by instances of shooting out of hand". 9032

2720. In January 1992, in a conversation in which there was discussion about having Bosnian Muslims within their borders, the Accused said "they will have their region, we will have our own region". ${ }^{9033}$ The Accused also spoke about the importance of creating their country first and then establishing "krajinas" and the danger that they would never create their state if they started establishing "krajinas" first. ${ }^{9034}$

2721. In February 1992, Krajišnik stated that if they were successful in creating a confederal BiH it would consist of three states and he was "not interested in Muslims in [BiH]". ${ }^{9035} \mathrm{He}$ also stressed that everything which the Bosnian Serb Assembly did, and everything he did, was "for pure areas" of $\mathrm{BiH}$, that he was in favour of a "monolithic Serbian state" where all Serbs live

9027 P958 (Radovan Karadžić's speech at the Plebiscite of the Serb People, November 1991), p. 10.

9028 P958 (Radovan Karadžić's speech at the Plebiscite of the Serb People, November 1991), p. 12.

9029 D84 (Shorthand Record of $3^{\text {rd }}$ session of SerBiH Assembly, 11 December 1991), pp. 13-14; P958 (Radovan Karadžić's speech at the Plebiscite of the Serb People, November 1991), p. 7. See also D424 (Intercept of conversation between Radovan Karadžić and Vojo Kuprešanin, 10 February 1992), p. 11.

9030 D87 (Transcript of $9^{\text {th }}$ session of SRBiH Assembly, 24-25 January 1992), pp. 103-104.

9031 D87 (Transcript of $9^{\text {th }}$ session of SRBiH Assembly, 24-25 January 1992), p. 103; P5762 (Intercept of conversation between Radovan Karadžić and Dobrica Ćosić, 22 January 1992), p. 6. See also Herbert Okun, T. 1715-1717 (27 April 2010); P5621 (Intercept of conversation between Radovan Karadžić and Dobrica Ćosić, 25 January 1992), p. 3; P5615 (Intercept of conversation between Radovan Karadžić and Nikola Koljević, 11 December 1991), p. 4; D4523 (Intercept of conversation between Radovan Karadžić and an unidentified male, 3 March 1992).

9032 P5774 (Intercept of conversation between Radovan Karadžićand Vladislav Jovanović, 5 January 1992 ), pp. 6-7. See also D2149 (Aide mémoire of Manojlo Milovanović), pp. 18, 28.

9033 P2596 (Intercept of conversation between Radovan Karadžić and "Miroslav", 7 January 1992), p. 5.

9034 P2596 (Intercept of conversation between Radovan Karadžić and "Miroslav”, 7 January 1992), p. 6. 
together. $^{9036}$ Koljević also emphasised that they would not allow the Bosnian Muslims to have a sovereign state which extended over both the Serb and Croat parts of $\mathrm{BiH}$ and that they had therefore constituted a Serb Assembly. ${ }^{9037}$ Koljević acknowledged that the process of re-organising municipalities was with the aim of creating "homogeneity of certain areas" and argued that contrary to the political assertions, it was not impossible to divide $\mathrm{BiH} .{ }^{9038}$ Koljević stated that at a municipal level they had tried separate municipal assemblies and formed new municipalities. ${ }^{9039}$ Further, he repeatedly called for the expulsion of Bosnian Muslims and the homogeneity of territories, claiming it was impossible for Serbs to live with anyone else. ${ }^{9040}$

2722. Krajišnik also stated that "[o]ur aim is to divide with the Muslims, if the Muslims were to capitulate we would remain with them, if they remained with us they would soon be the majority?" and outlined the Strategic Goals, including dividing from Bosnian Muslims and Bosnian Croats. ${ }^{9041}$

2723. In February 1992, the Accused spoke about having less than $10 \%$ of Bosnian Muslims in their "canton" of $\mathrm{BiH}$ according to the proposed maps. ${ }^{9042}$ The Accused continued to deliver speeches in which he (i) spoke about avoiding the subjugation of the Serb people; (ii) advocated the creation of a "Serbian state"; and (iii) blamed the Muslims and Croats for destroying the unity of BiH and Yugoslavia. ${ }^{9043}$ The Accused in May 1992 spoke with Krajišnik, Mladić, and other military leaders and said that $\mathrm{BiH}$ as a state did not exist because it did not have any territory and that the Serbs were "on the threshold of achieving our centuries-old dream of creating our own state without many internal enemies". 9044 In this regard, the Accused also stated that they were "controlling the Serbian settlements" in Sarajevo and were expanding them. ${ }^{9045}$

D88 (Shorthand Record of $8^{\text {th }}$ session of SerBiH Assembly, 25 February 1992), pp. 62-63.

P5623 (Speech of Momčilo Krajišnik at the Assembly of Serbian People of BiH, 28 February 1992), pp. 3-4. P986 (Transcript of a meeting between Nikola Koljević, Franjo Tuđman, and Franjo Boras, 8 January 1992), pp. 11, 24.

9038 P986 (Transcript of a meeting between Nikola Koljević, Franjo Tuđman, and Franjo Boras, 8 January 1992), p. 13.

9039 P986 (Transcript of a meeting between Nikola Koljević, Franjo Tuđman, and Franjo Boras, 8 January 1992), pp. 22-23.

9040 Vitomir Žepinić, T. 33594-33595 (13 February 2013); Herbert Okun, P776 (Transcript from Prosecutor v. Krajišnik), T. 4220. During a meeting with Serb and Muslim representatives in May 1992, Koljević precluded any possibility of Muslims and Serbs cohabitating in Pale; the former had to leave. P733 (Witness statement of Sulejman Crnčalo dated 1 November 2009), para. 38; Sulejman Crnčalo, T. 1164-1165 (14 April 2010).

9041 P1479 (Ratko Mladić's notebook, 16 July-9 September 1992), pp. 140, 143-144.

9042 P12 (Extended session of Main and Executive Boards of the SDS, 14 February 1992), pp. 2, 15.

9043 P1347 (Shorthand record of $5^{\text {th }}$ session of SerBiH Assembly, 9 January 1992), pp. 45, 47-49; P956 (Transcript of $16^{\text {th }}$ session of SerBiH Assembly, 12 May 1992), e-court pp.3-4.

9044 P1477 (Ratko Mladić's notebook, 14 February-25 May 1992), pp. 256-258. See also D4025 (Excerpt of SDS Main Board meeting, 14 February 1992), pp. 13, 15 (where Kuprešanin spoke about BiH ceasing to exist as their "holy mission").

9045 P1477 (Ratko Mladić’s notebook, 14 February-25 May 1992), p. 257.
} 
2724. In February 1992, the Accused went on to state "now our main goal is the only goal that can be achieved: to solve the issue of the majority of the Serbian people", namely the creation of their republic of $\mathrm{BiH}^{9046} \mathrm{He}$ also stated that "it is clear to every Serb that Croats and Serbs cannot live in a single state. Consequently, they cannot be in the same army, and also that $\mathrm{BiH}$ cannot have its army. There would remain national guards in each of the republics, and the police which would be under the control of the respective republics". 9047 The Accused emphasised that there was tension and conflict in undefined territories where "two national communities touch each other" and that they should be defined as soon as possible. ${ }^{9048}$

2725. In meetings with international representatives, Bosnian Serb leaders including the Accused, Krajišnik, and Plavšić openly stated that it was impossible for Bosnian Serbs to co-exist with the other communities, particularly the Bosnian Muslims, and that it was better to separate the communities. $^{9049}$ For example in discussions with Owen and Morillon, the Accused repeated that separation from the Bosnian Muslims and Croats was essential. ${ }^{9050}$

2726. In meetings with Harland, the Accused as well as Plavšić openly said that the basic Serb war aim was to redistribute the population of $\mathrm{BiH}$ so that the Serbs would be left in control of a single continuous block of territory embracing the whole border with Montenegro and Serbia and also including all of the traditionally Serb-inhabited areas. ${ }^{9051}$ The Bosnian Serb leadership said that due to "an historical accident", Bosnian Muslims were a majority in certain areas and to achieve their goal, large numbers of Bosnian Muslims had to be removed because the majority of the population along the Drina River in northeast BiH, was Muslim. ${ }^{9052}$ They openly stated that the purpose of war was for the Bosnian government to accept this redistribution of the population and the Accused acknowledged that some "old people will probably want to remain" but he envisaged that to a large extent the overwhelming majority of the population that would remain in Serb areas

\footnotetext{
9046 P938 (Minutes from SDS Deputies’ Club meeting, 28 February 1992), p. 35.

9047 P938 (Minutes from SDS Deputies' Club meeting, 28 February 1992), p. 6.

9048 P1353 (Shorthand record of $10^{\text {th }}$ session of SerBiH Assembly, 11 March 1992), pp. 2, 7; D90 (Shorthand Record of $11^{\text {th }}$ session of SerBiH Assembly, 18 March 1992), pp. 4-5, 10.

9049 KDZ240, P2935 (Transcript from Prosecutor v. Krajišnik), T. 6751-6752, 6843 (under seal); KDZ240, T. 16064-16065, 16068 (5 July 2011) (closed session); Herbert Okun, P776 (Transcript from Prosecutor v. Krajišnik), T. 4205; Herbert Okun, T. 1496-1497 (23 April 2010); P785 (Second notebook of Herbert Okun's ICFY diary), e-court p. 25; P1029 (Witness statement of John Wilson dated 4 November 2008), para. 120; KDZ088, T. 6253-6255, 6314 (7 September 2010) (closed session) [REDACTED]; Hussein Ali Abdel-Razek, T. 5512-5514, 5522-5523 (20 July 2010). See also KDZ088, T. 6314 (7 September 2010) ; P5748 (Intercept of conversation between Radovan Karadžić and Lukić, 13 February 1992), p. 1; P5063 (Video footage depicting interview of Radovan Karadžić on "Ask the President”, undated, with transcript), pp. 8-9. [REDACTED].

9051 P820 (Witness statement of David Harland dated 4 September 2009), para. 269.

9052 P820 (Witness statement of David Harland dated 4 September 2009), para. 270.
} 
would be Serb and Muslim in Muslim areas. ${ }^{9053}$ At these meetings, some members of the Bosnian Serb leadership openly stated that it was good if all non-Serbs left and that they wanted them to go because they were not living well together. ${ }^{9054}$

2727. Biljana Plavšić spoke about the importance of the partition of territory and executing this partition "properly as this business awaits us". 9055 She also expressed the idea that Bosnian Serbs could no longer live with Bosnian Muslims; on one occasion at a funeral for a Bosnian Serb soldier she said that the Bosnian Muslims should be slaughtered or exterminated. ${ }^{9056}$ In May 1992, Plavšić spoke of the entitlement of the Serbs to $70 \%$ of the territory and that Bosnian Serbs "were used to living in wide spaces" while Muslims typically lived in cities. ${ }^{9057}$ Plavšić further stated that "if it takes the lives of 3 million people to solve this crisis, lets get it done and move on". 9058 Plavšić also spoke about creating the conditions for "forced emigration" and that the "last thing that can be allowed $[\ldots]$ is a compromise at the expense of conquered territories" and that foreign countries should be reminded that the Bosnian Serbs would not give up what they had conquered. ${ }^{9059}$

2728. Koljević was particularly extreme in his views and continued to repeat at important meetings that it was impossible for the communities to live together. ${ }^{9060}$ A deputy at the Bosnian Serb Assembly echoed this sentiment and spoke about their common wish for an "ethnically pure Serbian state" and the need, in the context of negotiations, to "emphasise that we can not live with them". 9061 Lukić, who was the second Prime Minister of the RS, also advocated "ethnic cleansing" and told leaders in Serbia that Bosnian Muslims could not be trusted. ${ }^{9062}$ International observers reported that the JNA acquiesced in, or in some cases supported, the creation of ethnically homogeneous regions in $\mathrm{BiH}$ which involved "the seizure of territory by military force and intimidation of the non-Serb population". 9063

\footnotetext{
9053 P820 (Witness statement of David Harland dated 4 September 2009), paras. 270, 272.

9054

9055

9056

9057

9058

9059

9060

9061 1993), p. 34.

P820 (Witness statement of David Harland dated 4 September 2009), para. 274.

P1353 (Shorthand record of $10^{\text {th }}$ session of SerBiH Assembly, 11 March 1992), p. 36.

Colm Doyle, T. 2667-2668, 2670-2672 (21 May 2010); [REDACTED]; Vitomir Žepinić, T. 33594-33595 (13 February 2013).

Colm Doyle, T. 2671-2672 (21 May 2010).

Colm Doyle, T. 2672 (21 May 2010).

D92 (Transcript of $17^{\text {th }}$ session of SerBiH Assembly, 24-26 July 1992), pp. 38-39, 52.

Vitomir Žepinić, T. 33595 (13 February 2013). See also Herbert Okun, T. 1497-1498 (23 April 2010); P785 (Second notebook of Herbert Okun's ICFY diary), e-court p. 44.

P1379 (Transcript of $34^{\text {th }}$ session of RS Assembly, 27-29 August, 9-11 September, 29 September to 1 October 12 March 1993), pp. 1-2.

9063 P937 (UNSG Report re peacekeeping operation in BiH, 12 May 1992), paras. 3-5; Colm Doyle, T. 2663-2666 (21 May 2010).
} 
2729. Krajišnik often recalled that the main Bosnian Serb objective was to separate from the Bosnian Muslims and to create their own state which was ethnically "pure". 9064

2730. In July 1992, Mandić spoke about the Bosnian Serb territories which were "supposed to be taken", had already been taken, and identified areas which were still disputable, including in Sarajevo. ${ }^{9065}$ Mandić also questioned "what to do with the Turks" and suggested that there "should be an airlift established with Turkey and let them go, we should split Bosnia in two parts". 9066 In this same conversation, Mandić said “[w]e don't want to have a single-nation state, man. We want to have democratic state where the Serbian people would be in the majority."9067 Mandić acknowledged that Croats and "the rest of Muslims" would also have rights after "we clean them out". 9068

2731. The Chamber recalls that Kuruzović, the Commander of Trnopolje, confirmed that the plan of the Serb authorities was to reduce the number of Bosnian Muslims in Prijedor to $10 \%$ or less, and then later to reduce this to $2 \%$ or less. ${ }^{9069}$ The Chamber also heard from KDZ051 that around September 1992, he was told by the President of the Rogatica SDS, Sveto Veselinović, that "all the Muslims were going to disappear from the territory" and that in conversations with the Accused in Pale, "[i]t has been decided that one third of Muslims would be killed, one third would be converted to the Orthodox religion and a third will leave on their own". 9070 Sveto Veselinović testified that he did not meet KDZ051 in person, that he did not make such a statement, and that he did not have such a conversation with the Accused, as he did not speak to him between

\footnotetext{
9064 P1479 (Ratko Mladić's notebook, 16 July-9 September 1992), pp. 140, 143-144; P5623 (Speech of Momčilo Krajišnik at the Assembly of Serbian People of BiH, 28 February 1992), pp. 3-4; P1481 (Ratko Mladić's notebook, 5 October-27 December 1992), pp. 146-147; P1379 (Transcript of $34^{\text {th }}$ session of RS Assembly, $27-$ 29 August, 9-11 September, 29 September to 1 October 1993), p. 48; Herbert Okun, P776 (Transcript from Prosecutor v. Krajišnik), T. 4293, 4295. See Adjudicated Fact 2411. Živanović acknowledged that separation from the Bosnian Muslims was discussed. Milenko Živanović, T. 42585-42590 (30 October 2013).

9065 P1104 (Intercept of conversation between (i) Momčilo Mandić and Ivo Rezo; (ii) Momčilo Mandić and Branko Kvesić, 10 July 1992), pp. 7-8; Momčilo Mandić, T. 4619-4620 (5 July 2010). In an earlier conversation in May 1992, Mandić said that they "should settle the Sarajevo problem through war and then sit down and talk". P1149 (Intercept of conversation between Momčilo Mandić and Milanko Mučibabić, 26 May 1992), p. 8.

9066 P1104 (Intercept of conversation between (i) Momčilo Mandić and Ivo Rezo; (ii) Momčilo Mandić and Branko Kvesić, 10 July 1992), p. 8.

9067 P1104 (Intercept of conversation between (i) Momčilo Mandić and Ivo Rezo; (ii) Momčilo Mandić and Branko Kvesić, 10 July 1992), p. 10.

9068 P1104 (Intercept of conversation between (i) Momčilo Mandić and Ivo Rezo; (ii) Momčilo Mandić and Branko Kvesić, 10 July 1992), p. 11.

9069 See para. 1910 (referring to Adjudicated Fact 1093). But see D4195 (Witness statement of Milomir Stakić dated 16 November 2013), paras. 28, 42; Milomir Stakić, T. 45266-45267 (17 December 2013). Stakić testified that he never had any knowledge or heard of such a plan and the municipal authorities in Prijedor never planned for the municipality to be mono-ethnic and that the rights of all citizens were maintained. In light of the weight of contrary evidence received by the Chamber and Stakić's interest in distancing himself and the authorities from events in Prijedor, the Chamber does not find his evidence in this regard to be reliable.

9070 P3405 (Witness statement of KDZ051 dated 17 September 2011), para. 95.
} 
January 1992 and autumn of 1993. ${ }^{9071}$ The Chamber finds that Veselinović's evidence casts reasonable doubt on this issue and thus dismisses KDZ051's evidence on this point.

2732. The Accused made a number of speeches which spoke about the inability of the "three peoples" in $\mathrm{BiH}$ to live together, and for example compared them to "plants which cannot grow side by side. They have to be separated to flourish". ${ }^{9072}$ He also stated that "they lived together only when occupied or under a dictatorship. [...] We can only be together like oil and water. When you mix us, we are together. When you leave us alone, we separate" and that if they were put in the same pot the soup would not mix..$^{9073}$ The Accused stated that "[w]e are really something different $[\ldots]$ we should not hide that. We are not brothers. We must know that" and that when the world asked why they could not live together, he would answer that "we are three cultures, three peoples and three religions" and that they had never lived together in democracy. ${ }^{9074}$

2733. This sentiment was also reflected in speeches delivered by Bosnian Serb leaders at a municipal level. For example, the Chamber recalls that in early April 1992, there were radio announcements in Foča in which SDS President Miroslav Stanić said it was no longer possible for Bosnian Serbs to live with their Bosnian Muslim neighbours, that they could not be woken every morning by the hodža from the mosque, and that there was a danger that the Bosnian Serb population would be circumcised. ${ }^{9075}$ In May 1992, the Accused attended a meeting where he said

9071 D4192 (D4192 (Supplemental witness statement of Sveto Veselinović dated 17 November 2013). Similarly Karabeg, the President of the SDA Executive Board in Sanski Most, testified that the "goal of the Serbian side was not to have more than 10 per cent of the population in Sanski Most". Mirzet Karabeg, T. 18700-187002 (13 September 2011). However, the Chamber does not consider that Karabeg's testimony provided any basis for him to reach this conclusion, or that he was privy to that kind of information. The Chamber therefore does not rely on his evidence in this regard.

9072 D304 (Shorthand Record of $14^{\text {th }}$ session of RS Assembly, 27 March 1992), p. 8. See also Vitomir Žepinić, T. 33586-33587 (13 February 2013) (also testifying that in his own talks with the Accused, he "was not convinced that [the Accused] really thought about physical elimination of non-Serbs from [BiH]", but that it was impossible to live together due to the extremism of the nationalist parties). While the Chamber accepts that this was Žepinić's own assessment, it does not rely on his opinion in this regard.

9073 P5596 (Video footage depicting interview of Radovan Karadžić on CNN, with transcript), p. 1; P12 (Extended session of Main and Executive Boards of the SDS, 14 February 1992), p. 19; P6688 (Interview with Radovan Karadžić in Duga Magazine, 23 May 1992), p. 3.

9074 P12 (Extended session of Main and Executive Boards of the SDS, 14 February 1992), pp. 19-20. KDZ310 testified that the Accused as the head of the SDS pursued a policy which was designed to prove to "both peoples that they can no longer live together" even though they had lived together for years. KDZ310, T. 9178, 91829183 (29 November 2010). During cross-examination, KDZ310 acknowledged that he was in no way involved in politics and he formed these views based on conversations with people and what was reported in the media. The Chamber therefore places no weight on his assessment. Similarly the Chamber places no weight on Mujadžić's opinion that in Prijedor, the Accused placed his confidence in Stakić as a municipal leader, as he came from a typical "Chetnik" background, to create a rift between Bosnian Muslims and Serbs and to impair the belief that it was possible for the two ethnic groups to co-exist. Mirsad Mujadžić, P3703 (Transcript from Prosecutor v. Stakić), T. 3737-3739, 3903-3904.

9075 KDZ239, P3336 (Transcript from Prosecutor v. Krnojelac), T. 1185. See para. 852. 
that if there was a response to the mobilisation of the $1^{\text {st }}$ Krajina Corps, "then we clear the Posavina of Croats". 9076

2734. These speeches are in stark contrast with an interview on 20 July 1990, where the Accused stated that

an illusion was created about a discord between the Serbs and the Muslims. [...] Basically, there is nowhere a conflict of interest between the Serbs and the Muslims. Regardless of what may happen, the Serbs and the Muslims will always live in a common state, and they know how and they will know in future how to live together. There is no need for a third party to fix the things between them. ${ }^{9077}$

2735. The Accused also stated:

Here, the Muslims are Slavs, people with our blood and language who, for the most part, opt for the European quality of life and preservation of the Islamic faith. There is no room for panic neither among the Serbs nor among the Muslims. According to my estimation, the Serbs do not have to defend the boundaries of the Christian Europe and fight the Islam. We are much closer to our Muslims than with that Europe. ${ }^{9078}$

2736. The Chamber notes, however, that these statements were made by the Accused in a very different environment and were delivered in a period where the political objective of the Bosnian Serb leadership was to emphasise the unity of Yugoslavia and the existence of a common state.

2737. Similarly the Chamber recalls that in the summer of 1991, the Accused attended an SDS rally in Zvornik; ${ }^{9079}$ thereafter, the SDS and SDA issued a joint declaration expressing the need to maintain peace in the municipality and calling for greater tolerance between ethnic groups there. ${ }^{9080}$ In August 1991, the Accused spoke about peace and reaching an agreement with the Bosnian Muslims. ${ }^{9081}$

\footnotetext{
9076 P1478 (Ratko Mladić's notebook, 27 May-31 July 1992), pp. 38, 41.

9077 D269 (Radovan Karadžić's interview with NIN, 20 July 1990), p. 8.

9078 D269 (Radovan Karadžić's interview with NIN, 20 July 1990), p. 9. See also Momčilo Mandić, T. 4748 (6 July 2010); D363 (Intercept of conversation between Radovan Karadžić and Momčilo Krajišnik, 13 July 1991), p. 5.

9079 D3693 (Witness statement of Marinko Vasilić dated 9 June 2013), paras. 17-18; D3723 (Witness statement of Čedomir Zelenović dated 22 June 2013), paras. 15, 18. See para. 1230. Vasilić stated that the Accused at SDS rallies in 1991 spoke in favour of a peaceful solution and respect for everyone in BiH. D3693 (Witness statement of Marinko Vasilić dated 9 June 2013), para. 17. The Chamber notes that Vasilić's testimony was marked by inconsistencies, evasiveness and other indicators that he was not forthright in his evidence. The Chamber therefore does not consider his evidence on what the Accused said at SDS rallies to be reliable.

9080 D3724 (Witness statement of Branko Grujić dated 22 June 2013), para. 15; D3725 (Joint declaration of Zvornik SDS and SDA, undated). See also D4533 (Intercept of conversation between Radovan Karadžić and unidentified male, 9 July 1991) (in which the Accused instructs an unidentified man to ensure that nothing happens to the Muslims in Bosnian Krajina); D4550 (Intercept of conversation between Radovan Karadžić and Dragan Đokanović, 13 December 1991), p. 2.

9081 D276 (Intercept of telephone conversation between Radovan Karadžić and Momčilo Krajišnik, 7 August 1991), p. 2; D277 (Intercept of conversation between Nenad Stevandić and Radovan Karadžić, 17/18 August 1991), pp. 1-2. See also D272 (Intercept of conversation between Radovan Karadžić and Vitomir Žepinić and
} 
2738. On 12 May 1992, there was a large public rally in Banja Luka. The Accused, Mićo Stanišić, and Stojan Župljanin, amongst others, were present. ${ }^{9082}$ The Accused addressed the rally and said that it demonstrated the organisation and power of the $\mathrm{SerBiH}$ and that he regretted that the war in $\mathrm{BiH}$ had been imposed on them by the two other national communities and that the "mutual extermination, killings and tortures have been imposed to us". ${ }^{9083}$ The Accused stated that while they had no conflict with the Croats and Muslims they would not allow their "militant leadership" to make them second class citizens and this was the reason why they created their state unit in BiH. ${ }^{9084}$ The Accused also said that they were proud to say that Muslims and Croats were not in danger in $\mathrm{SerBiH}$ and that they had to defend the borders of $\mathrm{SerBiH}$ for all citizens of $\mathrm{BiH}$ regardless of their "confession or nationality". 9085 Similarly in June 1992, the RS Presidency issued a press statement condemning the $\mathrm{BiH}$ declaration of war and noting that this placed pressure on Serbs to fight "against their brothers" and that they wanted a peaceful resolution of the conflict and that all those who sought protection in $\mathrm{SerBiH}$ would be provided the bare necessities "irrespective of their nationality". ${ }^{9086}$

2739. In contrast to these public statements, when the Accused spoke to Žepinić about his view that the different nationalities could not live together in $\mathrm{BiH}$, Žepinić expressed his concern about what was going to happen to the large number of mixed families in $\mathrm{BiH}$ and the difficulty of dividing people who lived in the same high-rise buildings. ${ }^{9087}$ Žepinić was threatened by Mićo Stanišić and later arrested for his opposition to ethnically based parties and also faced pressure from both Koljević and the Accused. ${ }^{9088}$

Momčilo Mandić, 24 June 1991), p. 2; Robert Donia, T. 3470-3472 (8 June 2010); D4195 (Witness statement of Milomir Stakić dated 16 November 2013), para. 32; Milomir Stakić, T. 45193-45194 (16 December 2013) (stating that he met the Accused for the first time in 1991 when they were having issues with the political party in Prijedor and the Accused told him that "everything should be resolved democractically and through elections"). See D4546 (Intercept of conversation between Radovan Karadžić and Levko Žar, 21 September 1991), p. 3 (wherein the Accused stated that [a]ll disputed issues should be resolved peacefully.”); D4545 (Intercept of conversation between Radovan Karadžić and Slobodan Milošević, 13 September 1991), p. 2 (referring to a Bosnian Muslim and Bosnian Serb agreement).

9082 D494 (Video footage of rally in Banja Luka, 12 May 1992, with transcript); Momčilo Mandić, T. 5331-5336 (16 July 2010).

9083 D494 (Video footage of rally in Banja Luka, 12 May 1992, with transcript), pp. 4-5.

9084 D494 (Video footage of rally in Banja Luka, 12 May 1992, with transcript), p. 5.

9085 D494 (Video footage of rally in Banja Luka, 12 May 1992, with transcript), pp. 5-7; Momčilo Mandić, T. 53345335 (16 July 2010). See also D1587 (Radovan Karadžić's platform for the solution of crisis in BiH, 22 April 1992).

9086 D2244 (Statement by SRBiH Presidency, 23 June 1992), p. 1.

9087 Vitomir Žepinić, T. 33588-33589 (13 February 2013). Žepinić also testified that he could not accept this policy of division and he did not believe that the Accused was able to do so either, but that the Accused faced problems from extremists in his own ranks. Vitomir Žepinić, T. 33589 (13 February 2013).

9088 Vitomir Žepinić, T. 33603-33607, 33619-33620 (13 February 2013). Žepinić testified, however, that the Accused did in certain situations try to protect him from extremists in the SDS. When questioned about whether the Accused took a position that Bosnian Muslims and Croats should be expelled, he testified that if the Accused 
2740. In May 1992, the Accused issued an announcement to Bosnian Muslims appealing for a cessation of hostilities and assured them that Muslims who remained in $\mathrm{SerBiH}$ and had laid down their arms had full protection and lived peacefully. ${ }^{9089}$ The Accused warned against the "crazy idea of an Islamic state" and that the West wanted Muslims to be "obliterated" but the Serbs wanted to reach an agreement with them. ${ }^{9090} \mathrm{He}$ also assured Bosnian Muslims that they would be allowed to leave in the direction of their choice with the right to return when the war was over. ${ }^{9091}$ Okun described this announcement as "thoroughly disingenuous" and noted that it was issued at the same time as the Bosnian Serb Assembly issued its war aims. ${ }^{9092}$

2741. On 2 June 1992, the Accused issued a decision which called for all citizens who had temporarily left the territory of the SerBiH to return and report to the Crisis Staff in their place of residence by 20 May 1992. ${ }^{9093}$ It also promised the right of return to "[p]ersons whose actions were not contrary to the interests of the $[\mathrm{SerBiH}] " .{ }^{9094}$ It provided that persons who had left and did not return or did not explain their inability to return to the relevant municipal crisis staff, would be denied the right of citizenship of SerBiH and all acquired rights regarding employment, housing, health and retirement insurance would cease and their property would be used temporarily for the needs of defence of SerBiH. ${ }^{9095}$

2742. On 4 July 1992, at the $36^{\text {th }}$ session of the Bosnian Serb Government, it was noted that the "question has been raised whether there are agreed criteria regarding the moving out of the Muslim population from the territory of the $[\mathrm{SerBiH}]$. It has been concluded that the Government has not until now had a point of view on this matter. The Ministry of the Interior is entrusted with preparing information on this issue that the Government would consider and take the appropriate standpoint". 9096 This idea of ethnic separation was also supported and reinforced by municipal leaders such as Prstojević who said that "those who convert to Orthodox religion on the spot, they can stay". 9097

or the SDS had directly made such a statement he would have been arrested for such an unconstitutional decision. Vitomir Žepinić, T. 33619-33620 (13 February 2013), T. 33655-33656 (14 February 2013).

D119 (Radovan Karadžić's speech re cessation of hostilities, May 1992), pp. 1-2. See also Momčilo Mandić, T. 5183 (15 July 2010).

D119 (Radovan Karadžić's announcement re cessation of hostilities, May 1992), pp. 1-2.

D119 (Radovan Karadžić's announcement re cessation of hostilities, May 1992), p. 2.

Herbert Okun, T. 1810-1811 (28 April 2010).

P2617 (Radovan Karadžić Decisions, May-June 1992), pp. 2-3.

P2617 (Radovan Karadžić Decisions, May-June 1992), p. 3.

P2617 (Radovan Karadžić Decisions, May-June 1992), pp. 2-3.

P1098 (Minutes of $36^{\text {th }}$ session of SerBiH Government, 4 July 1992), pp. 4-5.

P1086 (Intercepts of conversations between (i) Neđeljko Prstojević and Milenko LNU; (ii) Neđeljko Prstojević and FNU Novaković, 14 May 1992), p. 3. 
2743. At a meeting of the Bosnian Serb leadership on 10 July 1992, the Accused stated that unlike the Bosnian Muslims and Croats, the Bosnian Serbs were going to build a law-abiding state rather than an ethnically clean state. Other attendees expressed their agreement as to the stance to be taken in that regard. ${ }^{9098}$

2744. On 11 July 1992, at the $17^{\text {th }}$ session of the Bosnian Serb Presidency, attended by the Accused, it was decided "that a decision be adopted on the signing of a proclamation on the moving out and retention of citizens from certain parts of the former $[\mathrm{BiH}]$, and on guarantees and safety, on condition that the people be disarmed, enemy activities halted and peace established".9099 On the same date, the Presidency made an announcement to the citizens of RS stating that civilians living in areas affected by war must be allowed to leave those areas and that any emigration had to be voluntary and cannot be obstructed or encouraged. ${ }^{9100}$ This same announcement indicated that Croats and Muslims in the RS were "guaranteed all rights granted by a legal state" and that the authorities were not forcibly detaining people in war zones, as that would make them hostages, or forcing them to emigrate as that would amount to "ethnic cleansing". 9101 The announcement also indicated that all refugees would be allowed to return. ${ }^{9102}$

2745. Despite these public announcements, the Accused continued to advocate the division of $\mathrm{BiH}$ on ethnic lines. ${ }^{9103}$ For example in July 1992, he spoke about the dangers of living in a unitary state where they could not control the Muslims. In this regard he said "[w]e know very well what the fundamentalism is and that we cannot live together, there's no tolerance, they quadruple through the birth-rate, and we Serbs are not up to that". 9104 The Accused also spoke about the Bosnian

\footnotetext{
9098 P1478 (Ratko Mladić's notebook, 27 May-31 July 1992), pp. 309, 313-314.

9099 D444 (Minutes of $17^{\text {th }}$ session of Presidency of SerBiH, 11 July 1992, p. 1. See also Momčilo Mandić, T. 51315132 (14 July 2010).

9100 D445 (SerBiH announcement to the public, 11 July 1992); Momčilo Mandić, T. 5133 (14 July 2010).

9101 D445 (SerBiH announcement to the public, 11 July 1992). See also D3051 (Witness statement of Momir Bulatović dated 25 February 2013), paras. 16, 18-18A, 46; Momir Bulatović, T. 34540-34541 (28 February 2013).

9102 D445 (SerBiH announcement to the public, 11 July 1992), p. 1. See also D112 (Radovan Karadžić's Request to Serbian MUP, 1 September 1992); D113 (Radovan Karadžić's Request to Montenegrin MUP, 1 September 1992) (both requests provided that all refugees regardless of religion or nationality were obliged to return to their place of residence in SerBiH).

9103 D90 (Shorthand Record of $11^{\text {th }}$ session of SerBiH Assembly, 18 March 1992), pp. 5, 10; P921 (Transcript of $24^{\text {th }}$ session of RS Assembly, 8 January 1993), pp. 5, 9-10; P1367 (Transcript of $26^{\text {th }}$ session of RS Assembly, 2 April 1993), p. 7; KDZ240, P2935 (Transcript from Prosecutor v. Krajišnik), T. 6751-6752 (under seal). See also P3474 (News report re meeting of Derventa SDS Executive Board, 13 February 1992), p. 1; D1591 (Radovan Karadžić's interview from Le Figaro, 23 April 1991), p. 1.

9104 D92 (Transcript of $17^{\text {th }}$ session of SerBiH Assembly, 24-26 July 1992), p. 86. See also D115 (Transcript of $25^{\text {th }}$ session of RS Assembly, 19-20 January 1993), p. 5. See also P12 (Extended session of Main and Executive Boards of the SDS, 14 February 1992), pp. 18-19; P5828 (Intercept of conversation between Radovan Karadžić and Slobodan Milošević, 1 November 1991), p. 1; Ronald Hatchett, T. 31958 (16 January 2013); D4686 (Article from SRNA entitled "Political platform for the survival of the Serbian People in BiH", 12 June 1992), p. 1.
} 
Muslims overwhelming the Bosnian Serbs "with their birth rate and their tricks. We cannot allow that to happen". 9105

2746. In meetings with international observers, these sentiments were repeated by Bosnian Serb who kept emphasising that "they simply couldn't live with the Muslims" and that Bosnian Muslims wanted all of $\mathrm{BiH}$ which they could achieve through their higher birth rate. ${ }^{9106}$ The Accused continued to emphasise this issue and stated that in "all variants we must be cautious so that Muslims don't wind up in our state" and cited to the example of Serbia as being unstable even though the population was $65 \%$ Serb. ${ }^{9107}$ Other Bosnian Serb deputies also spoke about the danger faced by the Serb people due to the high birth-rate of Bosnian Muslims which would change the demographic percentages in $\mathrm{BiH} .{ }^{9108}$

2747. The SDS leadership also commissioned a number of studies on the changing demographics in $\mathrm{BiH}$ which showed the growth rate of the Muslim population and reflected the fears of the SDS leadership that Bosnian Muslims would soon become an absolute majority in an independent BiH and impact the position of the Serbs. ${ }^{9109}$ This concern about demographics and the Bosnian Muslim birth rate continued to be emphasised by the Accused throughout the conflict. For example, at the $37^{\text {th }}$ Bosnian Serb Assembly Session on 10 January 1994, the Accused stated that the Muslim population increases by $1 \%$ daily because "that is how it is with them". 9110

2748. Rajko Dukić in July 1992 delivered a speech at the Bosnian Serb Assembly in which he asked "why we expelled all Muslim judges from Vlasenica, Bratunac and Zvornik. Will we be accused then, I hope we will not [...] I would be ashamed and I would regret all the victims if I lived in a state in which Muslims and Muslim ideology would judge and where their justice is done". ${ }^{9111}$ Dukić also stated that there were 120,000 Muslims in the Birač region and he hoped that this number "has at least been halved". ${ }^{9112}$ In August 1992, at a Bosnian Serb Assembly session, Brđanin proposed that they "appoint only those judges who are of Serbian nationality. We cannot

\footnotetext{
9105 P938 (Minutes from SDS Deputies' Club meeting, 28 February 1992), p. 36.

9106 Colm Doyle, T. 2668, 2670 (21 May 2010); Herbert Okun, P776 (Transcript from Prosecutor v. Krajišnik), T. 4163-4164, 4168-4169, 4220; Herbert Okun, T. 1487-1489 (22 April 2010); P1417 (Transcript of 55 ${ }^{\text {th }}$ session of RS Assembly, 22-23 October 1995), p. 60; P777 (Fourth notebook of Herbert Okun's Vance Mission diary), e-court p. 21; P785 (Second notebook of Herbert Okun's ICFY diary), e-court p. 26.

9107 P1485 (Ratko Mladić's notebook, 9 January-21 March 1994), pp. 88-89.

9108 D92 (Transcript of $17^{\text {th }}$ session of SerBiH Assembly, 24-26 July 1992), p. 82.

9109 Patrick Treanor, T. 14006-14007, 14009 (1 June 2011); P2541 (Report on demographic trends in BiH prepared by SDS, June 1991). The Chamber notes that Treanor's testimony also included his own assessment about the objectives of the Bosnian Serb leadership and the meaning of certain speeches. The Chamber considers that this falls outside the scope of his expertise and does not rely on his evidence in this regard.

9110 P1385 (Transcript of $37^{\text {th }}$ session of RS Assembly, 10 January 1994), p. 109.

9111 D92 (Transcript of $17^{\text {th }}$ session of SerBiH Assembly, 24-26 July 1992), pp. 71-73.

9112 D92 (Transcript of $17^{\text {th }}$ session of SerBiH Assembly, 24-26 July 1992), p. 73.
} 
say this to Europe or the rest of the world, but we can say it here between ourselves. Our people do not have the right to live, yet here we are, crying over those ones". 9113

2749. On 2 September 1992, the Accused was among the Bosnian Serb poltical and military leaders who met in Bijeljina on 2 September 1992. ${ }^{9114}$ At this meeting, the Accused observed that " $[w]$ e are close to the goal and we must run across it [...] the Serbian people will either create their own state [...] or we will be squeezed into a small area". 9115 At this meeting it was observed that there was "no political position as to how to proceed with Muslims who have declared loyalty". 9116 The Accused expressed his view that "we must have ethnic minorities in the state as well".9117 Krajišnik reminded those present that the VRS should not distance itself from the SDS. He also recalled that the aim of the Bosnian Serbs was to divide with the Muslims. ${ }^{9118}$ The Accused then noted that he had not heard a "single political difference". 9119 At a meeting with the Bosnian Serb Presidency and VRS commanders in October 1992, the Accused stated that the Bosnian Serbs must insist on having a single Serbian community. ${ }^{9120}$

2750. The Bosnian Serb leadership did envisage small enclaves in RS where Bosnian Muslims could live. $^{9121}$ For example, the Accused said that while Bosnian Muslims could stay in the enclaves, "it is going to be our state". ${ }^{9122}$ At a meeting on 19 June 1993 in Pale with members of the Supreme Command with, inter alios, Krajišnik, Koljević, Lukić, Mladić, and Milovanović in attendance, the Accused stated that the Serbs and Croats should work together so that the Muslims get some territory in central $\mathrm{BiH}^{9123}$

2751. At the $34^{\text {th }}$ session of the Bosnian Serb Assembly, Mladic stated that they had not allowed "any connection of the enclaves in Eastern Bosnia" and that his "aim was, and I am sure that if we establish Republika Srpska they could not wait to get out of the enclaves. However, if they don't

\footnotetext{
9113 D422 (Transcript of $19^{\text {th }}$ session of SerBiH Assembly, 12 August 1992), p. 12.

9114 P1479 (Ratko Mladić's notebook, 16 July-9 September 1992), pp. 131-132.

9115 P1479 (Ratko Mladić's notebook, 16 July-9 September 1992), p. 132.

9116 P1479 (Ratko Mladić's notebook, 16 July-9 September 1992), p. 134.

9117 P1479 (Ratko Mladić's notebook, 16 July-9 September 1992), p. 156.

9118 P1479 (Ratko Mladić's notebook, 16 July-9 September 1992), pp. 131, 141, 143.

9119 P1479 (Ratko Mladić's notebook, 16 July-9 September 1992), p. 153.

9120 P1481 (Ratko Mladić's notebook, 5 October-27 December 1992), pp.48, 52.

9121 Herbert Okun, T. 1698-1699 (27 April 2010). KDZ026 testified that the Accused advocated and pursued a policy under which in Serb territory, $90 \%$ of the population would be Serb and 10\% of Muslims would be allowed to remain. KDZ026, T. 10414 (18 January 2011) (closed session). However, it is unclear on what basis KDZ026 reached this conclusion. The Chamber therefore does not rely on his evidence in this regard.

9122 P2451 (Witness statement of Anthony Banbury dated 19 May 2009), para. 149.

9123 P1483 (Ratko Mladić's notebook, 2 April-24 October 1993), p. 212.
} 
want to, we have to provide the conditions so that they could feel glad when we offer it to them". 9124

2752. The Accused in meetings with international negotiators stated that "Serbs would never accept to be ruled by Muslims", but that if Muslims gave up their claim to rule over all of BiH, "they could quite happily live alongside each other" but each with their own administrations and safeguards for minorities. ${ }^{9125}$ In contrast, at a meeting on 8 September 1992, the Accused stated that there were no Serbs, except in Sarajevo, who wanted to live with the Bosnian Croats and Bosnian Muslims in one state..$^{9126}$

2753. Later on, in meetings with international negotiators, the Bosnian Serb leadership indicated that they were prepared to accept changes in internal borders "to accommodate ethnic realities". 9127 However, by the time these statements were made, there had already been a large forcible displacement of Bosnian Muslims from their homes and the Bosnian Serb leadership sought a peace deal on the basis of the large percentage of territory in BiH which they had already taken. ${ }^{9128}$ Similarly, the Bosnian Serb leadership also suggested holding referenda in early 1993 to solve "controversial areas" but in reality by this time there were very few Bosnian Muslims or Bosnian Croats who remained to vote. ${ }^{9129}$

2754. In September 1992, the Accused continued to stress that their objective was to have a state and that its borders "towards the Muslims and Croats are to be thicker than our borders towards Serbia and Montenegro and the Serbian Krajina". ${ }^{9130}$ When the Accused discussed maps of BiH and issues of population and division of territories this also caused a feeling of fear, anxiety, insecurity and uncertainty amongst people who "saw themselves living in the territory of another people or another nation". 9131

\footnotetext{
9124 P1379 (Transcript of 34 ${ }^{\text {th }}$ session of RS Assembly, 27-29 August, 9-11 September, 29 September to 1 October 1993), p. 70.

9125 P4216 (UNPROFOR report re meeting with Radovan Karadžić, 20 November 1992), p. 3; P4203 (Witness statement of Pyers Tucker dated 12 May 2010), para. 69; Pyers Tucker, T. 23236-23237 (18 January 2012). See also D539 (UNPROFOR report re meeting with Radovan Karadžić and Ratko Mladić, 27 November 1992), p. 2.

9126 P1479 (Ratko Mladić's notebook, 16 July-9 September 1992), pp. 167, 171.

9127 P785 (Second notebook of Herbert Okun's ICFY diary), e-court pp. 34, 44. Okun's assessment was that the phrase "to accommodate ethnic realities" was a "very clear, not-so-subtle reference to the ethnic cleansing". Herbert Okun, P776 (Transcript from Prosecutor v. Krajišnik), T. 4215-4216.

9128 Herbert Okun, P776 (Transcript from Prosecutor v. Krajišnik), T. 4215-4216, 4218-4219.

9129 Herbert Okun, P776 (Transcript from Prosecutor v. Krajišnik), T. 4245; Herbert Okun, T. 1519, 1522-1524 (23 April 2010); P789 (Sixth notebook of Herbert Okun's ICFY diary), e-court p. 58; P790 (Seventh notebook of Herbert Okun's ICFY diary), e-court p. 40.

9130 D456 (Transcript of 20 $0^{\text {th }}$ session of RS Assembly, 14-15 September 1992), p. 55.

9131 KDZ310, T. 9177-9178 (29 November 2010).
} 
2755. On 30 October 1992, the Accused delivered a speech at the $21^{\text {st }}$ Session of the Bosnian Serb

Assembly in which he described

an artificial state in which we were forcefully held in an artificial creation that is Bosnia and Herzegovina together with our centuries-old foes. It all reminds me of the experiment in which a dog and cat are held in a box together against their will, or a bad marriage maintained by all sorts of forceful means. It transpired that a dog and cat can remain in the box together under only one condition, namely that they lose their natural characteristics and cease being a dog and a cat. We will remember that we could not be Serbs and live in such a box..$^{9132}$

2756. The Accused characterised the conflict in $\mathrm{BiH}$ as a "conflict among peoples" and stated that "Muslims cannot live with others. We must be clear on that. They couldn't live with the Hindu, who are as peaceful as sheep. [...] They couldn't live with the Greek on Cyprus, they couldn't live in the Lebanon with Arabs of the same blood, same language, but of a different faith. There can be no discussion here [...] We are in power, and we should exercise that power". ${ }^{9133}$ In this regard the Accused noted that there was nothing new, and that in the case of India and Pakistan there had been a "huge resettlement of the people" and the separation was "covered in blood". 9134

2757. At a gathering in January 1993 attended by UN personnel, the Accused emphasised that they could not live together anymore with the Bosnian Muslims, they would not allow the past to repeat itself, and that therefore the Bosnian Muslims would be transferred out of Bosnian Serb territory. ${ }^{9135}$ The Bosnian Serb leaders who attended included Mladić, Krajišnik, and Plavšić, and they all agreed with what the Accused said in this regard. ${ }^{9136}$ They spoke about "ethnic cleansing" as something which was necessary. ${ }^{9137}$

2758. In January 1993, at a meeting attended by Bosnian Serb and Serbian leaders, Vladislav Jovanović spoke about the importance of ensuring the territory they got was "nationally homogeneous as soon as possible". ${ }^{9138}$ Jovanović stated that this was not to be achieved by "ethnic cleansing" but through the "exchange of inhabitants", and stressed that where life in BiH becomes

\footnotetext{
9132 P939 (Video footage of Radovan Karadžić's speech at the $21^{\text {st }}$ Session of RS Assembly, 30 October 1992, with transcript), pp. 1, 3 .

9133 P938 (Minutes from SDS Deputies' Club meeting, 28 February 1992), p. 36. See P2451 (Witness statement of Anthony Banbury dated 19 May 2009), para. 153. See also P2493 (Anthony Banbury's notes, 30 April 1995).

9134 P938 (Minutes from SDS Deputies' Club meeting, 28 February 1992), p. 36; P12 (Extended session of Main and Executive Boards of the SDS, 14 February 1992), pp. 18-19.

9135 P1258 (Witness statement of Hussein Ali Abdel-Razek dated 16 July 2002), pp. 5-7.

9136 P1258 (Witness statement of Hussein Ali Abdel-Razek dated 16 July 2002), pp. 6-7, 11-12. See also P1154 (Witness statement of KDZ088 dated 27-29 April 2010), pp. 113-115, 120 (under seal).

9137 P1258 (Witness statement of Hussein Ali Abdel-Razek dated 16 July 2002), p. 7.

9138 P794 (Excerpt from expanded session of Council for Harmonising State Policy Positions, 21 January 1993), ecourt p. 3; Herbert Okun, P776 (Transcript from Prosecutor v. Krajišnik), T. 4284-4285.
} 
impossible everybody rushes off to their "original provinces". 9139 This was described by Jovanović as a "strategic goal to which we should aspire, and which should be achieved". 9140 Jovanović stated that they had to be conscious that there was attention on Serbs and they were trying to catch them on "anything that even resembles ethnic cleansing or linking" and that they would have to look out for these traps and try to 'catch' them where they are weak". ${ }^{9141}$

2759. Jovanović also spoke of the need to ensure in an "indisputable way" a territorial link with Serbia and Montenegro. ${ }^{9142}$ Jovanović also cautioned against freedom of settlement which could result in the "mixing of the composition of the population to our disadvantage" and that what they had gained would "gradually erode". 9143

2760. The Accused went on to say that "this which Jovanović is talking about, has already happened to a huge extent. There was fifty-fifty of us in Zvornik. The number of inhabitants of Zvornik is now the same, approximately 50,000, and they are all Serbs. More than 24,000 Serbs from Zenica and Central Bosnia have arrived and stopped in Zvornik."9144 The Accused also stated that there will not be a unitary $\mathrm{BiH}$ of the civic type or one in which the Muslim majority will come to the fore. ${ }^{9145}$

9139 P794 (Excerpt from expanded session of Council for Harmonising State Policy Positions, 21 January 1993), ecourt p. 3. See also Herbert Okun, T. 1824-1825 (28 April 2010). Jovanović acknowledged that this meeting took place but that when he spoke about developing an area which would be as "nationally homogeneous" as soon as possible, this was to be achieved by allowing people to freely move to other cantonal units if they did not want to live in a particular canton. D3015 (Witness statement of Vladislav Jovanović dated 22 February 2013), paras. 53, 64; Vladislav Jovanović, T. 34318-34319 (26 February 2013). The Chamber notes however, that Jovanović's testimony was marked by indicators of evasiveness and bias. In addition, the Chamber considers that he had an interest in characterising his own words in a favourable light. The Chamber therefore does not find his evidence to be reliable with respect to the voluntary nature of the movement of population which was envisaged.

9140 P794 (Excerpt from expanded session of Council for Harmonising State Policy Positions, 21 January 1993), ecourt p.3.

9141 P794 (Excerpt from expanded session of Council for Harmonising State Policy Positions, 21 January 1993), ecourt p. 5; Herbert Okun, P776 (Transcript from Prosecutor v. Krajišnik), T. 4284-4287.

9142 P794 (Excerpt from expanded session of Council for Harmonising State Policy Positions, 21 January 1993), ecourt p. 3.

9143 P794 (Excerpt from expanded session of Council for Harmonising State Policy Positions, 21 January 1993), ecourt p. 3.

9144 P794 (Excerpt from expanded session of Council for Harmonising State Policy Positions, 21 January 1993), p. 4; See also Herbert Okun, T. 1823-1824 (28 April 2010); P4518 (Excerpts from Robert Đurđević's diary, $7-$ 25 September 1993), p. 2. Jovanović's assessment was that the Accused had merely been pointing out undesirable and unavoidable consequences of any war, which was that the Serbs had been fleeing the Muslimdominated and heading to the regions where the Serbs made up a majority. D3015 (Witness statement of Vladislav Jovanović dated 22 February 2013), para. 53. The Chamber refers to its credibility assessment in fn. 9139 in concluding that it does not find Jovanović's evidence to be reliable in this regard.

9145 D4765 (Notes from expanded session of Council for Harmonising State Policy Positions, 21 January 1993 ), p. 3. 
2761. The Accused further stated that Serbs must fight for these territories to get a quality piece and said "we want some of our rich areas to belong to us". 9146 The Accused also said that the Neretva was disputable and that they could live without it, but that they could not give up Podrinje and Posavina. ${ }^{9147}$ Further, the Accused agreed with Slobodan Milošević and Kontić that they could not invoke the democratic principle if they abandoned the "ethnic criterion". 9148 The Accused said that they would gladly exchange prisoners but would no longer make unilateral releases. ${ }^{9149}$ Slobodan Milošević also expressed the view that had there not been the war, the changes on the ethnical basis would not have taken place, but that now they had the changes based on the ethnical principle. $^{9150}$

2762. Krajišnik said that what was important was not how big the territory was but the "quality of that territory" and that they had to seriously consider the issue of maps. ${ }^{9151}$ Krajišnik also stated that they had to "solve one part at a time - something through politics, something else through migration, and some things through settlement". ${ }^{9152}$ He also emphasised that the continuity of the territory which they had was very important to allow for the unification of Serb territory in the RS and also spoke in favour of connection with their motherlands in Serbia and Montenegro. ${ }^{9153}$ Koljević stated that they would have to "develop the activity of settlement homogenisation" while there was still time. ${ }^{9154}$

2763. In 1993, Velibor Ostojić also referred to their goal of "ethnical - geographical continuity of Serb population" and that they were "building new demographic politics for the RS" and the need to have Serbs settle in areas which they held. ${ }^{9155}$ Ostojić was responible for the Commission for

\footnotetext{
9146 D4765 (Notes from expanded session of Council for Harmonising State Policy Positions, 21 January 1993), pp. 7-8.

9147 P6164 (Excerpt from notes of enlarged session of Council for Coordinating Positions on State Policy, 9 January 1993), e-court p. 65

9148 D4765 (Notes from expanded session of Council for Harmonising State Policy Positions, 21 January 1993), p. 43.

9149 D4765 (Notes from expanded session of Council for Harmonising State Policy Positions, 21 January 1993 ), p. 43.

9150 P6164 (Excerpt from notes of enlarged session of Council for Coordinating Positions on State Policy, 9 January 1993), e-court p. 41.

9151 P794 (Excerpt from expanded session of Council for Harmonising State Policy Positions, 21 January 1993), ecourt pp. 5-6.

9152 P794 (Excerpt from expanded session of Council for Harmonising State Policy Positions, 21 January 1993), ecourt p. 6.

9153 P6164 (Excerpt from notes of enlarged session of Council for Coordinating Positions on State Policy, 9 January 1993), e-court p. 51.

9154 P794 (Excerpt from the session of the Council for Coordinating Positions on the State Policy, 21 January 1993), e-court pp. 8-9; Herbert Okun, P776 (Transcript from Prosecutor v. Krajišnik), T. 4292 (testifying that in his assessment, this "settlement homogenisation" referred to "ethnic cleansing").

9155 P1379 (Transcript of $34^{\text {th }}$ session of RS Assembly, 27-29 August, 9-11 September, 29 September to 1 October 1993), pp. 212-213. Vladimir Lukić testified that the Bosnian Serb Government sought the return of refugees regardless of ethnicity. D3563 (Witness statement of Vladimir Lukić dated 18 May 2013), paras. 33,
} 
Refugees and Humanitarian Aid which organised this settlement of Serbs and did not provide for the return of Bosnian Muslims or Bosnian Croats. ${ }^{9156}$ Ostojić was the Minister of Information and was trusted by, and had direct contact with, the Accused. ${ }^{9157}$ This process of settling Serbs was done with a view to filling a particular area so Bosnian Muslims did not have a place to return to. ${ }^{9158}$ This was in contrast with statements made at sessions of the Bosnian Serb Government in March and May 1993 where they emphasised the need to create conditions for the return of refugees who had left the RS during the conflict. ${ }^{9159}$

2764. In April 1993, in discussions with international representatives, the Accused stated that he could not persuade Bosnian Serbs to remain in the Posavina and that they were asking for new land and territories. ${ }^{9160}$ Mladić also spoke at this meeting and suggested that all sides sit down to resolve the problems. ${ }^{9161}$ The Accused also explained why the proposals at the time were absolutely unacceptable to the Serbs and questioned whether they could set up a regime to identify areas where they had to withdraw from and areas where they would have to resettle Bosnian Serbs. ${ }^{9162}$ In April 1993, Krajišnik also expressed his opposition to "any kind of joint state with the murderers of Serbian people, Muslims and Croats". 9163 In August 1993, Krajišnik noted with respect to Banja Luka that the Muslims and Croats had asked for the municipality during negotiations, but he stressed that the Bosnian Serbs did not accept that "because we must have that territory clean". 9164

46; Vladimir Lukić, T. 38787-38790 (28 May 2013). See also P3129 (Minutes of the $66^{\text {th }}$ session of RS Government, 20 March 1993), p. 8. The Chamber finds that Vladimir's Lukić's testimony with respect to this issue was marked by evasiveness and indicators of insincerity particularly when confronted with the speeches made by Ostojić which suggested that the Bosnian Serb policy on refugees was connected with its goal of achieving ethnic geographic continuity of the Serb population and did not make provision for the return of Bosnian Muslims and Bosnian Croats. The Chamber therefore does not find his evidence in this regard to be reliable.

9156 P1388 (Transcript of $39^{\text {th }}$ session of RS Assembly, 24-25 March 1994), pp. 168-169; D3588 (Minutes of $89^{\text {th }}$ session of RS Government, 18 January 1994), p. 4. Radoslav Brđanin was tasked along with Velibor Ostojić with preparing a programme for the accommodation of refugees in the RS. D3588 (Minutes of $89^{\text {th }}$ session of RS Government, 18 January 1994), p. 4; P1392 (Transcript of $41^{\text {st }}$ session of RS Assembly, 31 May to 1 June 1994), p. 50.

9157 P4982 (Witness Statement of Branko Đerić dated 5 April 2012), para. 10. See also D422 (19 ${ }^{\text {th }}$ session of SerBiH Assembly, 12 August 1992), p. 38.

9158 P1419 (Transcript of 56 ${ }^{\text {th }}$ session of RS Assembly, 17 December 1995), pp. 94-95.

9159 P3129 (Minutes of the $66^{\text {th }}$ session of RS Government, 20 March 1993), p. 8; P3112 (Minutes of the $71^{\text {st }}$ session of RS Government, 26-27 May 1993), pp. 10-11.

9160 P792 (Ninth notebook of Herbert Okun's ICFY diary), e-court pp. 46-48.

9161 P792 (Ninth notebook of Herbert Okun's ICFY diary), e-court p. 47.

9162 P792 (Ninth notebook of Herbert Okun's ICFY diary), e-court pp. 48-49.

9163 P1367 (Transcript of $26^{\text {th }}$ session of RS Assembly, 2 April 1993), p. 34.

9164 P1379 (Transcript of 34 $4^{\text {th }}$ session of RS Assembly, 27-29 August, 9-11 September, 29 September to 1 October 1993), p. 48. See Herbert Okun, P776 (Transcript from Prosecutor v. Krajišnik), T. 4293, 4295. 
2765. The Accused also suggested that Krajina would "take on an appearance of a rotten apple" if their enemy was in Krajina. ${ }^{9165}$ Similarly the Accused spoke about a "green stain" which had appeared on maps given that there were proposals for portions of territory to be allocated to Bosnian Muslims and that the Serbs in that area would not allow that to happen. ${ }^{9166}$

2766. At the $37^{\text {th }}$ session of the Bosnian Serb Assembly on 10 January 1994, Mladić addressed the assembly on the issue of lack of resources and material support for the VRS. ${ }^{9167} \mathrm{He}$ went on to describe how the Bosnian Serbs had an historical chance to create an "all Serbian state" with as little enemies as possible and that the Muslims and the Croats represented a danger. ${ }^{9168} \mathrm{He}$ thus recommended to keep on fighting as the enemy the Bosnian Serbs were facing was getting stronger and stated: "They started the war at first, they are heading this war, but that is not my concern. My concern is not that they will create the state. My concern is to have them vanish completely."9169

2767. At the same session, Krajišnik stated that "the biggest tragedy would be if the Muslims accepted to live with us now. [...] That is the only thing I would never accept, and I would rather accept that we get a smaller percentage of the territory than it is the case now, provided that we remain separated from the Muslims and that we have our country". ${ }^{9170}$ He also spoke about their goal being "to separate from the Croats and Muslims forever". ${ }^{9171}$ Krajišnik continued to make similar statements and by 1995 spoke about their first Strategic Goal being to separate from the Bosnian Muslims and Bosnian Croats. ${ }^{9172}$

2768. At the same Bosnian Serb Assembly session on 10 January 1994, the Accused noted that they were now a "state and what we hold is $100 \%$ ours". 9173 The Accused also acknowledged that "[i]f we are going to divorce from the Muslims, we must give them something. It is impossible to make the Muslims vanish, and that we keep the entire territory". 9174 The Accused also noted that

P1394 (Transcript of 42 ${ }^{\text {nd }}$ session of RS Assembly, 18-19 July 1994), e-court p. 12.

P6134 (Video footage of interview with Radovan Karadžić, with transcript), p. 2. See also Jose Cutileiro, T. 33964-33967 (19 February 2013).

9167 P1385 (Transcript of $37^{\text {th }}$ session of RS Assembly, 10 January 1994), p. 43.

9168 P1385 (Transcript of $37^{\text {th }}$ session of RS Assembly, 10 January 1994), p. 47.

9169 P1385 (Transcript of $37^{\text {th }}$ session of RS Assembly, 10 January 1994), pp. 48-49.

9170 P1385 (Transcript of $37^{\text {th }}$ session of RS Assembly, 10 January 1994), pp. 121, 124. See also P796 (Excerpt from $37^{\text {th }}$ session of RS Assembly, 10 January 1994), p. 2; Herbert Okun, P776 (Transcript from Prosecutor $v$. Krajišnik), T. 4298 (testifying that the comments of Krajišnik were consistent with what they heard during international negotiations about the position taken by the Bosnian Serb leadership with respect to ethnic purity and the creation of a Bosnian Serb state).

9171 P1477 (Ratko Mladić's notebook, 14 February-25 May 1992), p. 262; P1479 (Ratko Mladić's notebook, 16 July-9 September 1992), pp. 140, 144.

9172 P1419 (Transcript of $56^{\text {th }}$ session of RS Assembly, 17 December 1995), p. 104.

9173 P1385 (Transcript of $37^{\text {th }}$ Session of RS Assembly, 10 January 1994), pp. 107, 110.

9174 P1385 (Transcript of $37^{\text {th }}$ Session of RS Assembly, 10 January 1994), p. 132.
} 
they could not declare a ban on the return of refugees according to international law and that in principle they would say that all refugees could return on a reciprocal basis. ${ }^{9175}$

2769. In April 1994, Mladić was quoted as encouraging VRS operations because "[t]he Turks must disappear from these areas". ${ }^{9176}$ Michael Rose testified that he and other international representatives had thought that the objective of the combat operations in Goradže was to move the Bosnian Muslims out of the right bank of the town and therefore he suspected the reference in the order to "[t]he Turks must disappear from these areas" to mean just that. ${ }^{9177}$

2770. In July 1994, the Accused in an address before the Bosnian Serb Assembly, spoke about achieving

our primary strategic aim, which is to get rid of the enemies in our house, the Croats and Muslims, and not to be in the same state with them any more. Every divorce has a price, we have to give something up, but we are the winners, we have a majority of the territory now, not only under our control, but also in our ownership. ${ }^{9178}$

2771. In August 1994, in video footage taken of Mladić and Milan Lešić, the founder of a Canadian charitable organisation called "Serbian Humanitarian Public Organisation", 9179 in a car as they drove through Han Pijesak and Crna Rijeka, Mladić boasted that he "kicked the hell out of the Turks [...] who gives a fuck about them!" and commented that Lešić should film what they had done to the Turks and pointed to abandoned Bosnian Muslim houses. ${ }^{9180}$

2772. At a Bosnian Serb Assembly session in November 1994, the Accused gave a speech in which he explained that "[w]e have created new realities" and that Zvornik used to be $60 \%$ Muslim but that Bosnian Serbs from Zenica arrived, occupied Kozluk and the Bosnian Muslims left. ${ }^{9181} \mathrm{He}$ went on to say that they were requesting Zvornik "which comes out of a new reality. [...] This war has created the new reality, there are now the Serbs from Zenica here. [...] We request Zvornik according to this right". ${ }^{9182}$ At this same session, Krajišnik stated that "the primary strategic goal of our people and this Parliament is partition and separation from Croats and Muslims. And the

\footnotetext{
9175 P1385 (Transcript of $37^{\text {th }}$ Session of RS Assembly, 10 January 1994), p. 132. The Chamber places no weight on Vladimir Lukić's asssement about the meaning of this statement. Vladimir Lukić, T. 38794-38796 (28 May 2013). In doing so the Chamber refers to its credibility assessment in fn. 9155.

9176 P1645 (Order of Višegrad Tactical Group, 11 April 1994).

9177 Michael Rose, T. 7274-7275 (5 October 2010).

9178 P1394 (Transcript of $42^{\text {nd }}$ session of RS Assembly, 18-19 July 1994), e-court p. 76 . See also P1387 (Transcript of $38^{\text {th }}$ session of RS Assembly, 17 January 1994), p. 67.

9179 Milan Lešić, T. 25010 (21 February 2012).

9180 P4442 (Video footage depicting a conversation between Milan Lešić and Ratko Mladić, with transcript); Milan Lešić, T. 25030-25032 (22 February 2012).

9181 P1403 (Transcript of First Part of $46^{\text {th }}$ session of RS Assembly, 9-11 November 1994), p. 157.

9182 P1403 (Transcript of First Part of $46^{\text {th }}$ session of RS Assembly, 9-11 November 1994), p. 157.
} 
partition can only be made if they will have their state while we have our own. How big these states will be is another issue. We cannot get entire Bosnia". ${ }^{9183}$ The Accused in 1995 confirmed this objective when he stated that if they were able to secure the territory they decided on and if it was "nearly $100 \%$ Serbian", they would be great victors and would have realised their ultimate dream, a Serbian State west of the Drina. ${ }^{9184}$ The Accused also acknowledged that they had undertaken military operations to expand the territory but that after the Bosnian Muslims had been packed into small areas, "thus achieving their concentration", there was not much more that could be done. ${ }^{9185}$

2773. At a meeting of the Supreme Command on 31 March 1995, the Accused made reference to the danger posed by Bosnian Muslims who remained in their territory and stated that "Muslims remaining there in any way is disastrous for us", and that their policy had been the "separation of peoples, of cultures, of worlds", based on the idea that "birds of a feather flock together". ${ }^{9186} \mathrm{He}$ also spoke about turning a blind eye to private agencies and arrangements through which Bosnian Muslims left for western Europe because in those situations "no one can accuse us", whereas if a state institution was involved they would be accused of "ethnic cleansing".9187 Krajišnik stressed that freedom of movement was allowed in order to pull Serbs out of Muslim territory and "if the Muslims want to go from our territory, then we enable them to leave our area, without coercion, because we do not have the right to do that, nor should anyone take on himself their ethnic cleansing, but there would be no crying if they left from here". 9188

\section{(b) Territorial claims and control}

2774. On 23 December 1991, the Accused spoke about the plebiscite which had been conducted and stated that in principle, even if Serbs constituted only $5 \%$ of the population, "everywhere where Serbs live and where they have voted against secession, or to remain in Yugoslavia, no one can break away there. In other words, there remain only five municipalities that could separate from Yugoslavia". ${ }^{9189}$ In a conversation with Koljević in December 1991, the Accused stated that there

\footnotetext{
9183 P1403 (Transcript of First Part of $46^{\text {th }}$ session of RS Assembly, 9-11 November 1994), p. 262.

9184 P1417 (Transcript of 55 ${ }^{\text {th }}$ session of RS Assembly, 22-23 October 1995), p. 60. See also P5608 (Intercept of conversation between Todor Dutina and Radovan Karadžić, 29 June 1995), p. 2 (where the Accused continued to emphasise the importance of the Strategic Goals into 1995).

9185 P988 (Transcript of 53 ${ }^{\text {rd }}$ session of RS Assembly, 28 August 1995), p. 64. See also D2149 (Aide mémoire of Manojlo Milovanović), pp. 25, 27.

9186 P3149 (Minutes of $14^{\text {th }}$ session of Supreme Command, 31 March 1995), p. 65.

9187 P3149 (Minutes of $14^{\text {th }}$ session of Supreme Command, 31 March 1995), pp. 65-66.

9188 P3149 (Minutes of $14^{\text {th }}$ session of Supreme Command, 31 March 1995), p. 28. See also D3565 (RS Government conclusion, 26 January 1993).

9189 D4555 (Intercept of conversation between Radovan Karadžić and Maristela Lučić, 23 December 1991), pp. 1-2; D86 (Shorthand Record of $4^{\text {th }}$ session of SerBiH Assembly, 21 December 1991), pp. 37-38.
} 
was great media interest in whether the Serbs wanted war but they had said that "we want war by no means" and that "we have no aims, we don't want to take what belongs to someone else"; "we just don't want them to take ours". 9190

2775. In February 1992, Krajišnik suggested that the Serbian people had two options, to either fight by political means or to "break off the talks and go for what we have done over the centuries: win our own territories by force". 9191 In this regard, Krajišnik said "[y]ou know what our profession has always been - to wage war". 9192

2776. In March 1992, Krajišnik also stated that "[s]ince municipality borders may be adjusted, we have already made some adjustments and we plan to include all parts that will be Serbian territory in our municipalities, and what remains to be discussed, the discussion will be about where it is going to be, where are we going to put our lines" and that for strategic reasons "we could start implementing what we have agreed upon, the ethnic division on the ground. That we start determining the territory". ${ }^{9193}$ Krajišnik, in interviews, also spoke about the borders and territory held by the VRS but refuted the suggestion that they were holding territories populated by other national communities, although he acknowledged that it may have been the case with certain enclaves within their territory. ${ }^{9194}$

2777. In March 1992, the Accused explained that SerBiH existed, that there would be no return to a unitary $\mathrm{BiH}$ and the only contest was of "quantity, there is a tug of war about who will have more. We won, we have drawn the rope to a certain point and we are not going to yield it back". 9195 The Accused stated that the goals of the Bosnian Serbs were being accomplished stage by stage. ${ }^{9196}$ The Accused also said that the Bosnian Muslims were forced to accept that $\mathrm{BiH}$ was divisible along national lines, and that the Bosnian Serbs would "decide what our constituent unit is" based on "what conditions we establish on the ground". 9197 P5789 (Intercept of conversation between Radovan Karadžić and Nikola Koljević, 21 December 1991), p. 1. D88 (Shorthand Record of $8^{\text {th }}$ session of SerBiH Assembly, 25 February 1992), p. 21. D88 (Shorthand Record of $8^{\text {th }}$ session of SerBiH Assembly, 25 February 1992), p. 64. D90 (Shorthand Record of $11^{\text {th }}$ session of SerBiH Assembly, 18 March 1992), p. 13. P797 (TV Belgrade interview with Momčilo Krajišnik), p. 1. See also Herbert Okun, P776 (Transcript from Prosecutor v. Krajišnik), T. 4306-4307.

9195 D90 (Shorthand Record of $11^{\text {th }}$ session of SerBiH Assembly, 18 March 1992), p. 43.

9196 D90 (Shorthand Record of $11^{\text {th }}$ session of SerBiH Assembly, 18 March 1992), p. 43.

9197 D90 (Shorthand Record of $11^{\text {th }}$ session of SerBiH Assembly, 18 March 1992), p. 43.
} 
2778. On 23 April 1992, Mandić was informed that Višegrad had been taken. ${ }^{9198}$ On 30 April 1992, the Bosnian Serb Government was informed about the situation in Foča and that Bosnian Serb authorities had control over "liberated areas". 9199

2779. In meetings with international representatives in April 1992, the Accused showed maps on which the ethnic composition was marked, as was Bosnian Serb claimed or controlled territory; in total, this amounted to approximately $70 \%$ of $\mathrm{BiH}^{9200}$ This was consistent with earlier speeches by the Accused where he stated that it would be impossible for Izetbegović to establish authority in $70 \%$ of the territory in $\mathrm{BiH}^{9201}$ Many of the areas which the Bosnian Serbs claimed included municipalities along the Drina River and in the Posavina area which had a majority Bosnian Muslim population but later became Bosnian Serb controlled areas with very few Bosnian Muslims remaining. ${ }^{9202}$

2780. The Accused had previously spoken about territorial issues. For example in an intercepted conversation in September 1991, the Accused spoke about negotiations regarding territories and the plan to free Bosanska Krajina, Semberija and Doboj and said that Eastern Herzegovina and Romanija were "clean". ${ }^{9203}$ In November 1991, the Accused had a conversation about the situation in Novo Sarajevo and said that they would teach the SDA "the law pretty soon" given that they had blocked the work of the Municipal Assembly and that they would "probably carry out some kind of reorganisation of the city". ${ }^{9204}$ The Accused then said, "[a]nd they can go to fucking hell". ${ }^{9205}$ The Accused also asked where Bosnian Muslim settlements were in Novo Sarajevo and questioned how many Bosnian Muslims lived in specific areas and in the municipality generally. ${ }^{9206}$

2781. On 6 May 1992, Mladić was at a meeting where he was informed that "Foča has been finished". ${ }^{9207}$ At the $16^{\text {th }}$ Session of the Bosnian Serb Assembly on 12 May 1992 the Accused

P5701 (Intercept of conversation between Momčilo Mandić, Zorica and Traparić, 23 April 1992), p. 5.

P4986 (Report of SerBiH Government, 30 April 1992), p. 1. See also P2716 (Notebook of Radovan Karadzić), p. 28.

9200 [REDACTED]. See also P797 (TV Belgrade interview with Momčilo Krajišnik); Herbert Okun, P776 (Transcript from Prosecutor v. Krajišnik), T. 4300-4301; Herbert Okun, T. 1477-1483, 1485-1486 (22 April 2010); P784 (First notebook of Herbert Okun's ICFY diary), e-court p. 45; P802 (Map of BiH marked by Herbert Okun); P788 (Fifth notebook of Herbert Okun's ICFY diary), e-court p. 29; P780 (Seventh notebook of Herbert Okun's Vance Mission Diary), e-court p. 27.

9201 P958 (Radovan Karadžić's speech at the Plebiscite of the Serb People, November 1991), p. 11.

9202 Herbert Okun, T. 1487-1488 (22 April 2010), T. 1498-1499 (23 April 2010); P783 (Ethnic map of BiH).

9203 P5864 (Intercept of conversation between Radovan Karadžić and Slobodan Milošević, 19 September 1991), p. 1.

9204 P2574 (Intercept of conversation between Radovan Karadžić and Žarko Đurović, 19 November 1991), p. 2.

9205 P2574 (Intercept of conversation between Radovan Karadžić and Žarko Đurović, 19 November 1991), p. 2.

9206 P2574 (Intercept of conversation between Radovan Karadžić and Žarko Đurović, 19 November 1991), pp. 2-3; Radomir Nešković, P2568 (Transcript from Prosecutor v. Krajišnik), T. 16641-16645.

9207 P1477 (Ratko Mladić's notebook, 14 February-25 May 1992), pp. 253, 255.
} 
stated that the conflict in municipalities, including Foča, Zvornik, and Višegrad, had ended successfully. ${ }^{9208}$ On 19 May 1992, in an intercepted conversation, Mićo Stanišić said that Foča had fallen along with Višegrad and that all those who had left these municipalities were in Goražde. ${ }^{9209}$ Stanić reported to Mladić that in contrast to what it was before the conflict, the percentage of Serbs in Foča was $99 \% .^{9210}$

2782. On 8 May 1992, the National Security Council tasked the Ministry of Justice with proposing the state borders of SerBiH. ${ }^{9211}$ On 24 May 1992, Prime Minister Branko Đeric wrote a letter in which he stated the Serbs in BiH were "not an invented people as we have been living on this land for thirteen centuries". He also wrote that the Bosnian Serbs held title to $64 \%$ of the arable land, and that they used to be a majority in $\mathrm{BiH}$ before the genocide jointly carried out against Serbs by Muslims and Croats during World War II. ${ }^{9212}$

2783. The Accused also stated "[w]e must prove to the international factor that $[\ldots]$ we hold no siege over Sarajevo. Basically, we are protecting our territories and here it is visible that Sarajevo sprung up in Serbian territory, as Serbian property, and the entire surrounding of Sarajevo is Serbian". ${ }^{9213}$ The Accused spoke about Serbian villages, towns, and settlements which were beyond dispute and that they should seek to solve issues where ethnic areas and maps overlap. ${ }^{9214}$

2784. At a meeting of the Bosnian Serb leadership on 6 June 1992, Krajišnik stated that "we have to conquer what is ours and be prepared to defend our state" and that the goal was to form and unite the "Birač-Romanija area". 9215

2785. After a meeting on 30 June 1992 when he received reports on the combat success of voluntary formations, the Accused stressed that the Bosnian Serbs had "by and large outlined their territory" and the most pressing tasks involved successfully establishing democratic civilian

\footnotetext{
9208 P956 (Transcript of $16^{\text {th }}$ Session of Assembly of SerBiH, 12 May 1992), p. 12. See also D115 (Transcript of $25^{\text {th }}$ session of RS Assembly, 19-20 January 1993), p. 51 (where a deputy in the Bosnian Serb Assembly referred to the struggle for Serbdom and the fighters in Foča who had liberated $98 \%$ of Serbian territories).

9209

9210

9211

9212 P5671 (Intercept of conversation between Mićo Stanišić and Janković, 19 May 1992), e-court pp. 8, 11-12. P1480 (Ratko Mladić's notebook, 10-30 September 1992), p. 66.

P3078 (Minutes of meeting of the National Security Council and the SerBiH Government, 8 May 1992), p. 1. P1094 (Letter from Government of SerBiH to James Baker, 24 May 1992). See also D3015 (Witness statement of Vladislav Jovanović dated 22 February 2013), paras. 45, 51; D3026 (Article from Yugoslav Daily Survey entitled "Montenegrin President: Decisive Step towards Peace in Bosnia", 21 June 1993), p. 1; Neđeljko Prstojević, T. 13639-13640 (17 March 2011); P5063 (Video footage depicting interview of Radovan Karadžić on "Ask the President", undated, with transcript), pp. 5-7.

9213 P2578 (Excerpt of transcript of movie entitled "Bosnia 1992-Serbian Epics"), p. 5.

9214 P2578 (Excerpt of transcript of movie entitled "Bosnia 1992-Serbian Epics”), p. 5. See also Radomir Nešković, P2568 (Transcript from Prosecutor v. Krajišnik), T. 16694-16698.

9215 P1478 (Ratko Mladić's notebook, 27 May-31 July 1992), pp. 93-94, 108-109.
} 
authorities and that the Serb side was ready for a political outcome and negotiations. ${ }^{9216}$ At a meeting on 30 June 1992 attended by the Accused and General Mladić, a municipal leader from Vlasenica reported that part of Cerska would be liberated in the days to come and if they brought back their forces from Kalesija they "would liberate everything" and that "[w]hoever controls Vlasenica, controls eastern Bosnia". 9217

2786. At the $17^{\text {th }}$ session of the Bosnian Serb Assembly held in July 1992, Krajišnik stated that there were territories which were not under their control but which should be part of SerBiH "due to them being ethnic territories" and over which the Bosnian Serbs claimed their rights. ${ }^{9218}$ Krajišnik on this issue explained that the territories they held constituted the $\mathrm{SerBiH}$ and were indisputable to them, "[w]hat is ours, is ours. We do not want to take the territories of others and we cannot give away what is ours". ${ }^{9219}$ He also emphasised that the final goal was the formation of a state and that the "single space" of the SerBiH "must be achieved". 9220

2787. At the same session, the Accused reported that "we control all of our territories, and perhaps also some territories that will be given to other national communities once a deal is reached" but that those territories could not be handed over during the war. ${ }^{9221}$ The Accused gave credit to the JNA, the TO, and the army of the SerBiH and stated that the borders of their state had been marked by a difficult and bloody battle. ${ }^{9222}$ Koljević also acknowledged how much had been achieved militarily. ${ }^{9223}$ The Accused emphasised the significance of controlling territory and the factual situation on the ground. ${ }^{9224}$ At this session there was a statement made about the danger of losing Foča which would allow the creation of the "green transversal". 9225

2788. Prstojević also spoke at the $17^{\text {th }}$ Bosnian Serb Assembly session and said that after the Accused visited Ilidža and encouraged them, "the Serbs from Sarajevo retained control over the

\footnotetext{
9216 D3658 (TANJUG news report, 30 June 1992); D3654 (Witness statement of KW317 dated 26 September 2012) (under seal), para. 70. See also D2149 (Aide mémoire of Manojlo Milovanović), p. 40.

9217 P1478 (Ratko Mladić's notebook, 27 May-31 July 1992), pp. 246, 261-262.

9218 D92 (Transcript of $17^{\text {th }}$ session of SerBiH Assembly, 24-26 July 1992), p. 49.

9219 D92 (Transcript of $17^{\text {th }}$ session of SerBiH Assembly, 24-26 July 1992), p. 50.

9220 D92 (Transcript of $17^{\text {th }}$ session of SerBiH Assembly, 24-26 July 1992), p. 50.

9221 D92 (Transcript of $17^{\text {th }}$ session of SerBiH Assembly, 24-26 July 1992), pp. 14, 19.

9222 D92 (Transcript of $17^{\text {th }}$ session of SerBiH Assembly, 24-26 July 1992), pp. 14, 21.

9223 D92 (Transcript of $17^{\text {th }}$ session of SerBiH Assembly, 24-26 July 1992), pp. 32-33. See also D2149 (Aide mémoire of Manojlo Milovanović), pp. 7, 25, 27.

9224 D92 (Transcript of $17^{\text {th }}$ session of SerBiH Assembly, 24-26 July 1992), p. 87. See also Anthony Banbury, T. 13307, 13310, 13338-13339, 13341 (15 March 2011) (testifying about the importance of the "facts on the ground" in international negotiations); P5063 (Video footage depicting interview of Radovan Karadžić on "Ask the President", undated, with transcript), p. 19.

9225 D92 (Transcript of $17^{\text {th }}$ session of SerBiH Assembly, 24-26 July 1992), p. 41.
} 
territory, and even extended their territory in some areas, driving the Muslims out of the territories where they had actually been the majority". 9226

2789. At the same session, the Accused said that the conflict had been "roused in order to eliminate the Muslims. [...] They think they are being nationally established, but in fact they are vanishing. If that's the case, then we have our interests for our historical territories". ${ }^{9227}$ Right after making this statement, the Accused went on to say:

I think we have to save the Serb people in their ethnic and also historical territories [...]. We'll have for sure, we'll have in the beginning so many Serbs, but I think that they will leave those states, both the Muslim and the Croat state. In the state that we are building, we have to ensure that they have all the rights that we have, under the condition that they are not hostile and that they leave the weapons. ${ }^{9228}$

2790. At the end of the $17^{\text {th }}$ Bosnian Serb Assembly session in July 1992, the Bosnian Serb Assembly adopted the "Decision on establishing disputable and indisputable borders of its territory" and identified where those borders would run, which could be subject to corrections and verifications in accordance with international agreements. ${ }^{9229}$

2791. The Accused acknowledged with time that during negotiations they risked losing traditional and "centuries-old Serb territories". ${ }^{9230}$ These historical territorial claims were also reflected in the proclamation of the Bosnian Serb Assembly in January 1992 where reference was made to "areas in which the Serbian people is now a minority due to the genocide carried out against it in World War II" and in the statements to the international observers that these areas should be part of the RS. ${ }^{9231}$

2792. The objectives which the Bosnian Serb leadership spoke about in the lead-up to and during the conflict were also reflected in VRS reports. For example, the VRS Main Staff analysis of armed activities in 1992 noted that the declaration of independence by $\mathrm{BiH}$ and its premature

\footnotetext{
9226 D92 (Transcript of $17^{\text {th }}$ session of SerBiH Assembly, 24-26 July 1992), p. 66.

9227 D92 (Transcript of $17^{\text {th }}$ session of SerBiH Assembly, 24-26 July 1992), p. 86.

9228 D92 (Transcript of $17^{\text {th }}$ session of SerBiH Assembly, 24-26 July 1992), p. 86.

9229 D92 (Transcript of $17^{\text {th }}$ session of SerBiH Assembly, 24-26 July 1992), pp. 103-104.

9230 P1379 (Transcript of 34 ${ }^{\text {th }}$ session of RS Assembly, 27-29 August, 9-11 September, 29 September to 1 October 1993), p. 11. See also D1278 (Transcript of Radomir Nešković's interview with Karadžić's legal associate, 8 October 2009), p. 26.

9231 P6444 (Declaration of the Assembly of Serbian people in BiH, 9 January 1992), p. 2; Herbert Okun, P776 (Transcript from Prosecutor v. Krajišnik), T. 4165-4168, 4188-4189, 4370; Herbert Okun, T. 1489-1491 (22 April 2010). See also P6540 (Excerpt of video from Banja Luka, 3 March 1991, with transcript); Milan Babić, P742 (Transcript from Prosecutor v. Krajišnik), T. 3400; KDZ240, T. 16068-16069 (5 July 2011) (closed session); Momčilo Mandić, C2 (Transcript from Prosecutor v. Krajišnik), T. 8617; P5746 (Intercept of conversation between Radovan Karadžić and Dobrica Ćosić, 15 February 1992), p. 5. Čeklić testified that the Bosnian Serb leadership did not want to occupy territories but instead wanted to protect Serbian people in those territories. Savo Čeklić, T. 41227-41229 (11 July 2013). However, the Chamber does not find Čeklić's evidence to be reliable in this regard. In reaching that conclusion the Chamber noted that Čeklić's evidence was marked by evasiveness and contradictions and as such did not find his evidence to be reliable in this regard.
} 
recognition threatened the Bosnian Serbs and made them a national minority that faced the prospect of being "subjected to genocide". 9232 This report noted that in order to prevent this "humiliation", the Serbian people organised itself politically and when it was attacked, "it started a defensive and liberating war" with the SDS taking on the most significant political role in the organisation of the Serbian people. ${ }^{9233}$

2793. The VRS reported that during the early phase of the conflict in the RS there were units of the Serb TO which had been "formed on the initiative and under the leadership" of the SDS and had been able to protect the Serbs until the formation of the VRS. ${ }^{9234}$ The VRS reported however, that these units failed to achieve the "main strategic objectives of the armed struggle of the Serbian people" in $\mathrm{BiH}^{9235}$ They failed to open and secure the required corridors and to "gain control over a considerable part of the territory of former $[\mathrm{BiH}]$ which historically and ethnically belongs to the Serbian people". ${ }^{9236}$ This report further noted that the VRS was capable of protecting the Serbs and "liberating territories which by [historic] birthright are ours" and that this would lay the foundations for a Serb state. ${ }^{9237}$

2794. This report noted that the strategic objectives of the war were promptly defined and formed the general guidelines for their operations. ${ }^{9238}$ Mladić reflected this sentiment and said that the people and the VRS had carried out most of the tasks and the Strategic Goals set for them. ${ }^{9239} \mathrm{He}$ noted that the VRS had "liberated the territories we consider our own" which had created conditions for the Bosnian Serb leadership to go to negotiations in a stronger territorial position. ${ }^{9240}$ The report further noted that the Accused, as the Supreme Commander, orally assigned a number of tasks which were vital to "protecting the Serbian people and its territories" and the Main Staff "translated the set objectives and tasks into general and individual missions". 9241 The Accused spoke in favour and praised the military successes of the VRS under Mladić. ${ }^{9242}$

\footnotetext{
9232 D325 (VRS Main Staff analysis of combat readiness and army activities in 1992, April 1993), pp. 46, $152,159$.

9233 D325 (VRS Main Staff analysis of combat readiness and army activities in 1992, April 1993), p. 46.

9234 D325 (VRS Main Staff analysis of combat readiness and army activities in 1992, April 1993), pp. 69, 75.

9235 D325 (VRS Main Staff analysis of combat readiness and army activities in 1992, April 1993), p. 69.

9236 D325 (VRS Main Staff analysis of combat readiness and army activities in 1992, April 1993), p. 69.

9237 D325 (VRS Main Staff analysis of combat readiness and army activities in 1992, April 1993), p. 159. See also D232 (Directive 1, 6 June 1992), p. 1; D2149 (Aide mémoire of Manojlo Milovanović), p. 40.

9238 D325 (VRS Main Staff analysis of combat readiness and army activities in 1992, April 1993), p. 159.

9239 P1379 (Transcript of 34 ${ }^{\text {th }}$ session of RS Assembly, 27-29 August, 9-11 September, 29 September to 1 October 1993), p. 66. See also D2149 (Aide mémoire of Manojlo Milovanović), p. 27; D232 (Directive 1, 6 June 1992); D593 (Directive 2, 22 July 1992), pp. 1, 3; D235 (Directive 3, 3 August 1992); P977 (Directive 5, 25 June 1993), p. 2; P3039 (Directive 6, 11 November 1993), p. 6.

9240 D593 (Directive 2, 22 July 1992), p. 1. See also D235 (Directive 3, 3 August 1992), p. 7.

9241 D325 (VRS Main Staff analysis of combat readiness and army activities in 1992, April 1993), p. 159.

9242 P4440 (Excerpt from video of Radovan Karadžić's speech, with transcript).
} 
2795. On 26 August 1992, in a meeting with Vance and Carrington at the London Conference, the Accused stated that following the recognition of $\mathrm{BiH}$, "Serbs had been forced to act in order to protect the Serbian population" and that they wanted full autonomy. ${ }^{9243}$ The Accused further stated that the Bosnian Serbs were willing to negotiate and even return some territory as part of an overall agreement, as long as Serb property rights in predominantly Croat and Muslim areas were protected. $^{9244}$ When the Accused spoke about Bosnian Serb territory being geographically continuous, Vance asked how this could be achieved without "moving people". 9245

2796. At an international press conference in September 1992, the Accused stated that Bosnian Serbs owned, possessed, and controlled $64 \%$ of $\mathrm{BiH}$ and that they were only a minority in $\mathrm{BiH}$ because of the genocide during World War II. ${ }^{9246}$ When questioned about whether those in the "wrong part of the territory" would have to leave their homes, the Accused denied the suggestion vigorously and stated that they had to guarantee minority rights. 9247

2797. The Accused told Van Lynden in September 1992 that the Serbs had to have the northern areas and Banja Luka. He also said that Eastern Bosnia was all Serb and that the enclaves of Goražde, Srebrenica, and smaller enclaves were unacceptable and had to become part of Serb territory. ${ }^{9248}$

2798. Šešelj, on behalf of the SRS, also expressed his support for the formation of the SerBiH and his view that the Bosnian Serb authorities should demarcate Serbian territory, proclaim its own TO and police in territories under its control, and simultaneously "liberate" those areas which were not under Serbian control but which were "part of the Serbian territorial corpus". 9249 In April 1992, Šešelj spoke about the necessity of dividing $\mathrm{BiH}$, where Serbs would end up with the majority of the area. ${ }^{9250}$ In an interview in September 1992, Šešelj recognised that it was "obvious that Serbs P941 (London Conference record of a meeting with Radovan Karadžić, 26 August 1992), p. 1.

See para. 347; P941 (London Conference record of a meeting with Radovan Karadžić, 26 August 1992), pp. 12.

9246 P809 (Video footage of Radovan Karadžić's Press Conference at ICFY, 18 September 1992, with transcript), p. 6; Vladislav Jovanović, T. 34309-34310 (26 February 2013).

9247 P809 (Video footage of Radovan Karadžić's Press Conference at ICFY, 18 September 1992, with transcript), p. 9.

9248 P926 (Witness statement of Aernout van Lynden dated 26 February 2010), para. 71; Aemout van Lynden, T. 2419 (19 May 2010).

9249 D3667 (Transcript of Vojislav Šešelj's press conference, 26 March-16 April 1992), pp. 3, 8, 11; See also P6393 (Video clip of interview with Vojislav Šešelj, with transcript).

9250 D3667 (Transcript of Vojislav Šešelj's press conference, 26 March-16 April 1992), p. 27 (stating that "Serbian Herzegovina with a border on Neretva, Romanija to the Serbs, Ozren to the Serbs, Podrinje to the Serbs, Semberija to the Serbs, Bosnian Krajina to the Serbs. The Central Bosnia to the Muslims. The Western Herzegovina to the Croats. That is the best solution"). See also D3668 (Interview with Vojislav Šešelj and Nikola Poplašen, September 1992), p. 1; Vojislav Šešelj, T. 39585-39586 (10 June 2013).
} 
hold larger territories today than they would have if there had been a peaceful demarcation of borders with Croats and Muslims". 9251 He further stated that Serbs would continue to gain more and more territories and Muslims would end up with nothing. ${ }^{9252}$

2799. In November 1992, in a meeting attended by General Morillon, Pyers Tucker, Mladić, and Koljević, the Accused showed maps with the ethnic distribution in $\mathrm{BiH}$ and claimed that "Bosnian Serbs had only seized those territories to which they had a right, which [were] territories where the population was more than 50 per cent Bosnian Serb" and they had "no wish to live with the Muslims", whom he called "Turks". ${ }^{9253}$ On 7 November 1992, at a meeting attended by Đerić and other ministers, the situation in a number of municipalities was discussed and it was reported that the largest part of the municipality of Vlasenica was "free". 9254 In January 1993, the Accused also spoke about how they had created a state with their own forces. ${ }^{9255}$

2800. The Chamber recalls that on 15 January 1993, at a meeting with Okun and Vance, the representative for the Bosnian Serbs, Aleksa Buha, stated that the Bosnian Serbs needed the Posavina "corridor", which was a road that connected Belgrade to Banja Luka via Bijeljina and Brčko. ${ }^{9256}$ For territories still under dispute, Buha noted the Accused's request for a resolution by referendum. ${ }^{9257}$ The importance of certain municipalities to the political objectives of the Bosnian Serbs was underscored by statements in the Bosnian Serb Assembly in January 1993 to the effect that there could be no Serbian state or prospects for the Serbian people "without Podrinje [...] from Foča to Bijeljina". ${ }^{258}$ A deputy from Prijedor spoke against the proposal of sharing the municipality of Prijedor and stated that they had "conquered, actually restored only the Serb territory that they took away from us back in 1941".9259 This sentiment reflected the statements by the Accused and the Bosnian Serb leadership regarding the historical crimes committed against the Serb people and their historical claim to the land which they viewed as belonging to them.

2801. Following the ICFY, the Vance-Owen Plan was formally introduced on 2 January 1993 and provided for constitutional and military arrangements in $\mathrm{BiH}$ and a map of the provincial

D3668 (Interview with Vojislav Šešelj and Nikola Poplašen, September 1992), p. 7. D3668 (Interview with Vojislav Šešelj and Nikola Poplašen, September 1992), p. 7.

P4203 (Witness statement of Pyers Tucker dated 12 May 2010), paras. 78-79; Pyers Tucker, T. 23217 (17 January 2012).

9254 D3696 (Minutes of RS Government session, 7 November 1992), pp. 1, 3.

9255 D115 (Transcript of $25^{\text {th }}$ session of RS Assembly, 19-20 January 1993), p. 7.

$9256 \quad$ See para. 362.

9257 Herbert Okun, P776 (Transcript from Prosecutor v. Krajišnik), T. 4245 (opining that holding a referendum would benefit Bosnian Serbs in territories from which non-Serbs had been removed).

9258 D115 (Transcript of $25^{\text {th }}$ session of RS Assembly, 19-20 January 1993), p. 42.

9259 P921 (Transcript of $24^{\text {th }}$ session of RS Assembly, 8 January 1993), pp. 31-32.
} 
structure. $^{9260}$ Izetbegović objected to the map on the basis that regions from which the population had been removed could not come under the control of those who removed them. ${ }^{9261}$ The Accused noted that certain territories were still under dispute and when the map was discussed, he asked for a larger Bosnian Serb territory and proposed his own boundaries. ${ }^{9262}$

2802. In April 1993, the Accused also spoke about the importance of certain Serb areas in the context of international negotiations pertaining to maps of $\mathrm{BiH}^{9263}$ In the context of discussing whether or not to accept the Vance-Owen Plan, Brđanin at the Bosnian Serb Assembly stated "[e]verything we have liberated is Serbian land. No one will be able to convince the people of Prijedor, Sanski Most $[\ldots]$ and all the places under threat all the way to Foča that we have passed a just decision". ${ }^{9264}$ The Accused stressed for example that they could not give up on Sanski Most because it was in the middle of their territory. ${ }^{9265}$ The Accused also spoke about Brčko being their "mutual concern" and that they would "finish with Brčko the way it should be [...] [a]nd if there is war we will be strong and repel them 50 kilometres to the south". 9266 The Chamber recalls that on 2 May 1993, the Accused signed the Vance-Owen Plan in Athens, but this was subject to ratification by the Bosnian Serb Assembly, which ultimately rejected the plan. ${ }^{9267}$

2803. At a meeting on 28 May 1993 between members of the Bosnian Serb leadership, including the Accused, and the leadership of the FRY, disagreements were voiced among the participants as to whether to continue fighting, or whether to negotiate a path towards peace. ${ }^{9268}$ During this meeting, the Accused stated that there was "no other way but to fight". ${ }^{9269}$

2804. At the $34^{\text {th }}$ Session of the Bosnian Serb Assembly in August 1993, the Accused cautioned against the view that they had given up on their far-reaching goals with respect to the union of Serb states and explained that "[i]t is a phase we have to finish". ${ }^{9270}$ When the Accused refused to accept the Vance-Owen Plan, he claimed that the old BiH ceased to exist and that there was now a

\footnotetext{
9260 See paras. 359-360.

9261 See para. 363.

9262 See para. 363. For more detail on the course of the negotiations the Chamber refers to Section II.E: International peace negotiations.

9263 P1367 (Transcript of $26^{\text {th }}$ session of RS Assembly, 2 April 1993), p. 8.

9264 P1371 (Transcript of 30 ${ }^{\text {th }}$ session of RS Assembly, 5-6 May 1993), p. 93.

9265 P1379 (Transcript of $34^{\text {th }}$ session of RS Assembly, 27-29 August, 9-11 September, 29 September to 1 October 1993), p. 80.

9266 P1379 (Transcript of $34^{\text {th }}$ session of RS Assembly, 27-29 August, 9-11 September, 29 September to 1 October 1993), p. 80.

9267 See International Peace Negotiations Section, para. 61.

9268 P1483 (Ratko Mladić's notebook, 2 April-24 October 1993), pp. 164-180.

9269 P1483 (Ratko Mladić's notebook, 2 April-24 October 1993), p. 175.

9270 P1379 (Transcript of $34^{\text {th }}$ session of RS Assembly, 27-29 August, 9-11 September, 29 September to 1 October 1993), p. 93.
} 
state with three constituent peoples. ${ }^{9271}$ Given the Accused's refusal, Owen stated "I weep for your country. The path you are heading on is bitterness, hatred and death". 9272

2805. At this same session, the Accused stated that while he did not think there would be a broader war in Europe, if there was one "we shall be stronger" and that they would have a corridor again on the map of $\mathrm{BiH}^{9273}$ The Accused explained that "[i]f we want it by force, we could have taken some more, we can still do it". ${ }^{9274}$ He went on to state that they were militarily ready and would not withdraw from anywhere until they had firm guarantees about the resolution of the conflict. ${ }^{9275}$ He stated that while they did not want the war to continue and would be willing to lessen their territory, he wanted the land they retained to remain theirs "for all [...] time". ${ }^{9276}$ The Accused also suggested that the Serbs would vanish if they were weakened, but they would be given a state if they were seen as strong militarily, economically, and politically. ${ }^{9277}$

2806. Koljević at the $34^{\text {th }}$ Session of the Bosnian Serb Assembly stated his view that they had entered "this fight" not with the aim of winning the most territory but with the aim of the "spiritual and moral revitalisation of Serbhood". ${ }^{9278}$ At the same Bosnian Serb Assembly session, Mladić stated that if the negotiations and agreement failed, they would "have to find the means and organise ourselves for the continuation of the even bloodier war". ${ }^{9279}$ Another deputy spoke and recognised that they held 13 municipalities including Prijedor, Sanski Most, Ključ, Zvornik, Vlasenica, Rogatica, Višegrad, Foča and part of Brčko even though they "did not belong to Serbs, according to indicators of relative or absolute majority". ${ }^{9280}$ The Chamber recalls its finding that

\footnotetext{
9271 P791 (Eighth notebook of Herbert Okun's ICFY diary), e-court pp. 76-77.

9272 P791 (Eighth notebook of Herbert Okun's ICFY diary), e-court pp. 76-77. See also P792 (Ninth notebook of Herbert Okun's ICFY diary), e-court pp. 33-34, 50.

9273 P1379 (Transcript of $34^{\text {th }}$ session of RS Assembly, 27-29 August, 9-11 September, 29 September to 1 October 1993), p. 62.

9274 P1379 (Transcript of $34^{\text {th }}$ session of RS Assembly, 27-29 August, 9-11 September, 29 September to 1 October 1993), p. 63.

9275 P1379 (Transcript of $34^{\text {th }}$ session of RS Assembly, 27-29 August, 9-11 September, 29 September to 1 October 1993), p. 63.

9276 P1379 (Transcript of $34^{\text {th }}$ session of RS Assembly, 27-29 August, 9-11 September, 29 September to 1 October 1993), p. 63.

9277 P1379 (Transcript of $34^{\text {th }}$ session of RS Assembly, 27-29 August, 9-11 September, 29 September to 1 October 1993), p. 240.

9278 P1379 (Transcript of $34^{\text {th }}$ session of RS Assembly, 27-29 August, 9-11 September, 29 September to 1 October 1993), pp. 44, 46.

9279 P1379 (Transcript of $34^{\text {th }}$ session of RS Assembly, 27-29 August, 9-11 September, 29 September to 1 October 1993), pp. 66-67

9280 P1379 (Transcript of $34^{\text {th }}$ session of RS Assembly, 27-29 August, 9-11 September, 29 September to 1 October 1993), pp. 105-106.
} 
the control of municipalities, including Bijeljina and Vlasenica, ${ }^{9281}$ was geographically important with respect to the Strategic Goals of the Bosnian Serb leadership.

2807. The municipality of Brčko was an example of where the Accused and the Bosnian Serbs continued to emphasise their territorial and strategic interests. Brčko was considered of strategic importance by the Bosnian Serb leadership as it was viewed as necessary for the formation of a corridor in the Posavina region through to Bosanska Krajina; this was in accordance with the second Strategic Goal. ${ }^{9282}$ Given the strategic importance of Brčko, despite the Bosnian Serbs constituting a minority, the Bosnian Serb leadership insisted that it would become a province of RS. ${ }^{9283}$ The Accused also spoke about negotiations relating to Brčko and the importance of protecting Serb interests. ${ }^{9284}$ A representative from Brčko acknowledged that it had never been a Serb town, but that even before the war there had been "strictly defined Serb areas within the town, separated from the areas in which the other two peoples lived" and by agreement this area had been defined. ${ }^{9285}$ This representative spoke about the possibility of having to return "Muslim territories that we have liberated" but emphasised which areas of Brčko should be retained. ${ }^{9286}$

2808. At a meeting held in August 1994 between the Accused, Krajišnik, and Milan Martić, Krajišnik stated: "Everyone is telling us not to give up Brčko". ${ }^{9287}$ The Accused stressed that the corridor being offered to them through Brčko was too narrow and could not be defended. ${ }^{9288}$ In a meeting with UNPROFOR on 19 August 1994, the Accused expressed his view that if an "arrangement" was reached for Brčko similar to the plan for Sarajevo, it should "not prevent the

\footnotetext{
$9281 \quad$ See paras. 600, 1099.

9282 P2888 (Brčko's War Presidency Summary of events in Brčko Municipality), pp. 1-2; Herbert Okun, P776 (Transcript from Prosecutor v. Krajišnik), T. 4244, 4258, 4265-4266, 4276. 4306; Herbert Okun, T. 1481-1482 (22 April 2010); P3023 (Witness statement of Đorđe Ristanić dated 15 June 2011), paras. 66, 229-231; Đorđe Ristanić, T. 16763, 16768-16769, 16819 (18 July 2011). While the Chamber notes that the only crimes charged in Indictment with respect to Brčko are limited to the Luka camp, it has had regard to this evidence as supporting the pattern of what occurred in the Municipalities and how this corresponded with the strategic interests of the Accused and the Bosnian Serb leadership.

9283 Herbert Okun, P776 (Transcript from Prosecutor v. Krajišnik), T. 4278; P2888 (Brčko's War Presidency Summary of events in Brčko Municipality), p. 2.

9284 P1379 (Transcript of $34^{\text {th }}$ session of RS Assembly, 27-29 August, 9-11 September, 29 September to 1 October 1993), p. 13.

9285 P1379 (Transcript of $34^{\text {th }}$ session of RS Assembly, 27-29 August, 9-11 September, 29 September to 1 October 1993), pp. 37-38.

9286 P1379 (Transcript of 34 ${ }^{\text {th }}$ session of RS Assembly, 27-29 August, 9-11 September, 29 September to 1 October 1993), p. 37.

9287 P2563 (Minutes of meeting between Milan Martić and Radovan Karadžić, 20 August 1994), pp. 1, 10.

9288 Patrick Treanor, T. 14056-14057 (1 June 2011); P2563 (Minutes of meeting between Milan Martić and Radovan Karadžić, 20 August 1994), p. 5.
} 
Serbs from transiting the area with their armaments" and that if the Bosnian Serbs kept "sovereignty in Brčko" they would seriously consider the proposal of not attacking Tuzla. ${ }^{9289}$

2809. At a Bosnian Serb Assembly session on 11 May 1994, the Accused stated: "We have never been [a] majority in Brčko, but we were always the third, but we have to solve that with a combination, we cannot call upon one principle, that is ethnic and historical. [...]This is not [an] important town for the Muslims, but it is important to us". ${ }^{9290}$ In meeting with Akashi in May 1994 the Accused warned of an $\mathrm{ABiH}$ offensive on Brčko and that they would not agree to withdraw Bosnian Serb troops to make Brčko a safe area because it was historically a Serb area and it had been under Bosnian Serb control since the beginning of the war. ${ }^{9291}$

2810. When the Accused visited Foča to open a medical school, he gave a speech in which he said that he was "satisfied and happy that Foča has been preserved" and it was important for the citizens to know that the Bosnian Muslims had given up on Foča in negotiations. ${ }^{9292}$ In 1994, Krajišnik attended a celebration in Foča with other members of the Bosnian Serb leadership and delivered a speech in which he addressed the people of Srbinje, which was the new Serb name of Foča. ${ }^{9293}$ In this speech Krajišnik said:

Today you are not as you were before. Now I see a true Serbian town. And you proudly bear your Serbian name. You are the example to every Serb. All that was coming from this town you've managed to eliminate you prevented it from happening. [...] Izetbegović said that this town would be another Mecca. But you did not let them. And for that, in the name of all Serbs, I thank you. ${ }^{9294}$

2811. The Accused also noted that in Foča the Bosnian Muslims had a plan to "build a big Islamic centre" and that Foča was extremely important to the Bosnian Muslims but "it will never be theirs again". 9295

2812. In 1993 and 1994, commemorations were held to celebrate the anniversary of the "liberation" of Zvornik which were attended amongst others by the Accused, Koljević, and

\footnotetext{
9289 D704 (UNPROFOR report re meeting with Radovan Karadžić, 19 August 1994), para. 9.

9290 P1390 (Transcript of 40 ${ }^{\text {th }}$ session of RS Assembly, 10-11 May 1994), p. 40.

9291 D3499 (UNPROFOR report, 4 May 1994), e-court pp. 7, 11. See also: P5422 (UNPROFOR report, 8 May 1994), p. 7.

9292 P6205 (Excerpts of radio broadcast of Radovan Karadžić's visit to Foča medical centre, with transcript), pp. 1-2. See Veljko Marić, T. 35595-33596 (19 March 2013).

9293 P6204 (Excerpt of video clip of Momčilo Krajišnik's speech in Foča, with transcript). See Veljko Marić, T. 35590-33591 (19 March 2013).

9294 P6204 (Excerpt of video clip of Momčilo Krajišnik's speech in Foča, with transcript). See also Adjudicated Fact 2411.

9295 P1385 (Transcript of $37^{\text {th }}$ Session of RS Assembly, 10 January 1994), p. 110.
} 
Arkan. ${ }^{9296}$ The Accused in an interview also said that the Bosnian Serbs would "never leave Zvornik again, and the state of facts established by this war, by this one year of the war, will not be reconciliated without large crimes". 9297 The Accused's position was that Zvornik could not be given to the Bosnian Muslims because that would mean that the Serbs could not return and would be refugees. ${ }^{9298}$

2813. The Accused stated that during the war he had placed the SDS on hold but that in the first 45 days of the conflict, the SDS had been instrumental in "practically defin[ing] the borders". 9299 In an interview in July 1995 the Accused stressed that everyone should accept the reality that BiH was completely Serbian. He went on to state:

We now possess $64 \%$ of the land and control $70 \%$ of the territory of that false State Bosnia, which does not exist, and we are not going to accept anything less than $50 \% \mathrm{We}$ are not going to give up on our own State, the ultimate objective for any nation; it is like our home. And we are not going to end up homeless in a Bosnia dominated by Muslims. ${ }^{9300}$

2814. In the same interview, the Accused stated that they were ready to end the war on the condition that the Bosnian Serbs' right to self-determination was recognised and observed that if "we are fighting and dying for certain places, we cannot hand them over afterwards. Nobody can expect us to guarantee the Muslims that they are always going to keep the same percentage of territory $[\ldots]$. If they want a military solution, they will get to keep what they have now, at most. But if they want a political solution, we are ready to be flexible". 9301 The Accused also said that they would "never accept giving up a single Serbian place, especially if it was taken by force". 9302

2815. In August 1995, Mladić issued a notice to the Main Staff of the VRS which, inter alia, praised the VRS and observed that it had thwarted "a planned and prepared genocide of the Serbian

\footnotetext{
9296 KW317, T. 39352-39353 (6 June 2013), 39353-39354 (6 June 2013) (private session), T. 39355-39356, (6 June 2013); P6371 (Photographs re celebration of anniversary of Zvornik liberation); P5167 (Report of Zvornik Brigade, 10 April 1993), p. 2. The Chamber notes that the Accused and Koljević are only reported to have attended the first anniversary in April 1993. The Chamber also received evidence that Arkan and the Accused both attended a celebration in Zvornik in 1995. Čedomir Zelenović, T. 40323-40326 (24 June 2013), T. 4033840339 (25 June 2013); P6412 (Photograph of Radovan Karadžić); P6413 (Photograph of Željko Ražnatović aka Arkan). P5591 (Video footage of Radovan Karadžić on SRT Talk Show). Momčilo Krajišnik, T. 43782 (19 November 2013). P5595 (Excerpt of video footage of Radovan Karadžić's speech, with transcript), p. 1. P2564 (Radovan Karadžić's interview in El Pais, 16 July 1995), p. 3. P2564 (Radovan Karadžić's interview in El Pais, 16 July 1995), p. 2.

P5063 (Video footage depicting interview of Radovan Karadžić on "Ask the President", undated, with transcript), p. 7.
} 
people, protecting the greater part of Serbian territories, and achieving victory after victory in the liberation of occupied historically and ethnically Serbian areas". 9303

2816. At a Bosnian Serb Assembly session in August 1995, the Accused said:

To tell the truth, there are towns that we've grabbed for ourselves, and there were only $30 \%$ of us. I can name as many of those as you want, but we cannot give up the towns where we made up 70\%. Don't let this get around, but remember how many of us were in Bratunac, how many in Srebrenica, how many in Višegrad, how many in Rogatica, how many in Vlasenica, in Zvornik, etc. Due to strategic importance they had to become ours, and no one is practically questioning it any more. ${ }^{9304}$

\section{(c) Creation of a Bosnian Serb state}

2817. In December 1991, the Accused spoke about how in some municipalities it was "really necessary to create separate municipalities" and to have dual municipal authorities. ${ }^{9305}$

2818. The Chamber recalls that on 11 January 1992, the first session of the Council of Ministers was attended by Bosnian Serb leaders including the Accused, Krajišnik and Plavšić. ${ }^{9306}$ At this meeting one of the identified priorities with respect to the declaration on the promulgation of the SerBiH was "the defining of ethnic territory, establishment of government organs in the territory and the economic disempowerment of the current authorities in the [SRBiH]". ${ }^{9307}$ On 17 January 1992, the Council of Ministers discussed the need to adopt the Constitution of the Republic as soon as possible and to consolidate and organise the territory of the regions, including through the formation of new municipalities. ${ }^{9308}$

2819. In February 1992, the Accused spoke about their hope that nearly $90 \%$ of the Serb population would be in their republic in $\mathrm{BiH}$ and that this would be a "sovereign area of the Serbian people". ${ }^{9309}$ At a meeting of the SDS Deputies' Club in February 1992, the Accused stated until two or three months ago we were hoping to be able to play the 'Yugoslav card' [...]. This is slipping out of our grasp. That's why we started on another track: a Serbian Bosnia and Herzegovina. Our sovereign right, our army. We are preparing the constitutional framework to be able to have immediately [...] to have a national guard, to

\footnotetext{
9303 P2566 (Ratko Mladić notice, 5 August 1995), p. 1.

9304 P988 (Transcript of 53 ${ }^{\text {rd }}$ session of RS Assembly, 28 August 1995), pp. 68-69.

9305 D84 (Shorthand Record of $3^{\text {rd }}$ session of SerBiH Assembly, 11 December 1991), p. 13.

$9306 \quad$ See para. 104.

9307 P1082 (Minutes of $1^{\text {st }}$ meeting of Ministerial Council of SerBiH Assembly, 13 January 1992), pp. 2-3; P2536 (Patrick Treanor's expert report entitled “The Bosnian Serb Leadership 1990-1992”, 30 July 2002), para. 227.

9308 See para. 105; P3111 (Minutes of the $2^{\text {nd }}$ meeting of the Ministerial Council of SerBiH Assembly, 17 January 1992), pp. 4-5.

9309 P12 (Extended session of Main and Executive Boards of the SDS, 14 February 1992), p. 14.
} 
have our own police force, to have a government, to turn the Yugoslav army into the army of the Serbian Bosnia and Herzegovina. ${ }^{9310}$

2820. At this meeting Koljević expressed his agreement with the Accused over the outcome of the recently held peace negotiations and the proposed division of $\mathrm{BiH}$ into a confederation. ${ }^{9311}$ Koljević stated "our only chance is to draw borders, to tear them down. That's what we have been doing in Bosnia and Herzegovina, what we have begun in order to be able to draw the borders and to create our own, and then not to give up on our goal until the times are better". ${ }^{9312}$ Krajišnik stated with respect to the creation of a unitary Islamic $\mathrm{BiH}$, "that will not succeed. We are a force to be reckoned with. We will not agree to that [...] there is nothing more important than Serbian freedom". 9313

2821. The Accused also spoke to other Bosnian Serb leaders about the chance to create "our independent state and our Army". ${ }^{9314}$ In this regard, the Accused also spoke about the preparation of their constitution and laws which would create "the basis to receive the Army on our territory". 9315

2822. The Accused at Bosnian Serb Assembly sessions reported on the progress of international negotiations with respect to the situation in $\mathrm{BiH}$ and his view on what conditions and developments were unacceptable to Bosnian Serbs and what he viewed as attempts to prevent the Serbs from creating a state and exercising their right to self-determination. ${ }^{9316}$ In March 1992, the Accused complained about the manner in which Bosnian Muslim leaders were conducting negotiations but stated that "[f]ortunately we have not been relying on those talks but have created preconditions for the security of the Serb people in their ethnic space within $\mathrm{BiH}[\ldots]$ we have not passed the opportunity to complete all the actions necessary for the protection of Serb people". ${ }^{9317}$

\footnotetext{
$9310 \quad$ P938 (Minutes from SDS Deputies' Club meeting, 28 February 1992), p. 37.

9311 P938 (Minutes from SDS Deputies' Club meeting, 28 February 1992). pp. 6, 8.

9312 P938 (Minutes from SDS Deputies' Club meeting, 28 February 1992). p. 39.

9313 P938 (Minutes from SDS Deputies' Club meeting, 28 February 1992). p. 44-45.

9314 P5754 (Intercept of conversation between Radovan Karadžić and Dobrica Ćosić, 9 February 1992), p. 2.

9315 P5754 (Intercept of conversation between Radovan Karadžić and Dobrica Ćosić, 9 February 1992), p. 8.

9316 D88 (Shorthand Record of $8^{\text {th }}$ session of SerBiH Assembly, 25 February 1992), pp. 5-12, 16-19, 71-72; P1353 (Shorthand record of $10^{\text {th }}$ session of SerBiH Assembly, 11 March 1992), pp. 4-10; P921 (Transcript of $24^{\text {th }}$ session of RS Assembly, 8 January 1993), pp. 5-16; D115 (Transcript of $25^{\text {th }}$ session of RS Assembly, 1920 January 1993), p. 4; P1371 (Transcript of 30 $30^{\text {th }}$ session of RS Assembly, 5-6 May 1993), p. 10; D92 (Transcript of $17^{\text {th }}$ session of SerBiH Assembly, 24-26 July 1992), pp. 12, 56; D456 (Transcript of $20^{\text {th }}$ session of RS Assembly, 14-15 September 1992), p. 13. See also P5476 (Report of $1^{\text {st }}$ Krajina Corps, 1 October 1992). Other Bosnian Serb leaders including Koljević and Krajišnik gave similar updates on international negotiations. P1105 (Transcript of 22 ${ }^{\text {nd }}$ session of RS Assembly, 23-24 November 1992), pp. 110-112; P6164 (Excerpt from notes of enlarged session of Council for Coordinating Positions on State Policy, 9 January 1993), e-court p. 9. 
2823. In March 1992, the SDS Executive Board confirmed the objective of creating a Serb state in $\mathrm{BiH}$, with its own army and media. ${ }^{9318}$ Doyle testified that at the conferences he attended the general understanding was that "the overall objective of Serbs was to join physically the territories that the Serbs controlled in Bosnia to the territory of Serbia to create a Greater Serbia". ${ }^{9319}$ Okun also testified that the goal of the Bosnian Serb leadership was to create an ethnically Serb state in $\mathrm{BiH}^{9320}$ The difficulty of this objective of ethnic separation was that $\mathrm{BiH}$ was highly intermixed. $^{9321}$ Vitomir Žepinić, for example, warned Plavšić that if they tried to separate the ethnic communities "there would be violence and thousands of innocent civilians would be killed". 9322

2824. Krajišnik in March 1992 wrote to Cutileiro and emphasised that the Bosnian Serbs were opposed to the independence of $\mathrm{BiH}$ and the creation of a unitary state which could have "catastrophic consequences" and he advocated the creation of "three-national state entities". 9323 Krajišnik also expressed their fear about becoming a national minority in a fundamentalistic Muslim BiH. ${ }^{9324}$

2825. On 17 May 1992, the Accused, Krajišnik, and Mladić attended a meeting with the SAO Romanija and heads of neighbouring municipalities in Sokolac where the political and security situation was discussed and the Accused indicated that "[w]e are looking for results from the army [...] [w]e want our people to be kept safe". ${ }^{9325}$ The Accused went on to recall that creating a separate Serb state and taking that state out of $\mathrm{BiH}$ remained the priority and that they should

\footnotetext{
9318 D1277 (Minutes of joint meetings of SDS's General and Executive Committees and Political Council, 11 March 1992), pp. 1-2.

9319 Colm Doyle, T. 2994 (28 May 2010).

9320 Herbert Okun, P776 (Transcript from Prosecutor v. Krajišnik), T. 4352-4355, 4414-4415 (further testifying that there was no way to achieve this objective and to separate the people except by forcible means). Similarly, other witnesses testified that (i) the SDS had "a policy of ethnically cleansing the territories which they conquered and removing the non-Serb populations from most of those territories"; (ii) the identical pattern in which the Bosnian Muslim population was moved out of areas where the SDS was in power meant that it "could not have happened spontaneously" and that it was a planned, organised, and systematic operation in accordance with the policy of the SDS and that the local authorities were simply implementing the instructions they had been given; (iii) the forced expulsions could not have occurred without there being a policy or participation by Bosnian Serb authorities. Milorad Davidović, T. 15536-15537 (28 June 2011); D1450 (Milorad Davidović's statement to Belgrade District Court, 26 December 2007), p. 21; Anthony Banbury, T. 13337-13338 (15 March 2011); P3804 (Witness statement of Charles Kirudja dated 17 November 2010), para. 79.

9321 Herbert Okun, P776 (Transcript from Prosecutor v. Krajišnik), T. 4205.

9322 Vitomir Žepinić, T. 33589-33590 (13 February 2013).

9323 D2970 (Letter from SerBiH Assembly to Jose Cutileiro, 11 March 1992), p. 1. See also D2969 (Letter from Radovan Karadžić, Nikola Koljević, and Momčilo Krajišnik to Jose Cutileiro, 2 March 1992), p. 1.

9324 D2970 (Letter from SerBiH Assembly to Jose Cutileiro, 11 March 1992), p. 2.

9325 P1477 (Ratko Mladić's notebook, 14 February-25 May 1992), pp. 349-351; P6254 (Article from TANJUG entitled "Serb Leaders Promote Ethnic Demarcation", 17 May 1992), p. 1.
} 
continue with the transformation of the JNA. ${ }^{9326}$ Krajišnik at this meeting indicated that the "time is ripe for a demarcation of the areas between Croats, Serbs, and Muslims because [...] a common state with them is no longer possible, not because we do not want that but because that is what they want. The Muslims leadership has imposed the war on us even though the Serbs wanted a political solution of all problems". ${ }^{9327}$

2826. Even in August 1992, Krajišnik spoke about Serbs wanting a unified state: "We have our plan, which we must carry out by political, military, and other means, depending on the situation". 9328

2827. At a meeting of the $1^{\text {st }}$ Krajina Corps in September 1992, attended by Mladić and Bogdan Subotić, and the commanders and presidents of municipalities, it was also noted that the temporary ceasefire "cannot replace the aims of our struggle to create a new Serbian Republic". ${ }^{9329}$ At this meeting, a conclusion was reached to "[e]liminate sectarian feelings towards other nations" based on certain conditions, including their contribution to the advancement of the Serbian Republic. ${ }^{9330}$

2828. In October 1992, the Accused outlined how before the international recognition of BiH they were able to declare their republic "a sovereign and independent state" and that he, along with Buha, and Koljević had insisted in meetings with diplomats on a constituent entity for the Serbian people. $^{9331} \mathrm{He}$ expressed his view that the criteria for establishing provinces in $\mathrm{BiH}$ were unacceptable and noted that Serbs would only be a temporary majority in one or two provinces. ${ }^{9332}$ During this speech, the Accused also outlined his view on the position to be taken during negotiations and that one of the provinces would be a Serbian state called Republika Srpska. ${ }^{9333}$

2829. When the RS and RSK were unified on 31 October 1992, Bosnian Serb leaders including Plavšić emphasised the unity of the Serbian people and their right to self-determination and

\footnotetext{
9326 P6254 (Article from TANJUG entitled "Serb Leaders Promote Ethnic Demarcation", 17 May 1992), p. 1; Milovan Bjelica, T. 36443-36447 (3 April 2013).

9327 P6254 (Article from Tanjug entitled "Serb Leaders Promote Ethnic Demarcation", 17 May 1992), p. 2.

9328 P1357 (Transcript of $18^{\text {th }}$ session of SerBiH Assembly, 11 August 1992), p. 19. See also P5476 (Report of $1^{\text {st }}$ Krajina Corps, 1 October 1992), pp. 3-4.

9329 D3702 (Report of $1^{\text {st }}$ Krajina Corps, 14 September 1992), pp. 1-2.

9330 D3702 (Report of $1^{\text {st }}$ Krajina Corps, 14 September 1992), p. 5. See also D3695 (Witness statement of Bogdan Subotić dated 16 June 2013), para. 292.

9331 P939 (Video footage of Radovan the Accused's speech at the $21^{\text {st }}$ Session of RS Assembly, 30 October 1992 , with transcript), p. 1.

9332 P939 (Video footage of Radovan the Accused's speech at the $21^{\text {st }}$ Session of RS Assembly, 30 October 1992 , with transcript), pp. 3, 6.

9333 P939 (Video footage of Radovan the Accused's speech at the $21^{\text {st }}$ Session of RS Assembly, 30 October 1992 , with transcript), p. 4.
} 
continued to make similar speeches emphasising this right. ${ }^{9334}$ The declaration of unification also decided that a co-ordinating committee would consist of the presidents of the republics, the presidents of the assemblies of the republics and the prime ministers of the republics. ${ }^{9335}$

2830. In November 1992, Koljević stressed that "we should finish everything that's necessary militarily as soon as possible, because that's going to improve our political and diplomatic position" and that once fighting calmed down, the media scrutiny and pressure would reduce and they would be able to postpone a political solution based on the territory they held. ${ }^{9336}$

2831. In June 1993, the Accused spoke about recognition of the Bosnian Serb legitimate right to self-determination, that $\mathrm{BiH}$ would certainly be divided into three parts, and that Bosnian Muslims should be satisfied with the division because of the municipalities which they would obtain, but if they continued with the war the Bosnian Muslims could lose everything because the Bosnian Serbs would not allow themselves to be "subjugated and dominated" by Muslims. ${ }^{9337}$

2832. The Chamber recalls that, at a meeting with international negotiators on 11 January 1993, Krajišnik stressed the Bosnian Serb objective of territorial continuity and named three conditions from the Bosnian Serb Assembly: (i) BiH must be a "composite state community"; (ii) the Bosnian Serbs must have relations with other "states"; and (iii) they must have territorial continuity. ${ }^{9338}$ Mladić told Okun and Owen that the Bosnian Serbs wanted "peace with justice" for all three peoples but that the Bosnian Muslims could not "beat", "exterminate", or "cause [the Serbs] to disappear". 9339 The following day, at a plenary meeting, the Accused expressed his reservations about the ICFY's constitutional principles and stated he could not accept them but that he would convey the ICFY's proposals to the Bosnian Serb Assembly. ${ }^{9340}$

2833. At a meeting with VRS commanders on 29 January 1994, the Accused stated that while everyone was aware of the Bosnian Serb objectives, "appropriate statements" should be issued to hand trump cards to other parties; he instructed not to make "war-mongering statements" but

9334 P1360 (Transcript from Joint session (21 ${ }^{\text {st }}$ session) of RS Assembly and Assembly of Serbian Krajina, 31 October 1992), p. 4; D115 (Transcript of $25^{\text {th }}$ session of RS Assembly, 19-20 January 1993), pp. 20-21. See P5541 (Prijedor Declaration on the Unification of the RSK and RS, 31 October 1992), pp. 1, 4.

9335 P5541 (Prijedor Declaration on the Unification of the RSK and RS, 31 October 1992), pp. $3-4$.

9336 P1105 (Transcript of 22 ${ }^{\text {nd }}$ session of RS Assembly, 23-24 November 1992), p. 112.

9337 D3026 (Article from Yugoslav Daily Survey entitled "Montenegrin President: Decisive Step towards Peace in Bosnia", 21 June 1993), p. 2.

9338 See para. 361; P789 (Sixth notebook of Herbert Okun's ICFY diary), e-court p. 43.

9339 P789 (Sixth notebook of Herbert Okun's ICFY diary), e-court p. 45.

9340 See para. 361; P789 (Sixth notebook of Herbert Okun's ICFY diary), e-court p. 48. According to Milovanović, in November 1992, the Accused issued a public statement that BiH should be made of its three constituent states with the RS as a "single whole" and rejected the Vance-Owen proposal for a "centralised BiH with ten cantons". D2149 (Aide mémoire of Manojlo Milovanović), p. 12. 
instead to discuss peace. ${ }^{934}$ The Chamber recalls that in April 1994, UNPROFOR representatives went to Pale to speak to the Accused, who declared that the right bank of the Drina will be the Bosnian Serbs'. 9342

2834. The Chamber recalls that on 7 July 1994, the Contact Group unveiled a new peace plan under which $51 \%$ of $\mathrm{BiH}$ would be administered by a newly formed Bosnian-Croat Federation and that $49 \%$ be administered by the Bosnian Serbs. ${ }^{9343}$ On 19 July 1994, at the Bosnian Serb Assembly, the Accused spoke about the Contact Group's proposed plan stating that the acceptance of the plan would not be a guarantee for peace. ${ }^{9344}$ The Bosnian Serbs rejected the plan stating that the plan was unfair and their demands were not met and in a later referendum in Bosnian Serb-held territory, $96 \%$ of voters rejected the plan. ${ }^{9345}$

2835. The Accused met with Ronald Hatchett in 1994 to discuss a proposal to end the war and asked Hatchett to bring back the proposal to the highest level that he could reach in the United States of America. ${ }^{9346}$ The Accused proposed that: (i) BiH would remain a single country; (ii) it would be comprised of two autonomous republics; (iii) each republic would have its own constitution and government; and (iv) he would be willing to accept a division of $\mathrm{BiH}$ which would give Bosnian Serbs $49 \%$ of the territory so long as it was contiguous and that there would be some trade of areas held by Bosnian Muslims and Bosnian Serbs. ${ }^{9347}$

2836. At a meeting held in August 1994 between the Accused, Krajišnik and Martić, the President of the RSK, the Accused advocated that "we should unite in essence, and use formal unification as a threat. Our unification is not enough to arrive at a complete solution. The right solution is unification of all Serbian lands". 9348 Krajišnik also stated that the "[t]he objective is a single Serbian state to be agreed upon between the Republic of Serbian Krajina and Republika Srpska. We must work towards that objective without ever losing ties with Serbia". ${ }^{9349}$ In September 1994, when discussing the possibility of tightened sanctions on Pale with international representatives, the Accused said "if the international community treats us like a beast, then we will behave like a

\footnotetext{
9341 P1485 (Ratko Mladić's notebook, 9 January-21 March 1994), pp. 51, 78-79.

9342 See para. 393.

$9343 \quad$ See para. 398.

9344 See para. 399; P1394 (Transcript of $42^{\text {nd }}$ Session of RS Assembly, 18-19 July 1994), pp. 15-18. See also D2149 (Aide mémoire of Manojlo Milovanović), pp. 45-46.

9345 See paras. 401-406.

9346 D2741 (Witness statement of Ronald Hatchett dated 13 January 2013), para. 15.

9347 D2741 (Witness statement of Ronald Hatchett dated 13 January 2013), para. 16; D2744 (Article from Dallas Morning News entitled "Don't Ignore the Serbs' Peace Plan”, 4 August 1995). See also D2149 (Aide mémoire of Manojlo Milovanović), p. 12.

9348 P2563 (Minutes of meeting between Milan Martić and Radovan Karadžić, 20 August 1994), p. 7.

9349 P2563 (Minutes of meeting between Milan Martić and Radovan Karadžić, 20 August 1994), p. 11.
} 
beast". ${ }^{9350}$ The Accused made a similar observation in an interview when he said that if they were treated as animals or "wild beasts in a cage" they could not be expected to "act in a tolerant and correct manner". ${ }^{9351}$

2837. Through Directive 7, issued on 8 March 1995, the Accused continued to call on the VRS to "by force of arms, impose the final outcome of the war on the enemy, forcing the world into recognising the actual situation on the ground and ending the war". ${ }^{9352}$ In this same directive, the Accused called for full support for the creation of a "free and unified Serbian state". 9353 The Chamber recalls that at a press conference in April 1995 in the context of further international negotiations, the Accused stated that if peace was not possible through political means, the Bosnian Serbs would put an end to the war by military means. ${ }^{9354}$

2838. The Chamber recalls that the Dayton peace talks began in November 1995 and even though the Accused had been removed from the RS negotiating team he played a central consultative role in regards to RS negotiations. ${ }^{9355}$ These talks concluded in the Dayton Agreement, however, the RS delegation was unsatisfied with specific details of the agreement and refused to attend the final plenary session of the peace talks as well as the ceremonial initialling of the peace agreement. ${ }^{9356}$ The Dayton Agreement was initialled by Tuđman, Slobodan Milošević, and Izetbegović on 21 November 1995 and signed on 14 December $1995 .^{9357}$

\section{(2) $\underline{\text { Conclusion }}$}

2839. The Chamber finds based on this evidence that the Accused as early as September 1991 was identifying territories which were to be claimed by Bosnian Serbs. It is clear that the Accused and the Bosnian Serb leadership advocated and worked towards a territorial re-organisation which would allow the Bosnian Serbs to claim control and ownership of a large percentage of the territory in $\mathrm{BiH}$. In terms of establishing control over this territory, the Accused worked towards the creation of parallel institutions, organs of government, and military and police structures which could gain or retain control of those areas. The Chamber's findings with respect to the creation of these parallel structures will be further elaborated in Section IV.A.3.ii.

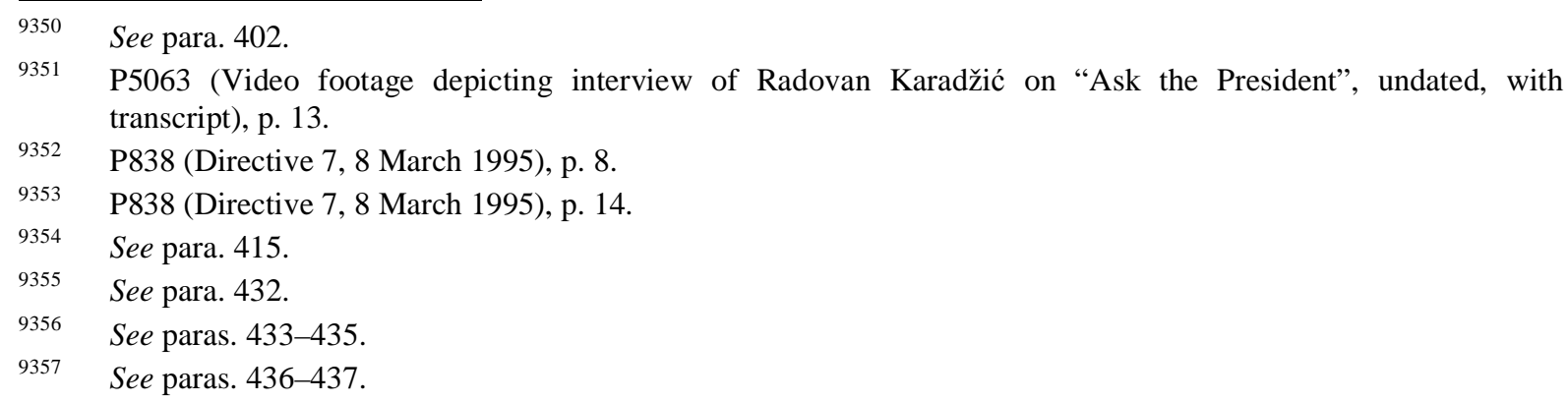


2840. Having considered this evidence, the Chamber finds that from November 1991 the Accused and the Bosnian Serb leadership spoke against Bosnian Muslims being allowed to stay in Bosnian Serb claimed territory and emphasised the importance of taking control of power and the creation of separate municipalities and municipal structures. The Chamber considers the Accused's statement in February 1992 and the supporting statements of both Koljević and Krajišnik to be highly probative in terms of explaining the changing objectives of the Accused and the Bosnian Serb leadership. The Chamber finds that this speech by the Accused confirms that until late 1991, the Bosnian Serbs were still hopeful of maintaining Yugoslavia, but when it became apparent that this objective was slipping away, they changed course and made preparations for the creation of their own sovereign Serb entity in $\mathrm{BiH}$ which would include its own political, civilian, and military structures.

2841. The Accused's rhetoric and discussions with international representatives also made it clear that he advocated the separation of people and believed that co-existence with the Bosnian Muslims and Bosnian Croats was not possible. His rhetoric also emphasised that they were fundamentally different people who had been forced to live together. The Chamber finds that this ideology was repeated and used by the Accused and the Bosnian Serb leadership as justification for the creation of ethnically homogeneous entities in $\mathrm{BiH}$ and for minimising the number of Bosnian Muslims and Bosnian Croats who would remain in Bosnian Serb claimed territory. The Chamber notes that these sentiments were in contrast with public statements the Accused had made in 1990 when the Accused and the Bosnian Serb leadership continued to emphasise the unity of Yugoslavia and the existence of a common state.

2842. The Chamber further finds that the Accused made extensive use of maps to highlight the territorial claims of the Bosnian Serbs. These territorial claims included strategically significant areas where Bosnian Muslims were a majority prior to the conflict. The Accused defended these claims and noted that they only seized territories to which they had a right. This rhetoric was also linked with the stated position of the Accused and the Bosnian Serb leadership that they had no interest in living with Bosnian Muslims.

2843. The Accused and the Bosnian Serb leadership repeatedly referred to and re-asserted the historic territorial claims of the Bosnian Serbs. In making these arguments and territorial claims, reference was also made to the historic crimes committed against the Bosnian Serbs, which meant they were no longer a majority in $\mathrm{BiH}$ and in areas which they claimed as a "birthright". The Chamber finds that the Accused's position with respect to these historic territorial claims was endorsed by the Bosnian Serb Assembly and formed a core aspect of the Bosnian Serb objectives in 
including these territories in the RS. The Chamber finds that constant references to historic crimes committed against Bosnian Serbs were used as a means of justifying their territorial acquisitions which they viewed as belonging to them. The Chamber also finds that the Accused and the Bosnian Serb leadership referred back to historic attacks they faced from their "enemies" and the manner in which the Serbs became a minority in $\mathrm{BiH}$ to justify their objective of creating a Bosnian Serb State.

2844. The Accused and the Bosnian Serb leadership also spoke about the importance of controlling Bosnian Serb claimed territories and how significant the factual situation on the ground in terms of controlling territory was for the purposes of international negotiations. The Accused and the Bosnian Serb leadership emphasised the Serb nature of the land which they claimed and controlled and the importance of those territorial claims in preventing the Islamisation of those areas.

2845. The Chamber further finds that the strategic objectives of the Accused and the Bosnian Serb leadership were also communicated to and formed a core element in the military strategy of the VRS which was to create the RS. These speeches and statements also demonstrate that the Accused and the Bosnian Serb leadership supported and endorsed the territorial acquisitions which had been achieved militarily by Serb Forces. The Chamber finds that while these military operations were described by the Bosnian Serbs as being "defensive" or for the purposes of "liberation", their purpose and effect was to take control of Bosnian Serb claimed territory in BiH and to expand the area which would be included in the RS. The Accused supported these military successes and viewed them as a means of defining Bosnian Serb territory and creating their own state which they would not relinquish.

2846. While the Accused publicly claimed that he had no influence over the issue of war, it was clear that he envisaged that in a war, there would be bloodshed and all the communities would flee towards their "fully homogeneous" areas. In contrast to public statements where the Accused foreshadowed what could happen, the Accused was simultaneously calling for seizing power in Bosnian Serbs claimed territories which would result in the population movements which he envisaged. The Chamber finds that the Accused was not simply foreshadowing what he thought could happen, he was outlining the pattern which was actually put into practice. The Chamber also finds that the Accused and Bosnian Serb leadership were aware and put on notice that the objective of ethnic separation would result in violence given the extent to which the population in $\mathrm{BiH}$ was intermixed and yet still proceeded to pursue this objective. 
2847. The Chamber finds that in international settings and press conferences, the Accused defended the actions of Bosnian Serbs and spoke in favour of the interests of minorities and denied the suggestion that people would be forced from their homes. However, despite these public statements, the Chamber finds that the evidence demonstrates that the Accused and the Bosnian Serb leadership were informed when municipalities were taken over by Serb Forces and were also aware that their territorial claims and the military manner in which those claims were asserted resulted in the displacement of thousands of non-Serbs. The Bosnian Serb leadership was also informed about the drastic demographic changes which resulted in Serbs becoming a majority in a number of municipalities. The Accused himself acknowledged the new demographic and territorial realities which they had created and that in undertaking military operations to expand their territory the Bosnian Muslim population had been concentrated in small areas. This demonstrates yet again the difference between the public statements made by the Accused and the Bosnian Serb leadership and the reality on the ground, of which they were fully aware.

2848. The Chamber also finds that the Accused and the Bosnian Serb leadership were aware that some of the territory which they took over and controlled were areas where Serbs had not been a majority but the Accused emphasised that these municipalities had to be taken for strategic and/or historic reasons.

2849. The Chamber notes that there were some speeches, statements, and announcements by the Accused which placed the blame on the Bosnian Muslims and Bosnian Croats for the separation of people and claimed that in contrast the Bosnian Serbs were not creating "an ethnically clean state". However, the Chamber finds that these statements and announcements were used as a means of creating a narrative, particularly for the international audience in which the Bosnian Serbs would not be blamed for the separation and the movement of people. In this regard the Chamber notes for example that the Accused made it clear that the Bosnian Serbs were making preparations for their own "ethnic space" in $\mathrm{BiH}$ regardless of the tone of negotiations between the parties to the conflict at that time. The Chamber finds that this is indicative of the position taken by the Accused and the Bosnian Serb leadership and that their public statements often directly contradicted the plans which they had for ethnic separation.

2850. The Accused also issued public announcements which promised respect for the rights of all citizens, promised the free movement of people, prohibited the forcible detention or movement of people, and guaranteed the right of return of refugees. However, the Chamber finds that these public announcements were also in stark contrast to the reality on the ground which was marked by 
the unlawful detention and forced movement of thousands of people. ${ }^{9358}$ The Chamber finds that these public announcements were also issued by the Accused following repeated protests at an international level about the treatment of non-Serbs in Bosnian Serb controlled territory. The Chamber finds these announcements were issued as means of easing that political pressure but did not translate into a real improvement in the situation on the ground given that the pattern of mistreatment, detention, and forcible transfer continued. The Chamber also finds that these expulsions were discussed at Bosnian Serb Assembly sessions by deputies who warned that they could only talk about these issues amongst themselves but could not speak about it to the rest of the world.

2851. The Chamber also finds that these announcements were inconsistent with the Accused's continued emphasis and rhetoric on the importance of a division of $\mathrm{BiH}$ along ethnic lines and the dangers and impossibility of living with Bosnian Muslims. The Chamber finds that while the Accused did envisage some minorities in the state the Bosnian Serbs were creating, his position was that this number should be kept at a minimum and that the Bosnian Muslims and Bosnian Croats should have their own entities in $\mathrm{BiH}$ and should be moved out of Bosnian Serb territory. The Chamber finds that the Accused disseminated propaganda about demographics and the Bosnian Muslim birth-rate as a further justification for ethnic separation even after he had issued public announcements guaranteeing that nobody would be forced to leave Bosnian Serb territory.

2852. The Chamber also finds that the Bosnian Serb policy on refugees was connected with its goal of achieving ethnic geographic continuity of the Serb population and did not make provision for the return of Bosnian Muslims and Bosnian Croats. The Chamber finds that with respect to the right of refugees to return, the Accused was aware that from a legal perspective they could not declare a ban on their return but that they should insist that it occur on a reciprocal basis. The Chamber finds that this is instructive in terms of interpreting statements or declarations which ostensibly guaranteed the right of return of refugees. It demonstrates that the Accused and the Bosnian Serb leadership were conscious of making public statements which were in accordance with international expectations and obligations, but which were at odds with the reality on the ground.

2853. The Chamber finds that there was a clear disjuncture between the public announcements and statements made to international representatives and the continued speeches and policy of the Accused and the Bosnian Serb leadership which advocated ethnic separation and the creation of an ethnically homogeneous Bosnian Serb state. In this regard the Chamber finds that the Accused

9358 See Section IV.A.2.b. (in relation to deportation, forcible transfer, and unlawful detention). 
spoke about the importance of the Strategic Goals to the creation of their state and how they had succeeded in forcing acceptance of the division of $\mathrm{BiH}$ along ethnic lines. The Chamber also finds that the Accused continued to advocate a military solution to achieving the Bosnian Serb objectives and issued orders in this regard towards creating a unified Serbian state.

2854. The Chamber also finds that the Bosnian Serb leadership was conscious of the international attention and were warned by Jovanović that they should be conscious of taking steps which would be construed as "ethnic cleansing" but that they should still persist with ensuring that their territory was as ethnically homogeneous as possible. It was also clear from these meetings and speeches that the Accused and the Bosnian Serb leadership were not only aware of but also supported the demographic changes and ethnic homogenisation which had occurred in Bosnian Serb claimed territory. The Accused and the Bosnian Serb leadership in 1994 and 1995 continued to speak about removing Bosnian Muslims and Bosnian Croats from the state they had created and the continued importance of the unification of all Serbian lands.

2855. In the course of international negotiations into 1993, 1994, and 1995, the Accused continued to emphasise the territorial objectives of the Bosnian Serbs and the territories which were still in dispute but were vital to the Bosnian Serb interests. The Accused also adhered to the basic position that the Bosnian Serbs wanted a separate Serb entity in $\mathrm{BiH}$. The Chamber also finds that in speeches before the Bosnian Serb Assembly the Accused and the Bosnian Serb leadership spoke strongly against having "enemies" in their state and also indicated that they would not allow certain areas to be allocated to Bosnian Muslims. The Chamber finds that the Accused and the Bosnian Serb leadership adhered to a primary objective of partition and separation from Bosnian Muslims and Bosnian Croats who would have their own entities in $\mathrm{BiH}$ and that the Bosnian Serbs would control territory which was "nearly $100 \%$ Serbian".

2856. Even until 1995 the Bosnian Muslims and Bosnian Croats continued to be portrayed as the enemies of the Bosnian Serbs and their state. The evidence also shows the importance that the Bosnian Serb leadership and the Accused placed on territorial acquisition and control. 


\section{(E) Strategic Goals}

\section{(1) Analysis of evidence}

2857. The Chamber recalls that during the $16^{\text {th }}$ session of the Bosnian Serb Assembly on 12 May 1992, the Accused presented the Strategic Goals. ${ }^{939}$ The Strategic Goals were adopted by the Bosnian Serb Assembly at the same session. ${ }^{9360}$ These goals were:

a. separation from the other two national communities and the separation of states;

b. creation of a corridor between Semberija and Krajina;

c. creation of a corridor in the Drina Valley thus eliminating the Drina as a border between Serbian states;

d. creation of a border on the Una and Neretva Rivers;

e. division of the city of Sarajevo into Serbian and Muslim parts; and

f. access of the SerBiH to the sea. ${ }^{9361}$

2858. The Accused stated that the Assembly of $\mathrm{BiH}$ had neglected all other tasks and moved towards "gaining independence for Bosnia and Herzegovina as a unitarist state under Muslim domination" and that the Muslim and Croatian national communities with the assistance of opposition parties "decided to enclose us in their own state, to make us wake up in a foreign state", which forced the Serbian people to exercise their "right to self-determination and set up our own state". ${ }^{9362}$ The Accused also stated that they would finally "finish the job of the freedom struggle of the Serbian people. That job is not finished. Anything in history that is not properly finished

9359 See para. 57 See also Branko Đerić, T. 28067-28068 (25 April 2012) (testifying that the Strategic Goals were presented by the SDS leadership and that the Bosnian Serb Government was not involved in developing these goals).

9360 P955 (SerBiH Assembly Decision on Strategic Goals of Serbian People in BiH, 12 May 1992). Prstojević was evasive as to whether the Bosnian Serb leadership had established a goal of division from Bosnian Muslims and why. In addition his evidence was marked by indicators that he was trying to mislead the Chamber. The Chamber therefore does not find his evidence with respect to this issue to be reliable. Neđeljko Prstojević, T. 13244, 13247 (11 March 2011), T. 13619-13620 (17 March 2011), T. 13748, 13850-13851 (21 March 2011).

9361 P956 (Transcript of $16^{\text {th }}$ Session of SerBiH Assembly, 12 May 1992), e-court pp. 8-10; P955 (SerBiH Assembly Decision on Strategic Goals of Serbian People in BiH, 12 May 1992); P2561 (Map of BiH re six strategic objectives). See also P1379 (Transcript of 34 ${ }^{\text {th }}$ session of RS Assembly, 27-29 August, 9-11 September, 29 September to 1 October 1993), pp. 14-15.

9362 P956 (Transcript of $16^{\text {th }}$ Session of SerBiH Assembly, 12 May 1992), e-court p. 4. 
does not die but it returns to the agenda again, each time with many more casualties."9363 The Accused also cautioned against the "Serbian megalomania of trying to include as many of our enemies in our areas as possible", and that while their brave people had taken as much as they could, this "could put us in danger of including in our state too many of our enemies, who will again work against that state". 9364

2859. With respect to the first of the Strategic Goals, the separation of the national communities, the Accused emphasised that separation from their "enemies" was necessary and that their goal was the "separation of states". 9365 In this regard the Accused stated that their enemies had attacked them at every opportunity in the last century and would continue to do so if they lived in the same state. $^{9366}$

2860. In a similar fashion the Accused explained the importance of each of the Strategic Goals by reference to the interests of the Serbian people. ${ }^{9367}$ The second Strategic Goal outlined by the Accused was the importance of a corridor between Semberija and Krajina to allow for an integration of Serbian lands with unimpeded flow from one part of the state to another. ${ }^{9368}$ With respect to the Strategic Goal of creating a corridor, Krajišnik stated that the "size of the corridor depends on you. Whether it will reach to the Sava river or be five kilometres wide, if it is five kilometres wide we will not be able to defend it, but if it is $30 \mathrm{~km}$ we will defend it". 9369

2861. With respect to the third Strategic Goal the Accused stated that the belt along the Drina must belong to the SerBiH and that this would not only be strategically useful to them but also damaging to the "interests of our enemy" and would prevent the Muslims from connecting to the

\footnotetext{
9363 P956 (Transcript of $16^{\text {th }}$ Session of SerBiH Assembly, 12 May 1992), e-court p. 10.

9364 P956 (Transcript of $16^{\text {th }}$ Session of SerBiH Assembly, 12 May 1992), e-court pp. 10-11. See also Ewan Brown, T. 21720 (22 November 2011).

9365 P956 (Transcript of $16^{\text {th }}$ Session of SerBiH Assembly, 12 May 1992), e-court p. 9. The Chamber places no weight on Brown's opinion that the implementation of the first Strategic Goal would involve the creation of a Serb state and the movement of a significant part of the non-Serb population out of that state. P3914 (Ewan Brown's expert report entitled "Military Developments in the Bosanska Krajina - 1992", 27 November 2002), para. 1.43. See also Patrick Treanor, T. 14052 (1 June 2011); P2561 (Map of BiH re six strategic objectives). The Chamber places no weight on Treanor's opinion as to the reasons behind the Strategic Goals or the way in which the Strategic Goals formed part of the objectives of the Bosnian Serb leadership. For example, see Patrick Treanor, T. 14019, 14051, 14054, 14067-14068 (1 June 2011), T. 14378 (7 June 2011). The Chamber also does not rely on Bulatović's understanding that the first Strategic Goal did not involve physical separation of people or his belief that the expulsions did not result from any policy. D3051 (Witness statement of Momir Bulatović dated 25 February 2013), paras. 19-20.

9366 P956 (Transcript of $16^{\text {th }}$ session of SerBiH Assembly, 12 May 1992), e-court p. 9. For further evidence and discussion on this issue, see Section IV.A.3.a.i.B: Identification of historic enemies.

9367 P956 (Transcript of $16^{\text {th }}$ session of SerBiH Assembly, 12 May 1992), e-court p. 9.

9368 P956 (Transcript of $16^{\text {th }}$ Session of SerBiH Assembly, 12 May 1992), e-court p. 9; P2561 (Map of BiH re. six strategic objectives). See also Patrick Treanor, T. 14052 (1 June 2011).

9369 P956 (Transcript of $16^{\text {th }}$ session of SerBiH Assembly, 12 May 1992), e-court p. 45.
} 
"Muslim International". ${ }^{9370}$ Part of the fear of the Bosnian Serbs was to prevent the creation of the so called "green transversal". 9371 The Accused also spoke about the "elimination of the Drina as a border between two worlds. We are on both sides of Drina, and our strategic interest and our living space are there". ${ }^{9372}$ This objective was also reflected at a municipal level, where in Foča for example, Stanić stated the Bosnian Serb position that "the Drina would never become a border but a windpipe between two lungs". 9373

2862. The Accused concluded that the achievement of the Strategic Goals would allow them to finish the freedom struggle of the Serbian people and that they should avoid including too many "enemies" in their state. 9374

2863. At this session, Mladić advocated a path which would involve fighting and waging war. ${ }^{9375}$ Mladić stressed that there would be victims, but that the other option was one of chaos, passivity and empty talk and would be the "path to our extinction". 9376 Mladić also stated that "we cannot cleanse nor can we have a sieve to sift so that only Serbs would stay, or that the Serbs would fall through and the rest leave" and that he did not know how the Accused and Krajišnik would be able to explain this to the world and it would be "genocide". 9377

2864. Mladić stated that there are ways of neutralising the Muslims which do not mean that they have to be expelled or drowned. ${ }^{9378}$ In this regard, Mladić identified a common enemy and described them as Muslim and Croatian "hordes" and that they had to determine whether "to throw both of them out employing political and other moves, or to organise ourselves and throw out one by force of arms, and we will be able to deal somehow with the other". 9379 At the same session, Mladić also spoke about the importance of defining their goals and the territory of SerBiH and having the forces to achieve this. ${ }^{9380}$ He also said that their goal should be to have "a state of our own where we have left our mark, the bones of our fathers, and that is the goal we must fight

\footnotetext{
9370 P956 (Transcript of $16^{\text {th }}$ session of SerBiH Assembly, 12 May 1992), e-court p. 9.

9371 Radomir Nešković T. 14378 (7 June 2011). Bosnian Serbs also expressed fear about Izetbegović's Islamic Declaration. D3695 (Witness statement of Bogdan Subotić dated 16 June 2013), paras. 4, 25-26, 30. See also D3645 (Witness statement of Nenad Kecmanović dated 27 May 2013), para. 28; Milorad Dodik, T. 36834 36835 (9 April 2013).

9372 P956 (Transcript of $16^{\text {th }}$ session of SerBiH Assembly, 12 May 1992), e-court p. 9.

9373 P3476 (Video clip of interview with Miroslav Stanić, with transcript), p. 2; KDZ379, T. 18831-18834 (15 September 2011).

9374 P956 (Transcript of $16^{\text {th }}$ session of SerBiH Assembly, 12 May 1992), e-court pp. 10-11.

9375 P956 (Transcript of $16^{\text {th }}$ session of SerBiH Assembly, 12 May 1992), e-court p. 31.

9376 P956 (Transcript of $16^{\text {th }}$ session of SerBiH Assembly, 12 May 1992), e-court pp. 31-33.

9377 P956 (Transcript of $16^{\text {th }}$ session of SerBiH Assembly, 12 May 1992), e-court p. 35.

9378 P956 (Transcript of $16^{\text {th }}$ session of SerBiH Assembly, 12 May 1992), e-court p. 35.

9379 P956 (Transcript of $16^{\text {th }}$ session of SerBiH Assembly, 12 May 1992), e-court p. 41.

9380 P956 (Transcript of $16^{\text {th }}$ session of SerBiH Assembly, 12 May 1992), e-court pp. 32-33.
} 
for". 9381 Mladić stated that if "we have taken something in this war that was not ours, we need to keep hold of it so that in political negotiations we can get those things that were ours, and that we cannot get in any other way". 9382 Mladić advocated that the actions of the Bosnian Serbs should remain secret and recommended that they adopt a common rhetoric towards the public. ${ }^{9383} \mathrm{He}$ also stressed the importance of identifying enemies and that on this basis, "we must make our move and eliminate them, either temporarily or permanently". ${ }^{9384}$

2865. Towards the end of the same session on 12 May 1992, Krajišnik acknowledged that "we will surely go to war" and that "it will be possible to solve this thing with Muslims and Croats only by war" but that they should select the political solution because it would not look good if the conclusion of Assembly was that they had chosen the option of war. ${ }^{9385}$

2866. Other deputies supported the Strategic Goals and indicated that in order for them to be realised they could be "developed further and presented as variations" and that the borders would be established "when we make them a fact" and that peace could "only be achieved by war". 9386 They also emphasised the importance of finding a way to "keep in peace what we have won in war" and in areas where they were a minority there would need to be a resettlement of the population. ${ }^{9387}$

2867. At this session, Brđanin explained that in areas where Serbs were a majority, "most of them are still asking whether they should injure the Muslims, whether they can hold certain posts, whether loyal Muslims and loyal Croats exist". 9388 Brđanin was one of the Bosnian Serb leaders who engaged in anti-Muslim rhetoric and this rhetoric created a great deal of animosity, mistrust and hatred towards the Bosnian Muslim population. ${ }^{9389}$ For example, Brđanin said that he did not know why the Muslims were pickling cabbage for the winter because they would not be there to eat it. ${ }^{9390}$ Brđanin at a meeting for Serb unity in August 1994 attended by Krajišnik said "[t]hose leftist forces which are offering us co-existence again must know that it is the obligation of Serbs over the

\footnotetext{
9381 P956 (Transcript of $16^{\text {th }}$ session of SerBiH Assembly, 12 May 1992), e-court p. 39.

9382 P956 (Transcript of $16^{\text {th }}$ session of SerBiH Assembly, 12 May 1992), e-court p. 32.

9383 P956 (Transcript of $16^{\text {th }}$ session of SerBiH Assembly, 12 May 1992), e-court pp. 33-34 (stating "[t]he thing that we are doing needs to be guarded as our deepest secret" and "[o]ur people must know how to read between the lines", and suggesting that they "adopt such a wisdom that we are against the war but that we will fight if attacked, and that we do not want a war against the Muslims as a people, or against the Croats as a people, but against those who steered and pitted these peoples against us").

9384

9385

9386

9387

9388

9389

9390 P956 (Transcript of $16^{\text {th }}$ session of SerBiH Assembly, 12 May 1992), e-court p. 33.

P956 (Transcript of $16^{\text {th }}$ session of SerBiH Assembly, 12 May 1992), e-court pp. 45, 47.

P956 (Transcript of $16^{\text {th }}$ session of SerBiH Assembly, 12 May 1992), e-court p. 27. This speech was delivered by Velibor Ostojić.

P956 (Transcript of $16^{\text {th }}$ session of SerBiH Assembly, 12 May 1992), e-court pp. 29-30.

P956 (Transcript of $16^{\text {th }}$ session of SerBiH Assembly, 12 May 1992), e-court p. 25.

[REDACTED].

[REDACTED].
} 
next hundred years to wipe their feet from the foul non-Christians who have befouled this soil of ours". ${ }^{9391}$ Krajišnik then took the stand and praised the words and patriotism of those who had spoken before him. ${ }^{9392}$

2868. On 7 May 1992, a week before being presented before the $16^{\text {th }}$ session of the Bosnian Serb Assembly, the Strategic Goals were discussed in the presence of the Accused, Mladić, and Krajišnik. $^{9393}$ Krajišnik acknowledged that he had taken part in adopting the Strategic Goals and that the first goal was the most important and that the remaining goals were sub-items of this goal. ${ }^{9394}$ Mladić also stated that he had "read, mulled over for a long time and discussed with the most select circle of comrades whom we convened, the strategic goals that are of substance". 9395

2869. At this same session a deputy from Brčko referred to the tasks set by the Accused, and noted that one of the first priorities "is establishing communication between Semberija and the Bosnian Krajina" and that while military operations had been completed to some extent, there were still Bosnian Muslim forces in Brčko, and that Brčko "remains uncompleted". 9396 He noted that in order to have "definitive clearing of the area it will be necessary to have many more forces there" and called on the Accused and Krajišnik to promote general mobilisation of the Serbian people and referred to the "conquests that are currently necessary". 9397

2870. At this same session, Dragan Kalinić, the health minister, spoke in favour of choosing the "option of war" and that their enemy was perfidious and "cannot be trusted until they are physically, militarily destroyed and crushed, which, of course, implies eliminating and liquidating their key people". ${ }^{9398}$ He further noted that "only what has been conquered militarily can be really and truly ours" and that there was no point in making maps until they had "succeeded in defining and marking our territory militarily". 9399

2871. Kalinić also noted that since they were in closed session, he could make it clear that when they called for cease-fires this was only done to demonstrate that they were in favour of negotiations and a peaceful solution but these statements were for "external, public use" and that

\footnotetext{
9391 P14 (TV footage of Serb unity meeting in Banja Luka, 21 August 1994, with transcript), pp. 5-6.

9392 P14 (TV footage of Serb unity meeting in Banja Luka, 21 August 1994, with transcript), p. 8.

9393 P1477 (Ratko Mladić's notebook, 14 February-25 May 1992), pp. 262-263.

9394 P956 (Transcript of $16^{\text {th }}$ session of SerBiH Assembly, 12 May 1992), e-court p. 45.

9395 P956 (Transcript of $16^{\text {th }}$ session of Assembly of SerBiH, 12 May 1992), e-court p. 32.

9396 P956 (Transcript of $16^{\text {th }}$ session of SerBiH Assembly, 12 May 1992), e-court p. 12.

9397 P956 (Transcript of $16^{\text {th }}$ session of SerBiH Assembly, 12 May 1992), e-court pp. 12-13.

9398 P956 (Transcript of $16^{\text {th }}$ session of SerBiH Assembly, 12 May 1992), e-court p. 17.

9399 P956 (Transcript of $16^{\text {th }}$ session of SerBiH Assembly, 12 May 1992), e-court p. 18.
} 
cease-fires could be used to consolidate their armed forces. ${ }^{9400}$ Kalinić also spoke in favour of the destruction of radio and television facilities and medical facilities "so that the enemy has nowhere to go for medical help". ${ }^{9401}$ Bosnian Serb leaders often proposed cease-fires at times when they already controlled a large percentage of the territory in $\mathrm{BiH} .{ }^{9402}$

2872. A deputy who spoke in favour of the Strategic Goals noted that in Bosanka Krupa, "there are no more Muslims in the Serbian Municipality of Bosanska Krupa" and that they had been "evacuated" and that it was unlikely that they would have a place to return to given that the Accused told them "the happy news that the right bank of the Una is the border". 9403

2873. These Strategic Goals were also communicated to and discussed during Crisis Staff meetings at a municipal level. ${ }^{9404}$ On 18 May 1992, the SDS Municipal Board in Prijedor was informed about developments at the Bosnian Serb Assembly and informed about the main guidelines for future activities which related to the Strategic Goals. ${ }^{9405}$

2874. The Strategic Goals were more than mere theoretical objectives and they were concretely discussed at meetings. For instance, at a meeting of $1^{\text {st }}$ Krajina Corps commanders and Banja Luka leaders on 2 June 1992, the implementation of the second goal, i.e. creating a corridor between Semberija and Krajina, ${ }^{9406}$ was discussed. ${ }^{9407}$ At the same meeting which was attended by the Accused and Mladić, Brđanin stated that "everything in the ARK is done at the [Crisis Staff] level". ${ }^{9408}$ The Accused also referred to the Strategic Goals at a meeting with Bosnian Serb representatives on 10 June 1992 at which he said that "[w]e have full control of many of our

9400 P956 (Transcript of $16^{\text {th }}$ session of SerBiH Assembly, 12 May 1992), e-court p. 18.

9401 P956 (Transcript of $16^{\text {th }}$ session of SerBiH Assembly, 12 May 1992), e-court p. 19.

9402 Herbert Okun, T. 1779 (28 April 2010). See also Anthony Banbury, T. 13397 (15 March 2011); D1146 (International Conference on Former Yugoslavia report, 8 June 1994).

9403 P956 (Transcript of $16^{\text {th }}$ session of SerBiH Assembly, 12 May 1992), e-court pp. 20-21. While the Chamber notes that the events in Bosanka Krupa are not charged in the Indictment, the Chamber has had regard to this evidence as it supports the pattern of the Accused's involvement in setting objectives which were implemented at the municipal level.

9404 See P3431 (Handwritten diary of KDZ192), p. 14 (under seal); KDZ192, P3416 (Transcript from Prosecutor v. Brđanin), T. 11526-11527 (under seal). See also Neđeljko Prstojević, T. 13245-13246 (11 March 2011); Neđeljko Prstojević, T. 13564-13565 (17 March 2011). The Chamber places no weight on Donia's opinion that the Strategic Goals were published again in 1993 given an "assessment of the leaders that these were important goals that should be publicly known and that they had not changed". It also places no weight on his assessment about the significance of and the ideological basis for the Strategic Goals. Robert Donia, T. 3073-3075 (31 May 2010).

9405 P6589 (Minutes of Prijedor Municipal Board meeting, 18 May 1992), p. 1. See Boško Mandić, T. 45774-45775 (21 January 2014); Simo Mišković, T. 45382-45383 (18 December 2013).

9406 P955 (SerBiH Assembly Decision on Strategic Goals of Serbian People in BiH, 12 May 1992).

9407 P1478 (Ratko Mladić's notebook, 27 May-31 July 1992), pp. 53, 60.

9408 P1478 (Ratko Mladić's notebook, 27 May-31 July 1992), pp. 53-54. See P6514 (Excerpt from military diary), pp. 2-3 (under seal); Radoslav Brđanin, T. 43679-43684 (18 November 2013), T. 43685-43689 (18 November 2013) (private session). See also D4056 (News report on Ratko Mladić and Radovan Karadžić visit to Banja Luka, 2 June 1992) (confirming that the Accused was on a short working visit on 2 June 1992). 
territories", that Bosnian Serbs had strong support from the Serbian DB, and that they had formed their own army. ${ }^{9409}$

2875. At another meeting in June 1992 of the Bosnian Serb military and political leadership, the Accused noted that the Bosnian Serb Assembly had defined the strategic aims and further reiterated the importance of those objectives and that the Bosnian Serbs had to protect their territories militarily. ${ }^{9410} \mathrm{He}$ also noted that "the birth of a state and the creation of borders does not occur without war" and that according to the map they had $66 \%$ of the territory in $\mathrm{BiH}^{9411}$ At this same meeting, Ostojić reported that there were no Muslims in Bratunac. ${ }^{9412}$

2876. On 17 June 1992, Mladić issued an order raising the combat readiness of the Birač Brigade and emphasising that the order was to allow for full control over Birač, to secure the corridor between Romanija and Semberija, and maintain a link with Serbia. ${ }^{9413}$ In November 1992, Mladić issued Directive 4 to "cleanse the free territory of RS of the remaining enemy groups and paramilitary formations". ${ }^{9414}$ One of the tasks of Directive 4 was addressed to the Drina Corps which was instructed "to inflict the heaviest possible losses" on the "enemy" and force them to leave certain areas such as Birač, Žepa, and Goražde with the Bosnian Muslim population. 9415

2877. On 8 November 1992 at a meeting of Corps Commanders attended by the Accused and Mladić, Krajišnik expressed his admiration for the military successes and noted that they had a "disproportionate engagement of the army in relation to the strategic objectives". 9416 Krajišnik also reminded the attendees of the progress made in relation to the Strategic Goals and noted that the most important objective had been assigned to Milenko Živanović, namely to mop up the Drina and repeated that the most important task was the "separation from the Muslims" and that the "Muslims must not stay with us". 9417

\footnotetext{
9409 P1478 (Ratko Mladić's notebook, 27 May-31 July 1992), pp. 130, 132-133.

9410 P1478 (Ratko Mladić's notebook, 27 May-31 July 1992), pp. 93-95.

9411 P1478 (Ratko Mladić's notebook, 27 May-31 July 1992), p. 97.

9412 P1478 (Ratko Mladić's notebook, 27 May-31 July 1992), p. 101.

9413 P3238 (Order of the VRS Main Staff, 17 June 1992), p. 1.

9414 P976 (Directive 4, 19 November 1992), pp. 3-4.

9415 P976 (Directive 4, 19 November 1992), p. 5. While Krajišnik had in his own case testified that this was an "order for ethnic cleansing" he somewhat qualified this during his testimony in this case. The Chamber therefore does not find his evidence to be reliable in this regard. Momčilo Krajišnik, T. 43823-43824 (19 November 2013).

9416 P1481 (Ratko Mladić's notebook, 5 October-27 December 1992), pp. 141, 146-147.

9417 P1481 (Ratko Mladić's notebook, 5 October-27 December 1992), p. 147. Živanović acknowledged that separation from the Bosnian Muslims was discussed but testified that his task was not to engage in "ethnic cleansing" and there was no mention of killing. Milenko Živanović, T. 42585-42590 (30 October 2013).
} 
2878. At a session of the Bosnian Serb Government on 20 March 1993, a debate on the draft law on the territorial organisation of municipalities was held, during which the criteria for the establishment of municipalties was decided. ${ }^{9418}$

2879. At a meeting of 19 June 1993 in Pale with members of the Supreme Command with, inter alios, Krajišnik, Koljević, Lukić, Mladić, and Milovanović in attendance, the Accused gave an update as to developments in relation to the Strategic Goals and the territorial situation in $\mathrm{BiH}^{9419}$ In June 1993, Mladić issued Directive 5 and noted that given the developments, a unified BiH was no longer an option. ${ }^{9420}$ Directive 6 was issued by the Accused in November 1993 and included specific instructions with respect to the strategic goals of the VRS. ${ }^{9421}$ Directive 6 referred to the goals of (i) liberating Sarajevo; (ii) defining the borders of RS on the Neretva River and gaining access to the sea; (iii) defining the borders of RS in the Una River basin; and (iv) expanding the borders of RS in the north-east and establishing firmer ties with Serbia. ${ }^{9422}$

2880. Bosnian Serb leaders, including the Accused, discussed the Strategic Goals openly with international representatives who were told that RS would be ethnically "pure" "9423 and that their aim was to redistribute the population in $\mathrm{BiH}$ to allow Bosnian Serb control of a "single continuous block of territory" which also included "traditionally Serb-inhabited areas". 9424

2881. The Chamber also recalls that during the negotiation process at the ICFY, Bosnian Serbs pushed for an agenda consistent with the Strategic Goals and identified the areas of BiH they wanted to be under Bosnian Serb control while the Bosnian Muslims maintained their position for the creation of a unitary state with centralised powers. ${ }^{9425}$ The position of the Bosnian Croats was to take $\mathrm{BiH}$ out of the FRY, to declare independence, and to establish their own state called the Community of Herceg-Bosna with territorial contiguity with Croatia. ${ }^{9426}$

\footnotetext{
9418 P3129 (Minutes of the $66^{\text {th }}$ session of RS Government, 20 March 1993), p. 5.

9419 P1483 (Ratko Mladić's notebook, 2 April-24 October 1993), pp. 212-213.

$9420 \quad$ P843 (Directive 5, 25 June 1993), p. 1.

9421 P3039 (Directive 6, 11 November 1993), pp. 1, 6.

9422 P3039 (Directive 6, 11 November 1993), p. 6.

9423 Herbert Okun, T. 1474-1475 (22 April 2010); Herbert Okun, P776 (Transcript from Prosecutor v. Krajišnik), T. 4157-4158, 4169.

9424 P820 (Witness statement of David Harland dated 4 September 2009), paras. 267-270. While Harland also stated that this required the removal of very large numbers of Bosnian Muslims as they were a majority in certain areas, this appears to be his own assessment and not to be what the Bosnian Serb leadership said. The Chamber therefore does not place any weight on this aspect of his evidence. See also P4203 (Witness statement of Pyers Tucker dated 12 May 2010), para. 33.

9425 See paras. 354-356.

$9426 \quad$ See para. 355.
} 
2882. In January 1993, the Accused reported to the Bosnian Serb Assembly on disputes the Bosnian Serb leadership had at international negotiations with respect to disputed territories in municipalities including Prijedor, Sanski Most, Ključ, Rogatica, and Srebrenica. ${ }^{9427}$ The Accused also noted that in municipalities including Zvornik, Vlasenica, and Rogatica the municipal authorities agreed to the legitimate division of those municipalities before the war with the effect that "there are areas that are [i]ndisputably Serb, Croat or Muslim". ${ }^{9428}$

2883. At a meeting held at the Presidency of Serbia on 8 November 1993, with inter alios Slobodan Milošević, the Accused, Krajišnik, Martić, Mladić, and Perišić in attendance, the following common objectives were discussed: (i) unconditionally strengthen the integrity of Serbia, (ii) set up the RS as a completely independent state; and (iii) ensure Serbs have complete power in the Krajina. ${ }^{9429}$ Emphasis was placed on reinforcing co-operation between the armies and unity in the Krajina. ${ }^{9430}$ At the end of the meeting, conclusions were presented, one of which was to "work out offensive moves to correct frontlines in the RS, but go quietly and without noise as soon as possible". 9431

2884. On 1 October 1993, the Accused held a meeting with VRS generals, during which he declared: "Our fundamental ideology is Serbdom and the Serbian state". ${ }^{9432}$ Mladić asked that further goals of the war and tasks of the army be defined at the level of the state and the Supreme Command. ${ }^{9433}$

2885. In December 1993, Krajišnik noted that at the beginning of the war the Strategic Goals were "one of the most important documents" and that the Bosnian Serb Assembly endorsed these objectives and "organised the people to implement them". ${ }^{9434}$ He also noted that the first and most important objective had been achieved and that the RS now existed with its own state organisation and territory. ${ }^{9435}$ Krajišnik noted that in the first months of the war, efforts were directed towards "establishing full unity throughout the territory of [RS]" and that they had created the organisational and personnel conditions to allow the state to function normally and to allow "a more stable defence and the liberation of Serbian ethnic spaces". ${ }^{9436}$ Krajišnik noted that in

\footnotetext{
9427 P921 (Transcript of $24^{\text {th }}$ session of RS Assembly, 8 January 1993), p. 8.

9428 P921 (Transcript of $24^{\text {th }}$ session of RS Assembly, 8 January 1993), p. 9.

9429 P1484 (Ratko Mladić's notebook, 28 October 1993-15 January 1994), pp. 19-20.

9430 P1484 (Ratko Mladić's notebook, 28 October 1993-15 January 1994), p. 28.

9431 P1484 (Ratko Mladić's notebook, 28 October 1993-15 January 1994), p. 27.

9432 P1483 (Ratko Mladić's notebook, 2 April-24 October 1993), p. 369.

9433 P1483 (Ratko Mladić's notebook, 2 April-24 October 1993), p. 372.

9434 P1383 (Transcript of $36^{\text {th }}$ session of RS Assembly, 30-31 December 1993), p. 12.

9435 P1383 (Transcript of $36^{\text {th }}$ session of RS Assembly, 30-31 December 1993), pp. 12-13.

9436 P1383 (Transcript of $36^{\text {th }}$ session of RS Assembly, 30-31 December 1993), p. 13.
} 
defining the borders of the RS in accordance with their strategic objectives they "did not violate the like rights of the Muslim and Croat communities" and what remained was to struggle for "just borders of our Republic, to be internationally recognised". 9437

2886. At a meeting in Belgrade on 13 December 1993 with the Bosnian Serb and Serbian leadership in attendance, ${ }^{9438}$ the Accused stated that the end of the conflict was close and that the Bosnian Serbs were holding $75 \%$ of the territory, some of which he noted would have to be returned as the international community would not allow it. ${ }^{9439}$ The Accused then listed the Strategic Goals. ${ }^{9440}$

2887. At the $37^{\text {th }}$ Bosnian Serb Assembly Session on 10 January 1994, the Accused stated: "We can consider ourselves as winners after occupying this land, since the land is $100 \%$ Serbian now. Therefore, even if we come down to around 50\%, we should be more than happy and satisfied, it is Dušan's empire." 9441 In this speech the Accused also stated that their first Strategic Goal was separation and not the occupation of $60 \%$ of the land and they had also achieved their second objective, which was to have a contiguous territory connected by a corridor. ${ }^{9442}$ The Accused later that month delivered a speech in which he stressed that they had not lost any vital territories and had "kept everything that was important for the Serbian people". 943 During a meeting with VRS leaders, the Accused recalled the substance of the six Strategic Goals and declared that "they have been defined with the highest level possible of brazenness". ${ }^{9444}$

2888. At a meeting with VRS commanders held on 29 January 1994, the Accused stated that the "plan" was, inter alia, the following: (i) do everything to maintain the Croat/Muslim schism; (ii)

P1383 (Transcript of $36^{\text {th }}$ session of RS Assembly, 30-31 December 1993), p. 13.

From Serbia, inter alios, Slobodan Milošević, General Perišić, and Jovića Stanišić were present. From the RS, inter alios, the Accused, Krajišnik, Mladić, Milovanović, Miletić, Salapura, and Mićo Stanišić were present. P1484 (Ratko Mladić's notebook, 28 October 1993-15 January 1994), p. 53.

9439 P1484 (Ratko Mladić's notebook, 28 October 1993-15 January 1994), p. 53.

9440 P1484 (Ratko Mladić's notebook, 28 October 1993-15 January 1994), p. 53. See also Momčilo Mandić, C2 (Transcript from Prosecutor v. Krajišnik), T. 9064-9067 (confirming that the ethnic division of Sarajevo, drawn along the Miljacka River, was one of the political objectives of the Bosnian Serb leadership).

$9441 \quad$ P1385 (Transcript of $37^{\text {th }}$ session of RS Assembly, 10 January 1994), p. 107.

9442 P1385 (Transcript of $37^{\text {th }}$ session of RS Assembly, 10 January 1994), p. 108. See also P5748 (Intercept of conversation between Radovan Karadžić and Lukić, 13 February 1992), pp. 1-2; P5723 (Intercept of conversation between Jovan Tintor and Žika LNU, 7 March 1992), p. 5. Brđanin testified that the second Strategic Goal was absolutely necessary, otherwise, those in the ARK would not have survived; the separation was an unavoidable consequence and the Accused insisted that the Bosnian Serbs should only defend the regions where they were the majority; and that the Accused never wanted to take any territory that did not belong to Bosnian Serbs. Radoslav Brđanin, T. 43687 (18 November 2013) (private session). The Chamber does not find his evidence to be reliable in this regard. In reaching that conclusion the Chamber noted that Brđanin's testimony was marked by evasiveness and in addition the witness had a self-interest in portrarying these measures in a positive light.

9443 P1387 (Transcript of $38^{\text {th }}$ session of RS Assembly, 17 January 1994), p. 75.

9444 P5593 (Video footage of Radovan Karadžić speech).
} 
separate from the Croats and the Muslims; (iii) let the boundaries of the territory of the Muslims be clearly "detained" if they do not want to stay in Yugoslavia; ${ }^{9445}$ and (iv) be in conflict everywhere with the Muslims and the Croats. ${ }^{9446}$ The following day, at a meeting of the Supreme Command, the Accused reiterated that their task was to defeat the Muslims and that they should be careful that the Muslims do not end up in the Bosnian Serb state. ${ }^{9447}$

2889. At a conference in Vlasenica on 29 January 1994, the Accused delivered a speech in which he spoke about conquering the

entire territory in which there is probably about a million or a million and two hundred thousand Muslims, if there are still so many out there. Here I mean not only those who were killed but also those who fled; in order that we achieve and realize it. It is very hard to imagine. [...] We must defeat them everywhere we can and keep the territory. If possible, we should try to expand the territory; [...] and we should force them to agree to a kind of political and military capitulation [...] the starting point will be the actual situation on the ground..$^{9448}$

2890. The Accused further stated "[f]rom the very beginning, I accepted entirely the view of all the commanders and [G]eneral Mladić. We must change the rhetoric. We must speak on TV, we must participate in live TV shows; we must motivate people for chivalry and prepare them for victories; and, of course, we must nurture their anger toward the enemy". ${ }^{9449}$ With respect to the Bosnian Muslims, the Accused also said:

We prepared ourselves better during the time of peace than they. We knew what they are doing but they did not know what we are doing. They were astonished by the way we organized defense of the municipalities. We were organized; [G]eneral Kovačević knows that, because we were supported by [G]eneral Adžić. He worked on distribution of ammunition, he knew about. General Subotić also knew about it. ${ }^{9450}$

The Accused also stated that he was certain that no territory except in Sarajevo would have to be returned. $^{9451}$

2891. At a meeting of Bosnian Serb and Serbian officials in Belgrade on 27 February 1994, the Accused initially declared that the Bosnian Serbs might agree for the Muslims to have $33.3 \%$ of the

\footnotetext{
9445 The Chamber notes the reference to a policy of "immigration" with a question mark in the English version of exhibit P1485. Having gone back to the original version, the Chamber cannot be satisfied that this is indeed the term referred to since this part of the original document is not sufficiently legible.

9446 P1485 (Ratko Mladić notebook, 9 January-21 March 1994), pp. 51, 77. The part of the plan related to Sarajevo will be discussed further below.

9447 P1485 (Ratko Mladić notebook, 9 January-21 March 1994), pp. 88-89.

9448 P5581 (Radovan Karadžić's speech at a conference in Vlasenica, 29 January 1994), p. 1.

9449 P5581 (Radovan Karadžić's speech at a conference in Vlasenica, 29 January 1994), p. 2.

9450 P5581 (Radovan Karadžić's speech at a conference in Vlasenica, 29 January 1994), p. 4.

9451 P5581 (Closing Remarks by Radovan Karadžić at a Conference in Vlasenica, 29 January 1994), p. 4.
} 
territory, the Croats 14 or $15 \%$, and the Bosnian Serbs 52 or $53 \%$; he then stated that the Bosnian Serbs could be satisfied with $49 \%$ of the territory. ${ }^{9452}$

2892. At a Bosnian Serb Assembly session in March 1994, Ostojić identified four areas which he described as extremely sensitive in terms of establishing "geographic continuity of the Serbian population" in the RS. ${ }^{9453}$ The areas included Rogatica, Vlasenica, Bratunac, Prijedor, Ključ, and Sanski Most. ${ }^{9454}$ The Accused at this session again emphasised the importance of the actual physical control of territory and that there would be a division of $\mathrm{BiH}$ into three based on ethnicity and that he had been discussing before the war and making plans about which areas would form part of their state. ${ }^{9455}$

2893. At a meeting on 8 May 1994 with members of the Supreme Command, including Krajišnik, Koljević, Mićo Stanišić, and Mladić, Plavšić stressed the importance of Posavina-that the percentage is less important but that it could not "exist in two parts". ${ }^{9456}$ Mićo Stanišić responded: " $49-51 \%$, there is importance, especially if an association is to be entered in with them". ${ }^{9457}$ The strategic goals referred to in Directive 6, including the operations to reach the Neretva River and gaining access to the sea, as well as reaching the right bank of the Una River, were also discussed at this meeting. ${ }^{9458}$

2894. Even into 1995 the Accused continued to emphasise the Strategic Goals and stated that the "Drina should be clean" and that the "corridor must be wide". 9459 Krajišnik also shared this objective about a clear Drina. ${ }^{9460}$ In another interview in May 1995, the Accused maintained that they had not given up and would never give up on the Strategic Goals and that they would "seek to achieve them either through political or military means". 9461

\footnotetext{
9452 P1485 (Ratko Mladić notebook, 9 January-21 March 1994), pp. 134, 137-141 (wherein Mladić opposed the Accused's position and commented that the Accused was denying the actual state of affairs).

9453 P1388 (Transcript of 39 ${ }^{\text {th }}$ session of RS Assembly, 24-25 March 1994), p. 168.

9454 P1388 (Transcript of $39^{\text {th }}$ session of RS Assembly, 24-25 March 1994), p. 168.

9455 P1388 (Transcript of $39^{\text {th }}$ session of RS Assembly, 24-25 March 1994), e-court pp. 86, 88.

9456 P3148 (Handwritten notes of Supreme Command meeting, 8 May 1994), p. 2.

9457 P3148 (Handwritten notes of Supreme Command meeting, 8 May 1994), p. 2.

9458 P3148 (Handwritten notes of Supreme Command meeting, 8 May 1994), pp. 3-5.

9459 P988 (Transcript of 53 ${ }^{\text {rd }}$ session of RS Assembly, 28 August 1995), p. 68; P5144 (Interview with Radovan Karadžić on Banja Luka Srpska Televizija, 23 August 1995), p. 1. See also D1934 (Video interview with Radovan Karadžić and Momčilo Krajišnik, undated, with transcript), p. 5.

9460 P1377 (Transcript of 33 ${ }^{\text {rd }}$ session of RS Assembly, 20-21 July 1993), p. 49. See also Herbert Okun, T. 1822 (28 April 2010).

9461 P2562 (Radovan Karadžić’s interview in Nevesinje), p. 1-4; Patrick Treanor, T. 14055-14056 (1 June 2011 ).
} 


\section{(2) Conclusion}

2895. The Chamber finds that the Accused played a central role in formulating, promoting, and disseminating the Strategic Goals. In promoting the Strategic Goals, the Accused continued to emphasise not only the interests of the Serbs to self-determination but also the threat they faced from the Bosnian Muslims and Bosnian Croats who he continued to identify as their historic enemies. Through these speeches, the Accused continued to disseminate propaganda against the Bosnian Muslims and Bosnian Croats which allowed him to promote the measures envisaged by the Strategic Goals. The Accused's rhetoric was also picked up by other deputies in the Bosnian Serb Assembly who similarly spoke about the danger posed by their enemies and used this to advocate taking military measures to protect their interests.

2896. The Chamber further finds that the Accused promoted the implementation of the Strategic Goals as a means of creating a Bosnian Serb state and warned against including "too many of our enemies" in the state which they would create. In doing so the Accused emphasised the first Strategic Goal and the importance of separation from the other two ethnic communities in $\mathrm{BiH}$. The Accused was adamant that this ethnic separation was necessary and acknowledged that the "freedom struggle" of the Serbs had not been finished and would result in many casualties and again made reference to the historic crimes committed against the Serbs. The Chamber finds that the first Strategic Goal and the separation of the national communities was the most important to the Bosnian Serb leadership and their objectives.

2897. The Accused, in promoting the Strategic Goals, and more specifically the third Strategic Goal, emphasised the importance of eliminating the Drina as a border between Serbian states. The Chamber finds that this Strategic Goal was a practical elucidation of the ideology of Serbian unity and the non-separation of Serbs which was repeatedly promoted by the Accused.

2898. The speeches of other Bosnian Serb deputies and Bosnian Serb leaders demonstrate that they supported the Strategic Goals and the approach advocated by the Accused. It is also clear that war, the military conquest of territory, and the movement and resettlement of the population were envisaged by the Bosnian Serb leadership in the implementation of the Strategic Goals. The Accused promoted and shared the objective of creating a Bosnian Serb state which was ethnically pure and creating contiguous Serb areas which would require a redistribution of the population.

2899. The Chamber also finds that the Strategic Goals not only reflected the objectives of the Accused and Bosnian Serb leadership but were also viewed as instructions to be followed at a municipal level in order to achieve those objectives. In this regard, the Strategic Goals were 
communicated to and discussed by municipal bodies and also formed the basis for military operations by the VRS. The Accused, in meetings with Bosnian Serb military and political leaders, continued to emphasise the importance of their Strategic Goals and that the creation of their Serb state required war and the military protection of territories.

2900. The Chamber also finds that there was a clear difference between what the Accused and the Bosnian Serb leadership were willing to say about the Strategic Goals in closed or confidential settings versus what they generally said to international representatives. The Accused in private meetings was far more candid about their willingness to pursue their territorial objectives even at the cost of lives and the displacement of thousands of people. The Accused went so far as to say that they had to motivate their people and "nurture their anger toward the enemy".

2901. The Chamber also finds that the Accused received and also gave updates about developments and progress made towards the achievement of their Strategic Goals, including territorial control and the separation of people. He welcomed these territorial gains and spoke about the victory of the Bosnian Serbs in achieving their objectives and how they had retained control of all vital territories and continued to emphasise that they did not want Bosnian Muslims in their state.

2902. The Chamber therefore finds that the Accused and the Bosnian Serb leadership not only formulated and promoted the Strategic Goals, they also took steps to ensure they were implemented through military operations and that organisational structures were created to allow for the creation of a Serb state.

2903. The Chamber finds that the Strategic Goals continued to be the central element with respect to the Bosnian Serb objectives for the duration of the conflict in $\mathrm{BiH}$ and the Accused continued to emphasise their importance into 1995.

\section{ii. Bosnian Serb political and governmental structures}

2904. The Prosecution alleges that the Bosnian Serb political and governmental organs played a crucial role in the implementation of the alleged common criminal purpose of the Overarching JCE, that the Accused had a pivotal role in establishing and maintaining these organs, and exercised authority and control over them. ${ }^{9462}$ In this regard, the Prosecution argues that the Accused as the leader of the Bosnian Serbs exercised ultimate authority over these organs. ${ }^{9463}$ In this section the Chamber will consider the creation of the political and governmental organs and the extent of the

$9462 \quad$ Prosecution Final Brief, para. 208. 
Accused's involvement in this process as well as the manner in which those organs were used towards achieving the objectives of the Accused and the Bosnian Serb leadership.

\section{(A) Authority over political and governmental structures}

\section{(1) Analysis of evidence}

\section{(a) $\underline{\operatorname{SDS}}$}

2905. The SDS party had a hierarchical structure and, from 1990 to 1995 , the Accused was at the head of this structure as the ex officio president of the SDS Main Board. ${ }^{9464}$ The Accused implemented his policies and the policies of the Bosnian Serb leadership through, inter alia, the structures of the SDS. ${ }^{9465}$ The SDS policies were communicated to the SDS Municipal Boards through members of the Main Board. ${ }^{9466}$ SDS Municipal Boards were obligated to implement the instructions issued by the Main Board or Executive Board. ${ }^{9467}$ While municipal organs had some independence with respect to local issues they were obliged and expected to obey and implement the policies and decisions of the SDS at the higher level and the Accused insisted on respect for his own personal authority. ${ }^{9468}$ It was difficult for other Bosnian Serb officials, particularly at a municipal level to openly contradict the Accused who had "undisputed authority". ${ }^{9469}$ For example, the Accused said that he would "dismiss the idiots [...] who are not implementing the SDS

\footnotetext{
9463 Prosecution Final Brief, para. 206.

9464 See Section II.B.1: Serbian Democratic Party (SDS).

9465 Radomir Nešković, P2568 (Transcript from Prosecutor v. Krajišnik), T. 16844.

9466 Radomir Nešković, P2568 (Transcript from Prosecutor v. Krajišnik), T. 16630-16632.
}

9467 See Section II.B.1: Serbian Democratic Party (SDS). See also Milorad Dodik, T. 36872-36873, 36877-36880, 36887-36888 (9 April 2013); Izet Redžić, P3189 (Transcript from Prosecutor v. Krajišnik), T. 5071, 5075; P2571 (Intercepts of conversations between (i) Radovan Karadžić and Radomir Nešković; (ii) Radovan Karadžić and Mišković; and (iii) Radovan Karadžić and Srdo Srdić, 20 December 1991), p. 3; P2529 (Letter from Radovan Karadžić to SDS Municipal Boards, 15 August 1991); P2556 (Intercept of conversation between Radovan Karadžić and Nenad Stevandić, 11 January 1992), pp. 3, 5, 8, 13, 16; P5550 (Report of the SDS Executive Board, 24 February 1993).

9468 Radomir Nešković, P2568 (Transcript from Prosecutor v. Krajišnik), T. 16623-16625, 16672-16676, 16751; P2572 (Intercept of conversation between Radovan Karadžić and Miroslav Stančić, 26 September 1991), p. 2; Radomir Nešković T. 14235 (6 June 2011); P2571 (Intercepts of conversations between (i) Radovan Karadžić and Radomir Nešković; (ii) Radovan Karadžić and Mišković; and (iii) Radovan Karadžić and Srdo Srdić, 20 December 1991), pp. 3-4; D1277 (Minutes of joint meetings of SDS's General and Executive Committees and Political Council, 11 March 1992), p. 2; P3118 (Minutes of meeting of the Club of Deputies from the SDS and SPO, 14 October 1991), p. 1.

9469 Radomir Nešković, P2568 (Transcript from Prosecutor v. Krajišnik), T. 16625-16626, 16689-16690; P2557 (Intercept of conversation between Radovan Karadžić and Goran Babić, 24 June 1991), pp. 3-5; P2559 (Intercept of conversation between Radovan Karadžić and Radoslav Brđanin, 18 October 1991), pp. 2-3. 
policy". 9470 The Accused issued express instructions to the SDS Municipal Boards including a mandatory directive with respect to the structure and activities of all SDS Municipal Boards. ${ }^{9471}$

2906. Top and local levels in the SDS communicated in both directions, and municipal leaders, members of Executive and Municipal Boards of the SDS would frequently visit, write to or phone the Accused to speak about municipal matters. ${ }^{9472}$ For example, the Chamber found that there was a very close relationship between the Bijeljina branch of the SDS and the SDS party in Pale, and that the SDS leadership, including the Accused and Krajišnik, often visited Bijeljina. ${ }^{9473}$ Similarly, the Chamber found that a line of communication existed between the Municipal Board of the Bratunac SDS and the SDS leadership, including the Accused. ${ }^{9474}$ Another example can be found in Sanski Most where the SDS was extremely well-structured and disciplined, so that orders came from the top and were implemented without any objections. ${ }^{9475}$ When there were problems in Banja Luka for example, the Accused told Krajišnik that they, along with Koljević, needed to visit to "establish some order there, separate the soldiers from the people, and appoint some sort of command for these soldiers and some sort of board for the people". 9476

2907. The Accused also emphasised the importance of local SDS boards ${ }^{9477}$ and in an interview, he indicated that the political life of Serbs in $\mathrm{BiH}$ "had been fully revived and established, which was the main purpose of setting up the party", and that in all places where Serbs lived they had set up municipal organisations with municipal and local boards. ${ }^{947}$ The Accused also took an active role in determining the organisational structure of the SDS at a municipal level and the appointment of personnel. ${ }^{9479}$ On 31 October 1991, the Accused emphasised the importance of strong SDS leaders who would implement directions from the leadership, stating that whoever is "not able to be

\footnotetext{
9470 P2572 (Intercept of conversation between Radovan Karadžić and Miroslav Stančić, 26 September 1991), p. 3.

9471 P2529 (Letter from Radovan Karadžić to SDS Municipal Boards, 15 August 1991). See also D4658 (Instructions from Radovan Karadžić to all Municipal Boards of BiH SDS, 11 September 1991).

9472 See para. 71; Radomir Nešković, P2568 (Transcript from Prosecutor v. Krajišnik), T. 16632. See also D2265 (Srđo Srdić's interview with OTP), pp. 50-51. See also P5827 (Intercept of conversation between Radovan Karadžić and Trifko Komad, 2 November 1991); D4038 (Conclusions of ARK Crisis Staff, 18 May 1992).

9473 See para. 606. See also P2929 (Witness statement of KDZ531 dated 25 June 2011) p. 4.

9474 See para. 690. See also P3197 (Minutes of sessions of Bratunac SDS Crisis Staff and Municipal Board), e-court pp. 9, 13; Dževad Gušić, T. 17804 (24 August 2011); P1357 (Transcript of $18^{\text {th }}$ session of SerBiH Assembly, 11 August 1992), pp. 5-6; P1478 (Ratko Mladić's notebook, 27 May-31 July 1992), p. 101.

9475 P3634 (Witness statement of KDZ490, undated), pp. 6-8, 12 (under seal).

9476 P5798 (Intercept of conversation between Radovan Karadžić and Momčilo Krajišnik, 15 December 1991 ), p. 1.

9477 P3431 (Handwritten diary of KDZ192), p. 4 (under seal).

9478 P2539 (Radovan Karadžić's interview in NIN, 9 November 1990), p. 1.

9479 P2570 (Book of minutes of Prijedor's SDS Municipal Board meetings, 1991), p. 40.
} 
the boss in the municipality, to carry out the mobilisation and even to the full if necessary, should resign immediately". 9480

2908. The Chamber recalls that as early as February 1991, the SDS had considered specific actions to be taken should $\mathrm{BiH}$ move towards independence. ${ }^{9481}$ The SDS envisaged that in such a case municipal authorities were to ensure that only Yugoslav (federal) law would apply, suspending the implementation of republican regulations. ${ }^{9482}$ This policy was adopted by the SDS Deputies' Club and was made public in a document dated 10 June $1991 .{ }^{9483}$ The Accused in a conversation with Žepinić in September 1991, stated that "[e]verything we did so far and everything we are doing now is strictly according to the Law."9484 At a meeting of the SDS Municipal Board on 12 April 1991, it was agreed that instructions would be requested from the SDS headquarters "regarding the referendum, our behaviour and functioning" and that the regional redrawing of municipal borders, which was occurring in Banja Luka, was "fully supported, and those questions should be posed in our areas as well". ${ }^{9485}$ It was also noted that the Presidency of Bratunac should meet with the Accused urgently with respect to the questions raised. ${ }^{9486}$ The Accused and Krajišnik took a leading role in using the SDS structures to call on all Serbs in $\mathrm{BiH}$ to boycott the referendum on the independence of $\mathrm{BiH}$ as it was against their interests. ${ }^{9487}$

2909. The Accused led the SDS deputies out of the SRBiH Assembly on 15 October 1991; the HDZ and SDA delegates then reconvened without the Serb delegates and passed a declaration of sovereignty. ${ }^{9488}$ Subsequently there was a meeting of the SDS Political Council, at which statements were made that it was necessary to "shed the illusion that a form of coexistence with the Muslims and the Croats can be found". 9489 Koljević stated that they could not lose the momentum and had to announce their plebiscite the next day and that they should emphasise this was a peaceful act in contrast to the decision on the sovereignty of $\mathrm{BiH}$, which was described as an act of

\footnotetext{
9480 P5830 (Intercept of conversation between Radovan Karadžić and Veljko Džakula, 31 October 1991), pp. 2-3.

$9481 \quad$ See para. 73.

9482 See para. 73.

9483 See para. 73.

9484 D2926 (Intercept of conversation between Radovan Karadžić and Vitomir Žepinić, 18 September 1991), p. 3. Both Žepinić and KDZ020 testified that the subsequent measures taken, including the formation of the Bosnian Serb Assembly and a separate republic, were unconstitutional. D2923 (Witness statement of Vitomir Žepinić dated 11 February 2013), para. 51; KDZ020, T. 12575 (28 February 2011).

9485

9486

9487

9488

9489 P3197 (Minutes of sessions of Bratunac SDS Crisis Staff and Municipal Board), e-court p. 13.

See para. 1931. See also P3431 (Handwritten diary of KDZ192), p. 4 (under seal); P942 (ECMM report re the BiH Assembly meeting held on 24-25 January 1992), p. 1.

See paras. 46, 76. See also Vitomir Žepinić, T. 33654 (14 February 2013).

D294 (Minutes of SDS Council meeting, 15 October 1991), p. 1. See also Adjudicated Facts 1937, 1938.
} 
"political violence". ${ }^{9490}$ The Accused and other Bosnian Serb leaders, including Krajišnik, emphasised the illegal and unconstitutional nature of the declaration of sovereignty by $\mathrm{BiH}$ and the threat it posed to Serb interests. ${ }^{9491}$ At this meeting, the following items were also discussed: (i) the aim of creating a Greater Serbia; (ii) the activation of parallel government bodies such as a Serb Assembly; (iii) the intensification of the process of regionalisation; and (iv) the military organisation at a local level. ${ }^{9492}$

2910. With respect to the referendum the Accused said in an intercepted conversation that not only was this an illegal decision but through this action, the Bosnian Muslims "set everything up for us just perfectly; it's all fallen right in place". ${ }^{9493}$ In this regard the Accused said they would be strong and establish their own state and that $\mathrm{BiH}$ would consist of three sovereign nations. ${ }^{9494}$

2911. On 16 October 1991, the SDS issued its "Announcement to the Serbian people" in which it stated that the SDA and HDZ had breached the constitutional order and reiterated its support for federal institutions, including the JNA. ${ }^{9495}$ In an intercepted telephone conversation that day, the Accused assured SDS officials in Banja Luka: "We've worked out a scenario. We won't make a single move today. If necessary, we'll do it tomorrow, [...] it would be very useful. Everything's been worked out. You don't need to worry. [...] They can only start fighting us, killing us, but everyone knows what's gonna happen then!"9496

2912. The SDS Deputies' Club met again on 18 October 1991, and the Accused rejected the decision of the $\mathrm{BiH}$ Assembly because the Bosnian Serb deputies had not participated. ${ }^{9497}$ The

9490 D294 (Minutes of SDS Council meeting, 15 October 1991), pp. 1-2; P2581 (Minutes of meeting of SDS Deputies' Club, 18 October 1991), p. 3. See also D3206 (Witness statement of Milovan Bjelica dated 30 March 2013), para. 11; D4077 (Witness statement of Anđelko Grahovac dated 23 November 2013), para. 7; D4212 (Intercept of conversation between Radovan Karadžić and Simo Mišković, 15 November 1991), p. 4.

9491 D294 (Minutes of SDS Council meeting, 15 October 1991), p. 2; P5631 (Intercept of conversation between Radovan Karadžić and Božidar Vučurević, 19 October 1991), pp. 2, 5; P5622 (Intercept of conversation between Radovan Karadžić and Jovica Stanišić, 25 January 1992), p. 2; P5621 (Intercept of conversation between Radovan Karadžić and Dobrica Ćosić, 25 January 1992), p. 2; P5615 (Intercept of conversation between Radovan Karadžić and Nikola Koljević, 11 December 1991), p. 4; P5776 (Intercept of conversation between Radovan Karadžić and Dobrica Ćosić, 5 January 1992), p. 11.

9492 D294 (Minutes of SDS Council meeting, 15 October 1991), pp. 2-3. See also P2581 (Minutes of meeting of SDS Deputies' Club, 18 October 1991), pp. 2-3; see para. 46. Ćeklić stated that regionalisation was not a secret grouping of Serb municipalities, nor was its goal to join Serbia and the Serbian Krajina, and in fact it was done in an effort to decentralise BiH. D3854 (Witness Statement of Savo Ćeklić dated 7 July 2013), para. 15.

9493 P5622 (Intercept of conversation between Radovan Karadžić and Jovica Stanišić, 25 January 1992), p. 2. See also P5754 (Intercept of conversation between Radovan Karadžić and Dobrica Ćosić, 9 February 1992), p. 4.

9494 P5621 (Intercept of conversation between Radovan Karadžić and Dobrica Ćosić, 25 January 1992), pp. 2-3.

9495 See Adjudicated Fact 1939.

9496 P2555 (Intercepts of conversation between (i) Radovan Karadžić and Anđelko Vukić, and (ii) between Radovan Karadžić and Boro Sendić, 16 October 1991), p. 6. See also P5842 (Intercept of conversation between Radovan Karadžić and Vukić, 15 October 1991), p. 1 (in which the Accused tells Vukić to summon all members of the Executive Board from the Banja Luka region to make a very important declaration).

9497 P2581 (Minutes of meeting of SDS Deputies' Club, 18 October 1991), p. 1. 
Accused noted that a "team made up of the leading men of the party, the Government and the Political Council has been working day and night" and that he had decided to impose a state of emergency in the SDS. ${ }^{9498}$ This state of emergency, which was declared by the Accused, was binding on all its members, bodies and officials. ${ }^{9499}$ The Accused emphasised that there needed to be maximum discipline that they had to listen to their leaders and there was no room for a "single wrong step". 9500 As part of this state of emergency, the Accused ordered that there should be daily meetings of the municipal boards and that they would receive daily instructions on the measures to be taken. ${ }^{9501}$ Following the Accused's order, an emergency meeting of the SDS Municipal Board of Bratunac was held where Miroslav Deronjić informed those present about the SDS Main Board instructions and said that they imposed a duty to "act accordingly". ${ }^{9502}$ The next day, Jovan Tintor from Vogošća stated in a telephone conversation that following the plenary session, only Serb Assembly decisions would be binding on the Serb population and that parallel institutions would be formed. ${ }^{9503}$

2913. The Accused was the undisputed authority within the SDS for the duration of the war. ${ }^{9504}$ Some people who resisted the Accused were expelled from the Main Board. ${ }^{9505}$ On 24 June 1991, the Accused told a Bosnian Serb leader in Prijedor that if the party could not organise themselves, he will do it for them by introducing new people into the Prijedor SDS party leadership. ${ }^{9506}$ In September 1991, the Accused intervened to replace the local SDS President in Prijedor, Srdo Srdić, with Simo Mišković, who promised to follow the policies of the SDS Main Board. ${ }^{9507}$ The

9498 P2581 (Minutes of meeting of SDS Deputies' Club, 18 October 1991), p. 4. See also P2556 (Intercept of conversation between Radovan Karadžić and Nenad Stevandić, 11 January 1992), pp. 8-9; P5837 (Intercept of conversation between Miro Galić and Peda, 19 October 1991), p. 1.

9499 P6238 (Radovan Karadžić's Decision, 18 October 1991). See also P5831 (Intercept of conversation between Radovan Karadžić and Miljana LNU, 17 October 1991), pp. 1-2.

9500 P2581 (Minutes of meeting of SDS Deputies' Club, 18 October 1991), p. 4. See also P2716 (Notebook of Radovan Karadzić), p. 30; P5643 (Intercept of conversation between Radovan Karadžić and an unidentified male, 8 July 1991); P5749 (Intercept of conversation between Radovan Karadžić and Božidar Vučurović, 13 February 1992), pp. 3, 5; P5747 (Intercept of conversation between Radovan Karadžić and Gojko Đogo, 15 February 1992), pp. 3-4; P5730 (Intercept of conversation between Radovan Karadžić and Jovan Čizmović, 1 March 1992), p. 2.

9501 P6238 (Radovan Karadžić's Decision, 18 October 1991), p. 1.

$9502 \quad$ See para. 701.

9503 P5836 (Intercept of conversation between Jovan Tintor and Krunić, 19 October 1991), pp. 1-3.

9504 Radomir Nešković T. 14218 (6 June 2011). See also Neđeljko Prstojević, T. 12963 (8 March 2011); P5730 (Intercept of conversation between Radovan Karadžić and Jovan Čizmović, 1 March 1992), p. 1; P5722 (Intercept of conversation between Jovan Tintor and Žika LNU, 11 March 1992), p. 4.

9505 Radomir Nešković, P2568 (Transcript from Prosecutor v. Krajišnik), T. 16626-16627.

9506 P2557 (Intercept of conversation between Radovan Karadžić and Goran Babić, 24 June 1991), pp. 3-5.

9507 P3706 (Minutes of meeting of Prijedor Municipal Assembly, 11 September 1991), pp. 3-4; P2571 (Intercepts of conversations between (i) Radovan Karadžić and Radomir Nešković; (ii) Radovan Karadžić and Mišković; and (iii) Radovan Karadžić and Srdo Srdić, 20 December 1991); Simo Mišković, T. 45351-45361 (18 December 2013). See P12 (Extended session of Main and Executive Boards of the SDS, 14 February 1992), p. 17. 
Accused spoke with an SDS member in Banja Luka on 11 January 1992. When the Accused was faced with the suggestion that there were some individuals in the Krajina who wanted to act independently on certain issues, he insisted on party discipline and stated "they cannot. We have all of that in the plans. We have all moves in the envelopes. They must not do it before we do it in the whole of Bosnia. Why are they playing smart? They're explaining my policy to me". ${ }^{9508}$ The Accused also insisted that he would expel and discipline those who did not follow the SDS policies or acted without his approval or the approval of the Bosnian Serb Assembly. ${ }^{9509}$ The Accused also spoke about having a council of ministers, and said "we have plans for everything" and that in the Krajina they had to "synchronise their work with the party". ${ }^{9510} \mathrm{He}$ also spoke about the importance of pursuing the Serbian policy in a synchronised fashion otherwise "the Serbs would not have a state". 9511

\section{(b) Bosnian Serb Assembly and governmental structures}

2914. The Chamber found that on 24 October 1991, the Bosnian Serb deputies of the SRBiH Assembly met and decided to establish a separate assembly, which was constituted the same day. ${ }^{9512}$ Krajišnik explained that the Bosnian Serb deputies in the SRBiH Assembly were prompted to form the Bosnian Serb Assembly due to what they saw as a violation of the sovereignty of the Bosnian Serbs and a threat to their existence in $\mathrm{BiH}$ "where they had lived from time immemorial". ${ }^{9513}$ Krajišnik also expressed the right of the Serbs to self-determination and remaining in their "historical and ethnic territories". 9514

\footnotetext{
9508 P2556 (Intercept of conversation between Radovan Karadžić and Nenad Stevandić, 11 January 1992), pp. 2, 6, 10, 12. See also P6228 (Intercept of conversation between Radovan Karadžić and Božidar Vučurević, 2 September 1991), p. 3; P6229 (Intercept of conversation between Radovan Karadžić and Božidar Vučurević, 3 September 1991), pp. 6-8; P6230 (Intercept of conversation between Radovan Karadžić and Božidar Vučurević, 9 September 1991), pp. 3-6, 8-13.

9509 P2556 (Intercept of conversation between Radovan Karadžić and Nenad Stevandić, 11 January 1992), pp. 2-5, 10-12, 15-18; P5732 (Intercept of conversation between Radovan Karadžić and Jovan Čizmović, 25 February 1992), pp. 1-2; D4536 (Intercept of conversation between Nikola Koljević and Radovan Karadžić, 26 July 1991), pp. 1-2; P5841 (Intercepts of conversations between (i) Ljubo Grković and Radoslav Brđanin; (ii) Radovan Karadžić and Radoslav Brđanin, 16 October 1991), pp. 3-5. See also P5639 (Intercept of conversation between Radovan Karadžić and Nenad Stevandić, 13 December 1991), pp. 2-4.

9510 P2556 (Intercept of conversation between Radovan Karadžić and Nenad Stevandić, 11 January 1992), pp. 6-7, 13-14.

9511 P2556 (Intercept of conversation between Radovan Karadžić and Nenad Stevandić, 11 January 1992), p. 8.

9512 See paras. 47, 77.

9513 P3121 (Stenograph of the session of the Club of Deputies from the SDS, 24 October 1991), pp. 5-7, 18; P1343 (Transcript of $1^{\text {st }}$ Session of SerBiH Assembly, 24 October 1991), p. 6. See also Milorad Dodik, T. 3684136842 (9 April 2013).

9514 P3121 (Stenograph of the session of the Club of Deputies from the SDS, 24 October 1991), p. 5.
} 
2915. Krajišnik was elected as the first president of the Bosnian Serb Assembly. ${ }^{9515}$ On the same day the Bosnian Serb Assembly decided that the Bosnian Serbs would remain in the joint state of Yugoslavia and called for the conduct of a plebiscite to confirm this decision. ${ }^{9516}$ In November 1991, Brđanin was quoted in a newspaper article as having stated that all directors and managers in the ARK who did not participate in the plebiscite should be urgently dismissed from their positions. ${ }^{9517}$ Following the publication of this article, the Accused said that Brđanin was "out of order" in his statement about the dismissals of directors, but that he "wanted to get [him] off the hook" for the statement and ultimately told Brđanin that “it has to be done, but you mustn't say that" out loud. 9518

2916. The Accused was also involved in organising steps to be taken to carry out the plebiscite. ${ }^{9519}$ After the decision of the Constitutional Court of $\mathrm{BiH}$ and the Bosnian Serb Presidency declaring the plebiscite of Serb people unconstitutional and illegal, the plebiscite was launched and the Accused stated that the Serbs no longer had any duties towards the $\mathrm{BiH}$ Constitution, that they had obligations towards the Constitution of Yugoslavia which guaranteed their right to self-determination and the right for the people to organise themselves. ${ }^{9520}$

2917. The Chamber recalls that on 9 and 10 November 1991, a plebiscite was held to determine whether Serbs in $\mathrm{BiH}$ wished to remain in a joint state of Yugoslavia with the overwhelming majority of Serbs voting in favour of remaining in Yugoslavia. ${ }^{9521}$ On 21 November 1991, the Bosnian Serb Assembly proclaimed as part of the territory of federal Yugoslavia all those municipalities, communes, and settlements where a majority of registered Serb citizens had voted in favour of remaining in Yugoslavia. ${ }^{9522}$ In an intercepted conversation on 23 December 1991, the Accused said: "A political principle is being introduced. In principle, everywhere where Serbs live and where they have voted against secession, or to remain in Yugoslavia, no one can break away

\footnotetext{
9515 P3121 (Stenograph of the session of the Club of Deputies from the SDS, 24 October 1991), p. 12. See also para. 77.

9516 P3121 (Stenograph of the session of the Club of Deputies from the SDS, 24 October 1991), pp. 13-14, 16. See also Adjudicated Fact 1940; Herbert Okun, P776 (Transcript from Prosecutor v. Krajišnik), T. 4187-4188.

9517 P1632 (Article from Oslobođenje, entitled "After the Plebiscite: You should better give yourselves up", 12 November 1991); Predrag Radić, P1 (Transcript from Prosecutor v. Krajišnik), T. 7373-7377.

9518 P4 (Intercepts of conversations between (i) Radovan Karadžić and Vukić; (ii) Radovan Karadžić and Predrag Radić; (iii) Radovan Karadžić and Radoslav Brđanin), pp. 4-5, 10-11; Predrag Radić, P1 (Transcript from Prosecutor v. Krajišnik), T. 7375-7377.

9519 P2570 (Book of minutes of Prijedor's SDS Municipal Board meetings, 1991), p. 63; P5840 (Intercept of conversation between Radovan Karadžić and Vukić, 16 October 1991).

9520 P6249 (Excerpt from video of Radovan Karadžić's statement, with transcript), p. 1.

9521 See para. 47. See also D83 (Shorthand Record of $2^{\text {nd }}$ Session of SerBiH Assembly, 21 November 1991), pp. 1923; P5733 (Intercept of conversation between Jovan Tintor and unidentified male, 17 March 1992), p. 2 ; P3456 (Decision of SerBiH Assembly, 21 November 1991).

9522 P5412 (Decision of SerBiH Assembly, 21 November 1991), pp. 1-2. See also Adjudicated Facts 1946, 1947; D3989 (Minutes of the SDS Main Board, 21 November 1991), p. 1.
} 
there. [...] However, we don't want to stop the Croatian and Muslim peoples from reorganising themselves, meaning that their links to Yugoslavia would be weaker than ours."9523

2918. The Bosnian Serb Assembly functioned as the central body representing Bosnian Serbs and was the mechanism through which other institutions and political structures were set up. ${ }^{9524}$ This included a Council of Ministers, which was established on 21 December 1991 and replaced by the Bosnian Serb Government on 24 March 1992. ${ }^{9525}$ In January 1992 the Accused spoke about how their republic had already started functioning, had its own authorities, structures organs and a Council of Ministers and that all Yugoslav institutions including the JNA "will back us up [...] Nobody can do anything about that. They cannot do anything, because that is $60 \%$ of the territory they would not be able to control as an independent state". 9526

2919. In addition, the National Security Council ("SNB”) was established on 27 March 1992. ${ }^{9527}$ The Accused described the SNB as an advisory body to the Bosnian Serb Assembly which would be composed of "all the important organs and institutions" of the Serbian people. ${ }^{9528}$ The SNB was responsible for military matters during the war and matters relating to security. ${ }^{9529}$ The SNB served, until the creation of the Presidency in May 1992, as the de facto Presidency of the SerBiH. The Accused was the ex officio president of the SNB, ${ }^{9530}$ and the decisions of the SNB were made under the control of the Accused. ${ }^{9531}$

2920. At a meeting held in the Presidency of the SFRY in Belgrade on 9 December 1991, the Accused stated that Europe "does not accept legality but the factual status. Therefore we have to be wise enough and prepare both legality and the factual status". 9532 The Accused declared: "We

D4555 (Intercept of conversation between Radovan Karadžić and Maristela Lučić, 23 December 1991), p. 1.

Radomir Nešković, P2568 (Transcript from Prosecutor v. Krajišnik), T. 16778-16779; Radomir Nešković T. 14274-14275 (6 June 2011). See also P5749 (Intercept of conversation between Radovan Karadžić and Božidar Vučurović, 13 February 1992), p. 2.

9525 See paras. 87, 103.

9526 P5620 (Intercept of conversation between Radovan Karadžić and an unidentified male, 21 January 1992), pp. 24. See also P5618 (Intercept of conversation between Radovan Karadžić and Slobodan Vidović, 27 December 1991), p. 5 (where the Accused spoke about the importance of only having the JNA in BiH); P5746 (Intercept of conversation between Radovan Karadžić and Dobrica Ćosić, 15 February 1992), p. 5.

9527

9528

9529

9530

9531

9532

P961 (Shorthand Record of $12^{\text {th }}$ session of SerBiH Assembly, 24 March 1992), p. 14. See also Momčilo Mandić, C2 (Transcript from Prosecutor v. Krajišnik), T. 9124-9125.

Momčilo Mandić, C2 (Transcript from Prosecutor v. Krajišnik), T. 9125.

See para. 89.

P4982 (Witness Statement of Branko Đerić dated 5 April 2012), para. 28.

P2554 (Notes from SFRY's Presidency meeting, 9 December 1991), p. 78.
} 
have made a list of moves. Ten moves in the direction we want, so that there are results. [...] But we don't do anything until Alija messes something up."9533

2921. On 11 December 1991, the Bosnian Serb Assembly adopted a recommendation that SDS deputies in municipal assemblies in $\mathrm{BiH}$ in which the SDS did not have a majority establish "municipal assemblies of the Serbian people". ${ }^{9534}$ The recommendation stated that the assemblies would be composed of SDS deputies and "other deputies of Serb nationality who make a statement on joining the Assembly". ${ }^{9535}$ Attached to the recommendation was a model decision on the establishment of "municipal assemblies of the Serbian people" to be adopted by individual municipalities. ${ }^{9536}$ These decisions were to be verified by the Bosnian Serb Assembly. ${ }^{9537}$

2922. Municipal level leaders reported to the municipal bodies on developments at a republican level including the formation of the Bosnian Serb Assembly and noted that the assembly had been created as a means of resisting attempts to divide the Serbian people. ${ }^{9538}$ The SDS Municipal Board in Prijedor, for example, was informed on 28 October 1991, that Serb assemblies had to be formed in all the municipalities, that they were establishing their own state with their own forces and preparations had to be made for the plebiscite of the Serb people and military organisation. ${ }^{9539}$ The SDS Municipal Board in Prijedor also referred to the position of the Accused that given the secession of $\mathrm{BiH}$ arranged by the SDA, they were forced "to form ethnic communities in our ethnic territories". ${ }^{9540}$ They also discussed the importance of establishing control over their territories. ${ }^{9541}$

2923. The Chamber found that on 20 December 1991 the SRBiH Presidency, Koljević and Plavšić dissenting, voted to apply to the Badinter Commission for the recognition of $\mathrm{SRBiH}$ as an independent state. ${ }^{9542}$ Members of the Bosnian Serb Assembly met on 21 December 1991, expressed their strong opposition to the Badinter Commission process, and approved preparations for the formation of a Serb Republic..$^{9543}$ On 5 January 1992, the Badinter Commission recommended that $\mathrm{SRBiH}$ be required to hold a referendum to determine the will of its people

\footnotetext{
9533 P2554 (Notes from SFRY's Presidency meeting, 9 December 1991), p. 78. See also Patrick Treanor, T. 1403814039 (1 June 2011). See also P5774 (Intercept of conversation between Radovan Karadžićand Vladislav Jovanović, 5 January 1992), p. 2.

$9534 \quad$ See para. 131.

9535 D84 (Shorthand Record of $3^{\text {rd }}$ session of SerBiH Assembly, 11 December 1991), p. 11.

9536 D84 (Shorthand Record of $3^{\text {rd }}$ session of SerBiH Assembly, 11 December 1991), pp. 11, 18-20.

9537 D84 (Shorthand Record of $3^{\text {rd }}$ session of SerBiH Assembly, 11 December 1991), p. 29.

9538 P2570 (Book of minutes of Prijedor's SDS Municipal Board meetings, 1991), p. 60.

9539 P2570 (Book of minutes of Prijedor's SDS Municipal Board meetings, 1991), pp. 62, 64, 73.

9540 P2570 (Book of minutes of Prijedor's SDS Municipal Board meetings, 1991), p. 90.

9541 P2570 (Book of minutes of Prijedor's SDS Municipal Board meetings, 1991), p. 91.

9542 See para. 48.

9543 See para. 50.
} 
regarding independence and the SRBiH Assembly voted to hold such a referendum on 29 February and 1 March 1992. ${ }^{9544}$

2924. On 9 January 1992, the Bosnian Serb Assembly proclaimed the SerBiH. ${ }^{954}$ This proclamation noted that the territory of the SerBiH was composed of the SAOs and "additional territories, not precisely identified but to include areas where the Serbs had been in a majority before the genocide of World War II". ${ }^{9546}$ The area which would comprise the territory of the SerBiH would include all areas where a majority of Bosnian Serbs had voted in the plebiscite to remain in Yugoslavia. ${ }^{954}$ On 13 January 1992, the Council of Ministers identified the priorities emerging from the declaration of the promulgation of the SerBiH of 9 January 1992, which included defining the ethnic territory and the establishment of government organs in the territory. ${ }^{9548}$ The Accused and Krajišnik participated in the discussion on the execution of these tasks. $^{9549}$

2925. In an intercepted conversation on 13 January 1992, the Accused informed Kuprešanin, President of the ARK Assembly, that "[w]e have a complete concept of a polycentric development. Therefore, centres must exist, and the centres will be developed more powerfully" and that "not a single move should be made which will not be a hundred percent agreed on". 9550 In another conversation, the Accused also spoke of the territorial claims of the Bosnian Serbs and in particular that regionalisation should not disrupt the authority of the Bosnian Serb state, namely that "I want Serbs to organise themselves in those Krajinas [...] but that the unified Serbian [BiH] still exist". 9551

2926. On 17 January 1992, at a session of the Council of Ministers, a draft programme of its work was presented. ${ }^{9552}$ It called for the adoption of the Constitution and for the organisation of the territory in such a way so as to "enlarge the territory of the regions and encompass a larger number of inhabitants wherever possible in order to consolidate the regions both ethnically and

\footnotetext{
9544 P971 (Robert Donia's expert report entitled “The Origins of Republika Srpska”, 1990-1992, 30 July 2003), ecourt p. 36. See also P1349 (Transcript of $6^{\text {th }}$ session of SerBiH Assembly, 26 January 1992), p. 16.

9545 See para. 50; Robert Donia, T. 3564 (9 June 2010); P1346 (Minutes of $5^{\text {th }}$ session of SerBiH Assembly, 9 January 1992), pp. 2-3. See also Adjudicated Fact 394.

9546 Patrick Treanor, T. 14027 (1 June 2011).

9547 Herbert Okun, P776 (Transcript from Prosecutor v. Krajišnik), T. 4188.

9548 P1082 (Minutes of $1^{\text {st }}$ meeting of Ministerial Council of SerBiH Assembly, 13 January 1992), p. 2.

9549 P1082 (Minutes of $1^{\text {st }}$ meeting of Ministerial Council of SerBiH Assembly, 13 January 1992), p. 2.

9550 P5678 (Intercept of conversation between Radovan Karadžić and Vojo Kuprešanin, 13 January 1992), p. 2. See also P5803 (Intercept of conversation between Radovan Karadžić and Momčilo Krajišnik, 11 December 1991), p. 1.

9551 P5819 (Intercept of conversation between Radovan Karadžić and Gojko Đogo, 11 November 1991$)$, p. 11.

9552 See Adjudicated Fact 1964.
} 
economically." 9553 At that same session it was decided that draft legislation to enable the SerBiH to start functioning would be prepared by 15 February 1992. ${ }^{9554}$ The Bosnian Serb Assembly also authorised the Council of Ministers and other Bosnian Serb representatives, including Krajišnik, to prepare a Constitution and "other relevant documents in order to regulate further state organisation of the Serbian people" in $\mathrm{BiH}^{9555}$ Krajišnik was elected to the commission appointed to prepare a Constitution. ${ }^{9556}$ The Accused and Krajišnik discussed the timing of the announcement of the Bosnian Serb Constitution. ${ }^{9557}$

2927. On 26 January 1992, during an extraordinary session convened to discuss how to respond to the moves towards the independence of $\mathrm{BiH},{ }^{9558}$ the Bosnian Serb Assembly adopted a series of conclusions. This included a conclusion that the decision to hold the referendum on the independence of $\mathrm{BiH}$ was brought about illegally and that it was therefore not mandatory for the Serb people. ${ }^{959}$ The Chamber recalls that the referendum on the question of independence was held on 29 February and 1 March 1992. It was largely boycotted by the Bosnian Serbs and yielded an overwhelming majority of votes in favour of independence. ${ }^{9560}$

2928. One of the Bosnian Serb deputies spoke about the immense duties they had "because we are setting up our own state" and called on the Bosnian Serb Assembly to set deadlines for the completion of this plan. ${ }^{9561}$ The Accused was also asked to "give us an order [...] that the Serbs should occupy their territories so that no other forces could enter them". 9562

2929. In February 1992, before the Bosnian Serb Assembly, the Accused spoke about the Bosnian Serb strategic aims beginning to materialise and the importance of establishing internal borders "as wide as possible", and that if those internal borders are wider than the external borders of BiH they would be able to say "[w] ho cares about external borders". 9563 In March 1992, the Accused called

\footnotetext{
9553 Adjudicated Fact 1965. The Council of Ministers placed "particular stress [...] on the need for political and territorial organization of the regions by the formation of new municipalities in border areas of these regions. See Adjudicated Fact 1966.

$9554 \quad$ See Adjudicated Fact 1967.

9555 D1185 (Conclusions of SerBiH Assembly session, 26 January 1992). See Adjudicated Fact 1951.

$9556 \quad$ See Adjudicated Fact 1951.

9557 P5744 (Intercept of conversation between Radovan Karadžić and Momčilo Krajišnik, 23 February 1992), p. 2.

9558 Momčilo Krajišnik, T. 43870-43871 (20 November 2013).

9559 See para. 53.

$9560 \quad$ See para. 54; see Adjudicated Fact 395.

9561 P1349 (Transcript of $6^{\text {th }}$ session of SerBiH Assembly, 26 January 1992), p. 12.

9562 D90 (Shorthand Record of $11^{\text {th }}$ session of SerBiH Assembly, 18 March 1992), p. 39.

9563 D88 (Shorthand Record of $8^{\text {th }}$ session of SerBiH Assembly, 25 February 1992), p. 20.
} 
for frequent sittings of the Bosnian Serb Assembly to "accelerate our preparations for the events that will follow" 9564 and "because we are now entering the final stage of a process". ${ }^{9565}$

2930. The Bosnian Serb Assembly also concluded that the "[p]lace of the Republic of the Serbian People in $[\mathrm{BiH}]$ is in the common state of all Serbian people. Democratic transformation of Yugoslavia must be [a] parallel process with the state organisation of the Serbian people into the Serbian federation or alliance of the Serbian states." 9566 On 15 February 1992, the Bosnian Serb Assembly discussed a draft constitution, according to which the SerBiH would become part of federal Yugoslavia, and not BiH. ${ }^{9567}$ On 28 February 1992, the SDS Deputies' Club recommended that the Bosnian Serb Assembly pass the constitution that day as "a form of protection against the referendum"; the Bosnian Serb Assembly then unanimously adopted the Bosnian Serb Constitution. ${ }^{9568}$ The Constitution provided for equal rights and freedoms before the law for all citizens of the republic regardless of, inter alia, their race, ethnicity and beliefs. ${ }^{9569}$

2931. On 24 March 1992, the Bosnian Serb Assembly elected Branko Đerić as the Prime Minister, Aleksa Buha as Minister of Foreign Affairs, and Mićo Stanišić as Minister of Internal Affairs in the Bosnian Serb Government. ${ }^{9570}$ As recalled earlier, while the Bosnian Serb Constitution provided that the prime minister propose candidates for ministerial positions to the Assembly, in fact it was the SDS and the SDS President that chose the nominees. ${ }^{9571}$ For instance, the Accused, as president of the SDS, asked that Đerić nominate Mićo Stanišić and Buha. ${ }^{9572}$

2932. With regard to Ministers Mićo Stanišić and Mandić, Đerić testified that they kept visiting the Accused and failed to attend government's sessions as they felt that "the government could be

\footnotetext{
9564 P1349 (Transcript of $6^{\text {th }}$ session of SerBiH Assembly, 26 January 1992), p. 8.

9565 D90 (Shorthand Record of $11^{\text {th }}$ session of SerBiH Assembly, 18 March 1992), p. 4.

9566 D1185 (Conclusions of SerBiH Assembly session, 26 January 1992).

9567 See Adjudicated Facts 1989, 1996.

9568 P938 (Minutes from SDS Deputies' Club meeting, 28 February 1992), pp. 15, 17. See also para. 53; D89 (Shorthand Record of $9^{\text {th }}$ session of SerBiH Assembly, 28 February 1992), p. 14; P1351 (Transcript of $7^{\text {th }}$ Session of SerBiH Assembly, 15 February 1992) (containing lengthy discussions on the draft constitution); Adjudicated Fact 414.

9569 See Adjudicated Fact 1997.

9570 P1354 (Minutes of $13^{\text {th }}$ session of SerBiH Assembly, 24 March 1992), pp. 4-7; P2536 (Patrick Treanor's expert report entitled “The Bosnian Serb Leadership 1990-1992”, 30 July 2002), para. 223.

9571 P4982 (Witness Statement of Branko Đerić dated 5 April 2012), paras. 7-9; P1105 (Transcript of 22 ${ }^{\text {nd }}$ session of RS Assembly, 23-24 November 1992), p. 12. The SDS and the Accused exercised control over personnel appointments more generally, including to assistant minister positions and in public enterprises, though the Government could propose candidates. See Vladimir Lukić, T. 38760-38764 (23 May 2013); P6338 (Letter from RS Government to SDS Executive Board, 29 August 1993); P6339 (Letter from SDS Executive Board to RS Government, 28 December 1993); P6340 (Letter from RS Government to SDS Executive Board, 12 March 1994).

9572 Branko Đerić, T. 27942-27943 (24 April 2012); P4982 (Witness Statement of Branko Đerić dated 5 April 2012), para. 9.
} 
pushed aside" and "thought themselves as belonging to the top leadership". 9573 As described by Đerić, the SerBiH was a "party state" where the Accused as the president of the SDS held all the power, took control of all functions of the SDS and was practically the government too. ${ }^{9574}$ Đeric added that "the government was there just as a kind of technical attachment, not a body that should create policies" and that it was a state in which the government did not have any opposition. ${ }^{9575}$ The Accused himself said: "But, believe me, the Government is mine. I am responsible for its functioning. I appoint and propose". 9576

2933. On 28 February 1992, Koljević proposed that the Assembly be convened immediately after the referendum and "divide up the Television" and steps be taken to establish a Bosnian Serb newspaper. ${ }^{9577}$ These proposals were accepted by the SDS Deputies' Club. ${ }^{9578}$ Similar measures had already been taken to establish a separate structure for Bosnian Serb propaganda and the media. For example in September 1991 the SDS Executive Board adopted the decision on the appointment of the Commission for Information and Propaganda. ${ }^{9579}$ On 27 September 1991, in an intercepted phone conversation, the Accused issued an instruction to replace the Bosnian Muslim director of Radio Banja Luka, stating "replace him immediately. Appoint a man of yours. These are war times." 9580 In October 1991, the Accused advocated the creation of their own radio television network which would unite Serbian information as well as their own news agency. ${ }^{9581}$

2934. On 7 April 1992, the Bosnian Serb Assembly declared the independence of the SerBiH and Plavšić and Koljević resigned from their positions in the Presidency of BiH. ${ }^{9582}$ The Ministry of Defence was set up around April 1992. ${ }^{9583}$

\footnotetext{
9573 P4982 (Witness Statement of Branko Đerić dated 5 April 2012), para. 22

9574 P4982 (Witness Statement of Branko Đerić dated 5 April 2012), paras. 13-14. See also Milorad Dodik, T. 36877-36880 (9 April 2013).

9575 P4982 (Witness Statement of Branko Đerić dated 5 April 2012), paras. 13-14. See also Radomir Nešković, P2568 (Transcript from Prosecutor v. Krajišnik), T. 16844. Skoko stated that he never noticed that the Accused attempted to influence on the work of the Government and the decision-making that was within his power. D3321 (Witness statement of Milorad Skoko dated 1 April 2013), para. 30. However, the Chamber does not find his evidence to be reliable in this regard given that his testimony was marked by multiple contradictions and indicators of partiality and bias. Krajišnik testified that it was inaccurate to say that the Bosnian Serb Government and the Ministerial Council were subordinated to him or the Accused and that these structures were answerable to the Bosnian Serb Assembly. Momčilo Krajišnik, T. 43358-43359 (13 November 2013). While the Chamber accepts that these structures may not have been formally subordinated to the Accused, the evidence demonstrates that he did play a significant and influential role in the way in which they operated.

9576 P1379 (Transcript of $34^{\text {th }}$ session of RS Assembly, 27-29 August, 9-11 September, 29 September to 1 October 1993), p. 255.

9577 P938 (Minutes from SDS Deputies' Club meeting, 28 February 1992), p. 7.

9578 P938 (Minutes from SDS Deputies' Club meeting, 28 February 1992), p. 15. See also Adjudicated Fact 1952.

9579 P6486 (Decision of SDS Executive Board, 9 September 1991), p. 1.

9580 P6509 (Intercept of conversation between Radovan Karadžić and Vukić, 27 September 1991), p. 2.

9581 D3988 (Minutes of the $1^{\text {st }}$ meeting of Committee for Mass Communication, 8 October 1991), p. 2.

9582 See Adjudicated Fact 2011.
} 
2935. On 8 May 1992, the Bosnian Serb Government established a Central Commission for the Exchange of Prisoners of War and Arrested Persons. ${ }^{9584}$ At a session of the Bosnian Serb Government on 20 March 1993, it decided to dissolve the Central Commission for the Exchange of Prisoners, due to problems including "private arrangements and smuggling in the exchange of prisoners". 9585 The Bosnian Serb Government decided to form a new Commission for the Exchange and Release of Prisoners of War and Civilians which would answer directly to the government and would be more systematic and organised and would co-operate with other relevant government bodies in order to address the accommodation of exchanged prisoners in the RS. ${ }^{9586}$

2936. A three-member Presidency was established on 12 May 1992, composed of Plavšić, Koljević, and the Accused, with the Accused elected the President of the Presidency. On or around 2 June 1992, the Presidency was enlarged to five members to include the Prime Minister, Đerić, and the President of the Bosnian Serb Assembly, Krajišnik. On 6 July 1992 the members of the Presidency allocated tasks among themselves and the Accused was charged with military issues. ${ }^{9587}$ On 17 December 1992, the Bosnian Serb Assembly replaced the structure of the Presidency by establishing a single president structure. The Accused was elected to the position of President of the SerBiH. Plavšić and Koljević were elected as Vice-Presidents. ${ }^{9588}$ During its operations in 1992, the Accused exercised the most authority in the Presidency. ${ }^{9589}$ When international observers met with the top level of the Bosnian Serb leadership, including Krajišnik, Koljević and Plavšić, they all deferred to the Accused, and he was seen as "undoubtedly and indisputably the leader of the Bosnian Serbs". 9590

2937. The Accused attended and addressed almost every session of the Bosnian Serb Assembly. ${ }^{9591}$ The Accused's speeches were often met with explicit approval and praise by

\footnotetext{
9583

See para. 115 .

Seepara. 125.

9585 P3129 (Minutes of the $66^{\text {th }}$ session of RS Government, 20 March 1993), p. 10. See also P3113 (Minutes of the $73^{\text {rd }}$ session of RS Government, 29 June 1993), p. 16.

9586 P3129 (Minutes of the $66^{\text {th }}$ session of RS Government, 20 March 1993), pp. 10-11. See also P3138 (Minutes of the $67^{\text {th }}$ session of RS Government, 6 April 1993), pp. 8-9.

9587 See paras. 96-98.

9588 See paras. 96-98.

9589 Momčilo Mandić, C2 (Transcript from Prosecutor v. Krajišnik), T. 8618; Colm Doyle, T. 2677-2678 (21 May 2010); Radomir Nešković, P2568 (Transcript from Prosecutor v. Krajišnik), T. 16844. See also Robert Đurđević, T. 25908 (7 March 2012); Herbert Okun, P776 (Transcript from Prosecutor v. Krajišnik), Anthony Banbury, T. 13313 (15 March 2011); Patrick Treanor, T. 14043 (1 June 2011).

9590 Colm Doyle, P918 (Transcript from Prosecutor v. S. Milošević), T. 25256-25257; Colm Doyle, T. 2677-2678 (21 May 2010). See also D88 (Shorthand Record of $8^{\text {th }}$ session of SerBiH Assembly, 25 February 1992), p. 65.

9591 See, e.g., P1343 (Transcript of $1^{\text {st }}$ session of SerBiH Assembly, 24 October 1991), pp. 56-60; D84 (Shorthand Record of $3^{\text {rd }}$ session of SerBiH Assembly, 11 December 1991), pp. 12-14; D86 (Shorthand Record of $4^{\text {th }}$ session of SerBiH Assembly, 21 December 1991), pp. 37-42; D87 (Transcript of $9^{\text {th }}$ session of SRBiH Assembly, 24-25 January 1992), pp. 103-104; D90 (Shorthand Record of $11^{\text {th }}$ session of SerBiH Assembly, 18
} 
Bosnian Serb representatives. ${ }^{9592}$ For example, at a session on 25 February 1992, Kuprešanin said that the Accused "as the President of the SDS, is truly the leading figure among the Serbian people. And five of his sentences are enough to change the entire course of the session". 9593 On another occasion, after the Accused spoke about the need to centralise the authority, a deputy said "things that are ordered by [the Accused], the Assembly, the Presidency, the Minister of Defence and the Army General, must be carried out to the last man". 9594 Mladić also spoke after the Accused and stated: "I support everything he said [...] I am much more optimistic now than I was ever before". 9595

2938. While the Bosnian Serb Assembly operated in a democratic fashion, the Accused was described as "the greatest authority", who had "the best ideas and the best solutions for all issues crucial to the Serbian people in BiH."9596 The Accused emphasised the supremacy of the Bosnian Serb Assembly but at the same time stated that he would not allow a few people to "jeopardise the entire project" and that once the SDS had adopted a policy, anything outside of that policy would be treason and that maximum discipline was needed. ${ }^{9597}$

2939. Defence witnesses testified that (i) the Accused was a weak president with very little power; (ii) the Accused did not have "unquestionable power"; (iii) the Accused was a democrat who did not dominate the state or the SDS; and (iv) the local SDS leadership was completely autonomous. $^{9598}$ However, the Chamber notes that the evidence of Zametica, Kondić and Sojić in

March 1992), pp. 4-10; D92 (Transcript of $17^{\text {th }}$ session of SerBiH Assembly, 24-26 July 1992), pp. 85-86; D456 (Transcript of $20^{\text {th }}$ session of RS Assembly, 14-15 September 1992), pp. 51-57; D115 (Transcript of 25 $5^{\text {th }}$ session of RS Assembly, 19-20 January 1993), pp. 3-9; P1373 (Transcript of $31^{\text {st }}$ session of RS Assembly, 9 May 1993), pp. 1, 18-19, 22; P1379 (Transcript of 34 ${ }^{\text {th }}$ session of RS Assembly, 27-29 August, 9-11 September, 29 September to 1 October 1993), pp. 9-16.

9592 P1347 (Shorthand record of $5^{\text {th }}$ session of SerBiH Assembly, 9 January 1992), pp. 57-58; P961 (Shorthand Record of $12^{\text {th }}$ session of SerBiH Assembly, 24 March 1992), p. 23.

9593 D88 (Shorthand Record of $8^{\text {th }}$ session of SerBiH Assembly, 25 February 1992), p. $65 . \quad$ See Vojislav Kuprešanin, T. 43486 (14 November 2013) (further testifying that “[q]uite simply, [the Accused]'s five sentences meant more than who knows how many speeches of mine”). See also para. 2962.

9594 D456 (Transcript of $20^{\text {th }}$ session of RS Assembly, 14-15 September 1992), p. 31.

9595 D456 (Transcript of $20^{\text {th }}$ session of RS Assembly, 14-15 September 1992), p. 58.

9596 Andelko Grahovac, T. 44053 (26 November 2013). See also D3364 (Witness statement of Dušan Kozić dated 7 April 2013), para. 28 (describing the democratic atmosphere in the Assembly).

9597 D88 (Shorthand Record of $8^{\text {th }}$ session of SerBiH Assembly, 25 February 1992), pp. 45-47; P961 (Shorthand Record of 12th session of SerBiH Assembly, 24 March 1992), p. 17. Dodik testified that the Accused's role in the Bosnian Serb Assembly was to present the situation and that he never requested that certain decisions be taken. Milorad Dodik, T. 36857-36858 (9 April 2013). The Chamber notes, however, that Dodik's evidence was marked by contradictions, indicators of insincerity and partisanship which undermined the reliability of his evidence in this regard.

9598 John Zametica, T. 42453-42457 (29 October 2013); D2683 (Witness statement of Dragan Šojić dated 15 December 2012), paras. 9, 17; D4163 (Witness statement of Boro Tadić dated 1 December 2013), paras. 27, 30; D3854 (Witness Statement of Savo Čeklić dated 7 July 2013), paras. 4, 6; Savo Čeklić, T. 41239-41240 (11 July 2013); D4063 (Witness statement of Novak Kondić dated 23 November 2013), paras. 6-7; D4027 (Witness statement of Nikola Poplašen dated 11 November 2013), para. 21; D4166 (Witness statement of Mikan 
this regard is expressed in general terms and is based on their own feeling, impression, opinion, and in some cases incomplete information. The Chamber does not therefore find their evidence to be of much weight in this regard. In addition the evidence of Šojić, Poplašen, and Tadić was marked by contradictions, evasiveness or indicators of partisanship and bias. The Chamber therefore does not find their evidence to be reliable in this regard. In addition the Chamber finds that this evidence is outweighed by the volume of reliable evidence discussed above which on the contrary demonstrates the power and control of the Accused.

\section{(2) Conclusion}

2940. Having considered the evidence above, the Chamber finds that the Accused, as the president of the SDS Main Board, had de jure and de facto authority over the SDS party and its members. From 1990 to 1995 the Accused was at the head of the SDS and he exerted great control and authority over its institutions and direction. In addition, as the President of the SNB, President of the Presidency and subsequently President of the RS, the Accused was the highest civil servant within the SerBiH and later the RS. The Accused had great authority over the Presidency, the Government and its key members and, as a result of his position and gravitas, had great influence at the Bosnian Serb Assembly. The SDS operated with strict respect for the hierarchical structures which ran from the Main Board and Executive Board to the Municipal Board structures. The Chamber also finds that the Accused enforced discipline within the party and was the most powerful and influential authority within the party. These SDS party structures facilitated communication between the higher level leaders including the Accused and the municipal SDS leaders.

2941. The Chamber further concludes that from 1991 the Accused, the SDS, and the Bosnian Serb leadership planned for and developed measures to be taken should $\mathrm{BiH}$ move toward independence. When the SRBiH Assembly passed a declaration of sovereignty on 15 October 1991 in the absence of the Serb delegates, these plans were further developed and ultimately put into practice.

2942. The Accused and the Bosnian Serb leadership responded vehemently to what they viewed as an illegal and unconstitutional move towards independence. The Chamber finds that the Accused and SDS structures played a crucial role in this period in developing a response to further the objectives and interests of the Bosnian Serbs. When confronted with the possibility of $\mathrm{BiH}$ independence, the SDS discussed the objective of Serb unity, activating parallel government

Davidović dated 1 December 2013), paras. 5-6, 8-9, 12-14; D3861 (Witness statement of Radovan M. Karadžić dated 14 July 2013), para. 3. 
structures, intensifying the process of regionalisation, and furthering military organisation at a local level.

2943. The Accused's intercepted conversation on 16 October 1991 in which he reassured municipal leaders that they had "worked out a scenario. We won't make a single move today [...] Everything's been worked out" is instructive. The Chamber, having considered the context in which this conversation took place, finds that it demonstrates the central role played by the Accused during this period and that the Bosnian Serbs had already made careful preparations to respond to any move towards independence by $\mathrm{BiH}$. This conclusion is further supported by the evidence that the Accused declared a state of emergency in the SDS on 18 October 1991, and in so doing emphasised that leaders of the SDS had been working towards developing the measures which would have to be taken at a municipal level. This declaration also made it clear that the steps to be taken were meticulously planned and that the Accused insisted on the highest level of discipline to ensure that there would not be a "single wrong step".

2944. The Accused and the Bosnian Serb leadership were also instrumental in the formation of the Bosnian Serb Assembly. The establishment of the Bosnian Serb Assembly was one of the first steps towards creating parallel structures, which formed the basis for the formation of a separate Serb state in BiH. The Chamber finds that from the date of its creation on 24 October 1991 throughout the duration of the conflict in $\mathrm{BiH}$, this body played a central role in organising the Bosnian Serb people and forming a separate state. The Chamber finds that the Bosnian Serb Assembly was the formal means through which the ideology and objectives of the Accused and the Bosnian Serb leadership were officially sanctioned and disseminated. It was also one of the bodies used to communicate instructions down to the municipal representatives regarding these objectives.

2945. For example, the Bosnian Serb Assembly passed decisions which reflected the position of the Accused and the Bosnian Serb leadership that the Serb people would remain in the joint state of Yugoslavia. It also organised a plebiscite of the Bosnian Serb people to confirm that decision and then endorsed the result of that plebiscite and declared that areas where Serbs had voted to remain in Yugoslavia would remain part of the territory of Yugoslavia. When Brđanin threatened dismissal of directors and managers who did not participate in the plebiscite, the Accused cautioned him against making such statements publicly but did not condemn the substance of the statements themselves. The Chamber finds that this evidence demonstrates that the Accused worked towards full participation in the plebiscite as a means of showing public support for the policies of the Bosnian Serb leadership. 
2946. The Chamber finds that when it became apparent that the objective of remaining in a joint state with Yugoslavia was no longer possible, the Bosnian Serb Assembly approved preparations for the formation of a separate Serb Republic. In this regard, the Chamber also finds that from late 1991 through until mid-1992, the Bosnian Serb Assembly played a central role in forming other parallel Bosnian Serb institutions and structures, such as the Council of Ministers and the SNB. It also worked towards the drafting of a constitution for the Serb State they wanted to create. The Chamber finds that the creation of parallel structures at a municipal level was also propagated by the Bosnian Serb Assembly, which called for example the establishment of "municipal assemblies of the Serbian people". The Chamber finds that the Accused led the discussions during the Bosnian Serb Assembly sessions where these decisions were made. The Accused directly promoted the measures which corresponded with his objectives.

2947. The Chamber finds that the Accused was at the forefront in explaining and promoting the policies which led to the conclusions taken by the Bosnian Serb Assembly and other Bosnian Serb political structures. He also promoted the importance of the Bosnian Serb Assembly itself and explained that it needed to sit often in order to accelerate their preparations for the creation of a Bosnian Serb state. The Chamber also finds that the Accused took on a very active role in the creation of the structures which would support the existence of a separate Bosnian Serb state. For example, the Accused and the SDS played the central role in the selection of ministers in the SerBiH. In addition the Chamber finds that the evidence demonstrates that the Accused exercised a high degree of control over the Bosnian Serb Government and its key members.

2948. The Chamber also finds that the Accused took the leading role in terms of identifying the measures which had to be taken in order to take control of territory and forming the Serb municipalities in $\mathrm{BiH}$ with their own structures of power. For instance, he spoke about the importance of taking over power at a municipal level. He was also pivotal in emphasising the level of contact and co-ordination there needed to be and entrusted Bosnian Serb Assembly deputies to be in permanent contact with municipal leaders to create the structures necessary in order to assume control at a municipal level in accordance with the plans which he had prepared. The Bosnian Serb Assembly was also one of the means through which the policies of the Bosnian Serb leadership were communicated to a municipal level.

2949. The proclamation of the SerBiH in January 1992 by the Bosnian Serb Assembly was confirmation of the territorial objectives and ideology of the Bosnian Serb leadership which sought the creation of a separate Serb state. This proclamation also made reference to historic crimes committed against the Bosnian Serbs which has been discussed above. The Chamber finds that the 
territorial delimitation of Bosnian Serb claimed territories was also intimately linked to this discourse on these historic crimes, given the view that the Bosnian Serbs had only become a minority in certain areas because of the crimes committed against them in World War II.

2950. From late 1991, it was clear that the Accused and the Bosnian Serb leadership had prepared "moves" which they would implement in order to achieve their objectives and had clearly calculated when they would take action. The Accused made it clear that there needed to be agreement and uniformity in the timing of these moves. He also emphasised the importance of SDS structures at a local level, including SDS municipal and local boards.

2951. The Accused was also the leading figure and authority in the Bosnian Serb Assembly and insisted on the greatest discipline in following the policies of the SDS in order to achieve their objectives. The evidence demonstrates that the deputies in the Bosnian Serb Assembly showed a high level of respect and adherence to the policies and measures which were promulgated by the Accused and that the Accused also exercised considerable influence over the Bosnian Serb governmental organs.

(B) Regionalisation and creation of SAOs

\section{(1) Analysis of evidence}

2952. The Chamber recalls its discussion on the process of regionalisation which began with the establishment of communities of municipalities organised by the SDS in early $1991 .{ }^{9599}$ In January 1991, SDS presidents of municipal assemblies in Bosnian Krajina began preparations for the formation of the ZOBK which was approved by the SDS regional board in April $1991 .^{9600}$ On 11 April 1991, the SRBiH Assembly recommended municipal assemblies to stop issuing decisions in connection with regionalisation. ${ }^{9601}$ However, municipalities with large Serb majorities voted to affiliate with the ZOBK, which held its founding assembly on 25 April $1991 .^{9602}$ At the constitutive session of the ZOBK, it was said that this community had been established "regardless of ethnic affiliation" and that unity of Yugoslavia was affirmed as one of their objectives in creating this community of municipalities. ${ }^{9603}$

\footnotetext{
$9599 \quad$ See paras. 40, 43, 72-75.

$9600 \quad$ See paras. 40, 129.

9601 D284 (SRBiH Assembly recommendation on regionalisation, 11-12 April 1991).

$9602 \quad$ See para. 42.

9603 D1890 (Transcript from Krajina Assembly Meeting), pp. 3, 11-13, 53. See also P5896 (Intercept of conversation between Radovan Karadžić and an unidentified female journalist, 24 June 1991).
} 
2953. In May 1991 two other communities of municipalities were created in Romanija and in Eastern and Old Herzegovina. ${ }^{9604}$ In September 1991, these communities of municipalities were renamed SAOs. ${ }^{965}$ The Chamber recalls that the SAOs Semberija-Majevica, Northern Bosnia, and Birač were formed between September and November 1991. ${ }^{9606}$ On 21 November 1991, the Bosnian Serb Assembly certified the proclamation of the SAOs in $\mathrm{BiH}^{9607}$

2954. On 30 September 1991 the SDS Deputies' Club held a session which was attended by Krajišnik and the Accused. ${ }^{9608}$ At this meeting the Accused declared that he wanted to ask the representatives from the Krajina to inform their municipalities that all those who could report to the army do so and that the Serbs were preparing for regionalisation. ${ }^{969}$ On 7 October 1991, the Accused referred to the SAOs as assisting "so that there is no tension, and that each is the master of his own, and that there is peaceful co-existence among the peoples here". 9610 The Accused had discussed the issue of regionalisation with Izetbegović, but Izetbegović's position was that regionalisation could not be carried out because the population in $\mathrm{BiH}$ was intermixed. ${ }^{9611}$ The Chamber recalls that while the SDA opposed these moves towards regionalisation in $\mathrm{BiH}$, the Accused and SDS leaders spoke in favour of it for economic reasons, by reference to their view that there was a concentration of power in Sarajevo. ${ }^{9612}$ The Chamber took judicial notice that despite these justifications, among the functions the SDS assigned to the ZOBK was the organisation of its defence in times of war or imminent threat of war. ${ }^{9613}$

2955. The Accused also took an active role in instructing authorities regarding decisions to be implemented and measures to be taken in the Bosnian Krajina area. ${ }^{9614}$ For example, on

\footnotetext{
$9604 \quad$ See para. 42.

9605 See paras. 42, 75. The Chamber does not place any weight on the assessment of Treanor and Donia as to the motives and objectives of the Bosnian Serb leadership with respect to this process of regionalisation. Patrick Treanor, T. 14011, 14015-14016, 14027, 14035-14036, 14069-14070 (1 June 2011), T. 14381 (7 June 2011); Robert Donia, T. 3407-3410 (7 June 2010).

See para. 75. See also Milorad Dodik, T. 36881 (9 April 2013).

9607 See Adjudicated Fact 1950.

9608 P2543 (Minutes of meeting of SDS Deputies' Club, 30 September 1991).

9609 P2543 (Minutes of meeting of SDS Deputies' Club, 30 September 1991).

9610 P5849 (Intercept of conversation between Radovan Karadžić and Goran Đukić, 7 October 1991), pp. 3-4.

9611 D1278 (Transcript of Radomir Nešković's interview with Karadžić's legal associate, 8 October 2009), p. 14. Nešković also testified that the SDS objectives with respect to the regionalisation was to first keep BiH within Yugoslavia but if that was impossible, to keep one part of $\mathrm{BiH}$ in Yugoslavia and that regionalisation was a means of countering centralisation. Radomir Nešković T. 14259-14260 (6 June 2011), T. 14355, 14357-14360 (7 June 2011).

9612 See para. 41. See also P2570 (Book of minutes of Prijedor's SDS Municipal Board meetings, 1991), p. 10.

9613 See Adjudicated Fact 1915.

9614 D4077 (Witness statement of Anđelko Grahovac dated 23 November 2013), paras. 20-21; P747 (Co-operation agreement between SAO Krajina and Bosanska Krajina, 24 June 1991); P5892 (Intercept of conversation between Radovan Karadžić, Nenad, and Vojo Kuprešanin, 24 June 1991); P5894 (Intercept of conversation between Radovan Karadžić and Anđelko Grahovac, 24 June 1991); P5891 (Intercept of conversation between Radovan Karadžić and Vukić, 24 June 1991), pp. 1-2; P5895 (Intercept of conversation between Radovan
} 
12 October 1991, in a conversation with Mišković in Prijedor, the Accused instructed that the party should be in "full mobile state" and that units should be on duty 24 hours a day. ${ }^{9615}$

2956. The Chamber found that in late 1991, the SDS started implementing a policy of "regionalisation", which involved taking steps towards the creation of "regions" in which Serbs were the relative majority. ${ }^{9616}$ In September 1991, in a conversation with Slobodan Milošević, the Accused expressed that the goal of the Bosnian Serb leadership was regionalisation, or cantonisation, and that their aim was to take half of Sarajevo and to have strong links with Yugoslavia. ${ }^{9617}$ On 16 September 1991, the SDS Executive Board approved the appointment of a Regionalisation Staff. ${ }^{9618}$ This body was tasked with monitoring the implementation of the decision on the proclamation of autonomous regions and this decision was distributed to the municipal boards of the SDS. ${ }^{9619}$ For example on 25 September 1991, the Sarajevo SDS Main Board decided to implement the decision and conclusions of the republican levels SDS organs with respect to regional organisation and appointed individuals who would co-ordinate the implementation of the decision. ${ }^{9620}$ This included the promulgation of autonomous regions as part of Yugoslavia and the separation of settlements in some municipalities and their integration into another municipality. ${ }^{9621}$ The Accused also convened a plenary of Bosnian Serb officials in September 1991 to discuss these issues. ${ }^{9622}$

2957. At a meeting of the SDS Executive Board in November 1991, attended by the Accused, there was discussion of a report on "regionalisation" and that conditions should be created which

Karadžić and Vukić, 24 June 1991), pp. 1-2; P5885 (Intercept of conversation between Radovan Karadžić and Željković, 9 July 1991); P5846 (Intercept of conversation between Radovan Karadžić and an unidentified male, 12 October 1991); P5799 (Intercept of conversation between Radovan Karadžić, Mičević, and Radić, 15 December 1991).

9615 P5845 (Intercept of conversation between Radovan Karadžić and Mišković, 12 October 1991), p. 1.

$9616 \quad$ See para. 74.

9617 P5867 (Intercept of conversation between Radovan Karadžić and Slobodan Milošević, 19 September 1991), pp. 2-3.

9618 See para. 75. Sejmenović testified that in his assessment the SDS pursued regionalisation in order to create ethnically Serb regions in $\mathrm{BiH}$ and that the position taken at a Republic level by the SDS with respect to ethnic separation were also mirrored at a municipal level. However, the Chamber considers this to be his own opinion and therefore does not consider this evidence to be of much weight. Mevludin Sejmenović, T. 20457, 20464 (27 October 2011).

9619 P2584 (Minutes of $3^{\text {rd }}$ meeting of SDS Executive Board, 16 September 1991), p. 1; P6484 (Information from Đukić Rajko to SDS, 13 September 1991). See also P3431 (Handwritten diary of KDZ192), p. 3 (under seal); Radomir Nešković T. 14357-14360 (7 June 2011). While Treanor testified about the territorial objectives of the Bosnian Serb leadership and the reasons for the steps taken towards regionalisation, the Chamber considers these conclusions and opinions to fall outside the scope of his expertise and will thus not rely on it in this regard. Patrick Treanor, T. 14015-14016 (1 June 2011).

9620 P2530 (SDS decision on appointment of staff, 25 September 1991). See also Patrick Treanor, T. 14017 (1 June 2011), T. 14450-14451 (8 June 2011).

9621 P2530 (SDS decision on appointment of staff, 25 September 1991).

9622 P2544 (Intercept of conversation between Radovan Karadžić and Slobodan Milošević, 6 September 1991), p. 3. See also Patrick Treanor, T. 14018 (1 June 2011). 
would allow every region to "include and incorporate the national and territorial treasures" with the aim of creating a Serb BiH within Yugoslavia. ${ }^{9623}$ The pursuit of regionalisation, according to Krajišnik, was used by the SDS in response to the attempts of the HDZ and SDA to discuss independence of $\mathrm{BiH}^{9624}$ Regionalisation was leverage, in his view, to suggest to the SDS's coalition partners that the three parties should reach an overall agreement on the whole of $\mathrm{BiH}$ : its status within Yugoslavia as well as its internal organisation. ${ }^{9625}$

2958. The Chamber recalls that on 16 September 1991, the ZOBK was transformed into the ARK. ${ }^{9626}$ The ARK was vested with both executive and legislative powers within its area of jurisdiction and acted as an intermediate level of authority between the $\mathrm{SerBiH}$ and the municipalities. ${ }^{9627}$ As the ARK was a voluntary association, the ARK Statute made provision for other municipalities to join, and typically these decisions were taken only by Bosnian Serb delegates at a municipal level. ${ }^{9628}$ In addition while the ARK was established as a multi-ethnic institution, in practice the ARK Assembly was a Serb body. ${ }^{9629}$ Brđanin was chosen by the Accused to lead the ARK and held this position until the ARK was abolished. ${ }^{9630}$ The Accused was in regular contact with Brđanin and instructed him that he should not call him about "every trivial matter" but that he could call about issues which he could not resolve. ${ }^{9631}$ The Accused instructed Brđanin "You have power in your hands, and you have presidents of municipalities through whom you can exercise this power, until we achieve autonomy [...] You should execute power vigorously and to the fullest. Not a single bird should be allowed to fly over Krajina [...] You must establish all that. I've seen what was written and sent. All of that must be implemented. Take care of that. Call each and every municipality president and keep checking if it has been implemented and accomplished". 9632

\footnotetext{
9623 P2585 (Minutes of $5^{\text {th }}$ meeting of SDS Executive Board, 7 November 1991), p. 5. See also P2586 (Minutes of session of SDS Deputies' Club, 3 December 1991), p. 1; P794 (Excerpt from expanded session of the Council for Harmonising State Policy Positions, 21 January 1993), e-court p. 6; Radomir Nešković T. 14358 (7 June 2011).

9624 See Adjudicated Fact 1926. See also D4551 (Intercept of conversation between Radovan Karadžić and Salko Ališehić, 21 December 1991), p. 3.

9625 See Adjudicated Fact 1926.

9626 See para. 42.

9627 See Adjudicated Fact 520.

9628 See paras. 2041-2042.

9629 See para. 2042.

9630 See para. 2045 (referring to the ARK being abolished as a territorial unit of the RS on 15 September 1992).

9631 P2549 (Intercept of conversation between Radovan Karadžić and Radoslav Brđanin, 31 October 1991), p. 5; P2556 (Intercept of conversation between Radovan Karadžić and Nenad Stevandić, 11 January 1992), pp. 3-5, 8. See also P5640 (Intercept of conversation between Radovan Karadžić and Trifko Komad, 18 September 1991), p. 1; P5889 (Intercept of conversation between Radovan Karadžić and Radoslav Brđanin, 2 July 1991).

9632 P2549 (Intercept of conversation between Radovan Karadžić and Radoslav Brđanin, 31 October 1991), p. 5.
} 
2959. On 18 October 1991, three days after the SRBiH Assembly session at which the SDA and $\mathrm{HDZ}$ adopted a declaration of sovereignty of $\mathrm{BiH}$, the Accused informed the leaders of the Krajina municipalities, including Grahovac and Brđanin, to come urgently as very important decisions were going to be made. ${ }^{9633}$ On 21 October 1991, Grahovac, as President of the ARK Executive Council, initiated a meeting with the Accused, Krajišnik, Koljević, and Babić in Banja Luka to discuss the situation following the 15 October 1991 SRBiH Assembly session. ${ }^{9634}$ Following the plebiscite of the Serbian people on 9 and 10 November 1991, the Bosnian Serb Assembly issued a decision which verified the declared SAOs as part of $\mathrm{BiH}$, a federal entity in Yugoslavia. ${ }^{9635}$

2960. The Chamber recalls that the Bosnian Serb Assembly approved on 21 December 1991 the appointment of Jovan Čizmović as the co-ordinator of activities of the executive bodies of the SAOs. ${ }^{9636}$ In addition on 24 February 1992, the SDS Executive Board assigned "coordinators" for the SAOs. ${ }^{9637}$ The SAOs had their own governmental, institutional, and political structures. ${ }^{9638}$

2961. At a meeting on 5 February 1992, attended by municipal leaders from the Bosanska Krajina, Semberija and Northern Bosnia SAOs, there was discussion about the SDS position with respect to regionalisation, the establishment and definition of Serb territories in $\mathrm{BiH}$, and Serbia's objective of preserving Yugoslavia and ensuring Serbs live in a single state. ${ }^{9639}$ In February 1992, at a meeting with Mladić, Adžić discussed the preparations that needed to be carried out in the Krajina but stressed that these plans were to be kept "strictly secret" and that "trustworthy people" were to be used to implement them. ${ }^{9640}$

\footnotetext{
9633 P5838 (Intercept of conversation between Radovan Karadžić and Boško, 18 October 1991). See D4077 (Witness statement of Anđelko Grahovac dated 23 November 2013), para. 28.

9634 D4077 (Witness statement of Anđelko Grahovac dated 23 November 2013), para. 29; D4082 (Article from Glas entitled "Resolutely in a United State", 21 October 1991).

9635 D83 (Shorthand Record of $2^{\text {nd }}$ session of SerBiH Assembly, 21 November 1991), pp. 33-34. See also Adjudicated Fact 1950.

9636 See para. 130; D86 (Shorthand Record of $4^{\text {th }}$ session of SerBiH Assembly, 21 December 1991), p. 34.

9637 See para. 75. See Adjudicated Fact 2181. Radislav Vukić, a member of the SDS Executive Board, was appointed as co-ordinator for SAO Krajina. His duties were, inter alia, to co-ordinate the activities of SDS municipal boards in SAO Krajina, to work in co-operation with the Assembly president and the SAO Krajina prime minister to implement the decisions of the Bosnian Serb Assembly and Council of Ministers, and to take part in the work of the SAO Krajina Crisis Staff. P6530 (Decision of SDS Executive Board, 24 February 1992).

9638 Momčilo Mandić, C2 (Transcript from Prosecutor v. Krajišnik), T. 9101.

9639 P3431 (Handwritten diary of KDZ192) (under seal), p. 3. See also KDZ192, P3416 (Transcript from Prosecutor v. Brđanin), T. 11437-11442, 11452-11455, 11485-11487 (under seal); P3474 (News report re meeting of Derventa SDS Executive Board, 13 February 1992), p. 1. The Chamber notes KDZ192's evasiveness with respect to who attended this meeting and what precisely was discussed and is satisfied that both the Accused and Krajišnik attended this meeting.

9640 P1476 (Ratko Mladić's notebook, 30 December 1991-14 February 1992), pp. 163-167 (referring more specifically to the setting up of a police force, and the legal and illegal armament of individuals).
} 
2962. By early 1992, there was increasing tension between the leadership in Pale and the ARK authorities. $^{9641}$ The ARK authorities were moving towards independence and wished to establish the Krajina as a state within a state, or a "constituent entity" of Yugoslavia; the Accused strongly opposed this position, maintaining that Yugoslavia should be preserved and that the Krajinas should not advocate for changes to the borders. ${ }^{9642}$ On 23 February 1992, the Accused told Kuprešanin to remind the representatives of the Krajina who wanted an independent state "of their loyalty to the initial Assembly". 9643 Kuprešanin also opposed the independence of the ARK and urged the Accused to attend an ARK Assembly session to resolve the issue. ${ }^{9644}$ The Accused agreed and attended an ARK Assembly session on 29 February 1992, during which he stated that "it would be a crime against the Krajina if it were declared a republic. Those who advocate such childish ideas are exposing the Serbian people to trouble". ${ }^{645}$ At the same session, all 148 of the ARK deputies in attendance voted to accept the Bosnian Serb Constitution in full, and the status of

9641 P2552 (Intercept of conversation between Radovan Karadžić and Jovan Čizmović, 16 January 1992), pp. 2-7; D424 (Intercept of conversation between Radovan Karadžić and Vojo Kuprešanin, 10 February 1992), pp. 5-7; D4077 (Witness statement of Anđelko Grahovac dated 23 November 2013), para. 37; P5784 (Intercept of conversation between Radovan Karadžić and Vojo Kuprešanin, 27 December 1991), pp. 4-5; D4011 (Witness statement of Vojislav Kuprešanin dated 11 November 2013), paras. 26, 29, 40. Kuprešanin stated that individuals in Krajina did not respect the Accused or the SDS, before or during the course of the war. D4011 (Witness statement of Vojislav Kuprešanin dated 11 November 2013), para. 29. While the Chamber finds that there were certainly tensions between the Accused and Krajina leaders, the Chamber does not find Kuprešanin's evidence to be reliable in this regard. In reaching that conclusion the Chamber noted that his testimony was marked by multiple contradicitons, evasiveness, indicators that he was trying to mislead the Chamber and lacked sincerity. His demeanour and testimony also indicated partiality and bias through his attempts to protect the Accused and distance him from any responsibility.

D4077 (Witness statement of Anđelko Grahovac dated 23 November 2013), paras. 35-38; D4034 (Witness statement of Radoslav Brđanin dated 8 November 2013), para. 7; D4011 (Witness statement of Vojislav Kuprešanin dated 11 November 2013), paras. 27, 29-33; D4081 (Intercept of conversation between Radovan Karadžić and Anđelko Grahovac, 7 January 1992), pp. 4-5 (wherein the Accused states that the Krajina had not implemented the wishes of the SDS, including carrying out its elections); D4021 (Agenda and Minutes of $11^{\text {th }}$ session of ARK Assembly, 8 January 1992), pp. 3-6; P2556 (Intercept of conversation between Radovan Karadžić and Nenad Stevandić, 11 January 1992); P2552 (Intercept of conversation between Radovan Karadžić and Jovan Čizmović, 16 January 1992); D4085 (Intercept of conversation between Anđelko Grahovac and Radovan Karadžić, 15 January 1992); D4025 (Excerpt of SDS Main Board meeting, 14 February 1992), pp. 3-7, 15-19; D4015 (Excerpt of Minutes of $13^{\text {th }}$ session of ARK Assembly, 24 February 1992). See also P5784 (Intercept of conversation between Radovan Karadžić and Vojo Kuprešanin, 27 December 1991), pp. 4-7; D424 (Intercept of conversation between Radovan Karadžić and Vojo Kuprešanin, 10 February 1992).

9643 P5745 (Intercept of conversation between (i) Radovan Karadžić and an unidentified male; and (ii) Radovan Karadžić and Vojo Kuprešanin, 23 February 1992), pp. 5-7. See also P938 (Minutes from SDS Deputies' Club meeting, 28 February 1992), pp. 36-37 (during which the Accused asserted that presidents of municipal boards from Krajina "should implement the policy of the party that has given them their posts, not to veer away from it").

9644 D88 (Shorthand Record of $8^{\text {th }}$ session of SerBiH Assembly, 25 February 1992), p. 65; D4025 (Excerpt of SDS Main Board meeting, 14 February 1992), pp. 14-15 (wherein Kuprešanin emphasised that Serb territories cannot be divided and “our goal is to finally live in one country"); P938 (Minutes from SDS Deputies' Club meeting, 28 February 1992); D4011 (Witness statement of Vojislav Kuprešanin dated 11 November 2013), paras. 33-34; Vojislav Kuprešanin, T. 43470-43471 (14 November 2013) (further testifying on cross-examination that the "holy mission" was that Serbian people be equal in $\mathrm{BiH}$ ).

9645 P5452 (Extract from minutes of $14^{\text {th }}$ session of ARK Assembly, 29 February 1992), p. 2. 
the ARK was incorporated therein accordingly. ${ }^{9646}$ A separate Krajina state never resulted because ultimately the leadership opted for the integration of all of the Krajinas. ${ }^{9647}$

2963. At a Bosnian Serb Assembly session in September 1992, a deputy stated: "Since we are at war, we must adopt a system which will best defend ourselves and create our own state. At a time when we had to destroy a unitary Bosnia, the SAO regions and districts were politically and territorially the best solution". ${ }^{9648}$ The Accused also spoke about the creation of SAOs as one of the ten measures which were taken before the war which they had "brainstormed" together and which were carried out after "Alija made a mistake". 9649 The Accused spoke on multiple occasions about his responsibility for developing the process of regionalisation. ${ }^{9650}$ At a Bosnian Serb Assembly session, Kuprešanin stated that the reason for the creation of regions was to "destroy Alija's state". 9651 In an interview in January 1995, the Accused confirmed that the SDS played the greatest role in "introducing Serbian awareness and discarding the inferior position of a dignified nation with its own sovereignty and state". ${ }^{9652}$ He went on to state that "[w]e had a list of the actions and steps to take, but we always waited for the Muslims to make a mistake and after they made one, we created a union of municipalities and the Serbian autonomous areas next, followed by the regions and eventually our assembly, and finally Republic". 9653

\section{(2) $\underline{\text { Conclusion }}$}

2964. The Accused argues that the concept of regionalisation and division of municipalities was something envisaged and provided for by the constitution. ${ }^{9654}$ Having considered the evidence above, the Chamber finds that the process of regionalisation was a precursor towards creating and identifying Bosnian Serb claimed territory in $\mathrm{BiH}$, whether or not this was provided for by a

9646 P5452 (Extract from minutes of $14^{\text {th }}$ session of ARK Assembly, 29 February 1992). See also Anđelko Grahovac, T. 44052 (26 November 2013); D4011 (Witness statement of Vojislav Kuprešanin dated 11 November 2013), para. 34.

9647 Anđelko Grahovac, T. 44051-44052 (26 November 2013); D4077 (Witness statement of Anđelko Grahovac dated 23 November 2013), para. 45. See also D4034 (Witness statement of Radoslav Brđanin dated 8 November 2013), para. 8; D3970 (Article from Glas entitled "There are Differences, But No Divisions", 15 March 1992).

9648 D456 (Transcript of 20 $0^{\text {th }}$ session of RS Assembly, 14-15 September 1992), p. 68.

9649 P1387 (Transcript of $38^{\text {th }}$ session of RS Assembly, 17 January 1994), pp. 74-75. See also P6510 (Excerpt of Vojo Kuprešanin's interview with OTP), p. 9.

9650 P5619 (Intercept of conversation between Radovan Karadžić Miroslav Toholj, 13 January 1992), p. 3; P2556 (Intercept of conversation between Radovan Karadžić and Nenad Stevandić, 11 January 1992), pp. 6, 11; P1084 (Intercept of conversation between Radovan Karadžić and Vojo Kuprešanin, 23 July 1991), p. 4; D424 (Intercept of conversation between Radovan Karadžić and Vojo Kuprešanin, 10 February 1992), p. 8.

9651 D456 (Transcript of $20^{\text {th }}$ session of RS Assembly, 14-15 September 1992), pp. 68, 70 . See also P1377 (Transcript of 33rd session of RS Assembly, 20-21 July 1993), p. 175.

9652 P953 (Article from Oslobođenje entitled "Happy Birthday Republic", 6 January 1995), p. 3.

9653 P953 (Article from Oslobođenje entitled "Happy Birthday Republic", 6 January 1995), p. 3. See also Patrick Treanor, T. 14036-14037 (1 June 2011). 
constitutional provision. This process of regional organisation along ethnic lines was a means of responding to and opposing the proposed independence of $\mathrm{BiH}$. Regionalisation, and specifically the delineation of the SAOs, was a means of identifying which Bosnian Serb territories and settlements in $\mathrm{BiH}$ could be separated and remain a part of Yugoslavia in the event of $\mathrm{BiH}$ independence. This process of regionalisation was also an early means of identifying strategically significant territorial areas. Structures were also created in order to have co-ordination between the SAOs and the higher authorities within the SDS.

2965. The Chamber finds that the Accused and the SDS played a leading role in this process. The Accused himself spoke about the creation of SAOs as one of the measures which the Bosnian Serb leadership had "brainstormed" and implemented before the war to respond to moves towards independence by $\mathrm{BiH}$. He emphasised that regionalisation and the creation of SAOs were the first steps which eventually led to the creation of the Bosnian Serb Assembly and the RS. The Chamber also finds that the Accused opposed the independence of the ARK and was successful in ensuring that the authorities in the ARK adhered to the SDS policies and supported the creation of the RS and the unity of the Bosnian Serbs.

\section{(C) Split in the MUP and creation of a Bosnian Serb MUP}

\section{(1) Analysis of evidence}

2966. In July 1991, at a meeting of SDS Deputies' Club attended by the Accused, Mićo Stanišić and Mandić took the floor and focused on the Serbs being thrown out of the MUP; they complained that some people in charge were not doing their jobs as required. ${ }^{9655}$ After these speeches the Accused reacted forcefully, and said it was necessary for there to be a balance in the personnel of the MUP and that developments at the MUP should not be permitted without his knowledge. ${ }^{9656}$ In 1991, there were also problems with Bosnian Muslim personnel clandestinely being sent to Croatia for training without the knowledge of the official MUP. ${ }^{9657}$

\footnotetext{
9654 Defence Final Brief, paras. 194-204.

9655 D3917 (Witness Statement of Čedomir Kljajić dated 30 July 2013), para. 15. See also Momčilo Mandić, C2 (Transcript from Prosecutor v. Krajišnik), T. 8656, 9319.

9656 D3917 (Witness Statement of Čedomir Kljajić dated 30 July 2013), para. 15.

9657 Momčilo Mandić, T. 4734-4739 (6 July 2010); D360 (SDA recommendation for training by Croatian MUP, 11 July 1991), p. 1; D361 (CSB Banja Luka's letter to Biljana Plavšić, 25 July 1991), p. 1; D362 (CSB Banja Luka report re training by Croatian MUP, 25 July 1991).
} 
2967. In July 1991, the Accused had also warned Izetbegović that if the Bosnian Serb demands were not met, they would establish a parallel state which would include a parallel police. ${ }^{9658}$

2968. The Accused was in regular contact with Mandić and other Bosnian Serb leaders and discussed personnel issues at the MUP and in September 1991, the Accused told Mandic that they had to be in touch almost daily. ${ }^{9659}$ The Accused insisted that all nominations had to come from the party level and took an active role in identifying those SDS members who should be nominated. ${ }^{9660}$ The Accused was also informed about personnel problems and warned that this could lead to conflict. ${ }^{9661}$

2969. At the municipal level, a division of the police structures based on personnel disagreements was already envisaged by Bosnian Serb leaders as early as September $1991 .^{9662}$ On or around 6 September 1991, the Accused informed Brđanin that there would be a meeting the following day where important decisions would be made and that he or someone from the Krajina should attend. ${ }^{9663}$ On 17 September 1991, the Accused instructed Simović to relay an important message to Žepinić regarding the separation of the MUP, stating that "as of tomorrow, we are withdrawing all our ministers and all our officials in [the MUP]"; further the Accused stated that he was going to confront Izetbegović that evening and said "we are going to [...] break apart and then we are going to establish our own [SUP] [...] and we'll make the government separately, we'll make everything separately". 9664

2970. Around 21 September 1991, the Accused wrote a letter to all Municipal Boards of the SDS informing them that there were rumours about the mobilisation of Bosnian Muslim police, which

\footnotetext{
9658 D364 (Intercept of conversation between Radovan Karadžić and Vitomir Žepinić, 24 July 1991), p. 9; P5625 (Intercept of conversation between Radovan Karadžić and Vitomir Žepinić, 8 July 1991), p. 1. See also D365 (Intercept of conversation between Radovan Karadžić and Slobodan Milošević, undated); P5806 (Intercept of conversation between Radovan Karadžić and Momčilo Mandić, 3 December 1991).

9659 P1081 (Intercept of conversation between Radovan Karadžić and Momčilo Mandić, 30 September 1991), pp. 23. See also P2999 (Intercept of conversation between Radovan Karadžić and Momčilo Mandić, 23 July 1991); D262 (Radovan Karadžić's letter to Presidency of SRBiH, 28 July 1991).

9660 P1080 (Intercept of conversation between Radovan Karadžić and Momčilo Mandić, 26 August 1991), pp. 1-2. See also P2222 (Intercept of conversation between Biljana Plavšić and Radovan Karadžić, 17 June 1991).

9661 P2360 (Intercept of conversation between Radovan Karadžić and Rajko Koprivica, 23 September 1991), pp. 12; D4287 (Intercept of conversation between Radovan Karadžić and Avdo Hebib, 17 September 1992), p. 6.

9662 P2347 (Intercept of conversation between Jovan Tintor and Milan Plakalović, 7 September 1991), p. 9.

9663 P5886 (Intercept of conversation between Radovan Karadžić and Radoslav Brđanin, 6 September 1991), pp. 2-3 (wherein the Accused stated further that "now they are looking for any way to mess that Conference" to suggest that Serbs do not want peace). See P6513 (Press release on Yugoslavia Peace Conference, 7 September 1991).

9664 P5868 (Intercept of conversation between Radovan Karadžić and Miodrag Simović, 17 September 1991), p. 1.
} 
would result in a Bosnian Muslim police force and would create conditions for a civil war. ${ }^{965}$ The Municipal Boards were instructed by the Accused to follow developments closely in this regard. ${ }^{9666}$

2971. In an intercepted conversation on 8 October 1991 the Accused was informed about problems in Višegrad. ${ }^{9667}$ The Accused spoke about the option of establishing "our public security station" and that in negotiations "[w]e will say, here you are, if you can solve it within that deadline, if you cannot we have our own in our area". ${ }^{9668}$ The Accused also gave an instruction to give "seven days to bring things to an end and punish the culprits" and "[i]f not, we shall proceed to organise parallel organs of power...[w]ith a view to protecting the Serbian people". ${ }^{969}$ The Accused also inquired whether the towns were separated and whether the mixed town centre could not be separated. ${ }^{9670}$ In December 1991, Mandić and the Accused discussed the preparations for the creation of a separate Serb MUP. ${ }^{9671}$

2972. The Chamber recalls that from early January 1992, employees of the SJB in Zvornik were instructed by the SDS to gather support and prepare for the formation of a Serb SJB.$^{9672}$

2973. On 11 February 1992, at a meeting in Banja Luka, Mićo Stanišić, Mandić, and other Bosnian Serb leaders were informed that the Bosnian Serb Assembly had decided to form a separate Serb MUP. ${ }^{9673}$ This was a means of ensuring that Bosnian Serb authority was felt in territories which they claimed. ${ }^{9674}$ Stanišić at this meeting spoke about the need to work towards organising a Serb MUP starting at the municipal and regional levels and moving towards a Serb ministry. ${ }^{9675}$ At this meeting there were also discussions about the problems in the MUP of the

\footnotetext{
9665 D369 (Radovan Karadžić's instructions to SDS municipal boards, 21 September 1991); Momčilo Mandić, T. 4789-4790 (7 July 2010).

9666 D369 (Radovan Karadžić's instructions to SDS municipal boards, 21 September 1991).

9667 P2558 (Intercept of conversation between Brane and Radovan Karadžić, 8 October 1991), p. 1.

9668 P2558 (Intercept of conversation between Brane and Radovan Karadžić, 8 October 1991), p. 2. See also, Patrick Treanor, T. 14045-14046 (1 June 2011).

9669 P2558 (Intercept of conversation between Brane and Radovan Karadžić, 8 October 1991), p. 3.

9670 P2558 (Intercept of conversation between Brane and Radovan Karadžić, 8 October 1991), p. 2.

9671 P5806 (Intercept of conversation between Radovan Karadžić and Momčilo Mandić, 3 December 1991), p. 2 (wherein Mandić informs the Accused "[i]t's not your police, you're going to get ours" and the Accused responds "[w]e're going to get ours that wouldn't tap").

9672 See para. 1234. See also Adjudicated Facts 1963, 1981, 1982.

9673 P1083 (Minutes of meeting of representatives of SerBiH MUP, 11 February 1992), pp. 1, 4-5; Čedomir Kljajić, T. 42192-42196 (30 July 2013); Momčilo Mandić, C2 (Transcript from Prosecutor v. Krajišnik), T. 8646-8648, 8676. See also P1116 (Letter from Momčilo Mandić to SRBiH MUP re division of MUP, 31 March 1992); P1103 (Intercept of conversation between Momčilo Mandić and Branko Kvesić/Bruno Stojić/Mićo Stanišić, 5 May 1992), p. 25; D2923 (Witness statement of Vitomir Žepinić dated 11 February 2013), para. 55.

9675 P1083 (Minutes of meeting of representatives of SerBiH MUP, 11 February 1992), p. 1.
} 
SRBiH. ${ }^{9676}$ Župljanin indicated that with respect to the Banja Luka CSB not a single new Muslim or Croat employee would be hired until the status of Serb police who had fled from Croatia had been resolved. ${ }^{9677}$ Mićo Stanišić claimed that the MUP was being divided by the Muslims, through the actions of the SDA, and not the Serbs. ${ }^{9678}$

2974. At this meeting a resolution was passed to create a steering committee, a "Serbian advisory board" within the MUP under the direction of Mandić "to carry out all preparations necessary for the functioning of the Serbian MUP" following the adoption of the Bosnian Serb constitution. ${ }^{9679}$ Part of the preparation for separation included the arming of Serb police officers and Serb police stations. ${ }^{9680}$ The CSBs and SJBs reassigned stockpiled weapons belonging to the reserve police force to the new Serb MUP. ${ }^{9681}$ A separate Serb MUP would be organised at state, regional, and municipal levels. ${ }^{9682}$

2975. Following this meeting, Mandic wrote to the CSBs and SJBs and asked them to act in accordance with the conclusions reached at the meeting in Banja Luka and to set up and have a meeting of senior MUP executives in their areas. ${ }^{963}$ After this order, each centre distributed the stockpile of weapons for the reserve police force to members of the Serb MUP. ${ }^{9684}$ In Bijeljina for example, following the 11 February 1992 meeting, the SJB in Bijeljina was instructed by Mandić to begin preparations for the purpose of creating a Bosnian Serb MUP. ${ }^{9685}$

2976. This was the second of two meetings on this topic, the first having taken place in Sarajevo. ${ }^{9686}$ The meeting was not held secretly and Mandić personally informed Delimustafić about it. ${ }^{9687}$ The minutes and conclusions of the meeting were forwarded to Delimustafić. ${ }^{9688}$

\footnotetext{
9676 Momčilo Mandić, C3 (Transcript from Prosecutor v. Stanišić and Župljanin), T. 9663; Momčilo Mandić, T. 4471-4473 (1 July 2010), T. 4838-4841 (7 July 2010); P1083 (Minutes of meeting of representatives of SerBiH MUP, 11 February 1992); P1112 (Order of SRBiH MUP to all CSBs and SJBs, 13 February 1992).

9677

9678

9679

9680

9681

9682

9683

9684

9685

9686

9687

9688 P1083 (Minutes of meeting of representatives of SerBiH MUP, 11 February 1992), p. 1.

See Adjudicated Fact 1983.

Momčilo Mandić, C2 (Transcript from Prosecutor v. Krajišnik), T. 8655. See also Adjudicated Fact 1984.

Adjudicated Fact 1985.

See Adjudicated Fact 1982.

P1112 (Order of SRBiH MUP to all CSBs and SJBs, 13 February 1992); Momčilo Mandić, C2 (Transcript from Prosecutor v. Krajišnik), T. 8649-8650. See also Petko Panić, P3380 (Transcript from Prosecutor v. Stanišić \& Župljanin), T. 2869-2870.

Momčilo Mandić, C2 (Transcript from Prosecutor v. Krajišnik), T. 8652-8653, 8655. See also P1113 (Interview with Momčilo Mandić in Slobodna Bosna, 10 April 1998), p. 2.

See para. 604. See also Čedomir Kljajić, T. 42192, 42194-42915, 42197 (30 July 2013).

Momčilo Mandić, C3 (Transcript from Prosecutor v. Stanišić and Župljanin), T. 9663.

Momčilo Mandić, C3 (Transcript from Prosecutor v. Stanišić and Župljanin), T. 9663, 9667.

Momčilo Mandić, C3 (Transcript from Prosecutor v. Stanišić and Župljanin), T. 9663-9664.
} 
2977. By March 1992, there were further problems given the failure to carry out the 1990 coalition agreement regarding personnel issues in the MUP which resulted in proposals for its reorganisation. $^{9689}$ The Accused on 6 March 1992 emphasised the Bosnian Serb demands with respect to the re-organisation of the MUP and protested about appointments where the legal procedure had not been followed. ${ }^{9690}$ There were also complaints received from a municipal level about the divisions in the SJB which were blamed on the SDA ${ }^{9691}$ The Accused wanted the Serb collegium in the MUP to reach agreement on its own personnel. ${ }^{9692}$ In March 1992, the Accused spoke about announcing their withdrawal from the MUP and that they had already obtained the badges. $^{9693}$

2978. On 24 March 1992, the Accused spoke at the Bosnian Assembly about following forthcoming instructions so that the sovereign authority of the "Serbian Assembly and Serbian people be established on the ground as soon as possible". 9694 In this regard the Accused spoke about having their own separate MUP and that the then newly established municipalities should set up police stations and their organs as soon as possible. ${ }^{965}$ Mićo Stanišić was also in contact with municipal level leaders in March 1992 and discussed the splitting of police structures. ${ }^{9696} \mathrm{He}$ also reported on steps taken to establish "police stations in our parts" to Đerić. 9697

2979. The law on the establishment of the Serbian MUP was passed on 27 March 1992. ${ }^{9698}$ The Law on Internal Affairs provided for the structure and duties of the organs of the MUP. ${ }^{9699}$ The Chamber recalls that at the end of March 1992, a decision was adopted by the Bosnian Serb Assembly, calling on the Bosnian Serb police to separate by 1 April 1992. ${ }^{9700}$ On 30 March 1992, Mićo Stanišić addressed the members of the police unit of the SAO Romanija stating that as of that

\footnotetext{
9689 Momčilo Mandić, T. 4876-4877, 4881-4882 (8 July 2010); D214 (Minutes of 56 ${ }^{\text {th }}$ SRBiH Presidency session, 2 March 1992), p. 4;

9690 D380 (Radovan Karadžić's letter to SR BiH organs, 6 March 1992) p. 1; Momčilo Mandić, T. 4830-4833 (7 July 2010), T. 4877 (8 July 2010).

9691 D386 (Letter from Serb employees of Stari Grad SJB to SR BiH MUP, 5 March 1992), p. 1; Momčilo Mandić, T. 4889 (8 July 2010).

9692 Momčilo Mandić, T. 4758-4759 (6 July 2010); D364 (Intercept of conversation between Radovan Karadžić and Vitomir Žepinić, 24 July 1991), p. 5.

9693 D90 (Shorthand Record of $11^{\text {th }}$ session of SerBiH Assembly, 18 March 1992), p. 45.

9694 P961 (Shorthand Record of $12^{\text {th }}$ session of SerBiH Assembly, 24 March 1992), p. 16.

9695 P961 (Shorthand Record of $12^{\text {th }}$ session of SerBiH Assembly, 24 March 1992), pp. 16-17.

9696 P5598 (Intercept of conversation between Mićo Stanišić and Miroslav Toholj, 2 March 1992), p. 3.

9697 P5698 (Intercept of conversation between Branko Đerić and Mićo Stanišić, 1 May 1992), p. 4; P5716 (Intercept of conversation between Branko Đerić and Mićo Stanišić, 18 April 1992), p. 5.

9698 Momčilo Mandić, C2 (Transcript from Prosecutor v. Krajišnik), T. 9322.

9699 P2964 (SerBiH Decree on the promulgation on the Law of Internal Affairs, 23 March 1992).

9700 See para. 1237; Petko Panić, P3380 (Transcript from Prosecutor v. Stanišić \& Župljanin), T. 2869-2870; P1116 (Letter from Momčilo Mandić to SRBiH MUP re division of MUP, 31 March 1992). See also Adjudicated Fact 2729; KDZ555, T. 17263-17264 (16 August 2011) (private session), T. 17346-17347 (17 August 2011).
} 
day, the SerBiH had their own police force. ${ }^{9701}$ On 31 March 1992, Mandić sent a dispatch to all SJBs and CSBs indicating that the Bosnian Serb Assembly had promulgated the Law on Internal Affairs. $^{9702}$

2980. Mandić's dispatch indicated that when this law came into force on 1 April 1992, all CSBs and SJBs on the territory of the SerBiH would be abolished and their functions taken over by organisational units of the Bosnian Serb MUP. ${ }^{9703}$ Mandić in a later intercepted conversation said "when I sent that dispatch and fucked the MUP to pieces" and "[y]ou have your state, we have ours. The Muslims should work on their own, fuck them". ${ }^{9704}$ Mandić sent this dispatch following the instructions of the Bosnian Serb political leadership. ${ }^{9705}$

2981. On 31 March 1992, Delimustafić, in response to Mandić's dispatch of 31 March 1992, ${ }^{9706}$ wrote a letter to the MUP administrations of all SDBs, CSBs, and SJBs stating that the dispatch reflected problems in the leadership and appealed to all MUP workers to continue to work responsibly and noted that the greatest number of MUP workers wish to remain in a united MUP. ${ }^{9707}$ Žepinić was also opposed to the split in the MUP given his view that the split would "inevitably lead to an armed conflict" in $\mathrm{BiH} .{ }^{9708}$ Žepinić at a meeting attended by the Bosnian Serb leadership was criticised by Mićo Stanišić for "destroying" their idea of dividing the MUP and Žepinić said that the division could not be done peacefully. ${ }^{9709}$

\footnotetext{
9701 D4271 (Video footage of Mićo Stanišić's speech, 30 March 1992, with transcript).

9702 P1116 (Letter from Momčilo Mandić to SRBiH MUP re division of MUP, 31 March 1992), p. 1; P2964 (SerBiH Decree on the promulgation on the Law of Internal Affairs, 23 March 1992).

9703 P1116 (Letter from Momčilo Mandić to SRBiH MUP re division of MUP, 31 March 1992), p. 1.

9704 P1103 (Intercept of conversation between Momčilo Mandić and Branko Kvesić/Bruno Stojić/Mićo Stanišić, 5 May 1992), pp. 25-26.

9705 Momčilo Mandić, C2 (Transcript from Prosecutor v. Krajišnik), T. 8702. Mandić later testified that the political leadership was not aware of his dispatch and he was simply following the decisions of the Assembly, the Law on Internal Affairs, and the Cutileiro Plan. Momčilo Mandić, T. 4474 (1 July 2010) The Chamber does not find this evidence to be reliable and notes that this is directly contradicted by his prior testimony that this dispatch was sent following instructions from the political leadership. The Chamber noted that Mandic in his testimony in this case was evasive and was marked by indicators of bias. Similarly the Chamber does not rely on Mandić's evidence about the effect or motivation for the division of the MUP given that this evidence was marked by efforts by Mandić to distance himself from responsibility for the events in $\mathrm{BiH}$. Momčilo Mandić, C2 (Transcript from Prosecutor v. Krajišnik), T. 8687-8688; C3 (Transcript from Prosecutor v. Stanišić and Župljanin), T. 9681-9683, 9664. The Chamber does not find Samouković's evidence with respect to the extent to which municipal level divisions followed instructions from the central authorities to be reliable. Nevenko Samouković, T. 34602 (1 March 2013). In reaching that conclusion the Chamber noted that his testimony was marked by contradictions, and evasiveness which undermined his evidence in this regard.

9706 P1117 (Letter from SRBiH Minister of Interior to all MUP administrations, 31 March 1992).

9707 P1117 (Letter from SRBiH Minister of Interior to all MUP administrations, 31 March 1992), p. 2. See also Momčilo Mandić, C3 (Transcript from Prosecutor v. Stanišić and Župljanin), T. 9685-9686.

9708 Vitomir Žepinić, T. 33582-33583 (13 February 2013). See also Dragomir Andan, D3774 (Transcript from Prosecutor v. Stanišić \& Župljanin), T. 21394.

9709 Vitomir Žepinić, T. 33601-33602 (13 February 2013).
} 
2982. The BiH MUP was then divided and allowed for the creation of the Bosnian Serb MUP. Employees of the abolished CSBs and SJBs who wished to work in the Bosnian Serb MUP were obliged to swear an oath of allegiance before taking up employment. ${ }^{9710}$ After the dispatch of 31 March 1992, Mandić issued a further explanation on how the new MUP would be organised across the territory of the $\mathrm{BiH} .{ }^{9711}$

2983. On 1 April 1992, it was reported that Mandić had invited all Serb police officers to put themselves at the disposal of a "MUP of Serbian Republic" pursuant to the Constitution of the SerBiH. ${ }^{9712}$ On 1 April 1992, the SRBiH MUP collegium issued a dispatch that in order to prevent a further deterioration of the security situation that the existing MUP "should be transformed peacefully and without any excesses" and that equipment of the SJB and SDB should not be seized by any nation unilaterally and that employees should not be dismissed because of their national or political affiliations. ${ }^{9713}$ On 3 April 1992, Župljanin sent a dispatch indicating that the reorganisation of the MUP organs and their security services had begun in line with the dispatch from the Bosnian Serb MUP Collegium dated 2 April 1992. ${ }^{9714}$

2984. On 5 April 1992, Mandić sent a dispatch to Zvornik, noting that the MUP was being divided into Serb and Muslim components and ordered the movement of the Bosnian Serb institutions to Karakaj. ${ }^{9715}$ Following this instruction, the police stations in the municipality, were divided into Serb and Muslim parts. ${ }^{9716}$ With respect to the division of the police, the Accused stated that the "[p]olicemen simply do not work together any more" and that this situation had been "forced upon us". 9717 The Chamber also found that in Bratunac at the beginning of April 1992, in a meeting between SDS and SDA representatives, Deronjić reiterated that the police should be divided and that separate Bosnian Muslim and Bosnian Serb police units should be formed. ${ }^{9718}$ When the SDA representatives opposed the idea as it would lead to greater tensions, Deronjić threatened that if they did not comply "Muslims would disappear". 9719

\footnotetext{
9710 Momčilo Mandić, T. 4473-4474 (1 July 2010); P1116 (Letter from Momčilo Mandić to SRBiH MUP re division of MUP, 31 March 1992), p. 2.

9711 Momčilo Mandić, C3 (Transcript from Prosecutor v. Stanišić and Župljanin), T. 9687-9688.

9712 P1118 (Article from Oslobođenje, entitled "April Fool Reality", 1 April 1992), p. 1.

9713 D390 (SRBiH MUP dispatch to MUP Ministers, all CSBs, and all SJBs, 1 April 1992), p. 2. See also Momčilo Mandić, C3 (Transcript from Prosecutor v. Stanišić and Župljanin), T. 9688-9689.

9714 D391 (CSB Banja Luka dispatch to SerBiH MUP, 3 April 1992), p. 1. See also Momčilo Mandić, T. 49124913 (8 July 2010).

9715 See para. 1237.

$9716 \quad$ See para.1237.

9717 P961 (Shorthand Record of $12^{\text {th }}$ session of SerBiH Assembly, 24 March 1992), p. 16.

9718 See para. 705.

9719 See para. 705.
} 
2985. The Chamber further recalls that Bosnian Serb SJBs were formed in municipalities including Bijeljina, ${ }^{9720}$ Bratunac, ${ }^{9721}$ Brčko, ${ }^{9722}$ Foča,${ }^{9723}$ Rogatica, ${ }^{9724}$ Vlasenica, ${ }^{9725}$ Zvornik, ${ }^{9726}$ Ključ, ${ }^{9727}$ Prijedor, ${ }^{9728}$ Sanski Most, ${ }^{9729}$ Hadžići, ${ }^{9730}$ Ilidža, ${ }^{9731}$ Pale,,${ }^{9732}$ and Vogošća. ${ }^{9733}$

2986. In a decision issued on 25 April 1992, Mićo Stanisić ordered that CSB heads were allowed to take over the employees from the former MUP and assign jobs within the CSBs and SJBs, however, they had to inform the Minister of the Interior of all such decisions. Furthermore, all heads of CSB had to obtain prior approval from the MUP before assigning posts at the higher levels, such as the head of the SJBs. ${ }^{9734}$

2987. In May 1992, there was a meeting between the Accused, RS MUP officials and the Chiefs of the CBSs at which the existing situation, the problems on the ground, and the work of the MUP were discussed. ${ }^{9735}$ The Chiefs of the CSBs were informed that a MUP had been formed and of the applicable procedure, and the Accused used this opportunity to inform those present about the general situation and issues, emphasising that the MUP had to function according to the legal provisions. ${ }^{9736}$ A bulletin of daily events was compiled on the work between April and December 1992 in order to provide the Accused and the RS Prime Minister with information on the security situation. In addition, the Accused received 80 reports on security issues. ${ }^{9737}$

2988. The Accused, as President, also had the power to issue orders for the deployment of the police during the war. ${ }^{9738}$

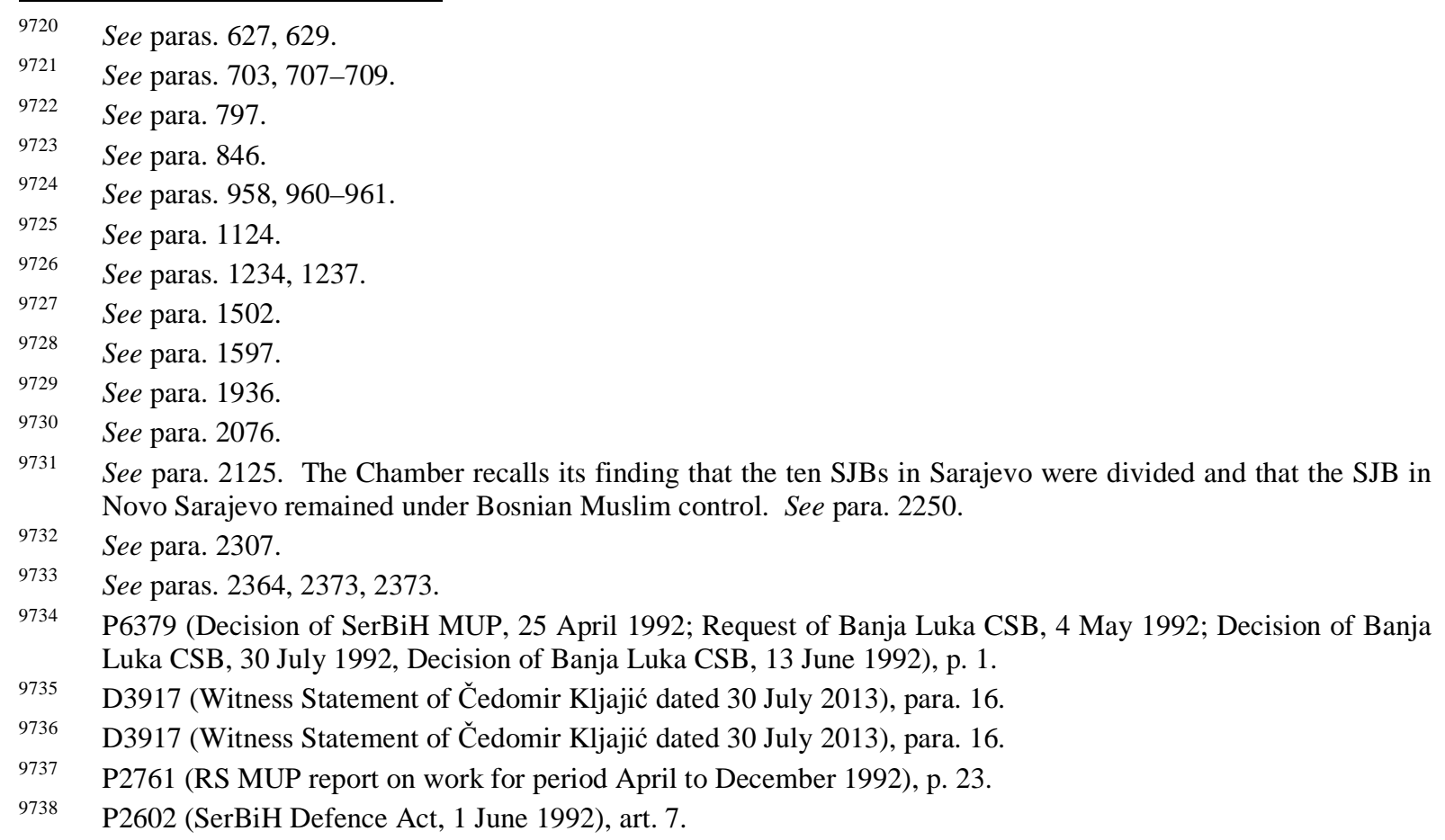




\section{(2) $\underline{\text { Conclusion }}$}

2989. The Accused's argues that there were multiple factors which contributed to the ultimate division of the MUP, particularly personnel disagreements with the SDA. ${ }^{9739} \mathrm{He}$ also argues that the Cutileiro Plan envisaged all constituent entities having their own police forces. ${ }^{9740}$

2990. Having considered the evidence above, the Chamber finds that prior to the conflict in $\mathrm{BiH}$ there were already disputes, personnel issues and divisions between the Bosnian Serb and Bosnian Muslim personnel in the MUP. ${ }^{9741}$ The Chamber finds that the Accused himself had warned that if the Bosnian Serb demands were not met, a parallel police structure could be created. The Chamber finds that the Accused closely monitored developments in the MUP. The Chamber concludes however that, even if such a division was also influenced by personnel disagreements or was provided for by the Cutileiro Plan, the ultimate split in the MUP structures was precipitated by a decision of the Bosnian Serb leadership and formed a core part of their objective to create a separate Bosnian Serb state with parallel structures. The Chamber finds that Mandić took a leading role in ensuring that this division was carried out at a municipal level and in detailing how this new Bosnian Serb MUP was to be structured. It also finds that the creation of a separate Bosnian Serb MUP was a means of undermining the proposed independence of $\mathrm{BiH}$. The Chamber finds that the directives with respect to the division of the MUP structures and the creation of the Bosnian Serb MUP were communicated to and implemented at a municipal level.

2991. The Chamber further finds that the separation of the BiH MUP and creation of a Bosnian Serb MUP was also a crucial step in the take-over of municipalities as it created a separate police structure which would allow Bosnian Serb authority to be maintained in those municipalities. The Chamber also finds that the Accused spoke in favour and promoted the creation of this separate police structure as a means of achieving their objective of sovereignty of the Serb people in the territories which they claimed. Following the division of the BiH MUP, the Accused was informed about developments and the functioning of the Bosnian Serb MUP. The Chamber recalls its finding that the separate Bosnian Serb MUP, as a component of the Serb Forces, were involved in

\footnotetext{
9739 Defence Final Brief, paras. 111-124, 134-154.

9740 Defence Final Brief, paras. 176-179.

9741 While the Chamber finds that these disputes did play a role in the decision to ultimately divide the MUP, the Chamber does not find Mandić's evidence that it was the SDA and these personnel issues which contributed most to the division of the MUP to be reliable: Momčilo Mandić, T. 4917 (8 July 2010); Momčilo Mandić, C2 (Transcript from Prosecutor v. Krajišnik), T. 9406. See also P1115 (Video footage of interview with Momčilo Mandić, July-August 1994, with transcript). In reaching that conclusion the Chamber found that Mandić's evidence was marked by evasiveness, inconsistencies and indicators of bias. In addition it was clear that he had an interest in downplaying his own role and the real reason for the division of the MUP.
} 
the violent take-over of Municipalities and in crimes committed against Bosnian Muslims and Bosnian Croats upon which the Chamber has entered findings above.

(D) Variant A/B Instructions and take-over of power

(1) Analysis of evidence

(a) Distribution and contents of the Instructions

2992. Above, the Chamber found that the Variant A/B Instructions were issued by the SDS Main Board on 19 December 1991. ${ }^{9742}$ They were distributed by the Accused at a meeting on or around 20 December 1991. ${ }^{9743}$ This meeting was held in Sarajevo and attended by hundreds of high ranking Bosnian Serbs, including Krajišnik, Plavšić, Koljević, members of the Main Board and Executive Board, deputies, municipal representatives, and members of the government. ${ }^{974}$

2993. This document was adopted without any discussion, vote, or amendment and was presented as a set of measures which were to be practically implemented. ${ }^{9745}$ The stated purpose of these instructions was to "carry out the results of the plebiscite at which the Serbian people in Bosnia and Herzegovina decide to live in a single state" and to "increase mobility and readiness for the defence of the interests of the Serbian people". ${ }^{9746}$ The Chamber further recalls that Serb-majority municipalities were designated Variant A, while Serb-minority municipalities were designated Variant B. ${ }^{9747}$ The instructions were a means of creating Serb authority in both Variant A and Variant B municipalities. ${ }^{9748}$ According to the instructions, the tasks laid out therein were to be

9742 See paras. 49, 132; P5 (SDS Instructions for Organisation of Organs of the Serbian People in BiH, 19 December 1991); Patrick Treanor, T. 14027-14028 (1 June 2011); Dorothea Hanson, T. 14502 (9 June 2011).

9743 See paras. 49, 132. The Chamber also notes that on cross-examination Grujić was confronted with his prior testimony where he claimed the Variant A/B instructions came directly from the Accused, but he retracted from this and said he did not know whether the Accused was directly involved or not. Branko Grujić, T. 4036940371, 40405-40407, 40417-40418 (25 June 2013); P6415 (Excerpt from Branko Grujić's testimony before Belgrade District Court, 30 November 2005), p. 3.

9744 Radomir Kezunović T. 13938-13939 (31 May 2011); Radomir Nešković, P2568 (Transcript from Prosecutor v. Krajišnik), T. 16651, 16654-16656, 16795-16796. See para. 132. See also Neđeljko Prstojević, T. 1293412935, 12939-12941, 12942 (3 March 2011).

9745 Radomir Nešković, P2568 (Transcript from Prosecutor v. Krajišnik, Case No. IT-00-39), T. 16647-16650, 16657-16659; Radomir Nešković T. 14215, 14264, 14272 (6 June 2011), 14325-14327, 14352-14353 (7 June 2011); D1278 (Transcript of Radomir Nešković's interview with Karadžić's legal associate, 8 October 2009), pp. 28-29; Radomir Kezunović T. 13939 (31 May 2011). But see KDZ192, T. 19508-19509, 19516-19517 (27 September 2011). KDZ192 agreed with the Accused's suggestion that the Variant A/B Instructions were not binding but then distanced himself from his answer when questioned by the Chamber. The Chamber notes that KDZ192's evidence was marked by contradictions and indicators of bias and partiality and does not rely on his evidence in this regard.

9746 P5 (SDS Instructions for Organisation of Organs of the Serbian People in BiH, 19 December 1991), paras. 1-2.

9747 See paras. 49, 132. See also Dorothea Hanson, T. 14504 (9 June 2011). The Chamber does not rely on Hanson's opinion that in practice, the instructions essentially mapped out the take-over of power.

9748 Radomir Nešković T. 14326-14327 (7 June 2011). The Chamber places no weight on Nešković's own assessment that the instructions were a means of subjugating the Bosnian Muslims and Bosnian Croats to Serb 
implemented over the entire territory of the SRBiH or in every municipality where Serbs lived, in their entirety in Variant A municipalities and partially in Variant B municipalities. ${ }^{9749}$

2994. Before the Accused distributed the document, he spoke about the position of the Bosnian Serbs, the threat posed by Bosnian Muslims and Bosnian Croats, the secession and the disintegration of Yugoslavia, but did not actually go into the details of the document. ${ }^{9750}$ The fear of Bosnian Muslim and Croat dominance "was a key element that contributed to the emotional atmosphere" which prevailed during the meeting and nobody wanted to be seen as a traitor by questioning the instructions. ${ }^{9751}$ The Accused called out individuals on a list and distributed copies of the instructions and approximately 100 people were given these instructions to read and return. ${ }^{9752}$ The instructions were numbered as they knew which Bosnian Serb municipal leaders were supposed to be given copies of the document. ${ }^{9753}$ The Accused also discussed these instructions at a meeting of the SDS Deputies' Club, which was attended by municipal representatives. ${ }^{9754}$ On 18 December 1991, the day before the Variant A/B Instructions were distributed, the Accused told Krajišnik in an intercepted phone conversation that he was "working on something", "some measures and so on". 9755

2995. The Variant A/B Instructions required SDS municipal boards in the first level to "establish immediately Crisis Staffs of the Serbian People in the municipality". ${ }^{9756}$ The instructions also specified that the composition of these Crisis Staffs should include all members of the SDS municipal board secretariat, SDS candidates in certain municipal organs (for Variant A municipalities) or SDS candidates in every municipal organ (for Variant B municipalities), deputies of the Bosnian Serb Assembly, and members of the SDS Main Board from the municipality. ${ }^{9757}$ The Chamber recalls that instructions also provided that the Commander of the Crisis Staff was, in

power. See also P4634 (Witness statement of KDZ145 dated 22 February 2012), para. 14 (under seal); KDZ145, T. 26516 (21 March 2012) (closed session).

9749 P5 (SDS Instructions for Organisation of Organs of the Serbian People in BiH, 19 December 1991), p. 2.

9750 Radomir Nešković, P2568 (Transcript from Prosecutor v. Krajišnik), T. 16657, 16793.

9751 Radomir Nešković, P2568 (Transcript from Prosecutor v. Krajišnik), T. 16659-16660; Radomir Nešković, T. 14215 (6 June 2011).

9752 Radomir Nešković, P2568 (Transcript from Prosecutor v. Krajišnik), T. 16648, 16788. See also P6550 (Excerpt from Rajko Kalabić's testimony in Prosecutor v. Brđanin), T. 22576-22577.

9753 Radomir Nešković, P2568 (Transcript from Prosecutor v. Krajišnik), T. 16648, 16651, 16656.

9754 P6369 (Excerpts from KW317's statement to OTP, 14 June 2002), e-court p. 2 (under seal); KW317, T. 39337 (5 June 2013).

9755 P5793 (Intercept of conversation between Radovan Karadžić and Momčilo Krajišnik, 18 December 1991 ), p. 1.

9756 See para. 139. Kosta Čavoški testified that the Variant A/B Instructions were purely precautionary in nature. Kosta Čavoški, T. 37059-37060 (11 April 2013). The Chamber places no weight on Čavoški's opinion in this regard given that it falls outside the scope of his expertise. In addition the Chamber also found his testimony was marked by contradictions, evasiveness and clear indicators of partiality and bias which undermined his evidence as an expert and does not find his evidence in this regard to be reliable.

9757 See para. 139. 
Variant A municipalities, the president of the municipal assembly or the chairman of the municipal executive board and, in Variant B municipalities, the president of the SDS municipal board. ${ }^{9758}$

2996. The Variant A/B Instructions also called for, in the first level, convening and proclaiming an assembly of the Serbian people to be composed of Serbian representatives in the municipal assembly and presidents of SDS local boards. ${ }^{9759}$ In this phase, preparations were to be undertaken for the establishment of municipal government organs such as an executive committee, administration organs, a misdemeanour court and an SJB and for the preparation of a list of nominees to take on duties in these organs. ${ }^{9760}$ This first level also required preparations for the take-over of "staff, buildings and equipment of security services centres and their integration" into newly established organs. ${ }^{9761}$

2997. The first level of the instructions also required an estimate of the number of active and reserve police, TO units, and civilian protection units and to bring these units "to full manpower" and take necessary action for their engagement depending on developments. ${ }^{9762}$ The instructions also provided that these units would be activated by order of the municipal Crisis Staffs and also called for a replenishment of wartime units. ${ }^{9763}$ The instructions also required preparations to be taken to allow for the protection and evacuation of children, pregnant women, the elderly and sick. $^{9764}$

2998. The Variant A/B Instructions also contained provisions to establish "constant communication and cooperation" between the SDS municipal boards and local boards and to provide for daily meetings of the SDS municipal board to constantly monitor the situation on the ground. ${ }^{9765}$

2999. The second level of the Variant A/B Instructions called for, inter alia, convening a session of the Serb municipal assembly, establishing a municipal executive board and municipal state or government organs, mobilising and re-subordinating all Serb police forces in co-ordination with JNA command and staff, and ensuring the implementation of the order for mobilisation of JNA

\footnotetext{
$9758 \quad$ See para. 139.

9759 See para. 133.

9760 P5 (SDS Instructions for Organisation of Organs of the Serbian People in BiH, 19 December 1991), pp. 3-4.

9761 P5 (SDS Instructions for Organisation of Organs of the Serbian People in BiH, 19 December 1991), pp. 4, 7.

9762 P5 (SDS Instructions for Organisation of Organs of the Serbian People in BiH, 19 December 1991), pp. 4, 8.

9763 P5 (SDS Instructions for Organisation of Organs of the Serbian People in BiH, 19 December 1991), pp. 4-5, 8.

9764 P5 (SDS Instructions for Organisation of Organs of the Serbian People in BiH, 19 December 1991), pp. 4, 8.

9765 P5 (SDS Instructions for Organisation of Organs of the Serbian People in BiH, 19 December 1991), pp. 2, 6.
} 
reserve and TO units. ${ }^{9766}$ This second level also provided for the take over of "staff, buildings and equipment of security services centres and [to] place them at the disposal of the newly established organs of the interior". ${ }^{9767}$ In Variant B municipalities, the Crisis Staff was tasked with organising the defence of Serbs and to constantly monitor the political, military and security situation and to respond in a timely fashion. ${ }^{9768}$

3000. For Variant B municipalities there was a further provision which required that members of the "other nations" who had expressed loyalty to Yugoslavia be "proportionately represented in government organs". ${ }^{9769}$ Also in Variant B municipalities there was an additional instruction for predominantly Serb local communes and settlements to establish "secret warehouses and depots" to store food, raw materials and manufacturing components. ${ }^{9770}$

3001. The second level of the Variant A/B Instructions was to be activated pursuant to an order of the Accused "in accordance with a specifically defined secret procedure". 9771

\section{(b) Implementation of the Instructions at the municipal level}

3002. The Variant A/B Instructions were communicated from SDS leaders to municipal leaders and SDS municipal boards which discussed and implemented the variant which was applicable to their respective municipality. ${ }^{9772}$ The Chamber also recalls its finding that the implementation of these instructions were viewed by the recipients as mandatory. ${ }^{9773}$ Those who received the document had to decide the best way to implement the instructions at a municipal level. ${ }^{974}$ There are also municipal decisions on the record which specifically reference the Variant A/B Instructions. ${ }^{9775}$ The Chamber recalls that after the Variant A/B Instructions were distributed by the

9766 P5 (SDS Instructions for Organisation of Organs of the Serbian People in BiH, 19 December 1991), pp. 5-6, 910. See para. 134.

9767 P5 (SDS Instructions for Organisation of Organs of the Serbian People in BiH, 19 December 1991), pp. 5-6.

9768 P5 (SDS Instructions for Organisation of Organs of the Serbian People in BiH, 19 December 1991), pp. 9-10.

9769 P5 (SDS Instructions for Organisation of Organs of the Serbian People in BiH, 19 December 1991), pp. 6-7.

9770 P5 (SDS Instructions for Organisation of Organs of the Serbian People in BiH, 19 December 1991), pp. 7, 9.

9771 P5 (SDS Instructions for Organisation of Organs of the Serbian People in BiH, 19 December 1991), p. 10.

9772 See para. 132.

9773 See para. 2245. KW317 testified that the Variant A/B Instructions were not orders and that nobody had to report on whether they were implemented or not. KW317, T. 39333-39334, 39337-39338 (5 June 2013), T. 39412 (6 June 2013). However, the Chamber notes that when KW317 was confronted with a prior interview where he confirmed that he did attend a meeting where they were instructed to implement the second phase of the Variant A/B Instructions. In light of this qualification the Chamber does not find KW317's evidence in this regard to be of much weight.

9774 Ra00domir Nešković, P2568 (Transcript from Prosecutor v. Krajišnik), T. 16806. For evidence on the manner in which the Variant A/B Instructions were implemented in Brčko for example, see P3023 (Witness statement of Đorđe Ristanić dated 15 June 2011), paras. 51-59, 73-76, 94-95.

9775 See, e.g., P2593 (Decision on the establishment of the Serbian Municipality of Tuzla, 3 March 1992), p. 1; P2594 (Decision on the establishment of the Serbian Municipality of Donji Vakuf, 15 February 1992), p. 1; 
Accused they were conveyed, discussed and implemented through SDS structures at a municipal level in municipalities including Bratunac, ${ }^{9776}$ Brčko, ${ }^{9777}$ Rogatica, ${ }^{9778}$ Vlasenica, ${ }^{9779}$ Zvornik, ${ }^{9780}$ Bosanski Novi, ${ }^{9781}$ Ključ, ${ }^{9782}$ Prijedor, ${ }^{9783}$ Ilidža, ${ }^{9784}$ and Novo Sarajevo. ${ }^{9785}$

3003. The Chamber further recalls that the implementation of the Variant A/B Instructions resulted in the formation of municipal Crisis Staffs and Serb municipal assemblies, and the declaration of Serbian municipalities. ${ }^{9786}$ For example, the Chamber recalls that the decision to form the Serbian Municipality of Zvornik directly cited to the Variant A/B Instructions. ${ }^{9787}$ From late 1991, municipalities established Crisis Staffs and some were re-established or re-formed in around April or May 1992. ${ }^{9788}$ These Crisis Staffs were formed and in existence between 1991 and 1993 in the Municipalities. ${ }^{9789}$

3004. In other municipalities such as Bijeljina, ${ }^{9790}$ Foča, ${ }^{9791}$ Sokolac, ${ }^{9792}$ Banja Luka, ${ }^{9793}$ Sanski Most, ${ }^{9794}$ Hadžići, ${ }^{9795}$ Novi Grad, ${ }^{9796}$ Pale, ${ }^{9797}$ and Vogošća, ${ }^{9798}$ while the Chamber did not receive

P975 (Decision of Serbian Municipal Assembly of Ilidža, 3 January 1992), p. 1; P2591 (Decision regarding the formation of the Serbian Municipality of Zvornik, 27 December 1991), p. 1.

9776

9777

9778

9779

9780

9781

9782

9783

9784

9785

9786

9787

9788

9789

9790

9791

9792

9793

9795

9796

9797

9798
See para. 698.

See para. 796.

See para. 955.

See para. 1109.

See paras. 1231, 1233.

See para. 1439.

See para. 1497.

See para. 1578. See also P2570 (Book of minutes of Prijedor's SDS Municipal Board meetings, 1991), p. 75.

See para. 2123.

See paras. 2245

See paras. 698, 796, 955, 1109, 1231, 1233, 1439, 1497, 1578, 2123. But see Radojica Mlađenović, T. 3662636630, 36680-36682 (5 April 2013). Mlađenović testified that the Serbian Municipality of Foča was not formed pursuant to instructions from the Accused and tried to characterise the Variant A/B document as a recommendation rather than an instruction. However, the Chamber notes that his evidence was marked by multiple contradictions and indicators of extreme evasiveness and does not find his evidence to be reliable in this regard. See also para. 137.

See para. 1233; P2591 (Decision regarding the formation of the Serbian Municipality of Zvornik, 27 December 1991), pp. 1-2.

See para. 137.

See para. 146.

See paras. 605-606.

See para. 845.

See para. 1051.

See paras. 1371-1372. But see D4063 (Witness statement of Novak Kondić dated 23 November 2013), paras. 8-9, 11 (stating that he did not remember seeing or hearing about the Variant A/B Instructions in Banja Luka and that there was only one session of the Crisis Staff in that municipality).

See para. 1934.

See para. 2080.

See paras. 2173, 2180 (referring to creation of the Rajlovac Crisis Staff).

See para. 2303.

See para. 2361. 
direct evidence about the discussion of the Variant A/B Instructions per se, it found that Crisis Staffs and other Bosnian Serb municipal structures were created in late 1991 or early 1992. The Chamber is satisfied given the timing and pattern of events in these municipalities, that these structures were also created pursuant to the Variant A/B Instructions.

\section{$\underline{\text { Instructions }}$}

\section{(c) Monitoring of developments and implementation of}

3005. The Accused also followed up on the implementation of the Variant A/B Instructions. For example in an intercepted conversation on 21 December 1991, the Accused asked Krajišnik "who will implement what we issued last night?" and Krajišnik replied that it would be the Council of Ministers. ${ }^{9799}$ When the Accused observed that the Council of Ministers would not be able to "run from municipality to municipality and say do this, do that", Krajišnik replied: "He won't run either" and the Accused countered with "[B]ut he must run." 9800 From the context of the conversation the Chamber finds that the Accused and Krajišnik were speaking about Jovan Čizmović. His role is discussed in further detail below.

3006. On 26 December 1991, Krajišnik informed the Accused that he had been to a Novi Grad Municipal Assembly session in which voting had been blocked. ${ }^{9801}$ In an intercepted conversation on 27 December 1991, the Accused was asked by Bjelica whether he would come to Sokolac and was informed: "We're doing the job here, everything is normal" and the Accused asked whether Tupajić was doing a good job in the municipality. ${ }^{9802}$

3007. In January 1992, in an intercepted conversation, the Accused asked Miroslav Stanić, the president of the SDS in Foča, about the situation there. ${ }^{9803}$ The Accused specifically asked Stanić "[c]an they introduce independence in Foča", to which Stanić replied that they would not and they had told journalists who visited them that "we'll never allow that". 9804 Stanić proceeded to tell the Accused that they had formed a "Serb municipality and you have that information" and that if "things should go differently on the fifteenth, we'll have a public promotion". 9805 The Accused expressed his agreement and said: "Yes, yes, and take complete control over your affairs"; to which

\footnotetext{
9799 P2550 (Intercept of conversation between Radovan Karadžić and Momčilo Krajišnik, 21 December 1991), p. 3; See also Momčilo Krajišnik, T. 43857 (20 November 2013); P5792 (Intercept of conversation between Radovan Karadžić and Milan Novaković, 19 December 1991), p. 2; Radomir Nešković T. 14272-14273 (6 June 2011).

9800 P2550 (Intercept of conversation between Radovan Karadžić and Momčilo Krajišnik, 21 December 1991 ), p. 3.

9801 P5785 (Intercept of conversation between Radovan Karadžić and Momčilo Krajišnik, 26 December 1991 ), p. 1.

9802 P5783 (Intercept of conversation between Radovan Karadžić and Bjelica, 27 December 1991), p. 2.

9803 P3337 (Intercept of conversation between Miroslav Stanić and Radovan Karadžić, 6 January 1992), p. 2; KDZ239, T. 18909 (15 September 2011).

9804 P3337 (Intercept of conversation between Miroslav Stanić and Radovan Karadžić, 6 January 1992), p. 2; KDZ239, T. 18909-18910 (15 September 2011).
} 
Stanić agreed and said that "everything [is] as it is in the instructions".9806 The Accused expressed his satisfaction and said: “Good, good. That's very important [...] never again in history will they $[\ldots]$ if we give in now, we'll never have a chance and if, if we succeed, we will have succeeded for all times". 9807

3008. The Accused was kept informed of the implementation of the instructions. As such, in an intercepted conversation on 10 February 1992 between the Accused and Vitomir Žepinić, the plan to divide the Bratunac municipality and establish a separate Serb municipality was discussed and encouraged by the Accused. ${ }^{9808}$ Similarly, the previous day, Krajišnik informed the Accused of a meeting he had recently attended in Novi Grad, and the discussions he had about forming the Rajlovac municipality. ${ }^{9809}$

3009. There was direct communication between the municipal Boards and their representatives and the Accused with respect to the implementation of the Variant A/B Instructions and people came from the field to see the Accused. ${ }^{9810}$ Municipal leaders would frequently visit the Accused or would communicate in writing or by phone with respect to municipal issues. ${ }^{9811}$ The Accused also had regular contact with Bosnian Serb municipal leaders and made frequent visits to municipalities. ${ }^{9812}$

9805

P3337 (Intercept of conversation between Miroslav Stanić and Radovan Karadžić, 6 January 1992), p. 2.

P3337 (Intercept of conversation between Miroslav Stanić and Radovan Karadžić, 6 January 1992), p. 2. The Chamber finds that considering the timing of this conversation and the context, the reference to "the instructions" is a reference to the Variant A/B Instructions which were distributed in December 1991. P5 (SDS Instructions for Organisation of Organs of the Serbian People in BiH, 19 December 1991), pp. 6, 10. See also P5617 (Intercept of conversation between Radovan Karadžić and Predrag Radić, 25 December 1991), p. 4. P3337 (Intercept of conversation between Miroslav Stanić and Radovan Karadžić, 6 January 1992), p. 2.

D381 (Intercept of conversation between Radovan Karadžić and Vitomir Žepinić, 10 February 1992), p .2. KDZ605 stated that he heard that Deronjić went to Pale, met with the Accused to "discuss and organise the takeover of Bratunac". However, the Chamber is not satisfied that it can rely on this unsourced second handhear say to establish that this meeting did take place or what was discussed at this meeting.

9809 P5753 (Intercept of conversation between Radovan Karadžić and Momčilo Krajišnik, February 1992), p. 1. Also, sometime in February 1992, Krajišnik informed Koljević about a meeting he was going to attend in Rajlovac "in connection with this one municipality." P5758 (Intercept of conversation between Momčilo Krajišnik and Nikola Koljević, February 1992), p. 1. On 11 May 1992, the Bosnian Serb Assembly adopted a law according to which the municipality of Rajlovac included certain areas. P2315 (Law on Establishment of Rajlovac Municipality, 11 May 1992 and corresponding Decree on promulgation), p. 1; Stojan Džino, T. 29865, 29901 (7 November 2012). See also Adjudicated Fact 2580; P967 (Intercept of conversation between Radovan Karadžić and Ljubo Grković, 22 February 1992).

9810 Radomir Nešković, P2568 (Transcript from Prosecutor v. Krajišnik), T. 16758-16759.

9811 Radomir Nešković, P2568 (Transcript from Prosecutor v. Krajišnik), T. 16632, 16641.

9812 D88 (Shorthand Record of $8^{\text {th }}$ session of SerBiH Assembly, 25 February 1992), p. 44 (the Accused stated he had been to Banja Luka 27 times to deal with some problems with the local leadership). See also P4982 (Witness Statement of Branko Đerić dated 5 April 2012), para. 41 (stating that municipal leaders often visited the Accused and Krajišnik on municipal business); P2332 (Intercept of conversation between Čedo and Radovan Karadžić, 30 May 1992), p. 3; P2534 (Intercepts of conversations between (i) Duško and Radovan Karadžić and (ii) Ljubo Grković and Radovan Karadžić, 19 February 1992, pp. 1, 4-5; P5749 (Intercept of conversation between Radovan Karadžić and Božidar Vučurović, 13 February 1992); P5733 (Intercept of conversation 
3010. The Accused invited representatives of Crisis Staffs to report on their work. ${ }^{9813}$ He was in contact with municipal leaders and questioned them on how the local authorities and structures were functioning. ${ }^{9814}$ The Accused was regularly informed about, and gave instructions with respect to, specific developments at a municipal and regional level. ${ }^{9815}$ When there were problems in a specific municipality, Nešković or other Bosnian Serb officials would be sent by the Accused or by the Main Board. Nešković would then provide a brief verbal report on the work he had done even though the Accused had already been informed from municipal sources about these developments. ${ }^{9816}$

3011. The Accused sometimes intervened personally to resolve problems which arose at a municipal level. ${ }^{9817}$ For example, in around February 1992, the Accused and Krajišnik were involved in resolving an internal conflict in Novo Sarajevo. ${ }^{9818}$ The Accused and Krajišnik attended at least one meeting of the Novo Sarajevo SDS Municipal Board. ${ }^{9819}$ In June 1992, in a letter from Novo Sarajevo Crisis Staff, the Accused was informed about developments in the Serbian Municipality of Novo Sarajevo, including the mobilisation of the population, the formation

between Jovan Tintor and unidentified male, 17 March 1992), p. 1; P2556 (Intercept of conversation between Radovan Karadžić and Nenad Stevandić, 11 January 1992), pp. 5, 12; P5738 (Intercept of conversation between Momčilo Krajišnik and Momčilo Mandić, 4 April 1992), p. 1; P6688 (Interview with Radovan Karadžić in Duga Magazine, 23 May 1992), p. 4; P3104 (Minutes of the 59th session of RS Government, 19 November 1992), pp. 4-5.

9813 Radomir Nešković, P2568 (Transcript from Prosecutor v. Krajišnik), T. 16685.

9814 P2572 (Intercept of conversation between Radovan Karadžić and Miroslav Stančić, 26 September 1991).

9815 P5603 (Intercept of conversation between Mirko Čabrilo and Radovan Karadžić, 3 March 1992); P5741 (Intercept of conversation between Momčilo Mandić and Milenko Kepeš, 5 April 1992), pp. 2, 5; P5730 (Intercept of conversation between Radovan Karadžić and Jovan Čizmović, 1 March 1992), p. 1; P5729 (Intercept of conversation between Biljana Plavšić, Rajko Dukić, and Radovan Karadžić, 2 March 1992), p. 4; P5747 (Intercept of conversation between Radovan Karadžić and Gojko Đogo, 15 February 1992), p. 3.

9816 Radomir Nešković, P2568 (Transcript from Prosecutor v. Krajišnik), T. 16618-16619, 16621-16622, 1662816629, 16738-16739, 16748, 16760, 16762; Radomir Nešković T. 14217 (6 June 2011). See also P2572 (Intercept of conversation between Radovan Karadžić and Miroslav Stančić, 26 September 1991), p. 2; P2571 (Intercepts of conversations between (i) Radovan Karadžić and Radomir Nešković; (ii) Radovan Karadžić and Mišković; and (iii) Radovan Karadžić and Srdo Srdić, 20 December 1991), pp. 1-2. See also D1278 (Transcript of Radomir Nešković's interview with Karadžić's legal associate, 8 October 2009), pp. 12, 46.

9817 Radomir Nešković, P2568 (Transcript from Prosecutor v. Krajišnik), T. 16641. See also D1276 (Minutes of meeting of Novo Sarajevo SDS local boards, 3 February 1992), p. 8.

9818 See para. 2246. There was a debate about the role of the SDS Municipal Board versus other municipal institutions, and a conflict emerged between Prijić, the president of the Municipal Board, and Đurović, the president of the executive board. D1276 (Minutes of meeting of Novo Sarajevo SDS local boards, 3 February 1992), pp. 1-3; Radomir Nešković, P2568 (Transcript from Prosecutor v. Krajišnik), T. 16641, 16672-16679. The Accused and Krajišnik used their authority to defuse the conflict and Đurović held onto his position as "president of the municipal authorities". Radomir Nešković, P2568 (Transcript from Prosecutor v. Krajišnik), T. 16641, 16673. See also Zdravko Šalipur, T. 31640 (18 December 2012).

9819 P2576 (Minutes of $13^{\text {th }}$ session of Novo Sarajevo's SDS Municipal Board, 28 February 1992), p. 3; Radomir Nešković, P2568 (Transcript from Prosecutor v. Krajišnik), T. 16641, 16675; Zdravko Šalipur, T. 31640,31657 (18 December 2012); Branko Radan, T. 31092-31093 (6 December 2012). 
of a Crisis Staff, Executive Board and Municipal Assembly, and was requested to provide further instructions with respect to the formation of war presidencies. ${ }^{9820}$

3012. The Accused sent commissioners to various locations when the municipal authorities were not functioning. ${ }^{9821}$ Jovan Čizmović, who was a member of the Council of Ministers, was appointed as republic level co-ordinator of the activities of the SAOs and the ARK and had the duty of monitoring the implementation of the Variant A/B Instructions. ${ }^{9822}$ In an intercepted conversation on 21 December 1991 the Accused gave Čizmović the "full authorisation to visit all our municipalities" and indicated that the municipalities would identify the problems they were facing and that it would be good to hear advice from Čizmović. ${ }^{9823}$

3013. In another intercepted conversation on 16 January 1992, Čizmović reported to the Accused that he had spoken to Bijeljina and that they were "prepared for full-cooperation" and that he had prepared a questionnaire for Northern Bosnia to allow them to identify what they had managed to do and how far they had come and to what extent they were prepared to "implement the first level of the instruction" and any problems they were facing or needed help with. ${ }^{9824}$ Čizmović indicated that he was prepared to form a team with the help of the Accused to provide professional help with any problems the municipalities faced. ${ }^{9825}$

3014. In another intercepted conversation on 22 January 1992 between the Accused and Čizmović, there was discussion on sending experts and teams to assist municipalities to deal with problems and Čizmović said: "It's the same situation with Bijeljina [...] I've finished with them, too". 9826 Čizmović reported about measures taken in Doboj and Bijeljina and indicated that he still

\footnotetext{
9820 D885 (Letter from Novo Sarajevo Crisis Staff to Radovan Karadžić, 5 June 1992), pp. 1, 3-4 (indicating that "mobilisation was carried out in various ways personally and directly, through SDS [...] local boards and local communes, with the help of police, etc.”). See also P2575 (Excerpt from session of Novo Sarajevo's Crisis Staff, 23 December 1991).

9821 Momčilo Mandić, C2 (Transcript from Prosecutor v. Krajišnik), T. 8633-8634.

9822 D86 (Shorthand Record of $4^{\text {th }}$ Session of SerBiH Assembly, 21 December 1991), p. 34; P1345 (Minutes of $4^{\text {th }}$ session of SerBiH Assembly, 21 December 1991), p. 6. See also P2536 (Patrick Treanor's expert report entitled “The Bosnian Serb Leadership 1990-1992", 30 July 2002), p. 162; Patrick Treanor, T. 14030-14031 (1 June 2011).

9823 P2551 (Intercept of conversation between Radovan Karadžić and Jovan Čizmović, 21 December 1991), p. 3. See also P5770 (Intercept of conversation between Radovan Karadžić and Jovan Čizmović, 10 January 1992), p. 4.

9824 P2552 (Intercept of conversation between Radovan Karadžić and Jovan Čizmović, 16 January 1992), p. 7. See also Patrick Treanor, T. 14031 (1 June 2011).

9825 P2552 (Intercept of conversation between Radovan Karadžić and Jovan Čizmović, 16 January 1992 ), p. 7.

9826 P2553 (Intercept of conversation between Radovan Karadžić and Jovan Čizmović, 22 January 1992), p. 5.
} 
had to "see about Birač, Romanija and Herzegovina. [...] But I'll see to it that that should be finished within this short time, too". 9827

3015. In another phone conversation, Čizmović indicated, and the Accused, agreed that "movements which are taking place here shouldn't be seen as some sort of secession" but as an alternative "to a situation, if there should be a need for a reaction, that everything should be on a hair-trigger". ${ }^{9828}$ The Accused said that it would allow them to react within two hours. ${ }^{9829}$ The Accused responded positively to Čizmović's reports that: "Tonight we also established the Crisis Staff, which will act when nobody can get together, when they can assemble more quickly [...] So, that's working. Because the objective must be carried out, instructions must be carried out". 9830 At the $6^{\text {th }}$ session of the Bosnian Serb Assembly on 26 January 1992, Čizmović spoke and called for the urgent operationalisation and declaration on the establishment of the $\mathrm{SerBiH}$ and stated that the "[t]asks set out in the instructions of 19 December 1991 should be carried out". 9831

3016. In February 1992, the Accused addressed the Bosnian Assembly and stressed the importance of co-operation with regional structures and leaders and the development of their strategic objectives. ${ }^{9832}$ This included creating a questionnaire to be used to check the progress of municipalities with respect to "preparations". ${ }^{933}$ The Accused spoke about Čizmović visiting municipalities, including Bijeljina and Banja Luka, with a questionnaire to check on preparations at the municipality level and to check on their loyalty. ${ }^{9834}$

3017. In March 1992, the Accused wrote to all the presidents of the municipalities to inform them that a Republic Operations Centre had been established and that the task of the municipalities was to urgently connect their own information centres with district centres, to provide personnel and ensure that other requirements were met so as to monitor the situation on the ground. ${ }^{9835}$ The Accused noted that the district centres were already connected by telephone and radio communication with the republic centres and it was also necessary to co-operate with the SJBs

\footnotetext{
9827 P2553 (Intercept of conversation between Radovan Karadžić and Jovan Čizmović, 22 January 1992), pp. 5-6; Patrick Treanor, T. 14034-14035 (1 June 2011).

9828 P2553 (Intercept of conversation between Radovan Karadžić and Jovan Čizmović, 22 January 1992), p. 6.

9829 P2553 (Intercept of conversation between Radovan Karadžić and Jovan Čizmović, 22 January 1992), p. 6.

9830 P2553 (Intercept of conversation between Radovan Karadžić and Jovan Čizmović, 22 January 1992), p. 7.

9831 P1349 (Transcript of $6^{\text {th }}$ session of SerBiH Assembly, 26 January 1992), p. 14.

9832 P1351 (Transcript of $7^{\text {th }}$ session of SerBiH Assembly, 15 February 1992), pp. 58-59; D88 (Shorthand Record of $8^{\text {th }}$ session of SerBiH Assembly, 25 February 1992), pp. 19-20, 45; D90 (Shorthand Record of $11^{\text {th }}$ session of SerBiH Assembly, 18 March 1992), p. 43; D304 (Shorthand Record of 14 ${ }^{\text {th }}$ session of RS Assembly, 27 March 1992), pp. 9, 20.

9833 P1351 (Transcript of $7^{\text {th }}$ session of SerBiH Assembly, 15 February 1992), p. 59.

9834 P1351 (Transcript of $7^{\text {th }}$ session of SerBiH Assembly, 15 February 1992), p. 59.

9835 P5575 (Letter from Radovan Karadžić to Presidents of all Municipalities, 23 March 1992).
} 
continuously to allow for the transmission and receipt of information 24 hours a day. ${ }^{9836}$ The Accused stated that consultative meetings would soon be held to go over technical and organisational issues related to the work of municipal and district centres. ${ }^{9837}$

3018. Municipal leaders also requested assistance from the higher level Bosnian Serb institutions. For example, in July 1992, the President of the Executive Committee in Foča informed Đerić that the political and security situation in Foča remained critical and requested assistance to find the best solution. ${ }^{9838}$ Similarly, in September 1992 the Command of the $2^{\text {nd }}$ Romanija Motorised Brigade reported to the Accused about disputes and difficulties in co-operation with the civilian authorities in Sokolac. ${ }^{9839}$ The Accused was also informed of the situation with regard to the institutions in Bratunac and, for example, in a speech to the Bosnian Serb Assembly in September 1992 he spoke about the need to ensure the functioning of authorities. ${ }^{9840}$

3019. The Chamber received evidence that described disruptions of road systems at different locations or breakdown of telecommunications between the RS institutions and the local levels, from March until December 1992. ${ }^{9841}$

3020. However, the consistent communications between different levels of the SDS party and RS institutions, both regional and municipal, as depicted above, including other evidence, ${ }^{9842}$ clearly

9836 P5575 (Letter from Radovan Karadžić to Presidents of all Municipalities, 23 March 1992) p. 1.

9837 P5575 (Letter from Radovan Karadžić to Presidents of all Municipalities, 23 March 1992) p. 2.

9838 P2809 (Foča Municipal Assembly dispatch to SerBiH Prime Minister, 26 July 1992).

9839 D3232 (Letter from $2^{\text {nd }}$ Romanija Motorised Brigade to Radovan Karadžić, 3 September 1992), p. 1.

9840 D456 (Transcript of $20^{\text {th }}$ session of RS Assembly, 14-15 September 1992), p. 18. See also D1643 (Intercept of conversation between Radovan Karadžić and Zvonko Bajagić, 4 September 1991), pp. 1-4, 6-7.

9841 See, e.g., Momčilo Mandić, T. 4962-4963, 4969-4971 (8 July 2010), T. 5194-5195 (15 July 2010); D3105 (Witness statement of Slobodan Avlijaš dated 9 March 2013), para. 9; D4147 (Information of RS MUP, 7 September 1993), p. 1; D3917 (Witness statement of Čedomir Kljajić dated 30 July 2013), para. 12; Čedomir Kljajić, T. 42231 (30 July 2013); Goran Mačar, T. 39518 (7 June 2013); D3197 (Witness statement of Dobrislav Planojević dated 23 March 2013), para. 20; D3695 (Witness statement of Bogdan Subotić dated 16 June 2013), paras. 57, 92; Momčilo Krajišnik, T. $43314-43315$ (12 November 2013); D3750 (Intercept of conversation between Tomislav Kovač and Milenko Karišik, 4 May 1992), p. 1; Cvijetin Simić, T. 35713 (20 March 2013); KW317, T. 39412 (6 June 2013).

9842 See, e.g., D4147 (Information of RS MUP, 7 September 1993), p. 1 (stating that "with a great deal of work and effort [breakdown of every form of communication] was gradually overcome and remedied"); D3197 (Witness statement of Dobrislav Planojević dated 23 March 2013), para. 20 (stating that since there was a communication breakdown a dispatch was conveyed in person to Bratunac); D3695 (Witness statement of Bogdan Subotić dated 16 June 2013), paras. 86, 91-92 (while stating that they had poor communication, Subotić also mentioned efforts to remedy it and that "ministers were reduced to telephones or written communications sent by messengers or couriers”); Slobodan Avlijaš, T. 35149-35153 (11 March 2013); P6194 (SerBiH Government request to Foča Crisis Staff, 23 May 1992); Predrag Radić, P1 (Transcript from Prosecutor v. Krajišnik), T. 7530-7536; D414 (Minutes of $19^{\text {th }}$ session of Government of SerBiH, 2 June 1992), p. 2; P1478 (Ratko Mladić's notebook, 27 May-31 July 1992), p. 246 (showing that the Accused and Mladić met with civilian and military representatives from municipalities including Zvornik, Vlasenica, and Bratunac); P1105 (Transcript of $22^{\text {nd }}$ session of RS Assembly, 23-24 November 1992), p. 105 (while deputies acknowledged that there were periods when telephone lines were down and that mail did not function, during those periods "it was necessary to go to the municipalities to see what the situation was like and report to the Presidency"); Momčilo Mandić, T. 5109 (14 July 2010) referring to D440 (Minutes of $15^{\text {th }}$ session of Presidency of SerBiH, 6 July 1992), p. 2 
demonstrate that notwithstanding disruptions in telecommunications from March until December 1992, it was still possible for the leadership of the SDS, including the Accused, and RS institutions to communicate with lower levels and that generally obstacles were overcome. ${ }^{943}$ More specifically, with respect to the RS MUP, CSBs, and SJBs, there were always communication channels with most communication by fax and telephone and daily communication between the CSB and SJBs. If there were limited interruptions, for example if the telephone lines were down, there would be communication by courier. ${ }^{9844}$

\section{(d) Activation of second level of the Instructions}

3021. In January 1992, in an intercepted conversation, the Accused spoke about "level two" of "that paper of ours" and the importance of quickly taking over "real functions". 9845

(commissioners were introduced to establish a link between the central organs and the municipalities and as a way of exercising "control over the municipal organs on the ground"); Momčilo Krajišnik, T. 43314 (12 November 2013) (while testifying about the communication problems in 1992, the witness stated that throughout 1992 telephones, faxes and printers "worked with lots of difficulties"); P956 (Transcript of $16^{\text {th }}$ session of SerBiH Assembly, 12 May 1992), e-court pp. 8, 21 (indicating that the Accused was aware of developments in municipalities such as Foča, Zvornik and Višegrad, and a deputy of the Bosnian Serb Assembly reported on his visit to Bosanski Novi the day before and stated that it was "sealed off".); Radomir Nešković T. 14364-14365 (7 June 2011) (testifying about different modes of communication when there was an absence of telephone contact in Novo Sarajevo between 10 April and 10 May 1992); P2752 (SerBiH MUP order, 17 May 1992), p. 1 (indicating that Mićo Stanišić issued an order to the Security Service Centres in Banja Luka, Bijeljina, Doboj, Sarajevo and Trebinje municipalities to send reports via "courier or coded"); Neđeljko Prstojević, T. 13261, 13264 (11 March 2011) (describing a meeting in or around September 1992 in Jahorina to which the state and political leadership, including the Accused, and all municipal presidents and presidents of Executive Boards attended); P2794 (Witness statement of Ranko Vuković dated 24 May 2011), pp. 3-5 (testifying that following the establishment of the Republican Communications Centre in Pale in April 1992, there was communication between the municipalities, the MUP, and the VRS, which included telephone, short wave and ultra-short wave radio, fax machines, teleprinters, radio relay communications, wire communications, and, when other systems were not working, a courier system. The Chamber notes that Mlađenović testified that communications with Pale were non-existent, however, it does not find his evidence to be reliable in this regard. In reaching this conclusion the Chamber notes multiple contradictions and extreme evasiveness in Mlađenović's evidence. More specifically Mlađenović testified that while communication was non-existent they did receive some communication including orders and warnings from the Accused to adhere to the Geneva Conventions. Radojica Mlađenović, T. 36612 (4 April 2013).

9843 See for example P2240 (Intercept of conversation between Momčilo Krajišnik, Branko Đerić, and Milenko Karišik, 7 May 1992); P2220 (Intercept of conversation between Milinković and Momčilo Krajišnik, 21 April 1992); P5708 (Intercept of conversation between Momčilo Krajišnik and unidentified male, 21 April 1992); P5604 (Intercept of conversation between Gvozden and Radovan Karadžić, 3 March 1992), p. 3; D885 (Letter from Novo Sarajevo Crisis Staff to Radovan Karadžić, 5 June 1992), p. 3; P2625 (Minutes of $11^{\text {th }}$ session of SerBiH Government, 18 May 1992), p. 2; P3109 (Minutes of the $8^{\text {th }}$ extraordinary session of RS Government, 1 September 1995), pp. 2-3. The Chamber notes evidence suggesting that there were few or no telephone lines available for communication between Novo Sarajevo and Pale during the war. Zdravko Šalipur, T. 31656-31657 (18 December 2012); D1278 (Transcript of Radomir Nešković's interview with Karadžić's legal associate, 8 October 2009), p. 32. However, considering the communications above, the Chamber finds that even if there was some disturbance in the telephone lines during the war, it was still possible to establish a line of communication between Novo Sarajevo and Pale.

9844 Milorad Davidović, T. 15460-15463 (24 June 2011). See also P2850 (Fax of Bijeljina CSB, 29 April 1992); D3695 (Witness statement of Bogdan Subotić dated 16 June 2013), para. 92; P3050 (Minutes of joint meeting of SNB and SerBiH Government, 15 April 1992), p. 1; P2851 (Fax of Bijeljina CSB, 24 April 1992); P2752 (SerBiH MUP order, 17 May 1992), p. 1.

9845 P2596 (Intercept of conversation between Radovan Karadžić and "Miroslav", 7 January 1992), p. 7. 
3022. The Chamber recalls that on 14 February 1992, the Accused at an extended session of the SDS Main Board and Executive Board activated the second level of the Variant A/B Instructions. $^{9846}$ The presidents of SDS municipal boards, presidents and members of regional boards, presidents of assemblies, and executive boards of municipalities were invited to this meeting. ${ }^{9847}$ This discussion and instruction to implement level two were conveyed to SDS structures at a municipal level. ${ }^{9848}$

3023. The Accused called for the "second level" to be introduced and to "intensify the functioning of the government at any cost and on every single millimetre of our territory". ${ }^{9849}$ At this meeting, the Accused said that they needed to be wise and united "in order to take the last drop of the power into our hands, in a humane way of course, carry it out in a humane way, a just way towards both Muslims and Croats who live there, that is particularly important, that there would be no fleeing from our areas". ${ }^{950}$ The Accused in this regard noted that "our image with foreign monitors" had to change and if Bosnian Serbs defended themselves too aggressively they would "lose an awful lot of points". ${ }^{9851}$ The Accused said that "stage number two should also be converted, the one we've talked about, the one you have [...] in order to have authorities in the field functioning, that a bird cannot fly over really." 9852

3024. At this session, the Accused spoke about the Bosnian Serb strategic objectives. ${ }^{985}$ He also noted the importance of international opinion and sympathy and that they should not be the aggressors, and stated that they "seek nothing that belongs to somebody else" and that they should defend what was theirs but not "in an aggressive way, in a combat way" but defend it with firm

9846 P12 (Extended session of Main and Executive Boards of the SDS, 14 February 1992), pp. 5-7, 17, 24; Simo Mišković, T. 45373-45374 (18 December 2013); P5516 (Minutes of Meeting of SDS Prijedor Municipal Board, 17 February 1992), p. 1. See also P6588 (Receipt of Holiday Inn Hotel, 14-15 February 1992); Adjudicated Fact 1010.

9847 P12 (Extended session of Main and Executive Boards of the SDS, 14 February 1992), p. 1. Vučurević stated that he does not remember any reference made by the Accused to the Variant A./B Instructions. The only variants that he knew of were: first, "[i]f we cannot live together, we should split in peace", and the second "if everything else fails" to "defend ourselves". Božidar Vučurević, T. 35985-35986 (25 March 2013). See D3146 (Witness statement of Božidar Vučurević, 22 March 2013), para. 25. However, the Chamber does not find his evidence to be reliable in this regard. In reaching this conclusion the Chamber concluded that the evidence of the witness was marked by insincerity, contradictions, and bias.

Simo Mišković, T. 45373-45374 (18 December 2013); P5516 (Minutes of Meeting of SDS Prijedor Municipal Board, 17 February 1992); P6587 (Excerpts from Simo Mišković's testimony from Prosecutor v. Stanišić \& Župljanin), T. 15187-15188; P2597 (Minutes of meeting of Bratunac's SDS Municipal Board, 24 February 1992), p. 1; P4374 (Witness statement of Milenko Katanić dated 11 October 2011), para. 18; KW317, T. 39337 (5 June 2013).

9849 P12 (Extended session of Main and Executive Boards of the SDS, 14 February 1992), p. 24. See also Predrag Radić, P1 (Transcript from Prosecutor v. Krajišnik), T. 7364-7366.

9850 P12 (Extended session of Main and Executive Boards of the SDS, 14 February 1992), p. 5.

9851 P12 (Extended session of Main and Executive Boards of the SDS, 14 February 1992), p. 13.

9852 P12 (Extended session of Main and Executive Boards of the SDS, 14 February 1992), p. 17.

9853 P12 (Extended session of Main and Executive Boards of the SDS, 14 February 1992), pp. 11-12. 
conviction that their rights had been repeatedly violated and that they would be dominated in a unitary BiH. ${ }^{9854}$ In contrast the Accused also stated that he and the Serbs wanted to "let everything go to fucking hell and that we take the express way" but that they needed to find a balance between power and tactfulness in order to achieve their goal. ${ }^{9855}$ For example he noted that for international political reasons they could not organise their assembly "without a major provocation" and that they knew exactly where they were heading. ${ }^{9856}$

3025. The Accused emphasised that he, Koljević and Krajišnik were of the opinion that "it would be more important to gain the real situation, the factual situation on the ground" for the purposes of international negotiations. $^{9857}$ The Accused also emphasised that they would have a right to "introduce the stage number two in functioning of your areas and, relying on your own forces, to absolutely defend yourselves from the independent $\mathrm{BiH}$ ". 9858 He also explained that according to their "scheme" there would be a municipal board and a local board structure so that not "a single Serbian house should be left without contacts with the party". 9859 The Accused explained that they had their "moves ready", that the deputies knew about it and that whenever the Bosnian Muslims did something foolish they would "disclose our next move, which is ten times more powerful than theirs". 9860

3026. Mlađenović at this meeting spoke on behalf of the Bosnian Serb Executive Committee of Foča and reported that "we did everything that the centre had requested us to do, and considering the instructions we received in this field when setting up the Serbian Assembly and Executive Committee". ${ }^{9861}$ Mlađenović continued by saying that "we wish to finally round up the Serbian territory of Foča Municipality" within the SAO of Herzegovina and that he found it necessary to "establish Serbian municipalities regardless of the borders of existing municipalities". 9862

3027. Following the activation by the Accused of the second level of the Variant A/B Instructions, the Chamber recalls that, for example, on 24 February 1992 the SDS Municipal Board in Bratunac

\footnotetext{
9854 P12 (Extended session of Main and Executive Boards of the SDS, 14 February 1992), p. 14. Ristanić testified that the Strategic Goals were only put in a document form later, but these objectives were to be achieved in peaceable conditions. Đorđe Ristanić, T. 16761-16762 (18 July 2011). See also Milorad Dodik, T. 36846 (9 April 2013).

9855 P12 (Extended session of Main and Executive Boards of the SDS, 14 February 1992), p. 26.

9856 P12 (Extended session of Main and Executive Boards of the SDS, 14 February 1992), p. 26.

9857 P12 (Extended session of Main and Executive Boards of the SDS, 14 February 1992), p. 5.

9858 P12 (Extended session of Main and Executive Boards of the SDS, 14 February 1992), p. 7.

9859 P12 (Extended session of Main and Executive Boards of the SDS, 14 February 1992), p. 10.

9860 P12 (Extended session of Main and Executive Boards of the SDS, 14 February 1992), p. 25.

9861 P6264 (Excerpt from transcript of extended session of SDS Main Board and Executive Board, 14 February 1992, with audio), p. 1; Radojica Mlađenović, T. 36631-36632 (5 April 2013).

9862 P6264 (Excerpt from transcript of extended session of SDS Main Board and Executive Board, 14 February 1992, with audio), p. 2.
} 
discussed the implementation of this second level. ${ }^{9863}$ On 2 March 1992, the SDS Municipal Board of Foča sent a letter addressed to the office of the President of the SDS Crisis Staff in Sarajevo indicating that they were facing pressure in Foča but they were "ready to carry out any order". ${ }^{9864}$ The Chamber also recalls that the Serbian Municipality of Zvornik was proclaimed on 15 March 1992 and decided to join the SAO Majevica-Semberija. ${ }^{9865}$ On 13 March 1992, the President of the Executive Board of the SDS required all SDS Municipal Board to assess the possibility of establishing Serbian municipalities and the projected territory that would become part of these Serbian municipalities. ${ }^{9866}$

\section{(e) Activation of Crisis Staffs and other structures}

3028. On 4 April 1992, the Accused, as President of the SNB, issued an announcement that the Crisis Staffs should be activated. ${ }^{9867}$ The Accused, made an announcement that the "rump" presidency of $\mathrm{BiH}$, operating without any Serbs, issued highly irresponsible and illegal instructions to raise the TO, civilian protection, and reserve police and that by doing so, the "rump" Presidency acknowledged the collapse of the constitutional and legal order and instigated chaos, violence, and civil war. ${ }^{9868} \mathrm{He}$ called upon the population to disregard these moves by the BiH Presidency and ordered that Crisis Staffs and Serb TO be activated in response to Bosnian Muslim mobilisation in specified areas with the purpose of maintaining peace, order, and safety of civilians of all nationalities. $^{9869}$

\footnotetext{
$9863 \quad$ See para. 701.

9864 P5515 (Letter from SDS Municipal Board of Foča to SDS Crisis Staff in Sarajevo, 2 March 1992).

9865 See para. 1235; D1693 (Decision of Zvornik Assembly, 15 March 1992), p. 1. See also Marinko Vasilić, T. 39920-39922 (13 June 2013); D3654 (Witness statement of KW317 dated 26 September 2012), paras. 28-29 (under seal); D3656 (Decision of Zvornik Municipal Assembly, 15 March 1992).

9866 D1187 (Letter from SDS Executive Board to all SDS Municipal Boards, 13 March 1992).

9867 D394 (Announcement of SNB, 4 April 1992). See also Dorothea Hanson, T. 14525 (9 June 2011); P2589 (Dorothea Hanson's expert report entitled "Bosnian Serb Crisis Staffs, War Presidencies and War Commissions 1991-1995”, 10 September 2009), para. 36. See para. 141. Šojić testified that Crisis Staffs were only established following the example of the SDA and HDZ and not pursuant to any instructions and that they were formed spontaneously at the initiative of local authorities and they were not controlled at the republican level. Dragan Šojić, T. 31752-31754 (19 December 2012). However, the Chamber notes that the evidence of Šojić was marked by evasiveness, contradictions, and indicators that he was trying to mislead the Chamber. The Chamber therefore does not find his evidence to be reliable in this regard.

9868 D394 (Announcement of SNB, 4 April 1992), p. 1; Momčilo Mandić, C3 (Transcript from Prosecutor v. Stanišić and Župljanin), T. 9705-9706. See also D392 (Conclusions of SRBiH Presidency, 4 April 1992); D393 (Minutes of $65^{\text {th }}$ session of SRBiH Presidency, 4-8 April 1992).

9869 D394 (Announcement of SNB, 4 April 1992), p. 2; Momčilo Mandić, C3 (Transcript from Prosecutor v. Stanišić and Župljanin), T. 9707. Subotić stated that TO units were also "self-organised" and nobody had an overview of how many local TO units had been formed and they were not under anyone's command until the VRS was formed. Subotić also stated that the Accused did not have effective command and control over the TO in the period from 1 April to 12 May 1992. D3695 (Witness statement of Bogdan Subotić dated 16 June 2013), paras. 52-54, 57-59, 68, 118; Bogdan Subotić, T. 40125-40126 (20 June 2013). However, the Chamber notes that the evidence of Subotić was marked by evasiveness, contradictions, and indicators of partisanship and bias. The Chamber therefore does not find his evidence to be reliable in this regard. For further discussion on the
} 
3029. On 26 April 1992, Đerić on behalf of the Bosnian Serb Government issued instructions for the work of Crisis Staffs in the SerBiH. ${ }^{9870}$ These instructions provided that in wartime conditions the Crisis Staffs would take over "all the prerogatives and functions of the municipal assemblies" when they were not in a position to meet. ${ }^{9871}$ The Chamber recalls that the 26 April 1992 instructions provided that the Crisis Staffs "shall co-ordinate governmental functions for the purpose of the defence of territory, safety of the population and its property, establishment of authority and organisation of all other aspects of life and work". 9872 They also provided that the Crisis Staff was to create conditions to allow the municipal executive board to exercise power. ${ }^{9873}$ The Crisis Staffs were also required to work in accordance with the Constitution, law and decisions of the Bosnian Serb Assembly, the Bosnian Serb Government and the Presidency. ${ }^{9874}$

3030. According to the 26 April 1992 instructions, the Crisis Staffs were "obliged to gather information on the situation in the field and notify and consult the competent authorities in $[\mathrm{SerBiH}]$, i.e. commissioners of the Government appointed for the areas and regions especially threatened by war". ${ }^{9875}$ These same instructions obligated the Crisis Staff to ensure the safe passage of humanitarian aid convoys and to act humanely towards non-combatants, the wounded, and POWs. ${ }^{9876}$

3031. The Accused gave explicit instructions on how the Crisis Staffs and the TO would be structured, including who would be the highest ranking officials in these structures namely the presidents of municipalities and executive boards. ${ }^{9877}$ For example at a meeting of the SNB on 27 April 1992, it was concluded that "comprehensive instructions for crisis staffs should be drafted in which the manner of political work on the ground and organisation of the functioning authorities will be presented". ${ }^{9878}$ The SNB also concluded that material and equipment would be provided for

Accused's involvement with mobilisation of the TO, see Section IV.A.3.iii: Authority over military and police forces acting in $\mathrm{BiH}$.

9870 P2717 (SerBiH Government instructions for Crisis Staffs, 26 April 1992).

9871 P2717 (SerBiH Government instructions for Crisis Staffs, 26 April 1992), para. 1.

9872 See para. 143. P2717 (SerBiH Government instructions for Crisis Staffs, 26 April 1992), para. 3. In these instructions, the Bosnian Serb Government mandated that all Crisis Staffs include the commander of the TO Staff. P2717 (SerBiH Government instructions for Crisis Staffs, 26 April 1992), para. 2. The instructions also stated that the Crisis Staffs were to "create all the conditions for the life and work of members of the JNA". P2717 (SerBiH Government instructions for Crisis Staffs, 26 April 1992), para. 8. P2717 (SerBiH Government instructions for Crisis Staffs, 26 April 1992), para. 3.

9874 P2717 (SerBiH Government instructions for Crisis Staffs, 26 April 1992), para. 6.

9875 P2717 (SerBiH Government instructions for Crisis Staffs, 26 April 1992), para. 11.

9876 D407 (Excerpts from instructions of SerBiH Government for municipal crisis staffs, 26 April 1992), p. 2.

9877 D304 (Shorthand Record of $14^{\text {th }}$ session of RS Assembly, 27 March 1992), pp. 20-21. See para. 140.

9878 D406 (Minutes of meeting of SNB and SerBiH Government, 27 April 1992), p. 2. See para. 142. Subotić stated that Crisis Staffs were operating independently and that this decision related to the provision of instructions relating to respect for international humanitarian law and the laws and customs of war. D3695 (Witness statement of Bogdan Subotić dated 16 June 2013), para. 270. The Chamber does not find Subotić's 
the defence of the SerBiH and that the Crisis Staffs needed to inform the government about developments. $^{9879}$ The Accused emphasised that these steps were for defensive purposes and that peace was in their interests and would benefit them politically. ${ }^{980}$ He also stressed that the Bosnian Muslims did not have the forces required to take-over the extensive territory held by Bosnian Serbs and these "Serbian areas" would never be incorporated in their state. 9881

3032. Crisis Staffs operated to some extent independently in each municipality, but ultimately they had direct contact with the Presidency and followed the SDS party line. ${ }^{9882}$ For example in Hadžići, the Crisis Staff President, Ratko Radić had a very good relationship with the Accused—he often visited Pale and got instructions from the Accused. ${ }^{9883}$ The Chamber also recalls that all important decisions of the SDS Main Board that needed to be implemented in Sokolac were sent to the SDS Municipal Board of Sokolac and the Crisis Staff was informed of these decisions. ${ }^{9844}$ The Chamber also recalls that the Rogatica Crisis Staff for example had direct, oral and written contact with the Presidency and ministries of the SerBiH, the Government, the army, and the police. ${ }^{9885}$

3033. Similarly in Sanski Most, policy formulated by the SDS leadership at the republican level would come down to the municipal Crisis Staff to implement. ${ }^{986}$ The Sanski Most Crisis Staff was directly subordinated to the ARK Crisis Staff, which was subordinated to the Bosnian Serb leadership, including the Accused. ${ }^{9887}$ The Chamber notes that Vlado Vrkeš, the deputy president of the Crisis Staff, was in charge of implementing policies from the Republic level ${ }^{9888}$ and was close to the Accused. ${ }^{9889}$ In April 1992, Kuprešanin said in an intercepted conversation to General Kukanjac that they were waiting for the Accused to return from Europe to tell them what to do next

characterisation of this conclusion to be reliable. In reaching that conclusion the Chamber refers to its credibility assessment in fn. 9869.

(1)

1296 (Witness statement of Tihomir Glavaš dated 13 February 2011), para. 25; Tihomir Glavaš, T. 1197611978 (16 February 2011). The Chamber notes however, that Radić sometimes would push ideas by exaggerating the extent to which the Accused had agreed to them. Tihomir Glavaš, T. 11796 (14 February 2011), T. 11949 (16 February 2011). The Chamber places no weight on Glavaš’s impression that the Accused left the municipalities of Ilidža and Hadžići to care for themselves.

9884 See para. 1051.

9885 See para. 957.

9886 KW540, D4449 (Transcript from Prosecutor v. Stanišić \& Župljanin), T. 3340-3341 (under seal). See, e.g., P3399 (Conclusions of meeting of Sanski Most Crisis Staff, 20 April 1992).

9887 KDZ490, T. 20282 (20 October 2011) (closed session); P3634 (Witness statement of KDZ490, undated), pp. 8183, 103 (under seal); P3634 (Witness statement of KDZ490, undated), pp. 11, 57, 66, 81-83 (under seal).

9888

9889 P3634 (Witness statement of KDZ490, undated) (under seal), pp. 103-104.

KDZ490, T. 20282 (20 October 2011) (closed session); P3634 (Witness statement of KDZ490, undated), p. 9 (under seal). 
and "when [the Accused] comes whatever he tells us we will do. He is now for us the supreme commander and we have no other commander". 9890

3034. As found above, by early April 1992 the SNB was issuing instructions to, and receiving reports from, municipal Crisis Staffs and TOs. ${ }^{981}$ On 28 April 1992, Branko Đerić and the Accused attended a meeting of the SNB where the reports on the work of Crisis Staffs and municipal organs of government were adopted. At this same meeting there was also discussion of the need to keep the Crisis Staffs more fully informed about developments and for the Crisis Staffs to also inform the Bosnian Serb Government about developments. ${ }^{9892}$

3035. In this regard the Chamber found that the Bijeljina Crisis Staff kept the SDS Main Board informed of its activities. ${ }^{983}$ In addition the Chief of the Bijeljina SJB reported to Mićo Stanišić on the situation in the municipality, ${ }^{9894}$ and an almost daily report system was operating between the Bijeljina CSB and the Bosnian Serb MUP. ${ }^{985}$ Similarly the Chamber found that the Rogatica Crisis Staff had direct, oral, and written contact with the Presidency and ministries of the SerBiH, the Government, the army, and the police. ${ }^{996}$ For example, during negotiations in April and May 1992 between the Rogatica Crisis Staff and the Bosnian Muslim leadership regarding the demarcation of territory and division of power within the municipality, the SDS representatives said they would report to the Main Board of the SDS in Pale. ${ }^{989}$ The Chamber also found that in

9890 P987 (Intercept of conversation between Milutin Kukanjac and Vojo Kuprešanin, 27 April 1992), p. 2.

9891 See para. 92.

9892 P2627 (Minutes of meeting SNB and SerBiH Government, 28 April 1992), p. 1. See also Dorothea Hanson, T. 14558 (9 June 2011). The Chamber notes that Hanson testified about the involvement and role of Crisis Staffs in take-overs and the arming of the population, connections between the Crisis Staffs and the military and police and detention of non-Serbs: However, the Chamber considers that these conclusions fall outside the scope of her expertise and will not rely on her evidence in this regard. Dorothea Hanson, T. 14563-14564, 1456614567, 14577-14579, 14582 (9 June 2011).

9893 See para. 606. For example, see P2626 (Report of Bijeljina Crisis Staff, 1 April 1992) (in which the Bijeljina Crisis Staff reported to the SDS Main Board on the situation in the municipality).

9894 P2629 (Report of Bijeljina SJB, undated).

9895 P2851 (Fax of Bijeljina CSB, 24 April 1992); Milorad Davidović, T. 15462-15463 (24 June 2011); P2752 (SerBiH MUP order, 17 May 1992), p. 1. The Chamber notes the evidence of Kezunović that, considering power cuts and continuous interruption in communication, he did not know whether the CSB from locations such as Bijeljina were able to deliver daily reports to the ministry. Dragan Kezunović, T. 15067-15069 (21 June 2011). However, considering the evidence presented and Kezunović's unsubstantiated speculation, the Chamber gives little weight to his evidence in this regard. Cvijetin Simić testified that because of the conflicts the whole area of Bijeljina did not have telephones working for several months and that it was cut off from the outside world until May 1992. Cvijetin Simić T. 35713 (20 March 2013). The Chamber finds that it stands in contradiction with accepted evidence that demonstrates that communication existed. Further, the Chamber found that Simić's evidence was marked by indicators which led to the conclusion that he withheld information from the Chamber, was evasive, and lacked sincerity. The Chamber shall therefore no rely on this portion of this evidence.

9896 See para. 957.

9897 P2835 (Report of Rogatica Crisis Staff, April - June 1992), p. 2; KDZ606, T. 18265-18267 (2 September 2011 ) (closed session); P3279 (Witness statement of KDZ606 dated 1 September 2011), para. 71 (under seal); D2950 (Witness statement of Sveto Veselinović dated 15 February 2013), para. 14. The Chamber received Defence evidence that the Bosnian Serb authorities wanted to avoid the conflicts which had already broken out in the 
Sokolac, all important decisions of the SDS Main Board that needed to be implemented in Sokolac were sent to the SDS Municipal Board of Sokolac and the Crisis Staff was informed of these decisions. $^{9898}$

3036. In addition Crisis Staffs were also established in SAOs, including the SAO Semberija and Majevica, ARK, and SAO Birač. ${ }^{989}$ The Chamber recalls that the ARK Crisis Staff was formally established on 5 May 1992 by a decision of the ARK Executive Council; however, it had been functioning since January 1992..$^{990}$ On 9 July 1992, the ARK Crisis Staff was renamed the ARK War Presidency. ${ }^{9901}$

3037. The Chamber recalls its finding that the ARK Crisis Staff acted as an intermediary regional body between the republican-level authorities and the ARK Municipalities by co-ordinating the implementation of instructions sent by the republic-level authorities in the ARK Municipalities. ${ }^{9902}$ In addition, municipal Crisis Staff presidents in the ARK regularly gave reports to the ARK Crisis Staff with respect to events within their area of responsibility and received directives from the ARK Crisis Staff. ${ }^{9903}$ The Chamber also found that decisions and conclusions of the ARK Crisis Staff were binding on the ARK Municipalities and were implemented by the municipal Crisis Staffs. ${ }^{9904}$

3038. On 11 June 1992, the ARK Crisis Staff issued a statement setting forth the composition of municipal Crisis Staffs/War Presidencies in the ARK and placing responsibility on these structures for leading the defence and establishing co-operation with organs in other municipalities and the command of armed units. ${ }^{995}$ In addition members of the ARK Crisis Staff were regularly briefed about military developments. ${ }^{9906}$ The ARK Crisis Staff was also involved in organising contact with Pale to discuss defining territory. ${ }^{9907}$ The Chamber also recalls its findings with respect to the involvement of the ARK Crisis Staff in the dismissal and movement of Bosnian Muslims and Bosnian Croats from ARK municipalities and the implementation of ARK Crisis Staff policy at a

neighbouring municipalities and continued with negotiations until 22 May 199. Mile Ujić, T. 33438-33439 (12 February 2013). See also KDZ606, T. 18317 (5 September 2011) (closed session); P3279 (Witness statement of KDZ606 dated 1 September 2011) (under seal), para. 84.

9898

9899

9900

9901

9902

9903

9904

9905

9906

9907 
municipal level. ${ }^{9908}$ For example, the ARK Crisis Staff issued a decision that all leading positions, involving access to information, protection of public property and other positions of importance for the functioning of the economy could be occupied exclusively by persons of Serb nationality. ${ }^{9909}$

3039. On 29 May 1992, the ARK Crisis Staff concluded that all Muslims and Croats would be able to move out of the ARK on the condition that Serbs living outside the SAOs be allowed to move into SerBiH and the ARK. ${ }^{9910}$ This would help carry out the exchange of population or resettlement of people in an organised manner. ${ }^{9911}$ The ARK Crisis Staff also decided to oppose the forceful movement of population and to prevent any such attempts. ${ }^{9912}$ However, the Chamber finds that the wording of this conclusion was completely at odds with the forcible nature of the movement of the non-Serb population from municipalities in the ARK. ${ }^{9913}$

3040. After receiving the Bosnian Serb government instructions on the work of the Crisis Staffs, the Bosanski Novi Crisis Staff re-organised itself on 20 May 1992 to "take over the prerogatives and functions" of the Municipal Assembly. ${ }^{9914}$ Similarly on 5 June 1992, the Novo Sarajevo Crisis Staff wrote to the President of the SerBiH Presidency and stated: "The Crisis Staff has performed the function of Municipal Assembly in war conditions." 9915 The letter also indicated that the Crisis Staff co-ordinated and organised a variety of municipal services, including accommodation for "all refugees from the occupied territory and people who were left homeless", mobilisation, and accommodation of fighters from other areas. ${ }^{9916}$

3041. From 1993 onwards, when municipal authorities acted autonomously and failed to follow regulations, these issues were discussed and addressed by the Bosnian Serb Government. ${ }^{9917}$ The

\footnotetext{
9908 See paras. 2054-2061.

9909 D4040 (Article entitled "Leaders - Only Loyal Serbs", 22 June 1992), pp. 1-2; D4039 (Decision of ARK Crisis Staff, 22 June 1992).

9910 D4045 (Conclusions of ARK Crisis Staff, 29 May 1992).

9911 D4045 (Conclusions of ARK Crisis Staff, 29 May 1992).

9912 D4045 (Conclusions of ARK Crisis Staff, 29 May 1992). See also D4194 (Witness statement of Sveto Kovačević dated 7 December 2013), para. 37. Kovačević stated that the leadership in Pale had no influence on decisions of the ARK. The Chamber found that Kovačević's evidence was marked by condradictions, evasiveness and indicators of insincerity which undermined the reliability of his evidence in this regard.

9913

9914 See Section IV.A.2.b.iii: Deportation and inhumane acts (forcible transfer): Counts 7 and 8.

P2717 (SerBiH Government instructions for Crisis Staffs, 26 April 1992); P2632 (Report of Bosanski Novi's Crisis Staff, undated), p. 7. Hanson testified to seeing evidence of these instructions of 26 April 1992 being implemented in several municipalities including Bosanksi Novi, Kljuc, Prijedor, and Bijeljina. Dorothea Hanson, T. 14533, 14539 (9 June 2011).

D885 (Letter from Novo Sarajevo Crisis Staff to Radovan Karadžić, 5 June 1992), pp. 1, 4. Nešković stated that the police, TO and later the VRS were responsible for protecting the territory and defending the population. Radomir Nešković, T. 14277-14278 (6 June 2011).

9916 D885 (Letter from Novo Sarajevo Crisis Staff to Radovan Karadžić, 5 June 1992), pp. 1-3. See also Radomir Nešković, T. 14288-14290 (6 June 2011).

9917 P3142 (Minutes of 80 ${ }^{\text {th }}$ session of RS Government, 7 September 1993), pp. 5-6. See also P3139 (Minutes of the $74^{\text {th }}$ session of RS Government, 11 July 1993), p. 6; P3135 (Minutes of the $97^{\text {th }}$ session of RS Government,
} 
Bosnian Serb Government was also conscious of controlling the parallel organs of government at a municipal level to ensure that the Bosnian Serb Government was the only authorised executive organ in $\mathrm{RS}^{9918}$

3042. In 1994, the Accused reminded the Bosnian Serb Assembly about the Variant A/B Instructions, and said "remember how we used to work before the war. Not everything was as clear as day in the municipalities where we were majority and in those where we were minority. Do you remember the Instruction A and instruction B? We had Crisis Staffs, and it was clear that they were the authority". 9919 In 1995, the Accused recalled that pursuant to the Variant A/B Instructions in areas where the Bosnian Serbs were a majority they controlled everything at a municipal level and that when they were in a minority they "set up secret government, municipal boards, municipal assemblies, presidents of executive boards" and also established military units. ${ }^{9920}$ The Accused recalled that the JNA had been involved in the distribution of weapons to Serbian areas and that the SDS had "organised the people and created the army" and that with the help of the police "liberated and created the space", sometimes with the help of the JNA. ${ }^{9921}$

\section{(f) War Presidencies / War Commissions}

3043. At a joint session of the SNB and the Bosnian Serb Government, on 22 April 1992, it was concluded that the Government was to appoint a war presidency and war executive boards in all municipalities where executive boards "are not functioning". 9922 On 23 May 1992, the Bosnian Serb Government decided to abolish the Crisis Staffs. ${ }^{9923}$ The Chamber recalls that the Bosnian Serb Government concluded that "the conditions for functioning of the regular governing organs should be created as soon as possible" and War Presidencies established in municipalities. ${ }^{9924}$ After

27 April 1994), pp. 13-14; P3129 (Minutes of the $66^{\text {th }}$ session of RS Government, 20 March 1993), p. 5; P3124 (Minutes of the $30^{\text {th }}$ session of RS Government, 22 September 1995), pp. 3-4; P3112 (Minutes of the 71 session of RS Government, 26-27 May 1993), pp. 15, 20-21. P3112 (Minutes of the $71^{\text {st }}$ session of RS Government, 26-27 May 1993), pp. 20-21.

9919 P1403 (Transcript of First Part of $46^{\text {th }}$ session of RS Assembly, 9-11 November 1994), pp. 347-348.

9920 P970 (Transcript of 50 ${ }^{\text {th }}$ session of RS Assembly, 15-16 April 1995), p. 316.

9921 P970 (Transcript of 50 ${ }^{\text {th }}$ session of RS Assembly, 15-16 April 1995), p. 316. But see D3695 (Witness statement of Bogdan Subotić dated 16 June 2013), paras. 63-66 (stating that no organised part of the JNA took part in the defence of areas and those JNA commanders who were involved were acting on their own and their actions were purely defensive). The Chamber refers to its credibility assessment in fn. 9869 in concluding that it does not find Subotić's evidence to be reliable in this regard.

9922 P3051 (Minutes of expanded meeting of SNB and SerBiH Government, 22 April 1992), p. 2.

9923 See para. 147; P3082 (Minutes of the $13^{\text {th }}$ session of SerBiH Government, 23 May 1992), para. 4; P2589 (Dorothea Hanson's expert report entitled "Bosnian Serb Crisis Staffs, War Presidencies and War Commissions 1991-1995”, 10 September 2009), para. 46.

9924 See para. 147; P3082 (Minutes of the $13^{\text {th }}$ session of SerBiH Government, 23 May 1992), para. 4; P2589 (Dorothea Hanson's expert report entitled "Bosnian Serb Crisis Staffs, War Presidencies and War Commissions 1991-1995", 10 September 2009), para. 46. See also D3715 (Article from Glas entitled "Crisis Staffs Abolished", 7 July 1992), p. 1. 
the Crisis Staffs were disbanded, they were transformed into War Presidencies or War Commissions. ${ }^{9925}$

3044. On 31 May 1992, the Presidency issued a decision constituting War Presidencies and provided for the structure of these bodies including who would be members, including a republican commissioner. ${ }^{9926}$ The Chamber further recalls that the republican commissioner, who would be a member of the War Presidencies, was to be appointed by the SerBiH Presidency and have the "right and duty [...] to ensure permanent coordination and implementation of the policies and measures that are established and adopted by the republican state organs and the Main Staff of the [VRS]". 9927

3045. This decision also stated that the War Presidency "shall organise, coordinate and adjust activities for the defence of the Serbian people and the establishment of legal organs of authority in the municipality"; "shall perform all the functions of the assembly and the executive organ until there is a possibility for these organs to convene and work"; and "shall create and secure conditions for the work of military organs and units on the defence of the Serbian people", inter alia. ${ }^{9928}$ This decision also provided that Crisis Staffs in municipalities were to cease operating when the War Presidencies were constituted. ${ }^{9929}$

3046. On 31 May 1992, the SDS Executive Board informed the SAOs that the Crisis Staffs were to be abolished and that War Commissions/Presidencies were being established instead and instructed the SAOs to ensure the implementation of this decision. ${ }^{9930}$ On 2 June 1992, at a meeting of commanders of the $1^{\text {st }}$ Krajina Corps and ARK leaders, the Accused referred to the need to immediately introduce a threat of war and referred to the issuance of the decree on War Presidencies. $^{9931}$

3047. The Chamber recalls that on 10 June 1992, the Presidency issued a decision establishing War Commissions in SerBiH municipalities "which are either affected by war or are facing

\footnotetext{
9925 See paras. 138, 155; Radomir Nešković T. 14280 (6 June 2011); D3695 (Witness statement of Bogdan Subotić dated 16 June 2013), para. 287; Bogdan Subotić, T. 40037-40038 (19 June 2013). See also D3715 (Article from Glas entitled "Crisis Staffs Abolished", 7 July 1992), pp. 1-2.

9926 See para. 148.

9927 See para. 150; P2607 (SerBiH Presidency decision on constituting war presidencies in municipalities at a time of imminent threat of war or state of war, 31 May 1992), art. 4; P2611 (SerBiH Presidency Decision on the establishment of War Commissions in municipalities, 10 June 1992), art. 4.

9928 See para. 149; P2607 (SerBiH Presidency decision on constituting war presidencies in municipalities at a time of imminent threat of war or state of war, 31 May 1992), art. 3.

9929 See para. 151.

9930 See para. 151. See also P3060 (Minutes of the $2^{\text {nd }}$ session of the SerBiH Presidency, 31 May 1992).

9931 P1478 (Ratko Mladić's notebook, 27 May-31 July 1992), p. 53.
} 
imminent threat of war". ${ }^{9932}$ These War Commissions were to supersede Crisis Staffs and War Presidencies. ${ }^{9933}$ The War Commissions were tasked with maintaining very close co-operation with the legal authorities, to convey directives issued by the War Presidency of the Republic, to convey information about problems and the work of the municipal bodies and to co-operate with the authorities to create military organs and units. ${ }^{9934}$ The Chamber notes for example that War Presidencies existed at least in Bijeljina, Vogošća, Brčko, Ključ, Zvornik, Sanski Most, Ilidža, Hadžići, and Prijedor. ${ }^{9935}$ War Commissions existed at least in Foča, Pale, Zvornik, Vlasenica, Bratunac, Novo Sarajevo, Vogošća, and Ilidža. ${ }^{9936}$

3048. From June 1992 onwards, the Accused confirmed the appointment of or himself appointed members of the War Presidency or War Commission in municipalities including Bijeljina, ${ }^{9937}$ Foča, ${ }^{9938}$ Ilidža,${ }^{9939}$ Rogatica, ${ }^{9940}$ Novo Sarajevo, ${ }^{9941}$ Vlasenica, ${ }^{9942}$ and Zvornik. ${ }^{9943}$ With respect to

9932 See para. 153; P2611 (SerBiH Presidency Decision on the establishment of War Commissions in municipalities, 10 June 1992), art. 1; P1093 (Minutes of $5^{\text {th }}$ session of SerBiH Presidency, 10 June 1992); P2536 (Patrick Treanor's expert report entitled “The Bosnian Serb Leadership 1990-1992”, 30 July 2002), para. 262.

9933 See para. 155.

9934 See para. 154; P2611 (SerBiH Presidency Decision on the establishment of War Commissions in municipalities, 10 June 1992), art. 3.

9935 P1142 (Letter from Ministry of Justice of SerBiH to Vogošća War Presidency, 10 August 1992); P2391 (Vogošća War Presidency order, 6 November 1992); P2874 (Freedom of movement pass issued by Brčko War Presidency, 7 May 1992); P3025 (Travel permit issued by Brčko's War Presidency, 9 May 1992); P2888 (Brčko War Presidency Summary of events in Brčko Municipality); P3452 (Extract from Minutes of Ključ War Presidency, 10 July 1992); P3453 (Decision of Ključ War Presidency, 13 July 1992); P3462 (Decision of Ključ War Presidency, 30 July 1992); D4365 (Report from Ključ War Presidency to Banja Luka SJB dated 22 August 1992); P5205 (Minutes from $3^{\text {rd }}$ session of the Zvornik Municipality War Presidency, 2 August 1995); P5536 (Decision of the War Presidency of Sanski Most Municipality, 14 July 1992); D2563 (Radovan Karadžić's Decision on appointment of Ilidža War Presidency, 20 June 1995); D2920 (Decision of Bosanski Hadžići War Presidency, 23 October 1993); D4472 (Conclusions of Prijedor War Presidency, 6 August 1995); P2929 (Witness statement of KDZ531 dated 25 June 2011), p. 3 (under seal). See also D3144 (Witness statement of Dragomir Ljubojević dated 18 March 2013), para. 11; Dragomir Ljubojević, T. 35899-35901 (22 March 2013) (testifying that while he was not aware of the Crisis Staff, he was aware that the War Presidency had an active role in decision making in Bijeljina and acted openly).

9936 P2642 (Report of Foča War Commission, 18 June 1992); P5417 (Confirmation of a decision of the Pale SDS, 25 June 1992); P5479 (Radovan Karadžić's confirmation of appointment of Zvornik War Commission members, 17 June 1992); D1623 (Order of Zvornik War Commission, 1 July 1992); P5486 (RS Presidency Confirmation of Appointment of Members of the War Commission in Vlasenica, 17 June 1992); P5491 (RS Presidency Confirmation of Appointment of Members of the War Commission in Bratunac, 17 June 1992); P5543 (Radovan Karadžić's Decision appointing a War Commission in Novo Sarajevo, 21 July 1992); D4031 (Decision of Vogošća War Commission, 18 June 1992); P6001 (Request of Vogošća Municipality War Commission, 27 June 1992); P6059 (Order of Vogošća War Commission, 29 July 1992); P2390 (Vogošća War Commission order, 6 November 1992); D1244 (Ilidža War Commission Decision, 4 April 1993).

9937 D1428 (Radovan Karadžić's decision, 17 September 1992).

9938 P6266 (Radovan Karadžić's Decision, 17 September 1992).

9939 D1228 (Radovan Karadžić's order, 21 August 1992), p. 1.

9940 P3413 (Radovan Karadžić's Order confirming appointment of Rogatica officials, 20 July 1992), p. 1.

9941 P5543 (Decision of Radovan Karadžić appointing a War Commission in Novo Sarajevo, 21 July 1992); D3654 (Witness statement of KW317 dated 26 September 2012), paras. 67-68, 73 (under seal) (stating that this appointment was not implemented until August 1992).

9942 P5486 (RS Presidency Confirmation of Appointment of Members of the War Commission in Vlasenica, 17 June 1992); P5399 (Notification by the Vlasenica Serb Municipality, 16 June 1992). Considering the evidence regarding communication that existed between the municipality and republic institutions, the Chamber sees no 
Brčko, the War Presidency was formed following the instructions of the Accused and as a body would directly approach the government in Pale or the Bosnian Serb Assembly or Presidency if they had requests. ${ }^{9944}$

3049. On 17 December 1992, the Bosnian Serb Assembly declared that the decision on forming War Commissions ceased to be valid. ${ }^{9945}$

3050. In November 1994, the Accused spoke about introducing a state of war, and stressed that this did not mean that military rule would be introduced; rather, civilian powers would be concentrated and implemented through operational bodies in the municipalities, thereby "ensuring more effective functioning of the state". 9946

\section{(g) Take-over of power in the Municipalities}

3051. As mentioned above, in March 1992 the Accused advocated that Bosnian Serbs take power into their own hands in Bosnian Serb claimed territories and that the structure of $\mathrm{BiH}$ would depend on the conditions they could establish on the ground. ${ }^{9947}$ The Accused emphasised that their right to self-determination "will happen according to the actual conditions which are up to you to create". 9948 In this regard the Accused spoke about when to "reveal our next move" and that it "will all be happening in a flash and the set up of the de facto situation based on our documents". 9949 He explained that there would be "no signing before we have achieved what we want, and you all know our strategic plans. [...] The ultimate strategic goal must still remain a secret". 9950 The Accused said they did not "plan to attack anybody but our plan is to defend ourselves and the army is at our disposal for that purpose"; they had the "right to use the army for the final countdown and

basis for the Accused's assertion that the chaos created by Bosnian Muslim attacks led the Vlasenica Crisis Staff to make decisions independent of the authorities in Sarajevo and Pale. See Defence Final Brief, para. 2838. 
for the final establishment of authority" and that if a border was established unjustly they would "establish a just border". 9951

3052. The Accused also warned against the perception that Bosnian Serbs were taking "other people's land through war" and that they should not mention war, but establish their authority and defend that and state that they did not plan to attack anybody. ${ }^{9952}$ The Accused spoke about "[p]eace at any cost, wherever it is possible". 9953 The Accused stated that they did not need war, and they could accomplish what they wanted by political means but once they had achieved their goals if they were attacked they would defend themselves, including against genocide, and had "the right to use the army for the final countdown and for the final establishment of authority". ${ }^{9954}$

3053. On 15 April 1992, the Accused attended a meeting of the SNB in which it was proposed that a state of imminent threat of war be declared. ${ }^{955}$ The imminent threat of war was declared on 15 April 1992. ${ }^{9956}$ On 24 April 1992, the SNB met with the Bosnian Serb Government and adopted a decision to form a TO Staff composed of current municipal TO commanders with the Accused responsible for its realisation. ${ }^{9957}$ In addition, it was decided to compile instructions on the use of national symbols and to procure uniforms and insignia for the TO. ${ }^{9958}$ At this meeting it was concluded that a group of lawyers would be tasked with preparing the basic laws in order to set up a legal system for the SerBiH. ${ }^{9959}$ On 17 April 1992, the Accused issued a decision that all Serb employees who had been appointed from an SDS list be withdrawn from their positions in bodies and organisations of the "former Republic of BiH" and the City of Sarajevo. 9960 This decision also provided that all these employees be appointed to bodies and organisations in the SerBiH. ${ }^{9961}$

\footnotetext{
9951 P961 (Shorthand Record of $12^{\text {th }}$ session of SerBiH Assembly, 24 March 1992), p. 17.

9952 P961 (Shorthand Record of $12^{\text {th }}$ session of SerBiH Assembly, 24 March 1992), pp. 16-17. See also D115 (Transcript of $25^{\text {th }}$ session of RS Assembly, 19-20 January 1993), p. 6; P1371 (Transcript of 30 ${ }^{\text {th }}$ session of RS Assembly, 5-6 May 1993), p. 9.

9953 P961 (Shorthand Record of $12^{\text {th }}$ session of SerBiH Assembly, 24 March 1992), p. 17.

9954 P961 (Shorthand Record of $12^{\text {th }}$ session of SerBiH Assembly, 24 March 1992), p. 17. See also P1364 (Transcript of $23^{\text {rd }}$ session of RS Assembly, 17 December 1992), e-court p. 8 (where the Accused continue to speak about the defensive nature of the war which had been imposed on them); D115 (Transcript of 25th session of RS Assembly, 19-20 January 1993), pp. 3, 7; P1367 (Transcript of $26^{\text {th }}$ session of RS Assembly, 2 April 1993), p. 5; P1375 (Transcript of 32 ${ }^{\text {nd }}$ session of RS Assembly, 19-20 May 1993, e-court p. 8.

9955

9956

9957 P1087 (Minutes of meeting between SNB and SerBiH Government, 24 April 1992).

9958 P1087 (Minutes of meeting between SNB and SerBiH Government, 24 April 1992), p. 1.

9959 P1087 (Minutes of meeting between SNB and SerBiH Government, 24 April 1992), p. 2.

9960 P5413 (Decision of the SDS, 17 April 1992).

9961 P5413 (Decision of the SDS, 17 April 1992).
} 
3054. While the Accused called on leaders at the Bosnian Serb Assembly to "do whatever is necessary on the ground to establish the de facto situation" he also stated that there should be "full respect for citizens of other nationalities" and that "no one must be harmed, regardless of their religion, nation". 9962 The Accused also acknowledged that there would probably be resettlement but that "none of it should occur under pressure". 9963 When the SerBiH was proclaimed, this proclamation provided that the constitution of this entity would "guarantee the full equality of peoples and citizens before the law and their full protection against any form of discrimination". 9964 Krajišnik had also spoken previously about creating a state which would be the home for the entire Serbian people and "for all others who so wish". 9965

3055. Bogdan Subotić also made an announcement that Bosnian Muslims who wished to remain in RS would have the same rights, and those who did not wish to should go to their own people of their own free will. ${ }^{9966}$ He spoke in favour of clear borders between ethnic communities. ${ }^{9967}$ Đerić testified that the Bosnian Serb leadership took into account that a certain percentage of Serbs, Croats and Muslims would live in each constituent unit in $\mathrm{BiH}$ and worked towards "preserving the equality of people who remained in their original places of residence" on a reciprocal basis and that the Accused in his speeches did not question the rights or freedoms of other ethnic communities to live in RS. ${ }^{9968}$ The Accused also spoke about ensuring that Muslims and Croats have equal rights and privileges in the state they were building on the "condition that they are not hostile and that they leave the weapons". 9969 The Accused continued to emphasise that Muslims and Croats living in the RS would always have their rights protected as a minority group. ${ }^{9970}$ He also emphasised the enormous responsibility of the SDS to defend the "Serbian Republic" and that their state should

\footnotetext{
9962 D90 (Shorthand Record of $11^{\text {th }}$ session of SerBiH Assembly, 18 March 1992), p. 45; Branko Đerić, T. 28018 (24 April 2012).

9963 D90 (Shorthand Record of $11^{\text {th }}$ session of SerBiH Assembly, 18 March 1992), p. 46.

9964 P6444 (Declaration of the Assembly of Serbian people in BiH, 9 January 1992), p. 2. See also P5558 (Declaration on Constitutional and Political Arrangements of the SerBiH Assembly, 3 September 1992), pp. 2-4 (which provided for the equality of citizens of SerBiH before the law and for freedom of religion).

9965 P3121 (Stenograph of the session of the Club of Deputies from the SDS, 24 October 1991), p. 8.

9966 D3695 (Witness statement of Bogdan Subotić dated 16 June 2013), para. 49; D3715 (Article from Glas entitled "Crisis Staffs Abolished", 7 July 1992), p. 3.

9967 D3715 (Article from Glas entitled "Crisis Staffs Abolished”, 7 July 1992), p. 3.

9968 Branko Đerić, T. 28017 (24 April 2012), T. 28073 (25 April 2012).

9969 D92 (Transcript of $17^{\text {th }}$ session of SerBiH Assembly, 24-26 July 1992), pp. 86-87. See also D2852 (Witness statement of Srđan Šehovac dated 27 January 2013), para. 41; John Zametica, T. 42470-42471 (29 October 2013) (testifying that in his opinion the Accused did not appear to have any ethnic hatred and the Accused did appoint some Bosnian Muslims and Bosnian Croats to certain positions within the RS including himself). The Chamber does not find Čeklić and Bajagić's evidence that the Accused never proposed removing Bosnian Muslims and Bosnian Croats and always insisted on co-existence to be reliable. D3854 (Witness Statement of Savo Čeklić dated 7 July 2013), para. 21; D3853 (Witness statement of Zvonko Bajagić dated 5 July 2013), paras. 36C, 40. In reaching that conclusion the Chamber refers to its credibility assessment in fn. 9231, 11086.

9970 P1375 (Transcript of $32^{\text {nd }}$ session of RS Assembly, 19-20 May 1993, e-court p. 8.
} 
"rest on rule of rights and humanity". 9971 The Accused called on the SDS members to "constantly monitor our behaviour, so that the glory of our just battle would not be tarnished by inhumane actions" with special attention to "just behaviour towards civilians of other nationalities". 9972 In practice these words were not carried out or followed. ${ }^{9973}$

3056. The Chamber notes that Krajišnik stated at one of the sessions: "I have discussed this [the creation of a unified Serb state] openly, even though this is being recorded and even though the journalists might write it down". 9974 Similarly when the Accused invited Mladić to brief the Bosnian Assembly on the military situation and their intentions, he qualified that by asking that he present "what can be said at a place like this". 9975 This is indicative that what was said at these sessions was often for public consumption and included rhetoric which the Chamber has approached with caution and weighed in light of the other evidence received.

3057. The Accused said that in certain municipalities, such as Bijeljina and Pale, where Bosnian Muslims accepted co-existence and were "not showing the will to fight against the Serbs and against their state", they were living peacefully and well. ${ }^{9976}$ The Accused stated that Muslims in Bijeljina and Pale were not being bothered or considered second-class citizens and that the government officials were trying to convince them that they had nothing to fear. ${ }^{9977}$ In this regard, the Accused also mentioned that in Sanski Most, Ključ, and Prijedor, while there was some fighting caused by "Muslim extremists", once they were eliminated those who remained were not willing to fight the Serbs. ${ }^{9978}$ However, the Accused characterisation of what was happening in those municipalities does not accord with the Chamber's factual findings in section IV.A.1 about the conditions which Bosnian Muslims faced in those municipalities at the time.

3058. The Accused also visited Rogatica in March 1992 and met with municipal level leaders. ${ }^{9979}$ On 25 March 1992, the Accused was informed that Rajko Kušić had threatened to attack Rogatica unless the municipality and SJB were unconditionally divided into Serb and Muslim parts within two hours. ${ }^{9980}$ This letter further indicated that in accordance with the Accused's instructions, "the

\footnotetext{
9971

D94 (Radovan Karadžić's letter to SDS members, 11 July 1992).

D94 (Radovan Karadžić's letter to SDS members, 11 July 1992).

Herbert Okun, T. 1740 (27 April 2010).

P1357 (Transcript of $18^{\text {th }}$ session of SerBiH Assembly, 11 August 1992), p. 18.

D456 (Transcript of $20^{\text {th }}$ session of RS Assembly, 14-15 September 1992), pp. 17-18.

D92 (Transcript of $17^{\text {th }}$ session of SerBiH Assembly, 24-26 July 1992), pp. 15, 21, 86. See also Branko Đerić, T. 28022-28023 (24 April 2012).

9977 D92 (Transcript of $17^{\text {th }}$ session of SerBiH Assembly, 24-26 July 1992), p. 21.

9978 D92 (Transcript of $17^{\text {th }}$ session of SerBiH Assembly, 24-26 July 1992), p. 15.

9979 P3279 (Witness statement of KDZ606 dated 1 September 2011), paras. 43, 45 (under seal); KDZ606, T. 1831018311 (5 September 2011) (closed session).

9980 P6105 (Notice of resignation, 25 March 1992), p. 1.
} 
factual division on the ground should be and is already there, however the official division must be accompanied by laws issued by relevant Serbian Ministries, as well as party agreements at the highest level". ${ }^{9981}$ The Accused was informed that it would be dangerous to "be the originator of the war situation when the Serbian people are not sufficiently prepared". 9982

3059. On 24 March 1992 the Bosnian Serb Assembly adopted a decision which verified the decisions of municipal assemblies which had proclaimed newly established Serbian Municipalities. $^{9983}$ These municipalities included Vogošća, Srebrenica, Bratunac, Prijedor, Višegrad, Foča, Brčko, and Zvornik. ${ }^{9984}$ The SAOs were also required to report on the establishment of Serbian Municipalities. ${ }^{9985}$ At the same session the Accused said:

\begin{abstract}
at a desired moment, and this will be very soon, we can form whatever we want. There are reasons why this could happen in two or three days. Such are the forecasts but I cannot tell you the reasons now. At that moment, all the Serbian municipalities, both the old ones and the newly established ones, would literally assume control of the entire territory of the municipality concerned. The Zvornik municipality takes control of everything that constitutes the Serbian Municipality of Zvornik. Then at a given moment, in the next three of four days, there will be a single method used and you will be able to apply it in the municipalities you represent, including both things that must be done as well as how to do them. How to separate the police force, take the resources that belong to the Serbian people and take command. The police must be under the control of the civilian authority, it must obey it, there is no discussion about that - that's the way it must be. ${ }^{9986}$
\end{abstract}

3060. The Accused also stated: "Newly established municipalities must establish their organs as soon as possible, have their stamps made and start to work. The police, that is, our organs must be positioned at the border." ${ }^{9987}$ At this session, the Bosnian Serb Assembly instructed the Government to prepare and submit to the Assembly for adoption an operational plan "of assuming power and rendering operational the authorities in the territory of the Serbian Republic of Bosnia and Herzegovina". 9988

\footnotetext{
9981 P6105 (Notice of resignation, 25 March 1992), p. 1.

9982 P6105 (Notice of resignation, 25 March 1992), p. 1. See also Tomislav Batinić, T. 33675-33678 (14 February 2013).

9983 P961 (Shorthand Record of $12^{\text {th }}$ session of SerBiH Assembly, 24 March 1992), pp. 23-24. See also Adjudicated Fact 2010.

9984 P961 (Shorthand Record of $12^{\text {th }}$ session of SerBiH Assembly, 24 March 1992), pp. 23-24. See also P1354 (Minutes of $13^{\text {th }}$ session of SerBiH Assembly, 24 March 1992), pp. 8-9; P2536 (Patrick Treanor's expert report entitled “The Bosnian Serb Leadership 1990-1992”, 30 July 2002), para. 223.

9985 P961 (Shorthand Record of $12^{\text {th }}$ session of SerBiH Assembly, 24 March 1992), p. 24.

9986 P961 (Shorthand Record of $12^{\text {th }}$ session of SerBiH Assembly, 24 March 1992), p. 22. The Chamber places no weight on KW317's opinion that what prompted these actions was not the will of the Accused or the SDS but was the result of the actions of Bosnian Muslims. KW317, T. 39338-39339 (5 June 2013).

9987 See para. 136; P961 (Shorthand Record of $12^{\text {th }}$ session of SerBiH Assembly, 24 March 1992), p. 17.

9988 P1354 (Minutes of $13^{\text {th }}$ session of SerBiH Assembly, 24 March 1992), pp. 8-9. See also P2536 (Patrick Treanor's expert report entitled “The Bosnian Serb Leadership 1990-1992", 30 July 2002), para. 223; Adjudicated Fact 2009.
} 
3061. The Accused also emphasised that in the period when the State was being created, the deputies would have to be the "pillars of our power" in their locations and "remain in permanent contact with presidents of municipalities and work on the establishment of local government". 9989 The Accused also acknowledged that the president of the municipality was who "carried out our plans". 9990

3062. On 27 March 1992 when the Bosnian Serb Assembly promulgated the Constitution of SerBiH, the Accused delivered a speech in which he addressed criticism that they had taken steps "with undue haste" and stated that "we are clean before God, because we have not made a single move which was not provoked". 9991 He also stated that the Serbs had responded to "nondemocratic measures democratically" and formed its state unit legitimately based on the law exercising their right to self-determination. ${ }^{992}$ The Accused also spoke about the possibility that all three peoples in $\mathrm{BiH}$ may flourish "if [the declaration of $\mathrm{BiH}$ independence] passes without bloodshed". 9993 The Accused also said that a war in BiH would not solve anything but that if war did break out "you will get the plans". 9994

3063. There was a break in the Bosnian Serb Assembly sessions and the $16^{\text {th }}$ session was held on 12 May 1992 and was described by Krajišnik as the "first war session". 9995 The Accused spoke about how the Bosnian Serbs had tried to avoid war, that they had no need to organise themselves militarily because their policies were being realised politically. ${ }^{9996} \mathrm{He}$ explained that the political maneuvering of the Bosnian Muslims and the recognition of $\mathrm{BiH}$ resulted in war, and that Serbs had been attacked in Sarajevo, Zvornik and Bijeljina. ${ }^{9997}$ He went further and stated that the Bosnian Serbs in "areas bordering other national communities, it has to fight for its survival against genocide". ${ }^{9998}$ The Accused also claimed that Serbs had been "very cautious not to take what is not ours, not to fight more than is necessary", that they would mark their borders and "defend them

\footnotetext{
9989 P961 (Shorthand Record of $12^{\text {th }}$ session of SerBiH Assembly, 24 March 1992), p. 15. The Accused also met with some municipal leaders and discussed the functioning of municipal organs of authority. D3126 (Witness statement of Jovan Nikolić dated 10 March 2013), para. 61.

9990 P961 (Shorthand Record of $12^{\text {th }}$ session of SerBiH Assembly, 24 March 1992), p. 17.

9991 D304 (Shorthand Record of $14^{\text {th }}$ session of RS Assembly, 27 March 1992), p. 8; P956 (Transcript of $16^{\text {th }}$ session of SerBiH Assembly, 12 May 1992), e-court p. 4. See also D89 (Shorthand Record of $9^{\text {th }}$ session of SerBiH Assembly, 28 February 1992).

9992 D304 (Shorthand Record of $14^{\text {th }}$ session of RS Assembly, 27 March 1992), p. 8; P956 (Transcript of $16^{\text {th }}$ session of SerBiH Assembly, 12 May 1992), e-court p. 4.

9993 D304 (Shorthand Record of $14^{\text {th }}$ session of RS Assembly, 27 March 1992), p. 8.

9994 D304 (Shorthand Record of 14 ${ }^{\text {th }}$ session of RS Assembly, 27 March 1992), p. 20.

9995 P956 (Transcript of $16^{\text {th }}$ session of SerBiH Assembly, 12 May 1992), e-court p. 1.

9996 P956 (Transcript of $16^{\text {th }}$ session of SerBiH Assembly, 12 May 1992), e-court pp. 5, 9; D3697 (Article from Glas entitled "Own Army”, 13 May 1992), p. 1.

9997 P956 (Transcript of $16^{\text {th }}$ session of SerBiH Assembly, 12 May 1992), e-court pp. 5-6, 8.
} 
until they are recognised" and that the "factual situation will be decisive".999 In addition, at a sesssion in September 1992, he emphasised that without publicly saying so, their internal borders between Muslims and Croats "are to be thicker" than their borders with Serbia and Serbian Krajina. $^{10000}$

3064. The Chamber recalls that on 18 May 1992, the Rogatica Serb Municipal Assembly abrogated the original agreement on the division of the municipality alleging that the Bosnian Muslim side had avoided attempts to implement that agreement. ${ }^{10001}$ This was one day after the Accused, Mladić, and Krajišnik held a meeting with representatives of municipalities, including Rogatica, and discussed the creation of a Bosnian Serb state in $\mathrm{BiH}$, stating that the time had come for the demarcation of areas between the national groups. ${ }^{10002}$

3065. At a meeting held in Belgrade on 11 July 1992, the Minister of the Interior noted that the government was "preparing a new political and territorial division of the Serbian Republic which will replace the previous necessary forms, such as autonomous Serb areas and regions, with districts". 10003 The Accused at a meeting of the Presidency of SerBiH August 1992 said that the European Community would accept the "factual state of affairs" and that therefore they "should not make a single concession in military terms". ${ }^{10004}$

3066. The Accused in September 1992 acknowledged the responsibility of municipal authorities in defining borders and the importance of the government and the Presidency visiting municipalities in order to restore order. ${ }^{10005}$ Krajišnik acknowledged the presence of presidents of executive boards and presidents of local SDS branches who attended Bosnian Assembly sessions as it was the "best way to keep our people aware of what is going on. We have seen that the people were leaving Assembly sessions with a clear vision of what they are supposed to do."10006

3067. On 20 December 1992, at a meeting of the Supreme Command attended by the Accused, Koljević, Krajišnik, Mladić, and Stanišić, Koljević addressed the issue of the truce, claiming that

\footnotetext{
9998 P956 (Transcript of $16^{\text {th }}$ session of SerBiH Assembly, 12 May 1992), e-court p. 6. See also P5492 (Record of speech by Radovan Karadžić, 9 January 1994), pp. 6-7.

9999 P956 (Transcript of $16^{\text {th }}$ session of SerBiH Assembly, 12 May 1992), e-court pp. 6-7. See also D456 (Transcript of $20^{\text {th }}$ session of RS Assembly, 14-15 September 1992), pp. 53-55, 57; P1367 (Transcript of $26^{\text {th }}$ session of RS Assembly, 2 April 1993), p. 109.

10000 D456 (Transcript of $20^{\text {th }}$ session of RS Assembly, 14-15 September 1992), p. 55.

10001 See para. 963; P2835 (Report of Rogatica Crisis Staff, April - June 1992), p. 3.

10002 P1477 (Ratko Mladić's notebook, 14 February-28 May 1992), pp. 349-351; P6254 (Article from Tanjug entitled "Serb Leaders Promote Ethnic Demarcation", 17 May 1992).

10003 P1096 (SerBiH MUP Report on Some Aspects of Work Done to Date and the Tasks Ahead, 17 July 1992 ), p. 3.

10004 P1479 (Ratko Mladić's notebook, 16 July-9 September 1992), p. 22.

10005 D456 (Transcript of 20 ${ }^{\text {th }}$ session of RS Assembly, 14-15 September 1992), p. 15.

10006 P1367 (Transcript of $26^{\text {th }}$ session of RS Assembly, 2 April 1993), p. 7.
} 
they should refrain from offensive operations to earn the world's trust, to which the Accused responded that nothing is over yet, that they must strengthen the army, reinforce and reorganise their borders, and prove that the Muslims do not want peace to be established. ${ }^{10007}$

3068. In April 1993, the Accused stated that as a result of the war they had created new entities which would have to be recognised and noted for example that nobody could now "return the 50,000 Serbs from Zvornik to Zenica, or to central Bosnia". ${ }^{10008}$ The Accused continued to speak about the RS as something they had "created by our own strength, own weapons, own politics". 10009 In January 1994, the Accused acknowledged the contribution of the SDS party as the "main political force", the army, police, TO, SDS members, municipal level structures and leadership to the preservation of the RS. ${ }^{10010}$

3069. In November 1994, the Accused continued to speak about this reality on the ground which had to be retained. ${ }^{10011}$ This sentiment was also reflected in statements made by Mladic that they would "impose by the force of arms the final settlement of the war on the enemy" which would then mean the international community had to recognise the actual situation on the ground. ${ }^{10012}$ The Accused stated that their strategic goal was to separate themselves and not to take the whole of $\mathrm{BiH}$ but insisted that they should be prepared to resist attempts to take back as much Serb territory as possible and to establish new borders. ${ }^{10013}$

3070. The Accused continued to speak about their right to claim territories on the basis that "[w]e have created new realities". He then cited to the example of Zvornik, where there had previously been a Bosnian Muslim majority, but he noted that Serbs from other locations had arrived and occupied the municipality while the Bosnian Muslims had left "for Europe and I do not know where else". ${ }^{10014}$ He noted that in this scenario they would claim Zvornik "based on the right which comes out of a new reality" which had been created through the war and that if they wanted "to give Zvornik to the Muslims then you have to wage a new war in order to expel these Serbs back to

\footnotetext{
10007 P1469 (Minutes of VRS Supreme Command meeting, 20 December 1992), pp. 1, 4.

10008 P1367 (Transcript of $26^{\text {th }}$ session of RS Assembly, 2 April 1993), pp. 109-110.

10009 P1379 (Transcript of $34^{\text {th }}$ session of RS Assembly, 27-29 August, 9-11 September, 29 September to 1 October 1993), p. 9.

10010 P5492 (Record of speech by Radovan Karadžić, 9 January 1994), pp. 8-9.

10011 P1403 (Transcript of First Part of $46^{\text {th }}$ session of RS Assembly, 9-11 November 1994), p. 155. See also P1390 (Transcript of $40^{\text {th }}$ session of RS Assembly, 10-11 May 1994), pp. 36, 43.

10012 P970 (Transcript of 50 ${ }^{\text {th }}$ session of RS Assembly, 15-16 April 1995), pp. 21-21.

10013 P1390 (Transcript of 40 ${ }^{\text {th }}$ session of RS Assembly, 10-11 May 1994), pp. 41-42.

10014 P1403 (Transcript of First Part of $46^{\text {th }}$ session of RS Assembly, 9-11 November 1994), p. 157.
} 
Zenica. We request Zvornik according to this right. We use the same right to ask for our state. And we will get it."10015

3071. The Accused also observed that the SDS "endured the armed struggle in a superior manner. [...] With such, well organised defence, the majority of our people has been saved. [...] We should always remember that the people themselves and the SDS fought and set up the frontlines in 45 days, from 5 April to 20 May". 10016

\section{(2) $\underline{\text { Conclusion }}$}

3072. The Prosecution argues that the Variant A/B Instructions established the bodies which were the primary instruments through which the Accused and the Bosnian Serb leadership were able to assert control over territories and remove non-Serbs. ${ }^{10017}$ It also alleges that the Accused supervised the implementation of the Variant A/B Instructions and issued specific guidelines in that regard. ${ }^{10018}$ With respect to the Variant A/B Instructions, the Accused contends that there was "absolutely nothing wrong with this document" and that it only envisaged defensive measures in response to moves towards the independence of $\mathrm{BiH} .{ }^{10019}$

3073. Having considered the evidence above, the Chamber finds that the Variant A/B Instructions was a core document in terms of furthering the objectives of the Accused and the Bosnian Serb leadership from December 1991 onwards. The instructions reduced to writing the practical measures and steps which had to be taken at a municipal level in order to achieve those objectives. The Chamber finds that the Variant A/B Instructions reflected the ideology and objectives of the Accused and the Bosnian Serb leadership which have been discussed above.

3074. The Chamber finds that the Accused played the leading role in the distribution and promotion of the Variant A/B Instructions. In doing so the Accused re-emphasised the interests of the Bosnian Serbs and also repeated the threats which Bosnian Muslims and Bosnian Croats and the independence of $\mathrm{BiH}$ posed to those interests. The manner in which the Variant $\mathrm{A} / \mathrm{B}$ Instructions were distributed demonstrates a high level of organisation, planning, and co-ordination to ensure that all key Bosnian Serb leaders at a municipal level received those instructions.

\footnotetext{
10015 P1403 (Transcript of First Part of $46^{\text {th }}$ session of RS Assembly, 9-11 November 1994), p. 157.

10016 P953 (Article from Oslobođenje entitled "Happy Birthday Republic", 6 January 1995), p. 3-4.

10017 Prosecution Final Brief, para. 122.

10018 Prosecution Final Brief, paras. 123, 129.

10019 Defence Final Brief, paras.75-78. The Accused also makes a suggestion that there are inconsistencies "that may bring into question its authenticity or origin, and dispute its conspiratorial nature". Defence Final Brief, para. 75.
} 
3075. The Chamber also finds that accepted evidence demonstrates that not only were the Variant A/B Instructions distributed, they were subsequently discussed and implemented at a municipal level and were considered mandatory. The instructions formed the basis on which Bosnian Serb Crisis Staffs, Bosnian Serb municipal assemblies, and other parallel municipal structures were established in the Municipalities. These instructions provided the basis for the declaration of Serb municipalities and not only called for the creation of Crisis Staffs, it also specified their structure, composition, and functions.

3076. The Chamber notes that in Variant B municipalities, the instructions did make provision for the proportional representation of "other nations" in government organs, but this included a proviso that this only applied to those who expressed loyalty to Yugoslavia. The Chamber finds that this is a reflection of the position taken at the time by the Bosnian Serb leadership and that such statements promising protection of the rights of other ethnicities were highly conditional on them accepting and following the objectives of the Bosnian Serb leadership.

3077. The Chamber also finds that in addition to forming the basis for the creation of parallel political structures, the Variant A/B Instructions also included provisions directed towards the military organisation of the Bosnian Serb population at a municipal level. This involved taking steps to ensure that police, reserve, and TO structures were prepared and ready to be engaged depending on developments. The Crisis Staff was tasked with taking a central role in making these military preparations.

3078. The Chamber also finds that the content of the Variant A/B Instructions included preparations for the physical take-over and maintenance of power in Bosnian Serb claimed territory, which ultimately took place. The Chamber refers to its factual findings with respect to the pattern of take-overs in the Municipalities. It recalls the involvement of the structures created pursuant to the Variant A/B Instructions in preparing for and carrying out these take-overs. It also recalls the central role that these structures played in maintaining power and regulating the functioning of the municipalities after the take-overs were completed.

3079. The Chamber finds that while municipalities had some autonomy in terms of the precise manner in which they implemented the Variant A/B Instructions, they were considered to be mandatory. The Accused took an active role in monitoring the implementation of the Variant A/B Instructions and also following developments which occurred at a municipal level and difficulties municipal authorities faced. In this regard the Accused not only was in direct contact with municipal leaders he also specifically tasked Bosnian Serb officials with monitoring developments and problems at a municipal level in general and the implementation of the Variant A/B 
Instructions in particular. He co-ordinated efforts to ensure the implementation of the Variant A/B Instructions and sent Bosnian Serb officials to provide assistance to municipalities in this regard. The evidence also demonstrates that this system of monitoring was also a means of ensuring discipline and checking loyalty to the party leadership and programme of action which they had developed.

3080. The Chamber also finds that a direct and regular line of communication existed between the Bosnian Serb authorities at a municipal level and the Bosnian Serb leadership or RS authorities, including the Accused. This line of communication allowed the Bosnian Serb leadership and the Accused to monitor developments at a municipal level and to issue precise directions with respect to the establishment and maintenance of Bosnian Serb authority.

3081. The evidence above also demonstrates that the Accused took very seriously the precise implementation of these instructions at a municipal level. The evidence, including intercepted conversations, also shows that municipal level leaders were in contact with the Accused and reported on progress in developments in the municipalities and how they were following the Variant A/B Instructions. The Accused emphasised the importance of these instructions in achieving the objectives of the Bosnian Serb leadership, namely the creation of a separate Bosnian Serb state.

3082. The Chamber also finds that the SDS structures were the core mechanism through which the SDS policies which had to be implemented were communicated from the SDS Main Board to the SDS Municipal Boards. The Accused played a leading role in insisting on party discipline and the imperative to implement SDS policy and the importance of following the timing of the measures which had to be taken. The Chamber finds that these moves were designed and implemented to ensure that Bosnian Serb structures were created and these structures could be quickly activated when necessary in order to take-over power in the municipalities.

3083. The Chamber finds that when the Accused activated the second level of the Variant A/B Instructions this was the signal that the structures which had been created pursuant to the first level had to be activated in order to take-over power. The evidence demonstrates that the second level of the Variant A/B Instructions was intrinsically linked to the physical control of territory and the activation of the second level of the Variant A/B Instructions was also communicated to and acted upon at a municipal level.

3084. While the Chamber notes that the Accused spoke in terms of taking power in a "humane way" with respect to the Bosnian Muslims and Bosnian Croats, it is clear that he said this in the 
context of trying to "change [the Bosnian Serbs'] image with foreign monitors". ${ }^{10020}$ In addition instructions which were given to Crisis Staffs also required the humane treatment of civilians and respect for POWs. Despite these statements and orders, the Accused also clearly stated that he was prepared to "let everything go to fucking hell and that we take the express way"10021 but he spoke about taking a tactful approach in order to achieve their goals given the importance of international opinion and not being seen as the aggressors. The Chamber finds that this is indicative of the approach taken by the Accused that while he envisaged the use force and violence to take-over power he was cautious about the way in which this would be portrayed at an international level. The international image and ensuring political points were not lost were very important to the Accused, but the Chamber does not find that there was a genuine concern about the manner in which power was taken.

3085. On the contrary, the Chamber refers to its factual findings in section IV.A.1, which demonstrates that the manner in which Serb Forces and Bosnian Serb Political and Governmental Organs took over power in the Municipalities and the way in which Bosnian Muslims and Bosnian Croats were treated during and after the take-overs was anything but humane. The Chamber recalls its legal finding that Serb Forces were involved in a widespread and systematic attack directed against the Bosnian Muslim and Bosnian Croat civilian populations of $\mathrm{BiH}$ which was characterised by a widespread and systematic campaign of violence, including through acts of murder, persecution, and forcible displacement. While the Accused was making these public statements about the protection of minorities, Bosnian Muslims continued to be forced out of municipalities in $\mathrm{BiH}$ where Bosnian Serbs had taken-over the territory. The Chamber also finds a disjuncture between the Accused's public statements and his private discourse in this regard.

3086. The Chamber also finds that by April 1992, the work and function of Crisis Staffs were further elaborated by instructions which provided for them to take on the central role in wartime conditions at a municipal level, particularly with respect to defence. It was also clear that the Crisis Staffs were to work in accordance with decisions of the higher level authorities, including the Presidency, the Bosnian Serb Assembly and Bosnian Serb Government and were also a crucial structure in ensuring that the higher level authorities were informed about developments on the ground.

3087. The Chamber finds that the Accused played a central role in instructing how the Crisis Staffs would function and be structured and this demonstrates one of the ways in which the

$10020 \quad$ See para. 3023.

10021 See para. 3024 
Accused exercised his authority over the Crisis Staffs. The Chamber does not find that isolated and limited acts of insubordination at the municipal level negated the Accused's overall clear authority over Crisis Staffs. In this regard, the Chamber notes that, in September 1992, the Accused acknowledged that "some municipal officials behaved unlawfully" and that the Bosnian Serb Assembly needed to point out these incidents and to take measures to arrest and punish them. ${ }^{10022}$ The Accused added "we must visit municipalities and restore order even at the risk of introducing extraordinary measures, making replacement, arrests, appointments and naming others who, with the help of deputies, will be able to pull the municipality out of a crisis". ${ }^{10023}$ The Chamber finds this shows that on the limited occasions where municipal officials failed to follow directions, the Accused had the authority and the means to rectify such situations.

3088. From May 1992, War Presidencies and War Commissions took over the functions of the Crisis Staffs and the leading role at a municipal level and were the link to the higher level authorities. The Accused himself in 1994 and 1995 recalled the central role which the Variant A/B Instructions and the Crisis Staffs played during the conflict in order to create parallel Serb structures and military units, which ultimately took control of territory and power at a municipal level.

3089. Based on the above, the Chamber finds that the Variant A/B Instructions were formulated, distributed, and ultimately followed at a municipal level. The Accused was intimately involved in this process through his distribution of the instructions and his subsequent involvement in monitoring the implementation of those instructions. The Chamber further finds that the Variant A/B Instructions were used to create parallel Bosnian Serb structures and bodies at a municipal level. The instructions also provided for the military organisation of the Bosnian Serbs at a municipal level. The Variant A/B Instructions were a crucial initial step towards establishing Bosnian Serb authority in Bosnian Serb claimed territory. As discussed in Section IV.A.1 of this Judgement, following the creation of these parallel structures, Serb Forces were able to take-over power in the Municipalities. Following these take-overs, the parallel structures including the Crisis Staffs and Bosnian Serb municipal assemblies were able to maintain power in the Municipalities.

3090. The Chamber finds that one of the first steps in the Bosnian Serb objective of creating a separate state was the expansion and delineation of territory. The parallel municipal structures which were created pursuant to the Variant A/B Instructions, played a pivotal role in this process of territorial expansion and delineation of territory.

10022 D456 (Transcript of 20 $0^{\text {th }}$ session of RS Assembly, 14-15 September 1992), p. 15.

10023 D456 (Transcript of $20^{\text {th }}$ session of RS Assembly, 14-15 September 1992), p. 15. 
3091. The Chamber finds that the Accused played a central role in promoting this territorial delineation and the steps that needed to be taken in order to establish the borders of the SerBiH in accordance with their territorial and strategic aspirations. The Accused actively encouraged and supported the division of municipalities on ethnic lines. He also emphasised the importance of taking control and power of territory in establishing the de facto situation which would form the basis for the creation of their state. The Chamber also finds that the Accused played a leading role in the separation of municipal structures and the establishment of parallel Serb structures which would allow this objective to be achieved. The steps taken with respect to the creation of the SerBiH were also informed by the objectives of the unity and non-separation of the Serb people which has been previously discussed.

3092. The Chamber finds that what the Accused said at the Bosnian Serb Assembly on 18 March 1992 is particularly instructive as it underscores that he and the Bosnian Serb leadership had clearly made plans which would allow for the rapid seizing of power at a municipal level when the time was right. ${ }^{10024}$ This speech also demonstrates that the Accused was adamant that the Bosnian Serbs would achieve what they wanted, that they clearly had strategic objectives which had to remain secret but which would be realised. The Chamber finds that this objective was the seizure and control of Bosnian Serb claimed territory in a manner which would allow for the creation of an ethnically homogeneous state.

3093. The Chamber also finds that while the Accused expressed caution and emphasised that the steps they would take were defensive for the purposes of international opinion, he clearly envisaged that if their objectives could not be achieved politically they would use military means and if there was war he would issue plans about how to proceed. The Chamber notes that when war did break out the Accused repeated his emphasis on the need to protect the Bosnian Serbs from genocide and characterised their fight as one which was defensive in order to achieve their objectives.

3094. The Chamber notes textual provisions, including the Bosnian Serb Constitution, included protections for the rights of all people. The Accused also spoke about the full respect for the rights of other nationalities and that the probable resettlement of people should not occur under pressure. Other Bosnian Serb leaders also spoke about respecting the rights of non-Serbs who decided to remain in the SerBiH. However, the Chamber finds that there was a clear disjuncture between what was written on paper, what the Accused and the Bosnian Serb leadership said in public, and the way in which Bosnian Muslims and Bosnian Croats were treated in practice following the formation of the SerBiH. In this regard the Chamber refers to its extensive factual findings with $10024 \quad$ See para. 3051. 
respect to the crimes which were committed against Bosnian Muslims and Bosnian Croats in the Municipalities and which resulted in the creation of a largely ethnically homogeneous state.

3095. The Chamber finds that these public announcements, speeches, and decisions were often for the consumption of international public opinion and to show that the Bosnian Serb state which was being created was one which respected the law and the rights of all people. The Chamber does not find that either the statements of the Accused or the Bosnian Serb leadership in this regard were genuine; in fact, they were completely disingenuous, having regard to the reality of what was happening on the ground in the Municipalities. The Chamber also refers to its findings below with respect to the Accused's knowledge of crimes which were being committed in $\mathrm{BiH}$. The Chamber notes for example its finding above, that while the Accused made these public statements about the protection of minorities, Bosnian Muslims continued to be forced out of municipalities in $\mathrm{BiH}$. In addition, the Chamber finds the evidence above demonstrates that the Bosnian Serbs were aware that some of their speeches were being recorded and could be reported on by journalists and in that context were cautious in terms of what was said.

3096. The Accused and the Bosnian Serb leadership continued to emphasise that they wanted to create a reality on the ground, which then in negotiations could be used to claim territory which they viewed as belonging to them. The Accused used this factual control of territory and the creation of a "new reality" as a means of securing international recognition for the RS. It was also clear that the Accused acknowledged the military manner in which this "reality" was created and gave credit to the Serb Forces for their role in achieving this objective of territorial control.

\section{iii. Authority over military and police forces acting in BiH}

\section{(A) VRS}

3097. The Chamber noted above that the Army of SerBiH was established on 12 May 1992 and was renamed the VRS on 12 August 1992. ${ }^{10025}$ It was formed from parts of the JNA, TO, and volunteer units. ${ }^{10026}$ It inherited both officers and soldiers from the JNA, many of whom were of Bosnian Serb origin, as well as a substantial amount of weaponry and equipment. ${ }^{10027}$

\footnotetext{
10025 See para. 160. For ease of reference the acronym "VRS" will be used throughout this section to also cover the period prior to 12 August 1992, when the Army of SerBiH was renamed the VRS.

10026 See para. 161.

10027 See para. 161.
} 


\section{(1) $\underline{\text { Supreme commander }}$}

3098. As noted above, whether in the three-member or the five-member Presidency, the Accused was in charge of military affairs. ${ }^{10028}$ As the RS President the Accused was the Supreme Commander of the VRS, ${ }^{10029}$ a position that he held until July $1996 .{ }^{10030}$ The Accused's position as the Supreme Commander of the VRS was clearly recognised by the civilian and military Bosnian Serb leadership. ${ }^{10031}$ During the time period relevant to the Indictment, the Accused was the highest authority in the VRS chain of command. ${ }^{10032}$

3099. In an interview on 6 January 1995, the Accused stated that "all speculations about the army not obeying the civilian authority are out of place. As the supreme commander, I get all the respect from the officers and soldiers. [...] I want them to 'argue' with me about various solutions because it helps me to make the right decision, but when I make a decision, they carry it out brilliantly". ${ }^{10033}$ The Accused cited the example of an order he gave to "cut the territories taken by the Muslims on the Bihać battlefield, and to pursue and destroy them, I was absolutely sure that our army would comply. [...] Whatever the Supreme Command decides gets fully done". ${ }^{10034}$

\footnotetext{
10028 See paras. 96-97; Momčilo Mandić, T. 5107 (14 July 2010); D440 (Minutes of $15^{\text {th }}$ session of SerBiH Presidency, 6 July 1992), p. 3.

10029 P2603 (SerBiH Law on the Army, 1 June 1992), art. 174; Manojlo Milovanović, T. 25441 (28 February 2012); Mićo Stanišić, T. 46360 (3 February 2014), T. 46577 (5 February 2014); Momčilo Mandić, C2 (Transcript from Prosecutor v. Krajišnik), T. 9108.

10030 See para. 167.

10031 See, e.g., D456 (Transcript of 20 $0^{\text {th }}$ session of RS Assembly, 14-15 September 1992), p. 19; Momčilo Mandić, C2 (Transcript from Prosecutor v. Krajišnik), T. 9436-9440; P3149 (Minutes of $14^{\text {th }}$ session of Supreme Command, 31 March 1995), p. 49; P970 (Transcript of 50 ${ }^{\text {th }}$ session of RS Assembly, 15-16 April 1995), p. 313; Bogdan Subotić, T. 40061 (19 June 2013); P5053 (Conclusions from a meeting attended by the highest representatives of RS, 7 October 1993), pp. 4-5. See also P2451 (Witness statement of Anthony Banbury dated 19 May 2009), paras. 112, 208, 211 (stating that he never sensed that the Accused lost control of the military; instead "at all times the military was responsive to the political leadership" and that the military and political leadership were not always in agreement and there were occasional reticent or divergent views, however, "the chain of command remained intact"); Anthony Banbury, T. 13349-13350 (15 March 2011).

10032 P2603 (SerBiH Law on the Army, 1 June 1992), art. 174; D422 (Transcript of $19^{\text {th }}$ session of SerBiH Assembly, 12 August 1992), pp. 63-64; P5578 (Amended Text of the Constitution of the RS and Rules of Procedure of RS Assembly, 17 December 1992), art. 106; Momčilo Mandić, C2 (Transcript from Prosecutor v. Krajišnik), T. 9108; KDZ088, T. 6357 (8 September 2010) (private session); Jovan Šarac, T. $47162-47163$ (14 February 2014). See also P3036 (Radovan Karadžić's Decision on the establishment of the VRS Supreme Command, 30 November 1992); P1388 (Transcript of 39 ${ }^{\text {th }}$ session of RS Assembly, 24-25 March 1994), pp. 85-86; Ljubomir Obradović, T. 25108-25109 (22 February 2012); P3041 (VRS Main Staff Report, 31 March 1994), p. 5; P4493 (VRS Main Staff Order, 7 February 1994); P4447 (Radovan Karadžić's Order, 24 April 1994); P4495 (Radovan Karadžić's Order to VRS Main Staff and RS MUP, 29 March 1995); Rupert Smith, T. 11326-11328 (8 February 2011); Manojlo Milovanović, T. 25444-25445 (28 February 2012), T. 25484-25486 (29 February 2012); Dušan Kovačević, T. 39657 (11 June 2013); Jovan Šarac, T. $47162-47163$ (14 February 2014); Petar Škrbić, T. 26024-26026 (8 March 2012); P1469 (Minutes of VRS Supreme Command meeting, 20 December 1992); P3148 (Handwritten notes of Supreme Command meeting, 8 May 1994); P3149 (Minutes of $14^{\text {th }}$ session of Supreme Command, 31 March 1995); Milan Ninković, T. 40505-40506 (26 June 2013).

10033 P953 (Article from Oslobođenje entitled "Happy Birthday Republic", 6 January 1995), p. 9.

10034 P953 (Article from Oslobođenje entitled "Happy Birthday Republic", 6 January 1995), pp. 9-10.
} 


\section{(2) Command and control system}

3100. The Chamber notes that, on 15 June 1992, in his capacity as the President of the Presidency, the Accused established a system of command and control in the VRS, which included a Main Staff —directly subordinated to him—-that had command and control over the operative groups. ${ }^{10035}$

3101. During the first months of the conflict, the Accused, Krajišnik, Koljević, and Plavšić did not deal with issues that related to military affairs and warfare and Mladić enjoyed freedom in devising and executing military operations while claiming that he was fully subordinate to the Bosnian Serb political leadership. ${ }^{10036}$ However, this restraint on the part of the Bosnian Serb political leadership waned starting in June 1992 when they began to gradually limit Mladić and eventually the "political power was on top". 10037

3102. On 30 November 1992, the Accused established the Supreme Command for the purpose of co-ordinating and improving the efficiency of the command system of the VRS. ${ }^{10038}$

3103. In a report, prepared by the Main Staff, analysing the combat readiness of the VRS in 1992, it is noted that the VRS had evolved into the "highest strategic organisational formation of the Serbian people in the former $[\mathrm{BiH}]$, capable of realising the strategic and other tasks assigned to it by the Supreme Command." 10039 It further stated that the VRS

has been under a single control and command structure, despite the fact that initially we had a large number of different armies and paramilitary formations. This unity has been attained by following well-known principles, such as: unity, continuity, flexibility, efficiency,

10035 P3035 (Decision on Army of SerBiH, 15 June 1992), p. 3; P4917 (Richard Butler's expert report entitled "VRS Main Staff Command Responsibility Report", 9 June 2006), paras. 2.0-2.1. In 1992, the Main Staff was subordinated to the Presidency. The Chamber recalls that on 17 December 1992, the Bosnian Serb Assembly replaced the structures of the Presidency by establishing a single President and two vice-Presidents; from then on the VRS Main Staff was subordinated to the President of the RS. See para. 98. The Chamber also notes the evidence that while the formal conditions for establishing the army were created on 19 May 1992, it took a while to pass the bylaws and implement regulations on the ground. See Momčilo Mandić, T. 5202 (15 July 2010). However, the Chamber notes that already on 14 May 1992 the Accused was involved in discussions as to the establishment of the command and control system. P3079 (Minutes of joint session of the National Security Council and the SerBiH Government, 14 May 1992), p. 2. See also D3695 (Witness statement of Bogdan Subotić dated 16 June 2013), para. 276. A similar conclusion was reached to place members of the Cabinet on duty. D414 (Minutes of $19^{\text {th }}$ session of Government of SerBiH, 2 June 1992), p. 3

10036 [REDACTED]. John Wilson stated that he attended a meeting on 25 May 1992, in relation to opening the Sarajevo airport and in the presence of Plavšić, Mladić stated that he was subordinated to the political leadership. P1040 (UNPROFOR report re meeting with Biljana Plavšić and Ratko Mladić, 25 May 1992), para. 7; P1029 (Witness statement of John Wilson dated 4 November 2008), para. 74.

[REDACTED]. See also D3960 (Witness Statement of Tomislav Kovač dated 28 October 2013), paras. 91,96 (stating that since the founding of the VRS there was an "ideological conflict" between the civilian authorities and the Main Staff).

10038 See para. 165.

10039 D325 (VRS Main Staff analysis of combat readiness and army activities in 1992, April 1993), p. 7. See also P976 (Directive 4, 19 November 1992), p. 2 (wherein Mladić reported that the SRK "has fully stabilised command and control in the Corps and subordinate units"). 
operationability [sic] and security, with subordination and a single command having a crucial bearing on relations in the control and command process. ${ }^{10040}$

3104. The strategic level of command was within the remit of the Supreme Command and the Main Staff whereas the operative level of command was at the corps level. ${ }^{10041}$ However, as shown below, the Accused's involvement went beyond planning strategy and in several cases he was involved in the operational level as well.

3105. The military chain of command went from the Accused to the Commander of the Main Staff and then down to the corps commands and brigades. ${ }^{10042}$ The Main Staff would prepare proposals for operations for the Accused; he would then consider them and issue instructions. ${ }^{10043}$ In the context of the SRK, Stanislav Galić testified that he could receive orders from both the Accused, as the Supreme Commander, and Mladić, as commander of the Main Staff. ${ }^{10044}$ Similarly, in a meeting between Milovanović and Bogdan Subotić, the former confirmed to the latter that the Accused, as the Supreme Commander, had the ultimate say and that in a situation where there is a standing order by Mladić the military subordinates had to obey it unless and until they received an order from the Accused. ${ }^{10045}$

3106. The Accused stated in 5 April 1993 that:

10040 D325 (VRS Main Staff analysis of combat readiness and army activities in 1992, April 1993), p. 7.

10041 Stanislav Galić, T. 37593-37597 (23 April 2013).

10042 D3695 (Witness statement of Bogdan Subotić dated 16 June 2013), paras. 60, 69; Bogdan Subotić, T. 40061 (19 June 2013). Subotić also stated that this chain of command was only formed after 12 May 1992 and that before this date the Accused had no formal control of the military. See also Petar Škrbic, T. 25971-25972 (7 March 2012); P1029, (Witness statement of John Wilson 4 November 2008), para. 127. The Chamber notes that according to Kuprešanin there was no co-ordination or subordination between the civilian authorities and the military authorities, as they each operated independently with their own chains of command, whereas, according to KDZ490 the SDS party in Sanski Most had enormous influence over the VRS, especially after October 1992, since the VRS Light Brigades were directly financed by the municipality budgets, except for former JNA officers who were still paid by the JNA. Vojislav Kuprešanin, T. 43518-43520 (14 November 2013); P3634 (Witness statement of KDZ490, undated), pp. 13, 38 (under seal) (testifying, inter alia, that when the SDS wanted to remove Colonel Basara, Commander of the $6^{\text {th }}$ Sana Brigade, because he was "too soft for the SDS", the SDS in Sanski Most exercised pressure on General Talić to remove him). See also P6510 (Excerpt of Vojislav Kuprešanin's interview with OTP), e-court p. 7. However, the Chamber notes that the Main Staff of the VRS, when it found it necessary, reminded the commanders of corps and brigades that they could receive assignments and orders only from the Main Staff of the VRS and the Accused, as the Supreme Commander. P3041 (VRS Main Staff Report, 31 March 1994), p. 5. See also Manojlo Milovanović, T. 25632 (1 March 2012); P4494 (Eastern Bosnia Corps Order, 1 April 1994), pp. 5-6.

10043 D3695 (Witness statement of Bogdan Subotić dated 16 June 2013), paras. 72, 84, 89-90. See also Stanislav Galić T. 37594 (23 April 2013); John Zametica, T. 42457, 42517 (29 October 2013); P1029 (Witness statement of John Wilson 4 November 2008), para. 136. The Chamber places no weight on Subotić's opinion that until the formation of the Supreme Command, Mladic did not report to anyone or if he did report to anyone it was to the Accused.

10044 Stanislav Galić, T. 37593-37597 (23 April 2013). However, the Chamber notes that Galić could not remember any "immediate combat orders" received from the Supreme Command. Stanislav Galić, T. 37602-37603 (23 April 2013). See also paras. 3129, 4755-4756, 4762.

10045 Bogdan Subotić, T. 40061 (19 June 2013). 
The Main Staff of the Army of Republika Srpska has performed the functions of the Staff of the Supreme Command and at the same time that of the superior command for operational and some joint tactical formations, which presupposed the agreement of the Supreme Command in respect of all tasks and objectives of the armed struggle. This relationship between the command structures and the organs of the government and the Supreme Command made it impossible for the Main Staff to make decisions absolutely on its own, rather every operational battle was politically endorsed on the basis of interests of the Serbian people, and approved by the highest authorities of Republika Srpska. ${ }^{10046}$

3107. The military reporting chain in the VRS followed a hierarchical structure with the information originating from the lower military units being reported, up the chain of command, to the Accused. ${ }^{10047}$ The Chamber recalls its finding that while there were disruptions in telecommunications in 1992, the RS authorities were still able to communicate, ${ }^{10048}$ and notes that the VRS had at its disposal a superior communication system. ${ }^{10049}$ In its report analysing the combat readiness of the VRS in 1992, the Main Staff concluded with "a high degree of certainty" that the existing communication system met the needs of command co-ordination and reporting at all levels, from the Supreme Command, the Supreme Commander, the Main Staff to lower levels. ${ }^{10050}$ The Chamber also observes that Mladić and other members of the Main Staff had direct telephone contact with the Accused, ${ }^{10051}$ and that Mladić also visited the Accused frequently. ${ }^{10052}$

3108. The Accused received regular reports from the army ${ }^{10053}$ and even during 1992, while the communication was more limited he received reports based on the modes of communication which

10046 D325 (VRS Main Staff analysis of combat readiness and army activities in 1992, April 1993), p. 153. See also Manojlo Milovanović, T. 25632 (1 March 2012) (stating that the army remained under the Accused's personal command and that "no one from the Supreme Command could issue orders to the Main Staff other than [the Accused]". See also para. 3129.

10047 Ljubomir Obradović, P4444 (Transcript from Prosecutor v. Tolimir), T. 11973-11974. See also P4446 (Organisational Chart of the VRS Main Staff Structure for July 1995); Ljubomir Obradović, T. 25092-25093 (22 February 2012); P2068 (Witness statement of Jeremy Bowen dated 10 August 2009), para. 31 (referring to an interview with the Accused in Geneva in the winter of 1992-1993 during which the Accused spoke of the "disciplined" Bosnian Serb police and army).

10048 See paras. 3019-3020. See also, e.g., para. 2293; Dragomir Milošević, T. 32871-32879 (29 January 2013) (testifying about difficulties in the communication system in the SRK but added that the system of command is always repaired and improved, and towards the end it functioned meticulously); P4203 (Witness statement of Pyers Tucker dated 12 May 2010), paras. 6, 106 (testifying that in the period of October 1992 until March 1993 "the Bosnian Serb Army had very efficient and comprehensive communications" and "[w]henever General Mladić wanted to speak with someone or find something out from someone, It always happened quickly."); P1478 (Ratko Mladić's notebook, 27 May-31 July 1992), p. 228 (Colonel Živanović reporting that he had established communications with several municipalities, including Bratunac, Zvornik and Vlasenica, and that "Motorola hand-held radios are in companies-platoons in those sectors.")

10049 P1029, (Witness statement of John Wilson 4 November 2008), para. 130. See also P4203 (Witness statement of Pyers Tucker dated 12 May 2010), paras. 6, 106; P2794 (Witness statement of Ranko Vuković dated 24 May 2011), p. 4.

10050 D325 (VRS Main Staff analysis of combat readiness and army activities in 1992, April 1993), pp. 8-9.

10051 Ljubomir Obradović, T. 25103-25104 (22 February 2012).

10052 P4358 (Witness statement of Mira Mihajlović, 6 February 2012), para. 30.

10053 D3695 (Witness statement of Bogdan Subotić dated 16 June 2013), paras. 86, 91-92. See also P3061 (Minutes of the $3^{\text {rd }}$ session of the SerBiH Presidency, 8 June 1992) (summarising a session in which the Presidency was briefed on the situation at the front and agreed on a plan of daily activities); D428 (Minutes of $4^{\text {th }}$ expanded meeting of SerBiH War Presidency, 9 June 1992) (briefing the Accused in detail about the overall situation in 
were available. ${ }^{10054}$ [REDACTED] testified that the Accused "was exceptionally well informed about the complete situation in Bosnia-Herzegovina" and the army sent him regular written or oral reports. $^{10055}$

3109. The Accused received, for example, military intelligence information reports, ${ }^{10056}$ reports about the situation in Rogatica in May 1992, ${ }^{10057}$ reports concerning military formations in the ARK following a visit of Bogdan Subotic there in September 1992, ${ }^{1058}$ and a report from the Command of the $2^{\text {nd }}$ Romanija Motorised Brigade about disputes and difficulties in co-operation with the civilian authorities in Sokolac. ${ }^{10059}$

3110. The level of knowledge of the Accused regarding military issues was also apparent when he informed Bosnian Serb institutions about military developments in RS. ${ }^{1006}$

3111. Occasionally, the Accused visited VRS units in the field. ${ }^{10061}$ For example, the Accused was in the SRK command post at the time of the operation to take over Dobrinja in June 1992,

the VRS, including figures on the quantities of weapons, ammunition, spare parts and reserves and a reporting on the situation in the area of Banja Luka Corps); P1093 (Minutes of $5^{\text {th }}$ session of SerBiH Presidency, 10 June 1992); P3063 (Minutes of the $7^{\text {th }}$ session of the SerBiH Presidency, 16 June 1992); P3064 (Minutes of the $8^{\text {th }}$ session of the SerBiH Presidency, 17 June 1992); P3072 (Minutes of the $27^{\text {th }}$ session of RS Presidency, 31 August 1992) p. 2; P1465 (Minutes of $19^{\text {th }}$ session of SerBiH Presidency, 13 July 1992); P1467 (Minutes of $21^{\text {st }}$ session of SerBiH Presidency, 2 August 1992), p. 2; P1508 (VRS Main Staff Order, 1 June 1992); P1786 (VRS Main Staff Report, 14 April 1994).

10054 D3695 (Witness statement of Bogdan Subotić dated 16 June 2013), paras. 86, 91-92.

10055 [REDACTED].

10056 John Zametica, T. 42443 (29 October 2013). See also P1469 (Minutes of VRS Supreme Command meeting, 20 December 1992); D3685 (RS President's Office request to VRS Main Staff, 3 October 1995); D4780 (VRS Main Staff Intelligence Report, 14 July 1993); D4785 (VRS Main Staff Intelligence Report, 10 August 1993); P5086 (Report of RS Main Staff, 19 March 1995). But see D3682 (Witness statement of Gordan Milinić dated 8 June 2013), para. 31, referring to D3685 (RS President's Office request to VRS Main Staff, 3 October 1995). The Chamber does not accept Milinić's suggestion that the RS President's Office request to the VRS Main Staff showed that the Main Staff ignored the Accused and did not inform him about developments. The Chamber notes that the testimony of Milinić was marked by contradictions, bias, and indicators that he lacked candour. The Chamber therefore does not find his evidence to be reliable in this regard. Rather, the Chamber finds that this requeset is indicative of the extent to which the Accused was kept informed by the VRS about developments.

10057 See P3265 (Report of Rogatica Batallion, 23 May 1992); D2965 (Rogatica Brigade report, 29 May 1992); D3037 (Rogatica Brigade report, 9 June 1992); P3414 (Report of the Rogatica Brigade Command, 11 June 1992); P3266 (Report of $2^{\text {nd }}$ Romanija Motorised Brigade, 15 August 1992).

10058 P3073 (Minutes of the $27^{\text {th }}$ session of RS Presidency, 1 September 1992); D3695 (Witness statement of Bogdan Subotić dated 16 June 2013), para. 291.

10059 D3232 (Letter from $2^{\text {nd }}$ Romanija Motorised Brigade to Radovan Karadžić, 3 September 1992), p. 1.

10060 See, e.g., P3114 (Minutes of the $32^{\text {nd }}$ session of RS Government, 13 October 1995), p. 4 (stating that the Accused informed the Government about the military and political situation in the RS, especially in Krajina). See also D3364 (Witness statement of Dušan Kozić dated 7 April 2013), para. 25; P956 (Transcript of $16^{\text {th }}$ Session of Assembly of SerBiH, 12 May 1992), e-court p. 8.

10061 P1466 (Herzegovina Corps combat report, 4 June 1992); P5522 (Communication of Drina Corps Command re Meeting with Radovan Karadžić, 2 July 1993); P2845 (Report of Bratunac Brigade, 4 August 1995). 
given the importance of the operation, and, as consequence, the Accused was aware of developments in this operation. ${ }^{10062}$

3112. Considering the above, the Chamber rejects the Accused's arguments that there was no communication with VRS units in the field and finds that such communications did exist. ${ }^{10063}$ As will be discussed in further detail below, the Chamber also rejects the Accused's argument that Mladić did not report to him. ${ }^{10064}$ With regard to the argument that there was a phenomenon of false reporting in the VRS, ${ }^{10065}$ the Chamber notes a few instances, in late 1994 and 1995, in which the issue was raised, ${ }^{10066}$ but is not satisfied that the evidence demonstrates a phenomenon of false reporting within the VRS, nor that such alleged false reports could affect the Chamber's finding regarding the authority of the Accused over the VRS.

\section{(3) Relationship between the Accused and Mladić}

3113. The Prosecution argues that the Accused had firm control over Mladic by virtue of his de jure powers as President and Supreme Commander. ${ }^{10067}$ While the Prosecution admits tensions existed between Mladić and the Accused, it asserts that their disagreement did not concern the common purpose of the Overarching JCE but emerged from Mladić's complaints about the Accused undercutting the chain of command. ${ }^{10068}$ The Prosecution ultimately argues that the heated discussions and arguments between the Accused and Mladić were not a sign of an existing

\footnotetext{
10062 [REDACTED].

10063 Defence Final Brief, paras. 523-529. The Chamber notes, for example, the Accused's reference in fn. 1123 to D325 (VRS Main Staff analysis of combat readiness and army activities in 1992, April 1993), p. 39, concerning the problem of understaffing in respect of officers and critical specialities in communications which affected the communication system and the battle readiness. However, the Chamber also notes that it was stated afterwards in the analysis that "[d]espite its being undermanned the signals corps has on the whole efficiently performed its tasks of providing good quality and uninterrupted communications links, whereby it has contributed to more successful control and command in all our units and commands."

Defence Final Brief, paras. 560-563.

10065 Defence Final Brief, paras. 565-567.

10066 P1487 (Ratko Mladić's notebook, 4 September 1994-29 January 1995), p. 142 (noting that the Accused talked about "[i]nstances of false reporting"); P970 (Transcript of $50^{\text {th }}$ session of RS Assembly, 15-16 April 1995), pp. 328-329, 336 (wherein the Accused said: "I have realised that I do not have control over the Army" and mentioned misinformation regarding the supply of the VRS and the need to monitor and inspect; he further talked about false reports with regard to military casualties and "war losses", and concluded that "[a]ll this, gentlemen, could be tolerated while things were going well for us, while it had no dangerous consequences"); John Zametica, T. 42443-42444 (29 October 2013). See also P3872 (UNPROFOR report, 10 June 1995), p.1 (reporting that "Stanisic appeared certain, on the basis of information supplied by the UN, that Mladic was withholding a few things from him about the situation with the [UN] hostages"); para. 4860. In the Chamber's view, the Accused's statement to Zametica that "[t]hey just send me lies", following reading an intelligence report from Tolimir, was to indicate the Accused's dissatisfaction with the quality of the report. Zametica recalled in this context that the Accused said that in his view Tolimir was using only newspapers articles for his intelligence report. John Zametica, T. 42443-42444 (29 October 2013).

10068 See Prosecution Final Brief, paras. 434-443.
} 
rift, but were rather healthy and constructive conversations within a superior-subordinate relationship. ${ }^{10069}$

3114. In response, the Accused argues that he had no control over the VRS, and that there were de facto two commanders throughout the war: Mladić, who retained operative command of the military authorities as the commander of the VRS, and himself, who retained political and strategic command of the civilian authorities as the Supreme Commander. ${ }^{10070}$ The Accused further argues that from the beginning, there was a lack of co-operation, mistrust, and a chasm between Mladić and him and as a result, the Accused had little to no control over VRS operations. ${ }^{10071}$

3115. As discussed earlier, on 12 May 1992, the VRS was established pursuant to a decision adopted unanimously at the $16^{\text {th }}$ Session of the Bosnian Serb Assembly; Mladic who had assumed command of the JNA $2^{\text {nd }}$ Military District two days earlier, was appointed as its Commander. ${ }^{10072}$ The Accused himself explained in April 1995 how he had sought out Mladić and supported his appointment:

I asked for Mladić. General Ninković, then a colonel, and General Perišić had visited me before that, and I had noticed Mladić's blunt statements in the newspapers. He was already in Knin then. I took an interest in him, and together with Mr. Krajišnik, I went to General Kukanjac's office and listened to him issuing orders and commanding around Kupres and Knin. We spent countless nights in the office of General Kukanjac at that time. President Krajišnik was already President of the Assembly, and I was just the president of the Party, I did not have any state function. We asked for Mladić and said that they should set up the headquarters as they saw fit, we wouldn't interfere. ${ }^{10073}$

3116. From the outset of their relationship, the Accused had authority to control the VRS, including over Mladić as its commander. ${ }^{10074}$ During the same 12 May 1992 Bosnian Serb Assembly session at which he was appointed Commander of the Main Staff, Mladić affirmed that "the President of the $[\mathrm{SerBiH}]$ should have command and control over the army". ${ }^{10075}$ Mladic himself referred to the Accused as the "Supreme Commander". ${ }^{10076}$

\footnotetext{
10069 See Prosecution Final Brief, paras. 434-438, 443.

10070 See Defence Final Brief, paras. 1268-1271.

10071 See Defence Final Brief, paras. 1251-1285.

10072 See paras. 160-161, fn. 424.

10073 P970 (Transcript of 50 ${ }^{\text {th }}$ session of RS Assembly, 15-16 April 1995), p. 317. See also P1477 (Ratko Mladić's notebook, 14 February-28 May 1992), p. 292 (showing that during a meeting with Mladić on 11 May 1992, Perišić had indicated that he and Ninković together proposed to the Accused that Mladić should come to the BiH). See also paras. 160, 169.

10074 See paras. 3099, 3105.

10075 P956 (Transcript of $16^{\text {th }}$ session of SerBiH Assembly, 12 May 1992), e-court p. 41.

10076 D456 (Transcript of $20^{\text {th }}$ session of RS Assembly, 14-15 September 1992), p. 19. See also P1379 (Transcript of $34^{\text {th }}$ session of RS Assembly, 27-29 August, 9-11 September, 29 September to 1 October 1993), p. 255 (wherein the Accused affirmed his role as Supreme Commander and in particular over the "strategic usage of the army, but only in situations when things go wrong [...]". See also para. 3098.
} 
3117. International observers noted that while Mladić did what the Accused or the Bosnian Serb Assembly directed him to do with respect to the VRS, there were occasions where Mladic did not necessarily do what he was ordered to do. ${ }^{10077}$ While Mladić sometimes expressed different opinions in the context of international meetings, the Accused often took the lead and Mladic allowed himself to be persuaded by the Accused or deferred to him in the context of these meetings and indicated that he would do what the Accused said. ${ }^{10078}$ International observers noted that there was a "moderately healthy" relationship between the Accused and Mladić. 10079

3118. According to Harland and Rupert Smith, the Accused and Mladić, as well as other members of the Bosnian Serb leadership, acted like a collective leadership; despite the existence of some tension between the political and military leadership, this tension was not destructive and they were "joined at the hip" and conducted themselves in a single direction. ${ }^{10080}$

3119. Michael Rose, who spent much of his time in Sarajevo meeting with the Accused and Mladić, testified that "it was clear" that they were at the peak of the pyramid of control of the Bosnian Serb forces. ${ }^{10081}$ He also testified that the relationship between the Accused and Mladić "was, as one would expect in a confused and brutal situation, of varying intensity" but that "generally speaking, the military were in support of the civil power, and they did not replace it". ${ }^{10082}$ Throughout his time in $\mathrm{BiH}$, he observed nothing to suggest there was disunity between the

\footnotetext{
10077 Pyers Tucker, T. 23226 (18 January 2012); P4203 (Witness statement of Pyers Tucker dated 12 May 2010), paras. 277-278. See also D4483 (UNPROFOR report, 4 August 1993); D3876 (Letter from Radovan Karadžić to Ratko Mladić, 15 March 1995).

10078 David Harland, T. 2029-2030 (6 May 2010); P1029 (Witness statement of John Wilson dated 4 November 2008), paras. 133-134; Pyers Tucker, T. 23226 (18 January 2012); D2026 (Excerpt from Pyers Tucker's diary, 13 March 1993), p. 26; P4203 (Witness statement of Pyers Tucker dated 12 May 2010), paras. 68, 72, $277-278$.

10079 P4203 (Witness statement of Pyers Tucker dated 12 May 2010), paras. 68, 72.

10080 P820 (Witness statement of David Harland dated 4 September 2009), paras. 283-284 (stating further that when the Accused and Mladić were together, usually the Accused was the protagonist); Rupert Smith, T. 1130211304, 11326 (8 February 2011); T. 11671-11672 (11 February 2011); T. 11848 (15 February 2011) (on crossexamination, Smith could not confirm the Accused's contention that Slobodan Milošević, the UN, and UNPROFOR were trying to sow discord between the Accused and Mladić but acknowledged that the political and military leadership were not always in agreement).

10081 P1638 (Witness statement of Michael Rose dated 26 March 2009), para. 207.

10082 P1638 (Witness statement of Michael Rose dated 26 March 2009), paras. 211-212. Rose recounted, however, an incident where Mladić rejected an agreement Rose had earlier made with the Accused, concerning the reopening of the Tuzla airport. See P1638 (Witness statement of Michael Rose dated 26 March 2009), para. 32. During his time in Sarajevo, Bell heard that there was tension between the Accused and Mladić, which increased towards the latter part of the war when the Accused began wearing a military uniform. Bell was told by an UNPROFOR source that, especially in the final year of the war, the military was less inclined to take orders from the political leadership and supported Mladić more. See P1996 (Witness statement of Martin Bell dated 8 March 2010), paras. 113-114.
} 
military and political arms of the Bosnian Serb leadership; thus, according to Rose, the hierarchy was functioning adequately. ${ }^{10083}$

3120. Wilson also testified that there seemed to be a very comfortable relationship between the Bosnian Serb civilian leadership and Mladić. ${ }^{10084}$ While Mladić was a strong personality, and capable of independent action, he would repeatedly say that he was a soldier with no political ambitions and ultimately he did "what his political masters told him to do". ${ }^{10085}$

3121. At the end of 1992, Mladic also stressed that he and the Accused had a "natural relationship" and there were no differences between them; they were united and struggling for the same objectives. ${ }^{10086}$ Whenever it was considered necessary, the Presidency would call on Mladić or his deputy to brief them on developments. ${ }^{10087}$ Mladić visited the Accused frequently. ${ }^{10088} \mathrm{He}$ and other members of the Main Staff had direct telephone contact with the Accused. ${ }^{10089}$

3122. However, during the same period, international observers noted that Mladić was increasingly powerful and they speculated that the Accused might "be on the way out". ${ }^{10090}$ At this time, the Accused had informed international observers that he wanted to move Mladić but this was unlikely to succeed. ${ }^{10091}$

3123. Mladić also gave the impression to international observers that nothing of military significance could or would happen in Bosnian Serb-controlled $\mathrm{BiH}$ without his specific

10083 P1638 (Witness statement of Michael Rose dated 26 March 2009), para. 164 (opining that the Accused's insistence on wearing a camouflage uniform suggested that the Bosnian Serb leaders were at pains to demonstrate unity).

10084 P1029 (Witness statement of John Wilson dated 4 November 2008), paras. 127, 132, 134.

10085 P1029 (Witness statement of John Wilson dated 4 November 2008), paras. 132-134 (citing, as another example, an incident during the Sarajevo airport negotiations where the Accused took Mladić into an adjoining room and engaged in a heated argument, after which Mladić changed his position and accepted the proposal to hand over the airport).

10086 P1364 (Transcript of $23^{\text {rd }}$ session of RS Assembly, 17 December 1992), e-court p. 105. But see D3682 (Witness statement of Gordan Milinić dated 8 June 2013), paras. 11-12, 24-25, 28, 31; D3687 (RS President's Office request to VRS Main Staff, 7 August 1994); Gordan Milinić, T. 39724-39725, 39727 (11 June 2013), T. 39799_ 39800 (12 June 2013). Milinić stated that the Accused did not have control of the VRS and that he was not viewed as their supreme commander and that neither the Main Staff of the VRS nor Mladic respected the Accused and the Accused was powerless. However, the Chamber notes that the testimony of Milinić was marked by contradictions, bias, and indicators that he lacked candour. The Chamber therefore does not find his evidence to be reliable in this regard. See also fn. 10056.

10087 Bogdan Subotić, T. 40050-40051 (19 June 2013).

10088 P4358 (Witness statement of Mira Mihajlović, 6 February 2012), para. 30 (stating further that as the Accused's secretary between January 1993 and January 1996, she could not recall any confrontations between Mladić and the Accused in her presence).

10089 Ljubomir Obradović, T. 25103-25104 (22 February 2012).

10090 P787 (Fourth notebook of Herbert Okun's ICFY diary), e-court pp. 67-68, 72.

10091 P787 (Fourth notebook of Herbert Okun's ICFY diary), e-court p. 77. 
approval. ${ }^{10092}$ At a meeting with Mladić on 4 May 1993, General Panić and Bulatović suggested that Mladić take the floor after the Accused at the Bosnian Serb Assembly session the following day where the Vance-Owen Plan was scheduled to be discussed and put to a vote, as "Mladić has the greatest influence on the Serbian people", greater even than the Accused. ${ }^{10093}$

3124. In 1993 and 1994, the Accused and Mladić denied any rift between them. In August 1993, Mladić emphasised that he had never taken a decision by himself and that "all claims about some rift in military and political leadership are untrue". ${ }^{10094}$ In June 1993, Plavšić attempted to "inflict damage" on the Accused by referring to a conflict between him and Mladić in public, however, according to Milovanović, there were never any open conflicts between the Accused and Mladić, "not even then or after that". 10095 They may have had "harsh exchanges of opinion" when discussing major joint tasks, but for him, this was a normal aspect of the relationship between the military and political leadership. ${ }^{10096}$ Further, the Accused wrote to Mladić in April 1994 and emphasised the importance of the VRS respecting his authority and the decisions of the political leadership. ${ }^{10097}$ At a 4 August 1994 briefing by commanders of the VRS, the Accused was recorded as saying: "Everyone is looking to find a rift among individuals in the leadership, especially between me and Mladić. They will fail at that, because Mladić and I talk about things as brothers [...] and our aim is to move together towards the same goal."10098

3125. However, the Chamber received evidence of disagreements between the Accused and Mladić in 1993 and 1994. On 4 August 1993, in relation to a concern that Mladić would not withdraw from Mt. Igman and Bjelašnica in Sarajevo and a "fall-out" between UNPROFOR and Mladić the day before, the Accused told Milovanović, "if I give him some orders, he has to carry them out. He has the right to say that they are not useful and that they are damaging, but if I later make a decision, he has to carry that out to the end". ${ }^{10099}$ In another conversation later on the same

\footnotetext{
10092 P4203 (Witness statement of Pyers Tucker dated 12 May 2010), paras. 59, 282 (wherein Tucker states that Mladic referred to himself as the Napoleon of the Balkans and that "he and he alone" would decide on issues pertaining to the safety of Serbs in $\mathrm{BiH}$ ).

10093 P1483 (Ratko Mladić's notebook, 2 April-24 October 1993), pp. 86-87.

10094 P1379 (Transcript of $34^{\text {th }}$ session of RS Assembly, 27-29 August, 9-11 September, 29 September to 1 October 1993), p. 72.

10095 D2149 (Aide mémoire of Manojlo Milovanović), p. 26.

10096 D2149 (Aide mémoire of Manojlo Milovanović), p. 26. See also P5237 (Video footage of interview with Radovan Karadžić by CNN, undated).

10097 D1590 (Radovan Karadžić 's letter to Chief of VRS Main Staff, 27 April 1994).

10098 P1486 (Ratko Mladić's notebook, 31 March 1994-3 September 1994), pp. 252, 269.

10099 D3871 (Intercept of conversation between Radovan Karadžić and Milovanović, 4 August 1993). See also D4483 (UNPROFOR report, 4 August 1993), para. 1 (reporting that Mladić made strong statements to UNMOs the day before that he had no intention of withdrawing Bjelašnica and noting generally that Mladić does not always follow political directions); D4508 (Intercept of conversation between Radovan Karadžić and Manojlo Milovanović, 3 August 1993), p. 3 (during which the Accused told Milovanović to tell Mladić that "only one
} 
day, the Accused told Milovanović not to come between him and Mladić, namely that he should not "be between the hammer and the nail, I am the supreme commander and I am ordering; order them to withdraw and tell Mladic to report to me from the airport". ${ }^{10100}$ In the same conversation, the Accused told Milovanović that if Mladić was preventing him from executing his orders, "you are then obliged to inform me and I will replace him [...] you are to carry out my executive orders because I am your supreme commander. Mladić has to carry out every one of my orders; if he hasn't, I will replace him and arrest him.,"10101

3126. The Accused suggested that Milovanović replace Mladić as commander of the Main Staff on a number of occasions. ${ }^{10102}$ On 6 August 1993, the Accused presented Milovanović with a "fait accompli" in front of a large group of journalists, stating that he would hand over the army to Milovanović as commander of the Main Staff in place of Mladić; however, Milovanović said he would deny it without an Assembly decision to that effect. ${ }^{10103}$ In December 1993, the Accused was openly critical of Mladić to Milovanović because he was upset that he never knew Mladić's whereabouts; he asked Milovanović to meet with him in Pale and stated again that it would be better if Milovanović were in command of the VRS. ${ }^{10104}$ Milovanović refused and stood by Mladić, who remained as commander of the Main Staff until the end of the war. ${ }^{10105}$

3127. In September 1993, there were clear tensions between the Accused and Mladić, including during their exchanges in Bosnian Serb Assembly sessions in relation to a number of issues. ${ }^{10106}$ The Accused's authority remained clear, however, and the Accused himself emphasised the authority he held, stating: "I have issued an order to the general who is under my command, that is not testing, that is an order", "I am the Commander-in-Chief and I am ordering necessary measures

wrong move he might make could wreck the entire country, the entire nation. He must be cautious now and not fall for their provocations").

10100 P4786 (Intercept of conversation between Radovan Karadžić and General Milovanović, 4 August 1993), p. 2. See also D3872 (Intercept of conversation between Radovan Karadžić and Tomanić, 11 August 1993).

10101 P4786 (Intercept of conversation between Radovan Karadžić and General Milovanović, 4 August 1993), p. 3.

10102 Manojlo Milovanović, T. 25632, 25642-25643 (1 March 2012). See also para. 3135.

10103 Manojlo Milovanović, T. 25632, 25642-25643 (1 March 2012). See also para. 3135.

10104 Manojlo Milovanović, T. 25642-25643 (1 March 2012). The Accused requested that this conversation remain private but Milovanović told him that he was obliged to inform Mladić of their conversation pursuant to the law. Manojlo Milovanović, T. 25643 (1 March 2012).

10105 Manojlo Milovanović, T. 25642-25643, 25670 (1 March 2012); D3671 (Witness statement of Dušan Kovačević dated 7 June 2013), para. 35. See also P1489 (Ratko Mladić's notebook, 28 August 1995-15 January 1996), p. 135 (noting that Mladić was at a meeting of the RS Supreme Command on 1 December 1995 with the Accused, Krajišnik, Plavšić, and others).

10106 P1379 (Transcript of $34^{\text {th }}$ session of RS Assembly, 27-29 August, 9-11 September, 29 September to 1 October 1993), pp. 270-272, 274-275, 306; D3695 (Witness statement of Bogdan Subotić dated 16 June 2013), paras. 124-125, 127-129, 140. 
to be taken". 10107 The Accused also stated that of the civilian authorities, only he had the possibility of controlling the army and the army had to get "used to the fact that they are under the command and control of the civilian authority". ${ }^{10108}$ The Accused further stressed at this meeting that if he did not continue to trust Mladić, he could and would have dismissed him, describing him as "the glorious fighter from Krajina". ${ }^{10109}$

3128. In November 1993, UNPROFOR reported that the Serbs seemed to be "directionless", noting that the Accused is "blocked by Serbia and by the international community at large" and Mladić is "frustrated and is becoming increasingly bellicose". ${ }^{10110}$ They observed that Mladić was more dangerous as he was feeling ineffective as a military commander and marginalised as an individual. $^{10111}$

3129. There were similar disagreements and tension between the Accused and Mladic during meetings in 1994. ${ }^{10112}$ On 26 April 1994, Milovanović spoke with Gvero over the phone in relation to an agreement with UNPROFOR whereby heavy weapons were to be withdrawn, or put under the control of UNPROFOR, and the Accused had ordered the weapons to be withdrawn; Milovanović told Gvero, "[f]uck it, pardon my French, you put my balls in a vice. [...] Well, because [the Accused] has ordered weapons to be withdrawn, Mladić doesn't allow it". ${ }^{10113}$ Milovanović further stressed that "here's what's important, it's important that [the Accused] is making me pull out heavy weapons $20 \mathrm{~km}$ " ${ }^{10114}$ In May 1994, Mladić proposed to the SDC that some generals who he believed to support the Accused be pensioned off. ${ }^{10115}$ In September 1994, Gvero complained about not having enough "real contacts with the state leadership", ${ }^{10116}$ and that the Accused was

\footnotetext{
10107 P1379 (Transcript of $34^{\text {th }}$ session of RS Assembly, 27-29 August, 9-11 September, 29 September to 1 October 1993), pp. 278-279, 281. See also P4203 (Witness statement of Pyers Tucker dated 12 May 2010), para. 283 (stating that in meetings, the Accused "always held himself up as the Head of State" and stated a number of times that the VRS reported to the Government and referred to "my soldiers" and "my army").

10108 P1379 (Transcript of $34^{\text {th }}$ session of RS Assembly, 27-29 August, 9-11 September, 29 September to 1 October 1993), p. 428.

10109 P1379 (Transcript of $34^{\text {th }}$ session of RS Assembly, 27-29 August, 9-11 September, 29 September to 1 October 1993), p. 316.

10110 P823 (UNPROFOR Weekly Political Assessment, 3 November 1993), p. 1.

10111 P823 (UNPROFOR Weekly Political Assessment, 3 November 1993), p. 6.

10112 See D3695 (Witness statement of Bogdan Subotić dated 16 June 2013), para. 148.

10113 D4526 (Intercept of conversation between Milan Gvero, Manojlo Milovanović and "Tosa" a.k.a Zdravko Tolimir, 26 April 1994), p. 1. Gvero responded it was impossible to implement and that there was a NATO ultimatum. D4526 (Intercept of conversation between Milan Gvero, Manojlo Milovanović and "Tosa" a.k.a Zdravko Tolimir, 26 April 1994), p. 1.

10114 D4526 (Intercept of conversation between Milan Gvero, Manojlo Milovanović and “Tosa” a.k.a Zdravko Tolimir, 26 April 1994), p. 2.

10115 D3051 (Witness statement of Momir Bulatović dated 25 February 2013), para. 44.

10116 P1487 (Ratko Mladić's notebook, 4 September 1994-29 January 1995), pp. 38-39.
} 
taking decisions without the approval of the Main Staff. ${ }^{10117}$

In October 1994, Mladić was

informed that the Accused did not know what to do with him. ${ }^{10118}$

3130. The Chamber notes that although the Accused and Mladić may have had their differences, in the spring of 1995, they maintained their superior and subordinate relationship within the chain of command. ${ }^{10119}$ At a session of the Supreme Command on 31 March 1995, Mladić stated that he and the Accused had the greatest responsibility for the army, with the Accused "as the Supreme Command" and Mladić as "[his] right hand in the army."10120 While Mladić also complained that the Accused had stripped him of his authority to make unilateral promotions of lower-ranking officers, ${ }^{10121}$ Mladic affirmed that the Accused, as the Supreme Commander, had the right to give orders. $^{10122}$

3131. Furthermore, in a speech at the $50^{\text {th }}$ Bosnian Serb Assembly session on 15 and 16 April 1995, the Accused reassured the attendees that despite rumours of a split between he and Mladić: "How can there be a split between the Supreme Commander and his subordinate commander? There is no split", but further stated "[i]f there is a split, it is clear who will have to go". ${ }^{10123}$ The Accused further stated he had not resorted to firing Mladić or any of his assistants, and that on the whole, he had a good personal relationship with Mladić and that "he and his Main Staff members [...] respect and recognise me". ${ }^{10124}$ Mladić responded later that despite the Accused's public statements about replacing Mladić "at the stroke of a pen", Mladić had made a commitment when he was sworn in and he requested that the Assembly and the deputies "take a vote of confidence in me and the Main Staff" and reassured them that "we'll work together". ${ }^{10125}$

10117 P1487 (Ratko Mladić's notebook, 4 September 1994-29 January 1995), p. 51.

10118 P1487 (Ratko Mladić's notebook, 4 September 1994-29 January 1995), pp. 123, 125.

10119 P953 (Article from Oslobođenje, entitled "Happy Birthday Republic", 6 January 1995), p. 9 (wherein the Accused states in an interview that "as the supreme commander, I get all the respect from the officers and soldiers, and I wouldn't even want our officers to be obedient or soft like an old woman. I want them to 'argue' with me about various solutions because it helps me to make the right decision"); P3149 (Minutes of $14^{\text {th }}$ session of Supreme Command, 31 March 1995), pp. 13, 15, 20, 21, 57; P970 (Transcript of $50^{\text {th }}$ session of RS Assembly, 15-16 April 1995), p. 315.

10120 P3149 (Minutes of $14^{\text {th }}$ session of Supreme Command, 31 March 1995), p. 49.

10121 P3149 (Minutes of $14^{\text {th }}$ session of Supreme Command, 31 March 1995), p. 9 (during which Mladić stated "[w]e have never proposed anything that you have done outside your jurisdication; we have proposed everyone to you, that is correct. [...] You have taken all operational powers from us and from the Main Staff'). A few days earlier on 28 March 1995, Mladić wrote to the Accused asking him to order the Minister of Defence to annul an order he issued without consulting the Main Staff regarding promotions and that the Minister of Defence not take away the Main Staff commanders' "right to approve promotions up to the rank and authority which they have so far had". D4062 (Request of VRS Main Staff to Radovan Karadžić, 28 March 1995). See also Momčilo Krajišnik, T. 43978-43979 (21 November 2013).

10122 P3149 (Minutes of $14^{\text {th }}$ session of Supreme Command, 31 March 1995), pp. 8-14, 32.

10123 P970 (Transcript of 50 ${ }^{\text {th }}$ session of RS Assembly, 15-16 April 1995), p. 315.

10124 P970 (Transcript of 50 $0^{\text {th }}$ session of RS Assembly, 15-16 April 1995), p. 315.

10125 P970 (Transcript of 50 ${ }^{\text {th }}$ session of RS Assembly, 15-16 April 1995), pp. 361-362. 
3132. However, further tensions between the VRS and the Bosnian Serb leadership were apparent during meetings in the spring of 1995. ${ }^{10126}$ On 29 April 1995, the Accused addressed a letter to the VRS Main Staff accusing them of preparing a coup d'état, and summoned them to a meeting in Pale. $^{10127}$ On 1 May 1995, the Accused met with the officers of the Main Staff and Corps commanders in Pale and complained about the actions and Mladić's recent behaviour and the tension between the military and political leadership. ${ }^{10128}$

3133. In the summer of 1995, the Accused communicated directly with Milovanovic on a few occasions and forwarded him reports he received and decisions he made; this caused suspicion among the other generals. ${ }^{10129}$ Milovanović reported this to Mladić, and cautioned the Accused that the "system of command was being duplicated"; however, Milovanović never refused any of the Accused's orders and merely forwarded them to Mladić. ${ }^{10130}$ If no response was received, then Milovanović would act on the Accused's order. ${ }^{10131}$ By August 1995, Mladić was more vocal and arrogant in his interactions with the Accused, and Mladić claimed that he was in charge. ${ }^{10132}$ The Accused complained about the army, the difficulties in influencing the Main Staff and stated that the army, as a state organ, needed to be under the command of the state and not Mladić. ${ }^{10133}$ There were also fears of a military coup but the Accused continued to speak in the capacity of the Supreme Commander of the VRS and in the interests of Serb unity. ${ }^{10134}$

3134. During a meeting with journalist Robert Đurđević on 14 July 1995, the Accused told him that he had heard in April 1995 that Mladić was planning a coup d'état in compliance with

10126 P1473 (Ratko Mladić's notebook, 24 January-5 September 1995), pp. 130-131, 146-147. Pyers Tucker had the impression that there were also attempts by Mladić and others to sideline Plavšić. P4203 (Witness statement of Pyers Tucker dated 12 May 2010), para. 36. See also P820 (Witness statement of David Harland dated 4 September 2009), paras. 285-286 (stating that as time passed, the Accused seemed to have less control and there was a rift in the relationship in 1995 which appeared to be due to policy differences).

10127 Manojlo Milovanović, T. 25659 (1 March 2012); D2155 (Letter from Radovan Karadžić to Supreme Command, 29 April 1995).

10128 P1473 (Ratko Mladić's notebook, 24 January-5 September 1995), pp. 123, 127-129 (wherein the Accused is recorded as stating that the most recent behaviour, especially that of Mladić, resembles a "putsch" and furthermore, that "[i]t is impermissible to lecture the head of state on the state"); Manojlo Milovanović, T. 25658, 25661 (1 March 2012); D3695 (Witness statement of Bogdan Subotić dated 16 June 2013), para. 163.

10129 Manojlo Milovanović, T. 25647-25648 (1 March 2012); D2149 (Aide mémoire of Manojlo Milovanović), p. 57. See D3512 (UNPROFOR report, 17 July 1995), pp. 1-2 (wherein Akashi refers to the possibility of Mladić being a "free operator" and states that, "[f]or the past several months, the military commanders in Pale had been challenging the authority of the civilian colleagues").

10130 Manojlo Milovanović, T. 25648 (1 March 2012).

10131 Manojlo Milovanović, T. 25648 (1 March 2012).

10132 D3695 (Witness statement of Bogdan Subotić dated 16 June 2013), paras. 166, 168-169.

10133 D3695 (Witness statement of Bogdan Subotić dated 16 June 2013), para. 169. See also P2683 (Radovan Karadžić's request to SRK commander, 5 August 1995).

10134 D3695 (Witness statement of Bogdan Subotić dated 16 June 2013), paras. 173-177; Momčilo Mandić, T. 5340 (16 July 2010). 
instructions from Slobodan Milošević, so the Accused had to act to prevent it. ${ }^{10135}$ The Accused told Đurđević that he had called a meeting of all senior officers, including Mladić, and had confronted them with the plan; afterwards the Accused had a one-on-one conversation with Mladić where, according to the Accused, the two of them had patched up their differences, at least so as to be civil and respectful of each other. ${ }^{10136}$ The Accused told Đurđević that Mladić had promised to work together with the Accused and other RS political leaders. ${ }^{10137}$ However, according to Đurđević, the Accused still did not seem to be "speaking very warm terms about Mladić" and he told Đurđević that he would have to pension Mladić off. ${ }^{10138}$ The next day, on 15 July, in a meeting with Slobodan Milošević and Mladić, Akashi remembered Mladić being "under very tense pressure" ${ }^{10139}$ Akashi recalled that the absence of the Accused at this meeting gave rise to some speculation about the relationship between the Accused and Mladić, but Akashi had no actual knowledge of what was taking place. ${ }^{10140}$

3135. On 2 August 1995, pursuant to a decision issued by the Accused, in his capacity as President and Supreme Commander, the Main Staff was renamed as the VRS General Staff and would be called the Supreme Command Staff in "times of war". ${ }^{10141}$ According to this decision, on 4 August 1995, Mladić was appointed as Special Advisor to the Supreme Commander, and removed as VRS commander. ${ }^{10142}$ In response, on 5 August 1995, Mladić sent a notice to the corps commands, stating that the Accused's decision to rename the Main Staff and to take over the authority of direct leadership and command of the VRS was unconstitutional and highly dangerous and could bring into question the results they had already achieved; he further stressed that such a decision could lead to the collapse of the VRS. ${ }^{10143}$

\footnotetext{
10135 Robert Đurđević, T. 25939 (7 March 2012). See also P4515 (Excerpts from Robert Đurđević's diary, 531 July 1995), e-court p. 10; P4513 (Witness statement of Robert Đurđević dated 18 December 2002), e-court pp. 29-30. See also para. 5778.

10136 P4513 (Witness statement of Robert Đurđević dated 18 December 2002), e-court pp. 29-30; Robert Đurđević, T. 25939 (7 March 2012). See P4515 (Excerpts from Robert Đurđević's diary, 5-31 July 1995), e-court pp. 1011.

10137 P4515 (Excerpts from Robert Đurđević's diary, 5-31 July 1995), e-court p. 11.

10138 P4513 (Witness statement of Robert Đurđević dated 18 December 2002), e-court p. 31; Robert Đurđević, T. 25939-25940 (7 March 2012).

10139 Yasushi Akashi, T. 37746 (25 April 2013).

10140 Yasushi Akashi, T. 37747-37749 (25 April 2013); D3512 (UNPROFOR report, 17 July 1995), p. 2.

10141 See para. 174.

10142 See para. 174. On 6 August 1995, an extraordinary government session was held, where the RS Government decided to support the Accused's proposal to remove Mladić as General of the VRS. P3108 (Minutes of the $7^{\text {th }}$ extraordinary session of RS Government, 6 August 1995); D3364 (Witness statement of Dušan Kozić dated 7 April 2013), para. 26.

10143 D2158 (Statement by Ratko Mladić, forwarded by Novica Simić, 5 August 1995), pp. 1-2. See also D4858 (Communique of VRS Main Staff, 5 August 1995). See also D3882 (SRNA news report, 5 August 1995).
} 
3136. On 5 or 6 August 1995, Milovanović authored a petition that was sent to the Bosnian Serb Assembly and the Accused in his capacity as RS President on behalf of 18 generals. ${ }^{10144}$ The petition stated the generals' unanimous refusal to implement the Supreme Command's order to reorganise the Main Staff. ${ }^{10145}$

3137. However, even following Mladić's removal as Main Staff commander, both the Accused and Mladić re-affirmed their subordinate-superior relationship. In an interview on 16 August 1995, the Accused stated that "[t]here is no conflict, the competence is very clear"; he was the President and Commander-in-Chief of the army and that Mladic was the second in the hierarchy, despite mutual criticism and disagreements. ${ }^{10146}$ Furthermore, at an SDC session on 23 August 1995 with the FRY leadership, during which Slobodan Milošević attempted to pressure Mladić to support peace and issue a statement which was contrary to the Accused's position at the time, Mladic refused and instead stated that he would leave this to the politicians as he was "only a soldier of the people" and "not an elected representative". ${ }^{10147}$

3138. On 27 August 1995, the Accused abrogated his decision of 2 August 1995 to re-organise the Main Staff, including the decree appointing Mladić as Special Advisor to the Supreme Commander. ${ }^{10148}$ Following the annulment of his decision, the Accused sent a letter to the VRS Main Staff generals, requesting that they "trust the state leadership" and the importance "finally for us to respect each other" and establish a relationship based on mutual respect. ${ }^{10149}$

10144 D2159 (Letter from VRS Main Staff to RS National Assembly, 5-6 August 1995); Manojlo Milovanović, T. 25674-25676 (1 March 2012); D2149 (Aide mémoire of Manojlo Milovanović), p. 57; D2843 (Telegram from VRS Main Staff, 7 August 1995); Petar Skrbić, T. 26028-26030 (8 March 2012). See also Radislav Krstić, D4136 (Transcript from Prosecutor v. Krstić), T. 6700 (testifying that he had signed a document in support of Mladić on 6 or 7 August 1995, not because he wanted to but because all generals had signed it).

10145 D2159 (Letter from VRS Main Staff to RS National Assembly, 5-6 August 1995), p. 1; Manojlo Milovanović, T. 25676 (1 March 2012). See D2843 (Telegram from VRS Main Staff, 7 August 1995); Dragomir Milošević, T. 32888-32892 (30 January 2013); Stanislav Galić, T. 37606 (23 April 2013). See also D3695 (Witness statement of Bogdan Subotić dated 16 June 2013), para. 99 (stating that he and Dušan Kovačević were the only generals who chose not to sign the petition).

10146 P6407 (Radovan Karadžić's interview with Telegraf, 16 August 1995), pp. 3-4.

10147 P2567 (Note from FRY's SDC 42 ${ }^{\text {nd }}$ session, 23 August 1995), pp. 2, 5-6. See also D3681 (Intercept of conversation between Slobodan Milošević and Ratko Mladić, undated), p. 4 (during which Milošević tells Mladić that "unfortunately you have a completely mad political leadership, which is dragging you to death", to which Mladić responds that he cares about people and not "about a certain individual from any leadership here").

10148 D2844 (Radovan Karadžić's Decision, 27 August 1995), p. 2; Manojlo Milovanović, T. 25678 (1 March 2012 ) (testifying that he later learned from Gvero that the Assembly had adopted the petition and annulled the Accused's decision to reorganise the Main Staff). See also para. 174. At a Bosnian Serb Assembly session held on 22 August 1995, the Accused reported on the conflict between the military and RS state organs, stating that if it was not resolved, it may have a "huge negative impact on the safeguarding of the [RS] territory and state". P3146 (Minutes of $28^{\text {th }}$ session of RS Government, 22 August 1995), p. 9. See also D3364 (Witness statement of Dušan Kozić dated 7 April 2013), para. 27.

10149 D4861 (Letter from Radovan Karadžić to VRS Main Staff, 27 August 1995), p. 1. 
3139. However, on 5 September 1995, Akashi reported further miscommunication and discord between the Accused and Mladić, stating that "the pronouncements of the 'RS' civilian leadership and the [VRS] military leadership are clearly at odds" and that there had been a noticeable rupture in the RS power structure. ${ }^{10150}$

3140. The Chamber received evidence from Defence witnesses that the relationship between the Accused and Mladić was always one of intolerance and that the Accused had de jure control over Mladić, but that he did not have control over him in fact. ${ }^{10151}$ Furthermore, Defence witnesses testified that within the VRS structure, there was always a duality of command between Mladic and the Accused, starting with Mladić's appointment as commander of the Main Staff and throughout the conflict. ${ }^{10152}$ According to Mandić, there was a lack of trust and co-operation between the Accused and Mladić from the beginning and that Mladić did not respect orders issued by the Accused or other members of the Presidency. ${ }^{10153}$

3141. However, the Chamber notes that the evidence of these witnesses, namely of Kuprešanin, Zametica, Kozić, Kovač, and Ninković, in this regard is expressed in general terms and is often based on their own impression or opinion. The Chamber does not therefore find their evidence to be of much weight in this regard. In addition the Chamber finds that this evidence is outweighed

10150 D3353 (UNPROFOR report, 5 September 1995), pp. 1-2 (referring to a letter from Mladić sent to UNPROFOR on 4 September 1995 regarding his position on conditions established by NATO and the UN for the cessation of NATO air attacks which conflicted with the position of the Bosnian Serb leadership; Koljević reassured UNPROFOR of the position of the Bosnian Serb leadership and that Mladić's letter was not valid, which Mladić ultimately accepted). See Prvoslav Davinić, T. 45529-45531 (16 January 2014) (testifying about a conversation between the Accused and Mladić on 4 September 1995, in which Mladić stated: "I cannot but act in keeping with your decisions, your directives, and in line with my legal authority", and that Mladić's statement did not indicate subservience to the Accused because Mladić had a "great deal of freedom to act" within the scope of his "legal authority").

10151 D3864 (Radovan Radinović's expert report entitled "The Control Authority of Dr. Radovan Karadžić in the Strategic Command System of the VRS”, 2012), pp. 5-6; Radovan Radinović, T. 41618-41619 (19 July 2013) (testifying that the Accused did not have actual operative control over the VRS in July and August 1995); D4011 (Witness statement of Vojislav Kuprešanin dated 11 November 2013), paras. 44, 52 (stating further that during the war, it became clear that the Accused "was President of the state but did not have power, while, on the other hand, [...] Mladić had power but did not have the state"); Vojislav Kuprešanin, T. 43519 (14 November 2013); D3682 (Witness statement of Gordan Milinić dated 8 June 2013), paras. 11-12 (stating that Mladic did not respect the Accused in the slightest and instead always wanted to do the opposite of what the Accused advocated; as such the Accused had been trying to dismiss Mladić since as early as 1993 but without success, as the VRS held the power and "did as it pleased and acted at its own discretion"); John Zametica, T. 42453-42455 (29 October 2013) (testifying that the Accused had very little power over the VRS and the VRS was regularly insubordinate to the Accused); D3364 (Witness statement of Dušan Kozić dated 7 April 2013), para. 26 (stating that there was a lack of co-operation between the civilian and military authorities throughout the war); D3932 (Witness statement of Milenko Živanović dated 27 October 2013), para. 9; D3960 (Witness statement of Tomislav Kovač dated 28 October 2013), para. 99.

10152 D3864 (Radovan Radinović's expert report entitled "The Control Authority of Dr. Radovan Karadžić in the Strategic Command System of the VRS”, 2012), pp. 5-6; D3733 (Witness statement of Milan Ninković dated 23 June 2013), paras. 29, 39; Vojislav Kuprešanin, T. 43519 (14 November 2013); D4011 (Witness statement of Vojislav Kuprešanin dated 11 November 2013), paras. 44, 52. See also D3960 (Witness statement of Tomislav Kovač dated 28 October 2013), paras. 91, 96, 111.

10153 Momčilo Mandić, T. 5340-5341 (16 July 2010). 
by the volume of reliable evidence discussed above. Therefore, in light of all the evidence, the Chamber finds that while there may have been a lack of trust and periods of discord between the Accused and Mladić, the Accused and Mladić acted as a collective leadership and conducted themselves in a single direction. The Chamber therefore finds that the Accused maintained his role as Mladić's superior, had de jure control over him, and exercised such control in fact throughout the conflict.

\section{(4) Accused's powers}

3142. The Accused, as the President, had the power to organise and implement plans for defence, order mobilisation, and command and control the army. ${ }^{10154}$ In addition, as the Supreme Commander, the Accused had the power to issue regulations, to define the organisation of the VRS, to appoint, promote, and dismiss officers of the VRS, to establish a system of command, and to monitor the implementation of orders. ${ }^{10155}$ The Accused had also the power to issue decrees, instructions, orders, and requests related to the general planning for the preparation of the army, the mobilisation of the army, and its deployment. ${ }^{10156}$

3143. In application of these powers, the Accused, for example, issued instructions to different units in the VRS and occasionally sent direct orders to corps and brigade commanders to answer directly to him. ${ }^{10157}$

3144. The Accused's personal involvement at the operational level can also be seen in his order to the Main Staff, on 5 December 1992, to provide reinforcements for the Drina Corps; to "disarm the opponent in the local communities of Cerska and Konjević Polje and take control of the MilićiDrinjača-Zvornik and Konjević Polje- Bratunac road"; and to inform him personally on the realisation of this order. ${ }^{10158}$ Also demonstrative of his level of involvement are his instructions at a

\footnotetext{
10154 See para. 162

10155 See para. 167; P2603 (SerBiH Law on the Army, 1 June 1992), art. 174 (stating, inter alia, that the RS President is the Commander-in-Chief of the VRS).

10156 See para. 168.

10157 See, e.g., P846 (Radovan Karadžić's Order to VRS, 7 February 1994) (which was relayed via P4493 (VRS Main Staff Order, 7 February 1994); Stanislav Galić, T. 38033 (9 May 2013) (stating that the SRK commander would receive information and directives directly from the Supreme Command and the Accused); P2276 (VRS Main Staff Order, 9 July 1995); P4925 (Supplement to Directive 6, 12 December 1993); P2645 (Radovan Karadžić's order to VRS Main Staff, MUP, and Ministry of Defence, 20 May 1992) (the Accused ordered the creation of a military police company within the SRK); D43 (Radovan Karadžić's Order to VRS Main Staff, 16 April 1993); P4495 (Radovan Karadžić's Order to VRS Main Staff and RS MUP, 29 March 1995); D4812 (Radovan Karadžić's Order, 15 January 1994); P1503 (Radovan Karadžić's Order re Nedžarići, 1 July 1992); P1299 (VRS Main Staff request for information from SRK, 26 April 1995); D4739 (Letter from Radovan Karadžić to all local civilian and police authorities, 31 October 1992).

10158 P5083 (Radovan Karadžić's Order to the VRS Main Staff, 5 December 1992). See also P1493 (Letter from Ratko Adžić to Radovan Karadžić, 12 June 1992) (by which the Accused was informed of the progress of battles around Sarajevo and was asked to use "his influence" for additional weaponry to be provided).
} 
meeting of the Supreme Command, on 7 May 1993, to be directly in charge of approving operations; that all offensive operations be halted; and that any action should be approved by the Supreme Command personally. ${ }^{10159}$

3145. The Accused also exercised his power to order the VRS to carry out mobilisation. ${ }^{10160}$ For example, already on 20 May 1992, the Accused issued a decision on the general mobilisation of all military conscripts and the requisition of material for the needs of the VRS and noted that this decision would be delivered to the "competent organs of all municipalities" of the SerBiH. ${ }^{10161}$ This decision was delivered and acted upon at the municipal level. ${ }^{10162}$

3146. The Accused exercised his power to promote VRS officers ${ }^{10163}$ and to reassign VRS officers. ${ }^{10164}$ As mentioned above with regard to his relationship with Mladić, the power to dismiss officers was acknowledged by the Accused himself when he stated at the Bosnian Serb Assembly that if he did not trust Mladić he would have dismissed him and added: "I have the authority to do that." 10165

10159 P1483 (Ratko Mladić's notebook, 2 April-24 October 1993), pp. 89-90. The Chamber notes John Zametica’s evidence that he did not think that the Accused was "particularly involved" in "day-today operative and tactical level", that the Accused was "largely uninterested" in the operation and tactical conduct of warfare, but notes that at the same time Zametica testified that he "never asserted that [the Accused] had not been involved" whatsoever. John Zametica, T. 42457-42458, 42522 (29 October 2013). The Chamber does not find that Zametica's qualified observation regarding the involvement of the Accused in operative and tactical level affects the Chamber's conclusion in this regard.

10160 P5482 (Radovan Karadžić's Order to Municipal Assembly Presidents and VRS Main Staff, 26 March 1995), p. 1; P5192 (Radovan Karadžić's Decision on general mobilisation, 5 August 1995); P4926 (RS Declaration of war, 16 June 1995); P2248 (Radovan Karadžić's Order to RS Government, VRS Main Staff, and Presidents of Municipalities, 26 March 1995). The Chamber notes that the Accused's order was relayed the same day by Mladić to the VRS units. P2249 (VRS Main Staff Order, 26 March 1995). See also P5546 (VRS Main Staff Order, 30 July 1995), p. 1.

10161 P3919 (Radovan Karadžić's Decision, 20 May 1992), pp. 1-2.

10162 P3537 (Decision of Prijedor Crisis Staff, 22 May 1992); Branko Đerić, T. 28059-28060 (25 April 2012).

10163 P2650 (Radovan Karadžić's decree on exceptional promotion, 16 December 1992); P2677 (Radovan Karadžić's decree on Dragomir Milošević's promotion, 24 March 1994); P5532 (RS Presidential Decree, 25 July 1993); P5533 (RS Presidential Decree, 28 June 1994), pp. 1-2; P3046 (Radovan Karadžić's Decree on promotion of Ratko Mladić, 28 June 1994); P2649 (Radovan Karadžić's decree on early promotion, 7 August 1994).

10164 Stanislav Galić, T. 37594-37595 (23 April 2013); P3044 (Radovan Karadžić's Decree, 14 July 1995); P5190 (Letter from RS MUP to RS President, 6 July 1995); P5085 (RS Presidential Decree, 15 July 1995); P5085 (RS Presidential Decree, 15 July 1995). The Chamber notes that, while the Accused's decree is dated 14 July 1995 , according to a memorandum of the Drina Corps "the handover of duties of the Drina Corps Commander was carried out on 13 July 1995". However, it finds that this minor inconsistency with regard to the date does not affect the substance of the document of the Drina Corps, according to which reassignments were made "[p]ursuant to the Decree of the President of Republika Srpska". P4485 (Drina Corps information, 13 July 1995). See also D3874 (Letter from Radovan Karadžić to Ratko Mladić and $2^{\text {nd }}$ Krajina Corps commander, 14 December 1994); P5451 (RS MUP request to Radovan Karadžić, 13 July 1995), p. 1. See paras. 5768. 5776.

10165 P1379 (Transcript of $34^{\text {th }}$ session of RS Assembly, 27-29 August, 9-11 September, 29 September to 1 October 1993), p. 316. See also P970 (Transcript of 50 th session of RS Assembly, 15-16 April 1995), p. 315. See also D3495 (Letter from Radovan Karadžić to Yasushi Akashi, 24 March 1994) (responding to D3494 (Letter from Yasushi Akashi to Radovan Karadžić, 23 March 1994)). 
3147. The Accused also assisted the VRS in his capacity as RS President. In April 1994, following a letter from the Main Staff informing that there were volunteers from the SRS who had been operating in two municipalities without the knowledge or consent of the VRS, ${ }^{10166}$ the Accused reminded the municipal authorities that this interfered with the system of single command and control. The Accused also required to be informed about developments so he could take measures. ${ }^{10167}$

3148. The Chamber observes that Mladić took note in 1994 that while subordination was good at the Main Staff and corps level, insubordination was found at the lower levels, ${ }^{10168}$ and it also observes that in 1995 lack of co-operation and certain acrimony existed between the civilian and military authorities. ${ }^{10169}$

3149. The Chamber notes that according to Božidar Vučurević officers of the VRS turned to Belgrade rather than to the RS. ${ }^{10170}$ The Chamber finds that Vučurević was not forthright in this regard and does not accept his evidence. The Chamber also notes that Momir Bulatović testified that the Accused told Milošević that "he did not understand why the VRS took Jajce, a Muslim town that they would never be able to preserve" and that Bulatović "believe[d]" that the Accused's statement to Milošević referred to the lack of the Accused's control over military operations. ${ }^{10171}$ The Chamber does not find that Bulatović's interpretation of the Accused's statement has any weight as Bulatović was not present when it was made.

3150. Finally, Colm Doyle testified that he informed the Accused, via one of the Accused's officials, of a planned attack against a TV station in Sarajevo and that the Accused replied that the attack will not take place. However, the TV station was bombed, and Doyle relayed information to the Accused that he "was going to hold him personally responsible" for the attack. ${ }^{10172}$ When the Accused met with Doyle later that day he said to Doyle that he had not ordered the attack, that he

\footnotetext{
10166 D1454 (Request of RS President's Office, 29 April 1994); D1446 (Radovan Karadžić's Order to RS MUP, 29 April 1994).

10167 D1454 (Request of RS President's Office, 29 April 1994); D1446 (Radovan Karadžić's Order to RS MUP, 29 April 1994); Milorad Davidović, T. 15809 (1 July 2011). See also D1448 (Letter from RS President's Office to President of Petrovo Municipal Assembly, 29 April 1994).

10168 P1485 (Ratko Mladić's notebook, 9 January-21 March 1994), pp. 46, 117.

10169 D3364 (Witness statement of Dušan Kozić dated 7 April 2013), paras. 26, 33; D3366 (Report of 1st Igman Infantry Brigade, 20 October 1995); P3114 (Minutes of the 32 ${ }^{\text {nd }}$ session of RS Government, 13 October 1995), p. 4; Dragan Kijac, T. 44317 (3 December 2013); D4143 (Witness statement of Dragan Kijac dated 30 November 2013) para. 59. The Chamber notes that Kijac later testified that had normal relations with the military security services. D4143 (Witness statement of Dragan Kijac dated 30 November 2013) para. 60.

10170 D3146 (Witness statement of Božidar Vučurević, 22 March 2013), para. 8.

10171 D3051 (Witness statement of Momir Bulatović dated 25 February 2013), paras. 29-30.

10172 Colm Doyle, T. 2678-2679 (21 May 2010); Colm Doyle, P918 (Transcript from Prosecutor v. S. Milošević), T. 25278-25281.
} 
had condemned it, and that he "didn't control all of the military all of the time." 10173 The Chamber finds the Accused's statement to Doyle regarding his lack of continuous control over the military to be of minimal weight. The Accused had a clear interest in distancing himself from, and minimising his involvement in, the attack after Doyle told the Accused that he would be held personally responsible for it and that he was going to condemn this attack on television.

3151. In addition, the Chamber finds that the limited evidence regarding the Accused's lack of control over the VRS ${ }^{10174}$ is not only of minimal weight in and of itself, but that, in any event, it is inconsistent with the overwhelming evidence to the contrary, described above.

$\underline{\text { Goals }}$

(5) The issuance of military directives in pursuance of the Strategic

3152. Above, the Chamber found that the Strategic Goals, which embodied the fundamental objectives of the Bosnian Serb leadership were communicated to the VRS and formed a core element of its military strategy. ${ }^{10175}$ They were the basis for the military operations that were formulated in the seven main VRS military directives issued between June 1992 and March 1995. ${ }^{10176}$

3153. These directives constituted "the highest level of political-military direction" for the conduct of the war. ${ }^{10177}$ They were "act[s] of command used by the highest echelons of command" that delegated long-term tasks and assignments. ${ }^{10178}$ They regulated the actions of the military forces by setting tasks in the form of guidelines governing the division of responsibilities between

10173 Colm Doyle, T. 2678-2679 (21 May 2010). See also Colm Doyle, P918 (Transcript from Prosecutor v. S. Milošević), T. 25279-25281. The Chamber notes that Doyle's testimony could be interpreted as referring to the Accused's authority over paramilitary forces. However, considering the features of the attack described by Doyle and the knowledge of the Accused about the attack the Chamber concludes that, in this context, the Accused was referring to regular military forces rather than paramilitaries.

10174 The Chamber also notes evidence of a rift in August 1994 between the RS leadership and the FRY concerning negotiations, which included a message from the FRY leadership to the VRS to refuse obedience to, and not to be manipulated by, the RS leadership. P1486 (Ratko Mladić's notebook, 31 March-3 September 1994), pp. 277-279. However, the Chamber notes that this message was not accepted by the VRS officers and did not affect the hierarchial control of the RS leadership over the VRS. P1486 (Ratko Mladić's notebook, 31 March3 September 1994), pp. 283, 286 (according to which Milovanović qualified this rift as "not ideological conflicts, but conflicts in the struggle for power" and Miletić stated that "[d]emanding that the officers turn against the Serbian leadership is against the people, and that is the biggest crime").

10175 See para. 2845.

10176 See para. 2899. See also D232 (Directive 1, 6 June 1992); D593 (Directive 2, 22 July 1992); D235 (Directive 3 , 3 August 1992); P976 (Directive 4, 19 November 1992); P843 (Directive 5, 25 June 1993); P3039 (Directive 6, 11 November 1993); P838 (Directive 7, 8 March 1995).

10177 Richard Butler, T. 27439 (17 April 2012).

10178 Ljubomir Obradović, P4444 (Transcript from Prosecutor v. Tolimir), T. 11992. 
the army, police, and civilian protection. ${ }^{10179}$ They identified objectives, forces and resources that should be used in achieving the objectives, and contained basic guidelines. ${ }^{10180}$

3154. There were three methods of drafting directives: the "complete" method, the "shortened" method, and the method that did no include any consultation with the organs and commands. ${ }^{10181}$ The complete method entailed that the Commander of the Main Staff first opened the discussion, the corps commanders then gave a briefing, and the chiefs of sectors of the Main Staff-such as security, logistics, training, and morale - in turn also provided input. ${ }^{10182}$ During this analysis, conclusions would be made related to the level of accomplishment of the tasks defined for the previous year, before moving on to define the tasks for the following year. ${ }^{10183}$

3155. On this basis, the Commander of the Main Staff, Mladić, would formulate the basic principles and the command organs would submit proposals to him. ${ }^{10184}$ He would then adopt the proposals, and the operative organ would integrate the adopted proposals into a unified text; ${ }^{10185}$ this text would then be forwarded to the Accused, as Supreme Commander. ${ }^{10186}$ The Accused would provide guidelines and revisions would be made pursuant to his instructions. ${ }^{10187}$ Directives were either signed by the Accused as Supreme Commander or by Mladić as the Commander of the Main Staff but in any event, the Accused examined and approved all of the seven directives mentioned above. ${ }^{10188}$ Once signed, the directive was finalised and could not be altered or amended

\footnotetext{
10179 Manojlo Milovanović, T. 25494 (29 February 2012). See also Mirko Trivić, T. 40538-40539 (26 June 2013 ).

10180 Radovan Radinović, T. 41392 (17 July 2013).

10181 Radovan Radinović, T. 41394 (4 April 2013); Ljubomir Obradović, P4444 (Transcript from Prosecutor v. Tolimir), T. 11992.

10182 Ljubomir Obradović, P4444 (Transcript from Prosecutor v. Tolimir), T. 11993; Radovan Radinović, T. 41394 (4 April 2013).

10183 Ljubomir Obradović, P4444 (Transcript from Prosecutor v. Tolimir), T. 11993.

10184 Ljubomir Obradović, P4444 (Transcript from Prosecutor v. Tolimir), T. 11993. For example, proposals pertaining to the enemy were made by the intelligence organ, proposals for use of the corps and subordinate units were made by the operations sector, and proposals pertaining to arms were made by the organ in charge of arms. Ljubomir Obradović, P4444 (Transcript from Prosecutor v. Tolimir), T. 11993-11994.

10185 Ljubomir Obradović, P4444 (Transcript from Prosecutor v. Tolimir), T. 11993. Obradović specified that tasks from prior directives would need to be reformulated and included in superseding directives in order to remain valid. Ljubomir Obradović, P4444 (Transcript from Prosecutor v. Tolimir), T. 12179 (31 March 2011).

10186 Ljubomir Obradović, P4444 (Transcript from Prosecutor v. Tolimir), T. 12040. Obradović stated that the Supreme Commander would receive a typed document, would look at it and enter comments in the margin, and would then return the document for retyping into a version that included his statements. However, he then stated that he was not privy to or aware of the editing process within the cabinet of the Supreme Commander. Ljubomir Obradović, P4444 (Transcript from Prosecutor v. Tolimir), T. 12040. The Chamber shall therefore not rely on this part of his evidence.

10187 Manojlo Milovanović, T. 25495 (29 February 2012) (specifically referring to the drafting of Directive 7).

10188 Ljubomir Obradović, P4444 (Transcript from Prosecutor v. Tolimir), T. 11992. Directives 6 and 7 and the supplement to Directive 6 were signed by the Accused. P3039 (Directive 6, 11 November 1993), p. 16; P838 (Directive 7, 8 March 1995), p. 15; P4925 (Supplement to Directive 6, 12 December 1993), p. 3. See also P1415 (Transcript of $54^{\text {th }}$ session of RS Assembly, 15-16 October 1995), p. 84; P3149 (Minutes of $14^{\text {th }}$ session of Supreme Command, 31 March 1995), p. 24.
} 
by others who might receive it. ${ }^{10189}$ Once finalised, the directive would be forwarded to the assistant commanders and the chiefs of sectors would receive copies. ${ }^{10190}$

3156. Thereafter, Mladić would produce a further executive order or directive effectively operationalising the directive. ${ }^{10191}$ The Main Staff was then responsible for disseminating the directive to subordinate units in accordance with the directive. ${ }^{10192}$

\section{(6) $\underline{\text { Conclusion }}$}

3157. The Chamber concludes that from May 1992 the Accused had continuous de jure authority and control over the VRS, which he exercised in fact, while serving as the President of the SNB, President of the Presidency, and later President of the RS and Supreme Commander. The Accused was regularly informed of the developments in the VRS and in the field. The Accused was involved at the strategic level and, when he desired, at the operational level as well.

\section{(B) Bosnian Serb MUP}

3158. The Minister of the MUP was the head of the MUP. ${ }^{10193}$ The Chamber recalls that Mićo Stanišić was Minister of the MUP from 24 March 1992 until the end of 1992 and again from January 1994 until July 1994 and that Tomislav Kovač was acting Minister from September 1993 until January 1994. ${ }^{10194}$

3159. The Chamber recalls that the Law on Internal Affairs, issued on 23 March 1992, established a network of CSBs to carry out the work of the Bosnian Serb MUP. ${ }^{10195}$ The CSBs were located in Banja Luka (for the ARK), Trebinje (for the SAO Herzegovina), Doboj (for the SAO of Northern $\mathrm{BiH}$ ), Sarajevo (for the SAO of Romanija-Birač), and Bijeljina (for the SAO of Semberija) and coordinated the functions of the SJBs. ${ }^{10196}$ The SJBs, which were established within the territory of each municipality, were tasked with dealing with all public security matters. ${ }^{10197}$ The Chamber further recalls that the SBP, commanded by Goran Sarić, functioned as a combat unit and was divided into five detachments located in Banja Luka, Trebinje, Doboj, Sarajevo, and Bijeljina. ${ }^{10198}$

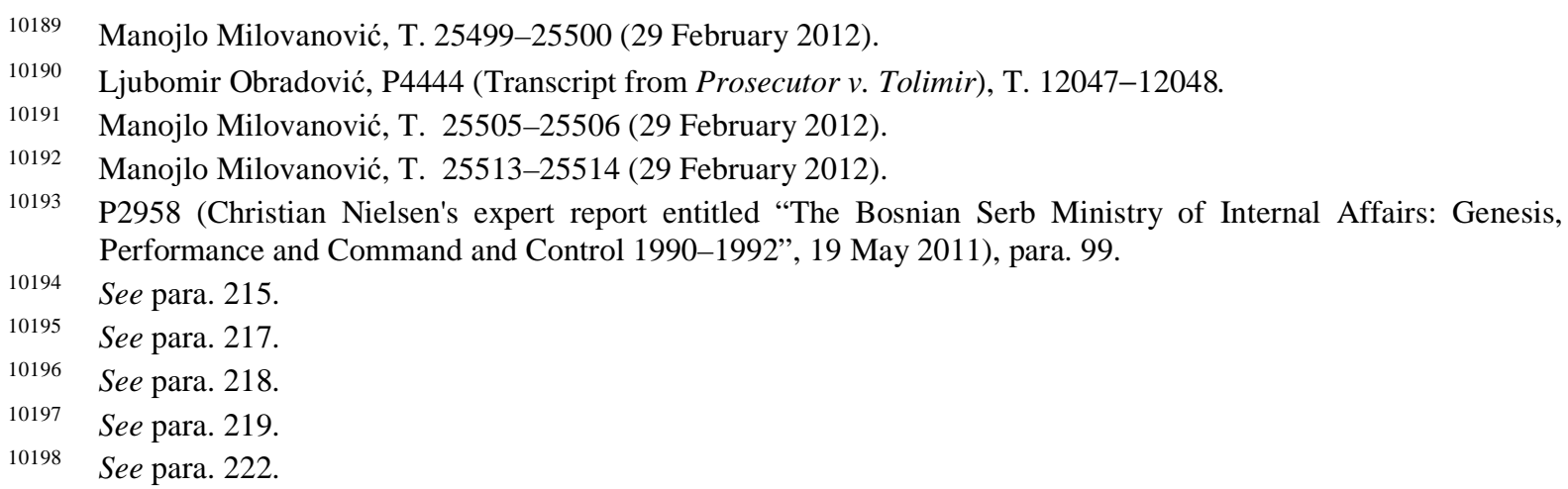


PJPs, which participated in combat activities, were organised by the CSBs at the regional level and their detachments were located at each of the five CSBs. ${ }^{10199}$

\section{(1) Accused's powers}

3160. As Supreme Commander of the VRS, the Accused had the authority to issue orders for the deployment of the police and define the basis for the organisation and size of the police force during times of war in order to protect the rights and duties of the RS and its citizens. ${ }^{10200}$ The Presidency declared an "imminent threat of war" on 15 April 1992. ${ }^{10201}$ In addition, the Chamber recalls that on 15 May 1992, Mićo Stanišić issued an order formalising the co-operation of the Bosnian Serb MUP and VRS, such that the MUP personnel would be organised into "war units" and be re-subordinated to the VRS during their participation in combat activities. ${ }^{10202}$ Therefore, the Chamber finds that the Accused had de jure authority over the MUP.

3161. Branko Đerić testified that Mićo Stanišić took his orders directly from the Accused and that the Accused was in charge of the "use of the police". ${ }^{10203}$ He explained that as Minister of the MUP, Stanišić should have implemented government decisions; instead he ignored the government and failed to attend government sessions. ${ }^{10204}$ The Prosecution points to one example of Stanišić receiving instructions from the Accused in an intercepted conversation from 18 April 1992. ${ }^{10205}$ In this intercepted conversation, the Accused and Stanišić discussed the whereabouts of a team of European observers and then moved on to discuss the arming of a group of people preparing for an attack on Foča. ${ }^{10206}$ The Accused told Stanišić to stop the chain of weapon delivery and inform Hadžići and Ilidža not to cross over to Kiseljak. ${ }^{10207}$

3162. In addition, the Accused issued an order with respect to the deployment of police forces into combat. On 20 May 1992, the Accused ordered that manpower in SRK units was to be replenished by agreement with the MUP and SJBs in, inter alia, Ilidža, Vogošća, Novo Sarajevo, Rajlovac,

\footnotetext{
10199 See para. 222. The Chamber notes that CSBs were renamed CJBs at the beginning of 1994. Christian Nielsen, T. 16320 (7 July 2011).

10200 P2602 (SerBiH Defence Act, 1 June 1992), art. 7(6); Mićo Stanišić, T. 46484 (4 February 2014); Momčilo Mandić, C2 (Transcript from Prosecutor v. Krajišnik), T. 9107-9110. See also Manojlo Milovanović, T. 25445 (28 February 2012).

10201 P3922 (Decision of SerBiH Presidency, 15 April 1992).

10202 See para. 230.

10203 P4982 (Witness Statement of Branko Đerić dated 5 April 2012), paras. 20-22.

10204 P4982 (Witness Statement of Branko Đerić dated 5 April 2012), para. 22.

10205 Prosecution Final Brief, para. 133, referring to P5606 (Intercept of conversation between Mićo Stanišić and Radovan Karadžić, 18 April 1992).

10206 P5606 (Intercept of conversation between Mićo Stanišić and Radovan Karadžić, 18 April 1992), p. 1.

10207 P5606 (Intercept of conversation between Mićo Stanišić and Radovan Karadžić, 18 April 1992), pp. 2-3.
} 
Sokolac, and Pale. ${ }^{10208}$ On 2 June 1992, he ordered two PJP platoons to be redeployed to Nedžarići and put under the military command of the SRK via, inter alia, Ilidža where they were to report to Tomislav Kovač regarding the continuation of their journey. ${ }^{10209}$

3163. Municipal Crisis Staffs and War Presidencies issued orders to MUP units. For example, the Crisis Staff in Sanski Most issued orders to the SJB. ${ }^{10210}$ The Banja Luka CSB instructed its subordinate SJBs to implement decisions of the ARK War Presidency. ${ }^{10211}$ The Chamber further notes that the Bratunac Crisis Staff issued the decision that the Bratunac TO and SJB would take over the defence of the Serbian municipality of Bratunac and issued decisions authorising the SJB to disarm citizens, and that members of the SJB assist other Serb Forces with actions against Bosnian Muslims during the take over of Bratunac. ${ }^{10212}$ In Foča, the SJB acted alongside the TO during the take-over. ${ }^{10213}$ The Rogatica Crisis Staff ordered the implementation of the division of the Rogatica SJB. ${ }^{10214}$ In Vlasenica, the Crisis Staff was involved in the co-ordination of the takeover of the town, which was carried out with police acting alongside other Serb Forces, and its aftermath, which involved the police confiscating weapons from non-Serbs and arresting those who refused to surrender their weapons. ${ }^{10215}$ The Vlasenica Crisis Staff also commanded a Special Police Platoon, ${ }^{10216}$ and was able to issue orders to the Chief of the SJB in Vlasenica. ${ }^{10217}$ In Hadžići, the police implemented a decision of the Crisis Staff to arrest and detain all Bosnian Muslim men of military age. ${ }^{10218}$ The Vogošća Crisis Staff also had the authority to provide

\footnotetext{
10208 P2645 (Radovan Karadžić's order to VRS Main Staff, MUP, and Ministry of Defence, 20 May 1992).

10209 P1503 (Radovan Karadžić's Order re Nedžarići, 1 July 1992).

10210 KW540, D4449 (Transcript from Prosecutor v. Stanišić \& Župljanin), T. 3342 (under seal). See, e.g., P2613 (Conclusions of Sanski Most Crisis Staff, 22 May 1992); P2614 (Conclusions of Sanski Most Crisis Staff, 30 May 1992).

10211 See paras. 2055, 2061.

10212 See paras. 713-714, 717-718.

10213 D3319 (Belgrade Radio news report, 8 April 1992). See also para. 858

10214 See para. 960.

10215 See paras. 1113, 1121, 1149

10216 See para. 1124. The Special Police Platoon in Vlasenica was within the organisational structure of the SJB, received payment from the SJB, and reported daily to the SJB. See paras. 1125, 1161, 1182, 1193. The Special Police Platoon engaged in illegal activities, mistreated Bosnian Muslims, and was involved in take-overs of villages surrounding Vlasenica and expelling Bosnian Muslims. See paras. 1125-1134, 1161-1163.

10217 See para. 1217.

10218 See para. 2094.
} 
instructions to the Vogošća SJB. ${ }^{10219}$ Finally, the Chamber notes that in many municipalities, the head of the police was also a member of the Crisis Staff. ${ }^{10220}$

\section{(2) Communication and Bosnian Serb MUP reporting system}

3164. The Chamber recalls that the system of reporting within the MUP consisted of daily reports and other reports about more significant security information. ${ }^{10221}$ Information was collected from the municipal level by the SJB, then sent to the regional level of the CSB, and finally sent to the Bosnian Serb MUP. ${ }^{10222}$ The information was also sent from the MUP to the Bosnian Serb Government, including to the Presidency. ${ }^{10223}$

3165. The Chamber received evidence that there were some difficulties in communication during the first year of the conflict in $1992 .^{10224}$ However, there were always communication channels between the Bosnian Serb MUP, CSBs and SJBs. ${ }^{10225}$ Communication between the CSB and the ministerial level was on a daily basis, with communication several times a day if there was a problem or every couple of days if there were no real developments. ${ }^{10226}$ Mandić testified that the police, in the absence of a special problem, were not bound to report regular activities to the

10219 See para. 2372. In early March 1992, Tintor, on behalf of the Vogošća Crisis Staff, sent a dispatch to the Vogošća SJB and Kemo Šabović, prohibiting the SJB from conducting any investigations in Serb villages in connection with the alleged killing of a young Bosnian Muslim by a Serb.

10220 See paras. 698, 957 (referring to P2835 (Report of Rogatica Crisis Staff, April-June 1992)), 961, 1051, 1109 (referring to P6121 (Decision of Vlasenica's SDS Municipal Board, 4 April 1992)), 1581, 2125-2126 (referring to D1193 (Ilidža Crisis Staff Members, 10 April 1992)).

10221 See para. 228.

10222 See para. 228.

10223 See para. 228.

10224 KW317, T. 39412 (6 June 2013); D3695 (Witness statement of Bogdan Subotić dated 16 June 2013), para. 57. See also D4229 (Witness statement of Boško Mandić dated 18 January 2014), para. 16. The Chamber does not find Grahovac's evidence that it was impossible for the municipal leaders to communicate or contact the Republican leadership to be reliable. D4077 (Witness statement of Andelko Grahovac), para. 8.

10225 Milorad Davidović, T. 15460-15461 (24 June 2011). See also Christian Nielsen, T. 16270-16271 (7 July 2011); P2850 (Fax of Bijeljina CSB, 29 April 1992); D3695 (Witness statement of Bogdan Subotić dated 16 June 2013), para. 92. For example the SNB confirmed that it would communicate with the Bosnian Serb Assembly and the government by way of phone and courier. P3050 (Minutes of joint meeting of SNB and SerBiH Government, 15 April 1992), p. 1. But see D2852 (Witness statement of Srđan Šehovac dated 27 January 2013), para. 47. Šehovać's stated that in the period of hampered communication in 1992 that the Bosnian Serb leadership could not issue instructions and that matters were left to the municipal leadership. See also paras. 3019-3020, 4862.

10226 Milorad Davidović, T. 15462-15463 (24 June 2011). See also P2851 (Fax of Bijeljina CSB, 24 April 1992). But see Branko Đerić, T. 27937, 27941 (24 April 2012); D456 (Transcript of $20^{\text {th }}$ session of RS Assembly, 14 15 September 1992), p. 16. Đerić testified that the government over which he presided was cut off in terms of communication and that some regions became so independent that it was difficult to establish any kind of communication with them. 
Accused but reported to the Prime Minister. ${ }^{10227}$ In addition, the Chief of the Bijeljina SJB reported to Mićo Stanišić on the situation in the municipality. ${ }^{10228}$

3166. Until the end of 1992, the SDB did not send any reports to the RS President; this was done through the MUP. Only from 1993, were SDB reports sent to the state leadership of the RS (President, President of the Assembly, Prime Minister, and other government bodies as required). ${ }^{10229}$ The Accused received the information verbally and via written reports multiple times per month. ${ }^{10230}$

\section{(3) Conclusion}

3167. The Chamber finds that the Accused had de jure authority over the Bosnian Serb MUP from at least 15 April 1992, which he exercised in fact, in his position as President of the Presidency, and later President of the RS, and Supreme Commander of the VRS. Although the evidence of his involvement in the day to day operations of the MUP is limited, the evidence establishes that he had the ability to re-deploy police officers and give instructions to Mićo Stanišić and lower level MUP officials. In addition, the evidence establishes that while the communication system was sometimes interrupted, the Accused frequently received reports from the MUP.

3168. The Chamber further finds that Crisis Staffs and War Presidencies played a role in commanding or co-ordinating the tasks of MUP units in the Municipalities. In this regard, the Chamber recalls that the Accused exercised authority over such institutions and played a central role in instructing how they would function. ${ }^{10231}$ In light of the co-operation between MUP units and Bosnian Serb authorities, the TO, and the VRS, the Chamber finds that the Accused supported the use of MUP units during combat activities throughout the Municipalities.

\section{(C) Territorial Defence}

3169. In the second half of 1991, in the context of the conflict in Croatia, the Accused issued instructions to the SDS and to municipalities in which SDS was in power, to mobilise all citizens into the TO and to subordinate them to the command of the JNA. ${ }^{10232}$ The Accused monitored this mobilisation effort. ${ }^{10233}$

\footnotetext{
10227 Momčilo Mandić, T. 5050 (13 July 2010).

10228 P2629 (Report of Bijeljina SJB, undated).

10229 D4143 (Witness statement of Dragan Kijac dated 30 November 2013), para. 39.

10230 Dragan Kijać, T. 44320-44321 (3 December 2013).

10231 See paras. 3087-3089.

10232 P5884 (Intercept of conversation between Radovan Karadžić and Nikola Uzelac, 9 July 1991), p. 2; P2547 (Intercept of conversation between Radovan Karadžić and Tomislav Simović, 2 November 1991), p. 4; P2548
} 
3170. As long as the JNA officially operated in BiH territory, the Accused supported the mobilisation of armed forces that operated under the JNA's command. ${ }^{10234}$ With regard to the mobilisation and the arming of Serbs who were not subordinated to the JNA, the Accused's position at that time was that the SDS would not arm the Serbs but would not prevent them from acquiring weapons in other ways. ${ }^{10235}$ However, the Chamber also recalls that the SDS in Bijeljina, Bratunac, Rogatica, Vlasenica, Ključ, and Hadžići provided Serbs with weapons while the JNA still operated in $\mathrm{BiH}^{10236}$

3171. On 27 March 1992, before the Bosnian Serb Assembly, the Accused gave instructions to the newly-formed Serb municipalities to "organise the people so that they can defend themselves" as a TO and place them under the command of the JNA present at that time. ${ }^{10237}$

3172. Following the declaration of a state of imminent threat of war in mid-April 1992, the Presidency of the SerBiH decided that a SerBiH TO "shall be formed as the armed force of $[\mathrm{SerBiH}] ",{ }^{10238}$ led and commanded by municipal, district and regional staffs and the republican

(Telex entitled "The Sarajevo SDS Order", 29 October 1991); P970 (Transcript of 50 ${ }^{\text {th }}$ session of RS Assembly, 15-16 April 1995), pp. 316-317. See also D4504 (Intercept of conversation between Radovan Karadžić and Slobodan Vidović, 8 February 1992).

10233 P3406 (Intercept of conversation between Radovan Karadžić and Sveto, 20 September 1991); Sveto Veselinović, T. 45093-45101 (16 December 2013); D1643 (Intercept of conversation between Radovan Karadžić and Zvonko Bajagić, 4 September 1991), p. 6; D1653 (Intercept of conversation between Zvonko Bajagić and Radovan Karadžić, 11 December 1991); Zvonko Bajagić, T. 41172-41176 (10 July 2013).

10234 See P2542 (Vojislav Maksimović's diary, 24 December 1990 to 24 December 1991), p. 8 (the Accused stated during an SDS Council session that paramilitary organisations could not be formed and that the SDS should not take any step to provoke the army). See also D4077 (Witness statement of Anđelko Grahovac dated 23 November 2013), paras. 3, 14, 31-32 (the Accused told the Prime Minister of the ARK, Anđelko Grahovac, with regard to a paramilitary unit in Banja Luka led by Veljko Milanković, that the municipal Serb authorities should not support or rely on "criminals", stating that "these independent vojvodas" have already done them great damage); Anđelko Grahovac, T. 44036, 44045-44048 (26 November 2013) (stating further that this unit was allowed to eventually join the army-first the JNA and later the VRS).

10235 P2542 (Vojislav Maksimović's diary, 24 December 1990 to 24 December 1991), p. 8.

10236 See paras. 607, 695, 944, 1104, 1492, 2070.

10237 See para. 211; D325 (VRS Main Staff analysis of combat readiness and army activities in 1992, April 1993), p. 69. See also P5604 (Intercept of conversation between Gvozden and Radovan Karadžić, 3 March 1992), p. 3 (Gvozden informed the Accused that he had mobilised Serbs from Pale and would do the same in other municipalities, including Novi Grad).

10238 P2412 (Decision SerBiH Ministry of Defence, 16 April 1992) p. 1. See also para. 212; D325 (VRS Main Staff analysis of combat readiness and army activities in 1992, April 1993), pp. 69, 75; Neđeljko Prstojević, T. 12967-12969 (8 March 2011); D394 (Announcement of SNB, 4 April 1992). Bogdan Subotić also stated that given that during this early phase, the central authorities did not establish control over the TO, the appointment of a Chief of the TO for SerBiH was an attempt to centralise the command. D3695 (Witness statement of Bogdan Subotić dated 16 June 2013), paras. 264-267; D3709 (Decision of SerBiH Government, 15 April 1992); P3050 (Minutes of joint meeting of SNB and SerBiH Government, 15 April 1992), p. 2; D3703 (Decision of SerBiH Ministry of Defence, 18 April 1992), p. 1; Bogdan Subotić, T. 40020-40021 (19 June 2013). 
staff of the SerBiH. ${ }^{10239}$ The TO was subordinated to Minister of Defence Bogdan Subotic until the appointment of the commander. ${ }^{10240}$ In addition, a general mobilisation of the TO was ordered. ${ }^{10241}$

3173. The SNB decided that the Accused, as the President of the SNB, would co-ordinate the command of the TO forces. ${ }^{10242}$ The SNB adopted decisions on the appointment of the acting commander of the $\mathrm{TO}$ and the chief of staff of the $\mathrm{TO},{ }^{10243}$ the procurement of uniforms and insignia for the TO with instructions on markings, ${ }^{10244}$ and the securing of salaries for members of the TO. ${ }^{10245}$ On 24 April 1992, it was decided to charge the Accused with the responsibility of establishing a Town TO Staff. ${ }^{10246}$ Subotić asked, on 27 April 1992, for assistance from the Military Command in filling "most vital personnel" posts in the TO and also for the provision of uniforms. $^{10247}$

3174. In a report of 5 June 1992 from the Novo Sarajevo Crisis Staff to the Accused, it was stated that the Crisis Staff had mobilised about 900 people over the previous two months, including about 700 in the Lukavica and Tilava areas and about 200 in Grbavica. ${ }^{10248}$ In addition, as found above, on 16 April 1992, following an order by the Presidency of the SerBiH, the Bratunac Crisis Staff issued an order for general mobilisation and also required military conscripts assigned to Bratunac

\footnotetext{
10239 P2412 (Decision SerBiH Ministry of Defence, 16 April 1992) p. 1.

10240 See para. 91; Neđeljko Prstojević, T. 12970 (8 March 2011).

10241 D3703 (Decision of SerBiH Ministry of Defence, 18 April 1992), p. 2; P2412 (Decision of SerBiH Ministry of Defence, 16 April 1992). See also D406 (Minutes of meeting of SNB and SerBiH Government, 27 April 1992), p. 1.

10242 P3051 (Minutes of expanded meeting of SNB and SerBiH Government, 22 April 1992), p. 1.

10243 P3050 (Minutes of joint meeting of SNB and SerBiH Government, 15 April 1992), p. 2.

10244 P1087 (Minutes of meeting between SNB and SerBiH Government, 24 April 1992), p. 1, P2627 (Minutes of meeting of SNB and SerBiH Government, 28 April 1992), p. 1. The Chamber notes the evidence of Subotić that the attempts of the "central authorities" to procure military uniforms for TO members were only aimed at "providing logistical support for the TO units" and not commanding them. D3695 (Witness statement of Bogdan Subotić dated 16 June 2013), para. 272. However, the Chamber finds that this evidence is not consistent with evidence regarding the creation of a hierarchical command structure nor with Subotic's own statement with regard to P5565 (Request of the Ministry of Defence for Personnel, 27 April 1992) in relation to which he testified that this was part of "our efforts to organize an efficient command and control over the TO units up until the formation of the VRS.” D3695 (Witness statement of Bogdan Subotić dated 16 June 2013), para. 271.

10245 D406 (Minutes of meeting of SNB and SerBiH Government, 27 April 1992), p. 1.

10246 See para. 92.

10247 P5565 (Request of the Ministry of Defence for Personnel, 27 April 1992); D3695 (Witness statement of Bogdan Subotić dated 16 June 2013), paras. 271-272; P2627 (Minutes of meeting of SNB and SerBiH Government, 28 April 1992), p. 1; Bogdan Subotić, T. 40020 (19 June 2013).

10248 See para. 2260.
} 
TO units to immediately respond to the mobilisation. ${ }^{10249}$ Similarly, the SAO Birač Crisis Staff ordered, on 29 April 1992, mobilisation in the entire SAO of Birač. ${ }^{10250}$

3175. The VRS reported that during the period before 20 May 1992 "the municipal authorities and party leaderships, primarily of the [SDS], mobilised the Serbian TO as a self-organised defence form of the Serbian people."10251 It also reported that in 1992 infantry units "grew on a massive scale out of the territorial defence and other units" and that they were only used at the beginning of the war "according to the decisions of crisis staffs and similar administrative bodies". ${ }^{10252}$

3176. On 12 May 1992, after the formal establishment of the VRS, the SerBiH TO was directly integrated into the VRS. The Accused, as the President, was to determine the organisation of the integrated SerBiH TO units and staff. ${ }^{10253}$ The Accused participated in the creation of the VRS by organising the manpower at the local level and facilitating the transfer of personnel and supply from the JNA. ${ }^{10254}$

3177. Based on the above the Chamber finds that the Accused was instrumental in the creation of the SerBiH TO and local TO units in mid-April 1992 and that he had de jure authority over the TO. In addition, given the Accused's authority over Crisis Staffs, ${ }^{10255}$ the Chamber finds that the Accused also had de facto authority over the TO.

(D) Paramilitary units

(1) Accused's initial attitude towards paramilitary units

3178. As stated above, while the JNA was operating in $\mathrm{BiH}$, the Accused's position was that the SDS would not arm the Serbs but would not prevent them from acquiring weapons in other

\footnotetext{
10249 See para. 713; P4383 (Order of Bratunac Crisis Staff, 16 April 1992), p. 1; D2061 (List of decisions and orders issued by the Crisis Staff, War Staff, and Wartime Presidency of Bratunac Municipality, 29 August 1992), p. 4. See also Adjudicated Fact 2309; D3118 (Witness statement of Aleksandar Tešić dated 10 March 2013), para. 16. P2615 (Decision of Birač Crisis Staff, 29 April 1992). Subotić stated that nobody really knew how many local units had been formed. D3695 (Witness statement of Bogdan Subotić dated 16 June 2013), para. 58.

10251 D325 (VRS Main Staff analysis of combat readiness and army activities in 1992, April 1993), p. 75. See also D325 (VRS Main Staff analysis of combat readiness and army activities in 1992, April 1993), p. 69.

10252 D325 (VRS Main Staff analysis of combat readiness and army activities in 1992, April 1993), p. 13.

10253 See para. 214; D325 (VRS Main Staff analysis of combat readiness and army activities in 1992, April 1993), p. 13 (stating that when the VRS was formed the infantry units that grew from TO and other units were incorporated into the VRS).

10254 P970 (Transcript of 50 $0^{\text {th }}$ session of RS Assembly, 15-16 April 1995), pp. 316-317; D1464 (Radovan Karadžić's Interview in Delo, 8 November 1993), p. 2; KDZ088 T. 6245 (6 September 2010) (closed session); P1154 (Witness statement of KDZ088 dated 27-29 April 2010) (under seal), pp. 18-19. See also D325 (VRS Main Staff analysis of combat readiness and army activities in 1992, April 1993), pp. 69, 75; D409 (Minutes of meeting of SNB and SerBiH Government, 10 May 1992); P979 (Report from JNA $2^{\text {nd }}$ Military District to JNA General Staff, 20 March 1992), pp. 5-7; Colm Doyle, T. 2653 (21 May 2010), T. 2738-2739 (26 May 2010).

10255 See paras. 3072-3096.
} 
ways. ${ }^{10256}$ However, the Chamber notes that already at the end of 1991 the SOS, commanded by Duško Šaović, was formed and received orders from the SDS in Sanski Most. ${ }^{10257}$

3179. Mandić testified that in March and April 1992 the municipalities controlled and coordinated the activities of the paramilitary formations active in their respective territories. ${ }^{10258}$ At around the same time, the Accused stated before the Bosnian Serb Assembly that "[w]e know that our people have armed themselves. We don't know the various ways and means by which this was done, but we do know that the people have enough weapons". ${ }^{10259}$ He added, however, that they did not have paramilitary units and called for the urgent creation of Crisis Staffs and for the organisation of TOs to be placed under the command of the JNA or reserve officers. ${ }^{10260}$

3180. In mid-April 1992, following a question by Vance about the presence of Arkan and Serb irregulars in $\mathrm{BiH}$, the Accused and Koljević claimed to have never seen Arkan and that "somebody" invited Arkan to Bijeljina after a problem was caused by a Serb in a café, following which "Muslims even sent a cable thanking Arkan". ${ }^{10261}$

3181. During an interview that was published on 23 April 1992, the Accused was asked how he justified that "Arkan Serbian militia are still seizing control of large sections of Bosnian territory", to which he responded that "[t]hose militias are paramilitary groups. They arrived in Bosnia to respond to the infiltration by units of regular Croatian army in Her[z]egovina". ${ }^{10262}$ When he was asked whether he agreed to disband the paramilitary forces he answered that the Bosnian Serbs did not have an armed force and that "[w]e have always asked the Serbs not to mobilize, unlike the Muslims". 10263

3182. The Chamber recalls that the Bijeljina Crisis Staff invited Arkan to the municipality and that the take-over of Bijeljina on 1 and 2 April 1992 was carried out, inter alios, by the local TO, the police, the JNA, and Arkan's men who operated under the supervision of the Bijeljina Crisis

\footnotetext{
10256 See paras. 3169-3170.

10257 See para. 1925. The Chamber recalls that in April 1992, the Crisis Staff decided to integrate the SOS as a special unit of the TO and notes that the order was never executed because the SOS refused to be placed under the TO's command. See para. 1928; KW540, D4449 (Transcript from Prosecutor v. Stanišić \& Župljanin), T. 3325 (under seal). The Chamber finds, therefore, that the SOS in Sanski Most remained a paramilitary formation.

10258 Momčilo Mandić, C2 (Transcript from Prosecutor v. Krajišnik), T. 9119.

10259 D304 (Shorthand Record of $14^{\text {th }}$ session of RS Assembly, 27 March 1992), p. 20. See also Herbert Okun, T. 1515 (23 April 2010).

10260 D304 (Shorthand Record of $14^{\text {th }}$ session of RS Assembly, 27 March 1992), p. 20.

10261 Herbert Okun, T. 1515 (23 April 2010); P780 (Seventh notebook of Herbert Okun's Vance Mission Diary), p. 38.

10262 D1591 (Radovan Karadžić's interview from Le Figaro, 23 April 1992), p. 1.

10263 D1591 (Radovan Karadžićss interview from Le Figaro, 23 April 1992), p. 1.
} 
Staff. ${ }^{10264}$ Davidović stated that although Mićo Stanišić knew what Arkan and his staff were doing in Bijeljina, Stanišić dared not interfere because of Arkan's links with the Serbian MUP. ${ }^{10265}$ In April 1992, Mandić was also aware of Arkan's involvement in Bijlejina and that Arkan had "introduced order". 10266

3183. Starting in early April 1992, Arkan's men also operated in Zvornik municipality, in conjunction with the police, the Zvornik TO, and the JNA. ${ }^{10267}$ In Bratunac, in mid-April, Arkan's men operated together with the Serb Forces that consisted of JNA troops, TO members, and local reservists. ${ }^{10268}$ In Ilidža, they co-operated with the local forces in April $1992 .{ }^{10269}$ At the beginning of May 1992, Arkan's men participated in the attack on Brčko in conjunction with Serb units of the JNA, active and reserve police officers, soldiers, military reserves, and a TO battalion. ${ }^{10270}$ Similarly, after Rogatica was attacked on or about 22 May 1992, Arkan's men were posted in Borike ready to start operations as soon as Kušić, who commanded the Rogatica Brigade, so ordered. $^{10271}$

3184. The Chamber notes the evidence that Arkan was not subordinated to the RS authorities. Milan Martić testified that Arkan was close to the federal SDB and that "he was practically there in that capacity". ${ }^{10272}$ Martin Bell testified that "Arkan took orders from nobody"; ${ }^{10273}$ however, he noted that Arkan “couldn't have got across the border through the roadblocks without some collusion somewhere and somebody letting his men across". 10274 John Wilson stated that Arkan's

10264 See paras. 608, 611-612, 672.

10265 P2848 (Witness statement of Milorad Davidović dated 22 June 2011), para. 125. Davidović also testified that Arkan's men were controlled and subordinated to the Serbian MUP and that he had a training camp at Erdut for which he had received the consent of the Serbian MUP. See para. 232.

10266 P5741 (Intercept of conversation between Momčilo Mandić and Milenko Kepeš, 5 April 1992), p. 3.

10267 See paras. 1245-1246, 1252, 1255, 1319, 1361. The Chamber noted that the local authorities in Zvornik faced difficulties in controlling the actions of the paramilitaries but that, in some cases the paramilitary formations carried out their illegal activities with the knowledge and consent of members of the Bosnian Serb authorities. See paras. 1286, 1288.

10268 See para. 714. The Chamber noted that the municipal authorities faced problems with paramilitaries and volunteers who arrived in Bratunac, tried to take power, terrorised the population and did not accept the command structures or local authorities. See paras. 750-751, 754.

10269 See para. 2142.

10270 See para. 798. The Chamber noted that the Bosnian Serb local authorities had difficulties in controlling paramilitary groups which entered and operated in Brčko. See para. 824. See also paras. 826-833.

10271 See paras. 969, 3322.

10272 Milan Martić, T. 38158-38159 (13 May 2013). See also KDZ446, P28 (Transcript from Prosecutor v. S. Milošević), T. 23628-23629 (under seal) (testifying: "I think that [Arkan] didn't have any official position [within the Ministry of Interior]" and that Arkan had been in contact with the Federal SUP and the main inspector in the Federal SUP).

10273 Martin Bell, T. 9787 (14 December 2010).

10274 Martin Bell, T. 9787 (14 December 2010). See also Martin Bell, T. 9788, 9809-9810 (14 December 2010); P2002 (BBC news report re Zvornik, with transcript); P2001 (BBC news report re Zvornik, with transcript); D916 (BBC news report re Ilidža, with transcript). While the Chamber accepts Bell testimony that according to 
men "enjoyed cooperation with Mladić by the fact that they were able to move about freely in an otherwise relatively tightly controlled area."10275

3185. With regard to the events in Zvornik in early April 1992, ${ }^{10276}$ KW317 testified that while there was an attempt of the SDS to negotiate with the Muslims in Zvornik, Arkan and his group arrived and took control over the situation. Arkan rejected the idea of negotiating and he launched an attack without the authorisation of the local authorities in Zvornik. KW317 added that they had no means of contacting the Accused and he was not aware of anything that would suggest that the Accused knew of Arkan's attack on Zvornik, let alone approved it. ${ }^{10277}$ Similarly, Šešelj testified that the Accused had no role to play in the events in Zvornik in early April 1992 and did not have any power to exert any influence. ${ }^{10278}$

3186. However, as depicted above, Arkan's men were in contact and co-operated with RS authorities. In addition, Kuprešanin testified that when he and other deputies from ARK called an extraordinary session of the ARK Assembly to receive explanations from the Accused about recent events involving Croatian and Muslim forces in the ARK Municipalities, Arkan interrupted the session while the Accused was not present and stated that he had come with 300 volunteers; he demanded that the republican authorities authorise him to defend the municipalities given that the VRS was not doing so. ${ }^{10279}$

3187. The Chamber recalls that when Davidović reported to Mićo Stanišić that some of Arkan's men had taken over the SUP in Bijeljina, Stanišić commented that he knew, that nothing else could be done, and that's "how it ha[d] to be". ${ }^{10280}$ Stanišić also told Davidović that Arkan's men were in Bijeljina and Zvornik "helping to liberate territory that they believed should become part of the [RS]". ${ }^{10281}$ The evidence also shows that at the same period, after Arkan had entered Bijeljina, Davidović was at a meeting in Belgrade where further activities of the Serbian MUP were

his observations there were paramilitary groups operating in $\mathrm{BiH}$, it finds however that Bell was not in a position to conclude that such groups were under no one's control.

10275 P1029 (Witness statement of John Wilson 4 November 2008), para. 128. Wilson stated that Mladić commanded not only the VRS, but the TO and paramilitaries, except, for example, Arkan's men.

10276 See paras. 1248-1253.

10277 D3654 (Witness statement of KW317 dated 26 September 2012) (under seal), para. 46. See also paras. 12511253.

10278 Vojislav Šešelj, T. 39594 (10 June 2013). See also KDZ610, T. 27199-27200 (29 March 2012).

10279 D4011 (Witness statement of Vojislav Kuprešanin dated 11 November 2013), para. 51.

10280 See para. 616.

10281 See para. 616. See also para. 1244 (referring to the fact that Grujić and Spasojević were among the Bosnian Serb officials who invited and paid for paramilitaries to come to Zvornik). 
discussed. ${ }^{10282}$ Arkan arrived at this meeting, which was also attended by the Accused, Momčilo Krajišnik, and Mićo Stanišić. ${ }^{10283}$

3188. Davidović also testified that during a meeting with the Accused and Mladić around May 1992 at the Lukavica barracks, some of Arkan's men arrived. According to Davidović, Mladić was angry and the Accused stated, "[i]t's all right, we asked them to come. They should help with the liberation of Sarajevo. And, if they can do it, let them do it. Let them take whatever they can take."10284

3189. However, in an interview in November 1993, the Accused claimed that not a "single soldier from Serbia was fighting at the beginning of the war, only Arkan was in Bijeljina, but only briefly, however, and not at our invitation". ${ }^{10285}$ When asked whether Arkan was also in Ilidža, the Accused replied in the negative stating “[w]e have Šešelj's and Arkan's followers but they are our boys, however, who are only wearing their symbols."10286

3190. In addition to Arkan's men the Chamber noted that Mauzer's Panthers, whose commander was also the commander of the SAO Semberija TO, operated in Bijeljina with the support of the Presidency of the Bijeljina Municipal Assembly and under the supervision of the Bijeljina Crisis Staff. During the take-over in April 1992, Mauzer's Panthers operated in conjunction with the local TO, the police, and the JNA ${ }^{10287}$ In April 1992 Mauzer's unit also operated in Zvornik, ${ }^{10288}$ and at the beginning of May 1992 participated in the attack on Brčko, in co-operation with Serb units of the JNA, active and reserve police officers, soldiers, military reserves and a TO battalion. ${ }^{10289}$

\footnotetext{
10282 P2848 (Witness statement of Milorad Davidović dated 22 June 2011), para. 66.

10283 P2848 (Witness statement of Milorad Davidović dated 22 June 2011), para. 66. Davidović commented that in light of this meeting Arkan probably did "what he was authorised to do" and he believed that given that there was discussion of tasks and activities that the Accused knew about Arkan's activities.

10284 Milorad Davidović, T. 15465 (24 June 2011); P2848 (Witness statement of Milorad Davidović dated 22 June 2011), para. 55.

10285 D1464 (Radovan Karadžić's Interview in Delo, 8 November 1993), p. 2. But see Dragomir Andan, D3774 (Transcript from Prosecutor v. Stanišić \& Župljanin), T. 21491-21492, 21539-21541. Andan stated that he regularly informed the political structures of government about the situation in Bijeljina, and that the Accused supported the measures Andan was implementing against paramilitary units.

10286 D1464 (Radovan Karadžić's Interview in Delo, 8 November 1993), p. 2.

10287 See paras. 608, 611-612, 672. The core of Mauzer's Panthers were SDS members close to the leadership of the Crisis Staff in Bijeljina. See para. 233. The Chamber also found that it was only after paramilitaries started undermining the authority of the local institutions by forming their own parallel authorities and also attacking Bosnian Serbs that the municipal authorities sought to exercise some real control over paramilitary units, and that there were difficulties in controlling Mauzer and his unit which opposed the attempts by Davidović and Andan to restore order in the municipality. However, following demands by Mauzer for his expulsion and the arrest of one of Arkan's men by Davidović's unit, Davidović's authority was obstructed by the Bijeljina Crisis Staff and his unit was ordered to leave for Belgrade. See paras. 632-633, 637-638.

10288 See para. 1244

10289 See para. 798.
} 
3191. With regard to Šešelj's men, the Chamber noted that in April 1992 they operated in conjunction with the Serb Forces in Bratunac. ${ }^{10290}$ Šešelj's men also operated in Zvornik, ${ }^{10291}$ in Hadžići in co-operation with the TO, ${ }^{10292}$ in Novo Sarajevo with the VRS and the police, ${ }^{10293}$ and took part in combat activities in Vogošća alongside the Bosnian Serb authorities. ${ }^{10294}$

3192. In addition, on or about 22 May 1992, ${ }^{10295}$ Šešelj's men were involved in the attack on Rogatica. ${ }^{10296}$ The Chamber notes Šešelj's testimony that all members of the SRS who went to BiH as volunteers joined the VRS or the TO and that the SRS party never sponsored or supported paramilitaries, ${ }^{10297}$ but finds his testimony in this regard to be unreliable. ${ }^{10298}$ The Chamber also recalls that Šešelj met with the Accused a few times each year during the war. ${ }^{10299}$

3193. The White Eagles also operated in conjunction with the Serb Forces in Bratunac in April 1992. ${ }^{10300}$ In addition, they operated in Rogatica in March 1992 with the JNA and TO; ${ }^{10301}$ in Zvornik in April 1992 with the Zvornik TO and the JNA; ${ }^{10302}$ and in Ilidža with the co-operation of the local forces. ${ }^{10303}$ The Chamber found that the White Eagles took part in the main attack on the town of Foča that commenced on the morning of 8 April 1992, in conjunction with soldiers from Serbia and Montenegro and the Foča Tactical Group. ${ }^{10304}$ The White Eagles also participated at the

10290 See para. 714. The Chamber already noted above the problems faced by the Bratunac municipal authorities with paramilitaries and volunteers. See fn. 10268.

10291 See paras. 1244.

10292 See paras. 2104-2105.

10293 See para. 2255.

10294 See para. 2396. See also paras. 2405-2406.

10295 See para. 965.

10296 See para. 969.

10297 D3665 (Witness statement of Vojislav Šešelj dated 1 June 2013), paras. 68-69; D3667 (Transcript of Vojislav Šešelj's press conference, 26 March 1992), pp. 36-37; D3668 (Interview with Vojislav Šešelj and Nikola Poplašen, September 1992), pp. 2-3.

10298 The Chamber does not find this evidence to be reliable given the interest of Šešelj in minimising his own involvement in this regard. In addition, the Chamber notes that in a later interview Šešelj said that he was a true friend of the Accused "as long as [the Accused] pursues this kind of politics" and that he will not tell the interviewer "anything that someone else might use against [the Accused] or that might put him in an unpleasant situation." P6388 (Excerpt from video of interview with Vojislav Šešelj for "Death of Yugoslavia" documentary, with transcript).

10299 D3666 (TANJUG news report, 15 May 1993); D3665 (Witness statement of Vojislav Šešelj dated 1 June 2013 ), paras. 36-37. See also para. 3327.

10300 See para. 714. The Chamber already noted above the problems faced by the Bratunac municipal authorities with paramilitaries and volunteers. See fn. 10268.

10301 See paras. 958, 969.

10302 See paras. 1244, 1249, 1276, 1317. See also Milorad Davidović, T. 15492-15495 (28 June 2011) (referring inter alia to P2865 (White Eagles' payroll, June 1992). The Chamber noted that the local authorities faced difficulties in controlling the actions of the paramilitaries but that, in some cases the paramilitary formations carried out their illegal activities with the knowledge and consent of members of the Bosnian Serb authorities in Zvornik. See fn. 10267.

10303 See para. 2142.

10304 See para. 855. The Chamber noted that by May 1992 the authorities attempted to expel paramilitary formations from the municipality. See para. 866 . 
beginning of May 1992 in the attack on Brčko in conjunction with Serb units of the JNA, active and reserve police officers, soldiers, military reserves and a TO battalion. ${ }^{10305}$

3194. The Chamber found that members of the Yellow Wasps would regularly report to the Zvornik Crisis Staff, had close co-operation with, and were issued arms by the TO and were subsequently under the command of the Zvornik Brigade. ${ }^{10306}$

3195. Plavšić acknowledged during a session of the Bosnian Serb Assembly, in November 1992, in the presence of the Accused, ${ }^{10307}$ that following the call of the "president of the Republic" for volunteers, she sent letters in order to gather anyone who wanted to fight for the Serb cause in RS, and that she sent letters, inter alios, to Šešelj and Arkan. ${ }^{10308}$ Mandić testified that Plavsić "was an advocate of having all paramilitary units from territories where Serbs lived outside $\mathrm{BiH}$ coming to the assistance of their brethren [...] in the religious war being waged there", ${ }^{10309}$ and was the "bridge" between Bosnian Serbs and the people who came from other states to the conflict. ${ }^{10310}$

3196. Milorad Dodik testified in broad terms that paramilitary groups which operated in $\mathrm{BiH}$ were not under the control of the RS authorities. ${ }^{10311}$ Similarly, Momir Bulatovic testified that the expulsions that were suffered by "all ethnic groups" was the result of the "collective mentality of

\footnotetext{
10305 See para. 798.

10306 See paras. 1280, 1287, 1297, fn. 10267. See also Milorad Davidović, T. 15492-15495 (28 June 2011) (referring to P2862 (Yellow Wasps payroll, 1 May 1992) and to P2863 (Yellow Wasps payroll, June 1992).

10307 P1105 (Transcript of $22^{\text {nd }}$ session of RS Assembly, 23-24 November 1992), pp. 2, 60.

10308 P1105 (Transcript of 22 ${ }^{\text {nd }}$ session of RS Assembly, 23-24 November 1992), p. 20; Milorad Davidović, T. 15473-15474 (28 June 2011); Momčilo Mandić, T. 4625-4626 (5 July 2010). See also P2857 (Video footage of Arkan in Bijeljina), p. 1; P4982 (Witness Statement of Branko Đerić dated 5 April 2012), paras. 42-44; Momčilo Mandić, T. 5163 (14 July 2010) (explaining that mop-up operations included paramilitary and military formations in combat operations aimed at taking new territory or territory under the control of another warring party).

10309 Momčilo Mandić, T. 4625-4626 (5 July 2010). See also Mićo Stanišić, T. 46385-46386 (3 February 2014); P2848 (Witness statement of Milorad Davidović dated 22 June 2011), para. 72; P1106 (Intercept of conversation between Biljana Plavšić and "Rus", 23 April 1992), pp. 1-2.

10310 Momčilo Mandić, T. 4660-4661 (6 July 2010). According to Mandić, while Đeric supported Plavsić, he and Mićo Stanišić opposed Plavsić's approach to paramilitaries. Momčilo Mandić, T. 4625-4626 (5 July 2010). The Chamber notes that Davidović testified that he heard from many sources that the Accused invited those who wanted to fight for RS to report as volunteers in $\mathrm{BiH}$ and join units of the army. See Milorad Davidović, T. 15473-15474 (28 June 2011). The Chamber rejects this portion of Davidović's evidence as it is based on unattributed hearsay. The Chamber also notes Redžić's assessment that the paramilitaries were formed by leaders of the SDS. Izet Redžić, P3189 (Transcript from Prosecutor v. Krajišnik), T. 5070-5071. The Chamber notes that Redžić was the president of the Executive Board of Vlasenica, but, as he could not elaborate the basis for his assessment, the Chamber does not place any weight on his assessment.

10311 See Milorad Dodik, T. 36919 (9 April 2013). See also Milorad Dodik, T. 36852 (9 April 2013).
} 
the population" and that it was impossible for any political leader to "control the population". 10312 The Chamber, however, does not find that these broad statements have any weight. ${ }^{10313}$

3197. The Chamber finds, to the contrary, that the fact that paramilitary formations, such as Arkan's men, Šešelj's men, Mauzer's Panthers, and White Eagles were able to move freely in "an otherwise relatively tightly controlled area"10314 and to operate in concert with local forces and authorities, in several of the Municipalities throughout $\mathrm{BiH}$, supports the conclusion that such cooperation was approved by the Bosnian Serb leadership.

3198. With regard to Arkan's men and Šešelj's men specifically, the Chamber concludes that the Accused knew that they were operating in $\mathrm{BiH}$ during the spring of 1992 and that they were invited by the RS Presidency to operate in conjunction with local authorities and forces. ${ }^{10315}$ The Chamber also notes the Accused's direct interaction with Arkan and Šešelj and, moreover, that in May 1992 the Accused invited, without Mladić's knowledge, Arkan's men to participate in operations in the Sarajevo area. ${ }^{10316}$

\section{(2) Disbandment of paramilitary forces}

3199. The Chamber found above that over the course of the conflict the Bosnian Serb leadership and military commanders increasingly expressed opposition to having units that were outside of the command and control of the army. ${ }^{10317}$

3200. On 2 June 1992, at a meeting of commanders of the $1^{\text {st }}$ Krajina Corps and Banja Luka political leaders, which the Accused attended, there was agreement that paramilitary formations should be dissolved. ${ }^{10318}$

3201. On 3 June 1992, the Eastern Bosnia Corp Command issued an order, pursuant to the decision on the formation of the VRS, that certain volunteer units, including Mauzer's Panthers, be

\footnotetext{
10312 See D3051 (Witness statement of Momir Bulatović dated 25 February 2013), para. 20.

10313 The Chamber notes that Dodik's evidence was marked by contradictions, indicators of insincerity and partisanship which undermined the reliability of his evidence in this regard. With regard to Bulatović's evidence, the Chamber finds his statement to be broad, general and unsubstantiated.

10314 P1029 (Witness statement of John Wilson 4 November 2008), para. 128. See also Martin Bell, T. 9787 (14 December 2010).

10315 See paras. 3181, 3195.

10316 See paras. 3188, 3192.

10317 See para. 238. The Chamber notes that in certain regions orders against paramilitary formations were already issued by the local authorities in April and May 1992. See paras. 854, 1943, 2052. However, the Chamber also notes that such orders were not necessarily enforced or were selectively enforced against non-Serbs. See paras. 855, 2053.

10318 P1478 (Ratko Mladić's notebook, 27 May-31 July 1992), pp. 53-59. See also D1464 (Radovan Karadžić's Interview in Delo, 8 November 1993), p. 1.
} 
transformed into units of the VRS and that Mauzer be appointed Assistant Chief of Staff. ${ }^{10319}$ Similarly, as found above, on 13 June 1992, the Accused banned the formation and operation of armed groups and individuals which were not under the control of the VRS on the territory of the RS. ${ }^{10320}$ The Accused also stated that he was "disowning" groups that continued to operate independently and that those groups would suffer the strictest sanctions for their operations. ${ }^{10321}$

3202. As a result Arkan's men left BiH, though they returned from time to time. ${ }^{10322}$ In addition, Mauzer's Panthers were formally incorporated in the VRS as a "Special Brigade"10323 that functioned as a separate unit under Mauzer's authority. ${ }^{10324}$ The Accused was aware that Mauzer's Panthers were incorporated in the VRS as a "Special Brigade". ${ }^{10325}$

3203. As described earlier, in June 1992, the Accused and Mladić visited Zvornik after the Zvornik Government and Crisis Staff building was encircled by paramilitary formations and a member of Captain Dragan's unit threatened the President of the Municipality. ${ }^{10326}$ On 30 June 1992, Grujić reported to the Accused and Mladić that in addition to "major accomplishments" there were also many problems from paramilitary formations which broke free after Arkan's withdrawal and called for their removal. ${ }^{10327}$ Marko Pavlović reported that the "[v]olunteer formations enjoyed exceptional success" and were led by Arkan and Šešelj, and that "Arkan's withdrew orderly, but some that stayed broke free of his control". ${ }^{10328}$ At this meeting, the Accused stated that it would

\footnotetext{
10319 D1458 (Order of Eastern Bosnia Corps, 3 June 1992).

10320 See para. 239. See also KDZ088, T. 6562-6563 (13 September 2010) (closed session); D455 (Report re events in Doboj, 27 July 1992), pp. 1-2; D3485 (SRK report, 26 June 1993), p. 1.

10321 See para. 239. See also D1933 (Fax from Radovan Karadžić to Boutros Ghali, 13 June 1992).

10322 See paras. 239; 3226-3228.

10323 See D1458 (Order of Eastern Bosnia Corps, 3 June 1992), p. 2; P2855 (VRS Main Staff report on paramilitary formations, 28 July 1992), p. 5; P1480 (Ratko Mladić's notebook, 10-30 September 1992), p. 40 (referring to the "Special Brigade (Ljubiša Savić)"); P2716 (Notebook of Radovan Karadžić), p. 7 (referring to "Ljubiša Savić, Mauzer, Special Brigade”); P6133 (Drina Corps Order, 12 February 1993), para. 5.3; D2137 (VRS analysis of combat operations, undated), p. 1.

10324 Milorad Davidović, T. 15812-15813 (1 July 2011); P2848 (Witness statement of Milorad Davidović dated 22 June 2011), paras. 94, 96; Dragomir Andan, D3774 (Transcript from Prosecutor v. Stanišić \& Župljanin), T. 21656-21657. See also P2855 (VRS Main Staff report on paramilitary formations, 28 July 1992), p. 5 (while reporting that Mauzer's unit "formally joined the so-called Special Brigade" it was also stated that Mauzer's unit "was formed by the Bijeljina SDS, and the Presidency of Bijeljina Municipal Assembly decided that this would be the army of Bijeljina [...] The greater part of the municipal authorities in Bijeljina still back [Mauzer's unit]").

10325 See P2716 (Notebook of Radovan Karadžić), p. 7. The Chamber also notes that in 1993 the Accused was present at a ceremony which was attended by Mauzer. See P2856 (Video footage of Radovan Karadžić at public ceremony); Milorad Davidović, T. 15481-15482 (28 June 2011).

10326 See para. 1286.

10327 See para. 1286; P1478 (Ratko Mladić's notebook, 27 May-31 July 1992), pp. 249-250, 252.

10328 P1478 (Ratko Mladić's notebook, 27 May-31 July 1992), p. 252.
} 
be a shame to abolish Captain Dragan's training centre at Diviči and that it would be easiest to "put the incident behind us". ${ }^{10329}$

3204. The Chamber notes the Accused's efforts to disband certain paramilitary groups, including through the assistance of the Federal SUP. After the Accused complained at an international peace conference about being unable to control paramilitaries in $\mathrm{BiH}$ who had come from Serbia, it was proposed that a group of Federal SUP officers go and assist the Bosnian Serb MUP to deal with problems with paramilitaries and Milorad Davidović was tasked to lead the investigative team. ${ }^{10330}$ According to Davidović, the Accused had called on him to assist in preventing crime. ${ }^{10331}$ Davidović was instructed by Pavle Bulatović to arrest and prosecute paramilitaries who were found to engage in looting and robbing and was also requested by Mladić to take all measures envisaged by law against these persons. ${ }^{10332}$ Davidović acknowledged that he was given complete autonomy by the Accused in planning operations and arresting individuals. ${ }^{10333}$

3205. Similarly, the Chamber found that in the summer of 1992, following increasing security problems related to paramilitaries in north-east $\mathrm{BiH}$, including in Brčko, the Accused requested that a special unit be sent to Brčko, and the Bosnian Serb MUP requested support from the Federal SUP and Davidović to stabilise the security situation. ${ }^{10334}$

3206. However, the Chamber notes that according to Davidović, while some members of armed groups were arrested, the continued support for armed groups by local authorities, Crisis Staffs, and "high-ranking functionaries" made investigative measures difficult. ${ }^{10335} \mathrm{He}$ also testified that while Mladić was always against paramilitary formations, he was unable to confront them because "they were protected by those whose existence suited them."10336 In Davidović's view, it was only when paramilitaries turned against the Bosnian Serb authorities and stopped sharing their "booty" that the local authorities wanted to have them removed. ${ }^{10337}$

\footnotetext{
10329 See para. 1286; P1478 (Ratko Mladić's notebook, 27 May-31 July 1992), pp. 250, 270.

10330 P2848 (Witness statement of Milorad Davidović dated 22 June 2011), paras. 73-74; P2899 (Report of Bijeljina CSB, 29 July 1992), p. 2; D1412 (Report of Republic of Serbia MUP, 8 August 1992), p. 1; Milorad Davidović, T. 15735 (30 June 2011); D1450 (Milorad Davidović's statement to Belgrade District Court, 26 December 2007), p. 4.

10331 Milorad Davidović, T. 15735 (30 June 2011).

10332 Milorad Davidović, T. 15604-15605, 15607 (29 June 2011); D1450 (Milorad Davidović's statement to Belgrade District Court, 26 December 2007), p. 72.

10333 Milorad Davidović, T. 15735 (30 June 2011).

10334 See para. 829.

10335 Milorad Davidović, T. 15519-15520 (28 June 2011).

10336 Milorad Davidović, T. 15519-15520 (28 June 2011).

10337 P2848 (Witness statement of Milorad Davidović dated 22 June 2011), para. 72.
} 
3207. For example, Davidović testified that measures were taken in Bijeljina only after paramilitaries established parallel authorities which posed a threat to the local Bosnian Serb authorities. ${ }^{10338}$ The Chamber notes in this regard that the Accused issued on 30 August 1992 a decision addressed to the War Presidency of the Bijeljina municipality, indicating that all decisions of the municipality of Bijeljina pertaining to military matters would be suspended. He also ordered the civilian authorities to "investigate personal responsibility of officials who issued the illegal decisions in times of war", with a report to be sent to the Presidency on what had been done. ${ }^{10339}$

3208. The Chamber found that Davidović planned the operation to arrest paramilitary groups in Zvornik in co-operation with Andan and special units of the MUP and that, on 29 July 1992, Žućo, the commander of the Yellow Wasps, was arrested and brought to Bijeljina. ${ }^{10340}$ During this operation, other leaders and members of the Yellow Wasps were arrested, as were municipal leaders who had links with or collaborated with the Yellow Wasps, including Pavlović. ${ }^{10341}$ However, when the 30 day remand period expired, ${ }^{10342}$ Davidović was told that pressure was exerted on the authorities by the Accused and Krajišnik who ordered that the Yellow Wasps be released. ${ }^{10343}$

3209. In contrast, Mandić testified that following this operation the leader of the Yellow Wasps, Vucković, was tried and sentenced for a war crime. ${ }^{10344}$ Mandić added that at the initiative of the Accused and the Prime Minister, the police and army arrested and handed over to competent organs a dozen men belonging to paramilitary units who had "committed crimes in the Podrinje area between Zvornik and Bratunac and Bijeljina". ${ }^{10345}$ Mandić confirmed that Brano Grujić testified in

\footnotetext{
10338 D1436 (Report of SerBiH MUP, 17 June 1992), p. 6; P2848 (Witness statement of Milorad Davidović dated 22 June 2011), paras. 78-79, 121.

10339 D454 (Decision of Presidency of SerBiH, 30 August 1992); Momčilo Mandić, T. 5199 (15 July 2010). See also [REDACTED].

10340 See para. 1290.

10341 See para. 1290.

10342 The Chamber recalls that when a person was arrested by the military police and a criminal report was given to the Prosecutor's Office, the person could be initially detained by the military police for three days. The military prosecutor could then recommend to the investigative judge that the accused be detained for one month, during which an investigation would begin, and then a panel of judges could decide to extend detention for another two months. See para. 305 .

10343 Milorad Davidović, T. 15647-15649, 15653-15654, 15663-15664 (29 June 2011); D1450 (Milorad Davidović's statement to Belgrade District Court, 26 December 2007), pp. 30, 79. See also P2848 (Witness statement of Milorad Davidović dated 22 June 2011), para. 144. Milorad Davidović, T. 15612-15613 (29 June 2011); P6435 (Article entitled "The Sting of the 'Yellow Wasp'”, 10 December 2002), p. 3.

10344 Momčilo Mandić, T. 5289 (16 July 2010). See also Momčilo Mandić, T. 5152-5153 (14 July 2010). But see Dragomir Andan, D3774 (Transcript from Prosecutor v. Stanišić \& Župljanin), T. 21541.

10345 Momčilo Mandić, T. 5289 (16 July 2010). See also Fadil Banjanović, P104 (Witness statement dated 30 March 2002), p. 5; KDZ446, P28 (Transcript from Prosecutor v. S. Milošević), T. 23637-23638 (under seal).
} 
Belgrade that the Accused asked Mićo Stanišić and Karišik to send a special unit to arrest the Yellow Wasps because the local forces could not arrest them. ${ }^{10346}$

3210. However, as found above, in July 1992, even though the Yellow Wasps did not place themselves under the joint military command of the VRS, members of the Yellow Wasps went to Pale and received weapons from the Pale SJB after which Žućo, their commander, met with Plavšić. ${ }^{10347}$ Žućo also spoke to the Minister of Defence about the status of his group and Bogdan Subotic confirmed that all those who received orders from VRS officers were part of the VRS whether they were reservists, volunteers, or paramilitaries. ${ }^{10348}$ Subotić alerted these units that they needed to fully comply with the rules and regulation of the VRS, including those relating to uniforms, insignia and command structures. ${ }^{10349}$

3211. Branimir Tešić testified that the VRS and the civilian authorities had problems with paramilitaries and that the "police often brought them [into] the station, took away the items they had stolen and expelled them to Serbia."10350

3212. The Chamber notes that at the $17^{\text {th }}$ session of the Bosnian Serb Assembly dated 24 and 26 July 1992, the Accused emphasised to the Assembly the importance of the effective elimination of paramilitary and "para-state" factions. ${ }^{10351} \mathrm{He}$ also stated that at that stage, the priority was to introduce order, by virtue of, inter alia, placing all special police units which were being misused by some, under the single command of the Bosnian Serb MUP, rather than under the command of "local lords". ${ }^{10352}$ Mandić confirmed that at that session the Accused highlighted the problem of paramilitary formations and explained that paramilitaries were an armed force not under the control of any state organ or the army. ${ }^{10353}$

3213. On 27 July 1992, in talks with Mladić and Mićo Stanišić, Tolimir stated that crime was a problem and that persons prone to crime must be removed from the military police but reiterated that paramilitaries were "[t]he biggest problem". ${ }^{10354}$ The following day, Mladić ordered that

\footnotetext{
10346 Momčilo Mandić, T. 5206 (15 July 2010).

10347 See para. 1287.

10348 See para. 1287.

10349 See para. 1287.

10350 D3115 (Witness statement of Branimir Tešić dated 9 March 2013), para. 30.

10351 D92 (Transcript of $17^{\text {th }}$ session of SerBiH Assembly, 24-26 July 1992), p. 20; Momčilo Mandić, T. 5188-5189 (15 July 2010).

10352 D92 (Transcript of $17^{\text {th }}$ session of SerBiH Assembly, 24-26 July 1992), p. 19; Momčilo Mandić, T. 5186 (15 July 2010).

10353 Momčilo Mandić, T. 5188-5189 (15 July 2010). See also D1534 (Order of Romanija-Birač CSB, 28 July 1992), p. 1; D4709 (Letter from Radovan Karadžić to Lord Carrington, 16 July 1992).

10354 P1478 (Ratko Mladić's notebook, 27 May-31 July 1992), p. 375.
} 
paramilitary formations must join the regular VRS units, that individuals and groups who had been involved in criminal acts were not to be included into units, and that all paramilitary groups should be disarmed by 15 August $1992 .{ }^{10355}$ The order, which was relayed to the Accused, ${ }^{10356}$ also stated that paramilitary organisations rarely entered the area of combat activities, but usually followed VRS units when liberating parts of the territory and were mainly motivated by looting. ${ }^{10357}$

3214. On 6 August 1992, the Accused issued an announcement that the Presidency's order to subordinate all groups to the single command of the army and police has been implemented "apart from a few renegade groups". ${ }^{10358}$ He conveyed the information that the MUP had arrested "groups and individuals who defied the law and looted and committed arson" and praised those units that had subordinated themselves to the single command of the VRS and were "fighting courageously for the freedom of their Serbian BiH". 10359

3215. At a "military-political consultation meeting" held on 2 September 1992 in Bijeljina, the Accused was informed that paramilitaries and parallel authorities were still an issue. ${ }^{10360} \mathrm{He}$ reminded all those present that there should be maximum military discipline and training and stated that municipal authorities should not take too many things in their own hands. ${ }^{10361}$ On 8 November 1992, representatives from the Bijeljina civilian and military authorities alerted Mladić that paramilitaries had to be dealt with. ${ }^{10362}$

3216. In September 1992, following an update from Manojlo Milovanović that a high-ranking official of the SDS, Rajko Dukić, ${ }^{10363}$ formed a paramilitary unit in Milići, the Accused ordered

\footnotetext{
10355 P1500 (VRS Main Staff Order, 28 July 1992), pp. 1-2. But see Ewan Brown, T. 21699-21701 (22 November 2011) (suggesting that, as long as they would come under VRS control, paramilitaries on RS territory were accepted, even if they had committed crimes). See also Momčilo Mandić, C2 (Transcript from Prosecutor v. Krajišnik), T. 9119.

10356 P1500 (VRS Main Staff Order, 28 July 1992), p. 3.

10357 P1500 (VRS Main Staff Order, 28 July 1992), p. 1. See also P2855 (VRS Main Staff report on paramilitary formations, 28 July 1992), pp. 1-2. According to this Main Staff report the paramilitaries lacked a cohesive unity, expressed hatred of non-Serbs, were motivated by war profiteering or looting, had links to corrupt political leaderships, and were not affiliated with the SDS but with opposition parties from Serbia.

10358 D98 (Radovan Karadžić's announcement re paramilitary groups, 6 August 1992). See also P3058 (Radovan Karadžić's announcement, 6 August 1992), p. 1.

10359 D98 (Radovan Karadžić's announcement re paramilitary groups, 6 August 1992). See also P3058 (Radovan Karadžić's announcement, 6 August 1992), p. 1.

10360 P1479 (Ratko Mladić's notebook, 16 July-9 September 1992), pp. 131, 133.

10361 P1479 (Ratko Mladić's notebook, 16 July-9 September 1992), pp. 154-156.

10362 P1481 (Ratko Mladić's notebook, 5 October-27 December 1992), pp. 152, 156.

10363 See para. 2253.
} 
Milovanović to "route" Dukić's unit. ${ }^{10364}$ However, the Chamber notes that in 1994 the Accused awarded him the "Order of Nemanjići". 10365

3217. On 12 September 1992, the SRK informed its subordinate units including the Višegrad Brigade and Rogatica Brigade of the tasks it received from the VRS Main Staff on 7 September 1992, which included the task to eliminate the creation of any paramilitary unit. ${ }^{10366}$

3218. On 16 October 1992, Bogdan Subotić informed the Zvornik Municipality Executive Board, following their query about the engagement of Arkan and other volunteer units, that the VRS was the only legal and legitimate force and all "volunteer units" would be allowed to enlist in the VRS if they wore the VRS insignia and adopted the VRS command structure. ${ }^{10367}$ In a letter addressed to the Accused on 20 October 1992, Bogdan Subotić proposed that due to the tensions caused, inter alia, by "increasingly active paramilitary formations" and the fact that decisions issued by the Government and other state organs were not being respected, that military rule be introduced in several municipalities, including Zvornik. ${ }^{10368}$

3219. Notwithstanding, around the end of October 1992, the Accused informed Milovanović that "400 volunteers from Serbia will also be taking part in defending the [Višegrad Hydroelectric] Power Plant [...] under the command of Professor Košuti [...] and that [the VRS is] to take them on and bring them into combat." 10369

3220. During a Bosnian Serb Assembly session on May 1993, attended by the Accused, Vladimir Lukić stated that they had naively "raised paramilitaries" and called them "brotherly assistance" but "they were slowly less and less engaged in fighting and more and more in looting". ${ }^{10370 ~ S i m i l a r l y, ~}$ a Bosnian Serb leader from Sarajevo noted that in certain municipalities "chaos, disturbances, looting and stealing was the greatest where [paramilitaries] were stationed". ${ }^{10371}$ Complaints were also raised that while certain individuals were arrested, they were released. ${ }^{10372}$ During the session, Mladić criticised the audience about how they asked him to let Mauzer "do as he likes" and stated

\footnotetext{
10364 D2149 (Aide mémoire of Manojlo Milovanović), p. 8.

10365 P5525 (Audio Recording and Transcript of the Ceremonial RS National Assembly, 9 January 1994), pp. 16-18 (referring to "Rajko Dukić from Milići").

10366 P1006 (SRK Order, 12 September 1992), p. 1.

10367 D3705 (Letter from RS Ministry of Defence to Zvornik Municipality Executive Board, 16 October 1992); D3695 (Witness statement of Bogdan Subotić dated 16 June 2013), paras. 293-294.

10368 D458 (RS Ministry of Defence letter to Radovan Karadžić, 20 October 1992); D3695 (Witness statement of Bogdan Subotić dated 16 June 2013), para. 299.

10369 D2149 (Aide mémoire of Manojlo Milovanović), p. 12. The Chamber notes that this unit never arrived. See D2149 (Aide mémoire of Manojlo Milovanović), p. 12.

10370 P1375 (Transcript of $32^{\text {nd }}$ session of RS Assembly, 19-20 May 1993), e-court p. 39.

10371 P1375 (Transcript of 32 ${ }^{\text {nd }}$ session of RS Assembly, 19-20 May 1993), e-court p. 65.

10372 P1375 (Transcript of $32^{\text {nd }}$ session of RS Assembly, 19-20 May 1993), e-court p. 67.
} 
that "you found your patron in Arkan, who brought you together to tell you how you should vote". 10373

3221. On 28 August 1993, in an order focused on the organisation of the VRS, the Accused instructed the Main Staff and MUP to create a plan to seize uniforms from people who were not members of the army or police and who were committing crimes and other illegal activity in uniforms. ${ }^{10374}$

3222. The Chamber notes that in 1994 the Accused awarded Mauzer's Panthers and personally promoted Vojkan Đurković, a member of Arkan’s men. ${ }^{10375}$

3223. Davidović testified that while some paramilitaries were arrested the measures were not successful because the paramilitaries continued to have the support of the local authorities, Crisis Staffs and "high-ranking functionaries" and as a result they were released and continued with their actions. $^{10376} \mathrm{He}$ also testified that Mladić was always against paramilitary formations; could not confront them; and said that "they were protected by those whose existence suited them."10377

3224. In April 1994, following a letter from the Main Staff reporting that there were volunteers from the SRS who had been operating in two municipalities without the knowledge or consent of the VRS, the Accused reminded the municipal authorities that this interfered with the system of single command and control and that it was necessary to inform him about developments so he could take measures. ${ }^{10378}$

\footnotetext{
10373 P1375 (Transcript of 32 ${ }^{\text {nd }}$ session of RS Assembly, 19-20 May 1993), e-court p. 90.

10374 D4790 (Radovan Karadžić's Order to VRS Main Staff, 28 August 1993), p. 5.
}

10375 See paras. 3429, 3431; P5525 (Audio Recording and Transcript of the Ceremonial RS National Assembly, 9 January 1994), pp. 16-18 (the Accused awarded "the 'Panteri' Guard Unit from Bijeljina" the "Order of Nemanjići"). See also para. 672.

10376 Milorad Davidović, T. 15519-15520 (28 June 2011). The Chamber notes Andan's "impression" that the Accused was not dealing with the problems of paramilitary formations adequately. However, since this impression is based on his position that "the leadership itself was not timely informed of certain things", the Chamber does not find it to be of great weight. See Dragomir Andan, T. 40883 (5 July 2013). See also P6434 (Excerpt from Dragomir Andan's interview with OTP), pp. 3-4 (stating "I also think that I stood in the way of a few politicians [...] I think that this went all the way to [...] [the Accused]".) The Chamber also recalls its finding regarding the proceedings against Đurković. See para. 676. The Chamber found that Đurković was arrested after he expelled a Bosnian Muslim but that he was released when he provided documents which suggested that he was authorised and had orders to expel Bosnian Muslim residents from Bijeljina. The Chamber also found with regard to the proceedings against Đurković in 1995 that the evidence led on this issue was inconclusive.

10377 Milorad Davidović, T. 15519-15520 (28 June 2011). See also para. 3206.

10378 D1454 (Request of RS President's Office, 29 April 1994); D1446 (Radovan Karadžić's order to RS MUP, 29 April 1994; Milorad Davidović, T. 15809 (1 July 2011). See also D1448 (Letter from RS President's Office to President of Petrovo Municipal Assembly, 29 April 1994). 
3225. The Accused informed Mladić in April 1994 that he had ordered the MUP and other municipal authorities to assist the VRS in preventing the organisation of paramilitary units and that the strictest measures would be taken. ${ }^{10379}$

3226. In the summer of 1995, Manojlo Milovanović asked the Accused for a meeting to be organised with Arkan to discuss the latter's presence in the combat zone under the Milovanović's responsibility. ${ }^{10380}$ During the meeting, following Milovanović's question concerning Arkan's presence, Arkan replied that his presence was in accordance with the order issued by the Supreme Command, but he did not present such order. ${ }^{10381}$ Milovanović then asked the Accused whether he had issued Arkan with such an order, but the Accused did not reply— “[h]e didn't say yes and he didn't say no."10382

3227. In September 1995, in a letter from Mladić to the Accused, the former asked that Arkan and his paramilitary units be expelled from the RS and that the Accused "revoke his decision that gave Željko Ražnjatović the power to make arrests, mistreat, disarm and take away VRS members and civilians with his paramilitary units including /his authority/ to use firearms on persons who oppose or resist him." 10383

3228. In the autumn of 1995, the Accused attended an event in Bijeljina where he inspected the ranks of Arkan's men under the escort of Arkan, and said: "I am deeply thankful and I congratulate you, and I hope that we will meet again in peace and you will always have a place in the heart of those who you have defended". ${ }^{10384}$ Arkan responded on behalf of his unit by saying that "we are ready if you call us and that we will be back to defend our ancient homeland, to defend our women and children, to defend the Serbian territory and our Orthodox religion". ${ }^{10385}$ According to Mihaljović this event was a product of Arkan's manipulation that surprised the Accused and that

\footnotetext{
10379 D1447 (Radovan Karadžić's letter to VRS Main Staff, 29 April 1994).

10380 Manojlo Milovanović, T. 25455-25456 (28 February 2012).

10381 Manojlo Milovanović, T. 25457-25458 (28 February 2012).

10382 Manojlo Milovanović, T. 25457-25458 (28 February 2012). The Chamber notes also the evidence that on 19 September 1995 it was agreed in Bijeljina that Arkan will get paid by the "Republican Government" for liberating Teočak. See P6210 (Report of Eastern Bosnian Corps, 20 September 1995). However, the Chamber does not grant this evidence any weight as it is based on an unknown and uncorroborated "reliable source" which "has not been verified". See P6210 (Report of Eastern Bosnian Corps, 20 September 1995), p. 2.

10383 P3056 (RS MUP dispatch, 24 September 1995), pp. 2-3. See also D2265 (Srđo Srdić's interview with OTP), ecourt pp. 52-53.

10384 P2858 (Video footage of Radovan Karadžić and Arkan at award ceremony in Bijeljina, with transcript); D3137 (Witness statement of Svetozar Mihajlović dated 17 March 2013), paras. 10-11; Svetozar Mihajlović, T. 3572135722 (20 March 2013).

10385 P2858 (Video footage of Radovan Karadžić and Arkan at award ceremony in Bijeljina, with transcript). See also P2854 (Letter from Party for Serbian Unity to Radovan Karadžić, 16 April 1994) (in which Arkan states that "[a]s always we, with all our available forces, stand to protect Serbian people. We are expecting your call so we can join armed forces of [RS]").
} 
Arkan used this event to legitimise his presence in RS given the stance taken by the Main Staff and the VRS with respect to units not under the VRS command. ${ }^{10386}$ However, considering the evidence and the behaviour of the Accused, who gave documents to Arkan at this event, the Chamber is not convinced by the argument that the Accused was manipulated or taken by surprise.

3229. The Chamber notes the general statement of Nikola Poplašen that the Accused "argued for all Serbian forces to be placed under single command" and that "[i]ndividual incidents did occur, but this was not [...] with the approval or knowledge of the Serbian authorities", ${ }^{10387}$ but finds this statement to be in contradiction with the clear evidence that at least some paramilitary formations operated in RS with the consent of the authorities. ${ }^{10388}$ Similarly, the Chamber notes the evidence of Bulatovic that when he spoke to the Accused, the Accused was not in favour of the presence of paramilitaries in $\mathrm{BiH}$ but did not have the ability to remove them. ${ }^{10389}$ However, the Chamber notes in this regard that at a Supreme Defence Council session in August 1992, Bulatović said "[l]et's be honest, we needed those paramilitary formations for a while. They are now a great burden and a problem."10390 This is also corroborated by evidence that in $\mathrm{BiH}$, given a poor response to mobilisation, the military forces were reinforced by volunteers and paramilitaries. ${ }^{10391}$

\section{(3) $\underline{\text { Conclusion }}$}

3230. In light of the above, the Chamber finds that, in mid-1992, following the creation of the VRS, the Accused sought to have paramilitary groups integrated in and subordinated to the regular army or otherwise be disarmed and dissolved. ${ }^{10392}$ However, his attitude towards these groups shifted depending on the group and according to the Bosnian Serb interests.

3231. With regard to Arkan's men, for instance, the Chamber finds that the Accused knew that they were invited by the RS Presidency to operate in conjunction with local authorities and forces and that in the spring of 1992 they were indeed operating in BiH. ${ }^{10393}$ The Accused had direct

\footnotetext{
10386 D3137 (Witness statement of Svetozar Mihajlović dated 17 March 2013), paras. 10-11; Svetozar Mihajlović, T. 35721-35722, 35728-35731 (20 March 2013).

10387 D4027 (Witness statement of Nikola Poplašen dated 11 November 2013), para. 12.

10388 See, e.g., paras. 3182, 3187-3188, 3195.

10389 D3051 (Witness statement of Momir Bulatović dated 25 February 2013), paras. 40-41; Momir Bulatović, T. 34560-34561, 34565-34566 (1 March 2013). The Chamber notes that it is not clear which period of time Bulatović is referring to in his statement.

10390 P6165 (Excerpt from notes of FRY's SDC $5^{\text {th }}$ session, 7 August 1992), p. 5.

10391 Aleksandar Vasiljević, T. 34699-34700 (4 March 2013).

10392 The Chamber also notes that evidence that the co-operation between Bosnian Serb authorities and paramilitary formations existed as long as the paramilitaries' objectives were aligned with those of the Bosnian Serb leadership. See paras. 3208, 3220, 3223.

10393

See paras. 3181, 3195.
} 
contact with Arkan in 1992 and 1995, ${ }^{10394}$ and in May 1992 he invited, without Mladić's knowledge, Arkan's men to participate in operations in the Sarajevo area. ${ }^{10395}$ While Arkan's men left $\mathrm{BiH}$ in mid-1992, the Accused supported their presence and activities in BiH in $1995 .{ }^{10396}$ The Chamber also notes that it was important to Arkan that his actions in $\mathrm{BiH}$ would be approved by the Bosnian Serb authorities. ${ }^{10397}$

3232. Similarly, the Accused knew that Šešelj's men were invited by the RS Presidency to operate in conjunction with local authorities and forces in the spring of $1992,{ }^{10398}$ and he met with Šešelj a few times each year during the war. ${ }^{10399}$

3233. In addition, the Accused was aware that Mauzer's Panthers was incorporated in 1992 in the VRS as a "Special Brigade" and, in 1994, he awarded Mauzer's Panthers. ${ }^{10400}$

3234. The Chamber therefore finds that during the spring of 1992, following the withdrawal of the JNA from $\mathrm{BiH}$, the Accused supported the operational co-operation of military forces and local authorities with Arkan's men, Šešelj's men, and Mauzer's Panthers. These paramilitary groups were able to operate in several municipalities, in an otherwise relatively tightly controlled area, ${ }^{10401}$ in concert with the military forces and the local authorities. ${ }^{10402}$

3235. The Accused's shifting approach to paramilitaries is further demonstrated by his approach to Captain Dragan's training centre; ${ }^{10403}$ and his order to have the Yellow Wasps released after they were arrested by Davidović. ${ }^{10404}$

3236. Based on all of the above, the Chamber concludes that the Accused supported the cooperation of Arkan's men, Šešelj's men and Mauzer's Panthers with Serb Forces during the takeovers in the Municipalities-during the course of which crimes were committed. The Chamber also concludes that from mid-1992 onwards, following the completion of the take-overs and

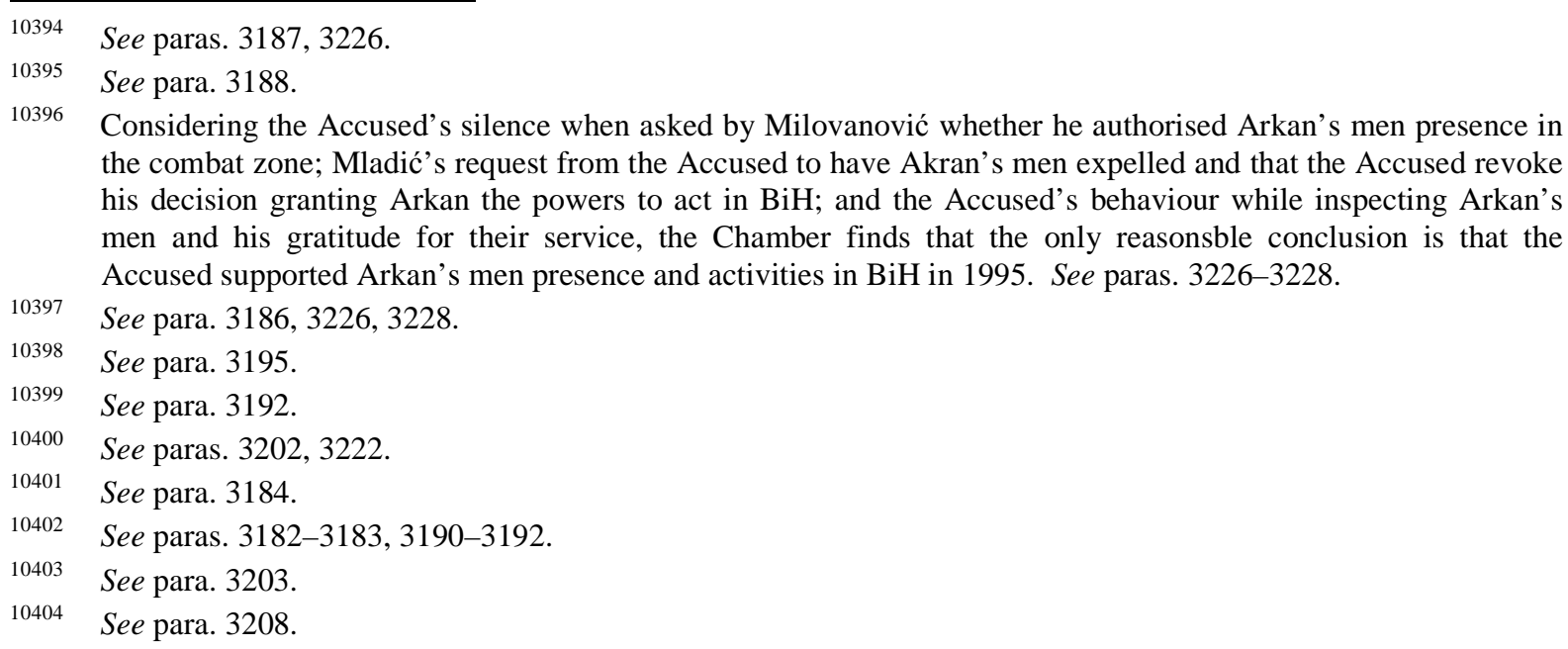

10396 Considering the Accused's silence when asked by Milovanović whether he authorised Arkan's men presence in the combat zone; Mladić's request from the Accused to have Akran's men expelled and that the Accused revoke his decision granting Arkan the powers to act in $\mathrm{BiH}$; and the Accused's behaviour while inspecting Arkan's men and his gratitude for their service, the Chamber finds that the only reasonsble conclusion is that the Accused supported Arkan's men presence and activities in BiH in 1995. See paras. 3226-3228.

10397 See para. 3186, 3226, 3228.

10398 See para. 3195.

10399 See para. 3192.

10400 See paras. 3202, 3222.

10401 See para. 3184.

10402 See paras. 3182-3183, 3190-3192.

10403 See para. 3203.

10404 See para. 3208. 
considering the creation of the VRS, the Accused endeavored to disband paramilitary groups in general. However, the Accused still tolerated and even supported the activities of certain paramilitary groups, namely, Akran's men, Yellow Wasps and Mauzer's Panthers.

\section{iv. Knowledge and acts of named alleged JCE members}

3237. The Prosecution alleges that the Accused worked together with other Serb military and political leaders to achieve the objective of the alleged Overarching JCE to permanently remove Bosnian Muslims and Bosnian Croats from Bosnian Serb-claimed territory in $\mathrm{BiH}$ from at least October 1991 to 30 November 1995, in concert with Momčilo Krajišnik, Ratko Mladić, ${ }^{10405}$ Slobodan Milošević, Biljana Plavšić, Nikola Koljević, Mićo Stanišić, Momčilo Mandić, Jovica Stanišić, Franko Simatović, Željko Ražnatović (Arkan), and Vojislav Šešelj. ${ }^{10406}$ According to the Prosecution, while the membership in the JCE fluctuated over time, each member made a significant contribution to achieving the common criminal purpose. ${ }^{10407}$

3238. In response, the Accused argues that there was no criminal plan or design in the first place and second, that at no point in time did any of the alleged JCE members have, let alone share, any common mental state to carry out an agreed criminal plan or design. ${ }^{10408}$

3239. The Chamber has considered the involvement of the named alleged JCE members in earlier sections of this Judgement in the context of the objectives of the Bosnian Serb leadership and the creation of and authority over the Bosnian Serb political and governmental structures and military and police structures. ${ }^{10409}$ In this section, the Chamber will consider their further knowledge and acts in relation to the common purpose of the alleged Overarching JCE. As a part of this analysis, the Chamber will examine the relationship between the Accused and alleged JCE members where necessary.

\footnotetext{
10405 The Prosecution alleges that Mladić joined the alleged JCE as of May 1992. See Indictment, para. 6.

10406 See Prosecution Final Brief, para. 84; Indictment, paras. 9-14. Other alleged members of the Overarching JCE are listed in paragraph 12 of the Indictment and include, among others, members of SDS and Bosnian Serb government bodies at the republic, regional, municipal, and local levels, including Crisis Staffs, War Presidencies, and War Commissions, and commanders and senior officers of JNA, VJ, VRS, TO, and MUP units.

10407 See Prosecution Final Brief, para. 84; Indictment, paras. 9-14.

10408 See Defence Final Brief, para. 327.

10409 See Sections IV.A.3.a.i: Objectives of the Accused and the Bosnian Serb leadership, IV.A.3.a.ii: Bosnian Serb political and gonvermental structures, IV.A.3.a.iii: Authority over military and police forces.
} 


\section{(A) Momčilo Krajišnik}

3240. As discussed above, Momčilo Krajišnik was a member of the SDS Main Board from July 1991 and was in the core leadership of the party. ${ }^{10410}$ The Chamber recalls that Krajišnik was also elected as the first president of the Bosnian Serb Assembly in October $1991^{10411}$ and by virtue of his position, he was also a member of the SNB which was established on 27 March $1992 .{ }^{10412}$ The Chamber further recalls that the original three-member Presidency, comprised of the Accused, Plavšić, and Koljević, was enlarged to five members to include Krajišnik and Branko Đerić, and on 6 July 1992, Krajišnik was assigned to deal with issues related to commissioners and the economy. ${ }^{10413}$

3241. Krajišnik was described as the Accused's "closest associate" and they had a close relationship before the SDS was even formed; this relationship continued throughout the conflict. ${ }^{10414}$ For instance, the Accused personally insisted on Krajišnik's appointment as president of the Bosnian Serb Assembly. ${ }^{10415}$

3242. Koljević, Plavšić, Krajišnik, and the Accused were considered to be the four most powerful leaders in the RS, with Krajišnik and the Accused at the top. ${ }^{10416}$ There was very little divergence of views between the Accused and Krajišnik ${ }^{10417}$ and these two were characterised as the "Alpha and Omega" of the Bosnian Serb government. ${ }^{10418}$

\footnotetext{
10410 See paras. 62, 77.

10411 See para. 77.

10412 See para. 89.

10413 See para. 97.
}

10414 Radomir Nešković, P2568 (Transcript from Prosecutor v. Krajišnik), T. 16605-16607; P2526 (Witness statement of Radomir Kezunović dated 21 May 2011), para. 75. See P5816 (Intercept of conversation between Radovan Karadžić and Momčilo Krajišnik, 15 November 1991); P5803 (Intercept of conversation between Radovan Karadžić and Momčilo Krajišnik, 11 December 1991); P5793 (Intercept of conversation between Radovan Karadžić and Momčilo Krajišnik, 19 December 1991).

10415 Radomir Nešković, P2568 (Transcript from Prosecutor v. Krajišnik), T. 16606-16607, 16765-16767.

10416 Herbert Okun, P776 (Transcript from Prosecutor v. Krajišnik), T. 4154-4155; Milan Babić, P742 (Transcript from Prosecutor v. Krajišnik), T. 3396; Momčilo Mandić, C2 (Transcript from Prosecutor v. Krajišnik), T. 8610, 8618-8619. See also Radomir Nešković, P2568 (Transcript from Prosecutor v. Krajišnik), T. 16603, 16607, 16744-16747, 16843; P3396 (Photographs depicting Radovan Karadžić, Ratko Mladić, Biljana Plavšić, Momčilo Krajišnik, and others). While Krajišnik, Plavšić, and Koljević were also present at SDS Main Board meetings, they did not play an active role in this body. Radomir Nešković T. 14235-14236 (6 June 2011); D1278 (Transcript of Radomir Nešković's interview with Karadžić's legal associate, 8 October 2009), p. 18.

10417 P4982 (Witness Statement of Branko Đerić dated 5 April 2012), paras. 30-31. See also Radomir Nešković, P2568 (Transcript from Prosecutor v. Krajišnik), T. 16766-16767; Herbert Okun, P776 (Transcript from Prosecutor v. Krajišnik), T. 4156; Momčilo Mandić, C2 (Transcript from Prosecutor v. Krajišnik), T. 8622$8623,8635-8636,8644-8645$ (testifying that after a few years of war, a rivalry developed between the Accused and Krajišnik).

10418 Branko Đerić, T. 27951-27952 (24 April 2012). See also P1387 (Transcript of $38^{\text {th }}$ session of RS Assembly, 17 January 1994), p. 46; Herbert Okun, P776 (Transcript from Prosecutor v. Krajišnik), T. 4154-4156; D89 (Shorthand Record of $9^{\text {th }}$ session of SerBiH Assembly, 28 February 1992), p. 11; P1029 (Witness statement of 
3243. Krajišnik and the Accused communicated regularly about, inter alia, meetings and negotiations with international representatives; ${ }^{10419}$ mobilising Serb forces in $\mathrm{BiH} ;{ }^{10420}$ discussions with political and military leaders in Serbia; ${ }^{10421}$ and the involvement of the Bosnian Serb leadership in municipal level affairs. ${ }^{10422}$

3244. The Accused, Koljević, and Krajišnik led political negotiations on behalf of the Bosnian Serbs and had the support of the SDS Executive Board. ${ }^{10423}$ The Accused would often seek the advice of Krajišnik during negotiations. ${ }^{10424}$ Krajišnik emphasised that there was no difference between the Accused, Koljević, and himself who worked as a team in negotiations; Krajišnik tended to repeat "the established, party line" in negotiations. ${ }^{10425}$

3245. Furthermore, Krajišnik had "great authority" among the Bosnian Serb municipal leaders and influenced how power should be exercised at the municipal level. ${ }^{10426}$ As the President of the Bosnian Serb Assembly, Krajišnik was noted as a "skillful leader" of the local deputies. ${ }^{10427}$ The Accused described Krajišnik to Slobodan Milošević as a "great Bosnian patriot" and told him that Krajišnik "would not give one foot of Bosnian land" and wanted all of $\mathrm{BiH}$ to remain in Yugoslavia. ${ }^{10428}$ The Chamber recalls that the Accused and the Bosnian Serb leadership, including

John Wilson dated 4 November 2008), para. 121; Izet Redžić, P3189 (Transcript from Prosecutor v. Krajišnik), T. 5071-5073; P2526 (Witness statement of Radomir Kezunović dated 21 May 2011), para. 75.

10419

10420

10421

P5805 (Intercept of conversation between Radovan Karadžić and Momčilo Krajišnik, 6 December 1991). P5860 (Intercept of conversation between Radovan Karadžić and Momčilo Krajišnik, 23 September 1991). See P5805 (Intercept of conversation between Radovan Karadžić and Momčilo Krajišnik, 6 December 1991).

P5874 (Intercept of conversation between Radovan Karadžić and Momčilo Krajišnik, 6 September 1991); P5835 (Intercept of conversation between Radovan Karadžić and Momčilo Krajišnik, 22 October 1991).

P5833 (Intercept of conversation between Radovan Karadžić and Momčilo Krajišnik, 29 October 1991), p. 2 (wherein Krajišnik told the Accused that he had gone to Ilidža the night before for a meeting of the board and "the right people got information, we invigorated them, they got a realistic evaluation, they were very pleased"). D1277 (Minutes of joint meetings of SDS's General and Executive Committees and Political Council, 11 March 1992), p. 1. See also paras. 2700, 2703-2705, 2824, 2832.

P1029 (Witness statement of John Wilson dated 4 November 2008), paras. 140-141.

P2451 (Witness statement of Anthony Banbury dated 19 May 2009), para. 214 (stating further that Krajišnik was often difficult to deal with during negotiations); P1353 (Shorthand record of $10^{\text {th }}$ session of SerBiH Assembly, 11 March 1992), p. 16.

Momčilo Mandić, C2 (Transcript from Prosecutor v. Krajišnik), T. 8628. However, as President of the Banja Luka Municipal Assembly and Banja Luka Crisis Staff, Radić testified that he did not receive any instructions from Krajišnik in his municipality, other than Bosnian Serb Assembly decisions signed by him. Between the beginning of the war and the end of 1992, Radić only saw Krajišnik in Banja Luka a few times when he came for the RS Assembly sessions held there. Predrag Radić, P1 (Transcript from Prosecutor v. Krajišnik), T. 75247526, 7571-7574. However, the Chamber does not find Radić's testimony in this regard, in particular regarding his presence in Banja Luka, to be determinative regarding Krajišnik's authority among all Bosnian Serb municipal leaders.

Predrag Radić, P1 (Transcript from Prosecutor v. Krajišnik), T. 7431-7432, 7538-7540, 7607. See also P2 (Predrag Radić's interview with OTP, 16 July 2001), pp. 62-63.

P5687 (Intercepts of conversations between (i) Ljiljana Karadžić and Slobodan Milošević and (ii) Radovan Karadžić and Slobodan Milošević, 12 June 1991), p. 8. 
Krajišnik, formulated and promoted the Strategic Goals; for Krajišnik, the goal of separating from the Bosnian Muslims was the most important task. ${ }^{10429}$

3246. Between April and May 1992 the Accused, Krajišnik, Koljević, Plavšić, Đerić, and Bogdan Subotić met often to discuss a number of issues pertaining to the conditions in municipalities and decisions were issued as a result of these meetings. ${ }^{10430}$ Krajišnik was also informed about events and operations in the Municipalities. ${ }^{10431}$ For instance, the Chamber notes that Krajišnik visited Bijeljina, often with the Accused, and that there was a close relationship between the Bijeljina branch of the SDS and the SDS in Pale. ${ }^{10432}$ Krajišnik and the Accused also visited Sanski Most on the occasion of the formation of the SDS there. ${ }^{10433}$

3247. In May 1992, the Accused, Mladić, and Krajišnik held a meeting with representatives of municipalities, including Rogatica, and discussed the creation of a Bosnian Serb state in BiH. ${ }^{10434}$ Krajišnik also had close connections with Kušić, commander of the Rogatica Brigade, who was involved in the take-over of Rogatica and in the mistreatment and crimes against Bosnian Muslim civilians there. ${ }^{10435}$

3248. Krajišnik was also aware of Bosnian Muslim men being detained at Rajlovac Barracks in Novi Grad and in June 1992, he gave instructions to authorities at Rajlovac that nothing should happen to Bosnian Muslim detainees there. ${ }^{10436} \mathrm{He}$ was informed of details regarding the take-over in Vogošća, and he attended sessions of the Vogošća Serb Assembly, Novi Grad Municipal Assembly, and Novo Sarajevo SDS Municipal Board. ${ }^{10437}$

\footnotetext{
10429 See paras. 2865, 2868, 2877, 2885, 2895-2903. According to Kecmanović, however, Krajišnik stressed respect for "other ethnicities, religions and customs". D3645 (Witness statement of Nenad Kecmanović dated 27 May 2013), paras. 32-33. The Chamber however recalls its earlier finding that Kecmanović's evidence was marked by evasiveness, contradictions, partisanship and indicators that his testimony lacked sincerity and candour. His testimony was also marked by indicators that he was seeking to protect the Accused. The Chamber therefore does not consider that it can rely on his evidence in this regard.

10430 D3695 (Witness statement of Bogdan Subotić dated 16 June 2013), paras. 61-62. See P5858 (Intercept of conversation between Radovan Karadžić and Biljana Plavšić, 27 September 1991).

10431 See, e.g., P5740 (Intercept of conversation between Momčilo Krajišnik and Jovan Tintor, 4 April 1992), p. 2.

10432 See para. 606.

10433 See para. 1920.

10434 See para. 936.

10435 See paras. 944, 948-951, 969-970, 973, 986, 999-1000, 1020.

10436 See Novi Grad Fact section, para. 2221 (referring to P2334 (Intercept of conversation between Momčilo Krajišnik, Mijatović, and Ljubiša Vladušić, 8 June 1992), pp. 1-2, 4).

10437 See Vogošća Fact section, paras. 2171-2172, 2246, 2359, 2375, 2386.
} 
3249. During a January 1994 RS Assembly session, Krajišnik and the Accused were exalted by a member of the Assembly for "standing on top of the Serbian liberation movement and war" and described as their "highest leaders". 10438

\section{(B) Nikola Koljević}

3250. The Chamber recalls that Koljević was a member of the SNB, one of the interim bodies that served as the de facto Presidency of the SerBiH in 1992, and functioned as one of the acting presidents of the SerBiH. ${ }^{10439}$ Koljević was subsequently elected by the Bosnian Serb Assembly to the three-member RS Presidency on 12 May 1992. ${ }^{10440}$ As stated above, the Presidency was enlarged to five members and on 6 July 1992, Koljević was allocated the task of international relations as well as information and propaganda-related issues. ${ }^{10441}$ On 17 December 1992, the Bosnian Serb Assembly replaced the structures of the Presidency by establishing a single president and two vice-presidents of the Republic, electing the Accused to the position of President of the RS and Koljević as one of the Vice-Presidents. ${ }^{10442}$

3251. As early as October 1990, in a meeting before Serb representatives in Banja Luka, Koljević identified the purpose of establishing the SDS in furtherance of the unity of the Serb people and the promotion of Serb interests. ${ }^{10443}$

3252. The Chamber recalls Koljević's acknowledgement that the process of re-organising municipalities was with the aim of creating "homogeneity of certain areas" and that he repeatedly called for the expulsion of Bosnian Muslims and the homogeneity of territories, claiming it was impossible for Serbs to live with anyone else. ${ }^{10444}$ Koljević was particularly extreme in his views and continued to repeat at important meetings that it was impossible for Bosnian Serbs, Muslims, and Croats to live together. ${ }^{10445}$ Koljević also made a statement at the $34^{\text {th }}$ session of the Bosnian Serb Assembly in 1993 about the aim being the "spiritual and moral revitalisation of

\footnotetext{
10438 P1387 (Transcript of $38^{\text {th }}$ session of RS Assembly, 17 January 1994), p. 46.

10439 See para. 90.

10440 Adjudicated Fact 1898; P3032 (Minutes of $1^{\text {st }}$ constitutive session of SerBiH Presidency, 12 May 1992). See para. 96.

10441 D440 (Minutes of $15^{\text {th }}$ session of SerBiH Presidency, 6 July 1992), p. 3. See para. 97. In April 1992, Koljević had already been tasked with communicating with the international public on the situation in SerBiH. P3050 (Minutes of joint meeting of SNB and SerBiH Government, 15 April 1992), p. 2. See also KDZ240, T. 16116 (5 July 2011) (closed session); P1029 (Witness statement of John Wilson dated 4 November 2008), para. 139 (stating that Koljević tended to be more on the periphery of the Bosnian Serb leadership). However, given this is a personal opinion from Wilson, the Chamber placed no weight on that aspect of his evidence.

10442 See para. 98.

10443 See para. 2637.

10444 See paras. 2721, 2762.

10445 See para. 2728.
} 
Serbhood". ${ }^{10446}$ Koljević also discussed his views with the Accused and other members of the Bosnian Serb leadership in private conversations. ${ }^{10447}$

3253. Koljević was closely involved in negotiations with international representatives. ${ }^{10448}$ In January 1992, Koljević warned of the danger of an Islamic republic being created. ${ }^{10449}$ In this regard, Koljević met with Tuđman and noted that they had a common interest of separating people, that an independent BiH did not suit them as it would separate them from their "mother lands", and that they advocated a sovereign Muslim, Serb, and Croat BiH. ${ }^{10450}$ At the same meeting, Koljević also suggested that an agency be established to regulate the exchange of property. ${ }^{10451}$ During another meeting related to the ICFY in September 1992, the Accused and Koljević reiterated that the Bosnian Serbs and the Bosnian Croats would not accept a unitary BiH state; a state based on one-man, one-vote. ${ }^{10452}$

3254. In April 1992, Koljević proposed that Bogdan Subotić set up a separate Ministry of Defence, which he accepted and thereafter, Subotić started organising and preparing drafts of the Law on Defence and Law on the Army. ${ }^{10453}$

3255. In May 1992, Koljević spoke to Bosnian Muslims in Pale and when they asked for guarantees that they could stay in their homes, he replied that "Serbs don't want to continue living with you here." 10454 Koljević also visited units on the ground and attended meetings in inter alia Bratunac, Foča, Vlasenica, and Pale. ${ }^{10455}$

\footnotetext{
10446 See para. 2806.

10447 See, e.g., P5810 (Intercept of conversation between Radovan Karadžić and Nikola Koljević, 22 November 1991); P5760 (Intercept of conversation between Biljana Plavšić and Nikola Koljević, 25 January 1992), pp. 1, 4 (during which Koljević said "[t]he procedure itself and everything indicates that we are heading in the right direction. I mean, how good the objective we have chosen is" and Koljević and Plavšić further agreed on the idea of separation and the treatment of Bosnian Muslims "with indifference").

10448 See paras. 2694, 2699-2700, 2703. Koljević and the Accused also discussed such meetings and negotiations with international representatives in private conversations. See, e.g., P5878 (Intercept of conversation between Radovan Karadžić and Nikola Koljević, 27 August 1991), pp. 5-9.

10449 See para. 2694.

10450 See para. 2694

10451 P986 (Transcript of a meeting between Nikola Koljević, Franjo Tuđman, and Franjo Boras, 8 January 1992), pp. 13-14.

10452 See para. 2705. Koljević also stated that the Bosnian Serbs would not accept the internal borders of BiH without some form of cantonisation. See para. 357.

10453 See para. 115.

10454 See para. 2317. See also fn. 9040.

10455 See paras. 693, 789, 841, 1106, 2317.
} 
3256. Finally, on 14 March 1995, the Accused issued a decision to form a State Committee for Co-operation with the UN and International Humanitarian Organs, appointing Koljević as its President. $^{10456}$

\section{(C) Biljana Plavšić}

3257. Plavšić was also a member of the SNB, one of the interim bodies that served as the de facto Presidency of the SerBiH in 1992, and functioned as the other acting president of the SerBiH, along with Koljević. ${ }^{10457}$ Plavšić was subsequently elected by the Bosnian Serb Assembly to the threemember RS Presidency on 12 May 1992. ${ }^{10458}$ When the Presidency was enlarged to five members on 6 July 1992, Plavšić was allocated the task of, inter alia, dealing with contacts with UNPROFOR, except for military issues, and questions related to refugees and humanitarian aid. ${ }^{10459}$ Plavšić was in charge of issues related to detention centres, including co-ordinating with the ICRC and other international organisations on this issue. ${ }^{10460}$ On 17 December 1992, the Bosnian Serb Assembly replaced the structures of the Presidency by establishing a single president and two vice-presidents of the Republic, electing the Accused to the position of President of the RS and Plavšić as one of the Vice-Presidents. ${ }^{10461}$

3258. The Chamber recalls that Plavšić attended the first session of the Council of Ministers on 11 January 1992, during which the declaration on the promulgation of the SerBiH was discussed, including the priorities of defining the ethnic territory, establishing government organs in the territory, and the economic disempowerment of the current authorities. ${ }^{10462}$ In another meeting, Plavšić emphasised the unity of the Serb people and their right to self-determination and thereafter continued to make similar speeches emphasising this right. ${ }^{10463}$

3259. Plavšić and the Accused communicated about preserving the common state of Yugoslavia and necessary steps to take to further Serb interests. ${ }^{10464}$ The Chamber recalls that in May 1992,

\footnotetext{
10456 See P4543 (Radovan Karadžić's Decision, 14 March 1995), pp. 1, 3. See para. 173.

10457 See para. 90.

10458 See para. 96.

10459 D440 (Minutes of $15^{\text {th }}$ session of SerBiH Presidency, 6 July 1992), p. 3. See para. 97. See also KDZ240, T. 16116, 16141 (5 July 2011) (closed session). Prior to this, Plavšić had been authorised to represent the SerBiH in contacts with the UN. P3050 (Minutes of joint meeting of SNB and SerBiH Government, 15 April 1992), p. 2.

10460 Momčilo Mandić, C2 (Transcript from Prosecutor v. Krajišnik) T. 8942.

10461 See para. 98.

10462 See para. 2818.

10463 See para. 2829.

10464 See para. 2641; P5729 (Intercept of conversation between Biljana Plavšić, Rajko Dukić, and Radovan Karadžić, 2 March 1992), pp. 3-4; P5727 (Intercept of conversation between Biljana Plavšić and Radovan Karadžić, 2 March 1992), pp. 1-3.
} 
Plavšić spoke of the entitlement of the Serbs to $70 \%$ of the territory and that Bosnian Serbs "were used to living in wide spaces" while Muslims typically lived in cities. ${ }^{10465}$ Plavšić further stated that "if it takes the lives of 3 million people to solve this crisis, lets get it done and move on". ${ }^{10466}$

3260. On 4 April 1992, a commission consisting of Plavšić and Fikret Abdić, among others, as well as high-ranking army officials visited Bijeljina to assess the situation there. ${ }^{10467}$ Plavšić visited the Bijeljina Serb Crisis Staff and congratulated Arkan for saving the Bosnian Serbs and was filmed kissing and hugging Arkan. ${ }^{10468}$ When, in the course of the visit, Plavšić asked Arkan to hand over control of Bijeljina to the JNA, he replied that he had not yet finished his "business" there. ${ }^{10469}$ On 23 April 1992, Plavšić was in contact with Arkan's men and left a message for him asking whether it was possible for her to visit. ${ }^{10470}$ Plavšić also asked whether they could "possibly bring the merchandise" and the member of Arkan's men she spoke with responded "understood, understood". 10471

3261. Plavšić openly supported paramilitary units, or "weekend warriors" as she called them, and during a Bosnian Serb Assembly session in November 1992, she openly invited them-including Arkan's men and the White Eagles-to "send their volunteers to help the defence of the Serbian people in [RS]". ${ }^{10472}$ As stated above, Plavsić was an advocate of having all paramilitary units from territories where Serbs lived outside $\mathrm{BiH}$ come to assist them and was the "bridge" between Bosnian Serbs and the people who came from other states to assist in the conflict. ${ }^{10473}$ Mićo

\footnotetext{
10465 See para. 2727.

10466 See para. 2727.

10467 See para. 626.

10468 See para. 626.

10469 See para. 626. The Chamber further recalls that at a dinner with UNPROFOR representative, Cedric Thornberry, on 20 April 1992, Plavšić described Bijeljina as a "liberated" town. See para. 626.

10470 P1106 (Intercept of conversation between Biljana Plavšić and "Rus", 23 April 1992), pp. 1-2.

10471 P1106 (Intercept of conversation between Biljana Plavšić and "Rus", 23 April 1992), p. 2. Without further context, the Chamber is not in a position to determine the meaning behind Plavšić's reference to "merchandise" and will not make a finding thereon.

10472 Mićo Stanišić, T. 46385-46386 (3 February 2014); Momčilo Mandić, T. 4625-4626 (5 July 2010); P1105 (Transcript of $22^{\text {nd }}$ session of RS Assembly, 23-24 November 1992), p. 20. See para. 608.

10473 See para. 3195.
} 
Stanišić and Plavšić clashed over this issue. ${ }^{10474}$ According to Mandić, Mićo Stanišić arrested paramilitary units and Plavšić would intercede on their behalf and have them released. ${ }^{10475}$

3262. The Chamber also recalls that in mid-April 1992, Plavšić visited the Alhos factory in Zvornik and met with Bosnian Serb local leaders, including members of the Zvornik Crisis Staff. $^{10476}$

3263. In meetings attended by the Accused in May or June 1992, as well as in a television interview in July 1992, Plavšić acknowledged that there were detention facilities run by Bosnian Serbs in BiH, including in Pale, Ilidža, Banja Luka, and Prijedor; however she qualified that those in detention were only able-bodied men of military age who actively participated in "rebellions", assisted such rebellions, or financed the purchase of weapons. ${ }^{10477}$

3264. On 7 July 1992, Plavšić was informed in writing that there had been "forced and wilful" efforts to move Bosnian Muslims out of Pale, resulting in a large number of criminal acts. ${ }^{10478}$ Plavšić was informed by the UN that on 30 September 1992, approximately 300 Bosnian Muslim civilians were expelled by Serbs from the area of Grbavica in Novo Sarajevo; when questioned about the situation, Plavšić deferred any response. ${ }^{10479}$

3265. In meetings with international representatives, Plavšić openly stated that it was impossible for Bosnian Serbs to co-exist with the other communities, particularly the Bosnian Muslims, and that it was better to separate the communities; she also emphasised the importance of partitioning the territory so that the Serbs would be left in control of a single continuous block of territory. ${ }^{10480}$

10474 Momčilo Mandić, T. 4625-4631 (5 July 2010) (testifying that Đerić supported Plavišić and Mandić supported Stanišić on this issue and it culminated in a clash between Plavšić and Đerić, on one side, and Stanišić and Mandić, on the other). According to Đerić, he never approved of Plavšić's statements or actions with respect to paramilitaries and Đerić did not consider that this "was the way things should be done". P4982 (Witness Statement of Branko Đerić dated 5 April 2012), para. 43. In June 1991, the Accused had discussed personnel issues in the MUP with Plavšić. P2222 (Intercept of conversation between Biljana Plavšić and Radovan Karadžić, 17 June 1991).

10475 Momčilo Mandić, T. 4626, 4630, 4649-4650 (5 July 2010); Momčilo Mandić, C3 (Transcript from Prosecutor v. Stanišić \& Župljanin), T. 9725-9726 (testifying that Plavšić ordered the release of the Yellow Wasps in late November 1992). Furthermore, Mandić stated that he did not speak to the Accused for half a year because he allowed Plavšić to do this. Momčilo Mandić, T. 4627-4630 (5 July 2010); Momčilo Mandić, C3 (Transcript from Prosecutor v. Stanišić \& Župljanin), T. 9725-9726.

10476 See para. 1253.

10477 P1099 (Video footage of interview with Biljana Plavšić, with transcript) (stating further that the number of prisons run by Muslims, in Sarajevo in particular, "vastly outnumbers" the number of prisons run by Bosnian Serbs in BiH); P1029 (Witness statement of John Wilson dated 4 November 2008), paras. 101-103, 138 (stating further that Plavšić countered that similar camps were maintained by other parties to the conflict). Mandić confirmed that this was one example of war propaganda spread by Plavšić as Bosnian Muslims did not have as many camps as Bosnian Serbs. Momčilo Mandić, C2 (Transcript from Prosecutor v. Krajišnik) T. 8936-8942.

10478 See para. 2324.

10479 See para. 2286. See also Hussein Ali Abdel-Razek, T. 5521 (20 July 2010).

10480 See paras. 2725-2727. 
At a meeting with a delegation from Greece in March 1994, in the presence of Mladić, Plavšić expressed her disapproval of the Accused's appeasement and "diplomatic juggling" displayed at international negotiations. ${ }^{10481}$

\section{(D) Ratko Mladić}

3266. The Chamber recalls that Ratko Mladić was appointed Commander of the VRS Main Staff on 12 May 1992, after being selected by the Accused. ${ }^{10482}$ The Main Staff was the highest operative body of the VRS. ${ }^{10483}$

3267. As the Commander of the VRS Main Staff, Mladic commanded the VRS in compliance with the authority that the President delegated to him; he issued regulations, orders, and instructions relating to the implementation of orders that the President had issued. ${ }^{10484}$ The Accused selected Mladić for this role and promoted him to the rank of Colonel-General on 28 June $1994 .{ }^{10485}$ Mladić remained in this position throughout the conflict until 8 November $1996 .^{10486}$

3268. Mladić was in contact with and received instructions from the Accused and Krajišnik. ${ }^{10487}$ In one conversation in May 1992, Mladić told Krajišnik that he would "stop by to get new instructions [...] So we'll arrange for what we should do next". ${ }^{10488}$

3269. Mladić was informed of military developments and take-overs throughout the Municipalities, as well as crimes which occurred there, during his time as Commander of the Main Staff. For example, the take-over of Rogatica beginning on or about 22 May 1992 was planned and

\footnotetext{
10481 P1485 (Ratko Mladić's notebook, 9 January-21 March 1994), pp. 180, 184, 186-187.

10482 See para. 3115.

10483 See para. 169.

10484 See para. 170. See also paras. 3107, 3116, 3152-3156.

10485 P970 (Transcript of 50 $0^{\text {th }}$ session of RS Assembly, 15-16 April 1995), p. 317 (noting that the Accused, together with Krajišnik, had taken an interest in Mladić and requested that he come to assume the role as VRS Main Staff Commander); P3046 (Radovan Karadžić's Decree on promotion of Ratko Mladić, 28 June 1994), Reynaud Theunens, T. 16863 (19 July 2011). See also P1477 (Ratko Mladić's notebook, 14 February-25 May 1992), p. 292). See also para. 3115.

10486 See fn. 461 (referring to P3034 (Track changes version of Reynaud Theunens's expert report entitled "Radovan Karadžić and the SRBiH TO-VRS (1992-1995)"), e-court pp. 287, 293); Ewan Brown, T. 21504-21505 (17 November 2011); P3914 (Ewan Brown's expert report entitled "Military Developments in the Bosanska Krajina - 1992", 27 November 2002), para. 1.64; P1355 (Minutes of $16^{\text {th }}$ Session of SerBiH Assembly), 12 May 1992, p. 2; Manojlo Milovanović, T. 25439 (28 February 2012); P4446 (Organisational Chart of the VRS Main Staff Structure for July 1995). See also P1489 (Ratko Mladić's notebook, 28 August 1995-15 January 1996), p. 135 (noting that Mladić was at a meeting of the RS Supreme Command on 1 December 1995 with the Accused, Krajišnik, Plavšić, and others).

10487 See Section IV.A.3.a.iii.A.3: Relationship between Mladić and Accused. See also, e.g., P1145 (Intercept of conversation between Momčilo Krajišnik and Ratko Mladić, 24 May 1992); P1519 (Intercept of conversation between Ratko Mladić and Momčilo Krajišnik, 27 May 1992), p. 2.

10488 P1519 (Intercept of conversation between Ratko Mladić and Momčilo Krajišnik, 27 May 1992), p. 2.
} 
executed by the SRK and Mladić was informed of it. ${ }^{10489}$ In May 1992, Mladić was informed that "Foča has been finished" and later in September 1992, that the percentage of Serbs in Foča was 99\%. ${ }^{10490}$ Furthermore, Batković camp was established in Bijeljina following an order from Mladić to set up a camp for "war prisoners" in June 1992. ${ }^{10491}$ On 6 June 1992, Mladić issued an urgent directive to secure communications from Sarajevo to Zvornik and mop up or cleanse the zone of "remaining enemy groups", also stating that the maltreatment of the unarmed civilian population was prohibited. ${ }^{10492}$ Mladić was also kept informed of events during the take-over in Vlasenica and was consulted during the armed conflict in Ilidža. ${ }^{10493}$

3270. On 1 July 1992, Mladić paid tribute to all members of the VRS for having successfully organised and implemented the co-ordinated "operation for breakthrough, expansion and cleansing of [the] corridor in Bosanska Posavina, between Eastern and Western Bosnia". ${ }^{10494}$ Mladić specifically congratulated the units of the Eastern Bosnia Corps and the $1^{\text {st }}$ Krajina Corps for their unified efforts to support the position of the VRS Main Staff to realise its military and political goals for the "preservation of Serbianhood" in $\mathrm{BiH}^{10495}$

3271. On 3 August 1992, Mladić ordered that inter alia Omarska, Trnopolje, and Manjača be prepared for upcoming visits from foreign journalists and members of the ICRC. ${ }^{10496}$ Furthermore, in a meeting with Jovi Banjac in September 1992, Mladić was informed that only 5,000 Bosnian Muslims remained in Ključ, and that another 1,500 were leaving on that same day. ${ }^{10497}$

3272. The Chamber also recalls that in meetings with international representatives, Mladić spoke about the genocide committed against Serbs in World War II in areas including Srebrenica and Sarajevo. ${ }^{10498}$ Furthermore, the Chamber recalls that Mladić agreed with the Accused when he said in January 1993 that they could not live together with Bosnian Muslims anymore and that therefore Bosnian Muslims would be transferred out of Bosnian Serb territory. ${ }^{10499}$ Mladić continued to make statements into 1994 about the necessity to fight against Bosnian Muslims and Bosnian

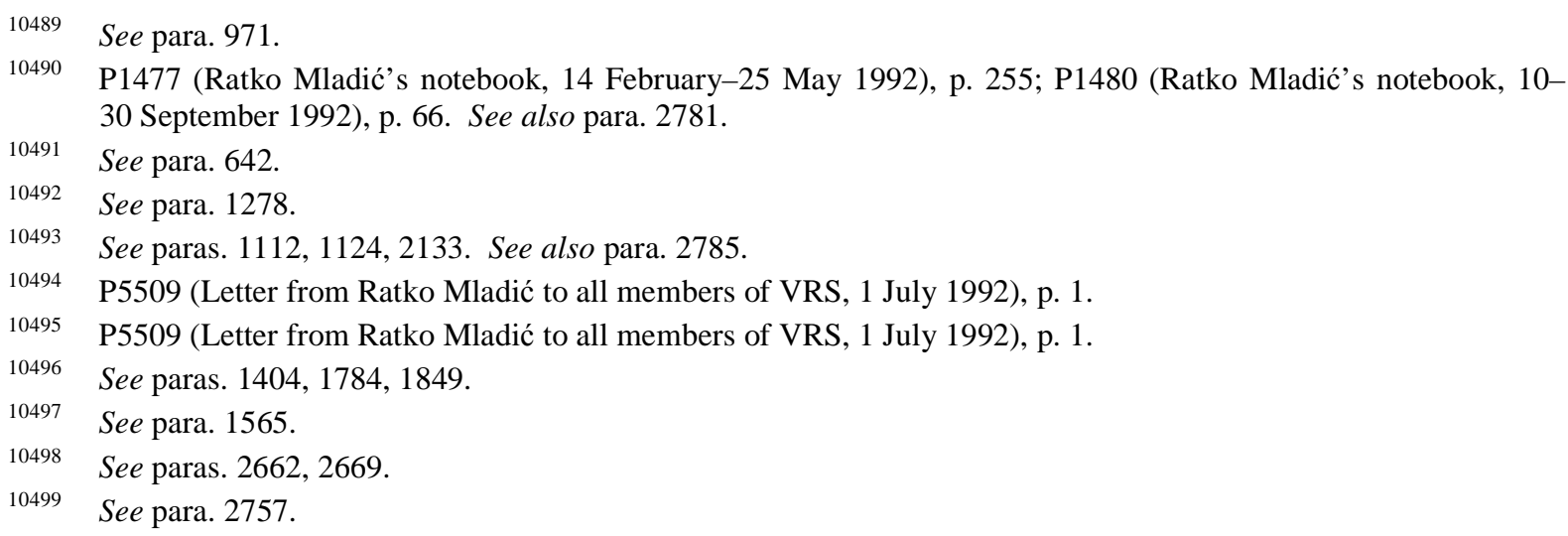


Croats to the end that they vanish completely or disappear. ${ }^{10500}$ Finally, the Chamber recalls the notice Mladić issued to the Main Staff in August 1995 in which, inter alia, he praised the VRS for thwarting "a planned and prepared genocide of the Serbian people, protecting the greater part of Serbian territories, and achieving victory after victory in the liberation of occupied historically and ethnically Serbian areas". ${ }^{10501}$

3273. The Chamber also recalls that Mladić was involved in defining, adopting, and carrying out the Strategic Goals. ${ }^{10502}$ Mladić advocated that the actions of the Bosnian Serbs should remain secret and recommended the adoption of a common rhetoric towards the public. ${ }^{10503} \mathrm{He}$ also stressed the importance of identifying a common enemy and that on this basis, "we must make our move and eliminate them, either temporarily or permanently". ${ }^{10504}$ In relation to carrying out the Strategic Goals, the Chamber recalls that Mladić issued important military directives, such as Directive 4 in November 1992 and Directive 5 in June 1993. ${ }^{10505}$

\section{(E) Slobodan Milošević}

3274. Slobodan Milošević was the President of the Republic of Serbia. ${ }^{10506}$ Milan Babić described Milošević as "the president of all Serbs, not only those in Serbia" 10507 and was referred to by Jovica Stanišić as the "main boss". ${ }^{10508}$ He had control over the JNA. ${ }^{10509}$

3275. Beginning in November 1990, Milošević and the Accused had a close association and the Accused would visit him frequently in Belgrade. ${ }^{10510}$ Other Bosnian Serb leaders such as Krajišnik also met with Milošević but their meetings were less frequent. ${ }^{10511}$ Prior to the start of the conflict and into 1992, Slobodan Milošević and the Accused were in constant communication with each

\footnotetext{
$10500 \quad$ See paras. 2766, 2769, 2771, 2806, 2832.

10501 See para. 2815.

10502 See paras. 2794, 2863-2864, 2868, 2874, 2876-2877. The Chamber notes that on 15 July 1994, Mladić complained that the Strategic Goals adopted by the Bosnian Serb Assembly had not been given the financial support needed and that on the contrary, political structures had hindered the VRS from carrying out certain operations which were directly within the purview of carrying out the set Strategic Goals. P1486 (Ratko Mladić's notebook, 31 March-3 September 1994), pp. 209-210.

10503 See para. 2864.

10504 See para. 2864.

10505 See paras. 2876, 2879, 3155-3156.

10506 P3048 (Record of $21^{\text {st }}$ session of FRY's SDC, 7 June 1994), p. 1; Yasushi Akashi, T. 37705-37706 (24 April 2013).

10507 P754 (Milan Babić's interview in NIN, 18 June 1991), p. 10; Milan Babić, P743 (Transcript from Prosecutor v. Martić), T. 1473.

10508 P5818 (Intercept of conversation between Ljiljana Karadžić and Jovica Stanišić, 12 November 1991).

10509 Herbert Okun, P776 (Transcript from Prosecutor v. Krajišnik), T. 4147.

10510 Milan Babić, P742 (Transcript from Prosecutor v. Krajišnik), T. 3397; Radomir Nešković, P2568 (Transcript from Prosecutor v. Krajišnik), T. 16612, 16614-16615, 16768.

10511 Radomir Nešković, P2568 (Transcript from Prosecutor v. Krajišnik), T. 16616.
} 
other to discuss and co-ordinate both political and military tactics in relation to developments in $\mathrm{BiH}$ and Croatia. ${ }^{10512}$ There was a close connection between the authorities in Pale and Belgrade, and the Bosnian Serb leadership consulted with Belgrade on developments in BiH. ${ }^{10513}$ Points of

10512 D1282 (Intercept of conversation between Radovan Karadžić and Slobodan Milošević, 29 May 1991), pp. 1-4; P5686 (Intercept of conversation between Radovan Karadžić and Slobodan Milošević, 11 June 1991), pp. 1-2; P5687 (Intercepts of conversations between (i) Ljiljana Karadžić and Slobodan Milošević and (ii) Radovan Karadžić and Slobodan Milošević, 12 June 1991), pp. 2-3, 5, 7-9; P5688 (Intercept of conversation between Radovan Karadžić and Slobodan Milošević, 17 June 1991), pp. 1-3; P5893 (Intercept of conversation between Radovan Karadžić and Slobodan Milošević, 24 June 1991), pp. 1-2; D3531 (Intercept of conversation between Radovan Karadžić and Slobodan Milošević, 28 June 1991); P5890 (Intercept of conversation between Radovan Karadžić and Slobodan Milošević, 1 July 1991), pp. 1-2; P5887 (Intercept of conversation between Radovan Karadžić and Slobodan Milošević, 8 July 1991), pp. 2-5; P5883 (Intercept of conversation between Radovan Karadžić and Slobodan Milošević, 9 July 1991), pp. 1-3; P5875 (Intercept of conversation between Radovan Karadžić and Slobodan Milošević, 29 July 1991), pp. 1-3; P5881 (Intercept of conversation between Radovan Karadžić and Slobodan Milošević, 31 July 1991), pp. 4-12; P5880 (Intercept of conversation between Radovan Karadžić and Slobodan Milošević, 6 August 1991), pp. 1-5; P5877 (Intercept of conversation between Radovan Karadžić and Slobodan Milošević, 4 September 1991), pp. 1-6; D365 (Intercept of conversation between Radovan Karadžić and Slobodan Milošević, undated); D4545 (Intercept of conversation between Radovan Karadžić and Slobodan Milošević, 13 September 1991); P5866 (Intercept of conversation between Radovan Karadžić and Slobodan Milošević, 18 September 1991); P5864 (Intercept of conversation between Radovan Karadžić and Slobodan Milošević, 19 September 1991), pp. 2-4; P5865 (Intercept of conversation between Radovan Karadžić and Slobodan Milošević, 13 September 1991); P5863 (Intercept of conversation between Radovan Karadžić and Slobodan Milošević, 22 September 1991); P5861 (Intercept of conversation between Radovan Karadžić and Slobodan Milošević, 23 September 1991), pp. 2-7; P5853 (Intercept of conversation between Radovan Karadžić and Slobodan Milošević, 23 September 1991), pp. 3-6; P5859 (Intercept of conversations between Radovan Karadžić, Slobodan Milošević and unidentified persons, 24 September 1991), pp. 7-11; D4496 (Intercept of conversation between Radovan Karadžić and an unidentified female and Slobodan Milošević, 24 September 1991), pp. 4-8; D4497 (Intercept of conversation between Radovan Karadžić and Slobodan Milošević, 26 September 1991); P5848 (Intercept of conversation between Radovan Karadžić and Slobodan Milošević, 8 October 1991), pp. 2-6; P5847 (Intercept of conversation between Radovan Karadžić and Slobodan Milošević, 9 October 1991), pp. 1-3; P5834 (Intercept of conversation between Radovan Karadžić and Slobodan Milošević, 26 October 1991), pp. 1-6; P5832 (Intercept of conversation between Radovan Karadžić and Slobodan Milošević, 29 October 1991), pp. 1-13; P5828 (Intercept of conversation between Radovan Karadžić and Slobodan Milošević, 1 November 1991), pp. 1-9; P5897 (Intercept of conversation between Radovan Karadžić and Slobodan Milošević, 14 November 1991), pp. 1-3; P5815 (Intercept of conversation between Radovan Karadžić and Slobodan Milošević, 15 November 1991), pp. 1-2; P5813 (Intercept of conversation between Radovan Karadžić and Slobodan Milošević, 18 November 1991), pp. 1-4; P5811 (Intercept of conversation between Radovan Karadžić and Slobodan Milošević, 22 November 1991), pp. 1-4; P5809 (Intercept of conversation between Radovan Karadžić and Slobodan Milošević, 23 November 1991), pp. 1-2; P5808 (Intercept of conversation between Radovan Karadžić and Slobodan Milošević, 26 November 1991), pp. 2-3; P5796 (Intercept of conversation between Mirko Krajišnik and Mirče Radić, 16 December 1991); P5795 (Intercept of conversation between Radovan Karadžić and Slobodan Milošević, 17 December 1991), pp. 1-3; P2224 (Intercept of conversation between Radovan Karadžić and Slobodan Milošević, 9 September 1991) (the Chamber notes that while this intercepted conversation is dated 20 December 1991, it is clear from the context of the conversation that it should be dated 9 September 1991); P5790 (Intercept of conversation between Radovan Karadžić and Slobodan Milošević, 20 December 1991), pp. 1-4; P5787 (Intercept of conversation between Radovan Karadžić and Slobodan Milošević, 25 December 1991), pp. 1-4; P5780 (Intercept of conversation between Radovan Karadžić and Slobodan Milošević, 30 December 1991), pp. 1-3; P5775 (Intercept of conversation between Radovan Karadžić and Slobodan Milošević, 5 January 1992), pp. 2-5; P5769 (Intercept of conversation between Radovan Karadžić and Slobodan Milošević, 9 January 1992); P5767 (Intercept of conversation between Radovan Karadžić and Slobodan Milošević, 12 January 1992), pp. 26; P5766 (Intercept of conversation between Radovan Karadžić and Slobodan Milošević, 15 January 1992), pp. 1-3; P5752 (Intercept of conversation between Radovan Karadžić and Slobodan Milošević, 10 February 1992), p. 1; P5751 (Intercept of conversation between Radovan Karadžić and Slobodan Milošević, 10 February 1992). P2848 (Witness statement of Milorad Davidović dated 22 June 2011), paras. 72, 199. See also P2926 (Official note of Serbia RDB, 27 June 1994); Milorad Davidović, T. 15830-15834 (1 July 2011). P2926 refers a group identified as the "Tajfun" group operating in Banja Luka and that the Serbian MUP would only accept the initiative of this group if the Accused and Mićo Stanišić gave their approval. However, Davidović was unable to give direct evidence about the nature of this group and measures taken in that regard. 
discussion included (i) their opposition to the secession of $\mathrm{BiH}$ and the desire to remain part of Yugoslavia; ${ }^{10514}$ (ii) opposition to the creation of an Islamic State; ${ }^{10515}$ (iii) political negotiations; ${ }^{10516}$ (iv) regionalisation; ${ }^{10517}$ (v) developments in Croatia and Slovenia; ${ }^{10518}$ (vi) military preparations including mobilisation of the Serb population and the provision of arms; ${ }^{10519}$

10514 D1282 (Intercept of conversation between Radovan Karadžić and Slobodan Milošević, 29 May 1991), pp. 1, 3; P5687 (Intercepts of conversations between (i) Ljiljana Karadžić and Slobodan Milošević and (ii) Radovan Karadžić and Slobodan Milošević, 12 June 1991), pp. 2-3; D3531 (Intercept of conversation between Radovan Karadžić and Slobodan Milošević, 28 June 1991), pp. 3-4; P5880 (Intercept of conversation between Radovan Karadžić and Slobodan Milošević, 6 August 1991), p. 1; D4545 (Intercept of conversation between Radovan Karadžić and Slobodan Milošević, 13 September 1991), p. 2; P5834 (Intercept of conversation between Radovan Karadžić and Slobodan Milošević, 26 October 1991), p. 1; P5828 (Intercept of conversation between Radovan Karadžić and Slobodan Milošević, 1 November 1991), p. 6; P5897 (Intercept of conversation between Radovan Karadžić and Slobodan Milošević, 14 November 1991), p. 3; P5787 (Intercept of conversation between Radovan Karadžić and Slobodan Milošević, 25 December 1991), p. 4; P5775 (Intercept of conversation between Radovan Karadžić and Slobodan Milošević, 5 January 1992), p. 3.

10515 D1282 (Intercept of conversation between Radovan Karadžić and Slobodan Milošević, 29 May 1991), p. 3; P5877 (Intercept of conversation between Radovan Karadžić and Slobodan Milošević, 4 September 1991), pp. 2, 4-5; P5828 (Intercept of conversation between Radovan Karadžić and Slobodan Milošević, 1 November 1991), pp. 1, 9; P5766 (Intercept of conversation between Radovan Karadžić and Slobodan Milošević, 15 January 1992), p. 2.

10516 P5687 (Intercepts of conversations between (i) Ljiljana Karadžić and Slobodan Milošević and (ii) Radovan Karadžić and Slobodan Milošević, 12 June 1991), pp. 3-5; P5688 (Intercept of conversation between Radovan Karadžić and Slobodan Milošević, 17 June 1991), pp. 1-3; P5893 (Intercept of conversation between Radovan Karadžić and Slobodan Milošević, 24 June 1991), p. 2; P5875 (Intercept of conversation between Radovan Karadžić and Slobodan Milošević, 29 July 1991), p. 2; D365 (Intercept of conversation between Radovan Karadžić and Slobodan Milošević, undated), pp. 1-2; P5859 (Intercept of conversations between Radovan Karadžić, Slobodan Milošević and unidentified persons, 24 September 1991), p. 8; D4497 (Intercept of conversation between Radovan Karadžić and Slobodan Milošević, 26 September 1991), p. 1; P5832 (Intercept of conversation between Radovan Karadžić and Slobodan Milošević, 29 October 1991), p. 11; P5897 (Intercept of conversation between Radovan Karadžić and Slobodan Milošević, 14 November 1991), pp. 2-3; P5813 (Intercept of conversation between Radovan Karadžić and Slobodan Milošević, 18 November 1991), p. 2; P5808 (Intercept of conversation between Radovan Karadžić and Slobodan Milošević, 26 November 1991), p. 2; P5790 (Intercept of conversation between Radovan Karadžić and Slobodan Milošević, 20 December 1991), p. 1.

10517 P5688 (Intercept of conversation between Radovan Karadžić and Slobodan Milošević, 17 June 1991), p. 3; D365 (Intercept of conversation between Radovan Karadžić and Slobodan Milošević, undated), p. 2.

10518 D3531 (Intercept of conversation between Radovan Karadžić and Slobodan Milošević, 28 June 1991), p. 5; P5890 (Intercept of conversation between Radovan Karadžić and Slobodan Milošević, 1 July 1991), p. 1; P5887 (Intercept of conversation between Radovan Karadžić and Slobodan Milošević, 8 July 1991), pp. 3-5; P5875 (Intercept of conversation between Radovan Karadžić and Slobodan Milošević, 29 July 1991), p. 3; P5880 (Intercept of conversation between Radovan Karadžić and Slobodan Milošević, 6 August 1991), p. 2; P5877 (Intercept of conversation between Radovan Karadžić and Slobodan Milošević, 4 September 1991), pp. 1, 4; P5867 (Intercept of conversation between Radovan Karadžić and Slobodan Milošević, 19 September 1991), pp. 1-2; P5861 (Intercept of conversation between Radovan Karadžić and Slobodan Milošević, 23 September 1991), pp. 5-6; P5853 (Intercept of conversation between Radovan Karadžić and Slobodan Milošević, 23 September 1991), p. 6; P5848 (Intercept of conversation between Radovan Karadžić and Slobodan Milošević, 8 October 1991), p. 5; P5811 (Intercept of conversation between Radovan Karadžić and Slobodan Milošević, 22 November 1991), p. 3.

10519 P5861 (Intercept of conversation between Radovan Karadžić and Slobodan Milošević, 23 September 1991), p. 5; P5883 (Intercept of conversation between Radovan Karadžić and Slobodan Milošević, 9 July 1991), pp. 1-2; P5887 (Intercept of conversation between Radovan Karadžić and Slobodan Milošević, 8 July 1991), pp. 3-5; P5853 (Intercept of conversation between Radovan Karadžić and Slobodan Milošević, 23 September 1991), pp. 3-5; P5859 (Intercept of conversations between Radovan Karadžić, Slobodan Milošević and unidentified persons, 24 September 1991), p. 10; D4496 (Intercept of conversation between Radovan Karadžić and an unidentified female and Slobodan Milošević, 24 September 1991), p. 4. 
(vii) developments in Krajina; ${ }^{10520}$ and (viii) issues pertaining to recognition of the independence of BiH. ${ }^{10521}$

3276. The Chamber recalls that from 1990 and into mid-1991, the political objective of the Accused and the Bosnian Serb leadership was to preserve Yugoslavia and to prevent the separation or independence of $\mathrm{BiH}$, which would result in a separation of Bosnian Serbs from Serbia; the Chamber notes that Slobodan Milošević endorsed this objective and spoke against the independence of $\mathrm{BiH}^{10522}$

3277. The Chamber found that based on a conversation between the Accused and Milošević on 24 October 1991, it was also clear that Slobodan Milošević was attempting to take a more cautious approach while the Accused was adamant that the goal of the Bosnian Serb leadership was to ensure that they would establish full authority in their territories and that they would announce their own Bosnian Serb Assembly. ${ }^{10523}$ The Chamber also found that while Milošević expressed reservations about excluding Bosnian Muslims, the Accused was adamant that there were not even $10 \%$ of Bosnian Muslims who supported Yugoslavia and that they could not take such a risk. ${ }^{10524}$

3278. The Chamber recalls that in December 1991, Milošević told the Accused that he should not give in to Izetbegović and that they had to stick to their line and that "if they want to fight, we'll fight" given that the Serbs were stronger. ${ }^{10525}$ They also spoke about the unconstitutional nature of the decision changing the status of $\mathrm{BiH} .{ }^{10526}$

10520 P5866 (Intercept of conversation between Radovan Karadžić and Slobodan Milošević, 18 September 1991), pp. 1-2; P5867 (Intercept of conversation between Radovan Karadžić and Slobodan Milošević, 19 September 1991), p. 1; P5864 (Intercept of conversation between Radovan Karadžić and Slobodan Milošević, 19 September 1991), p. 3; P5863 (Intercept of conversation between Radovan Karadžić and Slobodan Milošević, 22 September 1991), p. 2; P5861 (Intercept of conversation between Radovan Karadžić and Slobodan Milošević, 23 September 1991), p. 4; P5859 (Intercept of conversations between Radovan Karadžić, Slobodan Milošević and unidentified persons, 24 September 1991), p. 9; P5832 (Intercept of conversation between Radovan Karadžić and Slobodan Milošević, 29 October 1991), pp. 1, 11; P5787 (Intercept of conversation between Radovan Karadžić and Slobodan Milošević, 25 December 1991), p. 1; P5769 (Intercept of conversation between Radovan Karadžić and Slobodan Milošević, 9 January 1992), p. 2; P5751 (Intercept of conversation between Radovan Karadžić and Slobodan Milošević, 10 February 1992), pp. 1-2.

10521 P5832 (Intercept of conversation between Radovan Karadžić and Slobodan Milošević, 29 October 1991), p. 2; P5795 (Intercept of conversation between Radovan Karadžić and Slobodan Milošević, 17 December 1991), p. 1; P5775 (Intercept of conversation between Radovan Karadžić and Slobodan Milošević, 5 January 1992), p. 4; P5769 (Intercept of conversation between Radovan Karadžić and Slobodan Milošević, 9 January 1992), p. 1; P5766 (Intercept of conversation between Radovan Karadžić and Slobodan Milošević, 15 January 1992), p. 1.

10522 See paras. 2644-2645, 2651

10523 See para. 2710. See also P5782 (Intercept of conversation between Radovan Karadžić and Momčilo Krajišnik, 28 December 1991), pp. 1-2.

10524 See para. 2711.

10525 See para. 2691

10526 See para. 2691. 
3279. On 26 December 1991, the Accused and Krajišnik spoke about their political strategies and the issues of sovereignty in $\mathrm{BiH}$, regionalisation, and their mutual disappointment with Slobodan Milošević. ${ }^{10527}$ The Accused in this regard stated that they would have to pursue their own policy even if it meant "splitting with Milošević". ${ }^{10528}$ In January 1992, Milošević told the Accused in an intercepted phone conversation that he would not describe the Accused as one of his "satellites". 10529

3280. In March 1992, in a meeting with international representatives, Slobodan Milošević described the situation in $\mathrm{BiH}$ as similar to "dynamite", and if anyone favoured one of the parties, there would be hell but he had called the Accused and told him to "cool it". ${ }^{10530}$ Milošević also said that Yugoslavia hoped for intensive links with $\mathrm{BiH} .{ }^{10531}$ Later in the war, in meetings with international representatives, Milošević also made assurances that he would speak to the Bosnian Serbs, that he continued to condemn "ethnic cleansing" but that the world was "satanizing" the Serbs without condemning actions by the other parties. ${ }^{10532}$

3281. Beginning in 1992, Slobodan Milošević was informed by international representatives about the expulsion of Muslims in $\mathrm{BiH}$; he responded that everything that would happen in $\mathrm{BiH}$ would be horrendous and the responsibility for these acts remained with those who decided to separate $\mathrm{BiH}$ and that he had no authority as far as the Bosnian Serbs were concerned. ${ }^{10533}$ In September 1992, in meetings with international representatives, leaders of the FRY expressed the view that the international representatives were justified in asking them to pressure the Accused. ${ }^{10534}$

3282. The Accused in September 1992 acknowledged the support given by "leading figures both in Serbia and in Yugoslavia" who strongly supported the Bosnian Serbs in achieving their goal, even if it was temporarily within $\mathrm{BiH}$, but on the condition that the Bosnian Serbs defined "the borders towards the Muslims and Croats". ${ }^{10535}$ By January 1993, deputies in the Bosnian Serb

\footnotetext{
10527 P5785 (Intercept of conversation between Radovan Karadžić and Momčilo Krajišnik, 26 December 1991), pp. $3-7$.

10528 P5785 (Intercept of conversation between Radovan Karadžić and Momčilo Krajišnik, 26 December 1991 ), p. 7.

10529 P5769 (Intercept of conversation between Radovan Karadžić and Slobodan Milošević, 9 January 1992), p. 6.

10530 P779 (Sixth notebook of Herbert Okun's Vance Mission Diary), e-court pp. 36-37.

10531 P779 (Sixth notebook of Herbert Okun's Vance Mission Diary), e-court p. 36.

10532 D1140 (Letter to UN Secretary General, 2 February 1993) (under seal), p. 4; P4246 (UNPROFOR report re meetings with Slobodan Milošević, 25 March 1993), p. 2. See also D3054 (Notes of session of Council for Coordinating Positions on State Policy, 18 August 1992), pp. 10-12.

10533 [REDACTED].

10534 P784 (First notebook of Herbert Okun's ICFY diary), e-court p. 53.

10535 D456 (Transcript of $20^{\text {th }}$ session of RS Assembly, 14-15 September 1992), p. 16.
} 
Assembly called on Slobodan Milošević and the Serbian people to do more to help their brothers in the RS. ${ }^{10536}$

3283. In May 1993, Slobodan Milošević addressed the Bosnian Serb Assembly and confirmed the solidarity of Serbia with the Bosnian Serbs but stressed that the assembly should accept the VanceOwen Plan to avoid the disastrous consequences of the war continuing. ${ }^{10537} \mathrm{He}$ acknowledged that the war had been imposed on the Serbs who simply defended themselves. ${ }^{10538}$ On this point, the Accused disagreed and stated that he felt deceived by Milošević and explained that the VanceOwen Plan was catastrophic for the Serbs, that they would live in enclaves and areas like Zvornik would be "Turkish", and that there was a danger that they would be bombed whether or not they signed. ${ }^{10539}$

3284. At a meeting on 24 September 1993 with Slobodan Milošević and Mladić, Perišić discussed the danger of war in the Krajina and stated that help in manpower, combat equipment, and financial resources was needed. ${ }^{10540}$ Milošević stated that with respect to the "final verification of RS" it required political co-ordination with the Accused, economic co-ordination, military co-ordination with one Main Staff, as well as liaising regarding intelligence and security functions. ${ }^{10541}$ Milošević further declared that crime needed to be fought decisively. ${ }^{10542}$

3285. In October 1993, Perišić discussed personnel issues related to officers from the FRY who had been engaged in the VRS and there was discussion of whether the FRY should pull out their personnel from the RS. ${ }^{10543}$ At this meeting, Slobodan Milosević said that "Mladić needs to come here so that we can hear what he has to say". ${ }^{10544}$

3286. The Chamber recalls that Slobodan Milošević attended a meeting held at the Presidency of Serbia on 8 November 1993, with among others, the Accused, Krajišnik, Martić, Mladić, and Perišić, where the following common objectives were discussed: (i) unconditionally strengthen the

\footnotetext{
10536 P921 (Transcript of $24^{\text {th }}$ session of RS Assembly, 8 January 1993), pp. 55-56.

10537 P1371 (Transcript of 30 ${ }^{\text {th }}$ session of RS Assembly, 5-6 May 1993), pp. 29-30, 157-160; Herbert Okun, P776 (Transcript from Prosecutor v. Krajišnik), T. 4235; Herbert Okun, T. 1828 (28 April 2010).

10538 P1371 (Transcript of $30^{\text {th }}$ session of RS Assembly, 5-6 May 1993), p. 161.

10539 P1373 (Transcript of $31^{\text {st }}$ session of RS Assembly, 9 May 1993), p. 18.

10540 P1483 (Ratko Mladić's notebook, 2 April-24 October 1993), pp. 339-340.

10541 P1483 (Ratko Mladić's notebook, 2 April-24 October 1993), pp. 341, 343-344.

10542 P1483 (Ratko Mladić's notebook, 2 April-24 October 1993), p. 345.

10543 P6162 (Excerpt from notes of FRY's SDC 14 ${ }^{\text {th }}$ session, 11 October 1993), e-court pp. 1, 5, 7.

10544 P6162 (Excerpt from notes of FRY's SDC 14 ${ }^{\text {th }}$ session, 11 October 1993), e-court, p. 7. See also P6163 (Excerpt from notes of FRY's SDC $28^{\text {th }}$ session, 2 November 1994), p. 47.
} 
integrity of Serbia, (ii) set up the RS as a completely independent state; and (iii) ensure Serbs have complete power in the Krajina. ${ }^{10545}$

3287. At a meeting in December 1993, with Slobodan Milošević, Jovica Stanišić and others, the Accused stated that the end of the conflict was close and that the Bosnian Serbs were holding 75\% of the territory; he acknowledged that some of this territory would have to be returned as the international community would not allow it. ${ }^{10546}$ The Accused listed the Strategic Goals at this meeting. ${ }^{10547}$ This meeting was convened to improve the "operational and tactical position" of the Bosnian Serbs and to discuss help from Serbia. ${ }^{10548}$ Milošević agreed with a proposal from Mladić and suggested that "the operation" should be planned and the forces prepared but only following negotiations in Brussels. ${ }^{10549} \mathrm{He}$ also promised to provide fuel supplies from the state reserves for the operations. ${ }^{10550}$ Milošević offered further assistance, stating that Perišić will "give everything that does not jeopardise combat readiness of units" in Serbia. ${ }^{10551}$ Perišić further stated that they would help with weapons while Jovica Stanišić spoke about a special combat group which could be deployed; ${ }^{10552}$ these units included the Red Berets and Arkan's men. ${ }^{10553}$ The following day, continuing the meeting, Stanišić and Perišić confirmed that that they would provide manpower of a few hundred men. ${ }^{10554}$

3288. At a meeting in Belgrade on 15 March 1994 attended by Jovića Stanišić, Martić, Mladić, and the Accused, Slobodan Milošević stated that "[a]ll members of other nations and ethnicities must be protected" and that "[t]he national interest of the Serbs is not discrimination". ${ }^{10555}$

\footnotetext{
10545 See para. 2883.

10546 See para. 2886.

10547 See para. 2886.

10548 P1484 (Ratko Mladić's notebook, 28 October 1993-15 January 1994), p. 53.

10549 P1484 (Ratko Mladić's notebook, 28 October 1993-15 January 1994), pp. 57-58.

10550 P1484 (Ratko Mladić's notebook, 28 October 1993-15 January 1994), p. 58. See also P3048 (Record of $21^{\text {st }}$ session of FRY's SDC, 7 June 1994), p. 5; P2451 (Witness statement of Anthony Banbury dated 19 May 2009), para. 55.

10551 P1484 (Ratko Mladić's notebook, 28 October 1993-15 January 1994), p. 57.

10552 P1484 (Ratko Mladić's notebook, 28 October 1993-15 January 1994), pp. 59-61; P1473 (Ratko Mladić's notebook, 27 January-5 September 1995), p. 80. See also KDZ446, P29 (Transcript from Prosecutor v. S. Milošević), T. 21025-21027; P31 (List of names referred to during testimony of KDZ446) (under seal); KDZ555, T. 17248-17258 (16 August 2011) (private session) (pertaining to the distrubution of weapons); D1412 (Report of Republic of Serbia MUP, 8 August 1992), p. 10.

10553 P2848 (Witness statement of Milorad Davidović dated 22 June 2011), paras. 80, 112-113, 166. See also P6210 (Report of Eastern Bosnian Corps, 20 September 1995).

10554 P1484 (Ratko Mladić's notebook, 28 October 1993-15 January 1994), p. 61. Later, in June 1994, Perišić spoke about requests Serbia had received for assistance in the war from the RS and the assistance they had provided with respect to financing and material assistance for combat operations and the strain this was placing on their own resources. P3048 (Record of $21^{\text {st }}$ session of FRY's SDC, 7 June 1994), pp. 5-8.

10555 P1485 (Ratko Mladić's notebook, 9 January-21 March 1994), p. 169.
} 
3289. International observers noted that Milošević had a dominant influence over the Bosnian Serb leadership and played a role in convincing them to accept certain proposals during international negotiations. ${ }^{10556}$ However, by July 1994, there were rifts in the relationship between the RS and Serbia, and Slobodan Milošević complained about criticisms directed against Serbia. ${ }^{10557}$ In private meetings, Milošević was extremely angry at the Bosnian Serb leadership for rejecting the Vance-Owen Plan and he cursed the Accused. ${ }^{10558}$

3290. The Chamber notes that while originally Milošević had similar interests to those as the Bosnian Serbs, when their interests diverged, his influence over the Bosnian Serb leaders also reduced. ${ }^{10559}$ Milošević also questioned whether the world would accept that the Bosnian Serbs who represented only one third of the population of $\mathrm{BiH}$ would get more than $50 \%$ of the territory and he encouraged a political agreement. ${ }^{10560} \mathrm{He}$ stated that the Serbs had won the war, and that there were "hardly any" Bosnian Muslims in RS. ${ }^{10561}$ By August 1994, leaders in Serbia criticised Bosnian Serb leaders of committing "crimes against humanity" and continuing "ethnic cleansing" and the war for their own purposes. ${ }^{10562}$

3291. At a meeting held on 22 August 1994 between Slobodan Milošević and Akashi, it was clear to Akashi that Milošević's break with the Accused was "serious" and stemmed from differences that arose over a long period of time. ${ }^{10563}$ Milošević gave the impression that he was "a politician who is more in command of the overall situation" while the Accused was "a local leader wrapped up in the emotions of an ongoing civil war". ${ }^{10564}$ At the meeting, Milošević made it clear that there

\footnotetext{
10556 Yasushi Akashi, T. 37705-37706 (24 April 2013). See also P820 (Witness statement of David Harland dated 4 September 2009), paras. 277-280.

10557 P1486 (Ratko Mladić's notebook, 31 March 1994-3 September 1994), p. 216. See also P820 (Witness statement of David Harland dated 4 September 2009), paras. 280-281; P2451 (Witness statement of Anthony Banbury dated 19 May 2009), paras. 52-53, 161; P2457 (UNPROFOR Weekly BiH Political Assessment, 28 August 1994), p. 3; Anthony Banbury, T. 13336-13337 (15 March 2011); Vojislav Šešelj, T. 39564 (10 June 2013).

10558 P2848 (Witness statement of Milorad Davidović dated 22 June 2011), paras. 188-190. See also John Zametica, T. 42468-42469 (29 October 2013) (testifying that Milošević tried to have the Accused removed after the Vance-Owen Plan); D3665 (Witness statement of Vojislav Šešelj dated 1 June 2013), para. 41; D3051 (Witness statement of Momir Bulatović dated 25 February 2013), para. 42; Momir Bulatović, T. 34532-34533 (28 February 2013). The Chamber does not rely on Zametica's general opinion that there was no joint criminal enterprise between the Accused and Milošević or that Milošević was not interested in a Greater Serbia.

10559 P2451 (Witness statement of Anthony Banbury dated 19 May 2009), para. 54.

10560 P1486 (Ratko Mladić's notebook, 31 March 1994-3 September 1994), pp. 219, 221, 228. See also P3863 (UNPROFOR report, 18 May 1995), p. 1.

10561 P1486 (Ratko Mladić's notebook, 31 March 1994-3 September 1994), pp. 219-220.

10562 P2457 (UNPROFOR Weekly BiH Political Assessment, 28 August 1994), p. 3. See also D1140 (Letter to UN Secretary General, 2 February 1993) (under seal), p. 4.

10563 P3861 (UNPROFOR report, 23 August 1994), pp. 1, 3 (noting that among others, Sergio de Mello and Kirudja were also present at the meeting). See P3804 (Witness statement of Charles Kirudja dated 17 November 2010), para. 135.

10564 P3861 (UNPROFOR report, 23 August 1994), p. 1.
} 
was a difference of views emerging in the Bosnian Serb leadership on the execution of the war. ${ }^{10565}$ Specifically, Milošević stated that Krajina Serbs were well aware that a solution based on negotiations was the only way out and this is why they had not accepted the Accused's suggestion to merge with the RS. ${ }^{10566}$

3292. Given the difference of opinion between the Bosnian Serb and the Serbian leaderships, in 1993 and 1994, the FRY reduced its support for the RS and encouraged the Bosnian Serbs to accept peace proposals. ${ }^{10567}$ In this regard the FRY leadership was on notice about some of the extreme views held by the Bosnian Serb leadership and they could not support those views, including with respect to ethnic cleansing. ${ }^{10568}$

3293. During a meeting held on 20 September 1994 with Mladić, Perišić, and others, Milošević stressed that there had been a break between Pale and Serbia and reminded them that Serbian policy was defined in Belgrade, not Pale. ${ }^{10569}$ He declared that the war must end and that the Bosnian Serbs' biggest mistake was to want a complete defeat of the Bosnian Muslims. ${ }^{10570}$ During the course of this meeting, Milošević further expressed his disapproval of the Bosnian Serb leadership's disunity from the Bosnian Serbs in Krajina, stating that "the crazy doctor may think that Serbia must toady up to him—it's not going to happen". ${ }^{10571}$

3294. By November 1994, Perišić noted that the Bosnian Serbs accounted for $20 \%$ of the population but held more than $70 \%$ of the territory which, in his view, was unsustainable; however, according to Perišić, the Bosnian Serbs wanted "to preserve this at all cost", but loss of territory was inevitable. ${ }^{10572}$ Slobodan Milošević referred to the Accused's belief that they could "wage an infinite war and they won't give up on anything". ${ }^{10573}$ Milošević noted however that "our biggest advantage is that the territories, which are to be allocated to Serbs by the peace plan, are already in the Serbian hands so that nobody has to be removed from them". ${ }^{10574}$ He also explained that when they tried to convince the Accused and Krajišnik that they would be forced to do certain things,

\footnotetext{
10565 P3861 (UNPROFOR report, 23 August 1994), p. 1.

10566 P3861 (UNPROFOR report, 23 August 1994), p. 3.

10567 D3051 (Witness statement of Momir Bulatović dated 25 February 2013), para. 43.

10568 Momir Bulatović, T. 34543-34546, 34549-34550 (1 March 2013); P6161 (Excerpt from notes of FRY's SDC $8^{\text {th }}$ session, 12 March 1993), e-court pp. 1-2; P6162 (Excerpt from notes of FRY's SDC $14^{\text {th }}$ session, 11 October 1993), e-court. p. 3.

10569 P1487 (Ratko Mladić's notebook, 4 September 1994-29 January 1995), pp. 16-17, 21.

10570 P1487 (Ratko Mladić's notebook, 4 September 1994-29 January 1995), pp. 23-24.

10571 P1487 (Ratko Mladić's notebook, 4 September 1994-29 January 1995), p. 26.

10572 P6163 (Excerpt from notes of FRY's SDC 28 $8^{\text {th }}$ session, 2 November 1994), p. 7; Momir Bulatović, T. $34552-$ 34553 (1 March 2013).

10573 P6163 (Excerpt from notes of FRY's SDC $28^{\text {th }}$ session, 2 November 1994), p. 25.

10574 P6163 (Excerpt from notes of FRY's SDC $28^{\text {th }}$ session, 2 November 1994), pp. 25-26.
} 
they replied that it was better to be forced than to accept. ${ }^{10575}$ Milošević noted that the Bosnian Serb political leadership would "sacrifice many lives in order to preserve their vanity and to prove that they are not the ones who accepted the peace plan because a half of $\mathrm{BiH}$ is too little for them". 10576 He spoke about the Bosnian Serbs wanting to take even more territory by force even while they already controlled half of $\mathrm{BiH}$ and described this as "complete madness". 10577

3295. Milošević tried to reason with the Bosnian Serbs saying that he understood their concerns, but that it was most important to end the war and that they would achieve any objectives denied them by the plan when peace talks resumed. ${ }^{10578}$ When the RS did not accept this plan, Milošević imposed a blockade on the Drina River and suspended political and economic relations with the Bosnian Serb leadership; Milošević even wanted to remove the leaders from Pale and have them replaced by exerting influence on the deputies and the Bosnian Assembly. ${ }^{10579}$

3296. By May 1995, it appeared to international representatives that the split between Slobodan Milošević and the Accused was complete. ${ }^{10580}$ At a 3 May 1995 meeting with Milošević, Milinović, Akashi, Banbury, and Kirudja, among others, Milošević stated: "I have good personal relations with Mladić. However, as long as Karadžić and Krajišnik are there, they will not accept a peaceful solution."10581 Kirudja observed that Slobodan Milošević still exerted influence over officials in the RS and RSK, including Mladić. ${ }^{10582}$ This influence appeared to vary over time, but Kirudja was under the impression that Milošević considered Mladić to be loyal to him even after

\footnotetext{
10575 P6163 (Excerpt from notes of FRY's SDC $28^{\text {th }}$ session, 2 November 1994), p. 26.

10576 P6163 (Excerpt from notes of FRY's SDC 28 ${ }^{\text {th }}$ session, 2 November 1994), p. 26.

10577 P6163 (Excerpt from notes of FRY's SDC $28^{\text {th }}$ session, 2 November 1994), pp. 33-34. See also P3049 (Record of $31^{\text {st }}$ session of FRY's SDC, 18 January 1995), e-court pp. 1-2. Milošević also acknowledged that Koljević was in favour of signing a peace plan, but the Accused and Krajišnik did not ask for his opinion. P6163 (Excerpt from notes of FRY's SDC $28^{\text {th }}$ session, 2 November 1994), p. 41.

10578 D3015 (Witness statement of Vladislav Jovanović dated 22 February 2013), para. 66.

10579 D3015 (Witness statement of Vladislav Jovanović dated 22 February 2013), para. 66; Vladislav Jovanović, T. 34273-34276 (26 February 2013) (further characterising the relationship between the Accused and Milošević as a "marriage out of necessity" given their opposing political and ideological views, and it moved from a cordial relationship to a point where Milošević imposed a blockade against the Bosnian Serbs); D3027 (Report re humanitarian activity, 17 August 1994) (under seal), p. 1.

10580 P3804 (Witness statement of Charles Kirudja dated 17 November 2010), paras. 144-147. See also P2567 (Note from FRY's SDC 42 ${ }^{\text {nd }}$ session, 23 August 1995), p. 2 (during which Milošević expressed his reticence to meet with the Accused due to the Accused and his team having demonstrated fickleness and disloyalty; Milošević also showed Mladić a confidential letter from the Accused which showed the Accused's intention to "blame Serbia and the FRY for any debacle ensuing from the disastrous policies of the RS leadership").

10581 P3804 (Witness statement of Charles Kirudja dated 17 November 2010), para. 145. The Chamber notes that from the context of the conversation, Milošević is referring to the Bosnian Serbs when he said "they".

10582 P3804 (Witness statement of Charles Kirudja dated 17 November 2010), paras. 133, 147. In his role as Delegate of the Special Representative of the Secretary General to the FRY from August 1994 to June 1995, Kirudja dealt with all matters involving UNPROFOR's relations with the FRY that were not military in nature. P3804 (Witness statement of Charles Kirudja dated 17 November 2010), paras. 2, 131.
} 
the relations between Belgrade and Pale deteriorated. ${ }^{10583}$ Milošević also criticised Martić, and Kirudja noted that the Accused and Martić were aligned at the time. ${ }^{10584}$ According to Kirudja, Milošević seemed to be "playing his usual game of switching his support for RSK leaders as the situation best suited his aims at the moment" and that Milošević's control over RSK or RS officials seemed to vary with time, depending on events in the region. ${ }^{10585}$ When Martić aligned himself with the Accused, both Martić and the Accused fell out of favour with Milošević. ${ }^{10586}$

3297. In November 1995, Slobodan Milošević addressed the Supreme Defence Council of the FRY, spoke about the leadership in Pale being the biggest obstacle to solving the problems in $\mathrm{BiH}$, and criticised them for rejecting plans for the territorial division of $\mathrm{BiH} .{ }^{10587}$ Milošević told the Bosnian Serb leadership that they were not entitled to have more than half the territory in BiH, stating that

there is no way that more than that could belong to us! Because, we represent one third of the population. [...] We are not entitled to in excess of half of the territory - you must not snatch away something that belongs to someone else! [...] How can you imagine two thirds of the population being crammed into $30 \%$ of the territory, while $50 \%$ is too little for you?! Is it humane, is it fair?! ${ }^{10588}$

\section{(F) Mićo Stanišić}

3298. Mićo Stanišić was a member of the Preparatory Committee that established the SDS. ${ }^{10589}$ He was also a member of the Council of Ministers and the SNB. ${ }^{10590}$ On 24 March 1992, Mićo Stanišić was appointed Minister of the MUP. ${ }^{10591}$ Stanišić served in this position until the end of December 1992 when he was relieved of his duties by the Bosnian Serb leadership, specifically at

\footnotetext{
10583 P3804 (Witness statement of Charles Kirudja dated 17 November 2010), para. 147. See also P2567 (Note from FRY's SDC 42 ${ }^{\text {nd }}$ session, 23 August 1995), p. 2.

10584 P3804 (Witness statement of Charles Kirudja dated 17 November 2010), paras. 146, 148 (stating further that in February 1995, he referenced the fact that Milošević would influence Martić over what was going on in the Bihać pocket, but not the Accused). See P3868 (UNPROFOR report, 16 February 1995), p. 4.

10585 P3804 (Witness statement of Charles Kirudja dated 17 November 2010), paras. 146-147.

10586 P3804 (Witness statement of Charles Kirudja dated 17 November 2010), para. 147 (stating further that based on comments made by Milošević, it appeared that Mladić remained loyal to him even when Milošević closed the border between the FRY and $\mathrm{BiH}$ ).

10587 P2604 (Minutes of 47th session of SDC, 28 November 1995), pp. 6-7.

10588 P2604 (Minutes of $47^{\text {th }}$ session of SDC, 28 November 1995), p. 9. See also P6163 (Excerpt from notes of FRY's SDC $28^{\text {th }}$ session, 2 November 1994), p. 32.

10589 P1383 (Transcript of $36^{\text {th }}$ session of RS Assembly, 30-31 December 1993), p. 57.

10590 P3111 (Minutes of the $2^{\text {nd }}$ meeting of the Ministerial Council of SerBiH Assembly, 17 January 1992), p. 1; Mićo Stanišić, T. 46341 (3 February 2014); P3050 (Minutes of joint meeting of SNB and SerBiH Government, 15 April 1992), p. 1.

10591 Mićo Stanišić, T. 46327, 46353 (3 February 2014), T. 46440 (4 February 2014); P1354 (Minutes of $13^{\text {th }}$ session of SerBiH Assembly, 24 March 1992), p. 7. See also Adjudicated Fact 2146; para. 3158.
} 
the request of Plavšić and Koljević. ${ }^{10592}$ Stanišić went to Belgrade until he was appointed by the Accused again as Minister of the Bosnian Serb MUP during an interim six month period between January and July $1994 .^{10593}$

3299. Mićo Stanišić was considered to be in the top leadership of the RS and had a very close relationship with the Accused, as well as his support. ${ }^{10594}$ According to Branko Đerić, Mićo Stanišić and Mandić were the "President's men" and Stanišić took orders directly from the Accused. ${ }^{10595}$ Stanišić also reported to the Accused. ${ }^{10596}$

3300. The Chamber refers to Section IV.A.3.a.ii.C regarding the split in the MUP and the creation of a Bosnian Serb MUP and Mićo Stanišić's involvement therein. ${ }^{10597}$ It recalls that the ultimate split in the MUP structures was precipitated by a decision by the Bosnian Serb leadership which formed part of their decision to create a separate Bosnian Serb state with parallel structures. Mićo Stanišić was involved in the decision making and promulgation of this idea from as early as February 1992, where he spoke of the need to work towards organising a Bosnian Serb MUP starting at the municipal and regional levels and moving towards a Serb ministry. ${ }^{10598}$ The Chamber also found that the creation of a separate Bosnian Serb MUP was a means of undermining the proposed independence of $\mathrm{BiH}$. Finally, the Chamber found that the directives with respect to the division of the MUP structures and the creation of the Bosnian Serb MUP were communicated to and implemented at a municipal level and were a crucial step in the take-over of the

10592 Mićo Stanišić, T. 46327, 46353 (3 February 2014); T. 46437-46438 (4 February 2014); P1383 (Transcript of $36^{\text {th }}$ session of RS Assembly, 30-31 December 1993), pp. 51, 59; Momčilo Mandić, C2 (Transcript from Prosecutor v. Krajišnik), T. 9267-9270 (testifying that Krajišnik informed Mandić and Stanišić of the decision from the Bosnian Serb leadership, specifically at the request of Plavšić and Koljević, to send them to Belgrade and terminate their positions). See Branko Đeric, T. 27947-27948, 27983 (24 April 2012) (testifying, however, that the Accused did not accept to have Mićo Stanišić and Mandić removed from their positions).

10593 Mićo Stanišić, T. 46327, 46353 (3 February 2014); T. 46437-46439 (4 February 2014) (testifying that in the interim period he was in Belgrade, he did not work, but the Accused issued a decision appointing Stanišić as a "republican advisor" in order to protect Stanišić from being mobilised into the army during this time); Momčilo Mandić, C2 (Transcript from Prosecutor v. Krajišnik), T. 9267-9270.

10594 P4982 (Witness Statement of Branko Đerić dated 5 April 2012), paras. 14, $20-22$ (stating that with regard to Mićo Stanišić and Mandić, they kept visiting the Accused and failed to attend government's sessions as they felt that "the government could be pushed aside" and "thought of themselves as belonging to the top leadership"); P1105 (Transcript of $22^{\text {nd }}$ session of RS Assembly, 23-24 November 1992), p. 12. See P5646 (Intercept of conversation between Radovan Karadžić and Mićo Stanišić, 21 June 1992); P6624 (Intercept of conversation between Mićo Stanišić and Radovan Karadžić, 12 June 1991). See also P2848 (Witness statement of Milorad Davidović dated 22 June 2011), para. 47.

10595 P4982 (Witness Statement of Branko Đerić dated 5 April 2012), paras. 21-22. See paras. $2932,3161$.

10596 See paras. 3164-3167.

10597 For example, as early as September 1991, Mićo Stanišić was informed that the Bosnian Serbs wanted to split the police structures in Vogošća given the disputes they were facing, but Stanišić said that "it needs some more time. One should act with his head cool". P2219 (Intercept of conversation between Jovan Tintor and Mićo Stanišić, 12 September 1991), pp. 2-5.

10598 See para. 2973. See also D4271 (Video footage of Mićo Stanišić's speech, 30 March 1992, with transcript). 
Municipalities, as it created a structure which would allow Bosnian Serb authority to be maintained through a separate police structure. ${ }^{10599}$

3301. Furthermore, the Chamber recalls that Mićo Stanisić also ordered that CSB heads were allowed to take-over the employees from the former MUP and assign jobs within the CSBs and SJBs, however, they had to inform the Minister of the Interior of all such decisions. ${ }^{10600}$ Furthermore, all heads of CSB were required to obtain prior approval from the MUP before assigning posts at the higher levels, such as the head of the SJBs. ${ }^{10601}$ In addition, on 15 May 1992, Stanisić issued an order formalising the co-operation of the Bosnian Serb MUP and VRS, such that MUP personnel would be organised into war units and re-subordinated to the VRS during their participation in combat activities. ${ }^{10602}$

3302. In April 1992, Davidović was sent with others from Belgrade to help set up the Bosnian Serb MUP and to establish a special purpose unit under the direction of Mićo Stanišić. ${ }^{10603}$ Those who went to assist the Bosnian Serb MUP were to act with Bosnian Serb MUP IDs in order to conceal their identity and the fact that the FRY was assisting in the war. ${ }^{10604}$ On arrival in Pale, Davidović reported to and then met with Mićo Stanišić and Mandić. ${ }^{10605}$ Also, surplus weapons from the Federal SUP were sent to the Bosnian Serb MUP and were controlled by Mićo Stanišić and Momčilo Mandić. ${ }^{10606}$ These weapons were transported from Belgrade to Pale in JNA helicopters in around April 1992 and consisted of uniforms, flak jackets, and automatic weapons. ${ }^{10607}$

\footnotetext{
10599 See paras. 2990-2991.

10600 See para. 2986.

10601 See para. 2986.

10602 See paras. 230, 3160.

10603 P2848 (Witness statement of Milorad Davidović dated 22 June 2011), para. 43; P2893 (Intercept of conversation between Pero Mihajlović and an unidentified person, 6 May 1992), p. 2.

10604 P2848 (Witness statement of Milorad Davidović dated 22 June 2011), paras. 43-44, 46.

10605 P2848 (Witness statement of Milorad Davidović dated 22 June 2011), paras. 45-46. See also P2221 (Intercept of conversation between Mićo Stanišić and Mićo Davidović, 17 May 1992). The Chamber recalls that Davidović was later tasked to lead a special unit of the Federal SUP to address problems with paramilitaries in northeastern $\mathrm{BiH}$ and arrived in Bijeljina on 27 June 1992; while Davidović's unit came from the Federal SUP in Belgrade it was re-subordinated to the command of the Bosnian Serb MUP. See paras. 634, 3204.

10606 P2848 (Witness statement of Milorad Davidović dated 22 June 2011), para. 39.

10607 P2848 (Witness statement of Milorad Davidović dated 22 June 2011), paras. 39-40; Milorad Davidović, T. 15447 (24 June 2011). See also P2876 (Receipt of weapons issued to Brčko TO, 13 May 1992); P2877 (Authorisation from Brčko garrison); P2902 (JNA's travel log for vehicles, 8-31 May 1992). But see D3695 (Witness statement of Bogdan Subotić dated 16 June 2013), paras. 18, 67. The Chamber notes that Subotić's evidence was marked by evasiveness and bias which undermined his credibility. The Chamber therefore does not rely on his evidence that no arms came from outside to arm the Bosnian Serbs and that he was not aware of any organised arming in the first year of the war. The Chamber does find, however, that the Accused proposed that Subotic be promoted for his organisation of the arming and training of Bosnian Serbs in RS for their "defence and survival" particularly in relation to attacks from Croatia. D3704 (Radovan Karadžić's clarification
} 
3303. In Bijeljina, the Chief of the Bijeljina SJB reported to Mićo Stanišić on the situation in the municipality, and an almost daily reporting system was operating between the Bijeljina CSB and the Bosnian Serb MUP. ${ }^{10608}$ The Chamber recalls that Mićo Stanišić informed Milorad Davidović that Arkan's forces were in Zvornik and Bijeljina and "helping to liberate territory [that] they believed should become part of [the RS]" ${ }^{10609}$ In addition, Mićo Stanišić was informed that Arkan's men had taken over the Bijeljina SUP, and Stanišić commented that he knew, that nothing else could be done, and that's "how it ha[d] to be". ${ }^{10610}$ In April or May 1992, after Arkan entered Bijeljina, the Accused met with Krajišnik, Mićo Stanišić, Frenki Simatović, Arkan, Pero Mihajlović, and Davidović in Belgrade to discuss "further activities" of the SDB. ${ }^{10611}$

3304. At the end of May 1992, Bosnian Serb leaders from Zvornik informed Mićo Stanišić and Mandić about the situation in the municipality, including the actions of the paramilitaries. ${ }^{10612}$ Mićo Stanišić was also informed in May 1992 about the situation in Ilidža, and in particular, that they had received reinforcements which included "Arkanovci and Šešeljevci” to which Stanišić responded: "Good". 10613 In June 1992, the Accused received a report on the combat situation in Ilidža from Mićo Stanišić and the Accused instructed him “don't hurry, just proceed according to your plan". 10614

3305. In an interview in October 1992, Mićo Stanišić stressed that the Bosnian Serb MUP assisted the VRS in combat operations, yet at the beginning of the conflict, the "burden of defence was borne by the police" and due to its organisation and dedication, "we established most of our borders, exactly like what they look like today". ${ }^{0615}$ Finally, during an Assembly meeting in November 1992, Stanišić affirmed his allegiance to the Accused and the SDS stating that he had always followed the policies of the SDS Presidency and he would not allow himself to be separated from them. ${ }^{10616}$

of promotion proposal, undated); D3695 (Witness statement of Bogdan Subotić dated 16 June 2013), paras. $22-$ 24.

10608 See paras. 606, 3165.

10609 See paras. 616, 1251.

10610 See para. 616.

10611 P2848 (Witness statement of Milorad Davidović dated 22 June 2011), para. 66.

10612 See para. 1284. By the end of July 1992, pursuant to instructions by Stanišić, Davidović planned an operation to arrest the paramiltary groups in Zvornik and Foča in co-operation with Andan and special units of the MUP. See paras. 866, 1290-1291.

10613 P2229 (Intercept of conversation between Mićo Stanišić and Nedjelko Žukić, 15 May 1992), pp. 1-2.

10614 P5646 (Intercept of conversation between Radovan Karadžić and Mićo Stanišić, 21 June 1992), pp. 2-3.

10615 D4274 (Article from Javnost, entitled “A Legal State is Being Established”, 3 October 1992), p. 3.

10616 P1105 (Transcript of $22^{\text {nd }}$ session of RS Assembly, 23-24 November 1992), p. 15. See also Mićo Stanišić, T. 46369-46370, 46403 (3 February 2014). 


\section{(G) Momčilo Mandić}

3306. Momčilo Mandić was the Deputy Minister of the Bosnian Serb MUP between 1991 and May 1992, and was then appointed the first RS Minister of Justice from May to November 1992. ${ }^{10617}$ Mandić left his position and went to Belgrade in November 1992 due to a conflict with Plavšić and Koljević. ${ }^{10618}$

3307. All decisions relating to staffing policies at the Bosnian Serb MUP required Mandić's approval and he consulted with the Accused and regional leaders in selecting candidates. ${ }^{10619}$ Mandić worked with the support and approval of the Accused. ${ }^{10620}$

3308. The Chamber refers to Section IV.A.3.a.ii.C regarding the split in the MUP and creation of a Bosnian Serb MUP and Mandić's involvement therein. ${ }^{10621}$ The Chamber found that Mandić took a leading role in ensuring that this division was carried out at a municipal level and in detailing how the new Bosnian Serb MUP was to be structured. ${ }^{10622}$

3309. Through the Ministry of Justice, Mandić was given the responsibility for the exchange of detainees through the Central Commission for the Exchange of Prisoners of War and Arrested Persons established by the Bosnian Serb Government on 8 May 1992. ${ }^{10623}$ Mandić was directly involved in organising the exchange of detainees. ${ }^{10624}$

10617 Momčilo Mandić, C2 (Transcript from Prosecutor v. Krajišnik), T. 8603, 8605; Momčilo Mandić, T. 44274428, (30 June 2010), T. 4545 (5 July 2010); P1083 (Minutes of meeting of representatives of SerBiH MUP, 11 February 1992), p. 4; P3051 (Minutes of expanded meeting of SNB and SerBiH Government, 22 April 1992), p. 3.

10618 Momčilo Mandić, C2 (Transcript from Prosecutor v. Krajišnik), T. 8609-8610, 9267-9270 (testifying that Krajišnik informed Mandić and Stanišić of the decision from the Bosnian Serb leadership, specifically at the request of Plavšić and Koljević, to send them to Belgrade and terminate their positions). See Branko Đeric, T. 27947-27948 (24 April 2012). See also Milorad Dodik, T. 36909-36910 (9 April 2013); D3321 (Witness statement of Milorad Skoko dated 1 April 2013), para. 30 (stating that he noticed animosity between Biljana Plavšić and Nikola Koljević on one side and ministers Mandić and Stanišić on the other).

10619 P1083 (Minutes of meeting of representatives of SerBiH MUP, 11 February 1992), pp. 1, 4; Momčilo Mandić, C2 (Transcript from Prosecutor v. Krajišnik), T. 8614, 8648.

10620 Branko Đeric, T. 27947-27950 (24 April 2012); P4982 (Witness Statement of Branko Đerić dated 5 April 2012), para. 22. See also Radomir Nešković T. 14340 (7 June 2011).

10621 The Chamber also recalls that Mandić and the Accused discussed the preparations for the creation of a separate Bosnian Serb MUP early on. See para. 2971 (referring to P5806 (Intercept of conversation between Radovan Karadžić and Momčilo Mandić, 3 December 1991), p. 2).

10622 See paras. 2990.

10623 See paras. 124-128. In June 1992, Mandić spoke to Krajišnik about criticism they had received about prisoner exchanges, and the fact that they were holding 400 prisoners at Kula Prison. P1101 (Intercept of conversation between Momčilo Krajišnik and Momčilo Mandić, 26 June 1992), pp. 2-3; Momčilo Mandić, C2 (Transcript from Prosecutor v. Krajišnik), T. 8886. See also P1129 (Letter from BIH Commission for Exchange of POWs to Central Commission for Exchange of Persons, undated).

10624 See paras. 2111, 2160, 2417. In August 1992, Mandić and a Serb journalist visited Planjo's House in Vogošća, and were asked by one of the detainees about possible exchanges; Mandić replied that there was no need for any 
3310. Mandić was advised about Bosnian Muslims being driven out of Ilidža in May 1992 and he further informed Prstojević that he was aware that Prstojević was issuing ultimatums to Bosnian Muslims and evicting them from settlements. ${ }^{10625}$ In a conversation with Prstojević in June 1992, Mandić said:

It has come to our attention and that of the Government that you are issuing ultimatums to some Turks; evicting people from certain settlements and people respond badly to it [...] Well please do not do anything like it, consult with Đerić first and those people up there, because this is very bad publicity for us [...] You have to be a little bit more flexible there and not touch those Muslims who are willing to listen and who are loyal. We cannot ethnically cleanse Ilidža or any other place. At least that is the attitude of the Government and political leadership and all. ${ }^{10626}$

Mandić continues and says that they should "place two or three Muslims somewhere" so that they could say that they were employing everyone who was loyal to the Serb state, regardless of nationality. ${ }^{10627}$ The Chamber finds that it is clear from this conversation that what was important to the Bosnian Serb authorities was maintaining a certain appearance regarding what was said in public, rather than the protection of the non-Serbs.

3311. Mandic was also aware that the Crisis Staffs used detainees for forced labour, including digging trenches and fortifying barracks on the frontlines. ${ }^{10628} \mathrm{He}$ was involved in providing detainees from Kula Prison and Planjo's House to perform forced labour in Ilidža and Vogošća. ${ }^{10629}$

\section{(H) Jovica Stanišić}

3312. Jovica Stanišić was the head of the SDB, which was part of the Serbian MUP. ${ }^{10630}$

3313. Stanišić and the Accused were in regular contact and discussed and co-ordinated a number of issues including political and military developments in BiH and Croatia. ${ }^{10631}$ There was also co-

exchanges as the detainees were at their "homes". See para. 2417. See also P1128 (Intercept of conversation between Momčilo Mandić and Nenad Vanovac, 23 June 1992).

10625 See para. 2159

10626 P1110 (Intercept of conversation between Momčilo Mandić and Neđeljko Prstojević, 2 June 1992), pp. 3-4.

10627 P1110 (Intercept of conversation between Momčilo Mandić and Neđeljko Prstojević, 2 July 1992), p. 4.

10628 Momčilo Mandić, C2 (Transcript from Prosecutor v. Krajišnik), T. 8768-8769, 8983-8985, 9107-9108 (testifying further that although Prime Minister Đerić insisted that prisoners of war not be used for physical labour, detainees were expected to perform labour and pursuant to the law on the military the army and the police had the right to request detainees to dig trenches or other similar types of work to defend facilities). See also P1143 (Intercept of conversation between Momčilo Mandić and Radivoje Grković, 3 July 1992).

10629 See paras. 2149, 2427.

10630 KDZ446, P28 (Transcript from Prosecutor v. S. Milošević), T. 23620 (under seal); P34 (Structure of Serbian SDB and Zvornik/Bijeljina MUP) (under seal); Momčilo Mandić, C2 (Transcript from Prosecutor v. Krajišnik), T. 9082. Jovica Stanišić was opposed to the multi-ethnic character of the Federal SUP and was of the view that its role could be handled by the Serbian MUP. P2848 (Witness statement of Milorad Davidović dated 22 June 2011), para. 38. The Chamber recalls that Davidović was tasked to lead a special unit of the Federal SUP and while Davidović's unit came from the Federal SUP in Belgrade it was re-subordinated to the command in RS MUP. See paras. 634, 3204. 
ordination pertaining to the involvement of the JNA ${ }^{10632}$ and recruiting volunteers. ${ }^{10633}$ Stanišić also liaised between the Accused and Slobodan Milošević. ${ }^{10634}$

3314. In May 1991, the Accused met with Jovica Stanišić and others including Franko Simatović at the Accused's apartment in Sarajevo, where among other issues they discussed maps of BiH. ${ }^{10635}$ The Accused and Jovica Stanišić were also involved in creating an account which could be used for "fictitious payments" relating to weapons and ammunition which had been procured in FRY for the RS and which evaded the embargo. ${ }^{10636}$ Stanišić told the Accused in November 1991 that he hoped to have a chance to work with him. ${ }^{10637}$ On 4 December 1991, Jovica Stanišić asked the Accused when he should send "men", to which the Accused responded, "[a]s soon as possible". ${ }^{10638}$

3315. Jovica Stanišić invited Arkan to visit the Serbian MUP and Arkan called Stanišić directly occasionally. ${ }^{10639}$ Jovica Stanišić attended meetings with the Accused, Slobodan Milošević, and others throughout the conflict to discuss providing assistance from Serbia to the Bosnian Serbs, including in the form of personnel, such as units of the Red Berets and Arkan's men. ${ }^{10640}$ According to Davidović, the Pale authorities, which included the Accused, Krajišnik, Mićo Stanišić, and Mladić, consulted the authorities in Belgrade-Slobodan Milošević, Jovica Stanišić,

10631 P2223 (Intercept of conversation between Radovan Karadžić and Jovica Stanišić, 8 September 1991), pp. 1-3; P5801 (Intercept of conversation between Radovan Karadžić and Jovica Stanišić, 4 December 1991), pp. 1-5; P5788 (Intercept of conversation between Radovan Karadžić and Jovica Stanišić, 21 December 1991), pp. 1-3; P5781 (Intercept of conversation between Radovan Karadžić and Jovica Stanišić, 29 December 1991); P5771 (Intercept of conversation between Radovan Karadžić and Jovica Stanišić, 7 January 1992); P5768 (Intercept of conversation between Radovan Karadžić and Jovica Stanišić, 12 January 1992); D301 (Intercept of conversation between Radovan Karadžić and Jovica Stanišić, 22 January 1992), pp. 2-9, 11-13; P5622 (Intercept of conversation between Radovan Karadžić and Jovica Stanišić, 25 January 1992), pp. 2-3 (wherein the Accused informed Stanišić about their opposition to the independence of $\mathrm{BiH}$ ). At times, Jovica Stanišić and the Accused spoke in code. D301 (Intercept of conversation between Radovan Karadžić and Jovica Stanišić, 22 January 1992), p. 5. See also P6305 (Photograph of Milan Martić, Radovan Karadžić, Momčilo Krajišnik, Jovica Stanišić, Franko Simatović, and others).

10632 P5771 (Intercept of conversation between Radovan Karadžić and Jovica Stanišić, 7 January 1992), pp. 2-3.

10633 P5801 (Intercept of conversation between Radovan Karadžić and Jovica Stanišić, 4 December 1991), p. 5.

10634 See, e.g., P5872 (Intercept of conversation between Radovan Karadžić and Jovica Stanišić, 20 December 1991); P5772 (Intercept of conversation between Radovan Karadžić and Jovica Stanišić, 5 January 1992); P5773 (Intercept of conversation between Radovan Karadžić and Jovica Stanišić, 5 January 1992), pp. 2-3.

10635 Milan Babić, P741 (Transcript from Prosecutor v. S. Milošević), T. 13082-13084; Milan Babić, P742 (Transcript from Prosecutor v. Krajišnik), T. 3407-3409.

10636 Milan Babić, P741 (Transcript from Prosecutor v. S. Milošević), T. 13083-13085.

10637 P5614 (Intercept of conversation between Radovan Karadžić and Jovica Stanišić, 29 November 1991), p. 2.

10638 P5801 (Intercept of conversation between Radovan Karadžić and Jovica Stanišić, 4 December 1991), pp. 3-4.

10639 KDZ446, P28 (Transcript from Prosecutor v. S. Milošević), T. 23651-23652 (under seal).

10640 P1484 (Ratko Mladić's notebook, 28 October 1993-15 January 1994), pp. 53-61. See para. 3287. See also P1485 (Ratko Mladić's notebook, 9 January-21 March 1994), pp. 165-179 (wherein Mladić provided details about another meeting on 15 March 1994 in Belgrade attended by Jovića Stanišić, Martić, Mladić, and the Accused). 
and later Perišić—“about everything”; this was "common knowledge as they did not have enough resources of their own". ${ }^{10641}$

3316. Stanišić spoke about the possibility of an all-out war and that they would "exterminate them completely". ${ }^{10642}$ In 1994, Stanišić told RSK MUP officials that he supported the objective to "fight to achieve the common goals of all the Serbian lands". 10643

3317. The authorities in Serbia were also involved in establishing multiple training camps for Bosnian Serbs including special police units of the RS and a camp run by Captain Dragan. ${ }^{10644}$ The Accused supported the work of these training camps. ${ }^{10645}$

\section{(I) Franko Simatović}

3318. Franko Simatović, also known as "Frenki", served under Jovica Stanišić in the SDB, as part of the Serbian MUP. ${ }^{10646}$ The Chamber recalls that units such as the Red Berets and Arkan's men were directly subordinated to the Serbian MUP and to Franko Simatović. ${ }^{10647}$

3319. In a conversation on 28 January 1992 with the Accused regarding plans to meet, Simatović told the Accused: "You're the main man there doctor, and that's how it stays". ${ }^{10648}$ As stated above, Simatović also attended the meeting in April or May 1992 with the Accused, Mićo Stanišić, Arkan, and others to discuss "further activities" of the SDB. ${ }^{10649}$

\footnotetext{
10641 P2848 (Witness statement of Milorad Davidović dated 22 June 2011), para. 72 (stating further that he often saw Mićo Stanišić at the Federal SUP and Serbian MUP buildings).

10642 D301 (Intercept of conversation between Radovan Karadžić and Jovica Stanišić, 22 January 1992), p. 4.

10643 P6307 (Letter from RDB to RSK MUP, 5 July 1994), p. 1.

10644 P2852 (Video clips depicting award ceremonies), p. 3; [REDACTED]; P4262 (Request of Municipal Assembly Executive Board of Banja Luka, 19 August 1994); P3384 (Report of Eastern Bosnia Corps, 7 June 1992), p. 1; P3023 (Witness statement of Đorđe Ristanić dated 15 June 2011), paras. 97-103; Milan Martić, T. 38149-38152 (13 May 2013); P6317 (Letter from Captain Dragan to Serbia TO command, 8 November 1991); Milan Babić, P741 (Transcript from Prosecutor v. S. Milošević), T. 13119, 13121-13122; Milorad Davidović, T. 1551315514 (28 June 2011).

10645 P1478 (Ratko Mladić's notebook, 27 May-31 July 1992), p. 270; P3384 (Report of Eastern Bosnia Corps, 7 June 1992), p. 1.

10646 P34 (Structure of Serbian SDB and Zvornik/Bijeljina MUP) (under seal); Milan Babić, P741 (Transcript from Prosecutor v. S. Milošević), T. 13118; Milorad Davidović, T. 15824 (1 July 2011). See also P6305 (Photograph of Milan Martić, Radovan Karadžić, Momčilo Krajišnik, Jovica Stanišić, Franko Simatović, and others).

10647 P2848 (Witness statement of Milorad Davidović dated 22 June 2011), paras. 80, 112. See also para. 830, 3287.

10648 P5759 (Intercepts of conversations between (i) Radovan Karadžić and "Braco" and (ii) Radovan Karadžić and "Frenki" Simatović, 28 January 1992), pp. 4-8. In the summer of 1992, after Davidović arrested members of the Red Berets, Frenki Simatović phoned Davidović twice, cursed him, and asked how he had the right to act in that way. See para. 830 .

10649 P2848 (Witness statement of Milorad Davidović dated 22 June 2011), para. 66.
} 
3320. Simatović was also responsible for monitoring the training of Serb Forces, includings units trained in camps run by Captain Dragan. ${ }^{10650}$

\section{(J) Željko Ražnatović (Arkan)}

3321. Željko Ražnatović, also known as Arkan, was the commander of a Serbian paramilitary group named after him. ${ }^{10651}$

3322. Arkan's men were involved in operations in Bijeljina, Bratunac, Brčko, Rogatica, Sokolac, Vlasenica, Zvornik, Ilidža, and Pale in spring of 1992. ${ }^{10652}$ Arkan himself was personally involved in the take-over operations in Bijeljina and Zvornik. ${ }^{10653}$ Arkan also trained members of the Mauzer's Panthers who operated in Bijeljina, Zvornik, and Brčko. ${ }^{10654}$

3323. The Chamber recalls that after successfully taking over Bijeljina on 4 April 1992, Arkan was welcomed there and "treated like a god"; some of his men were given official positions and based themselves in the local SDS building. ${ }^{10655}$ The Chamber recalls that Plavšić was in communication with Arkan beginning in April 1992. ${ }^{10656}$ She congratulated Arkan for saving the Bosnian Serbs in Bijeljina and was filmed kissing and hugging him. ${ }^{10657}$

3324. Arkan's men were also involved in killings of Bosnian Muslim civilians in Bijeljina and Zvornik in April 1992. ${ }^{10658}$ Arkan's men and Mauzer's Panthers were also involved in mistreating Bosnian Muslims in Bijeljina, Bratunac, Rogatica, Vlasenica, Zvornik, and Hadžići, including in detention centres; these units also looted property of Bosnian Muslims and were involved in expelling Bosnian Muslims from Bijeljina and Zvornik after the take-overs in those municipalities. $^{10659}$

\footnotetext{
10650 Milan Babić, P741 (Transcript from Prosecutor v. S. Milošević), T. 13118-13125; P5614 (Intercept of conversation between Radovan Karadžić and Jovica Stanišić, 29 November 1991), p. 2; [REDACTED]. See also P6388 (Excerpt from video of interview with Vojislav Šešelj for "Death of Yugoslavia” documentary, with transcript), pp. 2-4.

10651 See para. 232.

10652 See paras. 232, 611-616, 714, 724, 768-769, 798, 969, 986-987, 1049, 1155, 1242-1246, 1249, 1251, 1255, 1260, 2301, 3182-3183.

10653 See paras. 611-616, 1245-1246.

10654 See paras. 233, 608, 611-612.

10655 See para. 614.

10656 See para. 3260; see also Momcilo Mandić, T. 4664 (6 July 2010).

10657 See para. 3260.

10658 See Scheduled Incidents A.1.1, A.16.1.

10659 See paras. 631-632, 672, 768-769, 771, 986-987, 1155, 1245-1247, 1317-1319, 1361, 1365, $2104,2112$.
} 
3325. Arkan attended meetings and had direct contact with the Accused. ${ }^{10660}$ As noted above, Arkan wrote to the Accused in 1994 to inform him that his men supported the Accused's "heroic resistance" against NATO and that "[a]s always we, with all our available forces, stand to protect Serbian people" and that they were expecting the Accused's call to join the VRS to "protect Serbian nationality and Orthodoxy". ${ }^{10661}$ In the autumn of 1995, at an event in Bijeljina, Arkan repeated his commitment to the Accused to return to defend the "Serbian territory and our Orthodox religion" if called by the Accused. ${ }^{10662}$ On this occasion, the Accused awarded Arkan a certificate to congratulate him and thank him and his unit for their efforts in defending the Bosnian Serbs. ${ }^{10663}$

\section{(K) Vojislav Šešelj}

3326. Šešelj was the leader of the SRS and of the "Serbian Chetnik Movement". ${ }^{1064}$ In May 1991, Šešelj praised the Accused as "the true leader of the Serbian people" in BiH, stating further that he enjoyed their "undivided trust" and that the SRS supported the policies of the SDS. ${ }^{10665}$ Šešelj stated that $\mathrm{BiH}$ was fundamentally Serbian and that either Muslim fundamentalists should leave or the Muslims should accept this and become loyal citizens of Serbia. ${ }^{10666}$ Also in May 1991, the Accused in an interview spoke of Šešelj and his "political force" but said that they differed in terms of the choice of method. ${ }^{10667}$

3327. Šešelj met with the Accused and the Bosnian Serb leadership on several occasions during the war in BiH. ${ }^{10668}$ In May 1992, Šešelj spoke about contacting the Accused with respect to the

\footnotetext{
10660 See paras. 3187-3188. (referring to P2848 (Witness statement of Milorad Davidović dated 22 June 2011), para. 55; Milorad Davidović, T. 15465 (24 June 2011).

10661 P2854 (Letter from Party for Serbian Unity to Radovan Karadžić, 16 April 1994); Milorad Davidović, T. 15477 (28 June 2011). See also para. 3228.

10662 See para. 3228.

10663 See para. 3228 (referring to P2858 (Video footage of Radovan Karadžić and Arkan at award ceremony in Bijeljina, with transcript). After this, Arkan left RS and went to Serbia. D3137 (Witness statement of Svetozar Mihajlović dated 17 March 2013), para. 10.

10664 P6390 (Article from Der Spiegel entitled “Šešelj: Serbian Policy Must Not Be Defined in Washington”, 8 August 1991), p. 1; D3666 (TANJUG news report, 15 May 1993); Vojislav Šešelj, T. 39543-39545 (7 June 2013); P6389 (Vojislav Šešelj's interview with Pogledi, 31 May 1991), pp. 1-2.

10665 P6387 (Vojislav Šešelj's interview with ON newspaper, 24 May 1991), pp. 1-2. See also Vojislav Šešelj, T. 39543-39544 (7 June 2013); D3665 (Witness statement of Vojislav Šešelj dated 1 June 2013), para. 37 ; D3667 (Transcript of Vojislav Šešelj's press conference, 26 March 1992), p. 1.

10666 P6387 (Vojislav Šešelj's interview with ON newspaper, 24 May 1991), p. 6-7, 9 (wherein Šešelj further stated that Serbs, with their genetic coding, were born to be soldiers and were always ready to go to war and that they had fully achieved their objectives that they were trying to establish SRS boards in every Serbian municipality and consolidate the party).

10667 D1281 (Articles from Večernje Novine entitled "Karadžić shocked me” and "Šešelj is amiable", 9 May 1991), p. 2.

10668 D3666 (TANJUG news report, 15 May 1993); D3665 (Witness statement of Vojislav Šešelj dated 1 June 2013), paras. 36-37.
} 
withdrawal and deployment of his men. ${ }^{10669}$ Šešelj sent large groups of SRS volunteer fighters from Serbia to assist in Serb operations in Croatia and BiH. ${ }^{10670}$ Šešelj acknowledged that his men were in $\mathrm{BiH}$ and were in all areas for the "protection of the Serbian people" and the defence of their borders. ${ }^{10671}$ Slobodan Milošević approved of the SRS's action in sending volunteers. ${ }^{10672}$

3328. Šešelj's men were involved in operations in Bratunac, Zvornik, Hadžići, Novo Sarajevo Vogošća, Brčko, and Rogatica in April and May 1992. ${ }^{10673}$ Furthermore, Šešelj made public statements about the participation of SRS volunteers in the take-over of Bijeljina and specifically the significant contribution of Mirko Blagojević as the commander of the SRS units to the "liberation" of Bijeljina. ${ }^{10674}$ In May 1993, Šešelj proclaimed Mirko Blagojević a "Vojvoda" in recognition of his participation in operations in municipalities including Bijeljina. ${ }^{10675}$

3329. The SRS and Šešelj advocated the idea of a homogeneous Greater Serbia which involved the unification of all Serb lands and the removal of the non-Serb population. ${ }^{10676}$ In March 1992, Šešelj spoke about the prospect of great bloodshed in $\mathrm{BiH}$ and called upon the Bosnian Serbs to preserve all their ethnic areas. ${ }^{10677}$ In a speech, Šešelj said that the "Muslims and Croats do not represent a threat for us for a long time already. Only, brothers and sisters Serbs, there should not be hesitating, waiting [...] the next time they strike, we should finish them off, so they never strike back". ${ }^{0678}$ Šešelj also spoke about BiH being undoubtedly Serbian, and that if "any Muslim

\footnotetext{
10669 P2228 (Intercept of conversation between Vojislav Šešelj and Branislav Gavrilović, April 1992); D3665 (Witness statement of Vojislav Šešelj dated 1 June 2013), paras. 58-59.

10670 P6388 (Excerpt from video of interview with Vojislav Šešelj for "Death of Yugoslavia" documentary, with transcript), pp. 2-4; Milan Babić, P742 (Transcript from Prosecutor v. Krajišnik), T. 3394-3395; D3665 (Witness statement of Vojislav Šešelj dated 1 June 2013), paras. 24, 29-30, 50, 55-59.

10671 P6389 (Vojislav Šešelj's interview with Pogledi, 31 May 1991), p. 1.

10672 Vojislav Šešelj, T. 39571 (10 June 2013).

10673 See paras. 3191-3192.

10674 D3667 (Transcript of Vojislav Šešelj's press conference, 26 March 1992), p. 12; P3033 (Reynaud Theunens's expert report entitled "Radovan Karadžić and the SRBiH TO-VRS (1992-1995)"), e-court pp. 379-380.

10675 D3665 (Witness statement of Vojislav Šešelj dated 1 June 2013), para. 49; P3033 (Reynaud Theunens's expert report entitled "Radovan Karadžić and the SRBiH TO-VRS (1992-1995)"), e-court pp. 381-382.

10676 Milan Babić, P742 (Transcript from Prosecutor v. Krajišnik), T. 3393-3394. See also D3665 (Witness statement of Vojislav Šešelj dated 1 June 2013), paras. 15-16; Vojislav Šešelj, T. 39554-39555 (10 June 2013); P2527 (Video footage of speeches of Vojislav Šešelj and Radovan Karadžić, 6 May 1991, with transcript), p. 1; P6391 (Excerpts from Vojislav Šešelj's speech); P6389 (Vojislav Šešelj's interview with Pogledi, 31 May 1991), p. 7; P6390 (Article from Der Spiegel entitled "Šešelj: Serbian Policy Must Not Be Defined in Washington", 8 August 1991), p. 1. Šešelj also stated the SRS advocated brotherhood and unity of "Orthodox Serbs, Catholic Serbs, Muslim Serbs, Protestant Serbs and atheist Serbs" and complete respect for the rights of national minorities: D3665 (Witness statement of Vojislav Šešelj dated 1 June 2013), paras. 15-16, 31-35, 39, 41; D3667 (Transcript of Vojislav Šešelj's press conference, 26 March-16 April 1992), p. 20; Vojislav Šešelj, T. 39600-39605 (10 June 2013). The Chamber does not find this evidence to be reliable. In reaching that conclusion the Chamber considered that Šešelj had a clear self-interest in testifying in this regard and his evidence was marked by political statements which undermined his credibility in this regard.

10677 D3667 (Transcript of Vojislav Šešelj's press conference, 26 March 1992), p. 1.

10678 P6393 (Video clip of interview with Vojislav Šešelj). See also Vojislav Šešelj, T. 39589 (10 June 2013).
} 
fundamentalists do not like that, they will have to pack their suitcases and leave". ${ }^{10679}$

3330. In May 1992, Šešelj spoke about the "traditional enemies" of the Serbs and the need for them to be united to prevent a "new genocide against the Serbian people" and of the revenge Serbs would take against Muslims if they repeated history again. ${ }^{10680}$ Šešelj, on behalf of the SRS, also expressed his support for the formation of the $\mathrm{SerBiH}$ and his view that the Bosnian Serb authorities should demarcate Serb territory, proclaim its own TO and police in territories under its control, and simultaneously "liberate" those areas which were not under Serb control. ${ }^{10681}$

\section{v. Accused's knowledge of crimes and measures he took to prevent and punish them}

(A) Knowledge of crimes committed throughout the Municipalities

3331. The Prosecution argues that from the beginning of the conflict in 1992, the Accused was notified of crimes committed against non-Serbs in the Municipalities by Serb Forces. ${ }^{10682}$ The Accused acknowledges that he received information from the VRS, the MUP, and municipal bodies but argues that the information rarely referred to illegal activities at the local level, and when it did, the Bosnian Serb leadership reacted immediately. ${ }^{10683}$

3332. At the outset, the Chamber notes that the Accused received information about occurrences in the Municipalities from a number of sources. As President of the RS, he received reports and attended Bosnian Serb Assembly sessions where representatives would report on the situation in their municipalities. ${ }^{10684} \mathrm{He}$ also met regularly with municipal representatives and obtained reports in this manner. ${ }^{10685}$ His close associates also regularly visited the field and communicated with municipal leaders. ${ }^{10686}$ Furthermore, the Bosnian Serb leadership followed international coverage of the events in BiH during the conflict. ${ }^{10687}$ Finally, the Chamber notes that from the beginning of the conflict in 1992, the Accused was informed by international representatives, such as Okun,

\footnotetext{
10679 P6387 (Vojislav Šešelj's interview with ON newspaper, 24 May 1991), p. 6; Vojislav Šešelj, T. 39546-39548 (7 June 2013).

10680 See para. 2657.

10681 See para. 2798.

10682 Prosecution Final Brief, para. 512.

10683 Defence Final Brief, paras. 555, 641.

10684 D3695 (Witness statement of Bogdan Subotić dated 16 June 2013), para. 86; P1478 (Ratko Mladić's notebook, 27 May-31 July 1992), pp. 125-126.

10685 P1478 (Ratko Mladić's notebook, 27 May-31 July 1992), p. 246 (notes from a meeting on 30 June 1992 between Mladić, the Accused, and municipal representatives from Srebrenica, Bratunac, Vlasenica, and Zvornik). See also paras. 3246-3247.

10686 See paras. 3246-3248, 3260, 3262, 3269, 3303-3304, 3310.

10687 Momčilo Mandić, C2 (Transcript from Prosecutor v. Krajišnik), T. 9126; KDZ240, P2935 (Transcript from Prosecutor v. Krajišnik), T. 6825-6826 (closed session).
} 
Mazowiecki, and UNPROFOR officials of the forcible displacement of non-Serb civilians ${ }^{10688}$ and that the issue of "ethnic cleansing" was also often raised with the Accused in media interviews. ${ }^{10689}$ The Chamber will assess below the evidence pertaining to the information that the Accused received about specific municipalities.

3333. In relation to Bijeljina, when at least 45 non-Serb civilians were killed by Serb Forces on 1 and 2 April 1992 the Accused was informed of the event. ${ }^{10690}$ On 4 April 1992, members of the $\mathrm{BiH}$ presidency and high ranking army officials assessed the situation in Bijeljina municipality, ${ }^{10691}$ and the Accused made a public announcement referring to the "regrettable" incidents in Bijeljina but blamed the BiH Presidency for instigating chaos by calling for mobilisation. ${ }^{10692}$

3334. At a meeting of the Bosnian Serb Presidency on 23 June 1992, the Accused expressed his view that Mauzer and Blagojević's paramilitary units, which were active in Bijeljina, were very extreme, and that all units should be placed under a single command of the army or the police. ${ }^{10693}$ Meanwhile, at a Bosnian Serb Assembly session in late June 1992, the Accused said that the Bosnian Muslims who continued to live in Bijeljina, forming 20\% of the population, were not considered "second class citizens" and that the government officials were actually trying to persuade them that they had nothing to fear. ${ }^{10694}$ The Chamber recalls that in fact during the summer of 1992, Serb Forces instilled fear in the Bosnian Muslims who remained in Bijeljina and that Bosnian Muslims were forcibly expelled from Bijeljina by members of the Bijeljina Crisis Staff, SDS, Mauzer's unit, special police units, and Vojkan Đurković, while others were sent to Batković camp. ${ }^{10695}$

3335. The Accused was later informed by the Bijeljina SJB on 29 July 1992 about the criminal behaviour of paramilitary groups during and after the take-over of Bijeljina, which resulted in rapes, thefts, robberies, killings, and the displacement of Bosnian Muslim and Serb civilians. ${ }^{10696}$ Živan Filipović, former chief of the Bijeljina Municipal TO Staff, testified that the Accused and Mladić attempted to "shake off these paramilitary formations which only caused damage, both to

\footnotetext{
10688 Herbert Okun, P776 (Transcript from Prosecutor v. Krajišnik), T. 4191; KDZ240, P2935 (Transcript from Prosecutor v. Krajišnik), T. 6830-6832, 6834-6835 (closed session).

10689 Jeremy Bowen, T. 10095-10096 (13 January 2011).

10690 D3089 (Witness statement of Milivoje Kićanović dated 3 March 2013), para. 18. See Scheduled Incident A.1.1.

10691 D3133 (Witness statement of Cvijetin Simić dated 16 March 2013), para. 32.

10692 D394 (Announcement of SNB, 4 April 1992); D392 (Conclusions of SRBiH Presidency, 4 April 1992).

10693 P1478 (Ratko Mladić's notebook, 27 May-31 July 1992), pp. 219-220; Milorad Davidović, T. 15770-15773 (30 June 2011). See also P2900 (Letter from Bijeljina CSB to Radovan Karadžić, 29 July 1992).

10694 D92 (Transcript of $17^{\text {th }}$ session of SerBiH Assembly, 24-26 July 1992), p. 21.

10695 See paras. 671-673.

10696 P2900 (Letter from Bijeljina CSB to Radovan Karadžić, 29 July 1992), p. 2. See also paras. 610-638.
} 
the people and the army and the political sphere". ${ }^{10697}$ After the Accused complained to the Prime Minister of the FRY that Serbian paramilitaries were out of control, Davidović was sent to Bijeljina in early July 1992 to investigate the situation. ${ }^{10698}$ Moreover, on 2 September 1992 the Accused was among the attendees who participated in a meeting with military and political officials in Bijeljina. ${ }^{10699}$ The Accused acknowledged that the chief of the party, the MUP and the president of the municipality had been involved in crime "here and there". ${ }^{10700}$

3336. In relation to Zvornik, Colm Doyle passed on information to the Accused that he received from Martin Bell of the BBC that on 10 April 1992, 25,000 people were leaving the municipality. ${ }^{10701}$ The Accused "seemed to be a little bit alarmed" and then advised Doyle that he did not trust or believe the BBC. ${ }^{10702}$ At a mid-April 1992 meeting with international humanitarian organisations and members of the SDS and JNA, the Accused placed the blame for events in Zvornik on irregular paramilitaries who he claimed were not under the control of the SDS. ${ }^{10703}$ At a meeting held on 30 June 1992 between representatives of the Zvornik municipality, the Accused, Mladić and other officials, ${ }^{10704}$ Branko Grujić, a representative of the Interim Government of Zvornik, stated that "[w]e have successfully implemented the President's decision to settle Divič and Kozluk with our children."10705 Marko Pavlović said that they were active in moving out Muslims, and had also moved people for the sake of their "heroes" who had fled from Kovačevići. ${ }^{10706}$ The Chamber recalls that in fact, most of the inhabitants of Divič and Kozluk

\footnotetext{
10697 Živan Filipović, T. 35818 (21 March 2013).

10698 P2848 (Witness statement of Milorad Davidović dated 22 June 2011), paras. 73-75. See also paras. 634-638.

10699 P1479 (Ratko Mladić's notebook, 16 July-9 September 1992), pp. 131-132.

10700 P1479 (Ratko Mladić's notebook, 16 July-9 September 1992), p. 155.

10701 Colm Doyle, P918 (Transcript from Prosecutor v. S. Milošević), T. 25275. See also Martin Bell, T. 9787 (14 December 2010); P1996 (Witness statement of Martin Bell dated 8 March 2010), para. 25 (testifying that he informed Doyle of the events in Zvornik and suggested it be brought to the attention of the Accused). In this regard, the Chamber recalls that following the attack on Zvornik by the Bosnian Serb Forces on 8 April 1992, approximately 10,000 people, the majority of whom were Bosnian Muslim, left Zvornik. See paras. 1250, 1360.

10702 Colm Doyle, P918 (Transcript from Prosecutor v. S. Milošević), T. 25275. The Chamber received additional evidence that the Accused received information about the displacement of civilians from Zvornik. On 8 April 2010, [REDACTED].

10703 [REDACTED].

10704 P1478 (Ratko Mladić's notebook, 27 May-31 July 1992), p. 246; D3654 (Witness statement of KW317 dated 26 September 2012), para. 69 (under seal). See also Marinko Vasilić, T. 39954 (13 June 2013).

10705 P1478 (Ratko Mladić's notebook, 27 May-31 July 1992), pp. 243, 249-250.

10706 P1478 (Ratko Mladić's notebook, 27 May-31 July 1992), pp. 249-251, 253-254; Petko Panić, T. 19138-19139 (19 September 2011). See also Milenko Stanić, T. 34033-34034 (19 February 2013) (testifying that he could not recall the issues discussed at this meeting pertaining to Zvornik which were presented by Marko Pavlović). Branko Grujić testified that the note in Mladić's notebook is incorrect as he never uttered the words attributed to him and he insisted that it was a local decision to remove the Bosnian Muslims and the Accused did not allow forcible transfer. Branko Grujić, T. 40418-40420 (25 June 2013). The Chamber recalls that that Grujić's evidence was marked by multiple contradictions, evasiveness, and bias. See paras. 4237, 4239, 4255, 4270, 4279, 4283, 4308, 4357, 4441, 4572. In light of this, the Chamber does not believe his denial as to the content of Mladić's notes. The Chamber further notes that Grujić testified that the BCS word "iseljavanje" in Exhibit P1478 was incorrectly translated as "evicting" when it means "moving out at their request". Branko Grujić, T.
} 
were Bosnian Muslims and that after they were relocated, Bosnian Serbs who had fled their homes in other areas settled there. ${ }^{10707}$

3337. On 5 July 1992, the Accused stated that he had ordered an immediate investigation into the displacement of Bosnian Muslim civilians from Zvornik and had been told that the Bosnian Muslim inhabitants of Kozluk had requested approval to move to third-countries because they felt like hostages. ${ }^{10708}$ He further advised that the Zvornik authorities possessed written evidence that they left of their own free will and added that they could return anytime they wanted. ${ }^{10709}$ The Chamber considers that the implication that the Accused learned that Bosnian Muslims were removed from Zvornik with the assistance of the Interim Government of Zvornik in order to settle Bosnian Serbs who had fled from elsewhere indicates that the Accused was aware of the forcible nature of the movement. This is corroborated by the fact that the Accused was informed that the Bosnian Muslims who fled Kozluk had felt like hostages. The Accused was later made aware of further efforts to remove Bosnian-Muslim civilians held in the collection centre in Divič in September 1992. ${ }^{10710}$ On 21 January 1993, the Accused commented that the number of inhabitants in Zvornik remained the same but it changed from being 50\% non-Serb to completely Serb, with more than 24,000 Serbs from Zenica and Central Bosnia having arrived. ${ }^{10711}$ On 10 April 1993, the Accused attended a celebration marking "the day of the liberation of Zvornik". 10712

3338. The Chamber also received evidence that the Accused knew that Neđeljko Prstojević, President of the Ilidža Crisis Staff, was involved in “ethnic cleansing” in Ilidža. In June 1992, after being relieved of his military command responsibilities due to his involvement in expelling Bosnian Muslims from Ilidža, Prstojević managed to return to Ilidža and continue this practice after he met with the Accused in Pale. ${ }^{10713}$ Furthermore, on 2 July 1992, in an intercepted telephone conversation, Mandić confronted Prstojević about his involvement in forcing Bosnian Muslims out of Ilidža and advised him that the information about this had "already reached the top". ${ }^{10714}$ In

40421 (25 June 2013), Branko Grujić, T. 40458 (26 June 2013). The Chamber accepts the clarification made by Grujić but considers that in the context of the notes of the meeting, the meaning is effectively the same as "evicting".

10707 Petko Panić, T. 19136-19137 (19 September 2011), T. 19151-19152 (20 September 2011). See also paras. 1261, 1267, 1269.

10708 P2937 (Radovan Karadžić letter, 5 July 1992) (under seal), p. 1.

10709 P2937 (Radovan Karadžić letter, 5 July 1992) (under seal), p. 1.

10710 P5402 (Telegram from Neimar to Kapija 333, 13 September 1992). See also P5403 (Telegram from Neimar to Kapija 333, 10 September 1992).

10711 See para. 2760. See also paras. 2772, 3068.

10712 P5167 (Report of Zvornik Brigade, 10 April 1993), p. 2.

10713 See para. 2132, [REDACTED].

10714 P1110 (Intercept of conversation between Momčilo Mandić and Neđeljko Prstojević, 2 July 1992), p. 4. See para. 2159. 
addition, at a July 1992 Bosnian Serb Assembly session, in the Accused's presence, Prstojević boasted about Ilidža's achievements in extending Bosnian Serb territory and driving Bosnian Muslims out of "territories where they had actually been [a] majority". 10715

3339. On 6 June 1992, the Bosnian Serb leadership, including the Accused, attended a briefing about Bratunac in which it was indicated that there were no Bosnian Muslims remaining in Bratunac and that it was a "fully liberated town". 10716 On 30 June 1992, the Accused was further informed by Ljubislav Simić, President of Bratunac, that from a situation where the Bosnian Muslims were the majority before the conflict, only two remained in the municipality. ${ }^{10717}$ Simić also reported on looting by the army. ${ }^{10718}$

3340. On 23 June 1992, the Accused was informed of events in Bosanski Novi regarding the 9,000 Bosnian Muslims who left after being subjected to intimidation and a policy of harassment and discrimination at the hands of the Bosnian Serbs. ${ }^{10719}$

3341. The Accused, in July 1992, acknowledged that there had been a number of "traitors" who had committed inhumane acts and that they would be tried and punished by law, but suggested that the most severe acts were rare and that there were more frequent examples of unlawful acquisition of property. ${ }^{10720}$ The Accused characterised this as a consequence of the "inter-ethnic and religious war" and that some individuals were involved in taking the property of both Muslims and Serbs. ${ }^{10721}$ The Accused stated that these crimes occurred without the knowledge of regular soldiers and affected their morale. ${ }^{10722}$

3342. On 17 July 1992, the Bosnian Serb MUP wrote a report to the Accused and the Prime Minister. ${ }^{10723}$ It stated that almost all paramilitaries lacked a unified command and engaged in looting, which posed a major threat to public peace and order. ${ }^{10724}$ The report also stated that the

\footnotetext{
10715 D92 (Transcript of $17^{\text {th }}$ session of SerBiH Assembly, 24-26 July 1992), p. 66.

10716 P1478 (Ratko Mladić's notebook, 27 May-31 July 1992), pp. 93-94, 101.

10717 P1478 (Ratko Mladić's notebook, 27 May-31 July 1992), pp. 246, 258. The Chamber notes that Ljubislav Simić testified that he said there were only two Muslims remaining in Bratunac ironically to highlight the problems being caused by paramilitaries. Ljubisav Simić, T. 37303-37304 (16 April 2013). The Chamber views Simić's evidence in this regard with caution given the problems with his credibility identified earlier in this Judgement at footnote 2268 and that he had an interest in distancing himself from such a statement.

10718 P1478 (Ratko Mladić's notebook, 27 May-31 July 1992), p. 259.

10719 KDZ240, P2935 (Transcript from Prosecutor v. Krajišnik), T. 6786-6789, 6834 (under seal).

10720 D92 (Transcript of $17^{\text {th }}$ session of SerBiH Assembly, 24-26 July 1992), p. 17.

10721 D92 (Transcript of $17^{\text {th }}$ session of SerBiH Assembly, 24-26 July 1992), p. 17. See also D456 (Transcript of $20^{\text {th }}$ session of RS Assembly, 14-15 September 1992), p. 14; P809 (Video footage of Radovan Karadžić's Press Conference at ICFY, 18 September 1992), p. 1.

10722 D92 (Transcript of $17^{\text {th }}$ session of SerBiH Assembly, 24-26 July 1992), p. 17.

10723 P1096 (SerBiH MUP Report on Some Aspects of Work Done to Date and the Tasks Ahead, 17 July 1992).

10724 P1096 (SerBiH MUP Report on Some Aspects of Work Done to Date and the Tasks Ahead, 17 July 1992), p. 2.
} 
army, Crisis Staffs, and War Presidencies had requested that the army round up as many Bosnian Muslim civilians as possible. ${ }^{10725}$ The Accused had already received information in May and June 1992 that Serb Forces were engaged in looting and that there were problems with robberies "of even Serbian people". 10726

3343. On 19 July 1992, the Accused wrote, inter alia, to the Novo Sarajevo, Pale, Ilidža, Hadžići, Rajlovac, and Sokolac municipalities, requesting that they, in co-operation with the SJBs, make an inventory of all housing facilities which were left vacant following the "voluntary departure" of the Bosnian Muslim population and that pursuant to a Presidency decision those facilities would be given for the temporary use of Bosnian Serbs from Sarajevo. ${ }^{10727}$

3344. The Accused was informed on 28 July 1992 that paramilitary groups frequently followed VRS units into inhabited areas in order to loot after combat was completed in those areas. ${ }^{10728}$

3345. On 16 August 1992, Doyle mentioned to the Accused that he was familiar with the practice of non-Serbs being forced to leave their homes and that some of these people were forced to pay money for permission to leave. The Accused agreed that this was not legal and should not happen. $^{10729}$

3346. On 22 August 1992, the Accused was informed by a report from the Banja Luka MUP and from international organisations of the incident at Korićanske Stijene in which approximately 200 non-Serb men were killed by Serb Forces and thrown down a ravine at Mount Vlašić on 21 August 1992. ${ }^{10730}$ The Accused was angry because he had already received calls from international

\footnotetext{
10725 P1096 (SerBiH MUP Report on Some Aspects of Work Done to Date and the Tasks Ahead, 17 July 1992), p. 3; Momčilo Mandić, C2 (Transcript from Prosecutor v. Krajišnik), T. 8944; Momčilo Mandić, T. 5166-5167 (14 July 2010).

10726 D414 (Minutes of $19^{\text {th }}$ session of Government of SerBiH, 2 June 1992), p. 1; P2848 (Witness statement of Milorad Davidović dated 22 June 2011), para. 54; Milorad Davidović, T. 15612, 15634-15636 (29 June 2011 ).

10727 P739 (RS Presidency request to various municipalities, 19 July 1992).

10728 P1500 (VRS Main Staff Order, 28 July 1992), pp. 1, 3. See also Momčilo Mandić, C2 (Transcript from Prosecutor v. Krajišnik), T. 9119.

10729 Colm Doyle, P918 (Transcript from Prosecutor v. S. Milošević), T. 25307-25308; Colm Doyle, T. 2874-2875 (27 May 2010).

10730 D3695 (Witness statement of Bogdan Subotić dated 16 June 2013), paras. 242-246; Bogdan Subotić, T. 4010540111 (20 June 2013); T. 40173-40175 (21 June 2013). See also D4379 (Witness statement of Vladimir Glamočić dated 10 February 2014), paras. 14-15; P3768 (Witness statement of Milan Komljenović dated 28 October 2011), para. 5 (stating that Glamočić admitted to him years after the incident, that the Accused had called him on the night of the Korićanske Stijene incident to demand answers); P5446 (Report of $1^{\text {st }}$ Krajina Corps, 22 August 1992); D2040 (Special report of the $22^{\text {nd }}$ Light Infantry Brigade, 21 August 1992). See Scheduled Incident B.15.6.
} 
organisations about the killings and "he simply couldn't believe that something like that had indeed happened". 10731

3347. On 25 August 1992, the Accused acknowledged his awareness of the "so called practice of ethnic cleansing" and that "the majority of those displaced are undoubtedly Bosnian Muslims". ${ }^{0732}$ He wrote a letter explaining that he had issued an order that the forced transfer of the civilian population must be prevented and any written statements by refugees that they would not return were considered legally invalid. ${ }^{10733}$ However, he stated that the civilian population must be allowed to move freely out of a war zone if that was their desire under the Geneva Conventions, blaming the failure on the part of the international community to understand the deep-rooted antagonism and hatred between the three ethnicities in $\mathrm{BiH}$, which caused people to leave their communities in droves. ${ }^{10734}$

3348. At an international press conference in September 1992, the Accused again acknowledged that there was "ethnic cleansing" in $\mathrm{BiH}$ and stated that this was not part of a policy, emphasising that people were leaving the territory out of fear and that if there were examples of expulsion by force this was to be condemned. ${ }^{10735}$ At this same press conference when confronted with allegations and reports of atrocities being committed by Bosnian Serbs, the Accused claimed the reports were not honest and did not report on what the Bosnian Muslims and Bosnian Croats were doing. He also questioned whether these acts were part of a policy and stated that in an "interethnic and inter-religious war", there was no need for a command to kill, given that the three ethnic communities had "been antagonised during centuries". 10736

3349. At a meeting attended by the Accused and Koljević on 30 September 1992, Lord Owen indicated that there was outrage with respect to a story in the New York Times regarding killings in Brčko in May and June 1992. ${ }^{10737}$ The Accused refuted allegations that his forces had massacred 3,000 Muslims at a camp near Brčko and called on the U.S.A. to provide evidence of these accusations. ${ }^{10738}$ While the number of persons killed as reported in the New York Times appears

\footnotetext{
10731 D3695 (Witness statement of Bogdan Subotić dated 16 June 2013), para. 246.

10732 D4720 (Letter from Radovan Karadžić re London Peace Conference, 25 August 1992), p. 1.

10733 See para. 346; D4720 (Letter from Radovan Karadžić re London Peace Conference, 25 August 1992), p. 1.

10734 See para. 346; D4720 (Letter from Radovan Karadžić re London Peace Conference, 25 August 1992), p. 1.

10735 P809 (Video footage of Radovan Karadžić's Press Conference at ICFY, 18 September 1992, with transcript), p. 10.

10736 P809 (Video footage of Radovan Karadžić's Press Conference at ICFY, 18 September 1992, with transcript), p. 3.

10737 Herbert Okun, P776 (Transcript from Prosecutor v. Krajišnik), T. 4224-4225.

10738 P3030 (Video of TV Belgrade news re Radovan Karadžić's statement on events in Brčko, with transcript).
} 
exaggerated, the Chamber has found that a large number of non-Serb men were indeed executed by Serb Forces at the Luka Camp in Brčko between at least 9 May and 16 May 1992. ${ }^{10739}$

3350. At a meeting of the Serbian leadership on 8 September 1992 with the Accused and Mladić in attendance, General Simonović stated that "ethnic cleansing" had been done more by paramilitary formations than by the VRS. ${ }^{10740}$

3351. On 19 October 1992, in reporting to members of the RS Presidency and VRS commanders on the Geneva peace talks, according to Mladić, the Accused stated that there had been a lot of discussion on "ethnic cleansing" and reminded the members that RS authorities must not participate in it. ${ }^{10741}$ He then said: "We find it important to make a distinction between what is done by irresponsible individuals and what is done by the authorities." 10742

3352. In November 1992, Milojević, an Assembly official, complained at a Bosnian Serb Assembly session attended by the Accused, that a proposed citizenship law could be interpreted to allow "all the Muslims and Croats we expelled" to be citizens of the RS. ${ }^{10743}$

3353. On 26 November 1992, Owen and Vance wrote to the Accused, advising him that they had received credible reports about "renewed ethnic cleansing" by Bosnian Serb Forces in the Banja Luka area. ${ }^{10744}$

3354. At a session of the Bosnian Serb Government held on 21 December 1992, at which the Accused was in attendance, Vladimir Lukić advised that all government bodies should be consistently applying regulations that require the return of illegally obtained property to its original owner. $^{10745}$

3355. Throughout the ICFY negotiations in Geneva from December 1992 to September 1993, the Bosnian Serbs were confronted with reports of ethnic cleansing committed by the Serbs in BiH. ${ }^{10746}$ During these negotiations, Lord Owen made very clear allegations about detention centres, military operations conducted against civilian populations, and the physical process of "ethnic cleansing" of areas. $^{10747}$ Lawrence Eagleburger, former U.S. Secretary of State, around January 1993, spoke in

\footnotetext{
10739 See Scheduled Killing Incident B.5.1.

10740 P1479 (Ratko Mladić's notebook, 16 July-9 September 1992), p. 173.

10741 P1481 (Ratko Mladić's notebook, 5 October-27 December 1992), pp. 48-49.

10742 P1481 (Ratko Mladić's notebook, 5 October-27 December 1992), pp. 48-49.

10743 P1105 (Transcript of 22 ${ }^{\text {nd }}$ session of RS Assembly, 23-24 November 1992), pp. 60, 78.

10744 P5420 (Fax from UNPROFOR forwarding ICFY letters, 27 November 1992), p. 4.

10745 P3106 (Minutes of the $61^{\text {st }}$ session of RS Government, 21 December 1992), pp. 1, 4.

10746 P1029 (Witness statement of John Wilson dated 4 November 2008), paras. 111-113.

10747 P1029 (Witness statement of John Wilson dated 4 November 2008), paras. 113-114.
} 
direct terms to all the parties about the nature of their activities and said that they would be held accountable. ${ }^{10748}$

3356. On 2 April 1993, the Accused was present at the Bosnian Serb Assembly when it was reported that Foča was completely under Bosnian Serb control. ${ }^{10749}$ At the same session, he acknowledged that "we could not swear that there are no crimes" and that Serbs who committed crimes should be tried. However, the Accused claimed that he had only heard of 18 allegations of rape, but the propaganda had turned this into 18,000 cases of rape. ${ }^{10750}$ On 10 January 1994, the Accused commented that Bosnian Muslims had planned to build a big Islamic centre in Foča but by then it belonged $100 \%$ to the Bosnian Serbs, and that "it will never be theirs again."10751

3357. During a Bosnian Serb Assembly session in May 1993, at which the Accused was present, Vladimir Lukić stated that they had naively "raised paramilitaries" and called them "brotherly assistance" but "they were slowly less and less engaged in fighting and more and more in looting". ${ }^{10752}$ Other deputies spoke about the problems they faced in municipalities with respect to disturbances, looting, and stealing where there were paramilitaries. ${ }^{10753}$

3358. At a Bosnian Serb Assembly session held in late summer 1993, at which the Accused was present, Mladić said, "we cannot allow leaving the mosques with two minarets there". 10754 Similarly another deputy complained to the Accused that if a proposed peace agreement went through and Bosnian Muslims were granted a right to return to their territory they would have to compensate them for everything that they destroyed and burned, including the 17 mosques which they had "flattened". 10755

3359. In April 1994, Akashi requested the Accused to allow the ICRC to evacuate Bosnian Muslims from Prijedor. ${ }^{10756}$ In response to Akashi's request, the Accused stated that the situation in Prijedor was an unfortunate development for the Serbs. While he accepted that the situation could have been predicted-he noted that civilians in the town had, at the beginning of the war,

\footnotetext{
10748 P1029 (Witness statement of John Wilson dated 4 November 2008), para. 115.

10749 P1367 (Transcript of $26^{\text {th }}$ session of RS Assembly, 2 April 1993), p. 25.

10750 P1367 (Transcript of $26^{\text {th }}$ session of RS Assembly, 2 April 1993), pp. 107-108.

10751 P1385 (Transcript of $37^{\text {th }}$ session of RS Assembly, 10 January 1994), p. 110. See also para. 2811.

10752 P1375 (Transcript of 32 ${ }^{\text {nd }}$ session of RS Assembly, 19-20 May 1993, e-court pp. 7, 39.

10753 P1375 (Transcript of 32 ${ }^{\text {nd }}$ session of RS Assembly, 19-20 May 1993, e-court p. 65.

10754 P1379 (Transcript of $34^{\text {th }}$ session of RS Assembly, 27-29 August, 9-11 September, 29 September to 1 October 1993), pp. 7, 72.

10755 P1379 (Transcript of $34^{\text {th }}$ session of RS Assembly, 27-29 August, 9-11 September, 29 September to 1 October 1993), p. 25.

10756 D705 (UNPROFOR report re meetings with Radovan Karadžić and Alija Izetbegović, 7 April 1994), p. 3; Yasushi Akashi, T. 37704 (24 April 2013).
} 
slaughtered each other-he maintained that the present situation had been prompted by a Muslim massacre of six Serb policemen from the town. ${ }^{10757}$ The Accused agreed to the evacuation as suggested. ${ }^{10758}$

3360. The Accused continued to receive information about crimes-predominantly mass expulsions, as well as mistreatment, including beatings, rapes, robberies, killing and forced labour-being committed against non-Serbs in Bijeljina and other municipalities from 1994. ${ }^{10759}$

3361. Even into 1995, the Accused was aware of, and involved in, arrangements made with respect to regulating the movement of non-Serbs out of Bosnian Serb territory which was described as being in accordance with the right to freedom of movement. ${ }^{10760}$

3362. In an interview in July 1995, the Accused stated that Muslims in places like Bijeljina were completely safe but that there "is some intimidation by terrorist elements, by extreme Serbs who have lost everything in central Bosnia. But the authorities protect our citizens, regardless of whether they are Muslims or Croats. Therefore, what is happening is not ethnic cleansing, but ethnic displacement, people who want to leave."10761

3363. Based on the evidence set forth above, the Chamber finds that the Accused was promptly and well informed of the forced displacement of non-Serb civilians from the Municipalities by Serb Forces from as early as April 1992. He continued to learn of such displacements throughout the conflict. In addition, he learned of other types of criminal activity committed against the non-Serb population by Serb Forces, including killings, rapes, and property related offences, from the beginning of April 1992 onwards. ${ }^{10762}$

10757

10758

10759 D704 (UNPROFOR report re meeting with Radovan Karadžić, 19 August 1994), p. 3. D3145 (UNPROFOR report, 6 September 1994; UNPROFOR press statement, 5 September 1994), p. 1; P2087 (UNHCR protest letter to Radovan Karadžić, 5 September 1994); D1136 (UNPROFOR report, 9 September 1994), p. 2; P2458 (UNPROFOR Weekly BiH Political Assessment, 11 September 1994), p. 4; Anthony Banbury, T. 13356 (15 March 2011); P5421 (Letter from humanitarian organisation to Radovan Karadžić, 16 September 1993), pp. 1-2 (under seal); P5423 (UNPROFOR report, 20 September 1994), p. 2; D3500 (UNPROFOR report, 7 October 1994), pp. 3-4.

10760 P5214 (Letter from Momčilo Krajišnik to VRS Main Staff, 7 April 1995); P5213 (VRS Main Staff request to Radovan Karadžić, 6 April 1995).

10761 P2564 (Radovan Karadžić's interview in El Pais, 16 July 1995), p. 5 (emphasis in the original).

10762 The Chamber notes that Davidović stated that the Accused must have known that crime was "rife and widespread" and that there was much collusion between those committing the crimes and those in high positions. Milorad Davidović, T. 15735 (30 June 2011). The Chamber considers this evidence to be speculative and will not rely on Davidović's evidence in this regard. 
detention centres

(B) Knowledge of inadequate conditions and mistreatment of non-Serbs in

3364. During the conflict, information about occurrences in many detention facilities was forwarded to the Accused, prime minister, and the relevant ministers, namely the Ministers of Defence, Interior, and Justice. ${ }^{10763}$

3365. The Accused was present at a 24 April 1992 joint session of the SNB and Bosnian Serb Government, where it was decided that the Ministry of Justice would be responsible for the exchange of detainees. ${ }^{10764}$ On 8 May 1992, the Government decided to form the "Central Commission for the Exchange of Prisoners-of-War, Arrested Persons and the Bodies of those Killed". ${ }^{10765}$ According to Mandić, the impetus for establishing the Commission was to provide "rule of law and legal security" for people detained, many of whom were civilians from conflict areas. ${ }^{10766}$ The Chamber considers that this evidence demonstrates that the Accused knew early on in the conflict in $\mathrm{BiH}$ that civilians were being detained by Serb Forces.

3366. Allegations of large-scale detention of civilians were reported in the international press in May and June 1992 and John Wilson raised these allegations with Plavšić in the presence of the Accused. ${ }^{10767}$ Plavšić acknowledged the existence of camps but said that they were only for military aged persons who were detained so they would not fight the Serbs and made counterclaims that the Bosnian Presidency was holding prisoners. ${ }^{10768}$

3367. In June and July 1992, the Bosnian Serb leadership requested several reports on detention camps and prisoners. ${ }^{10769}$ On 17 July 1992, the Bosnian Serb MUP wrote a report to the Accused and the Prime Minister, indicating, inter alia, that the conditions in detention centres were

\footnotetext{
10763 Momčilo Mandić, C2 (Transcript from Prosecutor v. Krajišnik), T. 8919, 9111. See paras. 3019-3020.

10764 P1087 (Minutes of meeting between SNB and SerBiH Government, 24 April 1992), p. 1. See also para. 124.

10765 P1088 (Decision of SerBiH, 8 May 1992), p. 1. At a further meeting of the SNB and Bosnian Serb Government held on 10 May 1992, members of the Central Commission for the Exchange of Prisoners of War and Arrested Persons were appointed. D409 (Minutes of meeting of SNB and SerBiH Government, 10 May 1992), p. 2. See also para. 125.

10766 Momčilo Mandić, C2 (Transcript from Prosecutor v. Krajišnik), T. 8750. See also para. 127.

10767 P1029 (Witness statement of John Wilson dated 4 November 2008), paras. 101-103.

10768 P1029 (Witness statement of John Wilson dated 4 November 2008), para. 102.

10769 P1093 (Minutes of $5^{\text {th }}$ session of SerBiH Presidency, 10 June 1992), p. 2; P1092 (Minutes of $25^{\text {th }}$ session of Government SerBiH, 10 June 1992), p. 3 (indicating that the Ministry of Justice should make a report on the treatment of civilians and prisoners to be considered by the government and then presented to the Presidency); P3098 (Minutes of the $48^{\text {th }}$ session of SerBiH Government, 28 July 1992), pp. 9-10 (stating that the Ministry of Justice and Administration was due to immediately prepare a Report on the state of detention centres and concentration centres for prisoners). See also D3109 (SerBiH MUP report, 22 August 1992) (reporting on the existence of detention centres in the SAO Herzegovina); P3549 (Report of the Commission for Inspecting Collection Centres and Other Facilities for Captives in the ARK, 17 August 1992) (reporting on the inspection of prisons in Trnopolje, Omarska, Keraterm in Prijedor; Manjača near Banja Luka, Krings Hall in Sanski Most, and the primary and secondary school in Bosanski Šamac).
} 
poor. ${ }^{10770}$ On 22 July 1992, it was reported to the government that there had been occurrences of unlawful treatment of detainees. ${ }^{10771}$

3368. On 25 July 1992, the Accused received a report from the ICRC following a visit to the Manjača camp. ${ }^{10772}$ The Accused was informed that: (i) the authorities at the camp refused to notify the ICRC about the identity of the detainees; (ii) the ICRC's visit was terminated prematurely when it was observed that two detainees had been subjected to ill treatment during the visit; (iii) the ICRC observed frequent and widespread traces of severe beatings; (iv) the general living conditions including food, hygiene, clothing and accommodation were "absolutely insufficient"; (v) many detainees showed marked weight loss and signs of anaemia. ${ }^{10773}$ The Accused was also informed about the medical conditions and concerns with respect to the detainees and that a list of detainees who allegedly died during detention would be submitted to the "Higher Authorities" with a request to open an investigation. ${ }^{10774}$

3369. Several news articles criticising the detention centres in $\mathrm{BiH}$ were released in a British publication, the Guardian, in late July 1992. ${ }^{10775}$ Also in late July, the Accused appeared on ITN and responded to allegations and reports about Omarska; during the broadcast, he said to the media: "come and see for yourselves". ${ }^{10776}$ On 30 July 1992, the Accused responded directly to the Guardian in a letter, stating that it was "completely false" that Bosnian Serbs had organised concentration camps or that they were holding civilian prisoners. ${ }^{10777}$

3370. At the London Conference in August 1992, there was an agreement between the parties on a program of action with respect to humanitarian issues. ${ }^{10778}$ It included recognition of the "acute problem of the unlawful detention of civilians and the deplorable conditions in which they were held". ${ }^{10779}$ This agreement recognised that the primary objective should be to secure the release and return of those detained. If this was not possible the agreement provided for other options

\footnotetext{
10770 P1096 (SerBiH MUP Report on Some Aspects of Work Done to Date and the Tasks Ahead, 17 July 1992), p. 3.

10771 D430 (Minutes of $41^{\text {st }}$ session of Government of SerBiH, 22 July 1992), p. 7.

10772 P3758 (Letter from Radovan Karadžić to Branko Derić, attaching an ICRC report, 7 August 1992), p. 4.

10773 P3758 (Letter from Radovan Karadžić to Branko Derić, attaching an ICRC report, 7 August 1992), p. 5.

10774 P3758 (Letter from Radovan Karadžić to Branko Derić, attaching an ICRC report, 7 August 1992), pp. 6-7.

10775 Edward Vulliamy, P3777 (Transcript from Prosecutor v. Stakić), T. 7904.

10776 Edward Vulliamy, P3777 (Transcript from Prosecutor v. Stakić), T. 7904, 8095-8096; Edward Vulliamy, T. 21037-21038, 21077-21078 (9 November 2011).

10777 P3778 (Radovan Karadžić's letter published in the Guardian, 30 July 1992).

10778 D1142 (Programme of Action of the London International Conference, 27 August 1992), p. 1.

10779 D1142 (Programme of Action of the London International Conference, 27 August 1992), p. 1.
} 
including "repatriation to areas under the control of their respective ethnic authorities" or relocation. ${ }^{10780}$

3371. The Chamber found that around 9 August 1992, Karadžić visited Kula prison with representatives of the media and the ICRC, and that the food was better that day and only clean rooms were shown. ${ }^{10781}$ He released ten detainees, some of whom were above the age of 60 and others were ill. ${ }^{10782}$

3372. Doyle encountered the Accused in the lobby of a hotel in Brussels on 16 August 1992 when the Times had published a photograph of an emaciated detainee in the Omarska camp. The Accused appeared to be taken aback by the news. ${ }^{10783}$

3373. On 17 August 1992, the Report of the Commission for Inspecting Collection Centres and Other Facilities for Captives in the ARK was issued. ${ }^{10784}$ It provided a sanitised version of the conditions in the camps, failing to mention the detention of any civilians and noting that most of the camps, especially Manjača, had inadequate premises with insufficient food, beds, and blankets. ${ }^{10785}$ It also alluded to difficulties with security due to poor co-ordination between the army and the police. $^{10786}$

3374. As a result of further reports received by the Accused from international representatives, Mandić tasked Avlijaš with drafting a report on the situation in camps from Sarajevo to Prijedor. ${ }^{10787}$ The report was issued on 22 October 1992 and was sent, inter alia, to the RS Presidency. ${ }^{10788}$ It included information on several detention centres in $\mathrm{BiH}$, including in Vlasenica, Zvornik, Prijedor, Sanski Most, and Banja Luka. ${ }^{10789}$ It also noted that SJBs in Zvornik, Hadžići, and Ilidža were detaining people without any authorisation in law. ${ }^{10790}$

D1142 (Programme of Action of the London International Conference, 27 August 1992), p. 1.

See para. 2150.

10782 P2840 (Video footage of Radovan Karadžić's visit to Kula prison), e-court p. 1. One of the prisoners was blind in one eye and not able to fight. P2840 (Video footage of Radovan Karadžić's visit to Kula prison), e-court p. 2. Colm Doyle, P918 (Transcript from Prosecutor v. S. Milošević), T. 25307.

P3549 (Report of the Commission for Inspecting Collection Centres and Other Facilities for Captives in the ARK, 17 August 1992) (reporting, inter alia, on the inspection of prisons in Trnopolje, Omarska, Keraterm in Prijedor, Manjača near Banja Luka, and Krings Hall in Sanski Most).

10785 P3549 (Report of the Commission for Inspecting Collection Centres and Other Facilities for Captives in the ARK, 17 August 1992), pp. 7-8.

10786 P3549 (Report of the Commission for Inspecting Collection Centres and Other Facilities for Captives in the ARK, 17 August 1992), pp. 7-8.

10787 D3105 (Witness statement of Slobodan Avlijaš dated 9 March 2013), para. 58; P1607 (RS Ministry of Justice report on prisons and camps on the RS territory, 22 October 1992).

10788 P1607 (RS Ministry of Justice report on prisons and camps on the RS territory, 22 October 1992), p. 1.

10789 P1607 (RS Ministry of Justice report on prisons and camps on the RS territory, 22 October 1992), pp. 2-6.

10790 P1607 (RS Ministry of Justice report on prisons and camps on the RS territory, 22 October 1992), p. 7.
} 
3375. The Chamber concludes that the Accused became aware of the detention of civilians in April 1992 and inadequate conditions in Bosnian Serb run detention facilities by at least May 1992. It further finds that the Accused sanctioned the forcible removal of civilians who were detained in these facilities either within $\mathrm{BiH}$ or to third countries. The Chamber notes the Accused's argument that during the rare visits by the RS authorities to Vlasenica, they were informed that the civilian population was well-treated, citing evidence that detainees at the Sušica camp told international representatives that they had received fine treatment in the camp. ${ }^{10791}$ The Chamber also notes that on or about 21 June 1992, Dragan Nikolić and Goran Tešić entered the Sušica camp and took two detainees out for questioning and beat them to death; a false report was subsequently prepared to suggest that the two detainees died of natural causes. ${ }^{10792}$ The Chamber accepts the Accused's submission that he and other members of the Bosnian Serb leadership did not learn of every single act of mistreatment of the non-Serb population throughout the Municipalities. However, the evidence establishes that the Accused was overall promptly and well-informed of crimes committed against non-Serbs in the Municipalities as described above.

(C) Misleading statements made by the Accused

3376. The Accused frequently minimised the extent of criminal activity in the Municipalities when speaking to the international media, negotiators, and to the public. Indeed, the Accused admitted to the Bosnian Serb Assembly that it was necessary to be cunning when faced with questions from the media and when dealing with international negotiators. ${ }^{10793}$ The Accused claimed that civilians were leaving of their own free will and had signed voluntary declarations that they wanted to leave. ${ }^{10794}$ The Accused made statements to the international media that the Bosnian Serb authorities did not participate in "ethnic cleansing", they were trying to stop this practice, and that acts of "ethnic cleansing" were being perpetrated by groups or individuals who did not originate from the Bosnian Serb authorities. ${ }^{10795}$ For example, in a 23 April 1992 media interview, when questioned about the fate of Bosnian Muslims and Bosnian Croats living in Serb areas, the Accused said that there were "very few such people" and that in any event they had

\footnotetext{
10791 Defence Final Brief, confidential, para. 2839 [REDACTED].

10792 See para. 1204 , fn. 4146.

10793 P1379 (Transcript of $34^{\text {th }}$ session of RS Assembly, 27-29 August, 9-11 September, 29 September to 1 October 1993), p. 276; P1417 (Transcript of 55 ${ }^{\text {th }}$ session of RS Assembly, 22-23 October 1995), p. 61 (where the Accused complained about media pressure in relation to questions about killings).

10794 KDZ240, P2935 (Transcript from Prosecutor v. Krajišnik), T. 6789-6790 (under seal); KDZ240, T. 1597215974, 15977 (4 July 2011) (closed session), T. 16057 (5 July 2011) (closed session); P2937 (Letter from Radovan Karadžić, 5 July 1992) (under seal); D4720 (Letter from Radovan Karadžić re London Peace Conference, 25 August 1992), p. 1.

10795 P5596 (Video footage depicting interview of Radovan Karadžić on CNN, with transcript), p. 1; P12 (Extended session of Main and Executive Boards of the SDS, 14 February 1992), p. 8.
} 
signed an agreement with the UNHCR to allow the return of people to their homes. ${ }^{10796}$ However, by that time, the Accused knew that thousands of non-Serb civilians had been expelled from Bosnian Serb controlled territory, ${ }^{10797}$ and he continued to learn of such expulsions during the conflict. $^{10798}$

3377. The Accused also shifted blame for the crimes away from Bosnian Serbs. For example, he often stated that: (i) his interlocutors had been misinformed; (ii) their sources were biased; (iii) crimes and terrible things had happened historically and were continuing to happen to Bosnian Serbs as well; (iv) everybody was guilty; (v) he had warned that the declaration of $\mathrm{BiH}$ independence would provoke a terrible war; and (vi) the international community was responsible. ${ }^{10799}$ In addition, Bosnian Serb leaders when confronted with allegations of rape and expulsion of Bosnian Muslims sometimes would also suggest that these abuses had been committed by Bosnian Muslims who were masquerading as Serb soldiers but did not deny that these crimes were happening. ${ }^{10800}$

3378. Throughout the conflict, the Accused boasted to the Bosnian Serb Assembly about the proper conduct of the Serb Forces, when he knew it was not true. In a television interview on 20 August 1992 regarding the release of detainees from detention centres, the Accused spoke of only releasing prisoners of war who were too ill or weak to go back into battle, after initially offering to close all of the camps. ${ }^{10801}$ He stated that "we don't have people in prisons that have been removed from their own homes. Those people have been captured in the battle-field". ${ }^{10802}$ The Accused claimed in a speech in December 1992 that "there were no civilians in our prisons", that no institution which inspected their prisons found any civilians or women, and that they had released a large number of detainees. ${ }^{10803}$ However, prior to that time, the Accused had been

\footnotetext{
10796 D1591 (Radovan Karadžićcs interview from Le Figaro, 23 April 1992), p. 1.

10797 See paras. 3332, 3336.

10798 See Section IV.A.3.a.v.A: Knowledge of crimes committed throughout the Municipalities.

10799 KDZ240, P2935 (Transcript from Prosecutor v. Krajišnik), T. 6789-6790, 6820, 6826, 6830-6835 (under seal); KDZ240, T. 15972-15974, 15977 (4 July 2011) (closed session); Herbert Okun, P776 (Transcript from Prosecutor v. Krajišnik), T. 4191-4192, 4200, 4203, 4252-4253, 4369, 4399; P790 (Seventh notebook of Herbert Okun's ICFY diary), e-court p. 37; Herbert Okun, T. 1505-1513 (23 April 2010); P811 (Herbert Okun's note re meeting with Radovan Karadžić, 31 October 1992); P1029 (Witness statement of John Wilson 4 November 2008), paras. 113-115, 122. See also P2451 (Witness statement of Anthony Banbury dated 19 May 2009), paras. 48-49; Anthony Banbury, T. 13337-13339, 13357-13358 (15 March 2011); D4720 (Letter from Radovan Karadžić re London Peace Conference, 25 August 1992), p. 2; P784 (First notebook of Herbert Okun's ICFY diary), e-court pp. 46, 53; P785 (Second notebook of Herbert Okun's ICFY diary), e-court p. 34 ; P786 (Third notebook of Herbert Okun's ICFY diary), e-court pp. 39-40; D1137 (Letter from RS, 2 April 1994), p. 2.

10800 Herbert Okun, P776 (Transcript from Prosecutor v. Krajišnik), T. 4224.

10801 P3695 (Excerpt from video clip of Manjača camp and interview with Radovan Karadžić). See Mevludin Sejmenović, T. 20496-20497 (27 October 2011).

10802 P3695 (Excerpt from video clip of Manjača camp and interview with Radovan Karadžić).

10803 P1364 (Transcript of $23^{\text {rd }}$ session of RS Assembly, 17 December 1992), e-court p. 8; P921 (Transcript of $24^{\text {th }}$ session of RS Assembly, 8 January 1993), p. 13.
} 
informed by Bosnian Serb government commissioned reports as well as by international representatives and the media that civilians were detained and many detention centres had inadequate or worse conditions. ${ }^{10804}$ On 8 January 1993, the Accused also stated that "no soldier of ours would be allowed to rape a woman in the presence of another soldier" and described these stories as "terrible lies". 10805

3379. On 2 April 1993, the Accused stated that the UN could present evidence of war crimes, but that it was for the RS to investigate and prosecute matters itself, and that their army could never have committed crime. ${ }^{10806}$

3380. On 9 January 1994, the Accused went so far as to say to the Bosnian Serb Assembly that "[c]ontrary to the lies and slander of international propaganda-mongers, the Serbian army maintained the knightly character and military honour, worthy of it."10807

3381. The Chamber finds that the Accused minimised what he knew about criminal activity committed by Serb Forces and misled international interlocutors and the public with respect to that activity in Bosnian Serb claimed territory in the Municipalities.

(D) Prevention of criminal activity

3382. The Prosecution argues that the orders issued by the Accused to address crimes committed against non-Serbs were "simply window dressing designed to disguise [his] role in supporting the very crimes he was purporting to address". ${ }^{10808}$ The Accused argues that he made legitimate efforts to prevent the commission of crimes and ensure Bosnian Serb Forces adhered to international humanitarian law. ${ }^{10809}$

(1) Unlawful detention and inadequate conditions in detention facilities

3383. In relation to the treatment of detainees, on 8 June 1992, the SRNA broadcasted an appeal by the Accused to local authorities and prominent Serbs to, inter alia, ensure protection for all wounded and ill individuals irrespective of what side of the conflict they were on and to treat all prisoners humanely. ${ }^{10810}$ On 13 June 1992, the Accused issued an order to the VRS and MUP to

\footnotetext{
10804 See paras. 3366-3370, 3372-3375.

10805 P921 (Transcript of $24^{\text {th }}$ session of RS Assembly, 8 January 1993), pp. 13-14.

10806 P1367 (Transcript of $26^{\text {th }}$ session of RS Assembly, 2 April 1993), p. 108.

10807 P5525 (Audio Recording and Transcript of the Ceremonial RS National Assembly, 9 January 1994), p. 10; P5492 (Record of speech by Radovan Karadžić, 9 January 1994), p. 9.

10808 Prosecution Final Brief, para. 541.

10809 Defence Final Brief, paras. 642, 741.

10810 D426 (Radovan Karadžić's appeal re ICRC's plan for humanitarian aid to BiH, 8 June 1992), p. 1.
} 
apply and respect the international law of war and authorised the Minister of Defence to prepare instructions on the treatment of captured prisoners, ${ }^{10811}$ which the Minister did. ${ }^{10812}$ In addition, the Chamber found that in June and July 1992, the Bosnian Serb leadership requested several reports on detention facilities and detainees. ${ }^{10813}$

3384. On 1 July 1992, the Accused asked Mandić to release a Croat who the Accused believed was detained at Kula prison. ${ }^{10814}$ The Chamber finds that this is indicative of the Accused's ability to secure the release of detainees when he felt like it. The Chamber also received evidence that Krajišnik and Mandić also intervened on behalf of detainees with whom they had personal connections. ${ }^{10815}$

3385. The Chamber recalls that around 15 July 1992, a high-ranking delegation of Bosnian Serbs from Banja Luka and Prijedor visited Omarska and were received by Drljača. ${ }^{10816}$ Following the delegation visit, the Accused called Kuprešanin to suggest that he influence the municipal authorities in Prijedor to close the "investigation centres" in the municipality. ${ }^{10817}$ Kuprešanin

10811 D434 (Radovan Karadžić's Order on the application of laws of war, 13 June 1992), p. 1; Momčilo Mandić, T. 5081-5082 (14 July 2010). See also D1849 (Radovan Karadžić's Order, 13 June 1992); P1134 (SerBiH Ministry of Defence Instructions on the Treatment of Captured Persons, 13 June 1992).

10812 P1134 (Minister of Defence of SerBiH Instructions on the Treatment of Captured Persons, 13 June 1992), p. 1; D3695 (Witness statement of Bogdan Subotić dated 16 June 2013), para. 281; Momčilo Mandić, T. 5083 (14 July 2010) (testifying that on the basis of this order Minister Subotic issued instructions on the treatment of captured persons and that those instructions made reference to international regulations, the treatment of those persons, who was in charge of detaining and releasing them and the conditions under which they could be used for work).

10813 P1093 (Minutes of $5^{\text {th }}$ session of SerBiH Presidency, 10 June 1992), p. 2; P1092 (Minutes of $25^{\text {th }}$ session of Government SerBiH, 10 June 1992) (indicating that the Ministry of Justice should make a report on the treatment of civilians and prisoners to be considered by the government and then presented to the Presidency); P3098 (Minutes of the $48^{\text {th }}$ session of SerBiH Government, 28 July 1992), pp. 9-10 (stating that the Ministry of Justice and Administration was due to immediately prepare a report on the state of detention centres and concentration centres for prisoners). See also D3109 (SerBiH MUP report, 22 August 1992) (reporting on the existence of detention centres in the SAO Herzegovina); P3549 (Report of the Commission for Inspecting Collection Centres and Other Facilities for Captives in the ARK, 17 August 1992) (reporting on the inspection of prisons in Trnopolje, Omarska, Keraterm in Prijedor; Manjača near Banja Luka, Krings Hall in Sanski Most, and the primary and secondary school in Bosanski Šamac).

10814 P1102 (Intercept of conversation between Radovan Karadžić and Momčilo Mandić, 1 July 1992), pp. 2-3; Momčilo Mandić, T. 4606-4607 (5 July 2010).

10815 P1101 (Intercept of conversation between Momčilo Krajišnik and Momčilo Mandić, 26 June 1992), p. 2; Momčilo Mandić, T. 4598-4603 (5 July 2010); P5651 (Intercept of conversation between (i) Momčilo Mandić and Petko Budiša; and (ii) Momčilo Mandić and Tomislav Kovač, 27 July 1992), p. 2.

10816 See para. 1782.

10817 See para. 1783; D4011 (Witness statement of Vojislav Kuprešanin dated 11 November 2013), para. 46; Vojislav Kuprešanin, T. 43530, 43543-43545 (14 November 2013). See also P6510 (Excerpt of Vojo Kuprešanin's interview with OTP), e-court p. 11. 
subsequently asked the authorities of Omarska and Keraterm to close the facilities and to improve the living conditions for the detainees until their disbandment. ${ }^{10818}$

3386. Vulliamy visited Omarska on 5 August $1992 .^{10819}$ He was told later by survivors from Omarska that the detainees who appeared to be in "better condition" were brought out to the tarmac area between the hangar and the canteen where the journalists would see them during their visit. $^{10820}$ The Chamber recalls that the authorities at detention facilities such as Omarska, Trnopolje and Manjača transferred the majority of their detainees to other locations during this time period and further cleaned up the facilities. ${ }^{10821}$ Furthermore, soon after the Accused agreed to open up the camps to international visitors, Keraterm was closed, with the detainees being moved to Trnopolje or Manjača by 5 August $1992 .^{10822}$

3387. On 6 August 1992 at a session of the RS Presidency, attended by the Accused, the treatment of detainees held in Serb controlled territory was discussed. It was concluded that the MUP would be ordered to examine the behaviour of all civilian authorities and individuals guarding detainees and report back to the MUP and the Presidency. ${ }^{10823}$ At this meeting it was stressed that international conventions on the treatment of prisoners of war should be followed to ensure the humane treatment of prisoners of war given that "they are in prisons and not concentration camps". ${ }^{10824}$ The decision was relayed to SJB Chiefs in a number of municipalities who were

10818 See para. 1783; D4011 (Witness statement of Vojislav Kuprešanin dated 11 November 2013), para. 46; Vojislav Kuprešanin, T. 43543-43545 (14 November 2013). See also P6510 (Excerpt of Vojo Kuprešanin's interview with OTP), e-court p. 11.

10819 Edward Vulliamy, T. 21079-21080 (9 November 2011).

10820 Edward Vulliamy, T. 21088 (9 November 2011). The Chamber recalls that the day after the international journalists visited Omarska, Sejmenović was taken out of Omarska by Kuprešanin. Kuprešanin had been instructed by the Accused to get Sejmenović a suit and allow him time to recuperate, and then he was planning round-table discussions for Sejmenović to speak publicly about the situation in Bosnian Krajina. See para. 1787.

10821 See paras. 1409, 1789, 1851. See also P731 (Video footage from Kula, Omarska, Trnopolje, and Manjača, with transcript) (wherein Christiane Amanpour, reporting on Manjača, stated that "even though Karadžić authorised our visit to this camp, journalists were allowed less than half an hour to assess the situation”); Idriz Merdžanić, T. 21396-21397 (16 November 2011).

10822 Idriz Merdžanić, T. 21395-21396 (16 November 2011); P3549 (Report of the Commission for Inspecting Collection Centres and Other Facilities for Captives in the ARK, 17 August 1992), p. 4; P6585 (SRNA press release, 22 August 1992); P5555 (Report of Prijedor SJB, 29 September 1992), p. 4. See also para. 1804. See also D4725 (Report from Slobodan Avljaš to RS Ministry of Legislation and Administration, 31 August 1992). The Chamber notes that Idriz Merdžanić, a Bosnian Muslim doctor who was detained at Trnopolje from 26 May until 30 September 1992, testified that after the Accused promised at the London Conference to allow journalists to visit detention centres, he ordered to have the camps "prepared" for the journalists' visits and suggested that the killing incident in Room 3 at Keraterm on or about 24 and 25 July 1992 occurred as a result of this. Idriz Merdžanić, T. 21394-21396 (16 November 2011). See Scheduled Incident B.15.1. The Chamber considers Merdžanić's evidence to be speculative as he was not in a position to know about specific orders issued by the Accused. Therefore, the Chamber will not rely on his evidence in this regard.

10823 D465 (Minutes of $24^{\text {th }}$ session of SerBiH Presidency, 6 August 1992), p. 2; P1603 (Decision of SerBiH Presidency, 6 August 1992); D97 (Conclusions of RS Presidency re prisoners of war, 6 August 1992); Momčilo Mandić, T. 5236-5238 (15 July 2010); D3105 (Witness statement of Slobodan Avlijaš dated 9 March 2013), para. 54.

10824 D465 (Minutes of $24^{\text {th }}$ session of SerBiH Presidency, 6 August 1992), p. 2. 
obliged to provide reports in accordance with the RS Presidency decision by 20 August $1992 .{ }^{10825}$ The SJB Chiefs were also informed about the RS Presidency order to release all civilians and to allow them freedom of movement. ${ }^{10826}$

3388. On 7 August 1992, the Accused wrote to Branko Đeric about reports they had received regarding detention facilities, including Manjača, and stated the ICRC and Mladić had been informed. ${ }^{10827}$ The Accused also noted his expectation that the government would, on the basis of these reports, "take immediate measures for the improvement of the living conditions in the jails that are operated by civilian authorities on our territory". ${ }^{10828}$ The Accused wrote to the ICRC with respect to these reports, and gave his re-assurance that the ICRC would be enabled to work without disturbance in RS and that he accepted "the majority of [their] remarks and recommendations for improvement of living conditions on these locations". ${ }^{1029}$ The Accused also accepted the ICRC suggestion to release all persons older than 60 years of age from detention and stated that they were ready to speed up the exchange of prisoners through a system of exchange commissions. ${ }^{10830}$

3389. On 8 August 1992, at a session of the RS Presidency, it was concluded, inter alia, that: (i) visits by representatives of the ICRC to all prisons must be arranged; (ii) all detainees above the age of 60 or seriously ill or wounded should be released; and (iii) amnesty should be declared for persons who have committed minor offences or were misled into committing such offences. ${ }^{10831}$

3390. On the same day, in a letter to, among others, the Accused, Tomislav Kovač, then Deputy Minister for Police Affairs and Tasks, identified the problems of detention of non-Serbs and proposed "that the status of these people be legally changed in compliance with international conventions on refugees, prisoners of war", given the failure to properly categorise civilians, prisoners of war and those who had committed criminal acts. ${ }^{10832}$ On 9 August 1992, the

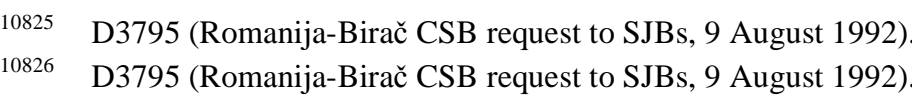

10827 D100 (Letter from Radovan Karadžić to Branko Đerić, 7 August 1992); Herbert Okun, T. 1753-1754 (28 April 2010). See also P4982 (Witness Statement of Branko Đerić dated 5 April 2012), para. 39; D3695 (Witness statement of Bogdan Subotić dated 16 June 2013), paras. 200, 219-221, 225. The Chamber does not find Subotić's evidence that the only places of detention were under local authority and that he was not informed about the detention of civilians to be reliable. In reaching that conclusion the Chamber refers to its credibility assessment in fn. 9869 and more specifically that his evidence with respect to this issue was marked by evasiveness and contradictions and attempts to distance himself from the detention of civilians.

10828 D100 (Letter from Radovan Karadžić to Branko Đerić, 7 August 1992).

10829 P3758 (Letter from Radovan Karadžić to Branko Derić, attaching an ICRC report, 7 August 1992), e-court pp. 2-3.

10830 P3758 (Letter from Radovan Karadžić to Branko Derić attaching an ICRC report, 7 August 1992), e-court p. 3.

10831 P3071 (Minutes of the $25^{\text {th }}$ session of RS Presidency, 8 August 1992), p. 1.

10832 P1100 (Letter from SerBiH MUP to Radovan Karadžić and Branko Đerić, 8 August 1992), p. 1; D3960 (Witness statement of Tomislav Kovač dated 28 October 2013), para. 84; Slobodan Avlijaš, T. 35170-35171 (11 March 2013). 
government responded to the letter immediately and established the Commission for Inspecting Collection Centres and Other Facilities for Captives in the ARK, which released its report on 17 August 1992. ${ }^{10833}$ The Commission was tasked with determining the status of persons detained in prisons in the RS "in accordance with international conventions, and to speed up the procedure of categorising such persons", inspecting those facilities and submitting a report to the government of the Republika Srpska. ${ }^{10834}$ Slobodan Avlijaš and Goran Šarić, as representatives of the Commission, visited Bileća, Trebinje, and Gacko and submitted a report to the Bosnian Serb government on 22 August 1992. ${ }^{10835}$

3391. According to the minutes of the $30^{\text {th }}$ session of the RS Presidency held on 6 September 1992, the Accused accepted a proposal from the Military Prosecutor's Office attached to the command of the $1^{\text {st }}$ Krajina Corp to pardon some detainees held at Manjača camp. ${ }^{10836}$ The proposal stated that the detainees were suspected of having committed crimes and asked that they be exempted from further prosecution; however the minutes do not indicate the reason for the request. $^{10837}$

3392. On 8 September 1992, the Accused sent a strictly confidential telegram to the presidents of all municipalities in RS instructing them to ensure "respect of international humanitarian law with regard to the treatment of prisoners of war" and that civilians who had not committed crimes should "not be kept in prisons and collection centres against their will" and that they should ensure their safe passage to territory where they seek refuge from the war. ${ }^{10838}$ He also indicated that officials must accommodate the ICRC and the High Commissioner for Refugees. ${ }^{10839}$

3393. In a meeting with international representatives in September 1992, the Accused agreed to "support any humanitarian issue" and "clean up" detention facilities but also in exchange requested that Bosnian Serbs, who he viewed as "hostages", be allowed to leave Sarajevo. ${ }^{10840}$ On

10833 D3960 (Witness statement of Tomislav Kovač dated 28 October 2013), para. 84; Momčilo Mandić, T. 5139 (14 July 2010), T. 5239-5240 (15 July 2010); Momčilo Mandić, C3 (Transcript from Prosecutor v. Stanišić \& Župljanin), T. 9603-9604, 9820-9821 (testifying that representatives from the Ministry of Justice and Administration and the Ministry of the Interior were appointed to this commission); P3549 (Report of the Commission for Inspecting Collection Centres and Other Facilities for Captives in the ARK, 17 August 1992), p. 2. See also para. 3373 .

10834 D466 (Decision of Government of SerBiH on establishment of Commission for Inspection of Collections Centres and other facilities for prisoners, 9 August 1992), pp. 2-3; D3105 (Witness statement of Slobodan Avlijaš dated 9 March 2013), para. 57. See also Slobodan Avljiaš, T. 35140-35142 (11 March 2013).

10835 D3105 (Witness statement of Slobodan Avlijaš dated 9 March 2013), para. 56; D3109 (SerBiH MUP report, 22 August 1992) (reporting on the existence of detention centres in the SAO Herzegovina).

10836 P3074 (Minutes of the $30^{\text {th }}$ session of RS Presidency, 6 September 1992).

10837 P3074 (Minutes of the 30 ${ }^{\text {th }}$ session of RS Presidency, 6 September 1992).

10838 D3241 (Letter from RS Presidency to presidents of all municipalities, 8 September 1992).

10839 D3241 (Letter from RS Presidency to presidents of all municipalities, 8 September 1992).

10840 P785 (Second notebook of Herbert Okun's ICFY diary), e-court pp. 23-24, 36. 
11 September 1992, the Accused granted amnesty from criminal prosecution to 69 detainees who were being held at Manjača and Trnopolje. ${ }^{10841}$ The Accused stated, a few days later, at a Bosnian Serb Assembly session that dealing with humanitarian issues would assist the Bosnian Serbs as they would get credit at an international level, and in this regard the disbandment of Trnopolje and Manjača camps would suit them so long as those detained were sent somewhere and did not return to the battlefield. ${ }^{10842}$

3394. An agreement between representatives of the Accused, Izetbegović, Mate Boban, and representatives of the SDA, SDS, and $\mathrm{BiH}$ Presidency was reached on 30 September and 1 October 1992. ${ }^{10843}$ They, inter alia, agreed to release all civilian detainees who were not suspected of having committed crimes. ${ }^{10844}$ The document lists several scheduled detention centres under Bosnian Serb control, including Manjača, Trnopolje, Batković camp, and Kula Prison. ${ }^{10845}$

3395. The Accused, in October 1992, informed Mladić, Mićo Stanišić and Mandić that he had received information that some local authorities had ignored his instruction to allow unfettered access for the ICRC to detention facilities. The Accused demanded that they inform their subordinates to respect his instruction to allow access and that he would order a thorough investigation of all cases of failure to comply. ${ }^{10846}$

3396. On 1 October 1992, Kuprešanin wrote to the Accused and requested a pardon to allow for the release of some Bosnian Muslim detainees who were being held at Manjača who had not participated in "the rebellion" against the RS. ${ }^{10847}$ On 7 October 1992, pursuant to a decision of the RS Presidency, Kuprešanin authorised ten detainees who had been released and pardoned to be permitted to leave the territory of RS through the ICRC in Banja Luka. ${ }^{10848}$ On 13 November 1992, the Accused issued an amnesty from prosecution in respect of numerous detainees who were held at

\footnotetext{
10841 P3721 (Report of $1^{\text {st }}$ Krajina Corps re decision by Radovan Karadžić, 11 September 1992).

10842 D456 (Transcript of 20 ${ }^{\text {th }}$ session of RS Assembly, 14-15 September 1992), p. 55.

10843 P4859 (Agreement on the release and transfer of prisoners, 30 September and 1 October 1992), p. 1.

10844 P4859 (Agreement on the release and transfer of prisoners, 30 September and 1 October 1992), p. 2.

10845 P4859 (Agreement on the release and transfer of prisoners, 30 September and 1 October 1992), pp. 7-9.

10846 D103 (Letter from Radovan Karadžić to Ratko Mladić, Mićo Stanišić, and Momčilo Mandić, 22 October 1992). See also Mićo Stanišić, T. 46403-46404 (3 February 2014).

10847 P3722 (Request sent from Vojo Kuprešanin to Radovan Karadžić, 1 October 1992). A similar report was sent from the Manjača camp to the $1^{\text {st }}$ Krajina Corps Command identifying individuals who did not deserve to be criminally prosecuted and who could be released and noting that not a single criminal report or other criminal documentation had been filed against individuals on a list and reported on their release: P3723 (Manjača camp daily report to the $1^{\text {st }}$ Krajina Corps, 14 November 1992) (under seal).

10848 D4211 (List of persons pardoned and released signed by Vojislav Kuprešanin, 7 October 1992).
} 
Manjača. ${ }^{10849}$ The Chamber considers that this further demonstrates the Accused's ability to intervene in matters related to detention.

3397. It was not until 27 October 1992, that the Bosnian Serb Government officially decided that the existing illegal camps and assembly centres were to be dissolved as soon as possible and that the existing penal institutions legally formed in large centres in Republika Srpska were to be used, since the conditions there were suitable for legal treatment of prisoners and inmates. ${ }^{10850}$

3398. On 4 December 1992, the Accused indicated that he would order the release of all detainees held in Manjača provided that they be transferred to third countries. ${ }^{10851}$ The Chamber found above that this is what indeed happened. ${ }^{10852}$

3399. Having considered the evidence recounted above of the Accused's efforts to end the unlawful detention of non-Serb civilians and to ameliorate the conditions in detention centres, the Chamber notes that while the Accused was aware of the large-scale detention of civilians as early as April 1992, it was not until June 1992 that he issued orders on the protection of detainees and requested reports. ${ }^{10853}$ By that time, many civilians were already unlawfully detained in appalling conditions. The Chamber further finds that the Accused had the authority to order the closure of detention centres and order the release of detainees as evidenced by how quickly his instructions to close Omarska, Keraterm and later Manjača and his instructions to release specific detainees were followed by the relevant authorities. However, by the time the Bosnian Serb Government officially decided to close all "illegal camps" on 27 October 1992, the make-shift detention facilities used throughout the Municipalities by Serb Forces to detain non-Serbs had already largely served their purpose of facilitating the process of the forcible removal of non-Serbs. The Chamber considers that the Accused could have intervened much sooner if he had had the will to do so. However, instead of excercising his authority to close make-shift detention centres, he spent months denying that the conditions in these centres were appalling and that civilians were included among the detainees. Furthermore, the Chamber notes that Batković camp, Kula Prison and the Rasadnik detention facility remained in existence during the war and that they continued to unlawfully detain non-Serb civilians. ${ }^{10854}$

\footnotetext{
10849 [REDACTED].

10850 P3102 (Minutes of the $57^{\text {th }}$ session of RS Government, 27 October 1992), p. 6.

10851 D1851 (Letter from Radovan Karadžić to Daniel Shiffer, 4 December 1992).

10852 See paras. 1408-1409.

10853 See para. 3365

10854 See Scheduled Detention Facilities C.2.1, C.18.2, C.21.3.
} 
(2) Forced removal of non-Serbs and protection of non-Serbs remaining

in Serb controlled territory

3400. With respect to forced displacement of non-Serb civilians, in advance of the London Conference, the Accused issued an instruction to the VRS and MUP, on 19 August 1992 ordering that the forced resettlement of civilians should be prevented and that "any certificates of sale of property or statements that refugees will not return shall be considered as legally invalid and are declared null and void". 10855 On 21 August 1992, the Accused pledged to prevent "ethnic cleansing" and punish persons involved in expelling the civilian population. ${ }^{10856}$ On 25 August 1992, on the eve of the London Conference, the Accused stated, in a letter to the international community, that he had issued the 19 August 1992 instruction, but that the civilian population must be allowed to move freely out of a war zone if that was its desire, blaming the failure on the part of the international community to understand the deep-rooted antagonism and hatred between the three ethnicities in $\mathrm{BiH}$, which caused people to leave their communities in droves. ${ }^{10857}$ The Chamber considers that the Accused's comments in the 25 August letter were an attempt to downplay the forced nature of the movement of the population that was occurring, whereas by that time thousands of non-Serbs had already been expelled from Bosnian Serb claimed territory by Serb Forces. This suggests that the Accused's 19 and 21 August orders were not genuine efforts to stop "ethnic cleansing", and were rather designed as an attempt to cast a positive light on the actions of the Bosnian Serbs in view of the commencement of the London Conference.

3401. In August 1992, the Accused issued instructions to the presidents of all municipalities to keep accurate records on the temporary use of abandoned flats by refugees and prevent any abuse in this regard. ${ }^{10858}$ However, the Chamber recalls that the transfer of abandoned non-Serb housing to Serb refugees had the effect of ensuring that non-Serbs who had fled their homes did not return to Serb held territory. ${ }^{10859}$

\footnotetext{
10855 D101 (Radovan Karadžić's Order to VRS Main Staff and RS MUP, 19 August 1992); Colm Doyle, T. 28752876 (27 May 2010). See also KW609, T. 46140-46142 (29 January 2014) (testifying that although the 19 August 1992 order was forwarded on by Drljača, these provisions were not observed in detention facilities in Prijedor to a large extent due to a small group of individuals, including guards and inspectors at the facilities, who did not behave in accordance with their authority or the law).

10856 D109 (RS Presidency Declaration, 21 August 1992).

10857 See para. 346; D4720 (Letter from Radovan Karadžić re London Peace Conference, 25 August 1992), p. 1.

10858 D111 (Radovan Karadžić's Instructions to Presidents of Municipalities, 23 August 1992). See also Branko Đerić, T. 28018 (24 April 2012). Đerić also issued a decree regulating the temporary use of abandoned agricultural land and buildings. D2246 (Decree on the Temporary Use of Abandoned Agricultural Land, Agricultural Buildings and Agricultural Machinery and Tools, 20 August 1992); Branko Đerić, T. 28031 (25 April 2012).

10859 See, e.g., para. 2162.
} 
3402. Furthermore, the Accused issued orders for the protection of non-Serbs remaining in Serb controlled territory. On 11 July 1992 at the $38^{\text {th }}$ session of the Bosnian Serb Government, a working group was formed to prepare regulations on the treatment of civilians of all ethnicities in the RS in accordance with constitutional rights and international conventions and obligations. ${ }^{10860}$ On 14 July 1992, the Accused instructed the presidents of the municipalities in the Goražde area to ensure that all Bosnian Croat and Bosnian Muslim inhabitants in villages who surrendered their weapons and did not intend to fight should enjoy the full protection of the RS state. ${ }^{10861} \mathrm{He}$ issued a similar order on 23 July 1992 that Serb authorities must act in accordance with the law and international humanitarian law and all inhabitants who surrender weapons and agree to live peacefully must be permitted to stay and be protected by the RS. ${ }^{10862}$ However, the Chamber notes that during this time period, Bosnian Muslims and Bosnian Croats were forced to leave Bosnian Serb claimed territory in the Municipalities through threats, coercion, or as a result of physical force.

3403. On 3 April 1994, the Accused issued an order to the Bosnian Serb MUP and VRS authorities to, inter alia, investigate criminal activity committed in the RS with particular attention to Prijedor, which was subsequently distributed to all RBD centres and Drina Corps units. ${ }^{10863}$ On 4 July 1994, the Accused conveyed to the municipal authorities in Prijedor that they should ensure full protection for the non-Serb population. ${ }^{10864}$ There had been incidents in mid-1994 of individuals attacking non-Serbs and their property, causing them to apply to municipal authorities to organise their collective departure abroad. ${ }^{10865}$ The Accused instructed the highest authorities of the municipality to publicly condemn such cases of assaults on non-Serbs and to maintain law and order, punish the perpetrators, and take measures to protect all citizens and their property against looting, including the property of individuals who had left or been killed. ${ }^{10866}$ A state commission was to be set up to deal with each registered case. ${ }^{10867}$ The Chamber considers by this time there were so few non-Serbs remaining in Prijedor after the overwhelming majority had already been expelled during 1992 that his instructions in this regard were rendered otiose.

\footnotetext{
10860 D446 (Minutes of $38^{\text {th }}$ session of Government of SerBiH, 11 July 1992), p. 6; Momčilo Mandić, T. 5136 (14 July 2010).

10861 D95 (Instructions from RS Presidency to presidents of municipalities in Goražde area, 14 July 1992), p. 1; Momčilo Mandić, T. 5183 (15 July 2010). See also Herbert Okun, T. 1741-1742 (27 April 2010) (testifying that those who received these 14 July 1992 instructions may have understood that the Accused did not really mean them). The Chamber places no weight on Okun's testimony in this regard because it is speculative.

10862 P2970 (Radovan Karadžić order, 23 July 1992).

10863 D1138 (Radovan Karadžić's letter, 3 April 1994); D4151 (Dispatch of RS MUP to all RBD Centres, 5 April 1994); D4816 (Drina Corps Order, 4 April 1994), para. 1. See also [REDACTED].

10864 D4213 (Order of Radovan Karadžić, 4 July 1994).

10865 D4213 (Order of Radovan Karadžić, 4 July 1994).

10866 D4213 (Order of Radovan Karadžić, 4 July 1994).
} 
3404. In response to concerns about the "ethnic cleansing" in Bijeljina in late 1994, the Accused explained to UNPROFOR that the authorities in Bijeljina intended to replace the Chief of Police given that he was providing unsatisfactory security for the population, ${ }^{10868}$ and later claimed that people leaving Bijeljina were being forced from their homes by criminal elements. ${ }^{10869}$ While the Chief of Police was replaced in Bijeljina, the UNHCR office continued reporting on the arrival of "large numbers of refugees who had been forced to leave the Bijeljina area" including over 2,000 people between 18 August to 4 September 1994. ${ }^{10870}$ On 9 September 1994, Vieira de Mello requested that the Accused allow Akashi and UNPROFOR to verify the humanitarian conditions in these regions and pressed for the arrest of Vojkan and his gang, who the Accused suggested might be acting under Arkan's instructions in the area. ${ }^{10871}$ On 15 September 1994, the Accused was told by international negotiators that his response to the crisis in Bijeljina was "insufficient [...] as the cleansing itself was apparently continuing" and that by the time investigations were completed "there would be nobody left to expel". ${ }^{10872}$ On 26 September 1994, the Accused said to international negotiators that Serbs in Bijeljina were "fighting for their own land" and that "ethnic cleansing" would be an inevitable outcome of the international community's failure to establish any legal mechanism allowing the population to exchange their homes and move into cantons in which their nationality would be dominant. ${ }^{10873}$ The Chamber considers that the Accused's statements to the international negotiators demonstrate his knowledge that "ethnic cleansing" was directly linked to the Bosnian Serb objective to establish a Bosnian Serb state and that he was not interested in preventing it.

D704 (UNPROFOR report re meeting with Radovan Karadžić, 19 August 1994), p. 3. See also D3145 (UNPROFOR report, 6 September 1994; UNPROFOR press statement, 5 September 1994), p. 1.

10869 P2458 (UNPROFOR Weekly BiH Political Assessment, 11 September 1994), p. 4; P2451 (Witness statement of Anthony Banbury dated 19 May 2009), paras. 60-61.

10870 D3145 (UNPROFOR report, 6 September 1994; UNPROFOR press statement, 5 September 1994), p. 1. See also P799 (Excerpts from David Owen's book entitled "Balkan Odyssey”), e-court p. 14.

10871 D1136 (UNPROFOR report, 9 September 1994), p. 2.

10872 P3862 (UNPROFOR report, 15 September 1994), para. 7. See also D3145 (UNPROFOR report, 6 September 1994; UNPROFOR press statement, 5 September 1994), p. 1. The Chamber recalls that on 23 September 1994, the Security Council passed Resolution 941 in which it noted that UNHCR and the ICRC had reported grave violations of international humanitarian law in Banja Luka, Bijeljina, and other areas of $\mathrm{BiH}$ under Bosnian Serb control, which it described as "ethnic cleansing". See para. 403.

10873 P820 (Witness statement of David Harland dated 4 September 2009), para. 140; David Harland, T. 2113-2114 (7 May 2010). The Chamber notes that Gordan Milinić testified that the Accused formed a commission to examine the situation in Bijeljina in October 1994 and that the Bosnian Muslims living in Bijeljina told the Commission that they preferred to leave and the Presidency received letters of gratitude from Bosnian Muslims who emigrated. D3682 (Witness statement of Gordan Milinić dated 8 June 2013), para. 13; Gordan Milinić, T. 39771-39772 (12 June 2013). The Chamber notes that testimony of Milinić was marked by contradictions, bias and indicators that he lacked candour. The Chamber therefore does not find his evidence to be reliable in this regard.
} 


\section{(3) Other crimes}

3405. With respect to crimes more generally, including looting and property related crimes, when the Bosnian Serb government was informed on 27 February 1993 that public law and order in the Republic was extremely bad, it put the MUP, Ministry of Defence and the Military Security Service in charge of protecting the citizens and their property. ${ }^{10874}$ In May 1993, the Accused also issued an order for the security and protection of all places of worship in Banja Luka and called for the immediate execution of this order and a report on measures taken. ${ }^{10875}$ At a session of the Bosnian Serb Government on 11 July 1993, in which the Accused participated, the "need for a swift drive against crime", including killing, robbery, and profiteering was discussed. ${ }^{10876}$ On 28 August 1993, in an order focused on the organisation of the VRS, the Accused instructed the Main Staff and MUP to create a plan to seize the uniforms of people who were not members of the army or police and who were committing crimes and other illegal activity in the uniforms. ${ }^{10877}$

3406. Furthermore, Mićo Stanišić made efforts to remove criminals from the MUP. On 17 April 1992, Mićo Stanišić wrote to municipal CSBs and SJBs warning them that there had been reports of MUP members appropriating property and collaborating with persons with a history of organised crime and requesting that measures, including termination of employment and criminal prosecution, be taken against perpetrators. ${ }^{10878}$ On 23 and 24 July 1992, Stanišić ordered that members of the MUP who had been criminally prosecuted or against whom criminal proceedings were being conducted should be dismissed from duty and placed at the disposal of the VRS. ${ }^{10879}$

3407. The Chamber notes that the rules on disciplinary responsibility of Bosnian Serb MUP employees during war stipulated that MUP employees who are terminated for disciplinary reasons should be reported to the VRS. ${ }^{10880}$ However, the Chamber does not consider this an effective means of punishment or prevention of further crimes because such persons would continue to carry arms in proximity to civilian areas.

3408. Furthermore, on 27 July 1992, Stanišić issued an order stating that, in accordance with an order by the Accused, it was necessary to immediately remove individuals from the MUP who had

\footnotetext{
10874 D3569 (Excerpt from Minutes of $65^{\text {th }}$ session of RS Government, 27 February 1993), p. 4.

10875 D106 (Radovan Karadžić's Order to RS MUP, 12 May 1993). See also Herbert Okun, T. 1767-1768 (28 April 2010).

10876 P3139 (Minutes of the $74^{\text {th }}$ session of RS Government, 11 July 1993), p. 8.

10877 D4790 (Radovan Karadžić's Order to VRS Main Staff, 28 August 1993), p. 5.

10878 D1671 (Warning of SerBiH MUP, 17 April 1992); KDZ601, T. 18625-18626 (8 September 2011).

10879 P2771 (Order of SerBiH MUP, 23 July 1992); P2971 (Order of SerBiH MUP, 24 July 1992).

10880 D4455 (Letter from Mićo Stanišić to all CSBs forwarding Rules on Disciplinary Responsibility, 19 September 1992), Art. 3.
} 
been held criminally responsible for crimes or were known to have committed crimes during the war in BiH. ${ }^{10881}$ On 12 September 1992, Zoran Cvijetić issued a document to all SJBs, advising that despite Stanišić's orders to remove criminals from the ranks of the MUP, a number of SJBs had not taken the problem seriously enough and that it was necessary for them to analyse the involvement of MUP employees in criminal acts and dereliction of duty so that it could be reported to the MUP. ${ }^{10882}$ In an interview in October 1992, Mićo Stanišić acknowledged that some individual members of the MUP had been expelled from their ranks because of acts which they had committed but he claimed that the number of such cases were rare but were taken seriously. ${ }^{10883}$ He also spoke about measures taken to deal with war profiteering and that most of the acts occurred at the beginning of the war when "there was a kind of legislative vacuum". ${ }^{10884}$

3409. In addition, members of the government, VRS, JNA and MUP, including Mićo Stanišić, issued orders to various divisions in the Bosnian Serb MUP or VRS on crime prevention, to ensure compliance with international humanitarian law, prevent the abuse of detainees and mistreatment of civilians, and to report crimes or illegal camps on 24 April 1992, ${ }^{10885} 26$ April 1992, ${ }^{10886}$ 30 April 1992, ${ }^{10887} 10$ June 1992, ${ }^{10888} 23$ June 1992, ${ }^{10889} 10$ August 1992, ${ }^{10890} 17$ August 1992, ${ }^{10891} 19$ August 1992, ${ }^{10892} 21$ August 1992. ${ }^{10893}$ On 24 August 1992, Mićo Stanišić sent a dispatch to all CSBs and SJBs, requiring data by 30 August 1992 on all detention camps, prisons or collection centres, their location, the number of persons detained and who ordered the establishment and detention of people at the camps. ${ }^{10894}$ On 14 May 1993, pursuant to an order by

10881 D4273 (Order of RS MUP, 27 July 1992). See also D1534 (Order of Romanija-Birač CSB, 28 July 1992) (wherein the RS MUP ordered all special units formed by SJBs during the war be disbanded and placed under the command of the VRS or dismissed from their areas of operation. Any crimes committed by these groups were to be reported to the appropriate institution).

10882 D1077 (RS MUP order, 12 September 1992).

10883 D4274 (Article from Javnost, entitled “A Legal State is Being Established”, 3 October 1992), p. 2.

10884 D4274 (Article from Javnost, entitled “A Legal State is Being Established”, 3 October 1992), pp. 4-5.

10885 D3826 (Order of JNA $5^{\text {th }}$ Corps, 24 April 1992).

10886 D2676 (Excerpts from instructions of SerBiH Government for municipal crisis staffs, 26 April 1992), pp. 1-2.

10887 D4670 (Telegram from Banja Luka CSB to all SJBs, 30 April 1992), pp. 1-2.

10888 D3829 ( $1^{\text {st }}$ Krajina Corps dispatch, 10 June 1992; Order of $1^{\text {st }}$ Krajina Corps, 9 June 1992), p. 15.

10889 D3837 ( $1^{\text {st }}$ Krajina Corps dispatch, 23 June 1992).

10890 D467 (Order of MUP of SerBiH to CSBs Sarajevo, Trebinje, Doboj, Bijeljina, Banja Luka, 10 August 1992), p. 1; Momčilo Mandić, T. 5240-5241 (15 July 2010).

10891 D469 (Order of MUP of SerBiH, 17 August 1992), p. 1. See also Momčilo Mandić, T. 5268 (15 July 2010$)$; Mićo Stanišić, T. 46401-46403 (3 February 2014).

10892 D4255 (Prijedor SJB dispatch forwarding order from Mićo Stanišić to Banja Luka CSB, 19 August 1992).

10893 D4256 (Banja Luka CSB dispatch to all SJBs, 21 August 1992; Prijedor SJB dispatch forwarding Banja Luka CSB dispatch, 24 August 1992); see KW609, T. 46144-46148 (29 January 2014).

10894 D475 (SerBiH MUP Order to all CSBs and SJBs, 24 August 1992), p. 1; Momčilo Mandić, T. 5268-5270 (15 July 2010). 
the Accused, Mladić ordered that the Geneva and Hague Conventions and other provisions of "the international law of war" be observed in all respects. ${ }^{10895}$

3410. The Chamber considers that while the Accused and his subordinates issued orders during the conflict regarding respect for international humanitarian law, the rampant criminal acts being committed against non-Serbs in the Municipalities continued. The Accused continued to learn about the commission of serious crimes committed by Serb Forces against non-Serbs throughout the conflict and yet he continued to issue the same type of generic orders. ${ }^{10896}$ He made no efforts to ensure that these orders were implemented on the ground so as to generate a positive effect on the prevention of crime. The Chamber therefore finds that these orders are not reflective of genuine efforts to prevent such crimes.

(E) Investigation and prosecution of crimes committed against non-Serbs

3411. The Prosecution submits that the Accused supported a policy of non-prosecution of crimes committed against non-Serbs, which resulted in a climate of impunity for crimes committed against non-Serbs. ${ }^{10897}$ The Accused submits that the RS was committed to proper military and civilian prosecutions but that with the chaos of war and difficulties associated with institution building, there were reasonable delays. ${ }^{10898}$

3412. The Chamber recalls that the Bosnian Serb civilian courts were established on 16 May 1992 in some Bosnian Serb Municipalities and that the military courts began to function in August 1992. ${ }^{10899}$ On one occasion in 1993, the Accused claimed to have the ability to stop criminal proceedings. At a Bosnian Serb Assembly session in the fall of 1993, the Accused advised that whenever there was an indication that someone had committed a criminal act it should be forwarded to the authorised body but that "if it is the state interest to stop it, we will see that, we will stop it just before the trial, but all of you will know that. All of you will know why something was postponed or why it was stopped for the interest of the state. However, it is not to be stopped without being investigated [...]." 10900 Furthermore, the evidence demonstrates that the Accused was able to intervene in proceedings as he had a military judge removed from his position in 1994 after

\footnotetext{
10895 D3309 (VRS Main Staff Order, 14 May 1993); D104 (Radovan Karadžić's Directive to VRS Main Staff, 11 May 1993)

10896 See Section IV.A.3.a.v: Accused's knowledge of crimes and measures he took to prevent and punish them.

10897 Prosecution Final Brief, paras. 549, 562.

10898 Defence Final Brief, paras. 761, 771.

10899 See paras. 253, 292.

10900 P1379 (Transcript of $34^{\text {th }}$ session of RS Assembly, 27-29 August, 9-11 September, 29 September to 1 October 1993), pp. 410-411. But see D3695 (Witness statement of Bogdan Subotić dated 16 June 2013), paras. 212-213, 217 (stating that the Accused never exerted any pressure on the work of the judiciary).
} 
the judge refused to follow instructions from the Accused about how to rule on a case. ${ }^{10901}$ In light of the foregoing, the Chamber finds that the Accused had influence and authority over the courts. ${ }^{10902}$

3413. In July 1992, the Accused assured international representatives that "war criminals" would be subjected to legal procedures. ${ }^{10903}$ However, Branko Đerić stated that when he advocated that procedures be put in place to prevent and try crimes in 1992, the Accused blocked such efforts and "thought that this could be dealt with later", and the MUP and Ministry of Justice did not implement government decisions that crimes be prosecuted. ${ }^{10904}$ In addition, the Accused, in a meeting with Milorad Davidović and Mladić in the spring of 1992, said that while they should be trying to prevent looting and stealing by the Bosnian Serb MUP, it was more important to avoid conflicts between Serbs, even at the expense of not punishing criminal offences. ${ }^{10905}$ According to Branko Đerić, Mandić and Mićo Stanišić were the "President's men", taking orders directly from the Accused, and Đerić was dissatisfied with their work insofar as it related to security as they ignored government decisions with respect to prevention and prosecution of criminal activity. ${ }^{10906}$

3414. As discussed in greater detail below, there was a systemic failure to investigate and prosecute crimes committed against non-Serbs and few cases in which Bosnian Serbs committed crimes against non-Serbs reached military courts. ${ }^{10907}$ The cases prioritised by the military courts in Bijeljina and Banja Luka in August 1992 pertained to failure to respond to mobilisation and desertion by Bosnian Serb Forces and cases involving Serb victims. ${ }^{10908}$ The 10 July 1992 logbook for the prosecutor's office in Ključ shows that criminal reports were filed against Bosnian Muslims, with only few being filed against Bosnian Serbs. ${ }^{10909}$ Furthermore, it was reported that most cases under investigation in the Military Court in Sarajevo in November 1993 pertained to crimes against the VRS. ${ }^{10910}$

\footnotetext{
10901 P3773 (Witness statement of KDZ532 dated 31 October 2011), paras. 32-36, $43-44$ (under seal).

10902 See also D2986 (Witness statement of Novak Todorović dated 17 February 2013), para. 36.

10903 P2937 (Letter from Radovan Karadžić, 5 July 1992) (under seal).

10904 P4982 (Witness Statement of Branko Đerić dated 5 April 2012), paras. 14-15, 17, 22; Branko Đerić, T. $28002-$ 28003 (24 April 2012).

10905 P2848 (Witness statement of Milorad Davidović dated 22 June 2011), para. 54.

10906 P4982 (Witness Statement of Branko Đerić dated 5 April 2012), paras. 21-22, 24.

10907 See KDZ492, P3596 (Transcript from Prosecutor v. Krajišnik). T. 3929-3930 (under seal); P3632 (Schedules A and B of ICTY indictment against Momčilo Krajišnik); P2929 (Witness statement of KDZ531 dated 25 June 2011), pp. 9-10 (under seal); KDZ531, T. 15852-15855 (1 July 2011) (closed session); paras. 639-640 .

10908 P2929 (Witness statement of KDZ531 dated 25 June 2011), p. 9 (under seal); P3773 (Witness statement of KDZ532 dated 31 October 2011) (under seal), paras. 7-8.

10909 Slobodan Jurišić, T. 47083-47085 (14 February 2014); P6671 (Excerpt from logbooks from Brčko, Doboj, Ključ, Sanski Most and Travnik Prosecutor's Offices).

10910 D4880 (Report of Sarajevo Military Court, 2 December 1993).
} 
3415. In relation to crimes committed by Bosnian Serbs against non-Serbs, authorities either failed to investigate or actively prevented investigations or prosecutions. ${ }^{10911}$ In Zvornik, municipal authorities were made aware of the massacre at Drinjača Dom Kulture but nothing was done to investigate nor was there anything done to investigate the crimes committed at Karakaj Technical School. ${ }^{10912}$ Bratunac municipal authorities and police learned that civilians were brought to the hangar of Vuk Karadžić School and heard rumours some may have been killed but the Bratunac SJB Chief forbade the police from investigating. ${ }^{10913}$ The Prijedor Crisis Staff and SJB, as well as the Banja Luka CSB and VRS were aware of the Room 3 massacre at Keraterm, however there was no investigation into the shootings or mention of the incident in reports on Keraterm. ${ }^{10914}$ Sokolac municipal authorities became aware of the killings at Novoseoci on 22 September 1992 the same day but no investigation was carried out. ${ }^{10915}$ Municipal authorities were aware of the crimes committed in the Luka Camp in Brčko. ${ }^{10916}$ Slobodan Avlijaš visited Brčko and was informed that approximately 226 non-Serb civilians were killed in Brčko and buried in mass graves and subsequently prepared a report which indicated that the victims were killed in combat. ${ }^{10917}$ However, there was never an investigation because according to Ristanić, it was impossible at the time. ${ }^{10918}$ Crimes committed in Vlasenica were widely known and criminal reports were filed but there were no criminal or disciplinary proceedings. ${ }^{10919}$ While the police organs and courts were

\footnotetext{
10911 In addition, to the proceeding examples, the Chamber notes that when Vojkan was arrested in 1993 for expelling Bosnian Muslims from Bijeljina, he was released after he produced documentation showing that he had been authorised to locate and expel Bosnian Muslims by Krajišnik. Svetozar Mihajlović, T. 35737-35740 (20 March 2013); Milorad Davidović, T. 15702-15703 (30 June 2011); D3137 (Witness statement of Svetozar Mihajlović dated 17 March 2013), para. 14; [REDACTED].

10912 Marinko Vasilić, T. 39937-39938 (13 June 2013). See Scheduled Incidents B.20.1, B.20.3.

10913 D3194 (Witness statement of Rodoljub Đukanović dated 24 March 2013), para. 40; D3115 (Witness statement of Branimir Tešić dated 9 March 2013), para. 24. See Scheduled Detention Facility C.6.2, Scheduled Incident B.4.1.

10914 See Scheduled Incident B.15.1; D470 (CSB Banja Luka Report concerning collection centres, undated), e-court pp. 2-4, 28-30; P3549 (Report of the Commission for Inspecting Collection Centres and Other Facilities for Captives in the ARK, 17 August 1992), p. 4; P2968 (Report of Prijedor SJB, January 1993); P6536 (Report of Banja Luka CSB, 20 January 1993), p. 3; Dušan Janković, T. 47341-47343 (18 February 2014).

10915 Dragomir Obradović, T. 36096-36097, 36100-36103 (26 March 2013). See Scheduled Incident A.13.1.

10916 See Scheduled Killing Incident B.5.1; D1436 (Report of SerBiH MUP, 17 June 1992), p. 3; D1412 (Report of Republic of Serbia MUP, 8 August 1992), p. 2; D1574 (Report of Brčko SJB, undated), pp. 2, 4; P2848 (Witness statement of Milorad Davidović dated 22 June 2011), paras. 115-116; Dragomir Andan, D3774 (Transcript from Prosecutor v. Stanišić \& Župljanin), T. 21423-21424.

10917 P1607 (RS Ministry of Justice report on prisons and camps on the RS territory, 22 October 1992), p. 3; P3023 (Witness statement of Đorđe Ristanić dated 15 June 2011), para. 212-223; Slobodan Avlijaš, T. 35196 (11 March 2013). See also D3105 (Witness statement of Slobodan Avlijaš dated 9 March 2013), para. 23.

10918 P3023 (Witness statement of Đorđe Ristanić dated 15 June 2011), para. 210; Đorđe Ristanić, T. 16736 (15 July 2011).

10919 See, e.g., Scheduled Incident A.15.1; D3093 (Witness statement of Mane Đurić dated 3 March 2013), paras. 34, 44; Mane Đurić, T. 35006, 35030-35031, 35059-35061 (7 March 2013) (private session); P3227 (Witness statement of KDZ033 dated 7 April 2010), paras. 64, 167 (under seal); D447 (SerBiH MUP, Analysis of functioning of the MUP, July 1992), pp. 18-19. Several perpetrators of crimes committed against non-Serbs in Vlasenica were eventually tried and convicted before the Tribunal and courts in BiH. See Dragan Nikolić
} 
fully organised and constituted in Novo Sarajevo they were not active in prosecuting individuals or protecting individuals. ${ }^{10920}$ Batko was committing crimes over a period of months there and the military police and prosecutor's office had the capacity to arrest and prosecute him but did not do so. ${ }^{10921}$

3416. Furthermore, local or municipal authorities, SDS members, soldiers, and family members of accused persons often pressured authorities to release persons accused of committing crimes against non-Serbs. ${ }^{10922}$ The military court in Banja Luka released Bosnian Serbs from custody before their cases had been completed so they could return to combat activities. ${ }^{10923}$ For example: (i) Zoran Žigić was released from prison a few days after being arrested due to a request for him to return to active duty even though it was reported to the Prijedor SJB by the Commander of Keraterm that he had beaten and killed prisoners there ${ }^{10924}$ (ii) the perpetrators of the killings of at least 77 men at Velagići School on 1 June 1992 were arrested but returned to their units without being tried with the support of the deputy prime minister of the RS and the chairman of the Ključ Executive Board; ${ }^{10925}$ and (iii) Daniluško Kajtez admitted to killing 12 individuals in Manjača in November 1992 but was released as a result of pressure exerted on the Military Court. ${ }^{10926}$ The Chamber considers that this evidence suggests a systemic vulnerability of the justice system to external pressure, including by low-level municipal officials.

3417. On 20 December 1992, at a meeting of the Supreme Command in the presence of the Accused, Mićo Stanišić spoke of the need to strengthen the judiciary and to consider whether the

Sentencing Appeal Judgement; P6132 (Verdict of BiH Court against Predrag Bastah and Goran Višković, 4 February 2010).

10920 Radomir Nešković, T. 14308-14309, 14316-14317, 14319 (7 June 2011); P5065 (Minutes of SRK Command consultation meeting, 15 November 1992), p. 12.

10921 Radomir Nešković, T. 14316-14317 (7 June 2011).

10922 [REDACTED]. See e.g. P3611 (Proposal of the Military Prosecutor's Office attached to the $1^{\text {st }}$ Krajina Corps, 29 July 1993) (under seal); P3616 (Proposal of the Military Prosecutor's Office attached to the $1^{\text {st }}$ Krajina Corps, 29 July 1993). See also D2986 (Witness statement of Novak Todorović dated 17 February 2013), para. 15. [REDACTED].

10923 [REDACTED]. See also P3612 (Submission to Banja Luka Military Court, 26 January 1993), p. 2; P3610 (Tactical Group 3 request, 27 August 1992); [REDACTED].

10924 D1926 (Order of Banja Luka CSB, 1 July 1992); D1925 (Prijedor SJB criminal report, 2 July 1992), e-court p. 2; P6597 (Request from Prijedor Prosecutor's Office, 3 July 1992); D4140 (Official note of Prijedor SJB, 4 July 1992); Dragan Radetić, T. 45690-45691, 45700-45701, 45711-45713, 45715 (21 January 2014); P6598 (Decision of Prijedor Lower Court, 9 July 1992). See also P6596 (Letter from ARK sabotage and reconnaissance unit to Prijedor Prosecutor's Office, undated). See para. 1802. Žigić was eventually convicted by the Tribunal for the crimes he committed at Keraterm. See Kvočka et al. Trial Judgement; Kvočka et al. Appeal Judgement.

10925 Adjudicated Fact 2447; P3616 (Proposal of the Military Prosecutor's Office attached to the $1^{\text {st }}$ Krajina Corps, 29 July 1993); P6143 (Excerpt from ruling of Banja Luka Military Court, 29 July 1993), pp. 1-2; [REDACTED]; Novak Todorović, T. 34077 (20 February 2013). See Scheduled Incident B.10.1.

10926 See Scheduled Incident B.1.1. 
situation at the time was satisfactory since the courts were then attached to commands and corps. $^{10927}$

3418. The Chamber notes that in response to specific events, the Accused and other members of the Bosnian Serb leadership or Serb Forces sometimes called for criminal investigations. The Chamber notes the Accused's efforts to disband certain paramilitary groups, including through the assistance of the Federal SUP. ${ }^{10928}$ Furthermore, on hearing of the Korićanske Stijene incident, the Accused requested an investigation and on 31 August 1992, Mićo Stanišić ordered Župljanin, the chief of the Banja Luka CSB, to investigate the massacre. ${ }^{10929}$ However, Župljanin was advised by Drljača that an investigation could not be carried out because the officers who had participated in the convoy and incident were currently deployed in the battlefield. ${ }^{10930}$ The Chamber recalls that none of the policemen involved in the incident were held accountable for their involvement in the killings. ${ }^{10931}$ Rather the intervention squad involved in the killings was disbanded and subsequently returned to active combat. ${ }^{10932}$

3419. On 6 April 1993, Prime Minister Vladimir Lukić, with the support of the Accused, demanded the Command of the SRK and the Main Staff of the VRS to investigate allegations of looting, killing, arson and rape in Novo Sarajevo committed by the VRS. ${ }^{1093}$ On 20 December 1994 Bogdan Subotić, on behalf of the Office of the RS President, ordered a thorough investigation of an incident involving members of special police and members of military police of the $2^{\text {nd }}$ Krajina Corps. ${ }^{10934}$ In February 1994, the Accused was notified about a meeting of the municipal leaders, MUP, and military and judicial organs due to "a very bad situation regarding public law and order in Trebinje municipality" and that military security organs failed to execute

\footnotetext{
10927 P1469 (Minutes of VRS Supreme Command meeting, 20 December 1992), p. 3.

10928 See paras. 3204-3210.

10929 D4194 (Witness statement of Sveto Kovačević dated 7 December 2013), para. 40; D1881 (Dispatch from Mićo Stanišić to Banja Luka CSB, 31 August 1992).

10930 D1882 (Letter from Simo Drljača, 14 September 1992); D1885 (Dispatch from Simo Drljača to Stojan Župljanin, 13 October 1992). See also Adjudicated Fact 2492.

10931 See para. 1845. The Chamber notes that Subotić testified that everybody "did their part of the job" with respect to the investigation. D3695 (Witness statement of Bogdan Subotić dated 16 June 2013), paras. 242-246; Bogdan Subotić, T. 40105-40111 (20 June 2013); T. 40173-40175 (21 June 2013). However, the Chamber does not find this evidence to be reliable because Subotić's evidence was marked by indicators that he was seeking to minimise his own knowledge of the investigation which followed this incident and in light of the fact that none of the perpetrators were ever held accountable.

10932 See paras. 1844-1845.

10933 D3574 (Letter from RS Office of Prime Minister to VRS Main Staff and SRK command, 6 April 1993); D3563 (Witness statement of Vladimir Lukić dated 18 May 2013), para. 36; Vladimir Lukić, T. 38801 (28 May 2013).

10934 D4640 (Letter from RS President's Office to RS MUP and VRS Main Staff, 20 December 1994).
} 
their part, as "groups of servicemen were harassing refugees". ${ }^{10935}$ The Accused ordered the VRS Main Staff to report back to him about the measures taken. ${ }^{10936}$

3420. During the conflict, there were some prosecutions of Serbs for crimes committed against non-Serbs. ${ }^{10937}$ However, the calls for investigations and the prosecutions were insufficient in light of the sheer number of serious offences which were not investigated and went unpunished.

3421. The Chamber has considered evidence that in 1994 and 1995, the Accused issued orders with respect to improving the military justice system. ${ }^{10938}$ However, the Chamber is not convinced

10935 P3053 (Radovan Karadžić's order to VRS, 19 May 1994), p. 3.

10936 P3053 Radovan Karadžić's order to VRS, 19 May 1994), p. 3.

10937 D3695 (Witness statement of Bogdan Subotić dated 16 June 2013), paras. 208-215, 218, 297; Savo Bojanović, T. 34817-34828, 34830-34835, 34842-34843 (5 March 2013); D3076 (Witness statement of Savo Bojanović dated 2 March 2013), paras. 11-12, 23-27; [REDACTED]; Novak Todorović, T. 34095-34098 (20 February 2013) (private session); D2986 (Witness statement of Novak Todorović dated 17 February 2013), para. 18; Radomir Nešković, T. 14310-14311 (7 June 2011). For cases in the civilian courts, see D1467 (Bijeljina High Court judgement in Branko Đurić case, 27 October 1995); D1490 (Indictment of Brčko Public Prosecutor, 28 July 1993); D4239 (Banja Luka Public Prosecutor's Office file on Sredo Aleksić), p. 8; D4240 (Banja Luka Public Prosecutor's Office file on Boško Bavarčić), e-court pp. 3-4, 14-15; D1798 (Banja Luka CSB criminal case file, August-September 1992), e-court p. 48. D4235 (Witness statement of Jevto Janković dated 24 January 2014), para. 7; Jevto Janković, T. $45956-45957$ (27 January 2014). For cases in the military courts, see D1465 (Bijeljina Military Court indictment of Radovan Mićanović, 17 August 1993); D1466 (Bijeljina Military Court judgement in Radovan Mićanović case, 22 March 1995); D1481 (Bijeljina Military Prosecutor request re Cvjetković/Jurošević case, 29 October 1992); D1482 (Bijeljina Military Court record re Cvjetković/Jurošević case, 29 October 1992); D1483 (Bijeljina Military Prosecutor request re Cvjetković/Jurošević case, 30 October 1992); P6181 (Bijeljina Military Court's Dispatch to Military Prosecutor's Office, 28 January 1993); D1489 (Bijeljina Military Court decision in Cvjetković/Jurošević case, 1 April 1993) (under seal); D1757 (Indictment of the Military Prosecutor's Office attached to the $1^{\text {st }}$ Krajina Corps, 18 July 1993); D1758 (Banja Luka Military Court's Judgement, 13 October 1993) (under seal); D1759 (RS Supreme Military Court's Judgement, 12 November 1994) (under seal); D1799 (Indictment of the Military Prosecutor's Office attached to the $1^{\text {st }}$ Krajina Corps, 10 February 1993); D3081 (Bijeljina Military Court's verdict, 18 January 1994); D3077 (Supreme Military Court's Judgement, 16 May 1994); D1468 (Correspondence between Bijeljina Lower Court and Radovan Karadžić, 9 June 2011); D1469 (Correspondence between Bijeljina District Prosecutor and Radovan Karadžić, 24 August 2009); D3082 (Bijeljina Military Court's Verdict, 24 June 1993); D3083 (Bijeljina Military Court's Verdict, 27 August 1993); D3084 (Bijeljina Military Court's Verdict, 11 October 1993); D3085 (Bijeljina Military Court's Verdict, 16 September 1993); D3086 (Bijeljina Military Court's Verdict, 9 March 1993); D3087 (Bijeljina Military Court's Verdict, 22 June 1993); D3088 (Bijeljina Military Court's Verdict, 17 June 1993); D3079 (Bijeljina Military Court's Ruling, 19 June 1993); D3080 (Bijeljina Military Court's Proposition, 26 April 1993); D596 (VRS Military Court judgement against Jovo Pejanović, 17 December 1992); P3597 (Criminal report of the $6^{\text {th }}$ Krajina Brigade, Sanski Most Military Post, 7 December 1992) (under seal); P3519 (Indictment of the $1^{\text {st }}$ Krajina Corps Military Prosecutor's Office, 2 June 1993); D1788 (Banja Luka Military Court's Ruling, 5 April 1994) (under seal); D1793 (Banja Luka CSB criminal case file, OctoberDecember 1992); D1776 (Record of trial of Banja Luka Military Court, 17 December 1992) (under seal); D1777 (Letter from Banja Luka Military Court to Srbac SJB, 18 December 1992) (under seal); D1780 (Record of deliberation and voting of Banja Luka Military Court, 21 October 1993) (under seal); D1781 (Record of deliberation and voting of Banja Luka Military Court, 20 April 1995) (under seal); D1782 (Record of trial of Banja Luka Military Court, 20 April 1995) (under seal); P3633 (Judgement of the Banja Luka Military Court, 20 April 1995) (under seal); D1796 (Delivery Note of Banja Luka Military Court, 19 October 1994); P3631 (Judgement of the Banja Luka Military Court, 6 February 1993) (under seal). See P2931 (Bijeljina Military Court indictment of Zoran Tomić and Dragan Matović, 24 June 1993), pp. 54-60, 84-87; [REDACTED]. See also D4279 (Verdict of Banja Luka District Court against Mile Zgonjanin, 25 November 2008); Mićo Stanišić, T. 46395-46396 (3 February 2014) (testifying that the judgement was passed based on the evidence that was collected in 1992.

10938 On 1 January 1994, the Accused ordered an inspection into the military prosecution system in Bijeljina after receiving reports of flaws in the system, primarily relating to the release of persons detained under reasonable 
that they were sufficient to hold persons accountable for the very serious offences which had been committed in the Municipalities against non-Serbs in light of the fact that so many crimes against non-Serbs went without investigation. In any event, the most serious crimes had already been committed by that time. ${ }^{10939}$

3422. In fact, the Accused was more concerned with punishing offences committed against Bosnian Serb Forces than the non-Serb civilian population. This is demonstrated by the fact the Accused made efforts to ensure that crimes committed against Serbs were investigated and documented. On 17 June 1992, the Accused created the State Documentation Centre for Investigation of War Crimes against Serb People and appointed its head. ${ }^{10940}$ On 13 July 1992 the Presidency concluded that the work of the Commission for War Crimes Committed against the Serbian People of BH be urgently activated. ${ }^{10941}$ On 14 July 1992 the Government decided that measures be taken for the Commission to be activated for the establishment of war crimes perpetrated against the Serbs. ${ }^{10942}$ On 6 August 1992, at a RS Presidency session, it was decided that the Commission for Investigating War Crimes Committed against the Serbian People must

suspicion of having committed grave criminal offences. D1419 (Radovan Karadžić's order to president of Supreme Military Court, 1 January 1994). On 8 August 1994, the Accused ordered the VRS Main Staff to submit a report on problems in the military disciplinary tribunals and proposals to improve their function D1421 (Radovan Karadžić's order to VRS Main Staff, 8 August 1994). On 6 September 1994, the Accused directed that criminal offences against life, limb, and property and the offence of war profiteering should be given priority and detention measures "applied to the maximum in the punishment of these offences" and instructing the Court and Prosecutor's Office to urgently review all murder cases currently being tried in military courts and to submit analysis to him so that he could take further measures as President of the Republic. D2993 (Radovan Karadžić's instruction to Supreme Military Court and Supreme Military Prosecutor's Office, 6 September 1994). The Military Prosecutor's Office of the VRS conveyed similar instructions to the Intelligence and Security Sector of the VRS Main Staff with reference to instructions from the President. D2998 (Supreme Military Prosecutor's Office report, 8 September 1994) On 11 September 1994, the Accused instructed the organs of military security to review murder cases and report any irregularities observed to the Office of the President of the Republic. D1423 (RS President's Office request to VRS Main Staff, 11 September 1994). See also D2994 (Supreme Military Court's instruction, 16 September 1994), p. 1; D2986 (Witness statement of Novak Todorović dated 17 February 2013), para. 10. In a session on 15 September 1994, the RS Government, with the support of the Accused, authorised the MUP and the Ministry of Justice and Administration to collect information on crimes against humanity and other crimes violating international law, irrespective of the ethnicity of the victims of those crimes. D3364 (Witness statement of Dušan Kozić dated 7 April 2013), para. 18; D3373 (Excerpt from minutes of $4^{\text {th }}$ session of RS Government, 15 September 1994), p. 2. On 15 December 1994, the Accused ordered the VRS Main Staff to issue instructions to security and military police organs setting forth their duty to act in accordance with requests and orders by military prosecutors' offices and military courts. D1425 (Radovan Karadžić's order to VRS Main Staff, 15 December 1994), p. 1. See also D1426 (Instructions of RS Military Prosecutor's Office, 29 December 1994), pp. 2-5. On 4 January 1995, the Accused promulgated the Law on the Mandatory Submission of Information on Crimes against Humanity and International Law, which the Bosnian Serb Assembly had passed at its session on 29 to 30 December 1994. D1424 (Radovan Karadžić's Decree on promulgation of Law on mandatory submission of information on crimes against humanity and international law, 4 January 1995), p. 1; P1405 (Transcript of $48^{\text {th }}$ session of RS Assembly, 29-30 December 1994), p. 129.

10939 See Section IV.A.2: Legal findings on crimes.

10940 P3064 (Minutes of the $8^{\text {th }}$ session of the SerBiH Presidency, 17 June 1992), p. 1; D3990 (Radovan Karadžić's Decree, 17 June 1992), p. 1.

10941 P1465 (Minutes of $19^{\text {th }}$ session of SerBiH Presidency, 13 July 1992), p. 8.

10942 P1137 (Minutes of 39th session of SerBiH Government, 14 July 1992), p. 10. 
commence its work. ${ }^{10943}$ Mladić issued an order on 25 September 1992 that information about victims of crimes committed by the "Croatian-Muslim coalition" should be reported. ${ }^{10944}$ On the same day, Plavšić ordered that all SAOs spread the word to their municipalities that it was necessary to urgently set up commissions to gather information on crimes perpetrated against the Serbs by the Croats and Muslims. ${ }^{10945}$

3423. On 28 September 1992, the Presidency concluded that the Committee for Investigation of Crimes against Serbian People should intensify its work. ${ }^{10946}$ On 14 December 1992 the Banja Luka CSB Department Chief wrote to all SJBs to inform them that a meeting of senior criminal investigators from all centres would occur the following week in Bijeljina, at which the process of documenting crimes against the Serb civilians, their property, and Orthodox cultural and religious property would be analysed. ${ }^{10947}$ At sessions of the Bosnian Serb Government on 6 April and 26 to 27 May 1993, the work of the "State Documentation Centre for the Investigation of Crimes Against Serbs" was discussed, as was the "special importance" to instigate criminal proceedings against individual and group perpetrators of "crimes and genocide against the Serbian people". ${ }^{1048}$ In March 1995, the Accused advised the Bosnian Serb Assembly that after reviewing data prepared by the Ministry of Justice and the Republican Prosecutor's Office on cases in civilian courts in 1994, that "on the whole, the situation in the domain of penal policy is unsatisfactory" and stated that "this might have far-reaching detrimental consequences for the overall defence capability of the Republic and the continued successful conduct of the war"; he proposed that the Assembly adopt a conclusion that civilian and military courts step up their work and pass more stringent sentences, especially with respect to criminal offences against the Serb Forces. ${ }^{10949}$

3424. The Chamber notes that some witnesses provided evidence that: (i) the MUP and justice systems treated perpetrators and victims of different ethnicities in the same manner; ${ }^{10950}$ (ii) there

\footnotetext{
10943 D465 (Minutes of $24^{\text {th }}$ session of SerBiH Presidency, 6 August 1992), p. 2.

10944 D3987 (Order of Ratko Mladić, 25 September 1992).

10945 P5506 (Request of RS Presidency to Municipal Assembly President, 25 September 1992), p. 1.

10946 P3120 (Minutes of the $32^{\text {nd }}$ session of RS Presidency, 28 September 1992), p. 3.

10947 P6642 (Dispatch from Banja Luka CSB to all SJBs, 14 December 1992).

10948 P3138 (Minutes of the $67^{\text {th }}$ session of RS Government, 6 April 1993), pp. 5-6; P3112 (Minutes of the $71^{\text {st }}$ session of RS Government, 26-27 May 1993), p. 12.

10949 D1427 (Radovan Karadžić's letter to RS National Assembly, 10 March 1995), p. 1. In this regard, the Chamber notes that on 17 May 1995, following a meeting of the Government's Commission for gathering data on international crimes committed in the RS, Marko Lugonja on behalf of the Intelligence and Security Department of the SRK Command sent out a request to the Commands of all SRK units to "gather all the data and evidence in the zones of your units on war crimes against humanity and international law committed by the enemy against the Serbs and Serbian people. P2646 (Request of SRK's Intelligence and Security Department, 17 May 1995); P2715 (SerBiH MUP dispatch, 16 May 1992).

10950 D4235 (Witness statement of Jevto Janković dated 24 January 2014), paras. 2, 7; Jevto Janković, T. 45949 (27 January 2014); D3663 (Witness statement of Goran Mačar dated 3 May 2013), paras. 26-27. See Dobrislav
} 
was no cover-up of crimes in the MUP, including the CSBs and SJBs; ${ }^{10951}$ (iii) there were problems in finding witnesses to proceed with a prosecution, especially in cases involving Muslim or Croat victims, ${ }^{10952}$ (iv) there were purported issues deriving from the jurisdiction of the civilian and military systems, including confusion on the part of civilian and military authorities and inefficiency; ${ }^{10953}$ and (v) that investigations and prosecutions were made difficult due to lack of resources. ${ }^{10954}$

3425. Having considered all of the evidence, the Chamber finds that there was a systemic failure to investigate and prosecute criminal offences committed against non-Serbs in the Municipalities during the conflict. The Chamber rejects the evidence presented that the justice system treated all ethnicities the same in light of the compelling evidence demonstrating a lack of investigation and prosecution of the serious criminal acts committed against non-Serbs which were brought to the attention of authorities, as opposed to a clear willingness to investigate and prosecute crimes committed against Serbs. ${ }^{10955}$ In addition, lack of resources and difficulties with the determination of jurisdiction or finding witnesses does not explain or justify the lack of proceedings initiated against Serbs alleged to have committed crimes against non-Serbs because the evidence establishes that in most cases in 1992, absolutely nothing was done to investigate or prosecute the horrific crimes which were known to authorities. The Chamber considers that the inadequate level of investigations and prosecutions of crimes committed against non-Serbs is consistent with the Accused's position that such matters could be delayed during the conflict. ${ }^{10956}$

Planojević, T. 36258, 36262-36263, 36297 (28 March 2013); D3981 (Witness statement of Miroslav Toholj dated 31 October 2013), para. 72; Branko Đerić, T. 28047-28048 (25 April 2012).

10951 Goran Mačar, T. 39525 (7 June 2013); Dobrislav Planojević, T. 36297 (28 March 2013). See also Čedomir Kljajić, T. 42241 (30 July 2013).

10952 KDZ492, P3596 (Transcript from Prosecutor v. Krajišnik), T. 3937-3938 (under seal).

10953 See Momčilo Mandić, T. 5125-5127 (14 July 2010); D3076 (Witness statement of Savo Bojanović dated 2 March 2013), para. 16; Savo Bojanović, T. 34844-34846 (5 March 2013).

10954 D3663 (Witness statement of Goran Mačar dated 3 May 2013), paras. 23-24; Mićo Stanišić, T. 46360 (3 February 2014); D3197 (Witness statement of Dobrislav Planojević dated 23 March 2013), paras. 22-23. See also D447 (SerBiH MUP, Analysis of functioning of the MUP, July 1992), e-court p. 20; D2986 (Witness statement of Novak Todorović dated 17 February 2013), paras. 4-5, 20; P3773 (Witness statement of KDZ532 dated 31 October 2011), para. 8 (under seal); KDZ532, T. 21011-21012 (8 November 2011) (closed session); KDZ492, T. 20058, 20061, 20078-20079 (18 October 2011) (closed session). See also D1752 (Request from VRS Main Staff, 5 August 1992); D1755 (Information on crime trends and review of work of Military Prosecutor's Office attached to the $1^{\text {st }}$ Krajina Corps, 19 September 1992), p. 1; D2836 (SRK information, 23 December 1993), pp. 3-4; Dragomir Milošević, T. 32869-32870 (29 January 2013) D2987 (Report of Supreme Military Court on the work of Military Courts, 20 February 1996), pp. 4-5, 10.

10955 See paras. 3414-3416, 3422-3423.

10956 See para. 3413. 
(F) Rewarding of those who committed crimes against non-Serbs

3426. The Prosecution submits that the Accused rewarded officials who had committed crimes against non-Serbs rather than punish them. ${ }^{10957}$ The Accused submits that there is no evidence that he rewarded an official who he knew had committed a crime and that proposals for promotions came from below. ${ }^{10958}$

3427. The Law on the Army provided the Accused with the exclusive competence to, inter alia, decide on the initial commission of officers, promote officers to the rank of Major General and above, and decide on the admission into service, subsequent appointment, transfer, and termination of service of officers with the rank of General. ${ }^{10959}$ It also authorised him to effect "exceptional promotion" with respect to those officers who did not meet the ordinary criteria of rank promotion and to raise the rank of those officers who were found to have exhibited courage and excelled in command and control skills. ${ }^{10960}$

3428. The Accused promoted several officials who he knew had committed criminal acts against non-Serbs or held extremist views. On 24 August 1992 the Accused appointed Jovan Tintor, then president of the Vogošća Crisis Staff, ${ }^{10961}$ as a presidential advisor and in April 1995 praised him before the Bosnian Serb Assembly for giving "everything for this Party, for this people". ${ }^{0962}$ Tintor had been involved in the expulsion and mistreatment of non-Serbs from Vogošća, and surrounding areas. ${ }^{10963}$ He also held extremist views which were known to the Accused. ${ }^{10964}$

3429. The Accused awarded Mauzer's Panthers on 9 January 1994. ${ }^{10965}$ The Accused was aware that Mauzer's Panthers, a paramilitary group active in Bijeljina, was involved in planning and executing the forcible displacement of Bosnian Muslim civilians, committed killings and other crimes against non-Serb civilians in Bijeljina in 1992. ${ }^{10966}$

\footnotetext{
10957 Prosecution Final Brief, paras. 567-569

10958 Defence Final Brief, paras. 1335-1336.

10959 P2603 (SerBiH Law on the Army, 1 June 1992), Arts. 11, 369.

10960 P2603 (SerBiH Law on the Army, 1 June 1992), Arts. 36, 40.

10961 See para. 2361.

10962 P5430 (Decision of the RS Presidency, 23 August 1992); P970 (Transcript of 50 ${ }^{\text {th }}$ session of RS Assembly, 1516 April 1995), p. 317.

10963 See Section IV.A.1.c.vi.C.1: Take-over of Vogošća town; Section IV.A.1.c.iii.C: Attack on Ahatovići.

10964 [REDACTED].

10965 P5525 (Audio Recording and Transcript of the Ceremonial RS National Assembly, 9 January 1994), p. 18.

10966 See Section IV.A.1.a.1: Bijeljina; para. 3334.
} 
3430. The Accused also awarded Miroslav Deronjić on 9 January 1994 and later appointed him as Civilian Commissioner for Srebrenica on 11 July 1995. ${ }^{10967}$ Deronjić was the President of the SDS and chief of the Bratunac Crisis Staff and oversaw a policy of discrimination against Bosnian Muslims and was involved in operations leading to their expulsion from Bratunac and killings. ${ }^{10968}$ On 6 May 1992, it was reported to the Accused and Mladić that Deronjić was "killing all Muslims by slitting their throats". 10969

3431. The Accused personally promoted Vojkan Đurković to the rank of major and awarded him a medal at a ceremony in Bijeljina in 1994 although the Accused knew that he had participated in "ethnic cleansing" of non-Serbs during the conflict. ${ }^{10970}$ Furthermore, at a meeting of the VRS Main Staff on 5 April 1995, the Accused acknowledged that Vojkan had worked illegally. ${ }^{10971}$

3432. In November 1993 and June 1994, the Accused promoted and awarded medals of bravery to members of the intervention squad, as well as high officials who were implicated in the Korićanske Stijene, such as Drljača, Paraš, Milutin Čađo. ${ }^{10972}$ On 3 September 1992, the $1^{\text {st }}$ Krajina Corps reported to the VRS Main Staff that Drljača was responsible for the incident at Korićanske Stijene and that it had caused indignation among citizens and members of the $1^{\text {st }}$ Krajina Corps, creating a "dark stain", but that it was fortunate that the "international community did not find out about it in more detail". ${ }^{10973}$ Drljača was also the chief of the SJB in Prijedor and established Omarska by written order. ${ }^{10974}$

\footnotetext{
10967 P5525 (Audio Recording and Transcript of the Ceremonial RS National Assembly, 9 January 1994), p. 18; D2055 (Decision of RS President, 11 July 1995). See also para. 5692.

10968 See Section IV.A.1.a.ii: Bratunac.

10969 P1477 (Ratko Mladić's notebook, 14 February-28 May 1992), p. 253. The Chamber notes that Mladić's notebook refers to the President of the SDS as "Rodoljub Deronjić". In addition one of the other Bosnian Serb leaders referred to in the notebook was "Rodoljub Đukanović". In light of Miroslav Deronjić's position as SDS President at the time, the Chamber finds that the reference is indeed to Miroslav Deronjić.

10970 Milorad Davidović, T. 15712 - 15715 (30 June 2011) (questioning the Accused in his testimony about how the Accused could have presented Vojkan Đurković an award if the Accused knew that Đurković carried out "ethnic cleansing" throughout the war); D1136 (UNPROFOR report, 9 September 1994), p. 2 (noting that the Accused identified Vojkan Đurković as a member of Arkan's men who was involved in "ethnic cleansing" in Bijeljina in 1994. See also D1432 (Report of Eastern Bosnian Corps Command, 22 August 1994), p. 7 (wherein the Accused condemned Vojkan Đurković for criminal activies directed against members of the VRS).

10971 P3149 (Minutes of $14^{\text {th }}$ session of Supreme Command, 31 March 1995), p. 65 (indicating that the Accused stated at a meeting of the VRS Main Staff on 5 April 1995: "It is the standpoint of our policy, there has been a separation of peoples, of cultures of worlds" but acknowledged that Vojkan worked illegally). See also para. 3404; D1429 (Request of Bijeljina's Municipal Assembly, 24 July 1995) (which demonstrates that Vojkan was still at large in July 1995).

10972 See para. 1845; KDZ523, P4257 (Transcript from Prosecutor v. Brđanin), T. 21164-21166 (under seal); P4264 (Award for bravery presented by Radovan Karadžić) (under seal); P4261 (Article in the Kozarski Vesnik entitled "Shoulder to Shoulder with the Army", 26 November 1993); P4265 (Compilation of video footage from various Serbian TV stations, undated, with transcript).

10973 P3929 (Report of $1^{\text {st }}$ Krajina Corps, 3 September 1992), p. 4.

10974 See para. 1751.
} 
3433. The Chamber finds that the evidence that the Accused rewarded or promoted his subordinates, who he knew had committed crimes, demonstrates that the Accused was indifferent to whether they participated in criminal activity directed at non-Serbs during the conflict as long as the core objectives of the Bosnian Serbs were fulfilled.

b. Existence of a common plan shared by a plurality of persons

\section{i. Common plan}

3434. In this section the Chamber refers to its factual findings with respect to the Overarching JCE discussed above and will assess whether those facts establish that a common criminal purpose existed, and if so, when it came into existence and what was entailed in that common plan. The Chamber will also assess whether a plurality of persons acted pursuant to that common plan.

3435. The Chamber found that from 1990 and into mid-1991, the political objective of the Accused and the Bosnian Serb leadership was to preserve Yugoslavia and to prevent the separation or independence of $\mathrm{BiH} .{ }^{10975}$ The central themes of this objective were to preserve the unity of the Serb people and to ensure that Bosnian Serbs would not become a minority in an independent BiH. ${ }^{10976}$ The Chamber also found that in October 1991, when it became clear to the Bosnian Serb leadership that $\mathrm{BiH}$ was pursuing the path to independence and the Bosnian Serbs' objective of preserving Yugoslavia had been undermined, the focus shifted and plans were developed for the creation of a Bosnian Serb state. ${ }^{10977}$ The process of regionalisation and the creation of SAOs were the first steps in this process, ${ }^{10978}$ and were followed on 24 October 1991 by the decision of the Bosnian Serb deputies in the SRBiH Assembly to establish a separate assembly, which was

10975 See para. 2651.

10976 See para. 2652. See also para. 2942.

10977 See paras. 2654, 2711, 2941-2951. The Chamber recalls that it considered the Accused's statement in February 1992 about creating a "sovereign area of the Serbian people", and the supporting statements of both Koljević and Krajišnik, to be highly probative in terms of explaining the changing objectives of the Accused and the Bosnian Serb leadership. See paras. 2819-2820, 2840. The Chamber notes that during his testimony Jovanović tried to downplay any knowledge of statements made by the Bosnian Serb leadership regarding their aspirations in $\mathrm{BiH}$ and characterised them as "euphoric statements". The Chamber also noted that the witness showed indicators of bias during his testimony. The Chamber therefore does not rely on Jovanović's opinion or assessment about the goal of the Accused or the Bosnian Serb leadership. Similarly the Chamber has had regard to this credibility assessment and does not rely on Jovanović's assessment and characterisation of the Accused's rhetoric during the war. It also does not find his evidence regarding the objective of "Greater Serbia" to be reliable. Vladislav Jovanović, T. 34268-34271, 34296, 34301 (26 February 2013), 34347-34348, 34351-34352 (27 February 2013); D3015 (Witness statement of Vladislav Jovanović dated 22 February 2013), para. 54. See also D3026 (Article from Yugoslav Daily Survey entitled "Montenegrin President: Decisive Step towards Peace in Bosnia", 21 June 1993), p. 1.

10978 See paras. 2964-2965. Pašić stated that the Accused did not participate in the establishment of the communities of municipalities and was opposed to it and was not aware that the Bosnian Serb leadership used regionalisation as a means of grouping "Serbian" territories. D3849 (Witness statement of Radomir Pašić dated 5 July 2013), paras. 28-29, 32. However, the Chamber notes that Pašić's testimony was marked by evasiveness and indicators of insincerity which undermined the reliability of his evidence in this regard. 
constituted the next day. ${ }^{10979}$ From that point on, there came into existence a plan which entailed the creation of parallel governmental structures to be followed by the physical take-over of Bosnian Serb claimed territory. ${ }^{10980}$ Physical control of territories was a core element of this plan and the plan envisaged a territorial re-organisation which would allow the Bosnian Serbs to claim control of a large percentage of the territory in $\mathrm{BiH} .{ }^{10981}$ These territorial claims were closely linked to the ideology promoted by the Bosnian Serb leadership, as they tried to revive historical territorial rights and focused on the perceived threats faced by the Bosnian Serbs from Bosnian Muslims and Bosnian Croats who were portrayed as their historic enemies. ${ }^{10982}$

3436. The Accused and the Bosnian Serb leadership intended that these take-over operations be achieved militarily and that Bosnian Serbs maintain control over this territory through parallel structures of authority. ${ }^{10983}$ This plan to take physical control of Bosnian Serb claimed territory in the Municipalities through military means required the mobilisation and co-ordinated actions of the Serb Forces. ${ }^{10984}$ Earlier in this Judgement, the Chamber found that the use of force was envisaged to take-over power and there was no genuine concern about the manner in which power was taken. $^{10985}$

3437. Once the Bosnian Serb Assembly was set up, the Accused issued the Variant A/B Instructions in December 1991 to ensure preparations at the municipal level for the establishment of an ethnically homogeneous separate state. The Chamber found above that these instructions were central in terms of furthering the objectives of the Accused and the Bosnian Serb leadership from December 1991 onwards. ${ }^{10986}$ The Chamber found that the structures and organs created pursuant to the Variant A/B Instructions-first and foremost the Crisis Staffs-played a central role in preparing for, and carrying out, the Bosnian Serb take-overs in the Municipalities and in maintaining Bosnian Serb authority and power after the take-overs were completed. ${ }^{10987}$ These

\footnotetext{
10979 See paras. 2914, 2944.

10980 See paras. 2708-2710, 2941-2951.

10981 See paras. 2839-2856.

10982 See paras. 2839-2856, 2948.

10983 See paras. 2654, 2707-2715, 2844-2848, 2991.

10984 See paras. 2844-2845. See also paras. 2898-2899, 3077.

10985 See para. 3084

10986 See paras. 3073-3079, 3083, 3089.

10987 See paras. 3072-3096. Defence witnesses testified inter alia that Crisis Staffs (i) were established at various levels in $\mathrm{BiH}$ and were simply a means of responding to a crisis situation; (ii) were by no means "a secret system of command and control"; (iii) operated independently and did not receive instructions from the SDS leadership; and (iv) did not plan for the persecution of non-Serbs. D4194 (Witness statement of Sveto Kovačević dated 7 December 2013), paras. 10, 23; D4027 (Witness statement of Nikola Poplašen dated 11 November 2013), para. 5. While the Chamber did find that Crisis Staffs were created at different levels in $\mathrm{BiH}$ and also by Bosnian Muslims, the Chamber does not find the remainder of the evidence of these witnesses to be reliable in this regard. In reaching that conclusion, the Chamber had regard to the manner in which the Crisis Staffs were created pursuant to the Variant A/B Instructions and the manner in which they were used to establish Bosnian
} 
parallel structures were also created in such a way that the objectives, plans, and instructions of the Bosnian Serb leadership were easily communicated to Bosnian Serb leaders at a municipal level. $^{10988}$

3438. On 12 May 1992, six months after the issuance of the Variant A/B Instructions, and after the second level of those instructions had been activated, the Accused presented the Strategic Goals before the Bosnian Serb Assembly. The Chamber found earlier that these Strategic Goals not only reflected the objectives of the Accused and the Bosnian Serb leadership but were also viewed as instructions to be followed at a municipal level in order to achieve those objectives. ${ }^{10989}$

3439. The Chamber finds that there was nothing in the Variant A/B Instructions or the Strategic Goals which called for the commission of crimes per se. However, the Chamber found that ethnic separation and the creation of a largely ethnically homogeneous entity were some of the core aspects of the Strategic Goals and that the Accused and the Bosnian Serb leadership planned the military implementation of these goals which necessarily entailed the take-over of territory and the forcible movement of the non-Serb population to achieve that objective. ${ }^{10990}$ Therefore, it is clear that the Variant A/B Instructions and Strategic Goals created the basis, and laid the foundations, for the structures through which a criminal purpose could be achieved. In reaching that conclusion, the Chamber also had regard to the manner in which the Variant A/B Instructions and Strategic Goals were implemented throughout the Municipalities and the objectives of the Bosnian Serb leadership with respect to ethnic separation. This involved a widespread and systematic pattern of crimes committed by Serb Forces against non-Serbs throughout the Municipalities, which is discussed in further detail below.

3440. The Chamber finds that the planned take-over of Bosnian Serb claimed territories went beyond the establishment of authority; it also entailed the removal of Bosnian Muslims and Bosnian Croats in order to create a largely ethnically homogeneous entity. ${ }^{10991}$ This was founded on the ideology that Bosnian Serbs could not co-exist with Bosnian Muslims and Bosnian Croats. $^{10992}$

Serb authority and control over municipalities and their involvement in crimes committed against non-Serbs. It also noted that the evidence of the relevant witnesses was marked by contradictions, evasiveness, and indicators of bias which undermined the credibility of their evidence in this regard.

10988 See paras. 2940, 2944, 2947.

10989 See paras. 2899-2903.

10990 See paras. 2895-2903.

10991 See paras. 2839-2856.

10992 See paras. 2839-2956, 2895-2896. See also paras. 2670-2673. 
3441. The Chamber further recalls that there was an organised and systematic pattern of crimes committed by members of the Serb Forces and Bosnian Serb Political and Governmental Organs in the Count 1 Municipalities. ${ }^{10993}$ A similar systematic pattern of crimes against Bosnian Muslims and Bosnian Croats was repeated in the remaining Municipalities which spread over the three main regions relevant to the Municipalities component of this case, namely Eastern Bosnia, the ARK, and the Sarajevo area.

3442. The Chamber found that a vast number of Bosnian Muslims and Bosnian Croats in the Municipalities were forcibly displaced from the homes, villages, and towns in which they were lawfully present to other locations in $\mathrm{BiH}$ or third countries. Victims were given limited time to leave their homes, loaded onto trucks, buses, or trains and transported out of the Municipalities. The Chamber found that in many cases Bosnian Muslims and Bosnian Croats were forced to leave following attacks against their villages or after the take-over of towns by Serb Forces. Many others were first arrested, and then unlawfully detained in detention facilities and transported out of the Municipalities. These expulsions resulted in drastic changes to the ethnic composition of towns and by 1995, almost no Bosnian Muslims or Bosnian Croats remained in many of the Municipalities.

3443. In particular, the Chamber found that, in a similar pattern throughout the Municipalities, Serb Forces and Bosnian Serb Political and Governmental Organs were involved in the systematic forced movement of Bosnian Muslims and Bosnian Croats from the Municipalities, including in creating an environment of fear in which Bosnian Muslims and Bosnian Croats had no choice but to leave the Municipalities. ${ }^{10994}$ The Chamber found that Bosnian Muslims and Bosnian Croats were displaced as a result of, or following physical force, threat of force, or coercion, or that they fled out of fear. This fear was caused by ongoing violence and various crimes committed against non-Serbs including inter alia killings, cruel and inhumane treatment, unlawful detention, rape and other acts of sexual violence, discriminatory measures, and wanton destruction of villages, houses and cultural monuments. 10995

3444. Further, the similar manner and the short time period in which these crimes were committed support the conclusion that these crimes were committed during the course of well planned and coordinated operations which involved the military take-over of Municipalities and the expulsion of non-Serbs. The Chamber found that most of the crimes were committed between April to October 1992 in each of the Municipalities but then continued through to the end of the conflict.

10993 See Section IV.A.2.v: Genocide: Count 1.

10994 See Section IV.A.2.iii: Deportation and inhumane acts (forcible transfer): Counts 7 and 8. 
The Chamber found that many of the attacks on towns and villages in the Municipalities were carried out in an organised and co-ordinated fashion and involved members of the Serb Forces. These attacks and the crimes which were committed during and after the take-overs followed a similar pattern across the Municipalities. ${ }^{10996}$

3445. Having regard to the clear systematic and organised pattern of crimes which were committed in each of the Municipalities by members of the Serb Forces, over a short time period, the Chamber finds that these crimes were not committed in a random manner, but were committed in a co-ordinated fashion.

3446. The Accused disputes that there was a systematic expulsion of non-Serbs from the RS by arguing that the Prosecution disregarded the majority of municipalities where non-Serbs were protected and that this undermines the theory that there was a common plan. ${ }^{10997}$ The Chamber does not consider that there is any merit to this argument, given that the Chamber found that the twenty municipalities in which these crimes were committed, and in relation to which the Chamber was tasked with entering findings, were of strategic importance to the Accused and the Bosnian Serb leadership and formed part of Bosnian Serb claimed territory. Even if there were no crimes committed in other municipalities in $\mathrm{BiH}$, not covered by the Indictment, it would not affect the Chamber's conclusion that crimes were committed in a systematic and organised manner in the Municipalities.

3447. Having weighed the evidence discussed above in light of the systematic and organised manner in which crimes were committed in each of the Municipalities, the Chamber finds beyond reasonable doubt that between October 1991 and 30 November 1995 there existed a common plan to permanently remove Bosnian Muslims and Bosnian Croats from Bosnian Serb claimed territory through the crimes as set out in more detail below. The Chamber finds that starting in October 1991, the Accused and the Bosnian Serb leadership agreed on how they would respond to the declaration of sovereignty in $\mathrm{BiH}$ and the measures they would take to create their own ethnically homogeneous state.

\section{ii. Plurality of persons}

3448. The Prosecution alleges that the Accused worked together with other Bosnian Serb military and political leaders to achieve the objective of the common plan. ${ }^{10998}$ While the Prosecution

\footnotetext{
10995 See Section IV.A.2.iii: Deportation and inhumane acts (forcible transfer): Counts 7 and 8.

10996 See Section IV.A.2: Legal findings on crimes.

10997 See Defence Final Brief, paras. 966-972, 979.

10998 Prosecution Final Brief, para. 84.
} 
submits that the membership of the alleged JCE fluctuated over time, it argues that each member made a significant contribution to achieving the common criminal purpose. ${ }^{10999}$ The Prosecution then proceeds to list the named members of the alleged Overarching JCE and their respective contributions to the common plan. ${ }^{11000}$

3449. Beginning in late 1991, Krajišnik, Koljević, and Plavšić were intimately involved with the Accused in developing the policies and plans which formed the foundation of the common plan as defined above. They made speeches on the themes of preventing the independence of $\mathrm{BiH}$ and that Bosnian Serbs could not live with Bosnian Muslims and Bosnian Croats, and ultimately advocated the separation of the three peoples and the creation of a separate Serb state. ${ }^{11001}$ For Krajišnik, the goal of separating from the Bosnian Muslims was the most important task and he often recalled that the main Bosnian Serb objective was to create their own, "ethnically pure" state. ${ }^{11002}$ Krajišnik and Plavšić both spoke of ethnic cleansing as something that was necessary to achieve the goals of the Bosnian Serb leadership. ${ }^{11003}$ Krajišnik and Plavšić specifically agreed with the Accused that Bosnian Muslims should be transferred out of Bosnian Serb territory given that they could not live together. ${ }^{11004}$ Plavšić went as far as to state that "if it takes the lives of 3 million people to solve this crisis, lets get it done and move on". ${ }^{11005}$ In addition, Koljević repeatedly called for the expulsion of Bosnian Muslims and the homogeneity of territories, claiming it was impossible for Serbs to live with anyone else. ${ }^{11006}$ Krajišnik, Koljević, and Plavšić also participated in formulating and promoting the Strategic Goals, and took steps to ensure they were implemented, and that organisational structures were created through which the criminal purpose could be achieved. ${ }^{11007}$

3450. In addition to their participation in the creation of the common plan and agreement with the political objectives of the Accused and the Bosnian Serb leadership, the roles held by Krajišnik, Koljević, and Plavšić throughout the conflict are indicative of their further contributions to the common plan. Together with the Accused, Krajišnik, Koljević, and Plavšić were considered the top most powerful leaders in the RS. ${ }^{11008}$ Krajišnik, Koljević, and Plavšić were three of the five members of the RS Presidency; Krajišnik was President of the Bosnian Serb Assembly and

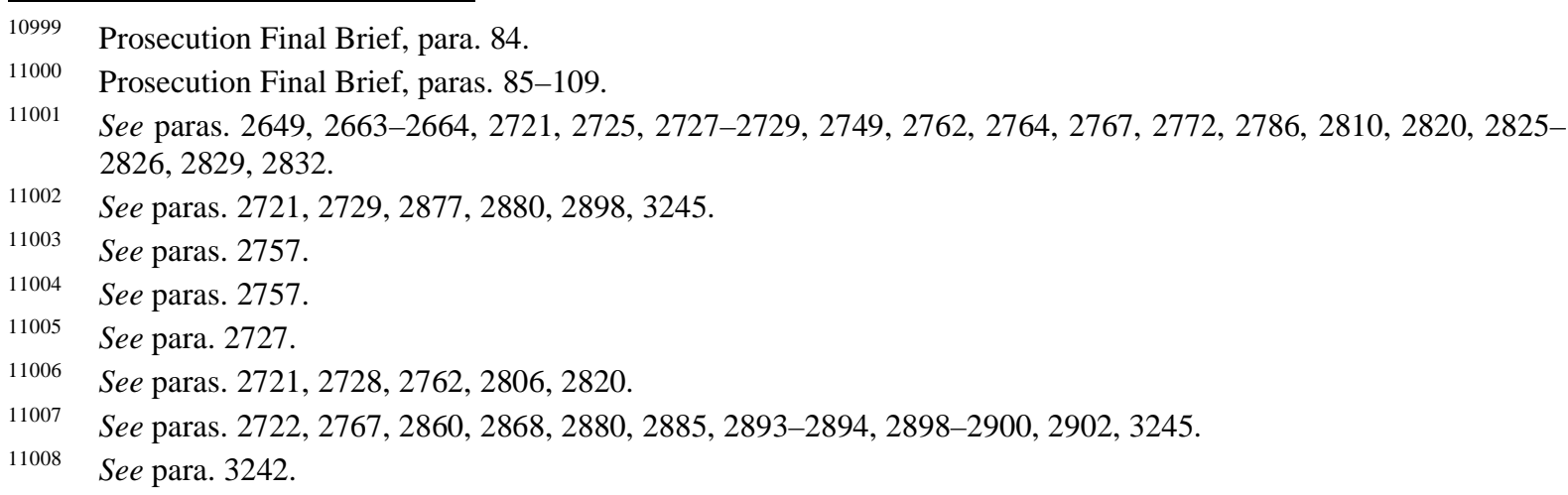


Koljević and Plavšić were Vice-Presidents of the RS; all three were appointed to deal with important issues throughout the conflict, relating to detention centres, communications with international organisations, as well as information and propaganda. ${ }^{11009}$

3451. Krajišnik had great authority among the Bosnian Serb municipal leaders and had the ability to issue orders and influence how power should be exercised at the municipal level. ${ }^{11010}$ Plavšić herself openly supported Serbian paramilitary units and invited them to BiH to support the war efforts and was a link between these units and the Bosnian Serb leadership. ${ }^{11011}$ The Chamber further found that Krajišnik, Koljević, and Plavšić attended meetings and events throughout the Municipalities and were informed of crimes committed during and after the take-over of the Municipalities and in detention facilities there; furthermore, they were specifically informed of efforts to forcibly remove non-Serbs from the Municipalities which was the very result intended by the Bosnian Serb leadership from the inception of their plan. ${ }^{11012}$

3452. Based on the above, the Chamber finds that together with the Accused, Krajišnik, Koljević, and Plavšić shared the intent to effect the common plan to permanently remove Bosnian Muslims and Bosnian Croats from Bosnian Serb claimed territory, and through their positions in the Bosnian Serb leadership and involvement throughout the Municipalities, they contributed to the execution of the common plan from October 1991 until at least 30 November 1995.

3453. Turning to Mladić, beginning on 12 May 1992 when the Accused recruited and appointed him as Commander of the Main Staff, he commanded the highest body of the VRS pursuant to the authority delegated to him by the Accused, and issued regulations, orders, and instructions, implementing orders issued by the Accused. ${ }^{11013}$ Given his position and influence, Mladić was closely involved with, and was kept well-informed of, military developments throughout the Municipalities, including during the take-over of towns by units of the VRS and in detention facilities where non-Serbs were held between April 1992 and November 1995. ${ }^{11014}$ As stated above, the Chamber found that Mladić shared the objective with the Bosnian Serb leadership that Bosnian Serbs could not co-exist with Bosnian Muslims and Bosnian Croats and agreed with and promoted the plan to create a separate Bosnian Serb state and in particular took steps to ensure that the Strategic Goals were implemented. The Chamber therefore finds that Mladić shared the intent to effect the common plan and contributed to the execution of the common plan through his role as

\footnotetext{
11009 See paras. $3240,3250,3257$.

11010 See para. 3245.

11011 See para. 3261.

11012 See paras. 3246-3248, 3253-3255, 3260, 3262-3264.

11013 See paras. 3266-3267.
} 
Commander of the Main Staff and close involvement in operations by VRS units during which there were forced expulsions of non-Serbs and other crimes committed in the Municipalities. Furthermore, the Chamber found that despite periods of tension and disagreements between the Accused and Mladić on certain aspects, the Accused maintained his role as Mladić's superior and had de jure control over him, and exercised such control over him in fact throughout the conflict; thus, any temporary disagreements between the Accused and Mladić did not undermine their agreement or Mladić's contributions to the common plan at any point between his appointment on 12 May 1992 until at least 30 November $1995 .{ }^{11015}$

3454. With respect to Mićo Stanišić and Mandić, Stanišić was the Minister of the MUP in 1992 and Mandic was the Deputy Minister of the MUP until May 1992, and subsequently, the RS Minister of Justice from May to November 1992; both were closely involved in the creation and development of the Bosnian Serb MUP from as early as 1992. ${ }^{11016}$ The Chamber found that the directives with respect to the division of the MUP structures and the creation of the Bosnian Serb MUP were communicated to and implemented at a municipal level. These were crucial steps in the take-over of Municipalities, as a separate police structure would allow Bosnian Serb authority to be maintained in the Municipalities. ${ }^{11017}$ The creation of this separate Bosnian Serb MUP was a means of achieving the objectives of the Accused and the Bosnian Serb leadership, and Mićo Stanišić and Mandic contributed to the execution of the common plan through their involvement in this process.

3455. In addition, as head of the MUP, Mićo Stanišić was informed of operations throughout the Municipalities during which there were forced expulsions of non-Serbs and other crimes committed. $^{11018}$ Mandić was responsible for the exchange of detainees through the Central Commission for the Exchange of Prisoners of War and Arrested Persons and was informed of nonSerbs being forcibly moved out of the Municipalities. ${ }^{11019}$ Both Mićo Stanišić and Mandić were considered the "President's men"; Stanišić affirmed his allegiance to the Accused and the SDS stating that he had always followed the policies of the SDS Presidency and he would not allow himself to be separated from them. ${ }^{11020}$ Furthermore, Mandić made statements during the conflict that demonstrated his participation in the shared common plan, including when he stressed "we

\footnotetext{
11014 See paras. 3269-3271.

11015 See para. 3141.

11016 See paras. 3298, 3300, 3306, 3308.

11017 See paras. 3300, 3308.

11018 See paras. 3301-3304.

11019 See paras. 3309-3310.

11020 See paras. 3299, 3305, 3307.
} 
should split Bosnia in two parts" and that Muslims and Croats would have rights after "we clean them out". ${ }^{11021}$

3456. Based on the above, the Chamber finds that through their participation in the creation of the Bosnian Serb MUP structure, its very goal being to achieve Bosnian Serb authority in the Municipalities, together with the fact that through their positions as Minister and Deputy Minister of the MUP, and later Minister of Justice, Mićo Stanišić and Mandić were closely involved with the units carrying out the operations to forcibly remove non-Serbs from the Municipalities as well as the commission of other crimes. As such, the Chamber finds that Mićo Stanišić and Mandić contributed to the execution of the common plan until the end of 1992. Given that both Mandic and Mićo Stanišić left their positions at the end of 1992, the Chamber cannot find that they were members of the Overarching JCE after this period.

3457. Turning to Arkan and Šešelj, both provided and trained units of men who were involved in operations throughout the Municipalities during which forced expulsions of non-Serbs and other crimes occurred. In addition, the Chamber found that Arkan communicated with Plavšić during the conflict and the Accused and Mićo Stanišić were informed of the involvement of Arkan's men in the take-over of Municipalities and crimes committed by his units. ${ }^{11022}$ Arkan was invited by the RS Presidency to participate in military operations in the Municipalities; Arkan was also openly praised by Plavšić and the Accused for his contributions to the efforts to defend the Bosnian Serbs throughout the conflict. ${ }^{11023}$ Even as he left $\mathrm{BiH}$, Arkan repeated his commitment to the Accused to return to defend the "Serbian territory" if called upon by the Accused. ${ }^{11024}$

3458. Regarding Šešelj, he was in frequent contact with the Accused and the Bosnian Serb leadership and supported the policies of the SDS. More specifically, Šešelj advocated for a homogeneous Greater Serbia which involved the unification of all Serb lands and the removal of the non-Serb population; as such he clearly shared the common plan. He sent large groups of SRS volunteer fighters to assist the Bosnian Serbs in $\mathrm{BiH}$ in the implementation of the common plan throughout the conflict and contributed to the execution of the common plan as such. ${ }^{1025}$

\footnotetext{
11021 See para. 2730.

11022 See paras. 3198, 3260-3261, 3303-3304.

11023 See paras. 3198, 3323, 3325.

11024 See para. 3325.

11025 See paras. 3327-3330. Šešelj also stated there was no joint criminal enterprise between the Accused, himself, and other individuals to expel Bosnian Muslims and Bosnian Croats and that the Accused did not have an antagonistic attitude towards Bosnian Muslims and Bosnian Croats. D3665 (Witness statement of Vojislav Šešelj dated 1 June 2013), paras. 31-35, 39, 41; D3667 (Transcript of Vojislav Šešelj's press conference, 26 March 1992), p. 20; Vojislav Šešelj, T. 39600-39605 (10 June 2013). The Chamber does not find this evidence
} 
3459. The Chamber therefore finds that Arkan and Šešelj both contributed to the common plan as envisaged by the Accused and the Bosnian Serb leadership by providing and training men who were involved in operations throughout the Municipalities during which there were forced expulsions of non-Serbs and other crimes were committed.

3460. With regard to the evidence presented in this case in relation to Slobodan Milošević and his membership in the JCE, the Chamber recalls that he shared and endorsed the political objective of the Accused and the Bosnian Serb leadership to preserve Yugoslavia and to prevent the separation or independence of $\mathrm{BiH}$ and co-operated closely with the Accused during this time. The Chamber also recalls that Milošević provided assistance in the form of personnel, provisions, and arms to the Bosnian Serbs during the conflict. ${ }^{11026}$ However, based on the evidence before the Chamber regarding the diverging interests that emerged between the Bosnian Serb and Serbian leaderships during the conflict and in particular, Milošević's repeated criticism and disapproval of the policies and decisions made by the Accused and the Bosnian Serb leadership, ${ }^{11027}$ the Chamber is not satisfied that there was sufficient evidence presented in this case to find that Slobodan Milošević agreed with the common plan.

3461. Finally, with respect to Jovica Stanišić and Franko Simatović, head and deputy head of the SDB, respectively, the Chamber recalls that Arkan's men and the Red Berets were subordinated to them and that they sent units to $\mathrm{BiH}$ which were involved in take-over operations in the Municipalities during the conflict; Stanišić and Simatović were also involved in establishing and monitoring training camps for Bosnian Serbs. ${ }^{11028}$ However, the Chamber is not satisfied that there was sufficient evidence presented in this case to find that Jovica Stanišić and Franko Simatović agreed with the common plan.

3462. The Chamber therefore finds beyond reasonable doubt that the Accused, Momčilo Krajišnik, Nikola Koljević, Biljana Plavšić, Ratko Mladić, ${ }^{11029}$ Mićo Stanišić, ${ }^{1030}$ Momčilo

to be reliable. In reaching that conclusion, the Chamber considered that Šešelj had a clear self-interest in testifying in this regard and his evidence was marked by political statements.

11026 See paras. 3275-3288.

11027 The Chamber notes that the relationship between Milošević and the Accused had deteriorated beginning in 1992; by 1994, they no longer agreed on a course of action to be taken. Furthermore, beginning as early as March 1992, there was apparent discord between the Accused and Milošević in meetings with international representatives, during which Milošević and other Serbian leaders openly criticised Bosnian Serb leaders of committing "crimes against humanity" and "ethnic cleansing" and the war for their own purposes. See paras. 3280, 3289-3297.

11028 See paras. 3312, 3314-3315, 3317-3320.

11029 The Chamber finds that Ratko Mladić was a member of the Overarching JCE from 12 May 1992.

11030 The Chamber finds that Mićo Stanišić was a member of the Overarching JCE until the end of 1992. 
Mandić, ${ }^{1031}$ Željko Ražnatović (Arkan), and Vojislav Šešelj were members of the Overarching JCE and that they formed a plurality of persons who acted pursuant to the common plan that existed between October 1991 and 30 November 1995 as defined above.

iii. Scope of common plan

3463. In concluding that a common plan existed to permanently remove Bosnian Muslims and Bosnian Croats from Bosnian Serb claimed territory in the Municipalities from October 1991 to 30 November 1995, the Chamber had regard to its findings that in internal discussions among Bosnian Serb leaders it was clear that the forcible movement of the population had occurred and had taken place in accordance with instructions received from the highest level of the Bosnian Serb leadership and was well planned. ${ }^{11032}$ The Chamber also had regard to its findings that the Accused and the other members of the Overarching JCE were not only informed about the forcible take-over of towns and municipalities by Serb Forces, but were also aware that this had led to massive demographic changes through the forcible displacement of non-Serb civilians and resulted in ethnic homogenisation, which they supported. ${ }^{11033}$ The Chamber found that the Overarching JCE members, including the Accused, promoted and shared the objective of creating a Bosnian Serb state which was ethnically pure and contiguous Serb areas that would require a re-distribution of the population. ${ }^{11034}$

11031 The Chamber finds that Momčilo Mandić was a member of the Overarching JCE until the end of 1992.

11032 The Chamber notes that Defence witnesses testified, inter alia, that the Accused and the Bosnian Serb leadership (i) pursued policies which tried to preserve peace; (ii) tried to accommodate and respect the rights of non-Serbs; and (iii) did not support or plan the forcible movement of the population or the commission of crimes against non-Serbs. Kosta Čavoški, T. 37052 (11 April 2013); Dragomir Keserović, T. 40914-40915, 40944-40946 (8 July 2013); D4194 (Witness statement of Sveto Kovačević dated 7 December 2013), paras. 5, 9, 15-16, 37; D4063 (Witness statement of Novak Kondić dated 23 November 2013), paras. 5-7; D4166 (Witness statement of Mikan Davidović dated 1 December 2013), para. 7; D3861 (Witness statement of Radovan M. Karadžić dated 14 July 2013), paras. 5, 10-11; D3051 (Witness statement of Momir Bulatović dated 25 February 2013), paras. 16, 18-18A, 46; Momir Bulatović, T. 34540-34541 (28 February 2013), T. 34560-34561 (1 March 2013); D4027 (Witness statement of Nikola Poplašen dated 11 November 2013), paras. 18, 21; D3089 (Witness statement of Milivoje Kićanović dated 3 March 2013), paras. 18-19; D3072 (Witness statement of Pero Marković dated 1 March 2013), para. 28; D4313 (Witness statement of Gojko Kličković dated 7 February 2014), paras. 3-8; D3146 (Witness statement of Božidar Vučurević, 22 March 2013), para. 5. However, the Chamber finds that their testimony was marked by contradictions, evasiveness, and clear indicators of partiality and bias, or was based on their own unfounded assessment or impressions. The Chamber found that these factors undermined their evidence and does not find their evidence in this regard to be reliable. While Ronald Hatchett also testified that the Accused was committed to ending fighting and saving civilians, this observation was only limited to his own assessment during meetings with the Accused in 1994 and is thus of limited weight. D2741 (Witness statement of Ronald Hatchett dated 13 January 2013), paras. 10-12.

11033 See paras. 2846, 2850, 2852, 3363. Dodik testified that he never heard anyone at a Bosnian Serb Assembly or meeting speak about the permanent removal of Bosnian Croats or Muslims from $\mathrm{BiH}$ and that the Accused sought to resolve conflicts peacefully and the crimes in $\mathrm{BiH}$ were committed by paramilitaries. Milorad Dodik, T. 36842-36843, 36914 (9 April 2013). The Chamber notes however that Dodik's evidence was marked by contradictions, indicators of insincerity, and partisanship which undermined the reliability of his evidence in this regard.

11034 See paras. 2896, 2898. 
3464. The Chamber finds that the only reasonable inference to draw from all of the evidence analysed earlier in this Judgement is that the crimes of deportation, inhumane acts (forcible transfer), and persecution (forcible transfer and deportation) were intended to achieve the objective of the Overarching JCE and that the Accused and other members of that JCE shared the intent for these crimes. With respect to forcible transfer and deportation as underlying acts of persecution, the Chamber also finds that the Accused and the other members of the Overarching JCE shared the specific intent to discriminate on the basis of the identity of the victims as Bosnian Muslims or Bosnian Croats. ${ }^{11035}$

3465. Similarly, the Chamber also had regard to the manner in which the take-over of Municipalities was carried out by Serb Forces and the number of Bosnian Muslims and Bosnian Croats who were residing in the Municipalities prior to their take-over. With respect to the widespread practice of unlawfully arresting and detaining non-Serbs prior to removing them from Bosnian Serb claimed territory, the Chamber notes that there were repeated attempts by the Accused and the Bosnian Serb leadership to justify the existence of detention facilities in which they knew that civilians were detained. Promises were also made to international representatives to improve conditions and release detainees. ${ }^{11036}$ However, the Chamber finds, in light of its factual findings with respect to the Municipalities, that these assurances were completely at odds with the reality on the ground. This reality involved the unlawful arrest and detention of thousands of Bosnian Muslims and Bosnian Croats following the forcible take-over by Serb Forces of villages, towns, and municipalities, before they were ultimately transferred to other locations. ${ }^{11037}$ The Chamber finds that the Accused and the Bosnian Serb leadership were not only aware of these detention facilities but used unlawful detention at these facilities as a core element in achieving their objective of the permanent removal of Bosnian Muslims and Bosnian Croats from Bosnian Serb claimed territory. They also used the unlawful detention of civilians to secure the "exchange" of Bosnian Serbs detained by Bosnian Muslims. The Chamber therefore finds that the Accused and the Bosnian Serb leadership shared the intent to unlawfully detain Bosnian Muslims and Bosnian Croats as one of the means through which they could achieve their objective of ethnic separation. The Chamber therefore finds that the only reasonable inference from this evidence is that the crime of persecution, through the underlying acts of unlawful detention and the imposition and maintenance of restrictive and discriminatory measures, was intended to achieve the objective of

\footnotetext{
11035 In addition, based on all the evidence, the Chamber finds that the Accused was aware that his conduct as discussed further below was part of a widespread and systematic attack directed against a civilian population.

11036 See Section IV.A.3.a.v.B: Knowledge of inadequate conditions and mistreatment of non-Serbs in detention centres.

11037 See Section IV.A.3.a.v.B: Knowledge of inadequate conditions and mistreatment of non-Serbs in detention centres.
} 
the Overarching JCE and that the Overarching JCE members, including the Accused, shared the intent for these crimes. With respect to these underlying acts of persecution, the Chamber also finds that the Accused and the Overarching JCE members shared the specific intent to discriminate against the Bosnian Muslims and Bosnian Croats on the basis of their identity. ${ }^{11038}$

3466. Thus the scope of the Overarching JCE includes the crimes of deportation, inhumane acts (forcible transfer), persecution (forcible transfer and deportation), and persecution through the underlying acts of unlawful detention and the imposition and maintenance of restrictive and discriminatory measures ("JCE I Crimes"). However, having considered all of the relevant evidence, the Chamber finds that it is insufficient to demonstrate that the only reasonable inference is that the other acts of persecution charged in Count 3 of the Indictment or the crimes of murder and extermination charged in Counts 4, 5, and 6 of the Indictment were included in the common plan or intended by the Accused. In coming to this conclusion, the Chamber has considered not only the evidence of the Accused's intent for the JCE I Crimes, but also that the Accused received information about the perpetration of crimes committed by Serb Forces against non-Serbs throughout the conflict, including that Serb Forces killed approximately 45 non-Serb civilians in Bijeljina in April 1992 and approximately 200 non-Serb detainees at Korićanske Stijene in August 1992 and continued to act in furtherance of the common plan. The Chamber is of the view that another reasonable inference available on the evidence is that while the Accused did not intend for these other crimes to be committed, he did not care enough to stop pursuing the common plan to forcibly remove the non-Serb population from the Municipalities. While the Chamber considers that these other crimes resulted from the campaign to forcibly remove the non-Serb population from the Municipalities, the Chamber does not find them to be an intended part of the common plan. The Chamber will therefore consider below whether the Accused is responsible for these crimes pursuant to the third form of JCE liability below.

\section{c. Accused's contribution to the Overarching JCE}

\section{i. Submissions of the Parties}

3467. Having found that the Overarching JCE existed from October 1991 and continued until at least 30 November 1995, the Chamber will now assess whether the Accused's significantly contributed towards that JCE during this time period. In making that assessment the Chamber has limited itself to the Accused's conduct during the period of the Overarching JCE. Any conduct which falls outside the temporal scope of the Overarching JCE has only been considered, if at all,

11038 In addition, based on all the evidence, the Chamber finds that the Accused was aware that his conduct as discussed further below was part of a widespread and systematic attack directed against a civilian population. 
for the purpose of establishing the Accused's intent to participate in the JCE. It can now turn to each of the alleged contributions through which the Prosecution alleges the Accused implemented the Overarching JCE.

3468. In paragraph 14 of the Indictment, the Prosecution alleges that the Accused significantly contributed to achieving the objective of the Overarching JCE through the commission of crimes in one or more of the following ways:

(a) Formulating, promoting, participating in, and/or encouraging the development and implementation of SDS and Bosnian Serb governmental policies intended to advance the objective of the JCE;

(b) Participating in the establishment, support and/or maintenance of Bosnian Serb Political and Governmental Organs and Bosnian Serb Forces through which the objective of the JCE was implemented;

(c) Disseminating, encouraging and/or facilitating the dissemination of propaganda to Bosnian Serbs intended to engender in Bosnian Serbs fear and hatred of Bosnian Muslims and Bosnian Croats or to otherwise win support for and participation in achieving the objective of the JCE; ${ }^{1039}$

(d) Directing, encouraging, facilitating, and/or authorising Bosnian Serb Political and Governmental Organs, SDS officials and members, and Serb Forces to carry out acts in furtherance of the objective of the JCE;

(e) Participating in the design or formulation of acts carried out by Bosnian Serb Political and Governmental Organs, SDS officials and members, and Serb Forces in furtherance of the objective of the JCE;

(f) Obtaining, facilitating, encouraging and/or supporting the participation of JNA/VJ forces and Serbian paramilitary forces to further the objective of the JCE;

(g) Failing to take adequate steps to ensure that Bosnian Serb Political and Governmental Organs and/or Bosnian Serb Forces would act to protect Bosnian Muslims and Bosnian Croats residing in areas under their control;

(h) Facilitating and/or encouraging the commission by Serb Forces and Bosnian Serb Political and Governmental Organs of crimes that furthered the objective of the JCE by failing to take adequate steps to prevent and/or investigate such crimes, and/or arrest and/or punish the perpetrators of such crimes;

(i) Engaging in, supporting, and/or facilitating efforts to deny or provide misleading information about crimes against Bosnian Muslims and Bosnian Croats and about the role Serb Forces had played in those crimes to representatives of the international community, non-governmental organisations, the media, and the public; and

11039 The Prosecution submits that this included claims (i) that Bosnian Serbs were in jeopardy of oppression, including genocide, at the hands of Bosnian Muslims and Croats; and (ii) that territories on which Bosnian Muslims and Bosnian Croats resided were Bosnian Serb land. See Indictment, para. 14(c). 
(j) Directing and/or authorising the restriction of humanitarian aid to Bosnian Muslim and/or Bosnian Croat enclaves located in territory controlled by Bosnian Serb Political and Governmental Organs and/or Bosnian Serb Forces in an effort to create unbearable living conditions for inhabitants there in furtherance of the objective of the JCE. ${ }^{11040}$

3469. The Prosecution argues that the Accused led the Overarching JCE in translating the proSerb ideology into SDS and governmental policies designed to further the objective of the permanent forcible removal of Bosnian Muslims and Bosnian Croats from Bosnian Serb claimed territory. ${ }^{11041}$ The Prosecution submits that the Accused was the key figure in creating power structures that would transform policy into action by transforming the SDS bodies into RS structures and laying the groundwork for the creation of the Bosnian Serb MUP, Crisis Staffs, Bosnian Serb Government and Presidency, TO brigades, and the VRS. ${ }^{11042}$

3470. The Prosecution alleges that the Accused dominated, guided, and directed the actions of the Bosnian Serb Political and Governmental Organs and Serb Forces throughout the period of the Indictment. ${ }^{11043}$ The Prosecution further argues that the Accused disseminated propaganda to incite Bosnian Serb fear and hatred of Muslims and Croats, which had the effect of encouraging his subordinates to follow his example. ${ }^{11044}$ The Prosecution also argues that the Accused obtained, facilitated, and encouraged the participation of JNA forces in arming Serbs and in the take-over of the Municipalities; the Accused further oversaw and encouraged the participation of Serb paramilitaries in pursuit of the common purpose. ${ }^{11045}$

3471. The Prosecution argues that the Accused, by denying the commission of crimes, justifying them, and/or misleading the international community and the media, created an environment of impunity, through which he encouraged the ongoing implementation of the common plan ${ }^{11046}$ The Prosecution further submits that the Accused (i) failed to take adequate steps to ensure that Bosnian Serb Political and Governmental Organs and/or Bosnian Serb Forces would act to protect nonSerbs in Serb claimed territory, and (ii) by doing so, in turn facilitated and/or encouraged the commission of crimes in furtherance of the common purpose of the Overarching JCE. ${ }^{11047}$

\footnotetext{
11040 Indictment, para. 14.

11041 See Prosecution Final Brief, para. 597; Indictment, para. 14(a), 14(e).

11042 See Prosecution Final Brief, para. 598; Indictment, para. 14(b).

11043 See Prosecution Final Brief, paras. 598, 600; Indictment, para. 14(d).

11044 See Prosecution Final Brief, paras. 597, 600; Indictment, para. 14(c).

11045 See Prosecution Final Brief, para. 599; Indictment, para. 14(f). With regard to whether the Accused's contribution to the Overarching JCE through obtaining, facilitating, encouraging, and/or supporting the participation of the JNA/VJ forces and Serbian paramilitary forces, the Chamber has included the VJ/JNA and Serbian paramilitary forces under the definition of Serb Forces. See Indictment, para. 14(f). See also para. 159.

11046 See Prosecution Final Brief, para. 601; Indictment, para. 14(i).

11047 See Prosecution Final Brief, para. 601; Indictment, para. 14(g), 14(h).
} 
3472. In response, the Accused argues, inter alia, that he never had the objective of expelling Bosnian Muslims and Bosnian Croats from Serb areas of BiH and that he did everything humanely possible to avoid the war. ${ }^{11048}$ The Accused further alleges that he did not promote hatred against other peoples and that, in fact, he always promoted respect for the Geneva Conventions and insisted on humane treatment of non-Serb civilians and prisoners of war. ${ }^{11049}$ Furthermore, he concedes that at a state level, there were plans to defend Serbs or to protect Serb territory, but that there were never any plans or instructions on harming, expelling, or disenfranchising non-Serbs. ${ }^{11050}$ According to the Accused, the Bosnian Serb Political and Governmental Organs were not created or maintained for the purpose of committing crimes against non-Serbs. ${ }^{11051}$ The Accused also contends that he had no control over the VRS and that he did not support or use paramilitaries to implement the common plan. ${ }^{11052}$ The Accused argued inter alia that the Strategic Goals were not the basis for the expulsion or destruction of non-Serbs in RS and were merely political goals to be realised through negotiations. ${ }^{11053}$ The Accused submits that he did not promote a climate of impunity for crimes committed against non-Serbs. ${ }^{11054}$ Furthermore, the Accused argues that there was no JCE and moreover, that he did not possess the intent to further any common plan of the JCE or to commit crimes. ${ }^{11055}$ Finally, according to the Accused, his only "significant contribution" is shown in his efforts to maintain peace, legal order, and the security for all citizens in $\mathrm{BiH} .{ }^{11056}$

3473. The Chamber will assess these alleged contributions as far as they are relevant to the Overarching JCE. In that regard, the Chamber notes the alleged contribution at paragraph 14(j) of the Indictment which pertains to the Accused's role in restricting humanitarian aid to Bosnian Muslim and Bosnian Croat enclaves in Bosnian Serb claimed territory. In its final brief, the Prosecution refers to the restriction of humanitarian aid in relation to the implementation of the third of the Strategic Goals through the issuance of Directive 4, namely the establishment of a corridor in the Drina Valley and the elimination of the Drina as a border between the RS and Serbia. ${ }^{11057}$ It also refers, more generally, to the fact that in directing and authorising the restriction

\footnotetext{
11048 See Defence Final Brief, para. 218.

11049 See Defence Final Brief, para. 222.

11050 See Defence Final Brief, para. 223.

11051 See Defence Final Brief, paras. 226-230.

11052 See Defence Final Brief, confidential, paras. 1052-1137, 1248-1285, 1293-1298.

11053 See Defence Final Brief, paras. 1286-1293.

11054 See Defence Final Brief, para. 761.

11055 See Defence Final Brief, paras. 231-285.

11056 See Defence Final Brief, para. 285.

11057 See Prosecution Final Brief, para. 175.
} 
of humanitarian aid to the Eastern enclaves in an effort to create unbearable living conditions, the Accused furthered the common purpose of the Overarching JCE. ${ }^{11058}$

3474. However, the Chamber does not consider restrictions on humanitarian aid to be relevant to the Accused's alleged contribution to the achievement of the objective of the Overarching JCE for the following reasons. The Chamber recalls that the crime base for which the Accused ultimately faces responsibility in relation to the Overarching JCE mainly pertains to events in 1992 and 1993 in twenty municipalities in $\mathrm{BiH}$ defined by the Chamber earlier in this Judgement as the "Municipalities". Above, the Chamber found that the crimes of murder, extermination, persecution, deportation, and inhumane acts (forcible transfer) were committed in the Municipalities by Serb Forces during and after their take-over and in detention facilities there. The Chamber did not receive any evidence of restrictions of humanitarian aid into the Municipalities, which would have contributed to the creation of unbearable living conditions forcing the Bosnian Muslim and/or Bosnian Croat populations from these Municipalities to move out. The evidence that the Chamber did receive was that there were restrictions on humanitarian aid going into the Eastern BiH enclaves-Bihać, Goražde, Žepa, and Srebrenica from the spring of 1993 until the summer of $1995 .^{11059}$ The Chamber is not satisfied that such restrictions can attach in any meaningful way to the Accused's alleged contribution to the common purpose of the Overarching JCE, which was implemented through the commission of crimes committed in the Municipalities primarily in 1992 and 1993; therefore well before the period of these restrictions elsewhere in $\mathrm{BiH}$.

\section{ii. Analysis}

3475. The Chamber found that the Accused was at the forefront of developing and promoting the ideology of the SDS. This ideology included the non-separation of Serbs, the identification of historical Serb territories, and the creation of a unified Serb nation. These principles formed a core element of the policies of the SDS and informed the objectives of the Bosnian Serb leadership. ${ }^{1060}$ As the Chamber found above, while the political objectives themselves were not criminal, they created the basis and laid the foundations for the structures through which a criminal purpose could be achieved. ${ }^{11061}$ The Chamber finds that the Accused, first as President of the SDS, and then in

\footnotetext{
11058 Prosecution Final Brief, para. 600.

11059 Restrictions of humanitarian aid into Srebrenica, as well as in Sarajevo, will be dealt with elsewhere in this Judgement. See Sections. IV.B.1.a: Chronology of events in Sarajevo, IV.B.1.f.i.B: Shortage of food and supplies in Sarajevo, IV.C.1.b.ii: Restrictions on humanitarian convoys and the humanitarian situation in Srebrenica. For evidence on restrictions of humanitarian aid going into the Eastern BiH enclaves, see, e.g., [REDACTED]; P2243 (UNPROFOR report re meeting with Ratko Mladić, 14 February 1995); P1470 (UNPROFOR report re meeting with Ratko Mladić, 5 March 1995), pp. 3-4.

11060 See paras. 2651-2653, 2940-2943.

11061 See paras. 3435-3440, 3447
} 
turn as President of the SNB, Presidency, and RS, played the most important role in laying the ground work for that criminal implementation through the creation of, and support for, the structures and bodies which carried out that plan. He did so by developing an ideology which was loaded with Serb nationalism and emphasising the unity of Serbs and the importance of creating an ethnically homogeneous Serb state. ${ }^{11062}$ The Chamber finds that the Accused was central in outlining the goals of the Bosnian Serb leadership and the measures which would have to be taken to establish Bosnian Serb authority in territories which they claimed. ${ }^{11063}$

3476. The Chamber found that the Accused envisaged a separation of the Bosnian Serbs from non-Serbs in $\mathrm{BiH}$ and that war in $\mathrm{BiH}$ would result in "population homogenisation" and that he called for the creation of ethnically based entities in BiH. ${ }^{11064}$ The Accused also encouraged the identification of Serb areas from which Bosnian Muslims would be excluded. ${ }^{11065}$ Not only did the Accused formulate and promote these policies, the Chamber finds that he was adamant that he would not allow anything to stop the Bosnian Serbs from achieving their objectives. ${ }^{11066}$

3477. The Chamber also found that the Accused was pivotal in making careful preparations to allow the Bosnian Serbs to respond to any move towards independence by $\mathrm{BiH}$ with the creation of its own parallel structures and take-over of power at a municipal level. ${ }^{11067}$ The Accused's involvement in this regard included formulating policies and actively promoting the creation of the parallel governmental, military, police and political structures that were used to gain or retain control of Bosnian Serb claimed territory. ${ }^{11068}$ These parallel structures were designed to support the existence of a separate Bosnian Serb state and allow for the furtherance of the objective of the Overarching JCE. ${ }^{11069}$

3478. For example, the Accused was responsible for the distribution and promotion of the Variant A/B Instructions, which the Chamber has found formed the basis on which Bosnian Serb Crisis Staffs, Bosnian Serb municipal assemblies, and other parallel municipal structures were established in the Municipalities. ${ }^{11070}$ The Accused actively monitored the implementation of the Variant A/B Instructions, followed developments which occurred at a municipal level, and co-ordinated efforts

\footnotetext{
11062 See paras. 2651-2654, 2670-2673, 2839-2841.

11063 See paras. 2707-2714.

11064 See para. 2711.

11065 See para. 2711.

11066 See para. 2710.

11067 See paras. 2940-2942, 2947.

11068 See para. 2839.

11069 See paras. 2944-2951.

11070 See paras. 3073-3075.
} 
to ensure they were implemented. ${ }^{11071} \mathrm{He}$ issued precise directions with respect to the establishment and maintenance of Bosnian Serb authority and emphasised the importance of the Instructions in achieving the objective of creating a Bosnian Serb state. ${ }^{11072}$ In this regard the Chamber found that the Accused instructed how the Crisis Staffs would function and be structured and this was one of the ways in which the Accused exercised his authority over them. ${ }^{11073}$

3479. The Accused was instrumental in the formation of, and support for, the Bosnian Serb Assembly and used this as the formal means through which the Bosnian Serb ideology and objectives were officially sanctioned and disseminated. ${ }^{11074}$ The Chamber also found that the Accused had influence and authority as the leading figure in the Bosnian Serb Assembly. ${ }^{11075}$

3480. Throughout the existence of the Overarching JCE, the Chamber found that the Accused was at the apex of a number of political, governmental, and military structures and was not only instrumental in establishing these structures, but he was also able to use his power and influence over them in order to further the objective to permanently remove the Bosnian Muslims and Bosnian Croats from Bosnian Serb-claimed territory. The Chamber found that the Accused demanded and enforced the strictest of discipline within the SDS in its adherence to the policies which he had developed. ${ }^{11076}$ In this regard, the Chamber found that the Accused had de jure and de facto authority over the SDS party and its members and exerted the greatest control and authority over its institutions. ${ }^{11077}$

3481. The Chamber finds that through insisting on this strict discipline and relying on his extensive authority, the Accused was more easily able to direct, encourage, facilitate, and authorise actions which furthered the objective of the Overarching JCE. The Chamber also found that the SDS party structures, which the Accused supported, facilitated communication between the higher level leaders, including the Accused, and the municipal SDS leaders. ${ }^{11078}$ The Chamber finds that this was a crucial link in the chain to ensure that the Accused's policies were effectively disseminated and that he could monitor the way in which they were implemented at a municipal level. There was a direct and regular line of communication between the Bosnian Serb authorities at a municipal level and the Bosnian Serb leadership or RS authorities, including the Accused. This

\footnotetext{
11071 See paras. 3079-3081.

11072 See paras. 3080-3081.

11073 See paras. 3086-3087.

11074 See paras. 2944-2950.

11075 See para. 2951.

11076 See paras. 2940-2943.

11077 See para. 2940.

11078 See para. 2940.
} 
line of communication allowed the Accused to monitor developments at a municipal level and to issue precise directions with respect to the establishment and maintenance of Bosnian Serb authority. ${ }^{11079}$

3482. The Chamber found that the Accused was intimately involved in identifying Bosnian Serb claimed territories, and advocated and worked towards a territorial re-organisation which would allow the Bosnian Serbs to claim control and ownership of a large percentage of the territory in $\mathrm{BiH}$. This was done in order to establish the borders of the Bosnian Serb state in accordance with their territorial and strategic aspirations. ${ }^{1080}$ The Chamber also found that the Accused supported the military successes of the Serb Forces which resulted in major changes to the demographic landscape of $\mathrm{BiH}$. He ultimately supported the military implementation of their goals which necessarily entailed the take-over of territory and the forcible movement of the non-Serb population to achieve that objective. He viewed these military operations as a necessary means of defining Bosnian Serb territory and creating their own state and these operations resulted in the ethnic homogenisation of Bosnian Serb claimed territory in the Municipalities. ${ }^{11081}$

3483. The Chamber further recalls its finding that the Accused formulated, promoted, and disseminated the Strategic Goals and that he tied the promotion of these goals to the threat faced from the Bosnian Muslims and Bosnian Croats who he continued to identify as their historic enemies and to minimising the number of those "enemies" who would remain in their state. ${ }^{11082}$ The Chamber found that the Accused was steadfast in emphasising that ethnic separation was necessary in the promotion of these Strategic Goals. ${ }^{11083}$ Further, he received and gave updates about developments and progress made towards their achievement, including territorial control through military operations and the separation of people. ${ }^{11084}$

3484. The Accused also activated the second level of the Variant A/B Instructions which were intimately linked to the physical control of Bosnian Serb claimed territory. ${ }^{1085}$ The Chamber

\footnotetext{
11079 See para. 3080.

11080 See paras. 2839, 3090-3091.

11081 See paras. 2845-2846, 3091-3096.

11082 See paras. 2895-2896, 2901-2903. Kecmanović stated that the Accused and Krajišnik were among those who shared the view that it was necessary to find a solution to conflicts in $\mathrm{BiH}$ through political negotiations and to avoid or stop war at all costs and that the Accused did not view Bosnian Muslims and Croats as enemies. D3645 (Witness statement of Nenad Kecmanović dated 27 May 2013), para. 35; Nenad Kecmanović, T. 39124 39125 (31 May 2013). The Chamber however notes that Kecmanović's evidence was marked by evasiveness, contradictions, partisanship and indicators that his testimony lacked sincerity and candour. His testimony was also marked by indicators that he was seeking to protect the Accused. The Chamber therefore does not consider that it can rely on his evidence in this regard.

11083 See para. 2896.

11084 See para. 2901.

11085 See para. 3083
} 
found that while the Accused envisaged the use of force to take-over power he was cautious about the way in which this would be portrayed at an international level. However, there was no genuine concern about the manner in which power was taken and there was a clear disjuncture between the Accused's public statements to international observers and his private discourse in this regard. ${ }^{1086}$ There was an even greater disparity between his assurances given in speeches and orders and the reality on the ground. What transpired in the Municipalites were widespread crimes committed by Serb Forces against Bosnian Muslims and Bosnian Croats and this resulted in the creation of a largely ethnically homogeneous state which corresponded to the objective of the Bosnian Serb leadership. ${ }^{11087}$

3485. The Chamber now turns to consider the Prosecution's submission that the Accused disseminated propaganda to incite Bosnian Serb fear and hatred of Muslims and Croats, which had the effect of encouraging his subordinates to follow his example. The Chamber recalls that the Accused was also a central figure in the dissemination of propaganda against Bosnian Muslims and Bosnian Croats. This propaganda identified them as the historic enemies of the Serbs. ${ }^{11088}$ More specifically, the Accused in speeches repeatedly referred to the crimes committed against Serbs during World War II, and that they could not allow the Bosnian Muslims to declare themselves a majority people in $\mathrm{BiH}$ on this basis and threaten the Serbs again. ${ }^{11089}$ The Accused's speeches were also used to promote the idea that the Bosnian Serbs could not live together with the Bosnian Muslims and Bosnian Croats and formed the foundation for the separation of the three people and the creation of a Serb state. ${ }^{11090}$ The Chamber finds that the Accused played on this historical narrative and amplified its effect to suggest that the Serbs faced a similar existential threat. ${ }^{11091}$

\footnotetext{
11086 See paras. 3084-3085. Defence witnesses stated that the Accused was very moderate and tolerant both in speeches he gave in the lead-up to the war and through his policies and that he insisted on respect for minorities and the peaceful resolution of problems. Savo Čeklić, T. 41230-41231, 41239 (11 July 2013); D3126 (Witness statement of Jovan Nikolić dated 10 March 2013), para. 60; D3853 (Witness statement of Zvonko Bajagić dated 5 July 2013), para. 41; D4077 (Witness statement of Anđelko Grahovac dated 23 November 2013), para. 10; D3724 (Witness statement of Branko Grujić dated 22 June 2013), para. 44; Branko Grujić, T. $40373-40374$ (25 June 2013); D3692 (Witness statement of Jovan Ivanović dated 9 June 2013), para. 33; D3528 (Witness statement of Milan Martić dated 7 May 2013), paras. 23, 70-71; D3051 (Witness statement of Momir Bulatović dated 25 February 2013), para. 12; D2549 (Witness statement of Branko Radan dated 3December 2012), para. 20. The Chamber notes that the evidence of the relevant witnesses were marked by evasiveness, contradictions and/or indicators of insincerity and therefore does not find their evidence that the Accused did not intend to commit crimes and always called for respect of minorities to be reliable. However, the Chamber finds that the Accused did speak in terms which portrayed himself publicly as the peaceful negotiator but he insisted that this peace was conditional on following the objectives of the Bosnian Serbs. The Chamber also places no weight on Filipović's personal opinion that the Accused prevented "bigger bloodshed in BiH" through his policies. D3140 (Witness statement of Živan Filipović dated 18 March 2013), para. 21.

11087 See paras. 3091-3096.

11088 See para. 2670.

11089 See paras. 2671, 2843, 2851.

11090 See paras. 2672, 2711, 2841.

11091 See paras. 2672, 2708, 2841-2843.
} 
3486. The Chamber finds that this rhetoric was used by the Accused to engender fear and hatred of Bosnian Muslims and Bosnian Croats and had the effect of exacerbating ethnic divisions and tensions in $\mathrm{BiH} .{ }^{11092}$ The Accused used fear and hatred to promote the historical territorial claims of the Bosnian Serbs and to garner support for the idea of creating a largely ethnically homogeneous Bosnian Serb state on this land. ${ }^{1093}$ The Chamber also found that the Accused's position with respect to these historic territorial claims was endorsed by the Bosnian Serb Assembly and formed a core aspect of the Bosnian Serb objectives in including these territories in the RS. ${ }^{11094}$

3487. The Chamber finds that these speeches and statements went beyond mere rhetoric and formed a core element in the policies and plans developed by the Accused and the Bosnian Serb leadership. The Chamber also found that the Accused disseminated propaganda about demographics and the Bosnian Muslim birth-rate as a further justification for ethnic separation. ${ }^{11095}$ The Chamber found that this ideology was repeated and used by the Accused and the Bosnian Serb leadership as justification for the creation of ethnically homogeneous entities in $\mathrm{BiH}$ and to decrease the number of Bosnian Muslims and Bosnian Croats who remained in the Bosnian Serb state. ${ }^{11096}$ The Chamber finds that the Accused persisted with promoting the objectives of ethnic separation and the territorial claims of the Bosnian Serbs into 1995. ${ }^{11097}$

3488. The Chamber found that the Accused was instrumental in the creation of the SerBiH TO and local TO units in mid-April 1992 and that he had de jure and de facto control over the TO. ${ }^{1098}$ The Chamber also found that the Accused was closely involved in giving instructions for mobilisation of the TO at a municipal level and the creation of the Bosnian Serb TO which was used to take-over and maintain Bosnian Serb authority in the Municipalities. ${ }^{11099}$ The Accused also took a leading role in the co-ordination of TO forces and their subsequent integration into the VRS. ${ }^{11100}$

3489. The Accused, as the highest authority in the VRS chain of command, ${ }^{11101}$ had the power to organise and implement plans for defence, order mobilisation, and command and control the

\footnotetext{
11092 See paras. 2671-2672, 2895.

11093 See paras. 2670, 2711, 2713, 2841-2843.

11094 See para. 2843.

11095 See para. 2851.

11096 See paras. 2839-2840, 2851, 2854-2855.

11097 See paras. 2854-2856.

11098 See para. 3177.

11099 See paras. 3172-3173.

$11100 \quad$ See para. 3176.

$11101 \quad$ See para. 3098.
} 
army. ${ }^{11102}$ The Accused exercised his powers, for example, by ordering the VRS to carry out general mobilisation, which was delivered and acted upon at the municipal level, and by reassigning VRS officers. ${ }^{1103}$ He was key in planning strategy and was closely involved in examining and approving the VRS military directives, which were issued in furtherance of the Strategic Goals. ${ }^{11104}$

3490. The Chamber also found that the Accused's involvement in the command of the VRS as Supreme Commander went beyond planning and strategy as he was involved at the operational level as well. For example, the Accused issued instructions based on proposals for operations he received from the Main Staff and occasionally sent direct orders to the corps and brigade commanders to answer directly to him. ${ }^{1105}$

3491. The Accused was central in promoting the creation of a separate police structure. ${ }^{11106}$ This reflected his objective of creating a separate Bosnian Serb state with parallel structures and this separate police structure was a means of achieving the objective of sovereignty of the Serb people in the territories which they claimed. ${ }^{1107}$ In addition, as Supreme Commander of the VRS and the President of the RS, the Accused had de jure authority over the MUP during times of war, which he exercised in fact directly, as well as through the municipal Crisis Staffs. ${ }^{11108}$

3492. Turning to whether the Accused obtained, facilitated, encouraged, and/or supported the participation of JNA forces and Serbian paramilitary forces, the Chamber found that the VRS was formed from parts of the JNA, TO, and volunteer units and inherited both officers and soldiers from the JNA, many of whom were of Bosnian Serb origin, as well as a substantial amount of weaponry and equipment. ${ }^{1109}$ The Accused participated in the creation of the VRS by organising the manpower at the local level and facilitating the transfer of personnel and supply from the JNA. ${ }^{1110}$ Furthermore, following the withdrawal of the JNA from $\mathrm{BiH}$, the Accused supported the operational co-operation of military forces and local authorities with Arkan's men, Šešelj's men, and Mauzer's Panthers. ${ }^{11111}$

\footnotetext{
$11102 \quad$ See para. 3142.

11103 See paras. 3145-3146.

11104 See paras. 3142, 3152-3156.

11105 See paras. 3104, 3142-3144.

11106 See paras. 2990-2991.

11107 See paras. 2990-2991.

11108 See paras. 3167-3168.

11109 See para. 3097.

11110 See para. 3176.

11111 See paras. 3234-3236.
} 
3493. The Chamber now turns to consider the Prosecution's submission that the Accused failed to make meaningful efforts to exercise his authority to prevent or punish crimes committed by his civilian and military subordinates and that these failures significantly contributed to the Overarching JCE. ${ }^{1112}$ The Chamber recalls that for an Accused to contribute to a JCE by omission, he must have had a legal duty to act, and that the failure to act pursuant to that legal duty significantly contributed to the JCE. ${ }^{1113}$ The Chamber found that during the time period relevant to the Indictment, the Accused was the highest authority in the VRS chain of command. ${ }^{1114}$ Prior to its establishment, the Accused had de jure authority over the TO and took steps to create a hierarchical command and control structure, which included some municipal Crisis Staffs over which he had authority. ${ }^{11115}$ According to the Bosnian Serb Constitution and the Law on the Army, as Supreme Commander, the Accused had the authority to, inter alia: (i) appoint, promote, and dismiss VRS officers in accordance with the law; (ii) appoint and dismiss presidents, judges, and assistant judges of military courts and military prosecutors; (iii) issue regulations prescribing internal order and relations in the military service; and (iv) issue regulations on military training and discipline. ${ }^{1116}$ The Chamber also found that the Accused had de jure authority over the MUP, which he exercised in fact. ${ }^{11117}$ The Chamber finds that in light of his position of authority over the VRS, TO, Crisis Staffs, and MUP, the Accused had a legal duty to prevent and punish crimes committed by them.

3494. The Chamber will now consider the efforts made by the Accused to ensure the protection of Bosnian Muslims and Bosnian Croats residing in areas of Bosnian Serb control and to prevent and punish crimes committed by his subordinates. The Chamber recalls that the Accused established the military courts and that the civilian courts existed during the conflict; however the Chamber found that the system functioned in a discriminatory manner, with a lack of attention to crimes committed against non-Serbs. ${ }^{1118}$ The Chamber found that the inadequate level of investigations

\footnotetext{
11112 Prosecution Final Brief, paras. 535, 601.

11113 See para. 566.

11114 See para. 3098.

11115 See para. 3177.

11116 P5578 (Amended Text of the Constitution of RS and Rules of Procedure of RS Assembly, 17 December 1992), Art. 106; P2603 (SerBiH Law on the Army, 1 June 1992), Art. 174(12), (13). See also D434 (Radovan Karadžić's Order on the application of laws of war, 13 June 1992) (in which the Accused issued an order, imposing a duty on the "competent superior officer" to initiate proceedings to punish persons who violate the laws of war).

11117 See para. 3167.

11118 See para. 3425.
} 
and prosecutions of crimes committed against non-Serbs was consistent with the Accused's position that such matters could be delayed during the conflict. ${ }^{1119}$

3495. The Chamber found that the Accused made minimal efforts to prevent or punish the crimes of forcible displacement and deportation after he learned about such crimes repeatedly throughout the conflict, starting from as early as April 1992. ${ }^{11120}$ This is unsurprising given that he established and co-ordinated the political and military structures which implemented the goal of the Bosnian Serb leadership to create an ethnically homogeneous state and intended for these very crimes to be committed. For example, within a few months of being presented with information that non-Serb civilians were being expelled from Zvornik in early April 1992, the Accused ordered an investigation and then advised international representatives that Bosnian Muslim inhabitants in Zvornik had requested to move out because they felt like hostages. However, the Chamber found that the Accused had also been informed that the municipal authorities in Zvornik had participated in the expulsion of non-Serb civilians in order to allow Serb refugees to settle there and also blamed paramilitaries for these events. He therefore clearly knew that the expulsion was forced but took no actions to punish the perpetrators of such acts. He later celebrated the "liberation" of Zvornik and the fact that there were almost no non-Serbs remaining there in 1993. ${ }^{11121}$

3496. The Accused continued to learn about instances of "ethnic cleansing" throughout the conflict. ${ }^{11122}$ However, it was not until 19 August 1992 that he issued an instruction to the VRS and MUP ordering that the forced resettlement of the civilians should be prevented and that "any certificates of sale of property or statements that refugees will not return shall be considered as legally invalid and are declared null and void" and 21 August 1992 that he pledged to prevent "ethnic cleansing" and punish persons involved in it. ${ }^{1123}$ On 25 August 1992, the Accused wrote a letter to the international community explaining that he had issued the 19 August 1992 instruction and stated that the civilian population must be allowed to move freely out of a war zone if that was the desire of the civilian population, under the Geneva Conventions, blaming the failure on the part of the international community to understand the deep-rooted antagonism and hatred between the three ethnicities in $\mathrm{BiH}$, which caused people to leave their communities in droves. ${ }^{1124}$ The Chamber considers this latter statement to be an attempt by the Accused to cover up and minimise the forced nature of the removal of non-Serbs from the Municipalities and indicates that his orders

\footnotetext{
11119 See para. 3425.

11120 See Section IV.A.3.a.v.E: Accused's knowledge of crimes and measures he took to prevent and punish them.

11121 See paras. 2812, 3337.

11122 See Section IV.A.3.a.v.A: Knowledge of crimes committed throughout the Municipalities.

11123 See para. 3400.

11124 See para. 3400; D4720 (Letter from Radovan Karadžić re London Peace Conference, 25 August 1992), p. 1.
} 
to prevent such forced removal were not intended. This finding is supported by the fact that he continued to share the intent to forcibly remove non-Serbs from the Municipalities until 30 November 1995.

3497. It is further supported by comments that the Accused made in response to information he received from international representatives about "ethnic cleansing" in Bijeljina in late 1994. On 26 September 1994, the Accused said to international negotiators that Serbs in Bijeljina were "fighting for their own land" and that "ethnic cleansing" would be an inevitable outcome of the international community's failure to establish any legal mechanism allowing the population to exchange their homes and move into cantons in which their nationality would be dominant. ${ }^{11125}$ The Chamber found that these statements demonstrated that "ethnic cleansing" was directly linked to the Accused's objective to take-over Serb claimed land and that he was not interested in preventing it. ${ }^{11126}$

3498. With respect to the crime of unlawful detention, the Chamber found that the Accused was aware of the unlawful detention of non-Serb civilians from conflict areas by 24 April 1992. ${ }^{11127}$ On 8 June and 13 June 1992, the Accused issued an appeal to local Bosnian Serb authorities and an order to the VRS and MUP, respectively, to ensure protection for all detainees. ${ }^{11128}$ Furthermore, members of the government, VRS, JNA, and MUP, including Mićo Stanišić, issued orders to their subordinates to, inter alia, prevent abuse of detainees and mistreatment of civilians and report illegal camps from April to August 1992. ${ }^{11129}$ In mid-July, the Bosnian Serb government received reports from the MUP that conditions in detention centres were poor and that there had been occurrences of unlawful treatment of detainees. ${ }^{11130}$ On 25 July 1992, the Accused received a report from the ICRC following a visit to the Manjača camp, informing him that the conditions there were "absolutely insufficient" and that there was evidence that detainees were being subjected to ill treatment. ${ }^{11131}$ But it was only when the international media started reporting on the inhumane conditions in the detention centres in Prijedor in July 1992 and following a Bosnian Serb delegation to visit the camps, that the Accused made efforts to close them down. ${ }^{1132}$ Meanwhile, on 30 July 1992, the Accused continued to present to the public that the allegations made by the

\footnotetext{
11125 See para. 3404.

11126 See para. 3404.

11127 See paras. 3365, 3375.

11128 See para. 3383.

11129 See para. 3409.

11130 See para. 3367.

11131 See para. 3368.

11132 See paras. 3385-3386, 3399.
} 
Guardian that the Bosnian Serbs had organised concentrations camps or were holding civilian prisoners were "completely false". 11133

3499. The Chamber notes that it was concluded at a session of the RS Presidency on 6 August 1992, that the MUP would be ordered to examine civilian authorities and individuals guarding detainees and report back to the Presidency. The decision was relayed to SJB Chiefs in a number of municipalities who were obliged to provide reports in accordance with the RS Presidency decision by 20 August 1992. The SJB Chiefs were also informed about the RS Presidency order to release all civilians and to allow them freedom of movement. ${ }^{1134}$ From August to October, the Accused made further efforts to reduce the number of civilians who were unlawfully detained in Serb controlled detention centres. ${ }^{1135}$ In October 1992, the Accused informed Mladić, Mićo Stanišić, and Mandić that he had received information that some local authorities had ignored his instruction to allow unfettered access for the ICRC to detention facilities and demanded that they inform their subordinates to respect his instruction to allow access and that he would order a thorough investigation of all cases of failure to comply. ${ }^{11136}$ On 27 October 1992, the Bosnian Serb Government officially decided to close all illegal camps as soon as possible and in December 1992, pursuant to the Accused's order, all detainees held in Manjača were released on the condition that they be transferred to third countries. ${ }^{11137}$ The Chamber considers that prior to the Accused's intervention in Prijedor to close the camps with the worst conditions in August 1992, the measures taken to prevent or punish the unlawful detention of civilians were completely inadequate. The Chamber further considers that after that point, he began to take measures to close the temporary detention centres in the Municipalities, however, these measures did not have much effect until closer to the end of 1992. The Chamber further notes that ultimately, while many civilians were released from detention by the end of 1992, detention centres remained in existence for the duration of the war and continued to hold non-Serb civilian detainees. ${ }^{11138}$

3500. The Chamber now turns to consider whether the Accused was able to do more to prevent and punish crimes committed by his subordinates. The Chamber recalls that Momčilo Mandić, Minister of Justice, and Mićo Stanišić, MUP Minister, ignored government decisions with respect to prevention and prosecution of criminal activity and answered more to the Accused than to the

\footnotetext{
11133 See para. 3369.

11134 See para. 3387.

11135 See paras. 3388-3390, 3392-3394.

11136 See para. 3395.

11137 See para. 3397.

11138 See Scheduled Detention Facilities C.2.1, C.18.2, C.21.3.
} 
government. ${ }^{11139}$ This implies that the Accused had the ability to influence Mandić and Stanišić to ensure that their respective ministries functioned to prevent and punish crimes more effectively. Furthermore, the fact that the Accused, when he chose to act to remedy the situation in detention centres, was able to influence the closure of camps, shows that had he wanted, he could have used this influence more effectively and quickly to prevent crimes.

3501. The Chamber considers that the Accused's failure to exercise his authority to adequately prevent or punish crimes committed against non-Serbs signalled to Serb Forces and Bosnian Serb Political and Governmental Organs that criminal acts committed against non-Serbs were tolerated throughout the period of the Overarching JCE. In light of this, his failure to take adequate steps to prevent and punish criminal activity committed against non-Serbs in the Municipalities had the effect of encouraging and facilitating the JCE I Crimes. The Chamber further finds that the Accused's failure to prevent and punish crimes committed by Serb Forces against non-Serbs and his tolerance for such crimes demonstrate a failure on his part to take adequate steps to ensure that Serb Forces and Bosnian Serb Political and Governmental Organs would act to protect Bosnian Muslims and Bosnian Croats residing in areas under their control.

3502. In addition, the Chamber found that during the spring of 1992 the Accused supported the operational co-operation of military forces and local authorities with Arkan's men, Šešelj's men, and Mauzer's Panthers. While the Accused took actions to have paramilitary formations disbanded, these actions were initiated in mid-1992, after all the take-overs had already been completed in the Municipalities with the active involvement of these paramilitaries. These takeovers resulted in the forcible removal of thousands of non-Serbs. The Chamber also found that the Accused's attitude towards certain paramilitary formations after the creation of the VRS was flexible and shifted according to Bosnian Serb interests and concluded that he tolerated or even supported the co-operation of Arkan's men, Šešelj's men, Mauzer's Panthers, and the Yellow Wasps with Serb Forces. ${ }^{1140}$ The Chamber finds that this had the effect of encouraging and facilitating the JCE I Crimes committed by Serb Forces.

3503. Above, the Chamber found the many different ways in which the Accused, having been informed of crimes in the Municipalities, provided misleading information to representatives of international organisations, the public, and to the media in relation to these crimes. ${ }^{1141} \mathrm{He}$ covered up, for instance, the severity of the conditions in detention facilities, ${ }^{1142}$ and he deflated criticism

\footnotetext{
11139 P4982 (Witness Statement of Branko Đerić dated 5 April 2012), paras. 21-22, 24.

11140 See paras. 3234-3235.

11141 See paras. 3333-3334, 3337, 3341, 3347-3348, 3359, 3369, 3376-3381.

11142 See para. 3378
} 
expressed by internationals in relation to claims of "ethnic cleansing" by claiming that non-Serbs were leaving "out of fear". ${ }^{1143}$ The Chamber found a clear disjuncture between the manner in which the Accused defended the actions of the Bosnian Serbs in international settings and press conferences and the reality on the ground, of which he was fully aware. ${ }^{1144}$ In statements and speeches, the Accused created a narrative for an international audience in which the Bosnian Serbs would not be blamed for the movement of the non-Serb population. ${ }^{11145}$

3504. At the same time that he was learning about crimes committed against non-Serbs and not taking sufficient steps to prevent or punish them, the Accused was providing misleading information to international observers on the ground and the media. By his denials that Bosnian Serbs were committing crimes in the Municipalities and his disingenuous portrayal of the reality on the ground, of which he was in fact fully aware, the Accused created an environment in which Bosnian Serbs could continue to commit the crimes through which the common purpose of the Overarching JCE was implemented.

\section{iii. Conclusion}

3505. In the preceding paragraphs, the Chamber identified the various ways through which the Accused, in his functions as Supreme Commander, SDS President, SNB President, President of the Presidency, and President of the RS, participated in furthering the objective of the Overarching JCE, namely the permanent removal of the Bosnian Muslims and Bosnian Croats from Bosnian Serb claimed territory. Considering the totality of the Chamber's findings in this regard, and the extent of the Accused's contribution by virtue of the functions and positions he held at the time, and the impact of his conduct — through his acts and omissions—on the implementation of this JCE, the Chamber finds that the Accused significantly contributed to the Overarching JCE.

\section{d. Link to crimes committed by non-members of the JCE}

3506. In order to hold the Accused criminally responsible for crimes committed by non-members of the JCE, there must be a link between the Accused or another JCE member and the criminal conduct. This link is established if the Accused or another JCE member used the non-member in accordance with the common purpose of the JCE to carry out the actus reus of the crimes included therein. ${ }^{11146}$ This may be inferred from the close co-operation of the accused, or any other JCE member, with the non-member in order to further the common criminal purpose. The non-member

\footnotetext{
11143 See paras. 3337, 3347-3348.

11144 See para. 2847.

11145 See para. 2849.

11146 See para. 567.
} 
of the JCE need not share the intent of the members of the JCE. ${ }^{11147}$ It is also not necessary to establish the existence of an additional understanding or agreement between the accused and the non-member to commit that particular crime. ${ }^{11148}$

3507. The Chamber found that the Crisis Staffs, paramilitaries, and members of the TO, MUP, and VRS carried out crimes in furtherance of the common plan of the Overarching JCE during the take-over of the Municipalities. ${ }^{11149}$

3508. The Chamber found that the Accused had de jure and de facto authority over the SDS party and its members from at least October 1991 until 1995. ${ }^{11150}$ It also found that the municipal Crisis Staffs and Serb municipal assemblies were formed as a result of the implementation of the Variant A/B Instructions, which the Accused had issued and distributed to high ranking Bosnian Serbs, and the implementation of which he monitored through meetings and discussions with municipal leaders. ${ }^{11151}$ Crisis Staffs had direct contact with the Presidency and followed the SDS party line. ${ }^{11152}$ The Accused was instrumental in creating and activating the Crisis Staffs. ${ }^{1153}$ They played a central role in preparing for and carrying out the take-over of the Municipalities by Serb Forces and in maintaining Bosnian Serb authority and power after the take-overs were completed. ${ }^{11154}$ Crisis Staffs were tasked with making military and security preparations and the Accused gave explicit instructions on how the Crisis Staffs and the TO would be structured, including who would be the highest ranking officials in these structures, namely the presidents of municipalities and executive boards. ${ }^{1155}$ The Chamber also found that the Variant A/B Instructions required that all active and reserve police, TO, and civilian protection units be brought "to full manpower" and provided that the units would be activated by order of the municipal Crisis Staffs. ${ }^{11156}$ The Accused announced in March 1992 that while they did not plan to attack anyone, they had the "right to use the army for the final countdown and for the final establishment of authority". ${ }^{1157}$ During this time, he was preparing for the take-over of power in the Municipalities. In addition, the Chamber found that Krajišnik, a member of the Overarching JCE, had "great

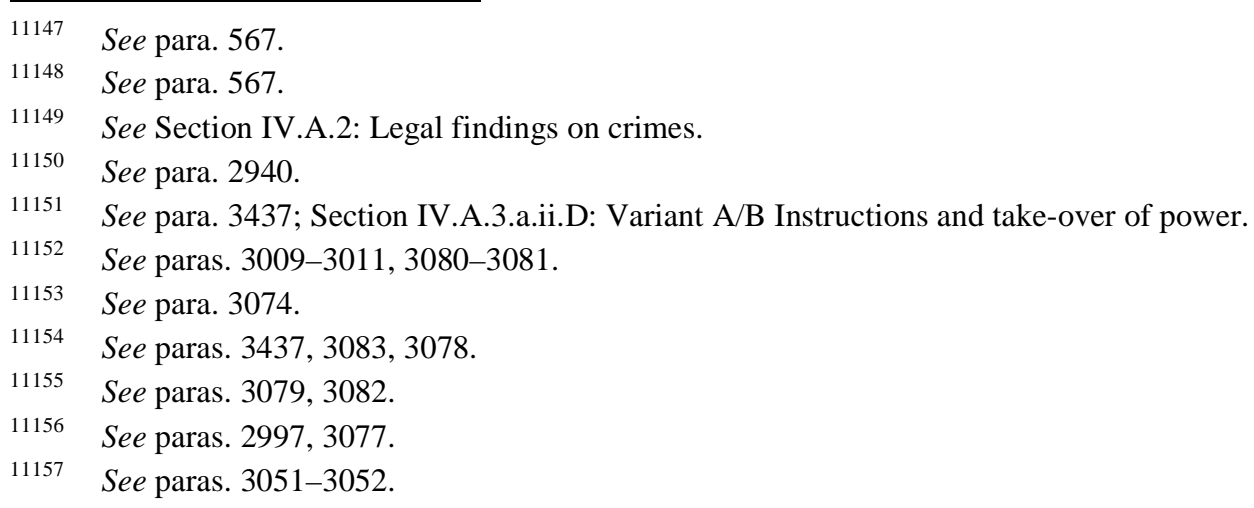


authority" among the Bosnian Serb municipal leaders and influenced how power should be exercised at the municipal level. ${ }^{11158}$

3509. The Chamber found that the Accused had de jure and de facto authority over the TO from mid-April until mid-May 1992 when the TO units were transformed into the VRS. ${ }^{1159}$ The Chamber found that from May 1992, the Accused had de jure control over the VRS, which he exercised in fact continuously as the President of the SNB, President of the Presidency, and President of the RS. ${ }^{1160}$ Furthermore, the Chamber found that the Accused had de jure authority over the Bosnian Serb MUP, which he exercised in fact. ${ }^{11161}$ Mićo Stanišić, a member of the Overarching JCE, was the head of the MUP from 24 March 1992 until the end of December 1992. ${ }^{11162}$

3510. With respect to paramilitary forces, the Chamber found that armed groups, including groups from Serbia, were at times invited by Crisis Staffs to assist in combat activity in the Municipalities, and acted in concert with units of the Serb Forces. ${ }^{11163}$ In other instances, paramilitary forces were invited by JCE members, notably Plavšić, ${ }^{11164}$ or were affiliated with other members of the Overarching JCE, namely Arkan and Šešelj. ${ }^{11165}$ The Chamber found that the Accused supported the operational co-operation of military forces and local authorities with Arkan's men, Šešelj's men, Mauzer's Panthers, and White Eagles as long as the objectives of these groups were aligned with those of the Bosnian Serb leadership. ${ }^{11166}$

3511. The Accused and other members of the JCE used their authority and influence over Crisis Staffs, TO, VRS, Bosnian Serb MUP, and paramilitaries to carry out the crimes envisaged by the common plan of the Overarching JCE. Furthermore, at times, paramilitaries, local Serbs, JNA, MUP, TO, and VRS units acted at the behest of the Crisis Staffs, which were under the Accused's authority and influence, to commit crimes in furtherance of the common plan. Therefore, the Chamber finds that the crimes that were found to be committed by Serb Forces in the Municipalities are imputed to the JCE members or to the Accused. The Chamber finds that such a link existed based on the identity of the perpetrators, which takes into consideration their affiliation,

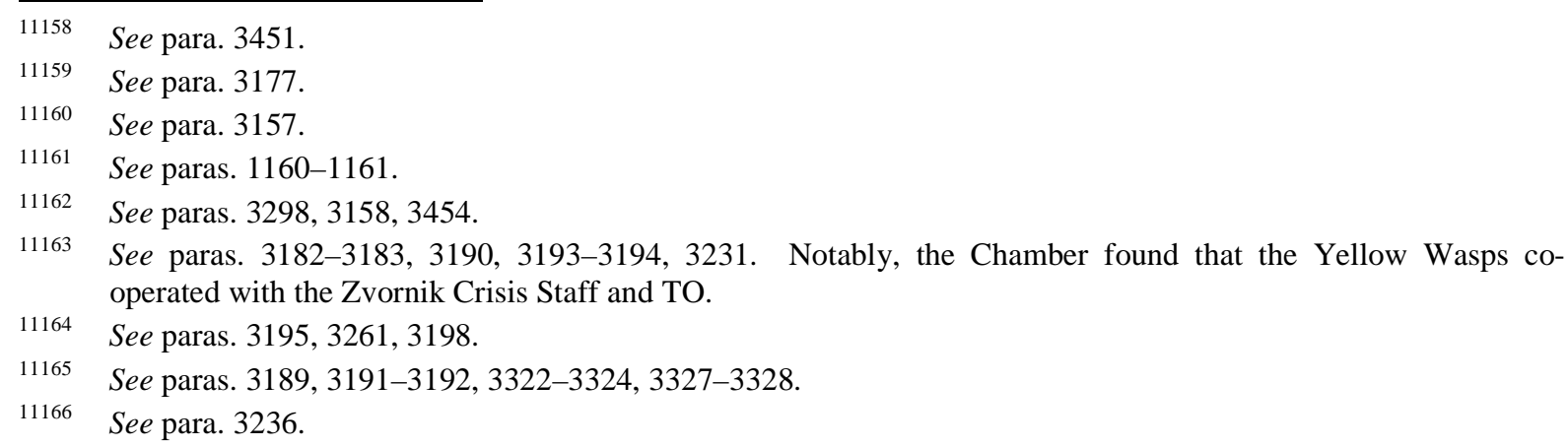


uniforms, and vehicles; the behaviour and utterances of the perpetrators while the crimes were committed; and the identity of the victims. This finding is also based on the assessment of the context in which the crimes were committed, including the timing and the correlation with the actions taken and crimes committed by other Serb Forces and Bosnian Serb authorities who acted in furtherance of the common plan.

\section{e. Accused's responsibility for crimes outside the scope of the Overarching JCE}

3512. The Chamber found that the common purpose of the Overarching JCE was to permanently remove Bosnian Muslims and Bosnian Croats from Bosnian Serb claimed territory through the commission of the crimes of deportation, inhumane acts (forcible transfer), and persecution through forcible transfer, deportation, unlawful detention, and the imposition and maintenance of restrictive and discriminatory measures. The Chamber turns now to consider whether the Accused is responsible pursuant to the third form of JCE liability for the other acts of persecution charged in Count 3 of the Indictment or the crimes of extermination and murder charged in Counts 4, 5, and 6 of the Indictment in relation to the Overarching JCE, which have been proven beyond reasonable doubt. The crimes in question are:

i. Persecution, as a crime against humanity through killings, cruel and/or inhumane treatment (through torture, beatings, physical and psychological abuse, rape and other acts of sexual violence, and the establishment of and perpetuation of inhumane living conditions in detention facilities), forced labour at the frontline and use of non-Serbs as human shields, appropriation or plunder of property, and the wanton destruction of private property, including cultural and sacred sites; $;^{11167}$

ii. murder as a crime against humanity and/or a violation of the laws or customs of war; ${ }^{1168}$ and

iii. extermination as a crime against humanity. ${ }^{11169}$

3513. The Chamber must determine whether it was reasonably foreseeable to the Accused that any of these crimes might be committed if he acted in furtherance of the common plan of the Overarching JCE and whether he willingly took that risk. ${ }^{11170}$ The Chamber recalls that the assessment of what was reasonably foreseeable to the Accused must be made on the basis of his individual knowledge and that what may be foreseeable to one member of a JCE may not be

\footnotetext{
11167 See Indictment, paras. 10, 60. See also paras. 2482-2518, 2531-2559.

11168 See Indictment, paras. 10, 60, 63-64, 67. See also paras. 2446-2456.

11169 See Indictment, paras. 10, 63-64, 67. See also paras. 2457-2464.

11170 See para. 570.
} 
foreseeable to another. ${ }^{11171}$ It is not necessary for the purposes of JCE III liability that an accused be aware of the past occurrence of a crime in order for the same crime to be foreseeable to him. However, it must be established that the possibility of any of these crimes being committed was sufficiently substantial as to be foreseeable to the Accused. ${ }^{11172}$

3514. The Chamber recalls that in coming to the conclusion that the Accused shared the intent to commit the crimes encompassed by the Overarching JCE, the Chamber found, inter alia, that the Accused: (i) knew that the forcible take-over of towns and municipalities by Serb Forces led to massive demographic changes through the forcible displacement of non-Serb civilians; ${ }^{11173}$ and (ii) promoted and shared the objective of creating an ethnically pure Bosnian Serb state and the creation of contiguous Serb areas which would require a redistribution of the population. ${ }^{1174}$ Furthermore, the Chamber found that the Accused contributed to the commission of those crimes by participating in the Overarching JCE through promoting an ideology of ethnic separation, using a rhetoric that amplified historical ethnic grievances and promoting propaganda to that effect, establishing the institutions used to carry out the objective of the common plan, and creating a climate of impunity for criminal acts committed against non-Serbs.

3515. The Chamber notes that the geographical scope of the common plan of the Overarching JCE was broad and it was implemented in a manner that involved many groups and individuals spanning several levels of the Serb Forces and Bosnian Serb Political and Governmental Organs. There was no genuine concern about the manner in which power in the Municipalities was taken. Furthermore, the Chamber found that there was an environment of extreme fear in which the Bosnian Muslim and Bosnian Croat population was forced to leave the Municipalities in circumstances that included displacement by physical force, threat of force or coercion, or fear of ongoing violence, killings, cruel and inhumane treatment, unlawful detention in terrible conditions, rape and other acts of sexual violence, discriminatory measures, and destruction of villages, homes, and cultural monuments. ${ }^{11175}$ In several municipalities, the Chamber found that non-Serbs left because they were being terrorised and conditions made it impossible for them to continue living in the area. ${ }^{11176}$ In many cases Bosnian Muslims were forced to leave or fled following killings in and/or attacks against their villages or following the take-over of towns or villages by Serb Forces and in many cases they were first arrested and detained before being transported out of the

\footnotetext{
11171 See para. 570.

11172 See para. 570; Šainović, et al. Appeal Judgement, para. 1081.

11173 See para. 3463.

11174 See para. 3463.

11175 See para. 2468.

11176 See para. 2471.
} 
Municipalities. ${ }^{11177}$ Based on the nature of the common plan and the manner in which it was carried out, the Chamber considers that it was foreseeable to the Accused that Serb Forces might commit violent and property-related crimes against non-Serbs during and after the take-overs in the Municipalities and the campaign to forcibly remove non-Serbs.

3516. In addition, the evidence of the Accused's knowledge of criminal activity in the Municipalities demonstrates that the Accused was well aware of this environment in which the forcible displacement of non-Serbs occurred. The Chamber notes the Accused learned of the killings of non-Serb civilians in early April 1992 in the town of Bijeljina immediately after their occurrence. ${ }^{11178}$ Furthermore, on 23 June 1992, the Accused was informed that Bosnian Muslims were subjected to intimidation and a policy of harassment and discrimination at the hands of the Bosnian Serbs, causing thousands to leave. ${ }^{11179}$ In addition, he frequently discussed or was informed of the violent criminal behaviour of armed groups during the take-over of some municipalities. ${ }^{11180}$ For example, on 29 July 1992 he was told about the criminal behaviour of paramilitary groups during and after the take-over of Bijeljina, which resulted in rapes, thefts, robberies, killings, and the displacement of Bosnian Muslim civilians. ${ }^{11181}$ On 22 August 1992, the Accused was informed of the incident at Korićanske Stijene in which approximately 200 non-Serb men were killed by Serb Forces and thrown down a ravine at Mount Vlašić on 21 August $1992 .{ }^{11182}$ The Accused was also aware that paramilitaries, volunteers, and other irregular armed groups were being used to further the common purpose of the Overarching JCE, and were difficult to control. $^{11183}$ The Chamber considers that in light of his knowledge of crimes committed in the Municipalities, the Accused was aware of the environment of extreme fear in which non-Serbs were forced to leave and of other acts of violence committed by Serb Forces against non-Serbs during the campaign of forcible displacement.

3517. The Accused was also told about looting, particularly of Bosnian Muslim homes, on several occasions, ${ }^{11184}$ and knew that paramilitary groups involved in the JCE I Crimes were notorious for pillaging and stealing. ${ }^{1185}$

\footnotetext{
11177 See para. 2470.

11178 See para. 3333.

11179 See para. 3334.

11180 See paras. 3334-3336, 3341, 3350.

11181 See para. 3335.

11182 See para. 3346.

11183 See paras. 3230-3236, 3334-3336, 3341-3342, 3344, 3350.

11184 See paras. $3335,3339,3341-3342,3344$.

11185 See paras. $3220,3357$.
} 
3518. The Chamber found that the Accused intended the unlawful detention of civilians. ${ }^{11186}$ The Chamber notes that thousands of individuals, including women, children, and elderly people were detained for extended periods of time before they were ultimately transferred out of the Municipalities. In several of these detention facilities, Bosnian Serb Political and Governmental Organs and Serb Forces deliberately established and perpetuated inhumane living conditions. ${ }^{11187}$ The Chamber found that the Accused knew early on in the conflict in $\mathrm{BiH}$ that civilians were being detained by Serb Forces. ${ }^{11188}$ The Accused was told by international representatives of the large scale detention of civilians as early as May 1992. ${ }^{11189}$ On 17 July 1992, the Bosnian Serb MUP wrote a report to the Accused and the Prime Minister, indicating, inter alia, that the conditions in detention centres were poor. ${ }^{1190}$ On 22 July 1992, it was reported to the Bosnian Serb Government that there had been occurrences of unlawful treatment of detainees. ${ }^{11191}$ On 25 July 1992, the Accused received a report from the ICRC following a visit to the Manjača camp, informing the Accused, inter alia, that two detainees had been subjected to ill treatment during the visit, frequent and widespread traces of severe beatings were observed, and that the general living conditions were "absolutely insufficient". 11192 At the London Conference in August 1992, the "acute problem of the unlawful detention of civilians and the deplorable conditions in which they were held" was recognised. ${ }^{11193}$ In light of this evidence, the Chamber considers that the Accused knew that the conditions in many of the detention centres where non-Serbs were detained were poor while others were inadequate at best.

3519. The Chamber also notes that prior to the outbreak of armed conflict in April 1992, the Accused was well aware of the ethnic animosity between Bosnian Serbs, Bosnian Croats, and Bosnian Muslims and played on these historic antagonisms in order to further the objective of the Overarching JCE and its common plan. ${ }^{11194}$ The Accused knew that leading up to the outbreak of armed conflict, ethnic tensions were rising. ${ }^{11195}$ Furthermore, during the conflict, the Accused frequently dismissed the commission of crimes by armed groups, blaming this ethnic animosity. ${ }^{11196}$ For example, at an international press conference in September 1992, in response to a question about a report alleging atrocities, including executions, and brutal "Nazi-like"

\footnotetext{
11186 See para. 3465.

11187 See para. 2511.

11188 See paras. $3365,3375$.

11189 See para. 3366.

11190 P1096 (SerBiH MUP Report on Some Aspects of Work Done to Date and the Tasks Ahead, 17 July 1992 ), p. 3.

11191 D430 (Minutes of $41^{\text {st }}$ session of Government of SerBiH, 22 July 1992), p. 7.

11192 P3758 (Letter from Radovan Karadžić to Branko Derić, attaching an ICRC report, 7 August 1992), pp. 4-7.

11193 D1142 (Programme of Action of the London International Conference, 27 August 1992), p. 1.

11194 See Section IV.A.3.a.i.B: Identification of historic enemies.

11195 See paras. 2714, 2895, 2900.
} 
conditions, the Accused said that in an "inter-ethnic and inter-religious war", there was no need for a command to kill, given that the three ethnic communities had "been antagonised during centuries". ${ }^{11197}$

3520. Having assessed all the evidence on the information available to the Accused prior to and during the execution of the common plan of the Overarching JCE, the Chamber considers that the Accused knew that the common plan, whereby thousands of non-Serb civilians were expelled en masse from their homes during and after the forcible take-over of towns and villages, and detained in facilities throughout the Municipalities, occurred in a context of inter-ethnic animosity and violence. Furthermore, he knew that a climate of impunity for crimes committed against non-Serbs existed in Bosnian Serb claimed territory, particularly in 1992. ${ }^{11198}$ In light of these factors, he ought to have known that the non-Serb population was vulnerable to violent crimes that might be perpetrated by Serb Forces.

3521. On the basis of the foregoing, the Chamber is convinced beyond reasonable doubt that it was foreseeable to the Accused that persecution through torture, beatings, physical and psychological abuse, rape and other acts of sexual violence, and the establishment and perpetuation of inhumane living conditions in detention facilities as cruel or inhumane treatment, killings, forced labour at the frontline, the use of non-Serbs as human shields, the appropriation or plunder of property, and the wanton destruction of private property, including cultural and sacred sites, might be committed by Serb Forces used to carry out the objective of the common plan, during the execution of the common plan, with discriminatory intent. Furthermore, the Chamber finds that it was foreseeable to the Accused that murder might be committed by Serb Forces used to carry out the objective of the common plan, during the execution of the common plan. Finally, the fact that the Accused knew that the common plan was executed across a large geographic scope which involved numerous protagonists from civilian and military units, and was directly made aware of mass killings at the beginning of April 1992, demonstrates that he knew of the possibility that killings on a large scale might be committed by Serb Forces used to carry out the objective of the common plan. Therefore, the Chamber finds that the possibility that extermination might be committed by Serb Forces was sufficiently substantial as to be foreseeable to the Accused. These crimes will hereinafter be referred to as "JCE III Crimes".

\footnotetext{
11196 See para. 3341.

11197 P809 (Video footage of Radovan Karadžić's Press Conference at ICFY, 18 September 1992, with transcript), p. 3. See para. 3348.

11198 See Section IV.A.3.a.v: Accused's knowledge of crimes and measures he took to prevent and punish them.
} 
3522. The Accused's continued participation in the Overarching JCE until 1995 demonstrates that he acted in furtherance of the common plan with the awareness of the possibility that the JCE III Crimes might be committed either by members of the Overarching JCE or Serb Forces who were used by him or other members of the Overarching JCE to carry out the common plan, ${ }^{1199}$ during the execution of the common plan, demonstrating that he willingly took that risk. ${ }^{11200}$

3523. The Chamber is satisfied that the JCE III Crimes which have been found to be proven beyond reasonable doubt are sufficiently linked to the Accused because they were found to have been carried out by members of the Serb Forces who were used by the Accused or another JCE member to carry out the JCE I crimes. ${ }^{11201}$ The Chamber has found that the JCE III Crimes were committed either during or after the take-overs of Municipalities during the campaign to forcibly remove the non-Serb population or in connection with unlawful detention in a scheduled detention facility. The Chamber has also considered the context in which the crimes were committed, including the timing and the correlation with the actions taken and crimes committed by other Serb Forces and Bosnian Serb authorities who acted in furtherance of the common plan.

\section{f. Conclusion: Accused's individual criminal responsibility}

3524. The Chamber found above that the Overarching JCE came into existence in October 1991 and continued until at least 30 November 1995, that the Accused significantly contributed to the Overarching JCE, and shared the intent with respect to the JCE I Crimes. In addition the Chamber found that the Accused acted in furtherance of the Overarching JCE with the awareness of the possibility that the JCE III Crimes might be committed either by members of the Overarching JCE or Serb Forces who were used by him or other members of the Overarching JCE to carry out the common plan, and that he willingly took that risk. The Chamber therefore finds that the Accused bears individual criminal responsibility pursuant to Article 7(1) of the Statute for persecution, a crime against humanity (Count 3); extermination, a crime against humanity (Count 4); murder, a crime against humanity (Count 5); murder, a violation of the laws or customs of war (Count 6); deportation, a crime against humanity (Count 7); and inhumane acts (forcible transfer), a crime against humanity (Count 8). The Chamber will address the issue of cumulative convictions in Section IV.F below.

\footnotetext{
11199 See para. 3511.

11200 See para. 3466, where the Chamber found that the evidence of the Accused's intent to commit the JCE I crimes, coupled with his knowledge of the commission of crimes by Serb Forces against non-Serbs in the Municipalities did not rise to the level of intention for the crimes discussed herein.

11201 Judge Morrison dissenting with respect to Scheduled Incident B.12.2.
} 
3525. In addition to the Accused's liability through participation in a JCE, the Prosecution also alleges that the Accused is individually criminally responsible for planning, instigating, ordering, and/or aiding and abetting the crimes relevant to the Municipalities component through certain acts and omissions. ${ }^{1202}$ It also charges the Accused with individual criminal responsibility pursuant to Article 7(3) of the Statute. ${ }^{11203}$ However, having considered all of the evidence and in light of the findings made above, the Chamber finds that commission through JCE pursuant to Article 7(1) most accurately and appropriately reflects the Accused's responsibility for the crimes in the Municipalities component as charged in the Indictment. The Chamber will therefore not analyse the Accused's responsibility under the other modes alleged by the Prosecution in the Indictment.

11202 Indictment, paras. 30-31; Prosecution Final Brief, paras. 1115-1118.

11203 Indictment, para. 32; Prosecution Final Brief, paras. 1113-1114. 


\section{B. SARAJEVO COMPONENT}

1. Facts

a. Chronology of events in Sarajevo

3526. In this section of the Judgement the Chamber will discuss the situation in the city of Sarajevo and the relevant events that occurred therein during the conflict in $\mathrm{BiH}$. The section also refers to various shelling and sniping incidents, including the casualties resulting therefrom. Some of these are specifically charged in the Indictment under Schedules F and G while others are not. Those that are listed in Schedules $F$ and $G$ are discussed in later parts of the Judgement in more detail. The Chamber notes that shelling and sniping incidents not listed in Schedules $\mathrm{F}$ and $\mathrm{G}$ of the Indictment are only relevant to the pattern and the nature of the campaign. ${ }^{11204}$

3527. The city of Sarajevo, capital of $\mathrm{BiH}$, lies in a valley, stretching from east to west along both banks of Miljacka River. ${ }^{11205}$ Hills and mountains overlook Sarajevo to the south and the north; from these elevations, it is possible to have unobstructed and clear views of the distinguishable features of the city and to see into its streets. ${ }^{11206}$

3528. In 1991, Sarajevo was made up of ten municipalities: Stari Grad (Old Town), Centar (Centre), Novo Sarajevo, Novi Grad, Vogošća, Ilidža, Pale, Ilijaš, Hadžići, and Trnovo. ${ }^{11207}$ According to the 1991 census, Sarajevo had 527,049 inhabitants of whom approximately $49 \%$ were Bosnian Muslims, 30\% were Bosnian Serbs, and 7\% were Bosnian Croats. ${ }^{1208}$ Before the conflict, it was the largest and most important political, cultural, industrial, and commercial centre of BiH. ${ }^{11209}$ Citizens of Sarajevo took pride in the city's diversity, referring to themselves as "Sarajlijas" or Sarajevans. ${ }^{11210}$ Sarajevo was well-known as a multi-ethnic, multi-religious city,

\footnotetext{
11204 Hearing, T. 5479-5481 (19 July 2010); T. 7670-7672 (11 October 2010); T. 10932 (31 January 2011). See also Prosecution Rule 73 bis Submission, para. 16 (wherein the Prosecution stated that it "will not present evidence in order to secure a conviction in respect of any crime sites or incidents not listed in the Schedules to the Indictment).

11205 P926 (Witness statement of Aernout van Lynden dated 26 February 2010), para. 17; Aernout van Lynden, T. 2398 (19 May 2010); P5926 (Map of Sarajevo); Herbert Okun, P776 (Transcript from Prosecutor v. Krajišnik), T. 4356; David Harland, T. 2017-2018 (6 May 2010); P2068 (Witness statement of Jeremy Bowen dated 10 August 2009), para. 14.

11206 P926 (Witness statement of Aernout van Lynden dated 26 February 2010), paras. 17, 46; Aernout van Lynden, T. 2398 (19 May 2010); P1154 (Witness statement of KDZ088 dated 27-29 April 2010), p. 26 (under seal).

11207 See Adjudicated Fact 2.

11208 P5964 (Census data for BiH by municipality in 1971, 1981, and 1991, April 1995), e-court p. 2. See also Adjudicated Fact 2885.

11209 D3864 (Radovan Radinović's expert report entitled “The Control Authority of Dr. Radovan Karadžić in the Strategic Command System of the VRS”, 2012), para. 176. See also Adjudicated Fact 1.

11210 Vitomir Žepinić, T. 33651 (14 February 2013); P2007 (BBC news report re Sarajevo, with transcript).
} 
with a long history of religious and cultural tolerance. ${ }^{11211}$ The great majority of the urban areas of Sarajevo were ethnically mixed. ${ }^{11212}$

3529. A number of important JNA installations, including the Viktor Bubanj Barracks, the Maršal Tito Barracks, the Jusuf Džonlić Barracks, and the Jajce Barracks, were located in Sarajevo. ${ }^{1213}$ The Command of the $2^{\text {nd }}$ Military District of the JNA was located in Bistrik, at one end of Dobrovoljačka street, across from the Gavrilo Princip Bridge. ${ }^{11214}$

3530. Starting in September 1991, various JNA units withdrew from Slovenia and parts of Croatia and subsequently assumed position in barracks throughout $\mathrm{BiH}$, including those located in and around Sarajevo; the retreating JNA units brought a significant amount of weaponry and ammunition. ${ }^{11215}$ The Bosnian Muslim leadership did not look at this development favourably. ${ }^{11216}$

3531. While nationalist propaganda increased during the course of $1991,{ }^{11217}$ up until late 1991, the inhabitants of Sarajevo lived relatively peacefully together. ${ }^{1218}$ Inter-ethnic tensions started to appear in late 1991 and gradually escalated. ${ }^{1219}$

3532. In the early months of 1992, the JNA, which by then had become a Serb-dominated army, began distributing weaponry and ammunition to Bosnian Serbs at the barracks around Sarajevo. ${ }^{1220}$

\footnotetext{
11211 Adjudicated Fact 2776.

11212 David Harland, T. 2107-2108 (7 May 2010); P1154 (Witness statement of KDZ088 dated 27-29 April 2010), p. 72 (under seal).

11213 KDZ310, T. 9201 (29 November 2010); P950 (Agreement on withdrawal of JNA from BiH), p. 1; John Wilson, T. 3919 (21 June 2010), T. 4035 (22 June 2010); P1029 (Witness statement of John Wilson dated 4 November 2008), para. 30.

11214 KDZ310, T. 9201 (29 November 2010); D825 (Manojlo Milovanović's book entitled "My View of the War in Bosnia 1992-1995”), p. 4; D2341 (Witness statement of Dušan Škrba dated 14 October 2012), para. 5.

11215 Dušan Kovačević, T. 39643 (10 June 2013); P1938 (Witness statement of KDZ310 dated 28 November 2010), para. 10; KDZ310, T. 9200-9201 (29 November 2010); P1866 (Witness statement of Youssef Hajir dated 25 February 2010), para. 4; Colm Doyle, P918 (Transcript from Prosecutor v. S. Milošević), T. 25271, 25341; P1029 (Witness statement of John Wilson dated 4 November 2008), para. 30. See also Section IV.A.1.c: Sarajevo area.

11216 Colm Doyle, P918 (Transcript from Prosecutor v. S. Milošević), T. 25341.

11217 P1938 (Witness statement of KDZ310 dated 28 November 2010), para. 19; KDZ310, T. 9172-9179 (29 November 2010); P1866 (Witness statement of Youssef Hajir dated 25 February 2010), para. 6; D2418 (Witness statement of Božo Tomić dated 5 November 2012), para. 4.

11218 P1217 (Witness statement of Milan Mandilović dated 24 February 2010), para. 15; P1866 (Witness statement of Youssef Hajir dated 25 February 2010), para. 3; P2007 (BBC news report re Sarajevo, with transcript); D2418 (Witness statement of Božo Tomić dated 5 November 2012), para. 4.

11219 P1217 (Witness statement of Milan Mandilović dated 24 February 2010), paras. 17-18; Colm Doyle, P918 (Transcript from Prosecutor v. S. Milošević), T. 25249; D2443 (Witness statement of Željka Malinović dated 9 November 2012), paras. 3, 6; D3645 (Witness statement of Nenad Kecmanović dated 27 May 2013), para. 38.

11220 P1938 (Witness statement of KDZ310 dated 28 November 2010), para. 10; KDZ310, T. 9201-9203 (29 November 2010); Colm Doyle, T. 2848, 2864-2865, 2890 (27 May 2010). On 20 March 1992, the JNA General Staff was informed that in Sarajevo, 300 automatic rifles had been distributed by the JNA to retired officers and that another 100 individuals would be armed in a matter of days. P979 (Report from JNA $2^{\text {nd }}$ Military District to JNA General Staff, 20 March 1992), p. 6. See also Section IV.A.1.c: Sarajevo area. As
} 
In the same period, Bosnian Muslims in Sarajevo also armed themselves, though to a lesser extent. $^{11221}$

3533. On or about 1 March 1992, during a Serb wedding ceremony held at a historic Orthodox Church located in the old part of Sarajevo, Ramiz Delalić and Suad Šabović, two Bosnian Muslims, shot and killed the father of the bridegroom who was carrying a Serb flag and wounded a priest. $^{11222}$ Soon after, on the orders of Rajko Dukić, the President of the SDS Executive Board, barricades were erected at strategic locations in and around Sarajevo by armed Serbs in civilian clothes and black masks. ${ }^{11223}$ Muslims for their part erected barricades in front of the Assembly building later that evening. ${ }^{11224}$ The barricades blocked all passages in and out of the city and cut off parts of the town. ${ }^{11225}$ Soon after the erection of the barricades, Momčilo Mandić asked Čedomir Kljajić, the Chief of Police Affairs in Sarajevo, to accompany him to the office of the Accused and the headquarters of the SDS, located in the Holiday Inn at the time. ${ }^{11226}$ After arriving at the Holiday Inn, Kljajić observed that Dukić was issuing instructions to those manning the Serb

mentioned above, the Presidency of SRBiH immediately denounced the JNA's mobilisation order of 28 September 1991 and most Bosnian Croat and Bosnian Muslim reservists did not respond. See paras. 45, 52.

11221 Colm Doyle, T. 2737, 2739-2740 (26 May 2010), T. 2889-2890 (27 May 2010); D4865 (Report of BiH Ministry of Defence, 24 December 1999); D2344 (Witness statement of Miloš Škrba dated 14 October 2012), para. 2; D2665 (Witness statement of Izo Golić dated 15 December 2012), para. 20.

11222 D385 (SRBiH MUP Report on Sarajevo, 13 March 1992), p. 2; Momčilo Mandić, T. 4877 (8 July 2010$)$; Momčilo Mandić, C3 (Transcript from Prosecutor v. Stanišić and Župljanin), T. 9692-9693; D2923 (Witness statement of Vitomir Žepinić dated 11 February 2013), para. 58; P1940 (Interview with Radovan Karadžić from Naša Borba entitled "Yugoslavia or Three Bosnians", 16 March 1992), p. 1; Colm Doyle, P918 (Transcript from Prosecutor v. S. Milošević), T. 25333-25334; P924 (ECMM report, 1-2 March 1992), p. 1; D214 (Minutes of $56^{\text {th }}$ SRBiH Presidency session, 2 March 1992), p. 2; D215 (Excerpts from Ljubo Grcković's diary), p. 118; Dragan Šojić, T. 31768 (19 December 2012); D2665 (Witness statement of Izo Golić dated 15 December 2012), para. 7; Martin Bell, T. 9856 (15 December 2010); D2379 (Witness statement of Momir Garić dated 2 November 2012), para. 8; Mirsad Kučanin, P17 (Transcript from Prosecutor v. S. Milošević), T. 28972; P1353 (Shorthand record of $10^{\text {th }}$ session of SerBiH Assembly, 11 March 1992), e-court p. 6; D3864 (Radovan Radinović's expert report entitled "The Control Authority of Dr. Radovan Karadžić in the Strategic Command System of the VRS”, 2012), para. 191.

11223 P1938 (Witness statement of KDZ310 dated 28 November 2010), para. 6; Colm Doyle, P918 (Transcript from Prosecutor v. S. Milošević), T. 25264; P920 (ECMM report, 13 March 1992), p. 1; Colm Doyle, T. 2848-2849, 2854-2855 (27 May 2010); D2923 (Witness statement of Vitomir Žepinić dated 11 February 2013), para. 59; Vitomir Žepinić, T. 33611 (13 February 2013); D2443 (Witness statement of Željka Malinović dated 9 November 2012), para. 4; D3671 (Witness statement of Dušan Kovačević dated 7 June 2013), para. 47; D3070 (JNA $2^{\text {nd }}$ Military District report, 12 March 1992), p. 3; P2444 (Witness statement of KDZ354 dated 5 February 2011), para. 4 (under seal). See also Adjudicated Fact 6. On Serb barricades, see Section IV.A.1.C: Sarajevo area.

11224 P5612 (Intercept of conversation between Mićo Stanišić and Rajko Dukić, 2 March 1992), p. 2; D2443 (Witness statement of Željka Malinović dated 9 November 2012), para. 4; D3070 (JNA $2^{\text {nd }}$ Military District report, 12 March 1992), p. 3.

11225 Colm Doyle, P918 (Transcript from Prosecutor v. S. Milošević), T. 25338-25340; P924 (ECMM report, 1-2 March 1992), p. 1.

11226 P6468 (Excerpts from Čedomir Kljajić's interview with OTP), e-court p. 2; Čedomir Kljajić, T. 42197-42198 (30 July 2013); P1996 (Witness statement of Martin Bell dated 8 March 2010), paras. 19, 21; P1029 (Witness statement of John Wilson dated 4 November 2008), para. 25; P927 (Aerial photograph of Sarajevo marked by Aernout van Lynden); Aernout van Lynden, T. 2393 (19 May 2010). During the early months of 1992, the Holiday Inn also hosted a number of foreign journalists. See Martin Bell, T. 9810 (14 December 2010). 
barricades via the telephone. ${ }^{11227}$ In the early afternoon, Serbs who were manning a barricade near the main entrance to the city came under gunfire from a nearby building. ${ }^{11228}$ When Colm Doyle, the head of the ECMM in Sarajevo, ${ }^{11229}$ approached one of the Serb barricades and asked for it to be dismantled, he was told that the barricade would be dismantled only on the orders of the Accused. ${ }^{1230}$ At another barricade, while negotiating the passage of ECMM monitors to the airport, Doyle came under Serb gunfire. ${ }^{1231}$ During the night of 1 March 1992, there was considerable shooting in the city and as a result, three people were killed. ${ }^{11232}$

3534. The following day, the SDS leadership formally demanded that the $\mathrm{BiH}$ government (i) arrest the perpetrators of the killing of the Serb at the wedding ceremony; ${ }^{11233}$ (ii) divide Sarajevo RTV into separate Muslim, Serb, and Croat channels and crack down on the Sarajevobased broadcaster JUTEL; (iii) stop seeking international recognition for $\mathrm{BiH}$ until such time that all three parties reach agreement with respect to the constitutional arrangement of $\mathrm{BiH}$; (iv) order an immediate halt to the media campaign which describes the independence and sovereignty of $\mathrm{BiH}$ as a fait accompli; (v) urgently resume participation in the Peace Conference on Yugoslavia, under the auspices of the EC; ${ }^{11234}$ (vi) immediately effect personnel changes in the MUP so as to comply with the inter-party agreement on the division of power; (vii) order MUP to avoid violent confrontation with Bosnian Serbs, in particular those manning the barricades; and (viii) dissolve the BiH Presidency Crisis Staff headed by Ejup Ganić. ${ }^{11235}$ Later that day, Plavšić instructed Velibor Ostojić, the Minister of Information of $\mathrm{BiH}$, to prevent confrontation at the barricades as negotiations were underway. ${ }^{11236}$

3535. On 2 March 1992, in an intercepted telephone conversation, Dukić informed Mićo Stanišić that he and Plavšić had spoken to Čengić and Izetbegović, respectively, about the Muslim

\footnotetext{
11227 Čedomir Kljajić, T. 42199 (30 July 2013).

11228 Colm Doyle, P918 (Transcript from Prosecutor v. S. Milošević), T. 25265.

11229 Colm Doyle, P918 (Transcript from Prosecutor v. S. Milošević), T. 25248.

11230 Colm Doyle, P918 (Transcript from Prosecutor v. S. Milošević), T. 25267-25268, 25341; P924 (ECMM report, 1-2 March 1992), e-court p. 2; Colm Doyle, T. 2659-2660 (21 May 2010), T. 2695 (26 May 2010).

11231 Colm Doyle, T. 2848, 2861 (27 May 2010).

11232 P924 (ECMM report, 1-2 March 1992), e-court p. 1.

11233 Žepinić stated that Delalić was eventually arrested by the MUP and that he told the crime inspectors that the killing had been ordered by Izetbegović. Žepinić believed Delalić's claim, particularly after Delalić was released and no charges were filed against him. See D2923 (Witness statement of Vitomir Žepinić dated 11 February 2013), para. 58.

11234 On EC Peace Conference on Yugoslavia, see Section II.E.1.

11235 P5729 (Intercept of conversation between Biljana Plavšić, Rajko Dukić, and Radovan Karadžić, 2 March 1992), pp. 1-2; P924 (ECMM report, 1-2 March 1992), p. 1; D214 (Minutes of $56^{\text {th }}$ SRBiH Presidency session, 2 March 1992), pp. 2-3; Colm Doyle, T. 2701 (26 May 2010); P5553 (Conditions for Negotiation of the Crisis Staff of the Serb People in BiH, 2 March 1992), pp. 1-2.

11236 P5726 (Intercept of conversation between Rajko Dukić, Biljana Plavšić, Ostojić, and Čengić, 2 March 1992), pp. $2,4$.
} 
barricades in front of the Assembly building; Dukić then told Stanišić that Serb barricades in Sarajevo should not be removed so long as the Muslim barricades remained in place. ${ }^{11237}$ In the same conversation, Stanišić informed Dukić that he had visited all the check-points and commented that "Sarajevo is ours [...] a hundred percent". ${ }^{11238}$ Dukić replied to this by saying "Mićo, we have done a big thing." 11239

3536. On the same day, a special meeting of the BiH Presidency was convened during which it was decided that many of the demands made by the SDS should be met. ${ }^{1240}$ The Presidency also called for the barricades to be dismantled and for citizens to return to everyday life. ${ }^{11241}$ After the special meeting of the $\mathrm{BiH}$ Presidency, Plavšić, Franjo Boras, the Bosnian Croat member of BiH Presidency, and Vitomir Žepinić, the Deputy MUP Minister, spoke with Dukić and convinced him to make arrangements for the removal of the Serb barricades. ${ }^{11242}$ On 2 March 1992, more people were killed or injured in Sarajevo, some of them in close vicinity of the barricades. ${ }^{11243}$

3537. On 3 March 1992, the decision of the BiH Presidency on the demands of the SDS was published; shortly after, the Serb barricades began to be dismantled. ${ }^{11244}$ On the same day, however, upon receiving reports that Arkan's and Šešelj's men were on their way from Pale to Sarajevo, Bosnian Muslims set up barricades in predominantly Muslim inhabited parts of Sarajevo. ${ }^{11245}$ Later that day, the Accused and Izetbegović agreed to meet that same night with the $2^{\text {nd }}$ Military District Commander, Lieutenant-General Milutin Kukanjac, in order to diffuse the unfolding crisis. ${ }^{11246}$ In this meeting, based on Kukanjac's proposal, it was agreed that in order to

\footnotetext{
11237 P5612 (Intercept of conversation between Mićo Stanišić and Rajko Dukić, 2 March 1992), p. 2.

11238 P5612 (Intercept of conversation between Mićo Stanišić and Rajko Dukić, 2 March 1992), pp. 2-3.

11239 P5612 (Intercept of conversation between Mićo Stanišić and Rajko Dukić, 2 March 1992), p. 3.

11240 P924 (ECMM report, 1-2 March 1992), e-court pp. 2, 4-5; D214 (Minutes of $56^{\text {th }}$ SRBiH Presidency session, 2 March 1992), p. 4. The BiH Presidency refused to accept the proposed division of Sarajevo RTV. P5602 (Intercept of conversation between Jovanović, Stanišić, and Radovan Karadžić, 2 March 1992), pp. 3-4.

11241 D214 (Minutes of 56 ${ }^{\text {th }}$ SRBiH Presidency session, 2 March 1992), p. 4; P924 (ECMM report, 1-2 March 1992), e-court pp. 2, 4-5; D3070 (JNA $2^{\text {nd }}$ Military District report, 12 March 1992), p. 3.

11242 D2928 (Intercept of conversation between Biljana Plavšić, Rajko Dukić, Franjo Boras, and Vitomir Žepinić, 2 March 1992).

11243 D385 (SRBiH MUP Report on Sarajevo, 13 March 1992), pp. 2-4; Momčilo Mandić, T. $4886-4887$ (8 July 2010); P5602 (Intercept of conversation between Jovanović, Stanišić, and Radovan Karadžić, 2 March 1992), p. 2; P5725 (Intercepts of conversations between (i) Rajko Dukić and "Dragan" and (ii) Rajko Dukić and Biljana Plavšić, 2 March 1992), p. 1.

11244 P924 (ECMM report, 1-2 March 1992), e-court p. 3.

11245 Colm Doyle, P918 (Transcript from Prosecutor v. S. Milošević), T. 25269; Colm Doyle, T. 2713 (26 May 2010); P5605 (Intercept of conversation between Radovan Karadžić, Goran Milić, Alija Izetbegović, and an unidentified woman, 3 March 1992), p. 6; D4522 (Intercept of conversation between Radovan Karadžić and Todor Dutina, 3 March 1992), e-court p. 1. See also Adjudicated Fact 6.

11246 P5605 (Intercept of conversation between Radovan Karadžić, Goran Milić, Alija Izetbegović, and an unidentified woman, 3 March 1992), pp. 10-14; D1523 (Notes of meeting between Cyrus Vance and HansDietrich Genscher, 8 March 1992), e-court pp. 4-5 (under seal).
} 
control the situation, mixed units, involving Bosnian Muslims, Bosnian Serbs, and JNA troops would patrol Sarajevo. ${ }^{11247}$ The following day, Muslim barricades were dismantled. ${ }^{11248}$

3538. On 20 March 1992, representatives of the SDA concluded that division of Sarajevo RTV into ethnic channels as well as any appointment of non-Muslims to the posts of general manager and editor-in-chief of Sarajevo RTV would run contrary to the interests of Bosnian Muslims. ${ }^{11249}$

3539. Around the same time, Serb units began moving artillery onto the hills around Sarajevo. ${ }^{11250}$ Bosnian Muslims and Bosnian Serbs once again set up barricades in and around Sarajevo, inhibiting the movement of the population. ${ }^{11251}$

3540. At the end of March or the beginning of April 1992, JNA forces took control of Sarajevo airport and began using it exclusively to move JNA personnel and their families out of $\mathrm{BiH} .{ }^{11252}$ By this time, the activities of JNA personnel in the barracks contributed to the tensions. ${ }^{1253}$ In early April 1992, residents of Sarajevo demonstrated for peace in large numbers in front of the Assembly building. ${ }^{11254}$ However, during the protest they came under sniper fire which was said to have come from the direction of Holiday Inn. ${ }^{11255}$

11247 D3070 (JNA 2 ${ }^{\text {nd }}$ Military District report, 12 March 1992), pp. 3-4; Martin Bell, T. 9813 (14 December 2010).

11248 Colm Doyle, P918 (Transcript from Prosecutor v. S. Milošević), T. 25270; Colm Doyle, T. 2713 (26 May 2010 ). After these events, people in Sarajevo organised and armed themselves in order to guard their homes. See D3321 (Witness statement of Milorad Skoko dated 1 April 2013), para. 6.

11249 D213 (SDA letter re Sarajevo TV personnel changes, 20 March 1992).

11250 Herbert Okun, T. 1729 (27 April 2010).

11251 D2540 (Witness statement of Goran Sikiraš dated 2 December 2012), para. 8; P1029 (Witness statement of John Wilson dated 4 November 2008), paras. 27-28; D2443 (Witness statement of Željka Malinović dated 9 November 2012), para. 5.

11252 Colm Doyle, P918 (Transcript from Prosecutor v. S. Milošević), T. 25273, 25344; D331 (Intercept of conversation between Danilo Veselinović and Radovan Karadžić, 13 April 1992), e-court p. 3. See also Adjudicated Fact 2778.

11253 P1029 (Witness statement of John Wilson dated 4 November 2008), para. 30. In November 1991, Jure Pelivan, the Prime Minister of $\mathrm{BiH}$, informed Doyle of his serious concerns about JNA involvement in illicit transfers of armament into BiH and characterised the build-up of JNA forces in BiH territory as a "military occupation". P946 (ECMM report re meeting with Prime Minister Pelivan, 27 November 1991). In March 1992, BiH Deputy Prime Minister, Rusmir Mahmutčehajić announced that after the declaration of independence by BiH, the JNA would be viewed as an occupation force. See D3070 (JNA $2^{\text {nd }}$ Military District report, 12 March 1992), p. 5.

11254 P1938 (Witness statement of KDZ310 dated 28 November 2010), para. 9; P1217 (Witness statement of Milan Mandilović dated 24 February 2010), para. 19; P1996 (Witness statement of Martin Bell dated 8 March 2010), para. 21; D2379 (Witness statement of Momir Garić dated 2 November 2012), para. 11; D2538 (Witness statement of Milan Pejić dated 2 December 2012), para. 11; D3065 (Witness statement of Aleksandar Vasiljević dated 26 February 2013), paras. 181-182.

11255 P1938 (Witness statement of KDZ310 dated 28 November 2010), para. 9; Colm Doyle, T. 2968-2969 (28 May 2010); P1996 (Witness statement of Martin Bell dated 8 March 2010), para. 21; D3065 (Witness statement of Aleksandar Vasiljević dated 26 February 2013), paras. 181-182. The evidence on the identity of those who targeted the protesters with gunfire is inconsistent. 
3541. During the night of 4 April 1992, Bosnian Muslim units attacked and took control of the MUP building in Sarajevo, expelling the Bosnian Serb employees. ${ }^{11256}$ Soon after, BiH police and TO forces surrounded the $2^{\text {nd }}$ District Command building complex and the Sarajevo Military Hospital which was at the time run by the JNA. ${ }^{11257}$ Around the same date, Bosnian Muslims began attacking JNA forces and installations in Sarajevo. ${ }^{11258}$ On 6 April 1992, extensive gunfire erupted, with each side accusing the other of having started the hostilities. ${ }^{11259}$ Armed Muslims detained and mistreated Žepinić on several occasions, prompting him to eventually leave for Belgrade. $^{11260}$ A number of Serbs had their houses searched and ransacked, were mistreated by armed Bosnian Muslim units, faced harassment at their workplace, were purged from employment, or were prevented from entering and departing Sarajevo. ${ }^{11261}$ Following these events, some Serb families left for parts of Sarajevo where Serbs were in the majority while others moved to Pale. ${ }^{1262}$ Around the same period, a large number of Bosnian Muslim civilians began moving into areas of Sarajevo which were under the control of the BiH government. ${ }^{11263}$

3542. By 10 April 1992, the security situation in Sarajevo had deteriorated; the command of the $2^{\text {nd }}$ Military District reported that mortar fire had again been directed against features in the city and that all movements and all roads to the city were being controlled by Green Berets, armed civilians, and BiH MUP forces. ${ }^{11264}$ On 12 April 1992, the leaders of all three parties agreed to an immediate and total cease-fire in BiH, including in Sarajevo. ${ }^{11265}$ They also agreed that Bosnian Serbs should

11256 D396 (Announcement of SerBiH MUP, 5 April 1992), p. 1; Momčilo Mandić, T. 4926 (8 July 2010). See also D2538 (Witness statement of Milan Pejić dated 2 December 2012), para. 11.

11257 D3671 (Witness statement of Dušan Kovačević dated 7 June 2013), para. 8; P1217 (Witness statement of Milan Mandilović dated 24 February 2010), para. 27; Milan Mandilović, T. 5366 (16 July 2010), T. 5397-5398 (19 July 2010); D495 (JNA $2^{\text {nd }}$ Military District combat report, 21 April 1992), p. 2; D3671 (Witness statement of Dušan Kovačević dated 7 June 2013), para. 47.

11258 D495 (JNA $2^{\text {nd }}$ Military District combat report, 21 April 1992), pp. 1-4; P6170 (Transcript of conversation between Branko Kostić, Alija Izetbegović, and Blagoje Adžić, 26 April 1992), pp. 18-19.

11259 Adjudicated Fact 7.

11260 D2923 (Witness statement of Vitomir Žepinić dated 11 February 2013), paras. 72-73; Martin Bell, T. 9857 (15 December 2010); P926 (Witness statement of Aernout van Lynden dated 26 February 2010), para. 61.

11261 D2443 (Witness statement of Željka Malinović dated 9 November 2012), paras. 8-9, 22-23; D3671 (Witness statement of Dušan Kovačević dated 7 June 2013), para. 16; D1400 (SRNA news report, 11 April 1992); Hajrudin Karić, T. 15320-15321 (23 June 2011); D396 (Announcement of SerBiH MUP, 5 April 1992), e-court p. 1; D447 (SerBiH MUP, Analysis of functioning of the MUP, July 1992), e-court p. 11; D2538 (Witness statement of Milan Pejić dated 2 December 2012), para. 10; D3138 (Witness statement of Mirko Šošić dated 17 March 2013), paras. 6-7; Mirko Šošić, T. 35759-35760 (21 March 2013).

11262 D2443 (Witness statement of Željka Malinović dated 9 November 2012), paras. 8, 12; D8 (SRNA news report, 10 April 1992).

11263 P2444 (Witness statement of KDZ354 dated 5 February 2011), para. 22 (under seal); Bakir Nakaš, T. 66876688 (14 September 2010).

11264 P925 (JNA $2^{\text {nd }}$ Military District combat report, 10 April 1992), pp. 2-3.

11265 P947 (Cease-fire Agreement, 12 April 1992); Colm Doyle, P918 (Transcript from Prosecutor v. S. Milošević), T. 25283-25284. See also para. 329. 
have a greater role with respect to Sarajevo RTV broadcasts. ${ }^{11266}$ The following day, however, during a meeting with Doyle and Sarajevo RTV management, Bosnian Serb representatives claimed that the agreement concerning Sarajevo RTV essentially required that all the assets which belonged to the station be divided between the three ethnic groups. ${ }^{11267}$ As a result, the meeting did not lead to any progress. ${ }^{11268}$ The next day, Serbs from Pale warned the employees at Sarajevo RTV that if the station did not get off the air, it would be targeted. ${ }^{11269}$ Doyle, having been informed of this threat, immediately contacted the Accused who then assured him that this attack would not take place. ${ }^{11270}$ Shortly after, however, mortar fire targeted the Sarajevo RTV building, killing a number of people. ${ }^{11271}$ The Accused later admitted to Doyle that the bombing had been carried out by Bosnian Serbs but insisted that the attack did not have his permission. ${ }^{11272}$

3543. On 16 April 1992, the Accused told Herbert Okun, who was an adviser to the Special Envoy of the Secretary General at the time, ${ }^{11273}$ that the situation in Sarajevo was urgent and that people were fighting because the ethnic groups could not and did not want to live together. ${ }^{11274}$ Around the same time, the JNA's $216^{\text {th }}$ Mountain Brigade was relocated to Grbavica in anticipation of the withdrawal of JNA units from the barracks in the city. ${ }^{11275}$ In the preceding months, on the basis of Kukanjac's directives, the JNA had already moved most of its heavy weaponry, ammunition and explosives from Sarajevo to Serb-held positions on the elevations outside the city. ${ }^{11276}$

Colm Doyle, P918 (Transcript from Prosecutor v. S. Milošević), T. 25277; Colm Doyle, T. 2683 (21 May 2010). Colm Doyle, P918 (Transcript from Prosecutor v. S. Milošević), T. 25277-25278; Colm Doyle, T. 2683-2684 (21 May 2010). A month earlier, during an exchange with Izetbegović in the presence of Cutileiro, the Accused stated that by ignoring the Bosnian Serb perspective, Sarajevo RTV had caused further deterioration of the situation; the Accused subsequently reiterated the SDS demand that there be a separate TV channel for each ethnic group in $\mathrm{BiH}$. D1284 (Handwritten notes of meetings attended by Radovan Karadžić in relation to Conference on BiH, February and March 1992), p. 25.

11268 Colm Doyle, P918 (Transcript from Prosecutor v. S. Milošević), T. 25278.

11269 Colm Doyle, P918 (Transcript from Prosecutor v. S. Milošević), T. 25278, 25348; Colm Doyle, T. 2678 (21 May 2010).

11270 Colm Doyle, P918 (Transcript from Prosecutor v. S. Milošević), T. 25278, 25348; Colm Doyle, T. 2678 (21 May 2010).

11271 Colm Doyle, P918 (Transcript from Prosecutor v. S. Milošević), T. 25278-25279; Colm Doyle, T. 2678 (21 May 2010), T. 2728, 2736 (26 May 2010); P1996 (Witness statement of Martin Bell dated 8 March 2010), para. 101. These killings are not charged in the Indictment.

11272 Colm Doyle, P918 (Transcript from Prosecutor v. S. Milošević), T. 25279; Colm Doyle, T. 2678-2680 (21 May 2010). By contrast, in a letter addressed to the directors of the prominent media outlets in Sarajevo, including Sarajevo RTV and the Oslobođenje newspaper, Mićo Stanišić denied that Bosnian Serbs bore any responsibility for the attack on Sarajevo RTV and instead attributed the attack to the Green Berets. D4272 (Letter from Mićo Stanišić to the BiH media, 18 April 1992), pp. 1-2.

11273 Herbert Okun, P776 (Transcript from Prosecutor v. Krajišnik), T. 4139.

11274 Herbert Okun, P776 (Transcript from Prosecutor v. Krajišnik), T. 4174, 4205.

11275 D2375 (Witness statement of Milorad Džida dated 30 October 2012), paras. 4, 14; D2379 (Witness statement of Momir Garić dated 2 November 2012), para. 22; D2665 (Witness statement of Izo Golić dated 15 December 2012), para. 13.

11276 P979 (Report from JNA $2^{\text {nd }}$ Military District to JNA General Staff, 20 March 1992), p. 9; D239 (Report of $17^{\text {th }}$ Corps, 3 April 1992), p. 2; D236 (JNA $4^{\text {th }}$ Corps Report, 7 May 1992), p. 2; D3671 (Witness statement of Dušan
} 
3544. On 20 April 1992, Kukanjac reported that BiH MUP and TO forces had made specific plans to attack JNA installations in Sarajevo. ${ }^{11277}$ On the same day, SerBiH Prime Minister Branko Đerić prohibited Bosnian Serb units from firing heavy artillery at the city unless the SerBiH Minister of Defence authorised such fire due to "exceptional conditions". ${ }^{11278}$ Despite this order, Serbs engaged in the shelling of Sarajevo. ${ }^{11279}$ Two days after Đerić's order concerning the use of heavy artillery and the day before his planned meeting with Carrington, Cutileiro, and Izetbegović, the Accused issued his so-called "peace platform". ${ }^{11280}$ With this document, the Accused proposed, amongst other things, (i) an unconditional and immediate cease-fire; (ii) the continuation of the EC Peace Conference on Yugoslavia; (iii) prioritisation of drawing of maps of Sarajevo and the constituent states; and (iv) clarification of the role of the JNA in $\mathrm{BiH}^{1{ }^{1281}}$

3545. On 25 April 1992, after giving Martin Bell, a BBC war correspondent, ${ }^{11282}$ a tour of the frontlines in Trebević, the Accused stated: "If we didn't have hope for political solutions we would already free Sarajevo". ${ }^{11283}$ In late April 1992, Bosnian Serbs, backed by the JNA, again shelled various neighbourhoods in and around the city. ${ }^{11284}$ At the same time, armed Serb units, supported by JNA tanks, attacked Muslim neighbourhoods around the airport, forcing the inhabitants of the affected areas to seek refuge in Sarajevo. ${ }^{11285}$

3546. Around the same period, Hasan Efendić, the Commander of the $\mathrm{BiH} \mathrm{TO}$, ordered his forces to capture weapon and ammunition depots in $\mathrm{BiH}$ territory, blockade the JNA barracks, and capture JNA personnel. ${ }^{11286}$ Soon after, Bosnian Muslims blockaded the JNA barracks and installations in Sarajevo, including the complex in Bistrik where Kukanjac and his entire staff, numbering 400 persons, were still stationed. ${ }^{11287}$ By the end of April 1992, Bosnian Muslim and Bosnian Serb

Kovačević dated 7 June 2013), para. 47; Dušan Kovačević, T. 39643 (10 June 2013); D312 (SRK analysis of combat readiness of artillery rocket units, July 1994), p. 2.

11277 D3069 (JNA $2^{\text {nd }}$ Military District report, 20 April 1992), p. 1. See also D4636 (Report of the Command of the $2^{\text {nd }}$ Military District, 22 April 1992), p. 2.

11278 D219 (Order by Branko Đerić re artillery ban, 20 April 1992). The Chamber notes that in the English translation of D219, the surname "Đerić" has been mistakenly transcribed as "Ćerić".

11279 Colm Doyle, T. 2772 (26 May 2010).

11280 D220 (Radovan Karadžić’s Peace Platform, 22 April 1992).

11281 D220 (Radovan Karadžić’s Peace Platform, 22 April 1992).

11282 P1996 (Witness statement of Martin Bell dated 8 March 2010), para. 3.

11283 P1997 (BBC news report re interview with Radovan Karadžić at Trebević, with transcript); Martin Bell, T. 9769-9770 (14 December 2010).

11284 P1690 (Witness statement of Alen Gičević dated 16 February 2010), p. 9; P937 (UNSG Report re peacekeeping operation in BiH, 12 May 1992), para. 3; Colm Doyle, T. 2665 (21 May 2010); P941 (London Conference record of a meeting with Radovan Karadžić, 26 August 1992), para. 4; Herbert Okun, T. 1634 (26 April 2010), T. 1729 (27 April 1992), T. 1781-1782 (28 April 2010).

11285 P1996 (Witness statement of Martin Bell dated 8 March 2010), para. 64. See also Section IV.1.1.c.ii: Ilidža.

11286 D222 (TO directive, 23 April 1992), p. 2; D332 (Order of TO Sarajevo, 29 April 1992).

11287 Colm Doyle, T. 2752, 2791 (26 May 2010); Colm Doyle, P918 (Transcript from Prosecutor v. S. Milošević), T. 25368; P937 (UNSG Report re peacekeeping operation in BiH, 12 May 1992), para. 3; D217 (Excerpt from 
military formations as well as criminal bands were engaged in fierce clashes in the city; the shelling and sniping activities by both sides also increased exponentially. ${ }^{11288}$ The fighting ebbed somewhat when Lord Carrington arrived in the city to broker a cease-fire. ${ }^{11289}$

3547. On 2 May 1992, in a letter to Doyle, Đerić indicated that given the attacks launched by the $\mathrm{BiH} \mathrm{TO}$, the Bosnian Serbs were unwilling to remove heavy artillery from around Sarajevo and threatened to take possession of radio and television relays which were being used by broadcasters from the Muslim side to propagate "informative terror". 11290

3548. On the same day around noon, Green Berets and HOS units attacked the JNA social centre in downtown Sarajevo, seriously wounding its director. ${ }^{1291}$ Subsequently, units from the $65^{\text {th }}$ Motorised Protection Regiment of the JNA were dispatched to the social centre in order to evacuate the JNA personnel there, some of whom were wounded. ${ }^{11292}$ However, these units were ambushed by Bosnian Muslims. ${ }^{1293}$ An armoured battalion from Grbavica as well as an anti-sabotage detachment, which had been hitherto securing the Military Hospital, were dispatched to rescue the ambushed units but they too were attacked on their way. ${ }^{11294}$

3549. During the evening of 2 May 1992, after arriving from Lisbon, Izetbegović, his daughter, and his bodyguard were taken into custody by the JNA at the Sarajevo airport and taken to the

General MacKenzie's book entitled “The Road to Sarajevo"), e-court p. 3; D236 (JNA $4^{\text {th }}$ Corps Report, 7 May 1992), p. 1; John Wilson, T. 4007 (21 June 2010); D2375 (Witness statement of Milorad Džida dated 30 October 2012), para. 14.

11288 Milan Mandilović, T. 5379 (16 July 2010); Colm Doyle, P918 (Transcript from Prosecutor v. S. Milošević), T. 25273; Colm Doyle, T. 2720 (26 May 2010), 2928 (28 May 2010); Barko Zečević, T. 12152 (22 February 2011); D495 (JNA $2^{\text {nd }}$ Military District combat report, 21 April 1992), p. 1; D331 (Intercept of conversation between Danilo Veselinović and Radovan Karadžić, 13 April 1992), e-court pp. 1, 4; D4636 (Report of the Command of the $2^{\text {nd }}$ Military District, 22 April 1992), pp. 1-2; D920 (Intercept of conversation between Radovan Karadžić and Radovan Pejić, 23 April 1992); D917 (BBC news report re Sarajevo, with transcript); D918 (BBC news report re Sarajevo, with transcript); P1996 (Witness statement of Martin Bell dated 8 March 2010), paras. 33, 61; Martin Bell, T. 9802, 9815-9816, 9818-9819, 9827, 9829 (14 December 2010), 9930 (15 December 2010); John Wilson, T. 3962, 4004-4005 (21 June 2010). On 22 April 1992, Alen Gičević, a resident of Sarajevo at the time, was injured by a mortar shell which landed near his home at Džidžikovac street in Sarajevo's centre. See P1690 (Witness statement of Alen Gičević dated 16 February 2010), p. 9.

11289 Martin Bell, T. 9835 (14 December 2010); P2025 (BBC news report re Ilidža, with transcript). On Lord Carrington's visit, see para. 329.

11290 D229 (Branko Đerić's letter to Colm Doyle, 2 May 1992). Richard Gray, who was the Chief Operations Officer for the UNMOs in Sarajevo until June 1992, stated that the BiH government regularly used Sarajevo RTV to circulate inflammatory propaganda against Bosnian Serbs. See D2398 (Witness statement of Richard Gray dated 22 April 2012), para. 23.

11291 D236 (JNA $4^{\text {th }}$ Corps Report, 7 May 1992), p. 2; D825 (Manojlo Milovanović's book entitled "My View of the War in Bosnia 1992-1995”), p. 4; Martin Bell, T. 9830 (14 December 2010).

11292 D236 (JNA $4^{\text {th }}$ Corps Report, 7 May 1992), p. 3.

11293 D236 (JNA $4^{\text {th }}$ Corps Report, 7 May 1992), p. 3.

11294 D236 (JNA $4^{\text {th }}$ Corps Report, 7 May 1992), p. 3; P1217 (Witness statement of Milan Mandilović dated 24 February 2010), para. 23; Milan Mandilović, T. 5375-5376 (16 July 2010). 
Lukavica Barracks. ${ }^{11295}$ At around the same time, the Military Hospital also came under Bosnian Muslim attack. ${ }^{11296}$ In response to the attacks against the JNA social centre and the Military Hospital, Kukanjac ordered the use of artillery against the city centre. ${ }^{11297}$

3550. In the morning hours of 3 May 1992, members of the $65^{\text {th }}$ Motorised Protection Regiment were captured by Green Berets and the HOS. ${ }^{11298}$

3551. On 3 May 1992, General MacKenzie, the Commander of UNPROFOR Sector Sarajevo, Doyle, Ganić, and General Aksentijević of the JNA began negotiating the release of Izetbegović. ${ }^{11299}$ During these negotiations, it was agreed that under the supervision and guarantee of the ECMM and UNPROFOR, Izetbegović would be released by the JNA and that in return, Bosnian Muslim forces would allow Kukanjac to leave his headquarters in downtown Sarajevo and move to Lukavica Barracks, on the Serb side of the confrontation lines. ${ }^{11300}$

3552. MacKenzie and Doyle then travelled to Lukavica Barracks where Izetbegović had been detained in order to persuade him to accept the exchange agreement. ${ }^{11301}$ While MacKenzie and Doyle were at the barracks, Kukanjac contacted Izetbegović by telephone and indicated that there would be no exchange unless his entire staff, along with their equipment, were also removed from Bistrik and taken to safety. ${ }^{11302}$ Despite the reservations expressed by MacKenzie and Doyle as to the feasibility of the plan to move such a large number of JNA personnel through Muslimcontrolled parts of the city, Izetbegović accepted Kukanjac's proposal, assuming personal responsibility for their safety. ${ }^{11303}$ Later that day, Izetbegović and MacKenzie, along with a large convoy of empty trucks belonging to the $2^{\text {nd }}$ Military District, departed for downtown Sarajevo in order to pick up Kukanjac and his personnel; after the convoy arrived in Bistrik, the trucks were

\footnotetext{
11295 D236 (JNA $4^{\text {th }}$ Corps Report, 7 May 1992), p. 4; Colm Doyle, P918 (Transcript from Prosecutor $v$. S. Milošević), T. 25294-25295, 25384; Colm Doyle, T. 2859 (27 May 2010); P1996 (Witness statement of Martin Bell dated 8 March 2010), para. 66.

11296 D3671 (Witness statement of Dušan Kovačević dated 7 June 2013), paras. 9-10; D236 (JNA $4^{\text {th }}$ Corps Report, 7 May 1992), pp. 3-4; D825 (Manojlo Milovanović's book entitled "My View of the War in Bosnia 19921995”), p. 4; D919 (BBC news report re attack of JNA convoy, with transcript); Martin Bell, T. 9825 (14 December 2010); D2667 (Witness statement of Ratomir Maksimović dated 14 December 2012), para. 3.

11297 P1996 (Witness statement of Martin Bell dated 8 March 2010), para. 65.

11298 D236 (JNA $4^{\text {th }}$ Corps Report, 7 May 1992), p. 3.

11299 Colm Doyle, P918 (Transcript from Prosecutor v. S. Milošević), T. 25266; D236 (JNA $4^{\text {th }}$ Corps Report, 7 May 1992), p. 4.

11300 Colm Doyle, P918 (Transcript from Prosecutor v. S. Milošević), T. 25295; Colm Doyle, T. 2680 (21 May 2010); D236 (JNA $4^{\text {th }}$ Corps Report, 7 May 1992), pp. 4-5; D919 (BBC news report re attack of JNA convoy, with transcript); Martin Bell, T. 9830-9831 (14 December 2010).

11301 Colm Doyle, P918 (Transcript from Prosecutor v. S. Milošević), T. 25368.

11302 Colm Doyle, T. 2752-2753 (26 May 2010); D217 (Excerpt from General MacKenzie's book entitled "The Road to Sarajevo"), e-court pp. 4-5.

11303 Colm Doyle, T. 2754, 2757 (26 May 2010); D217 (Excerpt from General MacKenzie's book entitled "The Road to Sarajevo"), e-court p. 5.
} 
loaded with JNA personnel and equipment. ${ }^{11304}$ It was then decided that the convoy should drop off Izetbegović and his daughter near the Presidency building and then proceed to the Lukavica Barracks with Kukanjac and his personnel. ${ }^{11305}$ Shortly after embarking on its route on Dobrovoljačka street, however, Muslim forces intercepted and attacked the convoy's rear, killing at least 14 JNA members, including two Colonels, and taking a large number of prisoners. ${ }^{11306}$ At this point, Izetbegović emerged from the vehicle he was in and addressed the attackers, explaining to them that he had promised safety to the convoy. ${ }^{11307}$ Following Izetbegović's intervention, the convoy proceeded to a location where Izetbegović and his daughter were transferred to an APC bound for the Presidency building. ${ }^{11308}$ From there, the rest of the convoy travelled to Lukavica Barracks. ${ }^{11309}$ Soon after, a battalion from the $216^{\text {th }}$ Mountain Brigade of the JNA was ordered to move from Lukavica Barracks to Dobrovoljačka street where the incident had taken place; before the battalion arrived, however, Bosnian Muslims took away the dead and the captured JNA soldiers and disappeared from the scene. ${ }^{11310}$ In the days that followed, Doyle and MacKenzie successfully negotiated the release of the JNA personnel. ${ }^{11311}$

3553. After the events of 3 May 1992, the situation in Sarajevo deteriorated further. ${ }^{11312}$ The trams which connected the eastern and western parts of the city and which were regarded as symbols of normalcy stopped running. ${ }^{11313}$

11304 D217 (Excerpt from General MacKenzie's book entitled “The Road to Sarajevo"), e-court p. 6; D236 (JNA $4^{\text {th }}$ Corps Report, 7 May 1992), p. 5; D825 (Manojlo Milovanović's book entitled "My View of the War in Bosnia 1992-1995"), p. 5; D919 (BBC news report re attack of JNA convoy, with transcript).

11305 D236 (JNA $4^{\text {th }}$ Corps Report, 7 May 1992), pp. 5-6; D919 (BBC news report re attack of JNA convoy, with transcript).

11306 Colm Doyle, T. 2755, 2757, 2785-2786 (26 May 2010), T. 2860 (27 May 2010); Colm Doyle, P918 (Transcript from Prosecutor v. S. Milošević), T. 25370-25371; P1217 (Witness statement of Milan Mandilović dated 24 February 2010), para. 22; Milan Mandilović, T. 5372-5374 (16 July 2010); P937 (UNSG Report re peacekeeping operation in BiH, 12 May 1992), para. 26; D216 (Article entitled "Colm Doyle Interview with Vecernje Novosti", 12 May 1992); D236 (JNA $4^{\text {th }}$ Corps Report, 7 May 1992), p. 6; D2540 (Witness statement of Goran Sikiraš dated 2 December 2012), para. 10; D825 (Manojlo Milovanović's book entitled "My View of the War in Bosnia 1992-1995"), p. 8; P1996 (Witness statement of Martin Bell dated 8 March 2010), para. 66; Martin Bell, T. 9825 (14 December 2010); D919 (BBC news report re attack of JNA convoy, with transcript); D2379 (Witness statement of Momir Garić dated 2 November 2012), para. 21; D3671 (Witness statement of Dušan Kovačević dated 7 June 2013), paras. 10, 12-13, 15. See also D2974 (Letter from Momčilo Krajišnik to Jose Cutileiro and others, 28 May 1992), p. 1.

11307 D217 (Excerpt from General MacKenzie's book entitled "The Road to Sarajevo"), e-court p. 9.

11308 D217 (Excerpt from General MacKenzie's book entitled "The Road to Sarajevo"), e-court p. 9.

11309 D236 (JNA $4^{\text {th }}$ Corps Report, 7 May 1992), p. 6.

11310 D236 (JNA $4^{\text {th }}$ Corps Report, 7 May 1992), p. 6.

11311 Colm Doyle, T. 2786 (26 May 2010); D236 (JNA $4^{\text {th }}$ Corps Report, 7 May 1992), pp. 6-7; D825 (Manojlo Milovanović's book entitled "My View of the War in Bosnia 1992-1995"), p. 10.

11312 Colm Doyle, P918 (Transcript from Prosecutor v. S. Milošević), T. 25370-25382.

11313 P1996 (Witness statement of Martin Bell dated 8 March 2010), para. 48; Martin Bell, T. 9830 (14 December 2010). 
3554. Sometime later, representatives of the BiH Presidency and the JNA reached an agreement for the withdrawal of all JNA units from $\mathrm{BiH} .{ }^{1314}$ With this agreement, the JNA undertook to return all equipment, armament, and ammunitions of the TO which had been left in its custody and stored in the military barracks around town. ${ }^{11315}$ Soon after, the JNA units were evacuated from the Military Hospital; medical equipment and medicines were, however, left behind. ${ }^{11316}$

3555. On 11 May 1992, the JNA declared that its personnel would be evacuated from the Maršal Tito Barracks, Viktor Bubanj Barracks, Jusuf Džonlić Barracks, and Gavrilo Princip Barracks and that the following day the weaponry and ammunition in these barracks would be handed over to the TO forces from each the four municipalities in which these barracks were located. ${ }^{11317}$

3556. By mid-May 1992, after several weeks of intense urban combat, the frontlines in Sarajevo were established. ${ }^{11318}$ "Serb irregulars" completely surrounded the city and controlled all the traffic. ${ }^{1319}$ Using the heavy artillery and sniper rifles made available to them by the JNA, they regularly targeted the city, including its civilian areas, from the surrounding hills. ${ }^{11320}$ The shelling became particularly intense and widespread on 14 May 1992, prompting John Wilson, the Chief of the UNMOs in Sarajevo, ${ }^{11321}$ to conclude that several thousand shells had fallen on the city that day. ${ }^{11322}$ As a result of the continued shelling, the number of civilian casualties increased significantly; economic life came to a halt and there were growing shortages of food, medicine and

\footnotetext{
11314 P950 (Agreement on withdrawal of JNA from BiH), p. 1; Colm Doyle, P918 (Transcript from Prosecutor v. S. Milošević), T. 25296.

11315 P950 (Agreement on withdrawal of JNA from BiH), p. 1; Colm Doyle, P918 (Transcript from Prosecutor v. S. Milošević), T. 25296.

11316 P1217 (Witness statement of Milan Mandilović dated 24 February 2010), paras. 25-26; Milan Mandilović, T. 5364-5365 (16 July 2010). See also Adjudicated Fact 2884.

11317 D231 (JNA Order re TO arming of Muslims, 11 May 1992).

11318 P953 (Article from Oslobođenje, entitled "Happy Birthday Republic", 6 January 1995), p. 4; Colm Doyle, T. 2995 (28 May 2010); P1996 (Witness statement of Martin Bell dated 8 March 2010), paras. 33, 61; Martin Bell, T. 9861 (15 December 2010).

11319 P937 (UNSG Report re peacekeeping operation in BiH, 12 May 1992), para. 3; P1029 (Witness statement of John Wilson dated 4 November 2008), para. 39; P1154 (Witness statement of KDZ088 dated 27-29 April 2010), p. 77 (under seal).

11320 P937 (UNSG Report re peacekeeping operation in BiH, 12 May 1992), para. 3; Colm Doyle, T. 2737 (26 May 2010); Colm Doyle, P918 (Transcript from Prosecutor v. S. Milošević), T. 25297-25298; P1029 (Witness statement of John Wilson dated 4 November 2008), paras. 41-42; John Wilson, T. 3915, 3919, 3977 (21 June 2010); P1154 (Witness statement of KDZ088 dated 27-29 April 2010), p. 45 (under seal). See also Adjudicated Fact 8.

11321 P1029 (Witness statement of John Wilson dated 4 November 2008), para. 5. Following his time as UNMO, John Wilson was then appointed as military adviser to Vance and UNPROFOR liaison officer to the ICFY in December 1992. See P1029 (Witness statement of John Wilson dated 4 November 2008), paras. 6, 8 ; P1046 (John Wilson's Report to Australian Army, 15 November 1992), p. 9.

11322 P1029 (Witness statement of John Wilson dated 4 November 2008), paras. 41-42, 73; John Wilson, T. 3994 (21 June 2010), T. 4040 (22 June 2010), T. 4131 (23 June 2010). See also Richard Gray, T. 29982-29983 (8 November 2012).
} 
other essential supplies. ${ }^{11323}$ The heavy shelling also forced the UNPROFOR mission in Sarajevo, which had hitherto been located in the Post Office building (PTT), to be temporarily relocated to Belgrade. ${ }^{11324}$ Wilson, along with seven UNMOs and a French protection unit nevertheless stayed in Sarajevo in order to provide humanitarian assistance and to facilitate dialogue between the warring parties. ${ }^{11325}$ The remaining UN personnel could only venture out of the PTT building in armoured vehicles, and even then, were frequently and deliberately targeted by both sides. ${ }^{11326}$ On 18 May 1992, a UN convoy was organised to take Plavšić who had been in Sarajevo for negotiations back to her residence; Bosnian Muslims targeted the convoy with gunfire and prevented Plavšić from leaving the city that day. ${ }^{11327}$

3557. On 12 May 1992, Mladić was appointed as the Commander of the newly-established VRS and by late May was interacting with representatives of the international community. ${ }^{11328}$ On 19 May 1992, Mladić appointed Colonel Tomislav Šipčić as the SRK Commander and the SRK was assigned to the greater Sarajevo area, the former zone of responsibility of the $4^{\text {th }}$ JNA Corps. ${ }^{11329}$ The SRK's main forces were positioned around what was colloquially called the inner ring of Sarajevo, in particular in the areas of Ilidža, Nedžarići, and Grbavica. ${ }^{1330}$ The inner ring extended from the northern bank of Miljacka River in Marin Dvor, across the river and westward to Dobrinja, then upwards to the neighbourhood of Alipašino Polje, nearing the Stupska Petlja in the west of city of Sarajevo, northward to the areas of Sokolja Dol and Zuca, and following eastward to complete the circle near Grdonj and Debelo Brdo near Grbavica. ${ }^{11331}$ Auxiliary forces of the SRK

11323 P944 (Letter from Sarajevo Mayor to EC President, 1 May 1992), p. 1; P937 (UNSG Report re peacekeeping operation in BiH, 12 May 1992), paras. 3, 18; Colm Doyle, T. 2665-2666 (21 May 2010); P1996 (Witness statement of Martin Bell dated 8 March 2010), paras. 33, 49; P814 (Witness statement of Fatima Zaimović dated 26 February 2010), para. 10. See also P4997 (Ewa Tabeau's expert report entitled "Persons Killed and Wounded in Sarajevo During the First Months of the 'Siege' from 1 April to 9 September 1992", 1 May 2009), pp. 21, 26 (indicating a significant rise in the number of wounded and killed civilians in Sarajevo in midMay 1992).

11324 P1029 (Witness statement of John Wilson dated 4 November 2008), paras. 7, 64; P1046 (John Wilson's Report to Australian Army, 15 November 1992), para. 5; D2398 (Witness statement of Richard Gray dated 22 April 2012), para. 9.

11325 P1029 (Witness statement of John Wilson dated 4 November 2008), paras. 7, 64.

11326 John Wilson, T. 3919-3920, 3952 (21 June 2010); D2398 (Witness statement of Richard Gray dated 22 April 2012), para. 10. The attacks on UN personnel were condemned by the Security Council. See P1031 (UNSC Resolution 757, 30 May 1992), p. 2; John Wilson, T. 3926-3927 (21 June 2010).

11327 Plavšić spent the night at the PTT building while UN personnel controlled the angry crowds which had gathered outside; she returned to her residence the following day. D2398 (Witness statement of Richard Gray dated 22 April 2012), para. 15.

11328 John Wilson, T. 3982 (21 June 2010), T. 4123 (23 June 2010). On the creation of VRS and the appointment of Mladić, see Section II.C.1: VRS; Section IV.B.3.c.i: Accused's support for Mladić and SRK.

11329 See fn. 526; Adjudicated Fact 20.

11330 See Adjudicated Fact 21.

11331 Stanislav Galić, T. 37161-37166 (15 April 2013), 37347-37348 (16 April 2013), T. 37390 (18 April 2013 ), T. 37471 (22 April 2013); D3381 (Map of Sarajevo marked by Stanislav Galić). Radinović stated that throughout the entire war, the frontlines in and around Sarajevo remained relatively constant. Changes in the position of the warring parties occurred in Stup where the VRS assumed control of additional territory in the 
were positioned on the so-called exterior ring of the Sarajevo front. ${ }^{11332}$ During this period, the SRK had about 200 pieces of artillery of many different calibres in its possession whereas the Bosnian Muslim forces inside the city had only a dozen pieces of heavy weaponry, including a few tanks, and a number of mortars. ${ }^{11333}$ Frontlines were not shifting much from that moment on, and after 1992, were more or less set. ${ }^{11334}$ The SRK held the high ground around the city and could often see directly what its forces were firing at, while the $\mathrm{ABiH}$ held the lower ground in most parts. ${ }^{11335}$ The SRK's forward command post was in Lukavica while on the opposing side, the $1^{\text {st }}$ Corps of $\mathrm{ABiH}$ had its headquarters in downtown Sarajevo (until it moved to Visoko in March 1994). ${ }^{11336}$ The ABiH $1^{\text {st }}$ Corps troops were positioned mostly on the confrontation lines. ${ }^{11337}$ In

autumn of 1992 and in Žuč and Orlić, two elevations overlooking the city, where ABiH forces made advances in late 1992. See D3864 (Radovan Radinović's expert report entitled "The Control Authority of Dr. Radovan Karadžić in the Strategic Command System of the VRS”, 2012), paras. 191, 270. See also Adjudicated Fact 32.

11332 Adjudicated Fact 23.

11333 D312 (SRK analysis of combat readiness of artillery rocket units, July 1994), p. 3; P1029 (Witness statement of John Wilson dated 4 November 2008), para. 43; John Wilson, T. 3933, 3937-3938, 3978 (21 June 2010); [REDACTED].

11334 P2068 (Witness statement of Jeremy Bowen dated 10 August 2009), para. 14; Jeremy Bowen, T. 10105 (13 January 2011); P820 (Witness statement of David Harland dated 4 September 2009), para. 30; David Harland, T. 2018 (6 May 2010), T. 2078-2094 (7 May 2010); D134 (Aerial photograph of Sarajevo marked by David Harland); P1762 (Witness statement of David Fraser dated 17 October 2010), pp. 15-20 (testifying that the ABiH held Mojmilo, Sokolje, Hum, Žuč, Grdonj, Debelo Brdo, Čolina Kapa which were also in the hilltops and overlooked some Bosnian-Serb held territory); P1767 (Map of Sarajevo marked by David Fraser); P1996 (Witness statement of Martin Bell dated 8 March 2010), para. 33; Manojlo Milovanović. T. 25753 (5 March 2012); P1005 (SRK Order, 9 September 1992), p. 1 (indicating that by September 1992 the SRK had achieved most of its "military goals for the war" and did not expect "major movements of the frontline"); Savo Simić, T. 30039-30041 (12 November 2012). SRK-held areas, such as Grbavica and Dobrinja, were at a disadvantageous position vis-à-vis $\mathrm{ABiH}$-held territories); John Wilson, T. 3979-3980 (21 June 2010); P926 (Witness statement of Aernout van Lynden dated 26 February 2010), paras. 18, 77-82, 87, 155 (testifying that during his interview with Ratko Mladić, Mladić pointed to the city from one of the SRK positions in the east, indicating that the city was in the palm of his hand); P806 (SKY news report re Sarajevo, with transcript); P933 (SKY news report re Sarajevo, with transcript); P842 (VRS map of Sarajevo, 31 August 1995); Aernout van Lynden, T. 2398, 2419-2423 (19 May 2010), T. 2499-2506 (20 May 2010); P934 (Map of Sarajevo marked by Aernout van Lynden); D198 (Aerial photograph of Sarajevo marked by Aernout van Lynden); P2068 (Witness statement of Jeremy Bowen dated 10 August 2009), paras. 14, 29; Colm Doyle, T. 2737-2738 (26 May 2010); P1996 (Witness statement of Martin Bell dated 8 March 2010), paras. 43, 84-86; P1997 (BBC news report re interview with Radovan Karadžić at Trebević, with transcript); P1998 (BBC news report re interview with Colonel Bartula, with transcript); Martin Bell, T. 9767-9772 (14 December 2010); P1558 (Witness statement of Francis Roy Thomas dated 13 May 2009), para. 43; Pyers Tucker, T. 23291-23292 (18 January 2012); KW570, T. 32216 (18 January 2013) (private session).

11336 P2407 (Witness statement of KDZ304), p. 7; P1558 (Witness statement of Francis Roy Thomas dated 13 May 2009), para. 41; Francis Roy Thomas, T. 6880 (15 September 2010); P2414 (Witness statement of KDZ182), pp. 83-84 (under seal) (testifying that the headquarters was located slightly to the west of the Presidency building); David Fraser, T. 8006 (18 October 2010). Asim Džambasović confirmed that the command post of the $1^{\text {st }}$ Corps was located in Danijela Ozme street, at number 7. See Asim Džambasović, T. 15192-15193 (22 June 2011); D617 (Map of Sarajevo).

11337 P2414 (Witness statement of KDZ182), p. 83 (under seal); KDZ185, T. 4241 (28 June 2010) (private session) (testifying also that because of the lack of weapons many of these soldiers would go home leaving their weapons at the frontlines for the other soldiers to use). But see Stanislav Galić, T. 37239-37240 (15 April 2013) (who testified that, judging by the $\mathrm{ABiH}$ maps, the $\mathrm{ABiH}$ forces were located at least one to three kilometres deep within their territory). 
addition, there were a number of their command posts and military targets within the city. ${ }^{11338}$ The frontline within Sarajevo city was between 42 and 64 kilometres long, depending on the period. ${ }^{1339}$

3558. During the latter part of May 1992, Bosnian Serbs on average fired several hundred shells a day at Sarajevo. ${ }^{11340}$ In late May and early June 1992, the city of Sarajevo was subjected to heavy shelling by the SRK, with a variety of artillery and from various positions. The events immediately preceding and following these bombardments, as well as the related findings, are outlined in more detail in another section of the Judgement. ${ }^{11341}$

3559. Following the above mentioned shelling incidents, the city of Sarajevo continued to be subjected to shelling and sniping attacks. ${ }^{11342}$ These attacks persisted throughout the summer of 1992, which was deemed by Bell to have been one of the worst periods of the conflict in Sarajevo. ${ }^{11343}$ At the same time, the food had become scarce in Sarajevo. ${ }^{11344}$ The markets were empty and the humanitarian operations were very limited. ${ }^{11345}$

3560. On 29 June, the Sarajevo airport in Butmir, which up until that point had been under the control of the Bosnian Serbs, was handed over to UNPROFOR, to be used by UNPROFOR

\footnotetext{
11338 See e.g. David Fraser, T. 8006, 8088-8092 (18 October 2010); D772 (ABiH General Staff list of ABiH units in Sarajevo, 10 April 1995); KDZ185, T. 4384 (30 June 2010).

11339 Francis Roy Thomas, T. 6903 (16 September 2010). Stanislav Galić testified that the confrontation line in Sarajevo was 65 kilometres long during his time as the SRK Commander. See Stanislav Galić, T. 37185 (15 April 2013), T. 37343-37344 (16 April 2013). Dragomir Milošević, noting that it was not possible to be exact, testified that the SRK estimated that the frontline in Sarajevo and surrounding areas was about 50 kilometres long. See Dragomir Milošević, T. 32516 (23 January 2013); D2788 (Map of Sarajevo marked by Dragomir Milošević).

11340 Herbert Okun, P776 (Transcript from Prosecutor v. Krajišnik), T. 4202; Herbert Okun, T 1655-1656 (26 April 2010), T. 1678 (27 April 2010); John Wilson, T. 3915-3916 (21 June 2010).

11341 See discussion on Scheduled Incidents G.1 and G.2.

11342 P1996 (Witness statement of Martin Bell dated 8 March 2010), paras. 71-72; P2005 (BBC news report re Sarajevo, with transcript); P2031 (BBC news report re Sarajevo, with transcript); P2035 (BBC news report re Sarajevo, with transcript); Martin Bell, T. 9793-9795 (14 December 2010).

11343 Martin Bell, T. 9797 (14 December 2010); P1996 (Witness statement of Martin Bell dated 8 March 2010), para. 78; P2026 (BBC news report re Sarajevo, with transcript); P2030 (BBC news report re Sarajevo, with transcript); D228 (Report re humanitarian activity, 12 June 1992), para. 13 (under seal). See Adjudicated Fact 8. See also P4997 (Ewa Tabeau's expert report entitled "Persons Killed and Wounded in Sarajevo During the First Months of the 'Siege' from 1 April to 9 September 1992", 1 May 2009), pp. 6, 52-53 (indicating that June and August were months with high numbers of killed and wounded civilians); P5002 (Ewa Tabeau's expert report entitled "Killed and Wounded Persons from the Siege of Sarajevo: August 1994 to November 1995", 19 March 2007), pp. 58-59.

11344 P926 (Witness statement of Aernout van Lynden dated 26 February 2010), para. 27; Youssef Hajir, T. 8786 (1 November 2010); D228 (Report re humanitarian activity, 12 June 1992), para. 13 (under seal).

11345 See P926 (Witness statement of Aernout van Lynden dated 26 February 2010), para. 27; P928 (SKY news report re Sarajevo, with transcript); P1866 (Witness statement of Youssef Hajir dated 25 February 2010), para. 52. Jeremy Bowen recalled that there were some aid flights in the early months of the war but that they were coming on an ad hoc basis. See P2068 (Witness statement of Jeremy Bowen dated 10 August 2009), para. 21. Youssef Hajir testified that food shortages were especially severe at the beginning of the war, but improved once UNPROFOR and other humanitarian organisation arrived. See Youssef Hajir, T. 8786 (1 November 2010).
} 
exclusively. ${ }^{11346}$ On 17 July 1992, a 14-day cease-fire agreement was signed in London by the representatives of three warring sides, including the Accused. ${ }^{11347}$ On 22 July, Mladić issued Directive 2, referring to the cease-fire agreement and instructing all units to "respect the agreed fortnight cease-fire" but to stay in full combat readiness. ${ }^{11348}$

3561. On 3 August 1992, Directive 3 was issued by Mladić in which he instructed the units to "keep Sarajevo firmly under blockade and prevent its breaking" and then ordered the SRK specifically to "gradually tighten the encirclement of Sarajevo". ${ }^{11349}$ Hussein Abdel-Razek, the Sector Sarajevo commander between 21 August 1992 and 20 February 1993, ${ }^{11350}$ testified that, upon his arrival in Sarajevo, he immediately assessed the city as a dangerous place, with constant sniping and shelling and no working infrastructure and utilities. ${ }^{1351}$ Following the London Conference, ${ }^{11352}$ the Accused and Koljević agreed, on 28 August 1992, to group together Bosnian Serb heavy weapons around Sarajevo and place them under the supervision of UN monitors, regardless of the actions of the other side. ${ }^{11353}$ However, this agreement was never fully implemented. ${ }^{11354}$

3562. In mid-September 1992, Sarajevo was also shelled indiscriminately. ${ }^{11355}$ When Pyers Tucker, a military assistant to Morillon, ${ }^{11356}$ arrived in Sarajevo in October 1992, life in the city

\footnotetext{
11346 See para. 339. See also P4203 (Witness statement of Pyers Tucker dated 12 May 2010), para. 118.

11347 D4710 (Agreement signed by Mate Boban, Radovan Karadžić and Haris Silajdžić, 17 July 1992), e-court pp. 12 (providing that all heavy weapons were to be placed under international supervision).

11348 D593 (Directive 2, 22 July 1992). See also P1478 (Ratko Mladić's notebook, 27 May-31 July 1992, pp. 357358 (wherein the Accused informs Mladić on 21 July 1992 of the cease-fire agreement, and tells him that the Bosnian Serbs are to not respond to provocations, and that it would be important for them to observe the ceasefire).

11349 D235 (Directive 3, 3 August 1992). The orders relevant to Sarajevo in this directive were relayed the next day to the SRK units by the SRK Command. See P5979 (SRK Order, 4 August 1992).

11350 P1258 (Witness statement of Hussein Ali Abdel-Razek dated 16 July 2002), e-court p. 2.

11351 P1258 (Witness statement of Hussein Ali Abdel-Razek dated 16 July 2002), e-court pp. 3-4.

11352 See Section II.E.4: London Conference.

11353 P1259 (UNPROFOR report re heavy weapons in BiH, 28 August 1992), e-court p. 2; Hussein Abdel-Razek, T. 5487-5488 (19 July 2010).

11354 Hussein Abdel-Razek, T. 5489-5491 (19 July 2010); T. 5563-5566 (20 July 2010), T. $5647-5650$ (21 July 2010) (also testifying that the Accused told him during their meeting that he was misinterpreted and that the UN would not be involved in handling weapons physically); P1260 (SRK information on ICFY, 30 August 1992) (Abdel-Razek testifying that this order was never implemented on the ground); P1261 (UNPROFOR report re meeting with Radovan Karadžić and Colonel Šiber, 13 September 1992); D503 (Marrack Goulding's note to UNSG, 7 September 1992), para. 14; D3384 (SRK report, 13 September 1992), p. 1.

11355 P1271 (UNPROFOR report re letter sent to Ratko Mladić, 15 September 1992), para. 3; P1258 (Witness statements of Hussein Ali Abdel-Razek dated 16 July 2002), e-court pp. 15, 22 (testifying that when he tried to send a letter of protest to the Accused about this particular shelling, it was refused because he did not address the Accused as the RS President). See also D3385 (SRK combat report, 17 September 1992), paras. 1-2 (in which Galić reports that an $\mathrm{ABiH}$ infantry attack was successfully repulsed and that offensive operations will continue throughout the day).

11356 P4203 (Witness statement of Pyers Tucker dated 12 May 2010), para. 6.
} 
was "very unpleasant" and there was daily random shelling of various parts of the city. ${ }^{11357}$ In early October 1992, following the resumption of humanitarian flights, aid was slowly starting to arrive in Sarajevo; however, it was being delivered far below the minimum required to satisfy basic needs. ${ }^{11358}$ The difficulties in delivery arose because the city was subjected to heavy shelling and sniping at this time and because Bosnian Serb forces blocked UNHCR convoys. ${ }^{11359}$ On 7 October UN officials protested to Koljević and Plavšić about "recent" artillery attacks on Sarajevo. ${ }^{11360}$ The UN reported on 8 October that the mood of people in Sarajevo has reached the lowest level since April 1992 due to the continued shelling and lack of utilities. ${ }^{11361}$ On 9 October 1992, the RS Presidency held a session in which it decided to halt the bombing of Sarajevo and do so through the Main Staff. ${ }^{11362}$ Thus, on 10 October, Galić issued an urgent order to all SRK units to stop firing on Sarajevo as of 3 p.m. that day, instructing them they could open fire only in case of "great necessity", and not before having been given permission from him or his deputy. ${ }^{11363}$ However, on 26 October, Galic reported on the fighting between the ABiH and the SRK around Hrasnica. ${ }^{11364}$ On 31 October, a major attack was launched by the Bosnian Serbs from the north and south of the centre of Sarajevo; the first few rounds caught people in the open and caused a number of casualties. ${ }^{11365}$ According to Tucker, this attack had the objective of cutting the city into eastern and western halves and relieving the pressure on Grbavica. ${ }^{1366}$ After that attack, which according to Tucker was a major military offensive, the Bosnian Serbs carried out mainly defensive or retaliatory operations, trying to pressure the other side to accept the status quo. ${ }^{11367}$

3563. On 10 November 1992, a cease-fire agreement was signed among the three parties, which was followed two days later by Galić's order to all SRK units to refrain from firing and to ask for

\footnotetext{
11357 P4203 (Witness statement of Pyers Tucker dated 12 May 2010), paras. 21-22. See also P4998 (Ewa Tabeau's expert report entitled "Population Losses in the 'Siege' of Sarajevo 10 September 1992 to 10 August 1994", 10 May 2002), pp. 80, 96 (indicating high numbers of civilian casualties in September and October).

11358 D1502 (Report of humanitarian organisation, 7 October 1992) (under seal), para. 8.

11359 KDZ240, P2935 (Transcript from Prosecutor v. Krajišnik), T. 6784-6785 (under seal); P4203 (Witness statement of Pyers Tucker dated 12 May 2010), para. 21.

11360 P1258 (Witness statement of Hussein Ali Abdel-Razek dated 16 July 2002), e-court p. 23; P1272 (UNPROFOR report re meetings with Presidency, HVO, and SDS, 7 October 1992), p. 3.

11361 P1262 (UN report on Sarajevo, 8 October 1992); Hussein Abdel-Razek, T. 5501-5502 (19 July 2010). See also Adjudicated Fact 133.

11362 D431 (Minutes of RS Presidency session, 9 October 1992), p. 2.

11363 P1264 (SRK Order, 10 October 1992); Hussein Abdel-Razek, T. 5507-5508 (19 July 2010).

11364 Stanislav Galić, T. 37216-37217 (15 April 2013); D3386 (SRK combat report, 26 October 1992).

11365 P4212 (UNPROFOR report, 31 October 1992), paras. 1-2; P4203 (Witness statement of Pyers Tucker dated 12 May 2010), paras. 37-38.

11366 P4203 (Witness statement of Pyers Tucker dated 12 May 2010), paras. 37-38, 44-45, 49 (also stating that this was the last attempt by the Bosnian Serbs during his time in Sarajevo to capture the city or to cut it in half); Pyers Tucker, T. 23198 (17 January 2012), T. 23222-23224 (18 January 2012).

11367 P4203 (Witness statement of Pyers Tucker dated 12 May 2010), para. 49.
} 
his permission to respond to fire. ${ }^{11368}$ According to Abdel-Razek, while the shelling incidents were numerous in the period of August through to October, November was relatively quiet. ${ }^{11369}$ On 19 November, Mladić issued Directive 4, in which he instructed the SRK to keep Sarajevo and Igman under "full blockade" and "tighten the circle". ${ }^{11370}$

3564. In a meeting on 20 November 1992 with the Accused, Morillon of UNPROFOR protested the "deliberate obstruction" of UNHCR and UNPROFOR convoys by Bosnian Serb forces over the previous three weeks. ${ }^{11371}$ The Accused responded that the Bosnian Serbs were "predisposed to be obstructive" because UNPROFOR was smuggling weapons and rations to the $\mathrm{ABiH}$ and UNHCR was delivering more aid to the Bosnian Muslims than the Bosnian Serbs. ${ }^{11372}$ On 22 November, the SRK lodged a protest with the UN, complaining about the ABiH putting pressure on SRK positions and causing civilian casualties. ${ }^{11373}$ On 27 November, Morillon and Tucker met with the Accused, Koljević, and Mladić. ${ }^{11374}$ Morillon had a private discussion with the Accused, during which the latter agreed that the demilitarisation of Sarajevo could be a catalyst for peace throughout $\mathrm{BiH} .{ }^{1375}$ Morillon also noted his belief that the Bosnian Serb authorities were interested in progress. ${ }^{11376}$

3565. In December 1992, during the fight for Oteš, the fighting and the shelling in and around Sarajevo was intensifying, prompting Abdel-Razek to hold a press conference in which he stated that the UN mandate was weak and that he was struggling to fulfil it as none of the parties was cooperating with the UN. ${ }^{11377}$ Tucker also confirmed that the period between 1 and 10 December

\footnotetext{
11368 D3388 (SRK Order, 12 November 1992); Stanislav Galić, T. 37221-37227 (15 April 2013). Another cease-fire then took effect on 27 November 1992. See D3389 (SRK Order, 26 November 1992). But see D3390 (Response by Stanislav Galić to UNPROFOR protest, 28 November 1992) (indicating that the UN protested to Galić about a number of SRK activities in this period, which Galić denied any SRK responsibility for). P1258 (Witness statement of Hussein Ali Abdel-Razek dated 16 July 2002), e-court p. 23. See also Stanislav Galić, T. 37217-37219 (15 April 2013) (testifying that the SRK refrained from firing on 10 November due to a cease-fire that was in place and because of the potential repercussions in the media); D3387 (SRK combat report, 10 November 1992).

11370 P976 (Directive 4, 19 November 1992), p. 5.

11371 P4216 (UNPROFOR report re meeting with Radovan Karadžić, 20 November 1992), para. 2.

11372 P4216 (UNPROFOR report re meeting with Radovan Karadžić, 20 November 1992), para. 2. See also D1514 (Minutes of meeting between Radovan Karadžić and a member of a humanitarian organisation, 28 November 1992), paras. 9, 12 (under seal) (the Accused raising concerns that food was not being equally distributed between the Bosnian Serbs and Bosnian Muslims in Sarajevo).

11373 D3467 (SRK protest letter to UNPROFOR, 22 November 1992).

11374 P4203 (Witness statement of Pyers Tucker dated 12 May 2010), para. 72; Pyers Tucker, T. 23243-23247 (18 January 2012); D539 (UNPROFOR report re meeting with Radovan Karadžić and Ratko Mladić, 27 November 1992).

11375 D539 (UNPROFOR report re meeting with Radovan Karadžić and Ratko Mladić, 27 November 1992), para. 4.

11376 D539 (UNPROFOR report re meeting with Radovan Karadžić and Ratko Mladić, 27 November 1992), para. 12; Richard Mole, T. 5875 (17 August 2010).

11377 P1258 (Witness statement of Hussein Ali Abdel-Razek dated 16 July 2002), e-court pp. 10-11, 12-13, 17, 27; P1269 (UNPROFOR report re Sarajevo, 6 December 1992); Hussein Abdel-Razek, T. 5535-5536, 5573-5576 (20 July 2010), T. 5639-5640 (21 July 2010); D519 (SRK combat report, 23 December 1992); D505 (Article from Independent entitled "UN Chief in Sarajevo Calls for Intervention to End Conflict", 18 January 1993). See
} 
"involved the worst sustained shelling of Sarajevo since the start of the war" by the Bosnian Serbs; while it concentrated around Oteš and Stup, in the west of Sarajevo, the city was also shelled by the Bosnian Serbs with the aim of breaking the people's and their leaders' will to resist. ${ }^{1378}$ According to Tucker, more than 1,500 rounds of explosives were fired per day at that time and the fight for Oteš involved house to house fighting as well as support by Bosnian Serb infantry and artillery. ${ }^{11379}$ By 7 December, Oteš and parts of Stup were captured by the Bosnian Serbs but the fighting in the surrounding areas petered out only around 19 December. ${ }^{1380}$ Thereafter, the intensity of the shelling in the city reduced. ${ }^{11381}$ On 13 December, a three year old, Anisa Pita, was shot and wounded in her right leg on the porch of her residence in Širokača. ${ }^{11382}$ In mid-December, the UN attempted to negotiate a cessation of hostilities agreement, which involved the withdrawal of heavy weapons around Sarajevo, but while signed by Mladić and Petković on 22 December, it was eventually not accepted by the Bosnian Muslim side. ${ }^{11383}$ At midnight on 24 December, Bosnian Serbs opened a 20 minute barrage of fire on Sarajevo from all around the city, and against random civilian targets. $^{11384}$ The same happened at midnight on 7 January $1993 .{ }^{11385}$

also D3391 (SRK combat report, 6 December 1992); D3392 (SRK combat report, 6 December 1992) (both indicating heavy fighting between the two sides); Stanislav Galić, T. 37171-37172 (15 April 2013) (testifying that capturing Oteš was a military necessity as the $\mathrm{ABiH}$ forces nearly surrounded Ilidža Brigade in the area); P1435 (UNMO report, 11 December 1992), paras. 13-30. Following the conference Abdel-Razek also made it clear to his superiors that he wanted to leave Sarajevo as he was unable to make progress. See Hussein AbdelRazek, T. 5536 (20 July 2010).

11378 P4203 (Witness statement of Pyers Tucker dated 12 May 2010), paras. 82-83, 86 (testifying also that in an attempt to break the siege of Sarajevo the ABiH attacked Ilidža which made the SRK panic, pummel the area from which the attack came with heavy weapons, and then also counter attack and shell the city persistently in order to "punish" the other side); P936 (SKY news report re Sarajevo, with transcript); D534 (Article from AFP entitled "Fierce Fighting Raging Around Sarajevo", 3 December 1992). See also P1481 (Ratko Mladić's notebook, 5 October-27 December 1992), pp. 261-262 (wherein General Nambiar expresses his deep concern about the escalation of the conflict in the Sarajevo area in a meeting with Mladić on 8 December 1992).

11379 P4203 (Witness statement of Pyers Tucker dated 12 May 2010), paras. 83-85, 89-90 (claiming also that this figure was probably an understatement); P4219 (UNMO daily situation report, 6 December 1992); P4218 (UNMO daily situation report, 5 December 1992); P1428 (UNMO report, 4 December 1992). See also Adjudicated Fact 133 (providing that fire into Sarajevo was intense between September and December 1992.

11380 P4203 (Witness statement of Pyers Tucker dated 12 May 2010), paras. 87-88; Stanislav Galić, T. 37163 (15 April 2013), T. 37475 (22 April 2013); D3381 (Map of Sarajevo marked by Stanislav Galić); D536 (Article from AFP entitled "Serbs Cut Airport Road", 8 December 1992).

11381 P4203 (Witness statement of Pyers Tucker dated 12 May 2010), para. 88.

11382 See discussion on Scheduled Incident F.1.

11383 Hussein Abdel-Razek, T. 5631-5638 (21 July 2010); D518 (Cease-fire agreement between Ratko Mladić and Milivoje Petković, 22 December 1992).

11384 P4203 (Witness statement of Pyers Tucker dated 12 May 2010), paras. 109-114 (this sort of co-ordinated fire indicated to Tucker that it must have been approved by Galić). See also D2452 (Report of Ilidža Brigade, 25 December 1992) (noting that ABiH was opening fire on Ilidža during the day on 25 December 1992). 
3566. In January 1993, the ABiH was preparing for an offensive ${ }^{11386}$ and the city continued to be shelled, including the Old Town where a shell fell on people queuing for water, killing a number of people. ${ }^{11387}$ KDZ185 testified that when he arrived to Sarajevo, the shelling was heavy, with a daily average of 1,200 shells being fired. ${ }^{11388}$ In January and February, the winter was at its coldest, with severe shortages of electricity, gas, and oil, and morale in the city was at its lowest. ${ }^{11389}$ Humanitarian convoys "continued to be harassed" and prevented from reaching the civilian population. ${ }^{11390}$ In an attempt to escape the deprivation in the city at this time, hundreds of civilians attempted to cross the airport to Butmir and Mt. Igman each night and would be shot at by Bosnian Serbs and killed or injured. ${ }^{11391}$

3567. According to the SRK report of 4 February 1993, the ABiH fired ten shells on Ilidža, resulting in the wounding of a child; however the SRK did not respond. ${ }^{11392}$ On 11 February 1993, the Bosnian Muslim authorities announced that they would refuse to accept further aid in Sarajevo because the Bosnian Serbs were refusing to allow relief convoys into the eastern enclaves. ${ }^{11393}$ UNHCR immediately suspended all aid flights into Sarajevo. ${ }^{11394}$ On 12 February, the SRK reported that after the $\mathrm{ABiH}$ fired another ten shells on SRK-held territory, its units responded to

\footnotetext{
11386 D336 (John Wilson and Graham Messervy-Whiting's report to ICFY, 22 January 1993) (in which Wilson also predicted, in paragraphs $6,8-9,11$, and $13(\mathrm{~d})$, that the SRK would continue to "maintain the siege" without taking the city while the $\mathrm{ABiH}$ would be launching an offensive if its position in negotiations was weak and it needed to provoke international intervention); John Wilson, T. 4135-4138 (23 June 2010). Wilson's prediction came true as the ABiH launched an attack on SRK positions on 31 January 1993. See D349 (SRK combat report, 31 January 1993).

11387 P1996 (Witness statement of Martin Bell dated 8 March 2010), paras. 59, 83; P2007 (BBC news report re Sarajevo, with transcript); P2004 (BBC news report re Sarajevo, with transcript); Martin Bell, T. 9799-9800 (14 December 2010).

11388 P6060 (Record of interview with KDZ185), e-court p. 14; KDZ185, T. 4187-4188 (28 June 2010). See also D3395 (SRK combat report, 11 January 1993) (indicating that some 200 shells were fired by the ABiH on various SRK positions and that the SRK units opened fire on $\mathrm{ABiH}$ positions in the Mojmilo and Hrasnica sectors); D3396 (SRK combat report, 15 January 1993); D3397 (SRK combat report, 24 January 1993) (stating that the $\mathrm{ABiH}$ opened infantry fire and fired a small number of shells on the SRK-held territory).

11389 P4203 (Witness statement of Pyers Tucker dated 12 May 2010), paras. 116-117. See also P2068 (Witness statement of Jeremy Bowen dated 10 August 2009), para. 42 (testifying that by 1993 the civilian population was "fully engaged in the grind of survival"); D1140 (Letter to UN Secretary General, 2 February 1993), e-court p. 1 (under seal) (the author stating that the "ongoing destruction of Sarajevo" and the "suffering of its people" was deeply moving).

11390 P4203 (Witness statement of Pyers Tucker dated 12 May 2010), para. 140.

11391 P4203 (Witness statement of Pyers Tucker dated 12 May 2010), paras. 116-120 (testifying that 5 to 30 people were killed or injured each night during these airport crossings); P1258 (Witness statement of Hussein Ali Abdel-Razek dated 16 July 2002), e-court p. 18; Youssef Hajir, T. 8841 (2 November 2010); John Hamill, P1994 (Transcript from Prosecutor v. Galić), T. 6176-6177.

11392 Stanislav Galić, T. 37336-37338 (16 April 2013), T. 37925-37927 (8 May 2013); D3410 (SRK combat report, 4 February 1993). See also D2776 (SRK combat report, 3 February 1993), para. 1.

11393 P4203 (Witness statement of Pyers Tucker dated 12 May 2010), para. 132.

11394 P4203 (Witness statement of Pyers Tucker dated 12 May 2010), para. 132; KDZ240, T. $16124-16125$ (5 July 2011) (closed session).
} 
the attack. ${ }^{11395}$ On 14 February, the ABiH launched an infantry attack on the Slaviša Vajner Čiča Barracks also resulting in the SRK response. ${ }^{11396}$

3568. By 3 March 1993 the warring parties had signed a BiH-wide cease-fire agreement, ${ }^{11397}$ according to which (i) the hostilities in Sarajevo and elsewhere were to cease, (ii) UNPROFOR was to monitor the confrontation lines in Sarajevo and the removal of heavy weapons (weapons above $12.7 \mathrm{~mm}$ calibre) from Mojmilo, Dobrinja, Lukavica, Gornji Kotorac, Vojkovići, Hrasnica, Sokolovići, Butmir, Ilidža, Oteš, Stup, and Nedžarići, (iii) civil infrastructures were to be restored, and (iv) Blue Routes were to be established in order to ensure freedom of movement for civilians and humanitarian aid. ${ }^{11398}$ This cease-fire was signed contrary to Galić's wishes. ${ }^{11399}$ Additionally, the $\mathrm{ABiH}$ never intended to respect it. ${ }^{11400}$ Instead it mounted an attack designed to cut the SRK's main re-supply line along the Pale road in response to which, on 21 March 1993, the SRK shelled the whole of Sarajevo, including civilian targets and the Old Town; around 2,400 shells fell that day. ${ }^{11401}$ The next day the ABiH shelled Ilidža while the SRK was engaging in an offensive operation in Stup. ${ }^{11402}$

3569. On 2 April 1993, General Manojlo Milovanović, Chief and Deputy Commander of the VRS Main Staff, ${ }^{11403}$ issued an order setting out in detail the procedures for checking UNPROFOR and humanitarian aid convoys. ${ }^{11404}$ On 11 April 1993, the RS Prime Minister Vladimir Lukić wrote a

11395

11396

11397 once the UN agreed to place the heavy weapons under its control. See D924 (ICFY Agreement for Peace in
one BiH, 3 March 1993), p. 2; P2538 (Patrick Treanor's research report entitled "Radovan Karadžić and the Serbian Leadership 1990-1995”, 1 May 2009), para. 155. See also para. 366.

11398 D924 (ICFY Agreement for Peace in BiH, 3 March 1993), pp. 6, 9, 19-21. See also para. 366.

11399 P1055 (UNPROFOR report re meeting with Stanislav Galić, 27 March 1993).

11400 D343 (ABiH Supreme Command Staff Order to $2^{\text {nd }}$ Corps, 16 March 1993); KDZ185, T. 4295-4296 (29 June 2010).

11401 P1048 (Record of interview with KDZ185), e-court pp. 5, 19 (under seal); P5908 (Record of interview with KDZ185), para. 5; KDZ185, T. 4184-4185 (28 June 2010) (private session), T. 4225-4226 (28 June 2010), T. 4239-4241 (private session), T. 4295-4296 (29 June 2010), T. 4305-4306, 4309-4318 (29 June 2010) (partly private session); P1065 (UNPROFOR report re shelling in Sarajevo, 21 March 1993); P1066 (SRK combat report, 22 March 1993); P1050 (UNPROFOR daily report, 21 March 1993); D344 (SRK combat report, 19 March 1993); D346 (ABiH $1^{\text {st }}$ Corps combat report, 20 March 1993); D347 (SRK combat report, 21 March 1993); D348 (ABiH $1^{\text {st }}$ Corps combat report, 21 March 1993); D3405 (SRK combat report, 15 March 1993); D3406 (SRK combat report, 18 March 1993).

11402 D3407 (SRK combat report, 22 March 1993); Stanislav Galić, T. 37348-37349 (16 April 2013). See also D3476 (SRK combat report, 24 March 1994); D4566 (SRK combat report, 28 March 1993); D3438 (SRK combat report, 29 March 1993).

11403 Manojlo Milovanović, T. 25431-25432 (28 February 2012).

11404 D2163 (VRS Main Staff Order, 2 April 1993). See also Dragomir Milošević, T. 32894-32895 (30 January 2013), T. 33237-33238 (5 February 2013); Milenko Inđić, T. 32423-32424 (22 January 2013). According to those procedures, before a convoy could move, a request had to be made to the VRS Main Staff via the VRS Liaison Group headed by Inđic and had to list, inter alia, the number of personnel and the type of vehicles in the convoy, the type and quantity of cargo transported, the route the convoy was taking, and the convoy's expected 
letter to the UN Secretary General protesting the use of humanitarian convoys to transport ammunition to $\mathrm{ABiH}$ units in Butmir, Sokolović Kolonija, and Hrasnica and stating that the RS government had issued an order to "strictly control all humanitarian convoys". ${ }^{11405}$

3570. On 4 April 1993 the $\mathrm{ABiH}$ forces fired six shells on Grbavica resulting in the VRS protesting to the $\mathrm{UN}$ about cease-fire violations by the $\mathrm{ABiH} .{ }^{11406}$ On 17 April, a nine year old girl was shot and wounded while playing in front of her house in Sedrenik. ${ }^{11407}$

3571. In early May 1993, fighting between the ABiH and the SRK along the confrontation line continued. $^{11408}$ On 6 May, the Security Council passed Resolution 824 which established Sarajevo as one of the safe areas, along with Tuzla, Žepa, Goražde, Bihać, and Srebrenica; it also provided for an immediate cease-fire and declared that the safe areas should be free from armed attack by all parties or any other hostile acts. ${ }^{11409}$ Further, it declared that all parties should respect the rights of UNPROFOR and international humanitarian agencies to free and unimpeded access and demanded full co-operation with UNPROFOR. ${ }^{11410}$ Nevertheless, the ABiH launched a number of attacks on 15 May, which were responded to by the SRK. ${ }^{11411}$ Galic testified that on that day the SRK response was restrained as one of the neighbourhoods from which the $\mathrm{ABiH}$ opened fire was a densely populated area. ${ }^{11412}$ On the same day, Galić ordered the SRK to ensure the unhindered

time of arrival. If the VRS Main Staff approved the convoy, the VRS Liaison Group would inform the relevant SRK units and its soldiers at relevant check-points would inspect the convoy "completely and thoroughly" to ensure that it was carrying only the type and quantity of cargo specified in the request. If a convoy appeared at a check-point unannounced, or without a declaration of what it was carrying, or using a different route to the one requested, it would "not be allowed to pass" and would be turned back until it complied with the correct procedures. See D2163 (VRS Main Staff Order, 2 April 1993), paras. 3, 5; Stanislav Galić, T. 37573 (23 April 2013), T. 38025 (9 May 2013); Dragomir Milošević, T. 32894-32895 (30 January 2013), T. $33237-$ 33238 (5 February 2013); D2774 (Witness statement of Milenko Inđić dated 19 January 2013), paras. 161-162; Milenko Inđić, T. 32423-32424 (22 January 2013); KW570, T. 32218-32219 (18 January 2013); D2845 (SRK instructions, 22 August 1993), p. 1; Adrianus van Baal, T. 8419-8420, 8439 (27 October 2010); P1818 (Witness statement of Adrianus van Baal dated 26 October 2010), para. 69; D2164 (VRS Main Staff Order, 9 April 1993); D3408 (SRK combat report, 5 April 1993), para. 7; D3261 (VRS Main Staff Order, 27 February 1994); D3469 (SRK combat report, 24 April 1993), para. 5.

11405 D3575 (TANJUG news report, 11 April 1993), p. 1; D3563 (Witness statement of Vladimir Lukić dated 18 May 2013), para. 38.

11406 D345 (VRS protest to UNPROFOR, 6 April 1993); D3408 (SRK combat report, 5 April 1993); D4567 (SRK combat report, 4 April 1993). See also D3468 (SRK combat report, 8 April 1993) (reporting that ABiH opened fire from Dobrinja and that SRK returned small arms fire in the Dobrinja sector); D3469 (SRK combat report, 24 April 1993) (reporting that one of the SRK brigades was engaged in intense combat).

11407 See discussion on Scheduled Incident F.2.

11408 D3409 (SRK combat report, 5 May 1993); D3441 (SRK combat report, 4 May 1993).

11409 P984 (UNSC Resolution 824, 6 May 1993). See also P820 (Witness statement of David Harland dated 4 September 2009), para. 102; P897 (UNPROFOR Weekly Situation Report (Sarajevo), 15 July 1995), p. 3; Michael Rose, T. 7523 (8 October 2010).

11410 P984 (UNSC Resolution 824, 6 May 1993), p. 2.

11411 D3411 (SRK combat report, 15 May 1993). See also D3470 (SRK combat report, 21 May 1993).

11412 Stanislav Galić, T. 37358-37359 (18 April 2013). See also D3442 (SRK combat report, 17 May 1993 ); D3412 (SRK combat report, 19 May 1993); D3413 (SRK combat report, 28 May 1993). 
passage of humanitarian aid to Sarajevo and to adhere to the Geneva Conventions and Additional Protocols. ${ }^{11413}$

3572. When David Harland, a Civil Affairs Officer for the UNPROFOR and later a political advisor to the Commander of the UNPROFOR BiH Command in Sarajevo, ${ }^{11414}$ arrived in Sarajevo in June 1993, the city seemed eerily empty, with burnt out cars on the streets, anti-sniping barricades made of containers and constant background noise of gunfire; its buildings were peppered with damage from shelling and gunfire. ${ }^{11415}$ On 1 June, two shells exploded in the suburb of Dobrinja during a football game resulting in a large number of casualties. ${ }^{11416}$ On 3 June, the SRK command reported that the $\mathrm{ABiH}$ opened sniper and mortar fire on a number of SRK-held areas, including civilian targets in Ilidža, resulting in the wounding of four soldiers and the killing of two women; Galić testified that the SRK did not respond to the attacks due to the cease-fire in force at the time. ${ }^{11417}$ On 15 June, another general cease-fire was signed and, on 17 June, the SRK command reported that the $\mathrm{ABiH}$ shelled SRK positions and that the $\mathrm{ABiH}$ forces would not be observing the cease-fire. ${ }^{11418}$ In a meeting with Andreev of UNPROFOR on 22 June 1993, Mladić acknowledged the urgency of "unblocking" Sarajevo for both sides and promised that all humanitarian convoys would be able to pass across RS territory but that the Bosnian Serbs would continue to check convoys at Sarajevo airport. ${ }^{11419}$ On 25 June, Mladić issued Directive 5, in which he instructed VRS units to thwart the "unblocking of Sarajevo" to be followed by "quick and rigorous operations to liberate the axis Sarajevo-Kijevo village-Trnovo village-Rogovo passKalinovik" and the area around Igman and Bjelašnica; the code-name for the operation was "Lukavac 93". ${ }^{11420}$ Lukavac 93 was thus launched by the SRK, Drina Corps, and Herzegovina Corps, with the SRK engaged in the area of Jahorina-Igman-Bjelašnica axis. ${ }^{11421}$ The SRK launched attacks with the aim of capturing Mt. Igman as the connection between Sarajevo and the

\footnotetext{
11413 D3482 (SRK Order, 15 May 1993), p. 1; Stanislav Galić, T. 37616-37618 (23 April 2013); D2561 (SRK Order, 15 May 1993), p. 1; D2562 (Witness statement of Vladimir Radojčić dated 8 December 2012), para. 97.

11414 P820 (Witness statement of David Harland dated 4 September 2009), para. 5.

11415 P820 (Witness statement of David Harland dated 4 September 2009), paras. 25-27.

11416 See discussion on Scheduled Incident G.4.

11417 D3443 (SRK combat report, 3 June 1993); Stanislav Galić, T. 37487-37489 (22 April 2013). See also D3471 (SRK combat report, 10 June 1993).

11418 D629 (SRK Order, 16 June 1993); D3415 (SRK combat report, 17 June 1993); Stanislav Galić, T. 37381-37383 (18 April 2013). See also D3444 (SRK combat report, 23 June 1993); D3416 (SRK combat report, 24 June 1993); D3420 (SRK report, 11 June 1993).

11419 D1499 (UNPROFOR report re meeting with Ratko Mladić, 22 June 1993), pp. 1-2 (Mladić also promised to cooperate on making Sarajevo a safe area so long as safety assurances were found for Lukavica and Grbavica).

11420 P843 (Directive 5, 25 June 1993), paras. 2, 4.

11421 Stanislav Galić, T. 37390 (18 April 2013), T. 37604 (23 April 2013) (although Dragomir Milošević testified that the operation started between 6 and 7 June); P5981 (SRK Order, 26 June 1993), para. 2; Savo Simić, T. 3004030043 (12 November 2012) (testifying that the main objective of the operation was to establish a link between the south and southeastern part of the RS); D568 (Speech of Dragomir Milošević, 30 March 1996), p. 4.
} 
rest of the $\mathrm{BiH}$ went across and underneath Sarajevo airport through to Mt. Igman. ${ }^{11422}$ Due to these attacks, Izetbegović asked that the talks in Geneva, set for July, be postponed, while NATO threatened the Bosnian Serb side with air strikes. ${ }^{11423}$ Michael Rose, who was the Commander of the UNPROFOR BiH Command in Sarajevo from January 1994 to January $1995,{ }^{11424}$ testified that the capture of Mt. Igman by the SRK was considered a full encirclement of Sarajevo and that therefore the Bosnian Serbs were given an ultimatum to withdraw. ${ }^{11425}$

3573. On 5 July 1993, the SRK command reported to the VRS Main Staff that the ABiH opened fire on a number of frontlines resulting in three dead and two wounded soldiers; Galić testified that SRK units did not respond in this instance as they were "preparing". ${ }^{11426}$ On 10 July, the SRK command reported that the $\mathrm{ABiH}$ opened infantry and mortar fire; it also noted that SRK units in all sectors were in full combat readiness and firing. ${ }^{1427}$ On 11 July, Munira Zametica, a 48 year old woman was shot dead while collecting water from the Dobrinja river in Dobrinja. ${ }^{1428}$ On 12 July, a shell exploded in Dobrinja near a water pump where people were queuing for water, resulting in a number of casualties. ${ }^{11429}$ On 18 July, the SRK command reported that its units were engaged in the Lukavac 93 operation while the $\mathrm{ABiH}$ opened infantry and mortar fire on a number of SRKheld positions, as well as on Grbavica and Ilidža, killing two civilians. ${ }^{11430}$ According to Galić, the $\mathrm{ABiH}$ was at this time trying to attack on the confrontation lines within Sarajevo and slow down the Lukavac 93 attacks taking place outside Sarajevo. ${ }^{11431}$ On 30 July, in a meeting with UNPROFOR, Milovanović expressed concern about the smuggling of weapons and ammunition in humanitarian

\footnotetext{
11422 P820 (Witness statement of David Harland dated 4 September 2009), paras. 43-46; Michael Rose, T. 7572 (8 October 2010); Francis Roy Thomas, T. 6849-6850 (15 September 2010).

11423 P820 (Witness statement of David Harland dated 4 September 2009), para. 49; David Fraser, T. 8152 (19 October 2010).

11424 P1638 (Witness statement of Michael Rose dated 26 March 2009), para. 5.

11425 Michael Rose, T. 7572-7573 (8 October 2010).

11426 Stanislav Galić, T. 37384-37386 (18 April 2013); D3417 (SRK combat report, 5 July 1993) (indicating that the SRK units were to continue preparing for the Lukavac 93 operation).

11427 D2819 (SRK combat report, 10 July 1993), paras. 1-2; Dragomir Milošević, T. 32802-32804 (29 January 2013). See also D2820 (SRK combat report, 16 July 1993).

11428 See discussion on Scheduled Incident F.3.

11429 See discussion on Scheduled Incident G.5.

11430 D3421 (SRK combat report, 18 July 1993).

11431 Stanislav Galić, T. 37405-37408 (18 April 2013); D3422 (SRK combat report, 25 July 1993) (indicating exchange of fire between the two sides); D3465 (SRK combat report, 24 July 1993); D2798 (SRK combat report, 28 July 1993); D3423 (SRK combat report, 29 July 1993); D4631 (Letter from Manojlo Milovanović to UNPROFOR, 2 August 1993); D3446 (SRK combat report, 2 August 1993); D3447 (SRK combat report, 8 August 1993).
} 
convoys. ${ }^{11432}$ That day, UNPROFOR reported that its freedom of movement across RS territory was being affected by "misunderstandings, bureaucracy and over zealous check-points". ${ }^{11433}$

3574. The SRK eventually managed to capture and take control of Mt. Igman and Bjelašnica. ${ }^{11434}$ Following a meeting with Briquemont, Andreev, Mladić, Plavšić, and Krajišnik on 5 August 1993, the Accused agreed to the withdrawal of the SRK forces from Mt. Igman, despite Mladić's protests, and on 14 August an agreement was signed according to which UNPROFOR was to monitor the vacated territory, which, together with the airstrip, became a demilitarised zone ("DMZ"). ${ }^{1435}$ However, neither party respected the $\mathrm{DMZ}$ - the $\mathrm{ABiH}$ was present in the northern part of the zone while there were some Bosnian Serb troops in the southern part; the DMZ was properly demilitarised only at the beginning of $1995 .{ }^{11436}$

3575. On 11 August 1993, the military commanders of the three warring sides in $\mathrm{BiH}$ signed the Military Agreement for Peace in $\mathrm{BiH}$, eventually leading to a follow-up agreement allowing UNMOs freedom of movement throughout $\mathrm{BiH}$ and turning the administration of Sarajevo, with the exclusion of Pale, to the UN. ${ }^{11437}$ This was followed up by an order from Galic to all SRK units not to open fire on Sarajevo "at any cost" and to remove "possible troublemakers" and "soldiers eager for adventure and provocations especially against UNPROFOR" by giving them secondary duties. ${ }^{11438}$ On 13 August, SRK command reported that the ABiH was launching mainly infantry attacks along various axes but that SRK units were not responding to provocations, "except for repulsing heavier attacks". ${ }^{11439}$ On 19 August, the SRK command, having listed ABiH activities, reported that all units were in full combat readiness and were "not responding to provocations

11432 D3579 (UNPROFOR fax, 30 July 1993), p. 2; D3563 (Witness statement of Vladimir Lukić dated 18 May 2013), para. 51.

11433 D3579 (UNPROFOR fax, 30 July 1993), p. 2 (adding, however, that the Bosnian Serb leadership did not appear to have a "genuine policy" of obstructing convoys at this time).

11434 P820 (Witness statement of David Harland dated 4 September 2009), paras. 43-46; Michael Rose, T. 7572 (8 October 2010); Francis Roy Thomas, T. 6849-6850 (15 September 2010).

11435 P820 (Witness statement of David Harland dated 4 September 2009), paras. 50-55; P824 (UNPROFOR report re meeting with Radovan Karadžić, 5 August 1993), pp. 2-3; Michael Rose, T. 7573 (8 October 2010); D722 (UNPROFOR report re letter from Ambassador Sacirbey, 19 October 1994), e-court p. 4; P2414 (Witness statement of KDZ182), p. 87 (under seal); KDZ182, T. 13160-13161 (10 March 2011); D1135 (Map of Sarajevo marked by KDZ182); Stanislav Galić, T. 37604-37605 (23 April 2013); D4645 (Letter from Radovan Karadžić to Boutros Boutros Ghali, Bill Clinton, Lord Owen, and Stoltenberg, 7 August 1993); D2755 (Fax from Vere Hayes, undated). See also Adjudicated Fact 2783.

11436 P2414 (Witness statement of KDZ182), pp. 57, 88 (under seal); P2447 (Witness statement of KDZ182), p. 62; P1774 (UNPROFOR report re meeting with Ejup Ganić, 2 October 1994); Milenko Inđić, T. 32465 (22 January 2013); D2784 (ABiH $1^{\text {st }}$ Corps minutes of meeting at Sarajevo airport, 5 January 1995).

11437 P5041 (Military Agreement for Peace in BiH, 11 August 1993) (Mladić representing the Bosnian Serbs, Rasim Delić the Bosnian Muslims, and Milivoj Petković the Bosnian Croats); P2538 (Patrick Treanor's research report entitled "Radovan Karadžić and the Serbian Leadership 1990-1995", 1 May 2009), para. 191. See also para. 379.

11438 P2665 (SRK order, 11 August 1993). But see D4617 (SRK Order, 11 August 1993).

11439 D3424 (SRK combat report, 13 August 1993). See also D3447 (SRK combat report, 8 August 1993). 
unless forced to do so, and then only with infantry weapons and sniper rifles."11440 On 31 August, Dragomir Milošević proposed opening several routes for the delivery of humanitarian aid to Sarajevo. ${ }^{11441}$

3576. On 2 September 1993, the SRK command again reported on the ABiH opening small arms and sniping fire on SRK positions and on Grbavica from, inter alia, Sedrenik; the SRK units returned fire on Sedrenik using a $12.7 \mathrm{~mm}$ anti-aircraft machine gun. ${ }^{11442}$ On 3 September, Nafa Tarić, a 35 year old woman and her eight year old daughter were shot and wounded by a single bullet in the centre of Sarajevo. ${ }^{11443}$ On 4 September, Galić reported to the VRS Main Staff that some of the soldiers were exhausted and that "considering that they respond only in exceptional circumstances, the question [...] is, how long can they restrain themselves". ${ }^{11444}$

3577. KDZ450 testified that the period between October 1993 and February 1994 was a "very difficult period" for the city for a number of reasons, including the volume and intensity of shelling and sniping activity, which impeded the supply of humanitarian aid to the city. ${ }^{11445}$ Following the rejection of the Owen-Stoltenberg plan by the Bosnian Muslim side at the end of September $1993,{ }^{11446}$ the situation in Sarajevo deteriorated and shelling was on the increase. ${ }^{11447}$ Francis Roy Thomas, a senior UNMO in Sarajevo between 15 October 1993 and 14 July 1994, ${ }^{11448}$ testified that, upon his arrival in Sarajevo on 15 October 1993, there was an unsuccessful attempt by the ABiH to take the Pale road, which was the Bosnian Serb's connection between Pale and Lukavica. ${ }^{11449}$ On

\footnotetext{
11440 D2827 (SRK combat report, 19 August 1993). Dragomir Milošević testified that this order clearly did not instruct the troops to open sniper fire on civilians. Dragomir Milošević, T. 32836-32837 (29 January 2013). See also D4570 (SRK combat report, 20 August 1993).

11441 D2849 (SRK proposal, 31 August 1993), p. 1; Dragomir Milošević, T. 32899 (30 January 2013).

11442 D3425 (SRK combat report, 2 September 1993); Stanislav Galić, T. 37410-37411 (18 April 2013) (testifying that this weapon is a more precise weapon).

11443 See discussion on Scheduled Incident F.4.

11444 D3429 (SRK combat report, 4 September 1993), p. 2; Stanislav Galić, T. 37424-37429 (18 April 2013 ) (testifying that the SRK command was warning the Main Staff that there could be unauthorised and random fire from SRK soldiers and that he personally took measures to prevent that from happening). See also D2809 (SRK combat report, 13 September 1993) (in which the SRK command reports that, given the frequency of $\mathrm{ABiH}$ operations, he foresees that certain units will not be able to tolerate the consequences of those operations and will be forced to return fire); D3426 (SRK combat report, 22 September 1993); Dragomir Milošević, T. 32719 32720 (28 January 2013).

11445 KDZ450, T. 10549 (19 January 2011), T. 10652-10654 (20 January 2011); D632 (Order of ABiH $1^{\text {st }}$ Corps, 8 December 1993). See also P820 (Witness statement of David Harland dated 4 September 2009), para. 61; David Harland, T. 2038-2039 (6 May 2010); Adjudicated Fact 134.

11446 P820 (Witness statement of David Harland dated 4 September 2009), paras. 56-59. See also para. 382.

11447 P820 (Witness statement of David Harland dated 4 September 2009), paras. 60-63; P845 (UNPROFOR report re meeting with Radovan Karadžić, 15 October 1993); P830 (UNPROFOR Weekly Political Assessment, 16 October 1993), p. 5. See also D3427 (SRK combat report, 13 October 1993) (in which SRK command reports that $\mathrm{ABiH}$ troops opened fire on a number of axes and that SRK units "periodically opened fire" when their positions were threatened); D3450 (SRK combat report, 24 October 1993).

11448 P1558 (Witness statement of Francis Roy Thomas dated 13 May 2009), para. 13.

11449 P1558 (Witness statement of Francis Roy Thomas dated 13 May 2009), paras. 46, 82.
} 
16 October, UNPROFOR reported that convoy deliveries to Sarajevo had increased recently; however, distribution to the civilian population had been very limited because large quantities of aid had been diverted to the military or stockpiled by Bosnian Muslim authorities while a smaller amount had been diverted to the black market. ${ }^{11450}$ On 19 October, ABiH soldiers, disguised as Bosnian Serbs, shot at the UNPROFOR BiH Commander and also began using tanks to fire from the city in an attempt to draw retaliatory fire. ${ }^{11451}$ On 29 October, Dragomir Milošević issued an order to the SRK units to intensify sniping against $\mathrm{ABiH}$ forces and that each brigade should set up a platoon-strength sniper group of 31 soldiers, each of whom should be supplied with sniper rifles. $^{11452}$ In late October and early November 1993, Sarajevo was heavily bombarded, with some 500 shells falling on the Old Town on 27 October alone. ${ }^{11453}$

3578. On 3 November 1993, UNPROFOR reported that the Bosnian Serbs were causing more difficulties for the humanitarian aid supply to Sarajevo than they had for some time, and that convoys carrying food, medicine, and equipment had been delayed. ${ }^{11454}$ On 11 November, the Accused issued Directive 6, in which he ordered the VRS to create objective conditions for the achievement of the VRS "war goals", including the "liberation of Sarajevo"; one of the tasks of the SRK units was to "prevent the deblockade of Sarajevo". ${ }^{11455}$ This was followed up by a supplement to the directive, sometime in December of the same year, in which the Accused ordered the VRS to seize Žuč and Mojmilo in order to ensure "the most favourable position for dividing the town". 11456

\footnotetext{
11450 P830 (UNPROFOR Weekly Political Assessment, 16 October 1993), p. 2.

11451 P1558 (Witness statement of Francis Roy Thomas dated 13 May 2009), paras. 88-89 (testifying also that he only saw $\mathrm{ABiH}$ using tanks once or twice during his time in Sarajevo, while there were numerous occasions where he observed Bosnian Serbs using tank fire); Francis Roy Thomas, T. 6813 (15 September 2010).

11452 D2902 (SRK Order, 29 October 1993). Milošević denied that this order could have been a basis for the firing on civilians in Sarajevo. Dragomir Milošević, T. 33272-33274 (6 February 2013).

11453 P823 (UNPROFOR Weekly Political Assessment, 3 November 1993), p. 7; P820 (Witness statement of David Harland dated 4 September 2009), para. 71; P1569 (UNMO report, 18 October 1993). See also D3428 (SRK combat report, 26 October 1993), para. 8 (reporting that "[d]espite disturbances and the chaos in Sarajevo, the enemy forces are firing various types of weapons on our positions as the line of contact" while the SRK is assessing "the possibilities of moving [their] forward line"); Stanislav Galić, T. 37416-37418 (18 April 2013). In contrast, the SRK report of 5 November notes that the $\mathrm{ABiH}$ fired around 800 shells in the whole month of October. The report also notes that in the area of Grbavica, 101 shells fell in the period from September to November. See D3431 (SRK report, 5 November 1993).

11454 P823 (UNPROFOR Weekly Political Assessment, 3 November 1993), p. 7.

11455 P3039 (Directive 6, 11 November 1993), para. 3(1)(a) and p. 9.

11456 P4925 (Supplement to Directive 6, 12 December 1993), para. 2(a); P3052 (VRS Main Staff Order, 14 December 1993); P5045 (Interim Report from Stanislav Galić to the VRS Main Staff, 27 December 1993). See also Dragomir Milošević, T. 33092-33099 (4 February 2013).
} 
3579. The shelling of the city, including on heavily populated areas, continued in November and December, often reported by the UNMOs as random SRK fire with no discernible target. ${ }^{11457}$ On 2 November, Ramiza Kundo, a 38 year old woman, was shot and wounded while carrying water in the west end of Sarajevo. ${ }^{1458}$ UNPROFOR reported that in mid-December the ABiH was launching "heavy infantry attacks" from Sarajevo on Serb-held territory. ${ }^{11459}$ On 26 December UNMOs also reported increased sniping activity in the city resulting in the wounding of women and children. ${ }^{11460}$

3580. In early January 1994, Sarajevo, including many of its residential areas, experienced heavy shelling again, resulting in a large number of civilian casualties. ${ }^{11461}$ In a meeting with the Accused on 3 January 1994, De Mello of UNPROFOR stated that the Joint Declaration on the provision of humanitarian relief, signed by the Accused, ${ }^{11462}$ was being "totally disregarded" by Bosnian Serb forces at check-points and that the "petty harassment" of convoys had become intolerable, indicating that the Bosnian Serbs had a deliberate strategy to "grind UNPROFOR to a halt". 11463 The Accused denied that this strategy existed but reiterated that humanitarian convoys had to be checked for weapons and ammunition. ${ }^{11464}$ On 6 January, Sanija Dževlan, a 32 year old woman, was shot and wounded while riding her bicycle in Dobrinja. ${ }^{11465}$ On 22 January, three shells landed

11457 P1571 (UNMO report, 21 November 1993); P1572 (UNMO report, 30 November-1 December 1993); P1573 (UNMO report, 2-3 December 1993); P1574 (UNMO report, 4-5 December 1993); P1575 (UNMO report, 6-7 December 1993); P1576 (UNMO report, 13-14 December 1993); P1577 (UNMO incident report, 19-26 December 1993); P1578 (UNMO report, 24-25 December 1993); P1579 (UNMO report, 26-27 December 1993); P1580 (UNMO report, 27-28 December 1993); P1581 (UNMO report, 30-31 December 1993); P1582 (UNMO incident report, 25 December 1993-1 January 1994); P1558 (Witness statement of Francis Roy Thomas dated 13 May 2009), paras. 33, 93-95; P5906 (Witness statement of KDZ450 dated 17 January 2011), para. 24; D2804 (SRK combat report, 8 December 1993) (indicating that SRK opened mortar fire on 8 December). On the other side, the SRK reported that in the month of November around 140 shells landed on its territory. See D3431 (SRK report, 5 November 1993).

11458 See discussion on Scheduled Incident F.5.

11459 D3490 (UNPROFOR report, 15 January 1994), p. 3.

11460 P1561 (UNMO report, 25-26 December 1993); P1560 (Map of Sarajevo showing shelling sites, 25-26 December 1993); Francis Roy Thomas, T. 6800-6806 (15 September 2010).

11461 D178 (Annex VI to UNSG's Report, 6 June 1994); P1558 (Witness statement of Francis Roy Thomas dated 13 May 2009), paras. 93, 96; Francis Roy Thomas, T.6860-6864 (15 September 2010); P1583 (UNMO report, 2-3 January 1994); P1584 (UNMO report, 3-4 January 1994); P1585 (UNMO report, 4-5 January 1994); P1586 (UNMO report, 4-5 January 1994); P1587 (UNMO report, 7-8 January 1994); D631 (UNMO report, 10-11 January 1994); P1588 (UNMO incident report, 1-8 January 1994); P1589 (UNMO incident report, 8-15 January 1994); P1590 (UNMO incident report, 22-29 January 1994); P1591 (UNMO summary of incident reports, January 1994), p. 1; P1592 (UNMO summary of shoot reports, January 1994); P1598 (UNMO summary of victims, December 1993 to February 1994), p. 2; P5906 (Witness statement of KDZ450 dated 17 January 2011), para. 24.

11462 See para. 384.

11463 P5034 (UNPROFOR report re meeting with Radovan Karadžić, 4 January 1994), paras. 2-3 (adding that UNPROFOR personnel were often personally searched at Bosnian Serb check-points, making it impossible for them to escort UNHCR convoys).

11464 P5034 (UNPROFOR report re meeting with Radovan Karadžić, 4 January 1994), para. 3.

11465 See discussion on Scheduled Incident F.6. 
in Alipašino Polje, resulting in the deaths of six children. ${ }^{11466}$ On his arrival in Sarajevo, on 23 January 1994, ${ }^{11467}$ Rose was told that there was indiscriminate shelling within the city centre by the Bosnian Serbs. ${ }^{11468}$ At that time, the intensity of the shelling was approximately 1,500 to 2,000 shells per day, going both ways, and sniping was also common. ${ }^{11469}$ According to Thomas, the high casualty rate in this period was partly caused by the fact that the Bosnian Serbs were shelling areas known to be used by civilians to avoid dangerous areas exposed to sniper fire. ${ }^{11470}$

3581. On 26 January, Galić issued an order in which he outlined a two-stage operation in Sarajevo; in the first stage the SRK units were ordered to prevent the "de-blocking" of Sarajevo and the linking of $\mathrm{ABiH}$ units from Sarajevo with $\mathrm{ABiH}$ units outside of Sarajevo by engaging in "decisive defence" and through improving the SRK's strategic-tactical position by capturing features such as Debelo Brdo, Mojmilo, Grdonj, Hum, and Čolina Kapa. ${ }^{11471}$ In the second stage, which was to start in the spring of 1994 and last 20 to 30 days, the SRK was to continue the above activities, prevent any supplies from getting into the city, prevent any medical evacuation, and "liberate the Serb part of the City of Sarajevo". ${ }^{11472}$ Despite the above, the humanitarian situation in Sarajevo began to improve; during a meeting with Rose on 30 January, the Accused stated that he had in the preceding days instructed the civilian and the military authorities to "ease further" the movement of UN convoys. ${ }^{11473}$

3582. On 4 and 5 February 1994, two shelling incidents took place, one in Dobrinja and the other at Markale market in the centre of Sarajevo, resulting in a large number of casualties. ${ }^{11474}$ On 9 February, as a result of these two incidents and particularly the Markale incident, ${ }^{11475}$ a cease-fire

\footnotetext{
11466 See discussion on Scheduled Incident G.6.

11467 P1638 (Witness statement of Michael Rose dated 26 March 2009), paras. 5, 21.

11468 P1638 (Witness statement of Michael Rose dated 26 March 2009), para. 23 (conceding that there was also shelling directed at the Bosnian Serbs in Grbavica). See also David Harland, T. 2317-2318 (11 May 2010); D178 (Annex VI to UNSG's Report, 6 June 1994).

11469 P1638 (Witness statement of Michael Rose dated 26 March 2009), para. 30. See also P1584 (UNMO report, $3-$ 4 January 1994); P1586 (UNMO report, 4-5 January 1994); P1588 (UNMO incident report, 1-8 January 1994); D3452 (SRK combat report, 6 January 1994).

11470 P1558 (Witness statement of Francis Roy Thomas dated 13 May 2009), para. 96; P1587 (UNMO report, 7-8 January 1994), para. 9.

11471 P5968 (SRK Order, 26 January 1994), pp. 5, 8.

11472 P5968 (SRK Order, 26 January 1994), pp. 6, 8.

11473 D700 (UNPROFOR report re meeting with Radovan Karadžić and Ratko Mladić, 30 January 1994), para. 2; Michael Rose, T. 7484 (7 October 2010) (testifying that when he arrived in BiH in January 1994, the flow of aid was “clearly not too bad"); D691 (TANJUG news report, 30 January 1994), p. 1; P1485 (Ratko Mladić's notebook, 9 January-21 March 1994), p. 90.

11474 See discussion on Scheduled Incidents G.7 and G.8.

11475 Harland testified that the overall effect of the Markale shelling was the stabilisation of the situation around Sarajevo. See P820 (Witness statement of David Harland dated 4 September 2009), para. 76 . See also P1638 (Witness statement of Michael Rose dated 26 March 2009), para. 40; Michael Rose, T. 7338-7340 (6 October 2010).
} 
negotiated by Rose was agreed upon by both sides whereby WCPs would be established, as well as a TEZ, a 20 kilometre circle around the city, from which both sides would withdraw all heavy weapons by 21 February. ${ }^{11476}$ The cease-fire was to start on 10 February and UN troops were to be positioned on key terrain between the warring parties. ${ }^{11477}$ In subsequent negotiations, the Accused and Yasushi Akashi, Special Representative of the Secretary General from January 1994, ${ }^{11478}$ agreed that there would be seven WCPs for SRK weapons, which would be located at the outskirts of the city, while one WCP would be set up in the city itself for $\mathrm{ABiH}$ weapons; all would be monitored by the UNPROFOR soldiers. ${ }^{1479}$ While the Bosnian Serbs attempted to negotiate a protocol to the agreement, under which they would be entitled to redeploy the weapons in case of an attack by the $\mathrm{ABiH}$, this was not accepted by the UN. ${ }^{11480}$

11476 P820 (Witness statement of David Harland dated 4 September 2009), paras. 79-80; P1638 (Witness statement of Michael Rose dated 26 March 2009), paras. 40-44 (testifying that the Bosnian Serb side was threatened with NATO air strikes if it did not pull out its guns 20 kilometres away from Sarajevo); Michael Rose, T. 7256, 7263-7264 (5 October 2010), T. 7338-7340 (6 October 2010), T. 7547-7550, 7562-7563 (8 October 2010); D718 (Map of Sarajevo and surrounding areas); P1642 (SRK Order, 10 February 1994); D162 (Michael Rose's book entitled "Fighting for Peace: Bosnia, 1994"), p. 48; D713 (UNPROFOR report re talks with Radovan Karadžić and Alija Izetbegović, 6 February 1994); Yasushi Akashi, T. 37691-37692 (24 April 2013); Adrianus van Baal, T. 8477-8480 (28 October 2010); D830 (UNPROFOR report re cease fire negotiations in Sarajevo, 8 February 1994); P1558 (Witness statement of Francis Roy Thomas dated 13 May 2009), paras. 97-98; P2119 (Witness statement of KDZ450 dated 17 January 2011), para. 86 (under seal); P2121 (UNPROFOR report re Joint Commission meeting, 10 February 1994); Stanislav Galić, T. 37446-37448 (18 April 2013); Milenko Inđić, T. 32446-32448 (22 January 2013). KDZ450 testified that Galić was eventually relieved of his duty as the SRK Commander because he had agreed to the TEZ and the WCPs, all of which was against Mladić's wishes. See P5906 (Witness statement of KDZ450 dated 17 January 2011), paras. 38-39; Stanislav Galić, T. 37449 (18 April 2013). All weapons above $81 \mathrm{~mm}$ were considered heavy weapons for the purposes of the agreement. See P1818 (Witness statement of Adrianus van Baal dated 26 October 2010), para. 15. See also Adjudicated Facts 2784, 2785.

11477 P1558 (Witness statement of Francis Roy Thomas dated 13 May 2009), para. 97.

11478 Yasushi Akashi, T. 37665 (24 April 2013).

11479 D842 (UNPROFOR report re meeting with Radovan Karadžić and Alija Izetbegović, 21 February 1994), paras. 11-12; P2120 (UNPROFOR report re meeting with Stanislav Galić, 16 February 1994); P1638 (Witness statement of Michael Rose dated 26 March 2009), paras. 46-49; P1558 (Witness statement of Francis Roy Thomas dated 13 May 2009), paras. 104-105; P1593 (SRK map of Sarajevo showing weapon sites); P1594 (SRK map of Sarajevo showing weapon sites); P1595 (SRK map of Sarajevo showing weapon sites); P1596 (SRK map of Sarajevo showing weapon sites); P1654 (Agreement between Yasushi Akashi and Radovan Karadžić, 18 February 1994; P1818 (Witness statement of Adrianus van Baal dated 26 October 2010, para. 11; P1762 (Witness statement of David Fraser dated 17 October 2010), pp. 20-21; P2119 (Witness statement of KDZ450 dated 17 January 2011), paras. 89, 91 (under seal); KDZ450, T. 10558-10559, 10590-10591 (19 January 2011) (private session); D961 (UNPROFOR report re meeting with Stanislav Galić, 18 February 1994). See Adjudicated Fact 2786. Since the $\mathrm{ABiH}$ stored a large amount of its equipment in the Koševo tunnel, that too was later agreed as a WCP. See P1558 (Witness statement of Francis Roy Thomas dated 13 May 2009), para. 99.

11480 D717 (UNPROFOR report re weapons collection points in Sarajevo, 16 August 1994), e-court p. 4; P2118 (UNPROFOR report re weapon collection points in Sarajevo, 12 September 1994); Yasushi Akashi, T. $37693-$ 37695 (24 April 2013), T. 37753-37757 (25 April 2013); Michael Rose, T. 7556-7562 (8 October 2010); D716 (UNPROFOR report re meetings with Radovan Karadžić and Alija Izetbegović, 20 February 1994); KDZ450, T. 10563-10565, 10591-10593 (19 January 2011) (private session), T. 10577-10583 (19 January 2011); D842 (UNPROFOR report re meeting with Radovan Karadžić and Alija Izetbegović, 21 February 1994), paras. 5-7; KDZ304, T. 10501, 10509-10510 (18 January 2011), T. 10534-10537 (19 January 2011). But see Adrianus van Baal, T. 8473-8474 (27 October 2010), T. 8496-8497 (28 October 2010); Dragomir Milošević, T. 33249-33251 (5 February 2013). 
3583. As a result of the above cease-fire agreement, delivery of aid to Sarajevo improved. ${ }^{11481}$ On 17 February, UNPROFOR reported that the humanitarian situation was relatively good, with a steady flow of food; however, the civilian population was receiving less than a third of the aid delivered as some of it was diverted to the military, some appeared on the black market, and the majority could not be accounted for. ${ }^{11482}$

3584. As agreed, by 21 February, the sites suspected of containing heavy weapons were inspected and found to be clear; according to Rose, during the withdrawal process, the Serbs produced a far greater number of weapons than the other side, reflecting the disparity between the two sides. ${ }^{11483}$ However, both sides were also disingenuous in complying with the agreement; for example, the SRK positioned a number of inoperative weapons around Sarajevo for the purpose of handing them

\footnotetext{
11481 P827 (UNPROFOR Weekly Political Assessment, 17 February 1994), pp. 1, 3; Michael Rose, T. 7484 (7 October 2010). See also D3466 (SRK Order, 16 January 1994) (ordering that "full protection and unhindered movement" be given to humanitarian convoys in order to avoid conflicts with UNPROFOR, especially during the Geneva talks); Stanislav Galić, T. 37570-37571 (23 April 2013).

11482 P827 (UNPROFOR Weekly Political Assessment, 17 February 1994), p. 3.

11483 P1638 (Witness statement of Michael Rose dated 26 March 2009), para. 50; Michael Rose, T. 7549 (8 October 2010) (testifying that the $\mathrm{ABiH}$ agreed to stop using its heavy weapons but did not agree to place them under the control of the UN; instead in a symbolic gesture it produced some weapons in one of the barracks in the city); P1818 (Witness statement of Adrianus van Baal dated 26 October 2010, paras. 14, 16; P2132 (UNPROFOR report re meeting with Stanislav Galić, 15 February 1994); P1558 (Witness statement of Francis Roy Thomas dated 13 May 2009), paras. 100, 104; P2119 (Witness statement of KDZ450 dated 17 January 2011), para. 93 (under seal); D962 (UNPROFOR daily report, 20 February 1994), para. 7; D4612 (SRK report, 22 February 1994).
} 
over to WCPs ${ }^{11484}$ while the $\mathrm{ABiH}$ had a number of heavy weapons on Mt. Igman to which the UN was never given access. ${ }^{11485}$

3585. On 24 February 1994, Andreev, De Mello, and Koljević agreed in principle to the creation of Blue Routes within Sarajevo for the delivery of humanitarian aid. ${ }^{11486}$ The routes included the Dobrinja-Butmir route for Bosnian Muslim civilians, the Lukavica-Ilidža route for Bosnian Serb civilians, and the pedestrian crossing in downtown Sarajevo at the Bratstvo Jedinstvo Bridge. ${ }^{1487}$

3586. As a result of the cease-fire agreement, Sarajevo was relatively calm for the rest of February; there were almost no war-related civilian deaths in the city in the last three weeks of February and few casualties later on. ${ }^{11488}$ While the ABiH continued to fire at SRK positions

11484 P820 (Witness statement of David Harland dated 4 September 2009), para. 81; P847 (VRS Main Staff Order, 9 February 1994); P848 (Order of Drina Corps, 9 February 1994); Rupert Smith, T. 11866-11867 (15 February 2011); P1638 (Witness statement of Michael Rose dated 26 March 2009), para. 143; P1670 (SRK Order, 21 August 1994); Michael Rose, T. 7260-7262 (5 October 2010), T. 7549-7552 (8 October 2010); P1641 (SRK proposal re artillery, 10 February 1994) (indicating that the SRK proposed to set aside artillery that is out of order for the purposes of the agreement); D714 (UNPROFOR report re situation in BiH, 13 August 1994), pp. 3, 4; P1818 (Witness statement of Adrianus van Baal dated 26 October 2010), paras. 13-16, 29; P1558 (Witness statement of Francis Roy Thomas dated 13 May 2009), paras. 100-102; P2447 (Witness statement of KDZ182), pp. 63-64; P2414 (Witness statement of KDZ182), pp. 64-65 (under seal); KDZ182, T. 13032 (9 March 2011); D3493 (Letter from Radovan Karadžić to Yasushi Akashi, 27 February 1994) (in which the Accused indicates that he has been made aware of problems relating to the re-grouping of the SRK weapons and promises to fix them); Dragomir Milošević, T. 32725-32728 (28 January 2013), 33216-33221 (5 February 2013); Milenko Inđić, T. 32447-32449 (22 January 2013), T. 32641-32646 (24 January 2013); P6087 (VRS Main Staff information, 12 February 1994); P6016 (SRK list of technical and material equipment, 21 February 1994). Galic testified that the SRK honoured the agreement to the "last letter". However, in anticipation of the agreement, Galić had already issued an order on 9 February for the SRK units to move defective weapons to fire positions around Sarajevo in order to then remove them once the agreement was signed and in order to have working weapons remain in their positions. He also ordered that this operation be conducted during the night. See Stanislav Galić, T. 37448 (18 April 2013), T. 37952-37959 (8 May 2013); P6303 (SRK Order, 9 February 1994); D2802 (SRK combat report, 20 February 1994). Accordingly, and in light of all the other evidence listed in this footnote, the Chamber does not accept Galić's evidence that he complied with the agreement to the "last letter".

11485 P1558 (Witness statement of Francis Roy Thomas dated 13 May 2009), paras. 103, 105; Francis Roy Thomas, T. 6848-6849 (15 September 2010); Michael Rose, T. 7260-7261 (5 October 2010); KDZ450, T. 10594-10595 (19 January 2011) (private session); KDZ304, T. 10463-10464 (18 January 2011).

11486 Harland testified that negotiations for the opening of Blue Routes had been on-going for a long time but went "nowhere" until the Bosnian Serbs felt an urgent need to forestall NATO air strikes through "bold and conciliatory gestures". See P820 (Witness statement of David Harland dated 4 September 2009), para. 89. The concept of 'Blue Routes' into Sarajevo was first proposed at the ICFY in January 1993. See para. 389. See also Adjudicated Fact 3020.

11487 P820 (Witness statement of David Harland dated 4 September 2009), para. 90.

11488 P820 (Witness statement of David Harland dated 4 September 2009), paras. 82-84, 91, 95; P827 (UNPROFOR Weekly Political Assessment, 17 February 1994), pp. 1-2; P849 (UNPROFOR Weekly Political Assessment, 1 March 1994), pp. 1-2; P850 (UNPROFOR Weekly Political Assessment, 9 March 1994), pp. 1-2; P1638 (Witness statement of Michael Rose dated 26 March 2009), para. 45; P1818 (Witness statement of Adrianus van Baal dated 26 October 2010), para. 10; P1558 (Witness statement of Francis Roy Thomas dated 13 May 2009), para. 107; P5906 (Witness statement of KDZ450 dated 17 January 2011), para. 94; P4998 (Ewa Tabeau's expert report entitled "Population Losses in the 'Siege' of Sarajevo 10 September 1992 to 10 August 1994", 10 May 2002), p. 33 (indicating that the number of casualties fell significantly between February and August 1994); P5002 (Ewa Tabeau's expert report entitled "Killed and Wounded Persons from the Siege of Sarajevo: August 1994 to November 1995", 19 March 2007), pp. 40-41. On the other hand, the SRK lost a number of soldiers in the area on 9 February 1994. See D832 (SRK combat report, 3 March 1994), para. 5. 
immediately following the cease-fire, the SRK forces kept abiding by the cease-fire and eventually the $\mathrm{ABiH}$ stopped its firing as well. ${ }^{11489}$ To Rose and Thomas, this indicated that the Bosnian Serb side had absolute control over its heavy weaponry. ${ }^{11490}$

3587. March 1994 was an encouraging time for Sarajevo as the cease-fire continued to hold. ${ }^{11491}$ By 15 March, the trams started operating again, which signified the beginning of better living conditions. ${ }^{11492}$ Life in Sarajevo improved as utilities were restored, including running water, and for the first time people started hoping for a return to normality. ${ }^{11493}$ On 17 March, the Blue Routes Agreement was negotiated between the parties under which several routes, including the Airport Routes, were opened on 23 March for the movement of civilians from both sides and to re-supply the city with humanitarian aid. ${ }^{11494}$ KDZ450 testified that the combination of the cease-fire, the TEZ, and the opening of the Blue Routes contributed to a significant improvement in the freedom of movement of convoys. ${ }^{1495}$ Rose confirmed that the flow of aid "improved immensely" in February as a result of the TEZ. ${ }^{11496}$ He recalled that aid came to a halt during the crisis in Goražde in April 1994, ${ }^{11497}$ but that after April 1994 aid flowed into Sarajevo "more or less unblocked". 11498

11489 Michael Rose, T. 7263-7264 (5 October 2010); P1642 (SRK Order, 10 February 1994); Adrianus van Baal, T. 8481-8485 (28 October 2010); D832 (SRK combat report, 3 March 1994), p. 2; P2119 (Witness statement of KDZ450 dated 17 January 2011), para. 70 (under seal) KDZ450, T. 10691-10692 (20 January 2011); D969 (UNMO report, 18 February 1994); D831 (SRK combat report, 16 February 1994); D4575 (SRK combat report, 21 February 1994); D4576 (SRK combat report, 22 February 1994); D3474 (SRK combat report, 28 February 1994); D3475 (SRK combat report, 1 March 1994); D4578 (SRK combat report, 11 March 1994); D4610 (Radovan Karadžić's Order, 13 March 1994) (in which the Accused instructed the VRS Main Staff to exercise maximum restraint and refrain from responding to fire during Bajram); D4580 (SRK combat report, 17 March 1994); D3433 (SRK combat report, 31 March 1994); D833 (UNPROFOR report re meeting Between Adrianus van Baal and Manojlo Milovanović, March 1994), e-court p. 4; D2803 (Report re truce violations, undated); P2711 (Letter from SRK to UNPROFOR, 1 March 1994).

11490 Michael Rose, T. 7263-7264 (5 October 2010); P1558 (Witness statement of Francis Roy Thomas dated 13 May 2009), para. 107.

11491 P849 (UNPROFOR Weekly Political Assessment, 1 March 1994), p. 1; P820 (Witness statement of David Harland dated 4 September 2009), paras. 91, 97.

11492 P1638 (Witness statement of Michael Rose dated 26 March 2009), para. 62; Michael Rose, T. 7257, 7269-7270 (5 October 2010); P850 (UNPROFOR Weekly Political Assessment, 9 March 1994), p. 2; P1996 (Witness statement of Martin Bell dated 8 March 2010), para. 48; D702 (Report of humanitarian organisation, 29 March 1994), paras. 28-29 (under seal).

11493 Michael Rose, T. 7256-7257 (5 October 2010); Adrianus van Baal, T. 8461-8462 (27 October 2010); P5906 (Witness statement of KDZ450 dated 17 January 2011), paras. 24, 70; KDZ450, T. 10549 (19 January 2011).

11494 See para. 390.

11495 KDZ450, T. 10549 (19 January 2011); P5906 (Witness statement of KDZ450 dated 17 January 2011), para. 94.

11496 Michael Rose, T. 7484 (7 October 2010).

11497 See P3042 (VRS Main Staff Report, 11 April 1994) (ordering that all relations with UNPROFOR "should be suspended" following a decision of the Supreme Command); P1786 (VRS Main Staff Report, 14 April 1994), p. 3 (stating that there had been no movement of UNPROFOR and humanitarian organisations across RS territory on 14 April in accordance with the decision of the Supreme Command); David Fraser, T. 8027, 8030 (18 October 2010) (testifying that this document was consistent with UNPROFOR's assessment that humanitarian aid and freedom of movement were "controlled by the Serbs").

11498 Michael Rose, T. 7484-7485 (7 October 2010) (adding that UNPROFOR rarely met the objectives of the World Health Organisation when it came to humanitarian aid, but that there were strong flows of aid into Sarajevo in particular periods). 
Harland also agreed that the opening of the Blue Routes led to "substantial relief of the humanitarian situation" in Sarajevo. ${ }^{11499}$

3588. By 19 March, however, the level of sniping in the city started increasing. ${ }^{11500}$ According to Adrianus van Baal, the Chief of Staff of UNPROFOR BiH Command at the time, ${ }^{1501}$ sniping activity continued during this time despite the cease-fire agreement-it was specifically directed at trams in Sarajevo. ${ }^{11502}$ Both Thomas and KDZ450 testified that after the creation of the TEZ, sniping became an important factor in the war and that the Serbs resorted to sniping because they lost the advantage of their heavy weapons and because the $\mathrm{ABiH}$ was undertaking "tunneling" towards the Serb lines at the time. ${ }^{11503}$

3589. In March 1994, Bosnian Muslims and Bosnian Croats formed a federation which tilted the military balance against the Bosnian Serb side; this signified a massive change in the strategic situation in $\mathrm{BiH}$, leading in particular to the unwillingness of the Bosnian Muslims to sign up to any peace accord which they felt was unjust and would reward the Bosnian Serbs. ${ }^{11504}$ On 21 March, Galić complained to the UN about violations of the cease-fire agreement by the $\mathrm{ABiH}$, consisting

11499 P820 (Witness statement of David Harland dated 4 September 2009), paras. 97, 120. See also Rupert Smith, T. 11349-11350 (8 February 2011) (testifying that "everything" which Sarajevo needed came from flights landing at the airport and convoys travelling on the Blue Routes); Michael Rose, T. 7258 (5 October 2010) (testifying that after the Blue Routes were opened people could buy fresh food again).

11500 P1638 (Witness statement of Michael Rose dated 26 March 2009), paras. 63, 65; P1656 (Letter from Radovan Karadžić to Yasushi Akashi, 21 and 28 March 1994), e-court p. 5; P1564 (UNMO report on sniping victims from March to June 1994); P1558 (Witness statement of Francis Roy Thomas dated 13 May 2009), para. 119; Francis Roy Thomas, T. 6808-6810 (15 September 2010); P5906 (Witness statement of KDZ450 dated 17 January 2011), para. 70.

11501 P1818 (Witness statement of Adrianus van Baal dated 26 October 2010), para. 5.

11502 Van Baal testified that the SRK's focus on trams was due to Milovanović being opposed to the running of the trams. According to Van Baal, Milovanović even stated at one of their meetings that trams would be targeted if allowed to operate. See P1818 (Witness statement of Adrianus van Baal dated 26 October 2010), paras. 36, 4045; Adrianus van Baal, T. 8444-8451 (27 October 2010); D825 (Manojlo Milovanović's book entitled "My View of the War in Bosnia 1992-1995”). p. 31. However, Van Baal made no record of this statement by Milovanović in his notes, which were taken contemporaneously during the meeting in question. See D1090 (Handwritten notes of Adrianus van Baal). In addition, during his testimony before the Chamber, Milovanović denied that he ever made such a statement to Van Baal. He testified that he told Van Baal that the UN should encourage Bosnian Muslims to put a stop to urban transport otherwise he could not guarantee that "some idiot won't open fire". See Manojlo Milovanović, T. 25689-25691 (1 March 2012). Given that Van Baal did not record Milovanović's statement in his contemporaneous diary despite it being such a striking threat, the Chamber is not persuaded by Van Baal's evidence that this is what transpired in his meeting with Milovanović. Instead, the Chamber accepts Milovanović's evidence as to the statement he made to Van Baal.

11503 P5906 (Witness statement of KDZ450 dated 17 January 2011), para. 70; P1558 (Witness statement of Francis Roy Thomas dated 13 May 2009), paras. 62-63.

11504 Michael Rose, T. 7248-7250 (5 October 2010), T. $7327-7328$ (6 October 2010); P1818 (Witness statement of Adrianus van Baal dated 26 October 2010,) para. 20; Yasushi Akashi, T. 37676-37677 (24 April 2013) (testifying that the Bosnian Serbs were more powerful in the beginning of the conflict but that Bosnian Muslim and Bosnian Croats became more powerful towards the end which meant they were against any long-term freezing of the military situation); D3489 (Excerpt from Yasushi Akashi's book entitled "In the Valley between War and Peace"), p. 103. 
mostly of infantry fire. ${ }^{11505}$ On 27 March, UNPROFOR protested to the ABiH about an attack on SRK positions, calling it a direct violation of the cease-fire. ${ }^{11506}$

3590. In mid-April, the TEZ was being openly violated. ${ }^{11507}$ According to Anthony Banbury, a Civil Affairs Officer in UNPROFOR and later an assistant to Akashi, ${ }^{11508}$ April 1994-during the crisis in Goražde — ${ }^{11509}$ was a particularly bad period for Sarajevo, with a prevalence of sniping and mortar attacks, and very little gas, electricity, and water in the city. ${ }^{11510}$ The period of May and June 1994, however, was generally quiet around Sarajevo. ${ }^{11511}$ On 28 May 1994, UNPROFOR reported that there had been a "major influx" of humanitarian and commercial goods into Sarajevo, leading to rapid deflation in food prices and the opening of new shops. ${ }^{11512}$

3591. On 25 May, the VRS Main Staff reported to the Accused that the ABiH opened sniper fire in the area of the Vrbanja Bridge and Zlatište and ordered the SRK units to respect the ceasefire. ${ }^{11513}$ On the same day, a bus was shot at in Dobrinja resulting in the wounding of two women. ${ }^{1514}$ June was marked by fighting in other parts of $\mathrm{BiH}$ and the failure of peace talks in Geneva, which in turn resulted in the Bosnian Serb side cutting off electricity and gas to Sarajevo and halting aid convoys into the city. ${ }^{11515}$ Thus, from around the middle of June 1994, the humanitarian situation in Sarajevo began to deteriorate again. ${ }^{1516}$ In his book, Rose wrote that in this period the Bosnian Serb leadership "lapsed into a state of lunacy, blocking convoys and cutting

\footnotetext{
11505 D834 (Letter from Stanislav Galić to UNPROFOR, 21 April 1994); Adrianus van Baal, T. $8488-8489$ (28 October 2010); KDZ450, T. 10644-10645 (20 January 2011).

11506 P2122 (UNPROFOR protest letter to ABiH, 31 March 1994); KDZ450, T. 10649-10650 (20 January 2011),

11507 P829 (UNPROFOR Weekly Political Assessment, 16 April 1994), p. 1.

11508 P2451 (Witness statement of Anthony Banbury dated 19 May 2009), paras. 3, 5; Anthony Banbury, T. 1330513306 (15 March 2011).

11509 P820 (Witness statement of David Harland dated 4 September 2009), paras. 102-118; P2451 (Witness statement of Anthony Banbury dated 19 May 2009), para. 13; P1638 (Witness statement of Michael Rose dated 26 March 2009), paras. 66-102; D3496 (UNPROFOR report, 16 April 1994); D3497 (UNPROFOR report, 17 April 1994). See also para. 391.

11510 P2451 (Witness statement of Anthony Banbury dated 19 May 2009), para. 12. See also P1762 (Witness statement of David Fraser dated 17 October 2010), pp. 21, 64-65.

11511 P820 (Witness statement of David Harland dated 4 September 2009), para. 120; D177 (UNPROFOR Weekly Summary, 14-20 May 1994) (reporting sporadic fire and few civilian casualties between 14 and 20 May). But see P5906 (Witness statement of KDZ450 dated 17 January 2011), para. 24 (testifying that May was marked by sniping and some shelling activities). See also D3434 (SRK combat report, 5 May 1994) (indicating that the $\mathrm{ABiH}$ opened sniper fire on 5 May but that the SRK did not respond and was preparing for the Strela 94 operation).

11512 P2520 (UNPROFOR Weekly Political Assessment, 28 May 1994), p. 5.

11513 D3453 (VRS Main Staff report, 25 May 1994).

11514 See discussion on Scheduled Incident F.7.

11515 P1638 (Witness statement of Michael Rose dated 26 March 2009), paras. 108-119 (testifying that, nevertheless, the standard of living in Sarajevo was better due to the lack of shelling, even though sniping incidents remained a feature of daily life); P1818 (Witness statement of Adrianus van Baal dated 26 October 2010), para. 68; Adrianus van Baal, T. 8393-8399 (27 October 2010); P1819 (Letter from Adrianus van Baal to Ratko Mladić, 28 June 1994).

11516 P1638 (Witness statement of Michael Rose dated 26 March 2009), paras. 116, 118.
} 
off communication with the world". ${ }^{11517}$ In response to a protest from Akashi about these restrictions, the Accused wrote on 24 June that UNPROFOR was taking little notice of the convoy procedures by carrying "undeclared goods and equipment". ${ }^{11518}$ In a meeting on 27 June with Banbury and Rose, Krajišnik stated that improvements in the quality of life in Sarajevo had angered many Bosnian Serbs living outside Sarajevo and that the Bosnian Serb side was about to send a letter to UNPROFOR stating that the Airport Routes were being misused and therefore had to be closed. ${ }^{11519}$ Despite these threats, all the Blue Routes remained open and were heavily used in late June and early July $1994 .^{11520}$

3592. On 8 June 1994, following the talks in Geneva, the parties signed an Agreement on the Cessation of Offensive Actions, which was to last for one month. ${ }^{11521}$ This prompted Galić to issue a declaration to the SRK units encouraging them to respect the agreement. ${ }^{11522}$ However, by the end of June sniping activities on both sides had increased. ${ }^{11523}$ On 19 June, a tram was shot at while travelling on Zmaja od Bosne street, resulting in casualties. ${ }^{11524}$ On 26 June, Sanela Muratović, a 16 year old girl, was shot and wounded while walking in the west end of Sarajevo 11525

3593. According to Rose, during the summer of 1994, the ABiH violated the cease-fire on more occasions than the SRK but this did not result in NATO air strikes against the ABiH because by the end of summer NATO changed its position that it would respond to violations by both sides. ${ }^{11526}$ In

11517 D162 (Michael Rose's book entitled "Fighting for Peace: Bosnia, 1994”), p. 167; P1638 (Witness statement of Michael Rose dated 26 March 2009), para. 117. See also P860 (Letter from Sergio Vieira de Mello to Radovan Karadžić, 31 July 1994, and Letter from VRS to UNPROFOR, 30 July 1994), e-court pp. 2-3 (in which De Mello expressed his dismay to the Accused at further restrictions on UNPROFOR's freedom of movement). D695 (Letter from Radovan Karadžić to Yasushi Akashi, 24 June 1994) (also stating that the Bosnian Muslims were mounting a military offensive and refusing to exchange prisoners); Michael Rose, T. 7463-7464 (7 October 2010) (stating that he would have taken "grave exception" to the allegations contained in this letter).

11519 P2465 (UNPROFOR report, 28 June 1994), paras. 7-8 (indicating that this anger probably explained why the Bosnian Serbs wanted to close the Airport Routes); P2451 (Witness statement of Anthony Banbury dated 19 May 2009), para. 21 (stating that it was his impression that Bosnian Serb leaders found the increased living standards in Sarajevo objectionable); P5906 (Witness statement of KDZ450 dated 17 January 2011), para. 102.

11520 D1172 (UNPROFOR report, 17 August 1994), p. 3; D1161 (UNPROFOR Weekly Political Assessment, 11 July 1994), p. 5; Anthony Banbury, T. 13465 (16 March 2011). See also P2470 (UNPROFOR report, 1 September 1994), p. 5 (stating that the $10,000^{\text {th }}$ UNHCR flight landed at Sarajevo airport on 12 July 1994).

11521 P2470 (UNPROFOR report, 1 September 1994), p. 4; D1147 (UNPROFOR report, 21 June 1994); P1638 (Witness statement of Michael Rose dated 26 March 2009), para. 113; P1665 (Agreement on Cessation of Hostilities in BiH, June 1994).

11522 Stanislav Galić, T. 37429-37432 (18 April 2013); D3430 (Letter from Stanislav Galić to SRK members, undated).

11523 P1771 (UNPROFOR report re anti-sniping measures, 25 June 1994); D3455 (SRK combat report, 24 June 1994); D2554 (SRK combat report, 26 June 1994).

11524 See discussion on Scheduled Incident F.8.

11525 See discussion on Scheduled Incident F.9.

11526 Michael Rose, T. 7554-7556 (8 October 2010); D715 (UNPROFOR report re situation in BiH, 15 February 1994), e-court p. 3; D835 (Letter from Manojlo Milovanović to Michael Rose) (complaining that the SRK had 
the meantime, incidents of sniping in the city increased in the months of July and August, particularly on trams. ${ }^{11527}$ On 22 July, Seid Solak, a 13 year old boy was shot and wounded while walking in the Čengić Vila area of Sarajevo. ${ }^{11528}$ On 23 July, the SRK command reported to the VRS Main Staff that the ABiH had opened infantry fire on SRK lines on various axes. ${ }^{11529}$ On the same day, Milovanović issued an order to the SRK to "carry out all necessary preparations" for the closure of the Airport Routes to civilians and humanitarian traffic. ${ }^{11530}$ On 26 July, citing the smuggling of weapons into the city as the reason, the Bosnian Serbs, under the orders of the Accused, decided to close the airport to commercial convoys using the Airport Routes; this resulted in Rose feeling obliged to close the airport, for security reasons, to all civilian traffic thus stopping the humanitarian airlift. ${ }^{11531}$ On 27 July, the SRK command reported a number of infantry attacks by the $\mathrm{ABiH}$, noting that SRK units responded both with infantry fire and mortars. ${ }^{1532}$ According to Rose, for the first time in many months the situation in Sarajevo was "moving backwards". ${ }^{11533}$

3594. By August 1994, the situation in Sarajevo began to deteriorate as incidents of sniping were on the increase. ${ }^{11534}$ On 1 August the ABiH launched a number of attacks on the SRK from within

been tricked by the $\mathrm{UN}$ in relation to this agreement and urging it to stop $\mathrm{ABiH}$ from engineering works towards SRK territory); D836 (SRK combat report, 6 July 1994); D2808 (SRK combat report, 1 July 1994); Yasuhi Akashi, T. 37714 (24 April 2013); Adrianus van Baal, T. 8492-8493, 8506 (28 October 2010) (conceding that strikes were only conducted against the Bosnian Serb side but stating also that the UN was unable to verify the claims of cease-fire violations made by the Bosnian Serb side as it had no access to their territory); Anthony Banbury, T. 13462 (16 March 2011); D966 (UNPROFOR Weekly Situation Report, 28 June 1994), p. 4.

11527 P1558 (Witness statement of Francis Roy Thomas dated 13 May 2009), para. 68; P1818 (Witness statement of Adrianus van Baal dated 26 October 2010), paras. 43, 56; P1822 (UNMO report on sniping incident of 11 August 1994).

11528 See discussion on Scheduled Incident F.10.

11529 D3435 (SRK combat report, 23 July 1994).

11530 P1639 (SRK Order, 23 July 1994) (indicating that the order was made pursuant to an oral order of the Accused). To Rose this indicated a "very close relationship" between the military and civilian authorities on the Bosnian Serb side. See Michael Rose, T. 7259-7260 (5 October 2010); Vlade Lučić, T. 30812-30813 (3 December 2012) (testifying that it was unclear whether this order was implemented or not because it was only an order to carry out "preparations").

11531 P1638 (Witness statement of Michael Rose dated 26 March 2009), paras. 127-129; P1668 (UNPROFOR report re negotiations in BiH, 2 August 1994); Michael Rose, T. 7258-7260 (5 October 2010), T.7431-7433 (7 October 2010); P1639 (SRK Order, 23 July 1994); P859 (UNPROFOR report re closing of Sarajevo routes, 26 July 1994) (attaching the letter of the Accused explaining his decision to close some of the Blue Routes); P820 (Witness statement of David Harland dated 4 September 2009), para. 122; P5906 (Witness statement of KDZ450 dated 17 January 2011), para. 102; D3928 (Article from Večernje Novosti entitled "Moslems to Blame for Blockade, Failure of Balkan Policy", 28 July 1994); John Zametica, T. 42463-42464 (29 October 2013); P2470 (UNPROFOR report, 1 September 1994), p. 8 (describing the Mt. Igman route as Sarajevo's "lifeline route").

11532 D3457 (SRK combat report, 27 July 1994).

11533 P1638 (Witness statement of Michael Rose dated 26 March 2009), para. 129. See also KDZ450, T. 10549_ 10550 (19 January 2011); P2470 (UNPROFOR report, 1 September 1994), p. 6 (stating that following the closure of the Airport Routes the "strangulation of Sarajevo" recommenced).

11534 P820 (Witness statement of David Harland dated 4 September 2009), para. 125; KDZ450, T. 10549-10550 (19 January 2011). See also P5002 (Ewa Tabeau's expert report entitled "Killed and Wounded Persons from the Siege of Sarajevo: August 1994 to November 1995”, 19 March 2007), p. 57 (indicating that the proportion of sniping incidents increased in the period between August 1994 and May 1995). 
the TEZ and from the outer ring. ${ }^{11535}$ On 2 August, while the $\mathrm{ABiH}$ attack continued, resulting in SRK casualties, the SRK sent a request to the UN to recover the weapons in the northwestern part of its area; however, the response was negative. ${ }^{11536}$ On the same day, De Mello reported to Annan that the situation in Sarajevo was "dire" following the closure of the Airport Routes as only two UNHCR convoys were permitted entry to Sarajevo in July 1994, the humanitarian airlift had not yet resumed, and UNHCR warehouses had emptied. ${ }^{11537}$ On 5 August, the Bosnian Serbs seized a number of heavy weapons from a WCP in Ilidža and in response NATO launched air strikes, targeting an SRK anti-tank gun located in the TEZ; when threatened with more strikes, the Bosnian Serbs returned the weapons the next day. ${ }^{1538}$ Violations of the TEZ by the ABiH continued following the air strikes. ${ }^{1539}$ On 10 August, the SRK command reported that its units were responding to attacks, including with sniper rifles. ${ }^{11540}$ On 11 August, after the humanitarian airlift had resumed, fire was opened on a UNHCR aircraft at the Sarajevo airport from ABiH controlled territory, resulting in the closure of the airport and the cancellation of UNHCR flights. ${ }^{11541}$

3595. By 12 August, the trams stopped operating due to sniping. ${ }^{11542}$ On that day, in a meeting between Rose, Koljević, Gvero and Tolimir, the Bosnian Serbs accepted the proposed anti-sniping agreement, which had been negotiated by Rose during the course of the previous weeks. ${ }^{11543}$ On

\footnotetext{
11535 Adrianus van Baal, T. 8493-8495 (28 October 2010); D837 (SRK combat report, 1 August 1994).

11536 D838 (SRK combat report, 2 August 1994), para. 3; Adrianus van Baal, T. 8498-8499 (28 October 2010).

11537 P1668 (UNPROFOR report re negotiations in BiH, 2 August 1994), paras. 1-2; P1638 (Witness statement of Michael Rose dated 26 March 2009), para. 128.

11538 P1638 (Witness statement of Michael Rose dated 26 March 2009), para. 132; P1818 (Witness statement of Adrianus van Baal dated 26 October 2010), para. 64; Adrianus van Baal, T. 8476-8477, 8499-8502 (28 October 2010); D837 (SRK combat report, 1 August 1994). Also in August, Rose threatened Ejup Ganić with air strikes as the $\mathrm{ABiH}$ was firing on the Ilijaš and Visoko areas. See P1638 (Witness statement of Michael Rose dated 26 March 2009), paras. 134-135; D839 (Letter from Adrianus van Baal to ABiH Supreme Command Staff, 12 August 1994).

11539 D840 (Letter from Adrianus van Baal to ABiH Supreme Command Staff, August 1994); D839 (Letter from Adrianus van Baal to ABiH Supreme Command Staff, 12 August 1994).

11540 D2828 (SRK combat report, 10 August 1994) (indicating that on 10 August, in the area of responsibility of the $3^{\text {rd }}$ Sarajevo Infantry Brigade, two ABiH soldiers were killed by sniper fire and UNPROFOR was involved in pulling their bodies out); Dragomir Milošević, T. 32838-32839 (29 January 2013).

11541 D827 (Letter from Adrianus van Baal to ABiH Supreme Command Staff, 13 August 1994); Adrianus van Baal, T. 8461 (27 October 2010); Anthony Banbury, T. 13471 (16 March 2011). See also John Zametica, T.4246642467 (29 October 2013) (testifying that Bosnian Muslim forces often deliberately shelled Sarajevo airport in order to prevent flights from landing and to increase black market prices). On 15 and 18 August, another two mortar rounds landed at Sarajevo airport, which UNPROFOR determined were fired from ABiH-controlled territory. See D828 (Letter from Adrianus van Baal to ABiH Supreme Command Staff, 15 August 1994); P2458 (UNPROFOR Weekly BiH Political Assessment, 11 September 1994), para. 12; P865 (UNPROFOR report on meeting with Bosnian Serb and Bosnian Muslim leadership, 26 September 1994), para. 17 (under seal) (de Mello reminding Izetbegović at a meeting of his obligation to make it public that the $\mathrm{ABiH}$ had targeted the airport on 18 August).

11542 P1638 (Witness statement of Michael Rose dated 26 March 2009), para. 136.

11543 P1638 (Witness statement of Michael Rose dated 26 March 2009), para. 136; P1669 (UNPROFOR report re meeting with Nikola Koljević and Milan Gvero, 13 August 1994); P820 (Witness statement of David Harland dated 4 September 2009), paras. 126-127; P2451 (Witness statement of Anthony Banbury dated 19 May 2009), paras. 28-32; P2465 (UNPROFOR report, 28 June 1994); P2123 (UNPROFOR letter to ABiH, 15 July 1994).
} 
14 August, the Anti-sniping Agreement was signed at Sarajevo airport under which both sides agreed to issue, within the next 24 hours, orders explicitly forbidding sniping activities against military personnel, civilians, and UN personnel. ${ }^{11544}$ Dragomir Milošević issued such an order to the SRK units on 18 August, instructing all the troops to immediately stop sniping activities and activities from other weapons. ${ }^{11545}$ There was a marked effect after this agreement was signed as the sniping incidents stopped almost immediately and went down from about 100 per week to about 10 per week; this lasted for about one month before a gradual increase in incidents occurred once again. ${ }^{11546}$ Also in mid-August, the $\mathrm{UN}$ reported that the $\mathrm{ABiH}$ was violating the cease-fire agreement by firing on the SRK from within the TEZ. ${ }^{11547}$

3596. On 19 August, at a meeting with Rose, Mladić, Tolimir, Koljević, Krajišnik, and Buha, the Accused explained that the Airport Routes had been closed not to stop the delivery of humanitarian aid to Sarajevo but to prevent the smuggling of black market goods and weapons. ${ }^{11548} \mathrm{He}$ also stated that he would not consider reopening them until the Bosnian Muslims released all Bosnian Serb POWs, and that he would close them for 30 days for every Bosnian Serb killed by sniping in Sarajevo. ${ }^{11549}$ Nevertheless, according to Rose, there was an improved flow of aid to Sarajevo following the Anti-Sniping Agreement. ${ }^{11550}$ The civilian population had also been growing food in

11544 P1638 (Witness statement of Michael Rose dated 26 March 2009), para. 139-140 (on the Bosnian Serb side, the agreement was signed by Koljević and Dragomir Milošević); P820 (Witness statement of David Harland dated 4 September 2009), paras. 129-131; P861 (UNPROFOR report re agreement on elimination of sniping in Sarajevo, 14 August 1994); P862 (Letter from UNPROFOR to Romanija Corps, 17 August 1994) (indicating that the SRK did not agree to having anti-sniping teams on its side); P1617 (Report from SRK SecurityIntelligence Organ to SRK Command, 15 August 1994); P1818 (Witness statement of Adrianus van Baal dated 26 October 2010, paras. 54-55; P5906 (Witness statement of KDZ450 dated 17 January 2011), paras. 70, 104; P1996 (Witness statement of Martin Bell dated 8 March 2010), para. 95; P1762 (Witness statement of David Fraser dated 17 October 2010), pp. 40-41; Dragomir Milošević, T. 32827-32829, 32839(29 January 2013). See also Adjudicated Fact 2789.

11545 Dragomir Milošević, T. 32840-32841 (29 January 2013); P863 (Excerpt from SRK Order, 18 August 1994).

11546 P1638 (Witness statement of Michael Rose dated 26 March 2009), para. 141; Michael Rose, T. 7267 (5 October 2010); P820 (Witness statement of David Harland dated 4 September 2009), para. 133; David Harland, T. 2097 (7 May 2010); P2451 (Witness statement of Anthony Banbury dated 19 May 2009), para. 50; Dragomir Milošević, T. 32841-32842 (29 January 2013); P2447 (Witness statement of KDZ182), p. 35, KDZ182, T. 13040-13041 (9 March 2011). Between 14 August and 8 September 1994, UNPROFOR reported four sniping incidents in the city. See P864 (UNPROFOR report re violations of anti-sniping agreement, 12 September 1994); P1818 (Witness statement of Adrianus van Baal dated 26 October 2010, para. 57; P2414 (Witness statement of KDZ182), pp. 35-36 (under seal); KDZ182, T. 13040-13041 (9 March 2011); P1762 (Witness statement of David Fraser dated 17 October 2010), pp. 42-43; P1773 (UNPROFOR report re efficacy of AntiSniping Agreement, 15 September 1994); Dragomir Milošević, T. 32841-32842 (29 January 2013) (testifying that SRK resumed sniping once the other side started opening sniping fire on them).

11547 D717 (UNPROFOR report re weapons collection points in Sarajevo, 16 August 1994), paras. 1-2; Adrianus van Baal, T. 8495-8496 (28 October 2010).

11548 D704 (UNPROFOR report re meeting with Radovan Karadžić, 19 August 1994), para. 11.

11549 D704 (UNPROFOR report re meeting with Radovan Karadžić, 19 August 1994), para. 11.

11550 Michael Rose, T. 7484, 7493 (7 October 2010). See also Michael Rose, T. 7429 (7 October 2010) (testifying that the UN managed to maintain a flow of aid throughout the conflict "in spite of all the difficulties that were placed in front of it”); P2457 (UNPROFOR Weekly BiH Political Assessment, 28 August 1994), para. 16. 
community and private gardens, which was sold in city shops at moderate prices. ${ }^{11551}$ However, there had been no progress on reopening the Airport Routes and consequently the city was receiving most of its supplies via the tunnel in Butmir. ${ }^{1552}$

3597. On 8 September 1994, in a meeting with the Accused, Koljević, and Zametica, UNPROFOR again called for the reopening of the Airport Routes. ${ }^{11553}$ The Accused agreed to consider a step-by-step process for opening the Airport Routes, starting with civilian traffic first, then humanitarian traffic, and then commercial traffic. ${ }^{11554}$ In the meantime, UNPROFOR was reporting that humanitarian flights were landing at Sarajevo airport and that UNHCR land convoys were delivering food; as a result, by 15 September, $100 \%$ of food needs in Sarajevo were met. ${ }^{11555}$ That same day, Brinkman of UNPROFOR protested to the ABiH over the opening of fire from $\mathrm{ABiH}$ positions at a convoy travelling on one of the open Blue Routes. ${ }^{11556}$

3598. By mid-September 1994, the quiet period came to an end as the $\mathrm{ABiH}$ forces launched an attack against the Bosnian Serb side on the Pale-Ilidža road which was easily repelled by the SRK but then led to the SRK blocking convoys into Sarajevo again. ${ }^{11557}$ The UN reported that the heaviest fighting since February 1994 erupted in Sarajevo on 18 September, with a large number of shells exchanged between the two sides; according to the UN report, the $\mathrm{ABiH}$ initiated the fighting by firing mortars from residential areas within the city while the SRK responded in a restrained manner. ${ }^{11558}$ Rose immediately wrote to both sides requesting them to immediately halt the

\footnotetext{
11551 P2457 (UNPROFOR Weekly BiH Political Assessment, 28 August 1994), para. 16.

11552 P2457 (UNPROFOR Weekly BiH Political Assessment, 28 August 1994), para. 2. Regarding this tunnel, see para. 3782.

11553 D1136 (UNPROFOR report, 9 September 1994), para. 5.

11554 D1136 (UNPROFOR report, 9 September 1994), para. 5. See also D1162 (UNPROFOR report, 14 September 1994), p. 2 (reporting that Muratović and Koljević endorsed this proposal in a meeting on 14 September 1994).

11555 D1173 (UNPROFOR report, 9 September 1994), pp. 7-8; D1164 (UNPROFOR report, 15 September 1994), p. 3; Anthony Banbury, T. 13481, 13512 (16 March 2011) (testifying that in September 1994 the supply of humanitarian aid to Sarajevo was "satisfactory"). Banbury explained that the airport was a "critical" source of humanitarian supplies for the civilian population, and that there were around eight to 15 UNHCR flights arriving in Sarajevo each day when the airport was operational. See Anthony Banbury, T. 13335 (15 March 2011), 13512 (16 March 2011); KDZ088, T. 6405-6406 (8 September 2010) (closed session) (testifying that an "exceptionally large number" of aircraft carrying humanitarian aid landed in Sarajevo throughout the conflict); Milenko Inđić, T. 32474 (22 January 2013) (testifying that there was somewhere between five to ten flights into Sarajevo airport each day); KDZ240, T. 16110 (5 July 2011) (closed session).

11556 D1165 (UNPROFOR protest to VRS, 15 September 1994); Anthony Banbury, T. 13482-13483 (16 March 2011).

11557 P820 (Witness statement of David Harland dated 4 September 2009), paras. 134-135; David Harland, T. $2227-$ 2231 (10 May 2010); P834 (UNPROFOR report re meetings with Bosnian Serb and Bosnian Muslim leadership, 20 September 1994); P1638 (Witness statement of Michael Rose dated 26 March 2009), para. 149; Michael Rose, T. 7256 (5 October 2010); David Fraser, T. 8102-8103 (19 October 2010); D773 (UNMO report, 19 September 1994); D777 (VRS Main Staff Order, 16 September 1994); D774 (UNPROFOR report re Sarajevo TEZ violations, 18 September 1994). According to KDZ450, this was the first attack by the ABiH that involved heavy weapons since the signing of the cease-fire. See KDZ450, T. 10598-10600 (19 January 2011).

11558 P1673 (UNPROFOR report re Sarajevo heavy weapons exclusion zone, 19 September 1994), paras. 1-3 (also reporting that this was an attempt by the $\mathrm{BiH}$ authorities to move Sarajevo to front page news and portray the
} 
military action and stop violating the TEZ. ${ }^{11559}$ Following the offensive, the supply of humanitarian aid was interrupted and the humanitarian situation deteriorated. ${ }^{11560}$ In a meeting on 20 September with Rose and in the presence of the Accused, Milovanović, and Koljević, Krajišnik stated that "it would be difficult to stop Serb soldiers from shooting at airplanes" if certain demands were not met, including that UNPROFOR formally recognise Bosnian Serb ownership of the airport, pay rent, and end the movement of Bosnian Muslim government delegations. ${ }^{11561}$ The Accused indicated that he wanted these demands included in an agreement which would supplement the Airport Agreement. ${ }^{11562}$

3599. On 21 September, the SRK reported that the ABiH had opened infantry, sniper, and some mortar fire on SRK positions on both that day and the preceding day. ${ }^{11563}$ On 22 September, following two sniping incidents in the city-one against a civilian and another against a UN soldier--Rose called for another air strike against a Bosnian Serb tank in the TEZ to the west of Sarajevo, which was followed by a Bosnian Serb attack on an UNPROFOR tank, wounding the driver. ${ }^{11564}$ In a meeting with the UN the next day, Mladić demanded an apology and told General David Fraser, who was in Sarajevo from April 1994 to May 1995 working as an assistant to the UNPROFOR commander of Sector Sarajevo, ${ }^{11565}$ that no convoy would pass through the Bosnian Serb territory without an apology; this materialised on the ground as all Serb check-points were closed for larger vehicles. ${ }^{11566}$ This decision of the VRS Main Staff to stop the movement of all

SRK as the aggressor shelling indiscriminately into civilian areas); D775 (SRK combat report, 19 September 1994). See also Michael Rose, T. $7563-7566$ (8 October 2010); P1762 (Witness statement of David Fraser dated 17 October 2010), pp. 65-66; David Fraser, T. 8106-8108 (19 October 2010); P5906 (Witness statement of KDZ450 dated 17 January 2011), para. 110; KDZ450, T. 10624-10627 (20 January 2011).

11559 P1638 (Witness statement of Michael Rose dated 26 March 2009), para. 149; P1673 (UNPROFOR report re Sarajevo heavy weapons exclusion zone, 19 September 1994), e-court pp. 3-4. Rose also had a meeting with Izetbegović in which the latter explained that the attack was in response to SRK sniping. See P1638 (Witness statement of Michael Rose dated 26 March 2009), para. 150.

11560 Michael Rose, T. 7484 (7 October 2010), T. 7604-7605 (8 October 2010).

11561 P834 (UNPROFOR report re meetings with Bosnian Serb and Bosnian Muslim leadership, 20 September 1994), para. 4.

11562 P834 (UNPROFOR report re meetings with Bosnian Serb and Bosnian Muslim leadership, 20 September 1994), para. 4.

11563 D776 (SRK combat report, 21 September 1994).

11564 P1638 (Witness statement of Michael Rose dated 26 March 2009), para. 152; Michael Rose, T. 7566-7569 (8 October 2010); D719 (Letter from Manojlo Milovanović to UNPROFOR, 23 September 1994); P1762 (Witness statement of David Fraser dated 17 October 2010), pp. 66-67; David Fraser, T. 8114 (19 October 2010); P5906 (Witness statement of KDZ450 dated 17 January 2011), para. 113; KDZ450, T. 1062910631 (20 January 2011); P2127 (UNPROFOR report re air strike, 22 September 1994); P2128 (Extract from UNPROFOR logbook, 22 September 1994) (under seal); P2129 (UNPROFOR letter to Ratko Mladić, 24 September 1994). This was preceded by the ABiH opening fire on SRK-held areas in the preceding two days.

11565 Fraser worked for two different Sector Sarajevo commanders during his time in Sarajevo, first for General Andre Sobirou and then for General Herve Gobilliard. See P1762 (Witness statement of David Fraser dated 17 October 2010), pp. 4-5.

11566 P1762 (Witness statement of David Fraser dated 17 October 2010), p. 67; D719 (Letter from Manojlo Milovanović to UNPROFOR, 23 September 1994). 
humanitarian organisations in the territory of the RS led the RS Minister of Health to draft a complaint to the Main Staff noting a shortage of medical supplies and humanitarian aid in RS territory. ${ }^{11567}$ On 25 September, Mladić informed UNPROFOR, via a liaison officer, that the safety of aircraft flying into Sarajevo airport could no longer be guaranteed; consequently, flights into Sarajevo were suspended. ${ }^{11568}$

3600. On 2 October 1994, in a meeting with the Accused, Zametica, Tolimir, Koljević, Krajišnik and Buha, De Mello insisted on reopening Sarajevo airport for humanitarian flights but the Accused reiterated his position that the airport would not reopen until the Airport Agreement was renegotiated and that the Airport Routes would remain closed until all Bosnian Serb POWs in Tarčin were released. ${ }^{11569}$ However, he agreed to re-establish freedom of movement for humanitarian convoys travelling on the other Blue Routes. ${ }^{11570}$ During a subsequent meeting on 5 October 1994, which was also attended by Akashi and Rose, Akashi agreed to ask the UN headquarters if there was any way to acknowledge that UNPROFOR "took over" the airport from the Bosnian Serbs in return for which the Bosnian Serbs would reopen Sarajevo airport to both UNPROFOR and UNHCR flights. ${ }^{11571}$

3601. On 6 October 1994, the ABiH conducted an operation on Mt. Igman, going through the DMZ and killing a number of SRK soldiers and four Serb nurses located there; it also established positions in the area, contrary to the August 1993 agreement. ${ }^{11572}$ As a result, in the days that

11567 D3873 (Aide mémoire of RS Minister of Health, 2 October 1994); Radovan Radinović, T. $41608-41611$ (19 July 2013) (testifying that the VRS was more restrictive than the politicians when it came to the issue of humanitarian convoys).

11568 P6272 (UNPROFOR report, 27 September 1994), para. 3; P1638 (Witness statement of Michael Rose dated 26 March 2009), para. 152; D3500 (UNPROFOR report, 7 October 1994), para. 15 (the Accused and Mladić acknowledging at a meeting with UNPROFOR that the airport was closed in response to the NATO air strikes).

11569 P4866 (UNPROFOR report, 2 October 1994), paras. 5-7.

11570 P4866 (UNPROFOR report, 2 October 1994), para. 5.

11571 D3500 (UNPROFOR report, 7 October 1994), paras. 13, 16 (reporting also that Mladić and Krajišnik stated that if their demands were not met, they would consider closing the airport again); Yasushi Akashi, T. 37716-37718 (24 April 2013).

11572 P820 (Witness statement of David Harland dated 4 September 2009), para. 142; P1638 (Witness statement of Michael Rose dated 26 March 2009), para. 155; P867 (UNPROFOR report on meeting with Ratko Mladić, 10 October 1994); Michael Rose, T. $7572-7579$ (8 October 2010); D721 (Letter from General Rose to Ejup Ganić, 16 October 1994); D722 (UNPROFOR report re letter from Ambassador Sacirbey, 19 October 1994); P2447 (Witness statement of KDZ182), p. 57; P2414 (Witness statement of KDZ182), pp. 90-91 (under seal); KDZ182, T. 13095-13098 (9 March 2011); P2439 (UNPROFOR report re Mount Igman incident, 8 October 1994); P2440 (UNPROFOR report re Mount Igman incident, 7 October 1994); D1120 (AFP daily report entitled "UN Believes Bosnians Attacked Serbs from DMZ", 13 October 1994); P1762 (Witness statement of David Fraser dated 17 October 2010), pp. 67-69; David Fraser, T. 8152-8153 (19 October 2010); D783 (Map of Mt. Bjelašnica and Mt. Treskavica area with confrontation lines, 1994); D2783 (UNPROFOR Memo, 6 October 1994). See also D3500 (UNPROFOR report, 7 October 1994), para. 6 (indicating that Mladić and the Accused met with Akashi the day before this incident and Mladić referred to the $\mathrm{ABiH}$ troops leaving Sarajevo through the Butmir tunnel and launching attacks on Mt. Igman). 
followed, the SRK opened sniper fire on Sarajevo and shelled the city, targeting civilians. ${ }^{11573}$ Having lodged a strong protest with the $\mathrm{ABiH}$, Rose also had a meeting with Mladić and Tolimir on 10 October in which Mladić threatened to operate against Sarajevo and restrict the freedom of movement of the UN if $\mathrm{ABiH}$ units were not cleared out of the DMZ. ${ }^{11574}$ On 8 October, a tram was shot at on Zmaja od Bosne street, resulting in casualties. ${ }^{11575}$ On 27 October, Milošević issued a warning to SRK units, stating that the "enemy does not respect any rules or principles of humanity" and that even though the SRK tried to "obey all Geneva conventions until now [...] if the enemy continues in the same way, they will force us that as of today we respond on [sic] every bullet fired [...] by firing at the selected target under the Muslim control in Sarajevo". ${ }^{1576}$ On 31 October, foreign media reported that $\mathrm{ABiH}$ forces had opened fire at UN planes at Sarajevo airport, but that the airlift had not been suspended. ${ }^{11577}$

3602. By November 1994, the ABiH forces were still positioned on Mt. Igman and launched an offensive from there, targeting both Bosnian Serbs and one UNPROFOR observation post. ${ }^{11578}$ According to Rose, this did not result in NATO air strikes because by that time NATO was no longer willing to launch strikes against the Bosnian Muslims. ${ }^{11579}$

11573 Michael Rose, T. 7272 (5 October 2010); P2447 (Witness statement of KDZ182), p. 57; P2414 (Witness statement of KDZ182), pp. 58-59, 61 (under seal); KDZ182, T. 13098-13102 (9 March 2011). See also P1487 (Ratko Mladić's notebook, 4 September 1994-29 January 1995), pp. 101-102. Following the ABiH attack on Mt. Igman, UNPROFOR attempted to get the parties to sign a number of follow up agreements to the antisniping agreement of 14 August 1994 and the cease-fire agreement of 9 February 1994 but was not successful. See P2447 (Witness statement of KDZ182), pp. 61-62; P2422 (Amendment to Anti-Sniping Agreement, October 1994); P2423 (Appendix I and II to Cease-fire Agreement); P2424 (Cease-fire Agreement, October 1994); KDZ182, T. 13107-13108 (10 March 2011); D1122 (UNPROFOR report, 20 November 1994) (under seal).

11574 P1762 (Witness statement of David Fraser dated 17 October 2010), pp. 68-69 (testifying that Mladić threatened to act against the city). But see P867 (UNPROFOR report on meeting with Ratko Mladić, 10 October 1994), para. 2; P1638 (Witness statement of Michael Rose dated 26 March 2009), para. 155; P820 (Witness statement of David Harland dated 4 September 2009), para. 143.

11575 See discussion on Scheduled Incident F.11.

11576 Later in the report Milošević forbids any "devious killing, injuring or capturing" that is not in accordance with the Geneva Conventions and international law. See D2812 (Warning of SRK command, 27 October 1994); Dragomir Milošević ,T. 32735-32737 (28 January 2013).

11577 D1121 (AFP daily report entitled "UN: Government Forces Fire on Planes at Airports", 31 October 1994); KDZ182, T. 13102-13103 (9 March 2011), T. 13108-13109 (10 March 2011).

11578 P1638 (Witness statement of Michael Rose dated 26 March 2009), paras. 157-158, 160; P1676 (UNPROFOR report re discussions with Radovan Karadžić and Ejup Ganić, 23 October 1994); Michael Rose, T. 7580-7581 (8 October 2010); D723 (UNPROFOR report re demilitarised zone violations by ABiH, 29 October 1994), ecourt pp. 1-4, 9; D162 (Michael Rose's book entitled "Fighting for Peace: Bosnia, 1994"), pp. 188, 191 (indicating that Izetbegović was directly responsible for not withdrawing the troops from Mt. Igman); P1776 (UNPROFOR report re meeting with Radovan Karadžić and General Tolimir, 20 November 1994); P2426 (UNPROFOR report re meeting between Hervé Gobilliard and Dragomir Milošević, 23 November 1994); D1121 (AFP daily report entitled "UN: Government Forces Fire on Planes at Airports", 31 October 1994); P1762 (Witness statement of David Fraser dated 17 October 2010), pp. 68-70; D2797 (SRK combat report, November 1994).

11579 Michael Rose, T. 7581, 7591 (8 October 2010). 
3603. On 17 November, Dragomir Milošević informed UNPROFOR that the SRK was imposing additional measures on convoy movement, including the inspection of all humanitarian convoys crossing SRK frontlines. ${ }^{11580}$ On 18 November, a woman and her seven year old son were shot at while walking on Zmaja od Bosne street, resulting in the death of the boy and injuries to the woman. ${ }^{11581}$ On 19 November, Gobilliard met with the Accused and Krajišnik, among others, and the Accused threatened that if the $\mathrm{ABiH}$ continued to fire from within the TEZ, the Bosnian Serbs would retaliate. ${ }^{11582}$ The situation in Sarajevo deteriorated and the number of reported cease-fire violations increased, although, according to Rose, that number was exaggerated as the civilian casualties in fact decreased. ${ }^{11583}$ At the same time, however, there was a "total halt" in the movement of convoys, the volume of humanitarian supplies was very low, and the arrival of humanitarian flights depended on the good will of the Bosnian Serbs; the Sarajevo population was being "strangled" as the Bosnian Serbs wanted to apply as much pressure on the city as possible before the winter set in. ${ }^{1584}$ On 23 November, a tram was shot at while travelling on Zmaja od Bosne street, resulting in the wounding of two women. ${ }^{11585}$

3604. At the beginning of December 1994, the SRK shelled Sarajevo's downtown area with wireguided missiles from within the TEZ. ${ }^{1586}$ On 5 December, at a meeting between Rose and Andreev on one side and Gvero and Tolimir on the other, Gvero connected the opening of the airport to assurances from NATO that it would not bomb targets in Bosnian Serb territory. ${ }^{11587}$ The

\footnotetext{
11580 P2425 (From SRK to UNPROFOR, 17 November 1994).

11581 See discussion on Scheduled Incident F.12.

11582 P1762 (Witness statement of David Fraser dated 17 October 2010), p. 70; P1776 (UNPROFOR report re meeting with Radovan Karadžić and General Tolimir, 20 November 1994), p. 1.

11583 P2451 (Witness statement of Anthony Banbury dated 19 May 2009), para. 69; David Fraser, T. 8118-8121 (19 October 2010); D778 (UNPROFOR report, 17 November 1994); P2454 (UNPROFOR report, 19 November 1994); P1638 (Witness statement of Michael Rose dated 26 March 2009), para. 168 (also testifying that the $\mathrm{ABiH}$ would fire into the air in this period in order to increase the tension around Sarajevo); D162 (Michael Rose's book entitled "Fighting for Peace: Bosnia, 1994"), p. 197; Michael Rose, T. 7485 (7 October 2010); P2414 (Witness statement of KDZ182), pp. $47-48$ (under seal); P2419 (VRS Main Staff Order, 6 November 1994); P2420 (Report of $2^{\text {nd }}$ Light Infantry Brigade re VRS Main Staff order, 7 November 1994); D2823 (SRK combat report, 6 November 1994).

11584 P2414 (Witness statement of KDZ182), pp. 27, 28 (under seal); P2447 (Witness statement of KDZ182), p. 62 (adding that the $\mathrm{ABiH}$ wanted to gain territory also before the winter set in); P2425 (From SRK to UNPROFOR, 17 November 1994) (in which Dragomir Milošević informed UNPROFOR that that the SRK would strictly control the crossings of the frontlines by UNPROFOR and humanitarian organisations).

11585 See discussion on Scheduled Incident F.14.

11586 P820 (Witness statement of David Harland dated 4 September 2009), paras. 151-152, 157; P1638 (Witness statement of Michael Rose dated 26 March 2009), para. 183; P870 (UNPROFOR daily report, 1 December 1994), p. 3; P872 (UNPROFOR Weekly Situation Report, 10 December 1994), p. 5; P2427 (UNPROFOR protest letter to SRK, 2 December 1994) (complaining about the attack and indicating that the projectiles landed at the Presidency, the Ministry of Interior, and a cinema); P2447 (Witness statement of KDZ182), pp. 67-68; KDZ182, T. 13178-13179 (10 March 2011).

11587 P2456 (UNPROFOR report, 5 December 1994), para. 5; P2451 (Witness statement of Anthony Banbury dated 19 May 2009), para. 75 (to Banbury this indicated the Accused's ability to control access to the airport). Gvero repeated this statement on 10 December at another meeting with the UN. See P872 (UNPROFOR Weekly Situation Report, 10 December 1994), p. 2,
} 
effectiveness of the WCPs began to deteriorate and on 6 December VRS members forcibly removed a number of weapons from various sites around Sarajevo. ${ }^{11588}$ On 8 December, Andreev wrote to the Accused protesting the Bosnian Serb forces' refusal to provide the necessary security guarantees for UNPROFOR and UNHCR flights into Sarajevo airport. ${ }^{11589}$ On 10 December, UNPROFOR reported that the first convoys in almost a month had arrived in Sarajevo. ${ }^{11590}$ On 12 December, Rose met with Krajišnik, Koljević, Gvero, and Tolimir and told the participants at this meeting that the "endless bureaucracy and checks" of the convoys were unacceptable. ${ }^{11591}$ They, in turn, gave assurances that regular convoys would run until a more permanent agreement on convoy procedures was reached. ${ }^{11592}$ According to Banbury, around mid-December, the Bosnian Serbs eased restrictions on freedom of movement in order to come across as the more reasonable party in peace negotiations with President Carter. ${ }^{11593}$

3605. On 22 December, a shelling incident took place in the Old Town of Sarajevo, in Baščaršija, resulting in a number of casualties. ${ }^{11594}$

3606. On 31 December 1994, the COHA was signed under the auspices of Jimmy Carter, followed by the agreement on its implementation signed on 11 January 1995; it was to last for an initial period of four months, subject to renewal by the parties. ${ }^{11595}$ As part of this agreement, the parties also agreed to provide full freedom of movement to UNPROFOR and UNHCR for the

\footnotetext{
11588 P1638 (Witness statement of Michael Rose dated 26 March 2009), para. 180; P2414 (Witness statement of KDZ182), pp. 27-28 (under seal).

11589 P2475 (UNPROFOR letter to Radovan Karadžić, 8 December 1994), p. 2; P2451 (Witness statement of Anthony Banbury dated 19 May 2009), para. 78.

11590 P872 (UNPROFOR Weekly Situation Report, 10 December 1994), p. 5; P820 (Witness statement of David Harland dated 4 September 2009), para. 156.

11591 P1638 (Witness statement of Michael Rose dated 26 March 2009), para. 182; P1640 (UNPROFOR report, 12 December 1994), paras. 3, 9; P2476 (UNPROFOR report, 13 December 1994); P2451 (Witness statement of Anthony Banbury dated 19 May 2009), paras. 79-83.

11592 P2476 (UNPROFOR report, 13 December 1994), paras. 5-6; P1640 (UNPROFOR report, 12 December 1994), para. 3.

11593 P2453 (UNPROFOR report, 15 December 1994), paras. 2(d), 3, 5; P2451 (Witness statement of Anthony Banbury dated 19 May 2009), paras. 84-85 (stating that this was an example of the Accused being able to "turn the pressure on and off as he pleased"); Anthony Banbury, T. 13321-13323 (15 March 2011). Yasushi Akashi testified that both the Bosnian Serbs and the Bosnian Muslims viewed humanitarian aid as "something very political and militarily significant" and that both sides interfered with humanitarian aid. See Yasushi Akashi, T. 37767-37768 (25 April 2013); D3489 (Excerpt from Yasushi Akashi's book entitled "In the Valley between War and Peace"), p. 16.

11594 See discussion on Scheduled Incident G.9.

11595 P1648 (Agreement on Cessation of Hostilities, 31 December 1994); P2428 (UNPROFOR report, 1 January 1995); P820 (Witness statement of David Harland dated 4 September 2009), paras. 158, 160-161 (testifying also that this agreement on implementation was never really implemented as all sides had other plans); P873 (Ceasefire Agreement, 11 January 1995); P874 (UNPROFOR report re cease-fire agreement, 11 January 1995); Rupert Smith, T. 11298 (8 February 2011), T. 11841 (15 February 2011); P1638 (Witness statement of Michael Rose dated 26 March 2009), para. 186-188, 190-194; KDZ182, T. 13183 (10 March 2011) (also testifying that nether side complied with the agreement in its entirety); Yasushi Akashi, T. 37674, 37723-37726 (24 April 2013); D3503 (UNPROFOR fax, 19 December 1994); D3504 (UNPROFOR fax, 20 December 1994); D3505 (Letter from Yasushi Akashi to Radovan Karadžić, 24 December 1994). See also para. 410.
} 
delivery of humanitarian aid resulting in the re-opening of the Blue Routes, including the Airport Routes. ${ }^{11596}$ As a result, the situation in Sarajevo improved, and January and February 1995 were relatively peaceful. ${ }^{11597}$ There was also a substantial improvement in the humanitarian situation and more than 5,000 people were using the Airport Routes daily. ${ }^{11598}$

3607. Yet, towards the end of February 1995 there was an increase in sniping incidents in the city, including the sniping of civilians. ${ }^{11599}$ On 27 February, a tram was shot at while travelling on Zmaja od Bosne street, resulting in a number of casualties. ${ }^{1600}$ In March the situation deteriorated in other parts of $\mathrm{BiH}$, and the $\mathrm{COHA}$ was beginning to collapse, largely due to $\mathrm{ABiH}$ activities, which then led to the resumption of sniping and shelling in Sarajevo on a regular basis. ${ }^{1601}$ On 3 March, another tram on Zmaja od Bosne street was shot at, resulting in casualties, while Tarik Žunić, a 14 year old boy, was shot at in the Sedrenik area while walking home from school. ${ }^{1602}$ On 5 March, Mladić told General Rupert Smith, commander of UNPROFOR BiH Command, ${ }^{11603}$ that the SRK's increase in sniping in Sarajevo was in response to Serb casualties suffered in the military offensives launched by the $\mathrm{ABiH}$, which to Smith was an explicit recognition that sniping was used by the SRK as a punitive measure rather than for any military gain. ${ }^{1604}$ On 8 March

\footnotetext{
11596 See para. 410.

11597 Anthony Banbury, T. 13314-13315 (15 March 2011); D1018 (UNPROFOR letter to Nikola Koljević, 4 February 1995) (indicating Smith's intention to open airport routes to civilian traffic); Martin Bell, T. 9903, 9906-9907 (15 December 2010); KDZ182, T. 13183 (10 March 2011).

11598 D1166 (UNPROFOR Weekly Situation Report, 18 February 1995), p. 2; Anthony Banbury, T. 13314-13315 (15 March 2011), T. $13488-13489$ (16 March 2011); D1124 (UNPROFOR report, 7 April 1995), para. 5; KDZ182, T. 13109-13111, 13183 (10 March 2011); P2478 (UNPROFOR Weekly Situation Report (Sarajevo), 4 March 1995), para. 19; P2455 (UNPROFOR Weekly Situation Report (Sarajevo), 11 March 1995), para. 10 (adding that the airport was closed to humanitarian flights on 7 March and 11 March after planes were hit by gunfire); D1123 (UNPROFOR report on the implementation of COHA during March 1995), p. 4; P2480 (Minutes of Kiseljak's Civil Affairs monthly meeting, 21 March 1995); Vladimir Radojčić, T. 31278 (12 December 2012) (recalling that after cease-fires were signed more humanitarian aid would arrive in Sarajevo). But see D2287 (UNPROFOR daily report, 9 February 1995), p. 1 (reporting that Bosnian Serb forces had rejected "a lot" of convoy requests for the following day and that this posed a "real threat" to UNPROFOR's freedom of movement).

11599 Rupert Smith, T. 11310, 11331 (8 February 2011), T. 11461-11463 (9 February 2011).

11600 See discussion on Scheduled Incident F.15.

11601 P2451 (Witness statement of Anthony Banbury dated 19 May 2009), paras. 91-92; P2478 (UNPROFOR Weekly Situation Report (Sarajevo), 4 March 1995); Anthony Banbury, T. 13315 (15 March 2011); P820 (Witness statement of David Harland dated 4 September 2009), paras. 164-167; P876 (UNPROFOR Memo re meeting with Ratko Mladić, 6 March 1995); Rupert Smith, T. 11309-11310, 11329-11331 (8 February 2011), T. 11461-11463 (9 February 2011), T. 11583-11592 (10 February 2011); D1019 (Ratko Mladić letter to UNPROFOR, 11 February 1995); D1020 (Ratko Mladić letter to UNPROFOR, 13 February 1995); D1023 (Ratko Mladić letter to UNPROFOR, 24 February 1995); D1024 (Ratko Mladić letter to UNPROFOR, 3 March 1995); P1470 (UNPROFOR report re meeting with Ratko Mladić, 5 March 1995), para. 6; P2255 (UNPROFOR report re meetings with Bosnian Serb and Bosnian Muslim leadership, 14 March 1995), e-court p. 6; P2429 (UNPROFOR report, 21 March 1995); D1124 (UNPROFOR report, 7 April 1995), para. 5(c).

11602 See discussion on Scheduled Incidents F.16 and F.17.

11603 Rupert Smith, T. 11296-11298 (8 February 2011).

11604 Rupert Smith, T. 11309-11311 (8 February 2011); P1470 (UNPROFOR report re meeting with Ratko Mladić, 5 March 1995), para. 3; P2451 (Witness statement of Anthony Banbury dated 19 May 2009), paras. 94-95;
} 
1995, Directive 7 was signed by the Accused, ordering the SRK to, among other things, prevent the lifting of the blockade of Sarajevo "from without" by using "decisive defence". ${ }^{1605}$ As a result, the conditions in Sarajevo deteriorated with an alarming upsurge in military activity, including a substantial increase in sniping activities against civilians causing the tram service to be stopped. ${ }^{11606}$ In this period, Grbavica was sniped by the ABiH, resulting in the deaths of two Serb girls; this in turn led to increased shelling in Sarajevo and prompted the Accused to close the Blue Routes. ${ }^{1607}$ Thus, on 12 March 1995, the city was subjected to the heaviest shelling since September 1994, while the number of sniping casualties in the period up to 18 March was the highest since August 1994. ${ }^{11608}$ According to Smith, the bulk of the shelling and sniping in this period came from the Bosnian Serb side and, in his view, was aimed at harassing the population at large. ${ }^{11609}$ On 14 March, Akashi met with the Accused, Mladić, Krajišnik, and Koljević, and the Accused reiterated the Bosnian Serb policy that the Airport Routes would close for one month for every Bosnian Serb killed by sniping in Sarajevo. ${ }^{11610}$ Subsequent attempts to negotiate the reopening of the Airport Routes failed. ${ }^{11611}$ On 25 March 1995, Smith met with Koljević who

P2455 (UNPROFOR Weekly Situation Report (Sarajevo), 11 March 1995), para. 9; Anthony Banbury, T. 13330-13331 (15 March 2011).

11605 P838 (Directive 7, 8 March 1995), pp. 7, 11-12. While the English translation of P838 refers to the lifting of the "siege" on page 7, the Chamber recalls the CLSS memorandum attached to D235 and the explanation therein as to how the BCS word "deblokada" (which is used on page 7 of P838) should be translated. The memorandum provides that the accurate translation is the "lifting of the blockade". See D235 (Directive 3, 3 August 1992). Accordingly, the Chamber considers that the reference to the "siege" in the English translation of P838, page 7, is inaccurate and has therefore used the term "lifting of the blockade" in the text above.

11606 P820 (Witness statement of David Harland dated 4 September 2009), paras. 169-171; P878 (UNPROFOR report re cease-fire agreement, 29 March 1995), para. 1.

11607 P820 (Witness statement of David Harland dated 4 September 2009), para. 171; P879 (VRS Main Staff Report, 11 March 1995); David Harland, T. $2099-2100$ (7 May 2010); Rupert Smith, T. 11329-11337 (8 February 2011), T. 11592-11594 (10 February 2011); P2256 (SRK combat report, 12 March 1995); P2257 (UNPROFOR Weekly Situation Report, 18 March 1995), para. 7; D1123 (UNPROFOR Report on the implementation of the Cessation of Hostilities Agreement During March 1995); Yasushi Akashi, T. 37730 (24 April 2013); D3509 (UNPROFOR report, 12 March 1995), paras. 1, 4; P2451 (Witness statement of Anthony Banbury dated 19 May 2009), para. 100; John Zametica, T. 42462 (29 October 2013); Dragomir Milošević, T. 33227-33228 (5 February 2013) (testifying that he could not recall this action but could not "exclude the possibility" that it took place).

11608 P2257 (UNPROFOR Weekly Situation Report, 18 March 1995), paras. 6-8; P2451 (Witness statement of Anthony Banbury dated 19 May 2009), paras. 99-101; Rupert Smith, T. 11332-11334, 11337-11338 (8 February 2011).

11609 Rupert Smith, T. 11333-11334 (8 February 2011). See also P2479 (UNPROFOR report, 14 March 1995), para. 3 (listing the Accused and Mladić's complaints to the UN about the Muslim and Croat offensives in BiH in breach of the COHA).

11610 P2255 (UNPROFOR report re meetings with Bosnian Serb and Bosnian Muslim leadership, 14 March 1995), p. 7; P2479 (UNPROFOR report, 14 March 1995), para. 6; Rupert Smith, T. 11335 (8 February 2011); P2451 (Witness statement of Anthony Banbury dated 19 May 2009), para. 98.

11611 P2258 (UNPROFOR report re meeting with Nikola Koljević, 27 March 1995), para. 5 (recounting a meeting with Koljević in which he stated that the policy of closing the airport for every Bosnian Serb killed by sniping was necessary to thwart the efforts of the Bosnian Muslims to force the Bosnian Serbs from Sarajevo); Rupert Smith, T. 11339 (8 February 2011). At a meeting on 5 April 1995, Koljević stated that another Bosnian Serb man had been killed by sniper fire, which meant that the Airport Routes had to close for a total of 90 days. See P2451 (Witness statement of Anthony Banbury dated 19 May 2009), para. 119; P2484 (UNPROFOR report, 5 April 1995), para. 5; P2485 (Anthony Banbury's notes, 5 April 1995), e-court p. 3. 
openly admitted that the Bosnian Serb side's intention now was to pursue the end of the war through military means; in Smith's view, given that the Serbs lacked manpower, they were going to do this by relying on fire-power. ${ }^{11612}$ By the end of March, there was a widespread resumption of fighting in Sarajevo. ${ }^{11613}$ On 29 March, UNPROFOR reported that an increase in Bosnian Serb firing at UN aircraft at Sarajevo airport led to the suspension of flights between 17 and 24 March. ${ }^{11614}$

3608. By April 1995 it became clear that the peace talks were going nowhere as a result of which the COHA was no longer operative, the TEZ was being violated by both sides, and the situation in Sarajevo escalated with a daily average of firing incidents close to $1,000 .{ }^{11615}$ On 5 April, the Accused indicated to Smith that a decision had been made to start a counter-offensive and that the Bosnian Serb Forces would employ weapons they had not used yet. ${ }^{11616}$ On 7 April, a modified air bomb exploded in Hrasnica inflicting civilian casualties. ${ }^{11617}$ On 8 April, the Bosnian Serbs halted the humanitarian airlift, alleging that the UN was violating the Airport Agreement by smuggling arms to the $\mathrm{ABiH}$ and subsequent attempts to negotiate the reopening of the airport failed. ${ }^{11618}$ In

11612 P2258 (UNPROFOR report re meeting with Nikola Koljević, 27 March 1995), paras. 1-2; Rupert Smith, T. 11338-11340 (8 February 2011). According to Smith, the same was the case with the Bosnian Muslim side. In his view, at this stage both sides wanted to resolve the situation through military means and not through negotiations. See Rupert Smith, T. 11342-11343 (8 February 2011), T. 11593-11595 (10 February 2011); P2248 (Radovan Karadžić's Order to RS Government, VRS Main Staff, and Presidents of Municipalities, 26 March 1995).

11613 P1996 (Witness statement of Martin Bell dated 8 March 2010), para. 99; P2032 (BBC news report re targeting safe areas, with transcript); D182 (Order of ABiH 12 ${ }^{\text {th }}$ Division, 20 March 1995); P1778 (UNPROFOR report re meeting with General Milošević, 21 March 1995).

11614 P878 (UNPROFOR report re cease-fire agreement, 29 March 1995), para. 3; P820 (Witness statement of David Harland dated 4 September 2009), para.171; D1123 (UNPROFOR report on the implementation of the COHA during March 1995), para. 17.

11615 P2451 (Witness statement of Anthony Banbury dated 19 May 2009), para. 120; P2486 (UNPROFOR Weekly Situation Report (Sarajevo), 16 April 1995), paras. 1, 3-4; P2068 (Witness statement of Jeremy Bowen dated 10 August 2009), para. 51; P820 (Witness statement of David Harland dated 4 September 2009), para. 174; P882 (UNPROFOR Weekly Situation Report (Sarajevo), 14 April 1995), pp. 1-2; Rupert Smith, T. 11341 (8 February 2011); P1996 (Witness statement of Martin Bell dated 8 March 2010), para. 39; P2011 (Video footage of Sarajevo, with transcript); P2414 (Witness statement of KDZ182), p. 52 (under seal); KDZ182, T. 1305413055, 13057-13058 (9 March 2011), T. 13185-13186 (10 March 2011); D1117 (UNPROFOR protest letter to Rasim Delić, 26 April 1995); P2442 (UNPROFOR letter re heavy weapon violations in safe areas, 26 April 1995).

11616 Rupert Smith, T. 11344-11346 (8 February 2011); P2260 (UNPROFOR report re meeting with Radovan Karadžić, 5 April 1995), paras. 9-10, 14.

11617 See discussion on Scheduled Incident G.10.

11618 P820 (Witness statement of David Harland dated 4 September 2009), para. 173. On 19 April 1995, in a meeting between Smith, Aguilar, Harland, Krajišnik, Mandić, and Stanišić, Krajišnik stated that he agreed "in principle" to the resumption of the humanitarian airlift, but that the details were in the hands of Koljević, who was in charge of humanitarian aid. See P881 (David Harland's note re meeting in Pale on Sarajevo Airport, 20 April 1995), p. 2; P820 (Witness statement of David Harland dated 4 September 2009), para. 173. At another meeting with Mandić on 26 April 1995, Harland sought assurances that security guarantees would be provided for flights carrying UN civilians and UNHCR flights, but these assurances were never provided. See P884 (David Harland's note re discussions in Pale on Sarajevo airport, 26 April 1995), p. 1; P820 (Witness statement of David Harland dated 4 September 2009), para. 176. 
mid-April, two members of UNPROFOR were killed by sniper fire. ${ }^{11619}$ On 21 April, Akashi and Smith met with both sides separately to negotiate an extension of the COHA; however, while both sides expressed a desire to extend it, they demanded that it be done on their terms so no mutual agreement was reached. ${ }^{11620}$ According to Akashi, while the Bosnian Serbs and Bosnian Croats were in favour of "some kind of continuation" of the COHA, the Bosnian Muslims were against it. $^{11621}$ During this meeting, the Accused told Akashi that the Airport Routes would remain closed as long as sniping against Bosnian Serbs continued. ${ }^{11622}$ Akashi and Smith had two more rounds of these meetings on 30 April and 1 May but no progress was made; afterwards, Smith reported that the Bosnian Muslim side refused the continuation of COHA but promised it would exercise restraint while the Bosnian Serb side unanimously decided to resolve the situation by military means. ${ }^{11623}$ At the meeting of 30 April, which was attended, among others, by Akashi, Smith, Janvier, Koljević, and Krajišnik, the Accused stated that the Bosnian Serbs would not uphold the Airport Agreement as long as the Anti-Sniping Agreement was not being upheld by the other side. ${ }^{11624}$ According to Harland, from this point there was no resumption of humanitarian airlift until the end of the war. ${ }^{11625}$ The Airport Routes also did not reopen until the end of the war. ${ }^{11626}$ Consequently, by May 1995, the humanitarian situation in Sarajevo was rapidly deteriorating. ${ }^{11627}$

11619 P820 (Witness statement of David Harland dated 4 September 2009), para. 172; P880 (UNPROFOR Memo re anti-sniping project, 24 April 1995); P1762 (Witness statement of David Fraser dated 17 October 2010), pp. 3436, 72; David Fraser, T. 8016-8017 (18 October 2010); Rupert Smith, T. 11333 (8 February 2011); D2907 (UNPROFOR report, 18 April 1995); P2414 (Witness statement of KDZ182), pp. 8, 42, $72-73$ (under seal); P2407 (Witness statement of KDZ304), p. 10; KDZ304, T. 10514-10515 (18 January 2011); P2011 (Video footage of Sarajevo, with transcript). While Harland, Fraser, KDZ304, and KDZ182 testified that one of those two French soldiers was killed by the SRK while erecting anti-sniping barriers, Edin Garaplija gave evidence that he was in fact shot by Nedžad Herenda, a member of the Bosnian Muslim Ševe unit. As discussed later, the Chamber considers this to be an accurate reflection of the events. The witnesses all agree that the other UN soldier shot in this period was shot by the $\mathrm{ABiH}$ in the area of Dobrinja. See para. 4505, fn. 15085.

11620 P2261 (UNPROFOR report re meetings with Bosnian Serb and Bosnian Muslim leadership, 22 April 1995), para. 1; Rupert Smith, T. 11347-11350 (8 February 2011), T. 11596-11599 (10 February 2011). See also P2489 (UNPROFOR Weekly Situation Report (Sarajevo), 24 April 1995), paras. 3-5.

11621 Yasushi Akashi, T. 37222 (24 April 2013).

11622 P2261 (UNPROFOR report re meetings with Bosnian Serb and Bosnian Muslim leadership, 22 April 1995), para. 10; Rupert Smith, T. 11348-11349 (8 February 2011).

11623 Rupert Smith, T.11352-11355 (8 February 2011), T.11601-11603 (10 February 2011); P2262 (UNPROFOR report re meetings with Bosnian Serb and Bosnian Muslim leadership, 30 April 1995), paras. 1-2, 4-5; P2263 (UNPROFOR report re meetings with Bosnian Serb and Bosnian Muslim leadership, 1 May 1995), pp. 3-4; D3511 (UNPROFOR report, 22 April 1995), para. 5; Yasushi Akashi, T. 37733-37735 (24 April 2013) (testifying that during their meeting he thought the Accused's position was non-compromising and that he was at that point ready to defy the international community).

11624 P2262 (UNPROFOR report re meetings with Bosnian Serb and Bosnian Muslim leadership, 30 April 1995), para. 11.

11625 P820 (Witness statement of David Harland dated 4 September 2009), para. 173.

11626 P2451 (Witness statement of Anthony Banbury dated 19 May 2009), para. 100.

11627 P820 (Witness statement of David Harland dated 4 September 2009), paras. 182-183; David Harland, T. 2217 (10 May 2010); P2407 (Witness statement of KDZ304), p. 33; P886 (UNPROFOR Weekly Situation Report (Sarajevo), 13 May 1995), p. 2; P2441 (UNPROFOR Weekly Situation Report (Sarajevo), 19 May 1995), p. 3. See also Adjudicated Facts 3088, 3089. 
3609. In response to Bosnian Serb mortar attacks on civilian areas of Sarajevo on 7 and 8 May 1995, Smith requested that NATO conduct air strikes but his request was denied; Smith informed the Accused of his reasons behind the request during their meeting on 9 May, at which point the Accused did not deny that civilian areas were attacked. ${ }^{11628}$ On 12 May, an ABiH offensive around Sarajevo started and the SRK suppressed the $\mathrm{ABiH}$ attacks displaying military prowess and dominant fire power. ${ }^{1629}$ By mid-May, the TEZ had largely collapsed and both sides were using their heavy weapons liberally, particularly around the confrontation lines. ${ }^{11630}$ In late May, there was an outbreak of fighting along the confrontation lines and both sides withdrew heavy weapons from the WCPs; the Bosnian Serb side then used them to shell civilian areas in Sarajevo, as a result of which, on 24 May, Smith issued an ultimatum that they would be subject to air strikes if they did not cease firing their heavy weapons on that day. ${ }^{11631}$ On the same day, two modified air bombs exploded in Safeta Zajke street and Majdanska street, killing and injuring a number of people. ${ }^{11632}$ The Bosnian Serbs did not return the weapons as instructed by Smith and air strikes were launched on 25 May; this led to further shelling of Sarajevo, as well as a number of UN personnel being detained around $\mathrm{BiH}$ and a crisis point in the relationship between the UN and the Bosnian Serb side. ${ }^{1633}$ On 26 May, yet another modified air bomb exploded, this time on Safeta Hadžića street, injuring a number of people. ${ }^{11634}$ On 27 May, an incident between the UN and the SRK soldiers

11628 P2264 (UNPROFOR report re meeting with Radovan Karadžić, 9 May 1995), para. 3; Rupert Smith, T. 11355 11360 (8 February 2011). See also P2415 (UNPROFOR protest letter to SRK, 7 May 1995) (in which Gobilliard complained to Dragomir Milošević about constant firing on civilians around the city and on the Mt. Igman route); P1762 (Witness statement of David Fraser dated 17 October 2010), p. 72.

11629 P820 (Witness statement of David Harland dated 4 September 2009), paras. 180-183; P886 (UNPROFOR Weekly Situation Report (Sarajevo), 13 May 1995); D184 (ABiH $1^{\text {st }}$ Corps combat report, 16 May 1995); Rupert Smith, T. 11469-11470 (9 February 2011); D1118 (UNPROFOR Weekly Situation Report (Sarajevo), 21 May 1995); D1119 (ABiH Security Information Center Sarajevo report, 18 May 1995) (indicating that fire was opened by the $\mathrm{ABiH}$ on Grbavica from civilian areas and from the areas in the vicinity of the UN); Dragomir Milošević, T. 32718-32719 (28 January 2013); KDZ304, T. 10496-10498 (18 January 2011).

11630 P2441 (UNPROFOR Weekly Situation Report (Sarajevo), 19 May 1995), pp. 1-2; P2414 (Witness statement of KDZ182), pp. 93-94 (under seal); D2900 (Order of ABiH 12 ${ }^{\text {th }}$ Division, 20 May 1995); P1762 (Witness statement of David Fraser dated 17 October 2010), p. 72; P2407 (Witness statement of KDZ304), p. 10. See also Adjudicated Fact 2791.

11631 P820 (Witness statement of David Harland dated 4 September 2009), para. 183; Rupert Smith, T. 11365-11372 (8 February 2011), 11470-11472 (9 February 2011), T. 11477-11483 (10 February 2011); D185 (12 ${ }^{\text {th }}$ Division ABiH combat report, 24 May 1995); D1009 (Excerpt from Rupert Smith's book entitled "The Utility of Force: The Art of War in the Modern World"); D1027 (UNPROFOR press statement, 22 May 1995); P2267 (UNPROFOR report re telephone conversation with Ratko Mladić, 25 May 1995); P2268 (UNPROFOR report re telephone conversations with Ratko Mladić, 26 May 1995); D1051 (UNPROFOR report on air strikes, 26 May 1995); P2447 (Witness statement of KDZ182), p. 74. Smith conceded that the ABiH also had heavy weapons outside of the WCP. See Rupert Smith, T. 11866-11871 (15 February 2011); D1052 (ABiH $1^{\text {st }}$ Krajina Corps combat report, 31 May 1995). See also Adjudicated Facts 2792, 2793; Section IV.D.1.a: NATO air strikes.

11632 See discussion on Scheduled Incidents G.11 and G.12.

11633 Rupert Smith, T. 11367-11369 (8 February 2011), T. 11493-11498 (10 February 2011); D1058 (UNPROFOR report to Marrack Goulding, 30 May 1995), paras. 8-12; D987 (Intercept of conversation between Radovan Karadžić and General Milovanović, 25 May 1995). See also Adjudicated Facts 2793, 2794, 2796; Section IV.D: Hostages component.

11634 See discussion on Scheduled Incident G.13. 
took place on the Vrbanja Bridge, deepening the crisis even further. ${ }^{11635}$ On 27 May, at a meeting of Akashi's staff, Banbury wrote that they were "paralysed on everything" including humanitarian aid. ${ }^{11636}$ On 28 May, UNPROFOR reported that, in response to NATO air strikes, the Bosnian Serbs blocked land access to Sarajevo and severely restricted UNPROFOR's freedom of movement. ${ }^{11637}$ On 26 May, Dragomir Milošević issued an order to SRK units to establish a "full blockade" of UNPROFOR and to disregard UN requests for food and water. ${ }^{1638}$ According to Harland, at this time the Bosnian Serbs sought to impose a "total blockade" on Sarajevo and cut off its food supply completely. ${ }^{11639}$ Following these events the WCPs ceased to exist. ${ }^{11640}$

3610. Due to the total blockade on its freedom of movement, UNPROFOR fortified the road over Mt. Igman so that at least some humanitarian aid could be provided to Sarajevo. ${ }^{11641}$ Until the end of the war, this road was the only viable route for the delivery of humanitarian aid to Sarajevo. ${ }^{11642}$ However, this road was also used by $\mathrm{ABiH}$ forces at night, as a result of which the SRK forces fired on vehicles using that route at night. ${ }^{11643}$ On 6 June UNHCR reported that a third of the civilian population of Sarajevo (approximately 100,000 people) was totally dependent on aid, that Sarajevo airport would be completely emptied of supplies by the following day, that the bakery would run out of flour on 8 June, that only $15 \%$ of the aid target would be achieved by 10 June, by which point there would be no aid to distribute to the civilian population. ${ }^{1644}$ However, on 8 June,

\footnotetext{
11635 D1058 (UNPROFOR report to Marrack Goulding, 30 May 1995), para. 13; P2447 (Witness statement of KDZ182), pp. 75-76. See also Section IV.D: Hostages component.

11636 P2451 (Witness statement of Anthony Banbury dated 19 May 2009), para. 167; P2498 (Anthony Banbury's notes, 27 May 1995), e-court p. 1.

11637 P6275 (UNPROFOR Weekly Situation Report, 28 May 1995), para. 6; D1058 (UNPROFOR report to Marrack Goulding, 30 May 1995), para. 14.

11638 P6097 (SRK Order, 26 May 1995), pp. 1-2; Dragomir Milošević, T. 33231 (5 February 2013) (explaining that the purpose of this order was to exert greater control over the movement of UNPROFOR convoys).

11639 P820 (Witness statement of David Harland dated 4 September 2009), para. 178.

11640 P2447 (Witness statement of KDZ182), p. 77.

11641 P820 (Witness statement of David Harland dated 4 September 2009), para. 178; David Harland, T. 2178, 22032204 (10 May 2010); P2068 (Witness statement of Jeremy Bowen dated 10 August 2009), para. 22 (testifying that when the airport was closed the only way to move in and out of Sarajevo was across Mt. Igman); P2407 (Witness statement of KDZ304), pp. 18, 25 (testifying that the only way that UNPROFOR could "bypass the blockade" established by the SRK was to use the Igman road, as all other access routes were blocked by SRK forces); Dragomir Milošević, T. 33232 (5 February 2013) (testifying that UNPROFOR was forced to use the Mt. Igman road at this time because all the other roads into Sarajevo were blocked). See also D4487 (UNPROFOR Report on meetings in Sarajevo and Pale, 13 November 1994), para. 2 (under seal).

11642 P820 (Witness statement of David Harland dated 4 September 2009), para. 178.

11643 P2407 (Witness statement of KDZ304), p. 26; Dragomir Milošević, T. 33239 (5 February 2013).

11644 P2451 (Witness statement of Anthony Banbury dated 19 May 2009), para. 172; P2503 (Anthony Banbury's notes, 6 June 1995), e-court p. 2; P4192 (UN Weekly Situation Report, 29 May-4 June 1995), para. 14.
} 
UNHCR and UNPROFOR met with the Accused and Koljević and successfully negotiated an agreement to deliver humanitarian aid to Sarajevo by land through the Sierra 1 check-point. ${ }^{11645}$

3611. In the last months of the conflict, the balance of power evolved and the ABiH was able to attack in much greater strength and with better equipment. ${ }^{1646}$ According to Akashi, at that juncture the $\mathrm{BiH}$ government, supported by the US government, did not want a long-term cease-fire as that would have made Bosnian Serb territorial gains permanent. ${ }^{11647}$ On 16 June 1995, the ABiH started a series of large-scale attacks, trying to break out of Sarajevo; they saw some success in the early stages, but were pushed back with heavy casualties. ${ }^{1648}$ As a result, the SRK retaliated and the situation in Sarajevo deteriorated, with a number of civilians killed at water lines and market places and the SRK firing modified air bombs at the city. ${ }^{11649}$ On the same day two modified air bombs exploded in different parts of Sarajevo, injuring a number of people. ${ }^{11650}$ On 17 June 1995, noting the $\mathrm{ABiH}$ offensive, the Accused declared a state of war in the zone of responsibility of the SRK. ${ }^{11651}$ Its aim was to "enable the full engagement of human and material potential" in defence of the RS and to "take all necessary measures to achieve the defined aims" of defeating the enemy. ${ }^{11652}$ The situation was becoming desperate and the morale was very low as the SRK adopted a new strategy to clench their grip on urban Sarajevo in response to every hill taken by the

11645 D1125 (UNPROFOR daily report to UNSC, 9 June 1995), p. 1; P890 (UNPROFOR Weekly Situation Report (Sarajevo), 10 June 1995), p. 3; P820 (Witness statement of David Harland dated 4 September 2009), para. 191.

11646 Martin Bell, T. 9911-9912 (15 December 2010).

11647 Yasushi Akashi, T. 37673-37674 (24 April 2013); D3489 (Excerpt from Yasushi Akashi's book entitled "In the Valley between War and Peace"), p. 32. See also P2407 (Witness statement of KDZ304 undated), pp. 23-24 (testifying about $\mathrm{ABiH}$ attacks in early June followed by disproportionate SRK response resulting in a protest by Gobilliard to Dragomir Milošević); P2134 (UNPROFOR protest letter to Dragomir Milošević, 8 June 1995).

11648 P820 (Witness statement of David Harland dated 4 September 2009), paras. 190, 203 (testifying that the offensive was a military operation, directed primarily at the SRK); P892 (UNPROFOR Weekly Situation Report Sarajevo), 24 June 1995), pp. 1-2; David Harland, T. 2340-2351 (11 May 2010); D183 (Orders of $102^{\text {nd }}$ Mountain Brigade of ABiH, May to June 1995); D186 (111 ${ }^{\text {th }}$ Brigade ABiH combat report, 16 June 1995); D187 $\left(115^{\text {th }}\right.$ Mountain Brigade ABiH combat report, 16 June 1995); D188 (105 ${ }^{\text {th }}$ Brigade ABiH combat report, 16 June 1995); D189 (105 ${ }^{\text {th }}$ Brigade ABiH combat report, 19 June 1995); D191 (12 ${ }^{\text {th }}$ Division ABiH combat report, 4 July 1995); Martin Bell, T. 9866 (15 December 2010); P2414 (Witness statement of KDZ182), p. 52 (under seal); D1130 (UNPROFOR report, 18 June 1995), e-court pp. 5, 9; D1131 (UNPROFOR Weekly Situation Report, 18 June 1995), para. 8; P2407 (Witness statement of KDZ304), pp. 29-30; KDZ304, T. 10506-10508 (18 January 2011) (private session) (testifying that the offensive was conducted on the confrontation line); D958 (UNPROFOR Weekly Situation Report, 17 June 1995). See also discussion on Scheduled Incidents G.14 and G.15, and the evidence outlined therein.

11649 P820 (Witness statement of David Harland dated 4 September 2009), paras. 195-199, 203; P892 (UNPROFOR Weekly Situation Report (Sarajevo), 24 June 1995), pp. 1-2; P1996 (Witness statement of Martin Bell dated 8 March 2010), paras. 54-55; P2006 (BBC news report re Sarajevo, with transcript); P1679 (BBC news report re Sarajevo, with transcript); Martin Bell, T. 9796-9797 (14 December 2010). See also discussion on Scheduled Incidents G.14 and G.15.

11650 See discussion on Scheduled Incidents G.14 and G.15.

11651 D2904 (Radovan Karadžić's Decision, 17 June 1995).

11652 D2904 (Radovan Karadžić's Decision, 17 June 1995), p. 1. 
ABiH outside of Sarajevo. ${ }^{11653}$ UNPROFOR's freedom of movement inside Sarajevo was also limited due to proliferation of $\mathrm{ABiH}$ check-points. ${ }^{11654}$ In a letter to the Accused dated 15 June, Akashi described the situation in Sarajevo and the eastern enclaves as a "developing disaster" where "humanitarian supplies and relief personnel are prevented from reaching their destinations, warehouses are empty, [and] whole families are crying out for food". ${ }^{1655}$ At the end of June and the beginning of July, Sarajevo experienced heavy fighting since the SRK was responding to the continued offensives of the $\mathrm{ABiH}$ by indiscriminately shelling and sniping downtown areas, resulting in civilian casualties. ${ }^{11656}$ On 24 June, UNPROFOR reported that the first food convoys in more than four weeks had reached Sarajevo but would satisfy the needs of only $20 \%$ of the civilian population. ${ }^{11657}$

3612. Throughout July 1995 the situation in the battlefield around Sarajevo was relatively quiet as the Bosnians Serbs focused their attention on Srebrenica, but the shelling and sniping in the city continued unabated, having no apparent military value. ${ }^{11658}$ According to Harland, in early July the humanitarian situation in Sarajevo had become "desperate" and the "civilian population's morale was very low, as was UNPROFOR's". ${ }^{11659}$ Despite the agreement reached on 8 June 1995, the

11653 P820 (Witness statement of David Harland dated 4 September 2009), paras. 204-206; P894 (UNPROFOR Memo re meeting in Lukavica, 29 June 1995); P1742 (Witness statement of Bogdan Vidović dated 28 September 2010), p. 32 (testifying that the summer of 1995 was one of the worst periods in terms of sniping and shelling).

11654 D1128 (UNPROFOR daily report, 16 June 1995), para. 1; KDZ182, T. 13123 (10 March 2011).

11655 P5084 (UNPROFOR report re letter sent to Radovan Karadžić, 15 June 1995), p. 2 (noting that the letter was also sent to Alija Izetbegović).

11656 P820 (Witness statement of David Harland dated 4 September 2009), paras. 213-215; P896 (UNPROFOR Weekly Situation Report (Sarajevo), 2 July 1995), pp. 1-3; P2451 (Witness statement of Anthony Banbury dated 19 May 2009), para. 179; P2507 (Anthony Banbury's briefing notes, 1 July 1995), para. 2; P2274 (UNPROFOR letter to Ratko Mladić, 26 June 1995); Rupert Smith, T. 11420-11421 (9 February 2011). See also P2407 (Witness statement of KDZ304), pp. 31-32; KDZ304, T. 10492-10493 (18 January 2011); D1132 (UNPROFOR report, 28 June 1995).

11657 P892 (UNPROFOR Weekly Situation Report (Sarajevo), 24 June 1995), pp. 1, 4; P820 (Witness statement of David Harland dated 4 September 2009), para. 190; P2443 (UNPROFOR report re humanitarian situation in Croatia and $\mathrm{BiH}, 6$ July 1995), p. 3 (reporting that the prospect for future aid convoys reaching Sarajevo was "not good" because $\mathrm{ABiH}$ forces shelled a convoy in the area of Rajlovac, in response to which Koljević indicated that the Bosnian Serbs would not allow convoys for the next week unless they received written security guarantees from the Bosnian Muslim authorities). See also Adjudicated Fact 3090.

11658 P820 (Witness statement of David Harland dated 4 September 2009), paras. 217-219; P822 (UNPROFOR Weekly Situation Report (Sarajevo), 8 July 1995), pp. 1-2; P897 (UNPROFOR Weekly Situation Report (Sarajevo), 15 July 1995), pp. 1, 4; P2134 (UNPROFOR protest letter to Dragomir Milošević, 8 June 1995), ecourt pp. 2-3; D4646 (SRK Order, 26 July 1995).

11659 P820 (Witness statement of David Harland dated 4 September 2009), para. 204; P2443 (UNPROFOR report re humanitarian situation in Croatia and $\mathrm{BiH}, 6$ July 1995), pp. 2-3 (reporting that UNHCR was facing the most serious disruption in its food distribution program in Sarajevo since it began in 1992 as the suspension of UNHCR airlift operations since 8 April 1995 was causing UNHCR to fall well below its food supply targets); P822 (UNPROFOR Weekly Situation Report (Sarajevo), 8 July 1995), p. 1. 
Bosnian Serb authorities continued to obstruct convoys. ${ }^{11660}$ Thus, UNPROFOR and UNHCR again resorted to using the Mt. Igman road in early July 1995 to provide aid, mainly flour, to Sarajevo. ${ }^{11661}$ However, Bosnian Serb forces, mainly the units of the Ilidža Brigade, regularly attacked convoys using this route. ${ }^{11662}$ On 15 July, UNPROFOR reported that civilians in Sarajevo were surviving on whatever food they had stockpiled, on what they could grow in vegetable gardens, and whatever goods were brought into Sarajevo through the tunnel. ${ }^{11663}$ On 19 July, in a meeting with Smith, Mladić agreed to allow UNPROFOR and UNHCR to move convoys into Sarajevo using a route from Kiseljak. ${ }^{11664}$ However, on 30 July, Mladić informed Smith that the Bosnian Muslims had attacked convoys using this route the day before in order to make the route impossible to use, leaving Mt. Igman as the only alternative. ${ }^{11665}$ Mladić also stated that use of the Mt. Igman route by the $\mathrm{ABiH}$ was "illegal" and something which the Bosnian Serbs would "never accept". ${ }^{11666}$ In another meeting with Mladić on 31 July, Smith emphasised the need to reopen Sarajevo airport for the delivery of humanitarian aid and to simplify procedures for checking convoys. ${ }^{11667}$ Mladić responded that the airport could not be opened until ABiH forces withdrew

11660 P2443 (UNPROFOR report re humanitarian situation in Croatia and BiH, 6 July 1995), p. 3 (stating that Bosnian Serb authorities had not given clearance for the delivery of aid to Sarajevo since 20 June 1995 and were demanding 50\% of deliveries, rather than the usual 23\%); KDZ182, T. 13186-13188 (10 March 2011).

11661 P2507 (Anthony Banbury's briefing notes, 1 July 1995), para. 4 (stating that UNHCR was considering sending a convoy to Sarajevo via Mt. Igman at dawn on 2 July 1995); P896 (UNPROFOR Weekly Situation Report (Sarajevo), 2 July 1995), p. 5 (stating that a UNHCR convoy carrying 62 tonnes of food arrived in Sarajevo at 3:30 a.m. via the Mt. Igman route)

11662 P2407 (Witness statement of KDZ304), pp. 25-26 (under seal); P896 (UNPROFOR Weekly Situation Report (Sarajevo), 2 July 1995), p. 3. A humanitarian convoy arriving on the night of 3 to 4 July 1995 was attacked by the Bosnian Serbs, causing injuries to two drivers and damage to two vehicles, while a second convoy arriving on the night of 6 to 7 July 1995 proceeded without incident. See P822 (UNPROFOR Weekly Situation Report (Sarajevo), 8 July 1995), p. 3; P820 (Witness statement of David Harland dated 4 September 2009), para. 218. On the evening of 14 July 1995, a convoy carrying flour on Mt. Igman was attacked from Bosnian Serb territory. Two vehicles were destroyed and two drivers injured. See P897 (UNPROFOR Weekly Situation Report (Sarajevo), 15 July 1995), pp. 4-5; Nikola Mijatović, T. 30764 (30 November 2012) (testifying that this report was "not accurate" and the Bosnian Serbs were not the ones who opened fire); D2512 (Report of $1^{\text {st }}$ Ilidža Infantry Brigade, 14 July 1995) (referring to an artillery attack on an "unannounced" convoy of trucks travelling on Mt. Igman). See also Rupert Smith, T. 11417 (9 February 2011); P2407 (Witness statement of KDZ304), p. 26 (testifying that the use of the Igman road was "unacceptable to the Serbs" and that they demanded that UNPROFOR use only the Blue Routes to supply Sarajevo); Dragomir Milošević, T. 33239 (5 February 2013) (testifying that convoys using the Igman route could not be inspected or controlled); Adjudicated Fact 3021. When asked about these attacks, Milošević testified that the SRK "was not shooting at humanitarian aid convoys" but "shooting at those who infiltrated [...] those convoys", including ABiH vehicles and vehicles transporting weapons. See Dragomir Milošević, T. 33235 (5 February 2013); Nikola Mijatović, T. 30764 (30 November 2012) (testifying that there were no problems when UNPROFOR announced their convoys and were not smuggling ammunition and weapons into Sarajevo).

11663 P897 (UNPROFOR Weekly Situation Report (Sarajevo), 15 July 1995), p. 5.

11664 P4178 (Agreement Between General Smith and General Ratko Mladić, 19 July 1995), paras. 4, 6.

11665 D2621 (Letter from VRS to UNPROFOR, 30 July 1995), e-court p. 2.

11666 D2621 (Letter from VRS to UNPROFOR, 30 July 1995), e-court p. 2; Dragomir Milošević, T. 33242-33243 (5 February 2013) (testifying that the Bosnian Serbs did not provide consent to use of the Mt. Igman road); Vladimir Radojčić, T. 31289 (12 December 2012) (testifying that the Bosnian Serbs objected to use of the Mt. Igman road because it was used to supply the $\mathrm{ABiH}$ ).

11667 D1047 (VRS Main Staff Report, 31 July 1995), p. 3. 
from Mt. Igman and that convoy procedures would be simplified in proportion to the "growth of mutual trust" between UNPROFOR and the VRS. ${ }^{11668}$

3613. On 8 August 1995, the VRS Main Staff issued an urgent order instructing all the corps to warn their units to save ammunition of all calibres as much as possible. ${ }^{11669}$ On 18 August, Milošević issued an order to all SRK units to use "all means to prevent a new offensive to lift the blockade of Sarajevo". ${ }^{11670}$ On 21 August, in a meeting with Koljević, Pedauye of UNPROFOR emphasised the importance of opening Sarajevo airport before the onset of winter. ${ }^{1671}$ Koljević, noting that the Bosnian Muslims were using the tunnel under the airport for military purposes, responded that the Bosnian Serbs were prepared to open the airport only if humanitarian activities were separated from the military ones. ${ }^{11672}$

3614. On 28 August 1995, the second Markale market incident took place which led to NATO air strikes, as described later in this judgement. ${ }^{11673}$ On 2 September 1995, Harland and Smith decided to open the airport for anyone wanting to cross it. ${ }^{1674}$ When they informed Krajišnik of this intention, Krajišnik threatened to shoot any vehicle that crossed the airport without Bosnian Serb approval. ${ }^{11675}$ UNPROFOR ignored the threat, which was never carried out-as a result, traffic began to flow in and out of Sarajevo for the first time since 1992. ${ }^{11676}$ On 14 September, the Accused and Holbrooke agreed on a framework for a cease-fire agreement according to which both the $\mathrm{ABiH}$ and the VRS were first to stop all operations within and around the TEZ in Sarajevo, the VRS was to remove its heavy weapons outside of the TEZ while the $\mathrm{ABiH}$ was to place its heavy weapons under the control of the UN, and NATO was to cease the air strikes; the framework also envisaged that after all of these steps were completed, an agreement would be signed on cessation of hostilities, first in Sarajevo and then in the rest of BiH. ${ }^{11677}$ At a meeting on 20 September, Smith informed Dragomir Milošević that as part of the cease-fire UNPROFOR required "full and unhindered" freedom of movement, including the removal of Bosnian Serb check-points on roads

\footnotetext{
11668 D1047 (VRS Main Staff Report, 31 July 1995), p. 3.

11669 D2813 (VRS Main Staff Order, 8 August 1995).

11670 D4619 (SRK report, 18 August 1995), p. 2 (noting also that there have been many false reports by the SRK units and ordering that all measures be taken for complete and correct reporting).

11671 P2287 (UNPROFOR report re meetings with Bosnian Serb leadership, 22 August 1995), para. 15.

11672 P2287 (UNPROFOR report re meetings with Bosnian Serb leadership, 22 August 1995), para. 14.

11673 See discussion on Scheduled Incident G.19.

11674 P820 (Witness statement of David Harland dated 4 September 2009), para. 240.

11675 P820 (Witness statement of David Harland dated 4 September 2009), para. 240.

11676 P820 (Witness statement of David Harland dated 4 September 2009), para. 240.

11677 D1017 (Drina Corps Order, 14 September 1995), p. 1. See also D1053 (UNPROFOR letter to Ratko Mladić, 4 September 1995); P2106 (Witness statement of KDZ304), pp. 5-7 (under seal); P2111 (UNPROFOR report re withdrawal of heavy weapons, 18 September 1995); Adjudicated Fact 2800.
} 
into Sarajevo. ${ }^{11678}$ On 25 September 1995, Sarajevo trams started working again. ${ }^{11679}$ At meetings on 6 and 8 October, Krajišnik, Dragomir Milošević, and Inđić, among others, proposed the opening of several routes into Sarajevo for the delivery of humanitarian aid. ${ }^{1680}$ Following these developments, the situation improved and a cease-fire was agreed upon on 12 October. ${ }^{11681}$ The fighting subsided by 14 October $1995 .^{11682}$

\section{b. Sniping}

3615. The Prosecution alleges that the Accused, together with a number of others, participated in a joint criminal enterprise to establish and carry out a campaign of sniping against the civilian population of Sarajevo between April 1992 and November 1995 the primary purpose of which was to spread terror among the civilian population. ${ }^{11683}$ In order to illustrate that campaign ${ }^{11684}$ the Prosecution presented, inter alia, detailed evidence in relation to 16 sniping incidents listed in Schedule F of the Indictment. ${ }^{11685}$ These incidents included sniping of trams as well as sniping of individual victims who found themselves on the streets of Sarajevo, all alleged to have been perpetrated by the "Sarajevo Forces". ${ }^{11686}$ In addition, the Prosecution also brought general evidence going to the nature of sniping in Sarajevo and a number of unscheduled sniping incidents, in order to establish a pattern of conduct by the Bosnian Serb military and political authorities. ${ }^{11687}$

3616. In response, the Accused argues that there is no evidence that the SRK was tasked with opening sniper fire against civilians; instead the SRK sniping practice was strictly "military on military" and the victims of sniping incidents were simply caught in the exchange of fire and shot

\footnotetext{
11678 D2899 (Fax from UNPROFOR, 20 September 1995), para. 3 (adding that Miletić and Milošević found it "difficult to accept" this requirement, but ultimately decided to comply with it).

11679 P2451 (Witness statement of Anthony Banbury dated 19 May 2009), para. 194; P2511 (Anthony Banbury's notes, 26 September 1995), e-court p. 1.

11680 These routes included the Ilidža-Kiseljak, Ilidža-Tarčin and Airport-Mt. Igman routes. See P908 (Minutes from the first meeting on the implementation of cease-fire agreement, 6 October 1995), e-court p. 5; P909 (Minutes from the second meeting on the implementation of cease-fire agreement, 8 October 1995), e-court p. 3; P820 (Witness statement of David Harland dated 4 September 2009), para. 243.

11681 P820 (Witness statement of David Harland dated 4 September 2009), paras. 240-242, 244-245; P910 (BiH Government's acceptance of the cease-fire agreement, 11 October 1995); P911 (RS Government's acceptance of the cease-fire agreement, 11 October 1995).

11682 Adjudicated Fact 2802.

11683 Indictment, para. 15.

11684 Indictment, paras. 15, 82 (referring to the sniping incidents in Schedule F as being "illustrative examples" of the campaign).

11685 Originally, the Indictment contained an additional scheduled incident of sniping but it was withdrawn by the Prosecution pursuant to Rule 73 bis. See Rule 73 bis Decision.

11686 Sarajevo Forces are defined in the Indictment as (i) members of JNA operating in and around Sarajevo until about 20 May 1992, (ii) members of the VRS, in particular the SRK, and (iii) members of other forces operating in or with responsibility over the Sarajevo area. See Indictment, para. 18.
} 
by stray bullets. ${ }^{11688}$ The Accused does concede, however, that civilian deaths may have occurred during the war due to "uncontrolled sniper[s]" but argues that there was an attempt by the SRK not to harm civilians. ${ }^{11689}$ In addition, the Accused claims that ABiH snipers opened fire on their own civilians. ${ }^{1690}$ The Prosecution argues in turn that the Accused's suggestions that $\mathrm{ABiH}$ forces fired on their own civilians are implausible and not supported by reliable evidence, while his claims that the victims were caught in exchanges of fire are also unsupported by the evidence. ${ }^{11691}$

\section{i. Sniping in general}

3617. With respect to sniping, the Chamber heard from two experts in this case, namely Patrick van der Weijden, a trained sniper himself, commissioned by the Prosecution, ${ }^{11692}$ and Mile Poparić, a ballistics expert, commissioned by the Accused, ${ }^{11693}$ both of whom have produced an expert report for the purpose of this case. ${ }^{11694}$

3618. Van der Weijden drew a distinction between a "popular sniper" and a "professional military sniper" noting that the latter is better trained in a number of specialised skills (including the ability to camouflage), has more and better quality equipment, and usually operates in a "shooter/spotter team". ${ }^{11695}$ A popular sniper, on the other hand, usually operates alone, with less equipment, and having had less training. ${ }^{11696}$ Van der Weijden also noted that the term "sniper" has been popularised by the media as it got a "new impulse" in the Balkan conflict and has since then been used to indicate a hidden shooter, shooting at whoever gets in his sight, including women and children. ${ }^{11697}$ According to Poparić, every bullet fired from small arms in Sarajevo was regarded as

\footnotetext{
11687 As indicated to the parties during the case, the Chamber will not be making findings as to the responsibility of the Accused for specific unscheduled incidents. See T. 5481 (19 July 2010). See also fn. 11204.

11688 Defence Final Brief, para. 2171; Closing Arguments, T. 48030 (2 October 2014).

11689 Defence Final Brief, para. 2171.

11690 Defence Final Brief, para. 2181.

11691 Prosecution Final Brief, Appendix C, para. 12.

11692 See P1611 (Patrick van der Weijden's curriculum vitae).

11693 See D4884 (Mile Poparić's expert report entitled "Small Arms Fire on the Sarajevo Area 1992-1995", 15 August 2012), which also contains Poparić's curriculum vitae at page 2. Mile Poparić never served as a sniper nor does he have any combat experience. However, he has had training in the use of infantry weapons. See Mile Poparić, T. 39020 (30 May 2013).

11694 P1621 (Expert Report of Patrick van der Weijden entitled "Sniping Incidents in Sarajevo '92-'94”); D4884 (Mile Poparić's expert report entitled "Small Arms Fire on the Sarajevo Area 1992-1995”, 15 August 2012).

11695 P1621 (Expert Report of Patrick van der Weijden entitled "Sniping Incidents in Sarajevo '92-'94”), pp. 2-4; P1762 (Witness statement of David Fraser dated 17 October 2010), p. 31; David Fraser, T. 8019 (18 October 2010).

11696 P1621 (Expert Report of Patrick van der Weijden entitled “Sniping Incidents in Sarajevo '92-'94”), p. 2. But note Mile Poparić's evidence that snipers can operate alone, in pairs, or in groups of snipers. See D4884 (Mile Poparić's expert report entitled "Small Arms Fire on the Sarajevo Area 1992-1995”, 15 August 2012), p. 27.

11697 P1621 (Expert Report of Patrick van der Weijden entitled "Sniping Incidents in Sarajevo '92-'94”), p. 2. See also P1426 (Witness statement of Richard Mole dated 7 May 2010), para. 88; P1029 (Witness statement of John Wilson dated 4 November 2008), para. 58.
} 
a bullet fired from a sniper weapon, which is "grossly erroneous" since sniper fire and ordinary small arms fire are "essentially very different" even though the difference between the two has become "imperceptibly blurred". ${ }^{11698}$ However, contrary to Poparić's position, the Chamber considers that for the purpose of entering factual and legal findings on the sniping incidents alleged in the Indictment, which are charged as murder, unlawful attacks on civilians, and terror, the distinction between a popular sniper and a professional military sniper is not important. What matters instead is the identity of the perpetrators, regardless of their level of training or the specific weapons they used, and whether their actions satisfied the elements of the crimes charged. ${ }^{11699}$ Accordingly, the Chamber's use of the term "sniper" throughout this judgement will be in line with the above-described popular use of the term, encompassing both professional military sniper teams and hidden shooters operating alone and targeting individuals and objects.

3619. The Chamber also heard that in an urban setting, large buildings or factories offer multiple possibilities to establish shooting positions, making it difficult for the enemy to locate the shot. ${ }^{11700}$ In those situations, snipers will prefer to stay away from the windowsills or if possible shoot through loopholes created by using a hole shot in the wall. ${ }^{11701}$ They will also choose positions on either side of the frontline but not right on it. ${ }^{11702}$ Van der Weijden also testified that in built up areas the shooting ranges of a sniper are at an average of 75 metres while long shots are possible only from dominating positions, with an overview from above. ${ }^{11703}$ He further noted that sniper rifles are usually fitted with magnifying scopes of varying sizes, making it possible to identify whether individuals are combatants or civilians, even at ranges of over two kilometres. ${ }^{11704}$ In terms of judging a distance when shooting, in a relatively static situation, where the frontlines remain unchanged for weeks or months as in Sarajevo, a sniper can choose an object for target practice and then set the settings on his scope for future shots at the same distance. ${ }^{11705}$ As for machine guns, which can also be used for sniping, the typical scope would have a magnification of

\footnotetext{
11698 D4884 (Mile Poparić's expert report entitled "Small Arms Fire on the Sarajevo Area 1992-1995”, 15 August 2012), p. 26.

11699 See Galić Appeal Judgement, para. 254, fn. 711.

11700 P1621 (Expert Report of Patrick van der Weijden entitled “Sniping Incidents in Sarajevo '92-'94”), p. 4.

11701 P1621 (Expert Report of Patrick van der Weijden entitled “Sniping Incidents in Sarajevo '92-'94”), p. 4.

11702 P1621 (Expert Report of Patrick van der Weijden entitled “Sniping Incidents in Sarajevo '92-'94”), p. 5.

11703 P1621 (Expert Report of Patrick van der Weijden entitled “Sniping Incidents in Sarajevo '92-'94”), p. 5.

11704 According to Van der Weijden, a sniper can distinguish between civilians and combatants through a number of indicators, including the target's size, the way in which he or she moves, clothing, sex, age, and actions. A sniper can also use a rangefinder on his rifle to identify children, noting that if children are hit at great distance with the use of the rangefinder, they would have been identified as such in order to be hit. P1621 (Expert Report of Patrick van der Weijden entitled "Sniping Incidents in Sarajevo '92-'94”), Appendix B, pp. 1-3. See also P1762 (Witness statement of David Fraser dated 17 October 2010), p. 31.

11705

Patrick van der Weijden, T. 6950, 6963 (27 September 2010).
} 
four and, if the machine gun was placed on a tripod and used in a static frontline, the sniper would have relatively accurate fire up to 1,500 metres. ${ }^{11706}$

3620. In terms of target identification, Van der Weijden testified that in an urban battle zone, more civilians are present and most targets will only be visible for a short moment. ${ }^{11707}$ Thus, strict rules of engagement are usually provided to guide the sniper. ${ }^{11708}$ He has to be extremely careful when taking his shots and must positively identify his target as the enemy beforehand. ${ }^{11709}$ As for the targets themselves, Van der Weijden explained that it is easy for people unaccustomed to shooting to get confused about the origin of fire as the bullet usually strikes before the sound of the shot reaches the victim. ${ }^{11710} \mathrm{He}$ also explained that being exposed to sniping causes great anxiety to the population as they never feel safe and never know exactly when or from where the shot would come. $^{11711}$

\section{ii. Sniping in Sarajevo}

(A) Nature of sniping in the city

3621. The Chamber heard that sniping within Sarajevo was constant throughout the conflict, resulting in many civilian casualties and the setting up of anti-sniping barriers all over the city to protect civilians. ${ }^{11712}$ Fraser testified that during his time there both sides conducted sniping

11706 Patrick van der Weijden, T. 6950-6951 (27 September 2010). P1621 (Expert Report of Patrick van der Weijden entitled "Sniping Incidents in Sarajevo '92-'94"), Appendix A, p. 1.

11707 P1621 (Expert Report of Patrick van der Weijden entitled “Sniping Incidents in Sarajevo '92-'94”), Appendix B, p. 1.

11708 P1621 (Expert Report of Patrick van der Weijden entitled “Sniping Incidents in Sarajevo '92-'94”), p. 5. According to Van der Weijden, the sniper is permitted to shoot a civilian only if that civilian poses an immediate threat to the sniper or his comrades; however, if the sniper is not sure that there is such a threat, he should not use force. Patrick van der Weijden, T. 6952 (27 September 2010); P1621 (Expert Report of Patrick van der Weijden entitled "Sniping Incidents in Sarajevo '92-'94”), Appendix B, p. 1.

11709 P1621 (Expert Report of Patrick van der Weijden entitled “Sniping Incidents in Sarajevo '92-'94”), Appendix B, p. 1 .

11710 P1621 (Expert Report of Patrick van der Weijden entitled "Sniping Incidents in Sarajevo '92-'94”), p. 7. This was confirmed by Dragan Mioković, an investigator at CSB Sarajevo, who testified that sniping victims on Zmaja od Bosne street in Sarajevo often had no idea where the bullets that injured them had come from, but nevertheless always assumed that they had come from the Metalka building and/or the four white high-rises in Grbavica. See P1830 (Witness statement of Dragan Mioković dated 26 October 2010), p. 36.

11711 P1621 (Expert Report of Patrick van der Weijden entitled “Sniping Incidents in Sarajevo '92-'94”), p. 7.

11712 P1426 (Witness statement of Richard Mole dated 7 May 2010), para. 86; P926 (Witness statement of Aernout van Lynden dated 26 February 2010), paras. 26, 47-49; Aernout van Lynden, T. 2398-2401 (19 May 2010); P2068 (Witness statement of Jeremy Bowen dated 10 August 2009), paras. 35, 37; Jeremy Bowen, T. $10107-$ 10111 (13 January 2011); P2074 (BBC news report re Sarajevo, with transcript); P2075 (BBC news report re Sarajevo, with transcript); P2106 (Witness statement of KDZ304), pp. 9-10 (under seal); David Harland, T. 2026-2029 (6 May 2010); P1029 (Witness statement of John Wilson dated 4 November 2008), para. 57; P1258 (Witness statement of Hussein Ali Abdel-Razek dated 16 July 2002), e-court pp. 18, 23-24; P1996 (Witness statement of Martin Bell dated 8 March 2010), paras. 37-38; P2018 (BBC news report, with transcript); P2010 (Video footage of Sarajevo); P1762 (Witness statement of David Fraser dated 17 October 2010), p. 34. 
activities which usually ended up in a tit-for-tat type of exchange. ${ }^{11713}$ Both sides, according to Fraser, were also indiscriminate and would shoot at men, women, and children. ${ }^{11714}$ This was confirmed by KDZ182 who told the Chamber that both sides would kill innocent people, including women, children, and the elderly, in order to show they were in control and to exert pressure through the reporting of the media. ${ }^{11715}$ However, both KDZ182 and Fraser, as well as many other witnesses, testified that the Serbs shot more, particularly in the Sedrenik and the so-called "Sniper Alley" ${ }^{11716}$ areas. ${ }^{11717}$ Harland also stated that both sides sniped but because the Bosnian Serbs held the higher ground around Sarajevo, they had a lot more opportunity and capacity to do so. ${ }^{11718}$ Van Baal testified that the SRK used sniping as a "means of repression and terror"-the sniping was carried out without any discrimination and citizens, women, and children were targeted "at unexpected places and unexpected times". ${ }^{11719}$ Rose himself testified that the presence of snipers in Sarajevo made normal life impossible and that there was an atmosphere of fear in the city. ${ }^{11720}$ Tucker testified that when he arrived to the city in October 1992 there was constant sniper fire and intense periods of small arms fire around the perimeters of the city. ${ }^{11721}$ Richard Mole, a senior

11713 P1762 (Witness statement of David Fraser dated 17 October 2010), p. 24; David Fraser, T. 8054 (18 October 2010). See also P6060 (Record of interview with KDZ185), e-court p. 13. Thomas testified that both sides used snipers as "instruments of policy". See P1558 (Witness statement of Francis Roy Thomas dated 13 May 2009), para. 61. See also P1426 (Witness statement of Richard Mole dated 7 May 2010), para. 87; P1258 (Witness statement of Hussein Ali Abdel-Razek dated 16 July 2002), e-court p. 24.

11714 P1762 (Witness statement of David Fraser dated 17 October 2010), p. 24

11715 P2414 (Witness statement of KDZ182), pp. 40, 46-47 (under seal). See also Anthony Banbury, T. 13317 (15 March 2011) (testifying that the large majority of sniping victims in Sarajevo were civilians).

11716 Sniper Alley was the stretch of Zmaja od Bosne street in the Marin Dvor area of Sarajevo and in front of the Holiday Inn. See P1762 (Witness statement of David Fraser dated 17 October 2010), p. 26.

11717 At the airport, the shooting was done by both sides in equal measure. See P1762 (Witness statement of David Fraser dated 17 October 2010), pp. 24, 26; David Fraser, T. 8015 (18 October 2010); P2414 (Witness statement of KDZ182), pp. 7, 41 (under seal); P1258 (Witness statement of Hussein Ali Abdel-Razek dated 16 July 2002), e-court p. 24. According to KDZ182, during his time in Sarajevo there were 66 incidents involving Serb sniper fire and six incidents involving ABiH sniper fire. See P2414 (Witness statement of KDZ182), pp. 41-42 (under seal). See also P1426 (Witness statement of Richard Mole dated 7 May 2010), para. 87 (testifying that the sniping threat was greater within the city due to the domination of high ground by the Serb side); P1638 (Witness statement of Michael Rose dated 26 March 2009), para. 217 (testifying that the level of sniping was greater on the Bosnian Serb side, while the greater number of civilians killed were within the city); P2451 (Witness statement of Anthony Banbury dated 19 May 2009), para. 163; P2495 (Anthony Banbury's notes, 23 May 1995), e-court p. 2; P2068 (Witness statement of Jeremy Bowen dated 10 August 2009), para. 29 ; P2031 (BBC news report re Sarajevo, with transcript). Some witnesses also acknowledged that the Bosnian Serb reluctance to report their casualties, coupled with the media's home base location being on the ABiH-held side of Sarajevo resulted in a somewhat unbalanced view of the sniping activity in the city. See P1558 (Witness statement of Francis Roy Thomas dated 13 May 2009), paras. 62-63; P820 (Witness statement of David Harland dated 4 September 2009), para. 299; David Harland, T. 2144-2145 (10 May 2010).

11718 P820 (Witness statement of David Harland dated 4 September 2009), paras. 294-295, 298 (testifying also that the Bosnian Muslim side engaged in two types of sniping: (i) counter-sniping which was the endless game of titfor-tat, or (ii) killing civilians to provoke a response from the Serbs).

11719 P1818 (Witness statement of Adrianus van Baal dated 26 October 2010, paras. 48-49. See also KDZ182, T. 13093 (9 March 2011); P1996 (Witness statement of Martin Bell dated 8 March 2010), para. 53; P2000 (BBC news report re Sarajevo, with transcript).

11720 Michael Rose, T. 7266-7267 (5 October 2010).

11721 P4203 (Witness statement of Pyers Tucker dated 12 May 2010), para. 22. 
UNMO in Sarajevo between 16 September and 26 December 1992, ${ }^{11722}$ testified that during his time in Sarajevo there was continual background noise of small arms and artillery fire in the city. ${ }^{11723}$ Even when Sarajevo was "calm”, the Bosnian Serbs would engage in sniping in order to put pressure on the city. ${ }^{11724}$ A number of local citizens of Sarajevo confirmed the above, testifying that the civilians in the city were continuously targeted by Bosnian Serb sniper fire no matter where they were, and that certain areas, such as Marin Dvor and Sedrenik, were particularly dangerous as far as sniper fire was concerned. ${ }^{11725}$ In addition, when in operation, the Sarajevo trams and the people onboard were also subjected to sniper fire from the Bosnian Serb side. ${ }^{11726}$ Confirming the evidence above about the targeting of civilians, the demographic expert Ewa Tabeau produced reports in which she analysed civilian deaths in Sarajevo and came to the conclusion that in the period between 1 April 1992 and August 1994, an absolute minimum of 503 civilians died as a result of sniper or firearm fire, while another 2,215 were wounded. ${ }^{11727}$ As for the period between September 1994 and November 1995, Tabeau used different sources of information and was able to conclude that, at a minimum, some 449 individuals died from war-related causes, including sniping, within the confrontation lines of Sarajevo. ${ }^{11728}$ In addition, in this period, an absolute minimum of 77 civilians were wounded due to sniping. ${ }^{11729}$

\footnotetext{
11722 P1426 (Witness statement of Richard Mole dated 7 May 2010), para. 4.

11723 P1426 (Witness statement of Richard Mole dated 7 May 2010), para. 65. See also Adjudicated Fact 135.

11724 KDZ450, T. 10550 (19 January 2011).
}

11725 See e.g. P1978 (Witness statement of Nedžib Đozo dated 7 December 2010), paras. 21-23; P21 (Witness statement of Mirsad Kučanin dated 21 February 1996), pp. 2-3; P2413 (Witness statement of KDZ289 dated 19 April 1996), p. 3; P2922 (Witness statements of KDZ079 dated 17 May 2006), para. 17; P733 (Witness statement of Sulejman Crnčalo dated 1 November 2009), paras. 86, 88-93; P492 (Witness statement of Sabina Šabanić dated 22 May 2006), para. 7; P2164 (Witness statement of KDZ477 dated 13 February 2010), para. 13; P1690 (Witness statement of Alen Gičević dated 16 February 2010), p. 2; Tarik Žunić, P494 (Transcript from Prosecutor v. D. Milošević), T. 1728; P496 (Witness statement of Tarik Žunić dated 21 April 2006), pp. 2-3; P496 (Witness statement of Tarik Žunić dated 25 April 2010), p. 2. See also Section IV.B.1.b.iii.A.: Zmaja od Bosne street (formerly Vojvode Putnika); Section IV.B.1.b.iii.C: Sredrenik.

11726 P2164 (Witness statement of KDZ477 dated 13 February 2010), para. 13; P495 (Witness statement of Slavica Livnjak dated 25 April 2006), paras. 6-7, 15; P1695 (Witness statement of Mirza Sabljica dated 11 February 2010), p. 66; P1762 (Witness statement of David Fraser dated 17 October 2010), p. 39; David Fraser, T. 81278128 (19 October 2010). See also para. 3645.

11727 Tabeau reached these numbers by using two main sources of information in the said period, namely the Households Survey conducted in September 1994 in the ABiH-held Sarajevo and the records of the Bakije Funeral home, the largest funeral home in Sarajevo. She then compared them to the 1991 census and, in order to distinguish between military and civilian casualties, to the ABiH lists of fallen soldiers. See P4997 (Ewa Tabeau's expert report entitled "Persons Killed and Wounded in Sarajevo During the First Months of the 'Siege' from 1 April to 9 September 1992”, 1 May 2009), pp. 1-2, 4-7; P4998 (Ewa Tabeau's expert report entitled “Population Losses in the 'Siege' of Sarajevo 10 September 1992 to 10 August 1994", 10 May 2002), pp. 1-4; Ewa Tabeau, T. 28173-28176, 28196-28197 (26 April 2012). Tabeau explained that the real number of civilian deaths is most likely higher because the number of those reported as soldiers in the Household Survey was higher than the numbers seen in $\mathrm{ABiH}$ lists of fallen soldiers, due to, among other things, families hoping to obtain a military pension. See P4997 (Ewa Tabeau's expert report entitled "Persons Killed and Wounded in Sarajevo During the First Months of the 'Siege' from 1 April to 9 September 1992”, 1 May 2009), p. 8.

11728 For this period, Tabeau's main source of information in relation to the wounded civilians were patient records of the three main Sarajevo hospitals. This source was somewhat incomplete as it did not include the records of a number of smaller hospitals in the city and because it included only hospitalised patients. Tabeau also used a 
3622. All SRK units had snipers rifles and dedicated marksmen. ${ }^{11730}$ They had various M48 rifles of $7.9 \mathrm{~mm}$ calibre in its arsenal. ${ }^{11731}$ These rifles had optical sights and were referred to as sniping rifles. ${ }^{11732}$ In addition, they had M76 sniper rifles which also used $7.9 \mathrm{~mm}$ calibre ammunition, albeit different to the ammunition used for the M48 rifles. ${ }^{1173}$ Finally, the SRK had semiautomatic $7.62 \mathrm{~mm}$ calibre rifles that could be equipped with optical sights, ${ }^{11734}$ which meant that they could fire with precision from up to 400 metres away, with an overall range of 800 metres. ${ }^{11735}$ However, Stanislav Galić, the SRK Commander from September 1992 to August 1994, ${ }^{11736}$ testified that there were no sniping units as such in the SRK, but only a small number of sharpshooters who would be assigned across various units down to the level of company. ${ }^{11737}$ Thus, the level of command and control which could issue tasks to snipers was at the level of the platoon commander at the highest and, occasionally, that of the company commander. ${ }^{11738}$ Higher levels of command did not deal with snipers except in extraordinary circumstances. ${ }^{11739}$

number of different sources relating to those killed in Sarajevo, including again the Bakije Funeral home records. For this period, however, she was unable to determine which deaths were attributed to shelling and which to sniping since, unlike the Household Survey, the sources she used here did not contain that type of information. She therefore classified 449 deaths as being war-related. See P5002 (Ewa Tabeau's expert report entitled "Killed and Wounded Persons from the Siege of Sarajevo: August 1994 to November 1995", 19 March 2007), pp. 3-5, 11-12, 17-18, 23, 51-54; Ewa Tabeau, T. 28206-28209 (26 April 2012).

P5002 (Ewa Tabeau's expert report entitled "Killed and Wounded Persons from the Siege of Sarajevo: August 1994 to November 1995”, 19 March 2007), pp. 6-7, 51-57 (adding that the real number was probably more around 320 civilians, based on the comparison she made to other partially overlapping sources).

11730 Dragomir Milošević, T. 32820-32821 (29 January 2013) (adding that it was difficult to find good "marksmen specialists" as the SRK soldiers did not want to be located close to the confrontation lines). See Adjudicated Fact 2808.

11731 Stanislav Galić, T. 37463-37464 (22 April 2013).

11732 Stanislav Galić, T. 37463-37464 (22 April 2013); D2827 (SRK combat report, 19 August 1993); D2828 (SRK combat report, 10 August 1994) (both orders referring to "sniper rifles"); P5945 (Report of $1^{\text {st }}$ Romanija Infantry Brigade to SRK, 29 October 1993). Van der Weijden referred to this rifle in his report but explained that it was a hunting rifle owned by many civilians in the region who used it to arm themselves when they became combatants. P1621 (Expert Report of Patrick van der Weijden entitled "Sniping Incidents in Sarajevo '92'94"), Appendix A, pp. 3-4.

11733 Dragomir Milošević, T. 32818-32820 (29 January 2013). See Adjudicated Fact 2812.

11734 Stanislav Galić, T. 37463-37464 (22 April 2013); P1279 (SRK request to VRS Main Staff, 10 July 1995). According to Van der Weijden's report, the VRS had the following $7.62 \mathrm{~mm}$ calibre semi-automatic rifles in its arsenal: Zastava M76, Zastava M59/66, and SVD Dragunov or M91. P1621 (Expert Report of Patrick van der Weijden entitled "Sniping Incidents in Sarajevo '92-'94"), Appendix A, p. 1.

11735 Stanislav Galić, T. 37463-37464 (22 April 2013). These ranges were confirmed by Van der Weijden. See P1621 (Expert Report of Patrick van der Weijden entitled "Sniping Incidents in Sarajevo '92-'94"), Appendix A.

11736 Stanislav Galić, T. 37155 (15 April 2013); Dragomir Milošević, T. 32503 (23 January 2013). See Adjudicated Fact 27.

11737 Stanislav Galić, T. 37192 (15 April 2103), T. 37465 (22 April 2013), T. 37840-37842 (7 May 2013), T. 38060 (9 May 2013).

11738 Stanislav Galić, T. 37472 (22 April 2013).

11739 Stanislav Galić, T. 37472 (22 April 2013), T. 37840-37842 (7 May 2013) (conceding, however, that it was possible that sniper squads existed at a battalion level but denying any personal knowledge of such squads). 
3623. Contradicting Galić, Dragan Maletić, commander of the $1^{\text {st }}$ Company of the $3^{\text {rd }}$ Battalion of the $1^{\text {st }}$ Romanija Infantry Brigade, ${ }^{11740}$ and KDZ310, a soldier in this battalion, ${ }^{11741}$ both testified that there was a sniper squad in the battalion and that it was directly subordinated to the battalion commander rather than to company or platoon commanders. ${ }^{11742}$ In addition, the order of Galićs deputy dated 4 November 1992 shows that the SRK Command would issue orders specifically concerning the use of snipers in SRK units. ${ }^{11743}$ Furthermore, on 29 October 1993, Milošević issued an order on behalf of Galić to all the SRK brigades to intensify sniping against the $\mathrm{ABiH}$ forces; the order also instructed each brigade to set up a platoon-strength "sniper group" of 31 soldiers, each of whom should be supplied with sniper rifles and silencers. ${ }^{11744}$ KDZ304 thought that SRK snipers were highly professional and were under the control of the SRK command. ${ }^{11745}$ Van der Weijden also testified that it appeared from some of the SRK orders that snipers were deemed to be an important asset for the SRK commanders. ${ }^{11746}$ Similarly, Fraser thought that the Serb snipers were controlled and regulated at the corps level, as shown by one of the SRK orders, and because three of the notorious sniping areas, namely Sedrenik, Sniper Alley, and the airport, crossed a number of different SRK Brigades. ${ }^{11747}$ Furthermore, the sniping activities appeared to be co-ordinated, and whenever he and UNPROFOR met with the SRK Commanders, namely Galić and later Milošević, to protest about sniping incidents, the number of incidents would decrease, giving him the impression that there was some control over the snipers' activities. ${ }^{11748}$ Van Baal

\footnotetext{
11740 The $3^{\text {rd }}$ Battalion later became part of the Sarajevo Mechanised Brigade and was renamed as the $2^{\text {nd }}$ Infantry Battalion. See Dragan Maletić, T. 30844 (3 December 2012); D2418 (Witness statement of Božo Tomić dated 5 November 2012), paras. 8, 25-26; Božo Tomić, T. 30178-30179 (13 November 2012); D2267 (Vlado Lizdek's interview with OTP), pp. 5-6; D2622 (Witness statement of Željko Bambarez dated 9 December 2012), para. 5.

11741 P1938 (Witness statement of KDZ310 dated 28 November 2010), paras. 28-29.

11742 D2519 (Witness statement of Dragan Maletić dated 9 November 2012), para. 31; Dragan Maletić, T. 3084630848 (3 December 2012), T. 30873-30874 (4 December 2012); P1938 (Witness statement of KDZ310 dated 28 November 2010), paras. 40-41, 43-44.

11743 P1010 (SRK Order re designation of sniper positions, 4 November 1992) (indicating also that every SRK unit should have at least two snipers); Dragomir Milošević, T. 32832-32833 (29 January 2013).

11744 D2902 (SRK Order, 29 October 1993). Dragomir Milošević denied that this order could have been a basis for the firing on civilians in Sarajevo. See Dragomir Milošević, T. 33272-33274 (6 February 2013).

11745 P2407 (Witness statement of KDZ304), pp. 8, 10.

11746 Patrick van der Weijden, T. 6941-6943, T. 6946-6949 (27 September 2010); P1614 (Order of $2^{\text {nd }}$ Sarajevo Light Infantry Brigade, 14 August 1994), para. 12; P1208 (Order of $2^{\text {nd }}$ Light Infantry Brigade, 30 July 1994), para. 4; P1617 (Report from SRK Security-Intelligence Organ to SRK Command, 15 August 1994), p. 2; P1618 (SRK Order, 1 October 1995), para. 4. See also P1762 (Witness statement of David Fraser dated 17 October 2010), pp. 30-31; P6060 (Record of interview with KDZ185), e-court pp. 13-14.

11747 David Fraser, T. 8018, 8021-8023 (18 October 2010); P1762 (Witness statement of David Fraser dated 17 October 2010), p. 25; P1613 (SRK Order, 19 January 1995), para. 5. See also P2414 (Witness statement of KDZ182), p. 36 (under seal). As far as Sniper Alley was concerned, Fraser conceded that the Muslim side benefited politically from the incidents that happened in that area and could not explain why the SRK commanders would allow something like that to happen. See David Fraser, T. 8123-8124 (19 October 2010). See also KDZ304, T. 10524 (19 January 2011); Dragomir Milošević, T. 32842 (29 January 2013) (testifying that the SRK had no political interest in continuing the sniping activity).

11748 P1762 (Witness statement of David Fraser dated 17 October 2010), pp. 8, 11, 21-22, 23, 25. See also P6060 (Record of interview with KDZ185), e-court pp. 12-13. As noted in paragraph 3595, following the signing of
} 
thought that there was a clear line, both politically and at the "highest military level", on the use of snipers as far as the Serb side was concerned. ${ }^{11749}$ Rose thought that sniping was clearly a part of the Bosnian Serbs' policy of terrorising the civilian population of Sarajevo and that there was "clear control" over the sniping in the city. ${ }^{11750}$ KDZ182 believed that the SRK snipers in Sarajevo were not just locals operating randomly but were perfectly co-ordinated and had the aim of terrorising civilians. ${ }^{11751}$ John Hamill, an artillery officer in the Irish Army and UNMO in BiH from May 1993 to July 1994, ${ }^{11752}$ thought that snipers in Sarajevo operated as the "tools of the management" and were under the control of someone in a position of authority. ${ }^{11753}$ Milenko Inđić, the SRK's liaison officer with UNPROFOR, ${ }^{11754}$ testified that the "SRK just controlled sniper group formations" but stated that it could not control the opening of fire and so the sniping was not stopped. ${ }^{11755}$

3624. Van der Weijden emphasised the importance of proper training for snipers, stating that, for a long range shot, the shooter must be either well trained or very experienced to make first round hits. ${ }^{11756}$ To show that this was the case, the Prosecution presented to the Chamber a number of documents showing that the SRK organised training for snipers during the Indictment period. For example, training for five sniper squad commanders was organised in $1994,{ }^{11757}$ and an eight-day course for sniper instructors took place on 23 January $1995 .{ }^{11758}$ Over 100 sniper instructors would

the Anti-Sniping Agreement in August 1994, the number of people killed and wounded on Zmaja od Bosne reduced dramatically, leading Rose and others to conclude that both parties had strict control over their snipers. See P2447 (Witness statement of KDZ182), p. 35, KDZ182, T. 13040-13041 (9 March 2011); P1638 (Witness statement of Michael Rose dated 26 March 2009), para. 141. See also P6060 (Record of interview with KDZ185), e-court pp. 3, 13.

11749 P1818 (Witness statement of Adrianus van Baal dated 26 October 2010), paras. 48, 50, 58; Adrianus van Baal, T. 8534-8535 (28 October 2010). See also P5906 (Witness statement of KDZ450 dated 17 January 2011), paras. 27-29, 67-68 (testifying that in his experience there were very few rogue shooters on both sides); KDZ450, T. 10574-10575 (19 January 2011), T. 10676 (20 January 2011).

11750 Michael Rose, T. 7267-7268 (5 October 2010).

11751 P2414 (Witness statement of KDZ182), pp. 36, 44 (under seal); KDZ182, T. 13091-13095 (9 March 2011).

11752 John Hamill, P1994 (Transcript from Prosecutor v. Galić), T. 6059-6060. Hamill became an artillery officer in September 1974 and had 20 years of experience with the Irish Defence Forces prior to serving as a UNMO on six occasions. See John Hamill, P1994 (Transcript from Prosecutor v. Galić), T. 6059-6060, 6124; John Hamill, T. 9673 (13 December 2010).

11753 John Hamill, P1994 (Transcript from Prosecutor v. Galić), T. 6217.

11754 D2774 (Witness statement of Milenko Inđić dated 19 January 2013), para. 39.

11755 D2774 (Witness statement of Milenko Inđić dated 19 January 2013), para. 144.

11756 P1621 (Expert Report of Patrick van der Weijden entitled “Sniping Incidents in Sarajevo '92-'94”), pp. 3-4, 106.

11757 P1615 (Report from $1^{\text {st }}$ Igman Infantry Brigade to SRK Command, 21 January 1995), para. 3. Van der Weijden estimated that five sniper squad commanders would have been responsible for between 30 to 40 snipers. See Patrick van der Weijden, T. 6943-6944 (27 September 2010).

11758 P1616 (SRK Order, 5 January 1995); P1612 (SRK Order, 29 January 1995), p. 6; P1613 (SRK Order, 19 January 1995), para.4. The instructors were told to bring their own rifles, namely M76, which was, according to Van der Weijden, the standard sniper rifle of the JNA. See Patrick van der Weijden, T. 6938-6940, 6945-6946 (27 September 2010). See also David Fraser, T. 8018-8023 (18 October 2010); P1783 (Report of $1^{\text {st }}$ Ilijaš 
have been trained by January $1995 .^{11759}$ This confirms Fraser's evidence that during his time in Sarajevo, namely 1994 and 1995, the sniper activity was confined to professional sharpshooters and that amateur shooters were long gone. ${ }^{11760}$

3625. Contradicting the evidence outlined above, Dragomir Milošević denied that civilians were deliberately targeted by sniper fire in Sarajevo, arguing that they were caught in combat activities, although he could not exclude the possibility that a "deranged mind on the Serbian side engaged in such activity". ${ }^{11761}$ Galić explained that the main task of SRK snipers or sharpshooters was to neutralise $\mathrm{ABiH}$ sniper enemy fire and target important military targets, and that civilians were not targeted but rather became collateral damage. ${ }^{11762}$ A number of other SRK soldiers and officers also testified that their specific units never deliberately targeted Sarajevo civilians by opening sniper fire on them and/or that snipers were used only on military targets and in response to $\mathrm{ABiH}$ fire. ${ }^{11763}$ They also denied using sniper fire on trams and other modes of public transport in the city. ${ }^{11764}$ In his book, however, Milovanović wrote that sniping was a huge problem for both Infantry Brigade to SRK re training, 13 January 1995); P1784 (Report of $3^{\text {rd }}$ Sarajevo Infantry Brigade to SRK re training, 5 January 1995).

11759 Patrick van der Weijden, T. 6945 (27 September 2010).

11760 P1762 (Witness statement of David Fraser dated 17 October 2010), pp. 24, 31; David Fraser, T. 8019-8020 (18 October 2010). See also KDZ450, T. 10555-10556 (19 January 2011). Van der Weijden also testified that, according to SRK documents, the SRK snipers worked in pairs, using sound suppressors, as is normally done by professional snipers who operate in two-man teams, consisting of the shooter and the marksman or spotter. See Patrick van der Weijden, T. 6942-6943, 6951-6952 (27 September 2010); P1621 (Expert Report of Patrick van der Weijden entitled "Sniping Incidents in Sarajevo '92-'94”), p. 3; P1208 (Order of $2^{\text {nd }}$ Light Infantry Brigade, 30 July 1994), para. 4.

11761 Dragomir Milošević, T. 32836-32837, 32840-32841 (29 January 2013), T. 33197-33207 (5 February 2013); D2827 (SRK combat report, 19 August 1993) (in which Milošević reported to the VRS Main Staff that SRK units were ordered to open sniper fire only on targets that pose a threat to SRK soldiers). See also D2774 (Witness statement of Milenko Inđić dated 19 January 2013), paras. 139-140.

11762 Stanislav Galić, T. 37465-37466 (22 April 2013), T. 37845-37846, 37852-37854 (7 May 2013), T. 38060 (9 May 2013).

11763 See e.g. Božo Tomić, T. 30214 (13 November 2012); D2519 (Witness statement of Dragan Maletić dated 9 November 2012), paras. 20, 26; Dragan Maletić, T. 30883-30886, 30889-30890 (4 December 2012); D2525 (Photograph of Sarajevo marked by Dragan Maletić); D2516 (Witness statement of Vlade Lučić dated 5 November 2012), para. 25; D2562 (Witness statement of Vladimir Radojčić dated 8 December 2012), para. 43; D2633 (Witness statement of Milorad Šehovac dated 8 December 2012), para. 36; D2667 (Witness statement of Ratomir Maksimović dated 14 December 2012), para. 41. Gengo testified that the Serbian side's response to sniper fire depended on the origin of the fire; sometimes they used a machine-gun, or if fire was opened from a forest, they used mortars to respond. See Slavko Gengo, T. 29784-29785 (6 November 2012); D2383 (Witness statement of Slavko Gengo dated 14 October 2012), para. 27.

11764 See Dragomir Milošević, T. 33209-33210 (5 February 2013); D2341 (Witness statement of Dušan Škrba dated 14 October 2012), para. 15; D2667 (Witness statement of Ratomir Maksimović dated 14 December 2012), para. 28; D2516 (Witness statement of Vlade Lučić dated 5 November 2012), para. 18; D2633 (Witness statement of Milorad Šehovac dated 8 December 2012), para. 27; D2331 (Witness statement of Blagoje Kovačević dated 14 October 2012), para. 28; D2562 (Witness statement of Vladimir Radojčić dated 8 December 2012), paras. 29-30; D2484 (Witness statement of Zoran Kovačević dated 25 November 2012), para. 10; D2387 (Witness statement of Stojan Džino dated 4 November 2012), paras. 50-51; D2379 (Witness statement of Momir Garić dated 2 November 2012), para. 25; D2686 (Witness statement of Mihajlo Vujasin dated 16 December 2012), para. 32; D2391 (Witness statement of Slobodan Tuševljak dated 5 November 2012), para. 20; D2622 (Witness statement of Željko Bambarez dated 9 December 2012), paras. 15-16. 
parties in Sarajevo "having completely got out of control". ${ }^{11765}$ Milošević conceded that he had received, from UNPROFOR and the media, allegations about Serb soldiers sniping at civilians, but claimed that the media exaggerated the situation on the ground and could not be trusted while at the same time he tried to establish if the information from UNPROFOR was true or not. ${ }^{11766}$ Similarly, Galić also conceded that he received protests about sniping or infantry fire causing civilian casualties, usually from UNPROFOR and through Inđić. ${ }^{11767}$ Inđić, on the other hand, testified that while he received protests about sniper fire being opened, he never received protests about such fire causing civilians casualties. ${ }^{11768}$

\section{(B) $\mathrm{ABiH}$ sniping practices}

3626. As noted above, the Bosnian Muslim side had and used snipers throughout the conflict, particularly targeting the suburb of Grbavica, including the civilians located therein. ${ }^{11769}$ In addition, according to the BiH MUP report of 13 October 1993 on the activities of the $2^{\text {nd }}$ Independent Battalion of the $\mathrm{ABiH}$, which had its headquarters in the Sarajevo dental clinic on Meše Selimovića street, the battalion had a number of "death sowers", 11770 one of which was placed near its headquarters, overlooking the Nemanjina street and two to three sniper nests on the third floor of the dental clinic, covering the petrol station plateau at Koševo, a large part of Moša Pijade

11765 D825 (Manojlo Manojlović's book entitled “My View of the War in Bosnia 1992-1995”), p. 31.

11766 Dragomir Milošević, T. 33276-33277 (6 February 2013) (adding that the extent of activities he had to carry out did not give him the opportunity to personally carry out the entire procedure of establishing guilt-he instead relied on the assistance of the military police and prosecutor's office).

11767 Stanislav Galić, T. 37788-37792 (7 May 2013) (clarifying that he never received protests in relation to individual sniping incidents listed in Schedule F of the Indictment).

11768 D2774 (Witness statement of Milenko Inđić dated 19 January 2013), paras. 142-143.

11769 P1762 (Witness statement of David Fraser dated 17 October 2010), p. 24. Maletić whose company was stationed along Miljacka, between the Vrbanja and Bratstvo Jedinstvo bridges, testified that the unit facing his unit had snipers and had used them, which is why a large number of civilians had been killed in Grbavica and Vraca. D2519 (Witness statement of Dragan Maletić dated 9 November 2012), paras. 8-9, 19, 32. See also Stanislav Galić, T. 37468-37469 (22 April 2013); Dragomir Milošević, T. 32821-32823 (29 January 2013); D2824 (Order of ABiH, March 1993); P926 (Witness statement of Aernout van Lynden dated 26 February 2010), para. 156; D201 ( $1^{\text {st }}$ Romanija Brigade combat report, 13 July 1992); P2068 (Witness statement of Jeremy Bowen dated 10 August 2009), para. 36; Jeremy Bowen, T. 10107-10108 (13 January 2011); P2074 (BBC news report re Sarajevo, with transcript); P820 (Witness statement of David Harland dated 4 September 2009), para. 171; P879 (VRS Main Staff Report, 11 March 1995); David Harland, T. 2099-2101 (7 May 2010); P1996 (Witness statement of Martin Bell dated 8 March 2010), paras. 46-47; P2022 (BBC news report re Grbavica, with transcript); Michael Rose, T. 7268 (5 October 2010); P5906 (Witness statement of KDZ450 dated 17 January 2011), para. 133; D3526 (Order of ABiH $1^{\text {st }}$ Motorised Brigade, 2 October 1993); D4633 (Order of ABiH $1^{\text {st }}$ Corps, 12 December 1993); P1753 (Order of ABiH 12 ${ }^{\text {th }}$ Division, 19 September 1995); D2825 (Report of $1^{\text {st }}$ Romanija Infantry Brigade, undated); D2826 ( $1^{\text {st }}$ Romanija Infantry Brigade combat report, 25 July 1992); P2407 (Witness statement of KDZ304), p. 28; KDZ304, T. 10485 (18 January 2011); KDZ088, T. 6369-6372 (8 September 2010) (closed session); D564 (SRK combat report, 23 July 1992), para. 1; D2779 (VRS Main Staff notes of meeting at Sarajevo airport, 7 April 1993), p. 2.

11770 KDZ485 explained that the "death sower" is a type of machinegun that can fire rounds at very high velocity thus making it difficult for the target to escape. See KDZ485, T. 8881 (3 November 2010); P1905 (Witness statement of KDZ485), Supplemental Information Sheet. 
street, and the area around the medical school. ${ }^{11771}$ The Chamber also heard that special sniper groups, referred to as Ševe and Laste, operated from ABiH-held territory. ${ }^{11772}$ Edin Garaplija, a former member of the BiH MUP's SDB, confirmed that Ševe was a special MUP unit that operated during the conflict with the task of sniping at Bosnian Serb positions. ${ }^{11773}$ According to Galić, the $1^{\text {st }}$ Corps of the $\mathrm{ABiH}$ had around 500 snipers in Sarajevo because the Zrak factory, which produced optical sights, was in ABiH-held territory. ${ }^{11774}$ Thomas testified that it was difficult for him to visit and inspect sniper locations in $\mathrm{ABiH}$-held territory due to the $\mathrm{BiH}$ government's stonewalling. ${ }^{11775}$ He was successful in seeing one such location, however, which was located in Dobrinja and which was manned by very professional police officers who had good sniping equipment. $^{11776}$

(C) Sniping investigations and anti-sniping measures undertaken in the city

3627. A number of witnesses before this Chamber, including both members of the BiH MUP and UNPROFOR, participated in the investigation of sniping incidents in Sarajevo. With respect to the BiH MUP investigations, the CSB Sarajevo's department for serious criminal acts was tasked with investigating sniping incidents in which one or more people were killed. ${ }^{11777}$ This department was notified of any such incident by the local police station concerned and would in turn inform an investigative judge of the Sarajevo Supreme Court who would become the head of the investigating team. ${ }^{11778}$ A team was then formed, including an investigator, criminal technicians, and a ballistics expert. ${ }^{11779}$ The investigative judge was responsible for the investigation, for ensuring that no legal

11771 D858 (BiH MUP Report re ABiH's $11^{\text {th }}$ Independent Battalion, 19 October 1993), pp. 2-3.

11772 Stanislav Galić, T. 37468 (22 April 2013), T. 38061 (9 May 2013); Dragomir Milošević, T. $32821-32822$ (29 January 2013); D2331 (Witness statement of Blagoje Kovačević dated 14 October 2012), para. 37; D2774 (Witness statement of Milenko Inđić dated 19 January 2013), paras. 151-152; Francis Roy Thomas, T. 68306834 (15 September 2010); P5906 (Witness statement of KDZ450 dated 17 January 2011), para. 68 (testifying that snipers on the $\mathrm{BiH}$ side were supplied by the police rather than the army). See also para. 4505. While Mirsad Kučanin, a CSB Sarajevo inspector, acknowledged the existence of a special police unit called Laste, which did get involved in combat, he also testified that it was poorly equipped and carried only rifles and some captured weapons. Kučanin encountered this unit when they were securing his crime scenes. P27 (Witness statement of Mirsad Kučanin dated 4 September 2000), p. 3.

11773 Edin Garaplija, T. 33382-33384, 33388 (7 February 2013). Garaplija also testified about this unit's other activities, which he labeled terrorist activities. See para. 4505.

11774 Stanislav Galić, T. 37468 (22 April 2013), T. 38060-38061 (9 May 2013).

11775 P1558 (Witness statement of Francis Roy Thomas dated 13 May 2009), para. 64; Francis Roy Thomas, T. 68306834 (15 September 2010).

11776 P1558 (Witness statement of Francis Roy Thomas dated 13 May 2009), para. 64.

11777 P1830 (Witness statement of Dragan Mioković dated 26 October 2010), p. 4; P1905 (Witness statement of KDZ485), para. 5.

11778 The investigating judge could authorise an investigator to conduct the investigation on his behalf. See P1830 (Witness statement of Dragan Mioković dated 26 October 2010), pp. 2, 4. See also P1905 (Witness statement of KDZ485), para. 5.

11779 P1830 (Witness statement of Dragan Mioković dated 26 October 2010), pp. 4-5; P1905 (Witness statement of KDZ485), para. 5. Mirza Sabljica testified that in most serious cases the investigation team would include two 
errors were made, and for conveying instructions to the investigator who would then pass them on to the other members of the team. ${ }^{11780}$ The bulk of the investigation was carried out by ballistic experts and criminal technicians, whose task was to determine the type of the projectile used and the direction from which it came. ${ }^{11781}$ Upon completion of the investigation, the investigator would write up an official report on the basis of his notes and "verbal comments" of the experts, providing a chronological description of the work conducted. ${ }^{11782}$ Later on, the investigator would also collect other documents prepared during the investigation, and would pass them on, together with his own report, to the investigating judge. ${ }^{1783}$ It was for the judge to then prepare a report outlining the findings of the investigation and appending the documents prepared by the CSB and its experts. ${ }^{11784}$ On rare occasions, the investigative judge would ask that further investigation be conducted, usually consisting of additional questioning of witnesses. ${ }^{11785}$

3628. If no ballistic expert was available, ${ }^{11786}$ determination of the origin and/or direction of fire was made by one of the criminal technicians who were also trained to determine the direction of fire. ${ }^{11787}$ With respect to methods that were used for establishing the origin and/or direction of fire, they depended on the type of the incident and the scene in question, as well as any evidence found on the scene and any assistance from eye-witnesses. ${ }^{11788}$ For example, in cases of sniping of trams, the first step was to examine the damage on the tram, including identifying the bullet's entry and exit holes and their dimensions. ${ }^{11789}$ Once this was done, a rope, glass tubes, ${ }^{11790}$ a measuring level, and a small optical device ${ }^{11791}$ would be used to establish the bullet's entry angle and to determine

ballistics experts rather than one. See P1695 (Witness statement of Mirza Sabljica dated 11 February 2010), p. 9.

11780 P1830 (Witness statement of Dragan Mioković dated 26 October 2010), p. 5. See also Dragan Mioković, T. 8555 (28 October 2010); P1695 (Witness statement of Mirza Sabljica dated 11 February 2010), pp. 67-68; Mirsad Kučanin, P16 (Transcript from Prosecutor v. Galić), T. 4643-4644; P1905 (Witness statement of KDZ485), para. 6.

11781 P1830 (Witness statement of Dragan Mioković dated 26 October 2010), p. 5; P1695 (Witness statement of Mirza Sabljica dated 11 February 2010), pp. 7, 67.

11782 P1830 (Witness statement of Dragan Mioković dated 26 October 2010), p. 5.

11783 P1830 (Witness statement of Dragan Mioković dated 26 October 2010), p. 5; P1905 (Witness statement of KDZ485), para. 7. See also KDZ485, T. 8900-8902 (3 November 2010).

11784 P1830 (Witness statement of Dragan Mioković dated 26 October 2010), p. 5.

11785 P1830 (Witness statement of Dragan Mioković dated 26 October 2010), pp. 33-34.

11786 According to KDZ485, "there were not too many [ballistics experts] to go around" during the war. P1905 (Witness statement of KDZ485), para. 11; KDZ485, T. 8900 (3 November 2010).

11787 P1905 (Witness statement of KDZ485), para. 11. KDZ485 could recall only one sniping incident where the ballistics expert was absent from the scene. KDZ485, T. 8900 (3 November 2010).

11788 P1905 (Witness statement of KDZ485), para. 12.

11789 Mirza Sabljica, T. 7732 (12 October 2010); P1695 (Witness statement of Mirza Sabljica dated 11 February 2010), p. 68.

11790 Mirza Sabljica testified that the team had a number of these tubes of different sizes, depending on the type and caliber of the ammunition that was used. See Mirza Sabljica, T. 7743 (12 October 2010).

11791 The device was a type of sophisticated binocular, with a 16 time zoom, made for the BiH MUP in order to assist in their investigations. Mirza Sabljica did not know if this device was ever tested as reliable for the purpose for 
the direction of fire and facilities from which the bullet may have originated. ${ }^{11792}$ This was done by connecting the entry and exit holes with a tube and a rope, ${ }^{11793}$ measuring the sides of the resulting triangle and its hypotenuse, using trigonometry to calculate the entry angle, and then, finally, using the optical device to look through the hole ${ }^{11794}$ to sight the area and potential facilities from which the bullet could have originated. ${ }^{11795}$ Mirza Sabljica, a ballistics expert working for CSB Sarajevo, ${ }^{11796}$ testified that the investigation team usually insisted on the tram remaining at the location of the incident although that was often impossible as trams were sometimes moved by the driver to avoid being shot again. ${ }^{11797}$ If the tram could not be returned to the location at which it was when hit, ${ }^{11798}$ the investigators would only take measurements and calculate the bullet's entry angle but would not use the optical device to conduct the sighting exercise as the difference in a few centimetres in the position of the tram would result in a different direction of fire. ${ }^{11799}$ In these instances, the ballistic experts were therefore able to establish only the general direction of fire but not the precise location from which the bullet had been fired. ${ }^{11800}$ The sniping investigations related to sniping of apartments were conducted in the same manner, using the equipment and the methodology described above. ${ }^{11801}$

3629. Sabljica also explained that the ballistics experts could not establish the distance which the bullets had travelled and, for that reason, in areas where VRS and $\mathrm{ABiH}$ positions were close to each other, they would not specify the exact origin of fire from within VRS-held territory or outside

which it was used. He did admit, however, that the device would be affected by certain aberrations in light and noted that the team did not have the equipment necessary to take into account those aberrations. See Mirza Sabljica, T. 7733, 7744-7745 (12 October 2010).

11792 Mirza Sabljica, T. 7732-7735, 7743 (12 October 2010); P1695 (Witness statement of Mirza Sabljica dated 11 February 2010), p. 68. See also P21 (Witness statement of Mirsad Kučanin dated 21 February 1996), e-court p. 2; P1742 (Witness statement of Bogdan Vidović dated 28 September 2010), pp. 2, 11; P1905 (Witness statement of KDZ485), para. 14; P1924 (Photograph of Sarajevo marked by KDZ485).

11793 According to Mirza Sabljica, the wall of the Sarajevo trams was somewhere between 12 and 15 centimetres thick. See Mirza Sabljica, T. 7742 (12 October 2010).

11794 The device would be lightly fixed to the tube that was inserted through the bullet's entry and exit holes and the investigators could look to see what particular buildings could be seen through it. See Mirza Sabljica, T. 7735 (12 October 2010).

11795 However, the bullet would sometimes get stuck in the body of a tram and there would be no exit hole. Mirza Sabljica, T. 7732-7735, 7743 (12 October 2010); P1734 (Sketch drawn by Mirza Sabljica); P1695 (Witness statement of Mirza Sabljica dated 11 February 2010), p. 68. See also P21 (Witness statement of Mirsad Kučanin dated 21 February 1996), e-court p. 2; P1742 (Witness statement of Bogdan Vidović dated 28 September 2010), pp. 2, 11.

11796 For Mirza Sabljica's qualifications, see Mirza Sabljica, T. 7702, 7705-7706 (11 October 2011); P1695 (Witness statement of Mirza Sabljica dated 11 February 2010), pp. 1-8, 60.

11797 P1695 (Witness statement of Mirza Sabljica dated 11 February 2010), pp. 67-68; P1830 (Witness statement of Dragan Mioković dated 26 October 2010), p. 5; P1905 (Witness statement of KDZ485), para. 13.

11798 Mirza Sabljica, T. 7736, 7746 (12 October 2010); P1905 (Witness statement of KDZ485), para. 13.

11799 Mirza Sabljica, T. 7736, 7745-7746 (12 October 2010).

11800 P1695 (Witness statement of Mirza Sabljica dated 11 February 2010), pp. 68-69; P1742 (Witness statement of Bogdan Vidović dated 28 September 2010), p. 34.

11801 Mirza Sabljica, T. 7734-7735 (12 October 2010); P1905 (Witness statement of KDZ485), para. 12. 
but simply referred to cardinal directions. ${ }^{11802}$ Dragan Mioković, an investigator in CSB Sarajevo, ${ }^{11803}$ stated that given the circumstances in which the investigations were carried out, the BiH MUP "practically just documented these incidents" rather than elucidating the crimes, which is why medical reports were not of primary importance when conducting investigations. ${ }^{11804}$

3630. Generally, UNPROFOR would be informed about the sniping incidents, either from its own troops or through protests by warring factions, and would conduct its own investigation and also assist the BiH MUP in their investigations. ${ }^{11805}$ Fraser testified that because UNPROFOR was not supposed to get involved in exchanges between the warring factions, it took great care to determine whether sniping incidents were directed against civilians or not. ${ }^{11806}$ If they were, it would then exercise particular caution to determine which side fired the shot against the civilian. ${ }^{11807}$ Fraser conceded, however, that the UNPROFOR investigation was not a criminal investigation. ${ }^{11808}$ Instead, UNPROFOR would get information from its troops positioned in the area of the incident and from the local authorities, including the local police, and would then protest, verbally or in writing, with the party found to have conducted the sniping attack. ${ }^{11809}$ Rose testified that the UN could not determine beyond reasonable doubt from where the sniper fire had come because it did not conduct investigations that would have established that. ${ }^{11810}$

3631. In addition, prompted by the number of sniping incidents in the Sniper Alley area, Sector Sarajevo also created an international anti-sniping task force wherein snipers from each UNPROFOR battalion were given anti-sniping tasks in their area of responsibility, with the aim of protecting civilians. ${ }^{11811}$ This force had a co-ordination centre and sniping incidents were reported

\footnotetext{
11802 P1695 (Witness statement of Mirza Sabljica dated 11 February 2010), p. 7.

11803 For Dragan Mioković's qualifications, see Dragan Mioković, T. 8544-8545, 8548-8551 (28 October 2010); P1830 (Witness statement of Dragan Mioković dated 26 October 2010), pp. 2, 28-29.

11804 Mioković testified that medical reports would be submitted to the investigating judge separately, after the team had completed its work. See P1830 (Witness statement of Dragan Mioković dated 26 October 2010), pp. 34-35. KDZ485 testified, however, that when investigating an incident, one of duties of the police was to establish if anyone was injured or killed and to follow up at the hospital or the mortuary. See P1905 (Witness statement of KDZ485), paras. 7, 15.

11805 David Fraser, T. 8016, 8054-8055 (18 October 2010); P1762 (Witness statement of David Fraser dated 17 October 2010), pp. 22-23; P1742 (Witness statement of Bogdan Vidović dated 28 September 2010), pp. 18-20.

11806 David Fraser, T. 8015-8016 (18 October 2010).

11807 David Fraser, T. 8016 (18 October 2010).

11808 David Fraser, T. 8054-8055 (18 October 2010). See also KDZ304, T. 10523 (19 January 2011).

11809 P1762 (Witness statement of David Fraser dated 17 October 2010), p. 23; David Fraser, T. 8016, 8054-8055 (18 October 2010), T. 8124-8125 (19 October 2010); P2414 (Witness statement of KDZ182), p. 31 (under seal).

11810 Michael Rose, T. 7293-7294 (5 October 2010).

11811 David Fraser, T. 8016 (18 October 2010); P1762 (Witness statement of David Fraser dated 17 October 2010), pp. 32, 34; P2407 (Witness statement of KDZ304), pp. 10-11; P1773 (UNPROFOR report re efficacy of AntiSniping Agreement, 15 September 1994).
} 
to the Sector Sarajevo headquarters as soon as possible after they occurred. ${ }^{11812}$ While part of the task force's duties was to deter both sides, it principally had to deter the Bosnian Serbs from shooting at civilians. ${ }^{1813}$ It would do that by, for example, physically interposing UNPROFOR soldiers between the Serb snipers and the civilians in the Sniper Alley area and then engaging the snipers themselves. ${ }^{11814}$ It would also install passive barriers throughout the city, although at times the $\mathrm{BiH}$ authorities would not allow this. ${ }^{11815}$ Another one of its tasks was to photograph all the possible areas in Grbavica where the Serbs were shooting from and observe the identified locations thus becoming very familiar with the sniper positions in the area. ${ }^{11816}$ That information would have then been sent up to the battalion and the sector level. ${ }^{11817}$ All of the above meant that the antisniping task force was "very good in determining the point of origin for specific incidents" and that UNPROFOR commanders were "certain" that Bosnian Serb forces were engaging in sniping attacks against civilians in Sarajevo. ${ }^{11818}$

11812 P1762 (Witness statement of David Fraser dated 17 October 2010), pp. 32-33, 37; P1771 (UNPROFOR report re anti-sniping measures, 25 June 1994); P1772 (UNPROFOR report re sniping in Sarajevo, 6 September 1994); KDZ182, T. 13083 (9 March 2011) (private session); P2407 (Witness statement of KDZ304), p. 15; P2113 (UNPROFOR report re anti-sniping, 23 September 1994).

11813 P1762 (Witness statement of David Fraser dated 17 October 2010), pp. 33-34; P2414 (Witness statement of KDZ182), pp. 6-7, 40-41 (under seal); KDZ182, T. 13083-13084 (9 March 2011) (private session). KDZ304 explained that it was difficult to monitor the snipers on the Bosnian Muslim side as most of the UNPROFOR forces, with the exception of RusBat, had no acces to SRK-held areas and could not observe or verify the number or the identity of sniping victims on the Serb side. Since RusBat never reported any sniping incidents on the Serb side, the anti-sniping task force was unable to locate the sniper nests on the Bosnian Muslim side. See P2407 (Witness statement of KDZ304), pp. 13-15.

11814 P2407 (Witness statement of KDZ304), p. 11. Fraser testified that this did not always work as UNPROFOR lost a number of soldiers through sniping, one of whom was shot by the Serbs while located in one of the UNIS towers, while another was shot near the airport by the Bosnian Muslim side. See P1762 (Witness statement of David Fraser dated 17 October 2010), pp. 33-34, 36; David Fraser, T. 8016 (18 October 2010). KDZ182 testified that UNPROFOR soldiers would engage the snipers only in a situation of self-defence, and were able to do that because they had thermal cameras which allowed them to see where the snipers were. He also confirmed that an UNPROFOR soldier was shot by the Bosnian Muslim side at the airport. See P2414 (Witness statement of KDZ182), pp. 29, 42, 44, 72 (under seal). See also P5908 (Record of interview with KDZ185), para. 8; P1075 (Photograph of UN APC in Sarajevo); D2907 (UNPROFOR report, 18 April 1995); D2774 (Witness statement of Milenko Inđić dated 19 January 2013), para. 158.

11815 David Fraser, T. 8016 (18 October 2010), T. 8121-8122 (19 October 2010); P1762 (Witness statement of David Fraser dated 17 October 2010), p. 34; P2414 (Witness statement of KDZ182), p. 40 (under seal); P6060 (Record of interview with KDZ185), e-court p. 13; P5908 (Record of interview with KDZ185), para. 8; P1069 (Photograph of anti-sniping barricades in Sarajevo); P1070 (Photograph of anti-sniping barricades (Maršal Tito Barracks)); P1071 (Photograph of anti-sniping barricades (Dobrinja)); P1072 (Photograph of anti-sniping barricades (Dobrinja)); P1073 (Photograph of anti-sniping barricades in Sarajevo); P1074 (Photograph of antisniping barricades (Parliament building)); P1075 (Photograph of UN APC in Sarajevo); P2407 (Witness statement of KDZ304), p. 11. Fraser also explained that while the barriers had a positive impact, they would simply result in moving the problem elsewhere as the snipers would find new positions from which they could gauge the target. See David Fraser, T. 8163-8164 (19 October 2010).

11816 P1762 (Witness statement of David Fraser dated 17 October 2010), pp. 24-25, 29; David Fraser, T. 8016-8018 (18 October 2010).

11817 David Fraser, T. 8018 (18 October 2010); P2407 (Witness statement of KDZ304), p. 12; P2112 (UNPROFOR report re sniper fire in Sarajevo, 21 September 1994).

11818 David Fraser, T. 8018 (18 October 2010). Fraser also testified that UNPROFOR did not use reports produced by the BiH government agencies. See David Fraser, T. 8034 (18 October 2010). 
3632. The Accused argues that both the BiH MUP and the UN investigators working on scheduled sniping incidents were "exceptionally unreliable" as they were biased and their work was riddled with mistakes. ${ }^{11819}$ The Prosecution responds that this is a broad allegation based on mischaracterisation of the evidence the relevant witnesses gave. ${ }^{1820}$ As will be seen below, in its analysis of the scheduled sniping incidents the Chamber has considered and analysed a number of CSB Sarajevo and UN reports prepared on the basis of the investigation methods outlined above. These were produced by ballistics experts and/or criminal technicians who were, in most cases, on site soon after the incident happened and who used accepted ballistics methods to determine the direction of fire. These individuals, particularly the UNPROFOR and its anti-sniping force, also had extensive knowledge of notorious sniping positions in the city, as well as access to the scene, contemporaneous information, and eye-witnesses. Given these factors, the Chamber generally gave considerable weight to the CSB Sarajevo and UN reports when analysing the scheduled sniping incidents. In doing so, the Chamber was also constantly cognisant of the shortcomings of the investigations conducted during the war, such as for example the difficulties faced by investigators when working on a crime scene while under threat of enemy fire, their inability to determine the exact origin of fire as opposed to the direction of fire, and inconsistencies between ballistic and other investigative reports. Whenever issues arose with respect to particular reports, they were considered by the Chamber in relation to each particular incident. Accordingly, while finding this type of evidence to be generally reliable and credible, the Chamber approached it as one piece of the puzzle assessed against the totality of evidence tendered in relation to each incident.

3633. The Chamber also heard from one of the Prosecution investigators, Barry Hogan, who visited Sarajevo on many occasions and prepared various materials relating to the incidents listed in Schedule $\mathrm{F}$ of the Indictment. ${ }^{1821}$ He testified that he visited each of the locations where the victims listed in Schedule F were wounded or killed, accompanied by one of those victims or eyewitnesses, and used a GPS unit to produce an accurate reading of the position of the victim and/or a tram at the time the shooting took place, as recounted by that victim or witness. These were then used to produce a map recording all the incident sites. ${ }^{11822}$ Hogan would then stand at the location where the victims were wounded and/or killed and would take GPS readings from there. ${ }^{1823}$ Hogan also explained that no local police reports or UN reports were used for the

\begin{tabular}{ll}
\hline 1819 & Closing Arguments, T. 47954-47959, 47989-47991 (2 October 2014). \\
11820 & Closing Arguments, T. 48056-48059 (7 October 2014). \\
11821 & Barry Hogan, T. 11192-11193 (3 February 2011). \\
11822 & $\begin{array}{l}\text { Barry Hogan, T. 11204-11206, 11230-11231, 11255 (3 February 2011); P2190 (GPS locations for shelling and } \\
\text { sniping incidents in Sarajevo); P2191 (Map of Sarajevo with scheduled sniping and shelling incidents). }\end{array}$ \\
11823 & $\begin{array}{l}\text { Barry Hogan, T. 11232-11233, 11241-11245 (3 February 2011) (adding that the readings were taken in degrees, } \\
\text { minutes, and seconds but that later, when preparing the maps, he converted those measurements into decimal } \\
\text { degrees which did not affect the location of the incident as recorded on the maps. See also P2190 (GPS }\end{array}$
\end{tabular} 
purpose of this exercise. ${ }^{11824}$ As for the origin of fire, the victims/witnesses simply indicated the direction from which the fire had come, as they were not in a position to identify the exact locations from which the bullets were fired. ${ }^{11825}$ These victims and/or witnesses were pointing out locations purely from memory as they were not given their own witness statements or any other materials in order to refresh their memories. ${ }^{11826}$ The Chamber has considered Hogan's evidence and found that he was a reliable and truthful witness. He was meticulous and did not overstep the boundaries of his mandate. However, the Chamber notes that his mandate was limited to simply recording the locations of the incident sites. In addition, for each alleged incident, his GPS recordings were dependent on the recollection of a singular victim/witness who was not given any material to refresh his or her memory despite being taken to the relevant locations years after the incident. Thus, at times, as will be seen below, ${ }^{11827}$ there was some inconsistency between those recollections and the official reports created by the BiH MUP and/or other evidence. Accordingly, while accepting Hogan's evidence as credible, the Chamber is fully aware of its limitations and also of the fact that his activities were dependent on the recollections of others.

3634. Finally, as noted above, ${ }^{1828}$ the Chamber heard from two experts relating to sniping in Sarajevo. For the Prosecution, Van der Weijden conducted investigations into all scheduled sniping incidents and considered the alleged origin of fire, as well as the opportunity the shooter in each incident would have had to identify the target as a combatant. He visited the incident sites in 2006 and 2009 and inspected the exact locations at which the victims were shot, using the GPS coordinates obtained by Hogan and provided to him by the Prosecution; while there, he observed the surroundings, usually from the location of the wound on the victims' bodies, checking for a clear line of sight to a possible shooting position. ${ }^{11829}$ He then visited the areas he identified as possible shooting positions to see if it would be technically feasible to fire from them. ${ }^{1830} \mathrm{He}$ would then eliminate the locations offering no views on the incident sites and/or offering no tactical advantage to the shooter, and would eventually arrive at the area he thought the shot had come from. ${ }^{11831}$

3635. When conducting this exercise, Van der Weijden was also provided with witness statements in which the origin of fire was often suggested by the witnesses; however, this did not have much

locations for shelling and sniping incidents in Sarajevo); P2191 (Map of Sarajevo with scheduled sniping and shelling incidents).

11824 Barry Hogan, T. 11231-11235 (3 February 2011); D990 (Photographs of GPS device).

11825 Barry Hogan, T. 11231 (3 February 2011).

11826 Barry Hogan, T. 11288 (3 February 2011).

11827 See e.g. para. 3963.

11828 See para. 3617.

11829 Patrick van der Weijden, T. 6953, 6968-6969 (27 September 2010).

11830 Patrick van der Weijden, T. 6953, 6970-6971 (27 September 2010). 
effect on his investigation as he would, using the method described above, independently assess whether their account was feasible. ${ }^{11832}$ For some incidents, he was also given reports prepared by the BiH MUP, but noted that these were not "very helpful" as they were not "very complete". 11833 Van der Weijden conceded that he did not review the medical information pertaining to the injuries of the victims in question nor did he always have knowledge of the exact position the victim was in when shot, but again explained that he was concerned mainly with lines of sight and with the general layout of the incident site. ${ }^{1834}$ Van der Weijden was only broadly aware of the confrontation lines in Sarajevo and not in relation to each specific incident; however, according to him, having detailed knowledge of these lines was not necessary since his investigation was concerned purely with the inquiry into where the shot might have come from, rather than from which side of the confrontation line it originated. ${ }^{11835} \mathrm{He}$ also noted that he never established that any of the shots were fired by a trained sniper as opposed to a regular soldier, ${ }^{11836}$ and accepted that he was never able to reach a definitive conclusion as to the exact location from which the bullet had come from. ${ }^{11837}$

3636. The Accused argues that Van der Weijden is the Prosecution's most important witness with respect to the alleged sniping incidents but is of highly questionable credibility, given that he attended only several military courses. In addition, according to the Accused, Van der Weijden was aware of the confrontation lines in Sarajevo only in "broad lines" and reached his conclusions purely by looking at the layout of the incident site, trying to establish possible origins of the shots. ${ }^{1838}$ Further, the Accused claims that Van der Weijden was never able to reach a definitive conclusion as to the exact origin of fire and acknowledged that the BiH MUP reports were not very helpful as they were incomplete. ${ }^{11839}$ The Prosecution responds that the Accused mis-characterised Van der Weijden's conclusions since, for a number of incidents, namely, F.1, F.3, F.6, and F.12, Van der Weijden either concluded there was only one possible origin of fire or excluded any reasonable possibility that the fire originated from ABiH-held territory. ${ }^{11840}$ The Prosecution also

\footnotetext{
11831 Patrick van der Weijden, T. 6967-6968 (27 September 2010).

11832 Patrick van der Weijden, T. 6954 (27 September 2010).

11833 Patrick van der Weijden, T. 6971-6972 (27 September 2010).

11834 Patrick van der Weijden, T. 6954, 6969-6970 (27 September 2010).

11835 Patrick van der Weijden, T. 6965-6966, 6971 (27 September 2010).

11836 Patrick van der Weijden, T. 6967 (27 September 2010).

11837 Patrick van der Weijden, T. 6972 (27 September 2010).

11838 Defence Final Brief, paras. 2163-2165.

11839 Defence Final Brief, paras. 2166-2167.

11840 Closing Arguments, T. 47734 (30 September 2014).
} 
notes that Van der Weijden's conclusions are only a part of the totality of evidence for each scheduled incident. ${ }^{11841}$

3637. The Chamber has analysed Van der Weijden's qualifications and testimony and is satisfied that he is an expert in sniping and a reliable witness and that his evidence, as far as its main purpose is concerned — namely to establish the lines of sight between possible origins of fire and the alleged location of the incident—can be accepted as generally credible. ${ }^{11842}$ The Chamber also notes, however, that Van der Weijden's methodology was dependent on the information given to him by the Prosecution as to the location of incident sites, which at times was confusing and/or internally inconsistent. $^{11843}$ In addition, as he himself stated, his investigation was concerned purely with the inquiry into where the shot might have come from, rather than from which side of the confrontation line it originated from, and he willingly admitted that he was never able to reach a definitive conclusion as to the exact location where the bullet originated. Accordingly, his evidence was approached as one of a number of factors in the Chamber's assessment of the totality of the evidence and, at times, was of relatively limited value in the Chamber's determination on the origin of fire in the incidents alleged.

3638. While preparing his expert report, Poparić visited Sarajevo twice, in September 2010 and May 2011. ${ }^{11844}$ The first visit lasted three days and its purpose was for Poparić to familiarise himself with the sites and to help the Accused prepare for cross-examination of Prosecution witnesses. ${ }^{11845}$ The purpose of the second visit was to prepare the Accused's legal adviser for the site visit. ${ }^{11846}$ Poparić explained that during the visits he was led to the relevant locations by a former member of the SRK who knew the best way to some of the more inaccessible areas. ${ }^{1847} \mathrm{He}$ also explained that in addition to the two official visits, he went to Sarajevo on a few more occasions on his own, usually when he needed further clarification, but did not meet with the victims of the sniping incidents. ${ }^{11848}$

\footnotetext{
11841 Closing Arguments, T. 47734 (30 September 2014).

11842 The Chamber has noted in relation to each individual incident where his evidence was not relied upon, due mainly to the inaccurate or confusing information he was given by the Prosecution.

11843 See e.g. discussion in relation to Scheduled Incident F.11.

11844 Mile Poparić, T. 39173 (4 June 2013).

11845 Mile Poparić, T. 39173 (4 June 2013).

11846 Mile Poparić, T. 39173 (4 June 2013).

11847 Mile Poparić, T. 39173-39177 (4 June 2013).

11848 He did meet, however, with a person who took one of the victims of one of the scheduled incidents to the hospital. See Mile Poparić, T. 39177-39180 (4 June 2013).
} 
3639. During his visits, Poparić visited locations of the scheduled incidents and locations from which the shots might have originated. ${ }^{1849}$ However, with respect to six scheduled sniping incidents that took place on Zmaja od Bosne street, he conceded that he did not go inside the four white high-rises in Grbavica claiming that this was not necessary because he had photographs from the Dragomir Milošević case and because it was not clear on which floors the sniper nests were located. ${ }^{1850}$ His analysis of the incidents relevant to the high-rises was in any event based primarily on (i) the height of the four high-rises and (ii) the distance between the high-rises and the incident site, which allowed him to calculate the maximum angle of descent of any bullets fired from there. ${ }^{11851}$ Poparić also clarified that he did not go inside the Metalka building but stood next to it to see the view down Franje Račkog street; he also had a set of photographs taken from the building in 2001, at the time when there was no vegetation, for the purposes of the Dragomir Milošević case. ${ }^{11852}$ Poparić did not dispute Van der Weijden's findings as to what was visible from the white high-rises and the Metalka building and assumed them to be correct for the purposes of his analysis. ${ }^{11853}$

3640. In terms of the equipment, Poparić had a compass, a camera, and a measuring tape. ${ }^{1854}$ The compass was not of much use to him due to the fact that many of incident locations were in or near certain facilities so there was no dispute about them. ${ }^{1855}$ He also did not use a GPS to identify the relevant locations because this was not necessary given that he had photographs and other information. $^{11856}$ In addition, small differences in measurements would not have made much difference for sniping incidents due to the fact that the trajectory of a bullet is horizontal and straight. ${ }^{11857}$ He also did not use a laser rangefinder which would have been useful only if there was information about the nature of the wounds of the victims, which was not available. ${ }^{1858}$

3641. As for the type and quality of materials available to him, Poparić explained that what was lacking in the materials available was information relating to medical and forensic evidence. ${ }^{11859}$ When preparing his report, he consulted a forensic medicine doctor in relation to one of the

\footnotetext{
11849 Mile Poparić, T. 39177 (4 June 2013).

11850 Mile Poparić, T. 39183-39189 (4 June 2013).

11851 According to Poparić, that angle was about ten degrees. See Mile Poparić, T. 39184-39185 (4 June 2013 ).

11852 Mile Poparić, T. 39185-39189 (4 June 2013).

11853 Mile Poparić, T. 39189-39190 (4 June 2013).

11854 Mile Poparić, T. 39182-39183 (4 June 2013).

11855 Mile Poparić, T. 39183 (4 June 2013).

11856 Mile Poparić, T. 39180-39181 (4 June 2013).

11857 Mile Poparić, T. 39181-39182 (4 June 2013).

11858 Mile Poparić, T. 39182-39183 (4 June 2013).

11859 Mile Poparić, T. 39191 (4 June 2013).
} 
incidents ${ }^{11860}$ but did not consult any professional snipers. ${ }^{11861}$ When pointed out to him that he used a map of confrontation lines from 1995 in relation to incidents from 1993, while failing to specify the date of the map in his report, Poparic denied that he deliberately and repeatedly omitted relevant information from his report and that he had developed premises based on incorrect information. ${ }^{11862}$

3642. The Prosecution submits that Poparić was neither credible nor reliable and that his evidence should be disregarded as a whole. ${ }^{11863}$ The Accused on the other hand claims that Poparić, unlike the Prosecution witnesses, stated all the facts, thus successfully challenging the Prosecution evidence. ${ }^{11864}$ The Chamber has analysed both Poparić's expert report and his testimony on the scheduled sniping incidents alleged in the Indictment and has found that on many occasions he ventured outside of his area of expertise and made conclusions on issues in which he had no training, such as for example determining entry and exit wounds from videos and photographs. ${ }^{11865}$ As will be seen from the Chamber's analysis in relation to each scheduled sniping incident, Poparić often jumped to conclusions, making questionable leaps in logic. ${ }^{11866}$ At times, he also reached conclusions based on incorrect information. ${ }^{11867}$ In addition, while expressing opinions as to what could and could not be seen from certain buildings in Sarajevo, such as the four white high-rises and the Metalka building, ${ }^{11868}$ he also conceded that he never entered those buildings. ${ }^{1869}$ All of these aspects of Poparić's evidence tended to compromise his credibility and impartiality. Accordingly, the Chamber has found his evidence to be of limited value, as will be seen in the sections analysing each specific scheduled incident.

\footnotetext{
11860 This was Dr. Dušan Dunjić and the consultation related to Scheduled Incident F12. See Mile Poparić, T. 3919139193, 39198 (4 June 2013).

11861 Mile Poparić, T. 39193-39194 (4 June 2013).

11862 Mile Poparić, T. 39195-39198 (4 June 2013).

11863 The Prosecution claims that Poparic changed his theories freely in an attempt to maintain that fire did not originate from Serb-held positions or that victims were caught in cross-fire. He produced graphic images that were inaccurately manipulated and distorted, and he intentionally omitted contrary evidence of which he was aware on the ground that it was "totally irrelevant". According to the Prosecution he also engaged in methodologically-flawed analyses and conducted limited on-site personal examinations. See Prosecution Final Brief, Appendix C, paras. 5-11.

11864 Closing Arguments, T. 48012-48013 (2 October 2014).

11865 See e.g. paras. 3719, 3738.

11866 See e.g. paras. 3758, 3763.

11867 See e.g. para. 3719.

11868 See para. 3667.

11869 As noted above in paragraph 3667, Poparić justified his decision not to enter the relevant buildings by saying, inter alia, that there was no evidence indicating the floors at which sniper nests operated. However, as will be seen below, this is incorrect-for example, exhibit P1738, which contains photographs of sniper nests in the four white high-rises clearly indicates the floors at which those nests were located. See P1738 (Photographs of sniper nests).
} 


\section{iii. Scheduled sniping incidents}

3643. The Prosecution submits in its Final Brief that the sniping fire in all scheduled incidents, with the exception of Scheduled Incident F.5, originated from "well-known SRK positions", namely Grbavica; Špicasta Stijena; the Orthodox Church in Dobrinja; upper parts of Hrasno Brdo and Ozrenska street; the School for the Blind, the Faculty of Theology, and other areas of Nedžarići; and Baba Stijena. ${ }^{1870}$ In addition, it alleges that the victims, as well as the bus and trams they were on, were deliberately targeted in those incidents and were not legitimate military objectives. $^{11871}$ Each scheduled sniping incident is discussed below according to the broad geographical area of Sarajevo where it took place. Some of these areas were notorious for sniper activity, such as Zmaja od Bosne street, Marin Dvor area, and Sedrenik.

\section{(A) Zmaja od Bosne street (formerly Vojvode Putnika)}

3644. According to the Indictment, Scheduled Sniping Incidents F.8. F.11, F.12, F.14, F.15, and F.16 took place on Zmaja od Bosne street, along Sniper Alley, and targeted trams and pedestrians in the area. ${ }^{11872}$ The Prosecution claims that the origin of fire in all those incidents was south of Zmaja od Bosne, namely the four white high-rises on Lenjinova street, the Metalka building, and the Jewish cemetery, all located in the area of Grbavica and controlled by the SRK. ${ }^{11873}$

3645. Zmaja od Bosne street, in particular the stretch near the Holiday Inn and the area around Marin Dvor, ${ }^{11874}$ was one of the most dangerous locations in Sarajevo during the war, where many civilians were wounded or killed by sniper fire; for that reason, it was also known as Sniper Alley. ${ }^{11875}$ It was close to the confrontation lines on Miljacka River, ${ }^{11876}$ and the trams that ran

\footnotetext{
11870 Prosecution Final Brief, Appendix C, para. 2.

11871 Prosecution Final Brief, Appendix C, para. 3.

11872 Indictment, Schedule F. See also Prosecution Final Brief, Appendix C, para. 15; Closing Arguments, T. 4774147742 (30 September 2014).

11873 Prosecution Final Brief, Appendix C, paras. 13-16. See also Closing Arguments, T. 47741-47742 (30 September 2014).

11874 The Chamber understands the Marin Dvor area to stretch from the St. Joseph Church in the east to the outer limits of the Maršal Tito Barracks in the west. David Fraser, T. 8081-8083 (18 October 2010); D771 (SRK combat report, 22 June 1994); D4884 (Mile Poparić's expert report entitled "Small Arms Fire on the Sarajevo Area 1992-1995", 15 August 2012), pp. 42-43, Image 18.

11875 P495 (Witness statement of Slavica Livnjak dated 25 April 2006), para. 7; KDZ289, P485 (Transcript from Prosecutor v. D. Milošević), T. 1624; P2413 (Witness statement of KDZ289 dated 19 April 2006), p. 3; Alma Mulaosmanović-Čehajić, P1551 (Transcript from Prosecutor v. D Milošević), T. 1657; P1695 (Witness statement of Mirza Sabljica dated 11 February 2010), p. 66; P21 (Witness statement of Mirsad Kučanin dated 21 February 1996), e-court p. 2; P1742 (Witness statement of Bogdan Vidović dated 28 September 2010), p. 33; P1762 (Witness statement of David Fraser dated 17 October 2010), pp. 13-14; P1765 (Map of Sarajevo marked by David Fraser); D4884 (Mile Poparić's expert report entitled "Small Arms Fire on the Sarajevo Area 19921995”, 15 August 2012), p. 42; P1217 (Witness statement of Milan Mandilović dated 24 February 2010), para. 52; P926 (Witness statement of Aernout van Lynden dated 26 February 2010), para. 143; P2068 (Witness statement of Jeremy Bowen dated 10 August 2009), paras. 15, 35; Jeremy Bowen, T. 10111-10112 (13 January 2011); P1258 (Witness statement of Hussein Ali Abdel-Razek dated 16 July 2002), e-court p. 24; P1996
} 
along it, as well as the pedestrians, were visible from a number of skyscrapers and high-rise buildings surrounding the area. ${ }^{1877}$ The intersections where Franje Račkog and Đure Daničića streets (which run from Miljacka River) cut across Zmaja od Bosne were particularly dangerous areas. ${ }^{11878}$ In addition, in front of the Holiday Inn, at the intersection between Franje Račkog and Zmaja od Bosne streets, the trams had to enter a so-called "S-curve" in the tracks, ${ }^{11879}$ in order to cross from one side of the street to the other, and thus had to slow down, becoming an easier target. ${ }^{11880}$ Because Zmaja od Bosne street was so dangerous, large transport containers and lorries filled with sand were placed on the south side, on the most exposed parts, such as intersections. ${ }^{11881}$

(Witness statement of Martin Bell dated 8 March 2010), paras. 35, 53; P2012 (Video footage of Sarajevo); P2000 (BBC news report re Sarajevo, with transcript); Martin Bell, T. 9778-9779 (14 December 2010). See also Adjudicated Facts 70, 71, 122, 2915.

11876 P2923 (Witness statement of KDZ090 dated 19 April 2006), para. 10; KDZ090, P481 (Transcript from Prosecutor v. D. Milošević), T. 831 (under seal); P495 (Witness statement of Slavica Livnjak dated 25 April 2006), para. 12; Sabina Šabanić, P491 (Transcript from Prosecutor v. D. Milošević), T. 1471-1474, 1487; P1690 (Witness statement of Alen Gičević dated 16 February 2010), p. 4; D4884 (Mile Poparić's expert report entitled "Small Arms Fire on the Sarajevo Area 1992-1995", 15 August 2012), p. 42, Image 18.

11877 KDZ090, P481 (Transcript from Prosecutor v. D. Milošević), T. 835-837 (under seal); P119 (Witness statement of Huso Palo dated 24 February 1996), p. 2; Huso Palo, P120 (Transcript from Prosecutor v. Milošević), T. 1539; Sabina Šabanić, P491 (Transcript from Prosecutor v. Perišić), T. 693, 696; P492 (Witness statement of Sabina Šabanić dated 16 November 1995), p. 2; P492 (Witness statement of Sabina Šabanić dated 22 May 2006), para. 6; Alma Mulaosmanović-Čehajić, P1551 (Transcript from Prosecutor v. D Milošević), T. 16571658; P1762 (Witness statement of David Fraser dated 17 October 2010), p. 14.

11878 Alen Gičević, T. $7642-7647$ (11 October 2010); D728 (Photograph of Sarajevo marked by Alen Gičević); D729 (Map of Sarajevo marked by Alen Gičević); Mirza Sabljica, T. $7677-7678$ (11 October 2010); P1724 (Aerial photograph of Sarajevo marked by Mirza Sabljica); P2068 (Witness statement of Jeremy Bowen dated 10 August 2009), paras. 16-17, 34. See Adjudicated Fact 2916.

11879 At one point during the case, the Accused attempted to show that there had been no such S-curve at the intersection of Franje Račkog and Zmaja od Bosne streets at the time of the scheduled incidents, and that the Scurve was constructed sometime after the conflict. See Patrick van der Weijden, T. 7039-7051 (28 September 2010); D653 (Map of Sarajevo marked by Patrick van der Weijden); D654 (Map of Sarajevo). However, the Prosecution brought sufficient evidence to indicate that the S-curve in that location has existed since 1984. See Patrick van der Weijden, T. 7191-7195, 7197 (29 September 2010); P1630 (Map of Sarajevo marked by Patrick van der Weijden); P1631 (Aerial photograph of Sarajevo marked by Patrick van der Weijden); Mirza Sabljica, T. 7680-7682 (11 October 2010); P1726 (Map of Sarajevo marked by Mirza Sabljica); Alen Gičević, T. 7611 (11 October 2010).

11880 P495 (Witness statement of Slavica Livnjak dated 25 April 2006), para. 7; Slavica Livnjak, P493 (Transcript from Prosecutor v. D. Milošević), T. 857-858; KDZ090, P481 (Transcript from Prosecutor v. D. Milošević), T. 825-826 (under seal); P1695 (Witness statement of Mirza Sabljica dated 11 February 2010), p. 66; Mirza Sabljica, T. 7678, 7680 (11 October 2010); P1724 (Aerial photograph of Sarajevo marked by Mirza Sabljica); P1725 (Map of Sarajevo marked by Mirza Sabljica); Patrick van der Weijden, T. 7036-7039 (28 September 2010); D652 (Aerial photograph of Sarajevo marked by Patrick van der Weijden); Barry Hogan, T. 1120311204, 11218, 11286-11287 (3 February 2011); P2189 (Aerial photograph of Sarajevo marked by Barry Hogan); P2213 (Image re scheduled sniping and shelling incidents in Sarajevo); D2656 (Photograph of Sarajevo marked by Milorad Katić); P1996 (Witness statement of Martin Bell dated 8 March 2010), para. 48.

11881 Alen Gičević, T. 7612-7613 (11 October 2010); P1690 (Witness statement of Alen Gičević dated 16 February 2010), p. 3; P1692 (Photograph of Sarajevo marked by Alen Gičević); P1742 (Witness statement of Bogdan Vidović dated 28 September 2010), pp. 33-34; P5908 (Record of interview with KDZ185), para. 8; P1074 (Photograph of anti-sniping barricades (Parliament building)); Adjudicated Fact 123; P926 (Witness statement of Aernout van Lynden dated 26 February 2010), paras. 47-48. 
Another dangerous area open to sniper attacks on Zmaja od Bosne was the area of Pofalići, close to Hotel Bristol, ${ }^{11882}$ as well as the area near the Presidency building. ${ }^{11883}$

3646. A number of locations and buildings are relevant to sniping incidents that took place on Zmaja od Bosne street. ${ }^{11884}$ One such building is a high-rise referred to as "Metalka", which is located in the neighbourhood of Grbavica, ${ }^{1885}$ on the southern side of Miljacka River, some 300 metres from Zmaja od Bosne street. ${ }^{1886}$ Its eastern side affords a view down Franje Račkog street. $^{11887}$ To the southeast of Metalka is a building similar in appearance and known as the "Invest Banka" building, which affords a view down Đure Daničića street from its eastern part. ${ }^{11888}$ Just south of Invest Banka is another building with a red façade ("Red Façade building"), ${ }^{11889}$ while further east of Metalka is the co-called Unioninvest building. ${ }^{11890}$ Southeast of the Unioninvest building, located on the slopes of Debelo Brdo, is the Jewish cemetery. ${ }^{11891}$ Also in Grbavica, on the street formerly known as Lenjinova street (now Grbavička street), stand four white skyscrapers, each 18 storeys tall. ${ }^{11892}$ They dominate Grbavica and face the Maršal Tito Barracks. ${ }^{11893}$

\footnotetext{
11882 Slavica Livnjak, P493 (Transcript from Prosecutor v. D. Milošević), T. 870-872; P495 (Witness statement of Slavica Livnjak dated 25 April 2006), para. 7; P440 (Map of Sarajevo marked by Slavica Livnjak).

11883 Jeremy Bowen, T. 10112-10114 (13 January 2011); P2076 (BBC news report re Sarajevo, with transcript).

11884 Barry Hogan, T. 11202-11203 (3 February 2011); P2188 (Aerial photograph of Sarajevo marked by Barry Hogan).

11885 Grbavica is a neighbourhood in the municipality of Novo Sarajevo. See Adjudicated Fact 65.

11886 P1621 (Expert Report of Patrick van der Weijden entitled “Sniping Incidents in Sarajevo '92-'94”), pp. 87, 91, 94, 97, 100. See also Patrick van der Weijden, T. 7016 (27 September 2010); KDZ090, P481 (Transcript from Prosecutor v. D. Milošević), T. 824 (under seal); P2923 (Witness statement of KDZ090 dated 19 April 2006), para. 9; Alen Gičević, T. 7611, 7642-7645 (11 October 2010); P1691 (Photograph of Sarajevo marked by Alen Gičević); D728 (Photograph of Sarajevo marked by Alen Gičević); P1695 (Witness statement of Mirza Sabljica dated 11 February 2010), pp. 66-67; P1720 (Photograph of Sarajevo marked by Mirza Sabljica); P1742 (Witness statement of Bogdan Vidović dated 28 September 2010), p. 33; Barry Hogan, T. 11199-11204, 11219 (3 February 2011); P2186 (Panoramic photograph of Sarajevo marked by Barry Hogan); P2188 (Aerial photograph of Sarajevo marked by Barry Hogan ); P2189 (Aerial photograph of Sarajevo marked by Barry Hogan); P2208 (Photograph of Sarajevo marked by Barry Hogan).

11887 D4884 (Mile Poparić's expert report entitled "Small Arms Fire on the Sarajevo Area 1992-1995", 15 August 2012), pp. 42-43, Image 18; D2656 (Photograph of Sarajevo marked by Milorad Katić).

11888 Poparić testified that while the Invest Banka building offers a direct view down Đure Daničića street, its close proximity to other buildings on Đure Daničić street presented a "serious obstacle" to its use as a firing position. See D4884 (Mile Poparić's expert report entitled "Small Arms Fire on the Sarajevo Area 1992-1995", 15 August 2012), pp. 42-43, Image 18.
}

11889 Alen Gičević, T. 7628-7629, $7642-7645$ (11 October 2010); D725 (Photograph of Sarajevo marked by Alen Gičević); D728 (Photograph of Sarajevo marked by Alen Gičević); Patrick van der Weijden, T. 7021-7027 (28 September 2010); D649 (Aerial photograph of Sarajevo marked by Patrick van der Weijden); D650 (Aerial photograph of Sarajevo marked by Patrick van der Weijden); D4884 (Mile Poparić's expert report entitled "Small Arms Fire on the Sarajevo Area 1992-1995", 15 August 2012), pp. 42-43, Image 18.

11890 Alen Gičević, T. 7628, 7642-7645 (11 October 2010); D725 (Photograph of Sarajevo marked by Alen Gičević); D728 (Photograph of Sarajevo marked by Alen Gičević); D4884 (Mile Poparić's expert report entitled "Small Arms Fire on the Sarajevo Area 1992-1995”, 15 August 2012), pp. 42-43, Image 18.

11891 See Adjudicated Facts 72 and 2829. See also D788 (Photograph of Sarajevo marked by Bogdan Vidović).

11892 P119 (Witness statement of Huso Palo dated 24 February 1996), p. 2; P119 (Statement of Huso Palo to BiH authorities, 24 November 1994), p. 2; Sabina Šabanić, P491 (Transcript from Prosecutor v. D. Milošević), T. 1453-1454; P442 (Aerial photograph of Sarajevo marked by Sabina Šabanić); P492 (Witness statement of 
3647. On the northern side of Miljacka River, to the northeast of the Holiday Inn stand two skyscrapers referred to as the "Unis towers". ${ }^{11894}$ The School of Technology is to the west of the Holiday Inn, and across the street from the Holiday Inn stands the Faculty of Philosophy and the Museum buildings. ${ }^{11895}$ To the east of the Faculty of Philosophy are the Executive Council and Assembly buildings. ${ }^{11896}$ The Maršal Tito Barracks, now no longer in existence, were located to the west of the School of Technology. ${ }^{11897}$

3648. The Vrbanja Bridge on Miljacka River is located just south of the Assembly building. ${ }^{1898}$

3649. The so-called "salvation route" or the "road of life", which ran north of and parallel to the Zmaja od Bosne street and was protected by transport containers and lorries filled with sand, ${ }^{11899}$

Sabina Šabanić dated 16 November 1995), p. 2; P492 (Addendum to witness statement of Sabina Šabanić dated 16 November 1995, 24 April 2010); P492 (Witness statement of Sabina Šabanić dated 22 May 2006), para. 6; P492 (Addendum to witness statement of Sabina Šabanić dated 22 May 2006, 24 April 2010); Mirza Sabljica, T. 7675 (11 October 2010); P1742 (Witness statement of Bogdan Vidović dated 28 September 2010), p. 33; Barry Hogan, T. 11199-11200, 11219-11220 (3 February 2011); P2186 (Panoramic photograph of Sarajevo marked by Barry Hogan); P2209 (Photograph of Sarajevo marked by Barry Hogan).

11893 D4884 (Mile Poparić's expert report entitled "Small Arms Fire on the Sarajevo Area 1992-1995", 15 August 2012), pp. 42-43, Image 18.

11894 Sabina Šabanić, P491 (Transcript from Prosecutor v. D. Milošević), T. 1485; P444 (Aerial photograph of Sarajevo marked by Sabina Šabanić); Alen Gičević, T. 7642-7645 (11 October 2010); D728 (Photograph of Sarajevo marked by Alen Gičević); Barry Hogan, T. 11199-11200 (3 February 2011); P2186 (Panoramic photograph of Sarajevo marked by Barry Hogan); P926 (Witness statement of Aernout van Lynden dated 26 February 2010), para. 59; Aernout van Lynden, T. 2580-2584 (21 May 2010); D211 (Aerial photograph of Sarajevo marked by Aernout van Lynden); D212 (Aerial photograph of Sarajevo marked by Aernout van Lynden).

11895 KDZ090, P481 (Transcript from Prosecutor v. D. Milošević), T. 835-836 (under seal); P436 (Aerial photograph of Sarajevo marked by KDZ090); Alen Gičević, T. 7642-7645 (11 October 2010); D728 (Photograph of Sarajevo marked by Alen Gičević); P1695 (Witness statement of Mirza Sabljica dated 11 February 2010), pp. 66-67; P1720 (Photograph of Sarajevo marked by Mirza Sabljica); Barry Hogan, T. 11202-11203 (3 February 2011); P2188 (Aerial photograph of Sarajevo marked by Barry Hogan); Aernout van Lynden, T. 2584-2590 (21 May 2010) D212 (Aerial photograph of Sarajevo marked by Aernout van Lynden).

11896 KDZ090, P481 (Transcript from Prosecutor v. D. Milošević), T. 835-836 (under seal); P436 (Aerial photograph of Sarajevo marked by KDZ090); Sabina Šabanić, P491 (Transcript from Prosecutor v. D. Milošević), T. 1486; P444 (Aerial photograph of Sarajevo marked by Sabina Šabanić); Alen Gičević, T. 7642-7645 (11 October 2010); D728 (Photograph of Sarajevo marked by Alen Gičević); Barry Hogan, T. 11199-11200, 11202-11203 (3 February 2011); P2186 (Panoramic photograph of Sarajevo marked by Barry Hogan); P2188 (Aerial photograph of Sarajevo marked by Barry Hogan).

11897 Sabina Šabanić, P491 (Transcript from Prosecutor v. D. Milošević), T. 1452-1454; P442 (Aerial photograph of Sarajevo marked by Sabina Šabanić); Barry Hogan, T. 11199-11200 (3 February 2011); P2186 (Panoramic photograph of Sarajevo marked by Barry Hogan); Aernout van Lynden, T. 2584-2590 (21 May 2010) D212 (Aerial photograph of Sarajevo marked by Aernout van Lynden).

11898 Barry Hogan, T. 11202-11203 (3 February 2011); P2188 (Aerial photograph of Sarajevo marked by Barry Hogan); Aernout van Lynden, T. 2584-2590 (21 May 2010); D212 (Aerial photograph of Sarajevo marked by Aernout van Lynden).

11899 Alen Gičević, T. 7610-7613 (11 October 2010); P1690 (Witness statement of Alen Gičević dated 16 February 2010), p. 3; P1691 (Photograph of Sarajevo marked by Alen Gičević); P1692 (Photograph of Sarajevo marked by Alen Gičević). 
was safer than any other road because it was protected from the view by a large number of buildings which provided cover for people who used it. ${ }^{11900}$

\section{(1) Confrontation lines in the area}

3650. The confrontation line in the Marin Dvor area ran along Miljacka River with ABiH positions on the north side of the river and VRS positions on the south side. ${ }^{11901}$ The $1^{\text {st }}$ Romanija Infantry Brigade and the $1^{\text {st }}$ Sarajevo Mechanised Brigade of the SRK held the area of Grbavica and the positions south and east of Grbavica. ${ }^{1902}$ The $3^{\text {rd }}$ Battalion of the $1^{\text {st }}$ Romanija Infantry Brigade, which was later absorbed into the $1^{\text {st }}$ Sarajevo Mechanised Brigade and became the $2^{\text {nd }}$ Infantry Battalion of that brigade, ${ }^{11903}$ had positions in the area that stretched from Vrbanja Bridge, along Miljacka River, to Strojorad, then to the football stadium, Šanac, Ozrenska street, Milinkladska street, and Slaviša Vajner Čiča Barracks. ${ }^{11904}$ The $1^{\text {st }}$ Company of that battalion held the line between the Vrbanja and Bratstvo Jedinstvo Bridges, along Miljacka River. ${ }^{1905}$ Thus, the Metalka building and the four white high-rises in Grbavica were in the area of responsibility of the SRK. ${ }^{11906}$ Further, due to Metalka being difficult to access, the troops at some point withdrew "in [the] depth" of the territory. ${ }^{11907}$

11900 P1690 (Witness statement of Alen Gičević dated 16 February 2010), pp. 3-4. See also Adjudicated Fact 64 (which provides that civilians developed alternative routes to traverse Sarajevo in order to avoid sniper fire but that even those would not afford protection from shelling).

11901 P1762 (Witness statement of David Fraser dated 17 October 2010), pp. 26-27; P1770 (Photograph of Sarajevo marked by David Fraser); Stanislav Galić, T. 37467-37468 (22 April 2013); Dragan Maletić, T. 30854-30855 (3 December 2012); P6018 (Photograph of Sarajevo); Milorad Katić, T. 31404-31407 (13 December 2012); P6044 (Photograph of Sarajevo marked by Milorad Katić); P815 (Map of Sarajevo showing confrontation lines). See also Adjudicated Facts 67, 68, 2826. Given that the ABiH held positions north of the Miljacka River, the area of Marin Dvor was under the control of the ABiH. See Adjudicted Fact 2827.

11902 Stanislav Galić, T. 37184 (15 April 2013); D3382 (Map of Sarajevo); P4498 (Report of $1^{\text {st }}$ Romanija Infantry Brigade, 3 September 1992); D2331 (Witness statement of Blagoje Kovačević dated 14 October 2012), paras. 2, 5; D2339 (Map of Sarajevo marked by Blagoje Kovačević); D2340 (Map of Sarajevo marked by Blagoje Kovačević); D2622 (Witness statement of Željko Bambarez dated 9 December 2012), para. 6; D2628 (Map of Sarajevo marked by Željko Bambarez); Adjudicated Facts 66, 2826.

11903 Dragan Maletić, T. 30844 (3 December 2012); D2418 (Witness statement of Božo Tomić dated 5 November 2012), paras. 8, 25-26; Božo Tomić, T. 30178-30179 (13 November 2012); D2267 (Vlado Lizdek's interview with OTP), pp. 5-6; D2622 (Witness statement of Željko Bambarez dated 9 December 2012), para. 5.

11904 According to Maletić, positions to the right of the $3^{\text {rd }}$ Battalion were manned by the brigade's $1^{\text {st }}$ Battalion. See D2519 (Witness statement of Dragan Maletić dated 9 November 2012), paras. 8-9, 17; Dragan Maletić, T. 30844 (3 December 2012); D2418 (Witness statement of Božo Tomić dated 5 November 2012), paras. 8, 25-26; Božo Tomić, T. 30178-30179 (13 November 2012); D2622 (Witness statement of Željko Bambarez dated 9 December 2012), para. 5; Blagoje Kovačević, T. 29041-29042 (18 October 2012).

11905 Dragan Maletić, T. 30849 (3 December 2012); D2519 (Witness statement of Dragan Maletić dated 9 November 2012), para. 9; D2521 (Map of Sarajevo marked by Dragan Maletić); [REDACTED].

11906 Dragan Maletić, T. 30849-30850 (3 December 2012); [REDACTED]; Blagoje Kovačević, T. 29042 (18 October 2012); P1695 (Witness statement of Mirza Sabljica dated 11 February 2010), pp. 62, 67; P1830 (Witness statement of Dragan Mioković dated 26 October 2010), p. 31. But see P4498 (Report of $1^{\text {st }}$ Romanija Infantry Brigade, 3 September 1992), p. 4 which refers to the $2^{\text {nd }}$ Infantry Battalion of the $1^{\text {st }}$ Romanija Infantry Brigade holding positions near Metalka in September 1992, with the $3^{\text {rd }}$ Battalion to its left. The Chamber also notes here that the English translation of the report refers to the $1^{\text {st }}$ Infantry Battalion manning the positions 
3651. As for the positions to the right of Vrbanja Bridge, the area from Vrbanja Bridge towards the Jewish cemetery up to the foot of Debelo Brdo was held by the $3^{\text {rd }}$ Infantry Battalion of the $1^{\text {st }}$ Sarajevo Mechanised Brigade of the SRK. ${ }^{11908}$ This battalion was positioned on the western side of the Jewish cemetery while the $\mathrm{ABiH}$ was stationed along its northeastern wall-the two sides were separated only by the width of the cemetery. ${ }^{11909}$ The confrontation line at the cemetery remained unchanged throughout the conflict. ${ }^{11910}$ According to Blagoje Kovačević, commander of the $3^{\text {rd }}$ Infantry Battalion from June $1993,{ }^{11911}$ the cemetery itself was never occupied by anyone as it was no-man's land. ${ }^{11912}$

3652. On the $\mathrm{ABiH}$ side, the confrontation line in the Zmaja od Bosne area was manned by the ABiH's $1^{\text {st }}$ Motorised Brigade. ${ }^{11913}$ This brigade was responsible for the line on Miljacka River from the area of the Vrbanja Bridge and through Hrasno Brdo, with soldiers deployed from the School of Economics to the Elektroprivreda building, with only the river separating them from the VRS. ${ }^{11914}$ The $1^{\text {st }}$ Motorised Brigade had outside trenches and held positions within certain buildings, namely, the cellars of the Mechanical Engineering Faculty, the School of Economics, and another faculty building, as well as in the exits that connected those positions to the trenches. ${ }^{11915}$ In March 1995, however, the confrontation line along Miljacka River ran from the Vrbanja Bridge to Topal-Osman Paše street. ${ }^{11916}$

3653. Maletić testified that his company's counterpart on the other side of the confrontation line was a Croatian unit called Kralj Tvrtko. ${ }^{11917}$ It was deployed along the axis of the Wood

around Metalka but the original document in BCS in fact refers to the $2^{\text {nd }}$ Infantry Battalion. Thus, the English translation contains a typographical error.

11907 Maletić could not remember if this took place in 1993 or 1994. Dragan Maletić, T. 30849-30851 (3 December 2012), T. 30888 (4 December 2012). Stanislav Galić confirmed that the $1^{\text {st }}$ Romanija Infantry Brigade was later redeployed beyond Grbavica. See Stanislav Galić, T. 37184 (15 April 2013).

11908 See Adjudicated Fact 2828; D2331 (Witness statement of Blagoje Kovačević dated 14 October 2012), para. 5; D2339 (Map of Sarajevo marked by Blagoje Kovačević); D2340 (Map of Sarajevo marked by Blagoje Kovačević).

11909 See Adjudicated Fact 73; D3382 (Map of Sarajevo); D2331 (Witness statement of Blagoje Kovačević dated 14 October 2012), paras. 2, 5; D2339 (Map of Sarajevo marked by Blagoje Kovačević); D2340 (Map of Sarajevo marked by Blagoje Kovačević); Blagoje Kovačević, T. 29054-29056 (18 October 2012). But see P4498 (Report of $1^{\text {st }}$ Romanija Infantry Brigade, 3 September 1992), p. 4 (which provides that in September 1992 the $1^{\text {st }}$ Battalion of the $1^{\text {st }}$ Romanija Infantry Brigade was manning the positions on Jewish cemetery).

11910 See Adjudicated Fact 74.

11911 D2331 (Witness statement of Blagoje Kovačević dated 14 October 2012), para. 2.

11912 D2331 (Witness statement of Blagoje Kovačević dated 14 October 2012), para. 22.

11913 Mirza Sabljica, T. 7704 (11 October 2010).

11914 Mirza Sabljica, T. 7704 (11 October 2010).

11915 Mirza Sabljica, T. 7901-7902 (13 October 2010).

11916 Mirza Sabljica, T. 7899-7902 (13 October 2010); D765 (Map of Sarajevo marked by Mirza Sabljica).

11917 D2519 (Witness statement of Dragan Maletić dated 9 November 2012), para. 19; D2331 (Witness statement of Blagoje Kovačević dated 14 October 2012), para. 19. The existence of this unit is also confirmed by D772 (ABiH General Staff list of ABiH units in Sarajevo, 10 April 1995) and D633 (Order of ABiH $1^{\text {st }}$ Corps, 25 
Processing School, Šumaprojekt facilities, Mechanical Engineering Faculty, and Unioninvest building, ${ }^{11918}$ in solid edifices that blocked the view of his frontline forces. ${ }^{11919}$ The Executive Council building, the Museum complex, the Assembly building, and the Faculty of Philosophy were all in the area of responsibility of the $\mathrm{ABiH} .{ }^{11920}$ The $\mathrm{ABiH}$ also held positions on the northern base Mt. Trebević and had a view onto the intersection of Maršal Tito and Vrazova streets. ${ }^{1921}$ In addition to the eastern side of the Jewish cemetery, Debelo Brdo, from which Grbavica and the Jewish cemetery are visible, was held by the $\mathrm{ABiH}$, as was Colina Kapa-both those positions overlooked Sarajevo but were still lower than the SRK positions. ${ }^{11922}$

3654. There is some controversy in the evidence in relation to several buildings along parts of the confrontation line in the area, which appear to have changed hands during the war and/or were divided between the warring parties. Sabljica testified that at the beginning of the conflict, in 1992, there were $\mathrm{ABiH}$ positions in one of the buildings near the Metalka building but that after 1992 they were no longer there. ${ }^{1923} \mathrm{He}$ also testified that the Red Façade building was in the area of responsibility of the VRS during the war. ${ }^{1924}$ Maletić, however, testified that part of Red Façade building was held by the Muslims while another part was held by the Serbs. ${ }^{1925}$ This was confirmed by Željko Bambarez, who in 1994 spent eight months in Grbavica as the Commander of a platoon in the $1^{\text {st }}$ Company of the $3^{\text {rd }}$ Battalion of the $1^{\text {st }}$ Sarajevo Mechanised Brigade. ${ }^{1926}$

October 1993), para. 5.6. See also Francis Roy Thomas, T. 6896-6897 (16 September 2010) (testifying that his UNMOs visited the Croatian unit in question).

11918 D2519 (Witness statement of Dragan Maletić dated 9 November 2012), paras. 22-23; D2523 (Map of Sarajevo marked by Dragan Maletić).

11919 D2519 (Witness statement of Dragan Maletić dated 9 November 2012), para. 25.

11920 Alen Gičević, T. 7628-7631, 7638-7639 (11 October 2010); D725 (Photograph of Sarajevo marked by Alen Gičević).

11921 See Adjudicated Fact 104; P1764 (ABiH Map of Sarajevo); P1058 (ABiH map); D1380 (Map of ABiH positions in Sarajevo marked by Asim Džambasović); Alen Gičević, T. 7657-7661 (11 October 2010); D733 (Photograph of Sarajevo marked by Alen Gičević); D734 (Photograph of street sign in Sarajevo). Gičević conceded that the $\mathrm{ABiH}$ was deployed in a number of places in the area between the white skyscraper in Grbavica and the intersection in question. See Alen Gičević, T. 7662-7663 (11 October 2010); D735 (Photograph of Sarajevo).

11922 See Adjudicated Facts 105, 2830, and 2845; D2389 (Witness statement of Predrag Trapara dated 3 November 2012), para. 21; Francis Roy Thomas, T. 6897-6898, 6906 (16 September 2010); D633 (Order of ABiH $1^{\text {st }}$ Corps, 25 October 1993), para. 5.7; David Harland, T. 2087-2090 (7 May 2010); D134 (Aerial photograph of Sarajevo marked by David Harland); P1762 (Witness statement of David Fraser dated 17 October 2010), pp. 15-18; P1767 (Map of Sarajevo marked by David Fraser); KDZ304, T. 10496 (18 January 2011).

11923 P1695 (Witness statement of Mirza Sabljica dated 11 February 2010), p. 63.

11924 Mirza Sabljica, T. 7705 (11 October 2010). See also Alen Gičević, T. 7628-7631 (11 October 2010); D725 (Photograph of Sarajevo marked by Alen Gičević). The Chamber notes that the regular SRK combat report of 24 July 1994 refers to the presence of soldiers of the $1^{\text {st }}$ Sarajevo Mechanised Brigade on top of a "Red Building”. See D4604 (SRK Report, 24 July 1994).

11925 Dragan Maletić, T. 30890 (4 December 2012); D2525 (Photograph of Sarajevo marked by Dragan Maletić). See also Francis Roy Thomas, T. 6898 (16 September 2010).

11926 Bambarez testified that he was first a commander of the $2^{\text {nd }}$ Platoon of the $2^{\text {nd }}$ Company of the $3^{\text {rd }}$ Battalion of the $1^{\text {st }}$ Romanija Infantry Brigade and that in June 1993 his battalion became part of the Sarajevo Mechanised Brigade of the SRK. In 1994 he was moved to Grbavica due to the killing of Mišo Čolić, a commander of the $1^{\text {st }}$ 
According to him, the Red Façade building was divided between the two warring sides and the Muslim-controlled part of the building afforded a view through Đure Daničića street onto Zmaja od Bosne street, as well as onto Marin Dvor and the UNPROFOR check-point on Vrbanja Bridge. ${ }^{1927}$ Bambarez, who was actually in the Red Façade building during his time in Grbavica, explained that of the two high buildings now blocking the view between the Red Façade building and Đure Daničića street one was not there during the war, while another, which was in his platoon's zone of responsibility, was there at the time but was not as high then as it is now. ${ }^{11928}$ However, another soldier of the $3^{\text {rd }}$ Battalion, Milorad Katić, testified during cross-examination that it was not possible to shoot from the $\mathrm{ABiH}$ part of this building onto the area in front of the Holiday Inn, as the view was obstructed by one of the buildings. ${ }^{11929}$ In any event, in cross-examination, Bambarez testified that his time in Grbavica was relatively quiet and that he was not aware of Muslims ever firing from the Red Façade building during that time. ${ }^{1930}$

3655. Sabljica and Gičević testified that the Unioninvest building was in the area of responsibility of the VRS during the war. ${ }^{11931}$ In contrast, Bambarez told the Chamber that it was under ABiH control. ${ }^{1932}$ This is confirmed by the SRK report from April 1994 to the VRS Main Staff, in which the SRK Commander Galić reported that the enemy had opened fire from the Unioninvest building. ${ }^{11933}$ [REDACTED] also thought that the building was either under ABiH control or in no-

Company of the $3^{\text {rd }}$ Battalion. See D2622 (Witness statement of Željko Bambarez dated 9 December 2012), paras. 3, 5; Željko Bambarez, T. 31299 (12 December 2012).

11927 D2622 (Witness statement of Željko Bambarez dated 9 December 2012), paras. 8-10; D2623 (Photograph of Sarajevo marked by Željko Bambarez). Blagoje Kovačević testified that four entrances of the Red Façade building were held by his battalion while the ABiH held one of the entrances. D2331 (Witness statement of Blagoje Kovačević dated 14 October 2012), para. 22.

11928 Željko Bambarez, T. 31299-31308 (12 December 2012); D2622 (Witness statement of Željko Bambarez dated 9 December 2012), paras. 8-10; D2623 (Photograph of Sarajevo marked by Željko Bambarez); D2624 (Photograph of a building marked by Željko Bambarez); D2625 (Photograph of a building marked by Željko Bambarez); D2626 (Photograph of a building marked by Željko Bambarez); D2627 (Photograph of a building marked by Željko Bambarez).

11929 Milorad Katić, T. 31407-31411 (13 December 2012); D2651 (Witness statement of Milorad Katić dated 10 December 2012), paras. 10, 16; D2623 (Photograph of Sarajevo marked by Željko Bambarez); P6045 (Photograph of Sarajevo marked by Milorad Katić). Katić also clarified that his battalion was not deployed in that area when he was its soldier, namely until 13 March 1993, but was instead in the sector overlooking Debelo Brdo via Zlatište and up to Osmice. See Milorad Katić, T. 31413-31414 (13 December 2012). During further re-examination, Katić stated that there was in fact no view from the whole of the Red Façade building onto the targets in front of the Holiday Inn. See Milorad Katić, T. 31414-31417 (13 December 2012); D2655 (Photograph of Sarajevo marked by Milorad Katić).

11930 Željko Bambarez, T. 31309-31311, 31328-31329 (12 December 2012).

11931 Mirza Sabljica, T. 7705 (11 October 2010); Alen Gičević, T. 7628-7631 (11 October 2010); D725 (Photograph of Sarajevo marked by Alen Gičević).

11932 Željko Bambarez, T. 31306, 31308 (12 December 2012). Blagoje Kovačević testified that it was the $10^{\text {th }}$ Mountain Brigade of the $1^{\text {st }}$ Corps of the $\mathrm{ABiH}$, led by Dušan Topalović Caco, that controlled the territory from Čolina Kapa to Vranjača towards Trebević and from Vranjača to the Unioninvest building towards Grbavica. See D2331 (Witness statement of Blagoje Kovačević dated 14 October 2012), para. 18; Blagoje Kovačević, T. 29039-29040 (18 October 2012).

11933 D4581 (SRK Report, 23 April 1994), p. 1. 
man's land but was adamant that it was never in the SRK hands. ${ }^{1934}$ Sabljica testified that by March 1995, the Unioninvest was indeed in the area of responsibility of the $\mathrm{ABiH} .{ }^{11935}$

\section{(2) $\underline{\text { Snipers in the area }}$}

3656. The Chamber heard that snipers were operating on both sides of Zmaja od Bosne street but that most of the snipers were on the Serb side of the confrontation line, firing into the ABiH-held territory. ${ }^{11936}$

3657. Mirsad Kučanin, a criminal inspector within CSB Sarajevo who investigated around 100 cases of sniping and shelling in Sarajevo, ${ }^{11937}$ testified that the most significant area where Serb snipers operated was Grbavica and that most of his investigations involved fire coming from there. ${ }^{11938}$ According to him, there was a sniper in every house between Vrbanja and Hrasno Bridges but the fire was most frequent from the Metalka building, the four white high-rises, and the three "shopping centre" skyscrapers. ${ }^{11939}$ In addition, the snipers fired from the Jewish cemetery covering the central part of the city called Skenderija and the Marin Dvor area. ${ }^{1940}$ Aernout van Lynden, a Sky News war correspondent who reported from Sarajevo starting in May 1992, ${ }^{11941}$ testified that he was taken by SRK commanders to a number of high-rises in Grbavica and to the Jewish cemetery and its surrounds where he saw gun placements of various sorts, including machine-guns and sniper rifles with telescopic sites. ${ }^{1942}$

\footnotetext{
11934 [REDACTED].

11935 Mirza Sabljica, T. 7899-7902 (13 October 2010); D765 (Map of Sarajevo marked by Mirza Sabljica).

11936 P1762 (Witness statement of David Fraser dated 17 October 2010), pp. 14, 29; David Fraser, T. 8015 (18 October 2010); P1558 (Witness statement of Francis Roy Thomas dated 13 May 2009), paras. 63, 65.

11937 P23 (Witness statement of Mirsad Kučanin dated 12 November 1995), e-court p. 2; Mirsad Kučanin, P16 (Transcript from Prosecutor v. Galić), T. 4555-4557, 4560.

11938 P23 (Witness statement of Mirsad Kučanin dated 12 November 1995), e-court p. 8. See also P1558 (Witness statement of Francis Roy Thomas dated 13 May 2009), para. 65; P1217 (Witness statement of Milan Mandilović dated 24 February 2010), para. 52; Adjudicated Fact 121.

11939 P23 (Witness statement of Mirsad Kučanin dated 12 November 1995), e-court pp. 8-9; Mirsad Kučanin, P16 (Transcript from Prosecutor v. Galić), T. 4609-4614; P20 (Map marked by Mirsad Kučanin).

11940 P23 (Witness statement of Mirsad Kučanin dated 12 November 1995), e-court p. 8; Mirsad Kučanin, P16 (Transcript from Prosecutor v. Galić), T. 4608-4609; P1217 (Witness statement of Milan Mandilović dated 24 February 2010), para. 52; Milan Mandilović, T. 5381-5383 (16 July 2010); P1558 (Witness statement of Francis Roy Thomas dated 13 May 2009), para. 65; Alen Gičević, T. 7612-7613 (11 October 2010); P1692 (Photograph of Sarajevo marked by Alen Gičević). See also Adjudicated Fact 124.

11941 P926 (Witness statement of Aernout van Lynden dated 26 February 2010), paras. 3-5, 11, 17.

11942 P926 (Witness statement of Aernout van Lynden dated 26 February 2010), paras. 94-95, 97, 99-102, 109-112 (Van Lynden also stated that the men manning these positions were in radio contact with other positions higher up in the slopes who were essentially the spotters for the snipers); P806 (Sky Newsreport re Sarajevo, with transcript); P935 (Sky Newsreport re Sarajevo, with transcript); Aernout van Lynden, T. 2425-2427 (19 May 2010).
} 
3658. KDZ310 testified that there were many SRK snipers in Grbavica, adding that the area between Vrbanja Bridge and Elektroprivreda alone had, on average, seven to eight snipers. ${ }^{1943}$ As noted earlier, they were part of the sniper squad responsible only to the $3^{\text {rd }}$ Battalion's commander ${ }^{11944}$ and would change positions often. ${ }^{1945}$ Galić confirmed that most of the SRK snipers were in Grbavica, along Miljacka River and in the white high-rises, but claimed that they were placed there to neutralise $\mathrm{ABiH}$ fire coming from Marin Dvor, the Faculty of Mechanical Engineering, and the government buildings. ${ }^{11946}$ However, contrary to Galić, KDZ310 testified that snipers in Grbavica opened fire at whatever they saw, mainly civilians, including the elderly and children, and that their sniping was constant. ${ }^{11947}$ Indeed, upon joining the battalion and receiving a $7.62 \mathrm{~mm}$ semi-automatic rifle, ${ }^{1948}$ KDZ310 and his fellow soldiers, who were not part of the sniper squad, were told by their commander that they could open fire freely and shoot anything that moved. ${ }^{11949}$

3659. Maletić testified that his company did not have snipers and that his soldiers were positioned at the foot of the buildings, including Metalka and the four white high-rises, with semi-automatic, and automatic rifles, and machine guns. ${ }^{11950}$ Because of these positions, they could only see the enemy's first line of defence. ${ }^{1951}$ Maletić also testified that it was prohibited to fire on civilian targets and that, therefore, his soldiers did not target trams from Metalka and/or wait for them to

11943 P1938 (Witness statement of KDZ310 dated 28 November 2010), paras. 40-41, 43. See also P2444 (Witness statement of KDZ354 dated 5 February 2011), paras. 93-94 (under seal); KDZ354, T. 13195-13197, 13120 (10 March 2011) (testifying that everyone in Grbavica knew who the snipers were, that they had special rifles and that they would go into a high-rise building and stay there for a few hours every day).

11944 According to KDZ310, the Commander of the sniper squad was Marinko Krneta. See P1938 (Witness statement of KDZ310 dated 28 November 2010), paras. 40-41, 43-44. See also D2519 (Witness statement of Dragan Maletić dated 9 November 2012), para. 31; Dragan Maletić, T. 30846-30848 (3 December 2012), T. $30873-$ 30874 (4 December 2012).

11945 According to KDZ310, the snipers also used their freedom of movement to loot. See P1938 (Witness statement of KDZ310 dated 28 November 2010), para. 43.

11946 Stanislav Galić, T. 37465-37466 (22 April 2013), T. 37843-37844 (7 May 2013). See also [REDACTED].

11947 KDZ310 would occasionally talk to these snipers who usually told him that they had shot someone, although he could not verify that and he never personally observed it. See P1938 (Witness statement of KDZ310 dated 28 November 2010), paras. 41, 43; KDZ310, T. 9278 (29 November 2010).

11948 P1938 (Witness statement of KDZ310 dated 28 November 2010), para. 38; KDZ310, T. 9208 (29 November 2010). KDZ310 also saw various other infantry weapons around him, including M76, M53, and M84 rifles. See P1938 (Witness statement of KDZ310 dated 28 November 2010), para. 50; P1946 (Excerpt of book on military equipment marked by KDZ310).

11949 P1938 (Witness statement of KDZ310 dated 28 November 2010), para. 37; KDZ310, T. 9275-9276, 9278 (29 November 2010).

11950 Dragan Maletić, T. 30883-30886 (4 December 2012).

11951 While, according to Maletić, civilian zones could be attacked from some of the $1^{\text {st }}$ Company's positions, this did not happen, at least not in a planned and organised manner. Maletić also explained that there were no civilians in the two apartment buildings between the Assembly building and the river as the Muslim side used them to fire on the SRK positions. See D2519 (Witness statement of Dragan Maletić dated 9 November 2012), paras. 14, 25, 27; Dragan Maletić, T. 30849-30850 (3 December 2012), T. 30886-30889 (4 December 2012). See also [REDACTED]. 
slow down at the S-curve. ${ }^{11952}$ When asked in cross-examination whether upper floors of Metalka afforded a view behind enemy lines, Maletić claimed his company was at the foot of the building and therefore had no knowledge about the view from the upper floors. ${ }^{11953}$ He did concede, however, that one could see behind the enemy lines from the white high-rises in Grbavica. ${ }^{11954}$ The Chamber recalls that it has already found above that there was a view onto Zmaja od Bosne street from both Metalka and Invest Banka buildings, the former affording the view down Franje Račkog street and the latter affording the view down Đure Daničića street. ${ }^{1955}$ In addition, the Chamber went on a site visit to Sarajevo and observed the area in and around those two buildings. ${ }^{11956}$ Accordingly, even accepting as true Maletić's testimony that he and/or his troops were never on the higher floors of Metalka, the Chamber considers his proclaimed lack of knowledge on the view from Metalka disingenuous, particularly since he spent some time in the area during the conflict. Maletić did, however, concede that there was such a view from the four white high-rises and this is indeed confirmed by other evidence before the Chamber. ${ }^{11957}$

3660. In contrast to Maletić, Katić testified on cross-examination that there were armed men inside the Metalka building and that they could, if they wanted to, hit targets in front of the Holiday Inn. ${ }^{11958}$ During re-examination, however, he clarified that he was never at the positions in the area and that given the height of the dominant buildings on the Muslim side of the confrontation line it would have been dangerous to have positions on Metalka's upper floors; he also explained that the armed men in the building were in fact soldiers who lived there and had weapons in their apartments. ${ }^{11959}$ The Chamber is not convinced by Katić's explanation during re-examination. First, it is illogical that soldiers would not have positions in Metalka because it was too dangerous and yet would then choose to live in the building. In addition, as will be seen below, the Chamber

\footnotetext{
11952 Dragan Maletić, T. 30889-30890 (4 December 2012); D2525 (Photograph of Sarajevo marked by Dragan Maletić).

11953 Dragan Maletić, T. 30851-30856 (3 December 2012), T. 30886-30889 (4 December 2012); P6018 (Photograph of Sarajevo); P6024 (Photograph of Sarajevo); D2525 (Photograph of Sarajevo marked by Dragan Maletić); D2526 (Photograph of Sarajevo). See also [REDACTED]. The Chamber notes that P6024 was admitted only for the purpose of understanding Maletić's testimony as the Accused challenged its provenance.

11954 Dragan Maletić, T. 30856 (3 December 2012); P6019 (Photograph of a tram and green building); P6020 (Photograph of a tram); P6020 (Photograph of a tram); P6021 (Photograph of Sarajevo); P6022 (Photograph of a street); P6023 (Photograph of a street). The Chamber notes that these photographs were admitted only for the purpose of understanding the testimony of the witness as the Accused challenged their provenance.

11955 See para. 3646.

11956 The Chamber recalls that in its Order on Submissions for a Site Visit, dated 15 November 2010, at paragraph 6, it stated that the purpose of its site visit to Sarajevo was not to gather evidence or receive any submissions from the parties but to allow the Chamber to become more familiar with the topography of certain key locations and thus assist its determination of the charges in the Indictment related to Sarajevo.

11957 See para. 3666. See also P1738 (Photographs of sniper nests); P1762 (Witness statement of David Fraser dated 17 October 2010), p. 32.

11958 Milorad Katić, T. 31404-31407 (13 December 2012); P6044 (Photograph of Sarajevo marked by Milorad Katić).

11959 Milorad Katić, T. 31417-31421 (13 December 2012).
} 
has heard evidence indicating that an improvised sniper nest was found on the last floor of the Metalka building. ${ }^{11960}$ Furthermore, when asked if the SRK had firing positions in the Metalka and Invest Banka buildings, Galić himself confirmed that the SRK opened fire from "that sector". ${ }^{11961}$

3661. Blagoje Kovačević, who commanded the SRK battalion located in the area of Jewish cemetery, testified that there were no professional snipers in his battalion as they were unnecessary given the short distances between the warring parties. ${ }^{1962}$ He explained that the company that held the Jewish cemetery was called the Anti-Armour Company; it was commanded by Slavko Aleksić, who liked to represent himself as a "Chetnik", and it had small calibre infantry weapons, such as rifles. ${ }^{11963}$ While conceding that he had some problems in exercising control over the members of his units and that there were instances of individuals opening fire without him knowing about it, Kovačević testified that his battalion did not open fire on civilians and/or trams in the city and that they never received orders to that effect. ${ }^{11964}$

3662. The FreBat was responsible for anti-sniping tasks in the area and had its vehicles and soldiers at the principal points where snipers would engage civilians, ready to place themselves between those civilians and the snipers. ${ }^{1965}$ It also had special reconnaissance troops whose task was to find the snipers and engage them. ${ }^{11966}$ In addition, the task force photographed all the possible areas in Grbavica where the Serbs were shooting from and mounted observation on the identified locations thus becoming very familiar with the sniper positions in the area. ${ }^{11967}$ Along Sniper Alley, the reconnaissance troops engaged mostly the Serb snipers. ${ }^{11968}$

3663. Fraser testified that the two warring factions in the area were close to each other and that, frequently, this proximity resulted in exchanges of fire in the area of Vrbanja Bridge and the Jewish

\footnotetext{
11960 See para. 3668.

11961 Stanislav Galić, T. 37844 (7 May 2013).

11962 D2331 (Witness statement of Blagoje Kovačević dated 14 October 2012), para. 36. In cross-examination, Kovačević claimed that the same was the case for the whole brigade, not just his battalion. While he conceded that the brigade had shooting positions in Grbavica he denied that these were manned by professionally trained snipers with sniper equipment. See Blagoje Kovačević, T. 29048-29053 (18 October 2012); P5930 (Report of $1^{\text {st }}$ Sarajevo Mechanised Brigade to SRK, 29 October 1993). Given the evidence referred to above regarding a sniper squad in the $2^{\text {nd }}$ Infantry Battalion of the $1^{\text {st }}$ Sarajevo Mechanised Brigade, the Chamber does not accept Kovačević's evidence that no snipers existed within the brigade.

11963 Blagoje Kovačević, T. 29055-29059 (18 October 2012); P5931 (Anti-Tank Company request for ammunition, 16 December 1993). See also P926 (Witness statement of Aernout van Lynden dated 26 February 2010), paras. $109-112$.

11964 D2331 (Witness statement of Blagoje Kovačević dated 14 October 2012), paras. 27-28, 34-35; Blagoje Kovačević, T. 29075-29076 (18 October 2012).

11965 P1762 (Witness statement of David Fraser dated 17 October 2010), pp. 32-35.

11966 P1762 (Witness statement of David Fraser dated 17 October 2010), pp. 33-34, 36.

11967 P1762 (Witness statement of David Fraser dated 17 October 2010), pp. 24-25, 29; David Fraser, T. 8016-8017 (18 October 2010).

11968 P1762 (Witness statement of David Fraser dated 17 October 2010), p. 33.
} 
cemetery. ${ }^{11969}$ Despite that, he thought it unlikely for civilians to be simply caught in an exchange of fire between the two factions in the Sniper Alley area because a professional sniper would take care to line up a military target and would be unlikely to miss it. ${ }^{1970}$ Similarly, even a regular rifleman would normally be proficient enough in firing his weapon and thus would be able to avoid shooting civilians. ${ }^{11971}$ As for the trams in the area, in Fraser's opinion, it was also unlikely that those were hit by mistake; in his experience, the trams seemed to be a favourite target of snipers because of the psychological effect this had on the people in Sarajevo. ${ }^{11972}$ KDZ485 could not recall any incidents where civilians were killed by snipers during combat activity as they would usually take cover or shelter during such times. ${ }^{11973}$

3664. Fraser also thought that the snipers operating in Sarajevo were "very competent", as demonstrated by the fact that in the Sniper Alley area they would regularly fire at a telephone pole in order to make their presence known to the UNPROFOR. ${ }^{11974}$ Furthermore, it was not uncommon for those snipers to register their positions by firing a couple of shots to check on wind and distance and to set themselves up for the day's activities. ${ }^{11975}$ It was also not uncommon for them to fire a round of bullets off the side of one of the UNPROFOR vehicles at the end of the day. ${ }^{11976}$ Fraser did accept, however, that UNPROFOR was not in a position to check the Serb side of the confrontation line with respect to each incident as it was not given freedom of movement in that area. ${ }^{1977}$ The Serbs would also not let UNPROFOR personnel come to their side of Miljacka River to investigate sniping incidents allegedly committed by the $\mathrm{ABiH}^{11978}$ Instead the

\footnotetext{
11969 David Fraser, T. 8125 (19 October 2010).

11970 P1762 (Witness statement of David Fraser dated 17 October 2010), pp. 32, 39. See also P1818 (Witness statement of Adrianus van Baal dated 26 October 2010), para. 46.

11971 P1762 (Witness statement of David Fraser dated 17 October 2010), p. 32.

11972 Fraser explained that if trams stopped running it meant that the situation was grave which in turn had a psychological effect on the people in the city. See P1762 (Witness statement of David Fraser dated 17 October 2010), p. 39; David Fraser, T. 8127-8128 (19 October 2010). However, Maletić testified that it was prohibited to fire on civilian targets and that, therefore, his soldiers did not target the trams and/or wait for the trams to slow down at the S-curve. See D2519 (Witness statement of Dragan Maletić dated 9 November 2012), paras. 8 9; Dragan Maletić, T. 30883-30886, 30889-30890 (4 December 2012); D2525 (Photograph of Sarajevo marked by Dragan Maletić). Dragomir Milošević placed the blame on the Bosnian Muslim side which would fire on the SRK positions while trams were running, resulting in the SRK response and trams getting shot. See Dragomir Milošević, T. 33208-33209 (5 February 2013). See also D2331 (Witness statement of Blagoje Kovačević dated 14 October 2012), para. 13 (testifying that one could not rule out the possibility of trams getting accidentally hit in cross-fire).

11973 P1905 (Witness statement of KDZ485), para. 30.

11974 P1762 (Witness statement of David Fraser dated 17 October 2010), p. 31

11975 P1762 (Witness statement of David Fraser dated 17 October 2010), p. 31

11976 P1762 (Witness statement of David Fraser dated 17 October 2010), p. 31

11977 David Fraser, T. 8127 (19 October 2010).

11978 See P1762 (Witness statement of David Fraser dated 17 October 2010), p. 24.
} 
UNPROFOR personnel had to speak to the SRK Commander and other Bosnian Serb leaders about those matters. ${ }^{11979}$

3665. In the spring or summer of 1995, Fraser and his superior asked the Serb side if they could visit some of Serb positions; together with other UNPROFOR soldiers they were escorted by the Commander of the Ilidža Brigade to a red brick building located to the south of the four white highrises in Grbavica. ${ }^{11980}$ It was a three to four storey building with holes in the walls of the upper floors through which one could see the Muslims side of Miljacka River; there were also sandbags and other paraphernalia that could be used by snipers. ${ }^{11981}$ Fraser, who commanded over snipers during the course of his career, ${ }^{1982}$ thought that the building was a good position for snipers and "definitely looked like it was prepared for that use". ${ }^{11983}$ KDZ182, who was also present during this visit, testified that whilst in the building he saw a certain device used for sniping that allowed the shooter to be located to the side of the gun, instead of behind it, as explained to the visiting group by the Commander of the Ilidža Brigade. ${ }^{1984}$

3666. In February and March 1996, after the BiH authorities were able to go to the neighbourhood of Grbavica again, CSB Sarajevo's ballistic experts, including Sabljica and Zlatko Međedović, visited Metalka, the four white high-rises, and two other buildings in the area, ${ }^{11985}$ on the order of an investigating judge. ${ }^{11986}$ In the white high-rises, the team found five or six apartments on higher floors, ${ }^{11987}$ which had been redesigned to serve as sniper nests. ${ }^{1988}$ Each apartment looked the same: the partition walls that divided the rooms within each apartment had holes while the outer wall of the building, facing Zmaja od Bosne street, had the smallest opening, thereby creating what

\footnotetext{
11979 David Fraser, T. 8032-8034 (18 October 2010).

11980 P1762 (Witness statement of David Fraser dated 17 October 2010), pp. 27-28; P1770 (Photograph of Sarajevo marked by David Fraser); P2414 (Witness statement of KDZ182), pp. 36-39 (under seal).

11981 P1762 (Witness statement of David Fraser dated 17 October 2010), p. 28.

11982 P1762 (Witness statement of David Fraser dated 17 October 2010), pp. 4, 30-31.

11983 P1762 (Witness statement of David Fraser dated 17 October 2010), p. 29. Fraser did concede, however, that the presence of sandbags and holes in the wall did not necessarily mean that the shooters were using sniper rifles with optical sights. See P1762 (Witness statement of David Fraser dated 17 October 2010), pp. 29-30; David Fraser, T. 8127 (19 October 2010).

11984 P2414 (Witness statement of KDZ182), pp. 38-39, 44-45 (under seal).

11985 One of the buildings was an 18 floor skyscraper on Rave Janković street, while the other was a private house in the neighbourhood of Vraca, in Smederevska street. See Mirza Sabljica, T. 7941-7943 (14 October 2010); P1736 (BiH MUP Reports re sniper nest sites, 25 April 1996); P1737 (Aerial photograph of Sarajevo marked by Mirza Sabljica).

11986 Mirza Sabljica, T. 7675 (11 October 2010), T. 7933 (14 October 2010); P1695 (Witness statement of Mirza Sabljica dated 11 February 2010), pp. 60-62.

11987 Sabljica testified that they were located above the tenth floor but could not remember exact floors. See P1695 (Witness statement of Mirza Sabljica dated 11 February 2010), p. 62.

11988 Mirza Sabljica, T. 7675 (11 October 2010); P1695 (Witness statement of Mirza Sabljica dated 11 February 2010), p. 61.
} 
is referred to as a "tunnel". ${ }^{11989}$ The perforations on the partition walls had a conical shape so that the shooter could fire from the depth of the apartment. ${ }^{11990}$ According to Sabljica, at least three such perforated walls would have separated the shooter from the fire coming into the building, as indicated by the sandbags placed behind the last partition wall, making it extremely difficult to spot the shooter from the outside. ${ }^{11991}$ Looking from what he believed to be the sniper's position, Sabljica could see the stretch of Zmaja od Bosne street from the Holiday Inn to the Faculty of Natural Sciences and Mathematics just west of the Maršal Tito Barracks. ${ }^{11992}$ Photographs of inspected sniper nests were taken during the investigation. ${ }^{11993}$

3667. Based on his analysis of the material relating to the sniper nests in four white high-rises, Poparić, testified that it was obvious that they were constructed professionally. ${ }^{11994}$ In his opinion, they were aimed at the Maršal Tito Barracks as the view from them reached only as far as the School of Technology. ${ }^{11995}$ Poparić also thought that the way these nests were constructed showed that a response was expected from the opposite side which to him meant that they were directed at the Maršal Tito Barracks. ${ }^{11996}$ During cross-exmination, however, Poparić conceded that he did not go inside the four white high-rises in Grbavica, noting that it was not necessary because he had the photographs from the Dragomir Milošević case and thus knew what could be seen from them. ${ }^{11997}$

3668. As for the Metalka building, Sabljica and the others inspected it as well but did not find such well-equipped sniper nests as found in the white high-rises. ${ }^{11998}$ However, in one of the apartments, on the eighth and top floor, they found an improvised sniping nest with an opening on one of the walls, as well as some empty automatic weapon shell casings. ${ }^{11999}$ Sabljica testified that the only type of automatic weapon available in the Balkans at the time was an M84 machine-gun,

\footnotetext{
11989 Mirza Sabljica, T. 7675-7676, 7706-7708 (11 October 2010); P1695 (Witness statement of Mirza Sabljica dated 11 February 2010), p. 61. This is in line with how Van der Weijden described professional sniper nests in an urban setting. See P1621 (Expert Report of Patrick van der Weijden entitled "Sniping Incidents in Sarajevo '92-'94'), p. 4.

11990 Mirza Sabljica, T. 7708 (11 October 2011); P1695 (Witness statement of Mirza Sabljica dated 11 February 2010), p. 61.

P1695 (Witness statement of Mirza Sabljica dated 11 February 2010), p. 61.

Mirza Sabljica, T. 7709 (11 October 2010), T. 7933-7934, 7944-7947 (14 October 2010); P1738 (Photographs of sniper nests). The Chamber notes that Metalka is not one of the buildings featuring in P1738.

D4884 (Mile Poparić's expert report entitled "Small Arms Fire on the Sarajevo Area 1992-1995", 15 August 2012), p. 42.

D4884 (Mile Poparić's expert report entitled "Small Arms Fire on the Sarajevo Area 1992-1995", 15 August 2012), p. 42.

D4884 (Mile Poparić's expert report entitled "Small Arms Fire on the Sarajevo Area 1992-1995", 15 August 2012), p. 42.

Mile Poparić, T. 39183-39189 (4 June 2013).

P1695 (Witness statement of Mirza Sabljica dated 11 February 2010), pp. 62-63.

Mirza Sabljica, T. 7676-7677 (11 October 2010).
} 
which uses $7.62 \mathrm{~mm}$ calibre bullets, ${ }^{12000}$ and also confirmed that the bullet casings found in the white high-rises were of $7.62 \mathrm{~mm}$ calibre, as well as $7.9 \mathrm{~mm}$ calibre. ${ }^{12001}$

3669. As for the $\mathrm{ABiH}$ side of the confrontation line, according to Fraser, the "legislative building" and the UNIS towers were used as sniping nests. ${ }^{12002}$ KDZ450 confirmed that snipers on the Bosnian Muslim side operated around the Presidency building, UNIS towers, and the Holiday Inn. $^{12003}$ Maletić testified that the enemy unit facing his company used snipers ${ }^{12004}$ and that the entire area of Grbavica was under sniper fire coming from buildings such as the high-rises in Pofalići, the Mechanical Engineering Faculty, the Unis towers, the Executive Council building, the Museum, the Unioninvest building, the red high-rises in Hrasno, the Elektroprivreda building, the Bristol Hotel, Debelo Brdo, and Trebević. ${ }^{12005}$ According to Galić, the sniper units of the $1^{\text {st }}$ Corps of the $\mathrm{ABiH}$ had "stronger buildings" on their side of Miljacka River, that is, buildings with reinforced concrete and higher than three floors, which gave them more possibilities for sniper use. $^{12006}$

3670. Based on the evidence outlined above, the Chamber finds that sniper nests and shooting positions of both warring factions existed in the area surrounding the confrontation lines on Zmaja od Bosne. The Chamber is also convinced that SRK sniper nests and shooting positions were located on the upper floors of all four white high-rises in Grbavica, as well as on the last floor of the Metalka building. They were also scattered in a number of other buildings in the area throughout the zone of responsibility of the $3^{\text {rd }}$ Battalion of the $1^{\text {st }}$ Romanija Infantry Brigade, later the $2^{\text {nd }}$ Battalion of the $1^{\text {st }}$ Sarajevo Mechanised Brigade and were, contrary to Galić's testimony,

12000 Mirza Sabljica, T. 7709-7710 (11 October 2010). The Chamber notes that the transcript records Sabljica as having referred to an M74 machine gun. However, given that the Chamber only ever heard about M84 machine guns in this case, the Chamber considers this to have been either a mistake in interpretation or a mistake on the part of Sabljica and should have been a reference to M84.

12001 Mirza Sabljica, T. 7939-7941 (14 October 2010); P1736 (BiH MUP Reports re sniper nest sites, 25 April 1996).

12002 P1762 (Witness statement of David Fraser dated 17 October 2010), p. 24; David Fraser, T. 8049 (18 October 2010). However, KDZ182 testified that as far as presence of snipers in UNIS towers was concerned, this was "an idea that was spread" and that he never saw a report or was able to check whether snipers were in fact there. He did know, however, that there were snipers in the "former parliament building". See P2414 (Witness statement of KDZ182), pp. 40, 43 (under seal). See also D4607 (SRK Report, 30 July 1994), p. 1; D4587 (SRK Report, date illegible), p. 1.

12003 P5906 (Witness statement of KDZ450 dated 17 January 2011), para. 133; KDZ450, T. 10669 (20 January 2011 ).

12004 D2519 (Witness statement of Dragan Maletić dated 9 November 2012), paras. 19, 32.

12005 D2519 (Witness statement of Dragan Maletić dated 9 November 2012), para. 20. See also D2651 (Witness statement of Milorad Katić dated 10 December 2012), para. 5; D2331 (Witness statement of Blagoje Kovačević dated 14 October 2012), paras. 13, 30, 36-37; Dragomir Milošević, T. 33275-33276 (6 February 2013); Stanislav Galić, T. 37450 (18 April 2013), T. 37466 (22 April 2013); D2826 (1 ${ }^{\text {st }}$ Romanija Infantry Brigade combat report, 25 July 1992). [REDACTED]. Edin Garaplija testified that a member of Ševe, Nedžad Herenda, operated as a sniper from the Executive Council building. See Edin Garaplija, T. 33388 (7 February 2013). Van Baal testified that he had reports that $\mathrm{ABiH}$ would snipe at Serb positions from "a government building and from a hotel". See Adrianus van Baal, T. 8457, 8459-8460 (27 October 2010).

12006 Stanislav Galić, T. 37467-37468, 37471 (22 April 2013). 
manned by snipers subordinated directly to the battalion commander. Further, the SRK shooting positions existed on the western side of the Jewish cemetery. Thus, there were many SRK snipers, as well as forces with semi-automatic rifles in the area. The Chamber finds, relying in particular on the evidence of KDZ310, that they would target civilians, both pedestrians and those riding in trams, as well as combatants on the $\mathrm{ABiH}$-held side of the confrontation line. ${ }^{12007}$ As for the $\mathrm{ABiH}$, the Chamber is satisfied that the $\mathrm{ABiH}$ had snipers in UNIS towers, Mechanical Engineering Faculty, Faculty of Natural Sciences and Mathematics, and the Executive Council and Assembly buildings. It is also satisfied that it opened fire on Grbavica, including on civilians, from those positions.

\section{(3) Zmaja od Bosne street, 19 June 1994 (Scheduled Incident F.8)}

3671. The Indictment alleges that on 19 June 1994 Jasmina Kučinar, a 31 year old woman, and her four year old son, Damir Kučinar were shot and lightly wounded in their legs while travelling in a crowded tram on Zmaja od Bosne street towards Alipašino Polje. According to the Indictment, Mensur Jusić, a 36 year old man, sustained a slight leg wound while Belma Sukić née Likić, a 23 year old woman, was wounded in her left armpit. The Indictment also alleges that the tram was near the Holiday Inn when the incident happened. ${ }^{12008}$ In its Final Brief, the Prosecution argues that the "likely origin of fire was a location 600 metres from the incident site in the area of the Jewish cemetery."12009 The Accused submits that the investigators did not know the origin of fire for this incident and claims that the bullet was in fact fired from the Executive Council building. ${ }^{12010}$

3672. On 19 June 1994, at approximately 5 p.m., Mensur Jusić was riding on a tram heading down Zmaja od Bosne street in the direction of Ilidža. ${ }^{12011}$ Jasmina Kučinar was on the same tram with her four year old son. ${ }^{12012}$ As the tram approached the intersection of Zmaja od Bosne and Fra Anđela Zvizdovića streets, Kučinar heard a shot and saw that her son who had been sitting by the

12007 The Chamber therefore rejects Galić's evidence on this issue. Given the contrary evidence outlined above, the Chamber finds that Galić was disingenuous when he testified that the SRK snipers in the area only fired in order to neutralise the fire coming from the enemy. See also Adjudicated Fact 2910.

12008 Indictment, Scheduled Incident F.8. In its Final Brief, the Prosecution argues that the tram was hit when located just east of the S-curve. Prosecution Final Brief, Appendix C, para. 15.

12009 Prosecution Final Brief, Appendix C, para. 17.

12010 Defence Final Brief, para. 2235; Closing Arguments, T. 47986-47987 (2 October 2014).

12011 See Adjudicated Fact 209. The Chamber notes that in its original form this Adjudicated Fact refers to the Vojvode Putnika street but that this is the old name for Zmaja od Bosne street and that the latter will be used throughout this judgement.

12012 See Adjudicated Fact 210. See also Prosecution Submission, filed confidentially on 30 January 2015, paras. 911. 
window had been injured. ${ }^{12013}$ Jusić was hit in the shin of his right leg. ${ }^{12014}$ Jusić saw that the arm of a woman standing to his right was bleeding. ${ }^{12015}$ The injured received medical treatment at a nearby emergency clinic. ${ }^{12016}$ No military vehicles were present in the close vicinity of the location of the incident. ${ }^{12017}$ No military activity was underway in the area. ${ }^{12018}$

3673. Bogdan Vidović, a criminal technician in the CSB Sarajevo, ${ }^{12019}$ participated in the investigation of the incident. ${ }^{12020}$ He testified that it happened while the westbound tram was in the area of Marin Dvor, in front of the St. Joseph Church. ${ }^{12021}$ The middle part of the left hand side of the tram was hit by one bullet, which pierced the wall of the tram, entered the tram right above the floor level, flew across the aisle, and then hit the carrying frame of the seat on the right hand side of the tram. The bullet split into pieces and caused the injuries to Jusić's right lower leg, ${ }^{12022}$ Belma Likić's left arm, and Damir Kučinar's knees. ${ }^{12023}$ The ballistic tests determined that the bullet fragments found in the tram belonged to a $7.9 \mathrm{~mm}$ calibre bullet which could have been fired from any of M48 rifle, carabine rifle, automatic rifle, or M53 machine-gun. ${ }^{12024}$ Finally, the report concludes that the bullet originated from the direction of Grbavica-Vraca and was "probably fired

\footnotetext{
12013 See Adjudicated Fact 211. The Chamber notes that this Adjudicated Fact refers to the intersection of Vojvode Putnika and Tršćanska streets. Those are former names of the said streets. The Chamber will use the current names, namely Zmaja od Bosne and Fra Anđela Zvizdovića, in this judgement.

12014 Adjudicated Fact 212.

12015 See Adjudicated Fact 213.

12016 Adjudicated Fact 214.

12017 Adjudicated Fact 216.

12018 Adjudicated Fact 217.

12019 P1742 (Witness statement of Bogdan Vidović dated 28 September 2010), pp. 2, 11-12, 31-32, 34.

12020 P1742 (Witness statement of Bogdan Vidović dated 28 September 2010), pp. 2-3.

12021 Bogdan Vidović, T. 8172-8174, 8177-8178, 8186 (19 October 2010); D787 (Map of Sarajevo marked by Bogdan Vidović); D788 (Photograph of Sarajevo marked by Bogdan Vidović); P1742 (Witness statement of Bogdan Vidović dated 28 September 2010), pp. 10, 26, 28; P1761 (Map of Sarajevo marked by Bogdan Vidović). See also P1758 (BiH MUP Report re sniping incident of 19 June 1994 on Zmaja od Bosne street), ecourt p. 5.

12022 While the reports refer to a Mesud Jusić, the Chamber is satisfied that this is Mensur Jusić referred to in the Indictment.

12023 P1742 (Witness statement of Bogdan Vidović dated 28 September 2010), pp. 3-9; P1757 (BiH MUP Report re sniping incident of 19 June 1994 on Zmaja od Bosne street); P1758 (BiH MUP Report re sniping incident of 19 June 1994 on Zmaja od Bosne street), e-court pp. 5, 7; P1759 (Photographs re sniping incident of 19 June 1994 on Zmaja od Bosne marked by Bogdan Vidović). See also Adjudicated Fact 218. The Chamber notes that none of the BiH MUP reports on this incident refers to any injuries sustained by Jasmina Kučinar. In fact, the Chamber received no evidence indicating that Jasmina Kučinar was injured in this incident.

12024 While the ballistics report states that the bullet in question was a $7.9 \mathrm{~mm}$ calibre bullet, the text under some of the CSB Sarajevo photographs taken at the scene refer to a bullet of $7.62 \mathrm{~mm}$ calibre. The Chamber considers this to be inaccurate and finds the ballistics analysis report to be determinative on this matter. See P1758 (BiH MUP Report re sniping incident of 19 June 1994 on Zmaja od Bosne street), e-court p. 7; P1742 (Witness statement of Bogdan Vidović dated 28 September 2010), pp. 27-29; Bogdan Vidović, T. 8190-8191, 8196, 8254-8255 (20 October 2010).
} 
from the aggressor's positions" in Grbavica. ${ }^{12025}$ When questioned on this conclusion, Vidović clarified that, for security reasons, the tram was moved some three stops away from the incident site when the investigation was conducted, ${ }^{12026}$ as a result of which, the ballistics experts were not sent to the site, ${ }^{12027}$ and the exact origin of fire could not be determined. ${ }^{12028}$ Instead, only the direction of fire, which ran from Grbavica, across the Unioninvest building, towards the incident site, could be established. ${ }^{12029}$

3674. During cross-examination, Vidović agreed that the fire in the area where the incident happened could have originated from the Assembly building. ${ }^{12030} \mathrm{He}$ also agreed that because of a tree seen in a photograph shown to him, the western boundary of the Jewish cemetery had no view on the incident site and that the tram tracks could have been fired on from the cemetery's eastern boundary. ${ }^{12031}$ As for the view of the site from Vraca, Vidovic testified that the extent of that view depended on the exact location of the tram when hit but accepted that the bullet fired from there would have hit the tram at an acute angle. ${ }^{12032}$ However, he stated that the bullet's actual entry point led him to the conclusion that the bullet came in at a right angle rather than an acute one. ${ }^{12033}$ He also indicated that the incident took place during a period of cease-fire, ${ }^{12034}$ and that he believed that UNPROFOR was informed about it. ${ }^{12035}$ When questioned about the area, Vidović confirmed that a police station was located some 200 to 300 metres away from the incident site, that the command of the $1^{\text {st }}$ Corps of $\mathrm{ABiH}$ was located in the centre of the city, and that the confrontation line was not far from the incident site, running along Miljacka River, to the east of the Vrbanja Bridge. $^{12036}$

12025 P1757 (BiH MUP Report re sniping incident of 19 June 1994 on Zmaja od Bosne street); P1742 (Witness statement of Bogdan Vidović dated 28 September 2010), pp. 6, 10; P1758 (BiH MUP Report re sniping incident of 19 June 1994 on Zmaja od Bosne street), e-court p. 5.

12026 P1742 (Witness statement of Bogdan Vidović dated 28 September 2010), pp. 10, 13.

12027 P1742 (Witness statement of Bogdan Vidović dated 28 September 2010), p. 12.

12028 P1742 (Witness statement of Bogdan Vidović dated 28 September 2010), p. 29.

12029 Bogdan Vidović, T. 8174-8175 (19 October 2010); D787 (Map of Sarajevo marked by Bogdan Vidović).

12030 Bogdan Vidović, T. 8179, 8182 (19 October 2010); D788 (Photograph of Sarajevo marked by Bogdan Vidović).

12031 Bogdan Vidović, T. 8178-8182 (19 October 2010); D788 (Photograph of Sarajevo marked by Bogdan Vidović).

12032 Bogdan Vidović, T. 8185-8187 (20 October 2010); D789 (Map of Sarajevo marked by Bogdan Vidović).

12033 Bogdan Vidović, T. 8192-8195 (20 October 2010).

12034 P1742 (Witness statement of Bogdan Vidović dated 28 September 2010), pp. 10-11.

12035 P1742 (Witness statement of Bogdan Vidović dated 28 September 2010), pp. 18-19. Indeed, the CSB Sarajevo report on the investigation provides that the UNPROFOR conducted its own investigation of this incident. See P1758 (BiH MUP Report re sniping incident of 19 June 1994 on Zmaja od Bosne street), e-court p. 5.

12036 With respect to the confrontation line, Vidović explained that he marked it not based on what he observed but what he heard. P1742 (Witness statement of Bogdan Vidović dated 28 September 2010), pp. 17-18, 23-27; P1761 (Map of Sarajevo marked by Bogdan Vidović). See also Bogdan Vidović, T. 8175-8176 (19 October 2010); D787 (Map of Sarajevo marked by Bogdan Vidović). 
3675. Hogan visited the site of the incident with Jusić and recorded the tram's approximate location when struck by the bullet, namely the intersection of Zmaja od Bosne and Fra Anđela Zvizdovića. ${ }^{12037}$ As seen on the photographs marked by Hogan in court, there was an unobstructed view towards the Jewish cemetery from that intersection. ${ }^{12038}$

3676. Van der Weijden also investigated this incident and had at his disposal the report prepared by CSB Sarajevo, as well as the statements of Vidović and Jusić. ${ }^{12039}$ Like Hogan, he visited the site of the incident, and then went to the Jewish cemetery which is about 600 metres away and which offered several good positions with a view of the incident site. ${ }^{12040}$ According to Van der Weijden, the fact that the tram's left hand side was facing south when it reached the incident site indicated that the shot was fired from the Jewish cemetery. ${ }^{12041}$ Because of the distance between the two sites, Van der Weijden was of the opinion that either a medium machine-gun or a sniper rifle was used in this incident, noting that both used either $7.62 \mathrm{~mm}$ or $7.92 \mathrm{~mm}$ calibre bullets. ${ }^{12042}$ Furthermore, he noted that at this distance it would have been impossible for the shooter to identify who the people in the tram were. ${ }^{12043}$ Noting also that the witnesses heard one shot but that three people were injured, Van der Weijden explained that this could be either because other shots were not heard due to the noise produced by the tram or because the one bullet that was fired fragmented on impact. ${ }^{12044}$ On the subject of hearing the bullet, Vidović testified that one would not have been able to determine, on the basis of the sound heard, that the fire came from the Jewish cemetery. ${ }^{12045}$

3677. Poparic pointed out that the CSB Sarajevo investigation team did not determine the direction from which the bullet was fired but simply assumed that it was fired from VRS positions in Grbavica. ${ }^{12046}$ Having gone to the scene, Poparić observed that the incident site is visible from

12037 Hogan explained that the tram locations he recorded were only approximations in light of the fact that the trams were moving when hit. Barry Hogan, T. 11214 (3 February 2011); P2190 (GPS locations for shelling and sniping incidents in Sarajevo); P2203 (Photograph re sniping incident of 19 June 1994 on Zmaja od Bosne street marked by Barry Hogan); P2207 (Images re scheduled sniping incidents in Sarajevo); D4884 (Mile Poparić's expert report entitled "Small Arms Fire on the Sarajevo Area 1992-1995", 15 August 2012), p. 105, Image 71.

12038 Barry Hogan, T. 11214 (3 February 2011); P2203 (Photograph re sniping incident of 19 June 1994 on Zmaja od Bosne street marked by Barry Hogan).

12039 P1621 (Expert Report of Patrick van der Weijden entitled “Sniping Incidents in Sarajevo '92-'94”), p. 65.

12040 P1621 (Expert Report of Patrick van der Weijden entitled "Sniping Incidents in Sarajevo '92-'94”), pp. 59-61. See also Patrick van der Weijden, T. 6955 (27 September 2010).

12041 P1621 (Expert Report of Patrick van der Weijden entitled "Sniping Incidents in Sarajevo '92-'94”), p. 61. See also Barry Hogan, T. 11214 (3 February 2011); P2203 (Photograph re sniping incident of 19 June 1994 on Zmaja od Bosne street marked by Barry Hogan).

12042 P1621 (Expert Report of Patrick van der Weijden entitled “Sniping Incidents in Sarajevo '92-'94”), p. 59.

12043 P1621 (Expert Report of Patrick van der Weijden entitled “Sniping Incidents in Sarajevo '92-'94”), p. 62.

12044 P1621 (Expert Report of Patrick van der Weijden entitled “Sniping Incidents in Sarajevo '92-'94”), p. 59.

12045 Bogdan Vidović, T. 8183 (19 October 2010).

12046 D4884 (Mile Poparić's expert report entitled "Small Arms Fire on the Sarajevo Area 1992-1995", 15 August 2012), p. 106. The Chamber notes that this is somewhat inaccurate as the forensic investigation report prepared by Vidović provides that the direction of fire was Grbavica-Vraca. It is the report prepared by the investigator 
both the Jewish cemetery and Debelo Brdo and that the closest line between the Jewish cemetery and the scene of the incident measured 570 metres. ${ }^{12047}$

3678. Poparic analysed the video footage recorded by Van Lynden of the VRS positions at the Jewish cemetery looking down on Marin Dvor area and concluded that the position shown in the video was not a sniper position as the soldier shown was armed with "a simple M70 $7.62 \mathrm{~mm}$ automatic rifle. ${ }^{12048} \mathrm{He}$ also observed that the tram lines were not visible from that position because the trees blocked the view. ${ }^{12049}$

3679. Following his analysis of the photographs of the tram taken by the CSB Sarajevo and his own examination of the scene, Poparic came to the conclusion that the bullet came "from the front half-sphere of the tram". ${ }^{12050}$ Using the size of the bullet entry point (which he determined by magnifying a photograph of it) ${ }^{12051}$ and assuming that the bullet exited the tram wall near a seat located in a certain location, ${ }^{12052}$ Poparić made an "approximate calculation" of the angle which the projectile formed with the tram wall, namely 28.8 degrees, and came to the conclusion that the bullet was fired from the $\mathrm{BiH}$ Executive Council building and not from the Jewish cemetery as alleged. ${ }^{12053}$ Had the bullet come from the Jewish cemetery, according to Poparić, it would have hit the tram at close to a 90 degree angle with an angle of descent being low, approximately five or six degrees. ${ }^{12054}$ Poparić also testified that the fact that the bullet had the energy to travel through the wall of the tram and then across the aisle where it hit the seat on the opposite side of the tram,

that referred to the origin of fire, as opposed to the direction of fire, "most probably" being the "aggressor's positions in Grbavica". Both these reports are part of the CSB Sarajevo report cited by Poparić in support of his proposition above. See P1758 (BiH MUP Report re sniping incident of 19 June 1994 on Zmaja od Bosne street), e-court pp. 4-5.

12047 D4884 (Mile Poparić's expert report entitled "Small Arms Fire on the Sarajevo Area 1992-1995", 15 August 2012), pp. 44-46 (Images 21 and 23), 106-107 (Image 72).

12048 D4884 (Mile Poparić's expert report entitled "Small Arms Fire on the Sarajevo Area 1992-1995", 15 August 2012), p. 108, Image 73; P935 (Sky Newsreport re Sarajevo, with transcript).

12049 D4884 (Mile Poparić's expert report entitled "Small Arms Fire on the Sarajevo Area 1992-1995", 15 August 2012), p. 108, Image 73; P935 (Sky Newsreport re Sarajevo, with transcript). In its Final Brief, the Prosecution argues that this evidence has inefficient factual basis and is contradicted by reliable evidence. Prosecution Final Brief, Appendix C, para. 16.

12050 D4884 (Mile Poparić's expert report entitled "Small Arms Fire on the Sarajevo Area 1992-1995", 15 August 2012), p. 109; Mile Poparić, T. 38976 (30 May 2013).

12051 Mile Poparić, T. 38976 (30 May 2013); D4884 (Mile Poparić's expert report entitled "Small Arms Fire on the Sarajevo Area 1992-1995”, 15 August 2012), p. 111, Image 77.

12052 Mile Poparić, T. 38976-38977 (30 May 2013); D4884 (Mile Poparić's expert report entitled "Small Arms Fire on the Sarajevo Area 1992-1995”, 15 August 2012), p. 110, Image 76; D3637 (Photograph of a tram marked by Mile Poparić).

12053 D4884 (Mile Poparić's expert report entitled "Small Arms Fire on the Sarajevo Area 1992-1995", 15 August 2012), pp. 110-113; Mile Poparić, T. 38975 (30 May 2013).

12054 Mile Poparić, T. 38975-38976 (30 May 2013). 
damaging the metal railing, indicates that it was fired from a "relatively short" range thus again implicating the Executive Council building as the origin of fire. ${ }^{12055}$

3680. Galić told the Chamber that the day before this incident he sent a regular combat report to the VRS Main Staff in which he reported that SRK units were honouring the cease-fire, despite the enemy's provocation, and reported on his decision to continue "to fully and consistently implement the agreement on the cessation of combat activities". ${ }^{12056}$ According to Galić, because of this decision, no shooting at the city by the SRK was expected the next day, especially not at public transportation. ${ }^{12057}$ He also issued another combat report at around 5 p.m. on the day of the incident, reporting that the enemy operated sniper rifles and a hand-held rocket launcher in the area of the Vrbanja Bridge, and that the provocation was responded to with adequate fire on enemy positions. ${ }^{12058}$ He then repeated in the combat report his decision to continue to implement the agreement on the cessation of combat activities. ${ }^{12059}$ There was no mention of the incident in the report and Galić stated that had he been informed of it he would have informed the Main Staff. ${ }^{12060}$

3681. In addition to the evidence and adjudicated facts outlined above, the Chamber has also taken judicial notice of two adjudicated facts which go to the origin of fire and provide as follows: (i) there was an unobstructed line of sight between the site of the event and the area of the Jewish cemetery under SRK control; ${ }^{12061}$ and (ii) the shot which struck the tram was fired from the area of the Jewish cemetery held by the SRK. ${ }^{12062}$

3682. The Chamber finds based on the evidence and adjudicated facts outlined above that the tram in question was shot at, most likely by a single bullet, in the area of Marin Dvor in front of the St. Joseph Church. It also finds that this tram was a civilian vehicle and that it was operating due to a cease-fire that was in place at the time. In addition, the three casualties in this incident, namely Damir Kučinar, Mensur Jusić, and Belma Sukić née Likić ${ }^{12063}$ were civilians and were not taking direct part in hostilities at the time of the incident.

\footnotetext{
12055 Mile Poparić, T. 38977-38979 (30 May 2013).

12056 Stanislav Galić, T. 37530-37531 (22 April 2013); D3454 (SRK combat report, 18 June 1994).

12057 Stanislav Galić, T. 37531 (22 April 2013).

12058 Stanislav Galić, T. 37531-37532 (22 April 2013); D2668 (SRK combat report, 19 June 1994), p. 1.

12059 Stanislav Galić, T. 37531-37532 (22 April 2013); D2668 (SRK combat report, 19 June 1994), p. 1.

12060 Stanislav Galić, T. 37532 (22 April 2013).

12061 See Adjudicated Fact 219.

12062 See Adjudicated Facts 220, 221.

12063 The Chamber notes that while the Indictment alleges that Jasmina Kučinar was also wounded in this incident, the Chamber has not received any evidence to support that allegation. Accordingly, the Chamber considers that three rather than four persons were injured in this incident. See fn. 12023.
} 
3683. In terms of the origin of fire, the Chamber does not accept Poparić's conclusion that the bullet came from the Executive Council building as it is based on speculation. For example, Poparic simply assumed that the bullet exited the tram's wall at a particular location, near a particular seat. ${ }^{12064}$ He made that assumption on the basis of another photograph made by the CSB Sarajevo, namely a close up of the bullet's exit point on the inside of the tram. ${ }^{12065}$ However, other than showing a portion of a red seat, that photograph does not show the actual location of that seat relative to the interior of the tram. ${ }^{12066}$ Thus, it is unclear to the Chamber how Poparic came to the conclusion that the bullet exited the tram wall at a particular location, which in turn allowed him to conclude that the bullet hit the tram at an acute angle. Further, Poparic calculated that angle based on a close-up photograph of the bullet's entry point, which the Chamber views as a highly speculative and potentially inaccurate calculation. Indeed, Poparić's analysis is also contradicted by Vidović's testimony, namely, that the bullet entered the tram at a right angle, as opposed to an acute angle which in turn suggests that a different seat from the one identified by Poparić was in the vicinity of the exit point. ${ }^{12067}$ Given that Vidović was able to observe the entry point on the tram itself, the Chamber considers his evidence here to be more persuasive than Poparić's speculations as to the acute nature of the angle.

3684. Accordingly, based on all the evidence before it, the Chamber finds that the bullet struck the tram at a right angle, from the direction of the Jewish cemetery. In addition, relying on the adjudicated facts and recalling Van der Weijden's evidence as to the lines of sight, the Chamber finds that it was the SRK forces, located on the western side of the Jewish cemetery, that opened fire on the tram. This is also consistent with the preponderance of evidence suggesting that the sniper fire in the area of Zmaja od Bosne street came from the Serb side, ${ }^{12068}$ and with the evidence that the SRK had a sniper squad active in the area, as well as a number of other units with semi-

12064 Poparic explains under Image 76 that the left circle he marked on that image indicates the point of the projectile entry while the right dotted circle marks the point where the projectile exited the paneling on the inner side "as assumed on the basis of Image 75". See D4884 (Mile Poparić's expert report entitled "Small Arms Fire on the Sarajevo Area 1992-1995”, 15 August 2012), p. 110, Image 76.

12065 D4884 (Mile Poparić's expert report entitled "Small Arms Fire on the Sarajevo Area 1992-1995", 15 August 2012), p. 109, Images 75 and 76; P1759 (Photographs re sniping incident of 19 June 1994 on Zmaja od Bosne marked by Bogdan Vidović), e-court p. 2. Indeed, under Image 76 in his report, Poparić explains that the exit point of the bullet was "assumed" on the basis of Image 75.

12066 P1759 (Photographs re sniping incident of 19 June 1994 on Zmaja od Bosne marked by Bogdan Vidović), ecourt p. 2. The Chamber notes that judging by the photograph depicting the exterior of the tram and the entry point of the bullet, there are two potential seats that could have been in the vicinity of the exit point, the one identified by Poparić and another one, just in front of it. See D4884 (Mile Poparić's expert report entitled “Small Arms Fire on the Sarajevo Area 1992-1995", 15 August 2012), p. 109, Image 75; P1759 (Photographs re sniping incident of 19 June 1994 on Zmaja od Bosne marked by Bogdan Vidović), e-court p. 6.

12067 Bogdan Vidović, T. 8192-8195 (20 October 2010).

12068 See paras. 3621, 3656-3662. In addition, the Chamber also recalls that it rejected the Accused's arguments that $\mathrm{ABiH}$ forces were the ones sniping at Bosnian Muslims civilians throughout Sarajevo. See Section IV.B.1.d: Bosnian Muslims targeting own civilians. 
automatic rifles. Given the distance involved and the fact that it was struck by one bullet only, the Chamber is also convinced that the tram was deliberately targeted by a single shot and that the SRK shooter would have known that the tram was a civilian vehicle carrying civilians.

\section{(4) Zmaja od Bosne street, 8 October 1994 (Scheduled Incident F.11)}

3685. The Indictment alleges that Alma Ćutuna, a 43 year old woman, was wounded in the upper right leg while travelling on a tram on Zmaja od Bosne. ${ }^{12069}$ In its Final Brief, the Prosecution argues that the shots were fired from sniper positions in Serb-held territory to the south of Miljacka River. ${ }^{12070}$ The Accused submits, however, that the source of fire in this incident was the Executive Council building. ${ }^{12071}$

3686. On 8 October 1994, Alma Ćutuna and her husband were on a tram travelling eastbound on Zmaja od Bosne street. ${ }^{12072}$ The tram was crowded as people had decided to come out due to a cease-fire. ${ }^{12073}$ While on the tram, Ćutuna was standing facing the middle doors, looking at Grbavica, wearing jeans and a red and black blouse. ${ }^{12074}$ According to KDZ090, sometime between 12 and 12:10 p.m., as the tram was passing the Museum and approaching the Faculty of Philosophy, it slowed down in order to enter the S-curve and, at that point, was shot at, the bullets first hitting the upper and then the lower section of the tram. ${ }^{12075}$ As a result, Ćutuna was wounded on the inside of her right thigh resulting in two exit wounds on the side of her right hip; she also

\footnotetext{
12069 Indictment, Scheduled Incident F.11. In footnote 22 of the Indictment, the Prosecution notes that "the evidence also shows that one person was killed and an additional nine were wounded in the incident." The Prosecution has stated on the record that this killing is not charged as part of this incident. See T. 39012-39014 (30 May 2013).

12070 Prosecution Final Brief, Appendix C, para. 18. The Prosecution also alleges in its Final Brief that the tram was hit on "either side of the S-curve". Prosecution Final Brief, Appendix C, para. 15. See also Closing Arguments, T. 47742-47747 (30 September 2014).

12071 Defence Closing Brief, para. 2266.

12072 P2923 (Witness statement of KDZ090 dated 21 February 1996), p. 1; P1028 (Video re sniping incident of 8 October 1994 on Zmaja od Bosne street) (under seal).

12073 KDZ090, P481 (Transcript from Prosecutor v. D. Milošević), T. 824-825 (under seal); P2923 (Witness statement of KDZ090 dated 21 February 1996), p. 1; P2923 (Witness statement of KDZ090 dated 19 April 2006), para. 8. See also Adjudicated Fact 2923.

12074 KDZ090, P481 (Transcript from Prosecutor v. D. Milošević), T. 826 (under seal); P2923 (Witness statement of KDZ090 dated 21 February 1996), p. 1 (under seal); P2923 (Witness statement of KDZ090 dated 19 April 2006), paras. 8, 9 .

12075 According to KDZ090, when the shooting started, the tram was still moving but once it was hit it stopped. See P2923 (Witness statement of KDZ090 dated 21 February 1996), p. 1; P2923 (Witness statement of KDZ090 dated 19 April 2006), para. 8; KDZ090, P481 (Transcript from Prosecutor v. D. Milošević), T. 825-826, 829832, 835-837 (under seal); P432 (Aerial photograph of Sarajevo marked by KDZ090) (under seal); P436 (Aerial photograph of Sarajevo marked by KDZ090); P437 (Aerial photograph of Sarajevo marked by KDZ090); P1028 (Video re sniping incident of 8 October 1994 on Zmaja od Bosne street) (under seal). See also Adjudicated Fact 2924.
} 
sustained cuts on her head from the tram's broken window glass. ${ }^{12076}$ She was admitted to the hospital, underwent an operation the same day, and discharged on 11 November 1994, having spent some of her recovery in intensive care. ${ }^{12077}$ Other persons were also wounded during this incident, ${ }^{12078}$ while, according to KDZ090, the driver of the tram travelling in front of Ćutuna's tram at the time of the attack was killed. ${ }^{12079}$ Ćutuna still suffers from pain in her leg and needs help with her day to day activities. ${ }^{12080}$

3687. KDZ090 testified that the shots were fired from the Metalka building. ${ }^{12081}$ There were no military institutions or equipment in the vicinity of the incident's location and the closest military installation was the Maršal Tito Barracks, some two tram stops away. ${ }^{12082}$ Furthermore, there was no fighting that day since the cease-fire was in place and no $\mathrm{ABiH}$ soldiers in the tram. ${ }^{12083}$

3688. CSB Sarajevo was informed about this incident around 12:45 p.m. on 8 October 1994 and then informed an investigative judge who sent out a team, which included KDZ485, to the scene to investigate. ${ }^{12084}$ The investigation started at 1 p.m. and lasted for an hour and 15 minutes. ${ }^{12085}$ A report, dated 10 October 1994, was compiled, listing one casualty, Nedžad Hadžijbarić, and 11 wounded, including Alma Ćutuna. ${ }^{12086}$ According to the report, the driver of the first tram ${ }^{12087}$ told the investigators that the first burst of shots was fired at his tram, tram number 206, at 12:19 p.m. by Serbs from the Metalka building, injuring three passengers. ${ }^{12088}$ Some two to three minutes

12076 P2923 (Witness statement of KDZ090 dated 21 February 1996), pp. 1-2; P2923 (Witness statement of KDZ090 dated 19 April 2006), para. 8 ; KDZ090, P481 (Transcript from Prosecutor v. D. Milošević), T. 824,827 (under seal). See also Adjudicated Facts 2921, 2925.

12077 P2923 (Witness statement of KDZ090 dated 21 February 1996), p. 2; P1257 (Medical report for Alma Ćutuna) (under seal); P1218 (Medical report for Alma Ćutuna) (under seal). See also Adjudicated Fact 2926.

12078 See P1254 (Medical report for Zumra Habibović); P1255 (Medical report for Aiša Gačević); P1256 (Medical report for Samir Moro).

12079 KDZ090, P481 (Transcript from Prosecutor v. D. Milošević), T. 824, 827 (under seal); P2923 (Witness statement of KDZ090 dated 21 February 1996), pp. 1-2; P2923 (Witness statement of KDZ090 dated 19 April 2006), para. 8.

12080 P2923 (Witness statement of KDZ090 dated 19 April 2006), para. 13. See also Adjudicated Fact 2927.

12081 KDZ090, P481 (Transcript from Prosecutor v. D. Milošević), T. 824, 831-832 (under seal); P2923 (Witness statement of KDZ090 dated 19 April 2006), paras. 9-10.

12082 KDZ090, P481 (Transcript from Prosecutor v. D. Milošević), T. 827 (under seal); P2923 (Witness statement of KDZ090 dated 19 April 2006), para. 9. See also Adjudicated Fact 2922.

12083 KDZ090, P481 (Transcript from Prosecutor v. D. Milošević), T. 827-828 (under seal). See also Adjudicated Facts 2922, 2923.

12084 KDZ485, T. 8880-8881 (3 November 2010); P1907 (BiH MUP Report re sniping incident of 8 October 1994 on Zmaja od Bosne street), p. 1.

12085 P1907 (BiH MUP Report re sniping incident of 8 October 1994 on Zmaja od Bosne street), p. 2.

12086 P1907 (BiH MUP Report re sniping incident of 8 October 1994 on Zmaja od Bosne street), pp. 3-5. See also Adjudicated Fact 2930.

12087 It would therefore appear that the tram driver was not killed in this incident as suggested by KDZ090. However, given that one person did die in the incident and that the situation would have been chaotic at the time, the Chamber does not consider that KDZ090's evidence as to the dead person's identity puts in doubt the remainder of KDZ090's testimony.

12088 P1907 (BiH MUP Report re sniping incident of 8 October 1994 on Zmaja od Bosne street), p. 2. 
later, the second burst was fired on tram 236 which was following tram 206 and entering the stretch between the Faculty of Philosophy and the Museum, that is the S-curve; again several civilians were wounded. ${ }^{12089}$ According to the report, soon thereafter bursts of fire were heard again and four children who were running across the aforementioned location were wounded. ${ }^{12090}$ The report also notes that the incident happened in front of UNPROFOR who were "hiding behind their transporters" at the scene. ${ }^{12091}$

3689. While it does not appear to contain ballistics analysis, the report notes that four entry and exit holes were identified and photographed on tram 236, and that they were probably caused by the "death sower."12092 KDZ485 testified that he knew of one incident where that weapon had been used by the Serbs but did not know if the ABiH had it in its arsenal. ${ }^{12093}$ However, as mentioned above, the BiH MUP had reported already in October 1993 that the $2^{\text {nd }}$ Independent Battalion of the $\mathrm{ABiH}$ had at least one death sower in its possession. ${ }^{12094}$

3690. The site of the incident was also visited by Rose and Gobilliard at 12:45 p.m., while the UNPROFOR soldiers conducted an investigation of the scene. ${ }^{12095}$ The next day, Rose sent a letter to the Accused, informing him of the incident and requesting that he "take all appropriate measures to identify and prosecute the perpetrators of this crime." 12096 On 10 October 1994, Rose and Gobilliard released a joint statement stating that there was no doubt that the fire had come from Serb positions at the Jewish cemetery. ${ }^{12097}$ On the same day, Rose met with Mladić and raised this incident but Mladić said that the shots came from the Holiday Inn and that the incident was staged by the Muslim side. ${ }^{12098}$

\footnotetext{
12089 P1907 (BiH MUP Report re sniping incident of 8 October 1994 on Zmaja od Bosne street), p. 2. See also Adjudicated Fact 2929.

12090 P1907 (BiH MUP Report re sniping incident of 8 October 1994 on Zmaja od Bosne street), p. 2. See also Adjudicated Fact 2929.

12091 P1907 (BiH MUP Report re sniping incident of 8 October 1994 on Zmaja od Bosne street), p. 2.

12092 P1907 (BiH MUP Report re sniping incident of 8 October 1994 on Zmaja od Bosne street), p. 2.

12093 KDZ485, T. 8902-8905 (3 November 2010).

12094 See para. 3626.

12095 P2421 (UNPROFOR report re sniping incident of Zmaja od Bosne on 8 October 1994, 13 October 1994), p. 6; P1638 (Witness statement of Michael Rose dated 26 March 2009), para. 156; P1675 (Video clip of Michael Rose and Herve Gobilliard in Sarajevo); P2414 (Witness statement of KDZ182), p. 60 (under seal).

12096 Rose also protested to Alija Izetbegović for a sniping incident in Vojkovići for which the ABiH was found to be responsible. See P1644 (Letters from Michael Rose to Alija Izetbegović and Radovan Karadžić, 9 October 1994). See also P1762 (Witness statement of David Fraser dated 17 October 2010), p. 43; P1674 (UNPROFOR report re meeting with Ratko Mladić, 11 October 1994).

12097 P1638 (Witness statement of Michael Rose dated 26 March 2009), p. 156; P1674 (UNPROFOR report re meeting with Ratko Mladić, 11 October 1994).

12098 P1638 (Witness statement of Michael Rose dated 26 March 2009), p. 155; Micheal Rose, T. $7268-7269$ (5 October 2010) P867 (UNPROFOR report on meeting with Ratko Mladić, 10 October 1994), p. 2. See also P1762 (Witness statement of David Fraser dated 17 October 2010), pp. 43-46.
} 
3691. UNPROFOR released a report on the incident, dated 13 October 1994, which states that all three instances of sniping occurred at the intersection of Đure Daničića and Zmaja od Bosne streets, that is, between the Faculty of Philosophy and the Executive Council building, as witnessed by the UNPROFOR personnel present near that intersection during the incident. ${ }^{12099}$ This location is located one block to the east of the S-curve and thus different from the location of the incident identified by KDZ090 and the CSB Sarajevo report. ${ }^{12100}$ Between the second and the third burst of fire, UNPROFOR soldiers intensified surveillance of the Invest Banka building, as well as the Red Façade building, the latter being under $\mathrm{ABiH}$ control according to the report. ${ }^{12101}$ The report also notes that it was impossible to carry out an investigation on the first tram, that is tram 206, as it was some 200 metres from the incident site but that the second tram, tram 236, stopped immediately, some 30 metres from the relevant intersection, in front of the Executive Council building, and showed bullet traces between its front and middle door at the height of about one metre. ${ }^{12102}$

3692. UNPROFOR soldiers also found six fresh bullet impact traces in the ground at the abovementioned intersection, which they used to identify the origin of fire, namely a "group of houses" situated in the SRK-held territory, west of the Jewish cemetery. ${ }^{12103}$ Later on in the day, when tram 236 was in the tram depot, UNPROFOR investigators measured the angle of the bullet entry point, which came to be 1450 mils from the vertical line. ${ }^{12104}$ The report concluded that the already

12099 According to the report, the first burst of fire took place at 12:20 p.m., the second at 12:23 p.m., and the third at 12:35 p.m.. See P2421 (UNPROFOR report re sniping incident on Zmaja od Bosne on 8 October 1994, 13 October 1994), pp. 2, 5-6, Annex 2.

The Prosecution acknowledged during Closing Arguments that the evidence identifies two different locations for the incident but noted that this ultimately did not matter because regardless of where the tram was when hit, the fire came from the "SRK-held positions to the south of the Miljacka river". See Closing Arguments, T. 4774247743 (30 September 2014).

12101 According to the map in Annex 2 of the report, the UNPROFOR referred to the Invest Banka building as "Prisunic" while the Red Façade building was referred to as "Butane". Another building, referred to as "Banane" in the report, and located just east of the Red Façade building, was also said to be under the control of the $\mathrm{ABiH}$ at the time. In fact, the report specified that Banane and Butane were the only two buildings in the area under the ABiH control. See P2421 (UNPROFOR report re sniping incident of Zmaja od Bosne on 8 October 1994, 13 October 1994), pp. 5-7, Annex 2. P2421 (UNPROFOR report re sniping incident on Zmaja od Bosne on 8 October 1994, 13 October 1994), p. 2.

Because the six impact points all had a furrow of about 10 centimetres deep and showed a clean "angle of incidence", the UNPROFOR soldiers were able to place an antenna rod in the furrows and found the same direction and the same origin of fire for all six points of impact. The latter part of the report refers to a single house, indicated by number 14 on the map in Annex 2 of the report, as the source of fire. P2421 (UNPROFOR report re sniping incident of Zmaja od Bosne on 8 October 1994, 13 October 1994), pp. 3, 6-7, Annex 2. The Chamber notes that this location is different to the location identified as the origin of fire in the Adjudicated Fact 2932 and by KDZ090, namely the Metalka building. This was acknowledged by the Prosecution during the Closing Arguments. The Prosecution also submitted that in such a case, namely where an adjudicated fact contradicts evidence brough by the Prosecution, the Chamber should follow the Tribunal jurisprudence and simply asses the relevance and the weight of the adjudicated fact in question in light of the evidence as a whole. Closing Arguments, T. 47442 (30 September 2014).

12104 They were able to do that because the bullet passed through the wall of the tram and then struck the seat support, thus creating a measurable line. See P2421 (UNPROFOR report re sniping incident of Zmaja od Bosne on 8 October 1994, 13 October 1994), p. 3, Annex 1. 
established origin of fire conformed with that angle of entry. ${ }^{12105}$ Finally, while the report records that the UNPROFOR soldiers stationed at the intersection of Đure Daničića and Zmaja od Bosne thought that the second burst of fire came from very close by, it concludes that this was most likely because the echo off the facades of the buildings made it seem louder. ${ }^{12106}$

3693. Hogan visited Zmaja od Bosne street and recorded the co-ordinates of the incident's location as remembered by KDZ090, which placed the incident at a location that was more in line with the location recorded in the UNPROFOR report of 13 October $1994 .^{12107}$ He noted that the Metalka building could not be seen from that location. ${ }^{12108}$ When cross-examined by the Accused, he explained that he could not remember whether the exact co-ordinates indicated by KDZ090 were on the sidewalk near the incident site or at the actual incident site. ${ }^{12109} \mathrm{He}$ did, however, agree that KDZ090, when pointing out the location of the incident to him, indicated that it happened between the Executive Council building and the Faculty of Philosophy. ${ }^{12110}$

3694. Van der Weijden visited both the incident site, as indicated to him by the Prosecution, as well as Grbavica. ${ }^{12111}$ He expressed the view that the co-ordinates for the site of the incident given to him by the Prosecution must have been wrong as (i) they indicated a location some 50 metres east to the one described in the materials provided to him, and (ii) this location was not visible from Grbavica. ${ }^{12112} \mathrm{He}$ found that, if situated in that location when hit, the tram would have been visible from another alleged sniping nest, the Jewish cemetery, but that in that case it would have been exposed to the shooter for a shorter period of time and the distance between the alleged origin of fire and the tram would have been quite far, more than 600 metres. ${ }^{12113}$ Thus, he believed that the incident probably occurred on or near the stretch of Zmaja od Bosne street between the Museum

\footnotetext{
12105 P2421 (UNPROFOR report re sniping incident of Zmaja od Bosne on 8 October 1994, 13 October 1994), p. 3.

12106 P2421 (UNPROFOR report re sniping incident of Zmaja od Bosne on 8 October 1994, 13 October 1994), pp. 56.

12107 Barry Hogan, T. 11217-11218 (3 February 2011); P2213 (Image re scheduled sniping and shelling incidents in Sarajevo); P1028 (Video re sniping incident of 8 October 1994 on Zmaja od Bosne street) (under seal); P2190 (GPS locations for shelling and sniping incidents in Sarajevo).

12108 Barry Hogan, T. 11217-11218 (3 February 2011); P2213 (Image re scheduled sniping and shelling incidents in Sarajevo).

12109 Barry Hogan, T. 11239 (3 February 2011). See also P1028 (Video re sniping incident of 8 October 1994 on Zmaja od Bosne street) (under seal).

12110 Barry Hogan, T. 11246-11247 (3 February 2011); P1028 (Video re sniping incident of 8 October 1994 on Zmaja od Bosne street) (under seal); P2191 (Map of Sarajevo with scheduled sniping and shelling incidents).

12111 P1621 (Expert Report of Patrick van der Weijden entitled “Sniping Incidents in Sarajevo '92-'94”), p. 88; Patrick van der Weijden, T. $7032-7034$ (28 September 2010); D651 (Aerial photograph of Sarajevo marked by Patrick van der Weijden).

12112 P1621 (Expert Report of Patrick van der Weijden entitled 'Sniping Incidents in Sarajevo '92-'94'), p. 89; Patrick van der Weijden, T. 7006-7008 (27 September 2010).

12113 P1621 (Expert Report of Patrick van der Weijden entitled “Sniping Incidents in Sarajevo '92-'94”), pp. 88-89.
} 
and the Faculty of Philosophy, i.e. near the S-curve. ${ }^{12114} \mathrm{He}$ also conceded during crossexamination that he determined this to be the place of the incident on the basis that, had the tram been a little further from the said location, it could not have been hit from the south as suggested by the BiH MUP reports. ${ }^{12115} \mathrm{He}$ also noted that he was aware that the area between Miljacka River and the tram tracks was under the control of the $\mathrm{ABiH} .{ }^{12116}$ Further, he conceded that no one told him to check whether Unioninvest or the Red Façade buildings could have been the origin of fire, but noted that the view from the latter to the S-curve would have been obstructed by the buildings in front of it. ${ }^{12117}$ He therefore never checked the Red Façade building. ${ }^{12118}$

3695. When shown the video footage of the third burst of fire at the children on the street, Van der Weijden accepted that the fire appeared to be coming down Đure Daničića street. ${ }^{12119}$ He further accepted that given the distance of the Serb positions to the location of this incident, the angle of descent of the bullet would have been some five degrees whereas the injuries sustained by one of the men indicated a greater angle of descent. ${ }^{12120}$ However, he also explained that he could hear machine-gunfire in the footage, which meant that shots would have landed in a cone of fire, making some shots higher than others. ${ }^{12121}$

3696. Noting that there were multiple victims in this incident and having described their injuries, Van der Weijden concluded that automatic fire was most likely used to shoot at the tram, and that the weapons used would have been either an M84 machine-gun in $7.62 \mathrm{~mm}$ calibre, or an M53 machine-gun in $7.92 \mathrm{~mm}$ calibre, mounted on a bipod or tripod. ${ }^{12122}$ He noted that machine-guns

12114 P1621 (Expert Report of Patrick van der Weijden entitled "Sniping Incidents in Sarajevo '92-'94”), p. 89; Patrick van der Weijden, T. $7032-7035$ (28 September 2010); D651 (Aerial photograph of Sarajevo marked by Patrick van der Weijden). See also Barry Hogan, T. 11218-11219 (3 February 2011); P2208 (Photograph of Sarajevo marked by Barry Hogan)

12115 Patrick van der Weijden, T. $7011-7014$ (27 September 2010); D647 (Aerial photograph of Sarajevo marked by Patrick van der Weijden).

12116 Patrick van der Weijden, T. 7017-7018 (27 September 2010); D648 (Aerial photograph of Sarajevo marked by Patrick van der Weijden).

12117 Patrick van der Weijden, T. $7021-7027$ (28 September 2010); D649 (Aerial photograph of Sarajevo marked by Patrick van der Weijden); D650 (Aerial photograph of Sarajevo marked by Patrick van der Weijden).

12118 Patrick van der Weijden, T. 7024-7025 (28 September 2010).

12119 Patrick van der Weijden, T. 7055 (28 September 2010); D655 (Video footage relating to a sniping incident in Sarajevo).

12120 Patrick van der Weijden, T. 7059-7060 (28 September 2010).

12121 Patrick van der Weijden, T. $7052-7061$ (28 September 2010); D655 (Video footage relating to a sniping incident in Sarajevo); D656 (Video footage relating to a sniping incident in Sarajevo); D657 (Photograph related to a sniping incident in Sarajevo); D658 (Photograph related to a sniping incident in Sarajevo); D659 (Photograph related to a sniping incident in Sarajevo); D660 (Photograph related to a sniping incident in Sarajevo); D661 (Photograph related to a sniping incident in Sarajevo).

12122 P1621 (Expert Report of Patrick van der Weijden entitled "Sniping Incidents in Sarajevo '92-'94”), p. 87. See also Adjudicated Fact 2928. If mounted on a tripod, an M84 can successfully reach targets which are 1000 metres away, while an M53 mounted on a tripod has the shooting accuracy of up to 1500 metres. See P1621 (Expert Report of Patrick van der Weijden entitled “Sniping Incidents in Sarajevo '92-'94”), Appendix A. 
are more effective against moving targets, such as trams that are only temporarily visible. ${ }^{12123}$ On cross-examination he confirmed that if Cutuna's entry wound was on her right thigh and the exit wound was on her right hip, this would imply that the bullet was travelling upwards rather than downwards. ${ }^{12124}$ However, he clarified that this would not necessarily be the case if the victim was crouching down when struck by the bullet and also explained that the bullet might change its trajectory once it enters the tram. ${ }^{12125}$

3697. Poparić analysed the material relevant to this incident, including the CSB Sarajevo report as well as the video footage of the scene, filmed by the BiH TV immediately after the incident, recording not only the position of the trams but also the last burst of shots on the four children running across the incident location. ${ }^{12126} \mathrm{He}$ did not seem to be aware of the UNPROFOR report of 13 October 1994, however. ${ }^{12127}$

3698. Poparić began his analysis by expressing doubt about the official character of the CSB Sarajevo report of 10 October 1994 because it had no log number. ${ }^{12128}$ Having analysed the video footage of the scene, which records the position of trams 206 and 236, and contains interviews with two people injured in the incident, he came to the conclusion that tram 206 was hit when passing by the Executive Council building, the stretch which at the time was protected by containers, while tram 236 was struck in front of the Executive Council building where it stopped immediately after being struck. ${ }^{12129}$ Poparić explained that he reached his conclusion on tram 236's location based on the statements of the people interviewed by the $\mathrm{BiH}$ TV, statement of an eye-witness, and the video footage of the scene which shows the tram at that location together with its broken window and the traces of broken glass on the ground, indicating that the tram stopped immediately, moving only a metre or two after being struck by the bullets. ${ }^{12130}$ Based on all this, Poparić concluded that trams 206 and 236 could not have been fired on from the VRS positions in Grbavica or from Metalka as

\footnotetext{
12123 P1621 (Expert Report of Patrick van der Weijden entitled “Sniping Incidents in Sarajevo '92-'94”), p. 87.

12124 Patrick van der Weijden, T. 7034 (28 September 2010).

12125 Patrick van der Weijden, T. 7050 (28 September 2010), T. 7186-7187 (29 September 2010). The Chamber notes that during this discussion the Prosecution referred to scheduled incident F15 but that the injuries in fact discussed relate to incident F11.

12126 D4884 (Mile Poparić's expert report entitled "Small Arms Fire on the Sarajevo Area 1992-1995", 15 August 2012), pp. 127-137.

12127 Mile Poparić T. 39254 (4 June 2013), T. 39263 (5 June 2013).

12128 D4884 (Mile Poparić's expert report entitled "Small Arms Fire on the Sarajevo Area 1992-1995", 15 August 2012), p. 128.

12129 D4884 (Mile Poparić's expert report entitled "Small Arms Fire on the Sarajevo Area 1992-1995", 15 August 2012), pp. 128-130, 132, Image 90. See also Mile Poparić, T. 38983-38986 (30 May 2013).

12130 D4884 (Mile Poparić's expert report entitled "Small Arms Fire on the Sarajevo Area 1992-1995", 15 August 2012), pp. 129-131, Images 92 and 93; Mile Poparić, T. 38985-38987 (30 May 2013). In its Final Brief, the Prosecution argues that Poparić's analysis of footage of the broken glass was speculative and ignored the reasonable explanation that the glass resulted from the evacuation after the incident. See Prosecution Final Brief, Appendix C, para. 11.
} 
they were protected by the $\mathrm{BiH}$ Assembly and Executive Council buildings, as well as by the above mentioned containers. ${ }^{12131}$

3699. Poparić also analysed the footage of the third burst of shots, which shows the moment when the bullets struck the area near the Faculty of Philosophy and the cloud of dust that rose from the ground as a result. He speculated that the cloud was about two metres high which in turn meant that the bullet hit the ground with high energy and at a high angle of descent. This, according to Poparić, indicated that it was fired from "a relatively small distance" thus excluding Metalka, Invest Banka, and the Red Façade buildings as the origins of fire. ${ }^{12132}$ Poparic concluded that the fire seen in the footage came from the Executive Council building and noted that this was confirmed by the footage of an UNPROFOR soldier talking to Rose and pointing in the direction of the Executive Council. ${ }^{12133}$

3700. During cross-examination, Poparic testified that his theory on the dust clouds was not based on any published studies but on his extensive experience with trajectories of small arms. ${ }^{12134} \mathrm{He}$ also explained that had the bullet come from the Red Façade building which was divided in half by the warring parties, then the angle of descent would have been no more than ten degrees. ${ }^{12135}$ When shown the UNPROFOR report of 13 October and the entry angle that UNPROFOR measured on the tram, namely 81 degrees from the vertical line and 9 degrees from the horizontal line, Poparic explained that having the angle alone was not enough to conclude where the bullet came from and that one needed to look at the firing tables for the weapon used in the incident. ${ }^{12136}$ Based on those, he concluded that had the bullet come from the Red Façade building, the angle would have been less than four or five degrees. ${ }^{12137}$ When asked whether such a small angle, be it

12131 D4884 (Mile Poparić's expert report entitled "Small Arms Fire on the Sarajevo Area 1992-1995”, 15 August 2012), pp. 131-132, 135.

12132 D4884 (Mile Poparić's expert report entitled "Small Arms Fire on the Sarajevo Area 1992-1995", 15 August 2012), pp. 132-134, Image 95; Mile Poparić, T. 38987-38989 (30 May 2013); D3638 (Photograph of tram track marked by Mile Poparić).

12133 D4884 (Mile Poparić's expert report entitled "Small Arms Fire on the Sarajevo Area 1992-1995", 15 August 2012), pp. 134-135, Image 96. During cross-examination Poparić conceded that the footage he viewed had no sound so that he did not know whether the UNPROFOR soldier mentioned the Executive Council building to Rose. He reiterated his position that the soldier was pointing at the Executive Council building but then also said that he was pointing in the direction of the Red Façade building and Grbavica. See Mile Poparić, T. 39264 39265 (5 June 2013).

12134 Mile Poparić, T. 39252-39253 (4 June 2013).

12135 Mile Poparić, T. 39253-39254 (4 June 2013). While the transcript records that Poparić referred to a "famous silver building which was divided in half by the VRS and the ABiH" the Chamber considers that this was a reference to the Red Façade building as that was the only famous building in the area that was divided in half by the warring parties. The Chamber is of the view that the reference to this building being silver must have been an error in interpretation or a mistake in Poparić's testimony.

12136 Mile Poparić, T. 39255-39257 (4 June 2013), T. 39260-39262 (5 June 2013).

12137 Mile Poparić, T. 39255-39257 (4 June 2013), T. 39260-39262, T.39294-39297 (5 June 2013); D3649 (Photograph of tram tracks marked by Mile Poparić). 
nine or four degrees, meant that the fire could not have come from the Executive Council building, Poparic stated that one could fire from the ground floor or from one of the upper floors of the Executive Council building so the angle of descent could range from two to 80 degrees. ${ }^{12138}$ When confronted with the report of the meeting between Mladić and Rose of 10 October 1994, Poparić accepted that Mladić's position that the fire came from Holiday Inn was wrong but denied that this meeting proved anything as to the actual origin of fire. ${ }^{12139}$

3701. The Chamber recalls that it has taken judicial notice of two Adjudicated Facts which provide that the visibility on 8 October 1994 was sufficient to allow a sniper at the Metalka Building to identify and target a tram negotiating the S-curve, that the shots came from the direction of the Metalka Building, which was held by the SRK and that they were fired by a member of the SRK. ${ }^{12140}$ However, as noted above, these Adjudicated Facts are inconsistent with some of the evidence offered by the Prosecution, including the UNPROFOR report of 13 October 1994 and the co-ordinates of the incident site obtained and used by Hogan. ${ }^{12141}$ That being the case, the Chamber is unable to rely on these two Adjudicated Facts and will disregard them for the purpose of its analysis of this incident.

3702. As far as the exact location of the incident is concerned, the Chamber is persuaded by the report prepared by UNPROFOR following the incident. This report refers to, inter alia, interviews with UNPROFOR soldiers who witnessed all three instances of fire being opened that day and who place all three instances at the intersection of Đure Daničića street and Zmaja od Bosne street. ${ }^{12142}$ In addition, the Chamber recalls that both CSB Sarajevo and UNPROFOR reports provide that the third burst of fire took place at the same location as the two previous bursts of fire. The video footage of that third burst of fire clearly shows that it took place at the intersection of Đure Daničića and Zmaja od Bosne streets. Bearing all that in mind, the Chamber considers that Ćutuna's tram was shot at when passing through that intersection rather than the intersection noted in the CSB Sarajevo report. This tram was a civilian vehicle, with civilians onboard, and was

\footnotetext{
12138 Mile Poparić, T. 39262-39266 (5 June 2013).

12139 Mile Poparić, T. 39263-39266 (5 June 2013).

12140 See Adjudicated Facts 2931, 2932.

12141 See 3692-3693, fn. 12103.

12142 The Chamber notes here that in determining the location of the incident the CSB Sarajevo investigators appear to have relied on the tram driver's recollection of what happened and did not speak to the UNPROFOR soldiers in the area. However, in contrast to those soldiers, the tram driver would have been engaged in driving the tram and, once the bullets struck the tram, would have been trying to get it to safety in a state of panic and chaos. Thus, the Chamber considers the description of the event by the UNPROFOR soldiers at the scene to be more persuasive than that of the driver. For the same reason, the Chamber has decided to disregard the evidence of KDZ090 as to the location at which the tram was first struck by the bullets, particularly since that evidence was not in line with the location KDZ090 actually showed to Barry Hogan.
} 
operating due to a cease-fire in place at the time. In addition, Alma Ćutuna herself was a civilian and was not taking direct part in hostilities when she was wounded in this incident.

3703. The Chamber does not accept Poparić's conclusion that the bullets came from the Executive Council building as it is based on a number of plainly unreasonable speculations. For example, on the basis of the footage showing pieces of tram's window on the ground next to the tram itself, Poparić concluded that the tram must have moved only about a metre or two after being struck by the bullets and that it therefore must have been shot at from the Executive Council building. However, this is pure speculation as some or all of the glass could have fallen out of the window frame after the tram had stopped. In other words, it is simply not possible to draw any conclusions from the video footage of the glass on the ground. ${ }^{12143}$ In addition, Poparić relied on the analysis of a dust cloud in relation to the third burst of shots fired on that day, to show that bullets came in at a high angle of descent. At the same time, he was unaware of the UNPROFOR investigation which found that the angle of descent was in fact low in relation to both the traces on the tram and the traces on the ground. Accordingly, the Chamber will disregard-in its entirety-Poparić's analysis in relation to this incident.

3704. As far as the origin of fire is concerned, the Chamber accepts UNPROFOR's conclusion that it came from the SRK-held area somewhere west of the Jewish cemetery. First, UNPROFOR conducted its own analysis of the bullet traces on both the tram in which Cutuna was riding and the ground at the intersection of Đure Daničića and Zmaja od Bosne streets, which led them to that location. Indeed, both sites indicated a low angle of descent, which is consistent with the fire coming from the SRK positions south of Miljacka. ${ }^{12144}$ Second, the Chamber is convinced, relying on Van der Weijden's evidence outlined above, ${ }^{12145}$ that the SRK forces in that area had a line of sight to the intersection between Đure Daničića and Zmaja od Bosne streets. Finally, the Chamber recalls the evidence it heard about the prevalence of sniping attacks from the area of the Jewish cemetery and Zmaja od Bosne generally. ${ }^{12146}$ Accordingly, the Chamber finds that the fire that struck Alma Ćutuna's tram and wounded her came from the SRK-held area to the west of Jewish

\footnotetext{
12143 Furthermore, as noted above, the UNPROFOR report clearly states that the tram moved some 30 metres after it was struck by the fire.

12144 The Chamber notes that Van der Weijden calculated that the angle of descent of a bullet fired from Metalka which is located 321 metres away and at the elevation of 35 metres would have been around five degrees. See Patrick van der Weijden, T. $7015-7017$ (27 September 2010), T. 7059 (28 September 2010). Thus, the fire involving a higher elevation while at the same time further away would have been coming at an angle higher than five degrees but still at a relatively low angle of descent.

12145 See para. 3694.

12146 See paras. 3657, 3659. In addition, Blagoje Kovačević admitted that sometimes he had problems in achieving control over his troops, which were located in the area of the Jewish cemetery, and that they would open fire without him knowing about it. See para. 3661. The Chamber also recalls that it rejected the Accused's arguments that $\mathrm{ABiH}$ forces were sniping at Bosnian Muslim civilians throughout Sarajevo. See para. 4519.
} 
cemetery. The Chamber is also satisfied that a machine gun, most likely an M84, was used in this incident and that it had the necessary range to accurately target the tram at that distance. Both the $1^{\text {st }}$ Sarajevo Mechanised Brigade and the $1^{\text {st }}$ Romanija Infantry Brigade had such a machine gun in its arsenal. ${ }^{12147}$ Finally, the Chamber has no doubt that the tram was deliberately targeted by the SRK shooter, as illustrated by the fact that after the two trams were shot and struck in the same location, fire was opened again in that same location at a number of people who were trying to leave the area. The Chamber is also confident that the shooter would have known that tram was a civilian vehicle with civilians travelling onboard.

(5) Zmaja od Bosne street, 18 November 1994 (Scheduled Incident F.12)

3705. The Indictment alleges that, on 18 November 1994, Dženana Sokolović, a 31 year old woman, and her seven year old son, Nermin Divović, were fired on while walking on Zmaja od Bosne street. According to the Indictment, Sokolović was wounded in her abdomen and the bullet passed through her and hit her son in the head, killing him. ${ }^{12148}$ In the Final Brief, the Prosecution argues that the bullet came from Metalka. ${ }^{12149}$ The Accused argues, however, that the bullet came from the side opposite to Grbavica, that is, from the ABiH-held territory. ${ }^{12150}$

3706. There was a cease-fire in place on 18 November 1994 and the trams were running. ${ }^{12151}$ Dženana Sokolović and her son, Nermin Divović, were shot at the zebra crossing, as they were crossing the Franje Račkog street. ${ }^{12152}$ There were no soldiers around and no combat going on in the area at the time. ${ }^{12153}$ Nermin Divović died on the way to the hospital and his body was taken to the mortuary. ${ }^{12154}$ Sokolović and her daughter were taken to Koševo Hospital by a UN vehicle. ${ }^{12155}$ Sokolović underwent surgery and stayed in hospital for seven or eight days. ${ }^{12156}$ She was unable to attend her son's funeral. ${ }^{12157}$ Since the incident, she has not been able to hold a full-time job. ${ }^{12158}$

\footnotetext{
12147 See fn. 11948.

12148 Indictment, Scheduled Incident F.12.

12149 Prosecution Final Brief, Appendix C, para. 19.

12150 Defence Final Brief, para. 2278.

12151 Adjudicated Fact 2938.

12152 See Adjudicated Fact 2940.

12153 Adjudicated Fact 2939.

12154 Adjudicated Fact 2941.

12155 Adjudicated Fact 2942.

12156 Adjudicated Fact 2942.

12157 Adjudicated Fact 2942.

12158 Adjudicated Fact 2942.
} 
3707. According to the CSB Sarajevo report dated 19 November 1994, the incident was witnessed by UNPROFOR, UNHCR, and GOFRS members, who were standing near the Museum. ${ }^{12159}$ They told the CSB Sarajevo investigators that as Sokolović and her son were crossing over to the other side of Franje Račkog street, the side further from the Museum, a shot was heard from the direction of Grbavica, "more precisely from the aggressor's positions". ${ }^{12160}$ The UNHCR member helped Sokolović and her son, while two UNPROFOR armoured personnel carriers arrived and positioned themselves on the Franje Račkog street. ${ }^{12161}$ Stationed at the corner of Franjo Račkog and Zmaja od Bosne streets, on the side of Franje Račkog closer to the Museum, was an UNPROFOR armoured personnel carrier. ${ }^{12162}$.

3708. The report also notes that CSB Sarajevo's investigation team, which included a forensic technician Sead Bešić, came to the incident site around 1:30 p.m., and noticed that the site was not secured by the police. ${ }^{12163}$ There was blood at the scene but, before the arrival of the team, the UNPROFOR soldiers washed it off and then covered it with sand. ${ }^{12164}$ During cross-examination, Bešić explained that the investigation was difficult due to the team being unable to access the site; further, he stated that it is difficult to determine the direction of fire just on the basis of the entry and exit wounds. ${ }^{12165}$

3709. In terms of the injuries the victims sustained, the description of the incident in the CSB Sarajevo report notes that the bullet first hit the boy in the head and then injured Sokolović. ${ }^{2166}$ When cross-examined on the accuracy of this, Bešić stated that he was not in charge of interviewing witnesses and/or writing the report but was there only to take photographs and collect

12159 Nermin Divović approached these men, as he was passing by with his mother, and asked them for some sweets. P459 (BiH MUP Report re sniping incident of 18 November 1994 on Zmaja od Bosne street), e-court pp. 4-5.

12160 P459 (BiH MUP Report re sniping incident of 18 November 1994 on Zmaja od Bosne street), e-court p. 4. See also Sead Bešić, T. 9491 (9 December 2010); Mile Poparić, T. 39291-39294 (5 June 2013).

12161 P459 (BiH MUP Report re sniping incident of 18 November 1994 on Zmaja od Bosne street), e-court pp. 4-5. See also Sead Bešić, T. 9490-9493 (9 December 2010); D901 (Photograph re sniping incident on 18 November 1994 on Zmaja od Bosne street marked by Sead Bešić).

12162 P459 (BiH MUP Report re sniping incident of 18 November 1994 on Zmaja od Bosne street), e-court pp. 4-5.

12163 Sead Bešić, T. 9489-9490 (9 December 2010); P1966 (Witness statements of Sead Bešić dated 18 February 2010), p. 35; P459 (BiH MUP Report re sniping incident of 18 November 1994 on Zmaja od Bosne street), ecourt p. 4.

12164 Sead Bešić, T. 9493 (9 December 2010); P1966 (Witness statements of Sead Bešić dated 18 February 2010 ), p. 37; P459 (BiH MUP Report re sniping incident of 18 November 1994 on Zmaja od Bosne street), e-court p. 5.

12165 Sead Bešić, T. 9491-9492 (9 December 2010). While Bešić also stated during cross-examination that the direction in which the victims were walking was never established, the Chamber notes that the CSB Sarajevo report clearly outlines that the direction in which they were walking was from the Museum to Marin Dvor. See Sead Bešić, T. 9494 (9 December 2010). Compare. P459 (BiH MUP Report re sniping incident of 18 November 1994 on Zmaja od Bosne street), e-court p. 4.

12166 The latter part of the report, however, refers to the entry wound being on the right side of the boy's head. P459 (BiH MUP Report re sniping incident of 18 November 1994 on Zmaja od Bosne street), e-court pp. 1, 5. 
physical evidence. ${ }^{12167}$ The report also notes that Sokolović had a wound in the abdominal area, with the entry wound on the right-hand side of her body and the exit wound on the left-hand side. $^{12168}$

3710. However, contrary to the report above, the medical records for Dženana Sokolović, which were attached to the above report, provide that the bullet that caused her injuries entered the left hand side of her abdomen and exited on the right hand side. ${ }^{12169}$ Bešić was unable to explain this discrepancy but speculated that his colleague at the scene probably failed to describe the wound accurately. ${ }^{12170} \mathrm{He}$ also noted that at the time only one forensic pathologist was working in Sarajevo and the people assisting him were not knowledgeable enough to determine which wound was the entry wound. ${ }^{12171}$

3711. Šefik Bešlić, an abdominal surgeon who operated on Sokolović, on 18 November 1994 and later in 2007, testified that he had no doubt that the bullet entered the right side of her body and exited on the left side. ${ }^{12172}$ While admitting that he could not remember the actual surgery he performed on Sokolović, ${ }^{12173}$ Bešlić remained adamant that the bullet entered on the right hand side of her body, because of a contusion on her liver, the wound on the right hand side being smaller in size than the wound on the left hand side (thus indicating an entry wound), and the size of the scars he saw on Sokolović's abdomen in 2007. ${ }^{12174}$ He explained that the doctor who prepared the medical report in question must have made a mistake when describing Sokolović's wounds, and noted that this was understandable given the circumstances under which the doctors had to work at that time. ${ }^{12175}$ Bešlić also testified that the line between Sokolović's entry and exit wounds was almost horizontal. ${ }^{12176}$

3712. As for the wound on Sokolović's son, the CSB Sarajevo report states that he had an entryexit wound on his head-the entry wound was at the back of his head, above the right ear, while the

\footnotetext{
12167 P1966 (Witness statements of Sead Bešić dated 18 February 2010), pp. 35-36.

12168 P459 (BiH MUP Report re sniping incident of 18 November 1994 on Zmaja od Bosne street), e-court p. 5.

12169 P1023 (Medical records for Dženana Sokolović); P459 (BiH MUP Report re sniping incident of 18 November 1994 on Zmaja od Bosne street), e-court p. 8.

12170 Sead Bešić, T. 9494-9496, 9526-9530 (9 December 20110).

12171 Sead Bešić, T. 9494-9496 (9 December 2010).

12172 P472 (Witness statement of Šefik Bešlić dated 30 January 2007), paras. 1-5.

12173 D3 (Supplemental statement of Šefik Bešlić dated 9 December 2009), para. 3. See also Šefik Bešlić, P471 (Transcript from Prosecutor v. D. Milošević), T. 4419.

12174 P472 (Witness statement of Šefik Bešlić dated 30 January 2007), paras. 3-5. See also Šefik Bešlić, P471 (Transcript from Prosecutor v. D. Milošević), T. 4422-4423, 4428-4429, 4435-4439, 4440-4441. However, Bešlić also accepted that it was the passage of bullet, regardless of where it entered and exited, that caused the contusion. See Šefik Bešlić, P471 (Transcript from Prosecutor v. D. Milošević), T. 4449-4450.

12175 Šefik Bešlić, P471 (Transcript from Prosecutor v. D. Milošević), T. 4419-4420, 4424-4427; P1023 (Medical records for Dženana Sokolović).
} 
exit wound was located below his eye. ${ }^{12177}$ According to the autopsy report, the entry wound was located on the boy's right cheek while the exit wound was at the back of his head on the left-hand side. $^{12178}$

3713. UNPROFOR reported this incident in its daily report of 19 November in which it stated that the fire that killed Nermin came from the SRK side, after which UNPROFOR returned fire towards the SRK. ${ }^{12179}$

3714. When visiting Zmaja od Bosne with Sokolović, Hogan recorded the co-ordinates of the location of the incident, placing it near the intersection between Zmaja od Bosne and Franje Račkog rather than on the actual crossing on Franje Račkog street. ${ }^{12180}$ He explained that when he conducted this exercise with the victim, he did not provide her with her statements in order to refresh her memory. ${ }^{12181}$ He was also shown the video footage of the aftermath of the incident and confirmed that Sokolović's son could be seen lying on a pedestrian crossing. ${ }^{12182}$

3715. Van der Weijden's report notes that Sokolović was walking eastbound on Zmaja od Bosne street with her seven year old son and her daughter when the shots were fired and her son fell down. $^{12183}$ Sokolović and her daughter were immediately pulled to safety behind a car by others, and Sokolović realised she had a stomach wound; the bullet had passed through her abdomen and hit her son, Nermin in the head. ${ }^{12184}$ Van der Weijden visited the incident site, as well as Grbavica, in November 2006. ${ }^{12185}$ He visited Metalka noting that its rooms offer direct and clear views of the stretch of the road on which the victims were located. ${ }^{12186}$ While in the building, he determined the shooter would have been some 300 metres away from the site of the incident and would have been

\footnotetext{
12176 Šefik Bešlić, P471 (Transcript from Prosecutor v. D. Milošević), T. 4443.

12177 P459 (BiH MUP Report re sniping incident of 18 November 1994 on Zmaja od Bosne street), e-court p. 5.

12178 P1544 (Autopsy report for Nermin Divović); P459 (BiH MUP Report re sniping incident of 18 November 1994 on Zmaja od Bosne street), e-court p. 10; Sead Bešić, T. 9496-9497 (9 December 2010).

12179 P6366 (UNPROFOR daily report, 19 November 1994), p. 8.

12180 Barry Hogan, T. 11204-11206, 11220, 11247-11253 (3 February 2011); P2189 (Aerial photograph of Sarajevo marked by Barry Hogan); P2190 (GPS locations for shelling and sniping incidents in Sarajevo); P2191 (Map of Sarajevo with scheduled sniping and shelling incidents); P2213 (Image re scheduled sniping and shelling incidents in Sarajevo); D991 (Photograph re sniping incident of 18 November 1994 on Zmaja od Bosne street marked by Barry Hogan); D992 (Photograph re sniping incident of 18 November 1994 on Zmaja od Bosne street marked by Barry Hogan).

12181 Barry Hogan, T. 11288 (3 February 2011).

12182 Barry Hogan, T. 11289 (3 February 2011); P2216 (Video footage re sniping incident of 18 November 1994 on Zmaja od Bosne street).

12183 P1621 (Expert Report of Patrick van der Weijden entitled "Sniping Incidents in Sarajevo '92-'94”), p. 91.

12184 P1621 (Expert Report of Patrick van der Weijden entitled “Sniping Incidents in Sarajevo '92-'94”), p. 91.

12185 P1621 (Expert Report of Patrick van der Weijden entitled “Sniping Incidents in Sarajevo '92-'94”), p. 92.

12186 P1621 (Expert Report of Patrick van der Weijden entitled "Sniping Incidents in Sarajevo '92-'94”), p. 92. Van der Weijden states in his report that the branches of trees "in the street" will have grown since the war and now obstruct some of the windows that at the time would have also offered an unobstructed view. See P1621 (Expert Report of Patrick van der Weijden entitled "Sniping Incidents in Sarajevo '92-'94”), p. 92.
} 
able to identify the victims as a woman and two children. ${ }^{12187}$ Noting the way in which the woman was injured and her child killed, as well as the fact that the witnesses reported hearing multiple shots, Van der Weijden concluded that either a machine-gun or a semi-automatic sniper rifle was used in this incident. ${ }^{12188}$ He also noted that both weapons use the same calibre bullets, namely $7.62 \mathrm{~mm}$, and that both are capable of hitting targets up to 800 metres. $^{12189}$

3716. On cross-examination, Van der Weijden reiterated that the Metalka building was the most likely position from which the shots were fired but conceded that there were other possibilities and that, for example, the shooter could have been "in the middle of the street", presumably referring to Franje Račkog street. ${ }^{12190} \mathrm{He}$ also conceded that at the time of his investigation he was unaware of the contradicting medical records relating to the entry and exit wounds on Dženana Sokolović's body, but agreed that if the entry wound was on the left-hand side of her body, it meant that the shot would have originated from the north rather than the south. ${ }^{12191}$

3717. Poparić, also analysed this incident stating that it was difficult to establish what happened given the lack of forensic information and a "lot of contradictory data". ${ }^{2192}$ For example, the precise location where the victims were standing when shot was never determined, according to Poparić. $^{12193}$

3718. While stating that it was impossible on the basis of available evidence to come to any reliable conclusions on the origin of fire, ${ }^{12194}$ Poparić then proceeded to conclude that Sokolović and her son were hit by two different bullets, and that the bullets came from the north rather than from the south of the incident site, that is, from the direction opposite to Grbavica. ${ }^{12195}$ Poparic came to this conclusion based in part on the assumptions he made relating to the evidence received in the Dragomir Milošević case, such as Sokolović's witness statements, video footage of

\footnotetext{
12187 P1621 (Expert Report of Patrick van der Weijden entitled “Sniping Incidents in Sarajevo '92-'94”), pp. 91, 93. See also Adjudicated Fact 2944.

12188 P1621 (Expert Report of Patrick van der Weijden entitled “Sniping Incidents in Sarajevo '92-'94”), p. 91.

12189 P1621 (Expert Report of Patrick van der Weijden entitled “Sniping Incidents in Sarajevo '92-'94”), p. 91.

12190 Patrick van der Weijden, T. 7094-7095 (28 September 2010). See also Barry Hogan, T. 11220 (3 February 2011); P2210 (Photograph of Sarajevo marked by Barry Hogan).

12191 Patrick van der Weijden, T. 7095-7096, 7099-7101 (28 September 2010).

12192 Mile Poparić, T. 38900-38901 (29 May 2013), T. 39248 (4 June 2013).

12193 Mile Poparić, T. 38916-38917, 38920-38923 (29 May 2013); D3629 (Photograph of Sarajevo marked by Mile Poparić); D4884 (Mile Poparić's expert report entitled "Small Arms Fire on the Sarajevo Area 1992-1995", 15 August 2012), pp. 137-139, 143-144.

12194 D4884 (Mile Poparić's expert report entitled "Small Arms Fire on the Sarajevo Area 1992-1995", 15 August 2012), p. 143. See also Mile Poparić, T. 38900-38901 (29 May 2013).

12195 Mile Poparić, T. 38922-38923 (29 May 2013); D4884 (Mile Poparić's expert report entitled "Small Arms Fire on the Sarajevo Area 1992-1995", 15 August 2012), pp. 137-145.
} 
Sokolović's injuries, video footage of her son's body at the scene, ${ }^{12196}$ and the footage of Hogan with Sokolović at the scene years later.

3719. For example, based on the video footage of them standing next to each other, Poparic determined the approximate heights of Hogan and Sokolović, which he then used, together with the medical reports and the video footage of the victims' wounds, ${ }^{12197}$ to show that two different bullets were involved in this sniping incident. ${ }^{12198} \mathrm{He}$ also concluded, based on the video footage of Nermin's head wound, that the bullet that killed the boy entered on the left hand side of the head and exited on the right-hand side, thus indicating that it came from the positions opposite to Grbavica. ${ }^{12199}$ He found further support for that conclusion in the mistaken belief that the CSB Sarajevo report states that, on the boy's arrival to the hospital, the doctors established that the entry wound was on the left-hand side of his head while the exit wound was on the right. ${ }^{12200}$ Poparić seemed to be under this impression despite stating in two different places in his report, namely on pages 139 and 144, that on the boy's arrival it was established that the entry wound was on the right hand side and the exit wound on the left hand side of the boy's head, which is in line with the CSB Sarajevo report. ${ }^{12201}$ Indeed, both the CSB Sarajevo report and the boy's autopsy report clearly state that the entry wound was on the right hand side of the boy's head and the exit wound was on the left; the only discrepancy being the exact location of the entry and exit wounds. ${ }^{12202}$ This discrepancy becomes significant, however, as the wounds seen in the video footage of the boy's head $^{12203}$ accurately reflect the autopsy report, namely that the entry wound was on the boy's right cheek while the exit wound was at the back of his head on the left-hand side. The trickle of blood

12196 This video was admitted into evidence in this case as P2216 and D3628. See Barry Hogan, T. 11289 (3 February 2011); Mile Poparić, T. 38915-38916, 38924 (29 May 2103).

12197 With respect to Skolović's wounds, Poparić relied on the footage of Sokolović lying in her hospital bed with bandages on her abdomen to determine the positioning or the height of her wound. See D4884 (Mile Poparić's expert report entitled "Small Arms Fire on the Sarajevo Area 1992-1995", 15 August 2012), pp. 141-142, Image 99.

12198 D4884 (Mile Poparić's expert report entitled "Small Arms Fire on the Sarajevo Area 1992-1995", 15 August 2012), pp. 142, 144-145.

12199 Mile Poparić, T. 38911-38912 (29 May 2013); D4884 (Mile Poparić's expert report entitled "Small Arms Fire on the Sarajevo Area 1992-1995”, 15 August 2012), p. 140; D3628 (Video footage of Nermin Divović's body).

12200 Mile Poparić, T. 38901-38902, 38912-38913 (29 May 2013); D4884 (Mile Poparić's expert report entitled "Small Arms Fire on the Sarajevo Area 1992-1995", 15 August 2012), pp. 139-141, 144, fn. 301.

12201 D4884 (Mile Poparić's expert report entitled "Small Arms Fire on the Sarajevo Area 1992-1995", 15 August 2012), pp. 139, 144, fn. 301; P459 (BiH MUP Report re sniping incident of 18 November 1994 on Zmaja od Bosne street), e-court p. 5. The Chamber notes that, while the English translation of the relevant part of Poparić's report on page 139 states that the entry wound on the boy's head was above the left ear and the exit wound below the right eye, the original BCS version of the report provides the opposite, namely that the entry wound was above the right ear and the exit wound below the left eye. It is the latter that is correct as suggested by the fact that it coincides with the CSB Sarajevo report cited to in footnote 301 of the report.

12202 See para. 3712; P459 (BiH MUP Report re sniping incident of 18 November 1994 on Zmaja od Bosne street), ecourt pp. 5, 10; P1544 (Autopsy report for Nermin Divović). 
that Poparić describes as coming from the entry wound above left ear ${ }^{12204}$ could have easily come from the entry wound on the right hand side of the head or from the exit wound on the back of the head. Thus, the Chamber does not accept Poparić's analysis in relation to the exit and entry wounds on the boy's head and his conclusion that those wounds showed that two bullets from the north wounded the victims.

3720. With respect to the confusion surrounding Sokolović's wound, Poparić referred to Bešlić's evidence and concluded that it is unlikely that the surgeon who wrote that the entry point of the wound was on the left-hand side of Sokolović's abdomen made a mistake because he recorded the size of the wounds, indicating that he performed the examination in a "detailed and conscientious manner". ${ }^{12205}$ Poparić also referred to the evidence of a medical doctor from another trial who testified that it would be impossible for Bešlić after so many years to see which wound was the entry wound and which was the exit wound. ${ }^{12206}$ The Chamber finds both these conclusions to be outside of Poparić's expertise and tenuous at best. Thus, it will not take them into account when making findings on this incident.

3721. Poparic criticised the fact that no one tried to establish the level of entry and exit wounds on Sokolović's body and explained that, had the bullet come from Metalka, it would have a downward trajectory so that the entry wound on Skolović's body would be higher than the exit wound ${ }^{12207}$ and the same would apply to her son's wound. ${ }^{12208}$ He then found it hard to reconcile such downwards trajectory to the boy's wound. ${ }^{12209}$ However, the Chamber first notes that, contrary to Poparićs criticism, Bešlić did note that the line between Sokolović's entry and exit wounds was almost horizontal. ${ }^{12210}$ In addition, the said trajectory can easily be reconciled with the boy's wound as established in the autopsy report, which notes that the entry wound was on the boy's right cheek while the exit wound was at the back of his head on the left-hand side. ${ }^{12211}$

12203 This is the image Poparic used to suggest that the bullet entered the boy's head from the left-hand side. D4884 (Mile Poparić's expert report entitled "Small Arms Fire on the Sarajevo Area 1992-1995", 15 August 2012), p. 141, Image 100.

12204 Mile Poparić, T. 38911-38912 (29 May 2013); D4884 (Mile Poparić's expert report entitled "Small Arms Fire on the Sarajevo Area 1992-1995”, 15 August 2012), p. 140, Image 100.

12205 D4884 (Mile Poparić's expert report entitled "Small Arms Fire on the Sarajevo Area 1992-1995", 15 August 2012), p. 140

12206 Mile Poparić, T. 38913-38914 (29 May 2013); D4884 (Mile Poparić's expert report entitled "Small Arms Fire on the Sarajevo Area 1992-1995”, 15 August 2012), p. 140.

12207 Mile Poparić, T. 38905-38906 (29 May 2013).

12208 Mile Poparić, T. 38906 (29 May 2013).

12209 Mile Poparić, T. 38905-38906 (29 May 2013).

12210 Šefik Bešlić, P471 (Transcript from Prosecutor v. D. Milošević), T. 4443.

12211 P1544 (Autopsy report for Nermin Divović); P459 (BiH MUP Report re sniping incident of 18 November 1994 on Zmaja od Bosne street), e-court p. 10; Sead Bešić, T. 9495-9497 (9 December 2010). 
3722. Poparić also noted that in the video footage of the scene, some people can be seen sheltering behind a vehicle and several bursts of fire are heard which to him indicated that the fire was being exchanged between warring parties. ${ }^{12212}$ The Chamber once again does not accept Poparićs conclusion here as it was based on pure assumptions without considering other possibilities, such as for example an exchange of fire between the UNPROFOR soldiers on the scene and the shooter. Indeed, when shown the UNPROFOR report of 19 November 1994 referred to above, ${ }^{1213}$ Poparić did not exclude the possibility that this was an exchange of fire between UNPROFOR and the person who shot Sokolović and her son. ${ }^{12214}$

3723. Poparić also pointed out that Skolović, when visiting the scene with Hogan, placed the location of the incident near the intersection between Zmaja od Bosne and Franje Račkog rather than on the actual crossing on Franje Račkog street, noting that it would be difficult for someone in the Metalka building to see a person at that particular location. ${ }^{12215}$ Once again, the Chamber recalls that Poparic never entered the Metalka building and thus cannot claim with sufficient certainty that this particular position would not be visible from the building. ${ }^{12216}$

3724. Poparić then estimated the boy's height based on the video footage of his body lying on the intersection and the estimated height of Sokolović, arguing that had the bullet come from Metalka, the boy would have been hit lower down his body; however, he also explained that if the boy was standing at a short distance from Sokolović, then it was possible for the bullet to hit both of them. ${ }^{12217}$ The Chamber is of the view that estimating the boy's height from the footage of him lying on the pedestrian crossing is questionable at best. In addition, as implied by Poparić's own testimony, it is not very useful given that there is no information as to how far the boy was from his mother at the moment when they were shot. Thus, the Chamber will not accept Poparić's analysis relating to the victims' height and bullet trajectory.

3725. In addition to the evidence and adjudicated facts outlined above, the Chamber has also taken judicial notice of the following adjudicated facts which go to the origin of fire: (i) Sokolović was shot in the right side of her body and the bullet went through her abdomen and exited on the left

\footnotetext{
12212 D4884 (Mile Poparić's expert report entitled "Small Arms Fire on the Sarajevo Area 1992-1995", 15 August 2012), p. 143.

12213 See para. 3713.

12214 Mile Poparić, T. 39248-39251 (4 June 2013), T. 39290-39294 (5 June 2013); P6366 (UNPROFOR daily report, 19 November 1994).

12215 Mile Poparić, T. 38906-38911 (29 May 2013); D3626 (Photograph of Barry Hogan and Dženana Sokolović marked by Mile Poparić); D3627 (Photograph of Barry Hogan and Dženana Sokolović marked by Mile Poparić).

12216 See para. 3639.

12217 Mile Poparić, T. 38908-38911 (29 May 2013).
} 
side, continuing through her son's head; ${ }^{12218}$ (ii) the shots came from the Metalka building; ${ }^{12219}$ (iii) the shot that wounded Sokolović and killed her son, both civilians, originated from Metalka, a known SRK sniper position; ${ }^{1220}$ and (iv) the shots were fired by a member of the SRK. ${ }^{12221}$

3726. The Chamber finds, based on the evidence and adjudicated facts outlined above, that Sokolović and her son were civilians and were not taking direct part in hostilities at the moment when they were shot. Indeed, they were walking in the city as a cease-fire was in place at the time. The Chamber is also satisfied that they were shot as they were crossing Franje Račkog street and approaching the museum. This is corroborated both by the footage of Nermin Divovic lying on the said zebra crossing having just been shot, and by the CSB Sarajevo report compiled at the time of the incident.

3727. The Chamber is also satisfied, relying both on Bešlić's evidence and the medical records of Nermin's head wounds, as well as the adjudicated facts, that the bullet that wounded Sokolović came from her right hand side and that it entered the right side of her abdomen, exited on the left side of her abdomen, and then struck Nermin in the head, causing devastating head injuries that lead to his death. As indicated above, the Chamber does not accept Poparić's analysis of the location of entry and exit wounds of the two victims. First and foremost, this is because, unlike Bešlić, Poparić is not a doctor and thus his opinion as to the entry and exit wounds of the victims carry little weight. In addition, the analysis he presented was extremely speculative, as he relied heavily on video footage and his own estimates of the height of the individuals seen in the footage. At times, he was also plainly mistaken as to the content of the evidence before him. ${ }^{12222}$ Accordingly, the Chamber does not accept Poparić's conclusion that the wounds on the victims show that two different bullets struck them and that those bullets came from the north rather than the south. Indeed, based on the evidence above, the Chamber is convinced that the opposite happened, namely that one bullet came from the south and that it wounded Sokolović and killed her son Nermin. The Chamber is particularly persuaded here by the medical evidence relating to their wounds ${ }^{12223}$ and the report of the CSB Sarajevo report, as well as the footage of the aftermath of the incident, all of which point to the conclusion that the bullet arrived from the south.

\footnotetext{
12218 See Adjudicated Fact 2945.

12219 See Adjudicated Fact 2943.

12220 See Adjudicated Fact 2946.

12221 See Adjudicated Fact 2946.

12222 See para. 3719.
}

12223 The Chamber notes that the only contradicting medical evidence is the initial report on Sokolović's injuries prepared by the physician who saw her immediately after the incident. The Chamber, however, accepts Bešlić's evidence that this physician made a mistake, which was understandable given the circumstances that doctors were operating under at the time of the incident. The Chamber also finds Bešlić's evidence as to Sokolović's 
3728. As for the origin of fire, the Chamber is convinced, relying on adjudicated facts and the evidence of Van der Weijden, as well as the evidence about the presence of well-equipped SRK snipers in Grbavica and particularly in the Metalka building, ${ }^{12224}$ that the shot that wounded Sokolović and killed her son was fired from Metalka, which at the time was in the SRK's zone of responsibility. This is further confirmed by the fact that UNPROFOR soldiers, who were at the scene after the incident, returned fire at the SRK The Chamber is also convinced that, given the distance between Metalka and the incident site, the SRK soldier who shot Sokolović and her son was able to see that they were both civilians. Despite that, he proceeded to target them deliberately, as there was no ongoing fighting in the area at the time of the incident. Further, the Chamber notes that all these findings are consistent with the evidence suggesting that the sniper fire in the area of Zmaja od Bosne street came from the Serb side. ${ }^{12225}$

(6) Zmaja od Bosne street, 23 November 1994 (Scheduled Incident F.14)

3729. The Indictment alleges that on 23 November 1994, Afeza Karačić (also referred to as Hafiza Karačić), a 31 year old woman, and Sabina Šabanić, a 26 year old woman, were both wounded in the right shoulder when the tram they were travelling in came under fire on Zmaja od Bosne, between the School of Technology and Maršal Tito Barracks. ${ }^{1226}$ In its Final Brief, the Prosecution clarifies that the tram was struck "in the area immediately west of the S-curve" and submits that the fire came either from the four white high-rises or from Metalka. ${ }^{12227}$ The Accused argues that the fire came either from the Executive Council building or from the $\mathrm{ABiH}$ positions on Golo Brdo. ${ }^{12228}$

3730. On 23 November 1994, Afeza Karačić and her sister took a tram to Otoka, where they lived. ${ }^{12229}$ Having left work at 3:30 p.m., Sabina Šabanić took a tram to go home. ${ }^{12230}$ Šabanić and Karačić were on the same crowded tram. ${ }^{12231}$ Huso Palo was driving this tram westbound on Zmaja od Bosne street in the direction of School of Technology and the Maršal Tito Barracks. ${ }^{12232}$ It was

entry and exit wounds convincing given that he was her doctor and that he examined her wounds on more than one occasion and operated on her twice. See para. 3711.

12224 See paras. 3658-3660, 3668.

12225 See paras. 3621, 3656, 3662. In addition, the Chamber also recalls that it rejected the Accused's arguments that $\mathrm{ABiH}$ forces were sniping at Bosnian Muslims civilians throughout Sarajevo. See Section IV.B.1.d: Bosnian Muslim side targeting own civilians.

12226 Indictment, Scheduled Incident F.14.

12227 Prosecution Final Brief, Appendix C, para. 20.

12228 Defence Final Brief, para. 2287.

12229 See Adjudicated Fact 2955.

12230 P492 (Witness statement of Sabina Šabanić dated 16 November 1995), p. 2. See also Adjudicated Fact 2955.

12231 See Adjudicated Fact 2955.

12232 P119 (Witness statement of Huso Palo dated 24 February 1996), p. 2; P1714 (BiH MUP Report re sniping incident of 23 November 1994 on Zmaja od Bosne street), p. 1; P1695 (Witness statement of Mirza Sabljica 
not yet dusk; the day was cold but there was no fog and the visibility was good. ${ }^{12233}$ There were also no leaves on the trees. ${ }^{12234}$ Sometime between 3:30 and 4 p.m., when the tram was between the School of Technology and the Maršal Tito Barracks (between the two museums), it was hit by what Huso Palo referred to as a "single bullet", which injured Šabanić and Karačić. ${ }^{12235}$

3731. Sabina Šabanić was standing at the rear of the front section of the tram, facing Grbavica, when the bullet entered an inch below the top of her front right shoulder, passed diagonally down the shoulder, and exited her body some two inches below the top of the shoulder. ${ }^{1236}$ Following the incident she spent four days in the Koševo Hospital and is now partially disabled. ${ }^{12237}$

3732. Karačić was standing in the middle of the tram, at the connecting platform between the front and the rear cars of the tram, facing east, when she was shot. ${ }^{12238}$ The bullet came from her right, entered her upper right shoulder and exited slightly lower on the right arm, severing a nerve. ${ }^{12239}$ Karačić was taken to the Koševo Hospital ${ }^{12240}$ and had several operations as a result of which her

dated 11 February 2010), p. 69; P1830 (Witness statement of Dragan Mioković dated 26 October 2010), p. 38. See also Adjudicated Fact 2958.

12233

12234

(Wicted Fact 2956 Šabanić dated 22 May 2006), paras. 2, 4; Sabina Šabanić, P491 (Transcript from Prosecutor v. D. Milošević), T. 1445, 1447-1451, 1457, 1465-1466; P441 (Aerial photograph of Sarajevo marked by Sabina Šabanić); Huso Palo, P120 (Transcript from Prosecutor v. Milošević), T. 1535-1536; P119 (Witness statement of Huso Palo dated 24 February 1996), p. 2; P119 (Statement of Huso Palo to BiH authorities, 24 November 1994), p. 2; P1714 (BiH MUP Report re sniping incident of 23 November 1994 on Zmaja od Bosne street), p. 1; P1833 (BiH MUP Report re sniping incident of 23 November 1994 on Zmaja od Bosne street), e-court p. 2; P1695 (Witness statement of Mirza Sabljica dated 11 February 2010), pp. 69-70; P1721 (Aerial photograph of Sarajevo marked by Mirza Sabljica); P1830 (Witness statement of Dragan Mioković dated 26 October 2010), p. 43; P1836 (Aerial photograph of Sarajevo marked by Dragan Mioković). See also Mirza Sabljica, T. 7888-7889 (13 October 2010); D763 (Aerial photograph of Sarajevo marked by Mirza Sabljica); Dragan Mioković, T. 86398644 (29 October 2010); D849 (Aerial photograph of Sarajevo marked by Dragan Mioković). See also Adjudicated Fact 2958.

P492 (Witness statement of Sabina Šabanić dated 16 November 1995), p. 2; P492 (Addendum to witness statement of Sabina Šabanić dated 16 November 1995, 24 October 2010); P491 (Transcript from Prosecutor v. D. Milošević), T. 1450, 1458; P1219 (Medical certificate for Sabina Šabanić) (under seal). See also Adjudicated Fact 2961. According to the MUP report compiled after the investigation of this incident, both Šabanić and Karačić were standing at the platform connecting the front and the rear part of the tram. See P1833 (BiH MUP Report re sniping incident of 23 November 1994 on Zmaja od Bosne street), e-court p. 2.

12237 P492 (Witness statement of Sabina Šabanić dated 16 November 1995), p. 2; P492 (Addendum to witness statement of Sabina Šabanić dated 16 November 1995, 24 October 2010). See also Adjudicated Fact 2962.

12238 See Adjudicated Fact 2959. According to the MUP report compiled after the investigation of this incident, both Šabanić and Karačić were standing at the platform connecting the front and the rear part of the tram. See P1833 (BiH MUP Report re sniping incident of 23 November 1994 on Zmaja od Bosne street), e-court p. 2.

12239 See Adjudicated Fact 2960; P1833 (BiH MUP Report re sniping incident of 23 November 1994 on Zmaja od Bosne street), e-court p. 2; P1714 (BiH MUP Report re sniping incident of 23 November 1994 on Zmaja od Bosne street), p. 2.

12240 See Adjudicated Fact 2962; P1833 (BiH MUP Report re sniping incident of 23 November 1994 on Zmaja od Bosne street), e-court p. 2; P1545 (Medical record for Hafiza Karačić); P1714 (BiH MUP Report re sniping incident of 23 November 1994 on Zmaja od Bosne street), p. 2. 
arm was shortened by six centimetres. ${ }^{12241}$ Due to her injuries, she has an $80 \%$ disability; she cannot drive a car or write properly and has difficulty eating with her right hand. ${ }^{12242}$

3733. Huso Palo testified that the shot came from the tram's left-hand side, from one of the four white skyscrapers in Grbavica on Lenjinova street as they were the only location from which the tram could be seen. ${ }^{12243}$ However, during cross-examination he explained that he did not know from where the shots were fired. ${ }^{12244}$ Given the location of her injury, as well as the fact that these four skyscrapers were thought by the locals to be sniping nests, Šabanić was also of the view that the shots were fired from there. ${ }^{12245}$ She also rejected the proposition that there was an exchange of fire when she was wounded, or at any other time when she was walking in this area. ${ }^{12246}$ There were no soldiers or military targets in, or in the vicinity of, the tram, and only UNPROFOR soldiers were on the street. ${ }^{12247}$ While admitting that the tram was very crowded and that she could not move within it, Šabanić remained adamant that no soldiers were on it because she saw all the passengers when they got off the tram following the sniping. ${ }^{12248}$ She confirmed, however, that buildings belonging to $\mathrm{BiH}$ civilian authorities and the Presidency were nearby. ${ }^{12249}$

3734. The incident was investigated by an investigating team from CSB Sarajevo, with Mioković as the team leader, and Sabljica as the ballistics expert. ${ }^{12250}$ When the team arrived on the scene, the tram had already been moved back to the depot, together with another tram which was shot five minutes earlier, in the same location between the Maršal Tito Barracks and the School of

\footnotetext{
12241 See Adjudicated Fact 2963.

12242 See Adjudicated Fact 2963.

12243 P119 (Witness statement of Huso Palo dated 24 February 1996), p. 2; P119 (Statement of Huso Palo to BiH authorities, 24 November 1994), p. 2. See also Barry Hogan, T. 11219-11220 (3 February 2011); P2209 (Photograph of Sarajevo marked by Barry Hogan).

12244 Huso Palo, P120 (Transcript from Prosecutor v. Milošević), T. 1535, 1539, 1543, 1547.

12245 Sabina Šabanić, P491 (Transcript from Prosecutor v. D. Milošević), T. 1452-1456; P442 (Aerial photograph of Sarajevo marked by Sabina Šabanić); Sabina Šabanić, P491 (Transcript from Prosecutor v. Perišić), T. 683686, 696-697; P467 (Aerial photograph of Sarajevo); P469 (Aerial photograph of Sarajevo marked by Sabina Šabanić); P492 (Witness statement of Sabina Šabanić dated 16 November 1995), p. 2; P492 (Addendum to witness statement of Sabina Šabanić dated 16 November 1995, 24 April 2010); P492 (Witness statement of Sabina Šabanić dated 22 May 2006), para. 6; P492 (Addendum to witness statement of Sabina Šabanić dated 22May 2006, 24 October 2010).

12246 Sabina Šabanić, P491 (Transcript from Prosecutor v. D. Milošević), T. 1472-1476; P443 (Aerial photograph of Sarajevo marked by Sabina Šabanić); Sabina Šabanić, P491 (Transcript from Prosecutor v. Perišić), T. 692693.

12247 Sabina Šabanić, P491 (Transcript from Prosecutor v. D. Milošević), T. 1457-1458; P492 (Witness statement of Sabina Šabanić dated 22 May 2006), para. 5; P119 (Witness statement of Huso Palo dated 24 February 1996), p. 2. See also Adjudicated Fact 2957.

12248 Sabina Šabanić, P491 (Transcript from Prosecutor v. Perišić), T. 698-699.

12249 Sabina Šabanić, P491 (Transcript from Prosecutor v. D. Milošević), T. 1485-1487; P444 (Aerial photograph of Sarajevo marked by Sabina Šabanić).

12250 P1714 (BiH MUP Report re sniping incident of 23 November 1994 on Zmaja od Bosne street), p. 1; P1830 (Witness statement of Dragan Mioković dated 26 October 2010), pp. 4, 39-40; P1695 (Witness statement of Mirza Sabljica dated 11 February 2010), p. 69. See also Dragan Mioković, T. 8638 (29 October 2010).
} 
Technology. ${ }^{12251}$ According to Sabljica, it was therefore not possible to establish the exact origin of fire but the team was able to determine that it came from the tram's left-hand side, from the direction of Sector South and the area of Grbavica. ${ }^{12252}$ However, a report prepared by Mioković, based on the notes he made at the scene, ${ }^{12253}$ concluded that the bullet was fired from the south or the southeast and that it came "from the aggressor's position". ${ }^{2254}$ Sabljica could not explain the basis for the reference to the "aggressor's position" given that the tram was in a depot when investigated and that the bullet's entry angle could not be determined. ${ }^{12255}$

3735. The CSB Sarajevo reports note that only one bullet was fired at the tram but since no entry point was found it was concluded, based on the damage to the right hand side of the interior of the tram, that the bullet entered through an open window from the left hand side of the tram and that it fragmented into pieces. ${ }^{12256}$ According to Sabljica, a bullet can fragment only upon impact with a hard surface so in his opinion the two victims were injured after the bullet impacted a metal plate on the tram and fragmented. ${ }^{12257}$ Mioković, on the other hand, thought that the bullet fragmented before it impacted any surface in the tram, and it was then that the fragments injured the two victims. $^{12258}$ However, he also conceded that there was no material evidence that a fragmentation bullet was used here. ${ }^{12259}$ Sabljica conceded that the team did not take into account the injuries of

12251 P1714 (BiH MUP Report re sniping incident of 23 November 1994 on Zmaja od Bosne street), p. 1; P1695 (Witness statement of Mirza Sabljica dated 11 February 2010), p. 71; P1830 (Witness statement of Dragan Mioković dated 26 October 2010), p. 38. See also Dragan Mioković, T. 8638-8639 (29 October 2010).

12252 P1714 (BiH MUP Report re sniping incident of 23 November 1994 on Zmaja od Bosne street), p. 1; P1695 (Witness statement of Mirza Sabljica dated 11 February 2010), p. 71. See also Mirza Sabljica, T. 7886-7887 (13 October 2010).

12253 P1830 (Witness statement of Dragan Mioković dated 26 October 2010), pp. 39-40.

12254 P1714 (BiH MUP Report re sniping incident of 23 November 1994 on Zmaja od Bosne street), p. 1. See also Dragan Mioković, T. 8639 (29 October 2010).

12255 Mirza Sabljica, T. 7887 (13 October 2010); P1714 (BiH MUP Report re sniping incident of 23 November 1994 on Zmaja od Bosne street), p. 1.

12256 P1714 (BiH MUP Report re sniping incident of 23 November 1994 on Zmaja od Bosne street), p. 1; P1834 (BiH MUP Report re sniping incident of 23 November 1994 on Zmaja od Bosne street), p. 1; P1830 (Witness statement of Dragan Mioković dated 26 October 2010), p. 38; P1695 (Witness statement of Mirza Sabljica dated 11 February 2010), pp. 71-72. See also Dragan Mioković, T. 8639 (29 October 2010). The Chamber notes that another BiH MUP report notes that the bullet entered through the rear "right" window of the front section of the tram, which does not seem to be recorded in the English translation of that report. However, given the description of the incident in this report, particularly the direction in which the train was travelling and the direction from which the bullet is said to have come, the reference to the "right" window must have been a description of the position of the said window in relation to other windows on the left hand side of the tram. See P1835 (BiH MUP Report re sniping incident of 23 November 1994 on Zmaja od Bosne street), p. 1; P1830 (Witness statement of Dragan Mioković dated 26 October 2010), p. 41.

12257 According to Sabljica, the metal plate was located "inside the tram on the wall, on the interior tram wall where the bullet hit" and it was "in the upper right-hand side corner of the tram's window frame." See P1695 (Witness statement of Mirza Sabljica dated 11 February 2010), pp. 71-72.

12258 According to Mioković, fragmentation bullets can fragment even without impacting something first. Dragan Mioković, T. 8571-8573 (29 October 2010); P1830 (Witness statement of Dragan Mioković dated 26 October 2010), pp. 5, 42.

12259 P1830 (Witness statement of Dragan Mioković dated 26 October 2010), pp. 42-43. Mirza Sabljica testified that some fragments of the bullet jacket were found in the tram but explained that this was not enough to establish 
the victims when coming to its conclusion about the bullet entering through an open window, and also confirmed that the team could not establish the angle at which the bullet entered the tram. ${ }^{12260}$

3736. Hogan visited the scene of the incident with one of the victims ${ }^{12261}$ and recorded the coordinates of the location of the incident, placing it at the intersection between Zmaja od Bosne and Franje Račkog streets instead of further to the west, as recounted by Huso Palo and Sabina Šabanić. ${ }^{12262}$ Van der Weijden then visited this site, as well as Grbavica, on 29 November 2006. ${ }^{12263}$ Judging by the photographs in his report, and because he used the co-ordinates given to him by the Prosecution, Van der Weijden placed the location of this incident at the intersection of Franje Račkog and Zmaja od Bosne streets, instead of further to the west, near the Maršal Tito Barracks as recounted by Huso Palo and Sabina Šabanić. ${ }^{12264}$ As a result, he visited Metalka noting that the rooms in the building offer direct and clear views of the stretch of Zmaja od Bosne, between the Museum and the Faculty of Philosophy. ${ }^{12265}$ When in the building, he determined that the tram would be exposed to the shooter located in the building for at least eight seconds. ${ }^{12266}$

3737. Noting that there were multiple victims in this incident and having described their injuries, Van der Weijden concluded that most likely automatic fire was used to shoot at the tram, and that the weapons used would have been either a M84 or a M53 machine-gun in $7.62 \mathrm{~mm}$ calibre, mounted on a bipod or a tripod. ${ }^{12267}$ He noted that machine-guns are more effective against moving targets, such as trams, that are only temporarily visible. ${ }^{12268}$

the type of the projectile used in this incident. See P1695 (Witness statement of Mirza Sabljica dated 11 February 2010), p. 71. See also P1714 (BiH MUP Report re sniping incident of 23 November 1994 on Zmaja od Bosne street), p. 1.

12260 P1695 (Witness statement of Mirza Sabljica dated 11 February 2010), p. 72.

12261 The Chamber notes that the identity of this victim is not clear from the evidence before it.

12262 Barry Hogan, T. 11204-11206 (3 February 2011); P2190 (GPS locations for shelling and sniping incidents in Sarajevo); P2191 (Map of Sarajevo with scheduled sniping and shelling incidents); P2213 (Image re scheduled sniping and shelling incidents in Sarajevo).

12263 P1621 (Expert Report of Patrick van der Weijden entitled “Sniping Incidents in Sarajevo '92-'94”), p. 95.

12264 P1621 (Expert Report of Patrick van der Weijden entitled "Sniping Incidents in Sarajevo '92-'94”), p. 94.

12265 P1621 (Expert Report of Patrick van der Weijden entitled “Sniping Incidents in Sarajevo '92-'94”), p. 95. Van der Weijden states in his report that the branches of the trees "in the street" will have grown since the war and now obstruct some of the windows that at the time would have also offered an unobstructed view. See P1621 (Expert Report of Patrick van der Weijden entitled "Sniping Incidents in Sarajevo '92-'94"), p. 95. See also Barry Hogan, T. 11219-11220 (3 February 2011); P2208 (Photograph of Sarajevo marked by Barry Hogan); P2209 (Photograph of Sarajevo marked by Barry Hogan). P1621 (Expert Report of Patrick van der Weijden entitled “Sniping Incidents in Sarajevo '92-'94”), p. 95.

12267 P1621 (Expert Report of Patrick van der Weijden entitled "Sniping Incidents in Sarajevo '92-'94”), p. 94. See also fn. 12122.

12268 P1621 (Expert Report of Patrick van der Weijden entitled “Sniping Incidents in Sarajevo '92-'94”), p. 94. 
3738. Poparić analysed this incident using the relevant CSB Sarajevo reports, as well as the statements of Palo, Šabanić, and Karačić. ${ }^{12269}$ He concluded that the bullet that struck the tram did not originate from the SRK positions in Grbavica but came from east, from a location with a much higher site angle, such as for example the Executive Council building or the $\mathrm{ABiH}$ positions on Golo Brdo. ${ }^{12270}$ He based his conclusion on the position at which the two victims were standing in the tram when shot, and their injuries. With respect to Karačić, he pointed out that she was standing facing the back of the tram, at 90 degrees to the axis of the tram-thus, if she had been wounded by a bullet coming from Grbavica, the bullet could not have exited through her upper right arm but would have ended up inside her body or exited on the side of it. ${ }^{12271}$ Poparic therefore concluded that her injury could have been caused only by a bullet coming from east, at a high angle of descent. ${ }^{12272} \mathrm{He}$ also explained that the differences in length between the entry and exit wounds of both victims were great, also suggesting that the bullet had a great angle of descent. ${ }^{12273} \mathrm{He}$ conceded, however, that he never spoke to Karačić or saw her injuries and that no measurements of her wounds were recorded in the available reports. ${ }^{12274} \mathrm{He}$ also conceded that he assumed that both her and Šabanić's arms were in straight vertical downwards position by their side when struck and noted that irrespective of the positions of Karačić's arm, had the bullet come from the white highrises, it would have stayed in her body and not exited on her upper arm. ${ }^{12275}$

3739. Poparić further challenged the report prepared by Mioković, saying that it was impossible for the bullet that entered through an open window to fragment before impacting any obstacle and also to hit the window frame after exiting the body of one of the victims. ${ }^{12276}$ He suggested that the bullet did not pass through an open window but through the tarpaulin of the joint on the tram and fragmented at that point, which was then missed by the investigators. ${ }^{12277}$ However, in that case, given the injuries to the victims, the bullet could not have come from the SRK positions in

\footnotetext{
12269 D4884 (Mile Poparić's expert report entitled "Small Arms Fire on the Sarajevo Area 1992-1995", 15 August 2012), pp. 145-146. The Chamber notes that Afeza Karačić did not testify in this case and thus the Chamber did not have access to her witness statement.

12270 Mile Poparić, T. 38989-38993 (30 May 2013); D3639 (Satellite image of Sarajevo marked by Mile Poparić); D4884 (Mile Poparić's expert report entitled "Small Arms Fire on the Sarajevo Area 1992-1995”, 15 August 2012), pp. 149-151.

12271 D4884 (Mile Poparić's expert report entitled "Small Arms Fire on the Sarajevo Area 1992-1995", 15 August 2012), p. 149.

12272 Mile Poparić, T. 38991-38993 (30 May 2013); D4884 (Mile Poparić's expert report entitled "Small Arms Fire on the Sarajevo Area 1992-1995”, 15 August 2012), p. 149.

12273 Mile Poparić, T. 38992-38993 (30 May 2013); D4884 (Mile Poparić's expert report entitled "Small Arms Fire on the Sarajevo Area 1992-1995”, 15 August 2012), p. 151.

12274 Mile Poparić, T. 39277-39278 (5 June 2013).

12275 Mile Poparić T. 39278-39279 (5 June 2013).

12276 Mile Poparić, T. 38989-38991 (30 May 2013); D4884 (Mile Poparić's expert report entitled "Small Arms Fire on the Sarajevo Area 1992-1995”, 15 August 2012), p. 149.

12277 Mile Poparić, T. 38993 (30 May 2013); D4884 (Mile Poparić's expert report entitled "Small Arms Fire on the Sarajevo Area 1992-1995”, 15 August 2012), pp. 149, 151.
} 
Grbavica. ${ }^{12278}$ Noting the position of the tram as testified to by Karačić in the Dragomir Milošević case, namely the intersection of Franje Račkog and Zmaja od Bosne, the joint of the tram would not have been visible from Metalka. ${ }^{12279}$

3740. In addition to the evidence and adjudicated facts outlined above, the Chamber has also tok judicial notice of the following adjudicated facts which go to contentious issues in this incident. They provide as follows: (i) the tram was shot at the intersection in front of the Holiday Inn, or shortly thereafter in front of the Maršal Tito Barracks between the two museums; ${ }^{1220}$ (ii) Afeza Karačić and Sabina Šabanić were hit by one single bullet which fragmented; ${ }^{1281}$ (iii) it was common for the VRS to fire fragmentation bullets at trams that would fragment on impact, even through glass; ${ }^{12282}$ (iv) the origin of fire was either the high-rise buildings on Lenjinova street or the Metalka building, both held by the SRK; ${ }^{12283}$ (v) the shots came from SRK-held territory;and were fired by a member of the SRK. ${ }^{12284}$

3741. As far as the exact location of the incident is concerned, the Chamber notes that the majority of the evidence before it places the tram somewhere between the School of Technology and the Maršal Tito Barracks at the moment when it was shot. ${ }^{12285}$ The Chamber is therefore convinced that this is the location of the incident. While Hogan's evidence suggests otherwise, the Chamber recalls that it is based on a recollection of a victim of the incident. However, the Chamber does not have any information as to who this victim was. As a result, and given the weight of other evidence, the Chamber does not accept Hogan's GPS co-ordinates as accurate.

3742. The Chamber further considers that this tram was a civilian vehicle, with civilians travelling onboard. In addition, Šabanić and Karačić were civilians and were not taking direct part in hostilities when they were shot and wounded.

3743. In terms of the origin of fire, the Chamber recalls that Poparic reached his conclusion that the bullet came from the Executive Council building or from Golo Brdo, based on a number of assumptions as to the location and the nature of Šabanić's and Karačić's injuries. However, he never checked if his assumptions were correct by talking to the two victims. Furthermore, he is not a doctor and thus his analysis as to whether and where bullets or bullet fragments should have

\footnotetext{
12278 Mile Poparić, T. 38993 (30 May 2013).

12279 Mile Poparić, T. 38993-38994 (30 May 2013).

12280 Adjudicated Fact 2967.

12281 See Adjudicated Fact 2965.

12282 See Adjudicated Fact 2966.

12283 Adjudicated Fact 2968.

12284 Adjudicated Fact 2969.
} 
exited the victims' bodies, carries little weight. His analysis in this respect also does not account for the possibility suggested by Sabljica, namely that the bullet fragmented upon impact before hitting the victims, which in turn would have affected the trajectory of the fragments that injured the victims. ${ }^{12286}$ Finally, aside from the general direction Šabanić and Karačić were facing when shot, there is no evidence as to the specifics of their body positions, such as whether they were standing with their arms down next to their bodies or whether they were holding onto the handrails, which would have been necessary to know in order to draw definitive conclusions about the bullet's trajectory. Thus, the Chamber does not accept that the approximate angle at which the bullet struck the tram can be determined from the description of the victims' injuries, particularly since the investigators found no traces of the bullet's entry point on the tram and since there is a possibility that the bullet fragmented before striking the victims. For all those reasons, the Chamber does not accept Poparić's conclusion that the fire came from east and from the Executive Council building or Golo Brdo.

3744. The Chamber, relying on the adjudicated facts and the evidence of Šabanić and Palo, is convinced that the bullet that wounded Šabanić and Karačić came from the south, from the SRK positions in Grbavica, most likely from one of the four white high-rises. Given that the SRK snipers in Grbavica, and particularly the snipers located in the four white high-rises, had an excellent view of the area in front of and around Maršal Tito Barracks, ${ }^{12287}$ and given that there was no ongoing fighting at the time of the incident, the Chamber is also convinced that the SRK shooter deliberately targeted the tram, while fully aware that it was a civilian vehicle. This is in line with the general evidence the Chamber heard about the prevalence of the SRK sniping in the area of Zmaja od Bosne street and about SRK sniper nests in the white high-rises. ${ }^{12288}$

\section{(7) Zmaja od Bosne street, 27 February 1995 (Scheduled Incident F.15)}

3745. According to the Indictment, on 27 February 1995, Senad Kesmer (also referred to as Senad Kešmer), a 31 year old man, Alma Čehajić, a 19 year old woman, Alija Holjan, a 55 year old man, and others were shot and wounded while travelling in a westbound tram on Zmaja od Bosne street, when the tram was near the Maršal Tito Barracks. ${ }^{12289}$ In its Final Brief, the Prosecution claims

\footnotetext{
12285 See para. 3730, fn. 12235.

12286 The Chamber also notes that Poparić appears to have assumed when assessing victims' injuries that the bullet struck the tram at a right angle. However, the angle was never established and the victims' injuries in fact appear to be consistent with fire coming at an acute angle.

12287 See paras. 3666-3667.

12288 See paras. 3621, 3656, 3662. In addition, the Chamber also recalls that it rejected the Accused's arguments that $\mathrm{ABiH}$ forces were sniping at Bosnian Muslim civilians throughout Sarajevo. See Section IV.B.1.d: Bosnian Muslim side targeting own civilians.

12289 Indictment, Scheduled Incident F.15.
} 
that five persons were wounded in this incident and that the fire on the tram was opened from the white high-rises in Grbavica. ${ }^{12290}$ The Accused claims, however, that the fire came from nearby buildings such as the Museum for example, which were under the ABiH control. ${ }^{12291}$

3746. On 27 February 1995, KDZ289 was on a tram on Zmaja od Bosne, travelling westbound from the centre of Sarajevo in the direction of Ilidža. ${ }^{12292}$ Also on the tram was Alma Mulaosmanović-Čehajić, who testified that the tram was fairly crowded. ${ }^{12293}$ Alija Holjan, a foreman of a street cleaning crew, was sitting on the right-side of the tram, next to an exit. ${ }^{12294}$ While the day was cloudy and cold, the weather conditions allowed for good visibility. ${ }^{12295}$ The day was also relatively quiet as cease-fire was in place. ${ }^{12296}$

3747. Around noon, while in the area of the Maršal Tito Barracks stop, the tram was shot at. ${ }^{12297}$ KDZ289 did not realise at first that the noise she was hearing were shots but then heard passengers scream and felt bullets hit the left hand side of the tram, starting at her seat and moving down towards the back of the tram. ${ }^{12298}$ As the shooting continued, the tram kept on driving for a while

\footnotetext{
12290 Prosecution Final Brief, Appendix C, para. 21.
}

12291 Defence Final Brief, paras. 2289-2291.

12292 P2413 (Witness statement of KDZ289 dated 16 November 1995), p. 2; P2413 (Witness statement of KDZ289 dated 2 March 1996), p. 2; P2413 (KDZ289's statement to BiH authorities, 1 March 1995), p. 1; KDZ289, P485 (Transcript from Prosecutor v. D. Milošević), T. 1616; Alma Mulaosmanović-Čehajić, P1551 (Transcript from Prosecutor v. D Milošević), T. 1652; P1695 (Witness statement of Mirza Sabljica dated 11 February 2010), p. 73. See also Adjudicated Fact 2976.

12293 Alma Mulaosmanović-Čehajić, P1551 (Transcript from Prosecutor v. D Milošević), T. 1657; Alma Mulaosmanović-Čehajić, T. 6759 (14 September 2010); D626 (Alma Mulaosmanović-Čehajić's statement to $\mathrm{BiH}$ authorities, 14 April 1995), p. 1. See also Adjudicated Fact 2979.

12294 Adjudicated Fact 2979.

12295 Alma Mulaosmanović-Čehajić, P1551 (Transcript from Prosecutor v. D Milošević), T. 1657; Alma Mulaosmanović-Čehajić, T. 6759 (14 September 2010); D626 (Alma Mulaosmanović-Čehajić's statement to $\mathrm{BiH}$ authorities, 14 April 1995), p. 1; P2413 (Witness statement of KDZ289 dated 19 April 2006), p. 2. See also Adjudicated Fact 2978.

12296 P2413 (Witness statement of KDZ289 dated 16 November 1995), p. 2. See also Adjudicated Fact 2977.

12297 Alma Mulaosmanović-Čehajić thought that the tram was just before the Maršal Tito Barracks, when she first heard the shots, although she admitted that she was unable to give the precise location. See Alma Mulaosmanović-Čehajić, P1551 (Transcript from Prosecutor v. D Milošević), T. 1652-1655, 1661-1664; P1553 (Map of Sarajevo marked by Alma Mulaosmanović-Čehajić); P1554 (Photograph of Sarajevo marked by Alma Mulaosmanović-Čehajić); P1555 (Photograph of Sarajevo marked by Alma Mulaosmanović-Čehajić); D626 (Alma Mulaosmanović-Čehajić's statement to BiH authorities, 14 April 1995), p. 1. KDZ289 thought that the tram had just left the Maršal Tito Barracks stop when shot, thus placing it further west than MulaosmanovićČehajić did. P2413 (Witness statement of KDZ289 dated 16 November 1995), p. 2; P2413 (Witness statement of KDZ289 dated 2 March 1996), p. 2; P2413 (KDZ289's statement to BiH authorities, 1 March 1995), p. 1; KDZ289, P485 (Transcript from Prosecutor v. D. Milošević), T. 1620-1622, 1633; P445 (Map of Sarajevo marked by KDZ289); P446 (Aerial photograph of Sarajevo marked by KDZ289); P447 (Aerial photograph of Sarajevo marked by KDZ289). Mirza Sabljica, while stating that the tram was shot at as it left the Maršal Tito Barracks stop, placed it further to the west than KDZ289. See P1695 (Witness statement of Mirza Sabljica dated 11 February 2010), p. 73; P1718 (Photograph of Sarajevo marked by Mirza Sabljica).

12298 P2413 (KDZ289's statement to BiH authorities, 1 March 1995), p. 1; P2413 (Witness statement of KDZ289 dated 16 November 1995), p. 2; P2413 (Witness statement of KDZ289 dated 2 March 1996), p. 2; P2413 (Witness statement of KDZ289 dated 19 April 2006), p. 2; KDZ289, P485 (Transcript from Prosecutor v. D. Milošević), T. 1625-1626, 1629-1630. 
and then stopped to let the passengers off. ${ }^{12299}$ KDZ289 observed a woman who was injured in the leg, as well as an eight or nine year old girl with a wound on her face. ${ }^{12300}$

3748. Mulaosmanović-Čehajić stated that when fired upon, the tram was located somewhere between the two Museums. ${ }^{12301}$ She was 18 years old at the time and was wearing a green blouse, a light purple jacket, and blue jeans. ${ }^{12302}$ She was standing in the last section of the tram facing the Maršal Tito Barracks, ${ }^{12303}$ and was wounded by the bullet which entered her left elbow, "passed through the muscle, slid down the bone and then exited" through her lower arm. ${ }^{12304}$ Once she got off the tram, she was taken to the "first aid station" where she saw an elderly woman and an elderly man being brought in too. ${ }^{12305}$ Like Mulaosmanović-Čehajić, Holjan was also seriously injured in the incident and taken to the first-aid station of the State Hospital. ${ }^{12306}$

3749. UNPROFOR and the local police arrived at the scene soon after the incident and conducted an investigation ${ }^{12307}$ at which point KDZ289 noticed that the left hand side of the tram was riddled with some 30 bullet holes and marks. ${ }^{12308}$ KDZ289 testified that because the shots came from her left, they must have come from the "Serbian Army" positions in Grbavica, but she could not say

12299 P2413 (Witness statement of KDZ289 dated 16 November 1995), p. 2; P2413 (KDZ289's statement to BiH authorities, 1 March 1995), p. 1; KDZ289, P485 (Transcript from Prosecutor v. D. Milošević), T. 1620-1621, T.1629-1634; P445 (Map of Sarajevo marked by KDZ289); P446 (Aerial photograph of Sarajevo marked by KDZ289); P447 (Aerial photograph of Sarajevo marked by KDZ289); KDZ289, P485 (Transcript from Prosecutor v. Perišić), T. 619-622; P468 (Map of Sarajevo marked by KDZ289). Alma MulaosmanovićČehajić, P1551 (Transcript from Prosecutor v. D Milošević), T. 1662; D626 (Alma Mulaosmanović-Čehajić's statement to $\mathrm{BiH}$ authorities, 14 April 1995), p. 1.

12300 P2413 (Witness statement of KDZ289 dated 16 November 1995), p. 2; P2413 (KDZ289's statement to BiH authorities, 1 March 1995), p. 1.

12301 Alma Mulaosmanović-Čehajić, P1551 (Transcript from Prosecutor v. D Milošević), T. 1652-1655, 1661-1664; P1555 (Photograph of Sarajevo marked by Alma Mulaosmanović-Čehajić); Alma Mulaosmanović-Čehajić, T. 6754-6755, 6764-6766 (14 September 2010); P1553 (Map of Sarajevo marked by Alma MulaosmanovićČehajić); D623 (Map of Sarajevo marked by Alma Mulaosmanović-Čehajić); D626 (Alma MulaosmanovićČehajić's statement to BiH authorities, 14 April 1995), p. 1.

12302 Alma Mulaosmanović-Čehajić, P1551 (Transcript from Prosecutor v. D Milošević), T. 1657-1658.

12303 Alma Mulaosmanović-Čehajić, T. 6759-6760 (14 September 2010), T. 6789-6790 (15 September 2010); Alma Mulaosmanović-Čehajić, P1551 (Transcript from Prosecutor v. D Milošević), T. 1652, 1661-1662.

12304 Alma Mulaosmanović-Čehajić, P1551 (Transcript from Prosecutor v. D Milošević), T. 1654, 1656, 1658; P1247 (Medical report for Alma Čehajić). See also D626 (Alma Mulaosmanović-Čehajić's statement to BiH authorities, 14 April 1995), p. 1.

12305 Alma Mulaosmanović-Čehajić, P1551 (Transcript from Prosecutor v. D Milošević), T. 1658; D626 (Alma Mulaosmanović-Čehajić's statement to BiH authorities, 14 April 1995), p. 1. The Prosecution tendered for admission a number of medical records, through Bakir Nakaš, submitting that they were related to this incident, namely, P1546 (Medical record for Rabija Jerlagić); P1549 (Medical report for Senad Kešmer); P1248 (Medical report for Sead Bečić).

12306 See Adjudicated Facts 2979, 2980; P1249 (Medical report for Alija Holjan). According to his medical report, Alija Holjan was born in 1939 and thus was around 56 years old at the time of the incident.

12307 P2413 (Witness statement of KDZ289 dated 16 November 1995), p. 2; P2413 (KDZ289's statement to BiH authorities, 1 March 1995), p. 1; P2413 (Witness statement of KDZ289 dated 19 April 2006), p. 2.

12308 P2413 (Witness statement of KDZ289 dated 16 November 1995), p. 2; P2413 (KDZ289's statement to BiH authorities, 1 March 1995), p. 1; P2413 (Witness statement of KDZ289 dated 19 April 2006), p. 2; KDZ289, P485 (Transcript from Prosecutor v. Perišić), T. 625. See also Adjudicated Fact 2983. 
where exactly the sniper was located. ${ }^{12309}$ During cross-examination in the Dragomir Milošević case, she accepted that the territory immediately to her left and up to Miljacka River was in the area of responsibility of the $\mathrm{ABiH}$ but also noted that UNPROFOR was stationed in the area around Marin Dvor. ${ }^{12310}$ KDZ289 denied that ABiH units were present in the centre of the city. ${ }^{12311}$ When faced with an UNPROFOR report ${ }^{12312}$ stating that there was an exchange of fire between the $\mathrm{ABiH}$ and VRS at the time of this incident, KDZ289 first noted that the report may not be describing the incident she was involved in, and also added that as far as she knew there was no exchange of fire between the two warring factions at the time, although she admitted that she could not be sure. ${ }^{12313}$ This was confirmed by Fraser, who having been shown the report, also interpreted it as involving two different incidents, namely a deliberate sniping on a tram and an exchange of fire that took place some 300 metres away at Vrbanja Bridge. ${ }^{12314}$

3750. Mulaosmanović-Čehajić testified that the shots came from behind her, that is, from the direction of Miljacka River, and the neighbourhoods of Grbavica and Vraca, stating that "the firing was not that close, because the sound of it would have been louder."12315 She identified the origin of fire as being under control of the "Serbian army" on the basis that "everybody knew that". ${ }^{12316}$ When asked during cross-examination, if she heard other shots being fired before she heard bullets hitting the tram, Mulaosmanović-Čehajić responded that she thought she may have, but said that she could not be absolutely certain and could not confirm where those initial shots were fired from. ${ }^{12317}$ She testified that she heard two bursts of fire, the second one being the one that struck the tram, but denied that this meant that the shots were fired from an automatic rifle with a shorter range and thus could have come from the tall buildings on the northern side of Miljacka River. ${ }^{12318}$ Like KDZ289, she too was presented with the UNPROFOR report, which referred to the exchange

\footnotetext{
12309 P2413 (Witness statement of KDZ289 dated 2 March 1996), p. 2; P2413 (Witness statement of KDZ289 dated 19 April 2006), p. 2; KDZ289, P485 (Transcript from Prosecutor v. D. Milošević), T. 1620, 1622; P445 (Map of Sarajevo marked by KDZ289); P446 (Aerial photograph of Sarajevo marked by KDZ289); KDZ289, P485 (Transcript from Prosecutor v. Perišić), T. 617-618.

12310 KDZ289, P485 (Transcript from Prosecutor v. D. Milošević), T. 1635-1637, 1640-1641; P448 (Map of Sarajevo marked by KDZ289). See also Alma Mulaosmanović-Čehajić, P1551 (Transcript from Prosecutor v. $D$ Milošević), T. 1664-1665; Alma Mulaosmanović-Čehajić, T. 6766-6767 (14 September 2010); D624 (Photograph of Sarajevo marked by Alma Mulaosmanović-Čehajić).

12311 KDZ289, P485 (Transcript from Prosecutor v. D. Milošević), T. 1637.

12312 See P435 (UNPROFOR daily report, 27 February 1995), p. 2.

12313 KDZ289, P485 (Transcript from Prosecutor v. D. Milošević), T. 1641-1645.

12314 P1762 (Witness statement of David Fraser dated 17 October 2010), pp. 46-50; David Fraser, T. 8129-8131, 8164-8168 (19 October 2010). .

12315 Alma Mulaosmanović-Čehajić, P1551 (Transcript from Prosecutor v. D Milošević), T. 1652-1655; Alma Mulaosmanović-Čehajić, T. 6754-6755, 6761-6763 (14 September 2010); P1552 (Photograph of Sarajevo marked by Alma Mulaosmanović-Čehajić); P1553 (Map of Sarajevo marked by Alma Mulaosmanović-Čehajić).

12316 Alma Mulaosmanović-Čehajić, P1551 (Transcript from Prosecutor v. D Milošević), T. 1657.

12317 Alma Mulaosmanović-Čehajić, P1551 (Transcript from Prosecutor v. D Milošević), T. 1662, 1666-1667.

12318 Alma Mulaosmanović-Čehajić, T. 6762-6763, 6768 (14 September 2010), T. 6786 (15 September 2010).
} 
of fire on that day, but denied any knowledge of such an exchange. ${ }^{12319}$ In addition, when told that the exchange of fire took place near Vrbanja Bridge, at first she testified that this location was not far away. ${ }^{12320}$ She later noted that Vrbanja Bridge was far enough from the buildings so that she did not hear any cross-fire "as the tram was passing" the buildings adjacent to it. ${ }^{12321}$ She then confirmed that there was generally a lot of fighting throughout Sarajevo. ${ }^{12322}$

3751. KDZ289 testified that there was one $\mathrm{ABiH}$ soldier on the tram, who was standing next to her at the time the shots were fired but could not remember any others in the tram or in its vicinity before the incident happened. ${ }^{12323}$ During her testimony in the Dragomir Milošević case, Mulaosmanović-Čehajić testified that she did not remember seeing any soldiers on the tram nor could she remember any combat activity surrounding it, ${ }^{12324}$ and explained this fact by noting that she was standing in the last section of the tram, while the soldier in question appears to have been standing next to KDZ289. ${ }^{12325}$

3752. This incident had a major psychological impact on KDZ289. After a medical assessment, she was moved to another job within the company. ${ }^{12326}$ Mulaosmanović-Čehajić still suffers from anxiety due to the fear experienced during the conflict although her fears have subsided due to her faith. ${ }^{12327}$ After his injury, Alija Holjan was unable to use his right hand for extended periods of time and experienced pain when the weather changed. ${ }^{12328}$ He was declared $20 \%$ disabled. ${ }^{12329}$

3753. The Chamber received a CSB Sarajevo's case file relating to this incident, containing a number of reports prepared by the CSB Sarajevo investigating team, including those prepared by witnesses Kučanin and Sabljica. ${ }^{12330}$ Kučanin, a criminal inspector within CSB Sarajevo, prepared

\footnotetext{
12319 Alma Mulaosmanović-Čehajić, P1551 (Transcript from Prosecutor v. D Milošević), T. 1668-1672. See P435 (UNPROFOR daily report, 27 February 1995).

12320 Alma Mulaosmanović-Čehajić, P1551 (Transcript from Prosecutor v. D Milošević), T. 1675-1677; P1552 (Photograph of Sarajevo marked by Alma Mulaosmanović-Čehajić).

12321 Alma Mulaosmanović-Čehajić, T. 6785-6786 (15 September 2010).

12322 Alma Mulaosmanović-Čehajić, P1551 (Transcript from Prosecutor v. D Milošević), T. 1674.

12323 P2413 (KDZ289's statement to BiH authorities, 1 March 1995), p. 1; P2413 (Witness statement of KDZ289 dated 19 April 2006), p. 2; KDZ289, P485 (Transcript from Prosecutor v. D. Milošević), T. 1623-1624; KDZ289, P485 (Transcript from Prosecutor v. Perišić), T. 624-625.

12324 Alma Mulaosmanović-Čehajić, P1551 (Transcript from Prosecutor v. D Milošević), T. 1656.

12325 Alma Mulaosmanović-Čehajić, T. 6759-6760 (14 September 2010), T. 6789-6790 (15 September 2010).

12326 KDZ289, P485 (Transcript from Prosecutor v. D. Milošević), T. 1626-1627. See also Adjudicated Fact 2982.

12327 Alma Mulaosmanović-Čehajić, P1551 (Transcript from Prosecutor v. D Milošević), T. 1659-1660.

12328 See Adjudicated Fact 2981.

12329 See Adjudicated Fact 2981.

12330 See P1729 (BiH MUP Reports re sniping incident of 27 February 1995 on Zmaja od Bosne street).
} 
his report on 28 February $1995 .{ }^{12331}$ He testified that the tram was hit by eight bullets, four of which passed through the tram causing entry and exit holes. ${ }^{12332}$ Because of the damage caused, the investigators were unable to move it back to the position it was in when hit. ${ }^{12333}$ Nevertheless, by interviewing the driver of the tram and determining the angle and direction of fire, the investigators concluded that the fire had come from the "fourth skyscraper in Grbavica" on the Lenjinova street, that is, from the westernmost building. ${ }^{12334}$ The report also notes that the tram was found some 100 metres away from where it was shot. ${ }^{12335}$ It also reports that five people were injured in this incident, ${ }^{12336}$ and that a "deformed $7.62 \mathrm{~mm}$ calibre bullet jacket" was found, as well as other bullet fragments, which were then sent for analysis. ${ }^{12337}$

3754. As stated above, Sabljica also participated in the investigation of this incident. ${ }^{12338}$ In his earlier testimony in the Perišić case he testified, like Kučanin, that the team was able to determine the origin of fire as being one of the four skyscrapers in Grbavica. ${ }^{12339}$ However, the ballistics report signed by him on behalf of Međedović, provides that the exact origin of fire could not be determined as the tram could not be moved back to the exact location where it was hit; it also notes that the bullets came from the left hand side of the tram, from the front backwards, from the left to the right, and from above downwards. ${ }^{12340}$ When asked in the present case to explain the discrepancy between Kučanin's report and his own ballistics report, Sabljica stated that he stood by the latter and that the most that could be established, given that the tram could not be returned to the location where it was when hit, is that the bullets came from the south, from the direction of

12331 Mirsad Kučanin, P16 (Transcript from Prosecutor v. Galić), T. 4712-4714; P23 (Witness statement of Mirsad Kučanin dated 12 November 1995), e-court p. 2; P21 (Witness statement of Mirsad Kučanin dated 21 February 1996), e-court pp. 2, 4-6.

12332 P21 (Witness statement of Mirsad Kučanin dated 21 February 1996), e-court pp. 2, 4-5. Mirza Sabljica testified, however, that only two bullets were found inside the tram and had entry and exit holes. See P1695 (Witness statement of Mirza Sabljica dated 11 February 2010), p. 73.

12333 P21 (Witness statement of Mirsad Kučanin dated 21 February 1996), e-court p. 2.

12334 P21 (Witness statement of Mirsad Kučanin dated 21 February 1996), e-court pp. 2, 5. See also Barry Hogan, T. 11219-11220 (3 February 2011); P2209 (Photograph of Sarajevo marked by Barry Hogan).

12335 P21 (Witness statement of Mirsad Kučanin dated 21 February 1996), e-court p. 4.

12336 In addition to Alma Mulaosmanović-Čehajić, the other victims listed are Rabija Jerlagić, Alija Holjan, Senad Kešmer, and Sead Bečić. See P21 (Witness statement of Mirsad Kučanin dated 21 February 1996), e-court p. 6. This is confirmed by their medical records, namely, P1546 (Medical record for Rabija Jerlagić); P1549 (Medical report for Senad Kešmer); P1248 (Medical report for Sead Bečić).

12337 P21 (Witness statement of Mirsad Kučanin dated 21 February 1996), e-court pp. 4-6.

12338 P1695 (Witness statement of Mirza Sabljica dated 11 February 2010), pp. 72-74.

12339 P1695 (Witness statement of Mirza Sabljica dated 11 February 2010), p. 73; P1719 (Aerial photograph of Sarajevo marked by Mirza Sabljica).

12340 The report also states that the bullets came in at the angles of 16, six, and seven degrees in relation to the ground. P1729 (BiH MUP Reports re sniping incident of 27 February 1995 on Zmaja od Bosne street), e-court p. 23. According to Sabljica, sometimes reports prepared following an incident would not be consistent with the ballistics report, mostly because the investigators would not wait for the final ballistics report and would instead draw conclusions on the basis of their own findings and observations. Sabljica denied, however, that he and his team were under pressure of any kind to identify particular buildings as the origin of fire. See Mirza Sabljica, T. 7693 (11 October 2010), T. 7735 (12 October 2010). 
Grbavica. ${ }^{12341}$ He could not explain how Kučanin reached the conclusion about the fourth skyscraper. ${ }^{12342}$ He also testified that it would be impossible for bullets fired from Vrbanja Bridge to reach the location of the tram incident at the moment at which it was shot due to a number of obstacles and the lack of visibility. ${ }^{12343}$

3755. Hogan visited Zmaja od Bosne with one of the victims of this incident ${ }^{12344}$ who, while standing at the intersection between Franje Račkog and Zmaja od Bosne streets, indicated that the location of the incident was between the School of Technology and the Holiday Inn, which is further east from the incident site as recounted by the witnesses above. ${ }^{12345}$

3756. Van der Weijden then visited the incident site, using the co-ordinates given to him by the Prosecution, as well as Grbavica. ${ }^{12346}$ In his report, he placed the location of this incident at the intersection of Franje Račkog and Zmaja od Bosne streets, that is the stretch of Zmaja od Bosne between the Museum and the Faculty of Philosophy, instead of further to the west, near the Maršal Tito Barracks, as recounted by the witnesses on the tram. ${ }^{12347}$ During cross-examination, however, Van der Weijden recognised this discrepancy and marked the location of the incident so that it coincided with the witnesses' accounts, conceding that for the purposes of his investigation it would have been important for him to know the exact location of the tram when it was hit. ${ }^{12348}$

3757. Noting that there were multiple victims in this incident and having regard to their injuries, Van der Weijden concluded that most likely automatic fire was used to shoot at the tram, and that

\footnotetext{
12341 Mirza Sabljica, T. 7689-7693 (11 October 2010).

12342 Mirza Sabljica, T. 7694 (11 October 2010). The Chamber notes that Kučanin's report is dated 28 February 1995 while the other reports in the dossier related to this incident were prepared on the day of the incident, namely 27 February. Thus, it appears that Kučanin had at his disposal all of the information prepared by the investigation team, including witness statements and Sabljica's ballistics report. See P1729 (BiH MUP Reports re sniping incident of 27 February 1995 on Zmaja od Bosne street).

12343 P1695 (Witness statement of Mirza Sabljica dated 11 February 2010), p. 74.

12344 The Chamber notes that the identity of the victim in question is not clear from the evidence. In the video footage recorded by Hogan he is referred to only as "Witness 61".

12345 In addition, while standing at the intersection between Franje Račkog and Zmaja od Bosne streets, and before the victim indicated the location of the incident, Hogan recorded the co-ordinates of what he referred to as "this location" implying that the co-ordinates taken were those of the location at which he and the victim were standing. Barry Hogan, T. 11204-11206, 11217-11218, 11255-11256 (3 February 2011); P2190 (GPS locations for shelling and sniping incidents in Sarajevo); P2191 (Map of Sarajevo with scheduled sniping and shelling incidents); P2213 (Image re scheduled sniping and shelling incidents in Sarajevo); D1007 (Video footage re sniping incident of 27 February 1995 on Zmaja od Bosne street); D1008 (Video footage re sniping incident of 27 February 1995 on Zmaja od Bosne street).

12346 P1621 (Expert Report of Patrick van der Weijden entitled "Sniping Incidents in Sarajevo '92-'94”), p. 98.

12347 P1621 (Expert Report of Patrick van der Weijden entitled “Sniping Incidents in Sarajevo '92-'94”), p. 98. Because of this, Van der Weijden visited the Metalka building and noted that the rooms in the building offer direct and clear views of the stretch of Zmaja od Bosne, between the Museum and the Faculty of Philosophy. P1621 (Expert Report of Patrick van der Weijden entitled “Sniping Incidents in Sarajevo '92-'94”), p. 98.

12348 Patrick van der Weijden, T. $7032-7034$ (28 September 2010); D651 (Aerial photograph of Sarajevo marked by Patrick van der Weijden).
} 
the weapons used would have been either M84 or M53 machine-guns in $7.62 \mathrm{~mm}$ calibre, mounted on a bipod or a tripod. ${ }^{12349}$ He noted that machine-guns are more effective against moving targets, such as trams, that are only temporarily visible. ${ }^{12350}$

3758. Poparic analysed this incident and concluded that the bullets came from a small distance, from a nearby building, such as the Museum of Revolution, for example, and not from Grbavica. ${ }^{12351}$ He came to this conclusion on the basis of the photographs taken by the CSB Sarajevo investigation team, in particular the photographs showing the entry and exit point of one of the bullets that hit the tram. ${ }^{12352}$ According to him, the photographs indicate that what was marked by the investigation team as the exit point of the bullet ${ }^{12353}$ was not an exit point but a dot drawn by a felt-tip pen, ${ }^{12354}$ whereas in fact the real exit point could be seen below the drawn dot. ${ }^{12355}$ The real exit point, according to Poparić, was between 20 and 25 centimetres lower than the bullet's entry point meaning that the bullet entered at a high angle of descent, which would not have been possible from the white high-rises in Grbavica. ${ }^{12356}$

3759. Poparic also recalled that four out of the eight bullets seem to have remained in the panelling of the tram, which indicated to him that they had not come from the white high-rises but rather at a great angle. ${ }^{12357}$ Furthermore, the differences in heights between the bullet entry points

12349 P1621 (Expert Report of Patrick van der Weijden entitled “Sniping Incidents in Sarajevo '92-'94”), p. 97. See fn. 12122.

12350 P1621 (Expert Report of Patrick van der Weijden entitled "Sniping Incidents in Sarajevo '92-'94”), p. 97.

12351 D4884 (Mile Poparić's expert report entitled "Small Arms Fire on the Sarajevo Area 1992-1995", 15 August 2012), p. 155, 156. See also Mile Poparić, T. 39281-39282 (5 June 2013). When put to him that a gunman shooting from the top of the Museum of Revolution would have been visible from SRK positions in the white high-rises, Poparić stated that the gunman could have opened fire and then hid immediately. See Mile Poparić, T. 39281-39282 (5 June 2013); P1738 (Photographs of sniper nests), e-court p. 109.

12352 D4884 (Mile Poparić's expert report entitled "Small Arms Fire on the Sarajevo Area 1992-1995", 15 August 2012), pp. 153-155, Images 107, 108, and 109.

12353 The CSB Sarajevo report described that exit point as being "in the same place" as the entry point only on the inside of the tram, thus making the trajectory relatively horizontal. See P1729 (BiH MUP Reports re sniping incident of 27 February 1995 on Zmaja od Bosne street), e-court p. 10, Mark 3. See also Mile Poparić, T. 38998 (30 May 2013).

12354 Poparic explained that he came to that conclusion because the dot was of the same thickness and colour as the arrow drawn by the investigation team. He did not, however, want to speculate whether that meant that the team on the scene manipulated the evidence on purpose. Mile Poparić, T. 38998-38999 (30 May 2013), T. 3927939281 (5 June 2013).

12355 D4884 (Mile Poparić's expert report entitled "Small Arms Fire on the Sarajevo Area 1992-1995", 15 August 2012), p. 154, Image 108.

12356 Mile Poparić, T. 38998-39000 (30 May 2013); D3641 (Photograph of a tram marked by Mile Poparić); D4884 (Mile Poparić's expert report entitled "Small Arms Fire on the Sarajevo Area 1992-1995", 15 August 2012), p. 155. Poparić explained that had the bullets come from the white high-rises, they would have had a trajectory of 90 degrees in relation to the axis of the tram. See Mile Poparić, T. 38996 (30 May 2013), T. 39184 (4 June 2103).

12357 D4884 (Mile Poparić's expert report entitled "Small Arms Fire on the Sarajevo Area 1992-1995", 15 August 2012), p. 152; Mile Poparić, T. 38997 (30 May 2013), T. $39284-39285$ (5 June 2013). Poparić argued that the angle would be even higher if the trace marked with a number 9 on Image 108 in his report was from a bullet. However, the Chamber notes that, according to the CSB Sarajevo report, number 9 marks traces of blood of one 
on the panelling of the tram were "very small" according to Poparić, and would have been "far greater" if they had been fired from the white high-rises. ${ }^{12358}$ He further stated that these holes were a result of a burst of fire and not due to sniper fire. ${ }^{12359}$

3760. In addition to the evidence outlined above, the Chamber has also taken judicial notice of the following adjudicated facts which go to the origin of fire and which provide as follows: (i) the shots came from the high-rise buildings in Grbavica, to the south of the tram, from SRK-held territory; ${ }^{12360}$ (ii) the shots were fired by a member of the SRK; ${ }^{12361}$ and (iii) there was a clear view from the high-rise buildings on Lenjinova street in Grbavica onto the intersection at the Maršal Tito Barracks. ${ }^{12362}$

3761. As far as the exact location of the incident is concerned, the Chamber notes that the majority of the evidence before it places the tram somewhere near the Maršal Tito Barracks at the moment it was shot. ${ }^{12363}$ The Chamber has no reason to doubt that this is where the incident happened. While Hogan's evidence suggests otherwise, the Chamber recalls that it is based on a recollection of a victim some 11 years after the incident took place. In addition, the Chamber does not have any information as to who this victim was. As a result, and given the weight of the other evidence, the Chamber does not accept Hogan's evidence on this point as accurate.

3762. The Chamber further considers that this tram was a civilian vehicle, with mainly civilians travelling onboard who were not taking direct part in hostilities at the time of the incident. While one $\mathrm{ABiH}$ soldier was riding in the front section of the tram, this does not change the fact that on the day of the incident the tram was a civilian vehicle used to transport civilians and as such provided no military advantage to the $\mathrm{ABiH}$, all of which would have been obvious to the shooter. ${ }^{12364}$ In addition, the evidence indicates that the tram was fairly crowded at the time, which would have made it difficult- from the SRK positions in Grbavica-to gauge the status of just one of its many passengers. The Chamber is also satisfied, relying on the CSB Sarajevo reports and the medical records, that five people were wounded in this incident, including civilians Alma Mulaosmanović-Čehajić and Alija Holjan.

of the victims. Mile Poparić, T. 39285-39287 (5 June 2013); D3647 (Photograph showing part of a tram marked by Mile Poparić); P1729 (BiH MUP Reports re sniping incident of 27 February 1995 on Zmaja od Bosne street), e-court p. 11.

12358 Mile Poparić, T. 38997-38998 (30 May 2013).

12359 Mile Poparić, T. 39000 (30 May 2013).

12360 Adjudicated Fact 2984.

12361 Adjudicated Fact 2984.

12362 Adjudicated Fact 2985.

12363 See para. 3747, fn. 12297.

12364 P1621 (Expert Report of Patrick van der Weijden entitled “Sniping Incidents in Sarajevo '92-'94”), p. 99. 
3763. In terms of the origin of fire, the Chamber recalls that Poparic reached his conclusion that the bullet came from the Museum or any other nearby building, on the basis of a number of speculations, some of which were highly questionable. For example, using a photograph of one of the bullets' exit holes, he posited a theory that somebody drew that hole, thus implicating CSB Sarajevo members in a large-scale conspiracy. In doing so, he relied purely on the visual observation of the thickness and the colour of the dot in relation to the thickness and the colour of the arrow drawn next to it. The Chamber notes, however, that it is simply impossible to make such a definitive conclusion from the photograph in question, and there is nothing on the photograph that suggests that the CSB Sarajevo team drew an exit hole on the tram wall. Further, if Poparić's speculation were true, presumably the investigators would not have at the same time photographed the actual exit point of the bullet according to Poparić. Thus, the Chamber considers it more likely, that the mark on the inside of the tram located below the mark indicated by the arrow as the exit point could have been related to an earlier incident or even completely unrelated to sniping incidents in Sarajevo. The Chamber will therefore not accept Poparić's conclusions as to the origin of fire in this incident. ${ }^{12365}$

3764. While there is a question mark as to whether the fourth white high-rise was the origin of fire in this incident, the Chamber is convinced that the burst of fire that struck the tram came from the south, namely from Grbavica. ${ }^{12366}$ In this respect the Chamber notes that the majority of the evidence, including the witness testimony and the ballistics report, clearly indicates that Grbavica was the origin of fire, as do the adjudicated facts. While the Accused also attempted to suggest during cross-examination of KDZ289 and Mulaosmanović-Čehajić that the tram was struck by the bullets due to the exchange of fire on Vrbanja Bridge, the Chamber does not consider this to have been the case in light of Sabljica's evidence that the number of obstacles between the incident site and Vrbanja Bridge makes the Accused's position impossible to maintain.

3765. In terms of the origin of fire, the Chamber is convinced, relying on the evidence outlined above and the adjudicated facts, that the fire came from one of the four white high-rises. This is

12365 The Chamber notes that Poparić does not explain why the fact that four bullets lodged in the tram wall suggested a high angle of descent. The Chamber considers that it is also likely that some of the bullets became lodged in the tram's wall due to the strength of the wall and/or the distance between the shooter and the tram. Indeed, of the eight bullets that hit the tram, only four pierced the tram, three of which did so by passing through the windows. This means that only one of the five bullets that hit the tram wall managed to pierce that wall and reach the inside of the tram. In addition, as noted earlier in fn. 12340, Sabljica determined the angles of descent for three of the bullet marks and they were low rather than high, namely, 16, six, and seven degrees. However, Poparić does not appear to have considered any of this when he made his conclusion as to the high angle of descent. Accordingly, the Chamber finds his evidence entirely unreliable in relation to this incident.

12366 The Chamber is also satisfied, relying on Van der Weijden's evidence, that a machine gun, most likely an M84, was used in this incident and that it had the necessary range to accurately target the tram at that distance. The 
consistent both with the approximate location of the tram when shot, the trajectory of the bullets and their angle of descent as described in the CSB Sarajevo report, and the witnesses' testimonies. In addition, it is also consistent with the evidence the Chamber heard throughout this case about the prevalence of SRK sniping on Zmaja od Bosne and the presence of SRK snipers in the four white high-rises. ${ }^{12367}$ The Chamber is also satisfied that a machine gun, most likely an M84, was used in this incident and that it had the necessary range to accurately target the tram at that distance. Both the $1^{\text {st }}$ Sarajevo Mechanised Brigade and the $1^{\text {st }}$ Romanija Infantry Brigade had such a machine gun in its arsenal. ${ }^{12368}$ Finally, given the visibility between the white high-rises and the location of the incident, the Chamber is also satisfied that the tram was deliberately targeted by the shooter, who would have been fully aware that it was carrying a large number of civilians.

\section{(8) Zmaja od Bosne street, 3 March 1995 (Scheduled Incident F.16)}

3766. The Indictment alleges that on 3 March 1995 Azem Agović, a 46 year old man, and Alen Gičević, a 33 year old man, were shot and wounded while travelling in the eastbound tram on Zmaja od Bosne street. According to the Indictment, the tram was near the Holiday Inn when shot. $^{12369}$ In its Final Brief, the Prosecution argues that the bullets were fired from the SRKcontrolled area of Grbavica. ${ }^{12370}$ The Accused claims, however, that the fire came from locations in the ABiH-held territory. ${ }^{12371}$

3767. On 3 March 1995, Slavica Livnjak, a tram driver by profession, was driving her tram on the Zmaja od Bosne street, travelling eastbound in the direction of Baščaršija, with Miljacka River to the right of the tram. ${ }^{12372}$ There was another tram in front of her. ${ }^{12373}$ The day was bright and sunny. ${ }^{12374}$ It was the first day of the Bajram holiday. ${ }^{12375}$ Livnjak's tram was full, as it was a

Chamber is further convinced that both the $1^{\text {st }}$ Sarajevo Mechanised Brigade and the $1^{\text {st }}$ Romanija Infantry Brigade had such a machine gun in its arsenal. See fn. 11948.

12367 See paras. 3621, 3656, 3662. In addition, the Chamber also recalls that it rejected the Accused's arguments that $\mathrm{ABiH}$ forces were sniping at Bosnian Muslim civilians throughout Sarajevo. See Section IV.B.1.d: Bosnian Muslim side targeting own civilians.

12368 See fn. 11948.

12369 Indictment, Scheduled Incident F.16.

12370 Prosecution Final Brief, Appendix C, para. 22.

12371 Defence Final Brief, paras. 2292-2296.

12372 Slavica Livnjak, P493 (Transcript from Prosecutor v. D. Milošević), T. 855-856; Slavica Livnjak, P493 (Transcript from Prosecutor v. Perišić), T. 643-644; P495 (Witness statement of Slavica Livnjak dated 20 November 1995), p. 2; P495 (Witness statement of Slavica Livnjak dated 25 April 2006), para. 8; P1690 (Witness statement of Alen Gičević dated 16 February 2010), p. 4. See also Adjudicated Fact 2987.

12373 Slavica Livnjak, P493 (Transcript from Prosecutor v. D. Milošević), T. 855-856, 859-860; Slavica Livnjak, P493 (Transcript from Prosecutor v. Perišić), T. 644; P495 (Witness statement of Slavica Livnjak dated 20 November 1995), p. 2; P495 (Witness statement of Slavica Livnjak dated 25 April 2006), para. 8.

12374 P495 (Witness statement of Slavica Livnjak dated 25 April 2006), para. 8.

12375 P1690 (Witness statement of Alen Gičević dated 16 February 2010), p. 4. See also Adjudicated Fact 2986. 
period of cease-fire, ${ }^{12376}$ and there were approximately 100 passengers on board, all of whom, according to Livnjak, were civilians. ${ }^{12377}$ Alen Gičević and his girlfriend were passengers on this tram. ${ }^{12378}$ Also on the tram was Azem Agović. ${ }^{12379}$ Gičević, who was an ambulance driver for the ABiH until July $1994,{ }^{12380}$ was standing on the tram's right-hand side, near the third door, facing Vraca, Grbavica, and the Jewish cemetery. ${ }^{12381}$ He was wearing black trousers. ${ }^{12382}$ Around noon, as the first tram slowed down to take the S-curve in front of the Holiday Inn, its right-hand side came under sniper fire. ${ }^{12383}$ Immediately thereafter, the right hand-side of Livnjak's tram also came under sniper fire. ${ }^{12384}$ Gičević confirmed that, as the tram was passing the area of the Holiday Inn and the S-curve, he heard two to three shots and was wounded above his right knee. ${ }^{12385}$ There was panic on the tram, everybody fell on the floor, and, according to Livnjak, an older man was badly injured in his neck. ${ }^{12386}$ Livnjak wanted to get cover for the tram so she continued driving and brought it to a stop near the Executive Council building. ${ }^{12387}$

12376 In fact, according to Slavica Livnjak, the trams were not in operation from the start of the war to March 1994, when they began operating again, but only in a limited circle line around the centre of Sarajevo, Skenderija, and Baščaršija. Nevertheless, in March of 1995, they would pass the Holiday Inn every four minutes or so. See P493 (Transcript from Prosecutor v. Perišić), T. 641-643; P495 (Witness statement of Slavica Livnjak dated 25 April 2006), para. 9; Alen Gičević, T. 7650 (11 October 2010). The Accused confronted Alen Gičević with a combat report from the VRS Main Staff which stated that on 3 March 1995 the enemy opened fire in the area of Vrbanja bridge but that the VRS forces were unaffected. When asked if he could see this in the report, Gičević answered in the affirmative and made no other comment about it. See Alen Gičević, T. 7650-7653 (11 October 2010); D730 (VRS Main Staff combat report to RS President, 3 March 1995), p. 2.

12377 Slavica Livnjak, P493 (Transcript from Prosecutor v. D. Milošević), T. 859-860; P495 (Witness statement of Slavica Livnjak dated 20 November 1995), p. 2; P495 (Witness statement of Slavica Livnjak dated 25 April 2006), para. 8; P1690 (Witness statement of Alen Gičević dated 16 February 2010), p. 4. P1690 (Witness statement of Alen Gičević dated 16 February 2010), p. 4. See also Adjudicated Fact 2988.

See Adjudicated Fact 2988.

Alen Gičević, T. 7616-7617, 7621-7623 (11 October 2010). See also Adjudicated Fact 2989.

P1690 (Witness statement of Alen Gičević dated 16 February 2010), p. 4.

See Adjudicated Fact 2989.

Slavica Livnjak, P493 (Transcript from Prosecutor v. D. Milošević), T. 857-858; P438 (Aerial photograph of Sarajevo marked by Slavica Livnjak); P495 (Witness statement of Slavica Livnjak dated 20 November 1995), p. 2; P495 (Witness statement of Slavica Livnjak dated 25 April 2006), paras. 7-9.

12384 Slavica Livnjak, P493 (Transcript from Prosecutor v. D. Milošević), T. 857-862; Slavica Livnjak, P493 (Transcript from Prosecutor v. Perišić), T. 645; P495 (Witness statement of Slavica Livnjak dated 20 November 1995), p. 2; P495 (Witness statement of Slavica Livnjak dated 25 April 2006), paras. 7-9; P438 (Aerial photograph of Sarajevo marked by Slavica Livnjak); P439 (Aerial photograph of Sarajevo marked by Slavica Livnjak); P2413 (Witness statement of KDZ289 dated 16 November 1995), p. 2; P2413 (KDZ289's statement to BiH authorities, 6 March 1995), p. 1; KDZ289, P485 (Transcript from Prosecutor v. Perišić), T. 625-626. See also Adjudicated Fact 2990.

12385 Alen Gičević, T. 7610-7612 (11 October 2010), 7640-7641; P1690 (Witness statement of Alen Gičević dated 16 February 2010), pp. 4-7; P1691 (Photograph of Sarajevo marked by Alen Gičević); P1693 (Map of Sarajevo marked by Alen Gičević); P1694 (Photograph of Sarajevo marked by Alen Gičević); P1532 (Medical record for Alen Gičević); P1547 (Medical records for Azem Agović and Alen Gičević).

12386 P1690 (Witness statement of Alen Gičević dated 16 February 2010), p. 7; P495 (Witness statement of Slavica Livnjak dated 25 April 2006), para. 9; P1547 (Medical records for Azem Agović and Alen Gičević). See Adjudicated Fact 2992.

12387 P495 (Witness statement of Slavica Livnjak dated 25 April 2006), para. 9. 
3768. Gičević, helped by his girlfriend, went to the nearby State Hospital. ${ }^{12388} \mathrm{He}$ was operated on seven days after the incident and a fragment of the bullet was removed from his knee. ${ }^{12389} \mathrm{He}$ continues to feel pain when walking, and also has Hepatitis $\mathrm{C}$, which he believes he contracted through a blood transfusion he received after either this incident or after the sniping incident he was the victim of in $1995 .{ }^{12390}$ Furthermore, he is "struggling somehow with the psychological effects" stemming from the "1.000 days of such uncertainty". ${ }^{12391}$ Agović was brought by a car to Koševo Hospital where he stayed for a month, 16 days of which were in intensive care. ${ }^{12392}$ He required treatment for another three years and initially could not walk far, drive a car, or carry heavy things. 12393

3769. Gičević was cross-examined by the Accused on the exact location of the tram when it was struck by fire. Despite his first statement to the Prosecution, in which he appeared to be saying that the tram had already passed the Executive Council building when hit, ${ }^{12394}$ Gičević remained adamant that the tram was hit before it entered the S-curve (and thus before it passed the Executive Council building). ${ }^{12395}$ He explained that he must have made a mistake and that he had always maintained that, once hit, the tram passed the Executive Council building and stopped at Marin Dvor. ${ }^{12396}$ Gičević was also asked about another discrepancy in relation to his position in the tram. While in his original statement he had stated that he was standing on the left hand side of the tram when the tram was struck, ${ }^{12397}$ in his later statement and testimony in these proceedings, he maintained that he was standing on the right hand side of the tram. ${ }^{12398}$ On cross-examination, Gičević remained adamant that he was standing on the right-hand side of the tram when wounded and that, from that position, he could see the Jewish cemetery and Vraca. ${ }^{12399}$

\footnotetext{
12388 P1690 (Witness statement of Alen Gičević dated 16 February 2010), p. 7; Alen Gičević, T. 7641 , $7666-7667$ (11 October 2010); P495 (Witness statement of Slavica Livnjak dated 25 April 2006), para. 9. See also Adjudicated Fact 2993.

12389 P1690 (Witness statement of Alen Gičević dated 16 February 2010), p. 8. See also Adjudicated Facts 2992 , 2993.

12390 P1690 (Witness statement of Alen Gičević dated 16 February 2010), p. 10. See also Adjudicated Fact 2993.

12391 Alen Gičević, T. 7614 (11 October 2010).

12392 See Adjudicated Fact 2994.

12393 Adjudicated Fact 2994.

12394 D727 (Witness statement of Alen Gičević dated 15 November 1995), p. 2.

12395 Alen Gičević, T. 7630-7633, 7642-7648, 7667 (11 October 2010); D728 (Photograph of Sarajevo marked by Alen Gičević); D729 (Map of Sarajevo marked by Alen Gičević).

12396 Alen Gičević, T. 7630-7633, 7642-7648, 7663-7666 (11 October 2010); D726 (Photograph of Sarajevo marked by Alen Gičević); D728 (Photograph of Sarajevo marked by Alen Gičević); D729 (Map of Sarajevo marked by Alen Gičević); D736 (Photograph of Sarajevo marked by Alen Gičević).

12397 D727 (Witness statement of Alen Gičević dated 15 November 1995), p. 2.

12398 P1690 (Witness statement of Alen Gičević dated 16 February 2010), p. 4. See also Alen Gičević, T. 7666-7667 (11 October 2010).

12399 Alen Gičević, T. 7633-7634, 7636-7637 (11 October 2011).
} 
3770. Immediately following the incident, the trams travelling behind Livnjak's tram were signalled by the local police and UNPROFOR soldiers at the scene to continue and stop at a safer spot. ${ }^{12400}$ As one UNPROFOR soldier was taking a statement from Livnjak, ${ }^{12401}$ shots were fired at the incident site again and UNPROFOR returned fire. The exchange lasted for about 15 minutes, resulting in the wounding of an UNPROFOR soldier. ${ }^{12402}$

3771. Livnjak testified that the sniper fire came from her right-hand side, and more specifically from the Metalka building. ${ }^{12403}$ KDZ289 (who was present during this incident) and Livnjak both testified that the second round of fire also came from VRS-held positions in Grbavica. ${ }^{12404}$ Livnjak also confirmed that the confrontation line was some 50 to 100 metres away from the scene of the incident, across Miljacka River, and that there were no military facilities in the vicinity of the location at which her tram was attacked, nor was there any fighting at the time of the incident. ${ }^{12405}$ On cross-examination, she reiterated that there were no uniformed soldiers (other than UNPROFOR soldiers) or any tanks or mortar/artillery pieces where her tram was shot. ${ }^{12406}$ Also during cross-examination, she confirmed that her tram consisted of two cars, with two doors each, connected by an "accordion" and that, as it entered the S-curve, it adopted the shape of a crescent and the second car of the tram was then hit, between the accordion and the third door from the front. $^{12407}$

3772. Gičević testified that he was sure that shots came from the south, either from Grbavica or the Jewish cemetery. He also identified two buildings in that area, namely the Metalka building and the tall white high-rise from where he thought the shots could have come from. ${ }^{12408} \mathrm{He}$ believed that the bullets were fired from one of these two buildings because these buildings were

\footnotetext{
12400 P2413 (KDZ289's statement to BiH authorities, 6 March 1995), p. 1.

12401 P495 (Witness statement of Slavica Livnjak dated 25 April 2006), para. 10.

12402 P2413 (Witness statement of KDZ289 dated 16 November 1995), p. 2; P2413 (KDZ289's statement to BiH authorities, 6 March 1995); p. 1; P495 (Witness statement of Slavica Livnjak dated 20 November 1995), p. 2; P1727 (BiH MUP Reports re sniping incident of 3 March 1995 on Zmaja od Bosne street), e-court pp. 2, 4, 5.

12403 P495 (Witness statement of Slavica Livnjak dated 20 November 1995), p. 2; P495 (Witness statement of Slavica Livnjak dated 25 April 2006), para. 9. See also Barry Hogan, T. 11219-11220 (3 February 2011); P2208 (Photograph of Sarajevo marked by Barry Hogan); P2209 (Photograph of Sarajevo marked by Barry Hogan).

12404 P495 (Witness statement of Slavica Livnjak dated 20 November 1995), p. 2; P2413 (Witness statement of KDZ289 dated 16 November 1995), p. 2; P2413 (KDZ289's statement to BiH authorities, 6 March 1995), p. 1.

12405 Slavica Livnjak, P493 (Transcript from Prosecutor v. D. Milošević), T. 862-863; Slavica Livnjak, P493 (Transcript from Prosecutor v. Perišić), T. 649-650; P495 (Witness statement of Slavica Livnjak dated 20 November 1995), p. 2; P495 (Witness statement of Slavica Livnjak dated 25 April 2006), paras. 9, 12-13. See also Adjudicated Facts 2986, 2991.

12406 Slavica Livnjak, P493 (Transcript from Prosecutor v. D. Milošević), T. 874, 877-878. See also Adjudicated Fact 2991.

12407 Slavica Livnjak, P493 (Transcript from Prosecutor v. D. Milošević), T. 865-869.

12408 P1690 (Witness statement of Alen Gičević dated 16 February 2010), p. 5; P1693 (Map of Sarajevo marked by Alen Gičević); Alen Gičević, T. 7634-7638 (11 October 2010). See also Barry Hogan, T. 11219-11220 (3
} 
fired from before. ${ }^{12409} \mathrm{He}$ also stated that there were no military installations near the incident site except for the Maršal Tito Barracks, some 400 to 500 metres away, where UNPROFOR was based. $^{12410}$ Further to the west of the Maršal Tito Barracks was the building of the traffic police. ${ }^{12411}$ He conceded that the Executive Council building, the Museum complex, the Assembly building, and the Faculty of Philosophy were all in the area of responsibility of the $\mathrm{ABiH}$ but said they were "merely observation posts manned by few soldiers". ${ }^{12412}$

3773. The incident was investigated by a CSB Sarajevo team, including, inter alia, an investigating judge, two ballistics experts, Međedović ${ }^{12413}$ and Sabljica, ${ }^{12414}$ and an investigator, Mioković. ${ }^{12415}$ Mioković was the team leader for the on-site investigation, ${ }^{12416}$ and the site was also visited by the investigating judge. ${ }^{12417}$ According to the reports prepared by this team, the incident happened at the cross-roads of Franje Račkog and Zmaja od Bosne streets, and resulted in injuries to three persons, namely Alen Gičević, Azem Agović, and another man. ${ }^{12418}$ The investigation was conducted at the Marin Dvor stop, some 200 to 300 metres from the site of the incident. ${ }^{12419}$ The

February 2011); P2208 (Photograph of Sarajevo marked by Barry Hogan); P2209 (Photograph of Sarajevo marked by Barry Hogan).

12409 P1690 (Witness statement of Alen Gičević dated 16 February 2010), p. 6.

12410 P1690 (Witness statement of Alen Gičević dated 16 February 2010), p. 6; P1694 (Photograph of Sarajevo marked by Alen Gičević).

12411 P1690 (Witness statement of Alen Gičević dated 16 February 2010), p. 6; P1830 (Witness statement of Dragan Mioković dated 26 October 2010), pp. 30-31; P1831 (Photograph of Sarajevo marked by Dragan Mioković).

12412 Alen Gičević, T. 7628-7631, 7638-7639 (11 October 2010); D725 (Photograph of Sarajevo marked by Alen Gičević).

12413 P129 (Witness statement of Zlatko Međedović dated 20 November 1995), p. 3; P1727 (BiH MUP Reports re sniping incident of 3 March 1995 on Zmaja od Bosne street), e-court p. 5. For Zlatko Međedović's qualifications, see P129 (Witness statement of Zlatko Međedović dated 20 November 1995), pp. 2-3; P130 (Witness statement of Zlatko Međedović dated 5 September 2000), pp. 3-5.

12414 P1727 (BiH MUP Reports re sniping incident of 3 March 1995 on Zmaja od Bosne street), e-court p. 7.

12415 P1727 (BiH MUP Reports re sniping incident of 3 March 1995 on Zmaja od Bosne street), e-court pp. 5, 7. This team did not investigate the wounding of the French UNPROFOR soldier as that soldier's command wanted to conduct its own investigation. See Mirza Sabljica, T. 7683 (11 October 2011); P1727 (BiH MUP Reports re sniping incident of 3 March 1995 on Zmaja od Bosne street), e-court p. 5.

12416 Dragan Mioković, T. 8610-8612 (29 October 2010); P1830 (Witness statement of Dragan Mioković dated 26 October 2010), pp. 25, 29. For Dragan Mioković's qualifications, see Dragan Mioković, T. 8544-8545, 85488551 (28 October 2010); P1830 (Witness statement of Dragan Mioković dated 26 October 2010), pp. 2, 28-29.

12417 Dragan Mioković, T. 8612 (29 October 2010); P1727 (BiH MUP Reports re sniping incident of 3 March 1995 on Zmaja od Bosne street), e-court p. 4.

12418 P1727 (BiH MUP Reports re sniping incident of 3 March 1995 on Zmaja od Bosne street). See also P1830 (Witness statement of Dragan Mioković dated 26 October 2010), p. 32; P1832 (Photograph of Sarajevo marked by Dragan Mioković); Dragan Mioković, T. 8613-8615, 8624 (29 October 2010); D846 (Photograph of Sarajevo marked by Dragan Mioković).

12419 Dragan Mioković, T. 8613-8615, 8624, 8632-8633 (29 October 2010); D846 (Photograph of Sarajevo marked by Dragan Mioković); D847 (Photograph of Sarajevo marked by Dragan Mioković); D848 (Photograph of Sarajevo marked by Dragan Mioković). See also P1727 (BiH MUP Reports re sniping incident of 3 March 1995 on Zmaja od Bosne street), e-court p. 3. 
team found a hole with an entry and exit points in the right hand side of the tram's body. ${ }^{12420}$ Međedović concluded that this damage was caused by a bullet which was fired from the right side of the tram, "from back to front, from right to left, and from above downwards". ${ }^{12421}$ The trajectory of this bullet, in relation to the right side of the tram, was 80 degrees, while, in relation to the ground, it was 4 degrees. ${ }^{12422}$ Međedović testified that, since the tram was moving when fired upon, the team could not identify the precise location at which it was hit, and, as a result, could not determine the precise origin of fire. ${ }^{12423}$ However, it was able to determine that the fire came from the south, from "enemy positions in Grbavica". ${ }^{2424}$ Mioković, like Međedović, testified that the team was unable to pinpoint the exact location of the sniper in this incident, and he could not say from which side of Miljacka River the bullet came. ${ }^{12425}$ Mioković also conceded that the area in and around Franje Račkog street, south of Zmaja od Bosne and north of Miljacka River, was in the area of responsibility of the $\mathrm{ABiH},{ }^{12426}$ but testified that the team never investigated the possibility that the bullet may have come from one of the buildings in the $\mathrm{ABiH}$ controlled territory. ${ }^{12427}$ When asked if the fact that three people were injured by what appeared to be one bullet meant that a fragmentation bullet was used in this attack, Mioković responded that he could not say this with certainty on the basis of BiH MUP reports, as the three victims could have been injured by regular bullet ricocheting. ${ }^{12428}$

3774. When visiting Zmaja od Bosne street with one of the victims, Hogan recorded the coordinates of the location of the incident, placing it at the intersection between Zmaja od Bosne and Franje Račkog streets. ${ }^{12429}$ He also testified that both Metalka and the four white high-rises in Grbavica had a view of this site. ${ }^{12430}$ Van der Weijden also visited the incident site, the Jewish

\footnotetext{
12420 P157 (BiH MUP Report re sniping incident of 3 March 1995 on Zmaja od Bosne street); P1727 (BiH MUP Reports re sniping incident of 3 March 1995 on Zmaja od Bosne street), e-court p. 13. See also Dragan Mioković, T. 8634, 8638-8637 (29 October 2010).

12421 P157 (BiH MUP Report re sniping incident of 3 March 1995 on Zmaja od Bosne street).

12422 P157 (BiH MUP Report re sniping incident of 3 March 1995 on Zmaja od Bosne street).

12423 P129 (Witness statement of Zlatko Međedović dated 20 November 1995), p. 3.

12424 P1727 (BiH MUP Reports re sniping incident of 3 March 1995 on Zmaja od Bosne street), e-court p. 2. See also P1830 (Witness statement of Dragan Mioković dated 26 October 2010), p. 32; Dragan Mioković, T. 8625-8627 (29 October 2010); D846 (Photograph of Sarajevo marked by Dragan Mioković).

12425 P1830 (Witness statement of Dragan Mioković dated 26 October 2010), p. 28.

12426 Dragan Mioković, T. 8635-8636 (29 October 2010); P1830 (Witness statement of Dragan Mioković dated 26 October 2010), p. 27.

12427 Dragan Mioković, T. 8636 (29 October 2010).

12428 P1830 (Witness statement of Dragan Mioković dated 26 October 2010), p. 26.

12429 Barry Hogan, T. 11204-11206, 11217-11218 (3 February 2011); P2190 (GPS locations for shelling and sniping incidents in Sarajevo); P2191 (Map of Sarajevo with scheduled sniping and shelling incidents); P2213 (Image re scheduled sniping and shelling incidents in Sarajevo).

12430 Barry Hogan, T. 11218-11220 (3 February 2011); P2208 (Photograph of Sarajevo marked by Barry Hogan); P2209 (Photograph of Sarajevo marked by Barry Hogan).
} 
cemetery, and Grbavica. ${ }^{12431}$ Having done so he did not consider the Jewish cemetery to have been the source of fire in this incident because of the "lack of warning" for approaching trams coming from the west, which is the direction from which the two trams were travelling on 3 March 1995. ${ }^{12432}$ Van der Weijden visited the Metalka building noting that the rooms in the building offer direct and clear views of the stretch of Zmaja od Bosne, between the Museum and the Faculty of Philosophy. ${ }^{12433} \mathrm{He}$ also determined that the tram would be exposed to the shooter located in the Metalka building for at least eight seconds. ${ }^{12434}$ Noting that there were multiple victims in this incident and having seen the medical reports relating to their injuries, Van der Weijden concluded that most likely automatic fire was used to shoot at the tram, and that the weapons used would have been either an M84 or an M53 machine-gun in $7.62 \mathrm{~mm}$ calibre, mounted on a bipod or a tripod. ${ }^{12435}$ He noted that machine-guns are more effective against moving targets, such as trams, that are only temporarily visible. ${ }^{12436}$

3775. Poparic testified that the tram was not hit from the Metalka building but from locations in ABiH-held territory. ${ }^{12437}$ According to him, the wound sustained by Agović, while sitting in a specific seat in the tram, did not correspond with the incoming trajectories of a projectile fired from the Metalka building. ${ }^{12438}$ He based this finding on the specific seat which was photographed by the CSB Sarajevo investigation team and was at an angle of 45 degrees vis-à-vis the tram wall, as well as on the injuries Agović described in his evidence in another case before this, namely that the bullet entered above his left hip, passed through his body, and exited on his right side. ${ }^{12439}$ Poparić did concede, however, that he did not know the specific position Agović was seated in and simply assumed that Agović's sitting position was "normal", that is, that he was facing directly forward while in his seat. ${ }^{12440}$ Poparić also pointed out that the witnesses all gave contradictory statements

\footnotetext{
12431 P1621 (Expert Report of Patrick van der Weijden entitled “Sniping Incidents in Sarajevo '92-'94”), p. 101.

12432 P1621 (Expert Report of Patrick van der Weijden entitled “Sniping Incidents in Sarajevo '92-'94”), p. 101.

12433 P1621 (Expert Report of Patrick van der Weijden entitled “Sniping Incidents in Sarajevo '92-'94”), p. 101. Van der Weijden states in his report that the branches of trees "in the street" will have grown since the war and now obstruct some of the windows that at the time would have also offered an unobstructed view. See P1621 (Expert Report of Patrick van der Weijden entitled "Sniping Incidents in Sarajevo '92-'94”), p. 101.

12434 P1621 (Expert Report of Patrick van der Weijden entitled “Sniping Incidents in Sarajevo '92-'94”), p. 102.

12435 P1621 (Expert Report of Patrick van der Weijden entitled "Sniping Incidents in Sarajevo '92-'94”), p. 100. See fn. 12122.

12436 P1621 (Expert Report of Patrick van der Weijden entitled “Sniping Incidents in Sarajevo '92-'94”), p. 100.

12437 D4884 (Mile Poparić's expert report entitled "Small Arms Fire on the Sarajevo Area 1992-1995”, 15 August 2012), pp. 159-160.

12438 D4884 (Mile Poparić's expert report entitled "Small Arms Fire on the Sarajevo Area 1992-1995", 15 August 2012), p. 159.

12439 D4884 (Mile Poparić's expert report entitled "Small Arms Fire on the Sarajevo Area 1992-1995", 15 August 2012), p. 157, Image 110; Mile Poparić, T. 38930-38931 (29 May 2013). See also Mile Poparić, T. 3893338936 (29 May 2013); D3633 (Diagram re sniping incident of 3 March 1995 on Zmaja od Bosne marked by Mile Poparić).

12440 Mile Poparić, T. 39240-39241 (4 June 2013).
} 
as to the location of the tram when hit and stated that even if Gičević's first statement was correct and the tram was hit after it passed the Executive Council building, the fire would have still come from the $\mathrm{ABiH}$-held positions. ${ }^{12441}$

3776. In addition to the evidence outlined above, the Chamber has also taken judicial notice of the following adjudicated facts which go to the origin of fire: (i) more than one bullet hit the tram and injured Azem Agović and Alen Gičević; ${ }^{1242}$ (ii) the shots came from Grbavica, which was SRKheld territory; ${ }^{1243}$ (iii) the shots were fired by a member of the SRK; ${ }^{12444}$ and (iv) the visibility on the day of the incident was sufficient for a shooter to identify the victims as civilians. ${ }^{12445}$

3777. As far as the exact location of the incident is concerned, the Chamber notes that the evidence before it places the tram at the intersection of Franje Račkog and Zmaja od Bosne streets at the moment it was shot. ${ }^{12446}$ Contrary to Poparić's testimony that the witnesses were inconsistent as to the tram's location, Gičević and Livnjak were in fact consistent on that issue. While at first he seemed to indicate a different location, the Chamber is satisfied with Gičević's explanation as to why that happened and notes that he was adamant that the tram was hit when passing the Holiday Inn and entering the S-curve. The Chamber also notes that Livnjak's evidence was given from the vantage point of a tram driver with another tram targeted in front of her. She first saw the sniping of that tram, as it slowed down to enter the S-curve, and then anticipated that the same would happen to her as she entered the S-curve. The Chamber finds her evidence on the location particularly credible and corroborative of Gičević's evidence. Accordingly, the Chamber is not convinced by Poparić's evidence that all witnesses testified to a different location.

3778. The Chamber further considers that this tram was a civilian vehicle, with around 100 civilians travelling onboard and that both Gičević and Agović were civilians, not taking direct part in hostilities at the time of the incident.

3779. The Chamber does not accept Poparić's evidence that the fire in this incident came from the locations in the $\mathrm{ABiH}$ territory. Poparic based this conclusion on the location and nature of Agović's injuries in relation to the location of his seat in the tram and his seating position. He also conceded that he simply assumed Agović's seating position was “normal”. However, as noted

\footnotetext{
12441 Mile Poparić, T. 38928-38930, 38931-38933 (29 May 2013); D3631 (Satellite image of Sarajevo marked by Mile Poparić); D3632 (Satellite image of Sarajevo marked by Mile Poparić); D4884 (Mile Poparić's expert report entitled "Small Arms Fire on the Sarajevo Area 1992-1995", 15 August 2012), p. 156.

12442 Adjudicated Fact 2996.

12443 Adjudicated Fact 2995.

12444 Adjudicated Fact 2995.

12445 Adjudicated Fact 2997.

12446 See paras. 3768-3769.
} 
above, the Chamber heard that the tram was full, with approximately 100 passengers onboard. Thus, it is also possible that Agović was sitting in his chair squeezed into the wall of the tram and thus with his left hip parallel to the wall. However, Poparić does not seem to have even considered that possibility. Further, Poparić never spoke to Agović to determine his actual seating position and the exact nature of his injuries. Accordingly, the Chamber does not accept the conclusions Poparic drew about the origin of fire as they were, at best, highly speculative.

3780. The Chamber is satisfied that the fire originated from Grbavica and more specifically from the Metalka building, which was held by the SRK at the time. In this respect, the Chamber relies on the adjudicated facts as well as the ballistics report which found an angle of descent to have been four degrees, which is in turn consistent with fire coming from Metalka. ${ }^{12447}$ Furthermore, the witnesses were all consistent that the source of fire was Metalka. While Gičević thought that the fire could have also come from the Jewish cemetery, Van der Weijden excluded that possibility due to lack of visibility. The Chamber also recalls that following the shooting on the tram, some of the witnesses were able to observe the exchange of fire between UNPROFOR and the SRK in Grbavica thus confirming that the fire on the tram came from SRK-held positions in Grbavica. Given the visibility on the day and relatively small distances involved, the Chamber is also convinced that the SRK shooter deliberately targeted the tram in question while fully aware of its civilian status. The Chamber notes that all these findings are consistent with the evidence it heard about the preponderance of SRK sniper fire in the area of Zmaja od Bosne. ${ }^{12448}$

\section{(B) Southwestern suburbs: Dobrinja, Nedžarići, Alipašino Polje}

3781. Dobrinja is a suburb of Sarajevo that lies to the western end of Sarajevo, close to the Butmir airport, and was constructed for the Winter Olympics in $1984 .{ }^{12449}$ It is divided into several apartment blocks, namely Dobrinja 1, 2, 3, 4, 5, C4, and the Airport Settlement. ${ }^{12450}$ It is a predominantly residential area with a number of high-rises, most of which are six storeys high and some of which have seven or eight storeys. ${ }^{12451}$ The Lukavica Barracks are located to the east of Dobrinja, Butmir airport is to the south of Dobrinja, the suburb of Nedžarići is to the west and northwest of Dobrinja, and Mojmilo Hill and Alipašino Polje are located to the north of

\footnotetext{
12447 The Chamber recalls that Van der Weijden calculated that the angle of descent of a bullet fired from Metalka would have been around four or five degrees. See Patrick van der Weijden, T. 7015-7017 (27 September 2010), T. 7059 (28 September 2010).

12448 See paras. 3621, 3656, 3662. In addition, the Chamber also recalls that it rejected the Accused's arguments that $\mathrm{ABiH}$ forces were sniping at Bosnian Muslim civilians throughout Sarajevo. See Section IV.B.1.d: Bosnian Muslim side targeting own civilians.

12449 P1866 (Witness statement of Youssef Hajir dated 25 February 2010), para. 8. See Adjudicated Fact 89.

12450 P1866 (Witness statement of Youssef Hajir dated 25 February 2010), para. 8.

12451 P1866 (Witness statement of Youssef Hajir dated 25 February 2010), para. 8.
} 
Dobrinja. $^{12452}$ Like Dobrinja, Alipašino Polje is a residential neighbourhood. ${ }^{12453}$ Nedžarići consisted mostly of low buildings, one or two storeys high. ${ }^{12454}$

3782. Until mid-June 1992, the Serb Forces held the Butmir airport and Mojmilo Hill, and were also positioned in Nedžarići and the Lukavica Barracks, thus cutting off communications between Dobrinja and the Sarajevo centre. ${ }^{12455}$ In mid-June 1992, the ABiH took control of Mojmilo Hill thus establishing contact with the city, while the airport was handed over to UNPROFOR in late June 1992. ${ }^{12456}$ In addition, after July 1993, Dobrinja was connected to Butmir via a tunnel built by the $\mathrm{ABiH}$ under the airport runway; many people would pass through the tunnel, including $\mathrm{ABiH}$ units, even though the entrance and the exit were frequently shelled by the Bosnian Serbs. ${ }^{12457}$ The purpose of the tunnel was to make it easier to get in and out of Dobrinja and Sarajevo proper, for both soldiers and civilians, and to get humanitarian aid into the city. ${ }^{12458}$ People who were not using the tunnel would run across the airstrip to come to Butmir and would get targeted. ${ }^{12459}$

12452 P1739 (Map of Dobrinja); P2191 (Map of Sarajevo with scheduled sniping and shelling incidents); P1866 (Witness statement of Youssef Hajir dated 25 February 2010), para. 10; Youssef Hajir, T. 8787 (1 November 2010).

12453 See Adjudicated Fact 82.

12454 See Adjudicated Fact 84.

12455 P1866 (Witness statement of Youssef Hajir dated 25 February 2010), paras. 10-11; Sanija Dževlan, P2291 (Transcript from Prosecutor v. Galić), T. 3515; P926 (Witness statement of Aernout van Lynden dated 26 February 2010), para. 62; Aernout van Lynden, T. 2413-2414 (19 May 2010); P2019 (BBC news report Dobrinja, with transcript). See Adjudicated Fact 90.

12456 P1866 (Witness statement of Youssef Hajir dated 25 February 2010), paras. 10, 12, 30; Youssef Hajir, T. 88048805 (1 November 2010); D2774 (Witness statement of Milenko Inđić dated 19 January 2013), para. 5; Milenko Inđić, T 32418-32419 (22 January 2013); P926 (Witness statement of Aernout van Lynden dated 26 February 2010), para. 62; Aernout van Lynden, T. 2413-2414 (19 May 2010). See Adjudicated Facts 11, 2834. See also para. 339.

12457 P1866 (Witness statement of Youssef Hajir dated 25 February 2010), para. 36; D856 (Excerpts from Nedžad Ajnadžić's book entitled "Odbrana Sarajevo"), p. 2; Mirsad Kučanin, P17 (Transcript from Prosecutor v. S. Milošević), T. 28974; P27 (Witness statement of Mirsad Kučanin dated 4 September 2000), p. 4 (testifying that the tunnel opened shortly before October 1993); P2414 (Witness statement of KDZ182), pp. 84-86 (under seal); Dragomir Milošević, T. 32799-32800 (29 January 2013); Stanislav Galić, T. 37380 (18 April 2013), T. 37565 (23 April 2013); P1056 (UNPROFOR letter to Ratko Mladić, 31 May 1993); KDZ185, T. 4276-4277 (29 June 2010) (private session); P2407 (Witness statement of KDZ304), pp. 34-35. Asim Džambasović testified that $\mathrm{ABiH}$ units would pass through the tunnel after it was opened. See Asim Džambasović, T. 15261-15262 (23 June 2011). The total length of the tunnel was 672 metres whereas its height ranged between 150 and 170 centimetres. D856 (Excerpts from Nedžad Ajnadžić's book entitled “Odbrana Sarajevo”), p. 3.

12458 Youssef Hajir, T. 8838-8842 (2 November 2010); D856 (Excerpts from Nedžad Ajnadžić's book entitled "Odbrana Sarajevo"); Adrianus van Baal, T. 8516 (28 October 2010); Michael Rose, T. 7573 (8 October 2010); P1638 (Witness statement of Michael Rose dated 26 March 2009), para. 127; Herbert Okun, P776 (Transcript from Prosecutor v. Krajišnik), T. 4204; John Wilson, T. 4117-4118, 4119 (23 June 2010); David Harland, T. 2113 (7 May 2010); Dušan Zurovac, T. 30295 (14 November 2012); Colm Doyle, T. 2867 (27 May 2010).

12459 P1866 (Witness statement of Youssef Hajir dated 25 February 2010), para. 36; John Hamill, P1994 (Transcript from Prosecutor v. Galić), T. 6176-6177; P1258 (Witness statement of Hussein Ali Abdel-Razek dated 16 July 2002), e-court p. 19; Hussein Abdel-Razek, T. 5658-5660 (21 July 2010) (testifying that Galić told him that UN should stop the crossings otherwise the SRK would continue to fire); D523 (UNPROFOR daily report, 10 January 1993); P6060 (Record of interview with KDZ185), e-court p.17; P1054 (UNPROFOR protest letter to Stanislav Galić, 10 February 1993); D2870 (Official note of Ilidža SNB, 25 November 1992); D2871 (Official note of Ilidža SNB, 3 December 1992) (noting that both civilians and military personnel were crossing across the airport runaway). In order to prevent the killings at the airport, UNPROFOR managed to negotiate an 
3783. The conflict in Dobrinja began on the night between 2 and 3 May 1992 after which the shelling and sniping did not cease until the end of the war. ${ }^{12460}$ Dobrinja residents, some 25,000 to 30,000 of them during the conflict, ${ }^{12461}$ would spend nights in cellars of their apartments but would get out during the day, when it was peaceful, to get some food. ${ }^{12462}$ According to Youssef Hajir, a doctor who established and worked in Dobrinja Hospital during the conflict, ${ }^{12463}$ there were no organised military units in the area in May 1992, only about 100 "unorganised people who were armed". 12464

3784. Around the end of 1992, after the confrontation line became established, residents of the ABiH-controlled part of Dobrinja became aware of sniping incidents at certain intersections. ${ }^{12465}$ Sniping would come mainly from Mojmilo, Lukavica, and Dobrinja 4. ${ }^{12466}$ As a result, barricades, usually bags filled with sand, containers, metal sheeting, or blankets, were erected as protection against sniper fire at those locations. ${ }^{12467}$ Even with those barricades, however, walking around the neighbourhood and between the buildings was very dangerous. ${ }^{12468}$ In addition, the people who went down to the Dobrinja river to fetch water for cooking and washing would get fired at. ${ }^{12469}$

3785. There was no water in Dobrinja during the conflict, but there were five wells where people would line up to get water. ${ }^{12470}$ These water lines were shelled about 15 or 20 times. $^{12471}$ There

agreement with the Bosnian Serbs and Bosnian Croats to allow UNPROFOR to transport people out of Sarajevo through the airport. However, the agreement was never implemented as the Bosnian Muslim side opposed it, in particular whent it came to Bosnian Serbs living in Sarajevo. See P6060 (Record of interview with KDZ185), ecourt pp. 17-18; P5908 (Record of interview with KDZ185), para. 4; P1064 (SRK combat report, 10 February 1993), p. 2; KDZ185, T. 4231-4234 (28 June 2010) (private session). See also Hussein Abdel-Razek, T. $5662-$ 5665 (21 July 2010) (testifying that UN was not allowed to cater to requests for people to leave the city as that was considered a type of ethnic cleansing); Pyers Tucker, T. 23233 (18 January 2012).

12460 P1866 (Witness statement of Youssef Hajir dated 25 February 2010), paras. 12, 17; Youssef Hajir, T. 8805 (1 November 2010). For example, Slavica Livnjak who lived in Dobrinja testified that some time in July of 1992, her husband was wounded when a bullet hit a wall of their apartment and then hit her husband on his right cheek. See Slavica Livnjak, P493 (Transcript from Prosecutor v. D. Milošević), T. 872-873; P495 (Witness statement of Slavica Livnjak dated 25 April 2006), para. 5.

12461 Hajir testified that before the war Dobrinja had around 40,000 residents but this number reduced to between 25,000 and 30,000 people during the war. See P1866 (Witness statement of Youssef Hajir dated 25 February 2010), fn. 91; Youssef Hajir, T. 8836-8837 (2 November 2010).

P1866 (Witness statement of Youssef Hajir dated 25 February 2010), paras. 1-2, 25-33; Youssef Hajir, T. 8786-8787, 8808 (1 November 2010); P1870 (Excerpts from Youssef Hajir's book entitled "Dobrinja Hospital").

12464 P1866 (Witness statement of Youssef Hajir dated 25 February 2010), para. 14; Youssef Hajir, T. 8845-8846 (2 November 2010). See also John Wilson, T. 3993-3994 (21 June 2010); D330 (Ilidža Police Station note re Green Berets in Dobrinja, 23 May 1992). Sanija Dževlan, P2291 (Transcript from Prosecutor v. Galić), T. 3516-3517.

According to Hajir, a large number of snipers were located in Dobrinja 4 as they had a good view from there. P1866 (Witness statement of Youssef Hajir dated 25 February 2010), paras. 19-20.

12467 Sanija Dževlan, P2291 (Transcript from Prosecutor v. Galić), T. 3517, 3533.

12468 Sanija Dževlan, P2291 (Transcript from Prosecutor v. Galić), T. 3534. See Adjudicated Facts 114, 128.

12469 Sanija Dževlan, T. 11744-11745 (14 February 2011).

12470 P1866 (Witness statement of Youssef Hajir dated 25 February 2010), para. 48. 
were also fuel and food shortages, especially at the beginning of the conflict, but UNPROFOR eventually provided aid - the French Battalion at the airport and the UN at the PTT building regularly provided food, fuel, and medical supplies to the hospital, which allowed it to survive throughout the war. ${ }^{12472}$

3786. People killed in Dobrinja were buried close to where they were killed, often in parks and people's yards, as the one cemetery in the area was full and it was too dangerous to give them a proper burial. $^{12473}$

\section{(1) Confrontation lines and snipers in the area}

3787. Dobrinja was divided between $\mathrm{ABiH}$ and VRS units and the confrontation line ran along the road between the apartment blocks referred to as Dobrinja 3 and Dobrinja $4 .^{12474}$ Dobrinja 1, Dobrinja 4, and the Airport Settlement were under Serb control. ${ }^{12475}$ The SRK's Ilidža Brigade was positioned in the area and its zone of responsibility ran from Dobrinja, across the Airport Settlement, Nedžarići, along the Dobrinja river, Pijačna street, and the railroad to Miljacka River. $^{12476}$ The other side of Dobrinja, namely the area between Dobrinja and Lukavica, was first in the zone of responsibility of the $2^{\text {nd }}$ Sarajevo Light Infantry Brigade and then was transferred, after August 1993, to the responsibility of the $1^{\text {st }}$ Sarajevo Mechanised Brigade of the SRK. ${ }^{12477}$

3788. Alipašino Polje was on the $\mathrm{ABiH}$ side of the confrontation line which separated it from Nedžarići, ${ }^{12478}$ which was under Serb control. ${ }^{12479}$ The line at this point extended from west to east

\footnotetext{
12471 P1866 (Witness statement of Youssef Hajir dated 25 February 2010), para. 48.

12472 Hajir explained that the aid depended on the airport being open so during the periods when the Serbs closed the airport the situation was more difficult for the population in Dobrinja. See P1866 (Witness statement of Youssef Hajir dated 25 February 2010), para. 51.

12473 P1866 (Witness statement of Youssef Hajir dated 25 February 2010), para. 55; Youssef Hajir, T. $8796-8797$ (1 November 2010), T. 8854-8855 (2 November 2010); P803 (Sky Newsreport, with transcript).

12474 Slavica Livnjak, P493 (Transcript from Prosecutor v. D. Milošević), T. 873; Sanija Dževlan, P2291 (Transcript from Prosecutor v. Galić), 3515-3516, 3528-3529; P2294 (Map of Sarajevo marked by Sanija Dževlan); D1254 (Decision on the Formation of the Serbian Municipality of Ilidža, 8 May 1992).

12475 P1866 (Witness statement of Youssef Hajir dated 25 February 2010), para. 20; Youssef Hajir, T. 8806 (1 November 2010); D2633 (Witness statement of Milorad Šehovac dated 8 December 2012), paras. 11, 15; D2648 (Map of Sarajevo marked by Milorad Šehovac); D2649 (Map of Sarajevo marked by Milorad Šehovac); Neđeljko Prstojević, T. 13561-13562 (17 March 2011); Adjudicated Facts 91, 2832.

12476 D2562 (Witness statement of Vladimir Radojčić dated 8 December 2012), para. 14; D2589 (Map of Sarajevo marked by Vladimir Radojčić); Stanislav Galić, T. 37162-37168 (15 April 2013); D3381 (Map of Sarajevo marked by Stanislav Galić); D3382 (Map of Sarajevo).

12477 D2633 (Witness statement of Milorad Šehovac dated 8 December 2012), paras. 11-12; D2648 (Map of Sarajevo marked by Milorad Šehovac); D2789 (Map of Sarajevo marked by Dragomir Milošević); D2790 (Map of Sarajevo marked by Dragomir Milošević).

12478 See Adjudicated Fact 83; Richard Mole, T. 5842-5845 (17 August 2010); P1430 (Map of Sarajevo marked by Richard Mole); D537 (Map of Sarajevo marked by Richard Mole).

12479 D2479 (Witness statement of Mile Sladoje dated 25 November 2012), para. 7; D2480 (Map of Sarajevo marked by Mile Sladoje); Mile Sladoje, T. 30563-30564 (28 November 2012); P6009 (Map of Sarajevo marked by Mile Sladoje); D2553 (Witness statement of Svetozar Guzina dated 3 December 2012), paras. 34-35; D2555 (Map of
} 
and curved into ABiH controlled territory. ${ }^{12480}$ The result was that Nedžarići was bordered on three sides by territory controlled by the $\mathrm{ABiH}$; a west-running corridor connected this neighbourhood with the more expansive SRK-controlled territory to the west. ${ }^{12481}$ The portion of Nedžarići east of Ante Babića street and south of Đure Jakšića street (now renamed Adija Mulaobegovića), where there are higher buildings, was controlled by the $\mathrm{ABiH}$, together with Alipašino Polje. ${ }^{12482}$

3789. Mile Sladoje, who was with the $1^{\text {st }}$ Battalion of the Ilidža Brigade in Nedžarići throughout the war, ${ }^{12483}$ and Svetozar Guzina, who commanded that Battalion from 1993 onwards, ${ }^{12484}$ both testified that the $1^{\text {st }}$ Battalion's zone of responsibility included buildings such as the Faculty of Theology and the School for the Blind, as well as the Nedžarići Barracks and a check-point on Kasindolska street. ${ }^{12485}$ Guzina explained that both the School for the Blind and the Faculty of Theology were very important facilities in the area-the former was a dominant building and faced the Oslobođenje building and the student dormitories, while the latter was not very tall but dominated that part of the area and had a view of Mojmilo Hill and Dobrinja. ${ }^{12486}$ In the area of the School for the Blind, the ABiH and SRK forces were only a few metres apart. ${ }^{12487}$ On the other side of Dobrinja, towards Lukavica, was an Orthodox Church, which could be seen from the three bridges that linked Dobrinja 2 to Dobrinja $3 .^{12488}$ The church was in the zone of responsibility of the $1^{\text {st }}$ Sarajevo Mechanised Brigade of the SRK. ${ }^{12489}$

Sarajevo marked by Svetozar Guzina); D2556 (Map of Sarajevo marked by Svetozar Guzina). See Adjudicated Fact 2833.

12480 See Adjudicated Fact 83.

12481 See Adjudicated Facts 83, 84.

12482 See Adjudicated Fact 85.

12483 D2479 (Witness statement of Mile Sladoje dated 25 November 2012), paras. 2, 5; Mile Sladoje, T. 30562 (28 November 2012).

12484 Guzina was the Commander of the $5^{\text {th }}$ Battalion until 1993 when the Ilidža Brigade was re-organised thus turning the $5^{\text {th }}$ Battalion into the $1^{\text {st }}$ Battalion. See D2553 (Witness statement of Svetozar Guzina dated 3 December 2012), paras. 34-35.

12485 D2479 (Witness statement of Mile Sladoje dated 25 November 2012), para. 7; D2480 (Map of Sarajevo marked by Mile Sladoje); Mile Sladoje, T. 30563-30564 (28 November 2012); P6009 (Map of Sarajevo marked by Mile Sladoje); D2553 (Witness statement of Svetozar Guzina dated 3 December 2012), paras. 34-35; D2555 (Map of Sarajevo marked by Svetozar Guzina); D2556 (Map of Sarajevo marked by Svetozar Guzina). Nedžarići Barracks was located some 300 to 350 metres away from the School for the Blind and some 150 to 200 metres from the Faculty of Theology. See Mile Sladoje, T. 30563 (28 November 2012). Guzina testified that the area around Kasindolska street was surrounded by Muslims on all three sides which meant that the battalion suffered more casualties than any other battalion in the brigade. See D2553 (Witness statement of Svetozar Guzina dated 3 December 2012), para. 35.

12486 According to Guzina, the tallest building in Nedžarići, namely the Old People's Home, was occupied by an UNPROFOR observation post. It was located some 100 metres in front of the Faculty of Theology. See D2553 (Witness statement of Svetozar Guzina dated 3 December 2012), para. 36; D2557 (Map of Sarajevo marked by Svetozar Guzina), Svetozar Guzina, T. 31153-31155 (6 December 2012), T. 31173, 31190 (11 December 2012); P6037 (Map of Sarajevo marked by Svetozar Guzina).

12487 See Adjudicated Fact 86.

12488 See Adjudicated Fact 93.

12489 Blagoje Kovačević, T. 29041 (18 October 2012). 
3790. The $1^{\text {st }}$ Battalion numbered about $300 \mathrm{men}^{12490}$ and had infantry weapons, 82 and $120 \mathrm{~mm}$ mortars, a tank, and two APCs. ${ }^{12491}$ In terms of infantry weapons, the $1^{\text {st }}$ Battalion had M48 and M76 rifles with scopes. ${ }^{12492}$ Vladimir Radojčić, the Commander of the Ilidža Brigade from January $1993,{ }^{12493}$ testified that the whole Ilidža Brigade had about 30 snipers, half of whom used M76 rifles, while the other half used M48 rifles with improvised sights. ${ }^{12494}$ As for the mortars, those were located around the Faculty of Theology, while the tank was at the Nedžarići Barracks. ${ }^{12495}$ The Battalion also had machine guns, as well as a recoilless gun, which were positioned at the Faculty of Theology and were used to open fire on Dobrinja 2 and 3 and Alipašino Polje. ${ }^{12496}$ Radojčić testified that the Faculty was not used as a sniper nest but rather as an observation post. $^{12497}$

3791. While the Ilidža Brigade had snipers in the section of Dobrinja it held, according to Stanislav Galić, the Commander of the SRK between September 1992 and August 1994, ${ }^{12498}$ the $\mathrm{ABiH}$ controlled the high-rise in Mojmilo and thus had better control and over-view of the area. $^{12499}$ Galić also testified that $\mathrm{ABiH}$ was most active in the direction of Dobrinja and Nedžarići ${ }^{12500}$ and confirmed that parts of ABiH-held Dobrinja were under constant fire. ${ }^{12501}$

3792. The units opposing the $1^{\text {st }}$ Battalion belonged to the $101^{\text {st }}$ Brigade of the $1^{\text {st }}$ Corps of the $\mathrm{ABiH}$, positioned in Alipašino Polje and Vojničko Polje, and the $102^{\text {nd }}$ Brigade of the $1^{\text {st }}$ Corps of

12490 Sladoje testified that there was not a single professional officer in his battalion. See D2479 (Witness statement of Mile Sladoje dated 25 November 2012), paras. 6, 20.

12491 D2479 (Witness statement of Mile Sladoje dated 25 November 2012), para. 6; Vladimir Radojčíc, T. 31236 (11 December 2012).

12492 D2479 (Witness statement of Mile Sladoje dated 25 November 2012), para. 21; P6014 (Reply of Ilidža Brigade to SRK order, 31 October 1993). Guzina at first denied having sniper rifles or trained sniper shooters in the battalion, stating that there was no need for them given the proximity of warring parties on the confrontation line. He later explained that the $4^{\text {th }}$ Company of his battalion had three snipers with M76 rifles, which were positioned towards Butmir airport. See Svetozar Guzina, T. 31156-31158 (6 December 2012), T. 31161-31162, 31165-31166 (11 December 2012).

12493 D2562 (Witness statement of Vladimir Radojčić dated 8 December 2012), paras. 1-2.

12494 Radojčić confirmed that these snipers were deployed mostly in the area of responsibility of the $2^{\text {nd }}$ and $3^{\text {rd }}$ Battalions, that is, outside the built-up areas, because they were more efficient there. See Vladimir Radojčić, T. 31224 (11 December 2012).

12495 D2479 (Witness statement of Mile Sladoje dated 25 November 2012), para. 6; D2481 (Map of Sarajevo marked by Mile Sladoje).

12496 D2479 (Witness statement of Mile Sladoje dated 25 November 2012), para. 6; D2553 (Witness statement of Svetozar Guzina dated 3 December 2012), para. 36; D2557 (Map of Sarajevo marked by Svetozar Guzina); Svetozar Guzina, T. 31192 (11 December 2012); P1558 (Witness statement of Francis Roy Thomas dated 13 May 2009), para. 65.

12497 D2562 (Witness statement of Vladimir Radojčić dated 8 December 2012), para. 116.

12498 Stanislav Galić, T. 37154-37155 (15 April 2013), T. 37528 (22 April 2013). See Adjudicated Fact 27.

12499 Stanislav Galić, T. 37162-37168 (15 April 2013); T. 37466 (22 April 2013); D3381 (Map of Sarajevo marked by Stanislav Galić); Svetozar Guzina, T. 31193 (11 December 2012); Youssef Hajir, T. 8844 (2 November 2010).

12500 Stanislav Galić, T. 37189-37190 (15 April 2013).

12501 Stanislav Galić, T. 37522-37533 (22 April 2013), T. 37831-37834 (7 May 2013). 
the ABiH located in Stup. ${ }^{12502}$ The $155^{\text {th }}$ Brigade of the $1^{\text {st }}$ Corps, formerly known as the Dobrinja Brigade and then as the $5^{\text {th }}$ Brigade, was located in Mojmilo and Dobrinja 5 where there were mainly high-rises from which the $\mathrm{ABiH}$ snipers would target $1^{\text {st }}$ Battalion's positions. ${ }^{12503}$ Indeed, Hajir testified that the "local BiH command building" was located some 150 to 200 metres to the west from the Dobrinja Hospital but clarified that the $\mathrm{ABiH}$ was never in the hospital itself. ${ }^{12504} \mathrm{He}$ also explained that at the beginning of the war there was no real army on the Bosnian Muslim side and that the army "in the true sense of the word" was formed later, around August or September 1992. ${ }^{12505}$ Galić testified that a larger part of Dobrinja was in the zone of responsibility of the $5^{\text {th }}$ Brigade, later $155^{\text {th }}$, of the $\mathrm{ABiH} 1^{\text {st }}$ Corps, which had been estimated to have had some 3,000 troops in the area. ${ }^{12506}$ According to him this brigade had a sniper unit since $\mathrm{ABiH}$ used specialised sniper units at the brigade level. ${ }^{12507}$

3793. According to Sladoje, all $\mathrm{ABiH}$ positions were in civilian areas where people lived in apartment buildings and there was not a single "entirely civilian settlement" that did not have a military target in it. ${ }^{12508}$ Nevertheless, according to Sladoje and Guzina, the battalion never received or issued any orders to target civilians and the soldiers were explicitly told that civilians

12502 D2479 (Witness statement of Mile Sladoje dated 25 November 2012), para. 7; D2480 (Map of Sarajevo marked by Mile Sladoje); Mile Sladoje, T. 30569 (28 November 2012); P6011 (Photograph of Sarajevo marked by Mile Sladoje); P6012 (Photograph of Sarajevo). See alsoAdjudicated Fact 83. According to Sladoje, these ABiH forces had infantry weapons, 82 and $120 \mathrm{~mm}$ mortars, a tank in depth of the Alipašino Polje, APCs mounted with $14.7 \mathrm{~mm}$ anti-aircraft guns, hand-held launchers, and rifle grenades. They were also supported by artillery from Mt. Igman. D2479 (Witness statement of Mile Sladoje dated 25 November 2012), para. 10.

12503 Emir Turkušić, T. 9040-9041 (4 November 2010); D2479 (Witness statement of Mile Sladoje dated 25 November 2012), paras. 6, 9, 25; Mile Sladoje, T. 30566-30569 (28 November 2012); P6008 (Photograph of Sarajevo marked by Mile Sladoje); P6010 (Photograph of Sarajevo marked by Mile Sladoje); P6012 (Photograph of Sarajevo); D2553 (Witness statement of Svetozar Guzina dated 3 December 2012), para. 46. This is confirmed by D4586 (SRK Report, 10 May 1994) in which SRK Command informed the VRS Main Staff that the Ilidža Brigade was receiving fire from Dobrinja 5. Radojčić testified that the $155^{\text {th }}$ Brigade of the ABiH's $1^{\text {st }}$ Corps was deployed in high-rises in Dobrinja and Mojmilo. See D2562 (Witness statement of Vladimir Radojčić dated 8 December 2012), paras. 16-17; D2591 (Map of Sarajevo marked by Vladimir Radojčić). See also Youssef Hajir, T. 8850 (2 November 2010); D2649 (Map of Sarajevo marked by Milorad Šehovac); D633 (Order of ABiH 1st Corps, 25 October 1993), para. 5.4.

12504 P1866 (Witness statement of Youssef Hajir dated 25 February 2010), paras. 24, 33; Youssef Hajir, T. 8779, 8783-8786 (1 November 2010), T. 8847-8848, 8850 (2 November 2010); P1867 (Map of Sarajevo marked by Youssef Hajir).

12505 Youssef Hajir, T. 8814-8817 (1 November 2010); P1866 (Witness statement of Youssef Hajir dated 25 February 2010), para. 34.

12506 Stanislav Galić, T. 37496-37498 (22 April 2013); D3445 (SRK combat report, 7 June 1993), pp. 1-2.

12507 Stanislav Galić, T. 37497-37498 (22 April 2013). He relied on the SRK combat report of 7 June 1993, which refers to sniper fire being opened from Dobrinja 1, 2, and 3 on the positions of the $1^{\text {st }}$ Sarajevo Mechanised Brigade. See D3445 (SRK combat report, 7 June 1993), pp. 1-3.

12508 D2479 (Witness statement of Mile Sladoje dated 25 November 2012), para. 11; Mile Sladoje, T. 30570-30571 (28 November 2012). According to Sladoje and Guzina, the following were military targets located in the territory controlled by the ABiH: Standard, Zora, Bitumenka, Oslobođenje, student dormitories, the Geodesic Institute, the Vodovod building in Majdan street, Prvomajska street, Geteova street, Radio Television building, and Fatima Gunić School. See D2479 (Witness statement of Mile Sladoje dated 25 November 2012), paras. 18, 25; D2482 (Map of Sarajevo marked by Mile Sladoje); Mile Sladoje, T. 30571-30573 (28 November 2012); 
should not be targeted. ${ }^{12509}$ Instead, soldiers were allowed to open fire only in response to enemy fire and only at observed firing positions, which, Sladoje conceded, meant that given the environment there was a high risk of "civilian collateral casualties". ${ }^{12510}$ When cross-examined, Guzina conceded that he had said, back in 2003 during his interview with the Prosecution, that any man or woman close to the confrontation lines was considered a threat. ${ }^{12511} \mathrm{He}$ also conceded that the targeting by his troops improved as the war went on. ${ }^{12512}$

3794. The goal of the $1^{\text {st }}$ Battalion was to prevent the $\mathrm{ABiH}$ from reaching Ilidža and connecting with the $\mathrm{ABiH}$ forces outside of the Sarajevo ring. ${ }^{12513}$ Guzina testified that the lines of disengagement in the $1^{\text {st }}$ Battalion's zone of responsibility were often only street-width apart, which meant that observation was difficult. ${ }^{12514} \mathrm{He}$ also stated that his soldiers had the right to use a firearm independently, without command, if they or their location were under attack and there was no other way to repel the attack. ${ }^{12515}$

3795. The UNPROFOR was based in the PTT building in Alipašino Polje, while the Radio Television building was nearby. ${ }^{12516}$

D2553 (Witness statement of Svetozar Guzina dated 3 December 2012), para. 46. See also D2633 (Witness statement of Milorad Šehovac dated 8 December 2012), para. 23.

12509 D2479 (Witness statement of Mile Sladoje dated 25 November 2012), paras. 12-13, 15, 17; Mile Sladoje, T. 30571 (28 November 2012); D2562 (Witness statement of Vladimir Radojčić dated 8 December 2012), paras. 25, 28-30; D2553 (Witness statement of Svetozar Guzina dated 3 December 2012), para. 39; Svetozar Guzina, T. 31192 (11 December 2012). During cross-examination, Guzina was confronted with his 2003 interview with the Prosecution in which he said that the battalion was never told not to shoot at civilians. He could not recall saying this and accused the Prosecution of playing word games. See Svetozar Guzina, T. 31181-31183 (11 December 2012); P6039 (OTP information report, 5-6 October 2003). On re-examination, however, he confirmed that the Accused issued orders to protect civilians. See Svetozar Guzina, T. 31195-31197 (11 December 2012); D2561 (SRK Order, 15 May 1993); D314 (Radovan Karadžić's letter to SRK, undated). Radojčić, Guzina's commander, testified that Ilidža Brigade received brochures from superior commands which contained explanations of the provisions of international humanitarian law and stated that he personally issued orders to the Ilidža Brigade soldiers that civiliant were not to be attacked. See D2562 (Witness statement of Vladimir Radojčić dated 8 December 2012), paras. 15, 31-32.

12510 D2479 (Witness statement of Mile Sladoje dated 25 November 2012), paras. 12, 15, 17; Mile Sladoje, T. 3057130574 (28 November 2012); D2562 (Witness statement of Vladimir Radojčić dated 8 December 2012), para. 30. Guzina explained that sometimes civilians in his zone of responsibility would turn up on the frontlines in order to visit their houses and speculated that the same happened on the $\mathrm{ABiH}$ side of the confrontation line thus resulting in civilian casualties. See D2553 (Witness statement of Svetozar Guzina dated 3 December 2012), para. 39; Svetozar Guzina, T. 31151-31152 (6 December 2012).

12511 Svetozar Guzina, T. 31170-31172 (11 December 2012); P6039 (OTP information report, 5-6 October 2003).

12512 Svetozar Guzina, T. 31184-31185 (11 December 2012); P6039 (OTP information report, 5-6 October 2003).

12513 D2479 (Witness statement of Mile Sladoje dated 25 November 2012), para. 8.

12514 D2553 (Witness statement of Svetozar Guzina dated 3 December 2012), para. 37.

12515 D2553 (Witness statement of Svetozar Guzina dated 3 December 2012), para. 38.

12516 D2479 (Witness statement of Mile Sladoje dated 25 November 2012), para. 18; D2482 (Map of Sarajevo marked by Mile Sladoje). See also Adjudicated Fact 14. 
3796. The Indictment alleges that on 11 July 1993 Munira Zametica, a 48 year old woman, was shot dead while collecting water from the Dobrinja river in the area of Dobrinja. ${ }^{12517}$ According to the Prosecution, the fire originated from the SRK-held territory in the area of the Orthodox Church, the tower of which was a "notorious sniping location". ${ }^{2518}$ The Prosecution also argues that Zametica was deliberately targeted. ${ }^{12519}$ The Accused argues that Zametica could not have been deliberately targeted from the Orthodox Church as it was too far from the incident site. ${ }^{12520} \mathrm{He}$ also argues that the SRK forces in the area were at the time deployed for operation Lukavac 93, taking place on the other side of the Butmir airport. ${ }^{12521}$

3797. On 11 July 1993, Munira Zametica was filling her bucket with water from the Dobrinja river when she was shot. ${ }^{12522}$ It was too dangerous for Sadija Šahinović and for Vahida Zametica, the 16 year old daughter of the victim, to leave the protection of the bridge over the Dobrinja River in order to assist the victim $^{12523}$ as the perpetrator repeatedly shot toward Munira Zametica, preventing rescuers from approaching her. ${ }^{12524}$ Vahida Zametica heard the shooting continue and saw the bullets hitting the water near her mother. ${ }^{12525}$ Munira Zametica was lying face down in the river, blood coming out of her mouth. ${ }^{12526} \mathrm{ABiH}$ soldiers passing by the bridge saw what had happened, positioned themselves on the bridge behind sandbags and shot in the direction of the Orthodox Church. ${ }^{12527}$ The victim, Munira Zametica, was pulled out of the water and taken to hospital; she died later that afternoon. ${ }^{12528}$

3798. Hogan visited the site of the incident and recorded the exact position of the victim when shot, as recounted to him by an eyewitness to the incident. ${ }^{12529}$ Hogan testified that he was told by witnesses that, when shot, Munira Zametica was kneeling on the concrete embankment of the river,

\footnotetext{
12517 Indictment, Scheduled Incident F.3.

12518 Prosecution Final Brief, Appendix C, paras. 26-27.

12519 Prosecution Final Brief, Appendix C, para. 4.

12520 Defence Final Brief, paras. 2194-2198.

12521 Defence Final Brief, para. 2198.

12522 Adjudicated Fact 165.

12523 See Adjudicated Fact 165.

12524 See Adjudicated Fact 171.

12525 Adjudicated Fact 165.

12526 Adjudicated Fact 165.

12527 Adjudicated Fact 166.

12528 Adjudicated Fact 167.

12529 Barry Hogan, T. 11209, 11257 (3 February 2011); P2196 (Photograph re sniping incident of 11 July 1993 in Dobrinja marked by Barry Hogan); P2207 (Images re scheduled sniping incidents in Sarajevo); P2190 (GPS locations for shelling and sniping incidents in Sarajevo); P2191 (Map of Sarajevo with scheduled sniping and shelling incidents).
} 
facing the river and trying to reach towards it with a bucket. ${ }^{12530}$ She was located some five metres away downstream from the bridge. ${ }^{12531}$

3799. Van der Weijden also visited the incident site, and described it as a canal forming a "natural trench", thus preventing the victim from being seen from all the buildings lining the canal. ${ }^{12532} \mathrm{He}$ explained that he was given the exact location of the victim, who was standing on the river bed on the north bank of the canal, by the Prosecution, but had no information as to which direction she was facing. ${ }^{12533}$ According to Van der Weijden, the only buildings with a line of sight on the incident site are the apartment block, which is 636 metres away, and the Orthodox Church, which is 1104 metres away. ${ }^{12534}$ Van der Weijden was told by the Prosecution that the apartment block was occupied by the $\mathrm{ABiH}$ at the time of the incident while the SRK troops occupied the red roofed apartment buildings across the street, the latter offering no view on the incident site. ${ }^{12535}$ He thus concluded that the shooter was most likely located in the Orthodox Church tower since (i) $\mathrm{ABiH}$ troops were unlikely to have their focus on the canal with their enemy so near by in the red roofed apartment buildings; (ii) the tower of the church was under construction at the time, thus providing a good location for a sniper nest or even a machine gun emplacement; and (iii) the church offered a clear unobstructed view of the incident site. ${ }^{12536}$ Van der Weijden never visited the Orthodox Church tower, however. ${ }^{12537}$

3800. During cross-examination, Van der Weijden accepted that his conclusion gave only the "most likely" position of the shooter. ${ }^{12538}$ However, he rejected the Accused's contention that Zametica was killed as a result of the exchange of fire, ${ }^{12539}$ noting that the civilians collecting water

\footnotetext{
12530 Barry Hogan, T. 11258 (3 February 2011).

12531 Barry Hogan, T. 11258-11259 (3 February 2011); D993 (Video footage re sniping incident of 11 July 1993 in Dobrinja).

12532 P1621 (Expert Report of Patrick van der Weijden entitled “Sniping Incidents in Sarajevo '92-'94”), p. 42.

12533 Patrick van der Weijden, T. 7156-7157 (29 September 2010).

12534 P1621 (Expert Report of Patrick van der Weijden entitled "Sniping Incidents in Sarajevo '92-'94”), p. 42. See also Barry Hogan, T. 11209 (3 February 2011); P2196 (Photograph re sniping incident of 11 July 1993 in Dobrinja marked by Barry Hogan). Van der Weijden also observed that there was some scrub lining the canal in places when he visited but noted that it would have not been there at the time of the incident to block the view. See P1621 (Expert Report of Patrick van der Weijden entitled “Sniping Incidents in Sarajevo '92-'94”), p. 43. P1621 (Expert Report of Patrick van der Weijden entitled "Sniping Incidents in Sarajevo '92-'94”), p. 43. This is confirmed by the evidence before the Chamber, namely that the confrontation line at Dobrinja ran along the road separating Dobrinja 3 and Dobrinja 4. See para. 3787.

12536 P1621 (Expert Report of Patrick van der Weijden entitled “Sniping Incidents in Sarajevo '92-'94”), p. 43.

12537 P1621 (Expert Report of Patrick van der Weijden entitled “Sniping Incidents in Sarajevo '92-'94”), p. 43.

12538 Patrick van der Weijden, T. 7165 (29 September 2010).

12539 The Accused based this claim on the statement of Sadija Šahinović in which she said that on her way to the river she heard "sniper fire" and was told by the people hiding under the bridge that the bullets were hitting the water. She also stated that two people managed to get water without being hit before Munira Zametica was shot. See Patrick van der Weijden, T. 7162-7163 (29 September 2010).
} 
were located under ground level so the $\mathrm{ABiH}$ forces would have had to have been in the water for there to have been an exchange of fire and, if so, would have been exposed to the SRK fire. ${ }^{12540}$

3801. Van der Weijden further opined that the calibre of the bullet used in this incident was either $7.62 \mathrm{~mm}$ or $7.92 \mathrm{~mm}$ and would not have been greater than $7.92 \mathrm{~mm}$ as that would have caused far more serious damage. ${ }^{12541}$ Thus, the most likely weapon used was a semi-automatic rifle, probably an M76 or M91, although the distance of 1,100 metres would be an extreme range for those rifles. $^{12542}$ This is why, according to Van der Weijden, the people saw bullets hitting the river before the incident as the shooter probably tried to target them but failed because of the great distance involved; in other words, according to Van der Weijden, the shooter was simply bracketing the distance. ${ }^{12543}$ Van der Weijden concluded, based on all of the above, that the shooter would have been able to identify the victim as an adult woman fetching water from the canal. ${ }^{12544}$

3802. Poparic accepted that there was a line of sight between the top of the Orthodox Church and the incident site. ${ }^{12545}$ However, he testified that Zametica most likely died as a result of an exchange of fire between the two forces positioned in the area, although not from the Orthodox Church. ${ }^{12546}$ He based his conclusion on several grounds. First, even though the time of the incident was uncertain, ${ }^{12547}$ Poparić argued that regardless of whether the incident took place in the afternoon or in the evening, the shooter would not have been able to identify the victim as a civilian

12540 Patrick van der Weijden, T. $7162-7165$ (29 September 2010).

12541 P1621 (Expert Report of Patrick van der Weijden entitled “Sniping Incidents in Sarajevo '92-'94”), p. 41. On cross-examination, Van der Weijden conceded that his conclusion on the calibre of the bullet was only a possibility as he had no access to the victim's medical records or any data on whether the bullet was retrieved from the victim. See Patrick van der Weijden, T. 7156, 7159 (29 September 2010).

12542 P1621 (Expert Report of Patrick van der Weijden entitled “Sniping Incidents in Sarajevo '92-'94”), p. 41. According to Van der Weijden's report, the "maximum effective range" for these two rifles is 800 metres. See P1621 (Expert Report of Patrick van der Weijden entitled "Sniping Incidents in Sarajevo '92-'94”), Appendix A, p. 1.

12543 Patrick van der Weijden, T. 7163-7164 (29 September 2010).

12544 P1621 (Expert Report of Patrick van der Weijden entitled “Sniping Incidents in Sarajevo '92-'94”), p. 43.

12545 D4884 (Mile Poparić's expert report entitled "Small Arms Fire on the Sarajevo Area 1992-1995”, 15 August 2012), p. 66; Mile Poparić, T. 38947 (29 May 2013).

12546 D4884 (Mile Poparić's expert report entitled "Small Arms Fire on the Sarajevo Area 1992-1995", 15 August 2012), pp. 65, 67. Poparić also thought that the bullets that hit her most probably ricocheted off of the concrete river bed. See Mile Poparić, T. 38948-38949 (29 May 2013).

12547 With respect to the uncertainty of the time of the incident, Poparić refers to Šahinović's testimony in the Galić case where she first said that she and Zametica went to fetch water as the night was about to fall but then corrected herself when prompted by the Prosecution, saying that they went to the river between 2 and 3 p.m.. Poparić also refers to the official $\mathrm{BiH}$ MUP report, which has not been tendered into evidence by the parties in this case, and which records the time of the incident as being between 7 and 7:30 p.m.. Poparić further refers to Zametica's death certificate which records the time of death as 4 p.m. and the evidence of her daughter in the Galic cases who was at the scene and who testified that the incident took place between 2 and 2:30 p.m.. Having outlined all of the above evidence, Poparic concluded that the BiH MUP's official report was the most reliable source and thus is of the view that the incident happened between 7 and 7:30 p.m.. See D4884 (Mile Poparić's expert report entitled "Small Arms Fire on the Sarajevo Area 1992-1995”, 15 August 2012), pp. 6364, 67; Mile Poparić, T. 38947-38948 (29 May 2013), T. 39199-39201 (4 June 2013). 
nor hit her twice from a distance of 1,100 metres ${ }^{12548}$ because she would have been in the shadow in the afternoon or because, at twilight, the visibility would have been bad. ${ }^{12549}$ Second, Poparić points out that, according to eyewitness's evidence, there was sniper fire throughout that day but two people nevertheless summoned the courage and collected water, one by one, before Zametica went to collect the water herself; to Poparić this meant that people knew that the bullets hitting the river were not intended for them but were the result of exchanges of fire. ${ }^{12550}$ Third, Poparic argues that the two $\mathrm{ABiH}$ soldiers who returned fire were not simply passing by, as testified to by Šahinović in the Galić case, but were on duty, positioned on the bridge. ${ }^{12551}$ This, he argues, is confirmed by the fact that the bridge was protected by sandbags which were up to two metres high, according to the witnesses, leading him to conclude that there were holes in the sandbags through which soldiers could shoot; in other words, the sandbags were not there to protect the civilians but to protect the $\mathrm{ABiH}$ forces. ${ }^{12552}$ Finally, Poparic testified that he went to the Orthodox Church tower and that he would never place a sniper there as the space was too small to be secured by sandbags and was exposed so that it could easily be destroyed by a rocket-launcher. ${ }^{12553} \mathrm{He}$ did concede, however, that he did not know what the church tower looked like at the time of the incident. ${ }^{12554} \mathrm{He}$ was also not privy to the report from the $\mathrm{ABiH}$ intelligence organ, dated 2 October 1993, which provides as follows:

\footnotetext{
12548 According to Poparić, this distance alone meant that the probability of targeting Zametica was low as the sniper rifle's best results are at 800 metres whereas anything above that would yield poorer results. See Mile Poparić, T. 38951-38952 (29 May 2013); D3635 (Map of Sarajevo marked by Mile Poparić). This was confirmed by Van der Weijden. See fn. 12542.

12549 Poparic argues that if the incident happened in the afternoon, the place where Zametica was collecting water would have been under a shadow, created by the sandbags, which in turn would have "greatly interfered" with the shooter's ability to identify her as a civilian and strike her from that distance. Similarly, if the incident happened during twilight, conditions would have been such that the shooter would not be able to deliberately target a person who was bending over. See D4884 (Mile Poparić's expert report entitled "Small Arms Fire on the Sarajevo Area 1992-1995”, 15 August 2012), pp. 66-67; Mile Poparić, T. 38951-38952 (29 May 2013). When cross-examined on this conclusion, Poparić conceded that he did not take any photographs of this shadow when he visited the incident site but explained that that would have been pointless as the sandbags were not there. See Mile Poparić, T. 39210-39213 (4 June 2013).

12550 D4884 (Mile Poparić's expert report entitled "Small Arms Fire on the Sarajevo Area 1992-1995", 15 August 2012), pp. 64-65.

12551 Poparic reached this conclusion by arguing that the ABiH was organised "under the same principles as the JNA" and thus the transfer of duty would normally take place in the mornings, meaning that these two men could not have been reporting for or returning from duty. See D4884 (Mile Poparić's expert report entitled "Small Arms Fire on the Sarajevo Area 1992-1995", 15 August 2012), pp. 65, 67. When cross-examined on this conclusion, he conceded that he never participatyed in combat and never served in the $\mathrm{ABiH}$. When asked if ever identified the two $\mathrm{ABiH}$ soldiers in question or tried to interview them, he responded in the negative but explained that he thought they were probably on duty because they were armed. See Mile Poparić, T. 39206-39209 (4 June 2013).

12552 D4884 (Mile Poparić's expert report entitled "Small Arms Fire on the Sarajevo Area 1992-1995", 15 August 2012), pp. 65-67.

12553 Mile Poparić, T. 38953 (29 May 2013).

12554 Mile Poparić, T. 39201-39202 (4 June 2013).
} 
From Dobrinja IV towards the [Orthodox Church], the enemy has made a connection trench, and in the area behind the garage, a bunker was built from which they open fire only at night. The area around the church towards our positions is mined with antipersonnel mines. The enemy uses the church at Veljine exclusively as an observation post. According to our information till now in the church there are 6 observers per shift. The observers are armed with snipers and pam /anti-aircraft machine-gun/ which is in a well fortified nest in the church. From the church fire is rarely being opened, and when it is opened, a sniper with a silencer is used. ${ }^{12555}$

3803. When asked if this report contradicted his opinion that a sniper should not be placed in the church tower, Poparic insisted that the report classified the post as an observer's post from which fire was seldom opened. ${ }^{12556}$

3804. Dragomir Milošević testified that according to his information there was no "activity" from the Orthodox Church and denied that the origin of fire that killed Zametica was the Orthodox Church as soldiers were not allowed to climb the church tower. ${ }^{12557}$ He also excluded the possibility that Zametica was deliberately targeted and noted that if this were the case then it did not come about as a result of an order or permission from the SRK. ${ }^{12558}$ Galić testified that he never received reports about sniping incidents such as the one involving Zametica and noted that he did not remember his soldiers ever going to the Orthodox Church because it was a new building at the time and was damaged by recoilless gun-fire from Mojmilo Hill. ${ }^{12559}$ Galić also stated that he never ordered or received a report that one of his subordinates ordered this attack. ${ }^{12560}$ When asked why a combat report sent by the SRK Command to the VRS Main Staff, on 11 July 1993 at 5 p.m. provides that "provocative enemy fire" was opened "along most of the corps' defence line" but makes no mention of the incident involving Zametica, Galić explained that this was a time of the Lukavac 93 operation, which meant that all forces on both sides were engaged on the other side of the airport, near Dobrinja. ${ }^{12561}$

12555 P6360 (ABiH $1^{\text {st }}$ Motorised Battalion report, 2 October 1993), p. 2. The information in this report was confirmed by Thomas, who visited an $\mathrm{ABiH}$ sniping location in a school in Dobrinja, which was located opposite to the Orthodox Church from which, according to Thomas, the Serbs were firing into Dobrinja. See P1558 (Witness statement of Francis Roy Thomas dated 13 May 2009), paras. 1, 64. See Adjudicated Fact 92.

12556 Mile Poparić, T. 39201-39205 (4 June 2013). Poparić was also referred to his conclusion that Šahinović's claim in the Galić case that she did not hear the bullets meant either that her hearing was impaired or that a silencer was used. When asked if the $\mathrm{ABiH}$ report of 3 October 1993 confirmed his theory that a silencer was used and responded that this was a possibility. See Mile Poparić, T. 39205-39206 (4 June 2013).

12557 Dragomir Milošević, T. 33117-33118 (4 February 2013).

12558 Dragomir Milošević, T. 33118 (4 February 2013).

12559 Stanislav Galić, T. 37495-37496 (22 April 2013). Another report of the SRK Command indicates that the ABiH had a recoilless gun in Dobrinja 2. See T. 37408 (18 April 2013); D3424 (SRK combat report, 13 August 1993).

12560 Stanislav Galić, T. 37496 (22 April 2013).

12561 Stanislav Galić, T. 37498-37500 (22 April 2013); D3418 (SRK combat report, 11 July 1993). The next day, on 12 July 1993, Galić ordered the continuation of operation Lukavica 93 but never ordered any activity against Dobrinja. See T. 37391-37393 (18 April 2013); D3419 (SRK Order, 12 July 1993). 
3805. The Chamber also took judicial notice of a number of adjudicated facts which provide as follows: (i) there was a line of sight between the tower of the Orthodox Church and the incident site; ${ }^{12562}$ (ii) the area of the Orthodox Church from where the fire came was within SRK-controlled territory; ${ }^{12563}$ (iii) at a distance of 1,100 metres, a well-equipped perpetrator would have been able to observe the civilian appearance of Zametica; ${ }^{12564}$ and (iv) on 11 July 1993, Zametica, a civilian, was deliberately shot from SRK-held territory. ${ }^{12565}$

3806. The Chamber notes that, in addition to the unpersuasive evidence of Galić and Milošević, ${ }^{12566}$ the only substantive evidence the Accused brought to rebut the above adjudicated facts was that of Poparić. However, the Chamber finds his analysis unconvincing as it is based on numerous tenuous speculations, often on issues that are completely outside of his area of expertise. For example, the Chamber is not convinced by Poparić's claim that because people ventured to the riverbank after having seen bullets hitting the river, they knew this was not sniper fire but thought it was an exchange of fire. The Chamber considers this to be pure speculation as it is equally plausible that the people in question, including Zametica, saw sniper fire but decided to wait until they felt it was safe to approach the river. The Chamber also cannot accept Poparić's claim that the two $\mathrm{ABiH}$ soldiers who returned fire were on duty at the time of the incident as he bases it on the fact that they were armed and that in the JNA, on which $\mathrm{ABiH}$ was supposedly based, the soldiers would transfer duty in the mornings. Having not served in the ABiH or even the SRK, Poparić's musings on when $\mathrm{ABiH}$ soldiers would transfer their duty and/or carry their weapons is baseless and outside of his expertise. Indeed, his opinions on military strategy in general were proven wrong when he was shown a document clearly indicating — contrary to his opinion — that the SRK had a post in the Orthodox Church tower from which it opened sniper fire, albeit seldomly. The Chamber also does not accept Poparić's analysis that the incident must have happened in the evening as opposed to the afternoon, given that he relies on the BiH MUP official note which was, as shown during his cross-examination, corrected by Sadija Šahinović during her testimony in the Galić case. Furthemore, his claim that if the incident happened in the afternoon Zametica would have been hidden by a shadow of the sandbags is pure speculation as the sandbags were not there

\footnotetext{
12562 See Adjudicated Fact 168.

12563 See Adjudicated Fact 169.

12564 See Adjudicated Fact 170.

12565 See Adjudicated Fact 172.

12566 The Chamber acknowledges that both Galić and Milošević testified that the Orthodox Church could not have been the source of fire in this incident because it was not used by the SRK soldiers. However, the Chamber is more persuaded by the report of the $\mathrm{ABiH}$ intelligence organ, dated 2 October 1993, in which the church is mentioned as an observation post and an occasional source of sniper fire, particularly as this seems to be corroborated by the evidence of Thomas. See para. 3802 .
} 
when he visited the incident site. For all those reasons, the Chamber has decided to discount most of Poparić's analysis on this incident.

3807. The Chamber notes, however, that both Poparić and Van der Weijden agree that there was a line of sight between the Orthodox Church tower and the incident site, and is therefore satisfied that such line of sight did exist. ${ }^{12567}$ The Chamber also acknowledges that Poparić and Van der Weijden are united in their view that the distance of 1,100 metres was somewhat extreme for the sniper rifle most likely used in this attack. The Chamber recalls, however, that neither Poparić nor Van der Weijden testified that it would have been impossible to hit Zametica from that distance, only that the probability of hitting her deliberately was lower than it would have been if she were 800 metres away from the origin of fire. ${ }^{12568}$ Further, Van der Weijden thought that the shots fired by the sniper prior to the killing of Zametica were indicative of the sniper "bracketing" or judging the distance immediately prior to the incident, thus preparing to hit his target when it appeared.

3808. Bearing all of the above in mind, and particularly recalling Van der Weijden's evidence that only one other building had a line of sight onto the location of the incident, which he discounted as the origin of fire in this case, the Chamber is persuaded that the origin of fire was the Orthodox Church, which was in the SRK's zone of responsibility at the time. The Chamber is further reinforced in this view by the fact that the two $\mathrm{ABiH}$ soldiers who were at the scene promptly returned fire and were also seen to be shooting in the direction of the Orthodox Church.

3809. The Chamber also finds, based on the evidence above, that Munira Zametica was a civilian who was simply attempting to collect water from the river and thus was not taking direct part in the hostilities at the time of the incident. In addition, given Van der Weijden's evidence, which the Chamber accepts, that the shooter was bracketing the distance immediately prior to the incident, the Chamber is convinced that an SRK sniper located in the Orthodox Church deliberately targeted Zametica, fully aware that she was a civilian collecting water at the river.

\footnotetext{
12567 In addition, the Chamber has been to the incident site during the site visit and confirmed that the line of sight does exist. The Chamber recalls that in its Order on Submissions for a Site Visit, dated 15 November 2010, at paragraph 6, it stated that the purpose of its site visit to Sarajevo was not be to gather evidence or receive any submissions from the parties but to permit the Chamber to become more familiar with the topography of certain key locations and thus assist it in its determination of the charges in the Indictment related to Sarajevo.

12568 As noted above, Poparić's conclusion that it was impossible for Zametica to be deliberately targeted by a sniper located in the Orthodox Church tower was based on the combination of two factors, namely great distance and lack of visibility due to either a shadow or twilight conditions. See para. 3802. However, as noted by the Chamber above, in paragrah 3806, the Chamber considers that the incident happened in the afternoon and it also does not accept Poparić's analysis as to the shadow.
} 


\section{(3) Nikole Demonje street, 6 January 1994 (Scheduled Incident F.6)}

3810. The Indictment alleges that, on 6 January 1994, Sanija Dževlan, a 32 year old woman, was shot and wounded in her buttocks while riding a bicycle across a bridge on Nikole Demonje street in Dobrinja. ${ }^{12569}$ According to the Prosecution, Dževlan was hit while on the northwest side of the bridge by fire that originated from the SRK positions in the direction of the Orthodox Church some 800 metres away. ${ }^{12570}$ The Accused argues that Dževlan was not hit by fire that originated at the Orthodox Church as she would have been difficult to detect from that distance. ${ }^{12571}$

3811. On 6 January 1994, Sanija Dževlan was cycling home from the Dobrinja Hospital where she had gone to pick up medication for her mother. ${ }^{12572}$ When crossing the bridge over the Dobrinja river, connecting Dobrinja 2 with Dobrinja 3, on Nikole Demonje street, ${ }^{12573}$ she was shot at and wounded in the buttocks. ${ }^{12574}$ Dževlan felt a blow but only realised she had been wounded once she saw three or four more bullets ricocheting from the concrete on the street. ${ }^{12575}$ She did not know how many bullets had struck her, ${ }^{12576}$ but the medical report relating to her injuries noted "an entry-exit wound through both gluteal areas". ${ }^{12577}$ She managed to cycle home where she was helped by her neighbours and taken to the hospital, from which she was discharged ten days later. ${ }^{12578}$ The day after Dževlan was shot, another person was brought to the hospital, having been shot in the same location. ${ }^{12579}$

\footnotetext{
12569 Indictment, Scheduled Incident F.6.

12570 Prosecution Final Brief, Appendix C, paras. 26, 28-29.

12571 Defence Final Brief, paras. 2213-2219.

12572 Sanija Dževlan, P2291 (Transcript from Prosecutor v. Galić), T. 3517. See also Sanija Dževlan, T. 1174811749 (14 February 2011). See also Adjudicated Fact 189.

12573 While the witness did not know the name of the street on which the bridge was located, the maps provided to the Chamber indicate that Nikole Demonje is the name of the street. See Sanija Dževlan, P2291 (Transcript from Prosecutor v. Galić), T. 3535.

12574 Sanija Dževlan, P2291 (Transcript from Prosecutor v. Galić), T3517-3519; P2295 (Video footage re sniping incident of 6 January 1994 on Nikole Demonje street); Sanija Dževlan, T. 11751-11752, 11758-11760 (14 February 2011); D1048 (Aerial photograph of Dobrinja marked by Sanija Dževlan); D1049 (Photograph of Dobrinja marked by Sanija Dževlan); D1050 (Video footage re sniping of Nikole Demonje street of 6 January 1994). See also Adjudicated Fact 189.

12575 Sanija Dževlan, P2291 (Transcript from Prosecutor v. Galić), T. 3519. See also Sanija Dževlan, T. 11754 (14 February 2011).

12576 Sanija Dževlan, P2291 (Transcript from Prosecutor v. Galić), T. 3519.

12577 P1893 (Discharge form for Sanija Dževlan). During cross-examination Sanija Dževlan indicated that she thought that she was hit with two bullets, even though originally she said she did not know how many bullets had hit her. However, on the basis of the medical report the Chamber is of the view that there was only one entry-exit wound rather than two and that therefore only one bullet hit and injured Sanija Dževlan. See Sanija Dževlan, T. 11761-11763 (14 February 2011).

12578 Sanija Dževlan, P2291 (Transcript from Prosecutor v. Galić), T. 3519-3520. See also Sanija Dževlan, T. 11748 (14 February 2011). See also Adjudicated Fact 190.

12579 Sanija Dževlan, P2291 (Transcript from Prosecutor v. Galić), T. 3529.
} 
3812. Dževlan was the only person in the area at the time of the shooting and was wearing brown pants and a yellow jacket; she had very long hair which was not tied up, carried no weapon, and there was no military equipment nearby. ${ }^{12580}$ Dževlan testified that the day was "exceptionally quiet" as there was no sniping or shelling, ${ }^{12581}$ and that it was still daylight and the visibility was good. ${ }^{12582}$ During her testimony in the Galić case, Dževlan testified that the shooting happened sometime between 3 and 4 p.m.. ${ }^{12583}$ However, in her earlier statement to the BiH police, dated 30 September 1994, she stated that the incident occurred at 4:30 p.m.. ${ }^{12584}$ When asked about this discrepancy, she explained that she did not know the exact time of the incident as she was not wearing a watch when she was wounded. ${ }^{12585}$ However, she noted that it must have been daylight, as it would have been impossible to move at night time due to the lack of electricity in the neighbourhood, and also explained that she had left her house around 3 p.m. to go to the nearby hospital and pick up the medication. ${ }^{12586}$

3813. As for the direction from which the bullets came, Dževlan testified that they came from her right as she was cycling, that is, from the direction of Dobrinja 4, either from the high-rise buildings or the Orthodox Church in that area. ${ }^{12587}$ According to her, this area was under the control of the VRS, ${ }^{12588}$ while the ABiH controlled Dobrinja 3, as well as the summit and the left side of the Mojmilo Hill, which was in front of her as she was cycling home. ${ }^{12589}$ Dževlan

12580 Sanija Dževlan, P2291 (Transcript from Prosecutor v. Galić), T. 3518, 3530; Sanija Dževlan, T. 11747,11769 (14 February 2011).

12581 Sanija Dževlan, P2291 (Transcript from Prosecutor v. Galić), T. 3518-3519, 3536; Sanija Dževlan, T. 11764 (14 February 2011). See also Adjudicated Fact 194. When confronted with an UNMO report suggesting that throughout the week of 31 December 1993 to 6 January 1994, the ABiH fired some 10 to 50 rounds in the areas of Lukavica, Grbavica, and Vogošća, she remained adamant that she could not hear any sniping or shelling on the day in question and that if she had, she would not have left the house. See Sanija Dževlan, P2291 (Transcript from Prosecutor v. Galić), T. 3536-3545; P2293 (UNMO weekly report, 7 January 1994). See also Sanija Dževlan, T. 11764-11766 (14 February 2011).

12582 Sanija Dževlan, P2291 (Transcript from Prosecutor v. Galić), T. 3517-3518. See also Sanija Dževlan, T. 11743-11744, 11757 (14 February 2011).

12583 Sanija Dževlan, P2291 (Transcript from Prosecutor v. Galić), T. 3518.

12584 D670 (Statement of Sanija Dževlan to BiH MUP, 30 September 1994).

12586 Sanija Dževlan, T. 11743, 11745-11746, 11755, 11757 (14 February 2011).

12587 Sanija Dževlan, P2291 (Transcript from Prosecutor v. Galić), T. 3523-3529; P2292 (Photograph of Dobrinja marked by Sanija Dževlan); P2294 (Map of Sarajevo marked by Sanija Dževlan); P2295 (Video footage re sniping incident of 6 January 1994 on Nikole Demonje street). See also Sanija Dževlan, T. 11742 (14 February 2011). When asked on cross-examination why she identified Dobrinja 4 as the area from which the fire came, Dževlan explained that it was because Serb forces were there and there was, therefore, no other place the fire could have come from. See Sanija Dževlan, T. 11763-11764 (14 February 2011).

12588 Sanija Dževlan, P2291 (Transcript from Prosecutor v. Galić), T. 3527. This is confirmed by Adjudicated Fact 192.

12589 Sanija Dževlan, P2291 (Transcript from Prosecutor v. Galić), T. 3515-3516, 3546-3547. See also Sanija Dževlan, T. 11751-11752 (14 February 2011); D1048 (Aerial photograph of Sarajevo marked by Sanija Dževlan). 
explained that there were barricades on both sides of the bridge, and noted that she was shot as soon as she emerged from behind them, while getting off the bridge on its northern side. ${ }^{12590}$

3814. Hogan visited the site of the incident and recorded Dževlan's exact location when she was shot. ${ }^{12591}$ Van der Weijden visited the same location and noted, bearing in mind that the shots came from the victim's right, that is east-southeast, ${ }^{12592}$ that while the bridge was largely screened off from view to the east and southeast, there were "uncovered stretches at both sides of the bridge". ${ }^{12593}$ He thought that the shooter must have seen Dževlan when she was getting on the bridge on the south side, as there was also a non-screened part on that side, and then waited for her to get off the bridge on the north side. ${ }^{12594}$ The only buildings located east of the bridge that had a line of sight on the bridge were the apartment block, which is 355 metres away, and the Orthodox Church, which is 820 metres away. ${ }^{12595}$ Van der Weijden was told that the apartment block was occupied by the $\mathrm{ABiH}$ at the time of the incident while the SRK troops occupied the red roofed apartment buildings across the street, the latter offering no view of the incident site. ${ }^{12596}$ Van der Weijden concluded that the shooter was most likely located in the Orthodox Church tower since (i) $\mathrm{ABiH}$ troops were unlikely to have their focus on the bridge with their enemy so near by in the red roofed apartment buildings; (ii) the tower of the church was under construction at the time, thus providing a good location for a sniper nest or even a machine gun emplacement; and (iii) the church offered a clear unobstructed view of the incident site. ${ }^{12597}$ As noted earlier, ${ }^{12598}$ Van der Weijden

\footnotetext{
12590 Sanija Dževlan, P2291 (Transcript from Prosecutor v. Galić), T. 3525, 3527; P2292 (Photograph of Sarajevo marked by Sanija Dževlan); P2295 (Video footage re sniping incident of 6 January 1994 on Nikole Demonje street). See also Sanija Dževlan, T. 11742-11743, 11745, 11753, 11754-11755 (14 February 2011). Following the two incidents at this location, more barricades made of sandbags were placed on the bridge to make the location safer. See Sanija Dževlan, P2291 (Transcript from Prosecutor v. Galić), T. 3529.

12591 Barry Hogan, T. 11211-11212 (3 February 2011); P2200 (Photograph re sniping incident of 6 January 1994 on Nikole Demonje street marked by Barry Hogan); P2201 (Map of Sarajevo marked by Barry Hogan); P2207 (Images re scheduled sniping incidents in Sarajevo); P2190 (GPS locations for shelling and sniping incidents in Sarajevo); P2191 (Map of Sarajevo with scheduled sniping and shelling incidents).

12592 Patrick van der Weijden, T. 7133 (29 September 2010).

12593 P1621 (Expert Report of Patrick van der Weijden entitled “Sniping Incidents in Sarajevo '92-'94”), p. 48.

12594 P1621 (Expert Report of Patrick van der Weijden entitled "Sniping Incidents in Sarajevo '92-'94”), p. 49; Patrick van der Weijden, T. 7138 (29 September 2010).

12595 P1621 (Expert Report of Patrick van der Weijden entitled "Sniping Incidents in Sarajevo '92-'94”), p. 49. See also Patrick van der Weijden, T. 7133 (29 September 2010). This is confirmed by the evidence before the Chamber, namely that the confrontation line at Dobrinja ran along the road separating Dobrinja 3 and Dobrinja 4. See para. 3787. See also Barry Hogan, T. 11211-11212 (3 February 2011); P2200 (Photograph re sniping incident of 6 January 1994 on Nikole Demonje street marked by Barry Hogan); P2201 (Map of Sarajevo marked by Barry Hogan).

12596 P1621 (Expert Report of Patrick van der Weijden entitled “Sniping Incidents in Sarajevo '92-'94”), p. 49. See also Barry Hogan, T. 11211-11212 (3 February 2011); P2200 (Photograph re sniping incident of 6 January 1994 on Nikole Demonje street marked by Barry Hogan); P2201 (Map of Sarajevo marked by Barry Hogan).

12597 P1621 (Expert Report of Patrick van der Weijden entitled “Sniping Incidents in Sarajevo '92-'94”), p. 49.

12598 See para. 3799.
} 
never visited the Orthodox Church tower. ${ }^{12599}$ Noting all of the information above, he concluded that the shooter would be able to identify the victim as an adult woman on a bike. ${ }^{12600}$

3815. Van der Weijden also noted that the calibre of the bullet used in this incident would not have been greater than $7.92 \mathrm{~mm}$ as bullets of such calibre would have caused far more serious damage. ${ }^{12601}$ He recalled Dževlan's evidence that she heard multiple bullets and assumed that this was a reference to automatic fire, which led him to conclude that the weapon used was a medium machine-gun, either an M84 or an M53 which can fire with $7.62 \mathrm{~mm}$ or $7.92 \mathrm{~mm}$ bullets. ${ }^{12602} \mathrm{He}$ also explained that these machine-guns can be mounted on a tripod and fitted with a telescopic sight which makes them suitable for long-range engagements. ${ }^{12603}$ Van der Weijden conceded that his conclusions in relation to the calibre of the bullet used were speculative, but denied the Accused's suggestion that the VRS did not possess $7.92 \mathrm{~mm}$ calibre bullets, noting that he personally saw "Serbian troops" with machine guns in that calibre. ${ }^{12604}$ The Chamber recalls that Galić confirmed that SRK had various M48 rifles of 7.92 millimetre calibre, which had optical sights and which were referred to as sniping rifles. ${ }^{12605}$

3816. On cross-examination, Van der Weijden was asked why he excluded the possibility that the shooter was located between the apartment block and the victim, and responded that that area was an open field, which meant that the shooter would be exposed to fire from all sides, and thus would be risking his own life. ${ }^{12606}$ Van der Weijden also confirmed that the confrontation line was around 400 metres to the east from the location of the incident and that the view of the bridge from that confrontation line was obstructed by the apartment block mentioned above. ${ }^{12607}$ When asked if he would conclude that the victim simply cycled into the line of fire given that she was shot as soon as she left the confines of the metal screen on the bridge, Van der Weijden, conceding that this was a possibility, said that he would not necessarily conclude so since the victim was visible before she cycled onto the bridge and thus the shooter could have been waiting for her to come out on the other side. ${ }^{12608}$ The Accused cross-examined Van der Weijden on visibility in the Sarajevo valley

\footnotetext{
12599 P1621 (Expert Report of Patrick van der Weijden entitled “Sniping Incidents in Sarajevo '92-'94”), p. 49.

12600 P1621 (Expert Report of Patrick van der Weijden entitled “Sniping Incidents in Sarajevo '92-'94”), p. 49.

12601 P1621 (Expert Report of Patrick van der Weijden entitled “Sniping Incidents in Sarajevo '92-'94”), p. 47.

12602 P1621 (Expert Report of Patrick van der Weijden entitled “Sniping Incidents in Sarajevo '92-'94”), p. 47.

12603 P1621 (Expert Report of Patrick van der Weijden entitled “Sniping Incidents in Sarajevo '92-'94”), p. 47.

12604 Patrick van der Weijden, T. 7138-7139 (29 September 2010).

12605 Stanislav Galić, T. 37463-37464 (22 April 2013).

12606 Patrick van der Weijden, T. 7133-7134 (29 September 2010).

12607 Patrick van der Weijden, T. 7135-7136 (29 September 2010); D668 (Aerial photograph of Sarajevo marked by Patrick van der Weijden).

12608 Patrick van der Weijden, T. 7136-7138 (29 September 2010); D669 (Witness statement of Sanija Dževlan dated 24 September 2001).
} 
at 4:30 p.m. but the latter was only able to agree that the surroundings would impact on visilibity and that the time of day would be relevant to a shooter but that the shooter's efficacy would also depend on the equipment used. ${ }^{12609}$

3817. Poparić testified that in his view Dževlan was shot from a much shorter distance then the Orthodox Church and by a bullet that was directed at the asphalt but then richocheted, which to him implied that this was an accident and that the shooter was trying to scare her. ${ }^{12610}$ He based his conclusion on several grounds. First, in his view the incident took place around 4:30 p.m. as first stated by Dževlan in her statement to the BiH MUP, ${ }^{12611}$ which meant that visibility was low, such that a sniper located at a distance of over 800 metres away would not have been able to see her. ${ }^{12612}$ Second, even if visibility was good at the time of the incident, Poparić concluded that she could not have been shot from the church because the sniper would have had to start shooting some 0.99 seconds before Dževlan came into his view. ${ }^{12613}$ Third, Poparić noted that Dževlan testified that she was hit by two bullets which would not have been possible given the time needed for each of those bullets to reach the incident site and the time she would have been visible and exposed to the sniper. ${ }^{12614}$ Finally, Poparić observed that the incident site was not a location known for being exposed to sniping from VRS positions and that, therefore, this incident did not involve a sniper but an automatic weapon. ${ }^{12615}$

12609 Patrick van der Weijden, T. 7139-7142 (29 September 2010).

12610 D4884 (Mile Poparić's expert report entitled "Small Arms Fire on the Sarajevo Area 1992-1995", 15 August 2012), p. 95.

12611 Poparić bases this conclusion on the fact that Dževlan went to visit her mother in the Dobrinja Hospital after 3 p.m. and that, since the visiting hours officially finished at 4 p.m. (but would often be "prolonged by an extra 15 minutes or so"), it was more likely that she was cycling back home around 4:30 p.m.. See D4884 (Mile Poparić's expert report entitled "Small Arms Fire on the Sarajevo Area 1992-1995", 15 August 2012), pp. 8889. However, Dževlan never went to visit her mother in the hospital - instead she went to buy medication for her mother. See para. 3811. See also Mile Poparić, T. 39164-39168 (4 June 2013); T. 39259-39260 (5 June 2013).

12612 To establish poor visibility, Poparić compiled a number of photos of the area taken on 6 January 2012 around 4:30 p.m.. See D4884 (Mile Poparić's expert report entitled "Small Arms Fire on the Sarajevo Area 19921995”, 15 August 2012), pp. 88-91; Mile Poparić, T. 38963-38964 (29 May 2013).

12613 Poparić bases this analysis on (i) the distance between the church and the incident site (which he says is 855 metres according to Google Maps), (ii) Dževlan's position when shot (which he obtained from the video footage of Barry Hogan with Dževlan) and the estimated distance between her and the protective fence on the bridge, (iii) the estimated distance she must have covered to go from one exposed side of the bridge to another, (iv) the estimated time Dževlan would have taken to cycle through that distance (based on average cycling speed of a female cyclist aged 35), and (v) the estimated time a bullet fired by an M84 rifle and travelling at its highest velocity would take to reach the incident site. D4884 (Mile Poparić's expert report entitled "Small Arms Fire on the Sarajevo Area 1992-1995”, 15 August 2012), pp. 92-93; Mile Poparić, T. 38961-38963 (29 May 2013).

12614 D4884 (Mile Poparić's expert report entitled "Small Arms Fire on the Sarajevo Area 1992-1995", 15 August 2012), p. 93.

12615 D4884 (Mile Poparić's expert report entitled "Small Arms Fire on the Sarajevo Area 1992-1995", 15 August 2012), p. 93. 
3818. Galić, in addition to his testimony about the Orthodox Church referred to above, ${ }^{12616}$ testified that he did not receive a report about this incident or issued orders to fire on that area. ${ }^{12617}$ When shown a regular combat report sent by the SRK Command to the VRS Main Staff on 6 January 1994 at 5 p.m. which makes no mention of the incident, Galić stated, noting that this was the eve of the Orthodox Christmas, that the SRK respected all religious holidays and would refrain from activities on such days. ${ }^{12618}$ On cross-examination, when confronted with an UNMO summary of events for the week ending on 6 January 1994, showing that the VRS was shelling northern and western areas of the city, together with the centre, all week long, Galić explained that all of the shelling happened outside of Dobrinja and that he could not see any link to the incident in which Dževlan was wounded. ${ }^{12619}$ In any event, according to him, the SRK was engaged in defensive action at the time as it had been attacked by the ABiH on 5 January. ${ }^{12620}$

3819. The Chamber has also taken judicial notice of the following adjudicated facts: (i) Dževlan's clothing, the activity she was engaged in (riding a bicycle), and the fact that she was unarmed were indicia of her civilian status and would have put a perpetrator on notice of her civilian status; ${ }^{12621}$ (ii) the bullet, coming from Dževlan's right-hand side, came from the direction of the Orthodox Church located approximately 800 metres from the site of the incident, ${ }^{12622}$ and (iii) Dževlan was a civilian who was deliberately targeted from SRK-controlled territory. ${ }^{12623}$

3820. The Chamber notes that, in addition to the unpersuasive evidence by Galić and Milošević relating to the Orthodox Church, ${ }^{12624}$ the only substantive evidence the Accused brought to rebut the above adjudicated facts and the evidence tendered by the Prosecution was that of Poparić. However, the Chamber finds his analysis problematic. First, he mistakenly concluded that Dževlan was on the bridge at around 4:30 p.m. whereas Dževlan testified that she was on the bridge somewhere between 3 and 4 p.m. which was in line with her activities on that day. More importantly, she confirmed that it was still daylight at the time, with good visibility. Second,

\footnotetext{
12616 See para. 3804.

12617 Stanislav Galić, T. 37517-37518 (22 April 2013).

12618 Stanislav Galić, T. 37519-37522 (22 April 2013); D3452 (SRK combat report, 6 January 1994).

12619 Stanislav Galić, T. 37827-37831 (7 May 2013); P2293 (UNMO weekly report 31 December 1993 - 6 January 1994).

12620 Stanislav Galić, T. 38045 (9 May 2013); D3523 (SRK combat report, 5 January 1994), p. 1.

12621 See Adjudicated Fact 191.

12622 See Adjudicated Fact 195.

12623 See Adjudicated Facts 196, 197.

12624 As noted earlier (see fn. 12566), the Chamber acknowledges that both Galić and Milošević testified that the Orthodox Church was not used by the SRK soldiers for sniping. However, the Chamber is more persuaded by the report of the $\mathrm{ABiH}$ intelligence organ, dated 2 October 1993, in which the church is mentioned as an observation post and an occasional source of sniper fire, particularly as this seems to be confirmed by the evidence of Francis Roy Thomas.
} 
Poparić's calculations as to the time Dževlan would have taken to cross the bridge are based on the average cycling speed of a woman aged 35. However, there is nothing to suggest that this is the speed at which Dževlan cycled on that day and he never spoke to her to confirm that fact. Accordingly, Poparić's analysis that a sniper located on the Orthodox Church tower would not have been able to deliberately target Dževlan is misguided. For the same reason, his argument that it was even less likely for her to be hit by two bullets is equally flawed, particularly given that the gun most likely used in this incident was a semi-automatic gun. Accordingly, the Chamber does not accept Poparić's evidence in relation to this incident.

3821. Bearing in mind her clothing and the fact that she was cycling, the Chamber is satisfied that Dževlan was a civilian and was not taking direct part in hostilities at the time of the incident. The Chamber is also satisfied that there was a line of sight between her location on the bridge-when she cycled outside of the protective barrier-and the Orthodox Church. In addition, the distance between the two locations was such that a sniper positioned in the Orthodox Church would have been able to observe Dževlan's civilian status. The Chamber also accepts Dževlan's evidence that it was daylight at the time of the incident and that the visibility was good and finds that, contrary to Poparić's claim, she would have been an easy target for a sniper located in the Orthodox Church, particularly given the range of the gun most likely used in this incident. The Chamber recalls Dževlan's evidence that the day was quiet and that she did not hear fire prior to getting shot. Accordingly, the Chamber is not convinced by the Accused's claim that she cycled into the line of fire, nor is it convinced by Poparić's conclusion that the incident happened by accident while the shooter was trying to scare her, as there appears to be no basis for that conclusion other than that Dževlan heard a bullet ricochet. Bearing in mind Van der Weijden's analysis as to why the Orthodox Church tower was the most likely origin of fire, and coupling that with Dževlan's testimony as to the direction the fire came from, the Chamber is of the view that she was hit by a bullet that originated from the Orthodox Church. Further, given that the church was located in the SRK-held territory, the Chamber finds that Dževlan was shot by an SRK sniper. Finally, since that sniper needed to carefully plan his shot from the moment Dževlan cycled onto the bridge until the moment she left the safety of the protective barrier, the Chamber has no doubt that the SRK sniper deliberately targeted her, fully aware that she was a civilian.

\section{(Scheduled Incident F.7)}

(4) Nikole Demonje street and Bulevar AVNOJ, 25 May 1994

3822. The Indictment alleges that, on 25 May 1994, Sehadeta Plivac, a 53 year old woman, and Hajra Hafizović, a 62 year old woman, were both shot and wounded in their legs while travelling in a crowded bus near the junction of Nikole Demonje and Bulevar AVNOJ (currently Bulevar 
Branioca Dobrinje) in Dobrinja. ${ }^{12625}$ According to the Prosecution, the fire came from Nedžarići which was an SRK-held area and from which there was a direct sight to the incident location. ${ }^{12626}$ The Accused denies that the fire came from the VRS positions and argues that the bullet must have come from a "relatively short distance". ${ }^{12627}$

3823. In 1994, Ramiz Grabovica, an ABiH conscript in logistics, was employed by the public transport company to drive civilians on a regularly scheduled bus route between the Alipašino bridge and Dobrinja during cease-fires. ${ }^{12628}$ On 25 May 1994, a sunny day, at approximately 11:40 a.m., Grabovica reached his last stop at the intersection of Nikole Demonje street and Omladinskih Brigada street in the centre of Dobrinja, stopped the red and white bus, opened the three doors of the bus and turned off the engine to save fuel. ${ }^{12629}$ The bus was visibly a civilian vehicle, which only functioned during cease-fires along a regularly scheduled bus route. ${ }^{12630}$ As he waited for passengers to board, Grabovica heard a single shot coming from the direction of Neđarići, which was controlled by the SRK, precipitating panic on the bus. ${ }^{12631}$ Ramiz Grabovica saw that two middle-aged women had been injured. ${ }^{12632}$ The one sitting on the right side of the bus was holding her knee and the other sitting in the opposite side of the aisle was bleeding profusely. ${ }^{12633}$ The victims, Sehadeta Plivac and Hajra Hafizović, were taken off the bus and remained at the hospital where they received medical assistance. ${ }^{12634}$ Medical documentation in evidence records that Hafizović was wounded in "both lower legs (through-and-through wounds)", while Plivac was wounded by a sniper bullet in the "upper part of the right lower leg" and had to have surgery so that a "foreign object retained in popliteal area" could be removed. ${ }^{12635}$

3824. Hogan visited the site of the incident with Ramiz Grabovica and filmed the visit while Grabovica indicated the exact location of the bus when shot at, as well as the location of the two victims when wounded. ${ }^{12636}$ Grabovica can be seen in the video footage indicating that the front of

\footnotetext{
12625 Indictment, Scheduled Incident F.7.

12626 Prosecution Final Brief, Appendix C, para. 34.

12627 Defence Final Brief, paras. 2224-2225.

12628 Adjudicated Fact 198.

12629 Adjudicated Fact 199.

12630 Adjudicated Fact 203.

12631 Adjudicated Fact 200.

12632 Adjudicated Fact 201.

12633 Adjudicated Fact 201.

12634 Adjudicated Fact 202.

12635 P1892 (Medical records for Sehadeta Plivac and Hajra Hafizović).

12636 Barry Hogan, T. 11213-11214, 11274-11276 (3 February 2011); P2202 (Photograph re sniping incident of 25 May 1994 in Dobrinja marked by Barry Hogan); P2207 (Images re scheduled sniping incidents in Sarajevo); D1004 (Video footage re sniping incident of 25 May 1994 in Dobrinja); P2190 (GPS locations for shelling and sniping incidents in Sarajevo); P2191 (Map of Sarajevo with scheduled sniping and shelling incidents).
} 
the bus was facing southwest, that the shots hit the right hand-side of the bus and came from the northwest, that is, from the direction of Nedžarići. ${ }^{12637}$

3825. Van der Weijden also went to the site of the incident where he was told by the Prosecution that the bus was parked with its nose orientated south/southwest and its right side exposed down the Branioca Dobrinje street to the northwest. ${ }^{12638}$ According to his report, the bullet that wounded the victims penetrated the wall of the bus on its right hand side, struck the knee of one of the victims, and then hit the other victim on the other side of the bus. ${ }^{12639}$ Van der Weijden noted that there were no possible shooting positions for some 550 metres away from the incident in the direction of the northwest, including between the protective barricades that were located at the end of the Branioca Dobrinje street and the incident site, as the shooter would have had to lean outside one of the buildings lining the street in order to shoot. ${ }^{12640}$ Therefore, the shooter must have been beyond that distance and above ground level to be able to see the bus. ${ }^{12641}$ While his report notes that the alleged shooting position was the Faculty of Theology in Nedžarići, Van der Weijden testified that he never visited that location and was in fact unable to determine the precise location of the shooter because the area had been heavily rebuilt since the time of the incident. ${ }^{12642}$

3826. Since there was a lack of possible shooting positions closer than 550 metres away, the bullet that was used was most probably of a $7.62 \mathrm{~mm}$ or $7.92 \mathrm{~mm}$ calibre. Furthermore, given the distance and the fact that only one shot was heard, it is most likely that a sniper rifle, either an M76

\footnotetext{
12637 Barry Hogan, T. 11724-11726 (3 February 2011); D1004 (Video footage re sniping incident of 25 May 1994 in Dobrinja).

12638 Patrick van der Weijden, T. 7961-7062 (28 September 2010).

12639 P1621 (Expert Report of Patrick van der Weijden entitled “Sniping Incidents in Sarajevo '92-'94”), p. 52.
}

12640 In response to a question by the Chamber, Van der Weijden conceded that if located on the top of one of the high-rise buildings lining the Branioca Dobrinje street on the $\mathrm{ABiH}$ side of the confrontation line, the shooter could have had a view of the incident site. See Patrick van der Weijden, T. 7066-7069 (28 September 2010); P1621 (Expert Report of Patrick van der Weijden entitled “Sniping Incidents in Sarajevo '92-'94”), pp. 53-54. The Chamber notes that in its Final Brief the Prosecution argues that the building mentioned by the Chamber during this questioning did not exist at the time. See Prosecution Final Brief, Appendix C, para. 35. While that may be so, the Chamber also notes that Van der Weijden's answer to the question seemed to be broader, referring to "a high-rise" and that it therefore covered any of the high-rise buildings lining the street in existence at the time of the incident.

12641 Patrick van der Weijden, T. 7066-7069 (28 September 2010); P1621 (Expert Report of Patrick van der Weijden entitled "Sniping Incidents in Sarajevo '92-'94”), pp. 53-54. On cross-examination, Van der Weijden conceded that he did not know which part of the right hand side of the bus was penetrated by the bullet and did not have access to any forensic or criminal investigation reports in relation to the incident, but claimed that this information was not necessary as he never established the exact location of the origin of fire, only a general direction and the general area from which it came. He also denied that he was told to place the origin of fire on the Serb side of the confrontation line. Patrick van der Weijden, T. 7062, 7066-7068 (28 September 2010); P1621 (Expert Report of Patrick van der Weijden entitled “Sniping Incidents in Sarajevo '92-'94”), p. 53.

12642 P1621 (Expert Report of Patrick van der Weijden entitled “Sniping Incidents in Sarajevo '92-'94”), pp. 52, 54; Patrick van der Weijden, T. 7071-7073 (28 September 2010); D662 (Photograph of Faculty of Theology in Sarajevo). 
or an M91, was used. ${ }^{12643}$ According to Van der Weijden, it would have been impossible to identify the passengers inside the bus from that distance but given that the bus was coloured in red and was stationary it would have been easily identifiable as a civilian vehicle. ${ }^{12644}$ On crossexamination, Van der Weijden conceded that the only conclusion he was able to reach about this incident, based on the information provided to him by the Prosecution, was that the bullet could have come down the Branioca Dobrinje street and that it was "probably of a certain calibre". ${ }^{2645}$

3827. In his report Poparić focused on the Faculty of Theology arguing that the bullet could not have come from there, as alleged by Grabovica in the Galic case, because the faculty was 1,527 metres away (and thus too far for either a sniper rifle or machine-gun to reach) and there was also no line of sight between the two locations. ${ }^{12646}$ However, the Chamber notes that the evidence tendered by the Prosecution in relation to this incident does not suggest that the fire came from the Faculty of Theology. ${ }^{12647}$ Instead, as noted above, the Prosecution argues that the fire came from Nedžarići generally. ${ }^{12648}$ Accordingly, the Chamber will not focus solely on the Faculty of Theology as the origin of fire.

3828. Poparic then argued that the fire could not have come from the VRS side of the confrontation line in the area because, according to a map marked by Ismet Hadžić in the Galić case, the confrontation line was some 250 metres behind the protective screens and the VRS

12643 P1621 (Expert Report of Patrick van der Weijden entitled "Sniping Incidents in Sarajevo '92-'94”), p. 52. See also Patrick van der Weijden, T. 7065-7066 (28 September 2010). Van der Weijden reiterated that he saw weapons that use those bullets at Serb check-points in Sarajevo throughout the war. Patrick van der Weijden, T. 7070-7071 (28 September 2010). In addition, Guzina testified that his battalion, which was located in the Nedžarići area, had three M76 sniper rifles. See fn. 12492.

12644 P1621 (Expert Report of Patrick van der Weijden entitled “Sniping Incidents in Sarajevo '92-'94”), p. 54.

12645 Patrick van der Weijden, T. 7072 (28 September 2010).

12646 D4884 (Mile Poparić's expert report entitled "Small Arms Fire on the Sarajevo Area 1992-1995", 15 August 2012), pp. 95-104; Mile Poparić, T. 38969, 38971-38974 (30 May 2013), T. 39241-39246 (4 June 2013); P6365 (Photograph of a building marked by Mile Poparić). Sladoje also testified that there was no line of sight between the Faculty of Theology and the incident site, and that the distance between the two was around 1,500 metres. He further noted that his battalion did not have a sniper with such a range and denied that there was a sniper in the Faculty of Theology. According to him, his battalion placed a recoilless gun at the Faculty in order to be able to neutralise enemy positions and sniper nests in high-rises in Vojničko Polje and Mojmilo. See D2479 (Witness statement of Mile Sladoje dated 25 November 2012), paras. 6, 29; Mile Sladoje, T. 30577 (28 November 2012). On the other hand, Guzina testified that the $1^{\text {st }}$ Battalion had machine guns in the Faculty of Theology. He did confirm, however, that the Faculty was some 1,500 metres away from the location of the incident site and that the latter was not visible from the former. D2553 (Witness statement of Svetozar Guzina dated 3 December 2012), para. 44. See also D2562 (Witness statement of Vladimir Radojčić dated 8 December 2012), para. 116.

12647 Indeed, Poparic was aware of that but testified that he nevertheless chose to examine that location as it was often mentioned as the source of fire for this incident. Mile Poparić, T. 38970, 38974-38975 (30 May 2013); D4884 (Mile Poparić's expert report entitled "Small Arms Fire on the Sarajevo Area 1992-1995”, 15 August 2012), p. 103.

12648 See para. 3822. Indeed, the adjudicated facts related to this incident, namely Adjudicated Facts 204, 206, and 207, do not suggest that the Faculty of Theology was the origin of fire. 
soldiers did not have a line of sight from those positions. ${ }^{12649}$ Furthermore, the protective screens were placed on Nikole Demonje street in order to protect the command of the ABiH Brigade which was located in the street, which meant that armed $\mathrm{ABiH}$ soldiers must have been in the area securing the facility. ${ }^{12650}$

3829. Sladoje, an assistant commander of the $1^{\text {st }}$ Battlion of the Ilidža Brigade positioned in the area of Nedžarići at the time of the incident, ${ }^{12651}$ testified that no one from his battalion's command issued orders to fire at the street where the incident happened. ${ }^{12652}$ While conceding during crossexamination that the very front of his battalion's defence position was approximately 550 metres from the incident site, Sladoje denied that the fire on the bus could have come from that position because the $\mathrm{ABiH}$ forces in Dobrinja 5 were only 100 to 150 metres away and, in addition, Dobrinja 5 was "sheltering" Dobrinja 2 and $3 .{ }^{12653}$ Guzina, however, conceded that it was possible that the fire came from the VRS side of the confrontation line but not from the Faculty of Theology. ${ }^{12654}$ Radojčić testified that he never received any information about this incident. ${ }^{12655}$ Similarly, Stanislav Galić testified that he received no reports about this incident and noted that there was a general ban on opening fire on public transport as it was well known that passengers were civilians. ${ }^{12656}$

3830. The Chamber has also taken judicial notice of a number of adjudicated facts which state that: (i) the passengers of the bus were targeted from the area of Nedžarići; ${ }^{12657}$ (ii) there was one line of sight between the site of the incident and Nedžarići; ${ }^{12658}$ and (iii) the area of Nedžarići was controlled by the SRK at the time of the incident. ${ }^{12659}$ The final adjudicated fact concludes that on

\footnotetext{
12649 D4884 (Mile Poparić's expert report entitled "Small Arms Fire on the Sarajevo Area 1992-1995”, 15 August 2012), pp. 101-102, 104; Mile Poparić, T. 38970-38971, 38975 (30 May 2013).

12650 Mile Poparić, T. 38971 (30 May 2013).

12651 D2479 (Witness statement of Mile Sladoje dated 25 November 2012), paras. 2, 5; Mile Sladoje, T. 30562 (28 November 2012).

12652 D2479 (Witness statement of Mile Sladoje dated 25 November 2012), para. 29. This was confirmed by Vladimir Radojčić, the Ilidža Brigade commander. See D2562 (Witness statement of Vladimir Radojčić dated 8 December 2012), para. 116.

12653 Mile Sladoje, T. 30578-30580 (28 November 2012). Guzina also testified as to the distance between the incident site and the confrontation line. When asked during cross-examination if that distance 550 metres, Guzina responded "If you say it's that way, then it's probably that way." Svetozar Guzina, T. 31162 (11 December 2012).

12654 Svetozar Guzina, T. 31164-31165 (11 December 2012).

12655 D2562 (Witness statement of Vladimir Radojčić dated 8 December 2012), para. 116.

12656 Stanislav Galić, T. 37522-37523 (22 April 2013). On the date of the incident the Accused received a report from the VRS Main Staff, but it made no mention of the incident. Galić testified that had he had information on the incident he would have sent it to the VRS Main Staff and the Main Staff would have probably sent it on to the Accused. See Stanislav Galić, T. 37524-37525 (22 April 2013); D3453 (VRS Main Staff report, 25 May 1994).

12657 Adjudicated Fact 204.

12658 Adjudicated Fact 206.

12659 Adjudicated Fact 207.
} 
25 May 1994 civilian passengers of a civilian vehicle were deliberately targeted from SRKcontrolled territory and such targeting resulted in the wounding of Sehadeta Plivac and Hajra Hafizović. ${ }^{12660}$

3831. Having weighed the above listed adjudicated facts against the evidence related to this incident, the Chamber is unable to come to the same conclusion beyond reasonable doubt. As noted above, the Prosecution does not allege a specific location for the origin of fire in this incident and instead argues that the fire came down the Branioca Dobrinje street, from Nedžarići and from the SRK side of the confrontation line, which was 550 metres away from the incident site and thus within the range of a number of sniper rifles at the SRK's disposal. ${ }^{12661}$

3832. It appears that the Prosecution's main argument as to the distance to the confrontation line is Van der Weijden's report in which he marked a location just behind the protective barriers which was 550 metres away from the incident site. ${ }^{12662}$ However, Van der Weijden never claimed that this particular location was the confrontation line and instead testified that it signified a distance within which it would have been physically challenging or impossible for a shooter to have a position from which to take an accurate shot at the bus. ${ }^{12663}$ While Guzina and Sladoje both appeared to concede during cross-examination that the confrontation line was approximately 550 metres away, their concessions did not appear to have been based on precise knowledge of the distances involved. ${ }^{12664}$

3833. Further throwing doubt on the Prosecution's suggestion that the distance between the incident site and the confrontation line was 550 metres is the evidence led by the Accused. For example, Guzina marked the relevant confrontation lines on a map, ${ }^{12665}$ which in turn correspond to the confrontation lines marked on a map Poparić used to suggest that the distance was bigger than 550 metres. ${ }^{12666}$ Thus, both maps suggest that the distance to the confrontation lines was more than 550 metres. In addition, in the Chamber's own assessment of the maps in evidence, it would

\footnotetext{
12660 Adjudicated Fact 208.

12661 See para. 3822.

12662 See T. 30579 (28 November 2012) where Prosecution referred to Van der Weijden's report during Sladoje's cross-examination to prove to Sladoje that the confrontation line was 550 metres away. See also T. 31163 (11 December 2012) where it did the same with Guzina.

12663 Indeed, Van der Weijden specifically said that he did not know where the confrontation line was in that area. Patrick van der Weijden, T. 7066 (28 September 2010).

12664 For example, when asked if the distance was 550 metres, Sladoje said that "perhaps" he could agree with that but only in relation to one part of the confrontation line. See Mile Sladoje, T. 30578-30580 (28 November 2012). Similarly, Guzina simply accepted the Prosecution's suggestion as to the distance, assuming it was correct. See Svetozar Guzina, T. 31162 (11 December 2012).

12665 D2556 (Map of Sarajevo marked by Svetozar Guzina).
} 
indeed appear that the confrontation lines in the area were more than 550 metres away from the incident site. Accordingly, the Chamber has serious doubt as to the approximate distance between the incident site and the confrontation line. Not knowing how far or where the SRK soldiers were located from the incident site, the Chamber is also unable to conclude that they had a line of sight to the bus from their positions particularly given that the evidence the Chamber received indicates that Nedžarići consisted of low-rise buildings, one or two storeys high. ${ }^{12667}$

3834. Accordingly, the Chamber considers that the Accused has successfully rebutted the adjudicated facts listed above, through both his cross-examination of Van der Weijden and the evidence he brought during his case.

3835. Additionally, the Chamber recalls that Van der Weijden conceded that the only conclusion he could come to from the information available to him was that the bullet could have come down the Branioca Dobrinje street and that it was "probably of a certain calibre". ${ }^{2668}$ The Chamber also acknowledges that the Prosecution managed to extract an admission from Guzina that it was possible that the fire came from the VRS side of the confrontation line. ${ }^{12669}$ However, those two pieces of evidence are insufficient for the Chamber to be satisfied, beyond reasonable doubt, that the bullet fired on the bus came from the SRK's side of the confrontation lines and that it was fired in order to deliberately target civilians.

3836. For the foregoing reasons, the Chamber is not satisfied beyond reasonable doubt that the bullet that hit the bus came from SRK positions in the area of Nedžarići.

\section{(5) Adija Mulaobegovića street (formerly Đure Jakšića street), 26 June}

1994 (Scheduled Incident F.9)

3837. The Indictment alleges that, on 26 June 1994, Sanela Muratović, a 16 year old girl, was shot and wounded in her right shoulder while walking with a girlfriend on Đure Jakšića street (presently Adija Mulaobegovića street) in the west end of Sarajevo. ${ }^{12670}$ In its Final Brief, the Prosecution argues that Muratović was shot from the SRK positions in the area of the School for the Blind,

12666 The Chamber notes that the map Poparić relied on was created by Ismet Hadžić, one of the ABiH commanders in the area at the time. See D4884 (Mile Poparić's expert report entitled "Small Arms Fire on the Sarajevo Area 1992-1995”, 15 August 2012), p. 102, Image 70.

12667 See para. 3781.

12668 Patrick van der Weijden, T. 7072 (28 September 2010).

12669 Svetozar Guzina, T. 31164-31165 (11 December 2012).

12670 Indictment, Scheduled Incident F.9. The incident occurred in Alipašino Polje, an area located in the southwest of Sarajevo, just northwest of Dobrinja and east of Nedžarići. See e.g. P1803 (Map of Alipašino Polje); D2556 (Map of Sarajevo marked by Svetozar Guzina); Adjudicated Fact 82. 
approximately 200 metres away. ${ }^{12671}$ The Accused argues that the wounding of Sanela Muratović can be attributed to the fact that it happened very near the confrontation line during active combat between the two sides, when no soldiers would have expected civilians to be present in the area. $^{12672}$

3838. On 26 June 1994, between 7 and 7:30 p.m., on a sunny early evening, Sanela Muratović, age 16, and Medina Omerović, age 17, were walking to Omerović's apartment at Đure Jakšića street 17 on the eastern side of Lukavička Cesta in Novi Grad ${ }^{12673}$ when some uniformed soldiers warned them of incoming sniper fire. ${ }^{12674}$ Muratović was shot in her right shoulder, while Omerović, walking to the left, was not injured. ${ }^{12675}$ Only one single shot was fired and it directly hit Muratović. ${ }^{12676}$ There was no fighting in the area at the time of the incident. ${ }^{12677}$

3839. Hogan visited the site of the incident and recorded the exact location where the victim was shot. ${ }^{12678}$ Van der Weijden also visited the incident site but not the upper floor of the School for the Blind in Nedžarići, which is 190 metres away from the location of the incident site and which offers a clear view of that location, according to the photograph provided to him by the Prosecution. ${ }^{12679}$ When at the site Van der Weijden considered other potential origins of fire and eventually concluded, eliminating all other possibilities, that the shot did indeed come from the School. ${ }^{12680}$ Van der Weijden was of the opinion that any bullet up to the $7.92 \mathrm{~mm}$ calibre was capable of causing the victim's injuries; however, he concluded that, given the distance between the alleged origin of fire and the site of the incident and the fact that the material provided to him by

\footnotetext{
12671 Prosecution Final Brief, Appendix C, para. 36.

12672 Defence Final Brief, para. 2243-2244.

12673 The incident occurred in the suburb of Sarajevo called Alipašino Polje, an area located in the southwest of Sarajevo, just northwest of Dobrinja and east of Nedžarići. See e.g. P1803 (Map of Alipašino Polje); D2556 (Map of Sarajevo marked by Svetozar Guzina).

12674 See Adjudicated Facts 222, 223.

12675 See Adjudicated Facts 224, 225. See also P1880 (Discharge sheet for Sanela Muratović).

12676 See Adjudicated Fact 228.

12677 See Adjudicated Fact 229.

12678 Barry Hogan, T. 11214-11215 (3 February 2011); P2204 (Photograph re sniping incident of 26 June 1994 on Đure Jakšića street marked by Barry Hogan); P2207 (Images re scheduled sniping incidents in Sarajevo); P2190 (GPS locations for shelling and sniping incidents in Sarajevo); P2191 (Map of Sarajevo with scheduled sniping and shelling incidents).

12679 P1621 (Expert Report of Patrick van der Weijden entitled “Sniping Incidents in Sarajevo '92-'94”), pp. 67-69. See also Barry Hogan, T. 11214-11215 (3 February 2011); P2204 (Photograph re sniping incident of 26 June 1994 on Đure Jakšića street marked by Barry Hogan).

12680 Van der Weijden denied that his task was simply to confirm that the School for the Blind was the location of the shooter. He conceded, however, that he did not know where the confrontation line was in the area between the School and the site of the incident, but noted that since the ABiH soldiers helped the victim they were probably in the buildings next to the incident site. He also conceded that he had no information as to the position of the victim's body when she was hit, or any information on the exact location of her wound. Patrick van der Weijden, T. 7142-7152 (29 September 2010); D671 (Aerial photograph of Sarajevo marked by Patrick van der Weijden).
} 
the Prosecution suggested that "only single shots or perhaps semi automatic fire were generally fired in that area", he thought that the most likely weapon used in this incident was an M79, an M91, or a civilian bolt action hunting rifle or an older generation rifle such as an M48. ${ }^{12681}$ In addition, given the short distance between the School for the Blind and the incident site, the victim would have been easily identifiable as a young woman; furthermore, the fact that she did not use a trench which was there to protect the people crossing the street, would have indicated to the shooter that she was not "tactically aware" and thus not a combatant. ${ }^{12682}$

3840. Poparic testified that there was very little information for this incident, most of it coming from Omerović. ${ }^{12683}$ He argued, based on Omerović's evidence in the Galić case and some of the images taken in the area, that it was clear that the location of the incident was right on the separation line between the warring parties and that Omerović's building was used by the $\mathrm{ABiH}$ soldiers. ${ }^{12684} \mathrm{He}$ also pointed out that there was an inconsistency in the evidence as to the precise location of the girls when Muratović was shot. ${ }^{12685}$ According to Poparić, Omerović did not accurately show her location to Hogan since she indicated to him that she and Muratović were already in front of the trench when Muratović was wounded, whereas in her testimony in the Galić case she said that they ran to the trench only after Muratović was wounded. ${ }^{12686}$ This is a crucial detail to Poparić since, unlike the location shown to Hogan, the location from which the girls ran to the trench was not visible from the School for the Blind. ${ }^{12687}$ Poparic also argued that no evidence was presented that there was a firing position at the School for the Blind window, which had the view on the incident site and that it would be illogical to have a firing position in that location as it would make an easy target. ${ }^{12688}$ Poparić concluded that if the girls were already running before P1621 (Expert Report of Patrick van der Weijden entitled “Sniping Incidents in Sarajevo '92-'94”), p. 70.

12683 Mile Poparić, T. 38981 (30 May 2013).

12684 D4884 (Mile Poparić's expert report entitled "Small Arms Fire on the Sarajevo Area 1992-1995", 15 August 2012), pp. 114-115.

12685 D4884 (Mile Poparić's expert report entitled "Small Arms Fire on the Sarajevo Area 1992-1995", 15 August 2012), pp. 115-116.

12686 D4884 (Mile Poparić's expert report entitled "Small Arms Fire on the Sarajevo Area 1992-1995", 15 August 2012), p. 116; Mile Poparić, T. 38979-38980 (30 May 2013).

12687 D4884 (Mile Poparić's expert report entitled "Small Arms Fire on the Sarajevo Area 1992-1995", 15 August 2012), pp. 116-117; Mile Poparić, T. 38979-38980 (30 May 2013). The photograph of the view from the School for the Blind to the incident site was shown to Guzina during re-examination. He first claimed that the small building partially blocking the view to the Đure Jakšića street was new but then changed his mind when prompted by the Accused. See Svetozar Guzina, T. 31193-31194 (11 December 2012); D2560 (Photograph of building in Sarajevo, undated). The Chamber is not convinced by Guzina's testimony in this regard, but notes that even if the small building was not new, the photograph shows that there was still a partial view from the School for the Blind onto the Đure Jakšića street. Furthermore, this was conceded by Poparić who testified that the area around the trench was visible from the School for the Blind.

12688 D4884 (Mile Poparić's expert report entitled "Small Arms Fire on the Sarajevo Area 1992-1995", 15 August 2012), p. 117. Poparić in fact argued that there was no evidence that the School for the Blind as a whole was used as a sniper nest. See Mile Poparić, T. 38980 (30 May 2013). When confronted with an UNMO report
} 
Muratović was shot then they were not shot from the School for the Blind and there must have been an exchange of fire or a ricochet. ${ }^{12689}$ If, however, the girls were just next to the trench when shot at, there was a "theoretical possibility" that the shooter was at the level of the ceiling in the room of the School that had the view onto the trench but this, according to Poparić, was improbable. ${ }^{12690}$ During cross-examination, when presented with a photograph of the School for the Blind taken in 1996 and shown a number of openings in the wall of the School on the side which was exposed to the incident location, Poparić denied that they were consistent with firing positions. ${ }^{12691}$

3841. Radojčić testified that he never issued an order to any unit of his brigade to open fire on Đure Jakšića street and that he never received any information about this incident. ${ }^{12692} \mathrm{He}$ did note, however, that he had information that one of the units of the $102^{\text {nd }}$ Brigade of the $A B i H 1^{\text {st }}$ Corps was positioned on that street. ${ }^{12693}$

3842. Guzina confirmed that the location of the incident was "just behind the first line" which was the "worst line during the conflict" and stated that it was not logical to assume that civilians would be at that location. ${ }^{12694}$ He also testified, based on the SRK's daily combat report of 26 June 1994, that there was fighting in the area in the evening and night of 25 June 1994 as the ABiH "fired infantry weapons provocatively on all the lines of disengagement" of the Ilidža Brigade and its units responded in order to protect themselves. ${ }^{12695}$ Thus, according to Guzina, Muratović could have been wounded during the battles in the area. ${ }^{12696}$ Guzina opined, however, that a civilian should not have been in this location as both sides were under obligation to remove civilians from

stating that the Commander of the $1^{\text {st }}$ Battalion of the Ilidža Brigade admitted that sniper fire was opened from the School for the Blind, Poparić responded that it was not clear that this was related to the incident involving Muratović. See Mile Poparić, T. 39271-39272 (5 June 2013); P1601 (UNMO report, 13 July 1994), p. 4.

Mile Poparić, T. 38982 (30 May 2013).

When told that he made conclusions in his report as to the presence of $\mathrm{ABiH}$ sniping nests based on a similar photograph of a building in the ABiH-held territory (Image 6 in his report), Poparic explained that there was a difference in the photographs as he was not able to see the openings properly in the photograph of the School for the Blind. Mile Poparić, T. 39272-39277 (5 June 2013); P6368 (Photograph of a building). The Chamber agrees with Poparic that the detail on the two photographs is different.

D2562 (Witness statement of Vladimir Radojčić dated 8 December 2012), para. 117. Stanislav Galić also testified in relation to this incident that no one ordered this attack. Stanislav Galić, T. 37532-37533 (22 April 2013).

12693 D2562 (Witness statement of Vladimir Radojčić dated 8 December 2012), para. 117.

12694 D2553 (Witness statement of Svetozar Guzina dated 3 December 2012), para. 45; Svetozar Guzina, T. $31167-$ 31168 (11 December 2012). On cross-examination, Guzina did agree that civilians lived in that area but noted that there was fighting on that day. Svetozar Guzina, T. 31169-31170 (11 December 2012).

D2553 (Witness statement of Svetozar Guzina dated 3 December 2012), para. 45; D2554 (SRK combat report, 26 June 1994), p. 1. When told that the SRK combat report of 26 June 1994 referred to the fighting that happened the day before and not on the day of the incident and when confronted with Adjudicated Fact 229 which provides that there was no fighting on 26 June 1994, Guzina remained adamant that the fighting lasted all day on 26 June as he had checked this fact in his diaries. Svetozar Guzina, T. 31174-31177 (11 December 2012). 
the frontline, and explained that in such circumstances every soldier had to make a decision as to whether he was under threat and whether to shoot on an observed target or not. ${ }^{12697}$ When Galić was shown the same SRK report, which provides that the SRK would "continue to strictly implement the cease-fire agreement and refrain from combat actions", he noted that a restraint from combat activities meant that there was to be no firing so that if an incident occurred it would have to be reported and processed in some way. ${ }^{12698}$ Galić also testified that two days prior to the incident an SRK combat report was sent to the VRS Main Staff, informing the latter that the SRK units were under orders to "consistently implement" cessation of hostilities. ${ }^{12699}$

3843. As noted above, Guzina conceded that the $1^{\text {st }}$ Battalion had three snipers but claimed that those were positioned towards Butmir and not towards the site of this incident. ${ }^{12700}$ When confronted with an UNMO report dated 11 July 1994 which indicates that there has been yet another sniping incident at a location near the School for Blind, whereby a 17 year old man was the third civilian casualty in the same spot in the last few days, Guzina responded that the UNMO report did not establish that this was sniper fire, and maintained that no professional snipers were located in that position. ${ }^{12701}$ When confronted with an UNMO report dated 13 July 1994, in which he is recorded as having admitted to the sniping activity from the School for the Blind and as having promised that this would not happen again, Guzina denied ever making that admission and claimed that the UN liaison officers were able to write whatever they pleased. ${ }^{12702}$

3844. The Chamber has also taken judicial notice of a number of adjudicated facts which suggest that: (i) the bullet did not hit Muratović by mistake nor was there a ricochet; ${ }^{2703}$ (ii) the shot which hit her originated from the area of the School for the Blind; ${ }^{12704}$ (iii) UNMO and other witnesses had found that the School for the Blind was a "sniping nest" from where civilians were shot at; ${ }^{12705}$ and (iv) the distance between the area of the School for the Blind and the position of the victim at

Stanislav Galić, T. 37533-37535 (22 April 2013); D2554 (SRK combat report, 26 June 1994), p. 3.

12699 Stanislav Galić, T. 37536-37537 (22 April 2013); D3455 (SRK combat report, 24 June 1994), p. 3. The report also notes, at page 1, that SRK units are at a heightened level of combat readiness and that they have been warned of the need to stop unnecessary opening of fire along the lines.

12700 See fn. 12492.

12701 Svetozar Guzina, T. 31177-31179, 31194-31195 (11 December 2012); P1600 (UNMO report, 11 July 1994), p. 5 .

12702 Svetozar Guzina, T. 31180-31181 (11 December 2012); P1601 (UNMO report, 13 July 1994), p. 4.

12703 Adjudicated Fact 230.

12704 See Adjudicated Fact 226.

12705 See Adjudicated Fact 227.
} 
the time of the incident was about 200 metres. ${ }^{12706}$ Further, Adjudicated Fact 233 states that Muratović was a civilian and that she was deliberately targeted from SRK-controlled territory. ${ }^{12707}$

3845. The Chamber considers, given Muratović's age at the time of the incident and the fact that she was walking with Omerović to Omerović's house on Đure Jakšića street without much tactical awareness, that both girls were civilians and were not taking direct part in hostilities at the time of the incident. Further, it is clear from the evidence outlined above ${ }^{12708}$ that civilians lived near the confrontation line in the area of Đure Jakšića street. It follows therefore that the civilian presence in the area was not unusual and that civilians had to, at times, move around the area, contrary to Guzina's evidence. This would have undoubtedly been known to the SRK units located in the area, including Guzina, and the Chamber does not accept his evidence that civilians should not have been there. Thus, it is completely logical that Muratović and Omerović, and other civilians, would have ventured outside whenever there was a cease-fire or a lull in fighting. As also noted above, the two SRK reports sent to the VRS Main Staff just before and on the day of the incident indicate that there was a cease-fire in place at the time, which further explains why the two girls were walking in the area even though it was close to the confrontation line. ${ }^{12709}$ Finally, contrary to Guzina's evidence, the Chamber is convinced that there was no fighting on the day of the incident as two young girls would not be out on the street in such a case. Furthermore, as also recounted above, ${ }^{12710}$ the girls were explicitly warned by the $\mathrm{ABiH}$ soldiers about sniper fire.

3846. The Chamber is also satisfied, based on the evidence above, that the School for the Blind was some 200 metres away from the incident site and that it had a line of sight to Đure Jakšića street. The Chamber does not accept Poparić's analysis as to discrepancies in Omerović's story since the description of the incident she gave in her evidence in the Galic case - as recounted by Poparić - is not necessarily inconsistent with the location of the incident shown to Hogan. The fact that Muratović was shot first and only then started running towards Omerović's house and found refuge in the trench does not mean that she was not shot when near the trench. In other words, other than saying that Muratović was not in the line of sight of the School for the Blind when shot, Poparić does not provide any explanation or visual information as to where she was in fact standing

\footnotetext{
12706 See Adjudicated Fact 232.

12707 See Adjudicated Fact 233.

12708 See paras. 3784, 3787-3788, fn. 12694.

12709 While the SRK report issued on the day of the incident does refer to some exchange of fire in the Ilidža Brigade's zone of responsibility, the Chamber notes that these exchanges took place mainly during the night of 25 June and in areas that were not close to Đure Jakšića street. See D2554 (SRK combat report, 26 June 1994), p. 1.

12710 See para. 3838 .
} 
when shot. Thus, the Chamber accepts the evidence of Hogan as to the location of the victim when shot and is satisfied that she could be seen from the School for the Blind at that location.

3847. The Chamber is further satisified, based on the evidence of Guzina outlined above, that the $1^{\text {st }}$ Battalion of the Ilidža Brigade of the SRK had positions in the School for the Blind. It is also satisfied that the soldiers located in the School opened sniper fire at the civilians in the area and thus possessed either a sniper rifle or an M48 rifle with an optic sight, which is in line with Van der Weijden's evidence as to the gun used in this incident. ${ }^{12711}$ Finally, the Chamber is satisfied that Sanela Muratović was deliberately targeted by one of those soldiers and that this soldier would have undoubtedly been aware of her civilian status given the short distance beween the School for the Blind and the location of the incident. ${ }^{12712}$

\section{(C) Sedrenik}

3848. Two of the 16 scheduled sniping incidents took place in a suburb of Sarajevo called Sedrenik. The Prosecution alleges in relation to both that the origin of fire was a rock-faced ridge called "Špicasta Stijena" or "Sharpstone", which overlooks Sedrenik. ${ }^{12713}$

3849. Sedrenik is a settlement located in the northeastern part of Sarajevo. ${ }^{12714}$ It is a residential area which was frequently targeted throughout the war by small arms fire, as well as shells and mortars, resulting in a number of casualties. ${ }^{12715}$ This made it difficult to live in Sedrenik during the conflict and Sedrenik's inhabitants were often forced to leave their houses early in the morning or late at night, while it was dark. ${ }^{12716}$ The areas known for being frequently exposed to sniper fire were protected by bed sheets and blankets, which would be hung from wires, all in order to block

12711 See P1600 (UNMO report, 11 July 1994), p. 5. This is further confirmed by the SRK combat report of 24 June 1994 which provides that SRK units have been "warned of the need to stop unnecessary opening of fire along the lines", thus implying that such was the practice of those units. D3455 (SRK combat report, 24 June 1994), p. 1.

12712 The Chamber does not consider that Muratović was caught in cross-fire as she was warned that there was sniper fire in the area. See Adjudicated Fact 223.

12713 Scheduled Incidents F.2 and F.17; Prosecution Final Brief, Appendix C, paras. 23-25. Scheduled Incident F.13 also took place in this area but was struck out of the Indictment pursuant to Rule 73 bis of the Rules.

12714 P1953 (Witness statement of Harry Konings dated 11 November 2010), para. 10. See Adjudicated Fact 2844.

12715 P496 (Witness statement of Tarik Žunić dated 21 April 2006), pp. 2-3; P496 (Witness statements of Tarik Žunić dated 10 November 1995), p. 2; P1762 (Witness statement of David Fraser dated 17 October 2010), pp. 24, 26; David Fraser, T. 8015-8016 (18 October 2010); P1978 (Witness statement of Nedžib Đozo dated 7 December 2010), paras. 16, 19-20; Nedžib Đozo, T. 9598-9609, 9642-9646 (10 December 2010); D911 (ABiH map of Sarajevo marked by Nedžib Đozo); P23 (Witness statement of Mirsad Kučanin dated 12 November 1995), p. 8. See also P1991 (Stari Grad Police Station war diary) generally for the various incident reported in Sedrenik. 
the line of sight to snipers. ${ }^{12717}$ The situation was such that many people left Sedrenik and moved to safer areas of Sarajevo. ${ }^{12718}$

3850. A team consisting of six to ten UNMO observers was based in a civilian house located in Sedrenik. ${ }^{12719}$ The base had a UN flag on the roof but it was nevertheless targeted by sniping fire on an almost daily basis, as were their cars. ${ }^{12720}$

3851. Two main locations featuring in the evidence relating to this area of the city were two elevations above Sedrenik, namely Grdonj Hill and Špicasta Stijena. ${ }^{12721}$ Špicasta Stijena is a bare rock, some 50 to 100 metres high, overlooking Sedrenik. ${ }^{12722}$ According to a number of witnesses, it was the origin of much of the sniping fire on Sedrenik. ${ }^{12723}$

\section{(1) Confrontation lines in the area}

3852. Slavko Gengo, the Commander of the $7^{\text {th }}$ Infantry Battalion of the $1^{\text {st }}$ Romanija Infantry Brigade of the SRK, ${ }^{12724}$ testified that his battalion was in control of the nine kilometre long confrontation line in the area, in the Kadrijina Kuća - Mala Tvrđava - Špicasta Stijena - Pašino Brdo - Velika Tvrđava - Pašino Brdo - Donje Bioško - Faletići - Zečija Glava - Borije -

12717 P1978 (Witness statement of Nedžib Đozo dated 7 December 2010), para. 22. See also P1762 (Witness statement of David Fraser dated 17 October 2010), p. 24.

12718 P1978 (Witness statement of Nedžib Đozo dated 7 December 2010), para. 22.

12719 P1953 (Witness statement of Harry Konings dated 11 November 2010), paras. 10-12; Harry Konings, T. 9300 (7 December 2010); P1961 (Photograph of Sarajevo hillside); P152 (Witness statement of Thomas Knustad dated 21 May 1996), pp. 2, 7; Thomas Knustad, P123 (Transcript from Prosecutor v. D. Milošević), T. 19851986.

12720 P1953 (Witness statement of Harry Konings dated 11 November 2010), para. 40; P496 (Witness statement of Tarik Žunić dated 21 April 2006), p. 2 ; Thomas Knustad, P123 (Transcript from Prosecutor v. D. Milošević), T. 2011.

12721 D4884 (Mile Poparić's expert report entitled "Small Arms Fire on the Sarajevo Area 1992-1995", 15 August 2012), pp. 37-38; Slavko Gengo, T. 29786 (6 November 2012); P1978 (Witness statement of Nedžib Đozo dated 7 December 2010), para. 16; Nedžib Đozo, T. 9590-9591 (10 December 2010); D909 (Photograph of Sarajevo marked by Nedžib Đozo) (marking Grdonj Hill with the number 1 and Špicasta Stijena with the number 2).

12722 Nedžib Đozo, T. 9545-9548 (9 December 2010), T. 9619-9621; P1980 (Photographs of Špicasta Stijena); P1953 (Witness statement of Harry Konings dated 11 November 2010), para. 12; P1961 (Photograph of Sarajevo hillside).

12723 P1953 (Witness statement of Harry Konings dated 11 November 2010), para. 40; P152 (Witness statement of Thomas Knustad dated 21 May 1996), p. 4; P1558 (Witness statement of Francis Roy Thomas dated 13 May 2009), para. 66; P496 (Witness statement of Tarik Žunić dated 21 April 2006), pp. 2-3; P23 (Witness statement of Mirsad Kučanin dated 12 November 1995), p. 8; P1978 (Witness statement of Nedžib Đozo dated 7 December 2010), para. 15. Knustad also testified that he even saw a modified air bomb being launched from Špicasta Stijena during his time in Sarajevo, namely after 21 June 1995. See P152 (Witness statement of Thomas Knustad dated 21 May 1996), p. 2; Thomas Knustad, P123 (Transcript from Prosecutor v. D. Milošević), T. 1990, 2028-2029.

12724 D2383 (Witness statement of Slavko Gengo dated 14 October 2012), para. 3. 
Tabakovo Guvno sector. ${ }^{12725}$ The Battalion numbered some 800 men $^{12726}$ and consisted of the command, six companies, one independent platoon, a logistics platoon, and a communication detachment. $^{12727}$ There was a deficit of professional officers; most of the soldiers in the battalion were locals, which had effect on the command's ability to control the units. ${ }^{12728}$

3853. According to Gengo, Špicasta Stijena was held by the VRS throughout the conflict. ${ }^{12729}$ Blaško Rašević, commander of a platoon and later a company in Mrkovići, ${ }^{12730}$ which was part of the $1^{\text {st }}$ Romanija Infantry Brigade, ${ }^{12731}$ confirmed this saying that from 5 April 1992 his platoon, as well as another Mrkovići platoon, took up positions on the Velika Tvrđava-Špicasta Stijena axis and "successfully defended that line until the end of the war". ${ }^{12732}$ According to Rašević, his unit carried out only defensive tasks and never received an order to attack. ${ }^{12733}$ Stanislav Galić, who was the SRK Commander until 1994, testified that Špicasta Stijena was around one kilometre away

12725 D2383 (Witness statement of Slavko Gengo dated 14 October 2012), para. 13; D2384 (Map of Sarajevo marked by Slavko Gengo); P1021 (VRS map of Sarajevo); P6295 (VRS map of Sarajevo). The Chamber notes that Mala and Velika Tvrđava were also known and referred to as Mala and Velika Kula throughout the evidence.

12726650 of those men were in infantry companies while the rest belonged to logistics support. See Slavko Gengo, T. 29766 (6 November 2012).

12727 D2383 (Witness statement of Slavko Gengo dated 14 October 2012), para. 13.

12728 D2383 (Witness statement of Slavko Gengo dated 14 October 2012), paras. 25-26. However, according to Gengo, disciplinary problems happened mostly when parts of the unit were dispatched on assignments outside the battalion's zone of responsibility. See D2383 (Witness statement of Slavko Gengo dated 14 October 2012), para. 26.

12729 Slavko Gengo, T. 29786 (6 November 2012). Two UNMO observers stationed in the area, namely Konings and Knustad, also testified to that effect. Knustad even saw a Bosnian Serb flag on Špicasta Stijena. See P1953 (Witness statement of Harry Konings dated 11 November 2010), para. 40; Thomas Knustad, P123 (Transcript from Prosecutor v. D. Milošević), T. 2036. Furthermore, senior UNMO observer, Francis Roy Thomas, visited the Serb positions on Špicasta Stijena. P1558 (Witness statement of Francis Roy Thomas dated 13 May 2009), para. 66.

12730 Rašević was the company commander between 31 January 1993 and September 1994. See D2527 (Witness statement of Blaško Rašević dated 1 December 2012), paras. 16-17. Mrkovići is a village north of Grdonj Hill and Sarajevo city. See D2794 (Satellite image of Sarajevo marked by Dragomir Milošević).

12731 With the formation of the VRS, the two Mrkovići platoons first became part of the $2^{\text {nd }}$ Romanija Brigade and then later the $1^{\text {st }}$ Romanija Infantry Brigade, which was part of the SRK. The commander of the $1^{\text {st }}$ Romanija Brigade was Dragomir Milošević, followed by Vlado Lizdek. See D2527 (Witness statement of Blaško Rašević dated 1 December 2012), para. 20; Blaško Rašević, T. 30911 (4 December 2012).

12732 D2527 (Witness statement of Blaško Rašević dated 1 December 2012), paras. 20, 29; D2528 (Map of Grdonj marked by Blaško Rašević). Siniša Maksimović, who briefly replaced Rašević as the Commander of Mrkovići Company in 1994, testified that the company's positions were located to the north of the Grdonj Hill, at the level of Mala Kula but he did place Špicasta Stijena in the Mrkovići Company's zone of responsibility. See D2354 (Witness statement of Siniša Maksimović dated 19 October 2012), paras. 5, 9; Siniša Maksimović, T. 29306 (23 October 2012); D2355 (Map of Sarajevo marked by Siniša Maksimović); D2356 (Photograph of Sarajevo from Grdonj Hill); D2357 (Photograph of Sarajevo from Grdonj Hill); P1978 (Witness statement of Nedžib Đozo dated 7 December 2010), para. 17.

12733 D2527 (Witness statement of Blaško Rašević dated 1 December 2012), para. 21. Rašević also testified that from their positions they could see the firing positions of the $\mathrm{ABiH}$ in the city, including near the Faculty of Physical Education, the Koševo Hill tunnel, the Koševo stadium, Nemanja Vlatković School, and Koševo Hospital grounds. See D2527 (Witness statement of Blaško Rašević dated 1 December 2012), para. 23. See also D2383 (Witness statement of Slavko Gengo dated 14 October 2012), para. 23. 
from Sedrenik, that it was partly under SRK control at one point, and that it then came under ABiH control. ${ }^{12734}$ However, he provided no detail as to when the change-over happened. ${ }^{12735}$

3854. Contrary to the evidence outlined above, Dragomir Milošević testified that the SRK forces were not located on Špicasta Stijena but in the area of Mala Kula, just behind Špicasta Stijena. ${ }^{12736}$ He went so far as to claim that Špicasta Stijena was not in the zone of responsibility of the SRK. ${ }^{12737}$ However, when questioned by the Chamber, he conceded that the SRK would have had "conditions from [Špicasta Stijena] to execute possible fire", and that "possible fire was executed to the degree required for [the units] to protect themselves". ${ }^{12738}$

3855. Accordingly, the Chamber is satisfied that, with the exception of a few days around mid1994, when it was temporarily taken over by the ABiH, Špicasta Stijena was in the zone of responsibility of the SRK, more precisely the $7^{\text {th }}$ Battalion of the $1^{\text {st }}$ Romanija Infantry Brigade, and that the SRK soldiers were able to open fire from that feature. ${ }^{12739}$ In addition, the Chamber is also satisfied that, since it is situated on a steep slope, Sedrenik could be easily seen from both Špicasta Stijena and the adjacent Grdonj Hill. ${ }^{12740}$

3856. The ABiH units opposing the $7^{\text {th }}$ Battalion, including the Mrkovići Company, belonged to the $105^{\text {th }}$ and $110^{\text {th }}$ Mountain Brigades and held the top of the Grdonj Hill, with the area of Sedrenik behind them, as well as the extensive views towards the city. ${ }^{12741}$ According to Nedžib

\footnotetext{
12734 Stanislav Galić, T. 37467, 37478-37479 (22 April 2013).

12735 The Chamber received evidence there was a temporary take over of Špicasta Stijena by Bosnian Muslim forces, which took place in mid-September 1994 and lasted for about two days. See D2354 (Witness statement of Siniša Maksimović dated 19 October 2012), para. 10; Siniša Maksimović, T. 29303 (23 October 2012); Blaško Rašević, T. 30914-30915 (4 December 2012); Slavko Gengo, T. 29786 (6 November 2012). In addition, Gengo testified that two trenches on Špicasta Stijena were taken from the SRK in summer of 1994. See D2383 (Witness statement of Slavko Gengo dated 14 October 2012), para. 33.

12736 Dragomir Milošević, T. 32567-32568 (23 January 2013), T. 33187-33188 (5 February 2013); D2794 (Satellite image of Sarajevo marked by Dragomir Milošević).

12737 Dragomir Milošević, T. 33189-33195 (5 February 2013).

12738 Dragomir Milošević, T. 33196-33197 (23 January 2013).

12739 Indeed, even the Accused's expert witness, Mile Poparić, prepared his report working on that assumption. See D4884 (Mile Poparić's expert report entitled "Small Arms Fire on the Sarajevo Area 1992-1995", 15 August 2012), p. 41. In his report, Mile Poparić provides photographs of various trenches on Grdonj and Špicasta Stijena. See D4884 (Mile Poparić's expert report entitled "Small Arms Fire on the Sarajevo Area 1992-1995", 15 August 2012), Images 13-17. See also Adjudicated Facts 101, 102, and 160.

12740 Slavko Gengo, T. 29786 (6 November 2012); D4884 (Mile Poparić's expert report entitled "Small Arms Fire on the Sarajevo Area 1992-1995", 15 August 2012), pp. 37-38. In addition, according to the witnesses, all the trees from Špicasta Stijena towards Sedrenik were cut by the civilians who needed firewood. D2383 (Witness statement of Slavko Gengo dated 14 October 2012), para. 34; Nedžib Đozo, T. 9546-9547 (9 December 2010), T. 9593-9595 (10 December 2010). The Chamber notes that Nedžib Đozo also testified that sniping fire on Sedrenik could only be opened from Špicasta Stijena as Sedrenik was not visible from Grdonj Hill. See P1978 (Witness statement of Nedžib Đozo dated 7 December 2010), para. 16. However, in light of Poparić's report, the Chamber does not accept this part of his testimony.

12741 D2527 (Witness statement of Blaško Rašević dated 1 December 2012), para. 26; D2354 (Witness statement of Siniša Maksimović dated 19 October 2012), para. 5; Siniša Maksimović, T. 29306 (23 October 2012); D2355 (Map of Sarajevo marked by Siniša Maksimović); D2356 (Photograph of Sarajevo from Grdonj Hill); D2357
} 
Đozo, who was a police investigator in the Stari Grad police station, ${ }^{12742}$ the $\mathrm{ABiH}$ units were not positioned directly below or at the foot of Špicasta Stijena as that would have been too close and too dangerous; instead, they were positioned to the left, towards Grdonj, and to the right, towards the forest. ${ }^{12743}$ Đozo also testified these were not proper lines but rather two or three positions protecting the area from the "onslaught of Serb forces towards Sedrenik."12744 Gengo also testified that in the area of Špicasta Stijena and Velika and Mala Tvrđava, the $7^{\text {th }}$ Battalion was deployed higher than the ABiH units. ${ }^{12745}$

3857. The positions of the $105^{\text {th }}$ Mountain Brigade were some 20 to 100 metres away from the positions of the Mrkovići Company and the line of disengagement on Špicasta Stijena was, in certain places, as narrow as 20 metres. ${ }^{12746}$

\section{(2) Snipers in the area}

3858. Milošević denied that the SRK had any snipers on Špicasta Stijena, explaining that the distances involved were great that any type of infantry weapons in that position would have been useless. ${ }^{12747}$ Gengo confirmed this, stating that there were no trained snipers in the $7^{\text {th }}$ Battalion and that opening fire towards Sedrenik was impossible because of the distances involved, the configuration of the terrain, and the fact that trenches on Špicasta Stijena were "always under crossfire". ${ }^{12748}$ Gengo did concede, however, that the $1^{\text {st }}$ Romanija Infantry Brigade had over sixty 7.62 and $7.9 \mathrm{~mm}$ sniper rifles in its arsenal. ${ }^{12749}$ While claiming that the Mrkovići Company did not have professional snipers or sniper rifles, Rašević testified that they had optical devices placed on hunting rifles, which then had a targeting accuracy of up to 1,000 metres, with the greatest accuracy

(Photograph of Sarajevo from Grdonj Hill); Dragomir Milošević, T. 32567, 32570 (23 January 2013); D2794 (Satellite image of Sarajevo marked by Dragomir Milošević); D2383 (Witness statement of Slavko Gengo dated 14 October 2012), para. 16; Slavko Gengo, T. 29838 (6 November 2012); Asim Džambasović, T. 15194, 15207, 15238-15240 (22 June 2011); D1378 (Map of ABiH positions in Sarajevo marked by Asim Džambasović); P1058 (ABiH map). According to Džambasović, the command post of the $105^{\text {th }}$ Brigade was located in the Šipad building in Trampina street. See Asim Džambasović, T. 15207 (22 June 2011). 
between 300 and 400 metres. ${ }^{12750}$ Siniša Maksimović, who briefly replaced Rašević as the Commander of Mrkovići Company in 1994, ${ }^{12751}$ conceded that his unit would open fire from Špicasta Stijena but only when attacked and only on $\mathrm{ABiH}$ positions. ${ }^{12752}$

3859. Contrary to Gengo and Milošević's evidence as to the presence of snipers on Špicasta Stijena, Thomas testified that due to a large number of sniping incidents originating from Špicasta Stijena, he tried to negotiate UNMOs' presence there and in the course of his negotiations with the SRK was able to visit their positions in the area some time after February 1994. ${ }^{12753}$ According to him, Špicasta Stijena was a "very well dug in position" such that there was "no need for special facilities for the snipers." 12754 The SRK soldiers could "just pick a trench and prepare themselves, shoot, and then move on to another trench" as they had a clear view. ${ }^{12755}$ Ultimately, negotiations to have UNMO presence on Špicasta Stijena were unsuccessful despite Thomas taking the matter to Major Inđić and thus bringing it to Galić's attention. ${ }^{12756}$ Thomas' evidence is confirmed by an UNMO report of 6 March 1995, according to which two civilians and the APC of the UNPROFOR's Egyptian battalion came under sniper fire from the positions of Špicasta Stijena; when the APC returned fire and engaged the SRK shooter, the UNMO Vogošca team was threatened by the Commander of the SRK's Radava Battalion ${ }^{12757}$ and told to leave his "target practice area (Sedrenik)" or it would be fired upon. ${ }^{12758}$

3860. In terms of the disposition of fire in Sedrenik, Fraser testified that it was the Serbs that fired more in the area, which is why protective screens were set up. ${ }^{12759}$ However, Galić testified that $\mathrm{ABiH}$ was constantly attacking SRK positions on the axis Sedrenik-Zlatište and that $\mathrm{ABiH}$ forces

\footnotetext{
12750 D2527 (Witness statement of Blaško Rašević dated 1 December 2012), para. 29. See also D2354 (Witness statement of Siniša Maksimović dated 19 October 2012), para. 8. The Chamber also recalls here Van der Weijden's evidence that a substantial number of combatants in Sarajevo had hunting rifles fitted with scopes, which were suitable for sniping. See P1621 (Expert Report of Patrick van der Weijden entitled "Sniping Incidents in Sarajevo '92-'94”), Appendix A, pp. 3-4.

12751 At the time of the incident, however, Maksimovic was a member of the intervention platoon in the $4^{\text {th }}$ Battalion of the Igman Brigade and held the line on Igman, which is far from Sedrenik. See D2354 (Witness statement of Siniša Maksimović dated 19 October 2012), paras. 3-5; Blaško Rašević, T. 30914-30915 (4 December 2012). When shown the UNMO report of 6 March 1995 referring to two civilians being wounded by fire from Špicasta Stijena, Maksimović explained that this happened when he was no longer the commander in the area. Siniša Maksimović, T. 29297-29298 (23 October 2012); P1619 (UNMO report, 6 March 1995).

12753 P1558 (Witness statement of Francis Roy Thomas dated 13 May 2009), para. 66.

12754 P1558 (Witness statement of Francis Roy Thomas dated 13 May 2009), para. 66. See also P1621 (Expert Report of Patrick van der Weijden entitled "Sniping Incidents in Sarajevo '92-'94”), p. 20.

12755 P1558 (Witness statement of Francis Roy Thomas dated 13 May 2009), para. 66.

12756 P1558 (Witness statement of Francis Roy Thomas dated 13 May 2009), para. 66.

12757 Radava is a village not far from Mrkovići. See D2354 (Witness statement of Siniša Maksimović dated 19 October 2012), para. 4; D2355 (Map of Sarajevo marked by Siniša Maksimović).

12758 P1619 (UNMO report, 6 March 1995).

12759 P1762 (Witness statement of David Fraser dated 17 October 2010), pp. 24, 26; David Fraser, T. 8015 (18 October 2010).
} 
would even open sniper fire on Sedrenik itself. ${ }^{12760}$ Rašević confirmed that ABiH forces launched several attacks on his positions between April 1992 and January 1993, noting that the area was deemed important because it was a dominant elevation that could cut off the connection between Vogošća and Hresa and leave all Serb-held municipalities in encirclement. ${ }^{12761}$ Dragomir Milošević also testified that the area was of strategic importance to the SRK, which is why the ABiH would regularly launch attacks on Mrkovići and the road leading from Pale to Vogošća via Špicasta Stijena. ${ }^{12762}$ Finally, Gengo too mentioned such attacks on the positions of his battalion, including by $\mathrm{ABiH}$ sniper fire- - he then stated that he and his forces would return fire in retaliation, and in doing so would use both machine gun and mortar fire. ${ }^{12763}$

3861. In Poparić's view, in terms of safety for Sedrenik, the positions at Špicasta Stijena and Grdonj were "very disadvantageous" because Sedrenik was situated on a steep incline, meaning that almost every bullet fired from Špicasta Stijena and Grdonj would have had a ricocheting angle, so that in an exchange of fire a substantial number of projectiles would fly in the direction of the inhabited area. ${ }^{12764}$

3862. Taking all the above evidence into account, particularly the evidence of Thomas, Milošević, and Gengo, the Chamber is satisfied that the SRK positions above Sedrenik were of strategic importance to the SRK and that the SRK was able to and would open fire both from Špicasta Stijena and from its positions around it. Additionally, it is also satisfied, relying on Gengo, Rašević and the SRK documents cited above, ${ }^{12765}$ that the SRK soldiers in the area had machine guns, sniper rifles, and hunting rifles with optic sights. Finally, relying on the evidence of UNMO witnesses, Žunić, Đozo, and in particular the UNMO report of 6 March $1995,{ }^{12766}$ the Chamber is satisfied that the SRK soldiers would open small arms and/or sniper fire at the civilians in Sedrenik, and that Sedrenik was used by the SRK for "target practice".

\footnotetext{
12760 Stanislav Galić, T. 37190 (15 April 2013), T. 37411 (18 April 2013), T. 37541-37542 (22 April 2013); D3425 (SRK combat report, 2 September 1993); D3457 (SRK combat report, 27 July 1994).

12761 D2527 (Witness statement of Blaško Rašević dated 1 December 2012), paras. 22, 26, 27; Blaško Rašević, T. 30906-30909 (4 December 2012); D2529 (Map of Sarajevo marked by Blaško Rašević).

12762 Dragomir Milošević, T. 32568-32569 (23 January 2013).

12763 D2383 (Witness statement of Slavko Gengo dated 14 October 2012), paras. 10, 27-28, 33; Slavko Gengo, T. 29782-29783 (6 November 2012).

12764 D4884 (Mile Poparić's expert report entitled "Small Arms Fire on the Sarajevo Area 1992-1995", 15 August 2012), p. 42.

12765 See fn. 12749.

12766 See paras. 3849-3851, 3859-3860.
} 


\section{(3) Sedrenik, 17 April 1993 (Scheduled Incident F.2)}

3863. The Indictment alleges that, on 17 April 1993, a nine year old girl was shot and wounded in the back while playing in the front garden of her house in the Sedrenik area of Sarajevo. ${ }^{12767}$ In its Final Brief, the Prosecution argues that the fire originated from Špicasta Stijena, which was controlled by the SRK and which had an unobstructed view of the location where the girl was hit. ${ }^{12768}$ The Accused argues, however, that the girl could not be seen from Špicasta Stijena when shot whereas she could be seen from the ABiH positions at Grdonj Hill. ${ }^{12769}$

3864. The Chamber has also taken judicial notice of a number of adjudicated facts relating to the events on the day of this incident. According to those, the weather was sunny and a nine year old girl, ${ }^{12770}$ who was wearing dark trousers and a blue jacket, had gone outside into her front yard to play underneath a window of her house in Sedrenik. ${ }^{12771}$ The bullet hit the girl in "the area of [her] shoulder blade [...] went through [her] body and ended up in the wall" behind her. ${ }^{12772}$ Some unspecified time thereafter that day, the girl was transported in a car to a hospital in Sarajevo with the help of neighbours. ${ }^{12773}$ A shot was fired at the car as it pulled away from the girl's house, hitting it in the back. ${ }^{12774}$

3865. Hogan visited the site of the incident and recorded the exact position of the girl when she was shot. ${ }^{12775}$ Van der Weijden also visited the incident site, as well as Špicasta Stijena, which is 1,108 metres away, towards the northwest. ${ }^{12776}$ He noted that the bullet that wounded the victim exited her body and struck the wall behind her, leaving a trace, which meant that its path could be roughly traced to the position of the shooter. ${ }^{12777}$ While observing the environment from the exact location and height at which the girl was located when shot, he found that there was only one possible location for the origin of fire, namely Špicasta Stijena. ${ }^{12778}$ When he visited Špicasta

\footnotetext{
12767 Indictment, Scheduled Incident F.2.

12768 Prosecution Final Brief, Appendix C, paras. 23-24.

12769 Defence Final Brief, paras. 2188-2193.

12770 As noted in Adjudicated Fact 157, the nine year old girl was known as Witness E in the Prosecutor v. Galic case. See also P5068 (Pseudonym sheet for Witness E in the Prosecutor v. Stanislav Galić case) (under seal).

12771 See Adjudicated Fact 157.

12772 See Adjudicated Fact 158.

12773 See Adjudicated Fact 159.

12774 Adjudicated Fact 159.

12775 Barry Hogan, T. 11208-11209 (3 February 2011); P2190 (GPS locations for shelling and sniping incidents in Sarajevo); P2195 (Photograph re sniping incident of 17 April 1993 in Sedrenik marked by Barry Hogan); P2207 (Images re scheduled sniping incidents in Sarajevo).

12776 P1621 (Expert Report of Patrick van der Weijden entitled “Sniping Incidents in Sarajevo '92-'94”), pp. $20-21$.

12777 In his report, Van der Weijden attaches a photograph of that view, showing unobstructed view from the incident site to Śpicasta Stijena. P1621 (Expert Report of Patrick van der Weijden entitled "Sniping Incidents in Sarajevo '92-'94”), pp. 22-23.

12778 P1621 (Expert Report of Patrick van der Weijden entitled “Sniping Incidents in Sarajevo '92-'94”), p. 22.
} 
Stijena, he found that it offered an unobstructed view towards the incident site and, like Thomas, thought that it was an obvious location for a sniper position or a machine-gun emplacement. ${ }^{12779}$ Van der Weijden also noted that a tree in a garden close to the incident site obscured the view somewhat but that this would not have been the case more than 15 years ago. ${ }^{12780}$

3866. As for the weapon used in this incident, Van der Weijden thought that the bullet that struck the victim could not have been greater than $7.92 \mathrm{~mm}$ as such a calibre would have caused greater damage. ${ }^{12781}$ Given that there was no evidence of multiple shots, Van der Weijden concluded that probably an M76 or M91 semi-automatic sniper rifle was used to shoot the girl, although he conceded that the range here would have been extreme for those rifles. ${ }^{12782}$ According to Van der Weijden, the shooter would have been able to conclude that the victim was a small child because (i) the weather was sunny on the day of the incident; (ii) the girl was standing next to her house, which would have indicated her size; (iii) she had long hair and was wearing civilian clothing; and (iv) she was playing in the garden for one and a half hours before being shot which would have made her visible to the shooter occasionally. ${ }^{12783}$

3867. Poparić, while acknowledging that the girl's house is visible from Špicasta Stijena, testified that the exact spot she was located at when shot ${ }^{12784}$ was not visible from the "outermost trench of the [VRS]" on Špicasta Stijena but was instead visible from Grdonj Hill. ${ }^{12785}$ In support of this claim, Poparić produced two photographs of the view on the house from both Špicasta Stijena and Grdonj Hill. ${ }^{12786}$ Another method Poparić used to prove his claim was to calculate the site angle between the incident site and the VRS trenches and then, based on the assumption as to the potential height of the house adjacent to the girl's house, calculate the distance the adjacent house would have to have been located at from the girl's house for the girl's exact location to be visible

12779 See P1621 (Expert Report of Patrick van der Weijden entitled “Sniping Incidents in Sarajevo '92-'94”), pp. 20, 22. This was confirmed by Barry Hogan and the photograph he took at the exact location where the girl was playing when shot. See Barry Hogan, T. 11208-11209 (3 February 2011); P2195 (Photograph re sniping incident of 17 April 1993 in Sedrenik marked by Barry Hogan).

12780 P1621 (Expert Report of Patrick van der Weijden entitled "Sniping Incidents in Sarajevo '92-'94”), p. 22.

12781 P1621 (Expert Report of Patrick van der Weijden entitled “Sniping Incidents in Sarajevo '92-'94”), p. 20.

12782 P1621 (Expert Report of Patrick van der Weijden entitled “Sniping Incidents in Sarajevo '92-'94”), p. 20.

12783 P1621 (Expert Report of Patrick van der Weijden entitled “Sniping Incidents in Sarajevo '92-'94”), p. 23.

12784 Poparić obtained that location from a photograph the girl marked during her testimony in the Galić case. See D4884 (Mile Poparić's expert report entitled "Small Arms Fire on the Sarajevo Area 1992-1995", 15 August 2012), p. 59, Image 34. In contrast, Van der Weijden used the GPS location obtained by Barry Hogan. See P1621 (Expert Report of Patrick van der Weijden entitled “Sniping Incidents in Sarajevo '92-'94”), p. 20.

12785 D4884 (Mile Poparić's expert report entitled "Small Arms Fire on the Sarajevo Area 1992-1995", 15 August 2012), pp. 61-63; Mile Poparić, T. 38945 (29 May 2013).

12786 D4884 (Mile Poparić's expert report entitled "Small Arms Fire on the Sarajevo Area 1992-1995", 15 August 2012), p. 61; Mile Poparić, T. 38942-38943, 38945-38946 (29 May 2013); D3634 (Two photographs of houses marked by Mile Poparić). Poparić also used Google-earth images. Mile Poparić, T. 38943-38944 (29 May 2013). 
from Špicasta Stijena. ${ }^{12787}$ That distance, according to him, was much bigger than the actual distance between the two houses (which he again gauged from photographs), thus proving in his view that the girl was not visible from Špicasta Stijena when shot. ${ }^{12788}$ Poparić also noted that the girl's house was far from Špicasta Stijena, over 1,100 metres away, which made it very difficult to see the girl, regardless of the optical equipment being used. ${ }^{12789} \mathrm{He}$ also expressed a view that in his personal opinion no one targeted the girl deliberately, but that she was hit by a stray bullet, which could not have come from Špicasta Stijena. ${ }^{12790}$

3868. In cross-examination, Poparić conceded that he did not visit the girl's house or examine the bullet trace in the wall because (i) he assumed the changes had been made to the house and the examination would not have been useful and (ii) soon after visiting Špicasta Stijena, he realised that the location of the victim was not visible from there. ${ }^{12791}$ He also clarified that the girl was a protected witness in a previous case and therefore the defence team did not consider contacting her. ${ }^{12792}$ When shown a photograph taken from Špicasta Stijena in 1996 and asked if it showed a much clearer line of sight to the victim's house than photos taken by him, Poparić argued that the house was indeed more visible but that the ground floor, where the girl was located when shot, still could not be seen. ${ }^{12793}$

3869. Rašević, who commanded the SRK's Mrkovići Company at the time of the incident, testified he held the positions on Špicasta Stijena, but that he never received an order to shoot at civilians or civilian targets, and that he never issued such orders to his subordinates. ${ }^{12794}$ Furthermore, his company never opened fire at civilians in Sedrenik. ${ }^{12795}$ In cross-examination, Rašević was shown the UNMO report of 6 March $1995 .{ }^{12796}$ When asked to comment how this information squared with his answer that his units never fired from Špicasta Stijena, Rašević

\footnotetext{
12787 D4884 (Mile Poparić's expert report entitled "Small Arms Fire on the Sarajevo Area 1992-1995", 15 August 2012), pp. 61-63.

12788 D4884 (Mile Poparić's expert report entitled "Small Arms Fire on the Sarajevo Area 1992-1995", 15 August 2012), pp. 62-63; Mile Poparić, T. 38945 (29 May 2013).

12789 Mile Poparić, T. 38941 (29 May 2013).

12790 Mile Poparić, T. 38945 (29 May 2013). See also Siniša Maksimović, T. 29306 (23 October 2012).

12791 Mile Poparić, T. 39222-39224 (4 June 2013). According to the Prosecution, Poparić's analysis of the origin of fire was undermined because of his failure to analyse the actual impact point of the bullet. See Prosecution Final Brief, Appendix C, para. 9.

12792 Mile Poparić, T. 39304 (5 June 2013).

12793 Mile Poparić, T. 39225-39227 (4 June 2013); P6362 (Photograph of houses in Sarajevo marked by Mile Poparić).

12794 D2527 (Witness statement of Blaško Rašević dated 1 December 2012), paras. 21, 29.

12795 D2527 (Witness statement of Blaško Rašević dated 1 December 2012), para. 29. In fact, Rašević testified that SRK never fired from Špicasta Stijena at all. See Blaško Rašević, T. 30917 (4 December 2012).

12796 See para. 3859; P1619 (UNMO report, 6 March 1995).
} 
responded that this incident happened after he left Mrkovići but conceded that, based on that report, he could not exclude that there was no firing from the SRK positions at Špicasta Stijena. ${ }^{12797}$

3870. Siniša Maksimović, the Commander of Mrkovići Company after this incident took place, ${ }^{12798}$ testified that the positions of the company were the same even before he arrived to the area and that, based on a photograph given to him by the Accused's defence team, these positions had no view onto the exact location of the incident. ${ }^{12799}$ When shown a different photograph, taken by Hogan at the precise location the victim was located when shot, which shows a different view towards the alleged origin of fire, he testified that if that was indeed the origin of fire then it was under control of another VRS unit—unit that was his neighbour on the left flank. ${ }^{12800}$

3871. Maksimović also explained that the distance between the incident site and the position of SRK units was somewhere between 800 and 1,000 metres and that, to his knowledge, the units at that location did not have soldiers trained for sniper fire, or guns of that range. ${ }^{12801}$ When shown a report from the $1^{\text {st }}$ Romanija Infantry Brigade to the SRK command, dated 29 October 1993, and reporting on the brigade's sniping capabilities, including that it possessed about 50 M76 $7.92 \mathrm{~mm}$ calibre rifles, Maksimović conceded that those rifles have a range of about 1,000 metres. ${ }^{12802}$

3872. Maksimović also testified that the position of his units was under constant fire by the $\mathrm{ABiH}$ units as Grdonj Hill was in a dominant position in relation to his company's positions. ${ }^{12803}$ Nevertheless, he conceded that SRK soldiers would open fire from Špicasta Stijena. ${ }^{12804}$ Finally, he

\footnotetext{
12797 Blaško Rašević, T. 30917-30920 (4 December 2012).

12798 At the time of the incident Maksimović was a member of the intervention platoon in the $4^{\text {th }}$ Battalion of the Igman Brigade and held the line on Igman, which is far from Sedrenik and only replaced Rašević briefly in 1994. See D2354 (Witness statement of Siniša Maksimović dated 19 October 2012), paras. 3-5; Blaško Rašević, T. 30914-30915 (4 December 2012). For that reason, the Prosecution submits that his evidence is irrelevant to this incident. See Prosecution Final Brief, Appendix C, para. 24.

Maksimović was able to make that conclusion based on the photograph given to him by the Accused's team and said to have been taken from the approximate location of the victim when shot. He marked this photograph, placing the location of his units behind the roof of the house adjacent to the victim's house. See D2354 (Witness statement of Siniša Maksimović dated 19 October 2012), para. 7; D2358 (Photograph of Sedrenik marked by Siniša Maksimović).

12800 Siniša Maksimović, T. 29299-29300 (23 October 2012); P2207 (Images re scheduled sniping incidents in Sarajevo).

12801 He explained that his units only had $7.62 \mathrm{~mm}$ automatic rifles which were most accurate at 300 to 400 metre range and for which 800 metres would be the extreme range. See D2354 (Witness statement of Siniša Maksimović dated 19 October 2012), para. 8; Siniša Maksimović, T. 29301, 29305-29306 (23 October 2012); P2193 (Map of Sarajevo).

12802 Siniša Maksimović, T. 29301-29304 (23 October 2012); P5945 (Report of $1^{\text {st }}$ Romanija Infantry Brigade to SRK, 29 October 1993).

12803 D2354 (Witness statement of Siniša Maksimović dated 19 October 2012), paras. 8, 10.

12804 Siniša Maksimović, T. 29297 (23 October 2012).
} 
testified that he never issued orders for civilians to be fired on in the area and that he never heard that civilian targets were fired on by the members of his unit. ${ }^{12805}$

3873. Galić testified that he had no knowledge about this incident at the time, but that he realised during his trial that SRK positons on Špicasta Stijena did not have a view of the area where the girl was located when shot. ${ }^{12806}$ Further, he stated that he never issued orders to target civilians in the area of Sedrenik and if anyone did open such fire, it was done unbeknownst to him. ${ }^{12807}$

3874. The Chamber has also taken judicial notice of a number of adjudicated facts going to the origin of fire, which state that (i) the bullet that injured the nine year old girl was fired from the area of Špicasta Stijena; ${ }^{12808}$ (ii) there was no military equipment or personnel near the girl at the time; ${ }^{12809}$ (iii) the girl, along with others, was targeted again from the direction of Špicasta Stijena as she was being taken to the hospital; ${ }^{12810}$ and (iv) the girl was a civilian and was deliberately targeted from SRK-controlled territory. ${ }^{12811}$

3875. The Chamber considers, given the girl's age at the time of the incident and the fact that she was playing in front of her house, that she was a civilian and that she was not taking direct part in hostilities at the time of the incident nor was she around soldiers or military targets when it happened. Contrary to Poparić's opinion that the girl was hit by a stray bullet from an exchange of fire, the Chamber is satisfied that there was no fighting at the moment she was playing in her yard as she would not have been engaging in such an activity if that were the case.

3876. The Chamber is also satisfied, based on the evidence above, that the area of Špicasta Stijena had a line of sight to the exact location where the girl was playing. In fact, the Chamber accepts Van der Weijden's evidence that Špicasta Stijena was the only location that had a view of the girl at the time. The Chamber is persuaded by his analysis because he personally observed the environment from the girl's position when shot and he also examined the bullet traces on the wall. In contrast, the Chamber does not accept Poparić's analysis of this incident as it is based on a number of speculations. First, unlike Van der Weijden, Poparić did not visit the victim's house nor was he able to observe the view from the house to Špicasta Stijena, which should have been the very first step for an expert to take. Second, his claim that the view between the location of the

\footnotetext{
12805 D2354 (Witness statement of Siniša Maksimović dated 19 October 2012), para. 9.

12806 Stanislav Galić, T. 37478-37482 (22 April 2013); D3439 (VRS Main Staff Order, 17 April 1993).

12807 Stanislav Galić, T. 37478-37479 (22 April 2013).

12808 See Adjudicated Fact 161.

12809 See Adjudicated Fact 162.

12810 See Adjudicated Fact 163.

12811 See Adjudicated Fact 164.
} 
victim when shot and Špicasta Stijena was obstructed is based on (i) various calculations based on the height of the adjacent house and its distance to the victim's house, and (ii) a photograph of the victim's house taken from Špicasta Stijena. Having considered his ground (i), the Chamber finds it unconvincing as it is based on a number of speculations as to the measurements involved-not having been to the location of the incident, Poparić is merely guessing the height of the adjacent house and the distance between the two houses. As for (ii), while the photograph does appear to show that the tree near the victim's house is obstructing the view of the location of the girl when shot, the Chamber also recalls Van der Weijden's testimony that when he visited Špicasta Stijena, he found that it offered an unobstructed view of the incident site. ${ }^{12812}$ He noted the existence of the said tree and partially obstructed view due to its branches, but concluded that the view would not have been so obstructed more than 15 years ago. ${ }^{12813}$ Accordingly, the Chamber is persuaded by Van der Weijden's analysis that Špicasta Stijena was the only possible origin of fire for this incident.

3877. The Chamber is further satisified, based on the evidence of local SRK commanders, that the $7^{\text {th }}$ Battalion of the $1^{\text {st }}$ Romanija Infantry Brigade of the SRK had positions in the area of Špicasta Stijena and would open fire from that area, as attested to by a number of witnesses, including Thomas, Milošević, and Gengo. Relying, among other things, on the UNMO report of 6 March 1995, the Chamber is also satisfied that the SRK soldiers located in the area would open sniper fire at the civilians in Sedrenik, as they used the area for "target practice". It is also satisfied, relying on the evidence above, ${ }^{12814}$ that the SRK soldiers in the area possessed either sniper rifles or hunting rifles with optic sights, which would have had the range needed to reach the victim in this case. ${ }^{12815}$ Finally, given the distance between the incident site and the area of Špicasta Stijena, which would have required a careful shot on the part of the shooter, as well as the fact that the car taking her to the hospital was also shot at, the Chamber is satisfied that the girl was deliberately targeted by one

12812 P1621 (Expert Report of Patrick van der Weijden entitled “Sniping Incidents in Sarajevo '92-'94”), p. $20,22$. See also Barry Hogan, T. 11208-11209 (3 February 2011); P2195 (Photograph re sniping incident of 17 April 1993 in Sedrenik marked by Barry Hogan).

12813 P1621 (Expert Report of Patrick van der Weijden entitled "Sniping Incidents in Sarajevo '92-'94”), p. 22. Indeed, this is confirmed by the photograph of the area taken in 1996, namely P6362, where the ground floor of the girl's house can be seen from Špicasta Stijena. The Chamber also notes that Poparić acknowledged Van der Weijden's evidence about the tree but testified that he "personally" thought that the bullet could not have come from Špicasta Stijena. Mile Poparić, T. 38945 (29 May 2013). However, in light of the evidence on visibility that Van der Weijden gave, which in turn was supported by the evidence of Barry Hogan, the Chamber does not accept Poparić's view that the fire could not have come from Špicasta Stijena.

12814 See para. 3858.

12815 The Chamber also recalls here Van der Weijden's evidence that a substantial number of combatants in Sarajevo had hunting rifles fitted with scopes, which were suitable for sniping. See P1621 (Expert Report of Patrick van der Weijden entitled “Sniping Incidents in Sarajevo '92-'94”), Appendix A, pp. 3-4. 
of the SRK soldiers. This soldier would have undoubtedly been aware of her civilian status, for all the reasons outlined above by Van der Weijden. ${ }^{12816}$

\section{(4) $\underline{\text { Sedrenik street, } 6 \text { March } 1995 \text { (Scheduled Incident F.17) }}$}

3878. The Indictment alleges that on 6 March 1995, Tarik Žunić, a 14 year old boy, was shot and wounded in the hand while walking home from school at Sedrenik street, in the northeast of Sarajevo. The Indictment also alleges that he was hit as he emerged from behind a protective screen about 100 metres from his house. ${ }^{12817}$ In its Final Brief, the Prosecution submits that the shot came from Špicasta Stijena and that the most likely weapon used was M84 machine-gun. ${ }^{12818}$ The Accused counterclaims that the location of the incident was not visible from the SRK positions in the area and that sniper fire was not possible due to distances involved and field configuration. ${ }^{12819}$

3879. On 6 March 1995, Tarik Žunić, then 14 1⁄2 years old, was walking home from school, which he would attend only on days when there was no shelling or fighting. ${ }^{12820}$ At around 1 p.m., he was on Sedrenik street, some 100 metres from his house, and had just passed a canvas erected on the street as protection against sniper fire, ${ }^{12821}$ when he heard two shots. ${ }^{12822}$ He immediately took shelter on the edge of the street and, while the shooting continued, realised that he had been hit in the right hand. ${ }^{12823}$ A civilian car tried to stop and help him but was also targeted by the sniper so drove on. ${ }^{12824}$ Another man also tried to help but he too was shot at. ${ }^{12825}$ Some five minutes later

\footnotetext{
12816 See para. 3866.

12817 Indictment, Scheduled Incident F.17.

12818 Prosecution Final Brief, Appendix C, para. 25.

12819 Defence Final Brief, paras. 2297-2303.

12820 Žunić also explained that when there was no shelling or sniping he would use the "main street" to get to school and back. There was also a more sheltered but more difficult route he would take in case fire started when he was coming back from school. On the day of the incident he was taking the main street route. See P496 (Witness statement of Tarik Žunić dated 10 November 1995), p. 2; P496 (Witness statement of Tarik Žunić dated 21 April 2006), p. 2. See also Adjudicated Fact 2998.

12821 Žunić also testified that there was a "canvas" along the street he was walking on, erected in order to shield the people from the snipers. However, the canvas did not shield the whole length of the street. In addition, there were trees lining the street which provided protection in summer. However, given that this was early March, the trees has no leaves on their branches. See P496 (Witness statement of Tarik Žunić dated 21 April 2006), p. 2.

12822 P496 (Witness statement of Tarik Žunić dated 10 November 1995), p. 2; P496 (Witness statement of Tarik Žunić dated 21 April 2006), p. 2; Tarik Žunić, P494 (Transcript from Prosecutor v. D. Milošević), T. 17071715, 1748-1754; P457 (Map of Sarajevo marked by Tarik Žunić); P449 (Aerial photograph of Sarajevo marked by Tarik Žunić); P450 (Aerial photograph of Sarajevo marked by Tarik Žunić); P451 (Photograph of Sarajevo marked by Tarik Žunić); P452 (Photograph of Sarajevo marked by Tarik Žunić); P453 (Photograph of Sarajevo marked by Tarik Žunić), P460 (Photograph of Sarajevo marked by Tarik Žunić).

12823 P496 (Witness statement of Tarik Žunić dated 10 November 1995), p. 2; P496 (Witness statement of Tarik Žunić dated 21 April 2006), p. 2; Tarik Žunić, P494 (Transcript from Prosecutor v. D. Milošević), T. 17251728, 1734, 1737-1738. See also Adjudicated Fact 3000.

12824 P496 (Witness statement of Tarik Žunić dated 10 November 1995), p. 2.
} 
an APC driven by Egyptian UNPROFOR soldiers arrived and Žunić managed to get on board, after which he was transported to the Koševo Hospital where his wound was attended to. ${ }^{12826}$

3880. On the day of the incident, which was cloudy but not foggy, Žunić was wearing jeans and a green jacket and carrying a blue rucksack on his right shoulder. ${ }^{12827}$ Žunić maintained during his evidence that his jacket was not olive-drab green but rather "Benetton-green", ${ }^{12828}$ and that he never fought in the $\mathrm{ABiH}$ as he was too young at the time. ${ }^{12829}$ Once in the hospital, he noticed two holes on the front of his jacket. ${ }^{12830}$ The bullet had first entered the left side of his jacket, then exited through the right side of his jacket and then passed through his right hand. ${ }^{12831}$

3881. Žunić testified that the shots came from Serb positions on Špicasta Stijena, to his left, because this location was the only location from which the snipers had a perfect sight of the Sedrenik street. ${ }^{12832}$ According to him, the ABiH forces were located at the foot of Špicasta Stijena and their positions were not visible from where he was walking when shot. ${ }^{12833}$ He believed, based on how loud the shots were and his experience with sniper fire until that point, that they were fired from an M84 machine-gun. ${ }^{12834}$ According to Žunić, there were no military installations or trenches in the vicinity of the location where he was shot, and the confrontation line was some 700 to 900 metres away. ${ }^{12835}$ Finally, he testified that he had been fired upon on two other occasions, also from Špicasta Stijena. ${ }^{12836}$

3882. The UNMO observers reported on this incident on the same day, as well as on another incident in the area some 25 minutes earlier, and concluded that the fire in relation to both had

12825 P496 (Witness statement of Tarik Žunić dated 21 April 2006), p. 2; Tarik Žunić, P494 (Transcript from Prosecutor v. D. Milošević), T. 1744-1745.

12826 Žunić testified that he does not suffer from the consequences of his wound except when the weather is about to change. See P496 (Witness statement of Tarik Žunić dated 10 November 1995), p. 2.

12827 P496 (Witness statement of Tarik Žunić dated 10 November 1995), p. 2. See also Adjudicated Facts 2998, 2999.

12828 Tarik Žunić, P494 (Transcript from Prosecutor v. D. Milošević), T. 1724-1725.

12829 Tarik Žunić, P494 (Transcript from Prosecutor v. D. Milošević), T. 1741, 1745-1746.

12830 P496 (Witness statement of Tarik Žunić dated 10 November 1995), p. 2; P496 (Addendum to Tarik Žunić's witness statement of 10 November 1995, 25 April 2010), p. 1; Tarik Žunić, P494 (Transcript from Prosecutor v. D. Milošević), T. 1725, 1740-1741.

12831 P494 (Transcript from Prosecutor v. D. Milošević), T. 1725, 1741; P1548 (Medical report for Tarik Žunić); P1534 (List of medical records of sniping victims), p. 3. See also Adjudicated Fact 3000.

12832 P496 (Witness statement of Tarik Žunić dated 10 November 1995), p. 2; Tarik Žunić, P494 (Transcript from Prosecutor v. D. Milošević), T. 1725, 1738-1739, 1753-1754; P453 (Photograph of Sarajevo marked by Tarik Žunić); P460 (Photograph of Sarajevo marked by Tarik Žunić).

12833 Tarik Žunić, P494 (Transcript from Prosecutor v. D. Milošević), T. 1723-1724, 1726-1727, 1741-1742.

12834 P496 (Witness statement of Tarik Žunić dated 10 November 1995), p. 2; P496 (Witness statement of Tarik Žunić dated 21 April 2006), p. 2; Tarik Žunić, P494 (Transcript from Prosecutor v. D. Milošević), T. 1740.

12835 P496 (Witness statement of Tarik Žunić dated 10 November 1995), pp. 2-3; P496 (Witness statement of Tarik Žunić dated 21 April 2006), p. 2; Tarik Žunić, P494 (Transcript from Prosecutor v. D. Milošević), T. 1709, 1712-1715, 1746-1748; P450 (Aerial photograph of Sarajevo marked by Tarik Žunić). 
come from Špicasta Stijena. ${ }^{12837}$ The observers also reported that, while assisting the victims of those two incidents, they came under occasional small arms fire, as a result of which the Egyptian battalion's anti sniping APC at that location returned fire on the Bosnian Serb positions on Špicasta Stijena. ${ }^{12838}$ Following this, the UNMO team from Vogošća received a phone call from the Bosnian Serb commander of the Radava Battalion, ${ }^{12839}$ stating that if the APC "in his target practice area (Sedrenik) is not removed within 30 mins it will be fired upon". ${ }^{2840}$ As a result, the APC was moved to another position from which it continued to monitor the Špicasta Stijena positions. ${ }^{12841}$

3883. Hogan visited the site of the incident and recorded Žunić's exact location when shot. ${ }^{12842}$ Van der Weijden then visited the incident site on 29 November 2006. ${ }^{12843}$ He noted that the ridgeline on Špicasta Stijena was in clear view and some 650 to 900 metres away from the incident site. ${ }^{12844}$ While the road on which Žunić walked before being shot had a metre high wall on the side of Špicasta Stijena and there was some growth hiding him from view, this offered little protection. ${ }^{12845}$ Van der Weijden also observed that the fence near which Žunić stood when hit had more bullet holes strengthening his opinion that the shots came from the direction of Špicasta Stijena. ${ }^{12846}$ Van der Weijden thought it possible for a boy of Žunić's age to be confused for a combatant; however, because there were protective screens on the street at the time when the incident happened, giving the shooter a limited time to see him, it would have been impossible for the shooter to determine in such a short time whether Žunić was a combatant or not. ${ }^{12847}$ Furthermore, given that this was a residential civilian area, under constant observation from SRK positions, there was no reason for the shooter to identify Žunić as a combatant. ${ }^{12848}$ Van der Weijden also commented on the UNMO report referred to above, noting that the SRK commander in question clearly saw this area as his target practice area. ${ }^{12849}$

\footnotetext{
12836 Tarik Žunić, P494 (Transcript from Prosecutor v. D. Milošević), T 1728.

12837 P1619 (UNMO report, 6 March 1995), para. 8.

12838 P1619 (UNMO report, 6 March 1995), para. 3.

12839 As noted earlier, Radava is a village near Mrkovići. See fn. 12757.

12840 P1619 (UNMO report, 6 March 1995), para. 3.

12841 P1619 (UNMO report, 6 March 1995), para. 3.

12842 Barry Hogan, T. 11220-11221 (3 February 2011); P2211 (Photograph re sniping incident of 6 March 1995 on Sedrenik street marked by Barry Hogan); P2213 (Image re scheduled sniping and shelling incidents in Sarajevo); P2190 (GPS locations for shelling and sniping incidents in Sarajevo); P2191 (Map of Sarajevo with scheduled sniping and shelling incidents); P2193 (Map of Sarajevo).

12843 P1621 (Expert Report of Patrick van der Weijden entitled “Sniping Incidents in Sarajevo '92-'94”), p. 32.

12844 P1621 (Expert Report of Patrick van der Weijden entitled “Sniping Incidents in Sarajevo '92-'94”), pp. 31-32.

12845 P1621 (Expert Report of Patrick van der Weijden entitled "Sniping Incidents in Sarajevo '92-'94”), p. 32.

12846 P1621 (Expert Report of Patrick van der Weijden entitled “Sniping Incidents in Sarajevo '92-'94”), p. 32.

12847 P1621 (Expert Report of Patrick van der Weijden entitled "Sniping Incidents in Sarajevo '92-'94”), p. 32. See also Appendix B to this report where Van der Weijden discusses target identification in urban settings.

12848 P1621 (Expert Report of Patrick van der Weijden entitled “Sniping Incidents in Sarajevo '92-'94”), p. 32.

12849 Patrick van der Weijden, T. 6956-6957, 6959 (27 September 2010).
} 
3884. In terms of the weapon used, Van der Weijden agreed with Žunić's assessment that it was probably an M84 as there was a burst of fire at a long range indicating a machine-gun and because the other two machine-guns that could have been used, namely an M87 and an M53, either would have caused a lot more damage or would have had a completely different sound to the M84. ${ }^{12850}$

3885. Poparić testified that there is very little information about this incident ${ }^{12851}$ and that in order to determine the direction of the shot it would have been indispensable to determine where Žunić's entry and exit wounds were located. ${ }^{12852} \mathrm{He}$ also stated that when he visited the incident site, as marked by Žunić, he was assured by a man and a woman who live next door that the incident happened in front of their house and not in front of the house which Žunić had marked as the location of the incident. ${ }^{12853}$ According to Poparić, that location is much less visible from Špicasta Stijena than the location marked by Žunić. ${ }^{12854}$ Poparić also went to Špicasta Stijena and observed the incident site from there, concluding that the distance was some 700 to 750 metres and that the possibility of observing people in the area where Žunić was shot is small. ${ }^{12855}$ In addition, he observed that the incident site was also visible from Grdonj Hill, meaning that Žunić could have been shot from that location as well. ${ }^{12856}$ Poparić too referred to the UNMO report from that day, which to him indicated that an $\mathrm{ABiH}$ combat unit was deployed in one of the houses on Sedrenik street as another man was wounded in the same area around the same time. ${ }^{12857}$ In addition, according to Poparić, the UNMO report also indicated that UNPROFOR forces interfered in the exchange of fire. ${ }^{12858}$ When put to him in cross-examination that the UNMO report in fact shows

12850 P1621 (Expert Report of Patrick van der Weijden entitled “Sniping Incidents in Sarajevo '92-'94”), p. 31.

12851 According to Poparić, the BiH MUP did not conduct an investigation at the site due to "combat operations". See D4884 (Mile Poparić's expert report entitled "Small Arms Fire on the Sarajevo Area 1992-1995", 15 August 2012), p. 160. However, in cross-examination, Poparić was shown an official note from the Stari Grad SJB referring to the fact that the investigation could not be conducted due to "firing from the aggressors's positions". He commented that this language did not rule out "the possibility that the fire was returned" but conceded that this was an assumption on his part. See Mile Poparić, T. 39213-39215 (4 June 2013); P6361 (Official note of Stari Grad SJB, 10 March 1995). The Chamber considers the language in the official note to be clear and directly contrary to Poparić's assumption. In other words, it is clear from the note that the investigators could not conduct an investigation due to fire from the SRK positions.

12852 Mile Poparić, T. 38925 (29 May 2013). However, the Chamber notes that medical report describing the location of entry and exit wounds suffered by Žunić is in evidence in this case and was in evidence in the Milošević case. See P1548 (Medical report for Tarik Žunić).

12853 D4884 (Mile Poparić's expert report entitled "Small Arms Fire on the Sarajevo Area 1992-1995", 15 August 2012), p. 161; Mile Poparić, T. 38926-38928 (29 May 2013), T. 39218-39221 (4 June 2013); D3630 (Photograph of houses marked by Mile Poparić).

12854 D4884 (Mile Poparić's expert report entitled "Small Arms Fire on the Sarajevo Area 1992-1995", 15 August 2012), p. 161; Mile Poparić, T. 38927 (29 May 2013).

12855 D4884 (Mile Poparić's expert report entitled "Small Arms Fire on the Sarajevo Area 1992-1995", 15 August 2012), p. 162; Mile Poparić. T. 38925 (29 May 2013), T. 39221 (4 June 2013).

12856 D4884 (Mile Poparić's expert report entitled "Small Arms Fire on the Sarajevo Area 1992-1995", 15 August 2012), p. 162.

12857 D4884 (Mile Poparić's expert report entitled "Small Arms Fire on the Sarajevo Area 1992-1995", 15 August 2012), p. 163; Mile Poparić, T. 38925 (29 May 2013).

12858 Mile Poparić, T. 38925 (29 May 2013). 
that the exchange of fire happened during Žunić's rescue and only because UNPROFOR came under sniper fire first, Poparić disagreed saying "if there is no information on any combat with $\mathrm{ABiH}$, there is information on combat with members of [UNPROFOR]." 12859

3886. Siniša Maksimović, who briefly replaced Rašević as the Commander of Mrkovići Company in 1994 but left before this incident took place, ${ }^{12860}$ testified that the positions of the company were more than 1,000 metres from the incident site and that it would be difficult to see the location of the incident site from those positions. ${ }^{12861}$ He conceded, however, that he assessed this distance without knowing the address of the incident and on the basis of a photograph given to him. ${ }^{12862}$ As noted earlier, Maksimović conceded during his evidence that SRK soldiers opened fire from Špicasta Stijena but claimed that this only happened in response to an attack and that their fire was aimed only at $\mathrm{ABiH}$ positions. ${ }^{12863}$ When confronted with the UNMO report referring to Žunić and another civilian being wounded by fire from Špicasta Stijena and the exchange of fire between the UNPROFOR and the SRK soldiers that followed, Maksimović refused to comment as this incident took place when he was no longer the commander in the area. ${ }^{12864}$

3887. In addition to the evidence outlined above, the Chamber has also taken judicial notice of a number of adjudicated facts going to the origin of fire, which state that (i) Žunić, a civilian, was shot and seriously wounded by a machine gun from SRK-held positions at Špicasta Stijena when he was walking on Sedrenik street and appeared from behind a sheet of canvas; ${ }^{12865}$ and (ii) there was no reason for the sniper to mistake Žunić for a combatant. ${ }^{12866}$

3888. The Chamber considers, given Žunić's age at the time of the incident and the fact that he was dressed in civilian clothing and was walking home from school, that he was a civilian and that he was not taking direct part in hostilities at the time of the incident. Contrary to Poparić's opinion that Žunić was caught in an exchange of fire, ${ }^{12867}$ the Chamber considers that there was no fighting

12859 Mile Poparić, T. 39215-39218 (24 June 2013).

12860 At the time of the incident, Maksimović was a member of the Igman Brigade and held the line on Igman, which is far from Sedrenik. D2354 (Witness statement of Siniša Maksimović dated 19 October 2012), paras. 3-6; Siniša Maksimović, T. 29296 (23 October 2012). In fact, Maksimović only briefly replaced Blaško Rašević in mid to late 1994 as the company commander. See Blaško Rašević, T. 30914-30915 (4 December 2012).

12861 D2354 (Witness statement of Siniša Maksimović dated 19 October 2012), para. 7; Siniša Maksimović, T. 29306 (23 October 2012).

12862 Siniša Maksimović, T. 29300-29301 (23 October 2012).

12863 See para. 3872.

12864 Siniša Maksimović, T. 29297-29298 (23 October 2012); P1619 (UNMO report, 6 March 1995).

12865 See Adjudicated Fact 3004.

12866 See Adjudicated Fact 3005.

12867 The Chamber also does not accept Poparić's testimony that the fact that another man was wounded on the same day and around the same time indicates that there was an $\mathrm{ABiH}$ military unit in one of the houses nearby. First, Poparić does not explain how he reached that conclusion given that such a similar incident can also be explained by the same SRK shooter opening fire at the other man, as was eventually found by the UNMO report. 
on that day as Žunić was able to go to school which, according to his testimony, he would not have done otherwise. Furthermore, he was walking on the main street to get home, which he would not have used had there been any fighting in the area. The Chamber is also convinced that there was no fighting when Žunić entered the protective screen on Sedrenik street as he would have otherwise stayed behind it for protection.

3889. The Chamber is also satisfied, based on the evidence above, that the area of Špicasta Stijena had a line of sight to the street on which Žunić was walking. Even Poparić's testimony, namely that the chances of seeing people in that area from Špicasta Stijena were small, still allows for that possibility. ${ }^{12868}$ In any event, the Chamber accepts Van der Weijden's evidence on this issue, namely that there was a clear view between the incident site and Špicasta Stijena. The Chamber recalls Poparić's testimony that Grdonj Hill also had the view on the incident site and accepts that to be the case. However, relying on the UNMO report of 6 March 1995, which specifically attributes the fire in this incident to the forces on Špicasta Stijena and even refers to an exchange of fire between UNPROFOR and those forces during Žunić's rescue, the Chamber is convinced that the bullet that hit Žunić in fact came from Špicasta Stijena.

3890. The Chamber is further satisfied, based on the evidence of local SRK commanders, that the $7^{\text {th }}$ Battalion of the $1^{\text {st }}$ Romanija Infantry Brigade of the SRK had positions in the area of Špicasta Stijena and would open fire from that area, as attested to by a number of witnesses, including Thomas, Milošević and Gengo. Relying, among other things, on the UNMO report of 6 March 1995, the Chamber is also satisfied that the SRK soldiers located in the area would open sniper fire at the civilians in Sedrenik, as they used the area for "target practice". It is also satisfied, relying on the evidence above, ${ }^{12869}$ that the SRK soldiers in the area possessed either sniper rifles or hunting rifles with optic sights, which would have had the range needed to reach Žunić who was around 750 metres away. Finally, given the distance between the incident site and the area of Špicasta Stijena, which would have required a careful shot on the part of the shooter, as well as the fact that the two people trying to help Žunić were also shot at, the Chamber is satisfied that he was deliberately targeted by one of the SRK soldiers on Špicasta Stijena. Given the clothing he was wearing on the day, as well as the fact that he was carrying a blue backpack and was walking in a

Furthermore, the Chamber recalls that the command post of the $105^{\text {th }}$ Mountain Brigade was located in in the Šipad building in Trampina street and thus was far away from the incident site. See fn. 12741.

12868

Poparić also claimed that the incident may have taken place in front of another house, based on what he was told at the scene by two people who claimed to have seen the incident. The Chamber notes that what Poparić heard from people living on Sedrenik street is not evidence in this case and that if the Accused wanted to challenge the precise location of this incident using this information he should have called the two people in question to give evidence. The Chamber therefore accepts Žunić's location as testified to by him and by Barry Hogan.

12869 See para. 3858. 
residential area, far from the command post of the ABiH's $105^{\text {th }}$ Mountain Brigade, the Chamber considers that the SRK soldier in question had no grounds on which to assume that Žunić was a combatant or that he was taking active part in hostilities.

\section{(D) Central area of Novo Sarajevo}

3891. Two of the 16 scheduled sniping incidents took place in the areas of Čengic Vila/Dolac Mala and Hrasno Brdo respectively. ${ }^{12870}$ Hrasno Brdo is a hill located just behind the suburbs of Hrasno and Dolac Malta, with Grbavica and Vraca to the east and Novi Grad municipality to the west. $^{12871}$ The Prosecution alleges in relation to both scheduled incidents relevant to this area that the fire originated from the SRK positions in the area of Ozrenska street ${ }^{12872}$ located on the upper parts of Hrasno Brdo in Novo Sarajevo. ${ }^{12873}$

\section{(1) Confrontation lines in the area}

3892. Ozrenska street was inhabited mostly by Serbs who, sometime in April 1992, organised night guards and armed themselves through the Serb TO. ${ }^{12874}$ In May 1992, with the formation of the SRK, the $2^{\text {nd }}$ Infantry Battalion was formed in the area; ${ }^{12875}$ it was part of the $1^{\text {st }}$ Romanija Brigade until mid-1993 when it became became part of the $1^{\text {st }}$ Sarajevo Mechanised Brigade. ${ }^{12876}$

3893. Slobodan Tuševljak, the Commander of the $1^{\text {st }}$ Platoon of the $4^{\text {th }}$ Company of the $2^{\text {nd }}$ Infantry Battalion from the beginning of the war, ${ }^{12877}$ testified that the original line of disengagement between the Bosnian Muslim and Bosnian Serb soldiers in the area of Hrasno Brdo

12870 These are Scheduled Incidents F.4 and F.10.

12871 See D2419 (Map of Sarajevo marked by Božo Tomić); Adjudicated Fact 75.

12872 This street is now called Novopazarska street. See D2389 (Witness statement of Predrag Trapara dated 3 November 2012), para. 4.

12873 See D2419 (Map of Sarajevo marked by Božo Tomić).

12874 Božo Tomić, a resident of Ozrenska street, was selected to be a squad commander and given an automatic rifle, while the other men had old M48 rifles or semi-automatic rifles. Muslim areas near Ozrenska street also armed themselves. See D2418 (Witness statement of Božo Tomić dated 5 November 2012), paras. 6-8; Božo Tomić, T. 30159-30164 (13 November 2012).

12875 Originally, while part of the $1^{\text {st }}$ Romanija Infantry Brigade, the $2^{\text {nd }}$ Infantry Battalion was known as the $3^{\text {rd }}$ Infantry Battalion but changed its name sometime in mid-1993 to $2^{\text {nd }}$ Infantry Battalion. See D2418 (Witness statement of Božo Tomić dated 5 November 2012), paras. 25-26; Božo Tomić, T. 30178-30179 (13 November 2012).

12876 Tomić later became deputy commander of a platoon and remained in that position until mid-1994 when he moved to the command of the $2^{\text {nd }}$ Infantry Battalion. See D2418 (Witness statement of Božo Tomić dated 5 November 2012), para. 8. The $2^{\text {nd }}$ Infantry Battalion had five companies, with over 1,000 men in total, and was commanded by a number of men, including Veljko Stojanović and Aco Petrović. See Slobodan Tuševljak, T. 29943-29944 (7 November 2012); D2418 (Witness statement of Božo Tomić dated 5 November 2012), para. 25; Božo Tomić, T. 30199 (13 November 2012); D2420 (Order of $3^{\text {rd }}$ Infantry Battalion, 3 May 1993); P1938 (Witness statement of KDZ310 dated 28 November 2010), para. 29.

12877 D2391 (Witness statement of Slobodan Tuševljak dated 5 November 2012), paras. 7, 13; Slobodan Tuševljak, T. 29940-29942, 29945-29947 (7 November 2012). 
was near Zagorska street ${ }^{12878}$ but that on 8 June 1992 the Muslim forces pushed his unit some 200 to 250 metres to the south, thus establishing a confrontation line near Ozrenska street, which did not move until the end of the war. ${ }^{12879}$ Dušan Zurovac, who was the Commander of the $4^{\text {th }}$ Company between November 1992 and April 1994, ${ }^{12880}$ testified that the area of responsibility of his company was on Ozrenska street, from "Pandurevića Kuća" to the cross-roads on Milinkladska street. $^{12881}$

3894. Thus, the $4^{\text {th }}$ Company was located some 150 to 200 metres below Ozrenska street, ${ }^{12882}$ and controlled the summit of Hrasno Brdo. ${ }^{12883}$ The $4^{\text {th }}$ Company numbered only around 120 local men who were often exhausted from manning the positions without much rest; as a result the company encountered absenteeism and disciplinary problems. ${ }^{12884}$ Božo Tomić, the deputy commander of the $3^{\text {rd }}$ Platoon in the $3^{\text {rd }}$ Company of the $2^{\text {nd }}$ Infantry Battalion, ${ }^{12885}$ testified that his platoon was positioned to the east of the $4^{\text {th }}$ Company positions, namely above the football stadium in Grbavica and up Hrasno Brdo towards Ozrenska street and beyond it. ${ }^{12886}$ According to Tomić, this part of the confrontation line did not change throughout the war. ${ }^{12887}$

3895. On the other side of the confrontation line were the members of the $101^{\text {st }}$ and $102^{\text {nd }}$ Mountain Brigades of the $1^{\text {st }}$ Corps of the $\mathrm{ABiH}$, which, according to Zurovac and Tuševljak,

12878 This street is now called Posavska street. Mile Poparić, T. 39236 (4 June 2013); D2418 (Witness statement of Božo Tomić dated 5 November 2012), para. 6; D2419 (Map of Sarajevo marked by Božo Tomić).

12879 D2391 (Witness statement of Slobodan Tuševljak dated 5 November 2012), paras. 8-9; D2392 (Map of Sarajevo marked by Slobodan Tuševljak); D2393 (Map of Sarajevo marked by Slobodan Tuševljak). See also Slobodan Tuševljak, T. 29948-29949 (7 November 2012).

12880 Dušan Zurovac, T. 30246-30247, 30319 (14 November 2012); D2391 (Witness statement of Slobodan Tuševljak dated 5 November 2012), para. 13.

12881 Dušan Zurovac, T. 30248-30249 (14 November 2012); D2427 (Map of Sarajevo marked by Dušan Zurovac). The Company command was located on Ozrenska street, just behind the lines, while the $2^{\text {nd }}$ Battalion command was on Banjalučka street in Grbavica. See Slobodan Tuševljak, T. 29944-29945 (7 November 2012); P1938 (Witness statement of KDZ310 dated 28 November 2010), para. 28.

12882 Slobodan Tuševljak, T. 29956 (7 November 2012). See also Dušan Zurovac, T. 30254-30259 (14 November 2012); D2428 (Photograph of Sarajevo); D2429 (Photograph of Sarajevo).

12883 Dušan Zurovac, T. 30254-30259 (14 November 2012); D2428 (Photograph of Sarajevo); D2429 (Photograph of Sarajevo).

12884 Dušan Zurovac, T. 30264-30273 (14 November 2012); D2432 (Report of $2^{\text {nd }}$ Infantry Battalion, 28 December 1993); D2433 (Report of $2^{\text {nd }}$ Infantry Battalion, 1 January 1994); D2434 (Report of $2^{\text {nd }}$ Infantry Battalion, 7 January 1994); D2435 (Report of $2^{\text {nd }}$ Infantry Battalion, 31 August 1993); D2436 (Report of $2^{\text {nd }}$ Infantry Battalion, 5 December 1993). Tuševljak testified that his platoon had 42 men at the beginning of the war and only 20 by the end. See D2391 (Witness statement of Slobodan Tuševljak dated 5 November 2012), paras. 14, 27; Slobodan Tuševljak, T. 29935-29939 (17 November 2012); D2396 (List of members of the $1^{\text {st }}$ Platoon of the $4^{\text {th }}$ Company); D2397 (List of members of the $4^{\text {th }}$ Company). See also D2418 (Witness statement of Božo Tomić dated 5 November 2012), para. 12; Božo Tomić, T. 30200 (13 November 2012).

12885 D2418 (Witness statement of Božo Tomić dated 5 November 2012), para. 8; Božo Tomić, T. 30165-30166, 30178-30179 (13 November 2012).

12886 Božo Tomić, T. 30165-30167 (13 November 2012); D2419 (Map of Sarajevo marked by Božo Tomić).

12887 Božo Tomić, T. 30165-30167 (13 November 2012); D2419 (Map of Sarajevo marked by Božo Tomić). 
heavily outnumbered the $4^{\text {th }}$ Company. ${ }^{12888}$ In some places the $\mathrm{ABiH}$ positions were only between 10 and 20 metres away from the $4^{\text {th }}$ Company's positions. ${ }^{12889}$ According to the information Tuševljak had, the command of the $101^{\text {st }}$ Mountain Brigade was located in the building of the Hrasno Brdo local commune and its units had positions in civilian zones. ${ }^{12890}$ The goal of the $\mathrm{ABiH}$ in this area, in Zurovac's view, was to move the $4^{\text {th }}$ Company further into the depth of the SRK territory and take control of Ozrenska street. ${ }^{12891}$

3896. According to Zurovac, his company respected the cease-fires as the situation on the frontline in the area was very difficult. ${ }^{12892}$ In contrast, ABiH soldiers would often provoke the $4^{\text {th }}$ Company's along the entire separation line, following which it would be forced to return fire. ${ }^{12893}$ UNPROFOR forces often visited the SRK units in the area as this was one of the most difficult

12888 Dušan Zurovac, T. 30265, 30284 (14 November 2012); D2391 (Witness statement of Slobodan Tuševljak dated 5 November 2012), para. 14; D2418 (Witness statement of Božo Tomić dated 5 November 2012), para. 16. See also Asim Džambasović, T. 15194, 15244 (22 June 2011); D1382 (Map of ABiH positions in Sarajevo marked by Asim Džambasović); Dragomir Milošević, T. 32566 (23 January 2013); D2794 (Satellite image of Sarajevo marked by Dragomir Milošević); Alen Gičević, T. 7616-7617 (11 October 2010); Mirza Sabljica, T. 7703-7704 (11 October 2010); David Harland, T. 2086-2087 (7 May 2010); KDZ450, T. 10665 (20 January 2011).

12889 Dušan Zurovac, T. 30248 (14 November 2012); D2391 (Witness statement of Slobodan Tuševljak dated 5 November 2012), para. 16; Božo Tomić, T. 30180-30181 (13 November 2012).

12890 D2391 (Witness statement of Slobodan Tuševljak dated 5 November 2012), para. 18; D2395 (Map of Sarajevo marked by Slobodan Tuševljak).

12891 Dušan Zurovac, T. 30270 (14 November 2012). Zurovac conceded in cross-examination, however, that ABiH was attacking in order to break the siege of Sarajevo. See Dušan Zurovac, T. 30294-30301 (14 November 2012); P5989 (SRK Order, 16 December 1993); P5980 (SRK conclusions and tasks, 1 April 1994). However, Tuševljak denied this, saying that $\mathrm{ABiH}$ would have nowhere to go as the depth of the territory was all Serb territory. See Slobodan Tuševljak, T. 29947-29948 (7 November 2012).

12892 Dušan Zurovac, T. 30273-30284 (14 November 2012); D2436 (Report of $2^{\text {nd }}$ Infantry Battalion, 5 December 1993); D2437 (Report of $2^{\text {nd }}$ Infantry Battalion, 16 December 1993); D2438 (Report of 2nd Infantry Battalion, 11 December 1993); D2439 (Report of $2^{\text {nd }}$ Infantry Battalion, 18 December 1993); D2440 (Report of 2nd Infantry Battalion, 9 January 1994); D2441 (Report of $2^{\text {nd }}$ Infantry Battalion, 3 February 1994); D4627 (Report of $2^{\text {nd }}$ Infantry Battalion, 13 June 1993). Zurovac conceded in cross-examination that ABiH was trying to break the siege of Sarajevo. See Dušan Zurovac, T. 30294-30301 (14 November 2012); P5989 (SRK Order, 16 December 1993); P5980 (SRK conclusions and tasks, 1 April 1994). See also D2418 (Witness statement of Božo Tomić dated 5 November 2012), para. 16; Božo Tomić, T. 30181 (13 November 2012).

12893 In addition, the positions of the $4^{\text {th }}$ Company were also shelled by the ABiH units and SRK-held territory was sniped from the skyscrapers on Pero Kosorić square. See Dušan Zurovac, T. 30273-30284, 30325 (14 November 2012); D2391 (Witness statement of Slobodan Tuševljak dated 5 November 2012), para. 15; D2418 (Witness statement of Božo Tomić dated 5 November 2012), paras. 9, 21; Božo Tomić, T. 30179-30180 (13 November 2012). According to Tuševljak, the attacks were so fierce that it was impossible to endure them mentally and physically so eventually, in September 1994, he stripped himself of his rank and moved to another platoon as a common soldier. See D2391 (Witness statement of Slobodan Tuševljak dated 5 November 2012), para. 17; Slobodan Tuševljak, T. $29962-29963$ (7 November 2012). See also D4622 (Report of $1^{\text {st }}$ Romanija Infantry Brigade, 14 August 1992) in which Dragomir Milošević reports about infantry fire being opened from Ozrenska street positions. 
frontlines. ${ }^{12894}$ Indeed, Zurovac testified that he lost 54 men largely due to the activities of the $101^{\text {st }}$ Mountain Brigade of the $\mathrm{ABiH}{ }^{12895}$

3897. Tuševljak testified that he and his men never received orders to attack civilians or civilian objects-they carried out defensive actions alone and were told to open fire only when attacked and only at enemy positions rather than in the depth of the ABiH territory. ${ }^{12896} \mathrm{He}$ conceded, however, that in October 1992 plans were made to attack ABiH positions in Asimovo Brdo, which was necessary as $\mathrm{ABiH}$ snipers would attack the company's positions from there, but clarified that the attack never took place and that $\mathrm{ABiH}$ remained in that location throughout the war. ${ }^{12897}$

3898. Based on the evidence above, the Chamber is satisfied that the SRK controlled the positions on and around Ozrenska street on the upper parts of Hrasno Brdo, as alleged by the Prosecution. ${ }^{12898}$ In particular, the Chamber finds that this area was in the area of responsibility of the $2^{\text {nd }}$ Infantry Battalion of the $1^{\text {st }}$ Sarajevo Mechanised Brigade. The Chamber is also satisfied that due to the proximity of two warring sides, it was one of the more difficult confrontation lines to man, and that the local SRK commanders in the area faced a number of issues in their units, including shortage of men, absenteeism, and desertion.

\section{(2) Snipers in the area}

3899. Initially, according to Zurovac, the $4^{\text {th }}$ Company was better armed than the $\mathrm{ABiH}$ units in the area but that changed by the time he left the company in April 1994, insofar as infantry weapons were concerned. ${ }^{12899}$

12894 Dušan Zurovac, T. 30273-30275 (14 November 2012); D2436 (Report of $2^{\text {nd }}$ Infantry Battalion, 5 December 1993); Božo Tomić, T. 30209-30214 (13 November 2012); D2421 (Order of $2^{\text {nd }}$ Infantry Battalion, 26 May 1993).

12895 Dušan Zurovac, T. 30275-30276 (14 November 2012). According to Tuševljak, around 230 Serb soldiers were killed in Ozrenska street, as well as a few dozen civilians. See D2391 (Witness statement of Slobodan Tuševljak dated 5 November 2012), para. 17. See also D2418 (Witness statement of Božo Tomić dated 5 November 2012), para. 22.

12896 D2391 (Witness statement of Slobodan Tuševljak dated 5 November 2012), paras. 19-21. See also D2418 (Witness statement of Božo Tomić dated 5 November 2012), paras. 17-18; Božo Tomić, T. 30181-30182, 30198-30199 (13 November 2012).

12897 Slobodan Tuševljak, T. 29949-29950 (7 November 2012). When confronted with an excerpt from Mladić's diary stating that this attack was underway, Tuševljak testified that he was not aware of the attack and that his men remained at the foot of Asimovo Brdo until the end of the war. See Slobodan Tuševljak, T. 29950-29951 (7 November 2012); P1478 (Ratko Mladić's notebook, 27 May-31 July 1992), p. 241.

12898 See also Adjudicated Facts 79, 80.

12899 Dušan Zurovac, T. 30284-30287 (14 November 2012); D2442 (Order of the $101^{\text {st }}$ Brigade, 13 June 1995); D2391 (Witness statement of Slobodan Tuševljak dated 5 November 2012), para. 16. In cross-examination, however, Zurovac confined this claim to infantry weapons alone. See Dušan Zurovac, T. 30301-30305 (14 November 2012); P5990 (Map of Sarajevo); P5985 (Request for ammunition of the $4^{\text {th }}$ Infantry Company, 3 December 1993). 
3900. Zurovac denied that the $4^{\text {th }}$ Company had snipers and stated that he did not know whether snipers were present in the $2^{\text {nd }}$ Infantry Battalion. ${ }^{12900}$ When shown a list he prepared and signed and which contained names of men who had deserted the unit and took weapons with them, he conceded that four such men were recorded as having taken a sniper rifle each, but testified that he did not know how they obtained those rifles since the weapons had been issued before he arrived to the area. ${ }^{12901}$ He remained adamant that his company did not have snipers to whom he, as a commander, assigned tasks. ${ }^{12902}$

3901. Tuševljak confirmed this but testified that at the end of 1993, due to constant sniper attacks by the $\mathrm{ABiH}$ on Ozrenska street, a trained sniper was sent to his unit in order to eliminate his counterpart on the $\mathrm{ABiH}$ side; however, he was killed two days later and no other snipers ever came to Tuševljak's unit. ${ }^{12903}$ In addition, he testified that neighbouring platoons also did not have any snipers in their ranks. ${ }^{12904}$ He confirmed, however, that his platoon had M84 and M53 machine-guns which used $7.62 \mathrm{~mm}$ and $7.9 \mathrm{~mm}$ calibre bullets respectively. ${ }^{12905}$ The members ofp's Platoon in the $3^{\text {rd }}$ Company also had M84 and M53 machine-guns, as well as other weapons that used $7.62 \mathrm{~mm}$ calibre bullets. ${ }^{12906}$ Tomić testified, however, that these weapons were used only in case of an attack and could not be used for sniper fire as they did not have optical sights. ${ }^{12907}$ While agreeing that in case of short distances the soldiers did not need optical sights, he also explained that one could not fire single shots from those weapons but rather bursts of fire, which made them less precise than a sniper rifle. ${ }^{12908}$

\footnotetext{
12900 Dušan Zurovac, T. 30309 (14 November 2012).

12901 Dušan Zurovac, T. 30309-30315 (14 November 2012); P5991 (List of personnel and claimed weapons of the $2^{\text {nd }}$ Infantry Battalion, 15 January 1994).

12902 Dušan Zurovac, T. 30326 (14 November 2012).

12903 D2391 (Witness statement of Slobodan Tuševljak dated 5 November 2012), para. 26; Slobodan Tuševljak, T. 29959-29960 (7 November 2012); P5945 (Report of $1^{\text {st }}$ Romanija Infantry Brigade to SRK, 29 October 1993).

12904 D2391 (Witness statement of Slobodan Tuševljak dated 5 November 2012), para. 26.

12905 Slobodan Tuševljak, T. 29942-29943 (7 November 2012); D2396 (List of members of the $1^{\text {st }}$ Platoon of the 4th Company). Zurovac was also shown a document created and signed by him, requesting ammunition, including 7.62 and $7.9 \mathrm{~mm}$ calibre ammunition. It shows that he requested $7.62 \mathrm{~mm}$ ammunition for the M84 rifle. See Dušan Zurovac, T. 30304-30305 (14 November 2012); P5985 (Request for ammunition of the 4th Infantry Company, 3 December 1993); Božo Tomić, T. 30185-30188 (13 November 2012); P5983 (List of weapons of the 4th Infantry Company, 22 October 1993). Tomić confirmed that M84 had a range of up to 1000 metres if on a tripod, while M53 had a range of up to 1500 metres if on a tripod. He explained, however, that M53 guns his unit had were old and unsafe for use. See Božo Tomić, T. 30187-30190 (13 November 2012); P5983 (List of weapons of the $4^{\text {th }}$ Infantry Company, 22 October 1993); P5984 (Ammunition status of the $4^{\text {th }}$ Infantry Company, 8 June 1993); P5985 (Request for ammunition of the $4^{\text {th }}$ Infantry Company, 3 December 1993).

Božo Tomić, T. 30183-30184 (13 November 2012). See also P1938 (Witness statement of KDZ310 dated 28 November 2010), para. 50; P1946 (Excerpt of book on military equipment marked by KDZ310). See also P926 (Witness statement of Aernout van Lynden dated 26 February 2010), para. 106 (testifying that he and his news crew visited SRK positions in Hrasno, above Grbavica, where his camerman observed an SRK machine-gun position).

12907 Božo Tomić, T. 30233 (13 November 2012).

12908 Božo Tomić, T. 30234-30235 (13 November 2012).
} 
3902. KDZ310 testified that he observed members of a sniping unit shooting from a house on Ozrenska street and could even see their long barrelled rifles with various optical equipment fitted to them. ${ }^{12909}$ He also observed them use a machine-gun with an optic sight fitted on it which would open bursts of automatic fire. ${ }^{12910}$ These snipers told KDZ310 that they targeted both civilians and soldiers alike. ${ }^{12911}$ KDZ310 himself observed that the snipers would usually shoot at intersections and transversals, which were built horizontally around town and could be seen well from the house in question. ${ }^{12912}$ While protective barriers and containers were set up in those areas as a shield from sniper fire, KDZ310 noted that he could still see-using his binoculars—people going up to these barriers; the snipers in question also confirmed to him that they would target persons near the barriers. $^{12913}$

3903. Accordingly, the Chamber is satisfied, relying particularly on the list of deserters referred to above, that the SRK units in the area had sniper rifles or at the very least rifles with optical sights. It is also satisfied, based on the above, that they had machine-guns that used both 7.62 and $7.9 \mathrm{~mm}$ ammunition. Finally, relying on the evidence of KDZ310, the Chamber finds that a number of professional SRK snipers were also positioned on Ozrenska street and would target civilians and combatants alike. ${ }^{12914}$

\section{(3) Azize Šećerbegović street, formerly Ivana Krndelja street, 3}

September 1993 (Scheduled Incident F.4)

3904. The Indictment alleges that, on 3 September 1993, Nafa Tarić, a 35 year old woman, and and her eight year old daughter Elma Tarić, were shot and wounded by a single bullet while walking together on Ivana Krndelja street, in the centre of Sarajevo. According to the Indictment, the bullet wounded the mother in her left thigh and wounded the daughter in her right hand and in her abdomen. ${ }^{12915}$ In its Final Brief, the Prosecution submits that the fire came from the SRK-held positions on Ozrenska street, which had a clear and unobstructed view of the incident site. ${ }^{12916}$ The

\footnotetext{
12909 KDZ310 explained that the guns these snipers used had much longer barrels than the guns of regular soldiers he was with. See P1938 (Witness statement of KDZ310 dated 28 November 2010), para. 48.

12910 P1938 (Witness statement of KDZ310 dated 28 November 2010), para. 48. The Chamber also recalls that Maletić testified that there was a sniper squad in his battalion and that it was subordinated directly to the battalion commander rather than to company or platoon commanders. See D2519 (Witness statement of Dragan Maletić dated 9 November 2012), para. 31; Dragan Maletić, T. 30846-30848 (3 December 2012), T. 3087330874 (4 December 2012).

12911 KDZ310 also testified that his own immediate commander told him and the other men in his platoon that they could open fire freely and shoot at anything that moved. See P1938 (Witness statement of KDZ310 dated 28 November 2010), paras. 37, 48; KDZ310, T. 9275-9276, 9278 (29 November 2010).

12912 P1938 (Witness statement of KDZ310 dated 28 November 2010), para. 48.

12913 P1938 (Witness statement of KDZ310 dated 28 November 2010), para. 49. See Adjudicated Fact 128.

12914 See Adjudicated Facts 76, 77.

12915 Indictment, Scheduled Incident F.4.

12916 Prosecution Final Brief, Appendix C, para. 31.
} 
Accused submits, however, that the victims could not have been shot from the SRK positions on Ozrenska street. $^{12917}$

3905. On 3 September 1993, Nafa Tarić and her eight year old daughter Elma Tarić were walking from their apartment in Hrasno down Ivan Krndelja street. ${ }^{12918}$ They crossed the street holding hands behind a line of containers installed to provide protection against sniper fire. ${ }^{12919}$ As they emerged from the cover of the barriers, they were shot. ${ }^{12920}$ A single bullet hit Nafa Tarić's left thigh, then grazed her daughter's hand and penetrated her stomach. ${ }^{12921}$ They managed to crawl away from the exposed position and were taken to the hospital. ${ }^{12922}$

3906. A police officer, known as Witness $\mathrm{J}$ in the Galic trial, concluded that the shot had been fired from the SRK positions on Ozrenska street and based his conclusion not only on common knowledge but also on the fact that the police was unable to immediately access the site because of on-going shooting from those positions. ${ }^{12923}$

3907. Hogan visited the site of the incident and recorded the GPS co-ordinates, as well as video footage, of the exact location of the victims when they were shot. ${ }^{12924}$ He explained that they had just left the protective barrier and were crossing the open stretch of the footpath when the bullet struck them. ${ }^{12925}$

3908. While investigating this incident, Van der Weijden had access to witness statements of a number of witnesses to this event, including Nafa Tarić, as well as to materials prepared by the Prosecution. ${ }^{12926}$ Looking at the victims' injuries first, Van der Weijden thought that any bullet up to the $7.92 \mathrm{~mm}$ calibre was capable of causing them, and that a higher calibre was not used as it would have caused more damage. ${ }^{12927}$ Given that only one bullet caused the injuries to the victims,

\footnotetext{
12917 Defence Final Brief, paras. 2199-2206.

12918 See Adjudicated Fact 173.

12919 See Adjudicated Fact 174.

12920 Adjudicated Fact 175.

12921 P1245 (Medical record for Nafa Tarić); P1235 (Medical file for Elma Tarić); P1241 (Medical records for Elma and Nafa Tarić); Adjudicated Fact 176.

12922 Adjudicated Fact 177

12923 See Adjudicated Fact 179.

12924 Barry Hogan, T. 11210, 11260-11261 (3 February 2011); P2197 (Photograph re sniping incident of 3 September 1993 on Ivana Krndelja street marked by Barry Hogan); P2207 (Images re scheduled sniping incidents in Sarajevo); D994 (Video footage re sniping incident of 3 September 1993 on Ivana Krndelja street); P2192 (Map of Sarajevo); P2190 (GPS locations for shelling and sniping incidents in Sarajevo); P2191 (Map of Sarajevo with scheduled sniping and shelling incidents). [

12925 Barry Hogan, T. 11260-11261 (3 February 2011).

12926 P1621 (Expert Report of Patrick van der Weijden entitled “Sniping Incidents in Sarajevo '92-'94”), p. 79.

12927 P1621 (Expert Report of Patrick van der Weijden entitled "Sniping Incidents in Sarajevo '92-'94”), p. 74. In cross-examination, Van der Weijden conceded that he was never given any information as to whether the bullet
} 
Van der Weijden concluded that the bullet was most likely fired from a semi-automatic sniper rifle, either an M76 or an M91, both of which are capable of delivering accurate fire at long ranges. ${ }^{12928}$ Van der Weijden was told that the alleged shooting position was Ozrenska street, to the south of and 829 metres away from the incident site, which was an extreme range for these types of rifles. ${ }^{12929}$ He visited both the incident site and Ozrenska street, and observed that the latter offers clear views of the former. ${ }^{12930}$ He opined that the bullet must have come from the south since the shooter located to the north of the incident had a view of the victims and would not have waited that long before firing at them as they were almost behind the cover again when they were shot. ${ }^{12931}$ Van der Weijden concluded that the bullet was fired somewhere from the area which was between 200 and 1,104 metres to the south of the incident site. ${ }^{12932}$ Further, given that the victims were walking hand in hand, the height of the daughter in relation to her mother would have led the shooter to instantly identify the two victims as civilians. ${ }^{12933}$

3909. During cross-examination Van der Weijden conceded that he was informed that Serbs were holding positions on Ozrenska street but never told that the street itself was a separation line and that $\mathrm{ABiH}$ was also there. ${ }^{12934} \mathrm{He}$ also conceded that the houses on the north side of Ozrenska street would have a better view of the incident site, but explained that some houses on the south side of the street would also have a view on the incident site. ${ }^{12935}$ Finally, Van der Weijden accepted in cross-examination that he could not conclude beyond reasonable doubt that the shot came from the Serb side. ${ }^{12936}$

that injured the victims was recovered, and thus had to guess the calibre. See Patrick van der Weijden, T. 71187119 (29 September 2010).

12928 
3910. Poparić testified that he visited both the incident site and the area of Ozrenska street ${ }^{12937}$ and that the victims could not have been shot from the closest SRK positions in Hrasno Brdo, which he calculated as being 680 metres away, ${ }^{12938}$ because they were visible only for about 1.2 seconds after leaving the protective barrier and before being struck by the bullet. ${ }^{12939}$ This, according to Poparić, would not have given the shooter sufficient time to spot them and then fire at them. ${ }^{12940}$ In other words, the victims could not have been deliberately targeted from SRK positions in Ozrenska street as they would have had to have been shot at before the shooter actually observed them. ${ }^{12941}$ The Chamber notes that the Prosecution never cross-examined Poparić on this part of his analysis.

3911. Poparić also testified that there was no line of sight between the incident site and the part of Ozrenska street indicated by Nafa Tarić to Hogan as the origin of fire. ${ }^{12942}$ He based this conclusion on the photograph he took of the Hrasno Brdo area from the surroundings of the incident site and which he compared with a photograph of the same area but taken from further away. ${ }^{12943}$ Because the relevant part of Ozrenska street indicated by Tarić cannot be seen in the first photograph but can in the second, Poparić concluded that there was no line of sight to the incident site. ${ }^{12944}$ When confronted in cross-examination with the photograph taken by Van der Weijden from that alleged sniping location and showing a clear, straight, line of sight to the incident site, he stated that he did not know where the photograph was taken from and that the co-

12937 Poparić explained that he knew the area very well as his wife lived nearby. He visited it a number of times. Mile Poparić, T. 38878-38879, 38892-38893 (29 May 2013).

12938 Poparic calculated this distance on the basis of the ABiH operations map, which outlines the confrontation line in the area. He also testified that the closest SRK positions in fact had no view onto the incident site so the distance between the alleged SRK shooter and the incident site would have to have been even greater than 680 metres. See D4884 (Mile Poparić's expert report entitled "Small Arms Fire on the Sarajevo Area 1992-1995", 15 August 2012), p. 73; Mile Poparić, T. 38874, 38892 (29 May 2013), T. 39229 (4 June 2013).

12939 Poparic determined the length of this time on the basis of the footage filmed by Hogan in which Nafa Tarić is seen walking from the area that was protected by the screen to the area where she was standing with her daughter when shot. D4884 (Mile Poparić's expert report entitled "Small Arms Fire on the Sarajevo Area 19921995”, 15 August 2012), pp. 67-69.

12940 Poparic came to this conclusion on the assumption that an M84 machine-gun was used and, using the firing tables for that gun, calculated that the bullet shot by it would have taken 1.21 seconds to reach the victims. D4884 (Mile Poparić's expert report entitled "Small Arms Fire on the Sarajevo Area 1992-1995", 15 August 2012), pp. 73-74; Mile Poparić, T. 38872-38874 (29 May 2013).

12941 D4884 (Mile Poparić's expert report entitled "Small Arms Fire on the Sarajevo Area 1992-1995", 15 August 2012), pp. 74, 75; Mile Poparić, T. 38872-38889 (29 May 2013); D3616 (Satellite image re sniping incident of 3 September 1993 on Ivana Krndelja street marked by Mile Poparić); D3617 (Photograph of Sarajevo marked by Mile Poparić); D3618 (Photograph of Sarajevo marked by Mile Poparić); D3623 (Photograph of buildings marked by Mile Poparić); D3624 (Map of Sarajevo marked by Mile Poparić).

12942 Tarić made this indication in the video footage recorded by Barry Hogan. While this footage is not in evidence in this case, Poparić produced stills from it in his report. D4884 (Mile Poparić's expert report entitled "Small Arms Fire on the Sarajevo Area 1992-1995", 15 August 2012), pp. 70-74.

12943 D4884 (Mile Poparić's expert report entitled "Small Arms Fire on the Sarajevo Area 1992-1995", 15 August 2012), p. 71.

12944 Poparic also calculated, using Google Earth, that 540 metres was the distance between the incident site and the line from which the incident site could actually be seen. D4884 (Mile Poparić's expert report entitled "Small Arms Fire on the Sarajevo Area 1992-1995”, 15 August 2012), pp. 71-73. 
ordinates given by Van der Weijden of that location "do not say a thing about the photograph itself". ${ }^{12945}$

3912. While not accepting that there was a line of sight from the alleged origin of fire as indicated by Tarić, Poparić conceded that there was a line of sight between the victims and the SRK positions on Ozrenska street located further to the east of the origin of fire alleged by Tarić-which he measured to be about 730 or 740 metres away from the incident site. ${ }^{12946}$ He also conceded that sniper rifles used by trained snipers would be sufficiently precise to hit a person at that distance. ${ }^{12947}$ However, he pointed out that, according to the witnesses, a burst of gunfire was heard in this incident, indicating that sniper rifle was not the weapon used. ${ }^{12948}$

3913. Zurovac testified that the incident site was about 900 metres away from the positions of the $4^{\text {th }}$ Company and that there was no clear line of sight between those two locations, as the company was located in "some sort of a valley" and there were hills in the way, obstructing the view. ${ }^{12949}$ However, Zurovac, like Poparić, conceded that a line of sight existed from an area further to the east of the positions of his company. ${ }^{12950}$ Tuševljak confirmed this and noted that a line of sight existed to the east of the $4^{\text {th }}$ Company's positions, in the locations manned by the $2^{\text {nd }}$ Company of the $2^{\text {nd }}$ Infantry Battalion. ${ }^{12951}$ However, he testified that, as far as he knew, on the day of the incident no fire was opened on civilians from Ozrenska street. ${ }^{12952}$ Galić also testified that he did

12945 Mile Poparić, T. 39230-39232 (4 June 2013); P6363 (Photograph of a crossroads in Sarajevo); D666 (Aerial photograph of Sarajevo marked by Patrick van der Weijden). The Chamber recalls that it admitted P6363 only for the purpose of understanding Poparić's evidence and is now citing to it for that purpose alone.

12946 Mile Poparić, T. 38872-38889, 38892 (29 May 2013); D3616 (Satellite image re sniping incident of 3 September 1993 on Ivana Krndelja street marked by Mile Poparić); D3617 (Photograph of Sarajevo marked by Mile Poparić); D3618 (Photograph of Sarajevo marked by Mile Poparić); D3623 (Photograph of buildings marked by Mile Poparić); D3624 (Map of Sarajevo marked by Mile Poparić).

12947 Mile Poparić, T. 38889 (29 May 2013).

12948 Mile Poparić, T. 38889-38890 (29 May 2013). However, the Chamber notes that Poparić recounted Tarić's evidence on this issue, which was that she heard two more shots after she was wounded. In other words, it is not necessarily clear that she heard a burst of fire as opposed to two more single bullets being fired by the shooter. D4884 (Mile Poparić's expert report entitled "Small Arms Fire on the Sarajevo Area 1992-1995", 15 August 2012), p. 69.

12949 The Chamber notes that at this point Zurovac incorrectly claimed that one could not see the incident site in a photograph shown to him by the Accused during examination-in-chief, which he said was taken in a location unfamiliar to him, but somewhere below Ozrenska street. When shown a second photograph, he conceded that the line of sight existed, noting that this photograph was taken from an area further to the east of the positions of his company in a location unknown to him. See Dušan Zurovac, T. 30249-30251, 30254, 30260-30262 (14 November 2012); D2430 (Photograph of Sarajevo); D2431 (Photograph of Sarajevo). The Chamber notes, however, that both photographs were taken from the same location and that the incident site is visible in both, as testified to by Poparić. See D3623 (Photograph of buildings marked by Mile Poparić). Further, the Prosecution stated on the record, during its cross-examination of Tuševljak, that both photographs were taken from the same location and that one was simply a more zoomed version of the other. See T. 29956-29957 (7 November 2012). D2391 (Witness statement of Slobodan Tuševljak dated 5 November 2012), para. 25; D2394 (Map of Sarajevo marked by Slobodan Tuševljak); Slobodan Tuševljak, T. 29957 (7 November 2012).

12952 Slobodan Tuševljak, T. 29961 (7 November 2012). 
not order any activity against the area where the incident took place and had received no information about it at the time. ${ }^{12953}$

3914. In addition to the above, the Chamber has also taken judicial notice of the following adjudicated facts going to the origin of fire: (i) there was an unobstructed line of sight from SRK positions on Hrasno Brdo to the location of the incident; ${ }^{12954}$ (ii) Nafa and Elma Tarić were injured by a shot fired from this area; ${ }^{12955}$ and (iii) Nafa and Elma Tarić, civilians, ${ }^{12956}$ were deliberately targeted from an SRK-controlled position. ${ }^{12957}$

3915. The Chamber considers, given their clothes, age, and gender, as well as the fact that they were walking home when the incident happened, that both Nafa Tarić and her daughter Elma were civilians and that they were not taking direct part in hostilities at the time of the incident. The Chamber is also satisfied that the SRK units, belonging to the $2^{\text {nd }}$ Infantry Battalion of the $1^{\text {st }}$ Sarajevo Mechanised Brigade, were located just below Ozrenska street on the upper parts of Hrasno Brdo and that they had a line of sight to the incident site, both from the location indicated by Nafa Tarić as the origin of fire, and the positions east of that location. In other words, the Chamber accepts Van der Weijden's evidence about there being a clear line of sight from Ozrenska street onto Ivana Krndelja street from the positions alleged to be the origin of fire by Nafa Tarić. ${ }^{12958}$ The Chamber is also satisfied, as found above, ${ }^{12959}$ that the SRK soldiers in the area possessed either sniper rifles or rifles with optic sights, as well as machine-guns, all of which had the range necessary to reach the incident site, which was between 680 and 900 metres away, depending on the positions. Finally, the Chamber finds that there was no military activity in the area at the time of the incident.

3916. In terms of the identity of the perpetrators in this incident, the Chamber finds that the bullet that struck the victims was fired by the SRK snipers on Ozrenska street and that the victims were deliberately targeted. In this respect, the Chamber recalls KDZ310's evidence according to which SRK snipers located on Ozrenska street would target civilians at major intersections visible from

\footnotetext{
12953 Galić expressed surprise that someone was hit by a bullet in that area as it was well protected by barriers. See Stanislav Galić, T. 37505-37510 (22 April 2013); D3448 (SRK combat report, 3 September 1993); D3429 (SRK combat report, 4 September 1993); D3449 (SRK combat report, 5 September 1993).

12954 Adjudicated Fact 180.

12955 Adjudicated Fact 181.

12956 See Adjudicated Fact 178.

12957 See Adjudicated Fact 182.

12958 While both Zurovac and Tuševljak testified that their company's positions did not have the line of sight to the incident site, this does not change the Chamber's finding that the units of the $2^{\text {nd }}$ Infantry Battalion were in positions that had such a line of sight on the incident site. Indeed, this was admitted by both Zurovac and Tuševljak, as well as Poparić.

12959 See para. 3903.
} 
Ozrenska street, including those that had protective barriers or containers. ${ }^{12960}$ In addition, the local police later established that the fire came from SRK positions on Ozrenska street and was unable to immediately access the site because of the on-going fire from those positions. ${ }^{12961}$ The Chamber also recalls that, as recounted by Poparić in his analysis of this incident, Nafa Tarić heard two shots after being struck by the bullet. ${ }^{12962}$ This indicates that the two victims were deliberately targeted by the shooter even after they were wounded.

3917. While accepting Poparić's evidence that the time during which the victims were visible to the shooter after clearing the barrier would have been quite short, the Chamber also recalls KDZ310's evidence that, despite the protective barriers being set up at different intersections visible from Ozrenska street, the people could nevertheless still be seen by snipers when walking up to the barriers. ${ }^{12963}$ Thus, the Chamber considers that the sniper who shot Nafa and Elma Tarić must have seen them already before they walked behind the barrier, and then simply waited for them to leave its protection on the other side.

(4) Ferde Hauptmana street, formerly Miljenka Cvitkovića street, 22 July 1994 (Scheduled Incident F.10)

3918. The Indictment alleges that on 22 July 1994, Seid Solak, a 13 year old boy was shot and wounded in the abdomen while window shopping with his mother and sister on Miljenka Cvitkovića (presently Ferde Hauptmana) street in the Čengić Vila area of Sarajevo. ${ }^{12964}$ In its Final Brief, the Prosecution alleges that the fire came from SRK positions on Hrasno Brdo, in the area of the Pržulj house on Zagorska street, which was a notorious sniping nest. ${ }^{12965}$ The Prosecution also explains that the site of the incident was erroneously alleged to be on Miljenka Cvitkovića street but is instead at Džemala Bijedića, number 20, which runs parallel to Miljenka Cvitkovića and lies just after a small passage from Miljenka Cvitkovića. ${ }^{12966}$ The Accused argues that these are in fact two unrelated incidents and that the boy was wounded on Miljenka Cvitkovića street under circumstances different than those discussed in the evidence. ${ }^{12967}$

\footnotetext{
$12960 \quad$ See para. 3902.

12961 See para. 3906.

12962 See para. 3912, fn. 12948.

12963 See para. 3902.

12964 Indictment, Scheduled Incident F.10.

12965 Prosecution Final Brief, Appendix C, para. 32.

12966 Prosecution Final Brief, Appendix C, para. 32, fn. 208.

12967 Defence Final Brief, paras. 2246-2254.
} 
3919. On 22 July 1994, Seid Solak, a 13 year old boy, and his sister went out with their mother to visit a relative. ${ }^{12968}$ It was a clear day. ${ }^{12969}$ They stopped to look at a shoe shop window on Miljenka Cvitkovića street. ${ }^{12970}$ Seid got off his bicycle and at that moment was shot in the lower part of his stomach. ${ }^{12971}$ The bullet tore through his body and shattered the shop window. ${ }^{12972}$ He was taken to an emergency unit where he was hospitalised for several days. ${ }^{12973}$ There was no military activity in the area at the time of the incident, ${ }^{12974}$ as indicated by the fact that several children were playing and a neighbourhood restaurant was open. ${ }^{12975}$

3920. Kučanin prepared an official note ${ }^{12976}$ relating to the incident. ${ }^{12977}$ When at the scene, he met with UNPROFOR soldiers and they conducted an investigation together. ${ }^{12978}$ Kučanin was informed that two shots were fired but that the victim had already been taken to the hospital so it was difficult to determine the position he was in when shot. ${ }^{12979}$ However, the investigators were able to get that information from an eyewitness. ${ }^{12980}$ According to Kučanin, the first shot hit the boy in the stomach while he was standing on Miljenka Cvetkovića street, at number 4, in front of a shoe shop and next to a passage in a building, which was near the entrance to a café called Arijana. ${ }^{12981}$ The other bullet went through the sunshade of the café, then passed through its window, changed direction as a result, hit an inner wall, ricocheted, and finally lodged in the floor

\footnotetext{
12968 See Adjudicated Fact 234. See also confidential Prosecution Submission dated 30 January 2015, paras. 9-11.

12969 Adjudicated Fact 235.

12970 See Adjudicated Fact 236.

12971 Adjudicated Fact 237.

12972 Adjudicated Fact 237.

12973 See Adjudicated Fact 238; P1239 (Sarajevo State Hospital discharge form) (under seal); P1240 (Medical report) (under seal).

12974 Adjudicated Fact 240.

12975 Adjudicated Fact 241.

12976 Mirsad Kučanin, P16 (Transcript from Prosecutor v. Galić), T. 4739; P18 (BiH MUP Report re sniping incident of 22 July 1994 on Miljenka Cvitkovića street). The Chamber notes that this official note is also attached to Kučanin's witness statement, that is, to P23.

12977 Mirsad Kučanin, P16 (Transcript from Prosecutor v. Galić), T. 4739. Mirsad Kučanin was supposed to be in charge of the investigation but handed it over to his colleague from the local police station as soon as he realised that the victim was only wounded; Kučanin remained on the scene, however, as an investigation assistant. See P23 (Witness statement of Mirsad Kučanin dated 12 November 1995), e-court p. 2; Mirsad Kučanin, P16 (Transcript from Prosecutor v. Galić), T. 4508-4509, 4661.

12978 P23 (Witness statement of Mirsad Kučanin dated 12 November 1995), e-court pp. 2, 12; Mirsad Kučanin, P16 (Transcript from Prosecutor v. Galić), T. 4509-4510, 4642-4646.

12979 P23 (Witness statement of Mirsad Kučanin dated 12 November 1995), e-court p. 2; Mirsad Kučanin, P16 (Transcript from Prosecutor v. Galić), T. 4509-4510.

12980 In addition, the investigators found a pool of blood next to the location of the victim when shot. See P23 (Witness statement of Mirsad Kučanin dated 12 November 1995), e-court p. 2; Mirsad Kučanin, P16 (Transcript from Prosecutor v. Galić), T. 4510, 4514-4515.

12981 P23 (Witness statement of Mirsad Kučanin dated 12 November 1995), e-court pp. 2, 12; Mirsad Kučanin, P16 (Transcript from Prosecutor v. Galić), T. 4510, 4514-4515, 4661-4662; P19 (Photographs re sniping incident of 22 July 1994 on Miljenka Cvitkovića street), pp. 1-2.
} 
of the café, thus leaving three different bullet impacts for the investigators to consider. ${ }^{12982}$ The bullet was removed for forensic analysis and it was established that it was of the $7.62 \mathrm{~mm}$ calibre. ${ }^{12983}$ By connecting the holes in the sunshade and the window, Kučanin concluded that the bullets came from “the aggressor's positions at Zagorska street, the Pržulja house”, which was a "well known [VRS] sniping place" located in Hrasno Brdo, in Novo Sarajevo. ${ }^{12984}$ On crossexamination, Kučanin admitted that he did not know where the confrontation lines in Sarajevo were but noted that his task was to establish where the bullet came from, regardless of whether that territory was in control of the ABiH or VRS. ${ }^{12985}$ Kučanin and the UNPROFOR team then talked to the doctor who treated the victim and learned that the injury was serious as the bullet had passed from the left to the right side of the victim's stomach, although it did not injure any of his internal organs. $^{12986}$

3921. Hogan visited the site of the incident with the victim and recorded the exact location of the victim when shot, namely in front of the shoe shop next to the passage of a building. ${ }^{12987}$

3922. When investigating this incident, Van der Weijden reviewed the photographs of the incident scene taken by the BiH MUP, as well as the witness statements of Kučanin and the victim. ${ }^{12988} \mathrm{He}$ also visited the incident site using Hogan's co-ordinates, checked for possible locations from which the shot might have been fired, ${ }^{12989}$ and then visited those locations to see which was most

12982 P23 (Witness statement of Mirsad Kučanin dated 12 November 1995), e-court pp. 2, 12; Mirsad Kučanin, P16 (Transcript from Prosecutor v. Galić), T. 4510, 4512, 4515-4516, 4647-4648, 4653-4657, 4759-4761, 47624767, 4768-4770; P19 (Photographs re sniping incident of 22 July 1994 on Miljenka Cvitkovića street), pp. 1, 4-6.

12983 P23 (Witness statement of Mirsad Kučanin dated 12 November 1995), e-court p. 12. See also Mirsad Kučanin, P16 (Transcript from Prosecutor v. Galić), T. 4516; P19 (Photographs re sniping incident of 22 July 1994 on Miljenka Cvitkovića street), p. 7.

12984 To connect the impact points of the bullet the BiH MUP investigators used a device devised by their experienced ballistics expert which was akin to an horizontal periscope, which could go through the smallers opening and which allowed them to see the origin of fire in this incident. See P23 (Witness statement of Mirsad Kučanin dated 12 November 1995), e-court pp. 3, 12; Mirsad Kučanin, P16 (Transcript from Prosecutor v. Galić), T. 4512-4513, 4516-4517, 4657-4659; P19 (Photographs re sniping incident of 22 July 1994 on Miljenka Cvitkovića street), p. 8. See also Barry Hogan, T. 11215-11216 (3 February 2011); P2205 (Photograph re sniping incident of 22 July 1994 on Miljenka Cvitkovića street marked by Barry Hogan); P2206 (Map of Sarajevo marked by Barry Hogan).

12985 Mirsad Kučanin, P16 (Transcript from Prosecutor v. Galić), T. 4735-4736.

12986 P23 (Witness statement of Mirsad Kučanin dated 12 November 1995), e-court p. 13. See also Mirsad Kučanin, P16 (Transcript from Prosecutor v. Galić), T. 4662.

12987 Barry Hogan, T. 11215-11216, 11270-11271 (3 February 2011); P2205 (Photograph re sniping incident of 22 July 1994 on Miljenka Cvitkovića street marked by Barry Hogan); P2206 (Map of Sarajevo marked by Barry Hogan); P2207 (Images re scheduled sniping incidents in Sarajevo); D1003 (Video footage re sniping incident of 22 July 1994 on Miljenka Cvitkovića street) (under seal); P2192 (Map of Sarajevo); P2190 (GPS locations for shelling and sniping incidents in Sarajevo); P2191 (Map of Sarajevo with scheduled sniping and shelling incidents).

12988 P1621 (Expert Report of Patrick van der Weijden entitled “Sniping Incidents in Sarajevo '92-'94”), p. 85.

12989 According to Van der Weijden, given that the bullet went through the shop window, it was clear that it came from the direction of the south. See Patrick van der Weijden, T. 7080 (28 September 2010). 
likely. ${ }^{12990}$ He visited the alleged location of the shooter, as provided to him by the Prosecution, and noted that there was now a new building near the incident site removing the line of sight between that particular location and the incident site. ${ }^{12991}$ However, he noted that in 1994 there would have been "plenty of view" towards the incident site from Hrasno Brdo. ${ }^{12992}$

3923. Van der Weijden was not able to determine the exact location from which the shot was fired but rather a general area from which it might have been fired, namely the area of Hrasno Brdo. ${ }^{12993}$ On cross-examination, he explained that he excluded the high-rise building near the site of the incident as the origin of fire because there was a large group of people present there at the time of the incident which would not have been the case if there was firing from that building. ${ }^{2994}$ Recalling that the bullet found on the scene was a $7.62 \mathrm{~mm}$ bullet, he noted that it was not possible to tell whether it was $7.62 \mathrm{X} 39 \mathrm{~mm}$ or $7.62 \mathrm{X} 54 \mathrm{R} \mathrm{mm}$ bullet; however, he excluded the former on the basis of the "distance from which [it] was likely fired" and thus concluded that the weapon most likely used was an M76 rifle or a civilian hunting rifle. ${ }^{12995}$ Van der Weijden testified that since children were playing at the incident site on the day of the incident, it is unlikely that any fighting would have been ongoing nearby. ${ }^{12996}$ In addition, even though the victim could have been confused for an adult, Van der Weijden thought that the presence of his mother, sister, and the other children would have indicated to the shooter that he was not a combatant. ${ }^{12997}$

3924. The Accused put to Van der Weijden and Hogan that a mistake was made during the investigation of this incident because the café that can be seen in the photographs prepared by the BiH MUP is actually on Džemala Bijedića street, the name of which was never changed, and that Miljenka Cvitkovića street is located behind it. ${ }^{12998}$ Van der Weijden, having no knowledge of the names of the streets involved, could not comment on this except to say that he visited the location of the incident on the basis of the GPS co-ordinates provided to him by the Prosecution and that he also identified it using the photographs of the BiH MUP. ${ }^{12999}$ Hogan was adamant that the location

\footnotetext{
12990 Patrick van der Weijden, T. 7073, 7080-7082 (28 September 2010).

12991 P1621 (Expert Report of Patrick van der Weijden entitled “Sniping Incidents in Sarajevo '92-'94”), pp. 81-82.

12992 P1621 (Expert Report of Patrick van der Weijden entitled “Sniping Incidents in Sarajevo '92-'94”), p. 81.

12993 P1621 (Expert Report of Patrick van der Weijden entitled “Sniping Incidents in Sarajevo '92-'94”), p. 81; Patrick van der Weijden, T. 7074, 7081-7086 (28 September 2010); D663 (Map of Sarajevo marked by Patrick van der Weijden).

12994 Patrick van der Weijden, T. 7087-7089 (28 September 2010); D663 (Map of Sarajevo marked by Patrick van der Weijden).

12995 P1621 (Expert Report of Patrick van der Weijden entitled “Sniping Incidents in Sarajevo '92-'94”), p. 80. See also Patrick van der Weijden, T. 7084 (28 September 2010).

12996 P1621 (Expert Report of Patrick van der Weijden entitled “Sniping Incidents in Sarajevo '92-'94”), p. 83.

12997 P1621 (Expert Report of Patrick van der Weijden entitled "Sniping Incidents in Sarajevo '92-'94”), p. 83.

12998 Patrick van der Weijden, T. 7089-7091, 7093 (28 September 2010). See also Barry Hogan, T. 11270-11273 (3 February 2011).

12999 Patrick van der Weijden, T. 7090 (28 September 2010).
} 
of the incident, as depicted in the video footage he prepared and on the photographs of the $\mathrm{BiH}$ MUP, was correctly recorded, regardless of the address used by the BiH MUP in its reports; he also noted that the location of the incident is known locally as "the hundred meter building on Ferde Hauptmana street" even though Ferde Hauptmana, formerly Miljenka Cvitkovića, is the square behind it. ${ }^{13000}$

3925. Poparić testified that, since all the documents specify that the incident took place on Miljenka Cvitkovića street, he could not accept that this was an accidental mistake, especially given that Džemala Bijedića is one of the best known and longest streets in Sarajevo. ${ }^{13001}$ Thus, and also based on the fact that there is no "physical evidence" that the victim was shot in front of the shop window, Poparić testified that he was convinced that the incident in fact occurred in Miljenka Cvitkovića street, not Džemala Bijedića street, under circumstances different to those described in the official BiH MUP report. ${ }^{13002}$

3926. In terms of the origin of fire, Poparić testified that it did not come, as alleged, from the Pržulj house, because when he visited that house there was no view of the incident site from it. ${ }^{13003}$ In addition, he explained that the distance between Pržulj house and the incident site is 1,245 metres while the altitude is 95 metres, meaning that the bullet would have to have a low angle of descent and a flat trajectory, which he conceded corresponded to the traces in the café. ${ }^{13004}$ However, Poparić then proceeded to argue that those traces were the result of an incident unrelated to the victim's wounding. ${ }^{13005}$

\footnotetext{
13000 Barry Hogan, T. 11270-11274 (3 February 2011); D1003 (Video footage re sniping incident of 22 July 1994 on Miljenka Cvitkovića street).

13001 D4884 (Mile Poparić's expert report entitled "Small Arms Fire on the Sarajevo Area 1992-1995", 15 August 2012), p. 125; Mile Poparić, T. 38893-38896 (29 May 2013); D3625 (Satellite image of Sarajevo marked by Mile Poparić).

13002 D4884 (Mile Poparić's expert report entitled "Small Arms Fire on the Sarajevo Area 1992-1995", 15 August 2012), pp. 119, 125. In cross-examination, Poparić was asked about the pool of blood seen in front of the shop on one of the contemporaneous photographs taken by the BiH MUP and how it came to be there if the boy was wounded on Miljenka Cvitkovića street. He responded that the boy sustained a small wound and that the pool of blood looked like water to him because it was too big to be blood. Poparić conceded, however, that he was not a doctor. See Mile Poparić, T. 39239-39240 (4 June 2013).

13003 D4884 (Mile Poparić's expert report entitled "Small Arms Fire on the Sarajevo Area 1992-1995", 15 August 2012), pp. 121-122. In cross-examination, Poparić confirmed that he did not know exactly where Pržulj house was and that he simply went to the most dominant house at the end of Zagorska street, which he assumed to be Pržulj house. See Mile Poparić, T. 39236 (4 June 2013).

13004 D4884 (Mile Poparić's expert report entitled "Small Arms Fire on the Sarajevo Area 1992-1995", 15 August 2012), pp. 120, 123, 126.

13005 Poparic made that conclusion on the basis of the contemporaneous photograph of the awning of the café and two different holes he detected on that photograph, arguing that the hole higher up in the awning was in fact a bullet hole, whereas the hole the BiH MUP focused on was not a bullet hole at all but a tear made by a sharp object. Analysing the higher hole, Poparić concluded that it was probably the result of a stray bullet fired in the air, which then led him to conclude that the incident involving the café was unrelated to the wounding of the boy. See D4884 (Mile Poparić's expert report entitled "Small Arms Fire on the Sarajevo Area 1992-1995", 15
} 
3927. Poparić also criticised the BiH MUP for failing to detect the traces that would indicate origin of fire more accurately and for using an instrument "whose principle of operation [he did] not know" but which he doubted, ${ }^{13006}$ instead of determining the angle of descent and incoming trajectory by measuring the co-ordinates of the traces. ${ }^{13007}$ Finally, he argued that the distance of 1,245 metres exceeds the capacity of a sniper rifle, meaning that the shot must have been fired by a machine-gun. ${ }^{13008}$

3928. Zurovac testified that his company's positions were some 1.5 kilometres away from the location of the incident and that the boy was standing with his back turned towards those positions when shot, so that there was no theoretical possibility for him to be shot by the soldiers of the $4^{\text {th }}$ Company soldiers. ${ }^{13009}$ Tuševljak testified that his platoon never fired on the boy, that their positions were some 1.2 kilometres away from the incident site and that they did not have weapons with that range. ${ }^{13010}$ Furthermore, he testified that no line of sight existed between his positions and the incident site and that there were no snipers in his unit. ${ }^{13011} \mathrm{He}$ conceded, however, that there was a line of sight between the positions of the company to his right, either the $2^{\text {nd }}$ or the $1^{\text {st }}$ Company. ${ }^{13012}$ He also conceded that M84 and M53 machine-guns his platoon had could cover the distance of 1.2 kilometres but explained that these machine-guns were located further back in the rear and did not have the optical sights necessary to accurately hit targets at that range. ${ }^{13013}$

3929. Galić explained that he did not know about this incident at the time and only heard about it during his own trial. ${ }^{13014} \mathrm{He}$ also testified that there were $\mathrm{ABiH}$ forces in the area of Čengić Vila where the incident took place. ${ }^{13015}$ He could not, therefore, deny that there was firing in the area and/or comment on what sort of firing it was. ${ }^{13016}$

August 2012), pp. 123-143; Mile Poparić, T. 38896-38898 (29 May 2013). In cross-examination, Poparić conceded that he reached this conclusion on the basis of a photograph but also on the basis of his extensive experience with bullet holes. Mile Poparić, T. 39236-39239 (4 June 2013).

13006 See fn. 12984.

13007 D4884 (Mile Poparić's expert report entitled "Small Arms Fire on the Sarajevo Area 1992-1995", 15 August 2012), p. 121.

13008 Mile Poparić, T. 38894-38895 (29 May 2013); D3625 (Satellite image of Sarajevo marked by Mile Poparić).

13009 The Chamber notes that Zurovac was no longer the company commander at the time of this incident. See Dušan Zurovac, T. 30251-30253, 30263 (14 November 2012); D2427 (Map of Sarajevo marked by Dušan Zurovac).

13010 D2391 (Witness statement of Slobodan Tuševljak dated 5 November 2012), para. 25; D2394 (Map of Sarajevo marked by Slobodan Tuševljak); Slobodan Tuševljak, T. 29961 (7 November 2012).

13011 D2391 (Witness statement of Slobodan Tuševljak dated 5 November 2012), para. 25.

13012 Slobodan Tuševljak, T. 29957-29958 (7 November 2012).

13013 Slobodan Tuševljak, T. 29958-29959 (7 November 2012); D2397 (List of members of the 4th Company).

13014 Stanislav Galić, T. 37538-37541 (22 April 2013); D3456 (SRK combat report, 22 July 1994).

13015 Stanislav Galić, T. 37538-37539 (22 April 2013).

13016 Stanislav Galić, T. 37538 (22 April 2013). When confronted with Blagoje Kovačević's evidence that the one area from which the SRK was never fired upon was the area of Čengić Vila, he responded that he was not in the 
3930. In addition to the above, the Chamber has also taken judicial notice of a number of adjudicated facts going to the origin of fire, namely: (i) Seid Solak was not hit by a stray bullet but was deliberately targeted; ${ }^{13017}$ (ii) a clear line of sight existed between the site of the incident and SRK positions; ${ }^{13018}$ and (iii) Seid Solak, a civilian, ${ }^{13019}$ was injured by a shot deliberately fired at him from SRK-controlled territory on Hrasno Brdo. ${ }^{13020}$

3931. Looking at the location of the incident first, the Chamber is satisfied that the location recorded by Hogan and seen in BiH MUP contemporaneous photographs is the actual location at which the incident happened. ${ }^{13021}$ It is also satisfied that it was erroneously noted in the official $\mathrm{BiH}$ MUP report and in the Indictment as being on Miljenka Cvitkovića street rather than on Džemala Bijedića street. This error occurred due to the fact that Miljenka Cvitkovića street is on the other side of the passage close to which Solak was standing when shot. However, this being an error as to the street name alone, it did not in any way affect the investigations done at the time of the incident, or subsequently, and does not therefore affect the evidence outlined above. Furthermore, this error was clarified during the trial and did not in any way undermine the Accused's notice of the allegations against him in relation to this incident. Finally, the Chamber finds Poparić's claim that the incident happened somewhere other than where the victim said it happened completely unreasonable. In making such a claim Poparić chose to ignore a number of factors, including (i) the fact that Kučanin and his colleagues, including ballistics experts, conducted an investigation at the location on the day of the incident, and that this was the location indicated to Hogan by the victim; (ii) that the Chamber has in evidence a contemporaneous photograph clearly showing a pool of blood in front of the shop marked by the victim; ${ }^{13022}$ and (iii) that at the time of the incident there would have been a number of eye-witnesses, including the victim's sister and mother, who talked to the police and, later, to Prosecution investigators about this incident and its location. What Poparić is implying by his testimony is a conspiracy of large magnitude, conducted over a number of years and involving various individuals and entities. However, there is not a shred of evidence to support this implication. For all those reasons, the

position to know and that the SRK commanders insisted that this area should never be targeted as it was the centre of Sarajevo and that museums were located there. See Stanislav Galić, T. 37836-37827 (7 May 2013).

\section{7}

Adjudicated Fact 243.

See Adjudicated Fact 239.

13020 See Adjudicated Facts 244.

13021 The Chamber recalls that it visited this location during its site visit to Sarajevo. The Chamber also recalls that in its Order on Submissions for a Site Visit, dated 15 November 2010, at paragraph 6, it stated that the purpose of its site visit to Sarajevo was not to gather evidence or receive any submissions from the parties but to permit the Chamber to become more familiar with the topography of certain key locations and thus assist its determination of the charges in the Indictment related to Sarajevo.

13022 The Chamber notes that Poparić uses this photograph in his report. D4884 (Mile Poparić's expert report entitled "Small Arms Fire on the Sarajevo Area 1992-1995", 15 August 2012), p. 120, Image 82. 
Chamber finds that Seid Solak was wounded on Džemala Bijedića street, near Miljenka Cvitkovića street.

3932. In terms of the origin of fire, the Chamber once again cannot accept Poparić's analysis as it is based on a number of speculations. For example, while Poparić testified that there was no view between Pržulj house and the incident site, he completely ignored the other evidence which suggests that a new building was built following the incident, blocking the previously existing line of sight between the two locations.

3933. In addition, Poparić's analysis that the damage to the awning of the café came about as a result of another incident is again unreasonable. First, it is based on a photograph of what may or may not be a hole in the awning. There is no close up photograph of that "hole" and it is difficult to see if it is indeed a hole or some entirely different type of trace, such as a stain or a shade. The Chamber notes that this "hole" was not referred to by the investigators on the scene at the time of the incident and there is nothing in the evidence suggesting that it is even a hole, let alone a bullet hole. Furthermore, in conducting this particular analysis, Poparić appears to ignore the fact that the BiH MUP investigators talked to the people in the café on the day of the incident, as well as the people outside of the café who witnessed the shooting. ${ }^{13023}$ Therefore, it would have been clear to those investigators that the café suffered the damage right after or around the time when the victim was wounded, which is why they noted this sequence of events in the official report at the time. To claim that the two incidents are unconnected is therefore unreasonable and seriously throws into doubt Poparić's credibility on this incident.

3934. Finally, as far as Poparić's criticism of the investigation method used by the BiH MUP investigators, the Chamber is satisfied that they used the well known and accepted method of tracing a bullet through its impact holes, as described earlier in this Judgement. ${ }^{13024}$ Thus, the Chamber does not accept Poparić's criticisms in this regard.

3935. Given the age of the victim, as well as the fact that he was on his bicycle and in the company of his mother and sister when shot, the Chamber has no doubt that he was a civilian and that he was not taking a direct part in hostilities at the time of the incident. Indeed, given the presence of a number of people around the incident site on that day, the Chamber finds that there was no military activity or fighting in the area. Based on the evidence above, the Chamber also considers that the location in which the boy was standing when shot was visible from the upper

13023 Indeed, in his official note, Kučanin refers to ten people being in the restaurant at the time the bullet struck and notes that it was fortunate that none of them was injured. P18 (BiH MUP Report re sniping incident of 22 July 1994 on Miljenka Cvitkovića street). 
parts of Hrasno Brdo, including from the area around Ozrenska and Zagorska streets. ${ }^{13025}$ Furthermore, the Chamber accepts Van der Weijden's evidence that at the time of the incident there would have been a clear line of sight between a number of positions on and near Ozrenska street, including the Pržulj house, and the incident site. ${ }^{13026}$ The Chamber is also satisfied that Ozrenska and Zagorska streets, as well as the Pržulj house, were in the zone of responsibility of the SRK's $2^{\text {nd }}$ Infantry Battalion of the $1^{\text {st }}$ Sarajevo Mechanised Brigade and that its units had sniper rifles and machine-guns which had the necessary range to reach the incident site. Furthermore, as noted above, ${ }^{13027}$ the Chamber accepts KDZ310's evidence that professional snipers were also positioned on Ozrenska street and would target civilians and combatants alike. Relying further on Van der Weijden's evidence that the shooter could not have been located near the incident site due to the large number of people in the area at the time of the incident, as well as the investigation conducted by the local investigators on the day of the incident, the Chamber is convinced that the shooter was located in the zone of responsibility of the $2^{\text {nd }}$ Infantry Battalion of the $1^{\text {st }}$ Sarajevo Mechanised Brigade, as established by the local investigators. The Chamber is also convinced that the shooter targeted the victim deliberately, as illustrated by the fact that more than one bullet was fired on the incident site.

\section{(E) Scheduled sniping incidents F.1 and F.5}

3936. The last two sniping incidents alleged in the Indictment took place in two different parts of Sarajevo, the southeastern suburb of Širokača and the northwestern area of Briješko Brdo respectively. Each is examined by the Chamber below.

\section{(1) Žagrići street, Širokača, 13 December 1992 (Scheduled Incident F.1)}

3937. According to the Indictment, on 13 December 1992, Anisa Pita, a three year old girl, was shot and wounded in her right leg on the porch of her residence on Žagrići street in the Širokača area of Sarajevo. ${ }^{13028}$ In its Final Brief, the Prosecution argues that the shot that wounded Pita was fired from the SRK-controlled area of Baba Stijena. ${ }^{13029}$ The Accused argues that Anisa Pita's

See para. 3628

While both Zurovac and Tuševljak testified that their company's positions did not have the line of sight to the incident site, this does not change the Chamber's finding that the units of the $2^{\text {nd }}$ Infantry Battalion were in positions that had such a line of sight onto the incident site. Indeed, as outlined above, this was admitted by Tuševljak during his testimony.

13026 See P1621 (Expert Report of Patrick van der Weijden entitled “Sniping Incidents in Sarajevo '92-'94”), p. 80; Patrick van der Weijden, T. 7074, 7081-7086 (28 September 2010); D663 (Map of Sarajevo marked by Patrick van der Weijden).

13027 See para. 3902

13028 Indictment, Scheduled Incident F.1.

13029 Prosecution Final Brief, Appendix C, paras. 37-38.
} 
house cannot be seen from Baba Stijena and that Pita was wounded in an exchange of fire taking place at the confrontation line. ${ }^{13030}$

3938. Širokača is a suburb located in the southeastern part of Sarajevo south of Miljacka River and east of Grbavica. ${ }^{13031}$ Baba Stijena, or Baba Rock, is a ridge on the northern slope of Mount Trebević, just below the Pale-Lukavica road, which overlooks Sarajevo, including Širokača. ${ }^{13032}$ During the war, it was in the zone of responsibility of the $2^{\text {nd }}$ Company of the $3^{\text {rd }}$ Infantry Battalion of the $1^{\text {st }}$ Romanija Infantry Brigade of the SRK. ${ }^{13033}$ On the other side of the confrontation line was the $10^{\text {th }}$ Mountain Brigade, later $115^{\text {th }}$ Mountain Brigade, of the $1^{\text {st }}$ Corps of the ABiH. ${ }^{13034}$

3939. On 13 December 1992, between 10 and 10:30 a.m., Anisa Pita and her father left their house in the morning as there was no ongoing fighting ${ }^{13035}$ and went to a water source about 150 metres from the house, where people were already lining up. ${ }^{13036}$ Anisa Pita remained there for a short time as she met another child, named Elma Smajkan, and they decided to go back to the Pitas' house to play. ${ }^{13037}$ As Anisa Pita arrived to her house, she was wounded above her right knee by a bullet which subsequently exited her body. ${ }^{13038}$ The fog had lifted by that time. ${ }^{13039}$

3940. Hogan visited the site of the incident and recorded Anisa Pita's exact position and location when she was shot, namely at the front door of her house. ${ }^{13040}$ Van der Weijden also visited the

13030 Defence Final Brief, paras. 2182-2186.

13031 P2191 (Map of Sarajevo with scheduled sniping and shelling incidents); D2347 (Map of Sarajevo marked by Miloš ̌̌krba).

13032 Stanislav Galić, T. 37473-37474 (22 April 2013); D2344 (Witness statement of Miloš Škrba dated 14 October 2012), paras. 5, 11; D2347 (Map of Sarajevo marked by Miloš Škrba); D2348 (Photograph of Baba Stijena); Miloš Škrba, T. 29188-29189 (22 October 2012).

13033 D2344 (Witness statement of Miloš Škrba dated 14 October 2012), paras. 5, 11; Miloš Škrba, T. 29189-29190 (22 October 2012). See Adjudicated Fact 152. While Škrba testified that the $2^{\text {nd }}$ Company in the area was part of the $2^{\text {nd }}$ Infantry Battalion of the $1^{\text {st }}$ Sarajevo Mechanised Brigade, the Chamber notes that prior to mid-1993, this battalion was called $3^{\text {rd }}$ Infantry Battalion and was part of the $1^{\text {st }}$ Romanija Infantry Brigade. See fn. 12875; D2622 (Witness statement of Željko Bambarez dated 9 December 2012), paras. 3, 5; D2418 (Witness statement of Božo Tomić dated 5 November 2012), paras. 8, 25-26; Božo Tomić, T. 30178-30179 (13 November 2012). Contrary to Škrba, Galić testified that the SRK forces "may have had access" to one part of the Baba Stijena area, while the $\mathrm{ABiH}$ forces had their positions in another part of the area, just below the Lukavica-Pale road. See Stanislav Galić, T. 37473-37474 (22 April 2013). Given that he was the local commander in the actual area of Baba Stijena, the Chamber accepts Škrba's evidence over that of Galić, and finds that Baba Stijena itself was under the SRK control.

13034 D2344 (Witness statement of Miloš Škrba dated 14 October 2012), para. 6; Stanislav Galić, T. 37474-37475 (22 April 2013); Asim Džambasović, T. 15224-15225 (22 June 2011); D1380 (Map of ABiH positions in Sarajevo marked by Asim Džambasović).

13035 See Adjudicated Fact 147.

13036 See Adjudicated Fact 148.

13037 See Adjudicated Fact 149.

13038 See Adjudicated Facts 150, 151; P1991 (Stari Grad Police Station war diary), pp. 3-4.

13039 Adjudicated Fact 150.

13040 Barry Hogan, T. 11207-11208 (3 February 2011); P2194 (Photograph re sniping incident of 13 December 1992 on Žagrići street marked by Barry Hogan); P2207 (Images re scheduled sniping incidents in Sarajevo); P2190 
incident site ${ }^{13041}$ and examined the doorway of the house; he crouched down to the girl's level, and then observed the surroundings to see where the shot may have originated from. ${ }^{13042}$ Since the garden of the house was completely walled off, he was only able to observe Baba Stijena and thus concluded that Baba Stijena was the only possible origin of fire. ${ }^{13043}$ He also visited Baba Stijena and observed that it offered a dominating view of the valley below and thus would have been an obvious location for a machine-gun emplacement and/or a sniper position. ${ }^{13044}$ Van der Weijden noted two other possible origins of fire which he excluded, namely (i) a house seen in the area between the girl's house and Baba Stijena, which he excluded because it would have made no sense tactically ${ }^{13045}$ to have a shooting position in that location and (ii) an area 25 metres away, directly next to Žagrići street, which he excluded because it would have been unlikely for the child to be playing on the street and later on her porch if the soldiers with guns were nearby. ${ }^{13046}$

3941. Van der Weijden also thought that the calibre of the bullet used in this incident would not have been greater than $7.92 \mathrm{~mm}$ as greater damage would have been caused to Anisa Pita's right leg in that case. ${ }^{13047}$ Noting the distance between Baba Stijena and the incident site, namely 920 metres, and noting also that "one or more" shots were heard, Van der Weijden concluded that either a semi-automatic sniper rifle (M76 or M91), or a machine-gun (M84 or M53) was used, although the range would have been extreme for sniper rifles. ${ }^{13048}$

3942. As for the identification of the victim by the shooter, Van der Weijden was told that she was wearing a red top and blue bottoms, and that she was standing in the doorway of her house when

(GPS locations for shelling and sniping incidents in Sarajevo); P2191 (Map of Sarajevo with scheduled sniping and shelling incidents).

As noted above, Van der Weijden testified that he visited the sites relevant to the Indictment in November 2006 and January 2009. See para. 3634.

13042 Patrick van der Weijden, T. 6973-6974 (27 September 2010); D637 (Photograph of a house).

13043 Patrick van der Weijden noted that the trees in the area have grown since the incident and now obscure the view somewhat, but he was nevertheless of the view that this was the location from which the fire originated. See P1621 (Expert Report of Patrick van der Weijden entitled "Sniping Incidents in Sarajevo '92-'94”), p. 15; Patrick van der Weijden, T. 6995-6996 (27 September 2010). See also Barry Hogan, T. 11207-11208 (3 February 2011); P2194 (Photograph re sniping incident of 13 December 1992 on Žagrići street marked by Barry Hogan).

13044 P1621 (Expert Report of Patrick van der Weijden entitled “Sniping Incidents in Sarajevo '92-'94”), pp. 13-14.

13045 Van der Weijden explained that it would have made no sense from a tactical point of view to have a shooting position down the hill, just below the enemy's shooting position. See Patrick van der Weijden, T. 7173 (29 September 2010).

13046 Patrick van der Weijden, T. 6995-6996 (27 September 2010), T. 7172-7173 (29 September 2010).

13047 Van der Weijden thought that both $7.62 \mathrm{~mm}$ and $7.9 \mathrm{~mm}$ bullets could have been used in this incident, although the former was less likely due to distances involved. He also noted that given the small size and mass of a three year old's leg, the bullet would not lose much energy while going through and thus would not have caused the same "devastation" as in the case of an adult. See P1621 (Expert Report of Patrick van der Weijden entitled “Sniping Incidents in Sarajevo '92-'94”), p. 13; Patrick van der Weijden, T. 6996-7004 (27 September 2010).

13048 P1621 (Expert Report of Patrick van der Weijden entitled “Sniping Incidents in Sarajevo '92-'94”), p. 13. See also Adjudicated Fact 153 in relation to the distance involved. 
shot, meaning that she did not reach above half of the doorway. ${ }^{13049}$ These factors, according to him, would have made her easily distinguishable as a civilian, even with the distances involved. ${ }^{13050}$

3943. On cross-examination, Van der Weijden rejected the Accused's submission that the shot may have been fired from the Muslim cemetery located southwest of the Pita house because it was clear that this location offered no view of the exact site where Anisa Pita was shot. ${ }^{13051} \mathrm{He}$ explained that during his visit, he in fact stopped at the cemetery to see if there was a line of sight to the incident site but could see none and so drove higher up the mountain. ${ }^{13052} \mathrm{He}$ also conceded that he did not know where the line of separation was in that area and noted that the only information he was provided with by the Prosecution was that the VRS controlled Baba Stijena. ${ }^{13053}$

3944. Poparić testified-relying on a number of photographs he took from Baba Stijena and from the incident site - that there was no line of sight between the two locations. ${ }^{13054}$ He also stated that this was confirmed when he physically visited Baba Stijena in September 2010 and May 2011. ${ }^{13055}$ He further argued that Van der Weijden mistakenly identified as Baba Stijena a small rock on a clearing under Baba Stijena, which had a line of sight and which was under the ABiH control. ${ }^{13056}$ Finally, he argued that there is no line of sight between the incident site and Baba Stijena because there is a natural obstacle, namely a terrain elevation, of two metres, at a distance of 403 metres from the incident site in the direction of Baba Stijena, which obstructs the view. ${ }^{13057}$ In crossexamination, Poparić conceded, however, that Anisa Pita's house had been renovated by the time he was at the scene so that it was no longer possible to stand or crouch at the specific location she

\footnotetext{
13049 P1621 (Expert Report of Patrick van der Weijden entitled “Sniping Incidents in Sarajevo '92-'94”), p. 16.

13050 P1621 (Expert Report of Patrick van der Weijden entitled "Sniping Incidents in Sarajevo '92-'94”), p. 16. See also Patrick van der Weijden, T. 6987-6988 (27 September 2010).

13051 Patrick van der Weijden, T. 6976-7005 (27 September 2020), 7172-7173 (29 September 2010); D638 (Map of Sarajevo marked by Patrick van der Weijden); D639 (Photograph of a house marked by Patrick van der Weijden); D640 (Map of Sarajevo marked by Patrick van der Weijden); D641 (Photograph of a cemetery); D642 (Aerial photograph of Sarajevo marked by Patrick van der Weijden); D643 (Aerial photograph of Sarajevo marked by Patrick van der Weijden); D644 (Aerial photograph of Sarajevo); D645 (Aerial photograph of Sarajevo); D646 (Aerial photograph of Sarajevo marked by Patrick van der Weijden).

13052 Patrick van der Weijden, T. 6996 (27 September 2010).

13053 Patrick van der Weijden, T. 6976, 6984 (27 September 2010); D642 (Aerial photograph of Sarajevo marked by Patrick van der Weijden).

13054 D4884 (Mile Poparić's expert report entitled "Small Arms Fire on the Sarajevo Area 1992-1995", 15 August 2012), pp. 51-52.

13055 D4884 (Mile Poparić's expert report entitled "Small Arms Fire on the Sarajevo Area 1992-1995", 15 August 2012), p. 52; Mile Poparić, T. 38937-38939 (29 May 2013).

13056 In addition, he argued that even if Van der Weijden had accurately marked the location of Baba Stijena, it was still clear that there was no line of sight to the incident site due to the density of the trees in the area. D4884 (Mile Poparić's expert report entitled "Small Arms Fire on the Sarajevo Area 1992-1995”, 15 August 2012), pp. 52-54; Mile Poparić, T. 39287-39288 (5 June 2013).

13057 In making this claim, Poparić relied on three different topographical maps of the area. D4884 (Mile Poparić's expert report entitled "Small Arms Fire on the Sarajevo Area 1992-1995", 15 August 2012), pp. 54-56; Mile Poparić, T. 38937-38939 (29 May 2013), T. 39266-39267 (5 June 2013).
} 
was at when shot. ${ }^{13058}$ When shown two different photographs taken from the incident site prior to the renovations, one marked by Anisa Pita's father and the other used by Van der Weijden in his report, Poparić denied that either of the photographs showed Baba Stijena and argued that, like Van der Weijden, Anisa Pita's father wrongly marked Baba Stijena. ${ }^{13059}$

3945. Even disregarding the fact that there was no line of sight, Poparić argued that it cannot be "realistically assumed" that Anisa Pita was deliberately targeted from Baba Stijena given that she was a three year old in a crouching position and thus too small to be detected and successfully hit from a distance of some 880 metres in overcast weather. ${ }^{13060}$ Poparić also observed that no medical records existed that would make it possible to identify the bullet track and thus determine the bullet's trajectory. ${ }^{13061}$ Using the statements of Anisa Pita's parents that they heard several shots at the time of the incident and the fact that Anisa Pita's injury was not serious, ${ }^{13062}$ Poparic theorised that she was probably struck by a ricocheted projectile as a result of an exchange of fire. ${ }^{13063}$

3946. Miloš Škrba, who was the Commander of the $2^{\text {nd }}$ Company of the $3^{\text {rd }}$ Infantry Battallion of the $1^{\text {st }}$ Romanija Infantry Brigade of the SRK at the time of the incident, testified that there were no sharpshooters or snipers in his company ${ }^{13064}$ and that he never issued orders to anyone to open fire at civilians from Baba Stijena. ${ }^{13065}$ He conceded that his company had rifles, as well as automatic and semi-automatic weapons, but claimed that it did not have optical equipment, such as binoculars and optical sights, because it did not need them. ${ }^{13066}$ In addition, according to Škrba, the $2^{\text {nd }}$

\footnotetext{
13058 Mile Poparić, T. 39266-39267 (5 June 2013).

13059 Mile Poparić, T. 39267-39269, 39287-39288 (5 June 2013); P6367 (Three photographs); D3648 (Three photographs marked by Mile Poparić).

13060 D4884 (Mile Poparić's expert report entitled "Small Arms Fire on the Sarajevo Area 1992-1995", 15 August 2012), p. 56; Mile Poparić, T. 38937 (29 May 2013).

13061 D4884 (Mile Poparić's expert report entitled "Small Arms Fire on the Sarajevo Area 1992-1995", 15 August 2012), p. 56; Mile Poparić, T. 38937 (29 May 2013).

13062 While Poparić claimed that Anisa Pita did not require hospital treatment, his account of her parents' evidence, namely that they took her to an emergency clinic and that she was then referred to the Koševo Hospital, seems to contradict that. While he does follow up this account by saying that there was no medical record of Pita's treatment, this is insufficient to conclude that no hospital treatment was required. See D4884 (Mile Poparić's expert report entitled "Small Arms Fire on the Sarajevo Area 1992-1995", 15 August 2012), p. 49.

13063 D4884 (Mile Poparić's expert report entitled "Small Arms Fire on the Sarajevo Area 1992-1995", 15 August 2012), p. 57.

13064 The Chamber recalls here that Maletić testified that there was a sniper squad in the battalion, which was directly subordinated to the commander. See D2519 (Witness statement of Dragan Maletić dated 9 November 2012), paras. 8-9, 31; Dragan Maletić, T. 30846-30848 (3 December 2012), T. 30873-30874 (4 December 2012).

13065 D2344 (Witness statement of Miloš Škrba dated 14 October 2012), paras. 9, 11, 16; D2622 (Witness statement of Željko Bambarez dated 9 December 2012), paras. 11-13, 15. When confronted with a report of the $1^{\text {st }}$ Sarajevo Mechanised Brigade sent to the SRK Command on 29 October 1993, informing the SRK Command that it was in possession of a number of sniper rifles and optical sights which were issued to combatants in subordinated units, Škrba responded that he could not speak as to the weapons at the level of his brigade and that his company did not have the weapons mentioned in the report. Miloš Škrba, T. 29186-29188 (22 October 2012); P5930 (Report of $1^{\text {st }}$ Sarajevo Mechanised Brigade to SRK, 29 October 1993).

13066 Miloš Škrba, T. 29193-29194 (22 October 2012).
} 
Company did not have "determined targets"; its only targets were ABiH soldiers and only when they opened fire on the company's positions. ${ }^{13067}$ He also explained that Baba Stijena was exposed to frequent $\mathrm{ABiH}$ fire, which is why it was a fortified position, ${ }^{13068}$ and that $\mathrm{ABiH}$ units had positions in depth, in civilian facilities and houses. ${ }^{13069}$ In cross-examination, he conceded that his company would return fire "in most cases", but denied that it would open fire on civilian housesinstead, he said, the fire was directed "at their lines". ${ }^{13070}$

3947. Stanislav Galić, the SRK Commander at the time, testified that no one issued an order to open fire on Anisa Pita, explaining that the positions and trenches of the $10^{\text {th }}$ Mountain Brigade of the $1^{\text {st }}$ Corps of $\mathrm{ABiH}$ were near her house and that $\mathrm{ABiH}$ soldiers would have been "moving around" the house to get to their positions. ${ }^{13071}$ He said that he never received any reports about this incident and that at that time there was fighting in Oteš, on the opposite side of the frontline, so there should have been no major activity in Širokača on that day. ${ }^{13072}$

3948. In addition to the evidence and adjudicated facts outlined above, the Chamber has also taken judicial notice of two adjudicated facts which go to the origin of fire and provide as follows: (i) Anisa Pita was injured by a shot fired from the area of the ridge known as Baba Stijena; ${ }^{13073}$ and (ii) on 13 December 1992 Anisa Pita, a three and a half years old civilian, was deliberately targeted and injured by a shot from an area that SRK soldiers had access to. ${ }^{13074}$

3949. The Chamber finds, given Anisa Pita's age at the time of the incident that she was a civilian and that she was obviously not taking direct part in hostilities at the time of the incident. Further, while Galić suggested that soldiers would have been moving around her house, he provided no specific evidence that soldiers were there when Anisa Pita was shot. Contrary to Poparić's opinion that she was hit by a ricocheted bullet as a result of an exchange of fire, the Chamber is satisfied

\footnotetext{
13067 D2344 (Witness statement of Miloš Škrba dated 14 October 2012), para. 16; Miloš Škrba, T. 29189-29193 (22 October 2012).

13068 D2344 (Witness statement of Miloš Škrba dated 14 October 2012), para. 11; Miloš Škrba, T. 29189-29190 (22 October 2012); P5938 (Video still of Baba Stijena); D4622 (Report of $1^{\text {st }}$ Romanija Infantry Brigade, 14 August 1992). Škrba marked two photographs showing positions from which ABiH opened sniper fire on various SRK-controlled areas, including Grbavica and Vraca. See D2344 (Witness statement of Miloš Škrba dated 14 October 2012), paras. 7-8; D2349 (Photograph of Sarajevo marked by Miloš Škrba); D2350 (Photograph of Sarajevo marked by Miloš Škrba); Miloš Škrba, T. 29190-29191 (22 October 2012).

13069 D2344 (Witness statement of Miloš Škrba dated 14 October 2012), para. 6; Miloš Škrba, T. 29191-29192 (22 October 2012).

13070 Miloš Škrba, T. 29191-29192 (22 October 2012).

13071 Galić stopped short of saying that $\mathrm{ABiH}$ soldiers were moving in the area on the day of the incident and acknowledged that this would have been speculation on his part. See Stanislav Galić, T. 37474-37475 (22 April 2013).

13072 Stanislav Galić, T. 37474-37476 (22 April 2013); D3436 (SRK combat report, 13 December 1992).

13073 Adjudicated Fact 154.

13074 Adjudicated Fact 155.
} 
that there was no fighting when she was shot because the morning was quiet, as illustrated by people lining up to get water near her house, and by the fact that she was walking home with another child and without her father. Neither would have been likely had there been fighting in the area at the time.

3950. The Chamber is also satisfied, based on the evidence above, that there was a line of sight between Baba Stijena and the exact location where Anisa Pita was located when shot, as testified to by Van der Weijden and illustrated by the photographs in his report. These photographs clearly show that line of sight, despite Poparić's claim to the contrary. ${ }^{13075}$ The Chamber further notes that Van der Weijden visited the area before the alterations were made to the incident site and thus was able to observe the environment from the girl's position when shot. In contrast, Poparić's evidence is based on his visits in 2010 and 2011, that is, after the relevant alteration took place. In terms of the origin of fire, the Chamber is also persuaded, again relying on Van der Weijden's evidence, that Baba Stijena was in fact the location from which the shot was fired in this incident. While Van der Weijden noted two other possible locations, he excluded them for reasons the Chamber finds persuasive.

3951. The Chamber is further satisfied, based on Miloš Škrba's evidence, that the $2^{\text {nd }}$ Company of the $2^{\text {nd }}$ Infantry Battalion of the $1^{\text {st }}$ Sarajevo Mechanised Brigade of the SRK had fortified positions in the area of Baba Stijena and that its soldiers possessed automatic and semi-automatic weapons. While Škrba testified that his company did not have binoculars or other optical instruments, the Chamber finds it difficult to believe that an SRK company would not have-at the very least—one pair of binoculars, and therefore does not accept his evidence in this respect. ${ }^{13076}$

3952. Relying again on Škrba's evidence, the Chamber is satisfied that SRK soldiers would frequently open fire from Baba Stijena. While Škrba claimed that they only opened fire on ABiH soldiers and their lines, he also testified that the $\mathrm{ABiH}$ positions were in depth of the Muslim territory, in civilian houses and facilities, thus confirming that the fire was opened on civilian houses and other civilian facilities. The Chamber does not find his denials as to the fire being opened on civilian areas and civilians themselves to be genuine.

3953. Finally, given the distance between the incident site and the area of Baba Stijena, which would have required a careful shot on the part of the shooter, the Chamber is satisfied that Anisa

13075 In this respect, the Chamber does not accept Poparić's claim that Van der Weijden wrongly identified Baba Stijena in the said photograph, something that would have been highly unlikely given that he visited Baba Stijena, using GPS co-ordinates of the relevant position, and given that he examined the area carefully.

13076 In addition, as testified by Maletić, the battalion itself had a sniper squad responsible directly to the battalion command. See fn. 13064. 
Pita was deliberately targeted by one of the SRK soldiers located on Baba Stijena. ${ }^{13077}$ This soldier would have undoubtedly been aware of her civilian status, for all the reasons outlined above by Van der Weijden. ${ }^{13078}$

\section{(2) Briješko Brdo street, 2 November 1993 (Scheduled Incident F.5)}

3954. The Indictment alleges that on 2 November 1993, Ramiza Kundo, a 32 year old woman, was shot and wounded in her left leg while carrying buckets of water across Briješko Brdo street (presently Bulbulistan street) in the west end of Sarajevo. ${ }^{13079}$ In its Final Brief, the Prosecution argues that the fire originated from a field, referred to as "Polje", in the Bačići and Briješće area in SRK-held territory, which had an unobstructed line of sight on the incident site. ${ }^{13080}$ The Accused argues that given the inconsistent evidence related to this incident it is impossible to determine even the direction from which the bullet was fired. ${ }^{13081} \mathrm{He}$ also argues that $\mathrm{ABiH}$ forces deployed in the area were in dominant positions and that the scene of the incident was not "sufficiently visible" from SRK positions. ${ }^{13082}$

3955. Briješko Brdo or Briješko Hill is a hilly area on the northwestern edge of Sarajevo, located between Rajlovac, which is to its north, and Briješće, which is to its south. ${ }^{13083}$

3956. The Chamber took judicial notice of a number of adjudicated facts related to the circumstances of this incident. They provide that (i) on 2 November 1993, at around 4 pm, Ramiza Kundo, 38 years old at that time, and Rasema Menzilović, were hurrying back from a well located about 50 metres away from Menzilović's house carrying full 10-litre canisters in each hand along Briješko Brdo street; ${ }^{13084}$ (ii) the ABiH confrontation line was between 300 and 400 metres away from the site of the incident; ${ }^{13085}$ and (iii) Ramiza Kundo was wounded by a shot fired from the direction of "Polje," a field in the area of Bačići and Briješce. ${ }^{13086}$

\footnotetext{
13077 The Chamber does not accept Poparić's evidence that the nature of Anisa Pita's injuries meant that it was caused by a ricocheted bullet. To the contrary, the Chamber is persuaded by Van der Weijden's conclusion that given the size of a three year old's leg, her injuries would not have been as devastating as they would have been with an adult.

13078 See para. 3942.

13079 Indictment, Scheduled Incident F.5.

13080 Prosecution Final Brief, Appendix C, para. 39.

13081 Defence Final Brief, paras. 2207-2211.

13082 Defence Final Brief, para. 2212.

13083 P2191 (Map of Sarajevo with scheduled sniping and shelling incidents); P1803 (Map of Alipašino Polje); P2199 (Map of Sarajevo marked by Barry Hogan); D2788 (Map of Sarajevo marked by Dragomir Milošević).

13084 See Adjudicated Fact 183.

13085 Adjudicated Fact 184.

13086 Adjudicated Fact 185.
} 
3957. According to Kundo's medical records, due to an entry-exit wound through her left calf, she was admitted to Koševo Hospital on 2 November 1993, where she was treated and then released several days later. ${ }^{13087}$

3958. Hogan visited the site of the incident with Ramiza Kundo and recorded her exact location and position when shot, as well as the direction from which she said the bullet came. The video footage of that reconstruction shows her walking on a hill, towards the well, and indicating to Polje, located down the slope to her left, as being the direction of fire. ${ }^{13088}$ The Chamber notes that this reconstruction contradicts one of the adjudicated facts referred to above, as it indicates that Kundo was on her way to the well when she was shot, not on her way back from the well.

3959. Van der Weijden investigated this incident after the Prosecution gave him the location of the incident and the alleged location of the shooter, namely "Polje". ${ }^{13089}$ He was of the view that the calibre of the bullet that struck the victim would not have been more than $7.92 \mathrm{~mm}$ as it would have caused greater damage. ${ }^{13090}$ He also noted that the road where the incident took place is lined on one side with houses and a concrete wall topped by a fence, while there is an earthen wall on the other side, thus creating a tunnel limiting the view of the incident site to locations in line with the street. $^{13091}$ Van der Weijden visited Polje and noted that there were several locations offering an unobstructed view of the incident site from the ground level and that the houses in those locations would offer an even better view. ${ }^{13092}$ He believed that the shooter would have been at a maximum distance of 825 metres from the incident site. ${ }^{13093}$ From that location, the victim would have been easily identifiable as a female carrying water containers. ${ }^{13094}$ Given the possible calibres of the bullet, the range involved, and the fact that only one shot was heard, Van der Weijden concluded that a semi-automatic rifle was probably used, either an M76 or an M91, although this range would have been extreme for those rifles. ${ }^{13095}$

\footnotetext{
13087 P1026 (Medical records for Ramiza Kundo).

13088 Barry Hogan, T. 11210-11211, 11261-11262 (3 February 2011); P2198 (Photograph re sniping incident of 2 November 1993 on Briješko Brdo street marked by Barry Hogan); P2199 (Map of Sarajevo marked by Barry Hogan); P2207 (Images re scheduled sniping incidents in Sarajevo); D995 (Video footage re sniping incident of 2 November 1993 on Briješko Brdo street). For the still of Kundo pointing to her left, in the direction of the field, see D4884 (Mile Poparić's expert report entitled "Small Arms Fire on the Sarajevo Area 1992-1995", 15 August 2012), p. 76, Image 50.

13089 P1621 (Expert Report of Patrick van der Weijden entitled “Sniping Incidents in Sarajevo '92-'94”), p. 34.

13090 P1621 (Expert Report of Patrick van der Weijden entitled "Sniping Incidents in Sarajevo '92-'94”), p. 34.

13091 P1621 (Expert Report of Patrick van der Weijden entitled “Sniping Incidents in Sarajevo '92-'94”), pp. 36-37.

13092 P1621 (Expert Report of Patrick van der Weijden entitled “Sniping Incidents in Sarajevo '92-'94”), p. 36. See also Barry Hogan, T. 11210-11211 (3 February 2011); P2198 (Photograph re sniping incident of 2 November 1993 on Briješko Brdo street marked by Barry Hogan).

13093 P1621 (Expert Report of Patrick van der Weijden entitled “Sniping Incidents in Sarajevo '92-'94”), p. 36.

13094 P1621 (Expert Report of Patrick van der Weijden entitled “Sniping Incidents in Sarajevo '92-'94”), p. 37.

13095 P1621 (Expert Report of Patrick van der Weijden entitled “Sniping Incidents in Sarajevo '92-'94”), p. 34.
} 
3960. Poparic testified that the information relating to this incident was so contradictory that it was impossible to establish what happened. ${ }^{13096}$ He explained that Kundo gave conflicting statements as to whether she was shot when on her way to the well or when returning from the well and that Menzilović's recollection was that they were on their way back. ${ }^{13097}$ Poparic further recounted the testimonies of both Kundo and Menzilović, from the Galić case, and noted that both testimonies failed to make clear whether the shot came from Polje or from a depot further west of the incident site. ${ }^{13098}$ Poparić also pointed out that Kundo conceded in her testimony in the Galić case that an $\mathrm{ABiH}$ tank was located some 500 metres above her house. ${ }^{13099}$

3961. Relying on an $\mathrm{ABiH}$ map showing confrontation lines in the area, ${ }^{13100}$ Poparic noted that the confrontation line was some 500 to 600 metres away from Kundo's house and that the incident site was thus also visible from a "rather wide area" controlled by the ABiH. ${ }^{13101}$ In cross-examination, he conceded that the configuration of terrain was such that it created a natural "tunnel" in terms of the line of sight to the incident site, as well as the fact that Kundo was visible from the Serb positions in the area. ${ }^{13102}$ When pointed out to him that his potential field of fire was much larger than the potential field of fire as assessed by Van der Weijden, he explained that Van der Weijden only marked what was visible from the SRK positions and did not check the visibility from the ABiH positions. ${ }^{13103}$

3962. Finally, referring to Kundo's medical records, Poparić observed that they do not identify the position of the entry and exit wounds or the orientation of the bullet track, thus adding to the

\footnotetext{
13096 Mile Poparić, T. 38954-38955 (29 May 2013).

13097 D4884 (Mile Poparić's expert report entitled "Small Arms Fire on the Sarajevo Area 1992-1995", 15 August 2012), pp. 75-76; Mile Poparić, T. 38955, 38958 (29 May 2013).

13098 When visiting the site, Poparic ruled out the depot as the origin of fire because it "did not afford a line of sight which would make it possible to shoot a person on the [Briješko Brdo] street in their lower leg." See D4884 (Mile Poparić's expert report entitled "Small Arms Fire on the Sarajevo Area 1992-1995”, 15 August 2012), pp. 77-79, 81 .

13099 D4884 (Mile Poparić's expert report entitled "Small Arms Fire on the Sarajevo Area 1992-1995", 15 August 2012), p. 79; Mile Poparić, T. 38959-38960 (29 May 2013). In cross-examination, when told that he failed to mention that Kundo also testified that this tank was there only for a week and that she could not remember when that was, Poparic explained that he mentioned the tank only to show that there were ABiH troops in the area. See Mile Poparić, T. 39168-39173 (4 June 2013).

13100 In cross-examination, Poparić conceded that the map he relied on was operative in the period 1 March to 14 September 1995 and explained that he used it nevertheless because the evidence he saw suggested that the confrontation line in the area did not change throughout the war. He denied that he deliberately omitted this information in order to mislead the Chamber and stated that he simply accepted the situation as alleged by the Prosecution insofar as the confrontation lines were concerned. See Mile Poparić, T. 39196-39198 (4 June 2013); P1764 (ABiH Map of Sarajevo).

13101 D4884 (Mile Poparić's expert report entitled "Small Arms Fire on the Sarajevo Area 1992-1995", 15 August 2012), pp. 79-81; Mile Poparić, T. 38955-38956 (29 May 2013). Poparić explained that the ABiH-controlled area from which Kundo could be seen was in fact bigger than the area from which the SRK units could see her. See Mile Poparić, T. 38958-38959 (29 May 2013).

13102 Mile Poparić, T. 39233-39236 (4 June 2013).

13103 Mile Poparić, T. 39234-39235 (4 June 2013); P6364 (Two satellite images of Sarajevo).
} 
difficulty in determining the direction of fire already made complicated by Kundo's inconsistent statements as to the direction in which she was walking when shot. ${ }^{13104}$

3963. Stanislav Galić testified that he received no reports about this incident at the time but pointed out that $\mathrm{ABiH}$ had forces in the area of Briješko Brdo and that the incident site was not "sufficiently visible" from the SRK positions, which were located in the area of Azići, towards Dobrinja river. ${ }^{13105}$ According to Galić, the SRK positions were at the foot of the hill on which the incident happened, meaning that the $\mathrm{ABiH}$ forces that controlled the hill were in a dominant position in that area. ${ }^{13106}$

3964. In addition to the evidence and adjudicated facts outlined above, the Chamber has also taken judicial notice of three more adjudicated facts which go to the origin of fire and provide as follows: (i) Ramiza Kundo was injured by a bullet fired from SRK-held territory in the field area, where Briješće and Bačići are; ${ }^{13107}$ (ii) Ramiza Kundo was not hit by a stray bullet or a ricochet as a consequence of regular combat activity; ${ }^{13108}$ and, (iii) on 2 November 1993, a civilian Ramiza Kundo was targeted from an SRK-controlled area in full awareness of the high risk that the target was a civilian. ${ }^{13109}$

3965. Having reviewed the evidence on this incident, as well as the adjudicated facts outlined above, the Chamber is unable to conclude, beyond reasonable doubt, that Ramiza Kundo was wounded by a shot fired by an SRK soldier positioned in the location of Polje. First, the Chamber is of the view that the Accused was successful in rebutting some of the adjudicated facts related to this incident, including those related to the direction and origin of fire. The Chamber recalls here the Accused's cross-examination of Hogan in relation to the direction in which Kundo was walking when shot, as well as Poparić's evidence on the various versions of the event given by Kundo in the Galić case. Despite being aware of inconsistencies in relation to that issue, the Prosecution chose

\footnotetext{
13104 Poparić also explained that, given the configuration of the terrain (that is, the difference in altitude of 100 metres between Kundo and the SRK positions), it would have been important to know how high up on Kundo's calf was her wound located, as that would have allowed him to check whether that part of the leg was visible from where the bullet had been fired. Poparic also referred to a police report on the incident, which is not in evidence in this case, and which provides that Kundo was wounded in her right leg. See D4884 (Mile Poparić's expert report entitled "Small Arms Fire on the Sarajevo Area 1992-1995", 15 August 2012), pp. 82-83, 85; Mile Poparić, T. 38955-38958 (29 May 2013); D3636 (Photograph re sniping incident of 2 November 1993 on Briješko Brdo street marked by Mile Poparić).

13105 Stanislav Galić, T. 37513-37516 (22 April 2013); D3451 (SRK combat report, 1 November 1993).

13106 Stanislav Galić, T. 37515 (22 April 2013).

13107 Adjudicated Fact 186.

13108 Adjudicated Fact 187

13109 Adjudicated Fact 188.
} 
not to call Kundo as a witness in this case. ${ }^{13110}$ Instead, it decided to rely on adjudicated facts, which in turn contradict the evidence of Hogan, the Prosecution's own investigator. The Chamber is therefore left with a situation in which it has adjudicated facts on one hand (which contradict the Prosecution's own evidence) and Poparić's recounting of Kundo's evidence on the other (which suggests a number of inconsistencies in her evidence). ${ }^{13111}$ Thus, the Chamber cannot rely on the adjudicated facts relating to this incident and in particular to the origin of fire.

3966. Turning then to the Prosecution evidence on this incident, it consists of Van der Weijden's observations as to the potential field of fire and Hogan's geo-positioning of the incident and the shooter as recounted to him by Kundo. Given, however, that Van der Weijden never made a determination that the bullet necessarily came from SRK positions, ${ }^{13112}$ while Hogan's evidence was not concerned with the exact origin of fire, ${ }^{13113}$ the Chamber deems the available evidence simply insufficient to conclude that the bullet that wounded Kundo came from the SRK positions. In that respect, the Chamber also notes the Prosecution's own admission that Polje was not one of the well-known sniping positions of the SRK. ${ }^{13114}$

3967. For these reasons, the Chamber finds that the Prosecution has failed to prove, beyond reasonable doubt, that the shot that hit and wounded Ramiza Kundo was fired by one of the SRK soldiers in the area.

\section{iv. Findings on sniping in Sarajevo}

3968. Having considered all the evidence presented in this case in relation to sniping in Sarajevo the Chamber is convinced that throughout the conflict SRK units deliberately shot at civilians in

13110 Calling Kundo as a witness would have allowed the Chamber to assess her credibility and the reliability of her evidence, and to come to its own conclusions as to the way in which the incident unfolded, including the direction in which she was walking when shot.

13111 The Chamber recalls its observation during trial that Poparic is an expert on ballistic matters and therefore not an expert on credibility of victims of the incidents. See Mile Poparić, T. 38905 (29 May 2013). While that remains the case, the adjudicated facts and the evidence presented by the Prosecution in this particular incident are not only scarce but also internally inconsistent. The Prosecution did not discuss this incident with Van der Weijden and it never cross-examined Poparić on this aspect of his analysis. It also appeared to ignore his overall assessment that the information about this incident was very inconsistent. In addition, in contrast to the other incidents, the Chamber has received no contemporaneous documents that would allow it to resolve the various inconsistencies in the evidence before it. Thus, Poparić's recounting of various inconsistencies in Kundo's evidence in the Galic case simply reinforced the inconsistencies already present between the evidence led by the Prosecution and adjudicated facts.

13112 Indeed, as suggested by Poparić, it would appear that when determining the potential field of fire, Van der Weijden limited his observations only on what was visible from Polje as there is no suggestion that he checked the line of sight between the incident and the areas east of Polje, which were controlled by the ABiH. See P1621 (Expert Report of Patrick van der Weijden entitled “Sniping Incidents in Sarajevo '92-'94”), pp. 35-36.

13113 See Barry Hogan, T. 11231 (3 February 2011).

13114 Prosecution Final Brief, Appendix C, para. 2. 
Sarajevo, including at trams and other means of public transport. ${ }^{13115}$ This was confirmed not only by the witnesses who lived and worked in Sarajevo and who experienced sniper fire on daily basis from notorious sniping locations but also by the evidence indicating that thousands of civilian casualties were caused by sniper or small arms fire in Sarajevo. ${ }^{13116}$ The Chamber was particularly persuaded by the evidence of international witnesses working with the UN on this issue as they not only observed the sniping within the city but also had a more complete picture of the situation through constant dealings with both sides to the conflict as well as through the reports of UNPROFOR forces tasked with anti-sniping operations.

3969. The Chamber is also satisfied that the evidence shows beyond reasonable doubt that the SRK soldiers' deliberate sniping of civilians was not particularly unusual in the Sarajevo battlefield. It was, in fact, persistent, took place on an almost daily basis, and continued unabated during the entirety of the conflict. Sarajevo civilians were shot while fetching water, walking in the city, and when using public transport (particularly trams). Furthermore, children were sniped at while playing in front of their houses, walking with their parents or walking home from school, and even when cycling. The fact that UNPROFOR had to set up anti-sniping barriers throughout the city and establish an anti-sniping unit which would, at times, exchange fire with SRK snipers is a clear proof of this. The evidence shows that the SRK used sniper rifles that both Galic and Milošević admitted were in the SRK arsenal. They also used machine guns, which allowed them to hit targets at much longer ranges than normally possible with sniper rifles.

3970. The Chamber is also convinced, relying particularly on the evidence of KDZ310 and Maletić, that the SRK had specialised sniping units or squads which were commanded at a battalion level or higher and in which the SRK Command took special interest, as indicated by its orders relating to snipers outlined above. ${ }^{13117}$ Futhermore, the Chamber has no doubt that these units were under the control of the SRK Command, despite Manojlović's claim that the sniping was out of control in Sarajevo. This is cofirmed not only by the SRK Command's orders and training exercises referred to above, but also by the events on the ground, such as, for example, the reduction in sniping following the signing of the Anti-sniping Agreement, as discussed in Section IV.B.1.a. The fact that these sniper units operated from professionally set up sniper nests which were located in buildings along the confrontation lines for a number of years, as amply illustrated by the sniper nests in the white high-rises in Grbavica, makes it unlikely that the SRK Command

\footnotetext{
13115 In reaching this conclusion, the Chamber relied not only on the findings on Scheduled Sniping Incidents discussed above, but also on the general evidence relating to the sniping situation in the city and specifically in the areas notorious for sniping, such as Sniper Alley, for example.

13116 See also paras. 4588-4591.

13117 See para. 3623.
} 
did not have control over the said sniper units. Instead, it confirms that the SRK Command was reliant on, and regularly used, professional sniper teams, positioning them at most opportune locations. $^{13118}$ SRK units also used most convenient nature-made elevations along the confrontation lines around the city, such as Špicasta Stijena and Baba Stijena, to position their snipers, again indicating the involvement of the higher levels of the SRK. While the Chamber does not exclude the possibility that there may have been some rogue shooters on the SRK side, the Chamber considers their activities to have been insignificant in light of the evidence on the sustained campaign of sniping against the civilian population in the city from notorious sniper locations and on the overall control over snipers exhibited by the SRK commands.

3971. In coming to the above conclusions, the Chamber has carefully assessed the evidence of former SRK soldiers and officers who denied the SRK practice of deliberate sniping on civilians in Sarajevo. The Chamber found these denials to be untenable and completely at odds with the reality on the ground when considered in combination with the accepted Prosecution evidence outlined above, as well as the evidence specifically related to the scheduled sniping incidents. The Chamber therefore considers that the evidence of these witnesses was self-serving and dishonest, seriously calling into question their credibility.

3972. The Chamber is also satisfied that the $\mathrm{ABiH}$ units and special police forces within the confrontation lines in Sarajevo had snipers, as claimed by the Accused, which they used against the SRK positions and against civilian targets on the Bosnian Serb side of the confrontation line. However, this being the Accused's trial, the sniping practices of the $\mathrm{ABiH}$ units and special police forces are only relevant to this case insofar as they allow the Chamber to determine whether the fire coming from the Bosnian Serb side was opened in response to $\mathrm{ABiH}$ sniper fire and, if so, whether that response was selective and proportionate. In other words, while regrettable that Bosnian Serb civilians were sniped by the $\mathrm{ABiH}$ forces and special police units located in the city, such activities are not part of the Indictment in this case and are also not an excuse for the Bosnian Serb side's targeting of Sarajevo civilians.

3973. On the other hand, the Accused's argument that the Bosnian Muslim units within the city opened sniper fire on their own civilians in order to lay the blame on the Serbs is relevant to the Indictment in this case. However, the Chamber has by and large rejected this claim for the reasons outlined in more detail in the later section of the Judgement. ${ }^{13119}$

\footnotetext{
13118 The other notorious sniping locations are discussed above in the sections relating to specific Scheduled Sniping Incidents.

13119 See Section IV.B.A.d: Bosnian Muslim side targeting own civilians.
} 


\section{c. Shelling}

3974. The Prosecution alleges that the Accused, together with a number of others, participated in a joint criminal enterprise to establish and carry out a campaign of shelling against the civilian population of Sarajevo between April 1992 and November 1995, the primary purpose of which was to spread terror. ${ }^{13120}$ To illustrate that campaign ${ }^{13121}$ the Prosecution presented, inter alia, detailed evidence in relation to 15 shelling incidents listed in Schedule G of the Indictment. ${ }^{13122}$ These incidents allegedly included opening mortar fire on residential areas in the city and using modified air bombs later in the conflict. As with the scheduled sniping incidents, they are all alleged to have been perpetrated by the Sarajevo Forces. In addition, the Prosecution brought general evidence on the nature of heavy weapon fire in Sarajevo and referred to a number of unscheduled shelling incidents to establish a pattern of conduct by the Bosnian Serb military and political authorities. ${ }^{13123}$

3975. In response, the Accused denies that the SRK deliberately shelled civilians, stating that there were military targets deep in $\mathrm{ABiH}$-held territory in the city and that the $\mathrm{ABiH}$ units "abused for military purposes premises of civilian and protected buildings", including UN facilities. ${ }^{13124}$ Nevertheless, according to the Accused, the SRK units took precautionary measures to prevent opening fire on civilians, such as 24-hour observation by artillery scouts and using more precise weapons when "returning fire on urban areas". ${ }^{3125}$ Further, the Accused submits that the SRK units were informed of the provisions of international humanitarian law and the laws of war, and that orders were issued requiring soldiers to act in accordance with these laws. ${ }^{13126}$ Finally, the Accused claims that $\mathrm{ABiH}$ units targeted their own civilians by opening mortar fire on them in order to bring about international intervention in $\mathrm{BiH}^{13127}$

\footnotetext{
13120 Indictment, paras. 15-17.

13121 Indictment, para. 82 (referring to the shelling incidents in Schedule G as being "illustrative examples" of the campaign).

13122 Originally, the Indictment contained four additional scheduled shelling incidents but these were withdrawn by the Prosecution pursuant to Rule 73 bis. See Rule 73 bis Decision.

13123 As indicated to the parties during the case, the Chamber will not be making beyond reasonable doubt findings as to the responsibility of the Accused for specific unscheduled incidents. See T. 5480 (19 July 2010); fn. 11204.

13124 Defence Final Brief, paras. 1954-1955.

13125 Defence Final Brief, paras. 1909-1911, 1944-1945, 1960-1961.

13126 Defence Final Brief, paras. 1850-1853.

13127 Defence Final Brief, paras. 1968, 1972-1974.
} 


\section{i. Shelling in general}

3976. With respect to shelling, the Chamber heard from several experts in this case. Richard Higgs, an expert on the operational use and technical and ballistic capabilities of mortars, ${ }^{13128}$ and Berko Zečević, an expert on ballistics, rockets, and warheads, ${ }^{13129}$ were both called by the Prosecution. Zorica Subotić, ballistics expert on firearms and white arms, ${ }^{13130}$ and Derek Allsop, an expert on conventional barrelled weapons and their ballistics, ${ }^{13131}$ were called by the Accused. The Chamber also admitted evidence from fact witnesses who provided information on the general mechanics of various shelling weapons, as well as shelling and crater analysis methodology. ${ }^{13132}$

3977. During the trial, the Chamber heard evidence about a number of shelling weapons, including (i) infantry weapons, such as mortars, (ii) artillery weapons, such as howitzers, guns, and cannons, and (iii) a weapon system used specifically in Sarajevo, namely modified air bombs. Categories (i) and (ii) will be discussed in this section, while the features of the modified air bombs will be discussed in the section dealing with specific Scheduled Incidents that involved modified air bombs. ${ }^{13133}$

3978. The Chamber heard that mortars can vary in calibre from light to heavy classes; the $60 \mathrm{~mm}$ mortar is classified as a light mortar, the $81 / 82 \mathrm{~mm}$ mortar is classed as medium and the 120/122 $\mathrm{mm}$ mortar is a heavier class. ${ }^{13134}$ Each mortar consists of a sight, indicating bearing and elevation; a barrel or tube; a bipod/tripod adjustable stand; and a platform on which the barrel rests known as the base plate. ${ }^{13135}$ The mortar rounds or "shells" are generally fired by placing each shell in the barrel—tail first—after which the shell strikes the firing pin, initiating the charge, and is then

\footnotetext{
13128 Richard Higgs, T. 5916-5918 (18 August 2010); P1437 (Richard Higgs's Consolidated Report on Sarajevo Shelling Incidents, 13 March 2009), p. 1.

13129 Berko Zečević, T. 12149-12150 (22 February 2011). See also the Chamber's oral decision of 22 February 2011. Hearing, T. 12145-12146 (22 February 2011).

13130 D3542 (Zorica Subotić's expert report entitled "Mortar Operations in Sarajevo Area in 1992-1995", 15 August 2012), pp. 2-23. In addition, Mile Poparić, a ballistics expert also commissioned by the Accused to give evidence about sniping, helped Subotic draft her report on mortar attacks in the Sarajevo area. See D3542 (Zorica Subotić's expert report entitled “Mortar Operations in Sarajevo Area in 1992-1995”, 15 August 2012).

13131 D2372 (Derek Allsop's expert report entitled "Shelling of Markale Market in Sarajevo 5" February 1994 ", 20 January 2012), para. 1.1, Appendix A.

13132 One of those witnesses was John Hamill, an artillery officer in the Irish Army and UNMO in BiH from May 1993 to July 1994. John Hamill, P1994 (Transcript from Prosecutor v. Galić), T. 6059-6060.

13133 See Section IV.B.1.c.iii.D: Scheduled modified air bomb incidents.

13134 See P1437 (Richard Higgs's Consolidated Report on Sarajevo Shelling Incidents, 13 March 2009), p. 2; Richard Higgs, T. 5981 (19 August 2010); Vlade Lučić, T. 30787 (3 December 2012); John Hamill, T. 9699 (13 December 2010); Berko Zečević, T. 12150 (22 February 2011).

13135 P1437 (Richard Higgs's Consolidated Report on Sarajevo Shelling Incidents, 13 March 2009), pp. 2-3. See also John Hamill, P1994 (Transcript from Prosecutor v. Galić), T. 6065, 6072-6075; D2372 (Derek Allsop's expert report entitled "Shelling of Markale Market in Sarajevo $5^{\text {th }}$ February 1994", 20 January 2012), paras. 2.1-2.2.
} 
propelled out of the barrel. ${ }^{13136}$ Higgs explained that mortar shells travel at a high trajectory and, with an adept crew, have an accuracy of less than 40 metres from their target and a maximum range of between 4,500 and 7,500 metres dependant upon, inter alia, the amount of propellant used and the elevation of the barrel. ${ }^{13137}$ Additional propellant or "charge" can be added starting from a small amount, charge 1 , to a maximum amount, charge $6 .{ }^{13138}$ At minimum charge, the range of the shell is reduced but the mortar is more accurate. ${ }^{13139}$ Mortar shells are stabilised by tail fins and their accuracy generally depends on a number of factors, including the charge used and the stability of the base plate. ${ }^{13140}$

3979. Mortars are capable of both direct and indirect fire. ${ }^{13141}$ Direct fire is when the target is directly visible to the unit and the sight of the mortar is used to aim at the target. ${ }^{13142}$ Conversely, indirect fire is where the target cannot be seen by the crew and the battery aims at a given target using instrumental methods, such as making adjustments to the bearing or azimuth on the horizontal plane and to the elevation of the barrel on the vertical plane. ${ }^{13143}$ The type of terrain, angle of descent, round velocity, calibre, and weather conditions are all determining factors in whether a crater will be formed by the explosion of a shell and whether the mortar's stabiliser will be found embedded within such a crater. ${ }^{13144}$ Mortar crews can also "pre-record" information about a given target from their position, such as the bearing, elevation, charge, and type of target. ${ }^{13145}$

13136 P1437 (Richard Higgs's Consolidated Report on Sarajevo Shelling Incidents, 13 March 2009), pp. 2-3; D2372 (Derek Allsop's expert report entitled "Shelling of Markale Market in Sarajevo $5^{\text {th }}$ February 1994", 20 January 2012), para. 2.1-2.3.

13137 P1437 (Richard Higgs's Consolidated Report on Sarajevo Shelling Incidents, 13 March 2009), pp. 2-3. See also John Hamill, T. 9704 (13 December 2010); Mirza Sabljica, T. 7720 (12 October 2010); P1925 (Witness statement of Emir Turkušić dated 16 February 2010), pp. 5-6.

13138 P1437 (Richard Higgs's Consolidated Report on Sarajevo Shelling Incidents, 13 March 2009), p. 2; John Hamill, P1994 (Transcript from Prosecutor v. Galić), T. 6074. Different charges will also affect the velocity of the projectile. See D2372 (Derek Allsop's expert report entitled "Shelling of Markale Market in Sarajevo $5^{\text {th }}$ February 1994", 20 January 2012), para. 2.3.

13139 The mortar battery also has less chance of being detected by Cymbeline radar at minimum charge. See Richard Higgs, T. 5933, 5935 (18 August 2010).

13140 P1437 (Richard Higgs's Consolidated Report on Sarajevo Shelling Incidents, 13 March 2009), p. 3. Having the base plate of a particular mortar in the same position for a long time increases the accuracy of the mortar and thus allows the mortar crew to engage or strike its target with only one round. See P1925 (Witness statement of Emir Turkušić dated 16 February 2010), p. 6.

13141 P1437 (Richard Higgs's Consolidated Report on Sarajevo Shelling Incidents, 13 March 2009), p. 2.

13142 P1437 (Richard Higgs's Consolidated Report on Sarajevo Shelling Incidents, 13 March 2009), pp. 4-5.

13143 Richard Higgs, T. 5986 (19 August 2010). See also D2372 (Derek Allsop's expert report entitled "Shelling of Markale Market in Sarajevo $5^{\text {th }}$ February 1994", 20 January 2012), para. 2.2.

13144 P1437 (Richard Higgs's Consolidated Report on Sarajevo Shelling Incidents, 13 March 2009), pp. 5-6. See also John Hamill, P1994 (Transcript from Prosecutor v. Galić), T. 6075. When a mortar is fired at the higher charges the increased velocity of the round increases the likelihood that the shell's stabiliser will be embedded within the crater. Conversely, at the low to medium charges the stabiliser will generally be blown away from the initial impact area. See Richard Higgs, T. 5980-5981 (19 August 2010). See also Zorica Subotić, T. 38457 (16 May 2013); P1695 (Witness statement of Mirza Sabljica dated 11 February 2010), p. 14.

13145 Richard Higgs, T. 5918 (18 August 2010); P1437 (Richard Higgs's Consolidated Report on Sarajevo Shelling Incidents, 13 March 2009), p. 4. 
This enables the crew to engage these "pre-recorded" targets in the future with a higher degree of accuracy. ${ }^{13146}$

3980. In terms of effectiveness, mortar shells are used against manpower as they generally make only a small crater on impact but will fragment and spread shrapnel over a wide area. ${ }^{13147}$ According to Higgs, in an urban area where there is a lot of cover, one would need to fire around five rounds as quickly as possible if the intention is to cause maximum casualties. ${ }^{13148}$ Thus, firing one to three rounds would serve no military purpose other than perhaps creating "harassing fire" designed to force the enemy to keep their head down and prevent movement. ${ }^{13149}$ Higgs explained that using that type of fire on a civilian area would serve only to cause casualties and inflict terror. ${ }^{13150}$ Fraser agreed and testified that mortars are not a good weapons system when used in an urban, densely-populated, area as they inflict little damage on urban buildings but cause a lot of damage to unprotected people who are in the open. ${ }^{13151}$

3981. Hamill testified that conventionally both mortars and guns/howitzers are used to "support the combat troops" even though they have their own distinct features. ${ }^{13152}$ According to him, guns and howitzers are generally used for their long-range ability to fire at distant targets and are therefore positioned farther from the frontline than mortars. ${ }^{13153}$ Mortars, due to their shorter range, are generally positioned closer to the frontline than guns and howitzers, but are used in what is termed a "shoot and scoot" fashion. ${ }^{13154}$ This means that they will fire a number of rounds in quick succession and then immediately move to another position in order to prevent "counter battery fire". ${ }^{13155}$ According to Hamill, the skill of firing a mortar can be learnt "relatively quickly". ${ }^{13156}$

\footnotetext{
13146 Richard Higgs, T. 5918 (18 August 2010); P1437 (Richard Higgs's Consolidated Report on Sarajevo Shelling Incidents, 13 March 2009), p. 4.

13147 P1437 (Richard Higgs's Consolidated Report on Sarajevo Shelling Incidents, 13 March 2009), p. 4. See also P1925 (Witness statement of Emir Turkušić dated 16 February 2010), pp. 15-16; David Fraser, T. 8008 (18 October 2010).

13148 P1437 (Richard Higgs's Consolidated Report on Sarajevo Shelling Incidents, 13 March 2009), p. 4.

13149 P1437 (Richard Higgs's Consolidated Report on Sarajevo Shelling Incidents, 13 March 2009), p. 4.

13150 P1437 (Richard Higgs's Consolidated Report on Sarajevo Shelling Incidents, 13 March 2009), p. 4.

13151 David Fraser, T. 8008-8010 (18 October 2010).

13152 John Hamill, P1994 (Transcript from Prosecutor v. Galić), T. 6064. See also David Fraser, T. 8007-8008 (18 October 2010). Hamill uses the terms gun and howitzer interchangeably. See John Hamill, T. 9694 (13 December 2010).

13153 John Hamill, P1994 (Transcript from Prosecutor v. Galić), T. 6064.

13154 John Hamill, P1994 (Transcript from Prosecutor v. Galić), T. 6064, 6072-6073.

13155 "Counter battery fire" is where "fire [is] directed by artillery at artillery". John Hamill, P1994 (Transcript from Prosecutor v. Galić), T. 6064. See also KDZ185, T. 4283 (29 June 2010).

13156 John Hamill, P1994 (Transcript from Prosecutor v. Galić), T. 6066.
} 
3982. Hamill observed that theoretically the maximum angle of elevation for a mortar battery of any calibre is 90 degrees, ${ }^{13157}$ but that firing at this angle would be rather precarious. ${ }^{13158} \mathrm{He}$ observed that a mortar shell is designed to suppress activity over a wide area and that the "danger radius" is considered to be 500 metres for a $120 \mathrm{~mm}$ mortar and 250 metres for an $81 \mathrm{~mm}$ mortar. ${ }^{13159}$ Similarly, Galić testified that the minimum "safety or security zone" for smaller calibre mortars is 200 metres and that for larger calibre mortars, such as the $120 \mathrm{~mm}$ mortar, it is around 400 metres. $^{13160}$

\section{ii. Shelling in Sarajevo}

3983. Due to its topography, the city of Sarajevo was well suited for the use of indirect fire weapons such as mortars because it is located in a valley, facilitating target observation by forces located on the surrounding hills. ${ }^{13161}$ The city's features, such as buildings and roads, were also good reference points that a mortar crew could use to make adjustments to their sights. ${ }^{13162}$

3984. Fraser testified that while both sides of the conflict used shelling, often against civilians, the ABiH forces in Sarajevo "couldn't hold a candle" to the artillery the SRK had. ${ }^{13163}$ Similarly, Harland confirmed that both sides used shelling against civilians, but explained that this was done according to each side's resources, which meant that the Serb side used such shelling much more. ${ }^{13164}$ When formed, the SRK was composed of nine light brigades, a mixed anti-armour regiment, a mixed armour artillery regiment, a light artillery regiment, a communications battalion, a medical battalion, and a transport battalion. ${ }^{13165}$ Each of these brigades had their own armaments,

13157 John Hamill, T. 9703 (13 December 2010).

13158 John Hamill, T. 9703 (13 December 2010) (agreeing with the Accused that in practical terms the maximum angle of elevation is probably 86 degrees). According to Allsop, the maximum angle of launch is 85 degrees, which will result in a minimum range of the shell, while the minimum angle of launch is 45 degrees, which will give the shell a maximum range. D2372 (Derek Allsop's expert report entitled "Shelling of Markale Market in Sarajevo $5^{\text {th }}$ February 1994", 20 January 2012), para. 2.1.

13159 John Hamill, T. 9703 (13 December 2010). The danger radius is the area within which splinters will travel from the point of detonation and can cause harm to those present. Within this radius, there is a smaller, "lethal radius" where it is highly likely that those within it will be fatally injured. For a $120 \mathrm{~mm}$ mortar shell this would be 54 metres from the point of impact. See John Hamill, P1994 (Transcript from Prosecutor v. Galić), T. 6191.

13160 Stanislav Galić, T. 37857 (7 May 2013), T. 38052 (9 May 2013).

13161 P1437 (Richard Higgs's Consolidated Report on Sarajevo Shelling Incidents, 13 March 2009), p. 6.

13162 P1437 (Richard Higgs's Consolidated Report on Sarajevo Shelling Incidents, 13 March 2009), p. 6.

13163 P1762 (Witness statement of David Fraser dated 17 October 2010), pp. 52, 75. See also D312 (SRK analysis of combat readiness of artillery rocket units, July 1994), p. 3 (providing that the initial period of the war was characterised by the fact that the SRK was superior to the ABiH when it came to heavy weapons).

13164 P820 (Witness statement of David Harland dated 4 September 2009), para. 290; David Harland, T. 2280 (10 May 2010). See also P1029 (Witness statement of John Wilson dated 4 November 2008), paras. 56-57; P2407 (Witness statement of KDZ304), p. 8 (adding that while superior to the $\mathrm{ABiH}$ forces in tank and artillery power, the SRK's arsenal was of mediocre quality and the SRK had difficulty with maintenance and replenishment).

13165 Stanislav Galić, T. 37157 (15 April 2013). On 1 November 1992, two brigades, the $1^{\text {st }}$ Romanija and the Rogatica Brigades, left the SRK for the Drina Corps. See Stanislav Galić, T. 37157 (15 April 2013). 
which their respective unit commander controlled. ${ }^{13166}$ The basic assets of each brigade were 100 mm howitzer and 60, 82, 105, and $120 \mathrm{~mm}$ mortars. ${ }^{13167}$ In contrast, the corps level controlled heavier weapons, such as $155 \mathrm{~mm}$ howitzers. ${ }^{13168}$ According to Wilson, the Bosnian Serbs had "something in the vicinity of 200 artillery and mortar barrels that they could direct at the city". 13169 KDZ185 estimated that the SRK had around 300 pieces of heavy weaponry around Sarajevo, with calibre greater than $14.5 \mathrm{~mm}$ and ranging up to $152 \mathrm{~mm}$, including multiple rocket launchers. ${ }^{13170}$ On 12 May 1992 during a Bosnian Serb Assembly session, Mladić in fact proclaimed that Sarajevo could not be taken "by spitting at it from a mortar or a howitzer" and that in order to make the Bosnian Muslims surrender they would have to densely plant 300 guns around Sarajevo, including rocket launchers. ${ }^{13171}$ From early on, the SRK therefore had large quantities of artillery and heavy weapons, with most of those weapons pointing towards the city. ${ }^{13172}$

3985. The SRK's mortar batteries surrounding Sarajevo remained in their positions throughout the conflict. $^{13173}$ This meant that the SRK had the whole city pre-recorded and therefore had "very accurate weapon platforms". 13174 Another feature of the SRK weapon sites was that the weapons

13166 Stanislav Galić, T. 37195, 37200-37201 (15 April 2013); D2774 (Witness statement of Milenko Inđić dated 19 January 2013), para. 31.

13167 Dragomir Milošević, T. 32759-32760 (28 January 2013).

13168 Dragomir Milošević, T. 32759-32760 (28 January 2013); Stanislav Galić, T. 37195, 37200-37201 (15 April 2013). The SRK generally used their mortar assets, these mainly being 82 and $120 \mathrm{~mm}$ mortars. See P1762 (Witness statement of David Fraser dated 17 October 2010), p. 53.

13169 P1029 (Witness statement of John Wilson dated 4 November 2008), para. 48. See also P1599 (UNMO report re VRS weapons, 16 January 1994); P1154 (Witness statement of KDZ088 dated 27-29 April 2010), pp. 26-27, 63 (under seal).

13170 P6060 (Record of interview with KDZ185), e-court pp. 15-16; KDZ185, T. 4207 (28 June 2010). See also Colm Doyle, T. 2737-2740 (26 May 2010); David Harland, T. 2295-2297 (11 May 2010); D173 (UNSG's letter to Ed Koch, 27 January 1993); P1558 (Witness statement of Francis Roy Thomas dated 13 May 2009), paras. 83, 119; P1568 (UNMO assessment of forces in BiH), e-court pp. 5-6; P1599 (UNMO report re VRS weapons, 16 January 1994). Once the TEZ was established, the VRS placed 282 weapons in WCPs. See P2447 (Witness statement of KDZ182), p. 63. In June 1994, the UN reported that the SRK had around 500 weapons within the TEZ in violation of the cease-fire agreement of February 1994. See P892 (UNPROFOR Weekly Situation Report (Sarajevo), 24 June 1995), p. 3.

13171 P956 (Transcript of $16^{\text {th }}$ session of SerBiH Assembly, 12 May 1992), e-court pp. 35-36.

13172 P1426 (Witness statement of Richard Mole dated 7 May 2010), paras. 21, 37, 39, 41, 83; Aernout van Lynden, T. 2467 (19 May 2010); P1998 (BBC news report re interview with Colonel Bartula, with transcript); KDZ185, T. 41804181 (28 June 2010) (private session); P4203 (Witness statement of Pyers Tucker dated 12 May 2010), para. 295; KDZ304, T. 10454 (18 January 2011). See Adjudicated Fact 2811.

13173 P1437 (Richard Higgs's Consolidated Report on Sarajevo Shelling Incidents, 13 March 2009), p. 6; John Hamill, P1994 (Transcript from Prosecutor v. Galić), T. 6065. One example where Hamill observed that the SRK mortars appeared to have been permanently stationed was at Gornji Kotorac, a hill overlooking the airport, Vojkovići, Hrasnica, Igman, Stup, and Mojmilo. See John Hamill, P1994 (Transcript from Prosecutor v. Galić), T. 6064-6066. See also P1258 (Witness statement of Hussein Ali Abdel-Razek dated 16 July 2002), e-court p. 11.

13174 Richard Higgs, T. 5918 (18 August 2010); P1437 (Richard Higgs's Consolidated Report on Sarajevo Shelling Incidents, 13 March 2009), pp. 4, 6. See also P1925 (Witness statement of Emir Turkušić dated 16 February 2010), p. 6; Savo Simić, T. 30047 (12 November 2012). 
were not camouflaged, indicating that they were not perceived as being under threat. ${ }^{13175}$ Fraser, who himself commanded mortar platoons, thought that the mortar crews in Sarajevo were competent and could generally hit the area they wanted to hit. ${ }^{13176}$ KDZ182 was of the opinion that the SRK artillery and mortars were controlled at the "highest level" because of the media scrutiny in Sarajevo; thus, the orders from Pale, and from Mladić in particular, would be transmitted directly by the SRK commander through the channels of communication. ${ }^{13177}$ According to KDZ182, leeway was also given to "underlings" in the field to use their weapons at any opportunity in order to generate a climate of terror. ${ }^{13178}$

3986. In terms of the $\mathrm{ABiH}$ fighting capabilities, while it outnumbered the SRK in terms of manpower, the number of heavy weapons available to the $\mathrm{ABiH}$ within the city was much smaller than that of the SRK, the majority of its arsenal being small arms and mortars with small quantities of artillery weapons. ${ }^{13179}$ The $\mathrm{ABiH}$ also had mortars mounted on trucks, which were thus mobile

13175 P1426 (Witness statement of Richard Mole dated 7 May 2010), para. 38. See also P6060 (Record of interview with KDZ185), e-court p. 15 (testifying that the most surprising fact about the SRK batteries around Sarajevo is that they were not guarded very carefully); Aernout van Lynden, T. 2423-2424 (19 May 2010) (testifying that the SRK positions he visited in the east of Sarajevo were not under threat from the city); Jeremy Bowen, $\mathrm{T}$. 10216-10218 (14 January 2011); D942 (BBC news report re Sarajevo, with transcript).

13176 P1762 (Witness statement of David Fraser dated 17 October 2010), p. 52. See also John Wilson, T. 4079-4080 (22 June 2010); P1258 (Witness statement of Hussein Ali Abdel-Razek dated 16 July 2002), e-court p. 11 . See Adjudicated Fact 2807.

13177 P2447 (Witness statement of KDZ182), p. 53; P2414 (Witness statement of KDZ182), pp. 11-13, 16, 20-22, 54 (under seal); KDZ182, T. 13046-13051, 13070 (9 March 2011); P2419 (VRS Main Staff Order, 6 November 1994); P2420 (Report of $2^{\text {nd }}$ Light Infantry Brigade re VRS Main Staff order, 7 November 1994). See also P6060 (Record of interview with KDZ185), e-court p. 14; KDZ185, T. 4216-4218 (28 June 2010); P5906 (Witness statement of KDZ450 dated 17 January 2011), paras. 27-29, 73, 75; KDZ304, T. 10453-10454 (18 January 2011); P2407 (Witness statement of KDZ304), p. 8; P2110 (SRK Order, 22 May 1995).

13178 P2414 (Witness statement of KDZ182), p. 54 (under seal).

13179 According to Mole, the $\mathrm{ABiH}$ had three $\mathrm{T}-54$ tanks and a few anti-aircraft weapons and little ammunition to operate those and other weapons, in contrast to the SRK. See P1426 (Witness statement of Richard Mole dated 7 May 2010), paras. 39, 59-63. See also P1638 (Witness statement of Michael Rose dated 26 March 2009), para. 133; KDZ450, T. 10597-10598 (19 January 2011). KDZ185 estimated that there were about 50 heavy weapons within Sarajevo, most of which were $82 \mathrm{~mm}$ mortars, and one multiple rocket launcher. However, this excluded the weapons on Mt. Igman, which he deemed as being outside of Sarajevo city. See P6060 (Record of interview with KDZ185), e-court p. 15; KDZ185, T. 4256-4264 (29 June 2010). See also P1029 (Witness statement of John Wilson dated 4 November 2008), para. 50; P1558 (Witness statement of Francis Roy Thomas dated 13 May 2009), para. 83; Francis Roy Thomas, T. 6828-6829, 6858, 6880-6885 (15 September 2010), T. 6910-6913 (16 September 2010); P1568 (UNMO assessment of forces in BiH); P1818 (Witness statement of Adrianus van Baal dated 26 October 2010), paras. 79, 82-83; KDZ450, T. 10652 (20 January 2011); D633 (Order of ABiH $1^{\text {st }}$ Corps, 25 October 1993); P1996 (Witness statement of Martin Bell dated 8 March 2010), para. 56; Martin Bell, T. 9863-9864 (15 December 2010); D924 (ICFY Agreement for Peace in BiH, 3 March 1993), p. 20; KDZ304, T. 10463-10464 (18 January 2011); P892 (UNPROFOR Weekly Situation Report (Sarajevo), 24 June 1995), p. 3 (indicating that in June 1994 there were some 100-150 ABiH weapons within the TEZ, which were in violation of the February cease-fire agreement); P926 (Witness statement of Aernout van Lynden dated 26 February 2010), para. 158; Aernout van Lynden, T. 2444-2445, 2447-2458 (19 May 2010) (testifying that he saw no artillery weapons on the ABiH side). But see D192 (Transcript of $17^{\text {th }}$ June 1992 session of the BiH Presidency), pp. 5-6 (indicating that already in June 1992 the BiH TO in the "Sarajevo region" had some artillery weapons in its possession); D338 (SRK combat report, 31 May 1993); D339 (Order of ABiH $1^{\text {st }}$ Corps, 16 February 1993); D632 (Order of ABiH $1^{\text {st }}$ Corps, 8 December 1993); D634 (Order of ABiH 102 ${ }^{\text {nd }}$ Motorised Brigade, 1 February 1994); Radovan Radinović, T. 41407-41408 (17 July 2013); P1154 (Witness statement of KDZ088 dated 27-29 April 2010), p. 26 (under seal). See also Adjudicated Fact 2810. 
and would move around the city, making it very difficult for the SRK to respond as the mortars would be in the middle of civilian areas. ${ }^{13180}$ UNPROFOR tried to find these mortars but was never successful. $^{13181}$

3987. Mole testified that the coverage of the city by UNMO's Papa observation posts was successful in that it covered $95 \%$ of the city, whereas the OPs on the Lima side did not necessarily cover all the weapon sites that UNMOs knew of, including between eight to ten unmonitored SRK batteries; this in turn resulted in discrepancies in the numbers of recorded rounds landing in Sarajevo versus outgoing rounds from the SRK side. ${ }^{13182}$

\section{(A) Nature of shelling in Sarajevo}

3988. The Chamber notes that the witnesses called by the Prosecution were consistent when testifying about the nature of the SRK shelling of Sarajevo. For example, Wilson explained that from the beginning of the conflict in Sarajevo, the SRK would fire large quantities of heavy weapons into the urban areas of the city and that the SRK fire, while often in response to some threat posed by the $\mathrm{ABiH}$, would be "undoubtedly disproportionate" and indiscriminate, striking most major buildings in the city. ${ }^{13183}$ In many cases, there seemed to be no military value in the targets that were selected, while the fire itself was spread out rather than focused on one area. ${ }^{13184}$ The fact that the SRK forces had an overwhelming superiority in heavy weapons made their

13180 P1762 (Witness statement of David Fraser dated 17 October 2010), p. 59; David Fraser, T. 8062-8063, 80728073 (18 October 2010) (adding that in cases where ABiH used mobile mortars, the SRK's only option was to fire at known military positions rather than at the mobile mortar itself); P1029 (Witness statement of John Wilson dated 4 November 2008), paras. 53-54; Francis Roy Thomas, T. 6841-6843 (15 September 2010) (explaining that if the $\mathrm{ABiH}$ mortars were moved too far into the city they could not be used against the SRK due to their limited range of fire; thus, contrary to the Accused's suggestion, any SRK fire deep into the city and out of the range of the $\mathrm{ABiH}$ mortars could not have been targeting those mortars); KDZ185, T. 4227 (28 June 2010).

13181 P1762 (Witness statement of David Fraser dated 17 October 2010), p. 74. See also KDZ185, T. 4283-4284 (29 June 2010).

13182 P1426 (Witness statement of Richard Mole dated 7 May 2010), paras. 15-17, 19-20, 111 (testifying also that the Papa OPs did not record any of the $\mathrm{ABiH}$ weapons which would fire outside of the city limits); P1429 (UNMO report for December 1992), pp. 1-10; Richard Mole, T. 5808, 5810, 5815-5817, 5847-5848, 5850-5851 (17 August 2010); D538 (UNMO report, 21 December 1992). See also Hussein Abdel-Razek, T. $5593-5596$ (20 July 2010) (giving similar evidence in relation to the limitations of UNPROFOR reports); D509 (UNPROFOR daily report, 30 January 1993).

13183 P1029 (Witness statement of John Wilson dated 4 November 2008), paras. 49, 51-52 (testifying also that when this was raised with the Accused, Mladić and Plavšić during airport negotiations, the response was that this type of fire was legitimate as they were defending the Serbs); John Wilson, T. 3977-3978, 3988-3990 (21 June 2010), T. 4131-4133, 4151-4154 (23 June 2010). See also P1258 (Witness statement of Hussein Ali AbdelRazek dated 16 July 2002), e-court pp. 15-16, 20-21, 27 (testifying that during his time in Sarajevo, the SRK shelling was constant and used indiscriminately against civilian targets); P1996 (Witness statement of Martin Bell dated 8 March 2010), paras. 41, 57; P2015 (Video footage of Sarajevo).

13184 P1029 (Witness statement of John Wilson dated 4 November 2008), para. 57; John Wilson, T. $4132-4133$ (23 June 2010); D335 (SRK Order, 23 June 1992); Francis Roy Thomas, T. 6798-6799, 6802-6803, 6830-6832 (15 September 2010); P1154 (Witness statement of KDZ088 dated 27-29 April 2010), pp. 81, 83-86 (under seal); KDZ088, T. 6320-6322 (7 September 2010) (closed session); P1502 (SRK Order, 15 July 1992), para. 2. 
responses more extreme. ${ }^{13185}$ Indeed, the weapons supremacy of the SRK was not really an advantage in urban fighting as the resort to "terror shelling" to discourage infantry attacks "in reality played into the hands of the Bosnians" according to Thomas. ${ }^{13186}$ Other witnesses testified that the SRK's use of indirect weapons, such as mortars, within the city was "entirely illegitimate". ${ }^{13187}$

3989. During his time in Sarajevo, Harland observed three distinct forms of shelling by the SRK in Sarajevo: (i) tactical use of heavy weapons in support of the SRK combat units, which occurred when the $\mathrm{ABiH}$ was trying to conduct an operation along the confrontation line; (ii) tit-for-tat shelling whereby the $\mathrm{ABiH}$ would fire some rounds into SRK-held territory, resulting in a "strong response" by the SRK directed against the area from which the $\mathrm{ABiH}$ fired; and (iii) "background terror shelling", which had no identifiable military tactical purpose but seemed intended to keep the population of Sarajevo vulnerable, fearful, and isolated. ${ }^{13188}$ Harland testified that at the time of his arrival in June 1993, ${ }^{13189}$ on average around 1,000 shells a day landed in the city, and sometimes up to $2,000 .{ }^{13190}$ Thereafter and until the end of the conflict, there was constant but relatively low level shelling by the SRK; on average there were several hundred shells fired every day throughout the whole war, the large bulk of those being fired by the SRK. ${ }^{13191}$ Tucker also testified that by far the majority of fire came from the Bosnian Serbs into the city rather than from the other side. ${ }^{13192}$

3990. According to Fraser, the shelling in the city was directed mostly at the BiH Presidency and various parts of the city, but "not principally [at] any military position". ${ }^{13193}$ Thus, while there were various military headquarters of the warring parties in Sarajevo, such as the SRK Command in Lukavica or the $\mathrm{ABiH} 1^{\text {st }}$ Corps Command in the city itself, during his time in Sarajevo these

\footnotetext{
13185 P1426 (Witness statement of Richard Mole dated 7 May 2010), para. 135. See also Jeremy Bowen, T. 10215 (14 January 2011).

13186 P1558 (Witness statement of Francis Roy Thomas dated 13 May 2009), para. 71.

13187 P4203 (Witness statement of Pyers Tucker dated 12 May 2010), para. 301; P1762 (Witness statement of David Fraser dated 17 October 2010), pp. 80-81 (explaining that he as a commander never would have used indirect weapons in the city but only guided munition and direct weapons); David Fraser, T. 8070, 8083 (18 October 2010).

P820 (Witness statement of David Harland dated 4 September 2009), paras. 32-33, 291; David Harland, T. 2023-2026 (6 May 2010), T. 2335-2336, 2351 (11 May 2010). See also John Wilson, T. 3947-3951 (21 June 2010); Rupert Smith, T. 11907-11909 (15 February 2011); P1558 (Witness statement of Francis Roy Thomas dated 13 May 2009), para. 71; Francis Roy Thomas, T. 6830-6832 (15 September 2010); KDZ185, T. 41824183, 4187-4188 (28 June 2010); P4203 (Witness statement of Pyers Tucker dated 12 May 2010), para. 300.

13192 Pyers Tucker, T. 23297-23298 (18 January 2012).

13193 P1762 (Witness statement of David Fraser dated 17 October 2010), pp. 51, 75.
} 
headquarters were never engaged as targets. ${ }^{13194}$ He also stated that whenever the ABiH fired out of the city, the SRK would always fire back, usually in a disproportionate manner. ${ }^{13195}$ Thus, if the $\mathrm{ABiH}$ fired a few mortar rounds, the SRK would respond with a "tremendous amount of shelling", on both military and civilian targets. ${ }^{13196}$ In his view, most of the SRK fire in response to the ABiH was disproportionate and indiscriminate, although sometimes the SRK responses were proportionate. ${ }^{13197}$ While acknowledging that the $\mathrm{ABiH}$ had mobile mortars, which in turn made it "very difficult" for the SRK to respond because the mortars were intermingled with civilians, Fraser noted that he would have refrained from firing as it would have been impossible to find the target and the collateral damage would have been too high. ${ }^{13198}$ Fraser also conceded that fighting in an urban setting is extremely difficult for any military, and stated that while he was in Sarajevo it was "particularly difficult for both parties". 13199

3991. Mole testified that the background noise of weapons firing in the city was "persistent" and "never ceased", so that the UNMOs would consider it a quiet day if around 100 rounds of high explosives had landed in the city, whereas a fairly active day would involve 400 to 500 rounds, with an extremely active day involving upwards of 600 rounds. ${ }^{13200}$ Mole estimated that, on average, around 14 or 15 civilians would die in Sarajevo per day. ${ }^{13201}$ According to him, it was almost impossible to record all incoming and outgoing fire in Sarajevo. ${ }^{13202}$ While there were times when the frontlines were extremely active, there was also constant pressure on the city, and the only thing that varied was the intensity of shelling; thus the whole city was an extremely dangerous

13194 P1762 (Witness statement of David Fraser dated 17 October 2010), p. 51. One exception to that, according to Fraser, was in 1995 when the $\mathrm{ABiH}$ fired at the Lukavica Barracks, which then resulted in a heavy barrage of fire back from the SRK and into the city as a whole. According to Fraser this response was completely disproportionate to the fire opened by the ABiH. David Fraser, T. 8006-8007, 8074-8088 (18 October 2010); P1762 (Witness statement of David Fraser dated 17 October 2010), pp. 51-52, 56-59, 75-77; D771 (SRK combat report, 22 June 1994). Dragomir Milošević confirmed that ABiH command posts were "mainly not targeted" as there was no danger emanating from them, such as fire being opened, for example. See Dragomir Milošević, T. 33124-33129, 33137 (4 February 2013).

13195 P1762 (Witness statement of David Fraser dated 17 October 2010), p. 52. According to Fraser, proportionate fire means returning sniper fire with sniper fire and mortar fire with mortar fire. If a military object was located in a predominantly civilian area, Fraser would not use indirect weapons at all because of the collateral damage but only direct weapons against a specific target. P1762 (Witness statement of David Fraser dated 17 October 2010), pp. 54-56, 80-81; David Fraser, T. 8069-8072, 8087-8092 (18 October 2010); D772 (ABiH General Staff list of ABiH units in Sarajevo, 10 April 1995).

13196 P1762 (Witness statement of David Fraser dated 17 October 2010), pp. 52, 56.

13197 P1762 (Witness statement of David Fraser dated 17 October 2010), pp. 56-59; David Fraser, T. 8102-8108 (19 October 2010); D774 (UNPROFOR report re Sarajevo TEZ violations, 18 September 1994).

13198 P1762 (Witness statement of David Fraser dated 17 October 2010), pp. 59, 61; David Fraser, T. 8062-8063, 8072-8074 (18 October 2010) (adding that in cases where ABiH used mobile mortars, the SRK's only option was to fire at known military positions rather than at the mobile mortar itself);

13199 P1762 (Witness statement of David Fraser dated 17 October 2010), p. 61-63.

13200 Richard Mole, T. 5819 (17 August 2010).

13201 P1426 (Witness statement of Richard Mole dated 7 May 2010), paras. 77-78 (adding a caveat that sometimes it was difficult to tell who was a civilian, as the $\mathrm{ABiH}$ forces did not always wear uniforms).

13202 Richard Mole, T. 5848 (17 August 2010). 
place to live, even for UN members and their clearly marked vehicles. ${ }^{13203}$ The PTT building, where the UNPROFOR and UNMOs were located, ${ }^{13204}$ and the surrounding area, were hit by shellfire on many occasions, sometimes having been specifically targeted. ${ }^{13205}$ In terms of damage to the city, Mole confirmed that the areas around the frontlines were heavily damaged but also testified that the remaining areas of the city "showed immense damage from incoming munitions", such that even apartment buildings suffered destruction. ${ }^{13206}$ He also testified that he observed random fire into the city's civilian areas that had no specific purpose and was not directed at a specific target. ${ }^{13207}$ According to him, if the Serbs failed to achieve their objective anywhere in $\mathrm{BiH}$, the general perception was that Sarajevo would suffer as a result; this sometimes came as a specific threat from Galić or from the RS liaison officer in the PTT building. ${ }^{13208}$ On most days they met, Mole would protest to Galić about the indiscriminate fire observed by the UNMOs, usually focusing on the most serious incidents. ${ }^{13209}$

3992. KDZ185 testified that, in his first few months in Sarajevo, the average number of shells per day was about 1,200, and that this "really kept a climate of terror". ${ }^{13210}$ The VRS was firing at the city "in a totally random fashion" so as to "increase psychological pressure on the population and

13203 P1426 (Witness statement of Richard Mole dated 7 May 2010), paras. 74-76; Richard Mole, T. 5819-5820, 5822-5823 (17 August 2010).

13204 P1426 (Witness statement of Richard Mole dated 7 May 2010), paras. 7, 67, 69 (testifying also that there were no military installations or activities near the PTT building).

13205 P1426 (Witness statement of Richard Mole dated 7 May 2010), paras. 66, 68. The Chamber heard evidence, however, that the $\mathrm{ABiH}$ would often fire at the SRK from the vicinity of the PTT building in order to draw a response. See also Stanislav Galić, T. 37571 (23 April 2013) (testifying that the SRK never deliberately targeted the UN or their equipment); P4203 (Witness statement of Pyers Tucker dated 12 May 2010), paras. 102-103, 105 (testifying that ABiH forces shelled the UN residency on two occasions); P4220 (UNPROFOR documents (reports and letters), 26 December 1992).

13206 P1426 (Witness statement of Richard Mole dated 7 May 2010), paras. 71-73. See also P6060 (Record of interview with KDZ185), e-court p. 16; KDZ185, T. 4220-4224 (28 June 2010) (private session) (testifying that most buildings in Sarajevo bore traces of fire but were not completely destroyed indicating that the fire opened on them was random); Hussein Abdel-Razek, T. 5535 (20 July 2010). Mole also explained that the damage to buildings caused by high-calibre artillery was not as extensive as one would expect from an aircraft bomb. See Richard Mole, T. 5820-5821 (17 August 2010).

13207 P1426 (Witness statement of Richard Mole dated 7 May 2010), paras. 79-82, 84-85, 108-109, 113-116,118119; P1434 (UNMO report for November 1992), p. 8; P1429 (UNMO report for December 1992), pp. 3-5; P1435 (UNMO report, 11 December 1992), para. 12; Richard Mole, T. 5817-5820, 5833-5836 (17 August 2010).

13208 P1426 (Witness statement of Richard Mole dated 7 May 2010), paras. 91-92, 94-96, 105, 107, 112; P1433 (UNMO report for October 1992), p. 4; P1434 (UNMO report for November 1992), p. 3; P1429 (UNMO report for December 1992), p. 3; Richard Mole, T. 5833-5836 (17 August 2010). See also Jeremy Bowen, T. 10105 (13 January 2011); P820 (Witness statement of David Harland dated 4 September 2009), para. 35 ; P1996 (Witness statement of Martin Bell dated 8 March 2010), para. 98; P1678 (BBC news report re attacks on Sarajevo and Bihać); P2017 (BBC news report re Sarajevo and Bihać, with transcript); Martin Bell, 9798 (14 December 2010); P2414 (Witness statement of KDZ182), p. 30 (under seal).

13209 P1426 (Witness statement of Richard Mole dated 7 May 2010), para. 97.

13210 KDZ185, T. 4187-4188 (28 June 2010). 
also on the Bosnian government". ${ }^{13211}$ The fact that the shelling was so random and hardly ever targeted military objects "kept the population in a state of terror". 13212

3993. Van Lynden testified that people in Sarajevo lived as much as they could in the basements of their apartments or in bomb shelters as they could be hit by shells or gunfire at any moment. ${ }^{13213}$ Shells would land in civilian areas in a random and unpredictable way-they were often not followed up by any movement of infantry or armour. ${ }^{13214}$ According to Van Lynden, the most sustained and concentrated shelling he witnessed bearing down on Sarajevo happened in June $1992 ;{ }^{13215}$ thereafter there was persistent shelling (except in March 1994) but it was sporadic, with few shells landing here and there. ${ }^{13216}$ KDZ182 testified that the SRK shelled not only military targets but also purely residential areas, with the aim of scaring the population; even in areas with military targets, the shelling was not focused on those targets exclusively. ${ }^{13217}$

3994. Harry Konings, another UNMO who was on duty in Sarajevo from 4 May to 23 October $1995,{ }^{13218}$ investigated about 100 shelling and sniping incidents in Sarajevo and much of that fire was determined to have originated in SRK-held territory with " 40 or 50 of the investigations concern[ing] civilian casualties". ${ }^{13219}$ He opined that mortar and artillery fire in Sarajevo was "overwhelmingly" of SRK origin but that only by doing a site investigation could the UNMOs actually determine direction of fire. ${ }^{13220}$

\footnotetext{
13211 KDZ185, T. 4182-4183 (28 June 2010).

13212 P6060 (Record of interview with KDZ185), e-court p. 16.

13213 P926 (Witness statement of Aernout van Lynden dated 26 February 2010), para. 21; Aernout van Lynden, T. 2394-2395 (19 May 2010).

13214 P926 (Witness statement of Aernout van Lynden dated 26 February 2010), para. 24; Aernout van Lynden, T. 2468-2475 (19 May 2010) (conceding that he did not know of all the military targets in the city); D193 (RS MUP Report on Sarajevo, 20 July 1992).

13215 See also discussion on Scheduled Incident G.2.

13216 P926 (Witness statement of Aernout van Lynden dated 26 February 2010), paras. 52-58, 122-126; P929 (Sky news report re Sarajevo, with transcript); P930 (Sky Newsreport re Sarajevo, with transcript); P931 (Sky news report re Sarajevo, with transcript); P954 (Sky news report re Sarajevo, with transcript); P936 (Sky Newsreport re Sarajevo, with transcript); P932 (Sky Newsreport re Sarajevo, with transcript); Aernout van Lynden, T. 24012413, 2427-2431, 2469-2470 (19 May 2010), T. 2479-2484, 2489-2498 (20 May 2010), T. 2598-2611, 26182619 (21 May 2010), T. 3055-3057, 3062-3064 (31 May 2010) (conceding that he did not observe the firing in all parts of the city nor claim that all of the shelling in that period came from the SRK, but remaining adamant that the fire he and his crew observed came from the southern hills overlooking Sarajevo and thus from the SRK positions); D195 (SRK Report, 8 June 1992); D196 (Aerial photograph of Sarajevo marked by Aernout van Lynden); P808 (Sky Newsreport re Sarajevo, with transcript). See also P1996 (Witness statement of Martin Bell dated 8 March 2010), para. 54.

13217 KDZ182, T. 13038-13039 (9 March 2011). See also P1263 (UNPROFOR report re Presidency talks, 18 October 1992) (indicating that the SRK shelled the flour mill in the city).

13218 P1953 (Witness statement of Harry Konings dated 11 November 2010), para. 9.

13219 P1953 (Witness statement of Harry Konings dated 11 November 2010), paras. 20-21; Harry Konings, T. 9327 (7 December 2010).

13220 P1953 (Witness statement of Harry Konings dated 11 November 2010), para. 34.
} 
3995. According to Tucker, the Bosnian Serbs subjected the inhabitants of Sarajevo to incessant, "daily random shelling of various parts of the city", and incoming fire from the surrounding Serb forces would land "arbitrarily around the city, [for] no military purpose". ${ }^{13221}$ No half hour would go by without the sound of shells or mortar bombs. ${ }^{13222}$ Tucker observed a pattern whereby there would be an $\mathrm{ABiH}$ infantry attack in a particular area and the SRK would initially respond using heavy weapons in order to stabilise the situation and push back the $\mathrm{ABiH}$ forces. ${ }^{13223}$ However, it would then also carry out a "punitive shelling" of the area of the city from which the attack had been mounted. ${ }^{13224}$ According to Tucker, because the SRK had less infantry forces than the ABiH $1^{\text {st }}$ Corps, Mladić felt that he had to use his "heavy artillery" to defend against ABiH infantry attacks. $^{13225}$

3996. Jeremy Bowen, a journalist who was reporting from Sarajevo between July 1992 and $1995,{ }^{13226}$ testified that the city had an almost constant sound of gunfire and explosions. ${ }^{13227} \mathrm{He}$ reported on, and personally saw, a lot of shelling during his time in Sarajevo noting that the shells could fall anywhere and at any time, even on cemeteries during funerals. ${ }^{13228}$ There was a pattern in the attacks in that nothing much would happen on the days when weather was bad, but these quiet periods would then be followed up by a sudden surge in shelling that would cause casualties. ${ }^{13229}$ In terms of the locations that were shelled, generally there was no pattern and the shelling was random. ${ }^{13230}$ In his view, the Bosnian Serbs were responsible for the bulk of the shelling, particularly since he personally observed SRK weaponry pointing towards the city, as well as empty shell cases nearby. ${ }^{13231}$

\footnotetext{
13221 P4203 (Witness statement of Pyers Tucker dated 12 May 2010), paras. 6, 22-23, 44, 49 (testifying that he observed two types of shelling in the city - concentrated fire with multiple shells landing in a short space of time on one area and the single shells landing arbitrarily around the city).

13222 P4203 (Witness statement of Pyers Tucker dated 12 May 2010), para. 22.

13223 P4203 (Witness statement of Pyers Tucker dated 12 May 2010), para. 91.

13224 P4203 (Witness statement of Pyers Tucker dated 12 May 2010), paras. 91, 295; Pyers Tucker, T. 23197-23198 (17 January 2012).

13225 P4203 (Witness statement of Pyers Tucker dated 12 May 2010), para. 299.

13226 P2068 (Witness statement of Jeremy Bowen dated 10 August 2009), paras. 5, 13.

13227 P2068 (Witness statement of Jeremy Bowen dated 10 August 2009), para. 14.

13228 Jeremy Bowen, T. 10115-10121, 10164-10165, 10167-10187 (13 January 2011); P2077 (BBC news report re Sarajevo, with transcript); P2078 (BBC news report re Sarajevo, with transcript); D936 (Excerpt from Jeremy Bowen's book entitled "War Stories"), e-court p. 6; D937 (Map of Sarajevo marked by Jeremy Bowen); D938 (Map of Sarajevo marked by Jeremy Bowen).

13229 P2068 (Witness statement of Jeremy Bowen dated 10 August 2009), para. 32. See also P1996 (Witness statement of Martin Bell dated 8 March 2010), para. 54.

13230 P2068 (Witness statement of Jeremy Bowen dated 10 August 2009), para. 33; Jeremy Bowen, T. 10236-10237 (14 January 2011).

13231 P2068 (Witness statement of Jeremy Bowen dated 10 August 2009), para. 29; Jeremy Bowen, T. 10186 (13 January 2011), T. 10216-10218, 10222-10224 (14 January 2011) (conceding at the same time that there were times when $\mathrm{ABiH}$ launched offensives on the SRK); D942 (BBC news report re Sarajevo, with transcript); D944 (BBC news report re Sarajevo, with transcript); D945 (BBC news report re Sarajevo, with transcript).
} 
3997. Confirming the evidence above about the shelling causing civilian casualties within the confrontation lines in Sarajevo, Ewa Tabeau produced a number of reports in which she analysed the numbers of civilian casualties in that area using several different sources. She came to the conclusion that in the period between 1 April 1992 and August 1994 at a very minimum some 1,482 civilians died as a result of shelling in the Bosnian-held parts of Sarajevo, while around 5,745 were wounded. ${ }^{13232}$ As for the period between September 1994 and November 1995, Tabeau used different sources of information and was able to conclude that, at a minimum, some 449 individuals died from war-related causes, including shelling, within the confrontation lines of Sarajevo. ${ }^{13233}$ In addition, in this period, an absolute minimum of 254 civilians were wounded due to shelling. ${ }^{13234}$

3998. In contrast to the evidence above, the Chamber heard from a number of SRK soldiers and officers who testified that the SRK troops did not open fire on civilians but were instead ordered to shell only military targets and only in response to enemy fire. ${ }^{13235}$ Dušan Škrba testified that the

13232 Tabeau reached these numbers by using two main sources of information in the said period, namely the Households Survey conducted in September 1994 in ABiH-held Sarajevo and the records of the Bakije Funeral Home, the largest funeral home in Sarajevo. She then compared them to the 1991 census and, in order to distinguish between military and civilian casualties, to the $\mathrm{ABiH}$ lists of fallen soldiers. See P4997 (Ewa Tabeau's expert report entitled "Persons Killed and Wounded in Sarajevo During the First Months of the 'Siege' from 1 April to 9 September 1992”, 1 May 2009), pp. 1-2, 4-7; P4998 (Ewa Tabeau's expert report entitled "Population Losses in the 'Siege' of Sarajevo 10 September 1992 to 10 August 1994", 10 May 2002), pp. 1-4; Ewa Tabeau, T. 28173-28176, 28196-28197 (26 April 2012). Tabeau explained that the real number of civilian deaths is most likely higher because the number of those reported as soldiers in the Household Survey was higher than the numbers seen in $\mathrm{ABiH}$ lists of fallen soldiers, due to, among other things, families hoping to obtain a military pension. See P4997 (Ewa Tabeau's expert report entitled "Persons Killed and Wounded in Sarajevo During the First Months of the 'Siege' from 1 April to 9 September 1992”, 1 May 2009), p. 8.

13233 For this period, Tabeau's main source of information in relation to the wounded civilians were patient records of three main Sarajevo hospitals. This source was somewhat incomplete as it did not include the records of a number of smaller hospitals in the city and because it included only hospitalised patients. Tabeau also used a number of different sources relating to those killed in Sarajevo, including again the Bakije Funeral Home records. For this period, however, she was unable to determine which deaths were attributed to shelling and which to sniping since, unlike the Household Survey, the sources she used here did not contain that type of information. She therefore classified 449 deaths as being war-related. See P5002 (Ewa Tabeau's expert report entitled "Killed and Wounded Persons from the Siege of Sarajevo: August 1994 to November 1995", 19 March 2007), pp. 3-5, 11-12, 17-18, 23, 51-54; Ewa Tabeau, T. 28206-28209 (26 April 2012).

13234 P5002 (Ewa Tabeau's expert report entitled "Killed and Wounded Persons from the Siege of Sarajevo: August 1994 to November 1995", 19 March 2007), pp. 6-7, 51-57, 62-65 (adding that the real number was probably more around 819 civilians, based on the comparison she made to other partially overlapping sources).

13235 D2351 (Witness statement of Stevan Veljović dated 19 October 2012), para. 15; Savo Simić, T. 30048-30049, 30139-30140 (12 November 2012); D2417 (SRK Order, 4 April 1995), para. 2; D2658 (Witness statement of Luka Dragičević dated 9 December 2012), para. 30; D2516 (Witness statement of Vlade Lučić dated 5 November 2012), paras.11, 18; Vlade Lučić, T. 30817 (3 December 2012); Stanislav Galić, T. 37204-37205 (15 April 2013), T. 37384 (18 April 2013); D2331 (Witness statement of Blagoje Kovačević dated 14 October 2012), para. 23; D2479 (Witness statement of Mile Sladoje dated 25 November 2012), paras. 12, 17; D2484 (Witness statement of Zoran Kovačević dated 25 November 2012), para. 11; D2387 (Witness statement of Stojan Džino dated 4 November 2012), para. 43; D2379 (Witness statement of Momir Garić dated 2 November 2012), para. 25; D2686 (Witness statement of Mihajlo Vujasin dated 16 December 2012), paras. 33, 35 ; D2391 (Witness statement of Slobodan Tuševljak dated 5 November 2012), para. 21; D2418 (Witness statement of Božo Tomić dated 5 November 2012), para. 18; D2622 (Witness statement of Željko Bambarez dated 9 December 2012), para. 17; Siniša Maksimović, T. 29297 (23 October 2012); D2665 (Witness statement of Izo Golić dated 15 December 2012), para. 25; D2344 (Witness statement of Miloš Škrba dated 14 October 2012), paras. 16, 20; Miloš Škrba, T. 29192-29193 (22 October 2012); Nikola Mijatović, T. 30728-30730, 30735- 
members of the Mixed Artillery Battalion for the $1^{\text {st }}$ Sarajevo Mechanised Brigade which he commanded ${ }^{13236}$ were ordered to use heavy weapons, including $120 / 122 \mathrm{~mm}$ mortars, only in selfdefence or on the order of the "superior command", and only in respect of specific military targets. ${ }^{13237}$ Izo Golić and Savo Simić also testified that their units had strict orders not to open fire without authorisation by the brigade or corps command. ${ }^{13238}$ Furthermore, the SRK witnesses testified that the SRK commands took measures to ensure that SRK forces complied with orders to fire only at military targets, ${ }^{13239}$ such as for example, repeatedly conveying orders on selectivity of fire to their units. ${ }^{13240}$ Vlade Lučić, who served in (and later was in the command of) the $1^{\text {st }}$ Romanija Brigade, ${ }^{13241}$ testified that the meaning of military target and the prohibition on attacking civilians were also explained to his unit. ${ }^{13242}$ According to Stean Veljović, an officer in the SRK's $1^{\text {st }}$ Romanija Brigade, ${ }^{13243}$ the preservation of Baščaršija, an area in the old part of the city, was evidence of this selectivity of the SRK artillery use. ${ }^{13244}$

30736 (30 November 2012); Slavko Gengo, T. 29781 (6 November 2012); Dragomir Milošević, T. 32582, 32585 (23 January 2013), T. 32758 (28 January 2013).

13236 D2341 (Witness statement of Dušan Škrba dated 14 October 2012), para. 7.

13237 D2341 (Witness statement of Dušan Škrba dated 14 October 2012), paras. 7, 14; Dušan Škrba, T. 29113, 29123 (18 October 2012). When confronted with the testimony of Richard Mole, an UNMO at the Lima 5 position where Škrba was commander, that he would be given trivial, irrational, and vague rationales by Škrba for the firing of weapons, such as being told that "the three rounds that had been fired were one for each finger of the Serb salute", Škrba denied this, claiming that Mole had never made any kind of oral or written objection about these reports. See Dušan Škrba, T. 29155-29156 (22 October 2012).

13238 D2665 (Witness statement of Izo Golić dated 15 December 2012), para. 25; Izo Golić, T. 31554 (17 December 2012); D2412 (Witness statement of Savo Simić dated 4 November 2012), para. 17.

13239 See e.g. Stanislav Galić, T. 37192 (15 April 2013); D2633 (Witness statement of Milorad Šehovac dated 8 December 2012), paras. 23, 30; D2331 (Witness statement of Blagoje Kovačević dated 14 October 2012), para. 32; D2562 (Witness statement of Vladimir Radojčić dated 8 December 2012), para. 23; D2484 (Witness statement of Zoran Kovačević dated 25 November 2012), para. 9; D2387 (Witness statement of Stojan Džino dated 4 November 2012), para. 43; D2686 (Witness statement of Mihajlo Vujasin dated 16 December 2012), para. 27; Miloš Škrba, T. 29192-29193 (22 October 2012). Blagoje Kovačević testified that his unit acted under orders to investigate and punish incidents of opening fire on civilians, and that individuals were punished for improper opening of fire despite no evidence that the fire "caused any consequences". However, on crossexamination, he was unable to provide any specific example of investigations conducted in cases of sniping or shelling civilians in ABiH controlled territory. See D2331 (Witness statement of Blagoje Kovačević dated 14 October 2012), paras. 33-34; Blagoje Kovačević, T. 29075-29078 (18 October 2012).

13240 D2351 (Witness statement of Stevan Veljović dated 19 October 2012), para. 20; D2497 (Witness statement of Nikola Mijatović dated 27 November 2012), para. 15; D2667 (Witness statement of Ratomir Maksimović dated 14 December 2012), para. 26; Vlade Lučić, T. 30817 (3 December 2012); D2479 (Witness statement of Mile Sladoje dated 25 November 2012), para. 17; D2444 (Witness statement of Miladin Trifunović dated 11 November 2012), para. 18; Miladin Trifunović, T. 30439 (27 November 2012); Dragomir Milošević, T. 32843 (29 January 2013).

13241 D2516 (Witness statement of Vlade Lučić dated 5 November 2012), para. 6.

13242 D2516 (Witness statement of Vlade Lučić dated 5 November 2012), para. 18; Vlade Lučić, T. 30817 (3 December 2012). The Chamber heard that members of the SRK were given training on the rules and laws of war. See D2633 (Witness statement of Milorad Šehovac dated 8 December 2012), paras. 13, 25

13243 D2351 (Witness statement of Stevan Veljović dated 19 October 2012), paras. 12, 15; Stevan Veljović, T. 29234-29236 (23 October 2012).

13244 D2351 (Witness statement of Stevan Veljović dated 19 October 2012), para. 26. When shown an UNPROFOR report of 3 November 1993 stating that the old town of Sarajevo received almost 500 shells in a one-hour period on 27 October 1993, he testified that 500 shells would have razed the old town to the ground, and that the entire 
3999. Most of the above-mentioned witnesses also testified that in addition to being selective, SRK fire was also always proportionate, ${ }^{13245}$ as illustrated by orders issued to use ammunition rarely and sparingly. ${ }^{13246}$ When confronted with the Accused's order of 7 February 1994 issued to the VRS Main Staff and all SRK Commands referring to there being "evidence that Serbs are not responding in equal measure to Muslim artillery provocation-sometimes twenty to thirty or even seventy times more", Gengo testified that the Accused's statement was "absolutely impossible" as the SRK did not have enough ammunition to respond even in equal measure to the fire opened by the opposing side. ${ }^{13247}$ Similarly, when Dragomir Milošević was confronted with his own warning to SRK units from July 1995 noting that the SRK was "spending ammunition as if [it] had it in abundance, trying at any cost to outfire the enemy artillery" and that its units would "very often fire at inhabited settlements and specific buildings when there are no combat actions whatsoever", he claimed that the warning referred to small abandoned settlements outside Sarajevo. ${ }^{13248}$ Galić testified that because $\mathrm{ABiH}$ units were commingled with civilians, the SRK would primarily seek to neutralise their targets, rather than destroy them, and the quantity of ammunition required to

VRS did not have 500 shells. He concluded that the UNPROFOR report was "grossly untrue". See Stevan Veljović, T. 29279-29281 (23 October 2012); P823 (UNPROFOR Weekly Political Assessment, 3 November 1993), p. 7.

13245 See e.g. Stanislav Galić, T. 37191-37192, 37205, 37208 (15 April 2013), T. 37342-37343 (16 April 2013); Dragomir Milošević, T. 33144-33145 (4 February 2013) (testifying that indiscriminate and disproportionate fire would have razed Sarajevo to the ground); Savo Simić, T. 30059 (12 November 2012); D2341 (Witness statement of Dušan Škrba dated 14 October 2012), para. 16; Dušan Škrba, T. 29121-29123 (18 October 2012) (describing proportionate fire as responding with one or two shells at the target in order either to drive them away or to stop their fire); D2686 (Witness statement of Mihajlo Vujasin dated 16 December 2012), para. 35; Blagoje Kovačević, T. 29071 (18 October 2012) (explaining that the basic principle for engagement and selection of targets was for artillery to target artillery, infantry to target infantry, and anti-tank units to engage anti-tank units); Dušan Škrba, T. 29136-29138 (22 October 2012); P1614 (Order of $2^{\text {nd }}$ Sarajevo Light Infantry Brigade, 14 August 1994), p. 1. Galić testified that he proposed the removal of Dunjić, the Commander of the Igman Brigade, and Radivoje Grković, the battalion commander in the Nedžarići Brigade, because of their disproportionate use of artillery. See Stanislav Galić, T. 37810-37814 (7 May 2013), T. 37895-37897 (8 May 2013).

13246 D2667 (Witness statement of Ratomir Maksimović dated 14 December 2012), para. 39; D2633 (Witness statement of Milorad Šehovac dated 8 December 2012), para. 35; D2562 (Witness statement of Vladimir Radojčić dated 8 December 2012), para. 42; D2484 (Witness statement of Zoran Kovačević dated 25 November 2012), para. 13; Zoran Kovačević, T. 30606-30607 (28 November 2012); D2622 (Witness statement of Željko Bambarez dated 9 December 2012), para. 19; D2813 (VRS Main Staff Order, 8 August 1995), p. 2; Slavko Gengo, T. 29825-29826 (6 November 2012); Savo Simić, T. 30059 (12 November 2012); D2341 (Witness statement of Dušan Škrba dated 14 October 2012), para. 16; Dragomir Milošević, T. 32745-32746 (28 January 2013).

13247 Slavko Gengo, T. 29825-29826 (6 November 2012); P846 (Radovan Karadžić's Order to VRS, 7 February 1994), para. 1.

13248 Dragomir Milošević, T. 33146-33148 (4 February 2013); P2668 (Warning of SRK, 19 July 1995), p. 1. Lučić and Kovačević testified that they had never seen this warning. However, Savo Simić acknowledged that there were probably cases where certain troops spent more ammunition than necessary and targeted targets that they should not have. See Vlade Lučić, T. 30797-30798 (3 December 2012); Zoran Kovačević, T. 30607-30608 (28 November 2012); Savo Simić, T. 30084 (12 November 2012). See also P1501 (SRK Order, 14 July 1992); [REDACTED]; D2587 (SRK instructions, 12 June 1993) (in which the SRK Deputy Commander first noted that they all wished to liquidate as many Bosnian Muslims as possible but not at the political price caused by firing a few shells on Sarajevo with minimal consequences, and then instructed the SRK commanders that the first priority was to save ammunition). 
destroy a target can be six times higher than the quantity needed to neutralise a target. ${ }^{13249}$ He gave an example of refraining from responding to fire on 5 June 1993 because a cease-fire was in effect at the time and because a response would have been likely to cause unnecessary losses of civilians. ${ }^{13250}$ Galic also testified that if the SRK received fire from the $\mathrm{ABiH}$, then the best response was to return fire with the same kind of assets; if this was mortar fire there were clearly options to return fire with a number of assets but the "best way to return fire [was] from mortars". ${ }^{13251}$ Savo Simić, Chief of Artillery of the $1^{\text {st }}$ Sarajevo Mechanised Brigade, ${ }^{13252}$ testified that, when authorising return of artillery fire into the city, he "always selected the most precise weapon in the division in order to avoid civilian casualties and the unnecessary destruction of surrounding buildings". ${ }^{13253}$ According to Mihajlo Vujasin, the SRK units also warned opposing forces before opening fire on military targets located in civilian zones. ${ }^{13254}$

4000. Some of the SRK witnesses also testified that their units never fired into the depth of Sarajevo. ${ }^{13255}$ The others who did, claimed to have done so only when they had reliable information that combat elements of the opposing brigades were located there. ${ }^{13256}$ According to Dragomir Milošević, the SRK forces were told to fire only when they were "certain that they would

13249 See Stanislav Galić, T. 37192 (15 April 2013), T. 37507-37508 (22 April 2013) (testifying that whether fire is "effective" is determined by whether the goal is to "neutralise" or "destroy" the target and whether that is achieved), T. 37897 (8 May 2013), T. 38043 (9 May 2013). See also Izo Golić, T. 31550-31551 (17 December 2012); Dragomir Milošević, T. 32747-32749 (28 January 2013) (testifying that there is a large difference in the amount of ammunition required to neutralise a target or destroy a target, because at best there is a "mere chance" to destroy something "in totality").

13250 Stanislav Galić, T. 37488-37489 (22 April 2013); D3443 (SRK combat report, 3 June 1993).

13251 Stanislav Galić, T. 37192 (15 April 2013). See also P1762 (Witness statement of David Fraser dated 17 October 2010), pp. 54-56.

13252 D2412 (Witness statement of Savo Simić dated 4 November 2012), para. 3.

13253 D2412 (Witness statement of Savo Simić dated 4 November 2012), paras. 20, 29; Savo Simić, T. 30046 (12 November 2012). When shown an intercepted telephone conversation of 25 May 1992 in which Mladić stated that he would "retaliate against [Sarajevo]", that "Sarajevo is going to shake" and that "more shells will fall on [Sarajevo] per second than in the entire war so far", Simić responded that he never received order to punish the population of Sarajevo by shelling them. See Savo Simić, T. 30059, 30070, 30074-30075 (12 November 2012); P1041 (Intercept of conversation between Ratko Mladić and unidentified male, 25 May 1992), p. 1. See also P1518 (Intercept of conversation between Ratko Mladić and Mirko Vukašinović, 28 May 1992); P1511 (Intercept of conversation between Ratko Mladić and Potpara, 29 May 1992); P1521 (Intercept of conversation between Ratko Mladić and Mirko Vukašinović, 28 May 1992), pp. 2-3.

13254 D2686 (Witness statement of Mihajlo Vujasin dated 16 December 2012), para. 36. See also D2562 (Witness statement of Vladimir Radojčić dated 8 December 2012), para. 35.

13255 For example, Dušan Zurovac testified that the $4^{\text {th }}$ Company of the $2^{\text {nd }}$ Battalion of the VRS never used mortars to fire deep into the city of Sarajevo, and Vlade Lučić testified that it was not the task of the $1^{\text {st }}$ Romanija Infantry Brigade to respond to fire from the depth of the city, and it did not do so. See Dušan Zurovac T. 30247, 30308 (14 November 2012); Vlade Lučić, T. 30789-30792 (3 December 2012). See also D2389 (Witness statement of Predrag Trapara dated 3 November 2012), para. 8; D2418 (Witness statement of Božo Tomić dated 5 November 2012), para. 18; Božo Tomić, T. 30182, 30191 (13 November 2012).

13256 D2562 (Witness statement of Vladimir Radojčić dated 8 December 2012), para. 27; D2444 (Witness statement of Miladin Trifunović dated 11 November 2012), para. 18; Miladin Trifunović, T. 30441-30442 (27 November 2012). 
hit the target" because "[o]ne cannot do anything running blind". ${ }^{13257}$ Thus, a number of brigades had orders to fire on a "sighted target"alone. ${ }^{13258}$ A number of witnesses also gave evidence about the SRK system of observation of fire. ${ }^{13259}$ This system, which according to Milošević was in operation at all times, ${ }^{13260}$ provided information about the firing positions of the $\mathrm{ABiH}$, including whether civilians were located at the targets. ${ }^{13261}$ Simić confirmed this by testifying that he required details of the position from which the enemy fire had originated before he would consider authorising return fire. ${ }^{13262}$ Dušan Škrba also explained that every military target had to be marked and described in terms of its size, location, and the kind of enemy assets located there but acknowledged that in cases of retaliatory artillery and mortar fire, his unit would employ "simple preparation", which could be done within five minutes of receiving enemy fire and which only required the topographical information about the target. ${ }^{13263}$ When shown an intercepted conversation in which Mladić issued an order to Potpara to fire at the railway station and "hit them with something and scatter them around", Škrba conceded that this was not a precise order but

13257 D2813 (VRS Main Staff Order, 8 August 1995), p. 2; Dragomir Milošević, T. 32745-32748 (28 January 2013 ). See also D2617 (SRK Order, 30 April 1995), para. 10; D2667 (Witness statement of Ratomir Maksimović dated 14 December 2012), para. 26. This evidence was contradicted by Defence expert witness Radovan Radinović, who testified that, as a general pattern, enemy fire would be observed by a VRS observer and then fire would be opened on those targets. However, this fire was opened without any tracking or correction of fire because that was impossible in the circumstances, which resulted in unplanned dispersion of shots. Since most of the targets in Sarajevo could not be observed visually, it was not possible to monitor the return of fire or perform accurate targeting. See D3864 (Radovan Radinović's expert report entitled "The Control Authority of Dr. Radovan Karadžić in the Strategic Command System of the VRS", 2012), para. 301. Similarly, Galić testified that the SRK returned fire on mobile mortars in civilian zones. See Stanislav Galić, T. 38055-38059 (9 May 2013).

13258 D2562 (Witness statement of Vladimir Radojčić dated 8 December 2012), paras. 30, 90; D2479 (Witness statement of Mile Sladoje dated 25 November 2012), para. 12; D2484 (Witness statement of Zoran Kovačević dated 25 November 2012), para. 9. Miloš Škrba and Željko Bambarez testified that similar orders existed in the $2^{\text {nd }}$ Infantry Company of the $2^{\text {nd }}$ Infantry Battalion of the $1^{\text {st }}$ Sarajevo Mechanised Brigade, and in the $2^{\text {nd }}$ Platoon of the $2^{\text {nd }}$ Company of the $1^{\text {st }}$ Sarajevo Mechanised Brigade respectively. See Miloš Škrba, T. 2919229193 (22 October 2012); D2622 (Witness statement of Željko Bambarez dated 9 December 2012), paras. 3, 5, 17.

13259 See e.g. D2341 (Witness statement of Dušan Škrba dated 14 October 2012), para. 14; Dušan Škrba, T. 29108, 29111, 29119-29120 (18 October 2012); D2633 (Witness statement of Milorad Šehovac dated 8 December 2012), paras. 23, 30; D2686 (Witness statement of Mihajlo Vujasin dated 16 December 2012), para. 35; Slavko Gengo, T. 29840-29841 (6 November 2012); Dragomir Milošević, T. 32745-32747 (28 January 2013); D2412 (Witness statement of Savo Simić dated 4 November 2012), para. 18; Savo Simić, T. 30128-30129 (12 November 2012).

13260 Dragomir Milošević, T. 32746-32747 (28 January 2013).

13261 D2412 (Witness statement of Savo Simić dated 4 November 2012), para. 18; D2562 (Witness statement of Vladimir Radojčić dated 8 December 2012), paras. 23, 34; Dragomir Milošević, T. 32584-32585 (23 January 2013) (testifying that if there was a chance of civilian casualties, fire would not be opened), T. 32702, 32750, 32757-32758 (28 January 2013), T. 33137-33138 (4 February 2013); Dušan Škrba, T. 29108, 29111 (18 October 2012), D2484 (Witness statement of Zoran Kovačević dated 25 November 2012), para. 12. Dragomir Milošević testified that once fire was observed from an area, it was necessary to narrow down the area, to identify the target, establish the type of weapon, the type of fire, and the number of weapons, and identify the surroundings and consider the damage that could be inflicted on the surroundings. See Dragomir Milošević, T. 32757-32758 (28 January 2013).

13262 D2412 (Witness statement of Savo Simić dated 4 November 2012), para. 29; Savo Simić, T. 30050-30051, 30053 (12 November 2012). See also D2379 (Witness statement of Momir Garić dated 2 November 2012), para. 25.

13263 Dušan Škrba, T. 29108, 29111 (18 October 2012), T. 29134-29135 (22 October 2012). 
testified that he never received such an order during his time with the SRK. ${ }^{13264}$ Similarly, Mijatović testified that Serb observers would report where the firing came from and confirm that, within a diameter of about 200 metres, everything was clear except for the target. ${ }^{13265}$ He later added that one could not rely on this as a rule when one's forces were under attack. ${ }^{13266}$

4001. However, most of the evidence of the SRK witnesses outlined above is directly contradicted by the July 1994 report analysing the combat readiness of the SRK's artillery rocket units prepared by the SRK's Chief of Artillery, Colonel Tadija Manojlović, in which he described the issues faced by the units from the beginning of the conflict up to July 1994. In that report, he stated the following:

The initial period of the war was also characterised by the fact that we were superior to the enemy when it comes to the equipment and ammunition [...]. The commanders of the general military provenance carried out their assignments mainly by use of the artillery, with an increased consumption of ammunition, which was normally used for hitting the targets in Sarajevo.

$[\ldots]$

Basic shortcomings and defects in the [control and command] involve the following: [...] shortage of commanding officers, poor knowledge about the equipment, poor choice of [firing positions], pounding the targets without necessary observation, high consumption of ammunition, poor maintenance.

$[\ldots]$

However, the precision of shooting was greatly influenced by the defects and shortcomings in the training process, as well as by an inadequate level of skilfulness attained by the marksmen, reckoners, reconnaissance teams and commanding officers; as a result of thus reduced preparations, they all were erring in determining the targets, as well as in reckoning and establishing the shooting elements and in launching the artillery attacks without prior observation of the targets. Group shooting used to be carried out without any corrections being made, so that the results, especially by night, were rather poor.

$[\ldots]$

13264 Dušan Škrba, T. 29109-29110 (18 October 2012); P1511 (Intercept of conversation between Ratko Mladić and Potpara, 29 May 1992). When also shown intercepted conversations in which Mladić asked whether there was a gun pointed at "some target" in Velešići and, on the following day, asked whether Velešići had been shelled, Dušan Škrba rejected the suggestion that Mladić had no information on any particular targets. See Dušan Škrba, T. 29141-29143 (22 October 2012); P1521 (Intercept of conversation between Ratko Mladić and Mirko Vukašinović, 28 May 1992); P1522 (Intercept of conversation between Rako Mladić and Potpara, 29 May 1992), p. 1.

13265 When asked why observers were not mentioned in his statement, Mijatović said that he had mentioned it in his interview with the Defence. See Nikola Mijatović, T. 30737-30739, 30744, 30760 (30 November 2012). Dušan Škrba testified that the $1^{\text {st }}$ Sarajevo Militarised Brigade never fired at or within 1 kilometre of hospitals or other "areas where larger groups of civilians tend to gather". See Dušan Škrba, T. 29123 (18 October 2012), T. 29131-29132 (22 October 2012).

13266 Nikola Mijatović, T. 30744-30745 (30 November 2012). 
The stocks of basic and other MTS have been used up, since the consumption of ammunition and fuel in the initial stages of the war exceeded the amounts that had been planned beforehand. Some of the officers and soldiers were of the opinion that the reserves of ammunition and fuel were unfathomable and that the war would not last. The measures to restrict the consumption yielded no results. Intensive use of the artillery and intensive shelling caused a considerable reduction of available resources [...]. ${ }^{13267}$

\section{(B) $\mathrm{ABiH}$ firing practices}

4002. As for the ABiH firing practices, ${ }^{13268}$ the Chamber heard that $\mathrm{ABiH}$ units in Sarajevo used their heavy weapons mostly for harassing fire and with the intention to draw a response, by for example, firing from civilian buildings such as hospital grounds or from the vicinity of the PTT building where the UN was located. ${ }^{13269}$ KDZ182 confirmed that ABiH troops would position themselves very close to the UN forces, particularly on confrontation lines, ${ }^{13270}$ while KDZ185 called this practice a "part of the game". ${ }^{13271}$ Indeed, on a number of occasions the UNMOs had to ask the Bosnian Muslim side to move its mortars away from UNMO positions as they were too close. $^{13272}$ According to Tucker, the ABiH strategy above all was to antagonise and provoke the Bosnian Serbs into over-reacting. ${ }^{13273}$ However, Harland disputed that the Bosnian Muslims purposely fired mortars from the vicinity of the PTT building in order to draw Serb fire against UNPROFOR; rather, he felt the UN was simply close to the scene of a major battle, and the Serbs were already firing shells in the area. ${ }^{13274}$ Both Abdel-Razek and Richard Gray, who was a senior

\section{7}

On this issue, see Section IV.B.1.d: Bosnian Muslim side targeting own civilians.

P1558 (Witness statement of Francis Roy Thomas dated 13 May 2009), para. 70; Francis Roy Thomas, T. 68306831, 6874-6876 (15 September 2010); D631 (UNMO report, 10-11 January 1994), p. 1; Yasushi Akashi, T. 37697 (24 April 2013); D3489 (Excerpt from Yasushi Akashi's book entitled "In the Valley between War and Peace"), p. 110; D3442 (SRK combat report, 17 May 1993), p. 2 (reporting that the ABiH was trying to provoke Serb fire onto their positions); Stanislav Galić, T. 37486-37487 (22 April 2013) (testifying that the $\mathrm{ABiH}$ forces had "both a political and military interest to provoke" Serb fire); D2331 (Witness statement of Blagoje Kovačević dated 14 October 2012), para. 12; D2270 (Witness statement of Andrey Demurenko dated 13 October 2012), para. 37.

13270 KDZ182, T. 13142-13145 (10 March 2011); D1132 (UNPROFOR report, 28 June 1995), p. 5. See also David Fraser, T. 8061 (18 October 2010).

13271 P6060 (Record of interview with KDZ185), e-court p. 18; KDZ185, T. $4228-4229$ (28 June 2010), T. 4335 (29 June 2010); D354 (UNPROFOR protest letter to ABiH, 20 February 1993).

13272 Francis Roy Thomas, T. 6812 (15 September 2010); P1029 (Witness statement of John Wilson dated 4 November 2008), para. 47. According to Thomas, whenever UNMOs protested about the Serb response to the $\mathrm{ABiH}$ fire from near the UNMO OPs and asked that they stop firing, Inđić was unsympathetic and would simply respond to UNMO protests by telling them to get the ABiH units out of the area. See P1558 (Witness statement of Francis Roy Thomas dated 13 May 2009), para. 56. This was confirmed by Abdel-Razek who testified that Galić openly admitted to shelling the UN building because UN allowed ABiH to shell at the SRK from the building. See P1258 (Witness statement of Hussein Ali Abdel-Razek dated 16 July 2002), e-court pp. 15, 21.

13273 P4203 (Witness statement of Pyers Tucker dated 12 May 2010), para. 302 (explaining also that ABiH would also arrange a media briefing and then carry out an infantry attack on the Bosnian Serbs nearby who would then respond with heavy weapons, which the media would see and condemn).

13274 P820 (Witness statement of David Harland dated 4 September 2009), paras. 207-208; P837 (UNPROFOR Update on Sarajevo, 30 June 1995); David Harland, T. 2303-2306 (11 May 2010). See also P2407 (Witness statement of KDZ304), p. 32; Hussein Abdel-Razek, T. 5580-5581 (20 July 2010) (testifying that when he 
UNMO in Sarajevo in $1992,{ }^{13275}$ thought the ABiH was using the UN headquarters as a shield to protect them from being attacked by return Serb fire. ${ }^{13276}$

4003. In addition to using UN facilities, Colonel Andrey Demurenko, Chief of Staff of Sector Sarajevo, ${ }^{13277}$ testified that he saw ABiH units also provoking Serb fire onto civilian buildings. ${ }^{13278}$ Similarly, Rose was certain that $\mathrm{ABiH}$ forces would fire on the Serbs at particularly important political moments, in order to provoke retaliatory Serb fire on Sarajevo. ${ }^{13279}$ He believed that there was only a fine line between such a tactic and directly firing upon their own citizens. ${ }^{13280}$ KW570 testified that with these practices and through drawing a response, the $\mathrm{BiH}$ government was trying provoke an international intervention on their side. ${ }^{13281}$ Bell also testified that Bosnian Muslims used "sacrificial attacks" to provoke an international reaction and would provoke the Bosnian Serbs into using their heavy weapons. ${ }^{13282}$ Galić testified that the $\mathrm{ABiH}$ would fire from schools, hospitals, and locations where the UN forces resided. ${ }^{13283}$

\section{(C) Shelling investigations in Sarajevo}

4004. A number of witnesses testifying before this Chamber participated in investigating shelling incidents in Sarajevo. These investigations were conducted by the BiH MUP and also by UNPROFOR and the UNMOs. With respect to the BiH MUP investigations, CSB Sarajevo's unit for serious criminal acts was tasked with investigating shelling incidents involving fatalities. ${ }^{13284}$ This department was notified of any such incident by the local police station concerned and would in turn inform an investigative judge of the Sarajevo Supreme Court who would become the head

brought up the issue of $\mathrm{ABiH}$ fire from civilian and $\mathrm{UN}$ areas with Ganić, the latter told him "where can we go to defend ourselves?").

13275 D2398 (Witness statement of Richard Gray dated 22 April 2012), paras. 4-5.

13276 D2398 (Witness statement of Richard Gray dated 22 April 2012), para. 12; P1258 (Witness statement of Hussein Ali Abdel-Razek dated 16 July 2002), e-court pp. 15, 20; Hussein Abdel-Razek, T. 5538-5541 (20 July 2010); D501 (ABiH report re meeting with UNPROFOR, 29 August 1992).

13277 D2270 (Witness statement of Andrey Demurenko dated 13 October 2012), para. 4.

13278 D2270 (Witness statement of Andrey Demurenko dated 13 October 2012), para. 37.

13279 P1638 (Witness statement of Michael Rose dated 26 March 2009), para. 215.

13280 P1638 (Witness statement of Michael Rose dated 26 March 2009), para. 215.

13281 D2770 (Witness statement of KW570 dated 21 November 2012) (under seal), para. 15.

13282 P1996 (Witness statement of Martin Bell dated 8 March 2010), para. 57; Martin Bell, T. 9901-9902 (15 December 2010); D921 (Witness statement of Martin Bell dated 7 February 1996), p. 14.

13283 Stanislav Galić, T. 37419 (18 April 2013).

13284 KDZ485, T. 8886 (3 November 2010); P1830 (Witness statement of Dragan Mioković dated 26 October 2010), p. 4. Initially, the CSB Sarajevo teams went out to investigate every larger shelling incident regardless of whether there were casualties or not but this practice ceased at the end of 1993 or beginning of 1994, and the department focused only on incidents which resulted in one or more deaths. See P1695 (Witness statement of Mirza Sabljica dated 11 February 2010), pp. 7-8., 10-11; P130 (Witness statement of Zlatko Međedović dated 5 September 2000), p. 4; Ekrem Suljević, T. 5683-5684 (21 July 2010). 
of the investigating team. ${ }^{13285} \mathrm{~A}$ team was then formed, including an investigator, criminal technicians, and a ballistics expert. ${ }^{13286}$ The investigative judge was in charge of the investigation and was responsible for ensuring that no legal mistakes were made and for conveying instructions to the investigator who would then pass them on to the other members of the team. ${ }^{13287}$ The criminal or forensic technicians were tasked with visually inspecting the scene, taking photographs, creating sketches of the scene, and collecting fragments of projectiles. ${ }^{13288}$ In more serious cases, involving a large number of casualties, the scene would also be video recorded. ${ }^{1328}$ The ballistics experts' task was to determine the direction rather than the origin of fire, as well as the calibre of the weapon used. ${ }^{13290}$ The team would come to the site as soon as it was informed of the incident by the local police and as soon as it was safe to do so. ${ }^{13291}$ At most incident sites, by the time the team arrived, the dead and wounded would already have been moved to the hospitals and the morgue. ${ }^{13292}$ The local police would usually inform the team what the security situation was at the scene, including whether there had been military activity in the area immediately prior to the incident taking place. ${ }^{13293}$ At the request of CSB Sarajevo, members of the counter-sabotage protection unit of the BiH MUP would on occasion also assist in these investigations. ${ }^{13294}$ Ekrem Suljević, a member of that unit who participated in approximately 50 to 60 investigations of shelling incidents during the conflict, testified that the difficult conditions in which the incidents

13285 The investigating judge could authorise an investigator to conduct the investigation on his behalf. See P1830 (Witness statement of Dragan Mioković dated 26 October 2010), pp. 2, 4; P1905 (Witness statement of KDZ485), para. 5.

13286 P1830 (Witness statement of Dragan Mioković dated 26 October 2010), pp. 4-5; P1905 (Witness statement of KDZ485), paras. 5-6. Mirza Sabljica testified that in most serious cases the investigation team would include two ballistics experts rather than one. See P1695 (Witness statement of Mirza Sabljica dated 11 February 2010), p. 9.

13287 P1830 (Witness statement of Dragan Mioković dated 26 October 2010), p. 5; P1905 (Witness statement of KDZ485), para. 6. See also Dragan Mioković, T. 8555 (28 October 2010); P1695 (Witness statement of Mirza Sabljica dated 11 February 2010), pp. 67-68; Mirsad Kučanin, P16 (Transcript from Prosecutor v. Galić), T. 4643-4644; P1276 (Witness statement of Ekrem Suljević dated 9 February 2010), para. 5; P1791 (Witness statement of KDZ166 dated 13 February 2010), pp. 2-3.

13288 P1791 (Witness statement of KDZ166 dated 13 February 2010), pp. 2-3; KDZ166, T. 8288-8289, 8291 (26 October 2010). In order to become a forensic technician, one needed to finish secondary engineering school and then attend a special police course which lasted six months. See KDZ166, T. 8288 (26 October 2010).

13289 KDZ166, T. 8295-8296 (26 October 2010).

13290 P1695 (Witness statement of Mirza Sabljica dated 11 February 2010), pp. 10, 18; P1276 (Witness statement of Ekrem Suljević dated 9 February 2010), para. 16; P130 (Witness statement of Zlatko Međedović dated 5 September 2000), p. 4; P1905 (Witness statement of KDZ485), para. 10.

13291 KDZ166, T. 8290-8291 (26 October 2010).

13292 KDZ485, T. 8883-8884 (3 November 2010); P1905 (Witness statement of KDZ485), para. 7; KDZ166, T. 8291-8294 (26 October 2010).

13293 KDZ485, T. 8886-8887 (3 November 2010).

13294 See P1276 (Witness statement of Ekrem Suljević dated 9 February 2010), paras. 4-5, 8, 13 (stating that this unit was tasked with, inter alia, providing security at meetings and doing on-site investigations of explosions, and included chemical, electrical, and mechanical engineers who were not trained in crater analysis but learned from colleagues and literature). 
were investigated influenced the detail of the work these teams were able to provide. ${ }^{13295}$ However, he also noted that they never left the incident site with any doubt as to the established direction of fire. $^{13296}$

4005. At the scene of a shelling incident, a ballistic expert would look at the mechanical traces resulting from the impact of the projectile and its fragments, which would be contoured on the asphalt or any other surface. The expert would also assess whether the shell stabiliser (also referred to as the tail fin of the shell) was embedded at the point of impact. ${ }^{13297}$ The ballistics expert would then conduct an "analysis of the central axis" or "axis of symmetry" to determine the direction from which the projectile came. ${ }^{13298}$ The central axis method is where the outer edges of a given crater's two most pronounced shrapnel traces are drawn back to the centre of the crater. ${ }^{13299}$ The angle that these two 'forks' create is then bisected along their central axis and this bearing is measured to determine the incoming trajectory of the projectile. ${ }^{13300}$ Having visually established the direction of fire, the team would also use high precision compasses to determine the azimuth, that is, the angle measured clockwise from the line of magnetic north to the line of the central axis or axis of symmetry. ${ }^{13301}$ For mortars, this method has a margin of error of plus or minus five degrees in relation to the direction of the shell. ${ }^{13302}$ The calibre of the weapon used was usually determined on

13295 P1276 (Witness statement of Ekrem Suljević dated 9 February 2010), paras. 3, 8-11. He was involved in determining the direction of fire, removing trace evidence, and analysising it in the laboratory. P1276 (Witness statement of Ekrem Suljević dated 9 February 2010), paras. 35-36. See also Ekrem Suljević, T. 6232-6233 (6 September 2010); Nedžib Đozo, T. 9584-9585 (10 December 2010); KDZ485, T. 8895-8899 (3 November 2010) (testifying also that he was unaware of any of his colleagues being the victim of shelling whilst attending an incident site); P1905 (Witness statement of KDZ485), para. 8.

13296 P1276 (Witness statement of Ekrem Suljević dated 9 February 2010), para. 10.

13297 P1695 (Witness statement of Mirza Sabljica dated 11 February 2010), pp. 11-12, 14; P1703 (Photograph re shelling incident on 8 November 1994 marked by Mirza Sabljica). The recovery and the analysis of traces would be easier when projectiles hit hard surfaces such as concrete or asphalt. See Mirza Sabljica, T. 7816 (13 October 2010); P1276 (Witness statement of Ekrem Suljević dated 9 February 2010), para. 30.

13298 P1695 (Witness statement of Mirza Sabljica dated 11 February 2010), pp. 11-14; P1717 (Photograph re shelling incident on 8 November 1994 marked by Mirza Sabljica); P1276 (Witness statement of Ekrem Suljević dated 9 February 2010), paras. 19-20. See also Mirza Sabljica, T. 7714-7715, 7721-7731 (12 October 2010); P1723 (Sketch drawn by Mirza Sabljica); P1730 (Photograph re shelling of Dobrinja on 1 June 1993 marked by Mirza Sabljica); P1731 (Photograph re shelling of Dobrinja on 1 June 1993 marked by Mirza Sabljica); P1732 (Photograph re shelling of Dobrinja on 1 June 1993 marked by Mirza Sabljica); P1733 (Photograph re shelling of Dobrinja on 1 June 1993 marked by Mirza Sabljica).

13299 Zorica Subotić, T. 38357-38359 (15 May 2013); John Hamill, P1994 (Transcript from Prosecutor v. Galić), T. 6092.

13300 Zorica Subotić, T. 38357-38359 (15 May 2013).

13301 P1276 (Witness statement of Ekrem Suljević dated 9 February 2010), para. 22. Suljević testified that the investigators were well aware of the interference effect of metal on the process of recording an angle using a compass; accordingly, they did not wear flak jackets and paid attention to any metal objects in the area. See P1276 (Witness statement of Ekrem Suljević dated 9 February 2010), para. 23.

13302 P1695 (Witness statement of Mirza Sabljica dated 11 February 2010), p. 13; P1276 (Witness statement of Ekrem Suljević dated 9 February 2010), para. 25. Sabljica testified that the margin of error using this method could never result in the miscalculation of the direction of fire by 40 to 50 degrees. He also testified that in $90 \%$ of the shelling incidents he investigated, that is over 50 cases, he was dealing with mortar projectiles. See P1695 (Witness statement of Mirza Sabljica dated 11 February 2010), pp. 10-11, 13; Mirza Sabljica, T. 7721-7722, 
the basis of the shell stabiliser which would embed in the surface in about $95 \%$ of the cases. ${ }^{13303}$ The form and type of the traces and of the damage also helped in establishing the calibre of the mortar. $^{13304}$

4006. The on-site investigation teams did not determine the range of fire, which depends on the type of the projectile used, as well as the charge with which it was fired. ${ }^{13305}$ Sabljica explained that it was possible to determine the distance from which the mortar was fired, based on the angle of descent of the projectile and the type of weapon used. ${ }^{13306}$ This determination however was not done by Sabljica's unit as they had neither the knowledge nor the equipment necessary; instead, they had a special team supported by persons with an expertise in rocket science and ballistics. ${ }^{13307}$ Sabljica explained that the angle of descent is the angle at which the projectile descends and can be determined by placing a stick into a fuse furrow, which has to be of a certain depth for the method to produce accurate results, and then by determining the resulting angle through geometry. ${ }^{13308}$ Suljević, testified however that determining the distance from which a shell was fired was impossible without knowing the propelling charges. ${ }^{13309}$ According to him, determining the origin of fire can be done through taking statements from witnesses who heard or observed the projectile, but since he and his colleagues were not able to interview witnesses on VRS-held territory, they

7729, 7740 (12 October 2010). The Chamber notes however that Subotić testified that the central axis method has a defined margin of error of plus or minus ten degrees. See Zorica Subotić, T. 38359-38360 (15 May 2013 ).

13303 P1695 (Witness statement of Mirza Sabljica dated 11 February 2010), pp. 12, 14, 16-17; P1276 (Witness statement of Ekrem Suljević dated 9 February 2010), paras. 29-31.

13304 P1695 (Witness statement of Mirza Sabljica dated 11 February 2010), pp. 12, 14.

13305 Mirza Sabljica, T. 7719-7720 (12 October 2010); P1276 (Witness statement of Ekrem Suljević dated 9 February 2010), para. 17; KDZ166, T. 8295 (26 October 2010). Thomas Knustad also confirmed that determining the precise range of fire was very difficult due to the impossibility of knowing the charge with which the projectile was fired. Thomas Knustad, P123 (Transcript from Prosecutor v. D. Milošević), T. 2040-2041.

13306 Mirza Sabljica, T. 7718-7720 (12 October 2010); P1695 (Witness statement of Mirza Sabljica dated 11 February 2010), pp. 17-18.

13307 Mirza Sabljica, T. 7718-7720 (12 October 2010); P1695 (Witness statement of Mirza Sabljica dated 11 February 2010), pp. 17-18. One of the members of that team was Berko Zečević whose evidence on his method for determining the relevant distance is discussed later, in relation to Scheduled Incident G.8. Another witness relevant to this issue is Emir Turkušić who used the method in his investigation of Scheduled Incident G.9, which is also discussed below.

13308 P1695 (Witness statement of Mirza Sabljica dated 11 February 2010), pp. 14-16; P1276 (Witness statement of Ekrem Suljević dated 9 February 2010), para. 15; P1701 (Photograph re shelling incident on 8 November 1994); Mirza Sabljica, T. 7714-7716 (12 October 2010); P1437 (Richard Higgs's Consolidated Report on Sarajevo Shelling Incidents, 13 March 2009), p. 6. Sabljica determined an angle of descent only once whereby he used the embedded stabiliser to create an imaginary axis. Mirza Sabljica, T. 7715-7720 (12 October 2010); P1722 (Sketch drawn by Mirza Sabljica); P1695 (Witness statement of Mirza Sabljica dated 11 February 2010), pp. 14-16; P1716 (Photograph of mortar impact marked by Mirza Sabljica); P1702 (Sketch of mortar impact marked by Mirza Sabljica). Sabljica admitted that this method was imprecise, with a margin of error of plus or minus ten degrees. Mirza Sabljica, T.7717-7718, 7740 (12 October 2010).

13309 P1276 (Witness statement of Ekrem Suljević dated 9 February 2010), para. 17. See also John Hamill, T. 9694 (13 December 2010). 
could not determine the origin of fire in the cases they investigated. ${ }^{13310}$ Međedović, a ballistics expert at CSB Sarajevo, noted that, when determining the direction of fire, the ballistics experts did not interview any victims or witnesses. ${ }^{13311}$

4007. Every time there was a shelling incident, UNPROFOR would also try to investigate it; usually the Sector Sarajevo headquarters undertook the investigation because they had the technical expertise. $^{13312}$ Thus, UNPROFOR soldiers were at many of the incident sites, either at the beginning of or during the investigation by the CSB Sarajevo. ${ }^{13313}$ In addition to conducting their own investigations, UNPROFOR soldiers also monitored the work of CSB Sarajevo teams. ${ }^{13314}$ At the end, the findings of both UNPROFOR and CSB Sarajevo would be compared and, according to Suljević, there was no deviation between those as far as direction of fire was concerned. ${ }^{13315}$

4008. UNMOs also investigated shelling incidents alongside the CSB Sarajevo, but kept their investigations separate. ${ }^{13316}$ They would travel to incident sites and investigate what they saw and evidence they found, and then file a written report. ${ }^{13317}$ Konings testified that UNMOs would exchange information with the CSB Sarajevo during these investigations but that in contrast to the police investigators they were not actually collecting evidence, just data. ${ }^{13318}$

4009. The Accused argues that both the BiH MUP and the UN investigators working on scheduled shelling incidents were "exceptionally unreliable" as they were biased and their work was riddled

13310 P1276 (Witness statement of Ekrem Suljević dated 9 February 2010), para. 18. Richard Higgs testified that sound on its own would not confirm a firing position, only an approximate direction. He stated, however, that the time delay between the fire and burst can give an approximate range to the firing position. See P1437 (Richard Higgs's Consolidated Report on Sarajevo Shelling Incidents, 13 March 2009), p. 5.

13311 P130 (Witness statement of Zlatko Međedović dated 5 September 2000), pp. 3-4.

13312 P1762 (Witness statement of David Fraser dated 17 October 2010), p. 50 (testifying also that all UNPROFOR reports on the incidents went back to the Sector Sarajevo Headquarters and those relating to more sensitive incidents were forwarded to the BiH Command); P2447 (Witness statement of KDZ182), p. 48; P6060 (Record of interview with KDZ185), e-court p. 18; P5906 (Witness statement of KDZ450 dated 17 January 2011), para. 72. Fraser conceded that these were not criminal investigations. See David Fraser, T. 8055 (18 October 2010).

13313 P1276 (Witness statement of Ekrem Suljević dated 9 February 2010), para. 34.

13314 P1276 (Witness statement of Ekrem Suljević dated 9 February 2010), para. 34.

13315 P1276 (Witness statement of Ekrem Suljević dated 9 February 2010), para. 34.

13316 P1953 (Witness statement of Harry Konings dated 11 November 2010), paras. 14, 18; Thorbjorn Overgard, P2058 (Transcript from Prosecutor v. D. Milošević), T. 662.

13317 P1953 (Witness statement of Harry Konings dated 11 November 2010), paras. 15-16; Thorbjorn Overgard, P2058 (Transcript from Prosecutor v. D. Milošević), T. 637-638. Fraser testified that he had reservations about UNMOs' utility and their reports, as their reliability was dependent on their country of origin. See David Fraser, T. 8034-8036 (18 October 2010).

13318 P1953 (Witness statement of Harry Konings dated 11 November 2010), para. 14. Thomas, testified that UNMOs in Sarajevo would investigate the number of people who were killed or wounded as a result of a particular shelling incident and that during this procedure an UNMO officer would personally see the victims either in hospital or in the morgue. See P1558 (Witness statement of Francis Roy Thomas dated 13 May 2009), para. 33. See also P1953 (Witness statement of Harry Konings dated 11 November 2010), paras. 16-17. 
with mistakes. ${ }^{13319}$ The Prosecution responds that this is a broad allegation based on mischaracterisation of the evidence of the relevant witnesses. ${ }^{13320}$ As already explained in relation to the sniping investigations ${ }^{13321}$ and as will be seen below, in its analysis of the scheduled shelling incidents, the Chamber has considered and analysed a number of CSB Sarajevo and UN reports prepared on the basis of the investigative methods outlined above. These were produced by ballistics experts and/or criminal technicians who were, in most cases, on site soon after the incident and who used accepted ballistics methods to determine the direction of fire. They had access to the scene, contemporaneous information, and eye-witnesses, as well as general knowledge about the shelling in Sarajevo. Thus, the Chamber generally gave considerable weight to the CSB Sarajevo and UN reports when analysing the scheduled shelling incidents. In doing so, the Chamber was also cognisant of the shortcomings of the investigations conducted during the war, such as the difficulties faced by investigators working under threat of fire and their inability to determine the exact origin of fire. Whenever issues arose with respect to particular reports, they were considered by the Chamber in relation to each particular incident. Accordingly, while finding this type of evidence to be generally reliable and credible, the Chamber approached it with caution and as one piece of the puzzle assessed against the totality of evidence tendered in relation to each incident.

4010. As mentioned above, ${ }^{13322}$ the Chamber heard from Prosecution investigator, Barry Hogan, who visited Sarajevo on multiple occasions and prepared various materials relating to the incidents listed in Schedule G of the Indictment. ${ }^{13323}$ He visited the locations relevant to that schedule in the company of a victim or an eyewitness and used a GPS unit to produce an accurate reading of the position where the shells impacted. ${ }^{13324}$ These recordings were then used to produce a map depicting the incident sites. ${ }^{13325}$ Hogan also recorded video footage of these visits, which show the individual eyewitnesses and/or victims indicating the location where they believed the shells landed, based purely on their own recollection of the incidents. ${ }^{13326}$ As stated earlier, the Chamber

\footnotetext{
13319 Closing Arguments, T. 47954-47959, 47989-47991 (2 October 2014).

13320 Closing Arguments, T. 48056-48059 (7 October 2014).

13321 See para. 3632.

13322 See para. 3633

13323 Barry Hogan, T. 11192-11193, 11196-11205 (3 February 2011).

13324 Barry Hogan, T. 11204-11205, 11230-11231, 11255 (3 February 2011). If multiple shells were involved in a particular incident, Hogan chose a particular impact site and took a reading from that position. See Barry Hogan, T. 11204-11205 (3 February 2011); P2190 (GPS locations for shelling and sniping incidents in Sarajevo).

13325 Barry Hogan, T. 11204-11206 (3 February 2011); P2191 (Map of Sarajevo with scheduled sniping and shelling incidents).

13326 Barry Hogan, T. 11207, 11232 (3 February 2011). These witnesses did not have access to their own prior witness statements or to other supporting material such as the original investigation reports or footage of an incident or its aftermath. Barry Hogan, T. 11288 (3 February 2011).
} 
has considered Hogan's evidence and found that he was a reliable and truthful witness but that his mandate was limited to simply recording the locations of the incident sites. Thus, and for the reasons explained in more detail Section IV.B.1.b.II.C while accepting Hogan's evidence as credible, the Chamber was aware of its limitations and of the fact that his activities were dependent on the recollections of others.

4011. As noted above, the Chamber heard from three experts in relation to shelling in Sarajevo. ${ }^{13327}$ For the Prosecution, Higgs conducted investigations into scheduled shelling incidents G.4, G.5, G.6, G.7, G.8, and G.19 looking at the alleged origin of fire, as well as the military value of the target. ${ }^{13328}$ He visited the relevant incident sites years after and due to the passage of time did not conduct any measured crater analysis or take photographs. ${ }^{1329}$ Instead, at each site he looked at the general area and surrounding features, as well as the remnants of craters. ${ }^{13330} \mathrm{He}$ was provided the forensic data of the relevant $\mathrm{BiH}$ and $\mathrm{UN}$ investigation teams for each incident by the Prosecution, and then opined as to the appropriateness of their methodology and accuracy of their conclusions. ${ }^{1331}$ In doing so, he checked the information contained within the original investigation reports against photographs of the area and his own site visits. ${ }^{13332}$ Higgs testified that, in the absence of grossly inaccurate facts, he had to believe that the original investigators described their methodology and findings honestly in their reports. ${ }^{1333}$

4012. The Accused argues that his expert witnesses identified deficiencies in Higgs' work. ${ }^{13334}$ He also asserts that the basic methodology of Higgs' investigation was to trust the prior investigations conducted by either the $\mathrm{BiH}$ authorities and/or the UN. ${ }^{13335}$ The Prosecution argues, on the other hand, that the entirety of the Accused's case in relation to shelling was "false, pretextual and invalid". ${ }^{1336}$ The Chamber has analysed Higgs qualifications and testimony and is

\footnotetext{
13327 One of the Prosecution experts, Berko Zečević, testified about scheduled incident G.8 and the incidents involving modified air bombs. His evidence and credibility will be discussed below, in the section dealing specifically with scheduled incident G.8 and the section dealing with incidents involving modified air bombs, respectively.

13328

13329

13330

The Accused presented this argument during the testimony of Richard Higgs. See T. 6009 (19 August 2010). Subotić also asserted that Higgs' acceptance of the conclusions of an UN investigation was a sign of bias. See D3542 (Zorica Subotić's expert report entitled “Mortar Operations in Sarajevo Area in 1992-1995", 15 August

2012), p. 69.

13336

P1437 (Richard Higgs's Consolidated Report on Sarajevo Shelling Incidents, 13 March 2009), p. 1.

P1437 (Richard Higgs's Consolidated Report on Sarajevo Shelling Incidents, 13 March 2009), pp. 6-12, 18; Richard Higgs, T. 6005-6007, 6015, 6025 (19 August 2010).

Richard Higgs, T. 6006, 6025 (19 August 2010).

Richard Higgs, T. 5946 (18 August 2010), T. 6015, 6023-6025 (19 August 2010). See P1437 (Richard Higgs's Consolidated Report on Sarajevo Shelling Incidents, 13 March 2009), pp. 7-12, 18.

Richard Higgs, T. 6025 (19 August 2010).

Richard Higgs, T. 6007 (19 August 2010).

Defence Final Brief, para. 2387.

Prosecution Final Brief, paras. 787-791.
} 
satisfied that he is an expert, as well as a reliable witness, and that his evidence about the operational use, technical and ballistic capabilities of mortars, and the methodology of crater analysis can be accepted as credible. The Chamber also found Higgs reliable and credible in relation to his evidence on a number of scheduled incidents alleged in the Indictment. However, already during trial, the Chamber made clear that Higgs' evidence is of a limited nature as it does not substantiate the findings of the original investigations, but simply appraises their methodology and the conclusions that were drawn. ${ }^{13337}$ Indeed, the majority of Higgs' testimony was based on interpretations of reports compiled by the investigation teams during or immediately after the incidents in question occurred. Accordingly, Higgs' evidence was approached by the Chamber as merely one piece of the puzzle and, at times, as having relatively limited value in the Chamber's determination on the origin of fire in the incidents alleged.

4013. Zorica Subotic visited the sites of the scheduled shelling incidents in and after $2010{ }^{13338}$ She testified that the central axis method was the most accurate and reliable method to determine the incoming trajectory of a projectile, save for the use of specialised radar. ${ }^{13339}$ Subotićs conclusions in relation to the scheduled shelling incidents were based on the investigations of the original investigators, such as the CSB or UNPROFOR, as well as witness testimony, footage and photographs relating to the incidents, documents and statements from previous trials before the Tribunal, and any physical traces that remained at the incident sites. ${ }^{13340}$ When challenged on cross-examination as to her use of contemporaneous photographs to conduct her analysis and calculations, Subotić explained that contemporary technology allows for the angle from which a photograph was taken to be removed by computer analysis, which in turn allows for more precise measurements. ${ }^{13341}$ However, Subotić did concede that there was a noticeable difference between de visu examination of mortar traces and what can be discerned from a photograph. ${ }^{13342}$

4014. The Prosecution argues that Subotic is of highly questionable credibility and that her analysis was the product of scientifically unsound methods, using secondary evidence, such as photographs and video footage, or degraded physical evidence. ${ }^{13343}$ According to the Prosecution, she revealed an "extraordinary bias" in her analysis and her conclusions were implausible in the

\footnotetext{
13337 Richard Higgs, T. 6008-6009, 6011 (19 August 2010). See also the Chamber's oral decision of 18 August 2010 on the time allocated for the cross-examination of Richard Higgs and the Accused's request to admit the underlying reports that Higgs relied on as source documents. Hearing, T. 5943-5944 (18 August 2010).

13338 Zorica Subotić, T. 38363 (15 May 2013).

13339 Zorica Subotić, T. 38357-38361 (15 May 2013).

13340 Zorica Subotić, T. 38183-38184 (13 May 2013).

13341 Zorica Subotić, T. 38362-38363 (15 May 2013).

13342 Zorica Subotić, T. 38363 (15 May 2013).

13343 Prosecution Final Brief, Appendix C, paras. 43, 46.
} 
face of the totality of the Prosecution evidence. ${ }^{13344}$ The Accused argues in response that Subotic based her analysis on the "laws of physics" and the ballistic characteristics of the weapons involved in the incidents. ${ }^{13345}$ Further, according to the Accused, the "advocacy" arguments made by the Prosecution in relation to Subotić's credibility could not make up for the lack of evidence or override the laws of physics. ${ }^{13346}$

4015. Having analysed both Subotić's expert report and her testimony on the various scheduled shelling incidents alleged in the Indictment, the Chamber notes that she often advanced theories of her own to neutralise the Prosecution evidence, some of which strained credulity and others which were blatantly misleading. ${ }^{13347}$ In some instances on cross-examination, Subotić was also evasive and would sidestep questions. ${ }^{13348}$ Ultimately, as will be seen from the Chamber's analysis in relation to each scheduled shelling incident, the Chamber found that in many instances Subotić's evidence was compromised by her partisanship. Accordingly, it has found her evidence to be of limited value.

\section{iii. Scheduled shelling incidents}

4016. The Prosecution submits in its Final Brief that all scheduled shelling incidents constituted acts of violence directed against the civilian population or individual civilians not taking direct part in hostilities, including indiscriminate and disproportionate attacks. ${ }^{13349}$ In addition, it alleges that in all of the incidents the impact locations were within civilian, residential, or commercial areas; that there were no ongoing combat activities in the vicinity at the time of the incidents; and that the shelling in question had no military purpose. ${ }^{13350}$

4017. As was the case in the section of the Judgement dealing with sniping incidents, each scheduled shelling incident is discussed below according to the broad geographical area of Sarajevo where it took place.

\footnotetext{
13344 The Prosecution argues that Subotic got her facts wrong on a number of occasions, that she often made bare assertions and unfounded assumptions, and that she either disregarded or misinterpreted available evidence. See Prosecution Final Brief, Appendix C, paras. 43-46; Closing Arguments, T. 47727 (30 September 2014).

13345 Defence Final Brief, paras. 2387, 2391.

13346 Defence Final Brief, para. 2391.

13347 See e.g. discussion on Subotić in relation to Scheduled Incidents G.4, G.5, G. 7, and G.13.

13348 See e.g. Zorica Subotić, T. 38458 (16 May 2013).

13349 Prosecution Final Brief, Appendix C, para. 40.

13350 Prosecution Final Brief, Appendix C, paras. 40-41.
} 


\section{(A) Scheduled Incidents G.1 and G.2}

4018. The Indictment alleges that from on or about 28 May 1992, the city of Sarajevo was heavily shelled, damaging and destroying civilian targets, causing the deaths of several civilians and injuring others. ${ }^{13351}$ In its Final Brief, the Prosecution describes Scheduled Incident G.1 as a "24hour bombardment of the entire city of Sarajevo on 28-29 May 1992". ${ }^{13352}$

4019. The Indictment also alleges that from on or about 6 June 1992, another massive bombardment of the city was carried out with a variety of artillery fired from positions all around the city, and that as a result of this bombardment, civilian targets were damaged and destroyed and a number of civilians were killed and wounded. ${ }^{13353}$ In its Final Brief, the Prosecution describes Scheduled Incident G.2 as the "second massive bombardment of the city centre on or about 6 June $1992 " .13354$

4020. The Accused challenges the vagueness of Scheduled Incidents G.1 and G.2 and argues that the Indictment fails to define the geographic and temporal scope of these incidents. ${ }^{13355}$ In relation to Scheduled Incident G.1, the Accused first submits that the only incident which took place on 27 May 1992 was the shelling of Vase Miskina street and presents arguments to the effect that there is no evidence that the shelling was done by the Bosnian Serb Forces. ${ }^{13356}$ Second, the Accused challenges the Prosecution's allegations that Mladić ordered indiscriminate shelling of Sarajevo and the "alleged civilian neighbourhood of Velešići" on 28 and 29 May 1992, referring to two intercepted conversations. ${ }^{13357}$ Further, the Accused submits that even if Mladić had ordered the shelling of Velešići, this shelling would not have been illegal because the area concerned had a heavy concentration of $\mathrm{ABiH}$ military hardware and personnel. ${ }^{13358}$ In relation to Scheduled Incident G.2, the Accused argues that around 6 June 1992, ABiH initiated infantry and artillery

\footnotetext{
13351 Indictment, Scheduled Incident G.1.

13352 Prosecution Final Brief, para. 640. See also Prosecution Final Brief, paras. 727-728.

13353 Indictment, Scheduled Incident G.2.

13354 Prosecution Final Brief, para. 728. The Prosecution also describes Scheduled Incident G.2 as "another massive and indiscriminate shelling of the city". See Prosecution Final Brief, para. 640.

13355 Defence Final Brief, paras. 1980, 1998-1999. The Accused submits that the impermissibly broad nature of Scheduled Incident G.2 prevents him from effectively refuting the allegations. See Defence Final Brief, para. 1999.

13356 Defence Final Brief, paras. 1980-1994. However, as noted earlier, the mortar attack of 27 May 1992 in Vase Miskina street is outside the scope of Scheduled Incident G.1. See Hearing, T. 37992-37993 (9 May 2013). The Chamber recalls that the Accused himself submitted that the shelling of Vase Miskina street is not charged in the Indictment. See Hearing, T. 6394 (8 September 2010) (closed session). See also Accused's Statement Pursuant to Rule 84 bis, T. 28867 (16 October 2012).

13357 Defence Trial Brief, paras. 1995-1996 (referring to P1041 and D207).

13358 Defence Trial Brief, para. 1997.
} 
attacks against Serb positions around Sarajevo such as Grbavica and Vraca, and that the combat operations on the part of the SRK were directed at repelling these attacks. ${ }^{13359}$

4021. The Chamber notes that in May 1992, about 800 to 900 JNA personnel and their family members were stationed in the Jusuf Džonlić Barracks, the Maršal Tito Barracks, and the Viktor Bubanj Barracks. ${ }^{13360}$ There were plans by the JNA to evacuate these soldiers and their families out of BiH but Bosnian Muslim forces blockaded all three barracks before they could be evacuated. ${ }^{13361}$ As a result, on the basis of a proposal advanced by Mladić, Bosnian Serb military and political leaders discussed moving armed units northwards, from Grbavica all the way up to the Maršal Tito Barracks; this operation was intended to allow for the evacuation of the JNA personnel from the Maršal Tito Barracks. ${ }^{13362}$ However, the military operation did not materialise at that time, in part due to the refusal of Mićo Stanišić to have MUP forces participate in it. ${ }^{13363}$

4022. On 19 May 1992, Lieutenant-Colonel Janković of the JNA reported to Mladić that the $\mathrm{ABiH}$ was threatening the barracks and the JNA personnel inside; Mladić responded that if Jovan Divjak, a Serb General in the $\mathrm{ABiH}$, attacked the Maršal Tito Barracks, Divjak "would sentence first himself and then [the] entire Sarajevo to death."13364 As noted earlier, on the same day, Šipčić was chosen by Mladić to be the new SRK Commander. ${ }^{13365}$

4023. In a continued effort to evacuate the JNA personnel, some time between 20 and 28 May 1992, most probably in the last week of May, there was a meeting between, among others, the Accused, Mladić, Krajišnik, Plavšić, Koljević, [REDACTED] during which Mladić proposed to use "all the equipment and arms" available to "massively bombard Sarajevo". ${ }^{1366}$ [REDACTED] prior to this time, the Bosnian Serbs had selectively chosen targets that they considered to be military

\footnotetext{
13359 Defence Trial Brief, paras. 2000-2001.

13360 [REDACTED]; P928 (Sky News report re Sarajevo, with transcript); P1478 (Ratko Mladić's notebook, 27 May31 July 1992), p. 36.

13361 [REDACTED]; P1478 (Ratko Mladić's notebook, 27 May-31 July 1992), pp. 17-18.

13362 [REDACTED]; P968 (Interview with Jovan Tintor on Pale TV, 1 August 1994, with transcript), e-court p. 2.

13363 [REDACTED].

13364 P6070 (Intercept of conversation between Milosav Gagović, Janković, and Ratko Mladić, 19 May 1992), p. 2; KDZ185, T. 4347 (30 June 2010); Milosav Gagović, T. 31872-31873 (15 January 2013); Michael Rose, T. 7291-7292 (5 October 2010). Also on 19 May 1992, Mladić reassured Miloš Baroš, a JNA general at the Maršal Tito Barracks, by stating that "[a]nything they deprive you of, we will deprive Sarajevo of! If a bullet is fired at you, you will see what will be fired at Sarajevo." See P5672 (Intercept of conversation between Miloš Baroš, Ratko Mladić, and Gagović, 19 May 1992), p. 2; [REDACTED]. Mladić spoke about retaliating against the city of Sarajevo in other conversations with members of VRS. See e.g. P5693 (Intercept of conversation between Ratko Mladić and Potpara, 11 May 1992), pp. 1-2; P5657 (Intercept of conversation between Zdravko Tolimir, Ratko Mladić, and “Jerko Doko", 24 May 1992), p. 2.

13365 See para. 3557.

13366 [REDACTED].
} 
assets. $^{13367}$ [REDACTED]. ${ }^{13368}$ [REDACTED] the members of the Bosnian Serb leadership present at the meeting, including the Accused, did not oppose Mladić's proposal. ${ }^{13369}$ [REDACTED]. ${ }^{13370}$ Following the meeting, preparatory measures went on for 10 to 15 days; weapons were deployed, ammunition supplied, and targets selected. ${ }^{13371}$ During that time, Mladić toured all of the artillery units deployed around Sarajevo and issued orders as to which weapons should be used. ${ }^{13372}$

4024. On 25 May 1992, Mladić informed an unidentified JNA officer that "[i]f a single bullet is fired [...] at Jusuf Džonlić barracks or Maršal Tito Barracks, or if a single soldier is wounded either at the front or in the barracks" he would "retaliate against the town". ${ }^{13373}$ He further stated:

Sarajevo will shake, more shells will fall on per second than in the entire war so far. [...] You can endure more than they can. It is not my intention to destroy the town and kill innocent people.[...] They should pull out the civilians, and if they want to fight we'll fight. It would be better to fight in the mountains than in the town, though. ${ }^{13374}$

4025. On the same day, during a meeting where Plavšić was also present, Mladić informed Wilson that if the JNA personnel in the military barracks around Sarajevo were not evacuated to safety within three days, he would "level the city."13375 Mladić also told UNPROFOR representatives that any discussion concerning the reopening of Sarajevo airport, the unblocking of the supply routes to Sarajevo, and the safeguarding of the chemical plants in Tuzla could only take place after the evacuation of JNA personnel and their families from the barracks around Sarajevo had been completed. ${ }^{13376}$ Mladić added that international military intervention would only result in the destruction of Sarajevo. ${ }^{13377} \mathrm{He}$ then requested that Wilson convey his words to the $\mathrm{BiH}$ Presidency. ${ }^{13378}$ Since Plavšić did not show any opposition, Wilson took this as a very serious

\footnotetext{
13367 [REDACTED].

13368 [REDACTED].

13369 [REDACTED].

13370 [REDACTED].

13371 [REDACTED].

13372 [REDACTED].

13373 P1041 (Intercept of conversation between Ratko Mladić and unidentified male, 25 May 1992), p. 1; [REDACTED].

13374 P1041 (Intercept of conversation between Ratko Mladić and unidentified male, 25 May 1992), p. 1.

13375 John Wilson, T. 3921-3922 (21 June 2010), T. $4053-4057$ (22 June 2010); P1029 (Witness statement of John Wilson dated 4 November 2008), paras. 6-7, 72-73; P1040 (UNPROFOR report re meeting with Biljana Plavšić and Ratko Mladić, 25 May 1992), para. 2.

13376 P1040 (UNPROFOR report re meeting with Biljana Plavšić and Ratko Mladić, 25 May 1992), paras. 2, 4, 6, 8.

13377 P1040 (UNPROFOR report re meeting with Biljana Plavšić and Ratko Mladić, 25 May 1992), para. 3.

13378 John Wilson, T. 4053-4054 (22 June 2010); P1040 (UNPROFOR report re meeting with Biljana Plavšić and Ratko Mladić, 25 May 1992), para. 2.
} 
threat and, afterwards, communicated Mladić's message to the Presidency as well as to his own superior, General Nambiar. ${ }^{13379}$

4026. On 27 May, while in Lisbon, the Accused declared that the Bosnian Serb leadership was ready to open the airport to humanitarian flights on the condition that it functioned under the command and control of the UN until such time that its final status was determined by the interested parties at a peace conference to be convened in the future. ${ }^{13380}$ On the same day, Bosnian Muslim forces attacked the Maršal Tito Barracks with, inter alia, rifles, hand-held rocket launchers, anti-tank weapons, and Molotov cocktails. ${ }^{13381}$

4027. On 28 May 1992, at around 9 p.m., a JNA convoy which was withdrawing from the Jusuf Džonlić Barracks pursuant to an agreement between representatives from the FRY and the BiH Presidency was attacked by Bosnian Muslim forces; during this attack, a number of JNA officers were killed and several others were captured by the Muslim forces. ${ }^{13382}$ That same day at 8:50 p.m., Bosnian Muslim forces attacked the Maršal Tito Barracks and Slaviša Vajner Čiča Barracks, as well as SRK positions in Hadžići, the Sarajevo airport, and the Jewish cemetery with, inter alia, anti-aircraft guns and mortars; as a result, two SRK soldiers were killed and a number were wounded. ${ }^{13383}$

4028. In a conversation on 28 May 1992, Mladić enquired of Colonel Mirko Vukašinović whether he could reach Velešići and Baščaršija from his position in Hreša. ${ }^{13384}$ Mladić then ordered Vukašinović to "[f]ire a salvo at Baščaršija" to which Vukašinović replied: "Yes, Sir!"13385 In another conversation, also on 28 May 1992, Mladić ordered Vukašinović to fire at Velešići and

\footnotetext{
13379 John Wilson, T. 4054 (22 June 2010).

13380 P949 (Announcement of SDS leadership re Sarajevo airport and humanitarian supplies, 27 May 1992); Colm Doyle, P918 (Transcript from Prosecutor v. S. Milošević), T. 25299-25300. On 20 May 1992, the Accused travelled to Lisbon for about a week to attend the peace negotiations there. See Colm Doyle, P918 (Transcript from Prosecutor v. S. Milošević), T. 25299-25300.

13381 P1478 (Ratko Mladić's notebook, 27 May-31 July 1992), p. 24.

13382 [REDACTED]; P1477 (Ratko Mladić's notebook, 14 February-28 May 1992), p. 392; D207 (Intercept of conversation between Ratko Mladić and Potpara, 29 May 1992), p. 5; D2974 (Letter from Momčilo Krajišnik to Jose Cutileiro and others, 28 May 1992), p. 1.

13383 [REDACTED]; P1477 (Ratko Mladić's notebook, 14 February-28 May 1992), pp. 393-394; D574 (SRK combat report, 28 May 1992), para. 1.

13384 P1521 (Intercept of conversation between Ratko Mladić and Mirko Vukašinović, 28 May 1992), p. 2; [REDACTED]. Veljović testified that no Serb bombardment of Baščaršija ever happened because Dragomir Milošević specifically prohibited it, given Baščaršija's cultural and historic significance. See Stevan Veljović, T. 29230, 29279-29280 (23 October 2012). However, in light of the credible evidence that bombardment of Baščaršija did take place in 1992 and given the numerous contradictions in Veljović's testimony, the Chamber rejects his assertion.

13385 P1521 (Intercept of conversation between Ratko Mladić and Mirko Vukašinović, 28 May 1992), p. 3.
} 
Pofalići and added "there is not much Serb population there". ${ }^{13386}$ In the same conversation, Mladić ordered Vukašinović to continue firing "so that they can not sleep, that we roll out their minds". ${ }^{13387}$ Before the end of the conversation, Mladić ordered the firing of "one more salvo at the Presidency." 13388

4029. Wilson testified that the shelling that began in the evening of 28 May in Sarajevo was "heavy even by Sarajevo standards", widespread, and scattered around the city, but at the same time focused on the centre of the city and not related to any conflict on the confrontation line. ${ }^{13389}$ Wilson also described it as a "heavy artillery bombardment" by the SRK, which to him was another example of an "undoubtedly disproportionate and indiscriminately directed fire" at the city, whereby there was no military value in the targets that were selected. ${ }^{13390}$

4030. At that time, Fadila Tarčin was 16 years old and living with her family in Širokača, a residential area on the southern side of Sarajevo which overlooks Stari Grad and Bistrik. ${ }^{13391}$ Tarčin testified that her home was not near any military positions; the barracks at Bistrik, located one and a half kilometres away, were the only military facility nearby, and the confrontation line was around one kilometre away. ${ }^{13392}$ When the shelling began in the evening of 28 May 1992, Tarčin, her mother, and other relatives moved to the cellar and waited for the shelling to stop. ${ }^{13393}$ After some two hours, for about a 20-minute period, the shelling abated. ${ }^{13394}$ However, just after midnight, shrapnel came through the cellar door, injuring Tarčin's right foot and bruising her left

13386 P1518 (Intercept of conversation between Ratko Mladić and Mirko Vukašinović, 28 May 1992); P470 (Witness statement of Ašida Fazlić dated 1 November 2008), paras. 1-6; D2 (Supplemental statement of Ašida Fazlić dated 22 April 2010), e-court p. 4. However, during a telephone conversation with Fikret Abdić on 29 May 1992, Mladić denied that the SRK had shelled the city on 28 May 1992, in particular Baščaršija and the Archive building. Mladić also complained that the Bosnian Muslim forces had attacked Kolonija, Pofalići, the Viktor Bubanj Barracks, and the Jusuf Džonlić Barracks. The two interlocutors then accused each other of breaking cease-fire agreements in the previous weeks and insisted that their forces were only firing after having been fired upon first. Abdić cautioned Mladić against responding with disproportionate fire. Mladić in turn insisted that Abdić's forces return equipment and vehicles which they confiscated from the Jusuf Džonlić Barracks and that his forces allow peaceful evacuation of the Maršal Tito Barracks. See P5663 (Intercept of conversation between Ratko Mladić and Fikret Abdić, 29 May 1992), pp. 1, 4-15, 20-21. In light of the vast body of accepted evidence to the contrary, the Chamber is of the view that Mladić's denials as to the shelling of Sarajevo on 28 May 1992, which was unfolding as the conversation was taking place, did not reflect the situation on the ground.

13387 P1518 (Intercept of conversation between Ratko Mladić and Mirko Vukašinović, 28 May 1992).

13388 P1518 (Intercept of conversation between Ratko Mladić and Mirko Vukašinović, 28 May 1992).

13389 John Wilson, T. 3922 (21 June 2010).

13390 P1029 (Witness statement of John Wilson dated 4 November 2008), paras. 51-52, 57. See also Savo Simić, T. 30076-30077 (12 November 2012) (agreeing that civilians were injured in this attack but arguing that the SRK was returning fire).

13391 P498 (Witness statement of Fadila Tarčin dated 24 February 2004), paras. 1-3.

13392 P498 (Witness statement of Fadila Tarčin dated 24 February 2004), paras. 2, 11.

13393 P498 (Witness statement of Fadila Tarčin dated 24 February 2004), paras. 5, 7-8.

13394 P498 (Witness statement of Fadila Tarčin dated 24 February 2004), para. 7. 
knee. ${ }^{13395}$ Tarčin waited in the cellar until 4:30 a.m. for the shelling to stop. ${ }^{13396}$ At around 5 a.m., a neighbour took her to the Koševo Hospital where they fitted a cast for her right leg; there she remained for two days. ${ }^{13397}$ When she returned from the hospital, she could see that the shell which had wounded her had caused extensive damage to three houses in the neighbourhood. ${ }^{13398}$ On 28 May 1992 and throughout the rest of the war, Tarčin's “neighbourhood remained under constant shelling", and her house was hit twice more with projectiles. ${ }^{13399}$

4031. Shortly after midnight during the night of 28 May 1992, Ašida Fazlić, an employee of the State Hospital who was living with her son and husband in a room at the same hospital, was severely injured in the head and leg by shrapnel from a shell that hit the third floor of the hospital as shelling of the city was well underway. ${ }^{13400}$

4032. Van Lynden arrived in Sarajevo in late May 1992 and was living on the top floor of the State Hospital from which he was able to film shelling throughout the city. ${ }^{13401}$ He saw that the State Hospital had been targeted already and was badly "shot up"; he then personally witnessed the hospital being targeted by anti-aircraft guns at that time. ${ }^{13402}$ While living in the hospital, Van Lynden found no indication that Bosnian Muslim forces were using the building or its immediate surroundings for military purposes. ${ }^{13403}$

\footnotetext{
13395 P498 (Witness statement of Fadila Tarčin dated 24 February 2004), paras. 2, 7-9; P1991 (Stari Grad Police Station war diary), pp. 71-72.

13396 P498 (Witness statement of Fadila Tarčin dated 24 February 2004), para. 9.

13397 P498 (Witness statement of Fadila Tarčin dated 24 February 2004), paras. 9-10 (stating that to this day she cannot walk properly due to her injuries).

13398 P498 (Witness statement of Fadila Tarčin dated 2 November 2008), paras. 2-3.

13399 P498 (Witness statement of Fadila Tarčin dated 24 February 2004), para. 5.

13400 P470 (Witness statement of Ǎ̌ida Fazlić dated 1 November 2008), paras. 4-6; P1022 (Medical records for Ašida Fazlić), e-court p. 1. See also Adjudicated Facts 2883, 2884. For the next 16 months, Fazlić underwent a series of operations and stayed in the State Hospital. In November 1993, UNHCR evacuated her to Norway where she underwent three surgeries, including plastic surgery to replace the destroyed bone in the frontal region of her skull but post-surgery meningitis prevented her from undergoing all the other necessary operations. P470 (Witness statement of Ašida Fazlić dated 1 November 2008), paras. 8-10; P1022 (Medical records for Ašida Fazlić), e-court p. 3.

13401 Aernout van Lynden, T. 2387-2394 (19 May 2010); P926 (Witness statement of Aernout van Lynden dated 26 February 2010), paras. 4, 31-32; P927 (Aerial photograph of Sarajevo marked by Aernout van Lynden).

13402 P926 (Witness statement of Aernout van Lynden dated 26 February 2010), para. 31; Aernout van Lynden, T. 2392 (19 May 2010).

13403 Aernout van Lynden, T. 2390-2391 (19 May 2010); P926 (Witness statement of Aernout van Lynden dated 26 February 2010), para. 33. But see the assertion of Savo Simić who was the Chief of artillery in the $1^{\text {st }}$ Sarajevo Mechanised Brigade at the time that the ABiH's $1^{\text {st }}$ Corps had mortar firing positions in the State Hospital which were used for attacking his brigade in May 1992, thereby rendering the hospital a legitimate military target. See D2412 (Witness statement of Savo Simić dated 4 November 2012), paras. 3, 16, 23; Savo Simić, T. 30074-30076 (12 November 2012). The Chamber, however, rejects Simić's assertion in light of its findings in Section IV.B.1.e: Hospitals in Sarajevo, and in light of his evasiveness and the contradictions that tainted his evidence on this point.
} 
4033. Velešići was also shelled at that time. ${ }^{13404}$ It consisted mostly of private houses and $60 \%$ of its population was Muslim while the rest were Serbs. ${ }^{13405}$ Two individuals were wounded in Pogledine and one in Močila due to shelling. ${ }^{13406}$ The shelling also inflicted extensive damage on the Old Town. ${ }^{13407}$ In Vratnik, one person was killed, two houses caught fire, and a number of housing facilities and passenger vehicles were damaged. ${ }^{13408}$

4034. On 29 May 1992 at around 8 a.m., Wilson met with General Bošković, Colonel Cađo, and Lieutenant Colonel Janković, all from the JNA, who told him that Mladić had ordered the firing of artillery rockets and mortars in response to an attack on Lukavica by the Bosnian Muslim forces. ${ }^{13409}$ According to Wilson, during the meeting, the JNA commanders sought to dissociate themselves from the shelling of the city and expressed their disapproval, noting that Mladic was acting independently of the JNA. ${ }^{13410}$ Later, a BiH delegation joined the meeting to discuss the evacuation of the JNA barracks and played a taped radio intercept from the previous night, showing that Mladić personally directed artillery attacks on the city. ${ }^{13411}$

4035. On the same day, Mladić informed Potpara, an artillery officer from the JNA, and Baroš that the attacks by Muslim forces on the barracks had been intended to provoke the Serbs to open fire on Sarajevo. ${ }^{13412}$ Mladić then advised Potpara to be careful and act with restraint. ${ }^{13413}$

\footnotetext{
13404 Almir Begić, T. 9956-9958 (15 December 2010); Dušan Škrba, T. 29141 (22 October 2012); P1522 (Intercept of conversation between Ratko Mladić and Potpara, 29 May 1992), p. 1.

13405 Dušan Škrba, T. 29141 (22 October 2012); Almir Begić, T. 9956 (15 December 2010). While accepting that the Bosnalijek Factory was located just southeast of his home, Begić denied that it manufactured explosives during the war. See Almir Begić, T. 9979 (16 December 2010). See also D930 (Map of Velešići marked by Almir Begić).

13406 P1991 (Stari Grad Police Station war diary), pp. 71-72. Considering that the Stari Grad Police Station war diary does not provide any information as to the status or the activities of these wounded individuals during the shelling, the Chamber is not convinced beyond reasonable doubt that they were civilians and, if so, that they were not taking direct part in hostilities at the time.

13407 P1029 (Witness statement of John Wilson dated 4 November 2008), para. 76. See also P1042 (UNPROFOR report re conversations with $\mathrm{BiH}$ and JNA delegations, 29 May 1992), paras. 1-3.

13408 P1991 (Stari Grad Police Station war diary), p. 72. As with the wounded individuals mentioned in fn. 13406, the Chamber is unable to find beyond reasonable doubt that the person killed during this shelling was a civilian and, if so, that he was not taking direct part in hostilities at the time.

13409 John Wilson, T. 3909-3910, 3923-3924 (21 June 2010); P1029 (Witness statement of John Wilson dated 4 November 2008), para. 76; P1042 (UNPROFOR report re conversations with BiH and JNA delegations, 29 May 1992), para. 3.

13410 John Wilson, T. 3924 (21 June 2010); P1029 (Witness statement of John Wilson dated 4 November 2008), para. 76; P1042 (UNPROFOR report re conversations with BiH and JNA delegations, 29 May 1992), paras. 3, 6. See also P1478 (Ratko Mladić's notebook, 27 May-31 July 1992), p. 18 (suggesting that there was a rift between the Serbian and Bosnian Serb contingents); P5663 (Intercept of conversation between Ratko Mladić and Fikret Abdić, 29 May 1992), p. 10 (indicating that Mladić did not see himself as belonging to the Serbian military or state).

13411 John Wilson, T. 3924 (21 June 2010); P1029 (Witness statement of John Wilson dated 4 November 2008), para. 76; P1042 (UNPROFOR report re conversations with BiH and JNA delegations, 29 May 1992), paras. 4-6.

13412 D207 (Intercept of conversation between Ratko Mladić and Potpara, 29 May 1992), pp. 2-3; P1478 (Ratko Mladić's notebook, 27 May-31 July 1992), p. 24.
} 
However, Mladić also told Potpara and Baroš that if the attacks by Muslim forces continued, he would no longer show restraint and would shell Sarajevo. ${ }^{13414}$ Later that day, Mladić asked Potpara where there had been shelling and Potpara replied "towards the tobacco factory [...] Pofalići.",13415 Mladić also asked Potpara whether Velešići had been shelled and after receiving an affirmative answer, commented that there will be more shelling there. ${ }^{13416}$ In the same conversation, he asked if Potpara had "the means to fire at the station". ${ }^{13417}$ When Potpara responded that he did have the means, Mladić then ordered Potpara to fire. ${ }^{13418}$ On the same day, Potpara reported to Mladić that his unit had returned fire towards "a museum, the hospital, and Crni Vrh" with $82 \mathrm{~mm}$ shells. ${ }^{13419}$ Mladić then ordered Potpara to fire at the railway station, "[a]nd scatter them around." 13420 According to a regular combat report issued by the SRK Command on 29 May 1992, SRK units had used 70 shells of $60 \mathrm{~mm}$ calibre, 140 shells of $82 \mathrm{~mm}$ calibre, 272 shells of $105 \mathrm{~mm}$ calibre, and 131 shells of $120 \mathrm{~mm}$ calibre, as well as various other types of projectiles and bullets on that day. $^{13421}$

4036. On 30 May 1992, there were intense negotiation efforts to end the shelling of Sarajevo. ${ }^{13422}$ Wilson met with Mladić in order to convey the Secretary General's appeal to bring an end to it. ${ }^{13423}$ During the meeting, Mladić stated that the Maršal Tito Barracks were under constant fire by Bosnian Muslim forces, maintained that he was simply defending the Serb people, and insisted that the JNA personnel be allowed to leave the barracks. ${ }^{13424}$ On the same day, around noon, Morillon met with Slobodan Milošević, to convey the Secretary General's appeal to bring an end to shelling

\footnotetext{
13413 In the same intercepted conversation, Mladić informed Potpara and Baroš that the conversation was being intercepted by Bosnian Muslims. See D207 (Intercept of conversation between Ratko Mladić and Potpara, 29 May 1992), pp. 2-3.

13414 D207 (Intercept of conversation between Ratko Mladić and Potpara, 29 May 1992), pp. 4-8.

13415 P1522 (Intercept of conversation between Ratko Mladić and Potpara, 29 May 1992), p. 1.

13416 P1522 (Intercept of conversation between Ratko Mladić and Potpara, 29 May 1992), p. 1.

13417 P1522 (Intercept of conversation between Ratko Mladić and Potpara, 29 May 1992), p. 2. The Chamber notes that it is clear from the context of the conversation that an error in the transcription of the conversation led to a number of statements by Mladić being attributed to Potpara and vice versa.

13418 P1522 (Intercept of conversation between Ratko Mladić and Potpara, 29 May 1992), p. 2.

13419 P1511 (Intercept of conversation between Ratko Mladić and Potpara, 29 May 1992); [REDACTED].

13420 P1511 (Intercept of conversation between Ratko Mladić and Potpara, 29 May 1992). As noted earlier, Dušan Škrba, who was with the SRK during the war, testified that this was not a precise order. See para. 4000.

13421 P1514 (SRK combat report, 29 May 1992), p. 2; [REDACTED]. The Chamber notes that while the translation of P1514 indicates that this combat report is dated 20 May 1992, the original version refers to 29 May 1992.

13422 P1029 (Witness statement of John Wilson dated 4 November 2008), para. 81.

13423 P1029 (Witness statement of John Wilson dated 4 November 2008), para. 77; John Wilson, T. 3924-3926 (21 June 2010); P1043 (UNPROFOR report re meeting with Ratko Mladić, 30 May 1992); P5050 (UN Press Release, 30 May 1992).

13424 During the meeting, Mladić also requested that a meeting between the Accused and Izetbegović be arranged, as numerous Serb attempts to organise one had failed. The attendees then discussed the issue of the hand-over of JNA weapons to the $\mathrm{BiH}$ forces in return for de-blocking the barracks but Mladic stated that this deal was made with the JNA and not with him. See P1043 (UNPROFOR report re meeting with Ratko Mladić, 30 May 1992), paras. 2-4.
} 
in Sarajevo and ask Milošević to exercise his influence over Mladić; during the meeting, Milošević stated that he disagreed with Mladić's actions and that he had been trying to contact the Accused to see if the Accused could use his influence to stop the "bloody, criminal" bombardment. ${ }^{13425}$

4037. Then, at around 2:30 p.m., Morillon met with the Accused and Koljević. ${ }^{13426}$ During the meeting, the Accused told Morillon that he would be able to convince Mladić to agree to a ceasefire. ${ }^{13427}$ The Accused also stated that the "Serb forces" were inexperienced and self-organised and therefore tended to over-react to attacks by the Green Berets; the Accused stated further that sometimes the Serbs were being blamed for attacks for which they were not responsible. ${ }^{13428}$ It was agreed at the meeting that the Accused would be responsible for seeing Mladić in person in order to stop the bombardment and implement a cease-fire starting "Monday at $1800 \mathrm{hrs".}{ }^{13429}$ The Accused did not manage to see Mladić but reached him by phone and the latter indicated that the bombardment would stop. ${ }^{13430}$ On 30 May 1992, the SRK reported that its units had fired 20 shells of $120 \mathrm{~mm}$ calibre and 15 shells of $122 \mathrm{~mm}$ calibre that day. ${ }^{13431}$

4038. On 3 June 1992, discussions began between UNPROFOR representatives, the Bosnian Muslim leadership and the Bosnian Serb leadership, including the Accused, on the question of the opening and control of Sarajevo airport. ${ }^{13432}$ On 5 June 1992, in a letter to José Cutileiro, the Accused asserted that despite the good will shown by the Bosnian Serb leadership in expressing their readiness to open Sarajevo airport, the Bosnian Muslims had threatened the lives of JNA personnel and their families who were present in the Maršal Tito Barracks and during the night, Bosnian Muslim forces had shelled residential areas of Sarajevo inhabited by Serbs. ${ }^{13433}$

4039. During the night of 5 June 1992, JNA personnel and their families, who had hitherto been blockaded inside the Maršal Tito Barracks, were finally evacuated to Bosnian Serb positions; the

\footnotetext{
13425 P1035 (UNPROFOR report re meeting with Slobodan Milošević, 30 May 1992), paras. 1-3; P5050 (UN Press Release, 30 May 1992).

13426 P1029 (Witness statement of John Wilson dated 4 November 2008), para. 80; P1036 (UNPROFOR report re meeting with Radovan Karadžić and Nikola Koljević, 30 May 1992).

13427 P1029 (Witness statement of John Wilson dated 4 November 2008), para. 80; P1036 (UNPROFOR report re meeting with Radovan Karadžić and Nikola Koljević, 30 May 1992), paras. 7-8, 11.

13428 P1029 (Witness statement of John Wilson dated 4 November 2008), para. 80; P1036 (UNPROFOR report re meeting with Radovan Karadžić and Nikola Koljević, 30 May 1992), paras. 3, 5.

13429 P1029 (Witness statement of John Wilson dated 4 November 2008), para. 80; P1036 (UNPROFOR report re meeting with Radovan Karadžić and Nikola Koljević, 30 May 1992), para.11.

13430 P1029 (Witness statement of John Wilson dated 4 November 2008), para. 80; P1036 (UNPROFOR report re meeting with Radovan Karadžić and Nikola Koljević, 30 May 1992), para. 15.

13431 P1513 (SRK combat report, 30 May 1992), p. 3.

13432 P1039 (UNPROFOR report re airport meetings in Sarajevo, 3 June 1992), e-court p. 1.

13433 D333 (Radovan Karadžić's letter to Jose Cutileiro, 5 June 1992). The Accused repeated this allegation to the UN Secretary General a few days later. See D1509 (Radovan Karadžić's letter to UN Secretary General, 10 June 1992), p. 1.
} 
JNA's heavy weaponry and ammunition was, however, left behind. ${ }^{13434}$ Immediately after the completion of the evacuation of the JNA personnel, a number of Bosnian Muslims entered the barracks in order to take hold of the weaponry left behind by the JNA. ${ }^{13435}$ Soon after, the barracks became the target of heavy artillery fire by the SRK. ${ }^{13436}$ The intensity of the shelling forced the Bosnian Muslims who had entered the barracks to flee. ${ }^{13437}$

4040. At the same time, various neighbourhoods of Sarajevo were shelled, including the old city centre, Vratnik, Baščaršija, Logavina, Bistrik, Sedrenik, Vasin Han, and Hrid-Jarčedoli. ${ }^{13438}$

4041. On or about 6 June 1992, Bosnian Muslim forces initiated a military operation to "de-block" Sarajevo from the north and the west. ${ }^{13439}$ On 6 June, Mladić issued Directive 1, informing the commands of the various VRS corps that Bosnian Muslim forces had launched a military operation in order to "de-block Sarajevo from the north and west". ${ }^{13440}$ With Directive 1, Mladic defined the immediate task of the VRS as using offensive action with a view to improving the operational and tactical position of the VRS in the wider area of Sarajevo and in northern and western Bosnia. ${ }^{13441}$ More particularly, Mladić ordered the securing and mopping up of Serb-inhabited parts of Sarajevo, including Zlatište, Dobrinja, Butmir, Sokolović Kolonija, Mojmilo, and the area around the airport, as well as the opening of the Sarajevo-Trnovo-Kalinovik communication line. ${ }^{13442}$ On the basis of

13434 D577 (SRK combat report, 6 June 1992), p. 1; D333 (Radovan Karadžić's letter to Jose Cutileiro, 5 June 1992); P929 (Sky News report re Sarajevo, with transcript); P930 (Sky News report re Sarajevo, with transcript); Aernout van Lynden, T. 2405-2407 (19 May 2010), T. 2610-11 (21 May 2010); P926 (Witness statement of Aernout van Lynden dated 26 February 2010), paras. 52-58; D1509 (Radovan Karadžić's letter to UN Secretary General, 10 June 1992), p. 1; P2760 (SerBiH MUP performance report, April to June 1992), p. 3; D2667 (Witness statement of Ratomir Maksimović dated 14 December 2012), para. 66; Dragomir Milošević, T. 32558 32559 (23 January 2013); Milosav Gagović, T. 31865, 31872 (15 January 2013); D2738 (Witness statement of Milosav Gagović dated 7 March 2014), paras. 29-30.

13435 P930 (Sky News report re Sarajevo, with transcript); Aernout van Lynden, T. 2599 (21 May 2010); P973 (Robert Donia's expert report entitled "Bosnian Serb Leadership and the Siege of Sarajevo, 1990-1995", January 2010), pp. 85-86; D2665 (Witness statement of Izo Golić dated 15 December 2012), para. 29; P6358 (Excerpts from transcript of $114^{\text {th }}$ session of BiH Presidency, 9 June 1992), pp. 3.

13436 P930 (Sky News report re Sarajevo, with transcript). The initial shells failed to hit the barracks, instead falling along the railway behind it. Subsequently, however, the shells hit the barracks, which then went up in flames. See P930 (Sky News report re Sarajevo, with transcript); P926 (Witness statement of Aernout van Lynden dated 26 February 2010), paras. 55, 58; Aernout van Lynden, T. 2405-2406 (19 May 2010).

13437 Aernout van Lynden, T. 2599 (21 May 2010). The Chamber is not satisfied that the Bosnian Muslims who entered the barracks were civilians.

13438 P930 (Sky News report re Sarajevo, with transcript); P926 (Witness statement of Aernout van Lynden dated 26 February 2010), para. 55-57; P1991 (Stari Grad Police Station war diary), pp. 77-80.

13439 D577 (SRK combat report, 6 June 1992), p. 1; D232 (Directive 1, 6 June 1992), p. 1; P998 (SRK instructions, 7 June 1992), p. 1; P1498 (Order of $2^{\text {nd }}$ Motorised Brigade, 8 June 1992), p. 1; P1478 (Ratko Mladić's notebook, 27 May-31 July 1992), p. 128; P1038 (John Wilson’s report to Australian Government, 15 June 1992), para. 1.

13440 D232 (Directive 1, 6 June 1992), p. 1.

13441 D232 (Directive 1, 6 June 1992), p. 1.

13442 D232 (Directive 1, 6 June 1992), pp. 2-4. During his testimony, Krajišnik, while casting doubt on the existence of a direct connection between the fifth Strategic Goal and Directive 1, stated that at the time, Serb areas around Sarajevo were disjointed and that the objective of Directive 1 was to link these areas together and to secure the roads that connected them. Krajišnik added that Directive 1 contained military instructions about the airport 
Directive 1, Šipčić ordered SRK units to, inter alia, continue to maintain the blockade of Sarajevo by barricading and reinforcing its positions, and to cut through the city by moving troops along the Nedžarići-Stup-Rajlovac axis. ${ }^{13443}$ The Muslim offensive lasted several days and despite some early successes, was in the end neutralised by Serb infantry and artillery. ${ }^{13444}$

4042. On 6 June 1992, Zilha Granilo lived on Bjelave street, in the Bjelave neighbourhood of Sarajevo. ${ }^{13445}$ She recalled that the whole city seemed to be shelled that day. ${ }^{13446}$ Between 4 and 5 p.m., she stopped to pick a few cherries in her yard on her way to the shelter in the basement of a nearby bank building. ${ }^{13447}$ A shell fell into her neighbour's shed, 10 or 15 metres away from where she was standing. ${ }^{13448}$ The impact threw her two or three metres away; shrapnel was lodged into her leg and back, and created a small puncture in her neck. ${ }^{13449}$ A neighbour drove her to the hospital where she received treatment. ${ }^{13450}$

4043. On the morning of 6 June 1992, Fatima Palavra, a 14 year old, and four members of her family, were sitting in the living room of her uncle's apartment, located on the top floor of a building known as "Papagajka", on Hamdije Kreševljakovića street, in the Skenderija neighbourhood of Sarajevo. ${ }^{13451}$ While looking at Miljacka River from the living room, Palavra suddenly saw a bright shining light, followed by an explosion which rendered her unconscious. ${ }^{13452}$ Palavra regained consciousness in the children's surgical ward of the Koševo Hospital and saw that her sister was also there. ${ }^{13453}$ Palavra had suffered shrapnel injuries to her right leg and temple and

because the security of the airport had been compromised and the flow of humanitarian aid into the area interrupted. See Momčilo Krajišnik, T. 43798-43801 (19 November 2013). However, for reasons that have been given in paragraph 2902, the Chamber does not accept Krajišnik's evidence on Directive 1 and its underlying basis.

13443 P998 (SRK instructions, 7 June 1992), pp. 1-2.

13444 P1478 (Ratko Mladić's notebook, 27 May-31 July 1992), p. 128; D195 (SRK Report, 8 June 1992), pp. 1-2; D611 (SRK Order, 11 June 1992), p. 1; D427 (Minutes of $23^{\text {rd }}$ session of Government of SerBiH, 8 June 1992), p. 1.

13445 P499 (Witness statement of Zilha Granilo dated 30 October 2008), para. 2; D123 (Map of Sarajevo marked by Fatima Zaimović); D731 (Map of Sarajevo marked by Alen Gičević).

13446 P499 (Witness statement of Zilha Granilo dated 30 October 2008), para. 3.

13447 P499 (Witness statement of Zilha Granilo dated 30 October 2008), paras. 3-4.

13448 P499 (Witness statement of Zilha Granilo dated 30 October 2008), para. 4.

13449 P499 (Witness statement of Zilha Granilo dated 30 October 2008), paras. 4-5.

13450 P499 (Witness statement of Zilha Granilo dated 30 October 2008), paras. 5-6. Granilo testified that her daughter Jasna Granilo, a member of the police at the time of the incident, was killed as a result of the shelling of Breka street, near the local commune office. See P499 (Witness statement of Zilha Granilo dated 30 October 2008), paras. 1, 6-7. Considering that Jasna Granilo was a member of the police and that the exact circumstances of her death in another shelling incident on that day are unknown, the Chamber is unable to conclude beyond reasonable doubt that she was not taking direct part in the hostilities when she was killed.

13451 P497 (Witness statement of Fatima Palavra dated 30 October 2008), paras. 2-3, 5.

13452 P497 (Witness statement of Fatima Palavra dated 30 October 2008), paras. 6-7.

13453 P497 (Witness statement of Fatima Palavra dated 30 October 2008), paras. 7-8. 
had undergone surgery. ${ }^{13454}$ At the hospital, Palavra's uncle told her that the explosion had killed his partner and had injured the rest of the family members. ${ }^{13455}$ As a result of the explosion, Palavra's uncle's apartment was completely destroyed. ${ }^{13456}$

4044. On the same day, Ziba Avdić, and her husband, Muhamed, were at an apartment in a residential complex situated on Koševo Hill. ${ }^{13457}$ There were no barracks, police stations or factories in the vicinity of this complex. ${ }^{13458}$ Avdić recalled that the shelling of her neighbourhood that day began at 8 a.m. and forced her and her husband to take shelter in the basement. ${ }^{13459}$ The shelling abated for a period; as it got dark, however, Avdić saw that illumination flares were fired from the direction of Poljine. ${ }^{13460}$ After this, two shells landed in the parking area in front of her building, setting a number of parked vehicles on fire. ${ }^{13461}$ Muhamed and four other individuals from the building went outside to extinguish the fires. ${ }^{13462}$ At 9:30 p.m., as these individuals were standing near the entrance of the building, a shell landed in front of them, killing some of them instantly and injuring Muhamed and some others. ${ }^{13463}$ Muhamed and the other injured individuals were taken by the TO to a hospital; however, Muhamed died from his injuries later that evening. ${ }^{13464}$

4045. On 7 June 1992, forces of the Vogošća Brigade shelled the UNIS towers and as a result, one of the towers was set ablaze. ${ }^{13465}$ Filming the UNIS towers from the State Hospital which was about 200 metres away, Van Lynden did not see any outgoing fire coming from the towers. ${ }^{13466} \mathrm{He}$ also did not see any Bosnian Muslim forces there during a visit to the towers with his film crew a few days earlier. ${ }^{13467}$ What he could see and film with his crew on 7 June 1992 was machine gun fire directed at the lower part of the UNIS towers, coming from the south, which were positions

\footnotetext{
13454 P497 (Witness statement of Fatima Palavra dated 30 October 2008), paras. 7-8.

13455 P497 (Witness statement of Fatima Palavra dated 30 October 2008), para. 10.

13456 P497 (Witness statement of Fatima Palavra dated 30 October 2008), para. 11.

13457 P500 (Witness statement of Ziba Avdić dated 31 October 2008), paras. 1, 3.

13458 P500 (Witness statement of Ziba Avdić dated 31 October 2008), para. 1.

13459 P500 (Witness statement of Ziba Avdić dated 31 October 2008), para. 3.

13460 P500 (Witness statement of Ziba Avdić dated 31 October 2008), para. 4.

13461 P500 (Witness statement of Ziba Avdić dated 31 October 2008), para. 5.

13462 P500 (Witness statement of Ziba Avdić dated 31 October 2008), para. 6.

13463 P500 (Witness statement of Ziba Avdić dated 31 October 2008), para. 7.

13464 P500 (Witness statement of Ziba Avdić dated 31 October 2008), paras. 7-8.

13465 Aernout van Lynden, T. 2408-2410 (19 May 2010); P931 (Sky News report re Sarajevo, with transcript); P926 (Witness statement of Aernout van Lynden dated 26 February 2010), para. 59; P1154 (Witness statement of KDZ088 dated 27-29 April 2010) (under seal), p. 82.

13466 Aernout van Lynden, T. 2410 (19 May 2010); P926 (Witness statement of Aernout van Lynden dated 26 February 2010), para. 59.

13467 Aernout van Lynden, T. 2474 (19 May 2010).
} 
held by the SRK. ${ }^{13468}$ Van Lynden also filmed the Parliament building being hit by artillery fire. $^{13469}$

4046. On 8 June 1992, Fahra Mujanović and her four year old son were in the yard of their family house, situated in Barica which was a purely residential area very close to Sarajevo and in the vicinity of Žuč Hill. ${ }^{13470}$ Suddenly, an $82 \mathrm{~mm}$ mortar shell landed in the yard and exploded, lodging shrapnel in Mujanović's legs, left arm, back, chest, and head and throwing her across the yard, onto the ground. ${ }^{13471}$ The shelling continued for another hour or so, preventing Mujanović's neighbours from coming to her aid; during this time, Mujanović who was lying on the ground, lost and regained her consciousness several times. ${ }^{13472}$ Eventually, a female neighbour approached her and after changing her blood-soaked clothes, asked a young man to take Mujanović to Koševo Hospital in his car. ${ }^{13473}$ During the ride from Barica to Koševo Hospital, the car was hit by sniper fire several times. ${ }^{13474}$ At the hospital, Mujanović saw approximately 150 other people who had been admitted due to "terrible and shocking injuries" resulting from the shelling in and around Sarajevo on that day. ${ }^{13475}$ She underwent surgery to remove the shrapnel from her body. ${ }^{13476}$

4047. The heavy shelling of the city continued well into the night of 8 June $1992 .{ }^{13477}$

4048. [REDACTED] around 1,000 to 1,500 members of the SRK bombarded Sarajevo during this operation $^{13478}$ and that the SRK used grenade launchers, 82 to $130 \mathrm{~mm}$ mortars, anti-aircraft guns, tanks, and multiple rocket launchers. ${ }^{13479}$ Due to the nature of the weaponry and Sarajevo's dense

\footnotetext{
13468 P931 (Sky News report re Sarajevo, with transcript); P926 (Witness statement of Aernout van Lynden dated 26 February 2010), para. 59.

13469 P931 (Sky News report re Sarajevo, with transcript).

13470 P1865 (Witness statement of Fahra Mujanović dated 5 November 2008), paras. 4, 8; Fahra Mujanović, T. 8770 (1 November 2010). In April 1992, Barica had been regularly subjected to shelling from Serb-held positions in Žuč, Krivoglavci, Kromolj, Vogošća, Poljine, and Tihovići. See P1865 (Witness statement of Fahra Mujanović dated 5 November 2008), paras. 4-6, 8, 12; Fahra Mujanović, T. 8751-8752, 8761 (1 November 2010).

13471 P1865 (Witness statement of Fahra Mujanović dated 5 November 2008), paras. 8-9; Fahra Mujanović, T. 87548756, 8765, 8767, 8770 (1 November 2010).

13472 P1865 (Witness statement of Fahra Mujanović dated 5 November 2008), para. 9.

13473 P1865 (Witness statement of Fahra Mujanović dated 5 November 2008), para. 10.

13474 P1865 (Witness statement of Fahra Mujanović dated 5 November 2008), para. 10.

13475 P1865 (Witness statement of Fahra Mujanović dated 5 November 2008), para. 12; Fahra Mujanović, T. 8756 (1 November 2010).

13476 P1865 (Witness statement of Fahra Mujanović dated 5 November 2008), para. 11. Despite her surgery, many pieces of shrapnel were not removed and, as a result, Mujanović suffers from constant pain and recurring headaches. See P1865 (Witness statement of Fahra Mujanović dated 5 November 2008), para. 11; Fahra Mujanović, T. 8756-8757 (1 November 2010).

13477 P931 (Sky News report re Sarajevo, with transcript); P932 (Sky News report re Sarajevo, with transcript).

13478 [REDACTED].

13479 [REDACTED]; P1029 (Witness statement of John Wilson dated 4 November 2008), para. 48.
} 
urban environment, "[e]verything was being hit," including housing and accommodation buildings. $^{13480}$

4049. As a result of the shelling of Sarajevo between the night of 5 June and 8 June 1992, a number of civilians, including women, children and the elderly, were killed or seriously wounded. ${ }^{13481}$ This shelling also caused extensive damage to civilian buildings and infrastructure, including the Music Academy, and a number of houses in Baščaršija. ${ }^{13482}$

4050. On the morning of 9 June 1992, during a session of the BiH Presidency in which Izetbegović was also present, Halilović referred to the continuous shelling of the city by Serb Forces during the previous days and stated that the Serb side had 150 artillery pieces in its possession whereas the Bosnian Muslims had only ten pieces, of which only five functioned properly. ${ }^{13483}$

4051. On the same day, after a detailed discussion during a meeting of the Bosnian Serb Presidency, attended by the Accused, Plavšić, Krajišnik, Koljević, Đerić and Mladić, it was concluded that "the heavy artillery fire on the city [should] be halted". ${ }^{13484}$ The next day, the Accused conveyed to the Secretary General that he was ready to bring to a halt "any artillery fire around Sarajevo". ${ }^{13485}$

4052. As noted earlier, the Accused challenges the vagueness of Scheduled Incidents G.1 and G.2. However, the Chamber considers that Scheduled Incidents G.1 and G.2 are geographically limited to the city of Sarajevo and temporally limited to a "24 hour bombardment" on 28 to 29 May 1992 and to a bombardment which began on or about 6 June 1992, respectively. Throughout the trial,

13480 [REDACTED].

13481 Based on all the evidence before it, the Chamber was able to conclude beyond reasonable doubt that the following individuals were civilians and that they were not participating in hostilities when they were killed: Osman Kapetanović, Abdulah Ferhatović, Muhamed Avdić, Hasija Neimarlija (67 years old), and Emir Arnautović (17 years old). Similarly, the Chamber was able to conclude beyond reasonable doubt that the following individuals were civilians and that they were not participating in hostilities when they were wounded: Fatima Palavra (14 years old), Ivan Onešćuk, Fahra Mujanović, Zilha Granilo, Jasmina Sanđaktarević (13 years old), Nezira Mušić (80 years old), Vasvija Hođić (62 years old), Ismeta Bećirević, Fatima Hajdini (15 years old), Hikmet Maletović, Senada Meletović, Simo Petrović (64 years old), and Sabina Bećirević (10 years old). See P1991 (Stari Grad Police Station war diary), pp. 77, 79-80, 82, 86; P497 (Witness statement of Fatima Palavra dated 30 October 2008), paras. 5-8, 10; P500 (Witness statement of Ziba Avdić dated 31 October 2008), paras. 3, 6-7; P499 (Witness statement of Zilha Granilo dated 30 October 2008), paras. 1-3; P1865 (Witness statement of Fahra Mujanović dated 5 November 2008), para. 12; P819 (Extracts from Fatima Zaimović's diary), p. 3. On 7 June 1992, while at the morgue of Koševo Hospital, Van Lynden saw an eight or nine year old boy on a stretcher who had died from shrapnel wounds. See P926 (Witness statement of Aernout van Lynden dated 26 February 2010), para. 59; Aernout van Lynden, T. 2408-2409 (19 May 2010); P931 (Sky News report re Sarajevo, with transcript).

13482 P1991 (Stari Grad Police Station war diary), pp. 79-80, 82.

13483 P6358 (Excerpts from transcript of $114^{\text {th }}$ session of BiH Presidency, 9 June 1992), pp. 1, 3.

13484 D428 (Minutes of $4^{\text {th }}$ expanded meeting of Bosnian Serb Presidency, 9 June 1992). 
the Prosecution limited the evidence it presented on these two Scheduled Incidents to those specific geographical and temporal frames. The Chamber therefore rejects the Accused's argument in this regard.

4053. The Chamber also recalls the Accused's contention that any potential shelling of Velešići on 28 and 29 May and the combat operations by the SRK around 6 June 1992 were in any event lawful either because the areas that were targeted had a heavy concentration of $\mathrm{ABiH}$ military hardware and personnel or because there were ongoing Bosnian Muslim military attacks against the SRK. The Chamber first notes that any military action launched in response to military attacks by the opposing party should be directed at military targets and proportionate. In this regard, the Chamber notes that Scheduled Incidents G.1 and G.2 occurred in a purely urban setting where large concentrations of civilians and civilian buildings were closely intermingled with a number of military targets. In this context, particular military prudence was warranted. Instead, as described above, the massive shellings conducted by the SRK on 28 and 29 May and around 6 June 1992 indiscriminately targeted entire civilian neighbourhoods of Sarajevo, without differentiating between civilian and military targets. [REDACTED]. Further, contrary to the Accused's reliance on the intercepted conversation of 25 May 1992 between Mladić and the unidentified JNA officer to show that the shelling of Velešići was not indiscriminate, it is clear that in this conversation, Mladić declares that "Sarajevo will shake" with more shells fired than in the entire war so far, while at the same time acknowledging the urban context of Sarajevo and the presence of civilians there. Three days later, large parts of urban Sarajevo were indeed hit with heavy artillery fire. Further, even if initially launched in response to Bosnian Muslim attacks originating from specific locations in Sarajevo, the Chamber finds, relying in particular on the evidence of Wilson, that the shellings by the SRK on 28 and 29 May and around 6 June 1992 were carried out in a disproportionate manner. Accordingly, the Chamber rejects the Accused's assertions in this regard.

4054. Based on the foregoing, the Chamber finds that from 28 May to 29 May 1992, in response to attacks by the $\mathrm{ABiH}$, the SRK subjected the entire city of Sarajevo, including the largely Bosnian Muslim populated areas of Pofalići, Vratnik and Velešići to indiscriminate and disproportionate shelling and that as a result of this shelling, a number of civilians were injured, and various civilian buildings and structures, including the State Hospital, were extensively damaged or destroyed.

4055. The Chamber also finds that between the night of 5 June and 8 June 1992, in response to an $\mathrm{ABiH}$ attack, the SRK subjected the entire city of Sarajevo, including the old city centre, Vratnik, Baščaršija, Logavina, Bistrik, Sedrenik, Vasin Han, and Hrid-Jarčedoli to indiscriminate and

13485 D1509 (Radovan Karadžić's letter to UN Secretary General, 10 June 1992), p. 1. 
disproportionate shelling, as a result of which a number of civilians were killed or injured, and various civilian buildings and structures, including the Music Academy, were extensively damaged or destroyed.

\section{(B) Southwestern suburbs: Dobrinja and Alipašino Polje}

(1) Confrontation lines and artillery in the area

4056. The Chamber has already discussed above, in the section on Scheduled Sniping Incidents in Sarajevo's southwestern suburbs, the exact location and the lay out of those suburbs, as well as the confrontation lines in the area during the conflict. ${ }^{13486}$ For that reason, the Chamber will not repeat the same evidence here but recalls that the confrontation line ran along the road between the apartment blocks referred to as Dobrinja 3 and Dobrinja $4 .{ }^{13487}$ Dobrinja 1, Dobrinja 4 and the Airport Settlement were under Serb control, ${ }^{13488}$ as the Ilidža Brigade's zone of responsibility ran from Dobrinja, across the Airport Settlement, Nedžarići, along the Dobrinja River, Pijačna street, and the railroad to Miljacka River. ${ }^{13489}$ The $1^{\text {st }}$ Battalion of the Ilidža Brigade was positioned in Nedžarići, ${ }^{13490}$ while the $5^{\text {th }}$ Battalion was positioned to the southeast of the $1^{\text {st }}$ Battalion, near the airport. $^{13491}$ To the west of Dobrinja the confrontation line ran through the former "Energoinvest" complex in Ilidža and Stup. ${ }^{13492}$ The $1^{\text {st }}$ Sarajevo Mechanised Brigade of the SRK had its positions to the southeast of Dobrinja in the direction of Lukavica, and to the northeast, in Grbavica. ${ }^{13493}$

\footnotetext{
13486 See Section IV.B.1.b.iii.B: Southwestern suburbs: Dobrinja and Alipašino Polje.

13487 Slavica Livnjak, P493 (Transcript from Prosecutor v. D. Milošević), T. 873; Sanija Dževlan, P2291 (Transcript from Prosecutor v. Galić), 3515-3516, 3528-3529; P2294 (Map of Sarajevo marked by Sanija Dževlan).

13488 P1866 (Witness statement of Youssef Hajir dated 25 February 2010), para. 20; Youssef Hajir, T. 8806 (1 November 2010); D2633 (Witness statement of Milorad Šehovac dated 8 December 2012), paras. 11, 15; D2648 (Map of Sarajevo marked by Milorad Šehovac); D2649 (Map of Sarajevo marked by Milorad Šehovac). See Adjudicated Fact 91.

13489 D2562 (Witness statement of Vladimir Radojčić dated 8 December 2012), para. 14; D2589 (Map of Sarajevo marked by Vladimir Radojčić); Stanislav Galić, T. 37162-37168 (15 April 2013); D3381 (Map of Sarajevo marked by Stanislav Galić); D3382 (Map of Sarajevo).

13490 D2479 (Witness statement of Mile Sladoje dated 25 November 2012) para. 7; D2480 (Map of Sarajevo marked by Mile Sladoje); D2562 (Witness statement of Vladimir Radojčić dated 8 December 2012), para. 14; Mile Sladoje, T. 30562-30563 (28 November 2012).

13491 D2553 (Witness statement of Svetozar Guzina dated 3 December 2012), para. 34; D2555 (Map of Sarajevo marked by Svetozar Guzina).

13492 Milomir Šoja, P1633 (Transcript from Prosecutor v. D. Milošević), T. 5122-5124, 5126, 5144-5145; Milomir Šoja, T. 7215-7217, 7219 (30 September 2010) (stating that Osjek and Ilidža were under the control of the SRK, but most of Stup, including the cold storage facility, was occupied by the ABiH); D676 (Map of Sarajevo marked by Milomir Šoja). See also David Harland, T. 2018 (6 May 2010); P820 (Witness statement of David Harland dated 4 September 2009), para. 30; P842 (VRS map of Sarajevo, 31 August 1995); D2562 (Witness statement of Vladimir Radojčić dated 8 December 2012), paras. 6, 14, 16-17; D2589 (Map of Sarajevo marked by Vladimir Radojčić).

13493 D2412 (Witness statement of Savo Simić dated 4 November 2012) para. 12; D2413 (Map of Sarajevo marked by Savo Simić); D2341 (Witness statement of Dušan Škrba dated 14 October 2012) para. 8; D2342 (Map of Sarajevo marked by Dušan Škrba).
} 
4057. The $1^{\text {st }}$ Battalion of the Ilidža Brigade had in its arsenal 82 and $120 \mathrm{~mm}$ mortars. ${ }^{13494}$ The mortar batteries of the battalion were located around the Faculty of Theology. ${ }^{13495}$ The $1^{\text {st }}$ Mechanised Sarajevo Brigade's mixed artillery division was equipped with a collection of armaments, including three $120 \mathrm{~mm}$ D30 howitzer batteries, two $122 \mathrm{~mm}$ self-propelled Gvozdika howitzer batteries, one $128 \mathrm{~mm}$ Plamen multiple rocket-launcher (VBR) battery, and two $120 \mathrm{~mm}$ mortar batteries. ${ }^{13496}$

4058. Alipašino Polje was on the $\mathrm{ABiH}$ side of the confrontation line, which separated it from the Serb-held Nedžarići. ${ }^{13497}$ As discussed earlier, ${ }^{13498}$ the ABiH units opposing the Ilidža Brigade belonged to the $101^{\text {st }}$ Brigade of the $1^{\text {st }}$ Corps of the $\mathrm{ABiH}$, positioned in Alipašino Polje and Vojničko Polje, and the $102^{\text {nd }}$ Brigade of the $1^{\text {st }}$ Corps of the $\mathrm{ABiH}$ located in Stup. ${ }^{13499}$ The $5^{\text {th }}$ Motorised Brigade of the $1^{\text {st }}$ Corps, later known as the $155^{\text {th }}$ Brigade, was located in Dobrinja. ${ }^{13500}$ Beyond the Sarajevo airport, to the southwest of the Ilidža Brigade's positions, the $104^{\text {th }}$ Brigade of the $1^{\text {st }}$ Corps of the $\mathrm{ABiH}$ occupied the areas of Butmir and Sokolović Kolonija. ${ }^{13501}$ According to

13494 D2479 (Witness statement of Mile Sladoje dated 25 November 2012), para. 6; Vladimir Radojčić, T. 31236 (11 December 2012).

13495 D2479 (Witness statement of Mile Sladoje dated 25 November 2012), para. 6; D2481 (Map of Sarajevo marked by Mile Sladoje). There were some inconsistencies in the evidence of the witnesses called by the Accused as to whether the brigade had mortars around the Institute for the Blind. See D2479 (Witness statement of Mile Sladoje dated 25 November 2012), para. 27; D2562 (Witness statement of Vladimir Radojčić dated 8 December 2012), paras. 1-2; 111. See also P1058 (ABiH map).

13496 D2412 (Witness statement of Savo Simić dated 4 November 2012), para. 9. The command post of the mixed artillery division and a battery of the division rocket launchers were located in the Uzdojnica village sector. The brigade's $120 \mathrm{~mm}$ mortar batteries were based in Prljevo Brdo and Uzdojnica sectors, and the howitzer artillery pieces were located in Tilava, Petrovići, and Klek villages. D2412 (Witness statement of Savo Simić dated 4 November 2012), para. 12; D2413 (Map of Sarajevo marked by Savo Simić).

13497 See Adjudicated Facts 83, 84; Richard Mole, T. 5842-5845 (17 August 2010); P1430 (Map of Sarajevo marked by Richard Mole); D537 (Map of Sarajevo marked by Richard Mole); D2479 (Witness statement of Mile Sladoje dated 25 November 2012), para. 7; D2480 (Map of Sarajevo marked by Mile Sladoje); Mile Sladoje, T. 30563-30564 (28 November 2012); P6009 (Map of Sarajevo marked by Mile Sladoje); D2553 (Witness statement of Svetozar Guzina dated 3 December 2012), paras. 34-35; D2555 (Map of Sarajevo marked by Svetozar Guzina); D2556 (Map of Sarajevo marked by Svetozar Guzina). The portion of Nedžarići east of Ante Babića street and south of Đure Jakšića street (now renamed Adija Mulaobegovića) was under the ABiH control, however. See Adjudicated Fact 85.

13498 See paras. 3787-3788, 3792 .

13499 D2479 (Witness statement of Mile Sladoje dated 25 November 2012), para. 7; D2480 (Map of Sarajevo marked by Mile Sladoje); Mile Sladoje, T. 30569 (28 November 2012); P6011 (Photograph of Sarajevo marked by Mile Sladoje); P6012 (Photograph of Sarajevo); D1384 (Map of ABiH positions in Sarajevo marked by Asim Džambasović). See Adjudicated Fact 83. Džambasović testified that a number of ABiH units changed their names throughout the war but in $90 \%$ of the cases did not change their disposition. The $6^{\text {th }}$ Mountain Brigade and the $105^{\text {th }}$ Brigade merged to form the $101^{\text {st }}$ Brigade while the $3^{\text {rd }}$ Motorised Brigade became the $102^{\text {nd }}$ Brigade. Asim Džambasović, T. 15194, 15200, 15202 (22 June 2011).

13500 Asim Džambasović, T. 15194, 15220 (22 June 2011); D1379 (Map of ABiH positions in Sarajevo marked by Asim Džambasović); Mirza Sabljica, T. 7835-7836 (13 October 2010); Dragomir Milošević, T. 32523 (23 January 2013).

13501 Asim Džambasović, T. 15229-15230 (22 June 2011); D1378 (Map of ABiH positions in Sarajevo marked by Asim Džambasović). 
Sladoje, all $\mathrm{ABiH}$ positions were in civilian areas where people lived in apartment buildings and there was not a single "entirely civilian settlement" that did not have a military target in it. ${ }^{13502}$

4059. Rose testified that by February 1994, Dobrinja had been "utterly destroyed" as the Bosnian Serbs had it completely surrounded and would fire directly into Dobrinja, thus forcing the residents to live in their basements. ${ }^{13503}$

\section{(2) Dobrinja, 1 June 1993 (Scheduled Incident G.4)}

4060. The Indictment alleges that on 1 June 1993, two shells were fired upon a crowd of approximately 200 persons who were watching and participating in a football game in a parking lot bordered on three sides by residential apartment blocks and on the fourth side by the Lukavica road in residential settlement, Dobrinja IIIB. ${ }^{13504}$ The Indictment further alleges that the origin of fire was VRS/SRK-held territory approximately to the east-southeast and that over 10 people were killed and approximately 100 were wounded. ${ }^{13505}$ In its Final Brief, the Prosecution alleges that two 81 or $82 \mathrm{~mm}$ calibre mortar shells exploded in this incident, killing 10 and wounding approximately 100 people. ${ }^{13506}$ The Accused argues that the incident did not actually take place at the site where it is alleged to have occurred. ${ }^{13507} \mathrm{He}$ also argues, that the shells did not come from SRK-held territory and further, regardless of their origin, that the location of the incident was a legitimate military target. ${ }^{13508}$

4061. On 1 June 1993, a sunny day, a football tournament was organised in Dobrinja IIIB. ${ }^{13509}$ The football pitch was set up in the corner of a parking lot, which was bounded by six-storey apartment blocks on three sides and on the fourth side, which faced the north, by Mojmilo Hill; it was not visible from any point on the SRK side of the confrontation line. ${ }^{13510}$ Around 200 spectators, including women and children, gathered to watch the teams play. ${ }^{13511}$ There were ABiH

\footnotetext{
13502 D2479 (Witness statement of Mile Sladoje dated 25 November 2012), para. 11; Mile Sladoje, T. 30570-30571 (28 November 2012). According to Sladoje and another officer Svetozar Guzina, the following were military targets located in the territory controlled by the $\mathrm{ABiH}$ : Standard, Zora, Bitumenka, Oslobođenje, student dormitories, the Geodesic Institute, the Vodovod building in Majdan street, Prvomajska street, Geteova street, Radio Television building, and Fatima Gunić School. D2479 (Witness statement of Mile Sladoje dated 25 November 2012), paras. 18, 25; D2482 (Map of Sarajevo marked by Mile Sladoje); Mile Sladoje, T. 30571 30573 (28 November 2012); D2553 (Witness statement of Svetozar Guzina dated 3 December 2012), para. 46.

13503 P1638 (Witness statement of Michael Rose dated 26 March 2009), para. 36.

13504 Indictment, Scheduled Incident G.4.

13505 Indictment, Scheduled Incident G.4.

13506 Prosecution Final Brief, Appendix C, para. 50.

13507 Defence Final Brief, paras. 2003-2005.

13508 Defence Final Brief, paras. 2007-2011

13509 See Adjudicated Facts 245, 246.

13510 See Adjudicated Facts 247, 268.

13511 See Adjudicated Fact 248.
} 
soldiers present at the parking lot, who were off-duty, unarmed, and not engaging in any military activity. ${ }^{13512}$ Ismet Fazlic was the referee of the second match. ${ }^{13513}$ About 10 to 20 minutes into that game, shortly after 10 a.m., the first shell landed among the players in the centre of the pitch. ${ }^{13514}$ Fazlić was hit by shrapnel and sustained serious injuries in both legs and other parts of his body. ${ }^{13515}$ There were eleven young men on the ground, eight of whom died on the spot. ${ }^{13516}$ Omer Hadžiabdić who was 15 years old at the time, was watching the match from the overturned cars when the first shell struck the football pitch. ${ }^{13517}$ He was wounded by shrapnel in his leg. ${ }^{13518}$ Nedim Gavranović, who was 12 years old at the time, was standing behind one of the goals when he heard the first explosion and felt a very strong blow. ${ }^{13519}$ He sustained an entry and exit wound in his right lower leg caused by shrapnel. ${ }^{13520}$ A second shell landed at almost the same spot within seconds of the first shell. ${ }^{13521}$ It fell in front of a young man and tore his leg off. ${ }^{13522}$ There were many wounded people on the ground. ${ }^{13523}$

4062. On the same day, the $5^{\text {th }}$ Motorised Brigade of the $\mathrm{ABiH}$ sent its daily report to the Command of the $1^{\text {st }}$ Corps of the $\mathrm{ABiH}$ in which it reported that two $82 \mathrm{~mm}$ mortar shells had fallen in its zone of responsibility on a parking lot where football was being played. ${ }^{13524}$ It was reported that six soldiers and five civilians lost their lives, whilst 55 soldiers and 32 civilians were wounded. ${ }^{13525}$ Similarly, the National Security Service of the RS MUP's Ilidža War Department reported on the incident on the same day, noting that 10 to 20 persons were killed and $50 \mathrm{ABiH}$ soldiers were wounded when 2 shells fell during a football match on a parking lot in Dobrinja III. $^{13526}$

4063. The next day, the BiH Presidency ordered the ABiH Supreme Command Staff to investigate this incident. ${ }^{13527}$ The Supreme Command reported back to the Presidency on 6 June that the

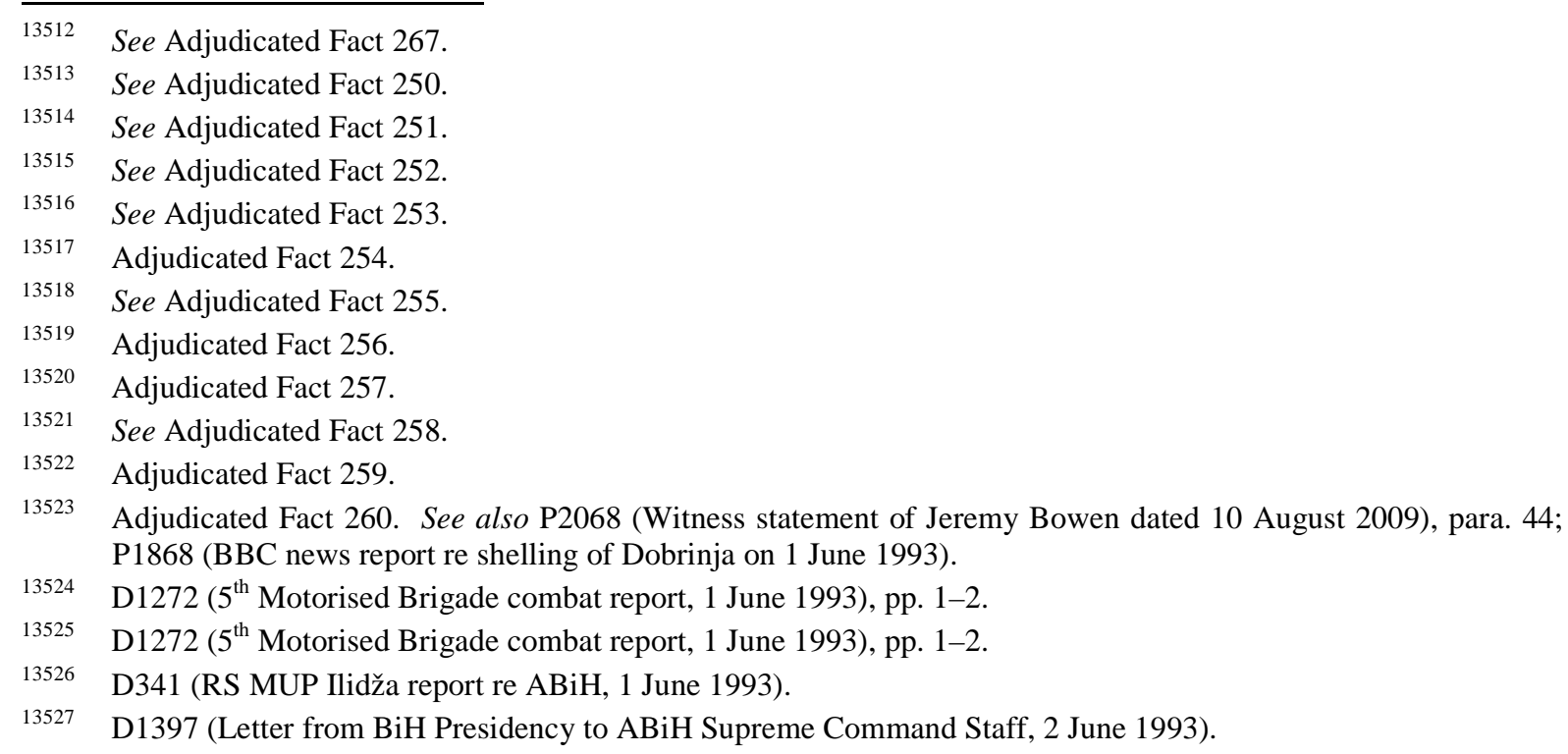


football tournament was organised by a group of $\mathrm{ABiH}$ soldiers from the $5^{\text {th }}$ Motorised Brigade, that the game was attended by a large number of civilians, children, and $\mathrm{ABiH}$ soldiers, and that 12 people (seven of whom were soldiers) were killed, while 101 people (51 of them combatants) were injured; the report also noted that the shells were fired from the direction of Lukavica. ${ }^{13528}$ Former ABiH General Asim Džambasović ${ }^{13529}$ testified that he knew about this incident and that the superior command criticised assembling of that type, as it was not reasonable at that time to organise sports activities. ${ }^{13530}$

4064. The UNPROFOR soldiers went to the site to perform shell crater analysis as soon as they heard of the incident. ${ }^{13531}$ Captain Houdet conducted the analysis ${ }^{13532}$ and found that the splinter pattern in what he referred to as "Crater 1" indicated that the projectile was at least an $81 \mathrm{~mm}$ mortar shell and that it had a bearing to the origin of fire of 143 degrees (2500 mils). ${ }^{13533}$ He found that the splinter pattern in what he termed "Crater 2" indicated a mortar shell of the same calibre, but with a bearing to the origin of fire of 138 degrees (2420 mils). ${ }^{13534}$ Houdet concluded that due to the crater fragments and the buildings surrounding the football pitch, the projectiles could only have been mortar shells with the only possible origin of fire in the direction of the SRK-held territory, to the south, southeast. ${ }^{13535}$ Houdet observed that there was no fuse furrow in either of the craters due to macadam surface, which is why the precise angle of descent and the range of the shells could not be determined. ${ }^{13536}$ Nevertheless, he concluded that if fired at the minimum range, the $81 \mathrm{~mm}$ shell that created Crater 1 would have originated approximately 300 metres south of Lukavica Barracks. ${ }^{13537}$ UNPROFOR commander, Lieutenant-General Morillon, faxed the

\footnotetext{
13528 D1398 (Report of ABiH Supreme Command Staff, 6 June 1993). See also Adjudicated Fact 261. The second ABiH Supreme Command report of 9 June 1993 clarified that Fazlić was one of the eight organisers of the game, and that the Supreme Command was taking steps to document the responsibility of the organisers of the event. D1399 (Report of ABiH Supreme Command Staff, 9 June 1993).

13529 From November 1992 Džambasović served as Chief of Staff of the $1^{\text {st }}$ Corps of the ABiH. In August 1993 he transferred to the General Staff of the ABiH. See Asim Džambasović, T. 15188 (22 June 2011).

13530 Asim Džambasović, T. 15288 (23 June 2011).

13531 P6060 (Record of interview with KDZ185), e-court p. 20; KDZ185, T. 4213 (28 June 2010).

13532 KDZ185, T. 4214 (28 June 2010) (private session); T. 4268 (29 June 2010) (private session); P1053 (UN Report re shelling of Dobrinja on 1 June 1993), e-court pp. 9-11.

13533 P1053 (UN Report re shelling of Dobrinja on 1 June 1993), e-court p. 9.

13534 P1053 (UN Report re shelling of Dobrinja on 1 June 1993), e-court p. 9.

13535 P1053 (UN Report re shelling of Dobrinja on 1 June 1993), e-court pp. 9-11; KDZ185, T. 4215 (28 June 2010 ); T. 4268-4269 (29 June 2010) (private session); P6060 (Record of interview with KDZ185), e-court p. 20.

13536 P1053 (UN Report re shelling of Dobrinja on 1 June 1993), e-court p. 9.

13537 Houdet calculated that for a shell to clear the buildings surrounding the incident site it would have to have a minimum angle of descent of 40.5 degrees. Noting that the minimum angle of descent for 81 and $120 \mathrm{~mm}$ mortars is around 45 degrees, he calculated that at that angle the minimum range for an $81 \mathrm{~mm}$ mortar would have been 1,120 metres. P1053 (UN Report re shelling of Dobrinja on 1 June 1993), e-court pp. 2, 9-11.
} 
Accused just after midnight on 2 June 1993 informing him that "the shelling this morning in $\mathrm{D}$ [obrinja] caused the deaths of a number of innocent women and children". ${ }^{13538}$

4065. The UN Commission on War Crimes investigated the incident some 27 days later and published a preliminary report on 7 July 1993 prepared by two Canadian officers. ${ }^{13539}$ Having analysed Houdet's report, they concluded that the incident occurred at approximately 10:20 a.m., that two mortar shells of minimum $81 \mathrm{~mm}$ calibre fell at the scene of the incident, and that they were fired from the direction of SRK-held Lukavica. ${ }^{13540}$

4066. The officers also interviewed two men wounded in the incident, namely Zlatan Steković and Eldin Zornić. ${ }^{13541}$ Steković told them that the day of the incident was clear and sunny, with good visibility. ${ }^{13542} \mathrm{He}$ also told them that despite the frontline being only 100 to 150 metres away, the site could not be seen from the Serb positions due to the height of the apartment buildings around the parking lot where the game was played. ${ }^{13543}$ Zornic told the officers that he was in the ABiH and knew that there were no military targets within one kilometre of the scene. ${ }^{13544} \mathrm{He}$ corroborated Steković's remarks that there was no direct line of sight from the Serb positions to the scene of the incident. ${ }^{13545}$ Zornic also speculated that the shells came either from Lukavica or Nedžarići. ${ }^{13546}$

4067. The officers were given a casualty list by the Bosnian State Commission for War Crimes from which they concluded that 13 persons were killed in this incident, while 133 were injured. ${ }^{13547}$ During their investigations, the two officers used a copy of the UNPROFOR map of Dobrinja, which indicated that the $\mathrm{ABiH}$ had mortars approximately 500 metres from the site of the incident,

\footnotetext{
13538 P5059 (Fax from UNPROFOR to Radovan Karadžić, 2 June 1993). The SRK Liaison Officer to UNPROFOR, Milenko Inđić, testified that he did not receive any protests in relation to this incident. D2774 (Witness statement of Milenko Inđić dated 19 January 2013), para. 130.

13539 P1053 (UN Report re shelling of Dobrinja on 1 June 1993), e-court pp. 1-2, 9-11. See also KDZ185, T. 4268 (private session), T. 4285-4286 (29 June 2010).

13540 P1053 (UN Report re shelling of Dobrinja on 1 June 1993), e-court pp. 7, 9.

13541 P1053 (UN Report re shelling of Dobrinja on 1 June 1993), e-court pp. 2-3, 12-35. Another eye-witness to the incident also provided information that the first shell fell near the perimeter, whilst the second fell almost in the centre of the football pitch. He further told them that at first he thought they were $82 \mathrm{~mm}$ mortar shells but he later found parts of a $60 \mathrm{~mm}$ mortar shell at the site. P1053 (UN Report re shelling of Dobrinja on 1 June 1993), e-court pp. 6-7, 57-59.

13542 P1053 (UN Report re shelling of Dobrinja on 1 June 1993), e-court pp. 3-4.

13543 He also opined that the cheering of the substantial crowd could have been heard at the confrontation lines and that there were no military targets in the area. See P1053 (UN Report re shelling of Dobrinja on 1 June 1993), ecourt pp. 3-4.

13544 P1053 (UN Report re shelling of Dobrinja on 1 June 1993), e-court p. 4.

13545 P1053 (UN Report re shelling of Dobrinja on 1 June 1993), e-court p. 4.

13546 P1053 (UN Report re shelling of Dobrinja on 1 June 1993), e-court p. 4.

13547 P1053 (UN Report re shelling of Dobrinja on 1 June 1993), e-court p. 4.
} 
outside of the Dobrinja Hospital. ${ }^{13548}$ However, when inspecting the area the two officers did not see the mortars in question. ${ }^{13549}$ When asked about these mortars, KDZ185 testified that $\mathrm{ABiH}$ mortar positions continually moved and had no fixed location. ${ }^{13550}$

4068. The CSB Sarajevo could not conduct the forensic investigation of this incident during the war due to "incessant attack operations" but conducted it two years later, ${ }^{13551}$ in November 1995 upon request of the Prosecution. ${ }^{13552}$ Ballistic experts Sabljica, Međedović, and Kučanin, amongst others, conducted the investigation in the presence of an eyewitness to the event, Refik Sokolar, and a Prosecution investigator. ${ }^{13553}$ According to Sabljica and Međedović's ballistics report, two shells fell on the parking lot, one landing on the parking lot tarmac surface and the other on the soil surface next to the parking lot. ${ }^{13554}$ Based on the size of the marks on the tarmac surface, it was determined that the shell that landed on the tarmac was an $82 \mathrm{~mm}$ shell. ${ }^{13555}$ Using the central axis analysis, the investigators concluded that the shell came from a southeasterly direction (the azimuth being 110 degrees from the north). ${ }^{13556}$ The point of impact of the second shell was not examined

\footnotetext{
13548 P1053 (UN Report re shelling of Dobrinja on 1 June 1993), e-court pp. 6, 52, 55-56.

13549 P1053 (UN Report re shelling of Dobrinja on 1 June 1993), e-court p. 6.

13550 KDZ185, T. 4283 (29 June 2010). See also John Hamill, P1994 (Transcript from Prosecutor v. Galić), T. 6168; John Hamill, T. 9697-9698 (13 December 2010).

13551 P1699 (BiH MUP Report re shelling of Dobrinja on 1 June 1993), p. 3. The Chamber notes that the report of the UN Commission on War Crimes states that CSB Sarajevo did not conduct an investigation because it considered the UNPROFOR's investigation sufficient. See P1053 (UN Report re shelling of Dobrinja on 1 June 1993), ecourt p. 5; KDZ185, T. 4282 (29 June 2010).

13552 P1699 (BiH MUP Report re shelling of Dobrinja on 1 June 1993), p. 3; Mirza Sabljica, T. 7726 (12 October 2010). Sabljica conceded that having an investigation two or three years later posed certain problems but explained that there was no mechanical intervention with the crater that they examined at the time of the on-site investigation; it was only later on that a red substance was poured into it, as was done all over Sarajevo (making the so-called "roses of death"), which made the crater more visible but also removed some of the traces. Mirza Sabljica, T. 7842, 7873-7874, 7881, 7883 (13 October 2010).

13553 P1699 (BiH MUP Report re shelling of Dobrinja on 1 June 1993), p. 3. See also Mirza Sabljica, T. 7836 (13 October 2010).

13554 P1699 (BiH MUP Report re shelling of Dobrinja on 1 June 1993), p. 3. See also Mirza Sabljica, T. 7849-7854, 7867 (13 October 2010); D757 (Photograph re shelling of Dobrinja on 1 June 1993 marked by Mirza Sabljica); D761 (Photograph re shelling of Dobrinja on 1 June 1993 marked by Mirza Sabljica).

13555 P1699 (BiH MUP Report re shelling of Dobrinja on 1 June 1993), p. 5. See also P1695 (Witness statement of Mirza Sabljica dated 11 February 2010), pp. 18-19. Sabljica confirmed on cross-examination that he was not informed that an eye-witness had reported finding fragments of $60 \mathrm{~mm}$ calibre shell on the scene. See Mirza Sabljica, T. 7867-7870 (13 October 2010); P1053 (UN Report re shelling of Dobrinja on 1 June 1993), e-court p. 57.

13556 P1699 (BiH MUP Report re shelling of Dobrinja on 1 June 1993), pp. 4-5. See also Mirza Sabljica, T. 7724 7731 (12 October 2010), T. 7840-7844 (13 October 2010); P1730 (Photograph re shelling of Dobrinja on 1 June 1993 marked by Mirza Sabljica); P1731 (Photograph re shelling of Dobrinja on 1 June 1993 marked by Mirza Sabljica); P1732 (Photograph re shelling of Dobrinja on 1 June 1993 marked by Mirza Sabljica); P1733 (Photograph re shelling of Dobrinja on 1 June 1993 marked by Mirza Sabljica); D753 (Photograph re shelling of Dobrinja on 1 June 1993 marked by Mirza Sabljica); P1695 (Witness statement of Mirza Sabljica dated 11 February 2010), pp. 18-19.
} 
due to the changed appearance of the soil surface. ${ }^{13557}$ Sabljica confirmed that the report purposefully did not state which of the two armies fired the shell. ${ }^{13558}$

4069. Sabljica further testified that the separation line was some 300 to 400 metres away from the incident site, noting that Dobrinja was divided between the two sides. ${ }^{13559}$ He also explained that Mojmilo Hill, which is north and northwest of the incident site, was under $\mathrm{ABiH}$ control, while the "Aerodromsko naselje" in Dobrinja, which is west and southwest of the incident, was under SRK control. ${ }^{13560}$ Finally, he explained that the minimum distance from which an $82 \mathrm{~mm}$ mortar shell can be fired is 600 to 650 metres, but that it gives "best results" at 4,200 metres. ${ }^{13561}$ During crossexamination he conceded that with a zero charge an $82 \mathrm{~mm}$ calibre mortar has a range of 80 metres. $^{13562}$

4070. Higgs visited the incident site accompanied by the Prosecution and "examined the two craters in question", ${ }^{13563}$ which were filled in with a red substance thus making a detailed crater analysis impossible. ${ }^{13564}$ However, he also noted that "enough of the crater is still present to draw some conclusion," namely the minimum angle of descent necessary to clear the surrounding buildings. ${ }^{13565}$ Having examined the two craters, Higgs agreed with the findings made by Houdet. ${ }^{13566}$ He noted that eye-witnesses said they heard the sound of a weapon firing and that the confrontation line was some 200 metres away from the incident site. ${ }^{13567}$ In his view, this meant

\footnotetext{
13557 P1699 (BiH MUP Report re shelling of Dobrinja on 1 June 1993), p. 5. See also P1695 (Witness statement of Mirza Sabljica dated 11 February 2010), p. 19.

13558 Mirza Sabljica, T. 7878 (13 October 2010).

13559 Mirza Sabljica, T. 7858-7865 (13 October 2010); D759 (Map of Sarajevo marked by Mirza Sabljica); D760 (Map of Sarajevo marked by Mirza Sabljica).

13560 Mirza Sabljica, T. 7858-7860, 7867 (13 October 2010); D757 (Photograph re shelling of Dobrinja on 1 June 1993 marked by Mirza Sabljica); D758 (Map of Sarajevo marked by Mirza Sabljica); D761 (Photograph re shelling of Dobrinja on 1 June 1993 marked by Mirza Sabljica).

13561 Mirza Sabljica, T. 7866-7867 (13 October 2010).

13562 Mirza Sabljica, T. 7869-7872 (13 October 2010); D762 (Excerpt from JNA manual).

13563 Richard Higgs, T. 6012 (19 August 2010) (testifying that both rounds fell in the area of the improvised football pitch made of tarmac).

13564 Richard Higgs, T. 6005-6006 (19 August 2010); P1437 (Richard Higgs's Consolidated Report on Sarajevo Shelling Incidents, 13 March 2009), p. 7. Sabljica agreed with the Accused that Higgs' reference to two craters was unusual, because only one shell landed on the tarmac according to his recollection. He opined that the craters examined by Higgs may be related to other incidents. See Mirza Sabljica, T. 7881-7883 (13 October 2010).

13565 Richard Higgs, T. 6006-6007 (19 August 2010); P1437 (Richard Higgs's Consolidated Report on Sarajevo Shelling Incidents, 13 March 2009), p. 7.

13566 P1437 (Richard Higgs's Consolidated Report on Sarajevo Shelling Incidents, 13 March 2009), p. 7.

13567 P1437 (Richard Higgs's Consolidated Report on Sarajevo Shelling Incidents, 13 March 2009), p. 7. Sabljica testified that in order for a witness to hear a shell being fired, they would have to be some 50 to 100 metres away from the origin of fire. However, he explained that information about witnesses hearing the firing was usually not taken into account by his team because it was a subjective opinion that should be taken with a grain of salt. See Mirza Sabljica, T. 7855-7858, 7872-7873 (13 October 2010).
} 
that the mortar was not far away and was firing on low charge to reduce the time of flight and increase accuracy. ${ }^{13568}$

4071. Higgs was also of the view that the purpose of those firing the mortar was to "harass" those present at the incident site because more than two shells would have been fired if the intention was to neutralise a certain target or the nearby water plant. ${ }^{13569}$ He thought that, rather than being an accident, this was a deliberate attack as the frontline was not far and the football match was not carried out covertly. ${ }^{13570}$ Higgs commented that given the closeness of the two rounds it was probable that the same mortar battery fired both rounds and agreed with Houdet's conclusion that the mortar rounds must have been fired from the Serb side of the confrontation lines. ${ }^{13571}$ Based on the statements of witnesses who heard the mortar fire, he came to the conclusion that the mortar battery may well have been situated in an area hidden from observation in the area of Lukavica Barracks to the southeast of Dobrinja. ${ }^{13572}$

4072. Hogan, accompanied by Fazlić, recorded the GPS co-ordinates and filmed the locations where the shells impacted in this incident. ${ }^{13573}$ On cross-examination, he testified that he was aware of-and disagreed with - the conclusion by the CSB Sarajevo team in 1995 that the second shell fell in soft soil next to the parking lot. ${ }^{13574}$

4073. John Hamill, an officer in the Artillery Corps of the Irish Army who served as an UNMO in Sarajevo from May until June $1993^{13575}$ visited the site at the request of the Prosecution on 18 September 2001. ${ }^{13576}$ He stated that the craters were old but largely preserved, despite having been filled with red substance. ${ }^{13577}$ He found that the easternmost crater, which he termed "Crater

\footnotetext{
13568 P1437 (Richard Higgs's Consolidated Report on Sarajevo Shelling Incidents, 13 March 2009), p. 7.

13569 P1437 (Richard Higgs's Consolidated Report on Sarajevo Shelling Incidents, 13 March 2009), pp. 4, 7-8 (also observing that the water plant was too far away from the point of impact).

13570 P1437 (Richard Higgs's Consolidated Report on Sarajevo Shelling Incidents, 13 March 2009), p. 8.

13571 P1437 (Richard Higgs's Consolidated Report on Sarajevo Shelling Incidents, 13 March 2009), p. 8.

13572 P1437 (Richard Higgs's Consolidated Report on Sarajevo Shelling Incidents, 13 March 2009), p. 8.

13573 D1005 (Video footage re shelling of Dobrinja on 1 June 1993); Barry Hogan, T. 11205-11206, 11277-11278 (3 February 2011); P2190 (GPS locations for shelling and sniping incidents in Sarajevo); P2191 (Map of Sarajevo with scheduled sniping and shelling incidents).

13574 Barry Hogan, T. 11278-11281 (3 February 2011).

13575 During his time in Sarajevo, Hamill worked exclusively in the SRK-held territory to the north and south of the city P1995 (Supplemental information sheet for John Hamill, 18 September 2001), e-court p. 2; John Hamill, T. 9673-9674 (13 December 2010); John Hamill, P1994 (Transcript from Prosecutor v. Galić). T. 6111, 6114.

13576 Hamill was accompanied by Hogan and Fazlić. See P1995 (Supplemental information sheet for John Hamill, 18September 2001), e-court p. 2; John Hamill, P1994 (Transcript from Prosecutor v. Galić). T. 6114; John Hamill, T. 9689 (13 December 2010).

13577 Hamill thought that the red substance preserved the crater and enabled him to do a reasonable job of determining what type of weapon was used and from where. See John Hamill, T. 9689-9693 (13 December 2010); P1995 (Supplemental information sheet for John Hamill, 18 September 2001), e-court p. 2; John Hamill, P1994 (Transcript from Prosecutor v. Galić). T. 6114, 6116-6117.
} 
1", was better preserved than the other crater, which he termed "Crater 2", but that the red substance now prevented the precise determination of whether the craters were made by gun or mortar. ${ }^{13578}$ With Crater 1, Hamill observed traces characteristic of a gun or howitzer shell, but also noted that this did not mean that the crater was not caused by a mortar. ${ }^{13579}$ He determined that the projectile that created Crater 1, be it a gun or a mortar shell, was fired from an approximate direction of 2,200 mils, plus or minus 150 mils, that is generally east-southeast of the impact site. ${ }^{13580}$ With respect to Crater 2, Hamill was only able to conclude, based on its shape that it appeared to have come from the same direction as Crater $1 .{ }^{13581}$ In relation to the exact origin of fire, Hamill observed that both rounds originated from a bearing that runs through the area of Toplik, where SRK forces had a battery of $122 \mathrm{~mm}$ guns which were monitored by the UNMOs at the time. ${ }^{13582}$ He believed that the SRK also operated $82 \mathrm{~mm}$ mortars in Toplik. ${ }^{13583}$

4074. Hamill testified that the minimum angle of descent necessary for the projectiles to have cleared the surrounding buildings and landed on the site indicates that they could have been fired from either a mortar or a howitzer. ${ }^{13584} \mathrm{He}$ further commented that the UN team came up with two different bearings, indicating that the weapons may have been fired at some distance from each other. ${ }^{13585}$ He equated this to his own findings, noting that he had a specific bearing for Crater 1 and a more indeterminate bearing for Crater 2 but that both rounds generally came from the same direction. ${ }^{13586}$ When asked to compare the bearing determined by the CSB Sarajevo team to the bearings determined by him and by the UNPROFOR investigators, Hamill stated that the difference

13578 P1995 (Supplemental information sheet for John Hamill, 18 September 2001), e-court p. 2. Hamill could not explain why the CSB Sarajevo investigation team in 1995 only found and examined one crater in the asphalt. He was adamant that he saw two craters in the tarmac in 2001 , one more obvious than the other. See John Hamill, T. 9708 (13 December 2010).

13579 Hamill also stated that if Crater 1 was created by a mortar, a medium mortar was probably used. P1995 (Supplemental information sheet for John Hamill, 18 September 2001), e-court p. 2; John Hamill, P1994 (Transcript from Prosecutor v. Galić). T. 6114-6115, 6172; John Hamill, T. 9693-9694, 9713, 9722 (13 December 2010).

13580 P1995 (Supplemental information sheet for John Hamill, 18 September 2001), e-court p. 2; John Hamill, P1994 (Transcript from Prosecutor v. Galić). T. 6114-6117; John Hamill, T. 9693 (13 December 2010).

13581 P1995 (Supplemental information sheet for John Hamill, 18 September 2001), e-court p. 2.

13582 P1995 (Supplemental information sheet for John Hamill, 18 September 2001), e-court p. 2; John Hamill, P1994 (Transcript from Prosecutor v. Galić). T. 6115, 6123, 6172-6173.

13583 P1995 (Supplemental information sheet for John Hamill, 18 September 2001), e-court p. 2.

13584 John Hamill, T. 9699-9700 (13 December 2010). Hamill also testified that the higher the angle of descent, the shorter the range from which the projectile was fired. When shown a photograph of the more preserved crater taken by the CSB Sarajevo investigators two years after the incident, he confirmed that its pattern was consistent with a higher angle of descent - assuming the damage was caused by a shell. However, if caused by a "mortar bomb" then the pattern did not indicate a high angle of descent. See John Hamill, T. 9700-9701, 9707-9710, 9716-9719 (13 December 2010).

13585 John Hamill, T. 9699-9700 (13 December 2010). When asked by the Chamber to comment on the firing capabilities of mortars, Hamill testified that it is possible to fire two rounds from the same tube within seconds of each other and then to have these rounds come down quite a distance away from each other. See John Hamill, T. 9702 (13 December 2010).

13586 John Hamill, T. 9700 (13 December 2010). 
was not as large as it seemed as all of these bearings would fall in the same area, that is "somewhere in east of southeast". 13587

4075. Zorica Subotic visited the site of the incident in September 2010. ${ }^{13588}$ She challenged the alleged location of the incident, stating that the match was not played on the parking lot but rather "on a five-a-side pitch located near the parking lot", ${ }^{13589}$ leading her to conclude that Fazlić falsely indicated the location of the football pitch to investigators. ${ }^{13590}$ She argued that, in addition, instances of imprecision within Houdet's report cast doubt on the accuracy of his analysis and even on whether he actually visited the scene of the incident at all. ${ }^{13591}$ Further, a number of witnesses who provided locations of the craters to investigators were contradicted by the CSB Sarajevo report which referred to only one crater on the asphalt surface of the parking lot. ${ }^{13592}$ Subotic argued that the second crater "was probably made by hand after 21 November 1995" and thus was not in existence when Houdet examined the scene. ${ }^{13593}$

13587 John Hamill, T. 9715-9716 (13 December 2010).

13588 D3542 (Zorica Subotić's expert report entitled "Mortar Operations in Sarajevo Area in 1992-1995”, 15 August 2012), p. 63.

13589 D3542 (Zorica Subotić's expert report entitled "Mortar Operations in Sarajevo Area in 1992-1995", 15 August 2012), pp. 55-62, 72-73, 156. Subotić based this claim on eyewitness statements and the Fédération Internationale de Football Association ("FIFA") rules of the game. According to her, the game roughly corresponded to FIFA's "five-a-side football game". Given that there was a sports pitch beside the parking lot, which met the requirements specified by FIFA, she thought that the game, and thus the incident, took place on that pitch. While acknowledging that video footage recorded immediately after the incident shows two goal posts on the parking lot, next to a large blood stain, she proceeded to discount this location as the scene of the incident because the size of the goal post did not correspond to the FIFA rules. See D3542 (Zorica Subotić's expert report entitled "Mortar Operations in Sarajevo Area in 1992-1995", 15 August 2012), pp. 55-62, 72-73, 156; Zorica Subotić, T. 38249-38251 (14 May 2013); D1005 (Video footage re shelling of Dobrinja on 1 June 1993).

13590 D3542 (Zorica Subotić's expert report entitled "Mortar Operations in Sarajevo Area in 1992-1995”, 15 August 2012), pp. 60-61, 157. She also claimed that the fact that the parking lot was presented by Fazlić and others as the scene of the incident could be construed "as a bid to cover up evidence". D3542 (Zorica Subotić's expert report entitled "Mortar Operations in Sarajevo Area in 1992-1995", 15 August 2012), pp. 65, 73.

13591 D3542 (Zorica Subotić's expert report entitled "Mortar Operations in Sarajevo Area in 1992-1995", 15 August 2012), pp. 61-62, 68, 156-157. These imprecisions were: (i) his reference to "macadam surface" which is a road laid with crushed stone and which was not present at the incident site and (ii) Houdet's grid references for the craters which indicated a location 200 metres away from the parking lot. D3542 (Zorica Subotić's expert report entitled "Mortar Operations in Sarajevo Area in 1992-1995", 15 August 2012), pp. 61-62; Mirza Sabljica, T. 7878-7879, 7883 (13 October 2010). With respect to (i), while Higgs testified that the English term macadam is equivalent to tarmac or asphalt, Subotić refused to accept that this was a case of linguistic confusion and maintained that macadam surface had multiple definitions. See Zorica Subotić, T. 38410-38412 (16 May 2013); Richard Higgs, T. 6013 (19 August 2010). As for (ii), she admitted on cross-examination that she did not know what map system Houdet used. See Zorica Subotić, T. 38409-38411 (16 May 2013).

13592 D3542 (Zorica Subotić's expert report entitled "Mortar Operations in Sarajevo Area in 1992-1995", 15 August 2012), pp. 62-63, 67. These witnesses, namely Ismet Fazlić, Nedim Gavranović, and Omer Hadžiabdić, testified in the Galić case.

${ }^{13593}$ D3542 (Zorica Subotić's expert report entitled "Mortar Operations in Sarajevo Area in 1992-1995", 15 August 2012), p. 64. 
4076. While Subotić agreed on the direction of fire for this incident, namely that it came from the southeast of the incident site, she thought that it originated from ABiH-held territory. ${ }^{13594}$ She confirmed Houdet's findings as to Crater 1, but found that the azimuth of Crater 2 was 108 degrees and claimed that it was not related to this particular incident and was also not the crater identified by Houdet as Crater 2. ${ }^{13595}$ In addition, she noted that Houdet based his conclusions about the distance from which the shells were fired on the minimum angle of descent whereas he should have used the maximum angle. ${ }^{13596}$ Furthermore, according to her, all the trajectories up to the maximum angle of descent could have struck the scene of the incident, meaning that the $82 \mathrm{~mm}$ mortar shell could have been fired from any range between 80 and 4,850 metres. ${ }^{13597}$ She also argued that investigators from CSB Sarajevo incorrectly determined the azimuth of the crater that they examined, as they arrived at 110 degrees compared to the 143 degrees calculated by Houdet and accepted by her. ${ }^{13598}$ Finally, Subotić concluded on the basis of the likely angle of descent of the shell, it being greater than 65 degrees, ${ }^{13599}$ and the distance to SRK positions, ${ }^{13600}$ that the shell that produced the crater in the parking lot during this incident was not fired from SRK positions. ${ }^{13601}$ On cross-examination she conceded that for the shell to have been fired from ABiH

\footnotetext{
13594 Zorica Subotić, T. 38407 (16 May 2013); D3542 (Zorica Subotić's expert report entitled "Mortar Operations in Sarajevo Area in 1992-1995”, 15 August 2012), pp. 67-74, 156-157.

13595 D3542 (Zorica Subotić's expert report entitled "Mortar Operations in Sarajevo Area in 1992-1995”, 15 August 2012), pp. 67-68.

13596 D3542 (Zorica Subotić's expert report entitled "Mortar Operations in Sarajevo Area in 1992-1995", 15 August 2012), pp. 68-69. During cross-examination, the Prosecution agreed with Subotic that Captain Houdet should have looked at the maximum angle of descent and determined the minimum firing distance on that basis. See Zorica Subotić, T. 38412 (16 May 2013).

13597 D3542 (Zorica Subotić's expert report entitled "Mortar Operations in Sarajevo Area in 1992-1995”, 15 August 2012), pp. 68-69.

13598 D3542 (Zorica Subotić's expert report entitled "Mortar Operations in Sarajevo Area in 1992-1995", 15 August 2012), p. 72. Subotic argued that, according to a photograph of the CSB Sarajevo investigation, the investigators positioned their magnetic compass incorrectly while determining the azimuth of the crater. See Zorica Subotić, T 38251-38252 (14 May 2013), T. 38417-38420 (16 May 2013). The Chamber notes that the photograph in question is not clear enough to show where exactly the compass was placed by the CSB Sarajevo team. In addition, even if that was the case, it does not mean that the measurements were taken at the exact moment at which the photograph was taken.
}

13599 Subotic thought it was greater than 65 degrees on the basis of the appearance and the dimensions of the crater. See D3542 (Zorica Subotić's expert report entitled "Mortar Operations in Sarajevo Area in 1992-1995", 15 August 2012), p. 70.

13600 D3542 (Zorica Subotić's expert report entitled "Mortar Operations in Sarajevo Area in 1992-1995", 15 August 2012), p. 57 (stating that the confrontation line was 270 metres away). See also Adjudicated Fact 263 which provides that the distance from the pitch to the confrontation lines in the direction of fire was approximately 300 metres. According to Subotić, the closest SRK position where a mortar could have been positioned was 400 metres to the southeast. At this range, an $82 \mathrm{~mm}$ shell can be fired with either primary, first, or second charge. She excluded the first and second charges because the resulting angle of descent would have been too high. She then argued that given the height of the surrounding buildings, the SRK mortars were likely to be at minimum 425 metres away from the scene, leaving a subsequent angle of descent on primary charge of 58.7 degrees, which was "manifestly smaller" than the angle at which the shell landed. D3542 (Zorica Subotić's expert report entitled "Mortar Operations in Sarajevo Area in 1992-1995", 15 August 2012), pp. 57, 68-71.

13601 D3542 (Zorica Subotić's expert report entitled "Mortar Operations in Sarajevo Area in 1992-1995", 15 August 2012), pp. 68-71. 
held-territory to the southeast, the furthest distance from the incident site that it could have been fired from was 200 metres. ${ }^{13602}$

4077. Noting the different data about the number of casualties, Subotic used the report of the Supreme Command of the $\mathrm{ABiH}$ of 6 June 1993 to point out that 58 out of 114 casualties, or $51.8 \%$, were $\mathrm{ABiH}$ personnel. ${ }^{13603}$ She also argued that the $\mathrm{BiH}$ security organs suspected the incident had been staged. ${ }^{13604}$

4078. Galić testified that on the day of the incident a cease-fire was in place in Sarajevo. ${ }^{13605}$ Commenting on his regular combat report for 1 June 1993, which provides that the SRK did not open fire that day, he stated that SRK forces respected the cease-fire and that had they been active in the area, this would have been stated in the report. ${ }^{13606} \mathrm{He}$ also stated that he neither received an order nor gave one to fire on the area, and that his command received no reports of fire being opened in the area. ${ }^{13607}$ Galić stressed that the incident occurred "perhaps 150 metres in-depth from the confrontation line at the positions of the $[\mathrm{ABiH}]$ " and that close to the parking lot there was an atomic shelter which was used to house soldiers and military material, thus making the area where the mortars landed a justified and legitimate military target. ${ }^{13608}$ In cross-examintion, however, he testified that he did not know if the fire was opened on the SRK position from the incident site on the day of the incident. ${ }^{13609} \mathrm{He}$ also confirmed that under normal circumstances he would not place a mortar on or even near a confrontation line nor would he fire a mortar at a target that was some 150 metres away because for calibres of up to $120 \mathrm{~mm}$, the "safety zone" from which they must fire is at least 200 metres away from the target, while for larger calibres it is 400 metres. ${ }^{13610}$ When

13602 Zorica Subotić, T. 38407 (16 May 2013). The Chamber notes that Hamill testified that the danger radius for a $120 \mathrm{~mm}$ mortar is 500 metres and for an $82 \mathrm{~mm}$ mortar it is 250 metres. John Hamil, T. 9703 (13 December 2010). See also para. 3982.

13603 D3542 (Zorica Subotić's expert report entitled "Mortar Operations in Sarajevo Area in 1992-1995", 15 August 2012), p. 52; D1398 (Report of ABiH Supreme Command Staff, 6 June 1993), e-court p. 2.

13604 Subotic relies here on the two $\mathrm{ABiH}$ reports that state that the military police placed into custody a number of persons who were "suspected in connection with the mentioned shelling". See D3542 (Zorica Subotić's expert report entitled "Mortar Operations in Sarajevo Area in 1992-1995", 15 August 2012), p. 55. These reports make it clear that the $\mathrm{ABiH}$ wanted to find persons responsible for organising the tournament and therefore make no mention of $\mathrm{ABiH}$ soldiers staging this incident. See D1398 (Report of ABiH Supreme Command Staff, 6 June 1993), e-court p. 2; D1399 (Report of ABiH Supreme Command Staff, 9 June 1993), e-court p. 2.

13605 Stanislav Galić, T. 37367-37368 (18 April 2013).

13606 Stanislav Galić, T. 37370, 37373-37380 (18 April 2013); D340 (SRK combat report, 1 June 1993 ); D3414 (Combat report of ABiH Igman Operations Group, 1 June 1993). But see KDZ185, T.4272-4273 (29 June 2010).

13607 Stanislav Galić, T. 37373 (18 April 2013).

13608 Stanislav Galić, T. 37368 (18 April 2013). See also Adjudicated Fact 265 which provides that a nuclear shelter was located approximately 100 metres away from the parking lot behind a block of flats.

13609 Stanislav Galić, T. 37854-37855 (7 May 2013).

13610 Stanislav Galić, T. 37855-37857 (7 May 2013) (explaining that doing so would be possible where there is a large obstacle, such as a high-rise building, that would then prevent fragments from reaching the forces that opened the fire but stated that even this would be too risky). 
asked if he would fire at his own faction located some 150 metres away as part of a conspiracy, he stated that it was possible but risky, and maintained that he would never order the shelling of civilians. ${ }^{13611}$ According to Galić, given the state of affairs in Sarajevo, it was "not normal" to have a football match or similar public gatherings so close to the confrontation lines. ${ }^{13612}$

4079. In terms of the casualties of this incident, the Chamber received evidence that on 1 June 1993 at least 122 people were brought to the Dobrinja Hospital as a result of the incident. ${ }^{13613}$ Due to the number of casualties, both the hospital and the morgue were over-crowded. ${ }^{13614}$ A number of victims were thus transferred to the Koševo Hospital ${ }^{13615}$ and State Hospital, ${ }^{13616}$ and at least three children were taken to the surgery ward of the Children's Department at the Koševo Hospital. ${ }^{13617}$ From the Dobrinja Hospital records it is clear that at least 27 of the victims were under the age of 18 , including 4 children who died as a result of their injuries. ${ }^{13618}$ As noted earlier, ${ }^{13619}$ the $\mathrm{ABiH}$ Supreme Command investigated this incident at the request of the $\mathrm{BiH}$ presidency and concluded that 12 persons died in the incident, including 7 who were $\mathrm{ABiH}$ personnel, and that 101 persons were injured, 51 of which were ABiH soldiers. ${ }^{13620}$ The medical records available to the Chamber also indicate that 12 people died in this incident. ${ }^{13621}$

13611 Stanislav Galić, T. 37857-37860 (7 May 2013).

13612 Stanislav Galić, T. 37372-37373 (18 April 2013).

13613 P1053 (UN Report re shelling of Dobrinja on 1 June 1993), e-court pp. 42-51; P1869 (List of patients from Dobrinja Hospital, 1 June 1993); P1898 (List of patients admitted to Dobrinja Hospital on 1 June 1993); P1896 (Medical record for Omer Hadžiabdić). Youssef Hajir, who was the director of the Dobrinja General Hospital, testified that the hospital received "about 130 to 140 persons injured" and it is evident that it was difficult to keep adequate medical records during this period. See P1866 (Witness statement of Youssef Hajir dated 25 February 2010), paras. 2, 41-43, 63-64, 69-70.

13614 Youssef Hajir, T. 8789-8790 (1 November 2010); P1866 (Witness statement of Youssef Hajir dated 25 February 2010), para. 42.

13615 P1866 (Witness statement of Youssef Hajir dated 25 February 2010), para. 43; Faris Gavrankapetanović, P473 (Transcript from Prosecutor v. Galić), T. 12615-12616, 12632; P461 (Admission records from Koševo Hospital), pp. 60-64; P462 (Surgery records from Koševo Hospital), pp. 2-4. See also P1868 (BBC news report re shelling of Dobrinja on 1 June 1993).

13616 P1243 (Medical reports of victims of shelling in Dobrinja III on 1 June 1993); P1873 (Medical records from Sarajevo State Hospital); P1525 (Witness statement of Bakir Nakaš dated 8 September 2010), para. 83; P1217 (Witness statement of Milan Mandilović dated 24 February 2010), para. 118.

13617 P818 (Extracts from Fatima Zaimović's diary), p.12; Fatima Zaimović, T. 1876-1878 (5 May 2010); P1869 (List of patients from Dobrinja Hospital, 1 June 1993), pp. 7, 11-12.

13618 P1053 (UN Report re shelling of Dobrinja on 1 June 1993), e-court pp. 42-51.

13619 See para. 4063

13620 D1398 (Report of ABiH Supreme Command Staff, 6 June 1993); D1399 (Report of ABiH Supreme Command Staff, 9 June 1993); D1397 (Letter from BiH Presidency to ABiH Supreme Command Staff, 2 June 1993). The Chamber also notes that RS MUP acquired intelligence about the incident and was informed that between 10 and 20 persons were killed, including nine of whom were $\mathrm{ABiH}$ soldiers, and additionaly $50 \mathrm{ABiH}$ members were wounded in the incident. See D341 (RS MUP Ilidža report re ABiH, 1 June 1993).

13621 These individuals were Dragan Osadcij, Asim Zagorica, Adnan Mirvić, Refik Ramić, Alija Gojak, Jusuf Ražić, Atif Bajraktarević, Marko Žižić, Damir Trebo, Adel Selmanović, Mirza Deljković and Munir Šabanović. P1053 (UN Report re shelling of Dobrinja on 1 June 1993), e-court pp. 42, 46, 48, 51; P1869 (List of patients from Dobrinja Hospital, 1 June 1993), pp. 2, 5-6, 12-14; P1872 (Death certificates from Dobrinja Hospital); P1888 (Death certificate for Asim Zagorica); P1889 (Death certificate for Atif Bajraktarević); P463 (Koševo Hospital 
4080. In addition to the evidence and adjudicated facts outlined above, the Chamber has also taken judicial notice of the following adjudicated facts that go to the origin and the nature of fire in this incident: (i) the shells that hit the football pitch were of at least $81-82 \mathrm{~mm}$ calibre and originated from the direction east-southeast, within SRK-held territory; ${ }^{13622}$ (ii) the headquarters of ABiH $5^{\text {th }}$ Motorised Brigade was not in the area of the parking lot in Dobrinja IIIB settlement where the football pitch was set up, but in the Dobrinja II settlement; ${ }^{13623}$ and (iii) the atomic shelter was not the intended target of the attack. ${ }^{13624}$.

4081. Having considered the evidence and the adjudicated facts recounted above, the Chamber is convinced that two shells of at least $81 \mathrm{~mm}$ calibre struck the parking lot in the Dobrinja IIIB residential settlement on 1 June 1993. The Chamber recalls that Subotić challenged this location, claiming that the football match was played on a purpose-built sports pitch beside the lot. Her claim, however, ignores the considerable evidence indicating that the match was in fact played on the parking lot. Furthermore, the Chamber considers her proposition that the residents of Dobrinja would have being playing soccer governed by the FIFA rules unacceptable given the wartime circumstances at the time and the fact that the primary concerns of the organisers was to find a location that would be protected from the view of the SRK forces. Accordingly, the Chamber considers that this type of analysis has seriously damaged Subotić's credibility both generally and specifically with respect to this incident.

4082. Relying on the medical evidence and the $\mathrm{ABiH}$ Supreme Command investigation discussed above, the Chamber finds that the explosion caused by the two shells on 1 June 1993 resulted in 122 casualties, at least 12 of whom died as a result of their injuries.

4083. In terms of the direction and origin of fire, the Chamber recalls that the UNPROFOR investigators came to the scene on the day of the incident and thus were able to observe the traces of the two points of impact, arriving at the conclusion that the shells originated from the southsoutheast of Dobrinja. ${ }^{13625}$ As noted above, a team from CSB Sarajevo conducted forensic examination at the incident site in November 1995 but examined only one point of impact, also

morgue records), pp. 9-10. See also D1398 (Report of ABiH Supreme Command Staff, 6 June 1993); D1399 (Report of ABiH Supreme Command Staff, 9 June 1993).

13622 See Adjudicated Fact 262.

13623 See Adjudicated Fact 264. The headquarters of the $5^{\text {th }}$ Motorised Brigade was in the northwest of Dobrinja, approximately 150 to 200 metres west of Dobrinja Hospital. See Youseff Hajir, T. 8783-8786 (1 November 2010); P1867 (Map of Sarajevo marked by Youssef Hajir); Asim Džambasović, T. 15247-15249 (22 June 2011); D1384 (Map of ABiH positions in Sarajevo marked by Asim Džambasović).

13624 See Adjudicated Fact 266.

13625 The Chamber does not accept Subotić's suggestion that a second crater on the parking lot was made by mechanical intervention as it is clear from the evidence that both shells landed on the asphalt surface of the parking lot. 
concluding that the projectile in question originated from a southeasterly direction. This was then confirmed by Higgs and Hamill who thought that southeast was the direction from which the fire came. Finally, even Subotić agreed that at least one of the incident-related shells originated from the southeast. Accordingly, the Chamber is convinced that both shells came from that direction.

4084. As far as the origin of fire is concerned, the precise angle of descent for the shells could not be determined at the incident site and therefore the shells may have originated anywhere along this trajectory to the southeast of Dobrinja. The Chamber notes that the UNPROFOR, CSB Sarajevo, and Hamill all concluded that the shells originated from the SRK-held positions to the south of Lukavica. In contrast, Subotić concluded that the fire originated from $\mathrm{ABiH}$-held positions along this same trajectory. Given the location of the incident site and the confrontation line to the southeast, ${ }^{13626}$ the furthest distance from the incident site that the shells could have been fired from if they had originated in ABiH-held territory was 200 metres. ${ }^{13627}$ In this respect, the Chamber recalls the evidence of Hamill and Galić in relation to danger radii and safety zones and that it would have been unsafe and extremely risky to fire a medium calibre shell at a target that is less than 200 metres away. ${ }^{13628}$ Thus, the fire must have originated in an area that was further than 200 metres away from the incident site in the approximate direction of fire to the southeast. This places it firmly within the SRK-held territory.

4085. As recounted above, Galić testified that the SRK did not open fire on Dobrinja on 1 June 1993. However, the Chamber cannot accept this evidence in light of the evidence analysed above in relation to this incident, as well as the evidence about the general situation in Dobrinja and the shelling its civilian inhabitants were exposed to on a regular basis during the conflict. ${ }^{13629}$

4086. In terms of the nature of the area and the status of the victims, the Chamber recalls that the incident site was a parking lot within a residential settlement and that it was not visible from any point of the SRK side of the confrontation line. While an atomic shelter was located approximately 100 metres away from the parking lot, no fire was opened on the SRK from that location that day. In addition, even if it was housing soldiers and military equipment at the time as suggested by Galić, the Chamber does not consider that this shelter was the intended target in this incident as

\footnotetext{
13626 See e.g. D759 (Map of Sarajevo marked by Mirza Sabljica); D760 (Map of Sarajevo marked by Mirza Sabljica). See also paras. 4069, 4076.

13627 See para. 4076.

13628 See para. 3982. The Chamber acknowledges that the apartment building in between the incident site and the confrontation line may have offered some protection for an $\mathrm{ABiH}$ unit to fire at the incident site from a position within the weapon's danger radius. It does not however consider that it is reasonable that the $\mathrm{ABiH}$ would have fired in the direction of its own territory, at short distance and at high elevation, as part of some conspiracy to garner international support against the VRS.

13629 See paras. 3783, 4059.
} 
more than two mortar rounds would have been necessary to destroy it. ${ }^{13630}$ Furthermore, assuming that there was an $\mathrm{ABiH}$ mortar battery approximately 500 metres away from the incident site, as suggested by one of the UNPROFOR maps, given the distance involved the Chamber does not consider it to have been the intended target either.

4087. The Chamber recalls that 58 of the casualties in this incident were members of the $\mathrm{ABiH}$ and thus were a legitimate military target. However, the Chamber also notes that, in total, around 200 spectators, including women and children, were watching the game and that an almost equivalent number of casualties in this incident were civilians not taking direct part in hostilities at the time. The Chamber recalls that the presence of soldiers within the civilian population does not deprive the population of its civilian character and that the mens rea of a person responsible for an attack is to be assessed according to the knowledge that he or she had at the time of launching the attack. ${ }^{13631}$ There is no evidence as to whether the SRK units responsible for this incident knew at the time when they launched the attack that $\mathrm{ABiH}$ soldiers would be present at the football event or how many of them would attend, but the evidence shows that the SRK units were not able to see the incident site from their positions. However, even if the presence and the number of $\mathrm{ABiH}$ soldiers were known to the SRK units in advance, it must have been obvious to those launching the attack that large numbers of civilians would inevitably gather at the event given (i) that the event involved a football match, that is, a purely civilian activity; (ii) the time of the event, that is, daytime and during a period of cease-fire; and (iii) the location of the event, that is, the middle of a residential area, surrounded by residential apartment blocks. Further, the SRK's decision to fire two mortar shells at such an event, those shells being designed to suppress activity over a wide area, ${ }^{13632}$ shows in turn that the SRK units in question did not take any precautionary measures in accordance with the laws of war. Therefore, the Chamber is convinced that this incident is an example of indiscriminate fire.

(3) Hakije Turajlića, Dobrinja, 12 July 1993 (Scheduled Incident G.5)

4088. The Indictment alleges that on 12 July 1993, an $82 \mathrm{~mm}$ mortar shell was fired at about 100 civilians who were waiting to access a communal water pump in the front yard of a residence at 39 Hakije Turajlića (previously Aleja Branka Bujića ${ }^{13633}$ then Spasenije Cane Babović), in Dobrinja,

\footnotetext{
13630 The Chamber also recalls that the two shells fell in quick succession to one another, landed at almost the same position, and that the second shell did not land any closer to the atomic shelter.

13631 See paras. 453, 457.

13632 See para. 3982.

13633 Indictment, Scheduled Incident G.5. While the Indictment provides that the street was called "Aleja Branka Bulića" at the time of the incident, the documentation received by the Chamber refers to "Aleja Branka Bujića", which is the correct spelling of that street's name.
} 
which was a residential settlement. ${ }^{13634}$ The Indictment further alleges that the origin of fire was VRS/SRK-held territory approximately to the west-northwest and that 13 people were killed and 14 were wounded. ${ }^{13635}$ In its Final Brief, the Prosecution submits that the shell exploded at approximately 3 p.m. on a group of approximately 50 to 60 civilians queuing to gather water from a well, killing more than ten and wounding more than ten others. ${ }^{13636}$ The Accused acknowledges that on 12 July 1993 an $82 \mathrm{~mm}$ calibre shell exploded in the settlement of Dobrinja leaving 27 casualties. ${ }^{13637}$ He argues, however, that the fire originated from the north-northeast area controlled by $\mathrm{ABiH}$ forces. ${ }^{13638} \mathrm{He}$ also submits that the incident occurred about 100 metres from an $\mathrm{ABiH}$ command post and that no orders were issued to SRK forces during this period to open fire at this location. ${ }^{13639}$

4089. The Chamber has taken judicial notice of the fact that due to a water cut-off in Dobrinja, inhabitants of "C5", a settlement in Dobrinja, replenished their water supply at well-known emergency water points, ${ }^{13640}$ one of which was located in Hakije Turajlića street. ${ }^{13641}$ In the middle of the afternoon of 12 July 1993, a fairly clear day until 5 p.m., there were 100 or more canisters in that street. ${ }^{13642}$ People, mostly elderly, were waiting for their turn to enter into the front yard of the house through an iron gate guarded by Enver Taslaman. ${ }^{13643}$ Rasim Mehonić, a retiree who had been queuing with his wife and two daughters since dawn, was crouched next to Taslaman, waiting for his turn to collect water when, at approximately 3 p.m., a mortar shell exploded, ${ }^{13644}$ and Mehonić felt the left side of his body hit by shrapnel. ${ }^{13645}$ Next to Mehonić, Taslaman was hit on the arm and the left leg. ${ }^{13646}$ The area around the well was then repeatedly shelled. ${ }^{13647}$

4090. According to the report on this incident prepared by CSB Sarajevo, on 12 July 1993, at around 3:27 p.m., in front of a family house at Aleja B. Bujića 155 in Dobrinja, ${ }^{13648}$ a shell

\footnotetext{
13634 Indictment, Scheduled Incident G.5.

13635 Indictment, Scheduled Incident G.5. See also Prosecution Final Brief, Appendix C, para. 51.

13636 Prosecution Final Brief, Appendix C, para. 51.

13637 Defence Final Brief, para. 2013.

13638 Defence Final Brief, para. 2015.

13639 Defence Final Brief, paras. 2013, 2017-2019.

13640 See Adjudicated Fact 271. Hajir testified that civilians in Dobrinja were deliberately targeted while waiting in line for water at those points. See Youseff Hajir, T. 8853 (2 November 2010).

13641 P1438 (BiH MUP Report re shelling of Dobrinja on 12 July 1993), e-court p. 2.

13642 See Adjudicated Fact 272.

13643 See Adjudicated Fact 273.

13644 See Adjudicated Fact 274.

13645 See Adjudicated Fact 275.

13646 Adjudicated Fact 276.

13647 See Adjudicated Fact 281.

13648 The official CSB Sarajevo report refers to the site of the incident as being in front of a family house at Aleja B. Bujića 155, across the street from a block of flats at S.C. Babović street Number 6, in Dobrinja V. Later, it
} 
impacted and exploded against the body of Zorka Simić, who was, together with around 30 others, lining up to get water. ${ }^{13649}$ The report also provides that the CSB Sarajevo investigation team, including the ballistics expert Hamdija Čavčić, was dispatched to the scene some two hours after the incident. ${ }^{13650}$ The team eventually found that the explosion killed 12 people, including Simić, while 15 others were injured. ${ }^{13651}$ The report notes that the people queuing for water were warned by the police just before the incident that they should not stay at this location as the frontline was only 200 metres away. ${ }^{13652}$

4091. A shell stabiliser was found at the scene of the explosion, next to Simić's body, which Čavčić determined belonged to an $82 \mathrm{~mm}$ calibre mortar shell. ${ }^{13653}$ Čavčić also concluded that the shell exploded some distance from the ground, "most probably upon impact with person" as there was no explosion crater at the scene, only the heavily damaged body. ${ }^{13654}$ Further, he thought that the shell had been fired from the northwest-west, that is, from the direction of Nedžarići. ${ }^{13655}$ According to the report, Čavčić made this conclusion on the basis of (i) traces of powder burns and mechanical damage from mortar shell fragments evident on the fence occupying the eastern side of the street; (ii) similar traces he observed on the rear seat of a green Škoda car, which was parked close to this section of the fence, facing eastwards; and (iii) the fact that the pavement to the northwest of the damaged fence showed mechanical damage forming an irregular arc towards the northwest-west. $^{13656}$

4092. Members of the UNPROFOR also conducted an investigation at the site and prepared a report, concluding that the projectile was an $82 \mathrm{~mm}$ mortar shell, that it was highly probable that it came from "the Serbian party", and that it "could have been shot from corridor Nedžarići-Ilidža nord." 13657 The UNPROFOR report also noted that "the absence of a characteristic crater and

describes the location as "B. Bujića 6", and then "155 Aleja B Bujića across the street from the entrance to apartment house at 6, Spasenija-Cana Babović street". The report of the forensic technician refers to SpasenijeCane Babović next to number 6, while the report of the ballistics expert refers to Spasenije Cane Babović street, next to 115. See P1438 (BiH MUP Report re shelling of Dobrinja on 12 July 1993), e-court pp. 2-6. Given that the incident took place at an intersection, the Chamber does not consider these discrepancies as to the actual address where it happened to have any bearing on the CSB Sarajevo's analysis and conclusions.

13649 P1438 (BiH MUP Report re shelling of Dobrinja on 12 July 1993), e-court p. 3.

13650 P1438 (BiH MUP Report re shelling of Dobrinja on 12 July 1993), e-court p. 3.

13651 P1438 (BiH MUP Report re shelling of Dobrinja on 12 July 1993), e-court pp. 3-4.

13652 P1438 (BiH MUP Report re shelling of Dobrinja on 12 July 1993), e-court p. 4.

13653 P1438 (BiH MUP Report re shelling of Dobrinja on 12 July 1993), e-court p. 6.

13654 P1438 (BiH MUP Report re shelling of Dobrinja on 12 July 1993), e-court p. 6.

13655 P1438 (BiH MUP Report re shelling of Dobrinja on 12 July 1993), e-court p. 6.

13656 P1438 (BiH MUP Report re shelling of Dobrinja on 12 July 1993), e-court p. 6.

13657 P1442 (UNPROFOR report re shelling of Dobrinja on 12 July 1993), e-court p. 3. 
furrow" and the spray pattern of damage to the asphalt showed the direction of 5100 mils (northwest-west). ${ }^{13658}$

4093. Higgs visited the incident site and noted that, "due to the lapse of time and the fact that the mortar hit a person before striking the ground little or no evidence still exists at this site." 13659 Thus, he commented mostly on the forensic report prepared by CSB Sarajevo and agreed with the findings made therein, concluding that the calibre of the weapon fired was an $82 \mathrm{~mm}$ mortar from the direction of west northwest. ${ }^{13660}$ He noted that the methodology used by CSB Sarajevo, as mentioned in the official report, was appropriate but that there would be a slightly larger margin of error because there was no crater to examine so that only the "approximate direction" from which the round came could be determined, as was indeed done. ${ }^{13661}$ Higgs also opined that, as this area was an emergency water supply, it would be "fair to assume" that it was well known and "recorded" 13662 that it would be full of civilians. ${ }^{13663}$ Given that only one shell was fired, which is not something that would happen if the aim was to neutralise a large area or a military target, Higgs concluded that "it is most probable that harassment was intended on the people at that location." 13664 The possibility that there was a sniper operating in the area approximately 200 metres away did not affect his opinion as the round would have been too inaccurate to target the sniper. ${ }^{13665}$ Higgs also commented on the discovery of the shell's tail fin next to the body of one of the victims, stating that "the body would have probably stopped the fins from being blown away any further". 13666

4094. When asked by the Accused to explain the slight difference between the directions of fire as determined by the CSB Sarajevo and UNPROFOR teams, he said that only general bearings could be determined due to the type of crater on the scene. ${ }^{13667}$ Higgs marked two contemporaneous photographs of the scene taken by CSB Sarajevo with the evident shrapnel marks, pieces of debris,

\footnotetext{
13658 P1442 (UNPROFOR report re shelling of Dobrinja on 12 July 1993), e-court pp. 2-3, 5.

13659 P1437 (Richard Higgs's Consolidated Report on Sarajevo Shelling Incidents, 13 March 2009), p. 8; Richard Higgs, T. 5994 (19 August 2010). Hogan also visited the site in 2009 and took GPS readings of the location where the shell impacted. See Barry Hogan, T. 11205-11206 (3 February 2011); P2191 (Map of Sarajevo with scheduled sniping and shelling incidents).

13660 P1437 (Richard Higgs's Consolidated Report on Sarajevo Shelling Incidents, 13 March 2009), p. 8; Richard Higgs, T. 5994 (19 August 2010).

13661 Richard Higgs, T. 5920 (18 August 2010); P1437 (Richard Higgs's Consolidated Report on Sarajevo Shelling Incidents, 13 March 2009), p. 9; P1438 (BiH MUP Report re shelling of Dobrinja on 12 July 1993).

13662 On the issue of "prerecorded" targets, see Richard Higgs, T. 5918 (18 August 2010).

13663 P1437 (Richard Higgs's Consolidated Report on Sarajevo Shelling Incidents, 13 March 2009), p. 8.

13664 P1437 (Richard Higgs's Consolidated Report on Sarajevo Shelling Incidents, 13 March 2009), pp. 8-9.

13665 P1437 (Richard Higgs's Consolidated Report on Sarajevo Shelling Incidents, 13 March 2009), p. 9.

13666 P1437 (Richard Higgs's Consolidated Report on Sarajevo Shelling Incidents, 13 March 2009), p. 9.

13667 Richard Higgs, T. 5995-5996, 6028 (19 August 2010).
} 
and also the explosion's likely direction of force. ${ }^{13668}$ While doing so, Higgs opined that the shell exploded very close to the Škoda, slightly to the rear of the car, but that a definite angle of the direction of the force was impossible to determine on the basis of the photograph, including whether the force came from above or below the car. ${ }^{13669}$

4095. Zorica Subotic first visited the site of the incident in $2010 .{ }^{13670}$ She testified that in her opinion the shell had come from the north or northeast, an area under ABiH control, rather than the west or northwest. ${ }^{13671}$ In coming to this conclusion, Subotić used the azimuth of the street, which she calculated using Google Earth, as well as the central-axis method that she applied to the pattern of the damage on the pavement shown in the photographs taken by CSB Sarajevo. ${ }^{13672}$ She argued that Čavčić misinterpreted the fragment marks that were left on the asphalt and also on the Škoda car, and that the true direction bisecting these marks actually slanted slightly eastward in relation to the pavement. ${ }^{13673}$ In addition, according to Subotić, the analysis undertaken by Čavčić to determine the centre of the explosion was done using an unacceptable "imaginary lines" methodology. ${ }^{13674}$ Subotić also observed that Simić's remains were located beside the rear right-

13668 D549 (Photograph marked by Richard Higgs); D550 (Photograph marked by Richard Higgs). Higgs stated that he did not use photographs as part of his analysis because of their poor quality and because some of the markings and the debris may not be visible. See Richard Higgs, T. 5996-5998, 6001, 6003 (19 August 2010).

13669 Higgs eventually stated, however, that the boot of the car did give the impression that some force pushed down on the boot in the right hand corner, which "may indicate that the blast could have been slightly higher than the level of the boot of the car". See Richard Higgs, T. 5998-5999 (19 August 2010); D549 (Photograph marked by Richard Higgs).

13670 Zorica Subotić, T. 38363 (15 May 2013).

13671 D3542 (Zorica Subotić's expert report entitled "Mortar Operations in Sarajevo Area in 1992-1995", 15 August 2012), pp. 89, 91, 158; Zorica Subotić, T. 38367 (15 May 2013).

13672 D3542 (Zorica Subotić's expert report entitled "Mortar Operations in Sarajevo Area in 1992-1995", 15 August 2012), pp. 81-83, 85, Figure 46; Zorica Subotić, T. 38255-38256 (14 May 2013). Subotić conducted this analysis by marking the traces of damage visible on a photograph of the scene taken by the CSB Sarajevo team. On cross-examination, she denied that she was at a disadvantage compared to Čavčić who conducted a de visu examination. See Zorica Subotić, T. 38357-38363, 38374-38379 (15 May 2013). When it was put to her that she marked more shrapnel marks at the scene (as seen on her photograph of the scene taken in 2010) than she did in the contemporaneous CSB Sarajevo photograph which she had used to determine the direction of fire, Subotic responded that she could see all the marks in the latter but only marked those necessary to show an approximate trajectory, the trajectory that was partly based on the damage to the car. See Zorica Subotić, T. 38380-38384 (15 May 2013), T. $38627-38630$ (22 May 2013); P6319 (Photograph showing shrapnel marks marked by Zorica Subotić); D3557 (Photograph of a street marked by Zorica Subotić).

13673 D3542 (Zorica Subotić's expert report entitled "Mortar Operations in Sarajevo Area in 1992-1995", 15 August 2012), p. 83. In relation to the Škoda, Subotić testified that the deformation to the rear of the vehicle seen in photographs and video footage indicates that the shell exploded from a direction to the east of north. See D3542 (Zorica Subotić's expert report entitled “Mortar Operations in Sarajevo Area in 1992-1995”, 15 August 2012), pp. 85-88, 92, 158; Zorica Subotić, T. 38256-38258, 38267 (14 May 2013), T. 38377 (15 May 2013). When put to her on cross-examination that the video footage was of such low quality that it was impossible to determine all those things from it, Subotić responded that she viewed it in the context of all the evidence. See Zorica Subotić, T. 38396-38399 (16 May 2013); P6320 (Excerpt from video footage re shelling of Hakije Turajlića on 12 July 1993).

13674 D3542 (Zorica Subotić's expert report entitled "Mortar Operations in Sarajevo Area in 1992-1995”, 15 August 2012), pp. 84-85. The Chamber notes that this methodology is not outlined in Čavčić's report but rather in his statement in the Galić case, which is not in evidence in this case. In his statement, as quoted in Subotić's report, Čavčić explicitly says that the team managed to determine the direction of fire based on the damage on the 
hand side of a Škoda car, which indicated to her that the shell had come from the direction slightly east of the north—had the shell come from the direction as determined by Čavčić, the force of the blast would have pushed the victim either onto the car or to its left hand side. ${ }^{13675}$ Finally, Subotić also noted that in his report Čavčić stated that the stabiliser was found next to the victim's body whereas in the video footage of the aftermath of the incident it can be seen next to the rear left tyre of the Škoda. ${ }^{13676}$ According to Subotić, had the shell come from the west or northwest as determined by CSB Sarajevo, the stabiliser would have been on the right hand side of the car, on Simić's body. ${ }^{13677}$

4096. In relation to the UNPROFOR investigation, Subotić argued that their conclusions, like those of CSB Sarajevo, ran counter to evidence at the scene. ${ }^{13678}$ In addition, she expressed concern that the UNPROFOR investigators relied on information given to them by CSB Sarajevo and therefore did not run an independent investigation. ${ }^{13679}$

4097. Subotić also referred to a number of witness testimonies from the Galić case in relation to the disposition of forces on 12 July 1993, arguing that the scene of the incident was about 120 metres from an $\mathrm{ABiH}$ command post. ${ }^{13680}$ She also argued that the large numbers of canisters seen in the contemporaneous photographs and footage of the scene indicate that there was a conspiracy

asphalt which indicated where the centre of explosion may have been. It is then that he drew imaginary lines from the damaged parts of the asphalt and noticed that they all converged on the victim's body.

13675 D3542 (Zorica Subotić's expert report entitled "Mortar Operations in Sarajevo Area in 1992-1995", 15 August 2012), pp. 82-83, 86.

13676 P6320 (Excerpt from video footage re shelling of Hakije Turajlića on 12 July 1993); D3542 (Zorica Subotić's expert report entitled "Mortar Operations in Sarajevo Area in 1992-1995", 15 August 2012), pp. 88-89, Figure 51.

13677 D3542 (Zorica Subotić's expert report entitled "Mortar Operations in Sarajevo Area in 1992-1995", 15 August 2012), p. 88; Zorica Subotić, T. 38267 (14 May 2013). In cross-examination, when it was put to her that the stabiliser could have easily ricocheted off an object after the explosion and/or could have been moved by people in the immediate aftermath of the incident, Subotic accepted that this was possible but explained that the stabiliser was just one piece of the puzzle in addition to the damage caused by the shell, which pointed her to the incoming trajectory of north or northeast. See Zorica Subotić, T. 38399-38406 (16 May 2013).

13678 D3542 (Zorica Subotić's expert report entitled "Mortar Operations in Sarajevo Area in 1992-1995", 15 August 2012), pp. 81, 83, 85, 92, 158.

13679 D3542 (Zorica Subotić's expert report entitled "Mortar Operations in Sarajevo Area in 1992-1995", 15 August 2012), pp. 81, 158. The Chamber notes that the UNPROFOR report provides that an $82 \mathrm{~mm}$ mortar shell fin found at the site was given to the UN officers by local police officials. See P1442 (UNPROFOR report re shelling of Dobrinja on 12 July 1993), e-court, p. 2. In cross-examination, Subotić conceded that she did not have access to the testimony of the UNPROFOR officer who, according to the Prosecution, testified in the Galic case in relation to the conduct of this investigation and who explained that the direction of fire was arrived at independently by two separate members of the UNPROFOR team. See Zorica Subotić, T. 38369-38373 (15 May 2013) (private session).

13680 D3542 (Zorica Subotić's expert report entitled "Mortar Operations in Sarajevo Area in 1992-1995", 15 August 2012), pp. 75-76, 157. Džambasović confirmed that the command post of the $2^{\text {nd }}$ Battalion of the $155^{\text {th }}$ Brigade of the ABiH was located in the Šipad building in the centre of Dobrinja. The map he marked showing the command post suggests that it was to the north of the incident site and several blocks away. See Asim Džambasović, T. 15220 (22 June 2011); D1379 (Map of ABiH positions in Sarajevo marked by Asim Džambasović). 
to show that "the water supply situation in Sarajevo was dramatic". ${ }^{13681}$ Further, she recalled that, shortly before the incident, local authorities warned people not to loiter in the area due to the proximity of the confrontation lines, which to her indicated that they had knowledge of the possibility of shelling. ${ }^{13682}$

4098. Galić testified that he did not remember issuing any orders to fire on Hakije Turajlića street and could not remember any subordinates informing him of such activities. ${ }^{13683}$ He also stated that during this period the SRK forces were engaged in operation Lukavac 93 and "it was not necessary to engage in any active operations towards the centre of the city."13684

4099. Radojčić testified that he never issued an order to open fire at Hakije Turajlića street to any unit of his brigade. ${ }^{13685}$ Sladoje testified that no orders to target civilians were issued and further that there was no line-of-sight between his unit's positions and the scene of the incident in Dobrinja C5. ${ }^{13686} \mathrm{He}$ also testified that the battalion positions in Nedžarići "were frequently targeted from high-rises in Dobrinja C5" during July 1993. ${ }^{13687}$ On cross-examination, Sladoje confirmed that the suburbs of Vojničko Polje, Mojmilo, Dobrinja, and Alipašino Polje were all within the range of the $1^{\text {st }}$ Battalion's weaponry. ${ }^{13688} \mathrm{He}$ also acknowledged that civilians lived in these areas but stated that "among the civilians it was the $[\mathrm{ABiH}]$ using practically all buildings for their purposes". ${ }^{13689}$

4100. Guzina testified that he never issued an order to fire at civilians, nor was he aware of any of his subordinates or superiors issuing any such orders. ${ }^{13690}$ In relation to the incident he stated that he was engaged in Operation Lukavac 93 and therefore had no information about it. ${ }^{13691}$

\footnotetext{
13681 D3542 (Zorica Subotić's expert report entitled "Mortar Operations in Sarajevo Area in 1992-1995", 15 August 2012), pp. 76-79, 91, 157.

13682 D3542 (Zorica Subotić's expert report entitled "Mortar Operations in Sarajevo Area in 1992-1995", 15 August 2012), pp. 76-79, 157-158. When cross-examined in relation to the suggestion that there may have been a conspiracy to shell, Subotić conceded that it "was merely an indication of a possibility"'. See Zorica Subotić, T. 38367-38369 (15 May 2013).

13683 Stanislav Galić, T. 37387-37388 (18 April 2013). Dragomir Milošević agreed in principle that the shelling of a water line was an unacceptable example of direct targeting of a group of civilians. In relation to this incident he testified that it had to have been properly investigated and that this was within Galić's remit. See Dragomir Milošević, T. 33120-33121 (4 February 2013).

13684 Stanislav Galić, T. 37390-37393 (18 April 2013); D3418 (SRK combat report, 11 July 1993); D3419 (SRK Order, 12 July 1993).

13685 D2562 (Witness statement of Vladimir Radojčić dated 8 December 2012), para. 110.

13686 D2479 (Witness statement of Mile Sladoje dated 25 November 2012), para. 26; D2483 (Map of Sarajevo marked by Mile Sladoje). Sladoje suspected that the ABiH shelled the area on purpose in order to accuse the Serbs. With respect to his evidence on the line of sight, he acknowledged that mortars are indirect fire weapons and explained that he simply meant to say that they could not see people gathering at the incident site. See Mile Sladoje, T. 30574-30576 (28 November 2012).

13687 D2479 (Witness statement of Mile Sladoje dated 25 November 2012), para. 25.

13688 Mile Sladoje, T. 30570 (28 November 2012).

13689 Mile Sladoje, T. 30570 (28 November 2012).

13690 D2553 (Witness statement of Svetozar Guzina dated 3 December 2012), para. 42.
} 
4101. Savo Simić, Chief of Artillery in the $1^{\text {st }}$ Sarajevo Mechanised Brigade from 29 May 1992 till the late May 1994, ${ }^{13692}$ commented that in his opinion the shell fired in this incident was "fired from the Butmir sector, from positions under the control of the $[\mathrm{ABiH}]$ forces". ${ }^{13693}$ However, he never explained the basis of this opinion and the Chamber is unable to assess its reliability. On cross-examination, speaking of the situation in Sarajevo generally, Simić testified that it was the $\mathrm{ABiH}$ 's responsibility to take into account whether a location was inhabited when they placed their firing positions. ${ }^{13694}$

4102. In terms of casualties in this incident, the CSB Sarajevo report lists the following 12 individuals as having been killed: Ljiljana Matić, Ibro Talić, Enisa Talić, Jasna Tvrtković, Stela Tvrtković, Rahima Mehonić, Sedajeta Mehonić, Nedžiba Mehonić, Ajdin Kirlić, Dragica Mičanović, Zora Simić, and Sulejman Selinović. ${ }^{13695}$ It also lists the following 15 persons as wounded: Ilhan Jelovac, Rasim Mahonić, Enver Taslaman, Ahmed Milić, Hamid Džozo, Vinka Kneht, Husein Grebić, Džulsuna Mršović, Derviš Fazlić, Majda Alihodžić, Kasim Čaušević, Enes Turhan, Manojlo Dangubić, Izet Čolaković, and Fehma Kurić. ${ }^{13696}$ Medical records from Dobrinja Hospital show that all of the 27 casualties listed in the CSB Sarajevo report on 12 July 1993 were admitted to that facility on the day of the incident. ${ }^{13697}$ Koševo Hospital morgue records further indicate that Ilhan Jelovac and Vinka Kneht were then placed in the morgue having eventually died in the Koševo Hospital. ${ }^{13698}$

4103. The Chamber has also taken judicial notice of a number of adjudicated facts which go to the origin of fire in this incident. They provide as follows: (i) the mortar shell which landed on 12 July

\footnotetext{
13691 D2553 (Witness statement of Svetozar Guzina dated 3 December 2012), para. 42; D2559 (Medical certificate, 2 March 1994) (stating that he was engaged in Operation Lukavac 93, on the Jahorina-Trnovo-Bjelašnica-Igman axis, that he spent 45 days there, and was wounded on 25 July 1993).

13692 D2412 (Witness statement of Savo Simić dated 4 November 2012), para. 3.

13693 D2412 (Witness statement of Savo Simić dated 4 November 2012), para. 26. The Chamber recalls that Butmir and Sokolović Kolonija are to the southwest of the Sarajevo Airport and were occupied by the ABiH. Dragomir Milošević, T. 32565 (23 January 2013); T. 32792-32793 (29 January 2013). See also para. 4058.

13694 Savo Simić, T. 30058 (12 November 2012).

13695 P1438 (BiH MUP Report re shelling of Dobrinja on 12 July 1993), e-court p. 3 See Adjudicated Fact 277. The Chamber has received death certificates for six of those individuals, all of which state that they died as a result of injuries sustained in an explosion on 12 July 1993. See P1881 (Death certificate for Stela Trtković); P1882 (Death certificate for Jasminka Trtković); P1883 (Death certificate for Nedžiba Mehonić); P1884 (Death certificate for Rahima Mehonić); P1885 (Death certificate for Sadeta Mehonić); P1886 (Death certificate for Sulejman Selimović).

13696 P1438 (BiH MUP Report re shelling of Dobrinja on 12 July 1993), e-court p. 4. See Adjudicated Fact 277.

13697 P1890 (Medical records from Dobrinja Hospital, 12 July 1993), e-court pp. 1-6; P1887 (Medical records from Dobinja Hospital).

13698 P461 (Admission records from Koševo Hospital), p. 54; P463 (Koševo Hospital morgue records), e-court p. 5; P462 (Surgery records from Koševo Hospital), e-court p. 8; Faris Gavrankapetanović, P473 (Transcript from Prosecutor v. Galić), T. 12603-12604.
} 
1993 in Dobrinja "C5" and which caused civilian casualties was of a caliber of $82 \mathrm{~mm} ;{ }^{13699}$ (ii) the mortar shell which landed on 12 July 1993 in Dobrinja "C5" and which caused civilian casualties was fired from the direction west-northwest to the point of impact of the mortar shell; ${ }^{13700}$ (iii) there were no immediate military objectives near the well, which could have explained the firing of a shell in that area, ${ }^{13701}$ and (iv) the water queue of civilians in Dobrinja "C5" was deliberately targeted on 12 July 1993 by an 82 mm mortar shell fired from SRK-held territory. ${ }^{13702}$

4104. Having considered the evidence and the adjudicated facts recounted above, the Chamber is convinced that the mortar that struck the water line on 12 July 1993 was of $82 \mathrm{~mm}$ calibre. The Chamber is also convinced, based on the traces left by the explosion and the CSB Sarajevo report, that the mortar struck Zorka Simić, killing her on the spot. Relying on the medical evidence and the CSB report discussed above, the Chamber finds that the explosion caused by the said mortar resulted in 27 casualties, 14 of whom-including Simić—died as a result.

4105. In terms of the direction and origin of fire, the Chamber recalls that both the CSB Sarajevo and the UNPROFOR investigators came to the scene on the day of the incident and were thus able to observe the traces of the impact, and that they all found the same direction of fire, namely northwest-west. This was confirmed by Higgs who thought that all the investigators were consistent in their conclusions and who also added that the methods they used were appropriate. In contrast, Subotic concluded that the fire came from the direction of north or northeast. The Chamber finds her conclusions in relation to this incident unreliable as they were mainly based on her analysis of the photographs taken at the time of the incident and thus highly speculative. For example, having confirmed that, aside from having radar, the central axis methodology performed on the day of the incident is the most reliable method to determine the direction of fire, she nevertheless proceeded to conduct her own central axis analysis using the photographs of the traces at the incident site. ${ }^{13703}$ However, as noted by Higgs who decided not to use the photographs in his analysis, they are of poor quality and thus unreliable since some of the markings and the debris may not be seen on them. Accordingly, the conclusions Subotic drew from the traces shown on the photographs cannot be considered reliable. Furthermore, Subotić also based her conclusions on the damage to the Škoda car observed on another photograph taken by the CSB Sarajevo. However, as noted by Higgs, it is impossible to determine a definite angle of the direction of fire on the basis of

\footnotetext{
13699 Adjudicated Fact 278.

13700 Adjudicated Fact 279

13701 Adjudicated Fact 280

13702 Adjudicated Fact 282.

13703 See fn. 13672.
} 
that photograph. ${ }^{13704}$ Finally, Subotić also discussed the location of the stabiliser as seen in one of the photographs and noted that it was in a different location to the one described in Čavčić's report. She then proceeded to make conclusions assuming that the stabiliser was found in the location seen on the photograph. However, she failed to consider in the report the possibility that the stabiliser may have been moved at some point during the investigation to the location seen on the photograph. ${ }^{13705}$ Indeed, this would have been highly likely given that its original location was next to Simić's body which was, by the time the photograph was taken, covered by a sheet. ${ }^{13706}$

4106. The Chamber also does not accept Subotić's insinuations that the scene was staged so as to show that the water supply in Sarajevo was dire, or that the authorities warned people queuing for water about the possibility of shelling because they knew it was definitely coming. Her insinuations simply ignore the evidence to the contrary, namely that this was a well known waterhole where people often gathered to collect water and that there was a lot of shelling all over Dobrinja, which would have prompted the authorities to warn the inhabitants not to congregate in that or any other area. The fact that Subotić was so quick to resort to conspiracy theory conclusions while wilfully ignoring evidence to the contrary is a serious stain on her credibility and yet another reason why the Chamber has decided not to accept any of her evidence in relation to this incident.

4107. As far as the origin of fire is concerned, the Chamber notes that both the CSB Sarajevo and the UNPROFOR investigators concluded that the fire came from the SRK-held positions in or around Nedžarići. Given the location of the incident site and the fact that the confrontation line in the direction of west and northwest was around 200 metres away from that location, ${ }^{13707}$ the Chamber is also convinced that the shell originated in the SRK-held territory. In this respect, the Chamber recalls Hamill and Galić's evidence about safety zones and that it would have been unsafe and risky to fire an $82 \mathrm{~mm}$ calibre mortar at a target that is less 200 metres away. ${ }^{13708}$ Thus, the fire must have originated in the area that was further than 200 metres away from the incident site in the direction of fire as determined by the CSB Sarajevo and UNPROFOR investigators. This places it firmly within the SRK-held territory.

\footnotetext{
13704 While Higgs eventually did express an opinion as to the direction of fire based on the damage to the car, he did so after having made a disclaimer, more than once, that it was not possible to be sure of this or the direction of fire based on the photographs alone. See Richard Higgs, T. 5995-5999 (19 August 2010).

13705 She did admit during cross-examination that that was possible however, thus invalidating her own analysis in her report in relation to the stabiliser. See fn. 13677.

13706 Furthermore, the location of the stabiliser as recorded by Čavčić places it to the right-hand side of the car, which in fact confirms that the fire came from the west-northwest direction, as explained by Subotić. See para. 4091.

13707 See e.g. D3381 (Map of Sarajevo marked by Stanislav Galić); D3382 (Map of Sarajevo). See also para. 4090.

13708 See para. 3982.
} 
4108. As recounted above, ${ }^{13709}$ a number of SRK witnesses, including Galić and Sladoje, testified that they never ordered this particular shelling or the shelling of civilians in Dobrinja in general, and seemed to imply that fire was not opened on civilians on that day as the SRK units were engaged in operation Lukavica 93. ${ }^{13710}$ However, while there is indeed no evidence of a specific SRK order to open fire on Hakije Turajlića, in light of the evidence above, the Chamber cannot accept the implication of their evidence that no fire was opened on that area.

4109. In terms of the nature of the area and the status of the victims, the Chamber recalls that the incident site was a well-known water collection point, located in the yard of a private house, at which civilians would get water. Accordingly, the house and the area around it were not military targets. In addition, the 27 casualties who died or were wounded in this incident were all civilians and, having come to collect water, were not taking direct part in hostilities at the time the shell exploded in the area. While the command of the $2^{\text {nd }}$ Battalion of the $5^{\text {th }}$ Motorised Brigade of the $\mathrm{ABiH}$ was several blocks away to the north of the incident site, the Chamber considers that this was too far away to explain the firing of the particular shell that landed at the incident site. In addition, had the command post been the intended target, the SRK soldiers, having missed it, would have presumably fired again until it was hit and destroyed. Thus, the Chamber does not consider that the command post was in fact the intended target. ${ }^{13711}$ To the contrary, given that only one shell was fired, the Chamber is convinced that it was the water collection point that was deliberately targeted by the SRK. This is also confirmed by the fact that this area was shelled again later during the conflict. $^{13712}$

\section{(4) Alipašino Polje, 22 January 1994 (Scheduled Incident G.6)}

4110. The Indictment alleges that on 22 January 1994, three mortar shells landed in the area of Alipašino Polje. The shells are alleged to have landed at the front and rear of residential apartments located at 3 Cetinjska street (currently Geteova street) and at 4 Klara Cetkin street (currently Bosanska street), where children were playing. The Indictment further alleges that the origin of fire was from VRS/SRK-held territory approximately to the west and that six children were killed and five other people wounded. ${ }^{13713}$ In its Final Brief, the Prosecution claims that two $82 \mathrm{~mm}$ and one

\footnotetext{
13709 See paras. 4098-4101.

13710 See para. 4098.

13711 Furthermore, the Chamber recalls Sladoje's testimony that the ABiH used "practically all" civilian buildings in Dobrinja for its purposes, thereby implying that most if not all of Dobrinja was considered to be a military target by the SRK soldiers and officers in the area. Similar attitude was exhibited by Simić. See para. 4099.

13712 The Chamber also recalls Hajir's evidence that water collection points in Dobrinja were deliberately targeted by the SRK on many occasions. See para. 3785; Adjudicated Fact 281.

13713 Indictment, Scheduled Incident G.6. The Indictment alleges that the first shell landed in a park behind the apartments and that the second and third landed in front.
} 
$120 \mathrm{~mm}$ mortar shells landed amongst two groups of children who were playing in the snow, killing six children and injuring other civilians, and that the shells originated either from Nedžarići (the Institute for the Blind) or from the area of Stup in the Serb part of Ilidža. ${ }^{13714}$ The Accused argues that, absent data about the size and shape of the relevant craters, it is "impossible" to determine the calibre of the shells but submits that at least two of the shells were of $120 \mathrm{~mm}$ calibre and they all originated from the southwest in ABiH-held territory near the UPI Institute. ${ }^{13715} \mathrm{He}$ also argues that the UNPROFOR investigation was inconclusive and that no order was issued by the SRK to fire on Alipašino Polje at the time. ${ }^{13716}$ In addition, regardless of the origin of fire, the location of the incident was a legitimate military target as it was within the zone of operation of the $\mathrm{ABiH}$ and there were military units stationed in the area. ${ }^{13717}$

4111. On 22 January 1994, Muhamed Kapetanović, who was nearly ten years old at the time and lived at 2 Cetinjska street, was playing with four friends in a parking lot. ${ }^{13718}$ Another group of children was playing in Klara Cetkin street. ${ }^{13719}$ It was a quiet day during a lull in hostilities. ${ }^{13720}$ No activity of a military nature was underway in the neighbourhood nor was any soldier to be seen. ${ }^{13721}$ Suddenly there was a loud explosion, whereupon the children ran for cover. ${ }^{13722}$ Just before Kapetanović reached the entrance of his building, another shell exploded 10 metres behind the child following Kapetanović; it killed him and wounded three others including Kapetanović, who suffered serious injuries to his leg. ${ }^{13723}$ Goran Todorović, a 12 year old boy, ran towards the buildings for cover and just as he started climbing the staircase to his apartment at 6 Klara Cetkin street, another shell exploded 10 to 15 metres away and wounded him. ${ }^{13724}$ A man was walking along Klara Cetkin street where he lived and heard two explosions at a distance of approximately 100 metres. $^{13725}$ Before he could take cover, a third shell fell three to five metres to his left; the explosion threw him into the air and seriously wounded him in the face. ${ }^{13726}$ Refik Aganović was in his apartment on the $14^{\text {th }}$ floor of the building at 4 Klara Cetkin street when, at around 1 p.m., he

\footnotetext{
13714 Prosecution Final Brief, Appendix C, para. 52.

13715 Defence Final Brief, paras. 2022, 2024-2026, 2028-2033. The Accused submits that the UPI Institute was also known as the "Butmir agricultural estate". Defence Final Brief, para. 2034.

13716 Defence Final Brief, paras. 2035-2036. He also argued that the Ilidža Brigade stationed in Nedžarići did not have any mortars stationed at the Institute for the Blind. Defence Final Brief, para. 2037.

13717 Defence Final Brief, para. 2038.

13718 See Adjudicated Fact 284.

13719 Adjudicated Fact 285.

13720 See Adjudicated Fact 298.

13721 See Adjudicated Fact 299.

13722 See Adjudicated Fact 286.

13723 See Adjudicated Fact 287.

13724 See Adjudicated Fact 283.

13725 See Adjudicated Fact 288.

13726 See Adjudicated Fact 289.
} 
heard the "usual" hissing sound of a shell and then a loud explosion nearby. ${ }^{13727}$ About a minute or two later a second shell exploded. ${ }^{13728}$ Aganović opened a west-facing window to see what had happened and a third explosion in front of his entrance threw him back. ${ }^{13729}$ He rushed downstairs to the entrance where he saw a 13 year old boy stagger over and die. ${ }^{13730}$ Another younger boy whom Aganović said he tried to assist also died in those moments. ${ }^{13731}$ Other children, whom Aganović did not recognise because they were covered in blood and were missing parts of their bodies, had also been killed. ${ }^{13732}$

4112. Sabljica participated in the investigation of this incident on 22 January 1994, together with another ballistics expert, Boris Stankov, and the rest of the CSB Sarajevo team. ${ }^{13733}$ Sabljica and Stankov concluded that two $82 \mathrm{~mm}$ and one $120 \mathrm{~mm}$ calibre mortar shells landed respectively in Cetinjska street, Klara Cetkin street, and in the park between the Klara Cetkin and Rade Končar square. ${ }^{13734}$ They found that the shell that fell in front of the building at number 3 Cetinjska street was an $82 \mathrm{~mm}$ mortar shell and that it came from a westerly direction, "where Nedžarići is located i.e. the Institute for the Blind." 13735 One child was killed by this shell. ${ }^{13736}$ As for the shell that landed at number 4 Klara Cetkin street, it was found to be an $82 \mathrm{~mm}$ mortar shell, that came from "a slightly northerly direction in relation to the west", where the Institute for the Blind is located. ${ }^{13737}$ Five children were killed by this shell. ${ }^{13738}$ The tail fin of a $120 \mathrm{~mm}$ shell was also

Adjudicated Fact 294.

See Adjudicated Fact 295.

P1443 (BiH MUP Report re shelling of Alipašino Polje on 22 January 1994), e-court pp. 3, 5; P1695 (Witness statement of Mirza Sabljica dated 11 February 2010), pp. 19-20; Mirza Sabljica, T. $7802-7803$ (12 October 2010). See also D978 (Map of Sarajevo marked by KDZ477).

13734 P1698 (BiH MUP Report re shelling of Alipašino Polje on 22 January 1994); P1695 (Witness statement of Mirza Sabljica dated 11 February 2010), p. 19; Mirza Sabljica, T. 7805-7808 (12 October 2010), T. 7815, 7825 (13 October 2010); D746 (Map of Alipašino Polje marked by Mirza Sabljica).

13735 P1698 (BiH MUP Report re shelling of Alipašino Polje on 22 January 1994), p. 1; P1697 (BiH MUP photographs re shelling of Alipašino Polje on 22 January 1994); P1695 (Witness statement of Mirza Sabljica dated 11 February 2010), pp. 20-21, 25, 27. Sabljica could not comment on why more detailed photographs, including those showing the craters after they had been cleaned up, were not available but noted that he believed they existed. Mirza Sabljica, T. 7810 (12 October 2010), T. 7816, 7826-7831 (13 October 2010); D751 (Photograph re shelling of Alipašino Polje on 22 January 1994 marked by Mirza Sabljica).

P1698 (BiH MUP Report re shelling of Alipašino Polje on 22 January 1994), p. 1; P1695 (Witness statement of Mirza Sabljica dated 11 February 2010), pp. 28-29; P1696 (BiH MUP Report re shelling of Alipašino Polje on 22 January 1994).

13737 P1698 (BiH MUP Report re shelling of Alipašino Polje on 22 January 1994), p. 1; P1697 (BiH MUP photographs re shelling of Alipašino Polje on 22 January 1994); P1695 (Witness statement of Mirza Sabljica dated 11 February 2010), pp. 24, 27-28; Mirza Sabljica, T. 7844-7850 (13 October 2010); D754 (Photograph re shelling of Alipašino Polje on 22 January 1994 marked by Mirza Sabljica); D755 (Photograph re shelling of Alipašino Polje on 22 January 1994 marked by Mirza Sabljica); D756 (Photograph re shelling of Alipašino Polje on 22 January 1994 marked by Mirza Sabljica). Mirza Sabljica agreed that Stankov did not establish the
} 
found near the area where the shell landed but, on the basis of the traces, it was concluded that the tail fin must have come from another location, most probably from the roof of a nearby building where, according to eyewitnesses, another shell had exploded at the time of the incident. ${ }^{13739}$ The impact sites in Klara Cetkin and Cetinjska streets were said to be within a radius of 50 to 100 metres from one another. ${ }^{13740}$ The shell that landed in the park between Klara Cetkin street and Rade Končar square, was found-based on the general shape of the crater and visible blast tracesto have been a $120 \mathrm{~mm}$ mortar shell. ${ }^{13741}$ The ballistics report notes that it is "possible to claim" that this shell came from the west, from the direction of Nedžarici and the Institute for the Blind. ${ }^{13742}$ Further, according to the report, this shell did not injure or kill anyone. ${ }^{13743}$ Sabljica confirmed that there is no line of sight between the Institute for the Blind and the incident site. ${ }^{13744}$

4113. KDZ477, who was a resident of Alipašino Polje during the conflict, testified that the suburb was "a strictly residential area [with] many high rises". ${ }^{13745}$ Both he and Sabljica testified that there were no military installations in the general area of Alipašino Polje and Sabljica was not aware of the existence of any reserve police stations in the settlement. ${ }^{13746}$ Mojmilo Hill, where ABiH troops were positioned, was located west of the incident site, as was Vojničko Polje. ${ }^{13747}$ Kučanin testified that a personnel department for an $\mathrm{ABiH}$ unit called Kulin Ban was located "some 200 metres away" from Rade Končara square, but that mostly women worked there and none of the personnel wore a uniform. ${ }^{13748}$

azimuth but instead simply described the direction the shell had come from. See Mirza Sabljica, T. 7810 (12 October 2010).

P1698 (BiH MUP Report re shelling of Alipašino Polje on 22 January 1994), p. 1; P1695 (Witness statement of Mirza Sabljica dated 11 February 2010), pp. 28-29; P1696 (BiH MUP Report re shelling of Alipašino Polje on 22 January 1994).

13739 P1698 (BiH MUP Report re shelling of Alipašino Polje on 22 January 1994), p. 2; P1695 (Witness statement of Mirza Sabljica dated 11 February 2010), pp. 19, 23, 25.

13740 KDZ477, T. 11018 (1 February 2011).

13741 P1698 (BiH MUP Report re shelling of Alipašino Polje on 22 January 1994), p. 2; P1695 (Witness statement of Mirza Sabljica dated 11 February 2010), pp. 19, 25-26. Sabljica explained that this shell was not analysed because there were no casualties and because it landed on the unpaved surface. See Mirza Sabljica, T. 7816 (13 October 2010).

13742 P1698 (BiH MUP Report re shelling of Alipašino Polje on 22 January 1994), p. 2.

13743 P1698 (BiH MUP Report re shelling of Alipašino Polje on 22 January 1994), p. 2.

13744 Mirza Sabljica, T. 7821-7822 (13 October 2010).

13745 KDZ477, T. 10918 (31 January 2011); P2165 (Map of Sarajevo marked by KDZ477).

13746 KDZ477, T. 10918-10923 (31 January 2011); P2165 (Map of Sarajevo marked by KDZ477); D977 (Map of Sarajevo marked by KDZ477). KDZ477 stated that this may have been the reason why the children who were killed or injured during the incident had been out playing in the snow. See KDZ477 T. 10923 (31 January 2011). See also P1695 (Witness statement of Mirza Sabljica dated 11 February 2010), p. 26.

13747 P1695 (Witness statement of Mirza Sabljica dated 11 February 2010), p. 26; Mirza Sabljica, T. 7822 (13 October 2010); D749 (Photograph of Vojničko Polje).

13748 Mirsad Kučanin, P16 (Transcript from Prosecutor v. Galić), T. 4499, 4522, 4663-4665, 4687-4689. 
4114. Sabljica admitted that he did not know precisely where the confrontation line was but noted that the $\mathrm{ABiH}$ controlled the "Oslobođenje" building (now Crowne Plaza), located immediately to the north of the Institute for the Blind, as well as the student dormitories, located northeast of the Institute, ${ }^{13749}$ which meant that three out of the four Institute walls were exposed to the confrontation line. ${ }^{13750} \mathrm{He}$ admitted that it would be unusual to place two mortars at the Institute given that it was exposed to the confrontation line but reiterated that the ballistics experts on the site were not able to establish the exact origin of fire but gave a "general direction", which in this particular case "involved Nedžarići and the Institute for the Blind."13751

4115. When it was put to Sabljica that another report for this incident, prepared by a forensic technician on the scene at the time, referred to two $120 \mathrm{~mm}$ shells falling on Cetinjska and Klara Cetkina streets, Sabljica responded that this report was inaccurate. ${ }^{13752}$ He further explained that the technician in question had not consulted the ballistics experts when he finalised his report. ${ }^{13753}$

4116. The UNPROFOR also reported on this incident; it noted that, on 22 January 1994, some 40 shots were fired by the VRS while three were fired by the $\mathrm{ABiH}$, and that six children were killed and nine wounded while playing in the snow. ${ }^{13754}$ The UNPROFOR further notes that it was too early to tell who was responsible, but that, "according to reports", at least four $82 \mathrm{~mm}$ shells fell in the area and that the Sarajevo radio station was reporting that the shells had come from the nearby Serb-held neighbourhood of Nedžarići. ${ }^{13755}$ However, an UNPROFOR ballistics report prepared by Captain Verdy the next day notes that three $120 \mathrm{~mm}$ mortar shells were fired in succession from a single tube over a period of several minutes. ${ }^{13756}$ It also states that the "angle of fall" was over

\footnotetext{
13749 Mirza Sabljica, T. 7806-7807 (12 October 2010), T. 7819-7821 (13 October 2010); D746 (Map of Alipašino Polje marked by Mirza Sabljica); D748 (Map of Sarajevo marked by Mirza Sabljica). See also P1695 (Witness statement of Mirza Sabljica dated 11 February 2010), p. 26.

13750 Mirza Sabljica, T. 7820-7821, 7823-7824 (13 October 2010); D750 (Photograph of the Institute for Blind in Sarajevo). Sabljica also conceded that, based on the map he was asked to look at, the Institute for the Blind is in fact located southwest of the broad area on which the shells fell, while the Oslobođenje building is west and the student dormitories are northwest of that area. Mirza Sabljica, T. 7808-7810 (12 October 2010); D746 (Map of Alipašino Polje marked by Mirza Sabljica).

13751 Mirza Sabljica, T. 7818, 7821, 7824 (13 October 2010).

13752 P1695 (Witness statement of Mirza Sabljica dated 11 February 2010), p. 29; P1696 (BiH MUP Report re shelling of Alipašino Polje on 22 January 1994).

13753 P1695 (Witness statement of Mirza Sabljica dated 11 February 2010), pp. 29-30. See also P2164 (Witness statement of KDZ477 dated 13 February 2010), para. 70; KDZ477, T. 10922, 10945-10946 (31 January 2011), T. 11018-11019 (1 February 2011).

13754 P1700 (UNPROFOR report re Sarajevo, 21-23 January 1994), p. 1; P1695 (Witness statement of Mirza Sabljica dated 11 February 2010), p. 30.

13755 P1700 (UNPROFOR report re Sarajevo, 21-23 January 1994), p. 1. See also D3432 (Report of ABiH $1^{\text {st }}$ Corps, 24 January 1994), p. 2.

13756 D752 (UNPROFOR report re shelling of Alipašino Polje on 22 January 1994); P1439 (UNPROFOR report re shelling of Alipašino Polje on 22 January 1994), e-court p. 8. The Chamber notes that P1439 is a duplicate of D752 but that it contains both the original version of Verdy's report in French and an English translation. D752, on the other hand, is only the translation of the report and lacks the photographs attached to the original report.
} 
1,100 mils, the "angle of approach" was between 4,200 and 4,250 mils, and the maximum range was between 2,000 and 3,000 metres. ${ }^{13757}$ Finally, the report concludes that the shells "could have been fired from the Stup or Ilidža neighbourhood on the Serb side", which are to the west and southwest of the incident site. ${ }^{13758}$ The Chamber notes that, in its Final Brief, the Prosecution chose not to rely on this report as Verdy only came to the scene one day after the incident and because his methodology was questioned by his superiors. ${ }^{13759}$ Nevertheless, as will be seen below, Zorica Subotić argues that Verdy's findings were for the most part accurate and relies on them in her analysis. ${ }^{13760}$ Therefore, the Chamber has examined his report as well.

4117. Higgs visited the incident site and noted that the crater locations, though still visible, had deteriorated to the extent that a detailed examination was not possible. ${ }^{13761} \mathrm{He}$, therefore, based his opinion on the data collected at the time, in particular on the report prepared by CSB Sarajevo. ${ }^{13762}$ He concurred with the conclusion in that report that $82 \mathrm{~mm}$ mortar bombs "were involved to the street side of the building with a $120 \mathrm{~mm}$ bomb falling on the other side". ${ }^{13763}$ Higgs then compared this report with Verdy's ballistics report, noting that he would accept the former as it was prepared on the day of the incident and by those with experience in dealing with mortars in the area. $^{13764} \mathrm{He}$ observed that both reports agreed on the direction of fire and that there was nothing he would disagree with in that respect. ${ }^{13765}$

4118. Higgs also noted that it was difficult to ascertain the purpose of firing in this incident, given that two different calibres were used. ${ }^{13766}$ However, focusing on the two $82 \mathrm{~mm}$ mortar shells, Higgs concluded that they constituted "harassing" fire aimed at causing maximum casualties

The Chamber considers the English translation in P1439 to be less accurate than the translation in D752 and will therefore use D752, unless it is referring to the photographs in question. See also Mirza Sabljica, T. $7832-7834$ (13 October 2010).

13757 P1439 (UNPROFOR report re shelling of Alipašino Polje on 22 January 1994), e-court pp. 4-8 (where Verdy indicates that the shell that landed on the curb in Klara Cetkin street had an azimuth of 4,200 mils while the shell that landed in Cetinjska street had an azimuth of 4,250 mils).

13758 D752 (UNPROFOR report re shelling of Alipašino Polje on 22 January 1994), p. 2

13759 Prosecution Final Brief, Appendix C, para. 52, fn. 330. But see P1558 (Witness statement of Francis Roy Thomas dated 13 May 2009), para. 96 (stating that Captain Verdy "did a very good job in this particular matter").

13760 See para. 4121.

13761 P1437 (Richard Higgs's Consolidated Report on Sarajevo Shelling Incidents, 13 March 2009), p. 9. Hogan also visited the site in 2009 and took GPS readings of the location where the shells impacted and plotted this on a map of Sarajevo. See P2190 (GPS locations for shelling and sniping incidents in Sarajevo), p. 6; P2191 (Map of Sarajevo with scheduled sniping and shelling incidents); Barry Hogan, T. 11205-11206 (3 February 2011).

13762 P1437 (Richard Higgs's Consolidated Report on Sarajevo Shelling Incidents, 13 March 2009), p. 9.

13763 P1437 (Richard Higgs's Consolidated Report on Sarajevo Shelling Incidents, 13 March 2009), p. 9.

13764 Richard Higgs, T. 5921-5924 (18 August 2010); P1437 (Richard Higgs's Consolidated Report on Sarajevo Shelling Incidents, 13 March 2009), p. 9.

13765 Richard Higgs, T. 5921-5923 (18 August 2010)

13766 P1437 (Richard Higgs's Consolidated Report on Sarajevo Shelling Incidents, 13 March 2009), pp. 9-10; Richard Higgs, T. 6020-6021 (19 August 2010). 
because they landed in front of building entrances. ${ }^{13767}$ Furthermore, the distance between the two rounds was greater than Higgs would expect in case of an error by the mortar crew. ${ }^{13768}$ In other words, the two shells fell exactly where the mortar crew intended them to fall and they originated from the direction of Nedžarići. ${ }^{13769}$

4119. KDZ450 who was with the UNPROFOR in Sarajevo between 1993 and 1994, testified that the incident was particularly striking to him as it occurred opposite the Sector Sarajevo Headquarters and "led to the death of six children in a residential area". ${ }^{1370}$ He testified that due to technical reasons the UNPROFOR could not definitively determine the origin of fire but that there were considerable "suspicions" the shells originated from SRK-held territory. ${ }^{13771}$

4120. Zorica Subotić visited the incident site in September 2010 and based on the available evidence, determined that the first shell exploded in Rade Končara square, the second in front of 3 Cetinjska street, and the third in front of 4 Klara Cetkin street. ${ }^{13772}$ She analysed in detail the two shells that landed in front of 4 Klara Cetkin and 3 Cetinjska streets and placed considerable emphasis on the inconsistencies between the original investigations as to the precise number and calibre of mortar shells involved and also on the fact that Sabljica and Stankov were at odds with one of their forensic technicians with respect to the calibre of the two shells. ${ }^{13773}$ Based on the distance between the two impact sites examined, namely "about 200 metres", she concluded that there was a deliberate adjustment of fire by the mortar crew that fired the shells. ${ }^{13774}$

4121. In relation to the crater in Klara Cetkin street, Subotić determined, using the central axis method on preserved marks at the scene, that the shell originated from an azimuth of 238 degrees and thus in an area about 30 degrees south of the Institute for the Blind in Nedžarići. ${ }^{13775}$ The

\footnotetext{
13767 P1437 (Richard Higgs's Consolidated Report on Sarajevo Shelling Incidents, 13 March 2009), p. 10. (Higgs also opined that two $82 \mathrm{~mm}$ mortar shells could not "achieve any military objective").

13768 P1437 (Richard Higgs's Consolidated Report on Sarajevo Shelling Incidents, 13 March 2009), p. 10.

13769 P1437 (Richard Higgs's Consolidated Report on Sarajevo Shelling Incidents, 13 March 2009), p. 10.

13770 KDZ450, T. 10618 (20 January 2011).

13771 KDZ450, T. 10618-10620, 10694-10697 (20 January 2011). See also D964 (ABiH $1^{\text {st }}$ Corps combat report, 24 January 1994) (under seal).

13772 D3542 (Zorica Subotić's expert report entitled "Mortar Operations in Sarajevo Area in 1992-1995", 15 August 2012), pp. 93, 108, 158-159; Zorica Subotić, T. 38260 (14 May 2013).

13773 Zorica Subotić, T. 38260 (14 May 2013); D3542 (Zorica Subotić's expert report entitled "Mortar Operations in Sarajevo Area in 1992-1995”, 15 August 2012), pp. 92-96, 108, 159.

13774 D3542 (Zorica Subotić's expert report entitled "Mortar Operations in Sarajevo Area in 1992-1995”, 15 August 2012), pp. 107-108; Zorica Subotić, T. 38266 (14 May 2013).

13775 D3542 (Zorica Subotić's expert report entitled "Mortar Operations in Sarajevo Area in 1992-1995", 15 August 2012), pp. 96-99. 109-110, 160-161. Subotić also stated that Sabljica agreed with how this trajectory was established based on a photograph of her investigation, implying that he was affirming the result despite it being contrary to the direction he established during the CSB Sarajevo investigation. See D3542 (Zorica Subotić's expert report entitled "Mortar Operations in Sarajevo Area in 1992-1995", 15 August 2012), p. 99; Zorica Subotić, T. 38262 (14 May 2013); T. 38423-38426 (16 May 2013). The Chamber notes, however, that Sabljica
} 
Chamber notes that this is almost identical to the azimuth established by Verdy. She observed, in contrast to CSB Sarajevo, that the radial marks left by the explosion extended towards the middle of the street, to a length of about three metres. ${ }^{13776}$ Acknowledging that the impact site on the curb had been repaired, she opined that the crater was about 60 centimetres in diameter and thus caused by a $120 \mathrm{~mm}$ calibre mortar shell, which was the calibre established by Verdy. ${ }^{13777}$ Subotić also noted that the azimuth from 4 Klara Cetkin street to the Institute for the Blind was 266 degrees, which to her reinforced the fact that the CSB Sarajevo ballistics investigators simply guessed the origin of fire. $^{13778}$

4122. In respect of the Cetinjska street crater, Subotić did not conduct any physical examination because the road had been resurfaced. ${ }^{13779}$ Using contemporaneous CSB Sarajevo photographs, however, she determined that the crater had a diameter of approximately $90 \mathrm{~cm}$, meaning that a 120 $\mathrm{mm}$ mortar shell impacted the scene-again agreeing with Verdy. ${ }^{13780}$ She also expressed the opinion that the forensic technician from CSB Sarajevo who concluded that both shells were 120 $\mathrm{mm}$ shells must have relied on the size of the crater he observed. ${ }^{13781}$ Using footage taken by Hogan in 2001 before the road had been resurfaced, Subotić also observed that there was a "central

did not agree to the direction but rather that the method used, as seen in the photograph, appeared to be accurate and thus could indicate the direction from which the projectile came. See Mirza Sabljica, T. 7846-7850 (13 October 2010); D755 (Photograph re shelling of Alipašino Polje on 22 January 1994 marked by Mirza Sabljica); D756 (Photograph re shelling of Alipašino Polje on 22 January 1994 marked by Mirza Sabljica).

13776 Zorica Subotić, T. 38260-38262 (14 May 2013). Subotić argued that the CSB Sarajevo description of the scene was therefore inaccurate and yet Higgs gave his "unreserved trust" towards their investigation as he did not notice that the shrapnel marks extended further than $120 \mathrm{~cm}$ from the crater. See D3542 (Zorica Subotićs expert report entitled "Mortar Operations in Sarajevo Area in 1992-1995", 15 August 2012), pp. 96-97;

13777 D3542 (Zorica Subotić's expert report entitled "Mortar Operations in Sarajevo Area in 1992-1995", 15 August 2012), p. 97, 108, 159. Subotic accepted that she did not investigate how the curb was repaired noting that the fragmentation pattern on the road meant that the shell could not have been an $82 \mathrm{~mm}$ mortar shell, regardless of the diameter of the crater. See Zorica Subotić, T. 38420-38423 (16 May 2013); T. 38632-38633 (22 May 2013); D3558 (Photograph depicting point of impact of shell marked by Zorica Subotić).

13778 D3542 (Zorica Subotić's expert report entitled "Mortar Operations in Sarajevo Area in 1992-1995", 15 August 2012), p. 98 (noting that the CSB Sarajevo's determination of origin to the west, or from a direction slightly north of west, translates into an azimuth of 270 degrees or more, rather than 266 degrees). See also Mirza Sabljica, T. 7810 (12 October 2010).

13779 D3542 (Zorica Subotić's expert report entitled “Mortar Operations in Sarajevo Area in 1992-1995”, 15 August 2012), p. 99; Zorica Subotić, T. 38262-38263 (14 May 2013).

13780 D3542 (Zorica Subotić's expert report entitled "Mortar Operations in Sarajevo Area in 1992-1995”, 15 August 2012), pp. 100-101; Zorica Subotić, T. 38262-38263 (14 May 2013) (wherein Subotić admitted that the photograph of the crater was blurry and using another image that depicts the broader street to confirm her calculation of the crater dimension. She explained that a manhole cover, which is substantially smaller in size when compared to the crater, can be seen in that photograph. Noting that the standard diameter of such covers is $70 \mathrm{~cm}$, she concluded that the crater must have been bigger than $70 \mathrm{~cm}$ ). The Chamber notes, however, that the quality of both photographs is poor and is therefore not persuaded that it is possible to determine the size of the crater from them. In addition, Subotic is not an expert on manholes and the Chamber has no evidence to verify her claim that the average size of a manhole is $70 \mathrm{~cm}$. See D3542 (Zorica Subotić's expert report entitled "Mortar Operations in Sarajevo Area in 1992-1995", 15 August 2012), p. 103.

13781 D3542 (Zorica Subotić's expert report entitled "Mortar Operations in Sarajevo Area in 1992-1995", 15 August 2012), p. 102. But see P2164 (Witness statement of KDZ477 dated 13 February 2010), para. 70; KDZ477, T. 10922, 10945-10946 (31 January 2011), T. 11018-11019 (1 February 2011). 
hole" within the crater, which was surrounded by a larger crater, and that the CSB investigators measured the smaller central hole thus mistakenly concluding that the crater was smaller than it actually was. ${ }^{13782}$ Using stills from Hogan's footage and a computer application, Subotic then concluded that this shell originated from a direction with an azimuth that was "slightly less than 240 degrees". 13783

4123. While essentially agreeing with Verdy's opinion as to the azimuth and the calibre of the two shells, Subotić argued that he made a mistake when assigning the azimuths of the shells to the two craters. ${ }^{13784}$ She then plotted the adjusted trajectories on Google Earth and saw that they intersected at a point 3,270 metres southwest of the impact site in Klara Cetkin street; namely in the $\mathrm{ABiH}-$ held territory, near the UPI institute in Sokolović Kolonija. ${ }^{13785}$ Subotić agreed with Verdy's determination as to the shells' angle of descent and calculated, using the firing tables for $120 \mathrm{~mm}$ mortars, that they were most probably fired using charge four. ${ }^{13786}$

4124. Galić testified that Alipašino Polje was in ABiH-held territory and that as far as he could remember at the time he did not order fire to be opened on the settlement. ${ }^{13787} \mathrm{He}$ observed that there were some military targets within Alipašino Polje and specifically he recalled that there was a unit of the $1^{\text {st }}$ Corps of the $\mathrm{ABiH}$ stationed in the area at a place called Kulin Ban, approximately "110 to 150 " metres away from the incident site. ${ }^{13788}$ He suggested that this may have been the reason behind fire being opened but that--due to a cease-fire--he did not think the SRK had in fact

13782 D3542 (Zorica Subotić's expert report entitled "Mortar Operations in Sarajevo Area in 1992-1995", 15 August 2012), pp. 102-103.

13783 D3542 (Zorica Subotić's expert report entitled "Mortar Operations in Sarajevo Area in 1992-1995”, 15 August 2012), pp. 103-104; Zorica Subotić, T. 38263-38264 (14 May 2013) (arguing that the shadow cast by an electricity pole within the footage had a similar trajectory to the central axis of the fragment pattern of the crater and calculating the azimuth of the sun to determine the azimuth of the shadow).

13784 D3542 (Zorica Subotić's expert report entitled "Mortar Operations in Sarajevo Area in 1992-1995", 15 August 2012), pp. 102, 104-5. According to Subotić, Verdy correctly determined a direction of fire towards the southwest for both shells. Since all three shells landed within the "range error margin" for mortars, all three were fired from the same mortar. This meant that Verdy's trajectories should intersect at their origin, to the southwest. Verdy marked the azimuth beside the photograph of the shell that landed at Klara Cetkin street as 4,200 mils and for the shell that landed at Cetinjska street as 4,250 mils. When plotting these trajectories, she found that they intersected at a point to the northeast of the incident site, which is impossible and thus indicates that Verdy swapped the azimuths when ascribing them to the respective craters. See Zorica Subotić, T. 38264 38265 (14 May 2013); T. 38426-38427, 38430-38436 (16 May 2013).

13785 D3542 (Zorica Subotić's expert report entitled "Mortar Operations in Sarajevo Area in 1992-1995", 15 August 2012), pp. 106-107; Zorica Subotić, T. 38265-38266 (14 May 2013) (explaining that UPI Institute was an agricultural institute).

13786 D3542 (Zorica Subotić's expert report entitled "Mortar Operations in Sarajevo Area in 1992-1995", 15 August 2012), p. 107.

13787 Stanislav Galić, T. 37436 (18 April 2013). See also Dragomir Milošević, T. 32710 (28 January 2013).

13788 Stanislav Galić, T. 37436 (18 April 2013); T. 38036-38040 (9 May 2013). See also D2497 (Witness statement of Nikola Mijatović dated 27 November 2012), para. 9; D2499 (Map of Alipašino Polje marked by Nikola Mijatović). 
opened fire. ${ }^{13789}$ He testified that the decision for further SRK operations on 23 January 1994 was for the Corps to adopt a defensive posture and that he did not receive a report or protest from the UNPROFOR in relation to the incident. ${ }^{13790} \mathrm{He}$ also testified that regardless of the faction that fired the shells, there was "no [valid] reasons or justifications" for the incident. ${ }^{13791}$ When asked about this incident, Milošević testified that he could not recall it but that the SRK "did not open fire [on areas] inhabited by the civilian population" or do anything that was prohibited. ${ }^{13792}$

4125. Sladoje testified that the $\mathrm{ABiH}$ units positioned in Vojničko Polje, Alipašino Polje, and Stup, had, inter alia, 82 and $120 \mathrm{~mm}$ mortars and a tank in depth of Alipašino Polje; they were also supported by artillery from Mt. Igman. ${ }^{13793}$ Sladoje's $1^{\text {st }}$ Battalion was equipped with 82 and 120 mm mortars, four or five of which were located near the Faculty of Theology; according to him, military targets in the area included the Oslobođenje building, the student dormitories, and a building located a few blocks from Cetinjska street in the vicinity of Prvomajska street, where civilians were also living. ${ }^{13794}$ He categorically denied, however, that the SRK had any mortars at the Institute for the Blind and further that anyone ordered this particular shelling. ${ }^{13795}$ Accepting that there was a substantial risk of civilian casualties when firing on any urban areas with military presence, such as Alipašino Polje, he nonetheless wondered "how can [the SRK] not open fire [on enemy soldiers] if [its] positions [are] jeopardized". 13796

4126. Contrary to Sladoje, Radojčić, commander of the Ilidža Brigade, testified that there was an $82 \mathrm{~mm}$ mortar platoon positioned close to the Institute for the Blind but that there were no $120 \mathrm{~mm}$

\footnotetext{
13789 Stanislav Galić, T. 37436 (18 April 2013), T. 37936 (8 May 2013).

13790 Stanislav Galić, T. 37436-37437 (18 April 2013); D2806 (SRK combat report, 23 January 1994). See also Dragomir Milošević, T. 32710 (28 January 2013).

13791 Stanislav Galić, T. 37441-37442 (18 April 2013). Galić also testified that numerous incidents during this period, including this particular incident, were part of the Sarajevo media campaign against the SRK and the VRS in general. See Stanislav Galić, T. 37442 (18 April 2013).

13792 Dragomir Milošević, T. 32710 (28 January 2013).

13793 D2479 (Witness statement of Mile Sladoje dated 25 November 2012), paras. 5, 7, 10 (stating that the ABiH units in the area were the $101^{\text {st }}$ and $102^{\text {nd }}$ Brigades of the $1^{\text {st }}$ Corps of the ABiH). See also Milomir Šoja, T. 7214 7216 (30 September 2010) (stating that $\mathrm{ABiH}$ would open small arms fire on the Ilidža Brigade positions from the cold storage plant in Stup). The Chamber notes that it appears from the evidence before it that the cold storage plant was part of the UPI Institute. See D676 (Map of Sarajevo marked by Milomir Šoja); D3542 (Zorica Subotić's expert report entitled “Mortar Operations in Sarajevo Area in 1992-1995”, 15 August 2012), p. 106, Figure 62.

13794 Mile Sladoje, T. 30563-30566, 30571-30573 (28 November 2012); D2479 (Witness statement of Mile Sladoje dated 25 November 2012), paras. 6-7; D2481 (Map of Sarajevo marked by Mile Sladoje); D2482 (Map of Sarajevo marked by Mile Sladoje); P6009 (Map of Sarajevo marked by Mile Sladoje). See also P1058 (ABiH map) (indicating that the SRK had mortars both near the Faculty of Theology and near the Institute for the Blind).

13795 D2479 (Witness statement of Mile Sladoje dated 25 November 2012), para. 27. Sladoje confirmed that Alipašino Polje was within the range of his battalion's weaponry and further that he was aware that civilians lived in the area but stated that the ABiH used most of the buildings. See Mile Sladoje, T. 30570, 30573 (28 November 2012).

13796 Mile Sladoje, T. 30573-30574 (28 November 2012).
} 
mortars at this location. ${ }^{13797} \mathrm{He}$ also stated that he never issued an order to open fire on the incident location and that he did not receive information from subordinates about such an attack. ${ }^{13798}$

4127. Savo Simić, who was with the $1^{\text {st }}$ Sarajevo Mechanised Brigade positioned towards Lukavica, stated that the shells in this incident originated from $\mathrm{ABiH}$-held territory in the direction of Butmir. ${ }^{13799}$ Dušan Škrba, Simić's subordinate, stated that, in his opinion, the "most probable" location of the origin of fire towards the southwest was the "Butmir agricultural estate" as this was an ideal place to fire mortars. ${ }^{13800}$

4128. In terms of casualties in this incident, the CSB Sarajevo report provides that the following children had been killed: Danijel Jurenić, Admir Subašić, Nermin Rizvanović, Jasmina Brković, Indira Brković, and Mirza Dedović. ${ }^{13801}$ The report also notes that the following persons were wounded, the majority of whom were children: Elvir Ahmethodžić, Admir Ahmethodžić, Muhamed Kapetanović, Nedžad Topel, Goran Todorović, and Samir Sarač. ${ }^{13802}$ The medical records available to the Chamber indicate that six persons died, and at least five persons were injured during the incident. ${ }^{13803}$

4129. In addition to the evidence and the adjudicated facts outlined above, the Chamber has also taken judicial notice of the following adjudicated facts which go to the direction and origin of fire, as well as the calibre of the shells used in this incident: (i) three mortar shells (two $82 \mathrm{~mm}$ and one $120 \mathrm{~mm}$ calibre) were fired into the residential neighbourhood of Alipašino Polje around noon on 22 January 1994, killing six children and injuring other civilians, including children; ${ }^{13804}$ (ii) the

\footnotetext{
13797 D2562 (Witness statement of Vladimir Radojčić dated 8 December 2012), paras. 1-2; 111 . See also P1058 (ABiH map).

13798 D2562 (Witness statement of Vladimir Radojčić dated 8 December 2012), para. 111.

13799 D2412 (Witness statement of Savo Simić dated 4 November 2012), paras. 3, 12, 26. The Chamber notes that Simić does not explain the basis for this opinion. The Chamber is therefore unable to assess its reliability and will not rely on this evidence.

13800 D2341 (Witness statement of Dušan Škrba dated 14 October 2012), paras. 7, 20.

13801 P1443 (BiH MUP Report re shelling of Alipašino Polje on 22 January 1994), e-court pp. 3-6, 8, 11-12, 15-16.

13802 P1443 (BiH MUP Report re shelling of Alipašino Polje on 22 January 1994), e-court pp. 3-7, 10, $13-16$.

13803 P463 (Koševo Hospital morgue records), pp. 1-4; P461 (Admission records from Koševo Hospital), p. 50; P818 (Extracts from Fatima Zaimović's diary), p. 21; P1025 (Medical records for Muhamed Kapetanović); P1236 (Medical reports for Elvir and Admir Ahmethodžić); P1443 (BiH MUP Report re shelling of Alipašino Polje on 22 January 1994), e-court pp. 10-12. The Chamber notes that Adjudicated Fact 296 states that the investigative Judge Zdenko Eterović "established by interviewing witnesses and by observation of bodily remains at the site, as well as by visiting the hospitals where the casualties had been taken" that six children were killed and another three children and one adult were seriously injured, bringing the total number of casualties to ten. However, Eterović did not include Goran Todorović among the list of casualties in his report even though Todorović was also wounded in the incident. The Chamber will therefore rely on another part of the CSB Sarajevo report which includes Todorović among the victims, as well as Samir Sarač. See P1443 (BiH MUP Report re shelling of Alipašino Polje on 22 January 1994), e-court pp. 4, 15-16.

13804 Adjudicated Fact 297.
} 
impact traces were considerably more pronounced to the west of the craters, ${ }^{13805}$ (iii) it can be safely concluded that the shells came in from either the west or north of west; ${ }^{13806}$ (iv) the impact traces were strongly elliptical and significantly displaced to the west; ${ }^{13807}$ (v) the three shells were fired from SRK positions somewhere to the west of Alipašino Polje; ${ }^{13808}$ and (vi) the sequence of explosions, together with the fact that the shelling ceased after just three volleys were fired, all of which landed wide of Kulin Ban (two at a distance of at least 150 metres) allowed for the conclusion that Kulin Ban was not the intended target of this attack. ${ }^{13809}$

4130. Having considered the evidence and the adjudicated facts recounted above, the Chamber is convinced that at least three mortar shells exploded in the area of Alipašino Polje on 22 January 1994. One of the shells landed in front of 3 Cetinjska street, another in front of 4 Klara Cetkin street, and a third in Rade Končara square behind these two locations. With respect to the calibre of the shells involved, the Chamber is more persuaded by the CSB Sarajevo findings than Subotić's analysis and her reliance on Verdy. First, Sabljica and Stankov conducted a detailed de visu examination on the day of the incident and were thus able to see the scene and fresh traces caused by the three shells in question. This was not the case with Verdy who only examined two of the three traces one day later, while Subotić examined the scene over a decade later. Second, Subotić's conclusions in relation to the craters are highly speculative, to the point of being unreasonable at times. For example, with respect to the Klara Cetkin street shell, she based her conclusions on the examination of a repaired curb, without knowing anything about the nature of those repairs or how much the repairs had affected the size of the crater. This means that her conclusions about the size of this crater carry no persuasive value. Similarly, with regard to her analysis of the site in Cetinjska street, Subotić relied on the footage taken by Hogan in 2001 and the contemporaneous photographs taken by the CSB Sarajevo, which were of a clearly inferior quality. Her analysis of these secondary sources, involving concepts such as the average size of a manhole cover and the relative size of an object in photographs, is highly speculative and unpersuasive. Therefore the Chamber does not accept that all of the shells in the incident were $120 \mathrm{~mm}$ in calibre and finds that at least two $82 \mathrm{~mm}$ and one $120 \mathrm{~mm}$ mortar shells exploded in Alipašino Polje on 22 January 1994.

4131. Relying on the medical evidence and the CSB Sarajevo investigation discussed above, the Chamber finds that the explosion caused by the three shells on 22 January 1994 resulted in 12 casualties, six of whom died (all children) and six of whom (majority children) were injured.

\footnotetext{
13805 Adjudicated Fact 300.

13806 Adjudicated Fact 301.

13807 Adjudicated Fact 302.

13808 Adjudicated Fact 303.

13809 Adjudicated Fact 304.
} 
4132. In terms of the direction of fire, the Chamber recalls that the CSB Sarajevo investigators concluded that the shells originated from a general direction to the west of Alipašino Polje, while Verdy thought that the projectiles in Cetinjska and Klara Cetkin streets originated from the same mortar, positioned in either Stup or Ilidža, that is either to the west or southwest of the incident site. The Chamber recalls that, to Higgs, the two investigations were not far apart in terms of direction as they both essentially concluded that the shells originated from approximately the west of Alipašino Polje in the direction of Nedžarići. However, Higgs considered that the CSB Sarajevo investigation would have been more accurate as it was more contemporaneous. The Chamber agrees with his analysis.

4133. While Subotic thought that the two shells analysed by both Verdy and CSB Sarajevo originated from approximately the southwest of Alipašino Polje, her conclusions were based on an examination of what was a substantially altered scene, as well as secondary sources such as unclear photographs and video footage of the scene. For example, with regard to the Cetinjska street shell, she calculated the azimuth using the 2001 video footage of Hogan standing next to the crater, as well as the azimuth of the sun and the shadows cast by objects in the footage. The Chamber considers that this type of analysis is unacceptable and further that it seriously damages her credibility in relation to both this incident and generally. Accordingly, the Chamber does not accept any of her evidence in relation to the direction of fire in this incident.

4134. The Chamber finds that the shells originated from the area approximately west of the incident site.

4135. As far as the precise origin of fire is concerned, the angle of descent for the shells was not determined by either the CSB Sarajevo investigators or Subotić, while Verdy concluded that it was more than 1,100 mils and that the shells had a maximum range of between 2,000 and 3,000 metres, thus placing the origin of fire in the SRK-held territory. Given that it is unclear from his report how Verdy managed to calculate the maximum range of the shells, the Chamber is unable to assess his method and thus cannot accept those findings. At the same time, the Chamber does not accept Subotić's analysis that the fire came from the UPI Institute southwest of the incident site either. This is because she based her analysis on Verdy's azimuths being absolutely accurate at 236 and 239 degrees, albeit reversed. However, the Chamber notes that Verdy also concluded in his report that the azimuths were "between" 236 and 239 degrees. In other words, the trajectories plotted by Subotić, which intersect at the UPI Institute, predicate an absolute accuracy. The Chamber finds this to be unrealistic in light of the margin of error with which ballistic experts have to work. 
4136. With respect to the origin of fire, the Indictment alleges that the shells came from the SRKheld territory to the west of the incident site and does not specify the exact origin of fire. The Prosecution Final Brief then refers to Nedžarići and the Institute for the Blind, or alternatively the Stup area in the Serb part of Ilidža, as the origin of fire. ${ }^{13810}$

4137. However, taking all of the above into account, as well as the adjudicated facts relating to this incident, the Chamber is not satisfied beyond reasonable doubt that the origin of fire was Nedžarići and the Institute for the Blind. First, the CSB Sarajevo report does not conclude that the fire came from there but only that it came from a westerly direction where Nedžarići and the Institute for the Blind are located. In addition, as noted earlier, ${ }^{13811}$ Sabljica conceded that CSB Sarajevo did not establish the azimuth of the shells, as was normal practice. Finally, the adjudicated facts do not provide that the origin of fire was Nedžarići or the Institute for the Blind.

4138. With respect to Stup, the Chamber notes that the adjudicated facts do not state that it was the origin of fire in this incident. In addition, as noted above, this area was mostly under the control of the $\mathrm{ABiH}$, while a small part was controlled by the SRK. ${ }^{13812}$ On the basis of the evidence before the Chamber, Verdy is the only person who determined the angle of descent and calculated the potential distance the shells had travelled, and thus placed the origin of fire in the SRK territory in Stup. However, in its Final Brief, the Prosecution states that it has chosen not to rely on his report as Verdy's methodology was criticised by his superiors and he did not come to the scene on the day of the incident. ${ }^{13813}$ The Chamber is therefore unable to conclude, beyond reasonable doubt, that the origin of fire was the Serb-held part of Stup, as neither the evidence before it nor the adjudicated facts indicate this location as the origin of fire.

4139. While Adjudicated Fact 303 states that the shells came from the SRK positions "somewhere to the west of the incident site", both $\mathrm{ABiH}$ and SRK held positions to the west of the incident site. Given the above findings with respect to Nedžarići and Stup, both of which are locations to the west of the incident site, and bearing in mind that the only report which placed the origin of fire in the SRK territory on the basis of something other than mere guesswork was discredited by the Prosecution, the Chamber is unable to rely on Adjudicated Fact 303. The Chamber therefore cannot conclude beyond reasonable doubt that the fire came from SRK positions.

\footnotetext{
13810 Prosecution Final Brief, Appendix C, para. 52.

13811 See fn. 13737.

13812 See para. 4056, fn. 13492. See also P1058 (ABiH map).

13813 See Prosecution Final Brief, Appendix C, para. 52, fn. 330. While Subotić does rely on Verdy's report to a large extent, she concludes that he made a mistake when determining the exact origin of fire. Accordingly, as neither party relies on his report with respect to the origin of fire and he did not give evidence before the Chamber explaining and defending his methodology, the Chamber cannot rely on it in this regard.
} 
4140. The Indictment alleges that on 4 February 1994, a salvo of three $120 \mathrm{~mm}$ mortar shells hit civilians in the Dobrinja residential settlement. ${ }^{13814}$ The first shell is alleged to have landed in front of a block of flats at Oslobodilaca Sarajeva street, hitting persons who were distributing and receiving humanitarian aid and also children attending religious classes. ${ }^{13815}$ The second and third shells are alleged to have landed amongst persons trading at a market in an open area to the rear of the apartment buildings at Mihajla Pupina street and Oslobodilaca Sarajeva street. ${ }^{13816}$ The shells are alleged to have originated from VRS/SRK-held territory to the east of Dobrinja, and to have resulted in the death of 8 persons and the wounding of at least 18 others. ${ }^{13817}$ In its Final Brief, the Prosecution submits that the $120 \mathrm{~mm}$ mortar shells were fired with at least three charges and originated from the direction of SRK-held territory to the east of Dobrinja, in the vicinity of Lukavica, possibly the Energoinvest complex. ${ }^{13818}$ The Accused argues that in fact four $120 \mathrm{~mm}$ mortar shells exploded at the scene, and that they originated from the ABiH-held positions. ${ }^{13819}$

4141. On 4 February 1994, humanitarian aid was being distributed along Oslobodilaca Sarajeva street in Dobrinja where a large number of people had gathered waiting for the aid when a number of shells exploded causing a number of casualties. ${ }^{13820}$ One of those present in the area was Sabahudin Ljuša who did not see any soldiers or military personnel at the place where humanitarian aid was being unloaded or in Oslobodilaca Sarajeva street. ${ }^{13821}$ The Chamber also took judicial notice that Ismet Hadžić, commander of the Dobrinja Brigade of the ABiH, stated that on that date there were no $\mathrm{ABiH}$ military units close to the site. ${ }^{13822}$

4142. Sabljica and Međedović participated in the investigation of this incident on 4 February 1994, together with a team from CSB Sarajevo, led by an investigating judge, Zdenko Eterović, and including a number of forensic technicians, such as Bešić and KDZ166. ${ }^{13823}$ According to the

\footnotetext{
13814 Indictment, Scheduled Incident G.7.

13815 Indictment, Scheduled Incident G.7.

13816 Indictment, Scheduled Incident G.7.

13817 Indictment, Scheduled Incident G.7.

13818 Prosecution Final Brief, Appendix C, para. 53.

13819 Defence Final Brief, paras. 2040-2046.

13820 P1710 (BiH MUP Report re shelling of Dobrinja on 4 February 1994), e-court pp. 5; P1695 (Witness statement of Mirza Sabljica dated 11 February 2010), p. 54. See also KW570, T. 32220 (18 January 2013) (private session).

13821 See Adjudicated Fact 318.

13822 See Adjudicated Fact 319.

13823 P1710 (BiH MUP Report re shelling of Dobrinja on 4 February 1994), e-court pp. 8-9. See also P1695 (Witness Statement of Mirza Sabljica dated 11 February 2010), p. 49; P129 (Witness statement of Zlatko Međedović dated 20 November 1995), p. 3; P1791 (Witness statement of KDZ166 dated 13 February 2010), pp. 14-15. Before the on-site investigation was conducted the bodies and the wounded people were removed and
} 
report prepared by Eterović on the day of the incident, three $120 \mathrm{~mm}$ shells landed in the area, the first two almost simultaneously at 11:30 a.m. ${ }^{13824}$ One of the two hit the ground floor of an apartment building at number 8 Oslobodilaca Sarajeva street, injuring a boy but causing no deaths. ${ }^{13825}$ The other hit a retaining wall in the backyard of an apartment at number 3 Mihajla Pupina street and a $120 \mathrm{~mm}$ shell stabiliser was found on the scene. ${ }^{13826}$ A boy and a woman were killed by this shell. ${ }^{13827}$ The third shell landed a few minutes later, hitting the playground located next to a covered parking lot and surrounded by buildings in the vicinity of Oslobodilaca Sarajeva street. ${ }^{13828}$ More specifically, the report states that this shell landed on the "asphalt sidewalk", on the side closer to the playground. ${ }^{13829}$ A $120 \mathrm{~mm}$ shell stabiliser was found embedded in the asphalt. ${ }^{13830}$ The report also notes that altogether six persons were killed on the scene and two more people died on admission to the Koševo Hospital; ${ }^{13831}$ while 22 others were seriously wounded. ${ }^{13832}$ The official report CSB prepared the following day lists eight killed and 18 wounded. ${ }^{13833}$

taken to either Dobrinja or Koševo Hospitals. See P1710 (BiH MUP Report re shelling of Dobrinja on 4 February 1994), e-court p. 3.

13824 P1710 (BiH MUP Report re shelling of Dobrinja on 4 February 1994), e-court pp. 2-3, 5.

13825 P1710 (BiH MUP Report re shelling of Dobrinja on 4 February 1994), e-court p. 3. This shell "hit the window frame" of an apartment at the ground floor of the building which was being used as a Muslim primary school. P1710 (BiH MUP Report re shelling of Dobrinja on 4 February 1994), e-court p. 3.

13826 P1710 (BiH MUP Report re shelling of Dobrinja on 4 February 1994), e-court p. 3; P1707 (Photographs re shelling of Dobrinja on 4 February 1994), e-court pp. 10-13; P1972 (Photographs re shelling of Dobrinja on 4 February 1994), e-court pp. 1-4; D998 (Video footage re shelling of Dobrinja on 4 February 1994); D896 (Video footage of shelling of Dobrinja on 4 February 1994, Markale on 5 February 1994, and Markale on 28 August 1995).

13827 P1710 (BiH MUP Report re shelling of Dobrinja on 4 February 1994), e-court p. 3.

13828 P1710 (BiH MUP Report re shelling of Dobrinja on 4 February 1994), e-court p. 3; P1707 (Photographs re shelling of Dobrinja on 4 February 1994), e-court pp. 2-9; P1972 (Photographs re shelling of Dobrinja on 4 February 1994), e-court pp. 5-10; D1001 (Video footage re shelling of Dobrinja on 4 February 1994); D1002 (Video footage re shelling of Dobrinja on 4 February 1994); D896 (Video footage of shelling of Dobrinja on 4 February 1994, Markale on 5 February 1994, and Markale on 28 August 1995). See Adjudicated Fact 316.

13829 P1710 (BiH MUP Report re shelling of Dobrinja on 4 February 1994), e-court p. 3. Pools of blood, pieces of flesh, spilled flour and a damaged boot were also found at the scene. P1710 (BiH MUP Report re shelling of Dobrinja on 4 February 1994), e-court pp. 3, 5, 7. See P1902 (Sketch re shelling of Dobrinja on 4 February 1994) (under seal); P1695 (Witness Statement of Mirza Sabljica dated 11 February 2010), pp. 49-50; P1707 (Photographs re shelling of Dobrinja on 4 February 1994).

13830 P1710 (BiH MUP Report re shelling of Dobrinja on 4 February 1994), e-court p. 3.

13831 While the report notes that three other individuals died on admission to the Koševo Hospital, the Chamber notes that one of the three listed is Sabahudin Ljuša who in fact survived the attack and is also listed in Eterović's report as one of the seriously wounded victims. Ljuša was 10 years old at the time of the attack. P1710 (BiH MUP Report re shelling of Dobrinja on 4 February 1994), e-court pp. 3, 5-6. Adjudicated Fact 318 makes it clear that Ljuša survived and went on to give evidence in the Galić case.

13832 While Eterović's report refers to 23 seriously wounded victims, the number is actually 18 as a number of persons appear to have been listed twice. The Chamber notes that "Mukšija Pribinja"/"Muskija Pubinja"-who appears to be the same individual-is listed both among those who died in the hospital and among those who were seriously wounded. The official report, prepared the next day, clarifies that this individual was among the dead and that 18 people were wounded in this incident. P1710 (BiH MUP Report re shelling of Dobrinja on 4 February 1994), e-court pp. 3-6. See also Adjudicated Fact 317, which provides that Eterović's report found that altogether eight people had been killed by shells and 22 were wounded. The Chamber notes, relying on the 
4143. Sabljica and Međedović examined only two out of the three impact sites, namely those that resulted in significant casualties. ${ }^{13834}$ They concluded, based on the size and shape of the shrapnel traces and on the recovered stabiliser, that a $120 \mathrm{~mm}$ calibre mortar shell landed in the backyard of number 3 on Mihajla Pupina street, from the direction of east-northeast, "where Lukavica, that is, the Energoinvest complex of buildings is located." ${ }^{13835}$ For the same reasons, the projectile that landed on the footpath beside the playground was also found to have been a $120 \mathrm{~mm}$ calibre mortar shell and the team concluded that it had originated "from the east", again where Lukavica and the Energoinvest complex were located. ${ }^{13836}$ When asked about the lack of reference to the shell that landed at number 8 Oslobodilaca Sarajeva street in his report, Sabljica explained that Eterović "insisted" on including in his official report some analysis relating to that shell, despite the fact that Sabljica and Međedović did not analyse it. ${ }^{13837}$ Commenting on Eterović's reported sequence in which the shells landed, Sabljica stated that he and Međedović did not know the sequence as all they did was look at the traces of the explosion. ${ }^{13838}$ Assuming that the sequence was correct, however, Sabljica could not explain why the children would still be on the playground when the third shell landed, if the two other shells had already landed nearby several minutes before it. ${ }^{13839}$

4144. Sabljica testified that the confrontation line to the north and northeast of Dobrinja was between 350 to 400 metres away from the incident site. ${ }^{13840}$ He acknowledged that there was a certain difference in his findings as to the origins of the two shells, namely east and northeast, and explained that the Energoinvest complex that is mentioned in the report was only used as an

available evidence, that the number of wounded was in fact 18 people. As a result, the Chamber will not rely on this particular Adjudicated Fact in its findings below.

13833 P1710 (BiH MUP Report re shelling of Dobrinja on 4 February 1994), e-court pp. 5-6.

13834 P1695 (Witness Statement of Mirza Sabljica dated 11 February 2010), p. 49; P1710 (BiH MUP Report re shelling of Dobrinja on 4 February 1994), e-court pp. 8-9; P129 (Witness statement of Zlatko Međedović dated 20 November 1995), p. 3; Mirza Sabljica, T. 7768-7769 (12 October 2010); Sead Bešić, T. 9488-9489 (9 December 2010); P1966 (Witness statements of Sead Bešić dated 18 February 2010), pp. 3-7.

13835 P1710 (BiH MUP Report re shelling of Dobrinja on 4 February 1994), e-court p. 9; P1695 (Witness statement of Mirza Sabljica dated 11 February 2010), p. 50; P1816 (BiH MUP Report re shelling of Dobrinja on 4 February 1994), p. 1; P1902 (Sketch re shelling of Dobrinja on 4 February 1994) (under seal).

13836 P1710 (BiH MUP Report re shelling of Dobrinja on 4 February 1994), e-court p. 9; P1695 (Witness statement of Mirza Sabljica dated 11 February 2010), p. 51; P1816 (BiH MUP Report re shelling of Dobrinja on 4 February 1994), p. 1; P1902 (Sketch re shelling of Dobrinja on 4 February 1994) (under seal).

13837 P1695 (Witness statement of Mirza Sabljica dated 11 February 2010), pp. 53-54; P1710 (BiH MUP Report re shelling of Dobrinja on 4 February 1994), e-court p. 9.

13838 Mirza Sabljica, T. 7791-7795 (12 October 2010).

13839 Mirza Sabljica, T. 7793-7794 (12 October 2010). On cross-examination, Sabljica testified that this site was what Eterović referred to as the third shell in the sequence, which in the CSB sketch was marked with number one. Mirza Sabljica, T. 7790-7791, $7795-7797$ (12 October 2010); D744 (Photograph re shelling of Dobrinja on 4 February 1994 marked by Mirza Sabljica); D743 (Photograph re shelling of Dobrinja on 4 February 1994 marked by Mirza Sabljica).

13840 P1695 (Witness statement of Mirza Sabljica dated 11 February 2010), p. 52. According to Sabljica, the confrontation line ran east and northeast of Dobrinja, in the direction of Lukavica. See Mirza Sabljica, T. 77717772 (12 October 2010); D741 (Map of Dobrinja marked by Mirza Sabljica). 
"orientation point" rather than as the actual calculated origin of fire. ${ }^{13841}$ Međedović testified that there were only one or two buildings between the incident site and the Serb lines. ${ }^{13842}$

4145. As part of the official report one of the CSB Sarajevo, a forensic technician drew a sketch of the incident site marking the three impact sites and noting the direction of the north. ${ }^{13843}$ However, during cross-examination of Sabljica, the Accused successfully established that the sketch was inaccurate, as was the direction of north marked on it. ${ }^{13844}$ KDZ166 explained that this mistake occurred because the forensic technician was unfamiliar with Dobrinja and under pressure to work fast. ${ }^{13845}$ Despite this error, Sabljica remained of the view that the second shell came from the east, while the third shell came from the northeast. ${ }^{13846}$ Both he and KDZ166 testified that the direction of fire was not determined on the basis of this sketch, nor was it indicated on it; rather it was determined on the basis of the traces at the scene. ${ }^{13847}$

4146. Shortly after the shelling, having heard about it from a journalist, Rose went to the incident site and ordered that the crater analysis be carried out. ${ }^{13848}$ The UNPROFOR determined that between 11 a.m and 11.02 a.m on 4 February 1994, three $120 \mathrm{~mm}$ mortar rounds exploded in Dobrinja. ${ }^{13849}$ The UNPROFOR found that the "presumed" origin of fire for all three shells was the

13841 P1695 (Witness statement of Mirza Sabljica dated 11 February 2010), pp. 52-53; Mirza Sabljica, T. 7768 (12 October 2010).

13842 P129 (Witness statement of Zlatko Međedović dated 20 November 1995), p. 3.

13843 P1902 (Sketch re shelling of Dobrinja on 4 February 1994) (under seal).

13844 Sabljica drew the correct direction of north on the sketch that was rotated in order to show accurate illustration of the area. See Mirza Sabljica, T. 7768-7773, 7777-7789 (12 October 2010), T. 7947-7951, 7953-7957 (14 October 2010); D741 (Map of Dobrinja marked by Mirza Sabljica); D742 (Sketch re shelling of Dobrinja on 4 March 1994 marked by Mirza Sabljica); P1739 (Map of Dobrinja); P1740 (Aerial photograph of Sarajevo marked by Mirza Sabljica); P1741 (Sketch re shelling of Dobrinja on 4 February 1994 marked by Mirza Sabljica); D768 (Composite images of P1740 and P1741 marked by Mirza Sabljica); D900 (Map of Dobrinja marked by Sead Bešić).

13845 KDZ166 also marked the correct direction of north on the image, which coincides with that marked by Sabljica. See KDZ166, T. 8281-8283, T. 8298-8299 (26 October 2010); P1802 (Sketch re shelling of Dobrinja on 4 February 1994 marked by KDZ166) (under seal).

13846 Mirza Sabljica, T. $7798-7799$ (12 October 2010); D742 (Sketch re shelling of Dobrinja on 4 March 1994 marked by Mirza Sabljica).

13847 Mirza Sabljica, T. 7800-7801 (12 October 2010), T. 7829-7830 (13 October 2010); KDZ166, T. 8297-8315 (26 October 2010); D798 (Sketch re shelling of Dobrinja on 4 February 1994 marked by KDZ166) (under seal); D799 (Map of Dobrinja marked by KDZ166); D800 (Sketch re shelling of Dobrinja on 4 February 1994 marked by KDZ166) (under seal); D801 (Sketch re shelling of Dobrinja on 4 February 1994 marked by KDZ166) (under seal); D802 (Photograph re shelling of Dobrinja on 4 February 1994 marked by KDZ166).

13848 P1638 (Witness statement of Michael Rose dated 26 March 2009), paras. 5, 35. See also KW570, T. 32220 (18 January 2013) (private session).

13849 P1597 (UNPROFOR report, 4 February 1994). The report lists three distinct UN grid reference points in relation to the location of the incident. It also records the damage at the scene as follows: shell one, hole on the tar lane; shell two, bedroom window; shell three, in front of a building. See P1597 (UNPROFOR report, 4 February 1994), e-court p.1. Thomas stated that based on his experience and under the circumstances the analysis conducted by the UNPROFOR appears to have been conducted in a thorough and professional manner. See P1558 (Witness statement of Francis Roy Thomas dated 13 May 2009), paras. 13, 108. 
SRK-held territory, in the general location of Lukavica. ${ }^{13850}$ Akashi informed journalists on 5 February 1994 that the UNPROFOR had confirmed that the mortar attack in Dobrinja on 4 February definitely originated from the SRK-held territory. ${ }^{13851}$ Rose also telephoned the VRS and wrote letters of protest to the Accused and Mladić. ${ }^{13852}$

4147. KDZ450 who was with the UNPROFOR in Sarajevo between 1993 and 1994, testified that this incident demonstrated to him that the SRK targeted the civilian population of Sarajevo. ${ }^{13853}$ On cross-examination, when put to him that Dobrinja was a military target given the presence of the $155^{\text {th }}$ Brigade, KDZ450 acknowledged that Dobrinja was on the confrontation line but maintained that the shells arrived in a residential area and caused only civilian casualties. ${ }^{13854}$

4148. Higgs went to the incident site and due to the scene not being well preserved decided to base his conclusions on the reports and data collected at the time of the incident. ${ }^{13855}$ Having examined the CSB Sarajevo report, Higgs testified that he had no reason to doubt any of the findings, including the fact that the mortars were of $120 \mathrm{~mm}$ calibre and that the direction of fire was from the east. ${ }^{13856} \mathrm{He}$ also observed that the distance between the three rounds on the ground was within a 40 metre radius, which can be expected from one barrel firing all three rounds. ${ }^{13857}$ Given the time delay between the firing of the rounds, as provided by the witness statement he had at his disposal, Higgs concluded that the aim of the fire was to harass those present at the incident site, disrupt whatever was going on, and prevent movement. ${ }^{13858}$ According to Higgs, this was a classic example of a harassing mission. ${ }^{13859}$

13850 Without referring to a specific crater, the UNPROFOR report lists the angle of descent as 1200 mils, angle of approach as 2000 mils, and the maximum range of 3500 to 4000 metres. Attached to the report is a map of Sarajevo depicting the three areas of impact and also an arrow from the likely point of origin, indicating the approach of the projectiles from the southeast of Dobrinja. See P1597 (UNPROFOR report, 4 February 1994).

13851 D4473 (UNPROFOR report re mortar bomb explosions in Sarajevo on 4 and 5 February 1994, 6 February 1994), e-court p. 2. Lieutenant Colonel Shadbolt of the UNPROFOR informed Akashi of the Crater Analysis on 6 February 1994. D4473 (UNPROFOR report re mortar bomb explosions in Sarajevo on 4 and 5 February 1994, 6 February 1994), e-court pp. 3-4. See also Michael Rose, T. 7352-7353 (6 October 2010); KW570, T. 32220 (18 January 2013) (private session); D682 (UNPROFOR report re local press summary, 7 February 1994). KDZ450 also testified that the UNPROFOR clearly established that the SRK shelled Dobrinja on 4 February 1994 and further that these actions led only to civilian death. See KDZ450, T. 10618, 10621, 10695 (20 January 2011).

13852 P1638 (Witness statement of Michael Rose dated 26 March 2009), para. 35.

13853 KDZ450, T. 10617-10618 (20 January 2011).

13854 KDZ450, T. 10620-10623 (20 January 2011). See also D965 (UNPROFOR report, 3 February 1994).

13855 P1437 (Richard Higgs's Consolidated Report on Sarajevo Shelling Incidents, 13 March 2009), p. 10.

13856 P1437 (Richard Higgs's Consolidated Report on Sarajevo Shelling Incidents, 13 March 2009), p. 10.

13857 P1437 (Richard Higgs's Consolidated Report on Sarajevo Shelling Incidents, 13 March 2009), p. 10.

13858 P1437 (Richard Higgs's Consolidated Report on Sarajevo Shelling Incidents, 13 March 2009), p. 10.

13859 P1437 (Richard Higgs's Consolidated Report on Sarajevo Shelling Incidents, 13 March 2009), p. 11. 
4149. Hogan visited the incident site in 2001 with several victims of the shelling ${ }^{13860}$ and on the basis of their recollections recorded the GPS co-ordinates and filmed the locations where two of the shells impacted on 4 February 1994. ${ }^{13861}$ He conceded that one of the victims made a mistake in relation to one of those locations, namely the point of impact for the shell that landed on or near the playground in the immediate vicinity of Oslobodilaca Sarajeva street, explaining that seven years had passed after the incident and that at the time of the incident this victim probably would not have been in a position to even see the precise point of impact. ${ }^{13862}$

4150. Zorica Subotic visited the incident site on 17 September $2010 .{ }^{13863}$ She confirmed that the CSB Sarajevo team incorrectly marked the position of north on their sketch, meaning that the fire coming from what was in fact the direction of north-northeast would look on the sketch as originating from the direction of east-southeast, namely the SRK positions. ${ }^{13864}$ In Subotićs opinion all of the $120 \mathrm{~mm}$ mortar shells that exploded on 4 February 1994 in fact originated from ABiH-held positions to the north and northeast. ${ }^{13865}$

4151. Focusing first on the shell that struck the building at no 8 Oslobodilaca Sarajeva street and for which CSB Sarajevo conducted no analysis, ${ }^{13866}$ Subotić observed that the façade of the

13860 See D996 (Video footage re shelling of Dobrinja on 4 February 1994); D1000 (Video footage re shelling of Dobrinja on 4 February 1994). The Chamber notes that it is not clear who the victims in question are from the evidence before it. However, it is clear that they were not witnesses in this case. The Chamber notes that Subotić provides in her expert report that two of those victims were Sabahudin Ljuša and Fata Spahić. See D3542 (Zorica Subotić's expert report entitled "Mortar Operations in Sarajevo Area in 1992-1995", 15 August 2012), pp. 118, 123

13861 Barry Hogan, T. 11204-11206, 11263-11269 (3 February 2011); P2190 (GPS locations for shelling and sniping incidents in Sarajevo); P2191 (Map of Sarajevo with scheduled sniping and shelling incidents); D996 (Video footage re shelling of Dobrinja on 4 February 1994); D997 (Video still re shelling of Dobrinja on 4 February 1994); D998 (Video footage re shelling of Dobrinja on 4 February 1994); D999 (Video still re shelling of Dobrinja on 4 February 1994).

13862 Barry Hogan, T. 11268-11269 (3 February 2011); D1000 (Video footage re shelling of Dobrinja on 4 February 1994); D1001 (Video footage re shelling of Dobrinja on 4 February 1994); D1002 (Video footage re shelling of Dobrinja on 4 February 1994).

13863 D3542 (Zorica Subotić's expert report entitled "Mortar Operations in Sarajevo Area in 1992-1995", 15 August 2012), p. 122; Zorica Subotić, T. 38363 (15 May 2013). Subotić based her conclusions on the documents produced by CSB Sarajevo and the remaining physical evidence at the scene in 2010. There were no remains of the craters, however. Zorica Subotić, T. 38437 (16 May 2013).

13864 D3542 (Zorica Subotić's expert report entitled "Mortar Operations in Sarajevo Area in 1992-1995”, 15 August 2012), pp. 120-121, 138, 164; Zorica Subotić, T. 38270-38271 (14 May 2013). On cross-examination, it was put to Subotic that she was misleading the Chamber when she asserted that the CSB findings were inaccurate based on this error as their ballistics experts did not use the sketch in any of their official calculations. She explained that she was not trying to mislead anyone and that without a correct reference point in the sketch and given the limited nature of the CSB investigation documentation it would be impossible to reconstruct and verify their results. Zorica Subotić, T. 38446-38452 (16 May 2013).

13865 D3542 (Zorica Subotić's expert report entitled "Mortar Operations in Sarajevo Area in 1992-1995", 15 August 2012), pp. 120-121, 137-139, 162-164.

13866 Subotić contended that it was suspicious that no analysis was conducted for this impact point as, according to her, and contrary to the CSB Sarajevo report, one person was in fact killed and five were injured by this shell. Subotic then lists the names of the relevant casualties in her report. D3542 (Zorica Subotić's expert report entitled "Mortar Operations in Sarajevo Area in 1992-1995", 15 August 2012), p. 112. However, it appears that 
building was not repaired after the incident and proceeded to argue that its physical appearance indicates that the shell landed with a large angle of descent and that it originated from the righthand side of the building, namely to the northeast. ${ }^{13867}$ Despite having conceded that she could not determine an accurate origin of fire given the lack of sufficiently preserved evidence, Subotić argued that the UNPROFOR findings for this impact were not accurate and further that the shell was fired from ABiH-held territory. ${ }^{13868}$

4152. Subotić determined that the shell that impacted at number 3 Mihajla Pupina street landed in front of a retaining wall, on pavement extending about 80 to 90 centimetres into the back yard. ${ }^{13869}$ Whilst the pavement had been repaired, she thought that the building's façade remained in the same condition as it had been when contemporaneously photographed by the CSB Sarajevo. ${ }^{13870}$ She then argued that Sabljica's description of the size of the shrapnel marks exceeded the size of the pavement which led her to conclude that his observations were not based on any physical evidence. ${ }^{13871}$ Subotić also thought that Sabljica's crater analysis was incorrect and that this particular shell was fired from $\mathrm{ABiH}$-held positions approximately to the north of Dobrinja. ${ }^{13872}$ She argued that the shell fragment dispersion pattern on the building's façade dispproved Sabljica's findings, as there were fewer shrapnel marks on the left-hand side of the building, which would not have been the case had the shell originated from the direction of Lukavica. ${ }^{13873}$ She also disparaged the CSB's use of a magnetic compass and a map to accurately determine the origin, and argued that

Subotić reached this conclusion simply on the basis that the people she lists lived on the Oslobodilaca Sarajeva street itself (their addresses are listed in the report). Given that the evidence shows that a large number of people were congregating in the area outside, queuing for humanitarian aid, the Chamber finds Subotić's assumption unacceptable. It shows her propensity to ignore contemporaneous evidence in order to reach completely unreasonable conclusions based on assumptions. This seriously brings into question her credibility as a legitimate and reliable expert witness.

13867 D3542 (Zorica Subotić's expert report entitled "Mortar Operations in Sarajevo Area in 1992-1995”, 15 August 2012), pp. 122-124, 138, 163-164.

13868 D3542 (Zorica Subotić's expert report entitled "Mortar Operations in Sarajevo Area in 1992-1995", 15 August 2012), pp. 122, 138-139, 163-164.

13869 D3542 (Zorica Subotić's expert report entitled "Mortar Operations in Sarajevo Area in 1992-1995", 15 August 2012), pp. 124-125. See also P1710 (BiH MUP Report re shelling of Dobrinja on 4 February 1994), e-court p. 9

13870 D3542 (Zorica Subotić's expert report entitled "Mortar Operations in Sarajevo Area in 1992-1995", 15 August 2012), pp. 124-130. See also P1972 (Photographs re shelling of Dobrinja on 4 February 1994), e-court pp. $2-4$.

13871 D3542 (Zorica Subotić's expert report entitled "Mortar Operations in Sarajevo Area in 1992-1995", 15 August 2012), p. 125.

13872 D3542 (Zorica Subotić's expert report entitled "Mortar Operations in Sarajevo Area in 1992-1995”, 15 August 2012), pp. 131, 138-139, 163-164.

13873 D3542 (Zorica Subotić's expert report entitled "Mortar Operations in Sarajevo Area in 1992-1995", 15 August 2012), pp. 125-127; Zorica Subotić, T. 38271-38272 (14 May 2013). On cross-examination, it was put to Subotic that she was misleading the Chamber as the shell would have landed at a downwards angle of 45 degrees or greater, and that shrapnel would have been dispersed at the scene accordingly and not on a horizontal axis. She responded that her point was simply that most of the shrapnel damage would have to have been on one side of the point of impact, dependant upon origin. See Zorica Subotić, T. 38452-38455 (16 May 2013); P6323 (Diagram depicting point of impact of shell marked by Zorica Subotić). 
the stabiliser that was recovered at this site did not support their findings. ${ }^{13874}$ Subotic also argued that the soot traces on the snow at this location, were misinterpreted by the CSB and that Sabljica wrongly marked the origin of fire during his testimony before the Chamber. ${ }^{13875}$

4153. Coming to the final impact point, Subotić argued that the material before her indicated that two shells landed there, thus bringing the total to four mortar shells involved in the incident. ${ }^{13876}$ She used photographs and footage from the CSB Sarajevo investigation to argue that some of the damage to the footpath and the soil traces around it could not have been caused by a singular shell exploding. ${ }^{13877}$ Using these soil traces and the damage to the footpath in a contemporaneous CSB photograph, she calculated that the second shell came from an incoming azimuth of 220 to 240 degrees or smaller, meaning that it had been fired from the northeast and that only ABiH forces could have fired it. ${ }^{13878}$ While noting that the stabiliser was found at the scene fully embedded into the soil with an almost vertical angle, Subotić thought that the shell could not have been fired at an almost maximum angle of elevation since the marks on the footpath did not correspond to that angle, indicating thus that the stabiliser changed its position when it penetrated the soil. ${ }^{13879}$ She

13874 D3542 (Zorica Subotić's expert report entitled "Mortar Operations in Sarajevo Area in 1992-1995", 15 August 2012), p. 127, 131; Zorica Subotić, T. 38451 (16 May 2013). Subotić argued that contemporaneous photographs of the scene show that parts of the stabiliser not in contact with the surface were deformed, indicating that the stabiliser had changed its position on impact, having already hit the surface and then rebounded to its final resting place. According to Subotić, this meant that it could not have been of use in determining origin of fire. See Zorica Subotić, T. 38276 (14 May 2013); D3542 (Zorica Subotić's expert report entitled "Mortar Operations in Sarajevo Area in 1992-1995", 15 August 2012), pp. 127-128; P1972 (Photographs re shelling of Dobrinja on 4 February 1994), e-court p. 3; D896 (Video footage of shelling of Dobrinja on 4 February 1994, Markale on 5 February 1994, and Markale on 28 August 1995).

13875 D3542 (Zorica Subotić's expert report entitled "Mortar Operations in Sarajevo Area in 1992-1995", 15 August 2012), pp. 129-130; Zorica Subotić, T. 38272-38273 (14 May 2013). On cross-examination, Sabljica was asked by the Accused to mark the incoming direction of fire on a contemporaneous photograph of the scene. He marked it with an arrow, but did not align the arrow with the impact point. See Mirza Sabljica, T. 7797-7798 (12 October 2010); D745 (Photograph re shelling of Dobrinja on 4 February 1994 marked by Mirza Sabljica). The Chamber notes, however, that Sabljica was simply asked during cross-examination to indicate direction of fire, not to be absolutely accurate or align that direction of fire to the actual point of impact.

13876 D3542 (Zorica Subotić's expert report entitled "Mortar Operations in Sarajevo Area in 1992-1995", 15 August 2012), pp. 115-116, 137-139, 162-164; Zorica Subotić, T. 38270 (14 May 2013). The Chamber notes, however, that the CSB Sarajevo photograph she used to come to this conclusion is not sufficiently clear to be able to determine with certainty where the arrow is pointing exactly.

13877 D3542 (Zorica Subotić's expert report entitled "Mortar Operations in Sarajevo Area in 1992-1995", 15 August 2012), p. 115-119; Zorica Subotić, T. 38437-38438 (16 May 2013); P6321 (Photograph of damage caused by shell explosion marked by Zorica Subotić).

13878 D3542 (Zorica Subotić's expert report entitled "Mortar Operations in Sarajevo Area in 1992-1995", 15 August 2012), p. 119, 131-133; Zorica Subotić, 38274 (14 May 2013), T. 38438-38444 (16 May 2013); P6322 (Photograph depicting incoming trajectory of shell marked by Zorica Subotić). Using a map of the disposition of forces in Sarajevo, Subotić conjectured that the boundary line between the SRK and the ABiH was about 239 degrees, and that given the hilly terrain to the northeast of Dobrinja, in her opinion it was impossible that the SRK would have operated a $120 \mathrm{~mm}$ mortar battery in that area. D3542 (Zorica Subotić's expert report entitled "Mortar Operations in Sarajevo Area in 1992-1995", 15 August 2012), pp. 131-133.

13879 D3542 (Zorica Subotić's expert report entitled "Mortar Operations in Sarajevo Area in 1992-1995", 15 August 2012), p. 134. She further opined that the video footage taken by the CSB Sarajevo team shows that the stabiliser was marked with the roman letter N, which would not have been the case if it belonged to an SRK shell. D3542 (Zorica Subotić's expert report entitled "Mortar Operations in Sarajevo Area in 1992-1995”, 15 
acknowledged, however, that it was practically impossible to verify the accuracy of Sabljica's findings in relation to this shell with any precision, due to the photograph of his investigation being a side view of the footpath and crater. ${ }^{13880}$

4154. Noting that the number of casualties recorded in relation to the incident varied, Subotic highlighted the casualty list provided by Eterović where some victims' names are listed among both the injured and the dead, and argued that these mistakes indicate that the investigation was conducted 'sloppily'. ${ }^{13881}$ She further challenged references made to Džavarhal Nehrua street within the CSB Sarajevo report arguing that there was intent to cover up the inconsistent presence of an eye-witness at the actual scene of the incident, namely the playground near the Oslobodilaca Sarajeva street. ${ }^{13882}$

4155. On cross-examination, Subotić agreed that the mortar shells would have to have been fired with a minimum of charge "three" as this is when a mortar shell penetrates the ground and one of the shell stabilisers had been recovered fully embedded in the footpath. ${ }^{13883}$ However, she did not want to accept, without first consulting the relevant firing tables, that the corresponding minimum firing distance for the shells would therefore have to have been roughly 600 metres. ${ }^{13884}$

4156. Galić testified that he did not order an attack on civilians waiting for humanitarian aid in Dobrinja on the day of the incident. ${ }^{13885}$ He testified that he was informed of the incident on the day it took place and that he ordered all of the relevant units in the area to report on what happened. ${ }^{13886}$ The SRK Command's regular combat report for 4 February 1994, sent at 6 p.m., states that the UNPROFOR did not send any kind of protest in relation to the incident but that

August 2012), pp. 133-136; 138-139; 164; Zorica Subotić, T. 38275-38276 (14 May 2013). On crossexamination, it was put to Subotic that the letter N was not visible on a CSB Sarajevo photograph of the stabiliser but she maintained that she could not be sure as that photograph was not clear. Zorica Subotić, T. 38457-38460 (16 May 2013); P6324 (Photographs comparing stabilisers in the crater). The Chamber notes that contrary to Subotić's evidence the photograph is in fact clearer than the footage and clearly shows that the letter $\mathrm{N}$ is not engraved on the stabiliser.

13880 D3542 (Zorica Subotić's expert report entitled “Mortar Operations in Sarajevo Area in 1992-1995”, 15 August 2012), pp. 131-132; P1707 (Photographs re shelling of Dobrinja on 4 February 1994), e-court p. 6; Zorica Subotić, T. 38274 (14 May 2013).

13881 D3542 (Zorica Subotić's expert report entitled “Mortar Operations in Sarajevo Area in 1992-1995”, 15 August 2012), pp. 111-112, 137, 162 .

13882 D3542 (Zorica Subotić's expert report entitled “Mortar Operations in Sarajevo Area in 1992-1995”, 15 August 2012), pp 113-114, 137, 162, 164; Zorica Subotić, T. 38268 (14 May 2013).

13883 Zorica Subotić, T. 38456 (16 May 2013).

13884 Zorica Subotić, T. 38457 (16 May 2013); P5921 (Firing tables for M74 $120 \mathrm{~mm}$ light mortar), p. 12. See also P5922 (Firing tables for M75 $120 \mathrm{~mm}$ light mortar); P5923 (Firing tables for M52 $120 \mathrm{~mm}$ mortar).

13885 Stanislav Galić, T. 37442 (18 April 2013).

13886 Stanislav Galić, T. 37442-37443 (18 April 2013). 
"after checking, it was established that no fire had been opened" by the SRK in Dobrinja. ${ }^{13887}$ Galić commented on the report stating that the UNPROFOR did not submit a protest at that time because it did not have enough information about the incident. ${ }^{13888}$ To Galic this incident was simply one of the examples of $\mathrm{BiH}$ propaganda directed against the SRK, with the Sarajevo media reporting in a politicised manner. ${ }^{13889}$ He further opined that UN protests during the conflict were not based on accurate and precise information. ${ }^{13890}$

4157. Dragomir Milošević also testified that the SRK did not open fire on Dobrinja on the day of the incident. Instead, the SRK used the period 4 to 10 February 1994 only to reinforce its positions and did not respond to ABiH "provocations". ${ }^{13891}$ Savo Simić stated that at the time of the incident all of the artillery weapons of the $1^{\text {st }}$ Sarajevo Mechanised Brigade were under the control of the UNPROFOR who would record each instance of an artillery weapon being fired. ${ }^{13892}$ Dušan Škrba testified that there were twelve $120 \mathrm{~mm}$ mortar weapons in his command, ${ }^{13893}$ but that his forces did not open fire on 4 February 1994 as these weapons could not have been fired without his order, which he did not give, and because there were "UNPROFOR observers" at his command who would have heard the firing of shells. ${ }^{13894}$ He also testified that neither he nor the members of his unit ever intended to cause civilian casualties or terrorise civilians on the Muslim side. ${ }^{13895}$ On cross-examination, Škrba described Dobrinja as a neighbourhood that was exclusively residential. ${ }^{13896}$ He disagreed with the Prosecution's proposition that the UNMOs who were based with his brigade only had information about attacks if informed by local SRK commanders. ${ }^{13897}$

\footnotetext{
13887 D1515 (SRK combat report, 4 February 1994). Milošević testified that Colonel Kosovac made inquiries into the incident on behalf of the SRK Command and concluded that the SRK had not opened fire on Dobrinja. See Dragomir Milošević, T. 32711-32712 (28 January 2013).

13888 Stanislav Galić, T. 37442-37443 (18 April 2013); D1515 (SRK combat report, 4 February 1994). See also D2774 (Witness statement of Milenko Inđić dated 19 January 2013), paras. 133-134. The Chamber recalls Rose's testimony that he personally protested to the VRS about the incident. See P1638 (Witness statement of Michael Rose dated 26 March 2009), para. 35. See also KDZ450, T. 10548 (19 January 2011) (private session).

13889 Stanislav Galić, T. 37441-37442 (18 April 2013), T. 38007 (9 May 2013).

13890 Stanislav Galić, T. 38008 (9 May 2013).

13891 Dragomir Milošević, T. 32711-32714 (28 January 2013). See also D1515 (SRK combat report, 4 February 1994); D2807 (SRK Order, 4 February 1994). Two other SRK regular combat reports from 1994 state that the SRK respected cease-fire agreements and further that the $\mathrm{ABiH}$ violated these truce agreements. See D4582 (SRK Report, 24 April 1994); D4588 (SRK Report, 19 May 1994).

13892 D2412 (Witness statement of Savo Simić dated 4 November 2012), para. 27.

13893 Dušan Škrba, T. 29111-29113 (18 October 2012); P5934 (Map of Sarajevo marked by Dušan Škrba).

13894 D2341 (Witness statement of Dušan Škrba dated 14 October 2012), paras. 14, 21; Dušan Škrba, T. 29153 (22 October 2012). Škrba also testified that his brigade did not target the areas where larger groups of civilians tend to gather such as hospitals, bus stations, railway stations, and schools. Dušan Škrba, T. 29131 (22 October 2012).

13895 D2341 (Witness statement of Dušan Škrba dated 14 October 2012), paras. 14-15.

13896 Dušan Škrba, T. 29152-29153 (22 October 2012).

13897 Dušan Škrba, T. 29153-29156 (22 October 2012) (stating that the $1^{\text {st }}$ Sarajevo Mechanised Brigade provided information such as the direction of fire and the number of shells fired to UNMOs and further that he never
} 
4158. The Chamber has received medical records indicating that on 4 February 1994, 26 injured persons were received at Dobrinja Hospital as a result of this shelling incident. ${ }^{13898}$ A number of these victims were transferred to Koševo Hospital, including Sabahudin Ljuša who was transferred to the Children's ward, ${ }^{13899}$ and "Muškija Pribinja" who was taken directly to surgery after receiving first aid at the scene. ${ }^{13900}$ The available medical records indicate that eight people died as a result of the shelling incident in Dobrinja on 4 February 1994 and that 18 persons were injured. $^{13901}$

4159. In addition to the evidence and adjudicated facts outlined above, the Chamber also took judicial notice of the following adjudicated facts which go to the origin of fire and other controversial issues in this incident: (i) on 4 February 1994 around 11 a.m. three mortar shells struck a residential neighbourhood in Dobrinja killing at least eight civilians including a child and injuring at least 18 people including two children; ${ }^{13902}$ (ii) three shells struck civilians engaged in peaceful activities; ${ }^{13903}$ (iii) the origin of fire was SRK-held territory in relation to the two shells that were investigated in detail; ${ }^{13904}$ and (iv) the first shell to strike formed part of the same attack and therefore also originated in SRK territory. ${ }^{13905}$

4160. Having considered the evidence and the adjudicated facts recounted above, the Chamber is convinced that, on 4 February 1994, three $120 \mathrm{~mm}$ mortar shells struck two of the buildings and the playground in the immediate vicinity of Oslobodilaca Sarajeva and Mihajla Pupina streets in Dobrinja. The Chamber is also convinced that these shells struck near persons who had gathered at

received a protest in relation to these reports). This was contradicted by the evidence of UNMO Richard Mole, however. See P1426 (Witness statement of Richard Mole dated 7 May 2010), paras. 79-81.

P1878 (List of patients from Dobrinja Hospital, 4 February 1994); P1891 (Medical record for Edlar Hafizović); P1895 (Medical record for Rajko Maksimović); P1879 (Medical record for Sevda Hasanović); P1899 (Medical record for Džanko Zumreta); P1024 (Medical records for Sabahudin Ljuša).

13899 P461 (Admission records from Koševo Hospital), p. 2; P1024 (Medical records for Sabahudin Ljuša); Fatima Zaimović, T. 1879-1880 (5 May 2010); P818 (Extracts from Fatima Zaimović's diary), p. 22; P462 (Surgery records from Koševo Hospital), p. 15.

13900 P462 (Surgery records from Koševo Hospital), p. 15; P463 (Koševo Hospital morgue records), p. 13 ; P1710 (BiH MUP Report re shelling of Dobrinja on 4 February 1994), e-court pp. 3, 6, 66-70. The Chamber notes that she was initially recorded as "Huskija Dubinja" in the Dobrinja Hospital records. See P1878 (List of patients from Dobrinja Hospital, 4 February 1994), p. 1.

13901 These individuals were Jadranka Tenžera, Selma Spahić, Enver Mustagrudić, Saida Balićević, Emin Kolar, Aiša Šito, Mirsad Spahić, and "Muškija Pribinja". See P1874 (Death certificate for Jadranka Tenžera); P1875 (Death certificate for Enver Mustagrudić); P1876 (Death certificate for Emin Kolar); P1877 (Death certificate for Aiša Šito); P463 (Koševo Hospital morgue records), p. 13; P462 (Surgery records from Koševo Hospital), p. 15; P461 (Admission records from Koševo Hospital), p. 2. See also Adjudicated Facts 317, 320; P1707 (Photographs re shelling of Dobrinja on 4 February 1994), e-court pp. 7-8, 14-21; P1878 (List of patients from Dobrinja Hospital, 4 February 1994).

13902 Adjudicated Fact 320.

13903 Adjudicated Fact 322.

13904 Adjudicated Fact 321.

13905 Adjudicated Fact 322. 
the incident site to receive humanitarian aid. The Chamber does not accept Subotić's evidence that there were actually four $120 \mathrm{~mm}$ mortar shells. Her conclusion was based principally on secondary evidence, such as traces and debris she identified in the contemporaneous video footage and photographs and is therefore not as reliable as the de visu examination that was conducted by CSB Sarajevo and the UNPROFOR. Furthermore, the Chamber considers, as discussed above, that her proposition that one of the two recovered $120 \mathrm{~mm}$ mortar stabilisers was engraved with a Roman letter "N" is blatantly false. The Chamber also does not accept Subotić's insinuations that references made to a nearby street contained within the amalgamated CSB Sarajevo report are indicative of some sort of conspiracy to pervert the truth. This insinuation simply ignores the evidence to the contrary, namely that the other CSB Sarajevo reports, including the official and onsite investigation reports, all refer to the incident site as being in the immediate vicinity of Oslobodilaca Sarajeva and Mihajla Pupina streets. The Chamber considers that this type of analysis, and Subotić's readiness to resort to conspiracy theory has seriously damaged her credibility both generally and specifically with respect to this incident.

4161. Relying on the medical evidence and the CSB Sarajevo report discussed above, the Chamber finds that the explosions caused by the mortar attack on 4 February 1994 resulted in 26 casualties, eight of whom died as a result.

4162. In terms of the direction of fire, the Chamber recalls that both the CSB Sarajevo and the UNPROFOR investigators came to the scene on the day of the incident and were thus able to observe traces of the impact, and further that they all arrived at the same general direction of fire, namely towards Lukavica, to the east of Dobrinja. The Chamber also notes that Higgs examined the incident site and the CSB Sarajevo investigation and concluded that there were no reasons to doubt any of their findings. In contrast, Subotic concluded that the fire came from the direction of the north and northeast. The Chamber however finds her conclusions in relation to this incident unreliable as they were mainly based on the analysis of secondary evidence or the remains of traces that were found at the scene in 2010 and thus are highly speculative. For example, having conceded that due to a lack of examinable evidence she could not accurately determine the origin of fire in relation to the impact site on Oslobodilaca Sarajeva street, she nevertheless concluded that the UNPROFOR findings were not accurate and that ultimately this shell, like the other shells, was fired from $\mathrm{ABiH}$-held territory.

4163. As for the origin of fire, the Chamber notes that both the CSB Sarajevo and the UNPROFOR investigators concluded that it came from the SRK-held positions in the general direction of Lukavica. Given the location of the incident site and the fact that the confrontation line 
in the direction of Lukavica was between 350 to 400 metres away from that location, ${ }^{13906}$ the Chamber is also convinced that the shells originated in the SRK-held territory. In this respect, the Chamber recalls that Subotić agreed with the Prosecution that the $120 \mathrm{~mm}$ mortar shells related to this incident would have to have been fired with a minimum of charge 3 and that this would have increased the minimum firing distance for the shells. ${ }^{13907}$ This places the origin of fire firmly within SRK-held territory.

4164. As recounted above, a number of SRK witnesses, including Galić and Milošević, testified that no fire was opened by the SRK on Dobrinja on the day of the incident. ${ }^{13908}$ The Chamber cannot accept this evidence, however, in light of the evidence analysed above, as well as the evidence about the general situation in Dobrinja and the shelling that its civilian inhabitants were exposed to on a regular basis during the conflict. ${ }^{13909}$

4165. In terms of the nature of the area and the status of the victims, the Chamber recalls that the incident site was a residential neigbourbood in Dobrinja where humanitarian aid was being unloaded and distributed. The Chamber also recalls that there were no $\mathrm{ABiH}$ military units close to the site. ${ }^{13910}$ In addition, the 26 casualties who died or were wounded in this incident were all civilians, including three children, and were all engaged in peaceful activites. The Chamber concludes based on the location of the incident, the lack of ongoing combat and military presence at the time, and the nature of the activity in which the victims were engaged, that the ultimate nature of the area and the population that was gathered on or near the playground on 4 February 1994 was civilian. The Chamber recalls that there was a time delay between the three rounds and is thus convinced that the purpose of fire was to harass those present and prevent movement rather than to destroy any target. The Chamber also has no doubt that the SRK deliberately targeted whomever may have gathered in this residential area.

\footnotetext{
13906 See e.g. D741 (Map of Dobrinja marked by Mirza Sabljica). See also para. 4144.

13907 See generally P5921 (Firing tables for M74 120 mm light mortar); P5922 (Firing tables for M75 120 mm light mortar); P5923 (Firing tables for M52 $120 \mathrm{~mm}$ mortar). See also para. 4155.

13908 See paras. 4156-4157.

13909 See paras. 3783, 4059. The Chamber also recalls here Sladoje's testimony that the ABiH used "practically all" civilian buildings in Dobrinja for its purposes, thereby implying that most if not all of Dobrinja was considered to be a military target by the SRK soldiers and officers in the area. Similar attitude was exhibited by Simić. See paras. 4049, 4101.

13910 See Adjudicated Facts 318, 319.
} 


\section{(C) Stari Grad (Old Town)}

4166. Three of the shelling incidents alleged in the Indictment took place in Stari Grad (Old Town) of Sarajevo. ${ }^{13911}$ Two of those happened in the area of the Markale market (namely Scheduled Incidents G.8 and G.19) and one in Baščaršija fleamarket (Scheduled Incident G.9). According to the Prosecution, these incidents were consistent with the pattern of SRK attacks on Stari Grad, the aim of which was to target large gatherings of civilians or locations with a significant number of civilians present. ${ }^{13912}$

4167. Đozo testified that from the very beginning of the conflict, the central part of Stari Grad, particularly the area around Mula Mustafe Bašeskije street was constantly shelled. ${ }^{13913}$ According to him, the SRK was targeting places where the most civilians would gather. ${ }^{13914}$ When asked why only two shells hit the area of the Markale market during the whole period of the conflict, he explained that many shells fell around the Markale market area and on nearby streets. ${ }^{13915}$ Indeed, the Chamber heard that in the three months leading up to the first Markale incident the area was shelled between 10 to 12 times. ${ }^{13916}$ Similarly, in the months prior to the second Markale incident, the area had also been shelled several times. ${ }^{13917}$

4168. The Chamber heard that in 1992 the SRK artillery firing plan included Baščaršija and other areas in its vicinity, although Galić explained that it was merely a plan in case of possible attacks by the $\mathrm{ABiH}$ and therefore did not mean that fire was in fact opened on the areas mentioned. ${ }^{13918}$ In May 1995, most of Stari Grad was placed under "fire control" by the SRK, which, according to Savo Simić, meant that the SRK endeavoured to improve its tactical positions so that it could

13911 Stari Grad is one of the ten constitutive municipalities of Sarajevo, located in the east part of the city and encompassing the areas of Baščaršija and Bistrik. See P966 (Map of Sarajevo marked by Robert Donia); P2362 (Map of Vogošća municipality with photographs); P973 (Robert Donia's expert report entitled "Bosnian Serb Leadership and the Siege of Sarajevo, 1990-1995", January 2010), e-court pp. 11, 126; Robert Donia, T. 3130 (1 June 2010); P2345 (Witness statement of KDZ020 dated 17 February 2011), para. 3. See also Adjudicated Fact 2.

13912 Prosecution Final Brief, Appendix C, para. 54.

13913 Nedžib Đozo, T. 9578 (10 December 2010).

13914 Nedžib Đozo, T. 9582 (10 December 2010).

13915 Nedžib Đozo, T. 9581-9583 (10 December 2010).

13916 P1441 (UNPROFOR report re shelling of Markale on 5 February 1994), e-court p. 24.

13917 P1978 (Witness statement of Nedžib Đozo dated 7 December 2010), paras. 24-35.

13918 P1009 (Order of Chief of Artillery of SRK, 11 October 1992), p. 2 (referring to "offensive combat operations"); P2656 (SRK order, 26 November 1992), p. 2; Stanislav Galić, T. 37937-37942 (8 May 2013). Galić also explained that fire was opened on his troops in Stari Grad from the residential area of Velešići. See Stanislav Galić, T. 37937 (8 May 2013). 
control the $\mathrm{ABiH}$ fire in that area; in other words, it did not mean that fire was in fact opened on the area. $^{13919}$

4169. Galić testified that the SRK endeavoured not to target certain areas, such as Baščaršija, as it was a symbol of Sarajevo. ${ }^{13920}$ He did not deny, however, that the SRK forces shelled Stari Grad, noting that it was a municipality that covered a wide area, including Bistrik, from which fire was opened on the SRK forces. ${ }^{13921}$ Contrary to Galić's evidence, as discussed above, ${ }^{13922}$ by 28 May 1992, Mladić had already ordered that Velešići and Baščaršija be shelled. ${ }^{13923}$

\section{(1) Confrontation lines in the area}

4170. The Chamber has already described some of the confrontation lines that surrounded Stari Grad in Sections IV.B.1.b.iii.A and C: Zmaja od Bosne Street (formerly Vojvode Putnika) and Sredrenik and shall not repeat the same evidence here.

4171. It suffices to recall that the $1^{\text {st }}$ Romanija Infantry Brigade and the $1^{\text {st }}$ Sarajevo Mechanised Brigade of the SRK held the area of Grbavica and the positions south and east of Grbavica towards Stari Grad. ${ }^{13924}$ The area from Vrbanja Bridge towards the Jewish cemetery up to the foot of Debelo Brdo was held by the $3^{\text {rd }}$ Infantry Battalion of the $1^{\text {st }}$ Sarajevo Mechanised Brigade of the SRK. ${ }^{13925}$ This battalion was positioned on the western side of the Jewish cemetery while the $\mathrm{ABiH}$ was stationed along its northeastern wall-the two sides were separated only by the width of the cemetery. ${ }^{13926}$ The $1^{\text {st }}$ Romanija Brigade (and later the $1^{\text {st }}$ Sarajevo Mechanised Brigade) held

13919 Savo Simić, T. 30084-30090 (12 November 2012); P5940 (SRK Order, 9 May 1995), pp. 1-2. See also Miloš Škrba, T. 29200-29202 (22 October 2012). However, when discussing the Hreša-Vogošća road, which was controlled by the SRK and fired upon by the ABiH, Simić also appeared to agree that the term "fire control" meant that the road was kept under constant fire. See Savo Simić, T. 30059-30061 (12 November 2012).

13920 Stanislav Galić, T. 37836-37837 (7 May 2013), T. 37929-37931 (8 May 2013).

13921 Stanislav Galić, T. 37931-37934 (8 May 2013).

13922 See para. 4028.

13923 P1521 (Intercept of conversation between Ratko Mladić and Mirko Vukašinović, 28 May 1992). See also D582 (SRK Order, undated), p. 1 (indicating the Baščaršija was one of the SRK targets).

13924 Stanislav Galić, T. 37184 (15 April 2013); D3382 (Map of Sarajevo); P4498 (Report of $1^{\text {st }}$ Romanija Infantry Brigade, 3 September 1992); D2331 (Witness statement of Blagoje Kovačević dated 14 October 2012), paras. 2, 5; D2339 (Map of Sarajevo marked by Blagoje Kovačević); D2340 (Map of Sarajevo marked by Blagoje Kovačević); D2622 (Witness statement of Željko Bambarez dated 9 December 2012), paras. 5-6; D2628 (Map of Sarajevo marked by Željko Bambarez); Adjudicated Facts 66 and 2826.

13925 See Adjudicated Facts 2828; D2331 (Witness statement of Blagoje Kovačević dated 14 October 2012), para. 5; D2339 (Map of Sarajevo marked by Blagoje Kovačević); D2340 (Map of Sarajevo marked by Blagoje Kovačević).

13926 See Adjudicated Fact 73; D3382 (Map of Sarajevo); D2331 (Witness statement of Blagoje Kovačević dated 14 October 2012), paras. 2, 5; D2339 (Map of Sarajevo marked by Blagoje Kovačević); D2340 (Map of Sarajevo marked by Blagoje Kovačević); Blagoje Kovačević, T. 29054-29056 (18 October 2012). But see P4498 (Report of $1^{\text {st }}$ Romanija Infantry Brigade, 3 September 1992), p. 4 (stating that in September 1992 the $1^{\text {st }}$ Battalion of the $1^{\text {st }}$ Romanija Infantry Brigade was manning the positions on Jewish cemetery). 
the area south of Debelo Brdo, including Zlatište Hill, which overlooked the city. ${ }^{13927}$ Much of Mt. Trebević, with the exception of the area to its north and northwest, lay in those brigades' zone of responsibility, thus covering also the areas of Bistrik Kula and Vidikovac. ${ }^{13928}$ The ABiH held positions on the northern base of Mt. Trebević. ${ }^{13929}$ In addition to the eastern side of the Jewish cemetery, it also controlled Debelo Brdo and Čolina Kapa. ${ }^{13930}$

4172. As far as positions to the north of the city are concerned, the $7^{\text {th }}$ Infantry Battalion of the $1^{\text {st }}$ Romanija Infantry Brigade of the SRK was in control of the nine kilometre long confrontation line in the Kadrijina Kuća-Mala Tvrđava-Špicasta Stijena-Pašino Brdo-Velika TvrđavaPašino Brdo-Donje Bioško-Faletići-Zečija Glava-Borije-Tabakovo Guvno sector. ${ }^{13931}$ Blaško Rašević, a commander of a platoon and later a company in Mrkovići, ${ }^{13932}$ which was part of the $1^{\text {st }}$ Romanija Infantry Brigade, ${ }^{13933}$ testified that from 5 April 1992 his platoon, as well as another Mrkovići platoon, took up positions on the Velika Tvrđava--Špicasta Stijena axis and

13927 See Adjudicated Fact 2831; Stanislav Galić, T. 37358-37359 (18 April 2013); P1021 (VRS map of Sarajevo); P6295 (VRS map of Sarajevo); D2389 (Witness statement of Predrag Trapara dated 3 November 2012), para. 21; D2351 (Witness statement of Stevan Veljović dated 19 October 2012), para. 12; Stevan Veljović, T. 29249_ 29250 (23 October 2012); Alen Gičević, T. 7664-7665 (11 October 2010); D736 (Photograph of Sarajevo marked by Alen Gičević); Desimir Šarenac, T. 34935-34944 (6 March 2013); D3091 (Map of Sarajevo marked by Desimir Šarenac); D584 (SRK combat report, 23 June 1992), p. 1; D2671 (SRK combat report, 30 May 1993), p. 1. It was from Zlatište that the area of Stari Grad was placed under fire control in 1995, with 82 and 120 mm mortar batteries. See Savo Simić, T. 30084-30090 (12 November 2012); P5940 (SRK Order, 9 May 1995), pp. 1-2; Miloš Škrba, T. 29200-29202 (22 October 2012).

13928 See Adjudicated Facts 106 and 107; Stanislav Galić, T. 37358-37359 (18 April 2013). See also P1058 (ABiH map); D1380 (Map of ABiH positions in Sarajevo marked by Asim Džambasović); P1021 (VRS map of Sarajevo); P6295 (VRS map of Sarajevo); D2389 (Witness statement of Predrag Trapara dated 3 November 2012), para. 21; Stevan Veljović, T. 29249-29250 (23 October 2012); Desimir Šarenac, T. 34935-34944 (6 March 2013); D3091 (Map of Sarajevo marked by Desimir Šarenac); D2149 (Aide mémoire of Manojlo Milovanović), p. 24; P1641 (SRK proposal re artillery, 10 February 1994), p. 2 (indicating that the SRK had self-propelling guns in the area of Zlatište and Vidikovac); P1496 (ABiH map of Sarajevo marked by KDZ088) (indicating that the SRK had a tank on Vidikovac); D850 (UNMO report, 17 June 1995), p. 11 (also indicating that the SRK had a tank in Vidikovac); P926 (Witness statement of Aernout van Lynden dated 26 February 2010), para. 91; Aernout van Lynden, T. 2425 (19 May 2010).

13929 See Adjudicated Fact 104. See also P1764 (ABiH Map of Sarajevo); P1058 (ABiH map); D1380 (Map of ABiH positions in Sarajevo marked by Asim Džambasović); Alen Gičević, T. 7657-7663 (11 October 2010); D733 (Photograph of Sarajevo marked by Alen Gičević); D734 (Photograph of street sign in Sarajevo); D735 (Photograph of Sarajevo); Desimir Šarenac, T. 34935-34944 (6 March 2013); D3091 (Map of Sarajevo marked by Desimir Šarenac).

13930 See Adjudicated Facts 105 and 2830; D2389 (Witness statement of Predrag Trapara dated 3 November 2012), para. 21; Desimir Šarenac, T. 34935-34944 (6 March 2013); D3091 (Map of Sarajevo marked by Desimir Šarenac).

13931 D2383 (Witness statement of Slavko Gengo dated 14 October 2012), para. 13; D2384 (Map of Sarajevo marked by Slavko Gengo); P1021 (VRS map of Sarajevo); P6295 (VRS map of Sarajevo). The Chamber notes that Mala and Velika Tvrđava were also known and referred to as Mala and Velika Kula throughout the evidence.

13932 Rašević was the company commander between 31 January 1993 and September 1994. D2527 (Witness statement of Blaško Rašević dated 1 December 2012), paras. 16-17, 29. Mrkovići is a village north of Grdonj Hill and the city of Sarajevo. See D2794 (Satellite image of Sarajevo marked by Dragomir Milošević).

13933 With the formation of the VRS, the two Mrkovići platoons first became part of the $2^{\text {nd }}$ Romanija Brigade and then later part of the $1^{\text {st }}$ Romanija Infantry Brigade, which was part of the SRK. The commander of the $1^{\text {st }}$ Romanija Brigade was Dragomir Milošević, followed by Vlado Lizdek. See D2527 (Witness statement of Blaško Rašević dated 1 December 2012), para. 20; Blaško Rašević, T. 30911 (4 December 2012). 
"successfully defended this line until the end of the war". ${ }^{13934}$ The ABiH units opposing the $7^{\text {th }}$ Battalion, including the Mrkovići Company, belonged to the $105^{\text {th }}$ and $110^{\text {th }}$ Mountain Brigades and held the top of the Grdonj Hill, with the area of Sedrenik behind them, as well as the extensive views towards the city. ${ }^{13935}$

\section{(2) Markale Market, 5 February 1994 (Scheduled Incident G.8)}

4173. The Indictment alleges that, on 5 February 1994, a $120 \mathrm{~mm}$ mortar shell hit the crowded open-air market called "Markale" situated in Old Town, killing 66 people and wounding over $140 .{ }^{13936}$ It further alleges that the origin of fire was VRS/SRK-held territory approximately to the north-northeast. ${ }^{13937}$ In its Final Brief, the Prosecution claims that the mortar shell struck the market between 12 and 12:30 p.m. and exploded when it hit the ground. ${ }^{13938}$ In response, the Accused puts forth three different arguments: (i) the shelling incident was staged; (ii) alternatively, it was orchestrated by the Bosnian Muslim side; (iii) in a further alternative, he argues that the evidence presented by the Prosecution does not allow for a conclusion beyond reasonable doubt that the shell was fired by the Bosnian Serb Forces. ${ }^{13939}$

4174. In late January and early February 1994 the situation in Sarajevo was difficult as the Bosnian Muslim side had rejected the Owen-Stoltenberg plan and there was no explicit threat by NATO to use force against the Bosnian Serbs. ${ }^{13940}$ Thus, neither side had any reason to restrain its military activity, resulting in a period characterised by a high level of shelling and sniping, as well

13934 D2527 (Witness statement of Blaško Rašević dated 1 December 2012), paras. 18, 20, 29; D2528 (Map of Grdonj marked by Blaško Rašević). See also D2354 (Witness statement of Siniša Maksimović dated 19 October 2012), paras. 5, 9; Siniša Maksimović, T. 29306 (23 October 2012); D2355 (Map of Sarajevo marked by Siniša Maksimović); D2356 (Photograph of Sarajevo from Grdonj Hill); D2357 (Photograph of Sarajevo from Grdonj Hill).

13935 D2527 (Witness statement of Blaško Rašević dated 1 December 2012), para. 26; D2354 (Witness statement of Siniša Maksimović dated 19 October 2012), para. 5; Siniša Maksimović, T. 29306 (23 October 2012); D2355 (Map of Sarajevo marked by Siniša Maksimović); D2356 (Photograph of Sarajevo from Grdonj Hill); D2357 (Photograph of Sarajevo from Grdonj Hill); Dragomir Milošević, T. 32567, 32570 (23 January 2013); D2794 (Satellite image of Sarajevo marked by Dragomir Milošević); D2383 (Witness statement of Slavko Gengo dated 14 October 2012), para. 16; Slavko Gengo, T. 29838 (6 November 2012); Asim Džambasović, T. 15194, 15207, 15238-15240 (22 June 2011); D1378 (Map of ABiH positions in Sarajevo marked by Asim Džambasović); P1058 (ABiH map). According to Džambasović, the command post of the $105^{\text {th }}$ Brigade was located in the Šipad building in Trampina street. Asim Džambasović, T. 15207 (22 June 2011). See also D633 (Order of ABiH 1st Corps, 25 October 1993), para. 5.

13936 Indictment, Scheduled Incident G.8. The Chamber notes that the Prosecution Final Brief refers to "over 60" dead. See Prosecution Final Brief, Appendix C, para. 55.

13937 Indictment, Scheduled Incident G.8.

13938 Prosecution Final Brief, Appendix C, para. 55.

13939 Defence Final Brief, paras. 2054-2076, 2098-2105. The Trial Chamber notes that throughout the trial the Accused led extensive evidence through, inter alios, his expert witness Subotić, seeking to establish that the incident was staged. Although he does not specifically address this line of argument in his Final Brief, the Chamber will nevertheless consider it and the related evidence in its analysis.

13940 David Harland, T. 2038-2039 (6 May 2010). 
as tight controls on utilities and convoys. ${ }^{13941}$ On 26 January 1994, Galić ordered the SRK units to "continue with offensive activities and liberate the Serb part of the city of Sarajevo". ${ }^{13942}$

(a) The incident

4175. On 5 February 1994, around noon, many people were shopping in the Markale open-air market. $^{13943}$ Around 12:20 p.m. a projectile exploded at the market. ${ }^{13944}$ The Chamber took judicial notice of the fact that Witness AF testified in the Galic case that between 12 and 12:30 p.m. he heard the sound of a heavy weapon like a mortar being fired from behind Špicasta Stijena, at Mrkovići. ${ }^{13945}$ It also took judicial notice of the fact that Vahid Karavelić, commander of the $1^{\text {st }}$ $\mathrm{ABiH}$ Corps, testified in the Galic case that the nearest location of a brigade headquarters appeared approximately 300 metres away from the market. ${ }^{13946}$

\section{(b) BiH MUP investigation}

4176. The CSB Sarajevo team that investigated this shelling included, inter alios, an investigative judge; ballistics experts Sabljica and Čavčić; a crime technician, Bešić; and a criminal investigator, Kučanin. ${ }^{13947}$ The team arrived at the scene at around 1:20 p.m., after all the bodies had been cleared away and only a few people remained in the area. ${ }^{13948}$ The market was already secured by the police, the stalls were overturned and body parts, human tissue, and bloodstains could be seen. ${ }^{13949}$ The site was video-recorded and sketched, and Bešić took

\footnotetext{
13941 David Harland, T. 2038-2039 (6 May 2010). See also P1562 (UNMO report, 4-5 February 1994).

13942 P5968 (SRK Order, 26 January 1994), o. 6. But see Slavko Gengo, T. 29831-29837, 29841-29842 (6 November 2012) (arguing that these were defensive activities).

13943 See Adjudicated Facts 324 and 342.

13944 P1440 (BiH MUP Report re shelling of Markale on 5 February 1994), e-court p. 2.

13945 See Adjudicated Fact 332. The Chamber also took judicial notice of the fact that "weapons specialists indicate that the noise made by the firing of a mortar can be used to determine the approximate direction of fire". See Adjudicated Fact 334.

13946 See Adjudicated Fact 336. See also Sead Bešić, T. 9425-9426, 9429-9430 (8 December 2010) (testifying that there was an "army hall" some 500 metres from the incident site).

13947 P1695 (Witness statement of Mirza Sabljica dated 11 February 2010), pp. 30-31; Mirza Sabljica, T. 7694-7695 (11 October 2010), T. 7907 (13 October 2010); P1966 (Witness statements of Sead Bešić dated 18 February 2010), pp. 2, 8-9; Sead Bešić, T. 9436 (8 December 2010); Mirsad Kučanin, P16 (Transcript from Prosecutor v. Galić), T. 4747.

13948 P1695 (Witness statement of Mirza Sabljica dated 11 February 2010), p. 31; P1966 (Witness statements of Sead Bešić dated 18 February 2010), pp. 8-9; Mirza Sabljica, T. 7907-7908 (13 October 2010), T. 7930 (14 October 2010); Sead Bešić, T. 9437-9440 (8 December 2010).

13949 Mirza Sabljica, T. 7911, 7927-7928 (14 October 2010); Sead Bešić, T. 9436, 9440-9441 (8 December 2010), T. 9458 (9 December 2010); P1966 (Witness statements of Sead Bešić dated 18 February 2010), p. 9; D767 (Photograph re shelling of Markale on 5 February 1994 marked by Mirza Sabljica).
} 
photographs of the scene. ${ }^{13950}$ The team also went to the morgue and video-recorded the bodies of the victims. ${ }^{13951}$

4177. Having examined the scene, Sabljica and Čavčić prepared a report noting that one projectile landed on the asphalt in the northeast part of the market area, 4.16 metres away from the buildings of the "UPI supermarket" and 11.1 metres away from the 22 December building. ${ }^{13952}$ The UPI supermarket buildings are to the north of the impact site and are 3.65 and 5.25 metres tall, while the 22 December building is to the east of the impact site and is 18.45 metres tall. ${ }^{13953}$ At the time of the impact, there were 18 rows of stalls, all located close to each other. ${ }^{13954}$

4178. To determine the direction of fire, Sabljica and Čavčić used the central axis method because, according to Sabljica, that was the only method that could be used in this case. ${ }^{13955}$ The projectile, the stabiliser of which was found in the centre of the crater, ${ }^{13956}$ was found to be a 120 $\mathrm{mm}$ calibre mortar shell that came from the north-northeast, that is, 18 degrees from the north

13950 P1695 (Witness statement of Mirza Sabljica dated 11 February 2010), pp. 31, 37-40; P1966 (Witness statements of Sead Bešić dated 18 February 2010), pp. 9-10, 16. See also Sead Bešić, T. 9418 (8 December 2010); P1709 (Photographs re shelling of Markale on 5 February 1994); P1970 (Photographs re shelling of Markale on 5 February 1994); P1711 (Video footage re shelling of Markale, 5-6 February 1994); P1440 (BiH MUP Report re shelling of Markale on 5 February 1994), e-court p. 5.

13951 Sead Bešić, T. 9415-9416 (8 December 2010); P1711 (Video footage re shelling of Markale, 5-6 February 1994).

13952 P1708 (BiH MUP Report re shelling of Markale on 5 February 1994), p. 1; P1966 (Witness statements of Sead Bešić dated 18 February 2010), p. 12; Sead Bešić, T. 9456 (9 December 2010); P1709 (Photographs re shelling of Markale on 5 February 1994), e-court pp. 6-7; D895 (Photograph re shelling of Markale on 5 February 1994 marked by Sead Bešić); P1970 (Photographs re shelling of Markale on 5 February 1994). Sabljica conceded that if the margin of error in placement of the point of impact was in metres rather than centimetres it could affect the conclusions as to the direction of fire. However, he was confident that his measurements were accurate and that the margin of error here would have been some five centimetres. See P1695 (Witness statement of Mirza Sabljica dated 11 February 2010), pp.45-46; P1712 (Sketch re shelling of Markale on 5 February 1994). See also Mirza Sabljica, T. 7917-7925 (14 October 2010); D766 (Sketch re shelling of Markale on 5 February 1994 marked by Mirza Sabljica).

13953 P1695 (Witness statement of Mirza Sabljica dated 11 February 2010), pp. 41-43, 45-46; P1440 (BiH MUP Report re shelling of Markale on 5 February 1994), e-court p. 5; P1712 (Sketch re shelling of Markale on 5 February 1994). See also Mirza Sabljica, T. 7917-7918, 7925-7926 (14 October 2010); P1709 (Photographs re shelling of Markale on 5 February 1994), photograph 4.

13954 P1695 (Witness statement of Mirza Sabljica dated 11 February 2010), pp. 43-44; P1713 (Sketches re shelling of Markale on 5 February 1994). For discussion of the size of the stalls, see also Mirza Sabljica, T. 7926-7928 (14 October 2010); D767 (Photograph re shelling of Markale on 5 February 1994 marked by Mirza Sabljica); Sead Bešić, T. 9444-9447 (8 December 2010); D891 (Sketch re shelling of Markale on 5 February 1994 marked by Sead Bešić).

13955 P1695 (Witness statement of Mirza Sabljica dated 11 February 2010), pp. 37-38; Mirza Sabljica, T. 7698 (11 October 2010), T. 7912-7913 (14 October 2010); P1711 (Video footage re shelling of Markale, 5-6 February 1994); P1966 (Witness statements of Sead Bešić dated 18 February 2010), pp. 12-13; P1709 (Photographs re shelling of Markale on 5 February 1994), e-court pp. 8-11; P1970 (Photographs re shelling of Markale on 5 February 1994); Sead Bešić, T. 9412-9413 (8 December 2010).

13956 P1973 (BiH MUP Report re shelling of Markale on 5 February 1994), p. 5; P1709 (Photographs re shelling of Markale on 5 February 1994), e-court pp. 8-12. Both Sabljica and Bešić testified that the stabiliser was discovered only once Bešić cleaned the surface layer of the tarmac by hand. See P1966 (Witness statements of Sead Bešić dated 18 February 2010), pp. 8, 12-14; Sead Bešić, T. 9418-9419 (8 December 2010); P1970 (Photographs re shelling of Markale on 5 February 1994); Mirza Sabljica, T. 7911-7912 (14 October 2010). 
(plus or minus five degrees). ${ }^{13957}$ It was activated at the moment of contact with the asphalt surface. ${ }^{13958}$ The depth between the asphalt surface and the top of the stabiliser in the crater was nine centimetres, but the team did not measure the depth of the crater once the stabiliser was removed from it. ${ }^{13959}$ Instead, this measurement was taken the next day by Zečević. ${ }^{13960}$ Sabljica also explained that his team did not try to determine what type of charge was used for this shell as this was very difficult and also not necessary in order to determine the direction of fire. ${ }^{13961}$

4179. Both Sabljica and Bešić testified that by the time the UNPROFOR had arrived that day, ${ }^{13962}$ some 10 to 15 minutes after the arrival of the CSB Sarajevo team, they had already determined the direction of fire and washed off the blood and debris at the centre of the impact. ${ }^{13963}$ However, the team left the stabiliser in the crater, which was then dug out by the UNPROFOR soldiers and eventually returned to CSB Sarajevo by Bešić. ${ }^{13964}$ Bešić identified the said stabiliser in court and testified that it was not tampered with at any time while in his possession; furthermore, its serial number was photographed at the scene in order to enhance the

13957 P1708 (BiH MUP Report re shelling of Markale on 5 February 1994), pp. 1-2; P1973 (BiH MUP Report re shelling of Markale on 5 February 1994), p. 5; P1967 (Mortar stabiliser from Markale I); P1695 (Witness statement of Mirza Sabljica dated 11 February 2010), pp. 37, 40-41, 44-45; P1440 (BiH MUP Report re shelling of Markale on 5 February 1994), e-court p. 5; P1966 (Witness statements of Sead Bešić dated 18 February 2010), p. 11; P1709 (Photographs re shelling of Markale on 5 February 1994), e-court p. 5; P1711 (Video footage re shelling of Markale, 5-6 February 1994). See also Mirza Sabljica, T. 7913 (14 October 2010); Sead Bešić, T. 9416-9417 (8 December 2010); Richard Higgs, T. 5924-5926 (18 August 2010).

13958 P1708 (BiH MUP Report re shelling of Markale on 5 February 1994), p. 2; P1695 (Witness statement of Mirza Sabljica dated 11 February 2010), pp. 40-41; Mirza Sabljica, T. 7914 (14 October 2010); Sead Bešić, T. 9417 (8 December 2010); P1711 (Video footage re shelling of Markale, 5-6 February 1994). This was confirmed by an expert in ballistics, Richard Higgs. See Richard Higgs, T. 6028-6031 (19 August 2010); P1451 (Video footage of Markale, 5 February 1994); P1452 (Video footage of Markale, 5 February 1994); P1453 (Video footage of Markale, 5 February 1994).

13959 P1695 (Witness statement of Mirza Sabljica dated 11 February 2010), p. 36; Mirza Sabljica, T. 7913 (14 October 2010).

13960 P1695 (Witness statement of Mirza Sabljica dated 11 February 2010), pp. 18, 36.

13961 P1695 (Witness statement of Mirza Sabljica dated 11 February 2010), p. 41.

13962 Sabljica explained that CSB Sarajevo team would usually wait for UNPROFOR every time there was an incident causing a great number of civilian casualties. See P1695 (Witness statement of Mirza Sabljica dated 11 February 2010), pp. 33-34.

13963 P1695 (Witness statement of Mirza Sabljica dated 11 February 2010), pp. 32-33; P1966 (Witness statements of Sead Bešić dated 18 February 2010), pp. 8, 20, 21-22; Mirza Sabljica, T. 7912 (14 October 2010); Sead Bešić, T. 9410-9412 (8 December 2010); P1711 (Video footage re shelling of Markale, 5-6 February 1994).

13964 P1695 (Witness statement of Mirza Sabljica dated 11 February 2010), p. 33-35; Mirza Sabljica, T. 7699-7701 (11 October 2010), T. 7912 (14 October 2010); P1709 (Photographs re shelling of Markale on 5 February 1994), e-court pp. 13-14; P1966 (Witness statements of Sead Bešić dated 18 February 2010), pp 8, 13-14, 17, 19-20; P1711 (Video footage re shelling of Markale, 5-6 February 1994); Sead Bešić, T. 9413-9414 (8 December 2010), T. 9456-9457 (9 December 2010). Sabljica could not say, however, whether the stabiliser, as well as the fragments of the projectile collected at the scene, were analysed by the CSB Sarajevo's crime laboratory but presumed this to be the case as it was part of the procedure. See P1695 (Witness statement of Mirza Sabljica dated 11 February 2010), pp. 34-35. See also Sead Bešić, T. 9420 (8 December 2010); P1711 (Video footage re shelling of Markale, 5-6 February 1994); P1966 (Witness statements of Sead Bešić dated 18 February 2010), pp. 13-14. 
reliability of the chain of custody. ${ }^{13965}$ Bešić also testified that the markings on the stabiliser indicated it had been manufactured in the Krušik Factory in Valjevo, Serbia, in $1987 .{ }^{13966} \mathrm{He}$ measured the stabiliser in the courtroom and stated that it was around 17 centimetres long, which was some three centimetres less than what could be seen in the photograph of the same stabiliser taken by his team back in $1994 .{ }^{13967}$ He explained this difference by the fact that the stabiliser was so damaged that it had to be held at an angle when photographed. ${ }^{13968}$

4180. As for the origin of fire, Kučanin testified that it was established that the shell had come from the direction of Mrkovići but did not provide any further explanation as to how this conclusion was reached. ${ }^{13969}$ Bešić compiled a criminal technician's report the day after the incident, without having access to Sabljica's ballistics reports, wherein he stated that the shell was fired from the "aggressor's position", basing this conclusion on the direction from which the mortar shell came as established by the ballistic experts on the scene. ${ }^{13970} \mathrm{He}$ did confirm, however, that in the part of the town from which the shell came, the confrontation lines were such that the SRK and $\mathrm{ABiH}$ were close to each other. ${ }^{13971}$

4181. Sabljica explained that he and Čavčić did not establish the angle of descent, the range of fire, or the origin of fire that day, but he confirmed that another team went to Markale the following day, 6 February, and that this team included Čavčić, Zečević, and an investigative judge. ${ }^{13972}$ Zečević's team brought the stabiliser back to the scene and placed it into the crater by first removing a few little stones that had fallen into the hole. ${ }^{13973}$ Zečević then removed the

\footnotetext{
13965 Sead Bešić, T. 9420-9421 (8 December 2010); P1966 (Witness statements of Sead Bešić dated 18 February 2010), pp. 8, 15; P1967 (Mortar stabiliser from Markale I); P1709 (Photographs re shelling of Markale on 5 February 1994), e-court pp. 13-14.

13966 P1966 (Witness statements of Sead Bešić dated 18 February 2010), pp. 15, 22-23. See also Berko Zečević, T. 12190-12191 (22 February 2011).

13967 Sead Bešić, T. 9458-9460 (9 December 2010); P1967 (Mortar stabiliser from Markale I); P1709 (Photographs re shelling of Markale on 5 February 1994), e-court pp. 13-14.

13968 Sead Bešić, T. 9461-9464 (9 December 2010).

13969 Mirsad Kučanin, P16 (Transcript from Prosecutor v. Galić), T. 4747.

13970 P1966 (Witness statements of Sead Bešić dated 18 February 2010), pp. 14-15, 20-21.

13971 P1966 (Witness statements of Sead Bešić dated 18 February 2010), p. 21.

13972 P1695 (Witness statement of Mirza Sabljica dated 11 February 2010), pp. 47-48; Mirza Sabljica, T. 7913-7916 (14 October 2010); P1711 (Video footage re shelling of Markale, 5-6 February 1994). See also P2317 (Report by Berko Zečević entitled "Study of the circumstances and causes of the massacre at the Markale market on 5 February 1994"), e-court p 3. Berko Zečević testified that he and another three colleagues volunteered to investigate the incident, having heard the then-UNPROFOR commander say that the direction of fire could not be established. Zečević also claimed that they were appointed by the investigative judge. See Berko Zečević, T. 12278-12291 (23 February 2011); D1093 (Information on engagement of Berko Zečević).

13973 Berko Zečević, T. 12159-12160 (22 February 2011), T. 12375-12376 (24 February 2011) (stating that the stabiliser could be lowered back into the crater without any difficulty); P2317 (Report by Berko Zečević entitled "Study of the circumstances and causes of the massacre at the Markale market on 5 February 1994"), e-court p. 5; P1966 (Witness statements of Sead Bešić dated 18 February 2010), p. 19 Sead Bešić, T. 9415-9417 (8 December 2010); P1711 (Video footage re shelling of Markale, 5-6 February 1994); P1711 (Video footage re shelling of Markale, 5-6 February 1994).
} 
stabiliser from the crater once more and measured the depth of the penetration of the stabiliser, which he found to be at 25 centimetres. ${ }^{13974}$ He used this depth to determine the angle of descent, as well as the direction and the origin of fire. ${ }^{13975}$ Within 36 hours of starting the investigation, Zečević and his team had compiled a report in which they confirmed that the shell came from the direction of north-northeast, that is, 18 degrees from the north, plus or minus five degrees, with an angle of descent of 60 degrees, plus or minus five degrees. ${ }^{13976}$ They also determined that the projectile was a $120 \mathrm{~mm}$ shell that detonated upon contact with the ground ${ }^{13977}$ and that its destructive power corresponded to the number of victims and the type of injuries they suffered in this incident. ${ }^{13978}$ His report concluded that, depending on the charges used to launch it, the shell could have come from six different areas, the first one being between 1,640 and 1,840 metres away $^{13979}$ and the last one between 6,170 and 6,546 metres away; only the first one was in the territory held by the $\mathrm{ABiH}$ in the area of Grdonj Hill. ${ }^{13980}$

13974 Berko Zečević, T. 12159-12160 (22 February 2011), T. 12338-12340, 12357 (24 February 2011); P2317 (Report by Berko Zečević entitled "Study of the circumstances and causes of the massacre at the Markale market on 5 February 1994”), e-court p. 5.

13975 Berko Zečević, T. 12159-12160 (22 February 2011), T. 12338-12340, 12357 (24 February 2011); P2317 (Report by Berko Zečević entitled "Study of the circumstances and causes of the massacre at the Markale market on 5 February 1994"), e-court p. 5. Zečević conceded that the method he used to establish the angle of descent was not standard at the time but stated that it has now been adopted in urban zones. See Berko Zečević, T. 12340 (24 February 2011).

13976 Berko Zečević, T. 12161-12162, 12173 (22 February 2011); P2317 (Report by Berko Zečević entitled "Study of the circumstances and causes of the massacre at the Markale market on 5 February 1994"), e-court pp. 5, 8. The Chamber notes that while e-court page 5 of the English translation of the report refers to a direction of "northwest", this is clearly a mistake in translation as the original BCS version of the report refers to a "northeast" direction.

13977 Berko Zečević, T. 12162-12163 (22 February 2011), T. 12332-12338, 12355-12357 (24 February 2011); P2317 (Report by Berko Zečević entitled "Study of the circumstances and causes of the massacre at the Markale market on 5 February 1994"), e-court pp. 5-6, 8.

13978 P2317 (Report by Berko Zečević entitled "Study of the circumstances and causes of the massacre at the Markale market on 5 February 1994”), e-court p. 8; Berko Zečević, T. 12311-12318 (24 February 2011); D1095 (Sketch re shelling of Markale on 5 February 1994).

13979 The range in the distances outlined here takes into account the range in the established angle of descent. In other words, if the angle of descent at the lowest spectrum, namely 55 degrees, and the shell was fired on charge one, then it came from 1,840 metres away. If however the angle of descent was 65 degrees, then it came from 1,640 metres away. Zečević used the same method for all other points he listed. The ranges were therefore as follows: on charge two, between 2,972 and 2,577 metres away, on charge three between 4,120 and 3,622 metres away, on charge four between 5,110 and 4,570 metres away, on charge five between 5,979 and 5,500 metres away, and on charge six between 6,546 and 6,170 metres away. These values also show that the higher the angle of descent, the shorter the distance the shell has to travel on a particular charge.

13980 P2317 (Report by Berko Zečević entitled "Study of the circumstances and causes of the massacre at the Markale market on 5 February 1994”), e-court pp. 6, 8; Berko Zečević, T. 12172-12173 (22 February 2011). The Chamber notes that, unlike the English version, the BCS version of P2317, at e-court page 17, contains a map on which Zečević marked the six locations and that the first location is near Grdonj, which was in the ABiH zone of responsibility during the conflict. See para. 3856. Although the Accused challenged Zečević's expertise in relation to his ability to conduct the above analysis, the Chamber found that Zečević had the necessary expertise. See Hearing, T. 12145-12146, 12171-12172 (22 February 2011); Berko Zečević, T. 12282-12284 (23 February 2011). 


\section{(c) UN investigations}

4182. On the day of the incident, Harland was at the Sarajevo airport, meeting with Krajišnik and Koljević. ${ }^{13981}$ Upon receiving news of the incident, he immediately sent a local doctor to the scene while he returned to UN headquarters to make contact with Rose and debrief him once he heard back from the local doctor and the investigators. ${ }^{13982}$ Rose was in Mostar on the day of the incident; on his return to Sarajevo the next day, the $\mathrm{BiH}$ government had already accused Bosnians Serbs of firing the shell, which was denied through a statement by the Accused, wherein he accused the Bosnian Muslims of firing on their own people. ${ }^{13983}$

4183. The UN conducted two sets of investigations into the incident. ${ }^{13984}$ The first investigation was conducted on the day of the incident and consisted of three separate crater analyses, done by FreBat's Major Cazaux, Sector Sarajevo's Captain Verdy, and Major Russell respectively; the second investigation took place on 11 through 13 February 1994 and was conducted by another UN team, which performed seven different crater analyses. ${ }^{13985}$

4184. Cazaux's team excavated the stabiliser fin from the crater and performed the first crater analysis, finding that the bearing of the shell was 620 mils (34.8 degrees). ${ }^{13986}$ It also noted that the fin belonged to a $120 \mathrm{~mm}$ mortar round and that it was buried approximately eight centimetres below the surface of the asphalt. ${ }^{13987}$

4185. Verdy conducted the second analysis for the UN and determined that the bearing of the shell was somewhere between 800 and 1,000 mils (45 to 56.2 degrees), while its angle of descent was 1,400 mils (78.7 degrees) and its maximum range somewhere between 2,000 and 3,500 metres; he further concluded that a $120 \mathrm{~mm}$ shell hit Markale market at 12:10 p.m., by first impacting on a market stall and then hitting the ground from short range, low-angle fire. ${ }^{13988} \mathrm{He}$

\footnotetext{
13981 David Harland, T. 2039 (6 May 2010).

13982 David Harland, T. 2039 (6 May 2010).

13983 P1638 (Witness statement of Michael Rose dated 26 March 2009), paras. 37-38.

13984 P1638 (Witness statement of Michael Rose dated 26 March 2009), para. 39; Michael Rose, T. 7340-7342 (6 October 2010); P1441 (UNPROFOR report re shelling of Markale on 5 February 1994), e-court pp. 9, 16.

13985 P1441 (UNPROFOR report re shelling of Markale on 5 February 1994), e-court pp. 9, 15-17; P2066 (UNPROFOR report re shelling of Markale on 5 February 1994), p. 1; D2368 (Witness statement of Michel Gauthier dated 6 February 2012), paras. 5, 7. See also Adjudicated Fact 331.

13986 P1441 (UNPROFOR report re shelling of Markale on 5 February 1994), e-court pp. 17-18.

13987 P1441 (UNPROFOR report re shelling of Markale on 5 February 1994), e-court p. 18. See also Adjudicated Fact 330.

13988 P1441 (UNPROFOR report re shelling of Markale on 5 February 1994), e-court p. 2. According to the later UN report on the incident, Verdy did not measure the angle of descent due to the crater being disturbed, but instead found the minimum possible angle of descent in order for the shell to clear the building along the calculated bearing. See P1441 (UNPROFOR report re shelling of Markale on 5 February 1994), e-court p. 16.
} 
informed his command that because of the prior impact on the market stall, the analysis was very difficult. $^{13989}$

4186. Major John Russell, who-at the relevant time, was deployed as Military Assistant to Sergio de Mello, the representative of the Secretary-General in Sarajevo, and possessed some experience in crater analysis ${ }^{13990}$ — was asked to go to the scene of the explosion by UNPROFOR Chief of Staff Ramsey. ${ }^{13991}$ He arrived at the incident site at about 4:30 p.m. on 5 February 1994, after the above two analyses had been completed, and observed blood and human remains, as well as the crater and a thoroughly swept impact site. ${ }^{13992}$ Concluding that the round had come in from east-northeast, at a bearing of 450 mils (25.3 degrees) and with an angle of descent between 1,200 and 1,300 mils (67.5 and 73.1 degrees), he was struck by how steep the angle of decent must have been in order to clear the adjacent large building, which led him to believe that it had come in from a location close to the crater. ${ }^{13993}$ At the time, he concluded that it was not possible to determine which side had fired the round as the minimum/maximum range straddled the confrontation line. ${ }^{13994}$ That evening, he noted in his diary that he believed that the ABiH had "shot at themselves" given the close distance from which the round must have been fired. ${ }^{13995}$ When put to him that firing tables for $120 \mathrm{~mm}$ shells indicate that the angle of descent remains the same regardless the distance from which the shell is fired on different charges, Russell accepted that, had he known this, he would have likely come to a different conclusion about the distance from which the shell was fired at the time. ${ }^{13996}$

4187. On 8 February 1994, Rose met with $\mathrm{ABiH}$ representatives Generals Divjak and Hajrulahović, and Colonel Dakić at the $\mathrm{ABiH}$ headquarters, where he told them that evidence was

\footnotetext{
13989 P1441 (UNPROFOR report re shelling of Markale on 5 February 1994), e-court p. 2.

13990 D2364 (Witness statement of John Russell dated 17 October 2012), paras. 4, 7-9; John Russell, T. 29381 (30 October 2012).

13991 D2364 (Witness statement of John Russell dated 17 October 2012), para. 12. See also David Harland, T. 23252328 (11 May 2010); KDZ450, T. 10676-10677 (20 January 2011).

13992 D2364 (Witness statement of John Russell dated 17 October 2012), paras. 12-14 (explaining that he was not aware at the time that the stabilizer had been removed from the crater); John Russell, T. 29382-29383 (30 October 2012); P1441 (UNPROFOR report re shelling of Markale on 5 February 1994), e-court p. 41.

13993 D2364 (Witness statement of John Russell dated 17 October 2012), paras. 20-23 (explaining also that he did not recall measuring the angle of the descent at the scene but had no reason to doubt the UN report's references to his measurements). See also P1441 (UNPROFOR report re shelling of Markale on 5 February 1994), e-court p. 17.

13994 D2364 (Witness statement of John Russell dated 17 October 2012), paras. 23, 31; D2367 (Handwritten notes of John Russell on UNPROFOR report re shelling of Markale on 5 February 1994) e-court p. 2; John Russell, T. 29406 (30 October 2012); D2365 (UNPROFOR report, 6 February 1994), e-court p. 2.

13995 D2364 (Witness statement of John Russell dated 17 October 2012), paras. 33-36; D2366 (Excerpt of John Russell's diary, 5 February 1994); John Russell, T. 29397 (30 October 2912).

13996 John Russell, T. 29397-29400 (30 October 2012); P5921 (Firing tables for M74 120 mm light mortar).
} 
emerging which indicated that the incident may have been caused by their side. ${ }^{13997}$ Rose conceded in cross-examination that after he told the Bosnian Muslim side of the results of the first UNPROFOR investigation, they decided to accept the cease-fire which they were initially refusing. ${ }^{13998}$

4188. Because of the significance of the incident, UNPROFOR headquarters in Zagreb ordered that a second investigation be carried out. ${ }^{13999}$ The UNPROFOR team was headed by Colonel Michel Gauthier and began its work on 11 February $1994 .{ }^{14000}$ The team also included, among others, Lieutenant Colonel Rumyantsev and technical advisers John Hamill and Eric Dubant. ${ }^{14001}$ According to Gauthier, the team was instructed to confine its investigation to crater analysis and related technical aspects of the explosion. ${ }^{14002}$ The investigation was concluded on 15 February and the team reported that the bearing of what was confirmed to have been a $120 \mathrm{~mm}$ mortar shell was somewhere between 330 and 420 mils (18.5 and 23.6 degrees). ${ }^{14003}$ The team further concluded that the crater analyses conducted by Cazaux and Verdy were flawed and that all of their associated findings were therefore questionable. ${ }^{14004}$ The report notes that Hamill measured the angle of descent at between 950 and 1,100 mils, (53.4 and 61.8 degrees), which meant that the shell must have come in from between 950 and 5,450 metres, depending on the charge used. ${ }^{14005}$ However, in its final conclusion, the team noted that the angle of descent measured by Hamill was

\footnotetext{
13997 Michael Rose, T. 7342 -7344 (6 October 2010); D2770 (Witness statement of KW570 dated 21 November 2012) (under seal) para. 11; D2772 (Redacted diary of KW570) (under seal) e-court pp. 3-4. KW570 explained that in fact Rose and the UNPROFOR Command were not that interested in who fired on Markale but rather wanted to use this opportunity to achieve something positive, such as a peace deal. See KW570, T. 32232 (18 January 2013).

13998 Michael Rose, T. 7339-7340 (6 October 2010).

13999 P1638 (Witness statement of Michael Rose dated 26 March 2009), para. 39. See also Yasushi Akashi, T. 37687-37688 (24 April 2013).

14000 D2368 (Witness statement of Michel Gauthier dated 6 February 2012), paras. 5, 7.

14001 D2368 (Witness statement of Michel Gauthier dated 6 February 2012), para. 5; P1441 (UNPROFOR report re shelling of Markale on 5 February 1994), e-court p. 13.

14002 D2368 (Witness statement of Michel Gauthier dated 6 February 2012), para. 7; P1441 (UNPROFOR report re shelling of Markale on 5 February 1994), e-court p. 9.

14003 P1441 (UNPROFOR report re shelling of Markale on 5 February 1994), e-court p. 20; D2368 (Witness statement of Michel Gauthier dated 6 February 2012), paras. 14-18.

14004 John Hamill, P1994 (Transcript from Prosecutor v. Galić), T. 6096-6098; D2368 (Witness statement of Michel Gauthier dated 6 February 2012), paras. 8-11; P1441 (UNPROFOR report re shelling of Markale on 5 February 1994), e-court pp. 10, 16, 19 (stating that Verdy's analysis was flawed because he made a mathematical error when calculating the bearing and because he estimated the angle of descent using the height of the buildings in the direction of fire he established, while FreBat's bearing was wrong because they used an unconventional method to determine it). See also Richard Higgs, T. 5928 (18 August 2010).

14005 P1441 (UNPROFOR report re shelling of Markale on 5 February 1994), e-court pp. 17, 19, 25 (stating that the angle of descent was "probably between 950 and 1,100 mils" but that it is not possible to be "more accurate" due to the fact that a several days elapsed between the impact and the analysis); D2368 (Witness statement of Michel Gauthier dated 6 February 2012), para. 20.
} 
not "beyond suspicion" due to the crater having been excavated. ${ }^{14006}$ Therefore, using the height of the buildings in the area to estimate that the minimum angle of descent necessary to clear those buildings was 870 mils (48.9 degrees), the team concluded that the possible range for the mortar shell was between 300 and 5,551 metres in the established direction of fire. ${ }^{14007}$

4189. In cross-examination, Gauthier confirmed that there were no known fixed mortar positions on the $\mathrm{ABiH}$ held-territory along the direction of fire from which the Markale shell had originated and in which the UNMOs were free to move about as they wished, whereas he could recall that the Bosnian Serb side had one such position in the identified area. ${ }^{14008}$ However, Gauthier also explained that mortars are mobile weapons that can be moved relatively quickly and leave little trace of their use and that, at the time, his team did not go to Bosnian Serb-held territory to investigate, given the extremely low probability of identifying a possible firing point. ${ }^{14009}$

4190. As noted above, Hamill was one of the technical advisers on the UNPROFOR team participating in the second investigation and was the person who prepared the UNPROFOR report. ${ }^{14010}$ According to him, the team conducted a detailed technical analysis based on the physical evidence gathered, crater analysis, and interviews with eyewitnesses and the UN personnel who conducted the first investigation. ${ }^{14011}$ Hamill personally analysed the crater twice, the first time using a "fuse tunnel method", ${ }^{14012}$ followed by the central axis method, through which he determined that the shell came from a north-northeasterly direction. ${ }^{14013}$

4191. Hamill concluded that the explosion took place between 12:10 and 12:15 p.m. and was caused by a "conventional factory-produced $120 \mathrm{~mm}$ high explosive mortar bomb" which was

\footnotetext{
14006 P1441 (UNPROFOR report re shelling of Markale on 5 February 1994), e-court p. 19; D2368 (Witness statement of Michel Gauthier dated 6 February 2012), para. 21.

14007 P1441 (UNPROFOR report re shelling of Markale on 5 February 1994), e-court p. 20; D2368 (Witness statement of Michel Gauthier dated 6 February 2012), paras. 19, 26. See also P1638 (Witness statement of Michael Rose dated 26 March 2009), para. 39.

14008 Michel Gauthier, T. 29417 (30 October 2012).

14009 Michel Gauthier, T. 29414, 29418 (30 October 2012).

14010 John Hamill, T. 9680 (13 December 2010); John Hamill, P1994 (Transcript from Prosecutor v. Galić), T. 60756079.

14011 John Hamill, P1994 (Transcript from Prosecutor v. Galić), T. 6077-6078, T. 6083-6085; P1441 (UNPROFOR report re shelling of Markale on 5 February 1994), e-court p. 10; P2066 (UNPROFOR report re shelling of Markale on 5 February 1994), p. 1.

14012 Hamill placed a stick in the fuse tunnel which then gave him a direction of the shell, the bearing of which he then measured using a compass. See John Hamill, P1994 (Transcript from Prosecutor v. Galić), T. 6087-6089. See also D2759 (Witness statement of KW571 dated 27 March 2012) (under seal), paras. 5-6.

14013 John Hamill, P1994 (Transcript from Prosecutor v. Galić), T. 6087-6088, 6092, 6095-6096; P1441 (UNPROFOR report re shelling of Markale on 5 February 1994), e-court pp. 17, 25. To KW571, the shape of the crater indicated that the shell had come in "following a curve" before hitting the ground, whereas a static explosion on the ground would have left different traces. See KW571, T. 32018 (16 January 2013).
} 
launched from a $120 \mathrm{~mm}$ heavy mortar tube and which detonated on impact with the ground. ${ }^{14014}$ The team was certain that the crater was formed by the explosion of a mortar shell. ${ }^{14015}$ While it was determined that the shell came from the northeast, it was not possible for the investigators to determine the exact distance from the firing point, other than that it was fired between 300 and 5,551 metres from the point of detonation. ${ }^{14016}$ Since this distance "clearly overlaps each side of the confrontation line" and since "both parties are known to have $120 \mathrm{~mm}$ mortars" the team concluded that the shell could have been fired by either side. ${ }^{14017}$ The report clarifies that determining the origin of fire was impossible because a number of days had passed since the incident, during which the crater had been tampered with by various personnel making it impossible to determine the angle of descent accurately. ${ }^{14018}$ Hamill testified that these findings were the most comprehensive possible, given the limitations of the methods used and events surrounding the incident, as well as the distance between the explosion and the frontlines of the warring parties. ${ }^{14019}$ The team was certain, however, that the explosion was not caused by a "booby trap" and that the shell could not have been hand-launched from one of the nearby buildings. ${ }^{14020}$

4192. Hamill explained that the UNMOs who were interviewed during the investigation indicated that they had been denied freedom of movement by the VRS in the northeast part of Sarajevo since October 1993. ${ }^{14021}$ Additionally, Hamill testified that he and others from the team personally met with Colonel Cvetković, the Commander of the SRK artillery regiment based in Mrkovići, to the north-northeast of Markale. ${ }^{14022}$ According to Hamill, Cvetković confirmed that there were $120 \mathrm{~mm}$ mortars in Mrkovići but stated that his unit had not fired the round, while at the same time admitting that in the previous year it had fired 30,000 to 40,000 rounds into the

\footnotetext{
14014 John Hamill, P1994 (Transcript from Prosecutor v. Galić), T. 6085-6086, 6092-6093; P1441 (UNPROFOR report re shelling of Markale on 5 February 1994), e-court pp. 11, 18-20, 25; P2066 (UNPROFOR report re shelling of Markale on 5 February 1994), p. 3.

14015 P1441 (UNPROFOR report re shelling of Markale on 5 February 1994), e-court pp. 18, 23-25.

14016 P1441 (UNPROFOR report re shelling of Markale on 5 February 1994), e-court pp. 11, 20, 23, 25, 33. See also P1638 (Witness statement of Michael Rose dated 26 March 2009), para. 39.

14017 P1441 (UNPROFOR report re shelling of Markale on 5 February 1994), e-court p. 11; John Hamill, P1994 (Transcript from Prosecutor v. Galić), T. 6083-6084; John Hamill, T. 9732 (13 December 2010); Francis Roy Thomas, T. 6832 (15 September 2010); Yasushi Akashi, T. 37687-37688 (24 April 2013). The results of this report were then forwarded to the Security Council by the UN Secretary General, while Akashi reported to Koffi Annan. See D179 (Letter from UNSG to the President of UNSC, 16 February 1994); D713 (UNPROFOR report re talks with Radovan Karadžić and Alija Izetbegović, 6 February 1994), pp. 1-2.

14018 P1441 (UNPROFOR report re shelling of Markale on 5 February 1994), e-court p. 23. See also D2759 (Witness statement of KW571 dated 27 March 2012) (under seal), paras. 8-9.

14019 John Hamill, P1994 (Transcript from Prosecutor v. Galić), T. 6084-6085.

14020 P1441 (UNPROFOR report re shelling of Markale on 5 February 1994), e-court pp. 25, 29; John Hamill, P1994 (Transcript from Prosecutor v. Galić), T. 6086, T. 6206. See also Michel Gauthier, T. 29416 (30 October 2012).

14021 John Hamill, P1994 (Transcript from Prosecutor v. Galić), T. 6105-6107. See also Michel Gauthier, T. 2941729418 (30 October 2012).
} 
city. ${ }^{14023}$ The Chamber also has in evidence a report on this meeting, sent to the VRS Main Staff and the SRK Command by Cvetković himself, which somewhat contradicts Hamill's evidence. $^{14024}$ According to this report, Cvetković informed the VRS Main Staff and the SRK Command that he was told by Gauthier that the shell was of $120 \mathrm{~mm}$ calibre, that the angle of descent was not established with precision, and that the shell could have been fired by either side. ${ }^{14025}$ Cvetković also reported that he "strongly denied" that the shell was launched by the Serbian side, offered that the commission visit the "suspected place", and asserted that the SRK did not have $120 \mathrm{~mm}$ mortars on this part of the frontline. ${ }^{14026}$ According to Gauthier, however, the team did not go to the SRK-held territory in the established direction of fire because the area to be inspected was vast and the team judged that they would not be able to locate the position from where the mortar was fired. ${ }^{14027}$

4193. While the team was not shown any ABiH mortar positions, the Deputy Chief of Staff of Sector Sarajevo, Colonel Pardon, visited two such positions and an ammunition storage facility on 9 February 1994, which included what appeared to be locally-produced $120 \mathrm{~mm}$ mortar bombs. ${ }^{14028}$ However, according to Hamill, because Pardon was working off of the results of the first flawed analysis by UNPROFOR, he examined the wrong area. ${ }^{14029}$

4194. Having conducted the investigation outlined above, Hamill and his team concluded that there were six possible firing locations in a line along the established direction of fire, two of which were on the ABiH side of the frontline and four on the SRK side. ${ }^{14030}$ He confirmed on cross-examination that because it was impossible to determine the charge with which the mortar was fired, it was also not possible to say which of these locations the round came from. ${ }^{14031}$ As

14022 John Hamill, P1994 (Transcript from Prosecutor v. Galić), T. 6109.

14023 John Hamill, P1994 (Transcript from Prosecutor v. Galić), T. 6109.

14024 While this report does not name Hamill as one of those present at the meeting, the Chamber notes that it does refer to Gauthier and two other members of the investigation "committee". The Chamber considers that one of these two members was Hamill. See D2378 (Report of $4^{\text {th }}$ Mixed Artillery Regiment to SRK, 14 February 1994), p. 1.

14025 D2378 (Report of $4^{\text {th }}$ Mixed Artillery Regiment to SRK, 14 February 1994), pp. 1-3.

14026 D2378 (Report of $4^{\text {th }}$ Mixed Artillery Regiment to SRK, 14 February 1994), p. 3.

14027 Michel Gauthier, T. 29418 (30 October 2012).

14028 John Hamill, P1994 (Transcript from Prosecutor v. Galić), T. 6107; P1441 (UNPROFOR report re shelling of Markale on 5 February 1994), e-court p. 44. Russell also testified that around 9 February 1994, he accompanied UNPROFOR personnel to an $\mathrm{ABiH}$ ammunition depot where they found $120 \mathrm{~mm}$ mortar shells after having been told that there were no such shells in this depot. See D2364 (Witness statement of John Russell dated 17 October 2012), paras. 36-37; John Russell, T. 29401, 29403 (30 October 2012); P1441 (UNPROFOR report re shelling of Markale on 5 February 1994), e-court pp. 48-49.

14029 John Hamill, P1994 (Transcript from Prosecutor v. Galić), T. 6108-6109.

14030 John Hamill, P1994 (Transcript from Prosecutor v. Galić), T. 6109-6110; John Hamill, T. 9726 (13 December 2010).

14031 John Hamill, P1994 (Transcript from Prosecutor v. Galić), T. 6189-6190; John Hamill, T. 9694 (13 December 2010). 
for the fuse tunnel in Markale, Hamill claimed that, while not "completely intact" it was "intact enough" for him to estimate the angle of descent. ${ }^{14032}$ In addition, he explained that the team also used other methods to establish the direction, and that there was a remarkable consistency across the results despite the fact that various investigators in his team did their tests independently and used different methods. ${ }^{14033}$

4195. Hamill also thought that the market hit was a fluke since a $120 \mathrm{~mm}$ mortar is not a terribly accurate weapon and no adjusting rounds were fired in this particular case. ${ }^{14034} \mathrm{He}$ did concede, however, that if the market was indeed the target, the probability of hitting it would have been slightly higher the closer the market was to the weapon. ${ }^{14035}$ Having looked at the report prepared by Sabljica and the others at the CSB Sarajevo, Hamill confirmed that the methodology used was good and the results consistent with the results he and his team produced. ${ }^{14036}$

4196. Colonel Steven Joudry, a trained artillery officer and instructor in gunnery and field techniques for crater analysis in the Royal Canadian Army who, at the relevant time, served at UNPROFOR headquarters in Croatia, stated that he was informally asked by "an UNPROFOR authority" to review the report of Colonel Gauthier's team, given his extensive experience in crater analysis. ${ }^{14037}$ Having done so, Joudry had serious reservations, although he had never seen the crater himself, about the procedures used in the Markale crater analysis, as it was neither conducted on a fresh, undisturbed crater, nor was crater analysis generally an exact-enough method "to determine culpability". ${ }^{14038}$ Joudry further considered that it would have been "virtually impossible" for a single mortar round to fire at the market and hit it, ${ }^{14039}$ and that,

14032 John Hamill, P1994 (Transcript from Prosecutor v. Galić), T. 6194; John Hamill, T. 9729, 9732-9733 (13 December 2010). On cross-examination, Hamill and Rose conceded that the best time to investigate an incident such as this would have been immediately after, and that interference with evidence would make such an investigation "less than perfect". See Michael Rose, T. 7340-7342, 7359 (6 October 2010); John Hamill, T. 9692-9693 (13 December 2010). Hamill denied, however, that any forensic evidence had been removed by the Bosnian Muslims as FreBat was on the scene soon after the explosion. See John Hamill, P1994 (Transcript from Prosecutor v. Galić), T. 6198-6201.

14033 John Hamill, P1994 (Transcript from Prosecutor v. Galić), T. 6194.

14034 John Hamill, P1994 (Transcript from Prosecutor v. Galić), T. 6191, T. 6218; John Hamill, T. 9722-9724, 9729_ 9732 (13 December 2010).

14035 John Hamill, P1994 (Transcript from Prosecutor v. Galić), T. 6192-6193; John Hamill, T. 9726-9727 (13 December 2010).

14036 John Hamill, P1994 (Transcript from Prosecutor v. Galić), T. 6098-6102.

14037 D2363 (Witness statement of Steven Joudry dated 14 August 2012), paras. 1-3, 13. Upon cross-examination, Joudry conceded that most of the analyses he had carried out were training exercises. See Stephen Joudry, T. 29329 (30 October 2012).

14038 D2363 (Witness statement of Steven Joudry dated 14 August 2012), paras. 10, 14, 16-24; Steven Joudry, T. 29339 (30 October 2012). Joudry stated that the fact that much of the information was gathered hours or even days after the explosion (rather than from a hot undisturbed crater) in a public area, rendered many of the results questionable. He added that in other field situations, such analyses would have been discarded.

14039 D2363 (Witness statement of Steven Joudry dated 14 August 2012), para. 24(c); Steven Joudry, T. 2935429355, 29369 (30 October 2012). 
alternatively, the mortar shell could have been dropped from one of the surrounding buildings and the stabiliser inserted into the crater in the "first few moments of confusion". 14040

4197. Rose testified that following the incident he stated to the press that, as with the Dobrinja incident of the day before-which had been determined by the UNPROFOR to have been committed by the Serb side-it was most likely that the shell that landed on Markale market had also come from the Serb side. ${ }^{14041}$ When shown the report prepared by Gauthier's team, including the statement that the measured angles were not "beyond suspicion" because of the crater disturbance, Rose refused to comment saying that he was not involved in the investigation or the writing of the report. ${ }^{14042}$

4198. Harland wrote the portion of the UN's weekly assessment relating to this incident in which he reported that 68 people were killed and up to 200 injured, almost all of whom were civilians. ${ }^{14043}$ While this assessment provided that the mortar bomb was fired from the northeast, from near the confrontation line, it also stated that it was not possible to say with certainty that it came from the Serb positions. ${ }^{14044}$ However, in Harland's view, the circumstantial evidence pointed to the Serbs because (i) the incident resembled the incident of the day before which was confirmed by UNPROFOR experts as having been perpetrated by the Serbs; (ii) public claims made by Krajišnik after the incident that body parts had been flown in by the United States or that mannequins were used as a part of an elaborate hoax were completely bizarre and outlandish; and (iii) the Bosnian Muslims gave access to UNPROFOR to all areas and personnel in the course of the UNPROFOR's investigation of this incident, whereas the Serbs did not. ${ }^{14045}$

\section{(d) Firing positions northeast of Markale}

4199. The Chamber recalls that the closest confrontation line in the north-northeastern area of Sarajevo was in the area above Sedrenik and around Špicasta Stijena, on the ABiH-held Grdonj

\footnotetext{
14040 D2363 (Witness statement of Steven Joudry dated 14 August 2012), paras. 24(c), 25-28; Steven Joudry, T. 29364-29368 (30 October 2012).

14041 Michael Rose, T. 7343-7344 (6 October 2010). When shown a UN summary of the media reports from 7 February 1994, where he is quoted as saying only that it was uncertain at that point who fired the shell, he commented that this report was incomplete because he had also said that it was most likely that the Serbs had shelled the market. See Michael Rose, T. 7363-7364 (6 October 2010), T. 7591-7592 (8 October 2010); D682 (UNPROFOR report re local press summary, 7 February 1994), e-court p. 4.

14042 Michael Rose, T. 7350-7354 (6 October 2010); P1441 (UNPROFOR report re shelling of Markale on 5 February 1994), e-court p. 19.

14043 P820 (Witness statement of David Harland dated 4 September 2009), para. 73; P826 (UNPROFOR Weekly Political Assessment, 9 February 1994), pp. 1-2.

14044 P826 (UNPROFOR Weekly Political Assessment, 9 February 1994), pp. 1-2.

14045 P820 (Witness statement of David Harland dated 4 September 2009), para. 75. See also David Harland, T. 2040-2041 (6 May 2010), T. 2320-2325, T. 2331-2332 (11 May 2010); P826 (UNPROFOR Weekly Political Assessment, 9 February 1994), p. 5; P827 (UNPROFOR Weekly Political Assessment, 17 February 1994), p. 7.
} 
Hill. ${ }^{14046}$ Hogan measured the distance to this point as being some 2,300 metres from Markale. ${ }^{14047} \mathrm{He}$ also measured the distance to the confrontation line on the bearing of 18 degrees plus or minus five degrees, and testified that it was approximately 2,800 metres away. ${ }^{14048}$ Hogan also testified that Markale market was at an altitude of 556 metres above sea level while Špicasta Stijena was at 874 metres. ${ }^{14049}$ According to Adjudicated Fact 335, the distance between Markale market and the SRK side of the confrontation line to the north-northeast at the time of the incident was approximately 2,600 metres. ${ }^{14050}$

4200. The Chamber further recalls its findings in Section IV.B.1.b.iii.C: Sedrenik that, with the exception of a few days around mid-1994, Špicasta Stijena was in the zone of responsibility of the SRK, more precisely the $7^{\text {th }}$ Battalion of the $1^{\text {st }}$ Romanija Infantry Brigade and that the two sides were very close to each other. ${ }^{14051}$ According to Gengo, the $7^{\text {th }}$ Battalion was deployed at a higher altitude than the ABiH forces in the sector of Špicasta Stijena, Mala Tvrđava, and Velika Tvrđava, whereas the forces at Borije, Faletići, and other sectors were mostly at the same level. ${ }^{14052} \mathrm{He}$ further stated that the $\mathrm{ABiH}$ forces opposed to his battalion were in possession of a variety of infantry weapons, including $120 \mathrm{~mm}$ mortars, which changed positions often. ${ }^{14053}$ According to Gengo, the $\mathrm{ABiH}$ units fired at his battalion mostly from the area of Koševo and from the Jajce Barracks. ${ }^{14054}$

4201. As regards SRK mortar positions, Milorad Džida, then-Assistant Commander for Intelligence and Security of the $7^{\text {th }}$ Battalion of the $1^{\text {st }}$ Romanija Infantry Brigade, ${ }^{14055}$ stated that the SRK had two fixed mortar positions, one at Debelo Brdo and one at Mrkovići, each equipped

\footnotetext{
14046 See paras. 3852-3857, 4172.

14047 Barry Hogan, T. 11221-11224 (3 February 2011); P2212 (Map of Sarajevo marked by Barry Hogan).

14048 Barry Hogan, T. 11221-11224 (3 February 2011); P2212 (Map of Sarajevo marked by Barry Hogan).

14049 Barry Hogan, T. 11221-11224 (3 February 2011).

14050 See Adjudicated Fact 335.

14051 See para. 3855

14052 D2383 (Witness statement of Slavko Gengo dated 14 October 2012), para. 16. Gengo also testified that the $7^{\text {th }}$ Battalion was bordered by the Koševo Battalion. The border between the two was "spread in the middle between the village of Mrkovići”. See D2383 (Witness statement of Slavko Gengo dated 14 October 2012), para. 37.

14053 D2383 (Witness statement of Slavko Gengo dated 14 October 2012), para. 17. But see P1058 (ABiH map) (indicating that $\mathrm{ABiH}$ had mortars in Breka but not near Špicasta Stijena); P6301 (Reference table of military symbols).

14054 D2383 (Witness statement of Slavko Gengo dated 14 October 2012), paras. 18, 23; Slavko Gengo, T. $29772-$ 29773, 29775-29780 (6 November 2012); P2193 (Map of Sarajevo); P5967 (Map of Sarajevo marked by Slavko Gengo). The Chamber notes that Jajce Barracks were located east of Stari Grad while the Koševo Hospital complex is located northwest of Stari Grad.

14055 D2375 (Witness statement of Milorad Džida dated 30 October 2012), para. 5.
} 
with two $82 \mathrm{~mm}$ and two $120 \mathrm{~mm}$ mortars. ${ }^{14056}$ According to Gengo, there were no $120 \mathrm{~mm}$ mortars beyond Mrkovići ${ }^{14057}$ and Mrkovići mortars were used to respond to incoming fire from the Mala Tvrđava-Velika Tvrđava axis, whereas the Debelo Brdo mortars were used when the Faletići-Zečija Glava sectors were attacked; he asserted that the mortars' positions were not used on any other axes, including towards the city. ${ }^{14058}$

4202. Galić testified that he never issued an order for the SRK to fire on Markale on that day and also stated that he never received a report from subordinate units that any of them ordered this fire. ${ }^{14059}$ On the day of the incident, he ordered a strict ban on fire into urban parts of Sarajevo, in which he stated that "[r]ecently, despite explicit orders, certain units, individuals and artillery weapons' crews have, arbitrarily and without approval, been opening fire on urban parts of Sarajevo, without need". ${ }^{14060}$ As a result, according to the order, the units were to fire into urban parts of Sarajevo only when given a special order of the SRK Commander. ${ }^{14061}$ In the order, Galić also mentioned that Sarajevo was the focus of media attention and that every action would be used for "propaganda purposes" against the Serbs. ${ }^{14062}$

4203. Similarly, on 7 February 1994, the Accused issued an order to the VRS Main Staff and the SRK, stating first that "there is evidence that Serbs are not responding in equal measure to Muslim artillery provocations-sometimes twenty to thirty, or even seventy times more" and ordering as a result that the VRS introduce "the strictest possible control of retaliation to provocations", respond only when threatened and against military targets, and strictly at the commander's commands. ${ }^{14063}$ Harland recalled that this order corresponded to his recollection of events after the Markale market incident, namely that an effective cease-fire did occur. ${ }^{14064}$

\footnotetext{
14056 D2375 (Witness statement of Milorad Džida dated 30 October 2012), paras. 15, 28; Milorad Džida, T. 2957729581 (1 November 2012); P5952 (Map of Sarajevo marked by Milorad Džida). See also P1058 (ABiH map) (indicating that SRK had $120 \mathrm{~mm}$ mortars in Mrkovići); P6301 (Reference table of military symbols).

14057 Slavko Gengo, T. 29772-29775, (6 November 2012); P5966 (Map of Sarajevo marked by Slavko Gengo); D2383 (Witness statement of Slavko Gengo dated 14 October 2012), para. 38.

14058 Slavko Gengo, T. 29772-29774, (6 November 2012); D2383 (Witness statement of Slavko Gengo dated 14 October 2012), para. 38. See also D2375 (Witness statement of Milorad Džida dated 30 October 2012), paras. 15, 28; Milorad Džida, T. 29589-29591 (1 November 2012).

14059 Stanislav Galić, T. 37443-37445 (18 April 2013).

14060 P5970 (SRK Order, 5 February 1994).

14061 P5970 (SRK Order, 5 February 1994).

14062 P5970 (SRK Order, 5 February 1994).

14063 P846 (Radovan Karadžić's Order to VRS, 7 February 1994).

14064 P820 (Witness statement of David Harland dated 4 September 2009), paras. 77-78.
} 


\section{(e) Bosnian Serb calls for joint investigation}

4204. Milovanović testified that, in the evening of 5 February 1994, Ramsey phoned him and claimed that the Serbs fired an $82 \mathrm{~mm}$ mortar shell killing 96 Muslims and wounding 213 civilians in Markale market. ${ }^{14065}$ Milovanović in turn asked that a joint commission, comprising of UN, $\mathrm{ABiH}$, and SRK representatives, go to the scene the next day together with ballistics experts to ascertain objectively who was to blame. ${ }^{14066}$ Milovanović followed up on his exchange with Ramsey with an official request for the establishment of a joint commission addressed to Rose. ${ }^{14067}$ In the follow-up he stated that if this request was refused, the VRS would suspend all co-operation with UNPROFOR and humanitarian organisations and would block any movement of humanitarian organisations and foreign nationals until further notice. ${ }^{14068}$ Later that evening, Ramsey informed Milovanović that the Muslim side was refusing to participate in the joint commission. ${ }^{14069}$ At around 2 a.m. on 6 February 1994, Ramsey finally informed him that there would be no such joint investigation. ${ }^{14070}$ Thus, neither the Serb nor the Muslim side was represented during the UN investigations of this incident, although their liaison officers were "permitted to maintain contact with the investigation team". ${ }^{4071}$

4205. On 6 February 1994, Rose met Milovanović at Lukavica Barracks. ${ }^{14072}$ During this meeting Milovanović adamantly denied that the shell had been fired from the Serb side and repeated his request for a joint investigative commission; however, Rose was "not interested" in

14065 Manojlo Milovanović, T. 25731-25732 (5 March 2012).

14066 Manojlo Milovanović, T. 25732 (5 March 2012); D683 (Intercept of conversation between General Ramsey and General Milovanović, 5 February 1994).

14067 Manojlo Milovanović, T. 25732-25733 (5 March 2012); D2182 (Letter from Manojlo Milovanović to General Rose, 5 February 1994). See also P1638 (Witness statement of Michael Rose dated 26 March 2009, para. 38; P1652 (Letter from VRS Main Staff to Michael Rose, 5 February 1994), paras. 1, 5.

14068 P1652 (Letter from VRS Main Staff to Michael Rose, 5 February 1994), paras. 1, 5; P1638 (Witness statement of Michael Rose dated 26 March 2009), para. 38; Michael Rose, T. $7364-7370$ (6 October 2010).

14069 D2183 (Public statement of Manojlo Milovanović, 5 February 1994).

14070 Manojlo Milovanović, T. $25732-25733$ (5 March 2012). See also D2774 (Witness statement of Milenko Inđić dated 19 January 2013), para. 136; D2562 (Witness statement of Vladimir Radojčić dated 8 December 2012), para. 109; Stanislav Galić, T. 37444 (18 April 2013), T. 37529-37530 (22 April 2013), T. 38065 (9 May 2013) (adding that General Gvero made a similar request to the level of command of the UNPROFOR Sector and that this request was also refused on the basis that the commission's safety could not be guaranteed); D2770 (Witness statement of KW570 dated 21 November 2012) (under seal), para. 10. The Chamber notes that there are two consecutive paragraphs 10 in KW570's witness statement. The one cited in this footnote is the second one.

14071 P1441 (UNPROFOR report re shelling of Markale on 5 February 1994), e-court pp. 9, 55-56; Michael Rose, T. 7592-7593 (8 October 2010); John Hamill, T. 9681-9682 (13 December 2010).

14072 D2770 (Witness statement of KW570 dated 21 November 2012) (under seal), para. 10. The Chamber notes that there are two consecutive paragraphs 10 in KW570's witness statement. The one cited in this footnote is the second one. 
the proposal. ${ }^{14073}$ In the days following this incident, Rose also met with the Accused, who denied Serb responsibility for the Markale incident. ${ }^{14074}$

4206. According to Milovanović, the Serb side carried out its own investigation into the incident under the leadership of Colonel Ljuban Kosovac, concluding that the explosion was not caused by a shell but rather by an explosive device detonated at ground level. ${ }^{14075}$ The Chamber has not received any other evidence about this investigation or its results. However, it did hear from Radojčić, who testified that he was appointed on 5 February 1994 to a mixed commission together with Lugonja and Cvetković, but that this commission was not allowed to work, and that he was then ordered by Dragomir Milošević to establish who had fired the shell. ${ }^{14076} \mathrm{He}$ was subsequently transferred to the SRK Command in Lukavica in order to go to the scene to establish the trajectory of the shell, but the Muslim side did not allow it. ${ }^{14077}$

4207. Contrary to Milovanović and Radojčić, who testified about an internal SRK investigation, Džida and Gengo claimed that a mixed commission, including an UNPROFOR delegation, "cleared" the SRK upon inspection of SRK mortar positions on 6 February $1994 .{ }^{14078}$ According to Gengo and Džida, they were informed on 5 and 6 February 1994, respectively, by the command of the $1^{\text {st }}$ Romanija Motorised Brigade that an inspection team escorted by UNPROFOR would come to visit the battalion. ${ }^{14079}$ This visit took place in the morning of 6 February 1994 and a report thereon was compiled by Jakovljević for the SRK. ${ }^{14080}$ Members of UNPROFOR and the VRS Main Staff arrived to inspect the Mrkovići mortar positions and while doing so spoke to

14073 D2770 (Witness statement of KW570 dated 21 November 2012) (under seal), para. 10. The Chamber notes that there are two consecutive paragraphs 10 in KW570's witness statement. The one cited in this footnote is the second one.

14074 P1638 (Witness statement of Michael Rose dated 26 March 2009), para. 41.

14075 Manojlo Milovanović, T. 25735-25736 (5 March 2012). See also Savo Simić, T. 30065 (12 November 2012); Stanislav Galić, T. 37862-37866 (7 May 2013) (testifying that the commission headed by Kosovac was established before Markale for the purposes of investigating every incident).

14076 D2562 (Witness statement of Vladimir Radojčić dated 8 December 2012), para. 109. See also D2774 (Witness statement of Milenko Inđić dated 19 January 2013), paras. 136-137.

14077 D2562 (Witness statement of Vladimir Radojčić dated 8 December 2012), para. 109. But see Manojlo Milovanović, T. 25735 (5 March 2012) (testifying that Kosovac managed to visit Sarajevo during his investigation).

14078 D2375 (Witness statement of Milorad Džida dated 30 October 2012), paras. 16-18, 29; Milorad Džida, T. 29573-29577, 29582, 29585-29590 (1 November 2012); Slavko Gengo, T. 29803-29809 (6 November 2012); D2383 (Witness statement of Slavko Gengo dated 14 October 2012), para. 32.

14079 D2383 (Witness statement of Slavko Gengo dated 14 October 2012), para. 32; D2375 (Witness statement of Milorad Džida dated 30 October 2012), paras. 16, 29; Milorad Džida, T. 29573-29575 (1 November 2012); Slavko Gengo, T. 29803-29804 (6 November 2012).

14080 D2383 (Witness statement of Slavko Gengo dated 14 October 2012), para. 32; D2375 (Witness statement of Milorad Džida dated 30 October 2012), para. 17; Milorad Džida, T. 29574-29576, 29591-29593 (1 November 2012); Slavko Gengo, T. 29805 (6 November 2012). 
those who were on duty on the day of the incident. ${ }^{14081}$ Gengo could not remember anything about the members of the UN who attended this visit, including their number, nationality, and/or names while Džida remembered that one of the UNPROFOR officers was Russian. ${ }^{14082}$ When confronted with daily combat reports of the SRK of 5, 6, and 8 February, which made no mention of any UNPROFOR visit, Gengo remained adamant that the visit did take place. ${ }^{14083}$ The Chamber notes that the UN report of the second UN investigation specifically states that the Mrkovići positions had not been visited by the UN in at least four months and that they could not be located with accuracy. ${ }^{14084}$

4208. Gordan Milinić, the Accused's Security Adviser at the time, ${ }^{14085}$ testified that when the Accused heard about the incident on the day, he expressed astonishment and said that it was "yet another Muslim hoax"; he then immediately called the "military experts" who explained to him that the shell could not have been fired from the SRK positions and that this was a hoax by the Muslim side. ${ }^{14086}$ On 6 February, the Accused met with Akashi and told him that it was the other side that fired the shell. ${ }^{14087}$ On 10 February 1994, the Accused gave a press statement calling for a joint commission to investigate the incident, reminding the public that the Muslim side had previously staged shelling incidents and stating that the Serbs had no reason to continue with peace negotiations until a joint commission was established and findings on the incident were made. $^{14088}$

\section{(f) Post-war investigations}

4209. Years later, in January 2003, for the purposes of the Galić case, ${ }^{14089}$ Zečević carried out an additional analysis of the Markale market incident and concluded that the first three of the six possible charges could not have been used to fire the shell because the speed of the shell would

\footnotetext{
14081 D2375 (Witness statement of Milorad Džida dated 30 October 2012), para. 17; Milorad Džida, T. 29576-29577, 29582, 25985-25990 (1 November 2012); D2383 (Witness statement of Slavko Gengo dated 14 October 2012), para. 32.

14082 Slavko Gengo, T. 29805-29807, 29831 (6 November 2012); Milorad Džida, T. 29585 (1 November 2012).

14083 Slavko Gengo, T. 29809-29810, 29815-29824, 29826-29827 (6 November 2012); P5969 (SRK combat report, 5 February 1994); P5971 (SRK combat report, 6 February 1994); P5972 (SRK combat report, 6 February 1994); P5973 (SRK combat report, 8 February 1994).

14084 P1441 (UNPROFOR report re shelling of Markale on 5 February 1994), e-court p. 44. See also Milorad Džida, T. 29590-29599 (1 November 2012).

14085 D3682 (Witness statement of Gordan Milinić dated 8 June 2013), para. 9.

14086 D3682 (Witness statement of Gordan Milinić dated 8 June 2013), para. 15. See also D3051 (Witness statement of Momir Bulatović dated 25 February 2013), paras. 32-35 (testifying that the Supreme Defence Council in FRY was informed by General Momčilo Perišić that the incident was caused by the Muslim side).

14087 Yasushi Akashi, T. 37688-37689 (24 April 2013); D713 (UNPROFOR report re talks with Radovan Karadžić and Alija Izetbegović, 6 February 1994), e-court p. 1; Michael Rose, T. 7547-7549 (8 October 2010).

14088 P5974 (Video footage of Radovan Karadžić press conference in Geneva, 10 February 1994).

14089 Berko Zečević, T. 12304-12306, 12373-12375 (24 February 2011).
} 
have been slower than necessary to embed the stabiliser in the crater. ${ }^{14090}$ Using the angle of descent and having calculated the speed of impact of the shell, ${ }^{14091}$ Zečević determined that it came from between 4,500 ${ }^{14092}$ and 6,400 metres away, and thus from three areas that would correspond to the three highest charges all of which were located in SRK-held territory. ${ }^{14093}$

4210. When asked by the Accused why he did not conduct this analysis back in 1994, Zečević explained that there had not been sufficient time. ${ }^{14094}$ He denied that he changed the original conclusion because he wanted to blame the Serbs for the incident or because he feared for his own safety. ${ }^{14095}$ When asked how it was possible that he alone was able to establish the origin of fire when all the other teams that worked on this incident could not, Zečević stated that the UNPROFOR investigators were soldiers and not engineers who worked on the design of the ammunition and its effects. ${ }^{14096}$

4211. Higgs also investigated this incident after the war. He visited the site years later but noted that it offered little evidence due to redevelopment. ${ }^{14097}$ Higgs agreed with Sabljica's report, noting that the UNPROFOR analyses corroborate it. ${ }^{14098}$ Like many others, Higgs also noted that while the calibre of the mortar and the direction of fire could be determined through crater examination, the distance from which the mortar was fired was more difficult to ascertain as a mortar can be fired using different charges. ${ }^{14099}$ According to Higgs, if the aim was to hit

14090 Berko Zečević, T. 12173-12175 (22 February 2011), T. 12303-12308 (24 February 2011).

14091 Based on the fact that the stabiliser was embedded in the crater and certain calculations relating to penetration into what he called "soft barriers", Zečević calculated that the minimum speed of the incoming shell would have been over 200 metres per second, with a margin of error of 20 metres. See Berko Zečević, T. 12164-12170 (22 February 2011); P2316 (Diagram of impact of stabiliser marked by Berko Zečević). Turkušić testified that the tarmac in the open area of Markale market where the shell landed is softer than the tarmac on the Mula Mustafe Bašeskije street, namely the location of the second Markale incident, as it was not designed for heavy vehicles to pass over it. See Emir Turkušić, T. 9075-9076 (4 November 2010). See also P1441 (UNPROFOR report re shelling of Markale on 5 February 1994), e-court pp. 28-29 (where Dubant explains that the first layer is asphalt and below it is a mix of soil and pebbles).

14092 The Chamber notes that at first Zečević referred to a distance of 5,400 metres but then was asked and answered a question referring to a distance of 4,500 metres. Later on, he mentioned 4,950 metres. See Berko Zečević, T. 12169, 12174 (22 February 2011), T. 12304 (24 February 2011). Given that the distance of a shell fired at charge four would have been between 4,570 and 5,110 metres and that he did not exclude charge four, the Chamber considers that the reference to 5,400 metres was probably a mistake and that he intended to say 4,500 metres.

14093 Berko Zečević, T. 12169-12175 (22 February 2011), T. 12303-12305, 12349-12352 (24 February 2011); P2317 (Report by Berko Zečević entitled "Study of the circumstances and causes of the massacre at the Markale market on 5 February 1994”), e-court p. 6.

14094 Berko Zečević, T. 12305-12306 (24 February 2011).

14095 Berko Zečević, T. 12310-12311, 12341-12343, 12375 (24 February 2011).

14096 Berko Zečević, T. 12358-12360 (24 February 2011).

14097 P1437 (Richard Higgs's Consolidated Report on Sarajevo Shelling Incidents, 13 March 2009), p. 11.

14098 Richard Higgs, T. 5924-5929 (18 August 2010); P1437 (Richard Higgs's Consolidated Report on Sarajevo Shelling Incidents, 13 March 2009), p. 11; P1441 (UNPROFOR report re shelling of Markale on 5 February 1994), e-court p. 20.

14099 P1437 (Richard Higgs's Consolidated Report on Sarajevo Shelling Incidents, 13 March 2009), p. 11. 
Markale, this would not have been too difficult to achieve as it is easily identified from a distance by other landmarks, especially since parts of the town were "pre-recorded". ${ }^{14100}$

4212. Higgs visited all six potential locations from which the shell could have been fired, depending on the charge used, including the area of Mrkovići located northeast of the incident site and in which he found many suitable sites for placing a mortar, as well as routes that could be used to supply it. ${ }^{14101}$ In his view, Mrkovići was the area from which the mortar shell was "possibly fired". ${ }^{14102}$ Elaborating further, Higgs explained that if the shell had been fired using two medium charges this would have placed the mortar in the area right on top of the confrontation line, which was not a good place for tactical reasons. ${ }^{14103}$ If the two lowest charges had been used, this would have placed the mortar within the confrontation lines and within the built up area of Sarajevo; yet, no shell fire noise was reported. ${ }^{14104}$ Finally, as for the two highest charges, which place the origin of fire farther behind the confrontation line, in Mrkovići, Higgs noted, like Zečević, that the stabiliser of a mortar shell fired on higher charges will usually embed itself into a crater, which is what happened in Markale. ${ }^{14105}$ Furthermore, he had the statement of a witness who heard a mortar being fired in the direction of fire, which indicated that higher charges were used. ${ }^{14106}$ According to Higgs, this witness ${ }^{14107}$ was in a good position to hear mortar fire in the vicinity and "[d]ue to the fact of distance from mortar to target the weapon would probably have been firing on a medium to high charge and therefore making a louder noise". ${ }^{14108}$ Since the attack consisted of only one round fired into the centre of the town, Higgs was of the view that its purpose was to "harass" the population. ${ }^{14109}$ He also noted that, while

\footnotetext{
14100 P1437 (Richard Higgs's Consolidated Report on Sarajevo Shelling Incidents, 13 March 2009), p. 11.

14101 P1437 (Richard Higgs's Consolidated Report on Sarajevo Shelling Incidents, 13 March 2009), pp. 11-12; Richard Higgs, T. 5955-5957 (18 August 2010), T. 6026-6027 (19 August 2010).

14102 Richard Higgs, T. 6026-6028 (19 August 2010).

14103 Richard Higgs, T. 6027 (19 August 2010).

14104 Richard Higgs, T. 6027 (19 August 2010).

14105 Richard Higgs, T. 6027 (19 August 2010). Higgs explained that the type of terrain, angle of descent, round velocity, calibre, and the weather conditions are all determining factors in whether a crater will be formed by the explosion of a shell and whether the mortar's stabiliser will be found embedded within such a crater. If a projectile is fired at the lower to medium charges a higher percentage of explosions would cause the stabiliser to be blown away from the impact site, while there would be a higher percentage chance that the stabiliser would embed in the crater if the projectile is fired with charges five and six, as those charges would result in higher velocity of the projectile. See P1437 (Richard Higgs's Consolidated Report on Sarajevo Shelling Incidents, 13 March 2009), pp. 5-6; Richard Higgs, T. 5980-5981, 5983 (19 August 2010). See also John Hamill, P1994 (Transcript from Prosecutor v. Galić), T. 6075.

14106 P1437 (Richard Higgs's Consolidated Report on Sarajevo Shelling Incidents, 13 March 2009), p. 11.

14107 The Chamber notes that Higgs did not identify this "witness" in his evidence. Further, this person did not testify in the present case. While the Prosecution implies in its Final Brief, in footnote 387 of Appendix C, that he is "Witness AF" (referred to in Adjudicated Fact 332), there is nothing in the evidence before the Chamber that allows it to make that connection between Higgs' evidence and Adjudicated Fact 332.

14108 P1437 (Richard Higgs's Consolidated Report on Sarajevo Shelling Incidents, 13 March 2009), pp. 11-12.

14109 P1437 (Richard Higgs's Consolidated Report on Sarajevo Shelling Incidents, 13 March 2009), p. 11.
} 
possible to hit the market with a single "initially sighted round", it is more likely that the market was "pre-recorded". ${ }^{14110}$

4213. Zorica Subotić investigated this incident and based her conclusions on the previous investigation reports, photographs taken by the different investigation teams, a video recording of the incident and its aftermath, and her own site visit in $2010 .^{14111}$ In her opinion, the events as established by the various investigation teams do not correctly reflect what happened in Markale as the shell was most likely detonated on site through static activation by means of a timer or remote control device. ${ }^{14112}$ She believed that the stabiliser could have been dug into the ground prior to the explosion, using a household tool such as a spade, and then compressed into the ground by the explosion. ${ }^{14113}$ In particular, it was Subotić's contention that the shell could not have hit the market from the air without first destroying the stall roofs, ${ }^{14114}$ as the area was almost completely covered by stall roofs. ${ }^{14115}$ She further put forth that the material she examined suggested that the incident did not in fact occur "all at once" or "in some sort of natural process". 14116

14110 P1437 (Richard Higgs's Consolidated Report on Sarajevo Shelling Incidents, 13 March 2009), p. 12.

14111 Zorica Subotić, T. 38363 (15 May 2013).

14112 D3551 (Zorica Subotić's expert report entitled "Mortar Attacks on the Sarajevo Area: Incidents at the Markale Market 5 February 1994 and 28 August 1995”, 15 August 2012), pp. 86, 111, 115, 120-121, 170-172; Zorica Subotić, T. 38317, 38319-38320 (15 May 2013), T. 38536, 38538-38539, 38560, 38566 (21 May 2013).

14113 Zorica Subotić, T. 38321-38322 (15 May 2013), T. 38558 (21 May 2013); D3548 (Photograph of a stall at Markale Market marked by Zorica Subotić).

14114 D3551 (Zorica Subotić's expert report entitled "Mortar Attacks on the Sarajevo Area: Incidents at the Markale Market 5 February 1994 and 28 August 1995”, 15 August 2012), pp. 105-107, 113, 116, 119, 170. Subotić further argued that a reconstruction of the stall lay-out based on video-recordings and police footage of the incident indicates that the sketches made at the scene do not correctly reflect the actual lay out at the time of the incident. See Zorica Subotić, T. 38298, 38317 (15 May 2013), T. 38564, 38565 (21 May 2013).

14115 D3551 (Zorica Subotić's expert report entitled "Mortar Attacks on the Sarajevo Area: Incidents at the Markale Market 5 February 1994 and 28 August 1995”, 15 August 2012), p. 41; Zorica Subotić, T. 38294 (15 May 2013).

14116 Zorica Subotić, T. 38325-38326 (15 May 2013). Asserting that the incident did not occur naturally, Subotić pointed to the presence of: (i) persons with ID badges whom she asserted to have been officials of some sort; (ii) a military truck; and (iii) civilian vehicles arriving at the Maršala Tita street entrance of Markale market from the prohibited traffic direction of the one-way street, in what she identified as the immediate aftermath of the explosion. She inferred from the presence of the "officials" around the Markale market area that they "were at the location on assignment". Similarly, from the "well-organised" evacuation of the wounded from both the Dženetića Čikma and Maršala Tita street market entrances she inferred that they "had known in advance that [they] should go in that direction" and that it was "also possible that taxi drivers had a work obligation to be at disposal in situations like that". See D3551 (Zorica Subotić's expert report entitled "Mortar Attacks on the Sarajevo Area: Incidents at the Markale Market 5 February 1994 and 28 August 1995", 15 August 2012), pp. 51, 52, 54; P1986 (BiHTV Video footage of Markale, 5 February 1994); P6327 (Excerpt from video footage re shelling at Markale Market); Zorica Subotić, T. 38540-38543 (21 May 2013). The Chamber finds all these assertions to be pure speculation and completely groundless. Furthermore, contrary to Subotić's suggestions, the Chamber considers the presence of officials on the scene, and of vehicles arriving from all sides, to be perfectly reasonable in the circumstances. 
4214. Subotic also questioned whether the incident occurred at 12:15 p.m. as recorded in the UN report, preferring the time recorded by UNMO observers, namely 12:30 p.m.. ${ }^{14117}$ She concluded that it was possible for the first wounded to have arrived at Koševo Hospital at 12:35 p.m.. ${ }^{14118}$ Relying on the CSB Sarajevo report of 5 February 1994 as well as witness testimony from the Galić case, Subotic concluded that the evacuation of the dead and the wounded was completed around 12:50 p.m., ${ }^{14119}$ whereas the Stari Grad police station was only informed of the explosion at 12:45 p.m. ${ }^{14120}$ She thus inferred that the bodies of the dead and the wounded were removed from the site before the police were informed, and within no more than 20 minutes, while photographers and cameramen appeared at the scene almost immediately after the explosion. ${ }^{14121}$ Based on the way in which dead and mutilated bodies were shown to photographers and cameramen on the scene, the repeated showings of severed legs, a prosthetic leg seen in different locations around the market area, the speed at which the evacuations were carried out, and the fact that a military medical vehicle arriving at the scene already contained a dead body, Subotić concluded that the entire incident was planned, staged, and exploited for its impact through media coverage. ${ }^{14122}$ In her opinion, the staging of the incident required professional preparation, including placing dead bodies at the scene of the explosion to amplify the media impact. ${ }^{14123}$

4215. As to the point of impact, Subotić referred to video footage which, according to her, shows that the impact site is covered with several objects, which is contrary to a typical explosion of a mortar shell where the detonation blows objects away from the crater. ${ }^{14124}$ According to Subotić,

\footnotetext{
14117 D3551 (Zorica Subotić's expert report entitled "Mortar Attacks on the Sarajevo Area: Incidents at the Markale Market 5 February 1994 and 28 August 1995”, 15 August 2012), pp. 45-46.

14118 D3551 (Zorica Subotić's expert report entitled "Mortar Attacks on the Sarajevo Area: Incidents at the Markale Market 5 February 1994 and 28 August 1995”, 15 August 2012), p. 46.

14119 D3551 (Zorica Subotić's expert report entitled "Mortar Attacks on the Sarajevo Area: Incidents at the Markale Market 5 February 1994 and 28 August 1995”, 15 August 2012), pp. 47, 54 (relying on P1708 and the testimony of Esad Hadžimuratović from the Galić Case who did not testify in this case).

14120 D3551 (Zorica Subotić's expert report entitled "Mortar Attacks on the Sarajevo Area: Incidents at the Markale Market 5 February 1994 and 28 August 1995", 15 August 2012), p. 47 (relying on P1708).

14121 D3551 (Zorica Subotić's expert report entitled "Mortar Attacks on the Sarajevo Area: Incidents at the Markale Market 5 February 1994 and 28 August 1995”, 15 August 2012), p. 47, 48; Zorica Subotić, T. 38540-38544 (21 May 2013).

14122 D3551 (Zorica Subotić's expert report entitled "Mortar Attacks on the Sarajevo Area: Incidents at the Markale Market 5 February 1994 and 28 August 1995”, 15 August 2012), pp. 61-77, 114, 165; Zorica Subotić, T. 38550-38552 (21 May 2013). Subotić suggested, inter alia, that photo material depicting a prosthetic leg in a number of different locations around the market in the aftermath of the explosion, a woman seen assisting in the loading of dead bodies onto a truck who later on appeared at the Koševo Hospital dispensary giving an account of what she saw at the market to the reporter, and the fact that a woman seen to have been killed in the incident has not been officially recorded as a victim of the incident, lead to the conclusion that the incident and its documentation were staged. In relation to the prosthetic leg, Subotic did not deny that its owner was killed at Markale that day but claimed that the prosthesis differed from the prosthesis shown in the courtroom as belonging to Ćamil Begić. See Zorica Subotić, T. 38550 (21 May 2013).

14123 Zorica Subotić, T. 38537-38538 (21 May 2013), T. 38644 (22 May 2013).

14124 Zorica Subotić, T. 38303-38304 (15 May 2013); D3551 (Zorica Subotić's expert report entitled "Mortar Attacks on the Sarajevo Area: Incidents at the Markale Market 5 February 1994 and 28 August 1995”, 15 August 2012),
} 
the surroundings of the crater should have been littered with soil, pebbles, asphalt, and everything else that may have been pushed out by the embedding of the stabiliser, while the stabiliser should have been partially or fully visible. ${ }^{14125}$ However, when it was later cleared of the rubble, the Markale crater did not have the typical appearance of a crater penetrated by the full length of a stabiliser but rather looked like it had been manually dug out. ${ }^{14126}$ She concluded, therefore, that a hole was dug out, after which the stabiliser was either buried in the ground prior to the explosion or placed there after the explosion. ${ }^{14127}$ In her opinion, it was during the investigation of 6 February 1994 that a "bigger and wider crater was made in which the stabiliser was later lowered". ${ }^{14128}$ The Chamber notes that in her analysis of another, unscheduled incident, Subotić opined that the stabiliser of an $82 \mathrm{~mm}$ mortar shell must embed when fired at charges four to six. ${ }^{14129}$ Furthermore, when providing an opinion on the second Markale incident of 28 August 1995, Subotic explained that it is "well-known" that a stabiliser, in that case a $120 \mathrm{~mm}$ stabiliser, would penetrate the ground when it is fired at a charge of three or higher, whereas shallow craters would be created by shells fired at low speed, such as on a charge one. ${ }^{14130}$

4216. Subotić also argued that Zečević's method of re-inserting the stabiliser into a disturbed crater to determine the angle of descent is not a recognised method as its accuracy is dependent on a variety of factors, which would make it impossible to determine a margin of error. ${ }^{14131}$ She also

pp. 85-87, 118, 169, Figure 66; P1711 (Video footage re shelling of Markale, 5-6 February 1994). Subotić also found it suspicious that the crater was initially seen in the video footage as fully covered with rubble but later on, after a 20 or 30 minute break in the footage, the recording jumped to Zečević's investigation, showing a fully visible crater together with the re-inserted stabiliser, affixed with a number of small stones. See Zorica Subotić, T. 38309-38314 (15 May 2013).

14125 D3551 (Zorica Subotić's expert report entitled "Mortar Attacks on the Sarajevo Area: Incidents at the Markale Market 5 February 1994 and 28 August 1995”, 15 August 2012), pp. 86-87, 118; Zorica Subotić, T. 38304 38307 (15 May 2013).

14126 D3551 (Zorica Subotić's expert report entitled "Mortar Attacks on the Sarajevo Area: Incidents at the Markale Market 5 February 1994 and 28 August 1995”, 15 August 2012), pp. 86-87, 96; Zorica Subotić, T. 38304 38309 (15 May 2013); D3546 (Photographs depicting penetration of stabiliser and crater marked by Zorica Subotić). Subotić found further support for this position in the fact that the recovered stabiliser did not show any traces of scratches it should have born from the impact and in the video footage showing two layers of asphalt under which the crater was located. See D3551 (Zorica Subotić's expert report entitled "Mortar Attacks on the Sarajevo Area: Incidents at the Markale Market 5 February 1994 and 28 August 1995”, 15 August 2012), pp. 98, 168-169; Zorica Subotić, T. 38315-38316 (15 May 2013).

14127 Zorica Subotić, T. 38554 (21 May 2013).

14128 Zorica Subotić, T. 38309-38312 (15 May 2013); D3547 (Video clips re Markale). The Chamber notes that this contradicts the evidence of Derek Allsop, an expert also called by the Accused (see below), who testified that the depth of the crater appeared to be similar on both days. See D2372 (Derek Allsop's expert report entitled "Shelling of Markale Market in Sarajevo $5^{\text {th }}$ February 1994", 20 January 2012), para. 7.3; Derek Allsop, T. 29461 (31 October 2012).

14129 D3542 (Zorica Subotić's expert report entitled "Mortar Operations in Sarajevo Area in 1992-1995”, 15 August 2012), pp. 48-49.

14130 D3551 (Zorica Subotić's expert report entitled "Mortar Attacks on the Sarajevo Area: Incidents at the Markale Market 5 February 1994 and 28 August 1995”, 15 August 2012), p. 137; Zorica Subotić, T. 38341-38342 (15 May 2013).

14131 D3551 (Zorica Subotić's expert report entitled "Mortar Attacks on the Sarajevo Area: Incidents at the Markale Market 5 February 1994 and 28 August 1995”, 15 August 2012), pp. 93, 96-97 (stating also that Zečević's 
criticised the measurements and estimates of the angle of descent calculated by other investigators and argued that the trajectory of the penetration of the stabiliser does not generally follow the trajectory of the mortar shell. ${ }^{14132}$ However, using another method, namely the density of the lateral beam of the fragment markings or splinter patterns on the asphalt, she calculated the angle of descent at between 64.6 and 70.32 degrees, that is, still within the range estimated by Zečević. ${ }^{14133}$

4217. With regard to the incoming trajectory, Subotić recalled that different investigation teams determined a variety of different bearings of the shell. ${ }^{14134}$ Based on the fragmentation effect on the UPI supermarket building, she established the baseline azimuth as being between 18 and 23, and up to 25 degrees, and thus was more or less consistent with the findings of CSB Sarajevo team, Zečević's team, and those of the second UN investigation. ${ }^{14135}$

4218. Derek Allsop was commissioned by the Accused to review Zečević's method of predicting the impact velocity of the stabiliser of the mortar shell based on its depth of penetration. ${ }^{14136}$ Allsop testified that, in order to determine where a projectile is fired from, its impact velocity and impact angle ${ }^{14137}$ must be established and compared with trajectory calculations or range tables. ${ }^{14138}$ According to Allsop, when a mortar shell hits the ground, the fuse at the tip of the mortar shell is driven into the ground and creates a hole--the so-called "fuse furrow"-with parts of the fuse embedded in it; the stabiliser is then either driven backwards or also gets embedded in the ground depending on whether or not its velocity is less than the forward velocity of the mortar bomb. ${ }^{14139}$ In addition, if the forward velocity of the stabiliser is greater than its ejection velocity,

method could produce an accurate result but that it would be necessary to show, using another method, that the results are reliable); Zorica Subotić, T. 38313-38315 (15 May 2013).

D3551 (Zorica Subotić's expert report entitled "Mortar Attacks on the Sarajevo Area: Incidents at the Markale Market 5 February 1994 and 28 August 1995", 15 August 2012), p. 104.

14133 D3551 (Zorica Subotić's expert report entitled "Mortar Attacks on the Sarajevo Area: Incidents at the Markale Market 5 February 1994 and 28 August 1995", 15 August 2012), pp. 104, 105.

14134 D3551 (Zorica Subotić's expert report entitled "Mortar Attacks on the Sarajevo Area: Incidents at the Markale Market 5 February 1994 and 28 August 1995", 15 August 2012), p. 167.

14135 Zorica Subotić, T. 38300, 38302-38303, 38362, 38364 (15 May 2013); D3544 (Photograph depicting crater at Markale Market marked by Zorica Subotić).

14136 D2372 (Derek Allsop's expert report entitled "Shelling of Markale Market in Sarajevo $5^{\text {th }}$ February 1994", 20 January 2012), para. 1.1; Derek Allsop, T. 29424-29425, 24927-24928, 29463-29464 (31 October 2012); D2369 (Derek Allsop's curriculum vitae).

14137 Allsop clarified in court that "impact angle" and "angle of descent" are synonymous terms. See Derek Allsop, T. 29473-28474, 29533 (31 October 2012).

14138 D2372 (Derek Allsop's expert report entitled "Shelling of Markale Market in Sarajevo $5^{\text {th }}$ February 1994", 20 January 2012), paras. 3.1-3.2; Derek Allsop, T. 29436-29439 (31 October 2012) (stating further that working out impact velocity from the evidence on the site of impact alone is extremely difficult).

14139 D2372 (Derek Allsop's expert report entitled "Shelling of Markale Market in Sarajevo $5^{\text {th }}$ February 1994", 20 January 2012), paras. 5.1-5.3, 9.1; Derek Allsop, T, 29439-29441, 29453-29456, 29471 (31 October 2012); D2370 (Diagram marked by Derek Allsop). See also KW571, T. 32015 (16 January 2013); D2759 (Witness 
it may also fragment the fuse and disperse it sideways so that no fuse fragments remain in the furrow. ${ }^{14140}$ In the case of an embedded stabiliser, its impact velocity will consist of the impact velocity of the mortar bomb itself minus the velocity at which the stabiliser was ejected upon impact. ${ }^{14141}$ However, according to Allsop, the latter velocity is almost impossible to determine. $^{14142}$ In addition, since the stabiliser will eject upon detonation of the explosive on impact, its final angle would generally be different from the impact angle of the mortar bomb itself so that measuring it would not in fact provide the angle of the impact of the mortar bomb. ${ }^{14143}$ Like the other experts, Allsop also testified that a high impact velocity would make it more likely for the stabilising fin to get embedded into the ground, ${ }^{14144}$ meaning that an accurate measurement of the stabiliser penetration would still help calculate the impact velocity of the mortar shell, assuming one took into account a number of factors, such as density of the soil and moisture levels, for example. ${ }^{14145}$

4219. With respect to the Markale crater, Allsop concluded that: (i) there was little evidence on which to base a forensic investigation into where the mortar shell was fired from; (ii) Zečević's method of calculating the ejection velocity of the stabiliser was "over simplistic" and incapable of producing reliable results; (iii) similarly, the method of calculating the impact velocity was flawed because no consideration was given to the fuse furrow or the fact that it would not have been possible to insert the stabiliser at the same depth from which it was removed; ${ }^{14146}$ and (iv) with the information available on the scene of the incident, it would not be possible to accurately calculate the range from which the mortar was fired. ${ }^{14147}$ With respect to (iii) above, he conceded however

statement of KW571 dated 27 March 2012) (under seal), paras. 8-9. The Chamber notes that there are two paragraphs 9.1 in Allsop's report. The one cited in this footnote is on page 7 of the report.

14140 Derek Allsop, T. 29445-29446, 29523 (31 October 2012).

14141 D2372 (Derek Allsop's expert report entitled "Shelling of Markale Market in Sarajevo 5 $5^{\text {th }}$ February 1994 ", 20 January 2012), para. 5.3, 9.2; Derek Allsop, T. 29436-29442 (31 October 2012).

14142 Furthermore, according to Allsop, predicting velocities at which the stabiliser would be ejected is not sufficiently developed. D2372 (Derek Allsop's expert report entitled "Shelling of Markale Market in Sarajevo $5^{\text {th }}$ February 1994”, 20 January 2012), paras. 6.1-6.7, 10.2-10.3; Derek Allsop, T. 29443, 29466-29467 (31 October 2012).

14143 D2372 (Derek Allsop's expert report entitled "Shelling of Markale Market in Sarajevo 5 ${ }^{\text {th }}$ February 1994 ", 20 January 2012), paras. 5.3-5.7; Derek Allsop, T. 29446-29453, 29460 (31 October 2012).

14144 Derek Allsop, T. 29441-29442, 29471-29472 (31 October 2012).

14145 D2372 (Derek Allsop's expert report entitled "Shelling of Markale Market in Sarajevo 5 $5^{\text {th }}$ February 1994", 20 January 2012), paras. 8.1-8.5 (stating also that those factors were not considered during the investigation in Markale); Derek Allsop, T. 29458-29461, 29503-29505 (31 October 2012). The Chamber notes that there are two paragraphs 8.5 in Allsop's report. The one cited in this footnote is on page 6 of the report.

14146 D2372 (Derek Allsop's expert report entitled "Shelling of Markale Market in Sarajevo 5" February 1994", 20 January 2012), paras. 7.1-7.5, 8.5, 10.7, 11.1-11.5; Derek Allsop, T. 29456-29459 (31 October 2012); D2371 (Photograph marked by Derek Allsop). The Chamber notes that there are two paragraphs 8.5 in Allsop's report. The one cited in this footnote is on page 7 of the report. Further, paragraph 10.7 follows after paragraph 11.5 and should have in fact been paragraph 11.6.

14147 Derek Allsop, T. 29428 (31 October 2012); D2372 (Report by Derek Allsop on the shelling of Markale Market in Sarajevo on 5 February 1994), paras. 10.7, 11.1-11.5. Allsop conceded, however, that he never visited 
that he was not aware that investigators at the scene looked for but found no fuse fragments in the crater so that it was possible that the fuse fragmented into several pieces upon impact, rather than ending up in the fuse furrow. ${ }^{14148} \mathrm{He}$ also conceded, in line with the evidence of Zečević, Higgs, and Subotić, that in cases where the stabiliser embeds into the ground, it is likely that a higher charge was used, although in practice it may not always be the case for every impact as this will depend on the characteristics of the particular mortar bomb used. ${ }^{14149}$ Similarly, if the launching position was located at a higher altitude than the altitude of the target/impact, the higher launching altitude would increase the acceleration of the bomb. ${ }^{14150}$

4220. Allsop did not think that it was possible to drop the mortar bomb onto Markale from one of the surrounding buildings since a mortar bomb requires set-back forces created through its launch to initiate the fuse. ${ }^{14151}$ Dropping it would also have caused it to hit the ground vertically, which was not the case given the appearance of the crater. ${ }^{14152}$ Similarly, Allsop did not consider it possible that a shell could have been activated in a static explosion, since the only way the stabilising fin could have become embedded into the ground was by travelling through the air at a higher velocity than its ejection velocity. ${ }^{14153}$ To Allsop, the Markale impact site displayed all characteristics of a conventional $120 \mathrm{~mm}$ mortar bomb strike. ${ }^{14154}$ Finally, Allsop explained that it would have been extremely difficult to achieve an exact hit of Markale from a very close range given that it would have been very dangerous for the launching crew. ${ }^{14155}$

4221. The Accused also called Poparić, who sought to specifically counter Higgs's suggestion that it would be possible to hit Markale market with a single round if the target was pre-

Markale and had no reason to dispute the observations of the people who were on the scene at the time of the incident. See Derek Allsop, T. 29505-29511 (31 October 2012); P5951 (Three photographs re shelling of Markale on 5 February 1994).

Derek Allsop, T. 29491-29499, 29523 (31 October 2012); P5950 (Fuse and shell body fragments from shelling of Markale 5 February 1994). Allsop agreed that firing tests of mortar bombs for research and testing purposes would usually be carried out under controlled conditions on soft surfaces where the crater would be less defined than the crater in Markale was. He also agreed that testing materials for $120 \mathrm{~mm}$ mortars suggested high fragmentation of the fuse, with the stabiliser remaining intact. See Derek Allsop, T. 29485-29490, 2952229523 (31 October 2012); P5947 (Photograph of crater formed by $120 \mathrm{~mm}$ mortar projectile); P5948 (Photograph of $120 \mathrm{~mm}$ light mortar projectile fragments); P5949 (Results of fragmentation of five $120 \mathrm{~mm}$ projectiles).

Derek Allsop, T. 29470-29484 (31 October 2012); P5946 (Excerpt from firing tables for $120 \mathrm{~mm}$ mortar). Derek Allsop, T. 29479-29480 (31 October 2012).

Derek Allsop, T. 29465-29466 (31 October 2012). But see D2363 (Witness statement of Steven Joudry dated 14 August 2012), pp. 5, 6

Derek Allsop, T. 29465-29466 (31 October 2012).

Derek Allsop, T. 29467 (31 October 2012.

Derek Allsop, T. 29467 (31 October 2012).

Derek Allsop, T. 29468-29469 (31 October 2012). 
recorded. ${ }^{14156}$ Based on the dimensions of the market and looking at the different charges and resulting ranges of the $120 \mathrm{~mm}$ mortar shell, he calculated the probability of the initial shell striking the market to be between $0.1 \%$ and $0.09 \%$, the lowest charge having the highest probability. ${ }^{14157}$ On cross-examination, Poparić was asked to consider the estimated impact area around a set target if a shell were fired at a charge five from a maximum range of 5,782 metres and agreed that the area struck would be within an ellipse of 58 by 24 metres, which would virtually cover the entire area of the market place, assuming the target point was the centre of the market; however, he also explained that these statistics were based on the firing of a group of projectiles, $50 \%$ of which would have hit the determined area. ${ }^{14158}$ Thus, according to him, these statistics could not be used to determine the probability in relation to the first and only shell fired, such as happened in Markale. ${ }^{14159}$

\section{(g) Casualties}

4222. Sabljica's report notes that 69 persons died in the explosion, while 197 sustained serious or minor injuries. ${ }^{14160}$ Bešić's report refers to 66 dead and 200 wounded. ${ }^{14161}$ Bešić also testified that the number of 68 dead was initially registered in the Koševo morgue and that more people died later. ${ }^{14162}$ Rose testified that early reports on the incidents provided that more than 200 people had been injured and at least 50 killed, while the final toll came to 68 casualties. ${ }^{14163}$

4223. In addition to his own father Ćamil, Almir Begić identified a number of victims who died in the Markale market incident on 5 February 1994, namely Muhamed Borovina, Nura Odžak, and

\footnotetext{
14156 D3644 (Expert report by Mile Poparić et al entitled "Inconsistencies of Experts Berko Zečević and Richard Higgs in Cases of the Shelling of Sarajevo", 15 August 2012), p.116. See also Mile Poparić, T. 39073-39080 (31 May 2013), T. 39313 (5 June 2013).

14157 D3644 (Expert report by Mile Poparić et al entitled "Inconsistencies of Experts Berko Zečević and Richard Higgs in Cases of the Shelling of Sarajevo", 15 August 2012), p.117

14158 Mile Poparić, T. 39073-39080 (31 May 2013).

14159 Mile Poparić, T. 39073-39080 (31 May 2013); P6349 (Diagram of stalls at Markale on 5 February 1994 marked by Mile Poparić).

14160 P1708 (BiH MUP Report re shelling of Markale on 5 February 1994), p. 1. During his testimony in the Galić case, Sabljica stated that there were over 90 wounded. See P1695 (Witness statement of Mirza Sabljica dated 11 February 2010), p.47.

14161 P1973 (BiH MUP Report re shelling of Markale on 5 February 1994), p. 5. See also Sead Bešić, T. 9441 (8 December 2010).

14162 Sead Bešić, T. 9450-9453 (9 December 2010).

14163 P1638 (Witness statement of Michael Rose dated 26 March 2009), para. 37. See also John Hamill, P1994 (Transcript from Prosecutor v. Galić), T. 6103-6105.
} 
Ruždija Trbić. ${ }^{14164}$ Furthermore, he identified two wounded victims, namely Muradif Čelik and Kenan Suvalija. ${ }^{14165}$ According to him, 67 people lost their lives in this incident. ${ }^{14166}$

4224. Faris Gavrankapetanović, the general manager of Koševo Hospital, ${ }^{14167}$ authenticated a number of records, including admission records, relating to patients brought to the Hospital on the day of this incident. ${ }^{14168}$ These records show that on 5 February 1994, at 12:35 p.m., Koševo Hospital received around 90 victims from Markale market, including both the dead and the wounded. ${ }^{14169}$ Gavrankapetanović also produced a list of persons who had surgery on the day of the incident, ${ }^{14170}$ as well as the records from the Koševo morgue, ${ }^{14171}$ both of which show that over 50 people were received by the Koševo morgue in relation to the incident in Markale on 5 February 1994. ${ }^{14172}$ A document with the names of all the victims related to the incident, namely 125 people treated at or registered by the Koševo Hospital, ${ }^{14173}$ as well as five victims transferred to other hospitals and eight victims transferred to the UNPROFOR hospital, was created shortly after the incident and used to provide information to the relatives of those wounded or killed. ${ }^{14174}$ Gavrankapetanović conceded that some victims could have appeared on different records if they were moved from one Hospital department to another. ${ }^{14175}$

4225. In addition to the above evidence, the Chamber also heard evidence on the lethal effect of mortar bombs. In particular, the second UN investigation team concluded that with a single $120 \mathrm{~mm}$ mortar shell fired into a dense crowd surrounded by metal-framed stalls, together with the

\footnotetext{
14164 Almir Begić, T. 9968 (15 December 2010); P2047 (List of the dead and injured re shelling of Markale on 5 February 1994).

14165 Almir Begić, T. 9968 (15 December 2010); P2047 (List of the dead and injured re shelling of Markale on 5 February 1994).

14166 Almir Begić, T. 10000 (16 December 2010).

14167 Faris Gavrankapetanović, P473 (Transcript from Prosecutor v. Galić), T. 12517-12519.

14168 Faris Gavrankapetanović, P473 (Transcript from Prosecutor v. Galić), T. 12525-12527.

14169 Faris Gavrankapetanović, P473 (Transcript from Prosecutor v. Galić), T. 12525-12526, 12616-12617, 1263412635; P461 (Admission records from Koševo Hospital), pp. 4-44.

14170 Faris Gavrankapetanović, P473 (Transcript from Prosecutor v. Galić), T. 12529-12530; P462 (Surgery records from Koševo Hospital).

14171 P463 (Koševo Hospital morgue records), pp. 15-23.

14172 Faris Gavrankapetanović, P473 (Transcript from Prosecutor v. Galić), T. 12603-12604, T. 12630-12632.

14173 While the list contains 127 names, Gavrankapetanović testified that two of those names were mistakenly included on the list as they were not victims of the shelling of Markale market. See Faris Gavrankapetanović, P473 (Transcript from Prosecutor v. Galić), T. 12634-12637.

14174 P464 (Admission records from Koševo Hospital, 5 February 1994); Faris Gavrankapetanović, P473 (Transcript from Prosecutor v. Galić), T. 12611-12613, 12620-12622, 12632. Explaining the discrepancy between the admission records referred to above and the document containing the list of all victims of the Markale market shelling, Gavrankapetanović stated that, unlike the former, the latter was based on all the records of the hospital, including those of the morgue. See Faris Gavrankapetanović, P473 (Transcript from Prosecutor v. Galić), T. $12620-12622$.

14175 Faris Gavrankapetanović, P473 (Transcript from Prosecutor v. Galić), T. 12622-12623. He also conceded that the Koševo Hospital staff was unable to perform post mortems except in very rare cases See Faris Gavrankapetanović, P473 (Transcript from Prosecutor v. Galić), T. 12625-12626.
} 
chaotic evacuation that followed, casualties of the magnitude of 275 dead and wounded are conceivable. $^{14176}$ Allsop also explained that the lethal effect of a mortar bomb would vary according to its size and the presence of obstacles in its vicinity. ${ }^{14177}$ While smaller projectiles could be stopped by barriers, larger projectiles could go a long way, pass trough a number of soft targets, and even create secondary projectiles, such as splinters. ${ }^{14178} \mathrm{He}$ added that tests on the effects of suicide bombs for instance showed that larger projectiles could even pass "through the equivalent of three people". ${ }^{14179}$

4226. In contrast, Subotić disputed the high number of victims. She noted that the video footage shows traces of blood and destruction of market stalls in a circle of approximately 10 to 11 metres around the point of impact of the mortar shell. ${ }^{14180}$ Having taken into account the lay-out of the market stalls, Subotić calculated that 40 market stalls were in the "lethal radius" of 10.56 metres from the point of impact of the detonation. ${ }^{14181}$ Based on these figures, and assuming there was one shopper per square metre and a seller at each stall, Subotić calculated that there were 164 persons within the impact zone-that is, 45 persons less than the number of casualties recorded in the official report on the incident. ${ }^{14182}$ Furthermore, Subotic opined that, given that "only one dead person" and "one trace of blood" could be seen in the video showing the area between Dženetića Čikma and Maršala Tita streets, the number of 164 casualties was unrealistic. $^{14183}$

\section{(h) Adjudicated facts}

4227. The Chamber notes that in addition to the evidence and adjudicated facts outlined above, it has also taken judicial notice of the following adjudicated facts that go to the issue of the origin of fire and other challenged issues in this incident: (i) the $120 \mathrm{~mm}$ mortar was fired from the

\footnotetext{
14176 P1441 (UNPROFOR report re shelling of Markale on 5 February 1994), e-court p. 11. See also P2317 (Report by Berko Zečević entitled "Study of the circumstances and causes of the massacre at the Markale market on 5 February 1994”), e-court p. 8; Berko Zečević, T. 12311-12318 (24 February 2011); D1095 (Sketch re shelling of Markale on 5 February 1994).

14177 Derek Allsop, T. 29534 (31 October 2012).

14178 Derek Allsop, T. 29534-29535 (31 October 2012).

14179 Derek Allsop, T. 29535 (31 October 2012).

14180 D3551 (Zorica Subotić's expert report entitled "Mortar Attacks on the Sarajevo Area: Incidents at the Markale Market 5 February 1994 and 28 August 1995", 15 August 2012), p. 81.

14181 D3551 (Zorica Subotić's expert report entitled "Mortar Attacks on the Sarajevo Area: Incidents at the Markale Market 5 February 1994 and 28 August 1995”, 15 August 2012), p. 82; Zorica Subotić, T. 38561 (21 May 2013).

14182 D3551 (Zorica Subotić's expert report entitled "Mortar Attacks on the Sarajevo Area: Incidents at the Markale Market 5 February 1994 and 28 August 1995", 15 August 2012), p. 82; Zorica Subotić, T. 38562 (21 May 2013). See also Derek Allsop, T. 29531-29535 (31 October 2012).

14183 D3551 (Zorica Subotić's expert report entitled "Mortar Attacks on the Sarajevo Area: Incidents at the Markale Market 5 February 1994 and 28 August 1995”, 15 August 2012), p. 83; Zorica Subotić, T. 38549 (21 May 2013), T. 38644-38645 (22 May 2013).
} 
direction north-northeast of the market or at a bearing of approximately 18 degrees; ${ }^{14184}$ (ii) the shell could not have been fired from any place on the $\mathrm{ABiH}$ side of the confrontation lines in a direction north-northeast of Markale market; ${ }^{14185}$ (iii) the mortar shell which exploded at Markale market on 5 February 1994 was fired from SRK-controlled territory; ${ }^{14186}$ and (iv) there was no reason to consider the market area as a military objective. ${ }^{14187}$

\section{(i) Staged incident and static explosion theories}

4228. As noted earlier, two alternative defences the Accused put forward in relation to this incident is that it was staged or that the local authorities detonated an explosive device in the market either by a remotely controlled device or by dropping a mortar shell from one of the surrounding buildings. ${ }^{14188}$

4229. In support of the staged incident theory, the Accused relied on various factors, including the fact that the video footage of the aftermath of the incident shows (i) a large number of empty stalls which in turn implied that the market could not have been so crowded that day; (ii) a man carrying a prosthetic leg around the empty, clean market, with no other traces of the explosion, implying therefore that the leg must have been planted there; and (iii) that the stabiliser cannot be seen in the earliest footage of the crater while Bešić can be heard instructing someone to look for it on the roof of one of the surrounding buildings. ${ }^{14189}$ He also argued that there was a gap of about an hour between the time the incident occurred and the time at which Bešić and his colleagues were informed of it. ${ }^{14190}$

4230. However, witnesses testified that Markale market was usually crowded whenever there was no shelling in the city and that the same would have been the case on the day of the incident. ${ }^{14191}$ Bešić, who was at the scene around an hour after the incident, strongly rejected the idea that the video footage of its aftermath shows that the incident was staged and that a prosthetic

\footnotetext{
14184 Adjudicated Fact 339.

14185 Adjudicated Fact 340.

14186 Adjudicated Fact 341.

14187 Adjudicated Fact 342

14188 See para. 4173.

14189 See e.g. Hearing, T. 10001 (16 December 2010) (where the Accused makes a claim that the market was empty); Hearing, T. 9468, 9476 (9 December 2010) (where the Accused makes a claim that the debris and the leg prosthesis were brought to the market); Hearing, T. 2321-2323 (11 May 2010) (where the Accused makes a number of claims about the planting of evidence); Hearing, T. 12352 (24 February 2011) (where the Accused makes a claim that the original video footage indicates that the stabiliser was not embedded but might be on the roof of a nearby building).

14190 See e.g. Hearing, T. 9451-9452 (9 December 2010).

14191 See e.g. Almir Begić, T. 10000-10001 (16 December 2010); Sead Bešić, T. 9447 (8 December 2010); Berko Zečević, T. 12313 (24 February 2011).
} 
leg had been planted there. ${ }^{14192}$ In addition, Almir Begić testified that the prosthetic leg visible in the video footage of the aftermath of the incident belonged to his father, Camil Begić, who died in the incident and whose body he identified in the Koševo morgue on the day of the incident. ${ }^{14193}$ The Chamber notes that during his cross-examination of Almir Begić, the Accused attempted to show that the prosthetic leg seen in the Markale market footage could not have belonged to his father Ćamil by using Ćamil's old photograph to show that the prosthetic leg found at the scene was too big for him. ${ }^{14194}$ The Chamber found this line of questioning completely unconvincing and misplaced and finds, in light of the evidence given by Almir Begić, that the prosthetic leg seen in the video footage belonged to his father Ćamil. The Chamber-having reviewed the video footage of the aftermath-further rejects as unfounded the contention that the prosthetic leg was purposely placed in different locations around the market. ${ }^{14195}$

4231. Concerning the Accused's claims as to the timing of the incident, Bešić confirmed that one of the reports on this incident states that the CSB Sarajevo investigation team was informed of the shelling only at around 1:20 p.m. and was at the scene by 1:30 p.m.; however, Bešić was adamant that the information about the incident was received much earlier, namely some 10 to 15 minutes after the explosion, and that it took the team around 40 minutes to come to the scene. ${ }^{14196}$ Contrary to the Accused's position that there was a gap of about one hour before the investigating team was informed of the incident, the Chamber is of the view, based on the timeline given by Bešić and all the other evidence to the effect that the explosion happened some time after 12 p.m., that the time recorded as " 1320 hours" in the report as being the time when the CSB Sarajevo investigation team was informed of the shelling incident is in fact a typographical error.

14192 Sead Bešić, T. 9468-9479, 9530-9533 (9 December 2010); D896 (Video footage of shelling of Dobrinja on 4 February 1994, Markale on 5 February 1994, and Markale on 28 August 1995); D897 (Photograph re shelling of Markale on 5 February 1994 marked by Sead Bešić); D898 (Photograph re shelling of Markale on 5 February 1994); D899 (Photograph re shelling of Markale on 5 February 1994); P1983 (Video footage of Markale, 5 February 1994); P1984 (Video footage of Markale, 5 February 1994); P1985 (Video footage of Markale, 5 February 1994); P1986 (Video footage of Markale, 5 February 1994).

14193 P2050 (Witness statement of Almir Begić dated 15 April 2010), paras. 1-9; P2051 (Supplemental statement of Almir Begić dated 14 December 2010); P2052 (Photograph of Ćamil Begić); P2053 (Death certificate for Ćamil Begić); P2054 (Burial certificate for Ćamil Begić); P2055 (Death certificate for Ćamil Begić); P2056 (Certificate of invalid status for Ćamil Begić); P2057 (Decision granting Sadika Begić status as a civilian war victim family member, 24 December 1996). See also Almir Begić, T. 9958-9959, 9961-9974 (15 December 2010), T. 9998-10000 (16 December 2010); D896 (Video footage of shelling of Dobrinja on 4 February 1994, Markale on 5 February 1994, and Markale on 28 August 1995); P2046 (Video stills of prosthetic leg); P2048 (Photographs of prosthetic leg); P2049 (Photographs of prosthetic leg).

14194 Almir Begić, T. 10002-10008 (16 December 2010); P2052 (Photograph of Ćamil Begić); D932 (Video still of prosthetic leg); D933 (Video still of prosthetic leg).

14195 P6327 (Excerpt from video footage re shelling at Markale Market).

14196 Sead Bešić, T. 9436-9438 (8 December 2010), T. 9457-9458 (9 December 2010); D892 (BiH MUP Report re shelling of Markale on 5 February 1994), e-court p. 4. 
4232. Harland also denied the suggestion that the incident was staged, calling it "completely bizarre" and noting that he personally sent out a member of his team, who was a doctor, to the scene immediately after the incident and who confirmed that there were many dead and wounded victims at the scene. ${ }^{14197}$ KDZ450 was also there an hour after the incident after all the wounded and injured had been removed but testified that he saw "a staggering number of blood traces" and that he spoke to a physician from Sector Sarajevo who had gone straight to the hospital and seen the injured and the dead. ${ }^{14198}$ The continuing presence of blood and human remains in the market area was further confirmed by Russell, who attended the scene at around 4:30 p.m. on 5 February 1994. ${ }^{14199}$ Thus, relying on the above evidence, and having analysed video footage of the immediate aftermath of the explosion in which substantial amounts of blood, human tissue, body parts and injured or dead persons can be seen, the Chamber finds that a large number of persons were killed and injured during the incident. ${ }^{14200}$ Accordingly, the Chamber dismisses the claim that the incident was staged.

4233. With respect to his theory that the explosion was caused by a static device placed on the scene by the local authorities or by a shell dropped from a nearby building, the Accused relied primarily on Subotić, as well as on several other witnesses. One such witness was KW554, who worked as an intelligence officer for UNPROFOR in Zagreb and who testified that an American soldier showed him a photograph of a mortar shell being dropped from a window overlooking the market, which he did not examine closely. ${ }^{14201}$ Similarly, Sergey Moroz, a member of the UKRBAT, testified that Rumyantsev, who was part of Gauthier's team, told him that "it was definitely proved that it could not be a mortar explosion from [the] Serbian side" but that a special explosive device had been brought in. ${ }^{14202}$ The Chamber found this evidence tenuous at best, particularly since KW554 said that he did not examine the alleged photograph closely and given that Rumyantsev was part of the team that unequivocally concluded that a $120 \mathrm{~mm}$ mortar bomb struck the market after being fired in a conventional manner.

4234. As noted earlier, the Accused's expert Subotić was the main proponent of the static detonation theory. However, she based her analysis on secondary material, such as photographs, video footage, previous investigation reports, and a visit to a substantially altered location 16 years after the incident. This renders her findings less reliable than the conclusions reached by the

\footnotetext{
14197 David Harland, T. 2040-2041 (6 May 2010).

14198 KDZ450, T. 10677 (20 January 2011).

14199 D2364 (Witness statement of John Russell dated 17 October 2012), para. 14.

14200 P6327 (Excerpt from video re shelling at Markale Market).

14201 D2762 (Witness statement of KW554 dated 14 September 2012), para. 11; KW554, T. 32036 (16 January 2013).
} 
investigation teams that investigated the scene immediately or shortly after the incident. Furthermore, much of her analysis in relation to this incident was based on highly speculative assumptions and conclusions, such as her assumption that there would be only one market vendor per stall in the market. ${ }^{14203}$ The Chamber also found some of her claims and resulting conclusions blatantly unreasonable and/or incorrect. For example, her claim that only one dead person and one trace of blood could be seen in the area between Dženetića Čikma and Maršala Tita streets is obviously inaccurate as can be seen from the video footage available to the Chamber. In addition, her theory about the appearance and manipulation of the crater clearly illustrates that she went to great lengths to fabricate conspiracy theories while wilfully ignoring other evidence such as the fact that none of the witnesses, including some of those called by the Accused, thought that the crater was manually created. Indeed, there is simply nothing in the evidence to suggest that the crater was manually created as opposed to simply disturbed during the excavation of the stabiliser. This has been confirmed by Allsop, who thought that the crater, as seen in the footage of 6 February, was very similar to the crater seen on the video footage of 5 February. This type of analysis on the part of Subotic is a serious stain on her credibility and resulted in the Chamber deciding not to accept her evidence in relation to this incident except when it was corroborated by other evidence.

4235. The Chamber further recalls that a number of witnesses, including Zečević, testified that the damage caused to the scene was consistent with the explosion of a $120 \mathrm{~mm}$ mortar, that throwing the mortar bomb from one of the surrounding buildings was unrealistic as it would have exposed the person throwing it to the explosion, and, further, that no one would be strong enough to embed a stabiliser into the asphalt without anyone at the market noticing. ${ }^{14204} \mathrm{He}$ was supported in this by Allsop's opinion that a stabiliser would embed into the ground only if fired at a higher charge, ${ }^{14205}$ as well as Allsop's evidence regarding the lethal effect of the mortar shrapnel. ${ }^{14206}$ Finally, neither Sabljica nor Zečević saw anything unusual in Bešić instructing someone to look for the stabiliser on a roof. ${ }^{14207}$

\footnotetext{
14202 Sergey Moroz, D2373 (Transcript from Prosecutor v. Galić), T. 18145, 18169; D2374 (Notification re the death of Nikolay Rumyantsev, 13 October 2011).

14203 See para. 4206, fn. 14116.

14204 See e.g. Berko Zečević, T. 12163-12164 (22 February 2011), T. 12318-12320, 12330-12332, 12352-12353 (24 February 2011); D1096 (Photograph re shelling of Markale on 5 February 1994 marked by Berko Zečević).

14205 See paras. 4219-4220.

14206 See para. 4225.

14207 P1695 (Witness statement of Mirza Sabljica dated 11 February 2010), pp. 46-47 (noting that Bešić, due to his lack of expertise, would not be able to immediately determine whether the stabiliser was embedded in the ground or not); Berko Zečević, T. 12327-12328 (24 February 2011); P1711 (Video footage re shelling of Markale, 5-6 February 1994).
} 
4236. For all of these reasons, the Chamber does not accept the Accused's claim that the shell was detonated remotely at ground level or that it was dropped from an adjacent building.

\section{(j) Other defences}

4237. The Accused further sought to show during the case that the shell was fired by the ABiH in order for it to be imputed to the Serb side, so as to advance the Bosnian Muslim side's political agenda. ${ }^{14208} \mathrm{He}$ also claims that there is not enough evidence to conclude beyond reasonable doubt that the SRK fired the shell that struck Markale on 5 February $1994 .{ }^{14209}$

4238. The Accused relied on a number of witnesses in this respect. For example, KW570 stated that the Serb side was blamed for the shelling of Markale even before the investigation had been carried out, whereas the first crater analysis showed that it could not be determined which side had fired the shell. ${ }^{14210}$ He personally formed the opinion that it was highly unlikely that the Serbs would have fired a single round, given their pattern of trying to hit their targets with multiple mortar rounds ${ }^{14211}$ [REDACTED]. ${ }^{14212}$ [REDACTED] when Rose confronted the ABiH delegation on 8 February and told them that evidence was emerging which suggested that they had fired the shell on Markale, they reacted with complete silence before "produc[ing] a number of excuses, which included a claim that they had taped a conversation involving the Serbs to the effect that they had confessed to the atrocity". ${ }^{14213}$ [REDACTED] UNPROFOR never received any evidence of such taped conversation. ${ }^{14214}$

4239. The Accused also relies on the evidence of Milovanović and KDZ185. The former testified that incidents such as Markale were a "way of stopping negotiations by way of carrying out combat or turning the whole situation against [...] the Serb delegation" by the Muslim side whenever they did not like the direction in which international negotiations were heading. ${ }^{14215}$

\footnotetext{
14208 Defence Final Brief, para. 2098.

14209 Defence Final Brief, para. 2115, fn. 5073.

14210 D2770 (Witness statement of KW570 dated 21 November 2012), para. 10 (under seal); D2772 (Redacted diary of KW570), e-court p. 3 (under seal). The Chamber notes that there are two consecutive paragraphs 10 in KW570's statement. The one cited in this footnote is the first of the two paragraphs.

14211 D2770 (Witness statement of KW570 dated 21 November 2012), para. 6 (under seal). KW570 explained that mortars are indirect fire weapons whereby the person launching them cannot see the target and has to fire them more than once in order to account for factors such as the atmospherics and to bed the mortar tube into the ground, thus increasing its accuracy. He also testified that the Serbs would usually fire a number or rounds in order to hit a target. It was for these reasons that he formed the opinion that it was highly unlikely that the Serb side had fired the mortar round on that day. KW570 did accept, however, that he had no experience commanding mortar units. See KW570, T. 32223-32226 (18 January 2013).

14212 [REDACTED].

14213 [REDACTED].

14214 [REDACTED].

14215 Manojlo Milovanović, T. 25580-25581 (1 March 2012). See also Momčilo Krajišnik, T. 43334 (12 November 2013).
} 
KDZ185, an UNPROFOR commander at the time, also testified that the Muslim side wished to keep Sarajevo the focus of international attention and tried to make up for their military inferiority by staging a "kind of media war", an example being the shelling of a courtyard of a residential block near Markale for which the UNPROFOR carried out a crater analysis and determined that the fire had most likely come from the Muslim territory to the north, close to the frontline. ${ }^{14216}$

4240. The Accused also called KW586, who, at the relevant time, was a member of Izetbegović's security detail and testified that a few days prior to the Markale market incident, he overheard a secret meeting between Izetbegović, Reis-ul-ulema Cerić, Sefer Halilović, Mustafa Hajrulahović, and others as to what "could happen" if the Markale market, being full of people, was hit by a shell. ${ }^{14217}$ After this meeting, two attempts to shell Markale ensued, the first "failed" attempt occurring only a few days prior to 5 February 1994 during which the roof of a building in its periphery was hit. ${ }^{14218}$ KW586 further stated that another meeting was held after the failed attempt, during which it was said that the shell had been fired from Špicasta Stijena near the location of the Serb artillery in Mrkovići and very close to the separation line, so as to ensure that the Serbs would be blamed for it; it was then also decided to try and hit Markale again, which happened several days later. ${ }^{14219}$ According to KW586, also involved in this conspiracy were the members of the Pakistani UNPROFOR team who had agreed not to register any shells fired from the $\mathrm{ABiH}$ side. ${ }^{14220}$

4241. Savo Simić, Chief of Artillery of the $1^{\text {st }}$ Motorised Brigade of the SRK at the time, ${ }^{14221}$ claimed that the Markale shell could not have been fired from a Bosnian Serb-held position. ${ }^{14222}$ He testified that it was not possible for the first shot to hit that target, and that, in any event, in order to hit such a small area encircled by high buildings it would have had to have been fired

\footnotetext{
14216 KDZ185, T. 4226-4230 (28 June 2010).

14217 KW586, T. 47192 (17 February 2014); D4375 (KW586's SRBiH SUP ID) (under seal); D4376 (KW586's BiH MUP ID card) (under seal); D4378 (Letter from the BiH Office of the Bosniak Liaison Officer to ICTY, 14 February 2014) (under seal); D4374 (Witness statement of KW586 dated 20 September 2013), paras. 5, 8 (testifying also that he attended many such meetings during which it was said that a military reaction from the international community had to be provoked through drawing attention to the suffering of the Bosnian Muslims, and that incidents were specifically provoked by opening fire from mobile positions so as to "cause the shelling of buildings such as hospitals and the like" and having TV crews ready in the vicinity to record the incidents). KW586, T. 47221 (17 February 2014); D4374 (Witness statement of KW586 dated 20 September 2013), para. 8.

14219 D4374 (Witness statement of KW586 dated 20 September 2013), paras. 4-5, 8; KW586, T. 47224-47225 (17 February 2014);

14220 D4374 (Witness statement of KW586 dated 20 September 2013), para. 8. During cross-examination, KW586 testified that he was referring to only one crew, consisting of two to three Pakistani UNPROFOR members, who were chosen because they were not as attentive as other UNPROFOR crews. See KW586, T. 47222-47224 (17 February 2014).

14221 D2412 (Witness statement of Savo Simić dated 4 November 2012), para. 3.

14222 Savo Simić, T. 30121 (12 November 2012); D2412 (Witness statement of Savo Simić dated 4 November 2012), para. 30.
} 
from a position close by to achieve the almost vertical angle of 85 degrees. ${ }^{14223}$ Furthermore, according to Simić, there was also no observation point on the Serb side from which the market could be seen, and therefore, it could not have been accurately targeted. ${ }^{14224}$

4242. Blaško Rašević, the Commander of the Mrkovići Company at the time of the incident, testified that "there was a firm conviction" in his unit that the SRK forces, particularly the forces from Mrkovići, did not fire the shell that landed in Markale. ${ }^{14225}$ On the day of the incident, Gengo was in Hreša, which is some seven kilometres away from Mrkovići, and testified that he did not hear a missile launch nor saw any reports on such use of weapons from his battalion. ${ }^{14226}$ He was adamant that his unit was not involved in this incident. ${ }^{14227}$

\section{(k) Final analysis and conclusion}

4243. Having considered the evidence presented to the Chamber as well as the adjudicated facts recounted above, and having discounted the staged incident and planted explosive theories, the Chamber finds that a $120 \mathrm{~mm}$ mortar shell exploded in Markale market on 5 February 1994. Relying on the hospital records, which the Chamber accepts were not entirely accurate given the chaotic situation at the time they were compiled, Adjudicated Fact 338, and the technical evidence regarding the lethal effect of mortar shells, the Chamber also finds that the explosion caused by the shell on 5 February 1994 caused the death of at least 67 people and injured over 140. Given its view of Subotić's credibility with respect to this incident, and in light of accepted contemporaneous video footage and hospital records, the Chamber rejects her claim that the number of victims is exaggerated and that dead bodies were brought to the scene.

4244. With respect to the nature of the area and the status of the victims of this shelling incident, the evidence clearly shows that Markale market was an open-air market frequented by the civilian population to buy and sell food and other goods. In addition, the Chamber recalls that it has taken judicial notice of the fact that there was no reason to consider it a military objective. ${ }^{14228}$ The Chamber therefore concludes that Markale market and the surrounding area was not a legitimate

\footnotetext{
14223 Savo Simić. T. 30121-30122 (12 November 2012); D2412 (Witness statement of Savo Simić dated 4 November 2012), para. 30. See also D2770 (Witness statement of KW570 dated 21 November 2012), para. 7 (under seal); KW570, T. 32229-32230 (18 January 2013).

14224 Savo Simić, T. 30121 (12 November 2012).

14225 D2527 (Witness statement of Blaško Rašević dated 1 December 2012), para. 29.

14226 D2383 (Witness statement of Slavko Gengo dated 14 October 2012), para. 36.

14227 Slavko Gengo, T. 29805 (6 November 2012).

14228 Adjudicated Fact 342.
} 
military target and that the casualties caused by the shelling were almost all civilians who were not taking direct part in the hostilities. ${ }^{14229}$

4245. In terms of the direction of fire, having regard to the majority of the evidence it received from expert witnesses and witnesses otherwise familiar with crater analysis, the Chamber is convinced that the shell hit Markale market from above ground level and was fired from a northnortheasterly direction. The Chamber recalls that CSB Sarajevo conducted a forensic examination at the incident site on 5 February 1994, as did a number of UNPROFOR investigators on the same day or shortly afterwards. All of these teams, with the exception of FreBat and Verdy who made errors in their calculations, concluded that the shell originated from a north-northeasterly direction along the confrontation line at the angle of 18 degrees, plus or minus five degrees. Even Subotić's calculations produced an azimuth that is in line with those investigators. Accordingly, the Chamber finds that the shell that struck Markale market had an azimuth of 18 degrees, plus or minus five degrees.

4246. With respect to the angle of descent, which is relevant to the origin of fire, the Chamber recalls that the second UN investigation established that this angle had to be higher than 49 degrees in order to clear the buildings around Markale. The Chamber also recalls that different experts provided five different estimates as to the angle of descent, most of which were expressed in terms of ranges. All of those experts, with the exception of Subotić, were at the scene either soon after the incident or six or seven days later. Although Verdy was at the scene, the Chamber will not rely on his estimate due to the flaws in his method. ${ }^{14230}$

4247. While the Chamber heard evidence to the effect that measurements and estimates of the angle of descent are unreliable in this incident due to the crater having been disturbed, the Chamber, by majority, Judge Baird dissenting was also struck by the fact that all but one of the estimated angle ranges are relatively close to each other and in fact overlap. The one exception is the angle of descent measured by Russell, which is slightly higher than all the other estimated angles. However, unlike Zečević and Hamill, who were brought into the investigation later and purely on the basis of their extensive technical expertise, ${ }^{14231}$ Russell made his estimate quickly on

\footnotetext{
14229 The Chamber heard evidence that one of the victims of this incident wore a uniform. See Sead Bešić, T. 94299430 (8 December 2010). While he may have been a soldier, his presence alone does not change the fact that most of those injured in this incident were civilians who were not taking direct part in hostilities but instead came to the market to buy goods. Indeed, many of the victims were women and elderly. See also para. 4330.

14230 See fn. 14004.

14231 Hamill was a technical adviser to the investigation team as he had extensive knowledge of artillery weapons and was also an instructor in gunnery in a military school. Zečević is a mechanical engineer with years of experience in the weapons industry, including testing of weapons. See John Hamill, P1994 (Transcript from Prosecutor v. Galić), T. 6077; P2318 (Report by Berko Zečević entitled "The use of modified aircraft bombs
} 
the day of the incident and, when testifying before the Chamber, could not remember having done so or having taken these measurements. At the time, he was a military adviser in Sector Sarajevo and was asked by Ramsey to examine the scene because he had some experience with crater analysis which, according to his own evidence, was not extensive. ${ }^{14232}$ Accordingly, the Chamber, by majority, Judge Baird dissenting, is more persuaded by Zečević's and Hamill's estimates, which-with their margins of error-overlap to a great extent. Even the angle of descent determined by Subotic on the basis of the fragment traces on the scene is in line with the angles provided by Zečević and Hamill. Given that Zečević's estimate contained the largest margin of error, the Chamber, by majority, considers that the angle of descent of the shell that struck Markale was somewhere between 55 and 65 degrees. This also means that the shell could have come from one of the six positions established by Zečević in his report. The Chamber, by majority, Judge Baird dissenting, has no reason to doubt the credibility of Zečević and the reliability of his report in this respect.

4248. While the Chamber cannot be sure that the speed of the shell as determined by Zečević is absolutely accurate, particularly in light of Allsop's evidence, the Chamber, by majority, Judge Baird dissenting, is satisfied that the margin of error in his calculations was such that it took into account all possible factors Allsop mentioned as having a significant impact on the calculations. Further, in this respect, the Chamber notes a common feature in the evidence of Zečević, Higgs, Allsop, and Subotić, which is that a mortar bomb fired at one of the higher charges would typically result in the stabiliser penetrating the ground and embedding therein. ${ }^{14233}$ While Higgs referred to two highest charges in this respect, and Zečević to charges four, five, and six, Subotić considered it "well-known" that a stabiliser would embed when fired with charge three or higher. ${ }^{14234}$ The Chamber recalls that, given the angle of descent of between 55 and 65 degrees, even if the mortar shell that landed on Markale was fired with charge three, this would have still placed the firing position squarely in the territory of the SRK, namely just below the area of Mrkovići. ${ }^{14235}$ As noted above, in this particular case, the stabiliser was found embedded into the ground with its top at a depth of around nine centimetres from the surface, thus leading to the

during the siege of Sarajevo, 1994-1995”), p. 1; Berko Zečević, T. 12156-12157 (22 February 2011); P1695 (Witness statement of Mirza Sabljica dated 11 February 2010), pp. 47-48 .

14232 D2364 (Witness statement of John Russell dated 17 October 2012), paras. 7-9, 12.

14233 See Berko Zečević, T. 12173-12175 (22 February 2011), T. 12303-12308 (24 February 2011); Richard Higgs, T. 5980-5981, 5983, 6027 (19 August 2010); D3551 (Zorica Subotić's expert report entitled "Mortar Attacks on the Sarajevo Area: Incidents at the Markale Market 5 February 1994 and 28 August 1995", 15 August 2012), p. 137; D3542 (Zorica Subotić's expert report entitled "Mortar Operations in Sarajevo Area in 1992-1995", 15 August 2012), pp. 48-49; Derek Allsop, T. 29470-29484 (31 October 2012). See also para. 3979.

14234 See D3551 (Zorica Subotić's expert report entitled "Mortar Attacks on the Sarajevo Area: Incidents at the Markale Market 5 February 1994 and 28 August 1995”, 15 August 2012), p. 137.

14235 See fn. 13980. 
conclusion that the shell was fired on a charge higher than charge one or charge two. While the $\mathrm{ABiH}$ forces could have fired the shell on charge three or higher, which then may have resulted in the embedded stabiliser, they would have had to launch it at a much steeper angle in order not to overshoot Markale. As testified by Allsop, ${ }^{14236}$ launching a shell from a closer distance, and thus at a steeper angle, and achieving an accurate hit of Markale would have placed the launching crew at a significant risk. In addition, it would have necessarily resulted in a higher angle of descent than the one measured on the scene.

4249. The majority notes that other evidence also indicates that the shell was fired from the SRK side of the confrontation line, more particularly, from the SRK positions in Mrkovići. For example, the Chamber heard that the SRK's $7^{\text {th }}$ Battalion of the $1^{\text {st }}$ Romanija Infantry Brigade had $120 \mathrm{~mm}$ mortars in the area of Mrkovići, which is north-northeast of Markale, whereas the evidence before the Chamber was consistent that the $\mathrm{ABiH}$ had no mortars in the area of Grdonj, which it held in the determined direction of fire. ${ }^{14237}$ In addition, Gengo testified that, rather than firing from Grdonj, the $\mathrm{ABiH}$ would open fire mostly from the area of Jajce Barracks and Koševo. ${ }^{14238}$ Similarly, Gauthier could not recall any $\mathrm{ABiH}$ mortar positions in the established direction of fire. ${ }^{14239}$ While Gauthier also suggested that $\mathrm{ABiH}$ could have used mobile mortars, the Chamber, by majority, Judge Baird dissenting, is not convinced that it would have been possible for the $\mathrm{ABiH}$ to fire at the market area from a mobile mortar, without being seen, given the densely populated area in the direction of fire and given the proximity of the residential area of Sedrenik to the $\mathrm{ABiH}$ positions in Grdonj. The majority also recalls the absence of any evidence as to the sighting of mobile mortars on that day or shell fire noise coming from within the city. In the majority's view, achieving an accurate hit of Markale market from a mobile mortar which has been placed on the back of a truck and the base plate of which has not been static for a period of time, by forces which have not pre-recorded this target and who are also trying to remain unseen and undetected, would have been extremely difficult, bordering on impossible. ${ }^{14240}$

\footnotetext{
14236 See para. 4220.

14237 See P1058 (ABiH map) (indicating that ABiH had mortars in Breka but not in Grdonj or near Špicasta Stijena); P6301 (Reference table of military symbols). See also Asim Džambasović, T. 15220-15221, 15239-15240 (22 June 2011).

14238 D2383 (Witness statement of Slavko Gengo dated 14 October 2012), paras. 18, 23; Slavko Gengo, T. 2977229773, 29775-29780 (6 November 2012).

14239 Michel Gauthier, T. 29417 (30 October 2012).

14240 The Chamber recalls that having the base plate of a particular mortar in the same position for a long time increases the accuracy of the mortar and thus allows the mortar crew to engage or strike its target with only one round. See P1437 (Richard Higgs's Consolidated Report on Sarajevo Shelling Incidents, 13 March 2009), p. 3; P1925 (Witness statement of Emir Turkušić dated 16 February 2010), p. 6. See also fn. 13140.
} 
4250. Further, the Chamber received evidence that the SRK would open fire on the area of Stari Grad from the SRK positions above Sedrenik. ${ }^{14241}$ Hamill also testified about Cvetković's admission that the SRK fired a large number of mortar rounds into Stari Grad prior to the incident in Markale. ${ }^{14242}$ Even on the morning of 5 February, just prior to the Markale incident, the UNMOs reported that the city centre was shelled on the night of 4 and 5 February. ${ }^{14243}$ The SRK's use of mortar fire on the urban parts of Sarajevo is indirectly confirmed by Galić's stern ban on fire issued on 5 February 1994, as well as the Accused's order of 7 February that the VRS respond only when threatened and do so against military targets and strictly at the commander's commands. ${ }^{14244}$ All of this activity on the Bosnian Serb side around the time of the incident suggests to the Chamber that the upper echelons of power were trying to exert and ensure strict control over the undisciplined firing of the SRK forces into the city.

4251. The Chamber unanimously rejects Gengo and Džida's denials of SRK's responsibility in relation to this incident and in particular their evidence as to the alleged visit by the UN to the positions in Mrkovići which apparently cleared the SRK side of any wrong-doing. The Chamber finds them not to be credible with respect to this incident as they were clearly contradicted by the UN report compiled following the second investigation, which specifically states that Mrkovići positions were not visited by the UN as it would have been difficult to locate the mortar positions there and that the Mrkovići positions had not been visited in at least four months prior to the incident. ${ }^{14245}$ This is in line with Gauthier's evidence, namely that his team chose not to visit the SRK positions in the direction of fire due to the area being vast. ${ }^{14246}$ Furthermore, even the SRK's own combat reports, issued after the incident, make no mention of any such visit. Similarly, the SRK's and the Accused's calls for the joint commission in the days after 6 February also suggest that such a visit never took place. Finally, while Gengo and Džida are consistent with each other as to a visit by a delegation, neither of them could say much about the UN members within that delegation and neither had the names of those members. Thus, the Chamber is convinced that even if the SRK positions in Mrkovići were indeed visited by a certain delegation on 6 February, that delegation did not include any UN members.

4252. While the Chamber accepts the general evidence given by KDZ185, KW570 and Milovanović that the Bosnian Muslim side tried to gain sympathy from the international

\footnotetext{
14241 See e.g. P6028 (UNPROFOR Situation Report (Sarajevo), 22 August 1995), e-court p. 6.

14242 See para. 4192.

14243 P1562 (UNMO report, 4-5 February 1994).

14244 See paras. 4202-4203.

14245 See para. 4207.

14246 See para. 4192.
} 
community and would provoke attacks by the SRK with that goal in mind, it is of general nature and does not, as such, cast doubt on the majority's finding above that the shell came from the SRK positions. Furthermore, the Chamber, by majority, Judge Baird dissenting, does not accept the evidence of KW586 that the Bosnian Muslim side then deliberately targeted Markale so as to achieve international condemnation of the Serbs and thus further its own political agenda. The majority found KW586 to be lacking credibility in relation to this evidence for a number of reasons. The majority found it unlikely that someone in KW586's position would have been privy to such high-level meetings where such sensitive matters were discussed. Furthermore, KW586 exhibited a high degree of animosity towards the current political leadership in $\mathrm{BiH}$, which obviously played a part in his coming forward with his evidence. ${ }^{14247}$ There were also inconsistencies between his testimony in court and his witness statement, such as his evidence about the level of involvement of members of the Pakistani UNPROFOR contingent in the Markale incident and the involvement of Halilović, who the witness acknowledged had been removed from his position by Izetbegović at that time. Essentially, KW586's evidence implies a conspiracy of a large scale. However, in the majority's view, such conspiracy is not supported by any other evidence on the record. Finally, if true, it would have meant that the $\mathrm{ABiH}$ was able to make a successful hit on Markale market in only its second attempt. Recalling the evidence the Accused led on the low likelihood of such an intentional hit, the Chamber finds this to be impossible.

4253. Thus, for all of the above reasons, the Chamber, by majority, Judge Baird dissenting, is persuaded beyond reasonable doubt that the shell that struck Markale market on 5 February 1994 was fired on one of the higher charges and thus came from the SRK-held territory, having been fired by SRK soldiers. While the market itself may not have been deliberately targeted on that specific day, the majority finds that the SRK forces deliberately targeted the area around it in full knowledge that there were no military targets there and in reckless disregard of potential civilian victims that such fire would cause. ${ }^{14248}$

\footnotetext{
14247 KW586 repeatedly referred to the leadership as "gang" or "bandits" and at times even "scum". See KW586, T. 47208-47211 (17 February 2014).

14248 The Chamber recalls that Poparić testified about the very low probability of the first mortar shell striking the market, while Higgs testified that it would not have been very difficult to target the market given that it was visible from the surrounding hills and because the city was pre-recorded. While accepting that the shot would have been a difficult one to make, given the majority's view that it was the general area around the market that was targeted, Poparić's evidence on probabilities of intentionally striking the market itself is ultimately irrelevant.
} 
4254. According to the Indictment, two $76 \mathrm{~mm}$ shells hit a flea market in the old commercial quarter of Baščaršija in Stari Grad in quick succession, killing two persons and injuring seven others. The Indictment further states that the fire originated from Trebević, in SRK-held territory. ${ }^{14249}$ In its Final Brief, the Prosecution further explains that the shells were fired from an M48 76mm B-1 artillery cannon which was in the SRK's possession, including at Vidikovac and Hreša, and which the $\mathrm{ABiH}$ did not have. ${ }^{14250}$ The Accused argues, however, that the incident scene was manipulated and that the two explosions were staged. ${ }^{14251}$ Further, the Accused notes that the Appeals Chamber in the Dragomir Milošević case overturned the Trial Chamber's findings that the SRK fired the shells in question on the basis that it was impossible to determine the source of fire because both armies had positions in the direction from which the shells arrived. ${ }^{14252}$ According to the Accused, no additional evidence was led in this case and thus this Chamber has no basis to conclude that the SRK fired the shells in question. ${ }^{14253}$

4255. On the foggy morning of 22 December 1994 at around 9:10 a.m., two shells exploded on the Baščaršija flea market. ${ }^{14254}$ The explosions resulted in civilian casualties; two civilians were killed and seven or eight were injured, three of them seriously. ${ }^{14255}$ Investigations into this incident were carried out by the BiH MUP, the FreBat, and two UNMOs, Major Hanga Tsori Hammerton and Major Ilonyosi. ${ }^{14256}$

4256. Suljević participated in the investigation of this incident, along with Bešić, Đozo, and others. ${ }^{14257}$ According to the official report prepared by CSB Sarajevo on the day of the incident, two shells landed on the Baščaršija flea market, on Petra Kočića street (now Telali street) and

\footnotetext{
14249 Indictment, Scheduled Incident G.9.

14250 Prosecution Final Brief, Appendix C, para. 61.

14251 Defence Final Brief, paras. 2119-2121.

14252 Defence Final Brief, para. 2122. The Accused also adds that, similarly, in the Perišić case the Trial Chamber was unable to conclude beyond reasonable doubt that the two shells that hit the flea market originated from VRS-held positions. See Defence Final Brief, para. 2123.

14253 Defence Final Brief, paras. 2122, 2124.

14254 See Adjudicated Fact 3029. Hogan visited the site of the incident and recorded the GPS co-ordinates of the location. See Barry Hogan, T. 11204-11207, 11217 (3 February 2011); P2190 (GPS locations for shelling and sniping incidents in Sarajevo); P2191 (Map of Sarajevo with scheduled sniping and shelling incidents); P2193 (Map of Sarajevo); P2213 (Image re scheduled sniping and shelling incidents in Sarajevo).

14255 Adjudicated Fact 3030.

14256 See Adjudicated Fact 3031. However, the Chamber does not have before it any UN reports related to this incident. The CSB Sarajevo report before the Chamber notes that members of the FreBat were on the scene, as were UNMOs. See P1317 (BiH MUP Report re shelling of Baščaršija on 22 December 1994), p. 3; D554 (BiH MUP Report re shelling of Baščaršija on 22 December 1994), p. 3.

14257 P1276 (Witness statement of Ekrem Suljević dated 9 February 2010), para. 44; P1317 (BiH MUP Report re shelling of Baščaršija on 22 December 1994), p. 2; P1978 (Witness statement of Nedžib Đozo dated 7 December
} 
Danila Ilića street (now Oprkanj street) around 9:10 a.m. ${ }^{14258}$ The explosions killed two and wounded seven persons. ${ }^{14259}$ The report also states that "judging by the incoming descent angle of the shells and the damage they inflicted, it was established that the shells had been fired from the south at Trebević where the aggressor forces are located."14260 While noting that the fragments indicate that they were fired from a B-1 $76 \mathrm{~mm}$ calibre cannon, the report also notes that "after the required evaluation, officials of the [CSB Sarajevo] will forward the final findings on the type and the calibre of the artillery weapon, direction and place from where the shells were fired" to the judge in charge of the investigation. ${ }^{14261}$ Suljević then prepared a report concluding that the fragments collected at the scene, including a part of the UTI M68 fuse, belonged to two M70 76 $\mathrm{mm}$ calibre shells and that they were fired from the direction of the "enemy's positions in the area of Trebević", the azimuth angle being 159 degrees from the north, with a margin of error of five degrees. ${ }^{14262}$ According to Suljević, the UNPROFOR soldiers, who were also present at the scene, agreed with his assessment as to the direction of fire but disagreed on the calibre of the projectiles, coming to the conclusion that they were most probably mortar shells of $82 \mathrm{~mm}$ calibre. ${ }^{14263}$

4257. Suljević explained that the order in which the shells fell could only be established on the basis of witness statements, noting that according to some of the eye-witnesses, the first shell fell

2010), paras. 42-45; Nedžib Đozo, T. 9637 (10 December 2010); P1905 (Witness statement of KDZ485), para. 17; KDZ485, T. 8925 (3 November 2010).

P1317 (BiH MUP Report re shelling of Baščaršija on 22 December 1994), p. 3; P1319 (Map of Sarajevo depicting Baščaršija shelling). See also Ekrem Suljević, T. 6196-6199, 6201-6203 (6 September 2010); D554 (BiH MUP Report re shelling of Baščaršija on 22 December 1994), e-court pp. 16-17 (of the BCS version); D553 (Photograph of Baščaršija marked by Ekrem Suljević); KDZ485, T. 8927-8929, 8931-8932, 8944-8945 (3 November 2010); D863 (Photograph of Baščaršija marked by KDZ485); D865 (Photograph of Baščaršija marked by KDZ485).

14259 Mirsad Delić and Hasan Hadžić died in the incident, while Remzija Kihić, Ismeta Pačariz, Saliha Lukšija, Envera Sadović, Samir Mujković, Kasim Krka, and Ramiz Hodžić are recorded as having been wounded. See P1317 (BiH MUP Report re shelling of Baščaršija on 22 December 1994), pp. 3-4. In addition to the CSB Sarajevo report referring to the number of victims of this incident, the Chamber has also received medical certificates relating to some of those victims. See P1550 (Medical record for Remzija Kikić); P1556 (Medical referral for Remzija Kikić); P1253 (Medical report for Ramiz Hodžić); P1246 (Medical report for Ramiz Hodžić); P1535 (Medical record for Ismet Pačariz); D554 (BiH MUP Report re shelling of Baščaršija on 22 December 1994), p. 14 (medical report related to Saliha Lukšija).

14260 The report also contains statements of two eye-witnesses (Bajraktarević and Bećirević) who claimed that they heard the firing of the shells before the explosions and that this firing sound originated in the area of Vidikovac in Trebević. Two other eye-witnesses (Subasić and Ibrulj) stated they heard the shells being fired somewhere in the area of Trebević. See P1317 (BiH MUP Report re shelling of Baščaršija on 22 December 1994), p. 3; D554 (BiH MUP Report re shelling of Baščaršija on 22 December 1994), pp. 5-7, 21-22, 25.

14261 P1317 (BiH MUP Report re shelling of Baščaršija on 22 December 1994), p. 3.

14262 P1276 (Witness statement of Ekrem Suljević dated 9 February 2010), paras. 45-46; P1318 (BiH MUP Report re shelling of Baščaršija on 22 December 1994), p. 2; P1319 (Map of Sarajevo depicting Baščaršija shelling); P1320 (Photographs relating to Baščaršija shelling); P1905 (Witness statement of KDZ485), para. 18; KDZ485, T. 8930-8931, 8936-8938 (3 November 2010); D864 (Photograph related to incident at Baščaršija flea market marked by KDZ485).

14263 P1276 (Witness statement of Ekrem Suljević dated 9 February 2010), para. 47; P1317 (BiH MUP Report re shelling of Baščaršija on 22 December 1994), p. 3. The Chamber notes that no UN report on this incident was tendered by either of the parties and thus it is unable to confirm and/or assess the findings of the UN in relation to this incident. 
on the curb of Danila Ilića street while the second fell near a window of a house located on Petra Kočića street. ${ }^{14264}$ KDZ485 testified that the shells fell "in a strictly civilian area, without any military activity". ${ }^{14265} \mathrm{He}$ also stated that when the CSB Sarajevo team arrived, all bodies had been removed from the scene and denied that the scene was altered in any other way. ${ }^{14266}$ Another investigator on the team, Đozo, was asked about the possibility that the explosion was a result of a device placed at the scene; he explained that the team found shrapnel, which came from a projectile that was not a mortar shell and thus discounted the theory of an explosive device at the scene. ${ }^{14267}$ Suljević also denied that anything other than projectiles exploded at the scene of this incident. ${ }^{14268}$

4258. With respect to the $76 \mathrm{~mm}$ calibre shells, Suljević testified that CSB Sarajevo had samples of fragments from such projectiles, which were collected after they were fired on the city by the SRK. ${ }^{14269}$ The Chamber has also received a number of VRS and SRK documents, which show that the SRK was in possession of a large number of M48 B1 cannons that fired $76 \mathrm{~mm}$ projectiles, including one such cannon in the area of Hreša and Vidikovac. ${ }^{14270}$ In contrast, the ABiH appears to have had only a handful of such cannons, all of which were located to the south and southwest of Ilidža and thus outside the control of the ABiH inside the city itself. ${ }^{14271}$

14264 Ekrem Suljević, T. 6191-6192 (6 September 2010); D554 (BiH MUP Report re shelling of Baščaršija on 22 December 1994), pp. 22-23; KDZ485, T. 8930-8931 (3 November 2010); D862 (Sketch of Baščaršija marked by KDZ485).

14265 P1905 (Witness statement of KDZ485), para. 18. The Stari Grad police station was located a number of blocks away from the incident site. See Nedžib Đozo, T. 9637-9638 (10 December 2010); D915 (Map of Sarajevo marked by Nedžib Đozo).

14266 KDZ485 confirmed that the soil around one of the craters was cleared but noted that this was done after the traces were examined and photographed as the same crime scene would be photographed at various stages of the investigation. See KDZ485, T. 8929, 8935-8936, 8938-8943, 8947-8948 (3 November 2010); D554 (BiH MUP Report re shelling of Baščaršija on 22 December 1994), e-court pp. 35-38 of the BCS version. Đozo also confirmed that the bodies were removed by the time the team arrived on the scene, which was some 15 minutes after the shells exploded. See P1978 (Witness statement of Nedžib Đozo dated 7 December 2010), para. 46; Nedžib Đozo, T. 9639-9641 (10 December 2010).

14267 P1978 (Witness statement of Nedžib Đozo dated 7 December 2010), para. 47.

14268 Ekrem Suljević, T. 6204-6206 (6 September 2010); D555 (Photograph of crater at Baščaršija marked by Ekrem Suljević).

14269 P1276 (Witness statement of Ekrem Suljević dated 9 February 2010), para. 29; Ekrem Suljević, T. 5684-5685, 5687-5688 (21 July 2010). In addition, Suljević explained that one could distinguish between a crater created by a mortar shell and the crater created by an artillery projectile. See Ekrem Suljević, T. 5735-5738 (22 July 2010); D525 (Sketch drawn by Ekrem Suljević).

14270 P5056 (Letter from Manojlo Milanović to General Hayes, 15 August 1993), p. 2; P1021 (VRS map of Sarajevo); P6295 (VRS map of Sarajevo); P1593 (SRK map of Sarajevo showing weapon sites); P1594 (SRK map of Sarajevo showing weapon sites); P1595 (SRK map of Sarajevo showing weapon sites); P1279 (SRK request to VRS Main Staff, 10 July 1995), p. 2; P1282 (SRK request to VRS Main Staff, 18 April 1995), p. 1; P1303 (SRK request to VRS Main Staff, 22 June 1995), p. 1; P5940 (SRK Order, 9 May 1995), p. 2; P5941 (Document re artillery fire and tanks), p. 1. See also P1058 (ABiH map); P6301 (Reference table of military symbols).

14271 P1021 (VRS map of Sarajevo); P6295 (VRS map of Sarajevo); P1058 (ABiH map); P6301 (Reference table of military symbols); D779 (SRK Order, 27 March 1995), pp. 2, 3. According to Dragomir Milošević, the $104^{\text {th }}$ Motorised Brigade of the $\mathrm{ABiH}$ had $76 \mathrm{~mm}$ cannons and would use them to target the Famos Factory located near Lukavica. See Dragomir Milošević, T. 32787-32788 (29 January 2013). The Chamber notes that the zone 
4259. Zorica Subotić agreed that two explosions occured at the incident site but disputed the manner in which they happened and argued that the scene was manipulated. ${ }^{14272}$ She claimed that the first explosion, the one related to the crater on the curb of Danila Ilića street, did not take place at that location, but at a location nearby, and that the crater near the curb was manually dug out. ${ }^{14273}$ She concluded this using the contemporaneous photographs made by the CSB Sarajevo team arguing that they show, inter alia, that (i) the crater was too big for a $76 \mathrm{~mm}$ round, (ii) the quantity of the debris expelled from the crater onto the left-hand side of the curb (as seen from the alleged incoming direction of the round) was disproportionately greater than the quantity on the right-hand side of the curb, (iii) some of the items surrounding the crater were still covered by snow even though the impact would have blown that snow away, (iv) the pattern of the soil traces and of a number of metal fragments and other objects seen near the crater indicates that the explosion actually occurred some metres away from the crater, and (v) on the house near the crater, damage was limited to the window shutters and not the façade surrounding those shutters, which is inconsistent with the laws of physics. ${ }^{14274}$ According to Subotić, this crater and its surroundings were manipulated in order to give the impression that a "fragmentation artillery round" exploded at that location, when in fact the actual explosion near the crater was caused by a "quantity of explosive"; the manipulation also intended to make the scene compatible with the direction of fire eventually determined by the investigators. ${ }^{14275}$

4260. With respect to the second explosion, Subotic noted that the crater was too big to have been caused by a $76 \mathrm{~mm}$ round and also too shallow when compared to the crater related to the first explosion. ${ }^{14276}$ She further noted that the shape of the crater was similar to craters caused by

of responsibility of the $104^{\text {th }}$ Motorised Brigade was south of the airport, in the area of Hrasnica and Mt. Igman. See P1058 (ABiH map).

14272 Zorica Subotić, T. 38277 (14 May 2013).

14273 D3542 (Zorica Subotić's expert report entitled "Mortar Operations in Sarajevo Area in 1992-1995", 15 August 2012), pp. 145-150.

14274 D3542 (Zorica Subotić's expert report entitled "Mortar Operations in Sarajevo Area in 1992-1995", 15 August 2012), pp. 145-146, 148-150; Zorica Subotić, T. 38277-38280 (14 May 2013); D3541 (Photograph of crater marked by Zorica Subotić). Subotić also argued that her claim was confirmed by the fact that the contemporaneous photographs show that the scene was "altered substantially for no reason that could be explained to facilitate the collection of physical evidence in the course of the on-site investigation". Further, she claimed that it was an "incontrovertible fact" that the incoming direction of fire was determined following the alteration of the scene. See D3542 (Zorica Subotić's expert report entitled "Mortar Operations in Sarajevo Area in 1992-1995", 15 August 2012), pp. 147-148.

14275 D3542 (Zorica Subotić's expert report entitled “Mortar Operations in Sarajevo Area in 1992-1995”, 15 August 2012), pp. 148, 153.

14276 According to Subotić, the difference in sizes between the two craters was strange given that the rounds that caused them were meant to have been fired from the same weapon and from the same location. See D3542 (Zorica Subotić's expert report entitled "Mortar Operations in Sarajevo Area in 1992-1995", 15 August 2012), p. 150; Zorica Subotić, T, 38280-38281 (14 May 2013). In cross-examination, Subotić confirmed that her claim that the crater was too big was the result of her comparison of this particular crater to the craters caused by 82 $\mathrm{mm}$ mortar shells. She then acknowledged that the $76 \mathrm{~mm}$ cannon projectile weighs over 8 kilograms, while an 
rounds exploding at low angles of descent or even rounds lying on the ground. ${ }^{14277}$ Recalling that a part of the fuse was found on the scene, Subotic opined that one of the contemporaneous photographs showing the fragments of the projectile also showed an intact fuse without the detonator, which in her view is "absolutely impossible" given that the fuse activates once it impacts the ground. ${ }^{14278}$ The only way in which this could happen, according to Subotić, was if the round was detonated while stationary, using an explosive charge. ${ }^{14279}$

4261. In addition to the evidence and adjudicated facts outlined above, the Chamber has also taken judicial notice of one additional Adjudicated Fact which goes to the direction of fire and provides that both shells were fired from the southeast. ${ }^{14280}$

4262. Having considered the evidence and the adjudicated facts outlined above, the Chamber is convinced that two projectiles struck the fleamarket in Baščaršija on 22 December 1994. Relying in particular on the CSB Sarajevo report and the evidence of Suljević and Đozo, the Chamber is of the view that both projectiles were $76 \mathrm{~mm}$ calibre shells and that they came from the direction of southeast. While Suljević noted that the UN established that the projectiles in question were 82 mm mortar shells, the Chamber is persuaded by the CSB Sarajevo team's conclusions on this issue. First, no traces of a mortar shell, such as its fin, appear to have been found at the scene. Second, the CSB Sarajevo ballistic experts, who were experienced with the ammunition and weapons used in the Sarajevo conflict, conducted a thorough ballistics analysis of the fragments collected at the scene, including a part of a fuse, and concluded that these fragments belonged to a $76 \mathrm{~mm}$ projectile. Third, the spray pattern of the craters at the scene tends to suggest that mortar shells did not strike the area. Finally, even the Accused's expert witness, Subotić, implicitly agreed that the fragments on the scene came from a $76 \mathrm{~mm}$ projectile. ${ }^{14281}$

4263. The Chamber recalls Subotić's claim that the scene was manipulated and the explosions caused by a device planted at the scene. The Chamber finds her claim plainly unacceptable for a number of reasons. First, Subotic made many of her assumptions solely on the basis of contemporaneous photographs of the scene, which were not of sufficient clarity and thus not

$82 \mathrm{~mm}$ mortar shell weighs around 3 kilograms. See Zorica Subotić, T. 38461-38465 (16 May 2013); P6325 (Excerpt from ammunition manual of SFRY Federal Secretariat for National Defence). D3542 (Zorica Subotić's expert report entitled “Mortar Operations in Sarajevo Area in 1992-1995”, 15 August 2012), p. 150.

14278 D3542 (Zorica Subotić's expert report entitled “Mortar Operations in Sarajevo Area in 1992-1995”, 15 August 2012), pp. 150-151; Zorica Subotić, T. 38281 (14 May 2013).

14279 D3542 (Zorica Subotić's expert report entitled “Mortar Operations in Sarajevo Area in 1992-1995”, 15 August 2012), pp. 151-154; Zorica Subotić, T. 38281 (14 May 2013), T. 38466-38469 (16 May 2013).

14280 Adjudicated Fact 3032.

14281 See D3542 (Zorica Subotić's expert report entitled "Mortar Operations in Sarajevo Area in 1992-1995”, 15 August 2012), pp. 151-152. 
particularly reliable. In other words, she was never able to examine the craters in question and yet was able to comment on their size, depth, and even conclude where the actual site of the first explosion was. Second, Subotić claimed that the incoming direction of fire was determined following the alteration of the scene and that the scene was "altered substantially for no reason that could be explained to facilitate the collection of physical evidence in the course of the on-site investigation". The Chamber finds her claim about substantial alteration untenable as the photographs of the scene all seem consistent and merely indicate that the craters were cleaned at some stage of the investigation, something that was done by CSB Sarajevo in many other scheduled incidents discussed in this judgement. ${ }^{14282}$ Finally, with respect to Subotić's evidence that the fuse found on the scene was intact, the Chamber notes that she reached that conclusion on the basis of an unclear photograph of the various projectile fragments found on the scene. ${ }^{14283}$ At the same time, she did not explain sufficiently why she thought that one of the fragments depicted was an intact fuse. ${ }^{14284}$ Furthermore, the Chamber sees no reason to doubt the CSB Sarajevo report which records that only a part of the fuse was found rather than an intact fuse. For all of the reasons above, the Chamber rejects Subotić's theory that this incident was staged.

4264. Relying on the CSB Sarajevo report, the medical evidence before it, and the adjudicated facts, the Chamber is also convinced that the explosions at the fleamarket resulted in two killed and seven wounded persons, all of whom were civilians and were not taking direct part in hostilities. Furthermore, the fleamarket was located in the residential part of Stari Grad and there were no military targets in or near the area at the time of the incident.

4265. In terms of the origin of fire, the Chamber recalls the Accused's contention that in both the Dragomir Milošević and Perišić cases, the evidence was found not to have been sufficient to conclude that the shells originated from SRK-held territory. However, contrary to his claim that no additional evidence was led in this case on this particular issue, the Chamber recalls that the Prosecution brought additional evidence, namely the fact that SRK had a large number of cannons that fired $76 \mathrm{~mm}$ projectiles in its arsenal, including one in the area of Vidikovac, identified by the

14282 See e.g. P1709 (Photographs re shelling of Markale on 5 February 1994); P1926 (Photographs re shelling of Markale on 28 August 1995). In addition, in relation to Scheduled Incident G.6, Sabljica testified about the established procedure of CSB Sarajevo technicians clearing and preparing impact locations, which in turn enables the ballistic experts to determine the direction of fire. See P1695 (Witness Statement of Mirza Sabljica dated 11 February 2010), pp. 20-21, 32. See also P1966 (Witness statements of Sead Bešić dated 18 February 2010), pp. 12, 20, 34; KDZ485, T. 8947-8948 (3 November 2010).

14283 The Chamber also notes that the annotation made on the photograph itself makes no mention of the fuse being one of the fragments depicted there.

14284 While Subotić included a photograph of an unexploded $76 \mathrm{~mm}$ round in her report — to illustrate that one of the fragments in the CSB Sarajevo photograph was the fuse--it is not obvious to the Chamber that one of the fragments depicted in the CSB Sarajevo photograph is indeed the intact fuse of a $76 \mathrm{~mm}$ round. See D3542 
CSB report as the origin of fire. In addition, the evidence before the Chamber also clearly shows that the $\mathrm{ABiH}$ did not possess such cannons in the direction of southeast from which the shells originated, but rather in the outer circle of Sarajevo in the area of Mt. Igman. Accordingly, the Chamber is convinced beyond reasonable doubt that the two $76 \mathrm{~mm}$ shells that struck the fleamarket originated in SRK-held territory, in the area of Vidikovac and Trebević. Given that only two shells were fired and that there was no military target nearby, the Chamber is convinced that the SRK forces deliberately targeted the area of Baščaršija, including the fleamarket, and the civilians therein.

$\underline{\text { G.19) }}$

(4) Mula Mustafe Bašeskije street, 28 August 1995 (Scheduled Incident

4266. According to the Indictment, on 28 August 1995, a $120 \mathrm{~mm}$ mortar shell landed on MulaMustafe Bašeskije street outside the entrance to the city market, killing 43 and injuring 75 people. ${ }^{14285}$ The Indictment also alleges that the shell came from the SRK-held territory of Trebević. ${ }^{14286}$ In its Final Brief, the Prosecution argues that the shell killed "at least 35 people" and injured "at least 78 others", the vast majority of whom were civilians. ${ }^{14287}$

4267. The Accused argues in his Final Brief that the shell could not have come from the SRK positions, thus suggesting, without explicitly saying so, that the shell came from the $\mathrm{ABiH}{ }^{14288}$ While the Final Brief does not outline how the $\mathrm{ABiH}$ caused the incident, the majority of the evidence led by the Accused throughout his case was that a static explosive device was planted at the scene. ${ }^{14289}$ Additionally, as with the first Markale incident, although he makes no mention of it in his Final Brief, the Accused claimed during the case that the incident was staged and bodies

(Zorica Subotić's expert report entitled “Mortar Operations in Sarajevo Area in 1992-1995”, 15 August 2012), pp. 151-152.

.

Indictment, Scheduled Incident G.19.

Prosecution Final Brief, Appendix C, para. 62. The Prosecution seems to be relying on Adjudicated Fact 3081 for these numbers. However, Appendix $\mathrm{H}$ in which the Prosecution list the names of those wounded and killed refers to 43 killed and 73 wounded, thus contradicting Adjudicated Fact 3081, at least as far as the wounded are concerned. See Prosecution Final Brief, Appendix H, pp. 20-27.

14288 Defence Final Brief, paras. 2125-2162.

14289 The Chamber notes that in his Final Brief the Accused simply summarises the evidence of his witnesses, but then stops short of recounting their ultimate conclusions as to what happened in Markale on 28 August 1995. For example, after outlining much of Subotić's evidence he fails to state her ultimate conclusion, namely that a static explosive device was planted at the scene. The same is the case with other witnesses, such as Demurenko and Veljović. While there is no explanation in the Final Brief, the Chamber assumes that the position the Accused took in relation to the first Markale incident, as outlined in footnote 5073 of the Final Brief, is the same in relation to this incident. Nevertheless, as with the first Markale incident, in its analysis, the Chamber will consider the evidence the Accused led in relation to this incident in its totality and will therefore consider the conclusions of his witnesses, both in assessing their credibility and in order to determine what happened in Markale on 28 August 1995. See fn. 13939. 
brought to the scene. ${ }^{14290}$ Given that these two theories were not explicitly abandoned in the Final Brief, the Chamber will consider them below, as it did with the first Markale incident.

\section{(a) The incident}

4268. The morning of 28 August 1995 was quiet, as a result of which a large number of people went to the Markale market area. ${ }^{14291}$ Between 10:50 and 11 a.m., four shells landed in succession on a square near Markale market, approximately 200 to 300 metres away from the market. ${ }^{14292}$ Just after 11 a.m., ${ }^{14293}$ a fifth shell landed in front of the main entrance to the Markale market building, about 100 to 150 metres away from the location that had already been shelled on 5 February 1994. ${ }^{14294}$ Đula Leka, who was standing five to seven metres from the point of impact, was wounded in her left breast and upper left arm, while her brother-in-law was killed. ${ }^{14295}$ Ismet Svraka was standing in front of the indoor market building with his two friends, Ramo Herceglija and Ibrahim Hajvaz, both pensioners, no more than three to four metres away from the impact. ${ }^{14296}$ Svraka lost his left leg in the blast and also sustained injuries to his right foot and stomach, while his two friends were killed. ${ }^{14297}$ He testified that there was no warning before the explosion and

14290 See e.g. Hearing, T. 6396 (8 September 2010) (closed session) (wherein he put this case to a witness).

14291 P1992 (Witness statement of Ismet Svraka dated 5 November 2008), paras. 4, 6.

14292 Harry Konings, T. 9307-9308 (7 December 2010); P1953 (Witness statement of Harry Konings dated 11 November 2010), para. 65; P1959 (Map of Sarajevo marked by Harry Konings); P1905 (Witness statement of KDZ485), paras. 24-29. But see Emir Turkušić, T. 9061 (4 November 2010) who thought, but was not entirely sure, that these shells hit after the Markale incident.

14293 During the trial the Accused pointed out that one of the reports prepared by the authorities following this incident-namely a report prepared by the Sarajevo High Court—refers to the time of incident as being 1:05 p.m., while the CSB Sarajevo report refers to CSB Sarajevo being informed of the incident at 11:30 a.m.. The Accused's implication was that the incident was therefore staged. See Emir Turkušić, T, 9059-9064 (4 November 2010); P1449 (Criminal investigation file re shelling of Markale on 28 August 1995), e-court pp. 1, 6. However, the Chamber notes that not only is all other evidence consistent with the victims' evidence that the incident happened around 11 a.m., the Sarajevo High Court report itself refers to the investigation commencing at 11:50 a.m.. Accordingly, the Chamber is satisfied that the time of "13:05" mentioned at the beginning of that report is a typographical mistake. See e.g. P1966 (Witness statements of Sead Bešić dated 18 February 2010), p. 24; P1449 (Criminal investigation file re shelling of Markale on 28 August 1995), e-court p. 1; P906 (UNPROFOR daily report, 28-29 August 1995), p. 2; P1444 (UNMO report, 30 August 1995), p. 20; P1445 (UNPROFOR report re shelling of Markale on 28 August 1995), e-court p. 2; Adjudicated Fact 3078. The Chamber also notes that the English translation of P1449 refers to the time of incident as being 13:03, which the Chamber considers to have been a typographical error made by the translator as it is clear that the BCS version refers to 13:05.

14294 P141 (Đula Leka's statement to BiH authorities, 29 August 1995); P117 (Witness statement of Đula Leka dated 25 February 1996), e-court p. 2; Sead Bešić, T. 9428-9429 (8 December 2010); P1450 (Video footage of Markale, 28 August 1995). For the exact location, see P2190 (GPS locations for shelling and sniping incidents in Sarajevo); P2191 (Map of Sarajevo with scheduled sniping and shelling incidents); P2193 (Map of Sarajevo); P2213 (Image re scheduled sniping and shelling incidents in Sarajevo); D617 (Map of Sarajevo). See also discussion on Scheduled Incident G.8.

14295 P141 (Đula Leka's statement to BiH authorities, 29 August 1995); P117 (Witness statement of Đula Leka dated 25 February 1996), e-court p. 2.

14296 P1992 (Witness statement of Ismet Svraka dated 5 November 2008), para. 6; Ismet Svraka, T. 9658, 9661-9664, 9668 (13 December 2010); P1450 (Video footage of Markale, 28 August 1995).

14297 P1992 (Witness statement of Ismet Svraka dated 5 November 2008), paras. 8, 11; Ismet Svraka, T. 9655 (10 December 2010). 
that he did not hear the other four shells prior to the Markale shell impacting. ${ }^{14298}$ Sulejman Crnčalo's wife, who had gone to the market to look for powdered milk, was also killed in this blast. ${ }^{14299}$ When she did not come home at the arranged time, Crnčalo went to the market to look for her and, once he arrived there at around noon, saw great commotion, blood traces everywhere, and pieces of human flesh scattered all over the area. ${ }^{14300}$ Crnčalo did not see any investigating organs or officials at the scene. ${ }^{14301}$ He was told to go to the Koševo Hospital and, when he could not find his wife on the list of the wounded there, he went to the morgue where he finally learned that she was dead and saw her body. ${ }^{14302}$

4269. Following the explosion, Leka was taken to the Koševo Hospital where she spent some four or five days; in 1996, she still suffered from some pain in her shoulder and chest. ${ }^{14303}$ While fading in and out of consciousness after the incident, Svraka was driven to the Koševo Hospital where he saw a lot of injured people; he was operated on several times and released 45 days later. ${ }^{14304}$ Following that treatment, he had to undergo extensive reconstructive surgery in order to be able to step on his right foot and is now deemed to have a $90 \%$ disability. ${ }^{14305}$

\section{(b) CSB Sarajevo and UNMO investigations}

4270. Soon after the explosion Đozo was instructed to go to the scene with his colleagues and all available vehicles in order to assist in transporting the injured. ${ }^{14306}$ Đozo testified that the scene was handled and secured mostly by the Centar police station as the shell had landed in the area between that station and the Stari Grad station. ${ }^{14307}$ By the time he and his colleagues arrived at the scene, some of the injured had already been taken away while the dead were still lying around the

\footnotetext{
14298 P1992 (Witness statement of Ismet Svraka dated 5 November 2008), para. 7; Ismet Svraka, T. 9669 (13 December 2010).

14299 P733 (Witness statement of Sulejman Crnčalo dated 1 November 2009), paras. 6, 94-96; Sulejman Crnčalo, T. 1167-1168 (14 April 2010).

14300 Sulejman Crnčalo, T. 1167, 1173-1176 (14 April 2010).

14301 Sulejman Crnčalo, T. 1173-1174 (14 April 2010).

14302 Sulejman Crnčalo, T. 1167-1168, 1178-1179 (14 April 2010), T. 1279-1280 (15 April 2010); P740 (Autopsy certificates for victims from Markale, 28 August 1995), e-court p. 35.

14303 P117 (Witness statement of Đula Leka dated 25 February 1996), e-court p. 2; P1217 (Witness statement of Milan Mandilović dated 24 February 2010), p. 21; P1229 (Medical certificates for Ajkuna Cocalić, Đula Leka, Razija Čolić, Janja Pašić, and Adisa Duran). See also Adjudicated Fact 3083.

14304 P1992 (Witness statement of Ismet Svraka dated 5 November 2008), paras. 8-10; Ismet Svraka, T. $9655-9656$ (10 December 2010), T. 9662-9663, 9669-9671 (13 December 2010); P1225 (Medical certificate for Ismet Svraka); P1217 (Witness statement of Milan Mandilović dated 24 February 2010), p. 20.

14305 Ismet Svraka, T. 9656-9657 (10 December 2010); P1993 (Medical certificates for Ismet Svraka).

14306 P1978 (Witness statement of Nedžib Đozo dated 7 December 2010), para. 41. Đozo testified that the Stari Grad police station is less than one kilometre away from Markale market. See Nedžib Đozo, T. 9542-9544 (9 December 2010); P1979 (Map of Sarajevo marked by Nedžib Đozo).

14307 Nedžib Đozo, T. 9636 (10 December 2010).
} 
market. ${ }^{14308}$ In addition, the scene was so chaotic that Đozo and his colleagues could not get through to provide assistance so they returned to the police station. ${ }^{14309}$ Other than taking a few statements from eyewitnesses later, Đozo did not participate in the investigation of this incident. ${ }^{14310} \mathrm{He}$ did, however, testify that prior to this incident he investigated two other shelling incidents, one on 25 June and another on 1 July 1995, where the shells landed in the immediate vicinity of Markale. ${ }^{14311}$ It was established in the first of these incidents, that the two or three shells that had landed came from the Serb positions in the north, from the settlements of Barice and Mrkovići, while in the later incident four shells came from the direction of Lukavica or Vraca which were also controlled by the SRK. ${ }^{14312}$ According to Đozo, fire was slowly being adjusted by the SRK until it finally reached Markale market on 28 August $1995 .{ }^{14313}$ When put to him that it was unusual that, despite this adjustment of fire, Markale was ultimately only hit twice, once in 1994 and once in 1995, Đozo stated that it was certain that the busiest streets of Sarajevo were targeted and that most people circulated around the Mula Mustafe Bašeskije street. ${ }^{14314}$

4271. KDZ304 was at the scene "roughly" 10 minutes after hearing the explosions. ${ }^{14315} \mathrm{He}$ testified that by the time he arrived most of the victims had already been removed. ${ }^{14316}$

4272. Emir Turkušić, a ballistics expert from CSB Sarajevo, ${ }^{14317}$ was on his way to Markale market to buy some goods when he saw cars passing by, full of dead bodies and injured persons. ${ }^{14318}$ He therefore immediately returned to the base where he was instructed by his boss to take the necessary ballistics equipment and go to the incident site with another member of the team,

\footnotetext{
14308 P1978 (Witness statement of Nedžib Đozo dated 7 December 2010), para. 41.

14309 Nedžib Đozo, T. 9634-9636 (10 December 2010); P1978 (Witness statement of Nedžib Đozo dated 7 December 2010), para. 41.

14310 Nedžib Đozo, T. 9635-9636 (10 December 2010); P1978 (Witness statement of Nedžib Đozo dated 7 December 2010), para. 41.

14311 P1978 (Witness statement of Nedžib Đozo dated 7 December 2010), paras. 24-34; Nedžib Đozo, T. 9548-9552 (9 December 2010), T. 9553-9558, 9562-9564 (10 December 2010); P1990 (BiH MUP Report re shelling incident of 1 July 1995).

14312 P1978 (Witness statement of Nedžib Đozo dated 7 December 2010), paras. 25-34.

14313 P1978 (Witness statement of Nedžib Đozo dated 7 December 2010), para. 35. See also Nedžib Đozo, T. 95489552 (9 December 2010), T. 9553-9562, 9564-9565, 9577-9586 (10 December 2010); P1981 (Sketch drawn by Nedžib Đozo); P1982 (Map of Sarajevo marked by Nedžib Đozo); P1988 (Sketch drawn by Nedžib Đozo); P1989 (Map of Sarajevo marked by Nedžib Đozo).

14314 During cross-examination Đozo agreed with the Accused that the Orthodox Church was located near Markale market and the area where the shells landed on 25 June and 1 July 1995. See Nedžib Đozo, T. 9577-9586 (10 December 2010); D908 (Sketch re shelling of Markale on 28 August 1995 marked by Nedžib Đozo).

14315 P2407 (Witness statement of KDZ304 undated), p. 16; KDZ304, T. 10528 (19 January 2011).

14316 KDZ304, T. 10528 (19 January 2011); P2407 (Witness statement of KDZ304), p. 16.

14317 P1925 (Witness statement of Emir Turkušić dated 16 February 2010), p. 3.

14318 Emir Turkušić, T. 9001-9002, 9059-9062 (4 November 2010); P1925 (Witness statement of Emir Turkušić dated 16 February 2010), p. 13.
} 
Nedim Bosnić. ${ }^{14319}$ Turkušić and Bosnić were at the market approximately 10 minutes later, when most bodies had been cleared away and some UNPROFOR members, and personnel from CSB Sarajevo were already there. ${ }^{14320}$ Turkušić described the scene as the "last deepest circle of Dante's hell" with huge pools of blood, severed body parts, and panic and fear among the people present. $^{14321}$

4273. Konings, an UNMO from the Sedrenik team, heard about the incident on the radio and soon after received a phone call from the "Bosnian police" asking the UNMOs to come to the scene. ${ }^{14322}$ Konings and two other UNMOs were on location near the market approximately 30 minutes after the incident where they met with the Bosnian police, including ballistics experts and the investigative judge. ${ }^{14323}$ The whole group was at the scene of the incident approximately 40 minutes after the explosion. ${ }^{14324}$ By that time, all the victims had been taken away but there was still a lot of glass on the street, large pools of blood, and a large number of severed body parts. ${ }^{14325}$

4274. By around noon - at which point the scene was sealed off by the police from the Centar police station and the wounded and the killed had been removed from the site- the CSB Sarajevo team, along with the three UNMOs commenced the onsite investigation. ${ }^{14326}$ Turkušić's role was to collect and analyse all relevant data that would indicate, among other things, the bearing and the type of the projectile. ${ }^{14327}$ Bešić, being a criminal technician, was tasked with taking photographs of the scene, while his colleague was video-recording the scene. ${ }^{14328}$ Already present at the scene

14319 Emir Turkušić, T. 9001-9002, 9009 (4 November 2010) (testifying further that he did not hear the explosion as he was in another building at the time); P1925 (Witness statement of Emir Turkušić dated 16 February 2010), p. 13.

14320 Emir Turkušić, T. 9083-9085 (4 November 2010); P1925 (Witness statement of Emir Turkušić dated 16 February 2010), pp. 13, 14. Bešić testified that whenever there was a large number of casualties, it was normal procedure to take the wounded to a hospital and the dead to the morgue. See Sead Bešić, T. 9423-9425 (8 December 2010); P1969 (Video footage of Markale on 28 August 1995).

14321 P1925 (Witness statement of Emir Turkušić dated 16 February 2010), p. 14. See also Emir Turkušić, T. $9002-$ 9004 (4 November 2010); P1450 (Video footage of Markale, 28 August 1995).

14322 P1953 (Witness statement of Harry Konings dated 11 November 2010), paras. 49-51.

14323 P1953 (Witness statement of Harry Konings dated 11 November 2010), para. 52.

14324 Harry Konings, T. 9302, 9372 (7 December 2010); P1953 (Witness statement of Harry Konings dated 11 November 2010), para. 53.

14325 Harry Konings, T. 9302, 9372-9374 (7 December 2010); P1953 (Witness statement of Harry Konings dated 11 November 2010), para. 53.

14326 KDZ485, T. 8882-8883 (3 November 2010); Sead Bešić, T. 9430-9431 (8 December 2010), T. 9481-9484 (9 December 2010); P1908 (BiH MUP Report re shelling of Markale on 28 August 1995), e-court p. 1 (under seal); P1966 (Witness statements of Sead Bešić dated 18 February 2010), pp. 23-24; P1925 (Witness statement of Emir Turkušić dated 16 February 2010), p. 13; P1450 (Video footage of Markale, 28 August 1995).

14327 Emir Turkušić, T. 9009 (4 November 2010).

14328 Sead Bešić, T. 9422-9423 (8 December 2010), T. 9481 (9 December 2010); P1966 (Witness statements of Sead Bešić dated 18 February 2010), pp. 24-25; P1926 (Photographs re shelling of Markale on 28 August 1995); P1968 (Photograph re shelling of Markale on 28 August 1995); P1971 (Photographs re shelling of Markale on 28 August 1995); P1449 (Criminal investigation file re shelling of Markale on 28 August 1995). 
were FreBat soldiers, who were conducting their own investigation. ${ }^{14329}$ Later in the day Harland came to the scene as well, at which point the blood had been washed away. ${ }^{14330}$

4275. Turkušić very quickly detected the crater on Mula Mustafe Bašeskije street, near the entrance to the market building and relatively close to the pavement, and testified that it would have been impossible to disturb it at that point since it would have required a lot of manual work that would have been noticed by the dozens of people who were present. ${ }^{14331}$ Konings and the other UNMOs also spotted and investigated the crater, and Konings did not notice any sign of tampering with the crater; to him it was immediately obvious that it was caused by a mortar rather than an artillery projectile. ${ }^{14332}$ The UNMOs also found the stabiliser, which, according to Konings, was located 10 to 20 metres away from the point of impact, and which had bent fins and writing in Cyrillic on its back. ${ }^{14333}$ Bešić testified that the stabiliser was located some 25 to 45 metres away from the point of impact. ${ }^{14334}$ Turkušić confirmed that he did not personally find the stabiliser, although he did see it, and explained that it was marked with letters "KB" in Cyrillic, signifying that the shell was produced in the Krušik Factory in Valjevo, Serbia. ${ }^{14335}$ According to the CSB Sarajevo report, the stabiliser had "KB 9307" and "MK M74" inscribed on it. ${ }^{1436}$ Konings testified that the stabiliser was taken by the "Bosnian police". ${ }^{14337}$

14329 Emir Turkušić, T. 9007-9008 (4 November 2010); P1925 (Witness statement of Emir Turkušić dated 16 February 2010), p. 13; Harry Konings, T. 9302 (7 December 2010); P2407 (Witness statement of KDZ304), p. 16.

14330 David Harland, T. 2042-2043 (6 May 2010); P820 (Witness statement of David Harland dated 4 September 2009), para. 229; P906 (UNPROFOR daily report, 28-29 August 1995).

14331 P1925 (Witness statement of Emir Turkušić dated 16 February 2010), p. 14; P1966 (Witness statements of Sead Bešić dated 18 February 2010), pp. 25-26; P1974 (Photograph re shelling of Markale on 28 August 1995 marked by Sead Bešić); Sead Bešić, T. 9423-9425, 9428-9429 (8 December 2010); P1969 (Video footage of Markale on 28 August 1995); P1450 (Video footage of Markale, 28 August 1995).

14332 P1953 (Witness statement of Harry Konings dated 11 November 2010), paras. 58, 60; P1968 (Photograph re shelling of Markale on 28 August 1995); Harry Konings, T. 9303-9306 (7 December 2010); P1958 (Photograph re shelling of Markale on 28 August 1995 marked by Harry Konings).

14333 Harry Konings, T. 9306 (7 December 2010); P1953 (Witness statement of Harry Konings dated 11 November 2010), paras. 56-57. On cross-examination, it transpired that Konings was not entirely certain as to exactly how far the stabiliser was from the crater and admitted to giving different distances on different occasions. See Harry Konings, T. 9378-9379 (7 December 2010).

14334 Bešić could not explain why the stabiliser was so far away from the point of impact but speculated that it may have been pushed away by the tires of the automobiles. See P1966 (Witness statements of Sead Bešić dated 18 February 2010), pp. 28-30; Sead Bešić, T. 9504-9505 (9 December 2010); P1926 (Photographs re shelling of Markale on 28 August 1995); P1971 (Photographs re shelling of Markale on 28 August 1995); P1975 (Sketch re shelling of Markale on 28 August 1995); D903 (Sketch re shelling of Markale on 28 August 1995 marked by Sead Bešić).

14335 Emir Turkušić, T. 8994, 9076-9078 (4 November 2010); P1925 (Witness statement of Emir Turkušić dated 16 February 2010), p. 13.

14336 P1908 (BiH MUP Report re shelling of Markale on 28 August 1995), e-court p. 2 (under seal). Sead Bešić testified that the first two digits following "KB" indicated the year and the second two the month of manufacture. See P1966 (Witness statements of Sead Bešić dated 18 February 2010), pp. 15, 22-23. This means that this shell was produced in Krušik in July 1993.

14337 Harry Konings, T. 9379-9380 (7 December 2010). 
4276. According to the CSB Sarajevo report prepared on the basis of the initial information obtained on the day of the incident, ${ }^{14338}$ as well as Turkušić's ballistics report prepared following his and Bosnić's investigation, the stabiliser belonged to a $120 \mathrm{~mm}$ calibre shell which, based on the measurements of the crater, came from the south, its azimuth being 170 degrees, plus or minus five degrees. ${ }^{14339}$ This azimuth corresponded to "aggressor positions at the Trebević area." "14340 The CSB Sarajevo report also provides that the fact that the "UN observers in the southern part of the city did not notice any artillery actions from the areas controlled by $[\mathrm{ABiH}]$ confirms that the shell was fired from the area temporally controlled by the aggressor."14341 According to Turkušić, the shell impacted against the road directly without hitting anything along its trajectory. ${ }^{14342}$

4277. As for the origin of fire, while the team calculated the angle of descent of the shell to have been 70 degrees, ${ }^{14343}$ Turkušić stated that the team was unable to say exactly from which point the shell was fired, as that determination depended on the number of charges used to fire it. ${ }^{14344}$ However, based on the UNMOs' information that on that particular day the $\mathrm{ABiH}$ did not fire any mortar shells from its positions on the northern side of Trebević, the CSB Sarajevo team concluded that the shell had originated from the part of the Trebević slopes held by the Serb forces. ${ }^{14345} \mathrm{He}$ also noted that many factors indicated that the shell was launched with three charges, which suggests an approximate distance of 2,400 to 2,500 metres from Markale. ${ }^{14346}$ When it was put to

\footnotetext{
14338 P1905 (Witness statement of KDZ485), para. 26.

14339 P1908 (BiH MUP Report re shelling of Markale on 28 August 1995), e-court p. 2 (under seal); P1934 (BiH MUP Report re shelling of Markale on 28 August 1995), e-court pp. 2-4. See also Emir Turkušić, T. 90199024, 9066-9067 (4 November 2010); P1925 (Witness statement of Emir Turkušić dated 16 February 2010), pp. 13, 16-30, 32-33; P1936 (Photograph re shelling of Markale on 28 August 1995 marked by Emir Turkušić); P1929 (Photograph re shelling of Markale on 28 August 1995 marked by Emir Turkušić); P1930 (Photograph re shelling of Markale on 28 August 1995 marked by Emir Turkušić); P1931 (Photograph re shelling of Markale on 28 August 1995 marked by Emir Turkušić); P1935 (Maps re shelling of Markale on 28 August 1995); P1966 (Witness statements of Sead Bešić dated 18 February 2010), pp. 27-28, 30-32; P1976 (Sketch re shelling of Markale on 28 August 1995 marked by Sead Bešić).

14340 P1908 (BiH MUP Report re shelling of Markale on 28 August 1995), e-court p. 2 (under seal).

14341 P1908 (BiH MUP Report re shelling of Markale on 28 August 1995), e-court p. 2 (under seal); P1905 (Witness statement of KDZ485), para. 28. See also P1977 (BiH MUP Report re shelling of Markale on 28 August 1995), e-court p. 1.

14342 P1925 (Witness statement of Emir Turkušić dated 16 February 2010), p. 15.

14343 Emir Turkušić, T. 9012-9019, 9072-9075 (4 November 2010); P1925 (Witness statement of Emir Turkušić dated 16 February 2010), pp. 30-32; P1927 (Sketch re shelling of Markale on 28 August 1995); P1928 (Sketch re shelling of Markale on 28 August 1995 marked by Emir Turkušić). See also Richard Higgs, T. 5939-5940 (18 August 2010); P1450 (Video footage of Markale, 28 August 1995).

14344 P1925 (Witness statement of Emir Turkušić dated 16 February 2010), pp. 19-20 (claiming also that even the most renowned military and artillery experts would be unable to provide the precise origin of fire for this incident).

14345 Emir Turkušić, T. 9071-9072 (4 November 2010); P1925 (Witness statement of Emir Turkušić dated 16 February 2010), pp. 19-20. See also Barry Hogan T. 11283-11284 (3 February 2011).

14346 Emir Turkušić, T. 9019 (4 November 2010).
} 
him that the UNMO's radar did not register any fire coming from the Serb side, Turkušić responded that this depended on the area the radar was adjusted to monitor. ${ }^{14347}$

4278. According to the UNMO report dated 29 August 1995, UNMO team from Sedrenik was tasked with investigating the Markale incident that took place at 11:10 a.m. on 28 August 1995, as well as the other four shells that fell nearby earlier that day, and it did so in conjunction with the local authorities. ${ }^{14348}$ As confirmed by Konings during his testimony in this case, this team concluded that all five impacts were $120 \mathrm{~mm}$ mortar projectiles, all bearing the same marks, namely "KB 9307" and "MK M74", and that the one that landed on Markale was fired from 170 degrees plus or minus five degrees from the north, with a minimum "angle of impact" of 67 degrees. ${ }^{14349}$ As for the other four rounds, the team found that they were fired from 220-240 degrees from the north and impacted the ground 200 to 300 metres from the shell that landed on Markale. ${ }^{14350}$ An accurate origin of fire for all five shells could not be determined because it was not known with which charge they were fired. ${ }^{14351}$ Following the investigation on the scene, the UNMO team went to the morgue where it confirmed that 31 persons had been killed. ${ }^{14352}$ In the morgue, Konings could see that the people had been killed by shrapnel and that their bodies were fresh. ${ }^{14353}$ Some hours later, the number of casualties was amended to 34 killed and 84 wounded. ${ }^{14354}$ Following a meeting with the Bosnian police at the police station, Konings submitted his report to his superiors. ${ }^{14355}$ He explained that during the meeting the Bosnian authorities wanted the UNMOs to

\footnotetext{
14347 Emir Turkušić, T. 9071-9072 (4 November 2010).

14348 P1446 (UNMO report, 29 August 1995), p. 20. See also P1445 (UNPROFOR report re shelling of Markale on 28 August 1995), e-court p. 17; P1444 (UNMO report, 30 August 1995), p. 20; Harry Konings, T. 9339-9340, 9372 (7 December 2010).

14349 P1445 (UNPROFOR report re shelling of Markale on 28 August 1995), e-court pp. 17-19; P1446 (UNMO report, 29 August 1995), pp. 20-22; P1444 (UNMO report, 30 August 1995), pp. 20-21. See Harry Konings, T. 9306-9307, 9373-9375 (7 December 2010); P1953 (Witness statement of Harry Konings dated 11 November 2010); paras. 61-63, 80; Thomas Knustad, P123 (Transcript from Prosecutor v. D. Milošević), T. 1998-2002; P151 (Map marked by Thomas Knustad).

14350 P1445 (UNPROFOR report re shelling of Markale on 28 August 1995), e-court pp. 17-18; P1444 (UNMO report, 30 August 1995), pp. 20-22; Harry Konings, T. 9307-9308 (7 December 2010); P1953 (Witness statement of Harry Konings dated 11 November 2010), paras. 64-65.

14351 P1445 (UNPROFOR report re shelling of Markale on 28 August 1995), e-court p. 17; P1444 (UNMO report, 30 August 1995), p. 21. See also P1953 (Witness statement of Harry Konings dated 11 November 2010), paras. 80-81.

14352 P1953 (Witness statement of Harry Konings dated 11 November 2010), para. 66; Harry Konings, T. 9333-9337 (7 December 2010).

14353 P1953 (Witness statement of Harry Konings dated 11 November 2010), para. 66; Harry Konings, T. 9337-9339 (7 December 2010).

14354 P1446 (UNMO report, 29 August 1995), p. 21.

14355 P1953 (Witness statement of Harry Konings dated 11 November 2010), para. 68; P150 (UNMO report, 28 August 1995). See also Thomas Knustad, P123 (Transcript from Prosecutor v. D. Milošević), T. 1998-2000.
} 
declare that the Markale shell had been fired by the Bosnian Serbs but that he was unable to do so at that moment as there was a possibility that the shell had been fired from ABiH-held territory. ${ }^{14356}$

4279. Konings testified that the next day, on 29 August 1995, Thomas Knustad and Paul Conway, two UNMOs who had been manning OP-1 on the day of the incident, told him that they did not observe or hear any outgoing shots from the $\mathrm{ABiH}$-held territory or from the part of the VRS-held territory they could see. ${ }^{14357}$ OP-1 was located in the south of Sarajevo, on Colina Kapa Hill, approximately 200 metres north of the $\mathrm{ABiH}$ side of the confrontation line and approximately 1,500 metres away from the SRK lines. ${ }^{14358}$ Hogan testified that, based on the measurements he made by GPS, the distance between Markale market and the frontline in that area was approximately 1,600 metres. $^{14359}$

4280. Knustad confirmed during his testimony that, on the morning of 28 August 1995, which was warm and clear, he was sitting at the UNMO house near OP-1 while Conway was manning the OP. ${ }^{14360}$ At around 11 a.m., they saw smoke rising from the area of Markale market and then heard the sound of an impact explosion in the city, which Knustad thought sounded like a mortar impact. ${ }^{14361}$ Knustad heard only one impact and thought that the mortar did not pass very close to OP-1 otherwise he and Conway would have heard it. ${ }^{14362} \mathrm{He}$ also explained that the mortar had not been fired from "within the confrontation line" because he would have heard that too. ${ }^{14363}$ Conversely, he testified that, if fired from behind the SRK lines, it is possible that he would not

14356 P1953 (Witness statement of Harry Konings dated 11 November 2010), paras. 68-70; Harry Konings, T. 93909393 (7 December 2010); P150 (UNMO report, 28 August 1995).

14357 P1953 (Witness statement of Harry Konings dated 11 November 2010), para. 72; Thomas Knustad, P123 (Transcript from Prosecutor v. D. Milošević), T. 1998, 2004-2008. See also Harry Konings, T. 9308-9310 (7 December 2010); P152 (Witness statement of Thomas Knustad dated 21 May 1996), p. 3.

14358 Thomas Knustad, P123 (Transcript from Prosecutor v. D. Milošević), T. 1987-1988, 1994, 1996, 2001, 20062008, 2024-2026; P152 (Witness statement of Thomas Knustad dated 21 May 1996), p. 3; P151 (Map marked by Thomas Knustad); Paul Conway, T. 29000, 29004-29006 (17 October 2012); P5927 (Map of Sarajevo marked by Paul Conway). Konings, on the other hand, placed the location of OP-1 some 500 to 600 metres away from the confrontation line. See Harry Konings, T. 9298-9302 (7 December 2010); P1954 (Map of Sarajevo marked by Harry Konings); P1955 (Photograph of Sarajevo marked by Harry Konings); P1956 (Photograph of Sarajevo); P1957 (Photograph of Sarajevo and uniformed men marked by Harry Konings); P1953 (Witness statement of Harry Konings dated 11 November 2010), para. 72; P1964 (Map of Sarajevo marked by Harry Konings).

14359 Barry Hogan, T. 11284-11285 (3 February 2011); D1006 (Aerial satellite image of Sarajevo marked by Barry Hogan).

14360 Thomas Knustad, P123 (Transcript from Prosecutor v. D. Milošević), T. 1993-1994; P152 (Witness statement of Thomas Knustad dated 21 May 1996), p. 3. Conway testified, however, that he believed that Knustad was taking a walk with their Bosnian interpreter at the time of the explosion. See D2329 (Witness statement of Paul Conway dated 7 November 2011), para. 16.

14361 Thomas Knustad, P123 (Transcript from Prosecutor v. D. Milošević), T. 1994-1998, 2023-2024; P152 (Witness statement of Thomas Knustad dated 21 May 1996), p. 3.

14362 Thomas Knustad, P123 (Transcript from Prosecutor v. D. Milošević), T. 2023-2024, 2039; P152 (Witness statement of Thomas Knustad dated 21 May 1996), p. 3.

14363 Thomas Knustad, P123 (Transcript from Prosecutor v. D. Milošević), T. 2003-2005, 2048-2049; P152 (Witness statement of Thomas Knustad dated 21 May 1996), p. 3. 
have heard it, as the SRK-held territory was on the other side of the hill. ${ }^{14364}$ Accordingly, Knustad excluded the possibility of any mortar being fired from the ABiH-held territory. ${ }^{14365}$

4281. Conway testified that he heard the sound of several muffled explosions at around 11 a.m. on 28 August 1995 from OP-1 and that when he looked towards the city he saw several plumes of smoke; he was unable to say, however, if the muffled sounds were from incoming or outgoing fire. ${ }^{14366} \mathrm{He}$ also testified that he may have missed other explosions from incoming or outgoing fire as he was going in and out of a shed near OP-1. ${ }^{14367}$ He noted that the sound of the explosions had been relatively low given that the impacts were only around three kilometres from the OP-1. ${ }^{14368}$ Accordingly, he did not agree that if someone at OP-1 did not hear sounds of outgoing mortar fire, then that fire must have come from the SRK side of the confrontation line. ${ }^{14369} \mathrm{He}$ conceded, however, that if mortar was fired from a reasonably close distance to the listener, one would hear a “very distinctive 'vrmph' and 'trmph' sound". ${ }^{14370}$

4282. Following his meeting with Knustad and Conway, Konings attended another meeting with the Bosnian authorities where they discussed the results of their investigations and, based on all the information in his possession, he came to the conclusion that the fire originated in the SRK-held territory. ${ }^{14371}$ He explained that if the round had been fired from the ABiH-held territory, then in combination with all the other parameters, this could only have been done using either charges zero or one. ${ }^{14372}$ Using charge zero would have placed the origin of fire near the OP-1 and the UNMOs manning that post would have heard or seen it being fired. ${ }^{14373}$ As for charge one, Konings testified

14364 Thomas Knustad, P123 (Transcript from Prosecutor v. D. Milošević), T. 2005-2006; Barry Hogan T. 1128311284 (3 February 2011).

14365 Thomas Knustad, P123 (Transcript from Prosecutor v. D. Milošević), T. 2005-2007.

14366 D2329 (Witness statement of Paul Conway dated 7 November 2011), paras. 12-15 (explaining that it is sometimes impossible to say whether a blast sound is from an outgoing or incoming fire and that the acoustics in Sarajevo often made that determination unreliable); Paul Conway, T. 29012-29014 (17 October 2012).

14367 D2329 (Witness statement of Paul Conway dated 7 November 2011), para. 13; Paul Conway, T. 29004-29005 (17 October 2012).

14368 D2329 (Witness statement of Paul Conway dated 7 November 2011), para. 13; Paul Conway, T. 28999-29000, 29009-29011 (17 October 2012).

14369 D2329 (Witness statement of Paul Conway dated 7 November 2011), para. 15.

14370 Paul Conway, T. 29011 (17 October 2012). This was also confirmed by Konings who testified that the firing of a $120 \mathrm{~mm}$ mortar shell produces a "very loud bang". See Harry Konings, T. 9309-9310 (7 December 2010). See also Thomas Knustad, P123 (Transcript from Prosecutor v. D. Milošević), T. 2004 (testifying that a $120 \mathrm{~mm}$ mortar is louder than a $82 \mathrm{~mm}$ mortar); Savo Simić, T. 30065-30066 (12 November 2012) (testifying that it would be impossible to conceal the firing of a round from UN observers located in the vicinity of firing positions); John Wilson, T. 4111 (23 June 2010) (testifying that if it was a quiet day, one could hear the outgoing fire of a mortar at more than one kilometre away); Stanislav Galić, T. 37860 (7 May 2013); Thorbjorn Overgard, T. 10031 (16 December 2010).

14371 P1953 (Witness statement of Harry Konings dated 11 November 2010), paras. 68-72; P1960 (UNMO report, 29 August 1995); Harry Konings, T. 9308-9312, 9314-9316 (7 December 2010).

14372 P1953 (Witness statement of Harry Konings dated 11 November 2010), paras. 88-90.

14373 P1953 (Witness statement of Harry Konings dated 11 November 2010), paras. 89-90, 95; Harry Konings, T. 9308-9310, 9385-9386 (7 December 2010). 
that in his experience it is not normally used with $120 \mathrm{~mm}$ mortars, as doing so can result in the round exploding in the vicinity of the firing troops. ${ }^{14374}$

\section{(c) $\underline{\text { UNPROFOR investigation }}$}

4283. In addition to the investigation by the UNMOs referred to above, the UN conducted an investigation by its Engineer Cell Sector Sarajevo, after which a follow-up analysis was conducted by Lieutenant Colonel Brian Powers, from the "G2 HQ UNPROFOR", who considered and analysed both the UNMO and the Engineer Cell Sector Sarajevo reports. ${ }^{14375}$ All three reports were then sent to the UNPROFOR Sarajevo HQ Commander by Lieutenant Colonel Baxter who summarised their findings in the final UN official report. ${ }^{14376}$

4284. The Engineer Cell Sector Sarajevo came to the conclusion similar to that reached by the Bosnian police and the UNMO teams, finding that the $120 \mathrm{~mm}$ mortar shell-of "[S]erb manufacture"--was fired from 2,850 mils, or 160 degrees, from the north. ${ }^{14377}$

4285. As for Powers' analysis, noting that the shell that landed on Markale was found to have a bearing different from the other four shells that fell in the vicinity, he reported on 29 August 1995 that the "analysis of the fuse farrow [sic] shows the bearing of [the Markale] round was most likely from 220-240 degrees and would have been fired from the same position as the other four rounds", namely from somewhere between Lukavica and Miljevići. ${ }^{14378}$ Powers also noted that there must have been some kind of an anomaly with the Markale shell, which was later explained by Baxter to have probably been the result of the shell first striking a building on its flight path. ${ }^{14379}$

\footnotetext{
14374 P1953 (Witness statement of Harry Konings dated 11 November 2010), para. 88; Harry Konings, T. 9391-9393 (7 December 2010).

14375 P1445 (UNPROFOR report re shelling of Markale on 28 August 1995), e-court p. 2. See also Richard Higgs, T. 5938-5941 (18 August 2010); P1450 (Video footage of Markale, 28 August 1995) (showing the Engineer Cell working on the scene). The Chamber notes that the Engineer Cell Sector Sarajevo report is dated 6 September 1995 even though the Engineer Cell conducted the crater analysis on 28 August and even though Powers ought to have analysed their report by 29 August 1995. The Chamber notes, however, that Demurenko can be seen in his interview of 2 September holding the original French version of the Engineer Cell report in his hand. See fn. 14399. Thus, the Chamber considers the date of 6 September to be the date of the English translation of the original Engineer Cell report rather than the date when the report itself was first prepared or submitted.

14376 P1445 (UNPROFOR report re shelling of Markale on 28 August 1995), e-court pp. 2-4.

14377 P2407 (Witness statement of KDZ304), p. 17; P2114 (UNPROFOR report re shelling of Markale on 28 August 1995); P1445 (UNPROFOR report re shelling of Markale on 28 August 1995), e-court pp. 6-7. See also Richard Higgs, T. 5948-5950 (18 August 2010); P1450 (Video footage of Markale, 28 August 1995).

14378 P1445 (UNPROFOR report re shelling of Markale on 28 August 1995), e-court p. 21. See also P1447 (UNPROFOR report re shelling of Markale on 28 August 1995), e-court pp. 1-2. The Prosecution submits that this analysis of the bearing should be disregarded as unreliable since Powers "applied the fuse-funnel method without a clear fuse funnel”. See Prosecution Final Brief, Appendix C, para. 64.

14379 P1445 (UNPROFOR report re shelling of Markale on 28 August 1995), e-court p. 21; P1447 (UNPROFOR report re shelling of Markale on 28 August 1995), e-court pp. 3, 21.
} 
4286. Powers' report also provided that the UN radar was operating at the time but that it did not detect any of the mortars fired and that "[a]t least several of the five rounds would have been detected if fired close to the [confrontation line]." ${ }^{14380}$ According to the report, if the shells were fired from a longer range, the arc of the trajectory would have most likely been below the beam of the radar and therefore not detected. ${ }^{14381}$ Powers further noted that the height of the buildings at the market was also considered and that, in order for a round to clear the top of the buildings on the south side of the street, it would have required either a high trajectory from close to the confrontation line or a low trajectory mortar shell fired from a middle to a long range. ${ }^{14382}$ However, none of the staff manning the UN OPs in the area along the confrontation line observed or heard any firing at the time of the Markale incident. ${ }^{14383}$ Based on all this data, Powers concluded that the firing position of the five shells was in the SRK territory, and probably fired from the Lukavica area at a range of between 3,000 and 5,000 metres. ${ }^{14384}$ Powers' conclusions were presented to Harland and Smith, who from that point on had no doubt that the shell was fired by the Bosnian Serbs. ${ }^{14385}$

4287. On 8 September 1995, Baxter reported to the UNPROFOR Zagreb HQ, attaching all the above reports and noting that Powers' report has attempted to clarify the "apparent discrepancy" between the direction of the Markale shell and the direction of the preceding four shells. ${ }^{14386}$ His report also noted that the UN radar would have detected any mortar fired at a range of 950 metres or less so that the "assessment was that the mortars were fired at a lower trajectory which passed under the radar beam"; this in turn meant that the round would have come from a firing position, dependent on the charge, at a range between 1,550 and 3,500 metres, whereas the confrontation line

\footnotetext{
14380 P1445 (UNPROFOR report re shelling of Markale on 28 August 1995), e-court p. 21; P1447 (UNPROFOR report re shelling of Markale on 28 August 1995), e-court p. 1 (noting that the angle od the radar would detect high, but not low, trajectories). But see D2762 (Witness statement of KW554 dated 14 September 2012), para. 12 (where KW554 testified that he "was informed that the round had been recorded" on the UN radar but that "it could not be determined from which side of the confrontation line it had been fired".)

14381 P1445 (UNPROFOR report re shelling of Markale on 28 August 1995), e-court p. 21; P1447 (UNPROFOR report re shelling of Markale on 28 August 1995), e-court pp. 1-2.

14382 P1447 (UNPROFOR report re shelling of Markale on 28 August 1995), e-court p. 2.

14383 P1445 (UNPROFOR report re shelling of Markale on 28 August 1995), e-court p. 21; P1447 (UNPROFOR report re shelling of Markale on 28 August 1995), e-court p. 2.

14384 P1445 (UNPROFOR report re shelling of Markale on 28 August 1995), e-court p. 21.

14385 P820 (Witness statement of David Harland dated 4 September 2009), para. 231; P821 (Supplemental witness statement of David Harland dated 4 May 2010), para. 15; P828 (UNPROFOR Report re shelling of Markale on 28 August 1995). See also David Harland, T. 2043-2044 (6 May 2010) (testifying further that the report was presented in the "hours and day or two that followed" but not giving the specific time at which that happened). Baxter's report states that Smith was briefed verbally in the evening of 28 August and then received a written report at 8 a.m. on 29 August 1995. See P1445 (UNPROFOR report re shelling of Markale on 28 August 1995), e-court p. 2.

14386 P1445 (UNPROFOR report re shelling of Markale on 28 August 1995), e-court pp. 2-4.
} 
was 1,050 metres from the impact point. ${ }^{14387}$ The report concluded "beyond reasonable doubt" that all five shells were fired from Bosnian Serb territory. ${ }^{14388}$

\section{(d) Andrey Demurenko's investigation}

4288. Demurenko, Chief of Staff of Sector Sarajevo at the time of the incident, ${ }^{14389}$ testified that he heard about the Markale incident within 30 minutes after it happened. ${ }^{14390} \mathrm{He}$ went to the incident site two hours later and observed both the crater and the experts working at the site, as well as blood on the street and the pavement. ${ }^{14391}$ Having spent around 30 minutes at the site and having given instructions to the teams working there, Demurenko returned to the headquarters and about an hour later learned that a spokesperson for UNPROFOR, a British Lieutenant-Colonel, had organised a press conference in which he blamed the SRK for the incident. ${ }^{14392}$ Demurenko thought that this was completely groundless as the investigation was still ongoing at that time. ${ }^{14393}$ As a result, in the evening of 28 August he proposed to his superior, at the time General Bachelet, to organise an investigation, to which Bachelet agreed. ${ }^{14394}$ Demurenko then selected his closest aids and, relying on the ballistic results he had at the time, they went to inspect possible firing locations both on the confrontation line, which was around 2,000 metres from the incident site, and in SRK-held territory, compiling photographs of those locations. ${ }^{14395}$ Their investigation lasted from 29 August to 1 September 1995, following which Demurenko prepared a report concluding that there were no suitable firing positions on the SRK side of the confrontation line; however,

\footnotetext{
14387 P1445 (UNPROFOR report re shelling of Markale on 28 August 1995), e-court p. 3.

14388 P1445 (UNPROFOR report re shelling of Markale on 28 August 1995), e-court p. 3.

14389 D2270 (Witness statement of Andrey Demurenko dated 13 October 2012), para. 4.

14390 D2270 (Witness statement of Andrey Demurenko dated 13 October 2012), para. 42.

14391 D2270 (Witness statement of Andrey Demurenko dated 13 October 2012), paras. 43, 67-68.

14392 D2270 (Witness statement of Andrey Demurenko dated 13 October 2012), paras. 43, 68-71, 74-75 (explaining that he could not remember the names or the battalions of the UN members working at the site and testifying that he did not remember interacting with Konings); D2272 (Supplemental information sheet for Harry Konings, 20 April 2009), para. 25.

14393 D2270 (Witness statement of Andrey Demurenko dated 13 October 2012), paras. 43, 138, 140.

14394 D2270 (Witness statement of Andrey Demurenko dated 13 October 2012), paras. 44, 55, 76, 78-79.

14395 D2270 (Witness statement of Andrey Demurenko dated 13 October 2012), paras. 43, 51, 63, 76-77, 80-81, 90, 95, 100-103, 110-111, 116, 122-123, 126, 135 (explaining that he had two ballistics reports, one prepared by a Dutch officer who was a ballistics expert and the other by a local expert from $\mathrm{BiH}$, as well as somewhere between ten and 20 different sources of information); D2281 (Drawing of angles and distance of mortar shells by Andrey Demurenko); D2274 (Map of Sarajevo marked by Andrey Demurenko); D2273 (Photograph of Andrey Demurenko); D2277 (Photograph of Andrey Demurenko); D2284 (Letter from SRK to VRS Main Staff, 29 August 1995) (indicating that Demurenko sought and the SRK granted permission for him to visit Trebević); Andrey Demurenko, T. 28990-28991 (17 October 2012).
} 
when he came to present his report to Bachelet, he was told by Bachelet's aide that the report would never be published due to its conclusions. ${ }^{14396}$

4289. As a result, Demurenko contacted the Associated Press and, on 2 September 1995, gave them an interview outlining his conclusions. ${ }^{14397}$ In the interview, Demurenko explained that he personally went to the positions from which the shell could have been fired had it been fired with charges three to six and found that these locations were unsuitable for firing positions, as were those found on the bearing line of the other four shells that fell on that day. ${ }^{14398}$ The Chamber notes that the video footage shows that Demurenko used a bearing of 176 degrees from the north, rather than 160 degrees as determined by UNPROFOR investigators or 170 plus or minus five degrees as determined by CSB Sarajevo and the UNMOs. ${ }^{14399}$ Demurenko testified that having given this interview, he was threatened by an $\mathrm{ABiH}$ officer and disciplined by his own command in Sector Sarajevo. ${ }^{14400}$

4290. Demurenko explained that in three of the four possible positions he visited, the ground was made up of stones, while the fourth position was forested, which is why he concluded that not a single one of these positions was suitable for mortar placement. ${ }^{14401} \mathrm{He}$ also stated that he and his team did not have GPS but went to the relevant sites using "traditional old fashioned instruments to determine the location". ${ }^{1402}$ When asked if the margin of error with which the ballistic experts were working meant that the firing positions would have encompassed an area bigger than the specific positions he visited, Demurenko at first testified that the deviation would have been about

14396 D2270 (Witness statement of Andrey Demurenko dated 13 October 2012), paras. 51-55, 81-85 (testifying also that the report was in his personal archive but that he was reluctant to provide it as it was a confidential UN document).

14397 D2270 (Witness statement of Andrey Demurenko dated 13 October 2012), paras. 56, 85, 96.

14398 D1010 (Video footage of Colonel Demurenko's interview, with transcript).

14399 D1010 (Video footage of Colonel Demurenko's interview, with transcript); D2270 (Witness statement of Andrey Demurenko dated 13 October 2012), paras. 99, 104-105, 109, 117-119, 122, 136; D2280 (Map of Sarajevo); D2285 (Satellite photograph of Sarajevo); Andrey Demurenko, T. 28912-28920 (16 October 2012), T. 28986-28990 (17 October 2012) (testifying that when he started his investigation he did not have the UNPROFOR report referring to 170 degrees and that the discrepancy in any event did not matter because ultimately his team looked at a broad area to the right and to the left of the precise location, thus encompassing the margin of error). The Chamber notes, however, that contrary to his evidence, Demurenko can be seen in his interview holding the very UNPROFOR report he claimed he did not have or use during his investigation. Later, in re-examination, Demurenko testified that the team also explored the area starting from 160 degrees. See Andrey Demurenko, T. 28991 (17 October 2012). The Chamber notes that Demurenko had not mentioned a visit to the areas covered by the direction of fire of 160 degrees despite having given detailed evidence about his investigation in the Dragomir Milošević case. In addition, he did not mention it in the interview he gave following his investigation. Accordingly, the Chamber does not find his evidence on this matter credible.

14400 D2270 (Witness statement of Andrey Demurenko dated 13 October 2012), paras. 56, 64, 88; D2311 (Interview with Andrey Demurenko, 6 September 1995).

14401 D2270 (Witness statement of Andrey Demurenko dated 13 October 2012), paras. 57, 90-91, 112-114; D2277 (Photograph of Andrey Demurenko); D2278 (Photograph of Andrey Demurenko); Andrey Demurenko, T. 28991 (17 October 2012) (explaining in court that the majority of the terrain was covered by forest).

14402 D2270 (Witness statement of Andrey Demurenko dated 13 October 2012), paras. 90, 107, 116. 
15 metres alone; later he conceded that the margin of error in the azimuth (of plus or minus five degrees) meant that each of the locations he visited would have had a radius of between 175 and 315 metres, depending on the charge. ${ }^{14403}$ He said that he visited those wider areas and conceded that some of them would have been suitable for placing a mortar, but testified that those showed no traces of mortar placement when he inspected them. ${ }^{14404}$ On cross-examination, when put to him that this is not what he said previously, in the Dragomir Milošević case, Demurenko agreed, explaining that he wanted to focus on the specific four locations in his testimony but that in fact the team went to many more. ${ }^{14405}$

4291. Demurenko further conceded that he used firing tables for an M52 $120 \mathrm{~mm}$ mortar but denied that this would have resulted in different positions to the positions given in firing tables for an M74 $120 \mathrm{~mm}$ mortar, which was said to have been used in Markale. ${ }^{14406}$ During crossexamination in this case, he conceded that he did not know which shell was used in Markale when he conducted his investigation, but that this made no difference to his team because they checked the entire slope. ${ }^{14407}$ The Chamber notes that according to his Associated Press interview, Demurenko placed charge three at 2,000 metres, rather than at 2,400 to 2,500 metres as done by Turkušić. ${ }^{14408}$

4292. Commenting on the UNPROFOR conclusions relating to the UN radar, Demurenko testified that they were "absolutely wrong" because mortars that fired from middle to long range would have had a higher, not lower, trajectory and thus would have been detected by the UN radar. ${ }^{14409} \mathrm{He}$ also

\footnotetext{
14403 D2270 (Witness statement of Andrey Demurenko dated 13 October 2012), paras. 97-99, 113, 122; Andrey Demurenko, T. 28921-28935 (16 October 2012). While Demurenko testified that his evidence on the deviation of 15 metres or less was misunderstood by the D. Milošević Chamber, the Chamber considers this not to be the case. Instead, Demurenko has simply changed his evidence following the Milošević judgement.

14404 D2270 (Witness statement of Andrey Demurenko dated 13 October 2012), paras. 106-109, 115, 124; D2282 (Photograph of a meadow); D2283 (Photograph of a meadow); D2285 (Satellite photograph of Sarajevo); D2279 (Photograph of Andrey Demurenko); Andrey Demurenko, T. 28913-28914, 28936-28939 (16 October 2012), T. 28941-28943 (17 October 2012); P5918 (SRK Order, 23 August 1995) (indicating that SRK was using temporary firing positions at the time).

14405 Andrey Demurenko, T. 28927-28935 (16 October 2012), T. 28952-28953 (17 October 2012).

14406 D2270 (Witness statement of Andrey Demurenko dated 13 October 2012), para. 92.

14407 Andrey Demurenko, T. 28946-28961 (17 October 2012); P5919 (Excerpt of Drina Corps inventory sheet); P5920 (Excerpt of mortar firing table); P5921 (Firing tables for M74 $120 \mathrm{~mm}$ light mortar); P5922 (Firing tables for M75 $120 \mathrm{~mm}$ light mortar); P5923 (Firing tables for M52 $120 \mathrm{~mm}$ mortar).

14408 Compare D1010 (Video footage of Colonel Demurenko's interview, with transcript) and D2281 (Drawing of angles and distance of mortar shells by Andrey Demurenko) with Emir Turkušić, T. 9019 (4 November 2010).

14409 D2270 (Witness statement of Andrey Demurenko dated 13 October 2012), paras. 125, 133; D2276 (Drawing by Andrey Demurenko).
} 
noted that, contrary to the report's conclusion that the confrontation line was 1,050 metres away from the incident site, it was in fact around 2,000 metres away. ${ }^{14410}$

4293. Demurenko thought that the incident was a "terrorist attack" organised within Sarajevo, as the $120 \mathrm{~mm}$ mortar shell could not have caused that many casualties and was not heard or registered by anyone. ${ }^{14411}$ Conceding that mortars were designed to hit targets behind obstacles, he also thought that the chances of the first shell hitting Markale was "one in a million" though the market was struck twice during the war. ${ }^{14412}$ According to Demurenko, it would have been very easy to create a crater by a detonation device placed in an urn, although he acknowledged that he had no evidence for this. ${ }^{14413}$

4294. Hogan testified that he tested Demurenko's evidence by going - as close as possiblepositions visited by him in 1995 and took photographs and GPS readings of them. ${ }^{1414}$ The Chamber notes that a number of these photographs show locations which are not covered by forest and look suitable for the placement of mortars. The Chamber also notes that Zorica Subotić, while criticising Hogan for checking the positions on this trajectory and implying that he did so in order to find a suitable firing position, contradicted Demurenko's conclusion by testifying that there was in fact a suitable firing position on the trajectory of 176 degrees. ${ }^{14415}$

\section{(e) Aftermath and NATO air strikes}

4295. After the incident and before he went to the scene that day, Harland spent much of his time discussing with Smith what the next steps would be and the fact that if it were determined that the shell was fired by the Serbs, there would have to be a major military response. ${ }^{14416}$ On the day of the incident itself and the following day, Smith had three conversations with Mladić, during which they discussed the circumstances surrounding the incident. ${ }^{14417}$ In the first conversation, which

\footnotetext{
14410 D2270 (Witness statement of Andrey Demurenko dated 13 October 2012), para. 133; D2281 (Drawing of angles and distance of mortar shells by Andrey Demurenko).

14411 D2270 (Witness statement of Andrey Demurenko dated 13 October 2012), paras. 54, 65, 139; Andrey Demurenko, T. 28926-28927, 28936-28938 (16 October 2012).

14412 D2270 (Witness statement of Andrey Demurenko dated 13 October 2012), paras. 58, 60, 65; D2286 (Drawing of shell trajectory re shelling of Markale on 28 August 1995); D2328 (Photograph of Sarajevo from Trebević); Andrey Demurenko, T. 28936-28939 (16 October 2012).

14413 D2270 (Witness statement of Andrey Demurenko dated 13 October 2012), paras. 65-66; Andrey Demurenko, T. 28971 (17 October 2012) (conceding that he was not an expert in terrorism and static explosions).

14414 Barry Hogan, T. 11225-11230, 11283-11284 (3 February 2011); P2214 (Aerial satellite image of Sarajevo); P2215 (Photographs re shelling of Markale on 28 August 1995.

14415 D3551 (Zorica Subotić's expert report entitled "Mortar Attacks on the Sarajevo Area: Incidents at the Markale Market 5 February 1994 and 28 August 1995”, 15 August 2012), p. 139.

14416 P820 (Witness statement of David Harland dated 4 September 2009), para. 229.

14417 Rupert Smith, T. 11454-11455 (9 February 2011); P2289 (UNPROFOR report re conversations with Ratko Mladić, 25-29 August 1995), e-court p. 3.
} 
took place at 2:13 p.m. on 28 August 1995, Smith explained to Mladic the seriousness of the situation and that all facts at that point were indicating that the incident was committed by the VRS. ${ }^{14418}$ Mladić agreed to carry out a comprehensive assessment to ensure that no weapons had been fired without authority but also claimed that this was an attack by the Bosnian Muslims designed to discredit the VRS. ${ }^{14419}$ Mladić also urged Smith to set up a joint investigation team comprising both warring factions and the UNPROFOR. ${ }^{14420}$

4296. On the same day, at around 1 p.m., Colonel Čedomir Sladoje issued an order on behalf of the SRK Command ordering a ban on use of fire and asking all SRK brigades to inform the Command, by 2 p.m. whether they had opened fire on Sarajevo between 10 a.m. and 12 p.m. that day. ${ }^{14421}$ Later that day the VRS Main Staff reported to the Accused that the SRK brigades did not open fire on Sarajevo between 10 a.m. and 12 p.m.. ${ }^{14422}$

4297. At 6:23 p.m. that day, Mladić reported to Smith that no VRS forces were involved in the incident. ${ }^{14423}$ In return, Smith told Mladić that the UNMO investigation had established that the round was a $120 \mathrm{~mm}$ mortar round probably fired from the south. ${ }^{14424}$ On the evening of 28 August 1995, while Janvier was on leave, Smith decided to initiate the NATO bombing campaign. ${ }^{14425} \mathrm{He}$ testified that he was confident at that point that the Bosnian Serbs were responsible for this incident based not only the findings on the direction of fire he received from the various UN investigators but, more significantly, on the fact that none of the UN personnel had heard these shells being fired from within the proximity of Sarajevo. ${ }^{14426}$

4298. The next day, 29 August at 10 a.m., Smith informed Mladić that it was now beyond reasonable doubt that the shells had come from the VRS territory and that the investigation had revealed that the origin of fire was approximately 3.5 to 4 kilometres southwest of the impact

\footnotetext{
14418 P2289 (UNPROFOR report re conversations with Ratko Mladić, $25-29$ August 1995), e-court p. 3.

14419 P2289 (UNPROFOR report re conversations with Ratko Mladić, 25-29 August 1995), e-court p. 3. See also Rupert Smith, T. 11544-11545 (10 February 2011); D1013 (SRK Order, 28 August 1995).

14420 P2289 (UNPROFOR report re conversations with Ratko Mladić, 25-29 August 1995), e-court p. 3.

14421 D1013 (SRK Order, 28 August 1995).

14422 D2313 (VRS Main Staff Report, 28 August 1995).

14423 P2289 (UNPROFOR report re conversations with Ratko Mladić, 25-29 August 1995), e-court p. 3. See also Rupert Smith, T. 11565-11571 (10 February 2011); D1015 (Intercept of conversation between Ratko Mladić and Unknown, undated), e-court pp. 3-4.

14424 P2289 (UNPROFOR report re conversations with Ratko Mladić, 25-29 August 1995), e-court p. 3.

14425 Rupert Smith, T. 11456 (9 February 2011), 11505-11509 (10 February 2010); D1009 (Excerpt from Rupert Smith's book entitled "The Utility of Force: The Art of War in the Modern World"), pp. 367-368.

14426 Rupert Smith, T. 11456-11458 (9 February 2011). When it was put to Smith during cross-examination that, in light of the first UNMO report prepared by Konings on 28 August, he could not have known on that day that the Bosnian Serbs were responsible for the Markale incident, Smith explained that he had other sources of reporting in his office. See Rupert Smith, T. 11509-11511 (10 February 2011); P150 (UNMO report, 28 August 1995).
} 
point. ${ }^{14427}$ Mladić responded that he had checked all SRK firing positions and that the shell had not been fired by his soldiers; he once again urged Smith to set up a joint commission claiming there were a number of indications to suggest that the incident had been "orchestrated by the BiH". ${ }^{14428}$ When shown a report Janvier sent to Kofi Annan on 29 August 1995 at 10:36 a.m.--half an hour after Smith's third conversation with Mladić-in which Janvier informed Annan that the origin of fire was still being investigated and was difficult to establish due to the impossibility of determining the charge with which the shell was fired, Smith stated that he could not comment on what was going on in the UN Headquarters. ${ }^{14429}$ When asked why he was sure "beyond reasonable doubt" that the Bosnian Serbs were responsible for the incident given the fact that the UN reports were using more careful language, such as "most likely", Smith explained that while his conclusion was not an "absolute positive", it meant that it was "most likely to be positive" and reiterated that it was based on a number of factors, including that no one heard a round being fired from the proximity of Sarajevo. ${ }^{14430}$

4299. Also on 29 August, at 4:30 p.m., the Accused, Mladić, Plavšić, Krajišnik, Tolimir and Gvero, among others, met with the FRY leadership, including Slobodan Milošević, Momir Bulatović, and Momčilo Perišić, to discuss the upcoming peace conference. ${ }^{14431}$ During this meeting, Milošević proposed that the Bosnian Serb leadership criticise the shelling and the killing of innocent civilians in Sarajevo "in a more severe way" to which Tolimir reacted saying that by 11 a.m. on that day, no one had precise information on where the shell had come from. ${ }^{14432}$ Milošević retorted, however, that Akashi had informed him at 2:30 p.m. that the shell came from the Bosnian Serb side to which Mladić said that the shells had come from two different directions (170 and 220 degrees) neither of which could have been from the Serb positions but only from the Muslim

See also Rupert Smith, T. 11922-11924 (15 February 2011); D1063 (UNPROFOR daily situation report, 29 August 1995), p. 2.

14427 Rupert Smith, T. 11511-11512 (10 February 2011); P2289 (UNPROFOR report re conversations with Ratko Mladić, 25-29 August 1995), e-court p.3.

14428 P2289 (UNPROFOR report re conversations with Ratko Mladić, 25-29 August 1995), e-court p. 3. Smith explained that he was not inclined to accept Mladić's proposal for a joint commission as it would have only prolonged the process but nevertheless wanted to be absolutely sure as to who had fired the shells before ordering the attacks. See Rupert Smith, T. 11456-11457 (9 February 2011).

14429 Rupert Smith, T. 11512-11514 (10 February 2011); P906 (UNPROFOR daily report, 28-29 August 1995), p. 2. During cross-examination, Smith was shown Demurenko's interview and conceded that he never visited these positions. He testified that he did not take Demurenko into account at the time, as the interview was filmed some days after Smith had already made the decision to initiate the bombing. See Rupert Smith, T. 11520 11526 (10 February 2011). See also P820 (Witness statement of David Harland dated 4 September 2009), para. 232; David Harland, T. 2320 (11 May 2010).

14430 Rupert Smith, T. 11514-11515 (10 February 1995), T. 11905-11906 (15 February 2011); P1445 (UNPROFOR report re shelling of Markale on 28 August 1995), e-court p. 3.

14431 D3051 (Witness statement of Momir Bulatović dated 25 February 2013), paras. 35A-35C; D3058 (Record of meeting between leaderships of FRY and RS, 29 August 1995), p. 1.

14432 D3058 (Record of meeting between leaderships of FRY and RS, 29 August 1995), p. 8. 
mobile launching pads. ${ }^{14433}$ Mladić also voiced his doubt about the number of victims given the size of the crater, which he deemed to be "not bigger than an ashtray". ${ }^{14434}$

4300. On 30 August 1995 at around 2 a.m., the NATO air strikes began and letters were sent to Mladić, the Accused, and Slobodan Milošević informing them of this fact. ${ }^{14435}$ The letter to Mladić was written by Janvier, informing him that a thorough investigation was conducted and found that the fire on Markale came from the VRS positions south-southwest of Sarajevo ${ }^{14436}$ thus resulting in the initiation of the air strikes, that the object of the air strikes was to prevent further shelling of Sarajevo, and that the attacks would cease once Janvier was convinced that the threat of further shelling by the SRK had been eliminated. ${ }^{14437}$ Letters to Milošević and the Accused were written by Akashi, wherein he informed them what the UN teams concluded with respect to Markale and about the initiation of the air strikes; in the letter to the Accused Akashi also wrote that the "key to stopping the air action" was in the Accused's and Mladić's hands and strongly urged him to ensure that the attacks on Sarajevo stopped. ${ }^{14438}$

4301. On 1 September 1995, the air strikes stopped and Janvier and Banbury met with Mladić, Perišić, Gvero, and Tolimir in Mali Zvornik to discuss the current situation; they told Mladić that the investigation results clearly identified the Bosnian Serbs as the perpetrators, to which Mladić responded that Markale was "a pretext to gain a corridor for the Muslims to Sarajevo". ${ }^{14439}$

4302. Smith also conceded that the preparations for military action against the Bosnian Serbs began before the Markale incident, namely following the London Conference, when he started withdrawing UN troops from Goražde, and that he was waiting for an "event to occur", such as an attack on a safe area, that would lead to a military action. ${ }^{14440}$ He testified that in the immediate

\footnotetext{
14433 D3058 (Record of meeting between leaderships of FRY and RS, 29 August 1995), pp. 8-9; D3051 (Witness statement of Momir Bulatović dated 25 February 2013), para. 35C.

14434 D3058 (Record of meeting between leaderships of FRY and RS, 29 August 1995), p. 9.

14435 P2826 (UNPROFOR report re NATO air strikes, 30 August 1995); D2815 (SRK report, 30 August 1995); see Adjudicated Fact 2798.

14436 The Chamber notes that the reference to the south-southwest direction in the letter, indicates that Janvier was relying on the conclusion that the shell came from a bearing of 220 to 240 degrees, rather than the findings made by the CSB Sarajevo and UNMO teams.

14437 P2826 (UNPROFOR report re NATO air strikes, 30 August 1995), e-court p. 2.

14438 P2826 (UNPROFOR report re NATO air strikes, 30 August 1995), e-court pp. 3-4.

14439 P2451 (Witness statement of Anthony Banbury dated 19 May 2009), paras. 183-192; P2509 (Anthony Banbury's notes, 1 September 1995), e-court p. 18-19, 22; Adjudicated Fact 2798.

14440 Rupert Smith, T. 11503-11508, 11531-11533 (10 February 2011); D1009 (Excerpt from Rupert Smith's book entitled "The Utility of Force: The Art of War in the Modern World"), pp. 363, 366-369.
} 
aftermath of the incident he was under pressure from UNPROFOR Headquarters in Zagreb, BiH authorities, and the NATO itself to make the "decision that was required of him". ${ }^{14441}$

4303. On 2 September 1995, Janvier sent a telegram to Annan, wherein he addressed speculation in the media that the shell could not have come from the Bosnian Serbs. ${ }^{14442}$ According to this telegram, "[t]here is no disagreement about the difficulty of deliberately hitting [that area]" but that it is "most likely that the shot was just fired in the general area" and that it was "blind fire"; the fact that it then landed in the market was a "great misfortune". ${ }^{14443}$ It also provides that "[a]fter 40 months of shelling the City, it should not be a cause of surprise that one should eventually find such a tragic target."14444 Finally, the telegram summarises the findings that point to the VRS being responsible for the incident, namely that (i) all five shells had the same markings on the stabiliser; (ii) the radar was observing the area at an elevation of 960 metres 24 hours a day such that anything fired above that height would have been detected; and (iii) had the mortar rounds been fired from the ABiH side, the UNMOs, FreBat 4, EgyBat, would have heard the fire and it would have been picked up by the radar. ${ }^{14445}$ The telegram also notes that the idea that the shell was fired from few streets away is not supported by the entries in the logs of the neighbouring OPs. ${ }^{14446}$

4304. Harland testified that the principal doubt as to who fired the five mortar shells arose because Smith made a statement to the press, on Harland's advice, that UNPROFOR's investigation showed that it was unclear who fired the shell. ${ }^{14447}$ Harland advised Smith to make a neutral statement even though both men already knew that the Bosnian Serbs were found to be responsible. ${ }^{14448}$ According to Harland, this was a "necessary deception" as they were about to initiate large-scale air strikes against the Bosnian Serbs for which they had been preparing for some time in order to end the war, and therefore did not want to make any public statements that would allow the Bosnian Serbs to prepare by, for example, taking international hostages. ${ }^{14449}$ While still convinced that it

\footnotetext{
14441 Rupert Smith, T. 11528-11531 (10 February 2011); D1011 (Intercept of conversation between Rupert Smith and Ratko Mladić, undated).

14442 D1014 (UNPROFOR report, 2 September 1995). Smith denied ever seeing this telegram. See Rupert Smith, T. 11549-11553 (10 February 2011).

14443 D1014 (UNPROFOR report, 2 September 1995), p. 2.

14444 D1014 (UNPROFOR report, 2 September 1995), p. 2. Smith also thought that it was not Markale specifically that was being targeted but civilians in general. See Rupert Smith, T. 11547-11553 (10 February 2011); T. 11906-11907 (15 February 2011). Similarly, Konings testified that the shell may have been a "lucky shot" since a $120 \mathrm{~mm}$ mortar shell is an "area weapon" and not a specific pinpoint targeting system. See P1953 (Witness statement of Harry Konings dated 11 November 2010), para. 96.

14445 D1014 (UNPROFOR report, 2 September 1995), pp. 2-3.

14446 D1014 (UNPROFOR report, 2 September 1995), p. 2.

14447 P820 (Witness statement of David Harland dated 4 September 2009), para. 233.

14448 David Harland, T. 2044-2046 (6 May 2010); P820 (Witness statement of David Harland dated 4 September 2009), para. 233.

14449 P820 (Witness statement of David Harland dated 4 September 2009), para. 233. See also David Harland, T. 2124-2126 (7 May 2010).
} 
was the right course of action to take, Harland noted that it has been a cause of distress to him that he may have contributed to an "enduring myth" that there was doubt about who was responsible for this incident. ${ }^{14450}$

4305. On 4 September 1995, Mladić sent an angry letter to Smith, suggesting again a joint commission of experts for an investigation of the incident, and posing the following questions, among others:

Why do you not inform the public of the role which the Muslim side and a foreign country's Intelligence experts had in the screenplay 'Markale-2'? Why the public has never been informed about the scenario of 'Markale-1'? Are you hiding from the public the truth about 'Markale-1' and 'Markale-2' in order to justify the aggression against the $[\mathrm{RS}]$ made by NATO [...]? ? ${ }^{1451}$

4306. Prvoslav Davinić, director of the UN Centre for Disarmament Affairs at the time, ${ }^{14452}$ testified that he heard about the incident on the day it happened in a meeting with Under Secretary Goulding, who told the attendees that there were no clear indications at the time that the shell came from the Serb side and that one could not exclude the possibility that it came from the $\mathrm{ABiH} .{ }^{14453}$ According to Davinić, Goulding then instructed one of his staff to follow the developments on the ground and the next day the staff member filed a report in which she emphasised that the aim of the investigation on the ground was to show that the Bosnian Serbs fired the shell as it made no sense that the other side would; according to Davinić, once the Bosnian Serb side was blamed, there was talk in the UN corridors that the incident was not investigated properly and that political considerations had prevailed. ${ }^{1454}$

\section{(f) Firing positions south and southeast of Markale}

4307. The Chamber has already outlined the positions of the SRK units in the area south and southeast of Stari Grad and Markale, and recalls that much of Mt. Trebević was in the zone of responsibility of the $1^{\text {st }}$ Romanija Brigade and later the $1^{\text {st }}$ Sarajevo Mechanised Brigade. ${ }^{14455}$ In early August 1995, the SRK was re-organised again and the $4^{\text {th }}$ Sarajevo Light Infantry Brigade

\footnotetext{
14450 P820 (Witness statement of David Harland dated 4 September 2009), para. 234.

14451 D2310 (Letter from Ratko Mladić to UNPROFOR, 4 September 1995), pp. 2, 5. On the same day Mladić also met with SRK commanders to discuss the situation on the ground. See P1489 (Ratko Mladić's notebook, 28 August 1995-15 January 1996), e-court pp. 11-18. The air strikes resumed on 5 September and lasted until 14 September. See Adjudicated Fact 2799.

14452 D4217 (Witness statement of Prvoslav Davinić dated 14 January 2014), paras. 1, 5.

14453 D4217 (Witness statement of Prvoslav Davinić dated 14 January 2014), paras. 5-6.

14454 D4217 (Witness statement of Prvoslav Davinić dated 14 January 2014), paras. 6-8; Prvoslav Davinić, T. $45522-$ 45528, 45537-45543 (16 January 2014) (conceding, however, that he was not privy to the various UN reports relating to the investigations conducted by the UN into this incident).

14455 See para. 4171. See also P1058 (ABiH map); P1052 (VRS map of Sarajevo); P1021 (VRS map of Sarajevo).
} 
was created, which incorporated the Trebević and other battalions of the $1^{\text {st }}$ Romanija Brigade, with Stevan Veljović as the Commander of the new brigade. ${ }^{14456}$ The zone of responsibility of this new brigade included the area of Trebević and Vidikovac, and its weapons arsenal included a $120 \mathrm{~mm}$ and $82 \mathrm{~mm}$ mortar battery with firing positions in the Brus sector, southeast of Sarajevo on Mt. Trebević. ${ }^{14457}$ According to Veljović, on 24 August, on the order of the SRK Commander, ${ }^{14458}$ he sent the whole battery, together with its firing crew, to Trebinje to assist the Herzegovina Corps dealing with attacks from Croatia, and they remained there until mid-September. ${ }^{14459}$ Veljović was adamant that at the time of the Markale incident there was therefore not a single $120 \mathrm{~mm}$ mortar pointed in the direction of Markale. ${ }^{14460}$

4308. Dušan Škrba, at the time the Chief of Artillery in the $1^{\text {st }}$ Sarajevo Mechanised Brigade, ${ }^{14461}$ testified that no fire was opened on the day of the incident from his zone of responsibility southwest of Markale, particularly not from $120 \mathrm{~mm}$ mortars as those were relocated outside of the 20 kilometre circle around Sarajevo; thus, there were no firing positions for $120 \mathrm{~mm}$ mortars on the Miljevići axis or on the road towards the tower of Trebević. ${ }^{14462}$ Contrary to Veljović, however, he did not deny that smaller calibres, such as $82 \mathrm{~mm}$ mortars, remained in the area south of Sarajevo. ${ }^{14463}$

14456 D2351 (Witness statement of Stevan Veljović dated 19 October 2012), paras. 28-29; Stevan Veljović, T. 29248-29250 (23 October 2012). While Veljović referred to this brigade as the "4 $4^{\text {th }}$ Serbian Brigade", the documents indicate that the brigade's official name was $4^{\text {th }}$ Sarajevo Light Infantry Brigade. See e.g. P5944 (Report of $4^{\text {th }}$ Sarajevo Light Infantry Brigade to SRK, 31 August 1995).

14457 D2351 (Witness statement of Stevan Veljović dated 19 October 2012), paras. 29-30. See P1058 (ABiH map) and P1052 (VRS map of Sarajevo) for the location of Brus.

14458 At this time, the Commander was Čedo Sladoje because Dragomir Milošević had been wounded. See Stevan Veljović, T. 29262 (23 October 2012).

14459 D2351 (Witness statement of Stevan Veljović dated 19 October 2012), paras. 31-33; Stevan Veljović, T. 29265 (23 October 2012).

14460 D2351 (Witness statement of Stevan Veljović dated 19 October 2012), para. 34; Stevan Veljović, T. 2926229267 (23 October 2012). When shown his report to the SRK command, dated 31 August 1995, and listing the available weapons including a number of $120 \mathrm{~mm}$ mortars, Veljović stated that the mortars were at his disposal even though they were located in Trebinje. See Stevan Veljović, T. 29267-29268 (23 October 2012); P5944 (Report of $4^{\text {th }}$ Sarajevo Light Infantry Brigade to SRK, 31 August 1995).

14461 D2341 (Witness statement of Dušan Škrba dated 14 October 2012), para. 7; Dušan Škrba, T. 29107-29108 (18 October 2012) (testifying that he became the chief of artillery in 1994, having replaced Savo Simić).

14462 D2341 (Witness statement of Dušan Škrba dated 14 October 2012), para. 24; Dušan Škrba, T. 29117 (18 October 2012).

14463 Dušan Škrba, T. 29117 (18 October 2012). Also contradicting Veljović's evidence was Miloš Škrba, a member of the $1^{\text {st }}$ Sarajevo Mechanised Brigade, who lived in Petrovići and had relatives in the village of Studenkovići, south of Markale. He testified that while he never saw $120 \mathrm{~mm}$ mortars in Studenkovići or in the vicinity of the road connecting Petrovići and Studenkovići, he saw one $82 \mathrm{~mm}$ mortar on that road in August 1995. See D2344 (Witness statement of Miloš Škrba dated 14 October 2012), para. 10; D2346 (Map of Sarajevo marked by Miloš Škrba); Miloš Škrba, T. 29195-29198 (22 October 2012) (appearing to then contradict his witness statement by testifying that his evidence about the lack of $120 \mathrm{~mm}$ mortars in the area concerned mostly 1992 and 1993 and that he did not in fact know about 1995); P5939 (Map of Trebević marked by Miloš Škrba). Miloš Škrba's witness statement is also contradicted by the SRK order of 9 May 1995 in which Dragomir Milošević refers to 
4309. Prior to becoming Chief of Artillery, Dušan Škrba was the Commander of the Mixed Artillery Battalion of the brigade, which had four firing positions, that included, among other weapons, $120 \mathrm{~mm}$ mortars; these mortars were located east of Lukavica, in the Prljevo Brdo and Uzdojnica sectors (that is, southwest of Markale), and were permanently positioned there until they had to be relocated outside of the TEZ in August 1995. ${ }^{14464}$ Contradicting Dušan Škrba was Blagoje Kovačević, whose unit's zone of responsibility covered the area at 220 degrees from the north, and who testified that there was no SRK artillery on that line, not even $82 \mathrm{~mm}$ mortars. ${ }^{14465}$

4310. Dragomir Milošević testified that following the incident he was told by Čedo Sladojević, Lugonja, and other SRK officers that on the day of the incident no fire was opened on Markale by the SRK. ${ }^{14466}$

4311. As noted earlier, ${ }^{14467}$ the $\mathrm{ABiH}$ held positions on the northern base of Mt. Trebević. ${ }^{14468}$ Asim Džambasović testified that the $10^{\text {th }}$ Mountain Brigade of the $\mathrm{ABiH} 1^{\text {st }}$ Corps held the area roughly from Miljacka River to the south up to the northern slopes of Trebević, and all the way up to Zlatište and the Vraca Monument beyond the Jewish cemetery; its zone of responsibility covered the areas of Soukbunar, Skenderija, Bostarići and the neighbourhood of Cicin Han Lipa. ${ }^{14469}$ Debelo Brdo and Čolina Kapa were also held by the $\mathrm{ABiH} .{ }^{14470}$ Conway recounted that in December 1995, as the UNMO mission was coming to a close, he came across four ABiH mortars "at the bottom of a steep hill in the southern hills of Sarajevo", an area in which the UNMOs had not been permitted to patrol; the four mortars were pointed north, towards the city, and appeared to

an $82 \mathrm{~mm}$ mortar platoon and a $120 \mathrm{~mm}$ mortar battery located in Trebević-Palež sector. See P5940 (SRK Order, 9 May 1995), pp. 4-5.

14464 See D2341 (Witness statement of Dušan Škrba dated 14 October 2012), paras. 7, 9; D2342 (Map of Sarajevo marked by Dušan Škrba); D2343 (Map of Sarajevo marked by Dušan Škrba); Dušan Škrba, T. 29104-29108, 2911129113 (18 October 2012); P5933 (Map of Sarajevo marked by Dušan Škrba); P5934 (Map of Sarajevo marked by Dušan Škrba); D2412 (Witness statement of Savo Simić dated 4 November 2012), para. 12; D2413 (Map of Sarajevo marked by Savo Simić).

14465 D2331 (Witness statement of Blagoje Kovačević dated 14 October 2012), para. 51; D2333 (Topographical map of Sarajevo).

14466 Dragomir Milošević, T. 32756 (28 January 2013).

14467 See para. 4171.

14468 See Adjudicated Fact 104; P1764 (ABiH Map of Sarajevo); P1058 (ABiH map); D1380 (Map of ABiH positions in Sarajevo marked by Asim Džambasović); Alen Gičević, T. 7657-7661 (11 October 2010); D733 (Photograph of Sarajevo marked by Alen Gičević); D734 (Photograph of street sign in Sarajevo).

14469 Asim Džambasović, T. 15223-15225 (22 June 2011) (noting also that the $10^{\text {th }}$ Mountain Brigade later merged with the $1^{\text {st }}$ Mountain Brigade to form the $115^{\text {th }}$ Brigade); D1378 (Map of ABiH positions in Sarajevo marked by Asim Džambasović); D1380 (Map of ABiH positions in Sarajevo marked by Asim Džambasović). See also Stanislav Galić, T. 37184, 37188 (15 April 2013), T. 37417 (18 April 2013), T. 37474 (22 April 2013), T. 37934 (8 May 2013).

14470 See Adjudicated Facts 105 and 2830; D2389 (Witness statement of Predrag Trapara dated 3 November 2012), para. 21. 
have been there for a considerable period of time as they were sandbagged and maintained. ${ }^{14471}$ At first Conway indicated, by placing them just north-east of Mrakuša, that these mortars were positioned south-southeast of Markale market. ${ }^{14472}$ However, when shown a more detailed map on cross-examination, he placed them north of Mrakuša, and thus south-southwest of Markale. ${ }^{14473}$

4312. The Chamber notes that an $\mathrm{ABiH}$ working map for the period relevant to the incident does show an $\mathrm{ABiH}$ mortar position in the relevant area; however, that position was located immediately northeast of Čolina Kapa, and thus southeast of Markale, rather than north of Mrakuša as testified to by Conway. ${ }^{14474}$

\section{(g) Post-war investigations}

4313. Higgs was asked by the Prosecution to investigate this incident based on many of the reports and investigative materials referred to above, including $\mathrm{BiH}$ MUP reports and videos, the statements of Konings and Knustad, and the UNPROFOR and UNMO reports. ${ }^{14475}$ He confirmed that the stabiliser found at the scene indicated the projectile was a $120 \mathrm{~mm}$ shell, the range of which spanned from 300 to 6,200 metres. ${ }^{14476}$ Higgs thought that Powers' report was incorrect as its conclusion was based on the fuse furrow despite the furrow not being of the best quality due to the nature of the ground and the shell's angle of descent. ${ }^{14477}$ Since there was no visible or reliable fuse furrow, the correct methodology for determining the bearing was to use the crater shape as the primary source of information, which was done by all the other investigation teams, who all came to the conclusion that the bearing was 170 degrees from the north. ${ }^{1448}$ Higgs commented on the four other shells that landed near Markale on the day of the incident, noting that the fact that they came from 220 to 240 degrees from north is what may have caused the confusion because the

\footnotetext{
14471 D2329 (Witness statement of Paul Conway dated 7 November 2011), paras. 17-23. Conway also testified that during his time as a patrolling UNMO, namely between 19 August and late September 1995, he never observed any mortar fire into the city from the south but did observe rocket, sniper, and rifle fire. See Paul Conway, T. 29001, 29016-29022 (17 October 2012). But see P5929 (UNMO report, 1 September 1995), pp. 3, 17 (indicating that on 30 August 1995 a $120 \mathrm{~mm}$ mortar round impacted inside the Maršal Tito Barracks, coming from a bearing of 160 degrees); P5928 (Map of Sarajevo marked by Paul Conway).

14472 D2329 (Witness statement of Paul Conway dated 7 November 2011), para. 18; D2330 (Map of Sarajevo marked by Paul Conway); Paul Conway, T. 28999-29000 (17 October 2012).

14473 Paul Conway, T. 29005-29007, 29015-29016 (17 October 2012); P5927 (Map of Sarajevo marked by Paul Conway).

14474 P1058 (ABiH map); P6301 (Reference table of military symbols).

14475 P1437 (Richard Higgs's Consolidated Report on Sarajevo Shelling Incidents, 13 March 2009), p. 18; Richard Higgs, T. 5929-5930 (18 August 2010).

14476 P1437 (Richard Higgs's Consolidated Report on Sarajevo Shelling Incidents, 13 March 2009), p. 19.

14477 P1437 (Richard Higgs's Consolidated Report on Sarajevo Shelling Incidents, 13 March 2009), p. 19; Richard Higgs, T. 5932 (18 August 2010).

14478 P1437 (Richard Higgs's Consolidated Report on Sarajevo Shelling Incidents, 13 March 2009), pp. 19-20, 23. See also Richard Higgs, T. 5936-5938 (18 August 2010); P1448 (BiH MUP Report re shelling of Markale on 28 August 1995); P1449 (Criminal investigation file re shelling of Markale on 28 August 1995), e-court p. 2.
} 
UNPROFOR investigators simply presumed that all five shells must have come from the same firing position. ${ }^{14479}$ Finally, Higgs conducted his own analysis of the bearing using the data supplied to him and came to the conclusion that the bearing of the Markale shell was one of 175 degrees. $^{14480}$

4314. As for the angle of descent, while difficult to ascertain, Higgs thought it probable that it was between 67 and 75 degrees and probably nearer 70 degrees, as determined by Turkušić. ${ }^{14481}$ Using that angle, Higgs identified several locations as the possible origin of fire, namely 900, 1,600, 2,400, and 3,000 metres away from Markale in the established direction of fire, starting with charge one and ending with charge four respectively. ${ }^{14482}$ Plotting these locations on the map, and noting the shallow crater and the fact that the UNMOs did not hear the shell being fired and that their radar did not detect it, Higgs concluded, again confirming Turkušić's testimony, that the shell was most likely fired from 2,400 metres away using charge three, as this would have put the firing position out of the ear shot of the UNMOs. ${ }^{14483}$ In this position, the mortar was also much higher than the target, giving it a large range and steeper angle of descent. ${ }^{14484}$

4315. According to Higgs, the firing of one single shell meant that there was only one objective to the fire, namely to "harass the enemy" by preventing free movement, causing casualties-which in urban environment will nearly always be civilian—and "pray[ing] on the minds of the people." 14485 Due to the nature of the conflict in Sarajevo, Higgs noted that it was simple to have the targets prerecorded all over the city and to know where the main meeting points were. ${ }^{14486}$ Thus, if one

\footnotetext{
14479 Richard Higgs, T. 5929-5932 (18 August 2010). Based on the traces around the crater, Turkušić also excluded the possibility of the bearing in the case of the Markale shell being between 220 and 240 degrees from the north. See Emir Turkušić, T. 9020-9022 (4 November 2010); P1929 (Photograph re shelling of Markale on 28 August 1995 marked by Emir Turkušić); P1930 (Photograph re shelling of Markale on 28 August 1995 marked by Emir Turkušić). Konings conceded that the team had to work very quickly and that there may have been a margin of error in the established bearing of 170 degrees. However, he thought that this was not sufficient to account for the difference between the bearing of the shell that hit Markale and the four earlier shells, concluding that the difference arose simply because the Markale shell was fired from a completely different location. See Harry Konings, T. 9328-9329, 9375-9377 (7 December 2010); P1953 (Witness statement of Harry Konings dated 11 November 2010), paras. 77-79, 82-87.

14480 P1437 (Richard Higgs's Consolidated Report on Sarajevo Shelling Incidents, 13 March 2009), pp. $20-21,23$. See also Richard Higgs, T. 5960-5977 (19 August 2010); D543 (Map of Markale); D544 (Map of Markale marked by Richard Higgs); D545 (Richard Higgs' report re shelling of Markale on 28 August 1995), pp. 10, 12; D546 (Photograph marked by Richard Higgs); D547 (Photograph marked by Richard Higgs).

14481 P1437 (Richard Higgs's Consolidated Report on Sarajevo Shelling Incidents, 13 March 2009), pp. $21,23$.

14482 P1437 (Richard Higgs's Consolidated Report on Sarajevo Shelling Incidents, 13 March 2009), p. 23. The Chamber received evidence that a $120 \mathrm{~mm}$ mortar shell cannot be fired on charge zero. See P5946 (Excerpt from firing tables for $120 \mathrm{~mm}$ mortar).

14483 Richard Higgs, T. 5932-5936 (18 August 2010), T. 5980-5982 (19 August 2010); P1437 (Richard Higgs's Consolidated Report on Sarajevo Shelling Incidents, 13 March 2009), pp. 23-24.

14484 P1437 (Richard Higgs's Consolidated Report on Sarajevo Shelling Incidents, 13 March 2009), p. 24.

14485 P1437 (Richard Higgs's Consolidated Report on Sarajevo Shelling Incidents, 13 March 2009), p. 20.

14486 P1437 (Richard Higgs's Consolidated Report on Sarajevo Shelling Incidents, 13 March 2009), p. 20. See also P1953 (Witness statement of Harry Konings dated 11 November 2010), para. 96.
} 
wanted to cause maximum effect from a single shell, then Markale would have been a prime target. ${ }^{14487}$ With respect to the other four shells that landed near Markale on the same day, Higgs noted that it is a common ploy to fire a shell that causes casualties in one area and then shortly afterwards fire others nearby where people may be gathering. ${ }^{14488}$ While it was not possible to determine that this was the case here, Higgs stated that the circumstances on that day were "similar and suspicious". 14489

4316. Zorica Subotić analysed this incident as well. Observing that it was the last of the nine Sarajevo incidents in which a large group of civilians died, she claimed that they all had in common a projectile of "unbelievable accuracy", with explosions occurring in places where many people were gathered. ${ }^{14490}$ According to her, while statistically possible for this to happen in one case, it is "statistically very improbable" and "for practical purposes [...] impossible" in nine separate cases. $^{14491}$

4317. Subotić also thought, having analysed the video footage of the incident, that it was difficult to find a "valid technical explanation" for certain scenes. ${ }^{14492}$ For example, she claimed that the nature of injuries sustained by some of the wounded persons "cannot be accepted as correct" given their respective proximity to the point of impact, so that it was inexplicable that they even survived the explosion, let alone were conscious, moving, and sitting up straight. ${ }^{14493}$ She dismissed Turkšić's evidence that a man seen hanging over a fence, with a large chest wound, was injured by mortar shell fragments, asserting that his injury could only have been caused by a "dense narrow

14487 P1437 (Richard Higgs's Consolidated Report on Sarajevo Shelling Incidents, 13 March 2009), p. 20.

14488 P1437 (Richard Higgs's Consolidated Report on Sarajevo Shelling Incidents, 13 March 2009), p. 21.

14489 P1437 (Richard Higgs's Consolidated Report on Sarajevo Shelling Incidents, 13 March 2009), p. 21. Konings testified that the four shells which landed some 10 minutes before the Markale incident could have been adjusting fire for the Markale shell and were fired into a different area in order to mask the intention of firing at the market. However, he thought it equally possible that the four shells were aimed at a completely different target. When asked during cross-examination how it was possible that the four shells landed near Markale without having been heard by the people in Markale, Konings stated that he did not know what the people in Markale market heard or did not hear that day. See Harry Konings, T. 9313-9314, 9387 (7 December 2010). See also P1953 (Witness statement of Harry Konings dated 11 November 2010), para. 65; P1959 (Map of Sarajevo marked by Harry Konings). However, Savo Simić, Dušan Škrba's predecessor, noted that the four shells that preceded the Markale shell could not have been adjusting fire for the Markale shell as they came from a different position, and that therefore Markale was struck on the first attempt, which he thought virtually impossible. See D2412 (Witness statement of Savo Simić dated 4 November 2012), para. 32; Savo Simić, T. 30120-30122 (12 November 2012).

14490 D3551 (Zorica Subotić's expert report entitled "Mortar Attacks on the Sarajevo Area: Incidents at the Markale Market 5 February 1994 and 28 August 1995”, 15 August 2012), p. 122.

14491 D3551 (Zorica Subotić's expert report entitled "Mortar Attacks on the Sarajevo Area: Incidents at the Markale Market 5 February 1994 and 28 August 1995”, 15 August 2012), p. 123.

14492 D3551 (Zorica Subotić's expert report entitled "Mortar Attacks on the Sarajevo Area: Incidents at the Markale Market 5 February 1994 and 28 August 1995”, 15 August 2012), p. 123.

14493 D3551 (Zorica Subotić's expert report entitled "Mortar Attacks on the Sarajevo Area: Incidents at the Markale Market 5 February 1994 and 28 August 1995”, 15 August 2012), pp. 123-125, 159; Zorica Subotić, T. 38345 (15 May 2013), T. 38596-38598 (22 May 2013). 
beam" of fragments, which is not how a mortar shell fragments. ${ }^{14494}$ She added that his injuries were even less realistic in view of the fact that there was "almost no blood under this body on the pavement." 14495 Another example, according to her, was the presence of glass in front of the market hall building and up to the point of impact, which Subotić claimed was unusual as the glass should have been pushed into the market hall due to the detonation wave created in the street. ${ }^{14496}$ She also pointed out the presence of persons wearing camouflage uniforms, arguing that these were most likely members of the $\mathrm{ABiH}$ who were not there by accident but were organised, with one person issuing orders. ${ }^{14497}$

4318. With respect to the other four other mortar shells that fell on that day, Subotić noted that they struck the area of the National Theatre, some 235 metres from Markale market, and yet were not heard by any of the 71 witnesses interviewed by the police or by the UNMOs at Sedrenik's OP1, including Knustad. ${ }^{14498}$ Thus, Subotić claimed that the four explosions did not precede the Markale explosion. ${ }^{14499}$

4319. Noting that the video footage of the impact site shows that the crater and the traces of shrapnel can hardly be seen, Subotic thought that this was because the traces in the asphalt were shallow, which is typical of cases where the mortar shell has very low speed or when it is activated in static conditions. ${ }^{14500}$ She thus concluded that if the crater was caused by a mortar shell, that shell impacted at very low speed and thus could not have been fired with a charge larger than charge one. ${ }^{14501}$ According to her, the fact that the stabiliser was not found near the crater supported this conclusion, since the stabiliser of a shell fired at a charge higher than three is usually

\footnotetext{
14494 D3551 (Zorica Subotić's expert report entitled "Mortar Attacks on the Sarajevo Area: Incidents at the Markale Market 5 February 1994 and 28 August 1995”, 15 August 2012), p. 125; Zorica Subotić, T. 38345-38346 (15 May 2013).

14495 D3551 (Zorica Subotić's expert report entitled "Mortar Attacks on the Sarajevo Area: Incidents at the Markale Market 5 February 1994 and 28 August 1995”, 15 August 2012), pp. 125, 159; Zorica Subotić, T. 38598-38603 (22 May 2013).

14496 D3551 (Zorica Subotić's expert report entitled "Mortar Attacks on the Sarajevo Area: Incidents at the Markale Market 5 February 1994 and 28 August 1995”, 15 August 2012), pp. 127, 159; Zorica Subotić, T. 38346-38347 (15 May 2013).

14497 D3551 (Zorica Subotić's expert report entitled "Mortar Attacks on the Sarajevo Area: Incidents at the Markale Market 5 February 1994 and 28 August 1995", 15 August 2012), p. 128.

14498 D3551 (Zorica Subotić's expert report entitled "Mortar Attacks on the Sarajevo Area: Incidents at the Markale Market 5 February 1994 and 28 August 1995”, 15 August 2012), pp. 134-136; Zorica Subotić, T. 38331 (15 May 2013).

14499 D3551 (Zorica Subotić's expert report entitled "Mortar Attacks on the Sarajevo Area: Incidents at the Markale Market 5 February 1994 and 28 August 1995”, 15 August 2012), p. 136.

14500 D3551 (Zorica Subotić's expert report entitled "Mortar Attacks on the Sarajevo Area: Incidents at the Markale Market 5 February 1994 and 28 August 1995”, 15 August 2012), p. 137; Zorica Subotić, T. 38332-38333 (15 May 2013).

14501 D3551 (Zorica Subotić's expert report entitled "Mortar Attacks on the Sarajevo Area: Incidents at the Markale Market 5 February 1994 and 28 August 1995”, 15 August 2012), p. 137.
} 
embedded in the ground. ${ }^{14502}$ On the other hand, a shell fired at charges one or two will usually propel the stabiliser into the immediate vicinity of the crater or is propelled back along the approximate trajectory of the shell. ${ }^{14503}$

4320. In Subotić's opinion, the conclusion of the final UNPROFOR report that all five shells were fired from the same weapon as part of the same salvo has no technical merit as it is inconceivable that the Markale shell could have travelled more than 200 metres farther than the other shells. ${ }^{14504}$ She further rejected the conclusion that the projectile hit a building first because the shell would have been activated upon the first impact and would have left a visible trace on the building; however, such trace was not registered. ${ }^{14505}$

4321. Subotić submitted that, while his method was acceptable, Higgs made a deliberate error when calculating the angle of the trajectory of the shell, as he took into account the wrong azimuth of the kerb on Maršala Tita street. ${ }^{14506}$ Correcting this mistake, she found that the trajectory of the shell was 155 degrees rather than 175 degrees, the former being within the margin of error of the azimuth determined by the Engineer Cell, namely 160 degrees plus or minus five degrees. ${ }^{14507}$

4322. Recalling that the minimum angle of descent had to be 67 degrees for the shell to clear the buildings, Subotic disputed the angle of descent determined by CSB Sarajevo and, using the specifications of an M62 120 mm mortar shell, calculated that the angle of descent was in fact 64

14502 D3551 (Zorica Subotić's expert report entitled "Mortar Attacks on the Sarajevo Area: Incidents at the Markale Market 5 February 1994 and 28 August 1995”, 15 August 2012), p. 137; Zorica Subotić, T. 38341-38342 (15 May 2013). Turkušić, however, denied that one could tell from the location of the stabiliser, some metres away from the point of impact, that the speed of the shell was low. See Emir Turkušić, T. 9078-9079 (4 November 2010) Higgs testified that the stabiliser could have landed any distance away from the crater and also could have bounced back off buildings to end up where it did. See Richard Higgs, T. 5982 (19 August 2010).

14503 D3551 (Zorica Subotić's expert report entitled "Mortar Attacks on the Sarajevo Area: Incidents at the Markale Market 5 February 1994 and 28 August 1995”, 15 August 2012), p. 137.

14504 D3551 (Zorica Subotić's expert report entitled "Mortar Attacks on the Sarajevo Area: Incidents at the Markale Market 5 February 1994 and 28 August 1995”, 15 August 2012), p. 139; Zorica Subotić, T. 38337-38338 (15 May 2013).

14505 D3551 (Zorica Subotić's expert report entitled "Mortar Attacks on the Sarajevo Area: Incidents at the Markale Market 5 February 1994 and 28 August 1995”, 15 August 2012), p. 139; Zorica Subotić, T. 38337-38338 (15 May 2013).

14506 D3551 (Zorica Subotić's expert report entitled "Mortar Attacks on the Sarajevo Area: Incidents at the Markale Market 5 February 1994 and 28 August 1995”, 15 August 2012), pp. 139-141, fn. 388 (Subotić believed that Higgs did not commit this error accidentally, because "there [were] indications that he also manipulated photos in other cases in order to prove the guilt of the accused, such as in the case of the mortar shell crater in Livanjska street [in the Milošević case].”); Zorica Subotić, T. 38330, 38334-38337 (15 May 2013); D3549 (Map of Sarajevo marked by Zorica Subotić).

14507 D3551 (Zorica Subotić's expert report entitled "Mortar Attacks on the Sarajevo Area: Incidents at the Markale Market 5 February 1994 and 28 August 1995", 15 August 2012), pp. 141-142 (relying also on photographs and video footage depicting the damage to the kerb in front of the Market Hall to confirm that the azimuth of the incoming trajectory was smaller than 160 degrees); Zorica Subotić, T. 38330, 38339-38341 (15 May 2013). See also D3644 (Expert report by Mile Poparić et al entitled "Inconsistencies of Experts Berko Zečević and Richard Higgs in Cases of the Shelling of Sarajevo", 15 August 2012), pp. 113-114; Mile Poparić, T. 39055-39057 (30 May 2013), T. 39061-39064 (31 May 2013). 
degrees. ${ }^{14508}$ Thus, the shell could not have landed in the location where the crater was but must have been statically activated or "reached the pavement in front of the Market Hall in some other way". 14509

4323. With respect to the stabiliser, Subotic claimed that because it was found 29 metres away from the crater, "laterally to the incoming trajectory", the explosion could not have occurred in a "regular" way, in which case the stabiliser would have been either embedded or located at the point of impact, or it would have been propelled back in the approximate direction from which it came. ${ }^{14510}$ Subotić also noted that the stabiliser fins were deformed in an unusual way and showed signs of erosion in some of the video footage, whereas the stabiliser in evidence, namely P1454, does not bear such traces. ${ }^{14511}$ Further, she thought that the holes on the cap of the stabiliser ${ }^{14512}$ which is in evidence, namely P1454, were differently aligned when compared to the video footage of the stabiliser at the scene, thus confirming that P1454 was not the stabiliser that hit Markale. ${ }^{14513}$ Looking at the video footage of the scene, Subotic saw an object marked by the police and thought that it was another stabiliser, which was purposefully not reported on by the police and the UN investigators; she also asserted that this stabiliser could not have been in that place as a result of an explosion. ${ }^{14514}$

4324. In order to support its case that P1454 is the stabiliser that was found in Markale on 28 August 1995, the Prosecution used it during Subotić's cross-examination to show that its cap was loose so that screwing it in or out would change the alignment of the holes; having confirmed this to be the case, Subotic claimed that when she had earlier looked at the stabiliser, in preparation

\footnotetext{
14508 D3551 (Zorica Subotić's expert report entitled "Mortar Attacks on the Sarajevo Area: Incidents at the Markale Market 5 February 1994 and 28 August 1995”, 15 August 2012), pp. 143-145; Zorica Subotić, T. 38332 (15 May 2013).

14509 D3551 (Zorica Subotić's expert report entitled "Mortar Attacks on the Sarajevo Area: Incidents at the Markale Market 5 February 1994 and 28 August 1995”, 15 August 2012), p. 145.

14510 D3551 (Zorica Subotić's expert report entitled "Mortar Attacks on the Sarajevo Area: Incidents at the Markale Market 5 February 1994 and 28 August 1995”, 15 August 2012), p. 147; Zorica Subotić, T. 38333-38334 (15 May 2013). When put to her in cross-examination that the stabiliser could have hit a building after it ejected and then landed in the location seen on the photograph, Subotic thought that this was not very likely given the distance from the crater. See Zorica Subotić, T. 38571-38572 (21 May 2013).

14511 D3551 (Zorica Subotić's expert report entitled "Mortar Attacks on the Sarajevo Area: Incidents at the Markale Market 5 February 1994 and 28 August 1995”, 15 August 2012), pp. 146-149; Zorica Subotić, T. 38348-38351 (15 May 2013); D3550 (Photograph of stabiliser marked by Zorica Subotić).

14512 The cap of the stabiliser is the casing for the standard charge of the shell. See Zorica Subotić, T. 38612-38613 (22 May 2013).

14513 D3551 (Zorica Subotić's expert report entitled "Mortar Attacks on the Sarajevo Area: Incidents at the Markale Market 5 February 1994 and 28 August 1995”, 15 August 2012), pp. 148-150; Zorica Subotić, T. 38351-38352 (15 May 2013) (testifying that the position of the holes could not be changed once fixed).

14514 D3551 (Zorica Subotić's expert report entitled "Mortar Attacks on the Sarajevo Area: Incidents at the Markale Market 5 February 1994 and 28 August 1995”, 15 August 2012), pp. 150-152 (Subotić also calculated the azimuth of the second stabiliser, basing her calculations on the assumption that it was some 20 metres away
} 
for her report, the cap was either not loose or she did not notice that it was. ${ }^{14515}$ The Prosecution also tendered a document indicating that the "KB 9307" series of shells was tested in Serbia in March 1994. ${ }^{14516}$

4325. Subotic challenged UNPROFOR's conclusion that the shell came from between 1,550 to 3,500 metres away, arguing that had that been the case, it would not have attained the minimum angle of descent necessary to clear the buildings. ${ }^{14517}$ Looking at the ranges used by the UNPROFOR in its analysis in relation to the UN radar, Subotić guessed which firing tables they used and then used the same tables to determine the height at which the radar beam would detect a shell, namely 550 metres or higher. ${ }^{14518}$ Analysing the possible trajectories, based on the angles of descent of 67 and 70 degrees, she found that the UN radar would have detected every shell fired from the SRK positions. ${ }^{14519}$ Arguing further that the shell would have been heard if fired from the $\mathrm{ABiH}$ positions, that is, with charges one and two, she concluded that the explosion at Markale market must have been static, the mortar shell having been activated in "one of the known ways" or thrown from a roof. ${ }^{14520}$ Nevertheless, she visited sites that corresponded to charges three and four for all the trajectories relevant to this incident and found no suitable firing positions due to hilly and forested terrain, except in one location, at the trajectory of 175 degrees and a distance of 3,800

from the point of impact; the azimuth she determined was around 250 degrees, which was similar to the azimuth of the other four shells that no one heard); Zorica Subotić, T. 38330, 38352-38353 (15 May 2013).

14515 Zorica Subotić, T. 38572-38580, 38586-38587, 38592-38593 (21 May 2013), T. 38612-38614 (22 May 2103); P6329 (Screenshot of a stabiliser); P6330 (Screenshot of a stabiliser). Later in re-examination, Subotić noted another difference between the photographs of the stabiliser found on the scene and P1454, namely the positioning of the imprint made by the firing pin, which to her indicated that the two stabilisers were fired from different assets. See Zorica Subotić, T. 38612-38621 (22 May 2013); D3553 (Photograph of a stabiliser marked by Zorica Subotić); D3554 (Photographs comparing two stabilisers marked by Zorica Subotić); D3555 (Photographs of stabilisers).

14516 Zorica Subotić, T. 38580-38581 (21 May 2013); P6328 (Technical Test Centre note of weapon performance test, 28 March 1994). See also D3560 (Report of Nikinci Technical Testing Centre, 3 January 1994).

14517 D3551 (Zorica Subotić's expert report entitled "Mortar Attacks on the Sarajevo Area: Incidents at the Markale Market 5 February 1994 and 28 August 1995”, 15 August 2012), pp. 153-157, 163; Zorica Subotić, T. 38331 (15 May 2013).

14518 D3551 (Zorica Subotić's expert report entitled "Mortar Attacks on the Sarajevo Area: Incidents at the Markale Market 5 February 1994 and 28 August 1995", 15 August 2012), pp. 153-154; Zorica Subotić, T. 38342-38345 (15 May 2013), T. 38568-38571 (21 May 2013). The Chamber notes that while Subotić claimed that the firing tables she used were those for M49P1 $120 \mathrm{~mm}$ mortar shell fired by the M75 light $120 \mathrm{~mm}$ mortar, the table she attached to her report refers to M74 mortar. See D3551 (Zorica Subotić's expert report entitled "Mortar Attacks on the Sarajevo Area: Incidents at the Markale Market 5 February 1994 and 28 August 1995", 15 August 2012), p. 154, Figure 112. See also Mile Poparić, T.39065-39073 (31 May 2013) (also claiming that he and Subotić had looked at M49 shell).

14519 D3551 (Zorica Subotić's expert report entitled "Mortar Attacks on the Sarajevo Area: Incidents at the Markale Market 5 February 1994 and 28 August 1995”, 15 August 2012), p. 156. See also D3644 (Expert report by Mile Poparić et al entitled "Inconsistencies of Experts Berko Zečević and Richard Higgs in Cases of the Shelling of Sarajevo", 15 August 2012), pp. 114-115.

14520 D3551 (Zorica Subotić's expert report entitled "Mortar Attacks on the Sarajevo Area: Incidents at the Markale Market 5 February 1994 and 28 August 1995”, 15 August 2012), pp. 156-157, 179; Zorica Subotić, T. 38342 38344, 38353-38354 (15 May 2013), T. 38588-38591, (21 May 2013), T. 38607 (22 May 2013). 
metres. ${ }^{14521}$ In cross-examination, she conceded that she did not "comb every step of the area" as that was considered unnecessary due to her opinion that the shell could not have originated from any of these directions. ${ }^{14522}$

\section{(h) Casualties}

4326. In terms of casualties, both Milan Mandilović and Bakir Nakaš, doctors at the Sarajevo State Hospital at the time, testified that following the explosion at Markale market, which was about a kilometre away from the hospital, cars started "flowing in" bringing in large numbers of seriously wounded persons. ${ }^{14523}$ Mandilović could immediately see that their injuries were caused by shell shrapnel. ${ }^{14524}$ He testified that in total approximately 40 persons arrived at the hospital, most of whom were civilians; he did see a "military person here and there" but testified that their number was "negligible". ${ }^{14525}$ Nakaš also confirmed that most of the victims were wearing civilian clothes. $^{14526}$ Mandilović authenticated a number of medical records from both the State and Koševo Hospitals relating to the victims of this incident, including autopsy reports. ${ }^{14527}$ These autopsy reports refer to 43 dead victims, one of whom is Crnčalo's wife. ${ }^{14528}$ Nakaš also authenticated a number of State Hospital's medical records relating to the victims of the Markale incident. $^{14529}$

14521 D3551 (Zorica Subotić's expert report entitled "Mortar Attacks on the Sarajevo Area: Incidents at the Markale Market 5 February 1994 and 28 August 1995”, 15 August 2012), p. 158; Zorica Subotić, T. 38338-38340 (15 May 2013).

14522 Zorica Subotić, T. 38582-38585 (21 May 2013), T. 38594-38595 (22 May 2013).

14523 P1217 (Witness statement of Milan Mandilović dated 24 February 2010), paras. 4-5, 87-89; P1525 (Witness statement of Bakir Nakaš dated 8 September 2010), paras. 4-10, 65.

14524 P1217 (Witness statement of Milan Mandilović dated 24 February 2010), para. 87.

14525 P1217 (Witness statement of Milan Mandilović dated 24 February 2010), para. 89.

14526 P1525 (Witness statement of Bakir Nakaš dated 8 September 2010), para. 66.

14527 P1217 (Witness statement of Milan Mandilović dated 24 February 2010), paras. 117-118; P1225 (Medical certificate for Ismet Svraka); P1226 (Medical report for Ruža Galić); P1227 (Medical report for Samir Marevac); P1228 (Medical reports for Rasim Koso, Ferid Kanlić, Mensuda Klarić, and Ferid Bajrić); P1229 (Medical certificates for Ajkuna Cocalić, Đula Leko, Razija Čolić, Janja Pašić, and Adisa Duran); P1230 (Admission records for Osman Leventa, Mehmed Ahmetović, Fatima Čulesker, Mumo Kadrić, Mirza Hodžić, Bilal Habibović, Muhidin Begić, and Mustafa Karkelja); P1231 (Medical certificates for Dževad Hodžić and Edhem Husović); P1232 (Medical report for Zijad Bejtić and Hasib Bjelak); P1233 (Sarajevo State Hospital documentation re patients admitted between 28 August and 1 September 1995); P1234 (Medical reports for patients admitted to the Sarajevo State Hospital on 28 August 1995); P740 (Autopsy certificates for victims from Markale, 28 August 1995).

14528 P740 (Autopsy certificates for victims from Markale, 28 August 1995). While the English translation of this document contains 47 certificates, four of those are duplicates (relating to Zeno Bašević and Salko Duraković, Najla Duraković, and Husein Duraković), thus leaving 43 autopsy certificates. In addition, two of those certificates, namely those related to Najla Duraković and Husein Duraković are in fact certificates for Najla Fazlić and Husein Bektašević. The Chamber considers this to have been a typographical error during translation.

14529 P1525 (Witness statement of Bakir Nakaš dated 8 September 2010), paras. 94-95; P1531 (Medical records from Sarajevo State Hospital). 
4327. The CSB Sarajevo report notes that on the day of the incident 35 persons were confirmed dead and 78 wounded, which was verified by KDZ485 who went to the hospitals and the morgue and identified the individuals in question. ${ }^{14530}$ Turkušić's ballistics report differs slightly as it notes that 34 persons were killed and 84 wounded in the explosion. ${ }^{14531}$ Both Bešić and KDZ485 testified that more people died later, with Bešić estimating that 30 other individuals later died from their injuries. ${ }^{14532}$ While in the morgue, Crnčalo saw, in addition to his wife, another eight bodies, most of whom were female. ${ }^{1453}$ He testified that around 40 people died in this incident and noted that they were brought to another part of the same morgue. ${ }^{14534}$

4328. With respect to casualties, Subotić argued that the final list of 118 casualties does not match what the findings of the police and the investigating judge during the on-site investigation, as the latter registered 35 dead and 78 wounded persons on 28 August 1995, which is a total of 113 casualties. ${ }^{14535}$ According to Subotić, the final total of 118 victims was eventually determined, albeit without explanation, by the CSB Sarajevo in a report under the codename "Action Truth" sent to the SDB that same day, whereby it was specified that 33 persons were killed, eight of whom could not be identified, and 85 wounded. ${ }^{14536}$ Thus, according to her, the final number of victims was in fact not determined by the teams investigating the incident. ${ }^{14537}$ Based on her own calculations of the parameters of the affected area, ${ }^{14538}$ she asserted that the final number of victims was exaggerated and that the number reported by the UNMOs, namely 90 casualties in total, is

\footnotetext{
14530 P1908 (BiH MUP Report re shelling of Markale on 28 August 1995), e-court p. 2 (under seal); KDZ485, T. 8884-8885 (3 November 2010).

14531 P1934 (BiH MUP Report re shelling of Markale on 28 August 1995), e-court p. 1.

14532 P1905 (Witness statement of KDZ485), para. 27; P1966 (Witness statements of Sead Bešić dated 18 February 2010), p. 33; P1977 (BiH MUP Report re shelling of Markale on 28 August 1995). See also KDZ485, T. 88848885 (3 November 2010).

14533 Sulejman Crnčalo, T. 1179-1180 (14 April 2010).

14534 Sulejman Crnčalo, T. 1175, 1180 (14 April 2010); P733 (Witness statement of Sulejman Crnčalo dated 1 November 2009), para. 6.

14535 D3551 (Zorica Subotić's expert report entitled "Mortar Attacks on the Sarajevo Area: Incidents at the Markale Market 5 February 1994 and 28 August 1995", 15 August 2012), p. 129.

14536 D3551 (Zorica Subotić's expert report entitled "Mortar Attacks on the Sarajevo Area: Incidents at the Markale Market 5 February 1994 and 28 August 1995", 15 August 2012), p. 129; P1449 (Criminal investigation file re shelling of Markale on 28 August 1995), e-court p. 10 (BCS version). The Chamber notes that the BCS version of this document does not fully correspond to the translation, however, the Chamber was able to discern the lists of victims from the BCS version as well as the reference to the "Action Truth" and thus was able to follow Subotić's reasoning. The Chamber notes that Subotić's claim that there is no explanation as to the discrepancy in numbers is plainly incorrect as the report in question clearly states that CSB Sarajevo was in constant contact with medical staff in different hospitals who are still working on identifying patients. Thus, it is clear that at that point the information was still being updated.

14537 D3551 (Zorica Subotić's expert report entitled "Mortar Attacks on the Sarajevo Area: Incidents at the Markale Market 5 February 1994 and 28 August 1995", 15 August 2012), p. 129.

14538 In making this calculation, Subotic assumed that the main street on which the trams were running must have been empty at the time and not crowded, which then meant that the remaining area was too small to contain all the people who were wounded or killed. D3551 (Zorica Subotić's expert report entitled "Mortar Attacks on the Sarajevo Area: Incidents at the Markale Market 5 February 1994 and 28 August 1995”, 15 August 2012), p. 130. The Chamber finds this calculation extremely speculative.
} 
more likely to be correct. ${ }^{14539}$ Relying on the evidence of a doctor who testified in the Dragomir Milošević case, but not in this case, Subotić then asserted that based on the photo documentation of the 35 persons killed in the incident, two of these persons were not killed by shrapnel but by a bullet from a small firearm. ${ }^{14540}$ In addition, she claimed that in the video footage, the appearance of two wounds on the body of another victim cast doubt on whether he was killed by shrapnel from the explosion. ${ }^{14541}$

4329. According to the Adjudicated Fact 3081, at least 35 persons died and at least 78 persons were wounded, many of them seriously, in Markale market. The great majority of those wounded were civilians, while one of the deceased was a soldier of the ABiH. ${ }^{14542}$

\section{(i) Markale area as a potential military target}

4330. Addressing whether there was a military target at or nearby the market, Konings testified that the area was a civilian area, noting that he had passed by the location that morning at around 9 or 10 a.m. and that it was crowded with mostly civilians. ${ }^{14543}$ Leka testified that the shell landed in a "strictly civilian area" and that there was no military activity in the neighbourhood. ${ }^{14544}$ Svraka also testified that he had never seen any military installations or activities in the Markale area. ${ }^{14545}$ He was never personally in the $\mathrm{ABiH}$ but was under a work obligation and would dig trenches at the frontlines, including at Mt. Igman and Žuč Hill. ${ }^{14546}$ Đozo also testified that there were no army facilities in that part of town but that he did not know whether $\mathrm{ABiH}$ used any civilian facilities there. ${ }^{14547}$ Turkušić explained that, while there may have been some soldiers passing through Markale, the highest concentration of people there were civilians, usually people selling or buying goods. ${ }^{14548}$ He was of the view that the shell was fired for its psychological impact, namely in order to cause terror and put pressure on the authorities. ${ }^{14549}$ Bešić stated that Markale was frequented by a large number of people—both civilians and those wearing military uniforms - and

\footnotetext{
14539 D3551 (Zorica Subotić's expert report entitled "Mortar Attacks on the Sarajevo Area: Incidents at the Markale Market 5 February 1994 and 28 August 1995”, 15 August 2012), p. 130.

14540 D3551 (Zorica Subotić's expert report entitled "Mortar Attacks on the Sarajevo Area: Incidents at the Markale Market 5 February 1994 and 28 August 1995”, 15 August 2012), pp. 130-131.

14541 D3551 (Zorica Subotić's expert report entitled "Mortar Attacks on the Sarajevo Area: Incidents at the Markale Market 5 February 1994 and 28 August 1995”, 15 August 2012), pp. 131-132.

14542 Adjudicated Fact 3081.

14543 P1953 (Witness statement of Harry Konings dated 11 November 2010), para. 74.

14544 P117 (Witness statement of Đula Leka dated 25 February 1996), e-court p. 2.

14545 P1992 (Witness statement of Ismet Svraka dated 5 November 2008), para. 6.

14546 P1992 (Witness statement of Ismet Svraka dated 5 November 2008), para. 3. See also Ismet Svraka, T. 96659666 (13 December 2010).

14547 P1978 (Witness statement of Nedžib Đozo dated 7 December 2010), paras. 39-40.

14548 Emir Turkušić, T. 9006-9007 (4 November 2010).

14549 Emir Turkušić, T. 9001-9003, 9025-9026 (4 November 2010).
} 
noted that he was not aware of any $\mathrm{ABiH}$ military facilities nearby but that there may have been some in the former military hall which was 400 to 500 metres away from Markale, separated by a park. ${ }^{14550}$ Bešić denied that a nearby building called Semberija was used by the $\mathrm{ABiH}$ as a storage area, stating that it was in fact used as a bakery where bread was made for the $\mathrm{ABiH} .{ }^{14551}$

\section{(j) Accused's defence theories}

4331. As with the first Markale incident, while not referring to this theory in his Final Brief, the Accused attempted to show throughout the trial that this incident was staged such that the bodies were brought from elsewhere in order to provoke NATO into bombing the Bosnian Serbs. ${ }^{14552}$ However, as with the first Markale incident, most witnesses rejected this theory. ${ }^{14553}$ For example, Konings was adamant that the incident could not have been staged because he had passed Markale earlier that morning, at around 9 or 10 a.m., and did not see a crater there, noting that making a crater artificially would have taken a long time, longer than one or two hours. ${ }^{14554}$ Furthermore, he stated that he saw fresh bodies in the morgue and noted that there were no reports that morning that such a large number of people had been killed somewhere else. ${ }^{1455}$ Bell testified that his cameraman filmed some of the very graphic footage at the scene, which BBC would not broadcast due to viewer discretion concerns. ${ }^{14556}$ Bell stated that this was one of the scenes that could not be replicated in a movie and that it was real. ${ }^{14557}$

4332. One of the bases for the Accused's contention was the type of injuries sustained by the victims and, in particular, those of one man who can be seen in the footage of the aftermath of the incident lying over the rail near the point of impact without much blood around him. In addition, Subotić mentioned a number of victims who, according to her, had small arms wounds on their bodies. However, Turkušić convincingly testified that the damage to the area, as well as the

\footnotetext{
14550 Sead Bešić, T. 9425-9426, 9429-9430 (8 December 2010), T. 9500-9502, 9506-9507 (9 December 2010); P1969 (Video footage of Markale on 28 August 1995); P1450 (Video footage of Markale, 28 August 1995); D902 (Photograph re shelling of Markale on 28 August 1995 marked by Sead Bešić).

14551 Sead Bešić, T. 9507-9508 (9 December 2010); D904 (Photograph re shelling of Markale on 28 August 1995).

14552 See e.g. Emir Turkušić, T. 9082, 9094-9095 (4 November 2010) (where the Accused put forward his theory to Turkušić and confirmed this position to the Chamber). But see Martin Bell, T. 9921 (15 December 2010) (where the Accused stated to the witness that the Bosnian Muslims did not dare stage such an event again after the first Markale incident).

14553 See e.g. Emir Turkušić, T. 9082 (4 November 2010); P1953 (Witness statement of Harry Konings dated 11 November 2010), para. 92; Martin Bell, T. 9920-9921 (15 December 2010). But see KDZ088, T. 6394-6398 (8 September 2010) (closed session) (conceding, however, that everything he knew about Markale came from the media and rumours).

14554 P1953 (Witness statement of Harry Konings dated 11 November 2010), para. 92.

14555 P1953 (Witness statement of Harry Konings dated 11 November 2010), para. 94.

14556 P1996 (Witness statement of Martin Bell dated 8 March 2010), paras. 104-107; P2013 (BBC news report re shelling of Markale on 28 August 1995, with transcript).

14557 P1996 (Witness statement of Martin Bell dated 8 March 2010), para. 107.
} 
injuries sustained by the victims, were consistent with what one would expect from an impact of a $120 \mathrm{~mm}$ mortar shell at that particular place, in particular that those closest to the impact would have serious blast and shrapnel injuries to their lower limbs while those further away would suffer upper body injuries from shrapnel. ${ }^{14558} \mathrm{He}$ also pointed out that the bodies were taken to the Koševo Hospital where anyone, including journalists, was able to see them and check how fresh they were. ${ }^{14559}$ Bešić too confirmed that the footage of the scene as well as the diversity of injuries that can be seen on people is consistent with what one would expect following such an explosion. ${ }^{14560}$ Furthermore, noting that he had experience with exchanges of dead bodies, Bešić stated that the bodies visible on the photos taken at the morgue and in the video footage were all fresh, with no soil on them or puckered up skin. ${ }^{14561}$ Konings testified that a single mortar shell could cause all these casualties given the area in which it happened, namely between two buildings. ${ }^{14562}$

4333. Another reason put forward by the Accused for claiming that the scene was staged is that the stabiliser can be seen in one place in Bešić's photographs of the scene and yet is seen in a different place in the footage of the aftermath of the incident at the point when it is being photographed by the UNPROFOR soldiers. ${ }^{14563}$ Bešić could not explain this discrepancy, stating that in all his photographs the stabiliser can be seen in the same place and that he had no knowledge of what the UNPROFOR soldiers did with it when photographing it. ${ }^{14564}$ The Accused then showed additional footage of the investigation in which the stabiliser is shown located in one place first, the same place in which it was photographed by Bešić and, five minutes later, the stabiliser can be seen in another location, close to the location where the UNPROFOR soldiers photographed

\footnotetext{
14558 Emir Turkušić, T. 9004-9006, 9010-9012, 9018-9019, 9080-9082, 9086-9101 (4 November 2010); P1450 (Video footage of Markale, 28 August 1995); P1926 (Photographs re shelling of Markale on 28 August 1995); P1928 (Sketch re shelling of Markale on 28 August 1995 marked by Emir Turkušić); P1971 (Photographs re shelling of Markale on 28 August 1995); D874 (Video still re shelling of Markale on 28 August 1995); D875 (Video still re shelling of Markale on 28 August 1995); D876 (Video still re shelling of Markale on 28 August 1995). See also Richard Higgs, T. 5938-5939, 5947-5948 (18 August 2010), T. 5983-5984, 6031-6032 (19 August 2010); P1953 (Witness statement of Harry Konings dated 11 November 2010), para. 67.

14559 Emir Turkušić, T. 9094-9096 (4 November 2010).

14560 P1966 (Witness statements of Sead Bešić dated 18 February 2010), pp. 26, 34-35.

14561 Sead Bešić, T. 9427-9428 (8 December 2010); P1450 (Video footage of Markale, 28 August 1995).

14562 P1953 (Witness statement of Harry Konings dated 11 November 2010), paras. 67, 93.

14563 Compare P1926 (Photographs re shelling of Markale on 28 August 1995), photograph 1 with P1450 (Video footage of Markale, 28 August 1995).

14564 Sead Bešić, T. 9511-9512 (9 December 2010).
} 
it. ${ }^{14565}$ However, Bešić stated that the stabiliser was a "mobile artefact" which was moved around in the commotion of the investigation. ${ }^{14566}$

4334. The Accused also claimed that the condition of the stabiliser provided to the court and admitted as exhibit P1454 indicated that it was not damaged due to the explosion but was instead modified manually. However, Konings, Higgs, Turkušić, and Bešić all testified that the stabiliser that was found on the scene looked exactly as a stabiliser of an exploded shell should look like, and explained that its fins could have been deformed due to a car running over it. ${ }^{14567}$ When shown P1454 in the courtroom, both Turkušić and Bešić testified that it seemed to be the stabiliser shown on the video footage of the incident and described in the reports. ${ }^{14568}$ Bešić, who personally photographed the stabiliser on the scene on the day of the incident, was in fact adamant that P1454 was identical to the stabiliser on the scene despite agreeing with the Accused that the holes on its cap looked to be in a slightly different position from the holes on the pictures of the stabiliser at the scene. ${ }^{14569}$ He theorised, however, that it was possible that the stabiliser cap was unscrewed in the lab following its removal from the scene, thus shifting the position of the holes on the cap. ${ }^{14570}$

4335. The Accused's alternative defence was that the $\mathrm{ABiH}$ was responsible for the incident by either firing the shell or planting an explosive device at the scene in order to garner sympathy from the international community and provoke NATO air strikes. ${ }^{14571}$ As noted above, the main proponent of the planted explosive device theory was Subotić. In addition, Veljović testified that it was impossible for a $120 \mathrm{~mm}$ mortar shell to hit Markale, which is why the SRK thought that the

14565 See D896 (Video footage of shelling of Dobrinja on 4 February 1994, Markale on 5 February 1994, and Markale on 28 August 1995).

14566 Sead Bešić, T. 9519-9525 (9 December 2010); D907 (Sketch re shelling of Markale on 28 August 1995 marked by Sead Bešić).

14567 Emir Turkušić, T. 9155 (5 November 2010); Sead Bešić, T. 9482-9483, 9511-9512 (9 December 2010); P1966 (Witness statements of Sead Bešić dated 18 February 2010), pp. 29-30; P1926 (Photographs re shelling of Markale on 28 August 1995); P1971 (Photographs re shelling of Markale on 28 August 1995); D905 (Photograph of mortar stabiliser from Markale II). See also Richard Higgs, T. 5951-5952 (18 August 2010); P1450 (Video footage of Markale, 28 August 1995); P1953 (Witness statement of Harry Konings dated 11 November 2010), para. 57; Harry Konings, T. 9380-9381, 9383-9385 (7 December 2010).

14568 Emir Turkušić, T. 9153-9155 (5 November 2010); Sead Bešić, T. 9512-9517 (9 December 2010). See also Richard Higgs, T. 6033-6034 (19 August 2010); P1454 (Stabiliser tail fin from $120 \mathrm{~mm}$ mortar re shelling of Markale on 28 August 1995).

14569 Sead Bešić, T. 9512-9517 (9 December 2010); P1454 (Stabiliser tail fin from 120 mm mortar re shelling of Markale on 28 August 1995); D906 (Photographs of mortar stabiliser from Markale II).

14570 Sead Bešić, T. 9517 (9 December 2010).

14571 Defence Final Brief, paras. 2158-2162. See e.g. D79 (US Senate Report re smuggling of Iranian arms into BiH, 16 January 1997), p. 11; D4217 (Witness statement of Prvoslav Davinić dated 14 January 2014), paras. 5-8; Prvoslav Davinić, T. 45522-45526, 45537 (16 January 2014) (suggesting that the investigation into the incident was not done properly in order to justify NATO air strikes). 
Muslims had planted an explosive device and activated it by remote control in order to gain sympathy and to ensure that the Bosnian Serbs were bombed. ${ }^{14572}$

\section{(k) Final analysis and conclusions}

4336. Looking first at the Accused's suggestion that the incident of 28 August 1995 in Markale was staged, the Chamber is convinced, as with the first Markale incident, that this was not the case. In this respect, the Chamber accepts the evidence of the witnesses who were at the scene at the time of the incident or in its immediate aftermath and who were adamant that what they saw could not have been staged. Any suggestion to the contrary by the Accused and/or his witnesses is simply preposterous.

4337. The Chamber, relying on Konings, Higgs, Turkušić, and Bešić and having examined the stabiliser in its possession, is also convinced that it is the stabiliser that was found in Markale on 28 August 1995. As eventually accepted by Subotić, it is clear that the cap of the stabiliser is loose and that it can be screwed in and out, thus resulting in a different alignment of the holes to the one seen in the photographs taken by the CSB Sarajevo. The Chamber therefore rejects Subotić's evidence, reliant as it was on these photographs and video footage, that this was a different stabiliser than the one seen in those secondary materials. Further, the Chamber does not accept her evidence that there was one more stabiliser at the scene as the photograph she based this conclusion on is so unclear that it is impossible to determine what the object seen therein is. The Chamber, therefore, finds Subotić's conclusion that this was a second stabiliser arbitrary and bordering on dishonest. Given that she was quick to resort to conspiracy theories based on photographs and video footage, to the point of seeing another stabiliser in them, the Chamber has decided not to accept any of her evidence relating to this incident unless corroborated by other credible evidence. The Chamber also rejects her theories about what she thought were inexplicable scenes and injuries seen in the video footage and photographs of the incident, as well as her conclusion that having nine incidents involving such mass casualties was impossible. ${ }^{14573}$

4338. Finally, the Chamber rejects her evidence, as well as the evidence of Veljovic, Demurenko, and others, that the explosion was a result of an explosive device planted at the scene. The Chamber found this proposition untenable given the weight of the evidence to the contrary,

\footnotetext{
14572 Stevan Veljović, T. 2926229265 (23 October 2012). See also Nikola Mijatović, T. 30702-30706 (30 November 2012); D2514 (Video clip of Nikola Mijatović's speech, with transcript); Momčilo Krajišnik, T. 43330-43332, 43334 (12 November 2013).

14573 The Chamber found this particular suggestion, namely that having nine incidents with mass casualties would have been impossible, simply unreasonable, particularly when one takes into account the fact that the conflict lasted from 1992 to 1995 and considers the number of shells that fell on the city in that period.
} 
including the fact that the $120 \mathrm{~mm}$ stabiliser was found on the scene. In addition, a number of witnesses who were on the scene immediately after the incident, such as Turkušić, Bešić, and Konings, testified that the damage to the people and the buildings could have been the result of the explosion of a $120 \mathrm{~mm}$ mortar bomb, given the enclosed space in question and the large number of people present. The Chamber found their evidence particularly convincing because they had by that point dealt with countless shelling incidents in the city. ${ }^{14574}$ Accordingly, the Chamber is satisfied that the explosion on 28 August 1995 in the Markale area was caused by the $120 \mathrm{~mm}$ mortar bomb that struck the Mula Mustafe Bašeskije street.

4339. Relying on the autopsy reports in evidence, the Chamber finds that 43 people died in this explosion. Relying further on CSB Sarajevo reports and various lists of wounded provided therein, the Chamber also finds that this explosion resulted in at least 70 wounded. The Chamber is satisfied that the great majority of those casualties were civilians who were not taking active part in hostilities at the time of the incident. Only one of those killed in the incident was a soldier. ${ }^{14575}$

4340. As found above in relation to the first Markale incident, the Chamber is also satisfied that there were no military facilities or targets in the area of Markale market. It was a market frequented by the civilian population in order to buy and sell food and other goods. In addition, the Chamber recalls that it has taken judicial notice of the fact that there was no reason to consider it a military objective on the day in question. ${ }^{14576}$ While there may have been some soldiers passing through Markale at any given time, the majority of people gathering there were civilians.

4341. In terms of the direction of fire, the Chamber recalls that the CSB Sarajevo team, the UNMOs, the UNPROFOR team that conducted the crater analysis, and Subotić, all came to the conclusion that the $120 \mathrm{~mm}$ shell came from the general south-southeasterly direction. According to the various calculations, it had an azimuth of between 155 and 175 degrees and a minimum angle of descent of 67 degrees, with the most likely angle of descent being 70 degrees. ${ }^{14577}$ The Chamber accepts this evidence and therefore rejects the final conclusion made by UNPROFOR's Powers and

\footnotetext{
14574 The Chamber notes that the only witness who was at the scene in the aftermath of the incident and yet testified that the explosion was caused by an explosive device was Demurenko. However, as will be seen below, the Chamber has found him to be unreliable in relation to this incident and thus does not accept his evidence that it was a "terrorist" attack. The other witnesses who thought it was a planted explosive device were neither on the scene at the time nor had the sufficient grounds, other than rumour and self-serving motives, to make that conclusion.

14575 See Adjudicated Fact 3081; P1450 (Video footage of Markale, 28 August 1995) (showing a victim in camouflage uniform).

14576 Adjudicated Fact 342.

14577 The Chamber rejects the angle of descent determined by Subotić, both due to her weak credibility and because it considers that the local investigators would have been better able to establish the angle of descent having observed the scene and the crater first hand in the immediate aftermath of the incident.
} 
Baxter that the Markale shell probably came from the same direction as the other four shells that hit an area near Markale on that day, namely from 220 to 240 degrees from the north. The Chamber agrees with both Higgs and Subotić that Powers and Baxter's analysis was speculative and ultimately wrong, particularly given Turkušić's evidence that the shell that struck Markale area was a direct hit and not a ricochet. Accordingly, the Chamber considers that the four shells came from a different direction and thus were fired by a different mortar. ${ }^{14578}$ That being the case, they cannot be considered to have been adjusting fire for the shell that hit Markale.

4342. Turning back to the Markale shell, as noted above, both the ABiH and SRK had positions in the established direction of fire, with the confrontation line located approximately 1,600 metres from Markale. Given the vastness of the area covered by the established direction of fire and the margin of error involved, the Chamber is convinced that there were many positions on the SRK side of the confrontation line suitable for placing a $120 \mathrm{~mm}$ mortar. Indeed, Veljović testified that he had a mortar battery in the Brus sector, which is in the established direction of fire. Thus, the Chamber did not find Demurenko credible when he testified that no suitable positions existed on the SRK side of the confrontation line nor did it believe him when he testified that he in fact examined an area much larger than the one he discussed in his interview of 2 September 1995 and in his evidence in the Dragomir Milošević case. The Chamber considers that examining an area covering all of the directions of fire established at the time, together with the margin of error, would have been impossible in the limited amount of time Demurenko had. In addition, the Chamber finds it telling that he only mentioned this broader inspection after the Trial Chamber in the Dragomir Milošević case had dismissed his investigation as having been too narrow. The Chamber is, therefore, convinced that Demurenko simply changed his testimony in order to counteract the findings of that Trial Chamber. Thus, the Chamber considers that Demurenko's investigation was based solely on the azimuth of 176 degrees from north as he had indicated in his interview at the time, which was ultimately the wrong azimuth. As such, his investigation was somewhat irrelevant to this incident. In addition, even if 176 degrees was the direction from which the Markale shell originated, the Accused's own expert witness, Subotić, contradicted Demurenko's evidence by testifying that there was one suitable mortar position in that direction of fire. For all these reasons, the Chamber does not accept Demurenko's evidence as credible and finds that there were a number

14578 As a result of this finding, the Chamber will not rely on the UN analysis relating to the UN radar as that analysis was based on the direction of fire of 220 to 240 degrees from the north and on the distance to the confrontation line in that direction. Furthermore, the evidence does not indicate where the radar was located, how high or low it was emitting radio-waves, or whether it covered only the area in the direction of 220 to 240 degrees or also the area of the direction of fire established in relation to the Markale shell. Similarly, the Chamber does not accept Subotić's analysis relating to the radar as it is based on pure speculation as to its location and effectiveness. Unlike Subotić, the Chamber does not exclude the possibility of the radar failing to record a shell fired from far 
of suitable positions for placing a mortar, both in the area of the established direction of fire, namely between 155 and 175 degrees, and in the area actually examined by Demurenko.

4343. As also noted above, the $\mathrm{ABiH}$ too had positions in the established direction of fire, including mortar positions near Čolina Kapa. ${ }^{14579}$ Nevertheless, the Chamber is convinced beyond reasonable doubt that the Markale shell was fired from the SRK side of the confrontation line. ${ }^{14580}$ First, the Chamber notes that the markings on the shell indicate that it came from Krušik Factory in Valjevo, Serbia, while its serial number indicates that it was tested in Serbia towards the end of the conflict, namely in 1994. The same is true for the other four shells that landed near Markale market on that day, all of which bear the same markings. This in turn means that the five shells were not part of the JNA arsenal in 1991 and thus could not have been part of the $\mathrm{ABiH}$ weapons arsenal at the time of the incident. All five therefore must have been fired by the SRK.

4344. Second, focusing on the Markale shell alone, the Chamber is persuaded by the evidence of Knustad and Konings that no firing sound-which would have been loud and distinctive in the case of a $120 \mathrm{~mm}$ mortar-was heard near OP-1 on the day of the incident, thus indicating that the shell was not fired from $\mathrm{ABiH}$ mortar positions near Čolina Kapa, or anywhere near the confrontation line. While Conway challenged the idea that one could draw such conclusion from the sounds of the explosions he had heard, he also conceded, in line with other witnesses, ${ }^{14581}$ that the sound of a mortar firing nearby would have been distinct whereas he had only heard muffled sounds on the morning of the incident. Given that the morning was quiet, it is clear from Conway's evidence and the description of the events he provided that the muffled sounds he heard were the sounds of the explosions in the centre of the city rather than the sound of a $120 \mathrm{~mm}$ mortar firing near OP-1. ${ }^{14582}$ Even the Accused's expert witness Subotic thought that the firing noise would have been heard had

away (as outlined by the UN), particularly given the configuration of the terrain and the elevation from which it would have been fired.

14579 While Conway testified that in December 1995 he saw ABiH mortars positioned north of Mrakuša and facing the city, this does not necessarily mean that these mortars had also been there in August 1995 or that they had been turned towards the city at that time. Even if this were the case, the Chamber notes that those positions were not in the established direction of fire but were located southwest of Markale.

14580 The Chamber notes that part of the Accused's case was that ABiH fired the shell (or staged the incident) in order to provoke NATO air strikes, which indeed took place following the incident. He outlined this theory mostly during his cross-examination of Smith and Harland. While the evidence of these two witnesses does show that the NATO attacks were initiated by Smith before the higher echelons of power within the UN were absolutely convinced that the SRK was responsible, this does not, contrary to the Accused's position, lead to the conclusion that the $\mathrm{ABiH}$ was responsible for the attack.

14581 See para. 4281

14582 The Chamber also notes that at that time of the incident Conway had only been in Sarajevo for nine days and thus was not as familiar as Knustad was with the sounds in and around the city. 
the $\mathrm{ABiH}$ fired the shell in question, which in turn led her to conclude that the explosion was caused by a planted explosive device. ${ }^{14583}$

4345. Finally, while the SRK soldiers and officers called by the Accused testified that no $120 \mathrm{~mm}$ mortars were located in the established direction of fire, the Chamber found their evidence unpersuasive and insincere as they were inconsistent when explaining why the $120 \mathrm{~mm}$ mortars were not there in August, despite their presence earlier in the year when the $4^{\text {th }}$ Sarajevo Light Infantry Brigade was formed. For example, Veljović testified that he sent all his mortars from the Brus sector to another frontline, while Dušan Škrba testified that $120 \mathrm{~mm}$ mortars were simply moved outside of the 20 kilometre heavy weapons exclusion zone. They were also inconsistent as to the calibres that did remain in the area. In general, the Chamber found the evidence of these witnesses, as well as the evidence of Dragomir Milošević, to have been largely self-serving-their credibility was affected by their desire to minimise the responsibility of the SRK for the incident.

4346. While Mula Mustafe Bašeskije street and the Markale market may not have been deliberately targeted on the day of the incident, the Chamber is convinced on the basis of the evidence above, including Đozo's evidence about earlier incidents in the area and the fact that another four shells landed near Markale on the day of this incident, that the SRK deliberately targeted the general area of the market, in full knowledge that there were no military targets there and with reckless disregard as to potential civilian victims such fire would create.

\section{(D) Scheduled modified air bomb incidents}

4347. Thoughout this case, the Chamber heard evidence about the nature and the use of so-called "modified air bombs" in Sarajevo during the conflict as six of the 16 shelling incidents charged in the Indictment, namely Scheduled Shelling Incidents G.10, G.11, G.12, G.13, G.14, and G.15, are alleged to involve such bombs. ${ }^{14584}$

4348. The Prosecution argues that the evidence establishes that modified air bombs were (i) possessed solely by the SRK; (ii) used by the SRK in the above mentioned incidents; and

14583 Subotic reached this conclusion arguing that a shell fired on a charge three or higher would have resulted in an embedded stabiliser at the scene. As discussed in the section dealing with the first Markale shelling incident, the other experts, who were found by the Chamber to be more credible than Subotić, thought that a stabiliser will embed if a shell is fired on charges higher than charge three. See para. 4248. Thus, Subotićs analysis that the lack of embedding in this particular case necessarily excludes the possibility that the shell was fired on charge three is not persuasive. The Chamber finds it perfectly plausible that the SRK fired the shell using charge three as testified by Higgs and Turkušić, resulting in the stabiliser being ejected at the moment of impact and landing near the impact site. The Chamber also notes that the location of the stabiliser as photographed by the CSB Sarajevo some 40 minutes after the incident is not necessarily the location at which the stabiliser first landed, as it could have been pushed around in the chaos of the evacuation of the wounded. 
(iii) inherently incapable of targeting anything more specific than a general neighbourhood in a densely-populated Sarajevo. ${ }^{14585}$ The Prosecution also claims that because of their great destructive power and because of their imprecision, these bombs were a "quintessential urban weapon of terror, used deliberately to that end in Sarajevo". ${ }^{14586}$ In addition, according to the Prosecution, the SRK also used these bombs in retaliation against the population in response to $\mathrm{ABiH}$ or NATO actions, often on areas where there was no combat activity. ${ }^{14587}$

4349. The Accused argues that the VRS used modified air bombs against military targets on the ground as a defensive measure due mainly to a shortage of artillery and mortar ammunition in 1994 and 1995 and because the $\mathrm{ABiH}$ grew in manpower and equipment at that point. ${ }^{14588}$ The Accused further claims that the modified air bombs were tested by expert engineers and were perfected such that they could be considered precise. ${ }^{14589}$ Finally, he claims that the ABiH also used modified air bombs in Sarajevo. ${ }^{14590}$

\section{(1) Expert evidence}

4350. The parties called a number of expert witnesses to testify about the nature of modified air bombs and to give their opinions as to the above-mentioned shelling incidents. Zečević was called by the Prosecution, while Subotić, Poparić, and Mirjana Anđelković-Lukić were called by the Accused.

4351. Earlier in the Judgement, the Chamber discussed the professional qualifications of both Subotić and Poparić and provided its assessments of these witnesses' credibility and of the reliability of their evidence. ${ }^{14591}$ These general assessments are equally applicable in relation to this section of the Judgement and will not be repeated here. ${ }^{14592}$

4352. Zečević is an expert in rocket motors and warheads who also worked in the Pretis Factory in Vogošća until April 1992. ${ }^{14593}$ This factory produced artillery and rocket ammunition, rocket

\footnotetext{
14585 Prosecution Final Brief, Appendix C, paras. 68-69.

14586 Prosecution Final Brief, Appendix C, para. 69.

14587 Prosecution Final Brief, Appendix C, para. 71 (referring to Scheduled Incidents G.10, G.13, and G.15).

14588 Defence Final Brief, para. 2348.

14589 Defence Final Brief, paras. 2349-2354, 2356.

14590 Defence Final Brief, paras. 2357-2358.

14591 See paras. 3642, 4015.

14592 However, the Chamber will provide further credibility assessments below, where relevant specifically to modified air bombs.

14593 P2318 (Report by Berko Zečević entitled "The use of modified aircraft bombs during the siege of Sarajevo, 1994-1995”), p. 1; Berko Zečević, T. 12155-12157 (22 February 2011).
} 
projectiles, and aircraft bombs, and was under VRS control during the conflict. ${ }^{14594}$ Zečević prepared a report and gave evidence on (i) the nature of modified air bombs, (ii) his involvement in investigating their mechanics during and after the conflict in Sarajevo, and (iii) his analysis of the above-mentioned scheduled incidents. ${ }^{14595}$ All three experts called by the Accused challenged Zečević's evidence and produced a joint report pointing out inconsistencies in his report. ${ }^{14596}$ Because of his expertise in rocket motors and warheads and given that he had an opportunity to examine the remnants of modified air bombs in Sarajevo, the Chamber has found Zečević to be a knowledgeable and trustworthy witness, particularly in relation to the process of modification of air bombs and their operation. The Chamber also found that many of the challenges outlined in the joint report prepared by Defence experts bordered on trivial and were at times completely irrelevant to the issues in this case. ${ }^{14597}$ On the other hand, some of the more relevant aspects of Zečević's evidence remained unchallenged, including his findings that modified air bombs were used in Scheduled Incidents G.10 to G.15. ${ }^{14598}$ Accordingly, the Chamber accepted much of Zečević's evidence as credible and reliable. On occasion, the Chamber rejected some of his conclusions as they were either contradicted by other accepted evidence or not sufficiently persuasive in light of other, more convincing, evidence. ${ }^{14599}$ This, however, did not affect the Chamber's assessment of Zečević's credibility in other aspects of his testimony.

14594 Berko Zečević, T. 12149, 12154-12158 (22 February 2011); D3540 (Zorica Subotić's expert report entitled "The Use of Modified Aircraft Bombs in the Sarajevo Area in 1994-1995", 15 March 2012), p. 41; Dragomir Milošević, T. 32762 (28 January 2013); Miladin Trifunović, T. 30378 (15 November 2012), T. 30443, 3045930461 (27 November 2012) (testifying that Pretis Factory was in the zone of responsibility of the Vogošća Brigade, which later became $3^{\text {rd }}$ Sarajevo Infantry Brigade); D2447 (Satelite image of Sarajevo marked by Miladin Trifunović).

14595 P2318 (Report by Berko Zečević entitled "The use of modified aircraft bombs during the siege of Sarajevo, 1994-1995”). Zečević prepared this report for the purposes of the Dragomir Milošević case. See Berko Zečević, T. 12175 (22 February 2011).

14596 D3644 (Expert report by Mile Poparić et al entitled "Inconsistencies of Experts Berko Zečević and Richard Higgs in Cases of the Shelling of Sarajevo", 15 August 2012). The Chamber notes that it ordered the redaction of a large part of this report. See Decision on Prosecution's Request to Exclude Portions of Reports of Mile Poparić, 12 March 2013, paras. 26-29. The Chamber also notes that the remaining analysis in D3644 contains more or less identical challenges to those outlined in Anđelković-Lukić's report (D2662).

14597 For example, in their report, at page 67, Poparić et al point out inconsistencies in Zečević's report regarding the weights of aircraft bombs discussed therein. In the Chamber's view, those inconsistencies are minor and ultimately irrelevant to the major issues in this case. Poparic et al also argue on pages 66, 67, and 70 that many of the weapons and technical concepts discussed in Zečević's report are irrelevant to this case. The Chamber notes that in his report Zečević clearly acknowledges that such weapons and concepts are used simply as examples and therefore does not mislead the Chamber in any way. Accordingly, being able to discern for itself the most relevant parts of Zečević's report, the Chamber does not consider that his analysis of additional weapons and ballistics concepts undermines his credibility in relation to the issues relevant to this case.

14598 The major challenge raised by the Accused regarding the Scheduled Shelling Incidents relates to Zečević's conclusions as to the type of modified air bomb used and the Chamber has dealt with this challenge in relation to each specific incident.

14599 See e.g. the Chamber's discussion of Scheduled Incidents G.10 to G.15 where the Chamber rejected Zečević's evidence that the bomb used was a fuel-air bomb. 
4353. Anđelković-Lukić is an expert on explosives who participated in the testing of various explosive weapons for the JNA. ${ }^{14600}$ The Prosecution asserts that her arguments regarding the weight and in some cases the explosive composition of the bombs were not credible and were ultimately irrelevant, given the overall destructiveness of all the types of modified air bombs used in Sarajevo. ${ }^{14601}$ The Chamber found Anđelković-Lukić evasive at times. In addition, some of her evidence was contradicted by other evidence on the record, including on one occasion by her own report, prepared jointly with Poparić and Subotić. ${ }^{14602}$ Nevertheless, the Chamber analysed her evidence on modified air bombs and each related scheduled incident separately and, as will be seen below, at times accepted certain parts thereof.

\section{(2) Modified air bombs in Sarajevo}

4354. Modified air bombs were first used in Sarajevo in early 1994 and then again at the end of 1994 and throughout $1995 .{ }^{14603}$ A modified air bomb is an aircraft bomb to which rocket motors have been attached so that it does not have to be dropped from an aircraft, as originally intended, but can instead be delivered from a launching pad. ${ }^{14604}$ It is comprised of three primary components: (i) a bomb intended for aircraft use; (ii) a rocket system made of rockets from a multiple rocket launcher; and (iii) the "adapting plate" joining the two. ${ }^{14605}$

14600 D2661 (Mirjana Anđelković-Lukić's curriculum vitae); Mirjana Anđelković-Lukić, T. 31467-31470 (14 December 2012). The Chamber notes that Mile Poparić worked at the Technical Testing Centre around the same time as Anđelković-Lukić and that he also worked in Pretis, like Berko Zečević. See Mile Poparić, T. 38850-38551 (28 May 2013), T. 39029 (30 May 2013); D4884 (Mile Poparić's expert report entitled "Small Arms Fire on the Sarajevo Area 1992-1995”, 15 August 2012), pp. 2-3.

14601 Prosecution Final Brief, Appendix C, para. 72.

14602 See e.g. paras. 4360-4361, 4413, fn. 14612.

14603 P2318 (Report by Berko Zečević entitled "The use of modified aircraft bombs during the siege of Sarajevo, 1994-1995”), pp. 2-3, 65, 180-181, 186-195; Berko Zečević, T. 12150-12151, 12206-12210 (22 February 2011); P1276 (Witness statement of Ekrem Suljević dated 9 February 2010), para. 39; Ekrem Suljević, T. $5723-$ 5724, 5732-5733 (22 July 2010); P1978 (Witness statement of Nedžib Đozo dated 7 December 2010), para. 49; P1762 (Witness statement of David Fraser dated 17 October 2010), p. 63; P1996 (Witness statement of Martin Bell dated 8 March 2010), paras. 55, 100; P1851 (Witness statement of Per Anton Brennskag dated 26 October 2010), para. 36; Per Anton Brennskag, T. 8656-8657 (29 October 2010). See also Adjudicated Fact 2816.

14604 P1276 (Witness statement of Ekrem Suljević dated 9 February 2010), para. 37; Ekrem Suljević, T. 5683 (21 July 2010); P1978 (Witness statement of Nedžib Đozo dated 7 December 2010), para. 49; Thomas Knustad, P123 (Transcript from Prosecutor v. D. Milošević), T. 1989, 1991; P1762 (Witness statement of David Fraser dated 17 October 2010), p. 63; David Fraser, T. 8010-8011 (18 October 2010), T. 8133 (19 October 2010); P1953 (Witness statement of Harry Konings dated 11 November 2010), para. 42; KDZ477, T. 10952 (31 January 2011); P2407 (Witness statement of KDZ304), pp. 18-19; Zorica Subotić, T. 38479 (16 May 2013); P2318 (Report by Berko Zečević entitled "The use of modified aircraft bombs during the siege of Sarajevo, 19941995”), p. 183; Dragomir Milošević, T. 32769 (28 January 2013); Savo Simić, T. 30091-30092 (12 November 2012). See also Adjudicated Facts 2815, 2816.

14605 Ekrem Suljević, T. 5684 (21 July 2010); P1276 (Witness statement of Ekrem Suljević dated 9 February 2010), para. 39; P1925 (Witness statement of Emir Turkušić dated 16 February 2010), p. 6; P1953 (Witness statement of Harry Konings dated 11 November 2010), para. 42; P2407 (Witness statement of KDZ304), p. 18; KDZ304, T. 10444-10445 (18 January 2011); P2318 (Report by Berko Zečević entitled "The use of modified aircraft bombs during the siege of Sarajevo, 1994-1995”), p. 183; Savo Simić, T. 30092-30095 (12 November 2012). 
4355. Several different weight categories of general purpose aircraft bombs, or "FABs" as they were referred to in the SFRY, were modified during the Sarajevo conflict. "FAB" is a Russian term to which a number is added to indicate the nominal value of the bomb mass; thus, a FAB-250 refers to an aircraft bomb with a nominal weight of 250 kilograms. ${ }^{14606}$ The explosive charge, which makes up around $40 \%$ of the aircraft bomb's nominal mass and usually consists of solid TNT or a mixture of TNT and other ingredients, is located within the casing of the FAB. ${ }^{14607}$ According to Zečević, Pretis produced FAB-100 and FAB-250 general purpose aircraft bombs. ${ }^{14608}$

4356. The aircraft bombs can also contain fuel-air explosive instead of TNT, which is a gaseous, liquid, or powder fuel dispersed into the air by a small explosion and then oxidised; the oxidation initialises the second explosion-a massive detonation wave. ${ }^{14609}$ According to Zečević, these types of modified air-bombs produce a longer lasting but less intense blast than bombs with solid explosive charges. ${ }^{14610}$ Zečević also explained that the best-known Russian fuel-air bomb is ODAB-500 aircraft bomb, which has a nominal mass of 520 kilograms and a fuel-air charge of 193 kilograms. ${ }^{14611}$ Prior to the war, Pretis was developing a fuel-air bomb called FAB-275, but the development was transferred to Belgrade in $1991 .^{14612}$

14606 P2318 (Report by Berko Zečević entitled "The use of modified aircraft bombs during the siege of Sarajevo, 1994-1995”), pp. 5-6, 24; Berko Zečević, T. 12210 (22 February 2011). See also Adjudicated Fact 2817.

14607 D2662 (Mirjana Anđelković-Lukić's expert report entitled "Expert Analysis of Documents”, 26 July 2012), pp. 3, 5, Mirjana Anđelković-Lukić, T. 31479, 31500 (14 December 2012); Vladimir Radojčić, T. 31248-31249 (11 December 2012); P2318 (Report by Berko Zečević entitled "The use of modified aircraft bombs during the siege of Sarajevo, 1994-1995”), pp. 4-5; Ekrem Suljević, T. 5724, 5747 (22 July 2010), T. 6175 (6 September 2010) (explaining that the weight of the bomb does not denote the quantity of the explosives but rather the actual weight of the bomb, without taking into account the propelling rocket; thus, a 250-kilogram air bomb would contain around 100 kilograms of explosives).

14608 P2318 (Report by Berko Zečević entitled "The use of modified aircraft bombs during the siege of Sarajevo, 1994-1995”), pp. 8, 93; D3540 (Zorica Subotić's expert report entitled “The Use of Modified Aircraft Bombs in the Sarajevo Area in 1994-1995”, 15 March 2012), pp. 41-42; Dragomir Milošević, T. 33150 (4 February 2013); D797 (Sketch of air bomb). See also Adjudicated Fact 2818.

14609 P2318 (Report by Berko Zečević entitled "The use of modified aircraft bombs during the siege of Sarajevo, 1994-1995”), pp. 58-59, 101; Berko Zečević, T. 12183, 12200-12201 (22 February 2011); Mirjana Anđelković-Lukić, T. 31477-31481, 31484-31485 (14 December 2012) (explaining that these bombs were made primarily for destruction of personnel and that it is impossible to survive the blast if enveloped by a cloud created by the first explosion).

14610 P2318 (Report by Berko Zečević entitled "The use of modified aircraft bombs during the siege of Sarajevo, 1994-1995”), pp. 58, 60-64, 103; Berko Zečević, T. 12199-12200 (22 February 2011). See also Adjudicated Fact 2820.

14611 P2318 (Report by Berko Zečević entitled "The use of modified aircraft bombs during the siege of Sarajevo, 1994-1995”), p. 59.

14612 P2318 (Report by Berko Zečević entitled "The use of modified aircraft bombs during the siege of Sarajevo, 1994-1995”), pp. 65, 93 (explaining that the first 50 of those bombs were produced in 1990); Berko Zečević, T. 12151-12152, 12211, 12213-12214 (22 February 2011); D3540 (Zorica Subotić's expert report entitled "The Use of Modified Aircraft Bombs in the Sarajevo Area in 1994-1995”, 15 March 2012), p. 43; Zorica Subotić, T. 38476-38477 (16 May 2013) (testifying that only 60 FAB-275 bombs were produced by Pretis, of which 58 were destroyed after the war, thus suggesting that only two were used but that it is not known where). But see D2662 (Mirjana Anđelković-Lukić's expert report entitled "Expert Analysis of Documents", 26 July 2012), pp. $6,10,13$ (arguing that there was no evidence that Pretis was developing this bomb and that neither the JNA nor 
4357. Based on the fragments found around the city and the photographs of the bombs obtained from the Dutch team tasked with the disposal of various weapons systems after the war, Zečević determined that FAB-100 and FAB-250 aircraft bombs, as well as a fuel-air bomb based on ODAB-500, which was given a code-name KREMA, were all modified by the Bosnian Serbs in order to be launched from the ground and used in Sarajevo. ${ }^{14613}$ In addition, according to Zečević, the damage to some of the sites in Sarajevo indicated that a fuel-air explosive was often used with FAB-250 modified air bombs. ${ }^{14614}$ Based on the recovered fragments he determined that various types of rockets were used to assist the flight of the air bombs, including $122 \mathrm{~mm}$ GRAD rockets. ${ }^{14615}$ Thus, the modified FAB-100 had either one or three rocket motors, the FAB-250 had three rocket motors, and the bomb based on ODAB-500 had four rocket motors attached to it. ${ }^{14616}$ According to Zečević, the three-rocket motor system was extremely primitive and inferior to the four-rocket system because it would deviate from the direction of flight due to the slightly nonparallel alignment of the rocket motors. ${ }^{14617}$ Zečević testified that he examined the fragments of the

the VRS had a fuel-air bomb in its arsenal); Mirjana Anđelković-Lukić, T. 31481-31482, 31515-31517, 31527 (14 December 2012) (basing this claim on the fact that testing of such a bomb never reached her desk at the testing centre, and was therefore never tested for the JNA); D3644 (Expert report by Mile Poparić et al entitled "Inconsistencies of Experts Berko Zečević and Richard Higgs in Cases of the Shelling of Sarajevo", 15 August 2012), pp. 72, 75-76. Anđelković-Lukić therefore seems to contradict Subotić's evidence on the issue of Pretis' work on a fuel-air bomb, as well as Subotić's report to which she contributed.

14613 P2318 (Report by Berko Zečević entitled "The use of modified aircraft bombs during the siege of Sarajevo, 1994-1995”), pp. 65-74, 101-102; Mirjana Anđelković-Lukić, T. 31502 (14 December 2012); Ekrem Suljević, T. 5722-5723, 5746 (22 July 2010) (explaining that he also knew about the existence of the 500-kilogram modified air bomb); P2407 (Witness statement of KDZ304), pp. 18-19 (explaining that the SRK referred to some of the modified air bombs as KREMA rockets); P2108 (UNPROFOR Memo re meeting with SRK, 9 July 1995). See also Adjudicated Fact 2817 (stating that there were two types of air bombs used in Sarajevo, namely the FAB-100 and the FAB-250, and making no mention of a 500-kilogram bomb).

14614 P2318 (Report by Berko Zečević entitled "The use of modified aircraft bombs during the siege of Sarajevo, 1994-1995”), pp. 77, 102; Berko Zečević, T. 12184-12186, 12210 (22 February 2011) (explaining that he reached this conclusion because in a large number of cases where the FAB-250 modified air-bomb was used, the significant fragmentation effect one would encounter with bombs using solid TNT was absent). See also Adjudicated Fact 2819 (which provides that the typical explosive charge for FAB-250 was a fuel-air mixture).

14615 P2318 (Report by Berko Zečević entitled "The use of modified aircraft bombs during the siege of Sarajevo, 1994-1995”), pp. 91-93, 103 (explaining that 122 mm GRAD rockets were not produced at Pretis but were imported and then modified); Berko Zečević, T. 12177 (22 February 2011); Ekrem Suljević, T. 5685-5686 (21 July 2010); P1277 (Request from Pretis Factory to VRS Main Staff, 10 May 1994); Zorica Subotić, T. 38479_ 38480 (16 May 2013), T. 38640 (22 May 2013); Vladimir Radojčić, T. 31251-31252 (11 December 2012). But see D3540 (Zorica Subotić's expert report entitled "The Use of Modified Aircraft Bombs in the Sarajevo Area in 1994-1995”, 15 March 2012), pp. 42, 212 (stating that Pretis did produce $122 \mathrm{~mm}$ GRAD rockets for the Iraqi armed forces). See also Mile Poparić, T. 39029-39030 (30 May 2013) (testifying that he participated in the development of GRAD $122 \mathrm{~mm}$ rockets when he worked for Pretis).

14616 P2318 (Report by Berko Zečević entitled "The use of modified aircraft bombs during the siege of Sarajevo, 1994-1995”), pp. 83-85, 101-102; Berko Zečević, T. 12194-12196 (22 February 2011); Ekrem Suljević, T. 5688-5689 (21 July 2010); P1280 (VRS Main Staff Order, 18 June 1995); D3540 (Zorica Subotić's expert report entitled “The Use of Modified Aircraft Bombs in the Sarajevo Area in 1994-1995”, 15 March 2012), p. 43; Zorica Subotić, T. 38479-38487 (16 May 2013); P6348 (Excerpt from Mile Poparić's expert report entitled "Inconsistencies of Experts Berko Zečević and Richard Higgs in Cases of the Shelling of Sarajevo", 15 August 2012); Mirjana Anđelković-Lukić, T. 31502-31503 (14 December 2012); D2497 (Witness statement of Nikola Mijatović dated 27 November 2012), para. 18.

14617 See Berko Zečević, T. 12175-12178 (22 February 2011). 
first modified air bomb ever launched into Sarajevo and that it was a fuel-air bomb with four 122 mm GRAD rocket motors. ${ }^{14618}$

4358. According to Poparić, attaching rockets to aircraft bombs essentially turned those bombs into rocketised projectiles from a ballistics point of view, meaning that the dispersion of fragments was larger at a shorter range than when fired at a longer range. ${ }^{14619}$ Poparić also testified that 122 $\mathrm{mm}$ GRAD rockets had a long range of up to 21 kilometres, were not recommended for use in ranges under five kilometres, and would usually be used from the rear and over friendly troops to target a larger area and provide fire support. ${ }^{14620}$

4359. While accepting that FAB-100 and FAB-250 aircraft bombs were modified and used in Sarajevo, Subotić testified that there is no evidence, in the form of material traces, that a single fuel-air bomb was used in Sarajevo. ${ }^{14621}$ Anđelković-Lukić also challenged Zečević's evidence on this issue, arguing that removing the solid explosive charge from the FAB-250 and filling its casing with fuel-air explosives would have been arduous, pointless, and dangerous work, and almost impossible to perform in war-time conditions. ${ }^{14622}$ She also stated that in case of the explosion of a fuel-air bomb, large parts of the bomb's metal casing should be found at the incident site, but that, according to materials available to her, no such pieces were found anywhere in Sarajevo. ${ }^{14623}$

14618 P2318 (Report by Berko Zečević entitled "The use of modified aircraft bombs during the siege of Sarajevo, 1994-1995”), pp. 65, 180.

14619 Mile Poparić, T. 39024, 39036-39037 (30 May 2013); P6347 (Excerpt from firing tables for M-21-OF 122mm and Vulkan $122 \mathrm{~mm}$ ).

14620 Mile Poparić, T. 39034-39038, 39048 (30 May 2013). When put to Poparić that attaching a 122 mm GRAD rocket to an aircraft bomb and then firing the resulting modified air bomb at targets less than five kilometres away was highly irresponsible, he responded that aircraft bombs have a much smaller range than GRAD rockets, meaning that modified air bombs could not be compared to the rockets when looking at the appropriate range. See Mile Poparić, T. 39047-39048 (30 May 2013). See also Savo Simić, T. 30107-30112 (12 November 2012).

14621 Zorica Subotić, T. 38230 (14 May 2013); D3540 (Zorica Subotić's expert report entitled "The Use of Modified Aircraft Bombs in the Sarajevo Area in 1994-1995", 15 March 2012), p. 43; Zorica Subotić, T. 38476-38477 (16 May 2013); D2662 (Mirjana Anđelković-Lukić's expert report entitled "Expert Analysis of Documents", 26 July 2012), p. 6; D3644 (Expert report by Mile Poparić et al entitled "Inconsistencies of Experts Berko Zečević and Richard Higgs in Cases of the Shelling of Sarajevo", 15 August 2012), p. 72. See also D2633 (Witness statement of Milorad Šehovac dated 8 December 2012), para. 47; D2562 (Witness statement of Vladimir Radojčić dated 8 December 2012), para. 57; D2667 (Witness statement of Ratomir Maksimović dated 14 December 2012), para. 54; D2497 (Witness statement of Nikola Mijatović dated 27 November 2012), para. 21.

14622 D2662 (Mirjana Anđelković-Lukić's expert report entitled "Expert Analysis of Documents", 26 July 2012), p. 911; D3644 (Expert report by Mile Poparić et al entitled "Inconsistencies of Experts Berko Zečević and Richard Higgs in Cases of the Shelling of Sarajevo", 15 August 2012), pp. 71-72; Mirjana Anđelković-Lukić, T. 3147131472, 31476-31477, 31481, 31488-31490 (14 December 2012) (also arguing that Zečević did not attempt to disassemble the unexploded modified air bombs found in Sarajevo to show that they in fact contained fuel-air explosive). When asked if Pretis would have had empty casings which it could then fill with fuel-air explosives, Anđelković-Lukić responded that there was no need to stock empty casings due to the longevity of TNT. See Mirjana Anđelković-Lukić, T. 31520-31522 (14 December 2012).

14623 Mirjana Anđelković-Lukić, T. 31485-31486, 31489-31491 (14 December 2012) (adding also that the injuries sustained by the victims did not correspond to injuries caused by fuel-air bombs). Anđelković-Lukić also denied that one could easily confuse the remains of FAB-250 modified air bombs with those of FAB-275 modified air bombs, as the former has thicker walls. See Mirjana Anđelković-Lukić, T. 31512-31513 (14 December 2012). 
Finally, she claimed that the SRK had no launchers for bombs based on ODAB-500 due to their heavy weight and thus discounted the existence of 500-kilogram bombs. ${ }^{14624}$ In addition, she challenged Zečević's evidence about the existence of KREMA bombs as baseless. ${ }^{14625}$

4360. On cross-examination, however, Anđelković-Lukić was confronted with a number of documents contradicting her evidence. For example, when confronted with an SRK document referring to a launcher for bombs weighing 500 kilograms, she observed that the document also noted that the testing had yet to be done. ${ }^{14626}$ When shown an article and a photograph describing and depicting the disposal of 58 modified and regular FAB-275 fuel-air bombs in Glamoč after the war, she concluded that this meant that all the FAB-275 that were produced prior to the war were disposed of after the war and thus had not been used in the conflict. ${ }^{14627}$ When further shown two SRK documents referencing preparation for the use of FAB-275 modified air bombs, she remained adamant that she never encountered any evidence about the use of this bomb. ${ }^{14628}$ She conceded, however, that she did not go to Sarajevo, including to the sites struck by modified air bombs, and did not inspect any of the recovered fragments of modified air bombs. ${ }^{14629}$

4361. As for the issue of KREMA rockets, the Chamber notes that Anđelković-Lukić is also contradicted by an UNPROFOR report, in which Captain Guegan reported to Sector Sarajevo that on 9 July 1995 the Liaison Officer of the Ilidža Brigade, Captain Novak Prodanović, acknowledged that around 12 "KREMA rockets" had been fired on Sarajevo, including on the TV building, as part of the "psychological warfare aimed at upsetting the Bosnian soldiers on the Treskavica front who would be worried about the safety of their families in Sarajevo". ${ }^{14630}$ According to this report, Prodanović referred to the weapon as "Terror". ${ }^{14631}$

\footnotetext{
14624 D2662 (Mirjana Anđelković-Lukić's expert report entitled “Expert Analysis of Documents”, 26 July 2012), pp. 8-9; Mirjana Anđelković-Lukić, T. 31491-31492 (14 December 2012).

14625 D2662 (Mirjana Anđelković-Lukić's expert report entitled "Expert Analysis of Documents”, 26 July 2012), pp. 7-8; Mirjana Anđelković-Lukić, T. 31489-31490 (14 December 2012); D3644 (Expert report by Mile Poparić et al entitled "Inconsistencies of Experts Berko Zečević and Richard Higgs in Cases of the Shelling of Sarajevo", 15 August 2012), pp. 71, 73-74.

14626 Mirjana Anđelković-Lukić, T. 31506-31508 (14 December 2012); P1313 (SRK request for launcher testing, 23July 1995).

14627 Mirjana Anđelković-Lukić, T. 31509-31512 (14 December 2012); P6052 (Photograph of bombs); P6053 (Article from UXB International entitled "UXB Balkans Disposes of Hazardous Ammunition in BiH", 24 January 2011).

14628 Mirjana Anđelković-Lukić, T. $31517-31519$ (14 December 2012); P1296 (VRS Main Staff Order, 19 April 1995); P2652 (Letter from VRS Main Staff to Igman Infantry Brigade, 17 November 1994).

14629 Mirjana Anđelković-Lukić, T. 31522-31524 (14 December 2012).

14630 P2108 (UNPROFOR Memo re meeting with SRK, 9 July 1995), pp. 3-4; KDZ304, T. 10446-10447 (18 January 2011) (private session); P2407 (Witness statement of KDZ304), pp. 26-27.

14631 P2108 (UNPROFOR Memo re meeting with SRK, 9 July 1995), pp. 3-4.
} 
4362. Having considered the evidence above, the Chamber is convinced that modified FAB-100 and FAB-250 general purpose air bombs were used on targets in Sarajevo. The Chamber also finds, relying in particular on the documentary evidence outlined above and Zečević's evidence, that Pretis produced FAB-275 fuel-air bomb before the war, that such bombs also featured in the Sarajevo theatre of war. However, as indicated by the article shown to Anđelković-Lukić, a large number of FAB-275 bombs seem to have been disposed of-unused-after the war. In addition, the Chamber saw only two SRK documents referring to the use of these bombs in Sarajevo. ${ }^{14632}$ Finally, as will be seen below, the Chamber is not convinced that a fuel-air bomb was in fact used in any of the scheduled shelling incidents, either because the evidence was clear that another type of bomb was used or because it was insufficient to conclude beyond reasonable doubt that a fuel-air bomb was used. Accordingly, the Chamber finds that while these fuel-air bombs may have been used in Sarajevo, their use was not prevalent during the war. ${ }^{14633}$

4363. As for the reasons behind the SRK's use of modified air bombs, while the Chamber accepts that the lack of ammunition may have prompted their creation and usage, the Chamber is also convinced that the SRK found them to be a valuable means of psychological warfare, knowing fullwell that they had a devastating effect on the civilian population as well as the $\mathrm{ABiH}$ forces. It also used them in retaliation against the civilian population in response to $\mathrm{ABiH}$ actions, often on areas where there was no combat activity. This is shown not only by the witnesses who testified about the devastating psychological effect these bombs had but also by (i) documentary evidence, such as the UNPROFOR report of 9 July 1995 referred to above; (ii) the intercepted conversation between Momčilo Krajišnik and Milorad Motika of 17 June 1995; and (iii) evidence outlined below in relation to several Scheduled Incidents. ${ }^{14634}$

\section{(3) Who possessed modified air bombs?}

4364. It is clear from the evidence before the Chamber that the SRK had and used modified air bombs in Sarajevo. Many of the witnesses called by the Accused, including the SRK Commander Dragomir Milošević, confirmed this fact. ${ }^{14635}$ In addition, UNMOs Knustad and Per Anton

\footnotetext{
14632 See P1296 (VRS Main Staff Order, 19 April 1995); P2652 (Letter from VRS Main Staff to Igman Infantry Brigade, 17 November 1994).

14633 The Chamber also does not accept Zečević's evidence that FAB-250 bombs were modified such that the solid explosive charge was removed and fuel-air explosive inserted. The Chamber finds the evidence of AnđelkovićLukić more persuasive on this matter. It is likely that Zečević simply confused the fragments of FAB-275 with the fragments of FAB-250 and thus came to the conclusion that a FAB-250 was filled with fuel-air explosive.

14634 See paras. 4417, 4468-4469.

14635 Dragomir Milošević, T. 32768-32769 (28 January 2013); Stanislav Galić, T. 37960 (8 May 2013); D2686 (Witness statement of Mihajlo Vujasin dated 16 December 2012), para. 51; D2633 (Witness statement of Milorad Šehovac dated 8 December 2012), para. 46; D2562 (Witness statement of Vladimir Radojčić dated 8 December 2012), paras. 54; Vladimir Radojčić, T. 31236 (11 December 2012); D2412 (Witness statement of
} 
Brennskag personally observed SRK forces launching modified air bombs into Sarajevo from Špicasta Stijena and Ilidža, respectively. ${ }^{14636}$ Milomir Šoja also observed one such launch by the Ilidža Brigade of the SRK from the area of Kasindolska street across Energoinvest. ${ }^{14637}$ A number of witnesses called by the Accused observed similar launches. ${ }^{14638}$ Not all SRK Brigades had modified air bombs in their arsenal; only the Ilidža, Ilijaš, and Vogošća Brigades did, as well as the brigades that had facilites near Pretis. ${ }^{14639}$

4365. In addition, a large number of documents issued by the VRS Main Staff and the SRK also indicate that modified air bombs were assembled by Pretis and that their use was directed by the SRK Commander and strictly controlled by the VRS Main Staff. ${ }^{14640}$ Pretis would assemble the aircraft bombs and rockets, some of which were obtained from the FRY. ${ }^{14641}$ Lieutenant-Colonel

Savo Simić dated 4 November 2012), para. 21; Savo Simić, T. 30118-30120 (12 November 2012); D2667 (Witness statement of Ratomir Maksimović dated 14 December 2012), para. 53; D2484 (Witness statement of Zoran Kovačević dated 25 November 2012), para. 14; Zoran Kovačević, T. 30613 (28 November 2012); D2497 (Witness statement of Nikola Mijatović dated 27 November 2012), para. 17. See also Adjudicated Fact 2862.

14636 Thomas Knustad, P123 (Transcript from Prosecutor v. D. Milošević), T. 2037; P1851 (Witness statement of Per Anton Brennskag dated 26 October 2010), para. 36; Per Anton Brennskag, T. 8656-8657 (29 October 2010).

14637 Milomir Šoja, P1633 (Transcript from Prosecutor v. D. Milošević), T. 5121-5125, 5134-5146, 5152-5154, 5157-5158 (explaining that he also saw a modified air bomb in Osjek, which was under the SRK control); Milomir Šoja, T. 7211-7228 (30 September 2010); D674 (Map of Sarajevo marked by Milomir Šoja); D675 (Photograph of Sarajevo marked by Milomir Šoja); D676 (Map of Sarajevo marked by Milomir Šoja); D677 (Order of ABiH 102 ${ }^{\text {nd }}$ Motorised Brigade, 9 November 1993); D634 (Order of ABiH $102^{\text {nd }}$ Motorised Brigade, 1 February 1994); D679 (Order of ABiH $102^{\text {nd }}$ Motorised Brigade, 1 December 1993).

14638 D2412 (Witness statement of Savo Simić dated 4 November 2012), para. 21; Savo Simić, T. 30090-30091 (12 November 2012); D2686 (Witness statement of Mihajlo Vujasin dated 16 December 2012), para. 51; Mihajlo Vujasin, T. 31793-31794 (20 December 2012); Stevan Veljović, T. 29291 (23 October 2012); Nikola Mijatović, T. 30746 (30 November 2012). Stevan Veljović, T. 29290 (23 October 2012); Nikola Mijatović, T. 30746-30747 (30 November 2012).

P1199 (VRS Main Staff Order, 16 June 1994); D782 (SRK Order, 4 April 1995); P1201 (SRK Order, 6 April 1995); P1782 (SRK combat report, 7 April 1995); P1316 (VRS Main Staff Order to Pretis Factory, 12 April 1994); D322 (SRK Order, 19 April 1995); P1309 (SRK Order, 21 April 1995), p. 2; P1299 (VRS Main Staff request for information from SRK, 26 April 1995); P1292 (SRK Order, 4 June 1995); P1198 (SRK Order, 16 May 1995); P1311 (Request from $1^{\text {st }}$ Ilidža Infantry Brigade to SRK, 10 June 1995); P1301 (SRK request for approval of use of aerial bombs, 18 June 1995); P1280 (VRS Main Staff Order, 18 June 1995); P1302 (VRS Main Staff Order, 20 June 1995); P1284 (VRS Main Staff Order, 21 June 1995); P1303 (SRK request to VRS Main Staff, 22 June 1995); P1287 (VRS Main Staff Order, 4 June 1995); P1294 (VRS Main Staff Order, 12 June 1994); P1295 (VRS Main Staff request for information, 7 June 1995); P1298 (VRS Main Staff Order, 16 May 1995); P1312 (SRK combat report, 27 June 1995), p. 2; P1626 (Request from $1^{\text {st }}$ Ilidža Infantry Brigade to SRK Command, 28 June 1995); P1300 (SRK Order, 11 July 1995); P1286 (SRK request to VJ Main Staff, 15 July 1995); P1308 (VRS Main Staff order to Pretis Factory, 20 July 1995); P1307 (VRS Main Staff order to Pretis Factory, 23 July 1995); P1314 (Request from 3rd Sarajevo Infantry Brigade to SRK, 25 July 1995); P1306 (SRK request to VRS Main Staff, 27 July 1995); P1305 (Report of $1^{\text {st }}$ Sarajevo Mechanised Brigade to SRK re weapons, 5 August 1995); P1203 (SRK Order, 24 August 1995); P1315 (SRK Order, 27 August 1995); P1202 (SRK Forward Command Post 2 reports to SRK, 3 August and 3 September 1995); P1304 (SRK request to VRS Main Staff, 11 September 1995); P2318 (Report by Berko Zečević entitled "The use of modified aircraft bombs during the siege of Sarajevo, 1994-1995”), p. 94; Radovan Radinović, T. 41516 (18 July 2013); Stevan Veljović, T. 29271 (23 October 2012); David Fraser, T. 8014-8015 (18 October 2010); P5048 (Letter from Pretis Vogošća to Manojlo Milanović, 19 February 1994). See also Adjudicated Facts 2863 to 2871 (stating that Dragomir Milošević was directly involved in the deployment of modified air bombs and outlining a number of his orders to that effect).

14641 P2318 (Report by Berko Zečević entitled "The use of modified aircraft bombs during the siege of Sarajevo, 1994-1995”), pp. 93-94, 181; Berko Zečević, T. 12193-12199, 12211-12213 (22 February 2011); P2320 (VRS 
Milan Ugrešić, the Chief of Anti-Aircraft Defence in the SRK, ${ }^{14642}$ was in charge of dealing with weapons experts who were working on the assembly of the bombs and on modifying launchers for their use. ${ }^{14643}$

4366. In addition to the modified air bombs themselves, the SRK also had a number of launchers produced for the specific purpose of launching such bombs. ${ }^{14644}$ In spring of 1995, Milomir Šoja, an electrical engineer and a former Ilidža Brigade member, ${ }^{14645}$ was asked by members of the Ilidža Brigade to go to Pretis and make certain modifications to the modified air bomb launchers. ${ }^{14646}$ The modifications were ordered and made-despite the protest from Major Krsmanović who headed the aircraft bombs department at Pretis ${ }^{14647}$-in order to solve ignition problems experienced up until that point. ${ }^{14648}$ However, Šoja's modifications were unsuccessful and Krsmanović demanded the removal of electrical components placed on the launchers. ${ }^{14649}$ Thus, it is also clear that the SRK faced problems with modified air bomb launchers. These events also confirm Zečević's opinion, based on the photographs he inspected, that launchers used by the SRK were simple, with no capacity for precise adjustment of angles of elevation and azimuth, which in turn meant that their precision was not on par with standard rocket launchers. ${ }^{14650}$

4367. The Chamber also heard that the SRK decided to use modified air bombs due to the shortage of ammunition within its units and because the $\mathrm{ABiH}$ forces were getting stronger and

Main Staff letter to Pretis Factory, 18 January 1995); P2321 (VRS Main Staff Order, 3 June 1995); P1277 (Request from Pretis Factory to VRS Main Staff, 10 May 1994); P1280 (VRS Main Staff Order, 18 June 1995); Ekrem Suljević, T. 5685-5686, 5692 (21 July 2010); P1286 (SRK request to VJ Main Staff, 15 July 1995); P1295 (VRS Main Staff request for information, 7 June 1995); P5064 (Decision of the VJ General Staff issued by Momčilo Perišić, 16 February 1994).

14642 Stevan Veljović, T. 29238 (23 October 2012).

14643 Dragomir Milošević, T. 32770-32771 (28 January 2013).

14644 P1283 (SRK report to VRS Main Staff, 15 June 1995); P1285 (SRK request for information, 8 June 1995); P1288 (Report of $3^{\text {rd }}$ Sarajevo Infantry Brigade to SRK, 14 June 1995); P1290 (Report of Igman Infantry Brigade to SRK re weapons, 9 June 1995); P1293 (1 $1^{\text {st }}$ Ilidža Infantry Brigade report to SRK re weapons, 12 June 1995); P1295 (VRS Main Staff request for information, 7 June 1995); P1297 (Report of $1^{\text {st }}$ Romanija Infantry Brigade to SRK, 10 June 1995); P6051 (SRK Order, 2 September 1995); Vladimir Radojčić, T. 31236 (11 December 2012) (testifying that Ilidža Brigade had a launcher for modified air bombs); Milomir Šoja, P1633 (Transcript from Prosecutor v. D. Milošević), T. 5125-5126 (testifying that the SRK had modified air bomb launchers in Ilidža, Ilijaš, Vogošća, and Blažuj); Zoran Kovačević, T. 30613-30614 (28 November 2012). See also Adjudicated Fact 2868.

14645 Milomir Šoja, P1633 (Transcript from Prosecutor v. D. Milošević), T. 5112, 5160-5162.

14646 Milomir Šoja, P1633 (Transcript from Prosecutor v. D. Milošević), T. 5115-5120, 5149-5151.

14647 P2318 (Report by Berko Zečević entitled "The use of modified aircraft bombs during the siege of Sarajevo, 1994-1995"), p. 1.

14648 Milomir Šoja, P1633 (Transcript from Prosecutor v. D. Milošević), T. 5116, 5120-5121 (explaining that Krsmanović did not want the modifications to be made because he thought that bringing electrical components would make the whole system unreliable).

14649 Milomir Šoja, P1633 (Transcript from Prosecutor v. D. Milošević), T. 5134-5144.

14650 P2318 (Report by Berko Zečević entitled "The use of modified aircraft bombs during the siege of Sarajevo, 1994-1995”), pp. 95, 97-100; Emir Turkušić, T. 5689-5691 (21 July 2010); P1281 (Request from Technical 
better-equipped towards the end of the conflict. ${ }^{14651}$ In addition, Milošević explained that the SRK considered these bombs to be useful in situations which could not be resolved with smaller caliber weapons. $^{14652}$

4368. As far as the $\mathrm{ABiH}$ is concerned, most of the witnesses, including some of those called by the Accused, consistently testified that $\mathrm{ABiH}$ did not have modified air bombs because it had no means to modify or launch aircraft bombs in Sarajevo, particularly fuel-air bombs. ${ }^{14653}$ Milošević claimed that $\mathrm{ABiH}$ had air bombs at its disposal because in mid-April 1992 the special forces of the BiH MUP led by Dragan Vikić entered Pretis and took away ammunition, including a stock of general purpose aircraft bombs. ${ }^{14654}$ In addition, according to Milošević, three air bombs landed on Vraca but did not explode, although he did not know what method was used to launch them. ${ }^{14655}$ The Accused also put forward an audio recording of the $291^{\text {st }}$ session of the BiH Presidency, held in August 1995, in which mention was made of 800 aerial bombs which were yet to arrive. ${ }^{14656}$

Overhaul and Repairs Institution to Ilijaš Ironworks, 26 May 1994); P1289 (SRK request for launcher testing, 23 July 1995); P1291 (SRK Order, 10 August 1995); P1313 (SRK request for launcher testing, 23 July 1995).

14651 Dragomir Milošević, T. 32769 (28 January 2013); D2562 (Witness statement of Vladimir Radojčić dated 8 December 2012), para. 54; D2412 (Witness statement of Savo Simić dated 4 November 2012), para. 22; D2667 (Witness statement of Ratomir Maksimović dated 14 December 2012), para. 53; D2484 (Witness statement of Zoran Kovačević dated 25 November 2012), para. 14; D2497 (Witness statement of Nikola Mijatović dated 27 November 2012), para. 17.

14652 Dragomir Milošević, T. 32768-32769 (28 January 2013); D2562 (Witness statement of Vladimir Radojčić dated 8 December 2012), paras. 93-94; P1311 (Request from $1^{\text {st }}$ Ilidža Infantry Brigade to SRK, 10 June 1995); P1626 (Request from $1^{\text {st }}$ Ilidža Infantry Brigade to SRK Command, 28 June 1995).

14653 P1851 (Witness statement of Per Anton Brennskag dated 26 October 2010), para. 38; Per Anton Brennskag, T. 8730-8732 (1 November 2010); Ekrem Suljević, T. 6174-6175 (6 September 2010); P1978 (Witness statement of Nedžib Đozo dated 7 December 2010), para. 49; P1762 (Witness statement of David Fraser dated 17 October 2010), pp. 63-64; Thorbjorn Overgard, P2058 (Transcript from Prosecutor v. D. Milošević), T. 647; P1953 (Witness statement of Harry Konings dated 11 November 2010), para. 42; Harry Konings, T. 9350 (7 December 2010); P2407 (Witness statement of KDZ304), pp. 19, 24; P2318 (Report by Berko Zečević entitled "The use of modified aircraft bombs during the siege of Sarajevo, 1994-1995"), pp. 183-184; Berko Zečević, T. 12181-12182, 12185-12186 (22 February 2011); Milomir Šoja, P1633 (Transcript from Prosecutor v. D. Milošević), T. 5125-5126; D2686 (Witness statement of Mihajlo Vujasin dated 16 December 2012), para. 54; Mihajlo Vujasin, T. 31793 (20 December 2012); P1996 (Witness statement of Martin Bell dated 8 March 2010), para. 101.

14654 Dragomir Milošević, T. 32762-32764 (28 January 2013); D3540 (Zorica Subotić's expert report entitled “The Use of Modified Aircraft Bombs in the Sarajevo Area in 1994-1995", 15 March 2012), p. 42. See also Emir Turkušić, T. 9045-9046 (4 November 2010) (accepting that these forces attacked Pretis in April 1992 but testifying that they took a number of hand-held rocket launchers); KDZ020, T. 12613-12614, 12621 (1 March 2011); D2678 (Witness statement of Svetozar Stanić dated 16 December 2012), paras. 7, 22 (testifying that a lorry full of artillery shells was taken); Svetozar Stanić, T. 31708, 31714 (18 December 2012); D2444 (Witness statement of Miladin Trifunović dated 11 November 2012), para. 10 (providing the list of the ammunition taken, which did not include air bombs); D3065 (Witness statement of Aleksandar Vasiljević dated 26 February 2013), para. 187 (testifying that "rocket systems" were taken); D2681 (Report of Vogošća Municipal Secretariat for National Defence, 18 April 1992); D3069 (JNA $2^{\text {nd }}$ Military District report, 20 April 1992).

14655 Dragomir Milošević, T. 32763-32766 (28 January 2013) (adding also that he heard at the time that the person responsible for creating those three bombs was Berko Zečević). See also D2562 (Witness statement of Vladimir Radojčić dated 8 December 2012), paras. 59, 129 (stating that the ABiH had modified projectiles, such as modified naval bombs); D2602 (Report of $1^{\text {st }}$ Ilidža Infantry Brigade, 1 April 1994).

14656 D2816 (Extract from transcript of $291^{\text {st }}$ session of RBiH Presidency, 10 August 1995). 
Nikola Mijatović, Chief of Security and later Chief of Staff in the Ilidža Brigade, ${ }^{14657}$ was the only witness who testified that the $\mathrm{ABiH}$ had modified air bombs and stated that his knowledge on this came from a documentary he saw after the war. ${ }^{14658}$

4369. Based on the evidence above, the Chamber is convinced that only the SRK possessed modified air bombs of the type discussed in this part of the judgement. The evidence is clear that only the SRK had the means to modify and then launch the air bombs in their possession, while the ABiH simply lacked such means. The Chamber does not accept Milošević's evidence that Vikić and his forces took air bombs from Pretis, as none of the witnesses, including those called by the Accused, confirm this. Instead, the evidence shows that Vikić and his forces removed artillery projectiles from Pretis. Similarly, the Chamber does not believe Milošević's evidence about three air bombs that landed in Vraca, particularly since he could not explain how they were launched by the $\mathrm{ABiH}$ and finds Mijatović's evidence equally unpersuasive. Thus, although there is some evidence that suggests that $\mathrm{ABiH}$ may have had (or was waiting to obtain) air bombs in its arsenal, there is no credible evidence that it modified them in the way described above or that it used them against targets in Sarajevo.

\section{(4) Accuracy and range of modified air bombs}

4370. As noted above, the Accused argues that modified air bombs were an accurate weapon properly tested by expert engineers. In addition, according to a number of SRK soldiers and officers, modified air bombs were used exclusively against military targets and with no intention to target or terrorise civilians. ${ }^{14659}$ Milošević suggested that the fact that only five people were killed in all the modified air bomb incidents alleged in the Indictment meant that these bombs were used selectively on non-residential targets. ${ }^{14660}$

4371. However, the Chamber heard a plethora of evidence indicating that modified air bombs were highly inaccurate because of the way in which they were constructed and because they were propelled by unguided rockets. ${ }^{14661}$ The trajectory of such bombs did not follow the classic ballistic

14657 D2497 (Witness statement of Nikola Mijatović dated 27 November 2012), para. 11.

14658 D2497 (Witness statement of Nikola Mijatović dated 27 November 2012), para. 20.

14659 Dragomir Milošević, T. 32773-32775, 32781-32782 (28 January 2013); D2562 (Witness statement of Vladimir Radojčić dated 8 December 2012), para. 58; D2686 (Witness statement of Mihajlo Vujasin dated 16 December 2012), para. 53; D2667 (Witness statement of Ratomir Maksimović dated 14 December 2012), paras. 53, 55; D2497 (Witness statement of Nikola Mijatović dated 27 November 2012), para. 19.

14660 Dragomir Milošević, T. 32781-32782 (28 January 2013).

14661 P2318 (Report by Berko Zečević entitled "The use of modified aircraft bombs during the siege of Sarajevo, 1994-1995”), pp. 23, 86-89; P1276 (Witness statement of Ekrem Suljević dated 9 February 2010), para. 40; P1925 (Witness statement of Emir Turkušić dated 16 February 2010), p. 6; Emir Turkušić, T. 8998-9000, 90539054 (4 November 2010); David Fraser, T. 8133 (19 October 2010); P1953 (Witness statement of Harry Konings dated 11 November 2010), paras. 42-44; Thomas Knustad, P123 (Transcript from Prosecutor v. D. 
arc of an artillery round; rather, the bomb would travel until the rocket motors stopped and then it would fall down to the ground. ${ }^{14662}$ Furthermore, the precision of modified air bombs was affected by their multiple rockets, which would not always ignite simultaneously and by the fact that the rocket motors would fire for different durations; these factors also affected the direction of the bomb. ${ }^{14663}$ Accordingly, while the forces firing such bombs would have some idea of the direction in which the bombs would be propelled, they could not be sure of the exact location where it would eventually land. ${ }^{14664}$ Veljović also confirmed that modified air bombs were not precise and could be off target by two kilometres, which is why the SRK forces were authorised to use them only outside of the urban areas. ${ }^{14665}$ In fact, according to Veljović, because these bombs were "completely inaccurate", they caused panic even among the SRK troops. ${ }^{14666}$ In his interview with the Prosecution, Neđeljko Prstojević, the Commander of the Ilidža Crisis Staff, ${ }^{14667}$ stated that one of the SRK unit commanders told him that another name for modified air bombs was "wherever it lands" because it was so imprecise. ${ }^{14668}$

Milošević), T. 1990; P1851 (Witness statement of Per Anton Brennskag dated 26 October 2010), paras. 34-35; KDZ304, T. 10444-10445 (18 January 2011); Per Anton Brennskag, T. 8705-8706 (1 November 2010) (stating that mortars were more precise than modified air bombs); P896 (UNPROFOR Weekly Situation Report (Sarajevo), 2 July 1995), p. 2 (referring to these weapons as "highly inaccurate, indiscriminate, highly destructive weapons of terror"); Zorica Subotić, T. 38477, 38480 (16 May 2013).

14662 P1851 (Witness statement of Per Anton Brennskag dated 26 October 2010), para. 34; Per Anton Brennskag, T. 8716-8723 (1 November 2010) (stating also that the trajectory of the modified air bomb was slightly more horizontal than that of an artillery projectile); Thomas Knustad, P123 (Transcript from Prosecutor v. D. Milošević), T. 1990 (stating that modified air bombs could travel for a maximum of 7,000 metres); Nikola Mijatović, T. 30749-30750 (30 November 2012); Thorbjorn Overgard, P2058 (Transcript from Prosecutor v. D. Milošević), T. 695.

14663 Emir Turkušić, T. 8998-9000 (4 November 2010); Berko Zečević, T. 12177-12178 (22 February 2011). But see Zorica Subotić, T. 38492-38495 (16 May 2013) (accepting that non-simultaneous ignition and/or different duration of work of the engines would affect the direction of the bomb but denying that it would result in the projectile being unstable); Mile Poparić, T. 39038-39040 (30 May 2013) (testifying that absolutely synchronous ignition was impossible but that the difference in ignition would be in milliseconds and thus would have no impact on the trajectory of the bomb); Nikola Mijatović, T. 30750 (30 November 2012).

14664 P1276 (Witness statement of Ekrem Suljević dated 9 February 2010), para. 40; P1925 (Witness statement of Emir Turkušić dated 16 February 2010), p. 6; Emir Turkušić, T. 8998-9000 (4 November 2010); P1978 (Witness statement of Nedžib Đozo dated 7 December 2010), para. 49; Thorbjorn Overgard, P2058 (Transcript from Prosecutor v. D. Milošević), T. 643-644; P1851 (Witness statement of Per Anton Brennskag dated 26 October 2010), para. 42. Turkušić also added that it is "absolutely impossible" given the combination of an air bomb and the rocket motors to achieve "sufficient precision in the parallel nature $[\ldots]$ of the rocket motors with the axis of the air bomb" so that every deviation in the angle would lead to imprecision in the direction. Emir Turkušić, T. 8999 (4 November 2010). See also Berko Zečević, T. 12178-12179 (22 February 2011); Adjudicated Fact 2821.

14665 Stevan Veljović, T. 29269-29270 (23 October 2012). See also Nikola Mijatović, T. 30750 (30 November 2012).

14666 Stevan Veljović, T. 29270-29271 (23 October 2012).

14667 Neđeljko Prstojević, T. 12961 (8 March 2011), 13658-13660 (18 March 2011).

14668 P2516 (Excerpt from transcript of Neđeljko Prstojević's interview, with audio); P2517 (Excerpt from transcript of Neđeljko Prstojević's interview, with audio). Later, during his testimony in this case, Prstojević rejected the interview, arguing that his words were not interpreted correctly. Having reviewed the relevant audio portions of those interviews, the Chamber found that they were accurately interpreted and transcribed. Accordingly, the Chamber finds Prstojević's statements in the interviews to have been accurately recorded and reliable. See Neđeljko Prstojević, T. 13570-13577 (17 March 2011). See also fn. 15005. 
4372. According to Zečević, the inaccuracy was to be expected because modified air bombs did not pass through any of the normal phases for the adoption of new weapon systems (which normally take five to seven years) and thus no stable production process was established. ${ }^{14669}$ Zečević conceded that he had no proof that this was the case, but explained that based on his knowledge of procedures for testing weapons, such testing could not have been done in the $\mathrm{BiH}$ at the time due to wartime conditions. ${ }^{14670}$ This was indeed confirmed by Veljović, who testified that modified air bombs were not tested, resulting in a few deaths among the firing crews. ${ }^{14671}$

4373. On the other hand, all three Defence experts argued in their joint report that Zečević could not be sure that modified air bombs were not tested. ${ }^{14672}$ When asked how long it would have taken the VRS to develop a modified air bomb, Poparić speculated that three years would have been enough because it was an integration of two properly tested weapons. ${ }^{14673}$ Further, Šoja testified that he heard of a testing exercise in an area where there were no residential buildings. ${ }^{14674}$ Sometime in 1994, Mihajlo Vujasin, Chief of Engineers in the SRK, ${ }^{14675}$ also observed a testing exercise of a modified air bomb in Nišići Plateau, which was unsuccessful as the bomb failed to launch due to rocket motors failing to ignite. ${ }^{14676}$ Radojčić testified that both "the missile engines and the whole aerial bomb kit were tested" in Kalinovik, following which his brigade received

\footnotetext{
14669 P2318 (Report by Berko Zečević entitled "The use of modified aircraft bombs during the siege of Sarajevo, 1994-1995”), pp. 91, 96; Berko Zečević, T. 12180-12181 (22 February 2011). See also Mirjana AnđelkovićLukić, T. 31493-31498, 31504-31506 (14 December 2012) and D3644 (Expert report by Mile Poparić et al entitled "Inconsistencies of Experts Berko Zečević and Richard Higgs in Cases of the Shelling of Sarajevo", 15 August 2012), p. 76, which both confirm that testing usually takes five to seven years.

14670 Berko Zečević, T. 12220-12229 (23 February 2011).

14671 Stevan Veljović, T. 29270-29271, 29286 (23 October 2012).

14672 D3644 (Expert report by Mile Poparić et al entitled "Inconsistencies of Experts Berko Zečević and Richard Higgs in Cases of the Shelling of Sarajevo", 15 August 2012), pp. 74-75 (the exception being 122 mm GRAD rockets which were produced in Russia).

14673 Mile Poparić, T. 39041-39044, 39051-39052 (30 May 2013).

14674 Milomir Šoja, T. 7217-7218 (30 September 2010).

14675 D2686 (Witness statement of Mihajlo Vujasin dated 16 December 2012), paras. 11-13.

14676 D2686 (Witness statement of Mihajlo Vujasin dated 16 December 2012), para. 51; Mihajlo Vujasin, T. 31793 31794 (20 December 2012). See also D2412 (Witness statement of Savo Simić dated 4 November 2012), para. 21 (explaining that he saw modified air bombs for the first time in the latter part of 1994 at the Nišići plateau); Savo Simić, T. 30090 (12 November 2012).
} 
"temporary firing tables". ${ }^{14677}$ Zečević himself acknowledged that there probably existed some "basic firing tables" for firing conditions of the rocket motors. ${ }^{14678}$

4374. Whether tested or not, Zečević claimed that none of the three types of modified air bombs was designed for firing at individual targets as they could only be used for firing at "area targets with lengths and widths of hundreds of meters". ${ }^{14679}$ Additionally, these bombs were very sensitive to cross-winds, changes in the impulse of the rocket engines, and air temperature changes. ${ }^{14680}$ Finally, all three types of modified air bombs would ricochet if the impact angle was less than 25 degrees. ${ }^{14681}$ Thus, according to Zečević, the use of these bombs in urban areas would inevitably lead to civilian casualties. ${ }^{14682}$ Similarly, a number of UN witnesses thought that modified air bombs had no military value as they were an indiscriminate weapon that had more detrimental effects on civilians and infrastructure, ${ }^{14683}$ and that its use in Sarajevo was inappropriate,

14677 D2562 (Witness statement of Vladimir Radojčić dated 8 December 2012), para. 55; Vladimir Radojčić, T. 31249-31250, 31252-31253 (11 December 2012) (explaining that he did not know what kind of testing was done and/or how many times the modified air bombs were fired during that testing), T. 31262-31266 (12 December 2012); P6040 (Excerpt from M-63 Plamen fire tables). When asked if he had the temporary firing tables in his possession, Radojčić responded that only the chief of artillery of Ilidža Brigade had them. Vladimir Radojčić, T. 31250-31251 (11 December 2012). See also Savo Simić, T. 30096-30100 (12 November 2012) (who also testified that he saw such firing tables for the modified air bombs); Stevan Veljović, T. 29285 (23 October 2012).

14678 P2318 (Report by Berko Zečević entitled "The use of modified aircraft bombs during the siege of Sarajevo, 1994-1995"), p. 95.

14679 P2318 (Report by Berko Zečević entitled "The use of modified aircraft bombs during the siege of Sarajevo, 1994-1995”), pp. 77-80, 86; Berko Zečević, T. 12179-12180 (22 February 2011), T. 12220 (23 February 2011). According to Zečević, the modified FAB-100 could only target an area measuring 500 metres by 200 metres, on the condition that no changes were made to the rocket motors and that firing was done in salvos. As for the FAB-250, it was only possible to target an area measuring 600 metres by 250 metres, so long as the same conditions mentioned above applied. See P2318 (Report by Berko Zečević entitled "The use of modified aircraft bombs during the siege of Sarajevo, 1994-1995”), pp. 79-80. See also P1309 (SRK Order, 21 April 1995), p. 2 (showing that the SRK Commander at the time, Dragomir Milošević, recognised that salvos of fire would be needed to hit the target using a modified air bomb); P1310 (SRK report to VRS Main Staff re weapons, 26 April 1995) (indicating that the SRK refrained from launching a modified air bomb at a certain target because UN soldiers were some 200 metres from the target and SRK troops were 500 metres from that target); Emir Turkušić, T. 5712-5713 (22 July 2010); Dušan Škrba, T. 29160-29161 (22 October 2012). But see D3644 (Expert report by Mile Poparić et al entitled "Inconsistencies of Experts Berko Zečević and Richard Higgs in Cases of the Shelling of Sarajevo", 15 August 2012), pp. 72-73 (challenging the area measurements on the ground that they were taken out of context and do not represent the characteristics of an rocket artillery system). See also Dragomir Milošević, T. 33165-33166 (4 February 2013), T. 33185-33186 (5 February 2013) (explaining that his order in P1309 was a question of terminology and that it was impossible to carry out given that only one modified air bomb could be launched at a time, after which two hours were needed to prepare for the next launch).

14680 P2318 (Report by Berko Zečević entitled "The use of modified aircraft bombs during the siege of Sarajevo, 1994-1995”), pp. 77-80; Zorica Subotić, T. 38470-38473 (16 May 2013).

14681 P2318 (Report by Berko Zečević entitled "The use of modified aircraft bombs during the siege of Sarajevo, 1994-1995”), pp. 81-84, 87.

14682 P2318 (Report by Berko Zečević entitled "The use of modified aircraft bombs during the siege of Sarajevo, 1994-1995”), p. 88. See also Mirjana Anđelković-Lukić, T. 31500-31502 (14 December 2012) (testifying that modified air bombs are to be used on lightly fortified targets, such as bunkers and other fortified enemy facilities).

14683 David Fraser, T. 8010-8011 (18 October 2010); P1762 (Witness statement of David Fraser dated 17 October 2010), pp. 63-64; Thorbjorn Overgard, P2058 (Transcript from Prosecutor v. D. Milošević), T. 643-644; P1851 (Witness statement of Per Anton Brennskag dated 26 October 2010), para. 35; Thomas Knustad, P123 
particularly given that the city was populated by civilians and that civilian houses were everywhere. $^{14684}$

4375. Dragomir Milošević, on the other hand, claimed that the weapon experts working on modified air bombs perfected their design such that the bombs were precise and could pinpoint and hit a target. ${ }^{14685} \mathrm{He}$ also argued that making these bombs precise was essential because they were fired from behind the SRK lines and over Serb residential areas. ${ }^{14686}$ Radojčić also testified that the precision of the modified air bombs was "satisfactory" as shown by the testing done in Kalinovik and that the deviation range in these bombs was, on average, 10 metres per 1,000 metres. ${ }^{14687}$ According to Savo Simić, Chief of Artillery of the $1^{\text {st }}$ Sarajevo Mechanised Brigade of the SRK, ${ }^{14688}$ there was almost no deviation in the trajectory of the modified air bombs. ${ }^{14689}$ Zečević claimed, however, that modifications made on the FAB-100 and FAB-250 at the Pretis Factory, as shown by documents found there in early 1996, fell well below the professional standards of Pretis and were inferior in comparison to the modifications made to the bomb based on ODAB-500. ${ }^{14690}$ This meant that it was in fact impossible to fire FAB-100 and FAB-250 modified air bombs in accordance with any firing tables. ${ }^{14691}$

(Transcript from Prosecutor v. D. Milošević), T. 1990, 1992. But compare KDZ477's evidence to the effect that, being an anti-personnel weapon, mortar shells would cause more casualties due to the fragmentation of the shell. On the other hand, modified air bombs would cause more damage to physical structures. P2164 (Witness statement of KDZ477 dated 13 February 2010), paras. 31-33; KDZ477, T. 10949-10950 (31 January 2011).

14684 Thomas Knustad, P123 (Transcript from Prosecutor v. D. Milošević), T. 1992.

14685 Dragomir Milošević, T. 32773 (28 January 2013) (stating that the testing was done in Kalinovik), T. 3318533186 (5 February 2013) (stating that modified air bombs were more accurate than air bombs dropped from the planes). See also D2667 (Witness statement of Ratomir Maksimović dated 14 December 2012), para. 54.

14686 Dragomir Milošević, T. 32773-32774 (28 January 2013), 33150-33151 (4 February 2013). See also D2562 (Witness statement of Vladimir Radojčić dated 8 December 2012), para. 55; D2497 (Witness statement of Nikola Mijatović dated 27 November 2012), para. 18.

14687 D2562 (Witness statement of Vladimir Radojčić dated 8 December 2012), para. 55; Vladimir Radojčić, T. 31249-31250, 31252-31253 (11 December 2012) (explaining that he did not know what kind of testing was done or how many times the modified air bombs were fired during that testing), T. 31262-31266 (12 December 2012); P6040 (Excerpt from M-63 Plamen fire tables). When asked if he had the temporary firing tables in his possession, Radojčić responded that only the chief of artillery of Ilidža Brigade had them. Vladimir Radojčić, T. 31250-31251 (11 December 2012). See also Savo Simić, T. 30096-30100 (12 November 2012) (who also testified that he saw such firing tables for the modified air bombs).

14688 D2412 (Witness statement of Savo Simić dated 4 November 2012), para. 3.

14689 D2412 (Witness statement of Savo Simić dated 4 November 2012), para. 21; Savo Simić, T. 30090-30091, 30096-30099, 30106-30112 (12 November 2012) (explaining that he based his opinion on the accuracy of modified air bombs on the fact that he observed them being used twice). See also D2497 (Witness statement of Nikola Mijatović dated 27 November 2012), para. 18, Nikola Mijatović, T. 30750 (30 November 2012) (testifying that if the rocket motors were checked and working properly, which they were, there was a chance of only a minimal deviation in the trajectory due to meteorological conditions).

14690 P2318 (Report by Berko Zečević entitled "The use of modified aircraft bombs during the siege of Sarajevo, 1994-1995”), pp. 74-75, 86-87, 91-92, 94 (explaining, among other things, that for FAB-250 the stabilising fins were fixed to rocket engines in an unstable way and the fins themselves were substandard).

14691 P2318 (Report by Berko Zečević entitled "The use of modified aircraft bombs during the siege of Sarajevo, 1994-1995"), pp. 76-77. 
4376. Subotić also claimed that modified air bombs were accurate and based this claim on her analysis of 16 modified air bomb incidents in Sarajevo, whereby she compared the locations at which the bombs landed with what she thought were the most likely targets, assuming that each bomb had an average range of 6,000 metres. ${ }^{14692}$ She concluded that in all incidents but one, the projectiles met the "general exterior ballistics demands for unguided rockets". ${ }^{14693}$ She conceded, however, that for any rocket-assisted projectile firing tables are necessary to hit the target. ${ }^{14694}$ In terms of the rockets themselves, she agreed that they were not designed for a simultaneous launch but thought that rocket motors on a modified air bomb launched "almost" simultaneously. ${ }^{14695}$ She also conceded that general purpose aircraft bombs were designed and tested for air-to-surface delivery, rather than surface-to-surface delivery, but then argued that there was not much difference between those bombs and mortar bombs in terms of their design. ${ }^{14696}$ She also agreed that for the modified air bomb to be accurate it was vital that each rocket was parallel to the longitudinal axis of the air bomb. ${ }^{14697}$

4377. Finally, she agreed that modified air bombs, including their rocket motors and the launchers, would have to be thoroughly tested before they were approved for use and conceded that she never participated in any such testing or saw any such test data for modified air bombs. ${ }^{14698}$ She denied that in her analysis of the incidents she simply combined the available testing data for aircraft bombs with the data for rockets and attempted to fuse those into one set of data for modified air bombs. ${ }^{14699}$

14692 D3540 (Zorica Subotić's expert report entitled "The Use of Modified Aircraft Bombs in the Sarajevo Area in 1994-1995”, 15 March 2012), pp. 187-189; Zorica Subotić, T. 38533-38535 (21 May 2013). On crossexamination, Mile Poparić, who co-authored Subotić's report, conceded that these calculations were made based on the assumption that the modified air bombs were fired six kilometres away from the target. He also explained that this was close to the maximum range for those bombs. Mile Poparić, T. 39022-39033 (30 May 2103); P6346 (Excerpt from Military Lexicon, 1981).

D3540 (Zorica Subotić's expert report entitled "The Use of Modified Aircraft Bombs in the Sarajevo Area in 1994-1995”, 15 March 2012), p. 189; Zorica Subotić, T. 38229-38230 (14 May 2013) (testifying that according to her analysis $44 \%$ of the bombs hit what she thought was the intended target).

14694 Zorica Subotić, T. 38472-38473 (16 May 2013), T. 38523 (21 May 2013).

14695 Zorica Subotić, T. 38480-38484 (16 May 2013), T. 38639-38642 (22 May 2013) (explaining that ignition of multiple rocket motors will differ only in milliseconds).

14696 Zorica Subotić, T. 38478-38479 (16 May 2013). In this regard, Subotić contradicted Poparić who thought that rocket motors on the air bomb essentially turned it into a rocket projectile rather than a mortar. See para. 4358. See also Mirjana Anđelković-Lukić, T. 31499, 31514-31515 (14 December 2012) (confirming that aircraft bombs were designed to be launched from an aircraft).

14697 Zorica Subotić, T. 38521-38522 (21 May 2013); P6326 (Photograph of four rockets attached together).

14698 Zorica Subotić, T. 38522-38525, 38527-38532 (21 May 2013) (testifying also that she did see some documents which indicated that launchers were sent for testing). Subotić also confirmed that Pretis was testing rocket motors on behalf of the SRK. Zorica Subotić, T. 38634-38637 (22 May 2013); D3559 (Notification of VRS Main Staff Technical Department, 26 July 1995). See also Mile Poparić, T. 39052-39054 (30 May 2013). 
4378. As for the range of modified air bombs, Zečević determined ${ }^{14700}$ that if launched at 45 degrees, the maximum range of the FAB-100 and FAB-250 is 5,560 and 7,680 metres respectively. ${ }^{14701}$ As noted above, Subotić assumed that the average range of modified air bombs was 6,000 metres. ${ }^{14702}$ Ratomir Maksimović, the Chief for Morale in the SRK Command, ${ }^{14703}$ testified that modified air bombs had a range of one to two kilometres. ${ }^{14704}$

4379. Having considered the evidence above, the Chamber is convinced that modified air bombs which were used in Sarajevo by the SRK were an inherently inaccurate weapon system and, as such, were not capable of targeting specific targets but only large areas. This is shown not only by witnesses who testified to that effect but also by the SRK's own documents indicating that the SRK was fully aware of the weapon's inaccuracy. ${ }^{14705}$ Indeed, even Veljović spoke of the panic the use of this weapon would produce among the SRK forces located in its flight path. The witnesses who testified to the contrary were SRK soldiers and officers, including Milošević, all of whom had a personal interest in minimising the danger these bombs posed to both the civilian population and their own troops. The Chamber therefore rejects their evidence on the accuracy of modified air bombs as unconvincing and marked by bias.

4380. While some test launches of modified air bombs were conducted by the SRK and its ballistics experts, the Chamber is of the view that they were inadequate as far as ensuring the necessary precision and optimal performance of the weapon was concerned. Given that all expert witnesses agreed that adequate testing of a new weapon system would take around five to seven years, any testing that was performed was obviously rushed and therefore deficient. The Chamber also rejects Poparić's evidence that three years of testing would have been sufficient to ensure the accuracy of this weapon system. Furthermore, even if correct, there is no evidence that the SRK did in fact spend three years doing so. Instead, the Chamber received evidence of only a few occasions on which modified air bombs were tested, sometimes unsuccessfully. The Chamber

\footnotetext{
14700 Zečević made this determination on the basis of the "nominal parameters of the rocket and the rocket motors, and a standard atmosphere with no wind". See P2318 (Report by Berko Zečević entitled "The use of modified aircraft bombs during the siege of Sarajevo, 1994-1995”), p. 81.

14701 P2318 (Report by Berko Zečević entitled "The use of modified aircraft bombs during the siege of Sarajevo, 1994-1995”), pp. 81-85 (stating also that the range would depend on the type of rocket motors used on the modified air bomb).

14702 D3540 (Zorica Subotić's expert report entitled "The Use of Modified Aircraft Bombs in the Sarajevo Area in 1994-1995”, 15 March 2012), pp. 55, 67, 187; Zorica Subotić, T. 38488-38489 (16 May 2013).

14703 Ratomir Maksimović, T. 31569-31571 (17 December 2012).

14704 D2667 (Witness statement of Ratomir Maksimović dated 14 December 2012), para. 53.

14705 See P1309 (SRK Order, 21 April 1995), p. 2 (showing that the SRK Commander at the time, Dragomir Milošević, recognised that salvos of fire would be needed to hit the target using a modified air bomb); P1310 (SRK report to VRS Main Staff re weapons, 26 April 1995) (indicating that the SRK refrained from launching a modified air bomb at a certain target because UN soldiers were located 200 metres from the target while the SRK troops were 500 metres from that target).
} 
further notes that these few testing occasions took place in wartime conditions, which would not have been an ideal environment for adequate testing, in turn raising doubt as to the reliability of the testing results. Finally, while some firing tables may have been produced to aid the SRK troops in launching modified air bombs, the Chamber does not consider that their existence made modified air bombs precise.

\section{(5) Damage caused by modified air bombs}

4381. The quantity of explosive in modified air bombs was much higher than in mortar shells and thus its purpose was to be destructive, in contrast to the mortar shells the purpose of which is to kill personnel with shrapnel. ${ }^{14706}$ Zečević explained that standard 250 kilogram aircraft bombs with solid TNT explosive will produce a crater that is between 1.8 and 3 metres deep, with a radius of anywhere between seven and 12 metres, depending on the fuse and the weight of the bomb used. ${ }^{14707}$ When they detonate, the primary effects will be caused by the blast wave and the kinetic energy of fragments. ${ }^{14708}$ On the other hand, when fuel-air bombs detonate, they do not create a crater and their primary effect is a lower intensity but longer lasting blast wave, with less fragmentation. ${ }^{14709}$ Accordingly, if human targets are in the open without any barriers shielding them, the bombs with solid TNT explosive charges would be more efficient at "destroying" them, while the fuel-air bombs would be better at "destroying" human targets hidden in the bunkers or tunnels. ${ }^{14710}$ Anđelković-Lukić explained that in case of solid TNT charges, the wounds inflicted on the human body come from shrapnel and thus resemble those inflicted by bullets, whereas fuel-

14706 P1276 (Witness statement of Ekrem Suljević dated 9 February 2010), para. 37; Ekrem Suljević, T. 5728 (22 July 2010), T. 5727-5728 (22 July 2010) (explaining that sometimes, a big aerial bomb would be referred to as "krmača" (meaning a "female pig"), exactly because it was intended for destruction); Milomir Šoja, P1633 (Transcript from Prosecutor v. D. Milošević), T. 5147-5148; P1925 (Witness statement of Emir Turkušić dated 16 February 2010), p. 6; P1953 (Witness statement of Harry Konings dated 11 November 2010), para. 42; P2407 (Witness statement of KDZ304), p. 18; KDZ304, T. 10444-10447 (18 January 2011); Dragomir Milošević, T. 33149-33150 (4 February 2013); Vladimir Radojčić, T. 31249 (11 December 2012); Stevan Veljović, T. 29270 (23 October 2012); Nikola Mijatović, T. 30745 (30 November 2012); P1996 (Witness statement of Martin Bell dated 8 March 2010), para. 102. See also P1762 (Witness statement of David Fraser dated 17 October 2010), p. 64 (stating that modified air bombs were much larger than mortars and that they were psychologically devastating for the people in Sarajevo).

14707 P2318 (Report by Berko Zečević entitled "The use of modified aircraft bombs during the siege of Sarajevo, 1994-1995”), p. 41; Berko Zečević, T. 12201-12202 (22 February 2011).

14708 P2318 (Report by Berko Zečević entitled "The use of modified aircraft bombs during the siege of Sarajevo, 1994-1995”), pp. 48, 103-105; Berko Zečević, T. 12182-12186 (22 February 2011) (explaining that the explosion of a FAB-250 bomb will produce over 7,000 fragments with a mass greater than five grams and a range greater than 150 metres). But see D2662 (Mirjana Anđelković-Lukić's expert report entitled "Expert Analysis of Documents", 26 July 2012), pp. 6, 16 (challenging Zečević's evidence here on the basis that he did not indicate where the analysis of the fragments came from). However, the Chamber notes that Zečević clearly indicates in his report, at page 49, that he made this calculation on the basis of the Mott method.

14709 P2318 (Report by Berko Zečević entitled "The use of modified aircraft bombs during the siege of Sarajevo, 1994-1995”), pp. 103-105; Berko Zečević, T. 12183, 12201-12202 (22 February 2011), T. 12230-12232 (23 February 2011); Mirjana Anđelković-Lukić, T. 31484 (14 December 2012).

14710 Berko Zečević, T. 12183-12184, 12202-12203 (22 February 2011). See also Adjudicated Fact 2820. 
air bomb injuries happen due to the blast effect of the cloud; this latter blast can can cause the heart to stop or force the eyes from their sockets, in addition to causing burns and injuries to the internal organs as a result of the pressure of the blast. ${ }^{14711}$

4382. Fraser testified that an air bomb of 250 kilograms landing on a concrete or brick apartment building might punch a hole in the building but would do little to no damage to an apartment block; however, it would probably have a much greater effect on a brick and mortar house, and if it landed on the ground, it would have a great impact because it would send up shrapnel and fragments, and would create a large crater. ${ }^{14712}$ According to Konings, modified air bombs had a 50-60 metre radius of destruction and could destroy a complete block of offices. ${ }^{14713}$

4383. Given the large quantity of explosive the modified air bombs contained, the Chamber finds that they were extremely destructive and as such capable of causing large craters and great damage to the surrounding buildings. Given that they were not an anti-personnnel weapon, the Chamber also does not consider that they would necessarily result in a high number of casualties, unless a fuel-air bomb was used.

(6) Investigations of modified air bomb incidents

4384. BiH MUP and UN investigators investigated incidents involving modified air bombs to determine the type of bomb used and the trajectory. ${ }^{14714}$ Whether or not a modified air bomb was used could be determined by examining the crater, which would often contain parts of the rocket engines. ${ }^{14715}$ An adapting plate connecting the aircraft bomb to the rocket motors was also often found at the site of the explosion. ${ }^{14716}$ Other factors that would assist investigators in determining

14711 Mirjana Anđelković-Lukić, T. 31483-31484 (14 December 2012).

14712 David Fraser, T. 8132 (19 October 2010).

14713 P1953 (Witness statement of Harry Konings dated 11 November 2010), para. 42.

14714 Ekrem Suljević, T. 5737 (22 July 2010); P1851 (Witness statement of Per Anton Brennskag dated 26 October 2010), para. 37; Thorbjorn Overgard, P2058 (Transcript from Prosecutor v. D. Milošević), T. 634. See also Adjudicated Fact 2895. Because there was a period where a large number of incidents involved modified air bombs, CSB Sarajevo conscientiously collected, documented, and recorded the fragments of those bombs and deposited them in a room which with time became overloaded. See Emir Turkušić, T. 8998 (4 November 2010); KDZ477, T. 10950 (31 January 2011). See also P1978 (Witness statement of Nedžib Đozo dated 7 December 2010), para. 48.

14715 P1851 (Witness statement of Per Anton Brennskag dated 26 October 2010), para. 34; Per Anton Brennskag, T. 8657 (29 October 2010); P2318 (Report by Berko Zečević entitled "The use of modified aircraft bombs during the siege of Sarajevo, 1994-1995”), p. 175. In most cases involving air-bombs investigated by Suljević, there were four rocket motors attached to the bomb to carry it to the point of impact. See P1276 (Witness statement of Ekrem Suljević dated 9 February 2010), para. 38; KDZ477, T. 10952-10953 (31 January 2011).

14716 P1276 (Witness statement of Ekrem Suljević dated 9 February 2010), para. 38. Suljević used literature about the 250-kilogram aerial bomb to find the diametre of that bomb and then compared this to the diametre of the adapter plate which was often found at the scene of an incident. This in turn enabled him to identify the type of the aerial bomb used. See Ekrem Suljević, T. 5725-5727 (22 July 2010). 
whether an explosion was caused by a modified air bomb was the scale of destruction, the type of fuse used (if located), and the presence of shrapnel. ${ }^{14717}$

4385. During their investigations, Suljević and his colleagues did not calculate the impact velocity of these bombs and instead arrived to their conclusions on the basis of fragments found at the incident sites and the damage caused there. ${ }^{14718}$ They did not calculate the angle of descent as they did not have the necessary resources and there would be no point given that the bombs were propelled by rocket motors. ${ }^{14719}$ However, it was possible to determine the direction from which the modified air bomb came by analysing the crater using the central axis method and by analysing the pattern of the fragments in the crater. ${ }^{14720}$ In addition to the central axis method, which for modified air bombs had a margin of error of plus or minus ten degrees, ${ }^{14721}$ in some cases it was possible to determine the direction of fire on the basis of the position of embedded rocket motors, as they would face the from which they came. ${ }^{14722}$ On occasion, direction of fire was also determined through the statements of witnesses who saw the modified air bomb flying low or heard the distinct sound of its rocket motors. ${ }^{14723}$

4386. As noted earlier, the Chamber generally gave considerable weight to the CSB Sarajevo and UN reports when analysing the scheduled shelling incidents. ${ }^{14724}$ In doing so, the Chamber was constantly cognisant of the shortcomings of investigations conducted during the war. Whenever issues arose with respect to particular reports, they were considered by the Chamber in relation to each particular incident. Accordingly, as stated earlier, while finding this type of evidence to be generally reliable and credible, the Chamber approached it as one piece of the puzzle assessed against the totality of evidence tendered in relation to each incident.

14717 P1276 (Witness statement of Ekrem Suljević dated 9 February 2010), para. 50.

14718 Ekrem Suljević, T. 5722-5723, 5725 (22 July 2010) (explaining that he had an occasion to see an unexploded 250-kilogram modified air bomb during one of the investigations and that, following the war, he saw photographs of such 250-kilogram bombs).

14719 Ekrem Suljević, T. 6171-6172 (6 September 2010).

14720 P1851 (Witness statement of Per Anton Brennskag dated 26 October 2010), paras. 34, 45.

14721 P1276 (Witness statement of Ekrem Suljević dated 9 February 2010), para. 25.

14722 P1276 (Witness statement of Ekrem Suljević dated 9 February 2010), para. 57; Ekrem Suljević, T. 6170-6171 (6 September 2010); P1322 (BiH MUP Report re shelling of Safeta Zajke and Majdanska streets on 24 May 1995), p. 1; P2318 (Report by Berko Zečević entitled "The use of modified aircraft bombs during the siege of Sarajevo, 1994-1995"), p. 175, 178-179.

14723 P1925 (Witness statement of Emir Turkušić dated 16 February 2010), pp. 6-7; Thomas Knustad, P123 (Transcript from Prosecutor v. D. Milošević), T. 1990; P2318 (Report by Berko Zečević entitled "The use of modified aircraft bombs during the siege of Sarajevo, 1994-1995”), pp 170-173. See also P1851 (Witness statement of Per Anton Brennskag dated 26 October 2010), paras. 34, 52; Per Anton Brennskag, T. 8656-8657 (29 October 2010), T. 8714, 8716 (1 November 2010) (stating that modified air bombs also had a smoke trail coming out of the rocket engines); Milomir Šoja, P1633 (Transcript from Prosecutor v. D. Milošević), T. 51715174 (explaining that he heard the sound of modified air bombs coming from the SRK controlled area of Poljane at Mt. Igman).

14724 See paras. $3632,4009$. 
(7) Bosnian Serb leadership and modified air bombs

4387. As addressed earlier in Section IV.B.1.a, during the ABiH offensives, the Accused indicated to Smith that a decision had been made to start a counter-offensive and that the Bosnian Serbs would employ weapons they had not used before. ${ }^{14725}$

4388. On 17 June 1995, Momčilo Krajišnik called Milorad Motika, the Director of Pretis at the time, to inquire about the availability of modified air bombs and whether Motika could arrange their purchase from the Krušik factory, ${ }^{14726}$ located in Valjevo, Serbia. ${ }^{14727}$

4389. On 20 June 1995, the Accused issued a decision establishing a team within the state committee for the procurement for armed forces, which included Mirko Krajišnik and Momčilo Mandić, whose task was to transfer the "relevant means" from the FRY and place them in a number of previously agreed upon locations. ${ }^{14728}$ Dragomir Milošević testified, however, that he and the Accused never discussed modified air bombs nor was the issue discussed in any meeting attended by the Accused. ${ }^{14729}$

(8) Scheduled incidents involving modified air bombs

$\underline{\text { Incident G.10) }}$

(a) Alekse Šantića street, Hrasnica, 7 April 1995 (Scheduled

4390. The Indictment alleges that on 7 April 1995, a modified air bomb fired from the SRK-held territory in Ilidža hit a residential area in Hrasnica at the foot of Mt. Igman, killing one person and injuring three others, as well as destroying one dwelling while severely damaging 11 others. ${ }^{14730}$ The Accused argues that the modified air bomb, a FAB-100 filled with solid explosive, was fired by the SRK in response to the violation of the truce then in force by the $\mathrm{ABiH}$ and that the intended

\footnotetext{
14725 Rupert Smith, T. 11344-11346 (8 February 2011); P2260 (UNPROFOR report re meeting with Radovan Karadžić, 5 April 1995), paras. 9-10, 14.

14726 Krušik Factory in Valjevo was a special purpose factory that produced artillery ammunition. D3540 (Zorica Subotić's expert report entitled "The Use of Modified Aircraft Bombs in the Sarajevo Area in 1994-1995", 15 March 2012), p. 43.

14727 P5653 (Intercept of conversation between Milorad Motika and Momčilo Krajišnik, 17 June 1995). While Momčilo Krajišnik denied that the conversation was about modified air bombs specifically and stated that he was simply asking for a bigger weapon to be used in retaliation in Visoko, the Chamber finds his denials in this respect false and is convinced that the conversation concerned modified air bombs, as illustrated by Motika's reference to all rocket motors having been attached to a "250". Momčilo Krajišnik, T. 43905-43911 (20 November 2013), T. 43951-43953 (21 November 2013).

14728 P2322 (Radovan Karadžić Decision, 20 June 1995).

14729 Dragomir Milošević, T. 33300 (6 February 2013). See also Stevan Veljović, T. 29284 (23 October 2012).

14730 Indictment, Scheduled Incident G.10. See also Prosecution Final Brief, para. 73.
} 
target was the Alekse Šantića School located approximately 20 metres from the dwelling that was destroyed. $^{14731}$

4391. Hrasnica is a civilian settlement located south of the Butmir airport at the foot of Mt. Igman. ${ }^{14732}$ It was in the $\mathrm{ABiH}$ zone of responsibility during the war, under the control of the $4^{\text {th }}$ (later the $104^{\text {th }}$ ) Motorised Brigade of the $\mathrm{ABiH}$, commanded by Fikret Prevaljak. ${ }^{14733}$ Slightly north of Hrasnica, but south of Butmir, is Sokolović Kolonija, also in the zone of responsibility of the $4^{\text {th }}$ Motorised Brigade. ${ }^{14734}$ This ABiH brigade was also deployed on Mt. Igman. ${ }^{14735}$

4392. To the northwest of Hrasnica is Ilidža, which was under the control of the SRK during the war, more precisely the Ilidža Brigade. ${ }^{14736}$ Famos Factory is located to the east of Hrasnica, and was on the confrontation line, but under the control of the $2^{\text {nd }}$ Sarajevo Light Infantry Brigade commanded by Milorad Šehovac. ${ }^{14737}$

\footnotetext{
14731 Defence Final Brief, paras. 2359-2362.

14732 See Adjudicated Fact 3035; P1792 (Map of Hrasnica).
}

14733 D2562 (Witness statement of Vladimir Radojčić dated 8 December 2012), para. 16; Vladimir Radojčić, T.31257 (11 December 2012); D2591 (Map of Sarajevo marked by Vladimir Radojčić); D2633 (Witness statement of Milorad Šehovac dated 8 December 2012), para. 15; D2649 (Map of Sarajevo marked by Milorad Šehovac); Thorbjorn Overgard, P2058 (Transcript from Prosecutor v. D. Milošević), T. 634, 657-661; P2061 (Map of Sarajevo marked by Thorbjorn Overgard); Thorbjorn Overgard, T. 10030 (16 December 2010); David Fraser, T. 8011 (18 October 2010); Dragomir Milošević, T. 32509-32512 (23 January 2013), T. 32784 (28 January 2013), T. 32786-32787, 32790 (29 January 2013); D2788 (Map of Sarajevo marked by Dragomir Milošević); D2789 (Map of Sarajevo marked by Dragomir Milošević); D2765 (Witness statement of Ilija Miščević dated 26 April 2012), para. 3; D2497 (Witness statement of Nikola Mijatović dated 27 November 2012), para. 25; Stanislav Galić, T. 37164, 37174-37175 (15 April 2013); D3381 (Map of Sarajevo marked by Stanislav Galić); Asim Džambasović, T. 15236 (22 June 2011) (testifying that the $4^{\text {th }}$ Motorised Brigade later merged with the $10^{\text {th }}$ Mountain Brigade and the Pazarići Brigade, forming the $14^{\text {th }}$ Division based outside of the city but still within the $1^{\text {st }}$ Corps). See Adjudicated Fact 2825.

14734 Dragomir Milošević, T. 32509-32512 (23 January 2013), T. 32792 (29 January 2013); D2788 (Map of Sarajevo marked by Dragomir Milošević); D2789 (Map of Sarajevo marked by Dragomir Milošević); D2633 (Witness statement of Milorad Šehovac dated 8 December 2012), paras. 11, 15; D2648 (Map of Sarajevo marked by Milorad Šehovac); D2649 (Map of Sarajevo marked by Milorad Šehovac); D2562 (Witness statement of Vladimir Radojčić dated 8 December 2012), para. 16; Vladimir Radojčić, T.31257 (11 December 2012); D2591 (Map of Sarajevo marked by Vladimir Radojčić).

14735 Dragomir Milošević, T. 32509-32512 (23 January 2013), T. 32791-32792 (29 January 2013); D2788 (Map of Sarajevo marked by Dragomir Milošević); D2789 (Map of Sarajevo marked by Dragomir Milošević); D2562 (Witness statement of Vladimir Radojčić dated 8 December 2012), para. 17; P5981 (SRK Order, 26 June 1993); D2633 (Witness statement of Milorad Šehovac dated 8 December 2012), para. 17.

14736 Thorbjorn Overgard, P2058 (Transcript from Prosecutor v. D. Milošević), T. 657-661; P2061 (Map of Sarajevo marked by Thorbjorn Overgard); D2562 (Witness statement of Vladimir Radojčić dated 8 December 2012), para. 14; D2589 (Map of Sarajevo marked by Vladimir Radojčić). See also para. 3787.

14737 Ekrem Suljević, T. 6151 (6 September 2010); Dragomir Milošević, T. 32787-32789 (29 January 2013), T. 33179-33180 (5 February 2013); D2633 (Witness statement of Milorad Šehovac dated 8 December 2012), paras. 2, 11, 15; D2648 (Map of Sarajevo marked by Milorad Šehovac); D2649 (Map of Sarajevo marked by Milorad Šehovac); D2903 (SRK combat report, 25 May 1995); Thorbjorn Overgard, P2058 (Transcript from Prosecutor v. D. Milošević), T. 657-661; P2061 (Map of Sarajevo marked by Thorbjorn Overgard). 
4393. Thorbjorn Overgard, an UNMO stationed in Hrasnica between October 1994 and May $1995,{ }^{14738}$ testified that Hrasnica was essentially surrounded by the SRK forces and was exposed to shelling and sniping incidents on a daily basis. ${ }^{14739}$ According to him, the UNMOs in the area investigated a number of such incidents and established in all instances that the fire had come from SRK-held territory. ${ }^{14740}$

4394. Overgard further testified that the $4^{\text {th }}$ Motorised Brigade of the ABiH had (i) one company headquarters in Hrasnica, close to the confrontation lines with Ilidža;(ii) the brigade command further east, in the centre of Hrasnica; and (iii) four mortars positioned in Kovači, not far from the company headquarters. ${ }^{14741}$ While Radojčić also testified that the $4^{\text {th }}$ Motorised Brigade's command was in the centre of Hrasnica, he stated that it was located in the post office building, which he identified as being in a different location to the location marked on the map by Overgard. ${ }^{14742}$ Ilija Miščević, a resident of Hrasnica during the war, confirmed that the command of the $4^{\text {th }}$ Motorised Brigade was located in the post office, but placed the post office building in a location further west of the location marked by Radojčić. ${ }^{14743}$ In addition, the Accused also tendered, through Radojčić, an official note from Ilidža Brigade dated 16 March 1995, which seemed to suggest that the brigade's headquarters had moved to Sokolović Kolonija by that time. ${ }^{14744}$

4395. The Chamber further heard that the $\mathrm{ABiH}$ was digging a tunnel under Butmir with the exit in Sokolović Kolonija, which was often targeted by the SRK forces, and that both civilians and the

\footnotetext{
14738 Thorbjorn Overgard, P2058 (Transcript from Prosecutor v. D. Milošević), T. 631-634, 667-669; P2062 (Map of Hrasnica marked by Thorbjorn Overgard).

14739 Thorbjorn Overgard, P2058 (Transcript from Prosecutor v. D. Milošević), T. 634-636, 638-639. Miščević also confirmed that Serbs opened fire on Hrasnica on a daily basis. See Ilija Miščević, T. 32088-32089 (17 January 2013).

14740 Thorbjorn Overgard, P2058 (Transcript from Prosecutor v. D. Milošević), T. 634-636, 638-639, 648-650; Thorbjorn Overgard, T. 10027-10029, 10043-10056, 10063 (16 December 2010) (conceding that the team was not able to determine the precise origin of fire, only the direction and the general area from which the fire came).

14741 Thorbjorn Overgard, P2058 (Transcript from Prosecutor v. D. Milošević), T. 634, 641-642, 681-683, 689; P2063 (Map of Hrasnica marked by Thorbjorn Overgard); P2064 (Map of Hrasnica marked by Thorbjorn Overgard); Thorbjorn Overgard, T. 10030-10031 (16 December 2010). See also Ekrem Suljević, T. 6151-6152 (6 September 2010); D2497 (Witness statement of Nikola Mijatović dated 27 November 2012), para. 25; Nikola Mijatović, T. 30747-30749 (30 November 2012). According to Šehovac, there was no exclusively civilian zone in Hrasnica. D2633 (Witness statement of Milorad Šehovac dated 8 December 2012), para. 23.

14742 D2562 (Witness statement of Vladimir Radojčić dated 8 December 2012), para. 20; D2590 (Map of Hrasnica marked by Vladimir Radojčić); D2353 (Report of $2^{\text {nd }}$ Sarajevo Light Infantry Brigade to SRK, 5 August 1994). See also D2633 (Witness statement of Milorad Šehovac dated 8 December 2012), para. 21; D2497 (Witness statement of Nikola Mijatović dated 27 November 2012), para. 25.

14743 D2765 (Witness statement of Ilija Miščević dated 26 April 2012), para. 3; D2766 (Map of Hrasnica marked by Ilija Miščević); Ilija Miščević, T. 32078-32082 (17 January 2013). Miščević testified that the location marked by Radojčić as the post office was in fact the community centre in Hrasnica, where food was served for both the residents of Hrasnica and the troops. See Ilija Miščević, T. 32085-32086, 32090-32091 (17 January 2013).

14744 D2562 (Witness statement of Vladimir Radojčić dated 8 December 2012), para. 141; D2614 (1 $1^{\text {st }}$ Ilidža Infantry Brigade official note, 16 March 1995).
} 
$\mathrm{ABiH}$ used the road between Mt. Igman and Hrasnica, referred to as the "Blue" or "Convoy" road. ${ }^{14745}$ Furthermore, according to the evidence, ABiH soldiers going to their positions on Mt. Igman would have to pass through Hrasnica. ${ }^{14746}$

4396. In April 1995, Ziba Šubo was living with her husband Zemir, twin sons Elmir and Elvir, daughter Emira Brajlović, and grandson Elvis Brajlović in a two-storey house at Alekse Šantića street, number 1, in Hrasnica. ${ }^{1474}$ On 7 April 1995, around 8:50 a.m., a projectile exploded at the house. ${ }^{14748}$ The projectile injured her and killed her cousin, Ziba Čustović, who was sitting in front of the house in Šubo's courtyard in which she lived. ${ }^{14749}$ Present in the house at the moment of the explosion were Šubo's two teenage sons and her grandson, all of whom survived the incident. ${ }^{14750}$ Following the explosion, Šubo saw that her 11 year old grandson was bleeding. ${ }^{14751}$ Šubo's husband, who was involved with "Civilian Protection", was not at home at the time of the explosion, neither was her daughter, who was a "member" of an ABiH brigade. ${ }^{14752}$

4397. Following the explosion, Šubo was taken to hospital, treated for her injuries, and released on the same day. ${ }^{14753}$ Six months after the incident, she still suffered back and arm pain as a result of this incident, as well as high blood pressure, and one of her sons continued to have problems with hearing. ${ }^{14754}$ Because their house was completely demolished, the family stayed in a field near

14745 Thorbjorn Overgard, P2058 (Transcript from Prosecutor v. D. Milošević), T. 650-651, 687 (explaining that the road was used for bringing supplies to Hrasnica and Sarajevo, but also to transport ABiH forces); Thorbjorn Overgard, T. 10060-10063 (16 December 2010); David Fraser, T. 8011-8012 (18 October 2010); P1782 (SRK combat report, 7 April 1995), p. 3; Dragomir Milošević, T. 32791, 32797-32801 (29 January 2013); D2818 (Order of ABiH Supreme Command Staff, 7 November 1992); D4620 (SRK Report, 24 July 1993).

14746 Thorbjorn Overgard, P2058 (Transcript from Prosecutor v. D. Milošević), T. 685-687; Ziba Šubo, P487 (Transcript from Prosecutor v. D. Milošević), T. 2774, 2776; Dragomir Milošević, T. 32783-32784 (28 January 2013), T. 32786-32787, 32791, 32797-32798 (29 January 2013).

14747 P488 (Witness statements of Ziba Šubo dated 8 April 1995 and 21 November 1995), e-court p. 7; P2190 (GPS locations for shelling and sniping incidents in Sarajevo); P2191 (Map of Sarajevo with scheduled sniping and shelling incidents); P2213 (Image re scheduled sniping and shelling incidents in Sarajevo). See also Adjudicated Fact 3033.

14748 KDZ166, T. 8266-8267 (20 October 2010); P1792 (Map of Hrasnica); P1796 (Sketch re shelling of Hrasnica on 7 April 1995). See also Thorbjorn Overgard, P2058 (Transcript from Prosecutor v. D. Milošević), T. 664-665; P1996 (Witness statement of Martin Bell dated 8 March 2010), para. 100; Martin Bell, T. 9906 (15 December 2010); D2765 (Witness statement of Ilija Miščević dated 26 April 2012), para. 10; Ilija Miščević, T. 3207632077 (17 January 2013).

14749 P488 (Witness statements of Ziba Šubo dated 8 April 1995 and 21 November 1995), e-court pp. 3, 7; Ziba Šubo, P487 (Transcript from Prosecutor v. D. Milošević), T. 2772-2773, 2775-2776; P1536 (Death certificate of Ziba Čustović). See also Adjudicated Facts 3034, 3038.

14750 P488 (Witness statements of Ziba Šubo dated 8 April 1995 and 21 November 1995), e-court pp. 3, 7-8.

14751 P488 (Witness statements of Ziba Šubo dated 8 April 1995 and 21 November 1995), e-court p. 8.

14752 P488 (Witness statements of Ziba Šubo dated 8 April 1995 and 21 November 1995), e-court pp. 3, 8.

14753 P488 (Witness statements of Ziba Šubo dated 8 April 1995 and 21 November 1995), e-court p. 8. See also Adjudicated Fact 3036.

14754 P488 (Witness statements of Ziba Šubo dated 8 April 1995 and 21 November 1995), e-court p. 8 . See also Adjudicated Fact 3036. 
their house for seven days after the explosion, following which they were given an apartment by her daughter's brigade. ${ }^{14755}$

4398. She also explained that, in the year and a half prior to the incident, there had been a lot of shelling in Hrasnica, often preventing her and her family from leaving their house and that about four shells had impacted within 100 metres of her garden. ${ }^{14756}$

4399. KDZ166, a criminal technician in CSB Sarajevo, was a member of the team that investigated this incident on the day it happened. ${ }^{14757}$ He prepared a sketch of the scene, took photographs, and prepared an on-site investigation report. ${ }^{14758}$ He testified that Šubo's house was completely demolished by the explosion while 11 surrounding houses were "rendered roofless", ${ }^{14759}$ and that the projectile was a modified air bomb fired from the northwest, where Ilidža is located. ${ }^{14760}$ He explained that the team came to this conclusion based on the statement provided by an eye-witness who saw "where the projectile was fired from" and "saw it flying and dropping". ${ }^{14761}$ The report itself notes that "according to the witnesses", the projectile was fired from "a truck located in the area of the rug weaving factory in Ilidža" and that the "truck left the factory area, fired a projectile and returned to the factory." ${ }^{, 14762}$ KDZ166 also explained that the air bomb struck the house and then detonated inside the house, which caused it to collapse "like a pile of cards". ${ }^{14763}$

14755 P488 (Witness statements of Ziba Šubo dated 8 April 1995 and 21 November 1995), e-court p. 8; Ziba Šubo, P487 (Transcript from Prosecutor v. D. Milošević), T. 2772-2774; P465 (Photograph of a collapsed house); P466 (Photograph of a collapsed house). See also Adjudicated Fact 3034.

14756 P488 (Witness statements of Ziba Šubo dated 8 April 1995 and 21 November 1995), e-court p. 7.

14757 KDZ166, T. 8267 (20 October 2010), T. 8370 (26 October 2010); P1791 (Witness statement of KDZ166 dated 13 February 2010), p. 3.

14758 P1791 (Witness statement of KDZ166 dated 13 February 2010), pp. 3-5; KDZ166, T. 8375-8376 (26 October 2010); P1796 (Sketch re shelling of Hrasnica on 7 April 1995); P1794 (Photographs re shelling of Hrasnica on 7 April 1995); P1798 (BiH MUP Report re shelling of Hrasnica on 7 April 1995); D817 (Sketch re shelling of Hrasnica on 7 April 1995).

14759 P1791 (Witness statement of KDZ166 dated 13 February 2010), pp. 5-6; P1794 (Photographs re shelling of Hrasnica on 7 April 1995); P1810 (Video footage of shelling incident site in Hrasnica); KDZ166, T. 8268 (20 October 2010). See also Adjudicated Fact 3039.

14760 KDZ166 explained that he made a mistake in his report when he referred to the direction of fire as being "southwest" but observed that in the report he also refers to fire coming from Ilidža, meaning that it came from northwest rather than southwest. He confirmed on cross-examination that the projectile flew over the secondary school in Hrasnica. KDZ166, T. 8269-8272 (20 October 2010); P1798 (BiH MUP Report re shelling of Hrasnica on 7 April 1995), e-court p. 1.

14761 KDZ166, T. 8271 (20 October 2010).

14762 P1798 (BiH MUP Report re shelling of Hrasnica on 7 April 1995), e-court p. 2.

14763 KDZ166, T. 8372-8373 (26 October 2010). 
4400. According to KDZ166's report, one person, Ziba Čustović, was killed in the incident while three people, Ziba Šubo, Šerif Brajlović, and Gara Sarajkić, were wounded. ${ }^{14764}$

4401. Overgard and another UNMO who, by virtue of being stationed near the incident site, heard the explosion went to the scene immediately. ${ }^{14765}$ Once there, they observed a totally demolished house and human legs in a camouflage uniform, protruding under the rubble, as well as a number of other damaged houses. ${ }^{14766}$ At that point, the Commander of the $4^{\text {th }}$ Motorised Brigade came to the scene and instructed the UNMOs to go to their base where they were guarded by $\mathrm{ABiH}$ soldiers; they were eventually allowed to return to the scene the next day when they conducted their own investigation and consulted with the local ballistics experts. ${ }^{14767}$ The next day they went to the morgue and confirmed that one woman died in the incident. ${ }^{14768}$ Overgard was told by the local authorities that the legs he saw belonged to a soldier who was wounded but did not die in the incident, which he found difficult to believe. ${ }^{14769}$

4402. Following their investigation, the UNMOs reported that the projectile that fell on Šubo's house was a modified air bomb fired from a truck in Ilidža on the Serb-held side of the confrontation line. ${ }^{14770}$ They determined the direction and the origin of fire on the basis of eyewitnesses they spoke to who were on Mt. Igman and who saw and heard the bomb being launched, as well as through traces on the scene, particularly the fact that all the windows in the direction

14764 P1798 (BiH MUP Report re shelling of Hrasnica on 7 April 1995), e-court p. 1. See Adjudicated Fact 3038. While the report refers to a "Šerif Brajlović" as one of the injured victims in this incident, the Chamber recalls Šubo's evidence that her 11 year old grandson, Elvis Brajlović, was bleeding following the explosion. She made no mention of "Šerif" being present. Accordingly, the Chamber considers this reference to a "Šerif" in the report to be a mistake.

14765 Thorbjorn Overgard, P2058 (Transcript from Prosecutor v. D. Milošević), T. 632-633, 641, 664-669; P2062 (Map of Hrasnica marked by Thorbjorn Overgard); Thorbjorn Overgard, T. 10033 (16 December 2010).

14766 Thorbjorn Overgard, P2058 (Transcript from Prosecutor v. D. Milošević), T. 641, 644-647, 666-667, 674-676; P2060 (Photographs re shelling of Hrasnica on 7 April 1995); P2059 (UNMO report, 10 April 1995), Annex A; Thorbjorn Overgard, T. 10034 (16 December 2010).

14767 Thorbjorn Overgard, P2058 (Transcript from Prosecutor v. D. Milošević), T. 641-642, 662-663, 667-674 (explaining that after he and his colleague went back to the UNMO base, three ABiH soldiers guarded the house and prevented them from leaving); Thorbjorn Overgard, T. 10033-10035 (16 December 2010).

14768 Thorbjorn Overgard, T. 10036 (16 December 2010) (conceding that he did not see the dead woman's body on the day of the incident but noting also that the scene was chaotic); P2059 (UNMO report, 10 April 1995), para. 1; D934 (Excerpt from Thorbjorn Overgard's testimony in Prosecutor v. Perišić), T. 2977.

14769 Thorbjorn Overgard, T. 10039. But see D3540 (Zorica Subotić's expert report entitled "The Use of Modified Aircraft Bombs in the Sarajevo Area in 1994-1995", 15 March 2012), pp. 45-46, Figure 3 (which includes a video still of a wounded man at the scene of the incident who was given help and, who according to Subotić, "in all probability" wore a camouflage jacket). See also P1810 (Video footage of shelling incident site in Hrasnica). The Chamber notes that it is unclear from the video footage whether the jacket the man is wearing is a camouflage jacket.

14770 Thorbjorn Overgard, P2058 (Transcript from Prosecutor v. D. Milošević), T. 640; Thorbjorn Overgard, T. 10019-10020 (16 December 2010); P2059 (UNMO report, 10 April 1995), para. 2, Annex B, Annex C. 
from which the bomb came were broken. ${ }^{1471}$ Being near the incident site just prior to the explosion, the UNMOs themselves also heard a noise, similar to an airplane flying low, and coming from the direction of Ilidža. ${ }^{14772}$ As for the type of the projectile, they concluded it was a modified air bomb on the basis of shrapnel they found on the scene and through having observed one of the rocket motors on the day of the incident. ${ }^{14773}$

4403. In an order issued on 6 April 1995, Dragomir Milošević states that "for the past three days, Muslim forces have been attacking" the positions of the $2^{\text {nd }}$ Sarajevo Infantry Brigade, in particular in the area of the Famos Factory, resulting in the wounding of several soldiers and a number of civilians. ${ }^{14774}$ In order to thwart "the enemy" and give them "a warning so they are forced to accept this truce", Milošević ordered the Ilidža Brigade to immediately prepare a "launcher with an aerial bomb and transport the bomb for launching", and to select "the highest yielding target in Hrasnica or Sokolović Kolonija, where there will be greatest human and material losses". ${ }^{14775}$

4404. Milošević explained this order by saying that the units of the Ilidža Brigade and the $2^{\text {nd }}$ Light Infantry Brigade, as well as the Serb villages east of Famos, were constantly under fire, including artillery fire, from Hrasnica and Sokolović Kolonija, an area through which weapons arrived and $\mathrm{ABiH}$ units were passing. ${ }^{14776}$ Further, the slopes of Mt. Igman controlled by the ABiH towered over those Serb villages and over parts of Lukavica and Dobrinja, thus exposing them to direct fire. ${ }^{1477}$ When informed by his subordinates that the $\mathrm{ABiH}$ fire was becoming unbearable and advised that the modified air bomb should be used, he decided to follow that advice but asked

\footnotetext{
14771 Thorbjorn Overgard, P2058 (Transcript from Prosecutor v. D. Milošević), T. 640, 676, 678-679, 691-693; P2059 (UNMO report, 10 April 1995), Annexes A, B, and C; Thorbjorn Overgard, T. 10020-10021, 1004210044 (16 December 2010).

14772 Thorbjorn Overgard, P2058 (Transcript from Prosecutor v. D. Milošević), T. 676-677, 693; P2059 (UNMO report, 10 April 1995), para. 4; Thorbjorn Overgard, T. 10021 (16 December 2010).

14773 Thorbjorn Overgard, P2058 (Transcript from Prosecutor v. D. Milošević), T. 676-678; P2059 (UNMO report, 10 April 1995), para. 3, Annex B; Thorbjorn Overgard, T. 10020, 10037-10039 (16 December 2010); D934 (Excerpt from Thorbjorn Overgard's testimony in Prosecutor v. Perišić).

14774 P1201 (SRK Order, 6 April 1995). See also D2633 (Witness statement of Milorad Šehovac dated 8 December 2012), para. 63; D782 (SRK Order, 4 April 1995); Milorad Šehovac, T. 31368 (13 December 2012). See also Adjudicated Fact 2878.

14775 P1201 (SRK Order, 6 April 1995).

14776 Dragomir Milošević, T. 32783-32784 (28 January 2013), T. 32786-32787, 32791, 32802-32814 (29 January 2013), T. 33179-33180 (5 February 2013); D2819 (SRK combat report, 10 July 1993); D2820 (SRK combat report, 16 July 1993); D2821 (SRK combat report, 3 August 1993); D2822 (SRK combat report, 10 August 1993); D2823 (SRK combat report, 6 November 1994). See also D2562 (Witness statement of Vladimir Radojčić dated 8 December 2012), para. 108; Vladimir Radojčić, T. 31274-31276 (12 December 2012); D2633 (Witness statement of Milorad Šehovac dated 8 December 2012), para. 63; Milorad Šehovac, T. 31384-31385 (13 December 2012); D2765 (Witness statement of Ilija Miščević dated 26 April 2012), para. 9; Ilija Miščević, T. 32087-32088 (17 January 2013).

14777 Dragomir Milošević, T. 32791-32792 (29 January 2013).
} 
them to identify a specific target that would ensure that the $\mathrm{ABiH}$ attacks ceased. ${ }^{14778}$ Milošević also explained that the reference to the "greatest human and material losses" was not a reference to civilians and that he had in mind only military targets, noting that the language he used was military parlance and that it would have been superfluous for him to provide further instruction on the nature of the targets. ${ }^{14779} \mathrm{He}$ also thought that the recipient of the order would not have interpreted it in any other way. ${ }^{14780}$ This was confirmed by Radojčić who received and implemented this order. ${ }^{14781}$ However, during his testimony, Fraser interpreted the order as an order to shoot at the civilian population; even if there were ABiH units in Hrasnica at the time, he considered the use of modified air bomb in this densly populated area completely inappropriate. $^{14782}$

4405. Later on the day of the incident, the SRK Command reported to the VRS Main Staff that in the morning the $\mathrm{ABiH}$ opened "fierce fire" on Famos from the area of Gradina-Igman and Lasica with, inter alia, infantry weapons and an $82 \mathrm{~mm}$ mortar, in response to which the Ilidža Brigade fired one air bomb weighing 250 kilograms "at the centre of Hrasnica". ${ }^{14783}$ The VRS Main Staff then sent a combat report to the Accused, informing him of these events, including the attack on Famos, as well as the fact that "[t]he enemy was adequately responded to whereby an A/B /air bomb/ (250kg) was launched on the centre of Hrasnica."14784

4406. Contradicting Milošević's order of 6 April and the SRK combat report of 7 April, Overgard testified that he could not remember any unusual military activity in the days prior to the incident, except for some small arms fire in the area of the Famos factory, which was a common

14778 Dragomir Milošević, T. 32784-32785 (28 January 2013), T. 33163-33165 (4 February 2013), 33171-33174 (5 February 2013) (explaining that the target assessment was made by estimating the possible collateral damage and comparing it to the option of halting the $\mathrm{ABiH}$ assets that endangered the SRK).

14779 Dragomir Milošević, T. 32793-32794 (29 January 2013), T. 33178-33183 (5 February 2013), T. 33278-33280 (6 February 2013).

14780 Dragomir Milošević, T. 32794 (29 January 2013). See also D2562 (Witness statement of Vladimir Radojčić dated 8 December 2012), para. 89 (explaining that there was no need for Milošević to specify in each of his orders the military targets on which fire was to be opened because the brigades already had that information). Šehovac testified that he suggested the school as one of the potential targets some eight months before the incident. Milorad Šehovac, T. 31369-31370 (13 December 2012); D2353 (Report of $2^{\text {nd }}$ Sarajevo Light Infantry Brigade to SRK, 5 August 1994).

14781 D2562 (Witness statement of Vladimir Radojčić dated 8 December 2012), para. 108; Vladimir Radojčić, T. 31254-31257 (11 December 2012) (explaining that the order left it to him to determine where to launch the modified air bomb). See also D2633 (Witness statement of Milorad Šehovac dated 8 December 2012), para. 63.

14782 David Fraser, T. 8013-8014 (18 October 2010). While Subotić also made comments on this order during her testimony, given that she does not have any military background and is not a military expert, the Chamber shall not consider her evidence on this issue. See D3540 (Zorica Subotić's expert report entitled "The Use of Modified Aircraft Bombs in the Sarajevo Area in 1994-1995”, 15 March 2012), p. 56.

14783 P1782 (SRK combat report, 7 April 1995), pp. 1-2.

14784 P5943 (VRS Main Staff Report, 7 April 1995), pp. 4-5. 
occurrence. ${ }^{14785}$ He could not recall any unusual military activity the morning of the incident, describing it as a quiet morning with only some shooting. ${ }^{14786}$ He also did not hear any outgoing fire from the centre of Hrasnica. ${ }^{14787}$ However, on 8 April 1995, the UN reported on the incident, stating that the "rocket which impacted in Hrasnica was most likely retaliation for the mortar round fired from Hrasnica some minutes before."14788

4407. Šubo testified that there was "some kind of military structure" on her street but that it was not close to her house and that she did not see any mortas in the vicinity of her house. ${ }^{14789}$ KDZ166 testified that there was nothing but "family houses" at the incident site, which was in the centre of Hrasnica. ${ }^{14790}$ He confirmed on cross-examination that the projectile flew over the secondary school in Hrasnica but denied any knowledge about the school being used to house members of the $4^{\text {th }}$ Brigade of the $\mathrm{ABiH} .{ }^{14791}$ Overgard explained that the two headquarters of the $4^{\text {th }}$ Motorised Brigade in Hrasnica ${ }^{14792}$ were somewhere between 800 and 1,000 metres away from the incident site. ${ }^{14793}$ Similarly, the road between Mt. Igman and Hrasnica was over a kilometre away from the incident site. ${ }^{14794}$

4408. In contrast, Milošević testified that four $\mathrm{ABiH} 120 \mathrm{~mm}$ mortars were in the "immediate vicinity" of the incident site. ${ }^{14795}$ When confronted with the VRS Main Staff report to the Accused referred to above-in which the $\mathrm{ABiH}$ fire on Famos was said to have come from areas outside of Hrasnica-Milošević explained that the modified air bomb was not fired to respond to the forces

\footnotetext{
14785 Thorbjorn Overgard, T. 10021-10023 (16 December 2010).

14786 Thorbjorn Overgard, T. 10024-10025 (16 December 2010).

14787 Thorbjorn Overgard, T. 10025, 10031-10032 (16 December 2010) (conceding also that the UNMO base was less than a kilometre away from the Famos Factory while the outgoing fire can be heard 200 to 300 metres from the origin of fire).

14788 D2817 (UNPROFOR report, 8 April 1995), p. 2. See also Dragomir Milošević, T. 32796-32797 (29 January 2013), T. 33290-33291 (6 February 2013).

14789 P488 (Witness statements of Ziba Šubo dated 8 April 1995 and 21 November 1995), e-court p. 7; Ziba Šubo, P487 (Transcript from Prosecutor v. D. Milošević), T. 2773-2774.

14790 KDZ166, T. 8267-8268 (20 October 2010).

14791 KDZ166, T. 8371-8379 (26 October 2010) D815 (Map of Hrasnica marked by KDZ166); D816 (Photograph of damaged house marked by KDZ166); D817 (Sketch re shelling of Hrasnica on 7 April 1995); D818 (Aerial photograph of Hrasnica and sketch re shelling of Hrasnica on 7 April 1995).

14792 See para. 4394

14793 Thorbjorn Overgard, P2058 (Transcript from Prosecutor v. D. Milošević), T. 648, 684-685; P2063 (Map of Hrasnica marked by Thorbjorn Overgard); P2064 (Map of Hrasnica marked by Thorbjorn Overgard). The Chamber notes that, according to the scale on the maps marked by Overgard, the company headquarters was located almost two kilometres to the northwest of the incident site, while the brigade headquarters was some 750 metres to the northeast of the incident site. The four mortars were located almost two kilometres away from the incident site.

14794 Thorbjorn Overgard, P2058 (Transcript from Prosecutor v. D. Milošević), T. 694-695.

14795 Dragomir Milošević, T. 32795 (29 January 2013), T. 33155-33159, 33162 (4 February 2013); D779 (SRK Order, 27 March 1995). When confronted with D779 showing the locations of ABiH weapons none of which was in the immediate vicinity of the incident site, Milošević claimed that this order was unrelated to the issue of the mortars in Hrasnica.
} 
firing on Famos but to neutralise the four mortars in Hrasnica because those were a long-standing problem for the SRK. ${ }^{14796}$ He could not recall, however, if following the incident, the subordinate units confirmed that the mortars had been neutralised; he assumed this to be the case as there was no more fire on the SRK from that area. ${ }^{14797}$

4409. The Chamber also heard from witnesses called by the Accused that the Alekse Šantića School in Hrasnica was used by the $\mathrm{ABiH}$ to anneal shells and train members of the $4^{\text {th }}$ Motorised Brigade. $^{14798}$ Radojčić testified that this is why he chose the school as the target after receiving Milošević's order of 6 April. ${ }^{14799}$ He stated that he used the temporary firing tables the brigade had received to launch the modified air bomb and missed the school by only 20 to 30 metres, striking instead a house in which $\mathrm{ABiH}$ guards were billeted. ${ }^{14800} \mathrm{He}$ further testified that he was told by Overgard that only one soldier was killed, and that Overgard had seen the legs of this soldier. ${ }^{14801}$ When a map was shown to him to illustrate that the school was in fact some 150 metres away from the incident site, Radojčić seemed to accept that this was so but disputed that the location marked as the incident site was accurately marked. ${ }^{14802}$

\footnotetext{
14796 Dragomir Milošević, T. 33159-33162 (4 February 2013), T. 33168-33171 (5 February 2013) (explaining that he personally observed those four mortars in a park in Hrasnica); P5943 (VRS Main Staff Report, 7 April 1995), pp. 4-5.

14797 Dragomir Milošević, T. 33174-33179 (5 February 2013).

14798 D2765 (Witness statement of Ilija Miščević dated 26 April 2012), paras. 3, 8; Ilija Miščević, T 32086-32087, 32090 (17 January 2013) (explaining that he personally observed shells being annealed in the school). While the other Defence witnesses argued that $\mathrm{ABiH}$ in fact produced or manufactured shells in the school, the Chamber does not consider this possible given that this was a school building and, as such, would not have had the equipment necessary for the production of shells. See Dragomir Milošević, T. 32796 (29 January 2013), T. 33162-33163 (4 February 2013); D2562 (Witness statement of Vladimir Radojčić dated 8 December 2012), paras. 20, 108; D2590 (Map of Hrasnica marked by Vladimir Radojčić); D2353 (Report of $2^{\text {nd }}$ Sarajevo Light Infantry Brigade to SRK, 5 August 1994); Vladimir Radojčić, T. 31257-31259 (11 December 2012), T. 3126131263 (12 December 2012); D2633 (Witness statement of Milorad Šehovac dated 8 December 2012), paras. 21, 63. Instead, the Chamber is more persuaded by Miščević's evidence that the school's furnace was used to anneal the shells.
}

14799 D2562 (Witness statement of Vladimir Radojčić dated 8 December 2012), paras. 20, 108; Vladimir Radojčić, T. 31257-31259 (11 December 2012), T. 31261-31263 (12 December 2012); D2633 (Witness statement of Milorad Šehovac dated 8 December 2012), para. 63; D2353 (Report of $2^{\text {nd }}$ Sarajevo Light Infantry Brigade to SRK, 5 August 1994); Milorad Šehovac, T. 31365-31367, 31371 (13 December 2012) (explaining that even though the school was identified as a target some eight months prior to the incident, it was still used by the $\mathrm{ABiH}$ at the time of the incident).

14800 Vladimir Radojčić, T. 31251-31252, 31258-31259 (11 December 2012), T. 31261-31266 (12 December 2012) (explaining that he used Plamen rockets without the explosive charge to propel the air bombs); P6040 (Excerpt from M-63 Plamen fire tables).

14801 Vladimir Radojčić, T. 31258-31259 (11 December 2012), T. 31268-31269, 31272-31273 (12 December 2012).

14802 Vladimir Radojčić, T. 31267-31268 (12 December 2012). The Chamber notes that the map of Hrasnica used with Radojčić was not admitted into evidence but that an almost identical map has been admitted into evidence through KDZ166, Overgard, and Miščević. See P1792 (Map of Hrasnica); P2063 (Map of Hrasnica marked by Thorbjorn Overgard); P2064 (Map of Hrasnica marked by Thorbjorn Overgard); D2766 (Map of Hrasnica marked by Ilija Miščević). Using the scale on these maps, the distance between the school and the incident site, which has been correctly marked, does appear to be over 100 metres. This was confirmed by Ilija Miščević. See Ilija Miščević, T. 32081-32082 (17 January 2013). See also Milorad Šehovac, T. 31370 (13 December 2012). 
4410. Zečević reviewed the material compiled by the CSB Sarajevo investigators on the day of the incident and concluded, based on the damage to Šubo's house, namely the undamaged interior wall with the destroyed exterior wall, as well as the damage to the surrounding houses, that the modified air bomb used in this incident must have been filled with fuel-air explosive. ${ }^{14803} \mathrm{He}$ testified that the azimuth of the modified air bomb was around 320 degrees from the north, as opposed to 305 degrees estimated by KDZ166 in his sketch, because 320 degrees would have placed the launcher in an area that avoided inhabited parts of Ilidža municipality, while KDZ166's azimuth would have placed it in an open area, exposed to fire. ${ }^{14804}$ He also established, on the basis of the probable point of impact (the top of one of the windows of the house) and the place where the rocket motors were found, that the angle of descent was around 25 degrees; this in turn enabled him to estimate that the origin of fire was somewhere between 5,820 and 4,800 metres from the incident site, in the area between Rimski Most and Plandište, in Ilidža municipality. ${ }^{14805}$

4411. Contrary to Zečević, both Subotić and Anđelković-Lukić argued that the modified air bomb fired in this incident was a FAB-100 with a solid explosive charge, as indicated by (i) the type of damage caused to the destroyed house and the neighbouring houses; (ii) the fact that two persons inside the house remained uninjured while two were wounded; ${ }^{14806}$ (iii) the fact that only two rocket motors were found on the scene of the incident whereas a FAB-250 would have required three; and (iv) the fact that no fragments of an air fuel container were found on the scene. ${ }^{14807}$ As for the direction of fire, Subotić agreed with Zečević and the CSB Sarajevo investigators, noting further that the azimuth determined by Zečević meant that the bomb flew over the Aleksa Šantića school, the schoolyard of which was 20 metres away from the incident site and which housed members of the $4^{\text {th }}$ Motorised Brigade of the $\mathrm{ABiH} .{ }^{14808}$ Finally, Subotić argued that Zečević's estimates as to

\footnotetext{
14803 P2318 (Report by Berko Zečević entitled "The use of modified aircraft bombs during the siege of Sarajevo, 1994-1995”), p. 114.

14804 P2318 (Report by Berko Zečević entitled "The use of modified aircraft bombs during the siege of Sarajevo, 1994-1995”), p. 114.

14805 P2318 (Report by Berko Zečević entitled "The use of modified aircraft bombs during the siege of Sarajevo, 1994-1995"), p. 112-115.

14806 Anđelković-Lukić added, relying on Zečević's own description of the effects of a fuel-air bomb explosion, that had the house been struck by a fuel-air bomb, there would have been no survivors in the radius of about 20 metres. See D2662 (Mirjana Anđelković-Lukić's expert report entitled "Expert Analysis of Documents", 26 July 2012), p. 18.

14807 D3540 (Zorica Subotić's expert report entitled "The Use of Modified Aircraft Bombs in the Sarajevo Area in 1994-1995”, 15 March 2012), pp. 47-51; Zorica Subotić, T. 38183-38186 (13 May 2013); D2662 (Mirjana Anđelković-Lukić's expert report entitled "Expert Analysis of Documents”, 26 July 2012), pp. 18-20.

14808 D3540 (Zorica Subotić's expert report entitled "The Use of Modified Aircraft Bombs in the Sarajevo Area in 1994-1995", 15 March 2012), pp. 44-46, 51-54, 182, 188-189 (also arguing that the wounded man treated on the scene as seen in a local TV footage was wearing a camouflage uniform); Zorica Subotić, T. 38186-38187 (13 May 2013).
} 
the distance from which the modified air bomb was fired was highly questionable and made without taking into account the specifications of the modified bomb used. ${ }^{14809}$

4412. In addition to the evidence and the adjudicated facts outlined above, the Chamber also took judicial notice of the following adjudicated facts that go to the origin and the nature of fire in this incident: (i) the projectile that exploded in Hrasnica on 7 April 1995 was a modified air bomb; ${ }^{14810}$ (ii) one civilian was killed and three civilians were injured, one of them seriously, in the explosion; ${ }^{14811}$ (iii) the modified air bomb was fired from the area northwest of the impact site, in the area of Ilidža, an area that was controlled by the SRK; ${ }^{14812}$ and (iv) the modified air bomb was launched by members of the SRK. ${ }^{14813}$

4413. Having considered the evidence and the adjudicated facts outlined above, and in particular the SRK combat report of 7 April, the Chamber is satisfied that the projectile that landed at Alekse Šantića street in Hrasnica on 6 April 1995 was a FAB-250 modified air bomb. The Chamber is also satisfied that it was launched by the members of the Ilidža Brigade, in direct application of the order issued by Dragomir Milošević on 6 April 1995. ${ }^{14814}$ Given that the SRK's own report states that the bomb used in this attack was a modified FAB-250, the Chamber does not accept the evidence of Subotić and Anđelković-Lukić that it was in fact a FAB-100. Similarly, it is also not persuaded by Zečević's evidence that the bomb in question was a fuel-air bomb.

4414. The Chamber is further satisfied that one person, Ziba Čustović, died in this incident, while three others, Ziba Šubo, Elvis Brajlović, ${ }^{14815}$ and Gara Sarajkić, were wounded. All four were civilians who were in their houses and not taking direct part in the hostilities at the time the incident took place.

4415. The Chamber recalls the Accused's argument that the intended target of the modified air bomb was the Alekse Šantića school, which according to him was some 20 metres away from the incident site and which was used by the ABiH's $4^{\text {th }}$ Brigade. The Chamber further recalls that it was Subotić who measured the distance between the school's backyard and the incident site as being some 20 metres away from the incident site. While the Chamber is satisfied that the school was used by the $\mathrm{ABiH}$, as confirmed by various SRK documents and by both Ilija Miščević and

\footnotetext{
14809 D3540 (Zorica Subotić's expert report entitled "The Use of Modified Aircraft Bombs in the Sarajevo Area in 1994-1995”, 15 March 2012), pp. 54-56.

14810 See Adjudicated Fact 3037.

14811 See Adjudicated Fact 3038.

14812 See Adjudicated Fact 3040.

14813 Adjudicated Fact 3041.

14814 See P1782 (SRK combat report, 7 April 1995), pp. 1-2; P1201 (SRK Order, 6 April 1995).

14815 See fn. 14764.
} 
Ziba Šubo, it does not accept Subotić's evidence that the school was 20 metres from the incident site. Instead, as noted above, the evidence shows that the school building itself was over 100 metres away from the incident site. ${ }^{14816}$ In addition, all the other ABiH-related locations in Hrasnica, including the four $\mathrm{ABiH}$ mortars, were far from the incident site. ${ }^{14817}$ The Chamber considers, therefore, that there were no legimitate military targets in the immediate vicinity of the incident site. ${ }^{14818}$

4416. The Chamber recalls that Radojčić testified that he was the one who selected the Alekse Šantića School as the target following Milošević's order of 6 April, thus contradicting the argument that the SRK was targeting civilians in this incident. However, as noted above, the modified air bomb overshot the school by over 100 metres. Given the inherent inaccuracy of modified air bombs and their destructive power, as found by the Chamber above, and the fact that the target selected was located in the central, mainly residential, part of Hrasnica, Radojčić and the other SRK soldiers involved in this launch should have been aware that such an attack would cause casualties among the civilian population and extensive destruction of civilian property.

4417. The Chamber also recalls here the Accused's argument that the launch was made in response to $\mathrm{ABiH}$ violation of a truce and its constant attacks on the SRK in the area. However, noting the combat report of 7 April, it is clear that while there was $\mathrm{ABiH}$ fire on the Famos Factory in the morning of 7 April, it came from infantry weapons and from an $82 \mathrm{~mm}$ mortar, which were fired from the area of Gradina-Igman and Lasica. The SRK response of launching the FAB-250, a highly destructive modified air bomb, was therefore disproportionate. In addition, it was directed at a location different to the one from which the fire was opened. The SRK response thus appears to have been an attempt to exact revenge rather than to neutralise incoming fire or defend the SRK positions at the moment of the attacks. In the Chamber's view the report of 7 April is also indicative of the general mind-set of the SRK units, including its command, according to which no distinction could be or was made between the civilian population and legitimate military targets. This meant that large areas of Sarajevo, such as the centre of Hrasnica, were considered to be legimitate military targets no matter how many civilians lived there. ${ }^{14819}$

\footnotetext{
14816 See fn. 14802.

14817 In this respect, the Chamber accepts Miščević's evidence as to the location of the post office in Hrasnica which housed the $4^{\text {th }}$ Brigade headquarters.

14818 While there is a possibility that a soldier may have been injured in this incident, given Overgard's testimony, the Chamber does not consider that his presence in the area turned the incident site into a legitimate military target.

14819 See D2479 (Witness statement of Mile Sladoje dated 25 November 2012), para. 11; Mile Sladoje, T. 30570 30571 (28 November 2012) (testifying that all ABiH positions were in civilian areas where people lived in apartment buildings and that there was not a single "entirely civilian settlement" that did not have a military
} 
(b) Safeta Zajke street (formerly 21. Maja street) and Majdanska street, 24 May 1995 (Scheduled Incidents G.11 and G.12)

4418. According to the Indictment, on 24 May 1995, a missile projectile landed on Safeta Zajke street, killing two people and wounding five others. ${ }^{14820}$ The alleged origin of fire was the SRKheld territory southeast of the incident site. ${ }^{14821}$ In its Final Brief, the Prosecution claims that the projectile was a modified air bomb and that it came from the direction of Lukavica. ${ }^{14822}$ According to the Indictment, also on 24 May 1995, a modified air bomb landed on Majdanska street "bb", killing two and wounding five civilians. ${ }^{14823}$ As with scheduled incident G.11, the alleged origin of fire was the SRK-held territory southeast of the incident site. ${ }^{14824}$

4419. The Accused argues that there was fierce combat in Sarajevo on the day of these incidents and that the modified air bomb used in both was a FAB-100, filled with solid explosive charge. ${ }^{14825}$ With respect to the Safeta Zajke incident he claims that the "most likely target" was the Žica factory, which was a part of an industrial complex and housed a command post of the $102^{\text {nd }}$ Motorised Brigade. ${ }^{14826}$ He also argues that the SRK used the bomb to neutralise six ABiH mortars near Stupsko Brdo. ${ }^{14827}$ As for the Majdanska street incident, the Accused argues that the intended target was the transformer station, located within an industrial zone and surrounded by military objects, such as the forward command post of the $102^{\text {nd }}$ Motorised Brigade; the point of impact was, according to the Accused, within the expected error range for unguided rocket projectiles. ${ }^{14828}$

4420. In May 1995, Anđa Gotovac lived at 43 Safeta Zajke street, in Alipašino Polje, approximately 100 to 150 metres behind the TV building. ${ }^{1429}$ Her house was also close to the power transformer station, the Žica Factory, and the Novi Grad municipality building. ${ }^{14830}$ This area was far from the frontlines, so there was no sniper fire, although there was constant

target in it); Savo Simić, T. 30058 (12 November 2012) (testifying that it was the ABiH's responsibility to take into account whether a location was inhabited when placing their firing positions).

Defo (Witness satement 2367

P490 (Witness statement of Anđa Gotovac dated 17 May 2006), para. 2; Anđa Gotovac, P489 (Transcript from Prosecutor v. D. Milošević), T.4465; D1271 (Witness statement of Anđa Gotovac dated 21 February 2011), para. 1; P1807 (Map of Sarajevo marked by KDZ166); P2190 (GPS locations for shelling and sniping incidents in Sarajevo); P2191 (Map of Sarajevo with scheduled sniping and shelling incidents); P2213 (Image re scheduled sniping and shelling incidents in Sarajevo). See also Adjudicated Fact 3042.

14830 Anđa Gotovac, P489 (Transcript from Prosecutor v. Perišić), T. 786-787; D1271 (Witness statement of Anđa Gotovac dated 21 February 2011), para. 3. 
shelling. ${ }^{14831}$ She could recall two other occasions on which the shells passed over her house, targeting the TV building. ${ }^{14832}$

4421. On 24 May 1995, it was a quiet morning and just after 10 a.m., Gotovac was outside her house when she heard something that sounded like a plane. ${ }^{14833}$ Before she could raise her head to see what the sound was, there was an explosion and she was blown over by the blast. ${ }^{14834}$ The roof of her house was also blown away and her house was destroyed. ${ }^{14835}$ According to Gotovac, as a result of this explosion, two people were killed and at least three, including Gotovac, were injured. ${ }^{14836}$ Gotovac sustained a deep wound in her shoulder and ribs from shrapnel, and had to have surgery; after she was discharged from hospital several days later but she had to be visited by a nurse on a daily basis for the next two months. ${ }^{14837}$ Two years after the incident, she still had breathing problems and could not lean on her left side. ${ }^{14838}$

4422. Gotovac testified that the explosion was caused by an air bomb and noted that, as she was being taken to hospital, she saw a "barrel" on the ground. ${ }^{14839}$ She admitted, however, that she did not know what a modified air bomb looked like. ${ }^{14840}$ Gotovac also testified that she never saw any $\mathrm{ABiH}$ weapons, positions, or military facilities in her street and that on the day of the explosion she did not see any ABiH soldiers nearby. ${ }^{14841}$ She confirmed, however, that ABiH troops were located on Žuč hill, which was to the north of her house, some distance away, and that they had to pass

\footnotetext{
14831 P490 (Witness statement of Anđa Gotovac dated 17 May 2006), paras. 3, 5; Anđa Gotovac, P489 (Transcript from Prosecutor v. Perišić), T. 785.

14832 D1271 (Witness statement of Anđa Gotovac dated 21 February 2011), paras. 2, 4-5. See also P490 (Witness statement of Anđa Gotovac dated 17 May 2006), para. 5.

14833 P490 (Witness statement of Anđa Gotovac dated 12 March 1997), p. 2. See also Adjudicated Fact 3043.

14834 P490 (Witness statement of Anđa Gotovac dated 12 March 1997), p. 2; Anđa Gotovac, P489 (Transcript from Prosecutor v. Perišić), T. 784.

14835 P490 (Witness statement of Anđa Gotovac dated 12 March 1997), p. 2; Anđa Gotovac, P489 (Transcript from Prosecutor v. D. Milošević), T. 4454.

14836 P490 (Witness statement of Anđa Gotovac dated 12 March 1997), p. 2; Anđa Gotovac, P489 (Transcript from Prosecutor v. D. Milošević), T. 4463; P1541 (Medical record for Anđa Gotovac).

14837 P490 (Witness statement of Anđa Gotovac dated 12 March 1997), p. 2; P490 (Witness statements of Anđa Gotovac dated 17 May 2006), para. 2; Anđa Gotovac, P489 (Transcript from Prosecutor v. D. Milošević), T. 4454-4455. See also Adjudicated Fact 3045.

14838 P490 (Witness statement of Anđa Gotovac dated 12 March 1997), p. 2. See also Adjudicated Fact 3046. Gotovac has also been permanently affected by the effects of war and has trouble sleeping. P490 (Witness statements of Anđa Gotovac dated 17 May 2006), para. 7. See also Adjudicated Fact 3046.

14839 Anđa Gotovac, P489 (Transcript from Prosecutor v. Perišić), T. 781.

14840 Anđa Gotovac, P489 (Transcript from Prosecutor v. Perišić), T. 781-782.

14841 P490 (Witness statement of Anđa Gotovac dated 17 May 2006), para. 4; Anđa Gotovac, P489 (Transcript from Prosecutor v. D. Milošević), T. 4455. See also Adjudicated Fact 3043.
} 
through her street in order to get to the hill. ${ }^{14842}$ Gotovac was told that the projectile came either from Hresa or from Trebević but noted that she did not know if that was really the case. ${ }^{14843}$

4423. On the same day, at around 2 p.m., another projectile exploded, this time on the nearby Majdanska street in Alipašino Polje. ${ }^{14844}$

4424. A team from CSB Sarajevo, which included Kučanin and KDZ166, investigated both incidents. ${ }^{14845}$ They first went to Safeta Zajke street and arrived at the incident site at 2:30 p.m.; no ballistics experts were on the scene but they were consulted later. ${ }^{14846}$ At Safeta Zajke street, KDZ166 took photographs, sketched the incident site, and marked all the physical evidence. ${ }^{14847}$ He concluded, based on the bomb fragments found embedded into the crater in the southeasterly direction, that the projectile came from the southeast. ${ }^{14848}$ He also noted that the crater was 250 centimetres long, 110 centimetres wide, and 30 centimetres deep. ${ }^{14849}$ In his report dated 26 May 1995, Kučanin stated that the crater made by the projectile was about two metres long and one metre wide, and that it stretched toward the south, ${ }^{14850}$ "that is the aggressor's positions in the Lukavica area". ${ }^{1451}$ Based on the connecting plate, parts of the fuse of the aircraft bomb, and two

14842 P490 (Witness statement of Anđa Gotovac dated 17 May 2006), para. 3. See also Anđa Gotovac, P489 (Transcript from Prosecutor v. D. Milošević), T. 4457-4459; P489 (Transcript from Prosecutor v. Perišić), T. 786.

14843 P490 (Witness statement of Anđa Gotovac dated 12 March 1997), p. 2. See also Anđa Gotovac, P489 (Transcript from Prosecutor v. D. Milošević), T.4463.

14844 P1322 (BiH MUP Report re shelling of Safeta Zajke and Majdanska streets on 24 May 1995), p. 3 ; P1323 (BiH MUP Report re shelling of Majdanska street on 24 May 1995), p. 1.

14845 P1322 (BiH MUP Report re shelling of Safeta Zajke and Majdanska streets on 24 May 1995); P1324 (BiH MUP Report re shelling of Safeta Zajke street on 24 May 1995). See also P1276 (Witness statement of Ekrem Suljević dated 9 February 2010), paras. 49, 52; P1925 (Witness statement of Emir Turkušić dated 16 February 2010), p. 8; P1791 (Witness statement of KDZ166 dated 13 February 2010), p. 6.

14846 P1322 (BiH MUP Report re shelling of Safeta Zajke and Majdanska streets on 24 May 1995), e-court p. 1 (stating that CSB Sarajevo was informed about the incident at 2 p.m.); P1791 (Witness statement of KDZ166 dated 13 February 2010), p. 8; P1925 (Witness statement of Emir Turkušić dated 16 February 2010), p. 8.

14847 P1791 (Witness statement of KDZ166 dated 13 February 2010), pp. 7, 10-11; KDZ166, T. 82748275 (20 October 2010), T. 83408341 (26 October 2010); P1808 (Sketch re shelling of Safeta Zajke street on 24 May 1995) (under seal); P1800 (Photographs re shelling of Safeta Zajke street on 24 May 1995). On crossexamination, KDZ166 conceded that he made a slight mistake, by some 20 degrees, when marking the direction of north on the sketch. See KDZ166, T. 8339-8340 (26 October 2010); D809 (Sketch re shelling of Safeta Zajke street on 24 May 1995 marked by KDZ166).

14848 P1791 (Witness statement of KDZ166 dated 13 February 2010), p. 8; P1808 (Sketch re shelling of Safeta Zajke street on 24 May 1995) (under seal); KDZ166, T. 8275-8277 (20 October 2010), 8346-8349 (26 October 2010); P1801 (Photograph of Safeta Zajke street marked by KDZ166); D811 (Photograph re shelling of Safeta Zajke street on 24 May 1995 marked by KDZ166). The tail fins were facing south when found, which also led Kučanin to conclude that the modified air bomb was launched from the Lukavica area. See P1322 (BiH MUP Report re shelling of Safeta Zajke and Majdanska streets on 24 May 1995).

14849 P1808 (Sketch re shelling of Safeta Zajke street on 24 May 1995) (under seal); P1812 (BiH MUP Report re shelling of Safeta Zajke street on 24 May 1995).

14850 The Chamber notes that while the English translation of this report refers to the direction of "south east", the BCS version refers only to the direction of "south". See P1322 (BiH MUP Report re shelling of Safeta Zajke and Majdanska streets on 24 May 1995), e-court p. 1. See also KDZ166, 8356 (26 October 2010).

14851 P1322 (BiH MUP Report re shelling of Safeta Zajke and Majdanska streets on 24 May 1995), e-court p. 1. KDZ166 explained that the conclusion on the origin of fire was based on the assumption that the ABiH would 
rocket tail fins found in the crater, it was determined that the projectile was a modified air bomb with four $128 \mathrm{~mm}$ multiple rocket launcher rockets and that it weighed between 400 and 450 kilograms. ${ }^{14852}$ According to the report, two people were killed and five, including Gotovac, were wounded as a result of this explosion. ${ }^{14853}$ KDZ166 testified that they were all civilians. ${ }^{14854}$

4425. Having completed the investigation on Safeta Zajke street, the CSB Sarajevo team then moved to Majdanska street and investigated this incident as well. ${ }^{1485}$ As with the previous incident, KDZ166 took photographs, marked the evidence, and prepared a sketch of the scene noting that the incident site overlooked the transformer station. ${ }^{14856} \mathrm{He}$ observed that the crater was five metres in diameter, two metres wide, and one metre deep, while the surface was soil. ${ }^{14857}$ On the basis of the positioning of the crater, he determined that the bomb came from the southeast, that is, from the area of Pavlovac. ${ }^{14858}$ Later, during his cross-examination, KDZ166 appeared to agree with the Accused's incorrect assertion that the location he noted in his report was Prljevo Brdo, which is a location northeast of Pavlovac and further east of Lukavica. ${ }^{1459}$

4426. Kučanin also prepared a report, dated 26 May 1995, and noted, based on the fragments found and the damage caused, including a crater that was five metres long, 1.5 metres wide, and about 1.5 metres deep, that the projectile was a modified air bomb with four $128 \mathrm{~mm}$ rockets. ${ }^{14860}$

not fire on its own positions. He also testified that he did not know why Kučanin's report recorded slightly different measurements for the size of the crater and had a slightly different direction of fire. KDZ166, T. 83448345, 8354 (26 October 2010); D810 (BiH MUP report re shelling of Safeta Zajke and Majdanska streets on 24 May 1995) (under seal). The Chamber notes, however, that Lukavica is in fact in the southeasterly direction in relation to the incident site. See P2191 (Map of Sarajevo with scheduled sniping and shelling incidents).

14852 P1812 (BiH MUP Report re shelling of Safeta Zajke street on 24 May 1995); P1322 (BiH MUP Report re shelling of Safeta Zajke and Majdanska streets on 24 May 1995), e-court pp. 1-2.

14853 Aiša Hrustan and Ivo Miletić are listed in the report as having been killed, while Dražen Gelo, Anđa Gotovac, Igor Vučičević, Džemal Kukuljac, and Franjo Tolić are listed as having been wounded. See P1322 (BiH MUP Report re shelling of Safeta Zajke and Majdanska streets on 24 May 1995), e-court p. 2. See also P1538 (Autopsy reports for Aisa Hrustan and Ivan Miletić); P1537 (Letter of discharge for Franjo Tolić); P1539 (Letter of discharge for Džemal Kukuljac); P1540 (Medical record for Igor Vučičević); P1541 (Medical record for Anđa Gotovac); Adjudicated Fact 3048.

14854 P1791 (Witness statement of KDZ166 dated 13 February 2010), p. 7.

14855 P1322 (BiH MUP Report re shelling of Safeta Zajke and Majdanska streets on 24 May 1995); P1324 (BiH MUP Report re shelling of Safeta Zajke street on 24 May 1995). See also P1276 (Witness statement of Ekrem Suljević dated 9 February 2010), paras. 49, 51.

14856 P1791 (Witness statement of KDZ166 dated 13 February 2010), pp. 11-12; KDZ166, T. 8360-8364 (26 October 2010) (correcting the direction of north marked on the sketch slightly); P1813 (Sketch re shelling of Majdanska street on 24 May 1995) (under seal); D813 (Sketch re shelling of Majdanska street on 24 May 1995 marked by KDZ166); P1817 (Photographs re shelling of Majdanska street on 24 May 1995).

14857 P1813 (Sketch re shelling of Majdanska street on 24 May 1995) (under seal); KDZ166, T. 8359-8360 (26 October 2010).

14858 P1813 (Sketch re shelling of Majdanska street on 24 May 1995) (under seal); KDZ166, T. 8361 (26 October 2010). The Chamber notes that Pavlovac is located just below Lukavica. See P2191 (Map of Sarajevo with scheduled sniping and shelling incidents).

14859 KDZ166, T. 8367-8369 (26 October 2010); D814 (Map of Sarajevo marked by KDZ166).

14860 P1322 (BiH MUP Report re shelling of Safeta Zajke and Majdanska streets on 24 May 1995), e-court p. 3. See also KDZ166, T. 8366 (26 October 2010) When asked why Kučanin's measurements of the crater did not 
According to the report, the crater stretched towards the south, indicating that the modified air bomb came from the same location as the bomb that struck Safeta Zajke street earlier in the day. ${ }^{14861}$ The report also notes that two people were killed in the explosion and six were seriously wounded; in addition, serious damage was caused to the Novi Grad power transformer station and one electricity pylon was destroyed. ${ }^{14862}$

4427. The fragments found on both sites were then sent to ballistics experts for analysis. The experts established that both projectiles were modified air bombs made of a destructive FAB-250 aircraft bomb and five $122 \mathrm{~mm}$ GRAD type rockets which served as a power unit. ${ }^{14863}$

4428. With respect to the facilities surrounding the incident sites, the Chamber heard that both sites were close to the TV building, the Novi Grad's Municipal Assembly building, Geodesic Institute, Žica Factory, ${ }^{14864}$ ŠIK Factory, and Energoinvest. ${ }^{14865}$ While the command post of the $102^{\text {nd }}$ Motorised Brigade of the ABiH was located in Žica factory, ${ }^{14866}$ Safeta Zajke street itself was

correspond to what he had noted in his report, KDZ166 stated that he did not know but that he stood by his report. KDZ166, T. 8365-8366 (26 October 2010).

14861 P1322 (BiH MUP Report re shelling of Safeta Zajke and Majdanska streets on 24 May 1995), e-court p. 3. KDZ166 did not know why his conclusion about the direction of southeast was different to the direction noted by Kučanin in the report of 26 May 1995. See KDZ166, T. 8365-8366 (26 October 2010). The Chamber notes, however, that Lukavica is in fact in the southeasterly direction in relation to the incident site. See P2191 (Map of Sarajevo with scheduled sniping and shelling incidents)

14862 Those listed as killed are Sulejman Prasko and Nezir Huseinović, while those listed as wounded are Fatima Konaković, Goran Jeličić, Enes Jašarević, Salko Slato, Lucija Jurišić, and Mira Lovrić. See P1322 (BiH MUP Report re shelling of Safeta Zajke and Majdanska streets on 24 May 1995), e-court p. 3. See also P1813 (Sketch re shelling of Majdanska street on 24 May 1995) (under seal); P1542 (Autopsy report for Sulejman Prasko); P1817 (Photographs re shelling of Majdanska street on 24 May 1995), e-court pp. 1-3, 9-10; Adjudicated Fact 3050.

14863 P1324 (BiH MUP Report re shelling of Safeta Zajke street on 24 May 1995), e-court p. 2 ; P1925 (Witness statement of Emir Turkušić dated 16 February 2010), p. 8; Emir Turkušić, T. 9103-9110 (4 November 2010); P1323 (BiH MUP Report re shelling of Majdanska street on 24 May 1995), p. 1. See also P1276 (Witness statement of Ekrem Suljević dated 9 February 2010), paras. 51-52.

14864 At first, KDZ166 stated that Žica Factory was about 300 to 500 metres away from the incident site on Safeta Zajke street but when asked to measure that distance on a map agreed that it was just under 100 metres away. See KDZ166, T. 8336-8338 (26 October 2010). See also D3540 (Zorica Subotić's expert report entitled "The Use of Modified Aircraft Bombs in the Sarajevo Area in 1994-1995", 15 March 2012), pp. 58, 188. According to the scale on the map used by the Chamber, the distance between the Žica Factory and the Safeta Zajke incident site is approximately slightly over 100 metres. See P1803 (Map of Alipašino Polje and surrounding areas).

14865 Ekrem Suljević, T. 5767-5777 (22 July 2010); D530 (Photograph of RTV BiH building marked by Ekrem Suljević); D531 (Aerial photograph of Sarajevo marked by Ekrem Suljević); KDZ166, T. 8330-8336 (26 October 2010); D808 (Aerial photograph of Sarajevo marked by KDZ166); P1803 (Map of Alipašino Polje and surrounding areas); D986 (Aerial photograph of Sarajevo marked by KDZ477). See also Emir Turkušić, T. 9111-9112 (4 November 2010); P2318 (Report by Berko Zečević entitled "The use of modified aircraft bombs during the siege of Sarajevo, 1994-1995"), p. 119.

14866 Asim Džambasović, T. 15200-15201, 15214-15215, 15222, 15245-15246 (22 June 2011); D1377 (Map of $\mathrm{ABiH}$ positions in Sarajevo marked by Asim Džambasović); D1379 (Map of ABiH positions in Sarajevo marked by Asim Džambasović); D1383 (Map of ABiH positions in Sarajevo marked by Asim Džambasović); D1385 (Locations of ABiH 1st Corps units in Sarajevo, 13 April 1993). 
lined with residential houses, with $\mathrm{ABiH}$ positions approximately two kilometres behind it. ${ }^{14867}$ The Novi Grad police station is located on Prvomajska street. ${ }^{14868}$ A number of residential buildings are located some 100 metres away from the incident site on Majdanska street. ${ }^{14869}$

4429. Zečević, Subotić and Anđelković-Lukić all analysed the reports and various witness statements in relation to the two incidents. With respect to the Safeta Zajke incident, Zečević thought that the projectile used was a modified fuel-air bomb with three $122 \mathrm{~mm}$ GRAD rocket motors. ${ }^{14870}$ He based this conclusion on (i) a "three pointed star" or "three pointed centering system" found on the scene, which was used to centre the three rocket motors; (ii) Gotovac's statement that after detonation she had a burning sensation; (iii) the absence of a large number of fragments on the facades of the surrounding buildings; and (iv) the fact that rocket motors were found in the crater. ${ }^{14871}$ Zečević determined, based on the sketch of the incident, that the azimuth of the modied air bomb was 155 degrees, plus or minus five degrees. ${ }^{14872}$ According to him, the modified air bomb was launched from a distance greater than 4,800 metres from the incident site as the angle of launch would otherwise have to have been 20 degrees; this would have resulted in the bomb ricocheting. ${ }^{14873}$ He testified that it probably came from a distance of about 5,800 metres or more. $^{14874}$

4430. Both Subotić and Anđelković-Lukić argued that the modified air bomb that landed on Safeta Zajke street was most probably a FAB-100 with three rocket motors ${ }^{14875}$ because the crater

14867 KDZ166, T. 8274 (20 October 2010); P1925 (Witness statement of Emir Turkušić dated 16 February 2010), p. 9.

14868 Ekrem Suljević, T. 5767-5777 (22 July 2010); D530 (Photograph of RTV BiH building marked by Ekrem Suljević); D531 (Aerial image of Sarajevo marked by Ekrem Suljević). See also KDZ166, T. 8330-8336 (26 October 2010); D808 (Aerial photograph of Sarajevo marked by KDZ166); P1803 (Map of Alipašino Polje and surrounding areas); P2318 (Report by Berko Zečević entitled "The use of modified aircraft bombs during the siege of Sarajevo, 1994-1995"), pp. 123-124. The Chamber notes that according to the scale on map P1803, the police station was located some 800 metres away from the Safeta Zajke incident site.

14869 P2318 (Report by Berko Zečević entitled "The use of modified aircraft bombs during the siege of Sarajevo, 1994-1995”), pp. 123-124; D3540 (Zorica Subotić's expert report entitled “The Use of Modified Aircraft Bombs in the Sarajevo Area in 1994-1995”, 15 March 2012), p 68.

14870 P2318 (Report by Berko Zečević entitled "The use of modified aircraft bombs during the siege of Sarajevo, 1994-1995”), pp. 118, 121.

14871 P2318 (Report by Berko Zečević entitled "The use of modified aircraft bombs during the siege of Sarajevo, 1994-1995”), pp. 117-119.

14872 P2318 (Report by Berko Zečević entitled "The use of modified aircraft bombs during the siege of Sarajevo, 1994-1995”), p. 119.

14873 P2318 (Report by Berko Zečević entitled "The use of modified aircraft bombs during the siege of Sarajevo, 1994-1995”), p. 120.

14874 P2318 (Report by Berko Zečević entitled "The use of modified aircraft bombs during the siege of Sarajevo, 1994-1995”), p. 120.

14875 Subotic explained that local ballistics experts concluded that the bomb contained five rocket motors because they overlooked the fact that $122 \mathrm{~mm}$ GRAD rockets have two chambers each, meaning that the five tubes found on the scene indicated that the projectile had at least three motors. See D3540 (Zorica Subotić's expert report entitled "The Use of Modified Aircraft Bombs in the Sarajevo Area in 1994-1995", 15 March 2012), p. 62. 
was smaller than craters created by FAB-250 bombs and because a three-pointed star was found among the fragments. ${ }^{14876}$ Both also thought that the bomb contained conventional explosive rather than fuel-air explosive because, inter alia, (i) no large fragments of projectile casing were found, indicating that the casing fragmented from the effects of a solid explosive charge; (ii) traces from the blast, such as blown-off rooftops and broken windows and doors, point to the conclusion that solid explosive was used; and (iii) had it been a fuel-air bomb more people would have been killed as they were near the explosion. ${ }^{14877}$

4431. Noting that the direction of north was marked incorrectly in KDZ166's sketch, Subotić corrected the mistake and determined that the azimuth of the bomb was 146 degrees, rather than 155 degrees as established by Zečević. ${ }^{14878}$ She argued that both directions cross over the Žica Factory, which was most likely the intended target. ${ }^{14879}$ Finally, Subotić criticised Zečević's analysis in relation to the distance from which the modified air bomb came and argued that it would have been more than 6,200 metres, and probably even farther than 7,000 metres. ${ }^{14880}$

4432. As for the Majdanska street incident, Zečević noted that on the basis of KDZ166's sketch, the azimuth was around 135 degrees from the north, but speculated that the actual azimuth was "probably identical" to the azimuth of the bomb that struck Safeta Zajke street, particularly given the proximity of the two locations. ${ }^{14881}$ Subotić disagreed and--having once again corrected the direction of north on KDZ166's sketch-found that the azimuth of the bomb was around 137 degrees. ${ }^{14882}$ Noting that the alleged origin of fire, namely Pavlovac, was on a trajectory that had an azimuth of 152 degrees, she concluded that it was impossible to establish with certainty which direction was correct but thought that it was definitely southeast and that it was between 120 and

\footnotetext{
14876 D2662 (Mirjana Anđelković-Lukić's expert report entitled “Expert Analysis of Documents”, 26 July 2012 ), p. 20; D3540 (Zorica Subotić's expert report entitled "The Use of Modified Aircraft Bombs in the Sarajevo Area in 1994-1995", 15 March 2012), pp. 62-64 (testifying also that the small number of fragment traces noted by Zečević can be explained by the FAB-100's smaller size); Zorica Subotić, T. 38188-38189 (13 May 2013). D2662 (Mirjana Anđelković-Lukić's expert report entitled "Expert Analysis of Documents”, 26 July 2012), p. 21; D3540 (Zorica Subotić's expert report entitled "The Use of Modified Aircraft Bombs in the Sarajevo Area in 1994-1995", 15 March 2012), pp. 64-65.

14878 D3540 (Zorica Subotić's expert report entitled "The Use of Modified Aircraft Bombs in the Sarajevo Area in 1994-1995”, 15 March 2012), pp. 59-61; Zorica Subotić, T. 38189 (13 May 2013). See also KDZ166, T. 83548355 (26 October 2010); D812 (Map of Alipašino Polje and sketch re shelling incident on 24 May 1995).

14879 D3540 (Zorica Subotić's expert report entitled "The Use of Modified Aircraft Bombs in the Sarajevo Area in 1994-1995”, 15 March 2012), pp. 59, 61, 180-181, 188-189; Zorica Subotić, T. 38189-38190 (13 May 2013).

14880 D3540 (Zorica Subotić's expert report entitled "The Use of Modified Aircraft Bombs in the Sarajevo Area in 1994-1995”, 15 March 2012), pp. 66-67.

14881 P2318 (Report by Berko Zečević entitled "The use of modified aircraft bombs during the siege of Sarajevo, 1994-1995”), p. 123.

14882 D3540 (Zorica Subotić's expert report entitled “The Use of Modified Aircraft Bombs in the Sarajevo Area in 1994-1995”, 15 March 2012), pp. 71-72.
} 
150 degrees. ${ }^{14883}$ According to her, the analysis of the possible trajectories indicates that the launching site was chosen so that the trajectory of the bomb passed over the least populated part of the city. ${ }^{14884}$

4433. To Subotić and Anđelković-Lukić, the size of the crater in Majdanska street, as measured by KDZ166, indicated that the projectile that landed there was a FAB-100 modified air bomb filled with solid charge. ${ }^{14885}$ Noting the discrepancy between KDZ166's report and Kučanin's report on the size of the crater, Subotić thought that Kučanin purposefully enlarged the crater so that it would fit with the damage caused by a FAB-250 bomb. ${ }^{14886}$ Further, she recalled that an electricity pylon was destroyed and thought that the most likely target in this incident was the transformer station. $^{14887}$

4434. A number of SRK witnesses called by the Accused testified about these two incidents. According to Radojčić, there was a "fierce" ABiH offensive on 24 May 1995; further, the area surrounding Majdanska street was an industrial zone, packed with military installations, including the forward command post of the $1^{\text {st }}$ Battalion of the $102^{\text {nd }}$ Motorised Brigade of the ABiH located on Prvomajska street. ${ }^{1488}$ Dragomir Milošević confirmed that there was an ABiH offensive on 24 May and testified that the $\mathrm{ABiH}$ had six $120 \mathrm{~mm}$ mortars on Safeta Zajke street with which they opened fire on Ilidža and Nedžarići but which were neutralised with the air bomb. ${ }^{14889}$ As part of that offensive, the $\mathrm{ABiH}$ forces were also trying to break through from Majdanska street onto Ozrenska street and were thus firing mortars on the SRK positions from there. ${ }^{14890}$ Milošević also claimed that the modified air bomb that struck Majdanska street caused no casualties according to

\footnotetext{
14883 D3540 (Zorica Subotić's expert report entitled "The Use of Modified Aircraft Bombs in the Sarajevo Area in 1994-1995", 15 March 2012), p. 72.

14884 D3540 (Zorica Subotić's expert report entitled "The Use of Modified Aircraft Bombs in the Sarajevo Area in 1994-1995", 15 March 2012), p. 73.

14885 D3540 (Zorica Subotić's expert report entitled "The Use of Modified Aircraft Bombs in the Sarajevo Area in 1994-1995”, 15 March 2012), pp. 70-71. See also D2662 (Mirjana Anđelković-Lukić's expert report entitled "Expert Analysis of Documents", 26 July 2012), p. 23.

14886 D3540 (Zorica Subotić's expert report entitled "The Use of Modified Aircraft Bombs in the Sarajevo Area in 1994-1995”, 15 March 2012), p. 70.

14887 D3540 (Zorica Subotić's expert report entitled "The Use of Modified Aircraft Bombs in the Sarajevo Area in 1994-1995”, 15 March 2012), pp. 70, 74, 188.

14888 D2562 (Witness statement of Vladimir Radojčić dated 8 December 2012), para. 112; D185 (12 ${ }^{\text {th }}$ Division ABiH combat report, 24 May 1995); D927 (12 ${ }^{\text {th }}$ Division $\mathrm{ABiH}$ combat report, 24 May 1995); D1052 (ABiH $1^{\text {st }}$ Krajina Corps combat report, 31 May 1995). See also para. 3609. According to Radojčić this forward command post was located in the Pavle Goranina school building. However, the Chamber heard no other evidence relating to this building, including its exact distance to the incident site.

14889 Dragomir Milošević, T. 32776-32777 (28 January 2013).

14890 Dragomir Milošević, T. 32777-32778 (28 January 2013); D2903 (SRK combat report, 25 May 1995).
} 
"their $[\mathrm{ABiH}]$ reports" and that the distance between Majdanska street incident site and the closest residential area, namely over 100 metres, was safe. ${ }^{14891}$

4435. Savo Simić, who had been Chief of Artillery in the $1^{\text {st }}$ Sarajevo Mechanised Brigade positioned in Lukavica prior to the incident, ${ }^{14892}$ testified that not a single modified air bomb was launched from the brigade's zone of responsibility. ${ }^{14893}$ Similarly, Dušan Škrba, Simić's subordinate, testified that Prljevo Brdo was in his zone of fire and immediately in front of his command post and was adamant that no air bomb was ever fired from there or from Lukavica. ${ }^{14894}$ He did concede, however, that his brigade had air bombs in its arsenal. ${ }^{14895}$

4436. In addition to the evidence and the adjudicated facts outlined above, the Chamber also took judicial notice of two adjudicated facts concerning the origin and nature of the fire in the incident on Safeta Zajke street: (i) on the morning of 24 May 1995, a FAB-250 air bomb with fuel-air explosive, propelled by at least three rockets, hit Safeta Zajke street ${ }^{14896}$ and (ii) it was fired from the SRK-controlled area of Lukavica by members of the SRK ${ }^{14897}$ Similarly, it also took judicial notice of two adjudicated facts going to the incident on Majdanska street, stating that: (i) in the afternoon of 24 May 1995 a FAB-250 modified air bomb exploded on Majdanska street; ${ }^{14898}$ (ii) two civilians were killed, and six civilians were injured, five of them seriously, as a result of this explosion; ${ }^{14899}$ and (iii) the modified air bomb originated from the SRK-held territory and was launched by members of the SRK. ${ }^{14900}$

4437. Having considered the evidence and the adjudicated facts outlined above, particularly the fragments found at both incident sites, the Chamber is satisfied that the projectiles that landed on those sites were modified air bombs. The Chamber does not accept the evidence of Subotić and Anđelković-Lukić that in both incidents the bombs in question were FAB-100 bombs. Instead, it is more persuaded by the analysis of the local ballistics experts who had the opportunity to examine

\footnotetext{
14891 Dragomir Milošević, T. 32778-32779 (28 January 2013). When confronted with an SRK document showing that in April 1995 the launch of a modified air bomb was abandoned because UN positions were 200 metres away from the intended target, while SRK positions were 500 metres away, Milošević remained adamant that a person located 100 metres from the explosion of a modified air bomb would not be hurt. See Dragomir Milošević, T. 33151-33154 (4 February 2013); P1299 (VRS Main Staff request for information from SRK, 26 April 1995); P1310 (SRK report to VRS Main Staff re weapons, 26 April 1995).

14892 D2412 (Witness statement of Savo Simić dated 4 November 2012), para. 3.

14893 D2412 (Witness statement of Savo Simić dated 4 November 2012), para. 28

14894 D2341 (Witness statement of Dušan Škrba dated 14 October 2012) paras. 17, 22-23; Dušan Škrba, T. 2915629157 (22 October 2012).

14895 Dušan Škrba, T. 29156 (22 October 2012).

14896 See Adjudicated Fact 3044.

14897 See Adjudicated Fact 3047.

14898 See Adjudicated Fact 3049.

${ }^{14899}$ See Adjudicated Fact 3050.
} 
the fragments found at the two incident sites and who reached the conclusion that FAB-250 bombs were used on both occasions. ${ }^{14901}$ Subotić showed yet again that she was prone to jumping to conspiracy theories when she speculated that Kučanin purposefully enlarged the description of the size of the crater in Majdanska street in order to implicate a larger modified air bomb. The Chamber does not accept her evidence on this point. ${ }^{14902}$ The Chamber is also not persuaded beyond reasonable doubt by Zečević's evidence that the bomb that landed on Safeta Zajke street was a fuel-air bomb. In fact, the Chamber considers that the damage he mentions in support of that conclusion could have equally been the result of an explosion of a modified air bomb with solid charge, as explained by Anđelković-Lukić and Subotić. Accordingly, the Chamber cannot accept as accurate that part of Adjudicated Fact 3044 which refers to the fuel-air explosive. Ultimately, however, the Chamber considers that the type of the charge used in the bombs here is irrelevant given their size and highly destructive nature.

4438. Given the proximity of the two incident sites, and the fact that they are on the same firing line, the Chamber is further of the view that both modified air bombs were launched from the same location and by the same launching crew. ${ }^{14903}$ Given the long range from which the two modified air bombs were fired, as testified to by Zečević and Subotić in relation to the Safeta Zajke incident, the Chamber is also satisfied that they were fired by the SRK. Additionally, the fact that the ABiH did not possess such bombs also indicates that they were launched by the SRK. The Chamber is also satisfied, that they were launched from the SRK positions southeast of the incident sites as determined by the CSB Sarajevo. While Dušan Škrba claimed that they were not launched from his zone of fire, namely from Prljevo Brdo, this location was never said to have been the origin of fire; instead, KDZ166 referred to the area of Pavlovac in his report, which is located south of Lukavica and is southeast of the incident sites. Ultimately, however, the Chamber does not consider it necessary to determine the exact origin of fire, given its findings above. ${ }^{14904}$

\footnotetext{
14900 See Adjudicated Fact 3051.

14901 In addition, the Chamber recalls that both Subotić and Anđelković-Lukić came to the same conclusion in relation to Scheduled Incident G.10, despite the fact that the SRK itself reported that the bomb launched on that occasion was a FAB-250. Accordingly, the Chamber considers that their reliability has been compromised in relation to their assessments of the type of the modified air bomb used in the scheduled incidents.

14902 The Chamber notes that in relation to the Safeta Zajke street incident, Kučanin described a crater that was in fact smaller than the crater measured by KDZ166. Thus, the Chamber considers that the differences between Kučanin and KDZ166 in their descriptions of the incident site were most likely the result of imprecision when describing and/or measuring the crater.

14903 The passage of time between the two modified air bomb launches on 24 May 1995 is in line with Milošević's evidence that launching crews needed at least two hours between launches. See fn. 14679.

14904 Thus, even if one were to accept Simić's evidence that no modified air bomb was ever launched from the zone of responsibility of the $1^{\text {st }}$ Sarajevo Mechanised Brigade, this does not exclude the possibility that it was launched from behind the lines of the $1^{\text {st }}$ Sarajevo Mechanised Brigade but still from the SRK-held territory,
} 
4439. With respect to the casualties, based on the evidence and adjudicated facts outlined above, and particularly the medical records and photographs of those killed, the Chamber is satisfied that four people died in these two incidents, while 11 were wounded. ${ }^{14905}$ The Chamber is also satisfied that they were civilians and were not taking direct part in hostilities at the time the bombs landed. Accordingly, Milošević's evidence that there were no casualties on Majdanska street is clearly incorrect and rather indicates that he was trying to minimise the damage caused by the SRK's actions on that day.

4440. Finally, with respect to the Accused's argument that both incident sites were located in an industrial zone, close to military facilities, the Chamber accepts that a number of industrial facilities were indeed in the vicinity of the two incident sites. However, this industrial zone was also interspersed with residential areas and many civilians lived and worked there. While the command post of the $102^{\text {nd }}$ Motorised Brigade of the $\mathrm{ABiH}$ was located in the Žica Factory, some 100 metres away from the incident site on Safeta Zajke street, the street itself was lined with residential houses and was a purely residential area. Even if, as speculated by Subotić, the Žica Factory had been the intended target of the modified air bomb that eventually struck Safeta Zajke street, the SRK missed it by around 100 metres.

4441. With respect to the Majdanska street incident, the Chamber recalls the Accused's claim that the target was the transformer station, while the forward command post of the $1^{\text {st }}$ Battalion of the $102^{\text {nd }}$ Motorised Brigade was nearby. Assuming that the transformer station was indeed the target, the Chamber does not accept that it was a legitimate military target; rather it was a civilian object, the purpose of which was to provide electricity for the city and its population. The same can be said for the electricity pylon that was destroyed in this incident. As for the presence of the forward command post of the $1^{\text {st }}$ Battalion of the $102^{\text {nd }}$ Motorised Brigade near Majdanska street, the Chamber received no evidence about its precise location or its distance from the incident site. Radojčić only testified that it was in a school building on Prvomajska street. The Chamber notes that this street is some 150 metres away from the incident site. ${ }^{14906}$ Once again, assuming that this school was indeed the target of this attack, the SRK missed it by over 100 metres.

4442. Accordingly, while the two modified air bombs were indeed launched on 24 May 1995 into an area with a number of industrial facilities and at least one military target, the Chamber is not

particularly given Subotić's evidence that the distance from which the Safeta Zajke modified air bomb was launched was over 6,000 metres.

14905

See fns. 14853, 14862.

14906 P1803 (Map of Alipašino Polje). See also P6009 (Map of Sarajevo marked by Mile Sladoje) (showing location of Prvomajska street). 
convinced that they were launched with the aim of neutralising any military targets. Had the SRK sought to destroy the command post located in the Žica Factory, it would have tried to do so with the second modified air bomb it launched later in the afternoon. However, the second bomb landed in the area that was about 600 metres from the Žica Factory. This happened either because the SRK was not in fact intent on destroying the command post in Žica or, if it was, then the second bomb deviated from its target by a large margin, indicating yet again the inherent inaccuracy of this weapon. Either way, given this inaccuracy and noting the destructive power of modified air bombs and the fact that there were residential areas around the above-mentioned industrial facilities, the SRK soldiers and officers who ordered and executed the launch of the two modified air bombs should have been aware that such an attack would cause casualties among the civilian population, as well as the extensive destruction of civilian property.

\section{$\underline{\text { G.13) }}$}

\section{(c) Safeta Hadžića street, 26 May 1995 (Scheduled Incident}

4443. According to the Indictment, on 26 May 1995, a modified air bomb struck a building near apartment blocks in Safeta Hadžića street (currently Prvomajska street) ${ }^{14907}$ destroying the top three floors of an apartment building and was followed by several artillery rounds. ${ }^{14908}$ The Indictment alleges that 17 persons were injured, two seriously, and that the fire came from the SRK-held territory in the west-southwest. ${ }^{1409}$ The Accused argues that the modified air bomb used in this incident was a FAB-100 and that it ricocheted off of its intended target, namely the TV building, and then struck the building on Safeta Hadžića street. ${ }^{14910}$ The Accused also argues that there is no evidence to support the police reports that ten artillery rounds were fired in the area after the modified air bomb; these projectiles, he claims, either did not land in the area or were staged. ${ }^{14911}$

4444. On 26 May 1995, at about 11 a.m., KDZ036 was in the square outside an apartment building on Prvomajska street, in Švrakino Selo. ${ }^{14912}$ There were between 40 and 50 people in the square at the time as the weather was fine and there was a lull in the shelling, with no military operations in the area. ${ }^{14913}$ KDZ036 heard a noise resembling that of a fast moving plane or a

\footnotetext{
14907 The address of this building changed several times. It was first Prvomajska street number 52, then it became Safeta Hadžića street 52, and then, in November 1995, it became Prvomajska street 4. See P5061 (Letter from the BiH Office of the Bosniak Liaison Officer to ICTY, 10 April 2012).

14908 Indictment, Scheduled Incident G.13.

14909 Indictment, Scheduled Incident G.13. See also Prosecution Final Brief, Appendix C, para. 76.

14910 Defence Final Brief, para. 2371.

14911 Defence Final Brief, paras. 2371-2372.

14912 KDZ036, P475 (Transcript from Prosecutor v. D. Milošević), T. 4523-4527 (under seal); P477 (Witness statement of KDZ036 dated 10 March 1997), p. 3 (under seal); P456 (Aerial photograph of Sarajevo).

14913 P477 (Witness statement of KDZ036 dated 10 March 1997), p. 3 (under seal); KDZ036, P476 (Transcript from Prosecutor v. D. Milošević), T. 4538. See Adjudicated Fact 3054. See also Adjudicated Fact 3053.
} 
helicopter and a couple of seconds later there was a large blast, which knocked him to the ground. ${ }^{14914}$ When he looked around, he saw bricks falling down from one of the buildings and people screaming. ${ }^{14915}$ He was taken to the Koševo Hospital as he had a deep cut on the right side of his back. ${ }^{14916}$ Later KDZ036 learned that the explosion occurred on the roof of a five storey building nearby and destroyed the three top floors; he saw a large crater in the roof of that building. ${ }^{14917}$ In addition, all the surrounding buildings had their windows blown out. ${ }^{14918}$ No one died as a result of this explosion, ${ }^{14919}$ but at least two persons were seriously injured and 14 others were slightly injured. ${ }^{14920}$ KDZ036 did not hear any other explosions that day. ${ }^{14921}$ He testified that this explosion was the loudest one he ever heard and that it was different from any other type of mortar or shell he had heard previously. ${ }^{14922}$

4445. The incident was investigated by a team from CSB Sarajevo, which included KDZ485 and KDZ477. ${ }^{14923}$ Having arrived at the scene at 1:15 p.m., the team examined the incident site and KDZ477 took photographs of the damage. ${ }^{14924}$ According to the official report of 1 June 1995, prepared by KDZ485, the investigation established that around ten artillery projectiles and one "highly destructive explosive device" landed on a part of the Švrakino Selo housing development near apartment buildings on Safeta Hadžića and Majdanska streets. ${ }^{14925}$ Safeta Hadžića street was a

14914 KDZ036, P475 (Transcript from Prosecutor v. D Milošević), T. 4523-4527 (under seal); P477 (Witness statement of KDZ036 dated 10 March 1997), p. 3 (under seal). KDZ477 also heard the noise and saw the bomb fly over the Novi Grad police station before it hit the street. According to him, the bomb resembled a small aircraft and came from the west. See P2164 (Witness statement of KDZ477 dated 13 February 2010), paras. 8586; D533 (Photographs relating to shelling of Safeta Hadžića street on 26 May 1995), e-court p. 1; KDZ477, T. 10913-10914, 10923-10924 (31 January 2011), T. 11027-11032 (1 February 2011) (testifying in court that he could not be sure now that the bomb he saw was related to this incident as opposed to an incident that happened one month later, but stating that his original statement given in 2006, where he stated that the noise was related to this incident, was the most accurate); D980 (Map of Sarajevo marked by KDZ477).

14915 P477 (Witness statement of KDZ036 dated 10 March 1997), p. 3 (under seal).

14916 KDZ036, P475 (Transcript from Prosecutor v. D. Milošević), T. 4533-4534 (under seal); P477 (Witness statement of KDZ036 dated 10 March 1997), p. 3 (under seal).

14917 P477 (Witness statement of KDZ036 dated 10 March 1997), p. 3 (under seal); P456 (Aerial photograph of Sarajevo marked by KDZ036).

14918 P477 (Witness statement of KDZ036 dated 10 March 1997), p. 3 (under seal).

14919 KDZ036, P476 (Transcript from Prosecutor v. D. Milošević), T. 4536-4537.

14920 See Adjudicated Fact 3056.

14921 P477 (Witness statement of KDZ036 dated 10 March 1997), p. 3 (under seal).

14922 KDZ036, P476 (Transcript from Prosecutor v. D. Milošević), T. 4537; P477 (Witness statement of KDZ036 dated 10 March 1997), p. 3 (under seal).

14923 P1905 (Witness statement of KDZ485), para. 20; KDZ485, T. 8950-8951 (3 November 2010); P2164 (Witness statement of KDZ477 dated 13 February 2010), paras. 84, 87; P2167 (BiH MUP Report re shelling of Safeta Hadžića street on 26 May 1995); D532 (SJB Novi Grad Report re shelling of Safeta Hadžića street on 26 May 1995).

14924 P1913 (BiH MUP Report re shelling of Safeta Hadžića street on 26 May 1995), p. 1; P2167 (BiH MUP Report re shelling of Safeta Hadžića street on 26 May 1995); P2164 (Witness statement of KDZ477 dated 13 February 2010), paras. 87-88; KDZ477, T. 10928-10930 (31 January 2011); D533 (Photographs relating to shelling of Safeta Hadžića street on 26 May 1995).

14925 P1913 (BiH MUP Report re shelling of Safeta Hadžića street on 26 May 1995), pp. 1-2; D532 (SJB Novi Grad Report re shelling of Safeta Hadžića street on 26 May 1995). 
residential area with apartment buildings and offices, close to the Majdanska street. ${ }^{14926}$ Pieces of artillery projectiles, some of which were marked with a swastika, were examined-the team concluded that they were all $90 \mathrm{~mm}$ armour piercing artillery projectiles produced in Nazi Germany and that all were fired from an unspecified weapon located west of the incident site, in the direction of Ilidža. ${ }^{14927}$ As for the highly destructive explosive device, the report notes that it hit the roof of the apartment building at 52 Safeta Hadžića street (formerly Prvomajska street), ${ }^{14928}$ completely destroyed an apartment on the top floor, and damaged a number of others down to the third floor. $^{14929}$ Three GRAD rocket motors were also found on the scene, as well as pieces of the connecting plate. ${ }^{14930}$ Upon inspection of its traces, it was determined that the projectile came from the south-southwest, corresponding to the positions of the Serbs in Lukavica. ${ }^{14931}$ According to the report, two persons were seriously injured while 16 others, including a two-month old baby, sustained light injuries. ${ }^{14932}$

4446. KDZ477 testified that the artillery shells and the modified air bomb that landed in the area on 26 May 1995 did not appear to be targeting anything in particular and that the area was a purely civilian neighbourhood with civilian buildings and the police station; there were no $\mathrm{ABiH}$ weapons there. $^{14933}$

14926 Adjudicated Fact 3052.

14927 P1913 (BiH MUP Report re shelling of Safeta Hadžića street on 26 May 1995), p. 2; D532 (SJB Novi Grad Report re shelling of Safeta Hadžića street on 26 May 1995).

14928 As noted earlier, the address of this building changed several times, going from Prvomajska street number 52, to Safeta Hadžića street 52, and then, in November 1995, becoming Prvomajska street 4. See P5061 (Letter from the BiH Office of the Bosniak Liaison Officer to ICTY, 10 April 2012).

14929 P1913 (BiH MUP Report re shelling of Safeta Hadžića street on 26 May 1995), p. 2; D532 (SJB Novi Grad Report re shelling of Safeta Hadžića street on 26 May 1995); KDZ485, T. 8952-8957 (3 November 2010); D866 (Aerial photograph of Sarajevo marked by KDZ485); D867 (Aerial photograph of Sarajevo marked by KDZ485). See also P2190 (GPS locations for shelling and sniping incidents in Sarajevo); P2191 (Map of Sarajevo with scheduled sniping and shelling incidents); P2213 (Image re scheduled sniping and shelling incidents in Sarajevo). While P1913 refers to number 152 and not 52 of Safeta Hadžića street, the Chamber is satisfied in light of all the evidence showing the actual location of the impact that, as explained by KDZ485, he simply made a typographical mistake when typing up the report.

14930 P1913 (BiH MUP Report re shelling of Safeta Hadžića street on 26 May 1995), p. 2.

14931 P1913 (BiH MUP Report re shelling of Safeta Hadžića street on 26 May 1995), p. 3. But see D532 (SJB Novi Grad Report re shelling of Safeta Hadžića street on 26 May 1995) (a report of an on-site investigation which states that a "highly destructive projectile was fired from the aggressor positions in the west").

14932 The two seriously injured persons were Albina Adrijata and Nura Osmanagić, while the other 15 listed in the report were Zaim Hatić, Ramiz Hevešlija, Alma Hevešlija, Zijada Redžepović, Haris Bešić, Ismet Osmanagić, Muharem Begović, Slavica Gavrilović, Adnan Abaza, Šefik Salčin, Nedžib Perović, Šaban Huremović, Emira Zahiragić, Štefica Kudra, and Hida Bengir. In one of the official notes in the report, an additional person, namely Lejla Redžepović, is also listed as lightly wounded. See P1913 (BiH MUP Report re shelling of Safeta Hadžića street on 26 May 1995), pp. 3, 14; P1251 (Sarajevo State Hospital discharge certificate for Nura Osmanagić); P1252 (Medical report for Nura Osmanagić); P1250 (Sarajevo State Hospital discharge certificate for Zijada Redžepović).

14933 KDZ477, T. 10924-10928 (31 January 2011); P2168 (Map of Sarajevo marked by KDZ477). When asked if the police station was about 150 metres away from the incident site, KDZ477 responded that he did not know. See 
4447. Following the investigation at the scene, the CSB Sarajevo asked for an expert opinion on the projectile that was said to have come from the west-southwest and hit an apartment building at 52 Safeta Hadžića street. ${ }^{14934}$ As a result, Suljević prepared a report analysing the fragments found and concluded that it was a modified air bomb, consisting of an aircraft bomb, the type of which could not be established, and "many $122 \mathrm{~mm}$ calibre GRAD type rocket projectiles used as engines". ${ }^{14935}$ When asked about the projectile with a swastika, he observed that it was not part of the material he inspected, but noted that he did encounter such a shell in another incident, where it was established that it was an $88 \mathrm{~mm}$ calibre artillery shell. ${ }^{14936}$

4448. Zečević analysed the incident and concluded that the projectile was a modified air bomb, filled with fuel-air explosive. ${ }^{14937}$ Noting that the reports of local investigators provided two different directions of fire, namely west (Ilidža) and south-southwest (Lukavica), Zečević thought, relying on eye-witness accounts which are not in evidence in this case, that the bomb in fact came from the direction of Ilidža-Rajlovac. ${ }^{14938}$ He speculated that the azimuth was most likely 285 degrees, as that would have avoided the inhabited parts of Ilidža. ${ }^{14939}$ Reasoning that the angle of descent had to have been higher than 25 degrees, he determined that the distance the modified air bomb travelled was around 5,800 metres, placing the origin of fire somewhere in Butile. ${ }^{14940}$

KDZ477, T. 11024-11026, 11053-11056 (1 February 2011); D979 (Map of Sarajevo marked by KDZ477); D986 (Map of Sarajevo marked by KDZ477).

14934 P1325 (BiH MUP Report re shelling of Safeta Hadžića street on 26 May 1995), e-court p. 1. The Chamber notes that while the English version of this document refers to "south-south-west", the original document written in BCS refers to the direction of "west-southwest".

14935 P1325 (BiH MUP Report re shelling of Safeta Hadžića street on 26 May 1995), p. 8. See also P1276 (Witness statement of Ekrem Suljević dated 9 February 2010), para. 53; Ekrem Suljević, T. 5782-5784 (22 July 2010). On cross-examination, Suljević conceded that the type of air bomb could not be established but remained adamant that, when taking into account the fragments found on the scene, there was no doubt that this device was a modified air bomb. See Ekrem Suljević, T. 5783-5785 (22 July 2010). When asked how the CSB Sarajevo managed to determine the trajectory of the projectile, Suljević did not know and reiterated that he was asked only to determine the type of projectile. See Ekrem Suljević, T. 5779-5781 (22 July 2010). See also KDZ485, T. 8955-8956, 8958 (3 November 2010) (also testifying that he did not know how the direction of fire was determined and that no member of the team on the scene was a ballistics expert); KDZ477, T. 10923-10924 (31 January 2011).

14936 Suljević also said that it was probably fired from a $90 \mathrm{~mm}$ cannon as there were no $88 \mathrm{~mm}$ launching pads. See Ekrem Suljević, T. 5786-5788 (22 July 2010).

14937 Zečević based this conclusion on the damage to the building and the eye-witness accounts as to the explosion they experienced. P2318 (Report by Berko Zečević entitled "The use of modified aircraft bombs during the siege of Sarajevo, 1994-1995”), pp. 125-126.

14938 P2318 (Report by Berko Zečević entitled "The use of modified aircraft bombs during the siege of Sarajevo, 1994-1995”), p. 126. The Chamber notes that Rajlovac is located northwest of the incident site and that, prior to 1992, was part of the Novi Grad municipality. See Section IV.A.1.c.iii: Novi Grad.

14939 P2318 (Report by Berko Zečević entitled "The use of modified aircraft bombs during the siege of Sarajevo, 1994-1995”), p. 126.

14940 P2318 (Report by Berko Zečević entitled "The use of modified aircraft bombs during the siege of Sarajevo, 1994-1995”), pp. 126-127. 
4449. Anđelković-Lukić disputed Zečević's analysis and thought, based on the damage caused, that the modified air bomb that exploded in this incident was a FAB-250 with three rocket motors filled with solid explosive charge. ${ }^{14941}$ While Subotić agreed that this was not a fuel-air bomb, she thought, based on the type of damage caused to the fifth floor of the apartment building and the survival of one of the victims who was located there, that it was in fact a FAB-100. ${ }^{14942}$ Subotic also challenged the azimuth that Zečević determined, noting that it was speculative and contrary to all local investigators' reports. ${ }^{14943}$ Further, based on the image of the damage caused to the fifth floor of the building, she challenged the directions of fire identified by the local investigators and argued that the modified air bomb in fact came from the direction of the TV building, the possible target of the attack, having ricocheted off of that building first. ${ }^{14944}$ As for the ten artillery projectiles that also landed in the area on 26 May 1995, Subotic argued that not a single one could be considered "proven" and opined that some of the damage seen in the photographs of the impact points indicated that some craters were dug out manually, while other damage was caused by planted explosive or by fire opened close to the incident site. ${ }^{14945}$ She also claimed that the traces on the projectiles with Nazi insignia indicated that they were fired during World War II. ${ }^{14946}$

4450. As with the incidents that took place on 24 May 1995, Radojčić recalled that there was a "fierce" $\mathrm{ABiH}$ offensive at the time of the incident ${ }^{14947}$ and that the incident site was "in the

14941 D2662 (Mirjana Anđelković-Lukić's expert report entitled “Expert Analysis of Documents”, 26 July 2012 ), pp. 23-26.

14942 D3540 (Zorica Subotić's expert report entitled "The Use of Modified Aircraft Bombs in the Sarajevo Area in 1994-1995”, 15 March 2012), pp. 75-79; Zorica Subotić, T. 38202-38203 (14 May 2013).

14943 D3540 (Zorica Subotić's expert report entitled "The Use of Modified Aircraft Bombs in the Sarajevo Area in 1994-1995”, 15 March 2012), pp. 79-81.

14944 D3540 (Zorica Subotić's expert report entitled "The Use of Modified Aircraft Bombs in the Sarajevo Area in 1994-1995", 15 March 2012), pp. 81-87, 181, 184 (also stating that the distance between the TV building and the building at 52 Safeta Hadžića street is approximately 620 metres, while the difference in height is 45 metres). See Zorica Subotić, T. 38194-38199 (13 May 2013). As part of his case that the modified air bomb ricocheted off of the TV building before exploding at 52 Safeta Hadžića street, the Accused challenged Suljević on the trajectory of the modified air bomb established by CSB Sarajevo in the TV building incident, which occurred one month later and which was withdrawn from the Indictment (Scheduled Incident G.17). However, Suljević explained that he only knew the sequence in which the modified air bomb hit the TV building on 28 June, not the precise trajectory in which it travelled before doing so. Ekrem Suljević, T. 5740-5778 (22 July 2010); D526 (BiH MUP report re shelling of RTV Centre on 28 June 1995); D527 (Sketch drawn by Radovan Karadžić's defence team); D528 (D527 marked by Ekrem Suljević); D529 (Photograph 5 from D526 marked by Ekrem Suljević); P1341 (BiH MUP Report re shelling of RTV Centre on 28 June 1995); D530 (Photograph of RTV BiH building marked by Ekrem Suljević); D531 (Aerial satellite image of Sarajevo marked by Ekrem Suljević). See also Berko Zečević, T. 12254-12272 (23 February 2011).

14945 D3540 (Zorica Subotić's expert report entitled "The Use of Modified Aircraft Bombs in the Sarajevo Area in 1994-1995”, 15 March 2012), pp. 87-102, 104-106; Zorica Subotić, T. 38208-38211 (14 May 2013); D3539 (Photograph of shelled building marked by Zorica Subotić).

14946 D3540 (Zorica Subotić's expert report entitled "The Use of Modified Aircraft Bombs in the Sarajevo Area in 1994-1995”, 15 March 2012), pp. 95-99.

14947 The Chamber notes that Radojčić's statement refers to 26 June instead of 26 May 1995. However, given his evidence on Scheduled Incident G.12, the Chamber considers this to be a typographical error and will proceed on the assumption that the witness was referring to the period of 24 to 26 May 1995. The same is the case with 
immediate vicinity of the television building and an industrial complex, which was packed with military installations", including the forward command post of the $1^{\text {st }}$ Battalion of the $102^{\text {nd }}$ Motorised Brigade of the ABiH located on Prvomajska street. ${ }^{14948}$ He testified that he never issued an order to open fire on the incident site or received information about this incident; he did allow, however, for the possibility that a military target may have been missed. ${ }^{14949}$ Milošević testified that the SRK would not have fired had it not been attacked and that at the time of this incident the $\mathrm{ABiH}$ forces were attempting a break-through in order to link up with the other $\mathrm{ABiH}$ forces through Nedžarići. ${ }^{14950}$

4451. In addition to the evidence and the adjudicated facts outlined above, the Chamber also took judicial notice of the following facts which go to the origin of fire in this incident and the status of the victims: (i) a modified air bomb hit Safeta Hadžića street on 26 May 1995; ${ }^{14951}$ (ii) the victims were all civilians; ${ }^{14952}$ (iii) the modified air bomb was fired from the area of Ilidža-Rajlovac, which was in SRK-held territory, having been launched by members of the SRK. ${ }^{14953}$

4452. Having considered the evidence and the adjudicated facts outlined above, the Chamber is satisfied that the projectile that landed on Safeta Hadžića street on 26 May 1995 was a modified air bomb. While CSB Sarajevo did not determine the type of bomb used, the Chamber is convinced, based on the extent of the damage caused to the three floors of a five-storey apartment building, that the bomb in question was larger than FAB-100. Relying on Anđelković-Lukić's evidence, the Chamber considers that this was most likely a FAB-250 modified air bomb with three rocket motors and thus is not convinced that this was a fuel-air bomb, as claimed by Zečević. Ultimately, however, the Chamber considers that the type of the charge used in the bomb is irrelevant given the size and the highly destructive nature of the bomb.

4453. The Chamber is also satisfied, relying on the CSB Sarajevo reports on the incident and the adjudicated facts, that the explosion of this modified air bomb resulted in significant damage to the five-storey residential building as well as the buildings around it. In addition, two persons were seriously wounded, while at least 14 others-including KDZ036 and a two month-old baby-were

respect to Nikola Mijatović's statement. See D2562 (Witness statement of Vladimir Radojčić dated 8 December 2012), paras. 112-113; D2497 (Witness statement of Nikola Mijatović dated 27 November 2012), para. 26.

D2562 (Witness statement of Vladimir Radojčić dated 8 December 2012), paras. 112-113. According to Radojčić this forward command post was located in the Pavle Goranina school building. However, the Chamber heard no other evidence relating to this building, including its exact distance to the incident site. See also D2497 (Witness statement of Nikola Mijatović dated 27 November 2012), para. 26.

14949 D2562 (Witness statement of Vladimir Radojčić dated 8 December 2012), para. 113.

14950 Dragomir Milošević, T. 32779 (28 January 2013).

14951 See Adjudicated Fact 3055.

14952 See Adjudicated Fact 3056.

14953 See Adjudicated Fact 3057. 
lightly wounded. All of them were civilians, who were in their apartments and were not taking direct part in hostilities at the time of the explosion.

4454. The Chamber recalls that the reports of local investigators provided two different directions of fire, namely west-southwest and south-southwest, while Zečević and Subotić thought that the bomb came from west-northwest and north-northwest, respectively. Adjudicated Fact 3057 refers to the direction of Ilidža-Rajlovac, which is the direction established by Zečević. Accordingly, there does not appear to be any agreement on the direction of fire in this incident. Ultimately, however, the Chamber considers this to be irrelevant as it is convinced, beyond reasonable doubt, that it was the SRK that launched the modified air bomb. This conclusion is based on the fact that (i) the SRK positions were located in all those directions of fire; ${ }^{14954}$ (ii) the range at which these bombs have to be fired to be effective is long, usually somewhere between 4,000 and 6,000 metres, thus placing the origin of fire within the SRK-held territory; ${ }^{14955}$ and (iii) only the SRK had modified air bombs in Sarajevo. ${ }^{14956}$

4455. As noted earlier, Subotić argued that the most probable target in this incident was the TV building, which she measured as being some 620 metres away from the incident site, and that the modified air bomb first ricocheted off of the roof of the TV building and then landed on Safeta Hadžića street. According to Subotić, the traces left by the ricochet were then wrongly assumed to have been part of a modified air bomb incident that took place on 28 June 1995, that is, over a month later. The Chamber rejects that evidence as it was based on secondary materials, such as photographs of the scene, and site visits that took place years later. It also finds it extremely speculative and tenuous. The Chamber is more persuaded by the reports of the local investigators who considered that the relevant traces on the roof of the TV building occurred on 28 June 1995, that is, one month after the incident in Safeta Hadžića street. However, even if Subotić's analysis is correct and the modified air bomb did indeed ricochet off of the roof of the TV building on 26 May 1995, the Chamber considers that the TV building was not a legimitate military target but a civilian object. $^{14957}$

\footnotetext{
14954 See paras. $3782,3787,4470$.

14955 See paras. 4358, 4378.

14956 See para. 4369.

14957 The Chamber notes that it heard no credible evidence that $\mathrm{ABiH}$ units were located in the TV building. While Demurenko mentioned in his witness statement that $\mathrm{ABiH}$ had units "in and around" the TV building, he did so in the context of an UNPROFOR report of 16 June 1995 which notes the movement of ABiH weapons to a "TV tower" and records $\mathrm{ABiH}$ mortar fire coming from a "TV2 building" at 1:45 p.m. on that day. See D2270 (Witness statement of Andrey Demurenko dated 13 October 2012), p. 80; D2299 (UNPROFOR daily report, 16 June 1995), p. 19. It is unclear, however, where this "TV2 building" was located and if it is the TV building referred to in Subotić's analysis. Demurenko was not asked to clarify this. The Chamber also recalls that
} 
4456. Furthermore, the Chamber finds that following the explosion of the modified air bomb a number of artillery projectiles were fired by the SRK and landed in the area. The Chamber rejects Subotić's evidence that those projectiles were either planted or fired from nearby, that is, by the $\mathrm{ABiH}$. Once again, she based her conclusion on secondary materials, such as photographs of the damage, while at the same time discounting all of the findings of the local investigators. In addition, if true, her claim would mean that there was a large conspiracy whereby a number of people would have had to plant exploded and unexploded pieces of artillery projectiles in the area, while $\mathrm{ABiH}$ was firing other projectiles from its positions nearby, and do all that while remaining unseen. This claim is simply unreasonable and once again indicates that Subotic was not an impartial expert witness and that her evidence was marked with bias in favour of the Accused.

4457. While the witnesses called by the Accused claimed that this incident happened during an $\mathrm{ABiH}$ offensive, the Chamber recalls KDZ036's evidence that the area where the incident took place was peaceful on that day and that a number of people were outside in the square before the modified air bomb struck. Thus, even if there had been fighting that day somewhere in Sarajevo, the Chamber does not consider that it was anywhere near the incident site. As for the suggestion that this was an industrial area and that the forward command post of the $102^{\text {nd }}$ Brigade was on Prvomajska street, the Chamber has heard no other evidence about this command post, including its distance to the incident site. Further, while some industrial buildings were in the neighbourhood, the incident site itself was part of a residential complex, strewn with residential buildings and civilians living therein. Accordingly, the Chamber does not consider that the modified air bomb and the artillery projectiles that followed it were aimed at neutralising a specific military target. Rather, the Chamber is convinced beyond reasonable doubt that the SRK soldiers fired this modified air bomb into a generally residential area, and that, given the inaccuracy of modified air bombs and their destructive power, these soldiers should have been aware that such an attack would cause great damage to civilian objects and result in civilian casualties.

1995 (Scheduled Incident G.14)

(d) UMC/Oncology Department at Dositejeva street, 16 June

4458. The Indictment alleges that on 16 June 1995 at about 10 a.m., a modified air bomb was fired from SRK-held territory in the northwest and struck the building of the "UMC and Oncology Department at Dositejeva street 4-a", resulting in substantial damage and in three persons being wounded. ${ }^{14958}$ In its Final Brief, the Prosecution alleges that the explosion injured "three or four

KDZ477 testified that he never heard of an ABiH presence in the TV building. See KDZ477, T. 11054 (1 February 2011).

14958

Indictment, Scheduled Incident G.14. 
civilians" and that the bomb came from SRK-held territory, without specifying the direction of fire. ${ }^{14959}$ The Accused argues that the bomb that struck Dositejeva street was a FAB-100 filled with solid explosive charge, and that the damaged building housed the offices of the Ministry of Defence and was near the command of the $1^{\text {st }}$ Corps of the $\mathrm{ABiH}$, as well as other military targets, including the BiH Presidency. ${ }^{14960}$

4459. On 16 June 1995, a projectile exploded at the University Medical Centre, Institute of Radiology and Oncology ("UMC") at Dositejeva street, number 4a. ${ }^{14961}$ CSB Sarajevo conducted an on-site investigation of this incident on 17 June $1995 .{ }^{14962}$ Two UNMOs were also present, including Konings. ${ }^{14963}$ The report prepared by the CSB Sarajevo noted that a "modified device with rocket projectiles was fired from the northwest direction" and exploded when it hit the window frame of the toilet on the first floor of the Sarajevo UMC/Oncology Department at around 11:03 a.m., wounding three persons and causing great material damage to that and the surrounding buildings. ${ }^{14964}$

4460. Suljević prepared an additional report, upon request from CSB Sarajevo, determining the type of projectile used in this incident as well as the direction from which it came. ${ }^{14965}$ He went to the incident site, together with the CSB Sarajevo team, to collect the fragments and examine the traces of the explosion. ${ }^{14966}$ His report recounts that a projectile fell at Dositejeva street following the shelling of the Centar municipality; it injured four people and caused great material damage. ${ }^{14967}$ Having examined the fragments found at the scene of the incident, including remains of rocket motors and a three-forked metal part, Suljević concluded that they were "remains of a device with three $122 \mathrm{~mm}$ calibre GRAD type rocket projectiles, most likely adapted with an aerial

\footnotetext{
14959 Prosecution Final Brief, Appendix C, para. 77.

14960 Defence Final Brief, paras. 2375-2376.

14961 See Adjudicated Fact 3058; P1328 (BiH MUP Report re shelling of Dositejeva street on 16 June 1995); P1746 (BiH MUP Report re shelling of Dositejeva street on 16 June 1995); P2190 (GPS locations for shelling and sniping incidents in Sarajevo); P2191 (Map of Sarajevo with scheduled sniping and shelling incidents); P2213 (Image re scheduled sniping and shelling incidents in Sarajevo).

14962 P1328 (BiH MUP Report re shelling of Dositejeva street on 16 June 1995); P1746 (BiH MUP Report re shelling of Dositejeva street on 16 June 1995).

14963 P1953 (Witness statement of Harry Konings dated 11 November 2010), paras. 45-46; P1746 (BiH MUP Report re shelling of Dositejeva street on 16 June 1995), p. 1.

14964 According to the report, the following persons were injured: Ivanka Skalj, Armin Skalj, and Marija Maljić. After they received medical attention they were sent home for further treatment. See P1328 (BiH MUP Report re shelling of Dositejeva street on 16 June 1995), p. 1; P1746 (BiH MUP Report re shelling of Dositejeva street on 16 June 1995), p. 1; P1963 (Photographs re shelling of Dositejeva street on 16 June 1995).

14965 P1276 (Witness statement of Ekrem Suljević dated 9 February 2010), paras. 56-57.

14966 Ekrem Suljević, T. 6161-6164, 6166-6167 (6 September 2010).

14967 P1327 (BiH MUP Report re shelling of Dositejeva street on 16 June 1995), p. 1.
} 
bomb."14968 A fragment of an irregular shape from the exhaust duct of a $128 \mathrm{~mm}$ Plamen rocket was also found, which "most probably was not a part of the device that exploded."14969 As for the type of air bomb used, Suljević thought it was either a 100- or a 250-kilogram air bomb. ${ }^{14970}$

4461. Suljević determined the direction from which the projectile came, on the basis of the fragments found and the position of the rocket motor parts. ${ }^{14971}$ The impact was on the north side of the building so he thought that the azimuth was 348 degrees from the north, plus or minus ten degrees, which coincides with the direction of "enemy positions in the general sector of Pionirska Dolina."14972 Suljević confirmed that the separation line between ABiH and VRS in that direction was somewhere in Pionirska Dolina. ${ }^{14973}$ However, he was adamant that the projectile was a modified air bomb launched by the VRS, as ABiH had no such weapon. ${ }^{14974}$

4462. Konings was also at the scene and testified that it was not possible to use the crater analysis so that the direction of fire, which was a "general northerly" direction, was established from the traces of damage. ${ }^{14975}$ Like Suljević, Konings thought that the bomb was fired by the Bosnian Serb side as he had never seen such a bomb on the $\mathrm{ABiH}$ side of the confrontation line and because, had it been fired by the $\mathrm{ABiH}$, the sound of firing would have been heard. ${ }^{14976}$

4463. Suljević testified that the BiH Railway Company was in the vicinity of the incident site, as was the Ministry of Foreign Affairs, the CSB Sarajevo, and the BiH Presidency. ${ }^{14977} \mathrm{He}$ did not know if there were any residential buildings in the area immediately surrounding the incident site but noted that to the south, towards Mis Irbina street, there was a series of residential buildings. ${ }^{14978}$

14968 P1327 (BiH MUP Report re shelling of Dositejeva street on 16 June 1995), p. 5; Ekrem Suljević, T. 6177-6178 (6 September 2010).

14969 P1327 (BiH MUP Report re shelling of Dositejeva street on 16 June 1995), p. 5; Ekrem Suljević, T. 6178-6180 (6 September 2010). When asked about this fragment during cross-examination, Suljević explained that people would often collect parts of projectiles so this fragment could have come from somewhere else but denied that it could have come from some $\mathrm{ABiH}$ military facility in the street as the building in question was a medical department. See Ekrem Suljević, T. 6163, 6180 (6 September 2010).

14970 Ekrem Suljević, T. 6172, 6176-6177 (6 September 2010).

14971 P1276 (Witness statement of Ekrem Suljević dated 9 February 2010), para. 57; Ekrem Suljević, T. 6170-6171 (6 September 2010). Suljević did not calculate the angle of descent as his department did not have the necessary resources and there would be no point given that modified air bombs were propelled by rockets. See Ekrem Suljević, T. 6171 (6 September 2010).

14972 P1276 (Witness statement of Ekrem Suljević dated 9 February 2010), para. 57; P1327 (BiH MUP Report re shelling of Dositejeva street on 16 June 1995), pp. 4-5; Ekrem Suljević, T. 6170-6174 (6 September 2010).

14973 Ekrem Suljević, T. 6172-6174 (6 September 2010).

14974 Ekrem Suljević, T. 6180, 6183-6186 (6 September 2010).

14975 P1953 (Witness statement of Harry Konings dated 11 November 2010), para. 47.

14976 P1953 (Witness statement of Harry Konings dated 11 November 2010), para. 48.

14977 Ekrem Suljević, T. 6164-6170 (6 September 2010); D552 (Map of Sarajevo marked by Ekrem Suljević). According to the scale on the map of the area in which the incident took place, the Presidency building was around 100 metres away from the incident site. See D617 (Map of Sarajevo).

14978 Ekrem Suljević, T. 6169 (6 September 2010). 
KDZ485 testified that the Presidency housed the kitchen of the Ministry of Defence. ${ }^{14979}$ According to the letter sent by Alija Izetbegović to Haris Silajdžić, UNPROFOR viewed the building as a military target because of this. ${ }^{14980}$

4464. The official CSB Sarajevo report also provides that later that day, at around 5 p.m., another modified air bomb landed, this time on Čobanija street. ${ }^{14981}$ It was also investigated by the CSB Sarajevo team, as well as by Konings and another UNMO. ${ }^{14982}$ According to Konings, this bomb came from the same direction in the north as the bomb that struck at Dositejeva street, namely the general northerly direction. ${ }^{14983}$

4465. Having analysed the materials relating to this incident, Zečević concluded that the projectile in question was a modified air bomb with three rocket motors and that it was filled with fuel-air explosive as indicated by the damage caused to the scene. ${ }^{14984}$ He disagreed with Suljević's azimuth, as it meant that the launching site was "deep in the canyon within the Pretis [F]actory" where the terrain would not allow for the launch. ${ }^{14985}$ He thought that the bomb "most probably" came from the direction of Kobilja Glava, that is, with the azimuth of 315 degrees plus or minus ten degrees (northwest); Zečević based this conclusion on the azimuth he had determined for the incident on Čobanija street because-in his view-both bombs were fired from the same position. ${ }^{14986}$ He then determined the distance to the launch site "on the basis of the ballistic analysis" as being around 5,820 metres, placing it inside the Pretis Factory compound. ${ }^{14987}$

4466. Anđelković-Lukić thought, based on the destructive effects at the scene and the fact that the UMC was an old brick building, that the bomb in question was a modified FAB-100, with three

\footnotetext{
14979 KDZ485, T. 8913-8916 (3 November 2010); D860 (Letter from Alija Izetbegović to Haris Silajdžić, 17 April 1995).

14980 D860 (Letter from Alija Izetbegović to Haris Silajdžić, 17 April 1995).

14981 P1746 (BiH MUP Report re shelling of Dositejeva street on 16 June 1995), p. 2. See also P1742 (Witness statement of Bogdan Vidović dated 28 September 2010), pp. 36-43.

14982 P1953 (Witness statement of Harry Konings dated 11 November 2010), paras. 45-46.

14983 P1953 (Witness statement of Harry Konings dated 11 November 2010), para. 47. But see P1742 (Witness statement of Bogdan Vidović dated 28 September 2010), pp. 36-43 (indicating that there was confusion as to whether the bomb arrived at Čobanija street from northeast or northwest).

14984 P2318 (Report by Berko Zečević entitled "The use of modified aircraft bombs during the siege of Sarajevo, 1994-1995”), p. 130.

14985 P2318 (Report by Berko Zečević entitled "The use of modified aircraft bombs during the siege of Sarajevo, 1994-1995”), pp. 130-131.

14986 P2318 (Report by Berko Zečević entitled "The use of modified aircraft bombs during the siege of Sarajevo, 1994-1995”), pp. 131, 135-139 (noting that the distance between Dositejeva and Čobanija streets was some 600 metres).

14987 P2318 (Report by Berko Zečević entitled "The use of modified aircraft bombs during the siege of Sarajevo, 1994-1995”), p. 131.
} 
rocket motors, filled with solid explosive. ${ }^{14988}$ Subotić agreed, arguing that, contrary to Zečević's opinion, the effects on the scene were not typical of damage caused by fuel-air explosive; in addition no large pieces of the metal casing housing the fuel-air explosive were found on the scene. ${ }^{14989}$ Subotić also disputed Zečević's azimuth arguing that he failed to explain how he determined it and that he incorrectly dismissed Suljević's azimuth, ignoring the fact that there were other suitable areas for the launch in that direction of fire. ${ }^{14990}$ She also challenged the distance to the origin of fire determined by Zečević on the basis that it was pure speculation and that it meant that the launch took place right on the confrontation line, which would not have been wise from a security point of view. ${ }^{14991}$ Ultimately, Subotić agreed with the azimuth determined by Suljević, basing her conclusion on the position of the rockets found on the scene. ${ }^{14992}$

4467. While accepting that the area where the bomb struck was in the centre of Sarajevo, Subotic argued that the building itself was not in a residential zone, as the BiH Presidency, CSB Sarajevo, the command of the $1^{\text {st }}$ Corps of the $\mathrm{ABiH}$ and the command of the $105^{\text {th }}$ Mountain Brigade were all in the immediate vicinity of the building. ${ }^{14993}$ In addition, she claims that the command of helicopter units of the ABiH was located "where this modified bomb landed". ${ }^{14994}$ Thus, according to her, the modified air bomb that struck the UMC was "practically directly at the target". ${ }^{14995}$ As for the fragments of the $128 \mathrm{~mm}$ Plamen rocket found on the scene, Subotic opined that the "only

14988 D2662 (Mirjana Anđelković-Lukić's expert report entitled "Expert Analysis of Documents", 26 July 2012 ), pp. 26-27.

14989 D3540 (Zorica Subotić's expert report entitled "The Use of Modified Aircraft Bombs in the Sarajevo Area in 1994-1995", 15 March 2012), pp. 109-110.

14990 D3540 (Zorica Subotić's expert report entitled "The Use of Modified Aircraft Bombs in the Sarajevo Area in 1994-1995”, 15 March 2012), pp. 112-114 (noting further that Suljević's azimuth means that the trajectory was of the bomb was such that it passed over the "narrowest residential zone in Sarajevo"). See also Zorica Subotić, T. 38207 (14 May 2013).

14991 D3540 (Zorica Subotić's expert report entitled "The Use of Modified Aircraft Bombs in the Sarajevo Area in 1994-1995”, 15 March 2012), p. 114.

14992 D3540 (Zorica Subotić's expert report entitled "The Use of Modified Aircraft Bombs in the Sarajevo Area in 1994-1995”, 15 March 2012), p. 114; Zorica Subotić, T. 38204-38205 (14 May 2013).

14993 D3540 (Zorica Subotić's expert report entitled "The Use of Modified Aircraft Bombs in the Sarajevo Area in 1994-1995”, 15 March 2012), pp. 107, 177-178, 183 (stating that the Presidency was 80 metres away from the incident site); Zorica Subotić, T. 38203-38204 (14 May 2013). Asim Džambasović confirmed that the command post of the $1^{\text {st }}$ Corps was located in Danijela Ozme street, at number 7. See Asim Džambasović, T. 15192-15193 (22 June 2011). See D617 (Map of Sarajevo). As for the command of the $105^{\text {th }}$ Brigade, he confirmed that it was located in the Šipad building in Trampina street. See Asim Džambasović, T. 15207, 15210 (22 June 2011); D1377 (Map of ABiH positions in Sarajevo marked by Asim Džambasović); D633 (Order of $\mathrm{ABiH} 1^{\text {st }}$ Corps, 25 October 1993), para. 5.9. According to the scale on the map of the area where the incident occurred, both these locations were around 200 metres away from the incident site.

14994 D3540 (Zorica Subotić's expert report entitled "The Use of Modified Aircraft Bombs in the Sarajevo Area in 1994-1995”, 15 March 2012), pp. 107-108, 183, 188. Relying on the letter from Alija Izetbegović to Haris Silajdžić, namely D860, Subotić also claimed that the Ministry of Defence was "later transferred" to the UMC. The Chamber sees no basis for her claim in the letter cited. Even if true, there is no evidence as to when the transfer happened and whether it was before or after this incident. This, however, did not prevent Subotić from claiming later in her report (on pages 183 and 188) that the Ministry of Defence was located in the UMC building, which was misleading on her part. 
logical explanation" was that it was in one of the rooms in the UMC, which to her was further confirmation that $\mathrm{ABiH}$ officers were in the building at the time of the incident. ${ }^{14996}$

4468. The Chamber also heard that the $\mathrm{ABiH}$ mounted an offensive in mid-June, directed primarily at the SRK positions. ${ }^{14997}$ When giving evidence about this incident, Dragomir Milošević testified that, on the night between 15 and 16 June, the ABiH forces moved against the SRK from both the inner and outer circles of Sarajevo as part of the beginning of the offensive to "lift the blockade of Sarajevo". ${ }^{4998}$ Thus, on 16 June, he reported to Mladić on the situation, including that the SRK had inflicted heavy losses on the enemy. ${ }^{14999}$ During this conversation, Mladić instructed Milošević to "attack the Turks until the last one is gone" and said "they're fighting tooth and nail and they should be made to pay for it". ${ }^{15000}$ Mladić also ordered Milošević to "one by one, destroy, attack, only military targets" which, according to Milošević, was the way the war in Sarajevo was waged throughout. ${ }^{15001}$ Milošević then vehemently denied that the SRK fired the bombs that landed on Dositejeva and Čobanija streets. ${ }^{15002}$ He also testified that the command of the $1^{\text {st }}$ Corps of the $\mathrm{ABiH}$ was in the vicinity of the incident site, while a helicopter squadron crew had residence at the incident site. ${ }^{15003}$

14996 D3540 (Zorica Subotić's expert report entitled “The Use of Modified Aircraft Bombs in the Sarajevo Area in 1994-1995", 15 March 2012), pp. 108-109.

14997 See para. 3611.

14998 Dragomir Milošević, 32532-32533 (23 January 2013), T. 32737-32740, 32779, 32782 (28 January 2013); D2792 (Order of ABiH 12 ${ }^{\text {th }}$ Division, 11 June 1995). See also D2444 (Witness statement of Miladin Trifunović dated 11 November 2012), para. 17. But see Harry Konings, T. 9363-9369 (7 December 2010) (conceding that there was a lot of fighting in those days but that it took place on the confrontation lines and that it was not a "massive offensive operation"); Savo Simić, T. 30137-30139 (12 November 2012) (testifying that the ABiH launched an attack "on all the defence lines"); KDZ304, T. 10506-10508 (18 January 2011) (private session) (testifying that the offensive was conducted on the confrontation line); D958 (UNPROFOR Weekly Situation Report, 17 June 1995); P2507 (Anthony Banbury's briefing notes, 1 July 1995), para. 2 (indicating that the attacks were launched along confrontation lines); P1860 (UNMO report, 19 June 1995), p. 2; D890 (ABiH $105^{\text {th }}$ Brigade report on consumption of ammunition, 18 June 1995); P820 (Witness statement of David Harland dated 4 September 2009), paras. 203, 213-214; P896 (UNPROFOR Weekly Situation Report (Sarajevo), 2 July 1995), pp. 1-3. The combat reports before the Chamber confirm Konings' evidence that the fighting on 15 and 16 June 1995 took place on the confrontation lines. See D2690 (SRK combat report, 15 June 1995); D2691 (SRK combat report, 15 June 1995); D2692 (SRK combat report, 15 June 1995); D2693 (SRK combat report, 25 June 1995); D2415 (102 ${ }^{\text {nd }}$ Mountain Brigade ABiH combat report, 16 June 1995); D2416 (12 $2^{\text {th }}$ Army Division ABiH combat report, 16 June 1995); D186 (111 ${ }^{\text {th }}$ Brigade ABiH combat report, 16 June 1995); D187 (115 ${ }^{\text {th }}$ Mountain Brigade ABiH combat report, 16 June 1995).

14999 P5642 (Intercept of conversation between Dragomir Milošević, unidentified male, and Ratko Mladić, 16 June 1995); Dragomir Milošević, T. 32737-32740 (28 January 2013).

15000 P5642 (Intercept of conversation between Dragomir Milošević, unidentified male, and Ratko Mladić, 16 June 1995).

15001 P5642 (Intercept of conversation between Dragomir Milošević, unidentified male, and Ratko Mladić, 16 June 1995); Dragomir Milošević, T. 32737-32740 (28 January 2013).

15002 Dragomir Milošević, T. 32779-32780 (28 January 2013).

15003 Dragomir Milošević, T. 32780 (28 January 2013). But see Ekrem Suljević, T. 6165 (6 September 2010) (testifying that he did not even know there was a helicopter squadron in Sarajevo); David Harland, T. 2351 (11 May 2010) (testifying that the $\mathrm{ABiH}$ did not have any helicopters in Sarajevo). 
4469. In another intercepted conversation of 16 June 1995, Prstojević told Rade Ristić, another member of the Ilidža Crisis Staff, ${ }^{15004}$ that there was an attack by the Muslim side in Nedžarići but that it was successfully deflected, and that his side "pounded" the "Turks" and sent a "krmača" or two to them, to which Ristić responded: "we need to shake them up a bit by all means". 15005

4470. The $3^{\text {rd }}$ Sarajevo Infantry Brigade of the SRK, which was created by merging the Vogošća, Rajlovac, and Koševo Brigades, ${ }^{15006}$ was located in the northwestern part of the Sarajevo front. ${ }^{15007}$ Zoran Kovačević, the Commander of the Mixed Artillery Battalion of the $3^{\text {rd }}$ Sarajevo Brigade at the time of the incident, ${ }^{15008}$ testified that the brigade's command post was in Vogošća while its firing positions were located in Blagovac and Krivoglavci and orientated towards the city and Žuč. ${ }^{15009}$ Kovačević testified that no one from Pretis or from his brigade launched the bomb that struck the UMC, explaining that he would have heard the launch had it happened. ${ }^{15010}$ Kovačević did confirm, however, that his brigade probably had an air bomb launcher. ${ }^{15011}$ This is corroborated by an SRK document which shows that Milošević reported to the VRS Main Staff on 15 June 1995 that four aerial bomb launchers were with the brigades in the northwestern part of the front. ${ }^{15012}$

15004 D1193 (Ilidža Crisis Staff members, 10 April 1992).

15005 P5638 (Intercept of conversation between Neđeljko Prstojević and Radomir Ristić, 16 June 1995). The Chamber notes that during his testimony, Prstojević denied that the term "krmača" was a reference to a modified air bomb, and claimed that it was also used to refer to artillery weapons of higher calibre. Having been confronted with his interview with the Prosecution given in 2006 where he discussed "krmača" bombs and their imprecise nature-which in light of all the evidence about these bombs clearly indicates that he was discussing modified air bombs--Prstojević rejected the 2006 interview, on the basis that it was wrongly interpreted. As noted earlier, the Chamber has reviewed the audio portion of the relevant interview and found that it was accurately interpreted and transcribed. Accordingly, the Chamber does not accept Prstojević's evidence on this matter and is convinced that in this intercepted conversation with Ristic he was referring to modified air bombs. See Neđeljko Prstojević, T. 13570-13577 (17 March 2011); P2516 (Excerpt from transcript of Neđeljko Prstojević's interview, with audio); P2517 (Excerpt from transcript of Neđeljko Prstojević's interview, with audio).

15006 See fn. 542. See also Miladin Trifunović, T. 30443 (27 November 2012).

15007 Zoran Kovačević, T. 30612-30613 (28 November 2012); Stanislav Galić, T. 37539 (22 April 2013); Dragomir Milošević, T. 32569-32570 (23 January 2013).

15008 D2484 (Witness statement of Zoran Kovačević dated 25 November 2012), para. 3. Before that, Kovačević was a soldier in the Vogošća Brigade, and also served in the $1^{\text {st }}$ KK. See D2484 (Witness statement of Zoran Kovačević dated 25 November 2012), para. 2.

15009 D2484 (Witness statement of Zoran Kovačević dated 25 November 2012), paras. 4-5; Zoran Kovačević, T. 30593-30595 (28 November 2012); D2486 (Map of Sarajevo marked by Zoran Kovačević); D2487 (Map of Sarajevo marked by Zoran Kovačević); D2488 (Map of Sarajevo marked by Zoran Kovačević). See also D2444 (Witness statement of Miladin Trifunović dated 11 November 2012), paras. 12-13; D2445 (Map of Sarajevo marked by Miladin Trifunović); D2446 (Map of Sarajevo marked by Miladin Trifunović); Miladin Trifunović, T. 30378-30387 (15 November 2012).

15010 D2484 (Witness statement of Zoran Kovačević dated 25 November 2012), para. 23; Zoran Kovačević, T. 30617 (28 November 2012).

15011 Zoran Kovačević, T. 30613-30615 (28 November 2012).

15012 P1283 (SRK report to VRS Main Staff re aircraft weaponry, 15 June 1995). See also P1300 (SRK Order, 11 July 1995) and P1314 (Request from 3rd Sarajevo Infantry Brigade to SRK, 25 July 1995) (both indicating that the $3^{\text {rd }}$ Sarajevo Infantry Brigade had modified air bombs in its arsenal). 
4471. Miladin Trifunović, a former Commander of the Vogošća Brigade and a Director of Transportation at Pretis at the time of the incident, ${ }^{15013}$ testified that no modified air bomb was ever launched from Pretis or from the brigade's zone of responsibility. ${ }^{15014}$ He stated that he was within the perimeter of Pretis at the time and did not hear anything that would resemble a modified air bomb launch. ${ }^{15015}$

4472. In addition to the evidence and the adjudicated facts outlined above, the Chamber also took judicial notice of the following adjudicated facts: (i) on 16 June 1995, a modified air bomb exploded at the UMC; ${ }^{15016}$ (ii) three or four civilians were injured as a result of the explosion and some surrounding buildings were destroyed; ${ }^{15017}$ and (iii) the modified air bomb was fired from outside the confrontation lines and within SRK-held territory and was launched by members of the SRK. ${ }^{15018}$

4473. Having considered the evidence and the adjudicated facts outlined above, the Chamber is convinced that a modified air bomb with three rocket motors struck the UMC on 16 June 1995. While Zečević thought that the bomb was a fuel-air bomb (and thus a FAB-250), Subotić and Anđelković-Lukić thought it was a FAB-100. Suljević thought that it was either a 100- or a 250kilogram modified air bomb. Given that the UMC was indeed made of brick as seen in the photographs of the damage, and given that both FAB-100 and FAB-250 bombs could be mounted with three rocket motors, the Chamber is unable to determine whether a FAB-100 or FAB-250 bomb was used in this incident. The Chamber is also not convinced that the bomb in question was filled with fuel-air explosive as the damage could have also been caused by a bomb filled with solid charge, as argued by Anđelković-Lukić. Ultimately, however, there is no doubt that the projectile in question was a highly destructive modified air bomb, as indicated by the damage caused by the explosion and the fragments gathered at the scene.

4474. Relying on the evidence and Adjudicated Fact 3059, the Chamber is further satisfied that the explosion resulted in the wounding of three civilians who were not taking direct part in hostilities at the time of the incident. ${ }^{15019}$

\footnotetext{
15013 D2444 (Witness statement of Miladin Trifunović dated 11 November 2012), para. 1.

15014 D2444 (Witness statement of Miladin Trifunović dated 11 November 2012), para. 22.

15015 Miladin Trifunović, T. 30442-30443 (27 November 2012).

15016 See Adjudicated Fact 3058.

15017 See Adjudicated Fact 3059.

15018 See Adjudicated Fact 3060.

15019 See also para. 4976.
} 
4475. In terms of the direction of fire, the Chamber is satisfied that it came from the northwest. While there is some discrepancy between Zečević's and Suljević's azimuths, ultimately the Chamber is convinced beyond reasonable doubt that the modified air bomb was fired from SRKheld territory. This is confirmed by the intercepted conversation on the day of the incident in which Prstojević told Ristić that they had sent over a "krmača" or two to the Bosnian Muslim side. Konings was also convinced that the bomb came from the SRK side of the confrontation line as the launch of a modified air bomb would have been heard had it come from within the city. Furthermore, as noted above, ${ }^{15020}$ the SRK positions were located in the established direction of fire, the range at which modified air bombs have to be fired is long, thus placing the origin of fire for this incident squarely within the SRK-held territory, and only the SRK had modified air bombs in Sarajevo.

4476. With respect to the Accused's argument that the bomb landed in a non-residential zone, and on a legitimate military target, the Chamber first recalls that Dositejeva street is in the centre of Sarajevo, not far from Mis Irbina street, and is thus in an area brimming with civilian objects and the civilian population. The Chamber also notes that, aside from the evidence given by Milošević and Subotić, it has heard no other evidence about members of a helicopter squadron residing in the UMC at the time of the incident, or even about the helicopter squadron as such. Further, the Chamber found both Subotić and Milošević to be lacking in credibility, as they both tried to minimise the damage caused by the SRK's activities in Sarajevo and were exceedingly biased during their testimony. Thus, the Chamber is not persuaded, without other corroborating and credible evidence, that a helicopter squadron was in the UMC building at the time of the incident. Furthermore, the Chamber has already dismissed Subotić's claim that parts of the Ministry of Defence were in the building at the time and, as indicated earlier, found her disingenuous on this issue. $^{15021}$

4477. As for the commands of the $1^{\text {st }}$ Corps and the $105^{\text {th }}$ Brigade of the $\mathrm{ABiH}$, the Chamber finds that they were located in Danijela Ozme and Trampina streets respectively, as testified to by Džambasović. However, as noted earlier, both those locations were around 200 metres away from the incident site. ${ }^{15022}$ Similarly, the BiH Presidency was some 100 metres away from the incident site. Assuming any one of these locations was indeed the intended target of the bomb that struck the UMC, it was missed by the SRK by around 200 and 100 metres respectively. Yet, when another modified air bomb was launched later in the day, it landed in Čobanija street, which is even

\footnotetext{
15020 See para. 4454.

15021 See fn. 14994.

15022 See fn. 14993.
} 
farther away from these locations, while another landed in Alipašino Polje. ${ }^{15023}$ Accordingly, the Chamber does not consider these locations to have been the intended targets. Even if they were, the fact that they were not hit but were, rather, missed by large margins simply shows the inherent inaccuracy of modified air bombs.

4478. While there may have been some fighting on the day, given that $\mathrm{ABiH}$ was in the middle of the offensive in those days, the Chamber is persuaded by Konings who explained that there was a lot of fighting at the time but that it took place on the confrontation lines; as noted earlier, his evidence that the fighting took place on the confrontation lines is confirmed by various combat reports of both the SRK and the ABiH. ${ }^{15024}$ Further, the UMC was in the centre of Sarajevo and not on the confrontation line. Accordingly, the Chamber does not consider that the modified air bomb that landed in Dositejeva street was aimed at neutralising a specific military target. Rather, the Chamber is convinced beyond reasonable doubt that it was launched into a generally residential area in retaliation for the attacks mounted by the $\mathrm{ABiH}$ on the confrontation lines. This is confirmed by Mladić's instruction to Milošević that the Bosnian Muslim side should be made to pay for fighting. Further, given the inaccuracy of the modified air bombs and recalling their destructive power, the Chamber is of the view that the SRK soldiers launching this modified air bomb into the central area of Sarajevo should have been aware that such an attack would cause great damage to civilian objects and result in civilian casualties.

\section{5 (Scheduled Incident G.15)}

\section{(e) Trg Međunarodnog Prijateljstva, Alipašino Polje, 16 June}

4479. According to the Indictment, on 16 June 1995 at about 3:20 p.m., a modified aircraft bomb, fired from SRK-held territory in Lukavica exploded next to $10 \mathrm{Trg}$ Međunarodnog Prijateljstva, lightly injuring seven persons and causing considerable damage to the neighbouring buildings. ${ }^{15025}$ The Accused argues that the bomb that exploded in this incident was a modified FAB-250 with three rocket motors and that its "most probable" target was the Bitumenka factory, which was 140 metres away from the incident site and in which $\mathrm{ABiH}$ was deployed. ${ }^{15026} \mathrm{He}$ also argues that a "major $\mathrm{ABiH}$ offensive was underway at the time of the incident". ${ }^{15027}$

\footnotetext{
15023 See discussion relating to Scheduled Incident G.15.

15024 See fn. 14998.

15025 Indictment, Scheduled Incident G.15. See also Prosecution Final Brief, Appendix C, para. 78.

15026 Defence Final Brief, paras. 2379, 2381.

15027 Defence Final Brief, para. 2380.
} 
4480. On 16 June 1995, the weather was fine and there was good visibility. ${ }^{15028}$ KDZ079 and four others were at the community centre office located at $10 \mathrm{Trg}$ Međunarodnog Prijateljstva in Alipašino Polje. ${ }^{15029}$ That centre was located in a residential area, across the street from the PTT Building, where UNPROFOR Sector Sarajevo Headquarters was based. ${ }^{15030}$ Throughout the day, there was sporadic shooting and shelling in the vicinity of Ilidža and, around 3:30 p.m., a bomb exploded near the centre, throwing KDZ079 onto a large table and then into a wall with significant force. ${ }^{15031}$ She lost consciousness and was taken to a nearby shelter, where she stayed for three to four days due to intensive shooting and shelling. ${ }^{15032}$ She had scratches on the side of her body, her hearing was damaged, and she could not hear properly for a year after the incident throughout which she also suffered from headaches and had pain in her liver and lungs. ${ }^{15033}$ No one was killed in the explosion or suffered serious injuries but the whole office was destroyed and only the exterior walls remained standing. ${ }^{15034}$ In total, seven people were injured in the explosion. ${ }^{15035}$

4481. KDZ079 described heariong a strange sound, "like a plane coming", just before the explosion. ${ }^{15036}$ She also testified that she heard later that the explosion was caused by an air bomb which landed about five to ten metres away from the community centre. ${ }^{15037}$ Several weeks later, when she visited this location, KDZ079 saw a large crater and noticed that the balconies and windows of the surrounding buildings were damaged. ${ }^{15038}$

\footnotetext{
15028 See Adjudicated Fact 3061.

15029 P2922 (Witness statement of KDZ079 dated 12 March 1995), p. 2; P2922 (Witness statement of KDZ079 dated 17 May 2006), paras. 3-4; P2922 (Addendum to witness statement of KDZ079, 22 April 2010). See also P479 (Transcript from Prosecutor v. D. Milošević), T. 3522-3524.

15030 See Adjudicated Fact 3062. See also P2190 (GPS locations for shelling and sniping incidents in Sarajevo); P2191 (Map of Sarajevo with scheduled sniping and shelling incidents); P2213 (Image re scheduled sniping and shelling incidents in Sarajevo).

15031 P2922 (Witness statement of KDZ079 dated 12 March 1995), p. 2; P2922 (Witness statement of KDZ079 dated 17 May 2006), paras. 5-7; KDZ079, P479 (Transcript from Prosecutor v. D. Milošević), T. 3539.

15032 P2922 (Witness statement of KDZ079 dated 17 May 2006), paras. 7, 12; KDZ079, P479 (Transcript from Prosecutor v. D. Milošević), T. 3516-3518; P454 (Aerial photograph of Sarajevo marked by KDZ079).

15033 P2922 (Witness statement of KDZ079 dated 17 May 2006), paras. 7, 13; P2922 (Witness statement of KDZ079 dated 12 March 1995), p. 2; KDZ079, P479 (Transcript from Prosecutor v. D. Milošević), T. 3516.

15034 P2922 (Witness statement of KDZ079 dated 17 May 2006), paras. 8-9; KDZ079, P479 (Transcript from Prosecutor v. D. Milošević), T. 3517.

15035 See Adjudicated Fact 3063.

15036 P2922 (Witness statement of KDZ079 dated 12 March 1995), p. 2; KDZ079, P479 (Transcript from Prosecutor v. D. Milošević), T. 3513, 3516.

15037 P2922 (Witness statement of KDZ079 dated 17 May 2006), paras. 10-11; KDZ079, P479 (Transcript from Prosecutor v. D. Milošević), T. 3514, 3519, 3535-3538, 3542-3544; P458 (Photograph of buildings in Sarajevo); P455 (Aerial photograph of Sarajevo marked by KDZ079). See also KDZ166, T. 8282-8283 (26 October 2010); P1803 (Map of Alipašino Polje).

15038 P2922 (Witness statement of KDZ079 dated 17 May 2006), para. 11.
} 
4482. KDZ079's witness statement records that at the time of the incident the TO had an office in the community centre. ${ }^{15039}$ When giving evidence in the Dragomir Milošević case, however, she testified that this office dealt with "civilian protection" or "civilian defence", which was a civilian institution, supplying the civilians with medicine, food, and humanitarian aid. ${ }^{15040}$ She also testified that there were no soldiers in the community centre, only civilians; usually these were the elderly people from the neighbourhood, who would come to take shelter in the building and help distribute aid. ${ }^{15041}$

4483. This incident was investigated by the CSB Sarajevo team, including Turkušić and KDZ166, but only 10 days later due to intensive shelling in the area. ${ }^{15042}$ The team noted in the official report prepared following the investigation that (i) the scene had been altered, (ii) parts of four rockets were found on the scene, and (iii) the projectile was a modified air bomb, probably fired from around Lukavica. ${ }^{15043}$

4484. As the criminal technician working on the case, KDZ166 took photographs, drew a sketch of the scene, and prepared his own report of the on-site investigation. ${ }^{15044}$ According to that report, the projectile landed on a "concrete path which runs above no. 10, Trg Međunarodnog Prijateljstva and leads to Ive Andrića St."15045 It was "probably a modified aircraft bomb with four in-built rocket engines" which came "from the direction of the aggressor's positions in the west" and created a large crater, over 11 metres long and 2.5 metres deep. ${ }^{15046}$ Seven people were wounded as a result. ${ }^{15047}$ During cross-examination, KDZ166 testified that the direction of fire was "west, north-west, roughly speaking", which meant that its trajectory was either over the student dormitories or over Bitumenka Factory. ${ }^{15048}$ He also slightly corrected the direction of the north on

\footnotetext{
15039 P2922 (Witness statement of KDZ079 dated 12 March 1995), p. 2.

15040 KDZ079, P479 (Transcript from Prosecutor v. D. Milošević), T. 3506, 3508-3509, 3513-3515.

15041 KDZ079, P479 (Transcript from Prosecutor v. D. Milošević), T. 3515, 3545-3546.

15042 KDZ166, T. 8316-8317 (26 October 2010); P1791 (Witness statement of KDZ166 dated 13 February 2010), p. 13; P431 (BiH MUP Report re shelling of Trg Međunarodnog Prijateljstva on 16 June 1995) (under seal).

15043 P431 (BiH MUP Report re shelling of Trg Međunarodnog Prijateljstva on 16 June 1995) (under seal).

15044 P1791 (Witness statement of KDZ166 dated 13 February 2010), pp. 13-14; P1805 (Sketch re shelling of Trg Međunarodnog Prijateljstva on 16 June 1995); P1806 (Photographs re shelling of Trg Međunarodnog Prijateljstva on 16 June 1995); P1814 (BiH Report re shelling of Trg Međunarodnog Prijateljstva on 16 June 1995) (under seal). See also KDZ166, T. 8284-8285 (26 October 2010).

15045 P1814 (BiH Report re shelling of Trg Međunarodnog Prijateljstva on 16 June 1995), p. 1 (under seal). See also KDZ166, T. 8322 (26 October 2010); D803 (Map of Alipašino Polje marked by KDZ166).

15046 P1814 (BiH Report re shelling of Trg Međunarodnog Prijateljstva on 16 June 1995), p. 1 (under seal). See also KDZ166, T. 8284-8286 (26 October 2010); P1805 (Sketch re shelling of Trg Međunarodnog Prijateljstva on 16 June 1995); P1806 (Photographs re shelling of Trg Međunarodnog Prijateljstva on 16 June 1995).

15047 P1814 (BiH Report re shelling of Trg Međunarodnog Prijateljstva on 16 June 1995), p. 1 (under seal); P431 (BiH MUP Report re shelling of Trg Međunarodnog Prijateljstva on 16 June 1995) (under seal).

15048 KDZ166, T. 8322-8323 (26 October 2010); D804 (Map of Sarajevo marked by KDZ166).
} 
the sketch he prepared, and stated that in his opinion the projectile did not come from Lukavica but, based on the diameter of the crater, from the west or the northwest. ${ }^{15049}$

4485. KDZ166 testified that Alipašino Polje was a residential area. ${ }^{15050}$ On cross-examination, he confirmed that Energoinvest was in the vicinity and that the area to the north of the incident site was industrial. ${ }^{15051}$ In addition, the TV building was nearby, as was the police station. ${ }^{15052}$

4486. Zečević thought that the damage and the effects experienced by KDZ079 and other victims pointed to a blast wave effect and thus to a fuel-air bomb. ${ }^{15053}$ Looking at other incidents in the area, including the one on Safeta Hadžića street, Zečević determined that the azimuth of the modified air bomb in this case was 285 degrees, which corresponds to the area of Butila and IlidžaRajlovac, namely to the northwest of the incident site. ${ }^{15054}$

4487. Basing her analysis on the size of the crater, Anđelković-Lukić thought that the bomb used in this case was a modified FAB-250 with three rocket motors and with solid explosive charge as indicated by the strong blast effect on the victims. ${ }^{15055}$ She challenged Zečević's determination that this was a fuel-air bomb, arguing that the victims who were in the vicinity of the explosion would not have survived had that been the case. ${ }^{15056}$ Finally, she challenged his determination of the azimuth, stating that he used the other incidents because he had no parameters from which he could determine that angle for this specific incident. ${ }^{15057}$

4488. Subotic also thought that the modified air bomb used in this incident was a FAB-250 with solid explosive charge, as the victims would not have otherwise survived and because the shape and the depth of the crater ruled out a fuel-air bomb. ${ }^{15058}$ Using the photographs of the rockets found on

\footnotetext{
15049 KDZ166, T. 8325-8329 (26 October 2010); D805 (Sketch re shelling of Trg Međunarodnog Prijateljstva on 16 June 1995 marked by KDZ166); D806 (Aerial photograph of Trg Međunarodnog Prijateljstva marked by KDZ166); D807 (Aerial photograph and sketch re shelling of Trg Međunarodnog Prijateljstva on 16 June 1995).

15050 KDZ166, T. 8283-8284 (26 October 2010).

15051 KDZ166, T. 8318-8319 (26 October 2010); D803 (Map of Alipašino Polje marked by KDZ166).

15052 KDZ166, T. 8320-8321 (26 October 2010); D803 (Map of Alipašino Polje marked by KDZ166).

15053 P2318 (Report by Berko Zečević entitled "The use of modified aircraft bombs during the siege of Sarajevo, 1994-1995”), pp. 132-133.

15054 P2318 (Report by Berko Zečević entitled "The use of modified aircraft bombs during the siege of Sarajevo, 1994-1995”), p. 133. See also D3540 (Zorica Subotić's expert report entitled "The Use of Modified Aircraft Bombs in the Sarajevo Area in 1994-1995”, 15 March 2012), p. 121, Figure 58.

15055 D2662 (Mirjana Anđelković-Lukić's expert report entitled "Expert Analysis of Documents", 26 July 2012), p. 28.

15056 D2662 (Mirjana Anđelković-Lukić's expert report entitled "Expert Analysis of Documents", 26 July 2012), pp. 28-29.

15057 D2662 (Mirjana Anđelković-Lukić's expert report entitled "Expert Analysis of Documents", 26 July 2012 ), p. 29.

15058 D3540 (Zorica Subotić's expert report entitled "The Use of Modified Aircraft Bombs in the Sarajevo Area in 1994-1995”, 15 March 2012), pp. 116-117; Zorica Subotić, T. 38212-38214 (14 May 2013).
} 
the scene, Subotic noted that only three nozzles can be seen and thus concluded that the bomb probably had three rocket motors, rather than four. ${ }^{15059}$ She noted the disagreement on the azimuth between KDZ166's report (west) and the official report (Lukavica, which is to the south), and determined based on KDZ166's corrected sketch of the incident site, that the azimuth was northnorthwest, and that the bomb's trajectory went over the Bitumenka Factory, which was 140 metres away and was "most probably" the target. ${ }^{15060}$ She also claimed that both the CSB Sarajevo and Zečević wanted to "show at any cost that the only target in this attack was a residential area and this is why they determined that the incoming trajectory crossed only the residential area". ${ }^{15061}$

4489. Radojčić testified, like Milošević above, ${ }^{15062}$ that this incident occurred in the midst of a "fierce" ABiH offensive and that he "allow[ed] for the possibility that the target may have been the [Bitumenka] building" which housed ABiH forces and mortars. ${ }^{15063}$ Moreover, according to him, the building of the Prvi Maj school, now called Fatima Gunić school, accommodated the command of one of the units of the $102^{\text {nd }}$ Brigade of the $\mathrm{ABiH} .{ }^{15064}$ Finally, he testified that he never ordered that fire be opened on Trg Međunarodnog Prijateljstva nor received any reports about this incident. ${ }^{15065}$ Milošević testified that the bomb was used in order to stop the attack of the $102^{\text {nd }}$ Brigade of the $\mathrm{ABiH}$ on Nedžarići. ${ }^{15066}$

4490. In addition to the evidence and the adjudicated facts outlined above, the Chamber also took judicial notice of the following two facts: (i) the projectile that exploded on Trg Medunarodnog Prijateljstva 10 was a modified air bomb; ${ }^{15067}$ and (ii) it was fired from an SRK position, having been launched by members of the SRK. ${ }^{15068}$

4491. The Chamber, relying on the evidence and the adjudicated facts recounted above, is satisfied that the projectile that landed on Trg Međunarodnog Prijateljstva on 16 June 1995 was a

\footnotetext{
15059 D3540 (Zorica Subotić's expert report entitled “The Use of Modified Aircraft Bombs in the Sarajevo Area in 1994-1995”, 15 March 2012), p. 118.

15060 D3540 (Zorica Subotić's expert report entitled "The Use of Modified Aircraft Bombs in the Sarajevo Area in 1994-1995”, 15 March 2012), pp. 119-121, 184, 188; Zorica Subotić, T. 38214-38216 (14 May 2013).

15061 D3540 (Zorica Subotić's expert report entitled "The Use of Modified Aircraft Bombs in the Sarajevo Area in 1994-1995”, 15 March 2012), p. 121 (adding further that CSB Sarajevo did so by rotating the direction of north, which was "a method frequently used in their investigations").

15062 See para. 4468.

15063 D2562 (Witness statement of Vladimir Radojčić dated 8 December 2012), paras. 64, 114.

15064 D2562 (Witness statement of Vladimir Radojčić dated 8 December 2012), para. 114 (not specifying which unit that was). See also D2553 (Witness statement of Svetozar Guzina dated 3 December 2012), para. 46 (testifying that the $\mathrm{ABiH}$ was located there throughout the war). The Chamber received no evidence, however, as to the location of this school or the distance between it and the incident site.

15065 D2562 (Witness statement of Vladimir Radojčić dated 8 December 2012), para. 114.

15066 Dragomir Milošević, T. 32780-32781 (28 January 2013).

15067 Adjudicated Fact 3063.

15068 See Adjudicated Fact 3064.
} 
modified air bomb. Given the extensive damage caused by the explosion, the Chamber is also convinced that it was a heavier bomb, most likely FAB-250 with three rocket motors. Given the conflicting evidence on this issue, the Chamber is not convinced that it was a fuel-air bomb as claimed by Zečević. Ultimately, however, the Chamber considers that the type of the charge used in the bomb is irrelevant given its highly destructive nature.

4492. In terms of the casualties, the Chamber finds, relying on the evidence and the Adjudicated Fact 3063, that seven people were injured in the explosion, including KDZ079. The Chamber also considers that they were all civilians and that they were not taking direct part in the hostilities at the time of the incident. ${ }^{15069}$

4493. With respect to the direction of fire, while there are some discrepancies among the experts and local investigators, the evidence nevertheless shows that the modified air bomb came from the general northwesterly direction. While Subotić claims that Zečević's direction of fire was closer to the west than to the north because he was trying to show that civilians were the only target, the Chamber does not accept her claim and recalls that Zečević explained the basis on which he determined this direction of fire, namely from his experience of other incidents in the area. Ultimately, as with the incident on Dositejeva street, the Chamber is convinced beyond reasonable doubt that the modified air bomb in this incident was fired from SRK-held territory. This is confirmed by the intercepted conversation in which Prstojević told Ristić that they sent over a "krmača" or two to the Bosnian Muslim side that day. Milošević also admitted that the SRK used the bomb in order to stop the attacks in Nedžarići.

4494. The Chamber further finds that the area of Alipašino Polje was a residential area with a large number of civilians living there. While Radojčić testified that Fatima Gunić School housed an $\mathrm{ABiH}$ command, the Chamber has received no evidence about the location of this school or its distance from the incident site. In any event, the Accused's argument is that the most probable target was the Bitumenka Factory, not the school, the factory being about 140 metres away from the incident site. The Chamber notes, however, that it has received no evidence that Bitumenka was used by $\mathrm{ABiH}$ or that it otherwise was a legitimate military target. Even if it was, however, the modified air bomb missed it by at least 140 metres, confirming once again the inherent inaccuracy of this weapon.

15069 While KDZ079 testified that the civilian protection, or civilian defence, was located in the community centre building, the Chamber considers that this did not make the building and the persons located therein a legitimate military target since, according to KDZ079, there were no soldiers in the building. Those in the building were usually the elderly from the neighbourhood who would come to take shelter there and help distribute aid. In addition, none of the Defence witnesses suggested that they considered this building to be a legitimate military target. 
4495. Finally, while there may have been some shelling and fighting during the day, KDZ079 testified that it was sporadic and that it took place in the vicinity of Ilidža, on the confrontation line. This is consistent with Konings who explained that there was a lot of fighting in those days but that it took place on the confrontation lines. ${ }^{15070}$ The incident site here was not on the confrontation line and there is no evidence that fire was opened from it on the SRK positions that day.

4496. Accordingly, the Chamber does not consider that the modified air bomb was aimed at neutralising a specific military target. Rather, the Chamber is convinced beyond reasonable doubt that the bomb was launched into a generally residential area, in retaliation for the attacks mounted by the $\mathrm{ABiH}$ on the confrontation lines. This is confirmed by Mladić's instruction to Milošević that the Bosnian Muslim side should be made to pay for fighting as well as by Milošević's admission that the bomb was used in order to stop the ABiH attacks in Nedžarići. Further, given the inaccuracy of the modified air bombs and recalling their destructive power, the Chamber is of the view that the SRK soldiers launching this modified air bomb into the central area of Sarajevo should have been aware that such an attack would cause great damage to civilian objects and result in civilian casualties.

\section{iv. Findings on shelling in Sarajevo}

4497. Having considered all the evidence presented in this case in relation to shelling in Sarajevo in the period relevant to the Indictment, the Chamber is convinced that throughout the conflict the SRK units engaged in deliberate, disproportionate, and indiscriminate shelling of the civilian objects and civilians in the city. ${ }^{15071}$ They did so using a multitude of heavy weapons, such as 80 and $120 \mathrm{~mm}$ mortars, as well as other artillery and higher calibre weapons. These were located, more or less permanently, on the hills surrounding Sarajevo, their permanent placement allowing the firing crews to acquire a certain degree of targeting accuracy. Nonetheless, the evidence of the witnesses who were in the city during the conflict shows that there often seemed to be no military value in the targets that were selected and that fire was often randomly scattered around the city. The evidence is also overwhelming as to the high numbers of shells that fell on the city during the conflict, including on its residential areas and civilian objects. The shells would fall on an almost daily basis, with the exception of a few quiet periods as outlined in Section IV.B.1.a, while the heaviest shelling took place in the early days of the conflict and in the summer of 1992. The fact that this type of shelling of the city continued for over three years indicates to the Chamber that the

\footnotetext{
15070 See fn. 14998.

15071 In reaching this conclusion, the Chamber relied not only on the findings on scheduled shelling incidents discussed above, but also on the general evidence relating to the situation in the city and the types of shelling it was exposed to on a regular basis.
} 
intention of the SRK forces was not in fact to target military targets alone, but rather to target civilians and/or use random and disproportionate fire in the city. Further, as with sniping, the Chamber is particularly persuaded by the evidence of international witnesses who worked for the UN in the city and, therefore, could not only observe the shelling practices of the SRK but were also able to have a more complete picture of the events on the ground through UNPROFOR and UNMO reports and through their dealings with the warring sides. All those witnesses were consistent as to the illegitimate nature of the SRK's shelling of the city and their heavy weapon supremacy. Further, the evidence outlined above clearly indicates that even when used in response to $\mathrm{ABiH}$ fire, the $\mathrm{SRK}$ fire was usually disproportionate and/or indiscriminate. The specific scheduled shelling incidents discussed in detail above also clearly illustrate the non-selective nature of the SRK fire. Furthermore, on top of the regular artillery weapons and mortars, the SRK used highly destructive modified air bombs, which were imprecise and completely unsuitable for an urban environment such as Sarajevo. Finally, the Chamber's finding that the SRK was shelling Sarajevo civilians, either through deliberate targeting or through indiscriminate and disproportionate attacks, is further reinforced by the high number of civilians who either died or were wounded as a result of the shelling undertaken by the SRK.

4498. In coming to the above conclusions, the Chamber also carefully assessed the evidence of the former SRK soldiers and officers who claimed that they were not deliberately targeting civilians and that their use of heavy weaponry was always selective and proportionate. The Chamber found this evidence disingenuous, as it flies in the face of the overwhelming and highly persuasive Prosecution evidence as to the facts on the ground. It is also contrary to the evidence specifically related to the scheduled shelling incidents. Finally, it is further contradicted by the SRK's own analysis of the targeting practices conducted by the SRK's Chief of Artillery in July 1994, as well as by the orders of the SRK and of the Accused concerning the preservation of ammunition. ${ }^{15072}$ All those documents clearly show that SRK units opened disproportionate and non-selective fire, achieving poor results in terms of striking relevant military targets. ${ }^{15073}$ The Chamber therefore considers that the evidence these witnesses gave on the issue of selectivity and proportionality was self-serving and dishonest and undermined their credibility. Furthermore, while the Chamber accepts that SRK units would sometimes open fire that was directed at the $\mathrm{ABiH}$ forces on the confrontation lines and/or was a proportionate response to $\mathrm{ABiH}$ fire, as confirmed by many of the above-mentioned international witnesses, this does not impact on the ultimate finding that much of the heavy weapon fire on the city was neither selective nor proportionate.

$15072 \quad$ See para. 3999. 
4499. While the evidence of the above-mentioned SRK witnesses on the selective and proportional nature of SRK fire is unreliable, their evidence on other aspects of SRK targeting shows that KDZ182's assessment that mortar and artillery fire was strictly controlled at higher command levels while leaving some leeway for "underlings" was ultimately accurate. As noted above, Galić and Inđić confirmed that higher calibre artillery was controlled at the corps level while the basic assets of the brigade were controlled by the brigade commanders. Similarly, both Galic and Simić testified that authorisation of the brigade command or of the corps command was necessary before mortar or artillery fire could be opened. In addition, as confirmed by Dušan Škrba and Nikola Mijatović, SRK units were allowed to open fire without permission and using simple preparation, without waiting to hear from the SRK observers, if directly threatened. Finally, as found above in the section dealing with modified air bombs, the use of such bombs was under strict VRS Main Staff control.

4500. In terms of the Accused's arguments that the $\mathrm{ABiH}$ was responsible for civilian casualties in the city because it did not remove the civilians from the vicinity of the military objectives or because it abused civilians objects for military purposes, the Chamber recalls that the parties to a conflict are indeed under an obligation to remove civilians, to the maximum extent feasible, from the vicinity of military objectives and to avoid locating military objectives within or near densely populated areas. ${ }^{15074}$ However, the failure of a party to abide by this obligation does not relieve the attacking side of its duty to abide by the principles of distinction and proportionality when launching an attack. ${ }^{15075}$ The evidence is clear that the SRK units did not abide by those principles.

4501. As for the use of mobile mortars by the $\mathrm{ABiH}$ from civilian areas, the Chamber accepts that this practice caused difficulties to the SRK units and that it was illegal. However, the legality or otherwise of $\mathrm{ABiH}$ firing practices is only relevant to the allegations made in this case if they go to one of the main allegations in this case, such as showing that the SRK observed the principles of distinction during the conflict in Sarajevo. In that respect, the Chamber agrees with Fraser that given the low probability of the SRK response actually hitting and destroying the mobile mortar in question, the SRK units should have refrained from firing back if the mobile mortar was intermingled with civilians. ${ }^{15076}$ In addition, as discussed in a later section of this Judgement, the $\mathrm{ABiH}$ would usually fire one or two rounds from those mortars but the SRK would then respond in

\footnotetext{
15073 The Chamber finds D2587 particularly telling in this context as it alludes to the fact that the SRK units all wanted to liquidate as many Bosnian Muslims as possible. See fn. 13248.

15074 Galić Appeal Judgement, para. 194; Article 58 of Additional Protocol I.

15075 Galić Appeal Judgement, para. 194.

15076 Indeed, Golić testified that in early June 1992 he received an order from the Chief of Artillery not to fire at a mobile mortar located in the National Museum. See D2665 (Witness statement of Izo Golić dated 15 December 2012), para. 29.
} 
a disproportionate manner, indicating that the aim was retaliation rather than that of neutralising the mobile mortar in question. ${ }^{15077}$

4502. Finally, the Accused's argument that the Bosnian Muslim units within the city opened mortar and artillery fire on their own civilians in order to lay the blame on the Serbs has been rejected by the Chamber for the reasons outlined in more detail in the later section of the Judgement. $^{15078}$

\section{d. Bosnian Muslim side targeting own civilians}

4503. Throughout this case the Accused argued, both generally and in relation to specific scheduled incidents, that it was the Bosnian Muslim side that sniped and shelled civilians in Sarajevo in order to gain international sympathy and to provoke an international response against the Serbs; he also claimed that the Bosnian Muslims were responsible for all major incidents in the city which resulted in civilian casualties. ${ }^{15079}$

4504. The Prosecution argues that these claims by the Accused should be rejected as "international witnesses" consistently "debunked" them; further, the Prosecution claims that, to the extent it occurred, any such activity was insignificant in light of the frequent sniping and shelling conducted by the Bosnian Serb Forces during the conflict. ${ }^{15080}$

4505. To support his claims, the Accused cross-examined a number of Prosecution witnesses on the topic and also called a number of witnesses, including Edin Garaplija. Soon after the war Garaplija, a former member of the BiH MUP's SDB, ${ }^{15081}$ conducted a police interview with Nedžad Herenda, a member of a secret police unit established in 1992 as part of the SDB called Ševe. ${ }^{15082}$ According to Garaplija, during this interview Herenda admitted that during the war he operated as a sniper and was tasked with shooting at Serb positions, which he often did from the Executive Council building. ${ }^{15083} \mathrm{He}$ also admitted that, in 1995, while positioned at the Executive Council building, he shot and killed the FreBat soldier who was erecting an anti-sniping barrier near the

\footnotetext{
15077 See paras. $4535,4544$.

15078 See Section IV.B.1.d: Bosnian Muslim side targeting own civilians.

15079 Defence Final Brief, paras. 1968, 1972-1974, 2181; Hearing, T. 10620 (20 January 2011).

15080 Prosecution Final Brief, para. 795.

15081 Edin Garaplija, T. 33381 (7 February 2013).

15082 D2906 (Video clip of interview with Edin Garaplija, with transcript); Edin Garaplija, T. 33382, 33384 (7 February 2013).

15083 Edin Garaplija, T. 33388, 33403, 33410 (7 February 2013) (adding that Herenda would also snipe at Bosnian Serb civilians in Grbavica).
} 
Holiday Inn ${ }^{15084}$ in order to cause the UN to "blame the Serbs". ${ }^{15085}$ Herenda further admitted that he and other members of Ševe attempted to kill Sefer Halilović by placing explosives in his house and by making it look as if the explosion was caused by a Serb projectile. ${ }^{15086}$ Mistaking Halilović's brother-in-law for Halilović, they activated the explosive before Halilović arrived home and killed his wife and brother-in-law instead. ${ }^{15087}$ Finally, Herenda confessed that he shot and wounded Ismet Bajramović Čelo, a military police commander in the $\mathrm{ABiH}$ who was also involved in organised crime, and that he shot at an $\mathrm{ABiH}$ unit that got out of control, killing two of the commander's guards. ${ }^{15088}$ Garaplija and his colleagues were shocked by these revelations as up until that point they thought that the Bosnian Serb side alone engaged in such activities. ${ }^{15089}$ When asked in cross-examination if Herenda ever confessed to sniping at Bosnian Muslim civilians in the city, Garaplija responded in the negative. ${ }^{15090}$

4506. Gray testified that he believed the ABiH strategy in Sarajevo involved, in part, "the killing of their own citizens" and that the "Presidency was killing their own people for the media". ${ }^{15091}$ As an example, he referred to the incident of 13 July 1992 when several mortar shells fell around the PTT building, killing and wounding a number of "young people" who had gathered nearby-

15084 The death of this soldier has been recounted earlier in the Judgement. See para. 3608, fn. 11619.

15085 Edin Garaplija, T. 33387-33389, 33391-33393 (7 February 2013); D2906 (Video clip of interview with Edin Garaplija, with transcript); D2907 (UNPROFOR report, 18 April 1995), paras. 5-6 (stating that both ABiH and VRS forces had sniping positions from which a sniper could have killed the French soldier); P2011 (Video footage of Sarajevo, with transcript); D2774 (Witness statement of Milenko Inđić dated 19 January 2013), paras. 153-157. But see P820 (Witness statement of David Harland dated 4 September 2009), para. 172; P1762 (Witness statement of David Fraser dated 17 October 2010), pp. 34-36, 72; David Fraser, T. 8016 (18 October 2010); P2414 (Witness statement of KDZ182), pp. 71-73 (under seal); P2407 (Witness statement of KDZ304), p. 10; KDZ304, T. 10514-10515 (18 January 2011) (all testifying that the French soldier was shot by a Serb sniper). Garaplija's evidence is indirectly corroborated by KDZ182's evidence outlined below about a sniper operating in one of the $\mathrm{BiH}$ government buildings. Accordingly, the Chamber considers Garaplija's evidence about Herenda being responsible for shooting the French soldier persuasive and therefore rejects the evidence of Harland, Fraser, KDZ304, and KDZ182, that this soldier was shot by the Bosnian Serb Forces. See para. 3608.

15086 D2908 (Video clip of interview with Edin Garaplija, with transcript); Edin Garaplija, T. 33393-33397 (7 February 2013). See also D171 (ABiH Supreme Command Staff Bulletin, 8 July 1993), p. 2.

15087 D2908 (Video clip of interview with Edin Garaplija, with transcript); Edin Garaplija, T. 33393-33395 (7 February 2013) (speculating that the motive for this incident might have been to retaliate for Halilović's earlier statements opposing the division of $\mathrm{BiH})$.

15088 Edin Garaplija, T. 33411-33414 (7 February 2013) (explaining that both those incidents were politically motivated). See also Francis Roy Thomas, T. 6816-6818 (15 September 2010) (testifying that UNMOs heard rumours of political murders within the city).

15089 Edin Garaplija, T. 33387 (7 February 2013). See also D2774 (Witness statement of Milenko Inđić dated 19 January 2013), paras. 151-152. When cross-examining Garaplija the Prosecution focused on his conviction relating to the mistreatment of Herenda during the interview. See Edin Garaplija, T. 33404-33409 (7 February 2013). However, there was no meaningful challenge by the Prosecution to Garaplija's evidence concerning Herenda's activities. In any event, the Chamber found Garaplija to have been truthful and credible in that respect and accepts his evidence in relation thereto.

15090 Edin Garaplija, T. 33411 (7 February 2013).

15091 D2398 (Witness statement of Richard Gray dated 22 April 2012), para. 14; Richard Gray, T. 29987-29990 (8 November 2012); D2411 (UNPROFOR report, 14 July 1992), para. 2 (reporting that Izetbegović would accept only intervention or death for his people). See also P1479 (Ratko Mladić's notebook, 16 July-9 September 1992), p. 73; D593 (VRS Main Staff Order, 22 July 1992), p. 2. 
though Gray conceded that he and his team were unable to determine the origin of fire on that occasion, he believed the $\mathrm{ABiH}$ was responsible due to (i) the lack of an unobstructed line of sight from the SRK positions to the incident site and (ii) because the accuracy of the round indicated to him that it was fired from close range. ${ }^{15092}$ Another example was an incident involving Douglas Hurd, a foreign dignitary who was visiting Izetbegović at the Presidency building. According to Gray, whenever foreign dignitaries were visiting the Presidency, shells would fall just outside of the building. ${ }^{15093}$ Gray suspected that this was an ABiH strategy, which he says was confirmed when he started talking to two $\mathrm{ABiH}$ officers while waiting on the steps of the Presidency for Hurd to arrive; the two soldiers at one point looked at their watches and swiftly moved inside the Presidency building, following which mortar bombs landed nearby, causing casualties. ${ }^{15094}$

4507. Demurenko stated that he and others in UNPROFOR had the impression that Bosnian Muslims were sniping at their own civilians, but that this was impossible to prove. ${ }^{15095}$ According to Demurenko, there was an effort within UNPROFOR not to blame Bosnian Muslims for the fighting in and around Sarajevo. ${ }^{15096}$ Demurenko nevertheless reported to his command on a small number of incidents of $\mathrm{ABiH}$ forces shelling and sniping at Bosnian Muslim civilians. ${ }^{15097}$

4508. Desimir Šarenac, Chief of Security in the $1^{\text {st }}$ Sarajevo Mechanised Brigade, ${ }^{15098}$ testified that the SRK obtained intelligence that $\mathrm{ABiH}$ forces occasionally shelled certain facilities and areas in order to portray it as Serb fire. ${ }^{15099}$ In addition, it appeared to him that some projectiles were simply makeshift projectiles, which were fired at Serb positions but accidentally exploded on ABiH-held civilian areas. ${ }^{15100}$ Dragomir Milošević claimed that there were instances of $\mathrm{ABiH}$ targeting their own territory with high-calibre weapons. ${ }^{15101}$ Both Galić and Milošević testified that whenever important delegations would come to Sarajevo and visit $\mathrm{ABiH}$-controlled parts, the $\mathrm{ABiH}$

\footnotetext{
15092 D2398 (Witness statement of Richard Gray dated 22 April 2012), para. 13; Richard Gray, T. 29979-29981 (8 November 2012). The Chamber notes that this is not one of the scheduled incidents charged in the Indictment.

15093 Richard Gray, T. 29990 (8 November 2012).

15094 Richard Gray, T. 29989-29991 (8 November 2012) (adding that he reported this to General MacKenzie who later spoke to the media about it and shortly after gave up his command of UN headquarters in Sarajevo). This is also not one of the scheduled incidents charged in the Indictment.

15095 D2270 (Witness statement of Andrey Demurenko dated 13 October 2012), para. 23.

15096 D2270 (Witness statement of Andrey Demurenko dated 13 October 2012), paras. 23-24.

15097 D2270 (Witness statement of Andrey Demurenko dated 13 October 2012), e-court pp. 75, 86, 89, 90. See also D2302 (UNPROFOR daily report, 8 June 1995), p. 5; D2317 (UNPROFOR daily report, 19 July 1995), p. 5; D2312 (UNPROFOR daily report, 30 July 1995), pp. 1, 6; D2326 (UNPROFOR daily report, 7 August 1995), p. 5 .

15098 Desimir Šarenac, T. 34921-34923 (6 March 2013).

15099 Desimir Šarenac, T. 34945-34946 (6 March 2013), T. 34972 (7 March 2013).

15100 Desimir Šarenac, T. 34946 (6 March 2013).

15101 Dragomir Milošević, T. 32586-32590 (23 January 2013); D2796 (SRK combat report, 14 August 1993); D2797 (SRK combat report, November 1994), para. 1.
} 
leadership would "try to attribute fire to [the Serbs]"; as a result, they had to warn SRK units to refrain from responding to the $\mathrm{ABiH}$ 's provocative fire. ${ }^{15102}$ Galic further claimed that $\mathrm{ABiH}$ forces would shell the Presidency building. ${ }^{15103}$ This was confirmed by KW570 who noticed a pattern in Sarajevo such that whenever there were high-level meetings or negotiations there, the ABiH would open mortar fire towards the Presidency. ${ }^{15104}$ The Accused himself made a claim in a video interview that Bosnian Muslims were placing explosives on the streets of Sarajevo in order to "kill their own people", particularly when "some high dignitary is coming". 15105

4509. Some witnesses called by the Prosecution also acknowledged certain incidences of $\mathrm{ABiH}$ targeting its own population in order to garner international sympathy. For example, Fraser testified that he was aware of one sniping and one shelling incident where Bosnian Muslims forces targeted their own civilians. ${ }^{15106}$ With respect to the sniping incident, Fraser heard stories from UN soldiers that the FreBat soldiers had video footage of $\mathrm{ABiH}$ sniper firing on his own people but he himself never saw the tape nor was told when this happened. ${ }^{15107}$ As for the shelling incident, Fraser recalled that it started with Serbs firing one shell, followed by the ABiH firing a shell at the same target some 40 minutes later. ${ }^{15108}$ A protest was lodged against the Bosnian Muslims forces for such actions. ${ }^{15109}$

4510. Harland agreed that there were some cases of Bosnian Muslims sniping at their own side, but not many-he could recall only two during his time in Sarajevo. ${ }^{1510}$ He further recalled the

\footnotetext{
15102 Stanislav Galić, T. 37235 (15 April 2013); Dragomir Milošević, T. 32591-32592 (23 January 2013); D2799 (SRK combat report, 30 September 1993).

15103 Stanislav Galić, T. 37232-37233 (15 April 2013), T. 37354-37355 (16 April 2013); D3409 (SRK combat report, 5 May 1993), p. 2.

15104 KW570, T. 32263-32264 (18 January 2013).

15105 P1274 (Video footage of interview with Radovan Karadžić, with transcript), p. 1.

15106 P1762 (Witness statement of David Fraser dated 17 October 2010), pp. 67, 77-79 (also describing a third incident where FreBat soldiers came across Bosnian Muslims filming a staged attack); David Fraser, T. 8054 (18 October 2010).

15107 P1762 (Witness statement of David Fraser dated 17 October 2010), p. 77; David Fraser, T. $8051-8054$ (18 October 2010); D770 (UNPROFOR report re Dobrinja, 23 September 1994), p. 2. See also P2414 (Witness statement of KDZ182), p. 43 (under seal) (testifying that the FreBat soldiers were sure that there was a "Bosnian army sniper" shooting from the "parliament building" in mid 1995 and that, after a few months of suspicion that this was the case, the UN intervened; this led to the shooter stopping to fire sometime in mid-June 1995); KDZ182, T. 13088-13091 (9 March 2011); P2417 (Article from New York Times, entitled "Conflict in the Balkans: in Sarajevo", 1 August 1995), pp. 1-2. This in turn confirms Garaplija's evidence about Herenda sniping from the Executive Council building and shooting a French soldier on 14 April 1995. See para. 4505.

15108 P1762 (Witness statement of David Fraser dated 17 October 2010), pp. 77-78; David Fraser, T. 8055-8057 (18 October 2010). See also Michael Rose, T. 7329 (6 October 2010); D162 (Michael Rose's book entitled "Fighting for Peace: Bosnia, 1994"), p. 197.

15109 David Fraser, T. 8053 (18 October 2010).

15110 P820 (Witness statement of David Harland dated 4 September 2009), paras. 296-297 (testifying also that more than $90 \%$ of the sniping victims on the ABiH-held territory appeared to have been shot at from the Bosnian Serb side of the confrontation line); David Harland, T. 2103 (7 May 2010). See also D681 (UNPROFOR report re situation in Sarajevo, 27 October 1994).
} 
$\mathrm{ABiH}$ statement that such sniping activities in September and October 1993 were carried out by "renegades". ${ }^{15111}$ Harland also agreed that the media was a key strategy of the Bosnian Presidency and that they had a need to engage in provocations where the media was present. ${ }^{15112}$

4511. KDZ185 testified that $\mathrm{ABiH}$ forces carried out a "media war" in Sarajevo which included staging "dramatic events" around the city and targeting their own citizens. ${ }^{15113}$ One such incident involved the firing of a shell into the Markale market area which UNPROFOR investigated immediately after the event and concluded that the shell was likely fired from a position close to the frontline in the north of the city. ${ }^{15114}$ In total, he could recall only a few occasions where the UN suspected that $\mathrm{ABiH}$ was responsible for firing on the city and also admitted that $\mathrm{ABiH}$ would occasionally fire at the airport. ${ }^{15115}$

4512. Other Prosecution witnesses testified, however, that while they were aware of the allegation that $\mathrm{ABiH}$ forces sniped or shelled their own civilians, they never personally observed it or received any conclusive proof to that effect. ${ }^{15116}$ For example, Mole acknowledged that there was a general perception that the $\mathrm{BiH}$ Presidency would gain more if they were perceived as the "beleaguered party" and that there may well have been instances in which $\mathrm{ABiH}$ forces fired on their own territory in order to maintain that perception. ${ }^{15117}$ However, no UNMO report established this as fact; the most UNMOs were able to establish is that there was doubt as to the origin of fire in certain incidents. 15118 According to Mole, there were "sufficient unknowns" for UNPROFOR members to be "reasonably sure" such allegations were true, emphasising that in war conditions it

\footnotetext{
15111 David Harland, T. 2184-2187 (10 May 2010); P823 (UNPROFOR Weekly Political Assessment, 3 November 1993), p. 3.

15112 David Harland, T. 2103 (7 May 2010).

15113 P6060 (Record of interview with KDZ185), e-court pp. 13, 15; KDZ185, T. 4229 (28 June 2010).

15114 P6060 (Record of interview with KDZ185), e-court p. 15; KDZ185, T. 4229-4230 (28 June 2010). See also KDZ088, T. 6394-6395 (8 September 2010) (closed session) (testifying that on 27 May an explosion occurred on Vase Miskina street which the Serbs were initially accused of causing but for which UNPROFOR later determined that the explosion was caused by mines placed in basement windows on the street). But see P155 (BiH MUP Report re shelling incident on 27 May 1992) (stating that the Bosnian police investigators determined that the explosion was caused by a shell launched from the direction of Trebević). The Chamber notes that neither of these incidents is part of the scheduled incidents charged in the Indictment.

15115 KDZ185, T. 4289 (29 June 2010), T. 4290-4291 (29 June 2010) (private session); D342 (ABiH $1^{\text {st }}$ Corps response to UNPROFOR protest, 10 February 1992).

15116 See e.g. Harry Konings, T. 9346-9348 (7 December 2010) (recalling one incident in which ABiH fired 20 mm rounds at his OP which then may have carried into the city); D889 (UNMO report, undated), p. 1; P1953 (Witness statement of Harry Konings dated 11 November 2010), p. 12; Pyers Tucker, T. 23309 (18 January 2012); Francis Roy Thomas, T. 6815-6817 (15 September 2010); Thomas Knustad, P123 (Transcript from Prosecutor v. D. Milošević), T. 2042; Herbert Okun, T. 1645 (26 April 2010); Adrianus van Baal, T. 8457-8459 (27 October 2010); D826 (Excerpt from Adrianus van Baal's testimony in Prosecutor v. Galić); Hussein AbdelRazek, T. 5549 (20 July 2010); P5906 (Witness statement of KDZ450 dated 17 January 2011), para. 77; KDZ450, T. 10670 (20 January 2011) (private session).

15117 P1426 (Witness statement of Richard Mole dated 7 May 2010), para. 121.

15118 P1426 (Witness statement of Richard Mole dated 7 May 2010), para. 121; Richard Mole; T. 5890 (18 August 2010).
} 
was impossible to conduct a complete forensic analysis that would conclusively determine whether ABiH forces targeted their own population. ${ }^{15119}$

4513. Rose also stated that, during his time in Sarajevo, allegations were made both in the media and by FreBat members that $\mathrm{ABiH}$ forces were firing on their own people; however, he himself never saw evidence of this and testified it was impossible for UNPROFOR to determine conclusively who fired a particular shot. ${ }^{15120}$ Further, the incidents in which UNPROFOR suspected Bosnian Muslims of firing at the UN, NATO aircrafts, or their own citizens were "very few". ${ }^{15121}$ KDZ182 also testified that in all UNPROFOR investigations of shelling incidents, nearly all fire came from the Bosnian Serb side, although some shells did appear to have come from the Bosnian Muslim side. ${ }^{15122}$ According to him, small arms shots originated from both sides, with the larger proportion coming from the Serbs. ${ }^{15123}$

4514. Finally, the Chamber also heard from a number of Prosecution witnesses who vehemently denied that $\mathrm{ABiH}$ units would target their own civilians. ${ }^{15124}$ For example, Bell testified that he never saw or reported any instances of $\mathrm{ABiH}$ forces firing upon themselves or staging incidents, and would give no credence to such allegations. ${ }^{15125}$ Bowen testified that he was first introduced to the theory that Bosnian Muslim forces were shelling their own territory in late August 1992 by a military aide to UNPROFOR Sarajevo Sector commander who admitted to having no proof for such theory. ${ }^{15126}$ Bowen did not accept this theory, noting that even now, some twenty years after the war, no "smoking gun" evidence of ABiH shelling its own people had come out. ${ }^{15127}$ KDZ304 also thought that the allegations that Bosnian Muslims shelled themselves were baseless and

\footnotetext{
15119 Richard Mole, T. 5885-5886 (18 August 2010).

15120 P1638 (Witness statement of Michael Rose dated 26 March 2009), paras. 213-214; Michael Rose, T. 7307-7308 (5 October 2010), T. 7328-7337 (6 October 2010) (testifying also that there were rumours that Ejup Ganić had a secret police unit tasked with sniping at trams in such a way that the Serb side would be blamed for it); D162 (Michael Rose's book entitled "Fighting for Peace: Bosnia, 1994"), p. 197; D680 (UNPROFOR report re shelling incident on 8 November 1994).

15121 Michael Rose, T. 7328-7334 (6 October 2010); D681 (UNPROFOR report re situation in Sarajevo, 27 October 1994) (reporting on a sniping incident involving a tram and that all the evidence suggested that the fire came from the ABiH-held territory). But see Mirza Sabljica, T. 7684-7688 (testifying that CSB Sarajevo investigated this incident and determined that the fire came from the Bosnian Serb side).

15122 P2447 (Witness statement of KDZ182), pp. 48-52, 54 (recalling only one instance where this happened).

15123 KDZ182, T. 13085-13088 (9 March 2011) (private session).

15124 See e.g. Mirsad Kučanin, P17 (Transcript from Prosecutor v. S. Milošević), T. 28971; Mirsad Kučanin, P16 (Transcript from Prosecutor v. Galić), T. 4729-4730; Adrianus van Baal, T. 8462-8463 (27 October 2010), T. 8533 (28 October 2010); KDZ166, T. 8354 (26 October 2010).

15125 P1996 (Witness statement of Martin Bell dated 8 March 2010), para. 117; Martin Bell, T. 9920-9921 (15 December 2010).

15126 Jeremy Bowen, T. 10165-10166 (13 January 2011), T. 10196, 10200-10201 (14 January 2011); P2068 (Witness statement of Jeremy Bowen dated 10 August 2009), para. 39.

15127 Jeremy Bowen, T. 10184-10185 (13 January 2011), T. 10196, 10200-10201 (14 January 2011); P2068 (Witness statement of Jeremy Bowen dated 10 August 2009), para. 39. See D936 (Excerpt from Jeremy Bowen's book entitled "War Stories"), e-court p. 6.
} 
testified that during his time in Sarajevo he did not witness any fire from the $\mathrm{ABiH}$ frontline against the civilian population of Sarajevo. ${ }^{15128}$

4515. The Chamber has analysed the evidence outlined above in the context of all the evidence it has heard in this case in relation to sniping and shelling in Sarajevo. While the Chamber found Garaplija to be credible, his evidence did not go as far as to show that the Bosnian Muslim side targeted its own civilians, let alone that the Bosnian Muslim side was responsible for all major shelling or sniping incidents in the city. Instead, his evidence merely showed that Herenda, a member of a special police unit, was engaged in political executions of notorious Bosnian Muslim individuals who were not civilians. Garaplija's evidence further revealed that Herenda killed an UNPROFOR soldier in order to blame the Bosnian Serb side and provoke international reaction against them. ${ }^{15129}$ However, as recounted above, when asked about the targeting of Bosnian Muslim civilians, Garaplija responded that Herenda did not admit to any such practice.

4516. Having said that, the Chamber accepts the evidence of Fraser, Harland, KDZ185, and other Prosecution witnesses that there were some incidents where Bosnian Muslim side targeted its own territory, usually near the Presidency building, for political purposes. However, all those witnesses limited the occurrence of such incidents to a minuscule number and all were firm in their position that most of the fire on Sarajevo came from the Bosnian Serb side.

4517. Furthermore, Harland testified that these few incidents were attributed to the "renegade forces" on the Bosnian Muslim side. In contrast, the Accused's claim, if true, would have meant a conspiracy on a large scale involving many, if not all, $\mathrm{ABiH}$ and police units in the city colluding over a number of years in order to secretly snipe and shell their own people. The Chamber does not accept this. In addition, as seen in preceding sections, in many of the charged sniping and shelling incidents, the Chamber found they were committed by the SRK. ${ }^{15130}$ There is therefore no evidence of such a wide scale conspiracy.

4518. Even the witnesses called by the Accused did not go as far as to claim that all or most major incidents in the city involving civilian casualties were caused by the Bosnian Muslim side. As noted earlier, Garaplija's evidence did not concern sniping on Bosnian Muslim civilians at all.

\footnotetext{
15128 P2106 (Witness statement of KDZ304), p. 28 (under seal); KDZ304, T. 10517 (18 January 2011).

15129 D2270 (Witness statement of Andrey Demurenko dated 13 October 2012), e-court pp. 85-86; D2271 (UNPROFOR daily report, 18 July 1995), pp. 4-5 (indicating that ABiH opened fire on UNPROFOR soldiers); D2398 (Witness statement of Richard Gray dated 22 April 2012), para. 10 (testifying that ABiH units sniped at UN personnel in the PTT building and that he was personally targeted by $\mathrm{ABiH}$ fire).

15130 The Chamber also recalls that it has discussed some of the evidence on the issue of ABiH targeting its own civilians in the sections dealing with specific scheduled and sniping incidents, when it was relevant to those.
} 
Demurenko testified of the impression he had that the Bosnian Muslims were sniping their own people, conceding that this impression was difficult to prove. More significantly, while he authored a large number of UN daily reports during his time in the city, many of which were admitted into evidence in this case, only a miniscule number of those recorded specific incidents in which the fire was said to have come from the ABiH-held territory. ${ }^{15131}$ Similarly, KW570's testimony was confined to the ABiH's pattern of firing towards the presidency when an important delegation was visiting the city. However, he made no mention of civilian victims resulting from such fire. Gray also mentioned $\mathrm{ABiH}$ fire on the Presidency during foreign visits but recalled only one such Presidency incident where civilian casualties were involved. ${ }^{15132}$ The SRK soldiers and officers, such as Galić, Milošević, and Šarenac, who testified on this subject, were not located in the city during these incidents and their testimony was based primarily on rumours and intelligence gathered by their units. As such, it is of limited value.

4519. Finally, it is clear from the evidence above that, with the exception of a few individuals, most of the international witnesses present on the ground never received any conclusive proof that the Bosnian Muslim side was sniping or shelling its own civilians. Had there been a large scale conspiracy of the kind alleged by the Accused, there is no doubt that those witnesses would have been informed of or would have reported on such incidents with much greater frequency. They would have also observed some of those incidents first-hand. Thus, for all these reasons, the Chamber rejects the Accused's argument that the Bosnian Muslim side was responsible for all major incidents in the city or was, as part of a general policy, sniping and shelling its own civilians throughout the conflict in Sarajevo. While such incidents may have taken place on a few occasions, this did not occur frequently enough to throw doubt on the other findings made in this Judgement relating to the conflict in Sarajevo.

\section{e. Hospitals in Sarajevo}

4520. The Prosecution alleges that as part of the sniping and shelling campaign against civilians in Sarajevo, the "Serb forces" repeatedly targeted ambulances and hospitals, killing and injuring

One example is the evidence of KW586 who blamed ABiH for the first Markale market incident and whose evidence was rejected, by majority.

15131 See fn. 15097. The same is the case with respect to the other UN reports tendered into evidence in this case: the vast majority of those contain no reports of the Bosnian Muslim side targeting its own civilians.

15132 Much of Gray's evidence focused on the ABiH targeting UN personnel, including himself. The Chamber also notes that the shelling incident near the PTT building Gray used as an example of ABiH forces targeting their own civilians was in fact inconclusive as it was not possible to tell where the shell came from. His belief that it was an $\mathrm{ABiH}$ shell was based on the assumption that the youths gathered near the PTT building were specifically targeted which would have been impossible for the SRK to do. However, it is equally possible that these youths were victims of a random shell fired by the SRK. 
members of staff and patients. ${ }^{15133}$ During the trial, the Prosecution called doctors who worked in the State Hospital, ${ }^{15134}$ the Koševo Hospital, ${ }^{15135}$ and the Dobrinja Hospital; they gave evidence about the fate of those hospitals during the war. Additionally, they authenticated various medical records relating to scheduled incidents and provided general information about Sarajevo casualties.

4521. The Accused in contrast argues that the "ABiH abused for military purposes premises of civilian character, such as hospitals" and that the SRK never fired on the Koševo Hospital. ${ }^{15136}$ The Prosecution in turn rejects that claim and argues that it is "misguided" as the hospitals were shelled even when there were no mortars or military targets in their vicinity; further, the Prosecution claims that hospital buildings showed damage which reflects disproportionate attacks by the SRK. ${ }^{15137}$

\section{i. State Hospital}

4522. Bakir Nakaš, a doctor at the State Hospital, a large building complex located in the centre of Sarajevo in the Marin Dvor area, ${ }^{15138}$ testified that the hospital was sniped and shelled from 13 May 1992 onwards, despite its south side being clearly marked with a Red Cross emblem. ${ }^{15139} \mathrm{He}$ estimated that, between 1992 and 1995, the hospital was hit by over 200 projectiles and was subjected to direct shooting, with the worst shelling taking place right after the departure of the JNA from Sarajevo, namely between 13 and 16 May 1992, when it was hit by around 40 shells. ${ }^{15140}$

\footnotetext{
15133 Prosecution Final Brief, paras. 758-759.
}

15134 Prior to 1992, this hospital was known as the Sarajevo Military Hospital and was run by the JNA. Following the JNA's withdrawal from Sarajevo in May 1992, it was referred to as the Sarajevo State Hospital. See P1525 (Witness statement of Bakir Nakaš dated 8 September 2010), paras. 5, 10; Bakir Nakaš, T. 6700 (14 September 2010).

15135 The Koševo Hospital was a civilian medical facility and was also known to as the "University Clinical Centre" Koševo. See P1525 (Witness statement of Bakir Nakaš dated 8 September 2010), para. 81; Adjudicated Facts 96, 97.

15136 Defence Final Brief, paras. 1937, 1955 (then stating, based on the evidence of Galić, that "any decision to fire" on buildings such as the Koševo Hospital would have taken into account the surroundings and the presence of any civilians; in doing so, the Accused implies that fire may have been opened on the Koševo Hospital); Closing Arguments, T. 47979 (2 October 2014).

15137 Prosecution Final Brief, para. 794; Closing Arguments, T. 47720 (30 September 2014).

15138 P1525 (Witness statement of Bakir Nakaš dated 8 September 2010), para. 12; P1529 (Map of Sarajevo marked by Bakir Nakaš); Aernout van Lynden, T. 2392-2394 (19 May 2010), T. 2580-2583 (21 May 2010); P927 (Aerial photograph of Sarajevo marked by Aernout van Lynden); D211 (Panoramic photograph of Sarajevo marked by Aernout van Lynden). The State Hospital comprised four main buildings, the tallest being twelve storey high, as well as an annex and two other buildings. See P1525 (Witness statement of Bakir Nakaš dated 8 September 2010), para. 13

15139 P1525 (Witness statement of Bakir Nakaš dated 8 September 2010), paras. 22-23, 27; P1526 (Photograph of the Sarajevo State Hospital); Bakir Nakaš, T. 6688-6689 (14 September 2010). See also P926 (Witness statement of Aernout van Lynden dated 26 February 2010), para. 35; P954 (SKY news report re Sarajevo, with transcript); Aernout van Lynden, T. 2392 (19 May 2010), T. 2595-2597 (21 May 2010), T. 3057-3059 (31 May 2010); P2068 (Witness statement of Jeremy Bowen dated 10 August 2009), para. 25. See also para. 4031.

15140 P1525 (Witness statement of Bakir Nakaš dated 8 September 2010), paras. 23, 34; Bakir Nakaš, T. 6675, 67196723, 6741, 6750 (14 September 2010); D619 (Photograph of Sarajevo State Hospital marked by Bakir Nakaš). The Accused challenged Nakaš's evidence about the State Hospital being hit by 200 projectiles on the basis that no extensive damage could be seen in a photograph of the hospital shown to Nakaš in court. However, the 
Milan Mandilović, also a doctor at the State Hospital during the war, confirmed that the hospital was shelled with varying levels of intensity by Bosnian Serbs and that it was hit by both infantry and artillery fire. ${ }^{15141}$ As it is situated near the Sniper Alley, the hospital was also subjected to sniper fire which injured both the hospital staff and its patients. ${ }^{15142}$ Almost 85 to $90 \%$ of the fire hit the south side of the State Hospital building which, according to Nakaš, meant that the source of the fire was the VRS-held area of Trebević, Vraca, and Grbavica. ${ }^{15143}$ As a result, the front part of State Hospital, facing south, was not operational throughout 1992 to $1995 .{ }^{15144}$

4523. It was determined, on the basis of the fragments found at the hospital, that the shells originated from various tanks and other types of artillery and mortar pieces. ${ }^{15145}$ Nakaš thought that "the Serbs were intent on destroying the vital parts of the hospital" once the JNA left, since the very first shelling targeted the pillars on the eighth floor, which were key to the building's stability, and also because the operating theatres were often targeted. ${ }^{15146}$

4524. The shelling negatively affected the functioning of the State Hospital. ${ }^{15147}$ Hospital staff and patients were wounded in the hospital on several occasions from September 1992 to mid-1994, and there was a particular incident, sometime in late summer 1994, where two patients in the hospital were injured by sniper fire. ${ }^{15148}$ The rooms above the second floor were abandoned as they

Chamber notes that this photograph was taken in the summer or autumn of 1992, that is, early on in the conflict whereas Nakaš's estimate concerned the whole period of the conflict. See Bakir Nakaš, T. 6749 (14 September 2010); P1525 (Witness statement of Bakir Nakaš dated 8 September 2010), para. 22.

15141 Milan Mandilović, T. 5350, 5390 (16 July 2010); T. 5400, 5405, 5407 (19 July 2010); P1217 (Witness statement of Milan Mandilović dated 24 February 2010), paras. 42-43, 53-58; P1222 (Photograph of the Sarajevo State Hospital).

15142 P1525 (Witness statement of Bakir Nakaš dated 8 September 2010), paras. 27, 29-32, 40. Mandilović did not know if the hospital was deliberately sniped at, but testified that it was repeatedly hit with small-arms fire. See P1217 (Witness statement of Milan Mandilović dated 24 February 2010), para. 47.

15143 P1525 (Witness statement of Bakir Nakaš dated 8 September 2010), paras. 23-25, 33; Bakir Nakaš, T. 66886690 (14 September 2010); P1526 (Photograph of the Sarajevo State Hospital). See also Milan Mandilović, T. 5350-5351 (16 July 2010); P1217 (Witness statement of Milan Mandilović dated 24 February 2010), para. 46. Mandilović thought that the north side of the hospital was hit by Bosnian Serb shells from Poljine. See Milan Mandilović, T. 5388 (16 July 2010), T. 5440 (19 July 2010); P6336 (UNMO report, 2 January 1993), e-court pp. 1-5. See also Adjudicated Fact 3016.

15144 P1525 (Witness statement of Bakir Nakaš dated 8 September 2010), para. 38; Milan Mandilović, T. 5390 (16 July 2010); P1217 (Witness statement of Milan Mandilović dated 24 February 2010), para. 53.

15145 P1525 (Witness statement of Bakir Nakaš dated 8 September 2010), para. 26.

15146 P1525 (Witness statement of Bakir Nakaš dated 8 September 2010), para. 48; Bakir Nakaš, T. 6690-6691 (14 September 2010). See also Adjudicated Fact 2884. Mandilović believed that the reason for shelling the hospital was to destabilise the city and affect the morale of the people. See Milan Mandilović, T. 5383 (16 July 2010).

15147 P1525 (Witness statement of Bakir Nakaš dated 8 September 2010), para. 41.

15148 P1217 (Witness statement of Milan Mandilović dated 24 February 2010), paras. 48, 50. See also P2068 (Witness statement of Jeremy Bowen dated 10 August 2009), para. 25; Adjudicated Fact 2883. On one occasion Mandilović was on the floor that was hit by a shell, only 10 metres away from the room that was destroyed. See P1217 (Witness statement of Milan Mandilović dated 24 February 2010), para. 43. 
were more exposed, and the only operating theatre used regularly was located in the basement. ${ }^{15149}$ The intensive care unit was in the gym and the rest of the patients were located in the corridor. ${ }^{15150}$ The medical staff could not respond to emergencies properly as only the most vital parts of the State Hospital were provided with electricity and there was lack of medical supplies, food, and water. ${ }^{15151}$ The most difficult period was from late July to the beginning of September 1993, when the State Hospital had no water, electricity, or gas. ${ }^{15152}$ The number of staff was greatly reduced and the only way the hospital could cope with the high demand for medical services was by only admitting patients with life-threatening conditions and injuries. ${ }^{15153}$ Because the higher floors of the State Hospital provided a good position for filming, international TV crews occupied some of them, including Sky News war correspondent Van Lynden. ${ }^{15154}$

\section{ii. Koševo Hospital}

4525. Koševo Hospital is a large compound containing 36 clinics, located just south of Breka, in the northeastern part of Sarajevo. ${ }^{15155}$ Fatima Zaimović, who was the head of nursing at the Children's Surgery ward at the Koševo Hospital, ${ }^{15156}$ testified that the main entrance of the hospital was on Bolnička street, close to her ward. ${ }^{15157}$ This ward dealt with children up to 14 years of age, but would also occasionally assist with the intake of civilian adults. ${ }^{15158}$

4526. As was the case with the State Hospital, the number of the medical staff in Koševo Hospital was greatly reduced during the war and the hospital itself was often shelled, resulting in death of and injuries to both staff and patients. ${ }^{15159}$ As a result, neither the staff nor the patients felt

15149 P1525 (Witness statement of Bakir Nakaš dated 8 September 2010), paras. 35-37. See also P2068 (Witness statement of Jeremy Bowen dated 10 August 2009), para. 25; P6336 (UNMO report, 2 January 1993), e-court pp. 1-5.

15150 P1525 (Witness statement of Bakir Nakaš dated 8 September 2010), para. 37; P2068 (Witness statement of Jeremy Bowen dated 10 August 2009), para. 25.

15151 P1525 (Witness statement of Bakir Nakaš dated 8 September 2010), paras. 37, 43-44; Milan Mandilović, T. 5356-5357 (16 July 2010); P1217 (Witness statement of Milan Mandilović dated 24 February 2010), paras. 34 35. See also Adjudicated Fact 3093.

15152 P1525 (Witness statement of Bakir Nakaš dated 8 September 2010), para. 42.

15153 P1525 (Witness statement of Bakir Nakaš dated 8 September 2010), para. 46.

15154 Bakir Nakaš, T. 6725-6726 (14 September 2010); D620 (Article from Dani magazine entitled "Sarajevo General Hospital-Hospital in the Line of Fire", 5 April 2002), p. 3; P926 (Witness statement of Aernout van Lynden dated 26 February 2010), paras. 31-32, 34, 42; Aernout van Lynden, T. 2389-2391 (19 May 2010).

15155 Fatima Zaimović, T. 1868 (5 May 2010); P816 (Map of Sarajevo); P817 (Aerial photograph of Koševo Hospital marked by Fatima Zaimović); P1525 (Witness statement of Bakir Nakaš dated 8 September 2010), para. 81; P1529 (Map of Sarajevo marked by Bakir Nakaš).

15156 P814 (Witness statement of Fatima Zaimović dated 26 February 2010), para. 1.

15157 Fatima Zaimović, T. 1869-1871 (5 May 2010); P817 (Aerial photograph of Koševo Hospital marked by Fatima Zaimović).

15158 P814 (Witness statement of Fatima Zaimović dated 26 February 2010), paras. 6-7.

15159 P814 (Witness statement of Fatima Zaimović dated 26 February 2010), paras. 2-4, 11-14, 31; Fatima Zaimović, T. 1888, 1894-1896 (5 May 2010); Thomas Knustad, P123 (Transcript from Prosecutor v. D. Milošević), T. 
safe. ${ }^{15160}$ In addition, during the conflict, Koševo Hospital lacked necessary medical and surgical supplies; there was often no electricity, and very little water. ${ }^{15161}$ All this made work conditions, and in particular the operating conditions, extremely difficult. ${ }^{15162}$ When Koševo Hospital was shelled or sniped, the children would be taken down to the basement while those who were bedridden, would be kept in the corridors and the nursing staff would stay with them. ${ }^{15163}$ Zaimović testified that in such times, the children would panic, start screaming, and rush to the nurses for protection. ${ }^{15164}$ Many of these children were so traumatised they withdrew into themselves and started wetting their beds. ${ }^{15165}$ Zaimović herself had a serious stress-related heart attack at the end of $1995 .^{15166}$

4527. Van Lynden and his TV crew set up a satellite dish in one of the hospital buildings and worked from there from June to August of 1992; he testified that hospital buildings within the Koševo Hospital complex were damaged by the shelling. ${ }^{15167}$

\section{iii. Dobrinja Hospital}

4528. As stated earlier, Youssef Hajir is a doctor who, based on the needs in the beginning of May 1992, established a medical clinic that eventually became Dobrinja Hospital and worked there during the conflict. ${ }^{15168}$ While this hospital was also referred to as a military or war hospital in some documents, the name arose because the Civilian Protection and Ismet Hadžić, who later

1993. See also P1258 (Witness statement of Hussein Ali Abdel-Razek dated 16 July 2002), e-court pp. 16, 20 (testifying that it was obvious to him that the hospital was not randomly shelled but specifically targeted by professional units); Hussein Abdel-Razek, T. 5637-5638 (21 July 2010); P1558 (Witness statement of Francis Roy Thomas dated 13 May 2009), para. 95; P1572 (UNMO report, 30 November-1 December 1993) (reporting that Koševo Hospital was shelled during the night, resulting in two deaths); P1576 (UNMO report, 13-14 December 1993); P1429 (UNMO report for December 1992), p. 3; P1584 (UNMO report, 3-4 January 1994); P1275 (UNPROFOR protest letter to Radovan Karadžić, 31 January 1993) (informing the Accused that Koševo Hospital was shelled resulting in injuries to patients and staff); Adjudicated Fact 3018.

15160 P814 (Witness statement of Fatima Zaimović dated 26 February 2010), paras. 33-39.

15161 P814 (Witness statement of Fatima Zaimović dated 26 February 2010), paras. 20-22.

15162 P814 (Witness statement of Fatima Zaimović dated 26 February 2010), para. 23.

15163 P814 (Witness statement of Fatima Zaimović dated 26 February 2010), paras. 27, 32; Fatima Zaimović, T. 1886-1887 (5 May 2010).

15164 P814 (Witness statement of Fatima Zaimović dated 26 February 2010), para. 33.

15165 P814 (Witness statement of Fatima Zaimović dated 26 February 2010), paras. 34-37, 41; Fatima Zaimović, T. 1886-1888 (5 May 2010).

15166 P814 (Witness statement of Fatima Zaimović dated 26 February 2010), para. 46.

15167 P926 (Witness statement of Aernout van Lynden dated 26 February 2010), paras. 38-39.

15168 Hajir explained that around 5 May 1992 he created an improvised emergency room in a storeroom, which is still a part of the Dobrinja Hospital today. This slowly expanded into a "low level hospital", which became fully operational and staffed by 17 July 1992, since by that time Mojmilo came under the control of the ABiH and Hajir was able to source supplies from the city centre. See P1866 (Witness statement of Youssef Hajir dated 25 February 2010), paras. 1-2, 25-33; Youssef Hajir, T. 8786-8787, 8808 (1 November 2010); P1870 (Excerpts from Youssef Hajir's book entitled "Dobrinja Hospital"). 
became the Commander of the $155^{\text {th }}$ Brigade of the $\mathrm{ABiH}$, decided to use that name. ${ }^{15169}$ However, this was done against Hajir's will and eventually, in 1993, at Hajir's insistence, the hospital was registered with the Ministry of Health and named the "General Hospital of Dobrinja". ${ }^{15170}$

4529. Dobrinja Hospital was located in the Dobrinja 2 apartment block, on the ground floor of an eight storey building, and was marked by a Red Cross sign above its door. ${ }^{15171}$ The medical staff in the hospital was often targeted by sniper fire when coming to and from work, leaving many killed and injured. ${ }^{15172}$ Furthermore, the few ambulances the hospital had, which were also marked with the Red Cross sign, were also targeted by sniper fire, leaving two drivers injured and one killed. ${ }^{15173}$ The hospital building itself was hit by heavy artillery shells on at least 15 occasions and "countless times by smaller projectiles". 15174

4530. Initially, Hajir was the only surgeon in the hospital and he would operate day and night in improvised conditions with any tools he could find; later on, additional surgeons and doctors arrived as well as better supplies. ${ }^{15175}$

\section{iv. Military targets in and around hospitals}

4531. A number of SRK officers and soldiers called to give evidence by the Accused testified that their positions and units were often targeted by both mortar and sniper fire from civilian premises within Sarajevo, including the city's hospitals. ${ }^{15176}$ Blaško Rašević of the $1^{\text {st }}$ Romanija Infantry

15169 P1866 (Witness statement of Youssef Hajir dated 25 February 2010), para. 31; Youssef Hajir, T. 8819-8823, 8825-8826 (1 November 2010); P1871 (Medical records from Dobrinja Hospital); P1870 (Excerpts from Youssef Hajir's book entitled "Dobrinja Hospital”).

15170 P1866 (Witness statement of Youssef Hajir dated 25 February 2010), para. 31; Youssef Hajir, T. 8819-8823, 8825-8826 (1 November 2010); P1871 (Medical records from Dobrinja Hospital); P1870 (Excerpts from Youssef Hajir's book entitled "Dobrinja Hospital"). Hajir conceded that 43 members of his medical staff were members of the $\mathrm{ABiH}$ but explained that, like him they simply worked in the hospital. See Youssef Hajir, T. 8868-8869 (2 November 2010).

15171 Hajir explained that because this was an improvised hospital, the red cross sign was placed above the door only some two or three months after the fighting started. See P1866 (Witness statement of Youssef Hajir dated 25 February 2010), para. 46; Youssef Hajir, T. 8781-8783 (1 November 2010); P1867 (Map of Sarajevo marked by Youssef Hajir). See also P1525 (Witness statement of Bakir Nakaš dated 8 September 2010), para. 81; P1529 (Map of Sarajevo marked by Bakir Nakaš).

15172 P1866 (Witness statement of Youssef Hajir dated 25 February 2010), para. 45. The Chamber notes that these killings are not charged in the Indictment.

15173 P1866 (Witness statement of Youssef Hajir dated 25 February 2010), para. 47; Youssef Hajir, T. 8788 (1 November 2010), T. 8867-8870 (2 November 2010); P803 (Sky Newsreport, with transcript). The Chamber notes that these killings are not charged in the Indictment.

15174 P1866 (Witness statement of Youssef Hajir dated 25 February 2010), para. 44.

15175 P1866 (Witness statement of Youssef Hajir dated 25 February 2010), paras. 30, 32.

15176 See e.g. D2658 (Witness statement of Luka Dragičević dated 9 December 2012), para. 29; D2351 (Witness statement of Stevan Veljović dated 19 October 2012), para. 18; D2852 (Witness statement of Srđan Šehovac dated 27 January 2013), para. 14; D2418 (Witness statement of Božo Tomić dated 5 November 2012), para. 19; D2331 (Witness statement of Blagoje Kovačević dated 14 October 2012), para. 44; Blagoje Kovačević, T. 29069-29070 (18 October 2012); D2665 (Witness statement of Izo Golić dated 15 December 2012), paras. 17, 24. 
Brigade, testified that $\mathrm{ABiH}$ maintained a firing position in the Koševo Hospital grounds and would fire from there daily. ${ }^{15177}$ Lučić testified that the $\mathrm{ABiH}$ used recoilless guns at night from the Koševo Hospital grounds. ${ }^{15178}$ Maletić testified that he had information on military targets deep in the territory on the Muslim side, and that these included positions within the perimeter of the State and Koševo Hospitals. ${ }^{15179}$ Dragomir Milošević also testified that the $\mathrm{ABiH}$ had a position at Koševo Hospital ${ }^{15180}$ While Milošević testified that the ABiH used only Koševo Hospital for military purposes, ${ }^{15181}$ Galić claimed that several hospitals were "abused" in order to fire at SRK positions. ${ }^{15182}$ Radojčić stated that his position was frequently targeted from Dobrinja Hospital. ${ }^{15183}$

4532. On the other hand, Nakaš testified that no armed members of the $\mathrm{ABiH}$ were allowed to be inside the State Hospital and that there was not a single military facility in the hospital's vicinity. ${ }^{15184}$ He confirmed, however, that towards the end of 1992, two buildings in the State Hospital complex were requisitioned by the $1^{\text {st }}$ Corps of the $\mathrm{ABiH}$ and used purely as a rehabilitation centre for $\mathrm{ABiH}$ soldiers. ${ }^{15185}$ Mandilović also testified that the State Hospital did not have any military positions or combatant personnel located within its premises at any time during the war. ${ }^{15186}$ Van Lynden explained that he and his crew made sure that the hospital was not being used by the military as they did not want to have their base on or near a military target. ${ }^{15187}$ In the months he was there he never saw the hospital building or its immediate surroundings being used by $\mathrm{ABiH}$ forces. ${ }^{15188}$ The Chamber notes that an $\mathrm{ABiH}$ report from January 1993 indicates that HOS units were located in Avde Jabučice street near the hospital premises. ${ }^{15189}$

\footnotetext{
15177 D2527 (Witness statement of Blaško Rašević dated 1 December 2012), para. 23; Blaško Rašević, T. 3091530916 (4 December 2012).

15178 D2516 (Witness statement of Vlade Lučić dated 5 November 2012), para. 14.

15179 D2519 (Witness statement of Dragan Maletić dated 9 November 2012), para. 28. See also D2622 (Witness statement of Željko Bambarez dated 9 December 2012), para. 18.

15180 Dragomir Milošević, T. 32581-32582 (23 January 2013), T. 33136-33138 (4 February 2013).

15181 Dragomir Milošević, T. 32581 (23 January 2013).

15182 Stanislav Galić, T. 37419-37421 (18 April 2013); D3429 (SRK combat report, 4 September 1993$)$, p. 1.

15183 D2562 (Witness statement of Vladimir Radojčić dated 8 December 2012), para. 21.

15184 P1525 (Witness statement of Bakir Nakaš dated 8 September 2010), paras. 14-15; Bakir Nakaš, T. 6743 (14 September 2010).

15185 P1525 (Witness statement of Bakir Nakaš dated 8 September 2010), para. 14; Bakir Nakaš, T. 6698-6701 (14 September 2010); D615 (Map of Sarajevo marked by Bakir Nakaš). Nakaš also testified that there was a police administration building in the Marin Dvor area, near the St. Joseph Church. See Bakir Nakaš, T. 6709 (14 September 2010); D616 (Map of Sarajevo marked by Bakir Nakaš).

15186 P1217 (Witness statement of Milan Mandilović dated 24 February 2010), paras. 37, 39-40. See also Adjudicated Fact 3017.

15187 P926 (Witness statement of Aernout van Lynden dated 26 February 2010), para. 33; Aernout van Lynden, T. 2391 (19 May 2010).

15188 P926 (Witness statement of Aernout van Lynden dated 26 February 2010), para. 33; Aernout van Lynden, T. 2591-2592 (21 May 2010).

15189 Bakir Nakaš, T. 67186719 (14 September 2010); D618 ( $7^{\text {th }}$ Mountain Brigade report re ABiH positions, 28 January 1993); D617 (Map of Sarajevo). See also D622 (ABiH Supreme Command Staff Bulletin, 24 October
} 
4533. As far as the Dobrinja Hospital is concerned, the ABiH command building was some 150 to 200 metres west from the hospital and, according to, there were no ABiH organised military units or barracks in the area around the hospital. ${ }^{15190}$

4534. With respect to the Koševo Hospital, Zaimović claimed that she never saw any ABiH positions, weapons, or $\mathrm{ABiH}$ activities close to the complex. ${ }^{15191}$ In addition, according to her, there was no military equipment in the hospital itself. ${ }^{15192}$ Abdel-Razek also testified that the "main hospital" of Sarajevo contained no military value. ${ }^{15193}$ Van Lynden never saw any artillery within the Koševo complex nor did he hear that the hospital was being used "for artillery purposes", although he did see one $82 \mathrm{~mm}$ mortar next to the hospital in July 1992. ${ }^{15194}$

4535. A number of international witnesses confirmed, however, that $\mathrm{ABiH}$ would position its forces and/or fire at the SRK from Koševo Hospital, using mobile mortars, in order to provoke retaliatory fire. ${ }^{15195}$ Richard Gray's military observers witnessed ABiH forces firing from mortars mounted on the back of trucks from the Koševo Hospital car-park, while he personally witnessed $\mathrm{ABiH}$ armoured vehicles located in the vicinity of Koševo Hospital. ${ }^{15196}$ Rose testified that ABiH "often fired $120 \mathrm{~mm}$ mortars at the Serbs in the Jewish cemetery from the grounds of the Koševo hospital". ${ }^{15197}$ Tucker recalled that on 11 January 1993 UN soldiers delivering fuel to the hospital's boiler witnessed an $82 \mathrm{~mm}$ mortar on the back of a truck being fired from a derelict house on the western side of the Koševo Hospital, some half an hour before a press conference which had been called by the hospital; this was then followed by retaliatory anti-aircraft, artillery, and mortar

1993) (in which it is reported that on 23 October 1992, members of the $10^{\text {th }}$ Mountain Brigade took positions in front of the State Hospital in order to stop UNPROFOR's fuel tanker).

15190 Youssef Hajir, T. 8845-8846, 8848 (2 November 2010). See also para. 3792.

15191 P814 (Witness statement of Fatima Zaimović dated 26 February 2010), para. 29. See also P1558 (Witness statement of Francis Roy Thomas dated 13 May 2009), para. 95.

15192 P814 (Witness statement of Fatima Zaimović dated 26 February 2010), para. 30; Fatima Zaimović, T. 18981910 (5 May 2010).

15193 P1258 (Witness statement of Hussein Ali Abdel-Razek dated 16 July 2002), e-court p. 16; Hussein AbdelRazek, T. 5552-5555 (20 July 2010) (testifying that despite going there very often he never saw any mortars near the Koševo Hospital). Throughout his witness statement Abdel-Razek refers to the "main hospital". Based on the context of his evidence in that statement as well as his oral testimony, the Chamber considers that when referring to the "main hospital" he was referring to the Koševo Hospital complex. See also Adjudicated Fact 95, which provides that Koševo Hospital was one the two main medical facilities in operation in Sarajevo at the time.

15194 P926 (Witness statement of Aernout van Lynden dated 26 February 2010), para. 39.

15195 See e.g. John Hamill, P1994 (Transcript from Prosecutor v. Galić), T. 6207, 6229; Francis Roy Thomas, T. 6842 (15 September 2010); David Fraser, T. 8060 (18 October 2010); John Wilson, T. 3948 (21 June 2010); D99 (UNPROFOR report re ABiH, 21 January 1993).

15196 D2398 (Witness statement of Richard Gray dated 22 April 2012), paras. 11, 16-18; Richard Gray, T. $29992-$ 29993 (8 November 2012).

15197 P1638 (Witness statement of Michael Rose dated 26 March 2009), para. 133. See also D162 (Michael Rose's book entitled "Fighting for Peace: Bosnia, 1994"), p. 172. 
fire. ${ }^{15198}$ Morillon reported this incident to Izetbegović, noting that "this disreputable and cowardly act" was a blatant breach of the Geneva Conventions and urging Izetbegović to take strong measures to stop the reoccurrence of this practice. ${ }^{15199}$ Mole testified that the $\mathrm{ABiH}$ units used mobile mortars around the Koševo Hospital in order to attract Serb fire. ${ }^{15200}$ According to him, the $\mathrm{ABiH}$ would fire one or two rounds and leave immediately; the SRK response would then attempt to target the mortar but it was neither immediate nor accurate enough to do so successfully. ${ }^{15201}$ In addition, there was a "degree of overkill" such that the SRK would respond in a heavily disproportionate manner. ${ }^{15202}$ This indicated to him that the response fire was retaliation rather than a military strategy and it also resulted in the hospital being frequently hit. ${ }^{15203}$ Mirko Šošić, another doctor who worked at the Koševo Hospital until summer 1992, ${ }^{15204}$ testified that, on several occasions, he saw a "cannon" the $\mathrm{ABiH}$ used to fire from the grounds of the Koševo Hospital, which was stored in the underground area below the traumatology clinic. ${ }^{15205}$

4536. Some contemporaneous SRK documents also indicate that Koševo Hospital was used by the ABiH. According to a report of the $1^{\text {st }}$ Romanija Brigade to the SRK Command, dated 1 October 1992, there were two $\mathrm{ABiH}$ intervention platoons positioned in the grounds of Koševo Hospital. ${ }^{15206}$ On 3 September 1993 the same brigade reported to the SRK Command that a TO unit and an intervention platoon were based in the Koševo Hospital grounds. ${ }^{15207}$ Almir Begić testified that his $\mathrm{ABiH}$ unit, consisting of around 50 men, was located in a dentistry clinic some 500 metres from the Koševo Hospital. ${ }^{15208}$ In a combat report of 15 May 1993, the SRK Command reported to the VRS Main Staff that the ABiH opened mortar fire on SRK positions "from the area

\footnotetext{
15198 P4203 (Witness statement of Pyers Tucker dated 12 May 2010), para. 303; Pyers Tucker, T. 23301-23303 (18 January 2012); D2034 (UNPROFOR report, 21 January 1993), e-court p. 5. See also D507 (Video footage of Lord Owen's statement re shelling of Sarajevo hospital).

15199 D2034 (UNPROFOR report, 21 January 1993), e-court p. 6; D351 (UNPROFOR report re protest letter to Alija Izetbegović, 21 January 1993); Hussein Abdel-Razek, T. 5552-5553 (20 July 2010).

15200 P1426 (Witness statement of Richard Mole dated 7 May 2010), paras. 122-124; Richard Mole, T. 5891 (18 August 2010). According to Mole, such incidents, when observed, were reported in the UNMOs daily sitreps. See P1426 (Witness statement of Richard Mole dated 7 May 2010), para. 128.

15201 P1426 (Witness statement of Richard Mole dated 7 May 2010), paras. 125-126.

15202 P1426 (Witness statement of Richard Mole dated 7 May 2010), para. 125; Richard Mole, T. 5891-5893 (18 August 2010).

15203 P1426 (Witness statement of Richard Mole dated 7 May 2010), paras. 125-126.

15204 D3138 (Witness statement of Mirko Šošić dated 17 March 2013), para. 2; Mirko Šošić, T. 35772 (21 March 2013).

15205 D3138 (Witness statement of Mirko Šošić dated 17 March 2013), para. 9; Mirko Šošić, T. 35773-35775 (21 March 2013).

15206 Dragomir Milošević, T. 32582-32584 (23 January 2013); D2795 (1 ${ }^{\text {st }}$ Romanija Brigade report, 1 October 1992), pp. 1-2. See also D2880 (Official note of Ilidža SNB, 16 September 1992), p. 1.

15207 P4498 (Report of $1^{\text {st }}$ Romanija Infantry Brigade, 3 September 1992), p. 2.

15208 P2051 (Supplemental statement of Almir Begić dated 14 December 2010), para. 3; Almir Begić, T. 9982-9985 (16 December 2010); D930 (Map of Velešići marked by Almir Begić). See also Dragomir Milošević, T. 32582 32584 (23 January 2013) (testifying that the SRK identified the dentistry school as a military target); D2795 ( $1^{\text {st }}$ Romanija Brigade report, 1 October 1992), p. 2.
} 
of Koševo hospital". ${ }^{15209}$ On 28 July 1993, the SRK Command reported to the VRS Main Staff that the $\mathrm{ABiH}$ fired $82 \mathrm{~mm}$ mortar shells from the Koševo Hospital at the SRK positions. ${ }^{15210}$ The Chamber also received an $\mathrm{ABiH}$ order of 11 June 1995, which states that the forward command post of the $105^{\text {th }}$ Brigade of the $1^{\text {st }}$ Corps of the $\mathrm{ABiH}$ was located in the "Koševo hospital sector (building under construction)". ${ }^{15211}$

4537. Some of the SRK soldiers and officers then testified that their units did not return fire on the city hospitals at all, despite being fired on from there. Dušan Šrkba stated that his brigade, namely the $1^{\text {st }}$ Sarajevo Mechanised Brigade, never opened fire on the State and Koševo Hospitals or the area around them as they were afraid of inflicting major civilian casualties. ${ }^{15212}$ Izo Golić, a mortar platoon commander in the Rogatica Battalion of the $1^{\text {st }}$ Romanija Brigade, testified that his unit's positions were fired upon from the Koševo Hospital some 10 to 15 times during 1992 but that they were never ordered to return fire on the hospital complex. ${ }^{15213}$ However, earlier in his statement he also said that the Koševo Hospital complex was one of the targets at which his unit opened fire in case of large concentration of $\mathrm{ABiH}$ forces or in case the $\mathrm{ABiH}$ forces fired first. ${ }^{15214}$ Similarly, Veljović testified that his unit was not allowed to fire at certain targets in the depth of the territory, such as "the hospital", even though they knew there were military targets there. ${ }^{15215}$

4538. On the other hand, Mirko Šošić testified that SRK shells fell on Koševo Hospital on a number of occasions but that this was a result of the $\mathrm{ABiH}$ forces opening artillery fire from within its grounds. ${ }^{15216}$ Dragomir Milošević first claimed that the SRK never fired on the Koševo Hospital but then proceeded to explain that if fire was opened from certain locations, such as the hospital, it would be returned, although not before the SRK units assessed the target and the presence of civilians at that location. ${ }^{15217}$ Blagoje Kovačević admitted that a response would be forthcoming when fire was opened from schools and hospitals. ${ }^{15218}$

\footnotetext{
15209 D3411 (SRK combat report, 15 May 1993), p. 1.

15210 D2798 (SRK combat report, July 1993), p. 1.

15211 D2792 (Order of ABiH 12 ${ }^{\text {th }}$ Division, 11 June 1995), para. 5.5.

15212 Dušan Škrba, T. 29122-29123 (18 October 2012), T. 29131-29132 (22 October 2012).

15213 D2665 (Witness statement of Izo Golić dated 15 December 2012), paras. 13, 24 (while Golić never explicitly said which brigade his battalion belonged to while in Sarajevo the Chamber notes that the battalion's positions Golić described in paragraph 13 of his statement were part of the positions held by the $1^{\text {st }}$ Romanija Brigade).

15214 D2665 (Witness statement of Izo Golić dated 15 December 2012), para. 17.

15215 Stevan Veljović, T. 29282 (23 October 2012).

15216 D3138 (Witness statement of Mirko Šošić dated 17 March 2013), para. 12.

15217 Dragomir Milošević, T. 33136-33138 (4 February 2013).

15218 Blagoje Kovačević, T. 29069-29070 (18 October 2012).
} 


\section{v. Protests regarding fire on hospitals}

4539. Abdel-Razek testified that on one occasion, after Koševo Hospital was shelled, ${ }^{15219}$ he raised the issue with Galić who responded, as he always did in relation to any civilian target, by saying that the Bosnian Muslims shelled the hospital in order to gain sympathy from the international community. ${ }^{15220}$ Abdel-Razek was convinced, however, that the shells came from the hills held by the SRK. ${ }^{15221}$

4540. Abdel-Razek and Tucker were also present during meetings on 18 and 19 December 1992 between Lord Owen on one side and the Accused, Mladić, and Koljević on the other wherein Owen protested about the shelling of the Koševo Hospital and told the attendees that he had visited the hospital and that the situation was a "disgrace" and "very very depressing". ${ }^{15222}$ At one stage during these meetings Owen became angry and told Mladić that the shelling of Sarajevo was a disgrace and that it had to stop; Mladić became angry and ended up shouting at Owen. ${ }^{15223}$

4541. The Chamber also heard that during the SerBiH Assembly session of 12 May 1992, Mladić stated that the Muslims would not be allowed to benefit from the State or Koševo Hospitals until they accepted peace. ${ }^{15224}$

\section{vi. Conclusion}

4542. Having considered the evidence and the adjudicated facts outlined above, the Chamber finds that, just like the rest of the city, the hospitals in Sarajevo were subjected to shelling and sniping by the SRK. This in turn affected their capacity to provide adequate medical care to their patients. In this respect, the Chamber accepts the evidence of the doctors who testified about the difficulties they faced while working in those hospitals and the dangers they, and other medical staff, exposed themselves to on a daily basis, in order to provide medical care to the citizens of Sarajevo. The Chamber also accepts their evidence regarding the frequent shelling and sniping their respective

\footnotetext{
15219 Abdel-Razek referred to the "main hospital" when discussing this incident. See P1258 (Witness statement of Hussein Ali Abdel-Razek dated 16 July 2002), e-court p. 16. As noted earlier, the Chamber considers this to have been the Koševo Hospital complex.

15220 P1258 (Witness statement of Hussein Ali Abdel-Razek dated 16 July 2002), e-court pp. 16, 21. According to Abdel-Razek, this was Galić's usual response, namely to deny that the Serb side conducted the shelling and to accuse the Bosnian Muslim side of it. If or when challenged on this by Abdel-Razek he would acknowledge that the Serbs conducted the shelling but then argue that they had been provoked. See P1258 (Witness statement of Hussein Ali Abdel-Razek dated 16 July 2002), e-court p. 21.

15221 P1258 (Witness statement of Hussein Ali Abdel-Razek dated 16 July 2002), e-court p. 16.

15222 Hussein Abdel-Razek, T. 5504-5505 (19 July 2010), T. 5545-5547 (20 July 2010); P1273 (Video footage of meeting between Lord Owen and Radovan Karadžić, with transcript); P4203 (Witness statement of Pyers Tucker dated 12 May 2010), paras. 92-98; P1996 (Witness statement of Martin Bell dated 8 March 2010), para. 82; P2034 (BBC news report re meeting between Lord Owen and Radovan Karadžić in Pale, with transcript).

15223 P4203 (Witness statement of Pyers Tucker dated 12 May 2010), paras. 95, 98

15224 P956 (Transcript of $16^{\text {th }}$ session of SerBiH Assembly, 12 May 1992), e-court p. 38.
} 
hospital buildings were subjected to. While Dušan Škrba claimed that the $1^{\text {st }}$ Sarajevo Mechanised Brigade never fired on the hospitals, this is clearly contrary to the evidence before the Chamber, namely that the State Hospital was shelled from the south of the city. While it is possible that Škrba's and Veljović's specific units did not open fire on these hospitals, there is no doubt that other SRK units did. Indeed, this was confirmed by Blagoje Kovačević, Šošić, and even Dragomir Milošević. Similarly, while Golić stated that in 1992 his unit never returned fire when fired upon from the Koševo Hospital complex, in doing so he contradicted his earlier statement wherein he accepted that his platoon would open fire on the Koševo complex if fired upon from there.

4543. As noted above, the Accused claims that hospitals were abused by the ABiH for military purposes. However, the majority of the evidence supporting this claim concerned the Koševo Hospital complex and not the State or Dobrinja Hospitals. While military units may have occasionally been located in the vicinity of the State and Dobrinja Hospitals, the Chamber is nevertheless convinced that those hospitals were civilian objects and were not used for military purposes by the ABiH. Furthermore, if the aim of the SRK forces was to target military units in the vicinity of the State and Dobrinja Hospitals, the frequent shelling and the extensive damage caused to those hospitals- particularly to the State Hospital-indicate that they were either deliberately targeted by the SRK forces or, at the very least, hit as a result of an indiscriminate fire onto the city by the SRK. ${ }^{15225}$

4544. In light of the evidence and the adjudicated facts outlined above, the Chamber is also satisfied that the SRK forces deliberately opened fire on the Koševo Hospital. At the same time, it is clear that there were occasions when the $\mathrm{ABiH}$ units used the grounds of Koševo Hospital to fire at SRK positions, usually with mobile mortars. In such cases, the SRK response fire was counterfire aimed at $\mathrm{ABiH}$ military targets. However, the Chamber also finds, in light of Mole's evidence above, as well as the general evidence about the nature of the SRK shelling in Sarajevo, ${ }^{1526}$ that the SRK response to such mobile mortars was often disproportionate and indiscriminate, targeting the hospital complex as a whole in a retaliatory manner, rather than neutralising the specific mobile mortar that opened fire. Furthermore, while parts of the Koševo Hospital complex may have become a military target whenever the $\mathrm{ABiH}$ opened fire from them, the SRK units returned fire without issuing an adequate warning as they were required to do by Geneva Convention IV and Additional Protocols I and II. ${ }^{15227}$

\footnotetext{
15225 See Adjudicated Fact 3019 which provides that SRK intentionally targeted the State Hospital.

15226 See paras. 3984-3986.

15227 See Galić Appeal Judgement, paras. 341-346.
} 


\section{f. Siege of Sarajevo}

\section{i. Blockade/Encirclement/Siege}

4545. The Prosecution alleges that, starting from early April 1992, the city of Sarajevo was subjected to "blockade". ${ }^{15228}$ It further argues that the campaign of shelling and sniping in Sarajevo furthered the blockade and refers to the city as being "besieged". ${ }^{1522}$ The Accused argues that Sarajevo was not under "siege"; instead the SRK practiced a "containment strategy"-directed at the $\mathrm{ABiH}$ forces in the city-and tried to maintain the status quo rather than alter the positions at the Sarajevo frontlines. ${ }^{15230} \mathrm{He}$ also claims that the Bosnian Muslim authorities in Sarajevo conducted an "internal siege" by preventing the population from leaving the city. ${ }^{15231}$

4546. Many of the Prosecution witnesses and some witnesses called by the Accused testified that during the Indictment period, Sarajevo was a city kept under "siege" by the Bosnian Serbs and/or that it was "encircled" by them. ${ }^{15232}$ Okun stated that the situation in Sarajevo was "obviously a siege" because "Serb forces surrounded the city" and the only way in or out of Sarajevo was "through Serb lines with Serb permission". ${ }^{15233}$ Bell thought that the situation in Sarajevo was one of "total siege". 15234 There were "very few" places within Sarajevo that were "entirely safe" and the civilian population suffered shortages of food, water, gas, and electricity. ${ }^{15235}$ Doyle stated that in April 1992, Sarajevo was "practically a city under siege" by the Bosnian Serbs and was "in

\footnotetext{
15228 Indictment, para. 78.

15229 Prosecution Final Brief, paras. 6, 609.

15230 Hearing, T. 13161 (10 March 2011) (explaining that what happened in Sarajevo was not a siege as ABiH units were able to move in and out of the city through the tunnel under the airport), T. 10242 (14 January 2011) (arguing that the objective of the Bosnian Serbs was to contain the $\mathrm{ABiH}$ forces in the city); Defence Final Brief, para. 1821-1836.

15231 Hearing, T. 10242 (14 January 2011).

15232 See e.g. P2451 (Witness statement of Anthony Banbury dated 19 May 2009), paras. 197-198 (adding that the siege changed the character and demographics of the city by driving out middle-class and moderate Sarajevans who believed in a multi-ethnic BiH); KDZ185, T. 4174-4175 (28 June 2010) (private session) (testifying that by 1993 the city was already besieged by the Bosnian Serbs for about eight months); KDZ240, T. 16122 (5 July 2011) (closed session); P1525 (Witness statement of Bakir Nakaš dated 8 September 2010), paras. 49-51; Alma Mulaosmanović-Čehajić, P1551 (Transcript from Prosecutor v. D. Milošević), T. 1673; Alma MulaosmanovićČehajić, T. 6756 (14 September 2010); Mirsad Kučanin, P17 (Transcript from Prosecutor v. S. Milošević), T. 28943; David Harland, T. 2103-2104 (7 May 2010); Radomir Kezunović, T. 13915-13916, 13982 (31 May 2011) (testifying that Sarajevo was the "epitome of a surrounded city"); KW570, T. 32208-32209, 32226 (18 January 2013) (private session); KW570, T. 32216 (18 January 2013); D2270 (Witness statement of Andrey Demurenko dated 13 October 2012), para. 30.

15233 Herbert Okun, P776 (Transcript from Prosecutor v. Krajišnik), T. 4204 (adding also that, while Bosnian Muslims did build a tunnel under the airport, the city was in fact "besieged"); Herbert Okun, T. 1782 (28 April 2010).

15234 P1996 (Witness statement of Martin Bell dated 8 March 2010), para, 49 (adding that while occasionally broken by relief flights from the UNHCR, this "didn't make it any less of a siege").

15235 P1996 (Witness statement of Martin Bell dated 8 March 2010), paras, 35-36, 49 (adding that civilians also resorted to cutting down trees for fuel and scooping water out of the river). See also P2068 (Witness statement of Jeremy Bowen dated 10 August 2009), paras. $18-19,25,41$ (adding that the Sarajevo citizens were also
} 
turmoil" as there was shelling "from the outside" and "freedom of movement was denied". ${ }^{15236}$ When Tucker arrived in Sarajevo in October 1992, he found a city surrounded by hostile forces who prevented the entry of food supplies into the city and cut water, electricity, and gas supplies. ${ }^{15237}$ Fraser testified that Bosnian Serbs were "definitely in control of all the movement and the situation inside the city" as they used all means at their disposal, particularly sniping and shelling, to control freedom of movement and the psyche of the population. ${ }^{15238}$ Rose recalled that upon his arrival in Sarajevo in January 1994, the whole city had been reduced to a state of siege as there were "no lights, no water, no electricity, no trams", and the city was in "an almost medieval state". ${ }^{15239}$ In addition, the Bosnian Serbs frequently interrupted the flow of UN aid into Sarajevo, with the intention of creating a "situation of siege". 15240 Thomas described Sarajevo as a "besieged city". ${ }^{15241}$ KDZ182 testified that when he arrived in Sarajevo in 1994 he saw a "total blockade" of the city with the Bosnian Serbs manning the surrounding hills, preventing anyone from moving around-according to him, it was "impossible" for Sarajevo to function normally because it was "circled" and therefore difficult to supply. ${ }^{15242}$ Bowen testified that the siege of Sarajevo had an "enormous effect" on the civilian population in the city, depriving them of security and effectively imprisoning them. ${ }^{15243}$ When asked on cross-examination whether both sides semi-encircled each other in Sarajevo, Van Lynden was adamant that the city was not semi-encircled, but fully encircled

denied lack of adequate medical care); P926 (Witness statement of Aernout van Lynden dated 26 February 2010), paras. 27-28; KDZ185, T. 4175 (28 June 2010) (private session).

15236 Colm Doyle, T. 2719-2720, 2736-2737 (26 May 2010), T. 2863, 2866 (27 May 2010), T. $2916-2918$ (28 May 2010); D235 (Directive 3, 3 August 1992), p. 5. According to Doyle, there would have been no need for a tunnel under the Sarajevo airport to move supplies and evacuate people if the city was not under siege. When put to him that at the London Conference Bosnian Serbs imposed restrictions around Sarajevo exclusively for military purposes, Doyle responded that this was not his experience. See Colm Doyle, T. 2866-2867 (27 May 2010).

15237 P4203 (Witness statement of Pyers Tucker dated 12 May 2010), paras. 21, 49, 116; Pyers Tucker, T. 23291 (18 January 2012). Tucker also described how in January and February 1993, hundreds of people tried to escape Sarajevo by crossing the airport at which point they would be shot and wounded or killed-to him, this was "one of the greater tragedies in Sarajevo". See P4203 (Witness statement of Pyers Tucker dated 12 May 2010), paras. $117,121$.

15238 P1762 (Witness statement of David Fraser dated 17 October 2010), p. 5. See also P2068 (Witness statement of Jeremy Bowen dated 10 August 2009), paras. 20, 23 (testifying that Bosnian Serbs decided who came in and who went out of the city).

15239 P1638 (Witness statement of Michael Rose dated 26 March 2009), para. 22. See also P733 (Witness statement of Sulejman Crnčalo dated 1 November 2009), paras. 82-84.

15240 P1638 (Witness statement of Michael Rose dated 26 March 2009), para. 22. See also P926 (Witness statement of Aernout van Lynden dated 26 February 2010), para. 22.

15241 Francis Roy Thomas, T. 6858 (15 September 2010).

15242 P2414 (Witness statement of KDZ182), p. 28 (under seal). See also P23 (Witness statement of Mirsad Kučanin dated 12 November 1995), pp. 4-5; Mirsad Kučanin, P17 (Transcript from Prosecutor v. S. Milošević), T. 28937.

15243 P2068 (Witness statement of Jeremy Bowen dated 10 August 2009), paras. 20, 27 (adding that life was also hard in Bosnian Serb-held areas surrounding the city, but noting that the people there at least "had access to decent food and a way out"); Jeremy Bowen, T. 10105 (13 January 2011) (calling the siege a "noose" around the necks of the people"). 
and besieged. ${ }^{15244}$ When the Accused put to KDZ185 that Sarajevo was a divided rather than a besieged city, KDZ185 responded that Sarajevo proper, that is the central city itself and the area near the airport, were in fact surrounded, and as such under siege. ${ }^{15245}$ KW570, a witness called by the Accused, also testified that Sarajevo was, "in reality", under siege, with the Bosnian Serbs dominating the high ground around the city; he considered it a siege even though UN convoys were going in and supplying the people with aid. ${ }^{15246}$ Similarly, Demurenko, also called by the Accused, testified that in terms of human suffering, Sarajevo was a case of "a full siege", even though it was not completely encircled, because all the roads were blocked and there was very little space for manoeuvre. ${ }^{15247}$ Noting that the tunnel under the airport allowed the Bosnian Muslims to move troops and humanitarian aid in and out of Sarajevo, Demurenko viewed the situation in Sarajevo as "a case of siege with [a] certain qualification". ${ }^{15248}$

4547. Contrary to the evidence above, a number of Defence witnesses, mainly former SRK soldiers and officers, claimed that Sarajevo was not besieged and that the term "siege" was created and misused by the biased media. ${ }^{15249}$ For example, Luka Dragičević testified that the "siege of Sarajevo" was a media term that did not accurately describe the situation since SRK positions in Sarajevo were "very disadvantageous", $\mathrm{ABiH}$ units were able to pass through the tunnel under the airport, and the SRK had not cut off utilities and humanitarian aid. ${ }^{15250}$ While acknowledging that the SRK blockaded part of the ABiH forces inside Sarajevo, he noted that the SRK was in turn completely encircled on the outside ring by the $\mathrm{ABiH} .{ }^{15251}$ Similarly, Veljovic disputed the accuracy of what he termed the "prevailing view" at the time, namely that the SRK had "laid siege to Sarajevo" by being positioned on dominant features around the city and constantly firing upon

\footnotetext{
15244 Aernout van Lynden, T. 2464-2465 (19 May 2010).

15245 KDZ185, T. 4366-4367, 4374-4375 (30 June 2010); KDZ185, T. 4387-4388 (30 June 2010) (private session). See also P2407 (Witness statement of KDZ304), p. 10; KDZ304, T. 10489-10491 (18 January 2011).

15246 KW570, T. 32208-32209, 32216, 32226 (18 January 2013) (private session) (adding that the Bosnian Muslim government was unable to break the siege using its own forces, and so it "clearly wished" for the siege to be broken through western intervention).

15247 D2270 (Witness statement of Andrey Demurenko dated 13 October 2012), para. 30 (stating that the VRS encircled about $90 \%$ of the city and that the situation in Sarajevo was akin to the siege of Leningrad in World War II).

15248 D2270 (Witness statement of Andrey Demurenko dated 13 October 2012), para. 30.

15249 See e.g. D2667 (Witness statement of Ratomir Maksimović dated 14 December 2012), paras. 8, 67 (stating that the media coverage of the situation was uneven); D2516 (Witness statement of Vlade Lučić dated 5 November 2012), para. 34 (adding that media reports were biased and malicious); D2387 (Witness statement of Stojan Džino dated 4 November 2012), para. 73. In addition, Bell testified that the pattern of the siege, that of $\mathrm{ABiH}$ forces attacking outward with small arms and infantry and SRK responding with heavier weapons, gave the world the impression that Sarajevo was subjected to constant and unprovoked bombardment by the Serb side, when the war was in fact being waged by both sides. See P1996 (Witness statement of Martin Bell dated 8 March 2010), para. 57.

15250 D2658 (Witness statement of Luka Dragičević dated 9 December 2012), para. 41.

15251 D2658 (Witness statement of Luka Dragičević dated 9 December 2012), para. 41. For the evidence on the socalled inside and outside rings of Sarajevo, see para. 3557.
} 
anyone within it. ${ }^{15252}$ Instead, he claimed that it was the $\mathrm{ABiH}$ forces that in fact held a number of elevations in and around Sarajevo, all of which were dominant in relation to SRK positions and from which the $\mathrm{ABiH}$ forces opened mortar and sniper fire. ${ }^{15253}$ Simić also testified about SRK being at a disadvantage because it was "surrounded doubly, internally and externally" by the $\mathrm{ABiH},{ }^{15254}$ while Ratomir Maksimović claimed that the SRK was in an "unfavourable operational position" because it was twice surrounded by a "ring" of the $\mathrm{ABiH}$ units inside Sarajevo and outside Sarajevo. ${ }^{15255}$ Dragomir Milošević noted that the "encirclement" of Sarajevo by SRK forces was "not complete" because there was a way out of Sarajevo between Butmir and Donji Kotorac (a distance of about one kilometre) where no SRK forces were present. ${ }^{15256}$ Zurovac denied that the SRK had a policy of "containment" of Sarajevo or that the objective of his battalion was to keep Sarajevo "under siege". ${ }^{15257}$ He claimed that the city was closed from the inside by "criminals" who became high-ranking officers in the ABiH. ${ }^{15258}$ However, he then acknowledged that $\mathrm{ABiH}$ units would fire out of Sarajevo in order to break out of the "siege". ${ }^{15259}$ Milosav Gagović also testified that Sarajevo was under "blockade" from the inside, not from the outside, because the Bosnian Muslim authorities would not allow people to leave the city. ${ }^{15260}$

4548. With respect to the Accused's argument that it was the Bosnian Muslim authorities that in fact prevented the population from leaving the city, KDZ450 indeed confirmed that the civilians were "held hostage" in Sarajevo by their own leaders who were using a strategy of "victimisation"; however, he thought that the population was also "obviously" held hostage by the Bosnian Serbs. ${ }^{15261}$ Similarly, while conceding that $\mathrm{ABiH}$ forces were preventing people from leaving

15252 D2351 (Witness statement of Stevan Veljović dated 19 October 2012), para. 27.

15253 D2351 (Witness statement of Stevan Veljović dated 19 October 2012), para. 27. See also D2667 (Witness statement of Ratomir Maksimović dated 14 December 2012), para. 16.

15254 D2412 (Witness statement of Savo Simić dated 4 November 2012), para. 14. When cross-examined on this issue, Simić conceded that "Muslim forces" were also "encircled" but noted that Sarajevo "had an exit in a certain sense". See Savo Simić, T. 30026-30034 (8 November 2012); P5978 (Map of Sarajevo marked by Savo Simić) (marking externally encircled area in blue and internally encircled area, under the control of the Ilidža Brigade, in red); P5979 (SRK Order, 4 August 1992), p. 2 (referring to the "blockade of Sarajevo").

15255 D2667 (Witness statement of Ratomir Maksimović dated 14 December 2012), para. 7. See also D2562 (Witness statement of Vladimir Radojčić dated 8 December 2012), para. 6; D2270 (Witness statement of Andrey Demurenko dated 13 October 2012), paras. 31, 37.

15256 Dragomir Milošević, T. 32793 (29 January 2013).

15257 Dušan Zurovac T. 30290-30294, 30297 (14 November 2012) (adding that it was not possible for 15,000 Serb troops to hold a siege against 60,000 troops of the $\mathrm{ABiH} 1^{\text {st }}$ Corps).

15258 Dušan Zurovac T. 30290 (14 November 2012).

15259 Dušan Zurovac T. 30294-30295 (14 November 2012) (denying at the same time that one of the reasons for $\mathrm{ABiH}$ attempts to break out of the siege was to allow humanitarian aid into the city).

15260 Milosav Gagović, T. 31918 (15 January 2013). See also D3138 (Witness statement of Mirko Šošić dated 17 March 2013), para. 7.

15261 P5906 (Witness statement of KDZ450 dated 17 January 2011), para. 65. See also Manojlo Milovanović. T. 25559-25600 (1 March 2012) (testifying that Alija Izetbegović prohibited the civilian population from leaving Sarajevo because the $\mathrm{ABiH}$ wanted "the civilian population in the vicinity of military targets"); P1483 (Ratko 
Sarajevo "up to a point", Van Lynden remained adamant that Sarajevo was "besieged by [Bosnian Serb] forces who would have shot these people or taken them prisoner if they had tried to get out". ${ }^{15262}$ UN officials were also aware of the Bosnian Muslim strategy to prevent civilians from leaving the city. ${ }^{15263}$

4549. In terms of the use of the word "siege", the Chamber also heard that in the summer of 1993 the UNPROFOR spokesman was ordered to avoid using the word "siege" and to use phrases like "tactical encirclement", "strategic encirclement" and "containment" instead. ${ }^{15264}$ According to Bowen, the rationale for this seemed to be that using the term "siege" would harm negotiations in Geneva, but in his view it had the effect of denying "an obvious reality" and "one of the most straightforward facts of a complicated war". ${ }^{15265}$ Richard Phillips, an expert witness called by the Prosecution, testified that he did not use the term "siege" in relation to Sarajevo because it is not a "military term currently in use"; he preferred to describe the events in Sarajevo as either "the battle for Sarajevo", the "encirclement" of Sarajevo, or the "blockade" of Sarajevo. ${ }^{15266}$ Radovan Radinović, a military expert called by the Accused, testified that he viewed the situation as one of a "blockade" of the $\mathrm{ABiH}$ forces inside Sarajevo. ${ }^{15267} \mathrm{He}$ further testified that, in the military documents he obtained, there were references by the $\mathrm{ABiH}$ to the need to "deblockade" Sarajevo and references by the SRK to "preventing deblockade". ${ }^{15268}$ Other witnesses thought that terms such as "encirclement" and "siege" describe the same situation, namely that in which people are kept inside an area and denied the "freedom to go about their daily lives". ${ }^{15269}$

\section{(A) Shortage of utilities}

4550. As noted above, a number of witnesses referred to the lack of gas, electricity, and water as one of the reasons they considered the city to have been under siege. ${ }^{15270}$ By April 1992, hostilities in $\mathrm{BiH}$ had seriously damaged the country's electricity system; as a result, Sarajevo was receiving

Mladić's notebook, 2 April-24 October 1993), p. 228 (wherein Morillion is recorded as saying in a meeting with Mladić on 25 June 1993 that Izetbegović has put the city under the blockade).

Aernout van Lynden, T. 3013-3016 (31 May 2010). See also KDZ185, T. 4365-4366 (30 June 2010). But see [REDACTED]; D2667 (Witness statement of Ratomir Maksimović dated 14 December 2012), para. 47.

15263 Jeremy Bowen, T. 10242-10244 (14 January 2011); D950 (UN report re meeting with General Soubirou, 17 August 1994), p. 2.

15264 P2068 (Witness statement of Jeremy Bowen dated 10 August 2009), para. 52; D949 (BBC news report re Sarajevo, with transcript).

15265 P2068 (Witness statement of Jeremy Bowen dated 10 August 2009), para. 52; Jeremy Bowen, T. 10239-10240 (14 January 2011). See also David Harland, T. 2103-2104 (7 May 2010).

15266 Richard Phillips, T. 3783-3784 (15 June 2010).

15267 Radovan Radinović, T. 41405-41407 (17 July 2013).

15268 Radovan Radinovic, T. 41407 (17 July 2013).

15269 Colm Doyle, T. 2867 (27 May 2010); KDZ088, T. 6385-6387 (8 September 2010) (closed session).

15270 See para. 4546. 
very little electricity and thus very little running water, which was directly dependent on the supply of electricity. ${ }^{15271}$ When Abdel-Razek arrived in Sarajevo in August 1992, there was no water, electricity and gas for the majority of the civilian population. ${ }^{15272}$ There were periods in Sarajevo where the utilities situation improved; for example, after the first Markale incident in early 1994 and after the COHA was signed in early $1995 .^{15273}$ However, generally speaking, and as reported by the UN, there were severe shortages of electricity, water, and gas in Sarajevo throughout the conflict. ${ }^{15274}$ This lack of utilities in Sarajevo made life especially difficult in winter time. ${ }^{15275}$ For Rose, the lack of utilities for heating during Sarajevo winters was "catastrophic", ${ }^{15276}$ while Van Lynden recalled an "endless" battle to obtain fuel. ${ }^{15277}$ Civilians cut down hundreds of trees for firewood, and when trees were depleted, they burned furniture, carpet, shoes, floorboards, doors,

15271 D3321 (Witness statement of Milorad Skoko dated 1 April 2013), paras. 9, 14 (explaining that major thermal and hydro-electric power plants supplying Sarajevo were out of operation, which reduced production capacity by 75\%); Youssef Hajir, T. 8860 (2 November 2010); Milenko Inđić, T. 32472-32474 (22 January 2013); D2541 (Witness statement of Veljko Lubura 3 December 2012), paras. 6-7; D3325 (Diagram of electric power system in Sarajevo, 1992-1995); Stanislav Galić, T. 37608 (23 April 2013); KDZ185, T. 4174-4175 (28 June 2010); Hussein Ali Abdel-Razek, T. 5623-5624 (21 July 2010); P6270 (UNPROFOR report, 29 July 1993), p. 1 (stating that electricity was the "key of all the utilities" because "all the others are connected with [it]"); Sergey Moroz, D2373 (Transcript from Prosecutor v. Galić), T. 18128-18129.

15272 P1258 (Witness statement of Hussein Ali Abdel-Razek dated 16 July 2002), e-court p. 4; Hussein Abdel-Razek, T. 5610 (21 July 2010). See also P4203 (Witness statement of Pyers Tucker dated 12 May 2010), para. 21; D2541 (Witness statement of Veljko Lubura 3 December 2012), para. 6.

15273 See Michael Rose, T. $7256-7257$ (5 October 2010); P5906 (Witness statement of KDZ450 dated 17 January 2011), para. 70; D1124 (UNPROFOR report, 7 April 1995), para. 5; D1166 (UNPROFOR Weekly Situation Report, 18 February 1995), p. 2; KDZ182, T. 13110 (10 March 2011); Anthony Banbury, T. 13488-13489 (16 March 2011).

15274 See e.g. P1262 (UN report on Sarajevo, 8 October 1992), para. 2; P835 (UNPROFOR BiH Political Assessment, 16 July 1993), e-court p. 7; P6270 (UNPROFOR report, 29 July 1993), p. 1; P830 (UNPROFOR Weekly Political Assessment, 16 October 1993), p. 2; P823 (UNPROFOR Weekly Political Assessment, 3 November 1993), p. 7; P827 (UNPROFOR Weekly Political Assessment, 17 February 1994), p. 3; P850 (UNPROFOR Weekly Political Assessment, 9 March 1994), p. 2; P6068 (Weekly Report of the Special Coordinator for Sarajevo, 19 September 1994), p. 1; P872 (UNPROFOR Weekly Situation Report, 10 December 1994), p. 5; P6275 (UNPROFOR Weekly Situation Report, 28 May 1995), paras. 6, 17; P888 (UNPROFOR Weekly Situation Report (Sarajevo), 3 June 1995), p. 4; P892 (UNPROFOR Weekly Situation Report Sarajevo), 24 June 1995), pp. 4-5; P896 (UNPROFOR Weekly Situation Report (Sarajevo), 2 July 1995), p. 6; P822 (UNPROFOR Weekly Situation Report (Sarajevo), 8 July 1995), p. 5; P897 (UNPROFOR Weekly Situation Report (Sarajevo), 15 July 1995), p. 5; P6276 (UNPROFOR Weekly Situation Report, 31 July 1995), p. 7. See also P490 (Witness statement of Anđa Gotovac dated 17 May 2006), para. 5; Alma Mulaosmanović-Čehajić, T. 6756 (14 September 2010).

15275 P2068 (Witness statement of Jeremy Bowen dated 10 August 2009), para. 41; P2922 (Witness statement of KDZ079 dated 17 May 2006), para. 20; P490 (Witness statement of Anđa Gotovac dated 17 May 2006), para. 5; P1262 (UN report on Sarajevo, 8 October 1992), para. 2; P1866 (Witness statement of Youssef Hajir dated 25 February 2010), paras, 51, 53; P4203 (Witness statement of Pyers Tucker dated 12 May 2010), para. 21.

15276 P1638 (Witness statement of Michael Rose dated 26 March 2009), para. 30.

15277 P926 (Witness statement of Aernout van Lynden dated 26 February 2010), para. 23. 
and even books to stay warm. ${ }^{15278}$ Many vulnerable people, particularly the elderly, died from the cold. $^{15279}$

4551. When the water supply failed, international aid agencies supplied water pumps which were installed at suitable locations around the city and where residents had to wait their turn to fill up their containers, sometimes for the whole day. ${ }^{15280}$ Civilians would venture out of their homes at great risk to collect water from Miljacka River or from wells around the city and would be shelled or sniped at, either on the way or while queuing for water. ${ }^{15281}$ Indeed, UNPROFOR reported incidents in which dozens of civilians were killed or injured while queuing for water. ${ }^{15282}$

4552. The Chamber heard that water pumps and electricity stations were located on Bosnian Serb territory, which enabled them to shut off the supply of water and electricity. ${ }^{15283}$ In addition, the

15278 P926 (Witness statement of Aernout van Lynden dated 26 February 2010), para. 23; P733 (Witness statement of Sulejman Crnčalo dated 1 November 2009), para. 83; P1996 (Witness statement of Martin Bell dated 8 March 2010), para. 49; P2027 (BBC news report re Sarajevo, with transcript); P2016 (BBC news report re Sarajevo, with transcript).

15279 P1866 (Witness statement of Youssef Hajir dated 25 February 2010), para. 53 (recalling several cases of death due to hypothermia at Dobrinja Hospital); P820 (Witness statement of David Harland dated 4 September 2009), para. 87.

15280 See Adjudicated Fact 61; Sergey Moroz, T. 29545 (1 November 2012).

15281 KDZ185, T. 4175 (28 June 2010) (private session); P1996 (Witness statement of Martin Bell dated 8 March 2010), paras. 49-50; P1999 (BBC news report re Sarajevo, with transcript); P2016 (BBC news report re Sarajevo, with transcript); P2068 (Witness statement of Jeremy Bowen dated 10 August 2009), para. 19 ; P926 (Witness statement of Aernout van Lynden dated 26 February 2010), para. 24; Sergey Moroz, T. 29545-29547 (1 November 2012); P733 (Witness statement of Sulejman Crnčalo dated 1 November 2009), para. 91; P2923 (Witness statement of KDZ090 dated 19 April 2006), para. 12; P1866 (Witness statement of Youssef Hajir dated 25 February 2010), para. 48; P2922 (Witness statement of KDZ079 dated 17 May 2006), paras. 20, 24; Alma Mulaosmanović-Čehajić, T. 6757 (14 September 2010). Examples of this are Scheduled Incidents G.5 and Scheduled Incident F. 3.

15282 See P892 (UNPROFOR Weekly Situation Report Sarajevo, 24 June 1995), p. 3 (reporting that 13 civilians were killed and 27 injured in Bosnian Serb attacks on water lines in Dobrinja on 18 June and 21 June 1995); P820 (Witness statement of David Harland dated 4 September 2009), para. 197-198. These killings are not listed in Schedule G of the Indictment. See also P1442 (UNPROFOR report re shelling of Dobrinja on 12 July 1993) (relating to Scheduled Shelling Incident G.5). Milorad Skoko, who was the General Director of the RS Electricity Supply Board, testified that the supply of electricity to ABiH-held Sarajevo was not a power supply disaster because, by his calculations, enough electricity was produced per household to satisfy basic needs. See D3321 (Witness statement of Milorad Skoko dated 1 April 2013), para. 21; Milorad Skoko, T. 36719-36721 (5 April 2013). However, the Chamber notes that in making these calculation Skoko assumed that there were 35,000 to 40,000 households within the confrontation lines in Sarajevo, whereas a household survey conducted within those confrontation lines in 1994 put the number of households as high as 85,000. See Milorad Skoko, T. 36727-36730 (8 April 2013) (testifying that he relied on the BiH census for 1991); P4997 (Ewa Tabeau's expert report entitled "Persons Killed and Wounded in Sarajevo During the First Months of the 'Siege' from 1 April to 9 September 1992", 1 May 2009), p. 1, fn. 4. Skoko's evidence also contradicts the overwhelming amount of accepted evidence that the civilian population of Sarajevo was not adequately supplied with electricity throughout the conflict. Indeed, at certain times in the conflict, the only source of electricity for Bosnian Muslim Sarajevo was a cable running over Mt. Igman and under the airport tunnel. See P888 (UNPROFOR Weekly Situation Report (Sarajevo), 3 June 1995), p. 4; P897 (UNPROFOR Weekly Situation Report (Sarajevo), 15 July 1995), p. 5; P6276 (UNPROFOR Weekly Situation Report, 31 July 1995), p. 7; D3321 (Witness statement of Milorad Skoko dated 1 April 2013), para. 20; P6269 (Excerpt from annual report of Elektroprivreda BiH for 1993). Accordingly, the Chamber does not consider Skoko's evidence as to the level of utilities in the city to be reliable.

15283 P1258 (Witness statement of Hussein Ali Abdel-Razek dated 16 July 2002), e-court p. 21; KDZ185, T. 41744175 (28 June 2010) (private session) (testifying that it was an objective of the Bosnian Serb "siege" to cut 
Bosnian Serbs could cut the gas supply because the gas pipeline passed through their territory. ${ }^{15284}$ The Bosnian Serbs would therefore cut the supply of utilities in response to $\mathrm{ABiH}$ offensives and NATO air strikes, including in mid-June 1994, in response to ABiH offensives in Ozren and on 26 May 1995, following the NATO air strikes. ${ }^{15285}$ On the other hand, if the Bosnian Serbs wished to restore utilities to Sarajevo, they could, and they did. ${ }^{15286}$

4553. In addition, Bosnian Serbs also obstructed repairs to utilities. ${ }^{15287}$ While in late September 1992, UNPROFOR, the Accused, Plavšić, and Ganić, among others, agreed to create joint groups of technicians for the repair of utilities around Sarajevo, Abdel-Razek recalled that this did not materialise. $^{15288}$ Instead, Bosnian Serb forces obstructed repair teams, shot at UNPROFOR

utilities to the city, particularly electricity which was crucial for heating and pumping water); P4203 (Witness statement of Pyers Tucker dated 12 May 2010), para. 21; Stanislav Galić, T. 37608, 37619 (23 April 2013); D2541 (Witness statement of Veljko Lubura 3 December 2012), para. 5; Veljko Lubura, T. 31052-31053 (5 December 2012). See also D3325 (Diagram of electric power system in Sarajevo, 1992-1995) (indicating the electricity stations in the city which were controlled by the VRS and the $\mathrm{ABiH}$ respectively).

15284 P2447 (Witness statement of KDZ182), p. 55; P830 (UNPROFOR Weekly Political Assessment, 16 October 1993), p. 2; P2457 (UNPROFOR Weekly BiH Political Assessment, 28 August 1994), para. 1; P2471 (UNPROFOR Weekly BiH Political Assessment, 3 September 1994), para. 11; P2470 (UNPROFOR report, 1 September 1994), p. 7; P6068 (Weekly Report of the Special Coordinator for Sarajevo, 19 September 1994), p. 1; P886 (UNPROFOR Weekly Situation Report (Sarajevo), 13 May 1995), p. 3; P2441 (UNPROFOR Weekly Situation Report (Sarajevo), 19 May 1995), p. 4; P4192 (UN Weekly Situation Report, 29 May-4 June 1995), para. 13; P888 (UNPROFOR Weekly Situation Report (Sarajevo), 3 June 1995), p. 4. See also P4203 (Witness statement of Pyers Tucker dated 12 May 2010), para. 116; D1502 (Report of humanitarian organisation, 7 October 1992) (under seal), para. 5.

15285 P1638 (Witness statement of Michael Rose dated 26 March 2009), paras, 116, 118; P6276 (UNPROFOR Weekly Situation Report, 31 July 1995), p. 7; Milorad Skoko, T. 36749 (8 April 2013) (testifying that utilities may have been cut off by local fighters but not by the Bosnian Serb authorities); P6274 (UNPROFOR Weekly Situation Report, 26 May 1995), p. 3; P6275 (UNPROFOR Weekly Situation Report, 28 May 1995), paras. 6, 17; P888 (UNPROFOR Weekly Situation Report (Sarajevo), 3 June 1995), pp. 3-4; P4192 (UN Weekly Situation Report, 29 May-4 June 1995), paras. 12-13; D1058 (UNPROFOR report to Marrack Goulding, 30 May 1995), para. 11. In a letter to the Accused, Krajišnik, and Lukić on 27 September 1994, the Assembly of the Serbian City of Sarajevo protested about the cutting of utilities to Sarajevo "for the purpose of raising and lowering tensions", and stated that such activities should only be carried out after consultation with the political organs of the municipalities and the city. See P6300 (Letter from City Assembly of Sarajevo to Radovan Karadžić, Momčilo Krajišnik, and RS Prime Minister, 27 September 1994), pp. 4-5; Stanislav Galić, T. 3787837879 (7 May 2013), T. 38022-38023 (9 May 2013) (who, when confronted with this document, testified that he did not know of any deliberate manipulation of the supply of utilities to Sarajevo as that would have disrupted utilities also to the Bosnian Serb side).

15286 P820 (Witness statement of David Harland dated 4 September 2009), paras. 38, 244; David Harland, T. 20182019 (6 May 2010); P1029 (Witness statement of John Wilson dated 4 November 2008), para. 123. See e.g. P5058 (Order of the VRS to SRK, 15 July 1993); P6272 (UNPROFOR report, 27 September 1994), p. 1.

15287 See e.g. D4764 (Letter from Elektroprivreda to Vladimir Lukić re electricity supply problems, 11 January 1993), pp. 1-2; D2548 (Minutes of a meeting at Sarajevo airport, 7 July 1994), paras. 2.1, 2.4; P6270 (UNPROFOR report, 29 July 1993), pp. 1, 7; P6273 (UNPROFOR report, 11 October 1994), p. 2; P823 (UNPROFOR Weekly Political Assessment, 3 November 1993), p. 7; D2547 (Minutes of meeting at Sarajevo airport, 27 July 1994), p. 1.

15288 Hussein Abdel-Razek, T. 5534 (19 July 2010), T. 5610 (21 July 2010); P1258 (Witness statement of Hussein Ali Abdel-Razek dated 16 July 2002), e-court pp. 8, 22 (stating that the Accused agreed on 30 September 1992 to create joint working groups and agreed not to use utilities as a "means of war"); P1267 (UNPROFOR report re meeting with Biljana Plavšić, 2 October 1992), para. 3; D2544 (Letter from RS Presidency to UNPROFOR General, 8 October 1992) (stating the names of the people chosen by the Bosnian Serb side to work in the joint working groups); Veljko Lubura, T. 31044, 31054 (5 December 2012). See also D4635 (Agreement on restoring public utilities in and around Sarajevo city, 12 July 1993). 
engineers, and shelled utilities soon after they were repaired. ${ }^{15289}$ They did so because they saw the flow of utilities as benefiting primarily the Bosnian Muslims living in Sarajevo or because they would use the issue of repairs as leverage in negotiations. ${ }^{15290}$ That the Bosnian Serbs had a strategy of obstructing repairs is indicated by a speech Mladić gave to the Bosnian Serb Assembly on 12 May 1992, where he declared:

We are not going to say we are going to destroy the power supply pylons or turn off the water supply, no, because that would get America out of its seat, but gentlemen, please, fine, well, one day there is no water at all in Sarajevo. What is it, we do not know, damage, we should fix it, no, we will fix it, slowly. [...] [W]e have to wisely tell the world, it was [the Bosnian Muslims] who were shooting, hit the transmission line and the power went off, they were shooting at the water supply facilities, there was a power cut at such and such a place, we are doing our best repairing this, that is what diplomacy is $[\ldots]^{15291}$

4554. In contrast to some of the above evidence, the witnesses called by the Accused testified that the Bosnian Serbs did not disrupt, but instead facilitated, the supply of utilities to civilians in Sarajevo. ${ }^{15292}$ To Galić's knowledge, the SRK never manipulated electricity, water, and gas supplies to Sarajevo. ${ }^{15293}$ Similarly, Dragomir Milošević testified that the SRK respected UNPROFOR's requests to repair utilities and did whatever was necessary to ensure there was

15289 P1258 (Witness statement of Hussein Ali Abdel-Razek dated 16 July 2002), e-court pp. 4, 8, 21; Hussein Ali Abdel-Razek, T. 5610, 5619, 5624-5625, 5627 (21 July 2010); KDZ182, T. 13110 (10 March 2011).

15290 P1426 (Witness statement of Richard Mole dated 7 May 2010), para. 103; P4203 (Witness statement of Pyers Tucker dated 12 May 2010), para. 116; P892 (UNPROFOR Weekly Situation Report Sarajevo), 24 June 1995), p. 5; P820 (Witness statement of David Harland dated 4 September 2009), para. 201.

15291 P956 (Transcript of $16^{\text {th }}$ session of SerBiH Assembly, 12 May 1992), e-court pp. 38-39.

15292 See e.g. D2516 (Witness statement of Vlade Lučić dated 5 November 2012), para. 27; D2562 (Witness statement of Vladimir Radojčić dated 8 December 2012), para. 49; D2633 (Witness statement of Milorad Šehovac dated 8 December 2012), para. 42; D2383 (Witness statement of Slavko Gengo dated 14 October 2012), para. 29; Slavko Gengo, T. 29796 (6 November 2012); D2667 (Witness statement of Ratomir Maksimović dated 14 December 2012), para. 47; D2331 (Witness statement of Blagoje Kovačević dated 14 October 2012), paras. 39, 41; D2541 (Witness statement of Veljko Lubura 3 December 2012), para. 17; Veljko Lubura, T. 31073, 31081-31083 (6 December 2012); D3695 (Witness statement of Bogdan Subotić dated 16 June 2013), para. 230; Vladimir Lukić, T. 38749-38750 (23 May 2013); D2686 (Witness statement of Mihajlo Vujasin dated 16 December 2012), para. 47; Mihajlo Vujasin, T. 31828 (20 December 2012); D2389 (Witness statement of Predrag Trapara dated 3 November 2012), para. 18; Predrag Trapara, T. 29924 (7 November 2012); D2497 (Witness statement of Nikola Mijatović dated 27 November 2012) para. 16; D2391 (Witness statement of Slobodan Tuševljak dated 5 November 2012), para. 23; D116 (Letter from Ministry of Agriculture to RS Presidency re Sarajevo, 20 July 1993) (a discussion of the RS Ministry of Agriculture, Forestry and Water Management about how to increase the supply of water and electricity to Bosnian Muslim Sarajevo); D104 (Radovan Karadžić's Directive to VRS Main Staff, 11 May 1993) (in which the Accused prohibits the VRS from misusing reservoirs and water dams for military purposes); D3478 (SRK combat report, 14 October 1992), p. 2 (reporting that the SRK had "done everything" necessary to supply water, electricity and gas to Sarajevo). See also KDZ088, T. 6501 (10 September 2010).

15293 Stanislav Galić, T. 37609 (23 April 2013), T. 37874 (7 May 2013), T. 38022 (9 May 2013). Galić explained that the SRK did not manipulate utilities because the SRK and ABiH were equally affected by power cuts. See Stanislav Galić, T. 37878-37879 (7 May 2013); P6300 (Letter from City Assembly of Sarajevo to Radovan Karadžić, Momčilo Krajišnik, and RS Prime Minister, 27 September 1994), pp. 4-5. See also D4623 (SRK report, 16 June 1992) (reporting that the SRK Command did not have electricity for its logistics due to a "power cut"). 
"water, electricity and all the other bare necessities for everybody". ${ }^{15294}$ While Skoko acknowledged that there may have been individual incidents of SRK soldiers obstructing repairs to utilities, he denied that there was any "systemic obstruction". 15295 Veljko Lubura, who was the Chief Engineer of the RS Electric Power Supply Company, ${ }^{15296}$ testified that if the Bosnian Serb authorities wanted to cut the electricity supply they would have had to ask him, and they never did. ${ }^{15297}$ In addition, he and his engineers never encountered problems while repairing transmission lines in Bosnian Serb territory. ${ }^{15298}$ In addition, according to Sergey Moroz, who served with UNPROFOR from October 1993 until October 1994 as a mission commander in the engineering section in Sector Sarajevo, ${ }^{15299}$ the reason for cuts to utilities was almost always damage on the transmission lines and he could not say whether that damage was deliberate. ${ }^{15300}$ While accepting Lubura's and Moroz's evidence, the Chamber considers that they ultimately do not contradict the evidence of Prosecution witnesses, such as that of Abdel-Razek, that SRK soldiers would deliberately obstruct utilities through shooting at UNPROFOR engineers and shelling utilities soon after they were repaired. Even Skoko accepted that this may have been the case, confining it to something individual SRK soldiers would do on their own. The Chamber is therefore convinced that the shortage of utilities in Sarajevo was caused not only by combat activities on confrontation lines and by $\mathrm{ABiH}$ activities, but also by deliberate obstruction of utilities by the SRK soldiers. ${ }^{15301}$

4555. The Bosnian Muslim side also interfered with or shelled the supply of utilities in Sarajevo, often to portray themselves as victims. ${ }^{15302}$ Harland personally witnessed their refusal to open gas

15294 Dragomir Milošević, T. 32897-32898 (30 January 2013). See also D2847 (SRK Order, 26 August 1993), p. 1 ; D2848 (SRK report, 30 September 1993), p. 1. Moroz testified that during "tense" periods in Sarajevo, such as January and February of 1994, repair missions were often cancelled due to exchanges of fire; however, there were periods of quiet in Sarajevo when repair missions were conducted successfully, such as in the summer of 1994. See Sergey Moroz, D2373 (Transcript from Prosecutor v. Galić), T. 18124-18125, 18132, 18140-18142. Milorad Skoko, T. 36735-36736, 36749, 36761, 36765 (8 April 2013).

D2541 (Witness statement of Veljko Lubura 3 December 2012), paras. 1-2.

Veljko Lubura, T. 31073 (6 December 2012).

Veljko Lubura, T. 31054 (5 December 2012).

Sergey Moroz, D2373 (Transcript from Prosecutor v. Galić), T. 18116.

Sergey Moroz, D2373 (Transcript from Prosecutor v. Galić), T. 18136. This was confirmed by Lubura who explained that the transmission lines supplying the city from SRK-held territory passed over the confrontation lines and thus were often damaged in combat operations during the conflict. See D2541 (Witness statement of Veljko Lubura 3 December 2012), paras. 6, 16; Veljko Lubura, T. 31052 (5 December 2012); D2542 (Map marked by Veljko Lubura). See also D3321 (Witness statement of Milorad Skoko dated 1 April 2013), para. 14; Milorad Skoko, T. 36757 (8 April 2013); Mihajlo Vujasin, T. 31809, 31828-31829 (20 December 2012); Milenko Inđić, T. 32472 (22 January 2013); Stanislav Galić, T. 37874 (7 May 2013).

15301 The Chamber notes here that it found the evidence of the SRK soldiers and officers who testified that their brigades or units never interfered with the supply of utilities to Sarajevo self-serving and insincere as it was contradicted by the evidence of credible Prosecution witnesses and UN documents and, most importantly, by some of the contemporaneous Bosnian Serb documents such as P630, P5058, and P6272. It is also inconsistent with the speech Mladić gave during the Bosnian Serb Assembly on 12 May 1992, where he outlined the strategy the Bosnian Serb side would use with respect to utilities.

15302 P1426 (Witness statement of Richard Mole dated 7 May 2010), para. 104; Sergey Moroz, T. $29549-29550$ (1 November 2012); D2331 (Witness statement of Blagoje Kovačević dated 14 October 2012), para. 41; D3321 
valves; he also witnessed their sniping at electrical insulators on high-voltage lines thus deliberately interrupting the electricity supply. ${ }^{15303}$ Another example was the $\mathrm{ABiH}$ shelling of the Blažuj power station on 26 November 1992, which cut Sarajevo's electricity and water supply until late January 1993. ${ }^{15304}$ There were also instances in which the ABiH obstructed, harassed or otherwise interfered with utility missions. ${ }^{15305}$ Despite this, however, Harland was adamant that the Bosnian Serbs were responsible for the majority of deprivations in utilities in Sarajevo. ${ }^{15306}$

\section{(B) Shortage of food and other supplies in Sarajevo}

4556. Another reason why the witnesses considered Sarajevo to have been under siege was the lack of food, as well as medical and other supplies, that the city experienced, which they testified was caused by the SRK's obstruction of humanitarian aid designated for Sarajevo. ${ }^{15307}$ The Chamber has already recounted above, in Section IV.B.1.a, the ebb and flow of the humanitarian aid into the city during the Indictment period and the procedures used by the SRK to control the convoys going to the city.

(Witness statement of Milorad Skoko dated 1 April 2013), paras. 18, 24; Milorad Skoko, T. 36767 (8 April 2013); D3563 (Witness statement of Vladimir Lukić dated 18 May 2013), paras. 14, 56; D3695 (Witness statement of Bogdan Subotić dated 16 June 2013), para. 230; Milenko Inđić, T. 32472 (22 January 2013); D2562 (Witness statement of Vladimir Radojčić dated 8 December 2012), para. 49; D2667 (Witness statement of Ratomir Maksimović dated 14 December 2012), para. 47; Stanislav Galić, T. 37613-37616 (23 April 2013); D2387 (Witness statement of Stojan Džino dated 4 November 2012), para. 59; D2622 (Witness statement of Željko Bambarez dated 9 December 2012), para. 22; D117 (Letter from Fred Cuny to Morton Abramowitz re Sarajevo, undated), p. 2; David Harland, T. 2110 (7 May 2010); Sergey Moroz, D2373 (Transcript from Prosecutor v. Galić), T. 18126-18128 (adding that it was very difficult to determine who was firing on transmission lines but that much of the damage occurred on the Bosnian Serb territory as a result of explosions near electricity pylons). See also Veljko Lubura, T. 31065 (6 December 2012); D1127 (UNPROFOR report, 15 June 1995), para. 3.

P820 (Witness statement of David Harland dated 4 September 2009), para. 88; David Harland, T. 2110 (7 May 2010), T. 2242-2243 (10 May 2010).

15304 P1426 (Witness statement of Richard Mole dated 7 May 2010), para. 104; Richard Mole, T. 5898-5899 (18 August 2010); Milorad Skoko, T. 36730-36731, 36755-36756, 36766 (8 April 2013); D2541 (Witness statement of Veljko Lubura 3 December 2012), para. 15; Stanislav Galić, T. 37613 (23 April 2013); D3479 (SRK combat report, 26 November 1992), p. 1; P921 (Transcript of $24^{\text {th }}$ session of RS Assembly, 8 January 1993), p. 19. For other examples, see D3481 (SRK combat report, 19 June 1993), p. 1; D2541 (Witness statement of Veljko Lubura 3 December 2012), para. 10; Veljko Lubura, T. 31075-31076 (6 December 2012); P6270 (UNPROFOR report, 29 July 1993), p. 7; D3321 (Witness statement of Milorad Skoko dated 1 April 2013), para. 18; Milorad Skoko, T. 36767 (8 April 2013); Stanislav Galić, T. 37871-37873 (7 May 2013); Herbert Okun, T. 1802-1805 (28 April 2010); D2770 (Witness statement of KW570 dated 21 November 2012) (under seal), para. 16; D2510 (Report of Ilidža Brigade, 13 December 1992), para. 1; D2497 (Witness statement of Nikola Mijatović dated 27 November 2012), para. 16.

15305 P1426 (Witness statement of Richard Mole dated 7 May 2010), para. 104; P1429 (UNMO report for December 1992), p. 8; D1498 (UNPROFOR protest letter to Alija Izetbegović, 23 January 1993), p. 2; KDZ240, T. 1612716128 (5 July 2011) (closed session); D3480 (SRK combat report, 13 January 1993), p. 1; D2541 (Witness statement of Veljko Lubura 3 December 2012), paras. 12-13; D2548 (Minutes of a meeting at Sarajevo airport, 7 July 1994), para. 2.1.

15306 P820 (Witness statement of David Harland dated 4 September 2009), para. 88; David Harland, T. 2109-2110 (7 May 2010).

15307 See para. 4546. 
4557. Prosecution witnesses testified that it was those procedures that made it difficult for UNPROFOR, UNHCR, and other humanitarian organisations to deliver humanitarian aid to Sarajevo. ${ }^{15308}$ Banbury testified that the Bosnian Serbs exercised "total control" over UN convoys, that convoy requests were rejected many times against UNPROFOR's judgement, and that the Bosnian Serbs provided many different reasons to block convoys, none of which was acceptable to UNPROFOR. ${ }^{15309}$ Harland testified that the Bosnian Serbs "never wanted to put in place a clear simple system that allowed [the UN] to have freedom of movement", but instead stole and shot at UN vehicles and abused UN personnel in the convoys. ${ }^{15310}$ Okun also confirmed that food convoys under escort from UNPROFOR were "routinely stopped, robbed, [and] made to pay money to get through certain check-points" by Bosnian Serb forces. ${ }^{15311}$ KW570, who was called by the Accused, testified that Bosnian Serb forces would often stop convoys, only to let them through when UNPROFOR threatened to use force. ${ }^{15312}$ Bowen personally witnessed convoys being held up "many times" by the SRK, sometimes for days. ${ }^{15313}$ While some of these witnesses acknowledged that the Bosnian Serbs were entitled to seek assurances from UNPROFOR and UNHCR about the contents of convoys, they claimed that the Bosnian Serbs implemented a very onerous control regime on UNPROFOR and UNHCR, which they used to restrict rather than to facilitate humanitarian aid. ${ }^{15314}$

4558. The Bosnian Muslims also obstructed humanitarian convoys by opening fire on them and then blaming the Bosnian Serb side or by blocking their passage. ${ }^{15315}$ However, Rose and AbdelRazek emphasised that the majority of blocking came from the Bosnian Serbs, who controlled all the major roads into Sarajevo. ${ }^{15316}$ Banbury also agreed that the Bosnian Muslim authorities "at times" obstructed the movement of convoys, but claimed that these obstructions were relatively few

\footnotetext{
15308 See e.g. Michael Rose, T. 7441 (7 October 2010), T. 7598 (8 October 2010); P1685 (UNPROFOR report re convoys, 23 August 1994), p. 7; P1258 (Witness statement of Hussein Ali Abdel-Razek dated 16 July 2002), ecourt p. 9.

15309 Anthony Banbury, T. 13443-13444, 13451, 13456-13458 (16 March 2011). See also Adrianus van Baal, T. 8394-8395, 8413 (27 October 2010); P1685 (UNPROFOR report re convoys, 23 August 1994), p. 7.

15310 David Harland, T. 2168-2169 (10 May 2010).

15311 Herbert Okun, T. 1763 (28 April 2010).

15312 KW570, T. 32217-32218 (18 January 2013). See also Michael Rose, T. 7420-7421 (7 October 2010).

15313 P2068 (Witness statement of Jeremy Bowen dated 10 August 2009), para. 23.

15314 Anthony Banbury, T. 13504 (16 March 2011); David Fraser, T. 8043 (18 October 2010); Rupert Smith, T. 11647-11648 (11 February 2011).

15315 Stanislav Galić, T. 37409-37410 (18 April 2013); D3424 (SRK combat report, 13 August 1993), p. 2; Vladimir Radojčić, T. 31289 (12 December 2012); D2621 (Letter from VRS to UNPROFOR, 30 July 1995), p. 2; Yasushi Akashi, T. 37767-37768 (25 April 2013); D3489 (Excerpt from Yasushi Akashi's book entitled "In the Valley between War and Peace"), p. 16.

15316 Michael Rose, T. 7426-7427 (7 October 2010); P1258 (Witness statement of Hussein Ali Abdel-Razek dated 16 July 2002), e-court p. 9 (testifying that it was "mostly" the Bosnian Serbs that blocked convoys).
} 
and easy to solve; they did not constitute a broad practice of stopping convoys. ${ }^{15317}$ KDZ182 testified that while UNPROFOR's freedom of movement was "somewhat limited" by the ABiH within Sarajevo, the restrictions imposed on freedom of movement by the SRK around Sarajevo were far greater. ${ }^{15318}$

4559. The Chamber also heard from Defence witnesses that SRK forces did not hinder but in fact facilitated the passage of humanitarian convoys. ${ }^{15319}$ Dragomir Milošević explained that the position of the SRK Command was that "no obstacles should be placed in the way of convoys". 15320 He testified that "very often" there would be a problem with the convoys, but that it was his impression that the flow of humanitarian aid was neither compromised nor obstructed. ${ }^{15321}$ Krajišnik agreed that SRK forces obstructed convoys at times, but claimed that they did so because weapons and other prohibited items were being smuggled. ${ }^{15322}$ Like Krajišnik, many Defence witnesses testified that humanitarian convoys were used to smuggle weapons, ammunition, and other military equipment to the $\mathrm{ABiH}$ in Sarajevo justifying the need to check them. ${ }^{15323}$ Contemporaneous documents produced by the Bosnian Serb side at the time also suggest that this

15317 Anthony Banbury, T. 13483 (16 March 2011). See e.g. D1165 (UNPROFOR protest to VRS, 15 September 1994), p. 1; D2621 (Letter from VRS to UNPROFOR, 30 July 1995), p. 2. See also KDZ240, T. 16184 (6 July 2011) (closed session).

15318 KDZ182, T. 13187-13188 (10 March 2011). See also Herbert Okun, T. 1798 (28 April 2010); P2407 (Witness statement of KDZ304), p. 33.

15319 See e.g. D2516 (Witness statement of Vlade Lučić dated 5 November 2012), paras. 26-27; Vlade Lučić, T. 30812 (3 December 2012); D2686 (Witness statement of Mihajlo Vujasin dated 16 December 2012), paras. 44, 46; Mihajlo Vujasin, T. 31827 (20 December 2012); D2444 (Witness statement of Miladin Trifunović dated 11 November 2012), para. 20; Miladin Trifunović, T. 30376 (15 November 2012); D2451 (Witness statement of Velimir Dunjić dated 12 November 2012), para. 14; D2389 (Witness statement of Predrag Trapara dated 3 November 2012), para. 17; D2479 (Witness statement of Mile Sladoje dated 25 November 2012), para. 22; D2562 (Witness statement of Vladimir Radojčić dated 8 December 2012), para. 46; D2633 (Witness statement of Milorad Šehovac dated 8 December 2012), para. 39; D2667 (Witness statement of Ratomir Maksimović dated 14 December 2012), para. 44; Ratomir Maksimović, T. 31575 (17 December 2012). However, in his oral testimony, Radojčić acknowledged that the SRK closed the land routes into Sarajevo in July 1995, forcing UN convoys to use the Mt. Igman route. See Vladimir Radojčić, T. 31238-31244 (11 December 2012), T. 31278 (12 December 2012).

15320 Dragomir Milošević, T. 32893-32894, 32899 (30 January 2013); D2849 (SRK proposal, 31 August 1993 ), p. 1.

15321 Dragomir Milošević, T. 32894 (30 January 2013), T. 33228 (5 February 2013). See also Stanislav Galić, T. 37571 (23 April 2013), T. 38025 (9 May 2013).

15322 Momčilo Krajišnik, T. 43322 (12 November 2013).

15323 See e.g. Stanislav Galić, T. 37573 (23 April 2013); Dragomir Milošević, T. 32893-32894 (30 January 2013 ); D2562 (Witness statement of Vladimir Radojčić dated 8 December 2012), para. 47; D2633 (Witness statement of Milorad Šehovac dated 8 December 2012), para. 40; D2667 (Witness statement of Ratomir Maksimović dated 14 December 2012), para. 45;D2686 (Witness statement of Mihajlo Vujasin dated 16 December 2012), para. 44; D2444 (Witness statement of Miladin Trifunović dated 11 November 2012), para. 20; D2331 (Witness statement of Blagoje Kovačević dated 14 October 2012), para. 40, 50; D2387 (Witness statement of Stojan Džino dated 4 November 2012), para. 59; D2497 (Witness statement of Nikola Mijatović dated 27 November 2012), para. 33; D2451 (Witness statement of Velimir Dunjić dated 12 November 2012), para. 14; D2389 (Witness statement of Predrag Trapara dated 3 November 2012), para. 17; D2479 (Witness statement of Mile Sladoje dated 25 November 2012), para. 23; Mile Sladoje, T. 30581 (28 November 2012); Vladislav Jovanović, T. 34280 (26 February 2013); Milenko Inđić, T. 32422, 32424 (22 January 2013); D2745 (Witness statement of Vere Hayes dated 14 January 2013), paras. 5, 7; D3960 (Witness Statement of Tomislav Kovač dated 28 October 2013), para. 69; D3695 (Witness statement of Bogdan Subotić dated 16 June 2013), para. 298. 
was the case on certain occasions. ${ }^{15324}$ Additionally, Smith confirmed that there was a suspicion that other things were being transported in humanitarian convoys, ${ }^{15325}$ while Okun stated that convoys were abused by all sides and that smugglers were active throughout the conflict. ${ }^{15326}$ Furthermore, significant amounts of humanitarian aid were diverted to a black market in Sarajevo, instead of reaching the civilian population. ${ }^{15327}$

4560. While accepting that at times weapons or other military equipment may have been smuggled into the city in some of the convoys and that the Main Staff and the SRK had the right to check that convoys were not being so misused, the Chamber also considers that the checks imposed by the Main Staff were too onerous and restrictive, as testified to by a number of witnesses. ${ }^{15328}$ As such, they obstructed, rather than facilitated, the passage of humanitarian aid. In addition, in view of the other evidence outlined in this section as well as the evidence discussed in Section IV.B.1.a, the Chamber does not believe the SRK soldiers and officers who testified that their units never prevented or delayed humanitarian convoys from reaching Sarajevo.

(C) Findings on the siege

4561. Having considered all of the evidence above and in all the preceding sections of the Judgement, the Chamber notes that the Prosecution witnesses, including the Sarajevo locals, were

15324 See e.g. D1086 (Ilidža Municipal Assembly report, 2 February 1993), p. 2; D2123 (Report on abuses of the mandate of international organisations, 14 February 1994), p. 1; D2747 (VRS Main Staff protest letter, 1993), p. 1; D688 (SRK combat report, 9 April 1994), p 2; D769 (SRK combat report, 12 May 1994), p. 3; D190 (Report re discovery of ammunition in convoy to Butmir, 4 April 1993) (under seal); D3575 (TANJUG news report, 11 April 1993).

15325 D1031 (Excerpt from Rupert Smith's testimony in Prosecutor v. Popović et al.), p. 2; Rupert Smith, T. 11644 (11 February 2011).

15326 Herbert Okun, T. 1764, 1798 (28 April 2010). Some Defence evidence also suggested that the UN was implicated or involved in the smuggling of weapons and black market goods in its convoys. See D143 (VRS Report on movement of UN convoys, undated), pp. 2-3; D2497 (Witness statement of Nikola Mijatović dated 27 November 2012), para. 33; D2667 (Witness statement of Ratomir Maksimović dated 14 December 2012), para. 45; D2389 (Witness statement of Predrag Trapara dated 3 November 2012), para. 17; Milenko Inđić, T. 32422 (22 January 2013); D3695 (Witness statement of Bogdan Subotić dated 16 June 2013), para. 298. At the same time, however, international witnesses strongly denied that the UN itself was involved in the abuse of the convoys. See Michael Rose, T. 7426 (7 October 2010); KDZ185, T. 4211-4212 (28 June 2010); KDZ240, T. 16101-16102 (5 July 2011) (closed session); Adrianus van Baal, T. 8396, 8425 (27 October 2010); D2745 (Witness statement of Vere Hayes dated 14 January 2013), para. 8.

15327 P2068 (Witness statement of Jeremy Bowen dated 10 August 2009), para. 20; David Harland, T. 2171, 2185 (10 May 2010); KDZ088, T. 6555 (13 September 2010) (closed session); D2270 (Witness statement of Andrey Demurenko dated 13 October 2012), para. 34; D2562 (Witness statement of Vladimir Radojčić dated 8 December 2012), paras. 47-48; Vladimir Radojčić, T. 31278 (12 December 2012); D2633 (Witness statement of Milorad Šehovac dated 8 December 2012), paras. 39, 40-41; D2686 (Witness statement of Mihajlo Vujasin dated 16 December 2012), paras. 44-45; D2667 (Witness statement of Ratomir Maksimović dated 14 December 2012), paras. 46-47; D2331 (Witness statement of Blagoje Kovačević dated 14 October 2012), para. 40; D2479 (Witness statement of Mile Sladoje dated 25 November 2012), para. 24; Vere Hayes, T. 31997 (16 January 2013); Vladislav Jovanović, T. 34280 (26 February 2013); John Zametica, T. 42466-42467 (29 October 2013); D2774 (Witness statement of Milenko Inđić dated 19 January 2013), para. 165.

15328 Indeed, as shown in D3873, even the RS Minister of Health complained about one of the VRS decisions restricting the movement of humanitarian convoys, albeit on the grounds that it affected the supplies in the RS. 
all consistent as to the description of the situation in Sarajevo and the life of the citizens there. They all described a city surrounded by the SRK, shelled continuously, and exposed to constant sniper fire, which in turn had the effect of imprisoning the Sarajevo citizens and led to shortage of food, water, and utilities in the city. The Chamber does not doubt that this was indeed the accurate reflection of the situation in the city.

4562. The fact that some humanitarian aid was coming into Sarajevo during the conflict and that the encirclement of Sarajevo was not complete does not change the reality of that situation. As explained earlier, while an exit out of the city did exist, those attempting to leave Sarajevo had to expose themselves to danger when crossing the airport strip or passing through the tunnel. ${ }^{15329}$ Furthermore, while humanitarian aid was indeed coming into Sarajevo throughout the conflict, the Bosnian Serbs controlled and restricted the flow of humanitarian convoys such that the city was rarely fully supplied, as described above in Section IV.B.1.a. ${ }^{1530}$ That being the case, the Chamber does not accept the evidence of SRK soldiers and officers who claimed that the situation was not one of siege because the tunnel could be used as an exit and because some humanitarian aid was coming in. Indeed, to imply, as these Defence witnesses did, that the underground tunnel which was created precisely because the city was surrounded by the SRK somehow made the situation less of a siege seriously affects their credibility as a whole. Similarly, the fact that humanitarian aid had to be sent to the city and that the UN required permission of Bosnian Serbs for this clearly indicates that it was an encircled city, a city under siege, and that the SRK controlled the situation. Had the SRK not surrounded the city and stopped supplies from coming in, neither the tunnel nor the humanitarian aid would have been necessary. ${ }^{15331}$

4563. The documentary evidence presented in this case about the situation in the city further confirms the findings above. For example, on 12 May 1992, during the $16^{\text {th }}$ Bosnian Serb Assembly session, Mladić said that “we have to put a ring around the dragon's head of Sarajevo this very moment, and only those whom we let out should be allowed out". ${ }^{15332}$ In an intercepted conversation with an unknown male on 25 May 1992, Mladić stated that he had "blocked Sarajevo

\footnotetext{
15329 See paras. $3566,3782$.

15330 See paras. e.g. 3559, 3562, 3566, 3569, 3577-3578, 3580, 3591, 3593-3594, 3596, 3599, 3603, 3607-3608, 3611-3612.

15331 As for the evidence of Defence witnesses that the SRK was disadvantaged because it was surrounded on the outside ring of Sarajevo by $\mathrm{ABiH}$ forces and because the $1^{\text {st }}$ Corps of the $\mathrm{ABiH}$ held some elevations within the city, the Chamber considers that this claim, whether accurate or not, ultimately has no real bearing on the relevant issues in this case such as whether the SRK was acting in compliance with international law when conducting its operations in and around Sarajevo.

15332 P956 (Transcript of $16^{\text {th }}$ session of SerBiH Assembly, 12 May 1992), e-court p. 38
} 
from four corners" and that the "city is trapped, there is no way out". ${ }^{1533}$ On 1 April 1994, that is, after the tunnel was built and operational, Galić issued an order to the SRK units, instructing them to "fortify positions around Sarajevo by erecting wire and concrete barriers, which would in turn strengthen the belief that they really are blocked ('in a camp')". ${ }^{15334}$ A number of VRS directives, as discussed earlier, also refer to the "blockade" of Sarajevo and the SRK's efforts to prevent the lifting of that blockade, as do many SRK orders. ${ }^{15335}$ Finally, the Chamber received in evidence a number of contemporaneous military maps, made by both the VRS and the $\mathrm{ABiH}$, showing the confrontation lines in the city at various times. ${ }^{15336}$ These maps clearly illustrate that the inner city of Sarajevo was almost completely encircled by the SRK and that the SRK was therefore able to control the fate of the Sarajevo citizens.

4564. In assessing the evidence before it, the Chamber has considered and accepted the Accused's argument that the media was somewhat unfavourable to the Bosnian Serb side when reporting on the situation in Sarajevo. The Chamber also took into account the fact that at one point the UN decided not to refer to the situation in the city as a "siege". Ultimately, however, the Chamber considers both to be of limited weight in light of all the evidence before it.

4565. Furthermore, while the Bosnian Muslim authorities at times prevented civilians from leaving the city or made it difficult for them to do so in order to ensure that the city remained in the news, the Chamber considers that the actions of the SRK forces positioned around the city left the civilian population with very little opportunity to leave Sarajevo safely.

4566. For all these reasons, the Chamber finds that the city of Sarajevo was essentially encircled and besieged by the SRK and, as such, under a blockade. The Chamber will therefore continue to refer alternatively to the terms "blockade", "siege" or "encirclement" where relevant in this Judgement.

15333 P1041 (Intercept of conversation between Ratko Mladić and unidentified male, 25 May 1992), p. 2. See also P1103 (Intercept of conversation between Momčilo Mandić and Branko Kvesić/Bruno Stojić/Mićo Stanišić, 5 May 1992), p. 5 (in which Mandić refers to holding the "Turks under siege" to starve them "a bit").

15334 P5980 (SRK conclusions and tasks, 1 April 1994), para. 8 (emphasis added). Dušan Zurovac denied seeing wire or barriers around Sarajevo as described in this document. See Dušan Zurovac T. 30301 (14 November 2012). Galić also issed an order on 17 November 1992, that is, two days prior to the issuance of Directive 4, in which he instructed the SRK units to "[f]irmly block Sarajevo". See P6297 (SRK conclusions and tasks, 17 November 1992), p. 3.

15335 See paras. 3561, 3563, 3572, 3578, 3607, 4041. See also e.g. P5968 (SRK Order, 26 January 1994); P3052 (VRS Main Staff Order, 14 December 1993); P6302 (SRK Order, 26 November 1992); P5979 (SRK Order, 4 August 1992).

15336 See e.g. D3382 (Map of Sarajevo); D3383 (Map of Sarajevo); D2788 (Map of Sarajevo marked by Dragomir Milošević); D2789 (Map of Sarajevo marked by Dragomir Milošević); D2790 (Map of Sarajevo marked by Dragomir Milošević); P6295 (VRS map of Sarajevo); P6296 (VRS map of Sarajevo); P1058 (ABiH map); P1764 (ABiH Map of Sarajevo) P842 (VRS map of Sarajevo, 31 August 1995). 


\section{ii. Objectives of the siege}

4567. There was also a marked contrast between the evidence of witnesses called by the Prosecution and those called by the Accused regarding the aims or objectives of the SRK forces around Sarajevo.

4568. According to Rose, the objective of the siege was to engineer an advantageous peace deal with the Bosnian Muslims and to demonstrate to the Bosnian Croats the strength of the Bosnian Serb position. ${ }^{15337}$ It was also used as a vehicle by Bosnian Serb leaders to exert pressure on the UN and the international community. ${ }^{15338}$ Since Bosnian Serbs had fewer infantry forces than the $\mathrm{ABiH}$ in Sarajevo and could not have taken the city without significant casualties, their objective, according to Fraser, was to "keep pressure" on the city through sniping, shelling, and controlling access to humanitarian aid. ${ }^{15339}$ Mole called this a "policy of containment", and of maintaining the status quo, the object of which was to control Sarajevo, not to occupy it. ${ }^{15340}$ Thomas thought that there were four objectives to the siege: (i) to create a situation of "out-right terror"; (ii) to shutdown the source of manpower for the $\mathrm{ABiH}$; (iii) to influence politicians who lived in Sarajevo; and (iv) to engage in "sheer retaliatory madness". ${ }^{1534}$ Banbury testified that the objectives of the siege were two-fold: first, to deny the $\mathrm{BiH}$ government a symbolically important capital city and make it more difficult for it to exercise sovereignty; and second, to punish the people in Sarajevo and cause them "as much pain as possible". ${ }^{15342}$ He thought that the Bosnian Serbs also wanted to exercise

15337 P1638 (Witness statement of Michael Rose dated 26 March 2009), para. 199. See also P1996 (Witness statement of Martin Bell dated 8 March 2010), para. 60; Martin Bell, T. 9770 (14 December 2010); KDZ185, T. 4174-4175 (28 June 2010) (private session).

15338 P1638 (Witness statement of Michael Rose dated 26 March 2009), para. 199; Michael Rose, T. 7252-7254, 7256-7257 (5 October 2010) (conceding, however, that there was a route out of Sarajevo via Mt. Igman and also through the tunnel at the airport); Jeremy Bowen, T. 10105 (13 January 2011).

15339 P1762 (Witness statement of David Fraser dated 17 October 2010), p. 5; David Fraser, T. 8030-8031 (18 October 2010). See also P1426 (Witness statement of Richard Mole dated 7 May 2010), paras. 35-36; KDZ450, T. 10655 (20 January 2011); D949 (BBC news report re Sarajevo, with transcript). On crossexamination, Fraser agreed that a "siege" can be a legitimate military tactic so long as it is not calculated to starve the civilian population. He further conceded that it was a legitimate military tactic for Bosnian Serb forces to encircle Sarajevo in order to prevent $\mathrm{ABiH}$ forces from leaving Sarajevo and from being deployed on other fronts in BiH. See David Fraser, T. 8062 (18 October 2010). See also KDZ088, T. 6425 (8 September 2010) (closed session).

15340 P1426 (Witness statement of Richard Mole dated 7 May 2010), paras. 35-36, 93-94 (adding that Bosnian Serbs could already achieve their political aims by applying pressure on Sarajevo through the siege, which would not have been the case if they captured the city; according to him Bosnian Serbs could also put pressure on the city in response to events elsewhere in $\mathrm{BiH}$ ); Richard Mole, T. 5825-5826 (17 August 2010). See also KDZ450, T. 10655 (20 January 2011); P1997 (BBC news report re interview with Radovan Karadžić at Trebević, with transcript) (in which the Accused states that the Bosnian Serb side could take the city tomorrow if it wished but that it was willing to negotiate for peace instead).

15341 P1558 (Witness statement of Francis Roy Thomas dated 13 May 2009), para. 75 . See also P4203 (Witness statement of Pyers Tucker dated 12 May 2010), para. 49; KDZ185, T. 4174-4175 (28 June 2010) (private session).

15342 P2451 (Witness statement of Anthony Banbury dated 19 May 2009), paras. 197-198 (adding that the siege changed the character and demographics of the city by driving out middle-class and moderate Sarajevans who believed in a multi-ethnic BiH). See also P27 (Witness statement of Mirsad Kučanin dated 4 September 2000), 
"total political control" over areas where Serbs had traditionally lived, including in Sarajevo. ${ }^{15343}$ Bowen thought that the siege itself was "as much a weapon of war as the bullets and shells that were fired into Sarajevo". ${ }^{15344}$ KDZ450 testified that the Bosnian Serbs wanted to remain present in Sarajevo because it was the "historic capital" of BiH and a city of "great symbolic importance", as well as an area of "great interest for strategic and military reasons". ${ }^{15345}$ Thus, their objective was to exert pressure on Bosnian Muslim leaders and force them to accept a division of Sarajevo. ${ }^{15346}$ He testified that a frequent method of applying pressure was blocking the flow of humanitarian aid. ${ }^{15347}$

4569. On the other hand, the majority of the witnesses called by the Accused denied the above were the SRK's objectives and claimed that the SRK simply wanted to (i) contain the ABiH forces within the city in order to prevent them from linking up with $\mathrm{ABiH}$ forces outside of the city, as that would have led to attacks on Serb territories around Sarajevo and (ii) protect and defend those territories as they belonged to Bosnian Serbs. ${ }^{15348}$ Additionally, KW570 thought that the objective of the Bosnian Serb siege was to contain and neutralise the ABiH forces in Sarajevo, in order to force the Bosnian Muslim government to the negotiating table, where a long-term peace settlement

p. 4 (testifying that in his opinion, the Bosnian Serbs made a "deliberate choice" to keep civilians "trapped" in Sarajevo and set about the "gradual annihilation" of the civilian population).

15343 Anthony Banbury, T. 13310 (15 March 2011).

15344 Jeremy Bowen, T. 10104-10105 (13 January 2011); P2068 (Witness statement of Jeremy Bowen dated 10 August 2009), para. 20.

15345 P5906 (Witness statement of KDZ450 dated 17 January 2011), paras. 48-49; KDZ450, T. 10553-10554 (19 January 2011) (private session).

15346 P5906 (Witness statement of KDZ450 dated 17 January 2011), paras. 48, 140; KDZ450, T. 10553 (19 January 2011) (private session). See also P1484 (Ratko Mladić's notebook, 28 October 199315 January 1994), pp. 53-54 (in which Mladić recounts a meeting in Belgrade on 13 December 1993 where the Accused lists division of Sarajevo as one of the Bosnian Serb goals). A number of witnesses called by the Accused, however, denied that the Bosnian Serb side wanted to divide Sarajevo. See e.g. D2351 (Witness statement of Stevan Veljović dated 19 October 2012), para. 21 (testifying that seizing or dividing parts of Sarajevo was never an objective of the SRK, and that even if there was such a plan at the higher levels, the soldiers "had no such motives").

15347 P5906 (Witness statement of KDZ450 dated 17 January 2011), para. 140.

15348 Dragomir Milošević, T. 32574-32577 (23 January 2013); D2412 (Witness statement of Savo Simić dated 4 November 2012), para. 14 (stating that the breaktrough by $\mathrm{ABiH}$ forces would have freed up a lot of men for use on other fronts in BiH); Savo Simić, T. 30028, 30031 (8 November 2012); D2658 (Witness statement of Luka Dragičević dated 9 December 2012), para. 22; D2479 (Witness statement of Mile Sladoje dated 25 November 2012), para. 8; Milosav Gagović, T. 31918 (15 January 2013); D2484 (Witness statement of Zoran Kovačević dated 25 November 2012), para. 6; D2516 (Witness statement of Vlade Lučić dated 5 November 2012), paras. 9, 12 (adding that the ABiH was intent on leaving Sarajevo with "huge military potential" and proceeding across the Romanija plateau to link up with other $\mathrm{ABiH}$ units in the upper and middle Drina Valley and Sandžak); Vlade Lučić, T. 30827 (3 December 2012); D2391 (Witness statement of Slobodan Tuševljak dated 5 November 2012), para. 11; D2633 (Witness statement of Milorad Šehovac dated 8 December 2012), paras. 4-5, 69; D2650 (Order of $3^{\text {rd }}$ Infantry Battalion of $2^{\text {nd }}$ Sarajevo Light Infantry Brigade, undated); D2331 (Witness statement of Blagoje Kovačević dated 14 October 2012), para. 9; D2383 (Witness statement of Slavko Gengo dated 14 October 2012), para. 12; D2562 (Witness statement of Vladimir Radojčić dated 8 December 2012), paras. 7-8; D2341 (Witness statement of Dušan Škrba dated 14 October 2012), para. 12; D2379 (Witness statement of Momir Garić dated 2 November 2012), para. 24; D2686 (Witness statement of Mihajlo Vujasin 
for BiH could be worked out. ${ }^{15349}$ Milenko Inđić testified that the SRK's basic task was to maintain "the established frontline" held by it. ${ }^{15350}$

4570. As noted earlier, the expert witness Radinović testified that the SRK wanted to keep ABiH forces under blockade and prevent them from breaking through to the Romanija plateau, from which they could access the Drina River valley, while the ABiH's $1^{\text {st }}$ Corps had as its main objectives to keep Sarajevo "under its control" and to "deblockade the city" so that it could link up with ABiH forces in Igman and reach the Romanija plateau. ${ }^{15351}$ Accordingly, Radinović opined, the SRK adopted a defensive strategy and the $\mathrm{ABiH}$ adopted an offensive strategy, both strategies being legal and legitimate. ${ }^{15352}$ According to him, the VRS had an exclusively "defensive strategy" to defend the territory and the people of RS as it had "absolutely no resources to commit aggression". 15353

4571. Dragomir Milošević testified that by the time he became the SRK Commander in August 1994, the situation on the battlefield crystallised and it was a matter of maintaining the status quo. ${ }^{15354}$ According to him, the task of the SRK was to defend its area of deployment while the $\mathrm{ABiH}$ conducted operations in an attempt to break through SRK lines; these operations included using artillery, conducting night-time and sabotage operations, planting explosives, and sniping, as well as conducting attacks on the SRK from the outside of Sarajevo. ${ }^{15355} \mathrm{He}$ also denied that the SRK's aim was to divide Sarajevo, as indicated in the supplement to Directive $6,{ }^{15356}$ saying that he

dated 16 December 2012), paras. 14-18; D2444 (Witness statement of Miladin Trifunović dated 11 November 2012), paras. 16-17; D2667 (Witness statement of Ratomir Maksimović dated 14 December 2012), para. 9. KW570, T. 32226 (18 January 2013) (private session). KW570 testified that the Bosnian Serbs were willing to end the siege of Sarajevo because it was doing their cause "horrendous damage" and in addition the Bosnian Serbs in Vogošća and Ilidža were subjected to $\mathrm{ABiH}$ fire and living under threatening conditions. However, the Bosnian Muslim government resisted all attempts to end the siege. See KW570, T. 32261-32262 (18 January 2013) (private session).

15350 D2774 (Witness statement of Milenko Inđić dated 19 January 2013), para. 1.

15351 Radovan Radinović, T. 41399, $41403-41404$ (17 July 2013). Asim Džambasović testified that the "priority military objective" of the ABiH's $1^{\text {st }}$ Corps was first to defend the city and only then to create conditions which would enable it to "break out of the siege", which was a "little bit unrealistic" because the ABiH needed seven times the amount of forces and equipment of the VRS to break the siege. See Asim Džambasović, T. 1527015271 (23 June 2011); D1391 (Order of ABiH $1^{\text {st }}$ Corps, 2 January 1993), p. 1.

15352 Radovan Radinović, T. 41404-41405 (17 July 2013). Both Dragičević and Tomić testified that, in contrast to the SRK, the strategy of the $\mathrm{ABiH}$ was to "capture all of $\mathrm{BiH}$ " through "offensive operations". See D2658 (Witness statement of Luka Dragičević dated 9 December 2012), para. 22; D2418 (Witness statement of Božo Tomić dated 5 November 2012), para. 21.

15353 Radovan Radinović, T. 41397-41398 (17 July 2013).

15354 Dragomir Milošević, T. 33103-33104 (4 February 2013). See also Savo Simić, T. 30028,30031 (8 November 2012).

15355 Dragomir Milošević, T. 32576-32578 (23 January 2013), T. 32715 (28 January 2013). An example of such operation was the ABiH offensive on 16 June 1995. See Dragomir Milošević, T. 32737-32739 (28 January 2013); P5642 (Intercept of conversation between Dragomir Milošević, unidentified male, and Ratko Mladić, 16 June 1995), p. 4.

15356 For the supplement to Directive 6, see para. 3578. 
was never given such an order; however, he did acknowledge that by maintaining and improving its position, as ordered in the supplement, the SRK may have been able to affect international negotiations. ${ }^{15357}$

4572. Like Milošević, a large number of former SRK soldiers and officers claimed that the SRK carried out predominantly defensive operations in the city in order to prevent $\mathrm{ABiH}$ forces from breaking out, at the same time acknowledging that there were some exceptions, such as operation Lukavac 93 and other offensive actions. ${ }^{15358}$ Lučić, for example, acknowledged that the SRK undertook offensive operations "designed to recapture lost positions" and to "neutralise the weapons and manpower" of the $\mathrm{ABiH}$ in locations where the $\mathrm{ABiH}$ was engaging civilian and military targets. ${ }^{15359}$

4573. On the other hand, Blagoje Kovačević testified that "not a single offensive action had been executed" at his positions as the SRK had no interest in taking areas which were not "ethnically

15357 Dragomir Milošević, T. 33093, 33099-33103 (4 February 2013) (adding also that such a division would have entailed great losses on both sides); P4925 (Supplement to Directive 6, 12 December 1993), para. 2(a) (referring to the Accused's order to the VRS to seize Žuč and Mojmilo in order to ensure "the most favourable position for dividing" Sarajevo). See also D2667 (Witness statement of Ratomir Maksimović dated 14 December 2012), para. 12; D2516 (Witness statement of Vlade Lučić dated 5 November 2012), para. 12; D2331 (Witness statement of Blagoje Kovačević dated 14 October 2012), para. 15; Blagoje Kovačević, T. 29088 (18 October 2012); P3052 (VRS Main Staff Order, 14 December 1993). But see D2562 (Witness statement of Vladimir Radojčić dated 8 December 2012), para. 11 and D2633 (Witness statement of Milorad Šehovac dated 8 December 2012), para. 8 (both of whom testified that the final objective of the Bosnian Serb authorities was to have parts of Sarajevo under their control).

15358 D2412 (Witness statement of Savo Simić dated 4 November 2012), para. 15 (also referring to some offensive actions the SRK took to improve the SRK's tactical position, including the liberation of part of the VracaTrebević road, and the attempted liberation of part of Šoping); Savo Simić, T. 30033 (8 November 2012), T. 30037-30040 (12 November 2012); D2633 (Witness statement of Milorad Šehovac dated 8 December 2012), para. 6; D2351 (Witness statement of Stevan Veljović dated 19 October 2012), paras. 21-22; D2519 (Witness statement of Dragan Maletić dated 9 November 2012), paras. 13-15; Milosav Gagović, T. 31918 (15 January 2013); D2774 (Witness statement of Milenko Inđić dated 19 January 2013), para. 2; D2484 (Witness statement of Zoran Kovačević dated 25 November 2012), para. 6; D2387 (Witness statement of Stojan Džino dated 4 November 2012), paras. 36-37; D2341 (Witness statement of Dušan Škrba dated 14 October 2012), para. 12; Dušan Škrba T. 29118 (18 October 2012); D2379 (Witness statement of Momir Garić dated 2 November 2012), para. 25; D2686 (Witness statement of Mihajlo Vujasin dated 16 December 2012), para. 18; Mihajlo Vujasin, T. 31799-31802 (20 December 2012); P6067 (Order of Rajlovac Infantry Brigade, 30 November 1992), p. 2; D2451 (Witness statement of Velimir Dunjić dated 12 November 2012), para. 7; D2389 (Witness statement of Predrag Trapara dated 3 November 2012), para. 5; D2391 (Witness statement of Slobodan Tuševljak dated 5 November 2012), paras. 11, 15-17; Slobodan Tuševljak, T. 29947-29948 (7 November 2012); D2398 (Witness statement of Richard Gray dated 22 April 2012), para. 19; D2418 (Witness statement of Božo Tomić dated 5 November 2012), para. 16; D2444 (Witness statement of Miladin Trifunović dated 11 November 2012), para. 16; D2622 (Witness statement of Željko Bambarez dated 9 December 2012), para. 12; [REDACTED]; Manojlo Milovanović. T. 25747 (5 March 2012); D2667 (Witness statement of Ratomir Maksimović dated 14 December 2012), para. 8, 10; D2516 (Witness statement of Vlade Lučić dated 5 November 2012), paras. 8, 10; Vlade Lučić, T. 30827 (3 December 2012); D2562 (Witness statement of Vladimir Radojčić dated 8 December 2012), para. 9; D2479 (Witness statement of Mile Sladoje dated 25 November 2012), para. 8.

15359 D2516 (Witness statement of Vlade Lučić dated 5 November 2012), para. 10 (as an example, Lučić identified the SRK offensive on a tower in Zlatište, which had to be taken because ABiH units were continuously targeting the road from Vraca to Trebević to Pale). 
defined as Serbian". ${ }^{15360}$ Gengo also testified that his battalion made no plans to move its lines forward and that there were "never" plans to undertake offensive operations in the Sarajevo area. $^{15361}$ When presented with an order issued by Galić on 26 January 1994 to "continue with offensive activities and liberate the Serb part of the City of Sarajevo", Gengo testified that his battalion never received such an order and that he neither planned nor was involved in offensive activities. ${ }^{15362} \mathrm{He}$ also explained that the references in the order to "fortifications" and "improving the tactical position" were all defensive in nature. ${ }^{15363}$ Milovanović testified that the VRS was "a defensive army with a defensive strategy, from a strategic point of view" and that, as such, it engaged in "active combat activities" only to improve its tactical positions. ${ }^{15364}$ Zurovac denied that simply by "encircling" the city, the SRK was engaged in "offensive" measures, explaining that the Serb units around Sarajevo were not the aggressor because it would not make sense to be an aggressor against one's own country. ${ }^{15365}$ When shown an SRK order dated 16 December 1993 instructing the units to conduct an "active defence" to prevent $\mathrm{ABiH}$ forces from unblocking their part of the town and to establish conditions for the division of Sarajevo into two parts, Zurovac disagreed that "active defence" was another term for offence, but agreed that splitting Sarajevo into two parts would constitute an offensive act "to a certain extent." 15366

4574. The above can be contrasted with the evidence of KDZ182 who testified that one of the techniques used by Bosnian Serbs during the siege of Sarajevo was to move the confrontation line toward the city "inch by inch". ${ }^{15367}$ Similarly, [REDACTED] explained that the encirclement of Sarajevo was only "partly" defensive because it was sometimes necessary to move units and engage in "subversive or sabotage operations" in order to achieve the goal of containing the $\mathrm{ABiH}$ forces within Sarajevo. ${ }^{15368}$

\footnotetext{
15360 D2331 (Witness statement of Blagoje Kovačević dated 14 October 2012), para. 8. When confronted with two post-war statements by Dragomir Milošević referring to SRK carrying out activities to extend its territory, Kovačević claimed that he had no knowledge as to Milošević's position, but testified that one of the SRK objectives was to keep the road from Lukavica to Pale, which required the taking of "small features". See Blagoje Kovačević, T. 29090-29094 (18 October 2012); D2901 (Letter from Dragomir Milošević to Ratko Mladić, 19 May 1996), p. 2; D568 (Speech of Dragomir Milošević, 30 March 1996), p. 3.

15361 D2383 (Witness statement of Slavko Gengo dated 14 October 2012), para. 33; Slavko Gengo, T. 29799 (6 November 2012).

15362 Slavko Gengo, T. 29800 (6 November 2012); P5968 (SRK Order, 26 January 1994), p. 8.

15363 Slavko Gengo, T. 29835-29836, 29841-29842 (6 November 2012) (also explaining that the phrase "wider-scale offensive activities" in the order was a reference to combat activities to improve the SRK's tactical position in order to prevent the $\mathrm{ABiH}$ from penetrating the external ring).

15364 Manojlo Milovanović, T. 25747 (5 March 2012).

15365 Dušan Zurovac T. 30297 (14 November 2012).

15366 Dušan Zurovac T. 30298-30300 (14 November 2012); P5989 (SRK Order, 16 December 1993), pp. 4-5.

15367 P2414 (Witness statement of KDZ182), p. 29 (under seal).

15368 [REDACTED].
} 
4575. Based on the evidence outlined above, the Chamber is satisfied that the siege or encirclement of Sarajevo by the SRK had a number of objectives, one of which was indeed the containment of the $\mathrm{ABiH}$ forces within the city in order to prevent them from linking up with $\mathrm{ABiH}$ forces outside of the city. However, the military directives issued by the VRS Main Staff and/or the Accused discussed in an earlier section of the Judgement ${ }^{15369}$ clearly indicate a number of additional Bosnian Serb goals and strategies in relation to Sarajevo, namely, (i) to keep it under firm blockade and gradually tighten the encirclement; (ii) to conduct, among other things, offensive operations and liberate remaining parts of "Serbian territory" that would in turn improve tactical positions and normal communication within the RS; (iii) to isolate parts of the city and surrounding settlements; and (iv) to ensure the most favourable position for dividing Sarajevo. ${ }^{15370}$ Additionally, in Directive 4, the VRS Main Staff noted that one of the tasks of the VRS as a whole was to "[c]reate conditions for the state leadership of [RS] to participate equally in resolving the crisis in the former $[\mathrm{BiH}]$ with other international factors". ${ }^{15371}$ This is in line with the evidence outlined above, namely that the siege was used as a means of putting pressure on Bosnian Muslim authorities and the UN in order to ensure the most favourable peace deal for the Bosnian Serb side during international negotiations. ${ }^{15372}$ Similarly, the goals listed above are in line with the evidence of Prosecution witnesses that one objective of the siege was to control the city and its people, and to keep those parts of the city deemed to be ethnically Serb under the control of the Bosnian Serb authorities. While some of the Accused's witnesses denied that the SRK's aim was to divide Sarajevo, others, like Radojčić and Šehovac confirmed that the final objective was to keep Bosnian Serb parts of the city under the control of the Bosnian Serb authorities. ${ }^{15373}$ Indeed, this aim is clearly outlined in the above mentioned directives and the Chamber also recalls that, by 1993, the frontlines in Sarajevo were more or less set and that certain parts of the city, such as Grbavica and parts of Dobrinja, were under the control of the Bosnian Serb side throughout the war, thus essentially creating a division of the city in certain areas.

\footnotetext{
15369 See paras. 3561, 3563, 3572, 3578, 3607, 4041.

15370 D232 (Directive 1, 6 June 1992), para. 2; D235 (Directive 3, 3 August 1992), pp. 2-3 ,5; P976 (Directive 4 , 19 November 1992), pp. 3, 5; P843 (Directive 5, 25 June 1993), paras. 2, 4-5; P3039 (Directive 6, 11 November 1993), pp. 6, 9-10 (referring to, among other things, the VRS strategic military goal of "liberation" of Sarajevo which was then changed to division of Sarajevo in the supplement to Directive 6); P4925 (Supplement to Directive 6, 12 December 1993), paras. 2(a), 4(e); P838 (Directive 7, 8 March 1995), pp. 7-8, 11-12. See also P5981 (SRK Order, 26 June 1993), para. 4 (indicating that as part of the Lukavac 93 operation the SRK units were tasked with "creating conditions for take over of Sarajevo"); P3052 (VRS Main Staff Order, 14 December 1993).

15371 P976 (Directive 4, 19 November 1992), p. 3.

15372 This is also confirmed by the evidence the Chamber heard of fighting in Sarajevo intensifying during peace negotiations.

15373 See fn. 15357.
} 
4576. Finally, although most defence witnesses testified that, with the exception of Lukavac 93, the SRK was engaging in defensive activities alone, some then proceeded to describe additional offensive actions their respective units undertook during their time in Sarajevo. ${ }^{15374}$ This again is in line with the language in the directives which clearly called for offensive actions by the SRK in order to strengthen and consolidate SRK positions and gain territories deemed ethnically Serb. It also confirms the evidence of KDZ182 who testified that the SRK strategy was to move the frontline inch by inch towards the city and with the evidence of [REDACTED] who characterised the encirclement of Sarajevo as only "partly" defensive. Milošević himself confirmed as much in statements he made following the conflict. ${ }^{15375}$ Ultimately, however, whether the VRS conducted offensive or defensive actions in and around the city is irrelevant for the purposes of this case. Instead, what matters-and what is thus addressed throughout this Judgement-is whether the VRS/SRK actions in and around Sarajevo were in compliance with international law.

g. Campaign of sniping and shelling causing terror

\section{i. Arguments of the parties}

4577. The Prosecution alleges that members of the Sarajevo Forces implemented a military strategy that used sniping and shelling to kill and wound the civilian population of Sarajevo, which in turn resulted in thousands of civilian casualties, including children and the elderly. ${ }^{15376}$ The Prosecution further alleges that the sniping and shelling comprised direct attacks on the civilian population or on individual civilians not taking direct part in hostilities, and that these attacks included indiscriminate and disproportionate attacks. ${ }^{15377}$ According to the Prosecution, "the only reasonable conclusion that can be drawn from the protracted campaign of sniping and shelling" of Sarajevo civilians is that "its primary purpose was terror". 15378

4578. The Accused accepts that civilians in Sarajevo experienced terror but argues that civilians on both sides of the confrontation line were terrified as is "always the case in civil wars and street

\footnotetext{
15374 See e.g. D2412 (Witness statement of Savo Simić dated 4 November 2012), para. 15; D2516 (Witness statement of Vlade Lučić dated 5 November 2012), para. 10; D2633 (Witness statement of Milorad Šehovac dated 8 December 2012), para. 6; Blagoje Kovačević, T. 29091-29092 (18 October 2012); (Witness statement of Mihajlo Vujasin dated 16 December 2012), para. 18; Mihajlo Vujasin, T. 31799-31802 (20 December 2012); P6067 (Order of Rajlovac Infantry Brigade, 30 November 1992), p. 2.

15375 See D2901 (Letter from Dragomir Milošević to Ratko Mladić, 19 May 1996), p. 2; D568 (Speech of Dragomir Milošević, 30 March 1996), p. 3.

15376 Indictment, para. 79; Prosecution Final Brief, paras. 714-715. Sarajevo Forces are defined in the Indictment as (i) members of JNA operating in and around Sarajevo until about 20 May 1992, (ii) members of the VRS, in particular the SRK, and (iii) members of other forces operating in or with responsibility over the Sarajevo area. See Indictment, para. 18.

15377 Indictment, para. 80.

15378 Prosecution Final Brief, para. 783; Indictment, para. 77.
} 
fights". ${ }^{15379}$ He claims that the SRK units did not intend to cause civilian casualties or to spread terror among the civilian population of Sarajevo. ${ }^{15380}$ According to him, any psychological pressure experienced by civilians in the city was caused by the Bosnian Muslim authorities who provoked Bosnian Serbs into responding to fire. ${ }^{15381}$ In addition, the nature of the conflict in and around Sarajevo meant that the SRK was unable to designate any areas in the city as exclusively civilian since fire was coming from those zones. ${ }^{15382}$ The Accused further submits that SRK units were never ordered, verbally or in writing, by SRK commands or civil authorities, to target civilians ${ }^{15383}$ and that there was no goal to deliberately make it impossible for the Bosnian Muslim government in Sarajevo to control the living conditions of civilians in the city. ${ }^{15384}$ The Accused's final argument, namely that the Bosnian Muslim side targeted its own civilians in order to gain international sympathy has been dealt with in the earlier part of the Judgement.

\section{ii. Terror in Sarajevo}

4579. A large number of Prosecution witnesses testified that Bosnian Serb Forces sniped and shelled the civilians in Sarajevo in order to instil terror in the civilian population, exert political pressure on their leaders or force them into accepting the status quo, and undermine the morale of the $\mathrm{ABiH}$ troops whose families were in the city. ${ }^{15385}$ Indeed the Chamber heard that already by August 1992, the UN Special Rapporteur on Human Rights reported back to the UN that the city was being shelled on a regular basis and that snipers are killing innocent civilians in what "appears to be a deliberate attempt to spread terror among the civilian population." ${ }^{15386}$ Similarly, towards

\footnotetext{
15379 Defence Final Brief, para. 1969.

15380 Defence Final Brief, paras. 1912, 1917.

15381 Defence Final Brief, para. 1920.

15382 Defence Final Brief, para. 1905.

15383 Defence Final Brief, paras. 1930-1938.

15384 Defence Final Brief, para. 1834.
}

15385 See e.g. P1217 (Witness statement of Milan Mandilović dated 24 February 2010), paras. 99, 101; P4203 (Witness statement of Pyers Tucker dated 12 May 2010), para. 49; P5906 (Witness statement of KDZ450 dated 17 January 2011), paras. 26, 48-49, 140; KDZ450, T. 10553 (19 January 2011) (private session); P2106 (Witness statement of KDZ304), pp.3, 9-10 (under seal); KDZ304, T. 10446-10447 (18 January 2011); P2414 (Witness statement of KDZ182), pp. 28-29, 54 (under seal); KDZ182, T. 13038-13039, 13093 (9 March 2011); P1558 (Witness statement of Francis Roy Thomas dated 13 May 2009), para. 75; P1953 (Witness statement of Harry Konings dated 11 November 2010), paras. 40, 43; Michael Rose, T. 7267 (5 October 2010); P6060 (Record of interview with KDZ185), e-court pp. 13, 16; KDZ185, T. 4175-4177 (28 June 2010) (private session), T. 4177-4179, 4182-4183 (28 June 2010); P1851 (Witness statement of Per Anton Brennskag dated 26 October 2010), para. 62; P820 (Witness statement of David Harland dated 4 September 2009), paras. 33-35; Rupert Smith, T. 11333-11334 (8 February 2011); P926 (Witness statement of Aernout van Lynden dated 26 February 2010), para. 25; Aernout van Lynden, T. 2412 (19 May 2010); P1996 (Witness statement of Martin Bell dated 8 March 2010), paras. 37, 46, 52.

15386 P1265 (Tadeusz Mazowiecki's Report on the situation in the former Yugoslavia, 28 August 1992), para. 17. See also Hussein Ali Abdel-Razek, T. 5514-5515 (20 July 2010). 
the end of the conflict, in July 1995, the UN was reporting on a "general atmosphere of terror in the city" caused by the Bosnian Serb sniping and shelling. ${ }^{15387}$

4580. More specifically, Fraser testified that this feeling of terror in Sarajevo was caused by a number of factors, including the fact that the city was besieged and that the residents were shelled and sniped so that they "never quite knew what was going to happen to them when they walked out the door". ${ }^{15388}$ KDZ304 testified that the SRK sniping and shelling aimed at "terrorising" and demoralising the civilian population ${ }^{15389}$ and that various measures were used by the Bosnian Serbs to make the people of Sarajevo "choke"; this included the increased targeting and killing of civilians, the disruption of Blue Routes for the supply of humanitarian aid, the disruption of public transport, and the cutting off of electricity and water supplies. ${ }^{15390}$ In Harland's view, terror was caused through several levers of pressure that the Bosnian Serbs used in relation to Sarajevo, such as the shelling and sniping of the civilian population, which he thought was a form of "terrorism directed at the civilians". 15391

4581. Harland further testified that the application of terror followed a discernible pattern so that when there was an explicit threat of intervention against the Bosnian Serbs, the pressure would be eased, but when the threat subsided, the pressure would be increased. ${ }^{15392}$ He gave as an example the events following the SRK's capture of Mt. Igman and the first Markale incident, where NATO action was threatened and resulted in a dramatic decline in the Serb sniping and shelling of the civilian population. ${ }^{15393}$ KDZ450 testified that there was also a correlation between the increase in

\footnotetext{
15387 P822 (UNPROFOR Weekly Situation Report (Sarajevo), 8 July 1995), p. 2; David Harland, T. $2022-2023$ (6 May 2010).

15388 David Fraser, T. 8030 (18 October 2010). See also P2451 (Witness statement of Anthony Banbury dated 19 May 2009), para. 199; KDZ185, T. 4175-4179 (28 June 2010); Rupert Smith, T. 11333-11334 (8 February 2011); P2361 (Witness statement of Eset Muračević dated 24 February 2011), para. 89; P733 (Witness statement of Sulejman Crnčalo dated 1 November 2009), paras. 87-88.

15389 P2407 (Witness statement of KDZ304), p. 10. KDZ304 did concede, however, that military positions of the $\mathrm{ABiH}$ were interspersed with the civilian areas. See P2407 (Witness statement of KDZ304), p. 35; KDZ304, T. 10493-10494 (18 January 2011).

15390 KDZ304, T. 10524-10525 (19 January 2011). See also P2361 (Witness statement of Eset Muračević dated 24 February 2011), para. 96; KDZ450, T. 10642-10644 (20 January 2011) (who was adamant that the Bosnian Serb side deliberately targeted civilians in Sarajevo).

15391 P820 (Witness statement of David Harland dated 4 September 2009), para. 38-39, 41; David Harland, T. 20182019 (6 May 2010). See also Yasushi Akashi, T. 37767-37769 (25 April 2013) (testifying that both sides in the conflict used humanitarian assistance as an instrument to either weaken the position of their opponent or strengthen their own position); D3489 (Excerpt from Yasushi Akashi's book entitled "In the Valley between War and Peace"), p. 26; P6293 (UNPROFOR report, 3 September 1994). Harland did not think that it was the Serb intention to actually capture the city and testified that the Accused admitted to him that it was not politically useful to force the city to surrender. See P820 (Witness statement of David Harland dated 4 September 2009), paras. 40-41.

15392 David Harland, T. 2019-2020, 2032-2034 (6 May 2010); P825 (SRK Order, 11 August 1993). See also P926 (Witness statement of Aernout van Lynden dated 26 February 2010), para. 25.

15393 David Harland, T. 2019-2020 (6 May 2010).
} 
ABiH offensives and the attacks directed against civilians in Sarajevo. ${ }^{15394}$ Finally, a number of witnesses testified that events at the frontlines outside of Sarajevo also had an effect on the situation in the city. ${ }^{15395}$

4582. According to Fraser, the conditions in Sarajevo were "absolutely the worst conditions for anybody to live in". ${ }^{15396}$ During his time in the city, Fraser asked people, including civilians working for him and locals in the shops, what it was like to live in the city and in response people expressed the terror of never knowing what was going to happen next. ${ }^{15397}$ Some residents said that life in Sarajevo was even worse than during the German occupation of $\mathrm{BiH}$ in the 1940 s. ${ }^{15398}$ In order to avoid being targeted, civilians in the city would defer the basic life-saving chores, such as collecting wood, to times of reduced visibility, including foggy weather or night-time darkness. ${ }^{15399}$ In addition, schools were closed and temporary neighbourhood schools were established in cellars, in order to minimise children's exposure to shelling and sniping. ${ }^{15400}$

4583. Fraser singled out two Bosnian Serb activities that had a devastating psychological impact on the citizens of Sarajevo; the first was the targeting of the trams because if they were not running due to sniper fire it meant that the situation was "grave", which would send "shudders through the city". ${ }^{15401}$ The second was the use of modified air bombs by the Bosnian Serbs, as those were "psychologically very devastating" for the civilian population. ${ }^{15402}$ KDZ304 also confirmed that modified air bombs were used as part of the psychological warfare and with the aim of terrorising

\footnotetext{
15394 P5906 (Witness statement of KDZ450 dated 17 January 2011), para. 33.

15395 See e.g. P2414 (Witness statement of KDZ182), p. 30 (under seal); P1426 (Witness statement of Richard Mole dated 7 May 2010), paras. 91-92, 94-96, 105, 107, 112; P1433 (UNMO report for October 1992), p. 4; P1434 (UNMO report for November 1992), p. 3; P1429 (UNMO report for December 1992), p. 3; Richard Mole, T. 5833-5836 (17 August 2010); Jeremy Bowen, T. 10105 (13 January 2011); P820 (Witness statement of David Harland dated 4 September 2009), para. 35; P1996 (Witness statement of Martin Bell dated 8 March 2010), para. 98; P1678 (BBC news report re attacks on Sarajevo and Bihać); P2017 (BBC news report re Sarajevo and Bihać, with transcript); Martin Bell, 9798 (14 December 2010); P5906 (Witness statement of KDZ450 dated 17 January 2011), paras. 33-37; KDZ450, T. 10550-10551 (19 January 2011)(indicating that the attacks were organised by the higher command).

15396 David Fraser, T. 8031 (18 October 2010).

15397 P1762 (Witness statement of David Fraser dated 17 October 2010), pp. 4, 73.

15398 P1762 (Witness statement of David Fraser dated 17 October 2010), p. 73; David Fraser, T. 8031 (18 October 2010). See also P1525 (Witness statement of Bakir Nakaš dated 8 September 2010), para. 56.

15399 See Adjudicated Facts 56, 57. When venturing out for these chores, civilians would often accompany each other so that there would be assistance if they were wounded. See Adjudicated Fact 63.

15400 See Adjudicated Fact 58. Many civilians would in fact live in cellars of their buildings in order to avoid the shells, and would move as little as possible. See Adjudicated Fact 59.

15401 P1762 (Witness statement of David Fraser dated 17 October 2010), p. 39.

15402 P1762 (Witness statement of David Fraser dated 17 October 2010), p. 64.
} 
both the civilian population and the $\mathrm{ABiH}$ soldiers whose families lived in the city and were subjected to modified air bomb attacks. ${ }^{15403}$

4584. Like Fraser, Mole testified that the psychological pressure in Sarajevo was intense because of "the constant danger of injury or death from all forms of weaponry and perceived military activity within the city", no matter where one was. ${ }^{15404}$ In other words, wherever people of Sarajevo went they were subject to this "incessant fear and concern" that was both "immense and protracted". 15405 Tucker testified that life in Sarajevo was "horrible" for the civilian population as the Bosnian Serbs blockaded the city and "subjected the inhabitants to incessant shelling, sniping, starvation, cold, as well as psychological pressure". ${ }^{15406}$ No ten minutes would go by without the sound of small arms fire, and no half hour would go by without the sound of shells or mortar bombs. ${ }^{15407}$ He called the activities of the SRK "terrorism by artillery" as its heavy weapons would fire all over the city in an arbitrary fashion and with no military purpose. ${ }^{15408}$ For KDZ185, the fact that the shelling was so random and hardly ever targeted military objects "kept the population in a state of terror". 15409

4585. According to Banbury, the siege of Sarajevo was "clearly a campaign of terror" and the people who lived through it "suffered immensely". ${ }^{15410}$ Nakaš, a doctor in the Sarajevo State Hospital, testified that many people in Sarajevo were in fact "visibly traumatised" and suffered from "post-traumatic stress disorder". ${ }^{1541}$ Bell confirmed this by stating that he had "never seen such anxiety etched on everybody's faces" and that "some [people] looked almost grey with fear". 15412 Mandilović, another doctor from the Sarajevo State Hospital, testified that Sarajevo's civilian population eventually became "numb to everything going on around them" and that people were in a state of "permanent fear". ${ }^{15413}$ Hajir, a doctor working in Dobrinja Hospital, testified that the civilian population suffered deep psychological scars as a result of the siege; life in Sarajevo

\footnotetext{
15403 P2407 (Witness statement of KDZ304), pp. 26-27; P2108 (UNPROFOR Memo re meeting with SRK, 9 July 1995).

15404 P1426 (Witness statement of Richard Mole dated 7 May 2010), paras. 4, 8-9, 65. See also P2068 (Witness statement of Jeremy Bowen dated 10 August 2009), paras. 24, 27-28, 43; Jeremy Bowen, T. 10212 (14 January 2011).

15405 Richard Mole, T. 5823 (17 August 2010). See also Adrianus van Baal, T. 8461 (27 October 2010).

15406 P4203 (Witness statement of Pyers Tucker dated 12 May 2010), para. 6, 22-23, 44.

15407 P4203 (Witness statement of Pyers Tucker dated 12 May 2010), para. 22.

15408 P4203 (Witness statement of Pyers Tucker dated 12 May 2010), paras. 23, 90.

15409 P6060 (Record of interview with KDZ185), e-court p. 16.

15410 P2451 (Witness statement of Anthony Banbury dated 19 May 2009), para. 199.

15411 P1762 (Witness statement of David Fraser dated 17 October 2010), p. 73; P1525 (Witness statement of Bakir Nakaš dated 8 September 2010), paras. 49-58.

15412 Martin Bell, T. 9777-9778 (14 December 2010); P1996 (Witness statement of Martin Bell dated 8 March 2010), paras. 52-53; P2000 (BBC news report re Sarajevo, with transcript).

15413 P1217 (Witness statement of Milan Mandilović dated 24 February 2010), para. 108-110.
} 
was hard for everyone and people experienced psychological problems and paranoia. ${ }^{15414}$ In addition, they felt fear and anxiety for the safety of their loved ones. ${ }^{15415}$ According to Van Baal, when he arrived to Sarajevo in February 1994, the situation was one of "desperation and horror", where people were underweight and had "fear in their eyes". 15416

4586. Bell testified that of all the conflicts he covered, the Sarajevo battlefield was the only one conducted continuously and intensively over a long period of time in a modern city and an urban environment. ${ }^{15417}$ According to him, one of the features of this conflict was the least distinction between soldiers and civilian when it came to targeting as he personally observed civilians being deliberately targeted within the city. ${ }^{15418}$ He also testified that there were essentially two conflicts in Sarajevo-one was the conflict between the two armies and the other was bombardment and sniping of civilians which happened constantly and on both sides. ${ }^{15419}$ Bogdan Vidović, who was a criminal technician in Sarajevo CSB, ${ }^{15420}$ testified that in most cases he investigated during the conflict the casualties were civilians, and were not wearing any uniforms. ${ }^{15421}$

4587. The Chamber also received in evidence a large number of contemporaneous video footage showing civilians in Sarajevo in their everyday lives, under constant shelling and sniping. ${ }^{15422}$ This footage shows that the situation in the city was extremely dangerous and that its citizens were afraid. In addition, the citizens of Sarajevo who gave evidence before the Chamber were all consistent about the constant danger and fear they lived with in the city during the conflict. ${ }^{15423}$

\footnotetext{
15414 P1866 (Witness statement of Youssef Hajir dated 25 February 2010), paras. 56-57; Youssef Hajir, T. 87978799 (1 November 2010).

15415 Youssef Hajir, T. 8798 (1 November 2010).

15416 Adrianus van Baal, T. 8461-8462 (27 October 2010).

15417 P1996 (Witness statement of Martin Bell dated 8 March 2010), para. 32; Martin Bell, T. 9802 (14 December 2010).

15418 P1996 (Witness statement of Martin Bell dated 8 March 2010), paras. 32-33, 37-38; P2018 (BBC news report, with transcript); P2010 (Video footage of Sarajevo); Martin Bell, T. 9772-9773 (14 December 2010).

15419 P1996 (Witness statement of Martin Bell dated 8 March 2010), paras. 57-58; Martin Bell, T. 9861-9862, 98709871 (15 December 2010).

15420 P1742 (Witness statement of Bogdan Vidović dated 28 September 2010), pp. 2, 11-12, 31-32, 34.

15421 P1742 (Witness statement of Bogdan Vidović dated 28 September 2010), p. 35.

15422 See e.g. P2077 (BBC news report re Sarajevo, with transcript); P2078 (BBC news report re Sarajevo, with transcript); P1999 (BBC news report re Sarajevo, with transcript); P2016 (BBC news report re Sarajevo, with transcript); P929 (SKY news report re Sarajevo, with transcript); P930 (SKY news report re Sarajevo, with transcript); P931 (SKY news report re Sarajevo, with transcript); P954 (SKY news report re Sarajevo, with transcript); P936 (SKY news report re Sarajevo, with transcript); P932 (SKY news report re Sarajevo, with transcript); P2027 (BBC news report re Sarajevo, with transcript); P1678 (BBC news report re attacks on Sarajevo and Bihać); P1868 (BBC news report re shelling of Dobrinja on 1 June 1993); P2000 (BBC news report re Sarajevo, with transcript); P2074 (BBC news report re Sarajevo, with transcript); P2075 (BBC news report re Sarajevo, with transcript).

15423 See e.g. P490 (Witness statement of Anđa Gotovac dated 17 May 2006), paras. 5,7 (testifying that she lived in "constant fear" throughout the war as shells would explode near her home); P2922 (Witness statement of KDZ079 dated 17 May 2006), paras. 17-19, 21-22 (testifying that there was a "constant threat" of shelling and
} 


\section{iii. Civilian casualties in Sarajevo}

4588. The Chamber also heard throughout the case that a large number of civilians were killed or wounded during the conflict in Sarajevo. ${ }^{15424}$ Nakaš provided the statistical breakdown of patients treated in the State Hospital between 1992 and 1995, showing a total of 8,105 patients, 85\% of whom were treated for war-related injuries. ${ }^{15425}$ According to Nakaš, 3,698 of those were civilians while the rest were military; however, the latter figure was overblown as it included individuals who had military health insurance, such as retired JNA officers and their dependents, as well as the members of police. ${ }^{15426}$ Mandilović estimated that the patients he treated were about $80 \%$ civilian and $20 \%$ soldiers, with $80 \%$ of the civilian casualties being shelling-related and $20 \%$ small-armsrelated. ${ }^{15427}$ Between August 1994 and November 1995, the proportion of patients treated for injuries caused by shelling rose to approximately $90 \%$ while the rest were wounded by sniper fire. $^{15428}$ In addition, between August 1994 and October 1995, the State Hospital treated 115 patients wounded by sniper fire, namely 8 children, 66 "adults", and 41 members of the armed forces. $^{15429}$ The State Hospital also treated many people who were suffering from Post-Traumatic Stress Disorder due to the living conditions in Sarajevo. ${ }^{15430}$

sniping in Sarajevo, which placed "enormous" psychological pressure on her and her family); P2923 (Witness statements of KDZ090 dated 19 April 2006), para. 12 (testifying that life in Sarajevo between 1992 and 1995 was very difficult as people lived in "constant fear"); P492 (Witness statement of Sabina Šabanić dated 22 May 2006), paras. 7-8; P2361 (Witness statement of Eset Muračević dated 24 February 2011), para. 96; P2413 (Witness statements of KDZ289 dated 19 April 2006), p. 3 (testifying that there was no place in Sarajevo where she felt safe from shelling and sniping); Alma Mulaosmanović-Čehajić, T. 6756 (14 September 2010); P495 (Witness statement of Slavica Livnjak dated 25 April 2006), para. 6; P496 (Witness statements of Tarik Žunić dated 21 April 2006), p. 3; Mirza Sabljica, T. 7737 (12 October 2010).

15424 See e.g. P1690 (Witness statement of Alen Gičević dated 16 February 2010), p. 2; Alen Gičević, T. 7624-7625 (11 October 2010); Dragan Mioković, T. 8555, 8557-8560 (28 October 2010), 8563-8566 (29 October 2010); P1830 (Witness statement of Dragan Mioković dated 26 October 2010), p. 2; Adrianus van Baal, T. 8461-8462 (27 October 2010).

15425 P1525 (Witness statement of Bakir Nakaš dated 8 September 2010), paras. 59-60, 63; Bakir Nakaš, T. 66816684 (14 September 2010). Nakaš testified that these figures do not distinguish between patients who were hospitalised and those who were sent home immediately after being treated for their injuries, and also do not reflect the exact circumstances in which injuries were sustained, including data on who inflicted them. See Bakir Nakaš, T. 6729-6733 (14 September 2010); D621 (RS MUP report re ABiH and HVO, 30 December 1992). See also P474 (Witness statement of Faris Gavrankapetanović dated 13 December 2011), e-court p. 10 (testifying that best efforts were made during the war to keep the State Hospital records as complete and as thorough as possible; however, the pressures of operating in a war led to a "small number of omissions and mistakes being made").

15426 P1525 (Witness statement of Bakir Nakaš dated 8 September 2010), paras. 59, 61; Bakir Nakaš, T. 6675-6676 (14 September 2010). See also Faris Gavrankapetanović, P473 (Transcript from Prosecutor v. Galić), T. 12627-12630; P926 (Witness statement of Aernout van Lynden dated 26 February 2010), para. 60; P932 (SKY news report re Sarajevo, with transcript); Aernout van Lynden, T. 2410-2413 (19 May 2010).

15427 P1217 (Witness statement of Milan Mandilović dated 24 February 2010), paras. 80-83.

15428 Nakaš also estimated that one third of the soldiers who sustained injuries during this period of time were off duty at the time. See P1525 (Witness statement of Bakir Nakaš dated 8 September 2010), para. 64.

15429 P1525 (Witness statement of Bakir Nakaš dated 8 September 2010), para. 91; P1242 (Reports of Surgery Section of Sarajevo State Hospital, 1994-1995), e-court pp. 5-6; Bakir Nakaš, T. 6684-6685 (14 September 2010).

15430 Milan Mandilović, T. 5357 (16 July 2010). 
4589. Zaimović testified that 331 children were brought in and treated in the Children's Surgery ward in Koševo Hospital during the war, ${ }^{15431}$ most of whom were injured by shrapnel or sniper fire. $^{15432}$ In 1992 alone, 163 children were brought to the ward, nine of whom died in the ward itself. ${ }^{15433}$ Zaimović also noted that 32 children who were severely injured and for whom the ward could not provide adequate care were taken for treatment outside of the country. ${ }^{15434}$ The worst period for her ward was when the Fatima Gunić School was shelled on 9 November 1993, followed by the shelling of Otoka on 10 November, resulting in a number of dead and wounded children. ${ }^{15435}$

4590. Hajir testified that throughout the entire war, Dobrinja Hospital received around 16,000 injured persons and that he performed thousands of major and minor surgeries on injuries related to the conflict. ${ }^{15436}$ On average 10 to 15 people would come to the hospital and approximately four minor surgeries were conducted each day. ${ }^{15437}$ According to Hajir, at the beginning of the war around $95 \%$ of the people treated in the Dobrinja Hospital were civilians. ${ }^{15438}$ Later on, that percentage decreased to about $85 \% .^{15439}$ Hajir did concede, however, that the hospital never conducted any statistical evaluations and that the numbers were problematic. ${ }^{15440}$ At one point Hajir treated a seven or eight year old child who had been shot by a sniper through the heart; he

15431 She also noted that other hospitals in the city would treat the wounded children. P814 (Witness statement of Fatima Zaimović dated 26 February 2010), paras. 6-10, 16-18; P818 (Extracts from Fatima Zaimović's diary); P819 (Extracts from Fatima Zaimović's diary); Fatima Zaimović, T. 1882-1884, 1892 (5 May 2010).

15432 Fatima Zaimović, T. 1871-1873 (5 May 2010); P814 (Witness statement of Fatima Zaimović dated 26 February 2010), para. 19 (adding that a small number were injured by phosphorous shells or gas explosions, which occurred due to intermittent gas supply in Sarajevo and improvised gas installations); P818 (Extracts from Fatima Zaimović's diary); P819 (Extracts from Fatima Zaimović's diary). See also Fatima Zaimović, T. 18821884 (5 May 2010).

15433 Fatima Zaimović, T. 1873 (5 May 2010).

15434 Fatima Zaimović, T. 1874 (5 May 2010); P818 (Extracts from Fatima Zaimović's diary), e-court p. 3 (entry 102 referring to a child being discharged from the hospital and sent to France).

15435 P814 (Witness statement of Fatima Zaimović dated 26 February 2010), paras. 16-18. The Chamber notes that these specific killings are not listed in Schedule G of the Indictment and therefore not specifically charged as murder under Counts 5 and 6. See Hearing, T. 5479-5481 (19 July 2010); T. 7670-7672 (11 October 2010); T. 10932 (31 January 2011). See also Prosecution Rule 73 bis Submission, para. 16 (wherein the Prosecution stated that it "will not present evidence in order to secure a conviction in respect of any crime sites or incidents not listed in the Schedules to the Indictment).

15436 According to Hajir, some of the injured person he treated sustained their injuries while trying to pass through ther Dobrinja tunnel. See P1866 (Witness statement of Youssef Hajir dated 25 February 2010), paras. 15-16; Youssef Hajir, T. 8794, 8823-8825 (1 November 2010), T. 8838-8839 (2 November 2010); P1900 (Photographs of victims treated at Dobrinja Hospital); P1901 (Photographs of victims treated at Dobrinja Hospital) (under seal).

15437 Youssef Hajir, T. 8824 (1 November 2010), T. 8854 (2 November 2010).

15438 P1866 (Witness statement of Youssef Hajir dated 25 February 2010), paras. 15, 34. Hajir explained that in the beginning of the war there were no uniforms and his criteria for identifying a soldier was to see if they were armed. Hajir also explained that he himself was recorded as being in the $155^{\text {th }}$ Brigade of the $\mathrm{ABiH}$ but explained that he did not know why that was since he never left the Dobrinja Hospital. See Youssef Hajir, T. 8811-8814 (1 November 2010), T. 8870-8871 (2 November 2010); D857 (ABiH $1^{\text {st }}$ Command Corps report on El Mudžahid).

15439 P1866 (Witness statement of Youssef Hajir dated 25 February 2010), paras. 15, 34. Hajir conceded that the hospital treated members of the ABiH's $105^{\text {th }}$ Brigade. See Youssef Hajir, T. 8825 (1 November 2010)

15440 Youssef Hajir, T. 8847 (2 November 2010). 
also testified that many of his civilian patients were wounded while waiting for water and for humanitarian aid. ${ }^{15441}$

4591. In addition to the evidence of the Sarajevo doctors, Tabeau's demographic evidence outlined earlier shows that, as an absolute minimum, over 10,000 civilians were either killed or wounded in the conflict in Sarajevo during the Indictment period. ${ }^{15442}$

\section{iv. Evidence of SRK witnesses}

4592. While the Accused conceded during the case that the civilians in Sarajevo felt terror, he denied that there was any intention to cause such terror on the part of the SRK and the Bosnian Serb side. He called a large number of former members of the SRK who testified that there was no intention, at any level of the SRK, to conduct a campaign of terror against civilians, and/or inflict psychological harm on them. ${ }^{15443}$ Galić denied that the SRK fired on Sarajevo without any military purpose and solely for the purpose of terrorising civilians, testifying that these kinds of attacks "did not happen" and "were never ordered" because "terror begets terror". ${ }^{15444}$ Similarly, Dragomir Milošević testified that the SRK did not create an atmosphere in Sarajevo where "people were being driven crazy" and that the thesis that the Sarajevo civilians were subjected to a "campaign of terror" could not be sustained. ${ }^{15445}$ Ratomir Maksimović dismissed reports suggesting that civilians were targeted by the SRK as propaganda, ${ }^{15446}$ and Dragomir Milošević claimed that these reports reflected an exaggeration or dramatisation of the situation. ${ }^{15447}$ Inđić gave evidence that there was

\footnotetext{
15441 Youssef Hajir, T. 8843, 8853 (2 November 2010).

15442 See paras. 3621, 3997.

15443 See e.g. D2341 (Witness statement of Dušan Škrba dated 14 October 2012), para. 15; D2667 (Witness statement of Ratomir Maksimović dated 14 December 2012), paras. 22-24; D2516 (Witness statement of Vlade Lučić dated 5 November 2012), para. 18; D2633 (Witness statement of Milorad Šehovac dated 8 December 2012), paras. 24-25; D2331 (Witness statement of Blagoje Kovačević dated 14 October 2012), para. 25; D2562 (Witness statement of Vladimir Radojčić dated 8 December 2012), para. 25; Vladimir Radojčić, T. 31192 (11 December 2012); D2479 (Witness statement of Mile Sladoje dated 25 November 2012), para. 13; D2519 (Witness statement of Dragan Maletić dated 9 November 2012), para. 26; D2484 (Witness statement of Zoran Kovačević dated 25 November 2012), paras. 9-11; D2387 (Witness statement of Stojan Džino dated 4 November 2012), paras. 44-46; D2379 (Witness statement of Momir Garić dated 2 November 2012), para. 25; D2686 (Witness statement of Mihajlo Vujasin dated 16 December 2012), paras. 28-30; D2389 (Witness statement of Predrag Trapara dated 3 November 2012), para. 9; D2391 (Witness statement of Slobodan Tuševljak dated 5 November 2012), para. 20; D2418 (Witness statement of Božo Tomić dated 5 November 2012), para. 17; Božo Tomić, T. 30214 (13 November 2012); D2622 (Witness statement of Željko Bambarez dated 9 December 2012), para. 13; Svetozar Guzina, T. 31183 (11 December 2012); Milorad Katić, T. 31419 (13 December 2012); D2665 (Witness statement of Izo Golić dated 15 December 2012), paras. 31-32; Izo Golić, T. 31555 (17 December 2012); D2383 (Witness statement of Slavko Gengo dated 14 October 2012), para. 20. See also [REDACTED].

15444 Stanislav Galić, T. 37408-37409 (18 April 2013).

15445 Dragomir Milošević, T. 33145 (4 February 2013).

15446 Ratomir Maksimović, T. 31591-31596 (17 December 2012).

15447 Dragomir Milošević, T. 33276-33277 (6 February 2013).
} 
no plan for "low intensity operations with the aim of terrorizing civilians in Sarajevo", 15448 while Milovanović denied that Bosnian Serbs intended or planned to terrorise the civilians in Sarajevo, whether through sniper or artillery fire. ${ }^{15449}$ As noted earlier, the SRK soldiers and officers called by the Accused testified that, instead of causing terror, the goal of the SRK was to stand its ground and oppose the ABiH's $1^{\text {st }}$ Corps and prevent their units from linking up with $\mathrm{ABiH}$ units outside of the city. ${ }^{15450}$ The Accused's military expert, Radinović, also stated that he found no evidence that the purpose of the operations of the Serb forces was to terrorise civilians, relying on the fact that places of worship were not targeted and that there were periods of inactivity and cease-fires in Sarajevo. ${ }^{15451}$

4593. Similarly, many of those SRK soldiers and officers testified that they and their units were never ordered, nor did they ever order, that civilians in Sarajevo be targeted. ${ }^{15452}$ Radojčić explained that it was "crystal clear" in SRK orders and reports that the use of phrases like "attack on the city" implied that only military targets were selected, that "reprisal" referred to an appropriate response to enemy fire, while "retaliation" referred to selective retaliation against military targets. ${ }^{15453}$ [REDACTED] testified that an order to clear the terrain of remaining individuals referred only to military individuals, not civilians, and that the reference to "mopping up the wider area of remaining groups and individuals" in Directive 1 referred to groups and

\footnotetext{
15448 D2774 (Witness statement of Milenko Inđić dated 19 January 2013), para. 128.

15449 Manojlo Milovanović. T. 25735 (5 March 2012).

15450 See paras. 4547, 4570-4573; Dragomir Milošević, T. 33145 (4 February 2013).

15451 Radovan Radinović, T. $41408-41409$ (17 July 2013); D3864 (Radovan Radinović's expert report entitled "The Control Authority of Dr. Radovan Karadžić in the Strategic Command System of the VRS”, 2012), paras. 2425, 290-292.

15452 See e.g. Dragomir Milošević, T. 32833 (29 January 2013), T. 33206-33207 (5 February 2013); Stanislav Galić, T. 37408-37409 (18 April 2013), T. 37472 (22 April 2013); D2351 (Witness statement of Stevan Veljović dated 19 October 2012), para. 15; D2667 (Witness statement of Ratomir Maksimović dated 14 December 2012), para. 27; D2516 (Witness statement of Vlade Lučić dated 5 November 2012), para. 18; D2633 (Witness statement of Milorad Šehovac dated 8 December 2012), para. 27; D2331 (Witness statement of Blagoje Kovačević dated 14 October 2012), para. 28; D2562 (Witness statement of Vladimir Radojčić dated 8 December 2012), para. 28; D2479 (Witness statement of Mile Sladoje dated 25 November 2012), para. 15; D2387 (Witness statement of Stojan Džino dated 4 November 2012), para. 49; D2686 (Witness statement of Mihajlo Vujasin dated 16 December 2012), paras. 27, 31; D2389 (Witness statement of Predrag Trapara dated 3 November 2012), para. 11; D2418 (Witness statement of Božo Tomić dated 5 November 2012), para. 18; D2344 (Witness statement of Miloš Škrba dated 14 October 2012), para. 11; D2553 (Witness statement of Svetozar Guzina dated 3 December 2012), para. 39; D2354 (Witness statement of Siniša Maksimović dated 19 October 2012), para. 9; Siniša Maksimović, T. 29297 (23 October 2012).); D2527 (Witness statement of Blaško Rašević dated 1 December 2012), para. 21; D2852 (Witness statement of Srđan Šehovac dated 27 January 2013), para. 29.

15453 D2562 (Witness statement of Vladimir Radojčić dated 8 December 2012), paras. 89, 91; D322 (SRK Order, 19 April 1995); D2580 (SRK instructions, 11 May 1995), p. 2; D2353 (Report of $2^{\text {nd }}$ Sarajevo Light Infantry Brigade to SRK, 5 August 1994).
} 
individuals belonging to enemy forces. ${ }^{15454}$ These witnesses also claimed that they never wanted to control the living conditions of the people in the city. ${ }^{15455}$

4594. According to those witnesses, the SRK troops were explicitly ordered not to target civilians. ${ }^{15456}$ They were issued orders to fire only at military targets, which they observed. ${ }^{15457}$ When shown an intercepted conversation in which Mladić ordered an attack on "only military targets", Dragomir Milošević testified that this order reflected complete agreement between the SRK Command and the Main Staff that the SRK should only target military targets. ${ }^{15458}$ Guzina explained that infantry weapons could be fired without a command or special order only if an SRK

15454 [REDACTED]; D232 (Directive 1, 6 June 1992), paras. 4-5.

15455 See D2667 (Witness statement of Ratomir Maksimović dated 14 December 2012), para. 11; D2686 (Witness statement of Mihajlo Vujasin dated 16 December 2012), para. 20.

15456 Dragomir Milošević, T. 32735-32736 (28 January 2013); Stanislav Galić, T. 37193-37194, 37219 (15 April 2013), T. 37472 (22 April 2013), T. 37846 (7 May 2013); D2341 (Witness statement of Dušan Škrba dated 14 October 2012), para. 16; D2497 (Witness statement of Nikola Mijatović dated 27 November 2012), para. 15; D2667 (Witness statement of Ratomir Maksimović dated 14 December 2012), paras. 21, 50; D2633 (Witness statement of Milorad Šehovac dated 8 December 2012), para. 28, 67; D2331 (Witness statement of Blagoje Kovačević dated 14 October 2012), para. 28; D2562 (Witness statement of Vladimir Radojčić dated 8 December 2012), paras. 31-32; D2479 (Witness statement of Mile Sladoje dated 25 November 2012), para. 17; D2519 (Witness statement of Dragan Maletić dated 9 November 2012), para. 27; Dragan Maletić, T. 30889 (4 December 2012); D2484 (Witness statement of Zoran Kovačević dated 25 November 2012), para. 11; D2686 (Witness statement of Mihajlo Vujasin dated 16 December 2012), para. 33; D2389 (Witness statement of Predrag Trapara dated 3 November 2012), para. 12; D2391 (Witness statement of Slobodan Tuševljak dated 5 November 2012), para. 21; D2444 (Witness statement of Miladin Trifunović dated 11 November 2012), para. 18; Miladin Trifunović, T. 30439 (27 November 2012); Svetozar Guzina, T. 31181 (11 December 2012); D2812 (Warning of SRK, 27 October 1994), p. 2; D2665 (Witness statement of Izo Golić dated 15 December 2012), para. 25; D2267 (Vlado Lizdek's interview with OTP), p. 52. Milorad Šehovac testified that the Accused "insisted on and demanded" that soldiers follow international humanitarian law and the laws of war. The Chamber heard that orders were issued to this effect. See D2633 (Witness statement of Milorad Šehovac dated 8 December 2012), para. 13; D2383 (Witness statement of Slavko Gengo dated 14 October 2012), para. 15; D2519 (Witness statement of Dragan Maletić dated 9 November 2012), para. 18; D2658 (Witness statement of Luka Dragičević dated 9 December 2012), para. 16; Stanislav Galić, T. 37193-37194 (15 April 2013).

15457 Stanislav Galić, T. 37472 (22 April 2013), T. 37219 (15 April 2013); D2351 (Witness statement of Stevan Veljović dated 19 October 2012), para. 15; D2658 (Witness statement of Luka Dragičević dated 9 December 2012), para. 30; D2667 (Witness statement of Ratomir Maksimović dated 14 December 2012), para. 29; D2516 (Witness statement of Vlade Lučić dated 5 November 2012), paras. 11, 18, 25; Vlade Lučić, T. 30817 (3 December 2012); D2562 (Witness statement of Vladimir Radojčić dated 8 December 2012), para. 30 ; D2617 (SRK Order, 30 April 1995); D2484 (Witness statement of Zoran Kovačević dated 25 November 2012), para. 11; Zoran Kovačević, T. 30610 (28 November 2012); D2686 (Witness statement of Mihajlo Vujasin dated 16 December 2012), para. 33; D2389 (Witness statement of Predrag Trapara dated 3 November 2012), para. 12; D2391 (Witness statement of Slobodan Tuševljak dated 5 November 2012), para. 21; D2622 (Witness statement of Željko Bambarez dated 9 December 2012), para. 17; D2267 (Vlado Lizdek's interview with OTP), pp. 35, 48-49, 52; P1000 (SRK Order, 26 June 1992), p. 2; D2417 (SRK Order, 4 April 1995), para. 2; Savo Simić, T. 30051-30052, 30139-30140 (12 November 2012); D2633 (Witness statement of Milorad Šehovac dated 8 December 2012), para. 26; D2331 (Witness statement of Blagoje Kovačević dated 14 October 2012), para. 27;; D2383 (Witness statement of Slavko Gengo dated 14 October 2012), para. 20; D2379 (Witness statement of Momir Garić dated 2 November 2012), para. 25; D2418 (Witness statement of Božo Tomić dated 5 November 2012), para. 18; Siniša Maksimović, T. 29297 (23 October 2012); D2665 (Witness statement of Izo Golić dated 15 December 2012), paras. 31-32; D2519 (Witness statement of Dragan Maletić dated 9 November 2012), para. 25; Dragan Maletić, T. 30864 (4 December 2012); Nikola Mijatović, T. 30728 (30 November 2012).

15458 P5642 (Intercept of conversation between Dragomir Milošević, unidentified male, and Ratko Mladić, 16 June 1995), p. 4; Dragomir Milošević, T. 32739 (28 January 2013). 
facility was attacked and there was no other way to repel the attack. ${ }^{15459}$ Similarly, Lučić testified that his unit had good means of communication, and therefore it engaged the enemy only on orders, only if necessary, and only against identified actual military objectives. ${ }^{15460}$

4595. A number of SRK witnesses also blamed the $\mathrm{ABiH}$ for failing to protect civilians in the area under the ABiH control. ${ }^{15461}$ According to them, military targets were located in civilian areas of $\mathrm{ABiH}$ controlled territory, and/or in the depth of $\mathrm{ABiH}$ controlled territory. ${ }^{15462}$ When asked whether it was reasonable to expect civilian casualties when firing on targets in areas where civilians lived, Mijatović answered that it was reasonable to expect a warring party to avoid firing from civilian areas. ${ }^{15463}$ Gengo thought that any potential civilian casualties in Sarajevo "could be considered collateral damage" while civilian facilities "could have been endangered" by SRK fire only due to their proximity to military targets. ${ }^{15464}$ When asked about precautions he took to minimise civilian casualties, Gengo responded that the "enemy side should have done that" as he and his unit could not see what was going on in Sarajevo from their positions. ${ }^{15465}$ Veljović conceded that there might have been civilian casualties from SRK fire in densely populated parts of the city, but only when SRK units were threatened by strong artillery fire from such zones. ${ }^{15466}$ After agreeing that there was a "pretty high risk" of civilian casualties when firing in the depth of the city, Sladoje stated that it was not possible for the SRK to fire at military objectives only without jeopardising the civilian population which was living in the city. ${ }^{15467}$ According to him, it

15459 D2553 (Witness statement of Svetozar Guzina dated 3 December 2012), para. 38.

15460 D2516 (Witness statement of Vlade Lučić dated 5 November 2012), para. 20.

15461 See e.g. Slavko Gengo, T. 29781-29782, 29828-29829 (6 November 2012); D2383 (Witness statement of Slavko Gengo dated 14 October 2012), para. 20; Nikola Mijatović, T. 30729 (30 November 2012); D2479 (Witness statement of Mile Sladoje dated 25 November 2012), para. 11; Mile Sladoje, T. 30570-30574 (28 November 2012); Stanislav Galić, T. 38041 (9 May 2013).

15462 D2633 (Witness statement of Milorad Šehovac dated 8 December 2012), para. 23, 29; D2331 (Witness statement of Blagoje Kovačević dated 14 October 2012), paras. 22, 29; D2387 (Witness statement of Stojan Džino dated 4 November 2012), para. 43; D2686 (Witness statement of Mihajlo Vujasin dated 16 December 2012), paras. 34, 35; Miloš Škrba, T. 29191 (22 October 2012); Nikola Mijatović, T. 30728, 30737 (30 November 2012); D2479 (Witness statement of Mile Sladoje dated 25 November 2012), para. 11; Mile Sladoje, T. 30570-30571, 30573 (28 November 2012) (testifying that practically not a single neighbourhood was purely civilian); D2389 (Witness statement of Predrag Trapara dated 3 November 2012), para. 8; D2484 (Witness statement of Zoran Kovačević dated 25 November 2012), para. 12; D2667 (Witness statement of Ratomir Maksimović dated 14 December 2012), para. 31.

15463 Nikola Mijatović, T. 30729 (30 November 2012). Prosecution witness Michael Rose testified that "the moral distinction between Bosnian forces firing at the Serbs with the intention of provoking retaliation against civilians and the Bosnians themselves firing on their own people is a fine one". See Michael Rose, T. 7330 (6 October 2010); D162 (Michael Rose's book entitled "Fighting for Peace: Bosnia, 1994”), pp. 230-231.

15464

D2383 (Witness statement of Slavko Gengo dated 14 October 2012), para. 20.

Slavko Gengo, T. 29781-29782, 29828-29829 (6 November 2012).

D2351 (Witness statement of Stevan Veljović dated 19 October 2012), para. 20. Referring to a UNMO report stating that approximately $80 \%$ of fire on both sides was on the frontline and $20 \%$ in residential areas, Galic stated that both sides were targeting military targets, some of which were located in depth. Whether $20 \%$ landing on civilian areas can be tolerated was therefore in his opinion a question of proportionality. See Stanislav Galić, T. 38047-38048 (9 May 2013); D3524 (UNMO report, 4 to 5 January 1994), p. 1.

Mile Sladoje, T. 30573-30574 (28 November 2012). 
was "impossible to say practically for any area" that there were no civilians there. ${ }^{15468}$ This is contrary to the evidence of Dragomir Milošević who testified that he considered and treated Sarajevo as a civilian area. ${ }^{15469}$ Thus, if it was not possible to avoid danger to civilians, an assessment would have to be made as to whether collateral damage would outweigh the military advantage. ${ }^{15470}$ Radinović claimed that "it was impossible to distinguish between civilians and soldiers in the Sarajevo theatre of war" because many ABiH soldiers wore civilian clothing. ${ }^{15471}$ However, Galić testified that SRK soldiers manning their positions were ordered to be "absolutely certain as to who was a civilian or who was a soldier", despite this being "quite difficult". ${ }^{15472}$ Galić and several other SRK witnesses also testified that, if the SRK Command found out about possible civilian casualties during an attack, it would order that the attack be stopped. ${ }^{15473}$ He later explained that, ultimately, civilian casualties and collateral damage in the Sarajevo area could have been stopped only by stopping the war, and that collateral civilian damage was a factor to be considered when returning fire into a civilian zone. ${ }^{15474}$

\section{v. Findings}

4596. Given the testimony of the Prosecution witnesses who lived in the city at various times and noting the Accused's acknowledgement to that effect, the Chamber has no doubt that the citizens of Sarajevo felt terrorised and experienced extreme fear and hardship during the conflict, due primarily to the sniping and shelling they were exposed to by the SRK forces everywhere in the city, including in their own homes. The evidence is clear that Sarajevo was under siege by the SRK

\footnotetext{
15468 Mile Sladoje, T. 30571 (28 November 2012).

15469 Dragomir Milošević, T. 33122, 33124-33125, 33129-33136 (4 February 2013) (adding that he determined that there were some 275 command posts in the city). The Chamber notes that Milošević came to that number by assuming that each major $\mathrm{ABiH}$ unit had three command posts, which was not the case in fact. See D633 (Order of $\mathrm{ABiH} 1$ st Corps, 25 October 1993).

15470 Dragomir Milošević, T. 33123, 33139-33140 (4 February 2013). See also D2562 (Witness statement of Vladimir Radojčić dated 8 December 2012), para. 37; D2484 (Witness statement of Zoran Kovačević dated 25 November 2012), para. 12.

15471 D3864 (Radovan Radinović's expert report entitled "The Control Authority of Dr. Radovan Karadžić in the Strategic Command System of the VRS”, 2012), para. 25. See also D2516 (Witness statement of Vlade Lučić dated 5 November 2012), para. 28; Svetozar Guzina, T. 31151-31152 (6 December 2012), T. 31192 (11 December 2012).

15472 Stanislav Galić, T. 37194 (15 April 2013).

15473 Stanislav Galić, T. 37194 (15 April 2013); D2667 (Witness statement of Ratomir Maksimović dated 14 December 2012), para. 33; D2633 (Witness statement of Milorad Šehovac dated 8 December 2012), paras. 26, 30; D2562 (Witness statement of Vladimir Radojčić dated 8 December 2012), paras. 36-37; D2484 (Witness statement of Zoran Kovačević dated 25 November 2012), para. 12; D2686 (Witness statement of Mihajlo Vujasin dated 16 December 2012), para. 37; D2479 (Witness statement of Mile Sladoje dated 25 November 2012), para. 18. However, Zoran Kovačević testified that he did not know of any civilian casualties in Sarajevo during the war. See Zoran Kovačević, T. 30612 (28 November 2012); D2484 (Witness statement of Zoran Kovačević dated 25 November 2012), para. 9.

15474 Stanislav Galić, T. 37890 (8 May 2013), T. 38041 (9 May 2013).
} 
forces $^{15475}$ and that, with the exception of a few months following the establishment of the TEZ, ${ }^{15476}$ its citizens were exposed to continuous small arms and heavy weapon fire. They were in danger of death or serious injury no matter where they were in the city and, as such, spent a number of years under enormous psychological pressure. The high numbers of civilian casualties in the city during the conflict clearly illustrate the enormity of the danger they were exposed to.

4597. As also discussed in the preceding sections of the Judgement, ${ }^{1547}$ the fire SRK opened on Sarajevo was deliberate fire, often used to directly target civilians and civilian objects in the city, including hospitals and trams. ${ }^{15478}$ This is particularly the case with respect to the sniping incidents discussed earlier in the Judgement, which by their very nature could have been nothing but deliberate attacks on civilians. ${ }^{15479}$ In addition, the shelling by the SRK forces was in most cases either indiscriminate or disproportionate and sometimes both, resulting in a high casualty count among the civilian population of Sarajevo. ${ }^{15480}$

4598. The Chamber rejects the evidence of Defence witnesses, outlined in this section and in the preceding sections of this Judgement, ${ }^{15481}$ that civilians in Sarajevo were neither deliberately targeted by the SRK forces nor victims of indiscriminate or disproportionate fire. As already indicated in some of the preceding sections of this Judgement, the Chamber found their evidence to be self-serving and far-fetched, designed to blindly absolve the SRK of any responsibility for most (or, in some cases, all) civilian casualties in the city. In the Chamber's view, the credibility of these witnesses, particularly the former SRK members and expert witnesses Subotić and Poparić, was seriously undermined by their descriptions of the SRK's campaign in Sarajevo. Their evidence is in stark contrast with the evidence of those living or working in Sarajevo during the siege, both local citizens and international observers, and with the evidence of high civilian casualty count in the city, particularly women, children, and the elderly. The falsity of their evidence is further illustrated by the specific sniping and shelling incidents discussed above in which the SRK was found to have been deliberately targeting the civilians or opening indiscriminate and/or disproportionate fire on the city. ${ }^{15482}$ Further, the claims of SRK witnesses that they only fired at military targets and with principle of distinction firmly etched in their mind, have also been

\footnotetext{
15475 See paras. $4561-4566$.

15476 See paras. 3583-3586.

15477 See Sections IV.B.1.a: Chronology of events in Sarajevo; IV.B.1.b: Sniping; IV.B.1.c: Shelling; IV.B.1.e: Hospitals in Sarajevo.

15478 See also Adjudicated Facts 51, 53.

15479 See paras. 3968-3969. See also discussion on specific Scheduled Sniping Incidents.

15480 See discussion on specific Scheduled Shelling Incidents.

15481 See paras. 3625, 3998- 4000. See also individual arguments of Defence witnesses in relation to specific Scheduled Incidents.

15482 See discussion on specific Scheduled Shelling and Sniping Incidents.
} 
consistently denied by many Prosecution witnesses. One of the more striking of those was the evidence of Bell who stated that of all the conflicts he covered, the conflict in Sarajevo was one where least distinction was made between civilians and combatants. ${ }^{15483}$

4599. The Chamber accepts the Accused's claim that the civilians on the Bosnian Serb side of the confrontation line also felt terror and experienced hardship due to wartime circumstances. However, the Chamber does not accept the implication of this argument, namely that the terror felt in Sarajevo was a normal state experienced by everyone in times of war. While it is indeed to be expected for any civilian population to be scared during chaotic times of war, the situation of the civilians living in Sarajevo was unique due to the siege perpetrated by the SRK. It was also different to that of the civilians in Bosnian Serb-held areas. The Chamber recalls here and accepts as accurate the evidence of Bowen who testified that the people in the SRK-held areas at least "had access to decent food and a way out" and that their existence was not as fraught with danger as that of the people confined within the city. ${ }^{15484}$ Furthermore, as testified to by some SRK witnesses, the SRK often moved Bosnian Serb civilians away from the confrontation lines in order to avoid civilian casualties. ${ }^{15485}$ The civilians living in Sarajevo, however, did not have that luxury and had no choice but to stay within the confrontation lines in the city.

4600. Accordingly, on the basis of all the evidence in this case, the Chamber is convinced that the SRK conducted a campaign of shelling and sniping of the city, including of its civilian population, with the intention to, inter alia, terrorise the civilian population of Sarajevo. Furthermore, the SRK's use of modified air bombs towards the end of the conflict was clearly aimed at terrorising the citizens as part of the strategy to demoralise the $\mathrm{ABiH}$ soldiers and, as such, is one of the clearest examples of the intention to terrorise. ${ }^{15486}$ Similarly, every single sniping incident in which a civilian was targeted by SRK snipers, including the specific sniping incidents discussed earlier in the Judgement, is an example of deliberate intention on behalf of the SRK forces to terrorise the civilian population of Sarajevo. ${ }^{15487}$

4601. This intention to terrorise can also be inferred from the pattern in which the terror was applied to the city. For example, it is clear, as explained by Harland and illustrated in the chronology of the events in Sarajevo, that the sniping and the shelling of the civilians in the city

\footnotetext{
15483 See para. 4586.

15484 P2068 (Witness statement of Jeremy Bowen dated 10 August 2009), para. 27.

15485 See e.g. D2553 (Witness statement of Svetozar Guzina dated 3 December 2012), para. 39; Nikola Mijatović T. 30760 (30 November 2012); D4619 (SRK report, 18 August 1995), p. 2 (wherein SRK command instructs the SRK units to relocate civilian population in an organized manner to "prevent mass losses in border settlements").

15486 See Section IV.B.1.iii.D: Scheduled modified air bomb incidents.
} 
would ease whenever there was an explicit threat of intervention by NATO but would then increase as soon as that threat subsided or in retaliation for $\mathrm{ABiH}$ offensives. ${ }^{15488}$ One of the most illustrative examples of this is the aftermath of the first Markale incident in February 1994. Similarly, the evidence shows that events elsewhere in BiH had an effect on the level of terror in the city, thus again showing intentional use of sniping and shelling to terrorise the civilian population. Given these patterns, the Chamber is convinced that terror was used intentionally by the SRK forces, both to demoralise the civilian population and to retaliate during times of $\mathrm{ABiH}$ offensives in the city and elsewhere. The SRK wanted to show to the Sarajevo residents that no one was safe and that they were helpless. ${ }^{15489}$

4602. The Chamber notes that throughout the case the Accused tendered into evidence a large body of SRK orders and combat reports in order to show that the situation in Sarajevo was one of war, waged equally by both sides. His aim was also to show that the $\mathrm{ABiH}$ forces constantly launched attacks on the SRK-held territory, thereby provoking a response which was always selective and proportionate. The Chamber has referred to many of these documents throughout the Judgement. It has also considered them all in coming to the conclusions outlined in this section. However, the Chamber found their value to be fairly limited in terms of the ultimate findings outlined in this section. While noting the location and the nature of the various attacks by the $\mathrm{ABiH}$ forces, including the number and types of mortar shells fired for example, these combat reports and orders provide very little information about the nature of the response the SRK units engaged in, which was one of the main issues in this case. ${ }^{15490}$ In other words, aside from stating that the SRK returned fire when attacked (or sometimes refrained from returning fire), these documents rarely provide any information on the specific weaponry used to return fire, or the quantity of fire used. They also rarely specify the exact locations targeted by the SRK in response to the $\mathrm{ABiH}$ fire and make no mention of most of the scheduled sniping or shelling incidents listed in the Indictment. ${ }^{15491}$ All of this makes any analysis regarding proportionality and selective nature

\footnotetext{
15487 See discussion relating to specific Scheduled Sniping Incidents.

15488 See para. 4581.

15489 See Adjudicated Facts 137, 138.

15490 See e.g. D4563 (SRK combat report, 27 November 1992); D4565 (SRK combat report, 24 January 1993); D4569 (SRK combat report, 18 August 1993); D4573 (SRK combat report, 12 October 1993); D4574 (SRK combat report, 16 October 1993); D4579 (SRK combat report, 14 March 1994); D4581 (SRK combat report, 23 April 1994); D4584 (SRK combat report, 9 May 1994); D4588 (SRK combat report, 19 May 1994); D4592 (SRK combat report, 20 June 1994); D4597 (SRK combat report, 7 July 1994); D4598 (SRK combat report, 10 July 1994); D4599 (SRK combat report, 12 July 1994); D4600 (SRK combat report, 14 July 1994); D4601 (SRK combat report, 15 July 1994); D4603 (SRK combat report, 17 July 1994); D4607 (SRK combat report, 30 July 1994); D4616 (SRK combat report, 29 June 1995); D4621 (SRK combat report, 11 December 1993); D4625 (Report of 1st Romanija Infantry Brigade, 24 December 1992); D4626 (SRK combat report, 22 March 1994).

15491 Indeed, Galić consistently testified that many of the incidents charged in the Indictment were not referred to in SRK reports.
} 
of the SRK response on the basis of these reports impossible. At the same time, given the level of detail as to the activities of the $\mathrm{ABiH}$ forces, down to the quantity and calibre of mortar shells the $\mathrm{ABiH}$ forces would fire, these documents illustrate that the $\mathrm{ABiH}$ engaged mainly in small scale attacks, often using sniper or firearms or limited small calibre mortar fire, and often along the limited number of confrontation lines. ${ }^{15492}$ As such, and contrary to the Accused's aim, these SRK orders and combat reports do not counter the evidence of Prosecution witnesses who testified that the SRK responses to $\mathrm{ABiH}$ fire were disproportionate and indiscriminate and at times not connected to $\mathrm{ABiH}$ attacks at all. They do in turn seem to be consistent with the evidence of the Prosecution witnesses who testified about the limited nature of $\mathrm{ABiH}$ attacks due to the $\mathrm{ABiH}$ inferior position in terms of heavy weaponry.

4603. The Chamber recalls that the Defence witnesses also claimed that there were no purely civilian areas in the city and/or that the $\mathrm{ABiH}$ was at fault for civilian casualties within the city as it did not move the population away from the military targets. However, as found in relation to various scheduled incidents above, the Chamber considers that the presence of certain military facilities in the city did not immediately convert the whole city or its residential areas into military targets or justified indiscriminate attacks by the SRK. Furthermore, while ABiH command posts were indeed present in the city, the evidence shows that the SRK did not seriously target them and/or try to destroy them with sustained fire, despite being aware of their exact location. ${ }^{15493}$

4604. It is worth noting that the intermingling of $\mathrm{ABiH}$ forces and facilities with civilians and civilian objects in Sarajevo was mainly due to the nature of the siege and the confrontation lines around Sarajevo. The $\mathrm{ABiH}$ sometimes had no choice but to locate its command posts and some of its forces among the civilian population. The claim of the SRK soldiers and officers that $\mathrm{ABiH}$ forces should therefore be blamed for all the casualties caused by the SRK fire in the city is not only disingenuous but also illustrates the reckless attitude these soldiers and officers ultimately exhibited towards the fate of the civilian inhabitants of Sarajevo. ${ }^{15494}$ Additionally, while possible that at times the SRK units found it difficult to distinguish between soldiers and civilians in the

\footnotetext{
15492 See e.g. D4570 (SRK combat report, 20 August 1993); D4571 (SRK combat report, 20 September 1993 ); D4572 (SRK combat report, 21 September 1993); D4582 (SRK combat report, 24 April 1994); D4583 (SRK combat report, 25 April 1994); D4586 (SRK combat report, 10 May 1994); D4587 (SRK combat report); D4589 (SRK combat report, 5 June 1994); D4590 (SRK combat report, 8 June 1994); D4591 (SRK combat report, 14 June 1994); D4593 (SRK combat report, 25 June 1994); D4594 (SRK combat report, 4 July 1994); D4595 (SRK combat report, 3 July 1994); D4596 (SRK combat report, 5 July 1994); D4605 (SRK combat report, 25 July 1994); D4606 (SRK combat report, 26 July 1994); D4629 (SRK combat report, 19 March 1994).

15493 See para. 3990. Furthermore, the evidence also shows that most of the ABiH forces were located at confrontation lines. See para. 3557.

15494 The Chamber recalls that it has discussed presence of military objects or targets wherever the Defence raised that issue in relation to the specific scheduled incidents discussed above.
} 
city, the Chamber notes that international humanitarian law dictates that in such cases they should have assumed that the individuals in question were civilians. ${ }^{15495}$

4605. Thus, for all the reasons outlined above, the Chamber is satisfied beyond reasonable doubt that the SRK forces embarked on a campaign of shelling and sniping of civilians in Sarajevo in order to terrorise those civilians. ${ }^{15496}$

\section{Legal findings on crimes}

\section{a. Chapeau requirements for Articles 3 and 5 of the Statute}

4606. In the Sarajevo component of the case, the Accused is charged with three counts of violations of the laws or customs of war under Article 3 of the Statute, namely murder, terror, and unlawful attacks on civilians, as well as with one count of crimes against humanity under Article 5 of the Statute, namely murder. ${ }^{15497}$ The Prosecution alleges that there was a state of armed conflict at all times relevant to the Indictment. ${ }^{15498}$ It also claims that all acts and omissions charged as crimes against humanity that formed part of the sniping and shelling campaign were part of a widespread or systematic attack directed against the civilian population of Sarajevo. ${ }^{15499}$

\section{i. Article 3}

4607. The Chamber found that there was an armed conflict in $\mathrm{BiH}$ throughout the period relevant to the crimes alleged in the Indictment. In Sarajevo, at the latest by early April 1992, heavy firing had erupted in and around the city, and my mid-April shelling had begun. ${ }^{15500}$

4608. For each of the crimes charged under Article 3 of the Statute in relation to the Sarajevo component of the case, namely murder, terror, and unlawful attacks on civilians, the Chamber has examined whether they were closely related to the armed conflict. ${ }^{15501}$

4609. In relation to the four so called "Tadic Conditions", 15502 the Chamber refers to the applicable law sections of this Judgement, which expanded on the legal basis for each of the crimes

\footnotetext{
15495 See para. 457 (citing to Dragomir Milošević Appeal Judgement, para. 60).

15496 While the Prosecution alleged that Sarajevo Forces were responsible for the campaign of sniping and shelling, the Chamber is unable to conclude that forces other than the SRK were responsible for the sniping and the shelling of civilians in Sarajevo.

15497 See para. 5.

15498 Indictment, para. 89.

15499 Indictment, para. 88.

15500 See paras. 3542-3543.

15501 See paras. 4618, 4628, 4635.

15502 See para. 443.
} 
charged in the Indictment under Article 3 of the Statute. ${ }^{15503}$ In relation to murder, the prohibition stems from Common Article 3 which is deemed to be part of customary international law. ${ }^{15504}$ Further, the Appeals Chamber has confirmed that violations of the provisions of Common Article 3 entail individual criminal responsibility. ${ }^{15505}$ In relation to terror, as mentioned above, the Appeals Chamber has confirmed that the prohibition of terror is part of customary law. ${ }^{15506}$ The Appeals Chamber also held that this offence incurs individual criminal responsibility. ${ }^{15507}$ Finally the Appeals Chamber has recognised that the prohibition of unlawful attacks on civilians reflects customary international law. ${ }^{15508}$ It further held that individual criminal responsibility is incurred for unlawful attacks on civilians if the attacks have resulted in death or serious injury to body or health of the victims in question. ${ }^{15509}$ The Chamber is therefore satisfied that the four Tadic Conditions are met, and consequently that the chapeau requirements for Article 3 of the Statute are fulfilled, in relation to all of the relevant offences charged in the Indictment.

\section{ii. Article 5}

4610. As found above, there was an armed conflict in $\mathrm{BiH}$ throughout the period of the Indictment. The Chamber is also satisfied that the evidence demonstrates that there was a widespread and systematic attack directed against the civilian population of Sarajevo. In reaching this conclusion, the Chamber had regard to the means and method used in the course of the attack, the status of the victims, ${ }^{15510}$ and their number. The SRK carried out a series of acts of sniping and shelling between May 1992 and August 1995 that deliberately targeted civilians and civilian areas in Sarajevo. ${ }^{15511}$ Over a period of more than three years, in different locations throughout Sarajevo, there were many sniping and shelling acts conducted by members of the SRK and which resulted in the deaths and injury of a high number of civilians. The Chamber is therefore satisfied that the attack on the civilian population of Sarajevo was both widespread and systematic.

\footnotetext{
15503 See Section III.A.1: Article 3 of the Statute of the Tribunal.

15504 Čelebići Appeal Judgement, para. 143.

15505 Čelebići Appeal Judgement, paras. 167, 170, 173-174 (holding at para. 173: "It is universally acknowledged that the acts enumerated in common Article 3 are wrongful and shock the conscience of civilised people, and thus are, in the language of Article 15(2) of the ICCPR, "criminal according to the general principles of law recognised by civilised nations'.”).

15506 See para. 458.

15507 Galić Appeal Judgement, para. 92.

15508 See para. 458.

15509 Kordić and Čerkez Appeal Judgement, para. 67. See also para. 455.

15510 The Chamber recalls that a population may qualify as civilian as long as it is predominantly civilian and as such considers that the population of the urban areas inside the confrontation lines of Sarajevo between 1992 and 1995 had civilian status as a whole.

15511 See Sections IV.B.1.b: Sniping; IV.B.1.c: Shelling.
} 
4611. The Chamber is therefore also satisfied that the chapeau requirements for murder charged under Article 5 of the Statute are met.

\section{b. Crimes}

\section{i. Murder: Counts 5 and 6}

(A) Sniping and shelling incidents

4612. The Chamber recalls its findings in Sections IV.B.1.b and IV.B.1.c above, namely that individuals were killed in Sarajevo by sniping or shelling by Serb Forces, specifically the SRK. ${ }^{15512}$

4613. The Chamber recalls that it found that six children were killed as a result of an explosion caused by three shells on 22 January 1994 but that it could not conclude beyond reasonable doubt that the fire came from SRK positions and therefore that Serb Forces were responsible. ${ }^{15513}$ The Chamber also recalls that it received evidence of one person dying in the shelling of 28 and 29 May 1992 but was unable to determine whether he was taking direct part in hostilities when killed. ${ }^{15514}$

\section{(B) Intent of perpetrators}

4614. The Chamber recalls its findings that the death of the victims in the incidents recalled above was a result of the acts of Serb Forces, specifically the SRK. ${ }^{15515}$ The Chamber finds that the perpetrators of each of these incidents acted with the intent to kill the victims or at least wilfully caused serious injury or grievous bodily harm, which they should reasonably have known might lead to death.

15512 The killing of Munira Zametica (Scheduled Incident F.3); the killing of Nermin Divović (Scheduled Incident F.12); the killing of a number of people between 5 and 8 June 1992 (Scheduled Incident G.2); the killing of at least 12 people, seven of whom were soldiers (Scheduled Incident G.4); the killing of 14 people (Scheduled Incident G.5); the killing of eight people (Scheduled Incident G.7); the killing of at least 67 people, by majority, Judge Baird dissenting (Scheduled Incident G.8); the killing of two people (Scheduled Incident G.9); the killing of Ziba Čustović (Scheduled Incident G.10); the killing of four people (Scheduled Incidents G.11 and G.12); the killing of 43 people, one of whom was a soldier (Scheduled Incident G.19). The Chamber notes that in the following Scheduled Incidents, the Prosecution alleged that individuals were injured but not killed as a result of the incidents: Scheduled Incidents F.1, F.2, F.4-F.11, F.14-F.17 and Scheduled Incidents G.13-G.15.

15513 See Scheduled Incident G.6.

15514 See Scheduled Incident G.1, fn. 13408. Similarly, the Chamber received evidence of a number of people dying in Scheduled Incident G.2 but was unable to determine whether some of them were taking part in hostilities when killed. See Scheduled Incident G.2, fn. 13481 (wherein the Chamber lists only those for whom it was sure that they were not participating in hostilities at the time and that they were civilians).

15515 The Chamber notes that this excludes Scheduled Incident G.6 as the Chamber was unable to determine, on the basis of evidence before it, who the perpetrators were. The Chamber also recalls, with respect to Scheduled Shelling Incident G.8, that the finding that the SRK was responsible was reached by majority, Judge Baird dissenting. 
4615. In reaching that conclusion, the Chamber had regard to the circumstances and the manner in which the victims were killed. With respect to the Scheduled Sniping Incidents, the Chamber found in all instances that the victims were deliberately targeted. ${ }^{15516}$ More specifically in relation to Sniping Incident F.3, the Chamber recalls its findings that the perpetrator bracketed the distance immediately prior to the incident and that the perpetrator shot the victim and then repeatedly shot towards her. In relation to Sniping Incident F.12, the Chamber found that the victim and his mother were shot at a crossing where there were no soldiers and at a time when there was no combat in the area and a cease-fire was in place.

4616. With respect to the Scheduled Shelling Incidents, the Chamber also found that the victims were either deliberately targeted or were the victims of indiscriminate and/or disproportionate attacks by the SRK. The Chamber recalls, for example, its findings in relation to Shelling Incident G.5 that only one shell was fired and landed at a well-known emergency water point in the yard of a private house, that the area around the well was shelled again later during the conflict, and that the nearest military presence was too far away from the incident site to explain the firing of the particular shell. In relation to Shelling Incident G.7, the shells exploded in a residential neighbourhood where humanitarian aid was being distributed and a large number of people had gathered waiting for the aid; there was no combat or military presence at the time. In relation to Shelling Incident G.9, only two shells were fired and they exploded on a flea market in a residential area and there was no military target in or near the area at the time. In relation to Scheduled Shelling Incidents G.10, G.11, and G.12, the Chamber noted the indiscriminate nature of the weapon used by the SRK. In relation to Markale incidents, the Chamber found that the SRK fired only one shell in an area it knew housed no military targets and with reckless disregard as to potential civilian victims. ${ }^{15517}$ Accordingly, the Chamber is satisfied that the only reasonable inference to be drawn from the circumstances and the manner in which the victims were killed is that the perpetrators had the intent to kill.

\section{(C) Status of victims}

4617. The Chamber recalls its findings that the large majority of the victims in these incidents were civilians who were not taking direct part in hostilities at the time of the incidents; otherwise they were part of a civilian population at the time of the incident. ${ }^{15518}$

\footnotetext{
15516 See paras. 3809, 3728.

15517 With respect to the Scheduled Shelling Incident G.8, however, this finding was that of a majority, as Judge Baird was not satisfied that the SRK fired the shell in question.

15518 The Chamber recalls that those killed in Scheduled Incident G.4 included seven ABiH soldiers while one of those killed in the second Markale shelling was a soldier. In both cases they were located in residential areas,
} 


\section{(D) Conclusion}

4618. In addition to the findings in this section, the Chamber refers to its finding that there was an armed conflict in $\mathrm{BiH}$ during the period relevant to the Indictment. The Chamber further finds that the killings referred to above are closely related to that armed conflict. The Chamber finds that the Scheduled Incidents referred to above, ${ }^{15519}$ constitute murder as a violation of the laws or customs of war against civilians. ${ }^{15520}$

4619. The Chamber refers to its findings above that there was a widespread and systematic attack directed against the civilian population of Sarajevo. The Chamber finds that the killings referred to above were part of this widespread and systematic attack and thus constitute murder as a crime against humanity. ${ }^{15521}$ In reaching that conclusion, the Chamber considered the locations, time period, and the status of the victims of these killings, which correspond to the scope of the widespread and systematic attack. Further, given the length, the magnitude, and the intensity of the attack on the civilian populations of Sarajevo, the Chamber finds that the perpetrators knew of the attack and that the killings were part of it.

\section{ii. Unlawful attack on civilians: Count 9}

\section{(A) Acts of violence causing death or serious injury to body or health}

4620. The Chamber recalls its findings in Sections IV.B.1.b: Sniping and IV.B.1.c: Shelling above that individuals were injured and/or killed in Sarajevo by sniping or shelling by Serb Forces, specifically the SRK. ${ }^{15522}$ The Chamber finds that these constitute acts of violence causing death or

where a large number of civilians had gathered. The Chamber also recalls that it was unable to determine (i) the status of the person killed in Scheduled Incident G.1 and (ii) the status of some of the individuals killed in Scheduled Incident G.2.

15519 See fn. 15512.

15520 The Chamber will not enter convictions under Count 6 for the seven soldiers killed in Scheduled Incident G.4 and one soldier who died in Scheduled Incident G.19 as they did not lay down their arms nor were they placed hors de combat by sickness, wounds, detention, or any other cause. Similarly, it will not enter convictions under Count 6 in relation to (i) Scheduled Incident G.1 as it was not able to determine the status of the person killed during that shelling, and (ii) a number of people killed in Scheduled Incident G.2 as it was unable to determine their status.

15521 The Chamber will not enter convictions under Count 5 in relation to soldiers who died in Shelling Incidents G.4 and G.19 as the Chamber is not satisfied that they had been placed hors de combat when they were killed. Similarly, it will not enter convictions under Count 5 in relation to (i) Scheduled Incident G. 1 as it was not able to determine the status of the person killed during that shelling, and (ii) a number of people killed in Scheduled Incident G.2 as it was unable to determine their status.

15522 The wounding of Anisa Pita (Scheduled Incident F.1); the wounding of a nine-year-old girl (Scheduled Incident F.2); the killing of Munira Zametica (Scheduled Incident F.3); the wounding of Nafa and Elma Tarić (Scheduled Incident F.4); the wounding of Sanija Dževlan (Scheduled Incident F.6); the wounding of Damir Kučinar, Mensur Jusić, and Belma Sukić née Likić (Scheduled Incident F.8); the wounding of Sanela Muratović (Scheduled Incident F.9); the wounding of Seid Solak (Scheduled Incident F.10); the wounding of Alma Ćutuna (Scheduled Incident F.11); the wounding of Dženana Sokolović and killing of Nermin Divović (Scheduled Incident F.12); the wounding of Afeza Karačić and Sabina Šabanić (Scheduled Incident F.14); the wounding of 
serious injury to body or health. For example, the Chamber recalls shelling incidents that took place in Markale market on 5 February 1994 and 28 August 1995 and during which horrific injuries were caused to a large number of people as illustrated by the video footage of those incidents. ${ }^{15523}$

4621. The Chamber notes that, with respect to Scheduled Incidents F.5, F.7, and G.6, it was not satisfied beyond reasonable doubt that fire had come from SRK positions and therefore could not conclude that Serb Forces were responsible.

\section{(B) Directed against a civilian population or individual civilians}

4622. The Chamber recalls its findings that, with the exception of Scheduled Incidents F.5 and F.7, the victims of sniping were deliberately targeted by the SRK. In reaching this conclusion, the Chamber considered, for example, that the distance between the incident site and the location from which the shot was fired would have required a skilful shot on the part of the shooter. ${ }^{15524}$ For some incidents, there were additional shots after the victims had been hit, such as for example when the victims were being driven to the hospital. ${ }^{15525}$ Similarly, in relation to Scheduled Incidents F.8, F.11, F.14, F.15, and F.16, respectively, the Chamber considered, inter alia, that the tram was struck by one bullet only; the tram concerned and the tram behind it were shot and struck in the same location and then fire was opened again in that same location at a number of people trying to leave the area; SRK snipers in the relevant area either had an unobstructed view of the incident site or there was sufficient visibility between the location from which the shot was fired and the incident site.

4623. The Chamber also found that, with the exception of Scheduled Incident G.6, the victims of shelling were deliberately targeted by the SRK or were victims of indiscriminate or

Alma Mulaosmanović-Čehajić, Alija Holjan, and three others (Scheduled Incident F.15); the wounding of Azem Agović and Alen Gičević (Scheduled Incident F.16); the wounding of Tarik Žunić (Scheduled Incident F.17); the wounding of a number of people (Scheduled Incident G.1); the wounding and death of a number of people (Scheduled Incident G.2); the wounding of 122 people, at least 12 of whom died as a result of their injuries (Scheduled Incident G.4); the killing of 14 people and wounding of 13 people (Scheduled Incident G.5); the killing of eight people and wounding of 18 people (Scheduled Incident G.7); the killing of at least 67 people and the wounding of over 140 people, Judge Baird dissenting as to the identity of the perpetrators (Scheduled Incident G.8); the killing of two and wounding of seven people (Scheduled Incident G.9); the killing of Ziba Čustović and the wounding of three other people (Scheduled Incident G.10); the killing of four and wounding of 11 people (Scheduled Incidents G.11 and G.12); the wounding of 16 people, two seriously and 14 lightly (Scheduled Incident G.13); the wounding of 3 people (Scheduled Incident G.14); the wounding of seven people (Scheduled Incident G.15); the killing of 43 and the wounding of at least 70 people (Scheduled Incident G.19).

15523 As noted earlier, the findings in relation to Scheduled Incident G. 8 were reached by majority, Judge Baird dissenting.

15524 See e.g. Scheduled Incidents F.1, F.2, F.17.

15525 See e.g. Scheduled Incident F.2 (the car taking the victim to the hospital was also shot at); Scheduled Incident F.4 (there were two shots after the bullet hit the victims); Scheduled Incident F.17 (a shot was fired at and hit the car carrying the victim as it pulled away from her house). 
disproportionate attacks. ${ }^{15526}$ In reaching this conclusion, the Chamber considered, for example, in relation to Scheduled Incidents G.5 and G.9 that only one or two shells were fired and landed in a civilian area and there was no military target nearby. In relation to Scheduled Incident G.7, the shells exploded in a residential neighbourhood where humanitarian aid was being distributed and a large number of people had gathered waiting for the aid; there was no combat or military presence at the time. Similarly, in relation to Scheduled Incidents G.8 and G.19, a large number of civilians had gathered to buy goods and there were no military targets in the vicinity of the incident sites. For all the incidents that involved indiscriminate or disproportionate fire by the SRK, the Chamber is satisfied that the only reasonable inference that can be made is that the attacks were directed against civilians. ${ }^{15527}$

4624. The Chamber further found that the large majority of the victims of the Scheduled Incidents were civilians who were not taking direct part in hostilities at the time of the incidents. In relation to Scheduled Incident F.15, the Chamber did not consider the presence of one $\mathrm{ABiH}$ soldier on the tram to change the fact that on the day of the incident the tram was a civilian vehicle used to transport civilians. The Chamber recalls that the casualties of Scheduled Incident G.4 included $\mathrm{ABiH}$ soldiers but that they were off-duty and involved in or watching a football game together with a large number of civilians. Similarly, one casualty in Scheduled Incident G.19 was found to have been a soldier who was at the Markale market together with a large number of civilians. Accordingly, the presence of these soldiers did not change the character of the population at the game and in the market, respectively, and thus does not undermine the Chamber's conclusion that the attacks in those two incidents were directed against a civilian population.

4625. The Chamber also described the deaths and the wounding of a large number of civilian victims in relation to each incident and thus finds that the victims of those incidents either died or suffered serious injuries.

\section{(C) Intent of perpetrators}

4626. The Chamber found that the perpetrators of the Scheduled Incidents were aware or should have been aware of the civilian status of the persons attacked and/or the lack of military targets in the areas subjected to mortar and artillery fire. In reaching these conclusions in relation to

15526 The Chamber recalls that Judge Baird dissented in relation to Scheduled Incident G.8.

15527 For example, in relation to incidents involving modified air bombs, namely Scheduled Incidents G.10-G.15, the Chamber considers that the indiscriminate nature of the weapon which was used in residential areas qualifies those incidents as attacks directed against the civilian population of Sarajevo. With respect to Scheduled Incident G.4, the Chamber found that the firing of the two shells at an event at which a large number of civilians had gathered constituted indiscriminate fire. Accordingly it is satisfied that, in launching this type of attack, the SRK deliberately targeted civilians. 
Scheduled Sniping Incidents, the Chamber considered, for example, that the victim's appearance, location, and/or activity — such as a child wearing civilian clothes standing in the doorway or front yard of her house, ${ }^{15528}$ an adult woman collecting water at a river, ${ }^{15529}$ a woman in civilian clothes cycling, ${ }^{15530}$ or a woman with two children crossing a street during a period of cease-fire ${ }^{15531}$ —and the sight and distances involved in the given Sniping Incident, would have made the victim or victims identifiable as civilians to the shooter. For the Sniping Incidents in which the target was a tram, the Chamber found that the shooter would have known that the tram was a civilian vehicle carrying civilians. ${ }^{15532}$ With respect to the Scheduled Shelling Incidents, the Chamber considered that the nature of the area, with no military targets in the immediate vicinity of the incident sites such as in the case of Markale market for example, and the activities in which the victims were engaged therein would have identified them as civilian objects and/or individual civilians. ${ }^{15533}$ In addition, the Chamber is satisfied that in the case of indiscriminate and/or disproportionate attacks, such as those involving modified air bombs for example, ${ }^{15534}$ the perpetrators who opened fire should have known that that the attack would result in civilian casualties.

4627. The Chamber finds that the perpetrators in the Scheduled Incidents above wilfully carried out the acts of violence referred to above and made the civilian population or individual civilians not taking direct part in hostilities the object thereof.

\section{(D) Conclusion}

4628. In addition to the findings in this section, the Chamber refers to its finding that there was an armed conflict in $\mathrm{BiH}$ during the period relevant to the Indictment. The Chamber further finds that the acts of violence referred to above are closely related to that armed conflict. As such, the Scheduled Incidents discussed above constitute unlawful attacks on civilians as a violation of the laws or customs of war. ${ }^{15535}$

\footnotetext{
15528 See Scheduled Incidents F.1, F.2.

15529 See Scheduled Incident F.3.

15530 See Scheduled Incident F.6.

15531 See Scheduled Incident F.12.

15532 See Scheduled Incidents F.8, F.11, F.14, F.15, F.16.

15533 See Scheduled Incidents G.4, G.5, G.7, G.8, G.9, G.19. The Chamber recalls that Judge Baird dissents with respect to Scheduled Incident G.8.

15534 See Scheduled Incidents G.10 to G.15.

15535 This excludes Scheduled Incidents F.5, F.7, and G.6 for which the Chamber was unable to determine, on the basis of the evidence presented, the identity of the perpetrators. The Chamber also recalls here that Judge Baird issued a dissent in relation to Scheduled Incident G.8.
} 


\section{iii. Terror: Count 10}

(A) Acts of violence directed against a civilian population or individual civilians

4629. The Chamber refers to its findings above that the cited Scheduled Incidents, with the exception of F.5, F.7, and G.6, constitute acts of violence directed against a civilian population or individual civilians causing serious injury to body or health and/or death.

4630. The Chamber also recalls its finding that the civilian population of Sarajevo and individual civilians therein experienced extreme fear, anxiety, and other serious psychological effects resulting from the campaign of sniping and shelling by the SRK. ${ }^{15536}$ Indeed, the Chamber found above that the citizens of Sarajevo in fact felt terrorised during the siege of their city. ${ }^{15537}$ The Chamber finds that this psychological harm formed part of the acts of violence directed against a civilian population or individual civilians in Sarajevo.

\section{(B) Intent of perpetrators}

4631. The Chamber recalls that the crime of terror requires both general and specific intent. With respect to general intent, the Chamber refers to its findings above in relation to unlawful attacks that the perpetrators wilfully made the civilian population or individual civilians not taking direct part in hostilities the object of acts of violence in the form of the cited Scheduled Incidents. ${ }^{15538}$

4632. The Chamber also finds that the perpetrators intended to spread terror among the civilian population of Sarajevo and that the infliction of terror was the primary purpose of the acts of violence directed against the civilian population upon which the Chamber has made findings above. In reaching that conclusion, the Chamber had regard to the nature, manner, timing, location, and duration of the acts of violence, as well as its finding that the civilians in Sarajevo were in fact terrorised by the SRK. The Chamber considered that some sniping and shelling attacks were carried out during times of cease-fire or during quiet periods, when civilians thought it was safe to walk around and when trams were operating. ${ }^{15539}$ In some instances, individual civilians were targeted while at their homes and there was no fighting in the area at the time, ${ }^{15540}$ or while they

\footnotetext{
15536 See paras. 4579-4587.

15537 See para. 4596.

15538 See paras. 4626-4627.

15539 See Scheduled Incidents F.8, F.9, F.11, F.12, F.14, F.15, F.16. The Chamber notes that the Appeals Chamber affirmed the Milošević Trial Chamber's consideration of attacks during cease-fires as an indicator of the intent to spread terror. See Dragomir Milošević Appeal Judgement, para. 37; Dragomir Milošević Trial Judgement, para. 881 .

15540 See e.g. Scheduled Incidents F.1, F.2, F.17, G.2, G.10, G.11.
} 
walked or cycled about the streets with no fighting in the area at the time. ${ }^{15541}$ The Chamber also considered that civilians were targeted at sites known to be areas where civilians went to or gathered for activities, ${ }^{15542}$ such as collecting water, ${ }^{15543}$ receiving humanitarian aid, ${ }^{15544}$ commercial activity, ${ }^{15545}$ and, in the case of trams, taking public transportation. ${ }^{15546}$

4633. In determining the existence of the intent to spread terror, the Chamber also considered the indiscriminate nature of some of the shelling attacks. ${ }^{15547}$ For example, the Chamber recalls its finding that the SRK launched highly destructive modified air bombs on the city, the indiscriminate nature of which was known to the SRK units, as described earlier. ${ }^{15548}$ These bombs were used in Scheduled Incidents G.10, G.11, G.12, G.13, G.14, and G.15. The Chamber also recalls that it found, in relation to Scheduled Incidents G.1 and G.2 that the SRK launched disproportionate and indiscriminate shelling attacks on the city resulting in a number of casualties. Further, the Chamber also found, in relation to Scheduled Incident G.5, that firing two shells, which are designed to suppress activity over a wide area, at a football match where a large number of civilians were gathered to watch, and at a time when there was no ongoing combat, constituted deliberate targeting of a civilian area or at the very least indiscriminate fire.

4634. The intent to spread terror was also demonstrated by the duration of the campaign of sniping and shelling, which started in late May 1992 and continued through much of 1995 and many other incidents of shelling and sniping recounted in Section IV.B.1.a. It was also demonstrated through the evidence of a multitude of witnesses on the general nature and pattern of the SRK's sniping and shelling practices in the city.

\section{(C) Conclusion}

4635. In addition to the findings in this section, the Chamber refers to its finding that there was an armed conflict in $\mathrm{BiH}$ during the period relevant to the Indictment. The Chamber further finds that

\footnotetext{
15541 See Scheduled Incidents F.4, F.6, F.10.

15542 The Chamber notes that the Appeals Chamber affirmed the Milošević Trial Chamber's consideration of targeting and attacks of civilians "at sites, well-known to be frequented by them during their daily activities, such as market places, water distribution points, on public transport, and so on" as indicia of the intent to spread terror. See Dragomir Milošević Appeal Judgement, para. 37; Dragomir Milošević Trial Judgement, para. 881.

15543 See Scheduled Incidents F.3, G.5.

15544 See Scheduled Incident G.7.

15545 See Scheduled Incidents G.8, G.9, G.19.

15546 See Scheduled Incidents F.8, F.11, F.14, F.15, F.16. The Chamber also found, in relation to these incidents, that no military vehicles were present in the close vicinity of the incident sites and no military activity was underway in the area.

15547 The Chamber notes that the Appeals Chamber affirmed the Dragomir Milošević Trial Chamber's consideration of the indiscriminate nature of attack as a factor in determining specific intent for terror. See para. 454.

15548 See paras. 4363, 4379-4380.
} 
the acts of violence referred to above were closely related to that armed conflict. The Chamber therefore finds that the Scheduled Incidents above constitute terror. ${ }^{15549}$

\section{Sarajevo JCE and the Accused's responsibility}

4636. The Accused is charged under Articles 7(1) and 7(3) of the Statute for his alleged role in the crimes committed in the city of Sarajevo between April 1992 and November 1995. Specifically, he is said to be responsible for murder, a crime against humanity and a violation of the laws or customs of war (Counts 5 and 6 respectively); acts of violence the primary purpose of which is to spread terror among civilian population ("terror"), a violation of the laws or customs of war (Count 9); and unlawful attacks on civilians, a violation of the laws or customs of war (Count 10). ${ }^{15550}$

4637. According to the Indictment, the Accused committed these crimes by virtue of his participation in a JCE to "establish and carry out a campaign of sniping and shelling against the civilian population of Sarajevo, the primary purpose of which was to spread terror among the civilian population" ("Sarajevo JCE"). ${ }^{15551}$ This objective is said to have involved the commission of the crimes of murder, terror, and unlawful attacks. ${ }^{15552}$ The Indictment further avers that the Accused shared the intent for the commission of each of these crimes with others ${ }^{15553}$ who acted in concert with him in the Sarajevo JCE, including, among others, Momčilo Krajišnik, Ratko Mladić, Biljana Plavšić, Nikola Koljević, Stanislav Galić, Dragomir Milošević, and Vojislav Šešelj. ${ }^{15554}$ The said members allegedly implemented their objective by personally committing crimes and/or by using the Sarajevo Forces to carry out those crimes. ${ }^{15555}$

\footnotetext{
15549 As with unlawful attacks on civilians, the Chamber excludes here Scheduled Incidents F.5, F.7 and G.6 as it was unable to determine who was responsible for them. The Chamber also recalls that Judge Baird appended a dissent in relation to Scheduled Incident G.8.

15550 Indictment, paras. 65, 76-82.

15551 Indictment, paras. 15-19, 77.

15552 Indictment, paras. 15, 77

15553 Accordingly, the Sarajevo JCE falls into the first or basic category of joint criminal enterprise where all participants acting pursuant to a common purpose possess the same criminal intention to effectuate that purpose, which in turn involves the commission of murder, terror, and unlawful attacks on civilians. In other words, the Prosecution does not allege that it was foreseeable that some of the crimes charged with regards to Sarajevo might be perpetrated by one or more members of the Sarajevo JCE or by persons they used in order to carry out the actus reus of crimes forming the objective of Sarajevo JCE.

15554 Indictment, para. 16. Other alleged members of the Sarajevo JCE are listed in paragraph 17 of the Indictment and include, among others, commanders and senior officers of JNA, VRS, TO, and MUP units responsible for the Sarajevo area.

15555 Indictment, para. 18 (defining "Sarajevo Forces" as (i) members of JNA operating in or with responsibility over the Sarajevo area until about 20 May 1992, (ii) members of the VRS, particularly the SRK; and (iii) members of other elements of Serb Forces operating in or with responsibility over the Sarajevo area).
} 
4638. The Prosecution claims that the Accused significantly contributed to achieving the objective of spreading terror through a campaign of sniping and shelling in a number of ways set out in paragraph 14 (a)-(f), (h)-(j) of the Indictment. ${ }^{15556}$

4639. The Prosecution also avers that, in addition to his liability through his participation in the Sarajevo JCE, the Accused is criminally responsible for planning, instigating, ordering, and/or aiding and abetting the said crimes. ${ }^{15557}$ Furthermore, he is alleged to be criminally responsible as a superior as he knew or had reason to know that crimes would be or had been committed but nevertheless failed to take necessary and reasonable measures to prevent them and/or to punish the perpetrators thereof. ${ }^{15558}$

4640. The Chamber will now turn to its assessment of the individual criminal responsibility of the Accused in relation to the events in Sarajevo, in particular the commission through JCE and the issue of whether there was a common plan, design or purpose, as alleged in the Indictment.

4641. As outlined in the Applicable Law section of this Judgement, in order to find an accused criminally responsible on the basis of his participation in the first or basic category of JCE, the Chamber must be satisfied that there existed a common plan, design or purpose which amounts to or involves a commission of crimes, that there was a plurality of persons who acted pursuant to that common purpose, and that the Accused significantly contributed to that common purpose through either his acts or his omissions. ${ }^{15559}$ In addition, the Prosecution must prove that the Accused shared the intent to effect the common purpose of the JCE and had the relevant mens rea for the crime with which he is charged. ${ }^{15560}$

a. The existence of a common plan

4642. The existence of a common plan can be inferred from the fact that plurality of persons acted in unison; furthermore, the plan need not be previously arranged or formulated but may materialise extemporaneously. ${ }^{15561}$ According to the Prosecution, the campaign of sniping and shelling in Sarajevo resulted from a common criminal plan emanating "from the top of the Bosnians Serb political and military hierarchy". ${ }^{15562}$ The Prosecution claims that this is evidenced by the (a)

\footnotetext{
15556 Indictment, paras. 14, 19. See para. 3468 for the outline of the relevant subparagraphs of paragraph 14.

15557 Indictment, paras. 30-31.

15558 Indictment, paras. 32-35.

15559 See para. 561.

15560 If the Accused is charged with a specific intent crime, he and the other members of the alleged JCE must share the requisite specific intent for that crime. See para. 569.

15561 See para. 563.

15562 Prosecution Final Brief, para. 604.
} 
nature and pattern of sniping and shelling attacks against civilians; (b) strict command and control of the SRK snipers, mortars, and other artillery; (c) longevity of the campaign; and (d) personal involvement of the Accused and Mladić in Sarajevo events. ${ }^{15563}$

4643. The Accused, on the other hand, claims that the Bosnian Serb side was simply trying to avoid "a unilateral, unlawful, and violent secession from Yugoslavia" by the Bosnian Muslim side and an "attempt to subjugate the Serb people to a hostile Islamist regime". 15564 According to him, the Bosnian Serbs were trying to prevent denial of their "rights of freedom and political life, of selfgovernance, enjoyment of their resources, and other rights guaranteed by the International Covenants on Human Rights"; had they not been deprived of those rights, "there would not have been any alleged JCE". ${ }^{15565}$ The Accused also states that "ultimate self-defense cannot be criminal enterprise" and that this was especially true in the context of the Sarajevo battlefield. ${ }^{15566}$

4644. The Chamber has already made a number of findings in the preceding sections of the Judgement relating to the campaign of sniping and shelling in Sarajevo. The Chamber found that the SRK besieged the city and then engaged in a campaign of sniping and shelling in Sarajevo, which lasted roughly from late May 1992 until October 1995 when hostilities in Sarajevo ceased. ${ }^{15567}$ As also found above, during this campaign the SRK targeted civilians in Sarajevo either directly or through the launching of indiscriminate and disproportionate attacks all over the city, resulting in thousands of wounded and killed civilians. ${ }^{15568}$ In addition, the Chamber concluded that the SRK conducted the said campaign of sniping and shelling with the intention to terrorise the civilian population and that it conducted the siege of the city with a number of objectives in mind, all outlined in the directives issued by the Main Staff and/or the Accused, including the objective of keeping the city under firm blockade and creating conditions for the Bosnian Serb leadership to participate "equally" in negotiations with the other sides and international community. ${ }^{15569}$

4645. The question then is whether or not this campaign of sniping and shelling, the purpose of which was to spread terror among the civilian population, resulted-as alleged-from a common criminal plan emanating from the Bosnian Serb military and political leadership. The Prosecution

\footnotetext{
15563 Prosecution Final Brief, para. 604.

15564 Defence Final Brief, para. 1815; Defence Final Brief, confidential, para. 1816.

15565 Defence Final Brief, para. 1815.

15566 Defence Final Brief, para. 1815.

15567 See Sections IV.B.1.a: Chronology of events in Sarajevo; IV.B.1.b: Sniping; IV.B.1.c: Shelling; IV.B.1.f: Siege of Sarajevo.

15568 See Sections IV.B.1.b: Sniping; IV.B.1.c: Shelling.

15569 See Sections IV.B.1.g: Campaign of terror; IV.B.1.f: Siege of Sarajevo.
} 
has presented a large body of evidence to show the existence of this common plan. Much of that evidence has been analysed and discussed in the preceding sections. Accordingly, the findings that follow rely on and draw from those sections, as well as from the evidence explicitly referred to below.

\section{i. Pattern and longevity of the campaign of sniping and shelling}

4646. In the Chamber's view the two most persuasive factors in favour of the Prosecution's claim that there existed a common criminal plan to establish the campaign of sniping and shelling with the intention of spreading terror among the civilian population in Sarajevo are the pattern and the longevity of the sniping and shelling in the city.

4647. In terms of the pattern, the Chamber has already discussed the numerous specific incidents of shelling and sniping alleged in Schedules F and G of the Indictment, which spanned a number of years. Furthermore, the Chamber has referred to many other sniping and shelling events in the city in the period between late May 1992 and October 1995. ${ }^{15570}$ Based on all those events ${ }^{15571}$ the Chamber is convinced that there was a well-established practice of sniping and shelling in the city conducted by the SRK whereby civilians were either specifically targeted, or were subjected to indiscriminate and/or disproportionate attacks. This practice was further confirmed by the more general evidence of various witnesses who lived in the city or were posted there with the UN and other international organisations, and whose evidence the Chamber recounted in the preceding sections. ${ }^{15572}$ The willingness of the SRK units and their commanders to engage in the sniping of Sarajevo civilians on an almost daily basis and their deliberate act of launching an indiscriminate and destructive weapon such as modified air bombs on the city are prime examples of that practice. Thus, as concluded in Section IV.B.2, there is no doubt that until October 1995 murder, terror, and unlawful attacks on civilians were committed on numerous occasions by the SRK forces in Sarajevo.

4648. In the Chamber's view, the fact that this state of affairs continued for over three years means that it cannot have been an accident or the work of "rogue" SRK soldiers. ${ }^{15573}$ Rather, the fact that the shelling and the sniping of civilians continued, more or less unabated, for such a long

\footnotetext{
15570 See Section IV.B.1: Facts.

15571 The Chamber excludes from this analysis Scheduled Incidents F.5, F.7, and G.6 as it was not satisfied that the evidence presented by the Prosecution was sufficient to establish beyond reasonable doubt that the SRK was responsible for these incidents. In addition, for his part in this analysis, Judge Baird does not rely on Scheduled Incident G.8 due to his dissent in relation thereto.

15572 See Sections IV.B.1.a: Chronology of events in Sarajevo; IV.B.1.b: Sniping; IV.B.1.c: Shelling.
} 
time means that it was actively encouraged by some in the military and political hierarchy in the RS and at the very least tolerated by others in that group. The only reasonable inference that can be drawn therefore is that the shelling and the sniping of the civilians, as well as the indiscriminate and/or disproportionate attacks launched against the city, were part of a plan.

4649. Further support for this conclusion can be found in the evidence outlined below regarding the knowledge that the Bosnian Serb military and political leadership had about the events in the city. ${ }^{15574}$ As that evidence shows, many of the Bosnian Serb military and political leaders were regularly put on notice that civilians were dying in Sarajevo due to direct targeting or due to indiscriminate and/or disproportionate fire by the SRK, but allowed this type of fire to continue for a protracted period of time. ${ }^{15575} \mathrm{Had}$ it not been a part of their plan, this practice would not have persisted unabated for so long. Accordingly, the Chamber is convinced that the campaign of sniping and shelling, the primary purpose of which was to cause terror among the civilian population, was planned and that it emanated from the higher military and political structures in the RS. Relying on the preceding sections which describe the events in the city from the start of the conflict to the cessation of hostilities in October 1995, as well as the specific shelling and sniping incidents listed in Schedules $F$ and $G$ of the Indictment, the Chamber finds that this plan materialised in late May 1992, with the events described in relation to the Scheduled Incident G.1 and that it then continued to be implemented until October 1995.

4650. As discussed in previous sections, the Chamber does not doubt that the SRK also sniped and shelled $\mathrm{ABiH}$ military positions and military personnel during the conflict in Sarajevo or that the war was being waged by both sides in the city and its surrounding areas. ${ }^{15576}$ The witnesses and documentary evidence confirm that this was indeed the case. For example, Harland testified that some of the SRK fire was tactical and used in support of SRK combat units on the confrontation lines or on ABiH military targets. ${ }^{15577}$ Similarly, a number of SRK combat reports clearly show that $\mathrm{ABiH}$ would launch attacks on the SRK forces and SRK-held territory, including the civilians living there. However, as recounted on many occasions in the preceding sections, the evidence in this case is also replete with examples of SRK fire not being directed at military targets in the city

15573 The Chamber also recalls here that it has rejected the Accused's claim that the major incidents in the city were caused by the $\mathrm{ABiH}$ or members of special police units in Sarajevo. See Section IV.B.1.d: Bosnian Muslim side targeting own civilians.

15574 In addition, the Chamber also relies on all the sections that deal with the Accused's contribution to the alleged JCE.

15575 See Section IV.B.3.b: Plurality of persons; IV.B.3.c.iii: Accused's knowledge of crimes and the measures he took to prevent them.

15576 See e.g. Section IV.B.1.a: Chronology of events in Sarajevo wherein the Chamber outlined a number of attacks and offensives launched by the $\mathrm{ABiH}$. 
and/or being opened in a random or disproportionate manner. As noted above, this practice was so widespread and so common during the conflict that the only reasonable conclusion one can draw is that it was planned and encouraged with the aim of terrorising the civilian population. In other words, the longevity of the sniping and shelling directed at the civilian population, including civilian objects such as trams and residential buildings, as well as the high number of civilian casualties cannot be explained by the fact that $\mathrm{BiH}$ was engulfed in an armed conflict and that the war in Sarajevo was being waged by both sides. Furthermore, even if the Bosnian Serbs were trying to protect their rights and/or were trying to defend themselves, as claimed by the Accused, the high number of civilian casualties cannot be explained, justified, or excused on that basis. ${ }^{15578}$ Instead, as already indicated earlier, the only reasonable inference that can be drawn from the events in the city is that the shelling and sniping of civilians, perpetrated with the intention to terrorise them, was planned.

\section{ii. Control over snipers and heavy weapons used by the SRK}

4651. As discussed earlier, the Chamber is satisfied that individual snipers and/or sniper units within the SRK were under control of the SRK brigade commanders and ultimately the SRK Command itself. ${ }^{15579}$ The Chamber found that the SRK sniper units had well-established, longstanding, professionally equipped sniper nests, from which they sniped at civilians and civilian objects, such as trams, in the city. ${ }^{15580}$ This would not have been possible without the involvement of the senior military leaders, particularly the SRK Command and the Main Staff.

4652. Further, the Chamber found that the SRK's heavy weapons, such as mortars and artillery weapons, were also under control of the SRK commanders, such that their use often required authorisation by artillery officers in the SRK brigades or the SRK Command itself. ${ }^{15581}$ The Chamber recalls here the evidence of many of the SRK soldiers and officers who were called by the Accused and who described in detail the procedures they followed before they could open mortar or artillery fire on the city. ${ }^{15582}$ Furthermore, in the case of modified air bombs, the evidence clearly shows that their use was directly controlled by the Main Staff. ${ }^{15583}$ Indeed, in the order of 12 June

\footnotetext{
15577 P820 (Witness statement of David Harland dated 4 September 2009), paras. 32-33, 291; David Harland, T. 2023 (6 May 2010), T. 2335-2336, 2351 (11 May 2010).

15578 The Chamber notes that the cause of the conflict in $\mathrm{BiH}$, or parties' motives for going to war, do not affect the issue of the Accused's guilt one way or the other. What is determinative is the manner in which that conflict was waged in Sarajevo by the Bosnian Serb side, and by the Accused in particular.

15579 See para. 3970.

15580 See para. 3970

15581 See para. 4499.

15582 See paras. 3998-4000.

15583 See para. 4365
} 
1994 issued by the Main Staff, Milovanović explicitly stated that the Main Staff was to decide on the use of modified air bombs and "possibly a Corps if the [Main Staff] approve[d]". ${ }^{15584}$ On 26 April 1995, Mladić, having heard that Dragomir Milošević was about to use two modified air bombs against "enemy targets and settlements in the area of Sarajevo", issued a request for information, "for Commander's eyes only", stating as follows:

You are to inform me whether the abovementioned information is correct, who ordered and why, the planned use of heavy weapons and beginning of operations in the area of Sarajevo, if it is a question of retaliation and for what reason, or exploitation of operative effects. If the Supreme Command has issued an order to begin combat operations and use heavy weapons in the area of Sarajevo, it is your duty to inform me. ${ }^{15585}$

4653. Additionally, as will be discussed in more detail below, the chain of command within the SRK and up to the Main Staff functioned well. Both Galić and Dragomir Milošević, and Mladić as the Main Staff Commander, exerted strict control over the SRK units. ${ }^{15586}$ This again indicates to the Chamber that the crimes committed in the city by the SRK soldiers could not have been the work of ill-disciplined or rogue soldiers and were not one-off, unrelated, incidents. As also noted later, while the various SRK commanders and the Main Staff did face some problems relating to discipline of the SRK units, those were not significant enough to undermine the Chamber's conclusion that the SRK was a professional military force with a well-functioning chain of command and efficient information flow.

4654. Accordingly, the only reasonable inference one can draw from this level of control over SRK soldiers and their infantry and artillery weapons is that the crimes perpetrated by the SRK units in relation to the civilian population in Sarajevo were part of the plan to snipe and shell that population in order to spread terror.

\section{iii. Strategic importance of Sarajevo}

4655. The Chamber has heard throughout the case that Sarajevo was considered extremely important to the Bosnian Serb side. In Galić's own words, it was "the media centre of the world" and the "war [was] won or lost" there. ${ }^{15587}$ Speaking to the Srpski Borac newspaper on 2 August 1995, the Accused himself acknowledged this by saying:

Before the war we were aware that if it happens it will start in Sarajevo. We decided that if we want to win we have to stay in Sarajevo. The strategic idea was to prevent the

\footnotetext{
15584 P1294 (VRS Main Staff Order, 12 June 1994).

15585 P1299 (VRS Main Staff request for information from SRK, 26 April 1995).

15586 See paras. 4742-4751.

15587 P969 (Article from Sarajevske Srpske Novine entitled "Aggression in Blue”, 25 March 1994), p. 6; P1818 (Witness statement of Adrianus van Baal dated 26 October 2010, paras. 31-32; P5906 (Witness statement of KDZ450 dated 17 January 2011), para. 48.
} 
independent Bosnian state from functioning whereas, on the other hand, our state would function. [...] Sarajevo is of special importance to us because of combat, strategic and tactical reasons. [...] Sarajevo is, as you know it, related to our survival, to the survival of our state and I suppose that, if the Muslim entity survives in Sarajevo, Sarajevo will be a melting point of cultures [...]. If the Muslims don't accept peaceful transformation of the city into two entities Sarajevo will suffer the fate of Beirut, where working hours are until noon and gunfire in the afternoon. [...] We need every inch in Serbian Sarajevo, we even claim rights on the centre of Sarajevo, say, the entire left bank of Miljacka river. $^{15588}$

4656. KDZ182 confirmed that Sarajevo was well known around the world as a multiethnic city so that whatever happened there "echoed very strongly"; it was very important to Mladić who, in KDZ182's view, elaborated the general strategy of terror against the Sarajevo population. ${ }^{15589}$ Mole explained that the encirclement of the city in and of itself proved to be a significant leverage, which the Bosnian Serb leadership successfully exploited throughout the duration of the conflict in order to obtain wide-ranging concessions. ${ }^{15590}$ This is indeed confirmed by the notes of a meeting the Accused, Krajišnik, Plavšić, Koljević, Mladić, Gvero, and Tolimir attended with Slobodan Milošević on 29 August 1995, during which the Accused opposed Milošević's proposal to withdraw heavy artillery from Sarajevo because the Bosnian Muslims would have no incentive to negotiate once the blockade was lifted. ${ }^{15591}$

4657. According to KDZ182, both sides used the symbolic nature of the city to demonstrate their purpose; the Bosnian Serb side used it to show that they could do what they wanted and that they "ruled the game". ${ }^{15592}$ One example of that is the 24 April 1995 statement by the Accused on Voice of America, wherein he said that the international community must accept Serb plans or the VRS would invade Sarajevo. ${ }^{15593}$ The Bosnian Muslim side, on the other hand, used it to keep the city

\footnotetext{
15588 D2660 (Article from Srpski Borac entitled "We are Sovereign over Sarajevo", 2 August 1995), pp. 2, 3, 4-5. See also P1410 (Transcript of $51^{\text {st }}$ session of RS Assembly, 14-15 June 1995), p. 329 (wherein the Accused said that whenever the situation escalate around Sarajevo the "internationals come and diplomatic activity speeds up").

15589 P2414 (Witness statement of KDZ182), pp. 16, 33 (under seal). See also P5906 (Witness statement of KDZ450 dated 17 January 2011), para. 48.

15590 P1426 (Witness statement of Richard Mole dated 7 May 2010), paras. 35-36; Richard Mole, T. 5825-5826, 5875 (17 August 2010); P1435 (UNMO report, 11 December 1992), para. 12.

15591 D3058 (Record of meeting between leaderships of FRY and RS, 29 August 1995), p. 9.

15592 P2414 (Witness statement of KDZ182), pp. 33-34 (under seal); KDZ182, T. 13068-13069 (9 March 2011) (private session). See also P5906 (Witness statement of KDZ450 dated 17 January 2011), paras. 25, 140-141 (testifying that Sarajevo was "both a focal point and a flashpoint" and that it was important also because the Bosnian Muslim leaders were located there); P2130 (UNPROFOR daily report, 25 September 1994), p. 2.

15593 The Accused also said that he had closed the airport over the weekend to show the world who was in control of the airport. See P2451 (Witness statement of Anthony Banbury dated 19 May 2009), para. 143; P2452 (Anthony Banbury's handwritten notes of meeting, 24 April 1995), p. 2; Anthony Banbury, T. 13316 (15 March 2011).
} 
and the rest of $\mathrm{BiH}$ in the focus of international attention, namely to carry out a media war in order to make up for their military inferiority and provoke an international reaction. ${ }^{15594}$

4658. The importance of Sarajevo was further illustrated by the fact that around the times of important negotiations and international conferences, as well as official visits, the city would experience an increase in activity, with disproportionate use of artillery on both sides. ${ }^{15595}$ Mole testified that it was an "accepted norm" that if the Serb side failed to achieve their objectives anywhere in $\mathrm{BiH}$, Sarajevo would suffer and fire would be opened on the city in response. ${ }^{15596}$ In fact, on several occasions, Galić expressly indicated to Mole that any military setback for the Bosnian Serbs, or any rejection of their political demands, even those pertaining to issues in areas far away from Sarajevo, was sufficient reason for the SRK to subject the city to heavy artillery fire. ${ }^{15597}$ At one point Galić told Mole that if the ABiH's firing from Mt. Igman did not cease, there would be reciprocal firing by his weapons onto the city. ${ }^{15598}$

4659. The Accused personally considered Sarajevo to be of extreme importance as indicated by the Srpski Borac interview referred to above, as well as some of his other statements about the city. For example, during the Bosnian Serb Assembly sessions in July and September 1992, the Accused identified Sarajevo as the most important battlefield. ${ }^{15599}$ Similarly, in a press conference he gave on 18 September 1992 in Geneva, the Accused stated:

Sarajevo is my state, my country, my city! [...] The entire ground where Sarajevo was built up was Serbian, is Serbian ownership! We are there 200,000 Serbs, 300,000 Muslims and 50 or 60,000 Croats. Sarajevo is my city. I have an apartment in the middle of it [...]. I used to have. Which is broken the second day of the war [sic]. And I'll tell you, when they stop posing their own artillery in the city, we will stop responding

15594 KDZ185, T. 4227, 4229 (28 June 2010). See also D336 (John Wilson and Graham Messervy-Whiting's report to ICFY, 22 January 1993), paras. 11, 13(d); D503 (Marrack Goulding's note to UNSG, 7 September 1992), para. 12; P5906 (Witness statement of KDZ450 dated 17 January 2011), para. 65.

15595 KDZ185, T. 4307 (29 June 2010); Hussein Abdel-Razek, T. 5534 (20 July 2010); D502 (SRK combat report, 23 September 1992); KDZ450, T. 10549-10550 (19 January 2011), T. 10615-10616 (20 January 2011); P1673 (UNPROFOR report re Sarajevo heavy weapons exclusion zone, 19 September 1994), para. 3 (indicating that $\mathrm{ABiH}$ launched an attack during Izetbegović's visit to New York). Galić testified that it was only the ABiH that partook in these types of activities but that he would warn his units not to respond. See Stanislav Galić, T. 37234-37236 (15 April 2013); D3394 (SRK combat report, 31 December 1992).

15596 P1426 (Witness statement of Richard Mole dated 7 May 2010), paras. 91-98, 105, 107, 116 (adding that Galić would also link the events in Brčko to Sarajevo); P1433 (UNMO report for October 1992), p. 4; P1429 (UNMO report for December 1992), p. 5.

15597 P1426 (Witness statement of Richard Mole dated 7 May 2010), paras. 91-96.

15598 P1426 (Witness statement of Richard Mole dated 7 May 2010), para. 94.

15599 D92 (Transcript of $17^{\text {th }}$ session of SerBiH Assembly, 24-26 July 1992), p. 16; D456 (Transcript of $20^{\text {th }}$ session of RS Assembly, 14-15 September 1992), p. 14. See also D3645 (Witness statement of Nenad Kecmanović dated 27 May 2013), para. 35 (testifying that the Accused, Koljević, and Plavšić were very concerned about the situation in Sarajevo while other parts of BiH were of secondary importance); D3864 (Radovan Radinović's expert report entitled "The Control Authority of Dr. Radovan Karadžić in the Strategic Command System of the VRS”, 2012), paras. 174, 176. 
fire [sic]. When they stop to kill our civilians by snipers they pose on the skyscrapers, there will be stop shelling of these buildings $[$ sic $] .{ }^{15600}$

Koljević, who was also present during this press conference, exclaimed "Sarajevo is a Serbian city, for God's sake!",15601

4660. Much earlier, during a session of the Bosnian Serb Assembly on 25 February 1992 and before the conflict started in Sarajevo, the Accused stated that he would never accept Sarajevo as the capital of a Muslim $\mathrm{BiH}$ given the number of Serbs in the city and given its enormous wealth. ${ }^{15602}$ Thus, during the very early stages of the conflict, the Bosnian Serb political leadership, including the Accused, began entertaining the idea of dividing Sarajevo by assuming control over the south bank of Miljacka River and leaving the areas on the north bank to the Bosnian Muslims. ${ }^{15603}$ As a reason for division of Sarajevo into separate and ethnically pure halves, the members of the Bosnian Serb political leadership, in particular Krajišnik and the Accused, would explain at length that coexistence between Bosnian Serbs and Bosnian Muslims had proven to be impossible. $^{15604}$ On 16 April 1992, at a meeting attended by Vance, Okun, Koljević, and the Accused, Koljević announced that he and the Accused had agreed to divide Sarajevo; this division of Sarajevo was something that continued to be "repeated endlessly by the Bosnian Serb leadership" according to Okun. ${ }^{15605}$ Okun also testified that one of the objectives of the shelling of Sarajevo was to create a "wall of fire" between the Muslim and Serb parts of the city in order to physically divide the city, as it could only be divided by force. ${ }^{15606}$

\footnotetext{
15600 P809 (Video footage of Radovan Karadžić's Press Conference at ICFY, 18 September 1992, with transcript), ecourt pp. 10-11. See also P6688 (Interview with Radovan Karadžić in Duga Magazine, 23 May 1992), p. 4; Herbert Okun, P776 (Transcript from Prosecutor v. Krajišnik), T. 4201-4202 (testifying that when he told the Accused that the Bosnian Serbs shelled Sarajevo first, the Accused responded that the Bosnian Muslims started the war by expelling him from his apartment); P784 (First notebook of Herbert Okun's ICFY diary), e-court pp. 45-47; D4474 (Report on visit by Steering Committee to Zagreb, Sarajevo and Belgrade 9-12 September 1992), paras. $18-21$.

15601 P809 (Video footage of Radovan Karadžić's Press Conference at ICFY, 18 September 1992, with transcript), ecourt p. 9.

15602 D88 (Shorthand Record of $8^{\text {th }}$ session of SerBiH Assembly, 25 February 1992), pp. 11, 20.

15603 P1154 (Witness statement of KDZ088 dated 27-29 April 2010), pp. 92, 94 (under seal); KDZ088, T. 6295-6296 (7 September 2010) (closed session).

15604 P1154 (Witness statement of KDZ088 dated 27-29 April 2010), pp. 94, 114-115, 118-119 (under seal). See also Vitomir Žepinić, T. 33586-33590, 33594-33595 (13 February 2013) (testifying that the Accused, Plavšić, and Koljević would all make such proclamations).

15605 P780 (Seventh notebook of Herbert Okun's Vance Mission Diary), p. 69; Herbert Okun, P776 (Transcript from Prosecutor v. Krajišnik), T. 4173-4174, 4204-4205, 4210-4211, 4249-4251, 4354-4355. The Accused had made statements suggesting to divide Sarajevo long before this. For example, on 21 December 1991, during the Bosnian Serb Assembly session, he suggested that Serbs, Croats, and Muslims could each organise their own administration within Sarajevo. See D86 (Shorthand Record of $4^{\text {th }}$ session of SerBiH Assembly, 21 December 1991), pp. 41-42.

15606 Herbert Okun, P776 (Transcript from Prosecutor v. Krajišnik), T. 4210-4211, 4354-4355.
} 
4661. The Chamber further recalls that Sarajevo also featured among the Bosnian Serb Strategic Goals indicating again the importance of the city to the Bosnian Serb side and the Accused in particular. The Chamber addressed the importance of the Strategic Goals to the Bosnian Serbs in preceding sections of the Judgement ${ }^{15607}$ and recalls here that the Accused presented them during the $16^{\text {th }}$ session of the Bosnian Serb Assembly on 12 May 1992 where they were adopted by the Assembly representatives. One of the six goals listed was the division of Sarajevo into Serbian and Muslim parts and the "creation of the efficient state authority in both parts". ${ }^{15608}$ Speaking about this particular goal, the Accused stated during the Assembly session that the battle for Sarajevo would be of decisive importance, that "Alija does not have a state while we have a part of Sarajevo", and that the fighting in the city prevented fighting in other areas where there could be conflicts with Bosnian Muslims. ${ }^{15609}$ Furthermore, since Sarajevo had been built on Serb land with Serb money, he exclaimed that they would not allow it to be excluded from the SerBiH. ${ }^{15610} \mathrm{He}$ also stated that the war in Sarajevo had been imposed on the Serbs but that their forces were doing well, holding their enemies in "complete encirclement". ${ }^{15611}$ In the same session Mladic made statements, such as “we have to put a ring around the dragon's head of Sarajevo this very moment and only those whom we let out should be allowed out". ${ }^{15612}$ He further explained that Sarajevo could not be taken "by spitting at it from two mortars" and that in order to make the Bosnian Muslims surrender they would have to densely plant 300 guns around Sarajevo including rocket launchers. ${ }^{15613}$

4662. The Chamber also heard that in September 1992 Van Lynden spent several evenings having informal conversations with the Accused during which he realised that taking Sarajevo was an obsession for the Accused. ${ }^{15614}$ According to Van Lynden, the Accused made it clear that in his

\footnotetext{
15607 The Accused and the Bosnian Serb leadership, including Mladić, formulated and promoted the Strategic Goals, and took steps to ensure that they were implemented and that they continued to be the central element of the Bosnian Serb objectives for the duration of the conflict in BiH. See paras. 2895-2903.

15608 See para. 2857; P955 (SerBiH Assembly Decision on Strategic Goals of Serbian People in BiH, 12 May 1992).

15609 P956 (Transcript of $16^{\text {th }}$ session of SerBiH Assembly, 12 May 1992), e-court p. 10. See also D92 (Transcript of $17^{\text {th }}$ session of SerBiH Assembly, 24-26 July 1992), p. 16 (during which the Accused stated that thanks to the Sarajevo battlefield Izetbegović's government and BiH are not functioning); Robert Donia, T. 3078-3079 (31 May 2010), T. 3144 (1 June 2010).

15610 P956 (Transcript of $16^{\text {th }}$ session of SerBiH Assembly, 12 May 1992), e-court p. 8. See also D92 (Transcript of $17^{\text {th }}$ session of SerBiH Assembly, 24-26 July 1992), p. 16.

15611 P956 (Transcript of $16^{\text {th }}$ session of SerBiH Assembly, 12 May 1992), e-court p. 8.

15612 P956 (Transcript of $16^{\text {th }}$ session of SerBiH Assembly, 12 May 1992), e-court p. 38 (emphasis added).

15613 P956 (Transcript of $16^{\text {th }}$ session of SerBiH Assembly, 12 May 1992), e-court pp. 36, 38. The Chamber heard evidence that Mladić attempted to ensure the division of Sarajevo in May 1992 by moving the Serb units from Grbavica all the way to Maršal Tito Barracks. [REDACTED]; P1478 (Ratko Mladić's notebook, 27 May-31 July 1992), p. 42 (where the Accused indicated his support for this plan and stated "we must have [...] part of Sarajevo"); P968 (Interview with Jovan Tintor on Pale TV, 1 August 1994, with transcript), e-court p. 2.

15614 P926 (Witness statement of Aernout Van Lynden dated 26 February 2010), paras. 71-74; Aernout van Lynden, T. 2418, 2445-2447 (19 May 2010).
} 
opinion Sarajevo belonged "solely to the Serbs", stating that "all the ground was actually Serb territory" and that the houses were Serb houses. ${ }^{15615}$ During one of these discussions, the Accused also suggested that one of the potential solutions in Sarajevo was to have a version of the Berlin wall in the city since the Serbs could never live with the Muslims again. ${ }^{15616}$ The idea of a division similar to the one in Berlin was supported by Mladić who, during a meeting with Morillon on 27 October 1992, offered two solutions to the situation in Sarajevo, one being to divide Sarajevo into two parts, mark the borders and have a split community like in Berlin and with the wall; or, if that was not accepted, for the Muslim side to surrender all weapons to UNPROFOR, at which point he would open the roads into the city. ${ }^{15617}$

4663. During the $34^{\text {th }}$ Assembly session in August 1993, in the context of trying to persuade the Assembly to accept the Owen-Stoltenberg Plan, the Accused stated that the goal relating to Sarajevo, namely to create the "Serb Sarajevo" out of "Serb territory in the town of Sarajevo" had been achieved but that he was ready to compromise as it was in their interests to make "two towns". ${ }^{15618}$ Later in the session, after stating that the Serbs could have taken more territory by force, the Accused stated "[w]e can even take Sarajevo" and, having referred to Grbavica, parts of Dobrinja, Vogošća, Ilijaš, and Nedžarići, indicated "[t]his is all ours" explaining that he would not have agreed to the Owen-Stoltenberg Plan if he was not sure that the Serbs would keep everything that was presently theirs in Sarajevo. ${ }^{15619}$ The Accused also stated that Sarajevo was not in the Muslim state but in the Serbian state because "everything around is Serbian"; that the Bosnian Serbs would not "cede a single footstep"; and that the most probable outcome was the division of

15615 P926 (Witness statement of Aernout Van Lynden dated 26 February 2010), para. 72; Aernout van Lynden, T. 2418 (19 May 2010).

15616 P926 (Witness statement of Aernout Van Lynden dated 26 February 2010), para. 73; Aernout van Lynden, T. 2418-2419, 2445-2446 (19 May 2010), T. 2563-2564 (20 May 2010). See also P785 (Second notebook of Herbert Okun's ICFY diary), e-court p. 24; Herbert Okun, P776 (Transcript from Prosecutor v. Krajišnik), T. 4204 (indicating that during a meeting on 17 September 1992 in Geneva the Accused told Okun and Vance that he could persuade Serbs to remain in Sarajevo if there were two entities there). Later in the conflict, the Accused proposed a solution that he said would create peace within two weeks in Sarajevo, namely to place the city under the UNPROFOR control and to have a "green line" akin to that in Cyprus. See D172 (UNPROFOR report re meeting with Radovan Karadžić, 20 February 1993), p. 2; David Harland, T. 2288 (11 May 2010).

15617 P4203 (Witness statement of Pyers Tucker dated 12 May 2010), paras. 26, 32-33.

15618 P1379 (Transcript of 34 ${ }^{\text {th }}$ session of RS Assembly, 27-29 August, 9-11 September, 29 September to 1 October 1993), p. 15.

15619 P1379 (Transcript of 34 ${ }^{\text {th }}$ session of RS Assembly, 27-29 August, 9-11 September, 29 September to 1 October 1993), p. 63. 
Sarajevo into two cities. ${ }^{15620}$ He stressed that "Serbian Sarajevo is of priceless importance" and that the Bosnian Serb side needed to prepare for war to gain Sarajevo. ${ }^{15621}$

4664. Similarly, during the $36^{\text {th }}$ Bosnian Assembly session in December 1993, the Accused stated that it was SDS policy that Sarajevo be preserved, through the fifth Strategic Goal and that the "Sarajevan battlefield has created the state" because, had it broken down, the Bosnian Muslims would have reached the Drina and cut across the corridor. ${ }^{15622}$

4665. On 13 and 14 December 1993, at a meeting in Belgrade with Slobodan Milošević, the Accused outlined the Strategic Goals, including the goal to have "our part of Sarajevo"; he then stated that Sarajevo was a priority and the "key to the war" and that he was afraid that "Islamic culture will try to spread its wings in Sarajevo". ${ }^{15623}$ The Accused also advocated capturing more elevation points around Sarajevo, including Mojmilo and Žuč. ${ }^{15624}$ To this Slobodan Milošević responded by issuing a reminder that "Sarajevo is primarily a political problem". ${ }^{15625}$ Krajišnik backed the Accused and spoke about Sarajevo as a priority, explaining that they were drawing maps of Sarajevo. ${ }^{15626}$ Dragomir Milošević, who was also at the meeting, spoke about the need for

15620 P1379 (Transcript of 34 ${ }^{\text {th }}$ session of RS Assembly, 27-29 August, 9-11 September, 29 September to 1 October 1993), pp. 64-65.

15621 P1379 (Transcript of 34 ${ }^{\text {th }}$ session of RS Assembly, 27-29 August, 9-11 September, 29 September to 1 October 1993), pp. 65, 116 (in this session the Accused also stated: "Sarajevo is the greatest problem as there must be water, electricity and gas and no shooting").

15622 P1383 (Transcript of $36^{\text {th }}$ session of RS Assembly, 30-31 December 1993), pp. 128-129.

15623 P1484 (Ratko Mladić's notebook, 28 October 1993-15 January 1994), pp. 53-54. Mladić's notebooks contain many references to meetings with the Accused during which the Accused emphasised the importance of Sarajevo. See e.g. P1477 (Ratko Mladić's notebook, 14 February-28 May 1992), p. 347 (recounting a meeting on 16 May 1992 with the representatives of the Bosnian Serb Government during which the Accused emphasised the importance of Sarajevo); P1480 (Ratko Mladić's notebook, 10-30 September 1992), p. 110 (recounting a meeting with the Accused, Krajišnik, and others, during which the Accused said that the Serbs would not be giving up on Sarajevo); P1483 (Ratko Mladić's notebook, 2 April-24 October 1993), pp. 194, 396 (recounting two meetings, one in Jahorina on 2 June 1993, attended by Galić, Mladić, Krajišnik, and the Accused, among others, during which the Accused said that Sarajevo battlefield was the most important, that nothing could be achieved by negotiation, and that Sarajevo had to be taken; the other meeting was that of the Supreme Command on 24 October 1993 during which the Accused again recalled the importance of Sarajevo); P1484 (Ratko Mladić's notebook, 28 October 1993-15 January 1994), pp. 133-134 (recounting a meeting in Pale on 14 January 1994 where the Accused emphasised that the Serbs must defeat the Muslims in Sarajevo).

Patko Mladić's notebook, 28 October 1993-15 January 1994), p. 54

P1484 (Ratko Mladić's notebook, 28 October 1993-15 January 1994), p. 54

P1484 (Ratko Mladić's notebook, 28 October 1993-15 January 1994), p. 56. Okun testified that division of Sarajevo was probably the Strategic Goal that Krajišnik emphasised more than any other. See Herbert Okun, P776 (Transcript from Prosecutor v. Krajišnik), T. 4244, 4249-4251, 4275-4276, 4299-4307; P790 (Seventh notebook of Herbert Okun's ICFY diary), e-court pp. 24-25, 30. See also P797 (TV Belgrade interview with Momčilo Krajišnik); KDZ240, P2935 (Transcript from Prosecutor v. Krajišnik), T. 6769-6772 (under seal); P1477 (Ratko Mladić's notebook, 14 February-28 May 1992), p. 262 (recounting a meeting between the Accused, Krajišnik, and Mladić, during which Krajišnik referred to the Strategic Goals and the division of Sarajevo); P2538 (Patrick Treanor's research report entitled "Radovan Karadžić and the Serbian Leadership 1990-1995", 1 May 2009), para. 261 (recounting an interview that Krajišnik gave to Srpsko Oslobođenje in which he said that the perspective for Sarajevo is such that in the future it will be a Serb town and the Muslims would have to seek a capital without Sarajevo); D3645 (Witness statement of Nenad Kecmanović dated 27 May 2013), paras. 17-19 (recounting a meeting between Krajišnik and Izetbegović in May 1992 during which the 
fresh forces which would "carry out the whole operation to its completion". ${ }^{15627}$ The Accused then said that Sarajevo should be divided so that the Bosnian Serb part of the city can function while Krajišnik stated, "we have to finish Žuč before the conference". ${ }^{15628}$

4666. On 6 April 1994, Akashi met with the Accused, Koljević, and Mladić in Pale. ${ }^{15629}$ The Accused indicated the Serbs were considering a new approach to the question of Sarajevo, which would entail two separate cities rather than splitting the present Sarajevo in two as previously demanded, wherein the Serb Sarajevo would be built from satellite Serb towns in the Sarajevo area. ${ }^{15630}$ Similarly, in a meeting with De Mello in the evening of 7 May 1994, the Accused presented his vision of Sarajevo, in which the inner city would remain Muslim, with Serb Sarajevo stretching from Ilidža to Lukavica, including the airport and Butmir. ${ }^{15631}$ He described this as "[t]wo cities, side by side, communicating and cooperating". 15632 Then, on 10 May 1994, during the $40^{\text {th }}$ session of the Bosnian Serb Assembly he said: “[W]e have to maintain the character of the Berlin kind of corridor in order to get Sarajevo definitely divided and the territories to become compact. Then we will give them square metre of the hill between Vogošća and Vis, and we will take away from them square kilometre on the Drina."15633

4667. Even in the later stages of the conflict, as the $\mathrm{ABiH}$ forces in Sarajevo were getting stronger and better equipped, the Accused and Mladić were unwilling to give up on the idea of Serb Sarajevo. Thus, on 9 May 1995, Smith reported to Akashi that during a meeting held in Pale earlier in the day, the Accused had made it clear to him that the Bosnian Serbs were not going to let go of Sarajevo. ${ }^{15634}$ In July 1995, when asked in an interview with El País what his view on the future of Sarajevo was, the Accused said that the city would be transformed into two neighbouring cities, if the Muslims wished; otherwise, it would be a Serb city, because the entire territory around Sarajevo

former recommended a temporary division of Sarajevo); P1385 (Transcript of $37^{\text {th }}$ Session of RS Assembly, 10 January 1994), p. 125 (wherein Krajišnik proposed to agree to a two-year mandate of the UN over Sarajevo and then, when the other Serb-held territories are merged, to fight to get Sarajevo back).

15627 P1484 (Ratko Mladić's notebook, 28 October 1993-15 January 1994), p. 56.

15628 P1484 (Ratko Mladić's notebook, 28 October 1993-15 January 1994), p. 59.

15629 D705 (UNPROFOR report re meetings with Radovan Karadžić and Alija Izetbegović, 7 April 1994), para. 1; Yasushi Akashi, T. 37703-37707 (24 April 2013); Michael Rose, T. 7497 (7 October 2010).

15630 D705 (UNPROFOR report re meetings with Radovan Karadžić and Alija Izetbegović, 7 April 1994), para. 17. See also P1486 (Ratko Mladić's notebook, 31 March 1994-3 September 1994), pp. 288-292 (recounting another meeting with Akashi, on 19 August 1994, during which the Accused insisted on splitting Sarajevo); D3500 (UNPROFOR report, 7 October 1994), p. 9 (reporting on a 5 October 1994 meeting between the Accused and Akashi, among others, during which the Accused again proposed that Sarajevo be split into "twin cities"); Yasushi Akashi, T. 37718 (24 April 2013).

15631 P5422 (UNPROFOR report, 8 May 1994), para. 23.

15632 P5422 (UNPROFOR report, 8 May 1994), para. 23.

15633 P1390 (Transcript of 40 $0^{\text {th }}$ session of RS Assembly, 10-11 May 1994), p. 71.

15634 P2265 (UNPROFOR report re meeting with Radovan Karadžić, 9 May 1995), e-court p. 3. 
and the ground on which it stood was Serb land. ${ }^{15635}$ He then stated: "We will either have half the city transformed into a Serbian city or we will have the whole thing". ${ }^{15636}$ Similarly, as indicated earlier, on 2 August 1995, in an interview with the Srpski Borac newspaper, the Accused discussed the strategic importance of Sarajevo for the Bosnian Serbs and stated that if the Bosnian Muslims disturbed the Bosnian Serb part of Sarajevo, the Bosnian Serbs will "seize [the city] entirely". 15637 On 28 August 1995, during the $53^{\text {rd }}$ session of the Bosnian Serb Assembly, the Accused said that the Serbs "absolutely cannot leave Sarajevo because then the Muslims would really have a good state". ${ }^{15638}$

4668. On 29 August 1995, one day after the Markale shelling, the political and military leaderships of the FRY and the RS met to discuss a peace initiative; the FRY delegation included Slobodan Milošević, whereas the RS was represented by the Accused, Krajišnik, Plavšić, Koljević, Buha, Mladić, Tolimir, and Gvero. ${ }^{15639}$ They discussed a number of issues and, at the end of the meeting, Milošević set forth the Bosnian Serb priorities he would present at the upcoming conference with the Contact Group, namely (i) the north corridor being as broad as possible, especially in Brčko; (ii) compactness of Bosnian Serb territory; (iii) the inclusion of as many towns as possible in territories formally assigned to Bosnian Serbs; and (vi) access to the sea. ${ }^{15640}$ At the insistence of the Accused, the list of priorities was amended in the last minute so as to include Bosnian Serb claims to three more areas, including "Serb Sarajevo", once again showing the importance he placed on that issue. ${ }^{15641}$

4669. On 28 November 1995, during an SDC meeting in Belgrade, Slobodan Milošević expressed concern about Mladić's behaviour and reported the following to the others at the meeting:

Mladić states two days ago: "We're not giving away what belongs to the Serbs, Sarajevo belongs to the Serbs." Please, tell me, when was it in this century that the Serbs were the majority in Sarajevo? When? [...] They got a part of Sarajevo-the south-eastern part; they asked that the entire Sarajevo District be completely separate, and Sarajevo District includes the Municipality of Pale [...] we plucked Pale out, then Lukavica, Vrace, Vojkovići, then down there towards Trnovo, and the remaining part-where the Muslims constitute a vast majority. ${ }^{15642}$

\footnotetext{
15635 P2564 (Radovan Karadžić's interview in El País, 16 July 1995), p. 5. See also P5063 (Video footage depicting interview of Radovan Karadžić on "Ask the President", undated, with transcript), e-court p. 17 (where the Accused threatens that if the Muslims do not accept the division of Sarajevo into two cities, Sarajevo will eventually be entirely Serb).

15636 P2564 (Radovan Karadžić's interview in El País, 16 July 1995), p. 5.

15637 D2660 (Article from Srpski Borac entitled "We are Sovereign over Sarajevo", 2 August 1995), pp. $2,6$.

15638 P988 (Transcript of 53 ${ }^{\text {rd }}$ session of RS Assembly, 28 August 1995), p. 26.

15639 D3058 (Record of meeting between leaderships of FRY and RS, 29 August 1995), p. 1.

15640 D3058 (Record of meeting between leaderships of FRY and RS, 29 August 1995), p. 13.

15641 D3058 (Record of meeting between leaderships of FRY and RS, 29 August 1995), p. 13.

15642 P2604 (Minutes of $47^{\text {th }}$ session of SDC, 28 November 1995), pp. 10-11.
} 
4670. As already concluded in Section IV.A.3.a.i.E, the Strategic Goals, including the goal to divide Sarajevo, formed the basis for military operations by the VRS. Thus, Sarajevo was explicitly mentioned in all but one of the seven military directives issued by the Main Staff and/or the Accused. ${ }^{15643}$ As early as in Directive 1, which was issued by the Main Staff on 6 June 1992, Mladic stated that the VRS had "received the task to use offensive actions [...] in order to improve operationally-tactical position in the wide area of Sarajevo". ${ }^{15644}$ He then tasked the SRK to "mop up parts of Sarajevo" and "cut it out" along the Nedžarići-Stup-Rajlovac axis; he also tasked them with mopping up Mojmilo, Dobrinja, Butmir, and Sokolović Kolonija, and with de-blocking of Sarajevo-Trnovo and Pale-Zlatište communication. ${ }^{15645}$ On the same day that Directive 1 was issued, the Accused had met with Mladić, Koljević, Krajišnik, Ostojić, and others in Jahorina and discussed the Strategic Goals, claiming "we have to protect our territories militarily" and that "the birth of a state and the creation of borders does not occur without war". 15646 Following these statements, Ostojić then presented the planned borders of a Bosnian Serb state on a map, including those around Sarajevo, saying that the plan regarding Sarajevo was to include as much industry as possible and most of the fertile land in the area. ${ }^{15647}$ The Accused again addressed the issue of Sarajevo and said "we could have gone for a compact and dispersed partition of Sarajevo if there had been the political means" and further "not all our wishes can be fulfilled, we have to be a mature people". ${ }^{15648}$

4671. In Directive 3, issued on 3 August 1992, Mladić outlined the objective of keeping Sarajevo "firmly under blockade" and thus instructed the SRK to "gradually tighten the encirclement". 15649 In Directive 4, dated 19 November 1992, he instructed the SRK to keep Sarajevo and Igman under "full blockade" and "tighten the circle". ${ }^{15650}$ As noted earlier, ${ }^{15651}$ in that same directive, Mladić also explained that one of the tasks of the VRS was to create conditions for the Bosnian Serb

\footnotetext{
15643 For more on the seven directives and their supplements, see Section IV.B.1.a: Chronology of events in Sarajevo; IV.B.1.c.iii.A: Scheduled Incidents G.1 and G.2.

15644 D232 (Directive 1, 6 June 1992), para. 2.

15645 D232 (Directive 1, 6 June 1992), para. 5. See also [REDACTED].

15646 P1478 (Ratko Mladić's notebook, 27 May-31 July 1992), pp. 95, 97. The Accused had also met Mladić, Koljević, Plavšić, and Krajišnik the day before, on 5 June, wherein he instructed those attending that "Sarajevo has to be resolved politically while acting quietly, inch by inch." He also instructed them to "clean up" Butmir, Hrasnica, Dobrinja, Sokolović Kolonija, and Hrasno. See P1478 (Ratko Mladić's notebook, 27 May-31 July 1992), p. 93 (emphasis added).

15647 P1478 (Ratko Mladić's notebook, 27 May-31 July 1992), p. 99.

15648 P1478 (Ratko Mladić's notebook, 27 May-31 July 1992), p. 104. Krajišnik also got involved during the meeting and outlined the goals in terms of having parts of Sarajevo area under the Bosnian Serb control, including "Dobrinja, if we can take it". See P1478 (Ratko Mladić's notebook, 27 May-31 July 1992), p. 108.

15649 D235 (Directive 3, 3 August 1992), pp. 3, 5. The orders relevant to Sarajevo in this directive were relayed the next day to the SRK units by the SRK Command. See P5979 (SRK Order, 4 August 1992).

15650 P976 (Directive 4, 19 November 1992), p. 5.

15651 See para. 4575.
} 
leadership to "participate equally" in resolving the crisis in $\mathrm{BiH}$ with "other international factors". ${ }^{15652}$ Sarajevo and its surroundings were also the focus of the Lukavac 93 operation outlined in Directive 5, in which Mladić tasked the SRK to "create conditions to assume control over [Sarajevo]". ${ }^{15653}$ He explained in the directive that the VRS had been tasked with preventing the capture of special-purpose facilities and the lifting of the blockade of Sarajevo. ${ }^{15654}$ Directive 6 was then issued by the Supreme Command and signed by the Accused in November 1993, wherein he ordered the VRS to create objective conditions for the achievement of "war goals", including the "liberation of Sarajevo", and tasked the SRK units with preventing the "deblockade of Sarajevo". ${ }^{15655}$ This was followed by a supplement to the directive, issued by the Accused on 12 December of the same year. In that supplement he noted the impending resumption of talks in Geneva and ordered the VRS to seize Žuč and Mojmilo in order to ensure "the most favourable position for dividing the town". ${ }^{15656}$ As noted above, the need to capture these elevation points was then discussed by the Accused, Mladić, Dragomir Milošević, and Slobodan Milošević on 13 December in Belgrade. ${ }^{15657}$ While the focus of Accused's Directive 7 was mainly on other areas of $\mathrm{BiH},{ }^{15658}$ it also included an order to the SRK, among other things, to prevent the lifting of the blockade of Sarajevo "from without" by using "decisive defence". ${ }^{15659}$

4672. The evidence in this case is also replete with examples of the Accused and Mladić, as well as Koljević, Plavšić, and Krajišnik participating in various meetings with representatives of international community on Sarajevo-related matters, including military matters, the issue of sniping and shelling in the city, cease-fire agreements, the issue of humanitarian convoys and humanitarian airlift to the city, the issue of free movement of UNPROFOR in and around Sarajevo, and flow of utilities. ${ }^{15660}$ For example, Abdel-Razek testified that at all times during his meetings with the Bosnian Serbs regarding the situation in the city, a senior Bosnian Serb political figure

\footnotetext{
15652 P976 (Directive 4, 19 November 1992), p. 3.

15653 P843 (Directive 5, 25 June 1993), para. 5(a) (ordering also that the SRK is to use "persistent and active defence" to stop the breakthrough of $\mathrm{ABiH})$.

15654 P843 (Directive 5, 25 June 1993), para. 2.

15655 P3039 (Directive 6, 11 November 1993), pp. 6, 9.

15656 P4925 (Supplement to Directive 6, 12 December 1993), p. 1; P3052 (VRS Main Staff Order, 14 December 1993). See also Dragomir Milošević, T. 33092-33099 (4 February 2013). A number of SRK soldiers and officers testified, however, that they had no knowledge that the objective of the SRK was to divide Sarajevo. See e.g. D2331 (Witness statement of Blagoje Kovačević dated 14 October 2012), para. 15; Blagoje Kovačević, T. 29088-29089 (18 October 2012); D2519 (Witness statement of Dragan Maletić dated 9 November 2012), para. 16.

15657 See para. 4665.

15658 See paras. 4979-4980.

15659 P838 (Directive 7, 8 March 1995), pp. 7, 11-12.

15660 Many of these are recounted earlier in the Judgement, such as the meetings relating to the creation of the TEZ and the WCPs, the opening and later the closure of Blue Routes, the Anti-sniping Agreement, and the Airport Agreement.
} 
would be present, either the Accused, Plavšić, or Koljević, despite the fact that these meetings were "military to military meetings". 15661

4673. Furthermore, from the very early days of unrest in and around Sarajevo, the Accused actively participated in organising the Bosnian Serb population and the setting up of the barricades around the city. ${ }^{15662}$ As the conflict intensified, he and the other members of the political leadership continued to be involved not only in political but also in military and security matters relating to Sarajevo. ${ }^{15663}$ Neđeljko Prstojević testified about frequent meetings with the Accused in Pale involving discussions about the military and political situation in Sarajevo, including logistics and co-operation between civilian authorities, the VRS, and the MUP. ${ }^{15664}$ For example, in a meeting in Pale on 14 January 1994, which was attended by the Accused, Krajišnik, Mladić, Galić, Dragomir Milošević, Mićo Stanišić, Prstojević, and other presidents of Sarajevo municipalities, as well as commanders of SRK brigades, the Accused stated that the purpose of the meeting was to discuss the military and political situation in Sarajevo. ${ }^{15665}$ During the meeting, the Accused updated everyone on the political negotiations in Geneva and stated that he offered Owen the "Trieste model for Sarajevo", that "the Muslims must not win a single victory in Sarajevo", that the Serbs must secure the Ilidža-Lukavica road, and that they must defeat the Muslims in Sarajevo as the international community will accept the factual situation on the ground. ${ }^{15666}$ Following the presentation by the various SRK brigade commanders about the situation on the frontline, Mladić stated that Sarajevo is strategic goal number one, which can be resolved militarily not

15661 P1258 (Witness statement of Hussein Ali Abdel-Razek dated 16 July 2002), e-court p. 5; Hussein Abdel-Razek, T. 5486-5487 (19 July 2010), T. 5650-5651 (21 July 2010).

15662 Čedomir Kljajić, T. 42197-42200 (30 July 2013); P6468 (Excerpts from Čedomir Kljajić's interview with OTP), e-court p. 2; P5731 (Intercept of conversation between Radovan Karadžić and Rajko Dukić, 1 March 1992) (in which the Accused instructs Dukić to prepare the people to rise up and "close everything tonight"); D331 (Intercept of conversation between Danilo Veselinović and Radovan Karadžić, 13 April 1992); D4506 (Intercept of conversation between Radovan Karadžić and Rade, May 1992).

15663 See e.g. D3960 (Witness Statement of Tomislav Kovač dated 28 October 2013), paras. 117, 130-132; P2242 (Radovan Karadžić's agenda, 2 January-25 December 1995), e-court pp. 91-92; P4367 (Excerpt from appointment calendar of Radovan Karadžić, 14 July 1995); Tomislav Kovač, T. 42855-42859 (4 November 2013).

15664 Neđeljko Prstojević, T. 13257-13261, 13264, 13267-13268 (11 March 2011) (recalling a meeting in Jahorina in September 1992 that involved the Accused, Krajišnik, Mladić, SRK Commander, various SRK brigade commanders, and representatives of local authorities; Prstojević also added that, in addition to such meetings, he would have frequent telephone communications with the Bosnian Serb leadership in Pale); P1006 (SRK Order, 12 September 1992) (in which Galić assigned tasks to the SRK in accordance with the decisions made at the Jahorina meeting).

15665 P1484 (Ratko Mladić's notebook, 28 October 1993-15 January 1994), p. 133.

15666 P1484 (Ratko Mladić's notebook, 28 October 1993-15 January 1994), pp. 133-134. See also D2660 (Article from Srpski Borac entitled "We are Sovereign over Sarajevo", 2 August 1995), p. 8 (in which the Accused stated that the Serb victories around Sarajevo were important as they would create factual situation on the ground that would have to be recognised by the international community). For more on the issue of importance of factual situation on the ground to the Accused, see paras. 2844-2845, 3090-3096. 
politically. ${ }^{15667}$ Krajišnik then spoke and insisted on Serbs keeping Sarajevo, stating that the whole of Sarajevo must be taken, as one cannot have two masters in such a small area and one cannot share with the Muslims. ${ }^{15668}$ Following all these presentations, the Accused agreed with Mladić that "Muslims will break down in Sarajevo", instructed the participants to make sure that the Muslims keep suffering defeats and feel inferiority, and then stated that "retaliation should be $1: 1 " .15669$

4674. Thus, it is clear on the basis of above, that, from the very beginning of the conflict in $\mathrm{BiH}$, the political and military leadership of the Bosnian Serbs, particularly the Accused, Krajišnik, Koljević, Plavšić, and Mladić, recognised and championed the importance of Sarajevo to the conflict in $\mathrm{BiH}$. The city was important not only because of its symbolism and the fact that without it the Bosnian Muslim side would not be able to have a functioning independent state but also because it carried special significance for the Accused who had lived there up until the start of the war and considered it his hometown. Because of this, the Accused, Krajišnik, Koljević, Plavšić, and Mladić all desired to gain control over Sarajevo, or parts thereof, a project in which they were invested throughout the conflict. ${ }^{15670}$ Furthermore, as will be explained in detail below, they were fully informed of the situation on the ground such that the Accused's level of knowledge regarding Sarajevo was said to have been higher than his knowledge about the other parts of $\mathrm{BiH}^{15671}$ Ultimately, in the Chamber's view, the Accused, Krajišnik, and Mladić were the "go-to-men" for all the Sarajevo-related issues.

4675. The Chamber is also convinced that this interest and involvement in the Sarajevo-related events by the Accused and the other political and military leaders demonstrates that the campaign of sniping and shelling in the city resulted from a plan which emanated from the top of the Bosnian Serb military and political leadership and was rooted in the idea of dividing Sarajevo. As noted by Okun, the city could have only been divided by a wall of fire.

\section{iv. Conclusion}

4676. Based on the findings made above as to the pattern and longevity of the campaign, the control that was exercised over the SRK units by the Main Staff and the SRK Command, and the importance of Sarajevo to the Bosnian Serb political and military leadership, and relying also on

\footnotetext{
15667 P1484 (Ratko Mladić's notebook, 28 October 1993-15 January 1994), pp. 139-144.

15668 P1484 (Ratko Mladić's notebook, 28 October 1993-15 January 1994), p. 147.

15669 P1484 (Ratko Mladić's notebook, 28 October 1993-15 January 1994), pp. 148-149.

15670 The Chamber notes that this interest also materialised in the take over of a number of Sarajevo municipalities, as outlined in Section IV.A.1.c: Sarajevo area.
} 
the relevant evidence in the sections below dealing with the activities of the Accused and other alleged Sarajevo JCE members throughout the conflict in $\mathrm{BiH},{ }^{15672}$ the Chamber finds that there existed a common plan that emanated from the Bosnian Serb political and military leadership, the primary purpose of which was to spread terror among the civilian population of Sarajevo through the campaign of sniping and shelling. Based on the evidence relating to scheduled sniping and shelling incidents, the Chamber is also satisfied that this plan involved the commission of murder, terror, and unlawful attacks against civilians.

\section{b. Plurality of persons}

4677. As stated above, in addition to the Accused, the Prosecution specifically names the following individuals as the members of the Sarajevo JCE: Momčilo Krajišnik, Ratko Mladić, Biljana Plavšić, Nikola Koljević, Stanislav Galić, Dragomir Milošević, and Vojislav Šešelj. ${ }^{15673}$ Further, it lists other un-named members of the Sarajevo JCE, including members of the Bosnian Serb leadership, commanders and senior officers in the VRS, JNA, TO and MUP units responsible for Sarajevo area, and leaders of Serbian and Bosnian Serb paramilitary forces. ${ }^{15674}$ In its Final Brief, however, the Prosecution does not list Šešelj as a member of the Sarajevo JCE but focuses instead on the Accused, Mladić, Galić, Dragomir Milošević, and the members of the RS Presidency. ${ }^{15675}$ The Prosecution also avers that, since these Sarajevo JCE members made contributions and worked together with the Accused to lead the campaign of sniping and shelling for the purpose of causing terror, "their shared intent for the underlying crimes similarly follows". 15676

4678. Based on the foregoing analysis of the evidence relating to Sarajevo, including (i) the chronology of events in the city between 1992 and 1995, (ii) the nature and the objectives of the siege in Sarajevo, (iii) the specific scheduled sniping and shelling incidents, (iv) the general evidence on the nature of the SRK's shelling and sniping in the city, (v) the control the SRK Command and the VRS Main Staff had over the SRK units and their weaponry, and (vi) the importance of Sarajevo to the political and military leadership of the Bosnian Serbs, the Chamber is

\footnotetext{
15671 P4203 (Witness statement of Pyers Tucker dated 12 May 2010), paras. 69, 281; P4216 (UNPROFOR report re meeting with Radovan Karadžić, 20 November 1992), para. 7.

15672 In addition, the Chamber also relied on other sections of this Judgement, primarily those dealing with the Municipalities and Hostages components of the case, which outlined the actions of the Accused, Mladić, Krajišnik, Koljević, and Plavšić throughout the conflict in $\mathrm{BiH}$.

15673 Indictment, para. 16.

15674 Alternatively, according to the Prosecution, some of those were not members of the Sarajevo JCE but were used by members to carry out crimes committed in the furtherance of the objective. See Indictment, para. 17.

15675 See Prosecution Final Brief, para. 604.

15676 Prosecution Final Brief, para. 797.
} 
satisfied beyond reasonable doubt that the common plan outlined in the preceding section involved a plurality of persons. Further, in the Chamber's view, it is inconceivable that the SRK's campaign of sniping and shelling of civilians_-which lasted more than three years, involved multiple brigades and units of the SRK, and required significant military resources, weaponry, and organisationwould not have involved a number of individuals operating at both the military and the political level. The Chamber is, therefore, satisfied that the common plan emanated from both the Bosnian Serb political and military leadership.

4679. Before turning to the main issue in this case, namely, whether the Accused was one of these individuals, the Chamber will consider the other named alleged Sarajevo JCE members.

\section{i. Military leadership: Ratko Mladić, Stanislav Galić, and Dragomir Milošević}

4680. Given the factors outlined in the preceding paragraphs, the Chamber is convinced beyond reasonable doubt that Mladić, Galić, and Dragomir Milošević were members of the Sarajevo JCE and shared the intent to effect the common plan outlined above. The fact that, as stated in the preceding paragraph, the SRK's campaign of sniping and shelling lasted more than three years, involved multiple brigades and units of the SRK, and required significant military resources, weaponry, and organisation, when coupled with the control found to have been exercised by the Main Staff and the SRK Command over the units engaging in that campaign, already leads to the inevitable conclusion that, at the very minimum, Mladić, Galić, and Dragomir Milošević were part of that plurality of persons. The only reasonable inference that can be drawn from the evidence relating to the sniping and shelling of civilians in Sarajevo is that Mladić, Galić, and Dragomir Milošević were willing participants in the Sarajevo JCE and that they intended to shell and snipe the civilians in the city and thus intended the common plan outlined above.

4681. In addition, the Chamber has also received evidence going to the acts and conduct of those three men, as well as to their state of mind, including their knowledge of the attacks on civilians in the city. Some of this evidence has already been outlined in the preceding sections of the Judgement, ${ }^{15677}$ including for example (i) Mladić's speech on 12 May 1992 at the Bosnian Serb Assembly session where he openly spoke about his intentions for Sarajevo, such as the need to place the ring around the dragon's head and to surround the city with 300 mortars and artillery weapons; ${ }^{15678}$ (ii) his involvement in the sourcing and the use of modified air bombs; ${ }^{15679}$ (iii) his

\footnotetext{
15677 In addition, some of that evidence is also discussed later on, in the sections dealing with the Accused's participation in and contribution to the Sarajevo JCE.

15678 See para. 4661.

15679 See para. 4562. See also fn. 14640 (listing a number of VRS orders reling to the use of modified air bombes).
} 
activities in relation to Scheduled Incident G.1, including his orders to shell Baščaršija, Pofalići, and Velešići, and to scatter the shells around Sarajevo, showing in turn his intent to shell the civilian population; ${ }^{15680}$ (iv) his directives which consistently ordered the tightening of the blockade of Sarajevo and the idea of "decisive" or "active" defence that in turn involved the shelling and the sniping of civilians and moving of the frontlines in Sarajevo, inch by inch; ${ }^{15681}$ (v) Galić's and Dragomir Milošević's implementation of the said directives; and (vi) Dragomir Milošević's orders regarding the use of modified air bombs. ${ }^{15682}$ The Chamber will not repeat that evidence here. The following paragraphs therefore outline only the evidence that has not yet been analysed by the Chamber. This evidence relates mainly to their knowledge of the attacks on civilians in the city and their reactions thereto.

4682. For example, the Chamber heard that, in the absence of the Accused, ${ }^{15683}$ the sniping and shelling of civilians was consistently raised with other members of the Bosnian Serb military and political leadership by the representatives of the international community and that UNPROFOR would go to the parties responsible anytime there was an incident, be it shelling or sniping. ${ }^{15684}$ Thus, in the event of major incidents, the Commander of UNPROFOR Sector Sarajevo would sign the protests which were addressed directly to the SRK Commander. ${ }^{15685}$ When the shelling was particularly violent, the Commander of UNPROFOR BiH Command would make oral protests over the phone, followed by written protests, with Mladić or with the political leaders in Pale. ${ }^{15686}$

4683. As far as Mladić's personal knowledge is concerned, the Chamber heard that, as early as 9 May 1992, General Kukanjac of the JNA informed Mladić that Sarajevo was a "ghost town" and

\footnotetext{
15680 See discussion on Scheduled Incidents G.1 and G.2.

15681 See paras. $4574,4576$.

15682 See discussion on Scheduled Incident G.10.
}

15683 The occasions where this has happened in the presence of the Accused are discussed later, in Section IV.B.3.iii: Accused's knowledge of crimes and the measures he took to prevent them.

15684 P1762 (Witness statement of David Fraser dated 17 October 2010), pp. 21-22, 25, 44-46; David Fraser, T. 8015-8016, 8018, 8056 (18 October 2010), T. 8106, 8110-8011 (19 October 2010); P2451 (Witness statement of Anthony Banbury dated 19 May 2009), para. 201; P6060 (Record of interview with KDZ185), e-court pp. 12, 20; KDZ185, T. 4231 (28 June 2010) (private session); P2106 (Witness statement of KDZ304), p. 17 (under seal) (testifying that the Sarajevo Sector Staff had a section in charge of preparing and transmitting protests); P5906 (Witness statement of KDZ450 dated 17 January 2011), paras. 54, 61-62; P2119 (Witness statement of KDZ450 dated 17 January 2011), paras. 35, 59-60 (under seal); KDZ450, T. 10548 (19 January 2011), T. 10659-10660, 10665 (20 January 2011) (private session), KDZ450, T. 10673, 10693 (20 January 2011); P2414 (Witness statement of KDZ182), pp. 31-32, 35 (under seal); P1558 (Witness statement of Francis Roy Thomas dated 13 May 2009), paras. 57-58, 66; Francis Roy Thomas, T. 6891-6892, 6928-6929 (16 September 2010) (testifying that, while it was difficult to protest before the February 1994 cease-fire, protests were made and "stonewalled" by Inđić who would prevent protests getting past him and put up obstacles to see Galić, and that during negotiations with "all levels of the warring factions" it was a "constant theme" that if there was any shooting the fire should be limited to combatants).

15685 P1558 (Witness statement of Francis Roy Thomas dated 13 May 2009), paras. 59, 95; Francis Roy Thomas, T. 6929 (16 September 2010); P2106 (Witness statement of KDZ304), p. 17 (under seal). 
the "Serbian leadership" had been shelling it for months with mortar and artillery. ${ }^{15687}$ Wilson testified that numerous incidents in which "a number of civilians were killed by artillery or mortars apparently fired from Serb positions" were raised with Mladić and that the latter would generally not deny that the Bosnian Serb side was responsible but would say that the shelling was done for the purpose of "defending the Serbs" or "responding to attacks". ${ }^{15688}$ For example, on 30 May 1992, Wilson met with Mladić to convey the Secretary General's appeal to cease or to moderate the shelling of Sarajevo. ${ }^{15689}$ Mladić responded that he shared the Secretary General's concern for Sarajevo, but that the Maršal Tito Barracks were under continuous fire and that it was important to evacuate the JNA from there. ${ }^{15690}$ He also stated that these attacks on Sarajevo were defending the Bosnian Serbs from attack. ${ }^{15691}$

4684. On 15 September 1992, Nambiar sent a letter to Mladić protesting the "indiscriminate shelling of civilian targets in Sarajevo" on the previous day, asking Mladić to "ensure that, under no circumstances, are non-military targets engaged", and urging him to place "all heavy weapons under UNPROFOR control". 15692

4685. On 15 November 1992, members of the SRK command and unit commanders, the presidents of a number of municipal assemblies as well as Mladić and Tolimir held a consultation session in Lukavica Barracks. ${ }^{15693}$ During the session, Galić raised a number of issues, including poor discipline and performance by troops, wastefulness in the use of ammunition, and involvement in "[g]enocide on other nations". ${ }^{15694}$ Marko Lugonja reiterated these concerns, stating that certain individuals and groups in the SRK held the conviction that they were the "masters of life and

\footnotetext{
15686 P5906 (Witness statement of KDZ450 dated 17 January 2011), para. 54; P2119 (Witness statement of KDZ450 dated 17 January 2011), para. 56 (under seal).

15687 P1477 (Ratko Mladić's notebook, 14 February-28 May 1992), pp. 268-273.

15688 P1029 (Witness statement of John Wilson dated 4 November 2008), para. 55. See also David Harland, T. 2037 (6 May 2010) (testifying that incidents of shelling and sniping were protested to Mladić at meetings).

15689 P1029 (Witness statement of John Wilson dated 4 November 2008), para. 77; John Wilson, T. 3924-3926 (21 June 2010); P1043 (UNPROFOR report re meeting with Ratko Mladić, 30 May 1992), para. 1; P1044 (UNPROFOR report re attack on UN, 30 May 1992), para. 1; P5050 (UN Press Release, 30 May 1992); P1478 (Ratko Mladić's notebook, 27 May-31 July 1992), pp. 34-35. This meeting was motivated by Security Council Resolution 757, which placed economic sanctions on the FRY, demanded that all parties create the conditions for the unimpeded delivery of humanitarian aid to Sarajevo and other destinations in $\mathrm{BiH}$, and established a security zone which encompassed Sarajevo and its airport. See John Wilson, T. 3926 (21 June 2010); P1031 (UNSC Resolution 757, 30 May 1992); P2284 (UNSG report entitled "The Fall of Srebrenica", 15 November 1999), para. 27. See also para. 332.

15690 P1043 (UNPROFOR report re meeting with Ratko Mladić, 30 May 1992), para. 2; John Wilson, T. 3926 (21 June 2010).

15691 John Wilson, T. 3926 (21 June 2010); P1029 (Witness statement of John Wilson dated 4 November 2008), para. 126.

15692 P1271 (UNPROFOR report re letter sent to Ratko Mladić, 15 September 1992), p. 2; P1258 (Witness statement of Hussein Ali Abdel-Razek dated 16 July 2002), e-court p. 22.

15693 P5065 (Minutes of SRK Command consultation meeting, 15 November 1992).

15694 P5065 (Minutes of SRK Command consultation meeting, 15 November 1992), p. 4.
} 
death" to members of other ethnic groups and that the Geneva Conventions and other relevant instruments were obsolete and unneeded. ${ }^{15695}$ In response, Mladić did not address the killing of civilians but urged a crackdown on insubordination and poor discipline and defined the task of the SRK as keeping Sarajevo under blockade and pulling as much of the population as possible out of the city. ${ }^{15696}$

4686. On 10 October 1994, Gobilliard issued a written protest to the Bosnian Serb side in response to the shelling of Sarajevo, which was a "reprisal" or reaction to a 5-6 October 1994 $\mathrm{ABiH}$ attack in the DMZ in the course of which 17 Serb soldiers were killed. ${ }^{15697}$ In retaliation to the shelling, $\mathrm{ABiH}$ gunners fired at Serb civilians in the village of Vogovišći, killing two people. ${ }^{15698}$ To avoid an escalation, Gobilliard and Rose issued a joint statement, protesting to both parties but to no effect. ${ }^{15699}$ On the same day, Rose, Gobilliard, and Harland met with Mladić and Tolimir at Jahorina. ${ }^{15700}$ At the meeting, Rose condemned the sniping incident of 8 October, involving Alma Ćutuna. ${ }^{15701}$ Mladić denied Serb responsibility for this incident, claiming that the shots came from the Holiday Inn and that the incident was engineered by the $\mathrm{ABiH} .{ }^{15702}$ An UNPROFOR technical expert then provided a map and assured Mladić that the shooting did not come from the Holiday Inn side. ${ }^{15703}$

4687. On 5 March 1995, Smith met with Mladić and Tolimir while Koljević joined during the closing stages of the meeting. ${ }^{15704}$ In the meeting, Smith questioned Mladić about the upsurge in sniping attacks on civilians in Sarajevo. ${ }^{15705}$ During this meeting Mladić told Smith that the

\footnotetext{
15695 P5065 (Minutes of SRK Command consultation meeting, 15 November 1992), pp. 8-9 (where Lugonja suggested addressing these problems with greater efforts to ensure full subordination of units, the reinstatement of "commissars", and the strengthening and swift application of repressive measures to wrongdoers).

15696 P5065 (Minutes of SRK Command consultation meeting, 15 November 1992), p. 26.

15697 [REDACTED].

15698 [REDACTED].

15699 [REDACTED].

15700 P1638 (Witness statement of Michael Rose dated 26 March 2009), para. 155; Michael Rose, T. $7268-7269$ (5 October 2010); P867 (UNPROFOR report on meeting with Ratko Mladić, 10 October 1994); P1674 (UNPROFOR report re meeting with Ratko Mladić, 11 October 1994); P820 (Witness statement of David Harland dated 4 September 2009), para. 143; P1762 (Witness statement of David Fraser dated 17 October 2010), pp. 44, 68-69; [REDACTED].

15701 P867 (UNPROFOR report on meeting with Ratko Mladić, 10 October 1994), para. 5; P820 (Witness statement of David Harland dated 4 September 2009), para. 143; P1762 (Witness statement of David Fraser dated 17 October 2010), p. 69; [REDACTED].

15702 P867 (UNPROFOR report on meeting with Ratko Mladić, 10 October 1994), para. 5; P820 (Witness statement of David Harland dated 4 September 2009), para. 143; P1762 (Witness statement of David Fraser dated 17 October 2010), p. 69; [REDACTED].

15703 P867 (UNPROFOR report on meeting with Ratko Mladić, 10 October 1994), para. 5; P820 (Witness statement of David Harland dated 4 September 2009), para. 143; Michael Rose, T. 7268-7269 (5 October 2010).

15704 P876 (UNPROFOR Memo re meeting with Ratko Mladić, 6 March 1995), para. 1.

15705 Rupert Smith, T. 11309-11310 (8 February 2011); P876 (UNPROFOR Memo re meeting with Ratko Mladić, 6 March 1995), para. 3; P2451 (Witness statement of Anthony Banbury dated 19 May 2009), paras. 94-95; P2455
} 
increase in sniping by the VRS in Sarajevo was in response to Serb casualties suffered in military offensives launched by the BiH government. ${ }^{15706}$ The UNPROFOR weekly report on this meeting noted that the "explicit recognition by Mladić of [VRS] responsibility for sniping is somewhat surprising". 15707

4688. On 26 June 1995, Smith wrote to Mladić and stated that, on an almost daily basis, he was receiving reports of shelling of the populated parts of safe areas, including Sarajevo. ${ }^{15708}$ He stated that "in Sarajevo alone nine civilians were killed yesterday due to sniping and shelling. Five of them were children." 15709 Smith also noted in the letter that despite Janvier raising this issue with Mladić in the past, there had been a noticeable increase in attacks on the civilian population. ${ }^{15710}$ Smith did not recall receiving any indication from Mladić in response that there would be a reversal of what was happening and that the attacks on the civilian population would stop. ${ }^{15711}$

4689. On 1 July 1995, Nicolai sent a letter of protest to Mladić in response to the shelling of Sarajevo on 28 and 29 June 1995. ${ }^{15712}$ In the letter, Nicolai protested "most strongly about the recent and still continued indiscriminate and deliberate shelling of the residential places of the city of Sarajevo, which unfortunately results in casualties amongst innocent civilian population". ${ }^{15713}$ Nicolai then warned Mladić: "[i]n this fashion you breach all international agreements on protection of civilians at a war, including the Geneva Conventions, recognised by all professional armies in the world. These very serious and inexcusable violations and killing of civilians are liable to trials by an international court."15714 In the letter, Nicolai included a copy of Meille's 30 June 1995 letter of protest to Dragomir Milošević, regarding the same events. ${ }^{15715}$

4690. As recounted earlier, between 28 and 29 August 1995, Smith and Mladić had three telephone conversations, during which the former informed the latter about the 28 August 1995 shelling of Markale market and told him that the Bosnian Serb side was responsible for it, which

(UNPROFOR Weekly Situation Report (Sarajevo), 11 March 1995), para. 9; Anthony Banbury, T. 1333013331 (15 March 2011).

15706 P2451 (Witness statement of Anthony Banbury dated 19 May 2009), para. 94; P2455 (UNPROFOR Weekly Situation Report (Sarajevo), 11 March 1995), para. 9; Anthony Banbury, T. 13330 (15 March 2011).

15707 P2455 (UNPROFOR Weekly Situation Report (Sarajevo), 11 March 1995), para. 9; Anthony Banbury, T. 13330 (15 March 2011).

15708 P2274 (UNPROFOR letter to Ratko Mladić, 26 June 1995); Rupert Smith, T. 11420 (9 February 2011).

15709 P2274 (UNPROFOR letter to Ratko Mladić, 26 June 1995); Rupert Smith, T. 11420 (9 February 2011).

15710 P2274 (UNPROFOR letter to Ratko Mladić, 26 June 1995).

15711 Rupert Smith, T. 11420-11421 (9 February 2011).

15712 P2107 (UNPROFOR protest letters to Ratko Mladić, 1 July 1995, and Dragomir Milošević, 30 June 1995), p. 2; [REDACTED].

15713 P2107 (UNPROFOR protest letters to Ratko Mladić, 1 July 1995, and Dragomir Milošević, 30 June 1995), p. 2.

15714 P2107 (UNPROFOR protest letters to Ratko Mladić, 1 July 1995, and Dragomir Milošević, 30 June 1995), p. 2.

15715 P2107 (UNPROFOR protest letters to Ratko Mladić, 1 July 1995, and Dragomir Milošević, 30 June 1995), p. 3. 
Mladić continued to deny. ${ }^{15716}$ In addition, on 30 August 1995, at around 2 a.m., letters were sent to Mladić, the Accused, and Slobodan Milošević informing them that NATO air strikes had commenced as a result of the Markale attack. ${ }^{15717}$ In the letter to Mladić, Janvier wrote that two separate UN teams had found that the shell that landed on Markale market on 28 August 1995 came from VRS positions south-southwest of Sarajevo, that this resulted in the initiation of air strikes, that the object of the air strikes was to prevent further shelling of Sarajevo, and that the attacks would cease once Janvier was convinced that the threat of further shelling by the SRK had been eliminated. ${ }^{15718}$

4691. On 1 September 1995, the air strikes stopped and Janvier and Banbury met with Mladić, Perišić, Gvero, and Tolimir in Mali Zvornik, in order to discuss the current situation; upon being told again that the investigation results clearly identified the Bosnian Serbs as the perpetrators, Mladić responded that Markale was "a pretext to gain a corridor for the Muslims to Sarajevo". ${ }^{15719}$

4692. The Chamber also heard throughout the case that in addition to Mladić, the SRK Commanders themselves were on notice as to the shelling and sniping in the city. Galić was present on the battlefield of Sarajevo throughout the period 10 September 1992 to 10 August 1994, in close proximity to the confrontation lines, and thus actively monitored the situation in the city. ${ }^{15720}$ Not only was he informed personally about both sniping and shelling activity attributed to SRK forces against civilians in Sarajevo, but his subordinates were conversant with such activity. ${ }^{15721}$ Similarly, Dragomir Milošević regularly toured the confrontation lines and visited different SRK units at their positions. ${ }^{15722}$ He also knew about allegations that SRK forces had targeted civilians. ${ }^{15723}$

\footnotetext{
15716 See paras. 4295-4298.

15717 P2826 (UNPROFOR report re NATO air strikes, 30 August 1995); D2815 (SRK report, 30 August 1995); Adjudicated Fact 2798.

15718 P2826 (UNPROFOR report re NATO air strikes, 30 August 1995), e-court p. 2.

15719 P2451 (Witness statement of Anthony Banbury dated 19 May 2009), paras. 183-192; P2509 (Anthony Banbury's notes, 1 September 1995); Adjudicated Fact 2798. On 4 September 1995, Mladić wrote a letter to Janvier protesting the use of NATO air strikes against Bosnian Serb targets, denying that the Bosnian Serbs were responsible for the shelling of Markale on 28 August, and protesting the ultimatum to withdraw heavy weapons. See D2310 (Letter from Ratko Mladić to UNPROFOR, 4 September 1995); D2270 (Witness statement of Andrey Demurenko dated 13 October 2012), pp. 91-92 (testifying that he believed Mladić's letter to be sincere as Mladic did not believe that the VRS was responsible for the Markale market shelling and that the questions and requests to Janvier were reasonable).

15720 See Adjudicated Facts 31, 33, and 34.

15721 See Adjudicated Facts 38, 39, and 41.

15722 See Adjudicated Fact 2854.

15723 See Adjudicated Fact 2873.
} 
4693. More specifically, Fraser testified that UNPROFOR had "countless engagements" with Galić and Milošević to discuss sniping, and implored them to stop sniping civilians. ${ }^{15724}$ At these meetings UNPROFOR would use summaries of the number of Muslims and Serbs wounded and killed by sniper fire, in an attempt to focus the discussion through the use of empirical data and facts. ${ }^{15725}$ Fraser noted that when UNPROFOR protested sniping, shelling, or freedom of movement to Dragomir Milošević or Mladić, "it was not uncommon for both parties to say they didn't do it $[\ldots]$ and then they would go away and things would get a little better in most cases". 15726

4694. Both Galić and Milošević would also imply that the shelling of Sarajevo was linked to other attacks by the $\mathrm{ABiH}$ throughout $\mathrm{BiH} .{ }^{15727}$ The SRK Commanders and the Commander of the ABiH $1^{\text {st }}$ Corps generally ignored UNPROFOR protests and did not take them seriously, while sometimes the parties would send a letter stating that they had nothing to do with it. ${ }^{15728}$ In general, Galić only reacted to letters of protest when he was able to provide proof that the firing did not come from his troops, which was "extremely rare". ${ }^{15729}$

4695. Abdel-Razek met with Galić and Plavšić on multiple occasions from 21 August 1992 to 20 February 1993 in his capacity as Commander of UNPROFOR Sector Sarajevo, and testified that the shelling of civilians was one of the major issues he raised with them. ${ }^{15730}$ However, there was no progress as they would deny that they were responsible or deny that the shelling and sniping incidents occurred; often they would gradually acknowledge responsibility but then claim that Bosnian Serb actions were justified retaliations against the ABiH. ${ }^{15731}$ Galic would also give the impression that the Bosnian Muslim side was conducting the shelling on purpose to attract the sympathy of the world and distort the Serb image; however, he would then gradually acknowledge

\footnotetext{
15724 Fraser, T. 8018 (18 October 2010).

15725 P1762 (Witness statement of David Fraser dated 17 October 2010), pp. 41-42. See also P1773 (UNPROFOR report re efficacy of Anti-Sniping Agreement, 15 September 1994); David Fraser, T 8130-8131 (19 October 2010).

15726 P1762 (Witness statement of David Fraser dated 17 October 2010), pp. 8-9, 23, 44; David Fraser, T. 8018, 8025 (18 October 2010). See also P2414 (Witness statement of KDZ182), p. 35 (under seal).

15727 [REDACTED].

15728 [REDACTED].

15729 [REDACTED]. See also P6298 (UNPROFOR protest letter to Stanislav Galić, 13 February 1993); P6299 (UNPROFOR protest letter to Stanislav Galić, 14 February 1993) (indicating that the UN had sent letters of protests on two different occasions in relation to a shelling of the UN OP but received no answer from Galić).

15730 P1258 (Witness statement of Hussein Ali Abdel-Razek dated 16 July 2002), e-court pp. 2, 12-18, 20-21, 25, 27, 33; Hussein Abdel-Razek, T. 5500 (19 July 2010), T. 5532-5533, 5537, 5580-5581 (20 July 2010).

15731 P1258 (Witness statement of Hussein Ali Abdel-Razek dated 16 July 2002), e-court pp. 13, 21, 27; Hussein Abdel-Razek, T. 5673 (21 July 2010). Abdel-Razek testified that he raised the issue of the capture of three Muslim drivers by the Bosnian Serbs with the Accused and Plavšić, but never received a "clear-cut" response. See Hussein Abdel-Razek, T. 5661 (21 July 2010); P4216 (UNPROFOR report re meeting with Radovan Karadžić, 20 November 1992), para. 8.
} 
that the shelling was retaliation by the Bosnian Serb side. ${ }^{15732}$ Galić would also threaten to continue shelling the city if the violations continued from the Bosnian Muslim side. ${ }^{15733}$ AbdelRazek thought that both Galić and the "Serb civilian leadership" knew about the sniping and shelling of the civilian population of Sarajevo. ${ }^{15734}$

4696. Like Abdel-Razek, Mole testified that when he would meet with Galić during his time in Sarajevo, indiscriminate SRK fire was "a topic of discussion most days", although Mole would focus only on the most serious incidents. ${ }^{15735}$ Galić's response to protests tended to be tangential and he would constantly respond "that the Muslims [...] were attacking in a particular sector of the city". ${ }^{15736}$ Galić also frequently threatened to shell Sarajevo "if a certain event did or did not materialise". 15737

4697. In terms of sniping, Van Baal testified that every incident that could be attributed to a Bosnian Serb sniper was the subject of an objection by the UNPROFOR Sector Sarajevo to the SRK. ${ }^{15738}$ These objections were directed at the leadership of the VRS, including Galić, Inđić, and Milovanović. ${ }^{15739}$ According to Van Baal, attempts to contact Galić were only occasionally successful and Inđić and Milovanović would respond to protests by denying that the SRK had snipers under its control and by blaming the Bosnian Muslims for shooting and targeting their own population. $^{15740}$

4698. KDZ182 testified that protests about shelling and sniping incidents were made to Milošević verbally by UNPROFOR liaison officers and in writing; several hours or days later, the written

15732 P1258 (Witness statement of Hussein Ali Abdel-Razek dated 16 July 2002), e-court p. 21 (testifying that, at his last meeting at Lukavica Barracks, he said to Galić, "there are a lot of civilian casualties in the city. Your shelling was heavy and targeting the UN building" to which Galić responded, "we did that because their mortars landed among Serb civilians", and further testifying that while Galić "always" denied the Serb shelling of civilians, at this meeting Galić "was more frank" in stating that the Serbs shelled the UN building because of UNPROFOR actions).

15733 P1258 (Witness statement of Hussein Ali Abdel-Razek dated 16 July 2002), e-court p. 15.

15734 P1258 (Witness statement of Hussein Ali Abdel-Razek dated 16 July 2002), e-court pp. 24-25.

15735 P1426 (Witness statement of Richard Mole dated 7 May 2010), para. 97.

15736 P1426 (Witness statement of Richard Mole dated 7 May 2010), para. 98-100, 108 (testifying that he could not recall the local tactical situation changing to a marked degree that would realistically justify the response of heavy weaponry firing into the city as appropriate); P1434 (UNMO report for November 1992), p. 15.

15737 P1426 (Witness statement of Richard Mole dated 7 May 2010), paras. 92, 107; P1434 (UNMO report for November 1992), pp. 5, 7.

15738 P1818 (Witness statement of Adrianus van Baal dated 26 October 2010), para. 37.

15739 P1818 (Witness statement of Adrianus van Baal dated 26 October 2010), para. 38. See also John Hamill, T. 9686 (13 December 2010); P1994 (Transcript from Prosecutor v. Galić), T. 6066-6069, 6109, 6115-6116, 6129, 6120-6122, 6146-6149, 6155-6159, 6161-6165 (testifying that he would inform the SRK liaison officers, including Inđić, of incidents of sniping and shelling of civilians or civilian areas, and adding that Galić spoke to his liaison officers "as a commander would").

15740 P1818 (Witness statement of Adrianus van Baal dated 26 October 2010), paras. 38-39. 
protests would often lead to meetings with Milošević. ${ }^{15741}$ Generally speaking, in those meetings Milošević would claim that he was responding to ABiH fire. ${ }^{15742}$ KDZ304 testified that letters of protest were not an effective method during the time he was in Sarajevo. ${ }^{15743}$ [REDACTED] it was impossible to speak directly to Dragomir Milošević because "everything was screened at the level of Major Inđić or his deputy". 15744

4699. In addition to the above evidence, the Chamber heard about many specific meetings during which Galić and Milošević were informed of the sniping and shelling on the city, including attacks on civilians. For example, on 7 October 1992 Morillon met with Galić and Koljević. ${ }^{15745}$ The parties discussed lifting the siege of Sarajevo, and Morillon expressed his "disappointment" about recent artillery attacks on Sarajevo. ${ }^{15746}$ On 10 February 1993, Valentin sent a letter of protest to Galić regarding the targeting of civilians with mortar fire while they were crossing the airfield at Sarajevo airport between 7 and 9 February 1993. ${ }^{15747}$ The letter stated that twenty civilians were injured, three of whom died, and that "[s]uch actions against civilian population run counter to all human norms of morals. We strongly protest against such irresponsible behaviour of your military and intend to inform international community of those facts." ${ }^{15748}$ On this topic, Abdel-Razek testified that when he protested the sniping of civilians crossing the airport, Galic stated that "if the civilians continued to cross the airport, his side would continue shooting at them". ${ }^{15749}$ Similarly, at a meeting with the Commander of FreBat, Galić said that he would continue shooting at civilians if they continued to move through the airport, blaming FreBat for allowing the civilians to do so. ${ }^{15750}$

4700. On 22 March 1993, Valentin met with Galić to request an explanation as to why Stari Grad was shelled the day before. ${ }^{15751}$ Galić denied that the Serbs were responsible for the shelling, despite the UN observers being sure that the shells were fired from Bosnian Serb artillery positions. ${ }^{15752}$ Similarly, in response to a rise in sniping incidents in April 1994, Soubirou met with

\footnotetext{
15741 P2447 (Witness statement of KDZ182), p. 31.

15742 [REDACTED]; P2447 (Witness statement of KDZ182), p. 31; [REDACTED]. See also P2407 (Witness statement of KDZ304), p. 17; [REDACTED].

15743 P2407 (Witness statement of KDZ304), pp. 17-18. According to Fraser, protesting orally by going to the SRK headquarters and dealing directly with the SRK Commander was far more effective than written protests. See P1762 (Witness statement of David Fraser dated 17 October 2010), p. 22-23.

15744 [REDACTED]. See also P5906 (Witness statement of KDZ450 dated 17 January 2011), para. 20 (testifying that the sole interlocutor of the liaison office at the SRK Command was Inđić).

15745 P1258 (Witness statement of Hussein Ali Abdel-Razek dated 16 July 2002), e-court p. 23.

15746 P1258 (Witness statement of Hussein Ali Abdel-Razek dated 16 July 2002), e-court p. 23.

15747 P1054 (UNPROFOR protest letter to Stanislav Galić, 10 February 1993), p. 2; [REDACTED].

15748 P1054 (UNPROFOR protest letter to Stanislav Galić, 10 February 1993), p. 2.

15749 P1258 (Witness statement of Hussein Ali Abdel-Razek dated 16 July 2002), e-court p. 18.

15750 P1258 (Witness statement of Hussein Ali Abdel-Razek dated 16 July 2002), e-court p. 18.

15751 P1066 (SRK combat report, 22 March 1993), para. 8.

15752 P1066 (SRK combat report, 22 March 1993), para. 8; [REDACTED].
} 
Galić on a number of occasions in May, June, and July 1994. ${ }^{15753}$ One of those meetings took place on 24 June 1994, whereby Soubirou and Fraser met with Galić at Lukavica barracks. ${ }^{15754}$ According to Fraser, this meeting was typical of all the meetings with Galić, as the latter would first give a lecture and deny that Bosnian Serbs were engaged in sniping on civilians, and then, over the course of the conversation would acknowledge that some of this was happening but would blame the other side for it. ${ }^{15755}$ Nevertheless, Fraser noted that generally there was a noticeable decrease in the level of sniping after talking to Galić. ${ }^{15756}$ Sometime between 8 and 12 July 1994, Soubirou met with Galić to improve relations between his office and the SRK. ${ }^{15757}$ During this meeting, Soubirou explained that he wanted to come to an agreement on anti-sniping and asked Galić to designate a Bosnian Serb to deal with this subject. ${ }^{15758}$ [REDACTED] Galić never acknowledged that there were Bosnian Serb snipers. ${ }^{15759}$

4701. The Chamber also received evidence about a number of specific written protests sent to Dragomir Milošević. ${ }^{15760}$ For example, on 2 December 1994, Gobilliard wrote to Milošević to "strongly protest" the shelling of Sarajevo that day. ${ }^{15761}$ The letter addressed the launching of four AT3 missiles at the MUP building, a cinema, and the Presidency building from SRK positions. ${ }^{15762}$ On 7 May 1995, Gobilliard wrote to Milošević again, protesting the "continuous shootings" against civilians around the city. ${ }^{15763}$ Gobilliard sent another letter on 8 June $1995 .{ }^{15764}$ This letter concerned violent artillery attacks along the southern side of the confrontation line. ${ }^{15765}$ Explaining the context of the letter, KDZ304 testified that the $\mathrm{ABiH}$ had launched an attack in the sector of the Jewish cemetery and in Debelo Brdo, and that the SRK retaliated with artillery fire and tanks and launched "several well-targeted counter-attacks"; however, the response was also disproportionate as it disregarded any possible collateral damage or civilians being affected. ${ }^{15766}$

\footnotetext{
15753 P1762 (Witness statement of David Fraser dated 17 October 2010), pp. 21-22.

15754 David Fraser, T. 8024-8025 (18 October 2010); P1785 (SRK report re meeting between General Galić and General Soubirou 24 July 1994).

15755 David Fraser, T. 8025 (18 October 2010).

15756 P1762 (Witness statement of David Fraser dated 17 October 2010), p. 21.

15757 P1762 (Witness statement of David Fraser dated 17 October 2010), p. 65

15758 P1762 (Witness statement of David Fraser dated 17 October 2010), p. 65.

15759 [REDACTED].

15760 The Chamber also took judicial notice of the fact that Milošević received protest letters from UNPROFOR about crimes committed by the SRK. See Adjudicated Fact 2876.

15761 P2427 (UNPROFOR protest letter to SRK, 2 December 1994), p. 3.

15762 P2427 (UNPROFOR protest letter to SRK, 2 December 1994), p. 3.

15763 P2415 (UNPROFOR protest letter to SRK, 7 May 1995).

15764 P2134 (UNPROFOR protest letter to Dragomir Milošević, 8 June 1995); P2407 (Witness statement of KDZ304), p. 23.

15765 P2134 (UNPROFOR protest letter to Dragomir Milošević, 8 June 1995).

15766 P2407 (Witness statement of KDZ304), p. 23 (adding that the SRK often shelled the town to "retaliate" against $\mathrm{ABiH}$ attacks).
} 
4702. On 30 June 1995, Meille sent a letter of protest to Dragomir Milošević in which he complained of "attacks on civilian targets in the city of Sarajevo, using very powerful bombs" on 28 and 29 June 1995 by the SRK. ${ }^{15767}$ Meille strongly protested against these bombardments “carried out on [Milošević's] orders", and demanded that Milošević immediately halt all attacks directed at either the civilian population or UNPROFOR. ${ }^{15768}$ The letter provided details of four different events including the date and the time at which they took place, namely, the firing of (i) the "extremely powerful rocket bomb" at the TV building; (ii) four heavy mortar rounds at the Alipašino Polje residential area; (iii) another rocket bomb at the Alipašino Polje residential area; and (iv) three mortar rounds at residential buildings in the city centre. ${ }^{15769}$ The letter continued to state that " $[\mathrm{t}] \mathrm{his}$ ill-considered and irresponsible escalation continued on the evening of 29 June when 3 high-power projectiles struck the PTT building, the HQ of Commander Sector Sarajevo". ${ }^{15770}$ Meille also reminded Milošević of the moral and legal obligations to adhere to international humanitarian law. ${ }^{15771}$ Despite all the details provided, Milošević did not react to this letter. $^{15772}$ As noted earlier, a copy of the letter was also sent to Mladić on 1 July $1995 .{ }^{15773}$

4703. Galić and Dragomir Milošević themselves confirmed that they received information about the sniping and shelling of civilians in Sarajevo. For example, Galic conceded that he received information that SRK shelling and sniping caused civilian casualties from his staff, through Inđić, in meetings with UNPROFOR representatives, and through written protests. ${ }^{15774}$ Galić testified that he took the protests that were sent to him by UNPROFOR or UNMOs very seriously. ${ }^{15775}$ However, he did not remember a single protest being lodged about a sniping incident alone, and in relation to Abdel-Razek's evidence regarding his protests about the SRK shelling of UNPROFOR and civilian structures, he testified that Abdel-Razek was not honest with him and misrepresented

\footnotetext{
15767 P895 (Letter from UNPROFOR to Dragomir Milošević, 30 June 1995); P820 (Witness statement of David Harland dated 4 September 2009), para. 210; P2107 (UNPROFOR protest letters to Ratko Mladić, 1 July 1995 , and Dragomir Milošević, 30 June 1995), p. 3; P2407 (Witness statement of KDZ304), pp. 18-20; KDZ304, T. 10448-10452 (18 January 2011) (private session).

15768 P895 (Letter from UNPROFOR to Dragomir Milošević, 30 June 1995).

15769 P895 (Letter from UNPROFOR to Dragomir Milošević, 30 June 1995); P820 (Witness statement of David Harland dated 4 September 2009), para. 210.

15770 P895 (Letter from UNPROFOR to Dragomir Milošević, 30 June 1995).

15771 P895 (Letter from UNPROFOR to Dragomir Milošević, 30 June 1995).

15772 P2407 (Witness statement of KDZ304), p. 20.

15773 P2107 (UNPROFOR protest letters to Ratko Mladić, 1 July 1995, and Dragomir Milošević, 30 June 1995)

15774 Stanislav Galić, T. 37230 (15 April 2013), T. 37788-37792 (7 May 2013). But see D2774 (Witness statement of Milenko Inđić dated 19 January 2013), paras. 88, 126, 142-143 (claiming that he never received any protest about deliberate or indiscriminate targeting of civilians, and testifying that, while he received protests about sniper fire being opened, he had never received protests about such fire causing civilians casualties because, after the matter had been "checked", it was determined that the protest concerned fighting and the exchange of infantry fire). The Chamber rejects this evidence, as it contradicts not only Galić's and Milošević's evidence but also all the other evidence presented regarding protests.

15775 Stanislav Galić, T. 37210-37211 (15 April 2013).
} 
himself. ${ }^{15776}$ Similarly, Milošević conceded that he had received, from UNPROFOR and the media, allegations about Bosnian Serb soldiers sniping at civilians. ${ }^{15777}$ While Milošević considered media reports to be "a certain indicator" and he attempted to see what was true and correct in these reports, he claimed that the media exaggerated or dramatised the situation. ${ }^{15778}$ According to Milošević, he also tried to establish whether the information from UNPROFOR was true or not, and if it was true, he issued orders to stop the actions. ${ }^{15779}$

\section{ii. Political leadership: Momčilo Krajišnik, Nikola Koljević, and Biljana Plavšić}

4704. As noted earlier, the Bosnian Serb political leadership, namely Krajišnik, Koljević, and Plavšić, had strong views as to the importance of Sarajevo to the Bosnian Serb cause, as illustrated for example by Krajišnik's insistence on taking the whole of Sarajevo. ${ }^{15780}$ Further, the Chamber heard that they also had knowledge of the sniping and shelling of civilians in the city, as illustrated by many meetings they attended regarding the situation in Sarajevo, both in the presence and in the absence of the Accused. ${ }^{15781}$ As noted above, Abdel-Razek met with Galić and Plavšić on many occasions during which he raised the issue of shelling of civilians. ${ }^{15782}$ According to him, Plavšić "was unconcerned" about this and viewed the Serb shelling of civilian targets as justified retaliation. ${ }^{15783}$ During their meetings she expressed concern only for the suffering of the Bosnian Serbs. ${ }^{15784}$ Abdel-Razek specifically recounted a meeting on 10 October 1992 where he discussed the shelling of Sarajevo with Koljević and Plavšić. ${ }^{15785}$ Koljević stated that the Bosnian Serbs had decided to stop their shelling of Sarajevo two days before the meeting, but that the propaganda service of $\mathrm{BiH}$ radio was saying that the Bosnian Serbs were shelling "in a major way" in an

\footnotetext{
15776 Stanislav Galić, T. 37397 (18 April 2013), T. 37647-37648, 37652 (23 April 2013), T. 37788-37792 (7 May 2013).

15777 Dragomir Milošević, T. 33276-33277 (6 February 2013). Dragomir Milošević also testified that civilians were never a target of the SRK and that the SRK never fired at civilian areas. See Dragomir Milošević, T. 32582 32583 (23 January 2013), T. 32845-32846 (29 January 2013), T. 33136-33137 (4 February 2013). The Chamber notes that it has rejected this argument in the preceding sections of the Judgement.

15778 Dragomir Milošević, T. 33276-33277 (6 February 2013).

15779 Dragomir Milošević, T. 33276-33277 (6 February 2013). See also Ratomir Maksimović, T. 31589-31596 (17 December 2012) (dismissing $\mathrm{ABiH}$ and media reports that suggested civilians were targeted by the SRK as propaganda).

15780 See e.g. paras. 4659, 4665, 4673.

15781 The meetings they attended in the presence of the Accused are discussed later. See Section IV.B.3.c: Accused's contribution.

15782 See para. 4695.

15783 P1258 (Witness statement of Hussein Ali Abdel-Razek dated 16 July 2002), e-court p. 21.

15784 P1258 (Witness statement of Hussein Ali Abdel-Razek dated 16 July 2002), e-court p. 5.

15785 P1258 (Witness statement of Hussein Ali Abdel-Razek dated 16 July 2002), e-court pp. 11-12; P1270 (UNPROFOR report re administrative issues, 10 October 1992), para. 6.
} 
attempt to discredit Serbs. ${ }^{15786}$ In turn, Plavšić simply insisted that the UN arrange and facilitate the evacuation of 500 Bosnian Serbs from Sarajevo. ${ }^{15787}$

4705. In addition to the many meetings attended by Koljević and Krajišnik and discussed throughout this Judgement, the Chamber also received evidence of the two men regularly attending meetings about the sniping in the city. For example, in a meeting of 27 June 1994, between Andreev, Rose, Banbury, and Krajišnik in Pale, Rose "forcefully requested" that an anti-sniping agreement be signed. ${ }^{15788}$ Krajišnik responded that the situation in Sarajevo had become very precarious because of continued sniping by the $\mathrm{ABiH}$, and because the quality of life was improving so much for the residents of the Bosnian Government controlled areas, which was angering many Serbs outside the city. ${ }^{15789}$ Krajišnik then denied that the Bosnian Serbs used snipers. ${ }^{15790}$ He also stated that an anti-sniping agreement was not possible, ${ }^{15791}$ that an agreement would not solve the problem, but that the Bosnian Serbs were very interested in abolishing sniping, as sniping could lead to an escalation of the conflict. ${ }^{15792}$ The negotiations continued and, on 1 August 1994, De Mello met with Krajišnik and Muratović at Sarajevo airport. ${ }^{15793}$ At the meeting, Muratović and Krajišnik agreed that the issue of sniping could be "de-linked" from the issues of detainees in Eastern Bosnia and the reopening of the airport routes. ${ }^{15794}$ On 12 August 1994, Rose met with Koljević, Gvero, and Tolimir at Pale. ${ }^{15795}$ The Bosnian Serbs accepted the wording of a proposed anti-sniping agreement during that meeting and the agreement was eventually signed at Sarajevo airport on 14 August 1994. ${ }^{15796}$ On 14 September 1994, Andreev met with Muratović and Koljević at Sarajevo airport. ${ }^{15797}$ On the subject of sniping, the parties noted with satisfaction the recent reduction in the incidence of sniping, and agreed to explore the possibility of an expanded

\footnotetext{
15786 P1270 (UNPROFOR report re administrative issues, 10 October 1992), para. 6(G).

15787 P1258 (Witness statement of Hussein Ali Abdel-Razek dated 16 July 2002), e-court p. 11.

15788 P2451 (Witness statement of Anthony Banbury dated 19 May 2009), paras. 28-32; P2465 (UNPROFOR report, 28 June 1994).

15789 P2465 (UNPROFOR report, 28 June 1994), para. 7; P2451 (Witness statement of Anthony Banbury dated 19 May 2009), para. 30.

15790 P2451 (Witness statement of Anthony Banbury dated 19 May 2009), paras. 31-32 (adding that Krajišnik’s denial of Bosnian Serb sniping was patently false).

15791 P2465 (UNPROFOR report, 28 June 1994), para. 7.

15792 P2451 (Witness statement of Anthony Banbury dated 19 May 2009), para. 31.

15793 P2124 (UNPROFOR report re negotiations with parties in BiH, 2 August 1994), paras. 7-10.

15794 P2124 (UNPROFOR report re negotiations with parties in BiH, 2 August 1994), para. 8.

15795 P1638 (Witness statement of Michael Rose dated 26 March 2009), para. 136; P1669 (UNPROFOR report re meeting with Nikola Koljević and Milan Gvero, 13 August 1994).

15796 P1638 (Witness statement of Michael Rose dated 26 March 2009), paras. 136, 139; P1669 (UNPROFOR report re meeting with Nikola Koljević and Milan Gvero, 13 August 1994), para. 2; P820 (Witness statement of David Harland dated 4 September 2009), para. 129; P861 (UNPROFOR report re agreement on elimination of sniping in Sarajevo, 14 August 1994); P1762 (Witness statement of David Fraser dated 17 October 2010), pp. 40-41; P2119 (Witness statement of KDZ450 dated 17 January 2011), para. 70 (under seal); P5906 (Witness statement of KDZ450 dated 17 January 2011), para. 104.

15797 D1162 (UNPROFOR report, 14 September 1994); Anthony Banbury, T. 13472 (16 March 2011).
} 
agreement which would include all small calibre weapons. ${ }^{15798}$ Thus, following the signing of the Anti-Sniping Agreement on 14 August 1994, the number of sniping incidents fell significantly. ${ }^{15799}$ This indicated to Harland that the level of sniping in Sarajevo was being "controlled and modulated" by the Bosnian Serb leadership. ${ }^{15800}$

4706. The Chamber also found that Krajišnik was involved in the sourcing of modified air bombs from Serbia for delivery to the Pretis Factory; he did so on 17 June 1995, a day after Scheduled Incidents G.14 and G.15 (and several weeks after Scheduled Incidents G.11, G.12, and G.13) occurred, all of which involved modified air bombs. ${ }^{15801}$ It is clear that it was his task, and the task of the special group including his brother, to ensure that VRS had sufficient numbers of this indiscriminate weapon in stock.

\section{iii. Conclusion}

4707. Based on all the evidence outlined in this section and in the sections that follow (insofar as they concern the alleged JCE members other than the Accused), the Chamber is convinced that Mladić, Galić, Dragomir Milošević, Krajišnik, Koljević, and Plavšić were all fully aware, throughout the conflict, that civilians in Sarajevo were being exposed to deliberate sniping and shelling by the SRK units and to indiscriminate and/or disproportionate attacks. ${ }^{15802}$ However not one of them made an effort to stop or prevent this practice, other than when it was in their political interest to do so and/or when they were pressured by the international community. Instead, the evidence shows that they actively sought and encouraged the practice of sniping and shelling in order to achieve their military and political goals, retaliate against the Bosnian Muslim side, and use it as a bargaining chip in their dealings with the international community. Indeed, Mladić himself, at one point, acknowledged that sniping was part of the retaliation for the $\mathrm{ABiH}$ attacks. ${ }^{15803}$ Similarly, Krajišnik was personally involved in the sourcing of modified air bombs. $^{15804}$ In addition, as is clear from their statements and actions, some of which were discussed above, they considered Sarajevo to be important to the achievement of the Bosnian Serb political goals and thus all worked together to effect the siege of the city and ensure that it was

\footnotetext{
15798 D1162 (UNPROFOR report, 14 September 1994), para. 4(ii); Anthony Banbury, T. 13472-13473 (16 March 2011)

15799 See para. 3595.

15800 P820 (Witness statement of David Harland dated 4 September 2009), paras. 133, 300; David Harland, T. 20962097 (7 May 2010).

15801 See para. 4388.

15802 In coming to this conclusion the Chamber has also considered the evidence concerning these individuals in relation to the other components of this case.

15803 See para. 4880.

15804 See para. 4388.
} 
divided by the aforementioned wall of fire. ${ }^{15805}$ For these reasons, the Chamber considers that all of these individuals intended the execution of the common plan embodied in the Sarajevo JCE.

4708. The Chamber also considers that Mladić, Galić, and Dragomir Milošević were in fact essential to the common plan such that without them, the SRK's campaign of sniping and shelling could not have been conducted and no common plan could have been effectuated. ${ }^{15806}$ As testified to by KDZ182, Mladić in particular was instrumental in the implementation of the common plan, being the "strategist" in Sarajevo. ${ }^{15807}$ Based on all the evidence in this case, in particular the pattern and the longevity of the campaign of sniping and shelling, the fact that indiscriminate and disproportionate shelling of the city would necessarily bring about civilian casualties, and the above findings in relation to their knowledge and their conduct, the Chamber is satisfied that the only reasonable inference is that the members of the Sarajevo JCE, namely Mladić, Krajišnik, Koljević, Plavšić, Galić, and Dragomir Milošević all shared the intent to commit murder, unlawful attacks, and terror in Sarajevo.

4709. While Šešelj is named in the Indictment as one of the members of the Sarajevo JCE, the Chamber has received very little evidence relating to his activities as far as the Sarajevo JCE is concerned. ${ }^{15808}$ Accordingly, the Chamber is not satisfied that Vojislav Sešelj was a member of the Sarajevo JCE as alleged by the Prosecution.

4710. The Chamber will now turn to examine whether the Accused significantly contributed to the Sarajevo JCE.

\section{c. Accused's contribution}

4711. In its Final Brief, the Prosecution submits that the ways in which the Accused contributed to the Sarajevo JCE as alleged in the Indictment are all reflected in the following actions and/or omissions of the Accused: (a) he did not end the campaign of sniping and shelling even though he could have by virtue of his control over the VRS and other Bosnian Serb Forces engaged in the campaign but in fact oversaw the strategy and implementation of the campaign; ${ }^{15809}$ (b) he modulated the violence against civilians and the level of terror in accordance with the Bosnian Serb

\footnotetext{
15805 See paras. $4659,4665,4673$.

15806 In this respect, see in particular Sections IV.B.3.c.i: Accused's support for Mladić and SRK; IV.B.3.c.ii: Accused's oversight of military activities in Sarajevo.

15807 See para. 4748.

15808 See e.g. P2445 (SRT news report re visit of Vojislav Šešelj to Grbavica).

15809 The Prosecution claims that by doing so the Accused contributed to the Sarajevo JCE as alleged in paragraph 14(a), 14(b), 14(d), 14(e), 14(f), and 14(h) of the Indictment. See Prosecution Final Brief, paras. 605, 612(1), 612(5).
} 
leadership's political and strategic interests; ${ }^{15810}$ (c) he recruited Mladić, supported Mladić's immediate intensification of the campaign, and also promoted and rewarded the key implementers of the campaign; ${ }^{15811}$ and (d) he allowed the campaign to continue for almost four years while denying or deflecting international protests and failing to take any genuine steps to punish the perpetrators. ${ }^{15812}$ The Chamber will consider each of these alleged contributions below.

4712. According to the Prosecution, as part of the Accused's efforts to modulate the campaign in Sarajevo, he directed and/or authorised the restriction of humanitarian aid to Sarajevo in an effort to create unbearable living conditions for these inhabitants in furtherance of the objectives of the Sarajevo JCE. ${ }^{15813}$ The Prosecution then alleges in its Final Brief that the "impact of the sniping and shelling campaign was amplified by restrictions on humanitarian aid and utilities that forced residents to expose themselves to attacks" when searching for fuel or queuing for water or food. ${ }^{15814}$ It also alleges that the Accused's "modulation of the campaign of terror" can be seen in the restrictions he imposed on the supply of humanitarian aid and utilities to the city. ${ }^{15815}$

4713. However, the Chamber does not consider restrictions on humanitarian aid to be relevant to the Accused's contribution to the achievement of the objective of the Sarajevo JCE for two reasons.

4714. First, the objective as defined in the Indictment was not to spread terror as such but to "establish and carry out a campaign of sniping and shelling against the civilian population of Sarajevo, the primary purpose of which was to spread terror". ${ }^{15816}$ Thus, it is the acts of sniping and shelling, the primary purpose of which was to spread terror among the civilian population, that are central to the alleged objective. That being the case, the Chamber does not consider that the

15810 The Prosecution alleges that by doing so the Accused contributed to the Sarajevo JCE as alleged in paragraph 14(a), 14(d), 14(e), and 14(j) of the Indictment. See Prosecution Final Brief, paras. 605, 612(2).

15811 The Prosecution alleges that by doing so the Accused contributed to the Sarajevo JCE as alleged in paragraph 14(a), 14(b), 14(d), and 14(h) of the Indictment. See Prosecution Final Brief, paras. 605, 612(4), 612(6).

15812 The Prosecution alleges that by doing so the Accused contributed to the Sarajevo JCE as alleged in paragraph 14(a), 14(c), 14(d), 14(i), and 14(h) of the Indictment. See Prosecution Final Brief, paras. 605, 612(3), 612(5).

15813 Indictment, paras. 14(j), 19.

15814 Prosecution Final Brief, paras. 603, 777.

15815 Prosecution Final Brief, para. 622. The Chamber notes that the cutting off of utilities is not mentioned as one of the Accused's alleged contributions in paragraph 14 of the Indictment. In fact, in relation to Sarajevo, utilities are mentioned in the Indictment only once, in paragraph 81, which provides: "The lack of gas, electricity or running water, forced people to leave their homes thereby increasing the risk of death." As such, neither this paragraph, nor the rest of the Indictment, assigns responsibility for the lack of utilities in the city or elaborates on how this practice contributed to the objective of the Sarajevo JCE, which is defined as a "campaign of sniping and shelling" the primary purpose of which is to spread terror. For that reason, the Chamber does not consider that the issue of utilities is relevant to the charges in the Indictment and/or the Accused's contribution to the Sarajevo JCE. Even if that were not the case, the evidence outlined by the Chamber earlier in the Judgement shows that utilities were often cut and obstructed by the Bosnian Muslim side as well as by the Bosnian Serb side. That being the case, it is impossible to determine how significant the contribution of the Accused and other alleged JCE members was to the cutting off of utilities in Sarajevo. See Sections IV.B.1.a: Chronology of events in Sarajevo; IV.B.1.f: Siege of Sarajevo. 
obstruction of humanitarian aid can have any effect, whether positive or negative, on those acts. Accordingly, restrictions on humanitarian aid, even if perpetrated in an effort to create unbearable living conditions for the inhabitants of Sarajevo, could not have furthered in any way the objective of the Sarajevo JCE as defined in the Indictment.

4715. Second, the Indictment alleges that the objective involved the commission of the crimes of terror and unlawful attacks on civilians. ${ }^{15817}$ As discussed earlier, the actus reus of these crimes consists of acts or threats of violence directed against the civilian population. ${ }^{15818}$ In the Chamber's view, restrictions on humanitarian aid (and also utilities) bear no connection to the "acts or threats of violence". Evidence of such restrictions is therefore not relevant to proving the Accused's contribution to achieving the objective of the Sarajevo JCE. ${ }^{15819}$ Accordingly, the Chamber will not consider the allegations in paragraph 14(j) of the Indictment as far as they relate to the Sarajevo component of the case.

\section{i. Accused's support for Mladić and SRK}

\section{(A) Arguments of the parties}

4716. The Prosecution alleges that the Accused recruited Mladić who then, with the approval of the Accused, marked his arrival in the Sarajevo theatre in May 1992 with an immediate intensification of the "terror campaign". ${ }^{15820}$ The Prosecution also alleges that the Accused promoted and rewarded the key implementers of the "campaign of terror" against Sarajevo, namely Mladić, Galić, and Dragomir Milošević, despite knowing that they were involved in the commission of crimes. ${ }^{15821}$ According to the Prosecution, by rewarding and promoting such individuals, the Accused not only created and sustained "a culture of impunity" but also showed his approval of the campaign of sniping and shelling. ${ }^{15822}$

4717. The Accused submits that Mladić was appointed by the Bosnian Serb Assembly, thus indirectly refuting the Prosecution's allegation that he personally "recruited" Mladić. ${ }^{15823}$ Further,

\footnotetext{
15816 Indictment, paras. 15-19, 77 (emphasis added).

15817 Indictment, paras. 15, 77. Additionally, the objective of the Sarajevo JCE involved the commission of the crime of murder. As with terror and unlawful attacks on civilians, the Chamber considers that the Accused's alleged contribution to restrictions on humanitarian aid has no connection to the actus reus of that crime.

15818 See paras. $450,459$.

15819 However, the Chamber has referred to such evidence in earlier sections of the Judgement in order to describe the situation that prevailed in the city throughout the period of the Indictment. See Sections IV.B.1.a: Chronology of events in Sarajevo; IV.B.1.f: Siege of Sarajevo.

15820 Prosecution Final Brief, paras. 605, 612(4), 636-642, 797.

15821 Prosecution Final Brief, paras. 612(6), 643, 652, 797.

15822 Prosecution Final Brief, paras. 643, 652.

15823 Defence Final Brief, paras. 1265, 1268.
} 
the Accused does not expressly respond to the allegation that he let Mladić intensify the campaign of sniping and shelling against the city of Sarajevo; instead, he denies that such a campaign ever existed. ${ }^{15824}$ The Accused further submits that there is no evidence that he promoted, rewarded, or otherwise decorated VRS officers while knowing that they were involved in criminal conduct. ${ }^{15825}$ Instead, he promoted them on the basis of the proposals from commanders of "lower units" in the field and because he had to respect the system of military subordination, which resulted in him rarely knowing whom he was actually promoting. ${ }^{15826}$

\section{(B) Accused's support for Mladić and SRK in relation to Sarajevo}

4718. As discussed earlier, on 12 May 1992, at the $16^{\text {th }}$ Session of the Bosnian Serb Assembly, at which point Sarajevo was already encircled by various Bosnian Serb Forces, ${ }^{15827}$ the VRS was established and Mladić was appointed as its commander. ${ }^{15828}$ The Chamber also outlined how the Accused personally sought out Mladić, having noticed his "blunt statements in the newspapers", discussed the relationship between the two men, and made findings thereon. ${ }^{15829}$

4719. In particular, during the $16^{\text {th }}$ Session of the Bosnian Serb Assembly, after the Accused had announced the Strategic Goals of the Bosnian Serbs and stated that the fighting around Sarajevo would decide the destiny of the BiH, Mladić pleaded with the Bosnian Serb political leadership to enunciate a set of realistic and clearly-defined strategic goals for the Bosnian Serb people. ${ }^{15830} \mathrm{He}$ then informed those present that Bosnian Muslims in Sarajevo had nowhere to go because the city was facing a blockade, before exclaiming that "the head of the dragon of fundamentalism lies beneath our hammer." 15831 He recounted how he had personally observed from a helicopter that Serb howitzers and tanks around Sarajevo were not adequately positioned and manned and warned the deputies that "[w]e should not spit at Sarajevo with two mortars." 15832 According to Mladić, the surrender of Bosnian Muslims required that 300 guns, including howitzers, and multiple rocket launchers, be positioned around the city. ${ }^{15833}$ Other measures advocated by Mladic during this session were denying the population of Sarajevo access to the hospitals located in the city and inhibiting the flow of utilities into Sarajevo while assigning the blame for the resultant shortages to

\footnotetext{
15824 Defence Final Brief, paras. 2967-2971.

15825 Defence Final Brief, paras. 1335, 1338.

15826 Defence Final Brief, paras. 1335, 1338, 1340, 1342.

15827 See para. 3556.

15828 See paras. $160,3115$.

15829 See paras. 3115-3141.

15830 P956 (Transcript of $16^{\text {th }}$ session of SerBiH Assembly, 12 May 1992), e-court pp. 10, 31-32.

15831 P956 (Transcript of $16^{\text {th }}$ session of SerBiH Assembly, 12 May 1992), e-court p. 35.

15832 P956 (Transcript of $16^{\text {th }}$ session of SerBiH Assembly, 12 May 1992), e-court pp. 35-36, 38.

15833 P956 (Transcript of $16^{\text {th }}$ session of SerBiH Assembly, 12 May 1992), e-court p. 36.
} 
the Muslim side. ${ }^{15834}$ After referring to the fact that pursuant to his orders, vital JNA assets in Croatia had been either evacuated to Serb-held areas or rendered completely useless, Mladić assured the Assembly that the disciplined officers of the JNA's Knin Corps were going to change the picture around Sarajevo and that ultimately, the Bosnian Muslim side was not going to reap any benefit from the city unless it accepted peace. ${ }^{15835}$ It is following this speech that the Assembly, including the Accused, voted unanimously to appoint Mladić as the Commander of the VRS. ${ }^{15836}$

4720. Even before these formalities relating to the creation of the VRS and his own appointment were completed, Mladić was engaged in the Sarajevo battlefield, primarily in efforts to evacuate the JNA personnel trapped in the various barracks in the city. ${ }^{15837}$ In the process of negotiating those evacuations, Mladić made serious threats against the city and its citizens, revealing his hard-line approach towards the city. For example, on 11 May 1992, Mladić told a JNA General trapped in one of the barracks in Sarajevo that if the other side attacked that would be "the end of them"; he then advised the said General to use artillery fire against anything that posed an immediate threat to the barracks and not to spare either the Bosnian Muslim forces or the town. ${ }^{15838}$ On the same day, in a conversation with another trapped JNA officer, Mladić said that he would "tear down all of Sarajevo for you". ${ }^{15839}$ Similarly, on 19 May in a conversation with yet another JNA officer, after being told that an $\mathrm{ABiH}$ General, Jovo Divjak, had threatened to attack the barracks, Mladić replied that if Divjak did that, he "would sentence first himself and then entire Sarajevo to death." 15840 The next day, Mladić warned two JNA officers about the potential cistern attack and told them that if this attack happened "the city would be burnt down." ${ }^{\text {"15841 }} \mathrm{He}$ also specifically instructed one of the officers to ensure that any Bosnian Muslim attack against the barracks was responded to with force which was a hundred times greater. ${ }^{15842}$ Further, on 24 May 1992, Mladić assured Tolimir that

\footnotetext{
15834 P956 (Transcript of $16^{\text {th }}$ session of SerBiH Assembly, 12 May 1992), e-court pp. 34-35.

15835 P956 (Transcript of $16^{\text {th }}$ session of SerBiH Assembly, 12 May 1992), e-court pp. 38-39.

15836 P956 (Transcript of $16^{\text {th }}$ session of SerBiH Assembly, 12 May 1992), e-court pp. 53-54.

15837 Mladić had arrived to Sarajevo on 10 May 1992. See fn. 424.

15838 P6069 (Intercept of conversation between Milosav Gagović, Ratko Mladić, and Miloš Baroš, 11 May 1992), pp. 1-2; Milosav Gagović, T. 31872-31873 (15 January 2013). See also P5672 (Intercept of conversation between Miloš Baroš, Ratko Mladić, and Gagović, 19 May 1992), p. 2 (wherein the Accused told the same General that "If a bullet is fired at you, you will see what will be fired at Sarajevo").

15839 P5693 (Intercept of conversation between Ratko Mladić and Potpara, 11 May 1992), p. 1.

15840 P6070 (Intercept of conversation between Milosav Gagović, Janković, and Ratko Mladić, 19 May 1992), pp. 23 (Mladić also added that the Bosnian Muslims were more vulnerable because they were encircled by Bosnian Serbs); Milosav Gagović, T. 31871-31873 (15 January 2013). See also P5670 (Intercept of conversation between Tomčić and Ratko Mladić, 19 May 1992) (during which Mladić said that the other side would not risk having the city destroyed over the JNA personnel in the barracks).

15841 P5673 (Intercept of conversation between Miloš Baroš, Ratko Mladić, and Potpara, 20 May 1992).

15842 P5673 (Intercept of conversation between Miloš Baroš, Ratko Mladić, and Potpara, 20 May 1992), p. 4.
} 
should the latter or any of his men be harmed in anyway, "Sarajevo will be gone!"15843 The following day, Mladić told an unidentified officer that if a single bullet was fired at Jusuf Džonlić barracks or Maršal Tito Barracks he would retaliate "against the town" such that "Sarajevo will shake, more shells will fall on [sic] per second than in the entire war so far."15844 He then also stated that it was not his intention to "destroy the town and kill innocent people" and he preferred to fight the war in the mountains rather than in Sarajevo. ${ }^{15845}$ As discussed earlier, on the same day, during a meeting with Plavšić and John Wilson, Mladić threatened to "level the city" if JNA barracks were not evacuated and added that international military intervention would only result in the destruction of Sarajevo. ${ }^{15846}$

4721. While these conversations with JNA officers took place in the absence of the Accused, the Accused was, however, privy to a number of other discussions and meetings during which Mladić elaborated his plans in relation to the city and the evacuation of the JNA personnel. ${ }^{15847}$ As mentioned earlier, during one such meeting in May 1992, involving [REDACTED], Mladić, the Accused, Krajišnik, Plavšić, and Koljević, Mladić outlined his plan to carry out a widespread artillery attack against the entire city of Sarajevo. ${ }^{15848}$ [REDACTED]. ${ }^{15849}$ Throughout this meeting, the Accused and the others remained silent. ${ }^{15850}$ [REDACTED] if those present in the meeting, including the Accused, had been against it the shelling would never have happened. ${ }^{15851}$

4722. Subsequently, Mladić issued direct orders to SRK brigade commands to carry out an indiscriminate and disproportionate artillery attack against Sarajevo on 28 and 29 May 1992, the nature of which has been described in more detail in an earlier section of the Judgement. ${ }^{15852}$ For example, on 28 May 1992, Mladić personally ordered Mirko Vukašinović to direct artillery fire at Baščaršija and also against Velešići and Pofalići where "there [was] not much Serb

\footnotetext{
15843 P5657 (Intercept of conversation between Zdravko Tolimir, Ratko Mladić, and "Jerko Doko", 24 May 1992), p. 2.

15844 P1041 (Intercept of conversation between Ratko Mladić and unidentified male, 25 May 1992), pp. 1-2 (Mladić also emphasised that the Bosnian Muslims were trapped in the city with no way out).

15845 P1041 (Intercept of conversation between Ratko Mladić and unidentified male, 25 May 1992), p. 3. While Mladić did state during this conversation that it was not his intention to destroy the city and that he preferred to fight this war in the mountains rather than in Sarajevo, the Chamber considers that it is clear from this and all the other conversations he had in this period that, if he deemed it necessary, he was prepared to retaliate against the city as a whole, destroy it, and kill civilians.

15846 See para. 4025.

15847 See e.g. para. 4021. [REDACTED].

15848 See para. 4023.

15849 See para. 4023.

15850 See para. 4023.

15851 [REDACTED].

15852 See paras. 4024-4035.
} 
population". ${ }^{15853}$ Mladić also ordered Vukašinović to use artillery fire so as to ensure "that they cannot sleep, that we roll out their minds". ${ }^{1554}$ The following day, Mladić told Potpara to be careful and not respond to provocations, and that he would not order the shelling of Sarajevo unless the Bosnian Muslims posed a threat to Potpara's men. ${ }^{15855}$ Later that day, however, Mladić ordered Potpara to fire at the railway station in Sarajevo and told him to scatter the fire around. ${ }^{15856}$ It is clear from these orders that Mladić showed no concern for the civilian population of Sarajevo nor for any civilian casualties that would result from his orders to shell the city, including Baščaršija, Velešići, and Pofalići.

4723. As also discussed earlier, on 30 May 1992, while the bombardment continued, Morillon and Mackenzie met with the Accused and Koljević to discuss these events. ${ }^{15857}$ During the meeting, the Accused defended the actions of Mladić and the SRK, saying that due to their inexperience, the forces over-reacted to attacks by the Green Berets and that Mladic did not have all the forces under his command. ${ }^{15858}$ In doing so, the Accused showed awareness that the bombardment of the city had been extensive and had gone too far.

4724. Nevertheless, despite the Accused's awareness, another massive attack on the city commenced on the night of 5 June and lasted until 8 June $1992 .{ }^{15859}$ It was preceded by a meeting on the same day involving Mladić, the Accused, Krajišnik, Plavšić, Koljević and Đerić, during which the Accused instructed those attending that Sarajevo had to be resolved politically while "acting quietly, inch by inch" and told them to clean up Butmir, Hrasnica, Sokolović Kolonija, and Hrasno. ${ }^{15860}$ The following day, while the bombing of the city was taking place, Mladic met the Accused, Koljević, Krajišnik, Ostojić, and others in Jahorina during which the Accused discussed the Strategic Goals, claiming "we have to protect our territories militarily" and that "the birth of a state and the creation of borders does not occur without war". ${ }^{15861}$ That same day Mladić issued Directive 1, in which he stated that the VRS had "received the task to use offensive actions [...] in

\footnotetext{
15853 P1521 (Intercept of conversation between Ratko Mladić and Mirko Vukašinović, 28 May 1992), p. 3; P1518 (Intercept of conversation between Ratko Mladić and Mirko Vukašinović, 28 May 1992).

15854 P1518 (Intercept of conversation between Ratko Mladić and Mirko Vukašinović, 28 May 1992). See also P1042 (UNPROFOR report re conversations with BiH and JNA delegations, 29 May 1992), para. 5.

15855 D207 (Intercept of conversation between Ratko Mladić and Potpara, 29 May 1992), p. 8.

15856 P1511 (Intercept of conversation between Ratko Mladić and Potpara, 29 May 1992); P1522 (Intercept of conversation between Ratko Mladić and Potpara, 29 May 1992), p. 1.

15857 See para. 4037.

15858 P1036 (UNPROFOR report re meeting with Radovan Karadžić and Nikola Koljević, 30 May 1992), para. 3; P1029 (Witness statement of John Wilson dated 4 November 2008), para. 80; John Wilson, T. 4079-4080 (22 June 2010).

15859 See paras. 4039-4048.

15860 P1478 (Ratko Mladić's notebook, 27 May-31 July 1992), p. 93.

15861 P1478 (Ratko Mladić's notebook, 27 May-31 July 1992), pp. 95, 97.
} 
order to improve operationally-tactical position in the wide area of Sarajevo". ${ }^{15862}$ He then tasked the SRK to "mop up parts of Sarajevo" and "cut it out" along the Nedžarići-Stup-Rajlovac axis; he also tasked them with mopping up Mojmilo, Dobrinja, Butmir, and Sokolović Kolonija, and with de-blocking of Sarajevo-Trnovo and Pale-Zlatište communication. ${ }^{15863}$

4725. There is no doubt, therefore, that at the very beginning of the conflict in Sarajevo the Accused fully supported and actively encouraged the heavy-handed military approach taken by Mladić in Sarajevo, including the shellings that took place between 28 and 30 May and 5 and 8 June 1992. Indeed, [REDACTED], during the first months of the conflict, the Accused, Krajišnik, Koljević, and Plavšić, mainly due to their lack of knowledge of army matters, gave Mladić absolute power over such matters. ${ }^{15864}$ Starting in June 1992, however, they began to gradually limit Mladić and eventually the "political power was on top". ${ }^{15865}$

4726. [REDACTED]. ${ }^{15866}$ [REDACTED]. ${ }^{15867}$

4727. Despite this [REDACTED], of which he was fully aware, the Accused nevertheless continued to support Mladić and his plans for the city. For example, in Directive 3, issued by the Main Staff on 3 August 1992, Mladić outlined the objective of keeping Sarajevo "firmly under blockade" and thus instructed the SRK to "gradually tighten the encirclement". ${ }^{15868}$ The next day, on 4 August 1992, at a meeting between the Accused, Mladić, Krajišnik, and Koljević, the participants accepted this directive without objection, although Koljević requested a "sabotage operation in Sarajevo" and the "[t]aking of Sarajevo". ${ }^{15869}$

4728. Similarly, in a meeting in Jahorina on 2 June 1993, attended by the Accused, Krajišnik, Prime Minister Lukić, Mladić, the SRK commanders, including Galić, and the presidents of Sarajevo municipalities, ${ }^{15870}$ Mladić presented a report on the situation in the SRK's zone of responsibility in which he outlined the problems in the zone, the ABiH's unsuccessful attempts to break the blockade of the city, and then suggested, inter alia, that:

\footnotetext{
15862 D232 (Directive 1, 6 June 1992), para. 2.

15863 D232 (Directive 1, 6 June 1992), para. 5. See also [REDACTED].

15864 [REDACTED].

15865 [REDACTED].

15866 [REDACTED].

15867 [REDACTED].

15868 D235 (Directive 3, 3 August 1992), pp. 3, 5. The orders relevant to Sarajevo in this directive were relayed the next day to the SRK units by the SRK Commander. See P5979 (SRK Order, 4 August 1992).

15869 P1479 (Ratko Mladić's notebook, 16 July-9 September 1992), p. 24.

15870 P1483 (Ratko Mladić's notebook, 2 April-24 October 1993), pp. 182-194.
} 
Activities of sabotage and terrorist groups should be used in the future, as well as ambushes and surprise elements, therefore keeping constant the negative effect on the moral [sic] of Muslim forces and population, keep them in fear and constant wondering as to the activities of our forces. It is necessary to develop in them a feeling that their fate depends of [sic] the Army of Republika Srpska through tactical actions and our propaganda activities. Through incessant activities and combat actions with all available SRK forces, cause as many losses as possible to the enemy and develop feelings of dependency, fear and in security $[$ sic $] .{ }^{15871}$

At the end of this meeting, the Accused stated that he supported everything that was said at the meeting, that "a wounded animal is the most dangerous one", that nothing could be achieved through negotiations with Izetbegović, and that Izetbegović therefore must be defeated while at the same time the Bosnian Serbs needed to ensure "favourable international conditions". ${ }^{15872}$ Following these remarks, Mladić addressed the Accused, Krajišnik, and Lukić, stating that the Main Staff would take into account their remarks and produce appropriate orders. ${ }^{15873}$ Thus, on 25 June 1993, Directive 5 was issued, outlining the Lukavac '93 operation, in which Mladić tasked the SRK to "create conditions to assume control over [Sarajevo]". ${ }^{15874} \mathrm{He}$ explained in the directive that the VRS had been tasked with preventing the lifting of the blockade of Sarajevo and the capture of special-purpose facilities under SRK control. ${ }^{15875}$ As discussed earlier, this operation in turn led to the capture of Mt. Igman and the threats of NATO air strikes against the Bosnian Serb side. $^{15876}$

4729. A year and a half later, on 14 January 1994, in a meeting between the Accused, Mladić, Krajišnik, Milošević, Galić, SRK brigade commanders, and Sarajevo municipality presidents, the Accused discussed the military and political situation in Sarajevo as well as the negotiations in Geneva. ${ }^{15877}$ During the meeting, Mladić stated that Sarajevo was to be resolved "militarily, not politically". ${ }^{15878}$ He called for improvement in the "operative positions" of the SRK. ${ }^{15879} \mathrm{He}$ also recommended cutting off the tunnel used by the Bosnian Muslims and emphasised "responsibility and discipline in the army". ${ }^{1580}$ Once again showing support for Mladić and his resolution to resolve the situation in Sarajevo militarily rather than politically, the Accused stated that Mladic

\footnotetext{
15871 P2710 (VRS conclusions, 31 May 1993), pp. 3-5, 9 (emphasis added). The Chamber notes that while the document itself does not contain Mladić's signature, it contains handwritten notes and was seized from Mladić's house, thus suggesting that he was the author. See Prosecution's Motion for the Admission of 68 Sarajevo Romanija Corps Documents from the Bar Table with Appendix A, para. 5, Appendix A, pp. 4-5.

15872 P1483 (Ratko Mladić's notebook, 2 April-24 October 1993), p. 194.

15873 P2710 (VRS conclusions, 31 May 1993), pp. 9-10.

15874 P843 (Directive 5, 25 June 1993), para. 5(a).

15875 P843 (Directive 5, 25 June 1993), para. 2.

15876 See paras. 3572-3275.

15877 P1484 (Ratko Mladić's notebook, 28 October 1993-15 January 1994), p. 133

15878 P1484 (Ratko Mladić's notebook, 28 October 1993-15 January 1994), p. 144.

15879 P1484 (Ratko Mladić's notebook, 28 October 1993-15 January 1994), p. 144.

15880 P1484 (Ratko Mladić’s notebook, 28 October 1993-15 January 1994), p. 145.
} 
was " $100 \%$ right" and that the Bosnian Muslims "will break down in Sarajevo". ${ }^{1581}$ He then ordered the creation of a "stand-by army" and for all soldiers recruited since April 1992 to remain in the army until the end of the war. ${ }^{15882} \mathrm{He}$ also ordered that the SRK's "[r]etaliation shall be $1: 1$ ". ${ }^{15883}$ He ended the meeting by ordering the SRK commanders to "[q]uickly line up the brigades". 15884

4730. In addition to the Accused's explicit exclamations of support of Mladić's strategy in Sarajevo recounted above, the Chamber has also received a number of Mladić's diaries in evidence which in turn reveal that a number of meetings took place throughout the conflict, which were attended by both the Accused and Mladić and during which the situation in Sarajevo was discussed and a course of action agreed upon. These also show that the two men continued to co-operate throughout the war and continued to agree on the course of action in relation to Sarajevo-related matters. $^{15885}$

4731. As well as lending support to Mladić's activities in the Sarajevo battlefield, the Accused, in accordance with his powers to promote VRS officers, ${ }^{15886}$ also granted Mladić an exceptional promotion on 28 June 1994 for his achievements as Commander of the VRS Main Staff, elevating his rank to Colonel General. ${ }^{15887}$ By that point, Sarajevo had been under siege for two years and the Accused had been told on a number of occasions about the indiscriminate and disproportionate shelling the city was exposed to by the SRK. ${ }^{15888}$

4732. Similarly, the Accused also issued decrees assigning senior officers to the SRK, promoted them after their assignments, and bestowed decorations on the members of the SRK war units. On 31 August 1992, the Accused appointed Stanislav Galić as Commander of the SRK. ${ }^{15889}$ On 16 December 1992, following a difficult period for the city of Sarajevo and particularly heavy indiscriminate shelling in September and October 1992 which resulted in the representatives of the international community protesting to Koljević, Plavšić, and the Accused, ${ }^{15890}$ the Accused used his

\footnotetext{
15881 P1484 (Ratko Mladić's notebook, 28 October 1993-15 January 1994), p. 148.

15882 P1484 (Ratko Mladić's notebook, 28 October 1993-15 January 1994), p. 148.

15883 P1484 (Ratko Mladić's notebook, 28 October 1993-15 January 1994), pp. 148-149.

15884 P1484 (Ratko Mladić's notebook, 28 October 1993-15 January 1994), p. 149.

15885 See e.g. P1478 (Ratko Mladić's notebook, 27 May-31 July 1992), pp. 38-40, 42, 308-315; P1473 (Ratko Mladić's notebook, 27 January-5 September 1995), p. 42.

15886 See para. 3427.

15887 P3046 (Radovan Karadžić's Decree on promotion of Ratko Mladić, 28 June 1994); Raynaud Theunens, T. 16863 (19 July 2011).

15888 See Section IV.B.3.c.iii.B: Accused's knowledge.

15889 P1200 (Decree of President of RS Presidency re Stanislav Galić, 31 August 1992).

15890 See para. 3562; P1258 (Witness statement of Hussein Ali Abdel-Razek dated 16 July 2002), e-court p. 22; Hussein Abdel-Razek, T. 5507 (19 July 2010) (testifying that he wrote a letter to the Accused requesting him to stop the shelling).
} 
powers of exceptional promotion to promote Galic to the rank of Major General. ${ }^{15891}$ Then, on 7 August 1994, just over a month after promoting Mladić, the Accused again granted an early promotion to Galić, giving him a rank of Lieutenant General. ${ }^{15892}$ On 12 August 1994, after Mladić initiated a procedure for termination of Galić's professional military service on the basis of Galić's completion of more than 30 years of pensionable service, Galić requested, amongst other things, that the Accused follow through on his promise and award him the highest RS decoration and allocate to him a furnished apartment in the Novi Sad Garrison or in the Banja Luka Garrison. ${ }^{15893}$

4733. The Accused was also imperative in the appointment and successive promotions of Dragomir Milošević. Thus, on 10 July 1993, the Accused assigned Milošević, who at the time was the Chief of Operations and Training in the Drina Corps Command, to the posts of Chief of Staff and Deputy Commander of the SRK. ${ }^{15894}$ Then, on 24 March 1994, only a month and a half after the shelling of Dobrinja and Markale on 4 and 5 February respectively, and despite receiving protests from the international community about these two incidents, ${ }^{15895}$ the Accused used his powers of exceptional promotion to raise Milošević's rank from that of Colonel to Major General, effective the following day. ${ }^{15896}$ Finally, on 8 August 1994, the Accused appointed Milošević as Commander of the SRK, effective as of 15 August 1994. ${ }^{15897}$ Within the VRS, Milošević was considered to have been the Accused's man. ${ }^{15898}$

4734. In addition to the above appointments and promotions, the Chamber heard that on 25 June 1995, some two months after Scheduled Incident G.10 for which Ilidža Brigade was responsible and of which the Accused was aware ${ }^{15899}$ Mladic informed the SRK Command that on the occasion of St. Vitus Day, the Accused was going to award Petar Mrkonjić medals to the members of the Ilidža Brigade and the $1^{\text {st }}$ Romanija Infantry Brigade, among others. ${ }^{15900}$

\footnotetext{
15891 P2650 (Radovan Karadžić's decree on exceptional promotion, 16 December 1992).

15892 P2649 (Radovan Karadžić's decree on early promotion, 7 August 1994)

15893 P1206 (Record of retirement of Stanislav Galić, 12 August 1994), p. 1. According to the evidence before the Chamber, Galić was relieved of his duty as the SRK Commander because he had agreed to the TEZ and the WCPs against Mladić's wishes. See fn. 11476.

15894 P2676 (Radovan Karadžić's decree on appointment of Dragomir Milošević as SRK Chief of Staff, 10 July 1993); D2149 (Aide mémoire of Manojlo Milovanović), p. 24.

15895 See paras. 4835-4836.

15896 P2677 (Radovan Karadžić's decree on Dragomir Milošević's promotion, 24 March 1994). The Chamber notes that while the English translation of P2677 refers to the promotion being effective from 25 March 1993, the original in BCS refers to 25 March 1994.

15897 P2678 (Radovan Karadžić's decree on appointment of Dragomir Milošević as SRK Commander, 8 August 1994), p. 2.

15898 D2901 (Letter from Dragomir Milošević to Ratko Mladić, 19 May 1996), p. 2.

15899 See para. 4405.

15900 P2814 (VRS Main Staff Order, 25 June 1995).
} 


\section{(C) Conclusion}

4735. Based on the foregoing, the Chamber finds that the Accused brought in and appointed Mladić to the post of VRS Main Staff Commander. According to the Accused's own words at the Bosnian Serb Assembly session in April 1995, he personally went into a lot of effort to bring in Mladić, having noticed Mladić's activities in Knin and having taken note of his "blunt statements". Then, during the $16^{\text {th }}$ Session of the Bosnian Serb Assembly and immediately prior to his appointment as VRS Commander, Mladić freely articulated his Sarajevo strategy in front of the Accused and other members of the Bosnian Serb political leadership, specifying in clear terms that in his view, besieging and targeting Sarajevo with large numbers of heavy weapons would compel Bosnian Muslims to accede to the demands made by the Bosnian Serbs. Despite this clear elucidation of what was to come for Sarajevo, the Accused and the other members of the Bosnian Serb leadership voted in favour of Mladić's appointment.

4736. The Chamber further finds that shortly after his appointment Mladic did indeed intensify the campaign against Sarajevo through his involvement in the widespread shelling of the city by the SRK as described above and in sections of the Judgement dealing with Scheduled Incidents G.1 and G.2. Despite this intensification, which various international observers brought to the Accused's attention and which he himself indirectly acknowledged in his meeting with Morillon and Mackenzie on 30 May 1992, the Accused nevertheless lent his unwavering support to Mladić, defending him before the international community and blaming the other side for the intensification

of the campaign. ${ }^{15901}$ Further, the Accused continued to actively participate in and approve of Mladić's acts and plans for the city, as illustrated by his acceptance of all the military directives signed by Mladić, as well as the 2 June meeting in Jahorina and a number of other meetings where the two men, along with others, discussed their plans for Sarajevo. Indeed, on 28 June 1994, by which stage the Accused was fully aware of the international community's objections to the SRK's and Mladić's activities in Sarajevo, ${ }^{15902}$ the Accused decided to use his de jure powers to promote Mladić to the rank of Colonel General, thus in fact rewarding his activities on the Sarajevo battlefield. Accordingly, the Chamber has no doubt that the Accused supported Mladic in his efforts to intensify the shelling and the sniping in the city throughout the conflict in Sarajevo and throughout the Indictment period.

\footnotetext{
15901 See para. 4723.

15902 See Section IV.B.3.c.iii: Accused's knowledge.
} 
4737. In reaching the above conclusions, the Chamber was cognisant of the tensions that existed at certain times between the Accused and Mladic ${ }^{15903}$ but finds that such tensions were not of such intensity and/or scope so as to diminish the level of support which the Accused provided to Mladić's policies vis-à-vis Sarajevo, as clearly shown by the evidence outlined above.

4738. The Chamber further finds that aside from Mladić, the Accused also promoted or otherwise decorated SRK officers and SRK units who were implicated by international observers in the commission of crimes against the population of Sarajevo, thus showing his support for them. As outlined above, the Accused promoted Galić and Dragomir Milošević, despite being constantly informed of problems with disproportionate firing into the city by the SRK units, as outlined later in this Judgement. ${ }^{15904}$ Indeed, his relationship with Milošević was particularly close and continued to be one of mutual support, despite the fact that Milošević was directly implicated, among other things, in the use of modified air bombs in the city. ${ }^{15905}$ Further, the Accused decorated the members of the Ilidža Brigade in July 1995, even though he was aware that Ilidža Brigade had fired a modified air bomb into the centre of Hrasnica, as found by the Chamber earlier in this Judgement. ${ }^{15906}$

4739. As for the Accused's claim that he hardly ever knew whom he was promoting because he would simply sign off on promotions on the basis of proposals from commanders of "lower units", the Chamber does not consider this to have been the case with regards to Mladić, Galić, and Dragomir Milošević. Indeed, given their high ranks and taking into account the Accused's particular interest and involvement in everything Sarajevo-related, the Chamber does not accept that he would have been unaware of their promotions and/or that he promoted them purely on the basis of the proposals from lower level commanders. Contrary to his submissions, the Chamber is convinced that when appointing and promoting these three men, the Accused was fully aware and supportive of their appointments and promotions, all the while having knowledge that they were implicated in indiscriminate and disproportionate shelling and in sniping attacks on the civilian population in the city. In doing so, he indicated that the criminal actions of Mladić, as well as the actions of the SRK Commanders and their units, were immune from investigation and punishment.

\footnotetext{
15903 See paras. 3122-3141.

15904 See Section IV.B.3.c.iii: Accused's knowledge.

15905 See paras. 4403-4405.

15906 See e.g. para. 4413.
} 


\section{ii. Accused's oversight of military activities in Sarajevo}

\section{(A) Arguments of the parties}

4740. The Prosecution argues that the Accused, as Supreme Commander of the VRS, oversaw the strategy and implementation of the plan through his command and control over the Bosnian Serb Forces in Sarajevo. ${ }^{15907}$ It argues that the Accused was at the "apex of control" of the Bosnian Serb Forces through his position as "President of the SDS, President of the Presidency, sole President and Supreme Commander" and that this power was acknowledged by the members of the VRS, including Mladić, Milovanović, Galić, and Dragomir Milošević. ${ }^{15908}$

4741. The Accused in turn argues that no substantial discussions took place during meetings of the RS political leadership and the SRK commanders as these meetings were of a formal nature. ${ }^{15909}$ He further claims that Galić and Dragomir Milošević did not receive orders or instructions from the Presidency that applied exclusively to the SRK, and that "any information arriving from the Presidency applied across the board to the VRS". ${ }^{15910}$ With respect to Galić, the Accused argues that communication between them was limited and "practically non-existent in terms of carrying out combat activities". ${ }^{15911}$ As for Dragomir Milošević, he argues that neither the civilian authorities of the RS nor the political leaders of the SDS ever influenced Milošević's command because they did not interfere in military matters. ${ }^{15912}$ He argues that communication on the ground between republican and military authorities was disrupted and that the system of command and control did not work well due to "obsolete technical equipment" of the SRK. ${ }^{15913}$ The Accused also argues that due to the shortage of professional officers in the SRK, the VRS faced problems achieving effective control over its units. ${ }^{15914}$ Finally, he argues that "in one period of the war" the relationship between the SRK and republican authorities was tense resulting in a refusal by the military to obey orders from the Supreme Command. ${ }^{15915}$

\section{(B) SRK as a professional army}

4742. The Chamber recalls that the VRS, including the SRK, was established as a professional army pursuant to a decision by the Bosnian Serb Assembly and enactment of the Defence Act and

\footnotetext{
15907 Prosecution Final Brief, paras. 612(1), 614-619.

15908 Prosecution Final Brief, paras. 614-615, 618.

15909 Defence Final Brief, confidential, para. 2325.

15910 Defence Final Brief, para. 2325.

15911 Defence Final Brief, para. 2965.

15912 Defence Final Brief, para. 2328.

15913 Defence Final Brief, para. 2962.

15914 Defence Final Brief, paras. 2329-2330.

15915 Defence Final Brief, para. 2327.
} 
the Law of the Army. ${ }^{15916}$ The Chamber also recalls its earlier finding that the Accused was involved in the creation of the VRS. ${ }^{15917}$

4743. Throughout the case, the Chamber received evidence that the SRK was a well-organised corps that functioned as a professional army within the structure of the VRS, with an effective command and control structure in place in its units at all levels. ${ }^{15918}$ On 19 November 1992, in Directive 4, Mladić himself stated that the SRK "has fully stabilised command and control in the Corps and subordinate units". ${ }^{15919}$ A July 1994 analysis on the combat readiness of the SRK artillery rocket units prepared by the SRK Chief of Artillery, Tadija Manojlović, states that while the SRK was debilitated by the departure of officers for the FRY in the early stages of the war which in turn had a negative effect on command and control, it still managed to attain "evident results in [the] protection of the Serbian people and the territory" and that, notwithstanding a number of problems it had faced, such as the lack of trained soldiers and officers, the results attained were "excellent and outstanding". ${ }^{15920}$ According to an April 1993 VRS report, during the previous year, the VRS had been under a "single control and command structure" whereby each corps was assigned specific missions, in their zones of responsibility, within a specific time period. $^{15921}$

4744. Thomas testified that from Mladić down to the brigade commanders, "there was a kind of command and control that I would expect to find in a NATO army", ${ }^{15922}$ while Van Baal testified that, by 1994, the VRS had a highly centralised command and control structure. ${ }^{15923}$ KDZ182 also thought that the chain of command of the VRS and the SRK was "working perfectly" and that "responsibility at each echelon was effectively implemented in the way the actions were actually

\footnotetext{
15916 See paras. $160-164$.

15917 See paras. 162-163, 3098.

15918 See Adjudicated Fact 37; Richard Philipps, T. 3755-3756, 3818-3819 (15 June 2010).

15919 P976 (Directive 4, 19 November 1992).

15920 D312 (SRK analysis of combat readiness of artillery rocket units, July 1994), pp. 2, 9. See also Richard Philipps, T. 3795-3809 (15 June 2010).

15921 D325 (VRS Main Staff analysis of combat readiness and army activities in 1992, April 1993), pp. 7-8. According to Galić, when he took command of the SRK in September 1992, Šipčić had been gone for approximately one month and there was a lack of discipline on the frontlines in the northwest due to the fact that the JNA had left but the TO units had not yet been sufficiently incorporated into the VRS. See Stanislav Galić, T. 37619-37622 (23 April 2013); D3483 (SRK Order, 22 September 1992), pp. 1-3. However, the Chamber recalls its finding made earlier that the TOs were integrated into the VRS in mid-May 1992. See para. 3176. According to Prosecution expert Philipps, when Galić took command of the SRK, the training and organisation within the corps improved. See Richard Philipps, T. 3807 (15 June 2010); D321 (SRK Order, 13 July 1994); P1616 (SRK Order, 5 January 1995).

15922 P1558 (Witness statement of Francis Roy Thomas dated 13 May 2009), para. 50 (adding that he could not recall a single instance where the Bosnian Serb brigade commanders did not follow a corps commander's direction). Thomas also noted that the cease-fire in February 1994 did have a significant impact on the city of Sarajevo and demonstrated the high level of command and control in the VRS. See P1558 (Witness statement of Francis Roy Thomas dated 13 May 2009), para. 107.
} 
carried out". ${ }^{15924}$ [REDACTED] Mladić exercised absolute power and complete control over everything that concerned the VRS, such as "fighting, logistics, and a number of other elements" but was not involved in the political agenda of the Bosnian Serb leadership. ${ }^{15925}$

4745. KDZ450 also testified that the chain of subordination of the armed forces in Sarajevo was "very simple", with Mladić being the "high command", then the SRK Commander, and then the brigades. ${ }^{15926}$ Military structures worked in a "very typical manner" in that responsibility was very entrenched and the room for individual initiative was "very slim". ${ }^{15927}$ On many occasions Mladić demonstrated effective control, for example, by arranging the opening of confrontation line crossing points, implementing temporary cease-fires, and directly commanding military operations. ${ }^{15928}$ Wilson testified that Mladić's command was far-reaching and that during the meetings they had together, Mladić never denied that he was in control of the war-like activities conducted by the military forces in Sarajevo. ${ }^{15929}$ KDZ182 considered that Mladic was the one who had the real power such that all the incidents in Sarajevo were in fact orchestrated, guided, and designed by him. ${ }^{15930}$ In his opinion, Mladić instructed the SRK Commander to exert pressure and terrorise the population. ${ }^{15931}$

4746. As for the SRK Commanders, Galić was very popular, had great authority, and was aware of everything that happened in his area of responsibility. ${ }^{15932}$ On the occasions when Abdel-Razek met with Galić at his command centre, he noticed that it was run in a professional manner, with officers who had professional relations. ${ }^{15933}$ While Mladić was the "supreme Serb military commander", Galić still had "everyday control over activities in Sarajevo", such that "militia

P1818 (Witness statement of Adrianus van Baal dated 26 October 2010), para. 24.

P2414 (Witness statement of KDZ182), pp. 20, 53 (under seal).

[REDACTED].

KDZ450, T. 10554-10555 (19 January 2011) (private session).

KDZ450, T. 10554 (19 January 2011) (private session).

P1029 (Witness statement of John Wilson dated 4 November 2008), paras. 73, 127(adding that Mladić was known for carrying out what he said he would do and that Mladić's threats were taken seriously by Wilson). See also John Wilson, T. 4055-4056, 4085 (22 June 2010)

15929 P1029 (Witness statement of John Wilson dated 4 November 2008), paras. 126, 128. See also D3695 (Witness statement of Bogdan Subotić dated 16 June 2013), para. 114 (testifying that Mladić treated his generals badly and that they were his "yes-men").

15930 P2447 (Witness statement of KDZ182), p. 13; P2414 (Witness statement of KDZ182), pp. 11, 16, 54, 65 (under seal).

15931 P2414 (Witness statement of KDZ182), p. 22 (under seal).

15932 P1818 (Witness statement of Adrianus van Baal dated 26 October 2010), para. 34; P1258 (Witness statement of Hussein Ali Abdel-Razek dated 16 July 2002), e-court pp. 23-24; P6060 (Record of interview with KDZ185), ecourt p. 10 (testifying that Galić had effective command and control over the SRK).

15933

Hussein Abdel-Razek, T. 5501 (19 July 2010).
} 
groups" in the Sarajevo area were under his control. ${ }^{15934}$ Tucker testified that, when he met with Galić, it was clear that the relationship between Mladić and Galić "was that of a senior commander and a subordinate" whereby Mladić was the highest ranking Bosnian Serb military commander and only considered himself subordinate to the Bosnian Serb Assembly, while Galić was a disciplined and obedient subordinate. ${ }^{15935}$ According to Mole, Galić was "extremely emotional”, but carried out his military duties extremely well and "could achieve what he wanted" regarding Sarajevo. 15936 Galic would visit the brigades, such as the $3^{\text {rd }}$ Sarajevo Brigade and $1^{\text {st }}$ Romanija Brigade for example, a few times per month, meet the commanders, gain knowledge of the situation on the frontlines, and then sometimes call everyone together for a briefing. ${ }^{15937}$ In essence, Galić actively monitored the situation in Sarajevo, was cognisant of the situation in the battlefield, was in a good position to instruct and order his troops, was in full control over the SRK artillery assets, and was aware of the quantity of ammunition being used. ${ }^{15938}$

4747. The SRK continued to operate as a professional military force after Dragomir Milošević took over from Galić as the SRK Commander; ${ }^{15939}$ he too was respected and highly esteemed by the SRK soldiers. ${ }^{15940}$ As was the case with Galić, Milošević regularly visited the troops and the frontlines. ${ }^{15941}$ He would have a briefing with his Chief of Staff and Corps Staff every morning, during which he made decisions and issued orders, and in the evening would receive reports from the Corps Staff. ${ }^{15942}$ Once a week or once a fortnight Dragomir Milošević had briefings with the brigade commanders. ${ }^{15943}$

15934 P1258 (Witness statement of Hussein Ali Abdel-Razek dated 16 July 2002), e-court p. 28 (explaining that once his vehicle was stopped and searched by "militia members" dressed in civilian clothes who were clearly under the control of a military officer under Galić's command); Hussein Abdel-Razek, T. 5501 (19 July 2010).

15935 P4203 (Witness statement of Pyers Tucker dated 12 May 2010), paras. 41, 55 (adding that the strategic plan for any operation would emanate from Mladić).

15936 P1426 (Witness statement of Richard Mole dated 7 May 2010), para. 46. See also P1048 (Record of interview with KDZ185), e-court p. 10 (under seal); KDZ185, T. 4216, 4246 (28 June 2010), T. 4263, 4269 (29 June 2010) (private session). On cross-examination, Mole testified that he did not think that the Accused or Mladić had direct involvement in the day-to-day events in Sarajevo as that was the task of Galic as the Commander; however, Galić would have responded to political pressure and military pressure from those above him. Richard Mole, T. 5906-5907 (18 August 2010).

15937 Ratomir Maksimović, T. 31583 (17 December 2012) (private session); D2267 (Vlado Lizdek's interview with OTP), e-court pp. 24-25.

15938 See Adjudicated Facts 33, 34, 36, 38-41.

15939 On the reasons behind Galić's removal, the Chamber recalls that KDZ450 testified that Galić was relieved of his duty as the SRK Commander because he had agreed to the TEZ and the WCPs, against Mladić's wishes. See P5906 (Witness statement of KDZ450 dated 17 January 2011), paras. 38-39; Stanislav Galić, T. 37449 (18 April 2013).

15940 See Adjudicated Fact 2855.

15941 Stevan Veljović, T. 29261-29262 (23 October 2012); Adjudicated Fact 2854.

15942 Stevan Veljović, T. 29245-29247 (23 October 2012).

15943 Stevan Veljović, T. 29248 (23 October 2012). See also Adjudicated Fact 2850. 
4748. While subordinated to Mladić, Dragomir Milošević was in command in the SRK and, therefore, according to KDZ304, was responsible for SRK operations, including for any SRK attacks against civilians or indiscriminate or disproportionate attacks. ${ }^{15944}$ According to Fraser, while Mladić was in charge and directed operations in the whole of $\mathrm{BiH}$, including Sarajevo, "within that little box called Sarajevo, Dragomir Milošević was the guy in command". ${ }^{15945}$ KDZ182 considered that "Mladić was the strategist and Dragomir Milošević was the technician in Sarajevo", that is, Mladić had "the power to design" and Dragomir Milošević had "the power to carry out" in that he "kept total mastery of the means needed to implement locally a certain number of actions". 15946

4749. Inđić was also important in the context of Sarajevo, being "Mladić's eye", a participant in all of the significant meetings held in Sarajevo, and always alongside Galić and Dragomir Milošević at those meetings; thus, while Inđić did not take decisions he had a lot of influence. ${ }^{15947}$ Indeed, Dragomir Milošević would not do anything without Inđić by his side and could not take any strategic initiatives. ${ }^{15948}$ In other words, Dragomir Milošević carried out orders but had very little freedom to act independently, as he only executed orders of his superiors. ${ }^{15949}$

4750. While the chain of command appeared to function well during the conflict, the Chamber received evidence, mainly from former SRK soldiers and officers, that the SRK had problems which had an impact on its functions as a professional army. For example, Dragan Maletić, Slavko Gengo, Blagoje Kovačević, and Stojan Džino testified that there was a lack of professionally trained soldiers and officers within their units, which in turn affected the command and control structure and combat effectiveness. ${ }^{15950}$ On the other hand, Vlade Lučić testified that the shortage of professional officers in his unit, the $2^{\text {nd }}$ Mountain Battalion of the $1^{\text {st }}$ Romanija Infantry Brigade,

\footnotetext{
15944 P2407 (Witness statement of KDZ304), pp. 6, 9; KDZ304, T. 10452 (18 January 2011) (private session), T. 10514 (18 January 2011). On cross-examination, KDZ304 conceded that he had not seen a single order from the SRK to target civilians. See KDZ304, T. 10514 (18 January 2011).

15945 P1762 (Witness statement of David Fraser dated 17 October 2010), p. 9; David Fraser, T. 8014-8015, 80288029 (18 October 2010).

15946 P2414 (Witness statement of KDZ182), pp. 12, 15-19, 48, 65 (under seal); KDZ182, T. 13041-13042, 1304613049 (9 March 2011); P2419 (VRS Main Staff Order, 6 November 1994); P2420 (Report of $2^{\text {nd }}$ Light Infantry Brigade re VRS Main Staff order, 7 November 1994).

15947 [REDACTED].

15948 [REDACTED].

15949 P2447 (Witness statement of KDZ182), p. 13; [REDACTED]. However, during a meeting with UNPROFOR on 21 March 1995, regarding aircraft arriving and departing from Sarajevo airport that were reportedly being fired upon by the SRK, Dragomir Milošević stated that he would ensure that the SRK refrain from firing at aircraft. It was noted that for the first time Dragomir Milošević appeared more dominant in the meeting with Inđic and Fraser, the drafter, records that this was uncharacteristic of the SRK Commander. See P2429 (UNPROFOR report, 21 March 1995); [REDACTED].

15950 D2519 (Witness statement of Dragan Maletić dated 9 November 2012), para. 30; D2383 (Witness statement of Slavko Gengo dated 14 October 2012), para. 26; D2331 (Witness statement of Blagoje Kovačević dated 14 October 2012), para. 35; D2387 (Witness statement of Stojan Džino dated 4 November 2012), paras. 52-55.
} 
did not have a major impact on the quality of command because the battalion conducted additional command training and took a professional approach to commanding. ${ }^{15951}$ Maletić also conceded that, over time, the level of training and combat proficiency improved because an effective command and control had been established. ${ }^{15952}$ This is indeed confirmed by Tadija Manojlović's July 1994 analysis of combat readiness, referred to above. ${ }^{15953}$

4751. Based on all the evidence outlined above, and relying also on the evidence and findings made in the earlier sections of this Judgement, ${ }^{15954}$ the Chamber considers that, from its creation and throughout the conflict the SRK, just like the rest of the VRS, functioned as a professional military force. It was fully integrated into the VRS chain of command, it had an effective command and control structure in place with the SRK Command, and it was fully in charge of the SRK brigades and other subordinate units. While the Chamber accepts that some of those units lacked officers and professional soldiers in the beginning of the conflict, as outlined in the July 1994 analysis of the combat readiness of SRK artillery rocket units, the evidence shows that, overall, the SRK was a well-functioning professional corps of the VRS. Galić and Dragomir Milošević were clearly in command of the SRK units during their respective tenures and had effective control over those units. Mladić as the commander of the Main Staff was their superior and exercised effective control over them, through the regular chain of command.

\section{(C) Accused's authority over the SRK}

4752. As described previously in this Judgement, the Accused in his capacity as President was also the Supreme Commander of the VRS. ${ }^{15955}$ As such, he held the highest de jure authority in the VRS. ${ }^{15956}$ Further, the Chamber found that from May 1992 and throughout the conflict, the Accused, in fact, exercised this authority over the VRS. ${ }^{15957}$ Accordingly, he was involved in the VRS at the strategic level, and when he desired, the operational level as well. ${ }^{15958}$

4753. The Chamber found in Section IV.A.3.a.iii that the Accused maintained his role as Mladić's superior and retained his authority over him throughout the conflict. ${ }^{15959}$ Many of the witnesses

\footnotetext{
15951 D2516 (Witness statement of Vlade Lučić dated 5 November 2012), paras. 6, 22-23 (adding that his unit "sometimes" had problems in achieving effective control over some of its members, but that these problems were not ignored).

15952 D2519 (Witness statement of Dragan Maletić dated 9 November 2012), para. 30.

15953 D312 (SRK analysis of combat readiness of artillery rocket units, July 1994), pp. 4-5.

15954 See paras. 3098-3099.

15955 See para. 3098.

15956 See para. 3098.

15957 See paras. 3142-3157.

15958 See para. 3157.

15959 See para. 3141.
} 
who were in Sarajevo during the conflict and interacted with the Accused and Mladic testified that the Accused, together with and through Mladić, was fully in control over the SRK. For example, Banbury testified that the Accused and Mladić absolutely had the ability to "modulate the level of terror" in Sarajevo as they could stop the shelling and the sniping. ${ }^{15960}$ [REDACTED] had the impression that there was a "very tight subordination" that was displayed from the corps commander towards the military commanders higher up and then the political leaders. ${ }^{15961}$ As noted earlier, during the first months of the conflict, the Accused, Krajišnik, Koljević, and Plavšić did not deal with issues that related to military affairs but this restraint on their part waned starting in June 1992 when they began to gradually limit Mladić. ${ }^{15962}$ The Chamber also recalls that a number of witnesses who were in Sarajevo during the conflict testified about unity between Mladić and the Accused. ${ }^{15963}$ Indeed, during his time in Sarajevo, Bowen observed that Mladić usually accompanied the Accused. ${ }^{15964}$

4754. The Chamber received evidence about a number of specific meetings where the Accused exerted control or demonstrated his influence over the forces in Sarajevo. For example, on 30 May 1992, in a meeting with the Accused, Morillon referred to the Secretary General's appeal to Mladić to "stop the bombardment" in Sarajevo. ${ }^{15965}$ While noting that the soldiers were inexperienced and self-organised and that Mladić did not have everyone under his command, the Accused nevertheless said he was in a position to stop the bombardment. ${ }^{15966}$ Eventually, the Accused informed UNPROFOR that Mladić had indicated by phone that the bombardment would cease. ${ }^{15967}$ On the same day, Wilson also met with Mladić to convey the Secretary General's appeal to cease or lessen the shelling of Sarajevo. ${ }^{15968}$ When asked for confirmation of the Accused's offer to

\footnotetext{
15960 P2451 (Witness statement of Anthony Banbury dated 19 May 2009), para. 200.
}

15961 [REDACTED].

15962 See para. 4725. Wilson testified that he attended a meeting on 25 May 1992, in relation to opening the Sarajevo airport. During this meeting, Mladić stated, in the presence of Plavšić, that he was subordinated to the political leadership. See P1040 (UNPROFOR report re meeting with Biljana Plavšić and Ratko Mladić, 25 May 1992), para. 7; P1029 (Witness statement of John Wilson dated 4 November 2008), para. 74. See also Bogdan Subotić, T. 40050-40051 (19 June 2013) (testifying that the RS Presidency would summon Mladić when necessary and the latter would come and brief the Presidency).

15963 See paras. 3117-3120.

15964 P2068 (Witness statement of Jeremy Bowen dated 10 August 2009), paras. 70, 72.

15965 P1036 (UNPROFOR report re meeting with Radovan Karadžić and Nikola Koljević, 30 May 1992), paras. 1-2.

15966 P1029 (Witness statement of John Wilson dated 4 November 2008), para. 80; P1036 (UNPROFOR report re meeting with Radovan Karadžić and Nikola Koljević, 30 May 1992), paras. 1-3, 8; John Wilson, T. 4079-4080 (22 June 2010). Wilson testified that while this lack of control may have existed at the very beginning of the conflict, it did not explain the overall strategy of the siege and bombardment of Sarajevo at the time; Wilson believed that Mladić had very firm control over heavy weapons and the firing in Sarajevo. See P1029 (Witness statement of John Wilson dated 4 November 2008), para. 82; John Wilson, T. 4079-4080 (22 June 2010).

15967 P1036 (UNPROFOR report re meeting with Radovan Karadžić and Nikola Koljević, 30 May 1992), paras. 11, 15; P1029 (Witness statement of John Wilson dated 4 November 2008), para. 80.

15968 P1029 (Witness statement of John Wilson dated 4 November 2008), para. 77; P1043 (UNPROFOR report re meeting with Ratko Mladić, 30 May 1992), para. 1; P1044 (UNPROFOR report re attack on UN, 30 May 1992), 
withdraw all heavy weapons, Mladic said that he had no knowledge of such an offer but would nevertheless give his advice to his government and abide by any agreement made, essentially confirming that he was responsive to and subordinate to the political leadership. ${ }^{15969}$ From this, Wilson concluded that there seemed to be a very comfortable relationship between the Bosnian Serb civilian leadership and Mladić; indeed, Mladić would repeatedly say that he was a soldier with no political ambitions. ${ }^{15970}$ While Mladić had a strong personality, and was capable of acting independently, ultimately he did "what his political masters told him to do". ${ }^{15971}$

4755. [REDACTED] a meeting on 16 February 1994 between UNPROFOR, Galić, and Inđić at Lukavica, where WCP sites and number and location of the deployment of UNMO and UNPROFOR personnel in Sarajevo were agreed upon, but the agreement had to be sent to the political authorities for approval; this demonstrated that any discussions with Galić that resulted in proposals could only be considered non-binding, as Galić was not able to commit himself without asking his superiors, both military and political. ${ }^{15972}$

4756. Van Baal recalled an incident on 20 March 1994, in which soldiers from the Ilijaš Brigade surrounded a CanBat contingent which had taken custody of heavy weapons in the TEZ; this prompted Van Baal to telephone the Accused in protest. ${ }^{15973}$ The Accused stated that he would give the order not to shoot and some 15 to 20 minutes later the VRS soldiers withdrew. ${ }^{15974}$ On the same day, Van Baal became aware of the presence of mines under CanBat APCs and requested that the Accused order their removal. ${ }^{15975}$ The Accused assured Van Baal that he would do so and the mines were subsequently removed. ${ }^{15976}$ Later that evening, Van Baal discovered that mines were again placed underneath the CanBat APCs. ${ }^{15977}$ The next day he met with the Accused and Galić

para. 1; John Wilson, T. 3924-3925 (21 June 2010). This meeting was motivated by Security Council Resolution 757. See John Wilson, T. 3926 (21 June 2010); P1031 (UNSC Resolution 757, 30 May 1992). John Wilson dated 4 November 2008), paras. 78, 127; John Wilson, T. 3926 (21 June 2010).

15970 P1029 (Witness statement of John Wilson dated 4 November 2008), paras. 127, 132, 134.

15971 P1029 (Witness statement of John Wilson dated 4 November 2008), paras. 132-133. Wilson cited as another example an incident during the Sarajevo airport negotiations where the Accused took Mladić into an adjoining room and engaged in a heated argument, after which Mladić changed his position and accepted the proposal to hand over the airport. See P1029 (Witness statement of John Wilson dated 4 November 2008), para. 134. [REDACTED]; P2120 (UNPROFOR report re meeting with Stanislav Galić, 16 February 1994).

P1818 (Witness statement of Adrianus van Baal dated 26 October 2010), paras. 21-22.

P1818 (Witness statement of Adrianus van Baal dated 26 October 2010), paras. 23-24.

15975 P1818 (Witness statement of Adrianus van Baal dated 26 October 2010), para. 25; Adrianus van Baal, T. 84068407 (27 October 2010).

15976 P1818 (Witness statement of Adrianus van Baal dated 26 October 2010), para. 26; Adrianus van Baal, T. 8406 (27 October 2010). However, upon questioning by the Chamber, Van Baal could not verify that the instructions came directly from the Accused to the SRK soldiers on the ground or whether they came through an intermediary. See Adrianus van Baal, T. 8535-8536 (28 October 2010).

15977 P1818 (Witness statement of Adrianus van Baal dated 26 October 2010), para. 27; Adrianus van Baal, T. 8406 (27 October 2010), T. 8535-8536 (28 October 2010). 
and told them that mines were there; the Accused then told Galić, "you promised me that this would be done last night" and ordered Galić to remove the mines. ${ }^{15978}$ Galić left the room and immediately carried out the orders of the Accused. ${ }^{15979}$ In the same meeting, the Accused also ordered Galić to remove heavy weapons from the TEZ; Galić implemented the order despite disagreeing with the Accused. ${ }^{15980}$ Van Baal deduced that the Accused was in a position to give orders to Galić, that Galić's orders were executed through the command and control system, and that there was immediate feedback through the SRK communications system. ${ }^{15981}$ Thus, the Accused was in control and capable of enforcing his political undertakings. ${ }^{15982}$

4757. Some of the witnesses noted, however, that the Accused was not always in control of the forces in Sarajevo and that Mladić would not always do as he was told in relation to Sarajevo. For example, Abdel-Razek explained that the Bosnian Serb political leadership was amenable during the meetings with him, but that there were problems with implementation on the ground resulting from the problems in the chain of command and the fact that the good intentions of the political leadership were not reaching the soldiers. ${ }^{15983}$ He later stated that it was a situation of civil war with "civilians who carried weapons and who were armed with strong passions" such that "there was a lack of control by the central command and that there was no full co-ordination between the leadership and the higher command and the subordinates on the ground". ${ }^{1598}$ Similarly, Momir Bulatović recalled a meeting of the FRY Council of Co-ordination of State Policy in Belgrade on 18 August 1992 discussing the situation in Sarajevo. ${ }^{15985}$ Milan Panić, the FRY Prime Minister, stated "the problem is war, they are shooting. [The Accused] told us yesterday that he did not

15978 P1818 (Witness statement of Adrianus van Baal dated 26 October 2010), para. 28. See also Adrianus van Baal, T. 8536 (28 October 2010).

15979 P1818 (Witness statement of Adrianus van Baal dated 26 October 2010), para. 28; Adrianus van Baal, T. 8407 (27 October 2010), T. 8535-8536 (28 October 2010). Van Baal testified that the order directly from the Accused to Galić was carried out within 20 minutes and he was notified by Galić, personally, meaning that the "remarks and instructions" from the Accused were being directly carried out. See Adrianus van Baal, T. 8536 (29 October 2010).

15980 P1818 (Witness statement of Adrianus van Baal dated 26 October 2010), para. 29.

15981 P1818 (Witness statement of Adrianus van Baal dated 26 October 2010), para. 30; Adrianus van Baal, T. 8536 (28 October 2010).

15982 P1818 (Witness statement of Adrianus van Baal dated 26 October 2010), para. 76 (according to Van Baal, this was demonstrated by a conversation he had with the Accused wherein the Accused promised him that he would contact General Milovanović and order a cease-fire); P1827 (Intercept of conversation between Adrianus van Baal and Radovan Karadžić, 31 May 1994), p. 2.

15983 Hussein Abdel-Razek, T. 5529-5531, 5534, 5585-5587, 5597 (20 July 2010), T. 5611, 5615-5616, 5618-5620, 5623-5624, 5640, 5676 (21 July 2010).

15984 Hussein Abdel-Razek, T. 5676-5677 (21 July 2010). The Chamber considers that this part of Abdel-Razek's evidence given on cross-examination is inconsistent with much of his testimony on direct examination, particularly the evidence that meetings with Bosnian Serb leaders were difficult and that, on both sides, "leaders manifested cooperation; however, in reality, they acted differently and undertook different actions that were not cooperative". See P1258 (Witness statement of Hussein Ali Abdel-Razek dated 16 July 2002), e-court pp. 7, 18, 22. 
command the guns, they do it themselves". ${ }^{15986}$ Also at this meeting, the Chief of the VJ General Staff stated, "when [the Accused] was at the talks the other day, you heard him say that he did not have control over the individuals who were doing that, but that he did know that they were doing it. They fire one shell at Sarajevo and it's like they fired a thousand shells. Some people get drunk and say, 'Let's fire one.' It's very damaging for us". ${ }^{15987}$ Bulatović also expressed an opinion that the Bosnian Serb leadership did not have "full control over the command" and that it was "somewhat detached from the staff that is working and operating [in Sarajevo]". ${ }^{15988}$ Bulatović testified that the FRY political leadership advised the Accused numerous times about the detrimental impact that the shelling of Sarajevo had on the political position of the Bosnian Serbs, which the Accused had agreed with but had been unable to solve. ${ }^{15989}$ In Bulatović's opinion, the Accused lacked control over the VRS. ${ }^{15990}$

4758. As for the Accused's relationship with Mladić, Abdel-Razek thought that Mladić was "one of the few people who could stop Karadžić's negations and influence" and that he was the only one who could "refuse or accept any of Karadžić's proposals". ${ }^{15991}$ Tucker testified that he, Morillon, and the UNPROFOR staff formed an opinion that, in most cases, Mladić would do what the Accused and the Bosnian Serb Assembly directed him and the VRS to do. ${ }^{15992}$ However, if Mladić believed that he was being ordered to do something that would "endanger" the Bosnian Serbs, he did not always do as ordered. ${ }^{15993}$ Tucker also stated that although the Accused would often make promises, he needed to speak to the military to actually get things done since the Accused did not know the details of what was going on in the military. ${ }^{15994}$ Based on the observations he made at the time, Tucker thought that Mladić "pretended he was subservient to Karadžić", and that the Accused and Koljević had limited power to "actually influence and decide tactical military

\footnotetext{
15985 D3051 (Witness statement of Momir Bulatović dated 25 February 2013), para. 25; D3054 (Notes of session of Council for Coordinating Positions on State Policy, 18 August 1992), p. 89.

15986 D3051 (Witness statement of Momir Bulatović dated 25 February 2013), para. 25; D3054 (Notes of session of Council for Coordinating Positions on State Policy, 18 August 1992), pp. 10-11; Momir Bulatović, T. 3452534526 (28 February 2013).

15987 D3054 (Notes of session of Council for Coordinating Positions on State Policy, 18 August 1992), p. 89.

15988 D3051 (Witness statement of Momir Bulatović dated 25 February 2013), para. 26; D3054 (Notes of session of Council for Coordinating Positions on State Policy, 18 August 1992), p. 89; Momir Bulatović, T. 34560-34561 (1 March 2013).

15989 D3051 (Witness statement of Momir Bulatović dated 25 February 2013), paras. 29-30; D3055 (Record of 6th session of FRY's SDC, 9 December), p. 24-25 (wherein, in relation to events in Sarajevo, Dobrica Ćosić, President of the FRY, commented, “[h]ow many times have we advised [the Accused] about Sarajevo?").

15990 D3051 (Witness statement of Momir Bulatović dated 25 February 2013), paras. 29-30.

15991 P1258 (Witness statement of Hussein Ali Abdel-Razek dated 16 July 2002), e-court p. 12. See also D3695 (Witness statement of Bogdan Subotić dated 16 June 2013), para. 115 (testifying that Mladić would belittle the Accused and other members of the RS Government).

15992 Pyers Tucker, T. 23225-23226 (18 January 2012).

15993 Pyers Tucker, T. 23226 (18 January 2012); P4203 (Witness statement of Pyers Tucker dated 12 May 2010), para. 277.
} 
events". 15995 However, after being shown a number of VRS orders and documents showing the involvement of the Accused in military matters, Tucker stated that the Accused's involvement with military planning and co-ordination was much greater than either he or Morillon believed at the time. ${ }^{15996}$ Tucker also explained that the Accused's level of knowledge of military detail was greater for Sarajevo than other parts of $\mathrm{BiH} .{ }^{15997}$

4759. Tucker gave two specific examples where Mladić seemed to be acting independently of the Accused. The first was the co-ordinated military attack on Sarajevo by the SRK, ${ }^{15998}$ which took place while the Accused was at peace talks in Geneva on 31 October 1992 and surprised the Bosnian Muslims side; Tucker thought that the attack appeared to be a military initiative on the part of Mladić and that it was no coincidence that it happened while the Accused was away. ${ }^{15999}$ It was Morillon's view that the Accused was unlikely to have approved a military attack while in Geneva. ${ }^{16000}$ Tucker believed that the attack was a message from Mladić and possibly "hardliners in the civilian leadership (e.g. Krajišnik)" that the international community had no real power to influence events in $\mathrm{BiH}^{16001}$

4760. The second was a meeting on 15 November 1992, attended by Morillon and Mladić in Lukavica, during which Mladić spoke as if he, and he alone, had the ability to make decisions and implement them and "barely made any effort to conceal the fact that nothing could or would happen in Bosnian Serb held territory without his specific approval”; according to Tucker, it was "very apparent that he made all the practical military decisions that mattered". ${ }^{16002}$ Tucker also

\footnotetext{
15994 P4203 (Witness statement of Pyers Tucker dated 12 May 2010), paras. 278, 280.

15995 P4203 (Witness statement of Pyers Tucker dated 12 May 2010), paras. 277-285; Pyers Tucker, T. 23224-23226 (18 January 2012).

15996 P4203 (Witness statement of Pyers Tucker dated 12 May 2010), paras. 285; P976 (Directive 4, 19 November 1992); P3037 (VRS Main Staff Order, 20 November 1992); P4248 (Timetable for Military-Political Conference in the Drina Corps, 23 November 1992); P2085 (Order of Drina Corps, 24 November 1992); P4924 (Amendment to Directive 4, 25 November 1992).

15997 P4203 (Witness statement of Pyers Tucker dated 12 May 2010), paras. 69, 281; P4216 (UNPROFOR report re meeting with Radovan Karadžić, 20 November 1992), para. 7.

15998 See paras. 3562.

15999 P4203 (Witness statement of Pyers Tucker dated 12 May 2010), paras. 37, 47.

16000 P4203 (Witness statement of Pyers Tucker dated 12 May 2010), para. 48.

16001 P4203 (Witness statement of Pyers Tucker dated 12 May 2010), para. 47.

16002 P4203 (Witness statement of Pyers Tucker dated 12 May 2010), paras. 56, 59; P4214 (UNPROFOR report, 15 November 1992), para. 21. However, Tucker testified that soon after, following a meeting on 20 November 1992 between Morillon and Accused, it became obvious that Mladić deferred to the Accused who had just come back from Geneva and that "in comparison with Mladić's bombastic behaviour at the meeting on 15 November, at this meeting Mladić is 'back in his box'." See P4203 (Witness statement of Pyers Tucker dated 12 May 2010), paras. 64-69; P4216 (UNPROFOR report re meeting with Radovan Karadžić, 20 November 1992); Pyers Tucker, T. $23226-23235$ (18 January 2012). Further, on 27 November, Morillon reported that the meeting he had with the Accused and Mladić on that day confirmed a moderately healthy military/political relationship between the two men. See D539 (UNPROFOR report re meeting with Radovan Karadžić and Ratko Mladić, 27 November 1992), para. 11(b); P4203 (Witness statement of Pyers Tucker dated 12 May 2010), para. 72.
} 
noticed inconsistencies in Mladić's own position, recalling that in one meeting Mladić stated he would defer to the Bosnian Serb Assembly, but in another meeting he spoke as if he alone had the ability to implement decisions, and then at a follow-up meeting, he deferred to the Accused. ${ }^{16003}$

4761. On 8 December 1994, Andreev and Banbury met with Koljević in Pale. ${ }^{16004}$ During the meeting Koljević conceded that "matters had gone too far and that the behaviour of the [VRS] needed to be fixed". ${ }^{16005}$ The meeting involved a serious discussion about UNPROFOR withdrawing due to unacceptable curtailment of freedom of movement, theft of property, and restrictions on re-supply, ${ }^{16006}$ and Banbury testified that is was unclear whether Koljević's remarks were genuine or whether it was a means of "shifting the blame". 16007 Following the meeting, Banbury drafted a report to Akashi, noting that there appeared to be a serious split between the political and military leadership of the Bosnian Serbs, with the former advocating a more cooperative approach in the face of resistance from the latter. ${ }^{16008}$ However, at a meeting of 12 December 1994, Krajišnik, Koljević, Gvero, and Tolimir protested against this report and denied the existence of any such a split. ${ }^{16009}$ Banbury thought that, if there was a split, it was a split on a policy level, which is usual in any institution, and there was nothing to suggest that there was a change or split in the chain of command. ${ }^{16010}$

4762. Galić testified that there was a parallel or dual command structure, where it was possible to receive orders both from the Accused, as the Supreme Commander, and from Mladic as the commander of the Main Staff, which led to confusion as to who actually commanded the VRS. ${ }^{16011}$ However, Galić did not remember a single occasion when a direct order came to him from the Supreme Commander as it would usually go through the Main Staff. ${ }^{16012}$ Had he received conflicting orders from the Accused and from Mladić, he would have followed the order of his

\footnotetext{
16003 P4203 (Witness statement of Pyers Tucker dated 12 May 2010), paras. 64-69; P4216 (UNPROFOR report re meeting with Radovan Karadžić, 20 November 1992); Pyers Tucker, T. 23226-23235 (18 January 2012).

16004 P2451 (Witness statement of Anthony Banbury dated 19 May 2009), para. 76; P2474 (UNPROFOR report, 8 December 1994).

16005 P2451 (Witness statement of Anthony Banbury dated 19 May 2009), para. 77.

16006 P2474 (UNPROFOR report, 8 December 1994), para. 3.

16007 P2451 (Witness statement of Anthony Banbury dated 19 May 2009), para. 77.

16008 P2451 (Witness statement of Anthony Banbury dated 19 May 2009), para. 76; P2474 (UNPROFOR report, 8 December 1994), para. 5. See also P2261 (UNPROFOR report re meetings with Bosnian Serb and Bosnian Muslim leadership, 22 April 1995), para. 8 (reporting that "cracks between the politicians and the military were very clear”); Rupert Smith, T. 11347-11350 (8 February 2011).

16009 P2451 (Witness statement of Anthony Banbury dated 19 May 2009), para. 80; P2476 (UNPROFOR report, 13 December 1994), para. 9.

16010 P2451 (Witness statement of Anthony Banbury dated 19 May 2009), para. 82.

16011 Stanislav Galić, T. 37593-37595 (23 April 2013).

16012 Stanislav Galić, T. 37596-37597, 37602-37603 (23 April 2013). See also Manojlo Milovanović, T. 25470 (28 February 2012) (testifying that the Supreme Command did not frequently bypass the Main Staff).
} 
immediate superior, Mladić. ${ }^{16013}$ Dragomir Milošević testified that the relationship between the Accused and Mladić was "detrimental" and he blamed Mladić for wanting to be dominant in all situations without respecting authority. ${ }^{16014}$ However, like Galić, Milošević did not have specific personal knowledge of Mladić being defiant against the Accused; it was the general impression he had. $^{16015}$

4763. As discussed earlier in the Judgement, many Defence witnesses, including SRK soldiers and officers, testified that the relationship between the Accused and Mladić was strained. ${ }^{16016}$ When Kovač met with Mladić in May 1992, they disagreed over the passage of convoys transporting civilians out of Sarajevo, with Kovač allowing the convoys and Mladić preventing them from departing. ${ }^{16017}$ The Accused settled the dispute by allowing the convoys to leave Sarajevo. ${ }^{16018}$ According to Kovač, as the war progressed, tensions between the civilian and military authorities increased and a particularly noticeable disagreement concerned the number of VRS soldiers deployed around Sarajevo as compared to Srebrenica and Žepa; Kovač thought the Main Staff was "depriving" units of the SRK, suspending delivery of ammunition, in an attempt to make Sarajevo fall. ${ }^{16019}$ The Chamber has analysed these tensions earlier in the Judgement and made findings thereon. ${ }^{16020}$

\section{(D) Accused's orders relevant to Sarajevo}

4764. The fact that the chain of command between the Accused and the SRK operated as intended and that the Accused was directly involved in Sarajevo-related military operations is confirmed by the evidence that the Accused issued orders directly relevant to the SRK and the Sarajevo

\footnotetext{
16013 Stanislav Galić, T. 37596, 37606 (23 April 2013).

16014 Dragomir Milošević, T. 32886-32887, 32902-32905 (30 January 2013). See also Dragomir Milošević, T. 32887-32891 (30 January 2013) (discussing the Accused's attempt to remove Mladić from his command); D2159 (Letter from VRS Main Staff to RS National Assembly, 5-6 August 1995) (order by the Accused to relieve Mladić of his command which was unanimously disagreed with by the VRS Generals); D2843 (Telegram from VRS Main Staff, 8 August 1995).

16015 Dragomir Milošević, T. 32905-32907 (30 January 2013), T. 33088-33089 (4 February 2013).

16016 See D2686 (Witness statement of Mihajlo Vujasin dated 16 December 2012), para. 62; D2562 (Witness statement of Vladimir Radojčić dated 8 December 2012), para. 67; D3695 (Witness statement of Bogdan Subotić dated 16 June 2013), paras. 112-115. See also para. 3140.

16017 D3960 (Witness Statement of Tomislav Kovač dated 28 October 2013), para. 91.

16018 D3960 (Witness Statement of Tomislav Kovač dated 28 October 2013), para. 91.

16019 D3960 (Witness Statement of Tomislav Kovač dated 28 October 2013), para. 97.

16020 See paras. 3113-3114.
} 
battlefield. ${ }^{16021}$ For example, as outlined above, the Accused issued Directives 6 and 7, as well as the supplement to Directive 6, all of which concerned Sarajevo. ${ }^{16022}$

4765. On 20 May 1992, the Accused issued an order to the Main Staff, MUP, and Ministry of Defence to establish a military police company within the SRK. ${ }^{16023}$ Similarly, on 2 June 1992, the Accused issued an order to send two platoons of special forces from Crepoljsko to Nedžarići to be placed under the command of the SRK where they were to report to Kovač. ${ }^{16024} \mathrm{He}$ also ordered that the "Presidency as the Supreme Command" be informed of the execution of this task. ${ }^{16025}$ [REDACTED] the Accused had an interest in Nedžarići as it was an important part of the frontline. ${ }^{16026}$

4766. On 9 October 1992, the RS Presidency held a session in which it decided to halt the bombing of Sarajevo and do so through the Main Staff. ${ }^{16027}$ Thus, on 10 October 1992, Galić issued an urgent order to all SRK units to stop firing on Sarajevo as of 3 p.m. that day, instructing them to open fire only in case of "great necessity", and not before given permission from him or his deputy. ${ }^{16028}$

4767. On 15 July 1993, pursuant to an order from the Accused, Milovanović ordered the SRK Command to immediately take all measures, through the subordinate units, to release water and gas to Sarajevo and enable repairs of the electrical system. ${ }^{16029}$ He also banned units from opening fire at the centre of the city, except "in defence of VRS positions", because "unnecessary and uncontrolled opening of fire at Sarajevo greatly damages the RS". ${ }^{6030}$ On the same day, Dragomir Milošević issued an order to all units of the SRK that they were "forbidden to fire on Sarajevo proper, unless defending VRS positions". ${ }^{16031}$ He also ordered that water, gas, and electricity be

16021 See P3033 (Reynaud Theunens's expert report entitled "Radovan Karadžić and the SRBiH TO-VRS (19921995)"), e-court pp. 27-28.

16022 See para. 4671. Following the issuance of the supplement to Directive 6, the Main Staff issued an order on 14 December 1993. P4925 (Supplement to Directive 6, 12 December 1993), para. 2(a); P3052 (VRS Main Staff Order, 14 December 1993). See also Dragomir Milošević, T. 33093-33099 (4 February 2013). The Accused also examined and approved the other five directives issued by the Main Staff, as discussed in paras. 31523156. See, e.g., P1479 (Ratko Mladić's notebook, 16 July-9 September 1992), p. 24 (a meeting between Accused, Mladić, Krajišnik, and Koljević, where they approved Directive 3).

16023 P2645 (Radovan Karadžić's order to VRS Main Staff, MUP, and Ministry of Defence, 20 May 1992).

16024 P1503 (Radovan Karadžić’s Order re Nedžarići, 1 July 1992); [REDACTED].

16025 P1503 (Radovan Karadžić's Order re Nedžarići, 1 July 1992); [REDACTED].

16026 [REDACTED].

16027 D431 (Minutes of RS Presidency session, 9 October 1992), p. 2.

16028 P1264 (SRK Order, 10 October 1992); Hussein Abdel-Razek, T. 5507-5508 (19 July 2010).

16029 P5058 (Order of the VRS to SRK, 15 July 1993).

16030 P5058 (Order of the VRS to SRK, 15 July 1993).

16031 P836 (SRK Order, 15 July 1993); David Harland, T. 2243-2245 (10 May 2010); Miladin Trifunović, T. 3038830389 (15 November 2012). 
provided to Sarajevo and stated that the "unnecessary and uncontrolled firing on Sarajevo is causing great harm to the RS". ${ }^{16032}$ On 23 July 1993, Milošević urgently informed Galić that the Accused had ordered, through the Main Staff, that the SRK "immediately provide water, electricity and gas supplies" to Sarajevo. ${ }^{16033}$

4768. Following another round of peace talks in Geneva and a cessation of hostilities agreement signed at the Sarajevo airport between Mladić and Delić, ${ }^{16034}$ on 30 July 1993, pursuant to consultations with the Accused, Mladić gave an order to cease fire on all frontlines effective on the same day at 12 p.m. ${ }^{16035}$

4769. On 26 September 1993, pursuant to an order of the Accused, Milovanović issued an order to the SRK and Drina Corps commands stating that approval has been given for the transport of "Muslim deputies and other persons from Srebrenica, Žepa, and Goražde" organised by UNPROFOR. ${ }^{16036}$ The SRK and Drina Corps Commands would be notified by telephone as to the time of the opening and closing of the corridor. ${ }^{16037}$ Milovanović noted that the order "shall be taken very seriously due to the political consequences it might have for [RS]" and the SRK and Drina Corps Commanders were personally responsible to him for implementing the order. ${ }^{16038}$

4770. On 16 January 1994, the Accused issued an order to the VRS in which he strictly prohibited any combat operations in the direction of the Sarajevo airport and against any positions of UNPROFOR, UNHCR, and other international organisations; allowed full protection and freedom of movement for their vehicles and convoys with necessary checks; and instructed that all contentious issues in relation to UNPROFOR and military observers must be processed exclusively by the Corps Commands and Main Staff. ${ }^{16039}$ He stated that given the attitude of international factors towards the war existing at the time, particularly during the talks in Geneva, it was necessary to prevent unwanted incidents with the international organisations. ${ }^{16040}$

\footnotetext{
16032 P836 (SRK Order, 15 July 1993).

16033 P2666 (Radovan Karadžić's order to SRK, 23 July 1993).

16034 See para. 378.

16035 D4507 (Summary of intercepted conversation between Milan Gvero and Radovan Karadžić, 30 July 1993).

16036 P5066 (VRS Main Staff Order, 26 September 1993).

16037 P5066 (VRS Main Staff Order, 26 September 1993), p. 1.

16038 P5066 (VRS Main Staff Order, 26 September 1993), p. 2.

16039 D4443 (Radovan Karadžić's Order, 16 January 1994).

16040 D4443 (Radovan Karadžić's Order, 16 January 1994).
} 
4771. On 13 March 1994, the Accused issued an order to the Main Staff instructing that the VRS was to exercise "maximum restraint" during Bajram, not respond to $\mathrm{ABiH}$ provocation, and to ensure that convoys safely arrive at their destinations. ${ }^{16041}$

4772. On 23 July 1994, pursuant to an oral order from the Accused, Milovanović issued an order to the SRK Commander to carry out all necessary preparations for the closure of the Blue Route across Sarajevo airport, "in order to prevent the transit of the Muslims- civilians and motor vehicles from Sarajevo and into Sarajevo" and to prevent the movement of UNPROFOR and humanitarian organisations towards Igman and Lukavica. ${ }^{16042}$

4773. On 19 August 1994, the Accused informed the Main Staff that two platoons of UNPROFOR soldiers and a medical unit would be travelling from Sarajevo through Pale and he approved this travel. ${ }^{16043}$ Accordingly, he ordered that these units be escorted from Pale to Kopaći and to treat them politely. ${ }^{16044}$ In another order relating to the treatment of UN representatives, on 25 August 1994, the Accused ordered the Main Staff to issue an order to the commander of the Ilidža Brigade to return radio communication equipment seized from a UNHCR radio technician. ${ }^{16045}$

4774. At one point during the conflict, the Accused ordered the Main Staff to secure the perimeter and building of the "Pretis-Holding, TAS, UTL, and Energetika" Factories in Vogošća, to ensure safe passage and constant control of the "Sumbulovac-Visojevica-Srednje-Vogošća" road, and to report to him on the results within 48 hours. ${ }^{16046}$

4775. The Accused also issued orders directly to the SRK. For example, on 1 November 1992, the SRK Command issued an order to its units, relaying an order from the Accused regulating the procedures for safe passage for ICRC delegates and vehicles authorised to visit prisons, military camps, and police stations. ${ }^{16047}$

4776. As mentioned earlier, on 7 February 1994, following the incident in Markale market on 5 February, the Accused issued an order to the Main Staff, SRK Commander, and commanders of the SRK brigades stating that there was evidence that the VRS was not responding in equal

\footnotetext{
16041 D4610 (Radovan Karadžić's Order, 13 March 1994).

16042 P1639 (SRK Order, 23 July 1994); Michael Rose, T. 7259 (5 October 2010) (confirming that this matched the situation as he observed on the ground).

16043 D4611 (Radovan Karadžić's Order, 19 April 1994).

16044 D4611 (Radovan Karadžić's Order, 19 April 1994).

16045 D4829 (Radovan Karadžić's Order, 25 August 1994).

16046 P5036 (Radovan Karadžić’s Order, undated).
} 
measure to the $\mathrm{ABiH}$ artillery but were responding, "sometimes twenty or thirty, or even seventy times more". ${ }^{16048}$ He therefore ordered to:

(1) Introduce the strictest possible control of retaliation to provocation, respond only when we are threatened and when there is full military justification, respond only against military targets and strictly at the commander's commands and respond in equal measure to the provocation in the 1:1 (one to one) ratio.

(2) Exclude any possibility of uncontrolled shelling. Keep the behaviour under control and sanction offences, urgently and in the strictest manner in keeping with the law.

(3) The Corps Commanders shall answer directly to me for acts of the Corps, while brigade commanders shall answer for the acts of the brigades.

(4) I am to be informed immediately about every incident. ${ }^{16049}$

Milovanović testified that he implemented this order. ${ }^{16050}$ He also testified that the Accused addressed the order to SRK Commander and SRK brigades because he wanted the order to reach them as soon as possible but also did not want to bypass the Main Staff order; to Milovanović this was an example of the Accused exercising his command and control as Supreme Commander and making the SRK Commander and brigade commanders directly answerable to the Accused. ${ }^{16051}$ As discussed above, there was a period of relative calm in Sarajevo following this order. ${ }^{16052}$ On 15 February 1994, at a meeting involving the Accused, Mladić, Krajišnik, Koljević, and Milovanović, Milovanović reported that he had agreed to a cease-fire and the placing of artillery under UNPROFOR, but had not signed anything yet. ${ }^{16053}$ Krajišnik expressed concern that nothing had been signed and stated that the Supreme Command must respond to the NATO ultimatum. ${ }^{16054}$ The Accused instructed that "three to four artillery positions must be secured at brigade level" and that "[c]oncealment and relocation must be carried out". 16055 In relation to UNPROFOR, the Accused stated that the Bosnian Serbs should not "say no"; instead, they should say "yes, but" as this is what good diplomats do. ${ }^{16056}$

\footnotetext{
16047 D4739 (Letter from Radovan Karadžić to all local civilian and police authorities, 31 October 1992); D4740 (SRK Command procedure for ICRC personnel and vehicles signed by Radovan Karadžić, 1 November 1992).

16048 P846 (Radovan Karadžić's Order to VRS, 7 February 1994); P820 (Witness statement of David Harland dated 4 September 2009), paras. 77-78; Reynaud Theunens, T. 16891-16893 (19 July 2011).

16049 P846 (Radovan Karadžić's Order to VRS, 7 February 1994); Manojlo Milovanović, T. 25475, $25477-25478$ (29 February 2012).

16050 Manojlo Milovanović, T. 25475-25477 (29 February 2012); P4493 (VRS Main Staff Order, 7 February 1994).

16051 Manojlo Milovanović, T. 25477-25478 (29 February 2012). See also P3033 (Reynaud Theunens's expert report entitled "Radovan Karadžić and the SRBiH TO-VRS (1992-1995)"), e-court p. 28.

16052 See paras. 386-390, 3582-3587.

16053 P1485 (Ratko Mladić's notebook, 9 January-21 March 1994), pp. 105-106.

16054 P1485 (Ratko Mladić's notebook, 9 January-21 March 1994), p. 106.

16055 P1485 (Ratko Mladić's notebook, 9 January-21 March 1994), p. 108.

16056 P1485 (Ratko Mladić’s notebook, 9 January-21 March 1994), p. 109.
} 
4777. On 19 March 1994, the Accused informed the Main Staff (Mladić personally) and the SRK Command (Galić personally) that he had given permission for a football match to be played between an UNPROFOR team and a local Sarajevo team on 20 March 1994. ${ }^{16057}$ He stated: "it is necessary to prevent the Serbian side from provoking an incident at all costs, as this might bring condemnation from the whole world". ${ }^{16058} \mathrm{He}$ also stated that the "further normalisation of life in Sarajevo is in our interest, all the more so because it does not cost us anything in terms of territory". ${ }^{16059}$ He instructed Mladić and Galić to inform all the brigades in the area that they must absolutely comply with this order. ${ }^{16060}$ Rose testified that this match did indeed go on without incident. $^{16061}$

4778. On 2 March 1995, a report from the SRK Colonel Luka Dragičević was sent to all SRK units, raising issues about the leadership of the VRS and Main Staff, and criticising the Accused. ${ }^{16062}$ On 9 March 1995, the Accused ordered the SRK Command to urgently send him a copy of that report and information on who sent it to the SRK Command, the identity of its author, and its intended recipients. ${ }^{16063}$

4779. Finally, at some point during the war, the Accused issued a message to the SRK stating that the "shelling of civilian targets is a war crime, which is chastised with the toughest punishment, and the enemy wishes to brush those crimes off on you". ${ }^{16064}$ He continued by stating that "we are a disciplined army" and it was not in their interest to provoke military intervention and risk losing their state. ${ }^{16065}$ He asked the SRK to keep vigil of the enemies and keep an eye out for "traitors"

\footnotetext{
16057 P1643 (Letter from Radovan Karadžić to Ratko Mladić and Stanislav Galić, 19 March 1994); P1638 (Witness statement of Michael Rose dated 26 March 2009), para. 64; Michael Rose, T. 7264-7266 (5 October 2010).

16058 P1643 (Letter from Radovan Karadžić to Ratko Mladić and Stanislav Galić, 19 March 1994); P1638 (Witness statement of Michael Rose dated 26 March 2009), para. 64; Michael Rose, T. 7264-7266 (5 October 2010).

16059 P1643 (Letter from Radovan Karadžić to Ratko Mladić and Stanislav Galić, 19 March 1994).

16060 P1643 (Letter from Radovan Karadžić to Ratko Mladić and Stanislav Galić, 19 March 1994); P1638 (Witness statement of Michael Rose dated 26 March 2009), para. 64; Michael Rose, T. 7264-7266 (5 October 2010).

16061 Michael Rose, T. 7264-7266 (5 October 2010); P1638 (Witness statement of Michael Rose dated 26 March 2009), para. 64.

16062 P2691 (SRK report, 2 March 1995); Luka Dragičević, T. 31435-31436 (13 December 2012).

16063 P2679 (Radovan Karadžić's order to SRK, 9 March 1995). Dragomir Milošević submitted an urgent report to the Accused stating that Dragičević's report was "made in a hurry" and that the core members of the SRK Command have not discussed it and he was not even aware of its contents. Milošević stated that it was agreed that the "Main Staff commander would get in touch with you and ask you not to subject the contents of the report to a separate discussion". See P2680 (SRK report to Radovan Karadžić, 10 March 1995); P2681 (SRK report, 10 March 1995).

16064 D314 (Radovan Karadžić's letter to SRK, undated). The document is undated and contains no stamp. While the Accused attempted, during Guzina's testimony, to make a connection between D314 and the follow up order of the SRK Command of 15 May 1993 (D2561), Guzina was unclear as to the alleged connection and thus as to the date of D314. See Svetozar Guzina, T. 31195-31197 (11 December 2012); D2561 (SRK Order, 15 May 1993). As such, this order has little probative value.

16065 D314 (Radovan Karadžić's letter to SRK, undated).
} 
who would fire mortars without command or permission; everyone was obliged to prevent "such a traitor from doing so, and to bring him to justice". 16066

4780. In addition to all of the above orders, the evidence also shows that the Accused issued oral orders and instructions in meetings and telephone conversations that were directly relevant to the military activities in Sarajevo. For example, on 31 May 1992, Mladić met with the Accused and other members of the Bosnian Serb political leadership. ${ }^{1607}$ In the meeting, the Accused gave a briefing on the negotiations in Lisbon and Belgrade and reported that Cutileiro had asked him to halt operations around Sarajevo and to leave the airport. ${ }^{16068}$ The Accused then stated, "[w]e have to issue decisions", including decisions to "determine comprehensible borders" and make the police and army "capable for some tasks". ${ }^{16069}$ The meeting concluded with the Accused stating that they needed to talk about Sarajevo and they must have a "part of Sarajevo". 16070

4781. On 5 June 1992, the Accused met with Mladić, Koljević, Plavšić, Krajišnik, and Đerić and instructed the attendees to "clean up" Butmir, Hrasnica, Dobrinja, Sokolović Kolonija, and Hrasno. ${ }^{16071}$ As discussed earlier, the SRK forces launched an attack on Sarajevo later that evening, which was indiscriminate and disproportionate, lasting three days and causing a number of civilian casualties. ${ }^{16072}$ On 15 June 1992, at a meeting between Mladić, the Accused, other members of the RS Presidency, and representatives from the Sarajevo municipalities, Koljević raised the problem of the Sarajevo airport which could not be solved "until the road to Ilidža and Nedžarići is sorted out" and urged the others to "treat Dobrinja as our territory into which [Bosnian Muslim] snipers and terrorists have infiltrated". ${ }^{16073}$ To this the Accused responded that the issue of Dobrinja must be resolved through co-operation with the police. ${ }^{16074}$ Prstojević provided an update on the situation in Ilidža, stating that the $\mathrm{ABiH}$ had around 6,500 soldiers in the area and that if the Bosnian Serbs surrendered the airport, "Ilidža would be cut off". ${ }^{1675}$ He thus requested the deployment of soldiers to Dobrinja to carry out an operation. ${ }^{16076}$ The meeting then concluded with the decision to "clear the Serbian territory", giving priority to Mojmilo and Dobrinja. ${ }^{16077}$

\footnotetext{
16066 D314 (Radovan Karadžić's letter to SRK, undated).

16067 P1478 (Ratko Mladić's notebook, 27 May-31 July 1992), pp. 36, 38.

16068 P1478 (Ratko Mladić's notebook, 27 May-31 July 1992), pp. 38-39.

16069 P1478 (Ratko Mladić's notebook, 27 May-31 July 1992), p. 40.

16070 P1478 (Ratko Mladić's notebook, 27 May-31 July 1992), p. 42.

16071 P1478 (Ratko Mladić's notebook, 27 May-31 July 1992), p. 93.

16072 See discussion in relation to Scheduled Incident G.2.

16073 P1478 (Ratko Mladić's notebook, 27 May-31 July 1992), pp. 166-167.

16074 P1478 (Ratko Mladić's notebook, 27 May-31 July 1992), p. 169.

16075 P1478 (Ratko Mladić's notebook, 27 May-31 July 1992), p. 170.

16076 P1478 (Ratko Mladić's notebook, 27 May-31 July 1992), p. 170.

16077 P1478 (Ratko Mladić's notebook, 27 May-31 July 1992), pp. 171-172.
} 
Following the protests by the Secretary General about the Bosnian Serb forces shelling civilian areas in Dobrinja and his calls for the shelling to cease immediately, ${ }^{16078}$ at a meeting on 27 June 1992 with Mladić, Koljević, and Plavšić, among others, Krajišnik stated that the Presidency was "walking on the edge of the abyss" and that operations against Dobrinja "must really stop". 16079 That day, the Accused issued an order to the Main Staff to cease all operations in Dobrinja immediately and warned that disregarding the order would have "political consequences". 16080

4782. On 21 July 1992, in a meeting between Mladić, the Accused, and other VRS officers, the Accused informed Mladić about the 14-day cease-fire agreement and said that all heavy weapons must be presented to UNPROFOR for inspection, that refugees be allowed to return to their homes, and that people moving from the "zones of operations" be allowed to go wherever they want. ${ }^{16081}$ Then, on 29 August 1992, at a meeting with Mladić, the Accused ordered that within 96 hours, UNPROFOR must be given information about heavy weaponry in the territory of Sarajevo excluding warehoused items. ${ }^{16082}$ He ordered that within seven days, heavy weapons around Sarajevo should be grouped. ${ }^{16083}$ He further ordered Mladić to "preserve the positions around Sarajevo" and to strengthen those positions by transferring 5,000 to 6,000 soldiers from the Bosnian Krajina. ${ }^{16084}$ Mladić warned the Accused about how to mobilise this many soldiers, to which the Accused responded: "With the police, forcibly". ${ }^{16085}$

4783. On 19 October 1992, at a meeting with Mladić, Plavšić, Krajišnik, Đerić, Gvero, Dukić, and Tolimir, the Accused reported on the negotiations in Geneva; he stated that the question of Sarajevo "dominated the conference" and that the Bosnian Serbs should ensure that Sarajevo survives the winter because the Bosnian Muslims wanted to create an image of a "drastic and horrible" situation in Sarajevo. ${ }^{16086}$ Towards the end of the meeting, the Accused stated that he was "convinced $101 \%$ that [NATO] will bomb" and that accordingly it was crucial not to fire on Sarajevo. ${ }^{16087}$

\footnotetext{
16078 P1523 (UNSG's statement to UNSC, 26 June 1992); KDZ088, T. 6662-6663 (13 September 2010) (closed session).

16079 P1478 (Ratko Mladić's notebook, 27 May-31 July 1992), p. 240.

16080 P1504 (Minutes of $12^{\text {th }}$ session of SerBiH Presidency, 27 June 1992), para. 3; P1154 (Witness statement of KDZ088 dated 27-29 April 2010), paras. 69-70 (under seal); P1478 (Ratko Mladić's notebook, 27 May-31 July 1992), p. 240 (stating that the Presidency had sent a letter to the Secretary General informing him that operations against Dobrinja had ceased); D2977 (Letter from Radovan Karadžić to Jose Cutileiro and others, 27 June 1992); D2968 (Witness statement of Jose Cutileiro dated 11 April 2012), para. 30.

16081 P1478 (Ratko Mladić's notebook, 27 May-31 July 1992), pp. 358-359.

16082 P1479 (Ratko Mladić's notebook, 16 July-9 September 1992), pp. 107-108.

16083 P1479 (Ratko Mladić's notebook, 16 July-9 September 1992), p. 108.

16084 P1479 (Ratko Mladić's notebook, 16 July-9 September 1992), p. 109.

16085 P1479 (Ratko Mladić's notebook, 16 July-9 September 1992), p. 109.

16086 P1481 (Ratko Mladić's notebook, 5 October-27 December 1992), pp. 48-50.

16087 P1481 (Ratko Mladić's notebook, 5 October-27 December 1992), p. 59.
} 
4784. On 20 December 1992, at a meeting of the Supreme Command, attended by Mladić, Koljević, Krajišnik, Lukić, Bogdan Subotić, and Milovanović, the Accused stated that the Bosnian Serbs were supposed to end the war in Sarajevo, but that the enemy was "on the rise" and was "conducting a big offensive". ${ }^{16088}$ The tasks agreed upon at the conclusion of the meeting included reorganising the army and border units and coming up with a co-ordinated plan with the Ministry of Defence to fulfil the needs of the army. ${ }^{16089}$

4785. On 21 February 1993, in a telephone conversation, the Accused instructed two SRK soldiers to "see to it that Izetbegović's declaration of a one-sided cease-fire be sent to us, Morillon and others have requested that [...] I am asking you that we don't fire anywhere except [...]" and was interrupted by Matišić who informed the Accused that they had received, two hours earlier, an order from Milovanović to carry on doing what has been planned regardless of the cease-fire. ${ }^{16090}$ The Accused responded, "absolutely, that's all right, but there is something that has to be done". 16091 The Accused informed them that "we think that shells should not be falling here on the city for no reason" and ordered them to "strictly forbid shelling in the city, except where operations have been planned and where they are in progress". 16092

4786. On 2 May 1993, in a telephone conversation, the Accused ordered Gvero to "call UNPROFOR to all gas stations to check that the Serbs are keeping this open" and that "nowhere around Sarajevo, there must be nothing firing anywhere". ${ }^{1693}$ The Accused said that no one from the VRS was allowed to give any more statements, and ordered the preparation of anti-aircraft defence in case of NATO intervention. ${ }^{16094}$ On the same day, the Accused ordered Milovanović to allow UNPROFOR to access Mt. Bjelašnica. ${ }^{16095}$

4787. On 2 June 1993, in another telephone conversation, the Accused ordered Gvero to contact those units responsible for targeting a pontoon bridge stating that they had damaged the good image of the VRS. ${ }^{16096}$ In relation to information that the "Zetra" area in Sarajevo had been hit by

\footnotetext{
16088 P1481 (Ratko Mladić's notebook, 5 October-27 December 1992), pp. 335, 339-340.

16089 P1481 (Ratko Mladić's notebook, 5 October-27 December 1992), p. 349.

16090 D4510 (Intercept of conversation between Radovan Karadžić and Matišić, 21 February 1993).

16091 D4510 (Intercept of conversation between Radovan Karadžić and Matišić, 21 February 1993).

16092 D4510 (Intercept of conversation between Radovan Karadžić and Matišić, 21 February 1993).

16093 D4512 (Intercept of conversation between Milan Gvero and Radovan Karadžić, 2 May 1993), p. 1.

16094 D4512 (Intercept of conversation between Milan Gvero and Radovan Karadžić, 2 May 1993), p. 2.

16095 D4513 (Intercept of conversation between Radovan Karadžić and unidentified general, 2 May 1993). See also P5660 (Intercept of conversation between Ratko Mladić and Momčilo Mandić, 25 May 1992) (in which Mandić tells Mladić that the Accused has requested to "arrange this thing over the airport" but Mladić reminds Mandić that they are not supposed to arrange anything over the phone but are supposed to meet instead).

16096 D4511 (Intercept of conversation between Milan Gvero and Radovan Karadžić, 2 June 1993).
} 
mortars, the Accused ordered Gvero to contact Briquemont and inform him that it was not the VRS. ${ }^{16097}$

4788. On 30 July 1993, in another telephone conversation between the Accused and Gvero, the Accused insisted on arresting and initiating criminal proceedings against the individuals who were responsible for firing on the UNPROFOR units in Sarajevo and also wanted to release a public statement to this effect. ${ }^{16098}$

4789. On 2 August 1993, also in a telephone conversation, the Accused ordered Gvero to "release immediately gas, electricity and water" to Sarajevo and "do everything that is in our power" as this was important for the Bosnian Serbs and the negotiations that day. ${ }^{16099}$

4790. On 3 August 1993, Milovanović called the Accused and reported that there was firing around Sarajevo and it came from the ABiH. ${ }^{16100}$ The Accused ordered Milovanović to take UNPROFOR observers to the SRK positions in Sarajevo so that UNPROFOR "can confirm who is attacking". ${ }^{16101}$ He also ordered Milovanović to inform Mladić to be cautious and not fall for the $\mathrm{ABiH}$ provocation because one wrong move and Mladić might "wreck the entire country, the entire nation" and that the "conference will fail, to our detriment". ${ }^{16102}$ The following day, in another telephone conversation, the Accused told Milovanović that he was looking for Mladić and that Mladić needed to call him. ${ }^{16103}$ The Accused was upset about the shelling of Mt. Igman and the "fallout" between UNPROFOR and Mladić. ${ }^{16104}$ The Accused stated, "if I give him some orders, he has to carry it out. He has the right to say that it's not useful and that it's damaging, but if I later make a decision, has to carry that out to the end". ${ }^{16105}$ Also on this day, in relation to a concern that Mladić may not order the withdrawal of troops from Mt. Igman, the Accused told Milovanović: "I am the supreme commander and I am ordering; order them to withdraw and tell Mladić to report to me from the airport". 16106

\footnotetext{
16097 D4511 (Intercept of conversation between Milan Gvero and Radovan Karadžić, 2 June 1993).

16098 D4507 (Summary of intercepted conversation between Milan Gvero and Radovan Karadžić, 30 July 1993).

16099 P4796 (Intercept of conversation between Radovan Karadžić and General Gvero, 2 August 1993), p. 2.

16100 D4508 (Intercept of conversation between Radovan Karadžić and Manojlo Milovanović, 3 August 1993), p. 1.

16101 D4508 (Intercept of conversation between Radovan Karadžić and Manojlo Milovanović, 3 August 1993), p. 1.

16102 D4508 (Intercept of conversation between Radovan Karadžić and Manojlo Milovanović, 3 August 1993), p. 3. The Chamber notes this was during the ICFY conference peace talks when the Bosnian Serbs had agreed, in principle, to open the Sarajevo airport by 4 August 1993. See para. 379.

16103 D3871 (Intercept of conversation between Radovan Karadžić and Milovanović, 4 August 1993).

16104 D3871 (Intercept of conversation between Radovan Karadžić and Milovanović, 4 August 1993), p. 1.

16105 D3871 (Intercept of conversation between Radovan Karadžić and Milovanović, 4 August 1993), p. 1.

16106 P4786 (Intercept of conversation between Radovan Karadžić and General Milovanović, 4 August 1993), p. 2.
} 
4791. As discussed earlier, on 5 August 1993 at a meeting with UNPROFOR representatives, the Accused agreed to withdraw the SRK forces from Mt. Igman and on 14 August 1993, despite Mladić's protests, an agreement establishing the Mt. Igman DMZ was signed. ${ }^{16107}$ On 5 August 1993, at a meeting of the Supreme Command, including Mladić, the Accused reported that NATO had made a decision to conduct air strikes on Bosnian Serb positions. ${ }^{16108}$ He stated that, to avoid air strikes, the Bosnian Serbs should withdraw from Mt. Igman and Mt. Bjelašnica, to supply utilities to Sarajevo, allow humanitarian convoys to pass though, supply fuel to Sarajevo (for bakeries), and not to fire any shells at Sarajevo. ${ }^{16109}$ On the same day, Milovanović issued an order to the SRK Command, "on the basis of an oral command of the Supreme Commander" in an effort to respect the signed agreement about the cessation of combat actions. ${ }^{16110}$ This order outlined measures that should be taken by the SRK in terms of reporting on weapons, ammunition, and rockets in each brigade. ${ }^{16111}$ It also ordered that as of 9 August 1993, within the regular combat reports, the SRK Command will report about the "number of fired bullets, grenades, mines and rockets in units that are in direct surroundings of Sarajevo, as well as reason for firing, the name of units where it happened and measures that are taken". ${ }^{16112}$

4792. On 10 August 1993, the Accused issued an order in a telephone conversation with a colonel from the Main Staff that no shell was to land on Sarajevo and that Sarajevo was to be given electricity, water, and gas. ${ }^{16113}$ On 11 August 1993, the Accused had a conversation with Prstojević and Gvero over the phone. ${ }^{16114}$ First, Prstojević confirmed that he was taking care of the weapons around Sarajevo. ${ }^{16115}$ The Accused then ordered him to issue a warning that no one should shoot at

\footnotetext{
16107 See paras. 379, 3574.

16108 P1483 (Ratko Mladić's notebook, 2 April-24 October 1993), pp. 262-263.

16109 P1483 (Ratko Mladić's notebook, 2 April-24 October 1993), p. 263. See also Bogdan Subotić, T. 40060-40061 (19 June 2013) (testifying that Mladić could have taken Sarajevo from Mt. Igman but was prevented from doing so by the Accused).

16110 P5054 (VRS Main Staff Order, 5 August 1993).

16111 P5054 (VRS Main Staff Order, 5 August 1993).

16112 P5054 (VRS Main Staff Order, 5 August 1993), p. 2.

16113 P4802 (Intercept of conversation between Radovan Karadžić and unidentified member of VRS Main Staff, 10 August 1993); Stanislav Galić, T. 37875-37877 (7 May 2013) (testifying that it was impossible to interrupt gas and electricity for only one side and that since it was not addressed to the SRK, but rather the Main Staff, he could not confirm that this order had come to his staff). One day prior, on 9 August 1993, pursuant to an order of the Accused, Vladimir Lukić, the Prime Minister of the RS, issued an order to the Presidents of the Executive Committees of the Municipal Assemblies, Chiefs of the SJBs, and all VRS Commanders to ensure the freedom of movement of humanitarian aid convoys and UNPROFOR, enable "maximum possible flow of electricity, water and gas for the entire area of the City of Sarajevo", and inform him of the execution of this order. D3328 (Order of RS Government, 9 August 1993); Milorad Skoko, T. 36759-36760 (8 April 2013).

16114 P4804 (Intercept of conversation between Radovan Karadžić, Colonel Prstojević, and General Gvero, 11 August 1993).

1611 P4804 (Intercept of conversation between Radovan Karadžić, Colonel Prstojević, and General Gvero, 11 August 1993), p. 1.
} 
Sarajevo, even if shot at. ${ }^{16116}$ Prstojević stated he understood and that his commander had issued an order to Galić. ${ }^{16117}$ Gvero then spoke and informed the Accused that the Military Agreement for Peace in BiH had been signed. ${ }^{16118}$ The Accused expressed concern about reports that the VRS was returning to Mt. Igman and Mt. Bjelašnica. ${ }^{16119}$ On the same day, in a conversation between the Accused and Tomanić, the Accused asked for Gvero because he wanted to know why Bosnian Serb soldiers had returned to Mt. Igman and Mt. Bjelašnica and stated that "all the agencies in the world" and UNPROFOR have reported this. ${ }^{16120}$ The Accused then ordered Tomanić to call Galić and "to pass on to him urgently to withdraw the troops regardless of how many UNPROFOR forces went up there". ${ }^{16121}$ The Accused also stated angrily that "someone is putting the state at risk [...] from Mladić to I-don't-know-who, I will relieve him of his duty". ${ }^{16122} \mathrm{He}$ further added that "the army is lying to me. They have been lying to me the whole time. The reports I receive are never accurate." ${ }^{" 16123}$ He ended the conversation by asking Tomanić to tell Galić to urgently call him. ${ }^{16124}$ Also on this day, the Accused ordered Miletic to call the director of the SRNA and to release a press statement stating that the information regarding the return of the forces to Igman and Bjelašnica is a lie and that the troops are progressively withdrawing from their positions. ${ }^{16125}$ In the evening, the Accused spoke to Gvero to ensure that SRK had moved all soldiers from Mt. Igman. ${ }^{16126}$ He also stated that the media from Sarajevo, including foreign media, should be allowed to go there and report that the roads to Sarajevo were open and that there was no siege to speak of. ${ }^{16127}$

4793. In a telephone conversation of 12 August 1993, the Accused ordered Milovanović to withdraw forces from certain lines around Mt. Igman by a strict deadline in an effort to save the

\footnotetext{
16116 P4804 (Intercept of conversation between Radovan Karadžić, Colonel Prstojević, and General Gvero, 11 August 1993), p. 1.

16117 P4804 (Intercept of conversation between Radovan Karadžić, Colonel Prstojević, and General Gvero, 11 August 1993), p. 1.

16118 P4804 (Intercept of conversation between Radovan Karadžić, Colonel Prstojević, and General Gvero, 11 August 1993), p. 1.

16119 P4804 (Intercept of conversation between Radovan Karadžić, Colonel Prstojević, and General Gvero, 11 August 1993), p. 2.

16120 D3872 (Intercept of conversation between Radovan Karadžić and Tomanić, 11 August 1993) [NB; duplicate of D2091 (Intercept of conversation between Radovan Karadžić and Tomanić, 11 August 1993)]; Ljubomir Obradović, T. 25186-25188 (24 February 2012); Radovan Radinović, T. 41607-41608 (19 July 2013).

16121 D3872 (Intercept of conversation between Radovan Karadžić and Tomanić, 11 August 1993).

16122 D3872 (Intercept of conversation between Radovan Karadžić and Tomanić, 11 August 1993).

16123 D3872 (Intercept of conversation between Radovan Karadžić and Tomanić, 11 August 1993). The Chamber notes the English translation was misspelled as "The army is laying [sic] to me. They have been laying [sic] to me the whole time." The Chamber has corrected it in the text.

16124 D3872 (Intercept of conversation between Radovan Karadžić and Tomanić, 11 August 1993).

16125 P4805 (Intercept of conversation between Radovan Karadžić and Colonel Miletić, 11 August 1993 ).

16126 P4803 (Intercept of conversation between Radovan Karadžić and General Gvero, 11 August 1993), p. 1.

16127 P4803 (Intercept of conversation between Radovan Karadžić and General Gvero, 11 August 1993), p. 2.
} 
current negotiations. ${ }^{16128}$ The Accused stated: "General, listen to me and follow the orders. I am telling you how it is. Our side accepted, after convincing and bargaining [...] you should be interested in my orders. Do you want to destroy the entire state?". ${ }^{16129}$ Milovanović responded, "yes, sir" and the Accused stated they would talk tomorrow. ${ }^{16130}$ The following day, the Accused spoke to Gvero over the phone as he was looking for Milovanović who could not be found. ${ }^{16131}$ Gvero responded that Milovanović had gone to meet Hayes. ${ }^{16132}$ The Accused then ordered Gvero to pass along his order to Galić to pull back the SRK troops on Mt. Igman "far enough to avoid us having any problems in relation to the international community."16133 The Accused also stated that the order must be complied with and that such information must reach Owen by 2 or 2:30 p.m. ${ }^{16134}$ On the same day, Galić issued an order to SRK commands, in accordance with an order issued by the Accused and "in order to avoid unjust punishment by the [USA] and its allies", to occupy new command positions by 8 p.m. on the same day. ${ }^{16135}$ The order outlined where various brigades should position themselves, including an order to the Igman Brigade that "after the take-over of positions in the area of Trešnjevo brdo and Butila by UNPROFOR, shall withdraw to positions in the area of Bresovača”. 16136

4794. On 24 October 1993, at a meeting of the Supreme Command, attended by Mladić, the Accused, Bogdan Subotić, and Gvero, the possibility of shortening VRS frontlines was discussed. ${ }^{16137}$ The Accused stated that the Bosnian Serbs must choose "quality" territory and not be overly concerned about the "quantity" of territory. ${ }^{16138}$ He stated that Sarajevo was "the most important territory" and that "1 km near Sarajevo is worth more than dozens near Teočak". ${ }^{16139}$ He instructed that priority must be given to the areas of Žuč, Orlić, and Mojmilo. ${ }^{16140}$

4795. As mentioned above, on 14 January 1994, in a meeting with Mladić, Krajišnik, Dragomir Milošević, Galić, SRK unit commanders, and Sarajevo municipality presidents, the Accused

\footnotetext{
16128 P4806 (Intercept of conversation between Radovan Karadžić, General Gvero, and General Milovanović, 12 August 1993).

16129 P4806 (Intercept of conversation between Radovan Karadžić, General Gvero, and General Milovanović, 12 August 1993).

16130 P4806 (Intercept of conversation between Radovan Karadžić, General Gvero, and General Milovanović, 12 August 1993).

16131 P4783 (Intercept of conversation between Radovan Karadžić and General Gvero, 13 August 1993), p. 1.

16132 P4783 (Intercept of conversation between Radovan Karadžić and General Gvero, 13 August 1993), p. 1.

16133 P4783 (Intercept of conversation between Radovan Karadžić and General Gvero, 13 August 1993), p. 1.

16134 P4783 (Intercept of conversation between Radovan Karadžić and General Gvero, 13 August 1993), p. 1.

16135 P5042 (SRK Order, 13 August 1993).

16136 P5042 (SRK Order, 13 August 1993).

16137 P1483 (Ratko Mladić's notebook, 2 April-24 October 1993), p. 392

16138 P1483 (Ratko Mladić's notebook, 2 April-24 October 1993), p. 396

16139 P1483 (Ratko Mladić's notebook, 2 April-24 October 1993), p. 396

16140 P1483 (Ratko Mladić's notebook, 2 April-24 October 1993), p. 396.
} 
ordered the creation of a "stand-by army" and that all soldiers recruited since April 1992 should remain in the army until the end of the war. ${ }^{16141}$ He ordered that the SRK's "[r]etaliation shall be 1:1". ${ }^{16142}$ He further ordered that SRK commanders "[i]mpress upon the army [...] a feeling of optimism and concord". ${ }^{16143}$ He ended the meeting by ordering the SRK commanders to "[q]uickly line up the brigades". 16144

4796. On 29 January 1994, the Accused and Mladić met with subordinate officers of the VRS. ${ }^{16145}$ At the meeting, the Accused stated that the Bosnian Serbs must create a "single, mobile army" whose sole ideology is Serbian nationalism. ${ }^{16146}$ He stated that the "most important point is Sarajevo" and that "[w]ith the blockade of Sarajevo we have created a state", which had forced Izetbegović to negotiate. ${ }^{16147}$ He stated that "[w]e must not give out a single war-mongering statement" but instead discuss peace in order to "save the Serbs from the blockade and pressure". ${ }^{16148}$ The Accused further ordered the army to "stay where it is" because "minor details may decide the division of $\mathrm{BiH} "{ }^{16149}$ He finally ordered those present to "[e]nsure civilised conduct at the checkpoints" and to respect UNPROFOR personnel. ${ }^{16150}$

4797. The Chamber also received evidence that even prior to the establishment of the SRK, the Accused was issuing orders to armed forces and influencing the military situation in Sarajevo. ${ }^{16151}$ On 13 April 1992, in a telephone conversation he ordered Danilo Veselinović to fire at the sports hall in Mojmilo after being informed it held the Green Berets' weapons and general staff headquarters. $^{16152}$ He also told Veselinović that it was important that no people were in the

\footnotetext{
16141 P1484 (Ratko Mladić's notebook, 28 October 1993-15 January 1994), p. 148.

16142 P1484 (Ratko Mladić's notebook, 28 October 1993-15 January 1994), pp. 148-149.

16143 P1484 (Ratko Mladić's notebook, 28 October 1993-15 January 1994), p. 149.

16144 P1484 (Ratko Mladić's notebook, 28 October 1993-15 January 1994), p. 149.

16145 P1485 (Ratko Mladić's notebook, 9 January-21 March 1994), p. 51.

16146 P1485 (Ratko Mladić's notebook, 9 January-21 March 1994), p. 75.

16147 P1485 (Ratko Mladić's notebook, 9 January-21 March 1994), p. 78.

16148 P1485 (Ratko Mladić's notebook, 9 January-21 March 1994), p. 78.

16149 P1485 (Ratko Mladić's notebook, 9 January-21 March 1994), p. 80.

16150 P1485 (Ratko Mladić's notebook, 9 January-21 March 1994), p. 80.

16151 See, e.g., P5731 (Intercept of conversation between Radovan Karadžić and Rajko Dukić, 1 March 1992) (the Accused being informed that 'Dragan' has asked that the people in Sarajevo rise up and the Accused ordering "get them to rise up and have things prepared"); D4525 (Intercept of conversation between Radovan Karadžić and Ilić, 3 March 1992) (the Accused being informed on 3 March 1992 of the situation in Sarajevo and ordering that the "[Bosnian Serbs] should all stay in their settlements and set up a defence formation"); D3755 (Intercept of conversation between Radovan Karadžić and Milenko Karišik, 24 April 1992) (the Accused telling Karišik that one of the "white" ones will be coming to see who is violating the cease-fire and thus not to retaliate unless threatened).

16152 D331 (Intercept of conversation between Danilo Veselinović and Radovan Karadžić, 13 April 1992), p. 2; John Wilson, T. 4002-4005 (21 June 2010). When shown this conversation, Mijatović testified that the Accused was always "very explicit, very imperative" that civilians and civilian facilities should not be fired upon. See Nikola Mijatović, T. 30762-30763 (30 November 2012). See also D920 (Intercept of conversation between Radovan
} 
building and that no civilians should be killed. ${ }^{16153}$ During the conversation, the Accused was informed about the situation around Dobrinja and the airport. ${ }^{16154}$

4798. Similarly, in May 1992, the Accused spoke to "Rade" inquiring about the situation in Sarajevo and was informed there was shelling in Sarajevo and Mojmilo; the Accused ordered the Bosnian Serbs not to fire back unless threatened. ${ }^{16155}$ The Accused also ordered Rade to call Plavšić "or someone" before they started shooting and to call UNPROFOR "to tell them that they're $[\mathrm{ABiH}]$ threatening you all the time and that you can't hold out". ${ }^{16156}$

(E) Accused receiving information about the military situation in Sarajevo

4799. The Chamber heard that the Accused regularly received reports from the VRS and the SRK as follows: companies to battalions to brigades to the SRK Command to Main Staff, and then from Main Staff on to the Supreme Command. ${ }^{16157}$ Accordingly, there was a system of communication which linked the companies, the battalions, the corps, including the SRK, the Main Staff, and the Supreme Command. ${ }^{16158}$ While Galić testified that when he took command of the SRK communication was not functioning properly, ${ }^{16159}$ Dragomir Milošević explained that although the communication system in the SRK was not working properly in the early period after its establishment, it was constantly worked on and improved upon and, by 1995, it was functioning meticulously. ${ }^{16160}$ As early as September 1992, regulations regarding the system of reporting between the units of the SRK and SRK Command were enacted in order to ensure accuracy in the reporting system. ${ }^{16161}$ Reports to the SRK Command were to include, "(i) situation and activities of

Karadžić and Radovan Pejić, 23 April 1992) (wherein the Accused informed Pejić that a cease-fire would be signed that day and that the Bosnian Serb side should not launch any attacks).

D331 (Intercept of conversation between Danilo Veselinović and Radovan Karadžić, 13 April 1992), pp. 2-3.

D331 (Intercept of conversation between Danilo Veselinović and Radovan Karadžić, 13 April 1992), pp. 2-5.

D4506 (Intercept of conversation between Radovan Karadžić and Rade, May 1992), p. 1; John Wilson, T. 40474051 (22 June 2010) (Wilson did not know anything about this conversation; however, he testified that the Bosnian Serbs did not always notify UNPROFOR when they were forced to respond).

D4506 (Intercept of conversation between Radovan Karadžić and Rade, May 1992), pp. 1-2.

Stevan Veljović, T. 29238-29243 (23 October 2012); D319 (SRK Order, 18 July 1993); KDZ088, T. 62586259 (7 September 2010) (closed session), T. 6332 (8 September 2010) (closed session), T. 6622-6624 (13 September 2010) (closed session); P1154 (Witness statement of KDZ088 dated 27-29 April 2010), pp. 109-110, 161-162 (under seal); Richard Philipps, T. 3755-3756 (15 June 2010). According to Van Baal, the VRS had very sophisticated communication equipment and systems. See P1818 (Witness statement of Adrianus van Baal dated 26 October 2010), paras. 24, 30, 63-65.

Stevan Veljović, T. 29241 (23 October 2012). See also P2414 (Witness statement of KDZ182), pp. 20, 53 (under seal); KDZ182, T. 13071-13073 (9 March 2011) (private session).

Stanislav Galić, T. 37618-37620 (23 April 2013). See, e.g., D2838 (SRK Order, 16 September 1992) (order issued by Galić to regulate the system of reporting); D2839 (SRK instructions, 4 November 1992) (order issued by Dragan Marčetić regulating the times reports are due to the SRK command).

Dragomir Milošević, T. 32871, 32877-32879 (29 January 2013); D2839 (SRK instructions, 4 November 1992) (regulating that reports be sent to the SRK command at specific times daily). See also D312 (SRK analysis of combat readiness of artillery rocket units, July 1994), pp. 3-4.

Dragomir Milošević, T. 32875 (29 January 2013); D2838 (SRK Order, 16 September 1992). 
the enemy, (ii) combat readiness of units, (iii) security and morale, (iv) decision for further action, (v) situation in the territory of the zone of responsibility, (vi) situation and problems in the rear, (vii) unusual incidents and casualties, and (viii) proposals and requests". ${ }^{16162}$ Reports were to be sent to the SRK Command daily at 2:30 p.m. and again at 6:30 p.m. ${ }^{16163}$ The reporting system functioned as regulated; daily combat reports from the SRK command would go to the Main Staff every evening ${ }^{16164}$ and interim reports would go to the Main Staff daily, usually around 2 p.m. ${ }^{16165}$ Simić testified that there was a daily deadline for the brigades submitting reports to the SRK Command, so that it could inform the Main Staff of the situation in its area of responsibility. ${ }^{16166}$ As described earlier, the Main Staff would integrate reports from the Corps into its daily combat reports, which were sent to the Supreme Commander on a daily basis. ${ }^{16167}$ Therefore, the Accused would receive a daily report from the Main Staff which would summarise the activities and events in the SRK's zone of responsibility. ${ }^{16168}$

4800. In addition to reports sent from the Main Staff, the Accused also received reports from the MUP, the intelligence services, and other sections that were close to the command of the VRS. ${ }^{16169}$ Galic recalled that the Accused toured the SRK Command once, talked to officers there, and was

16162 D2838 (SRK Order, 16 September 1992). See also Stevan Veljović, T. 29242-29243 (23 October 2012).

16163 D2838 (SRK Order, 16 September 1992). Stevan Veljović testified that the latest the reports would be sent was 8 p.m. Steven Veljović, T. 29242 (23 October 2012). See also D2774 (Witness statement of Milenko Inđić dated 19 January 2013), para. 30.

16164 See, e.g., D3396 (SRK combat report, 15 January 1993); D3403 (SRK combat report, 12 February 1993); D3404 (SRK combat report, 14 February 1993); D3405 (SRK combat report, 15 March 1993); D3409 (SRK combat report, 5 May 1993); D3410 (SRK combat report, 4 February 1993); D3411 (SRK combat report, 15 May 1993); D3412 (SRK combat report, 19 May 1993); D3413 (SRK combat report, 28 May 1993); D3416 (SRK combat report, 24 June 1993); D3417 (SRK combat report, 5 July 1993); D3418 (SRK combat report, 11 July 1993); D3421 (SRK combat report, 18 July 1993); D3422 (SRK combat report, 25 July 1993); D3423 (SRK combat report, 29 July 1993); D3424 (SRK combat report, 13 August 1993); D3425 (SRK combat report, 2 September 1993); D3426 (SRK combat report, 22 September 1993); D3427 (SRK combat report, 13 October 1993); D3428 (SRK combat report, 26 October 1993); D3452 (SRK combat report, 6 January 1994); D1515 (SRK combat report, 4 February 1994); D2801 (SRK combat report, 19 February 1994); D2802 (SRK combat report, 20 February 1994); D2804 (SRK combat report, 8 December 1993).

16165 Stanislav Galić, T. 37216 (15 April 2013). See e.g. D3393 (SRK combat report, 25 December 1992); D3394 (SRK combat report, 31 December 1992); D3395 (SRK combat report, 11 January 1993); D3406 (SRK combat report, 18 March 1993); D3407 (SRK combat report, 22 March 1993); D3408 (SRK combat report, 5 April 1993).

16166 Savo Simić, T. 30004, 30006-30007 (8 November 2012). Simić, who was Chief of Artillery of the SRK's $1^{\text {st }}$ Sarajevo Mechanised Brigade from May 1992 to May 1994, testified that the Chief of Artillery had a counterpart Chief of Artillery in the Main Staff with whom the SRK Chief of Artillery would intermittently communicate, usually over the phone. See Savo Simić, T. 30009-30010 (8 November 2012). See also Adjudicated Facts 2858, 2872.

16167 See para. 207.

16168 But see P4804 (Intercept of conversation between Radovan Karadžić, Colonel Prstojević, and General Gvero, 11 August 1993) (during which the Accused stated that the VRS was lying to him and the reports he was receiving were never accurate); D2841 (Warning of SRK, 2 April 1995); D4619 (SRK report, 18 August 1995), para. 6 (Čedomir Sladoje reporting on 18 August 1995 that "false reports, of which there have been unacceptably too many so far, do the greatest damage to combat operations" and to "take all measures for complete, prompt, and correct reporting to the superior command").

16169 Stanislav Galić, T. 37525 (22 April 2013). 
informed about various problems. ${ }^{16170}$ Further, he recalled that in 1993 the Accused attended a meeting with the SRK Command where the problem of disproportionate use of artillery was discussed as well as the pressure from "the mass media of the world" for such use to be decreased. ${ }^{16171}$ Galic stated that the Accused wanted to reduce the amount of artillery to the minimum depending on military necessity and objectives. ${ }^{16172}$ Mladić's diary confirms that on 2 June 1993, the Accused, Mladić, Krajišnik, and Lukić met with representatives of the RS authorities and SRK commanders, including Galić. ${ }^{16173}$ According to the diary, at the end of the meeting the Accused stated that the "Sarajevo battlefield is the most important today" and that Izetbegović could not be negotiated with but had to be defeated. ${ }^{16174} \mathrm{He}$ also instructed that the Bosnian Serbs must "take Sarajevo" while ensuring "favourable international conditions". 16175 [REDACTED]. ${ }^{16176}$ [REDACTED]. ${ }^{16177}$

4801. In addition to the official reporting procedure described above, the Accused would also receive information about the military situation in Sarajevo through meetings and telephone calls with various individuals on the ground, including VRS and SRK officers. ${ }^{16178}$ For example, following the bombardment of Sarajevo on 28 and 29 May 1992 described earlier in the Judgement, ${ }^{16179}$ on 31 May 1992, Mladić met with the Accused and other members of the Bosnian Serb leadership. ${ }^{16180}$ In the meeting, the Accused stated that they had to talk about Sarajevo and must have a "part of Sarajevo". ${ }^{16181}$ In a meeting a few days later, on 6 June 1992 during another massive bombardment described above, ${ }^{16182}$ Mladić met again with the Bosnian Serb political leadership, including the Accused, Krajišnik and Koljević, to discuss, inter alia, the borders of the RS. ${ }^{16183}$ During this meeting, Krajišnik informed the attendees that Hadžići and Vogošća had been

Stanislav Galić, T. 37883, 37888 (8 May 2013). See also [REDACTED]. Stanislav Galić, T. 37883-37889, 37897-37898 (8 May 2013). P1481 (Ratko Mladić's notebook, 5 October-27 December 1992), pp. 63-68; P1483 (Ratko Mladić's notebook, 2 April-24 October 1993), p. 259. In addition, even prior to the establishment of the VRS and the SRK, the Accused was being informed about the situation in Sarajevo. See e.g. P5604 (Intercept of conversation between Gvozden and Radovan Karadžić, 3 March 1992); P5702 (Intercept of conversation between Branko Kovačević, Momo and Radovan Karadžić, 22 April 1992); D920 (Intercept of conversation between Radovan Karadžić and Radovan Pejić, 23 April 1992); P1473 (Ratko Mladić's notebook, 27 January-5 September 1995), pp. 123-126.

16179 See discussion in relation to Scheduled Incident G.1.

16180 P1478 (Ratko Mladić's notebook, 27 May-31 July 1992), pp. 36, 38.

16181 P1478 (Ratko Mladić's notebook, 27 May-31 July 1992), p. 42.

16182 See discussion in relation to Scheduled Incident G.2.

16183 P1478 (Ratko Mladić's notebook, 27 May-31 July 1992), p. 93.
} 
"liberated" and that the goal was to form a Birač-Romanija area, which should also include Dobrinja. ${ }^{16184}$

4802. On 10 July 1992, in a meeting between Mladić, the Accused, Krajišnik, Koljević, Plavšić, Đerić, Buha, Gvero, and Tolimir, the attendees discussed the situation in Sarajevo at length. Koljević produced a map of Sarajevo showing routes for the passage of humanitarian aid and stated: "Let us take a stand regarding Sarajevo". ${ }^{16185}$ He also informed the others that Bosnian Serb fighters in Nedžarići were "embittered" with the RS political leadership because the fighters "[did] not know the status of Sarajevo". ${ }^{16186}$ Krajišnik stated that the issue of demilitarisation of Dobrinja was a "major problem" for the Bosnian Serbs and cautioned the Accused against offering the UN anything, stating that it was better to "let them ask for it". 16187

4803. On 24 February 1995, the Accused and Krajišnik met with the commanders and Presidents of the Sarajevo Municipalities and discussed, among other things, the shortage of troops in Rajlovac. ${ }^{16188}$ At the meeting, Krajišnik raised the issue of "[h]ow to hold on to Sarajevo". ${ }^{16189}$

4804. On 8 June 1995, at a meeting with Mladić, the Accused stated that the situation was "very serious" and that relationships between certain military officers and the civilian authorities had been "disrupted", and that soldiers were "abandoning the lines". ${ }^{16190}$ He stated that the Bosnian Serbs "must keep Sarajevo until a political solution". ${ }^{16191}$

\section{(F) Conclusion}

4805. Based on the foregoing evidence, the Chamber finds that the Accused exercised in fact his de jure authority over the SRK units in Sarajevo. As the evidence outlined above shows, the Accused had direct contact with Mladić throughout the conflict and was able to issue orders to him, such as in the aftermath of the bombardment in Sarajevo at the end of May 1992, which were then implemented on the ground. Even taking into account disagreements that arose between the Accused and Mladić during the conflict, which were to be expected given their respective positions, the Chamber finds that these disagreements did not undermine the Accused's ultimate authority over the situation in Sarajevo, including over the SRK units. Indeed, neither Galić nor Milošević

\footnotetext{
16184 P1478 (Ratko Mladić's notebook, 27 May-31 July 1992), p. 108.

16185 P1478 (Ratko Mladić's notebook, 27 May-31 July 1992), pp. 308-310.

16186 P1478 (Ratko Mladić's notebook, 27 May-31 July 1992), p. 312.

16187 P1478 (Ratko Mladić's notebook, 27 May-31 July 1992), p. 311.

16188 P1473 (Ratko Mladić's notebook, 27 January-5 September 1995), p. 42.

16189 P1473 (Ratko Mladić's notebook, 27 January-5 September 1995), p. 42.

16190 P1473 (Ratko Mladić's notebook, 27 January-5 September 1995), p. 168.

16191 P1473 (Ratko Mladić's notebook, 27 January-5 September 1995), pp. 168-169.
} 
could recall a single occasion where they received two inconsistent orders from Mladic and the Accused regarding combat operations in Sarajevo. ${ }^{16192}$ Furthermore, despite the tension that arose in August 1993, when the Accused wanted forces to withdraw from Mt. Igman and expressed concern over Mladić's resistance to that decision, the forces eventually withdrew in accordance with his wishes. Additionally, while the Accused claimed in his conversation with Tomanić on 11 August 1993 that the army was lying to him, he was nevertheless able to obtain the information he sought and eventually removed the forces from the Mt. Igman area.

4806. The Chamber is therefore satisfied that the Accused, as Supreme Commander, commanded the SRK mainly through the Main Staff and Mladić and sometimes directly through the SRK Commander. While Abdel-Razek and Bulatović thought that the Accused did not exercise effective control over the SRK, and his expert witness, Radinović, opined that the Accused failed to exert effective control over the Sarajevo situation because of unauthorised activities of the troops and the inability to control all the renegades on the ground, ${ }^{16193}$ this is contrary to the majority of evidence received by the Chamber as recalled above, including the credible observations of Smith, Rose, Banbury, KDZ450, and Van Baal, among others. Furthermore, Radinović's evidence directly contradicts the evidence the Chamber has received in relation to: (i) a number of specific meetings where the Accused successfully exerted control or showed influence over forces in Sarajevo, including the meetings of 30 May 1992 (with Morillon) and 21 March 1994 (with Van Baal); and (ii) orders issued by the Accused relevant to Sarajevo, some of which went directly to the SRK and which were implemented on the ground, including the order that followed the incident in Markale market on 5 February.

4807. The evidence is also clear that the Accused used his authority over the VRS and the SRK to organise and direct operations in and around Sarajevo. He did so through the directives he issued and/or approved, which ensured that the city was kept under blockade and, in turn, allowed for the SRK's sniping and shelling of civilians to continue. He also did it through other types of orders he issued to the Main Staff, all of which were in turn transmitted to the SRK Command and implemented. In addition, at times, the Accused would issue orders directly to the SRK units and

\footnotetext{
16192 While there may be some suggestion in Mladić's request for information from the SRK Command, dated 26 April 1995, that the Supreme Command issued an order to the SRK Command to launch a modified air bomb, thus bypassing the Main Staff, the Chamber notes that this was not the case, as reported back to Mladić on the same day. See P1299 (VRS Main Staff request for information from SRK, 26 April 1995); P1310 (SRK report to VRS Main Staff re weapons, 26 April 1995) (explaining that a decision to launch a modified air bomb had been made at the SRK Command's morning briefing).

16193 See D3864 (Radovan Radinović's expert report entitled "The Control Authority of Dr. Radovan Karadžić in the Strategic Command System of the VRS", 2012), paras. 4, 24, 81, 86-87, 90, 114-115, 247-249.
} 
SRK Commanders. ${ }^{16194}$ Finally, as illustrated by the various intercepted phone conversations and meetings outlined above, the Accused was also able at all times during the conflict to issue oral orders to VRS and SRK officers since he was in regular contact with Mladić, Milovanović, Gvero, Galić, and Dragomir Milošević. When he did so, these oral orders were relayed to the SRK units around the city. Accordingly, there is no doubt that throughout the conflict, the Accused was closely involved in military matters in Sarajevo, including in SRK operations and other activities, particularly if they concerned agreements he had reached with the representatives of the international community. The most striking example of this was his involvement in the withdrawal of the VRS and SRK soldiers from Mt. Igman and Mt. Bjelašnica. The Chamber is also convinced that the Accused's involvement in the Sarajevo military matters went beyond planning and strategy as the evidence shows that he was involved at the operational level as well. His orders to (i) send two platoons of special forces to Nedžarići, (ii) secure Pretis and other factories in Vogošća, and (iii) conceal artillery around Sarajevo following the first Markale incident are prime examples of that. ${ }^{16195}$

4808. The Chamber also finds that the chain of communication and reporting from the SRK to the Main Staff and to the Accused was functioning properly during the period relevant to the Indictment. The regulations governing the communication and reporting system were detailed and followed by the SRK, enabling the Main Staff and the Accused to receive daily information about the situation on the ground in Sarajevo. Thus, the Accused was constantly informed about SRK operations in Sarajevo through regular combat reports. In addition, he received information from other agencies such as the MUP, the intelligence services, and other sections in the VRS Command. Finally, the many private telephone conversations referred to above show that he was a wellinformed, hands on, president who was able to and who often did receive information on military matters from various individuals on the ground.

4809. Based on the findings above, namely (i) that the SRK was a professional corps of the VRS with a fully functioning chain of command, (ii) that the Accused successfully exercised his authority over the SRK units as testified to by a number of witnesses and as amply illustrated by numerous written and oral orders he issued relating to Sarajevo, and (iii) that the Accused was

\footnotetext{
16194 The Chamber notes that the Accused's orders outlined earlier clearly show that his submission that the SRK did not receive orders from the Presidency which applied exclusively to the SRK is incorrect. Indeed, there were several occasions where that did happen, the most striking being the order he issued in the aftermath of the first Markale shelling, which was implemented and led to a peaceful period in the city.

16195 See paras. 4765, 4774, 4776. The Chamber does not accept the Accused's claim that the political authorities never interfered in military matters or that he had no effective control over the SRK units due to the shortage of professional staff. Indeed, the evidence outlined above shows the opposite to have been the case as there are numerous examples of the Accused getting involved in and exerting influence over military matters.
} 
receiving regular reports from the SRK units and other sources about the situation in Sarajevo, the Chamber finds that the Accused was indeed at the apex of control of the forces in Sarajevo, in particular the SRK, despite the occasional tensions that arose between him and Mladić. As such the Accused oversaw the events in Sarajevo, both on a political and military level, and also had the power to stop and prevent the targeting of civilians and the indiscriminate or disproportionate firing on the city by the SRK.

\section{iii. Accused's knowledge of crimes and the measures he took to prevent them}

\section{(A) Arguments of the parties}

4810. The Prosecution alleges that the Accused knew about the nature and extent of the sniping and shelling campaign and its effects on the civilian population of Sarajevo, and allowed the campaign to continue for almost four years while denying or deflecting international criticism and failing to take any genuine steps to punish the perpetrators. ${ }^{16196}$ It alleges that the Accused was informed of the campaign through repeated protests from international observers, Security Council resolutions, and media reports. ${ }^{16197}$ In contrast, the Accused argues that he was not adequately informed of the crimes of terror and unlawful attacks. ${ }^{16198}$ He argues that his receipt of information must be "considered in light of the chaos" as power cuts, interruptions of telephone lines, obsolete technical equipment, and poor roads created problems with the system of command and control throughout the war. ${ }^{16199}$ He also submits that SRK combat reports made no mention of the scheduled incidents listed in the Indictment, and contends that communication between himself and Galić was limited to the TEZ, Markale I, and humanitarian issues, and was “practically non-existent in terms of carrying out combat activities". ${ }^{16200}$

4811. The Prosecution further submits that, while the Accused would sometimes acknowledge responsibility for the sniping and shelling of civilians, generally he denied and deflected international criticism, including through false assurances, false denials or excuses, blaming others, cavalier brush-offs, using tu quoque, or threatening to do worse. ${ }^{16201}$ The Prosecution argues that these denials and deflections were done for the purpose of advancing the campaign of sniping and shelling. ${ }^{16202}$ While not making a general argument in relation to this claim, the Accused maintains

\footnotetext{
16196 See Prosecution Final Brief, paras. 605, 612(3), 612(5).

16197 Prosecution Final Brief, paras. 644-649.

16198 Defence Final Brief, paras. 2962-2966.

16199 Defence Final Brief, paras. 2962-2963.

16200 Defence Final Brief, paras. 2965-2966.

16201 Prosecution Final Brief, para. 628.

16202 Prosecution Final Brief, para. 628.
} 
that his denials that the Bosnian Serbs fired at the Markale market on 5 February 1994 were wellfounded because the VRS had insisted that they had not fired the mortar. ${ }^{16203}$

4812. The Prosecution also submits that the Accused took no meaningful steps to prevent, investigate, and/or punish SRK unlawful attacks on civilians in Sarajevo. ${ }^{16204}$ It argues that, had the Accused wanted to order investigations of SRK crimes occurring in Sarajevo, he could have done so effectively. ${ }^{16205}$ Instead, he created and sustained a culture of impunity where those responsible for the campaign were promoted or awarded, and Mladić's plans for the campaign of terror were continually approved. ${ }^{16206}$ In contrast, the Accused submits that he took measures to ensure investigations were carried out and sanctions imposed in the event of any potential criminal activities, including ordering that members of the VRS act in accordance with the Geneva Conventions and the other provisions of the international laws of war. ${ }^{16207}$

\section{(B) Accused's knowledge}

\section{(1) Accused directly informed of the campaign}

4813. A large number of witnesses, mostly representatives of the international community called by the Prosecution, gave evidence that they or their colleagues protested and complained to the Accused about the sniping and shelling of the civilian population of Sarajevo. For example, Okun testified that, on more than one occasion, Lord Owen directly asked the Accused why the Bosnian Serbs continued to shell Sarajevo when it was giving them such bad public press but the Accused never answered him. ${ }^{16208}$ In his book "Balkan Odyssey", Owen wrote that when he asked the Accused why the Bosnian Serbs were shelling Sarajevo, the Accused replied: "We're not, it's the Muslims. We're not attacking, just protecting our homes in and around Sarajevo". ${ }^{16209}$ Okun and others "implored" the Accused to stop the Bosnian Serb shelling of Sarajevo, but the Accused did not order Mladić to stop the attacks. ${ }^{16210}$ The Chamber heard that Morillon repeatedly told the Accused and Mladić that world history would judge them on the way they were using their artillery

\footnotetext{
16203 Defence Final Brief, para. 2999.

16204 Prosecution Final Brief, para. 643.

16205 Prosecution Final Brief, para. 650.

16206 Prosecution Final Brief, paras. 636-644.

16207 Defence Final Brief, paras. 2974-2983, 2997-3000.

16208 Herbert Okun, T. 1635 (26 April 2010), T. 1694-1695 (27 April 2010), P776 (Transcript from Prosecutor v. Krajišnik), T. 4211. See also P1482 (Ratko Mladić's notebook, 2-28 January 1993), pp. 59-62 (Owen stating at a plenary meeting attended by the Accused that there was shelling of towns and Silajdžić noting that Sarajevo was shelled by very heavy artillery for 3 hours on the previous day).

16209 P799 (Excerpts from David Owen's book entitled “Balkan Odyssey”), e-court p. 10.

16210 Herbert Okun, T. 1694-1695 (27 April 2010).
} 
against cities, towns, and civilians, and that they had to stop. ${ }^{16211}$ [REDACTED] who attended meetings with the Accused, Krajišnik, Koljević, and Mladić on a number of occasions, testified that a primary issue raised in those meetings was the call to cease action against the civilian population. ${ }^{16212}$ [REDACTED] during the first months of the conflict, the Accused, Mladić, Krajišnik, Koljević, and Plavšić were fully aware of the general situation in the SRK's zone of responsibility, including the large-scale commission of crimes. ${ }^{16213}$ According to Tucker, the Accused's knowledge of military detail was greater for Sarajevo than other parts of BiH. ${ }^{16214}$

4814. Rose frequently met with the Accused during his time as Commander of UNPROFOR BiH Command from 5 January 1994 to 23 January 1995, and testified that when a serious incident occurred, such as the 8 October 1994 sniping of a Sarajevo tram, ${ }^{16215}$ it was always raised with the Bosnian Serb side; he personally raised the issue of the sniping and shelling of civilians with "the Bosnian Serb leadership" at every opportunity. ${ }^{16216}$ According to Rose, the usual response of the Accused was to blame the Bosnian Muslims for the incident, particularly when accused of a "terrible atrocity", such as the shelling of Markale market; when accused of shelling generally, the "Bosnian Serb leadership" would state that they were responding to ABiH attacks and that this was their method of responding because the $\mathrm{ABiH}$ had superior levels of infantry. ${ }^{16217}$

4815. Harland, who attended a number of meetings with the Accused, also testified that during those meetings he heard his superiors protesting about the sniping and shelling of civilians to the Accused or other members of the Bosnian Serb political or military leadership. ${ }^{16218}$ The Accused would usually deny that there was a problem, or say that he would look into it or that he had already issued orders that firing should stop. ${ }^{16219}$ According to Harland, the Accused and Mladić

\footnotetext{
16211 P4203 (Witness statement of Pyers Tucker dated 12 May 2010), para. 99.

16212 [REDACTED].

16213 [REDACTED].

16214 P4203 (Witness statement of Pyers Tucker dated 12 May 2010), paras. 69, 281; Pyers Tucker, T. 23226-23235 (18 January 2012); P4216 (UNPROFOR report re meeting with Radovan Karadžić, 20 November 1992), para. 7. See also Neđeljko Prstojević, T. 13258-13259, 13264, 13267-13268 (11 March 2011) (testifying about frequent meetings with the Accused in Pale involving discussions about the military and political situation in Sarajevo); P1004 (SRK Order, 5 September 1992); P1006 (SRK Order, 12 September 1992), p. 1 (noting that tasks were received at a conference with the RS Presidency in Jahorina held on 6 September 1992).

16215 See discussion in relation to Scheduled Incident F.11.

16216 Michael Rose, T. 7269 (5 October 2010); P1638 (Witness statement of Michael Rose dated 26 March 2009), paras. 35, 107, 151, 156, 200; P1644 (Letters from Michael Rose to Alija Izetbegović and Radovan Karadžić, 9 October 1994). See also P1762 (Witness statement of David Fraser dated 17 October 2010), p. 44.

16217 P1638 (Witness statement of Michael Rose dated 26 March 2009), paras. 201, 209 (commenting that the disproportionality of Serb responses undermined the credibility of this justification); Michael Rose, T. 7269 (5 October 2010).

16218 David Harland, T. 2037 (6 May 2010). See also P1258 (Witness statement of Hussein Ali Abdel-Razek dated 16 July 2002), e-court p. 21 (testifying that Goulding and Morillon discussed "the shootings and shelling" with both the Accused and Galić).

16219 David Harland, T. 2037 (6 May 2010).
} 
reacted to protests in entirely different ways: Mladić was more confrontational, while the Accused would "often link one problem to another, generally ensuring that the problem could never be resolved". ${ }^{16220}$ Harland concluded that the protests from the international community, both oral and written, had "very little effect" except at times of explicit military threat from NATO forces against the Serbs, in which case they might be responded to quite positively and decisions might be implemented. ${ }^{16221}$

4816. According to Tucker, the parties were "absolutely aware" of the existence of Security Council resolutions, and these resolutions were frequently discussed during negotiations. ${ }^{16222}$ Indeed, on 10 June 1992, the Accused wrote a letter to Secretary General Boutros-Ghali in which he stated that he accepted Security Council Resolution 758 "with satisfaction and great hope". ${ }^{16223}$ Similarly, on 5 October 1994, at a meeting between Akashi, the Accused, Mladić and others in Pale, the Accused discussed and expressed some satisfaction with Resolution 942. ${ }^{16224}$ While Security Council resolutions in evidence in this case do not explicitly refer to sniping and shelling of civilians in Sarajevo, they allude to the commission of these crimes by expressing deep disturbance at "the situation which now prevails in Sarajevo", repeatedly calling on all parties to comply with the obligations under international humanitarian law and in particular the Geneva Conventions, and expressing alarm at serious violations of international humanitarian law. ${ }^{1625}$ In Resolution 824, in which the Security Council declared Sarajevo, Bihać, Srebrenica, Goražde, Tuzla, and Žepa to be safe areas, the Security Council considered that these areas should be "free from armed attacks and from any other hostile acts which endanger the well-being and the safety of their inhabitants" and declared that all Bosnian Serb artillery or paramilitary units should withdraw "to a distance wherefrom they cease to constitute a menace to their security and that of their inhabitants". ${ }^{16226}$ One month later, on 4 June 1993, the Security Council reiterated its alarm at the

\footnotetext{
16220 David Harland, T. 2037-2038 (6 May 2010).

16221 David Harland, T. 2037 (6 May 2010). See also para. 4869.

16222 P4203 (Witness statement of Pyers Tucker dated 12 May 2010), para. 288. See also KDZ240, T. 16183-16184 (6 July 2011) (closed session).

16223 D1509 (Radovan Karadžić's letter to UN Secretary General, 10 June 1992).

16224 D3500 (UNPROFOR report, 7 October 1994), para. 5(d); Yasushi Akashi, T. 37716-37718 (24 April 2013 ). See also P2489 (UNPROFOR Weekly Situation Report (Sarajevo), 24 April 1995), para. 6 (indicating that the Accused was familiar with Security Council Resolution 988).

16225 P982 (UNSC Resolution 764, 13 July 1992); P983 (UNSC Resolution 770, 13 August 1992); P5424 (UNSC Resolution 941, 23 September 1994); P4209 (UNSC Resolution 819, 16 April 1993); P985 (UNSC Resolution 836, 4 June 1993). See also P1031 (UNSC Resolution 757, 30 May 1992) (referring to mortar attacks on UNPROFOR in Sarajevo).

16226 P984 (UNSC Resolution 824, 6 May 1993), pp. 1-2.
} 
grave and intolerable situation in $\mathrm{BiH}$ arising from serious violations of international humanitarian law, and its alarm at the plight of the civilian population, particularly in the safe areas. ${ }^{16227}$

4817. Several Defence witnesses also alluded to the Accused's knowledge of the sniping and shelling campaign. John Zametica, who advised the Accused on international relations from February 1994, ${ }^{16228}$ recalled that, despite rarely discussing military matters, the Accused told him that Bosnian Serb sniping was "stupid" and did not get the Serbs any military advantage; there were also times when the Accused disapproved of irresponsible shelling or thought that it was senseless or unnecessary. ${ }^{16229}$ Momir Bulatović, at the time the President of Montenegro, ${ }^{16230}$ testified that he had many conversations with the Accused on the shelling of Sarajevo, during which the Accused recognised that the shelling was a political liability for the Bosnian Serbs and that it damaged their cause in the opinion of the international community. ${ }^{16231}$ Bulatović and the Accused also discussed the allegations made by international negotiators that the shelling was not limited to military attacks but was also aimed at civilian areas, to which the Accused stated that he had banned shelling of civilian areas on a number of occasions and had done everything he could to prevent the unnecessary and disproportionate shelling of Sarajevo. ${ }^{16232}$ Vladislav Jovanović, the Foreign Minister of Serbia at the time, ${ }^{16233}$ questioned the Accused a few times about why Sarajevo was kept under siege for so long and why it was subjected to "all those snipers and misfortunes", and informed the Accused that this was causing a great deal of damage to the Bosnian Serbs and to the Serbians. ${ }^{16234}$ He testified that the Accused denied that the Bosnian Serbs had a policy of shelling Sarajevo; rather, he would say either that these incidents were sporadic and caused by "a few frustrated individuals" who had lost family members and who were doing it on their own initiative,

16227 P985 (UNSC Resolution 836, 4 June 1993), pp. 1-2. See also P5014 (UNSC Resolution 998, 16 June 1995$)$, pp. 2-3 (condemning the increasing attacks on the civilian population by Bosnian Serb forces and demanding that the parties respect fully the status of the safe areas and in particular the need to ensure the safety of the civilian population therein)

16228 John Zametica, T. 42441 (29 October 2013).

16229 John Zametica, T. 42458-42460 (29 October 2013).

16230 D3051 (Witness statement of Momir Bulatović dated 25 February 2013), para. 2.

16231 D3051 (Witness statement of Momir Bulatović dated 25 February 2013), para. 23.

16232 D3051 (Witness statement of Momir Bulatović dated 25 February 2013), para. 24. In addition, on 18 August 1992, Bulatović attended a meeting of the FRY Council of Co-ordination of State Policy in Belgrade. At this meeting, Milan Panić told the audience that the Accused said he had no control over the guns and the individuals responsible were acting on their own. See D3051 (Witness statement of Momir Bulatović dated 25 February 2013), para. 25; D3054 (Notes of session of Council for Co-ordinating Positions on State Policy, 18 August 1992), p. 11 (Milan Panić was the Federal Prime Minister and Chairman of the Council); Momir Bulatović, T. 34525-34526 (28 February 2013).

16233 D3015 (Witness statement of Vladislav Jovanović dated 22 February 2013), paras. 4-6.

16234 P6150 (Excerpt from record of interview with Vladislav Jovanović), p. 1; Vladislav Jovanović, T. 34333-34336 (27 February 2013). 
or that the Bosnian Muslims were responsible because they wanted to draw international attention to the Bosnian Serbs, infuriate the international community, and generate NATO action. ${ }^{16235}$

4818. In addition, the Chamber heard about a number of specific instances on which the Accused knew or was informed of various incidents of sniping and shelling, including those scheduled in the Indictment. For example, as discussed earlier in this Judgement, in the late May 1992 meeting between, inter alios, the Accused, Mladić, Krajišnik, Plavšić, Koljević, [REDACTED]. ${ }^{16236}$ [REDACTED] the members of the Bosnian Serb leadership present at the meeting, including the Accused, did not oppose Mladić's proposal. ${ }^{16237}$ On 30 May 1992, while this bombardment was taking place, Morillon and Mackenzie met with the Accused and Koljević to discuss these events. ${ }^{16238}$ During the meeting, the Accused indicated that Bosnian Serb forces were inexperienced and self-organised and thus over-reacted to attacks by the Green Berets; in addition, he said that Mladić did not have all the forces under his command. ${ }^{16239}$ The Accused also indicated that the Bosnian Serbs were sometimes blamed for attacks for which they were not responsible, and that they were in a no-win situation where they would either be blamed or defeated. ${ }^{16240}$ In response, Mackenzie indicated to the Accused and Koljević that an obstacle to progress in negotiations had been the linkage of one problem area to another and that this should be avoided. ${ }^{16241}$ When asked during the meeting whether he was in a position to stop the bombardment, the Accused "replied in the affirmative"; this response was qualified by Koljević, who stated that they thought they could persuade the people on the ground to stop the shelling. ${ }^{16242}$ The Accused then agreed that he would travel to Sarajevo to contact Mladic in order to stop the bombardment. ${ }^{16243}$ The Accused eventually reached Mladić by phone and the latter agreed to stop the bombardment. ${ }^{16244}$ On the same day, the Accused spoke to a certain Čedo and instructed him to

\footnotetext{
16235 D3015 (Witness statement of Vladislav Jovanović dated 22 February 2013), para. 52; Vladislav Jovanović, T. 34253-34254, 34325-34326 (26 February 2013).

16236 See para. 4023.

16237 See para. 4023.

16238 P1029 (Witness statement of John Wilson dated 4 November 2008), para. 80; P1036 (UNPROFOR report re meeting with Radovan Karadžić and Nikola Koljević, 30 May 1992), paras. 1-2. See also para. 4037.

16239 P1029 (Witness statement of John Wilson dated 4 November 2008), para. 80; P1036 (UNPROFOR report re meeting with Radovan Karadžić and Nikola Koljević, 30 May 1992), para. 3; John Wilson, T. 4079 (22 June 2010)

16240 P1029 (Witness statement of John Wilson dated 4 November 2008), para. 80; P1036 (UNPROFOR report re meeting with Radovan Karadžić and Nikola Koljević, 30 May 1992), paras. 5-6.

16241 P1036 (UNPROFOR report re meeting with Radovan Karadžić and Nikola Koljević, 30 May 1992), para. 9.

16242 P1029 (Witness statement of John Wilson dated 4 November 2008), para. 80; P1036 (UNPROFOR report re meeting with Radovan Karadžić and Nikola Koljević, 30 May 1992), paras. 7-8.

16243 P1029 (Witness statement of John Wilson dated 4 November 2008), para. 80; P1036 (UNPROFOR report re meeting with Radovan Karadžić and Nikola Koljević, 30 May 1992), para. 11.

16244 P1029 (Witness statement of John Wilson dated 4 November 2008), para. 80; P1036 (UNPROFOR report re meeting with Radovan Karadžić and Nikola Koljević, 30 May 1992), para. 15.
} 
try not to use artillery that night but to use infantry weapons and "let them go to hell [...] [i]f they want to die". 16245

4819. The Chamber also heard that, between 3 and 5 June 1992 Thornberry, Wilson, and AbdelRazek conducted three days of negotiations with the Bosnian Serbs and the BiH Presidency for the opening of the Sarajevo airport. ${ }^{16246}$ Wilson testified that during these negotiations he told the Accused, Plavšić, and Mladić that the Bosnian Serbs hit most of the major buildings in the city, that there did not appear to be any restraint applied to the selection of targets, and that from Bosnian Serb positions looking down on the city, they knew what they were engaging. ${ }^{16247}$ According to Wilson, the Accused, Plavšić, and Mladić responded that this type of fire was legitimate and that they were defending Serbs. ${ }^{16248}$

4820. As discussed earlier in the Judgement, the Accused was also aware of the heavy bombardment of the city between the night of 5 June and 8 June 1992, which the Presidency ordered to be halted on 9 June $1992 .^{16249}$

4821. Nenad Kecmanović, a Serb politician who was the President of the Alliance of Reform Forces of Yugoslavia political party and a member of the BiH Presidency from 1 June 1992 until July $1992,{ }^{16250}$ testified that in the summer of 1992 in meetings with leading representatives of the Bosnian Serb leadership, including the Accused, he raised the shelling of Sarajevo "several times". ${ }^{16251}$ The response he received was that the ABiH was opening fire against Bosnian Serb positions around the city, that the $\mathrm{ABiH}$ artillery was located in the most densely populated parts of the city, and that the Bosnian Serb artillery was therefore forced to respond by firing upon these locations. ${ }^{16252}$

\footnotetext{
16245 P2332 (Intercept of conversation between Čedo and Radovan Karadžić, 30 May 1992).

16246 P1029 (Witness statement of John Wilson dated 4 November 2008), paras. 84-86; P1039 (UNPROFOR report re airport meetings in Sarajevo, 3 June 1992); P1045 (UNPROFOR report re airport talks, 4 June 1992); John Wilson, T. 4082-4089 (22 June 2010); P1478 (Ratko Mladić's notebook, 27 May-31 July 1992), pp. 79-93.

16247 P1029 (Witness statement of John Wilson dated 4 November 2008), paras. 48-49.

16248 P1029 (Witness statement of John Wilson dated 4 November 2008), paras. 48-49. Wilson testified that he observed the Accused in many meetings, and that the Accused always attempted to justify the actions of the people he claimed to represent. See P1029 (Witness statement of John Wilson dated 4 November 2008), para. 122.

16249 See para. 4051.

16250 D3645 (Witness statement of Nenad Kecmanović dated 27 May 2013), paras. 3, 9; Nenad Kecmanović, T. 39105 (31 May 2013).

16251 D3645 (Witness statement of Nenad Kecmanović dated 27 May 2013), para. 50.

16252 D3645 (Witness statement of Nenad Kecmanović dated 27 May 2013), para. 50. See also D1509 (Radovan Karadžić's letter to UN Secretary General, 10 June 1992) ("The Muslim side [...] permanently attacks the Serbian side and the Serbian part of the city of Sarajevo"), p. 1; KDZ240, T. 16183-16184 (6 July 2011) (closed session).
} 
4822. On 26 August 1992, Vance, Carrington, and Doyle met with the Accused and Koljević at the London Conference. ${ }^{16253}$ Carrington raised Bosnian Serb attacks on Sarajevo, stating that "world opinion was firmly against the Serbs, particularly after the recent escalation of fighting around Sarajevo". ${ }^{16254}$ The Accused responded by stating that the Bosnian Muslims were responsible for the escalation as they regularly shelled their own people and only they could have been responsible for the heavy shelling of Sarajevo in the preceding days. ${ }^{16255}$ Doyle told the Accused that the UNPROFOR office in Sarajevo had confirmed that Serbian gunners were to blame. ${ }^{16256}$ To this the Accused said that he was willing to accept UN monitors at all Serbian artillery positions in and around Sarajevo. ${ }^{16257}$

4823. On 8 September 1992, at a meeting between, inter alios, the Accused, Mladić and General Simonović, Simonović stated that the blockade of Sarajevo was justified but mass-scale use of artillery against cities was damaging, and recommended that the Bosnian Serbs should prevent the bombardment of cities. ${ }^{16258}$

4824. On 8 December 1992, the Accused sent a letter to an international organisation in which he claimed that the citizens of Sarajevo had been prevented from leaving the city by the $\mathrm{BiH}$ government. ${ }^{16259}$ Ten days later he received a response from the representative of that organisation, stating that it was unacceptable for him to hold the international community responsible for the situation in Sarajevo, while the responsible party are those who are "shelling and keeping Sarajevo under siege on an indiscriminate basis". ${ }^{16260}$

4825. On 9 December 1992, members of the SDC, including, inter alios, Slobodan Milošević, Bulatović, and Dobrica Ćosić, met to discuss the war in $\mathrm{BiH} .{ }^{16261}$ At the meeting, Ćosić noted that the Serbian leadership had advised the Accused on numerous occasions that the shelling of

\footnotetext{
16253 P941 (London Conference record of a meeting with Radovan Karadžić, 26 August 1992); Colm Doyle, T. 26762677 (21 May 2010), T. 2871-2874 (27 May 2010); P1260 (SRK information on ICFY, 30 August 1992).

16254 P941 (London Conference record of a meeting with Radovan Karadžić, 26 August 1992), para. 4; Colm Doyle, T. 2872 (27 May 2010).

16255 P941 (London Conference record of a meeting with Radovan Karadžić, 26 August 1992), para. 4; Colm Doyle, T. 2872 (27 May 2010).

16256 P941 (London Conference record of a meeting with Radovan Karadžić, 26 August 1992), para. 4; Colm Doyle, T. 2872 (27 May 2010).

16257 P941 (London Conference record of a meeting with Radovan Karadžić, 26 August 1992), para. 4; Colm Doyle, T. 2872 (27 May 2010).

16258 P1479 (Ratko Mladić's notebook, 16 July-9 September 1992), pp. 167-173.

16259 [REDACTED].

16260 [REDACTED].

16261 D3051 (Witness statement of Momir Bulatović dated 25 February 2013), paras. 28-30.
} 
Sarajevo was detrimental to the political position of the Bosnian Serbs. ${ }^{16262}$ Bulatović testified that, although the Accused had fully agreed on every occasion, he was unable to solve the problem. ${ }^{16263}$

4826. As discussed earlier in the Judgement, ${ }^{16264}$ on 18 or 19 December 1992, Owen, Morillon, and Abdel-Razek met with the Accused, Mladić, and Koljević in Pale. ${ }^{16265}$ The meeting was called due to the intensification of shelling in Sarajevo, including the shelling of the Koševo Hospital. ${ }^{16266}$ At the meeting, Owen protested the shelling of the hospital. ${ }^{16267}$ Tucker, who was also present, testified that Owen and Mladić had a heated argument during which Owen stated that the shelling of Sarajevo was a disgrace and had to stop. ${ }^{16268}$

4827. Galić testified that sometime during 1993 the Accused met with the SRK command and expressed concern about the disproportionate use of artillery. ${ }^{16269}$ According to Galić, at these toplevel meetings where the Accused was present, the topic of proportionality was always discussed. ${ }^{16270}$ Galić noted that the Accused did not have to inform him that the disproportionate use of artillery by the SRK had caused civilian casualties, because "everybody saw that, there was a war going on and that fire came from both sides". ${ }^{6271}$ Galic recalled that the Accused asked to reduce disproportionate fire "to a minimum related to military necessity and military objectives". 16272

4828. On 28 January 1993, a representative of an international organisation met with the Accused in Geneva and asked him why he did not cease shelling Sarajevo at once. ${ }^{16273}$ The Accused

16262 D3055 (Record of $6^{\text {th }}$ session of FRY's SDC, 9 December), pp. 24-25; D3051 (Witness statement of Momir Bulatović dated 25 February 2013), paras. 29-30.

16263 D3051 (Witness statement of Momir Bulatović dated 25 February 2013), paras. 29-30 (adding that this was indicative of the Accused's lack of control over the VRS).

16264 See para. 4540.

16265 Hussein Abdel-Razek, T. 5503-5505 (19 July 2010), T. 5545-5547 (20 July 2010); P1273 (Video footage of meeting between Lord Owen and Radovan Karadžić, with transcript); P4203 (Witness statement of Pyers Tucker dated 12 May 2010), paras. 94-98; P1996 (Witness statement of Martin Bell dated 8 March 2010), para. 82; P2034 (BBC news report re meeting between Lord Owen and Radovan Karadžić in Pale, with transcript).

16266 Hussein Abdel-Razek, T. 5503-5505 (19 July 2010).

16267 Hussein Abdel-Razek, T. 5546 (20 July 2010); P1273 (Video footage of meeting between Lord Owen and Radovan Karadžić, with transcript); P4203 (Witness statement of Pyers Tucker dated 12 May 2010), para. 98; P1996 (Witness statement of Martin Bell dated 8 March 2010), para. 82; P2034 (BBC news report re meeting between Lord Owen and Radovan Karadžić in Pale, with transcript).

16268 P4203 (Witness statement of Pyers Tucker dated 12 May 2010), para. 95, 98.

16269 Stanislav Galić, T. 37884-37888, 37897-37898 (8 May 2013). Mladić's diary records a meeting, on 2 June 1993, between the Accused, Krajišnik, Mladić, Galić and others. However, the diary does not record the issue of proportionality being discussed. See P1483 (Ratko Mladić's notebook, 2 April-24 October 1993), pp. 182194.

16270 When asked how often these meetings took place, Galić failed to answer the question. Stanislav Galić, T. 37886-37887 (8 May 2013).

16271 Stanislav Galić, T. 37888-37889 (8 May 2013).

16272 Stanislav Galić, T. 37888 (8 May 2013).

16273 [REDACTED]. 
responded that the Bosnian Muslims were attacking Ilidža, that the Bosnian Serbs were merely defending themselves, and that the Bosnian Muslims had produced and provoked "fireworks" when the representative of that organisation was visiting the city. ${ }^{16274}$

4829. As discussed earlier, on 31 January 1993, Morillon sent a letter to the Accused protesting the shelling of the Koševo Hospital "by Serb artillery or mortars". ${ }^{16275}$ In the letter, Morillon stated that there can be no excuse for shelling a hospital, and demanded that the Accused take immediate and effective action to ensure that Bosnian Serb gunners respect the Geneva Conventions. ${ }^{16276}$

4830. Just after midnight on 2 June 1993, Morillon faxed the Accused to inform him that the shelling of the football game in Dobrinja which took place that morning and which was discussed by the Chamber earlier in the Judgement ${ }^{16277}$ caused the deaths of a number of innocent women and children. $^{16278}$

4831. On 12 October 1993, Andreev, Briquemont, De Mello, and Harland met with the Accused and Krajišnik in Pale. ${ }^{16279}$ In the meeting, Briquemont told the Accused that Bosnian Serb shelling of civilian areas in Sarajevo was increasing and that it had no military value but rather caused political damage to the Serbs. ${ }^{16280}$ The Accused responded that this was the action of "rogue individuals" and that he would take further action to curb it if the Bosnian Muslim side did the same. ${ }^{16281}$ Harland testified that the Accused's comment concerning "rogue individuals" was

16274

16275

[REDACTED].

P1275 (UNPROFOR protest letter to Radovan Karadžić, 31 January 1993). Morillon also wrote to Izetbegović 12 days earlier to protest against the firing of an $82 \mathrm{~mm}$ mobile mortar from a derelict house on the western side of the Koševo Hospital. The Chamber does not accept the Accused's argument that P1275 was an attempt by Morillon to "strike a balance" with respect to the earlier incident; instead the Chamber is satisfied that this is a genuine protest in relation to an incident that occurred on 31 January 1993. See D2034 (UNPROFOR report, 21 January 1993), e-court p. 6; D351 (UNPROFOR report re protest letter to Alija Izetbegović, 21 January 1993); Hussein Abdel-Razek, T. 5552-5553 (20 July 2010). A number of international witnesses confirmed that the $\mathrm{ABiH}$ would fire at the SRK from around the Koševo Hospital in order to provoke retaliatory fire. See para. 4035.

16276 P1275 (UNPROFOR protest letter to Radovan Karadžić, 31 January 1993).

16277 See discussion in relation to Scheduled Incident G.4.

16278 P5059 (Fax from UNPROFOR to Radovan Karadžić, 2 June 1993) (Morillon adding that that the world would not continue to tolerate irresponsible behaviour of this type from "your forces"). The SRK Liaison Officer to UNPROFOR, Milenko Inđić, testified that he did not receive any protests in relation to this incident. See D2774 (Witness statement of Milenko Inđić dated 19 January 2013), para. 130.

16279 P820 (Witness statement of David Harland dated 4 September 2009), paras. 60-61; P830 (UNPROFOR Weekly Political Assessment, 16 October 1993); P845 (UNPROFOR report re meeting with Radovan Karadžić, 15 October 1993). While Harland stated that this meeting happened on 15 October 1993 in paragraph 60 of his statement, P845, which is a report on this meeting and is dated 15 October, clearly indicates that the meeting happened on 12 October. The Chamber considers that Harland was mistaken in his testimony and influenced by the date of the report, rather than its content.

16280 P820 (Witness statement of David Harland dated 4 September 2009), para. 61; P830 (UNPROFOR Weekly Political Assessment, 16 October 1993), p. 5; P845 (UNPROFOR report re meeting with Radovan Karadžić, 15 October 1993), para. 3.

16281 P820 (Witness statement of David Harland dated 4 September 2009), para. 61; P830 (UNPROFOR Weekly Political Assessment, 16 October 1993), p. 5. 
disingenuous since often the impugned act was the firing of a heavy weapon such as a howitzer, which required crews of several men to operate. ${ }^{16282}$ At the meeting, the Accused also stated that he had given orders for the shelling and sniping to stop while Krajišnik said that he would like to see sniping stop. ${ }^{16283}$ The Accused then claimed that Bosnian Muslim shelling and sniping was a major problem and that he might be forced to take the Muslim part of Sarajevo if the sniping did not stop. ${ }^{16284}$

4832. On 4 January 1994, De Mello and Russell met with the Accused in Pale. ${ }^{1625}$ De Mello raised the disproportionate retaliation of the SRK to small levels of firing from the $\mathrm{ABiH}$, which served no military purpose, caused tragic civilian casualties, and was highly detrimental to the Serb image and cause. ${ }^{16286}$ The Accused agreed that Bosnian Serb retaliation was inappropriate and counter-productive and said that he would discuss the matter with Galić, but stated also that the $\mathrm{ABiH}$ was launching fierce ground attacks from inside Sarajevo. ${ }^{16287}$

4833. On 10 January 1994, Akashi met with the Accused and Koljević in Pale. ${ }^{16288}$ It was the first meeting between Akashi and the Accused. ${ }^{16289}$ Akashi emphasised that the recent excessive retaliations against the $\mathrm{ABiH}$ infantry attack were counter-productive, as they killed innocent people and created an unfavourable climate for the negotiations in Geneva. ${ }^{16290}$ Akashi recorded that the Accused "took the point", but expressed his impatience with the Bosnian Government's attitude in the Geneva negotiations and later threatened that if a peace agreement could not be reached soon the RS would have to "declare war". ${ }^{16291}$

4834. On 30 January 1994, Rose told the Accused, Krajišnik, Koljević, and Zametica that he was encouraged by the reduction in the shelling of Sarajevo in recent weeks and that he hoped this

P820 (Witness statement of David Harland dated 4 September 2009), para. 61; P830 (UNPROFOR Weekly Political Assessment, 16 October 1993), p. 5; P845 (UNPROFOR report re meeting with Radovan Karadžić, 15 October 1993), paras. 3, 5(i).

P845 (UNPROFOR report re meeting with Radovan Karadžić, 15 October 1993), para. 3; P820 (Witness statement of David Harland dated 4 September 2009), para. 62. Harland observed that the positions adopted by the Accused at this meeting, two weeks after the Bosnian Muslims had rejected the Owen-Stoltenberg agreement, were consistent with the assessment that the Accused sought to increase the pressure on the Bosnians when he wanted to punish the Bosnian government for not having accepted political arrangements acceptable to the Serbs. See P820 (Witness statement of David Harland dated 4 September 2009), paras. 61-63.

16285 P5034 (UNPROFOR report re meeting with Radovan Karadžić, 4 January 1994).

16286 P5034 (UNPROFOR report re meeting with Radovan Karadžić, 4 January 1994), para. 7.

16287 P5034 (UNPROFOR report re meeting with Radovan Karadžić, 4 January 1994), para. 7.

16288 D3491 (UNPROFOR report, 10 January 1994); Yasushi Akashi, T. 37680-37683 (24 April 2013).

16289 Yasushi Akashi, T. 37680-37681 (24 April 2013).

16290 D3491 (UNPROFOR report, 10 January 1994), para. 3.

16291 D3491 (UNPROFOR report, 10 January 1994), para. 3.
} 
would prove to be a durable pattern. ${ }^{16292}$ He also stated that he believed that demilitarisation was a means to solve the general issue of shelling in Sarajevo. ${ }^{16293}$ The Accused said that the continued shelling of Sarajevo was "senseless", that it should stop, and that there should be a global cease-fire starting with the demilitarisation of Sarajevo. ${ }^{16294}$

4835. On 4 February 1994, in protest to the SRK's 4 February 1994 mortar attack in Dobrinja discussed earlier in this Judgement, ${ }^{16295}$ Rose telephoned "the [VRS]" and wrote letters of protest to the Accused and Mladić. ${ }^{16296}$ However, he received no response to these protests. ${ }^{16297}$

4836. The Chamber also heard that one day after the first Markale incident on 5 February 1994, Akashi and Rose met with the Accused and Gvero at Lukavica Barracks. ${ }^{16298}$ During this meeting, the Accused told Akashi that it was the Bosnian Muslims who were responsible for the shelling and not the Bosnian Serbs. ${ }^{16299}$ This was followed up by another meeting on or about 7 February 1994, between Akashi, Rose, and the Accused, this time in Belgrade. ${ }^{16300}$ During the meeting, the Accused repeatedly denied Bosnian Serb responsibility for the first Markale incident. ${ }^{16301}$ On the same day, the Accused issued an order to the VRS Main Staff and the SRK, stating first that "there is evidence that Serbs are not responding in equal measure to Muslim artillery provocations sometimes twenty to thirty, or even seventy times more" and ordering as a result that the VRS

16292 P1638 (Witness statement of Michael Rose dated 26 March 2009), paras. 26, 30 (testifying that, on his arrival in Sarajevo on 23 January 1994, the intensity of the shelling was approximately 1,500-2,000 shells per day, going both ways, and that sniping was common); D700 (UNPROFOR report re meeting with Radovan Karadžić and Ratko Mladić, 30 January 1994); P1650 (UNPROFOR report on meeting with Radovan Karadžić and Ratko Mladić, 31 January 1994), para. 3.

16293 P1638 (Witness statement of Michael Rose dated 26 March 2009), para. 30.

16294 P1638 (Witness statement of Michael Rose dated 26 March 2009), para. 31; P1650 (UNPROFOR report on meeting with Radovan Karadžić and Ratko Mladić, 31 January 1994), para. 3; D700 (UNPROFOR report re meeting with Radovan Karadžić and Ratko Mladić, 30 January 1994), para. 3. Rose testified that, at this time, a global cease-fire was in the Bosnian Serb's interests because they held $70 \%$ of the territory of $\mathrm{BiH}$, and therefore a cease-fire represented an opportunity for them to consolidate their territorial gains. See P1638 (Witness statement of Michael Rose dated 26 March 2009), para. 31.

16295 See discussion in relation to Scheduled Incident G.7.

16296 P1638 (Witness statement of Michael Rose dated 26 March 2009), para. 35.

16297 P1638 (Witness statement of Michael Rose dated 26 March 2009), para. 35.

16298 D713 (UNPROFOR report re talks with Radovan Karadžić and Alija Izetbegović, 6 February 1994), e-court p. 1; Yasushi Akashi, T. 37688-37689 (24 April 2013); Michael Rose, T. 7547-7549 (8 October 2010). See also para. 4205.

16299 Yasushi Akashi, T. 37688-36789 (24 April 2013).

16300 P1638 (Witness statement of Michael Rose dated 26 March 2009), para. 41.

16301 P1638 (Witness statement of Michael Rose dated 26 March 2009), para. 41 (adding that Akashi told the Accused that unless he agreed to a cease-fire and pulled his big guns 20 kilometres away from Sarajevo, the UN would bow to mounting international pressure and agree to NATO air strikes; the Accused agreed to consider Akashi's proposal, but stated that the Serbs would not move until the Muslims moved). 
introduce "the strictest possible control of retaliation to provocations", respond only when threatened and against military targets, and strictly at the commander's commands. ${ }^{16302}$

4837. On 15 March 1994, at a meeting between, inter alios, the Accused, Mladić, and Slobodan Milošević in Belgrade, the Accused complained that "[o]ur idiots are firing on Sarajevo" and described the army as acting like a "pampered prima donna". ${ }^{16303}$ In his diary, Mladić stated that the Accused made these statements for the purpose of attacking the VRS. ${ }^{16304}$

4838. On 19 March 1994, Rose sent a letter to the Accused protesting, inter alia, the increased level of sniping in Sarajevo, and requesting that the Accused take measures to ensure that the sniping stopped immediately. ${ }^{16305}$ On 21 March 1994, the Accused wrote to Akashi in response to Rose's letter, suggesting that it was "extraordinary" that Rose was surprised at the level of sniping in Sarajevo when the UN was not controlling Bosnian Muslim infantry, and stating that Bosnian Serbs were "constantly" the victims of such sniping. ${ }^{16306}$

4839. On 20 September 1994, Rose and Andreev met with the Accused, Koljević, Krajišnik, Milovanović, and Tolimir. ${ }^{16307}$ During this meeting Rose reiterated his strong denunciation of VRS involvement in attacks on Sarajevo on 18 September 1994. ${ }^{16308}$ The Accused gave an "angry diatribe" about $\mathrm{ABiH}$ attacks, and stated that "[i]f the international community treats us like a beast, then we will behave like a beast". ${ }^{16309}$

4840. On 10 October 1994 Rose sent a letter of protest to the Accused in relation to Scheduled Incident F.11, informing the Accused of the incident and requesting that he "take all appropriate measures to identify and prosecute the perpetrators of this crime". 16310

\footnotetext{
16302 P846 (Radovan Karadžić's Order to VRS, 7 February 1994); P3033 (Reynaud Theunens's expert report entitled "Radovan Karadžić and the SRBiH TO-VRS (1992-1995)"), para. 76.

16303 P1485 (Ratko Mladić's notebook, 9 January-21 March 1994), pp. 165-179.

16304 P1485 (Ratko Mladić's notebook, 9 January-21 March 1994), p. 179.

16305 P1638 (Witness statement of Michael Rose dated 26 March 2009), para. 63; P1656 (Letters from Radovan Karadžić to Yasushi Akashi, 21 and 28 March 1994), e-court p. 5.

16306 P1656 (Letters from Radovan Karadžić to Yasushi Akashi, 21 and 28 March 1994), e-court p. 3.

16307 P1638 (Witness statement of Michael Rose dated 26 March 2009), para. 151; P820 (Witness statement of David Harland dated 4 September 2009), paras. 134-138; P834 (UNPROFOR report re meetings with Bosnian Serb and Bosnian Muslim leadership, 20 September 1994); David Harland, T. 2227-2235 (10 May 2010).

16308 P1638 (Witness statement of Michael Rose dated 26 March 2009), para. 151.

16309 D162 (Michael Rose's book entitled "Fighting for Peace: Bosnia, 1994"), p. 199; P1638 (Witness statement of Michael Rose dated 26 March 2009), para. 151; P820 (Witness statement of David Harland dated 4 September 2009), para. 135; David Harland, T. 2232 (10 May 2010); P834 (UNPROFOR report re meetings with Bosnian Serb and Bosnian Muslim leadership, 20 September 1994), para. 3.

16310 P1638 (Witness statement of Michael Rose dated 26 March 2009), para. 156; P1644 (Letters from Michael Rose to Alija Izetbegović and Radovan Karadžić, 9 October 1994) (Rose also protested to Alija Izetbegović for a sniping incident in Vojkovići for which the $\mathrm{ABiH}$ was found to be responsible); P1762 (Witness statement of
} 
4841. In early November 1994, during the $46^{\text {th }}$ Bosnian Serb Assembly session, the Accused himself recounted the "hard time" he had when "that pointless shelling of Sarajevo was going on" and explained that people told him that sometimes soldiers get drunk and fire a number of shells into Sarajevo "without aim and purpose". ${ }^{16311}$ The Accused continued by saying:

[T] hen I call General Galić and ask him whether the members of the Corps are shooting at Sarajevo. He tells me that they are not. I ask him how does he know that and he answers that he did not issue the order. I ask him if it could be done without the order and he says it should not be like that. I tell him to check it out. It happened that he did not issue the order but some idiot gave himself a right to waste the shells, which cost 500 German marks each. These acts do not make us look like a military or even like the people. This does not mean that I am attacking the soldiers but this is a request to improve the situation. Believe me, the line between the total triumph and the total disaster is very delicate. ${ }^{16312}$

4842. The Chamber recalls that, following Scheduled Incident G.10, on 7 April 1995, the SRK Command reported to the VRS Main Staff that in the morning the ABiH opened "fierce fire" on Famos with, inter alia, infantry weapons and an $82 \mathrm{~mm}$ mortar, in response to which the Ilidža Brigade fired one air bomb weighing 250 kilograms "at the centre of Hrasnica". ${ }^{16313}$ The VRS Main Staff then sent a combat report to the Accused, informing him of these events, including the attack on Famos, as well as the fact that "the enemy was adequately responded to whereby an A/B /air bomb/ (250kg) was launched on the centre of Hrasnica."16314

4843. On 30 April 1995, Akashi, Janvier, Smith, and Banbury met with, among others, the Accused, Koljević, Krajišnik, Zametica, and Bogdan Subotić in Pale. ${ }^{16315}$ After suggesting that the Bosnian Muslims should be told that there will be no more humanitarian aid because they are killing Serb people, the Accused said during this meeting that "retaliation is productive". 16316 Janvier responded by telling the Accused that the Serbs were targeting civilians, to which the Accused replied that they only targeted military targets. ${ }^{16317}$ When Janvier disagreed with this,

David Fraser dated 17 October 2010), pp. 43-44; P1674 (UNPROFOR report re meeting with Ratko Mladić, 11 October 1994); Vlade Lučić, T. 30817 (3 December 2012).

16311 P1403 (Transcript of First Part of $46^{\text {th }}$ session of RS Assembly, 9-11 November 1994), p. 324.

16312 P1403 (Transcript of First Part of $46^{\text {th }}$ session of RS Assembly, 9-11 November 1994), p. 324.

16313 P1782 (SRK combat report, 7 April 1995), pp. 1-2.

16314 P5943 (VRS Main Staff Report, 7 April 1995), pp. 4-5.

16315 P2262 (UNPROFOR report re meetings with Bosnian Serb and Bosnian Muslim leadership, 30 April 1995), para. 9; Rupert Smith, T. 11350-11352 (8 February 2011); Rupert Smith, T. 11657-11658 (11 February 2011); P2451 (Witness statement of Anthony Banbury dated 19 May 2009), para. 145; P2493 (Anthony Banbury's notes, 30 April 1995).

16316 P2451 (Witness statement of Anthony Banbury dated 19 May 2009), para. 154; P2493 (Anthony Banbury's notes, 30 April 1995), p. 9.

16317 P2451 (Witness statement of Anthony Banbury dated 19 May 2009), para. 154; P2493 (Anthony Banbury's notes, 30 April 1995), p. 9. 
citing Tuzla as an example, the Accused laughed and, according to Banbury, stated that "[m]aybe some of our gunners have bad eyes". 16318

4844. On 9 May 1995, Smith met with the Accused and Zametica at a hotel near Pale. ${ }^{16319}$ Smith informed the Accused that he had recommended NATO air strikes in response to a concentrated heavy-weapons attack on Sarajevo and the civilian population on 7 and 8 May $1995 .{ }^{16320}$ According to Smith, the Accused did not deny that the Bosnian Serbs had shelled civilian areas, but expressed disillusionment and dissatisfaction with the UN, stated that he had intelligence that the $\mathrm{ABiH}$ had begun an offensive to lift the siege of Sarajevo, and threatened that he "could not allow the UN to help them beat us". ${ }^{16321}$ The Accused also made clear that in the event of a NATO attack the UN would be treated as enemies. ${ }^{16322}$ The Accused expressed his discontent with the international community and emphasised that he would not respect any international bodies or resolutions unless they were in the interest of the Bosnian Serbs. ${ }^{16323}$ He then stated that the Serbs would make counter-oves against their enemies, particularly in Sarajevo. ${ }^{16324}$

4845. In an interview on 13 July 1995 in El País, when asked why he approved the shelling of the civilian population of Sarajevo, the Accused responded that the Bosnian Serbs never shelled the civilian population but were targeting the $\mathrm{ABiH} .{ }^{16325}$ He blamed the $\mathrm{ABiH}$ for firing their own artillery from or close to civilian areas, to which the VRS would respond. ${ }^{16326}$ The Accused stated that the ABiH were killing the Bosnian Serbs and that the VRS had to "eliminate" them. ${ }^{16327}$

16318 P2451 (Witness statement of Anthony Banbury dated 19 May 2009), para. 154; P2493 (Anthony Banbury's notes, 30 April 1995), p. 9.

16319 P2264 (UNPROFOR report re meeting with Radovan Karadžić, 9 May 1995), para. 1; Rupert Smith, T. 1135511360 (8 February 2011).

16320 P2264 (UNPROFOR report re meeting with Radovan Karadžić, 9 May 1995), paras. 2-3; Rupert Smith, T. 11355-11360 (8 February 2011) (testifying that there was no military justification for this shelling of the civilian population). See para. 3609.

16321 P2264 (UNPROFOR report re meeting with Radovan Karadžić, 9 May 1995), para. 3; Rupert Smith, T. 1135711358 (8 February 2011).

16322 P2264 (UNPROFOR report re meeting with Radovan Karadžić, 9 May 1995), paras. 2-3; Rupert Smith, T. 11355 (8 February 2011). See paras. 5964, 5978.

16323 P2264 (UNPROFOR report re meeting with Radovan Karadžić, 9 May 1995), para. 4; Rupert Smith, T. 11358 (8 February 2011).

16324 P2264 (UNPROFOR report re meeting with Radovan Karadžić, 9 May 1995), para. 6 (stating that it was "clear that we can expect a further increase in military activity in Sarajevo" and that "a general counter-offensive is not expected but pre-emptive attacks remain likely").

16325 P4359 (Radovan Karadžić's interview in El País, 13 July 1995), p. 4; Tomasz Blaszczyk, T. $27371-27373$ (11 April 2012); Mira Mihajlović, T. 24291-24294 (8 February 2012); P2242 (Radovan Karadžić's agenda, 2 January-25 December 1995), p. 91.

16326 P4359 (Radovan Karadžić's interview in El País, 13 July 1995), p. 4.

16327 P4359 (Radovan Karadžić's interview in El País, 13 July 1995), p. 5. The Accused also stated that Sarajevo was a divided city, and predicted that Sarajevo would either be transformed into two cities (Bosnian Muslim and Bosnian Serb), or if the Bosnian Muslims did not agree to split the city, "we would take the whole Sarajevo". See P4359 (Radovan Karadžić's interview in El País, 13 July 1995), pp. 5-6. 
4846. As discussed in the Judgement, ${ }^{16328}$ in the afternoon of 29 August 1995, one day after the second shelling incident at Markale market, the Accused, Mladić, Plavšić, Krajišnik, Tolimir, and Gvero, among others, met with Slobodan Milošević, Bulatović, and Perišić, to discuss the upcoming peace conference. ${ }^{16329}$ During this meeting, Milošević encouraged the Bosnian Serb leadership to criticise the shelling and the killing of innocent civilians in Sarajevo "in a more severe way", to which Tolimir reacted saying that by 11 a.m. on that day, no one had precise information as to where the shell had come from. ${ }^{16330}$ Milošević retorted, however, that Akashi had informed him that the shell that struck Markale came from the Bosnian Serb side, to which Mladic stated that the shells could have come only from the Muslim mobile launching pads. ${ }^{16331}$ Mladić also voiced his doubt about the number of victims, given the size of the crater which he deemed "not bigger than an ashtray". 16332

4847. As also discussed earlier, on 30 August 1995, at around 2 a.m., letters were sent to Mladić, the Accused, and Slobodan Milošević informing them that NATO air strikes had commenced. ${ }^{16333}$ Both Milošević and the Accused were informed of the UN's conclusions with respect to the second Markale incident and about the initiation of the air strikes; in the letter to the Accused, Akashi also wrote that the "key to stopping the air action" was in the Accused's and Mladić's hands and strongly urged him to ensure that the attacks on Sarajevo stopped. ${ }^{16334}$

\section{(2) Accused informed of the campaign through media reports}

4848. The Chamber also heard evidence that the sniping and shelling of civilians was widely covered in the press, and that the Accused closely followed this coverage. Events in Sarajevo were particularly well covered by the media, reporters from the international press corps were common in Sarajevo, and the media was critical of violations of international humanitarian law in the city. ${ }^{16335}$ Sniping incidents in particular received widespread coverage in the press. ${ }^{16336}$

\footnotetext{
16328 See para. 4299.

16329 D3051 (Witness statement of Momir Bulatović dated 25 February 2013), paras. 35A-35C; D3364 (Witness statement of Dušan Kozić dated 7 April 2013), para. 28; D3058 (Record of meeting between leaderships of FRY and RS, 29 August 1995).

16330 D3058 (Record of meeting between leaderships of FRY and RS, 29 August 1995), p. 8; D3364 (Witness statement of Dušan Kozić dated 7 April 2013), para. 28. With respect to paragraph 28 of Kozić's statement, the Chamber notes that P5039 is a duplicate of D3058.

16331 D3058 (Record of meeting between leaderships of FRY and RS, 29 August 1995), pp. 8-9; D3051 (Witness statement of Momir Bulatović dated 25 February 2013), para. 35C; D3364 (Witness statement of Dušan Kozić dated 7 April 2013), para. 28.

16332 D3058 (Record of meeting between leaderships of FRY and RS, 29 August 1995), p. 9.

16333 See para. 4300.

16334 P2826 (UNPROFOR report re NATO air strikes, 30 August 1995), e-court p. 4.

16335 P5906 (Witness statement of KDZ450 dated 17 January 2011), paras. 131-132. See also P2414 (Witness statement of KDZ182), p. 33 (under seal); P2068 (Witness statement of Jeremy Bowen dated 10 August 2009),
} 
Furthermore, UNPROFOR protests would be publicised through journalists and a statement would be made at the daily press point, which sometimes elicited a written response from the Bosnian Serbs or the Bosnian Muslims denying what was said. ${ }^{16337}$ [REDACTED] the Accused, Krajišnik, Plavšić, and Koljević had information from television and newspapers at their disposal, and were very well-informed about what the international media was saying about events in $\mathrm{BiH}^{16338}$

4849. Martin Bell also thought that the Accused was well-aware of his reports on the situation in Sarajevo, including the sniping and shelling of civilians, and testified that on one occasion the Accused took issue with a specific BBC report and phoned BBC News to complain. ${ }^{16339}$ Similarly, Van Lynden testified that both the Accused and Mladić told him that they watched Sky News and other international broadcasts. ${ }^{16340}$ According to Van Lynden, the Accused was eager to speak to Sky News because he considered it important to be able to put his point of view on one of the more important news organisations. ${ }^{16341}$ Van Lynden also concluded from meetings with Mladić that Mladić followed the news and was fully aware of what was happening. ${ }^{16342}$ In September 1992, Van Lynden referred to Mladić as the "scourge of Sarajevo" in a Sky News report of an interview conducted with Mladić. ${ }^{16343}$ Van Lynden testified that when he saw him next, Mladić "seemed very happy with the title" and "rather proud of it". 16344

4850. According to [REDACTED], the three parties to the conflict were all "very, very concerned about the international coverage of the events" in $\mathrm{BiH}$ and "very, very well informed by different means about what was being said about their activities or actions in the conflict". ${ }^{16345}$ On the basis of the Bosnian Serbs' comments on news stories by organisations such as BBC or CNN, and on the

para. 6; Jeremy Bowen, T. 10083, 10106 (13 January 2011) (testifying that he attempted to focus his reporting on the plight of civilians). See also para. 4587 (listing various news reports on the situation in Sarajevo).

16336

\section{7}

16338

16339

P926 (Witness statement of Aernout Van Lynden dated 26 February 2010), paras. 69-70. See also D4508 (Intercept of conversation between Radovan Karadžić and Manojlo Milovanović, 3 August 1993); and P4803 (Intercept of conversation between Radovan Karadžić and General Gvero, 11 August 1993), p. 2 (both showing that the Accused was able to contact the media when necessary).

16342 P926 (Witness statement of Aernout Van Lynden dated 26 February 2010), paras. 12-13; Aernout van Lynden, T. 2417-2418 (19 May 2010).

16343 P926 (Witness statement of Aernout Van Lynden dated 26 February 2010), paras. 13, 72, 76-90; P933 (SKY news report re Sarajevo, with transcript); Aernout van Lynden, T. 2419-2425 (19 May 2010).

16344 P926 (Witness statement of Aernout Van Lynden dated 26 February 2010), paras. 13, 86; Aernout van Lynden, T. 2424 (19 May 2010).

16345 [REDACTED]. 
basis of his visits to Pale, [REDACTED] thought that the Bosnian Serbs received information through Belgrade, from all the foreign embassies of Yugoslavia, and were also well-informed in terms of press clippings and international television coverage. ${ }^{16346}$ [REDACTED] testified that the Accused "normally had with him all these clippings and reports on the international media". ${ }^{16347}$ According to [REDACTED], the Accused would blame the international media for being part of a "complex plot against the Bosnian Serbs". ${ }^{16348}$

\section{(C) Accused's deflection of criticism and/or denial of crimes}

4851. In discussing various meetings and Accused's statements in the preceding section, the Chamber has outlined some of the ways in which the Accused reacted to specific protests and complaints. ${ }^{16349}$ In addition, KW570 testified that the Accused often tried to satisfy the demands of the international community and was a "moderating influence" on other members of the Bosnian Serb leadership and the VRS. ${ }^{16350}$ Similarly, Vere Hayes, who travelled with Briquemont to Pale to meet with the Accused, Mladić, Plavšić, and others, found the Accused to be "perfectly civil and reasonable". 16351

4852. However, many representatives of the international community gave evidence that the Accused attempted to manipulate and deceive them. For example, Banbury's impression was that the Bosnian Serb leadership "constantly played us". ${ }^{16352}$ In his opinion, when the Accused made a commitment that was not implemented, this was not because the Accused could not ensure that it was implemented but rather because he, or the Bosnian Serb leaders generally, chose not to do so. ${ }^{16353}$ In his book entitled "In the Valley between War and Peace", Akashi suggested that the Accused had a tendency to "twist the truth rather nonchalantly" in negotiations. ${ }^{16354}$ According to

\footnotetext{
16346 [REDACTED] (agreeing that the broadcast media-CNN, Sky News, BBC-were being received in BiH in 1992, and that they covered the shelling of Sarajevo).

16347 [REDACTED].

16348 [REDACTED].

16349 See paras. 4813-4847.

16350 D2770 (Witness statement of KW570 dated 21 November 2012), paras. 17-18 (under seal). See also D2658 (Witness statement of Luka Dragičević dated 9 December 2012), para. 47 (testifying that the VRS's "biggest complaint" about the Accused related to his attitude towards the international community and that ordinary soldiers felt that the Accused "made too many concessions to international elements"); D3321 (Witness statement of Milorad Skoko dated 1 April 2013), para. 30.

16351 D2745 (Witness statement of Vere Hayes dated 14 January 2013), para. 34; P824 (UNPROFOR report re meeting with Radovan Karadžić, 5 August 1993); D2752 (Photograph of a group of men in uniform).

16352 P2451 (Witness statement of Anthony Banbury dated 19 May 2009), para. 205.

16353 P2451 (Witness statement of Anthony Banbury dated 19 May 2009), para. 209. See also [REDACTED]; D94 (Radovan Karadžić's letter to SDS members, 11 July 1992); D101 (Radovan Karadžić's Order to VRS Main Staff and RS MUP, 19 August 1992). [REDACTED].

16354 D3489 (Excerpt from Yasushi Akashi's book entitled "In the Valley between War and Peace"), e-court p. 43 (giving two examples from the Goražde crisis); Yasushi Akashi, T. 37757-37759 (25 April 2013) (adding that,
} 
Tucker, all three warring parties lied, ${ }^{16355}$ while [REDACTED] UNPROFOR received written protests from the commanders of the parties and from the Accused and Mladić, but that these were characterised by "a lot of lies, of fiction" and were in fact attempts at manipulation. ${ }^{16356}$

4853. Okun gave an example where the Accused repeatedly claimed that Sarajevo was a concentration camp for Serbs, whereas Okun considered that to be "just talk" indicating "that the position taken by [the Accused] and the entire Bosnian Serb leadership was not, to put it charitably, was not based on a fair appreciation of how to solve the problem". ${ }^{16357}$ When the Accused put to Okun that "none of them said that I was a liar", Okun responded that this was not true since people, such as Carrington, would in fact say that the Accused did not tell the truth and Okun himself had direct experience of that. ${ }^{16358}$ When shown passages from Owen's book which referenced the Accused's "bare faced dishonour" and his ability "to deflect and defuse a hostile question with an innocent facial expression and apparent concern in his voice", Okun agreed that Owen was one of those involved in the negotiations who told him that the Accused did not tell the truth. ${ }^{16359}$

4854. On 10 September 1992, Vance, Owen, and Okun met with the Accused. ${ }^{16360}$ In response to the Accused's question as to why sanctions were being tightened when the Serbs were doing everything to help, Okun told the Accused that it was the Bosnian Serbs who shelled Sarajevo first. ${ }^{16361}$ The Accused responded by stating that it was the Bosnian Muslims who started the war by expelling him from his apartment in Sarajevo. ${ }^{16362}$ Okun was surprised that, in light of those already killed or displaced by the conflict and the heavy shelling occurring during this meeting, the Accused considered this to be a convincing argument. ${ }^{16363}$

as a result, Akashi became much more cautious in relation to the weight given to the Accused's undertakings, representations or agreements).

16355 Pyers Tucker, T. 23264 (18 January 2012).

16356 [REDACTED].

16357 Herbert Okun, P776 (Transcript from Prosecutor v. Krajišnik), T. 4191, 4200, 4225-4226; Herbert Okun, T. 1505-1506, 1524-1526 (23 April 2010), T. 1695 (27 April 2010); P809 (Video footage of Radovan Karadžić's Press Conference at ICFY, 18 September 1992, with transcript); D1140 (Letter to UN Secretary General, 2 February 1993), e-court p. 8 (under seal). Herbert Okun, T. 1662 (27 April 2010) (testifying that this was true on all three sides).

16359 P799 (Excerpts from David Owen's book entitled "Balkan Odyssey"), e-court pp. 10, 14; Herbert Okun, T. 1844-1846 (28 April 2010)

16360 Herbert Okun, P776 (Transcript from Prosecutor v. Krajišnik), T. 4198, 4201-4202; P784 (First notebook of Herbert Okun's ICFY diary), e-court pp. 45-47; D4474 (Report on visit by Steering Committee to Zagreb, Sarajevo and Belgrade 9-12 September 1992), paras. 18-21.

16361 Herbert Okun, P776 (Transcript from Prosecutor v. Krajišnik), T. 4201-4202; P784 (First notebook of Herbert Okun's ICFY diary), e-court p. 47.

16362 Herbert Okun, P776 (Transcript from Prosecutor v. Krajišnik), T. 4201-4202; P784 (First notebook of Herbert Okun's ICFY diary), e-court p. 47.

16363 Herbert Okun, P776 (Transcript from Prosecutor v. Krajišnik), T. 4201-4202. 
4855. Abdel-Razek testified that the Accused "showed respect to me and to the United Nations", but that there were problems with the implementation on the ground of the points of agreement in meetings, and while the meetings took place in a "positive atmosphere", the practices on the ground were "not at all acceptable" and contrary to what was agreed. ${ }^{16364}$ When asked whether this was a result of the nature of the civil war in which it was difficult to control everything in the field, Abdel-Razek responded hat he did not think he was being deceived at these meetings, but that "the problem was in the chain of command", and that the good intentions of the leadership was not reaching the soldiers. ${ }^{16365}$ He later clarified that "the discipline and rules of engagement that should be observed" by subordinate soldiers, and their obeying of orders "was loose on the ground" because there was a situation of civil war with "civilians who carried weapons and who were armed with strong passions". 16366

(D) Accused's measures to deal with crimes in Sarajevo

4856. The Accused issued a number of orders to the VRS, which were also applicable to the SRK, to comply with the laws of war and to initiate proceedings against those who broke those rules. For example, on 13 June 1992, the Accused issued an order on the application of the "rules of international law of war" in the VRS, which stated that the VRS and MUP were to apply and respect the rules of the international law of war and that commanders were responsible for the application of those rules. ${ }^{16367}$ The order also stated that it was the duty of superior officers to initiate proceedings for legal sanctions against individuals who "violate the rules of the international law of war". ${ }^{16368}$ Pursuant to this order, on 19 August 1992, the Accused issued

16364 Hussein Abdel-Razek, T. 5528-5531, 5534, 5586-5587, 5597 (20 July 2010), T. 5611, 5615-5616, 5618-5620, 5623-5624, 5640 (21 July 2010).

16365 Hussein Abdel-Razek, T. 5585-5587, 5597 (20 July 2010), T. 5611, 5615-5616, 5618-5620, 5676 (21 July 2010).

16366 Hussein Abdel-Razek, T. 5676-5677 (21 July 2010) (concluding that "there was a lack of control by the central command and that there was no full co-ordination between the leadership and the higher command and the subordinates on the ground"). The Chamber considers that this part of Abdel-Razek's evidence should be viewed alongside his other testimony, in particular his testimony that Galić and Plavšić falsely denied Bosnian Serb responsibility for sniping and shelling incidents; that neither side gave any importance to the role of the $\mathrm{UN}$; that, on both sides, "leaders manifested cooperation; however, in reality, they acted differently and undertook different actions that were not cooperative"; and that he sent a letter to the Accused instructing him to stop the shelling, but that Koljević sent a message saying that the letter could not be formally received unless Abdel-Razek properly titled the letter to the Accused as President of the RS. P1258 (Witness statement of Hussein Ali Abdel-Razek dated 16 July 2002), e-court pp. 7, 18, 22 (describing meetings with the Bosnian Serb leaders as "difficult meetings" with difficult discussions "with regard to getting the Serbs to agree to ceasing their activities of shelling, sniping and blocking the UN efforts in the Sarajevo Sector"). See also para. 4695.

D434 (Radovan Karadžić's Order on the application of laws of war, 13 June 1992); D1849 (Order of Radovan Karadžić's, 13 June 1992); D4688 (Excerpt from book entitled "Law on Defence and Law on the Army", June 1992). See also Momčilo Mandić, T. 5081-5083 (14 July 2010) (testifying that this order was issued due to the shortage of regulations governing the VRS and MUP, with the conflict already two months in progress, directing the VRS and MUP to observe international laws of war and the treaties signed by the SFRY). 
another order to the Main Staff and MUP instructing, inter alia, that "all protagonists" fulfil their obligations to observe "international humanitarian law, especially the Third and Fourth Geneva Conventions". ${ }^{16369}$ The Chamber recalls here that the Bosnian Serb military courts began to function in August 1992 and that the Accused, as Supreme Commander of the VRS, had influence and authority over the courts. ${ }^{16370}$ On 11 May 1993, the Accused issued a directive to the VRS to, inter alia, abide by the "Geneva Conventions for the protection of victims of war and their protocols 1 and 2, as well as the Hague Convention on Laws and Customs of Ground War from 1907, and other provisions of International Law of war". ${ }^{16371}$ In addition, the Chamber received a number of other examples of the Accused instructing the VRS and the SRK to avoid firing on Sarajevo and to avoid responding disproportionately to $\mathrm{ABiH}$ fire. ${ }^{16372}$

4857. The Chamber also received evidence of the Accused's ability to order prompt investigations into SRK activities, such as in relation to an SRK memo that criticised him. ${ }^{16373}$ Some Defence witnesses gave evidence of the Accused ordering investigations into alleged crimes against the civilian population of Sarajevo. In relation to the shelling of Markale market on 5 February 1994, Gordan Milinić, the Accused's Security Adviser at the time, testified that when the Accused heard about the incident on the day, he expressed astonishment and said that it was "yet another Muslim hoax"; he then "immediately called the military experts" who explained to him that the shell could not have been fired from the SRK positions and that this was a hoax by the Muslim side. ${ }^{16374}$ Similarly, Krajišnik testified that when the Accused received a protest about the shelling of Vase Miskina street on 27 May 1992, he contacted the VRS, and the VRS responded that the shell was

\footnotetext{
16369 D101 (Radovan Karadžić's Order to VRS Main Staff and RS MUP, 19 August 1992), p. 1.
}

16370 See para. 3412.

16371 D104 (Radovan Karadžić's Directive to VRS Main Staff, 11 May 1993). This directive is referred to in Mladić's order to all the VRS brigades. See D3309 (VRS Main Staff Order, 14 May 1993). The Chamber notes that the directive is dated 11 March 1993 but considers this to be a typographical error as the serial number of the directive is referred to in Mladić's follow up order of 14 May. Furthermore, the directive itself refers to a decision of the Accused of 11 May 1993.

16372 See Section IV.B.3.ii.D: Accused's orders relevant to Sarajevo.

16373 See para. 4778. Another example of the Accused's ability to order prompt investigations took place on 15 May 1995 when he ordered an investigation into the causes and consequences of the "unusual incident with tragic consequences" that happened in the Independent Prača Battalion on 10 May 1995. The following day, on 16 May 1995, Mladić implemented the Accused's order by instructing the SRK Command to, inter alia, designate two officers to a joint commission tasked with analysing the facts of the incident and drawing up a report to be submitted to the Accused. See P2682 (VRS Main Staff Order, 16 May 1995).

16374 D3682 (Witness statement of Gordan Milinić dated 8 June 2013), paras. 9, 15. See also D3051 (Witness statement of Momir Bulatović dated 25 February 2013), paras. 32-35 (testifying that the SDC was informed by Perišić that the incident was caused by the Muslim side). On 10 February 1994, the Accused held a press conference in Geneva calling for a joint commission to investigate the incident, reminding the public that the Muslim side had previously staged shelling incidents and stating that the Serbs had no reason to continue with peace negotiations until a joint commission was established and findings made. See P5974 (Video footage of Radovan Karadžić press conference in Geneva, 10 February 1994); Slavko Gengo, T. 29823-29824 (6 November 2012) (maintaining that every incident caused UNPROFOR and representatives of his brigade to attend the scene and that "controls were stepped-up as soon as something happened"). See para. 4208. 
not launched by them. ${ }^{16375}$ According to Krajišnik, the Accused immediately demanded that an inquiry be conducted. ${ }^{16376}$ Krajišnik testified that this same procedure was followed after the Markale incidents and after several shellings in Dobrinja. ${ }^{16377}$ Indeed, at around 1 p.m. on 28 August 1995, the day of the second Markale incident, Sladoje issued an order on behalf of the SRK Command banning fire on the city without approval, and asking all SRK brigades to inform the Command, by 2 p.m., as to whether they opened fire on Sarajevo between 10 a.m. and 12 p.m. that day. ${ }^{16378}$ Later that same day the VRS Main Staff reported to the Accused that the SRK brigades did not open fire on Sarajevo between 10 a.m. and 12 p.m.. ${ }^{16379}$

4858. The VRS Main Staff was also able to order investigations into the actions of SRK soldiers. For example, following an order of the VRS Main Staff on 19 August 1993, on 20 August 1993 Galić sent an order to the Ilidža Brigade Command informing it that UNPROFOR had reported mortar fire from Nedžarići over Dobrinja and that there were 14 victims; the order also requested the Ilidža Brigade Command to form a commission to investigate this incident. ${ }^{16380}$ The following day, Dragomir Milošević sent a report to the Main Staff stating that no $82 \mathrm{~mm}$ mortars were fired from Nedžarići, but that the ABiH had fired 12 "mines" of $82 \mathrm{~mm}$ calibre over the High School in Ilidža to endanger the lives of the students, and stating that the ABiH's provocation was responded to with infantry arms meaning that 14 victims was not possible. ${ }^{16381}$

4859. In addition to the above evidence of the Accused's reactions to specific incidents, the Chamber also received evidence of measures taken by him to collect information about crimes in $\mathrm{BiH}$ in general and has already outlined those in the preceding section of this Judgement. ${ }^{16382}$ The Chamber recalls in particular his attitude that it was important to prevent disagreement among the Serbs, even at the expense of not punishing crimes. ${ }^{16383}$ As has also been noted in an earlier section of the Judgement, ${ }^{16384}$ in a session on 15 September 1994, the RS Government, with the

Momčilo Krajišnik, T. 43333-43334 (12 November 2013).

Momčilo Krajišnik, T. 43334 (12 November 2013).

Momčilo Krajišnik, T. 43333-43334 (12 November 2013).

D1013 (SRK Order, 28 August 1995).

D2313 (VRS Main Staff Report, 28 August 1995). See also para. 4296.

D2586 (SRK Order, 20 August 1993).

D2582 (SRK report, 21 August 1993); D2562 (Witness statement of Vladimir Radojčić dated 8 December 2012), paras. 95, 101 (testifying also that this was an example of his brigade carrying out an investigation on the order of the Main Staff and that the accusations of UNMOs in this instance were unjustified). See also P2695 (SRK report, 26 August 1994) (SRK Command response to VRS Main Staff order of two days earlier, explaining that, pursuant to the order, an investigation commission was formed, interviews conducted, and that it had been concluded that there was no disciplinary offence so that the investigation should be suspended with a reprimand issued).

16382 See paras. 3212-3215.

16383 See para. 3413.

16384 See para. 266.
} 
support of the Accused, authorised the MUP and the Ministry of Justice and Administration to collect information on crimes against humanity and other crimes violating international law, irrespective of the ethnicity of the victims of those crimes. ${ }^{16385}$ On 4 January 1995, the Accused promulgated the Law on the Mandatory Submission of Information on Crimes against Humanity and International Law. ${ }^{16386}$ This law required that anyone in possession of information that could serve as evidence of "crimes against humanity and international law committed during the internal armed conflicts and civil war in [RS] and other parts of the former [BiH] which began in 1992" make the information available for inspection and, if necessary, submit them to the body in charge of gathering information on such crimes, and stated that anyone who refused to do so or thwarted the delivery or availability for inspection of such information would be punished with either a fine or maximum one year's imprisonment. ${ }^{16387}$ However, on 17 May 1995, Marko Lugonja on behalf of the Intelligence and Security Department of the SRK Command sent out a request to the Commands of all SRK units to "gather all the data and evidence in the zones of your units on war crimes against humanity and international law committed by the enemy against the Serbs and Serbian people”. ${ }^{1638}$ In the request, Lugonja stated that the evidence will be delivered to the Military Prosecutor's Offices, which will prepare criminal reports in co-operation with the Ministry of Justice depending on jurisdiction. ${ }^{16389}$

4860. The Chamber also recalls its finding that the VRS had a system for investigating and punishing crimes committed by VRS soldiers. ${ }^{16390}$ Thus, the SRK had its own military police company, military court, and military prosecutor's office. ${ }^{16391}$ Galić testified that, when he received protests of shelling or sniping of civilians, he would check with his subordinate units and would always conclude that "[t]here was nothing to investigate". ${ }^{16392}$ From 8 June 1992 to 31 December 1992, the SRK Military Prosecutor requested the VRS Military Prosecutor's Offices to initiate 610 investigations, one of which was a request to investigate an officer for crimes against

\footnotetext{
16385 D3364 (Witness statement of Dušan Kozić dated 7 April 2013), para. 18; D3373 (Excerpt from minutes of 4th session of RS Government, 15 September 1994), p. 2.

16386 D1424 (Radovan Karadžić's Decree on promulgation of Law on mandatory submission of information on crimes against humanity and international law, 4 January 1995), p. 1; P1405 (Transcript of $48^{\text {th }}$ session of RS Assembly, 29-30 December 1994), p. 129.

16387 D1424 (Radovan Karadžić's Decree on promulgation of Law on mandatory submission of information on crimes against humanity and international law, 4 January 1995), pp. 2-3.

16388 P2646 (Request of SRK's Intelligence and Security Department, 17 May 1995), p. 1 (emphasis added). This request followed a meeting of the Government's "Commission for gathering data on war crimes against humanity [sic] and international law committed on the territory of the [RS]", which was organised by the Ministry of Justice. P2646 (Request of SRK's Intelligence and Security Department, 17 May 1995).

16389 P2646 (Request of SRK's Intelligence and Security Department, 17 May 1995).

16390 See Section II.D.2: Military justice system.

16391 See paras. 282-292; P2645 (Radovan Karadžić's order to VRS Main Staff, MUP, and Ministry of Defence, 20 May 1992); Dragomir Milošević, T. 32859-32860 (29 January 2013).

16392 Stanislav Galić, T. 37807-37809, 37821-37824 (7 May 2013).
} 
humanity and international laws of war. ${ }^{16393}$ Dragomir Milošević estimated that, during his time as the SRK Commander, he submitted about 70 criminal reports to the prosecutor for further action. ${ }^{16394}$ Milošević did not know, however, whether any of the reports he submitted related to the shelling or sniping of civilians in Sarajevo. ${ }^{16395}$ Luka Dragičević confirmed that during his time as Assistant Commander for Moral Guidance, Religious and Legal Affairs in the SRK, from the beginning of December 1994 until the end of the war, he received monthly reports from the military prosecutor's office but never learned of any instances where an SRK commander reported a criminal violation of the international laws of war to the military prosecutor in relation to the firing on Sarajevo. ${ }^{16396}$ This was confirmed by SRK soldiers and officers who testified in this case. ${ }^{16397}$ Indeed, the Chamber received evidence of numerous reports regarding investigations into and punishments of crimes, none of which relates to the sniping or shelling of civilians in Sarajevo. ${ }^{16398}$

16393 P3629 (Report on the work of the VRS Military Prosecutor's Offices for 1992, 10 February 1993), pp. 6-12.

16394 Dragomir Milošević, T. 32859-32865 (29 January 2013) (adding that he did not interfere with the work of the military prosecutor or court). See, e.g., D2832 (1 ${ }^{\text {st }}$ Romanija Brigade combat report, 4 July 1992), p. 2 ; D2833 (SRK instructions, 15 October 1992, with 1992 Guidelines for the Establishment of Criteria for Criminal Prosecution); Dragomir Milošević, T. 32868-32871 (29 January 2013).

16395 Dragomir Milošević, T. 33211-33213 (5 February 2013), T. 33276-33277 (6 February 2013) (noting that, because of the extent of the activities and tasks he had to carry out as Corps Commander, he did not have the opportunity to personally carry out the full procedure of investigating UNPROFOR allegations about Serb soldiers sniping at civilians; instead, he relied on the assistance of the military police and the prosecutor's office).

16396 Luka Dragičević, T. 31437-31440 (13 December 2012) (confirming his testimony in the Dragomir Milošević case), T. 31461-31462 (14 December 2012); Dragomir Milošević, T. 33213-33216 (5 February 2013) (suggesting that some reports of the SRK Command may not have gone through Dragičević, but through Tolimir).

16397 Slavko Gengo, T. 29768, 29829-29830 (6 November 2012); D2267 (Vlado Lizdek's interview with OTP), ecourt p. 66; Vlade Lučić, T. 30785-30787, 30803-30804 (3 December 2012) (adding that if the question of whether a soldier had opened fire unnecessarily was raised, the unit would always reach the conclusion that no such thing happened). But see Blagoje Kovačević, T. 29075-29077 (18 October 2012) (testifying that while he was not aware of any investigations conducted in his brigade into cases of shelling civilians, there were instances of individuals opening unauthorised fire, whereby despite not knowing whether that fire had caused any consequences or killed or injured any civilians, the individual was punished for breach of discipline).

See, e.g. D4755 (Report of VRS Office of Military Prosecutor, November 1992) (noting that only "civiliansmembers of the enemy armed forces" were prosecuted for crimes against humanity and war crimes); D4880 (Report of Sarajevo Military Court, 2 December 1993); D2836 (SRK information, 23 December 1993) (reporting that, in November 1993, units of the SRK filed a total of 79 criminal reports with the Military Prosecutor's Office, and crimes included willful abandonment and desertion, violation of military duties, property crimes, violent crimes, and other crimes); D4634 (Sarajevo Military Court decision in Šehir Korjenić/Fatuša Korjenić case, 5 July 1993); D3483 (SRK Order, 22 September 1992); D3484 (SRK Order, 22 May 1993), p. 1; D3486 (SRK report, 31 May 1994); Stanislav Galić, T. 37629-37631 (23 April 2013); D2832 ( $1^{\text {st }}$ Romanija Brigade combat report, 4 July 1992), p. 3; D2834 (Report of $1^{\text {st }}$ Romanija Infantry Brigade, 15 December 1992); D2835 (SRK report, 27 August 1993); Dragomir Milošević, T. 32860-32861, 32865-32866 (29 January 2013); D327 (SRK Order, 18 August 1993); D2610 (Order of the Ilidža Brigade, 26 July 1993); D2568 (Order of $3^{\text {rd }}$ Ilidža Brigade, 11 September 1993) (assaulting the Commander of Herzegovina Company); D2562 (Witness statement of Vladimir Radojčić dated 8 December 2012), paras. 74, 137; P2706 (SRK request to VRS, 25 May 1995) (criminal and disciplinary responsibility against SRK soldiers, officers and commands because of the loss of territory and material and technical equipment and the deaths, wounding and disappearance of combatants in the area of Nišić plateau and Trnovo axis during 1994); P2701 (Report of $4^{\text {th }}$ Military Police Battalion, February 1995); P2702 (SRK order, 18 March 1995); P2705 (SRK Order, 16 April 1995); P2703 (Order of Military Post 7033, 2 April 1995); P2707 (SRK Order, 3 June 1995); P2701 (Report of $4^{\text {th }}$ Military Police Battalion, February 1995); P2708 (Letter from SRK to $4^{\text {th }}$ Military Police Battalion, 4 June 


\section{(E) Conclusion}

4861. In light of the evidence of numerous representatives of the international community, and even some Defence witnesses, about the regular protests that the Accused received throughout the conflict, the Chamber is convinced that the Accused knew that the SRK was sniping and shelling the civilian population of Sarajevo or launching indiscriminate and/or disproportionate attacks on the city throughout the conflict. This is further confirmed by the fact that he was aware of Security Council resolutions which were discussed at the meetings he attended and thus was fully aware of the international community's statements about the situation in Sarajevo, the plight of civilians, and violations of international humanitarian law. The evidence also shows that the Accused was cognisant of numerous media reports regarding the situation in the city and had interactions with journalists who repeatedly brought to his attention instances of shelling and sniping of civilians, as illustrated in his El País interview. Indeed, the fact that the Accused himself at times raised concerns and attempted to limit disproportionate attacks on the city, according to Galić and some of the orders he issued to the SRK, confirms the Chamber's conclusion that he was fully cognisant of the SRK's firing practices in Sarajevo.

4862. In relation to the Accused's submission that there were problems with the system of command and control during the war and that his receipt of information must be considered in this light, the Chamber already found that the command and control system, as well as the communication channels, within the SRK and the Main Staff through to the Accused, functioned

well. ${ }^{16399}$ Furthermore, the Chamber recalls that the section discussing the Accused's authority over the SRK and his involvement in Sarajevo-related matters contains a number of examples of him receiving information about the military situation in Sarajevo during meetings with various VRS and SRK commanders and during the meetings of the Supreme Command. Additionally, the Accused was based in Pale, not far from Sarajevo, and had direct access to the SRK Commander and SRK troops. Accordingly, the Chamber does not accept that any problems that might have existed with respect to the system of command and control had a significant effect on the information the Accused was receiving and/or was able to seek out from the VRS and the SRK with respect to Sarajevo.

4863. That notwithstanding, the Chamber accepts the Accused's submission that SRK combat reports did not contain information about many of the specific sniping and shelling incidents for

1995); D2331 (Witness statement of Blagoje Kovačević dated 14 October 2012), para. 34; Božo Tomić, T. 30199-30200 (13 November 2012); D2331 (Witness statement of Blagoje Kovačević dated 14 October 2012), paras. 33-34.

16399 See para. 4808 
which he is now charged. The Chamber has already found this to be the case, with the exception of a few reports which did in fact refer to some of the scheduled incidents. ${ }^{16400}$ The Chamber recalls here its finding that SRK combat reports generally stated that the SRK returned fire when attacked, but provided very little information about the nature of the SRK response to $\mathrm{ABiH}$ fire; they also rarely detailed the specific weaponry used, the quantity of fire used, the exact locations targeted by the SRK, and made no mention of most of the scheduled sniping or shelling incidents listed in the Indictment. ${ }^{16401}$ Nevertheless, as outlined above, the Accused was informed of the occurrence of Scheduled Incidents F.11, G.1, G.2, G.4, G.7, G.8, G.10, and G.19. ${ }^{16402}$ Further, it is clear that he was also informed, by the representatives of the international community, that the SRK was the responsible party. For example, with respect to Scheduled Incident G.1, when made aware that the SRK was responsible for the heavy bombardment he retorted that the fire was legitimate and that the SRK was defending Serbs. Further, as indicated by the intercepted conversation of 30 May with Čedo, while instructing that the use of artillery in the city should be halted, he also ordered that infantry fire should continue and to "let them all die". Similarly, with respect to Scheduled Incident G.2, the fact that the RS Presidency was involved in stopping the bombardment of the city and was successful in doing so clearly indicates that the Accused was aware that the SRK was responsible. As for Scheduled Incident G.4, Morillon sent a fax to the Accused, which placed the blame on the SRK, and also stated that the world would not tolerate the irresponsible behaviour of the Accused's troops. Similarly, with respect to Scheduled Incident G.7, Rose wrote a letter of protest to the Accused but received no response. With respect to Scheduled Incident F.11, the Accused was informed by Rose that the SRK was responsible for the sniping of Alma Ćutuna and that he should investigate and prosecute those responsible, but he failed to respond. As for Scheduled Incident G.19, the Accused was informed not only by the representatives of the international community but also by Slobodan Milošević, that the information was that the SRK was responsible for the incident and yet continued to deny it. In addition to the Accused's knowledge about some of the specific incidents charged, the Chamber also recalls that the representatives of the international community persistently informed the Accused of the SRK's general sniping and shelling of civilians for the duration of the campaign. The Chamber is therefore satisfied that the Accused knew that the SRK was committing crimes, including in relation to the incidents listed in Schedules F and G of the Indictment, or alternatively that he had reason to know but did not make a genuine effort to ascertain whether the SRK was responsible for these crimes. Accordingly, the lack of specific information in the SRK reports as to the scheduled

\footnotetext{
16400 See para. 4602.

16401 See para. 4602.

16402 See Section IV.B.3.iii.B: Accused's knowledge.
} 
shelling and sniping incidents does not undermine the Chamber's conclusion in the preceding paragraph.

4864. The Chamber also notes that the witnesses who gave evidence of protests and complaints directed at the Accused consistently described a pattern of responses characterised by him (i) denying Bosnian Serb responsibility, (ii) blaming the $\mathrm{ABiH}$ for perpetrating or orchestrating the incidents, (iii) justifying the actions on the basis of defending Serbs, or (iv) deflecting the criticism by making promises or raising other issues. The evidence shows that the same approach was used by Mladić, Galić, Dragomir Milošević, Krajišnik, Koljević, and Plavšić. There were repeated attempts by the Accused and the Bosnian Serb political and military leadership to justify the existence of the campaign of sniping and shelling and promises made to international representatives to improve the situation. However, the Chamber finds, in light of its factual findings as to the situation in Sarajevo during the siege, that these assurances were completely at odds with the reality on the ground. While Abdel-Razek and KW570 testified that the Accused was genuinely co-operative in his interactions with the international community and that the implementation problem lay in the chain of command, this is contrary to the majority of the evidence received by the Chamber, including Abdel-Razek's own witness statement and the credible observations of many witnesses, such as Akashi, that the Accused dealt with representatives of the international community in a dishonest, disingenuous, and evasive manner. ${ }^{16403}$ It is also contrary to the findings above that the chain of command within the SRK and the VRS was functioning well. ${ }^{16404}$

4865. The Chamber does accept KW570's evidence that the Accused was more moderate than some of those around him; however, it is also clear on the basis of the evidence before it that the Accused was moderate only as long as the Bosnian Serb objectives in relation to Sarajevo were not being jeopardised. ${ }^{16405}$ Further, the Accused was duplicitous in his dealings with the international community, as illustrated by the aftermath of the shelling of Sarajevo in late May 1992 whereby, having been pressured to do so by the international community, he stopped the shelling, but then ordered a certain Čedo to continue using infantry fire. Accordingly, the Chamber is convinced that while on notice of crimes that formed part of the campaign of sniping and shelling of the civilian

\footnotetext{
16403 The Chamber notes that KW570's and Hayes' evidence that the Accused was polite and civil is not inconsistent with the Chamber's conclusion. Further, the Chamber notes that KW570 was in Sarajevo for a short period of time, while Hayes based his evidence on one encounter with the Accused.

16404 See para. 4751.

16405 See e.g. para. 4663. The Chamber also notes here its finding in fn. 11086 that while he did speak in terms which portrayed him publicly as the peaceful negotiator, the Accused always insisted that this peace was conditional on following the objectives of the Bosnian Serbs.
} 
population being committed in Sarajevo by the SRK units, the Accused nevertheless deflected criticism and denied those crimes or provided misleading information about them.

4866. As regards the Accused's alleged failure to prevent or punish the perpetrators of crimes forming part of the campaign of sniping and shelling, the evidence before the Chamber does show that at times he attempted to address the issue of the disproportionate fire on the city and issued a number of orders throughout the conflict to the VRS and/or the SRK to respect the laws of war and stop shelling indiscriminately. However, in the Chamber's view these were few and far between, given that the campaign of sniping and shelling of civilians lasted for over three years. Furthermore, the evidence also shows that despite the existence of a functioning system for investigating and punishing soldiers for criminal actions, there were simply no examples of SRK soldiers being punished for the sniping or shelling of civilians. Multiple Defence witnesses suggested that, as Galić testified, "[t]here was nothing to investigate". ${ }^{16406}$ When investigations were conducted, whether pursuant to an order of the Accused or otherwise, the findings invariably stated that the SRK could not have been responsible for the attacks on civilians. However, this is contrary to the Chamber's findings on scheduled shelling and sniping incidents and on the SRK's general conduct which was brought to the Accused's attention continuously and consistently during the conflict. ${ }^{16407}$ In light of the Chamber's findings as to the existence of the campaign of sniping and shelling of civilians and the knowledge of the crimes on the part of the Accused and others, this pattern of impunity demonstrates that the orders issued by the Accused, as well as the few investigations and inquiries that were embarked upon by him, were not sincere. Instead, the Chamber is convinced that the Accused made no meaningful attempts to establish the accuracy of allegations made against the SRK. When a serious incident was brought to his attention, he would contact the VRS and then simply accept assurances that the SRK units were not responsible; he would also demand a joint investigation which he knew would never be accepted by the international community or by the Bosnian Muslim side. ${ }^{16408}$ This is in stark contrast to his reaction to Dragičević's report of 2 March 1995, following which he immediately ordered that an urgent report be sent to him. In contrast, when informed of the first Markale shelling and before even inquiring with the VRS officials about it, he immediately labelled it "another Muslim hoax". ${ }^{6409}$ This approach to the accusations made against his troops signifies a failure on the part

\footnotetext{
16406 See para. 4860.

16407 The Chamber excludes from this analysis Scheduled Incidents F.5, F.7, and G.6 as it was not satisfied that the evidence presented by the Prosecution was sufficient to establish beyond reasonable doubt that the SRK was responsible for these incidents. In addition, for his part in this analysis, Judge Baird does not rely on Scheduled Incident G. 8 due to his dissent in relation thereto.

16408 See paras. 4208, 4857.

16409 See para. 4857.
} 
of the Accused, as Supreme Commander of the VRS, and also on the part of Mladić, Galić and Milošević, to take meaningful steps to investigate and punish the attacks on civilians of which they were well-informed. ${ }^{16410}$

4867. The conclusion above is supported by evidence of a collective attitude of impunity for actions of the SRK taken in furtherance of the campaign as illustrated by Lugonja's call for evidence on crimes "committed by the enemy against the Serbs and Serbian people", which explicitly excluded crimes committed by Serbs. ${ }^{16411}$ In effect, the Accused encouraged this impunity by his consistent denials and deflections of international criticism and through his failure to insist on investigations and/or punishment of SRK units responsible for attacks on civilians in the city. ${ }^{16412}$

\section{iv. Accused's modulation of sniping and shelling}

(A) Arguments of the parties

4868. The Prosecution alleges that the Accused modulated the campaign of sniping and shelling in Sarajevo in accordance with the Bosnian Serb leadership's political and strategic interests. ${ }^{16413}$ It alleges that the Accused increased the level of sniping and shelling, and hence the level of terror, to pressure the $\mathrm{BiH}$ government into accepting peace on his terms, to influence negotiations, and to retaliate against the civilian population of Sarajevo for $\mathrm{ABiH}$ offensives. ${ }^{16414}$ It also alleges that he "ratcheted down" the campaign of sniping and shelling in response to international pressure, international agreements, and the threat of NATO military intervention. ${ }^{16415}$ The Accused does not respond to the allegation that he modulated the campaign of sniping and shelling; instead, he argues that no such campaign existed. ${ }^{16416}$

\footnotetext{
16410 The Chamber recalls that for an Accused to contribute to a JCE by omission, he must have had a legal duty to act, and that failure to act pursuant to that legal duty significantly contributed to the JCE. See para. 566. In that respect, the Chamber recalls that the Accused was the highest authority in the VRS chain of command during the entire campaign of sniping and shelling in Sarajevo and that he was able to exercise authority over the SRK forces. As such, he had a legal duty to prevent and punish crimes committed by those forces.

16411 See para. 4859.

16412 See para. 4739.

16413 Prosecution Final Brief, paras. 604-605, 607, 609, 612(2), 620-621, 623-627.

16414 Prosecution Final Brief, paras. 620-621.

16415 Prosecution Final Brief, paras. 620, 623-625.

16416 Defence Final Brief, paras. 2967-2971.
} 


\section{(B) Accused's modulation of the campaign}

4869. As discussed above, Sarajevo and its surroundings were strategically important to the Bosnian Serb leadership, who believed that the war would be won or lost in the city. ${ }^{16417}$ Harland testified that the overall strategy of the Accused in Sarajevo was to modulate the level of sniping and shelling, and hence the "level of pressure or terror", in order to achieve his political objectives. ${ }^{16418}$ According to him, the Accused would increase the level of sniping and shelling to force the Bosnian Muslims to accept peace on terms favourable to the Bosnian Serbs and to punish the Bosnian Muslims for their offensives. ${ }^{16419}$ He would also reduce it when necessary, usually in response to the threat of NATO military interventions. ${ }^{16420}$ Similarly, Banbury testified that the Accused modulated the level of sniping and shelling in Sarajevo in order to place pressure on the civilian population of Sarajevo, UNPROFOR, and the broader international community. ${ }^{16421} \mathrm{He}$ testified that the Accused would "squeeze" Sarajevo where the UN was most vulnerable in order to remain "strategically on top". ${ }^{16422}$ Bell noted during his evidence that the Accused always struck a balance between military actions in Sarajevo and "peace offensive[s]", and that he applied pressure to the city through the siege in order to force the Bosnian Muslims to accept peace on his terms. ${ }^{16423}$ According to KDZ450, the level of sniping and shelling in Sarajevo was closely related to political, diplomatic, and military events elsewhere in $\mathrm{BiH}$, which indicated that it was the Accused who modulated the pressure on Sarajevo in order to achieve his objectives. ${ }^{16424}$ KDZ450 further testified that the Accused could order attacks on Sarajevo "just to prove a point" or to "draw media attention to the region". ${ }^{16425}$ Similarly, Mole testified that it was an "accepted norm" that if the Bosnian Serb side failed to achieve their political or military objectives in $\mathrm{BiH}$, Sarajevo would be subjected to heavy indiscriminate shelling. ${ }^{16426}$ Indeed, the Accused himself acknowledged this, speaking at the Bosnian Serb Assembly session in mid-June 1995, when he said: "[T]he Supreme

\footnotetext{
16417 See Section IV.B.3.a.iii: Strategic importance of Sarajevo.

16418 P820 (Witness statement of David Harland dated 4 September 2009), paras. 36-38, 41; David Harland, T. 20182020, 2034 (6 May 2010).

16419 P820 (Witness statement of David Harland dated 4 September 2009), paras. 36-37, 291.

16420 P820 (Witness statement of David Harland dated 4 September 2009), paras. 36-37, 53; David Harland, T. 2019_ 2020, 2037 (6 May 2010)

16421 P2451 (Witness statement of Anthony Banbury dated 19 May 2009), para. 200; Anthony Banbury 13310-13311 (15 March 2011).

16422 P2451 (Witness statement of Anthony Banbury dated 19 May 2009), paras. 73, 205 (testifying that the Bosnian Serb leadership "constantly played" the UN).

16423 P1996 (Witness statement of Martin Bell dated 8 March 2010), para. 60; Martin Bell, T. 9769-9770 (14 December 2010); P1997 (BBC news report re interview with Radovan Karadžić at Trebević, with transcript).

16424 KDZ450, T. 10548-10551, 10571-10573 (19 January 2011), T. 10676 (20 January 2011); P5906 (Witness statement of KDZ450 dated 17 January 2011), para. 33.

16425 P5906 (Witness statement of KDZ450 dated 17 January 2011), para. 33.

16426 P1426 (Witness statement of Richard Mole dated 7 May 2010), paras. 91, 96, 116.
} 
Command and I as the Commander and with the Main Staff, we agreed that the worst for us is a war of low intensity, long duration etc., and that we have to heat up the situation, take whatever we can, create a fiery atmosphere and dramatize, threaten an escalation etc. because we noticed that whenever we advance on Goražde, on Bihać or elsewhere or if the situation escalates around Sarajevo, then the internationals come and diplomatic activity speeds up."16427

4870. During the trial, the Chamber was presented with a number of examples of the way in which the Accused, and occasionally other alleged JCE members, used the level of sniping and shelling in Sarajevo in order to further their political and strategic interests.

4871. As discussed earlier, in May and June 1992 Sarajevo was subjected to heavy shelling by the SRK. ${ }^{16428}$ The aftermath of that shelling and various meetings and measures undertaken by the members of international community to stop it were also discussed earlier and show that the Accused was able to stop the shelling of the city when pressed to do so by representatives of the international community. ${ }^{16429}$ As also mentioned earlier, on 15 June 1992, at a meeting between Mladić, the Accused, other members of the RS Presidency, and representatives from the Sarajevo municipalities, the issue of Dobrinja was discussed whereby Koljević urged the others to "treat Dobrinja as our territory into which [Bosnian Muslim] snipers and terrorists have infiltrated". ${ }^{6430}$ Following the Accused's instruction that the issue of Dobrinja must be resolved through cooperation with the police and Prstojević's request for deployment of soldiers to Dobrinja to carry out an operation, ${ }^{16431}$ the meeting concluded with the decision to "clear the Serbian territory", giving priority to Mojmilo and Dobrinja. ${ }^{16432}$ This resulted in the shelling of civilian areas in Dobrinja, as recounted by the 26 June 1992 letter of the Secretary General informing the Security Council that Bosnian Serb forces were shelling civilian areas in Dobrinja and calling for the shelling to cease immediately. ${ }^{16433}$ Thus, at a meeting on 27 June with Mladić, Koljević, and Plavšić, among others, Krajišnik stated that the Presidency was "walking on the edge of the abyss" and that operations against Dobrinja "must urgently stop". 16434 That day, the Accused issued an order to the Main Staff to cease all operations in Dobrinja immediately and warned that

\footnotetext{
16427 P1410 (Transcript of 51 ${ }^{\text {st }}$ session of RS Assembly, 14-15 June 1995), p. 329 (emphasis added).

16428 See discussion relating to Scheduled Incidents G.1. and G.2.

16429 See discussion relating to Scheduled Incidents G.1. and G.2.

16430 P1478 (Ratko Mladić's notebook, 27 May-31 July 1992), p. 167. The Chamber recalls that Dobrinja was also discussed by the Accused, Mladić, Krajišnik, Plavšić, Koljević, and Đerić several days earlier, on 5 June 1992, and the Accused issued orders to clean up Dobrinja. See para. 4781; P1478 (Ratko Mladić's notebook, 27 May31 July 1992), p. 93.

16431 P1478 (Ratko Mladić's notebook, 27 May-31 July 1992), pp. 169-170.

16432 P1478 (Ratko Mladić's notebook, 27 May-31 July 1992), pp. 171-172.

16433 P1523 (UNSG's statement to UNSC, 26 June 1992); KDZ088, T. 6662-6663 (13 September 2010) (closed session).
} 
disregarding the order would have "political consequences". ${ }^{16435}$ Also that day, the Accused sent a letter to Cutileiro and Carrington informing them of the decision to cease operations in Dobrinja and expressing hope that it would "open possibilities" for the continuation of international negotiations. $^{16436}$

4872. As discussed earlier, in September and October 1992 Sarajevo was again subjected to heavy indiscriminate shelling, resulting in representatives of the international community protesting to Koljević, Plavšić, and the Accused. ${ }^{16437}$ On 9 October 1992, at a meeting of the RS Presidency in the Accused's absence, Krajišnik, Koljević, and Đerić decided to order the Main Staff to halt the artillery bombardment of Sarajevo because UNPROFOR was "exerting control". ${ }^{16438}$ As a result, on 10 October 1992, pursuant to an order from the Main Staff, Galić prohibited the SRK from using all weapons and artillery with a calibre greater than $7.9 \mathrm{~mm}$ until further notice. ${ }^{16439}$ On 19 October 1992, at a meeting with Mladić, Plavšić, and Krajišnik, among others, the Accused stated that he was "convinced $101 \%$ that [NATO] will bomb" and that accordingly it was "crucial" not to fire on Sarajevo. ${ }^{16440}$

4873. Following the collapse of the Vance-Owen Peace Plan, ${ }^{16441}$ the SRK launched an offensive on Mt. Igman and Mt. Bjelašnica in late June 1993 and, while this operation was underway, shelled a water queue in Dobrinja on 12 July 1993, causing a large number of civilian casualties. ${ }^{16442}$ Harland testified that, at this time, the Accused was using the Igman offensive to secure as much territory as possible and "ratchet [...] up the pressure" on the Bosnian Muslims in advance of peace talks scheduled for late July in Geneva. ${ }^{16443}$ Indeed, on 16 July 1993, UNPROFOR reported that at a meeting with Briquemont and Andreev, the Accused stated that his "first priority" was to get the

\footnotetext{
16434 P1478 (Ratko Mladić's notebook, 27 May-31 July 1992), p. 240.

16435 P1504 (Minutes of $12^{\text {th }}$ session of SerBiH Presidency, 27 June 1992), para. 3; P1154 (Witness statement of KDZ088 dated 27-29 April 2010), paras. 69-70 (under seal); P1478 (Ratko Mladić's notebook, 27 May-31 July 1992), p. 240 (stating that the Presidency had sent a letter to the Secretary General informing him that operations against Dobrinja had ceased).

16436 D2977 (Letter from Radovan Karadžić to Jose Cutileiro and others, 27 June 1992); D2968 (Witness statement of Jose Cutileiro dated 11 April 2012), para. 30. See also para. 338.

16437 See para. 3562; P1258 (Witness statement of Hussein Ali Abdel-Razek dated 16 July 2002), e-court p. 22; Hussein Abdel-Razek, T. 5507 (19 July 2010) (testifying that he wrote a letter to the Accused requesting him to stop the shelling).

16438 D431 (Minutes of RS Presidency session, 9 October 1992), p. 2; P1270 (UNPROFOR report re administrative issues, 10 October 1992), p. 4 (reporting that Koljević stated that the Bosnian Serb side had decided to stop shelling Sarajevo).

16439 P1264 (SRK Order, 10 October 1992), para. 1. See also Hussein Abdel-Razek, T. 5506-5507 (19 July 2010).

16440 P1481 (Ratko Mladić's notebook, 5 October-27 December 1992), p. 59.

16441 See para. 372.

16442 See discussion on Scheduled Incident G.5.

16443 P820 (Witness statement of David Harland dated 4 September 2009), para. 45-48; David Harland, T. 2020 (6 May 2010).
} 
BiH government back to the negotiating table. ${ }^{16444}$ On the same day, Dragomir Milošević ordered the SRK to cease firing at central Sarajevo, except in self-defence, because the Accused had "reached an agreement" with UNPROFOR and the Bosnian Muslims. ${ }^{16445}$ However, because of the SRK's offensive, Izetbegović requested that the peace talks be postponed and NATO threatened to conduct air strikes. ${ }^{16446}$ Harland recalled that these developments "alarmed" the Accused and that consequently he took steps to "rapidly ratchet down" the pressure on the Bosnian Muslims. ${ }^{16447}$ On 4 August, the Accused told Milovanović that NATO was planning air strikes and that SRK forces had to withdraw from Mt. Igman and Mt. Bjelašnica as an expression of "good will". ${ }^{6448}$ Then, on 5 August, he told Mladić that, to avoid air strikes, SRK forces should withdraw from Mt. Igman and Mt. Bjelašnica and "[n]ot a single shell must fall on Sarajevo". ${ }^{16449}$ Also on 5 August, the Accused, Mladić, Krajišnik, Plavšić, and Lukić met with Briquemont, Hayes, and Andreev of UNPROFOR, and the Accused proposed, among other measures, withdrawing SRK forces from Mt. Igman and Mt. Bjelašnica to avoid air strikes. ${ }^{16450}$ The Accused then issued a series of orders to effect the withdrawal of SRK forces. ${ }^{16451}$ Harland recalled that at around this time there was a "dramatic decline" in SRK sniping and shelling of the civilian population of Sarajevo. ${ }^{16452}$

\footnotetext{
16444 P820 (Witness statement of David Harland dated 4 September 2009), para. 47; P835 (UNPROFOR BiH Political Assessment, 16 July 1993), e-court p. 5.

16445 P2661 (SRK Order, 16 July 1993).

16446 See para. 3572.

16447 P820 (Witness statement of David Harland dated 4 September 2009), para. 53.

16448 P4786 (Intercept of conversation between Radovan Karadžić and General Milovanović, 4 August 1993), pp. 1, 3. See also D4508 (Intercept of conversation between Radovan Karadžić and Manojlo Milovanović, 3 August 1993) (in which the Accused tells Milovanović that "everything should be halted around Sarajevo" in order not to "ruin" the peace negotiations in Geneva), p. 2.

16449 P1483 (Ratko Mladić's notebook, 2 April-24 October 1993), pp. 262-263.

16450 P824 (UNPROFOR report re meeting with Radovan Karadžić, 5 August 1993), pp. 2-3; David Harland, T. 2029-2032 (6 May 2010).

16451 See P5054 (VRS Main Staff Order, 5 August 1993) (in which Milovanović orders the VRS to cease combat operations around Sarajevo pursuant to an "oral command of the Supreme Commander"); D4645 (Letter from Radovan Karadžić to Boutros Boutros Ghali, Bill Clinton, Lord Owen and Stoltenberg, 7 August 1993) (in which the Accused informs the Secretary General that he is prepared to hand over Mt. Igman and Mt. Bjelašnica to the UN and cease all artillery fire around Sarajevo); D3872 (Intercept of conversation between Radovan Karadžić and Tomanić, 11 August 1993) (in which the Accused orders Tomanić to withdraw urgently any remaining troops from Mt. Igman and Mt. Bjelašnica in order to avoid NATO air strikes); P4805 (Intercept of conversation between Radovan Karadžić and Colonel Miletić, 11 August 1993) (in which the Accused orders Miletić to issue a statement to the media that SRK troops are being withdrawn from Mt. Igman and Mt. Bjelašnica); P4806 (Intercept of conversation between Radovan Karadžić, General Gvero, and General Milovanović, 12 August 1993) (in which the Accused orders Milovanović to determine the positions to which SRK troops should be withdrawn); P4783 (Intercept of conversation between Radovan Karadžić and General Gvero, 13 August 1993) (in which the Accused orders Gvero to convey to Galić that SRK troops must be withdrawn far enough to "avoid [...] problems in relation to the international community").

16452 David Harland, T. 2020 (6 May 2010); P820 (Witness statement of David Harland dated 4 September 2009), para. 55 (testifying further that the withdrawal of forces from Mt. Igman was an example of the way the Accused used "military operations for political purposes").
} 
4874. On 10 August 1993, on the eve of signing the Military Agreement on Peace in $\mathrm{BiH},{ }^{16453}$ the Accused told Milić from the Main Staff that "no shell" was to land on Sarajevo. ${ }^{16454}$ On 11 August 1993, in a conversation with Prstojević and Gvero, the Accused ordered "in the strongest terms" that no one was to fire grenades or shoot at Sarajevo. ${ }^{16455}$ That same day, Galić ordered the SRK "not to open fire over Sarajevo, at any price", in order to establish "favourable conditions" for the upcoming peace negotiations in Geneva and to avoid NATO air strikes. ${ }^{16456}$ Harland testified that this order from Galić aimed to reduce the level of pressure on Sarajevo and was a clear example of the way the Accused and the Bosnian Serb leadership modulated the level of terror in the city in accordance with their "political interests and conveniences". ${ }^{6457}$

4875. Following the rejection of the Owen-Stoltenberg Plan by the Bosnian Muslims in late September 1993, ${ }^{16458}$ the shelling of civilian areas in Sarajevo intensified. ${ }^{16459}$ According to Harland, the Accused increased the level of sniping and shelling at this time in order to punish the Bosnian Muslims for not accepting the plan. ${ }^{16460}$ On 12 October 1993, Andreev, Briquemont, De Mello, and Harland met with the Accused and Krajišnik, and Briquemont raised this increase in shelling with the Accused. ${ }^{16461}$ The Accused responded that the Bosnian Serbs would reduce the level of shelling only if the Bosnian Muslims did the same. ${ }^{16462}$

4876. In January 1994, Sarajevo experienced heavy indiscriminate shelling resulting in a large number of civilian casualties. ${ }^{16463}$ In a meeting with the Accused on 10 January, Akashi emphasised that the recent "excessive retaliations" against the $\mathrm{ABiH}$ were counter-productive as

\footnotetext{
16453 See paras. 379, 3575.

16454 P4802 (Intercept of conversation between Radovan Karadžić and unidentified member of VRS Main Staff, 10 August 1993) (the Accused also stating that he had withdrawn 50\% of his forces from Mt. Igman and Mt. Bjelašnica).

16455 P4804 (Intercept of conversation between Radovan Karadžić, Colonel Prstojević, and General Gvero, 11 August 1993), p. 1.

16456 P825 (SRK Order, 11 August 1993). See also P5042 (SRK Order, 13 August 1993) (in which Galić orders the withdrawal of SRK forces around Sarajevo in accordance with an order from the Accused and to "avoid unjust punishment by the US and its allies").

16457 David Harland, T. 2033-2034 (6 May 2010).

16458 See para. 382.

16459 See para. 3577.

16460 P820 (Witness statement of David Harland dated 4 September 2009), paras. 35, 63. See also KDZ450, T. 10549-10551 (19 January 2011) (testifying that in October 1993 there was a resumption of sniping and shelling because of the failure of the Owen-Stoltenberg Plan).

16461 P820 (Witness statement of David Harland dated 4 September 2009), paras. 60-61; P830 (UNPROFOR Weekly Political Assessment, 16 October 1993), p. 5; P845 (UNPROFOR report re meeting with Radovan Karadžić, 15 October 1993), para. 3.

16462 P820 (Witness statement of David Harland dated 4 September 2009), para. 61; P830 (UNPROFOR Weekly Political Assessment, 16 October 1993), p. 5; P845 (UNPROFOR report re meeting with Radovan Karadžić, 15 October 1993), para. 3.

16463 See para. 3580.
} 
they killed innocent people and created an unfavourable climate for the negotiations in Geneva. ${ }^{16464}$ Akashi reported that the Accused "took the point", but expressed impatience with the BiH government's attitude toward the Geneva negotiations, threatening to "declare war" if a peace agreement was not reached soon. ${ }^{16465}$ Then, at a meeting on 14 January between the Accused, Mladić, Krajišnik, Milošević, Galić, SRK unit commanders, and Sarajevo municipality presidents, the Accused discussed the negotiations in Geneva, the problem of "[m]edia pressure in the US", and the threat that "NATO will kill Serbs". ${ }^{16466}$ The Accused stated in the meeting that the Bosnian Serbs "must reach a victorious peace" and that the SRK's "retaliation" against the ABiH should be in a "1:1" ratio. ${ }^{16467}$ On 30 January, at a meeting between Rose and the Accused, Krajišnik, Koljević, and Zametica, the Accused stated that the shelling of Sarajevo was "senseless" and should stop. ${ }^{16468} \mathrm{He}$ further stated that there should be a global cease-fire starting with the demilitarisation of Sarajevo. ${ }^{16469}$ Rose testified that, at this time, a global cease-fire was in the Accused's interests because the Bosnian Serbs held $70 \%$ of the territory of $\mathrm{BiH}$, and therefore a cease-fire represented an opportunity for them to consolidate their territorial gains. ${ }^{16470}$

4877. On 7 February 1994, faced with the possibility of NATO air strikes following the first Markale incident of 5 February, ${ }^{16471}$ the Accused informed the Main Staff, SRK Commander, and SRK brigade commanders that the "international community" had objected to the SRK's "scale of retaliation". ${ }^{16472} \mathrm{He}$ ordered the SRK to introduce the "strictest possible control of retaliation" and to "[e]xclude any possibility of uncontrolled shelling". ${ }^{16473}$ The Accused also gave Milovanović the authority to negotiate a cease-fire agreement and, on 9 February, at a meeting with Rose, Milovanović agreed to an immediate cease-fire and the withdrawal of all heavy weapons from a 20 kilometre circle around Sarajevo, among other measures, which resulted in a significant reduction

\footnotetext{
16464 D3491 (UNPROFOR report, 10 January 1994), para. 3; Yasushi Akashi, T. 37680-37683 (24 April 2013 ).

16465 D3491 (UNPROFOR report, 10 January 1994), para. 3.

16466 P1484 (Ratko Mladić's notebook, 28 October 1993-15 January 1994), p. 149.

16467 P1484 (Ratko Mladić's notebook, 28 October 1993-15 January 1994), pp. 133, 149. See also D4443 (Radovan Karadžić's Order, 16 January 1994) (in which the Accused strictly prohibits any combat operations in the direction of Sarajevo airport in consideration of the "attitude" of the international community during the Geneva negotiations).

16468 P1638 (Witness statement of Michael Rose dated 26 March 2009), para. 31; P1650 (UNPROFOR report on meeting with Radovan Karadžić and Ratko Mladić, 31 January 1994), para. 3.

16469 P1638 (Witness statement of Michael Rose dated 26 March 2009), para. 31.

16470 P1638 (Witness statement of Michael Rose dated 26 March 2009), para. 31.

16471 See discussion on Scheduled Incident G.8.

16472 P846 (Radovan Karadžić's Order to VRS, 7 February 1994); Manojlo Milovanović, T. 25475 (29 February 2012) (testifying that the Accused addressed the order in this way so that it reached SRK units "as soon as possible"). See also para. 4776.

16473 P846 (Radovan Karadžić's Order to VRS, 7 February 1994); P820 (Witness statement of David Harland dated 4 September 2009), para. 77-78. See also P4493 (VRS Main Staff Order, 7 February 1994) (implementing the Accused's order); Manojlo Milovanović, T. 25475-25476 (29 February 2012).
} 
in sniping and shelling. ${ }^{16474}$ According to Harland, these were "dramatic concessions" consistent with the Accused's political strategy of reducing the "pressure" on Sarajevo in the face of Western threats. ${ }^{16475}$ Indeed, on 17 February, UNPROFOR reported that Krajišnik stated that the Bosnian Serbs would "do everything to avoid air strikes, except capitulate". ${ }^{16476}$

4878. On 22 September 1994, following the resumption of intense fighting in Sarajevo and the sniping of a civilian and a UN soldier, ${ }^{1647}$ the Accused informed the Main Staff that relations with the UNPROFOR were deteriorating and the Bosnian Serbs were "provoking" NATO air strikes. ${ }^{16478}$ The Accused ordered that "there be no incidents since our relationships with England and France are improving". ${ }^{16479}$ He further stated that "every attack by NATO is a humiliation" and is "getting the world used to the idea that the Serbs are to be bombarded". ${ }^{16480}$

4879. On 19 November 1994, as the military situation in Sarajevo was deteriorating, ${ }^{16481}$ the Accused, Krajišnik, Tolimir, Buha, and Zametica met with Andreev, Gobilliard, Brinkman, Banbury, and Fraser. ${ }^{16482}$ In the meeting, the Accused stated that if $\mathrm{ABiH}$ forces continued to fire on Bosnian Serb forces from within the TEZ, Bosnian Serb forces would retaliate. ${ }^{16483}$ He further stated: "The Muslims want a big war in Sarajevo. There is going to be a big war in Sarajevo". ${ }^{16484}$ Four days later, the SRK sniped at a tram travelling along Zmaja od Bosne street, injuring two

16474 See paras. 387-390, 3582-3587.

16475 P820 (Witness statement of David Harland dated 4 September 2009), paras. 79, 86; David Harland, T. 2020 (6 May 2010) (testifying that there was a "sharp dip in the pressure, the terror" applied to the civilian population of Sarajevo after the first Markale incident). The Accused argued that his order of 14 January 1994, three weeks before the first Markale incident, wherein he instructed the SRK to control its retaliation by applying a " $1: 1$ " ratio, meant that his response to the Markale incident cannot be considered modulation. See Closing Arguments, T. 47998 (2 October 2014). However, it was only after the Markale incident that the Accused agreed to establish WCPs and withdraw heavy weapons from around Sarajevo. Accordingly, the Chamber agrees with Harland's testimony that the Accused made "dramatic concessions" after the first Markale incident in response to the threat of NATO military intervention.

16476 P827 (UNPROFOR Weekly Political Assessment, 17 February 1994), p. 6; P820 (Witness statement of David Harland dated 4 September 2009), para. 84.

16477 See para. 3599.

16478 D3521 (Letter from Radovan Karadžić to VRS Main Staff, 22 September 1994), p. 3.

16479 D3521 (Letter from Radovan Karadžić to VRS Main Staff, 22 September 1994), p. 3.

16480 D3521 (Letter from Radovan Karadžić to VRS Main Staff, 22 September 1994), p. 3.

16481 See para. 3603.

16482 P2454 (UNPROFOR report, 19 November 1994), para. 1; P2451 (Witness statement of Anthony Banbury dated 19 May 2009), para. 69; P1762 (Witness statement of David Fraser dated 17 October 2010), p. 70 ; P1776 (UNPROFOR report re meeting with Radovan Karadžić and General Tolimir, 20 November 1994) paras. 1-2.

16483 P2454 (UNPROFOR report, 19 November 1994), para. 3; P1762 (Witness statement of David Fraser dated 17 October 2010), p. 70; P1776 (UNPROFOR report re meeting with Radovan Karadžić and General Tolimir, 20 November 1994), p. 1.

16484 P2454 (UNPROFOR report, 19 November 1994), para. 3; P2451 (Witness statement of Anthony Banbury dated 19 May 2009), para. 69; P1762 (Witness statement of David Fraser dated 17 October 2010), p. 70. 
women, ${ }^{16485}$ and at the beginning of December 1994, the SRK shelled Sarajevo's downtown area with wire-guided missiles. ${ }^{16486}$

4880. On 5 March 1995, the Accused wrote to Akashi and stated that the Bosnian Muslims were "completely ignoring" the COHA and that, if the situation did not change in the next 7 to 10 days, "our patience will have run out". ${ }^{6487}$ He further warned Akashi that there would be "calamity" if the Bosnian Muslims did "not abandon their obstructionist policy". ${ }^{16488}$ At the same time, in a meeting with Smith on the same day, Mladić explained that the increase in Bosnian Serb sniping in Sarajevo in late February and early March was a response to military offensives launched by the BiH government. ${ }^{16489}$ Banbury recalled being "struck" and "surprised" by this comment because it was an overt admission that the Bosnian Serbs were sniping civilians in order to punish the $\mathrm{BiH}$ government for its offensives. ${ }^{16490}$ He further testified that, like the Accused, Mladić had the ability to modulate the level of sniping and shelling in Sarajevo, which he used to influence negotiations. ${ }^{16491}$ Indeed, in a meeting with Akashi on 12 March, the Accused and Mladić indicated their intention to pursue their objectives through "military means" if they were unable to achieve them at the negotiating table. ${ }^{16492}$

4881. On 5 April 1995, in a meeting with Smith, the Accused stated that if the ABiH conducted an offensive to open a land corridor into Sarajevo, his forces would "take Sarajevo". 16493 The Accused further stated that he was prepared to take NATO on and would employ weapons that Bosnian Serb

\footnotetext{
16485 See discussion relating to Scheduled Incident F.14.

16486 See para. 3604.

16487 P2245 (Letter from Radovan Karadžić to Yasushi Akashi, 5 March 1995), pp. 1-2.

16488 P2245 (Letter from Radovan Karadžić to Yasushi Akashi, 5 March 1995), p. 2.

16489 See para. 3607; P876 (UNPROFOR Memo re meeting with Ratko Mladić, 6 March 1995), para. 3; P2451 (Witness statement of Anthony Banbury dated 19 May 2009), para. 94; P2455 (UNPROFOR Weekly Situation Report (Sarajevo), 11 March 1995), para. 9; Anthony Banbury, T. 13330 (15 March 2011).

16490 P2451 (Witness statement of Anthony Banbury dated 19 May 2009), para. 95; Anthony Banbury, T. 1333013331 (15 March 2011). See also P2414 (Witness statement of KDZ182), p. 22 (under seal) (testifying that Mladic ordered the SRK to terrorise the civilian population of Sarajevo and that this was a "line of conduct decided by the Supreme Command").

16491 P2451 (Witness statement of Anthony Banbury dated 19 May 2009), para. 200; Anthony Banbury, T. 1331013311 (15 March 2011).

16492 P2257 (UNPROFOR Weekly Situation Report, 18 March 1995), para. 3; Rupert Smith, T. 11337-11338 (8 February 2011). See also P2245 (Letter from Radovan Karadžić to Yasushi Akashi, 5 March 1995) (in which the Accused states that the Bosnian Muslims were "completely ignoring" the COHA and that, if the situation did not change in the next 7-10 days, the patience of the Bosnian Serbs would "run out").

16493 P2260 (UNPROFOR report re meeting with Radovan Karadžić, 5 April 1995), para. 9(b); Rupert Smith, T. 11344-11346 (8 February 2011).
} 
forces had not yet used. ${ }^{16494}$ Two days later, on 7 April, a modified air bomb exploded in Hrasnica, inflicting civilian casualties; this attack was reported to the Accused that evening. ${ }^{16495}$

4882. On 20 April 1995, as sniping and shelling in Sarajevo intensified, the Accused, Koljević, and Krajišnik met with Akashi, Smith, and Banbury; during the meeting, the Accused stated that if Bosnian Muslim sniping continued he would be forced to retaliate, leading to "renewed war" in Sarajevo. ${ }^{16496}$ On 30 April 1995, Akashi, Janvier, and Smith met with the Accused, Koljević, and Krajišnik, among others. ${ }^{16497}$ At the meeting, the Accused stated: "retaliation is productive. When [the $\mathrm{ABiH}]$ shell[s] Doboj and we retaliate, it's effective". ${ }^{16498}$ KDZ450 recalled that following offensives by the $\mathrm{ABiH}$ in Doboj, Maglaj, and the Brčko corridor, the Accused ordered attacks on Sarajevo in order to deter future offensives. ${ }^{16499}$

4883. On 1 May 1995, in a meeting with Akashi, Smith, Krajišnik, Zametica, and Bogdan Subotić, the Accused stated that the Bosnian Serbs were ready to accept a cessation of hostilities provided that they were treated equally to the Bosnian Muslims and sanctions against them were lifted. ${ }^{16500}$ He stated, however, that if the international community treated the Bosnian Serbs like "beasts in a cage", then they would behave that way. ${ }^{16501}$ A week later, on 7 and 8 May, the SRK carried out mortar and artillery attacks on civilian areas in Sarajevo. ${ }^{16502}$ When Smith explained to the Accused that he had requested NATO air strikes in response to these attacks, the Accused did not deny that attacks against civilians had occurred. ${ }^{16503}$ Instead, he explained that he had

\footnotetext{
16494 P2260 (UNPROFOR report re meeting with Radovan Karadžić, 5 April 1995), para. 10 (reporting that it was "not at all clear" what the Accused was referring to).

16495 See discussion on Scheduled Incident G.10; P5943 (VRS Main Staff Report, 7 April 1995), p. 5.

16496 P2451 (Witness statement of Anthony Banbury dated 19 May 2009), para. 123; P2487 (Anthony Banbury's notes, 20 April 1995), p. 2; D3511 (UNPROFOR report, 22 April 1995), para. 2. See also P2451 (Witness statement of Anthony Banbury dated 19 May 2009), para. 130 (testifying that the general consensus between Akashi, Smith, and himself was that the Accused had made a decision to go for "all-out war"); P883 (UNPROFOR report re Radovan Karadžić's press conference, 22 April 1995), pp. 2-3 (in which the Accused stated that he believed the Bosnian Serbs would be forced to engage in a "drastic counter offensive" to "put an end to the war by military means").

16497 P2262 (UNPROFOR report re meetings with Bosnian Serb and Bosnian Muslim leadership, 30 April 1995), para. 9; Rupert Smith, T. 11351 (8 February 2011); Rupert Smith, T. 11657-11658 (11 February 2011); P2451 (Witness statement of Anthony Banbury dated 19 May 2009), para. 145; P2493 (Anthony Banbury's notes, 30 April 1995).

16498 P2451 (Witness statement of Anthony Banbury dated 19 May 2009), para. 154; P2493 (Anthony Banbury's notes, 30 April 1995), p. 9.

16499 KDZ450, T. 10551 (19 January 2011).

16500 P2263 (UNPROFOR report re meetings with Bosnian Serb and Bosnian Muslim leadership, 1 May 1995), para. 7.

16501 P2263 (UNPROFOR report re meetings with Bosnian Serb and Bosnian Muslim leadership, 1 May 1995), para. 8; Rupert Smith, T. 11353 (8 February 2011).

16502 See para. 3609.

16503 See para. 3609.
} 
intelligence that the $\mathrm{ABiH}$ had begun an offensive to break the siege of Sarajevo and that he would "not allow the UN to help them beat us". ${ }^{16504}$

4884. As discussed earlier, following the second Markale incident on 28 August 1995, ${ }^{16505}$ NATO commenced air strikes on Bosnian Serb positions. ${ }^{16506}$ In response, the Accused agreed in a meeting with Holbrooke on 14 September 1995 to, inter alia, cease all operations within and around the TEZ in Sarajevo and remove all heavy weapons from around the TEZ, which led to an improvement in the situation in the city and the ultimate cessation of hostilities by 14 October 1995. ${ }^{16507}$

\section{(C) Conclusion}

4885. In light of the above evidence, as well as the evidence outlined in Section IV.B.1.a, the Chamber is satisfied that the sniping and shelling of Sarajevo was not random but followed a discernible pattern, indicating in turn that it was used by the Bosnian Serb political and military leadership, including the Accused, to achieve their political and military goals. Some of the more striking examples of this, as established by the evidence of international witnesses and contemporaneous UN and other documents, included the events surrounding the SRK's capture of Mt. Igman, the shelling of the city following the rejection of the Owen-Stoltenberg Plan by the Bosnian Muslims, the launch of the modified air bomb on Hrasnica in April 1995, and the aftermath of the Markale shellings. With respect to the first Markale shelling, as outlined above, the Chamber rejects the Accused's claim that he did not reduce the level of sniping and shelling specifically in response to this incident. ${ }^{16508}$ Indeed, the evidence outlined above clearly indicates that the Accused used his authority over the SRK to reduce the level of sniping and shelling when it furthered his political objectives, for example in the lead up to important peace negotiations, after the signing of significant agreements, and after NATO threatened to conduct air strikes. Similarly, as discussed above, on several occasions the Accused's threats in meetings with the UN materialised in the form of an increase in the level of sniping and shelling in the city, for example when a modified air bomb fell on Hrasnica on 7 April 1995 just two days after the Accused told the UN that the Bosnian Serbs would employ weapons they had not yet used, and when the city was heavily shelled on 7 and 8 May 1995 just a week after the Accused told Smith that if the

\footnotetext{
16504 P2264 (UNPROFOR report re meeting with Radovan Karadžić, 9 May 1995), para. 3; Rupert Smith, T. 11358 (8 February 2011).

16505 See discussion related to Scheduled Incident G.19.

16506 See paras. 425-426, 3614, 4297-4301.

16507 See paras. 430, 3614.

16508 See fn. 16475.
} 
international community treated the Bosnian Serbs like "beasts in a cage", then the Bosnian Serbs would behave that way.

4886. This evidence indicates that the Accused had the authority to increase the level of sniping and shelling and in fact did so on a number of occasions in order to influence negotiations with the UN and the Bosnian Muslims and to pressure them into accepting his demands. At other times, the Accused simply allowed the campaign of sniping and shelling to continue and, indeed, to intensify, particularly after $\mathrm{ABiH}$ offensives and the rejection by the $\mathrm{BiH}$ government of peace plans favoured by the Bosnian Serb leadership. He did so despite having de jure authority over the VRS and SRK units, which he was able to exercise in fact. ${ }^{16509}$ Indeed, the aftermath of the heavy bombardments of the city in late May and early June 1992, the aftermath of the two Markale shelling incidents, and the Accused's order enabling a football match between UNPROFOR and a Sarajevo team to proceed without incident, ${ }^{16510}$ are all testaments to the control and influence he was able to exert to stop the shelling and sniping in the city. Accordingly, the Chamber is satisfied that the Accused modulated the level of sniping and shelling in Sarajevo in order to further his political and strategic objectives.

4887. The Chamber notes that in reaching this conclusion, it relied to a significant extent on the evidence of David Harland, Anthony Banbury, and a number of other international witnesses. The Chamber recalls that the Accused argued that Harland's evidence was unreliable because he was a political advisor who was neither qualified nor competent to speak on military matters, he merely took notes at meetings and never exchanged a word with the Accused, he did not attend any of the peace conferences and therefore lacked knowledge of the Accused's political views, his weekly UN reports relied on information from UNMOs which in turn was unreliable, and he made sweeping statements about Sarajevo which were not based on investigations and "not even on superficial knowledge" of the military situation. ${ }^{16511}$ The Accused further argued that Harland "manifestly showed himself to be partial" in his UN reports, and that he admitted as much during his testimony when he said that UNPROFOR was more supportive of the $\mathrm{BiH}$ government than the Bosnian Serbs. ${ }^{16512}$ Similarly, the Accused argued that Banbury's evidence was unreliable because Banbury thought that the BiH government was "always right" while the Bosnian Serbs were "aggressors"

\footnotetext{
16509 See paras. 4805-4809.

16510 See paras. $4754,4776-4777$.

16511 Closing Arguments, T. 47975-47977 (2 October 2014).

16512 Closing Arguments, T. 47976 (2 October 2014); David Harland, T. 2121 (7 May 2010), T. 2231 (10 May 2010 ).
} 
and, like Harland, gave evidence on matters "which [he] did not know anything about nor could have known anything about". ${ }^{16513}$

4888. Addressing first the challenges to Harland, the Chamber notes that Harland served for several years with the UN in Sarajevo, including as a Civil Affairs Officer from May 1993 to January 1995, as Head of Civil Affairs from January to August 1995, and then as a Political Advisor to the UNPROFOR Commander until the end of the conflict. During this time, he was charged with the responsibility of observing and making contemporaneous notes at multiple highlevel meetings with the Bosnian Serb leadership, which included the Accused, where the most important political and military matters in Sarajevo were discussed. Accordingly, rather than being a mere note-taker as implied by the Accused, Harland was an important witness to the events in question and as such is more than qualified to provide evidence on what the Accused and other alleged members of the JCE said and how they behaved at the said meetings. Having spent so much time in Sarajevo, he was also able to provide evidence as to how the discussions at these meetings corresponded with the general situation in Sarajevo as he observed it. While the Chamber acknowledges that UNPROFOR's mandate was structured at times to support the BiH government, and that consequently some UN personnel may have sympathised with the Bosnian Muslim side, the Chamber recalls that on numerous occasions during cross-examination, Harland agreed with propositions put by the Accused which reflected poorly on the $\mathrm{BiH}$ government and the $\mathrm{ABiH} .{ }^{16514}$ He was a frank witness and the Chamber was left with the overall impression that he was credible. Furthermore, his evidence on the issue of modulation but also on a number of other issues was generally consistent with the accepted evidence of other credible witnesses.

4889. Like Harland, Banbury, as a Civil Affairs Officer in UNPROFOR and later an assistant to Akashi, participated in many high level meetings with the Bosnian Serb leadership, including the Accused. Thus, Banbury was also able to provide detailed evidence on a number of meetings and discussions involving the Accused and other alleged members of the Sarajevo JCE. Also like Harland, Banbury made significant efforts to remain impartial during his testimony; for example, he modified the evidence he gave in his examination-in-chief when shown evidence to the contrary on cross-examination, while standing firm on other issues. ${ }^{16515}$ This demonstrated his sincerity. As a result, the Chamber was left with the overall impression that he was a credible witness.

16513 Closing Arguments, T. 47974-47975 (2 October 2014)

16514 See David Harland, T. 2071-2072, 2075-2077, 2110 (7 May 2010).

16515 See e.g. Anthony Banbury, T. 13389-13391 (15 March 2011). 
4890. Accordingly, the Chamber rejects the challenges the Accused has made to these two witnesses and is satisfied that the evidence they gave and which was recounted in this section can be relied upon without reservation.

\section{v. Conclusion on the Accused's contribution}

4891. Relying on the evidence and conclusions outlined above in relation to the actions and omission of the Accused, namely (i) his continuous support of Mladić, who was central in the implementation of the Sarajevo JCE; (ii) his direct involvement in the military matters in and around Sarajevo at the planning and operational levels; (iii) his knowledge of the attacks on civilians in Sarajevo and of indiscriminate or disproportionate SRK fire, together with his persistent denials and deflections of any SRK responsibility; (iv) his failure to prevent the shelling and the sniping of civilians and to punish those responsible, despite being at the apex of control over the VRS and SRK; (v) his support for and promotion of the SRK commanders and units while aware of their involvement in the campaign of sniping and shelling of civilians; and (vi) his modulation of that campaign in accordance with his political goals, the Chamber is convinced beyond reasonable doubt that the Accused shared the common purpose of the Sarajevo JCE and had the intent to spread terror among the civilian population of Sarajevo through the campaign of sniping and shelling. Further, relying on the same evidence, the Chamber finds that the Accused provided a significant contribution to the Sarajevo JCE. ${ }^{16516}$ As was the case with Mladić, the Chamber finds that the Accused's contribution was so instrumental that, without his support, the SRK's attacks on civilians could not have in fact occurred.

4892. The Chamber is therefore convinced beyond reasonable doubt that the Accused worked together with Mladić, Galić, Dragomir Milošević, Krajišnik, Koljević, and Plavšić to establish and then to maintain the campaign of sniping and shelling against the civilian population in Sarajevo, the primary purpose of which was to spread terror among that population. In other words, they worked together in furthering the objective of the Sarajevo JCE. Their enterprise started in late May 1992 and continued until October 1995 when the hostilities in Sarajevo ceased.

d. Accused's intent for murder, unlawful attacks on civilians, and terror

4893. The Prosecution claims that the Accused's intent for the crimes underlying the common criminal plan, namely murder, terror, and unlawful attacks, "flows inevitably from [his]

16516 The Chamber is satisfied that, in contributing in these ways the Accused contributed to the Sarajevo JCE as alleged in paragraph 14(a), (b), (c), (d), (e), (h), and (i). As noted earlier, the Chamber does not consider that the contribution alleged in paragraph 14(j) was in fact relevant to the Sarajevo JCE. See paras. 4713-4715. With 
contributions" to the Sarajevo JCE. ${ }^{16517}$ The Accused denies that he is guilty of murder, terror, and unlawful attacks on civilians, and argues in support that he disapproved of the sniping and shelling in the city and repeatedly issued orders insisting that the soldiers adhere to international laws of war. $^{16518}$

4894. The Chamber has already outlined above some of the Accused's statements relating to his objective for the Bosnian Serbs to have either the whole city of Sarajevo or parts thereof under their control. ${ }^{16519}$ These statements clearly show that, as the conflict escalated, the Accused intended either to capture the city entirely or to divide it and assume control over part thereof, thereby gaining as much of the territory in the area as possible. The evidence outlined in preceding sections also shows that, in the pursuit of this objective, he had support from Krajišnik, Mladić, Koljević, and Plavšić. As also referred to earlier and testified to by Okun, given the multi-ethnic nature of the city, the only way to achieve this goal was through the "wall of fire". ${ }^{16520}$ In that respect, the Chamber has received evidence recounting some of the Accused's statements concerning the nature of the fighting in Sarajevo, the siege itself, and the use of violence against the civilian population in the city.

4895. For example, in 1991, the Accused was already aware that the encirclement of the city by the Bosnian Serbs was an option when, on 9 September 1991—following the arrest of Milan Martić in the Muslim-inhabited village of Otoka-Malko Koroman, the Chief of the Pale SJB, asked the Accused to tell the Bosnian Muslim side that if Martić was not released promptly, Serbs from the Romanija region would surround Sarajevo. ${ }^{16521}$ The Accused promised he would convey that message and, after intimating that he had been in contact with Slobodan Milošević and the JNA General Staff in connection with Martić's arrest, he instructed Koroman to "have the people prepared if [the Bosnian Muslims] fuck around" and later instructed him again as follows: "you have the people prepared [...] we will send them all to fucking hell because of this". ${ }^{16522}$ He also

respect to paragraph 14(f) of the Indictment, the Chamber recalls its finding that the Sarajevo JCE started in late May 1992 and that the campaign of sniping and shelling was perpetrated by the SRK units surrounding the city.

16517 Prosecution Final Brief, para. 797.

16518 Defence Final Brief, paras. 2969, 2971, 2974-2983.

16519 See Section IV.B.3.a.iii: Strategic importance of Sarajevo.

16520 See para. 4660.

16521 Milan Babić, P741 (Transcript from Prosecutor v. S. Milošević), T. 13269, 13279; P962 (Intercept of conversation between Radovan Karadžić and Malko Koroman, 9 September 1991), p. 2; D3528 (Witness statement of Milan Martić dated 7 May 2013), paras. 30-41; D3533 (Intercept of conversation between Radovan Karadžić and Muhamed Čengić, 8 September 1991); D3532 (Intercept of conversation between Radovan Karadžić and Milan Martić, 8 September 1991).

16522 P962 (Intercept of conversation between Radovan Karadžić and Malko Koroman, 9 September 1991), p. 2. See also P2224 (Intercept of conversation between Radovan Karadžić and Slobodan Milošević, 9 September 1991). The Chamber notes that while P2224 is dated 20 December 1991, given its context it should in fact be dated 9 September 1991) 
instructed a number of other Bosnian Serb interlocutors to prepare the population, while at the same time urging them not to make any hasty moves and stay calm until he ensured Martić's release. ${ }^{16523}$ He spoke to Momčilo Mandić as well, and told him that the handover of Martić to Croatia would immediately lead to war as Bosnian Serbs were already gathering in Romanija in order to encircle Sarajevo. ${ }^{16524}$ He contacted Vitomir Žepinić, the Deputy MUP Minister at the time, and warned him that Serbs from Romanija and Ilijaš were ready to set up barricades and block Sarajevo such that nobody would be able to leave the city. ${ }^{16525}$ Expressing fears that the Bosnian Serbs would rise up because of Martić's arrest, the Accused told Žepinić that if this happened they "will get going, they'll block Sarajevo and then they'll see how it is when Serbs block Sarajevo."16526 Martić was eventually released, without violent clashes, on 9 September, due to the Accused's efforts. ${ }^{16527}$

4896. The Accused showed his awareness of what encirclement of the city would bring yet again during his telephone conversation of 12 October 1991 with Gojko Đogo in which, angered by the fact that SDA and HDZ delegates in the SRBiH Assembly had proposed a draft declaration of independence, the Accused said: "[T]hey have to know that there are 20,000 armed Serbs around Sarajevo, that's insane, they will, they will disappear, Sarajevo will be a karakazan [black cauldron] where 300,000 Muslims will die, they're not right in the head". ${ }^{16528}$

4897. Similarly, in another intercepted telephone conversation, on 14 November 1991, the Accused told Božidar Vučurović:

Our /position/ is clear. If you want to change the Constitution, the procedure must be followed. We know that they have prepared something for war, we know where they keep it and what they have, but we must say that the war will not last long and that it will be terrible and that it really will, first of all Sarajevo and several of these Bosnian cities will be destroyed, so to speak. I think that all of that would be destroyed in three to five days. They can't play around. ${ }^{16529}$

4898. A month and a half later, on 1 January 1992, the Accused complained to Krajišnik that in a recent interview, Izetbegović had spoken openly about a sovereign and independent $\mathrm{BiH}$ and then

\footnotetext{
16523 D3534 (Intercept of conversation between Radovan Karadžić and Trifko Komad, 9 September 1991); D3537 (Intercept of conversation between Radovan Karadžić and unidentified male, 9 September 1991); D3535 (Intercept of conversation between Radovan Karadžić and unidentified male, 9 September 1991);

16524

16525

16526 
asked: "Does he want someone to destroy Sarajevo?" 16530 Indicating that he was growing more and more willing to take a hard-line approach, the Accused also added: “[F]uck him [...] We will release our tigers and let them do their job. [...] [W]e've been calming the Serb people for a year because of [Izetbegović's] foolishness. What can I do? I will not be calming anyone anymore, nor can I. [...] We need to release those people, we shouldn't hold them back". ${ }^{16531}$ To this, Krajišnik said "we have to use the first opportunity to tell [Izetbegović] that he's playing with fire"; the Accused agreed, stating that they should tell him so in public. ${ }^{16532}$

4899. Indeed, on 2 March 1992, the Accused spoke to Izetbegović on the phone, complaining about Bosnian Muslims attacking Serb settlements, at which point he said:

What are they doing in Serb settlements? [...] Believe me Sarajevo can burn, and burn out god forbid, there could be hundreds of thousands of dead people. [...] Look, we are, we are, we are making a big effort to hold Serbs from around Sarajevo not to scorch Sarajevo $[\ldots]$ please propose anything, but this has to stop absolutely [...]. ${ }^{16533}$

4900. Similarly, in late April 1992, during his interview with Le Figaro, the Accused publicly issued a veiled threat to the Bosnian Muslim side. He first openly stated during this interview that his plan for Sarajevo was to establish a "clear separation" between the Serb and Muslim parts of the city, claiming that without this separation there will be "horror and terrorism". 16534 When the interviewer asked him what he intended to do given Izetbegović's opposition to the partition of Sarajevo, the Accused stated: "We will not bombard everybody. But if the peace terms are not accepted, the chaos will continue. And that means war". ${ }^{16535}$

4901. Thus, as these conversations and statements reveal, by the end of April 1992, the Accused was not only aware of the chaos that would ensue in Sarajevo if the tensions escalated but appeared to take a more militant approach to the situation and in turn encourage the option of resorting to violence, which he knew would result in severe consequences for the city. The evidence above also shows that he tried to use the threats of impending violence to advance his political goals and to scare the other side into abandoning their plans for an independent $\mathrm{BiH}$.

\footnotetext{
16530 P5779 (Intercept of conversation between Radovan Karadžić and Momčilo Krajišnik, 1 January 1992), pp. 4-5.

16531 P5779 (Intercept of conversation between Radovan Karadžić and Momčilo Krajišnik, 1 January 1992), p. 5.

16532 P5779 (Intercept of conversation between Radovan Karadžić and Momčilo Krajišnik, 1 January 1992), p. 6.

16533 P5728 (Intercept of conversation between Biljana Plavšić and Radovan Karadžić, 2 March 1992), p. 2. See also P5605 (Intercept of conversation between Radovan Karadžić, Goran Milić, Alija Izetbegović, and an unidentified woman, 3 March 1992) (during which Izetbegović denied the Accused's claim that Muslims were attacking Serb settlements, stated that this was just an excuse to attack the city, and accused the Accused of bringing Serbs from outside of Sarajevo to encircle the city).

16534 D1591 (Radovan Karadžić's interview from Le Figaro, 23 April 1992), pp. 1-2.

16535 D1591 (Radovan Karadžić‘s interview from Le Figaro, 23 April 1992), p. 2 (emphasis added).
} 
4902. Indeed, by 12 May 1992, with Sarajevo already under siege and the shelling and sniping activities by both sides having increased in and around the city, the Accused indicated his support for this state of affairs by telling the Bosnian Serb Assembly at the $16^{\text {th }}$ Assembly session that the Bosnian Serb forces were doing "quite well" as they were holding the enemy in "complete encirclement" in Sarajevo. ${ }^{16536}$ As discussed earlier, it was at this session, having heard the Accused enunciate the Strategic Goals, that Mladić then outlined his plan for the city and the fact that Sarajevo could not be taken "by spitting at it from two mortars" but that instead 300 guns should be placed around Sarajevo, including rocket launchers. ${ }^{16537}$ The Chamber recalls that the SRK had between 200 and 300 heavy weapons in locations encircling the city and used them not only to fight the $\mathrm{ABiH}$ on the confrontation lines but also to target the civilian population in the city. ${ }^{16538}$

4903. On 23 May 1992, in an interview with Duga Magazine, the Accused acknowledged the uncompromising nature of the SRK's fire on the city and argued that the suffering of the civilian population living there was inevitable, saying: "As for the [Sarajevo] ruins, my heart aches about them, but five to six hundred Moslem snipers, who kill non-selectively, cannot expect the Serbian defence to make no response, which is, of course, more than fiery. It must be clear to all of us that Sarajevo must suffer from both sides". 16539

4904. In another, undated, interview, the Accused stated that the journalists in Sarajevo were "misinformed" and that it was the Bosnian Muslims who were bombarding Sarajevo and killing their own people in order to "accuse Serbs". ${ }^{16540}$ When asked about the comment of Colonel Gray from the UN that the Serbs had enough artillery to "demolish Sarajevo 10 times", the Accused stated:

But we do not want to conquer Sarajevo, we do not want to tear down Sarajevo. Sarajevo is our city too. But, please, when somebody puts a mortal artillery weapon on some skyscraper, and is hitting us, hitting us, and kills 25 of our men in one day, so to say, we must hit this, to neutralize it [...]. So, housing objects, religious objects in Sarajevo are turned into military objects and forces us, when we became threatened, our lives, then we have to answer to neutralize that. ${ }^{16541}$

4905. The Chamber has already described at various points in the Judgement how the Accused, following the intense negotiations at the end of May 1992, used his influence over Mladić to put a

\footnotetext{
16536 P956 (Transcript of $16^{\text {th }}$ session of SerBiH Assembly, 12 May 1992), e-court p. 8.

16537 See paras. 4661, 4902.

16538 See para. 3984. See also fn. 13170.

16539 P6688 (Interview with Radovan Karadžić in Duga Magazine, 23 May 1992), p. 6 (emphasis added).

16540 P1274 (Video footage of interview with Radovan Karadžić, with transcript), p. 1.

16541 P1274 (Video footage of interview with Radovan Karadžić, with transcript), p. 2 (emphasis added).
} 
halt to the SRK's heavy bombing of Sarajevo while at the same time justifying his actions, as well as those of the SRK forces. ${ }^{16542}$ However, the Chamber also heard that the Accused did not in fact intend for the shooting to stop completely. Instead, in the evening of 30 May 1992, he spoke to a certain Čedo who first reported to the Accused on the military situation in Rajlovac and Vraca and then received the following instructions from the Accused:

\begin{tabular}{|c|c|}
\hline Karadžić Radovan: & Alright. There is no artillery usage tonight, is there? \\
\hline Čedo: & No, no, no artillery on either side. \\
\hline$[\ldots]$ & \\
\hline Karadžić Radovan: & Try not to use artillery. Has Mladić called? \\
\hline Čedo: & Yes, yes, we've arranged that. \\
\hline Karadžić Radovan: & But, you should use infantry weapons. Let them go to hell. \\
\hline Čedo: & Exactly. \\
\hline Karadžić Radovan: & If they want to die, let ... \\
\hline Čedo: & They'll get what they're asking for. ${ }^{16543}$ \\
\hline
\end{tabular}

Thus, even though he bemoaned to Morillon the inexperience of the forces in Sarajevo and the inability of Mladić to control them, the Accused himself then proceeded to issue instructions to forces on the ground encouraging them to use infantry fire. This in turn shows not only that he did in fact order the use of fire on Sarajevo but also that he was duplicitous in his dealings with the international community. ${ }^{16544}$

4906. This duplicity was openly verbalised in a meeting that took place at 4 p.m., on 5 June 1992, attended by Mladić, Koljević, Plavšić, Krajišnik, and Đerić, where the Accused first reported on the meeting the political leadership had had with Thornberry that day and then instructed them that "Sarajevo has to be resolved politically while acting quietly, inch by inch."16545 He also instructed the attendees to "clean up" Butmir, Hrasnica, Dobrinja, Sokolović Kolonija, and Hrasno. ${ }^{16546}$ The SRK forces launched an attack on Sarajevo later that evening, that was indiscriminate and

\footnotetext{
16542 See e.g. discussion relating to Scheduled Incident G.1.

16543 P2332 (Intercept of conversation between Čedo and Radovan Karadžić, 30 May 1992), p. 3 (emphasis added).

16544 The Accused showed his duplicity again in May 1995 following the SRK's withdrawal of weapons from WCPs described earlier. During a 25 May 1995 telephone conversation with Milovanović, he first urged the latter to return the weapons but when told that the weapons were unaccounted for, he told Milovanović to "give them back something that's old". See D987 (Intercept of conversation between Radovan Karadžić and General Milovanović, 25 May 1995).

16545 P1478 (Ratko Mladić's notebook, 27 May-31 July 1992), p. 93 (emphasis added). See also para. 4574.

16546 P1478 (Ratko Mladić's notebook, 27 May-31 July 1992), p. 93.
} 
disproportionate, lasting three days and causing a number of civilian casualties. ${ }^{16547}$ The next day, while the bombardment of Sarajevo was continuing, the Accused attended a meeting in Jahorina with other political and military leaders, including Krajišnik, Koljević, and Mladić, during which he discussed the Strategic Goals, claiming "we have to protect our territories militarily" and that "the birth of a state and the creation of borders does not occur without war". ${ }^{16548}$ The bombing stopped only when the members of the RS Presidency and Mladić decided to put a halt to it. ${ }^{16549}$

4907. As outlined earlier, on 15 June 1992, the Accused met with Mladić, other members of the RS Presidency, and representatives from the Sarajevo municipalities, during which Koljević urged the others to "treat Dobrinja as our territory into which [Bosnian Muslim] snipers and terrorists have infiltrated". ${ }^{1650}$ To this, the Accused responded that the issue of Dobrinja must be resolved through co-operation with the police. ${ }^{16551}$ Prstojević then requested the deployment of soldiers to Dobrinja to carry out an operation and the meeting concluded with the decision to "clear the Serbian territory", giving priority to Mojmilo and Dobrinja. ${ }^{16552}$ As described earlier in the Judgement, Dobrinja was heavily shelled throughout the war by the SRK, such that it was utterly destroyed by February 1994. ${ }^{16553}$

4908. The Chamber also recalls a meeting on 10 September 1992, when Vance, Owen, and Okun met with the Accused and during which the Accused, having been told that his forces shelled Sarajevo first, responded that it was the Bosnian Muslims who started the war by expelling him from his apartment in Sarajevo. ${ }^{16554}$ Okun testified that the Accused was portraying an "anomalous picture" as Sarajevo was at that point being mercilessly shelled by the Accused's forces and yet he was complaining about the other side receiving weapons and about being expelled from his own apartment. $^{16555}$

4909. Several days later, on 18 September 1992, the Accused indicated his acceptance of disproportionate fire by the SRK during a press conference in Geneva, when he stated that when the Bosnian Muslims stopped killing Serb civilians with snipers located on buildings, the Bosnian Serb

\footnotetext{
16547 See discussion in relation to Scheduled Incident G.2.

16548 P1478 (Ratko Mladić's notebook, 27 May-31 July 1992), pp. 95, 97. As also explained earlier, this resulted in the issuance of Directive 1 on the same date. See para. 4724.

16549 See para. 4051.

16550 P1478 (Ratko Mladić's notebook, 27 May-31 July 1992), p. 167.

16551 P1478 (Ratko Mladić's notebook, 27 May-31 July 1992), p. 169.

16552 P1478 (Ratko Mladić's notebook, 27 May-31 July 1992), pp. 170-172.

16553 See paras. 3783, 4059.

16554 See para. 4854.

16555 Herbert Okun, P776 (Transcript from Prosecutor v. Krajišnik), T. 4198, 4201-4202.
} 
side would stop shelling those buildings. ${ }^{16556}$ Similarly, in a meeting of 29 January 1993, attended by VRS officers, including Galić and Mladić, the Accused stated that the Bosnian Serb objective was to be in conflict with Bosnian Muslims and Croats everywhere and then emphasised importance of Sarajevo after which he stated "the Muslims should be hit hard enough for the world to realise it's not worth going to war with Serbs". ${ }^{16557}$

4910. As noted earlier, at a meeting in Jahorina on 2 June 1993 with the SRK commanders, the Accused proclaimed that nothing could be achieved by negotiating with Izetbegović and that Izetbegović had to be defeated militarily, stating "if war is what he wants, we have to defeat him". 16558 As also discussed earlier, it is during this meeting that Mladić advocated for "keeping constant the negative effect on the moral [sic] of Muslim forces and population, keep them in fear and constant wondering as to the activities of our forces" and argued for "incessant activities and combat actions with all available SRK forces" in order to "cause as many losses as possible to the enemy and develop feelings of dependency, fear and insecurity". ${ }^{1659}$ The Accused then proclaimed that he supported everything that was said at the meeting. ${ }^{16560}$ Ultimately, this resulted in the issuance of Directive 5 and the Lukavac '93 operation. ${ }^{16561}$ As noted earlier, the directives issued and/or approved by the Accused ensured that the city remained blocked and under siege, which in turn allowed for the sniping and shelling to continue unabated.

4911. In the same vein, during the $34^{\text {th }}$ Bosnian Serb Assembly session in August 1993, the Accused stressed that "Serbian Sarajevo is of priceless importance" and then, in the context of the separation between Muslims and Serbs, stated as follows:

[T]hey write about the large barbed-wire fences that will be set between us. Furthermore, this implies for both across Bosnia, and in Sarajevo. Sarajevo is the most serious problem, as there must be water, electricity and gas, and no shooting. According to the international war laws we are not allowed to use weapons to move Sarajevo from the front-line television news, and then, for us everything is accomplished with less difficulty. I am convinced that we will not see this for another two years, as there will be a lot of blood-shed, and as Njegoš said "sorrow for the one whose forehead breaks". We have to prepare for two important wars: one to gain Sarajevo, and another to gain Krajina. ${ }^{16562}$

\footnotetext{
16556 See para. 4659.

16557 P1485 (Ratko Mladić's notebook, 9 January-21 March 1994), e-court pp. 77-78 (emphasis added).

16558 See para. 4728; P1483 (Ratko Mladić's notebook, 2 April-24 October 1993), e-court p. 194.

16559 See para. 4728; P2710 (VRS conclusions, 31 May 1993), pp. 3-5, 9.

16560 P1483 (Ratko Mladić's notebook, 2 April-24 October 1993), p. 194.

16561 See para. 4728

16562 P1379 (Transcript of $34^{\text {th }}$ session of RS Assembly, 27-29 August, 9-11 September, 29 September to 1 October 1993), pp. 65, 115-116 (emphasis added).
} 
4912. In a meeting in Pale on 14 January 1994, which was attended by the Accused, Krajišnik, Mladić, Galić, Dragomir Milošević, Mićo Stanišić, Neđeljko Prstojević, and other presidents of Sarajevo municipalities as well as commanders of SRK brigades, the Accused stated that "the Muslims must not win a single victory in Sarajevo", that the Serbs must secure the Ilidža-Lukavica road, and that they must defeat the Muslims in Sarajevo so the international community will accept the factual situation on the ground. ${ }^{16563}$ Following the presentation by the various SRK brigade commanders about the situation on the frontline, Mladić stated that Sarajevo is "strategic goal number one", to be resolved militarily not politically. ${ }^{16564}$ Krajišnik then spoke and insisted on Serbs keeping Sarajevo, stating that the whole of Sarajevo must be taken, as one cannot have two masters in such a small area and one cannot share with the Muslims. ${ }^{16565}$ Following all these presentations, the Accused agreed with Mladić that "Muslims will break down in Sarajevo", instructed the participants to make sure that the Muslims keep suffering defeats and feel inferior, and then stated that "retaliation should be $1: 1$ ". ${ }^{16566}$

4913. As recounted earlier, following the incidents in Dobrinja and Markale market on 4 and 5 February 1994, the city went through a period of relative peace and improvements in living conditions, which slowly deteriorated in the second half of $1994 .{ }^{16567}$ On 19 November 1994, following the $\mathrm{ABiH}$ take-over of Mt. Igman, and a number of $\mathrm{ABiH}$ offensives, ${ }^{16568}$ the Accused and Krajišnik, among others, met with Gobilliard; during the meeting, the Accused expressed his belief that the $\mathrm{ABiH}$ was trying to de-block the city and threatened to take the city if the $\mathrm{ABiH}$ tried to do so. ${ }^{16569}$ The situation in Sarajevo deteriorated again, until 31 December when the COHA was signed. $^{16570}$

\footnotetext{
16563 P1484 (Ratko Mladić's notebook, 28 October 1993-15 January 1994), pp. 133-134. See also D2660 (Article from Srpski Borac entitled "We are Sovereign over Sarajevo", 2 August 1995), p. 8 (in which the Accused stated that the Serb victories around Sarajevo were important as they would create a factual situation on the ground that would have to be recognised by the international community). For more on the issue of importance of factual situation on the ground to the Accused, see paras. 2844-2845, 3090-3096.

16564 P1484 (Ratko Mladić's notebook, 28 October 1993-15 January 1994), pp. 139-144.

16565 P1484 (Ratko Mladić's notebook, 28 October 1993-15 January 1994), p. 147.

16566 P1484 (Ratko Mladić's notebook, 28 October 1993-15 January 1994), pp. 148-149.

16567 See paras. 3582-3587.

16568 See paras. 3601-3602.

16569 P1762 (Witness statement of David Fraser dated 17 October 2010), p. 70; P1776 (UNPROFOR report re meeting with Radovan Karadžić and General Tolimir, 20 November 1994), p. 1.

16570 P2451 (Witness statement of Anthony Banbury dated 19 May 2009), para. 69; David Fraser, T. 8118-8121 (19 October 2010); D778 (UNPROFOR report, 17 November 1994); P2454 (UNPROFOR report, 19 November 1994); P1638 (Witness statement of Michael Rose dated 26 March 2009), para. 168; D162 (Michael Rose's book entitled "Fighting for Peace: Bosnia, 1994"), p. 197; Michael Rose, T. 7485 (7 October 2010); P2414 (Witness statement of KDZ182), pp. 47-48 (under seal); P2419 (VRS Main Staff Order, 6 November 1994); P2420 (Report of $2^{\text {nd }}$ Light Infantry Brigade re VRS Main Staff order, 7 November 1994); D2823 (SRK combat report, 6 November 1994).
} 
4914. As also noted earlier, on 19 November 1994, in a meeting with Krajišnik, Andreev, Gobilliard, Banbury, and Fraser, among others, the Accused stated that if $\mathrm{ABiH}$ forces continued to fire on Bosnian Serb forces from within the TEZ, Bosnian Serb forces would retaliate. ${ }^{16571} \mathrm{He}$ further stated: "The Muslims want a big war in Sarajevo. [...] There is going to be a big war in Sarajevo". ${ }^{16572}$ Four days later, the SRK sniped at a tram travelling along Zmaja od Bosne street, injuring two women, and at the beginning of December 1994, the SRK shelled Sarajevo's downtown area with wire-guided missiles. ${ }^{16573}$

4915. The Chamber also heard that in 1995 the Accused was ready to intensify the fighting in $\mathrm{BiH}$, including in Sarajevo. On 5 March 1995, the Accused wrote to Akashi and stated that the Bosnian Muslims were "completely ignoring" the COHA and that, if the situation did not change in the next 7 to 10 days, "our patience will have run out". ${ }^{16574}$ He further warned Akashi that there would be "calamity" if the Bosnian Muslims did "not abandon their obstructionist policy". 16575 On the same day, Mladić met with Smith and told him that the SRK's increased in sniping in Sarajevo was in response to Serb casualties suffered in the military offensives launched by the ABiH, which to Smith was an explicit recognition that sniping was used by the SRK as a punitive measure rather than for any military gain. ${ }^{16576}$

4916. In April 1995, UNPROFOR reported that, in response to VRS defeats in BiH, the Accused announced on 26 March 1995 a general mobilisation of the "entire human and material potential, with the goal of defense of the country". ${ }^{16577}$ The Accused was further reported as saying that if the "Muslims continue to pursue the war option, a major conflict will erupt" and that the Bosnian Serbs would be willing to fight "for decades". ${ }^{16578}$ The UNPROFOR report also recounts that, on 28 March 1995, the Accused stated on Bosnian Serb TV that unless the war was resolved "soon" by peaceful means, his soldiers "will determine the face of the map of former BiH". 16579 He further stated that if the UN called air strikes he would break off all relations with the UN and "consider

\footnotetext{
16571 See paras. $3603,4879$.

16572 P2454 (UNPROFOR report, 19 November 1994), para. 3; P2451 (Witness statement of Anthony Banbury dated 19 May 2009), para. 69; P1762 (Witness statement of David Fraser dated 17 October 2010), p. 70.

16573 See para. 3604. See also discussion relating to Scheduled Incident F.14.

16574 P2245 (Letter from Radovan Karadžić to Yasushi Akashi, 5 March 1995), pp. 1-2.

16575 P2245 (Letter from Radovan Karadžić to Yasushi Akashi, 5 March 1995), p. 2.

16576 Rupert Smith, T. 11309-11311 (8 February 2011); P876 (UNPROFOR Memo re meeting with Ratko Mladić, 6 March 1995), para. 3; P2451 (Witness statement of Anthony Banbury dated 19 May 2009), paras. 94-95; P2455 (UNPROFOR Weekly Situation Report (Sarajevo), 11 March 1995), para. 9; Anthony Banbury, T. 1333013331 (15 March 2011).

16577 P2483 (UNPROFOR Weekly Situation Report (Sarajevo), 1 April 1995), para. 3.

16578 P2483 (UNPROFOR Weekly Situation Report (Sarajevo), 1 April 1995), para. 3.

16579 P2483 (UNPROFOR Weekly Situation Report (Sarajevo), 1 April 1995), para. 7.
} 
them hostile troops". ${ }^{16580}$ This was followed up by a meeting between the Accused and Smith, on 5 April, during which the Accused indicated that the Bosnian Serbs would employ weapons they had not used yet. ${ }^{16581}$ His threat eventuated when, on 7 April, a modified air bomb was launched on Hrasnica inflicting civilian casualties. ${ }^{16582}$ In addition, in April 1995, the situation in Sarajevo escalated with an average of close to 1,000 firing incidents daily. ${ }^{16583}$

4917. Then, on 20 April 1995, the Accused met with Akashi and Smith, together with Gvero, Koljević, and Buha, and told Akashi that the constant sniping by the Bosnian Muslim side "could lead to a renewal of the war" and could force the Bosnian Serbs to retaliate, which would mean a "total war". ${ }^{16584}$ On 22 April, the Accused held a press conference, referring to ABiH offensives and stating, "we shall be forced to engage ourselves into a drastic counter-offensive i.e. to put an end to the war by military means." 16585 He also added that it was detrimental to the region to maintain the low intensity war and that the Bosnian Serbs were ready to achieve peace through victory. ${ }^{16586}$

4918. On 9 May 1995, Smith reported that during a meeting held in Pale earlier in the day, the Accused had made it clear to him that the Bosnian Serbs were not going to let go of Sarajevo. ${ }^{16587}$ Smith explained to the Accused that he had recommended NATO air strikes against VRS positions because of the concentrated artillery attack against Sarajevo and its civilian population. ${ }^{16588}$ When Smith questioned the Accused on the military options that the Bosnian Serbs thought were available to them, the Accused stated "we will watch what our enemies do, intend to do or we believe are capable of doing and make counter moves against them particularly in Sarajevo." 16589 On the basis of this meeting, Smith concluded that the Bosnian Serb political and military leadership were confident that they could contain and defeat the $\mathrm{ABiH}$ offensives in Sarajevo through vigorous defence and that a further increase in military activities in and around Sarajevo

\footnotetext{
16580 P2483 (UNPROFOR Weekly Situation Report (Sarajevo), 1 April 1995), para. 7.

16581 See para. 3608.

16582 See discussion relating to Scheduled Incident G.10.

16583 See para. 3608.

16584 D3511 (UNPROFOR report, 22 April 1995), para. 2; Yasushi Akashi, T. 37733-37735 (24 April 2013) (testifying that during their meeting he thought the Accused's position was uncompromising and that he was at that point ready to defy the international community).

16585 P883 (UNPROFOR report re Radovan Karadžić's press conference, 22 April 1995), p. 2.

16586 P883 (UNPROFOR report re Radovan Karadžić's press conference, 22 April 1995), p. 4 (emphasis added).

16587 P2265 (UNPROFOR report re meeting with Radovan Karadžić, 9 May 1995), e-court p. 3.

16588 P2265 (UNPROFOR report re meeting with Radovan Karadžić, 9 May 1995), e-court p. 6.

16589 P2265 (UNPROFOR report re meeting with Radovan Karadžić, 9 May 1995), e-court p. 7.
} 
was to be expected. ${ }^{16590}$ Smith also mentioned that during the meeting, the Accused was calm, rational, and less prone to his usual overstatements and wild assertions. ${ }^{16591}$

4919. The Accused himself confirmed that at this time his goal was to escalate the violence in Sarajevo. Speaking at the Bosnian Serb Assembly in mid-June 1995, just a day before a number of modified air bombs were launched on the city, ${ }^{16592}$ he said:

I must say that we decided to opt for an aggravation of the situation, and the Supreme Command and I as the Commander and with the Main Staff, we agreed that the worst for us is a war of low intensity, long duration etc., and that we have to heat up the situation, take whatever we can, create a fiery atmosphere and dramatise, threaten an escalation etc. because we noticed that whenever we advance on Goražde, on Bihać or elsewhere or if the situation escalates around Sarajevo, then the internationals come and diplomatic activity speeds up. We did that around Sarajevo, we took these artillery pieces, there are four artillery pieces, maybe they weren't crucial, but they resulted in the well-known bombing that unfortunately caused us material damage because we didn't disperse these weapons, although that would have been possible and dreadful had the depots been full, there would have been great, massive damage, which was significant anyway. ${ }^{16593}$

4920. Similarly, in an interview he gave in early June 1995, complaining about the international community's failure to understand that Bosnian Serbs had been in $\mathrm{BiH}$ for centuries and therefore had a right to their own state, the Accused stated:

[W]e are not going to indifferently watch each of our breathing pores being closed; we are going to close the Muslims theirs. That is our legitimate right. No one can demand from us that we act in a tolerant and correct manner, and that we are, at the same time, treated as wild beasts in a cage. If we are treated that way, we are going to treat other people in that manner as well. ${ }^{16594}$

4921. As recounted earlier, on 2 August 1995, several weeks before the second Markale incident, the Accused gave an interview to Srpski Borac newspaper where he threatened that if the Muslims did not accept "peaceful transformation of the city into two entities Sarajevo will suffer the fate of Beirut, where working hours are until noon and gunfire in the afternoon." 16595

4922. Accordingly, all these statements and the activities of the Accused show that, while not necessarily issuing orders to target civilians in Sarajevo on a daily basis, he did nevertheless adopt a hard-line position, threatening and encouraging violence on many occasions and particularly during

\footnotetext{
16590 P2265 (UNPROFOR report re meeting with Radovan Karadžić, 9 May 1995), e-court p. 8.

16591 P2265 (UNPROFOR report re meeting with Radovan Karadžić, 9 May 1995), e-court pp. 3, 6.

16592 See discussion relation to Scheduled Incidents G.14 and G.15.

16593 P1410 (Transcript of $51^{\text {st }}$ session of RS Assembly, 14-15 June 1995), p. 329 (emphasis added).

16594 P5063 (Video footage depicting interview of Radovan Karadžić on “Ask the President”, undated, with transcript), e-court p. 13 (emphasis added). The Chamber notes that the video footage contains no date but that based on the events discussed in it, namely the downing of the US plane above Bihać, the time period is early June 1995.

16595 D2660 (Article from Srpski Borac entitled "We are Sovereign over Sarajevo", 2 August 1995), pp. 2-5.
} 
meetings with Mladic and the other members of the Sarajevo JCE. This in turn resulted in the perpetuation of, and at times escalation in, the sniping and shelling directed at the city and its civilians throughout the period of the siege. As such it inevitably resulted in the killing and wounding of many Sarajevo civilians.

4923. That is not to say, however, that the Accused never made any attempts to calm dthe fighting in Sarajevo and it is clear that at times he did do so, such as in the aftermath of the first Markale incident. The Chamber also received evidence suggesting that the Accused did not always approve of the SRK's shelling and sniping of civilians in the city. For example, as already mentioned earlier, Galić stated that the Accused wanted to reduce the use of force to a "minimum related to military necessity and military objectives". ${ }^{16596}$ He also testified that sometime during 1993 the Accused met with the SRK command and expressed concern about the disproportionate use of artillery. ${ }^{16597}$ According to Galić, at these top-level meetings where the Accused was present, the topic of proportionality was always discussed. ${ }^{16598}$ Similarly, Dragomir Milošević testified that the Accused and others in the Main Staff were constantly reminding him never to take any military action that would threaten the civilian population in Sarajevo. ${ }^{16599}$ As an example, Dragomir Milošević testified that Mladić told him to only destroy military targets. ${ }^{16600}$ Vladimir Radojčić, Commander of the Ilidža Brigade from 1993, ${ }^{16601}$ also testified that the Accused would repeatedly point out during meetings that any actions against civilians would violate international humanitarian law and the laws of war. ${ }^{16602}$ Milorad Šehovac, Commander of the $2^{\text {nd }}$ Sarajevo Light Infantry Brigade, ${ }^{16603}$ testified that at the meetings he attended with the Accused, the latter always insisted that the forces act in accordance with the Geneva Conventions and the provisions of international humanitarian law. ${ }^{16604}$

\footnotetext{
16596 Stanislav Galić, T. 37888-37890 (8 May 2013).

16597 Stanislav Galić, T. 37884-37888, 37897-37898 (8 May 2013). The Chamber notes that Mladić's diary records a meeting, on 2 June 1993, whereby the Accused met with Krajišnik, Mladić, Galić and others. However, Mladić did not record the issue of proportionality being discussed. See P1483 (Ratko Mladić's notebook, 2 April-24 October 1993), pp. 182-194.

16598 When asked how often these meetings took place, Galić failed to answer the question. Stanislav Galić, T. 37886-37887 (8 May 2013).

16599 Dragomir Milošević, T. 32736 (28 January 2013), T. 33115-33116 (4 February 2013).

16600 Dragomir Milošević, T. $32737-32739$ (28 January 2013); P5642 (Intercept of conversation between Dragomir Milošević, unidentified male, and Ratko Mladić, 16 June 1995), p. 4.

16601 D2562 (Witness statement of Vladimir Radojčić dated 8 December 2012), paras. 1-2.

16602 D2562 (Witness statement of Vladimir Radojčić dated 8 December 2012), paras. 29, 31.

16603 D2633 (Witness statement of Milorad Šehovac dated 8 December 2012), para. 2.

16604 D2633 (Witness statement of Milorad Šehovac dated 8 December 2012), para. 13. See also D2658 (Witness statement of Luka Dragičević dated 9 December 2012), para. 16; D2667 (Witness statement of Ratomir Maksimović dated 14 December 2012), para. 30; Nikola Mijatović, T. 30762-30763 (30 November 2012); D331 (Intercept of conversation between Danilo Veselinović and Radovan Karadžić, 13 April 1992), p. 2.
} 
4924. The Accused's adviser, Zametica, recalled that the Accused stated once that the sniping by the Bosnian Serb side was "stupid", that it did not get the Serb side a military advantage, and that he was against it. ${ }^{16605}$ Similarly, with respect to shelling in Sarajevo, Zametica testified that the Accused disapproved of "irresponsible" or "senseless" shelling. ${ }^{16606}$ Bogdan Subotić testified that the Accused never issued an order to shell Sarajevo and that, if there had been such an order, he would have known about it. ${ }^{16607}$ He also testified that the Accused wanted a peaceful solution for Sarajevo from the very beginning of the conflict. ${ }^{16608}$ According to Krajišnik, there was no one in the civilian authorities that supported the shelling of Sarajevo. ${ }^{16609}$ In relation to shelling incidents, Krajišnik testified that the Accused would insist on having an immediate investigation conducted and Mladić, or someone else from the Main Staff, would deny that the shell originated from Bosnian Serb-controlled areas. ${ }^{16610}$ The Accused would also issue warnings that the VRS should not attack Sarajevo because that would be a "pretext" to attack the VRS with air strikes. ${ }^{16611}$

4925. Vladislav Jovanović, the Foreign Minister of Serbia, testified that on the occasions when they met, the Accused told him that he did not have a policy of shelling and targeting Sarajevo and that this was not part of the Bosnian Serbs' military aim. ${ }^{16612}$ If such incidents did occur, the Accused told Jovanović, they were sporadic and caused by "soldiers, a few frustrated individuals" who had lost family members and he did his best to prevent them. ${ }^{16613}$ Jovanović was also told by the Bosnian Serb leadership, including the Accused, that the Bosnian Muslims were responsible for a number of incidents, and that it was a method by which they used to infuriate the international community against the Bosnian Serbs and provoke a NATO reaction. ${ }^{16614}$

\footnotetext{
16605 John Zametica, T. 42458-42460 (29 October 2013).

16606 John Zametica, T. 42458-42460 (29 October 2013).

16607 D3695 (Witness statement of Bogdan Subotić dated 16 June 2013), para. 229.

16608 D3695 (Witness statement of Bogdan Subotić dated 16 June 2013), paras. 268-269.

16609 Momčilo Krajišnik, T. 43903 (20 November 2013).

16610 Momčilo Krajišnik, T. 43331 (12 November 2013). Krajišnik gave an example of a shelling on 27 May on Vase Miskina street, after which the Accused was informed about the incident and contacted the VRS. The VRS responded that the shell was not launched by them. The Accused immediately demanded that an inquiry be conducted. According to Krajišnik, the same procedure was followed after the two Markale shellings and the shelling in Dobrinja. See Momčilo Krajišnik, T. 43333-43334 (12 November 2013).

16611 Momčilo Krajišnik, T. 43332 (12 November 2013).

16612 D3015 (Witness statement of Vladislav Jovanović dated 22 February 2013), para. 52; Vladislav Jovanović, T. 34325-34326 (26 February 2013). Jovanović also testified that he stood by his previous testimony in the Slobodan Milošević case in which he stated that he and Slobodan Milošević condemned the shelling and demanded that "the parts of [RS] cease that activity". Vladislav Jovanović, T. 34325 (26 February 2013).

16613 D3015 (Witness statement of Vladislav Jovanović dated 22 February 2013), para. 52; Vladislav Jovanović, T. 34325-34326 (26 February 2013).

16614 Vladislav Jovanović, T. 34253-34254, 34325-34326 (26 February 2013) (also adding that he personally had doubts about the responsibility of the Bosnian Serbs for the incidents such as those that took place in Markale market).
} 
4926. Momir Bulatović testified that he had many conversations with the Accused on the topic of shelling in Sarajevo during which the latter recognised that the shelling was a political liability for the Bosnian Serbs and that it damaged their cause. ${ }^{16615}$ The Accused also told him that he had inquired with Mladić about whether the shelling could be stopped but was told that it was necessary in order to avoid VRS positions being overrun by the ABiH forces. ${ }^{16616}$ When Bulatović raised with the Accused the allegations that the shelling was not limited to military attacks, but aimed at civilian areas, the Accused stated that he had banned shelling of civilian areas on a number of occasions and had done everything he could to prevent the unnecessary and disproportionate shelling of Sarajevo. ${ }^{16617}$ In Bulatović's opinion, the shelling of civilian areas in Sarajevo was not the result of a policy of the Accused but was perpetrated by local soldiers who were untrained and were protecting their own homes and families. ${ }^{16618}$

4927. It is indeed true that the Accused issued several orders, either written or oral, instructing the forces in Sarajevo not to target civilians and/or to respect the laws of war. The Chamber has outlined these orders in more detail in Sections IV.B.3.c.ii.D and IV.B.3.c.iv. The Chamber notes, however, that almost all ${ }^{16619}$ of these orders were issued either while the Accused was engaged in the process of negotiating with foreign diplomats and/or had agreed to cease-fires ${ }^{16620}$ or during times when he was being pressured by the international community and/or threatened with air

\footnotetext{
16615 D3051 (Witness statement of Momir Bulatović dated 25 February 2013), para. 23.

16616 D3051 (Witness statement of Momir Bulatović dated 25 February 2013), para. 23.

16617 D3051 (Witness statement of Momir Bulatović dated 25 February 2013), para. 24.

16618 D3051 (Witness statement of Momir Bulatović dated 25 February 2013), para. 31.
}

16619 The Chamber notes that the Accused's message to the SRK units outlined in D314 is one such order but that it does not contain a date or a stamp making it difficult for the Chamber to place it in context. As also indicated earlier, Guzina's evidence on the issue of the date was unclear. See fn. 16064. Accordingly, the Chamber considers that the probative value of this order is low.

16620 See D920 (Intercept of conversation between Radovan Karadžić and Radovan Pejić, 23 April 1992), p. 2 (wherein the Accused instructed Pejić to refrain from launching any attacks due to a cease-fire being signed that day); D3755 (Intercept of conversation between Radovan Karadžić and Milenko Karišik, 24 April 1992) (wherein the Accused told Karišik that one of the "white" ones will be coming to see who is violating the ceasefire and thus not to retaliate unless threatened); D4491 (SRNA news report, 8 June 1992) (issued following the Accused's meeting in Geneva); D434 (Radovan Karadžić's Order on the application of laws of war, 13 June 1992) (issued one day after the Accused offered a cease-fire in Belgrade); D431 (Minutes of RS Presidency session, 9 October 1992), p. 2 and P1264 (SRK Order, 10 October 1992) (both of which were issued following the Accused's meeting during the ICFY conference in Geneva on 30 September); D4512 (Intercept of conversation between Milan Gvero and Radovan Karadžić, 2 May 1993) (wherein, on the day that he signed the Vance-Owen Plan, the Accused ordered Gvero not to fire anywhere in Sarajevo); D104 (Radovan Karadžić's Directive to VRS Main Staff, 11 May 1993) (issued some days after the Accused had signed the Vance-Owen plan); P5058 (Order of the VRS to SRK, 15 July 1993) and P836 (SRK Order, 15 July 1993) (both of which were issued during the Accused's talks with Owen and Stoltenberg); D4507 (Summary of intercepted conversation between Milan Gvero and Radovan Karadžić, 30 July 1993) (issued on the day a cessation of hostilities agreement was signed by the Accused); D4508 (Intercept of conversation between Radovan Karadžić and Manojlo Milovanović, 3 August 1993), p. 3 (which took place during the ICFY conference peace talks when the Bosnian Serbs had agreed, in principle, to open the Sarajevo airport by 4 August 1993); D4610 (Radovan Karadžić's Order, 13 March 1994) (issued during the cease-fire signed following the Dobrinja and Markale incidents in February 1994). See also P1643 (Letter from Radovan Karadžić to Ratko Mladić and Stanislav Galić, 19 March 1994) (which the Accused issued in order to appease UNPROFOR). 
strikes, such as in the aftermath of the SRK's capture of Mt. Igman in 1993 and in the aftermath of the first Markale incident in February 1994. ${ }^{16621}$ As such, the Chamber does not consider that these orders necessarily indicate that the Accused disapproved of the shelling and the sniping directed at the city, but rather that the shelling and sniping conducted by the SRK were at times inconvenient to him.

4928. Having therefore analysed all of the Accused's statements, orders, conversations, and activities mentioned above and bearing in mind all the preceding findings made by the Chamber in relation to the existence of the common plan, as well as the Accused's various contributions to that plan, the Chamber is convinced beyond reasonable doubt that the Accused had the intent to (i) commit unlawful attacks on civilians in Sarajevo, (ii) perpetrate acts of violence designed to cause terror among Sarajevo's civilian population, and (iii) murder civilians in Sarajevo. ${ }^{16622}$ His hardline approach and tendency to, at times, threaten and/or encourage the use of violence against the city for his own political purposes necessarily means that he also intended the consequences of that violence, including the killing, the wounding, and the terrorisation of the civilian population. Accordingly, given the pattern and the longevity of the campaign of sniping and shelling, the fact that indiscriminate and disproportionate shelling of the city would necessarily bring about civilian casualties, and the above findings in relation to his knowledge and conduct, the Chamber is satisfied that the only reasonable inference is that the Accused, together with the other Sarajevo JCE members, had the intent to commit unlawful attacks against civilians, terror, and murder.

4929. This is confirmed by a number of other factors. Starting first with the Accused's plans for the city, namely a division into two ethnically separate parts (as per the fifth Strategic Goal), the Chamber recalls that it could have been achieved only through what Okun labelled the "wall of fire", that is, through the sniping and shelling of the non-Serb parts of the city. While in the very early stages of the war the Accused may have had some concern for the fate of the civilians in the

16621 See P1483 (Ratko Mladić's notebook, 2 April-24 October 1993), p. 263; P5054 (VRS Main Staff Order, 5 August 1993); P4802 (Intercept of conversation between Radovan Karadžić and unidentified member of VRS Main Staff, 10 August 1993); P4804 (Intercept of conversation between Radovan Karadžić, Colonel Prstojević, and General Gvero, 11 August 1993); P846 (Radovan Karadžić's Order to VRS, 7 February 1994). Other orders provoked by threats from the international community were: P1504 (Minutes of $12^{\text {th }}$ session of SerBiH Presidency, 27 June 1992), para. 3 (order to stop attacks on Dobrinja); P1481 (Ratko Mladić's notebook, 5 October-27 December 1992), p. 59 (wherein the Accused argued it was crucial to stop firing on Sarajevo due to the danger of a NATO attack); D4510 (Intercept of conversation between Radovan Karadžić and Matišić, 21 February 1993) (wherein the Accused refers to Morillon's request to cease fire); D3521 (Letter from Radovan Karadžić to VRS Main Staff, 22 September 1994), p. 3 (wherein the Accused stated that every attack by NATO was a humiliation).

16622 In addition, based on all the evidence, the Chamber finds that the Accused was aware that his conduct as discussed in the preceding sections was part of a widespread and systematic attack directed against a civilian population. 
city, ${ }^{16623}$ this subsided once he realised that the wall of fire was the only way in which he could achieve the fifth Strategic Goal. Furthermore, the siege of Sarajevo, as well as the shelling and the sniping directed at the city and its civilians, also had an effect which was highly desired by the Accused: undermining the Bosnian Muslim authorities in Sarajevo and their desire to have Sarajevo be the capital of the independent $\mathrm{BiH}$.

4930. The Accused's statements in 1991 and early 1992, that is, prior to the Sarajevo JCE coming into existence, show that he recognised the possibility of the Bosnian Serbs encircling the city, the chaos that such encirclement would cause, and then used it to threaten the Bosnian Muslim side. By the time the Sarajevo JCE did come into being in late May 1992, the Accused embraced the siege and the very violence he predicted, all in order to retain the Serb-held territory around Sarajevo and undermine the Bosnian Muslim authorities in the city. This is yet another reason why his intent to commit the crimes outlined above is the only reasonable inference to be drawn from the evidence before the Chamber.

4931. The fact that the Accused had the intent to commit the crimes outlined above is further confirmed by his unwavering support of Mladić's strategy in Sarajevo, as illustrated by, among other things, the events surrounding Scheduled Incident G.1. In that respect, the Accused's argument that no one in the higher VRS command ever issued orders to target civilians is plainly wrong as the evidence analysed above shows that Mladic did issue such orders in his telephone conversations on 28 and 29 May 1992. ${ }^{16624}$ Further, the Accused himself, after ensuring that the bombing was brought to a halt on 30 May 1992, then issued orders for infantry fire to continue, showing in turn that he was involved in daily operations in Sarajevo, that he would issue orders to troops to open fire on Sarajevo, and finally, that he was duplicitous in his dealings with the international community, as ultimately confirmed by his own witness Akashi.

4932. The Accused's control over, and close involvement with, the SRK forces and their officers continued, as illustrated by numerous oral and written orders he issued to them. This too leads to the inevitable conclusion that the activities those forces engaged in during the period of the siege of Sarajevo were intended by the Accused. This is particularly so given the longevity of the siege and the campaign of sniping and shelling of civilians in Sarajevo as it is simply inconceivable that this state of affairs would have continued for over three years had it not had the active support of the Accused. In this respect, the Chamber recalls the Accused's knowledge of the SRK's targeting of

16623 See e.g. D331 (Intercept of conversation between Danilo Veselinović and Radovan Karadžić, 13 April 1992), pp. 2-3. 
civilians in the city from the very beginning of the conflict, his persistent failure to punish the perpetrators and/or stop that targeting, his continued support for various individuals implicated in crimes, such as Mladić, Galić, and Dragomir Milošević, and the control that the VRS and the SRK officers had over the heavy weapons and sniper units encircling the city. The Chamber also recalls the Accused's own admission in mid-June 1995 that creating a "fiery atmosphere" in the city and escalating the conflict inevitably leads to diplomatic activity speeding up and his subsequent efforts to intensify the terror in the city in mid-1995 through, among other things, supporting the use of a new weapon on the city. As found earlier, a number of modified bombs were launched on the city following this threat to use a new weapon. All these facts indicate that there was a clear intent on part of the Accused to support the SRK's shelling and the sniping of the civilians in the city.

4933. Many of the Accused's statements outlined above also show that, from the beginning of the conflict, the approach he adopted with international negotiators and in the public domain was that the Bosnian Serb side was not to blame for anything but was instead to be defended at all costs. Thus, the Accused made numerous claims throughout the conflict that the Bosnian Muslims were at fault for all the major incidents in the city, either because they were launching attacks on the Bosnian Serb-held territory or because they were sniping and shelling their own civilians. In the early stages of the conflict, as illustrated by statements outlined above, he also claimed that the Bosnian Muslims, due to their failure to abandon their political aims, would be and were to blame for the Bosnian Serb violence. This tendency of the Accused to automatically shift the blame to the other side for the civilian casualties in Sarajevo remained his approach throughout the conflict and he rarely acknowledged the SRK's responsibility for anything, even in private conversations with his peers. ${ }^{16625}$ However, given that he was physically close to the city and to the SRK forces surrounding it, given the extensive information he would receive in relation to the Sarajevo battlefield from various sources, and recalling the great interest he took in the events there, the Chamber considers that the Accused adopted this approach of shifting blame not because he actually believed that the SRK was not responsible but because he wanted to deflect that responsibility and continue the pursuit of his political goals.

4934. This being his approach, the Accused made no genuine attempts to ensure that the civilian population in Sarajevo was protected from attacks by his own forces, even though he was obliged to do so given his position as the Supreme Commander. While he did occasionally issue orders for

16624 See discussion relating to Scheduled Incident G.1. Similarly, Dragomir Milošević issued an order to the Ilidža Brigade to launch a modified air bomb on the centre of Hrasnica, as discussed earlier in the Judgement. See discussion relating to Scheduled Incident G.10. 
the Bosnian Serb Forces to stop the shelling and sniping attacks on the city and to respect the laws of war, as explained above, this only happened when he was pressured by the international community, under the threat of NATO air strikes, or when it was in his interest to do so in order to achieve his political goals. In other words, he never made any genuine attempts to stop the firing on the city outside of those situations. Furthermore, given the length of the siege of Sarajevo and of the SRK's campaign of sniping and shelling, the Accused's orders to stop the fire, particularly the indiscriminate and disproportionate fire, were few and far between. More importantly, they were never followed up by proper investigation and/or punishment for those who failed to obey his orders and therefore had no practical effect on the situation on the ground. ${ }^{16626}$ The fact that the Accused did not exercise his extensive influence more regularly and rigorously, which would have in turn prevented severe physical damage to the city, the terrorisation of civilians, and a large number of civilian casualties, indicates to the Chamber that the cessation of attacks on civilians in the city was not in the Accused's interests. Accordingly, the Chamber does not consider that these orders undermine its ultimate finding that the Accused had the intent to commit the crimes outlined above.

4935. The Chamber was not persuaded by the evidence of various Defence witnesses who testified to the Accused's state of mind. For example, Bogdan Subotić's evidence that the Accused always wanted a peaceful solution to the situation in Sarajevo is clearly incorrect given the various statements the Accused made and the activities he engaged in, such as giving the order to Bosnian Serb Forces to use infantry fire on 30 May 1992, threatening the destruction of Sarajevo, and signalling the use of modified air bombs. Further, while the Accused may have told Jovanović and Momir Bulatović that the shelling and the sniping in Sarajevo was the work of rogue soldiers and elements outside of his control, this clearly was not the case, as outlined earlier in the Judgement. ${ }^{16627}$ The Chamber considers that when making these claims the Accused was simply trying to avoid any personal responsibility in front of the various FRY officials.

4936. The Chamber also does not accept Krajišnik's evidence, and the evidence of the various SRK soldiers and officers, that no one in the civilian authorities supported the shelling of Sarajevo.

\footnotetext{
16625 An example of this approach is the aftermath of the first Markale incident when, according to Milinić, before even speaking to anyone in the VRS, the Accused concluded that the incident was yet another Bosnian Muslim hoax. See para. 4208.

16626 The one occasion when the Accused can be said to have made genuine attempts to prevent the shelling and the sniping of the civilian population in Sarajevo was in the immediate aftermath of the first Markale incident when he issued an order directly to the SRK commanders and units threatening to hold them personally responsible for any attacks on the civilians. This in turn resulted in a period of relative peace for the city. However, as the political pressure on him decreased and the $\mathrm{ABiH}$ forces grew more confident, the Accused allowed the shelling and the sniping commence again.

16627

See paras. 4648, 4751.
} 
The evidence before the Chamber clearly shows otherwise. ${ }^{16628}$ Indeed, Krajišnik himself advocated taking the whole of Sarajevo, something that could not have been achieved without an all-out shelling of the entire city, including of its civilian population. ${ }^{16629}$ As noted earlier, he also supported the use of modified air bombs in Sarajevo. ${ }^{16630}$ Given the continuous shelling and sniping in the city between late May 1992 and October 1995, the Chamber also does not believe Galić, Dragomir Milošević, and the other SRK witnesses who testified that the Accused always emphasised the protection of civilians in Sarajevo and was genuine in his concern for the civilians. In any event, given the lack of any effect of those instructions on the ground, they must have been understood among all those present that the Accused was, on most occasions, ${ }^{16631}$ simply paying lip service to the protection of Sarajevo's civilians. As indicated earlier, his failure to launch investigations and prosecutions against those in the SRK who were sniping and shelling civilians, ${ }^{16632}$ coupled with his habit to blame the Bosnian Muslim side for the incidents in the city and for provoking SRK fire, was a clear sign to everyone in the VRS and the SRK that they could continue sniping and shelling at the Sarajevo's civilian population as they wished. Accordingly, none of the Accused's witnesses undermine in any way the Chamber's conclusion that the Accused had the intent to commit murder, unlawful attacks on civilians, and terror in the city of Sarajevo.

\section{e. Conclusion: Accused's individual criminal responsibility}

4937. The Chamber found above that the Sarajevo JCE came into existence in late May 1992 and continued until October 1995; that it involved a plurality of persons, including the Accused; that the Accused significantly contributed to, and worked in furtherance of, the common plan embodied in Sarajevo JCE; and that he shared the intent with respect to the common plan and the Sarajevo JCE crimes. The Chamber also found that the crimes of murder, unlawful attack on civilians, and terror were carried out by the members of the SRK units. ${ }^{16633}$

16628 See e.g. P5599 (Intercept of conversation between Momčilo Mandić and Tomislav Kovač, 24 April 1992) (wherein Mandić told Kovač that Sokolović Kolonija should be razed to the ground despite the presence of moderate Muslims there); P5638 (Intercept of conversation between Neđeljko Prstojević and Radomir Ristić, 16 June 1995) (wherein Prstojević told Ristić that his side pounded the "Turks" and sent a "krmača" [modified air bomb] or two to them, to which Ristić responded: "we need to shake them up a bit by all means").

16629 See P1484 (Ratko Mladić's notebook, 28 October 1993-15 January 1994), p. 147.

16630 See para. 4388.

16631 The Chamber considers that the aftermath of the first Markale incident is one example where the Accused made genuine attempts to stop the firing on the city and its civilian population. As noted earlier, it was prompted by the pressure exerted on him by the international community.

16632 As discussed in relation to the two Markale incidents, the Accused would instead insist on establishing a joint commission comprised of both sides to the conflict, to which he knew the Bosnian Muslims would never agree. See paras. 4208, 4857.

16633 The Chamber excludes from this analysis Scheduled Incidents F.5, F.7, and G.6 as it was not satisfied beyond reasonable doubt that the SRK was responsible. In addition, for his part in this analysis, Judge Baird does not rely on Scheduled Incident G.8, due to his dissent in relation thereto. 
4938. The Chamber recalls that in order to hold the Accused criminally responsible for crimes committed by non-members of the Sarajevo JCE, in this case the SRK units, there must be a link between the Accused or another JCE member and the criminal conduct, which is established if the Accused or another JCE member used the non-member in accordance with the common objective of the JCE to carry out the actus reus of the crimes included therein. ${ }^{16634}$ This may be inferred from the close co-operation of the Accused-or any other Sarajevo JCE member-with the nonmember in order to further the common criminal plan. ${ }^{16635}$ In that respect, the Chamber recalls that it found that the Accused, Mladić, Galić, and Milošević all exercised in fact their de jure authority over the SRK forces. Similarly, all of the Sarajevo JCE members used their authority and influence over the SRK units in order to carry out the crimes envisaged by the common plan of the Sarajevo JCE. Accordingly, the Chamber is satisfied that there is a link between the Accused and other Sarajevo JCE members on one hand, and the criminal conduct of the SRK units in Sarajevo on the other. As a result, the acts of murder and terror, as well as the unlawful attacks on civilians committed in Sarajevo can be imputed to the Accused and the other Sarajevo JCE members.

4939. The Chamber therefore finds that the Accused bears individual criminal responsibility pursuant to Article 7(1) of the Statute for murder, a crime against humanity (Count 5); murder, a violation of the laws or customs of war (Count 6); terror, a violation of the laws or customs of war (Count 9); and unlawful attacks on civilians, a violation of the laws or customs of war (Count 10).

4940. As noted earlier, in addition to the Accused's liability through his participation in the Sarajevo JCE, the Prosecution also alleges that the Accused is individually criminally responsible for planning, instigating, ordering, and/or aiding and abetting murder, unlawful attacks on civilians, and terror. ${ }^{16636}$ It also charges the Accused with individual criminally responsibility pursuant to Article 7(3) of the Statute. ${ }^{16637}$ However, having considered all of the evidence and in light of the findings made above, the Chamber finds that commission through JCE pursuant to Article 7(1) most accurately and appropriately reflects the Accused's responsibility for murder, unlawful attacks on civilians, and terror as charged in the Indictment. The Chamber will therefore not analyse the Accused's responsibility under the other modes alleged by the Prosecution in the Indictment.

\footnotetext{
16634 See para. 567.

16635 See para. 567.

16636 Indictment, paras. 30-31; Prosecution Final Brief, paras. 1115-1118.

16637 Indictment, para. 32; Prosecution Final Brief, paras. 1113-1114.
} 


\section{SREBRENICA COMPONENT}

4941. Under Count 8, the Prosecution alleges that beginning in March 1995, the Accused, in concert with other members of the Overarching JCE, implemented and/or used others to implement a plan to take over the Srebrenica enclave and forcibly transfer its Bosnian Muslim population as part of that JCE. ${ }^{16638}$ According to the Prosecution, prior to the take-over of Srebrenica in July 1995, humanitarian aid to the enclave was restricted, and civilian targets were shelled and sniped in an effort to make life impossible for the inhabitants of the enclave and to remove its population. ${ }^{16639}$

4942. The Prosecution contends that Bosnian Serb Forces and Bosnian Serb Political and Governmental Organs attacked and/or took control of the Srebrenica enclave in July 1995 in pursuit of the objective of permanently removing the Bosnian Muslims and Bosnian Croats from Bosnian Serb-claimed territory. ${ }^{16640}$ The Prosecution further alleges that commencing in the days immediately preceding 11 July 1995, the Accused and others formed the shared objective to eliminate the Bosnian Muslims in Srebrenica by killing the men and boys of Srebrenica and forcibly removing the women, young children, and some elderly men from Srebrenica. ${ }^{16641}$ According to the Prosecution, commencing in the days immediately preceding 11 July 1995 and continuing until 1 November 1995, the Accused participated in a JCE to accomplish this objective through these means, ${ }^{16642}$ which was then implemented as of 11 July $1995 .{ }^{16643}$

4943. The Prosecution characterises the killing of Bosnian Muslims from Srebrenica during July and August 1995 as an underlying act of genocide under Count 2; persecution, a crime against humanity, under Count 3; extermination, a crime against humanity, under Count 4; murder, a crime against humanity, under Count 5; and murder, a violation of the laws or customs of war, under Count $6 .{ }^{16644}$ The Prosecution contends that the separation of men and boys from their families and the forcible removal of the women, young children, and some elderly men caused serious bodily or

\footnotetext{
16638 Indictment, paras. 44, 57, 74. During closing arguments, the Prosecution specified that it does not seek a finding that the Accused is responsible for deportation, under Count 7, in relation to Srebrenica. See Prosecution Closing Argument, T. 48034 (7 October 2014). As outlined earlier in this Judgement, under Count 3, the Prosecution alleges that persecution, a crime against humanity, including forcible displacement, was carried out in, inter alia, Bratunac and Vlasenica municipalities as part of the objective of permanently removing the Bosnian Muslims and Bosnian Croats from Bosnian Serb-claimed territory, and that Bosnian Muslims who were forcibly displaced from their homes in Eastern BiH both during and after 1992 fled to the enclave of Srebrenica. Indictment, paras. 56, 72, 73. See also paras. 683-684, 1097-1098.

16639 Indictment, paras. 57, 74.

16640 Indictment, paras. 45, 51-52.

16641 Indictment, paras. 45, 58, 75. The Prosecution contends that this objective amounted to or included the crimes of genocide, persecution, extermination, murder, and inhumane acts (forcible transfer). Indictment, para. 20.

16642 Indictment, paras. 20, 42, 45.

16643 Indictment, para. 58, 75.

16644 Indictment, paras. 47(a), 60(a)(iii), 60(a)(iv), 66. See also Indictment, Schedule E.
} 
mental harm to thousands of Bosnian Muslims of Srebrenica and thus constituted an underlying act of genocide under Count 2. ${ }^{16645}$

4944. With regard to the forcible displacement of Bosnian Muslims from Srebrenica, the Prosecution alleges that it constitutes persecution, a crime against humanity, under Count 3; and inhumane acts (forcible transfer), a crime against humanity, under Count $8 .{ }^{16646}$ Finally, also under Count 3, the Prosecution alleges that the terrorising and abuse of the Bosnian Muslims of Srebrenica in Potočari and the beating of men and boys of Srebrenica prior to their execution constitutes cruel or inhumane treatment, an act of persecution. ${ }^{16647}$

\section{Facts}

a. Events in eastern BiH between May 1992 and December 1994

4945. As discussed above, as early as mid-May 1992, the Bosnian Serb Political and Governmental Organs had adopted the goal of eliminating the Drina River as a border separating eastern $\mathrm{BiH}$ from Serbia by establishing a foothold in the Drina River valley. ${ }^{16648}$ By November 1992, the VRS had established territorial continuity between its holdings in eastern BiH and the Krajina, and began to focus on capturing the region bordering the Drina River. ${ }^{16649}$

4946. Although the Serb Forces were successful in taking over and holding town centres in Zvornik, Bratunac, and Vlasenica municipalities during the first half of $1992,{ }^{16650}$ pockets in the surrounding countryside, which had had a Bosnian Muslim majority population, remained under the control of Bosnian Muslim forces. ${ }^{16651}$ By the end of October 1992, the Bosnian Muslim forces had captured a number of Bosnian Serb villages, reducing the area of Bratunac municipality

\footnotetext{
16645 Indictment, para. 47(b).

16646 Indictment, para. 60(f) (emphasis added).

16647 Indictment, para. 60(e).

16648 See para. 57.

16649 Milenko Lazić, P4072 (Transcript from Prosecutor v. Popović et al.), T. 21825 (stating that liberating Srebrenica and the upper and middle Podrinje regions was an objective of the Bosnian Serb government and military as early as 1993); P1481 (Ratko Mladić's notebook, 5 October-27 December 1992), e-court pp. 141152; Richard Butler, T. 27433-27434 (17 April 2012); P4914 (Richard Butler's expert report entitled "Srebrenica Military Narrative (Revised): Operation 'Krivaja 95'”, 1 November 2002), para. 1.0; P4919 (Map of $\mathrm{BiH}$ marked by Richard Butler).

16650 See paras. Section IV.A.1.a: Eastern Bosnia.

16651 Richard Butler, T. 27433-27434 (17 April 2012), T. 27696 (19 April 2012). See also D2028 (Map of confrontation lines in Eastern BiH, April-December 1992); Pyers Tucker, T. 23271-23272 (18 January 2012); D2232 (Map of BiH); D3954 (Map of destroyed Serbian villages around Srebrenica); Milenko Živanović, T. 42580-42581 (30 October 2013); D2231 (Report of Tuzla District Defence Staff, 1 October 1992); Adjudicated Fact 1398.
} 
controlled by the VRS to Bratunac town and the predominantly Serb village of Kravica. ${ }^{16652}$ In November 1992, Bosnian Muslim forces based in Srebrenica began a two-stage offensive aimed at: (i) linking up with Bosnian Muslim forces based in Cerska, ${ }^{16653}$ which would isolate the Serb Forces holding the towns of Bratunac and Skelani, and (ii) capturing the town of Bratunac. ${ }^{16654}$ As major combat operations engulfed the broader Kamenica region in Zvornik municipality, ${ }^{16655}$ Bosnian Muslims fled towards Srebrenica town, which had a Bosnian Muslim majority, ${ }^{16656}$ and was itself under VRS attack. ${ }^{16657}$

\section{i. Issuance of Directive 4 and the VRS Spring 1993 Offensive}

4947. In response to this Bosnian Muslim offensive, the VRS devised a plan to secure the Podrinje region, which was articulated in Operational Directive 4 ("Directive 4"), issued on 19 November 1992. ${ }^{16658}$ Directive 4 provided that the Drina Corps was to

[...] defend with utmost persistence Višegrad (the dam), Zvornik and the corridor, while the rest of its forces in the wider Podrinje region are to exhaust the enemy, inflict the heaviest possible losses on them and force them to leave the Birač, Žepa, and Goražde areas with the Muslim population. First offer the able-bodied and armed men to surrender, and if they refuse, destroy them. ${ }^{16659}$

4948. On 23 November 1992, the Accused chaired a meeting held in Zvornik which was attended by the Drina Corps command, as well as the commanders of subordinate brigades and members of the VRS Main Staff, where the combat activities in their respective areas of responsibility were

16652 P4914 (Richard Butler's expert report entitled "Srebrenica Military Narrative (Revised): Operation 'Krivaja 95'”), 1 November 2002), para. 1.21. See also D1596 (Order of ABiH General Staff, 10 July 1992).

16653 The village of Cerska is located approximately 30 kilometres from Zvornik. Momir Nikolić, T. 24745 (15 February 2012).

16654 P4914 (Richard Butler's expert report entitled "Srebrenica Military Narrative (Revised): Operation 'Krivaja 95'”, 1 November 2002), para. 1.22; P4922 (Combat Report of Zvornik Brigade, 23 November 1992), para. 5.

16655 P4914 (Richard Butler's expert report entitled "Srebrenica Military Narrative (Revised): Operation 'Krivaja 95”'), 1 November 2002), para. 1.10; Richard Butler, T. 27695-27696 (19 April 2012).

16656 In 1991, the population of the municipality of Srebrenica was 37,000, of which $73 \%$ were Muslim and $25 \%$ were Serb. Adjudicated Fact 1396. The one kilometre wide and two kilometre long town is nestled in a valley in eastern BiH. See Adjudicated Facts 1393, 1394. See also P4279 (Video footage of Srebrenica, 2 July 2009); Jean-René Ruez, T. 23714-23715 (26 January 2012).

16657 See e.g. Mirsada Malagić, T. 23460-23463, 23511-23512 (24 January 2012); P395 (Witness Statement of Behara Krdžić dated 16 June 2000), e-court pp. 2, 7-8; P398 (Witness statement of Saliha Osmanović dated 18 June 2000), e-court p. 3; P398 (Statement of Saliha Osmanović to Tuzla Cantonal Court, 19 June 2000), ecourt pp. 9-10. The Chamber considers that this flight from Zvornik municipality does not fall within the scope of the allegations set out in paragraphs 72 and 73 of the Indictment, which pertains only to the movement of the population from Bratunac and Vlasenica municipalities.

16658 P4914 (Richard Butler's expert report entitled "Srebrenica Military Narrative (Revised): Operation 'Krivaja 95'”, 1 November 2002), para. 1.22. See also D3934 (Letter from Milenko Živanović to Drina Corps, 29 October 1993), p. 1.

16659 P976 (Directive 4, 19 November 1992), para. 5(d). See also Adjudicated Fact 1399. 
discussed. ${ }^{16660}$ The next day, in accordance with Directive 4, the then-Drina Corps Commander, Milenko Živanović, issued an order to the Zvornik Brigade to "launch an attack [...] to inflict on the enemy the highest possible losses, exhaust them, break them up or force them to surrender, and force the Muslim local population to abandon the area of Cerska, Žepa, Srebrenica, and Goražde". ${ }^{16661}$ That day, the VRS launched Operation Proboj-meaning "breakthrough"pursuant to Directive 4. ${ }^{16662}$ In early December, as the VRS faced stiff resistance from the $\mathrm{ABiH}$ in the Podrinje region, the Accused issued two orders to the Main Staff instructing them to disarm "opponents" in the Cerska and Konjević Polje areas. ${ }^{16663}$

4949. Meanwhile, Srebrenica town had been devastated by shelling. ${ }^{16664}$ The town was crowded with large numbers of Bosnian Muslim refugees from other parts of eastern $\mathrm{BiH}$, and severe hardship, including a serious food shortage, was visible on the streets. ${ }^{16665}$ The town's only medical clinic lacked medicine and anaesthetics. ${ }^{16666}$ The sole UNHCR convoy which had obtained clearance from the VRS to proceed to Srebrenica was halted in Bratunac, where it remained for three or four days before finally being allowed to proceed to Srebrenica. ${ }^{16667}$

16660 P4921 (Order from Milenko Živanović, 21 November 1992), pp. 1-2; P4922 (Combat Report of Zvornik Brigade, 23 November 1992), para. 2. Other attendees included Živanović, Krstić, Pandurević, and Milovanović. P4248 (Timetable for Military-Political Conference in the Drina Corps, 23 November 1992).

16661 P2085 (Order of Drina Corps, 24 November 1992), p. 1 (emphasis added). Milovanović suggested that the emphasised language in Živanović's order differed significantly from the language in Directive 4 and that perhaps it represented the personal view of Živanović. Manojlo Milovanović, T. 25525 (29 February 2012). The Chamber observes that although the language of Directive 4 differs slightly from the language contained in P2085, Živanović himself testified that he understood the task of forcing the Bosnian Muslim population to leave the area to be assigned to him under Directive 4. Milenko Živanović, T. 42596-42598 (30 October 2013); D3932 (Witness statement of Milenko Živanović dated 27 October 2013), para. 15. See also Vidoje Blagojević, T. 45036 (12 December 2013).

16662 D2135 (VRS Analysis of Operation "Proboj", undated). Through this operation, the VRS took parts of Bratunac and Skelani and escalated their combat activities in Kamenica, Cerska, Konjević Polje, Višegrad, and Rogatica. D2135 (VRS Analysis of Operation "Proboj”, undated). See also D1597 (Decision of Drina Corps Command, 8 December 1992); P5200 (Order of Drina Corps, 11 December 1992); Milenko Lazić, P4072 (Transcript from Prosecutor v. Popović et al.), T. 21827-21830.

16663 P5083 (Radovan Karadžić's Order to the VRS Main Staff, 5 December 1992); P4249 (VRS Main Staff Order, 7 December 1992), paras. 1-2 and page 2 (ordering the Corps commands to liberate, inter alia, Konjević Polje and Cerska and ordering additional units from outside the Drina Corps area of responsibility to be sent to the Podrinje region in order to prevent the Bosnian Muslim forces from capturing key areas and facilities). See also P4914 (Richard Butler's expert report entitled "Srebrenica Military Narrative (Revised): Operation 'Krivaja 95'”, 1 November 2002), para. 1.23. (Witness statement of Aernout Van Lynden dated 26 February 2010), para. 118

P926 (Witness statement of Aernout Van Lynden dated 26 February 2010), para. 118.

P926 (Witness statement of Aernout Van Lynden dated 26 February 2010), paras. 118-119. See also P4203 (Witness statement of Pyers Tucker dated 12 May 2010), para. 29.

16667 P926 (Witness statement of Aernout Van Lynden dated 26 February 2010), paras. 116-117. See also D3304 (VRS Main Staff dispatch, 30 November 1992). In addition to the local "lieutenant-colonel" preventing the convoy from proceeding, women from Bratunac, who were holding placards written in English, blocked the road and prevented the convoy from passing. P926 (Witness statement of Aernout Van Lynden dated 26 February 2010), para. 116; D210 ( $1^{\text {st }}$ Krajina Corps report re UN convoys, 2 December 1992), p. 1 (referring to the protest in Bratunac). Because the placards were written in English, Van Lynden deduced that the protest had been pre-organised to take advantage of the British and CNN media coverage. P926 (Witness statement of 
4950. Thereafter, Mladić told Morillon that he would not consider approving any aid convoy to Srebrenica until aid had reached some of the many Bosnian Serb refugees in eastern $\mathrm{BiH} .{ }^{16668}$ As a result, UNHCR suspended all deliveries of humanitarian aid to the region, ${ }^{16669}$ but continued to hold talks with Bosnian Serb officials, including the Accused, regarding the issue of access to the areas. ${ }^{16670}$ Ultimately, the Accused approved a convoy for Srebrenica on the condition that it would leave part of its cargo in Bratunac. ${ }^{16671}$ However, the humanitarian convoy that was scheduled to proceed to Srebrenica on 17 December 1992 was in fact postponed following heavy fighting in the area. $^{16672}$

4951. By December and January, famine prevailed. ${ }^{16673}$ Men often walked tens of kilometres in search of food, but returned empty-handed. ${ }^{16674}$ During this time, Bosnian Muslim forces infiltrated Bosnian Serb lines, attempting to retrieve food and weapons from Bosnian-Muslim held

Aernout Van Lynden dated 26 February 2010), para. 116; Aernout Van Lynden, T. 2571-2572, 2575-2576 (20 May 2010). See generally D241 (Report re humanitarian activity, 1-7 February 1993), para. 98 (under seal) (referring to the Bosnian Serb perception of a link between the aid received by Bosnian Muslims and attacks on Bratunac fueling Bosnian Serb resistance to the passage of aid convoys).

16668 P4213 (UNPROFOR Monthly Situation Report, 8 November 1992), para. 7; P4214 (UNPROFOR report, 15 November 1992), para. 8. See also P4203 (Witness statement of Pyers Tucker dated 12 May 2010), paras. 58, 60; D3953 (Report from Drina Corps to VRS Main Staff, 5 January 1993).

16669 P4203 (Witness statement of Pyers Tucker dated 12 May 2010), para. 60.

16670 Another meeting was held between Morillon and Mladić on 19 November 1992, where they again discussed the suspension of humanitarian aid and Srebrenica was again identified as UNHCR's highest priority; Mladić reiterated that it was not possible to provide aid to Srebrenica without aid being provided to the surrounding Bosnian Serb villages. P4203 (Witness statement of Pyers Tucker dated 12 May 2010), para. 63; P4215 (UNPROFOR report re meeting with Ratko Mladić, 19 November 1992), para. 3(b). See also P4216 (UNPROFOR report re meeting with Radovan Karadžić, 20 November 1992), para. 4; D4745 (RS Protocol of meeting between Radovan Karadžić, Colonel Žarković and representatives of humanitarian organisations, 22 November 1992), e-court p. 1.

16671 D4745 (RS Protocol of meeting between Radovan Karadžić, Colonel Žarković and UNHCR representatives, 22 November 1992), e-court p. 2; D4746 (Order from General Morillon, 23 November 1992), para. 1. On 9 December 1992, the Accused personally visited Bratunac and addressed the local population, telling them that the humanitarian aid convoys should be allowed through to the population of Srebrenica, and stating, "we are creating our state and with our behaviour, we have to show the world that we deserve it, and we will be most successful in this if we show our enemies that we are not building it with hatred towards them, because this is not in the spirit of the Serbian people". D3119 (Article from Naša Riječ entitled "Karadžić in Bratunac: We Are Building Our State", 22 December 1992); Aleksandar Tesić, T. 32595-32596 (12 March 2013); D3398 (Witness statement of Ljubisav Simić dated 7 April 2013), para. 82. See also D1504 (Report of humanitarian organisation, 21 December 1992), para. 7 (under seal). Milovanović testified that subordinate units had noticed that $\mathrm{ABiH}$ attacks became fiercer after receiving humanitarian aid; when forwarding convoy approvals to subordinate units, he had invoked the Accused's authority in an effort to avoid their criticism for ensuring the delivery of aid to Bosnian Muslims before Bosnian Serbs. Manojlo Milovanović, T. 25582-25584, 25621 (1 March 2012); D2140 (VRS Main Staff Order, 27 February 1993); D2148 (Report of Drina Corps, 19 February 1993), p. 2.

16672 D1504 (Report of humanitarian organisation, 21 December 1992), paras. 1-2 (under seal).

16673 Mirsada Malagić, T. 23464-23466 (24 January 2012).

16674 Mirsada Malagić, T. 23464-23465 (24 January 2012). 
territory. ${ }^{16675}$ Bosnian Muslim forces also launched raids from inside the Bosnian Muslim-held territories in eastern $\mathrm{BiH}$ in order to secure weapons, ammunition, and food. ${ }^{16676}$

4952. By January 1993, the Muslim Forces in Srebrenica ${ }^{16677}$ had gained control of 92 or $93 \%$ of the territory in Bratunac municipality and were poised to take the town of Bratunac itself; this successfully separated the Bratunac area from the rest of the Drina Corps' area of responsibility. ${ }^{16678}$ On about 8 January 1993, these forces attacked the village of Kravica, which fell the following day. ${ }^{16679}$

4953. In response, the VRS conducted a series of attacks, the first of which was aimed at separating Srebrenica from Cerska, which was then controlled by the Muslim Forces in Srebrenica. ${ }^{16680}$ During the first weeks, the Bratunac Brigade lost many men, assets, and territory to the Muslim Forces in Srebrenica, ${ }^{16681}$ and units from outside the Drina Corps' area of

16675 Pyers Tucker, T. 23272 (18 January 2012).

16676 Pyers Tucker, T. 23272-23273 (18 January 2012) (further stating that raids also targeted Bosnian Serb communication lines).

16677 The Bosnian Muslim armed forces operating in the Srebrenica area were originally named the Defence Staff of Eastern Bosnia, but were reorganised numerous times and renamed the " 8 th Operative Group of Srebrenica" by the Supreme Command of the ABiH on 1 January 1994. Radislav Krstić, D4136 (Transcript from Prosecutor v. Krstić), T. 5989; D2064 (Order of ABiH Supreme Command, 1 January 1994). See also D2018 (Report of $\mathrm{ABiH}$ on unit locations, 28 July 1993) (describing three brigades of the "Armed Forces of Srebrenica" formed by an order of 15 October 1992); D3935 (VRS Main Staff Intelligence Report, 16 December 1994), p. 1 (referring to the recent formation of the $8^{\text {th }}$ Operative Group). The unit was renamed again at the beginning of May 1995 as the $28^{\text {th }}$ Division. Radislav Krstić, D4136 (Transcript from Prosecutor v. Krstić), T. 5989, 6119; P4175 (Witness statement of Robert Franken dated 15 January 2012), para. 12; Robert Franken, T. 23095 (16 January 2012); Richard Butler, T. 27691 (19 April 2012). But see P4140 (Witness statement of Joseph Kingori dated 8 January 2002), para. 56 (stating that the $28^{\text {th }}$ Division became the $8^{\text {th }}$ Operative Group); Momir Nikolić, T. 24736 (15 February 2012). The Chamber notes that the name of the $\mathrm{ABiH}$ forces operating in and around Srebrenica differed depending on the period in question: before late 1994, the group was referred to as the "Armed Forces of Srebrenica"; between late 1994 and May 1995, the unit was referred to as the $8^{\text {th }}$ Operative Group; and from May 1995 onwards, it was referred to as the $28^{\text {th }}$ Division. The Chamber is satisfied that these terms refer to the same group, but for ease of reference will use the term "Muslim Forces in Srebrenica" to refer to the group throughout.

16678 Momir Nikolić, T. 24735, 24737-24740 (15 February 2012); D2063 (Report of Bratunac Brigade, 9 January 1993); P4914 (Richard Butler's expert report entitled "Srebrenica Military Narrative (Revised): Operation 'Krivaja 95'”, 1 November 2002), para. 1.24.

16679 Momir Nikolić, T. 24735, T. 24737, 24739 (15 February 2012); D2139 (VRS Main Staff Order, 10 January 1993), para. 1; Jean-René Ruez, T. 23995 (1 February 2012); P4914 (Richard Butler's expert report entitled “Srebrenica Military Narrative (Revised): Operation 'Krivaja 95”,, 1 November 2002), para. 1.24. Numerous civilian casualties resulted from the attack on Kravica, as well as other ABiH attacks on nearby villages. Momir Nikolić, T. 24738, 24745 (15 February 2012); D2139 (VRS Main Staff Order, 10 January 1993), para. 1; Manojlo Milovanović, T. 25579-25580 (1 March 2012); D2137 (VRS Analysis of Operation "Pesnica", undated), p. 1.

16680 P4203 (Witness statement of Pyers Tucker dated 12 May 2010), para. 156; P4914 (Richard Butler's expert report entitled "Srebrenica Military Narrative (Revised): Operation 'Krivaja 95", 1 November 2002), para. 1.25; Manojlo Milovanović, T. 25565-25667 (29 February 2012); D2137 (VRS Analysis of Operation "Pesnica", undated), p. 1. Before the proclamation of Srebrenica as a safe area, the Muslim Forces in Srebrenica operated in an area encompassing parts of Vlasenica, Šekovići, Zvornik, Bratunac, Milići, Srebrenica, Han Pijesak and Žepa. Radislav Krstić, D4136 (Transcript from Prosecutor v. Krstić), T. 7554; Pyers Tucker, T. 23273 (18 January 2012). See also P4251 (Order of Drina Corps, 1 February 1993), para. 2; Adjudicated Fact 1400.

16681 Momir Nikolić, T. 24742 (15 February 2012); P4251 (Order of Drina Corps, 1 February 1993), para. 1. 
responsibility were deployed to assist. ${ }^{16682}$ At the beginning of February 1993, the VRS initiated another counter-offensive aimed at capturing the "Bosnian Muslim strongholds" of Cerska and Srebrenica. ${ }^{16683}$ Within two weeks, the VRS controlled the area of Kamenica and had encircled Cerska, Konjević Polje, and Srebrenica, ${ }^{16684}$ but still anticipated that the Muslim Forces in Srebrenica might attack Bratunac. ${ }^{16685}$ In late February, units of the Drina Corps remained actively engaged in the area around Cerska. ${ }^{16686}$

4954. As the VRS approached and began to shell Cerska, residents fled toward Konjević Polje, leaving behind a small number of armed individuals. ${ }^{16687}$ VRS attacks generally followed a pattern of "lob[bing] a few shells an hour into a small number of villages" for two or three days, which would generally cause most of the population to flee, before approximately 50 infantrymen, a couple of tanks, and a couple of APCs would suddenly attack and capture the "largely deserted" villages. ${ }^{16688}$ Through this pattern, the villagers came to recognise the initial shelling as an indication that their village was about to be attacked and fled prior to the ground assault. ${ }^{16689}$ Thus, the vast majority of the Bosnian Muslim civilians from the villages withdrew before Bosnian Serb units entered. ${ }^{16690}$

16682 P4914 (Richard Butler's expert report entitled "Srebrenica Military Narrative (Revised): Operation 'Krivaja 95'”, 1 November 2002), para. 1.24; D4190 (VRS Main Staff Order, 22 January 1993); D3747 (Witness statement of Mirko Trivić dated 22 June 2013), p. 6.

16683 P4251 (Order of Drina Corps, 1 February 1993), para. 3; P5493 (Report of Drina Corps, 1 February 1993), p. 2; P4781 (Intercept of conversations between (i) Colonel Kutlešić and Lieutenant Colonel Mile Beronja and (ii) General Živanović and unknown interlocutor), 8 February 1993). See also P4914 (Richard Butler's expert report entitled "Srebrenica Military Narrative (Revised): Operation 'Krivaja 95'”, 1 November 2002), para. 1.25 .

16684 P6133 (Drina Corps Order, 12 February 1993), para. 1; P4204 (Zvornik Light Infantry Brigade report to the Drina Corps, 15 February 1993), para. 8. See also P5164 (Report of Zvornik Brigade, 13 February 1993), para. 2; P5082 (VRS Analysis of "Operation Udar", undated); P1474 (Ratko Mladić's notebook, 29 January31 March 1993), pp. 48, 52 (referring to VRS intelligence that up to 3,000 enemy soldiers were present in Kamenica and 800 present in Cerska and Konjević Polje as of 10 February 1993).

16685 See D2148 (Report of Drina Corps, 19 February 1993). At the time, the ABiH's main forces were concentrated near Bratunac, the Sase mine, Skelani, Žepa, Goražde, and Međeđa village. P4251 (Order of Drina Corps, 1 February 1993), para. 1. See also D4767 (Report of Zvornik Brigade, 11 February 1993).

16686 P5497 (Report of Drina Corps, 24 February 1993), pp. 1-2.

16687 Pyers Tucker, T. 23260, 23263 (18 January 2012); P4203 (Witness statement of Pyers Tucker dated 12 May 2010), para. 164. See also KW570, T. 32198 (18 January 2013) (private session).

16688 P4203 (Witness statement of Pyers Tucker dated 12 May 2010), para. 157. This pattern of using artillery to induce the population to flee also occurred in the areas to the south, southeast, and southwest of Srebrenica. Pyers Tucker, T. 23263 (18 January 2012).

16689 P4203 (Witness statement of Pyers Tucker dated 12 May 2010), para. 158. Once the women, children, and elderly had left, the VRS assumed that those who remained "[we]re able-bodied, and at the same time h[e]ld extremist views". P5187 (Report of Zvornik Brigade to Drina Corps, 2 February 1993), para. 8.

16690 Momir Nikolić, T. 24745 (15 February 2012); Milenko Živanović, T. 42672-42673, 42676 (31 October 2013). See also P6460 (Excerpt from report of Commission on Human Rights, 5 May 1993), para. 13. See para. 13. 
4955. The VRS also burned Bosnian Muslim villages as they moved through the area. ${ }^{16691}$ The Chamber notes that multiple witnesses who were members of the commands at various levels of the VRS at the time-including Živanović—suggested that certain villages were burned because they were fortified and used as strongholds by the $\mathrm{ABiH} .{ }^{16692}$ In considering these witnesses' testimony, the Chamber noted that as members of the commands at various levels of the VRS, each were-to some extent-connected to this campaign and would therefore have had an incentive to portray as legitimate the means employed therein. ${ }^{16693}$ The Chamber thus treated their testimony with caution. Moreover, the Chamber received evidence demonstrating that torching houses was a default tactic of the Bosnian Serb units, and that Živanović himself urged the burning of "as many [houses] as possible" at the time. ${ }^{16694}$ Furthermore, a contemporaneous report indicates that in at least one instance, the $\mathrm{ABiH}$ had already fled the village, leaving behind abandoned weapons. ${ }^{1665}$ The Chamber therefore does not accept the assertion that Bosnian Muslim villages were burned solely because they were fortified and being used by the $\mathrm{ABiH}$ as strongholds.

4956. Most of the hamlets near Cerska fell to the VRS in early March, followed by Konjević Polje on or around 10 March 1993. ${ }^{16696}$ Those who had fled towards Konjević Polje fled again, as

16691 P3162 (Report of $1^{\text {st }}$ Birač Infantry Brigade, 2 March 1993), para. 2 ("Our forces which are moving in the wider area of Kamenica, Gajići and Grobići worked according to plan without major problems. The village of Gobelji has been burnt and tomorrow the plan is to do Paljevine.") (emphases added).

16692 Milenko Živanović, T. 42601-42603 (30 October 2013), T. 42672 (31 October 2013); D3886 (Witness statement of Svetozar Andrić dated 16 July 2013), para. 8; Svetozar Andrić, T. 41697-41698, 41700-41701 (22 July 2013); Manojlo Milovanović, T. 25777-25780 (5 March 2012).

16693 See e.g. Svetozar Andrić, T. 41701-41702, 41704-41705 (22 July 2013) (denying that the Birač Brigade's strategy was to burn and destroy houses in order to force people out). At the same time of the events in question, Andrić was the Commander of the Birač Brigade. D3886 (Witness statement of Svetozar Andrić dated 16 July 2013), para. 1.

16694 See P4253 (Amendment to Zvornik Brigade Report, 10 March 1993) (Pandurević proposing that "houses should not be torched when taking control of Konjević Polje but that they be inhabited by people from Tuzla and other areas"); Manojlo Milovanović, T. 25783 (5 March 2012); P5261 (Intercept of conversation between Col. Milenko Živanović and Lt. Gaborović, 8 February 1993). When presented with this intercept, Živanović reiterated that civilians had already departed from the villages in question and the villages had been turned into ABiH strongholds. Milenko Živanović, T. 42604-42606 (30 October 2013). Živanović further asserted that Pandurević's suggestion not to burn Konjević Polje so that Serbs could move in was plausible only because the village was not being defended by any $\mathrm{ABiH}$ forces, and he maintained that houses were never burned unless the $\mathrm{ABiH}$ was using them for a military purpose. Milenko Živanović, T. 42607 (30 October 2013). The Chamber is of the view that had Živanović intended only to neutralise a military threat, he would not have urged that "as many [houses] as possible" be burned. The Chamber thus considers that Živanović's testimony is directly contradicted by the intercept in question and, accordingly, will not rely on the former in this regard. See also P6460 (Excerpt from report of Commission on Human Rights, 5 May 1993), para. 15.

16695 P3161 (Report of $1^{\text {st }}$ Birač Infantry Brigade, 2 March 1993), p. 1.

16696 D3747 (Witness statement of Mirko Trivić dated 22 June 2013), p. 5; P4205 (Order of Drina Corps, 14 March 1993), para. 1; Pyers Tucker, T. 23203-23204 (17 January 2012). See also P6460 (Excerpt from report of Commission on Human Rights, 5 May 1993), paras. 13, 15; KW570, T. 32197-32204 (18 January 2013) (private session). The Birač and Bratunac Brigades, as well as the Krajina Corps' "Vojvoda Mišić" $2^{\text {nd }}$ Battalion and Mauzer's Panthers also participated in the attacks on Konjević Polje and Kravica. P5500 (Instructions of Drina Corps Command, 8 March 1993), p. 1; D2967 (Witness statement of Momir Deurić dated 16 February 2013), para. 26; Momir Deurić, T. 33937-33938 (18 February 2013). 
thousands made their way southeast to Srebrenica or west towards Tuzla. ${ }^{16697}$ In some instances, the VRS targeted mixed columns of civilians and soldiers, ${ }^{16698}$ forcing them to flee. ${ }^{16699}$

4957. During the spring of 1993, the humanitarian situation in eastern BiH grew disastrous. As mentioned above, until February, the Bosnian Serbs had allowed only one convoy to Srebrenica. ${ }^{16700}$ They had not allowed any relief convoys to reach Cerska, and had let "a handful" through to Goražde and Žepa following lengthy negotiation and delays. ${ }^{16701}$ Bosnian Serb leaders continued to offer a number of justifications for the convoys not reaching the enclaves, such as roads and bridges being damaged or mined, snow blocking the roads, or the existence of local fighting. ${ }^{16702}$ Alternatively, they asserted that the Bosnian Serb population along the proposed convoy route was agitated and would not let convoys pass, or the leaders would invoke a Bosnian Muslim or UN action as justification for not letting convoys through. ${ }^{16703}$ As mentioned above, Bosnian Serb leaders also often placed conditions on the passage of convoys, such as food having to be delivered to Bosnian Serb refugees first, convoys having to be unloaded and inspected for

16697 Pyers Tucker, T. 23260 (18 January 2012); P4203 (Witness statement of Pyers Tucker dated 12 May 2010), para. 164; KDZ064, T. 1321, 1383-1384 (21 April 2010), T. 1416-1418 (22 April 2010); KDZ069, P339 (Transcript from Prosecutor v. Blagojević \& Jokić), T. 1380. See also Pyers Tucker, T. 23201 (17 January 2012), T. 23260-23261; D3886 (Witness statement of Svetozar Andrić dated 16 July 2013), para. 13; Vidoje Blagojević, T. 45031-45032 (12 December 2013); P6568 (Map of Drina Corps, 12 February 1993). Already at the beginning of February, around 200 women and children had fled Cerska and Kamenica; the VRS allowed them to leave the area through a corridor in the direction of Kalesija. P5499 (Report of Drina Corps, 31 January 1993), pp. 1-2; P4251 (Order of Drina Corps, 1 February 1993), para. 1. See also P5186 (Report of Zvornik Brigade to Drina Corps, 31 January 1993), para. 1; P5496 (Report of Zvornik Brigade, 31 January 1993), para. 1; P5493 (Report of Drina Corps, 1 February 1993), para. 2; P4251 (Order of Drina Corps, 1 February 1993), para. 1.

16698 P4250 (Zvornik Brigade report, 31 January 1993); P4252 (Zvornik Brigade report, 2 March 1993), para. 1; P4203 (Witness statement of Pyers Tucker dated 12 May 2010), paras. 270, 273-274.

16699 Milenko Lazić, P4072 (Transcript from Prosecutor v. Popović et al.), T. 21843-21844; P4251 (Order of Drina Corps, 1 February 1993), para. 1; P4203 (Witness statement of Pyers Tucker dated 12 May 2010), paras. 271272. See also P5163 (Report of Drina Corps, 17 March 1993), p. 2.

16700 See para. 4449

16701 P4203 (Witness statement of Pyers Tucker dated 12 May 2010), paras. 132, 140. For example, when Morillon attempted to accompany a relief convoy to Goražde in mid-February, Radomir Furtula and Rajko Kušić stopped the convoy at Rogatica, telling the group that they had received orders from Mladić to block the convoy and to check it for contraband, which they did, but found nothing. P4203 (Witness statement of Pyers Tucker dated 12 May 2010), paras. 131, 136-138. Eventually, the convoy was allowed to proceed, only to be stopped and held at subsequent roadblocks while each local commander sought direction from his superior. P4203 (Witness statement of Pyers Tucker dated 12 May 2010), para. 138. Ultimately, the convoy encountered a huge crater in the road and had to return to Sarajevo as no alternate routes were available; on the return journey, the convoy was "virtually waved through" all check-points and reached Sarajevo in a fraction of the time. P4203 (Witness statement of Pyers Tucker dated 12 May 2010), para. 139.

16702 P4203 (Witness statement of Pyers Tucker dated 12 May 2010), paras. 148, 175.

16703 P4203 (Witness statement of Pyers Tucker dated 12 May 2010), para. 143. For example, upon Mladić's orders, Morillon was barred from visiting Konjević Polje in mid-March because Morillon had not implemented an agreement regarding the exchange of captured Bosnian Serbs and Bosnian Muslims. P4790 (Intercept of conversation between Colonel Simić and unidentified person, 11 March 1993); P4791 (Record of intercept of conversation referring to an order given by Ratko Mladić, 11 March 1993). 
weapons smuggling, or large sums of money having to be paid to the RS for road maintenance. ${ }^{16704}$ If, however, the Bosnian Serb high command wanted to allow a particular convoy through, it passed with minimal obstruction. ${ }^{16705}$

4958. After receiving clearance to lead an aid convoy to Srebrenica, following several days of delays and detours, Morillon finally arrived in Srebrenica in the middle of the night on 12 March. ${ }^{16706}$ The town bore signs of having been subjected to continuous shelling. ${ }^{16707}$ It was saturated with refugees; people camped in the stairwells and corridors of apartment buildings, in cars, and in public buildings such as the school and sports centre, while others had no shelter and "simply huddled around what fires they could make" when the temperatures dropped to $-25^{\circ} \mathrm{C}$ at night. $^{16708}$

4959. Most who had fled to Srebrenica had not had any real food since leaving their villages, and the only water source, the river, was heavily polluted with offal, excrement, and oil. ${ }^{16709}$ There

16704 P4203 (Witness statement of Pyers Tucker dated 12 May 2010), para. 144. See also para. 4950. For example, after learning about 75 Bosnian Muslim military and civilian wounded who had been found in houses in and around Konjević Polje, Morillon obtained agreement from Gvero and "Dr. Lukić" for a military convoy to evacuate the wounded from Konjević Polje during a cease-fire, and for a humanitarian aid convoy to go to Srebrenica on 11 March 1993. P4203 (Witness statement of Pyers Tucker dated 12 May 2010), paras. $163,165$. However, permission for the convoy to pass was conditioned on the $\mathrm{ABiH}$ stopping offensive actions in other areas. P4203 (Witness statement of Pyers Tucker dated 12 May 2010), paras. 165-166.

16705 P4203 (Witness statement of Pyers Tucker dated 12 May 2010), para. 147. On multiple occasions, the Accused intervened directly with local authorities in order to allow convoys to pass. See e.g. P4203 (Witness statement of Pyers Tucker dated 12 May 2010), para. 148; D3194 (Witness statement of Rodoljub Đukanović dated 24 March 2013), para. 51.

16706 P4203 (Witness statement of Pyers Tucker dated 12 May 2010), paras. 175, 201; P4235 (UNPROFOR Special Situation Report re Srebrenica, 15 March 1993). The convoys set out around 10 March, reaching Zvornik by the following day, where Morillon and a small party met with Branko Grujić, the mayor of Zvornik, and Pandurević, who, after speaking with the Accused twice by phone, finally agreed to the medical evacuation from Konjević Polje as well as to Morillon and a small group going to Srebrenica. P4203 (Witness statement of Pyers Tucker dated 12 May 2010), paras. 168, 170.

16707 P4203 (Witness statement of Pyers Tucker dated 12 May 2010), para. 201; P4235 (UNPROFOR Special Situation Report re Srebrenica, 15 March 1993). See also Adjudicated Fact 1403. Morillon's group also found evidence of cluster bombs and $128 \mathrm{~mm}$ rockets having fallen within the enclave. P4203 (Witness statement of Pyers Tucker dated 12 May 2010), paras. 201-202. Additionally, after being halted in Zvornik, the other convoy evacuating the wounded came under direct fire from VRS tanks in Konjević Polje, causing it to withdraw. P4203 (Witness statement of Pyers Tucker dated 12 May 2010), paras. 188-189.

16708 P4203 (Witness statement of Pyers Tucker dated 12 May 2010), paras. 176-177. People relied on makeshift generators for electricity, and 15 to 20 people lived squeezed into single rooms. Adjudicated Fact 1402; Pyers Tucker, T. 23289-23290 (18 January 2012).

16709 P4203 (Witness statement of Pyers Tucker dated 12 May 2010), para. 178; Pyers Tucker, T. 23286-23288 (18 January 2012). The advancing VRS forces had destroyed the town's water supplies and there was almost no running water. See Adjudicated Fact 1402. 
were not enough beds in the clinic for the approximately 200 badly injured persons in the town. ${ }^{16710}$ Between 15 and 20 people died each night, and hygiene was deplorable throughout the town. ${ }^{16711}$

4960. The following morning, when Morillon's meeting ended and the convoy tried to leave, the crowd, which had grown and had become increasingly hostile overnight, swarmed around the vehicles and prevented them from moving. ${ }^{16712}$ In the afternoon, Morillon declared that Srebrenica was under the protection of the UN and specified conditions that would need to be satisfied before he would leave Srebrenica. ${ }^{16713}$ Morillon ordered his headquarters in Kiseljak to negotiate a helicopter air corridor to evacuate the seriously wounded and requested reinforcement from UNMOs, as well as free passage into Srebrenica for aid convoys and out of Srebrenica for all refugees who wanted to leave. ${ }^{16714}$

4961. Over the following two weeks, Morillon engaged in negotiations with various members of the VRS, including Milovanović, who insisted that Morillon would have to leave the enclave before aid convoys would be allowed in-a condition which Morillon refused. ${ }^{16715}$ On 19 March, Morillon left the town to meet the convoy and to help it through Bosnian Serbs roadblocks; while he was gone, the town was hit by a multiple rocket launcher, causing two civilian deaths and wounding three children. ${ }^{16716}$ That day, the first UN aid convoy to reach Srebrenica since the beginning of the year finally arrived. ${ }^{16717}$ Morillon reiterated that he would only leave the enclave permanently once UNMOs were deployed and convoys were allowed unimpeded access to the enclave. ${ }^{16718}$

16710 P4203 (Witness statement of Pyers Tucker dated 12 May 2010), para. 179. See also P4203 (Witness statement of Pyers Tucker dated 12 May 2010), para. 141; P2945 (ABC News video clip re Srebrenica, with transcript) (under seal).

16711 P4203 (Witness statement of Pyers Tucker dated 12 May 2010), paras. 180-181; P4231 (Dr. Simon Yardel's letter to the French Embassy in Belgrade re conditions in Srebrenica, 23 February 1993).

16712 P4203 (Witness statement of Pyers Tucker dated 12 May 2010), paras. 182, 184. No ABiH soldiers were present within the crowd, but they took up positions near the edges and positioned heavy machine guns and antitank rockets along the convoy's exit route. P4203 (Witness statement of Pyers Tucker dated 12 May 2010), paras. 182-183. Morillon made three more attempts to leave, but was blocked each time by an angry crowd. P4203 (Witness statement of Pyers Tucker dated 12 May 2010), paras. 186-187; P4232 (Pyers Tucker's report re situation in Srebrenica, 12 March 1993).

16713 P4203 (Witness statement of Pyers Tucker dated 12 May 2010), para. 191. See also Adjudicated Fact 1403.

16714 P4203 (Witness statement of Pyers Tucker dated 12 May 2010), para. 192. See also D2036 (Pyers Tucker's report re cease-fire in Central and Eastern $\mathrm{BiH}, 16$ March 1993) (including an appeal from Morillon to open an air corridor for humanitarian aid and the evacuation of the wounded).

16715 P4203 (Witness statement of Pyers Tucker dated 12 May 2010), paras. 197-199, 205-207; P4234 (UNPROFOR report re Srebrenica, 15 March 1993); P4238 (UNPROFOR Special Situation Report re Srebrenica, 18 March 1993); P4239 (General Morillon's order re convoy to Srebrenica, 18 March 1993).

16716 P4203 (Witness statement of Pyers Tucker dated 12 May 2010), paras. 208-209; P4240 (Pyers Tucker's report re Srebrenica, 19 March 1993).

16717 P4203 (Witness statement of Pyers Tucker dated 12 May 2010), paras. 207-208. See also KDZ240, T. 16003 (4 July 2011) (closed session).

16718 P4203 (Witness statement of Pyers Tucker dated 12 May 2010), para. 210. 
4962. Meanwhile, the VRS attack on the Srebrenica area continued unabated as the VRS took over four to five villages each day. ${ }^{16719}$ By approximately 20 March, all refugees from Kamenica, Cerska, and Konjević Polje had found their way to Srebrenica. ${ }^{16720}$

4963. On 20 March, Morillon left Srebrenica with a convoy of 673 persons consisting of women, children, and approximately 100 wounded. ${ }^{16721}$ Over the following two days, he held a series of meetings with various Bosnian Serb military and political leaders, including Gvero and Plavšić, with the aim of obtaining their agreement to his previously stated conditions before returning to Srebrenica. ${ }^{16722}$ Sometime between 22 and 24 March, the Accused approved an air corridor from Tuzla to Srebrenica that was scheduled to last for five days beginning on 24 March. ${ }^{16723}$

4964. That day, the football field where the helicopters were to land was shelled numerous times; a Bosnian Muslim policeman was killed. ${ }^{16724}$ Protests were lodged with the Bosnian Serb authorities throughout the day. ${ }^{16725}$ Ultimately, five helicopters were able to evacuate 24 civilians, but a total of three people were killed and six wounded during the process. ${ }^{16726}$

16719 P4241 (UNPROFOR Special Situation Report re Srebrenica, 20 March 1993), para. 8; P4207 (Drina Corps report, 17 March 1993). According to an UNPROFOR situation report, the VRS received support from across the border in Serbia in the form of artillery fire, aircraft-bombers, and ammunition resupply convoys, and were allowed by the Serbians to stage attacks on the southern and eastern parts of the Srebrenica enclave from within Serbian borders. P4241 (UNPROFOR Special Situation Report re Srebrenica, 20 March 1993), para. 8.

16720 P4203 (Witness statement of Pyers Tucker dated 12 May 2010), para. 211. The total number of refugees in the enclave, which was at that point defined as including Žepa, was estimated to be around 80,000. P4241 (UNPROFOR Special Situation Report re Srebrenica, 20 March 1993), para. 9; P4203 (Witness statement of Pyers Tucker dated 12 May 2010), para. 212.

16721 P4203 (Witness statement of Pyers Tucker dated 12 May 2010), para. 212; P4208 (Drina Corps report, 20 March 1993), para. 3. See also D1508 (Report of humanitarian organisation, 4 April 1993) (under seal).

16722 P4203 (Witness statement of Pyers Tucker dated 12 May 2010), paras. 214-218. While Morillon was away, the VRS offensive continued along the southeast edge of the enclave. P4203 (Witness statement of Pyers Tucker dated 12 May 2010), para. 219; P4242 (Major Dudley's report re Srebrenica, 22 March 1993).

16723 P4203 (Witness statement of Pyers Tucker dated 12 May 2010), para. 225; P4243 (Pyers Tucker's report re Srebrenica, 24 March 1993).

16724 P4203 (Witness statement of Pyers Tucker dated 12 May 2010), paras. 228-231; P4243 (Pyers Tucker's report re Srebrenica, 24 March 1993); P4244 (UNPROFOR report re Srebrenica, 25 March 1993). See also P4245 (UNHCR daily press summary re situation in Srebrenica, 25 March 1993). While en route to Sarajevo four days later, Tucker met a Bosnian Serb Special Forces officer who boasted about having killed five Bosnian Muslims while in the hills above Srebrenica. P4203 (Witness statement of Pyers Tucker dated 12 May 2010), para. 256. Tucker thus concluded that a member of the Bosnian Serb Special Forces must have infiltrated the enclave in order to advise the gunner who shelled the football field on 24 March. P4203 (Witness statement of Pyers Tucker dated 12 May 2010), para. 230. The shells were fired from the direction of Bratunac, but because Tucker had seen only $82 \mathrm{~mm}$ mortar positions along the road to Bratunac, Tucker surmised that the shells were fired from Serbia, over the Drina, and over Bratunac, towards the football field. P4203 (Witness statement of Pyers Tucker dated 12 May 2010), paras. 232, 254.

16725 P4243 (Pyers Tucker's report re Srebrenica, 24 March 1993), para. 4.

16726 P4245 (UNHCR daily press summary re situation in Srebrenica, 25 March 1993), p. 1. 
4965. By 25 March 1993, the population of Srebrenica town had swollen to 30,000. ${ }^{16727}$ Shelling continued sporadically throughout the day, the town was completely filled with people who were forced to live on the streets, and food stocks were predicted to last only ten more days. ${ }^{16728}$

4966. Pursuant to an agreement reached in Belgrade on 25 March, ${ }^{16729}$ an aid convoy of approximately 18 trucks accompanied by two teams of four UNMOs each made its way toward Srebrenica on 27 March. ${ }^{16730}$ As previously agreed, the convoy was to deliver aid and then to evacuate the wounded, women, and children on the return journey. ${ }^{16731}$ A total of approximately 5,560 women, children, and elderly, as well as several hundred wounded persons, were evacuated to Tuzla on the trucks' return journeys. ${ }^{16732}$

4967. Morillon left Srebrenica for Sarajevo on the morning of 28 March. $^{16733}$ While in Sarajevo, he met with RS Prime Minister Vladimir Lukić, who agreed to consider a plan to deploy UNPROFOR observers throughout BiH, including in Srebrenica. ${ }^{16734}$

4968. By early April, the VRS had re-gained much of the territory it had previously lost, and was within two kilometres of Srebrenica town. ${ }^{16735}$ As the VRS tightened its grip around the town, ${ }^{16736}$

16727 P2946 (Report of humanitarian organisation, 25 March 1993), para. 1 (under seal); P2947 (Letter of humanitarian organisation, 2 April 1993), e-court p. 1 (under seal); KDZ240, T. 16011-16014 (4 July 2011) (closed session). See also Adjudicated Fact 1401; P2284 (UNSG report entitled "The Fall of Srebenica", 15 November 1999), paras. 33-37.

16728 P2946 (Report of humanitarian organisation, 25 March 1993), para. 3 (under seal); P2947 (Letter of humanitarian organisation, 2 April 1993), e-court p. 1 (under seal); KDZ240, T. 16011-16014 (4 July 2011) (closed session).

16729 See P4246 (UNPROFOR report re meetings with Slobodan Milošević, 25 March 1993); P4247 ("Serbia Could Face New Measures If RS Drives Continues", United Press International, 25 March 1993). See also P1474 (Ratko Mladić's notebook, 29 January-31 March 1993), pp. 164, 170-171.

16730 P4203 (Witness statement of Pyers Tucker dated 12 May 2010), paras. 243-253. Morillon and Tucker also made their way from Belgrade towards Zvornik, reaching Srebrenica late in the afternoon of 27 March. P4203 (Witness statement of Pyers Tucker dated 12 May 2010), para. 253.

16731 P4203 (Witness statement of Pyers Tucker dated 12 May 2010), paras. 245, 253. The convoys were prevented from bringing in shelter material, however. P2947 (Letter of humanitarian organisation, 2 April 1993), e-court p. 2 (under seal). Additionally, as the convoy prepared to depart for its return journey, panic ensued during the boarding process and several refugees were crushed to death. Pyers Tucker, T. 23210-23211 (17 January 2012). See also D2035 (Pyers Tucker's report re two incidents, 12 March 1993), para. 2.

16732 P2947 (Letter of humanitarian organisation, 2 April 1993), e-court p. 2 (under seal). See also KDZ240, T. 16003-16004 (4 July 2011) (closed session). See also Adjudicated Fact 1404; Manojlo Milovanović, T. 2559925600 (1 March 2012) (recalling that Izetbegović prevented the civilian population, who wanted to leave, from doing so); D1508 (Report of humanitarian organisation, 4 April 1993) (under seal).

16733 P4203 (Witness statement of Pyers Tucker dated 12 May 2010), para. 255.

16734 D3573 (TANJUG news report, 29 March 1993). Morillon also agreed to use his influence with Bosnian Muslim authorities to press for the implementation of an agreement with Izetbegović on 8 March 1993 to allow Bosnian Serbs to leave Sarajevo, Tuzla, and other towns under Bosnian Muslim control. D3573 (TANJUG news report, 29 March 1993).

16735 Momir Nikolić, T. 24743-24744 (15 February 2012); P4790 (Intercept of conversation between Colonel Simić and unidentified person, 11 March 1993); D2141 (VRS Main Staff Order, 9 April 1993); P5167 (Report of Zvornik Brigade, 10 April 1993), para. 2. See also P4914 (Richard Butler's expert report entitled "Srebrenica Military Narrative (Revised): Operation 'Krivaja 95'”, 1 November 2002), para. 1.25. 
many fled from villages within the municipality into the town itself. ${ }^{16737}$ Calls were made to increase the international presence in Srebrenica, including that of UNPROFOR, in order to turn the enclave into a UN protected area and to provide more humanitarian assistance. ${ }^{16738}$

\section{ii. Proclamation of Srebrenica as a "safe area"}

4969. At the end of March and over the first two weeks of April, Morillon and Wahlgren met repeatedly with members of the VRS, including Mladić, Milovanović, and Gvero, with a view to halting the Bosnian Serb attack on Srebrenica and obtaining access to the enclave for UN observers, UNPROFOR, and humanitarian aid convoys. ${ }^{16739}$ In the meantime, however, the attack on Srebrenica continued. ${ }^{16740}$ On the morning of 16 April 1993, Mladić issued an order to the Drina Corps to initiate attacks aimed at seizing the town that day or the next. ${ }^{16741}$

4970. However, that day, the Security Council passed Resolution 819, which proclaimed Srebrenica a "safe area which should be free from any armed attack or any other hostile act" and demanded the immediate cessation of armed attacks against Srebrenica. ${ }^{16742}$ Resolution 819 further asked the Secretary General to "take immediate steps" to increase UNPROFOR's presence in Srebrenica and the surrounding areas and demanded that both warring parties co-operate fully towards that end. ${ }^{16743}$

\footnotetext{
16736 Pyers Tucker described this process as 'squeezing' the enclaves of Srebrenica and Žepa. P4203 (Witness statement of Pyers Tucker dated 12 May 2010), para. 155; Pyers Tucker, T. 23199, 23202-23203 (17 January 2012). See also P4205 (Order of Drina Corps, 14 March 1993), para. 1; D3747 (Witness statement of Mirko Trivić dated 22 June 2013), p. 5.

16737 KDZ425, P380 (Transcript from Prosecutor v. Popović et al.), T. 3500 (under seal); P391 (Witness statement of Hafiza Salihović dated 17 June 2000), e-court p. 2; P391 (Statement of Hafiza Salihović to Tuzla Cantonal Court, 17 June 2000), e-court p. 8; P392 (Witness statement of Semija Suljić dated 17 June 2000), e-court p. 2; P392 (Statement of Semija Suljić to Tuzla Cantonal Court, 17 June 2000), e-court p. 8; P404 (Witness statement of Samila Salčinović dated 18 June 2000), e-court p. 2; P404 (Statement of Samila Salčinović to Tuzla Cantonal Court, 18 June 2000), e-court p. 13.

16738 P2947 (Letter of humanitarian organisation, 2 April 1993), e-court p. 2 (under seal).

16739 See paras. 367-370.

16740 On the afternoon of 12 April, the town was shelled and 14 people, including two children, were killed. P6077 (UNPROFOR letter to Radovan Karadžić, 12 April 1993), p. 2.

16741 P4795 (Intercepts of conversations between (i) General Živanović and Colonel Prstojević; (ii) Ratko Mladić and Colonel Prstojević; and (iii) unidentified person and General Milovanović, 16 April 1993). Mladić further ordered that everyone in the town who had weapons was to be killed, while the civilians and the wounded were to be taken out of town. P4795 (Intercepts of conversations between (i) General Živanović and Colonel Prstojević; (ii) Ratko Mladić and Colonel Prstojević; and (iii) unidentified person and General Milovanović, 16 April 1993).

16742 P4209 (UNSC Resolution 819, 16 April 1993), p. 2. See also Adjudicated Facts 1405, 1407.

16743 P4209 (UNSC Resolution 819, 16 April 1993), p. 2. See also Adjudicated Fact 1410. The resolution further requested that "Bosnian Serb paramilitary units" withdraw from the area around the enclave. P4209 (UNSC Resolution 819, 16 April 1993), p. 2. See also para. 369.
} 
4971. That evening, the VRS forces at Pribićevac received an oral order from the Accused and Mladić to stay at their positions and not to enter Srebrenica. ${ }^{16744}$ The following day, Mladić and Halilović agreed to a cease-fire in the Srebrenica area which would enter into force at 4:59 a.m. on 18 April 1993. ${ }^{16745}$ According to this agreement, all weapons, ammunition, mines, explosives, and combat supplies were to be handed over to UNPROFOR within 72 hours of the arrival of an UNPROFOR convoy scheduled to depart from Tuzla at 11 a.m. that day. ${ }^{16746}$ Neither party was permitted to "hinder the freedom of civilians", ${ }^{16747}$ and disarmed Bosnian Muslim combatants were to be treated as civilians. ${ }^{16748}$ Additionally, a working group was established to discuss how to implement the demilitarisation process, as the VRS and $\mathrm{ABiH}$ disagreed on the geographical boundaries of the area to be demilitarised. ${ }^{16749}$

\section{iii. Deployment of UNPROFOR and demilitarisation efforts}

4972. Following the deployment of CanBat to the enclave on 18 April, ${ }^{16750}$ as well as several days of further negotiations regarding the boundaries of the safe area, the Bosnian Serbs and Bosnian Muslims agreed that despite their different positions on the delineation of the safe area, "the city" itself would be a part of such an area and would be demilitarised. ${ }^{16751}$ Thereafter, the demilitarised

16744 Momir Nikolić, T. 24749-24750 (15 February 2012). At 6 p.m. that day, the Accused issued a written order to the VRS Main Staff ordering the cessation of operations against Srebrenica and the surrounding area, as well as the facilitation of the passage of humanitarian convoys into and out of Srebrenica. D43 (Radovan Karadžić's Order to VRS Main Staff, 16 April 1993), paras. 1, 3. The Accused's order further stated that the VRS was to "ensure pacification of the town in such a way that Muslim forces surrender weapons to UNPROFOR", who would store them, and that after surrendering the weapons, Muslim soldiers would be "treated like all other civilians", who would be protected and given the liberty to choose between leaving and staying. D43 (Radovan Karadžić's Order to VRS Main Staff, 16 April 1993), paras. 4-5. Finally, the Accused ordered the Main Staff to carry out his order immediately and fully and to inform him thereof. D43 (Radovan Karadžić's Order to VRS Main Staff, 16 April 1993), para. 7.

16745 D2143 (Agreement on Demilitarisation of Srebrenica, 18 April 1993), para. 1. See also D2144 (VRS Main Staff Order, 18 April 1993), para. 1 (ordering the Drina Corps to ensure a full and total cease-fire in Srebrenica and its surroundings); Manojlo Milovanović, T. 25593-25595 (1 March 2012); para. 370.

16746 D2143 (Agreement on Demilitarisation of Srebrenica, 18 April 1993), para. 4. See also D2144 (VRS Main Staff Order, 18 April 1993), para. 6. According to the agreement, "after the completion of the demilitarisation process, not a single armed person or unit, apart from UNPROFOR forces, [would] remain in the [Srebrenica] town.” D2143 (Agreement on Demilitarisation of Srebrenica, 18 April 1993), para. 4; D2144 (VRS Main Staff Order, 18 April 1993), para. 6.

16747 D2143 (Agreement on Demilitarisation of Srebrenica, 18 April 1993), para. 7; D2144 (VRS Main Staff Order, 18 April 1993), para. 7.

16748 D2144 (VRS Main Staff Order, 18 April 1993), para. 7.

16749 D2745 (Witness statement of Vere Hayes dated 14 January 2013), paras. 17-20. See also para. 370.

16750 D2745 (Witness statement of Vere Hayes dated 14 January 2013), para. 18. See also para. 370; KDZ064, P769 (Transcript from Prosecutor v. S. Milošević), T. 28816; Momir Nikolić, T. 24752 (15 February 2012); Adjudicated Fact 1413. Despite the impending deployment of the UN personnel and troops, several artillery rounds fell on Srebrenica that morning and sporadic shelling continued to the north and northeast of the town until approximately noon. D2749 (UNPROFOR report re Srebrenica, 18 April 1993), e-court p. 2.

16751 D2745 (Witness statement of Vere Hayes dated 14 January 2013), para. 20; D2242 (Agreement on Implementation of the Demilitarisation of Srebrenica, 18 April 1993). The Bosnian Serbs were dissatisfied with this agreement, however, because they asserted that 16,000 small arms should have been handed in. D2745 (Witness statement of Vere Hayes dated 14 January 2013), para. 25. 
area was defined as the urban area of Srebrenica as well as the hills immediately overlooking the area from which a direct line of sight into the town existed. ${ }^{16752}$ Upon its arrival, CanBat established a small command centre (the "Bravo Company Compound") in Srebrenica itself, and a larger main compound about five kilometres north of the town in Potočari ("UN Compound"). ${ }^{16753}$ From these bases, the battalion oversaw the demilitarisation of the town. ${ }^{16754}$ The UNPROFOR troops were lightly armed and at any one time numbered no more than 600 men. ${ }^{16755}$

4973. On 8 May 1993, following the passage of Security Council Resolution 824 two days earlier, ${ }^{16756}$ Mladić and Halilović signed a further agreement, which also included provisions on the demilitarisation of Žepa. ${ }^{16757}$ Pursuant to this agreement, no one inside either enclave was allowed to have arms, and heavy weapons were taken to a collection point at the Bravo Company compound. ${ }^{16758}$ However, Halilović ordered members of the Muslim Forces in Srebrenica not to hand over serviceable weapons or ammunition to UNPROFOR and to pull all armed personnel and military equipment out of the newly-established demilitarised zone. ${ }^{16759}$ Subsequently, the Muslim

16752 D2745 (Witness statement of Vere Hayes dated 14 January 2013), para. 21. See also P4914 (Richard Butler's expert report entitled "Srebrenica Military Narrative (Revised): Operation 'Krivaja 95'”, 1 November 2002), para. 1.27. These boundaries never expanded outward, and the end result was a zone held by the $\mathrm{ABiH}$ which lay between the boundary of the safe area and the confrontation line with the VRS. D2745 (Witness statement of Vere Hayes dated 14 January 2013), paras. 25, 28; Vere Hayes, T. 31979-31981 (16 January 2013); D2756 (Diagram drawn by Vere Hayes); D2757 (UNPROFOR report re demilitarisation of Srebrenica, 21 April 1993), p. 9. See also Milenko Lazić, P4072 (Transcript from Prosecutor v. Popović et al.), T. 21754; P4914 (Richard Butler's expert report entitled "Srebrenica Military Narrative (Revised): Operation 'Krivaja 95", 1 November 2002), paras. 1.27-1.29.

16753 KDZ064, P769 (Transcript from Prosecutor v. Popović), T. 638-639; Adjudicated Fact 1416. See also P4308 (Book of photographs and maps prepared by Jean-René Ruez, 22 June 2009), e-court p. 16; Jean-René Ruez, T. 23716 (26 January 2012). UNMOs also deployed into Srebrenica on that day. P2284 (UNSG report entitled "The Fall of Srebrenica", 15 November 1999), para. 62; P4140 (Witness statement of Joseph Kingori dated 8 January 2002), para. 9; Joseph Kingori, T. 22825 (12 January 2012).

16754 P2284 (UNSG report entitled "The Fall of Srebrenica”, 15 November 1999), para. 62.

16755 See Adjudicated Fact 1415.

16756 See para. 371.

16757 D135 (Agreement on demilitarisation of Srebrenica and Žepa, 8 May 1993); Manojlo Milovanović, T. 25593 (1 March 2012); D2745 (Witness statement of Vere Hayes dated 14 January 2013), para. 29. See also D2145 (VRS Main Staff Order, 8 May 1993), para. 3; D3886 (Witness statement of Svetozar Andrić dated 16 July 2013), para. 14.

16758 P4140 (Witness statement of Joseph Kingori dated 8 January 2012), para. 15; Joseph Kingori, T. 22843 (12 January 2012); Paul Groenewegen, T. 22979-22980 (13 January 2012). See also P4175 (Witness statement of Robert Franken dated 15 January 2012), para. 17; P4140 (Witness statement of Joseph Kingori dated 8 January 2012), paras. 47, 49; Joseph Kingori, T. 22830-22831 (12 January 2012). The heavy weapons belonging to the Muslim Forces in Srebrenica-including mortars, at least two tanks, and heavy machine guns-remained in the compound of the Bravo Company in Srebrenica in January 1995. P3995 (Witness statement of Albert Rave dated 10 November 2011), para. 10; Albert Rave, T. 22193 (30 November 2011); Robert Franken, T. 23095-23096 (16 January 2012).

16759 See Adjudicated Fact 1426; D2745 (Witness statement of Vere Hayes dated 14 January 2013), para. 26; P2284 (UNSG report entitled "The Fall of Srebrenica", 15 November 1999), para. 61. At the point of demilitarisation, the $\mathrm{ABiH}$ had infantry weapons and artillery weapons of a calibre of up to $120 \mathrm{~mm}$. Radislav Krstić, D4136 (Transcript from Prosecutor v. Krstić), T. 7554. See also Pyers Tucker, T. 23273-23274 (18 January 2012). 
Forces in Srebrenica only turned old and dysfunctional weapons over to UNPROFOR. ${ }^{16760}$ Members of the Muslim Forces in Srebrenica were forbidden to carry their weapons openly. ${ }^{16761}$ UNPROFOR did not conduct house searches, only confiscating weapons if they encountered armed people while on patrol; this resulted in the demilitarisation process not being wholly successful. ${ }^{16762}$

4974. Thus, even after the "main demilitarisation" was completed immediately after the 1993 cease-fire, ${ }^{16763}$ the Muslim Forces in Srebrenica still had access to light arms, heavy machine guns, anti-tank weapons, and mortars. ${ }^{16764}$ The group was progressively organised into brigades under the command of Naser Orić, with Ramiz Bečirović as Chief of Staff. ${ }^{16765}$ However, the Muslim

16760 P4167 (Witness statement of Paul Groenewegen dated 11 November 2011), para. 11; P3948 (Witness statement of Johannes Rutten dated 8 November 2011), para. 10; P2284 (UNSG report entitled "The Fall of Srebrenica", 15 November 1999), para. 61; Adjudicated Fact 1426. See also Milenko Živanović, T. 42669 (31 October 2013).

16761 P4140 (Witness statement of Joseph Kingori dated 8 January 2012), paras. 49-50, 55; P4175 (Witness statement of Robert Franken dated 15 January 2012), paras. 15, 17; P4167 (Witness statement of Paul Groenewegen dated 11 November 2011), para. 11. See also KDZ064, T. 1320-1321 (21 April 2010); KDZ064, P769 (Transcript from Prosecutor v. S. Milošević), T. 28819-28820.

16762 P3995 (Witness statement of Albert Rave dated 10 November 2011), para. 11; P4175 (Witness statement of Robert Franken dated 15 January 2012), para. 17; Robert Franken, T. 23088-23089 (16 January 2012; Momir Nikolić, T. 24574 (13 February 2012); T. 24752 (15 February 2012); Vincentius Egbers, P331 (Transcript from Prosecutor v. Popović et al.), T. 2794-2795, 2903; Johannes Rutten, T. 22006-22007 (28 November 2011); Pieter Boering, P3969 (Transcript from Prosecutor v. Popović et al.), T. 1909-1910; Pieter Boering, T. 22097, 22105-22106 (29 November 2011); Milenko Lazić, P4072 (Transcript from Prosecutor v. Popović et al.), T. 21754; P4140 (Witness statement of Joseph Kingori dated 8 January 2012), para. 49; Joseph Kingori, T. 22827 22828, 22830, 22832 (12 January 2012).

16763 KDZ064, P769 (Transcript from Prosecutor v. S. Milošević), T. 28822. See also P4140 (Witness statement of Joseph Kingori dated 8 January 2002), para. 48; Joseph Kingori, T. 22827-22828, 22830, 22843 (12 January 2012).

16764 P3951 (Excerpt from Dutch debriefing report, 4 October 1995), para. 2.34; Radislav Krstić, D4136 (Transcript from Prosecutor v. Krstić), T. 6119; Joseph Kingori, T. 22836-22837 (12 January 2012). See also P4167 (Witness statement of Paul Groenewegen dated 11 November 2011), para. 10; Paul Groenewegen, T. 22982 (13 January 2012). The Chamber received evidence indicating that the Muslim Forces in Srebrenica did not have any heavy weapons inside the enclave, while other evidence suggested that the Muslim Forces in Srebrenica nevertheless had some type of access to heavy weaponry. See Pieter Boering, T. 22106-22107 (29 November 2011); Joseph Kingori, T. 22833, 22840 (12 January 2012); D1967 (Report of ABiH $8^{\text {th }}$ Operations Group, 17 February 1995); D151 (ABiH General Staff Order, 4 March 1995); Radislav Krstić, D4136 (Transcript from Prosecutor v. Krstić), T. 6119 (suggesting that the Muslim Forces in Srebrenica had access to a howitzer which was concealed around Srebrenica). In this regard, the Chamber recalls Halilović's order to pull military equipment out of the demilitarised zone and considers that such weaponry may have been present in the zone outside the urban area of the enclave or within the Bandera Triangle, both of which were controlled by the Muslim Forces in Srebrenica. See paras. 4973, 4978, fn. 16758.

16765 Robert Franken, T. 23095 (16 January 2012), T. 23144 (17 January 2012); D2018 (Report of ABiH on unit locations, 28 July 1993); Momir Nikolić, T. 24736, 24754-24755 (15 February 2012); P3995 (Witness statement of Albert Rave dated 10 November 2011), para. 8; P4140 (Witness statement of Joseph Kingori dated 8 January 2012), para. 15. See also Vincentius Egbers, P331 (Transcript from Prosecutor v. Popović et al.), T. 2859; P4175 (Witness statement of Robert Franken dated 15 January 2012), para. 12. Upon Orić's departure from the enclave in March 1995, Bečirović became acting commander. P3995 (Witness statement of Albert Rave dated 10 November 2011), para. 8; Robert Franken, T. 23113 (16 January 2012); Richard Butler, T. 27722 (20 April 2012). See also P4140 (Witness statement of Joseph Kingori dated 8 January 2012), para. 19; Joseph Kingori, T. 22831 (12 January 2012); Pieter Boering, P3969 (Transcript from Prosecutor v. Popović et al.), T. 1880-1881; D144 (ABiH Report re fall of Srebrenica and Žepa, 23 February 1996), e-court p. 4. In total, between 3,000 and 4,500 men were present in the enclave, but only a few hundred men comprised a permanent armed group. See P3951 (Excerpt from Dutch debriefing report, 4 October 1995), para. 2.34 ; P3948 (Witness statement of Johannes Rutten dated 8 November 2011), para. 9; Albert Rave, T. 22192-22193, 22198-22199 
Forces in Srebrenica lacked training, discipline, and ammunition. ${ }^{16766}$ Its members often wore civilian clothes rather than military uniforms and lived at home rather than in barracks. ${ }^{16767}$

4975. The establishment of the two safe areas limited the area of responsibility of the Muslim Forces in Srebrenica to the Srebrenica and Žepa enclaves. ${ }^{16768}$ They established headquarters in two locations: in a classroom in Potočari and in some rooms in the PTT building in Srebrenica town. ${ }^{16769}$

4976. Following Srebrenica being proclaimed a safe area, the Muslim Forces in Srebrenica received weapons and ammunition from outside the enclave, particularly from Žepa, which maintained a "pony express" link with Tuzla that also ferried items such as cigarettes, food items, essential commodities, and everyday goods. ${ }^{16770}$ Supplies also arrived via helicopter. ${ }^{16771}$ The

(30 November 2011). See also Joseph Kingori, T. 22835-22836 (12 January 2012); Vincentius Egbers, P331 (Transcript from Prosecutor v. Popović et al.), T. 2880-2881; D4480 (Report of Srebrenica Municipal Defence Secretariat, 9 March 1994).

16766 P4175 (Witness statement of Robert Franken dated 15 January 2012); para. 15; P3995 (Witness statement of Albert Rave dated 10 November 2011), paras. 8, 10; Albert Rave, T. 22185-22186 (30 November 2011); P4140 (Witness statement of Joseph Kingori dated 8 January 2002), para. 56; Joseph Kingori, T. 22836-22837 (12 January 2012); P3948 (Witness statement of Johannes Rutten dated 8 November 2011), para. 10; Johannes Rutten, T. 22050-22051 (28 November 2011). See also Adjudicated Fact 1422; D144 (ABiH Report re fall of Srebrenica and Žepa, 23 February 1996), e-court p. 4. But see P4167 (Witness statement of Paul Groenewegen dated 11 November 2011), para. 10; Paul Groenewegen, T. 22982 (13 January 2012).

16767 Robert Franken, T. 23130, 23145 (17 January 2012). The fact that the majority of members of the Muslim Forces in Srebrenica were municipal residents made it impossible to preclude humanitarian aid from reaching them, as they obtained such aid through their family members. Momir Nikolić, T. 24768-24769 (15 February 2012); Radislav Krstić, D4136 (Transcript from Prosecutor v. Krstić), T. 5993-5994. Indeed, the Muslim Forces in Srebrenica obtained supplies from among humanitarian aid deliveries. See e.g. D1997 (Report of Srebrenica Ministry of Defence to RBiH Tuzla Defence Secretariat, 5 June 1995); Radislav Krstić, D4136 (Transcript from Prosecutor v. Krstić), T. 6044-6045; D3307 (Report of ABiH 8th Operations Group, 25 May 1994); Slavko Kralj, T. 36552-36554, 36583-36584 (4 April 2013); D3308 (Report of Srebrenica Ministry of Defence to RBiH Tuzla Defence Secretariat, 31 March 1995); D3286 (Report of Srebrenica Ministry of Defence to RBiH Tuzla Defence Secretariat, 5 June 1995). Evidence indicates that international agencies may have consented to the distribution of aid to the Muslim Forces in Srebrenica. Robert Franken, T. 23104 (16 January 2012) (testifying that he had heard that UNHCR representatives had consented to the Muslim Forces in Srebrenica taking part of the food supplies arriving with UNHCR convoys); D3313 (Report of RBiH Tuzla SDB, 17 November 1995), p. 6; Slavko Kralj, D3245 (Transcript from Prosecutor v. Popović et al.), T. 2930929311; Slavko Kralj, T. 36551-36552, 36566-36567, 36569, 36588-36589 (4 April 2013). The Chamber notes that the fact that food found its way to the $\mathrm{ABiH}$ does not mean that any international organisations were necessarily providing it to the $\mathrm{ABiH}$ in an organised manner.

16768 Radislav Krstić, D4136 (Transcript from Prosecutor v. Krstić), T. 7554.

16769 P4175 (Witness statement of Robert Franken dated 15 January 2012), para. 12; Robert Franken, T. 23128 (17 January 2012). See also Robert Franken, T. 23128-28130 (17 January 2012); Pieter Boering, P3969 (Transcript from Prosecutor v. Popović et al.), T. 2029; D1994 (Report from Srebrenica's Ministry of Defence to Tuzla's Secretary of Defence, 22 February 1995).

16770 P3948 (Witness statement of Johannes Rutten dated 8 November 2011), para. 11; Johannes Rutten, T. 22005 (28 November 2011); Pieter Boering, P3969 (Transcript from Prosecutor v. Popović et al.), T. 1910, 2038; D1966 (Report of ABiH General Staff, 13 July 1995), p. 1; Radislav Krstić, D4136 (Transcript from Prosecutor v. Krstić), T. 5984, 6119, 7554-7556; P4175 (Witness statement of Robert Franken dated 15 January 2012), para. 16; P4140 (Witness statement of Joseph Kingori dated 8 January 2012), para. 51; Momir Nikolić, T. 24761 (15 February 2012). See also D1967 (Report of ABiH $8^{\text {th }}$ Operations Group, 17 February 1995); D2078 (Report of ABiH $1^{\text {st }}$ Žepa Light Brigade, 3 January 1995); D2940 (Order of ABiH $8^{\text {th }}$ Operations Group, 23 January 1995), e-court pp. 4-6, 8; D147 (1 ${ }^{\text {st }}$ Žepa Light Brigade communication with Naser Orić, 16 February 1995); Richard Butler, T. 27800 (20 April 2012); Radislav Krstić, D4136 (Transcript from Prosecutor v. Krstić), T. 
VRS requested that UNPROFOR prevent such smuggling, but the latter had insufficient personnel and materiel to patrol adequately, so could only convey the VRS complaints to the $\mathrm{ABiH} .{ }^{16772}$

\section{b. Lead-up to the attack on Srebrenica: January-June 1995}

4977. After the arrival of the initial group of UNPROFOR forces in April 1993, fresh troops rotated into the enclave approximately every six months. ${ }^{16773}$ In January 1995, DutchBat arrived. ${ }^{16774}$ Initially, DutchBat had eight OPs around the perimeter of the enclave; four additional OPs, including OP Papa, were added between February and July $1995 .{ }^{16775}$

4978. Part of DutchBat's regular activities involved carrying out patrols within the enclave. ${ }^{16776}$ This gave DutchBat personnel the opportunity to observe the comparative positions of the VRS and the $\mathrm{ABiH}$, although DutchBat's movement was restricted outside the enclave's borders. ${ }^{16777}$ Within the enclave, DutchBat enjoyed free movement except within the Bandera Triangle, an area on the west side of the enclave opposite the positions of the Milići Brigade. ${ }^{16778}$ When ordered to restore

6029; P4140 (Witness statement of Joseph Kingori dated 8 January 2012), paras. 48, 51; Joseph Kingori, T. 22833-22834, 22840 (12 January 2012).

16771 Pieter Boering, P3969 (Transcript from Prosecutor v. Popović et al.), T. 1910-1911, 2038; Robert Franken, T. 23132 (17 January 2012). See also D1965 (Analysis of ABiH air force, 17 February 1995), p. 3; D145 (ABiH General Staff Order, 18 January 1995); D3721 (VRS Main Staff Intelligence and Security sector report, 8 February 1995), pp. 2-3; D146 (ABiH General Staff Order, 13 February 1995); P3948 (Witness statement of Johannes Rutten dated 8 November 2011), para. 11; Joseph Kingori, T. 22921 (13 January 2012); Momir Nikolić, T. 24760 (15 February 2012). Helicopter activities increased between the middle of April and June 1995, during which time the members of the Muslim Forces in Srebrenica appeared in new combat suits and were seen possessing new Kalashnikovs. Pieter Boering, P3969 (Transcript from Prosecutor v. Popović et al.), T. 2038; P4175 (Witness statement of Robert Franken dated 15 January 2012), para. 15. See also P3948 (Witness statement of Johannes Rutten dated 8 November 2011), para. 11.

16772 Joseph Kingori, T. 22832 (12 January 2012); Pieter Boering, T. 22097, 22105-22106 (29 November 2011); Albert Rave, T. 22210 (30 November 2011).

16773 Adjudicated Fact 1414

16774 See P4167 (Witness statement of Paul Groenewegen dated 11 November 2011), para. 7. Two companies of DutchBat were assigned to the Srebrenica enclave: the Charlie Company, which was based in Potočari, and the Bravo Company. P4167 (Witness statement of Paul Groenewegen dated 11 November 2011), para. 6.

16775 Adjudicated Fact 1418. Some of these OPs were OP Bravo, OP Echo, OP Mike, OP November, OP Papa, OP Quebec, and OP Romeo. See e.g. P4941 (Srebrenica court binder containing maps), e-court pp. 7-8 (showing locations of OPs); Roger Patelski, T. 23018-23020 (13 January 2012); P4174 (Aerial photograph of SrebrenicaBratunac area marked by Roger Patelski) (marking the place of OP Papa). OP Papa was located approximately one kilometre north of the main entrance to the Potočari compound. P4173 (Witness statement of Roger Patelski dated 30 November 2011), para. 4. DutchBat maintained a telephonic link with the VRS military post at the Žuti Most ("Yellow Bridge"), which was located about 500 metres further down the road from OP Papa. P4173 (Witness statement of Roger Patelski dated 30 November 2011), paras. 4, 6. See also Roger Patelski, T. 23027 (16 January 2012).

16776 P4175 (Witness statement of Robert Franken dated 15 January 2012), para. 19. However, DutchBat lacked sufficient personnel to patrol comprehensively as a result of the VRS's refusal to allow DutchBat personnel to return to the enclave following leave periods. Johannes Rutten, T. 22018-22019 (28 November 2011).

16777 P4175 (Witness statement of Robert Franken dated 15 January 2012), paras. 19, 34. See also P4140 (Witness statement of Joseph Kingori dated 8 January 2012), para. 44.

16778 P4175 (Witness statement of Robert Franken dated 15 January 2012), para. 34; Robert Franken, T. 23138 (17 January 2012); Pieter Boering, P3969 (Transcript from Prosecutor v. Popović et al.), T. 1885; Pieter Boering, T. 22120 (29 November 2011); Johannes Rutten, T. 22022 (28 November 2011); P3995 (Witness 
freedom of movement within the Bandera Triangle in January 1995, ${ }^{16779}$ a group of DutchBat soldiers led by the DutchBat deputy commander was arrested and detained by approximately 40 armed men led by the local brigade commander, Zulfo Tursunović. ${ }^{16780}$ The DutchBat commander was able to negotiate their release only after several days. ${ }^{16781}$

\section{i. Issuance of Directives 7 and $7 / 1$}

4979. On 8 March 1995, the Accused issued the strictly confidential "Directive for Further Operations No. 7" (“Directive 7") analysing the military and political situation following the COHA. ${ }^{16782}$ According to the Accused, the COHA had "created conditions for the military strengthening and arming of Muslims and Croats [and] the survival of the Muslim enclaves", including Srebrenica. ${ }^{16783}$ The directive allocated tasks to the various corps of the VRS after describing the anticipated objectives of the Bosnian Muslim and Bosnian Croat forces. ${ }^{16784}$

4980. Specifically, the Drina Corps was tasked with "complet[ing] physical separation of Srebrenica from Žepa [...] as soon as possible, preventing even communication between individuals in the two enclaves". ${ }^{16785}$ Directive 7 further ordered the Drina Corps to "[b]y planned and well-thought-out combat operations create an unbearable situation of total insecurity with no hope of further survival or life for the inhabitants of Srebrenica and Žepa". ${ }^{16786}$ To accomplish these goals, among others, the "relevant State and military organs responsible for work with UNPROFOR and humanitarian organisations" were ordered to,

statement of Albert Rave dated 10 November 2011), para. 9; Albert Rave, T. 22187, 22189-22190 (30 November 2011); P4140 (Witness statement of Joseph Kingori dated 8 January 2012), para. 46; Joseph Kingori, T. 22851 (12 January 2012). Kingori testified that no reasons were given for this prohibition. P4140 (Witness statement of Joseph Kingori dated 8 January 2012), para. 46. However, the Chamber received evidence indicating that one reason for the Muslim Forces in Srebrenica restricting DutchBat movement in the area pertained to DutchBat's refusal to establish an OP at Ravni Buljim. D1956 (Report of ABiH $8^{\text {th }}$ Operations Group, 28 January 1995); P3987 (ABiH $8^{\text {th }}$ Operational Group report, 11 January 1995).

P4175 (Witness statement of Robert Franken dated 15 January 2012), para. 34.

P4175 (Witness statement of Robert Franken dated 15 January 2012), para. 34; Robert Franken, T. 2313823139 (17 January 2012); D1956 (Report of ABiH $8^{\text {th }}$ Operations Group, 28 January 1995); Albert Rave, T. 22186 (30 November 2011). See also Pieter Boering, T. 22119 (29 November 2011); Pieter Boering, P3969 (Transcript from Prosecutor v. Popović et al.), T. 1884; Momir Nikolić, T. 24819 (16 February 2012).

Albert Rave, T. 22187-22188 (30 November 2011); P4175 (Witness statement of Robert Franken dated 15 January 2012), para. 34 .

P838 (Directive 7, 8 March 1995), pp. 2-3; Petar Salapura, T. 40241-40244 (24 June 2013); Manojlo Milovanović, T. 25495, 25503-25504 (29 February 2012) (stating that Directive 7 had been drafted by Miletić according to the "complete method"); Ljubomir Obradović, P4444 (Transcript from Prosecutor v. Tolimir), T. 11993, 12008, 12040 (stating that according to the "complete method" through which Directive 7 was drafted the Accused would have had input into the drafting process). See also Milenko Lazić, P4072 (Transcript from Prosecutor v. Popović et al.), T. 21824-21825; para. 410.

P838 (Directive 7, 8 March 1995), p. 2.

P838 (Directive 7, 8 March 1995), pp. 3-7.

P838 (Directive 7, 8 March 1995), p. 10.

P838 (Directive 7, 8 March 1995), p. 10. 
through the planned and unobtrusively restrictive issuing of permits, reduce and limit the logistics support of UNPROFOR to the enclaves and the supply of material resources to the Muslim population, making them dependent on our good will while at the same time avoiding condemnation by the international community and international public opinion. ${ }^{16787}$

Additionally, Directive 7 stated that should the UNPROFOR forces leave Srebrenica and Žepa, the Drina Corps command should plan an operation "Jadar" to "brea[k] up and destro[y] the Muslims forces in these enclaves and definitively liberat[e] the Drina valley region". ${ }^{16788}$

4981. Directive 7 was disseminated to the various VRS corps on or around 18 March $1995 .{ }^{16789}$ Two days later, Živanović issued the strictly confidential "Order for Defence and Active Combat Operations, Operative No. 7". ${ }^{16790}$ Živanović's order effectively relayed the contents of Directive 7 to the brigade commanders of the Drina Corps by repeating the tasks outlined in Directive 7, namely that the Drina Corps was tasked with carrying out the "complete physical separation of Srebrenica from Žepa [...] as soon as possible, preventing even communication between the two enclaves. By planned and well-thought-out combat operations create an unbearable situation of total insecurity with no hope of further survival or life for the inhabitants of Srebrenica and Žepa". 16791

4982. The Chamber notes that both Živanović and Krstić asserted that this language was never "implemented in practice". ${ }^{16792}$ Similarly, Trivić minimised the operational significance of the directive, suggesting that it merely "provide[d] guidelines" to subordinate units. ${ }^{16793}$ Having considered these witnesses' evidence regarding the implementation of Directive 7 by the Drina Corps, the Chamber observes that it was marked by contradictions and a lack of candour. ${ }^{16794}$ The

P838 (Directive 7, 8 March 1995), p. 14.

P838 (Directive 7, 8 March 1995), p. 11.

P838 (Directive 7, 8 March 1995), p. 1; Manojlo Milovanović, T. 25497-25498 (29 February 2012); P6450 (VRS Main Staff dispatch to Drina Corps, 17 March 1995; Drina Corps dispatch to VRS Main Staff, 18 March 1995).

16790 P3040 (Order of Drina Corps, 20 March 1995), p. 1.

16791 P3040 (Order of Drina Corps, 20 March 1995), pp. 5-6; Milenko Lazić, P4072 (Transcript from Prosecutor v. Popović et al.), T. 21811, 21818-21819, 21822. See also Momir Nikolić, T. 24759-24760 (15 February 2012); Manojlo Milovanović, T. 25607 (1 March 2012).

16792 D3932 (Witness statement of Milenko Živanović dated 27 October 2013), para. 26; Radislav Krstić, D4136 (Transcript from Prosecutor v. Krstić), T. 6399-6400.

16793 Mirko Trivić, T. 40537-40538 (26 June 2013), T. 40546 (27 June 2013).

16794 As will be described in further detail below, Krstić's testimony was given during the course of his defence in his own trial, where he was evasive and displayed a lack of candour regarding his role as the Deputy Commanderand later Commander - of the Drina Corps during the Srebrenica campaign and the events leading up to it. See fn. 16891. The Chamber also recalls contradictions between Živanović's witness statement and his in-court testimony on these points, and observes that Živanović became combative under cross-examination. See e.g. Milenko Živanović, T. 42641-42642, 42647-42648 (31 October 2013). Similarly, Trivić initially suggested that Directive 7 was merely a written document, and that "none of [his] superiors had ever informed [him] verbally to act in that way", but when presented with P3040 (Order of Drina Corps, 20 March 1995), admitted that his unit had received that order, although he maintained that he did not remember seeing those words in the order.
} 
Chamber has also considered their positions at the time and observes that they would have reasons to minimise any implementation of an order targeting civilians. ${ }^{16795}$ Accordingly, the Chamber does not consider their testimony reliable on this point. Finally, the Chamber notes that such testimony is contradicted by other evidence showing that Directive 7 was implemented on the ground, as discussed below. ${ }^{16796}$

4983. On 31 March 1995, one day after the Main Staff had met to discuss the "operation pursuant to Directive 7", ${ }^{16797}$ Mladić issued the "Directive for Further Operations, Operative No. 7/1" ("Directive 7/1"), which was transmitted to the commands of the Krajina Corps, the Eastern Bosnia Corps, and the Drina Corps, as well as the air force and anti-aircraft defence. ${ }^{16798}$

4984. Directive 7/1 "further elaborated" upon Directive 7. ${ }^{16799}$ Noting that during the second half of March, the $\mathrm{ABiH}$ had "started wantonly violating" the COHA, Directive 7/1 stated that "on the basis of Directive No. 7", the addressees were to immediately begin planning and making preparations for the realisation of the strategic operation Sadjestvo 95, the basic objective of which was to "inflict the heaviest possible losses on the enemy, restoring the reputation of the VRS among the people and in the world, and forcing the enemy to negotiate and end the war at the achieved lines through successful actions by VRS forces along chosen axes". ${ }^{1680}$ Directive 7/1 further stated that VRS forces, "in accordance with Directive No. 7", would carry out active combat operations around the Srebrenica, Žepa, and Goražde pockets. ${ }^{16801}$ Directive 7/1 did not contain the reference in Directive 7 to "creat[ing] an unbearable situation of total insecurity with no hope of further survival or life for the inhabitants" of the two enclaves. ${ }^{16802}$

Mirko Trivić, T. 40539 (26 June 2013), T. 40542-40544 (27 June 2013). See also Mirko Trivić, T. 4054640547 (27 June 2013) (discussing whether a later attack plan was based upon Directives 7 and 7/1).

16795 See e.g. Radovan Radinović, T. 41527-41528 (18 July 2013) (conceding that the language constituted an illegal order). The Chamber also recalls that Trivic was the commander of the $2^{\text {nd }}$ Romanija Brigade at the time Directive 7 was issued. D3747 (Witness statement of Mirko Trivić dated 22 June 2013), p. 3; Mirko Trivić, T. 40530 (26 June 2013).

16796 See paras. 5004-5035.

16797 P1473 (Ratko Mladić's notebook, 27 January-5 September 1995), e-court p. 71.

16798 P2246 (Directive 7/1, 31 March 1995), p. 1. Directive 7/1 was marked "National Defence State Secret". P2246 (Directive 7/1, 31 March 1995), p. 1.

16799 D3932 (Witness statement of Milenko Živanović dated 27 October 2013), para. 26.

16800 P2246 (Directive 7/1, 31 March 1995), p. 2. Specifically, the VRS was tasked with stopping ABiH breakthroughs north of Zvornik. P2246 (Directive 7/1, 31 March 1995), p. 2.

16801 P2246 (Directive 7/1, 31 March 1995), p. 4.

16802 P2246 (Directive 7/1, 31 March 1995). Radovan Radinović testified that the words "in accordance with" meant that the language of Directive 7 did not need to be repeated in order to have effect. Radovan Radinović, T. 41535 (19 July 2013). 


\section{ii. Restrictions on humanitarian convoys and the humanitarian situation in Srebrenica}

4985. The Bosnian Serbs subjected all convoys, particularly UNPROFOR re-supply convoys that carried equipment and weaponry, to strict regulation entailing prior notification of convoy movements to the VRS. ${ }^{16803}$ They justified such regulation by citing several instances in which weapons were found in aid convoys, and by asserting that UNPROFOR and UNHCR were involved in organising the delivery of weapons to Bosnian Muslims. ${ }^{16804}$ Clearance for the movement of goods and people into and out of the enclaves had to be obtained from the highest levels of the Bosnian Serb military or government and permission was to be relayed to the subordinate units who actually allowed the convoys to pass. ${ }^{16805}$ In accordance with an order of the

16803 Momir Nikolić, T. 24593 (13 February 2012); P4186 (Principles for Freedom of Movement for UNPROFOR, 31 January 1995), p. 1; Slavko Kralj, D3245 (Transcript from Prosecutor v. Popović et al.), T. 29258, 29304, 29312. UNPROFOR escorted the convoys from the border of the enclave to the warehouse in Srebrenica town, where UNHCR and the municipal employees handled the distribution of the goods. P4175 (Witness statement of Robert Franken dated 15 January 2012), para. 28; P3948 (Witness statement of Johannes Rutten dated 8 November 2011), paras. 5, 7; P4173 (Witness statement of Roger Patelski dated 30 November 2011), para. 5. The convoys that re-supplied UNHCR and MSF were subject to the same regulations and restrictions as DutchBat. P4175 (Witness statement of Robert Franken dated 15 January 2012), para. 27: P3995 (Witness statement of Albert Rave dated 10 November 2011), para. 117. See also Momir Nikolić, T. 24602-24603 (13 February 2012). Pursuant to an agreement with UNPROFOR, UNPROFOR was to provide a request to the Main Staff 24 hours in advance stating what was to be delivered, to whom, how many vehicles were involved, and the name of the person in charge of the convoy; the Main Staff-usually Mladić, Milovanović, or, exceptionally, Tolimir - then approved the route of the convoy and ensured its freedom of movement through RS territory by notifying the approval to the corps through whose territory the convoy was scheduled to pass. Manojlo Milovanović, T. 25793 (5 March 2012); Ljubomir Obradović, P4444 (Transcript from Prosecutor v. Tolimir), T. 12022; Slavko Kralj, D3245 (Transcript from Prosecutor v. Popović et al.), T. 29229, 29260 29262, 29270, 29274; Momir Nikolić, T. 24595-24597 (13 February 2012). See e.g. P4190 (GS VRS Report, 2 April 1995), p. 1. The relevant corps would then report back to the Main Staff once the convoy passed through and if any problems were encountered. Slavko Kralj, D3245 (Transcript from Prosecutor v. Popović et al.), T. 29285-29286, 29307, 29365-29366. See e.g. D3270 (Drina Corps combat report, 4 May 1995), para. 3 (listing convoys that passed through the Drina Corps territory as of 4 May 1995); D3285 (Drina Corps record of humanitarian aids delivered to Muslim areas, 2 May 1994).

16804 Manojlo Milovanović, T. $25695-25696$ (1 March 2012); D2168 (Drina Corps Intelligence Report, 13 December 1993); Slavko Kralj, D3245 (Transcript from Prosecutor v. Popović et al.), T. 29270, 29284. See also D143 (VRS Report on movement of UN convoys, undated) (reporting that UNPROFOR and humanitarian organisations abused their mandate). The Chamber notes that in response to the Accused's suggestion that individual DutchBat members had smuggled fuel and ammunition into the enclave in convoys, Franken acknowledged that he had heard of such occurrences, but asserted that that had noppened in the case of his battalion, as demonstrated by the fuel shortages that DutchBat endured during his tenure. D157 (Order of $1^{\text {st }}$ Birač Infantry Brigade, 12 May 1995); Robert Franken, T. 23089-23093 (16 January 2012). See also paras. 4986, 4989. While the Chamber received evidence that isolated instances of misappropriation or smuggling occurred, the Chamber notes that the UNPROFOR witnesses who testified denied any practice of supplying the $\mathrm{ABiH}$, and the Chamber considers that there is insufficient evidence to establish any such practice. See e.g. Rupert Smith, T. 11347 (8 February 2011); Robert Franken, T. 23089-23093 (16 January 2012); D2745 (Witness statement of Vere Hayes dated 14 January 2013), paras. 5-8; Vere Hayes, T. 31987-31988 (16 January 2013) (stating that the incidents of apparent smuggling "fed [the VRS's] paranoia" that UNPROFOR was smuggling weapons to the ABiH); D190 (UNHCR report re discovery of ammunition in UNHCR Convoy to Butmir, 4 April 1993) (under seal); D2747 (VRS Main Staff protest letter, 1993) (protest received from Milovanović shortly after 8 April 1993). Moreover, regulations on convoy movement were applied arbitrarily and ultimately the re-supply of the enclaves was completely blocked. David Harland, T. 2203 (10 May 2010), T. 2358-2359 (11 May 2010).

16805 Milenko Živanović, T. 42609-42611 (private session), 42613 (30 October 2013); Radislav Krstić, D4136 (Transcript from Prosecutor v. Krstić), T. 6404-6405; Slavko Kralj, D3245 (Transcript from Prosecutor v. Popović et al.), T. 29287-29289, 29292-29293. See e.g. D3274 (UNPROFOR request to VRS Main Staff, 
Main Staff, each convoy and individual representative of an international organisation entering or leaving Srebrenica were checked at Yellow Bridge, which was the last VRS check-point outside the Srebrenica enclave. ${ }^{16806}$

4986. DutchBat depended on re-supply convoys for fuel, ammunition, spare vehicle parts, and communications radios. ${ }^{16807}$ During the fall of 1994, the VRS imposed a fuel blockade, diminishing reserves in Srebrenica. ${ }^{16808}$ Fuel stocks had dwindled even further by the time DutchBat received its last fuel convoy in February 1995. ${ }^{16809}$ Thereafter, DutchBat was forced to patrol on foot. ${ }^{16810}$ The lack of fuel also led DutchBat to discontinue providing support via their mobile medical stations and compromised their ability to operate the OPs. ${ }^{16811}$ Restrictions in resupply convoys further resulted in DutchBat's ammunition falling below adequate levels. ${ }^{16812}$

7 February 1995); D3275 (VRS Main Staff notification to UNPROFOR, 7 February 1995); Slavko Kralj, D3245 (Transcript from Prosecutor v. Popović et al.), T. 29290; D3276 (VRS Main Staff notification to UNPROFOR, 13 February 1995).

16806 Momir Nikolić, T. 24767-24768, 24804 (15 February 2012). See also D2140 (VRS Main Staff Order, 27 February 1993); P4387 (Order of Drina Corps, 24 July 1994), p. 2.

16807 P4175 (Witness statement of Robert Franken dated 15 January 2012), para. 22. The VRS categorically denied requests for ammunition, spare vehicle parts, and communications radios. P4175 (Witness statement of Robert Franken dated 15 January 2012), para. 24. See e.g. P4189 (VRS Main Staff convoy rejection list sent to UNPROFOR, 31 March 1995).

16808 P868 (UNPROFOR report on Serb fuel blockade, 19 October 1994). See also D4557 (Intercept of conversation between Manoljo Milovanović, Svetlana and Francis Brinquemont, 24 October 1994); P2454 (UNPROFOR report, 19 November 1994), e-court p. 2. However, at the beginning of January 1995, the VRS authorised 35 tonnes of fuel to be taken to Srebrenica. D3269 (Intercept of conversation between Ratko Mladić and "Svetlana", 3 January 1995).

16809 Robert Franken, T. 23066-23067 (16 January 2012); P4175 (Witness statement of Robert Franken dated 15 January 2012), para. 26. See also P4188 (VRS Main Staff Report, 10 March 1995).

16810 P4175 (Witness statement of Robert Franken dated 15 January 2012), para. 29; P4195 (Letter from UNPROFOR Gen. Nicolai to General Delić, 26 June 1995); P4196 (Letter from UNPROFOR Gen. Nicolai to Ratko Mladić, 26 June 1995); Robert Franken, T. 23075-23076 (16 January 2012) (recalling that P4195 and P4196 accurately described the situation at the time); P4173 (Witness statement of Roger Patelski dated 30 November 2011), para. 5; Adjudicated Fact 1432. See also Momir Nikolić, T. 24598-24600 (13 February 2012). The low fuel supplies further compromised DutchBat's ability to cook for itself, operate its medical station, and purify drinking water. P4175 (Witness statement of Robert Franken dated 15 January 2012), para. 29; Robert Franken, T. 2306723068 (16 January 2012); Pieter Boering, P3969 (Transcript from Prosecutor v. Popović et al.), T. 1893; P3948 (Witness statement of Johannes Rutten dated 8 November 2011), para. 6.

16811 P4175 (Witness statement of Robert Franken dated 15 January 2012), paras. 27, 29; Robert Franken, T. 23067 (16 January 2012); Pieter Boering, P3969 (Transcript from Prosecutor v. Popović et al.), T. 1893; P3948 (Witness statement of Johannes Rutten dated 8 November 2011), para. 6. See also D4842 (VRS Main Staff notification, 28 March 1995); P2244 (Letter from Yasushi Akashi to Radovan Karadžić, 4 March 1995) (stating that since November 1994, medical convoys were barred from entering the enclaves); P2245 (Letter from Radovan Karadžić to Yasushi Akashi, 5 March 1995).

16812 P4175 (Witness statement of Robert Franken dated 15 January 2012), para. 30; Robert Franken, T. 2311023111 (16 January 2012); P4175 (Witness statement of Robert Franken dated 15 January 2012), para. 30; Albert Rave, T. 22199-22200, 22202-22203 (30 November 2011). Further, DutchBat did not receive any supplies to test the functionality of their anti-tank systems, rendering the latter unusable. P4175 (Witness statement of Robert Franken dated 15 January 2012), para. 30. See also Robert Franken, T. 23110-23111 (16 January 2012). 
4987. After initially receiving a "relatively sufficient" amount of food from the early convoys, ${ }^{16813}$ by early 1994, amounts had decreased and every piece of tillable ground in Srebrenica had been sown with seeds as the residents attempted to grow vegetables to supplement the reduced aid convoys. ${ }^{16814}$ At the time, the average delivery rate for humanitarian convoys across the RS had fallen below $50 \%$, as the VRS had denied access to a number of areas. ${ }^{16815}$ In early 1995 , the restrictions on humanitarian convoys intensified, and drivers frequently encountered obstructions en route to Srebrenica. ${ }^{16816}$ Food supplies diminished and convoys arrived infrequently, bringing less food each time. ${ }^{16817}$ At the time, approximately 40,000 people were living in the enclave. ${ }^{16818}$

4988. By March 1995, DutchBat no longer had any fresh food and subsisted on combat rations still in stock at the UN Compound. ${ }^{16819}$ Food in the enclave was still in short supply, resulting in the emergence of a black market for smuggled goods. ${ }^{16820}$ The population within the enclave survived on what they could harvest, supplemented by what they could obtain from UNHCR, which supplied most of the food in the enclave. ${ }^{1621}$ Some residents of the enclave followed the

16813 Mirsada Malagić, T. 23468-23469 (24 January 2012). See e.g. D2109 (VRS Main Staff Notification, 25 September 1993), pp. 1-2; D2110 (VRS Main Staff Notification, 2 October 1993), pp. 1-2; D2111 (VRS Main Staff Notification, 8 October 1993); D2112 (VRS Main Staff Notification, 15 October 1993). Mirsada Malagić, T. 23469 (24 January 2012).

16815 P1687 (Report on Meeting between UNHCR and Radovan Karadžić in Geneva, 19 January 1994), para. 2 (under seal).

16816 P4175 (Witness statement of Robert Franken dated 15 January 2012), para. 26; P3948 (Witness statement of Johannes Rutten dated 8 November 2011), para. 6. See also D1123 (UNPROFOR report on the implementation of the COHA during March 1995), e-court p. 4. Items also disappeared en route when drivers were required to step out of the vehicles at VRS check-points. P4175 (Witness statement of Robert Franken dated 15 January 2012), paras. 24-25. See also P3995 (Witness statement of Albert Rave dated 10 November 2011), para. 17. On a few occasions, VRS soldiers were seen wearing DutchBat gear. Pieter Boering, P3969 (Transcript from Prosecutor v. Popović et al.), T. 1906. See also Slavko Kralj, T. 36547-36548 (4 April 2013), pp. 1-2; D3306 (Order of $1^{\text {st }}$ Birač Infantry Brigade, 19 March 1995).

16817 P3948 (Witness statement of Johannes Rutten dated 8 November 2011), para. 5; Adjudicated Fact 1429. Moreover, when the trucks arrived and the tarps covering the supplies were pulled back, one could see boot marks on the sacks of flour and salt, indicating that someone had walked on it; the residents deduced that some of the aid had been unloaded elsewhere first, as they assumed that the trucks would not have set out from their destination half empty. Mirsada Malagić, T. 23469-23470 (24 January 2012).

16818 P4140 (Witness statement of Joseph Kingori dated 8 January 2012), para. 33; Pieter Boering, P3969 (Transcript from Prosecutor v. Popović et al.), T. 1891; P4752 (Witness statement of Christine Schmitz dated 21 March 2012), para. 15; Momir Nikolić, T. $24763-24764$ (15 February 2012); Mirsada Malagić, T. 23470 (24 January 2012). But see D2065 (Letter from Srebrenica Municipality to Statistics Institute of Bosnia and Herzegovina, 11 January 1994); Momir Nikolić, T. 24764-24765, 24768 (15 February 2012); Jean-René Ruez, T. 2398623989 (1 February 2012).

16819 Robert Franken, T. 23066 (16 January 2012); P2478 (UNPROFOR Weekly Situation Report (Sarajevo), 4 March 1995), para. 15.

16820 Pieter Boering, P3969 (Transcript from Prosecutor v. Popović et al.), T. 1891; P3995 (Witness statement of Albert Rave dated 10 November 2011), para. 18; Robert Franken, T. 23099 (16 January 2012); P4173 (Witness statement of Roger Patelski dated 30 November 2011), para. 5; P4142 (UNMO Report, 8 July 1995); P4140 (Witness statement of Joseph Kingori dated 8 January 2012), paras. 34-36. See also P4752 (Witness statement of Christine Schmitz dated 21 March 2012), para. 16.

16821 Momir Nikolić, T. 24601 (13 March 2012); P4140 (Witness statement of Joseph Kingori dated 8 January 2012), para. 35. That winter, men made trips towards Žepa in search of food. Mirsada Malagić, T. 23470 (24 January 2012). See also P4140 (Witness statement of Joseph Kingori dated 8 January 2012), paras. 35-36. 
garbage truck carrying DutchBat's trash to the garbage dump and tried to salvage food and clothes. ${ }^{16822}$ It was estimated that without new supplies almost half of the population of Srebrenica would be without food by mid-June. ${ }^{1623}$ Due to the dwindling resources available to the civilian population, as well as UNPROFOR's extremely low supplies, plans were drawn up to re-supply the enclaves by force. ${ }^{16824}$

4989. Following the issuance of Directive 7 and 7/1 in March 1995, the humanitarian situation grew even worse. ${ }^{1625}$ The supply of fuel was limited, and electricity for the population was virtually non-existent. ${ }^{16826}$ The water supply was generally bad for both the population living in the enclave and for members of DutchBat. ${ }^{16827}$ The sanitation situation was dire as waste processing was difficult and medical care was insufficient. ${ }^{16828}$

16822 P3995 (Witness statement of Albert Rave dated 10 November 2011), para. 18; P3948 (Witness statement of Johannes Rutten dated 8 November 2011), para. 8; P3950 (Photograph of people around garbage truck).

16823 Adjudicated Fact 1431.

16824 P820 (Witness statement of David Harland dated 4 September 2009), para. 146; Adjudicated Fact 1430. See also P2257 (UNPROFOR Weekly Situation Report, 18 March 1995), e-court p. 4; P3995 (Witness statement of Albert Rave dated 10 November 2011), para. 21; P3948 (Witness statement of Johannes Rutten dated 8 November 2011), para. 6.

16825 See Section IV.C.1.b.i: Issuance of Directives 7 and 7/1. Around this time, Momir Nikolić received orders from the Main Staff to strengthen control measures imposed at the Yellow Bridge, and during April, May, and June 1995, the Bratunac Brigade conducted intensive checks of convoys entering the enclave at the Yellow Bridge. Momir Nikolić, T. 24598 (13 February 2012), T. 24804 (15 February 2012). From 2 April 1995, no humanitarian convoy could enter the Srebrenica enclave without Nikolić's permission. P4190 (GS VRS Report, 2 April 1995, p. 1; Momir Nikolić, T. 24595-24596 (13 February 2012). Nikolić described the situation in the enclave as "quite grave" and "hopeless", with families having "a terrible life". Momir Nikolić, T. 24601-24602 (13 March 2012). But see P831 (SRSG Weekly Situation Report, 26 April 1995), p. 8; David Harland, T. 2205 (10 May 2010) (stating that he had not seen P831 before, noting that its author, Akashi, was not in BiH at the time while Harland had been, and suggesting that the statement might have been correct but only for that particular week); Slavko Kralj, T. 36566 (4 April 2013). Kralj suggested that problems with convoy clearance were attributable to UNPROFOR not providing sufficient notice, leading to backlogs and confusion at checkpoints. Slavko Kralj, D3245 (Transcript from Prosecutor v. Popović et al.), T. 29285. See also D143 (VRS Report on movement of UN convoys, undated) (reporting on UNPROFOR and humanitarian organisations abusing their mandate).

16826 Pieter Boering, P3969 (Transcript from Prosecutor v. Popović et al.), T. 1892-1893; D4476 (Letter from Pasi Karonen to Mr. Stoltenberg, 20 July 1993), para. 3. The only electricity available was generated by diverting water from the main river. P4140 (Witness statement of Joseph Kingori dated 8 January 2012), para. 41. See also Joseph Kingori, T. 22880 (12 January 2012); P4140 (Witness statement of Joseph Kingori dated 8 January 2012), para. 42.

16827 Pieter Boering, P3969 (Transcript from Prosecutor v. Popović et al.), T. 1891; P4142 (UNMO Report, 8 July 1995), p. 2; P4140 (Witness statement of Joseph Kingori dated 8 January 2012), para. 40; P1483 (Ratko Mladić's notebook, 2 April-24 October 1993), e-court pp. 205-206, 209; D4476 (Letter from Pasi Karonen to Mr. Stoltenberg, 20 July 1993), para. 3.

16828 Pieter Boering, P3969 (Transcript from Prosecutor v. Popović et al.), T. 1892-1893; Momir Nikolić, T. 2460124602 (13 March 2012). But see D2125 (VRS Main Staff Notification, 2 March 1995), p. 1; D2126 (VRS Main Staff Notification, 27 March 1995), p. 1; D2127 (VRS Main Staff Report, 18 April 1995), p. 2; D4845 (VRS Main Staff notification, 18 April 1995); Ljubomir Obradović T. 25277, 25279 (24 February 2012). The VRS did permit occasional medical evacuations. Slavko Kralj, D3245 (Transcript from Prosecutor v. Popović et al.), T. 29287-29288; D3272 (VRS Main Staff notification, 21 March 1995); D3273 (VRS Main Staff notifications to UNPROFOR, 26 and 27 March 1995), pp. 1-7. 
4990. In mid-April 1995, DutchBat personnel rotations came to a halt as the VRS refused to allow soldiers to re-enter the enclave after taking leave, ultimately reducing DutchBat's personnel to $50 \% .{ }^{16829}$ Accordingly, DutchBat's combat readiness and ability to implement tasks was reduced to a minimum. ${ }^{16830}$

4991. Conditions deteriorated considerably between May and the beginning of July $1995 .{ }^{16831}$ In early June, the only food present in the enclaves was what the residents were able to raise for themselves, ${ }^{16832}$ as humanitarian aid deliveries to the enclaves fell to $29.7 \%$ of targeted levels in Srebrenica. ${ }^{16833}$ The Chamber notes the Accused's contention that there was no appreciable difference between the amounts of humanitarian aid delivered before and after the issuance of Directive 7. ${ }^{16834}$ The Chamber recalls that Ljubomir Obradović, a member of the VRS Main Staff, ${ }^{16835}$ agreed with this argument when presented with a series of Main Staff convoy notifications dated before and after the issuance of Directive $7 .{ }^{16836}$ However, Momir Nikolić

16829 Robert Franken, T. 23071, 23077 (16 January 2012); P4191 (Letters to Generals Mladić and Delić from General Janvier, 19 May 1995); P4175 (Witness statement of Robert Franken dated 15 January 2012), para. 31; Adjudicated Fact 1434. In June 1995, DutchBat personnel were not cleared to go on leave. P3995 (Witness statement of Albert Rave dated 10 November 2011), paras. 21-22; P4198 (28 ${ }^{\text {th }}$ Infantry Division Combat Report, 6 July 1995), para. 3; P4197 (GS VRS report, 1 July 1995), paras. 5-6; Robert Franken, T. 2307723078 (16 January 2012).

16830 Momir Nikolić, T. 24600 (13 March 2012); Adjudicated Fact 1433. But see Slavko Kralj, T. 36569, 3657136572, 36579-36580 (4 April 2013).

16831 Pieter Boering, P3969 (Transcript from Prosecutor v. Popović et al.), T. 1894; P4173 (Witness statement of Roger Patelski dated 30 November 2011), para. 5. Boering raised the issue of the restriction of aid convoys with Nikolić, who was given a letter to be transmitted to the command of the Drina Corps; however, raising this issue did not change the situation. Pieter Boering, P3969 (Transcript from Prosecutor v. Popović et al.), T. 18981899.

16832 Robert Franken, T. 23072, $23094-23095$ (16 January 2012) (characterising the food supplies as "absolutely insufficient for the civil population"); P4192 (UN Weekly Situation Report, 29 May-4 June 1995), para. 17. But see Milenko Živanović, T. 42676 (31 October 2013) (disputing that convoys were restricted and asserting that there was no arable land inside Srebrenica).

16833 P2443 (UNPROFOR report re humanitarian situation in Croatia and BiH, 6 July 1995), p. 6 . See also P4752 (Witness statement of Christine Schmitz dated 21 March 2012), para. 16; P5211 (UNPROFOR daily report, 20 June 1995), para. 3. In Žepa, humanitarian aid deliveries fell to $7.3 \%$ of targeted levels while no humanitarian aid was delivered to Goražde. P2443 (UNPROFOR report re humanitarian situation in Croatia and BiH, 6 July 1995), p. 6.

16834 Defence Final Brief, paras. 1326-1327.

16835 Ljubomir Obradović, P4444 (Transcript from Prosecutor v. Tolimir), T. 11929. Within the Main Staff, Obradović served as Chief of Operations and the deputy of Radivoje Miletić in the Administration for Operations and Training. Ljubomir Obradović, P4444 (Transcript from Prosecutor v. Tolimir), T. 11929, 11951-11952.

16836 See Ljubomir Obradović, T. 25257-25261, 25278 (24 February 2012); D2113 (VRS Main Staff Notification, 19 January 1995), p. 1; D2114 (VRS Main Staff Notification, 16 February 1995), p. 1; D2115 (VRS Main Staff Notification, 18 March 1995), p. 1; D2116 (VRS Main Staff Notification, 13 April 1995), p. 1; D2068 (VRS Main Staff notification, 30 April 1995), p. 1; D2077 (VRS Main Staff notification, 28 May 1995); P4452 (VRS Main Staff Report, 2 June 1995), p. 1; D2117 (VRS Main Staff Report, 12 June 1995), p. 1; D2118 (VRS Main Staff Notification, 19 June 1995), p. 1; D2119 (VRS Main Staff Notification, 30 June 1995), p. 1; D2120 (VRS Main Staff Notification, 7 July 1995), p. 1. See also D2067 (VRS Main Staff notification regarding clearance of convoy, 29 April 1995); D2068 (VRS Main Staff notification, 30 April 1995); D2069 (VRS Main Staff notification, 12 May 1995); D2070 (VRS Main Staff notification, 29 April 1995); D2071 (VRS Main Staff notification, 16 May 1995); D2072 (VRS Main Staff notification, 17 May 1995); D2073 (VRS Main Staff notification, 19 May 1995); D2075 (VRS Main Staff notification, 26 May 1995); D2076 (VRS Main Staff 
testified that he received frequent requests that the amount of goods in UNHCR convoys "be halved". ${ }^{16837}$ Having examined the documents cited above and analysed the testimonies of Obradović and Momir Nikolić on this point, and having compared them with the testimonies of numerous witnesses who testified to the deprivation visible in the enclave at the time, the Chamber observes that even if such convoys were ostensibly authorised on paper, this would not mean that such convoys ultimately arrived. ${ }^{16838}$ The Chamber recalls that the language of Directive 7 specifically called on the Bosnian Serb Political and Governmental Organs and Bosnian Serb Forces to "unobtrusively [...] reduce and limit the supply of material resources to the Muslim population"; ${ }^{16839}$ the Chamber finds that this directive was indeed implemented.

4992. Later that month, the combat ration stocks were also diminished and members of DutchBat subsisted on rice and peanut butter until a re-supply convoy arrived with food approximately ten days later. ${ }^{16840}$ By month's end, some residents had died of starvation. ${ }^{16841}$ At the time, the situation in Srebrenica was relatively calm from a military standpoint, though it was reported that the town "had the feel of an open air prison". 16842

\section{iii. Military actions, Spring 1995}

4993. Meanwhile, despite the relative stabilisation of the confrontation lines between the VRS and $\mathrm{ABiH}$ resulting from the conclusion of the COHA, ${ }^{16843}$ small scale fighting flared up "continually"

notification, 26 May 1995); Momir Nikolić, T. 24777-24782, 24785 (15 February 2012); D3287 (Drina Corps record of humanitarian aids delivered to Muslim enclaves, 3 May 1995) (recording the amounts of various items delivered in March and April 1995). The Chamber also notes that Živanović, whose units controlled access to the area at the time, asserted that neither he nor the Drina Corps units had obstructed humanitarian aid convoys bound for Srebrenica. D3932 (Witness statement of Milenko Živanović dated 27 October 2013), para. 26; Milenko Živanović, T. 42613-42614, 42616 (30 October 2013), T. 42687-42688 (31 October 2013); P6481 (Report of Drina Corps, 1 February 1993). See also D3947 (Summary of Humanitarian Aid Delivered to Srebrenica, 1994); D3957 (Report of Drina Corps, 3 May 1995). The Chamber observes that for the reasons mentioned above, including a lack of candour as well as an incentive to minimise any questionable conduct on the part of his subordinate units, Živanović's testimony regarding humanitarian aid convoys is not reliable. See para. 4982.

16837 Momir Nikolić, T. 24598, 24600-24601 (13 February 2012).

16838 See e.g. P4142 (UNMO Report, 8 July 1995), para. 3 (stating that although three UNHCR convoys were authorised to travel to the enclaves, only one arrived and that even the planned convoys would only serve approximately 65\% of the population's needs); P5174 (Report of RS Commission for Refugees and Humanitarian Aid to Radovan Karadžić, 29 June 1995).

16839 P838 (Directive 7, 8 March 1995), p. 14 (emphasis added).

16840 Robert Franken, T. 23074, 23094-23095 (16 January 2012); P4194 (VRS Main Staff Order, 18 June 1995$)$, para. 3.

16841 P4198 (28 $8^{\text {th }}$ Infantry Division Combat Report, 6 July 1995), para. 4.

16842 P4752 (Witness statement of Christine Schmitz dated 21 March 2012), para. 14. Every room in Srebrenica held a family, with remaining people occupying every available house, garage, shed, and improvised accommodation to full capacity. Mirsada Malagić, T. 23470 (24 January 2012).

16843 See paras. 410-416. 
along the borders of the enclave from mid-1993 until its fall in $1995 .^{16844}$ The Muslim Forces in Srebrenica carried out continuous reconnaissance and sabotage activities against VRS positions around the enclaves of Srebrenica and Žepa. ${ }^{16845}$ In October 1994, the Muslim Forces in Srebrenica carried out sabotage attacks in VRS territory along the Srebrenica-Konjević Polje, Cerska and Modrica axes. ${ }^{16846}$ Late in the fall of 1994, they began planning and carrying out actions aimed at linking up with the $\mathrm{ABiH}$ in Tuzla. ${ }^{16847}$ Despite the demilitarisation agreement, the Muslim Forces in Srebrenica continued to obtain arms and open fire on VRS lines. ${ }^{16848}$ Further, ABiH helicopters flew in violation of the no-fly zone. ${ }^{16849}$

4994. During the first few months of 1995 , the VRS and ABiH regularly exchanged fire. ${ }^{16850}$ In March and April 1995, there was a build-up of Bosnian Serb forces near OP Romeo and OP Quebec, where soldiers were seen arriving with new rifles and complete uniforms. ${ }^{1685}$ During this time, several skirmishes broke out between members of the VRS and the Muslim Forces in Srebrenica. ${ }^{16852}$

4995. In April and May 1995, close firing on DutchBat patrols and OPs—-the majority of which originated from VRS positions-increased. ${ }^{16853}$ As a result, Franken and Bečirović reached a "coordinated defence" agreement, according to which, in the event of a VRS attack on the enclave,

16844 P4914 (Richard Butler's expert report entitled "Srebrenica Military Narrative (Revised): Operation 'Krivaja 95'”, 1 November 2002), para. 1.27.

16845 Radislav Krstić, D4136 (Transcript from Prosecutor v. Krstić), T. 5990; D3918 (Witness statement of Milomir Savčić, dated 21 July 2013), para. 43. See e.g. D2937 (Order of ABiH Supreme Command Staff, 4 October 1994); D140 (Letter from ABiH Supreme Command Staff to ABiH $8^{\text {th }}$ Operations Group, 9 November 1994); D141 (Telegram from $1^{\text {st }}$ Žepa Light Brigade to ABiH Supreme Command Staff, 13 December 1994); Pieter Boering, T. 22098-22099 (29 November 2011); D2016 (Directive of ABiH General Staff, 5 January 1995), ecourt p. 4. See also Adjudicated Fact 1423.

16846 Radislav Krstić, D4136 (Transcript from Prosecutor v. Krstić), T. 5995, 6000-6001. During the previous summer, many members of the Muslim Forces in Srebrenica had left the enclave for Tuzla, travelling on foot and carrying their arms; combat ensued where they encountered the VRS, and both sides sustained large numbers of casualties. Radislav Krstić, D4136 (Transcript from Prosecutor v. Krstić), T. 5987-5989, 59915993. Defectors continued trying to reach Tuzla and Kladanj even up to the summer of 1995 . Radislav Krstić, D4136 (Transcript from Prosecutor v. Krstić), T. 6051-6052.

16847 Radislav Krstić, D4136 (Transcript from Prosecutor v. Krstić), T. 6002-6003, 6005-6007, 6011, 6013-6014, 6017-6020, 7557-7558.

16848 Adjudicated Fact 1427. See also P5086 (Report of RS Main Staff, 19 March 1995), p. 2; D156 (Podrinje $1^{\text {st }}$ Light Infantry Brigade combat report, 16 February 1995); D2178 (VRS Main Staff Report, 2 March 1995).

16849 Adjudicated Fact 1427. See also D142 (Telegram from $1^{\text {st }}$ Žepa Light Brigade to ABiH Supreme Command Staff, 31 December 1994); D156 (Podrinje $1^{\text {st }}$ Light Infantry Brigade combat report, 16 February 1995); Radislav Krstić, D4136 (Transcript from Prosecutor v. Krstić), T. 6031, 6033, 6071-6074. These helicopters flew mostly at night when visibility limited the VRS's ability to use anti-aircraft weapons. Radislav Krstić, D4136 (Transcript from Prosecutor v. Krstić), T. 6037.

16850 P4167 (Witness statement of Paul Groenewegen dated 11 November 2011), para. 9. See also Radislav Krstić, D4136 (Transcript from Prosecutor v. Krstić), T. 6077-6078, 6081-6082, 6116. But see D4446 (Report of Drina Corps to VRS Main Staff, 27 February 1995).

16851 Adjudicated Facts 1435, 1436.

16852 Adjudicated Fact 1438.

16853 P4175 (Witness statement of Robert Franken dated 15 January 2012), paras. 32-33. 
DutchBat would defend its OPs while the Muslim Forces in Srebrenica would defend the areas between the OPs. ${ }^{16854}$

4996. In May 1995, the VRS obtained information that the Muslim Forces in Srebrenica were in the final stages of preparing for an attack against the Drina Corps. ${ }^{16855}$ In late May 1995, tensions between the Muslim Forces in Srebrenica and the VRS increased in and around the enclave. ${ }^{16856}$

4997. From May to July 1995, the threat to the enclave increased, with more shootings occurring from the VRS side, limiting DutchBat's movements. ${ }^{1685}$ In late May and early June 1995, DutchBat faced direct fire when leaving the compound in Potočari. ${ }^{1658}$

4998. On the afternoon of 25 May 1995-in response to NATO air-strikes on Bosnian Serb military targets in Pale ${ }^{16859}$ —Živanović ordered all Drina Corps units' anti-aircraft defence forces to full combat readiness. ${ }^{16860}$ Živanović further ordered that if the conflict escalated, the units should turn the basic firing positions into decoys by moving artillery to reserve firing positions. ${ }^{16861}$

16854 P4175 (Witness statement of Robert Franken dated 15 January 2012), para. 36. According to the agreement, the weapons from the Bravo Company's collection point would also be made available to the Muslim Forces in Srebrenica in the event of an attack on the enclave, although the group declined to exercise this option when the attack eventually came in July 1995. P4175 (Witness statement of Robert Franken dated 15 January 2012), para. 36. Franken viewed this co-ordination as necessary because of the vulnerable positions of the OPs, which were painted white and illuminated at night; if the $\mathrm{ABiH}$ left without telling Franken, the OPs would be surrounded and indefensible in the middle of Bosnian Serb territory. P4175 (Witness statement of Robert Franken dated 15 January 2012), para. 37.

16855 Radislav Krstić, D4136 (Transcript from Prosecutor v. Krstić), T. 6029, 6049. See also D1993 (Order of $28^{\text {th }}$ Division Command, 2 June 1995); Radislav Krstić, D4136 (Transcript from Prosecutor v. Krstić), T. 6042; D2014 (Report of ABiH 28 ${ }^{\text {th }}$ Division, 30 June 1995); D2015 (VRS Main Staff Report, 26 June 1995). Earlier that spring, the $\mathrm{ABiH}$ had been ordered to secretly bring its units to full combat readiness and to be on standby for a co-ordinated action with the $1^{\text {st }}$ Žepa Light Brigade. D1955 (Order of ABiH General Staff, 17 February 1995), p. 2; D150 (Order of $2^{\text {nd }}$ Corps of ABiH, 17 February 1995); D149 (Report from Naser Orić to ABiH General Staff, 25 February 1995); D152 (ABiH General Staff Order, 15 April 1995); D153 (ABiH General Staff Order, 27 April 1995); D2939 (Decision of RBiH Ministry of Defence, 17 April 1995); D3721 (VRS Main Staff Intelligence and Security sector report, 8 February 1995), e-court p. 2-3. The Muslim Forces in Srebrenica made efforts to conceal their preparation and supply routes, as evidenced through their objection to DutchBat building a new OP near Ložina as it would negatively affect "unhindered passage" through the Žepa-Srebrenica corridor. D1963 (Order of ABiH $2^{\text {nd }}$ Corps, 29 April 1995); P3990 (2 ${ }^{\text {nd }}$ Corps instructions, 29 April 1995). See also D1955 (Order of ABiH General Staff, 17 February 1995), p. 2 (referring to the existence of a helicopter which was to be camouflaged until it could be "evacuated", and if found by UNPROFOR, ABiH members were to say that its purpose was to transport political representatives of Srebrenica and Žepa on state business). Accordingly, UNPROFOR did not know of these preparations. Johannes Rutten, T. 22025-22026 (28 November 2011); Albert Rave, T. 22197 (30 November 2011).

16856 Robert Franken, T. 23134-23138 (17 January 2012); Radislav Krstić, D4136 (Transcript from Prosecutor v. Krstić), T. 6040.

16857 Pieter Boering, P3969 (Transcript from Prosecutor v. Popović et al.), T. 1895, 1897; Milenko Živanović, T. 42700 (31 October 2013). See also Adjudicated Facts 1439, 1440.

16858 Pieter Boering, P3969 (Transcript from Prosecutor v. Popović et al.), T. 1897.

16859 See para. 5856.

16860 P6571 (Order of Drina Corps, 25 May 1995), p. 1; Vidoje Blagojević, T. 45048-45049 (12 December 2013). Several VRS units were stationed around Srebrenica during this time, including two with permanent positions. Vidoje Blagojević, T. 45051 (12 December 2013).

16861 P6571 (Order of Drina Corps, 25 May 1995), pp. 1-2. See also P4076 (Report of the Bratunac Brigade to Drina Corps, 25 May 1995). 
At approximately 7 p.m. that evening, pursuant to an oral order conveyed by Milenko Lazić, the Chief of Operations and Training for the Drina Corps, ${ }^{16862}$ the Bratunac Brigade fired four $105 \mathrm{~mm}$ howitzer shells towards Srebrenica. ${ }^{16863}$ Civilians were killed and wounded as a result. ${ }^{16864}$ DutchBat personnel based at Potočari continued to observe houses being shelled from VRS positions in Bratunac during June and July. ${ }^{16865}$

4999. During the following week, the VRS repeatedly requested that DutchBat surrender OP Echo, which had strategic significance due to its position near the road running toward Zeleni Jadar. ${ }^{16866}$ The VRS threatened that the OP would otherwise be taken by force. ${ }^{16867}$ DutchBat refused and warned that close air support would be requested if the VRS attacked. ${ }^{16868}$ On 3 June 1995, pursuant to a Drina Corps order issued the previous day, the VRS attacked OP Echo. ${ }^{16869}$ After the OP's tower sustained a direct hit, DutchBat withdrew from the post. ${ }^{16870}$ Thereafter, OP

16862 Milenko Lazić, P4072 (Transcript from Prosecutor v. Popović et al.), T. 21722-21724.

16863 P4076 (Report of the Bratunac Brigade to Drina Corps, 25 May 1995), para. 1; Vidoje Blagojević, T. 45049_ 45050 (12 December 2013); Milenko Lazić, P4072 (Transcript from Prosecutor v. Popović et al.), T. $21857-$ 21858. Artillery observers at Pribećevac reported that two shells fell near the Domavija hotel in the centre of Srebrenica, while the locations of the other two shelling impacts were not observed. P4076 (Report of the Bratunac Brigade to Drina Corps, 25 May 1995), para. 1; Vidoje Blagojević, T. 45077-45078 (12 December 2013). See also Milenko Lazić, P4072 (Transcript from Prosecutor v. Popović et al.), T. 21743, 21857.

16864 P4140 (Witness statement of Joseph Kingori dated 8 January 2012), paras. 57-58. See also P402 (Witness statement of Alma Gabeljić dated 24 May 2004), e-court p. 2. P6572 (Report of $28^{\text {th }}$ ABiH Division, 26 May 1995); P6575 (Report of VRS Main Staff, 25 May 1995), e-court p. 4; Vidoje Blagojević, T. 45052-45053 (12 December 2013).

16865 Pieter Boering, P3969 (Transcript from Prosecutor v. Popović et al.), T. 1895-1897.

16866 P4175 (Witness statement of Robert Franken dated 15 January 2012), para. 43. Approximately 100 metres of the road, which ran directly in front of OP Echo, lay within the enclave's boundaries. Robert Franken, T. 23098 (16 January 2012).

16867 P3995 (Witness statement of Albert Rave dated 10 November 2011), paras. 23-24; Albert Rave, T. 22212 (30 November 2011). The VRS was in fact already making preparations to take the area by force. See P5219 (Order of Drina Corps, 29 May 1995); P3995 (Witness statement of Albert Rave dated 10 November 2011), para. 25. See also D1035 (ABiH $2^{\text {nd }}$ Corps report, 30 May 1995), p. 2 (describing a meeting with DutchBat in which DutchBat reported seeing Bosnian Serb troop movements near the Zeleni Jadar OP).

16868 P3995 (Witness statement of Albert Rave dated 10 November 2011), para. 23; P4140 (Witness statement of Joseph Kingori dated 8 January 2012), para. 60.

16869 P4199 (Order of Drina Corps, 2 June 1995); Robert Franken, T. 23080 (16 January 2012); P4175 (Witness statement of Robert Franken dated 15 January 2012), para. 38; P3995 (Witness statement of Albert Rave dated 10 November 2011), para. 26.

16870 P4175 (Witness statement of Robert Franken dated 15 January 2012), para. 38; P3995 (Witness statement of Albert Rave dated 10 November 2011), para. 26. See also P4140 (Witness statement of Joseph Kingori dated 8 January 2012), para. 59; Joseph Kingori, T. 22799 (11 January 2012). The take-over of OP Echo formed a part of the "Jadar 95" operation, which was carried out by the Drina Corps between 31 May and 5 June 1995 and resulted in the VRS assuming control over the village of Zeleni Jadar. P5111 (Report of Bratunac Brigade to Drina Corps, 4 July 1995), p. 2; P4914 (Richard Butler's expert report entitled "Srebrenica Military Narrative (Revised): Operation 'Krivaja 95'”, 1 November 2002), para. 1.38; P5110 (Order of Bratunac Brigade, 4 June 1995). The take-over constituted a test of the UNPROFOR reaction to an attack on the enclave. Robert Franken, T. 23078-23079 (16 January 2012); P4202 (Written compilation booklet: Srebrenica Trial video), p. 256; Milenko Živanović, T. 42656-42657 (31 October 2013). See also Momir Nikolić, T. 24828-24829 (16 February 2012) (suggesting that the preparatory part of the attack on Srebrenica began with the take-over of OP Echo); P3996 (Situation Report from DutchBat to UNPROFOR Sector North HQ, 7 January 1995), p. 2. But see Radislav Krstić, D4136 (Transcript from Prosecutor v. Krstić), T. 6093, 6109-6110. 
Sierra was established on the approach to the Swedish Shelter Project and OP Uniform on the approach to the town of Srebrenica itself. ${ }^{16871}$

5000. That month, the $\mathrm{ABiH} 2^{\text {nd }}$ Corps ordered the Muslim Forces in Srebrenica to conduct raids out of the Srebrenica enclave for the primary purpose of engaging VRS forces in the area, in order to prevent them from being transferred to Sarajevo. ${ }^{16872}$ During this period, members of the Muslim Forces in Srebrenica were seen openly carrying weapons and seemed less concerned about their weapons being confiscated by DutchBat. ${ }^{16873}$

5001. Following the take-over of OP Echo, VRS units were ordered to carry out ambushes between the Srebrenica and Žepa enclaves. ${ }^{16874}$ In the early morning hours of 24 June, under the direction of Svetozar Kosorić, the Chief of the Drina Corps Intelligence Department, ${ }^{16875}$ approximately 30 members from both platoons of the $10^{\text {th }}$ Sabotage Detachment and members of the Bratunac Brigade entered Srebrenica town through an old mining tunnel, and used infantry weapons to fire into the town. ${ }^{16876}$ After about 15 minutes, the soldiers returned to VRS-held territory through the same tunnel. ${ }^{16877}$ The attack resulted in three casualties, including one death, in the town. ${ }^{16878}$

\footnotetext{
16871 P4175 (Witness statement of Robert Franken dated 15 January 2012), paras. 40-41; P3970 (Map of Eastern Bosnia) (showing the positions of OP Sierra and OP Uniform at "S" and "U" respectively); P3995 (Witness statement of Albert Rave dated 10 November 2011), para. 2. The Swedish Shelter Project provided housing for 4,000 refugees and was located in the southern part of the enclave. Pieter Boering, P3969 (Transcript from Prosecutor v. Popović et al.), T. 1898.

16872 D2233 (Report of ABiH, 28 June 1995), p. 1; D3919 (ABiH 285 ${ }^{\text {th }}$ Eastern Bosnia Light Brigade combat report, 28 June 1995), p. 1; D1062 (ABiH 28 ${ }^{\text {th }}$ Division situation report, 30 June 1995). See also Radislav Krstić, D4136 (Transcript from Prosecutor v. Krstić), T. 6052-6054, 6062, 6089, 7557-7558; Richard Butler, T. 27719-27720 (20 April 2012); D1962 (Order of ABiH 28 ${ }^{\text {th }}$ Division, 5 June 1995); Ljubomir Obradović, T. 25211 (24 February 2012); Joseph Kingori, T. 22855-22857 (12 January 2012).

16873 Pieter Boering, P3969 (Transcript from Prosecutor v. Popović et al.), T. 2170. Boering testified that from midJune, DutchBat "turned a blind eye" and allowed Muslim Forces in Srebrenica members to walk around with Kalashnikovs. Pieter Boering, P3969 (Transcript from Prosecutor v. Popović et al.), T. 2116.

16874 See e.g. D4447 (Order of Drina Corps, 4 June 1995), para. 3. On 14 June, the ABiH attacked the VRS near the village of Memići. D3959 (Report of Drina Corps, 15 June 1995), p. 1. See also Milenko Živanović, T. 4270142702 (31 October 2013).

16875 P6408 (VRS Main Staff Intelligence and Security sector order, 21 June 1995). para. 3.

16876 Petar Salapura, T. 40248 (24 June 2013); D3720 (Witness statement of Petar Salapura dated 17 June 2013), para. 18; P6408 (VRS Main Staff Intelligence and Security sector order, 21 June 1995); Dražen Erdemović, P332 (Transcript from Prosecutor v. Popović et al.), T. 10936-10937 (further testifying that his unit had been told that they were firing towards the command of Naser Orić). See also D2211 (MSF report, 26-30 June 1995), p. 1. According to Frank Kos, a member of the $10^{\text {th }}$ Sabotage Detachment, the aim of the operation was to create chaos and start infighting amongst the ABiH soldiers in the town. Frank Kos, T. 42393-42395 (1 August 2013). Salapura testified that the action was intended as a warning to the ABiH to discontinue their ambush and sabotage actions originating in Srebrenica. Petar Salapura, T. 40249-40251 (24 June 2013) (denying that the action was aimed at intimidating the civilian population).

16877 Dražen Erdemović, P332 (Transcript from Prosecutor v. Popović et al.), T. 10937.

16878 D2211 (MSF report, 26-30 June 1995), p. 1.
} 
5002. Meanwhile, units of the Muslim Forces in Srebrenica were carrying out co-ordinated sabotage actions deep within the Drina Corps territory. ${ }^{16879}$ On 26 June 1995, the Muslim Forces in Srebrenica attacked the Main Staff Headquarters at Crna Rijeka, carried out a further operation seven kilometres away against the $65^{\text {th }}$ Protection Regiment's tank company, and attacked the Serb village of Višnjica, located five kilometres west of the Srebrenica enclave. ${ }^{16880}$ The Drina Corpsalong with reinforcements from other corps-halted the offensive on the same day. ${ }^{16881}$

5003. During this period, DutchBat was aware of frequent shooting from both sides that occurred at the borders of the enclave, though the situation inside the enclave remained relatively calm. ${ }^{16882}$ Although DutchBat's local negotiation team received information from Momir Nikolić that the Muslim Forces in Srebrenica were conducting raids outside of the enclave, they were unable to independently verify this information as DutchBat lacked freedom of movement outside the enclave, especially during the latter part of June when tensions mounted and their freedom of movement became even more restricted. ${ }^{16883}$ However, throughout the month of June and into July, ${ }^{16884}$ the Muslim Forces in Srebrenica continued launching actions against VRS defensive lines from Srebrenica. ${ }^{16885}$

16879 Radislav Krstić, D4136 (Transcript from Prosecutor v. Krstić), T. 6040, 6043-6045, 6052-6053, 6066-6069, 6095, 6097-6103. See also D3920 (VRS Main Staff information, 24 June 1995); Vidoje Blagojević, T. 4507645077 (12 December 2013).

16880 D3918 (Witness statement of Milomir Savčić, dated 21 July 2013), para. 44; D2014 (Report of ABiH $28^{\text {th }}$ Division, 30 June 1995), p. 1; P2284 (UNSG report entitled "The Fall of Srebrenica", 15 November 1999), para. 225 (referring to a Bosnian Muslim attack on the Bosnian Serb village of Višnjica on 26 June). The nine sabotage groups came from Žepa and Srebrenica and were sent to the vicinity of the Main Staff, endangering the Main Staff and causing the Communications Regiment and $65^{\text {th }}$ Protection Regiment to sustain heavy losses. Ljubomir Obradović, T. 25211-25212 (24 February 2012). See also D3919 (ABiH 285 ${ }^{\text {th }}$ Eastern Bosnia Light Brigade combat report, 28 June 1995); D136 (ABiH $2^{\text {nd }}$ Corps combat report, 27 June 1995).

16881 Radislav Krstić, D4136 (Transcript from Prosecutor v. Krstić), T. 6103.

16882 P3995 (Witness statement of Albert Rave dated 10 November 2011), para. 9. See also Robert Franken, T. 23136 (17 January 2012).

16883 P3948 (Witness statement of Johannes Rutten dated 8 November 2011), para. 9; Johannes Rutten, T. 22017 (28 November 2011); Pieter Boering, T. 22089-22091 (29 November 2011). Serb villages that were reportedly attacked were not visible from DutchBat's OPs, and DutchBat's movement was already restricted as early as January 1995. P3948 (Witness statement of Johannes Rutten dated 8 November 2011), para. 9; Johannes Rutten, T. 22017-22018, 22022, 22029 (28 November 2011).

16884 In July 1995, attacks were launched from the Srebrenica enclave toward the area under VRS control: houses in the north of the enclave near OP Mike were burned, villages in the north of the enclave were attacked, and sniping incidents and ambushes occurred outside the enclave. P4175 (Witness statement of Robert Franken dated 15 January 2012), para. 35; Robert Franken, T. 23131, 23152 (17 January 2012); D1961 (Report of ABiH $2^{\text {nd }}$ Corps, 8 July 1995); P5268 (Intercept of conversation between Ratko Mladić and General Bernard Janvier, 10 July 1995), p. 1; Momir Nikolić, T. 24797 (15 February 2012). According to Nikolić, between 56 and 58 Bratunac Brigade soldiers were killed between the declaration of Srebrenica as a demilitarised enclave and the fall of the enclave in July 1995. Momir Nikolić, T. 24816-24817 (16 February 2012).

16885 Radislav Krstić, D4136 (Transcript from Prosecutor v. Krstić), T. 6106-6116. See also D1959 (UNMO Asssement, 7 July 1995), e-court p. 3; P4086 (Report of Drina Corps to VRS General Staff, 26 June 1995) p. 1; P5150 (RS MUP summary of information from and about the front, 26 June 1995) p. 2; D1062 (ABiH $28^{\text {th }}$ Division situation report, 30 June 1995). 


\section{c. Attack on Srebrenica}

\section{i. Issuance of the Krivaja 95 orders}

5004. In late June 1995, the Accused and Krajišnik came to the Drina Corps Command in Vlasenica and met with Krstić; Živanović was absent. ${ }^{16886}$ During this meeting, Krstić received a combat assignment. ${ }^{16887}$ That evening, Krstić summoned the command of the Drina Corps to the operations room and explained that the Drina Corps had been assigned to prepare for a military operation. ${ }^{16888}$ Following that meeting, the brigade commanders were ordered to report to the Drina Corps Command at 8 a.m. on the following day. ${ }^{16889}$ When the brigade commanders arrived, they received an oral briefing on the task. ${ }^{16890}$ Krstić and the Drina Corps command then began to draft a combat plan which would become known as Krivaja $95 .^{16891}$

16886 D3993 (Witness statement of Vujadin Popović dated 2 November 2013), para. 7. See also Petar Salapura, T. 40243 (24 June 2013). Popović testified that before leaving, the Accused and Krajišnik also met with the officers of the Drina Corps Command; according to Popović, the Accused and Krajišnik did not mention Srebrenica at all, but merely informed the officers about political negotiations. D3993 (Witness statement of Vujadin Popović dated 2 November 2013), para. 8.

16887 Milenko Lazić, P4072 (Transcript from Prosecutor v. Popović et al.), T. 21728, 21746. In reaching the conclusion that Krstić received a combat assignment during the meeting with the Accused and Krajišnik, the Chamber noted that Lazić testified that in late June 1995, Krstić relayed to the Drina Corps Command a combat assignment which had been given to the corps outside the normal chain of command. Milenko Lazić, P4072 (Transcript from Prosecutor v. Popović et al.), T. 21727, 21728, 21746. Taking Lazić's evidence together with the evidence establishing that the Accused and Krajišnik came to Vlasenica and met with Krstić in late June 1995, the Chamber considers that the only reasonable inference from such testimony is that a combat assignment was given during the meeting of Krstić, Krajišnik, and the Accused.

16888 Milenko Lazić, P4072 (Transcript from Prosecutor v. Popović et al.), T. 21728; D3993 (Witness statement of Vujadin Popović dated 2 November 2013), para. 9.

16889 Milenko Lazić, P4072 (Transcript from Prosecutor v. Popović et al.), T. 21728.

16890 Milenko Lazić, P4072 (Transcript from Prosecutor v. Popović et al.), T. 21728. All brigade commanders, as well as the commanders of independent units subordinated to the Drina Corps, attended the meeting. Milenko Lazić, P4072 (Transcript from Prosecutor v. Popović et al.), T. 21748.

16891 Milenko Lazić, P4072 (Transcript from Prosecutor v. Popović et al.), T. 21731. The Chamber notes that in his testimony, which was given while testifying in his own trial and admitted pursuant to Rule 92 quater in this case, Krstić denied that he had taken part in planning the Srebrenica operation, asserting that he had only learned about the Krivaja 95 operation when Živanović returned from the Main Staff and conveyed the assignment to his assistants on 2 July. Radislav Krstić, D4136 (Transcript from Prosecutor v. Krstić), T. 6125. Further, Krstić initially testified that Živanović did not really need to consult with his assistants or Krstić when planning the operation because of his familiarity with the Muslim Forces in Srebrenica, but later acknowledged that he had taken part in the assessment of which forces should take part in the Krivaja 95 task. Radislav Krstić, D4136 (Transcript from Prosecutor v. Krstić), T. 6128-6129. Krstić also later acknowledged that he took part in the elaboration and recording of the plans outlining the Krivaja 95 operation, but asserted that he "took very little part" and did not provide any specific advice to Živanović in formulating the proposal for the engagement of forces. Radislav Krstić, D4136 (Transcript from Prosecutor v. Krstić), T. 6370-6371, 6374, 6376-6377. The Chamber notes that because the extent to which Krstić was involved in the planning of the Krivaja 95 operation bore directly upon his responsibility for the crimes with which he was charged, Krstić had an incentive to minimise his role, and considers that his testimony regarding the extent of his own involvement is thus of dubious reliability. Accordingly, the Chamber will not attribute any weight to this part of Krstić's evidence. 
5005. On 2 July 1995, two orders, both of which drew reference from Directives 7 and 7/1, were issued in the name of Drina Corps Commander Živanović. ${ }^{16892}$ First, a preparatory order sent to all subordinate units referred to the VRS's anticipation of an $\mathrm{ABiH}$ attack aimed at dividing the Drina Corps' area of responsibility and connecting the Srebrenica and Žepa enclaves with Bosnian Muslim-held territory. ${ }^{16893}$ The subordinate units were ordered to prepare for active combat operations by "switching from defence to attack with all the forces in their areas of responsibility". ${ }^{16894}$

5006. The second order, which was an order for active combat operations implementing the basic concept outlined in the preparatory order, was issued later that day and addressed to the commands of the Zvornik, Birač, Romanija, Bratunac, and Milići Brigades, as well as the $5^{\text {th }}$ Mixed Artillery Regiment. ${ }^{16895}$ It was also delivered to the Main Staff and to the Drina Corps IKM at Pribićevac. $^{16896}$

5007. The active combat order referred to the Drina Corps' task of "carrying out offensive activities [...] as soon as possible, in order to split apart the enclaves of Žepa and Srebrenica, and to reduce them to their urban areas". ${ }^{1697}$ It then assigned specific tasks to be undertaken by the subordinate units, whose objective was "by surprise attack, to separate and reduce in size the Srebrenica and Žepa enclaves, to improve the tactical position of the forces in the depth of the area, and to create conditions for the elimination of the enclaves". ${ }^{1698}$ The tasks allocated did not

16892 P4571 (Order of Drina Corps, 2 July 1995), para. 2; P4481 (Order of Drina Corps, 2 July 1995), para. 2; Milenko Lazić, P4072 (Transcript from Prosecutorv. Popović et al.), T. 21731; Mirko Trivić, T. 40535 (26 June 2013); D3932 (Witness statement of Milenko Živanović dated 27 October 2013), para. 32.

16893 P4571 (Order of Drina Corps, 2 July 1995), para. 1; Mirko Trivić, T. 40534-40535 (26 June 2013); D3747 (Witness statement of Mirko Trivić dated 22 June 2013), p. 7.

16894 P4571 (Order of Drina Corps, 2 July 1995), paras. 2-3; Radislav Krstić, D4136 (Transcript from Prosecutor v. Krstić), T. 6126-6127. Acting pursuant to the preparatory order on 2 July, Zvornik Brigade Commander Pandurević issued an order establishing a tactical group from amongst the units of the Zvornik Brigade, and designating himself as commander and Milan Jolović as deputy commander. P177 (Order of Zvornik Brigade, 2 July 1995), para. 2.1.

16895 P4481 (Order of Drina Corps, 2 July 1995), e-court pp. 1, 17; Radislav Krstić, D4136 (Transcript from Prosecutor v. Krstić), T. 6131. According to Lazić, about 2,000 troops participated in the operation. Milenko Lazić, P4072 (Transcript from Prosecutor v. Popović et al.), T. 21734. Two to three MUP companies and the $1^{\text {st }}$ Company of the Vlasenica Brigade were also assigned as reserve forces but did not receive the order for active combat activities. P4481 (Order of Drina Corps, 2 July 1995), para.5; Radislav Krstić, D4136 (Transcript from Prosecutor v. Krstić), T. 6137-6139.

16896 P4481 (Order of Drina Corps, 2 July 1995), e-court p. 17; Radislav Krstić, D4136 (Transcript from Prosecutor v. Krstić), T. 6142.

16897 P4481 (Order of Drina Corps, 2 July 1995), para. 2. Krstić explained that "the urban area" of Srebrenica included the villages on the outskirts of town, such as Bojna, Bajramovići, Pusulići, and Potočari, but did not include the outlying villages in the enclave. Radislav Krstić, D4136 (Transcript from Prosecutor v. Krstić), T. 6390-6391.

16898 P4481 (Order of Drina Corps, 2 July 1995), paras. 4-5; Momir Nikolić, T. 24828 (16 February 2012); Ljubomir Obradović, T. 25220 (24 February 2012). See also Milenko Lazić, P4072 (Transcript from Prosecutor v. Popović et al.), T. 21732-21733. 
include taking over Srebrenica town. ${ }^{16899}$ The active combat order further instructed the units to, "in dealing with prisoners of war and the civilian population behave in every way in accordance with the Geneva Conventions", and designated the security organs and MP to indicate areas for gathering prisoners of war. ${ }^{16900}$ Combat readiness was ordered for 4 a.m. on 6 July $1995 .{ }^{16901}$ Late in the evening of 2 July, the Main Staff reported to the Accused that "the [Drina] Corps units [we]re in full combat readiness and [...] unengaged forces [we]re being prepared for forthcoming active combat operations". 16902

5008. Final preparations were made over the following few days. Upon receiving the active combat order on 2 July, the brigade commanders conveyed the order for active combat operations to their subordinate units. ${ }^{16903}$ Krstić was placed in charge of reconnaissance activities, and prepared a surveillance plan. ${ }^{16904}$ On 5 July, Živanović again assessed the overall situation in the Drina Corps' area of responsibility and decided that the units were ready to implement the task. ${ }^{16905}$ Krstić departed that afternoon for the Pribićevac IKM, where he met with Blagojević, whose IKM was located nearby. ${ }^{16906}$

5009. Around the same time, Bosnian Serb Forces appeared to establish a headquarters in a large house located between the Yellow Bridge and OP Papa. ${ }^{1607}$ DutchBat member Roger Patelski observed two tanks moving close to the house, members of Bosnian Serb Forces digging trenches and setting up rocket launchers in the hills above Potočari, as well as artillery and mortars firing in the direction of the enclave. ${ }^{16908}$ Snipers posted on the surrounding hills targeted Bosnian Muslim civilians, including women and children, who were living in the houses in the vicinity of OP

\footnotetext{
16899 P4481 (Order of Drina Corps, 2 July 1995). See also D3932 (Witness statement of Milenko Živanović dated 27 October 2013), para. 2; Radislav Krstić, D4136 (Transcript from Prosecutor v. Krstić), T. 6136-6137, 6152_ 6154, 6394-6395, 7349, 7351-7352; D3747 (Witness statement of Mirko Trivić dated 22 June 2013), p. 7; Mirko Trivić, T. 40534 (26 June 2013).

16900 P4481 (Order of Drina Corps, 2 July 1995), para. 10(b). Lazić testified that, as in any operation, it was anticipated that some prisoners would be taken, but a large number of prisoners was not expected due to the operation's initial limited scope. Milenko Lazić, P4072 (Transcript from Prosecutor v. Popović et al.), T. 21733-21735.

16901 P4481 (Order of Drina Corps, 2 July 1995), para. 4.

16902 P5126 (VRS Main Staff Report to RS President, 2 July 1995), p. 3.

16903 P5133 (Order of Bratunac Brigade, 5 July 1995); D4189 (Witness statement of Vidoje Blagojević dated 9 December 2013), pp. 3-4.

16904 Radislav Krstić, D4136 (Transcript from Prosecutor v. Krstić), T. 6156.

16905 Radislav Krstić, D4136 (Transcript from Prosecutor v. Krstić), T. 6158-6159, 6171-6172. See also D3950 (Order of Drina Corps, 5 July 1995) (stating that Drina Corps units had carried out all preparations for executing combat actions towards Srebrenica and ordering the $1^{\text {st }}$ and $5^{\text {th }}$ Podrinje Light Infantry Brigades to prepare for the commencement of combat operations towards Žepa on the morning of 6 July).

16906 Radislav Krstić, D4136 (Transcript from Prosecutor v. Krstić), T. 6159, 6172-6173, 6423.

16907 P4173 (Witness statement of Roger Patelski dated 30 November 2011), para. 8.

16908 P4173 (Witness statement of Roger Patelski dated 30 November 2011), paras. 9-10; P4174 (Aerial photograph of Srebrenica-Bratunac area marked by Roger Patelski); Roger Patelski, T. 23018-23019 (13 January 2012).
} 
Papa. ${ }^{16909}$ Bosnian Serb Forces also fired on a number of OPs, including OP Mike, with small and large calibre weapons. ${ }^{16910}$

\section{ii. Commencement of VRS combat operations and shelling of Srebrenica and Potočari}

5010. By 6 July, the Drina Corps units had been prepared and grouped for active combat operations towards Srebrenica and Žepa. ${ }^{16911}$ Combat activities towards Srebrenica began early that morning. ${ }^{16912}$ At approximately 3 a.m., Srebrenica town came under heavy and continuous fire. ${ }^{16913}$ Shells fell in a scattered manner throughout the town and the enclave. ${ }^{16914}$ Within half an hour, several rockets landed near the DutchBat compound in Potočari. ${ }^{16915}$ At about 1 p.m., a tank round hit the defence wall of OP Foxtrot, ${ }^{16916}$ which thereafter came under direct fire from tanks, mortars, and small-calibre machine guns. ${ }^{16917}$ The shelling of the area continued throughout the day, ${ }^{16918}$ initially concentrating at the southeastern part of the enclave. ${ }^{16919}$ Bosnian Serb Forces encountered heavy resistance from the $\mathrm{ABiH}$ along the southern approach to the town. ${ }^{16920}$ Krstic

16909 P4173 (Witness statement of Roger Patelski dated 30 November 2011), paras. 10-11; Roger Patelski, T. 2302323025 (16 January 2012); Momir Nikolić, T. 24574 (13 February 2012) (acknowledging that civilians inside the enclave were wounded or killed by sniper fire originating from the Bratunac Brigade and suggesting that such civilians "should not have been targeted"). These killings are not charged in the Indictment.

16910 P4167 (Witness statement of Paul Groenewegen dated 11 November 2011), paras. 14-15.

16911 D2097 (VRS Main Staff Report, 6 July 1995); Ljubomir Obradović, T. 25211 (24 February 2012).

16912 P4140 (Witness statement of Joseph Kingori dated 8 January 2012), para. 63; Radislav Krstić, D4136 (Transcript from Prosecutor v. Krstić), T. 6173. See also Ljubomir Obradović, T. 25297-25298 (27 February 2012); Adjudicated Fact 1472.

16913 P4140 (Witness statement of Joseph Kingori dated 8 January 2012), paras. 63-64. See also P4752 (Witness statement of Christine Schmitz dated 21 March 2012), para. 26; D2212 (Collection of MSF telex messages, 517 July 1995), e-court p. 3

16914 P4140 (Witness statement of Joseph Kingori dated 8 January 2012), paras. 71, 73; P4143 (UNMO Report, 6 July 1995), p. 1. See also P5113 (Report of Bratunac Brigade to Drina Corps, 6 July 1995) (reporting Bratunac Brigade fire against targets including the school in Potočari, the 11 Mart Factory, and the wider village area).

16915 P4144 (UNPROFOR Report, 6 July 1995), e-court pp. 5-6; P4143 (UNMO Report, 6 July 1995), pp. 1-2; Pieter Boering, P3969 (Transcript from Prosecutor v. Popović et al.), T. 1920, 1922. See also Adjudicated Fact 1473.

16916 P3995 (Witness statement of Albert Rave dated 10 November 2011), para. 30; P4144 (UNPROFOR Report, 6 July 1995), e-court p. 5; P4175 (Witness statement of Robert Franken dated 15 January 2012), para. 45.

16917 P4175 (Witness statement of Robert Franken dated 15 January 2012), para. 45.

16918 P4143 (UNMO Report, 6 July 1995), p. 1. An artillery impact killed a civilian and injured a boy in Srebrenica town. P4140 (Witness statement of Joseph Kingori dated 8 January 2012), paras. 70, 75; P4144 (UNPROFOR Report, 6 July 1995), para. 1; P4175 (Witness statement of Robert Franken dated 15 January 2012), para. 46. See also P398 (Witness Statement of Saliha Osmanović dated 18 June 2000), e-court p. 2; P398 (Statement of Saliha Osmanović to Tuzla Cantonal Court, 19 June 2000), e-court p. 10 (referring to the killing of her son, Edin, by a shell on 6 July 1995). These killings are not charged in the Indictment.

16919 P4175 (Witness statement of Robert Franken dated 15 January 2012), para. 45; P4144 (UNPROFOR Report, 6 July 1995), para. 1.

16920 Radislav Krstić, D4136 (Transcript from Prosecutor v. Krstić), T. 6174. Many fire fights as well as a rocket attack occurred in the Bandera Triangle. P3995 (Witness statement of Albert Rave dated 10 November 2011), para. 30 . 
ordered those who had not reached the lines they had been ordered to reach on 6 July to press ahead on the following day. ${ }^{16921}$

5011. Bosnian Serb Forces fired artillery and mortars as well as multiple rocket launchers all over the enclave throughout the day on 7 July. ${ }^{16922}$ Multiple impacts occurred in the vicinity of the DutchBat compound in Potočari, ${ }^{16923}$ as well as in Srebrenica town, wounding several civilians. ${ }^{16924}$ More than 200 shells fell on Srebrenica town during the course of the day. ${ }^{16925}$ However, the Bosnian Serb Forces did not progress further towards the enclave. ${ }^{16926}$

5012. Shelling resumed at 8 a.m. on 8 July, and was most concentrated in Potočari and Srebrenica town. ${ }^{1627}$ By 1 p.m., the UNMOs located in the PTT building had counted 34 explosions in Srebrenica town. ${ }^{16928}$ Having withstood increasingly more accurate fire since 6 July, OP Foxtrot finally fell on 8 July. ${ }^{16929}$ Later that day, OP Sierra and OP Uniform also came under fire from the Bosnian Serb Forces. ${ }^{16930}$ UNPROFOR protested to the Main Staff that the OPs were being

\footnotetext{
16921 Radislav Krstić, D4136 (Transcript from Prosecutor v. Krstić), T. 6175-6176.
}

16922 P3995 (Witness statement of Albert Rave dated 10 November 2011), paras. 30-31; P4140 (Witness statement of Joseph Kingori dated 8 January 2012), para.77; P5207 (UNPROFOR daily report, 7 July 1995), para. 1.

16923 P4175 (Witness statement of Robert Franken dated 15 January 2012), para. 46; P4140 (Witness statement of Joseph Kingori dated 8 January 2012), para.78; P4145 (UNMO Report, 7 July 1995), e-court p. 1; P5207 (UNPROFOR daily report, 7 July 1995), para. 1. For example, a small village called Budak, where only civilians lived, was attacked. P3995 (Witness statement of Albert Rave dated 10 November 2011), paras. 31, 36.

16924 P3995 (Witness statement of Albert Rave dated 10 November 2011), para. 31; P4145 (UNMO Report, 7 July 1995), p. 1; P4146 (UNPROFOR Report, 7 June 1995); P4140 (Witness statement of Joseph Kingori dated 8 January 2012), paras. 82, 87; P5207 (UNPROFOR daily report, 7 July 1995), para. 1.

16925 P4140 (Witness statement of Joseph Kingori dated 8 January 2012), para. 86.

16926 Radislav Krstić, D4136 (Transcript from Prosecutor v. Krstić), T. 6176; D2098 (VRS Main Staff Report, 7 July 1995), para. 6(a). See also P4308 (Book of photographs and maps prepared by Jean-René Ruez, 22 June 2009), e-court pp. 12-13; Jean-René Ruez, T. 23712-23713 (26 January 2012).

16927 P4140 (Witness statement of Joseph Kingori dated 8 January 2012), para. 89; P4147 (UNMO Report, 8 July 1995), para. 1.

16928 P4147 (UNMO Report, 8 July 1995); P4140 (Witness statement of Joseph Kingori dated 8 January 2012), paras. 90-92. Kingori testified that it was possible to conclude that buildings were being targeted because of the corrections that were made to the firing of an artillery weapon when a target was missed. Joseph Kingori, T. 22893-22894 (12 January 2012).

16929 P4144 (UNPROFOR Report, 6 July 1995), e-court pp. 5-6; P4175 (Witness statement of Robert Franken dated 15 January 2012), para. 47 . At 2 a.m., three tank rounds hit OP Foxtrot, and the defence wall was blown away; the Bravo Company commander then ordered the DutchBat personnel to withdraw. P3995 (Witness statement of Albert Rave dated 10 November 2011), para. 32; P4175 (Witness statement of Robert Franken dated 15 January 2012), para. 47; P5129 (Memorandum from Thomas Karremans to UNPROFOR, 9 July 1995), para. 3. As DutchBat withdrew, one of the DutchBat soldiers was killed by a member of the ABiH. P3995 (Witness statement of Albert Rave dated 10 November 2011), para. 32; P4175 (Witness statement of Robert Franken dated 15 January 2012), para. 47; Momir Nikolić, T. 24819 (16 February 2012); P5129 (Memorandum from Thomas Karremans to UNPROFOR, 9 July 1995), para. 3

16930 P3980 (UNMO report, 9 July 1995), e-court p. 2; P5129 (Memorandum from Thomas Karremans to UNPROFOR, 9 July 1995), para. 4; P4787 (Intercept of conversation between General Nicolai and unidentified person from VRS Main Staff, 8 July 1995). DutchBat personnel were prevented from leaving these areas by the ABiH. P3980 (UNMO report, 9 July 1995), e-court p. 2. The ABiH held positions near many of the DutchBat OPs and would fire at the VRS, trying to provoke the VRS into returning fire in the hope that DutchBat would 
attacked. ${ }^{16931}$ However, OP Mike, located in the northern part of the enclave, came under direct fire on the following day. ${ }^{16932}$ Thereafter, the VRS began taking over the OPs one by one. ${ }^{16933}$

5013. Meanwhile, the southern perimeter of the enclave began to collapse as the Bosnian Serb Forces moved into the enclave. ${ }^{16934}$ Late in the evening of 8 July, as Bosnian Serb Forces approached the Swedish Shelter Project near OP Sierra and OP Kilo, 4,000 refugees streamed towards Srebrenica town. ${ }^{16935}$ By then, the town was already packed, ${ }^{16936}$ and large numbers of people had begun to congregate at the Bravo Company compound in the centre of Srebrenica town. ${ }^{16937}$

then fire at the VRS. Pieter Boering, T. 22099 (29 November 2011); P3995 (Witness statement of Albert Rave dated 10 November 2011), para. 35.

16931 D4448 (Intercept of conversation between General Nicolai and an unidentified person, 8 July 1995); P4787 (Intercept of conversation between General Nicolai and unidentified person from VRS Main Staff, 8 July 1995). Živanović sent an urgent message to Krstić referring to such a protest and relaying an order from the Main Staff "not to attack UNPROFOR, but to prevent any surprises and stop the Muslims in their intention to join up Srebrenica and Žepa". D1964 (Urgent message from Živanović to Krstić re UNPROFOR protest, 8 July 1995); Radislav Krstić, D4136 (Transcript from Prosecutor v. Krstić), T. 6178. See also D3995 (Request of Vujadin Popović to Drina Corps IKM, 8 July 1995); Vujadin Popović, T. 43021 (5 November 2013). P4175 (Witness statement of Robert Franken dated 15 January 2012), para. 48.

16933 P4175 (Witness statement of Robert Franken dated 15 January 2012), paras. 48-49; P5129 (Memorandum from Thomas Karremans to UNPROFOR, 9 July 1995), para. 2 (stating that as of 9 July most DutchBat OPs were hit by mortar fire). See also Adjudicated Fact 1476. The last OPs to fall were taken over by the Bosnian Serb Forces on 11 July 1995. See para. 5031. In order to avoid an incident like the one that occurred at OP Foxtrot, instead of withdrawing toward Bosnian Muslim lines, the DutchBat soldiers began to wait for the VRS to take the OP and would then surrender. P4175 (Witness statement of Robert Franken dated 15 January 2012), para. 49; P5129 (Memorandum from Thomas Karremans to UNPROFOR, 9 July 1995), paras. 4-5. See also Adjudicated Facts 1478. After surrendering to the VRS on 9 and 10 July, the DutchBat soldiers at OP Uniform, OP Sierra, and OP Kilo were taken to Bratunac. P3995 (Witness statement of Albert Rave dated 10 November 2011), paras. 34, 38; Albert Rave, T. 22219-22220 (30 November 2011); P4175 (Witness statement of Robert Franken dated 15 January 2012), para. 51; Pieter Boering, P3969 (Transcript from Prosecutor v. Popović et al.), T. 1920, 1924; P5127 (Notes on telephone conversation between General Nicolai and Tolimir at 12:30 p.m., 9 July 1995). See also Adjudicated Fact 1479.

16934 Radislav Krstić, D4136 (Transcript from Prosecutor v. Krstić), T. 6177; D2099 (VRS Main Staff Report, 8 July 1995), paras. 6(a)-(b); P4482 (Drina Corps report, 8 July 1995), para. 2; P4930 (Combat Report of Drina Corps, 8 July 1995), para. 1. See also P4929 (Map of Eastern BiH marked by Richard Butler) (showing the location of three features seised by the VRS on 8 July); Richard Butler, T. 27478-27479 (17 April 2012).

16935 P4148 (UNMO Report, 9 July 1995), p. 1; P4140 (Witness statement of Joseph Kingori dated 8 January 2012), para. 95; Pieter Boering, T. 22119 (29 November 2011); P4148 (UNMO Report, 9 July 1995), p. 1. See also P3995 (Witness statement of Albert Rave dated 10 November 2011), paras. 39-40; Mirsada Malagić, T. 23471 (24 January 2012); Adjudicated Fact 1482; D2235 (Report of Presidency of Srebrenica Municipality, 9 July 1995); P4175 (Witness statement of Robert Franken dated 15 January 2012), para. 51. See also Vincentius Egbers, P331 (Transcript from Prosecutor v. Popović et al.), T. 2713-2714, 2943; Pieter Boering, P3969 (Transcript from Prosecutor v. Popović et al.), T. 1923.

16936 Mirsada Malagić, T. 23471-23472 (24 January 2012).

16937 P3980 (UNMO report, 9 July 1995), e-court pp. 2-3. 


\section{iii. Expansion of the Krivaja 95 Orders and continued shelling of Srebrenica}

5014. After several days of resistance from the $\mathrm{ABiH},{ }^{16938}$ the Bosnian Serb Forces pressed forward on 9 July. ${ }^{16939}$ Heavy shelling of Srebrenica town continued at 8 a.m. and lasted throughout the day. ${ }^{16940}$ Small arms fire was audible from the centre of town, signalling the proximity of Bosnian Serb infantry. ${ }^{16941}$ When the UNMOs stationed in town spotted a tank capable of delivering a direct hit later that day, they decided to leave the PTT building for Potočari. ${ }^{16942}$ This contributed to a growing feeling of insecurity and panic amongst the population, ${ }^{1643}$ whose numbers were constantly increasing due to the arrival of refugees from the outskirts of town. ${ }^{16944}$

5015. On multiple occasions throughout the day, the Bosnian Muslim municipal authorities attempted to contact the government in Sarajevo to obtain assistance for the population. ${ }^{16945}$ In the meantime, the shelling continued. ${ }^{16946}$ By 5:50 p.m., the Bosnian Serb Forces had advanced four kilometres into the enclave and stood only one kilometre away from Srebrenica town. ${ }^{16947}$

16938 Momir Nikolić, T. 24837 (16 February 2012). On 9 July, according to a VRS Main Staff report, the ABiH fired at the VRS using all types of weapons, including heavy weapons. D2100 (VRS Main Staff Report, 9 July 1995), para. 6(a).

16939 See P5104 (Message from Drina Corps, 9 July 1995).

16940 P4148 (UNMO Report, 9 July 1995), p. 1; Joseph Kingori, T. 22952 (13 January 2012); D2236 (Report of Presidency of Srebrenica Municipality, 9 July 1995). See also Adjudicated Fact 1474. Between approximately 2 and 3 p.m., the UNMOs recorded 78 explosions, 70\% of which were centred in Srebrenica town. P4149 (UNMO Report, 9 July 1995); P4140 (Witness statement of Joseph Kingori dated 8 January 2012), para. 98.

16941 P4140 (Witness statement of Joseph Kingori dated 8 January 2012), paras. 99-101; P4149 (UNMO Report, 9 July 1995).

16942 P4140 (Witness statement of Joseph Kingori dated 8 January 2012), paras. 102-104; Joseph Kingori, T. 22802 (11 January 2012); P3995 (Witness statement of Albert Rave dated 10 November 2011), para. 41.

16943 P4140 (Witness statement of Joseph Kingori dated 8 January 2012), paras. 107, 109. See also KDZ064, P769 (Transcript from Prosecutor v. Popović et al.), T. 641. See also KDZ425, P381 (Transcript from Prosecutor v. Popovic et al.), T. 3504. The deputy mayor tried to persuade the UNMOs not to leave the town because the population did not want to be left behind. P4140 (Witness statement of Joseph Kingori dated 8 January 2012), paras. 104-106.

16944 KDZ425, P381 (Transcript from Prosecutor v. Popović et al.), T. 3503; D2236 (Report of Presidency of Srebrenica Municipality, 9 July 1995) (referring to 32,000 displaced people and increasing numbers of new refugees, which totalled 4,000 at the time of the report).

16945 D2235 (Report of Presidency of Srebrenica Municipality, 9 July 1995); D2236 (Report of Presidency of Srebrenica Municipality, 9 July 1995); P4150 (Srebrenica Presidency's message to President of BiH and Commander of ABiH, 9 July 1995). See also P5119 (Report of $28^{\text {th }}$ Infantry Division to $2^{\text {nd }}$ Corps Command, 9 July 1995), p. 2 (reporting that the humanitarian situation was 'catastrophic' as the civilian population had no food, and medical supplies were becoming scarcer). At the time, the civilian population had no food reserves and the ABiH had enough food for seven days. D2236 (Report of Presidency of Srebrenica Municipality, 9 July 1995).

16946 Joseph Kingori, T. 22802(11 January 2012).

16947 P5229 (Notes re telephone conversation between General Nicolai and Tolimir at 5:50 p.m., 9 July 1995); P4788 (Intercept of conversation between General Tolimir and General Nicolai at 5:55 p.m., 9 July 1995). See also Adjudicated Fact 1483. Momir Nikolić recalled that the attack was halted to allow the VRS to regroup prior to advancing into the town. Momir Nikolić, T. 24838 (16 February 2012). 
5016. Cornelis Nicolai, Rupert Smith's Chief of Staff, ${ }^{16948}$ spoke to Tolimir several times throughout the day. ${ }^{16949}$ Nicolai first expressed concern about the Bosnian Serb incursion into the enclave and stated that UNPROFOR considered it an attack on the safe area, which would force UNPROFOR to defend the area with all available means. ${ }^{1690}$ Nicolai also requested the immediate withdrawal of the Bosnian Serb Forces. ${ }^{16951}$ Tolimir first replied that he would check the information with his subordinates on the ground, ${ }^{16952}$ but later stated that he had been informed that the Bosnian Serb Forces "had no particular problems with UNPROFOR or the civil population in Srebrenica", adding that the $\mathrm{ABiH}$ was using heavy weaponry, thereby necessitating Bosnian Serb action. ${ }^{16953}$ Nicolai pointed out that the ABiH's heavy weapons were still at the UNPROFOR collection point. ${ }^{16954}$ Nicolai reiterated that the Bosnian Serb Forces were directly attacking the safe area and again requested that the Bosnian Serbs withdraw. ${ }^{1695}$

5017. Meanwhile, earlier in the afternoon, Gvero had arrived at the Pribićevac IKM. ${ }^{16956}$ At about 5 p.m. Mladić and Živanović arrived. ${ }^{16957}$ Krstić briefed them each in turn, and Mladić and

16948 Rupert Smith, T. 11683 (11 February 2011).

16949 P5127 (Notes on telephone conversation between General Nicolai and Tolimir at 12:30 p.m., 9 July 1995); P5229 (Notes re telephone conversation between General Nicolai and Tolimir at 5:50 p.m., 9 July 1995); P4788 (Intercept of conversation between General Tolimir and General Nicolai at 5:55 p.m., 9 July 1995); P5128 (Notes on telephone conversation between General Nicolai and Tolimir at 7:30 p.m., 9 July 1995); P4821 (Intercept of conversation between General Tolimir and General Nicolai at 9:25 p.m., 9 July 1995).

16950 P5229 (Notes re telephone conversation between General Nicolai and Tolimir at 5:50 p.m).

16951 P5229 (Notes re telephone conversation between General Nicolai and Tolimir at 5:50 p.m).

16952 P5229 (Notes re telephone conversation between General Nicolai and Tolimir at 5:50 p.m., 9 July 1995).

16953 P5128 (Notes on telephone conversation between General Nicolai and Tolimir at 7:30 p.m., 9 July 1995). Tolimir also asserted that the ABiH was using six UNPROFOR APCs, which Nicolai denied. P5128 (Notes on telephone conversation between General Nicolai and Tolimir at 7:30 p.m., 9 July 1995), e-court p. 2. See also P4821 (Intercept of conversation between General Tolimir and General Nicolai at 9:25 p.m., 9 July 1995).

16954 P5128 (Notes on telephone converstaion between General Nicolai and Tolimir at 7:30 p.m., 9 July 1995), ecourt p. 2.

16955 P5128 (Notes on telephone converstaion between General Nicolai and Tolimir at 7:30 p.m., 9 July 1995), ecourt p. 2.

16956 Radislav Krstić, D4136 (Transcript from Prosecutor v. Krstić), T. 6178-6180. Krstić had not been informed in advance of Gvero's arrival and thus deduced that the Main Staff was displeased with the progress of the operation, and that Gvero had been sent to check and control the Pribićevac IKM and to report to Mladić. Radislav Krstić, D4136 (Transcript from Prosecutor v. Krstić), T. 6185-6186. Srbislav Davidović also visited the IKM in the early afternoon of 9 July; he and Gvero then departed for Bratunac, where Gvero left Davidović and continued "in a hurry" towards Vlasenica. Srbislav Davidović, P4100 (Transcript from Prosecutor v. Popović et al.), T. 9184- 9186, 9331-9334.

16957 Radislav Krstić, D4136 (Transcript from Prosecutor v. Krstić), T. 6185, 6427. See also D3932 (Witness statement of Milenko Živanović dated 27 October 2013), para. 4. Mladić had arrived in Bratunac on the previous afternoon; at the time, the Hotel Fontana was being used as the command post of the Main Staff. Milenko Katanić, T. 24498 (10 February 2012); KW582, D4291 (Transcript from Prosecutor v. Blagojević \& Jokić), T. 3504, 3626. See also Momir Nikolić, T. 24604-24606 (13 February 2012) (stating that in the days preceding the fall of Srebrenica he saw Mladić, Radoslav Janković, Živanović, Krstić, Popović, and Kosorić in Bratunac). Deronjić had been present at the Pribićevac IKM for the previous three days. P4374 (Witness statement of Milenko Katanić dated 11 October 2011), para. 57; Milenko Katanić, T. 24498 (10 February 2012). Members of the Bratunac municipal organs also visited the Pribićevac IKM on 11 July. Srbislav Davidović, P4100 (Transcript from Prosecutor v. Popović et al.), T. 9188; Srbislav Davidović, T. 24400-24401 (9 February 2012. 
Živanović monitored the units' progress. ${ }^{16958}$ Around 7:30 p.m., in between Tolimir's conversations with Nicolai, Krstić sent an interim combat report to the Main Staff stating that during the day, units of the Bosnian Serb Forces had "carried out the immediate task and created conditions for the extending the attack towards Srebrenica". ${ }^{1659}$ In the same report, Krstić reported that, "taking advantage of the success achieved", he would make a decision for further operations to "regroup the forces and carry out a vigorous and decisive attack towards Srebrenica". ${ }^{16960}$

5018. Tolimir reported the above information he had received from Krstić to the Accused, and the Accused approved the expansion of the Krivaja 95 plan and ordered the Bosnian Serb Forces to take over the town. ${ }^{16961}$ The Accused told Tolimir that "if they could take Srebrenica, they should". ${ }^{16962}$ Tolimir then drafted an order to that effect and sent it to Gvero and Krstic personally, as well as to the Drina Corps IKM. ${ }^{16963}$ In that order, Tolimir wrote: "The President of the Republic is satisfied with the results of combat operations around Srebrenica and has agreed with the continuation of operations for the takeover of Srebrenica, disarming of Muslim terrorist gangs and complete demilitarisation of the Srebrenica enclave". ${ }^{16964}$ Relaying the Accused's agreement with the expanded objective, Tolimir also conveyed the Accused's order that "full protection [should] be ensured to UNPROFOR members and the [Bosnian] Muslim civilian population", as well as his instruction to Krstić to issue an order to that effect. ${ }^{16965}$ Krstić testified that, thereafter, Mladić called each subordinate commander by encrypted RUP 12 radio and orally ordered them to continue the attack and to enter Srebrenica. ${ }^{16966}$

\footnotetext{
16958 Radislav Krstić, D4136 (Transcript from Prosecutor v. Krstić), T. 6185, 6430-6432, 6437.

16959 D2080 (Drina Corps report to VRS Main staff, 9 July 1995), para. 2. The Chamber notes that during his testimony in his own defence case, Krstić denied that there were changes in the plan of attack on 9 July because the Drina Corps units were still far from completing the assignments given to them in the Krivaja 95 plan, and that they only did so by noon on 10 July. Radislav Krstić, D4136 (Transcript from Prosecutor v. Krstić), T. 6424-6426, 6437, 7360-7361. The Chamber notes that these assertions are directly contradicted by Krstić's own contemporaneous description of the units' task on 9 July, and will not rely on Krstić's testimony in this regard.

D2080 (Drina Corps report to VRS Main staff, 9 July 1995), para. 3. Within the hour, Tolimir replied to Krstić, requesting Krstić to provide him with hourly battlefield situation reports "so that [Tolimir could] communicate with UNPROFOR which w[ould] enable [Krstić] to continue to work according to plan". P5131 (Report of Drina Corps, 9 July 1995).

16961 P2276 (VRS Main Staff Order, 9 July 1995); Zdravko Tolimir, T. 45063 (12 December 2013). See also Momir Nikolić, T. 24840-24842 (16 February 2012).

16962 Zdravko Tolimir, T. 45063 (12 December 2013).

16963 P2276 (VRS Main Staff Order, 9 July 1995); Zdravko Tolimir, T. 45063 (12 December 2013).

16964 P2276 (VRS Main Staff Order, 9 July 1995).

16965 P2276 (VRS Main Staff Order, 9 July 1995); Zdravko Tolimir, T. 45063 (12 December 2013); Radislav Krstić, D4136 (Transcript from Prosecutor v. Krstić), T. 6181.

16966 Radislav Krstić, D4136 (Transcript from Prosecutor v. Krstić), T. 6186-6187, 6425, 6427.
} 
5019. In the meantime, UNPROFOR conveyed an ultimatum to the VRS that air strikes would occur if the VRS continued to attack the DutchBat blocking positions. ${ }^{16967}$ When Tolimir spoke to Janvier at 11:10 p.m., however, he assured Janvier that the VRS "w[ould] do everything [they] c[ould] to calm down the situation and to find a reasonable solution". 16968

5020. DutchBat was given an order to defend the town of Srebrenica with all military means. ${ }^{16969}$ Franken then ordered the Bravo Company Commander to establish blocking positions closer to the southern edge of town, ${ }^{16970}$ a task which was accomplished by at 6:30 a.m. on 10 July. ${ }^{16971}$

5021. That morning, the situation in Srebrenica was tense as mortar and artillery rounds landed throughout the town beginning at 8 a.m. ${ }^{16972}$ Mladić and Janvier spoke at 10:25 a.m.; Janvier demanded that Mladić completely stop the Bosnian Serb offensive, and Mladić replied that the attack was a response to the Bosnian Muslim incursions outside the enclave. ${ }^{16973}$ By 1 p.m., Mladić had ordered the Bosnian Serb Forces to press further forward. ${ }^{16974}$ The Main Staff redeployed units

16967 P2275 (UNPROFOR report re warning to Bosnian Serbs, 9 July 1995); P3995 (Witness statement of Albert Rave dated 10 November 2011), para. 41.

16968 P5266 (Intercept of conversation between General Bernard Janvier and General Zdravko Tolimir, 9 July 1995), p. 3. Janvier and Tolimir also spoke about whether the DutchBat soldiers being held by the Bosnian Serb Forces could return to Potočari, and Tolimir alleged again that Bosnian Muslims were using UNPROFOR APCs. P5266 (Intercept of conversation between General Bernard Janvier and General Zdravko Tolimir, 9 July 1995), pp. 2-3.

16969 P4175 (Witness statement of Robert Franken dated 15 January 2012), para. 52; P2275 (UNPROFOR report re warning to Bosnian Serbs, 9 July 1995), e-court p. 2. See also Robert Franken, T. 23120-23121 (17 January 2012); P5129 (Memorandum from Thomas Karremans to UNPROFOR, 9 July 1995), paras. 8-9 (anticipating that if the Bosnian Serb Forces progressed, OP Kilo and OP Delta would also fall).

16970 P4175 (Witness statement of Robert Franken dated 15 January 2012), para. 52; Robert Franken, T. 23122 (17 January 2012); P242 (Dutchbat Order, 9 July 1995); P3995 (Witness statement of Albert Rave dated 10 November 2011), para. 39 (stating that the DutchBat commander ordered blocking positions south of the town in order to detect the VRS entry into town).

16971 P4175 (Witness statement of Robert Franken dated 15 January 2012), para. 52. Although DutchBat initially planned four blocking positions, one APC was shot off the road while trying to reach its position, and the Bosnian Serb Forces eventually gained control of it on their way into town. P242 (Dutchbat Order, 9 July 1995); P4175 (Witness statement of Robert Franken dated 15 January 2012), paras. 53-54; P4201 (Updated Srebrenica Trial video), Part 1, at 00:18:40-00:19:25 (showing Hageman's APC); Robert Franken, T. 23084 (16 January 2012). See also P3972 (Map of Eastern Bosnia marked by Pieter Boering) (showing blocking positions taken during the course of 10 July); P4175 (Witness statement of Robert Franken dated 15 January 2012), para. 54; Vincentius Egbers, P331 (Transcript from Prosecutor v. Popović et al.), T. 2715, 2717, 2910, 2935 (stating that he concluded that the Bosnian Serb Forces were targeting UNPROFOR because the Bosnian Serb fire persisted even after a Bosnian Muslim artillery unit nearby withdrew).

16972 P3995 (Witness statement of Albert Rave dated 10 November 2011), para. 44; KDZ186, P358 (Transcript from Prosecutor v. Popović et al.), T. 3632; D137 (UNPROFOR daily report, 10 July 1995), p. 4; P4151 (UNMO Report, 10 July 1995; P4153 (UNMO Report, 10 July 1995), e-court p. 3; P4140 (Witness statement of Joseph Kingori dated 8 January 2012), paras. 116-117. See also P3948 (Witness statement of Johannes Rutten dated 8 November 2011), para. 19; Adjudicated Fact 1487. The UNMOs recorded over 100 detonations during the course of the morning. P4152 (UNMO Report, 10 July 1995); P4153 (UNMO Report, 10 July 1995), e-court p. 3; P4140 (Witness statement of Joseph Kingori dated 8 January 2012), para. 121; Joseph Kingori, T. 2289722898 (12 January 2012); D137 (UNPROFOR daily report, 10 July 1995), p. 4.

16973 P4822 (Intercept of conversation between General Janvier and Ratko Mladić, 10 July 1995).

16974 P5106 (VRS Main Staff Order, 10 July 1995). 
assigned elsewhere to the Srebrenica front. ${ }^{16975}$ Additionally, a part of RS MUP forces deployed on the Sarajevo front, including the $2^{\text {nd }}$ Šekovići Detachment and a company of the Jahorina Recruits, was detached and sent as an independent unit to the Srebrenica sector under the command of Ljubiša Borovčanin, the Deputy Commander of the SBP. ${ }^{16976}$

5022. In the interim, the population of "the upper part" of Srebrenica had withdrawn to the area near the clinic, ${ }^{16977}$ which sustained two direct hits from $155 \mathrm{~mm}$ artillery shells around 1 p.m. ${ }^{16978}$ Approximately 50 shells landed during the following hour, and the UNMOs observed rockets flying over Potočari toward Srebrenica town. ${ }^{16979}$ Around 4 p.m., the town came under even heavier shelling, resulting in nine people being seriously injured. ${ }^{1690}$ That evening, a crowd of several thousand frightened people gathered outside the clinic and "voice[d] their desire to leave the town". ${ }^{16981}$ Residents of nearby villages continued to pour into town, reporting that their villages were being burned by the advancing Bosnian Serb Forces. ${ }^{16982}$

5023. During the course of the day, DutchBat received an ultimatum from the Bosnian Serb Forces which stated that since DutchBat had not been disarming the Bosnian Muslims, the VRS would do it, and DutchBat would be permitted to leave the enclave through OP Papa, along with the civilian population, if they left their equipment and weapons behind. ${ }^{16983}$ Franken transmitted the text of the ultimatum to the Bravo Company commander, along with the UN's response: an

16975 See Dragan Todorović, P4353 (Transcript from Prosecutor v. Popović et al.), T. 14002-14003; Dragan Todorović, T. 24194 (7 February 2012) (stating that Pelemiš ordered the Bijeljina platoon of the $10^{\text {th }}$ Sabotage Detachment to move towards Bratunac via Vlasenica under the command of Franc Kos, and that the group spent the night of 10 July in Zeleni Jadar). See also Petar Salapura, T. 40260-40263 (24 June 2013) (stating that he later heard from Pelemiš that Pelemiš had gone to Srebrenica on the orders of Krstić).

16976 See P2993 (Order of RS MUP, 10 July 1995), paras. 1, 3; D3659 (Witness statement of Ljubomir Borovčanin dated 30 May 2013), para. 15 (stating that he arrived at the Bratunac SJB around noon on 11 July). The order further provided that the $1^{\text {st }}$ Company of the PJP of the Zvornik CJB as well as a mixed company of RSK, Serbian, and RS MUP forces, were also to be a part of the independent unit. P2993 (Order of RS MUP, 10 July 1995), para. 2. See also D3196 (Witness statement of Dušan Mićić dated 24 March 2013), paras. 17-20 (describing the process of being deployed on 11 July); D3903 (Witness statement of Mendeljev Đurić dated 26 July 2013), paras. 6-7.

16977 KDZ064, T. 1424 (22 April 2010).

16978 P4152 (UNMO Report, 10 July 1995); P4153 (UNMO Report, 10 July 1995), e-court p. 3; Joseph Kingori, T. 22954 (13 January 2012) (stating that the hospital had been targeted). See also P4752 (Witness statement of Christine Schmitz dated 21 March 2012), para. 29; Adjudicated Fact 1487.

16979 P3991 (UNMO report, 10 July 1995); P4153 (UNMO Report, 10 July 1995), e-court p. 3; P4140 (Witness statement of Joseph Kingori dated 8 January 2012), para. 122.

16980 P4153 (UNMO Report, 10 July 1995), e-court p. 3. See also P4140 (Witness statement of Joseph Kingori dated 8 January 2012), para. 123.

16981 P4752 (Witness statement of Christine Schmitz dated 21 March 2012), para. 31.

16982 P4153 (UNMO Report, 10 July 1995), e-court p. 3; P4140 (Witness statement of Joseph Kingori dated 8 January 2012), paras. 123-125. See also D1968 (Witness statement Pieter Boering dated 28 September 1995), p. 5.

16983 P4175 (Witness statement of Robert Franken dated 15 January 2012), para. 56; P4176 (Order from Major Franken to Capt. Groen, 10 July 1995). 
order to the Bosnian Serb Forces to withdraw to the 1993 borders of the enclave as of 6 a.m. on 11 July 1995 or face the threat of "massive air attacks". ${ }^{16984}$

5024. On the evening of 10 July, the VRS attempted to enter Srebrenica town but was repelled by $\mathrm{ABiH}$ as well as DutchBat fire from the blocking positions. ${ }^{16985}$ DutchBat's blocking positions remained under fire and the "massive shelling" of Srebrenica town-including the Bravo Company compound-continued. ${ }^{16986}$ Members of international humanitarian organisations stationed in Srebrenica appealed to their colleagues in their offices in Belgrade, Zagreb, and Sarajevo for help. ${ }^{16987}$ Some civilians began to move towards Potočari, but were stopped by members of the Muslim Forces in Srebrenica, who asked them to return to the town. ${ }^{16988}$

5025. At 8:15 p.m., Janvier attempted to contact Mladić but was only able to reach Tolimir. ${ }^{16989}$ When Janvier asserted that the Bosnian Serb Forces were attacking DutchBat's positions, Tolimir replied that he would check the information on the ground and asked Janvier to call back 20 or 30 minutes later. ${ }^{16990}$ In a subsequent conversation, Tolimir told Janvier that DutchBat had opened fire on Bosnian Serb Forces, who could not withdraw before combat activities ended. ${ }^{16991}$ Janvier replied that DutchBat had been ordered to hold their positions and to defend themselves if anyone tried to take their weapons. ${ }^{16992}$ Tolimir then stated that he would check the information with the battalion commander and that he and Janvier should talk again. ${ }^{16993}$ In a third conversation at 10:30

16984 P4176 (Order from Major Franken to Capt. Groen, 10 July 1995), p. 1; P4175 (Witness statement of Robert Franken dated 15 January 2012), para. 56.

16985 Robert Franken, T. 23117 (16 January 2012); T. 23156 (17 January 2012). See also P3995 (Witness statement of Albert Rave dated 10 November 2011), para. 42. See also D3886 (Witness statement of Svetozar Andrić dated 16 July 2013), paras. 18, 24 (describing the Birač Brigade's approach to Srebrenica).

16986 P4175 (Witness statement of Robert Franken dated 15 January 2012), para. 55. Bravo Company stopped counting the number of impacts when they reached 160 or 200. P4175 (Witness statement of Robert Franken dated 15 January 2012), para. 55. The Chamber notes that during the day on 10 July, the ABiH fired mortar rounds from a location in Srebrenica town across from the Bravo Company compound. P4201 (Updated Srebrenica Trial video), Part 1 00:06:04-00:06:44; Jean-René Ruez, T. 24086 (2 February 2012).

16987 P5089 (Report of Sarajevo RDB, 11 July 1995).

16988 P4175 (Witness statement of Robert Franken dated 15 January 2012), para. 57.

16989 P5270 (Intercept of conversations between General Zdravko Tolimir and General Bernard Janvier at 8:15 p.m. and subsequent, 10 July 1995), p. 1. See also P5268 (Intercept of conversation between Ratko Mladić and General Bernard Janvier, 10 July 1995), p. 2 (agreeing at 10:45 a.m. to speak again at 6 p.m.).

16990 P5270 (Intercept of conversations between General Zdravko Tolimir and General Bernard Janvier at 8:15 p.m. and subsequent, pp. 1-2.

16991 P5270 (Intercept of conversations between General Zdravko Tolimir and General Bernard Janvier at 8:15 p.m. and subsequent), e-court pp. 3-4.

16992 P5270 (Intercept of conversations between General Zdravko Tolimir and General Bernard Janvier at 8:15 p.m. and subsequent), e-court p. 5.

16993 P5270 (Intercept of conversations between General Zdravko Tolimir and General Bernard Janvier at 8:15 p.m. and subsequent, e-court pp. 5-6. 
p.m., Tolimir reported that combat operations had stopped, and agreed to speak to Gobilliard in Sarajevo on the following day. ${ }^{16994}$

5026. That night, the DutchBat Commander, Thomas Karremans, and DutchBat soldiers Pieter Boering and Albert Rave held a meeting with the Bosnian Muslim military and civilian authorities, many of whom were armed, at the PTT building in Srebrenica. ${ }^{1695}$ There, Karremans informed the Bosnian Muslim authorities about UNPROFOR's ultimatum to the Bosnian Serb Forces. ${ }^{16996}$ Karremans also conveyed an ultimatum from the Bosnian Serb Forces "that they would like the Muslims to leave the enclave" within 48 hours in exchange for being given safe passage out. ${ }^{16997}$ After the meeting, many of the armed men remained outside in the vicinity of the PTT building and left the town in a northwestern direction. ${ }^{16998}$ By the following morning, the Muslim Forces in Srebrenica had disappeared from the town. ${ }^{16999}$

5027. During the night of 10 to $11 \mathrm{July}$, the town, as well as OP Hotel, were shelled frequently. ${ }^{17000}$ At 1 a.m., one of the DutchBat soldiers who had been at a blocking position reported that he had seen the VRS entering the houses, shooting, and then burning them. ${ }^{17001}$

\section{iv. The fall of Srebrenica and movement of the population to Potočari}

5028. The morning of 11 July was unusually quiet until about 11:15 a.m., when four shells were fired from the Budak area north of the enclave towards Srebrenica town. ${ }^{17002}$ DutchBat submitted

16994 P4836 (Intercept of conversation between General Tolimir and General Janvier at 10:30 p.m., 10 July 1995). See also P4784 (Intercept of conversation between General Janvier and General Tolimir at 10:35 p.m., 10 July 1995); P2451 (Witness statement of Anthony Banbury dated 19 May 2009), para. 180.

16995 P3995 (Witness statement of Albert Rave dated 10 November 2011), para. 45; Albert Rave, T. 22220 (30 November 2011). Many of these men were in uniform and carrying arms, including rifles, machine-guns, and hand-held rocket-launchers. P3995 (Witness statement of Albert Rave dated 10 November 2011), para. 47; Albert Rave, T. 22220-22221 (30 November 2011); P4154 (UNMO Report, 11 July 1995), e-court p. 3.

16996 P3995 (Witness statement of Albert Rave dated 10 November 2011), para. 48; Pieter Boering, P3969 (Transcript from Prosecutor v. Popović et al.), T. 1926; P4154 (UNMO Report, 11 July 1995), e-court p. 3. The civilian and military leaders did not believe that air strikes would be delivered because this promise had been made previously and nothing had happened. P3995 (Witness statement of Albert Rave dated 10 November 2011), para. 48; P4154 (UNMO Report, 11 July 1995), e-court p. 3.

P4140 (Witness statement of Joseph Kingori dated 8 January 2012), paras. 126-127; P4154 (UNMO Report, 11 July 1995), e-court pp. 2-3. The Bosnian Serb ultimatum further proposed that only MSF, UNHCR, and ICRC representatives and no refugees would be allowed inside the DutchBat compound. P4154 (UNMO Report, 11 July 1995), e-court pp. 2-3.

16998 P3995 (Witness statement of Albert Rave dated 10 November 2011), para. 49; P4175 (Witness statement of Robert Franken dated 15 January 2012), para. 57. See also paras. 5036-5038.

16999 P4175 (Witness statement of Robert Franken dated 15 January 2012), para. 57; Robert Franken, T. 2315523156 (17 January 2012).

17000 P3995 (Witness statement of Albert Rave dated 10 November 2011), paras. 50-51.

17001 P3995 (Witness statement of Albert Rave dated 10 November 2011), para. 50.

17002 P4154 (UNMO Report, 11 July 1995) e-court p. 3. 
several requests for close-air support but nothing happened. ${ }^{17003}$ By that time, thousands of Bosnian Muslims had gathered in front of the Bravo Company compound, asking to be let in because they thought the compound would be safe. ${ }^{17004}$ Eventually, around 11 a.m., the group broke through the Bravo Company's defences and entered the compound. ${ }^{17005}$ Around noon, a mortar shell landed between two APCs in the compound, wounding several people. ${ }^{17006}$

5029. Meanwhile, many Bosnian Muslims from throughout the town had begun to move towards Potočari. ${ }^{17007}$ After the Bravo Company compound was shelled, DutchBat soldiers began to accompany those inside the compound as they walked the four kilometres towards the UN Compound. ${ }^{17008}$ The Bosnian Muslims started as a disorganised mass and later formed a column which parted to make way for DutchBat vehicles transporting the sick and injured. ${ }^{17009}$

17003 P3995 (Witness statement of Albert Rave dated 10 November 2011), paras. 51-52; P4140 (Witness statement of Joseph Kingori dated 8 January 2012), para. 128. See also P4154 (UNMO Report, 11 July 1995), e-court p. 3; Adjudicated Fact 1495 .

17004 P3995 (Witness statement of Albert Rave dated 10 November 2011), para. 52; P4175 (Witness statement of Robert Franken dated 15 January 2012), para. 60; Mirsada Malagić, P356 (Transcript from Prosecutor v. Krstić), T. 1945-1946. See also Adjudicated Facts 1486, 1490.

17005 P3995 (Witness statement of Albert Rave dated 10 November 2011), para. 52. See also Pieter Boering, P3969 (Transcript from Prosecutor v. Popović et al.), T. 1931-1932; D1968 (Witness statement Pieter Boering dated 28 September 1995), p. 5.

17006 P3995 (Witness statement of Albert Rave dated 10 November 2011), para. 54. See also Pieter Boering, P3969 (Transcript from Prosecutor v. Popović et al.), T. 1932; KDZ064, T. 1424-1425 (22 April 2010); KDZ186, P358 (Transcript from Prosecutor v. Popović et al.), T. 3633-3634.

17007 Robert Franken, T. 23187 (17 January 2012); P4752 (Witness statement of Christine Schmitz dated 21 March 2012), para. 31; KDZ186, P358 (Transcript from Prosecutor v. Popović et al.), T. 3599; Mirsada Malagić, T. 23473-23474, 23477-23478 (24 January 2012); P397 (Witness Statement of Saliha Osmanović dated 18 June 2000), e-court p. 2; P397 (Statement of Saliha Osmanović to Tuzla Cantonal Court), e-court p. 10; P397 (Witness statement of Razija Pašagić dated 15 June 2000), p. 1; P397 (Statement of Razija Pašagić to Tuzla Cantonal Court, 15 June 2000), e-court p. 9; P403 (Witness statement of Rahima Malkić dated 17 June 2000), ecourt p. 2; P403 (Statement of Rahima Malkić to Tuzla Cantonal Court, 17 June 2000), e-court p. 9; P394 (Statement of Mevlida Bektić to Tuzla Cantonal Court, 16 June 2000), e-court pp. 7-8; P395 (Witness statement of Behara Krdžić dated 16 June 2000), p. 2; P395 (Statement of Behara Krdžić to Tuzla Cantonal Court, 16 June 2000), e-court p. 8; P399 (Statement of Salih Mehmedović to Tuzla Cantonal Court, 15 June 2000), e-court p. 11. See also P404 (Witness statement of Samila Salčinović dated 18 June 2000), e-court p. 2; P404 (Statement of Samila Salčinović to Tuzla Cantonal Court, 18 June 2000), e-court p. 13; P396 (Witness statement of Hanifa Hafizović dated 16 June 2000), pp. 2; P396 (Statement of Hanifa Hafizović to Tuzla Cantonal Court, 16 June 2000), e-court pp. 10-11; Adjudicated Fact 1500.

17008 P3995 (Witness statement of Albert Rave dated 10 November 2011), paras. 55-58; Johannes Rutten, T. 2203622037 (28 November 2011); Pieter Boering, P3969 (Transcript from Prosecutor v. Popović et al.), T. 19311932, 1937; Robert Franken, T. 23185 (17 January 2012); Vincentius Egbers, P331 (Transcript from Prosecutor v. Popović et al.), T. 2879; Mirsada Malagić, T. 23477-23478 (24 January 2012). See also KDZ425, P381 (Transcript from Prosecutor v. Popović et al.), T. 3504-3507, 3549-3351; KDZ064, P769 (Transcript from Prosecutor v. Popović et al.), T. 641; KDZ064, T. 1423 (22 April 2010); Adjudicated Facts 1491, 1492.

17009 Mirsada Malagić, T. 23478-23479, 23523 (24 January 2012). Around the same time, DutchBat began assisting MSF with the transportation of the sick and injured from the hospital to Potočari. Vincentius Egbers, P331 (Transcript from Prosecutor v. Popović et al.), T. 2929; P4752 (Witness statement of Christine Schmitz dated 21 March 2012), paras. 32-33; Johannes Rutten, T. 22036 (28 November 2011); Pieter Boering, P3969 (Transcript from Prosecutor v. Popović et al.), T. 1937-1938; D1968 (Witness statement Pieter Boering dated 28 September 1995), p. 5. 
5030. By 1 or 2 p.m., Bosnian Serb units were on the eastern heights overlooking the enclave. ${ }^{17010}$ In an apparent attempt to frighten the fleeing Bosnian Muslims and steer them towards Potočari, ${ }^{17011}$ Bosnian Serb Forces shot at and shelled the group of Bosnian Muslims moving northward. ${ }^{17012}$ Just then, NATO air strikes on Bosnian Serb positions began, and lasted approximately 30 minutes. ${ }^{17013}$ Franken soon received a message from the Bosnian Serb Forces that the UN Compound, including an area where refugees had gathered, would be shelled and the DutchBat soldiers being held by the Bosnian Serb Forces killed if the air strikes did not cease immediately. ${ }^{17014}$ The shelling soon resumed and the area around the bus station in Srebrenica town came under mortar fire. ${ }^{17015}$ Franken instructed Bravo Company to withdraw from Srebrenica town and to move towards Potočari at the tail end of the group of Bosnian Muslims, staying between them and the Bosnian Serb Forces. ${ }^{17016}$

5031. During the course of the day, the remaining OPs-with the exception of OP Papa-either withdrew or were overrun by the Bosnian Serb Forces. ${ }^{17017}$ VRS units involved in the approach to

17010 Radislav Krstić, D4136 (Transcript from Prosecutor v. Krstić), T. 6191.

17011 P3995 (Witness statement of Albert Rave dated 10 November 2011), paras. 58, 60; P4752 (Witness statement of Christine Schmitz dated 21 March 2012), para. 33; Pieter Boering, T. 22139 (30 November 2011); Mirsada Malagić, T. 23525-23526 (24 January 2012); P3948 (Witness statement of Johannes Rutten dated 8 November 2011), para. 19. See also Robert Franken, T. 23154 (17 January 2012) (testifying that had the VRS wanted to kill everyone in the column, they had the means to do so, but concluding nevertheless that the column was targeted by the VRS because the artillery and mortar hits were so close to the Srebrenica-Potočari road and because there were no military targets or movements in the vicinity).

17012 Momir Nikolić, T. 24608-24609 (13 February 2012), T. 24850-24851, 24855 (16 February 2012) (testifying that the column of civilians leaving Srebrenica for Potočari was targeted by a B1 cannon of the $2^{\text {nd }}$ Infantry Battalion of the Bratunac Brigade); Robert Franken, T. 23154 (17 January 2012). Shells fell close to the road on both sides of the column, wounding some and killing others. Mirsada Malagić, P356 (Transcript from Prosecutor v. Krstić), T. 1944-1945; Mirsada Malagić, T. 23476-23479 (24 January 2012) (testifying that she herself was wounded); Christine Schmitz, T. 26870 (26 March 2012); KDZ186, P358 (Transcript from Prosecutor v. Popović et al.), T. 3599. See also Adjudicated Facts 1489, 1501.

17013 P4175 (Witness statement of Robert Franken dated 15 January 2012), para. 65 (estimating that close air support was delivered at approximately 2 p.m.); P4140 (Witness statement of Joseph Kingori dated 8 January 2012), para. 130 (terming the "close air support" more of an "air strike"); Radislav Krstić, D4136 (Transcript from Prosecutor v. Krstić), T. 6191. See also Pieter Boering, P3969 (Transcript from Prosecutor v. Popović et al.), T. 1927-1928; Vincentius Egbers, P331 (Transcript from Prosecutor v. Popović et al.), T. 2716; Adjudicated Fact 1496.

17014 P4175 (Witness statement of Robert Franken dated 15 January 2012), para. 65; P3992 (UNMO report, 11 July 1995); Pieter Boering, P3969 (Transcript from Prosecutor v. Popović et al.), T. 1928-1929. See also Adjudicated Fact 1497.

17015 P4175 (Witness statement of Robert Franken dated 15 January 2012), para. 65; P4140 (Witness statement of Joseph Kingori dated 8 January 2012), paras. 130, 133.

17016 P4175 (Witness statement of Robert Franken dated 15 January 2012), para. 60.

17017 P4175 (Witness statement of Robert Franken dated 15 January 2012), para. 58. See also Radislav Krstić, D4136 (Transcript from Prosecutor v. Krstić), T. 6189. In most cases, the DutchBat soldiers manning the OPs had to surrender their weapons and were taken with their APC to Bratunac. P4175 (Witness statement of Robert Franken dated 15 January 2012), para. 59. 
Srebrenica included members of the $10^{\text {th }}$ Sabotage Detachment, the Drina Wolves, and parts of the Bratunac and Milići Brigades. ${ }^{17018}$

5032. Generally, the Bosnian Serb units encountered little resistance as they approached and then entered Srebrenica town. ${ }^{17019}$ Upon their arrival, members of the $10^{\text {th }}$ Sabotage Detachment called on the few people who remained in the town to leave their houses. ${ }^{17020}$ As the units neared the centre of town, an able-bodied man appeared, and although he declared that he was not a member of the $\mathrm{ABiH}$ and had no problems with Bosnian Serbs, $10^{\text {th }}$ Sabotage Detachment Commander Milorad Pelemiš ordered another Bosnian Serb soldier to slit the man's throat, which the soldier did. ${ }^{17021}$

5033. By 5 p.m., the Bosnian Serb Forces had stopped shelling the town. ${ }^{17022}$ Around that time, Pandurević reported to Mladić, who had remained with Živanović and Krstić at the Pribićevac IKM throughout the day, that part of his tactical group had entered the town. ${ }^{17023}$ Mladic then ordered Krstić and Živanović to accompany him, and immediately set out for Srebrenica. ${ }^{17024}$ As they

17018 Dražen Erdemović, P332 (Transcript from Prosecutor v. Popović et al.), T. 10944-10945; Dražen Erdemović, T. 25365 (27 February 2012); P4351 (Order of 10 ${ }^{\text {th }}$ Sabotage Detachment, 10 July 1995); Dragan Todorović, P4353 (Transcript from Prosecutor v. Popović et al.), T. 14001-14003. In light of the Bratunac Brigade's comparatively slower progress from the northern direction, Mladić ordered Živanović to provide additional Drina Corps units to engage along that axis. Radislav Krstić, D4136 (Transcript from Prosecutor v. Krstić), T. 6189-6191, 6433. Pursuant to Živanović's order, 50 to 60 men from the Vlasenica Brigade were then detached and sent to the Bratunac Brigade IKM at Kvac. Radislav Krstić, D4136 (Transcript from Prosecutor v. Krstić), T. 6138-6139, 6191.

17019 Dražen Erdemović, P332 (Transcript from Prosecutor v. Popović et al.), T.10945 (stating that he was surprised to encounter little resistance as the $10^{\text {th }}$ Sabotage Detachment entered town). See also Adjudicated Fact 1488; D3927 (Witness statement of Franc Kos dated 26 July 2013), p. 4; Radislav Krstić, D4136 (Transcript from Prosecutor v. Krstić), T. 6189.

17020 Adjudicated Fact 1498. While approaching Srebrenica, the Bosnian Serb Forces also burned Bosnian Muslim houses. See Adjudicated Fact 1493; Frank Kos, T. 42396 (1 August 2013) (admitting that during the advance, he heard Krstić over a walkie-talkie ordering the units to "push and burn down", which would mean to set houses on fire).

17021 Dražen Erdemović, P332 (Transcript from Prosecutor v. Popović et al.), T. 10946-10948; Dražen Erdemović, T. 25342-25343 (27 February 2012).

17022 P4154 (UNMO Report, 11 July 1995), e-court p. 4.

17023 Radislav Krstić, D4136 (Transcript from Prosecutor v. Krstić), T. 6192, 6434; P4823 (Intercept of conversation between two unidentified persons at 5:25 p.m., 11 July 1995) (one participant reporting that a flag was flying on the "Serbian church" in Srebrenica). Krstić estimated that this occurred approximately two to three hours after the air strikes. Radislav Krstić, D4136 (Transcript from Prosecutor v. Krstić), T. 6511. This information was relayed to the Main Staff in a Drina Corps' daily combat report. P6125 (Drina Corps combat report, 11 July 1995), para. 2.

17024 Radislav Krstić, D4136 (Transcript from Prosecutor v. Krstić), T. 6192, 6511; Dražen Erdemović, P332 (Transcript from Prosecutor v. Popović et al.), T. 10947-10948. Members of the $10^{\text {th }}$ Sabotage Detachment were ordered to secure the town's entrance for Mladić's arrival. Dražen Erdemović, P332 (Transcript from Prosecutor v. Popović et al.), T. 10947-10948; D3927 (Witness statement of Franc Kos dated 26 July 2013), p. 5 . 
walked through town, the group encountered Pandurević, Trivić, as well as other VRS officers. ${ }^{17025}$ In the centre of Srebrenica, Mladić stated into a television camera:

Here we are, on 11 July 1995, in Serb Srebrenica. On the eve of yet another great Serb holiday, we give this town to the Serb people as a gift. Finally, after the Rebellion against the Dahis the time has come to take revenge on the Turks in this region. ${ }^{17026}$

He then ordered the members of the Bosnian Serb Forces to proceed to Potočari. ${ }^{17027}$

5034. Gvero spoke to Nicolai and to Gobilliard in the late afternoon and early evening. ${ }^{17028}$ When speaking to Nicolai, Gvero denied that the Bosnian Serb Forces were attacking UN positions or targeting the civilian population. ${ }^{17029}$ When speaking to Gobilliard, Gvero repeated what he had said to Nicolai and suggested that DutchBat had been shot at by Bosnian Muslims. ${ }^{17030}$ Gobilliard informed Gvero that DutchBat had been ordered to meet the local Bosnian Serb commander in order to obtain a cease-fire, and reminded Gvero that aircraft still remained available to UNPROFOR to defend DutchBat and the civilian population. ${ }^{17031}$

5035. After most of the population of Srebrenica had moved north to Potočari, however, some Bosnian Muslims who lived in the vicinity of OP Papa remained in their homes, but they were eventually cleared by members of Borovčanin's units. ${ }^{17032}$ The soldiers threw grenades into the houses and entered, accompanied by dogs; after this, shootings and screams were heard and the

17025 Radislav Krstić, D4136 (Transcript from Prosecutor v. Krstić), T. 6193, 6501 (identifying the persons in P4202, e-court p. 31); P4202 (Written compilation booklet: Srebrenica Trial video), e-court p. 31; Adjudicated Fact 1499. Popović was also present in town at the time. D3993 (Witness statement of Vujadin Popović dated 2 November 2013), para. 12; P4202 (Written compilation booklet: Srebrenica Trial video), e-court p. 38 . The fact that the Bosnian Serb Forces had entered Srebrenica town that day was included in the Drina Corps' daily combat report that was sent to the Main Staff that evening, which also stated that further details would follow in an interim report. P6125 (Drina Corps combat report, 11 July 1995), para. 2.

17026 P4201 (Updated Srebrenica Trial video), Part 1, at 00:30:44-00:31:05.

17027 P4201 (Updated Srebrenica Trial video), Part 1, at 00:31:20; Dragan Todorović, P4353 (Transcript from Prosecutor v. Popović et al.), T. 14004-14005.

17028 P4632 (Intercept of conversation between Milan Gvero and General Nicolai at 4:10 p.m., 11 July 1995 ); P4679 (Intercept of conversation between Milan Gvero and General Gobilliard at 6 p.m., 11 July 1995).

17029 P4632 (Intercept of conversation between Milan Gvero and General Nicolai at 4:10 p.m., 11 July 1995). Gvero also asked Nicolai to have the NATO planes, which were still nearby, leave the airspace. P4632 (Intercept of conversation between Milan Gvero and General Nicolai at 4:10 p.m., 11 July 1995).

17030 P4679 (Intercept of conversation between Milan Gvero and General Gobilliard at 6 p.m., 11 July 1995). See also P2435 (Notes re telephone conversation between Hervé Gobilliard and Milan Gvero, 11 July 1995). Gvero also asserted that the Bosnian Serb Forces were not attacking the civilian population, and that DutchBat had nothing to fear. P4679 (Intercept of conversation between Milan Gvero and General Gobilliard at 6 p.m., 11 July 1995), p. 1.

17031 P2435 (Notes re telephone conversation between Hervé Gobilliard and Milan Gvero, 11 July 1995), p. 1. See also D1958 (UNPROFOR orders for Defence of DutchBat, 11 July 1995), para. a.

17032 Roger Patelski, T. 23028, 23032 (16 January 2012); D2005 (Map of Srebrenica enclave marked by Roger Patelski); P4173 (Witness statement of Roger Patelski dated 30 November 2011), paras. 18-19; D3196 (Witness statement of Dušan Mićić dated 24 March 2013), paras. 17-19. 
soldiers exited and set the houses on fire. ${ }^{17033}$ The process continued for a few hours on 11 July as well as on the following day. ${ }^{17034}$

\section{v. Formation and departure of the column of Bosnian Muslim men}

5036. As the women, children, and elderly men departed for Potočari, able-bodied men set out on foot through the woods, afraid that they would be killed if they went with their families. ${ }^{17035}$ Word spread that the men should head towards Šušnjari and Jaglići. ${ }^{17036}$

5037. During the night between 11 and 12 July, the group which had assembled in Šušnjari began to depart in a northwesterly direction towards Tuzla. ${ }^{17037}$ At the entrance of Buljim forest, the group, which was comprised of 10,000 to 15,000 people, most of whom were men and boys between the ages of 16 and 65, formed a column. ${ }^{17038}$ The last of the group departed Šušnjari on the afternoon of 12 July. ${ }^{17039}$

17033 P4173 (Witness statement of Roger Patelski dated 30 November 2011), para. 19; Roger Patelski, T. 2302923031 (16 January 2012).

17034 P4173 (Witness statement of Roger Patelski dated 30 November 2011), para. 19; Roger Patelski, T. 23031, 23034 (16 January 2012); D3196 (Witness statement of Dušan Mićić dated 24 March 2013), para. 19-22. See also P2996 (Report of Zvornik CJB, 12 July 1995), para. 6 (referring to a joint police force "advancing on Potočari with the aim of taking UNPROFOR personnel prisoner, surrounding the entire civilian population and clearing the terrain of enemy groups").

17035 P4308 (Book of photographs and maps prepared by Jean-René Ruez, 22 June 2009), e-court p. 14 (map showing the route of the people who left Srebrenica town for Šušnjari); Jean-René Ruez, T. 23713 (26 January 2012); KDZ064, P769 (Transcript from Prosecutor v. Popović et al.), T. 641, 794, 797; KDZ064, T. 1424-1425 (22 April 2010); KDZ069, P339 (Transcript from Prosecutor v. Blagojević \& Jokić), T. 1381; KDZ069, P338 (Transcript from Prosecutor v. Popović et al.), T. 3327, 3356; KDZ045, P5910 (Transcript from Prosecutor v. Krstić), T. 2943; Mirsada Malagić, T. 23527 (24 January 2012); P399 (Witness statement of Salih Mehmedović dated 15 June 2000) e-court p. 2; P399 (Statement of Salih Mehmedović to Tuzla Cantonal Court, 15 June 2000), e-court p. 10; P393 (Witness statement of Mejra Mešanović dated 19 June 2000), p. 2, P393 (Statement of Mejra Mušanović to Tuzla Cantonal Court, 19 June 2000), e-court p. 9; P394 (Witness statement of Mevlida Bektić dated 16 June 2000), e-court p. 3; P394 (Statement of Mevlida Bektić to Tuzla Cantonal Court, 16 June 2000), e-court p. 8; P396 (Statement of Hanifa Hafizović to Tuzla Cantonal Court, 16 June 2000), e-court p. 11; P404 (Witness statement of Samila Salčinović dated 18 June 2000), e-court p. 2; P403 (Witness statement of Rahima Malkić dated 17 June 2000), e-court p. 2; P403 (Statement of Rahima Malkić to Tuzla Cantonal Court, 17 June 2000), e-court p. 9.

17036 KDZ064, P769 (Transcript from Prosecutor v. Popović et al.), T. 812; KDZ064, P769 (Transcript from Prosecutor v. Popović et al.), T. 814 (under seal); KDZ063, P334 (Transcript from Prosecutor v. Popović et al.), T. 6972, 7032; KDZ071, P5029 (Transcript from Prosecutor v. Popović et al.), T. 7082, 7138; KDZ071, T. 28527-28528 (4 May 2012); KDZ425, P381 (Transcript from Prosecutor v. Popović et al.), T. 3507, 3509, 3511. See also Adjudicated Fact 1594.

17037 Jean-René Ruez, T. 23720-23723 (26 January 2012); P4308 (Book of photographs and maps prepared by JeanRené Ruez, 22 June 2009), e-court pp. 24-27 (depicting the route of the column); Tomislav Savkić, T. 3382133822 (15 February 2013); Mevludin Orić, P350 (Transcript from Prosecutor v. Popović et al.), T. 867, 874. See D2941 (Map of BiH marked by Tomislav Savkić), p. 1 (map showing the column route towards Tuzla); P4960 (Combat report signed by Ljubiša Borovčanin, 10-20 July 1995), p. 2. See also Adjudicated Fact 1604.

17038 KDZ045, P5910 (Transcript from Prosecutor v. Krstić), T. 2945-2997, 2996; KDZ425, P381 (Transcript from Prosecutor v. Popović et al.), T. 3510; KDZ425, P380 (Transcript from Prosecutor v. Popović et al.), T. 3574 (under seal); KDZ069, P339 (Transcript from Prosecutor v. Popović et al.), T. 3356; KDZ069, P339 (Transcript from Prosecutor v. Blagojević \& Jokić), T. 1381-1382; KDZ064, P769 (Transcript from Prosecutor v. Popović et al.), T. 646. See also Adjudicated Fact 1598; Jean-René Ruez, T. 23713-23714 (26 January 2012). A smaller number of women, children, and elderly also travelled with the column. KDZ069, P338 (Transcript from 
5038. The column stretched for approximately ten kilometres. ${ }^{17040} \mathrm{ABiH}$ soldiers, not all of whom were armed, led the front third of the column. ${ }^{17041}$ Others were interspersed among the unarmed civilians following behind. ${ }^{17042}$ The members of the column walked in a single file line towards Tuzla. ${ }^{17043}$

\section{d. Potočari}

\section{i. Hotel Fontana Meetings}

\section{(A) First meeting}

5039. On 11 July 1995, upon receiving information about the upcoming meeting between Mladić and DutchBat officers, Momir Nikolić went to Hotel Fontana with Mirko Janković to provide security. ${ }^{17044} 10$ to 15 members of the Bratunac Brigade MP were also sent in for this mission. ${ }^{17045}$

5040. At about 8 p.m., Karremans, Boering, and Rave arrived at the hotel. On entering the premises, they saw several DutchBat soldiers who had been taken prisoner from their OPs on 8 and 9 July $1995 .{ }^{17046}$ Shortly after, a meeting commenced between the VRS and the DutchBat officers. On the VRS side, Mladić, Živanović, Colonel Radoslav Janković of the Main Staff, and Svetozar Kosorić, the Assistant Chief of Staff for Intelligence of the Drina Corps, ${ }^{17047}$ attended the

Prosecutor v. Blagojević \& Jokić), T. 1382; KDZ069, P338 (Transcript from Prosecutor v. Popović et al.), T. 3327-3328, 3381; KDZ045, P5910 (Transcript from Prosecutor v. Krstić), T. 2944; KDZ425, P381 (Transcript from Prosecutor v. Popović et al.), T. 3510. See also Adjudicated Fact 1599.

17039 KDZ064, P769 (Transcript from Prosecutor v. Popović et al.), T. 646.

17040 KDZ069, P339 (Transcript from Prosecutor v. Popović et al.), T. 3356; KDZ064, P769 (Transcript from Prosecutor v. Popović et al.), T. 744.

17041 See Adjudicated Fact 1603; KDZ045, P5910 (Transcript from Prosecutor v. Krstić), T. 2944; KDZ064, P769 (Transcript from Prosecutor v. Popović et al.), T. 647, 744-745; KDZ064, T. 1425 (22 April 2010).

17042 KDZ069, P339 (Transcript from Prosecutor v. Blagojević \& Jokić), T. 1382-1383; KDZ069, P339 (Transcript from Prosecutor v. Popović et al.), T. 3348; KDZ045, P5910 (Transcript from Prosecutor v. Krstić), T. 29962997; KDZ045, T. 22672-22673 (10 January 2012). The Independent Battalion of the Muslim Forces in Srebrenica travelled at the end of the column. See Adjudicated Fact 1603; KDZ425, P381 (Transcript from Prosecutor v. Popović et al.), T. 3512 (stating that he saw about 50 armed Bosnian Muslim men with automatic, semi-automatic and hunting rifles near the end of the column).

17043 KDZ069, P338 (Transcript from Prosecutor v. Blagojević \& Jokić), T. 1383; KDZ069, P338 (Transcript from Prosecutor v. Popović et al.), T. 3354-3356, 3363; KDZ064, P769 (Transcript from Prosecutor v. Popović et al.), T. 646. See also Section IV.C.1.g.i: Opening a corridor for the passage of the column.

17044 Momir Nikolić, T. 24610-24612 (13 February 2012); KW582, D4291 (Transcript from Prosecutor v. Blagojević \& Jokić), T. 3505. See also D3562 (Witness statement of Svetozar Kosorić dated 27 February 2013), para. 5.

17045 Mile Janjić, P1194 (Transcript from Prosecutor v. Blagojević \& Jokić), T. 9759-9761. See also KW582, D4291 (Transcript from Prosecutor v. Blagojević \& Jokić), T. 3504-3506.

17046 P3995 (Witness statement of Albert Rave dated 10 November 2011), paras. 66-67; Pieter Boering, P3969 (Transcript from Prosecutor v. Popović et al.), T. 1942. See also Adjudicated Fact 1518. With regard to DutchBat soldiers taken prisoner from their OPs, see para. 5031, fn. 17017.

17047 D3562 (Witness statement of Svetozar Kosorić dated 27 February 2013), para. 2. 
meeting. ${ }^{17048}$ Also present was Petar Ušćumlić, acting as an interpreter for DutchBat. ${ }^{17049}$ A large camera crew videotaped part of the meeting. ${ }^{17050}$

5041. Mladic dictated the terms of the meeting. ${ }^{17051}$ The first ten minutes were very tense and the DutchBat representatives felt threatened. ${ }^{17052}$ Mladić angrily blamed Karremans for having armed Bosnian Muslims and for the NATO air strikes against VRS positions. ${ }^{17053}$ Mladić also accused DutchBat of having fired at VRS soldiers in Srebrenica. ${ }^{17054}$ Then Mladić asked Karremans what he wanted since he had asked for a meeting. ${ }^{17055}$ Karremans told Mladić that the UNPROFOR BiH Command had ordered Karremans to "negotiate or ask for" the transportation of the Bosnian Muslim population-about 10,000 women and children who were in the UN Compound-and that of DutchBat soldiers. ${ }^{17056}$ According to Karremans, these women and children were sick, tired, and very scared. ${ }^{17057}$ Karremans also asked for humanitarian assistance, such as food and medicine. ${ }^{17058}$

5042. At one point during the meeting, Mladić offered cigarettes to Karremans and the other DutchBat officers, saying "this is not your last cigarette in life". ${ }^{17059}$ When Karremans thanked

17048 Momir Nikolić, T. 24611 (13 February 2012), T. 24859 (16 February 2012); P3995 (Witness statement of Albert Rave dated 10 November 2011), paras. 68, 70; Pieter Boering, P3969 (Transcript from Prosecutor v. Popović et al.), T. 1941-1944, 1948-1949; Pieter Boering, T. 22080-22081 (29 November 2011); D3562 (Witness statement of Svetozar Kosorić dated 27 February 2013), para. 4; Svetozar Kosorić, T. 38694 (23 May 2013); D3932 (Witness statement of Milenko Živanović dated 27 October 2013), para. 7. See also Adjudicated Fact 1516.

17049 D3552 (Witness statement of Petar Ušćumlić 12 March 2013), para. 5.

17050 P3995 (Witness statement of Albert Rave dated 10 November 2011), para. 68; Pieter Boering, P3969 (Transcript from Prosecutor v. Popović et al.), T. 1942-1943, 1946.

17051 P3995 (Witness statement of Albert Rave dated 10 November 2011), para. 70; Adjudicated Fact 1519.

17052 P3995 (Witness statement of Albert Rave dated 10 November 2011), para. 69; Pieter Boering, P3969 (Transcript from Prosecutor v. Popović et al.), T. 1945-1946; P3974 (UNPROFOR letter re meetings with Ratko Mladić on 11 and 12 July 1995), p. 1.

17053 P4201 (Updated Srebrenica Trial Video), Part 1, at 00:40:02-00:40:12; P4202 (Written Compilation Booklet: Srebrenica Trial Video), e-court p. 209.

17054 P4201 (Updated Srebrenica Trial Video), Part 1, at 00:33:28-00:40:20; P4202 (Written Compilation Booklet: Srebrenica Trial Video), e-court pp. 205-210, 213-214; P3995 (Witness statement of Albert Rave dated 10 November 2011), para. 69 (further stating that Mladić threatened to shell the UN Compound); P3974 (UNPROFOR letter re meetings with Ratko Mladić on 11 and 12 July 1995), p. 1.

17055 P4201 (Updated Srebrenica Trial Video), Part 1, at 00:42:59-00:43:03; P4202 (Written Compilation Booklet: Srebrenica Trial Video), e-court p. 210.

17056 P4201 (Updated Srebrenica Trial Video), Part 1, at 00:43:04-00:45:36; P4202 (Written Compilation Booklet: Srebrenica Trial Video), e-court p. 210. See also Adjudicated Fact 1522. When asked by Mladić what was a "proposal for the resolution of this situation", Karremans suggested that DutchBat assist the Bosnian Muslim population to leave the enclave to a place where they would like to go, as the Bosnian Muslims were living in a very miserable way. P4201 (Updated Srebrenica Trial Video), Part 1, at 00:48:05-00:49:55; P4202 (Written Compilation Booklet: Srebrenica Trial Video), e-court pp. 212-213.

17057 P4201 (Updated Srebrenica Trial Video), Part 1, at 00:45:36-00:45:43; P4202 (Written Compilation Booklet: Srebrenica Trial Video), e-court p. 211.

17058 P4201 (Updated Srebrenica Trial Video), Part 1, at 00:45:43-00:47:05; P4202 (Written Compilation Booklet: Srebrenica Trial Video), e-court p. 211.

17059 P4201 (Updated Srebrenica Trial Video), Part 1, at 00:46:50-00:47:22; P4202 (Written Compilation Booklet: Srebrenica Trial Video), e-court p. 211. See also Pieter Boering, P3969 (Transcript from Prosecutor v. Popović et al.), T. 1946. 
Mladić for having treated the detained DutchBat soldiers properly, Mladić stated that DutchBat soldiers were in the hotel but they would not be hosted for a long time "[i]f you keep bombing. [...] We know how to bomb too". ${ }^{17060}$ Mladić also said that neither the DutchBat soldiers nor the Bosnian Muslim population were the objective of VRS operations. ${ }^{17061}$ He then told Karremans to bring the "representatives of the civilian population". ${ }^{17062}$ Mladić added that Karremans could also bring an $\mathrm{ABiH}$ representative should the $\mathrm{ABiH}$ wish to talk. ${ }^{17063}$ According to Rave, Mladić told the DutchBat officers to get in contact with the $\mathrm{ABiH}$ as $\mathrm{ABiH}$ soldiers needed to surrender their weapons and that, if they complied with this demand, they would be taken as POWs and detained. $^{17064}$

5043. Mladić told Karremans to return at 11 p.m. ${ }^{17065}$ and asked him to request some buses, to which Karremans responded that he believed it could be arranged. ${ }^{17066}$ Mladić offered drinks to all the participants and gave a toast. ${ }^{17067}$ After the meeting, which lasted between 30 minutes and one hour, ${ }^{17068}$ the DutchBat officers were escorted back to the Yellow Bridge by Momir Nikolić; they

17060 P4201 (Updated Srebrenica Trial Video), Part 1, at 00:47:35-00:48:05; P4202 (Written Compilation Booklet: Srebrenica Trial Video), e-court p. 212. See also P3995 (Witness statement of Albert Rave dated 10 November 2011), para. 69; P3974 (UNPROFOR letter re meetings with Ratko Mladić on 11 and 12 July 1995), p. 1. Towards the end of the meeting, Karremans asked Mladic if he could meet the detained DutchBat soldiers, to which Mladić agreed. P4201 (Updated Srebrenica Trial Video), Part 1, at 01:08:05-01:08:27; P4202 (Written Compilation Booklet: Srebrenica Trial Video), e-court pp. 226-227. See also P3995 (Witness statement of Albert Rave dated 10 November 2011), para. 72.

17061 P4201 (Updated Srebrenica Trial Video), Part 1, at 00:59:35-01:00:40; P4202 (Written Compilation Booklet: Srebrenica Trial Video), e-court p. 220. See also Adjudicated Fact 1522.

17062 P4201 (Updated Srebrenica Trial Video), Part 1, at 01:00:05-01:02:00: P4202 (Written Compilation Booklet: Srebrenica Trial Video), e-court pp. 220-221. See also P3995 (Witness statement of Albert Rave dated 10 November 2011), para. 70; Adjudicated Fact 1524.

17063 P4201 (Updated Srebrenica Trial Video), Part 1, at 01:02:00-01:02:35: P4202 (Written Compilation Booklet: Srebrenica Trial Video), e-court p. 222. See also P3995 (Witness statement of Albert Rave dated 10 November 2011), para. 70; Adjudicated Fact 1524.

17064 P3995 (Witness statement of Albert Rave dated 10 November 2011), para. 70.

17065 P4201 (Updated Srebrenica Trial Video), Part 1, at 01:09:58-01:10:12; P4202 (Written Compilation Booklet: Srebrenica Trial Video), e-court p. 228; Momir Nikolić, T. 24612 (13 February 2012). See also Adjudicated Fact 1526.

17066 P4201 (Updated Srebrenica Trial Video), Part 1, at 01:10:12-01:10:35; P4202 (Written Compilation Booklet: Srebrenica Trial Video), e-court p. 228. See also P3995 (Witness statement of Albert Rave dated 10 November 2011), para. 71; P3974 (UNPROFOR letter re meetings with Ratko Mladić on 11 and 12 July 1995), p. 1.

17067 P4201 (Updated Srebrenica Trial Video), Part 1, at 01:10:35-01:12:05; P4202 (Written Compilation Booklet: Srebrenica Trial Video), e-court p. 227-228. See also P3995 (Witness statement of Albert Rave dated 10 November 2011), para. 72. According to Živanović, the participants raised a toast for Živanović's departure from the post of the Drina Corps Commander, not for the VRS success in Srebrenica. D3932 (Witness statement of Milenko Živanović dated 27 October 2013), para. 7.

17068 P3995 (Witness statement of Albert Rave dated 10 November 2011), para. 72; Adjudicated Fact 1519. 
then tried to find a representative of the Bosnian Muslim population or the ABiH. ${ }^{17069}$ Nesib Mandžić, a former school teacher, agreed to act as spokesperson for the population. ${ }^{17070}$

\section{(B) Second meeting}

5044. At around 10:30 p.m., Karremans, Boering, and Rave again left Potočari for Hotel Fontana, together with Mandžić, and arrived there at 11 p.m. ${ }^{17071}$ Thereafter, a second meeting commenced. ${ }^{17072}$ Mladić, Radoslav Janković, Kosorić, and Krstić were present, together with Ušćumlić and the video crew. ${ }^{17073}$ Deronjić and Ljubisav Simić, the president of the Bratunac Municipal Assembly, were also present. ${ }^{17074}$ Karremans introduced Mandžić as a representative of the Bosnian Muslim population. ${ }^{17075}$

5045. Reiterating the desperate situation in Potočari, Karremans stated that there were now 15,000 to 20,000 people-amongst whom 88 were wounded - at the UN Compound and the factories around it, and more people—about 95\% women, children, and elderly—were arriving. ${ }^{17076}$ While Karremans was making these remarks, the screaming of a pig being killed was heard. ${ }^{17077}$ Karremans further stated that DutchBat was asking the Bosnian Muslims in Potočari where they wished to be transported, and that an evacuation could be planned depending on their age and

17069 Pieter Boering, P3969 (Transcript from Prosecutor v. Popović et al.), T. 1950; P3995 (Witness statement of Albert Rave dated 10 November 2011), para. 73. See also P4175 (Witness Statement of Robert Franken dated 15 January 2012), para. 68; Adjudicated Fact 1525.

17070 Pieter Boering, P3969 (Transcript from Prosecutor v. Popović et al.), T. 1950-1951; P3995 (Witness statement of Albert Rave dated 10 November 2011), para. 77; P3974 (UNPROFOR letter re meetings with Ratko Mladić on 11 and 12 July 1995), p. 1. Boering had met Mandžić on several occasions but asked him to attend the next meeting at Hotel Fontana only because he saw Mandžić at that time. Pieter Boering, P3969 (Transcript from Prosecutor v. Popović et al.), T. 2137, 2140.

17071 P3995 (Witness statement of Albert Rave dated 10 November 2011), paras. 77-78. See also Pieter Boering, P3969 (Transcript from Prosecutor v. Popović et al.), T. 1951; Radislav Krstić, D4136 (Transcript from Prosecutor v. Krstić), T. 6209; Adjudicated Fact 1531.

17072 Pieter Boering, P3969 (Transcript from Prosecutor v. Popović et al.), T. 1953; Pieter Boering, T. 22082 (29 November 2011); Radislav Krstić, D4136 (Transcript from Prosecutor v. Krstić), T. 6209. See also P1473 (Ratko Mladić's notebook, 27 January-5 September 1995), p. 224; Adjudicated Fact 1527.

17073 Pieter Boering, P3969 (Transcript from Prosecutor v. Popović et al.), T. 1952, 1954, 1959; P3995 (Witness statement of Albert Rave dated 10 November 2011), para. 80; D3552 (Witness statement of Petar Ušćumlić 12 March 2013), para. 5; D3562 (Witness statement of Svetozar Kosorić dated 27 February 2013), para. 4; Svetozar Kosorić, T. 38694 (23 May 2013); Radislav Krstić, D4136 (Transcript from Prosecutor v. Krstić), T. 6209.

17074 P3995 (Witness statement of Albert Rave dated 10 November 2011), para. 80. See also Pieter Boering, P3969 (Transcript from Prosecutor v. Popović et al.), T. 1952; D3398 (Witness statement of Ljubisav Simić dated 7 April 2013), para. 3.

17075 P4201 (Updated Srebrenica Trial Video), Part 1, at 01:13:05-01:13:12; P4202 (Written Compilation Booklet: Srebrenica Trial Video), e-court pp. 230-231. See also Momir Nikolić, T. 24615 (13 February 2012); P4175 (Witness Statement of Robert Franken dated 15 January 2012), para. 68.

17076 P4201 (Updated Srebrenica Trial Video), Part 1, at 01:13:15-01:16:35; P4202 (Written Compilation Booklet: Srebrenica Trial Video), e-court pp. 230-233. See also P1473 (Ratko Mladić's notebook, 27 January-5 September 1995), p. 224; P3995 (Witness statement of Albert Rave dated 10 November 2011), para. 83.

17077 P4201 (Updated Srebrenica Trial Video), Part 1, at 01:14:30-01:15:00; P3995 (Witness statement of Albert Rave dated 10 November 2011), paras. 78-79; Pieter Boering, P3969 (Transcript from Prosecutor v. Popović et al.), T. 1953-1954, 1958-1959. 
health condition. ${ }^{17078}$ According to Karremans, the UNHCR in Belgrade had 30 vehicles available which could be brought in if agreed. ${ }^{17079}$ Mladić then ordered a broken sign from the Srebrenica town hall to be brought in, ${ }^{17080}$ and explained that he took it from "there" and passed through the town on foot; ${ }^{17081}$ for the DutchBat members in attendance, this was a message that the VRS was now in charge. ${ }^{17082}$

5046. Mladić then asked Mandžić what he wanted, to which Mandžić responded that he was not an official representative of the "refugees" and he was "completely unprepared". ${ }^{17083}$ Mladić then told Mandžić as follows:

\begin{abstract}
Please write down the following: Number one, you need to lay down your weapons and I guarantee that all those who lay down their weapons will live. I give you my word, as a man and a General that I will use my influence to help the innocent Muslim population which is not the target of the combat operations carried out by the VRS. Nor are international humanitarian organisations and UNPROFOR forces the targets of our operations. Although NATO forces, as well as UNPROFOR forces, fired today at UNPROFOR's request not only at the positions of the VRS, but also at the civilian population. In order to make a decision as a man and a Commander, I need to have a clear position of the representatives of your people on whether you want to survive [...] stay or vanish. I am prepared to receive here tomorrow at 10 am a delegation of officials from the Muslim side with whom I can discuss the salvation of your people from the enclave, the former enclave of Srebrenica. I shall order a cessation of operations until 10 am tomorrow. If your fighters [...] lay down their arms we shall treat [them] in accordance with international conventions and we guarantee that everybody will live, even those who committed crimes against our people. Have I made myself clear? Nesib, the future of your people is in your hands, not only in this territory. ${ }^{17084}$
\end{abstract}

Mandžić again said that he had been chosen as a representative "by chance", but Mladić instructed him to bring "the people who can secure the surrender of weapons and save your people from

17078 P4201 (Updated Srebrenica Trial Video), Part 1, at 01:27:55-01:28:25; P4202 (Written Compilation Booklet: Srebrenica Trial Video), pp. 238-239.

17079 P4201 (Updated Srebrenica Trial Video), Part 1, at 01:42:59-00:43:03; P4202 (Written Compilation Booklet: Srebrenica Trial Video), pp. 234-235. Karremans added that DutchBat had not had diesel in the Srebrenica enclave since February 1995. P4201 (Updated Srebrenica Trial Video), Part 1, at 01:24:45-01:26:25; P4202 (Written Compilation Booklet: Srebrenica Trial Video), e-court p. 237. See also P3995 (Witness statement of Albert Rave dated 10 November 2011), para. 83.

17080 P4201 (Updated Srebrenica Trial Video), Part 1, at 01:20:22, 01:22:30-01:23:05; P4202 (Written Compilation Booklet: Srebrenica Trial Video), e-court p. 234; Pieter Boering, P3969 (Transcript from Prosecutor v. Popović et al.), T. 1959-1960; P3973 (Video still of Hotel Fontana meeting).

17081 P4201 (Updated Srebrenica Trial Video), Part 1, at 01:42:59-00:43:03; P4202 (Written Compilation Booklet: Srebrenica Trial Video), e-court p. 235; Pieter Boering, P3969 (Transcript from Prosecutor v. Popović et al.), T. 1959-1960.

17082 Pieter Boering, P3969 (Transcript from Prosecutor v. Popović et al.), T. 1960. See also P3995 (Witness statement of Albert Rave dated 10 November 2011), para. 81; Albert Rave, T. 22179 (30 November 2011).

17083 P4201 (Updated Srebrenica Trial Video), Part 1, 01:30:25-01:33:30 (depicting Mandžić asking if there was an agreement "at a higher level", international organisations); P4202 (Written Compilation Booklet: Srebrenica Trial Video), e-court pp. 239-240. See also Radislav Krstić, D4136 (Transcript from Prosecutor v. Krstić), T. 6211-6212.

17084 P4201 (Updated Srebrenica Trial Video), Part 1, at 01:33:30-01:37:15; P4202 (Written Compilation Booklet: Srebrenica Trial Video), e-court pp. 240-241; P3995 (Witness statement of Albert Rave dated 10 November 2011), paras. 82, 84, 86; P3974 (UNPROFOR letter re meetings with Ratko Mladić on 11 and 12 July 1995), p. 2. See also Momir Nikolić, T. 24618-24619 (13 February 2012); Radislav Krstić, D4136 (Transcript from Prosecutor v. Krstić), T. 6211-6214; Adjudicated Facts 1532, 1533, 1536. 
destruction". ${ }^{17085}$ According to Rave, Mladić also told Mandžić that the civilian population was free to go, adding that he could arrange buses to transport people wherever they wanted to go. ${ }^{17086}$

5047. After this meeting, the DutchBat officers and Mandžić returned to the UN Compound, escorted again by Momir Nikolić. ${ }^{17087}$ Mandžić appeared frightened, anxious, and "almost panicking". ${ }^{17088}$ He then went to look for additional representatives and eventually found two other civilians, Ćamila Purković and Ibro Nuhanović, who were willing to support Mandžić. ${ }^{17089}$

third meeting

(C) Conversation between Momir Nikolić, Popović, and Kosorić prior to 5048. On the morning of 12 July, as instructed by Mladić at the Bratunac Brigade Command, ${ }^{17090}$ Popović and Kosorić went to Hotel Fontana. ${ }^{17091}$ Just before the start of the third meeting, Popović and Kosorić met Momir Nikolić and Ušćumlić outside the premises. ${ }^{17092}$ When Nikolić asked Popović what would happen next, Popović replied that Bosnian Muslim women and children would be transferred to Bosnian Muslim-held territory and that military-aged men would be separated. ${ }^{17093}$

\section{(1) Summary of Momir Nikolić's evidence}

5049. Nikolić testified that he further asked Popović what would happen to those men, to which Popović responded that "all the balijas should be killed". ${ }^{17094}$ When Nikolić heard this statement, he thought that, as many officers would say similar things, it was "yet another statement by Popović who had the habit of saying things like that" and that Popović did not mean it. ${ }^{17095}$ Nikolić also stated that, having heard this statement, he thought that legitimate military procedures would be followed, which would entail the identification of suspected war criminals and their subsequent

\footnotetext{
17085 P4201 (Updated Srebrenica Trial Video), Part 1, at 01:37:15-01:37:40; P4202 (Written Compilation Booklet: Srebrenica Trial Video), e-court p. 241. See also Radislav Krstić, D4136 (Transcript from Prosecutor v. Krstić), T. 6212; Adjudicated Fact 1534.

17086 P3995 (Witness statement of Albert Rave dated 10 November 2011), para. 82.

17087 P3995 (Witness statement of Albert Rave dated 10 November 2011), para. 87; Momir Nikolić, T. 24615 (13 February 2012).

17088 P4175 (Witness Statement of Robert Franken dated 15 January 2012), para. 68; Pieter Boering, P3969 (Transcript from Prosecutor v. Popović et al.), T. 1962.

17089 Pieter Boering, P3969 (Transcript from Prosecutor v. Popović et al.), T. 1962, 1968; P3995 (Witness statement of Albert Rave dated 10 November 2011), para. 87. Mandžić was unable to get in touch with the $\mathrm{BiH}$ Government. P4175 (Witness Statement of Robert Franken dated 15 January 2012), para. 68.

17090 See para. 5086.

17091 D3993 (Witness statement of Vujadin Popović dated 2 November 2013), para. 17.

17092 D3993 (Witness statement of Vujadin Popović dated 2 November 2013), para. 18; Momir Nikolić, T. 2462024621 (13 February 2012), T. 24863 (16 February 2012).

17093 Momir Nikolić, T. 24620-24621 (13 February 2012), T. 24645-24646 (14 February 2012), T. 24863 (16 February 2012); D3993 (Witness statement of Vujadin Popović dated 2 November 2013), para. 18.

17094 Momir Nikolić, T. $24646-24647$ (14 February 2012), T. 24863 (16 February 2012). See also para. 2514 (describing the term "balija" as a taunt or insult).
} 
prosecution. ${ }^{17096}$ Nikolić further testified that it was only in Potočari that it became clear to him that something calamitous was in store for "these people who had been singled out". ${ }^{17097}$

5050. After having heard the statement that all the balijas should be killed, Nikolić told Popović that if the Bosnian Muslim men were to be separated, they would have to be detained somewhere and that some empty buildings, such as the Vuk Karadžić School in Bratunac, could be used for this purpose. ${ }^{17098}$ Then, they had a discussion about potential locations where "these people" should be killed, during which the Ciglana brick factory and the Sase mine were mentioned. ${ }^{17099}$ Popović told Nikolić that it was Nikolić's responsibility to "help coordinate and organise this operation". ${ }^{17100}$ According to Nikolić, the whole conversation lasted no longer than ten minutes ${ }^{17101}$ and after Popović left, he, Kosorić, and Ušćumlić had another conversation about the same topic. ${ }^{17102}$

\section{(2) Evidence of Defence witnesses}

5051. The Chamber notes that the Accused called Popović, Kosorić, and Ušćumlić to refute the evidence brought by the Prosecution on this conversation. These three witnesses all challenged Nikolić's evidence. ${ }^{17103}$ Popović, who did not contest that he and Kosorić encountered Nikolić and Ušćumlić prior to the third meeting, ${ }^{17104}$ claimed that Nikolić's statements that Popović had said

\footnotetext{
17095 Momir Nikolić, T. 24648 (14 February 2012).

17096 Momir Nikolić, T. 24644 (14 February 2012).

17097 Momir Nikolić, T. 24622 (13 February 2012).

17098 Momir Nikolić, T. 24622 (13 February 2012).
}

17099 Momir Nikolić, T. 24622-24623 (13 February 2012), T. 24647-24648 (14 February 2012). The Ciglana brick factory was located in Bratunac. See KDZ107, P345 (Transcript from Prosecutor v. Popović et al.), T. 93719372. The Sase mine was located in Srebrenica municipality. Mevludin Orić, P350 (Transcript from Prosecutor v. Popović et al.), T. 917. Momir Nikolić testified that he later heard that a group of officers had gone to the brick factory to investigate whether it would be a suitable execution site, but that ultimately, no killings occurred there. Momir Nikolić, T. 24622-24623 (13 February 2012), 24876-24877 (16 February 2012) (further stating that he heard that this visit occurred before 13 July and denying having taken part himself). Neđo Nikolić confirmed that a group of VRS officers, including Momir Nikolić and Beara, as well as police officer Brano Tešić, indeed came to his office at the Ciglana brick factory, but insisted that this did not occur until the morning of 14 July. D3690 (Witness Statement of Neđo Nikolić dated 8 June 2013), paras. 15, 18A18B; Neđo Nikolić, T. 39823 (12 June 2013). Neđo Nikolić also testified that the officers had not indicated that the site was being considered as a possible site for execution, and had enquired about the availability of drinking water. D3690 (Witness Statement of Neđo Nikolić dated 8 June 2013), paras. 17, 18C. In light of the overwhelming evidence before the Chamber indicating that the Bosnian Muslim males were transferred to Zvornik on the morning of 14 July, the Chamber considers that the events referred to by Neđo Nikolić must have in fact occurred one or two days prior. In view of the totality of evidence, the Chamber considers that the testimony of Neđo Nikolić does not raise any doubt in relation to the veracity of Momir Nikolić's testimony. See Defence Final Brief, paras. 2486-2488.

17100 D2081 (Momir Nikolić's statement of facts from Plea Agreement, 7 May 2003), para. 4.

17101 Nikolić testified that this encounter was not an official meeting. Momir Nikolić, T. 24863 (16 February 2012).

17102 Momir Nikolić, T. 24623 (13 February 2012).

17103 D3562 (Witness statement of Svetozar Kosorić dated 27 February 2013), paras. 6-7; D3552 (Witness statement of Petar Ušćumlić 12 March 2013), para. 7; D3993 (Witness statement of Vujadin Popović dated 2 November 2013), para. 18.

17104 D3993 (Witness statement of Vujadin Popović dated 2 November 2013), para. 18. 
that "men from Srebrenica would be separated and killed" and that they had talked about buildings in which they would be kept until their execution were particularly untrue. ${ }^{17105}$ Popović testified that he never discussed this and that he did not even know that men from Srebrenica would be separated until the third meeting, when Mladić mentioned it. ${ }^{17106}$ Popović claimed that the only thing that was mentioned in his presence was that the men would be questioned about war crimes against Serbs, not that the men being separated would be executed. ${ }^{17107}$

5052. Kosorić testified that Popović did not say anything of the sort claimed by Nikolić. ${ }^{17108}$ Kosorić stood by his prior testimony in the Popović et al. case, in which he denied even the fact that the conversation between Popović, Nikolić, and himself took place outside the hotel, and added that such "a decision must be taken at a higher level, at a meeting, this is not the sort of decision that is taken outside some hotel". ${ }^{17109}$ He also stated that he had no information that Bosnian Muslims from Srebrenica were going to be killed. ${ }^{1710}$ Lastly, Ušćumlić stated that he never heard anyone say that the prisoners from Srebrenica should or would be killed, and he had no knowledge that the prisoners would be killed. ${ }^{17111}$

\section{(3) Prosecution's submissions}

5053. In its final brief, the Prosecution submits that Nikolić's evidence relating to the conversation is reliable and corroborated by other reliable evidence. ${ }^{17112}$ First, video evidence shows that Nikolić was talking outside Hotel Fontana with Janković, Popović, and one of Mladić's bodyguards prior to the meeting, and that Kosorić and Popović were present at the meeting. ${ }^{17113}$ Second, Ušćumlić's evidence corroborates Nikolić's testimony that the conversation among Nikolić, Popović, and Kosorić took place and does not contradict the content of Nikolić's testimony. ${ }^{17114}$ Third, Boering saw Kosorić and Nikolić again in Bratunac after the third meeting. ${ }^{17115}$ Fourth, the Prosecution submits that the following events which unfolded after the conversation support

\footnotetext{
17105 D3993 (Witness statement of Vujadin Popović dated 2 November 2013), para. 18.

17106 D3993 (Witness statement of Vujadin Popović dated 2 November 2013), para. 18.

17107 D3993 (Witness statement of Vujadin Popović dated 2 November 2013), para. 18.

17108 D3562 (Witness statement of Svetozar Kosorić dated 27 February 2013), para. 7; Svetozar Kosorić, T. 38717 (23 May 2013).

17109 Svetozar Kosorić, T. 38715-38716 (23 May 2013).

17110 D3562 (Witness statement of Svetozar Kosorić dated 27 February 2013), para. 8.

17111 D3552 (Witness statement of Petar Ušćumlić 12 March 2013), para. 7.

17112 Prosecution Final Brief, para. 917.

17113 Prosecution Final Brief, para. 917, citing P4201 (Updated Srebrenica Trial Video), Part 2, 00:05:30-00:05:45, 00:06:47-00:15:06; P4202 (Written compilation booklet: Srebrenica Trial video), e-court pp. 61, 63, 65, 68, 245-250.

17114 Prosecution Final Brief, para. 917, citing D3552 (Witness statement of Petar Ušcumlić 12 March 2013).

17115 Prosecution Final Brief, para. 918, Pieter Boering, P3969 (Transcript from Prosecutor v. Popović et al.), T.1976-1977.
} 
Nikolić's version of what was discussed at the third meeting: (i) at that meeting, Mladić stated for the first time that the separation and "screening" of men would be carried out in Potočari; ${ }^{17116}$ (ii) the Vuk Karadžić School and the hangar that Nikolić had suggested as detentions sites during the conversation were indeed used for detention; ${ }^{17117}$ (iii) Beara and Deronjić visited the Ciglana brick factory which, according to Nikolić, was a potential execution site mentioned during the conversation; ${ }^{17118}$ and (iv) Nikolić's account of what he was told would happen to the Bosnian Muslim men in Potočari "corresponds exactly to the tragic events which then followed". ${ }^{17119}$

\section{(4) Accused's submissions}

5054. In his final brief, the Accused submits that Nikolić's testimony about his conversation with Popović and Kosorić is "untrue, unreliable and illogical". ${ }^{17120}$ The Accused argues that while, as seen in the video evidence, Nikolić and Popović were both outside Hotel Fontana on 12 July, Nikolić's testimony about what was said between them is uncorroborated and was refuted by Popović, Kosorić, and Ušćumlić. ${ }^{17121}$ Pointing to Nikolić's testimony that he did not believe that Popović meant what he said when he allegedly said that the men should be killed, the Accused submits that had Popović truly made the statement and discussed the execution sites, "there would have been no reason for Nikolić to expect legitimate military screening in Potočari". ${ }^{17122}$

\section{(5) Chamber's assessment}

5055. The Chamber notes that, in this context, the Accused contends that contrary to Nikolićs testimony indicating that there was a plan to kill the Bosnian Muslim prisoners of Srebrenica from 12 July 1995, such a plan did not exist "prior to the Kravica Warehouse mutiny" that took place around 5:30 p.m. on 13 July 1995, further referring to other pieces of evidence. ${ }^{17123}$ The Chamber is of the view that this specific argument relates more to his challenge to the JCE to eliminate the Bosnian Muslim population in Srebrenica, ${ }^{17124}$ and that it will therefore be discussed separately in

\footnotetext{
17116 Prosecution Final Brief, para. 918, citing Pieter Boering, T. 22063-22064 (29 November 2011); Pieter Boering, P3969 (Transcript from Prosecutor v. Popović et al.), T. 1968-1969, 1972-1973; Adjudicated Fact 1545.

17117 Prosecution Final Brief, para. 918, cross-referencing Prosecution Final Brief, Appendix D, Srebrenica, paras. 80-84.

17118 Prosecution Final Brief, para. 918, citing P4374 (Witness statement of Milenko Katanić dated 11 October 2011), para. 84.

17119 Prosecution Final Brief, para. 919.

17120 Defence Final Brief, para. 2480.

17121 Defence Final Brief, para. 2458 (further arguing that the Prosecution did not challenge Popović on this aspect of his evidence).

17122 Defence Final Brief, paras. 2471-2472.

17123 Defence Final Brief, paras. 2449-2452, 2455, 2459-2480.

17124 The Accused also argues that the issue of when the plan to kill the Bosnian Muslim men of Srebrenica was formed is not critical to his criminal responsibility, but "the fact that the plan to execute the prisoners arose only
} 
the relevant section of this Judgement. ${ }^{17125}$ In the present section, the Chamber will focus on the issue of Nikolić's testimony as to the content of his conversation with Popović and Kosorić, and determine whether the evidence is reliable in this regard.

(a) Momir Nikolić as a convicted person

5056. The Chamber first recalls its general assessment of the credibility of Nikolić as an individual convicted of crimes arising from events charged in the Indictment, ${ }^{17126}$ and notes that it approached his evidence, in particular salient and highly contested evidence, with the utmost caution.

(b) Momir Nikolić's avowed lie

5057. The Chamber first considered the avowed lie Nikolic told the Prosecution in one of his interviews. ${ }^{17127}$ He admitted that when he told the Prosecution that he had been at Kravica and had given orders, he did not speak the truth. ${ }^{17128}$

5058. The Chamber examined his explanation for this untruth, wherein he stated inter alia, in relation to his plea agreement ${ }^{17129}$ that "[...] we' $\mathrm{d}$ been working on [it] for a long time and I did not want it to fall through. I wanted this agreement to be reached". ${ }^{17130}$ In this situation, Nikolić was prepared to sacrifice himself and assume responsibility for something he had not in fact done. The Chamber reviewed his evidence and is satisfied that, unfortunate as it might have been, Nikolić's inconsistency was not the result of any oblique motive to lead the Chamber into error. It was extremely important to him that the agreement did not turn out to be an abysmal failure and he was willing to compromise the veracity of his statement in order to ensure that outcome. The Chamber was also mindful of the fact that Nikolić voluntarily corrected his inconsistency at the first available opportunity. ${ }^{17131}$

after the incident at the Kravica Warehouse is relevant to the Chamber's determination of whether the killings were done with the intent to destroy the group". Defence Final Brief, para. 2451.

17125 See Section IV.C.3.a.iii.B: The expansion of the common plan to eliminate the Bosnian Muslim population in Srebrenica.

17126 See paras. 16-17.

17127 P4385 (Tab B to Plea Agreement, 6 May 2003); Momir Nikolić, T. 24559-24560 (13 February 2012).

17128 P4385 (Tab B to Plea Agreement, 6 May 2003); Momir Nikolić, T. 24559-24560 (13 February 2012).

17129 The Chamber notes that this agreement was admitted into evidence as P4386 (Plea Agreement signed by Momir Nikolić, 7 May 2003).

17130 Momir Nikolić, T. 24880 (16 February 2012).

17131 P4385 (Tab B to Plea Agreement, 6 May 2003); Momir Nikolić, T. 24560 (13 February 2012). 
5059. The Chamber also notes the false identification Nikolić made of himself in a photograph that had been shown to him and the explanation he advanced for that falsity. ${ }^{17132}$ He testified that he thought the individual in the photograph looked like him. He did not want to tell the Prosecution that he was not the person in the photograph; he stated, "[p]erhaps I had forgotten something. So I didn't want to exclude the possibility." ${ }^{17133}$ Nikolić then felt himself impaled on the horns of a dilemma when he was told that the photograph had been taken in Sandići because he knew that he was never in Sandići. As it turned out, the photograph was of another man.

5060. The Chamber holds the view that in his desperation to ensure that he did nothing to jeopardise his agreement with the Prosecution, Nikolić found himself in an intractable situation of his own creation. Accordingly, the Chamber is satisfied that his inconsistency was not inspired by any insidious desire to mislead the Chamber. In its final analysis, the Chamber is convinced that the aforementioned inconsistencies in no way affect Nikolić's overall credibility, nor do they justify a rejection of his evidence. In reaching this conclusion, the Chamber also paid particular attention to the fact that the consistency of the witness remained undiminished throughout his various statements and testimonies in respect of other matters.

(c) Contradiction between the alleged plan to kill all balijas and Nikolić's understanding of the "military screening"

5061. The Chamber also considered what might appear at first sight to be an inconsistency in the testimony of Nikolić. From his evidence, the Chamber is of the view that on hearing Popović's declaration that all the men should be killed, Nikolić considered that Popović's statement was couched in extravagant language and he contemplated that this statement would have pertained only to the alleged war criminals among the men of military age ${ }^{17134}$ who would have been

17132 P4385 (Tab B to Plea Agreement, 6 May 2003); Momir Nikolić, T. 24560-24561 (13 February 2012 ); T. 24881-24882 (16 February 2012).

17133 Momir Nikolić, T. 24882 (16 February 2012).

17134 At times Nikolić referred to those he understood to be separated as "military-aged men", or "able-bodied men". Momir Nikolić, T. 24621, 24628 (13 February 2012), T. 24646-24647 (14 February 2012). However, he further testified, "[w]e would carry out a military task, that we would stick to military procedure, that we would single out those people from whom we had indicia or evidence or documents or witnesses to the effect that they had committed crimes [...]". Momir Nikolić, T. 24621 (13 February 2012), and "they worked on singling out these military-aged men, or, rather, those for whom they had had information to the effect that they had committed crimes during the previous operations". Momir Nikolić, T. 24628 (13 February 2012). He also testified that "[m]ilitary selection involves [...] identifying those who have committed a crime or those whom you suspect of having committed a crime, a war crime, or any other kind of crime, crime against the civilian population or against prisoners, soldiers, and so on and so forth". Momir Nikolić, T. 24644 (14 February 2012). He further stated, "When I heard what Mr. Popovic said, it was my understanding that by going to Potocari a military screening process was to take place, which is a legitimate military procedure entailing identification -- the identification of those who need to be separated, and checks are carried out because there is a possibility of those who committed war crimes and crimes against humanity being present." Momir Nikolić, T. 24645 (14 February 2012). In light of the above testimony, the Chamber finds that, by "military-aged men" or "able- 
separated, hence his participation in the discussion concerning possible locations for their execution. The Chamber considers this interpretation in itself indefensible. Nikolić sought to paint a picture of legality when he spoke of his assumption that they would have done "what was prescribed under the rules", ${ }^{17135}$ but the Chamber sees this as a device utilised by the witness to mask his real thoughts.

5062. The Chamber is satisfied that it was only when events began to unfold in Potočari that he realised that not only alleged war criminals but all men who tried to board the buses, irrespective of their age or physical constitution, were separated. ${ }^{17136}$ Indeed, evidence before the Chamber indicates that being a Bosnian Muslim man was the exclusive criterion for separation, ${ }^{17137}$ and that they were all earmarked for execution. ${ }^{17138}$

5063. The Chamber further considers that, by giving evidence about Popović informing him of plans to separate Bosnian Muslim men and to subsequently kill them, Nikolić directly incriminated himself in these matters. More importantly, ever since Nikolić entered a plea agreement with the Prosecution in 2003, his evidence on this point has remained constant. ${ }^{17139}$

5064. Accordingly, the Chamber is unable to discern any inconsistency in this area of Nikolić's evidence.

\section{(d) Credibility of Defence witnesses}

5065. Last but not least, the Chamber is of the view that the reliability of Nikolić's account is undiminished by Defence evidence. As previously discussed, when Popović gave evidence in this case as a Defence witness, his case was still on appeal and thus the Chamber approached his evidence with great caution. ${ }^{17140}$ With regard to Kosorić, the Chamber considers that he was generally evasive, insisting that he neither saw nor knew anything. Although he adhered to his prior evidence that there was no such conversation as claimed by Nikolić, he confirmed that he, Nikolić, and Popović were all present at Hotel Fontana on the morning of 12 July. ${ }^{17141}$ Taken together with the testimony of Ušćumlić, who testified that he was at the third meeting but denied

\footnotetext{
bodied men" in the above context, Nikolić meant those among the military-aged or able-bodied men who allegedly committed war crimes.

17135 Momir Nikolić, T. 24647-24648 (14 February 2012).

17136 Momir Nikolić, T. 24646-24647 (14 February 2012).

17137 See paras. 5109-5112.

17138 See Section IV.C.3.a.iii.B: The expansion of the common plan to eliminate the Bosnian Muslims in Srebrenica.

17139 See D2081 (Momir Nikolić's statement of facts from Plea Agreement, 7 May 2003), para. 4.

17140 See also para. 18.

17141 Svetozar Kosorić, T. 38694-38695 (23 May 2013); P4202 (Written compilation booklet: Srebrenica Trial video), e-court pp. 63, 65.
} 
the content of the conversation as related by Nikolić, the Chamber finds the evidence of these three witnesses unconvincing and insufficient to jeopardise the Chamber's view of the reliability of Nikolić's evidence on this point.

\section{(e) $\underline{\text { Conclusion }}$}

5066. Accordingly, the Chamber finds Nikolić's testimony reliable. The Chamber therefore accepts his account of the conversation in which Popović told him that all the men in Potočari should be killed.

\section{(D) Third meeting}

5067. On the morning of 12 July, Karremans and Boering went back to Hotel Fontana with the three Bosnian Muslims-Mandžić, Purković, and Nuhanović—escorted by Kosorić. ${ }^{17142}$ This third meeting started at around 10 a.m. ${ }^{17143}$ Mladić, Krstić, Radoslav Janković, Kosorić, and Popović were present, together with Dragomir Vasić, the Chief of the Zvornik CJB, Deronjić, Srbislav Davidović, President of the Bratunac Executive Board, and Ljubisav Simić. ${ }^{17144}$ The Bosnian Muslim civilian population in Potočari was represented by Mandžić, Purković, and Nuhanović. ${ }^{17145}$

17142 Pieter Boering, P3969 (Transcript from Prosecutor v. Popović et al.), T. 1968; Pieter Boering, T. 22060-22063 (29 November 2011); P3995 (Witness statement of Albert Rave dated 10 November 2011), paras. 88, 93; Svetozar Kosorić, T. 38994-38695 (23 May 2013); Srbislav Davidović, P4100 (Transcript from Prosecutor v. Popović et al.),, T. 9203-9204; Srbislav Davidović, T. 24405-24406 (9 February 2012); P4201 (Updated Srebrenica Trial video), Part 2, at 00:06:46; P4202 (Written compilation booklet: Srebrenica Trial video), ecourt p. 65; P4935 (Report of Zvornik CJB, 12 July 1995). See also Radislav Krstić, D4136 (Transcript from Prosecutor v. Krstić), T. 6215.

17143 Pieter Boering, P3969 (Transcript from Prosecutor v. Popović et al.), T. 1967-1968; Pieter Boering, T. 22060 22061 (29 November 2011); Momir Nikolić, T. 24616-24617 (13 February 2012); P2996 (Report of Zvornik CJB, 12 July 1995); P3995 (Witness statement of Albert Rave dated 10 November 2011), para. 93; P4373 (Report of Zvornik CJB, 12 July 1995). See also Adjudicated Fact 1537.

17144 Pieter Boering, P3969 (Transcript from Prosecutor v. Popović et al.), T. 1949, 1968-1969; Pieter Boering, T. 22061, 22063-22064 (29 November 2011); Srbislav Davidović, P4100 (Transcript from Prosecutor v. Popović et al.),, T. 9183, 9203-9204; Srbislav Davidović, T. 24405-24406 (9 February 2012); D3562 (Witness statement of Svetozar Kosorić dated 27 February 2013), para. 4; D3398 (Witness statement of Ljubisav Simić dated 7 April 2013), para. 73; Ljubisav Simić, T. 37270 (16 April 2013) (confirming that he was sitting at Mladić's right hand on the video); P4201 (Updated Srebrenica Trial video), Part 2, at 00:05:30-00:07:22, 00:12:52, 00:13:09; P4202 (Written compilation booklet: Srebrenica Trial video), pp. 66-68, 245-250; D3993 (Witness statement of Vujadin Popović dated 2 November 2013), para. 19; P4935 (Report of Zvornik CJB, 12 July 1995). See also Radislav Krstić, D4136 (Transcript from Prosecutor v. Krstić), T. 6215 . Ušćumlić also attended and interpreted for DutchBat. D3552 (Witness statement of Petar Ušćumlić 12 March 2013), para. 6; Srbislav Davidović, P4100 (Transcript from Prosecutor v. Popović et al.), T. 9203-9204; Srbislav Davidović, T. 24405-24406 (9 February 2012).

17145 Pieter Boering, P3969 (Transcript from Prosecutor v. Popović et al.), T. 1968, 1972; Pieter Boering, T. 22061 (29 November 2011); Srbislav Davidović, P4100 (Transcript from Prosecutor v. Popović et al.),, T. 9203-9204; Srbislav Davidović, T. 24405-24406 (9 February 2012); P4935 (Report of Zvornik CJB, 12 July 1995). See also Momir Nikolić, T. 24619-24620 (13 February 2012); D3398 (Witness statement of Ljubisav Simić dated 7 April 2013), para. 73; Ljubisav Simić, T. 37270-37271 (16 April 2013); Radislav Krstić, D4136 (Transcript from Prosecutor v. Krstić), T. 6215. Members of the Muslim Forces in Srebrenica were not present because they were believed to have already fled the enclave. Pieter Boering, P3969 (Transcript from Prosecutor v. Popović et al.), T. 1968. 
5068. Mladić told the Bosnian Muslim representatives that he wanted to help them and that they could request what they wished, but that he wanted "absolute co-operation". ${ }^{17146}$ Mladic then added that "you can either survive or disappear" and demanded that $\mathrm{ABiH}$ soldiers surrender their weapons. ${ }^{17147}$ He stated that upon compliance with this demand, the Bosnian Muslim civilian population "may choose to stay in the territory or, if so you wish, go wherever you want". ${ }^{17148}$ Furthermore, Mladić noted that he would provide vehicles, but that fuel should be procured by Bosnian Muslims or by UNPROFOR. ${ }^{17149}$

5069. The Bosnian Muslim representatives requested "free passage for able-bodied men because, allegedly they are unarmed and they are not in contact with their army in the woods". ${ }^{17150} \mathrm{~A}$ procedure for transferring the Bosnian Muslim population was also discussed. ${ }^{17151}$ In addition, Boering testified that Mladić mentioned "screening" of the Bosnian Muslim men in Srebrenica based on their ages between about 15 and 70, but the specifics of this screening were not made clear. $^{17152}$ Davidović was assigned to select potential war criminals among the civilian population. $^{17153}$

17146 P4201 (Updated Srebrenica Trial Video), Part 2, at 00:06:47-00:10:05; P4202 (Written Compilation Booklet: Srebrenica Trial Video), e-court pp. 246-248. This meeting was filmed again. Pieter Boering, T. 22065 (29 November 2011); P4201 (Updated Srebrenica Trial video), Part 2, at 00:05:50-00:15:05; P4202 (Written compilation booklet: Srebrenica Trial video), e-court pp. 245-250.

17147 P4201 (Updated Srebrenica Trial Video), Part 2, at 00:10:15-00:10:42; P4202 (Written Compilation Booklet: Srebrenica Trial Video), e-court p. 248. See also Adjudicated Fact 1540. Kosorić agreed to the proposition by the Prosecution that Mladić was saying that unless all the weapons were surrendered, the men might be killed. Svetozar Kosorić, T. 38695-38696 (23 May 2013).

17148 P4201 (Updated Srebrenica Trial Video), Part 2, at 00:10:45-00:11:10; P4202 (Written Compilation Booklet: Srebrenica Trial Video), e-court p. 248. See also P4201 (Updated Srebrenica Trial Video), Part 2, at 00:11:1700:12:50; P4202 (Written Compilation Booklet: Srebrenica Trial Video), pp. 248-249; Adjudicated Fact 1542.

17149 P4201 (Updated Srebrenica Trial Video), Part 2, at 00:11:50-00:12:15; P4202 (Written Compilation Booklet: Srebrenica Trial Video), e-court p. 249. See also Adjudicated Facts 1543, 1544. Davidović testified that it was agreed that DutchBat would provide fuel. Srbislav Davidović, T. 24421 (9 February 2012). However, Boering stated that he was unaware of any agreement between DutchBat and Mladić that DutchBat would supply diesel fuel for the evacuation. Pieter Boering, P3969 (Transcript from Prosecutor v. Popović et al.), T. 1974, 20772078.

17150 P4935 (Report of Zvornik CJB, 12 July 1995); Radislav Krstić, D4136 (Transcript from Prosecutor v. Krstić), T. 6217.

17151 Pieter Boering, T. 22082-20083 (29 November 2011). There was no clear arrangement for caring for the needs of the civilian population, however. Pieter Boering, P3969 (Transcript from Prosecutor v. Popović et al.), T. 1975.

17152 Pieter Boering, T. 22063-22064 (29 November 2011); Pieter Boering, P3969 (Transcript from Prosecutor v. Popović et al.), T. 1969, 1974; Srbislav Davidović, P4100 (Transcript from Prosecutor v. Popović et al.), T. 9209 (testifying that Mladić stated that those "who committed crimes against the Serbian people would be prosecuted"); Adjudicated Fact 1545. Vasić, reporting the outcome of this meeting, stated that it was up to Mladić to let the men go in order to get other men hiding in the woods to surrender. P4935 (Report of Zvornik CJB, 12 July 1995).

17153 Pieter Boering, T. 22063-22064 (29 November 2011); P4201 (Updated Srebrenica Trial Video), Part 2, at 00:13:09; Pieter Boering, P3969 (Transcript from Prosecutor v. Popović et al.), T. 1973; P4202 (Written Compilation Booklet: Srebrenica Trial Video), e-court p. 67. 
5070. At the end of the meeting, Mladic said that the Bosnian Serb civilian authorities should assist the Bosnian Muslim population in Potočari in terms of logistics, water, food, and health care. ${ }^{17154}$ After 11 a.m., the meeting ended hastily as the participants were told that the Bosnian Muslims in Potočari were getting restless, and it was feared that they would set out to Bratunac on foot. ${ }^{17155}$ The Bosnian Muslim representatives were asked to return to Potočari to tell the population that transportation would be provided. ${ }^{17156}$ Vasić reported to the RS MUP that "boarding of vehicles will commence at 1400 hours". 17157

5071. Radoslav Janković came out of the hotel and told Momir Nikolić that everything had been agreed upon regarding the transfer of Bosnian Muslims to Kladanj, and that Nikolić should assist in the transfer and the separation of Bosnian Muslim men. ${ }^{17158}$ Janković further stated that the commanders of the units in charge of the operation had already received orders and specific tasks, and were already in Potočari. ${ }^{17159}$ Janković told Nikolić to talk to Duško Jević- the director of the Jahorina Training Centre and a member of the Special Brigade of the MUP who was present in Potočari-and to assist him. ${ }^{17160}$

5072. Kosorić brought the DutchBat officers and the Bosnian Muslim representatives back to the UN Compound. ${ }^{17161}$ Since Karremans and Boering were not clear about the agreements reached, the procedure for the transportation, and DutchBat's role therein, Karremans instructed Boering and Rave to return to Bratunac to verify what the actual agreements were. ${ }^{17162}$ Around noon, Boering and Rave arrived in Bratunac and managed to meet Momir Nikolić, who was with Kosorić. ${ }^{17163}$

\footnotetext{
17154 Srbislav Davidović, P4100 (Transcript from Prosecutor v. Popović et al.), T. 9207; Srbislav Davidović, T. 24402-24403 (9 February 2012); Ljubisav Simić, T. 37273-37274 (16 April 2013).

17155 Srbislav Davidović, T. 24410, 24433-24434 (9 February 2012); Pieter Boering, T. 22064-22065 (29 November 2011); P4201 (Updated Srebrenica Trial video), Part 2, at 00:15:08. See also Radislav Krstić, D4136 (Transcript from Prosecutor v. Krstić), T. 6218.

17156 Srbislav Davidović, T. 24434 (9 February 2012).

17157 P4935 (Report of Zvornik CJB, 12 July 1995).

17158 Momir Nikolić, T. 24624 (13 February 2012); D2081 (Momir Nikolić's statement of facts from Plea Agreement, 7 May 2003), para. 5.

17159 Momir Nikolić, T. 24624-24625 (13 February 2012).

17160 Momir Nikolić, T. 24625 (13 February 2012). See also para. 5079.

17161 Svetozar Kosorić, T. 38696-38697 (23 May 2013).

17162 Pieter Boering, P3969 (Transcript from Prosecutor v. Popović et al.), T. 1976-1977; Pieter Boering, T. 2206522066 (noting that this confusion was in part due to translation problems), 22082 (29 November 2011); P3995 (Witness statement of Albert Rave dated 10 November 2011), para. 94; Albert Rave, T. 22230 (30 November 2011).

17163 Pieter Boering, P3969 (Transcript from Prosecutor v. Popović et al.), T. 1976-1977; Pieter Boering, T. 22066 (29 November 2011); P3995 (Witness statement of Albert Rave dated 10 November 2011), para. 94 (noting that Ušćumlić interpreted the conversation).
} 
Nikolić told them that everything had been agreed upon; they should get lost and leave immediately; and "things had already started". ${ }^{17164}$

\section{ii. Humanitarian situation and atmosphere in Potočari}

5073. As previously stated, by the morning of 11 July, several thousand Bosnian Muslims in Srebrenica town were making their way towards Potočari. ${ }^{17165}$ The majority, consisting mostly of women, children, and elderly individuals, arrived in Potočari on foot—while others were brought by UN vehicles-and were taken to several facilities in the vicinity of the UN Compound. ${ }^{17166}$ By the evening of 11 July, the UN Compound and the area of the surrounding buildings, including the lead factory and the Zinc factory, were full of Bosnian Muslims. ${ }^{17167}$ Many stayed outside without accommodation. ${ }^{17168}$ DutchBat tried to provide security, placing a red and white tape around the

17164 Pieter Boering, P3969 (Transcript from Prosecutor v. Popović et al.), T. 1976; Pieter Boering, T. 22066 (29 November 2011); P3995 (Witness statement of Albert Rave dated 10 November 2011), para. 94 . See also D2081 (Momir Nikolić's statement of facts from Plea Agreement, 7 May 2003), para. 5. The Chamber notes that Nikolić testified that when he, Kosorić, and Ušćumlić were still talking in front of Hotel Fontana prior to the third meeting, two DutchBat officers came up to them and asked when the buses would arrive and when the transportation would begin. After having taken them to Colonel Lazar Aćamović, Assistant Commander for Rear Services of the Drina Corps, who was standing in front of Hotel Fontana, Nikolic told them that they should go back to Potočari, that "everything had been agreed upon, [...] and that the evacuation would start". Momir Nikolić, T. 24623 (13 February 2012). In Nikolić's recollection, the DutchBat officers were Rave and his "associate". Momir Nikolić, T. 24623-24624 (13 February 2012). However, Rave did not go to Hotel Fontana with Karremans and Boering as he had other obligations. P3995 (Witness statement of Albert Rave dated 10 November 2011), para. 93. The Chamber is of the view that while Nikolić's account of this encounter coincides in large measure with the account described in paragraph 5067 certain areas were inconsistent with other evidence adduced in this case. The Chamber gave this full consideration and is firmly of the opinion that this inconsistency does not in any way compromise the reliability of Nikolić's evidence in general, and in particular the reliability of the conversation that took place before the third meeting.

17165 See paras. 5029-5030.

17166 P4167 (Witness statement of Paul Groenewegen dated 11 November 2011), para. 18; P3948 (Witness statement of Johannes Rutten dated 8 November 2011), paras. 26, 29; P422 (Aerial photograph of Potočari, 13 July 1995); Vincentius Egbers, P331 (Transcript from Prosecutor v. Popović et al.), T. 2717, 2883; KDZ071, P5029 (Transcript from Prosecutor v. Popović et al.), T. 7079-7082, 7138; KDZ039, P3940 (Transcript from Prosecutor v. Popović et al.), T. 17304, 17306-17307, 17371-17373; Mirsada Malagić, P356 (Transcript from Prosecutor v. Krstić), T. 1944-1946; Mirsada Malagić, T. 23475, 23523 (24 January 2012); P398 (Witness statement of Saliha Osmanović dated 18 June 2000), e-court p. 2; P398 (Statement of Saliha Osmanović to Tuzla Cantonal Court, 19 June 2000), e-court p. 10; P393 (Witness statement of Mejra Mešanović dated 19 June 2000), e-court p. 2; P393 (Statement of Mejra Mušanović to Tuzla Cantonal Court, 19 June 2000), e-court, p. 9; P403 (Witness statement of Rahima Malkić dated 17 June 2000), e-court p. 2; KDZ066, P337 (Transcript from Prosecutor v. Krstić), T. 2733-2735; KDZ065, P335 (Transcript from Prosecutor v. Krstić), T. 2329 (under seal). See also Pieter Boering, T. 22121-22123 (29 November 2011); D1968 (Witness statement Pieter Boering dated 28 September 1995), p. 5; P392 (Witness statement of Semija Suljić dated 17 June 2000), e-court p. 2; P392 (Statement of Semija Suljić to Tuzla Cantonal Court, 17 June 2000), e-court p. 8; KDZ186, P358 (Transcript from Prosecutor v. Popović et al.), T. 3600.

17167 Ahmo Hasić, P354 (Transcript from Prosecutor v. Popović et al.), T. 1221, 1231, 1264; P422 (Aerial photograph of Potočari, 13 July 1995); Mirsada Malagić, P356 (Transcript from Prosecutor v. Krstić), T. 1947, 1949-1950; Mirsada Malagić, T. 23479-23480, 23484 (24 January 2012). See also P3995 (Witness Statement of Albert Rave dated 10 November 2011), paras. 61-62.

17168 P4167 (Witness statement of Paul Groenewegen dated 11 November 2011), para. 22; P3948 (Witness statement of Johannes Rutten dated 8 November 2011), paras. 26; 31; P3954 (Aerial photograph of Potočari marked by Johannes Rutten). See also Joseph Kingori, T. 22803 (11 January 2012); KDZ265, P367 (Transcript from Prosecutor v. Krstić), T. 5751-5752; P4752 (Witness statement of Christine Schmitz dated 21 March 2012), para. 38. 
area to indicate that it was secure and under UN surveillance, and to prevent any contact between Bosnian Muslims and members of the Bosnian Serb Forces. ${ }^{17169}$

5074. Potočari and the facilities there were overcrowded with Bosnian Muslims carrying their possessions; they were all fearful. ${ }^{17170}$ There was constant shelling, ${ }^{17171}$ which injured a number of Bosnian Muslims and caused fear amongst them. ${ }^{17172}$ Panic was rampant. ${ }^{17173}$ Shelling continued throughout the night of 11 to 12 July around the UN Compound. ${ }^{17174}$

5075. On the morning of 12 July, panic increased even more when the Bosnian Muslims saw members of the Bosnian Serb Forces coming in from all directions. ${ }^{17175}$ During the course of the day, some houses surrounding Potočari and haystacks were set on fire by members of the Bosnian Serb Forces. ${ }^{17176}$

5076. By that time, between 25,000 and 30,000 Bosnian Muslims were in Potočari, of whom 5 to $10 \%$ were able-bodied men. ${ }^{17177}$ The humanitarian situation was catastrophic; there was not

17169 P3948 (Witness statement of Johannes Rutten dated 8 November 2011), paras. 26, 30; P4175 (Witness Statement of Robert Franken dated 15 January 2012), para. 66; P4167 (Witness statement of Paul Groenewegen dated 11 November 2011), paras. 23, 28-30; Paul Groenewegen, T. 22975-22976 (13 January 2012); P4201 (Updated Srebrenica Trial video), Part 2, at 00:27:16-00:28:47. See also Vincentius Egbers, P331 (Transcript from Prosecutor v. Popović et al.), T. 2719; P3948 (Witness statement of Johannes Rutten dated 8 November 2011), para. 35; Johannes Rutten, T. 21988-21989 (28 November 2011); P4201 (Updated Srebrenica Trial video), Part 2, at 00:20:39-00:24:00.

17170 P3995 (Witness Statement of Albert Rave dated 10 November 2011), para. 61; P4167 (Witness statement of Paul Groenewegen dated 11 November 2011), para. 19; P4752 (Witness statement of Christine Schmitz dated 21 March 2012), para. 38; KDZ070, P341 (Transcript from Prosecutor v. Krstić), T. 1250 (testifying that he and his family found refuge in the corner of the Remont bus compound); KDZ070, P340 (Transcripts from Prosecutor v. Popović et al.), T. 3423 (under seal); P300 (Sketch drawn by KDZ070) (under seal). The Bosnian Muslims were lethargic and in a bad condition. P4175 (Witness Statement of Robert Franken dated 15 January 2012), para. 67. See also KDZ084, P4904 (Transcript from Prosecutor v. Popović et al.), T. 14810 (under seal).

17171 P4752 (Witness statement of Christine Schmitz dated 21 March 2012), para. 38; Pieter Boering, T. 22154 22155 (30 November 2011); P3993 (UNMO report, 11 July 1995). See also KDZ265, P367 (Transcript from Prosecutor v. Krstić), T. 5750-5751; KDZ070, P341 (Transcript from Prosecutor v. Krstić), T. 1249-1250; P395 (Witness statement of Behara Krdžić dated 16 June 2000), e-court p. 2.

17172 KDZ265, P367 (Transcript from Prosecutor v. Krstić), T. 5750-5751; KDZ070, P341 (Transcript from Prosecutor v. Popović et al.), T. 3475; Pieter Boering, T. 22154-22155 (30 November 2011); P3993 (UNMO report, 11 July 1995); Mirsada Malagić, T. 23479 (24 January 2012); Mirsada Malagić, P356 (Transcript from Prosecutor v. Krstić), T. 1946-1947.

17173 Vincentius Egbers, P331 (Transcript from Prosecutor v. Popović et al.), T. 2719.

17174 Ahmo Hasić, P354 (Transcript from Prosecutor v. Popović et al.), T. 1221, 1231, 1264; Mirsada Malagić, T. 23478-23479 (24 January 2012).

17175 P3948 (Witness statement of Johannes Rutten dated 8 November 2011), paras. 32-35; KDZ070, P341 (Transcript from Prosecutor v. Krstić), T. 1250-1251.

17176 P3948 (Witness statement of Johannes Rutten dated 8 November 2011), para. 32, 34; P3995 (Witness Statement of Albert Rave dated 10 November 2011), paras. 89, 91; Adjudicated Fact 1507.

17177 P2987 (Report of RS MUP's Special Police Brigade, 13 July 1995), p. 1; P4935 (Report of Zvornik CJB, 12 July 1995); P4960 (Combat report signed by Ljubomir Borovčanin, 10-20 July 1995), p. 2; P4388 (Drina Corps report to VRS Main Staff, 12 July 1995), p. 2; P4936 (Report of Sarajevo RDB, 12 July 1995); P4140 (Witness statement of Joseph Kingori dated 8 January 2002), para. 164; P4156 (UNMO Report, 12 July 1995), p. 4; P4936 (Report of Sarajevo RDB, 12 July 1995). See also P3995 (Witness Statement of Albert Rave dated 10 November 2011), para. 96; P4173 (Witness statement of Roger Patelski dated 30 November 2011), para. 22. 
enough water, food, or medicine for the Bosnian Muslims, and there were insufficient toilet facilities. ${ }^{17178}$ The heat was stifling. ${ }^{17179}$ Some women gave birth. ${ }^{17180}$ Some people died, while others committed suicide or attempted to do so. ${ }^{17181}$

5077. During the night between 12 and 13 July, gunfire was heard in the vicinity of the UN Compound. ${ }^{17182}$ Bosnian Muslims in Potočari were beaten and sexually assaulted by members of the Bosnian Serb Forces. ${ }^{17183}$ Some were taken away from the facilities in Potočari and did not come back. ${ }^{17184}$ Such abuses continued on 13 July. ${ }^{17185}$

\section{iii. Taking control of Potočari and disarming of DutchBat}

5078. Early in the morning of 12 July, further to an order issued by Mladić to Borovčanin in Pribićevac during the night of 10 to 11 July 1995, ${ }^{17186}$ joint units of the Bosnian Serb Forces took control of OP Papa at Yellow Bridge. ${ }^{17187}$ The units involved consisted of MUP members commanded by Borovčanin-the $1^{\text {st }}$ PJP Company from Zvornik, the Jahorina Recruits led by

17178 Joseph Kingori, T. 22803 (11 January 2012); P4175 (Witness Statement of Robert Franken dated 15 January 2012), para. 66; KDZ265, P367 (Transcript from Prosecutor v. Krstić), T. 5751-5752; Vincentius Egbers, P331 (Transcript from Prosecutor v. Popović et al.), T. 2719; Pieter Boering, T. 22154 (30 November 2011); P841 (UNMO report, 11 July 1995); P3993 (UNMO report, 11 July 1995); P4936 (Report of Sarajevo RDB, 12 July 1995); P3995 (Witness Statement of Albert Rave dated 10 November 2011), para. 96; P3995 (Witness Statement of Albert Rave dated 10 November 2011), para. 96; Mirsada Malagić, P356 (Transcript from Prosecutor v. Krstić), T. 1954; P4165 (Report from the Srebrenica Enclave, 24 July 1995), p. 5. See also Adjudicated Facts 1503, 1504.

17179 See Adjudicated Fact 1503; P3995 (Witness Statement of Albert Rave dated 10 November 2011), para. 96; Vincentius Egbers, P331 (Transcript from Prosecutor v. Popović et al.), T. 2719, 2803; Mirsada Malagić, T. 23476, 23488 (24 January 2012); Mile Janjić, P1194 (Transcript from Prosecutor v. Blagojević \& Jokić), T. 9772; KDZ265, P367 (Transcript from Prosecutor v. Krstić), T. 5751-5752; P4752 (Witness statement of Christine Schmitz dated 21 March 2012), para. 38.

17180 P4173 (Witness statement of Roger Patelski dated 30 November 2011), para. 22.

17181 P4175 (Witness Statement of Robert Franken dated 15 January 2012), paras. 96-97; P4173 (Witness statement of Roger Patelski dated 30 November 2011), para. 24. See also P4167 (Witness statement of Paul Groenewegen dated 11 November 2011), para. 47; Mirsada Malagić, P356 (Transcript from Prosecutor v. Krstić), T. 19591960; Mirsada Malagić, T. 23533-23534 (24 January 2012). See also Adjudicated Fact 1510.

17182 P3995 (Witness Statement of Albert Rave dated 10 November 2011), para. 112.

17183 D2081 (Momir Nikolić's statement of facts from Plea Agreement, 7 May 2003), para. 6; P396 (Witness statement of Hanifa Hafizović dated 16 June 2000), e-court p. 2. See also Ahmo Hasić, P354 (Transcript from Prosecutor v. Popović et al.), T. 1176-1177; Mirsada Malagić, T. 23488 (24 January 2012); P395 (Witness statement of Behara Krdžić dated 16 June 2000), e-court p. 2.

17184 P401 (Witness statement of Šehra Ibišević dated 21 June 2000), e-court p. 3; P401 (Witness statement of Šehra Ibišević dated 21 June 2000), e-court p. 9; Mirsada Malagić, P356 (Transcript from Prosecutor v. Krstić), T. 1955-1959. See Adjudicated Fact 1509.

17185 P4752 (Witness statement of Christine Schmitz dated 21 March 2012), para. 54. But see Mile Janjić, P1194 (Transcript from Prosecutor v. Blagojević \& Jokić), T. 9779, 9783, 9796, 9828; Mile Janjić, P372 (Transcript from Prosecutor v. Popović et al.), T. 18005-18006; Srbislav Davidović, T. 24407 (9 February 2012); Zoran Petrović-Piroćanac, P376 (Transcript from Prosecutor v. Popović et al.), T. 18848.

17186 See P4960 (Combat report signed by Ljubomir Borovčanin, 10-20 July 1995), p. 1.

17187 P2987 (Report of RS MUP's Special Police Brigade, 13 July 1995), p. 1; P4960 (Combat report signed by Ljubomir Borovčanin, 10-20 July 1995), p. 2. See also P5091 (Report of Sarajevo RDB, 12 July 1995). 
Duško Jević and $1^{\text {st }}$ Company Commander Mendeljev Đurić, as well as a mixed company of the Janja MUP_and Bratunac Brigade soldiers. ${ }^{17188}$

5079. At OP Papa, these forces seized the DutchBat members' helmets, flak jackets, weapons, and an APC, and disconnected them from contact with their operations room. ${ }^{17189}$ The DutchBat soldiers were held at gunpoint and detained until 9 p.m. ${ }^{17190}$ Members of the Bosnian Serb Forces, including members of the Jahorina Recruits, ${ }^{17191}$ proceeded along the road towards Potočari. ${ }^{17192}$ They fired rounds which landed in the vicinity of the UN Compound. ${ }^{17193}$ Bosnian Serb soldiers deployed in attack formation towards the UN Compound, proceeding until they were stopped by the red and white tape used by DutchBat to demarcate the area where the Bosnian Muslims were. ${ }^{17194}$ DutchBat soldiers posted themselves around the compound and the factories. ${ }^{17195}$ Members of the Jahorina Recruits were deployed around the UN Compound. ${ }^{17196}$ Some Bosnian Serb soldiers, including the Drina Wolves, walked around the premises. ${ }^{17197}$ Borovčanin saw members of the Bratunac Brigade MP conducting "certain check-ups" for military-aged Bosnian

17188 P4960 (Combat report signed by Ljubomir Borovčanin, 10-20 July 1995), p. 1; P2987 (Report of RS MUP's Special Police Brigade, 13 July 1995), p. 1; KDZ084, P4904 (Transcript from Prosecutor v. Popović et al.), T. 14789, 14791, 14800 (under seal); Momir Nikolić, T. 24625 (13 February 2012); Ljubomir Borovčanin, T. 39459 (7 June 2013). See also P4935 (Report of Zvornik CJB, 12 July 1995), p. 2; P5091 (Report of Sarajevo RDB, 12 July 1995); P2996 (Report of Zvornik CJB, 12 July 1995); P4373 (Report of Zvornik CJB, 12 July 1995); P4173 (Witness statement of Roger Patelski dated 30 November 2011), paras. 14-17; P4167 (Witness statement of Paul Groenewegen dated 11 November 2011), para. 25; KDZ186, P358 (Transcript from Prosecutor v. Popović et al.), T. 3601; P4388 (Drina Corps report to VRS Main Staff, 12 July 1995), p. 1. See fn. 17302. Some of the units under Borovčanin's command had also taken part in the Bosnian Serb advance on Srebrenica. See para. 5021.

17189 P4173 (Witness statement of Roger Patelski dated 30 November 2011), para. 14. See also P4373 (Report of Zvornik CJB, 12 July 1995).

17190 P4173 (Witness statement of Roger Patelski dated 30 November 2011), para. 21; D2007 (Roger Patelski's ICTY UN Peacekeeper Interview Questionnaire), p. 1; Roger Patelski, T. 23038, 23040-23041, 23044, 23051 (correcting the date of his detention at OP Papa by members of the Bosnian Serb Forces, as stated in D2007, from 14 July 1995 to 12 July 1995) (16 January 2012).

17191 KDZ084, P4904 (Transcript from Prosecutor v. Popović et al.), T. 14802-14805, 14807-14809 (under seal).

17192 P4173 (Witness statement of Roger Patelski dated 30 November 2011), para. 13; P4167 (Witness statement of Paul Groenewegen dated 11 November 2011), para. 25; P4175 (Witness Statement of Robert Franken dated 15 January 2012), para. 69; P3995 (Witness Statement of Albert Rave dated 10 November 2011), paras. 69, 89; P4960 (Combat report signed by Ljubomir Borovčanin, 10-20 July 1995), pp. 1-2. See also P4173 (Witness statement of Roger Patelski dated 30 November 2011), para. 15; KDZ186, P358 (Transcript from Prosecutor v. Popović et al.), T. 3601; KDZ186, P357 (Transcript from Prosecutor v. Popović et al.), T. 3602, 3625 (under seal).

17193 P3995 (Witness Statement of Albert Rave dated 10 November 2011), para. 89.

17194 P4175 (Witness Statement of Robert Franken dated 15 January 2012), para. 69. See also KDZ186, P358 (Transcript from Prosecutor v. Popović et al.), T. 3601; KDZ186, P357 (Transcript from Prosecutor v. Popović et al.), T. 3602, 3625 (under seal).

17195 P3995 (Witness Statement of Albert Rave dated 10 November 2011), para. 92.

17196 KDZ084, P4904 (Transcript from Prosecutor v. Popović et al.), T. 14802-14805, 14807-14809, 14812 (under seal).

17197 KDZ084, P4904 (Transcript from Prosecutor v. Popović et al.), T. 14810 (under seal); P3995 (Witness Statement of Albert Rave dated 10 November 2011), para. 90. See also Mirsada Malagić, P356 (Transcript from Prosecutor v. Krstić), T. 1951; KDZ186, P358 (Transcript from Prosecutor v. Popović et al.), T. 3605. 
Muslims. ${ }^{17198}$ Some Bosnian Serb soldiers were cursing the Bosnian Muslims. ${ }^{17199}$ By 1 p.m. that day, the Bosnian Serb Forces had taken control of Potočari. ${ }^{17200}$

5080. Around the time vehicles for the transportation of the Bosnian Muslims arrived in Potočari, the DutchBat soldiers who were stationed near the bus premises were threatened with weapons by members of the Jahorina Recruits led by Đurić, and had to surrender their weapons, vests, armoury, and communication sets. ${ }^{17201} 11$ DutchBat soldiers and a DutchBat doctor were detained for a few hours at a place next to the bus premises. ${ }^{17202}$ Following repeated protests to Đurić, they were finally released and sent back to the UN Compound. ${ }^{17203}$

5081. On the morning of 13 July, Rave saw Mladić in Potočari and told him that members of the Bosnian Serb Forces had stolen DutchBat's weapons and material. ${ }^{17204}$ Mladić assured Rave that he would instruct his soldiers not to steal anything from DutchBat soldiers. ${ }^{17205}$

\section{iv. Transportation from Potočari between 12 and 21 July 1995}

(A) Provision of vehicles and fuel

5082. On the evening of 11 July, Mladić ordered Petar Škrbić to requisition buses for "an evacuation". 17206 Before 10 a.m. on the morning of 12 July, he placed an urgent call to the RS Ministry of Defence, requesting an order to its Sarajevo and Zvornik secretariats to mobilise at least 50 buses to be sent to the stadium in Bratunac town ("Bratunac stadium") by 2:30 p.m. that

\footnotetext{
17198 D3659 (Witness statement of Ljubomir Borovčanin dated 30 May 2013), para. 16.

17199 KDZ186, P358 (Transcript from Prosecutor v. Popović et al.), T. 3601.

17200 P2987 (Report of RS MUP's Special Police Brigade, 13 July 1995), p. 1. See also P3054 (VRS Main Staff Report, 12 July 1995), p. 4; P4388 (Drina Corps report to VRS Main Staff, 12 July 1995), p. 1.

17201 P3948 (Witness statement of Johannes Rutten dated 8 November 2011), paras. 43-46.

17202 P3948 (Witness statement of Johannes Rutten dated 8 November 2011), paras. 47-48; P3956 (Video still of two soldiers); P3957 (OTP questionnaire by Johannes Rutten, undated), p. 2.

17203 P3948 (Witness statement of Johannes Rutten dated 8 November 2011), para. 47. The Chamber notes that Đurić categorically denied that he took equipment from DutchBat soldiers and detained them. Mendeljev Đurić, T. 42080-42081 (29 July 2013). The Chamber does not find this evidence reliable. In reaching that conclusion, the Chamber considered that Đurić had an interest in removing himself from the events in Potočari and his evidence in this regard was marked by insincerity and evasiveness.

17204 P3995 (Witness Statement of Albert Rave dated 10 November 2011), para. 117.

17205 P3995 (Witness Statement of Albert Rave dated 10 November 2011), para. 117.

17206 Petar Škrbić, P4523 (Transcript from Prosecutor v. Popović et al.), T. 15472-15473, 15476 (stating that he first received information about the need for buses by telephone on the night of 11 July). Although Škrbić initially could not remember from whom he had received the order, he then adopted his prior statement in which he had said that the mobilisation request came from Mladić but was conveyed "indirectly through somebody". Petar Škrbić, P4523 (Transcript from Prosecutor v. Popović et al.), T. 15472-15473, 15476. See also Petar Škrbić, T. 25973-25974 (7 March 2012) (further testifying that he had received this order via a specific phone which only received calls from the Commander of the VRS Main Staff). The Chamber is therefore satisfied that this order came from Mladić.
} 
day. ${ }^{17207}$ Pursuant to this request, the RS Ministry of Defence ordered these secretariats to immediately procure buses and send them to the designated location by the designated time. ${ }^{17208}$ Following these orders, the RS Ministry of Defence further issued an order to all Ministry of Defence departments in Zvornik, Milići, Vlasenica, Šekovići, and Bratunac, to cancel all regular bus services until further notice, if necessary, so that buses and drivers could immediately report to the "Sports Centre" in Bratunac. ${ }^{17209}$ In compliance with the Ministry of Defence orders, vehicles were indeed mobilised that day, which paralysed regular passenger transport. ${ }^{17210}$

5083. Meanwhile, the Drina Corps also responded to Mladić's order. At 7:35 a.m. on 12 July, Krstić, in his capacity of Chief of Staff of the corps, ${ }^{17211}$ instructed Lieutenant Colonel Rajko Krsmanović, the Drina Corps Chief of Transportation, ${ }^{17212}$ to mobilise 50 buses in total from Pale, Višegrad, Rogatica, Sokolac, Han Pijesak, Vlasenica, Milići, Bratunac, and Zvornik, and send them to the Bratunac stadium by 5 p.m. that day. ${ }^{17213}$

5084. Also on the same morning, Živanović issued an order to his subordinate brigades that all available buses and minibuses belonging to VRS units were to be secured for the use of the Drina Corps and sent to the Bratunac stadium. ${ }^{17214}$ He also gave instructions about locations for fuel distribution, and stated that the Drina Corps command had sent a message to the RS Ministry of Defence asking for private buses to be mobilised. ${ }^{17215}$ The subordinate brigades complied with this order and sent the vehicles as requested. ${ }^{17216}$

\footnotetext{
17207 P4525 (VRS Main Staff Order, 12 July 1995); Petar Škrbić, P4523 (Transcript from Prosecutor v. Popović et al.), T. 15471-15472.

17208 P4526 (RS Ministry of Defence request to Sarajevo Secretariat of the Defence Ministry, 12 July 1995); P4527 (RS Ministry of Defence request to Zvornik Secretariat of the Defence Ministry, 12 July 1995); P4528 (RS Ministry of Defence request to Zvornik Secretariat of the Defence Ministry, 12 July 1995); Petar Śkrbić, P4523 (Transcript from Prosecutor v. Popović et al.), T. 15474-15477. See also Adjudicated Fact 1567.

17209 Petar Škrbić, P4523 (Transcript from Prosecutor v. Popović et al.), T. 15479-15481; P4538 (Order of RS Ministry of Defence, 12 July 1995); P4539 (Order of RS Ministry of Defence, 12 July 1995).

17210 See P4552 (RS Ministry of Defence report, 13 July 1995).

17211 Richard Butler, T. 27509 (17 April 2012).

17212 Richard Butler, T. 27509 (17 April 2012); P4920 (Diagrams of various VRS Military Command structures), p. 2.

17213 P4680 (Intercept of conversation between General Krstić and Lt. Col. Krsmanović, 12 July 1995). See also D2259 (Intercept of conversation between Krstić and Šobot, 12 July 1995); P5274 (Intercept of conversation between Lt. Col. Krsmanović and an unidentified person, 12 July 1995).

17214 P4533 (Order of Drina Corps, 12 July 1995) (indicating that the order was received at 8:35 a.m. on 12 July 1995); Petar Škrbić, P4523 (Transcript from Prosecutor v. Popović et al.), T. 15482; Adjudicated Fact 1566.

17215 P4533 (Order of Drina Corps, 12 July 1995). See also Adjudicated Fact 1566.

17216 P4577 (Zvornik Brigade Combat Report, 12 July 1995); KDZ122, T. 26151-26152 (13 March 2012) (closed session); P4540 ( $5^{\text {th }}$ Podrinje Light Infantry Brigade Combat Report, 12 July 1995) (indicating that Commander of the $5^{\text {th }}$ Light Infantry Brigade, Furtula, reported to the Drina Corps Command that his brigade carried out the Drina Corps Command order, P4533); Petar Škrbić, P4523 (Transcript from Prosecutor v. Popović et al.), T. 15483. See also Adjudicated Facts 1569, 1570.
} 
5085. Pursuant to Mladić's order, at 10 a.m. that morning, the Drina Corps command informed the Main Staff that buses it had requested from the Drina Corps units had been secured, noting that the command did not know the final destination of the transportation at that time. ${ }^{17217}$ On the same morning, Vasić reported to the RS MUP that 100 trucks had been provided for transport. ${ }^{17218}$

5086. Earlier that morning, at around 8 a.m., a meeting had been held at the Bratunac Brigade Command, where Mladić, Krstić, Deronjić, and Vasić, among others, were present, and "tasks were assigned to all participants". ${ }^{17219}$ Mladić asked Davidović, Simić, and Aleksandar Tešić-the Secretary of the Secretariat of National Defence in Bratunac-, all of whom were also present at this meeting, what to do with the Bosnian Muslims from Srebrenica. ${ }^{17220}$ Mladić stated that "there were many of [Bosnian Muslims from Srebrenica and] we need quite a few vehicles". ${ }^{17221}$ Mladić went on to instruct Tešić that buses and trucks be mobilised immediately to transport about " 20,000 residents, today or tomorrow."17222

5087. Meanwhile, the VRS was encountering problems with acquiring enough fuel. ${ }^{17223}$ For instance, the Drina Corps command requested additional fuel: 10,000 litres of diesel and 2,000 litres of petrol. ${ }^{17224}$ Furthermore, the Bratunac Brigade was monitoring fuel disbursements to buses and trucks on 12 and 13 July. ${ }^{17225}$

5088. In line with the order to provide vehicles for transportation from the Srebrenica enclave, on the same day, the Drina Corps command issued an urgent order to the Zvornik and Bratunac Brigades, instructing that traffic at the Konjević Polje intersection and on the Konjević Polje-

17217 D1971 (Order of Drina Corps, 12 July 1995). See also P5364 (Intercept of conversation between two unidentified persons, 12 July 1995) (reflecting the conversation of two unidentified individuals about vehicles they were collecting from several places, including Pale, Sokolac, Bratunac, and Bijeljina, and noting that "over 50 buses" had been thus far obtained).

17218 P4373 (Report of Zvornik CJB, 12 July 1995).

17219 P4373 (Report of Zvornik CJB, 12 July 1995); Momir Nikolić, T. 24617-24618 (13 February 2012); D3118 (Witness statement of Aleksandar Tešić dated 10 March 2013), para. 34.

17220 Srbislav Davidović, P4100 (Transcript from Prosecutor v. Popović et al.), T. 9198-9200; D3398 (Witness statement of Ljubisav Simić dated 7 April 2013), para. 72; Ljubisav Simić, T. 37264 (16 April 2013); D3118 (Witness statement of Aleksandar Tešić dated 10 March 2013), paras. 33-34.

17221 D3118 (Witness statement of Aleksandar Tešić dated 10 March 2013), para. 34.

17222 D3118 (Witness statement of Aleksandar Tešić dated 10 March 2013), paras. 35-36 (stating that after he went back to his office he received an order from the Zvornik Secretariat of National Defence for the mobilisation of vehicles, and that he then contacted the Vihor bus company; one bus from the company was eventually mobilised).

17223 P4681 (Intercept of conversation between two unidentified persons, 12 July 1995); P5364 (Intercept of conversation between two unidentified persons, 12 July 1995) (in which the interlocutors noted that the "request for fuel has been forwarded to Krstić”); P5901 (Intercept of conversations between Lt. Col. Krsmanović and unidentified person, 12 July 1995).

17224 D1971 (Order of Drina Corps, 12 July 1995).

17225 Adjudicated Fact 1568. 
Bratunac Road be regulated, and that priority should be given to the "buses for evacuation". ${ }^{17226}$ As instructed, the Zvornik Brigade implemented the order, sending its MP detachment to Konjević Polje. $^{17227}$

5089. At some point on 12 July, UNMO Joseph Kingori ${ }^{17228}$ saw Mladić in Potočari and told him about the UN's intention to remove the population from Srebrenica on buses. ${ }^{17229}$ Mladić responded that he already had his own buses and that he would transport the people to Tuzla to "join their brothers there". ${ }^{17230}$ Soon after, the buses started arriving. ${ }^{17231}$

5090. Around 2 or 3 p.m. in the afternoon, Colonel Lazar Aćamović, the Drina Corps Assistant Commander for Rear Services, ${ }^{17232}$ came to see Franken, said that he was responsible for the transportation of the civilians, and asked for transportation and fuel; however, DutchBat did not have any fuel. ${ }^{17233}$

5091. On 13 July, the RS Ministry of Defence sent similar orders to the Sarajevo and Zvornik secretariats, as well as to the Bijeljina secretariat this time requesting the immediate mobilisation of transportation vehicles and drivers from designated municipalities, either to be sent to the Bratunac stadium or to be on call. ${ }^{17234}$ The problem with fuel persisted; Vasić noted that they needed ten tons. $^{17235}$

5092. At about 10 to 11 a.m. on 13 July, Aćamović arrived at the UN Compound and spoke to DutchBat officers about the DutchBat convoy coming from Belgrade bringing diesel, rations, and water for DutchBat. ${ }^{17236}$ Aćamović wanted the diesel to be shared with the VRS and for buses to be

\footnotetext{
17226 P4574 (Order of Drina Corps, 12 July 1995). See also D2259 (Intercept of conversation between Krstić and Šbot, 12 July 1995) (in which Krstić instructed the Vlasenica Brigade to secure the road).

17227 KDZ122, T. 26144-26145 (12 March 2012) (closed session).

17228 P4140 (Witness statement of Joseph Kingori dated 8 January 2002), para. 3.

17229 P4140 (Witness statement of Joseph Kingori dated 8 January 2002), para. 167.

17230 P4140 (Witness statement of Joseph Kingori dated 8 January 2002), paras. 167-168. See also Joseph Kingori, T 22805 (11 January 2012) (noting that when he saw Mladić a second time, Mladić said that he had arranged vehicles for the transportation); Joseph Kingori, T. 22945-22947 (13 January 2012).

17231 P4140 (Witness statement of Joseph Kingori dated 8 January 2002), para. 169. See also P3995 (Witness statement of Albert Rave dated 10 November 2011), para. 97; para. 5093.

17232 P4920 (Diagrams of various VRS Military Command structures), p. 2.

17233 P4175 (Witness Statement of Robert Franken dated 15 January 2012), para. 75.

17234 Petar Škrbić, P4523 (Transcript from Prosecutor v. Popović et al.), T. 15477-15478; P4529 (RS Ministry of Defence request to Sarajevo Secretariat of the Defence Ministry, 13 July 1995); P4530 (RS Ministry of Defence request to Zvornik Secretariat of the Defence Ministry, 13 July 1995); P4531 (RS Ministry of Defence request to Bijeljina Secretariat of the Defence Ministry, 13 July 1995). Škrbić testified that all these mobilisation orders were in response to the Main Staff's 12 July 1995 request. Petar Škrbić, P4523 (Transcript from Prosecutor v. Popović et al.), T. 15474-15478, 15480-15481.

17235 P4942 (Report of Zvornik CJB, 13 July 1995).

17236 P3995 (Witness Statement of Albert Rave dated 10 November 2011), para. 120.
} 
used for the transportation of the Bosnian Muslims in Potočari. ${ }^{17237}$ Franken and Janković agreed that 30,000 litres of diesel from DutchBat would go to the VRS in Bratunac. ${ }^{17238}$ At the end of 14 July, a convoy arrived with diesel. ${ }^{17239}$ After the transportation of the Bosnian Muslims out of Potočari had ended, Franken received orders that as soon as DutchBat obtained fuel, it should be provided to the VRS. ${ }^{17240}$ Fuel was provided to the VRS on 16 July. ${ }^{17241}$

(B) Arrival of vehicles, the boarding process, and the separation of men

5093. On 12 July, buses and trucks started arriving in Potočari. ${ }^{17242}$ They aligned themselves along the road outside the UN Compound facing the direction of Bratunac. ${ }^{17243}$ There was a heavy presence of Bosnian Serb Forces. ${ }^{17244}$ Some of them were drunk and some had German shepherds with them. ${ }^{17245}$ At around 12:40 p.m., the transportation of the Bosnian Muslims in Potočari began. ${ }^{17246}$ The process was filmed by personnel from the press centre of the Drina Corps command. ${ }^{17247}$

5094. The Bosnian Muslims were led to the vehicles from the area where they were assembled. ${ }^{17248}$ DutchBat soldiers and members of the Bosnian Serb Forces formed a human chain, holding hands together, standing in the road between the Bosnian Muslims and the vehicles, letting

\footnotetext{
17237 P3995 (Witness Statement of Albert Rave dated 10 November 2011), para. 120.

17238 P3995 (Witness Statement of Albert Rave dated 10 November 2011), para. 120.

17239 P3995 (Witness Statement of Albert Rave dated 10 November 2011), para. 120.

17240 P4175 (Witness Statement of Robert Franken dated 15 January 2012), para. 75.

17241 P4175 (Witness Statement of Robert Franken dated 15 January 2012), para. 75.
}

17242 Momir Nikolić, T. 24638-24639 (14 February 2012); Pieter Boering, T. 22148 (30 November 2011). See also P4752 (Witness statement of Christine Schmitz dated 21 March 2012), para. 42; KDZ186, P358 (Transcript from Prosecutor v. Popović et al.), T. 3606; P4140 (Witness statement of Joseph Kingori dated 8 January 2002), para. 167; P3948 (Witness statement of Johannes Rutten dated 8 November 2011), para. 39; Vincentius Egbers, P331 (Transcript from Prosecutor v. Popović et al.), T. 2719; P3995 (Witness Statement of Albert Rave dated 10 November 2011), paras. 95-96.

17243 P4752 (Witness statement of Christine Schmitz dated 21 March 2012), para. 42; P4140 (Witness statement of Joseph Kingori dated 8 January 2002), para. 169.

17244 P4752 (Witness statement of Christine Schmitz dated 21 March 2012), paras. 42-43.

17245 P4752 (Witness statement of Christine Schmitz dated 21 March 2012), para. 43.

17246 P6694 (Intercept of conversation between Ratko Mladić and unknown, 12 July 1995) (in which one speaker informed Mladic that the buses had left ten minutes before, namely at 12:40); D2258 (Intercept of conversation between unidentified individuals in VRS, 12 July 1995) (a conversation at 12:40 p.m. in which one interlocutor informed the other that the transportation was beginning); Momir Nikolić, T. 24638-24639 (14 February 2012); P3995 (Witness Statement of Albert Rave dated 10 November 2011), para. 95; P4960 (Combat report signed by Ljubomir Borovčanin, 10-20 July 1995), p. 2.

17247 Momir Nikolić, T. 24635-24636 (14 February 2012) (testifying that "in those videos, one attempted to demonstrate that everything was being done in accordance with the rule, but in fact [...] only the first convoy and only one convoy was filmed and nothing else after that [...]").

17248 Momir Nikolić, T. 24631 (13 February 2012); P3995 (Witness Statement of Albert Rave dated 10 November 2011), para. 95; P4140 (Witness statement of Joseph Kingori dated 8 January 2002), para. 170; P4167 (Witness statement of Paul Groenewegen dated 11 November 2011), para. 32. 
people pass, and stopping them when a given bus was full. ${ }^{17249}$ While most of those who were taken to the vehicles were women, children, and elderly men, ${ }^{17250}$ some military-aged men were able to get onto them. ${ }^{17251}$ The first convoy consisted of more than ten buses and several trucks. ${ }^{17252}$ About 50 to 60 people were boarded onto each bus. ${ }^{17253}$

5095. After the first convoy departed, while women and children were heading towards the vehicles, men and boys were separated by members of Bosnian Serb Forces and taken to the White House, ${ }^{17254}$ a building located about 150 metres away from the entrance to the UN Compound from where they could have been seen. ${ }^{17255}$ Bosnian Serb soldiers with guns stood near the buses. ${ }^{17256}$ When a woman tried to run to her brother when he was separated from her, a soldier caught her by the hair, pushed her, and kicked her. ${ }^{17257}$ Those who tried to hide or withdraw to the back of the

17249 KDZ186, P357 (Transcript from Prosecutor v. Popović et al.), T. 3620 (under seal); KDZ186, P358 (Transcript from Prosecutor v. Popović et al.), T. 3630; KDZ039, P3940 (Transcript from Prosecutor v. Popović et al.), T. 17307-17308; KDZ070, P341 (Transcript from Prosecutor v. Krstić), T. 1256-1257; P4201 (Updated Srebrenica Trial video), Part 3, at 00:03:55-00:05:40. See also P4167 (Witness statement of Paul Groenewegen dated 11 November 2011), para. 30; Zoran Petrović-Piroćanac, P376 (Transcript from Prosecutor v. Popović et al.), T. 18847; Srbislav Davidović, T. 24407 (9 February 2012); Srbislav Davidović, P4100 (Transcript from Prosecutor v. Popović et al.), T. 9314.

17250 P4167 (Witness statement of Paul Groenewegen dated 11 November 2011), para. 42; Pieter Boering, P3969 (Transcript from Prosecutor v. Popović et al.), T. 2010. See also P398 (Statement of Saliha Osmanović to Tuzla Cantonal Court, 19 June 2000), e-court p. 10.

17251 Momir Nikolić, T. 24631 (13 February 2012), T. 24636-24637 (14 February 2012); Pieter Boering, P3969 (Transcript from Prosecutor v. Popović et al.), T. 2010.

17252 Vincentius Egbers, P331 (Transcript from Prosecutor v. Popović), T. 2720, 2804; Pieter Boering, P3969 (Transcript from Prosecutor v. Popović et al.), T. 2020.

17253 Vincentius Egbers, P331 (Transcript from Prosecutor v. Popović et al.), T. 2747.

17254 See Section IV.C.1.d.iv.D: Detention of the separated Bosnian Mulsim men at the White House and transportation to Bratunac.

17255 P4175 (Witness Statement of Robert Franken dated 15 January 2012), paras. 86-87; P3948 (Witness statement of Johannes Rutten dated 8 November 2011), para. 53; P3995 (Witness Statement of Albert Rave dated 10 November 2011), paras. 98, 108; Pieter Boering, P3969 (Transcript from Prosecutor v. Popović et al.), T. 2012, 2015, 2018; Momir Nikolić, T. 24631-24632 (13 February 2012); KDZ039, P3940 (Transcript from Prosecutor v. Popović et al.), T. 17309-17311, 17378; Mile Janjić, P1194 (Transcript from Prosecutor v. Blagojević \& Jokić), T. 9780, 9829-9830; P404 (Witness statement of Samila Salčinović dated 18 June 2000), e-court p. 2; P404 (Statement of Samila Salčinović to Tuzla Cantonal Court, 18 June 2000), e-court p. 13 ; P398 (Witness statement of Saliha Osmanović dated 18 June 2000), e-court pp. 2-3; P398 (Statement of Saliha Osmanović to Tuzla Cantonal Court, 19 June 2000), e-court p. 10; P393 (Witness statement of Mejra Mešanović dated 19 June 2000; Statement of Mejra Mešanović to Tuzla Cantonal Court, 19 June 2000), e-court, p. 9; P403 (Witness statement of Rahima Malkić dated 17 June 2000), e-court p. 2; P403 (Witness statement of Rahima Malkić dated 17 June 2000); Statement of Rahima Malkić to Tuzla Cantonal Court, 17 June 2000), e-court p. 9; KDZ186, P357 (Transcript from Prosecutor v. Popović et al.), T. 3608-3609, 3612-3614, 3616-3617 (under seal); P244 (Aerial image of Potočari marked by KDZ186); P311 (Aerial photograph of Potočari dated 13 July 1995 marked by KDZ186); P414 (Photograph of White House); P3959 (Photograph of the UN Compound and White House). See also P4167 (Witness statement of Paul Groenewegen dated 11 November 2011), para. 32; Vincentius Egbers, P331 (Transcript from Prosecutor v. Popović et al.), T. 2720, 2804; P401 (Witness statement of Šehra Ibišević dated 21 June 2000), e-court p. 3 (testifying that she heard from her mother in law that her father in law tried to get on a bus but Bosnian Serb soldiers separated him and told her mother in law that he would come later, but that she has never seen him since).

17256 P4173 (Witness statement of Roger Patelski dated 30 November 2011), para. 25 (further stating that the Bosnian Muslims "looked at me with death in their eyes, like they thought they would not survive that day").

17257 KDZ186, P357 (Transcript from Prosecutor v. Popović et al.), T. 3611 (under seal). 
group were threatened with weapons and physically forced to board the vehicles. ${ }^{17258}$ They were also kicked and hit. ${ }^{17259}$ Many fainted because of the heat and the crowd. ${ }^{17260}$

5096. At one point, outside the UN Compound, Karremans saw Mladić, who told him that Aćamović would be responsible for the transportation of the Bosnian Muslims. ${ }^{17261}$ Karremans instructed his soldiers to co-ordinate among themselves to provide support to the Bosnian Serb Forces. $^{17262}$

5097. In accordance with Mladić's instructions at the end of the third meeting at the Hotel Fontana, ${ }^{17263}$ at some point on 12 July Davidović and Simić travelled to Potočari with the first batch of bread, water, and medication. ${ }^{17264}$ After the same meeting, Popović was also instructed by Mladić to go to Potočari and to distribute bread and water to the Bosnian Muslims. ${ }^{17265}$ While members of the Bosnian Serb Forces were distributing these items, Mladić arrived and addressed

17258 P4167 (Witness statement of Paul Groenewegen dated 11 November 2011), paras. 32, 35-36, 46. See Adjudicated Fact 1574. See also Johannes Rutten, T. 22045 (28 November 2011); P4140 (Witness statement of Joseph Kingori dated 8 January 2002), para. 172; P4175 (Witness Statement of Robert Franken dated 15 January 2012), para. 81. The Chamber notes that in his Final Brief, citing the testimony of Srbislav Davidović and Ljubisav Simić, the Accused asserts that no Bosnian Muslims were forced onto buses. Defence Final Brief, para. 2432. The Chamber recalls that Davidović testified that the boarding process "seemed voluntary" and that no coercion was used. Srbislav Davidović, P4100 (Transcript from Prosecutor v. Popović et al.), T. 9326. Similarly, Simić stated that "as far as [he] was able to see", no one was forced to board the buses. Ljubisav Simić, T. 37265-37266 (16 April 2013). However, the Chamber notes that Simić became evasive when pressed as to whether Bosnian Muslims would have been free to return to the enclave. Ljubisav Simić, T. 37266 (16 April 2013). Additionally, Davidović stated that he was only in Potočari for two hours on 12 July. Srbislav Davidović, P4100 (Transcript from Prosecutor v. Popović et al.), T. 9209. The Chamber thus does not consider that such evidence directly contradicts the evidence of those who personally observed Bosnian Muslims being physically forced onto buses. Moreover, the Chamber considers that the mere absence of physical force, even if established, would not necessarily negate the forcible nature of the transfer.

17259 P4167 (Witness statement of Paul Groenewegen dated 11 November 2011), para. 36; Momir Nikolić, T. 24631 (13 February 2012); P4173 (Witness statement of Roger Patelski dated 30 November 2011), para. 26. See also Adjudicated Fact 1552.

17260 P3948 (Witness statement of Johannes Rutten dated 8 November 2011), para. 80; Ahmo Hasić, P354 (Transcript from Prosecutor v. Popović et al.), T. 1257-1258.

17261 P4175 (Witness Statement of Robert Franken dated 15 January 2012), para. 74. See also P4140 (Witness statement of Joseph Kingori dated 8 January 2002), paras. 189-190; P4159 (UNMO Report, 13 July 1995).

17262 P4175 (Witness Statement of Robert Franken dated 15 January 2012), para. 74. See also P4167 (Witness statement of Paul Groenewegen dated 11 November 2011), para. 51; P3948 (Witness statement of Johannes Rutten dated 8 November 2011), paras. 79-80.

17263 See paras. 5069-5070.

17264 Srbislav Davidović, P4100 (Transcript from Prosecutor v. Popović et al.), T. 9207-9208; Srbislav Davidović, T. 24403 (9 February 2012); D3398 (Witness statement of Ljubisav Simić dated 7 April 2013), para. 74 . See also P3948 (Witness statement of Johannes Rutten dated 8 November 2011), para. 39; Momir Nikolić, T. 24637 (14 February 2012); Mirsada Malagić, P356 (Transcript from Prosecutor v. Krstić), T. 1962; Ahmo Hasić, P354 (Transcript from Prosecutor v. Popović et al.), T. 1177-1178, 1258; P4165 (Report from the Srebrenica Enclave, 24 July 1995), pp. 5-6.

17265 D3993 (Witness statement of Vujadin Popović dated 2 November 2013), para. 20. The Bosnian Muslim representatives from the meeting at the Hotel Fontana were supposed to meet Davidović in Potočari and help distribute the aid, but the representatives never arrived. Srbislav Davidović, P4100 (Transcript from Prosecutor v. Popović et al.), T. 9316-9317; Srbislav Davidović, T. 24403 (9 February 2012). 
the crowd. ${ }^{17266}$ He told them that anyone wishing to be transported would be transported to Kladanj, and anyone wishing to stay could stay; that women and children would be transported first; and that they would not be harmed. ${ }^{17267}$ As Mladić was addressing the crowd, his soldiers distributed bread, water, and sweets. ${ }^{17268}$ This scene was filmed. ${ }^{17269}$

5098. The next morning, boarding of buses resumed in the approximately 15 buses that had arrived and were parked outside the UN Compound, alongside its fence, facing Bratunac. ${ }^{17270}$ The same process was followed as members of the Bosnian Serb Forces standing near the buses with

17266 D3993 (Witness statement of Vujadin Popović dated 2 November 2013), para. 20; P4175 (Witness Statement of Robert Franken dated 15 January 2012), para. 73; D3562 (Witness statement of Svetozar Kosorić dated 27 February 2013), para. 9 (stating that he went to Potočari with Mladić and Krstić). See also Srbislav Davidović, P4100 (Transcript from Prosecutor v. Popović et al.), T. 9208; Srbislav Davidović, T. 24404 (9 February 2012). Mladić addressed the crowd again on 13 July, telling them not to panic and that everyone would be evacuated before nightfall. Mirsada Malagić, P356 (Transcript from Prosecutor v. Krstić), T. 19631964.

17267 P4201 (Updated Srebrenica Trial video), Part 2, at 00:24:48-00:28:50; P4202 (Written Compilation Booklet: Srebrenica Trial Video), pp. 252, 254. See also P4140 (Witness statement of Joseph Kingori dated 8 January 2002), para. 159; Joseph Kingori, T. 22810 (11 January 2012); P396 (Witness statement of Hanifa Hafizović dated 16 June 2000), p. 2; P194 (Newspaper article entitled "Whitewash of the town has begun", 21 July 1995), p. 1; P2081 (BBC news report re Srebrenica, with transcript); Mile Janjić, P1194 (Transcript from Prosecutor v. Blagojević \& Jokić), T. 9772; P403 (Witness statement of Rahima Malkić dated 17 June 2000), e-court p. 2; P398 (Witness statement of Saliha Osmanović dated 18 June 2000), e-court p. 2; P398 (Statement of Saliha Osmanović to Tuzla Cantonal Court, 19 June 2000), e-court p. 10.

17268 P4175 (Witness Statement of Robert Franken dated 15 January 2012), para. 73 ; P3948 (Witness statement of Johannes Rutten dated 8 November 2011), para. 40; Pieter Boering, P3969 (Transcript from Prosecutor v. Popović et al.), T. 2008; D3993 (Witness statement of Vujadin Popović dated 2 November 2013), para. 20; Ahmo Hasić, P354 (Transcript from Prosecutor v. Popović et al.), T. 1177-1178, 1258. See also D3659 (Witness statement of Ljubomir Borovčanin dated 30 May 2013), para. 17; D3662 (Video still of Ljubomir Borovčanin); D3903 (Witness Statement of Mendeljev Đurić dated 26 July 2013), para. 10. In relation to the distribution of supplies, some witnesses stated that the supplies were only distributed while cameras were filming and they were even taken back when the cameras stopped rolling. P3948 (Witness statement of Johannes Rutten dated 8 November 2011), para. 40; Pieter Boering, P3969 (Transcript from Prosecutor v. Popović et al.), T. 2009. Groenewegen also stated that while he could not recall whether the distribution of bread stopped when filming stopped, he was certain that the distribution was done for purposes of the filming. P4167 (Witness statement of Paul Groenewegen dated 11 November 2011), para. 31. See also P3948 (Witness statement of Johannes Rutten dated 8 November 2011), paras. 41-42. On the other hand, Davidović, Popović, and Borovčanin, who participated in the distribution, refuted these claims. D3993 (Witness statement of Vujadin Popović dated 2 November 2013), para. 20; Srbislav Davidović, P4100 (Transcript from Prosecutor v. Popović et al.), T. 9299, 9315; D3659 (Witness statement of Ljubomir Borovčanin dated 30 May 2013), para. 17. On the basis of this evidence, the Chamber is satisfied that there were instances where the supplies were taken back from the Bosnian Muslims when the filming stopped. The Chamber is also satisfied that, whether food was distributed for the purposes of the cameras which were present or not, the quantities distributed were not such that they could have provided any kind of meaningful relief to the large majority of the population in Potočari.

17269 P4175 (Witness Statement of Robert Franken dated 15 January 2012), para. 73 ; P3948 (Witness statement of Johannes Rutten dated 8 November 2011), para. 40; Pieter Boering, P3969 (Transcript from Prosecutor v. Popović et al.), T. 2008; D3993 (Witness statement of Vujadin Popović dated 2 November 2013), para. 20; Ahmo Hasić, P354 (Transcript from Prosecutor v. Popović et al.), T. 1177-1178, 1258.

17270 P4173 (Witness statement of Roger Patelski dated 30 November 2011), para. 23. See also Vincentius Egbers, P331 (Transcript from Prosecutor v. Popović et al.), T. 2753-2756; Joseph Kingori, T. 22812 (11 January 2012); P4201 (Updated Srebrenica Trial video), Part 2, at 00:06:15-00:07:02; P4167 (Witness statement of Paul Groenewegen dated 11 November 2011), para. 48. 
dogs separated the Bosnian Muslim men from the rest, and took them to the White House. ${ }^{17271}$ Water and food were again distributed to the Bosnian Muslims. ${ }^{17272}$

5099. Members of Jahorina Recruits and the Bratunac Brigade MP controlled the boarding of the buses. ${ }^{17273}$ Members of the MUP, including Milisav Ilic from the Bratunac SJB, assisted in the task. $^{17274}$

5100. Mladić was present in Potočari on 12 and 13 July, constantly moving around with his staff. ${ }^{17275}$ At around 12:50 p.m. on 12 July, Mladić inquired whether buses and trucks had left. ${ }^{17276}$ When told that they had left ten minutes earlier, Mladić was pleased, instructing to continue to monitor the situation and adding: "they've all capitulated and surrendered and we'll evacuate them all-those who want to and those who don't want to". ${ }^{17277}$ Mladić further stated that a corridor towards Kladanj would be open. ${ }^{17278}$

(C) Transportation of women, children, and elderly men to Bosnian Muslim-held territory

5101. Following the boarding process on 12 July, the buses and trucks carrying the Bosnian Muslims from Potočari passed through the Bratunac-Konjević Polje Road, stopping at Tišća, where Bosnian Muslim males who appeared to be older than 14 and younger than 60 or 70 were separated. ${ }^{17279}$ The rest of the Bosnian Muslims, accompanied by DutchBat, continued on foot to

17271 P4201 (Updated Srebrenica Trial video), Part 3, at 00:02:44-00:03:55; KDZ265, P367 (Transcript from Prosecutor v. Krstić), T. 5756; P3948 (Witness statement of Johannes Rutten dated 8 November 2011), para. 85. See also D3126 (Witness statement of Jovan Nikolić dated 10 March 2013), para. 54; Mirsada Malagić, P356 (Transcript from Prosecutor v. Krstić), T.1964-1966, 1972; P414 (Photograph of White House); Mirsada Malagić, T. 23489 (24 January 2012); Mile Janjić, P1194 (Transcript from Prosecutor v. Blagojević \& Jokić), T. 9797-9798; Mile Janjić, P372 (Transcript from Prosecutor v. Popović et al.), T. 17944-17945.

17272 D3126 (Witness statement of Jovan Nikolić dated 10 March 2013), para. 54.

17273 D3903 (Witness Statement of Mendeljev Đurić dated 26 July 2013), paras. 9, 12; Mile Janjić, P372 (Transcript from Prosecutor v. Popović et al.), T. 17941. See Adjudicated Fact 1578. See also KDZ039, P3940 (Transcript from Prosecutor v. Popović et al.), T. 17308-17309.

17274 Mile Janjić, P1194 (Transcript from Prosecutor v. Blagojević \& Jokić), T. 9776; Mile Janjić, P372 (Transcript from Prosecutor v. Popović et al.), T. 17946-17947. See also Adjudicated Fact 1571.

17275 P4167 (Witness statement of Paul Groenewegen dated 11 November 2011), para. 57; P3995 (Witness Statement of Albert Rave dated 10 November 2011), paras. 108, 117; Albert Rave, T. 22182, 22230 (30 November 2011); P4173 (Witness statement of Roger Patelski dated 30 November 2011), para. 20; P3948 (Witness statement of Johannes Rutten dated 8 November 2011), paras. 86-87; P3966 (Photograph of Milenko Živanović). See also P393 (Statement of Mejra Mušanović to Tuzla Cantonal Court, 19 June 2000), e-court, p. 9.

17276 P6694 (Intercept of conversation between Ratko Mladić and unknown, 12 July 1995).

17277 P6694 (Intercept of conversation between Ratko Mladić and unknown, 12 July 1995).

17278 P6694 (Intercept of conversation between Ratko Mladić and unknown, 12 July 1995).

17279 Pieter Boering, T. 22148-22149 (30 November 2011) (testifying that DutchBat was not allowed to follow them); Pieter Boering, P3969 (Transcript from Prosecutor v. Popović et al.), T. 2021. See also P392 (Statement of Semija Suljić to Tuzla Cantonal Court, 17 June 2000), e-court p. 8; P393 (Statement of Mejra Mušanović to Tuzla Cantonal Court, 19 June 2000), e-court p. 9; P398 (Witness statement of Saliha Osmanović dated 18 June 2000), e-court p. 2; Adjudicated Fact 1582. 
Kladanj, and onwards to Bosnian Muslim-held territory. ${ }^{17280}$ The transportation was suspended in the evening. ${ }^{17281}$

5102. The transportation resumed at 7 or 8 a.m. on 13 July and by approximately 9 a.m., up to 10,000 Bosnian Muslims-most of whom were women, children, and elderly men-had been transported out of Potočari. ${ }^{17282}$ Buses continued to depart throughout the day. ${ }^{17283}$ As had been done the previous day, Bosnian Muslim women, children, and the elderly were transported to Kladanj, and then to $\mathrm{ABiH}$ held-territory in Tuzla, ${ }^{17284}$ while the men who had managed to get onboard were again separated and taken off at Tišća. ${ }^{17285}$

17280 Vincentius Egbers, P331 (Transcript from Prosecutor v. Popović et al.), T. 2726-2727; Pieter Boering, P3969 (Transcript from Prosecutor v. Popović), T. 2024-2025; Pieter Boering, T. 22149 (30 November 2011); P404 (Witness Statement of Samila Salčinović to Tuzla Cantonal Court, 18 June 2000), e-court p. 13; KDZ186, P357 (Transcript from Prosecutor v. Popović et al.), T. 3620 (under seal); P392 (Statement of Semija Suljić to Tuzla Cantonal Court, 17 June 2000), e-court p. 8; P393 (Statement of Mejra Mušanović to Tuzla Cantonal Court, 19 June 2000), e-court, p. 9. See also P4175 (Witness Statement of Robert Franken dated 15 January 2012), para. 82; P5112 (Report of Bratunac Brigade to Drina Corps, 12 July 1995), para. 7; Adjudicated Facts 1573, $1583,1584$.

17281 Momir Nikolić, T. 24639 (14 February 2012); D1972 (UNMO report, 12 July 1995); P4175 (Witness Statement of Robert Franken dated 15 January 2012), para. 79; P3995 (Witness Statement of Albert Rave dated 10 November 2011), para. 111; P4167 (Witness statement of Paul Groenewegen dated 11 November 2011), para. 41; P4939 (Report of Sarajevo RDB, 12 July 1995), p. 1.

17282 P3995 (Witness Statement of Albert Rave dated 10 November 2011), para. 113; P4173 (Witness statement of Roger Patelski dated 30 November 2011), para. 23; P4140 (Witness statement of Joseph Kingori dated 8 January 2002), para. 193; P4158 (Fax from UN Military Observer to UNPROFOR, 13 July 1995). See also P4939 (Report of Sarajevo RDB, 12 July 1995), p. 1; Dragan Kijac, T. 44351 (3 December 2013); P4388 (Drina Corps report to VRS Main Staff, 12 July 1995), p. 2; P4175 (Witness Statement of Robert Franken dated 15 January 2012), para. 83; D1972 (UNMO report, 12 July 1995); P5112 (Report of Bratunac Brigade to Drina Corps, 12 July 1995), para. 7; Mile Janjić, P1194 (Transcript from Prosecutor v. Blagojević \& Jokić), T. 9844 9845, 9775-9776; Mile Janjić, P372 (Transcript from Prosecutor v. Popović et al.), T. 17933, 17942-17943; P5366 (Intercept of conversation between Janković, an unidentified General, and an unidentified person, 13 July 1995).

17283 P3995 (Witness Statement of Albert Rave dated 10 November 2011), para. 116; P4175 (Witness Statement of Robert Franken dated 15 January 2012), paras. 83, 98; P4752 (Witness statement of Christine Schmitz dated 21 March 2012), para. 51; P4167 (Witness statement of Paul Groenewegen dated 11 November 2011), para. 48; Vincentius Egbers, P331 (Transcript from Prosecutor v. Popović et al.), T. 2753-2756; Joseph Kingori, T. 22812 (11 January 2012); P4201 (Updated Srebrenica Trial video), Part 3, at 00:06:15-00:07:02; Mile Janjić, P1194 (Transcript from Prosecutor v. Blagojević \& Jokić), T. 9798. At some point on 13 July, Vasić estimated that about 15,000 Bosnian Muslims remained to be transported. P4942 (Report of Zvornik CJB, 13 July 1995).

17284 KDZ064, T. 1294 (21 April 2010), T. 1423 (22 April 2010); KDZ064, P768 (Transcript from Prosecutor v. Popović et al.), T. 644-645, 789-790 (under seal); Mirsada Malagić, P356 (Transcript from Prosecutor v. Krstić), T. 1981-1982; Vincentius Egbers, P331 (Transcript from Prosecutor v. Popović et al.), T. 27562757; P396 (Witness statement of Hanifa Hafizović dated 16 June 2000), e-court p. 2; P396 (Statement of Hafiza Salihović to Tuzla Cantonal Court, 17 June 2000), e-court p. 11; KDZ265, P367 (Transcript from Prosecutor v. Krstić), T. 5756-5757; P401 (Witness statement of Šehra Ibišević dated 21 June 2000), e-court p. 3; P401 (Statement of Šehra Ibišević to Sarajevo Cantonal Court, 21 June 2000), e-court pp. 8-9. See also Adjudicated Facts 1573, 1583; P3948 (Witness statement of Johannes Rutten dated 8 November 2011), paras. 84, 105; P391 (Witness statement of Hafiza Salihović dated 17 June 2000), e-court p. 2; P391 (Statement of Hafiza Salihović to Tuzla Cantonal Court, 17 June 2000), e-court p. 9; P404 (Witness statement of Samila Salčinović dated 18 June 2000), e-court p. 2; P397 (Statement of Razija Pašagić to Tuzla Cantonal Court, 15 June 2000), e-court p. 10; P395 (Witness statement of Behara Krdžić dated 16 June 2000), e-court p. 2 ; P395 (Statement of Behara Krdžić to Tuzla Cantonal Court, 16 June 2000), e-court p. 8. The vehicles carrying Bosnian Muslims to Tuzla were again stopped by soldiers; they took money and valuables from the Bosnian 
5103. On both of these days, stones were thrown at the buses and trucks while en route. ${ }^{17286}$ They were stopped several times; Bosnian Serb soldiers entered the bus, threatened the passengers with knives and asked for foreign currency. ${ }^{17287}$ From the bus, one witness saw a long column of men walking through the woods, with their hands tied behind the nape of their neck. ${ }^{17288}$

5104. The vehicles were escorted by Bratunac Brigade MP members and/or members of the SJB. ${ }^{17289}$ Members of the Bratunac Brigade regulated traffic as the buses passed through Bratunac on their way to Konjević Polje. ${ }^{17290}$ Kosorić also escorted the vehicles. ${ }^{17291}$ On 13 July, the transportation of the remaining Bosnian Muslims was mainly organised by the MUP as the VRS was continuing operations towards Žepa. ${ }^{17292}$

5105. In an attempt to have some control over the transportation, DutchBat organised for the convoy to be escorted. ${ }^{17293}$ At one point, DutchBat cars were stopped and Bosnian Serb Forces threatened them with weapons. ${ }^{17294}$ Approximately 16 jeeps, as well as the weapons, flak jackets, helmets, ammunition, and equipment in the vehicles were stolen from DutchBat on the road from Bratunac to Konjević Polje and Kladanj. ${ }^{17295}$

5106. On both 12 and 13 July, while travelling from Konjević Polje to Milići en route to Kladanj, Egbers saw a few hundred men near the road to Nova Kasaba who were being escorted by members

Muslims; they also took two Bosnian Muslim girls who were not seen again. P401 (Statement of Šehra Ibišević to Sarajevo Cantonal Court, 21 June 2000), e-court p. 8.

17285 KDZ070, P341 (Transcript from Prosecutor v. Krstić), T. 1258-1259, 1261; KDZ070, P341 (Transcript from Prosecutor v. Popović et al.), T. 3426-3427. See also Adjudicated Fact 1582. As to the fate of the separated men, see Section IV.C.1.d.v.C: Transportation of women, children, and elderly men to Bosnian Muslim-held territory.

17286 KDZ265, P367 (Transcript from Prosecutor v. Krstić), T. 5756-5757; Momir Nikolić, T. 24638 (14 February 2012); Adjudicated Fact 1581. Some village residents taunted the passengers with the three-fingered Serb salute. See Adjudicated Fact 1581.

17287 Mirsada Malagić, P356 (Transcript from Prosecutor v. Krstić), T. 1975-1976. See also Vincentius Egbers, P331 (Transcript from Prosecutor v. Popović et al.), T. 2723-2724.

17288 Mirsada Malagić, P356 (Transcript from Prosecutor v. Krstić), T. 1976-1977.

17289 Mile Janjić, P372 (Transcript from Prosecutor v. Popović et al.), T. 17935.

17290 See Adjudicated Fact 1579.

17291 Pieter Boering, P3969 (Transcript from Prosecutor v. Popović et al.), T. 2020-2021; D3562 (Witness statement of Svetozar Kosorić dated 27 February 2013), para. 10.

17292 P4942 (Report of Zvornik CJB, 13 July 1995). See also P4073 (Order of Drina Corps, 13 July 1995), pp. 2, 4.

17293 P3995 (Witness Statement of Albert Rave dated 10 November 2011), para. 96; Momir Nikolić, T. 24631 (13 February 2012). See also Adjudicated Facts 1576, 1584; P4175 (Witness Statement of Robert Franken dated 15 January 2012), para. 79; Pieter Boering, P3969 (Transcript from Prosecutor v. Popović et al.), T. 2020; Vincentius Egbers, P331 (Transcript from Prosecutor v. Popović et al.), T. 2720, 2803-2804; P3995 (Witness Statement of Albert Rave dated 10 November 2011), para. 96.

17294 P4175 (Witness Statement of Robert Franken dated 15 January 2012), paras. 83-84; P3948 (Witness statement of Johannes Rutten dated 8 November 2011), paras. 102-104. See Adjudicated Fact 1584.

17295 P4175 (Witness Statement of Robert Franken dated 15 January 2012), para. 84; P3995 (Witness Statement of Albert Rave dated 10 November 2011), para. 119; Vincentius Egbers, P331 (Transcript from Prosecutor v. Popović et al.), T. 2753-2755. See Adjudicated Fact 1585. See also Albert Rave, T. 22182 (30 November 2011) (testifying that Mladić had told him that "irregular troops" were responsible). 
of the Bosnian Serb Forces to a football field; there, he saw the men kneeling with their hands behind their necks. ${ }^{17296}$ On 13 July, while Bosnian Muslims on trucks and buses from Potočari were passing by a meadow near Sandići, they saw a large group of men sitting by the road and a soldier with a rifle guarding them. ${ }^{17297}$

5107. By 8 p.m. on 13 July, the transportation was completed. ${ }^{17298}$ Personal belongings of the Bosnian Muslims who had left were strewn everywhere in Potočari. ${ }^{17299}$ A UNHCR convoy, which was supposed to arrive earlier, came in when the last Bosnian Muslims had left Potočari. ${ }^{17300}$

5108. In total, up to 30,000 Bosnian Muslims were transported from Potočari to Bosnian Muslimheld territory between 12 and 13 July. ${ }^{17301}$

(D) Detention of the separated Bosnian Muslim men at the White House and transportation to Bratunac

5109. As noted above, Bosnian Muslim men and boys were separated by members of the Bosnian Serb Forces and taken to the White House. ${ }^{17302}$ Boys as young as 12, some even younger, were

17296 Vincentius Egbers, P331 (Transcript from Prosecutor v. Popović et al.), T. 2724-2726, 2749, 2756; P210 (Photograph of football field near Nova Kasaba). See also Section IV.C.1.e.iii.C: Nova Kasaba football field.

17297 Mirsada Malagić, P356 (Transcript from Prosecutor v. Krstić), T. 1977-1978, 1981; KDZ071, T. 28541 (4 May 2012). See Section IV.C.1.e.iii.B: Sandići Meadow.

17298 P3995 (Witness Statement of Albert Rave dated 10 November 2011), para. 116; P4175 (Witness Statement of Robert Franken dated 15 January 2012), para. 98; P166 (Drina Corps report, 13 July 1995). See Adjudicated Fact 1586.

17299 P4173 (Witness statement of Roger Patelski dated 30 November 2011), para. 31.

17300 P4140 (Witness statement of Joseph Kingori dated 8 January 2002), para. 196; P4160 (UNMO Report, 13 July 1995).

17301 See para. 5076; P3995 (Witness Statement of Albert Rave dated 10 November 2011), para. 116; P4175 (Witness Statement of Robert Franken dated 15 January 2012), para. 86; Adjudicated Fact 1575.

17302 See paras. 5095, 5098. Defence witnesses, such as Popović, suggested that the men were not separated in Potočari. D3993 (Witness statement of Vujadin Popović dated 2 November 2013), para. 24. Borovčanin stated that during his brief stay in Potočari, he did not see any separation of men. D3659 (Witness statement of Ljubomir Borovčanin dated 30 May 2013), para. 19. Đurić also claimed that when he was in Potočari on 12 and 13 July, he did not know of or see the separation of men from their families. D3903 (Witness Statement of Đurić dated 26 July 2013), para. 13; Mendeljev Đurić, T. 42086-42097 (29 July 2013). See also Srbislav Davidović, P4100 (Transcript from Prosecutor v. Popović et al.), T. 9324. In light of the Chamber's view that these witnessses' testimony on this point was marked by insincerity and evasiveness, as well as overwhelming contradictory evidence, the Chamber does not consider their evidence reliable and will not place weight on it. Furthermore, Popović's testimony is directly contradicted by the contemporaneous report he sent to the VRS Main Staff, in which he stated: "[W]e were separating men from 17-60 years of age and we were not transporting them”. P4388 (Drina Corps report to VRS Main Staff, 12 July 1995), p. 2. With regard to P4388, which bears Popović's typed-signed signature, the Chamber notes that Popović claimed that the report had been drafted by Momir Nikolić from the Bratunac Brigade Command, and that he had only read it at the Drina Corps Command the next day. D3993 (Witness statement of Vujadin Popović dated 2 November 2013), para. 27; Vujadin Popović, T. 43028-43032, 43037-43038 (5 November 2013) (asserting that the number appearing in the heading of the report was not his own but Nikolić's and that 'there is no point' for Popović to send such a document to his department in the Drina Corps). Popović further testified that he was working on urgent matters-reviewing documents seized from the MUP building in Srebrenica-at the Bratunac Brigade Command at the time the document was sent, claiming that he was at the command without Momir Nikolić's knowledge. Vujadin Popović, T. $43032-43034$ (5 November 2013). The Chamber considers that Popović's evidence on this point is evasive and unreliable. The Chamber is satisfied that Popović drafted and sent P4388. 
separated. ${ }^{17303}$ The separations continued throughout 12 and 13 July. ${ }^{17304}$ According to Momir Nikolić, approximately 300 to 500 men and boys were separated, amounting to between 600 and 700 in two days. ${ }^{17305}$ There was a lot of fear among the males and the family they were leaving behind. ${ }^{17306}$ As Bosnian Muslim men protested against their separation from their families, ${ }^{17307}$ Janković told them they had no reason to be concerned and that "everything would be all right". He also said that the men would join their families later. ${ }^{17308}$

5110. Armed VRS soldiers of the $10^{\text {th }}$ Sabotage Detachment and the $65^{\text {th }}$ Protection Regiment forced the males to leave their personal belongings, which were piled about 30 to 40 metres from

17303 KDZ265, P367 (Transcript from Prosecutor v. Krstić), T. 5754-5755, 5763-5765; P4140 (Witness statement of Joseph Kingori dated 8 January 2002), para. 170; Christine Schmitz, T. 26843-24844 (26 March 2012); P395 (Witness statement of Behara Krdžić dated 16 June 2000), e-court p. 2; P395 (Statement of Behara Krdžić to Tuzla Cantonal Court, 16 June 2000), e-court p. 8; P401 (Statement of Šehra Ibišević to Sarajevo Cantonal Court, 21 June 2000), e-court p. 8; P3948 (Witness statement of Johannes Rutten dated 8 November 2011), para. 49; Johannes Rutten, T. 22046 (28 November 2011); P4173 (Witness statement of Roger Patelski dated 30 November 2011), para. 25. See also Joseph Kingori, T. 22938-22939 (13 January 2012); P398 (Witness statement of Saliha Osmanović dated 18 June 2000), e-court pp. 2-3; P398 (Statement of Saliha Osmanović to Tuzla Cantonal Court, 19 June 2000), e-court p. 10; KDZ186, P357 (Transcript from Prosecutor v. Popović et al.), T. 3608, 3611 (under seal); P4167 (Witness statement of Paul Groenewegen dated 11 November 2011), para. 43.

17304 Adjudicated Fact 1550; P3995 (Witness Statement of Albert Rave dated 10 November 2011), para. 113; P4388 (Drina Corps report to VRS Main Staff, 12 July 1995), p. 2; P4167 (Witness statement of Paul Groenewegen dated 11 November 2011), para. 56; Mirsada Malagić, P356 (Transcript from Prosecutor v. Krstić), T. 1966, 1972; P414 (Photograph of White House); Mirsada Malagić, T. 23489 (24 January 2012); Mile Janjić, P1194 (Transcript from Prosecutor v. Blagojević \& Jokić), T. 9797; Mile Janjić, P372 (Transcript from Prosecutor v. Popović et al.), T. 17944; Vincentius Egbers, P331 (Transcript from Prosecutor v. Popović et al.), T. 27492750; Ahmo Hasić, P354 (Transcript from Prosecutor v. Popović et al.), T. 1178-1179, 1251-1255. See also P3948 (Witness statement of Johannes Rutten dated 8 November 2011), para. 82; KDZ070, P340 (Transcript from Prosecutor v. Popović et al.), T. 3425 (under seal); P300 (Sketch drawn by KDZ070) (under seal); KDZ070, P341 (Transcript from Prosecutor v. Popović et al.), T. 3460; P404 (Witness statement of Samila Salčinović dated 18 June 2000), e-court p. 2; P397 (Statement of Razija Pašagić to Tuzla Cantonal Court, 15 June 2000), e-court p. 10.

17305 Momir Nikolić, T. 24640 (14 February 2012). Although Popović informed the VRS Main Staff on 12 July that "about 70" men had been separated so far, Nikolić stated that the number was higher than 70 and estimated that between 350 and 400 men were singled out on 12 July 1995. Momir Nikolić, T. 24640-24641 (14 February 2012); P4388 (Drina Corps report to VRS Main Staff, 12 July 1995), p. 2.

17306 P4140 (Witness statement of Joseph Kingori dated 8 January 2002), para. 160; KDZ186, P357 (Transcript from Prosecutor v. Popović et al.), T. 3611 (under seal).

17307 Mile Janjić, P1194 (Transcript from Prosecutor v. Blagojević \& Jokić), T. 9786.

17308 Mile Janjić, P1194 (Transcript from Prosecutor v. Blagojević \& Jokić), T. 9786-9787. Members of the Bosnian Serb Forces told DutchBat that the separation was necessary in order to find out whether there were soldiers among the men. P3995 (Witness Statement of Albert Rave dated 10 November 2011), para. 98; P4140 (Witness statement of Joseph Kingori dated 8 January 2002), para. 163 
the White House alongside the road. ${ }^{17309}$ The belongings included the men's ID cards, the money they had in their pockets, their wallets, luggage, clothing, and other valuables. ${ }^{17310}$

5111. At the very moment the transportation of women, children, and the elderly started, Mladic told Franken that he wanted to interrogate the men aged between about 16 and up to 60, as they were potential soldiers, and to check "whether there were war criminals". ${ }^{17311}$ Rave asked Mladić about the separation of Bosnian Muslim men, to which Mladić responded that the VRS was trying to find out if there were soldiers among the men; if so they would be separated, be made POWs, brought to a prison camp in the vicinity of Bijeljina, and exchanged for Bosnian Serb POWs. ${ }^{17312}$

5112. On both 12 and 13 July, Momir Nikolić came to the UN Compound to verify the list of the people in the UN Compound against the one he had in order to check whether there were any Bosnian Muslim soldiers inside. ${ }^{17313}$ No effort was made thereafter to distinguish the soldiers from the civilians. ${ }^{17314}$ Momir Nikolić himself testified that there was no process to identify and separate the men who were suspected of having committed war crimes, stating that "most of [the men] shouldn't have been separated out for any military reason". ${ }^{17315}$

5113. The White House was guarded by members of the Bosnian Serb Forces, some of whom had German Shepherd dogs. ${ }^{17316}$ There was no space inside the house. ${ }^{17317}$ Every room was filled with

\footnotetext{
17309 P4175 (Witness Statement of Robert Franken dated 15 January 2012), para. 87; P3995 (Witness Statement of Albert Rave dated 10 November 2011), paras. 98, 102; P4140 (Witness statement of Joseph Kingori dated 8 January 2002), para. 156; Johannes Rutten, T. 22039-22042 (28 November 2011); Joseph Kingori, T. 22813 (11 January 2012); P4201 (Updated Srebrenica Trial video), Part 3, at 00:09:54; Momir Nikolić, T. 2463124633 (13 February 2012). See also Mile Janjić, P1194 (Transcript from Prosecutor v. Blagojević \& Jokić), T. 9783, 9832.

17310 Momir Nikolić, T. 24631-24632 (13 February 2012); P4140 (Witness statement of Joseph Kingori dated 8 January 2002), paras. 174-175; P3948 (Witness statement of Johannes Rutten dated 8 November 2011), paras. 55, 63, 89; Johannes Rutten, T. 22044 (28 November 2011). See also Adjudicated Fact 1666.

17311 P4175 (Witness Statement of Robert Franken dated 15 January 2012), para. 86. See also P3948 (Witness statement of Johannes Rutten dated 8 November 2011), para. 49.

17312 P3995 (Witness Statement of Albert Rave dated 10 November 2011), para. 109.

17313 P4140 (Witness statement of Joseph Kingori dated 8 January 2002), paras. 160, 187. See also Mirsada Malagić, P356 (Transcript from Prosecutor v. Krstić), T. 1951-1952 (noting that she saw soldiers looking for men in the UN Compound); Joseph Kingori, T. 22936-22937 (13 January 2012); Mile Janjić, P372 (Transcript from Prosecutor v. Popović et al.), T. 18036 (noting that he heard rumours that there was a list of war criminals and that there was going to be an investigation in order to find out whether any of the Bosnian Muslims in Potočari were on that list). On 12 July 1995, Tolimir instructed to his subordinate intelligence and security organs, including the Bratunac Brigade organs, to record the names of "all men fit for military service who are being evacuated from the UNPROFOR base in Potočari." P4940 (Command Intelligence Report of Drina Corps, 12 July 1995), p. 2. The Bratunac Brigade had prepared a list, dated 12 July, of 387 suspected Bosnian Muslim war criminals in the Srebrenica enclave. Adjudicated Fact 1547.

17314 Adjudicated Fact 1549.

17315 Momir Nikolić, T. 24642-24643 (14 February 2012). See also Momir Nikolić, T. 24646 (14 February 2012).

17316 P4752 (Witness statement of Christine Schmitz dated 21 March 2012), para. 46; Pieter Boering, P3969 (Transcript from Prosecutor v. Popović et al.), T. 2012-2013; P3948 (Witness statement of Johannes Rutten dated 8 November 2011), para. 56. See also P4201 (Updated Srebrenica Trial video), Part 2, at 00:24:0200:24:28; P4140 (Witness statement of Joseph Kingori dated 8 January 2002), para. 158.
} 
males who were very frightened. ${ }^{17318}$ No food or water was provided. ${ }^{17319}$ Some detainees were interrogated at the house. ${ }^{17320}$

5114. On 12 July, Kingori confronted Mladić about the men detained in the White House. ${ }^{17321}$ Mladić responded that the men "were very comfortable" there. ${ }^{17322}$ Mladić then took Kingori to the house, which Kingori saw from outside was overcrowded. ${ }^{17323}$ Regardless of Kingori's protest about the conditions, Mladić insisted that the Bosnian Muslim men were fine. ${ }^{17324}$ At that time, a soldier started distributing beer, sweets, and soft drinks, while filming at the same time. ${ }^{17325}$ Mladić did not explain to Kingori why the men were separated nor did he allow Kingori to go inside, but instead repeated that they were okay. ${ }^{17326}$

5115. Also on the same day, DutchBat received reports that the Bosnian Muslim men detained in the White House were treated badly. ${ }^{17327}$ Franken sent patrols of DutchBat soldiers in the course of the afternoon but they were blocked by Bosnian Serb soldiers and could not go to the White House. ${ }^{17328}$ Franken informed Janković of this incident but Janković said that the Bosnian Muslim men were "POWs". ${ }^{17329}$ DutchBat received reports that the treatment of the Bosnian Muslim men

17317 Joseph Kingori, T. 22814 (11 January 2012); P4201 (Updated Srebrenica Trial video), Part 3, 00:10:53; Ahmo Hasić, P354 (Transcript from Prosecutor v. Popović et al.), T. 1178-1179. See also Joseph Kingori, T. 2293722938 (13 January 2012); P3948 (Witness statement of Johannes Rutten dated 8 November 2011), para. 57. The UNMOs tried to tell the command of the Bosnian Serb Forces that the crowding of the men who were being placed in the White House without food or water was not right. Joseph Kingori, T. 22812-22813 (11 January 2012).

17318 Vincentius Egbers, P331 (Transcript from Prosecutor v. Popović et al.), T. 2886-2887.

17319 KDZ039, P3940 (Transcript from Prosecutor v. Popović et al.), T. 17311.

17320 P4175 (Witness Statement of Robert Franken dated 15 January 2012), para. 87; P3995 (Witness Statement of Albert Rave dated 10 November 2011), para. 98; Pieter Boering, P3969 (Transcript from Prosecutor v. Popović et al.), T. 2012, 2015, 2018. See also P4140 (Witness statement of Joseph Kingori dated 8 January 2002), para. 153; P398 (Witness statement of Saliha Osmanović dated 18 June 2000), e-court p. 3; P398 (Statement of Saliha Osmanović to Tuzla Cantonal Court, 19 June 2000), e-court p. 10; KDZ084, P4904 (Transcript from Prosecutor v. Popović et al.), T. 14818-14819 (under seal). Although the Bosnian Muslim men were told that they would be interrogated and brought to Tuzla, no interrogations took place. Ahmo Hasić, P354 (Transcript from Prosecutor v. Popović et al.), T. 1179, 1251-1252. See also Svetozar Kosorić, T. 38708-38709 (23 May 2013) (stating that he was unaware whether the detainees were interrogated during 12 and 13 July 1995). P4140 (Witness statement of Joseph Kingori dated 8 January 2002), para. 154.

17322 P4140 (Witness statement of Joseph Kingori dated 8 January 2002), para. 154.

17323 P4140 (Witness statement of Joseph Kingori dated 8 January 2002), para. 154. See also P4140 (Witness statement of Joseph Kingori dated 8 January 2002), para. 191; P4201 (Updated Srebrenica Trial video), Part 3, at 00:05:43-00:10:20; Joseph Kingori, T. 22806 (11 January 2012).

17324 P4140 (Witness statement of Joseph Kingori dated 8 January 2002), para. 154. See also Joseph Kingori, T. 22806 (11 January 2012).

17325 P4140 (Witness statement of Joseph Kingori dated 8 January 2002), paras. 154-155. See also Joseph Kingori, T. 22806-22807 (11 January 2012); P3948 (Witness statement of Johannes Rutten dated 8 November 2011), para. 40.

17326 P4140 (Witness statement of Joseph Kingori dated 8 January 2002), para. 154; Joseph Kingori, T. 22807 (11 January 2012). See also KDZ039, P3940 (Transcript from Prosecutor v. Popović et al.), T. 17312-17313.

17327 P4175 (Witness Statement of Robert Franken dated 15 January 2012), para. 89.

17328 P4175 (Witness Statement of Robert Franken dated 15 January 2012), para. 89.

17329 P4175 (Witness Statement of Robert Franken dated 15 January 2012), para. 89. 
in the White House was getting worse. ${ }^{17330}$ Franken made a list of men who were still present in the UN Compound. ${ }^{17331}$ In total, 251 men were registered. ${ }^{17332}$ Franken sent the list up the chain of command in an effort to safeguard their lives; he also told Janković that the Bosnian Muslim men were registered and that the names were known within the UN and the Dutch government. ${ }^{17333}$

5116. On 13 July, Rutten and his colleague were able to enter the house, and saw what looked like an "interrogation room", although they could not enter the room as members of the Bosnian Serb Forces threatened them with weapons. ${ }^{17334}$ The rooms upstairs were filled with around 50 Bosnian Muslim men aged between 45 and 55, and some boys around 12 to 14 years-old. ${ }^{17335}$ Later on, Rutten went to the White House again while he was waiting for the last buses carrying the Bosnian Muslim civilians to leave; the house itself and the balcony were completely filled with Bosnian Muslim males; ${ }^{17336}$ they were about $300 .{ }^{17337}$ There was total fear on their faces. ${ }^{17338}$

5117. Starting in the afternoon of 12 July and continuing throughout 13 July, while the transportation of women, children, and the elderly on buses was in progress, the men detained at the White House were taken out, boarded onto buses, and transported to Bratunac. ${ }^{17339}$ The Bratunac

\footnotetext{
17330 P4175 (Witness Statement of Robert Franken dated 15 January 2012), para. 89.

17331 P4175 (Witness Statement of Robert Franken dated 15 January 2012), para. 91. See Adjudicated Facts 1513 , 1514. See also P3995 (Witness Statement of Albert Rave dated 10 November 2011), para. 115.

17332 P4175 (Witness Statement of Robert Franken dated 15 January 2012), para. 91 (noting that of the men inside the UN Compound, about 60 to 70 refused to be registered); P4181 (Handwritten list of names); P3995 (Witness Statement of Albert Rave dated 10 November 2011), para. 115.

17333 See Adjudicated Fact 1513; P4175 (Witness Statement of Robert Franken dated 15 January 2012), para. 91 . See also P3995 (Witness Statement of Albert Rave dated 10 November 2011), para. 115.

17334 P3948 (Witness statement of Johannes Rutten dated 8 November 2011), paras. 59, 61-62 (noting that they were wearing green camouflage uniforms). Two Bosnian Serb soldiers were sitting behind the house and would not let Rutten and his colleague go further. P3948 (Witness statement of Johannes Rutten dated 8 November 2011), para. 60.

17335 P3948 (Witness statement of Johannes Rutten dated 8 November 2011), para. 64; Johannes Rutten, T. 22046 (28 November 2011). Rutten took several pictures of them in both rooms. P3948 (Witness statement of Johannes Rutten dated 8 November 2011), para. 64. Rutten kept the film of the pictures he took at the White House and of the bodies that he found until he returned to The Netherlands after 21 July 1995; on 23 July 1995 , a member of the Dutch Army's intelligence branch picked up the film, and Rutten was later informed that "something happened to the film during the development process". P3948 (Witness statement of Johannes Rutten dated 8 November 2011), para. 101.

17336 Zoran Petrović-Piroćanac, P376 (Transcript from Prosecutor v. Popović et al.), T. 18770-18771; P666 (Video footage of White House - Studio B version and original version); at 00:02:30. Petrović-Piroćanac commented that the men shown in this footage were suspected criminals who had attempted to get onto the convoys, although he stated that that information could have been rumour. Zoran Petrović-Piroćanac, P376 (Transcript from Prosecutor v. Popović et al.), T. 18771-18772.

17337 P3948 (Witness statement of Johannes Rutten dated 8 November 2011), para. 90.

17338 P3948 (Witness statement of Johannes Rutten dated 8 November 2011), para. 91.

17339 Adjudicated Fact 1664; KDZ039, P3940 (Transcript from Prosecutor v. Popović et al.), T. 17313-17315, 17379; P3948 (Witness statement of Johannes Rutten dated 8 November 2011), paras. 51-52, 92-93; P4167 (Witness statement of Paul Groenewegen dated 11 November 2011), para. 56; P4173 (Witness statement of Roger Patelski dated 30 November 2011), para. 28; KDZ265, P367 (Transcript from Prosecutor v. Krstić), T. 5756; Ahmo Hasić, P354 (Transcript from Prosecutor v. Popović et al.), T. 1178; Vincentius Egbers, P331 (Transcript from Prosecutor v. Popović et al.), T. 2886-2887; P4175 (Witness Statement of Robert Franken dated 15 January 2012), para. 88; P3995 (Witness Statement of Albert Rave dated 10 November 2011), para.
} 
Brigade MP members assisted the transportation. ${ }^{17340}$ DutchBat tried to escort the buses but they were prevented from doing so. ${ }^{17341}$ On 12 July alone, between 10 and 15 buses with about 70 men onboard each left Potočari for Bratunac. ${ }^{17342}$ Mladić was seen standing with two other soldiers next to one of the buses on which men were forced to board. ${ }^{17343}$

5118. When the men came out of the White House, they were frightened, tried to escape, started screaming, and did not want to go into the buses and trucks. ${ }^{17344}$ The men were hit and kicked, and were forced to keep their heads down. ${ }^{17345}$ They were then crammed into the vehicles, ${ }^{17346}$ and were not allowed to take their belongings. ${ }^{17347}$

5119. From the evening of 13 to 14 July 1995, all the personal belongings and IDs of the Bosnian Muslim males held at the White House were set on fire by Bosnian Serb Forces. ${ }^{17348}$

(E) Presence and involvement of the Bosnian Serb Forces

5120. During 12 and 13 July, the following members of the Bosnian Serb Forces were on the ground in Potočari, and oversaw and/or assisted the boarding and transportation of women, children, and the elderly, as well as the separation of men, their detention, and the subsequent transportation to Bratunac: (i) from the VRS, Mladić; Janković; members of the $65^{\text {th }}$ Protection Regiment; members of the $10^{\text {th }}$ Sabotage Detachment; Drina Corps officers, including Živanović,

100. See also KDZ070, P340 (Transcripts from Prosecutor v. Popović et al.), T. 3425 (under seal); Adjudicated Facts 1663, 1665; P4167 (Witness statement of Paul Groenewegen dated 11 November 2011), para. 56; Mile Janjić, P372 (Transcript from Prosecutor v. Popović et al.), T. 17934, 18038; Mile Janjić, P1194 (Transcript from Prosecutor v. Blagojević \& Jokić), T. 9804-9805.

17340 Mile Janjić, P1194 (Transcript from Prosecutor v. Blagojević \& Jokić), T. 9804-9807; Mile Janjić, P372 (Transcript from Prosecutor v. Popović et al.), T.18016-18017.

17341 P3948 (Witness statement of Johannes Rutten dated 8 November 2011), paras. 51-52, 93 ; P4175 (Witness Statement of Robert Franken dated 15 January 2012), para. 88. See para. 5105.

17342 Mile Janjić, P1194 (Transcript from Prosecutor v. Blagojević \& Jokić), T. 9786; Mile Janjić, P372 (Transcript from Prosecutor v. Popović et al.), T. 17933, 17942-17944. See also Vincentius Egbers, P331 (Transcript from Prosecutor v. Popović et al.), T. 2886-2887; P3995 (Witness Statement of Albert Rave dated 10 November 2011), para. 100

17343 KDZ039, P3940 (Transcript from Prosecutor v. Popović et al.), T. 17314.

17344 KDZ186, P357 (Transcript from Prosecutor v. Popović et al.), T. 3617-3619 (under seal); P3995 (Witness Statement of Albert Rave dated 10 November 2011), para. 99. See also P4140 (Witness statement of Joseph Kingori dated 8 January 2002), paras. 176-177.

17345 P3995 (Witness Statement of Albert Rave dated 10 November 2011), paras. 99-100.

17346 P3995 (Witness Statement of Albert Rave dated 10 November 2011), para. 100. See also Adjudicated Fact 1664.

17347 P4140 (Witness statement of Joseph Kingori dated 8 January 2002), para. 173; Mile Janjić, P1194 (Transcript from Prosecutor v. Blagojević), T. 9783. See also Mirsada Malagić, P356 (Transcript from Prosecutor v. Krstić), T. 1966; Mirsada Malagić, T. 23489 (24 January 2012).

17348 P4175 (Witness Statement of Robert Franken dated 15 January 2012), para. 100; P4183 (Photograph of burning personal belongings at Potočari); P3948 (Witness statement of Johannes Rutten dated 8 November 2011), para. 66; P3961 (Photograph of burning personal belongings); Johannes Rutten, T. 22040-22042, 22045, 22051 (28 November 2011). See also Adjudicated Fact 1667. 
Krstić, Popović, ${ }^{17349}$ Kosorić, Aćamović, and Krsmanović; members of Drina Wolves; members of the Drina Corps MP Battalion; and members of the Bratunac Brigade, including its $2^{\text {nd }}$ and $3^{\text {rd }}$ Battalions as well as Momir Nikolić, and the brigade's MP; ${ }^{17350}$ (ii) from the MUP, members of the SBP, including Borovčanin; members of the Jahorina Recruits, including Jević and Đurić; ${ }^{17351}$ a MUP special unit with dogs; members of the Bratunac SJB; members of the Zvornik RDB; and SDB operatives. ${ }^{17352}$

17349 In the vicinity of the house, Rutten saw someone who was "not a plain soldier", was seemingly in charge, and was giving orders to other Bosnian Serb soldiers there, and he later identified that person as Popović. P3948 (Witness statement of Johannes Rutten dated 8 November 2011), paras. 58, 95-99; P3967 (Video still of Vujadin Popović).

17350 D2081 (Momir Nikolić's statement of facts from Plea Agreement, 7 May 2003), paras. 6, 8; Momir Nikolić, T. 24640-24641, 24650-24651 (14 February 2012); P4140 (Witness statement of Joseph Kingori dated 8 January 2002), para. 162. See also Adjudicated Facts 1551, 1553. But see Mile Janjić, P372 (Transcript from Prosecutor v. Popović et al.), T. 18015, 18017-18019, 18021 (indicating that that the Bratunac Brigade MP did not participate in the separation of the Bosnian Muslims on 12 July).

17351 KDZ084, P4904 (Transcript from Prosecutor v. Popović et al.), T. 14819, 14879 (under seal) (Jević was standing in front of the White House). Đuric disputed having participated in the separations of persons in Potočari on 12 or 13 July 1995 and denied any knowledge of property of documents being taken from civilians in Potočari at that time. D3903 (Witness Statement of Mendeljev Đurić dated 26 July 2013), para. 13. In this regard, the Chamber recalls Janjić's testimony that members of the MUP "Special Police" were dividing the Bosnian Muslims into groups, and that he saw Mane Đurić near that location. Mile Janjić, P1194 (Transcript from Prosecutor v. Blagojević \& Jokić), T. 9779-9780; Mile Janjić, P372 (Transcript from Prosecutor v. Popović et al.), T. 17937-17938, 17941. Having considered all of the relevant evidence, the Chamber finds that Đurić participated in the separations of the men and their subsequent detention.

17352 Momir Nikolić, T. 24625-24630 (13 February 2012), T. 24641 (14 February 2012); D3993 (Witness statement of Vujadin Popović dated 2 November 2013), para. 21; P4175 (Witness Statement of Robert Franken dated 15 January 2012), para. 76; P4180 (Video still of Radoslav Krstić); P4140 (Witness statement of Joseph Kingori dated 8 January 2002), para. 162; P3948 (Witness statement of Johannes Rutten dated 8 November 2011), para. 100; KDZ039, P3940 (Transcript from Prosecutor v. Popović et al.), T. 17311; P4388 (Drina Corps report to VRS Main Staff, 12 July 1995), p. 2; Mile Janjić, P1194 (Transcript from Prosecutor v. Blagojević \& Jokić), T. 9763-9764, 9794-9795, 9779-9780; Mile Janjić, P372 (Transcript from Prosecutor v. Popović et al.), T. 17937-17938, 17940-17941, 17964-17965; P227 (Photographs showing (i) Radoslav Krstić and Mile Janjić, and (ii) Mendeljev Đurić); Adjudicated Facts 1551, 1553, 1554, 1555, 1556, 1557, 1558, 1560, 1561, 1562, 1572, 1578. See para. 5110. With regard to the state security's involvement in the separation of men, Momir Nikolić confirmed that state security operatives gained information about the column that is reflected in the Sarajevo State Security Service Report of 13 July from interrogating the separated Bosnian Muslim men. Momir Nikolić, T. 24649-24650 (14 February 2012); P4389 (Report of Sarajevo RDB, 13 July 1995), p. 1. See also Momir Nikolić, T. 24628-24629 (13 February 2012); P4388 (Drina Corps report to VRS Main Staff, 12 July 1995), p. 2. Milinić disputed the veracity of Popović's report, claiming that the state security and VRS security organs never worked together, as stated in P4388. Gordan Milinić, T. 39779-39780 (12 June 2013). Similarly, Dragan Kijac testified that to the best of his knowledge the state security operatives did not participate in any interviews in Potočari, but he conceded that interviews took place at the Bratunac SJB. Dragan Kijac, T. 44331-44336 (3 December 2013). Having assessed the totality of the evidence before it, the Chamber rejects the testimony of Milinić and Kijac and is satisfied that state security operatives were indeed involved in the separation of men. 
(F) Evacuation of the wounded and the sick

5121. While the Bosnian Muslims were moving from Srebrenica to Potočari, DutchBat and MSF staff evacuated some of the patients in the Srebrenica Hospital to Potočari. ${ }^{17353}$ All the international and most local MSF staff also moved to Potočari. ${ }^{17354}$

5122. In the early afternoon of 12 July, Nicolai updated Gvero, informing him about the "matter of the evacuation of the refugees from Srebrenica to another area". ${ }^{17355}$ Nicolai told Gvero that he was arranging an air evacuation of the wounded, that a formal request for helicopters would be made to the VRS, and requested Gvero to instruct VRS soldiers to co-operate. ${ }^{17356}$ Gvero objected, noting that using helicopters was impermissible due to security reasons and that the VRS had already offered their hospitals for treating the wounded. ${ }^{17357}$

5123. At one point on 12 July in Potočari, Franken met Radoslav Janković, who was tasked with organising and co-ordinating DutchBat's withdrawal from the Srebrenica enclave. ${ }^{17358}$ That day, MSF staff were informed about Mladić's intention to start the "evacuation" of the wounded and sick. ${ }^{17359}$ DutchBat conducted the first medical evacuation around 6 p.m. that evening. ${ }^{17360}$ Some patients and local MSF staff who accompanied them were allowed to travel to Kladanj, while others were forced to return to Bratunac. ${ }^{17361}$ The next day, the convoy was allowed through to Kladanj, from where its members proceeded to Bosnian Muslim-held territory on foot. ${ }^{17362}$

5124. On the morning of 13 July, Aćamović came to the UN Compound and asked for a list of all individuals who would be evacuated with DutchBat, including its local staff, staff from MSF and

\footnotetext{
17353 Vincentius Egbers, P331 (Transcript from Prosecutor v. Popović et al.), T. 2716-2717; P4752 (Witness statement of Christine Schmitz dated 21 March 2012), paras. 31-32; Pieter Boering, P3969 (Transcript from Prosecutor v. Popović et al.), T. 1940.

17354 P4752 (Witness statement of Christine Schmitz dated 21 March 2012), para. 32.

17355 P4542 (Record of conversation between General Nicolai and General Gvero, 12 July 1995), p. 1; P5282 (Intercept of conversation between General Milan Gvero and General Nicolai, 12 July 1995).

17356 P4542 (Record of conversation between General Nicolai and General Gvero, 12 July 1995), pp. 1.

17357 P4542 (Record of conversation between General Nicolai and General Gvero, 12 July 1995), pp. 1-2; P5282 (Intercept of conversation between General Milan Gvero and General Nicolai, 12 July 1995). Nicolai also suggested that he and the VRS authorities meet regarding the conditions of evacuation of DutchBat "only after their support to the refugees in Srebrenica". P4542 (Record of conversation between General Nicolai and General Gvero, 12 July 1995), p. 2.

17358 P4175 (Witness Statement of Robert Franken dated 15 January 2012), para. 76; P4179 (Photograph of Col. Radislav Janković).

17359 P4752 (Witness statement of Christine Schmitz dated 21 March 2012), para. 44; Christine Schmitz, T. 26849 (26 March 2012).

17360 P4752 (Witness statement of Christine Schmitz dated 21 March 2012), para. 47; Christine Schmitz, T. 26875 (26 March 2012); P3995 (Witness Statement of Albert Rave dated 10 November 2011), para. 110.

17361 P4752 (Witness statement of Christine Schmitz dated 21 March 2012), para. 47. See also Christine Schmitz, T. 26875 (26 March 2012).

17362 P3995 (Witness Statement of Albert Rave dated 10 November 2011), para. 110.
} 
UNHCR, and interpreters. ${ }^{17363}$ Later that afternoon, when wounded people and UNHCR employees, as well as the local and international staffs of MSF and DutchBat, remained inside the UN Compound, ${ }^{17364}$ Aćamović collected the list of wounded provided by DutchBat, told DutchBat that there would be a medical evacuation from Bratunac, ${ }^{17365}$ and that after all the Bosnian Muslims were gone, DutchBat should assemble its personnel and stay inside the UN Compound. ${ }^{17366}$

5125. Meanwhile, in an attempt to collect patients who had been left behind, MSF staff member Schmitz and Kingori went to the clinic and social centre in Srebrenica with a Bosnian Serb escort, collected a total of six patients, and returned to Potočari. ${ }^{17367}$ There, Schmitz was told that the VRS had entered the UN Compound to inspect the patients but had quickly left due to the conditions and smell of the premises. ${ }^{17368}$ By 8 p.m., only the wounded remained in Potočari. ${ }^{17369}$ The UNMOs and MSF prepared a list of the wounded and sick in the UN Compound. ${ }^{17370}$

5126. On 15 July, DutchBat, the UNMOs, and MSF met with members of the VRS including Momir Nikolić, and gave them the lists of the 55 patients and several escorts in Potočari, as well as the 45 patients in Bratunac. ${ }^{17371}$ The next day, representatives of the Main Staff, the ICRC, and the UNHCR agreed that DutchBat would transport the Bosnian Muslim patients from Potočari to the Bratunac Health Centre the next morning, the ICRC would carry out the medical evacuation of the

\footnotetext{
17363 P3995 (Witness Statement of Albert Rave dated 10 November 2011), para. 120.

17364 P3995 (Witness Statement of Albert Rave dated 10 November 2011), para. 122.

17365 Some Bosnian Muslim wounded remained in Bratunac Health Centre. P4175 (Witness Statement of Robert Franken dated 15 January 2012), para. 101.

17366 P3995 (Witness Statement of Albert Rave dated 10 November 2011), para. 121. According to Aćamović, DutchBat's local staff would be permitted to stay. P3995 (Witness Statement of Albert Rave dated 10 November 2011), para. 121.

17367 P4752 (Witness statement of Christine Schmitz dated 21 March 2012), paras. 58-59; P4140 (Witness statement of Joseph Kingori dated 8 January 2002), para. 183; Joseph Kingori, T. 22902 (12 January 2012), T. 22956 (13 January 2012); P4166 (MSF telex messages, 9-13 July 1995), p. 5; D2000 (MSF telex messages, 13 July 1995). Kingori stated that the Bosnian Serb soldiers present wanted the patients to be removed from the hospital, threatening they would be killed. P4140 (Witness statement of Joseph Kingori dated 8 January 2002), para. 185.

17368 P4752 (Witness statement of Christine Schmitz dated 21 March 2012), para. 60. Around 6 p.m., Schmitz also heard that Mladić wanted to inspect the patients himself. P4752 (Witness statement of Christine Schmitz dated 21 March 2012), para. 57.

17369 P4140 (Witness statement of Joseph Kingori dated 8 January 2002), para. 199; P4173 (Witness statement of Roger Patelski dated 30 November 2011), para. 29; P4175 (Witness Statement of Robert Franken dated 15 January 2012), para. 101; P4752 (Witness statement of Christine Schmitz dated 21 March 2012), para. 63.

17370 P4140 (Witness statement of Joseph Kingori dated 8 January 2002), paras. 200-201; P4175 (Witness Statement of Robert Franken dated 15 January 2012), para. 101; P4184 (Handwritten list of 59 names); Robert Franken, T. 23175-23176 (17 January 2012); D2022 (Debriefing Statement to Royal Dutch Army by Robert Franken), p. 3; P4752 (Witness statement of Christine Schmitz dated 21 March 2012), para. 63; P4758 (List of MSF patients, 17 July 1995); Christine Schmitz, T. 26875 (26 March 2012); P4160 (UNMO Report, 13 July 1995); P166 (Drina Corps report, 13 July 1995).

17371 P4752 (Witness statement of Christine Schmitz dated 21 March 2012), para. 63; Christine Schmitz, T. 26819 (26 March 2012). See also P4175 (Witness Statement of Robert Franken dated 15 January 2012), para. 101. On the same day, a MSF staff gave a list with the names of MSF local staff to the VRS. Christine Schmitz, T. 26818-26819 (26 March 2012); P4757 (Collection of MSF telex messages, 5-17 July 1995), p. 6.
} 
wounded and sick from Bratunac to Tuzla, and the Bratunac Brigade Security Organ was tasked with directing and monitoring the transportation. ${ }^{17372}$

\section{(G) Meeting of VRS, Bosnian Serb civilian officers, and ICRC}

5127. On 17 July, a VRS delegation and Bosnian Serb civilian officers came to the UN Compound and met with the ICRC concerning details about the evacuation of the wounded out of Potočari and Bratunac. ${ }^{17373}$ The VRS delegation was headed by Janković, who was accompanied by Momir Nikolić, Deronjić, ${ }^{17374}$ and a VRS lawyer. ${ }^{17375}$ Franken, Rave, and an UNMO named De Haan were present, as was Nesib Mandžić. ${ }^{17376}$ Upon Nikolić's insistence that the wounded be inspected to see whether there were still soldiers or "criminals" among them, and regardless of Franken's objection, an inspection was conducted and seven men were identified as soldiers. ${ }^{17377}$ He agreed with the ICRC that these men would be treated as wounded POWs and be handed over to the Bosnian Serb Forces. ${ }^{17378}$

5128. At this meeting, the Bosnian Serb representatives brought a declaration outlining the agreement reached at the third Hotel Fontana meeting ("17 July 1995 Statement"). ${ }^{17379}$ Janković asked Mandžić to sign the statement and requested that Franken attest to the fact that Mandžić was

17372 D4851 (VRS Main Staff Report, 16 July 1995), pp. 1-2; P5123 (Approval of request by VRS Main Staff re movement of humanitarian organisations, 18 July 1995). See also P4752 (Witness statement of Christine Schmitz dated 21 March 2012), para. 64 (recalling that the agreement was reached on 15 July). Miletić reported to the Main Staff that approximately 100 men would be evacuated from Bratunac, and that "men fit for military service will be selected and kept in the hospital" in the RS. D4851 (VRS Main Staff Report, 16 July 1995), p. 1.

17373 P4175 (Witness Statement of Robert Franken dated 15 January 2012), para. 102; P3995 (Witness Statement of Albert Rave dated 10 November 2011), paras. 131-132; Adjudicated Fact 1590.

17374 Rave stated that Deronjić came to the UN Compound on 16 July 1995 to see Karremans, that Deronjić introduced himself to Rave as the new Mayor of Srebrenica, and that he talked about "his connections" and "direct touch" with the Accused. P3995 (Witness Statement of Albert Rave dated 10 November 2011), para. 127.

17375 P3995 (Witness Statement of Albert Rave dated 10 November 2011), paras. 129, 131; P4175 (Witness Statement of Robert Franken dated 15 January 2012), para. 108; Christine Schmitz, T. 26824-26825 (26 March 2012); P4758 (List of MSF patients, 17 July 1995), p. 10.

17376 P3995 (Witness Statement of Albert Rave dated 10 November 2011), para. 131.

17377 P4175 (Witness Statement of Robert Franken dated 15 January 2012), para. 103; P3995 (Witness Statement of Albert Rave dated 10 November 2011), para. 130; P4758 (List of MSF patients, 17 July 1995), pp. 3-8, 10; Christine Schmitz, T. 26823-26824 (26 March 2012). See also P4752 (Witness statement of Christine Schmitz dated 21 March 2012), paras. 67-68 (noting that the manner in which the interview was conducted was "clearly aggressive and intimidating"); P4758 (List of MSF patients, 17 July 1995), pp. 3-8, 10; Christine Schmitz, T. 26823-26824 (26 March 2012). But see P4161 (UNMO Report, 17 July 1995), p. 1 (reporting that the check was "very polite and nothing that could scare the refugees happened").

17378 P4175 (Witness Statement of Robert Franken dated 15 January 2012), para. 103.

17379 P3995 (Witness Statement of Albert Rave dated 10 November 2011), para. 131; P4175 (Witness Statement of Robert Franken dated 15 January 2012), paras. 104-105. 
not forced to sign it. ${ }^{17380}$ The 17 July 1995 Statement summarised the agreement reached at the third meeting, and read in part:

- that our civilian population could stay in the enclave or move out, depending on the wish of each individual;

- should we wish to move out from the enclave, it was agreed that we could choose where we wanted to go; we decided that the entire population move out of the enclave and be evacuated to the territory of Kladanj municipality;

- it was arranged that the evacuation would be carried out by the Army and Police of the Republic of Srpska and that UNPROFOR would supervise and provide an escort for the evacuation. ${ }^{17381}$

5129. It also stated that the "evacuation" had been conducted smoothly in accordance with the Geneva Conventions and International Humanitarian Law. ${ }^{17382}$ Franken signed the document in order "to ensure that the refugees and wounded [...] and the locals working for the aid organizations could be transported". ${ }^{17383}$ Mandžić and Deronjić also signed both the English and the BCS versions of the declaration. ${ }^{17384}$ At around 6:30 p.m. that evening, the Accused received the 17 July 1995 Statement. ${ }^{17385}$

17380 P4175 (Witness Statement of Robert Franken dated 15 January 2012), para. 104. See also P3995 (Witness Statement of Albert Rave dated 10 November 2011), para. 131.

17381 P4185 (Declaration by the Civilian Affairs Committee for Srebrenica re: proper implementation of evacuation procedures, 17 July 1995), p. 1. See also P3997 (Declaration of RS Civilian Affairs Committee for Srebrenica, 17 July 1995).

17382 P4185 (Declaration by the Civilian Affairs Committee for Srebrenica re: proper implementation of evacuation procedures, 17 July 1995), pp. 1-2; P3997 (Declaration of RS Civilian Affairs Committee for Srebrenica, 17 July 1995). See also P4175 (Witness Statement of Robert Franken dated 15 January 2012), para. 104. Before signing this declaration, Franken added by hand "as far as convoys actually escorted by UN forces are concerned" to the sentence which reads: "No incidents were provoked by any side during the evacuation and the Serbian side observed all the regulations of the Geneva Conventions and the International Law of War", in order to "neutralise the whole statement" by indicating that DutchBat had only had control over the first and second convoys, and that Bosnian Muslim men had been separated. P4175 (Witness Statement of Robert Franken dated 15 January 2012), para. 106. At one point Deronjić told Katanić that he was pleased with the outcome of the meetings as the UNPROFOR representatives and the Bosnian Muslim representative signed a document "stating that Deronjić was not responsible for any possible civilian casualties and that he had done his part of work well.” P4374 (Witness statement of Milenko Katanić dated 11 October 2011), para. 67.

17383 D2022 (Debriefing Statement to Royal Dutch Army by Robert Franken), p. 1. Janković made clear to Franken that the signing would not be "an absolute condition but favour the procedure with the evacuation of the wounded in Bratunac and out of [the UN] Compound". P4175 (Witness Statement of Robert Franken dated 15 January 2012), para. 107.

17384 P4175 (Witness Statement of Robert Franken dated 15 January 2012), para. 106; P3997 (Declaration of RS Civilian Affairs Committee for Srebrenica, 17 July 1995); P4185 (Declaration by the Civilian Affairs Committee for Srebrenica re: proper implementation of evacuation procedures, 17 July 1995). See also P5188 (Report of Sarajevo RDB, 18 July 1995), p. 1; D2022 (Debriefing Statement to Royal Dutch Army by Robert Franken), p. 1.

17385 D3977 (Witness statement of Mile Dmičić dated 29 October 2013), para. 17. See also para. 5785. 
5130. Also during this meeting, the VRS delegation announced that MSF and DutchBat local staff could leave the enclave with DutchBat. ${ }^{17386}$ There were eight MSF local employees, seven ablebodied men, and one female. ${ }^{17387}$

5131. Later that same day, approved by "the state and military leadership of RS", ${ }^{17388}$ and under the supervision of ICRC delegates, all the remaining wounded in the UN Compound were transported in DutchBat trucks to the Bratunac Health Centre, and together with some of the wounded there, they were all transported to Tuzla. ${ }^{17389}$ Among the wounded and sick at the Bratunac Health Centre, a number of men were selected as "fit for military service" as POWs, and were not allowed to leave. ${ }^{17390}$ They were subsequently taken by the Eastern Bosnia Corps MP to Batković Camp on 18 July, and were among the POWs exchanged at the end of 1995 in the presence of the ICRC. ${ }^{17391}$

\section{(H) Withdrawal}

5132. On 18 July, a report written by Janković was sent from the Bratunac Brigade to the Main Staff Sector for Intelligence and Security Affairs and the Drina Corps' corresponding departments, in which Janković and Momir Nikolić stated that the State Security Department informed them of

17386 P3995 (Witness Statement of Albert Rave dated 10 November 2011), para. 131. See also P4752 (Witness statement of Christine Schmitz dated 21 March 2012), para. 65; P4758 (List of MSF patients, 17 July 1995), p. 10 (including Schmitz's note that "all local staff amnestied”); Christine Schmitz, T. 26825-26826, 26843 (26 March 2012). See also P4161 (UNMO Report, 17 July 1995), p. 1.

17387 Christine Schmitz, T. 26826-26830 (26 March 2012); P4757 (Collection of MSF telex messages, 5-17 July 1995), p. 8; P4752 (Witness statement of Christine Schmitz dated 21 March 2012), paras. 62, 74; P4166 (MSF telex messages, 9-13 July 1995), p. 5; P5262 (Intercept of conversation between Janković and Col. Đurđić, 19 July 1995), pp. 3-5. The local staff members were all issued with ID cards. Christine Schmitz, T. 26820 (26 March 2012). See also Christine Schmitz, T. 26832, 26840-26841 (26 March 2012); P4754 (MSF ID card).

17388 P5188 (Report of Sarajevo RDB, 18 July 1995).

17389 P3995 (Witness Statement of Albert Rave dated 10 November 2011), paras. 128, 132; P4752 (Witness statement of Christine Schmitz dated 21 March 2012), para. 69; P4757 (Collection of MSF telex messages, 5-17 July 1995), pp. 10-11; P5188 (Report of Sarajevo RDB, 18 July 1995), p. 1; P4161 (UNMO Report, 17 July 1995), p. 1; P5177 (Report of UNSG, 30 August 1995), para. 50 (noting that the transport was also taken place on 18 July); P5318 (Intercept of conversation between Đurđić and Jelena, 16 July 1995). See also P4175 (Witness Statement of Robert Franken dated 15 January 2012), para. 107.

17390 P5188 (Report of Sarajevo RDB, 18 July 1995), p. 1; P5177 (Report of UNSG, 30 August 1995), para. 50. See also P4175 (Witness Statement of Robert Franken dated 15 January 2012), para. 103 (stating that he had heard from a DutchBat doctor that seven men with whom the doctor had stayed to ensure that they were treated as wounded had disappeared from the Bratunac Health Centre); P3995 (Witness Statement of Albert Rave dated 10 November 2011), para. 130; P4161 (UNMO Report, 17 July 1995), p. 1; P5440 (RS Ministry of Defence list of persons exchanged from the Batković Collection Centre, 13 March 2002) (showing that these seven men were transported to Batković and exchanged in 1995).

17391 P5440 (RS Ministry of Defence list of persons exchanged from the Batković Collection Centre, 13 March 2002). See para. 5502. 
"the view that President Karadžić apparently pardoned all the local staff who worked for UNPROFOR". ${ }^{17392}$

5133. On 19 July, Janković and Đurić discussed the transportation of MSF staff. ${ }^{17393}$ In response to Janković's remark that MSF local staff was allowed by the "Koljević government" to leave Potočari, Đurić said that they should be checked to determine whether they were able-bodied men. ${ }^{17394}$ On 20 July, MSF staff learned that they would be allowed to leave the enclave with DutchBat. $^{17395}$

5134. As instructed by the VRS command, at around 9:45 a.m. on 21 July, Karremans and Rave went to Hotel Fontana to finalise the arrangements for DutchBat's withdrawal with Mladić and Janković. ${ }^{17396}$ Mladić refused Karremans' request for the return of DutchBat's apprehended military equipment and material. ${ }^{17397}$ When Nicolai objected, Mladić threatened that "the entire battalion would walk [out] of the enclave only with their uniforms on". 17398

5135. As ultimately agreed that morning, ${ }^{17399}$ Mladić arrived at the UN Compound at noon. ${ }^{17400}$ He drove ahead of the DutchBat convoy, which also included MSF local and international staff as well as UNMOs, ${ }^{17401}$ and stopped briefly at the Iron Bridge before crossing the border into Serbia. ${ }^{17402}$ Nicolai, Karremans, Mladić, and some other officers were present in the vicinity of the bridge, saluting as the vehicles passed. ${ }^{17403}$

17392 P4390 (Report from Bratunac Brigade, 18 July 1995); Momir Nikolić, T. 24683-24684, 24687 (14 February 2012).

17393 P5262 (Intercept of conversation between Janković and Col. Đurđić, 19 July 1995).

17394 P5262 (Intercept of conversation between Janković and Col. Đurđić, 19 July 1995), pp. 3-5; P4752 (Witness statement of Christine Schmitz dated 21 March 2012), para. 74 (confirming that those mentioned in this intercept were the MSF local staff still in Potočari at the time).

17395 P4752 (Witness statement of Christine Schmitz dated 21 March 2012), paras. 75-76 (stating that MSF international staff remained with their local colleagues and five of their relatives after the departure of the wounded).

17396 P3995 (Witness Statement of Albert Rave dated 10 November 2011), para. 133.

17397 P3995 (Witness Statement of Albert Rave dated 10 November 2011), para. 133 (recalling that Mladić said that the equipment was not available at the moment).

17398 P3995 (Witness Statement of Albert Rave dated 10 November 2011), para. 133. Some DutchBat APCs, as well as a few jeeps, some heavy machine guns, and small calibre weapons were indeed taken by the Bosnian Serb Forces during the withdrawal. P4175 (Witness Statement of Robert Franken dated 15 January 2012), para. 84.

17399 P3995 (Witness Statement of Albert Rave dated 10 November 2011), para. 134.

17400 P3995 (Witness Statement of Albert Rave dated 10 November 2011), para. 134.

17401 P4752 (Witness statement of Christine Schmitz dated 21 March 2012), para. 76; P4140 (Witness statement of Joseph Kingori dated 8 January 2002), para. 218.

17402 P3995 (Witness Statement of Albert Rave dated 10 November 2011), para. 134; P4175 (Witness Statement of Robert Franken dated 15 January 2012), para. 110. From 13 July until its ultimate withdrawal on 21 July 1995 , DutchBat did not have any freedom of movement to leave the UN Compound. P4175 (Witness Statement of Robert Franken dated 15 January 2012), para. 109; P3995 (Witness Statement of Albert Rave dated 10 November 2011), para. 102. The DutchBat soldiers who had been taken prisoner at the OPs were still being 


\section{v. Killings}

\section{(A) Near the UN Compound}

5136. The Indictment refers to the killing on or about 12 July 1995 of nine Bosnian Muslim men near the UN Compound in Potočari on the Budak side of the main road. ${ }^{17404}$

5137. On 13 July 1995, DutchBat officers Rutten, Koster, and Van Schaik were patrolling near a blockade created out of four DutchBat APCs in Potočari. ${ }^{17405}$ There, the three officers heard from their Bosnian Muslim interpreter of rumours concerning men having been killed "near a well, near the road, on the Budak side" of Potočari. ${ }^{17406}$

5138. Directed by a local woman, the three officers walked up a dirt road towards a small stream until they reached a meadow located behind a house, approximately 80 or 100 metres southwest of the White House. ${ }^{17407}$ As they entered the meadow, they saw nine men, all about 45 to 55 years old, in civilian clothes, lying on the ground. ${ }^{17408}$ They had all been shot, with bullet holes from small calibre weapons in their backs at heart level. ${ }^{17409}$ Rutten could see that the men had been shot recently, as their bodies were still warm, without flies, and with blood still flowing from their

held at—and were eventually released directly from—the Hotel Fontana. P4175 (Witness Statement of Robert Franken dated 15 January 2012), para. 101.

17403 P4175 (Witness Statement of Robert Franken dated 15 January 2012), para. 110.

17404 Indictment, Scheduled Killing Incident E.14.1.

17405 P3948 (Witness statement of Johannes Rutten dated 8 November 2011), paras. 68-69, 73; P3958 (Aerial photograph of Potočari) (where Rutten marked the blockade. See also (Witness statement of Johannes Rutten dated 8 November 2011), para. 76; P3964 (Aerial photograph of Potočari marked by Johannes Rutten).

17406 P3948 (Witness statement of Johannes Rutten dated 8 November 2011), para. 68.

17407 P3948 (Witness statement of Johannes Rutten dated 8 November 2011), paras. 69, 74-75; P3962 (Sketch drawn by Johannes Rutten); P3958 (Aerial photograph of Potočari); P4175 (Witness statement of Robert Franken dated 15 January 2012), para. 94; P4177 (Photograph of Potočari dated 13 July 1995 marked by Robert Franken). See also Adjudicated Fact 1651.

17408 P3948 (Witness statement of Johannes Rutten dated 8 November 2011), para. 70. See also Adjudicated Fact 1651.

17409 P3948 (Witness statement of Johannes Rutten dated 8 November 2011), paras. 70, 74; Johannes Rutten, T. 22038-22039 (28 November 2011); P3962 (Sketch drawn by Johannes Rutten) (identifying the place where Rutten found the nine bodies); P3958 (Aerial photograph of Potočari) (depicting the location where Rutten found the nine bodies); P3963 (Aerial photograph of Potočari marked by Johannes Rutten); P3964 (Aerial photograph of Potočari marked by Johannes Rutten). See also P4175 (Witness statement of Robert Franken dated 15 January 2012), para. 94; Robert Franken, T. 23175 (17 January 2012); P3995 (Witness statement of Albert Rave dated 10 November 2011), para. 114; Pieter Boering, T. 22144 (30 November 2011). 
wounds. ${ }^{17410}$ According to Rutten, the bodies did not appear to have been moved. ${ }^{17411}$ The DutchBat officers concluded that the men were executed. ${ }^{17412}$

5139. Rutten took a photo of the bodies and told Van Schaik to collect the IDs lying on the grass in front of the bodies. ${ }^{17413}$ At that moment shots were fired, and Rutten ordered Van Schaik to drop the IDs. ${ }^{17414}$ The three officers then left the area. ${ }^{17415}$

5140. After returning to the UN Compound, Rutten reported the incident to Karremans, who told Rutten that he would report the events up the chain of command. ${ }^{17416}$

5141. The Chamber notes the lack of direct evidence indicating that these victims were Bosnian Muslims, or that they were killed by members of the Bosnian Serb Forces. However, the Chamber finds the circumstances in Potočari in July 1995 convincing in this respect. The Chamber notes the proximity of the killing site to Potočari, the presence of Bosnian Serb Forces there on the day in question, and the conclusion by Rutten that the men had been killed recently and that their bodies had not been moved. Accordingly, the Chamber finds that nine Bosnian Muslim men were killed on 13 July 1995 by members of the Bosnian Serb Forces in a meadow southwest of the White House in Potočari.

(B) The White House

5142. The Indictment refers to the killing on or about 13 July 1995 of one Bosnian Muslim man behind a building near the White House in Potočari. ${ }^{17417}$

17410 P3948 (Witness statement of Johannes Rutten dated 8 November 2011), para. 70.

17411 Rutten concluded that the bodies had not been moved after being shot, as there were no marks indicating that they had been transported; Rutten did not conduct an on-site investigation, but Koster and Van Schaik had the same impression. Johannes Rutten, T. 22038-22039 (28 November 2011); P3948 (Witness statement of Johannes Rutten dated 8 November 2011), para. 70.

17412 P4175 (Witness statement of Robert Franken dated 15 January 2012), para. 94; D2022 (Debriefing Statement to Royal Dutch Army by Robert Franken), p. 2.

17413 P3948 (Witness statement of Johannes Rutten dated 8 November 2011), para. 71. As mentioned above, although Rutten kept the film until he returned to The Netherlands, it was later lost during the development process. See fn. 17335.

17414 P3948 (Witness statement of Johannes Rutten dated 8 November 2011), para. 72 (stating that he gave the order to drop the IDs because they had to go back through the blockage of APCs and did not feel safe of having documents with them).

17415 P3948 (Witness statement of Johannes Rutten dated 8 November 2011), para. 72.

17416 P3948 (Witness statement of Johannes Rutten dated 8 November 2011), para. 73; P4175 (Witness statement of Robert Franken dated 15 January 2012), para. 94; Robert Franken, T. 23175 (17 January 2012); P3995 (Witness statement of Albert Rave dated 10 November 2011), para. 114.

17417 Indictment, Scheduled Killing Incident E.14.2. 
5143. Paul Groenewegen, a DutchBat soldier, testified that on 13 July 1995, while patrolling near the White House, he was drawn to a situation in which four Bosnian Serb soldiers had surrounded an unarmed Bosnian Muslim man and taken him out of the crowd of refugees. ${ }^{17418}$

5144. The soldiers then took the man behind the White House, made him stand facing a wall, and shot him in the head from a distance of about three metres. ${ }^{17419}$ Immediately after being hit by the bullet, the man collapsed. ${ }^{17420}$ The soldiers then ran away. ${ }^{17421}$ Other Bosnian Serb soldiers who were walking around the area saw the incident but continued their activities. ${ }^{17422}$ Groenewegen reported the incident the next morning to his senior officer, Lieutenant Schotman. ${ }^{17423}$

5145. The Chamber finds that a Bosnian Muslim man was killed on 13 July 1995 by members of the Bosnian Serb Forces behind the White House in Potočari.

\section{(C) Killings at Luke School near Tišća}

5146. The Indictment refers to the killing on or about 13 or 14 July 1995 of 25 Bosnian Muslim men who were detained at the Luke School near Tišća and summarily executed in an isolated nearby pasture. ${ }^{17424}$

5147. On 13 July 1995, a convoy of buses filled with Bosnian Muslim women and children, as well as several men, including KDZ070, departed from Potočari. ${ }^{17425}$ As convoys had the day before, ${ }^{17426}$ this convoy headed towards Bratunac, and then proceeded through Glogova, Kravica,

17418 Paul Groenewegen, T. 22972-22973 (13 January 2012); P4167 (Witness statement of Paul Groenewegen dated 11 November 2011), paras. 58, 60-63, 65, 67; P4168 (Photograph of buses and trucks marked by Paul Groenewegen).

17419 P4167 (Witness statement of Paul Groenewegen dated 11 November 2011), paras. 61, 67; P4168 (Photograph of buses and trucks marked by Paul Groenewegen); P4169 (Aerial image of Potočari dated 13 July 1995 annotated by Paul Groenewegen); P4171 (Aerial image marked by Paul Groenewegen) (indicating the spot where he saw the man being shot). Groenewegen explained that he was standing at a distance of about 30 metres from the execution site, and that there was nothing obstructing his view; however, because of his location, he could not see the man's face. P4167 (Witness statement of Paul Groenewegen dated 11 November 2011), para. 65. See also Adjudicated Fact 1662.

17420 P4167 (Witness statement of Paul Groenewegen dated 11 November 2011), para. 65.

17421 Paul Groenewegen, T. 23005 (13 January 2012).

17422 P4167 (Witness statement of Paul Groenewegen dated 11 November 2011), para. 65.

17423 P4167 (Witness statement of Paul Groenewegen dated 11 November 2011), para. 66. See also P4175 (Witness statement of Robert Franken dated 15 January 2012), para. 95; D2022 (Debriefing Statement to Royal Dutch Army by Robert Franken), p. 2.

17424 Indictment, Scheduled Killing Incident E.5.1.

17425 KDZ070, P341 (Transcript from Prosecutor v. Krstić), T. 1253-1259.

17426 On 12 July 1995, Boering, escorted by Kosorić, followed a convoy of buses carrying Bosnian Muslims from Potočari, which ultimately stopped at Luke. Pieter Boering, P3969 (Transcript from Prosecutor v. Popović et al.), T. 2020-2022; D3562 (Witness statement of Svetozar Kosorić dated 27 February 2013), para. 10; Svetozar Kosorić, T. 38699-38700 (23 May 2013). The Chamber notes that although he acknowledged being present in Potočari and escorting Pieter Boering to Luke, Kosorić claimed that he had nothing to do with the bussing operation. Svetozar Kosorić, T. 38697-38698, 38700 (23 May 2013). The Chamber considers that in light of 
Konjević Polje, Nova Kasaba, Milići, Vlasenica, and Tišća. ${ }^{17427}$ At Tišća, the Bosnian Muslims were instructed to disembark from the buses and proceed on foot. ${ }^{17428}$ Approximately 10 to 15 Bosnian Muslim men aboard the buses, including KDZ070, were separated by VRS soldiers and taken away in the direction of the Luke School, ${ }^{17429}$ which was located approximately one kilometre from Tišća near Vlasenica. ${ }^{17430}$

5148. In front of the Luke School, the Bosnian Muslim men were ordered to sit down on the grass; most had their hands tied behind their back. ${ }^{17431}$ Buses came and went, bringing more Bosnian Muslim men. ${ }^{17432}$ At the end of the day, a total of 22 men were assembled on the grass. ${ }^{17433}$ According to KDZ070, one detainee was named "Abdulkadir". ${ }^{17434}$ KDZ070 recognised three Bosnian Serb soldiers there: Savo Ristanović, a soldier named Željko, ${ }^{17435}$ and a soldier named Stanimir. ${ }^{17436}$ Later in the evening, after the men were taken into a classroom in the Luke School, ${ }^{17437}$ KDZ070 saw another Bosnian Serb soldier named Spomenko Garić inside the school. $^{17438}$

Kosorić's incentive to minimise any involvement he might have had in the bussing operation, Kosorić's testimony in this regard does not cast doubt on its finding that Kosorić accompanied the convoy as well as Boering on 12 July. See para. 5104, fn. 17426.

17427 KDZ070, P341 (Transcript from Prosecutor v. Krstić), T. 1258-1259. See also Adjudicated Fact 1737.

17428 KDZ070, P341 (Transcript from Prosecutor v. Krstić), T. 1260-1261. See also Pieter Boering, P3969 (Transcript from Prosecutor v. Popović et al.), T. 2022-2024; Pieter Boering, T. 22059 (29 November 2011).

17429 KDZ070, P341 (Transcript from Prosecutor v. Krstić), T. 1260-1263; KDZ070, P341 (Transcript from Prosecutor v. Popović et al.), T. 3426. See also Pieter Boering, P3969 (Transcript from Prosecutor v. Popović et al.), T. 2022-2024, 2159-2161; Pieter Boering, T. 22059 (29 November 2011); Adjudicated Fact 1737. These VRS soldiers were supervised by a VRS Major named Sarkić, a liaison officer in the Milići Brigade, who was there on an order from the Drina Corps. Pieter Boering, P3969 (Transcript from Prosecutor v. Popović et al.), T. 2023-2024. See also KDZ070, P341 (Transcript from Prosecutor v. Krstić), T. 1261-1262; Adjudicated Facts $1738,1739$.

17430 Jean-René Ruez, T. 23725 (26 January 2012); P4308 (Book of photographs and maps prepared by Jean-René Ruez, 22 June 2009), e-court pp. 28-31.

17431 KDZ070, P341 (Transcript from Prosecutor v. Krstić), T. 1262, 1268-1269.

17432 KDZ070, P341 (Transcript from Prosecutor v. Krstić), T. 1268; KDZ070, P341 (Transcript from Prosecutor v. Popović et al.), T. 3472.

17433 KDZ070, P341 (Transcript from Prosecutor v. Popović et al.), T. 3472; KDZ070, P341 (Transcript from Prosecutor v. Krstić), T. 1268-1269.

17434 KDZ070, P341 (Transcript from Prosecutor v. Krstić), T. 1262, 1269 (stating that Abdulkadir was young man from Srebrenica).

17435 KDZ070, P341 (Transcript from Prosecutor v. Krstić), T. 1270-1271 (further stating that Željko was seen on a field telephone transmitting and receiving orders). See also Adjudicated Fact 1743.

17436 KDZ070, P341 (Transcript from Prosecutor v. Krstić), T. 1270-1273, 1277.

17437 KDZ070, P341 (Transcript from Prosecutor v. Krstić), T. 1281; Adjudicated Fact 1744. KDZ070 identified the classroom of the Luke School. KDZ070, P341 (Transcript from Prosecutor v. Popović et al.), T. 3427; P220 (Photograph of classroom in Luke school). See also Jean-René Ruez, T. 23725-23726 (26 January 2012); P4308 (Book of photographs and maps prepared by Jean-René Ruez, 22 June 2009), e-court pp. 30-31.

17438 KDZ070, P341 (Transcript from Prosecutor v. Krstić), T. 1282-1283. KDZ070 and Garić had been colleagues at a bauxite mine company in Srebrenica. KDZ070, P341 (Transcript from Prosecutor v. Krstić), T. 1274. Stanimir told KDZ070 that Spomenko Garić was a Commander of a Special Intervention Unit in the army. KDZ070, P341 (Transcript from Prosecutor v. Krstić), T. 1276-1277 (further stating that Stanimir had said that 
5149. Soon after, a group of about ten Bosnian Serb soldiers, who were different than those who had been at the school during the day, entered the classroom. ${ }^{17439}$ The Bosnian Serb soldiers approached the group of detainees and began to ask them questions. ${ }^{1740}$ Every question was accompanied by a blow to the head or a kick to the chest. ${ }^{1741}$ The soldiers taunted the detainees with a flag of a mosque, referring to their balija mothers. ${ }^{17442}$ The beatings lasted for up to half an hour, after which these soldiers departed. ${ }^{17443}$

5150. After the soldiers left, at around midnight on 13 July, five or six Bosnian Serb soldiers who had been outside during the day entered the classroom. ${ }^{17444}$ They asked the detainees to exit the classroom one by one, and board a truck. ${ }^{17445}$ In total, there were 22 Bosnian Muslim men and seven Bosnian Serb soldiers in the truck. ${ }^{17446}$

5151. The truck departed towards Vlasenica, where it turned left on a macadam road, stopping at a small brook. ${ }^{17447}$ A Bosnian Serb soldier banged on the cabin roof and said "Not here. Take them up there, where they took people before." ${ }^{17448}$ The truck proceeded, and soon stopped in Rašića Gaj, in the middle of an abandoned and overgrown meadow, near an unfinished house. ${ }^{17449}$

5152. The headlights of the truck remained lit and Bosnian Serb soldiers got off. ${ }^{17450}$ Immediately thereafter, the Bosnian Serb soldiers started shooting the men who were still on the truck. ${ }^{17451}$ Two men sitting next to KDZ070 jumped off the truck and ran 20 metres before they were struck by bullets. ${ }^{17452}$ KDZ070 managed to free one of his hands, jumped off the truck, but was noticed by a

Spomenko Garić had been successful in his sabotage actions, especially one near the tunnel that belonged to the lead and zinc mine in the vicinity of Srebrenica).

17439 KDZ070, P341 (Transcript from Prosecutor v. Krstić), T. 1285, 1287-1288 (further stating that the soldiers were wearing the same coverall type uniform as Garić, with different coloured bandanas tied in the back, similar to those of sabotage units).

17440 KDZ070, P341 (Transcript from Prosecutor v. Krstić), T. 1285-1286; Adjudicated Fact 1744.

17441 KDZ070, P341 (Transcript from Prosecutor v. Krstić), T. 1285-1286. See also Adjudicated Fact 1745.

17442 KDZ070, P341 (Transcript from Prosecutor v. Krstić), T. 1286.

17443 KDZ070, P341 (Transcript from Prosecutor v. Krstić), T. 1287-1288; KDZ070, P340 (Transcript from Prosecutor v. Krstić), T. 3428-3429 (under seal); P301 (Photograph of KDZ070) (under seal).

17444 KDZ070, P341 (Transcript from Prosecutor v. Krstić), T. 1288-1290, 1292.

17445 KDZ070, P341 (Transcript from Prosecutor v. Krstić), T. 1288-1290, 1292. See also Adjudicated Fact 1746. Those who could not climb the truck by themselves because of their injuries were picked up by Bosnian Serb soldiers and loaded onto the truck. KDZ070, P341 (Transcript from Prosecutor v. Krstić), T. 1291.

17446 KDZ070, P341 (Transcript from Prosecutor v. Krstić), T. 1291.

17447 KDZ070, P341 (Transcript from Prosecutor v. Krstić), T. 1293.

17448 KDZ070, P341 (Transcript from Prosecutor v. Krstić), T. 1291-1293.

17449 KDZ070, P341 (Transcript from Prosecutor v. Krstić), T. 1295 (further stating that that he learned much later that the place was called Rašića Gaj from a man from Cerska who knew the area quite well and that Rašića Gaj was close to Vlasenica).

17450 KDZ070, P341 (Transcript from Prosecutor v. Krstić), T. 1295.

17451 KDZ070, P341 (Transcript from Prosecutor v. Krstić), T. 1296. See also Adjudicated Fact 1746.

17452 KDZ070, P341 (Transcript from Prosecutor v. Krstić), T. 1296. 
Bosnian Serb soldier who immediately opened fire at him. ${ }^{17453}$ However, KDZ070 managed to reach a forest approximately 50 metres away, and eventually came to a brook, where he stayed and hid for the night. ${ }^{17454}$ KDZ070 wandered around the forest until 27 July 1995, when he met other Bosnian Muslim men, and eventually managed to reach Bosnian Muslim-held territory. ${ }^{17455}$

5153. KDZ070 identified some of the Bosnian Muslims who were on the truck in Rašića Gaj and then killed: Azem Bečić from the village of Kotjevac; "Rizo", who worked as an electrician with DutchBat; "Abdulkadir"; and "Hasan". ${ }^{17456}$ Between 25 and 29 May 2009, the BiHCMP exhumed a grave in the village of Mršići near Vlasenica, and close to Rašića Gaj. ${ }^{17457}$ Based upon DNA analysis, 15 individuals were positively identified as persons listed as missing following the takeover of Srebrenica. ${ }^{17458}$ Nine ligatures were found in the grave. ${ }^{17459}$

5154. Based on the above, the Chamber finds that approximately 21 Bosnian Muslim men were killed by members of the Bosnian Serb Forces near Tišća on 14 July 1995.

\section{e. Bratunac area}

5155. As the Chamber has already described, Bratunac is a municipality in eastern BiH located to the south of Zvornik, the east of Vlasenica, and the north of Srebrenica. ${ }^{1740}$ For the purposes of

17453 KDZ070, P341 (Transcript from Prosecutor v. Krstić), T. 1297 (stating that the soldier said: "Look at this balija motherfucker. He's fleeing, he's escaping”); KDZ070, P341 (Transcript from Prosecutor v. Popović et al.), T. 3441.

17454 KDZ070, P341 (Transcript from Prosecutor v. Krstić), T. 1297-1298; KDZ070, P340 (Transcript from Prosecutor v. Krstić), T. 3439 (under seal).

17455 KDZ070, P341 (Transcript from Prosecutor v. Krstić), T. 1299-1301.

17456 KDZ070, P341 (Transcript from Prosecutor v. Krstić), T. 1301-1302 (further stating that he did not know many others who were detained with him). KDZ017 stated that these men had either been captured from the column heading toward Tuzla, or had been seeking refuge in Potočari in July 1995. KDZ070, P341 (Transcript from Prosecutor v. Krstić), T. 1338-1339.

17457 P4772 (Dušan Janc's report entitled "Update to the summary of Forensic Evidence - Exhumation of the Graves and Surface Remains Recoveries related to Srebrenica - January 2012”, 13 January 2012), e-court pp. 4, 33; P4941 (Srebrenica court binder containing maps), e-court p. 31.

17458 P4772 (Dušan Janc's report entitled "Update to the summary of Forensic Evidence - Exhumation of the Graves and Surface Remains Recoveries related to Srebrenica - January 2012”, 13 January 2012), e-court p. 33; P4771 (Dušan Janc's report entitled "Update to the summary of Forensic Evidence - Exhumation of the Graves and Surface Remains Recoveries related to Srebrenica - January 2012”, 13 January 2012), e-court p. 414 (under seal). See also P5917 (ICMP DNA identifications concerning identified victims related to Srebrenica, 6 December 2010). Four of the victims identified at the Mršići gravesite were Azem (Ramo) Bečić, Rizo (Abaz) Mustafić, Abdulkadir (Avdurahman) Velić, and Hasan (Juso) Smajić. P5917 (ICMP DNA identifications concerning identified victims related to Srebrenica, 6 December 2010); P4771 (Dušan Janc's report entitled "Update to the summary of Forensic Evidence - Exhumation of the Graves and Surface Remains Recoveries related to Srebrenica - January 2012”, 13 January 2012), e-court p. 414 (under seal). See also P6705 (Ewa Tabeau's expert report entitled "Srebrenica Missing: Persons Reported Missing and Dead after the Take-Over of the Srebrenica Enclave by the Bosnian Serb Army on 11 July 1995”, 9 April 2009), e-court pp. 149, 206 (under seal) (recording that Rizo (Abaz) Mustafić and Abdulkadir (Avdurahman) Velić were last seen in Tišća).

17459 P4772 (Dušan Janc's report entitled "Update to the summary of Forensic Evidence - Exhumation of the Graves and Surface Remains Recoveries related to Srebrenica - January 2012”, 13 January 2012), e-court p. 33.

17460 See para. 685. 
this section, the term "Bratunac area" encompasses the territory delimited by the BratunacKonjević Polje Road to the north, the Konjević Polje-Milići Road to the west, and the BratunacSrebrenica Road to the east.

5156. Bratunac town is located about five kilometres from Potočari and ten kilometres from Srebrenica in a northerly direction. ${ }^{17461}$ As stated above, the Bratunac Brigade was headquartered in Bratunac town in July $1995 .^{17462}$

\section{i. Deployment of Bosnian Serb Forces in the Bratunac area}

5157. The Chamber recalls that, during the night between 11 and 12 July 1995, the column of Bosnian Muslim men started moving in a northwesterly direction towards Tuzla, trying to cross the Bratunac-Konjević Polje Road. ${ }^{17463}$

5158. On 11 July, upon receiving information as to the movement of the column, VRS forces, which mostly consisted of Drina Corps units, were ordered to "block the return and withdrawal of Muslim forces to and from Srebrenica and their communicating along the enclave-Kladanj and Olovo axis and back", by "erecting additional obstructions, carrying out ambush activities and introducing patrols, ensur[ing] control over the territory along the frontline and deep in[to] the defence zones and areas". ${ }^{17464}$ That night, Kovač issued an order to urgently dispatch all available guides with police dogs to the Srebrenica sector in order to undertake the task of "mopping up the terrain". 17465

5159. On 12 July, the MUP had information that the ABiH was attempting a breakthrough from Srebrenica in the direction of Tuzla. ${ }^{1746}$ Similarly, the VRS continued tracking the movement of the column and, by the afternoon, the Drina Corps command and subordinate units knew the

\footnotetext{
17461 See P4308 (Book of photographs and maps prepared by Jean-René Ruez, 22 June 2009), e-court p. 20.

17462 See para. 195.

17463 See para. 5037.

17464 P4572 (Order of Drina Corps, 11 July 1995), pp. 1-2. See P6125 (Drina Corps combat report, 11 July 1995), pp. 1, 3 (stating that Drina Corps units have been engaged in offensive operations in and around the Srebrenica enclave according to the Krivaja 95 plan, and adding that part of the active operations forces shall continue to carry out combat tasks and completely crush the enemy in the Srebrenica enclave, while another part of the forces shall control the territory behind the lines and protect the property and population).

17465 P4934 (RS MUP Order to the centre for the breeding and training of police dogs, 12 July 1995) (ordering that such guides were to report to Srebrenica by 6 a.m. on 12 July). See Tomislav Kovač, T. 42746 (1 November 2013). The order further provided that once such troops and dogs were dispatched, dispatches were to be sent to the police forces staff headquarters in Pale notifying them that the deployment had taken place. P4934 (RS MUP Order to the centre for the breeding and training of police dogs, 12 July 1995), para. 5.

17466 Milenko Pepić, P373 (Transcript from Prosecutor v. Popović et al.), T. 13549; P4960 (Combat report signed by Ljubiša Borovčanin, 10-20 July 1995), p. 2; P4937 (Report of Zvornik CJB, 12 July 1995).
} 
precise direction in which the column was moving. ${ }^{17467}$ Intelligence on the movement of the column was relayed within the Bosnian Serb Forces throughout 12 and 13 July. ${ }^{17468}$

5160. Based on the intelligence received, some of the MUP forces under the command of Borovčanin-including the three platoons of the $2^{\text {nd }}$ Šekovići Detachment, the $1^{\text {st }}$ Company of the Zvornik PJP, the $5^{\text {th }}$ Company of the Zvornik CJB, and the $1^{\text {st }}$ Company of the Jahorina Recruitswere deployed along the Bratunac-Konjević Polje Road on 12 July to prevent the column from advancing towards Tuzla. ${ }^{17469}$ There was also a heavy VRS presence on the road that day. ${ }^{17470}$ By the evening, two tanks and a Praga — an anti-aircraft gun mounted on an armoured vehicle-as well as a BOV—an all-wheel drive combat armoured vehicle—had also been deployed along the road, in the same area as the $1^{\text {st }}$ Company of the Zvornik PJP. ${ }^{17471}$

5161. Members of the Bosnian Serb Forces remained overnight along the Bratunac-Konjević Polje Road. ${ }^{17472}$ On 13 July, Krstić issued an order tasking Blagojević with supervising, and coordinating with, the units of the Bosnian Serb Forces involved in the search and with submitting a

17467 See D2081 (Momir Nikolić's statement of facts from Plea Agreement, 7 May 2003), para. 7; P5279 (Intercept of conversation between three unidentified persons, Radislav Krstić, and Komjenović, 12 July 1995), p. 1; P6062 (Intercept of conversation, 12 July 1995), p. 2; P6063 (Intercept of conversation, 12 July 1995), pp. 1-2; P4388 (Drina Corps report to VRS Main Staff, 12 July 1995), p. 1; P5112 (Report of Bratunac Brigade to Drina Corps, 12 July 1995), p. 1; P5114 (Report of Bratunac Brigade to Drina Corps, 12 July 1995), p. 1; KDZ122, T. 2614926150 (13 March 2012) (closed session), T. 26273 (14 March 2012) (closed session). See also Adjudicated Fact 1631; P4914 (Richard Butler's expert report entitled "Srebrenica Military Narrative (Revised): Operation 'Krivaja 95'”, 1 November 2002), para. 4.9.

17468 See P5103 (Report of Drina Corps, 12 July 1995), p. 2; P4388 (Drina Corps report to VRS Main Staff, 12 July 1995), p. 1; P4940 (Command Intelligence Report of Drina Corps, 12 July 1995), p. 1; P5904 (Intercept of conversation between two unidentified persons, 12 July 1995); P5905 (Intercept of conversation between two unidentified persons, 12 July 1995); P5145 (Report of Drina Corps, 13 July 1995), p. 1; P4943 (Report of Sarajevo RDB, 13 July 1995), pp. 1-2; P4944 (Command Report of Drina Corps, 13 July 1995); P2988 (Report of RS MUP, 13 July 1995), pp. 1-2; P5098 (Report of RS MUP, 13 July 1995), pp. 1-2; P5099 (Report of Bijeljina RJB, 13 July 1995); P5115 (Report of Bratunac Brigade to Drina Corps, 13 July 1995), p. 1; P5234 (Report of Drina Corps, 13 July 1995); Adjudicated Fact 1608.

17469 P4937 (Report of Zvornik CJB, 12 July 1995); P4960 (Combat report signed by Ljubiša Borovčanin, 10-20 July 1995), p. 2; P2987 (Report of RS MUP's Special Police Brigade, 13 July 1995), p. 2; Milenko Pepić, P373 (Transcript from Prosecutor v. Popović et al.), T. 13552; KW558, T. $40753-40754$ (3 July 2013); Mendeljev Đurić, T. 42099 (29 July 2013); D3196 (Witness statement of Dušan Mićić dated 24 March 2013), paras. 25-27. See P4914 (Richard Butler's expert report entitled "Srebrenica Military Narrative (Revised): Operation 'Krivaja 95'”, 1 November 2002), para. 6.24; P6189 (Report of Zvornik CJB, 13 July 1995), p. 1; P6063 (Intercept of conversation, 12 July 1995), pp. 1-2; KDZ122, T. 26149-26150 (13 March 2012) (closed session); Adjudicated Facts 1469, 1471, 1606. See also para. 5021.

17470 See P4574 (Order of Drina Corps, 12 July 1995); P4960 (Combat report signed by Ljubiša Borovčanin, 10-20 July 1995), p. 2; P3054 (VRS Main Staff Report, 12 July 1995), p. 4; P4937 (Report of Zvornik CJB, 12 July 1995); Vincentius Egbers, P331 (Transcript from Prosecutor v. Popović et al.), T. 2723-2724; D2081 (Momir Nikolić's statement of facts from Plea Agreement, 7 May 2003), para. 7; P5100 (Order of Drina Corps, 13 July 1995), pp. 1-2; P6063 (Intercept of conversation, 12 July 1995), pp. 1-2.

17471 P4960 (Combat report signed by Ljubiša Borovčanin, 10-20 July 1995), p. 2. See also Milenko Pepić, P373 (Transcript from Prosecutor v. Popović et al.), T. 13554; D3196 (Witness statement of Dušan Mićić dated 24 March 2013), para. 27.

17472 P2987 (Report of RS MUP's Special Police Brigade, 13 July 1995), p. 2; Milenko Pepić, P373 (Transcript from Prosecutor v. Popović et al.), T. 13579; KDZ084, P4904 (Transcript from Prosecutor v. Popović et al.), T. 14821-14822 (under seal); D3196 (Witness statement of Dušan Mićić dated 24 March 2013), paras. 27-28. 
report at the end of the search on 17 July. ${ }^{17473}$ The Bosnian Serb Forces deployed along the Bratunac-Konjević Polje Road were reinforced with additional forces on 13 July, including members of the $5^{\text {th }}$ Company of the Zvornik PJP, and members of the $1^{\text {st }}$ and $2^{\text {nd }}$ Companies of the Jahorina Recruits. ${ }^{17474}$ The Jahorina Recruits were called up by the platoon leaders "to relieve [their] colleagues" who were guarding Bosnian Muslim detainees on the stretch of the road between Konjević Polje and Kravica. ${ }^{17475}$ They were to stand on the road to collect any Bosnian Muslims found coming down from the hills to surrender, and to prevent "any forcible passing". ${ }^{17476}$ Similarly, the members of the $2^{\text {nd }}$ Šekovići Detachment's $3^{\text {rd }}$ Skelani Platoon, who were stationed in groups of two positioned 30 to 40 metres apart along the road, were tasked with escorting detainees who surrendered into the Sandići Meadow. ${ }^{17477}$

\section{ii. Military action against the column}

5162. On the morning of 12 July, the column was shelled by the Bosnian Serb Forces as it moved through the area of Buljim. ${ }^{17478}$ That night, there was a large ambush against the column in Kamenica. ${ }^{17479}$ During the night of 12 July and the morning of 13 July, there was an exchange of fire between the Bosnian Serb Forces and members of the column, resulting in many Bosnian

17473 D2239 (Order of Drina Corps, 13 July 1995); Radislav Krstić, D4136 (Transcript from Prosecutor v. Krstić), T. 6700-6703, 6716. The Chamber notes that while testifying in his own defence, Krstić asserted that Blagojević lacked the authority to specify tasks of the MUP, but does not consider his testimony to be reliable on this point given that Krstić was Blagojević's superior. Rather, the Chamber considers that the text of Krstić's order is clear that Blagojević was responsible for coordinating the tasks of all units mentioned, and recalls that, as described above, MUP units engaged in combat activities were re-subordinated to the commander of the unit in whose area of combat operations they were conducting operations. See para. 229.

17474 P4960 (Combat report signed by Ljubiša Borovčanin, 10-20 July 1995), p. 2; D3903 (Witness statement of Mendeljev Đurić dated 26 July 2013), para. 18; KDZ084, T. 27336 (11 April 2012) (closed session). See also Adjudicated Fact 1616; P5376 (Intercept of conversation between two unidentified persons, 13 July 1995), p. 1 (referring to the arrival of certain police units); P4949 (Report of Zvornik CJB, 14 July 1995), p. 1; P316 (Report of Zvornik CJB to MUP of RS, 15 July 1995), para. 2.

17475 KDZ084, P4904 (Transcript from Prosecutor v. Popović et al.), T. 14821-14822, 14825 (under seal); KDZ084, T. 27336 (11 April 2012) (closed session).

17476 KDZ084, P4904 (Transcript from Prosecutor v. Popović et al.), T. 14824-14825 (under seal). The Jahorina Recruits stayed in the area for four or five days. P4904 (Transcript from Prosecutor v. Popović et al.), T. 14836, 14882 (under seal).

17477 D4113 (Witness statement of KW679 dated 23 November 2013), paras. 11-12 (under seal).

17478 KDZ071, P5029 (Transcript from Prosecutor v. Popović et al.), T. 7083, 7133; KDZ069, P339 (Transcript from Prosecutor v. Blagojević \& Jokić), T. 1383; KDZ069, P339 (Transcript from Prosecutor v. Popović et al.), T. 3347; KDZ425, P381 (Transcript from Prosecutor v. Popović et al.), T. 3511-3513; KDZ065, P336 (Transcript from Prosecutor v. Krstić), T. 2333. See P3975 (Map of Eastern Bosnia); D2218 (Map of Eastern BiH marked by Dušan Janc), p. 1 (map showing Buljim forest and the column's direction towards Tuzla). See also KDZ064, P769 (Transcript from Prosecutor v. Popović et al.), T. 744; KDZ333, T. 24143 (2 February 2012).

17479 Mevludin Orić, P350 (Transcript from Prosecutor v. Popović et al.), T. 877, 880, 907; KDZ063, P334 (Transcript from Prosecutor v. Popović et al.), T. 7040; KDZ069, P339 (Transcript from Prosecutor v. Popović et al.), T. 3364-3365; KDZ425, P381 (Transcript from Prosecutor v. Popović et al.), T. 3513-3514; KDZ045, T. 22673-22674 (10 January 2012); KDZ333, T. 24143 (2 February 2012). See P5102 (Report of Drina Corps, 12 July 1995); P4939 (Report of Sarajevo RDB, 12 July 1995), p. 1. 
Muslim deaths. ${ }^{17480}$ The attacks against the column continued throughout the night, and into the morning of 13 July. ${ }^{17481}$ Bosnian Serb Forces encircled a large group of men from the column in the area of Konjević Polje-Nova Kasaba-Pobuđe. ${ }^{17482}$ At different times, members of the column divided into separate smaller groups after being cut off from the main part of the column. ${ }^{17483}$ The Bosnian Serb Forces fired shells against the column and threw hand-grenades into the woods. ${ }^{17484}$ Hundreds of Bosnian Muslims were killed; the mutilated bodies of those killed lay on the ground. ${ }^{17485}$ Men cried and screamed, asking for help. ${ }^{17486}$ The situation was so unbearable that some Bosnian Muslim men committed suicide with guns or hand-grenades. ${ }^{17487}$

5163. On the morning of 13 July, the Bosnian Serb Forces began calling into the woods with a loudspeaker for the members of the column to surrender, telling them that they would be safe, and promising to comply with the Geneva Conventions. ${ }^{17488}$ However, if they did not surrender, they

17480 See P2987 (Report of RS MUP's Special Police Brigade, 13 July 1995), p. 2; P5136 (Bulletin of daily events of Zvornik CJB, 13-14 July 1995), p. 2; P4943 (Report of Sarajevo RDB, 13 July 1995), p. 1; P6189 (Report of Zvornik CJB, 13 July 1995); P5378 (Intercept of conversation between two unidentified persons, 13 July 1995); D3196 (Witness statement of Dušan Mićić dated 24 March 2013), paras. 27-28. See also Adjudicated Facts 1602, 1609. These killings are not charged in the Indictment.

17481 KDZ069, P339 (Transcript from Prosecutor v. Blagojević \& Jokić), T. 1384; KDZ069, P339 (Transcript from Prosecutor v. Popović et al.), T. 3348; KDZ045, P5910 (Transcript from Prosecutor v. Krstić), T. 2946; KDZ063, P334 (Transcript from Prosecutor v. Popović et al.), T. 7039-7040; Mevludin Orić, P350 (Transcript from Prosecutor v. Popović et al.), T. 884; Adjudicated Fact 1611. See P4960 (Combat report signed by Ljubiša Borovčanin, 10-20 July 1995), p. 2; P4943 (Report of Sarajevo RDB, 13 July 1995), p. 1; P667 (Zoran PetrovićPiroćanac's video footage), at 00:12:11-00:16:25.

17482 P5115 (Report of Bratunac Brigade to Drina Corps, 13 July 1995). See P4684 (Intercept of conversation between two unidentified persons, 14 July 1995), p. 1; P5234 (Report of Drina Corps, 13 July 1995), p. 2; P5098 (Report of RS MUP, 13 July 1995), p. 1. See also Dušan Janc, T. 27063-27064 (28 March 2012); D2218 (Map of Eastern BiH marked by Dušan Janc), p. 1 (where Janc marked the area of Pobuđe).

17483 KDZ069, P339 (Transcript from Prosecutor v. Popović et al.), T. 3348, 3355, 3363; KDZ064, P769 (Transcript from Prosecutor v. Popović et al.), T. 652, 744-745; KDZ045, P5910 (Transcript from Prosecutor v. Krstić), T. 2946; KDZ045, T. 22682 (10 January 2012). See P4578 (Zvornik Brigade report, 12 July 1995), p. 1; P5145 (Report of Drina Corps, 13 July 1995), p. 1. See also Adjudicated Fact 1610.

17484 KDZ045, P5910 (Transcript from Prosecutor v. Krstić), T. 2946-2948, 2990; KDZ045, T. 22681-22682 (10 January 2012); KDZ063, P334 (Transcript from Prosecutor v. Popović et al.), T. 7039-7040.

17485 KDZ064, P769 (Transcript from Prosecutor v. Popović et al.), T. 796; KDZ069, P339 (Transcript from Prosecutor v. Blagojević \& Jokić), T. 1383-1384; KDZ069, P339 (Transcript from Prosecutor v. Popović et al.), T. 3347-3349; KDZ425, P381 (Transcript from Prosecutor v. Popović et al.), T. 3514; KDZ045, P5910 (Transcript from Prosecutor v. Krstić), T. 2945-2946, 2948; KDZ045, T. 22673-22674 (10 January 2012); KDZ063, P334 (Transcript from Prosecutor v. Popović et al.), T. 7040. These killings are not charged in the Indictment.

17486 KDZ069, P339 (Transcript from Prosecutor v. Blagojević \& Jokić), T. 1383.

17487 KDZ069, P339 (Transcript from Prosecutor v. Popović et al.), T. 3342, 3345; KDZ064, P769 (Transcript from Prosecutor v. Popović et al.), T. 798; KDZ045, P5910 (Transcript from Prosecutor v. Krstić), T. 2946-2947, 2998; KDZ045, T. 22680-22681 (10 January 2012).

17488 KDZ069, P339 (Transcript from Prosecutor v. Blagojević \& Jokić), T. 1384; KDZ045, P5910 (Transcript from Prosecutor v. Krstić), T. 2946, 3008; KDZ064, P769 (Transcript from Prosecutor v. S. Milošević), T. 28824; KDZ064, P769 (Transcript from Prosecutor v. Popović et al.), T. 650, 801, 842; KDZ425, P381 (Transcript from Prosecutor v. Popović et al.), T. 3516; KDZ063, P334 (Transcript from Prosecutor v. Popović et al.), T. 6974; KDZ084, P4904 (Transcript from Prosecutor v. Popović et al.), T. 14823, 14827 (under seal); Milenko Pepić, P373 (Transcript from Prosecutor v. Popović et al.), T. 13553-13554; Momir Nikolić, T. 24662 (14 February 2012), T. 24864 (16 February 2012). See P5280 (Intercept of conversation between an unidentified person and “Zoran", 13 July 1995), p. 1; D2081 (Momir Nikolić's statement of facts from Plea 
would be shelled and killed. ${ }^{17489}$ In particular, along the Bratunac-Konjević Polje Road, members of the Bosnian Serb Forces drove a stolen UNPROFOR APC with a UN flag back and forth, and called on the column to surrender; the Bosnian Serb soldiers wore UN uniforms to deceive the Bosnian Muslims into thinking that they would be provided security upon their capture. ${ }^{17490} \mathrm{~A}$ Bosnian Muslim man was ordered to call out to the Bosnian Muslim men in the woods that it was "safe to come to the Serbs". ${ }^{17491}$

5164. At about 10 a.m., members of the Bosnian Serb Forces issued an ultimatum through a loudspeaker for the members of the column hiding in the woods to surrender; a second ultimatum was issued around 3 p.m. ${ }^{17492}$ Members of the column disagreed as to whether to surrender. ${ }^{17493}$ However, after the second ultimatum, large numbers of Bosnian Muslim men walked down the hill to the asphalt road and surrendered. ${ }^{17494}$ They were then stripped of their personal belongings. ${ }^{17495}$

Agreement, 7 May 2003), para. 9. See also Adjudicated Fact 1613; D4218 (Witness statement of Mile Petrović dated 29 September 2003), p. 2.

17489 KDZ069, P339 (Transcript from Prosecutor v. Blagojević \& Jokić), T. 1384. See KDZ064, P769 (Transcript from Prosecutor v. Popović et al.), T. 650.

17490 Momir Nikolić, T. 24661-24664 (14 February 2012); D2081 (Momir Nikolić's statement of facts from Plea Agreement, 7 May 2003), para. 9; Mile Petrović, T. 45548, 45552 (17 January 2014); D4218 (Witness statement of Mile Petrović dated 29 September 2003), p. 1; KW582, D4291 (Transcript from Prosecutor v. Blagojević \& Jokić), T. 3530-3532, 3536-3537; KDZ425, P381 (Transcript from Prosecutor v. Popović et al.), T. 3516, 3525; KDZ045, P5910 (Transcript from Prosecutor v. Krstić), T. 3002; KDZ045, T. 22679-22680 (10 January 2012); Milenko Pepić, P373 (Transcript from Prosecutor v. Popović et al.), T. 13554; Mevludin Orić, P350 (Transcript from Prosecutor v. Popović et al.), T. 884-885. See D4218 (Witness statement of Mile Petrović dated 29 September 2003), p. 1. See also Adjudicated Fact 1614.

17491 See P1178 (Excerpt from "Srebrenica Trial Video" shown to KDZ425); P1193 (Zoran Petrović-Piroćanac's documentary entitled "Operation Srebrenica"), at 00:15:23-00:16:30; Adjudicated Fact 1732.

17492 KDZ069, P339 (Transcript from Prosecutor v. Blagojević \& Jokić), T. 1384; KDZ064, P769 (Transcript from Prosecutor v. Popović et al.), T. 650, 759; KDZ064, T. 1435 (22 April 2010); KDZ425, P381 (Transcript from Prosecutor v. Popović et al.), T. 3516.

17493 KDZ069, P339 (Transcript from Prosecutor v. Popović et al.), T. 3349-3350; KDZ064, P769 (Transcript from Prosecutor v. Popović et al.), T. 759, 797; KDZ045, P5910 (Transcript from Prosecutor v. Krstić), T. 2991. See P5280 (Intercept of conversation between an unidentified person and "Zoran", 13 July 1995), p. 1.

17494 KDZ069, P339 (Transcript from Prosecutor v. Blagojević \& Jokić), T. 1384; KDZ069, P339 (Transcript from Prosecutor v. Popović et al.), T. 3364-3365; KDZ425, P381 (Transcript from Prosecutor v. Popović et al.), T. 3517; KDZ063, P334 (Transcript from Prosecutor v. Popović et al.), T. 6973; KDZ045, P5910 (Transcript from Prosecutor v. Krstić), T. 2948; KDZ045, T. 22679 (10 January 2012); KDZ071, P5029 (Transcript from Prosecutor v. Popović et al.), T. 7085, 7110; KDZ064, T. 1435 (22 April 2010); Mevludin Orić, P350 (Transcript from Prosecutor v. Popović et al.), T. 886; Momir Nikolić, T. 24868 (16 February 2012). See P667 (Zoran Petrović-Piroćanac's video footage), at 00:09:23-00:10:24; P5280 (Intercept of conversation between an unidentified person and "Zoran", 13 July 1995), p. 1. See also Adjudicated Fact 1618.

17495 KDZ063, P334 (Transcript from Prosecutor v. Popović et al.), T. 6973-6974; KDZ425, P381 (Transcript from Prosecutor v. Popović et al.), T. 3517, 3523; KDZ069, P339 (Transcript from Prosecutor v. Blagojević \& Jokić), T. 1384-1385; KDZ071, T. 28532 (4 May 2012); KDZ071, P5029 (Transcript from Prosecutor v. Popović et al.), T. 7085, 7087-7088. See also Adjudicated Fact 1617. 
5165. Despite the capture of thousands of Bosnian Muslims from the column on 13 July, it was reported that approximately 3,000 to 4,000 men succeeded in crossing the Bratunac-Konjević Polje and Konjević Polje-Milići Roads, advancing towards Cerska. ${ }^{17496}$

\section{iii. Detention of Bosnian Muslim men from the column}

5166. On the morning of 13 July, Bosnian Serb Forces obtained information that large numbers of Bosnian Muslim men were either being captured or were surrendering along the road. ${ }^{1749}$ An intercepted conversation from 13 July at 5:30 p.m. refers to about 6,000 Bosnian Muslims being detained at three locations, with roughly 1,500 to 2,000 men at each of them. ${ }^{17498}$ According to this intercepted conversation, one of the locations was "the one up there where the checkpoint at the intersection is", which the Chamber finds to be the Konjević Polje intersection; another one was "the one halfway between the checkpoint and the loading place", which the Chamber concludes to be the Sandići Meadow, and the third one was expressly referred to as the Kasaba stadium, which the Chamber finds to be the Nova Kasaba football field. ${ }^{17499}$

\section{(A) Konjević Polje}

5167. The $6^{\text {th }}$ Company of the Zvornik PJP was stationed at the check-point in Konjević Polje from 4 to 16 July $1995 .{ }^{17500}$ It was tasked with providing assistance to the Bratunac SJB, which had control over the check-point, as well as with securing the Nova Kasaba-Konjević Polje Road

17496 See P4960 (Combat report signed by Ljubiša Borovčanin, 10-20 July 1995), p. 2; P5100 (Order of Drina Corps, 13 July 1995), p. 1; P4532 (VRS Main Staff Order, 13 July 1995); P4949 (Report of Zvornik CJB, 14 July 1995), p. 1. See also Adjudicated Facts 1610, 1628, 1630.

17497 Momir Nikolić, T. 24651 (14 February 2012). See also D3918 (Witness statement of Milomir Savčić, dated 21 July 2013), para. 50; Milomir Savčić, T. 42250-42251 (30 July 2013) (testifying that in the early hours of 13 July, he received a phone call from Malinić informing him that Bosnian Muslim soldiers had been captured); D3918 (Witness statement of Milomir Savčić, dated 21 July 2013), para. 51 and Milomir Savčić, T. 42250 (30 July 2013) (testifying that Malinić had explained Savčić that his unit of approximately 20 men had taken two or three prisoners of war who had surrendered to his men at the army barracks in Nova Kasaba). Momir Nikolić testified that he told Jević that if he got in radio contact with the MUP units deployed along the road, he should tell them that all those men were to be transferred to the facilities designated for their detention. Momir Nikolić, T. 24651-24653 (14 February 2012). Savčić testified that he informed Malinić that the prisoners were to be incarcerated in relevant facilities, kept under Malinić's protection and treated in accordance with the prescribed military police regulations. D3918 (Witness statement of Milomir Savčić, dated 21 July 2013), para. 51; Milomir Savčić, T. 42251 (30 July 2013).

17498 P6704 (Intercept of conversation between two unidentified persons, 13 July 1995), p. 1.

17499 P6704 (Intercept of conversation between two unidentified persons, 13 July 1995), p. 1.

17500 KW558, T. $40752-40753$ (3 July 2013), T. 40743 (3 July 2013) (private session); KW558, D3764 (Transcript from Prosecutor v. Blagojević \& Jokić), T. 6517, 6528, 6540. See also Nenad Deronjić, D3760 (Transcript from Prosecutor v. Blagojević \& Jokić), T. 8201, 8206; Mile Simanić, P355 (Transcript from Prosecutor v. Popović et al.), T. 14638-14639, 14647; P4825 (Record of intercept of conversation regarding the arrest of Muslims running from Srebrenica, 13 July 1995). The $6^{\text {th }}$ Company was headquartered in an unfinished house close to the Konjević Polje elementary school; the house also hosted the unit's communications. While some members of the $6^{\text {th }}$ Company were stationed at the house, the remaining members were stationed at the school. KW558, T. 40747 (3 July 2013); KW558, D3764 (Transcript from Prosecutor v. Blagojević \& Jokić), T. 6524 
and controlling traffic. ${ }^{17501}$ A part of the $5^{\text {th }}$ Engineering Battalion, commanded by Milenko, a.k.a. "Mićo" Avramović, ${ }^{17502}$ as well as members of the Zvornik Brigade MP were also present at the Konjević Polje intersection at the time. ${ }^{17503}$

5168. On the morning of 13 July, approximately 30 Bosnian Muslim men from the columnincluding four or five wounded-surrendered to members of the Bosnian Serb Forces who were dressed in dark blue camouflage uniforms, near Konjević Polje. ${ }^{17504}$ Upon reaching the BratunacKonjević Polje Road, this group came across a group of 300 other Bosnian Muslims_-including approximately 20 wounded-who had previously surrendered. ${ }^{17505}$ The men were ordered to place the wounded at the intersection, and to hand over all their belongings, including their ID papers. ${ }^{17506}$ They were then taken to a warehouse at the Konjević Polje intersection, where they were given water, although it was insufficient. ${ }^{17507}$ After approximately 20 minutes, the men were placed in three or four trucks covered in canvas, which left in the direction of Nova Kasaba. ${ }^{17508}$

5169. As will be discussed in detail in the section relating to the Scheduled Killing Incident at the Jadar River, ${ }^{17509}$ during the early morning hours of 13 July, KDZ065 surrendered to policemen in

6527, 6542; D3766 (Photograph of a house); D3767 (Photograph of a house); D3768 (Photograph of houses along a road); D3771 (Photograph of a building). See also D3765 (Diagram drawn by KW558) (under seal). KW558, T. 40752-40753 (3 July 2013); KW558, D3764 (Transcript from Prosecutor v. Blagojević \& Jokić), T. 6517-6518, 6541, 6543-6544. See also Nenad Deronjić, D3760 (Transcript from Prosecutor v. Blagojević \& Jokić), T. 8179-8181; D3852 (Witness statement of Mirko Perić dated 1 July 2013), para. 13; P5900 (Intercept of conversation between Obrenović and an unidentified person, 12 July 1995).

17502 KW558, D3764 (Transcript from Prosecutor v. Blagojević \& Jokić), T. 6523-6524, 6538, 6544-6545, 65566557. See also Mile Simanić, P355 (Transcript from Prosecutor v. Popović et al.), T. 14679-14680; P5900 (Intercept of conversation between Obrenović and an unidentified person, 12 July 1995). The $5^{\text {th }}$ Engineering Battalion was billeted in several private houses in Konjević Polje, including the elementary school where part of the $6^{\text {th }}$ Company of the Zvornik PJP was stationed. Mile Simanić, P355 (Transcript from Prosecutor v. Popović et al.), T. 14625-14626; KW558, D3764 (Transcript from Prosecutor v. Blagojević \& Jokić), T. 6524-6526. See also D3765 (Diagram drawn by KW558) (under seal); D3770 (Photograph of a crossroads); Jean-René Ruez, T. 23731-23732 (26 January 2012); P4308 (Book of photographs and maps prepared by Jean-René Ruez, 22 June 2009), e-court pp. 42-43.

17503 D3852 (Witness statement of Mirko Perić dated 1 July 2013), para. 15. See also KW558, T. 40757 (3 July 2013); KW558, D3764 (Transcript from Prosecutor v. Blagojević \& Jokić), T. 6523-6524 (referring to the presence of other military and police units at Konjević Polje in July 1995).

17504 KDZ045, P5910 (Transcript from Prosecutor v. Krstić), T. 2948-2949; KDZ045, T. 22679-22680 (10 January 2012).

17505 KDZ045, P5910 (Transcript from Prosecutor v. Krstić), T. 2948. See also P5354 (Intercept of conversation between two unidentified persons, 13 July 1995), pp. 2-3 (referring to the presence of approximately 400 to 500 captured Bosnian Muslims in Konjević Polje); P4389 (Report of Sarajevo RDB, 13 July 1995), p. 1 (referring to the VRS and MUP capturing over 300 Bosnian Muslim soldiers in ambushes set up in the general Konjević Polje area).

17506 KDZ045, P5910 (Transcript from Prosecutor v. Krstić), T. 2948-2949; KDZ045, T. 22680, 22685 (10 January 2012).

17507 KDZ045, P5910 (Transcript from Prosecutor v. Krstić), T. 2949.

17508 KDZ045, P5910 (Transcript from Prosecutor v. Krstić), T. 2949-2950; KDZ045, T. 22683 (10 January 2012). See Section IV.C.1.e.iii.C: Nova Kasaba football field.

17509 See Section IV.C.1.e.iv.A: Jadar River. 
the area of Konjević Polje. ${ }^{17510}$ KDZ065 and 15 other Bosnian Muslim men were taken to different locations in the area; finally they were taken by bus to an isolated area on the bank of the Jadar River. $^{17511}$

5170. Momir Nikolić arrived at the Konjević Polje intersection after noon on 13 July and saw men detained at various locations in the vicinity. ${ }^{17512}$ Approximately 45 minutes later, Mladić arrived with his security detail and addressed some of the detainees briefly, reassuring them that everything would be fine and that they would be transferred to where they wanted to go. ${ }^{17513}$ Nikolic then asked Mladić what was going to happen to the detainees; Mladić did not answer but made a gesture by sweeping at his waist with his right hand from left to right. ${ }^{17514}$ Mladić then smiled, got in his car, and left. ${ }^{17515}$

5171. After Mladić left, Momir Nikolić drove to Bratunac to fetch Rešid Sinanović- the former chief of the SUP in Bratunac-for interrogation. ${ }^{17516}$ Sinanović had been detained at the communications house of the $6^{\text {th }}$ Company of the Zvornik PJP together with KDZ065. ${ }^{17517}$ Later, Nikolić, Mirko Janković, and Mile Petrović left Bratunac towards Konjević Polje in a white APC captured from DutchBat. ${ }^{17518}$ They drove along the Bratunac-Konjević Polje Road and Petrović sat on top of the APC with a megaphone calling for Bosnian Muslims to surrender. ${ }^{17519}$ After passing Sandići Meadow, six Bosnian Muslims surrendered to them; those six men were taken to Konjević Polje on the APC. ${ }^{17520}$ After arriving at Konjević Polje, Nikolić asked Petrović to take the six

\footnotetext{
17510 KDZ065, P336 (Transcript from Prosecutor v. Krstić), T. 3244-3246.

17511 KDZ065, P336 (Transcript from Prosecutor v. Krstić), T. 3246-3248, 3250, 3254-3255, 3258, 3262-3264, 3268-3269, 3271-3272, 3274-3276; KDZ065, P335 (Transcript from Prosecutor v. Krstić), T. 3265-3268 (under seal).

17512 Momir Nikolić, T. 24653-24655 (14 February 2012).

17513 Momir Nikolić, T. 24654-24655 (14 February 2012).

17514 Momir Nikolić, T. 24656-24657 (14 February 2012).

17515 Momir Nikolić, T. 24656 (14 February 2012).

17516 Momir Nikolić, T. 24657-24658 (14 February 2012). See D3852 (Witness statement of Mirko Perić dated 1 July 2013), para. 19. See also para. 5199.

17517 See para. 5192

17518 Momir Nikolić, T. 24661-24662 (14 February 2012); D2081 (Momir Nikolić's statement of facts from Plea Agreement, 7 May 2003), para. 9; [REDACTED]; Mile Petrović, T. 45552 (17 January 2014); D4218 (Witness statement of Mile Petrović dated 29 September 2003), p. 2. [REDACTED].

17519 Momir Nikolić, T. 24663 (14 February 2012), T. 24866 (16 February 2012); D2081 (Momir Nikolić's statement of facts from Plea Agreement, 7 May 2003), para. 9. [REDACTED] witnesses testified that there was no megaphone on the APC, and that Petrović did not call on the Bosnian Muslims to surrender. See Mile Petrović, T. 45552 (17 January 2014); D4218 (Witness statement of Mile Petrović dated 29 September 2003), p. 2; [REDACTED]. However, in light of the evidence before it, the Chamber does not accept the testimony of these witnesses on this point.

17520 Momir Nikolić, T. 24663 (14 February 2012); D2081 (Momir Nikolić's statement of facts from Plea Agreement, 7 May 2003), para. 9. See also Mile Petrović, T. 45552, 45568 (17 January 2014) and D4218 (Witness statement of Mile Petrović dated 29 September 2003), p. 1 (testifying that on their route to Konjević Polje two men in civilian clothes ran out in front of the APC and surrendered, and that Nikolić ordered Janković to stop the vehicle and Petrović to search the men and take them into the APC after which the men were taken to
} 
Bosnian Muslim men to join the group of between 250 and 300 detainees already held at the intersection. ${ }^{17521}$ Nikolić then went to a burned house about 50 metres away from the intersection, and heard two bursts of gunshots coming from a very short distance. ${ }^{17522}$ A few minutes later, Petrović appeared at the house and told Nikolić: "Boss, today I just took revenge for my brother [...] I've killed them". ${ }^{17523}$ Petrović told Nikolić that he had executed the six Bosnian Muslim men down a riverbank behind a yellow building. ${ }^{17524}$ Nikolić left the Konjević Polje intersection for Bratunac in the APC together with Janković, approximately 20 minutes later. ${ }^{17525}$

5172. During the afternoon of 13 July, a group of nine Bosnian Muslim men surrendered to members of the Bosnian Serb Forces deployed along the Bratunac-Konjević Polje Road. ${ }^{17526}$ The men were required to surrender their possessions and detained in the warehouse at the Konjević Polje intersection, where they were given water, cigarettes, and beer. ${ }^{17527}$ Between 9 and 10 p.m., the detainees were put in one of two buses which had previously arrived, and departed in the direction of Bratunac. ${ }^{17528}$

Konjević Polje); [REDACTED]. Petrović testified that when the men got into the APC, Nikolić hit one of them on the head with his rifle butt. D4218 (Witness statement of Mile Petrović dated 29 September 2003), p. 1. Petrović further testified that Nikolić, Janković, and himself were armed inside the APC, and that if there were six detainees, as Nikolić claimed, inside the APC, they would have had to push up against each other and the Bosnian Muslim men could have disarmed them. D4218 (Witness statement of Mile Petrović dated 29 September 2003), p. 3.

17521 Momir Nikolić, T. 24663-24664 (14 February 2012); D2081 (Momir Nikolić's statement of facts from Plea Agreement, 7 May 2003), para. 9.

17522 Momir Nikolić, T. 24664 (14 February 2012); D2081 (Momir Nikolić's statement of facts from Plea Agreement, 7 May 2003), para. 9.

17523 D2081 (Momir Nikolić's statement of facts from Plea Agreement, 7 May 2003), para. 9. See Momir Nikolić, T. 24664 (14 February 2012). But see Mile Petrović, T. 45552, 45555 (17 January 2014) and D4218 (Witness statement of Mile Petrović dated 29 September 2003), pp. 2-3 (testifying that, upon Nikolić's instructions, Petrović turned the two Bosnian Muslims over to the Bosnian Serb soldiers who were guarding the other detainees assembled there, and stating that he did not execute any detainees, but acknowledging however that he later heard about the two men who surrendered being executed by Bosnian Serb Forces). [REDACTED] Petrović's brother had been killed by Bosnian Muslim forces. [REDACTED]. See Mile Petrović, T. 45553 (17 January 2014). [REDACTED].

17524 D2081 (Momir Nikolić's statement of facts from Plea Agreement, 7 May 2003), para. 9. Nikolić did not observe Petrović killing the six Bosnian Muslim men. Momir Nikolić, T. 24866 (16 February 2012). These killings are not charged in the Indictment.

17525 D2081 (Momir Nikolić's statement of facts from Plea Agreement, 7 May 2003), para. 9.

17526 Mevludin Orić, P350 (Transcript from Prosecutor v. Popović et al.), T. 884-886, 1123.

17527 Mevludin Orić, P350 (Transcript from Prosecutor v. Popović et al.), T. 887-888, 890.

17528 Mevludin Orić, P350 (Transcript from Prosecutor v. Popović et al.), T. 889-890, 897. See para. 5292. See also D3960 (Witness Statement of Tomislav Kovač dated 28 October 2013), para. 119 (testifying that he arrived at Konjević Polje at approximately 7:30 p.m., where he saw Bosnian Muslim detainees who had surrendered boarding buses). 


\section{(B) Sandići Meadow}

5173. The Sandići Meadow, a large open plot of land on the Bratunac-Konjević Polje Road, was approximately one kilometre from the Kravica Warehouse in the direction of Konjević Polje; it was situated opposite from a burnt-out house. ${ }^{17529}$

5174. Throughout the day on 13 July 1995, Bosnian Muslim men from the column who had either surrendered or been captured after emerging from the woods, were assembled near the BratunacKonjević Polje Road. ${ }^{17530}$ There, members of the Bosnian Serb Forces forced the detainees to drop their belongings into large piles and to hand over their valuables. ${ }^{17531}$ The men were then forced to cross the road and walk towards the Sandići Meadow, where they were guarded by members of the Bosnian Serb Forces. ${ }^{17532}$

5175. Several units of the Bosnian Serb Forces who were under the command of Borovčanin, including the $2^{\text {nd }}$ Šekovići Detachment, and more specifically, the $3^{\text {rd }}$ Skelani Platoon; the $1^{\text {st }}$ Company of the Zvornik PJP, and the Jahorina Recruits, were present in and around the Sandići Meadow on 13 July. ${ }^{17533}$ Bosnian Serb armoured vehicles, including at least one tank, a Praga, and a BOV, as well as a UN APC, were also seen in and around the meadow. ${ }^{17534}$ The barrel of a tank

17529 Jean-René Ruez, T. 23757-23758 (27 January 2012); P4308 (Book of photographs and maps prepared by JeanRené Ruez, 22 June 2009), e-court pp. 46, 48-51, 87; P253 (Video still of Sandići meadow marked by KDZ425).

17530 See paras. 5163-5164, 5166.

17531 KDZ425, P381 (Transcript from Prosecutor v. Popović et al.), T. 3532-3533; KDZ069, P339 (Transcript from Prosecutor v. Blagojević \& Jokić), T. 1384-1385; KDZ063, P334 (Transcript from Prosecutor v. Popović et al.), T. 6973-6974; KDZ071, P5029 (Transcript from Prosecutor v. Popović et al.), T. 7085, 7087-7088. See P667 (Zoran Petrović-Piroćanac's video footage) at 00:21:16-00:21:32; P4308 (Book of photographs and maps prepared by Jean-René Ruez, 22 June 2009), e-court p. 53; Adjudicated Fact 1730.

17532 KDZ064, P769 (Transcript from Prosecutor v. Popović et al.), T. 655; KDZ425, P381 (Transcript from Prosecutor v. Popović et al.), T. 3523-3524; KDZ069, P339 (Transcript from Prosecutor v. Blagojević \& Jokić), T. 1387, 1389-1390; KDZ069, P339 (Transcript from Prosecutor v. Popović et al.), T. 3366-3367; KDZ063, P334 (Transcript from Prosecutor v. Popović et al.), T. 6973; KDZ071, T. 28532 (4 May 2012); KDZ071, P5029 (Transcript from Prosecutor v. Popović et al.), T. 7085-7086; P1181 (Excerpt from "Srebrenica Trial Video" shown to KDZ425).

17533 See Milenko Pepić, P373 (Transcript from Prosecutor v. Popović et al.), T. 13549-13556, 13589-13590; KDZ084, T. 27336, 27340 (11 April 2012) (closed session); KDZ084, P4904 (Transcript from Prosecutor $v$. Popović et al.), T. 14821-14823, 14825-14827 (under seal); D3196 (Witness statement of Dušan Mićić dated 24 March 2013), para. 32; Dušan Mićić, T. 36223 (27 March 2013); D2081 (Momir Nikolić's statement of facts from Plea Agreement, 7 May 2003), para. 9; P2987 (Report of RS MUP's Special Police Brigade, 13 July 1995), pp. 1-2; P6189 (Report of Zvornik CJB, 13 July 1995), p. 1; P4949 (Report of Zvornik CJB, 14 July 1995), p. 1; D3903 (Witness statement of Mendeljev Đurić dated 26 July 2013), para. 18; Tomasz Blaszcyk, T. 2358523590, 23598 (25 January 2012); P667 (Zoran Petrović-Piroćanac's video footage) at 00:09:24-00:10:24, 00:11:17-00:11:50, 00:17:59-00:21:15, 00:22:02-00:22:25; P4202 (Written compilation booklet: Srebrenica Trial video), e-court pp. 139-142, 146-154, 157-162.

17534 KDZ071, P5029 (Transcript from Prosecutor v. Popović et al.), T. 7088; KDZ064, P769 (Transcript from Prosecutor v. Popović et al.), T. 804; KDZ425, P381 (Transcript from Prosecutor v. Popović et al.), T. 3524; KDZ069, P339 (Transcript from Prosecutor v. Blagojević \& Jokić), T. 1386-1387; KDZ063, P334 (Transcript from Prosecutor v. Popović et al.), T. 6978, 6986; Momir Nikolić, T. 24654, 24661-24662 (14 February 2012); KDZ084, P4904 (Transcript from Prosecutor v. Popović et al.), T. 14822-14823 (under seal); P667 (Zoran Petrović-Piroćanac's video footage) at 00:09:30-00:09:34, 00:21:34-00:21:40; P4270 (Tomasz Blaszczyk's 
was pointed towards the hill from which the Bosnian Muslim men were descending, while its mounted machine-gun was pointed at the detainees. ${ }^{17535}$

5176. Between 900 and 2,000 Bosnian Muslim men from the column were detained at the Sandići Meadow. ${ }^{17536}$ There was also a group of women and young children. ${ }^{17537}$ The detainees were ordered to sit in rows, guarded at each end by two members of the Bosnian Serb Forces. ${ }^{17538}$ The detainees were not given any food but only a small amount of water and a few cigarettes. ${ }^{17539}$ At some point, some detainees, including children, were allowed to fetch water and to distribute it because many detainees kept fainting due to the heat. ${ }^{17540}$ In addition, some of the detainees were sprayed with water from a fire truck. ${ }^{17541}$

written compilation booklet entitled "Roadbook"), p. 28; P4202 (Written compilation booklet: Srebrenica Trial video), e-court pp. 155-156.

17535 KDZ425, P381 (Transcript from Prosecutor v. Popović et al.), T. 3524, 3540; P1183 (Excerpt from "Srebrenica Trial Video" shown to KDZ425); P1184 (Excerpt from "Srebrenica Trial Video" shown to KDZ425); KDZ069, P339 (Transcript from Prosecutor v. Blagojević \& Jokić), T. 1387; KDZ084, P4904 (Transcript from Prosecutor v. Popović et al.), T. 14822-14823 (under seal).

17536 The estimates on the number of men detained at the Sandići Meadow ranged from 900 to 2,000. KDZ425, P381 (Transcript from Prosecutor v. Popović et al.), T. 3524, 3557-3559; KDZ069, P339 (Transcript from Prosecutor v. Blagojević \& Jokić), T. 1386, 1391; KDZ069, P339 (Transcript from Prosecutor v. Popović et al.), T. 3352; KDZ063, P334 (Transcript from Prosecutor v. Popović et al.), T. 6975, 7049. See P207 (Aerial photograph of Sandići meadow, 13 July 1995); D2253 (Still image of prisoners in Sandići Meadow, 13 July 1995); KDZ064, P769 (Transcript from Prosecutor v. Popović et al.), T. 658 (stating that approximately 500 people were seated in the meadow when he arrived but others kept arriving afterwards); P5288 (Intercept of conversation between Lt. Col. Krsmanović and Višković, 13 July 1995), pp. 1-2 (referring to the presence of 700 people in the village of Sandići on 13 July at 9 p.m.); D2081 (Momir Nikolić's statement of facts from Plea Agreement, 7 May 2003), para. 9 (testifying that he saw a large mass of prisoners at the meadow); Adjudicated Fact 1619 (stating that several thousands Bosnian Muslim men from the column were collected in or near the Sandići Meadow). But see D3993 (Witness statement of Vujadin Popović dated 2 November 2013), paras. 31, 36 (referring to between 100 and 300 detainees standing or sitting by the road near Sandići after noon); D3196 (Witness statement of Dušan Mićić dated 24 March 2013), para. 32 and Dušan Mićić, T. 36234-36235 (27 March 2013) (both referring to a group of 50 or 60 people at the Sandići Meadow in the morning on 13 July); Zoran Petrović-Piroćanac, T. 28462 (3 May 2012) (referring to the presence of around 100 detainees at the Sandići Meadow when he passed the area by car); KDZ480 T. 24260 (8 February 2012) (closed session) (testifying to having seen between 150 and 200 people at the Sandići Meadow) and KDZ480, P4355 (Transcript from Prosecutor v. Blagojević \& Jokić), T. 7871 (under seal) (testifying to having seen a great number of prisoners at the Sandići Meadow after noon).

17537 KDZ063, P334 (Transcript from Prosecutor v. Popović et al.), T. 6976; KDZ064, P769 (Transcript from Prosecutor v. Popović et al.), T. 658-659; KDZ425, P381 (Transcript from Prosecutor v. Popović et al.), T. 3554-3555. See P667 (Zoran Petrović-Piroćanac's video footage) at 00:09:58-00:10:00

17538 KDZ064, P769 (Transcript from Prosecutor v. Popović et al.), T. 658; KDZ069, P339 (Transcript from Prosecutor v. Blagojević \& Jokić), T. 1385-1386.

17539 KDZ064, P769 (Transcript from Prosecutor v. Popović et al.), T. 660; KDZ071, P5029 (Transcript from Prosecutor v. Popović et al.), T. 7088. See Adjudicated Fact 1731.

17540 KDZ425, P381 (Transcript from Prosecutor v. Popović et al.), T. 3533; KDZ063, P334 (Transcript from Prosecutor v. Popović et al.), T. 6974, 7043; KDZ071, P5029 (Transcript from Prosecutor v. Popović et al.), T. 7088.

17541 KDZ063, P334 (Transcript from Prosecutor v. Popović et al.), T. 7047-7048; KDZ071, P5029 (Transcript from Prosecutor v. Popović et al.), T. 7088; KDZ480, T. 24223 (7 February 2012) (closed session), T. 24260, 24278 (8 February 2012) (closed session); KDZ480, P4355 (Transcript from Prosecutor v. Blagojević \& Jokić), T. 7871, 7898, 7900 (under seal). 
5177. Some of the detainees at the meadow were either singled out, taken away, and did not return, or were mistreated by members of the Bosnian Serb Forces. ${ }^{17542}$ No medical treatment was provided for those who had been previously wounded or injured. ${ }^{17543}$ Further, during the course of the day, the wounded and injured were taken to a house close to the meadow and later executed. ${ }^{17544}$ After a change of guards, the detainees were forced to lie down on their stomachs and put their hands above their necks for long periods of time, and to applaud and say, in unison: "Long live the king, long live Serbia". ${ }^{17545}$

5178. Later in the afternoon, the women and children, and about a dozen young boys who appeared to be under age, were allowed to leave onboard buses already full of women and children which had stopped at the Sandići Meadow on their way from Potočari to Bosnian Muslim-held territory. ${ }^{17546}$ Members of the Bosnian Serb Forces stopped those who looked old enough to be capable of carrying a weapon from boarding the buses. ${ }^{17547}$

5179. Also in the afternoon, Mladić arrived at the Sandići Meadow with five or six men in uniform and some journalists who took photographs and recorded the conditions there. ${ }^{17548}$ Mladić addressed the detainees; he promised they would be safe and exchanged the next day, and informed

17542 See KDZ071, P5029 (Transcript from Prosecutor v. Popović et al.), T. 7088-7089; KDZ063, P334 (Transcript from Prosecutor v. Popović et al.), T. 6975-6976, 6980, 7055; KDZ069, P339 (Transcript from Prosecutor v. Popović et al.), T. 3368; KDZ425, P380 (Transcript from Prosecutor v. Popović et al.), T. 3531-3532 (under seal); KDZ425, P381 (Transcript from Prosecutor v. Popović et al.), T. 3532; Adjudicated Facts 1733, 1735. See also D2081 (Momir Nikolić's statement of facts from Plea Agreement, 7 May 2003), para. 9. Some members of the Bosnian Serb Forces insulted the detainees and asked them for money. KDZ069, P339 (Transcript from Prosecutor v. Blagojević \& Jokić), T. 1386. The Chamber is satisfied that the individuals who were singled out and taken away were killed. However, these killings are not charged in the Indictment.

17543 KDZ064, P769 (Transcript from Prosecutor v. Popović et al.), T. 660.

17544 KDZ069, P339 (Transcript from Prosecutor v. Blagojević \& Jokić), T. 1397; KDZ063, P334 (Transcript from Prosecutor v. Popović et al.), T. 6975; KDZ071, P5029 (Transcript from Prosecutor v. Popović et al.), T. 7088; Adjudicated Fact 1734. These killings are not charged in the Indictment.

17545 KDZ064, P769 (Transcript from Prosecutor v. Popović et al.), T. 805; KDZ069, P339 (Transcript from Prosecutor v. Blagojević \& Jokić), T. 1393, 1396-1397; P339 (Transcript from Prosecutor v. Popović, Case No. IT-05-88), T. 3368. See Adjudicated Fact 1731.

17546 KDZ064, P769 (Transcript from Prosecutor v. Popović et al.), T. 656, 658-659; KDZ069, P339 (Transcript from Prosecutor v. Blagojević \& Jokić), T. 1388, 1393; KDZ063, P334 (Transcript from Prosecutor v. Popović et al.), T. 6976-6978, 6981. See KDZ425, P380 (Transcript from Prosecutor v. Popović et al.), T. 3567-3568 (under seal). One child was able to escape the Sandići Meadow when he went to fetch water, by sneaking into one of the buses which had stopped at the meadow and hiding under some bags; the bus departed with him on board. KDZ425, P381 (Transcript from Prosecutor v. Popović et al.), T. 3535, 3566-3567.

17547 KDZ064, P769 (Transcript from Prosecutor v. Popović et al.), T. 658-659; KDZ063, P334 (Transcript from Prosecutor v. Popović et al.), T. 6976-6977; KDZ069, P339 (Transcript from Prosecutor v. Blagojević \& Jokić), T. 1393.

17548 KDZ064, P769 (Transcript from Prosecutor v. Popović et al.), T. 661-662; KDZ063, P334 (Transcript from Prosecutor v. Popović et al.), T. 6977, 7055; KDZ071, P5029 (Transcript from Prosecutor v. Popović et al.), T. 7089 . 
them that their families had been transported safely to Tuzla. ${ }^{17549}$ The detainees applauded Mladic and he left five to ten minutes later. ${ }^{17550}$

5180. Later in the afternoon, the detainees were transported out of the Sandići Meadow; groups of detainees were put on buses or marched towards the Kravica Warehouse, ${ }^{17551}$ while others were put on trucks and buses and taken to Bratunac town. ${ }^{17552}$

\section{(C) Nova Kasaba football field}

5181. The Nova Kasaba football field was located next to the Konjević Polje-Milići Road, on the outskirts of Nova Kasaba. ${ }^{17553}$ In July 1995, the MP Battalion of the $65^{\text {th }}$ Protection Regiment was stationed at the Nova Kasaba elementary school, located near the football field. ${ }^{17554}$

5182. On 13 July 1995, approximately 300 Bosnian Muslims who had surrendered to, or been captured by, Bosnian Serb Forces and detained at the warehouse located at the Konjević Polje intersection were transported on trucks to the football field. ${ }^{17555}$ Approximately ten other Bosnian Muslim men who had been detained at the elementary school after being captured by members of the Bosnian Serb Forces were made to walk to the football field. ${ }^{17556}$ Throughout the day, other Bosnian Muslim men from the column who had surrendered or been captured were taken to the Nova Kasaba football field. ${ }^{17557}$ The Chamber notes the Accused's claim that, due to the size of the

\footnotetext{
17549 KDZ064, P769 (Transcript from Prosecutor v. S. Milošević), T. 28831; KDZ064, P769 (Transcript from Prosecutor v. Popović et al.), T. 662; KDZ063, P334 (Transcript from Prosecutor v. Popović et al.), T. 6977; KDZ071, P5029 (Transcript from Prosecutor v. Popović et al.), T. 7089-7090; D3659 (Witness statement of Ljubomir Borovčanin dated 30 May 2013), para. 25. See Adjudicated Fact 1624.

17550 KDZ071, P5029 (Transcript from Prosecutor v. Popović et al.), T. 7090; KDZ063, P334 (Transcript from Prosecutor v. Popović et al.), T. 6977.

17551 See paras. 5225-5226.

17552 See para. 5292.

17553 P4308 (Book of photographs and maps prepared by Jean-René Ruez, 22 June 2009), e-court pp. 37, 70.

17554 Mirko Trivić, T. 40556 (27 June 2013); Vincentius Egbers, P331 (Transcript from Prosecutor v. Popović et al.), T. 2757-2758; D3720 (Witness statement of Petar Salapura dated 17 June 2013), pp. 6-7; P211 (Photograph of Nova Kasaba school).

17555 KDZ045, P5910 (Transcript from Prosecutor v. Krstić), T. 2948-2950; KDZ045, T. 22683 (10 January 2012 ). See para. 5168.

17556 KDZ333, T. 24144-24145 (2 February 2012); KDZ333, P4342 (Transcript from Prosecutor v. Krstić), T. $3017-$ 3022. See D3918 (Witness statement of Milomir Savčić, dated 21 July 2013), paras. 50-52. Two to three soldiers wearing camouflage uniforms guarded the group as it walked towards the football field. KDZ333, P4342 (Transcript from Prosecutor v. Krstić), T. 3021-3022.

17557 See KDZ045, P5910 (Transcript from Prosecutor v. Krstić), T. 2948-2950; KDZ045, T. 22683 (10 January 2012); KDZ333, T. $24144-24145$ (2 February 2012); KDZ333, P4342 (Transcript from Prosecutor v. Krstić), T. 3017-3022; P210 (Photograph of football field near Nova Kasaba); P168 (Order of Motorised Protection Regiment, 13 July 1995), p. 1; P4670 (Intercept of conversation between two unidentified persons, 13 July 1995) (indicating that by 2 p.m. more than 1,000 detainees were being held at the field); P5380 (Intercept of conversation between two unidentified persons, 13 July 1995), p. 1 (indicating that by 4 p.m. the number of detainees at the field had risen to 1,500); P6704 (Intercept of conversation between two unidentified persons, 13 July 1995), p. 1 (suggesting that by 5:30 p.m. between 1,500 and 2,000 detainees were present). See also P4824 (Summary of intercepted conversation, 13 July 1995); D3918 (Witness statement of Milomir Savčić,
} 
Nova Kasaba football field, there could not have been more than 700 Bosnian Muslim men detained there on 13 July. ${ }^{17558}$ Based upon all the evidence before it, the Chamber rejects the Accused's calculation, and is satisfied that between 1,500 and 3,000 Bosnian Muslim men and boys were detained at the football field that day. ${ }^{17559}$

5183. Between 15 to 20 members of the Bosnian Serb Forces awaited the detainees at the football field. ${ }^{17560}$ They forced the detainees to forfeit their valuables and belongings at the entrance. ${ }^{17561}$ The detainees were guarded by members of the $65^{\text {th }}$ Protection Regiment's MP Battalion, dressed in camouflage uniforms, who were present across the entire field. ${ }^{17562}$ As the numbers of detainees at the football field grew, the Bosnian Serb Forces guarding them required reinforcements. ${ }^{17563}$ The soldiers pointed their weapons and swore at the detainees, who were sitting in rows. ${ }^{17564}$ The detainees were not given food or water. ${ }^{17565}$

dated 21 July 2013), paras. 50-52; Milomir Savčić, T. 42250-42251 (30 July 2013). The Chamber notes that Egbers testified that Bosnian Muslim men were already detained at the Nova Kasaba football field throughout 12 July 1995. Vincentius Egbers, P331 (Transcript from Prosecutor v. Popović et al.), T. 2724-2725, 27482749. See also P5370 (Intercept of conversation between an unidentified General and an unidentified person, 13 July 1995), p. 1.

17558 Defence Final Brief, paras. 2540-2541. See P4308 (Book of photographs and maps prepared by Jean-René Ruez, 22 June 2009), e-court p. 37. See also D3993 (Witness statement of Vujadin Popović dated 2 November 2013), para. 35 (referring to about 800 prisoners on the football pitch in Nova Kasaba on 13 July).

17559 KDZ045, T. 22632 (10 January 2012) (estimating between 2,000 and 2,500 men at the field); KDZ333, P4342 (Transcript from Prosecutor v. Krstić), T. 3022 (estimating between 1,500 and 2,000 men); P168 (Order of Motorised Protection Regiment, 13 July 1995), p. 1 (referring to the presence of over 1,000 ABiH members in the area of Kasaba); P4670 (Intercept of conversation between two unidentified persons, 13 July 1995), p. 1 (referring to more than a thousand men at the stadium); P5380 (Intercept of conversation between two unidentified persons, 13 July 1995) (referring to over 1,500 Bosnian Muslim men gathered in the Nova Kasaba stadium on 13 July at 4:02 p.m.); P6704 (Intercept of conversation between two unidentified persons, 13 July 1995) (referring to between 1,500 and 2,000 men), p. 1; Adjudicated Fact 1619 (stating that several thousands Bosnian Muslim men from the column were collected on the Nova Kasaba football field). See also Mirko Trivić, T. 40554-40558 (27 June 2013) (testifying that almost the entire field was taken up by a large group of men sitting on 13 July); D3720 (Witness statement of Petar Salapura dated 17 June 2013), p. 7 (referring to a large number of captured men at the stadium); Zvonko Bajagić, T. 41149 (10 July 2013) (testifying that there were a lot of Bosnian Muslim men sitting at the field when he drove by on 13 July).

17560 KDZ045, P5910 (Transcript from Prosecutor v. Krstić), T. 2950, 2952. See KDZ333, P4342 (Transcript from Prosecutor v. Krstić), T. 3022.

17561 KDZ045, P5910 (Transcript from Prosecutor v. Krstić), T. 2950. See also Adjudicated Fact 1621.

17562 KDZ045, P5910 (Transcript from Prosecutor v. Krstić), T. 2952-2953; KDZ333, P4342 (Transcript from Prosecutor v. Krstić), T. 3022; Mirko Trivić, T. 40556-40557, 40562 (27 June 2013); Milomir Savčić, T. 42250-42251, 42255 (30 July 2013); P168 (Order of Motorised Protection Regiment, 13 July 1995), p. 1; P5380 (Intercept of conversation between two unidentified persons, 13 July 1995). See also D3918 (Witness statement of Milomir Savčić, dated 21 July 2013), paras. 56-57, 59; Milomir Savčić, T. 42278-42279 (31 July 2013); D2204 (Intercept of conversation between Col. Beara and Lučić, 13 July 1995), pp. 1-2; Vincentius Egbers, P331 (Transcript from Prosecutor v. Popović et al.), T. 2725. Cf. D3720 (Witness statement of Petar Salapura dated 17 June 2013), p. 7 (testifying that he did not see a heavy security presence at the football field).

17563 D3918 (Witness statement of Milomir Savčić, dated 21 July 2013), paras. 52-53; Milomir Savčić, T. 4225142252 (30 July 2013).

17564 KDZ045, P5910 (Transcript from Prosecutor v. Krstić), T. 2952, 3008; KDZ333, P4342 (Transcript from Prosecutor v. Krstić), T. 3022. See Mirko Trivić, T. 40561-40562 (27 June 2013).

17565 KDZ045, P5910 (Transcript from Prosecutor v. Krstić), T. 2955. Savčić testified that Malinić called the Milići hospital so that a medical team was sent to the field to provide first aid to those detainees who had been 
5184. At 3:10 p.m., a document entitled "Procedure for [the] treatment of war prisoners" was sent under the name of Milomir Savčić, the commander of the $65^{\text {th }}$ Motorised Protection Regiment, to the commander of the regiment's MP Battalion, which was then engaged in the guarding of Bosnian Muslim men detained at Nova Kasaba. ${ }^{17566}$ The document conveyed Tolimir's proposals: (i) to prohibit access to the detainees by all "unauthorised" individuals, as well as filming and photographing of such detainees, (ii) to prohibit traffic for all UN vehicles between Zvornik and Vlasenica until further notice, and (iii) for the commander of the MP Battalion to take measures to remove the detainees from the main road and place them "somewhere indoors or in the area protected from sighting from the ground or air". ${ }^{17567}$ That evening, Mladić issued an order adopting Tolimir's proposals to restrict access to the area. ${ }^{17568}$

5185. Salapura and Popović were present at the Nova Kasaba football field in the afternoon on 13 July. ${ }^{17569}$ Zvonko Bajagić testified that when he drove by the football field that day one of the two men accompanying him took photos of those present; Popović, who was standing in front of the field, told the men they should not take photos and that the camera should be taken or the film exposed to light so that the photos would be lost. ${ }^{17570}$

wounded, and that, when the medical team arrived, the detainees were given first aid, food, and water. D3918 (Witness statement of Milomir Savčić, dated 21 July 2013), para. 54. However, in light of other credible evidence before it, the Chamber does not accept Savčić's testimony on this point.

17566 P168 (Order of Motorised Protection Regiment, 13 July 1995). The Chamber notes that Savčić testified that he did not recall having forwarded the document containing Tolimir's proposals, but allowed for the possibility that he sent it yet did not recall doing so. D3918 (Witness statement of Milomir Savčić, dated 21 July 2013), paras. 60, 67; Milomir Savčić, T. 42289-42290 (31 July 2013). Savčić also asserted that there were certain irregularities in the form of the document, namely that it was addressed from an IKM of the $65^{\text {th }}$ Motorised Protection Regiment in Borike, which was not a "formal forward command post" of that unit, that the document was not signed, and that Malinić had later told him that he had not received the document. D3918 (Witness statement of Milomir Savčić, dated 21 July 2013), paras. 56-57, 66; Milomir Savčić, T. 42342 (31 July 2013). The Chamber recalls, however, that Danko Gojković, a teleprinter operator from the Rogatica Brigade, testified that when the document was brought to him, he transmitted the document via teleprinter. Danko Gojković, P346 (Transcript from Prosecutor v. Popović et al.), T. 10716-10717. Gojković explained that the IKM at Borike lacked a teleprinter and thus could not send such a document directly; instead, documents that needed to be sent by telegram were routed through the teleprinter office at the Rogatica Brigade Command, which was located approximately 18 kilometres away from Borike; confirmation of the sending was then transmitted to the IKM by phone. P248 (Danko Gojković's interview with OTP), pp. 24-25; Danko Gojković, P346 (Transcript from Prosecutor v. Popović et al.), T. 10718-10719. The Chamber therefore does not consider Savčić's testimony to raise any doubt regarding the authenticity of P168. See also Milomir Savčić, T. 42291 (31 July 2013) (accepting Gojković's testimony about having sent the document via teleprinter); P4671 (Intercept of conversation between two unidentified persons at 2:05 p.m., 13 July 1995) (referring to a telegram that was to be sent to someone at the football pitch).

17567 P168 (Order of Motorised Protection Regiment, 13 July 1995), p. 1. The commander of the MP Battalion was instructed to contact Miletić for additional orders, and to verify that Tolimir's proposals had been approved by Mladić. P168 (Order of Motorised Protection Regiment, 13 July 1995), p. 2.

17568 P4407 (VRS Main Staff Order, 13 July 1995).

17569 D3720 (Witness statement of Petar Salapura dated 17 June 2013), pp. 6-7; Vujadin Popović, T. 43040 (5 November 2013); D3993 (Witness statement of Vujadin Popović dated 2 November 2013), para. 35. See P4824 (Summary of intercepted conversation, 13 July 1995).

17570 See Zvonko Bajagić, T. 41150-41154 (10 July 2013). But see Vujadin Popović, T. 43040-43041 (5 November 2013) (testifying that he did not remember this incident at all). 
5186. Also in the afternoon, Mladić arrived at the football field in an olive green APC. ${ }^{17571} \mathrm{He}$ insulted and cursed the detainees, and told them that there were special units with dogs covering every inch of the forest to ensure that nobody would be able to cross the Nova Kasaba-Konjević Polje Road. ${ }^{17572}$ Mladić also told the detainees that they would be given food and water after which "we'll see whether we send you to Krajina, to Fikret Abdić, or [...] to the Batkovići camp."17573 At that point, a detainee stood up; soldiers first kicked and hit him with rifle butts before shooting and killing him with a pistol. ${ }^{17574}$ Mladić witnessed this incident but did not respond in any way. ${ }^{17575}$ Soon after, Mladić left the football field in the direction of Konjević Polje. ${ }^{17576}$

5187. After Mladić's departure, the detainees were ordered into trucks and buses, and were transported to either Bratunac town or Kravica in the early evening, under the escort of members of the MP Battalion. ${ }^{17577}$ When the detainees tried to pick up their bags from the entrance of the field, they were told that they would not need them any longer. ${ }^{17578}$

5188. A group of about 13 DutchBat officers travelling back from Kladanj after having escorted a convoy of buses from Potočari was blocked at the Nova Kasaba football field on 13 July by members of the $65^{\text {th }}$ Protection Regiment's MP Battalion. ${ }^{17579}$ The officers' cars and equipment

17571 KDZ045, P5910 (Transcript from Prosecutor v. Krstić), T. 2953-2954; KDZ333, P4342 (Transcript from Prosecutor v. Krstić), T. 3024; D3993 (Witness statement of Vujadin Popović dated 2 November 2013), para. 35; Vujadin Popović, T. 43042 (5 November 2013); Adjudicated Fact 1623.

17572 KDZ045, P5910 (Transcript from Prosecutor v. Krstić), T. 2953-2954, 2992. See KDZ333, P4342 (Transcript from Prosecutor v. Krstić), T. 3024; KDZ333, T. 24145 (2 February 2012); Milomir Savčić, T. 42255 (30 July 2013).

17573 KDZ045, P5910 (Transcript from Prosecutor v. Krstić), T. 2953-2954. See KDZ333, P4342 (Transcript from Prosecutor v. Krstić), T. 3024; Milomir Savčić, T. 42255 (30 July 2013). At that point, Malinić ordered some of his men to start making a list with the names of all the detainees at the football field. KDZ333, P4342 (Transcript from Prosecutor v. Krstić), T. 3024-3025; D3918 (Witness statement of Milomir Savčić, dated 21 July 2013), para. 55. Additionally, an intercepted conversation of 13 July 1995 at 11:25 a.m. records that Beara sent four buses, two trucks, and one trailer truck to "Kasaba" for the transportation of the captured Muslims to a camp in the village of Batkovići, where a selection would be made "between the war criminals or just soldiers". D2197 (Intercept of report sent by Ljubo Beara, 13 July 1995). However, the Chamber received evidence that this selection did not occur. See Richard Butler, T. 27733 (20 April 2012).

17574 KDZ333, P4342 (Transcript from Prosecutor v. Krstić), T. 3024. This killing is not charged in the Indictment.

17575 KDZ333, P4342 (Transcript from Prosecutor v. Krstić), T. 3024.

17576 KDZ333, P4342 (Transcript from Prosecutor v. Krstić), T. 3025.

17577 KDZ333, P4342 (Transcript from Prosecutor v. Krstić), T. 3025-3028, 3049; KDZ045, P5910 (Transcript from Prosecutor v. Krstić), T. 2954-2956. See Momir Nikolić, T. 24869-24870 (16 February 2012); Radislav Krstić, D4135 (Transcript from Prosecutor v. Krstić), T. 6316 (under seal). The Chamber notes that KDZ045 was aboard one of three buses which did not proceed to Bratunac town but instead stopped overnight near a supermarket in Kravica. See KDZ045, P5910 (Transcript from Prosecutor v. Krstić), T. 2955-2956.

17578 KDZ045, P5910 (Transcript from Prosecutor v. Krstić), T. 2954.

17579 Vincentius Egbers, P331 (Transcript from Prosecutor v. Popović et al.), T. 2756-2757. But see D3918 (Witness statement of Milomir Savčić, dated 21 July 2013), para. 50 (testifying that when he spoke with Malinić on 13 July, he was informed that UNPROFOR members had asked for help because they did not consider it safe to return to Potočari, so Savčić ordered Malinić to ensure their safety); Milomir Savčić T. 42263-42270 (30 July 2013) (testifying inter alia that the DutchBat officers were stopped near the school, but by other VRS units and not by members of the MP Battalion). 
were confiscated and the men were taken to the MP Battalion's headquarters in the school. ${ }^{17580}$ At the headquarters, one of the DutchBat officers, Egbers, complained to Malinić about the situation; Malinić said that he would need to contact Beara to arrange a safe return for the officers to Potočari. ${ }^{17581}$ The officers spent the night at the school. ${ }^{17582}$ On the morning of 14 July, when Beara arrived at the headquarters, Egbers handed him a written complaint and asked him to bring the DutchBat officers to the UN Compound. ${ }^{17583}$ Beara left soon after, and Malinić arranged for the officers to return to Potočari on two MP BOVs. ${ }^{17584}$

iv. Killings

(A) Jadar River

5189. The Indictment refers to the killing on 13 July 1995 of about 15 Bosnian Muslim men in an isolated area on the bank of the Jadar River. ${ }^{17585}$

5190. The Chamber notes that it took notice of Adjudicated Facts 1689 to 1691 in relation to the killings at the Jadar River, which read as follows:

17580 Vincentius Egbers, P331 (Transcript from Prosecutor v. Popović et al.), T. 2757-2760.

17581 Vincentius Egbers, P331 (Transcript from Prosecutor v. Popović et al.), T. 2757-2760, 2784-2789, 2799-2800, 2824.

17582 Vincentius Egbers, P331 (Transcript from Prosecutor v. Popović et al.), T. 2766-2767. Egbers testified that while at Nova Kasaba, he saw between 20 and 30 Bosnian Muslim men and boys-a couple of whom were injured-being detained in a small building located on the school grounds, in front of the headquarters. Vincentius Egbers, P331 (Transcript from Prosecutor v. Popović et al.), T. 2774-2775. Throughout the evening of 13 July, Egbers heard shots in the environs of the headquarters; however, the next morning, he saw that the detainees were still alive. Vincentius Egbers, P331 (Transcript from Prosecutor v. Popović et al.), T. 2775. Two of the detainees were subsequently taken outside of the building to be used as human shields against Bosnian Muslims firing at the headquarters. Vincentius Egbers, P331 (Transcript from Prosecutor v. Popović et al.), T. 2775.

17583 Vincentius Egbers, P331 (Transcript from Prosecutor v. Popović et al.), T. 2776, 2778-2779, $2824 . \quad$ The Chamber notes that Beara denied being present in Bratunac and Zvornik on 13 and 14 July 1995, and, as he did during the Popović et al. case, maintained that he was in Belgrade during those days. See Ljubiša Beara, T. 45803 (22 January 2014). However, in light of the overwhelming evidence before the Chamber establishing Beara's ubiquitous presence in the Zvornik area as set out further below, as well as the fact that such presence bore directly upon Beara's criminal responsibility for the events discussed below as established in the Popovic et al. case, which was still pending before the Appeals Chamber at the time that Beara testified, the Chamber does not find Beara's testimony regarding his whereabouts on 13 and 14 July credible. Egbers described the man he identified as Beara "as a tall man with grey hair but with an atmosphere of a colonel. He was in a camouflage suit wearing a colonel's ranking”. Vincentius Egbers, P331 (Transcript from Prosecutor v. Popović et al.), T. 2776. The Chamber notes that Egbers's identification of Beara was extensively challenged during crossexamination in the Popović et al. case. See Vincentius Egbers, P331 (Transcript from Prosecutor v. Popović et al.), T. 2819-2831. In light of the evidence before the Chamber about the presence of Beara in Bratunac in the morning of 14 July 1995, the Chamber is satisfied that the individual referred to by Egbers was indeed Beara. See Srbislav Davidović, T. 24364 (9 February 2012); Srbislav Davidović, P4100 (Transcript from Prosecutor v. Popović et al.), T. 9230-9231; D3993 (Witness statement of Vujadin Popović dated 2 November 2013), paras. 42, 44.

17584 Vincentius Egbers, P331 (Transcript from Prosecutor v. Popović et al.), T. 2778-2780.

17585 Indictment, Scheduled Killing Incident E.1.1. In its Final Brief, the Prosecution argues that the killings at the Jadar River represent the "first known organised and systematic execution of Muslim men from Srebrenica". Prosecution Final Brief, Appendix D, para. 49. 
On the morning of 13 July, 16 Bosnian Muslim men who had been captured from the column were transported by bus from the warehouse in Konjević Polje to the Jadar River bank. Amongst them was a 15 year old boy. ${ }^{17586}$

After the men got off the bus they were lined up alongside the river. Four Serb soldiers who had escorted them in the bus opened fire with their automatic rifles. ${ }^{17587}$

One of the Bosnian Muslim men survived as he threw himself into the river after he was hit by a bullet. ${ }^{17588}$

5191. The Chamber admitted the transcript of KDZ065's testimony in the Krstić and Popovic et al. cases pursuant to Rule 92 bis. KDZ065 testified that he had been moving with the column of men fleeing Srebrenica and, at approximately 3 a.m. on 13 July 1995, surrendered to policemen wearing "slightly multicoloured" dark blue uniforms in the area of Konjević Polje. ${ }^{17589}$ After being deprived of his possessions, KDZ065 was taken to a small shed located in an area in front of the elementary school by KW558. ${ }^{17590}$ A "couple" of soldiers wearing camouflage uniforms were at the shed guarding two other Bosnian Muslim men whom KDZ065 knew and who had "traces of blows on them". ${ }^{17591}$ At around 7 or 9 a.m., KW558 led the three men to be questioned to another house across a meadow. ${ }^{17592}$ At the house, four men wearing military camouflage uniforms were sitting around a table, drinking alcohol. ${ }^{17593}$ Two of them questioned KDZ065 and the other detainees. $^{17594}$

\footnotetext{
17586 Adjudicated Fact 1689.

17587 Adjudicated Fact 1690.

17588 Adjudicated Fact 1691.

17589 KDZ065, P336 (Transcript from Prosecutor v. Krstić), T. 3240-3243, 3245-3247.

17590 KDZ065 identified this policeman and provided detailed information about him. According to KDZ065, KW558 was wearing a one-piece, dark blue camouflage suit, like other policemen in the area. KDZ065, P336 (Transcript from Prosecutor v. Krstić), T. 3246-3248, 3250, 3254. See also Jean-René Ruez, T. 23731-23732 (26 January 2012; P4308 (Book of photographs and maps prepared by Jean-René Ruez, 22 June 2009), e-court pp. 42-43. KDZ065, P335 (Transcript from Prosecutor v. Krstić), T. 3251-3253 (under seal). However, KW558 denied ever knowing KDZ065 and disputed KDZ065's evidence as it concerned him; KW558, D3763 (Transcript from Prosecutor v. Blagojević \& Jokić), T. 6519, 6533-6534 (under seal); KW558, T. 40740, 40773-40775, 40782 (3 July 2013); KW558, T. 40740-40746 (3 July 2013) (private session); KW558, D3764 (Transcript from Prosecutor v. Blagojević \& Jokić), T. 6528, 6542-6543, 6547. See also D3772 (Witness statement of Mirko Perić dated 1 July 2013) (under seal), para. 22.

17591 KDZ065, P336 (Transcript from Prosecutor v. Krstić), T. 3250, 3254. See also KDZ065, P335 (Transcript from Prosecutor v. Krstić), T. 3252 (under seal).

17592 KDZ065, P336 (Transcript from Prosecutor v. Krstić), T. 3254-3255. KDZ065 identified the house from a photograph he was shown in court. KDZ065, P336 (Transcript from Prosecutor v. Popović et al.), T. 3221; P243 (Photograph of houses near Jadar River).

17593 KDZ065, P336 (Transcript from Prosecutor v. Krstić), T. 3255, 3257, 3259. KDZ065 did not see any insignia on the men's uniforms, because their sleeves were rolled up. KDZ065, P336 (Transcript from Prosecutor v. Krstić), T. 3289.

17594 KDZ065, P336 (Transcript from Prosecutor v. Krstić), T. 3257-3260. During the questioning, KDZ065 and the two other Bosnian Muslim men were given some food, water, and alcohol. KDZ065, P336 (Transcript from Prosecutor v. Krstić), T. 3257-3258, 3262.
} 
5192. After a "short while", the detainees were taken by KW558 to the communications house of the $6^{\text {th }}$ Company of the Zvornik PJP and put in a room. ${ }^{17595}$ A $14-15$ year old boy was also brought to the room, questioned, and given some food. ${ }^{17596}$ After "a certain amount of time had passed", Rešid Sinanović, Hasan Salihović-a policeman in Srebrenica-, and a third man, were also brought to the room. ${ }^{17597}$ A Bosnian Serb man wearing civilian clothes named Mirko ${ }^{17598}$ then arrived and said that four of the detainees_-including KDZ065 and the boy—should be taken away, while Sinanović and Salihović should stay. ${ }^{17599}$

5193. After leaving the communications house, Mirko took the three Bosnian Muslim men and the boy to a warehouse situated on the banks of the Jadar River, at the cross-roads of Konjević Polje and the bridge leading to Nova Kasaba, which had been an "agricultural chemist" before the war. ${ }^{17600}$ Upon arriving at the warehouse, KDZ065 saw yet another Bosnian Serb policeman he knew, Nenad Deronjić, who was with four "colleagues" wearing "military camouflage"

17595 KDZ065, P336 (Transcript from Prosecutor v. Krstić), T. 3258, 3262-3263; KDZ065, P336 (Transcript from Prosecutor v. Popović et al.), T. 3221; P226 (Photograph of a house near Jadar River). While KDZ065 referred to this, the third building he was taken to, as an "empty house", in light of the totality of the evidence before it, the Chamber finds that this building was the communications house of the $6^{\text {th }}$ Company of the Zvornik PJP. See KW558, T. 40747 (3 July 2013); KW558, D3764 (Transcript from Prosecutor v. Blagojević \& Jokić), T. 6524 6527, 6542; D3766 (Photograph of a house); D3767 (Photograph of a house); D3768 (Photograph of houses along a road); D3771 (Photograph of a building); D3765 (Diagram drawn by KW558) (under seal). See also para. 5199 where the Chamber discusses in detail the inconsistent evidence admitted in this case in relation to the events at the communications house.

17596 KDZ065, P336 (Transcript from Prosecutor v. Krstić), T. 3263. See also Adjudicated Fact $1689 . \quad$ But see KW558, D37643 (Transcript from Prosecutor v. Blagojević \& Jokić), T. 6534-6535 (under seal).

17597 KDZ065, P335 (Transcript from Prosecutor v. Krstić), T. 3266 (under seal); KDZ065, P336 (Transcript from Prosecutor v. Krstić), T. 3263-3264; KDZ065, P335 (Transcript from Prosecutor v. Popović et al.), T. 3191; KDZ065, P336 (Transcript from Prosecutor v. Popović et al.), T. 3215 (under seal). See also D3852 (Witness statement of Mirko Perić dated 1 July 2013), para. 19.

17598 KDZ065 provided detailed information identifying the man referred to as "Mirko". KDZ065, P335 (Transcript from Prosecutor v. Krstić), T. 3265-3266 (under seal); KDZ065, P336 (Transcript from Prosecutor v. Krstić), T. 3269. Cf. D3852 (Witness statement of Mirko Perić dated 1 July 2013), paras. 13, $26-27$ (where Perić confirmed that he had been a policeman in Bratunac and acknowledged his presence in Konjević Polje on 13 July 1995, but denied wearing civilian clothes, adding that he was wearing a blue camouflage police uniform that day).

17599 KDZ065, P335 (Transcript from Prosecutor v. Krstić), T. 3266-3267 (under seal).

17600 KDZ065, P336 (Transcript from Prosecutor v. Krstić), T. 3264, 3268-3269; KDZ065, P335 (Transcript from Prosecutor v. Krstić), T. 3265-3268 (under seal); KDZ065, P336 (Transcript from Prosecutor v. Popović et al.), T. 3217-3221; P266 (Photograph of Konjević Polje marked by KDZ065). See also Jean-René Ruez, T. 23751 (27 January 2012); P4308 (Book of photographs and maps prepared by Jean-René Ruez, 22 June 2009), e-court p. 81. The Chamber notes that Perić denied escorting any detainees to a warehouse in Konjević Polje on 13 July, adding that the only detainee he escorted on that day was Sinanović who he brought to the communications house, after which he returned to the check-point. D3852 (Witness statement of Mirko Perić dated 1 July 2013), paras. 20, 27-28, 30. See also Mirko Perić, T. 40793 (3 July 2013). Perić added that he was not aware of the existence of a warehouse; however, upon being presented with two photographs of Konjević Polje, one of which was marked by KDZ065 identifying the warehouse, Perić acknowledged the existence of the building marked by KDZ065 but stated that he had never been inside; Mirko Perić, T. 40796-40802 (3 July 2013); P4308 (Book of photographs and maps prepared by Jean-René Ruez, 22 June 2009), e-court p. 81; P266 (Photograph of Konjević Polje marked by KDZ065). The Chamber received evidence of the detention of other Bosnian Muslim men at the warehouse in the evening on 13 July. See para. 5168. 
uniforms. ${ }^{17601}$ The three men and the boy were taken to a room where 12 other Bosnian Muslim men were being kept in their underpants. ${ }^{17602}$ The "soldiers", who were carrying automatic weapons, started shouting at the three men and the boy to take their clothes off, which they did; thereafter the men and the boy were lined up against a wall and beaten with "all kinds of things". ${ }^{17603}$ A man aged approximately 18 to 20 wearing short blue pants with a belt and a leather holster containing a pistol arrived and asked Nenad Deronjić why he had made the men remove their clothes since they were to be exchanged. ${ }^{17604}$ Deronjić rejected the prospect of an exchange, saying that he would "kill them all"; the man in short pants said that if anyone was going to kill them, it would be him. ${ }^{17605}$ Later, a thin man with a moustache named "Brko" arrived and told the three men and the boy to put their clothes back on; they were then beaten again. ${ }^{17606}$

5194. Some time before noon, ${ }^{17607}$ KDZ065 and the 15 other detainees-including the boy-were put on a bus, and ordered not to sit down. ${ }^{17608}$ Four of the uniformed men who had beaten the detainees in the warehouse, including Nenad Deronjić and Brko, were on the bus and carried automatic weapons. ${ }^{17609}$ The bus then drove towards Zvornik and travelled for about two kilometres before stopping again at the side of the road. ${ }^{17610}$

5195. The detainees got off the bus and were initially lined up against a fence; then, on Brko's instructions, were led downhill on a path for 15 to 20 metres and lined up alongside the Jadar

\footnotetext{
17601 KDZ065, P335 (Transcript from Prosecutor v. Krstić), T. 3267-3268 (under seal); KDZ065, P335 (Transcript from Prosecutor v. Popović et al.), T. 3249-3250 (under seal).

17602 KDZ065, P336 (Transcript from Prosecutor v. Krstić), T. 3269.

17603 KDZ065, P336 (Transcript from Prosecutor v. Krstić), T. 3269-3270, 3272-3274. Mirko started beating KDZ065 when he saw KDZ065 shaking with fear. KDZ065, P336 (Transcript from Prosecutor v. Krstić), T. 3269.

17604 KDZ065, P336 (Transcript from Prosecutor v. Krstić), T. 3270, 3286.

17605 KDZ065, P336 (Transcript from Prosecutor v. Krstić), T. 3270.

17606 KDZ065, P336 (Transcript from Prosecutor v. Krstić), T. 3270-3271, 3276.

17607 See KDZ065, P336 (Transcript from Prosecutor v. Krstić), T. 3286-3287 (stating that "it all happened before noon"); KDZ065, P336 (Transcript from Prosecutor v. Popović et al.), T. 3277 (stating that events took place "sometime around noon").

17608 KDZ065, P336 (Transcript from Prosecutor v. Krstić), T. 3272, 3275. But see D3852 (Witness statement of Mirko Perić dated 1 July 2013), para. 31; KW582, D4291 (Transcript from Prosecutor v. Blagojević \& Jokić), T. 3535. See also Mirko Perić, T. 40795-40796 (3 July 2013).

17609 KDZ065, P336 (Transcript from Prosecutor v. Krstić), T. 3272, 3274, 3276. See also Momir Nikolić, T. 24665-24666 (14 February 2012); D2081 (Momir Nikolić's statement of facts from Plea Agreement, 7 May 2003), para. 9. The Chamber notes that KDZ065 identified Nenad Deronjić as part of the "execution squad". KDZ065, P335 (Transcript from Prosecutor v. Krstić), T. 3287 (under seal); KDZ065, P335 (Transcript from Prosecutor v. Popović et al.), T. 3215 (under seal). But see Nenad Deronjić, T. $40718-40719$ (2 July 2013) (private session); Nenad Deronjić, D3760 (Transcript from Prosecutor v. Blagojević \& Jokić), T. 8191-8193 (where Deronjić denied being in Konjević Polje on 13 July, having participated in "any atrocities", and being acquainted with KDZ065).

17610 Jean-René Ruez, T. 23751-23753 (27 January 2012); P4308 (Book of photographs and maps prepared by JeanRené Ruez, 22 June 2009), e-court pp. 81-82; P4283 (Photograph of Zvornik-Konjević Polje road marked by Jean-René Ruez). See also KDZ065, P336 (Transcript from Prosecutor v. Krstić), T. 3272, 3275.
} 
River. ${ }^{17611}$ Brko then ordered the men to get into the river bed. ${ }^{17612}$ KDZ065 was positioned third from the left; he recalled waiting for his life to end in silence for approximately 30 seconds while images of his children appeared in his mind. ${ }^{17613}$ When the man next to KDZ065 was shot, KDZ065 saw the bullet come through the man's shirt and hit KDZ065 on his left hip. ${ }^{17614}$ He threw himself facedown into the river and held his breath for as long as he could. ${ }^{17615}$ When KDZ065 raised his head to take a breath, one of the members of the Bosnian Serb Forces noticed and began firing at him; KDZ065 felt the bullets whizzing around his head. ${ }^{17616}$ KDZ065 ducked under the water again and pulled himself to the centre of the river but the leather jacket he was wearing puffed up. ${ }^{17617}$ The current began to carry him down the river, and when he hit his head on a rock, he turned onto his back. ${ }^{17618}$ The members of the Bosnian Serb Forces fired again at KDZ065 who spread out his arms and let the current carry him, until structures began to shelter him from the soldiers' fire. ${ }^{17619}$

5196. Later, KDZ065 took hold of a rock, got out of the river, and dressed the wound on his left side with torn-up bits of his shirt. ${ }^{17620}$ He was bleeding heavily, but was able to walk, so he continued through meadows, woods, and villages. ${ }^{17621}$ KDZ065 came across ten men coming from Srebrenica and continued with them; at some point, they joined the column of Bosnian Muslim men proceeding in the direction of Nezuk. ${ }^{17622}$

5197. The Chamber notes that the evidence surrounding the events at the communications house, as well as KDZ065's identification of Nenad Deronjić as one of the perpetrators of the killings at the Jadar River, have been highly contested in this case.

\footnotetext{
17611 KDZ065, P336 (Transcript from Prosecutor v. Krstić), T. 3275-3276. See also Adjudicated Fact 1690; JeanRené Ruez, T. 23752-23753 (27 January 2012); P4308 (Book of photographs and maps prepared by Jean-René Ruez, 22 June 2009), e-court pp. 83-84; P4284 (Photograph of Zvornik-Konjević Polje road marked by JeanRené Ruez).

17612 KDZ065, P336 (Transcript from Prosecutor v. Krstić), T. 3276.

17613 KDZ065, P336 (Transcript from Prosecutor v. Krstić), T. 3276-3277.

17614 KDZ065, P336 (Transcript from Prosecutor v. Krstić), T. 3277 . KDZ065 was hit on the left side from behind, and the bullet passed by the bone, cutting through some tendons. KDZ065, P336 (Transcript from Prosecutor $v$. Krstić), T. 3280. See also Adjudicated Fact 1691.

17615 KDZ065, P336 (Transcript from Prosecutor v. Krstić), T. 3277. See also Adjudicated Fact 1691.

17616 KDZ065, P336 (Transcript from Prosecutor v. Krstić), T. 3277.

17617 KDZ065, P336 (Transcript from Prosecutor v. Krstić), T. 3277.

17618 KDZ065, P336 (Transcript from Prosecutor v. Krstić), T. 3277.

17619 KDZ065, P336 (Transcript from Prosecutor v. Krstić), T. 3277-3278.

17620 KDZ065 explained that the exit wound from the bullet was very large and he could see his ligaments through it. KDZ065, P336 (Transcript from Prosecutor v. Krstić), T. 3278, 3280. KDZ065 was shown a photograph depicting a scar on his body and explained that the scar resulted from the shooting; he then marked the entry and exit wounds. KDZ065, P336 (Transcript from Prosecutor v. Popović et al.), T. 3222-3223; P261 (Photograph of KDZ065's wound marked by KDZ065).

17621 KDZ065 testified that the bullet had cut through some tendons so he could not walk properly, but he did not have any broken bones. KDZ065, P336 (Transcript from Prosecutor v. Krstić), T. 3277-3278, 3280.
} 
5198. The Prosecution asserts that "[a] significant body of reliable evidence corroborates KDZ065's evidence". ${ }^{17623}$ On the other hand, the Accused argues that the evidence on the Jadar River killings comes from only one witness, namely KDZ065, whose testimony was admitted pursuant to Rule $92 \mathrm{bis}$, and alleges that untested evidence, in and of itself, cannot lead to a conviction. ${ }^{17624}$ Additionally, the Accused claims that KDZ065's evidence is unsupported by any physical or forensic evidence and is contradicted by the testimony of the three persons who KDZ065 named as being involved in those events. ${ }^{17625}$

5199. As regards the events at the communications house, the Chamber notes first that, contrary to KDZ065's evidence, KW558 testified that he was at the communications house on 13 July when Mirko Perić and Duško Nesković—a police officer from Bratunac-arrived with Sinanović and Salihović; ${ }^{17626}$ Sinanović and Salihović stayed at the house for about an hour, until taken away by Momir Nikolić and "another man"-both of whom were wearing dark green military uniforms—in the direction of Bratunac. ${ }^{17627}$ KW558 could not remember whether any other Bosnian Muslim men were brought to, or kept in, the communications house on that day. ${ }^{17628}$ Nenad Deronjić testified that he heard from KW558 that KW558 was in Konjević Polje with Salihović, and that he gave Salihović some food and cigarettes until someone came and took Salihović away. ${ }^{17629}$ Perić testified that, after capturing Sinanović near the Konjević Polje check-point, he brought him to the communications house where he met KW558, ${ }^{17630}$ who instructed Perić to leave Sinanović in a

\footnotetext{
17622 KDZ065, P336 (Transcript from Prosecutor v. Popović et al.), T. 3277-3278. See para. 5165.

17623 Prosecution Final Brief, Appendix D, para. 51.

17624 Defence Final Brief, para. 2494.

17625 Defence Final Brief, para. 2495.

17626 KW558 explained that Salihović was a former colleague "who used to work in Srebrenica" and that, while he did not know Sinanović personally, he was introduced by Perić as Perić's superior at the Bratunac SJB before the war; KW558, T. 40746-40747, 40755-40757 (3 July 2013); KW558, D3763 (Transcript from Prosecutor v. Blagojević \& Jokić), T. 6528-6529 (under seal); KW558, D3764 (Transcript from Prosecutor v. Blagojević \& Jokić), T. 6529, 6548, 6551, 6554. According to KW558, Sinanović and Salihović looked terribly frightened, so KW558 told them to relax and not to be afraid; the men were then offered breakfast and cigarettes but only Salihović accepted any of it. KW558, T. 40747-40748 (3 July 2013); KW558, D3764 (Transcript from Prosecutor v. Blagojević \& Jokić), T. 6529-6530, 6548.

17627 KW558, T. 40758-40759 (3 July 2013); KW558, D3764 (Transcript from Prosecutor v. Blagojević \& Jokić), T. 6530-6532, 6549-6551, 6554. KW558 asserted that he never dreamed that Sinanović and Salihović would be killed and was certain at the time that they would be exchanged. KW558, T. 40758 (3 July 2013).

17628 KW558, 40749-40751 (3 July 2013) (private session), T. 40752 (3 July 2013).

17629 Nenad Deronjić, D3759 (Transcript from Prosecutor v. Blagojević \& Jokić), T. 8220-8221 (under seal). Deronjić also confirmed that he graduated with Salihović from the police academy, got their first jobs together at Gradačac, and later worked together in Srebrenica. Nenad Deronjić, D3760 (Transcript from Prosecutor v. Blagojević \& Jokić), T. 8177, 8219. See also KW558, T. 40746-40747 (3 July 2013); KW558, D3764 (Transcript from Prosecutor v. Blagojević \& Jokić), T. 6536.

17630 D3852 (Witness statement of Mirko Perić dated 1 July 2013), paras. 19-20. Perić testified that he did not escort any other detainees that day other than Sinanović and confirmed that he alone had transported Sinanović to the communications house; he further denied knowing who Duško Nesković was. D3852 (Witness statement of Mirko Perić dated 1 July 2013), para. 28; Mirko Perić, T. 40789-40790, 40797 (3 July 2013).
} 
room, where he saw two other individuals being held. ${ }^{17631}$ According to Perić, he then returned to the check-point where he later met with Momir Nikolić and told him where he had earlier taken Sinanović. ${ }^{17632}$ KW582 also stated that, while in Konjević Polje on 13 July, Momir Nikolić told him that he had taken "someone who had worked in the MUP earlier on" from Konjević Polje to Bratunac; KW582 understood this person to be Sinanović though he never saw Nikolić with Sinanović. ${ }^{17633}$ Momir Nikolić confirmed that while at Konjević Polje on 13 July, he was informed by members of the police that Sinanović had been captured, so he brought Sinanović to Bratunac to be interrogated by Zlatan Čelanović. ${ }^{17634}$ Čelanović-who worked as a "desk officer" in the Bratunac Brigade in July 1995—confirmed that Momir Nikolić brought Sinanović to his office on 13 July to be interrogated; Sinanović was questioned for about an hour and was then transferred to the Vuk Karadžić School in Bratunac, together with other Bosnian Muslim detainees. ${ }^{17635}$ Srbislav Davidović testified that after being informed on 13 July that Sinanović was in custody at Čelanović's office, as a suspected war criminal, he requested to see Sinanović with whom he met for about an hour. ${ }^{17636}$ After the meeting took place, Čelanović informed Davidović that Sinanović would be transferred to the Vuk Karadžić School in the afternoon. ${ }^{17637}$

5200. The Chamber finds that Deronjić, Perić, and KW558 were contradicted with respect to various portions of their evidence which was also marked by evasiveness and a lack of forthrightness. The Chamber further notes that KW558 and Perić contradicted each other as to the events which took place in the communications house. Consequently, the Chamber finds that the evidence of these three witnesses is not reliable, and does not undermine the evidence of KDZ065. Thus, while the evidence provided by the various witnesses who were present at the communications house is not fully consistent, the Chamber is satisfied with KDZ065's recollection

\footnotetext{
17631 Perić clarified that when taking Sinanović to the room inside the communications house he saw two other individuals; however, since he did not enter the room, he did not know their identity; D3852 (Witness statement of Mirko Perić dated 1 July 2013), paras. 19-20; Mirko Perić, T. 40790 (private session), $40792-40793$ (3 July 2013).

17632 D3852 (Witness statement of Mirko Perić dated 1 July 2013), para. 21.

17633 KW582, D4291 (Transcript from Prosecutor v. Blagojević \& Jokić), T. 3543-3544.

17634 Momir Nikolić, T. 24657-24658 (14 February 2012); D2081 (Momir Nikolić's statement of facts from Plea Agreement, 7 May 2003), para. 9. See also para. 5171. Momir Nikolić explained that, after the interrogation, Čelanović determined Sinanović was not a war criminal; Sinanović was then transported to the Vuk Karadžić School with other Bosnian Muslims who had previously been detained. Momir Nikolić, T. 24658-24659 (14 February 2012).

17635 Zlatan Čelanović, P377 (Transcript from Prosecutor v Popović et al.), T. 6626, 6630-6637, 6645-6647, 66576658, 6671-6673, 6684, 6697; P171 (Bratunac Brigade interrogation notes, 13 July 1995). The Chamber notes that Čelanović referred to the school as the "Branko Radičević School" but stated that he was unsure of its name; Zlatan Čelanović, P377 (Transcript from Prosecutor v Popović et al.), T. 6638-6639, 6690.

17636 Davidović explained that Sinanović was a very good friend, as they had worked together at the Bratunac SJB, and had previously tried to help Sinanović and his family to leave Bratunac. Srbislav Davidović, T. 2438724388 (9 February 2012); Srbislav Davidović, P4100 (Transcript from Prosecutor v. Popović et al.), T. 9219, 9222-9226, 9248-9249.

17637 Srbislav Davidović, P4100 (Transcript from Prosecutor v. Popović et al.), T. 9226.
} 
of the events that took place there, particularly in light of his evidence concerning the presence of Sinanović and Salihović, which was corroborated by the other witnesses whose evidence was discussed in the previous paragraph. ${ }^{17638}$

5201. Next, as regards KDZ065's identification of Nenad Deronjić as one of the perpetrators of the killings at the Jadar River, Deronjić testified that despite being deployed with colleagues from the Bratunac SJB at the check-point in Konjević Polje on 11 July 1995, he left the check-point on 12 July for Srebrenica as part of the $2^{\text {nd }}$ Company of the Zvornik PJP, where he stayed for seven or eight days. ${ }^{17639}$ The Chamber received evidence as to the whereabouts of Deronjić in July 1995, aimed at proving that he was only deployed to Srebrenica on 21 July and that until then he was deployed with the $2^{\text {nd }}$ Company of the Zvornik PJP, which was engaged in combat activities in the area of Konjević Polje from 12 to 20 July. ${ }^{17640}$ However, Deronjić reiterated that he never moved

17638 See paras. 5192, 5199. In relation to Sinanović's whereabouts after 13 July 1995, the Chamber received evidence that, in the morning of 14 July, Sinanović was transferred from the Vuk Karadžić School to Zvornik, as part of the convoy of detainees who had been held in various locations within Bratunac the night before. Momir Nikolić, T. 24659-24660 (14 February 2012). See paras. 5313, 5316. On 15 July, Sinanović was found wounded, and taken to the sanatorium in Banja Koviljača and, subsequently, to the Loznica Hospital, after having survived-and escaped from-a mass execution near Kozluk. P4393 (Witness statement of Robert Block dated 14 February 2012), paras. 37-41; P4402 (15 ${ }^{\text {th }}$ Border Battalion report, 16 July 1995); P4403 (VJ General Staff report, 16 July 1995), p. 2; P246 (Letter including medical register from Banja Koviljača, 5 March 2003); P4401 (Article from The Independent entitled "River Killings' Shed Light on Scale of Horror after the Fall of Srebrenica", 25 July 1995). See also Richard Butler, T. 27876 (23 April 2012); Robert Block, T. 24920, 24934-24936 (21 February 2012). According to Momir Nikolić, a doctor from the Loznica Hospital recognised Sinanović and informed the Bratunac SJB of his whereabouts, which in turn informed the police in Zvornik; members of the civilian police in Zvornik then took Sinanović from the hospital. Momir Nikolić, T. 24660 (14 February 2012). The Chamber also received evidence that on 15 July, the Zvornik Brigade was informed of Sinanović's whereabouts. P4585 (Zvornik Brigade Duty Officers logbook, 29 May-27 July 1995), e-court p. 72. While the Chamber received no evidence as to what happened to Sinanović after he was removed from the Loznica Hospital, his remains were identified from remains found in the Čančari Road 4 gravesite, which was linked to the Branjevo Military Farm primary gravesite. P4771 (Dušan Janc's report entitled "Update to the summary of Forensic Evidence - Exhumation of the Graves and Surface Remains Recoveries related to Srebrenica - January 2012", 13 January 2012), Annex D, e-court p. 203 (under seal); P5917 (ICMP DNA identifications concerning identified victims related to Srebrenica, 6 December 2010). See paras. 5458, 5461.

17639 Nenad Deronjić, D3760 (Transcript from Prosecutor v. Blagojević \& Jokić), T. 8179-8187; D3761 (Excerpt from Srebrenica SJB logbook); P4935 (Report of Zvornik CJB, 12 July 1995); P6431 (Excerpt from Srebrenica SJB work schedule logbook, 12 and 13 July 1995), e-court p. 4 (which may suggest that Deronjić was in Srebrenica on 13 July 1995 but whose original version appears to have been altered). See also Nenad Deronjić, T. 40710-40713, 40728-40729 (2 July 2013); Nenad Deronjić, D3760 (Transcript from Prosecutor v. Blagojević \& Jokić), T. 8182-8184, 8194-8199. Deronjić explained that, upon arriving in Srebrenica on 12 July, he worked on setting up the new SJB, and was deployed at the check-point in the direction of Zeleni Jadar and the check-point near Domavija; occasionally, he also patrolled the town. See Nenad Deronjić, T. 40698, 40704 (2 July 2013); D3760 (Transcript from Prosecutor v. Blagojević \& Jokić), T. 8186-8191; para. 226. See also Nenad Deronjić, T. 40694 (2 July 2013); Nenad Deronjić, D3760 (Transcript from Prosecutor v. Blagojević \& Jokić), T. 8204-8205.

17640 KDZ065, P335 (Transcript from Prosecutor v. Krstić), T. 3287 (under seal); KDZ065, P335 (Transcript from Prosecutor v. Popović et al.), T. 3215-3216, 3267-3268, 3272-3273 (under seal); Momir Nikolić, T. 2466524666 (14 February 2012); D2081 (Momir Nikolić's statement of facts from Plea Agreement, 7 May 2003), para. 9; P5136 (Bulletin of daily events of Zvornik CJB, 13-14 July 1995); P6432 (5 $5^{\text {th }}$ Engineering Battalion combat report, 12 July 1995); P247 ( $5^{\text {th }}$ Engineering Battalion combat report, 14 July 1995), pp. 1-2; P6427 (Order of Zvornik CJB, 15 July 1995); P6428 (Srebrenica SJB dispatch to Zvornik CJB, 16 July 1995); P6429 (Order of Zvornik CJB, 18 July 1995). See also P6430 (Decision of RS MUP, 18 June 1996); D3761 (Excerpt from Srebrenica SJB logbook). 
from the centre of Srebrenica during the nine days he was deployed there. ${ }^{17641}$ KW558 corroborated Deronjić's testimony by stating that, while Deronjić was "occasionally" in Konjević Polje in early July 1995, he had left for Srebrenica by 13 July. ${ }^{17642}$ Perić also testified that he never saw Deronjić at the check-point in Konjević Polje during the three or four days he was deployed there around 13 July. ${ }^{17643}$ Similarly, KW582 testified that he did not remember seeing Deronjić on 13 July while at the Konjević Polje intersection. ${ }^{17644}$ Contrary to the evidence described in this paragraph, Momir Nikolić testified to having seen both Nenad Deronjić and Mirko Perić at the intersection on 13 July $1995 .{ }^{17645}$

5202. The Accused claims that the evidence of KDZ065 and Momir Nikolić to having seen Nenad Deronjić in Konjević Polje on 13 July has been contradicted by the evidence of Deronjić himself, plus that of Perić, KW558, and KW582, as well as by D3761. ${ }^{17646}$ On the other hand, the Prosecution claims that Deronjić is not a credible witness and has been contradicted by a number of documents, including D3761, which show that members of Deronjić's unit were on combat duty on 13 July in Konjević Polje, and that Deronjić himself was on duty that day. ${ }^{17647}$ Furthermore, according to the Prosecution, none of the evidence presented by KW558, KW582 or Perić contradicts or undermines KDZ065's identification of Deronjić first, because they simply did not see Deronjić on 13 July, and second, because none of them testified to being present at the locations where KDZ065 saw Deronjić. ${ }^{17648}$

5203. The Chamber has already found that the evidence of Deronjić, Perić, and KW558 regarding the events at the communications house cannot be relied upon. The Chamber considers that the

17641 Nenad Deronjić, T. 40700-40713 (2 July 2013); Nenad Deronjić, D3760 (Transcript from Prosecutor $v$. Blagojević \& Jokić), T. 8207-8213, 8223, 8228-8229. See also D3115 (witness statement of Branimir Tešić dated 9 March 2013), para. 41.

17642 KW558, T. 40759, 40768-40769 (3 July 2013); KW558, D3764 (Transcript from Prosecutor v. Blagojević \& Jokić), T. 6536, 6553. According to KW558, on 11 or 12 July 1995, an order arrived from the Zvornik CJB whereby all policemen who had worked in Srebrenica before the war were ordered to return there, to set up a new police station; KW558 assumed that Deronjić followed the order and left Konjević Polje on 11 or 12 July, given that the police station in Srebrenica was established in the afternoon of 12 July. KW558, T. 40759-40761 (3 July 2013); KW558, D3764 (Transcript from Prosecutor v. Blagojević \& Jokić), T. 6536-6538, 6552-6554. See also KW558, T. 40760-40763, 40767-40770 (3 July 2013).

17643 Mirko Perić, T. 40788-40789 (3 July 2013); D3852 (Witness statement of Mirko Perić dated 1 July 2013), paras. 22, 29. But see Nenad Deronjić, T. 40701-40702 (2 July 2013) (claiming to have seen Perić in Konjević Polje on 11-12 July). See also Nenad Deronjić, D3760 (Transcript from Prosecutor v. Blagojević \& Jokić), T. 8218-8219.

17644 KW582, D4291 (Transcript from Prosecutor v. Blagojević \& Jokić), T. 3534-3535.

17645 Momir Nikolić, T. 24665-24666 (14 February 2012); D2081 (Momir Nikolić's statement of facts from Plea Agreement, 7 May 2003), para. 9. The Chamber notes the Accused's claim that this corroboration by Momir Nikolić is yet another instance of Nikolić's intentional effort to corroborate the Prosecution's case as a whole, regardless of its accuracy. Defence Final Brief, para. 2496.

17646 Defence Final Brief, para. 2496.

17647 Prosecution Final Brief, Appendix D, para. 52.

17648 Prosecution Final Brief, Appendix D, para. 52. 
same logic also applies to their evidence on the presence of Deronjić at Konjević Polje on 13 July and as such, their evidence has not undermined or successfully challenged that of KDZ065. While the Chamber found that KW582's testimony was sufficiently reliable and probative for the purpose of admission under Rule 92 quater, ${ }^{17649}$ it also finds that the portions thereof which are relevant to this particular issue have not successfully challenged the evidence of KDZ065.

5204. In considering the evidence of KDZ065 on its own, the Chamber notes that KDZ065 first identified Deronjić as one of the perpetrators of the killings at the Jadar River in his 1999 statement, although he had not done so in his earlier statements. ${ }^{17650}$ While the Chamber does not find KDZ065's explanations regarding this omission wholly satisfactory, it considers that it neither affects his credibility, nor renders his testimony unreliable as a whole. More specifically, the Chamber accepts KDZ065's identification of Deronjić as one of the perpetrators of the killings. As stated above, KDZ065's evidence that he saw Sinanović and Salihović at the communications house was confirmed by various other witnesses. ${ }^{17651}$ Furthermore, the Chamber has heard evidence as to the presence of Bosnian Serb Forces at the Konjević Polje intersection on 13 July, which is consistent with KDZ065's story. ${ }^{17652}$ The Chamber has also found no indicia within KDZ065's evidence that would indicate that he falsely identified and incriminated Deronjić. Thus, despite the contradictory evidence received by the Chamber discussed in paragraph 5200 above, and in particular in light of Momir Nikolić's corroboration of KDZ065's identification of Deronjić, the Chamber finds that Nenad Deronjić was present at the Konjević Polje intersection on 13 July 1995, and participated in the killings at the Jadar River.

5205. For the reasons set out above, the Chamber finds that on 13 July 1995, members of the Bosnian Serb Forces-including at least one member of the Bratunac SJB, Nenad Deronjićexecuted 15 Bosnian Muslim men in an isolated area on the bank of the Jadar River. The Chamber further finds that a 14 or 15-year old boy was among the 15 Bosnian Muslim males killed.

\section{(B) Cerska Valley}

\section{(1) Introduction}

5206. The Indictment refers to the killing and subsequent burial on 13 July 1995 of approximately 150 Bosnian Muslim men in an area along a dirt road in the Cerska Valley about three kilometres

\footnotetext{
17649 See Decision on Accused's Motion to Admit Testimony of Witness KW582 pursuant to Rule 92 quater, 3 February 2014, paras. 13-15.

17650 KDZ065, P335 (Transcript from Prosecutor v. Popović et al.), T. 3215-3216; 3251-3255, 3268-3272 (under seal).

17651 See para. 5201.
} 
from Konjević Polje. ${ }^{17653}$ In its pre-trial brief, the Prosecution clarified its position that this execution did not take place on 13 July but at some point between 13 and 17 July $1995 .{ }^{17654}$ In its final brief, however, the Prosecution asserts that the execution took place on or around $17 \mathrm{July}$. ${ }^{17655}$

\section{(2) $\underline{\mathrm{KDZ} 066}$}

5207. The Chamber admitted the transcript of KDZ066's testimony in the Krstić case pursuant to Rule 92 bis. KDZ066 testified that on 13 July 1995, he and eight others fleeing from Srebrenica were on a hill between the villages of Krke and Jelah, around 500 metres from the Konjević PoljeNova Kasaba Road. ${ }^{17656}$ Around 2 p.m., while looking towards the Cerska Valley, ${ }^{17657}$ KDZ066 saw buses-which he and the others assumed were carrying women and children-going from Konjević Polje in the direction of Nova Kasaba. ${ }^{17658}$ KDZ066 then saw another three buses ${ }^{17659}$ which he again assumed were full of people ${ }^{17660}$ _leaving Konjević Polje, which turned right off the asphalt road towards Kamenica, crossed a bridge across the Jadar River, and moved uphill in the direction of Cerska. ${ }^{17661}$ The buses were followed by an APC "and two other trek vehicles". ${ }^{17662}$ One of the vehicles was green and was carrying soldiers in camouflage uniforms. ${ }^{17663}$ At some point, all the vehicles turned around a curve into the woods and KDZ066 lost sight of them. ${ }^{17664}$

5208. According to KDZ066, 5 to 15 minutes later, a yellow excavator, with a bucket or a shovel, drove in the same direction. ${ }^{17665}$ At the same time, shooting began first with small arms fire, but

\footnotetext{
17652 See para. 5167.

17653 Indictment, Scheduled Killing Incident E.2.1.

17654 Prosecution Pre-trial Brief, para. 241.

17655 Prosecution Final Brief, Appendix D, para. 145.

17656 KDZ066, P337 (Transcript from Prosecutor v. Krstić), T. 2735-2737, 2741-2743. KDZ066 explained that he made his way to the Dolina hill because he was familiar with the area from before the war. KDZ066, P337 (Transcript from Prosecutor v. Krstić), T. 2736, 2741-2743.

17657 From the hill, KDZ066 "had a very good view" of the area of Konjević Polje and Nova Kasaba, the road leading to Nova Kasaba, and the field beyond the road. KDZ066, P337 (Transcript from Prosecutor v. Krstić), T. 27412742.

17658 KDZ066 assumed that people were being transported from Potočari. KDZ066, P337 (Transcript from Prosecutor v. Krstić), T. 2737, 2785-2787.

17659 KDZ066 explained that he could not tell what kind of buses they were, or "what company [they] belonged to. There were some letters but I couldn't make them out. I was on the hill, I was far away from the buses". See KDZ066, P337 (Transcript from Prosecutor v. Krstić), T. 2740.

17660 KDZ066 testified that he could not see whether the buses were full of people, but "assumed" that they were. KDZ066, P337 (Transcript from Prosecutor v. Krstić), T. 2774, 2780.

17661 KDZ066, P337 (Transcript from Prosecutor v. Krstić), T. 2737-2738, 2772-2773.

17662 See KDZ066, P337 (Transcript from Prosecutor v. Krstić), T. 2737.

17663 KDZ066, P337 (Transcript from Prosecutor v. Krstić), T. 2738-2739.

17664 KDZ066, P337 (Transcript from Prosecutor v. Krstić), T. 2737, 2739-2740.

17665 KDZ066, P337 (Transcript from Prosecutor v. Krstić), T. 2737, 2740.
} 
the intensity then increased as machine gun fire echoed along the valley. ${ }^{17666}$ KDZ066 described the scene as: "very loud [...] there was a lot of noise, very heavy shell fire could be heard". ${ }^{17667}$ The shooting lasted 15 to 30 minutes. ${ }^{17668}$ When it stopped, the buses-which according to KDZ066 were now empty_drove back followed by the APC, and took the same road in the direction of Konjević Polje. ${ }^{17669}$ The excavator drove back along the same road roughly 30 minutes later. $^{17670}$

5209. KDZ066 testified that he remained in the area in and around Cerska until September 1995. ${ }^{17671}$ Some time in September, KDZ066 and some individuals he had encountered decided to try to find the site of the shooting on 13 July, by following the road that goes from Cerska to the Konjević Polje intersection. ${ }^{17672}$ The group eventually found the gravesite on the left side of the road, "with freshly dug earth over it". ${ }^{17673}$ Its crater was approximately 25 steps long and 10 steps wide. ${ }^{17674}$ KDZ066 could tell it was the grave by the stench. ${ }^{17675}$ Across the road from the gravesite, on the right side of the road, KDZ066 saw the place where the excavator had dug up the earth, as well as traces of the excavator's wheels, ${ }^{17676}$ but did not see any bones or bodies. ${ }^{17677}$

5210. The Chamber also heard from Jean-René Ruez that the Cerska gravesite was discovered in 1996 using, among others, on information provided by KDZ066. ${ }^{17678}$ Having found the area, Ruez

\footnotetext{
17666 KDZ066, P337 (Transcript from Prosecutor v. Krstić), T. 2737, 2739, 2741.

17667 KDZ066, P337 (Transcript from Prosecutor v. Krstić), T. 2781.

17668 KDZ066, P337 (Transcript from Prosecutor v. Krstić), T. 2739, 2781.

17669 KDZ066, P337 (Transcript from Prosecutor v. Krstić), T. 2739, 2780-2781, 2787.

17670 KDZ066, P337 (Transcript from Prosecutor v. Krstić), T. 2739, 2780.
}

17671 The Chamber notes that the timeline at this point in KDZ066's evidence is not very clear, but it appears that KDZ066 spent more than four months in the area in and around Cerska, moving through various locations and villages, before crossing into Bosnian Muslim-held territory around mid-November. See KDZ066, P337 (Transcript from Prosecutor v. Krstić), T. 2743, 2748-2750, 2759, 2774-2777, 2788.

17672 KDZ066, P337 (Transcript from Prosecutor v. Krstić), T. 2751-2752.

17673 KDZ066, P337 (Transcript from Prosecutor v. Krstić), T. 2752-2753, 2777.

17674 KDZ066, P337 (Transcript from Prosecutor v. Krstić), T. 2753. KDZ066 was asked to point at the approximate location of the mass grave on a sketch map, and he pointed to the rectangle just below and to the right of Cerska. KDZ066, P337 (Transcript from Prosecutor v. Krstić), T. 2753; P203 (Map showing mass grave site in Cerska). KDZ066 then identified the location of the mass grave on a series of photo stills put to him. KDZ066, P337 (Transcript from Prosecutor v. Krstić), T. 2757-2759; P222 (Photographs of a site in Cerska); P209 (Photograph of a mass grave in Cerska Valley).

17675 KDZ066, P337 (Transcript from Prosecutor v. Krstić), T. 2754, 2777.

17676 KDZ066, P337 (Transcript from Prosecutor v. Krstić), T. 2753-2754, 2777.

17677 KDZ066, P337 (Transcript from Prosecutor v. Krstić), T. 2778-2779.

17678 Ruez explained that while visiting the area with his team in 1996 and driving along the valley-and filming the entire journey-based on the information provided by KDZ066, they could not find the gravesite; upon his return, Ruez showed the video to a second eye-witness who was then able to point Ruez and his team to a specific area; it was only during a second trip that Ruez and his team followed the exact location provided by the second eye-witness, probed it, and found the gravesite. Jean-René Ruez, T. 23743-23744, 23746-23749 (27 January 2012). Ruez explained that the second witness told him that when he was crossing barefoot the area during the night on 13 July, he walked on "sticky material that he identified as being a pool of blood" and continued his way towards the top of the valley. Jean-René Ruez, T. 23740-23741 (27 January 2012), T. 23996 (1 February 2012). See also P4311 (William Haglund's expert report, entitled "Forensic Investigation of the 
used two aerial images from 5 and 27 July 1995 to demonstrate the disturbance at the left side of the road where the bodies had been dumped, as well as the disturbance at the right side of the road where the excavator took the soil to cover the bodies. ${ }^{17679}$

5211. For reasons explained in detail in the following paragraphs, the Chamber finds KDZ066's account of events problematic, casting serious doubts as to his credibility, and is thus not satisfied with the reliability of large portions of his evidence.

5212. First, during his testimony in the Krstic case, KDZ066 testified that the killings in the Cerska Valley took place on 13 July 1995. ${ }^{17680}$ KDZ066 was unequivocal in this assertion despite the fact that prior to that testimony, he had given two statements where he first claimed that the killings at the Cerska Valley took place on 22 July, and then contended that they occurred on 14 July. ${ }^{17681}$ As stated above, KDZ066 testified that, while on a hill, he saw buses which he and the others "assumed" were carrying women and children going from Konjević Polje in the direction of Nova Kasaba and towards the "free territory". ${ }^{17682}$ Considering that women and children were indeed being bussed from Potočari on that date, ${ }^{17683}$ KDZ066's assumption would lend support to his claim that the events he described took place on 13 July 1995.

5213. Throughout the proceedings, however, the Accused challenged the date provided by KDZ066 as being the date of the killings at the Cerska Valley. ${ }^{17684}$ While Ruez corroborated KDZ066's evidence regarding the date, the Chamber notes that his assertion was solely based upon KDZ066's account of events. ${ }^{17685}$ However, both Dušan Janc and Richard Butler conceded that

Cerska Grave Site - Volume I", 15 June 1998), e-court pp. 8, 11 (explaining that, while a preliminary reconnaissance of the Cerska area was conducted in April 1996, the Cerska gravesite was only located by Tribunal investigators, led by Ruez, in a subsequent investigation conducted on 29 May 1996).

17679 Jean-René Ruez, T. 23748-23749 (27 January 2012); P4308 (Book of photographs and maps prepared by JeanRené Ruez, 22 June 2009), e-court p. 68. See also P4512 (Photograph booklet entitled "Srebrenica Mass Graves - Primary and Secondary Mass Grave Aerial Imagery"), p. 3.

17680 See KDZ066, P337 (Transcript from Prosecutor v. Krstić), T. 2737 (stating that "on the 13" of July, it was a Thursday, I remember very well. It was about 2.00 in the afternoon [...].") The Chamber notes that 13 July 1995 was indeed a Thursday.

17681 The Chamber notes that KDZ066 gave a first statement to the BiH Ministry of the Interior on 22 November 1995 — only a few days after he claimed to have reached Bosnian Muslim-held territory — and that he also gave a second one to a Prosecution investigator a few months later, namely on 17 January 1996. KDZ066, P337 (Transcript from Prosecutor v. Krstić), T. 2772-2774. The Chamber further notes that KDZ066 failed to explain to the Krstić Trial Chamber why he had provided inconsistent dates on these three occasions. See KDZ066, P337 (Transcript from Prosecutor v. Krstić), T. 2772-2774, 2787-2788.

17682 See para. 5207.

17683 See para. 5102.

17684 See T. 23996 (1 February 2012); T. 27043 (28 March 2012); T. 27804-27805 (20 April 2012).

17685 See Jean-René Ruez, at T. 23996 (1 February 2012) where he was asked by the Accused whether it was possible that the killings at Cerska occurred on 14 July, to which Ruez replied: "No. From the interview of the witness who was above the hill [...] when he saw the three buses escorted by one APCs in front of and one at the back of this little convoy, and then later saw the excavator entering the valley. This was on 13. [...] So this execution took place on 13 July”. See also Jean-René Ruez, T. 23741 (27 January 2012). 
establishing the exact date of the Cerska Valley killings was problematic. ${ }^{17686}$ Further, Richard Haglund also noted that two of the victims buried in the Cerska gravesite were last seen alive after July. ${ }^{17687}$ As stated above, even the Prosecution has now acknowledged that the killings at the Cerska Valley did not take place on 13 July but on or around 17 July. ${ }^{17688}$ More importantly, and as discussed in detail below, the Chamber has received additional evidence which shows that a number of victims found in the Cerska gravesite were last seen alive on various dates on or after 13 July, including as late as August 1995. ${ }^{17689}$ Thus, while the Chamber takes no issue with a witness making a mistake as to the specific date of an event, KDZ066's description of witnessing the transportation of the population out of Potočari-which was no longer possible on or after 17 July—give the Chamber serious reservations as to his credibility.

5214. In addition to the discrepancies as to the date of the events at the Cerska Valley discussed in the previous paragraph, the Chamber finds that other portions of KDZ066's evidence also contain contradictions or inconsistencies. For example, KDZ066 testified that he saw three buses-which he assumed were full of people-leaving Konjević Polje, turning right off the asphalt road towards Kamenica, and moving uphill in the direction of Cerska; ${ }^{17690}$ they were followed by at least two other vehicles, one of which was carrying soldiers in camouflage uniforms. ${ }^{17691}$ However, KDZ066 failed to explain how, on one hand, he admitted having been so far away from the buses to be able to tell what company the buses belonged to and whether they were full of people or not and, on the other hand, he did not hesitate to say that one of the vehicles following the buses was carrying soldiers in camouflage uniforms. ${ }^{17692}$

5215. The Chamber acknowledges that minor inconsistencies in a particular testimony do not necessarily render it unreliable. However, in the present case, having considered KDZ066's

\footnotetext{
17686 See Dušan Janc, T. 27043-27044 (28 March 2012); Richard Butler, T. 27805 (20 April 2012). See also P4914 (Richard Butler's expert report entitled "Srebrenica Military Narrative (Revised): Operation 'Krivaja 95", 1 November 2002), paras. 6.26-6.27; Richard Butler T. 27804-27805 (20 April 2012).

17687 P4311 (William Haglund's expert report, entitled "Forensic Investigation of the Cerska Grave Site - Volume I", 15 June 1998), pp. viii, 56-57.

17688 Prosecution Final Brief, Appendix D, para. 145.

17689 See para. 5220.

17690 KDZ066, P337 (Transcript from Prosecutor v. Krstić), T. 2737-2738, 2772-2773.

17691 KDZ066, P337 (Transcript from Prosecutor v. Krstić), T. 2737-2739.

17692 See KDZ066, P337 (Transcript from Prosecutor v. Krstić), T. 2738-2740 (explaining that he could not tell what kind of buses it was, "what company it belonged to. There were some letters but I couldn't make them out. I was on the hill, I was far away from the buses"), T. 2774, 2780 (testifying that he could not see whether the buses were full of people, but "assumed" they were). Similarly, the Chamber found discrepancies in KDZ066's evidence as to the number and type of vehicles he claims to have seen following the three buses. See KDZ066, P337 (Transcript from Prosecutor v. Krstić), T. 2737 (stating: "There was an APC following [the buses] and two other trek vehicles."), T. 2738 (stating: "I can describe the APC. I also noticed a trek vehicle that was green in colour."), T. 2739 (only referring to the buses, the excavator, and the APC), and T. 2779-2781 (referring again, in response to the Chamber's questioning, to the vehicles he saw on 13 July without referring to "trek vehicles", but only to the buses, the APC, and the excavator).
} 
evidence on the transportation of the population on 13 July, and the other contradictions and inconsistencies identified in KDZ066's account of events, the Chamber finds that it cannot be satisfied that KDZ066 is credible or that his testimony is reliable. Therefore, the Chamber does not rely on KDZ066's account of events.

\section{(3) Forensic evidence}

5216. In addition to KDZ066's evidence, the Chamber received forensic evidence that, between 7 and 18 July 1996, Prosecution investigators and experts from Physicians for Human Rights exhumed a gravesite at the Cerska Valley. ${ }^{17693}$ William Haglund, the senior forensic adviser to the Prosecution in 1996, ${ }^{17694}$ prepared a report in 1998, based on the evidence collected during the examination and excavation of the gravesite conducted in $1996 .{ }^{17695}$

5217. Haglund testified that the gravesite at Cerska was a primary and undisturbed grave ${ }^{17696}$ located on the north side of an embankment along a dirt road; it was 30-metre long and six metre down an incline. ${ }^{17697}$ In his report, Haglund explained that the ages of the 150 male victims ranged between 11 and their 50's. ${ }^{17698}$ Of the 150 bodies exhumed, 147 were wearing civilian clothes. ${ }^{17699}$ Furthermore, a total of 48 ligatures were found in the gravesite, ${ }^{17700}$ of which 24 were found

17693 P4311 (William Haglund's expert report, entitled "Forensic Investigation of the Cerska Grave Site - Volume I", 15 June 1998), p. 1; P4504 (Dean Manning's Report, entitled "Summary of Forensic Evidence - Execution Points and Mass Graves”, 16 May 2000), e-court p. 37. See also Adjudicated Fact 1696.

17694 William Haglund, T. 23873 (30 January 2012); P4309 (Dr. William Haglund's curriculum vitae).

17695 P4311 (William Haglund's expert report, entitled "Forensic Investigation of the Cerska Grave Site - Volume I", 15 June 1998), e-court p. 1.

17696 Haglund explained that a finding that a gravesite is undisturbed can be made based on the fact that the remains are relatively intact and that, in these types of gravesites, decomposition is more accelerated. William Haglund, P4310 (Transcript from Prosecutor v. Krstić), T. 3737-3738. See William Haglund, T. 23949 (31 January 2012) (explaining, after being questioned by the Accused on whether there was a possibility of new bodies being added to the gravesite at a later stage, that when examining plant growth on the gravesite, the plants were younger than plants in the surrounding area, but had grown at the same time, which evidenced a single burial).

17697 William Haglund, T. 23887 (30 January 2012); P4310 (Transcript from Prosecutor v. Krstić), T. $3733,3737$.

17698 William Haglund, P4310 (Transcript from Prosecutor v. Krstić), T. 3734; P4311 (William Haglund's expert report, entitled "Forensic Investigation of the Cerska Grave Site - Volume I", 15 June 1998), pp. viii, 11, $25,28$. See also Adjudicated Facts 1698, 1699; Jose Baraybar, P4029 (Transcript from Prosecutor v. Krstić), T. 3811; P4036 (Jose Baraybar's expert report entitled "Report on the Anthropology Examination of Human Remains from Eastern Bosnia in 2000”, 2 February 2001), p. 5; P4037 (Jose Baraybar's expert report entitled "Calculation of Minimal Number of Individuals Exhumed by ICTY between 1996 and 2001", 4 January 2004), p. 7; Jean-René Ruez, T. 23749-23750 (27 January 2012).

17699 P4311 (William Haglund's expert report, entitled "Forensic Investigation of the Cerska Grave Site - Volume I", 15 June 1998), p. 50. See also Adjudicated Fact 1700.

17700 P4506 (Photograph booklet entitled "Srebrenica Blindfolds and Ligatures - Volume 2: Lazete 2, Hodžići Road 3, 4 and 5, Petkovci Dam, Liplje 2, Cerska and Zeleni Jadar 5”), pp. 231-232; P4507 (Chart of photographs of blindfolds, ligatures, and location, 16 September 2009); P4509 (Collage of Srebrenica blindfolds, 5 March 2012). 
binding the wrists or arms of individuals behind their backs; additionally, one individual was bound by the ankles. ${ }^{17701}$

5218. Regarding the cause and manner of death, Haglund concluded that, of the 150 individuals, 149 died of gunshot wounds, the majority of whom died from multiple gunshot wounds. ${ }^{17702}$ With regard to the circumstances of death and burial, Haglund explained that cartridge casings were strewn along the entire length of the far side of the road where the bodies had been deposited. ${ }^{17703}$ The cartridges found in the grave itself matched with those found along the road at the gravesite, indicating that the victims in the grave were shot at the gravesite. ${ }^{17704}$ Based on this evidence, Haglund concluded that the victims were lined up on the southern side of the road while those who shot them stood across the road, shooting the victims with automatic weapons, in a spraying-type fashion. ${ }^{17705}$ As the victims were shot they either fell over the side of the embankment or rolled down, and were superficially covered with soil which had been removed from the roadside opposite

17701 William Haglund, P4310 (Transcript from Prosecutor v. Krstić), T. 3734; P4311 (William Haglund's expert report, entitled "Forensic Investigation of the Cerska Grave Site - Volume I", 15 June 1998), p. viii; p. 50; P4506 (Photograph booklet entitled "Srebrenica Blindfolds and Ligatures - Volume 2: Lazete 2, Hodžići Road 3, 4 and 5, Petkovci Dam, Liplje 2, Cerska and Zeleni Jadar 5”), pp. 231-232. See also Adjudicated Fact 1701.

17702 The cause of death of one individual was undetermined; William Haglund, P4310 (Transcript from Prosecutor v. Krstić), T. 3734; P4311 (William Haglund's expert report, entitled "Forensic Investigation of the Cerska Grave Site - Volume I", 15 June 1998), pp. 51-52. See also Jean-René Ruez, T. 23749-23750 (27 January 2012); Adjudicated Fact 1698. The Chamber notes that Dušan Dunjić challenged the methodology used by William Haglund in his report for the Cerska gravesite, by highlighting some of the findings of the San Antonio Committee on Haglund's report. D3894 (Dušan Dunjić's expert report entitled "Forensic Analysis of Documents Pertaining to Exhumations, Autopsies and Identification of Bodies in the Srebrenica Area", 26 August 2012), pp. 3-4. See Dušan Dunjić, T. 41785-41787, 41820 (23 July 2013). See also Defence Final Brief, para. 2648. However, the Chamber is not satisfied with Dunjić's explanation as to his failure to include a reference in his report to the final conclusions of the Committee, finding that there were no indications of any actual wrong-doing on the part of Haglund nor anything regarding the exhumations that jeopardised their scientific validity. Dušan Dunjić, T. 41813-41818 (23 July 2013). See also P4338 (Report of the Oversight Committee (San Antonio) regarding William Haglund, 2 February 1998); William Haglund, T. 23880-23882 (30 January 2012) (acknowledging the findings of the San Antonio Committee). Having assessed the totality of evidence on this issue, the Chamber accepts Haglund's report and the findings therein.

17703 William Haglund, P4310 (Transcript from Prosecutor v. Krstić), T. 3733-3734.

17704 P4311 (William Haglund's expert report, entitled "Forensic Investigation of the Cerska Grave Site - Volume I", 15 June 1998), pp. 9-10. See also Adjudicated Fact 1703.

17705 William Haglund, T. 23887-23888 (30 January 2012); P4310 (Transcript from Prosecutor v. Krstić), T. 3734. See also Adjudicated Fact 1697; Jean-René Ruez, T. 23749 (27 January 2012); P4308 (Book of photographs and maps prepared by Jean-René Ruez, 22 June 2009), e-court p. 69. 
the burial site using earthmoving equipment. ${ }^{17706}$ According to Haglund, all victims were executed at the site. ${ }^{17707}$

5219. Based upon DNA analysis, experts were able to positively identify 144 of the exhumed bodies as persons listed as missing following the take-over of Srebrenica. ${ }^{17708}$

5220. As stated above, the Chamber has received additional evidence which shows that victims found in the Cerska gravesite were last seen alive on various dates on or after 13 July. ${ }^{17709}$ This evidence comes primarily from P6705, which, as will be explained in detail below, ${ }^{17710}$ contains records of individuals reported to have been missing since the fall of Srebrenica. ${ }^{17711}$ According to P6705, approximately one third of the 150 victims exhumed from the Cerska gravesite went missing on or after 18 July 1995, and in various locations within Bratunac municipality, as well as in Baljkovica and Žepa. ${ }^{17712}$ While the Chamber acknowledges that the compilation of information

17706 William Haglund, T. 23888 (30 January 2012), T. 23931-23932 (31 January 2012); P4310 (Transcript from Prosecutor v. Krstić), T. 3737. See also Adjudicated Fact 1704; Jean-René Ruez, T. 23745-23746, 23749 (27 January 2012); P4308 (Book of photographs and maps prepared by Jean-René Ruez, 22 June 2009), e-court pp. 62-64; P4282 (Photograph of Cerska Valley marked by Jean-René Ruez). Haglund added that the soil used was made of small pebbles and was not much piled up on top of the bodies so, when the gravesite was found, a lot of the bodies were partially skeletalised. William Haglund, T. 23888 (30 January 2012); P4310 (Transcript from Prosecutor v. Krstić), T. 3738. See also William Haglund, T. 23926 (31 January 2012).

17707 P4311 (William Haglund's expert report, entitled "Forensic Investigation of the Cerska Grave Site - Volume I", 15 June 1998), pp. 10, 56-57.

17708 P4772 (Dušan Janc's report entitled "Update to the summary of Forensic Evidence - Exhumation of the Graves and Surface Remains Recoveries related to Srebrenica - January 2012”, 13 January 2012), e-court pp. 3, 8 (referring to the identification of 149 individuals from the Cerka gravesite); Dušan Janc, T. 26951-26952, 26956, 26959-26961 (27 March 2012) (where Janc explained that the unique DNA assigned to five of these individuals has not been matched to any missing person and thus these five have actually not been identified); P4771 (Dušan Janc's report entitled "Update to the summary of Forensic Evidence - Exhumation of the Graves and Surface Remains Recoveries related to Srebrenica - January 2012", 13 January 2012), Annex D, e-court pp. 90-98 (under seal). See P5917 (ICMP DNA identifications concerning identified victims related to Srebrenica, 6 December 2010); P4773 (ICMP unmatched DNA victim profiles related to Srebrenica, 23 December 2011); P4774 (ICMP lists of unmatched unique DNA victims profiles related to Srebrenica, 15 February 2010). The Chamber notes that Adjudicated Fact 1702, which is based upon Manning's report as admitted in the Krstić case, refers to the identification of nine individuals. See Adjudicated Fact 1702; P4504 (Dean Manning's Report, entitled "Summary of Forensic Evidence - Execution Points and Mass Graves", 16 May 2000), e-court pp. 38, 96, 98. The apparent discrepancy between this fact and the evidence admitted in the present case referring to the identification of 144 individuals can be explained by the fact that in 2001 - the year in which the Krstić Trial Judgement was issued-the identification process of victims was ongoing.

17709 See para. 5213.

17710 See paras. 5569-5572.

17711 P6705 (Ewa Tabeau's expert report entitled "Srebrenica Missing: Persons Reported Missing and Dead after the Take-Over of the Srebrenica Enclave by the Bosnian Serb Army on 11 July 1995", 9 April 2009).

17712 See e.g. P4771 (Dušan Janc's report entitled 'Update to the summary of Forensic Evidence - Exhumation of the Graves and Surface Remains Recoveries related to Srebrenica - January 2012", 13 January 2012), Annex D, ecourt pp. 90-98 (under seal) (listing the names of bodies identified at the Cerska gravesite); P6705 (Ewa Tabeau's expert report entitled "Srebrenica Missing: Persons Reported Missing and Dead after the Take-Over of the Srebrenica Enclave by the Bosnian Serb Army on 11 July 1995", 9 April 2009), e-court pp. 26, 39, 41, 54, 58, 69, 75, 78, 89, 97, 129, 130, 132, 138, 141, 144, 179, 188, 190, 196, 202, 209. 
in P6705 may have suffered from defects and may not be $100 \%$ accurate for all individuals, ${ }^{17713}$ it considers the information reflected therein reliable for at least a number of those individuals.

5221. The Chamber notes that, save for the general challenges by Dunjić as described above, ${ }^{17714}$ the Accused did not challenge the forensic evidence the Chamber received in relation to the Cerska gravesite. In that regard, the Chamber has no reason to doubt the forensic evidence received as to the cause and manner of death of the victims exhumed therein and is satisfied that at least somebut most likely a lot—of them were victims of execution. However, the Chamber has doubts as to the circumstances of death. As stated above, approximately one third of the victims exhumed from the gravesite may have been last seen alive after 17 July 1995 in various locations. The Chamber notes specifically with respect to the 24 individuals whose bodies were found bound by ligatures, that most of them are listed as having disappeared in various locations on different dates, and at least eight of them after 18 July $1995 .{ }^{17715}$ This evidence makes it highly unlikely that all of the 150 victims were the subject of a single execution at the Cerska Valley, as described in Haglund's report, or as alleged in the Indictment. The Chamber recalls the evidence that a gravesite had been dug at the Cerska Valley by 27 July $1995 ;{ }^{17716}$ however, this evidence alone does not assist the Chamber in determining when exactly the killings took place, and whether more bodies were buried in this grave afterwards. Thus, while the Chamber is satisfied that at least some of the bodies exhumed from the Cerska gravesite were victims of execution, the Chamber is unable to make a finding as to how many or when they were killed. The discrepancies in the evidence as to the number of victims and their dates and place of disappearance are substantial and affect almost one third of the 150 victims exhumed from the Cerska gravesite. It is therefore the incident as a whole, as alleged in the Indictment, that is affected.

\section{(4) Conclusion}

5222. Consequently, in light of the totality of the evidence as discussed above, the Chamber is not satisfied beyond reasonable doubt that the incident at the Cerska Valley took place, as alleged in the Indictment.

\footnotetext{
17713 See para. 5571, fn. 19020.

17714 See fn. 17702.

17715 See e.g. P6705 (Ewa Tabeau's expert report entitled "Srebrenica Missing: Persons Reported Missing and Dead after the Take-Over of the Srebrenica Enclave by the Bosnian Serb Army on 11 July 1995", 9 April 2009), ecourt pp. 75, 78, 89, 129, 188, 190, 202, 209.

17716 See para. 5210.
} 


\section{(C) Kravica Warehouse}

\section{(1) Introduction}

5223. The Indictment refers to the killing on 13 July 1995 of over 1,000 Bosnian Muslim men in a large warehouse in the village of Kravica. The Indictment alleges that the bodies of the victims were transported to two large mass graves located in the nearby villages of Glogova and Ravnice on 14 July 1995 . $^{17717}$

5224. The Kravica Warehouse is a one-storey building within the Kravica agricultural cooperative on the Bratunac-Konjević Polje Road. ${ }^{17718}$ It is located on the right hand side in the direction from Konjević Polje towards Bratunac, approximately 700 metres from the Yellow Bridge to the east, and one kilometre from the Sandići Meadow to the west. ${ }^{17719}$ The Kravica Warehouse consisted of a bigger room located to the west ("West Room") and a smaller room located to the east ("East Room"). ${ }^{17720}$

\section{(2) The killings}

5225. In the afternoon of 13 July 1995, KDZ063 was ordered to board one of two buses transporting detainees from the Sandići Meadow to the Kravica Warehouse. ${ }^{17721}$ Upon arriving, members of the Bosnian Serb Forces ordered the detainees to run out of the buses as quickly as possible and enter the warehouse; KDZ063 entered the East Room. ${ }^{17722}$

\footnotetext{
17717 Indictment, Scheduled Killing Incident E.3.1.

17718 Milenko Pepić, P373 (Transcript from Prosecutor v. Popović et al.), T. 13555, 13559; Jean-René Ruez, T. 23757 (27 January 2012); P4308 (Book of photographs and maps prepared by Jean-René Ruez, 22 June 2009), e-court pp. 97-99; P205 (Photograph of Kravica warehouse).

17719 Milenko Pepić, P373 (Transcript from Prosecutor v. Popović et al.), T. 13555-13557, 13559-13561, 1357013571; Jean-René Ruez, T. 23757-23758 (27 January 2012), T. 24068 (2 February 2012); P4308 (Book of photographs and maps prepared by Jean-René Ruez, 22 June 2009), e-court pp. 97-99; P4285 (Aerial image of the Kravica Warehouse marked by Jean-René Ruez). See Jean-René Ruez, T. 23778-23779 (27 January 2012); P4289 (Video footage of Kravica Warehouse), at 00:00:40-00:01:08 (showing the distance from the Sandići Meadow to the Kravica Warehouse).

17720 Jean-René Ruez, T. 23759-23760, 23763, 23770 (27 January 2012); P4308 (Book of photographs and maps prepared by Jean-René Ruez, 22 June 2009), e-court pp. 100-101, 103, 110, 113; P4289 (Video footage of Kravica Warehouse).

17721 KDZ063, P334 (Transcript from Prosecutor v. Popović et al.), T. 6978-6983, 6987, 7056. See also Adjudicated Fact 1705; KDZ071, T. 28539, 28548 (4 May 2012).

17722 KDZ063, P334 (Transcript from Prosecutor v. Popović et al.), T. 6987-6989; P262 (Aerial photograph of Kravica warehouse marked by KDZ063); P263 (Aerial photograph of Kravica warehouse marked by KDZ063). See Jean-René Ruez, T. 23760-23762 (27 January 2012); P4308 (Book of photographs and maps prepared by Jean-René Ruez, 22 June 2009), p. 110; P4285 (Aerial image of the Kravica Warehouse marked by Jean-René Ruez); P205 (Photograph of Kravica warehouse) (depicting an arrow and a circle pointing at the East Room).
} 
5226. The rest of the Bosnian Muslim men at the Sandići Meadow, including KDZ071, were ordered to line up in a column of four and proceed on foot towards the Kravica Warehouse. ${ }^{17723}$ Members of the $3^{\text {rd }}$ Skelani Platoon were ordered to escort the group of detainees to the warehouse, and were assisted by "several lads from Šekovići". ${ }^{17724}$ The detainees were surrounded by the uniformed men armed with automatic rifles, who were placed every five metres along the road. ${ }^{17725}$ As the detainees reached the Kravica Warehouse, they were ordered to walk past a bus parked in front and to enter the building. ${ }^{17726}$ KDZ071 was taken to the West Room. ${ }^{17727}$

5227. Groups of detainees continued to be brought to the warehouse for about two hours, approximately between 3 and 5 p.m. ${ }^{17728}$ The detainees were guarded by members of the Bosnian Serb Forces-including members of the $3^{\text {rd }}$ Skelani Platoon and members of the Bratunac Brigade ${ }^{17729}$ - wearing green-multi-coloured uniforms. ${ }^{17730}$ The members of the $3^{\text {rd }}$ Skelani Platoon formed a semi-circle around the warehouse positioning themselves to the side and behind the building itself. ${ }^{17731}$ Other members of the Bosnian Serb Forces walked among the detainees, questioning some of them. ${ }^{17732}$ The men were ordered to surrender all valuables and were given

17723 KDZ071, T. 28538 (4 May 2012); KDZ071, P5029 (Transcript from Prosecutor v. Popović et al.), T. 70907091, 7094, 7112-7113, 7123; D4113 (Witness statement of KW679 dated 23 November 2013), para. 13 (under seal). See also Adjudicated Fact 1705.

17724 KW679, T. 44117 (27 November 2013) (closed session); D4113 (Witness statement of KW679 dated 23 November 2013), para. 13 (under seal). KW679 estimated that there were between 300 and 400 detainees in that group. D4113 (Witness statement of KW679 dated 23 November 2013), para. 13 (under seal).

17725 KDZ071 described these men as soldiers in military uniforms. KDZ071, T. 28538 (4 May 2012); KDZ071, P5029 (Transcript from Prosecutor v. Popović et al.), T. 7113.

17726 KDZ071, T. 28544 (4 May 2012); KDZ071, P5029 (Transcript from Prosecutor v. Popović et al.), T. 7094, 7102, 7119. See also KDZ070, P341 (Transcript from Prosecutor v. Krstić), T. 1259 (stating that when the bus he had boarded on 13 July drove passed the Kravica Warehouse, he saw about 50 Muslim men with their hands and arms around their neck who looked terrified).

17727 KDZ071, P5029 (Transcript from Prosecutor v. Popović et al.), T. 7101-7104; KDZ071, P5028 (Transcript from Prosecutor v. Popović et al.), T. 7127-7128 (under seal); P5030 (Photograph of Kravica warehouse marked by KDZ071); P5031 (Photograph of Kravica warehouse marked by KDZ071); P5032 (Aerial photograph of Kravica warehouse marked by KDZ071); P205 (Photograph of Kravica warehouse) (depicting an arrow pointing to the West Room). See Jean-René Ruez, T. 23763 (27 January 2012); P4308 (Book of photographs and maps prepared by Jean-René Ruez, 22 June 2009), e-court p. 103.

17728 KDZ071, T. 28546 (4 May 2012); KDZ071, P5029 (Transcript from Prosecutor v. Popović et al.), T. 7123; KDZ063, P334 (Transcript from Prosecutor v. Popović et al.), T. 6990.

17729 D4113 (Witness statement of KW679 dated 23 November 2013), para. 13 (under seal); D2081 (Momir Nikolić's statement of facts from Plea Agreement, 7 May 2003), para. 9. See also P195 (Excerpt from Bratunac Health Centre patient log) (containing an entry listing Miroslav Stanojević, a member of the Red Berets, as injured on 13 July 1995 in Kravica).

17730 One of these men was wearing a blue UN helmet. KDZ063, P334 (Transcript from Prosecutor v. Popović et al.), T. 6990-6992. See KDZ107, P345 (Transcript from Prosecutor v. Popović et al.), T. 9360; KDZ070, P341 (Transcript from Prosecutor v. Krstić), T. 1260.

17731 D4113 (Witness statement of KW679 dated 23 November 2013), para. 14 (under seal).

17732 KDZ063, P334 (Transcript from Prosecutor v. Popović et al.), T. 6991. 
water. ${ }^{17733}$ Some men were also given cigarettes. ${ }^{17734}$ Around 5 p.m. the warehouse became so tightly packed that the detainees almost suffocated. ${ }^{17735}$

5228. Some time after 4:30 p.m., one of the Bosnian Muslim detainees brought to the warehouse took away the rifle of Krsto Dragišević—a member of the $3^{\text {rd }}$ Skelani Platoon-and shot him dead. ${ }^{17736}$ Rade Čuturić, a.k.a. "Oficir", the commander of the $2^{\text {nd }}$ Šekovići Detachment, ${ }^{17737}$ burned his hand when getting hold of the barrel of Dragišević's rifle and was taken to the Bratunac Health Centre for treatment. ${ }^{17738}$ Members of the $3^{\text {rd }}$ Skelani Platoon started shooting at the detainees in response to the killing of Dragišević. ${ }^{17739}$

17733 KDZ063, P334 (Transcript from Prosecutor v. Popović et al.), T. 6990-6992, 6995, 7057-7058.

17734 KDZ063, P334 (Transcript from Prosecutor v. Popović et al.), T. 6990-6991, 6995, 7057.

17735 KDZ063, P334 (Transcript from Prosecutor v. Popović et al.), T. 6989-6990, 7057; KDZ071, T. 28544-28548 (4 May 2012); KDZ071, P5029 (Transcript from Prosecutor v. Popović et al.), T. 7095; KDZ071, P5028 (Transcript from Prosecutor v. Popović et al.), T. 7125 (under seal). The Chamber notes that evidence as to the number of Bosnian Muslim men ultimately held inside the Kravica Warehouse varies; an analysis of this evidence, together with the forensic evidence admitted in this case, is found below. See para. 5278.

17736 D3659 (Witness Statement of Ljubomir Borovčanin dated 30 May 2013), para. 28; Milenko Pepić, P373 (Transcript from Prosecutor v. Popović et al.), T. 13541, 13562, 13578-13579; P195 (Excerpt from Bratunac Health Centre patient log) (which contains an entry listing Krsto Dragišević from the Special Police of Skelani as "deceased?", and the date/place of wounding as 7 p.m. on 13 July 1995 in Kravica). While the "1900 hrs." time included in Dragišević's entry refers to "date [time] of wounding", the Chamber finds that 7 p.m. is the time when Dragišević was brought to the Bratunac Health Centre, which is consistent with KW679's evidence that Dragišević's body was picked up from the Kravica Warehouse by a medical vehicle from Bratunac at approximately 6:30 p.m. D4113 (Witness statement of KW679 dated 23 November 2013), para. 21 (under seal). See D4113 (Witness statement of KW679 dated 23 November 2013), paras. 15-19 (under seal).

17737 Milenko Pepić, P373 (Transcript from Prosecutor v. Popović et al.), T. 13539.

17738 Milenko Pepić, P373 (Transcript from Prosecutor v. Popović et al.), T. 13561-13562, 13578-13579; P195 (Excerpt from Bratunac Health Centre patient log) (containing an entry stating that Cuturić suffered "burns on the palms of the hands and 2 to 4 fingers" at Kravica at 5:40 p.m. on 13 July 1995). See D4113 (Witness statement of KW679 dated 23 November 2013), paras. 15-19 (under seal); D3659 (Witness Statement of Ljubomir Borovčanin dated 30 May 2013), paras. 28, 30.

17739 Milenko Pepić, P373 (Transcript from Prosecutor v. Popović et al.), T. 13563-13565; D4113 (Witness statement of KW679 dated 23 November 2013), para. 20 (under seal). See D3659 (Witness Statement of Ljubomir Borovčanin dated 30 May 2013), paras. 28, 30; Ljubomir Borovčanin, T. 39423 (6 June 2013), T. 39457 (7 June 2013); P4563 (Statement by KDZ122), p. 4 (under seal). See also D4113 (Witness statement of KW679 dated 23 November 2013), paras. 15-19 (under seal); Dane Katanić, T. 38669 (22 May 2013); D3115 (Witness Statement of Branimir Tešić dated 9 March 2013), para. 40; Franc Kos, T. $42406-42407$ (1 August 2013); D3927 (Witness Statement of Franc Kos dated 26 July 2013), p. 9; Zvonko Bajagić, T. 41210 (10 July 2013); Ljubisav Simić. T. 37308-37309 (16 April 2013); D3398 (Witness Statement of Ljubisav Simić dated 7 April 2013), para. 79; Neđo Nikolić, T. 39818-39819 (12 June 2013); D3690 (Witness Statement of Neđo Nikolić dated 8 June 2013), para. 20; Srbislav Davidović, T. 24413 (9 February 2012); Jovan Nikolić, T. 35498 35499, 35505-35506, 35511-35514, 35516-35517 (14 March 2013); D3126 (Witness Statement of Jovan Nikolić dated 10 March 2013), para. 59; P6201 (Record of interview with Jovan Nikolić, 10 October 2005), p. 5 KDZ480, T. 24224-24225 (7 February 2012) (closed session); KDZ122, T. 26276 (14 March 2012) (closed session); KDZ480, P4355 (Transcript from Prosecutor v. Blagojević \& Jokić), T. 7873 (under seal); KDZ107, P345 (Transcript from Prosecutor v. Popović et al.), T. 9363-9364, 9530-9531; Zoran Petrović-Piroćanac, P376 (Transcript from Prosecutor v. Popović et al.), T. 18797-18800; Momir Nikolić, T. 24873 (16 February 2012); D2081 (Momir Nikolić's statement of facts from Plea Agreement, 7 May 2003), para. 9. KW679 testified that members of the $3^{\text {rd }}$ Skelani Platoon only shot at the detainees inside the warehouse for a few minutes before the fire stopped; according to KW679, during the approximately two hours that he remained around the warehouse after the first shooting, several soldiers, mostly over 50 years old, wearing different military uniforms and armed with semi-automatic rifles, came into the warehouse and opened fire. D4113 (Witness statement of KW679 dated 23 November 2013), para. 22 (under seal) (stating that he heard one of these men saying that he wanted to 
5229. Milenko Pepić - a member of the $2^{\text {nd }}$ Platoon of the $2^{\text {nd }}$ Šekovići Detachment $^{17740}$ - who was ordered to stop the traffic on the Bratunac-Konjević Polje Road, ${ }^{17741}$ testified that while he was stopping the convoy of buses carrying Bosnian Muslim women, children, and the elderly out of Potočari, he could hear intense shooting coming from the direction of Kravica, which lasted about an hour. ${ }^{17742}$ Borovčanin arrived at the warehouse after being informed over his Motorola that something "terrible" happened and that he should go there. ${ }^{17743}$ Borovčanin saw a pile of 20 to 30 bodies lying in front of the main door of the warehouse which was at the time closed. ${ }^{17744}$ After stopping by the Kravica Warehouse, Borovčanin went to the Bratunac Health Centre to check on Čuturić. ${ }^{17745}$

avenge his two sons). The Chamber does not find this evidence reliable in light of the fact that KW679's evidence was marked by insincerity and evasiveness.

17740 Milenko Pepić, P373 (Transcript from Prosecutor v. Popović et al.), T. 13538-13541.

17741 Upon being informed that the column of detainees being held at the Sandići Meadow was moving, Borovčanin ordered Čuturić to stop the traffic on the Bratunac-Konjević Polje Road. P4201 (Updated Srebrenica Trial Video), Part 3, at 00:25:52-00:26:05; P4202 (Written Compilation Booklet: Srebrenica Trial Video), e-court p. 277; P667 (Zoran Petrović-Piroćanac's video footage), at 00:16:26-00:17:00; Milenko Pepić, P373 (Transcript from Prosecutor v. Popović et al.), T. 13559-13560. Cuturić in turn ordered Pepić to stop the convoy of buses carrying Bosnian Muslim women, children, and the elderly out of Potočari. Milenko Pepić, P373 (Transcript from Prosecutor v. Popović et al.), T. 13555-13557, 13559, 13595-13596.

17742 Milenko Pepić, P373 (Transcript from Prosecutor v. Popović et al.), T. 13560, 13598. According to Pepić, this shooting was different to the one that could constantly be heard around the area, in that it seemed as if fire was being opened from one side alone. Milenko Pepić, P373 (Transcript from Prosecutor v. Popović et al.), T. 13560 .

17743 D3659 (Witness Statement of Ljubomir Borovčanin dated 30 May 2013), paras. 26-27; Ljubomir Borovčanin, T. 39452 (7 June 2013); Zoran Petrović-Piroćanac, T. 28465, 28468-28469 (3 May 2012); P376 (Transcript from Prosecutor v. Popović et al.), T. 18797-18798. See Jean-René Ruez, T. 23993 (1 February 2012), T. 24105-24106 (2 February 2014).

17744 D3659 (Witness Statement of Ljubomir Borovčanin dated 30 May 2013), para. 27; Ljubomir Borovčanin, T. 39425 (6 June 2013), T. 39454-39455 (7 June 2013); Zoran Petrović-Piroćanac, T. 28465-28467 (3 May 2012); P376 (Transcript from Prosecutor v. Popović et al.), T. 18798-18799, 18804-18805; P4201 (Updated Srebrenica Trial Video), Part 3, at 00:36:20-00:36:24; P4202 (Written Compilation Booklet: Srebrenica Trial Video), e-court p. 283. See also Jean-René Ruez, T. 23774, 23777 (27 January 2012); P4308 (Book of photographs and maps prepared by Jean-René Ruez, 22 June 2009), e-court pp. 121-122, 117. The Chamber notes that when Ruez was asked whether the pile of bodies which could be seen lying in front of the warehouse was in fact lying in front of a closed door, he categorically denied this possibility and provided a detailed explanation for his conclusion. However, the Prosecution maintained its position in the Popovic et al. case in which it agreed that there was indeed a door. Jean-René Ruez, T. 24104-24111 (2 February 2012); P4269 (Panorama image of Kravica warehouse); P4308 (Book of photographs and maps prepared by Jean-René Ruez, 22 June 2009), e-court pp. 121-123, 125-128; P4340 (Photograph of Kravica warehouse marked by Jean-René Ruez). Petrović-Piroćanac testified that the door to the West Room was closed. Zoran Petrović-Piroćanac, T. 28466-28469 (3 May 2012). The Chamber notes that a number of other witnesses also testified to having seen the pile of bodies outside the Kravica Warehouse at some point in the evening of 13 July 1995 . See Franc Kos, T. 42403 (1 August 2013); D3927 (Witness Statement of Franc Kos dated 26 July 2013), p. 8; KDZ107, P345 (Transcript from Prosecutor v. Popović et al.), T. 9360-9361, 9521-9524; KDZ333, T. 24123-24124 (2 February 2012); P4342 (Transcript from Prosecutor v. Krstić), T. 3026; P4346 (Photograph of Kravica warehouse marked by KDZ333); Vujadin Popović, T. 43044 (5 November 2013). See also P4201 (Updated Srebrenica Trial Video), Part 3, at 00:36:19-00:36:47; Jovan Nikolić, T. 35498, 35500-35502, 35507 (14 March 2013); P6201 (Record of interview with Jovan Nikolić, 10 October 2005) p. 5.

17745 D3659 (Witness Statement of Ljubomir Borovčanin dated 30 May 2013), para. 30; Zoran Petrović-Piroćanac, P376 (Transcript from Prosecutor v. Popović et al.), T. 18798-18800. 
5230. According to KDZ063, some time after arriving at the Kravica Warehouse, the Bosnian Serb soldiers guarding the detainees became agitated and angry. ${ }^{17746}$ Shortly after, intense shooting began outside the warehouse, lasting approximately half an hour. ${ }^{17747}$ While the shooting was ongoing, the soldiers came in and out of the warehouse and seemed to be in a panic, yelling at the detainees that the Muslims were attacking the soldiers. ${ }^{17748}$ The detainees panicked and became frightened as they did not know what was happening outside. ${ }^{17749}$ After the first period of shooting ended, two uniformed men entered the East Room and started shooting at the detainees; five to ten soldiers followed and joined in. ${ }^{17750}$

5231. While testifying about the way in which the shooting into the warehouse started, KDZ071 explained that, as the last of the Bosnian Muslim detainees entered the West Room, one man protested to a guard that he had nowhere to sit after which the guard opened fire on him. ${ }^{17751}$ Immediately after that, guards started firing on the other detainees. ${ }^{17752}$ The Chamber notes that this account differs from KDZ063's account, but finds that this may be due to a number of reasons such as the fact that KDZ071 and KDZ063 were detained in different rooms, the location of each of these witnesses within each room, and the trauma they were undergoing at the time.

5232. As members of the Bosnian Serb Forces entered the warehouse and shot at the detainees with M-84 machine guns and automatic rifles, ${ }^{17753}$ gunshots were also fired at the doors and windows from outside. ${ }^{17754}$ In addition to the shooting, a number of hand-grenades were thrown in the warehouse through the windows. ${ }^{17755}$

\footnotetext{
17746 KDZ063, P334 (Transcript from Prosecutor v. Popović et al.), T. 6992-6995, 7059, 7064-7065; P333 (Transcript from Prosecutor v. Popović et al.), T. 7064-7065 (under seal).

17747 KDZ063 explained that the firing outside of the Kravica Warehouse came from machine-gun and automatic rifles, though he also heard a tank, an anti-aircraft, and a Praga shooting, as well as the detonation of grenades. KDZ063, P334 (Transcript from Prosecutor v. Popović et al.), T. 6992-6993, 6995-6996, 7057. See KDZ071, P5029 (Transcript from Prosecutor v. Popović et al.), T. 7095.

17748 KDZ063, P334 (Transcript from Prosecutor v. Popović et al.), T. 6993-6994, 6996-6999.

17749 KDZ063, P334 (Transcript from Prosecutor v. Popović et al.), T. 6998-6999. See KDZ071, T. 28549 (4 May 2012).

17750 KDZ063, P334 (Transcript from Prosecutor v. Popović et al.), T. 6999, 7060-7061.

17751 KDZ071, P5029 (Transcript from Prosecutor v. Popović et al.), T. 7095, 7123.

17752 KDZ071, P5029 (Transcript from Prosecutor v. Popović et al.), T. 7095, 7123.

17753 KDZ063, P334 (Transcript from Prosecutor v. Popović et al.), T. 6995-6996, 6999, 7060-7061; D4113 (Witness statement of KW679 dated 23 November 2013), para. 20 (under seal).

17754 KDZ071, T. 28549 (4 May 2012). See also Adjudicated Fact 1706.

17755 KDZ063, P334 (Transcript from Prosecutor v. Popović et al.), T. 7000. See also Adjudicated Fact 1706; JeanRené Ruez, T. 23764-23765, 23767 (27 January 2012); P4308 (Book of photographs and maps prepared by Jean-René Ruez, 22 June 2009), e-court p. 105-107; P6201 (Record of interview with Jovan Nikolić, 10 October 2005), p. 5; D3927 (Witness Statement of Franc Kos dated 26 July 2013), p. 9.
} 
5233. Franc Kos-the commander of the $10^{\text {th }}$ Sabotage Detachment's $1^{\text {st }}$ Platoon ${ }^{17756}$ - testified that while at the Drina Corps Command in Vlasenica around 6 p.m. on 13 July, his commander, Pelemiš, looked agitated after having talked with Krstić. ${ }^{17757}$ Pelemiš then ordered Kos to go to Kravica, together with other members of the $10^{\text {th }}$ Sabotage Detachment. ${ }^{17758}$ Upon arriving at the Kravica Warehouse, Pelemiš got out of the car and spoke to five VRS officers. ${ }^{17759}$ Kos overheard one of these officers tell Pelemiš: "they made a big mess. We have to bury all this and hide it". ${ }^{17760}$ Kos looked both inside the West Room and the East Room, and saw that the floors on both rooms were covered with bodies. ${ }^{17761}$ Marko Boškić, one of his colleagues from the detachment, headed towards the warehouse, took two hand-grenades, and threw them inside the East Room where detainees could still be heard murmuring. ${ }^{17762}$

5234. The shooting quieted down as the night fell, ${ }^{17763}$ but continued with breaks throughout the night. ${ }^{17764}$ By this time, the warehouse was filled with dead bodies. ${ }^{17765}$ Moans and shouts from people could be heard during the breaks in the shooting. ${ }^{17766}$ Those who tried to escape through the main door or windows were also killed by members of the Bosnian Serb Forces. ${ }^{17767}$

5235. In the morning of 14 July, members of the Bosnian Serb Forces called out for the wounded inside the warehouse to come out, assuring them that they would be picked up by the ICRC and taken to the hospital for treatment. ${ }^{17768}$ The wounded came out and were ordered to sing Serb

17756 D3927 (Witness statement of Franc Kos dated 26 July 2013), p. 2. See also P232 (Video still of $10^{\text {th }}$ Sabotage Unit Parade) (for a video still of Franc Kos, leader of the $1^{\text {st }}$ Platoon).

17757 Franc Kos, T. 42399-42400 (1 August 2013); D3927 (Witness Statement of Franc Kos dated 26 July 2013 ), p. 7.

17758 Franc Kos, T. 42399-42401 (1 August 2013); D3927 (Witness Statement of Franc Kos dated 26 July 2013), p. 7.

17759 While Kos assumed that these men were VRS Main Staff officers from Han Pijesak, as they were driving military jeeps exclusive to brigade and corps commanders, he could not be absolutely certain that they indeed were; Kos was certain, however, that these men were VRS officers. Franc Kos, T. 42401-42402 (1 August 2013).

17760 Franc Kos, T. 42402 (1 August 2013). See Franc Kos, T. 42425 (1 August 2013).

17761 Franc Kos, T. 42408-42409 (1 August 2013); P6473 (Sketch drawn by Franc Kos). Kos testified that, at the time, he thought that the men were still alive but sleeping. Franc Kos, T. 42409 (1 August 2013). The Chamber finds this statement unacceptable.

17762 Franc Kos, T. 42409-42410 (1 August 2013); D3927 (Witness Statement of Franc Kos dated 26 July 2013), p. 8; P6473 (Sketch drawn by Franc Kos). Cf. Franc Kos, T. 42402 (1 August 2013) (stating that he heard the explosions near the warehouse but did not know whether it actually came from inside or from behind).

17763 KDZ071, P5029 (Transcript from Prosecutor v. Popović et al.), T. 7095, 7123-7124.

17764 KDZ063, P334 (Transcript from Prosecutor v. Popović et al.), T. 7000.

17765 KDZ071, P5029 (Transcript from Prosecutor v. Popović et al.), T. 7095; Adjudicated Fact 1708.

17766 KDZ063, P334 (Transcript from Prosecutor v. Popović et al.), T. 7000.

17767 KDZ063, P334 (Transcript from Prosecutor v. Popović et al.), T. 7001, 7004, 7006; D3927 (Witness Statement of Franc Kos dated 26 July 2013), p. 9; Jean-René Ruez, T. 23777 (27 January 2012); P4308 (Book of photographs and maps prepared by Jean-René Ruez, 22 June 2009), e-court p. 127. See also Adjudicated Fact 1707.

17768 KDZ063, P334 (Transcript from Prosecutor v. Popović et al.), T. 7005-7006; KDZ071, T. 28554 (4 May 2012); KDZ071, P5029 (Transcript from Prosecutor v. Popović et al.), T. 7096. See also Adjudicated Fact 1710. 
nationalistic songs together for about half an hour, until bursts of fire were heard; no voice was heard thereafter. ${ }^{17769}$ The members of the Bosnian Serb Forces continued firing single shots to kill further survivors. ${ }^{1770}$ While shooting at the only survivors, the soldiers continued to make derogatory remarks about their "Turkish mother[s]" and their "Islam tribe". ${ }^{1777}$

5236. The Chamber heard evidence from both KDZ063 and KDZ071 that they survived by lying on the floor during the shooting on 13 July. ${ }^{17772}$

5237. KDZ063 was hit on his right leg, close to his knee. ${ }^{17773}$ His back was also scraped by a small piece of shrapnel from a grenade that fell three to four metres away from him. ${ }^{17774}$ After the night fell, during one of the breaks in shooting, KDZ063 crawled between dead bodies, climbed onto a container inside the East Room, and jumped out through a very narrow window. ${ }^{17775}$ As soon as he jumped out he was spotted by Bosnian Serb soldiers who were standing in the cornfield outside the warehouse. ${ }^{17776}$ KDZ063 immediately lay down on his stomach-with his head towards the wall-between two of the warehouse's windows. ${ }^{17777}$ A member of the Bosnian Serb Forces walked towards KDZ063, pointed a torch light at him, and shot him from a distance of two

17769 KDZ063, P334 (Transcript from Prosecutor v. Popović et al.), T. 7006; KDZ071, T. 28554 (4 May 2012 ); KDZ071, P5029 (Transcript from Prosecutor v. Popović et al.), T. 7096. See Jovan Nikolić, T. 35502, 35507, 35519 (14 March 2013); D3126 (Witness statement of Jovan Nikolić dated 10 March 2013), paras. 55-57; P6201 (Record of interview with Jovan Nikolić, 10 October 2005), pp. 6-8 (testifying that when he went to the Kravica Warehouse in the morning of $14 \mathrm{July}$, he saw several bodies in front, and witnessed the killing of between 10 and 20 people he did not recognise); Alexandar Tešić, T. 35324-35328 (13 March 2013) (testifying that, while on his way to Zvornik on 14 July 1995, he saw about 200 to 300 dead bodies piled outside the Kravica warehouse). See also Adjudicated Fact 1710.

17770 KDZ063, P334 (Transcript from Prosecutor v. Popović et al.), T. 7006; KDZ071, P5029 (Transcript from Prosecutor v. Popović et al.), T. 7096-7097.

17771 KDZ071, P5029 (Transcript from Prosecutor v. Popović et al.), T. 7096-7097.

17772 KDZ063, P334 (Transcript from Prosecutor v. Popović et al.), T. 6999-7000, 7007-7008; KDZ071, T. 28545 (4 May 2012); KDZ071, P5029 (Transcript from Prosecutor v. Popović et al.), T. 7095. The Chamber also heard from KW012 that he survived when a Bosnian Serb soldier who recognised him took him to an adjacent room prior to the start of the shooting; according to KW012, he jumped out of the window when the shooting started and escaped into the woods, where he lived for ten months. KW012, T. 44781-44782, 44787 (9 December 2013). In light of the various contradictions which arose during his viva voce testimony, the Chamber does not find KW012's evidence reliable. In addition the Chamber finds that KW012's evidence was marked by insincerity and evasiveness. For these reasons, the Chamber rejects KW012's story as to the events at the Kravica Warehouse.

17773 KDZ063, P334 (Transcript from Prosecutor v. Popović et al.), T. 7007-7008.

17774 KDZ063, P334 (Transcript from Prosecutor v. Popović et al.), T. 7000.

17775 KDZ063, P334 (Transcript from Prosecutor v. Popović et al.), T. 7000-7001. See Jean-René Ruez, T. 2377123773 (27 January 2012); P4308 (Book of photographs and maps prepared by Jean-René Ruez, 22 June 2009), e-court pp. 117-119; P4287 (Photograph of a window marked by Jean-René Ruez).

17776 KDZ063, P334 (Transcript from Prosecutor v. Popović et al.), T. 7003.

17777 KDZ063, P334 (Transcript from Prosecutor v. Popović et al.), T. 7003; P206 (Photograph of Kravica warehouse); P260 (Photograph of Kravica warehouse marked by KDZ063). 
to three metres, wounding him in the right shoulder. ${ }^{17778}$ KDZ063 lay on the ground for several hours until the morning, pretending to be dead. ${ }^{17779}$

5238. At some point on 14 July, while still lying on the ground outside the warehouse, KDZ063 crawled towards and through the cornfield; he passed by the bodies of men who had tried to escape before him. ${ }^{17780}$ KDZ063 was helped by other Bosnian Muslims he encountered who treated his wounds and, after seven or eight days, made his way to Žepa. ${ }^{17781}$

5239. Similarly, KDZ071 spent the whole day of 14 July lying inside the West Room. ${ }^{17782}$ In the evening, however, he decided to sit up and discovered two people doing the same. ${ }^{17783}$ After midnight, KDZ071 managed to escape from the West Room with one of the men, through the same door he had originally come in. ${ }^{17784}$ While escaping, he heard gunfire coming from the direction of the warehouse. ${ }^{17785}$ The two men spent a couple of days walking in the area, until they decided to go in the direction of Žepa, where KDZ071 arrived on 29 July. ${ }^{17786}$

\section{(3) Clean-up}

5240. On the evening of 13 July 1995, Borovčanin went to the Bratunac Brigade Command to report on the killings at the Kravica Warehouse, but was told that they had already been informed. ${ }^{17787}$ While still at the command, Borovčanin discussed with Miroslav Deronjić the incident at the Kravica Warehouse, including the fact that a number of detainees had been killed. ${ }^{17788}$

\footnotetext{
17778 KDZ063, P334 (Transcript from Prosecutor v. Popović et al.), T. 7004, 7008.

17779 KDZ063, P334 (Transcript from Prosecutor v. Popović et al.), T. 7004-7005 (further stating that the next morning, a soldier who came to check on KDZ063, did not realise that he was in fact alive).

17780 KDZ063, P334 (Transcript from Prosecutor v. Popović et al.), T. 7006-7007, 7009.

17781 KDZ063, P334 (Transcript from Prosecutor v. Popović et al.), T. 7009-7013.

17782 KDZ071, P5029 (Transcript from Prosecutor v. Popović et al.), T. 7095; KDZ071, P5028 (Transcript from Prosecutor v. Popović et al.), T. 7106 (under seal).

17783 The young man told KDZ071 that they could not escape together, but that he would follow him in 15 to 20 minutes; KDZ071 was told to cross the asphalt road and to find a path to the river. KDZ071, T. 28551 (4 May 2012); KDZ071, P5029 (Transcript from Prosecutor v. Popović et al.), T. 7097-7098.

17784 Upon leaving the warehouse, a soldier asked KDZ071 to stop; KDZ071 lay down as a response but managed to escape nonetheless. KDZ071, T. 28551, 28555 (4 May 2012); KDZ071, P5029 (Transcript from Prosecutor v. Popović et al.), T. 7098.

17785 KDZ071, T. 28551 (4 May 2012); KDZ071, P5029 (Transcript from Prosecutor v. Popović et al.), T. 7099.

17786 KDZ071, T. 28556-28558 (4 May 2012); KDZ071, P5029 (Transcript from Prosecutor v. Popović et al.), T. 7099-7100.

17787 D3659 (Witness Statement of Ljubomir Borovčanin dated 30 May 2013), paras. 31-33.

17788 Ljubomir Borovčanin, T. 39444 (6 June 2013); D3659 (Witness Statement of Ljubomir Borovčanin dated 30 May 2013), para. 36. See also P4374 (Witness statement of Milenko Katanić dated 11 October 2011), para. 72; Milenko Katanić, T. 24474, 24506 (10 February 2012) (testifying that he had been informed by Deronjić about the killings at the Kravica Warehouse in the evening on 13 July).
} 
5241. Earlier that afternoon, members of the Drina Corps had begun looking for available bulldozers and loading equipment, but were unsuccessful in securing any. ${ }^{17789}$ Sometime after 9 p.m., KDZ107 received a phone call asking him to meet Beara at the SDS Office in Bratunac. ${ }^{17790}$ KDZ107 met Beara in Deronjić's office with two officers he did not know; Deronjić himself was not present. ${ }^{17791}$ Beara asked what kind of machinery and manpower was available, and said it needed to go to Milići, adding that "[d]ead people have to be buried, there will be a lot of dead and they need to be buried". ${ }^{17792}$

5242. At approximately the same time, KDZ480 was called into a small meeting room in the Bratunac SDS Office to meet with Deronjić and two officers he did not know, who were wearing camouflage uniforms. ${ }^{17793}$ Deronjić told KDZ480 that there had been an incident at the Kravica Warehouse in which many detainees had been killed, and that they had to be transported to a bauxite mine in Milići, to be buried. ${ }^{17794}$ It was ultimately agreed that the two officers would procure vehicles for the transportation of the bodies, and that members of the sanitation unit of the Bratunac Civilian Protection would be sent to the Kravica Warehouse the next morning to load the bodies onto the vehicles. ${ }^{17795}$

17789 P5290 (Intercept of conversation between Col. Milanović and Palma duty officer, 13 July 1995); P5903 (Intercept of conversation between Col. Milanović and a $2^{\text {nd }}$ Class Warrant Officer, 13 July 1995).

17790 KDZ107, P345 (Transcript from Prosecutor v. Popović et al.), T. 9362, 9365-9366, 9370, 9434-9435, 9439, 9459-9460. The Chamber notes that KDZ107 was confronted with discrepancies in a number of statements he gave to the Prosecution, and between such prior statements and his testimony in the Popović et al. case. See KDZ107, P345 (Transcript from Prosecutor v. Popović et al.), T. 9393-9396, 9412-9420, 9440-9449. The Chamber is satisfied with KDZ107's explanations as to the apparent discrepancies and accepts his evidence.

17791 KDZ107, P345 (Transcript from Prosecutor v. Popović et al.), T. 9366, 9433-9434, 9460. The Chamber refers to its assessment of Beara's testimony regarding his whereabouts on 13 and 14 July. See fn. 17583.

17792 KDZ107, P345 (Transcript from Prosecutor v. Popović et al.), T. 9367-9369, 9484-9485; KDZ107, P344 (Transcript from Prosecutor v. Popović et al.), T. 9400 (under seal). See P4585 (Zvornik Brigade Duty Officers logbook, 29 May-27 July 1995), e-court p. 34 (noting a conversation between Jovan Mitrović-then president of the Zvornik Municipal Assembly - and Beara about the use of a flat-bed trailer for the transportation of a bulldozer to Bratunac). See also Adjudicated Fact 1712.

17793 KDZ480, T. 24224 (7 February 2012) (closed session); KDZ480, P4355 (Transcript from Prosecutor v. Blagojević \& Jokić), T. 7873, 7900-7901 (under seal). KDZ480 testified that the two officers were very arrogant in their behavior. KDZ480, P4355 (Transcript from Prosecutor v. Blagojević \& Jokić), T. 7878, 79007901 (under seal).

17794 KDZ480, T. $24224-24225$ (7 February 2012) (closed session); KDZ480, P4355 (Transcript from Prosecutor v. Blagojević \& Jokić), T. 7873-7874 (under seal). See also Adjudicated Fact 1712. But see Jovan Nikolić, T. 35520-35522 (14 March 2013); D3126 (Witness statement of Jovan Nikolić dated 10 March 2013), paras. 58-59; and P6201 (Record of interview with Jovan Nikolić, 10 October 2005), p. 7 (where Jovan Nikolić testified that he informed Deronjić and other municipal authorities about the killings at Kravica in the morning of 14 July and that only then the cleaning-up operation began). See also Ljubisav Simić, T. 37291-37292 (16 April 2013). [REDACTED].

17795 KDZ480, T. 24224-24225 (7 February 2012) (closed session); KDZ480, P4355 (Transcript from Prosecutor v. Blagojević \& Jokić), T. 7873-7874, 7888 (under seal). The Chamber heard evidence that, at the level of the Bratunac municipality, the president of the Municipal Executive Board was the commander of, and could issue orders to, the Civilian Protection Unit. [REDACTED]. An employee of the Ministry of Defence served as chief of staff of the Civilian Protection, and other staff members were assigned to carry out other tasks such as sanitation or "asanacija", medical aid, and fire fighting. [REDACTED]. A workers' obligation unit was 
5243. Some time between 1 and 2 a.m. on 14 July 1995, KDZ107 received a second phone call asking him to return to the SDS Office to receive further instructions. ${ }^{17796}$ There, Beara ordered KDZ107 to accompany an MP member who would show him the location where a grave was to be dug the next morning to bury the dead. ${ }^{17797}$ The two men drove between five and ten minutes until arriving at Glogova, where the MP member showed KDZ107 the exact place where a pit was to be dug. ${ }^{17798}$

5244. At around the same time, KDZ480 was called again to report to the SDS Office to meet with Deronjić, Momir Nikolić, and the two officers he had earlier met. ${ }^{17799}$ KDZ480 was informed that the director of the bauxite mine in Milići had forbidden the burial of bodies at that location. ${ }^{17800}$ Deronjić then instructed that some of the members of the sanitation unit of the Bratunac Civilian Protection should be sent to Glogova in the morning to help in the digging of a large gravesite, while other members should be sent to the Kravica Warehouse, together with the unit's skip excavator, loader, and tractor. ${ }^{17801}$ The two officers agreed to provide additional machinery for the digging up of the grave. ${ }^{17802}$

5245. Around 9:30 a.m., Srbislav Davidović received a call to report to the SDS Office, where Beara and two uniformed officers were present. ${ }^{17803}$ The two officers asked Davidović whether

directly attached to the municipality and was engaged throughout the war in various logistical tasks; this unit had a tractor, a Lada vehicle, a funeral hearse, and additional power tools. [REDACTED]. The unit for "asanacija" or sanitation of terrain was attached to the Rad Utilities Company and was only engaged "from time to time" in the transportation of wounded soldiers from different hospitals and the burial of bodies of those killed-soldiers, civilians and enemy soldiers-in individual and mass graves. [REDACTED]. The sanitation unit had a FAP heavy-duty vehicle, a tractor, a refuse disposal vehicle, and a small skip for digging. [REDACTED]. Dragan Mirković was the commander of the sanitation unit in addition of being a member of the Civilian Protection staff and the head of the utilities company. [REDACTED].

17796 KDZ107, P345 (Transcript from Prosecutor v. Popović et al.), T. 9369.

17797 KDZ107, P345 (Transcript from Prosecutor v. Popović et al.), T. 9369-9370, 9485-9486; P344 (Transcript from Prosecutor v. Popović et al.), T. 9400-9401 (under seal).

17798 KDZ107, P345 (Transcript from Prosecutor v. Popović et al.), T. 9485-9488.

17799 KDZ480, T. 24225 (7 February 2012) (closed session); KDZ480, P4355 (Transcript from Prosecutor v. Blagojević \& Jokić), T. 7876, 7901-7902 (under seal).

17800 KDZ480, T. 24226 (7 February 2012) (closed session); T. 24261 (8 February 2012) (closed session); KDZ480, P4355 (Transcript from Prosecutor v. Blagojević \& Jokić), T. 7876-7877 (under seal).

17801 KDZ480, T. 24224-24227 (7 February 2012) (closed session); T. 24261 (8 February 2012) (closed session); KDZ480, P4355 (Transcript from Prosecutor v. Blagojević \& Jokić), T. 7876-7877 (under seal).

17802 KDZ480, T. 24226-24227 (7 February 2012) (closed session); KDZ480, P4355 (Transcript from Prosecutor v. Blagojević \& Jokić), T. 7876-7877 (under seal).

17803 Srbislav Davidović, T. 24364 (9 February 2012); Srbislav Davidović, P4100 (Transcript from Prosecutor v. Popović et al.), T. 9230-9231. Davidović testified that Beara was sitting in one office and the two officers were sitting in a second office. Beara remained in the first office but directed Davidović to the second office; Davidović did not talk to Beara about what had been discussed with the two officers. Davidović also testified that he did not know who the two officers were, but was sure that they were not members of the Bratunac Brigade; he recalled that one of them was a colonel and the other one was a lieutenant-colonel. Srbislav Davidović, T. 24365 (9 February 2012); Srbislav Davidović, P4100 (Transcript from Prosecutor v. Popović et al.), T. 9231, 9233-9234, 9252. The Chamber refers to its assessment of Beara's testimony regarding his whereabouts on 13 and 14 July. See fn. 17583. 
there was any construction equipment for digging and loading in Bratunac municipality. ${ }^{17804}$ It was agreed that the ULT loader from the local brick company would be placed at their disposal. ${ }^{17805}$ Davidović then called Neđo Nikolić — the director of the brick factory—to tell him that "the army" would come and ask for an excavator. ${ }^{17806}$

5246. An excavator was used to remove the bodies from the Kravica Warehouse; in order to facilitate its entry into the warehouse, a section of the wall above the door had to be broken. ${ }^{17807}$ Soldiers used a water tank in the front of the warehouse to wash the blood off the asphalt. ${ }^{17808}$ Additionally, dead bodies were covered with hay. ${ }^{17809}$

5247. Between 11 a.m. and noon on 14 July, an alcoholic drink was brought to the two drivers from the Bratunac Brigade who were in charge of taking the bodies out of the building and who were operating the large ULT loader. ${ }^{17810}$ Also present at the warehouse were a small skip loader owned by the Rad Utilities Company and two orange trucks owned by the Sase construction company. ${ }^{17811}$ Momir Nikolić was at Kravica at the time, and appeared to be supervising how the

17804 Srbislav Davidović, T. 24364 (9 February 2012); Srbislav Davidović, P4100 (Transcript from Prosecutor v. Popović et al.), T. 9232. Davidović testified that he was not told what the machinery would be used for; however, since he had already been informed about the killings at the Kravica Warehouse the day before, he assumed it was needed "for sanitation and evacuation of persons that had been executed within Kravica". Srbislav Davidović, T. 24365 (9 February 2012); Srbislav Davidović, P4100 (Transcript from Prosecutor v. Popović et al.), T. 9235-9238, 9253.

17805 Srbislav Davidović, P4100 (Transcript from Prosecutor v. Popović et al.), T. 9232. The Chamber notes that in the Popović et al. case, Davidović was confronted with the fact that, while giving a prior statement to the Prosecution, he had not mentioned the meetings involving Beara on 14 July or the use of equipment for burials. Srbislav Davidović, P4100 (Transcript from Prosecutor v. Popović et al.), T. 9253-9256. The Chamber is satisfied with Davidović's explanation and finds this evidence consistent with other evidence in this case. The Chamber therefore finds that this meeting with Beara indeed took place in the morning of 14 July 1995.

17806 Neđo Nikolić, T. 39816-39817 (12 June 2013). See D3690 (Witness statement of Neđo Nikolić dated 8 June 2013), para. 13. See also Neđo Nikolić, T. 39826 (12 June 2013). Later that day, men from the Bratunac Brigade MP picked up the excavator from the brick factory. Neđo Nikolić, T. 39816-39817 (12 June 2013).

17807 KDZ480, T. 24264-24265 (8 February 2012) (closed session); P4355 (Transcript from Prosecutor v. Blagojević \& Jokić), T. 7879-7880, 7908-7909 (under seal); Jean-René Ruez, T. 23774, 23776-23777 (27 January 2012) (referring to the destruction of the door of the warehouse for the bulldozer to be able to enter and collect the bodies, and its subsequent reconstruction); P4308 (Book of photographs and maps prepared by Jean-René Ruez, 22 June 2009), e-court pp. 122-126. See KDZ063, P334 (Transcript from Prosecutor v. Popović et al.), T. 7006 (stating that while lying under the window outside of the warehouse, he heard excavators gathering the corpses); KDZ071, P5029 (Transcript from Prosecutor v. Popović et al.), T. 7124 (stating that he heard heavy machinery around noon); KDZ071, P5029 (Transcript from Prosecutor v. Popović et al.), T. 7097 (stating that on 14 July, while still inside the West Room, he could hear commands coming from outside like "park the loader"); KDZ071, P5028 (Transcript from Prosecutor v. Popović et al.), T. 7107 (under seal). See also Adjudicated Fact 1711; Jean-René Ruez, T. 23779 (27 January 2012), T. 24104 (2 February 2012); P4289 (Video footage of Kravica Warehouse), at 00:03:16-00:03:22.

17808 KDZ071, T. 28555 (4 May 2012). See KDZ071, P5029 (Transcript from Prosecutor v. Popović et al.), T. 7097. See also Adjudicated Fact 1711; P6201 (Record of interview with Jovan Nikolić, 10 October 2005), p. 8.

17809 KDZ071, T. 28551 (4 May 2012); KDZ071, P5028 (Transcript from Prosecutor v. Popović et al.), T. 71067107 (under seal); KDZ071, P5029 (Transcript from Prosecutor v. Popović et al.), T. 7097; Vujadin Popović, T. 43059-43060 (6 November 2013). See Milenko Pepić, P373 (Transcript from Prosecutor v. Popović et al.), T. 13573.

17810 [REDACTED]. See also Adjudicated Fact 1715.

17811 KDZ480, P4355 (Transcript from Prosecutor v. Blagojević \& Jokić), T. 7908-7909 (under seal). 
work was coming along. ${ }^{17812}$ The work at the Kravica Warehouse continued until 16 July. ${ }^{17813}$ KDZ107 testified that he went to the Kravica Warehouse three to five days after the killings took place when he was in charge of the people who came with two cisterns to wash the enclosed area where people had been killed. ${ }^{17814}$

\section{(4) Burials at Glogova}

5248. People from the Rad Utilities Company and staff of the sanitation unit of the Bratunac Civilian Protection arrived at Glogova to dig a grave in the morning of 14 July $1995 .{ }^{17815}$ Upon being informed that the ULT loader originally brought to Glogova from the brick factory was unable to dig three or four graves, Beara requested that a backhoe excavator which belonged to the Zvornik Brigade be sent to Glogova. ${ }^{17816}$ This backhoe excavator was ultimately used to complete the task. ${ }^{17817}$

5249. Towards the evening of 14 July, a few trucks with bodies arrived at Glogova, but it was only in the following days that trucks with bodies started arriving in large numbers. ${ }^{17818}$ The staff from the Rad Utilities Company and the Bratunac Civilian Protection dug four pits at Glogova, and transported and buried between 400 and 500 bodies in three days. ${ }^{17819}$ The Chamber heard that other bodies were subsequently buried at Glogova. ${ }^{17820}$ The Chamber received evidence that members of both the Bratunac and the Zvornik Brigades participated in the burials at Glogova. ${ }^{17821}$

\section{(5) Reburials in secondary gravesites}

5250. As will be discussed in detail below, between September and October 1995, the VRS conducted an operation to exhume and rebury in secondary gravesites the bodies of Bosnian

\footnotetext{
17812 KDZ480, P4355 (Transcript from Prosecutor v. Blagojević \& Jokić), T. 7909-7910 (under seal).

17813 KDZ480, P4355 (Transcript from Prosecutor v. Blagojević Jokić), T. 7912 (under seal). See Adjudicated Fact 1713.

17814 KDZ107, P345 (Transcript from Prosecutor v. Popović et al.), T. 9409-9411.

17815 According to KDZ107, it was about 9 a.m.. KDZ107, P345 (Transcript from Prosecutor v. Popović et al.), T. 9370-9371, 9535; KDZ107, P344 (Transcript from Prosecutor v. Popović et al.), T. 9402 (under seal); KDZ480, P4355 (Transcript from Prosecutor v. Blagojević \& Jokić), T. 7879, 7912-7913 (under seal).

17816 KDZ107, P345 (Transcript from Prosecutor v. Popović et al.), T. 9371-9372, 9387-9388; KDZ107, P344 (Transcript from Prosecutor v. Popović et al.), T. 9550-9553 (under seal); KDZ480, T. 24221 (7 February 2012) (closed session).

17817 KDZ107, P345 (Transcript from Prosecutor v. Popović et al.), T. 9371-9372, 9387-9388; KDZ107, P344 (Transcript from Prosecutor v. Popović et al.), T. 9550-9553 (under seal); KDZ480, T. 24221 (7 February 2012) (closed session).

17818 KDZ107, P345 (Transcript from Prosecutor v. Popović et al.), T. 9372.

17819 [REDACTED]. See also Adjudicated Fact 1713.

17820 [REDACTED].

17821 P169 (Bratunac Brigade Military Police log, 30 June-21 July 1995), e-court p. 18; KW582, D4291 (Transcript from Prosecutor v. Blagojević \& Jokić), T.3575-3576 (showing that on 19 July 1995, Bratunac Brigade MP patrols provided security to public utility workers carrying out work at Glogova); Adjudicated Facts 1714, 1716.
} 
Muslim men buried at various primary gravesites in July $1995 .{ }^{17822}$ Specifically, over the course of several nights in September or October 1995, the bodies which had initially been buried in the Glogova gravesites were transported and reburied in secondary mass graves at Zeleni Jadar, Budak, Blječeva, and Zalažje. ${ }^{17823}$

(6) Forensic evidence

(a) Kravica Warehouse

5251. Forensic examination of the Kravica Warehouse conducted in September 1996 revealed evidence of human blood, bones, and tissue adhering to the walls, floor and ceiling, as well as damage caused by arms, grenades and explosives. ${ }^{17824}$ Similarly, shell casings, dentures, and human bone fragments were found mingled with rubbish just in front of the warehouse. ${ }^{17825}$ Handgrenade handles were also found around the warehouse. ${ }^{17826}$

(b) Glogova and secondary gravesites

\section{(i) Glogova}

5252. Aerial images reveal that the Glogova gravesites were first dug between 17 and 27 July 1995, and that the gravesites were disturbed on or before 30 October 1995, as indicated by disturbed earth and the presence of a front loader. ${ }^{17827}$ Between 1999 and 2001, two primary disturbed gravesites were found on either side of a dirt road off the Konjević Polje-Bratunac Road, near the village of Glogova, approximately eight kilometres from the Kravica Warehouse. ${ }^{17828}$ The

\footnotetext{
17822 See Section IV.C.1.g.v: Reburial operation.

17823 See Section IV.C.1.g.v.A: The reburials from the Bratunac area. See also Dean Manning, T. 25830-25831 (6 March 2012); P4512 (Photograph booklet entitled "Srebrenica Mass Graves - Primary and Secondary Mass Grave Aerial Imagery”), pp. 10-15; Jean-René Ruez, T. 23860, 23863-23864 (30 January 2012); P4308 (Book of photographs and maps prepared by Jean-René Ruez, 22 June 2009), e-court pp. 257-259.

17824 P4009 (Richard Wright's expert report entitled "Report on Excavations and Exhumations at the Glogova 1 Mass Grave in 2000", 9 February 2001), p. 18; Dean Manning, T. 25803 (6 March 2012); P4504 (Dean Manning's Report, entitled "Summary of Forensic Evidence - Execution Points and Mass Graves", 16 May 2000), p. 5, Annex A, pp. 4-7.

17825 Jean-René Ruez, T. 23769-23770 (27 January 2012); P4308 (Book of photographs and maps prepared by JeanRené Ruez, 22 June 2009), e-court p. 112; P4286 (Photograph of shell casings marked by Jean-René Ruez).

17826 Jean-René Ruez, T. 23764-23767 (27 January 2012); P4308 (Book of photographs and maps prepared by JeanRené Ruez, 22 June 2009), e-court pp. 105-108.

17827 Jean-René Ruez, T. 23863 (30 January 2012); P4308 (Book of photographs and maps prepared by Jean-René Ruez, 22 June 2009), e-court p. 257. See also P4512 (Photograph booklet entitled "Srebrenica Mass Graves Primary and Secondary Mass Grave Aerial Imagery”), pp. 4-8.

17828 P4033 (Jose Baraybar's expert report entitled "Report on Excavations at Glogova 2, BiH 1999-2001”), p. 3; P4772 (Dušan Janc's report entitled "Update to the summary of Forensic Evidence - Exhumation of the Graves and Surface Remains Recoveries related to Srebrenica - January 2012”, 13 January 2012), e-court p. 11; P4502 (Dean Manning's Report, entitled "Summary of Forensic Evidence, Mass Graves Exhumed in 2000 - Lazete 1, Lazete 2C, Ravnice, Glogova 1", February 2001), e-court p. 13; P4512 (Photograph booklet entitled "Srebrenica Mass Graves - Primary and Secondary Mass Grave Aerial Imagery”), pp. 4-5; Dean Manning, T. 25830
} 
dirt road traversed a slope running north to south: the area south of the road was labelled Glogova 1, while that to the north was labelled Glogova $2 .{ }^{17829}$

5253. The primary exhumation of Glogova 2-which consisted of eight sub-gravesites-was conducted between 11 September and 22 October 1999 by a Tribunal exhumation team under the direction of Jose Pablo Baraybar. ${ }^{17830}$ The exhumation of Glogova 1—which consisted of six subgravesites-was conducted between 7 August and 20 October 2000 by a Tribunal exhumation team under the direction of Richard Wright. ${ }^{17831}$ The remains found in both Glogova 1 and Glogova 2 were then examined by a team of pathologists under the direction of John Clark. ${ }^{17832}$

5254. The manner in which the bodies were found, the lack of shell casings, and the presence of foreign soil show that the victims did not die at the site but were brought to the graves and dumped therein. ${ }^{17833}$ Various items from the Kravica Warehouse, including portions of the door, were

(6 March 2012). Glogova 1 is less than 400 metres from the command post of the $1^{\text {st }}$ Infantry Battalion of the Bratunac Brigade. Adjudicated Fact 1726.

17829 P4033 (Jose Baraybar's expert report entitled "Report on Excavations at Glogova 2, BiH 1999-2001”), p. 3.

17830 P4033 (Jose Baraybar's expert report entitled "Report on Excavations at Glogova 2, BiH 1999-2001"), p. 3; P4772 (Dušan Janc's report entitled "Update to the summary of Forensic Evidence - Exhumation of the Graves and Surface Remains Recoveries related to Srebrenica - January 2012”, 13 January 2012), e-court p. 12 . See Jose Baraybar, T. 22343-22344 (2 December 2011); P4105 (John Clark's expert report entitled "Report of the Chief Pathologist, Srebrenica Grave Sites (2001)”, 24 May 2003), p. 19. The Chamber notes that Dušan Dunjić challenged the methodology followed by Baraybar in his reports, including the one prepared for the Glogova gravesites. D3893 (Dušan Dunjić's expert report entitled "Forensic Analysis of Reports on the Locations of Mass Graves in the Area of Eastern Bosnia and Documentation Relating to Exhumations in the Srebrenica Area”, 27 August 2009), pp. 42-47. Having assessed the totality of evidence, the Chamber accepts Baraybar's report and the findings therein.

17831 P4009 (Richard Wright's expert report entitled "Report on Excavations and Exhumations at the Glogova 1 Mass Grave in 2000", 9 February 2001), p. 2; Richard Wright, T. 22265-22267 (1 December 2011); P4004 (Photograph of exhumation site at Glogova marked by Richard Wright); P4005 (Sketch of grave sites at Glogova marked by Richard Wright). See also P4105 (John Clark's expert report entitled "Report of the Chief Pathologist, Srebrenica Grave Sites (2001)", 24 May 2003), p. 13; P4772 (Dušan Janc's report entitled "Update to the summary of Forensic Evidence - Exhumation of the Graves and Surface Remains Recoveries related to Srebrenica - January 2012", 13 January 2012), e-court p. 11; P4502 (Dean Manning's Report, entitled "Summary of Forensic Evidence, Mass Graves Exhumed in 2000 - Lazete 1, Lazete 2C, Ravnice, Glogova 1", February 2001), e-court p. 13. See Adjudicated Fact 1723.

17832 John Clark, T. 22693 (10 January 2012); P4105 (John Clark's expert report entitled "Report of the Chief Pathologist, Srebrenica Grave Sites (2001)”, 24 May 2003), p. 29; P4102 (Dr. John Clark's curriculum vitae). The Chamber notes that Dušan Dunjić challenged the methodology followed by Clark in his report for the Glogova gravesite, including how he reached his conclusions as to the cause of death of victims, without carrying out further analysis on the "mechanism of injury", and basing such conclusions on a number of assumptions. D3893 (Dušan Dunjić's expert report entitled "Forensic Analysis of Reports on the Locations of Mass Graves in the Area of Eastern Bosnia and Documentation Relating to Exhumations in the Srebrenica Area", 27 August 2009), p. 48; D3894 (Dušan Dunjić's expert report entitled "Forensic Analysis of Documents Pertaining to Exhumations, Autopsies and Identification of Bodies in the Srebrenica Area", 26 August 2012), pp. 5-8. Having assessed the totality of evidence on this issue, the Chamber accepts Clark's report and the findings therein.

17833 Richard Wright, T. 22303-22306 (1 December 2011); P4009 (Richard Wright's expert report entitled "Report on Excavations and Exhumations at the Glogova 1 Mass Grave in 2000", 9 February 2001), p. 15. The Chamber notes that Dušan Dunjić challenged the reliability of the findings made by Wright in his report for the Glogova gravesite. D3894 (Dušan Dunjić's expert report entitled "Forensic Analysis of Documents Pertaining to Exhumations, Autopsies and Identification of Bodies in the Srebrenica Area”, 26 August 2012), p. 16. Wright was also challenged with the hypothesis that bodies found at Glogova 1 had a different degree of decomposition 
found amongst the bodies at Glogova 1 and Glogova 2 thus showing a direct physical link between the gravesites and the warehouse. ${ }^{17834}$ Furthermore, an analysis of three watches found on victims wrists at Glogova 2, led the expert to assume that the bodies were disposed of "about or after" 13 July. ${ }^{17835}$

5255. The forensic evidence reviewed by the Chamber shows that all of the victims exhumed at the Glogova gravesites were males, ${ }^{17836}$ with established ages ranging from as young as 12 to $75,{ }^{17837}$ and most of the bodies exhumed from the Glogova gravesites presented gunshot injuries. ${ }^{17838}$ Shrapnel injuries were also present in $21 \%$ of the bodies, and pieces of grenade and shrapnel were retrieved from the gravesite. ${ }^{17839} 12$ victims exhumed from one of the sub-graves at Glogova 1 were bound with ligatures, and each of those was killed by a gunshot to the head. ${ }^{17840}$

and thus were brought from different locations at different times, but denied this conclusion, stating that he saw nothing indicating that there had been several events behind the killings. Richard Wright, T. 22306-22308, 22312 (1 December 2011). See also Dušan Dunjić, T. 41746-41747 (22 July 2013). Having assessed the totality of evidence on this issue, the Chamber accepts Wright's report and the findings therein.

17834 Dean Manning, T. 25829-25831 (6 March 2012); Richard Wright, T. 22269-22270 (1 December 2011) (in relation to Glogova 1); P4009 (Richard Wright's expert report entitled "Report on Excavations and Exhumations at the Glogova 1 Mass Grave in 2000", 9 February 2001), pp. 2, 18-19 (in relation to Glogova 1); P4502 (Dean Manning's Report, entitled "Summary of Forensic Evidence, Mass Graves Exhumed in 2000 - Lazete 1, Lazete 2C, Ravnice, Glogova 1", February 2001), e-court p. 13 (in relation to Glogova 1); P4772 (Dušan Janc's report entitled "Update to the summary of Forensic Evidence - Exhumation of the Graves and Surface Remains Recoveries related to Srebrenica - January 2012", 13 January 2012), e-court p. 11 (in relation to Glogova 1 and Glogova 2). See also Jean-René Ruez, T. 24104 (2 February 2012); Adjudicated Fact 1721.

17835 P4033 (Jose Baraybar's expert report entitled "Report on Excavations at Glogova 2, BiH 1999-2001"), p. 20.

17836 It was not possible to determine the sex of two of the bodies at Glogova 1 because of their young age and injuries; however, all bodies found at Glogova 2 were identified as male. P4105 (John Clark's expert report entitled "Report of the Chief Pathologist, Srebrenica Grave Sites (2001)", 24 May 2003), pp. 13, 19, 22; John Clark, John Clark, P4110 (Transcript from Prosecutor v. Krstić), T. 3933, 3938-3939. See also Adjudicated Fact 1719.

17837 P4105 (John Clark's expert report entitled "Report of the Chief Pathologist, Srebrenica Grave Sites (2001)", 24 May 2003), p. 22.

17838 P4105 (John Clark's expert report entitled "Report of the Chief Pathologist, Srebrenica Grave Sites (2001)", 24 May 2003), pp. 15, 17, 20, 22; John Clark, John Clark, P4110 (Transcript from Prosecutor v. Krstić), T. 3934. See also Adjudicated Fact 1720.

17839 P4009 (Richard Wright's expert report entitled "Report on Excavations and Exhumations at the Glogova 1 Mass Grave in 2000", 9 February 2001), pp. 2, 16; Richard Wright, T. 22270-22272, 22310-22311 (1 December 2011); P4007 (Photograph of Exhumation site at Glogova marked by Richard Wright); P4008 (Photograph of exhumed body marked by Richard Wright); P4105 (John Clark's expert report entitled "Report of the Chief Pathologist, Srebrenica Grave Sites (2001)", 24 May 2003), pp. 16, 22; John Clark, T. 22700 (10 January 2012), T. 22729 (11 January 2012). See Dean Manning, T. 25856 (6 March 2012); P4502 (Dean Manning's Report, entitled "Summary of Forensic Evidence, Mass Graves Exhumed in 2000 - Lazete 1, Lazete 2C, Ravnice, Glogova 1", February 2001), e-court pp. 13-14. See also Adjudicated Fact 1722. The Chamber notes Dunjić's claim that this finding would support the fact that the victims did not die in an execution, but that such injuries are instead a reflection of armed conflicts between two warring parties; D3894 (Dušan Dunjić's expert report entitled "Forensic Analysis of Documents Pertaining to Exhumations, Autopsies and Identification of Bodies in the Srebrenica Area", 26 August 2012), pp. 12-13. As explained in detail in Section IV.C.1.h.B.2: Cause and manner of death, having assessed the totality of evidence on this issue, the Chamber accepts Wright and Clark's reports and the findings therein.

17840 P4009 (Richard Wright's expert report entitled "Report on Excavations and Exhumations at the Glogova 1 Mass Grave in 2000", 9 February 2001), p. 16; Richard Wright, T. 22322-22323 (1 December 2011); P4105 (John 
5256. Almost all sub-graves at Glogova showed evidence of "robbing", or that bodies were removed by machinery, thus leaving a few dismembered parts of the bodies behind. ${ }^{17841}$

5257. The Accused argues in his final brief that the Glogova gravesite was a "mixed grave" which contained not only victims from the Kravica Warehouse incident but from other killing incidents related to the fall of Srebrenica, as well as victims who had died years earlier. ${ }^{17842}$ The Prosecution acknowledges that a number of bodies found in the Glogova gravesites were brought from places other than the Kravica Warehouse. ${ }^{17843}$ The Prosecution explains that this number includes at least 80 victims executed in Bratunac, including at the Vuk Karadžić School, ${ }^{17844}$ plus approximately 100 individuals who cannot be determined beyond reasonable doubt to have been executed. ${ }^{17845}$

5258. As of 13 January 2012, DNA analysis led to the identification of 226 bodies from Glogova 1 and 171 from Glogova 2, as persons listed as missing following the take-over of Srebrenica. ${ }^{17846}$ However, Dušan Janc clarified that not all of these 397 individuals can be linked to the killings at the Kravica Warehouse, since bodies which cannot be linked to this execution site were brought to Glogova, namely at least 80 victims executed in Bratunac, plus approximately 100 bodies brought

Clark's expert report entitled "Report of the Chief Pathologist, Srebrenica Grave Sites (2001)", 24 May 2003), p. 14; P4507 (Chart of photographs of blindfolds, ligatures, and location). See also Adjudicated Fact 1725.

17841 P4033 (Jose Baraybar's expert report entitled "Report on Excavations at Glogova 2, BiH 1999-2001”), pp. 3-4, 18; P4009 (Richard Wright's expert report entitled "Report on Excavations and Exhumations at the Glogova 1 Mass Grave in 2000", 9 February 2001), pp. 5, 9, 16; John Clark, John Clark, P4110 (Transcript from Prosecutor v. Krstić), T. 3933-3934. Wright explained that the term "robbed" was used in the archaeological way to mean that things had been taken away from a specific area. Richard Wright, T. 22250 (1 December 2011). Wright and his team found dismembered parts of bodies at Glogova 1, which they took as evidence that some bodies had been dug up and moved. Richard Wright, T. 22267-22269, 22311 (1 December 2011); P4009 (Richard Wright's expert report entitled "Report on Excavations and Exhumations at the Glogova 1 Mass Grave in 2000", 9 February 2001), p. 5. Baraybar testified that five of the eight sub-gravesites at Glogova 2 has been robbed and concluded that the bodies had been moved due to the presence of foreign soil and multiple fractures of the bones, presumably due to large-scale machinery. Jose Baraybar, T. 22409-22410 (2 December 2011). See P4502 (Dean Manning's Report, entitled "Summary of Forensic Evidence, Mass Graves Exhumed in 2000 Lazete 1, Lazete 2C, Ravnice, Glogova 1", February 2001), e-court p. 13.

17842 Defence Final Brief, paras. 2597, 2601.

17843 Prosecution Final Brief, Appendix D, paras. 64, 171; Prosecution Closing Argument, T. 47795 (30 September 2014).

17844 Prosecution Final Brief, Appendix D, paras. 64, 171

17845 The Prosecution explains that this number includes 10 to 15 bodies retrieved from Konjević Polje, six to seven bodies from Potočari, and a 'truckload' from along the Bratunac-Konjević Polje Road. Prosecution Final Brief, Appendix D, paras. 64, 171. This number also includes the bodies of 12 individuals who are recorded as having been returned from Serbia and whose remains were also found at Glogova; although executed, their deaths were not charged in this case. Prosecution Final Brief, Appendix D, para. 171, fn. 716.

17846 P4772 (Dušan Janc's report entitled "Update to the summary of Forensic Evidence - Exhumation of the Graves and Surface Remains Recoveries related to Srebrenica - January 2012”, 13 January 2012), e-court pp. 3, 12; P4771 (Dušan Janc's report entitled "Update to the summary of Forensic Evidence - Exhumation of the Graves and Surface Remains Recoveries related to Srebrenica - January 2012”, 13 January 2012), Annex D, e-court pp. 148-168 (under seal). See also P5917 (ICMP DNA identifications concerning identified victims related to Srebrenica, 6 December 2010); P4773 (ICMP unmatched DNA victim profiles related to Srebrenica, 23 December 2011); P4774 (ICMP lists of unmatched unique DNA victims profiles related to Srebrenica, 15 February 2010). For a detailed analysis of the methodology followed by Janc in making DNA connections, see paras. 5586-5589. 
from other locations. ${ }^{17847}$ This is consistent with other evidence received by the Chamber that bodies collected from various places, including the Konjević Polje intersection, the Konjević PoljeBratunac Road, Potočari, the areas of Rađno Buljek, Kamenica, and Pobuđe, and around the Vuk Karadžić School in Bratunac, were brought to Glogova to be buried. ${ }^{17848}$

5259. Further, after reviewing P6705, the Chamber has found that victims whose bodies were found in the Glogova gravesites were last seen alive on and after 14 July $1995 .{ }^{17849}$ According to this document, roughly one in five bodies found in Glogova 1 and Glogova 2 were reported as having been last seen alive after 13 July, ${ }^{17850}$ the date of the Kravica Warehouse incident. Because the bodies in Glogova 1 and 2 were later reburied in various secondary gravesites, ${ }^{17851}$ the Chamber will discuss the minimum and maximum possible number of Kravica-related victims in all of these sites at the end of this section. ${ }^{17852}$

17847 D1975 (Dušan Janc's corrigendum to report entitled "Update to Summary of Forensic Evidence - Exhumation on the Graves Related to Srebrenica -March 2009”, 9 April 2009); P4772 (Dušan Janc's report entitled "Update to the summary of Forensic Evidence - Exhumation of the Graves and Surface Remains Recoveries related to Srebrenica - January 2012", 13 January 2012, e-court p. 40.

17848 KDZ107, P345 (Transcript from Prosecutor v. Popović), T. 9372, 9388-9389, 9392-9393, 9538-9539, 9544 (stating that, while a number of bodies collected from the Konjević Polje intersection, the Konjević PoljeBratunac Road, and outside the Vuk Karadžić School were brought to Glogova to be buried, he assumed most of the people buried in Glogova were killed at the Kravica Warehouse because the truck owned by the Rad Utilities Company, which is the one used to transport the bodies to Glogova, came from the direction of Kravica); KDZ480, T. 24221 (7 February 2012) (closed session); KDZ480, T. 24261, 24263, 24279-24280 (8 February 2012) (closed session); KDZ480, P4355 (Transcript from Prosecutor v. Blagojević \& Jokić), T. 7883-7884, 7920, 7923-7925 (under seal) (explaining that between 40 and 50 bodies collected from the Vuk Karadžić School on 14 July, seven or eight bodies collected at Potočari on 16 or 17 July, six to eight bodies collected at the premises of the " $11^{\text {th }}$ of march company", and a few others collected from the zinc workshop and private homes, were brought to Glogova); P407 (Witness statement of Desmir Đukanović dated 20 March 2007), paras. 5-6, P408 (Witness statement of Desmir Đukanović dated 23 March 2007, paras. 7, 10 and P406 (Desmir Đukanović's evidence in $\mathrm{BiH}$ state court), pp. 1-4 (testifying that he and his colleagues collected approximately 60 bodies from the Vuk Karadžić School and the surrounding area, which were then transported to the Glogova gravesite); Adjudicated Fact 1686 (in relation to the transportation of bodies from the Vuk Karadžić School). KDZ480 further added that there was an order that all the corpses found should be brought to the freshly dug up gravesite in Glogova. KDZ480, P4355 (Transcript from Prosecutor v. Blagojević \& Jokić), T. 7925 (under seal). See Jean-René Ruez, T. 23863 (30 January 2012), T. 24041 (1 February 2012).

17849 See paras. 5569-5573 for a detailed analysis of the methodology followed by Tabeau in compiling P6705.

17850 Specifically, approximately $21 \%$ of bodies identified from Glogova 1, and $19 \%$ of bodies identified from Glogova 2 were reported as having been last seen alive after 13 July 1995. See e.g. P4771 (Dušan Janc's report entitled "Update to the summary of Forensic Evidence - Exhumation of the Graves and Surface Remains Recoveries related to Srebrenica - January 2012”, 13 January 2012), Annex D, e-court pp. 148-168 (under seal) (listing the names of bodies identified in Glogova 1 and 2); P6705 (Ewa Tabeau's expert report entitled "Srebrenica Missing: Persons Reported Missing and Dead after the Take-Over of the Srebrenica Enclave by the Bosnian Serb Army on 11 July 1995”, 9 April 2009), e-court pp. 20, 35, 64, 114, 121.

17851 See para. 5260.

17852 See paras. 5280-5283. 


\section{(ii) $\underline{\text { Secondary gravesites }}$}

5260. The Zeleni Jadar gravesites, which consisted of seven secondary mass gravesites along the Zeleni Jadar Road, ${ }^{17853}$ were discovered in $1998 .{ }^{17854}$ Aerial images indicate that earth was disturbed at six locations along the Zeleni Jadar Road between 24 August and 23 October 1995, and that the reburials at these secondary graves were completed in late October $1995 .{ }^{17855}$ The gravesites were numbered Zeleni Jadar 1 through 6, with an additional gravesite, labelled 1A, examined at a later stage due to its location within a heavily mined area. ${ }^{17856}$ While the examination and probing at Zeleni Jadar 1 through 4 was conducted by a Tribunal team of experts, the responsibility for exhuming the gravesites was handed over to the $\mathrm{BiH}$ government in 2001. ${ }^{17857}$ Teams of Tribunal experts conducted the examination and exhumation of both Zeleni Jadar 5 and Zeleni Jadar $6 .{ }^{17858}$

5261. The Chamber notes that out of all the secondary gravesites associated with the Glogova gravesites, it only received forensic evidence in relation to Zeleni Jadar 5 and 6 . The exhumation of Zeleni Jadar 5 was conducted between 1 and 21 October 1998 by a team under the direction of Richard Wright. ${ }^{17859}$ The exhumation of Zeleni Jadar 6 was conducted between 25 July and 13 August 2001 by a team under the direction of Jose Pablo Baraybar. ${ }^{17860}$ The remains found at

17853 P4504 (Dean Manning's Report, entitled "Summary of Forensic Evidence - Execution Points and Mass Graves", 16 May 2000), e-court p. 12.

17854 P4000 (Richard Wright's expert report entitled "Exhumations in Eastern Bosnia in 1998", 12 May 1999), ecourt p. 11).

17855 Dean Manning, T. 25832-25835 (6 March 2012); P4512 (Photograph booklet entitled "Srebrenica Mass Graves - Primary and Secondary Mass Grave Aerial Imagery"), pp. 20-30.

17856 P4000 (Richard Wright's expert report entitled "Exhumations in Eastern Bosnia in 1998", 12 May 1999), ecourt p. 7; P4504 (Dean Manning's Report, entitled "Summary of Forensic Evidence - Execution Points and Mass Graves”, 16 May 2000), e-court p. 12; Dean Manning, T. 25832-25835 (6 March 2012); P4510 (Aerial photograph of Zeleni Jadar marked by Dean Manning); P4512 (Photograph booklet entitled "Srebrenica Mass Graves - Primary and Secondary Mass Grave Aerial Imagery”), pp. 21-22.

17857 P4772 (Dušan Janc's report entitled "Update to the summary of Forensic Evidence - Exhumation of the Graves and Surface Remains Recoveries related to Srebrenica - January 2012”, 13 January 2012), e-court pp. 26-28; P4000 (Richard Wright's expert report entitled "Exhumations in Eastern Bosnia in 1998", 12 May 1999), ecourt pp. 11-12. In relation to Zeleni Jadar 2, investigators found evidence that bodies had been removed from such gravesite and moved to an unknown location or an unknown tertiary gravesite. P4504 (Dean Manning's Report, entitled "Summary of Forensic Evidence - Execution Points and Mass Graves", 16 May 2000), e-court p. 12; P4000 (Richard Wright's expert report entitled "Exhumations in Eastern Bosnia in 1998”, 12 May 1999), e-court p. 11.

17858 P4000 (Richard Wright's expert report entitled "Exhumations in Eastern Bosnia in 1998”, 12 May 1999), ecourt p. 12; P4772 (Dušan Janc's report entitled "Update to the summary of Forensic Evidence - Exhumation of the Graves and Surface Remains Recoveries related to Srebrenica - January 2012”, 13 January 2012), e-court pp. 28-29.

17859 P4000 (Richard Wright's expert report entitled "Exhumations in Eastern Bosnia in 1998", 12 May 1999), ecourt p. 12; P4504 (Dean Manning's Report, entitled "Summary of Forensic Evidence - Execution Points and Mass Graves", 16 May 2000), e-court pp. 12, 24. See also Richard Wright, T. 22269 (1 December 2011); Adjudicated Fact 1727.

17860 P4772 (Dušan Janc's report entitled "Update to the summary of Forensic Evidence - Exhumation of the Graves and Surface Remains Recoveries related to Srebrenica - January 2012”, 13 January 2012), e-court p. 29. 
Zeleni Jadar 5 were then examined by a team of pathologists under the direction of Christopher Lawrence, while the remains at Zeleni Jadar 6 were examined by a team of pathologists under the direction of John Clark. ${ }^{17861}$

5262. The forensic evidence reviewed by the Chamber in relation to both Zeleni Jadar 5 and Zeleni Jadar 6 shows that all of the bodies where sex could be determined were male. ${ }^{17862}$ Approximately $25 \%$ of those were 25 years old or younger. ${ }^{17863}$ Most of the bodies exhumed presented gunshot injuries. ${ }^{17864}$ No bodies had been blindfolded, but two had ligatures. ${ }^{17865}$

5263. Various artefacts from the Kravica Warehouse, such as barbed wire, motorcar parts, bricks, tiles, china, and bunches of hay were collected from the Zeleni Jadar gravesites. ${ }^{17866}$ Specifically, motorcar parts and barbed wire found at Zeleni Jadar 5 mixed up with bodies were determined to be similar objects to those found at Glogova 1, which in turn were similar to those found at the Kravica Warehouse. ${ }^{17867}$ Bullets and cartridge casings were also found in Zeleni Jadar $5 .{ }^{17868}$ Furthermore, pollen and soil profiles taken from Glogova 2 sub-gravesites were identical to those

17861 Christopher Lawrence, T. 22447 (8 December 2011); P4059 (Christopher Lawrence's expert report entitled "Report on Autopsies of Human Remains from Zeleni Jadar Site 5, October 1998", 17 June 1999), p. 30; Christopher Lawrence, P4051 (Transcript from Prosecutor v. Krstić), T. 3978-3980; P4064 (Chart of primary and secondary graves); John Clark, T. 22693 (10 January 2012); P4105 (John Clark's expert report entitled "Report of the Chief Pathologist, Srebrenica Grave Sites (2001)", 24 May 2003), p. 29; P4102 (Dr. John Clark’s curriculum vitae).

17862 P4059 (Christopher Lawrence's expert report entitled "Report on Autopsies of Human Remains from Zeleni Jadar Site 5, October 1998”, 17 June 1999), pp. 2, 9; P4105 (John Clark's expert report entitled "Report of the Chief Pathologist, Srebrenica Grave Sites (2001)", 24 May 2003), pp. 23, 27. See also Adjudicated Fact 1728.

17863 P4059 (Christopher Lawrence's expert report entitled "Report on Autopsies of Human Remains from Zeleni Jadar Site 5, October 1998”, 17 June 1999), pp. 2, 9; P4105 (John Clark's expert report entitled "Report of the Chief Pathologist, Srebrenica Grave Sites (2001)", 24 May 2003), pp. 23, 27.

17864 P4105 (John Clark's expert report entitled "Report of the Chief Pathologist, Srebrenica Grave Sites (2001)", 24 May 2003), pp. 24-27; P4059 (Christopher Lawrence's expert report entitled "Report on Autopsies of Human Remains from Zeleni Jadar Site 5, October 1998”, 17 June 1999), pp. 2, 9-10, 12-13. See also Adjudicated Fact 1728.

17865 P4504 (Dean Manning's Report, entitled "Summary of Forensic Evidence - Execution Points and Mass Graves", 16 May 2000), e-court pp. 12, 84.

17866 Richard Wright, T. 22269 (1 December 2011); P4000 (Richard Wright's expert report entitled "Exhumations in Eastern Bosnia in 1998”, 12 May 1999), e-court pp. 25-26; Dean Manning, T. 25829-25831 (6 March 2012); P4502 (Dean Manning's Report, entitled "Summary of Forensic Evidence, Mass Graves Exhumed in 2000 Lazete 1, Lazete 2C, Ravnice, Glogova 1”, February 2001), e-court p. 13; P4504 (Dean Manning's Report, entitled "Summary of Forensic Evidence - Execution Points and Mass Graves", 16 May 2000), e-court p. 84. See Jean-René Ruez, T. 23860 (30 January 2012).

17867 Dean Manning, T. 25830-25831 (6 March 2012); Christopher Lawrence, P4051 (Transcript from Prosecutor v. Krstić), T. 4021-4023; P4059 (Christopher Lawrence's expert report entitled "Report on Autopsies of Human Remains from Zeleni Jadar Site 5, October 1998”, 17 June 1999), pp. 12-13; Richard Wright, T. 22269-22270 (1 December 2011).

17868 P4504 (Dean Manning's Report, entitled "Summary of Forensic Evidence - Execution Points and Mass Graves", 16 May 2000), e-court p. 86. 
of Zeleni Jadar 5. ${ }^{17869}$ Blast damage and pieces of shrapnel similar to those found at Glogova were found in bodies at the Zeleni Jadar gravesites. ${ }^{17870}$

5264. Furthermore, some DNA profiles were isolated from remains found in both Glogova and the Zeleni Jadar gravesites; each of these connections demonstrates that the remains of the same individual were found in more than one gravesite. The remains of 20 individuals were found in both Glogova 1 and one of the Zeleni Jadar gravesites 1A, 1B, 2, 3, or 4; 14 individuals with remains in Glogova 1 and Zeleni Jadar 5; three individuals' remains were found in Glogova 1 and Zeleni Jadar 6; and one individual's remains were found in Glogova 2 and Zeleni Jadar 5. ${ }^{17871}$ Similarly, DNA from a broken tooth found at the entrance of the Kravica Warehouse was matched to remains found at Zeleni Jadar 2. ${ }^{17872}$ Consequently, the Chamber finds that bodies were taken from the Glogova 1 and Glogova 2 gravesites to the secondary gravesites of Zeleni Jadar.

5265. As of 13 January 2012, DNA analysis led to the identification of 445 victims from the Zeleni Jadar gravesites as persons listed as missing following the take-over of Srebrenica: 22 from Zeleni Jadar 1A; 22 from Zeleni Jadar 1B; 19 from Zeleni Jadar 2; 30 from Zeleni Jadar 3; 64 from Zeleni Jadar 4; 166 from Zeleni Jadar 5; and 122 from Zeleni Jadar $6 .{ }^{17873}$ However, according to P6705, just over one fifth of the bodies found in all the Zeleni Jadar gravesites were reported as

17869 P4030 (Jose Baraybar's expert report entitled "Report on the Anthropology Examination of Human Remains from Eastern Bosnia in 1999", 8 December 1999), pp. 3-4, 8; P4033 (Jose Baraybar's expert report entitled "Report on Excavations at Glogova 2, BiH 1999-2001"), p. 20.

17870 John Clark, T. 22729 (11 January 2012); P4105 (John Clark's expert report entitled "Report of the Chief Pathologist, Srebrenica Grave Sites (2001)”, 24 May 2003), pp. 25-27; P4059 (Christopher Lawrence's expert report entitled "Report on Autopsies of Human Remains from Zeleni Jadar Site 5, October 1998", 17 June 1999), pp. 12-13. The Chamber notes that Lawrence was extensively questioned about his findings on shrapnel injuries found at bodies at Zeleni Jadar 5, in order to make him accept that those victims had indeed died in combat operations, and not in a mass execution. See Christopher Lawrence, T. 22505-22508 (8 December 2011); Christopher Lawrence, P4051 (Transcript from Prosecutor v. Krstić), T. 4024-4025. Given the evidence by survivors of the killings at the Kravica Warehouse that grenades were thrown inside the warehouse, the Chamber finds this evidence on shrapnel injuries to be consistent with the evidence as described above.

17871 P4772 (Dušan Janc's report entitled "Update to the summary of Forensic Evidence - Exhumation of the Graves and Surface Remains Recoveries related to Srebrenica - January 2012”, 13 January 2012), e-court p. 49; P4771 (Dušan Janc's report entitled "Update to the summary of Forensic Evidence - Exhumation of the Graves and Surface Remains Recoveries related to Srebrenica - January 2012”, 13 January 2012), Annex D, e-court pp. 353-380 (under seal).

17872 P4772 (Dušan Janc's report entitled "Update to the summary of Forensic Evidence - Exhumation of the Graves and Surface Remains Recoveries related to Srebrenica - January 2012”, 13 January 2012), e-court pp. $27,85,87$. P4772 (Dušan Janc's report entitled "Update to the summary of Forensic Evidence - Exhumation of the Graves and Surface Remains Recoveries related to Srebrenica - January 2012”, 13 January 2012), e-court pp. 4, 26-29; P4771 (Dušan Janc's report entitled "Update to the summary of Forensic Evidence - Exhumation of the Graves and Surface Remains Recoveries related to Srebrenica - January 2012", 13 January 2012), Annex D, e-court pp. 353-380 (under seal). See also P5917 (ICMP DNA identifications concerning identified victims related to Srebrenica, 6 December 2010); P4773 (ICMP unmatched DNA victim profiles related to Srebrenica, 23 December 2011); P4774 (ICMP lists of unmatched unique DNA victims profiles related to Srebrenica, 15 February 2010). For a detailed analysis of the methodology followed by Janc in making DNA connections, see paras. 5586-5589. 
having been last seen alive after 13 July $1995 .{ }^{17874}$ As stated above, the minimum and maximum

possible number of Kravica-related victims in all of these sites will be discussed at the end of this section. $^{17875}$

5266. The secondary gravesites of Budak 1, Budak 2, Blječeva 1, Blječeva 2, Blječeva 3, and Zalažje were discovered and exhumed from 2004 to 2009 by the BiHCMP. ${ }^{17876}$

5267. The Chamber received evidence of DNA-based connections between these secondary gravesites and the two Glogova gravesites, as well as between the various secondary gravesites. ${ }^{17877}$ Specifically, 12 DNA connections were found between Glogova 2 and Blječeva 1; 26 between Glogova 2 and Blječeva 2; 14 between Glogova 1 and Blječeva 3; three between Glogova 1 and Budak 1; 12 between Glogova 1 and Budak 2, and eight between Glogova 1 and Zalažje 1. ${ }^{17878}$ Consequently, the Chamber finds that bodies were taken from the Glogova 1 and Glogova 2 gravesites to the secondary gravesites of Budak, Blječeva, and Zalažje.

5268. As of 13 January 2012, DNA analysis led to the identification of 326 victims from the Budak, Blječeva, and Zalažje gravesites as persons listed as missing following the take-over of Srebrenica: 54 from Budak 1; 49 from Budak 2; 47 from Blječeva 1; ${ }^{17879} 81$ from Blječeva 2;

17874 Specifically, approximately $25 \%$ of the bodies identified from Zeleni Jadar 1A and 1B, 21\% from Zeleni Jadar 2, $23 \%$ from Zeleni Jadar 3, 27\% from Zeleni Jadar 4, 17\% from Zeleni Jadar 5, and 20\% from Zeleni Jadar 6 were listed as having been seen after 13 July 1995. See e.g. P4771 (Dušan Janc's report entitled "Update to the summary of Forensic Evidence - Exhumation of the Graves and Surface Remains Recoveries related to Srebrenica - January 2012”, 13 January 2012), Annex D, e-court pp. 353-380 (under seal) (listing the names of bodies identified in Zeleni Jadar 1A through 6); P6705 (Ewa Tabeau's expert report entitled "Srebrenica Missing: Persons Reported Missing and Dead after the Take-Over of the Srebrenica Enclave by the Bosnian Serb Army on 11 July 1995”, 9 April 2009), e-court pp. 27, 30, 34, 40, 54, 61, 74, 96, 106-107, 118, 125, 155, 170-171, 192, 199, 213, 216.

17875 See paras. 5280-5283.

17876 P4772 (Dušan Janc's report entitled “Update to the summary of Forensic Evidence - Exhumation of the Graves and Surface Remains Recoveries related to Srebrenica - January 2012”, 13 January 2012), e-court pp. $29-32$.

17877 P4772 (Dušan Janc's report entitled "Update to the summary of Forensic Evidence - Exhumation of the Graves and Surface Remains Recoveries related to Srebrenica - January 2012”, 13 January 2012), e-court pp. 29, 49-50, 85-87. The Chamber notes Dunjić's challenge that not all of the individual bodies found in Glogova 1 and 2 could be linked to the secondary gravesites by DNA connections. D3893 (Dušan Dunjić's expert report entitled "Forensic Analysis of Reports on the Locations of Mass Graves in the Area of Eastern Bosnia and Documentation Relating to Exhumations in the Srebrenica Area", 27 August 2009), pp. 13, 23. However, Dunjić admitted that this assertion was not supported by ballistic, soil, or material evidence on his part. Dušan Dunjić, T. 41883-41890 (24 July 2013). As explained in detail in Section IV.C.1.h: Forensic, demographic, and DNA evidence, and having assessed the totality of the evidence on this issue, the Chamber is satisfied that the reports generated by Janc and by the ICMP on the basis of the DNA analysis can be relied upon for the purposes of the present Judgement.

17878 P4772 (Dušan Janc's report entitled "Update to the summary of Forensic Evidence - Exhumation of the Graves and Surface Remains Recoveries related to Srebrenica - January 2012”, 13 January 2012), e-court pp. 49, 85, 87.

17879 The Chamber finds that the Blječeva 1 gravesite was a mixed grave and contained remains which were unconnected with the fall of Srebrenica. P4772 (Dušan Janc's report entitled "Update to the summary of Forensic Evidence - Exhumation of the Graves and Surface Remains Recoveries related to Srebrenica - January 2012”, 13 January 2012), e-court pp. 30-32; Dušan Janc, T. 27016-27017 (27 March 2012); D3893 (Dušan Dunjić's expert report entitled "Forensic Analysis of Reports on the Locations of Mass Graves in the Area of 
65 from Blječeva 3; and 30 from Zalažje. ${ }^{17880}$ However, according to P6705, just over one fifth of the bodies identified from Budak, just over one tenth of the bodies identified from Blječeva, and one fifth of the bodies identified in Zalažje were reported as having been seen alive after 13 July 1995. ${ }^{17881}$ As stated above, the minimum and maximum possible number of Kravica-related victims in all of these sites will be discussed at the end of this section. ${ }^{17882}$

\section{(iii) $\underline{\text { Ravnice }}$}

5269. The gravesite of Ravnice — which encompasses the sub-gravesites of Ravnice 1 and Ravnice 2-is located along a dirt roadway leading to the village of Adžici from the Konjević PoljeBratunac Road, and is close to Glogova. ${ }^{17883}$ There is no evidence that this gravesite was disturbed. ${ }^{17884}$ Ravnice 1 was partially exhumed in August 2000 by a Tribunal exhumations team

Eastern Bosnia and Documentation Relating to Exhumations in the Srebrenica Area", 27 August 2009), pp. 13, 36-37; D3894 (Dušan Dunjić's expert report entitled "Forensic Analysis of Documents Pertaining to Exhumations, Autopsies and Identification of Bodies in the Srebrenica Area", 27 August 2009), p. 20; Dušan Dunjić, T. 41746-41748 (22 July 2013). See also Defence Final Brief, paras. 2597, 2671. According to Janc, Blječeva 1 contained remains of victims from an incident in Bratunac in 1992; however, in reaching the total number of Srebrenica victims identified from remains found in that gravesite, Janc did not count those victims who had died in 1992. P4772 (Dušan Janc's report entitled "Update to the summary of Forensic Evidence Exhumation of the Graves and Surface Remains Recoveries related to Srebrenica - January 2012", 13 January 2012), e-court p. 30; Dušan Janc, T. 27016-27017 (27 March 2012). See also Accused Closing Argument, T. 48024 (2 October 2014). The Chamber compared Janc's list of Blječeva 1 victims to the data on P6705 and is satisfied that the 47 individuals identified by Janc from remains at Blječeva 1 are indeed victims from the fall of Srebrenica. See P4771 (Dušan Janc's report entitled "Update to the summary of Forensic Evidence Exhumation of the Graves and Surface Remains Recoveries related to Srebrenica - January 2012", 13 January 2012), Annex D, e-court pp. 381-383 (under seal); P6705 (Ewa Tabeau's expert report entitled "Srebrenica Missing: Persons Reported Missing and Dead after the Take-Over of the Srebrenica Enclave by the Bosnian Serb Army on 11 July 1995", 9 April 2009). However, as explained in detail below, the Chamber acknowledges that not all of these 47 victims were killed at the Kravica Warehouse. See paras. 5280-5283.

17880 P4772 (Dušan Janc's report entitled "Update to the summary of Forensic Evidence - Exhumation of the Graves and Surface Remains Recoveries related to Srebrenica - January 2012”, 13 January 2012), e-court pp. 4, 29-32; P4771 (Dušan Janc's report entitled "Update to the summary of Forensic Evidence - Exhumation of the Graves and Surface Remains Recoveries related to Srebrenica - January 2012”, 13 January 2012), Annex D, e-court pp. 381-403 (under seal). See also P5917 (ICMP DNA identifications concerning identified victims related to Srebrenica, 6 December 2010); P4773 (ICMP unmatched DNA victim profiles related to Srebrenica, 23 December 2011); P4774 (ICMP lists of unmatched unique DNA victims profiles related to Srebrenica, 15 February 2010).

17881 Specifically, 35\% of the bodies identified from Budak 1, 8\% from Budak 2, 11\% from Blječeva 1, 13\% from Blječeva 2, $8 \%$ from Blječeva 3, and 20\% from Zalažje were listed as having been seen after 13 July 1995. See e.g. P4771 (Dušan Janc's report entitled "Update to the summary of Forensic Evidence - Exhumation of the Graves and Surface Remains Recoveries related to Srebrenica - January 2012”, 13 January 2012), Annex D, ecourt pp. 381-403 (under seal) (listing the names of bodies identified in each of these gravesites); P6705 (Ewa Tabeau's expert report entitled "Srebrenica Missing: Persons Reported Missing and Dead after the Take-Over of the Srebrenica Enclave by the Bosnian Serb Army on 11 July 1995", 9 April 2009), e-court pp. 16-17, 25-26, 35, 58, 85, 91, 114, 121, 124, 131, 176, 186, 203.

17882 See paras. 5280-5283.

17883 P4502 (Dean Manning's Report entitled "Summary of Forensic Evidence, Mass Graves Exhumed in 2000 Lazete 1, Lazete 2C, Ravnice, Glogova 1”, February 2001), e-court p. 11; P4503 (Dean Manning's Report, entitled "Srebrenica Investigation, Summary of Forensic Evidence - Execution Points and Mass Graves 2001", 24 August 2003), e-court p. 3.

17884 P4502 (Dean Manning's Report, entitled "Summary of Forensic Evidence, Mass Graves Exhumed in 2000 Lazete 1, Lazete 2C, Ravnice, Glogova 1", February 2001), e-court p. 11. 
under the direction of Fredi Peccerelli. ${ }^{17885}$ Ravnice 2 was exhumed in July and August 2001 by members of the BiHCMP and the ICMP, and monitored by members of the Tribunal. ${ }^{17886}$ The remains found at both Ravnice 1 and 2 were examined by a team of pathologists under the direction of John Clark. ${ }^{17887}$

5270. The Chamber did not receive eye-witness evidence as to the burial of bodies at Ravnice. The only evidence received by the Chamber with respect to the exhumation of the Ravnice gravesite comes from Dean Manning, who was present at the gravesite during the exhumation process carried out by Peccerelli and his team, and from Clark, who referred to the exhumation process in his pathology report. ${ }^{17888}$

5271. According to Clark, the Ravnice gravesite was very different to the gravesites at Glogova, in that a number of bodies lay scattered on the surface rather than buried in the ground. ${ }^{17889}$ The bodies appear to have been dumped down a steep wooded embankment from the roadway, across a wide area. ${ }^{17890}$ After the first group of bodies was covered with soil, another dump occurred; there was no attempt to cover these additional bodies with dirt so they were left on the surface of the slope. ${ }^{17891}$ Many of these bodies were caught at the base of trees and on a fence running along the slope. ${ }^{17892}$

17885 P4105 (John Clark's expert report entitled "Report of the Chief Pathologist, Srebrenica Grave Sites (2001)", 24 May 2003), p. 6; P4502 (Dean Manning's Report, entitled "Summary of Forensic Evidence, Mass Graves Exhumed in 2000 - Lazete 1, Lazete 2C, Ravnice, Glogova 1", February 2001), e-court p. 11. See Fredi Peccerelli, T. 22736 (11 January 2012).

17886 P4105 (John Clark's expert report entitled "Report of the Chief Pathologist, Srebrenica Grave Sites (2001)", 24 May 2003), p. 6; P4772 (Dušan Janc's report entitled "Update to the summary of Forensic Evidence Exhumation of the Graves and Surface Remains Recoveries related to Srebrenica - January 2012", 13 January 2012), e-court p. 13.

17887 P4105 (John Clark's expert report entitled "Report of the Chief Pathologist, Srebrenica Grave Sites (2001)", 24 May 2003), pp. 6, 29.

17888 P4105 (John Clark's expert report entitled "Report of the Chief Pathologist, Srebrenica Grave Sites (2001)", 24 May 2003), p. 1; Dean Manning, T. 25802-25803, 25805, 25829 (6 March 2012); P4502 (Dean Manning's Report, entitled "Summary of Forensic Evidence, Mass Graves Exhumed in 2000 - Lazete 1, Lazete 2C, Ravnice, Glogova 1”, February 2001), e-court pp. 4-5, 11. See also P4503 (Dean Manning's Report, entitled "Srebrenica Investigation, Summary of Forensic Evidence - Execution Points and Mass Graves 2001", 24 August 2003), pp. 2, 8-9; P4772 (Dušan Janc's report entitled "Update to the summary of Forensic Evidence - Exhumation of the Graves and Surface Remains Recoveries related to Srebrenica - January 2012", 13 January 2012), e-court p. 13.

17889 P4105 (John Clark's expert report entitled "Report of the Chief Pathologist, Srebrenica Grave Sites (2001)", 24 May 2003), p. 6.

17890 P4105 (John Clark's expert report entitled "Report of the Chief Pathologist, Srebrenica Grave Sites (2001)", 24 May 2003), p. 6; P4502 (Dean Manning's Report, entitled "Summary of Forensic Evidence, Mass Graves Exhumed in 2000 - Lazete 1, Lazete 2C, Ravnice, Glogova 1", February 2001), e-court pp. 4, 11; P4503 (Dean Manning's Report, entitled "Srebrenica Investigation, Summary of Forensic Evidence - Execution Points and Mass Graves 2001", 24 August 2003), p. 2; P4772 (Dušan Janc's report entitled "Update to the summary of Forensic Evidence - Exhumation of the Graves and Surface Remains Recoveries related to Srebrenica - January 2012", 13 January 2012), e-court p. 12.

17891 P4502 (Dean Manning's Report, entitled "Summary of Forensic Evidence, Mass Graves Exhumed in 2000 Lazete 1, Lazete 2C, Ravnice, Glogova 1”, February 2001), e-court pp. 4, 11; P4503 (Dean Manning's Report, 
5272. Clark further explained that the remains found in the gravesite were broken up with parts missing, and individual body parts were much more numerous than whole bodies. ${ }^{17893}$ Civilian clothing was present on most of the bodies, along with personal belongings, and no bodies were found with military attire. ${ }^{17894}$ No ligatures or blindfolds were found. ${ }^{17895}$ Because the bodies were exposed to the open air, they had been skeletonised, with no soft tissue surviving, and their bones showed weathering and decay. ${ }^{17896}$

5273. Based on the pathology examination, Clark concluded that all of the victims exhumed at Ravnice were male. ${ }^{17897}$ At least 14 of these individuals were 17 years old or younger. ${ }^{17898}$ In relation to the cause and manner of death, Clark stated that the vast majority of the victims presented multiple gunshot injuries to the head, trunk, and legs, primarily from high velocity rifles, and there was no convincing evidence of serious injuries from shrapnel from grenades or other projectiles. ${ }^{17899}$ Clark was not able to make a finding on the distance from which the shots were fired. ${ }^{17900}$

entitled "Srebrenica Investigation, Summary of Forensic Evidence - Execution Points and Mass Graves 2001", 24 August 2003), p. 2.

17892 P4502 (Dean Manning's Report, entitled "Summary of Forensic Evidence, Mass Graves Exhumed in 2000 Lazete 1, Lazete 2C, Ravnice, Glogova 1", February 2001), e-court pp. 4, 11; P4772 (Dušan Janc's report entitled "Update to the summary of Forensic Evidence - Exhumation of the Graves and Surface Remains Recoveries related to Srebrenica - January 2012”, 13 January 2012), e-court p. 12.

17893 Clark explained that 175 bodies and 324 parts of bodies were scattered throughout the gravesite. P4105 (John Clark's expert report entitled "Report of the Chief Pathologist, Srebrenica Grave Sites (2001)", 24 May 2003), pp. 6, 10-11.

17894 P4105 (John Clark's expert report entitled "Report of the Chief Pathologist, Srebrenica Grave Sites (2001)", 24 May 2003), pp. 6, 11.

17895 P4105 (John Clark's expert report entitled "Report of the Chief Pathologist, Srebrenica Grave Sites (2001)", 24 May 2003), p. 11; P4502 (Dean Manning's Report, entitled "Summary of Forensic Evidence, Mass Graves Exhumed in 2000 - Lazete 1, Lazete 2C, Ravnice, Glogova 1", February 2001), e-court p. 11; P4503 (Dean Manning's Report, entitled "Srebrenica Investigation, Summary of Forensic Evidence - Execution Points and Mass Graves 2001", 24 August 2003), pp. 8-9.

17896 P4105 (John Clark's expert report entitled "Report of the Chief Pathologist, Srebrenica Grave Sites (2001)", 24 May 2003), p. 6.

17897 It was not possible to determine the sex of five of the bodies because of their young age or because of damage to the skeleton. P4105 (John Clark's expert report entitled "Report of the Chief Pathologist, Srebrenica Grave Sites (2001)", 24 May 2003), pp. 6, 11.

17898 P4105 (John Clark's expert report entitled "Report of the Chief Pathologist, Srebrenica Grave Sites (2001)", 24 May 2003), p. 6.

17899 Only ten of the men died from a single shot to the head. P4105 (John Clark's expert report entitled "Report of the Chief Pathologist, Srebrenica Grave Sites (2001)”, 24 May 2003), pp. 7-8, 11. The Chamber notes Dunjić's challenges to Clark's findings in relation to the Ravnice gravesites. See D3896 (Dušan Dunjić's expert report entitled "Forensic Analysis of Exhumation Reports from the Bišina Site and Documents Relating to the Update to the Summary of Forensic Evidence from Graves in the Srebrenica Area", April 2009), pp. 193-210; Dušan Dunjić, T. 41862-41864 (24 July 2013). Having assessed the totality of evidence, the Chamber accepts Clark's report and the findings therein.

17900 P4105 (John Clark's expert report entitled "Report of the Chief Pathologist, Srebrenica Grave Sites (2001)", 24 May 2003), pp. 8, 11. 
5274. Items from the Kravica Warehouse were collected from the Ravnice gravesites which, according to Manning, indicated a linkage between the gravesite and the Kravica Warehouse. ${ }^{17901}$ Furthermore, personal identification documents found at the warehouse were linked to two individuals who were identified by DNA analysis in Ravnice $2 .{ }^{17902}$

5275. As of 13 January 2012, DNA analysis led to the identification of 32 victims from Ravnice 1 and 174 victims from Ravnice 2 as persons listed as missing following the take-over of Srebrenica. ${ }^{17903}$

5276. Despite the fact that there is no eyewitness evidence as to the burials at Ravnice, the Chamber finds, in light of the location of the gravesite and the forensic evidence admitted in this case, that this gravesite is linked to the killings at the Kravica Warehouse on 13 July 1995. However, P6705 demonstrates that nearly one third of the bodies found in Ravnice 1 and nearly one fifth of the bodies found in Ravnice 2, totalling 43 individuals, were reported as having been last seen alive on and after 14 July $1995 .{ }^{17904}$ This evidence strongly suggests that some bodies found in the Ravnice gravesites were brought from a site or sites other than the Kravica Warehouse. ${ }^{17905}$ Considering this, the Chamber cannot find beyond reasonable doubt the exact number of Kravica

17901 Among these items was a piece of painted polystyrene foam found at Ravnice 2, which was identical to foam lettering located on the north face of the Kravica Warehouse, above an entrance doorway. P4772 (Dušan Janc's report entitled "Update to the summary of Forensic Evidence - Exhumation of the Graves and Surface Remains Recoveries related to Srebrenica - January 2012”, 13 January 2012), e-court p. 13; Dean Manning, T. 2582925831 (6 March 2012).

17902 P4772 (Dušan Janc's report entitled "Update to the summary of Forensic Evidence - Exhumation of the Graves and Surface Remains Recoveries related to Srebrenica - January 2012”, 13 January 2012), e-court p. 13.

17903 P4772 (Dušan Janc's report entitled "Update to the summary of Forensic Evidence - Exhumation of the Graves and Surface Remains Recoveries related to Srebrenica - January 2012”, 13 January 2012), e-court pp. 3, 14; P4771 (Dušan Janc's report entitled "Update to the summary of Forensic Evidence - Exhumation of the Graves and Surface Remains Recoveries related to Srebrenica - January 2012”, 13 January 2012), Annex D, e-court pp. 169-179 (under seal). See also P5917 (ICMP DNA identifications concerning identified victims related to Srebrenica, 6 December 2010); P4773 (ICMP unmatched DNA victim profiles related to Srebrenica, 23 December 2011); P4774 (ICMP lists of unmatched unique DNA victims profiles related to Srebrenica, 15 February 2010).

17904 See e.g. P4771 (Dušan Janc's report entitled "Update to the summary of Forensic Evidence - Exhumation of the Graves and Surface Remains Recoveries related to Srebrenica - January 2012”, 13 January 2012), Annex D, ecourt pp. 169-179 (under seal) (listing the names of bodies identified in Ravnice 1 and 2); P6705 (Ewa Tabeau's expert report entitled "Srebrenica Missing: Persons Reported Missing and Dead after the Take-Over of the Srebrenica Enclave by the Bosnian Serb Army on 11 July 1995”, 9 April 2009), e-court pp. 13, 17, 19, 22, 23, 30, 32, 43, 46, 47, 53, 58, 59, 65, 78, 84, 94, 118, 122, 123, 125, 142, 153, 154, 156, 168, 178, 191, $206,208$.

17905 Unlike the gravesites at Glogova and the Kravica-related secondary graves, neither party has provided evidence suggesting that bodies found in Ravnice were brought from locations other than the Kravica Warehouse incident. See D1975 (Dušan Janc's corrigendum to report entitled "Update to Summary of Forensic Evidence Exhumation on the Graves Related to Srebrenica -March 2009", 9 April 2009) (acknowledging that not all of the bodies in Glogova and the related secondary gravesites were brought from the Kravica Warehouse); P4772 (Dušan Janc's report entitled "Update to the summary of Forensic Evidence - Exhumation of the Graves and Surface Remains Recoveries related to Srebrenica - January 2012”, 13 January 2012), p. 40 (providing that, "[a]lthough most of these 1374 identified individuals [from all Kravica-related graves] must still be directly connected with the Kravica Warehouse execution point, it is impossible to provide the exact number.") (citations omitted). 
Warehouse victims found in Ravnice 1 and Ravnice 2. The Chamber will discuss the number of Kravica-related victims in the Ravnice gravesites at the end of this section. ${ }^{17906}$

\section{(7) $\underline{\text { Total number of Kravica Warehouse victims }}$}

5277. According to Janc, as of 13 January 2012, DNA analysis led to the identification 1,374 victims listed as persons missing following the take-over of Srebrenica, who are connected to the various gravesites associated with the killings at the Kravica Warehouse. ${ }^{17907}$ While Janc considered that most of these 1,374 victims can be connected to the Kravica Warehouse killing incident, he found it impossible to provide an exact number. ${ }^{17908}$ Accordingly, the Prosecution acknowledges in its final brief that some of these 1,374 victims were not killed at the Kravica Warehouse, but estimates that at least 1,200 individuals of those detained at the Sandići Meadow on 13 July 1995 were killed at the warehouse. ${ }^{17909}$

5278. The Chamber heard conflicting evidence as to the number of Bosnian Muslim men held inside the Kravica Warehouse before the execution took place. For example, KDZ063 estimated that there were between 2,500 and 3,000 men in the warehouse after the last detainee came in. ${ }^{17910}$ KDZ071 testified hearing from other men detained at the warehouse that there were 2,000 men inside. ${ }^{17911}$ By contrast, Franc Kos testified that there could not have been more than 150 people inside the Kravica Warehouse. ${ }^{17912}$ Further, Adjudicated Fact 1705 refers to between 1,000 and 1,500 Bosnian Muslim men being bussed or marched to the Kravica Warehouse after their

\footnotetext{
17906 See paras. 5284-5285.
}

17907 P4772 (Dušan Janc's report entitled "Update to the summary of Forensic Evidence - Exhumation of the Graves and Surface Remains Recoveries related to Srebrenica - January 2012", 13 January 2012), e-court pp. 40-41. The Chamber notes Dunjić's challenges to Janc's total number of victims identified as killed during the incident at the Kravica Warehouse, and his claims that this number is not accurate and reliable. D3893 (Dušan Dunjić's expert report entitled "Forensic Analysis of Reports on the Locations of Mass Graves in the Area of Eastern Bosnia and Documentation Relating to Exhumations in the Srebrenica Area", 27 August 2009), p. 23; Dušan Dunjić, T. 41744-41748 (22 July 2013).

17908 P4772 (Dušan Janc's report entitled "Update to the summary of Forensic Evidence - Exhumation of the Graves and Surface Remains Recoveries related to Srebrenica - January 2012”, 13 January 2012), e-court p. 40; D1975 (Dušan Janc's corrigendum to report entitled "Update to Summary of Forensic Evidence - Exhumation on the Graves Related to Srebrenica -March 2009”, 9 April 2009). See also D3893 (Dušan Dunjić's expert report entitled "Forensic Analysis of Reports on the Locations of Mass Graves in the Area of Eastern Bosnia and Documentation Relating to Exhumations in the Srebrenica Area", 27 August 2009), pp. 11-12 (referring to D1975).

17909 Prosecution Final Brief, Appendix D, paras. 64, 171. The Chamber considers that the Prosecution arrived at this number by subtracting the approximately 180 individuals brought to Glogova from other sites from the total number of victims identified in all Kravica-related graves.

17910 KDZ063, P334 (Transcript from Prosecutor v. Popović et al.), T. 6990.

17911 KDZ071 acknowledged however that he himself did not count the number of detainees. KDZ071, T. 28539 (4 May 2012).

17912 D3927 (Witness Statement of Franc Kos dated 26 July 2013), p. 9. The Chamber finds this estimate unacceptable. 
detention at the Sandići Meadow; ${ }^{17913}$ and Adjudicated Fact 1709 refers to approximately 1,000 Bosnian Muslim men being executed at the Kravica Warehouse. ${ }^{17914}$

5279. Given the connections between Glogova and the secondary gravesites, ${ }^{17915}$ as well as the uniqueness of the Ravnice gravesites, ${ }^{17916}$ the Chamber will discuss the total number of Kravica Warehouse victims found in these gravesites separately in the following paragraphs.

\section{(a) Glogova and secondary gravesites}

5280. According to Janc, as of 13 January 2012, DNA analysis led to the identification of 1,168 individuals found in Glogova and the related secondary gravesites as persons missing following the take-over of Srebrenica. ${ }^{17917}$ However, as discussed above, the Chamber has heard evidence that bodies from incidents or sites other than the Kravica Warehouse were also brought to Glogovanamely, approximately 80 victims executed in Bratunac, plus approximately 100 bodies brought from other locations — and were subject to reburial in secondary graves. ${ }^{17918}$

5281. Additionally, as noted above, P6705 shows that just over one fifth—or 235—of the victims whose bodies were found in Glogova and the related secondary gravesites were reported as having been seen alive on or after 14 July $1995 .{ }^{17919}$ The Chamber finds it unlikely that these victims were killed at the Kravica Warehouse incident, in light of the fact that the killings at the Kravica Warehouse took place on 13 July 1995.

5282. While the Chamber considers that some of these 235 individuals who were reported to have been seen alive on or after 14 July 1995 likely overlap with the approximately 180 individuals who were brought to Glogova from sites or incidents other than the Kravica Warehouse, the degree to which the two groups overlap cannot be determined beyond reasonable doubt. Therefore, in order to reach the minimum number of Kravica Warehouse victims found in Glogova and the related secondary gravesites, the Chamber has deducted both groups from the total of 1,168 bodies, leading

\footnotetext{
17913 See Adjudicated Fact 1705.

17914 See Adjudicated Fact 1709.

17915 See paras. 5264-5265.

17916 See paras. 5271-5274.

17917 P4772 (Dušan Janc's report entitled "Update to the summary of Forensic Evidence - Exhumation of the Graves and Surface Remains Recoveries related to Srebrenica - January 2012”, 13 January 2012), e-court pp. 40-41 (listing the total number of individuals identified as missing after the takeover from Srebrenica from each Kravica-related gravesite).

17918 D1975 (Dušan Janc's corrigendum to report entitled "Update to Summary of Forensic Evidence - Exhumation on the Graves Related to Srebrenica -March 2009”, 9 April 2009); P4772 (Dušan Janc's report entitled "Update to the summary of Forensic Evidence - Exhumation of the Graves and Surface Remains Recoveries related to Srebrenica - January 2012”, 13 January 2012, e-court p. 40. See also paras. 5257-5258, 5507.

17919 See paras. 5259, 5265, 5268.
} 
to a minimum of 753 victims. ${ }^{17920}$ Further, the maximum number of possible Kravica Warehouse victims found in Glogova and the related secondary gravesites can be reached by deducting those 235 individuals who were reported to have been seen last on or after 14 July 1995, as well as the approximately 80 individuals killed at the Vuk Karadžić School, from the total of 1,168 bodies, leading to a maximum total of 853 victims. ${ }^{17921}$

5283. Therefore, the Chamber finds that a minimum of 753 individuals and a maximum of 853 individuals found in Glogova and the related secondary gravesites were executed at the Kravica Warehouse incident.

\section{(b) $\underline{\text { Ravnice gravesites }}$}

5284. As noted above, some bodies found in the Ravnice gravesites were brought from a site or sites other than the Kravica Warehouse, making it impossible for the Chamber to find the exact number of Kravica Warehouse victims found in Ravnice 1 and $2 .{ }^{17922}$ However, the Chamber is satisfied that at least the two individuals recovered from Ravnice whose identification documents were found at the Kravica Warehouse were executed therein. ${ }^{17923}$ Furthermore, in finding the maximum number of Kravica Warehouse victims found in Ravnice 1 and 2, the Chamber has excluded those 43 individuals who were reported as having been seen alive on or after 14 July, ${ }^{17924}$ leading to a maximum of 163 victims.

5285. Consequently, the Chamber finds that a minimum of 2 individuals and a maximum of 163 individuals found in the Ravnice gravesites were executed at the Kravica Warehouse incident.

17920 Based on the witness testimony presented above, and the dates of disappearance of the bodies found in Glogova and the related secondary graves, the Chamber considers that the number of bodies brought to Glogova from other sites or incidents cannot have exceeded 415 individuals, equivalent to the 235 individuals reported as having been seen last alive on or after 14 July 1995 plus those approximately 180 individuals who the Prosecution itself accepts to have been brought from other sites or incidents. See paras. 5257, 5259.

17921 The Chamber considers that it is possible that the approximately 100 individuals brought to Glogova from Konjević Polje, Potočari, and the Bratunac-Konjević Polje Road, including the 12 individuals who are recorded as having been returned from Serbia and whose remains were also found at Glogova, are included in the group of individuals who were reported seen alive on or after 14 July 1995, while the approximately 80 bodies of individuals killed at the Vuk Karadžić School cannot have been, since most of those killings took place during the nights of 12 and 13 July. See para. 5258. Thus, while the maximum possible number of Kravica Warehouse victims excludes only the 235 individuals seen on or after $14 \mathrm{July}$, the Chamber must also exclude the approximately 80 individuals killed at the Vuk Karadzić School from the total.

17922 See para. 5276

17923 See para. 5274

17924 While 206 individuals in total were exhumed from the Ravnice gravesites, 43 of these individuals were listed in P6705 as having disappeared after 13 July, and therefore cannot be considered as having been executed at the Kravica Warehouse incident. See para. 5276. While it is not certain that the remaining 163 individuals were all executed at the Kravica Warehouse, the Chamber finds that an indeterminable proportion-and possibly the entirety-of this group were executed at the Kravica Warehouse. 


\section{(c) Conclusion}

5286. For all these reasons, the Chamber finds that, on 13 July 1995, between 755 and 1,016 Bosnian Muslim men were killed by members of the Bosnian Serb Forces at the Kravica Warehouse.

\section{(D) Sandići Meadow}

5287. The Indictment refers to the killing on 13 July 1995, after dark, of approximately 15 Bosnian Muslim men who were detained at Sandići Meadow and summarily executed in an area near Sandići. ${ }^{17925}$

5288. In the early evening on 13 July 1995, most of the Bosnian Muslim men who had previously been detained at the Sandići Meadow had been taken away, but 10 to 15 men were left behind. ${ }^{17926}$ Several members of the Jahorina Recruits asked the Deputy Commander of the $1^{\text {st }}$ Company's $4^{\text {th }}$ Platoon, a man by the name of "Aleksa", when the next bus would come to pick up the detainees. ${ }^{17927}$ Aleksa told the recruits that no more buses would come, and that they had to "get rid of them, shoot them". ${ }^{17928}$

5289. KDZ084 and two of his colleagues refused to comply with the order. ${ }^{17929}$ However, the remaining two agreed to shoot the Bosnian Muslim men together with a few other recruits who later volunteered, and took the detainees away. ${ }^{17930}$ Aleksa and the recruits who had volunteered to kill the detainees subsequently returned to the road near the Sandići Meadow where KDZ084 had remained. ${ }^{17931}$ KDZ084 did not witness the execution but rather heard the shots. ${ }^{17932}$ However,

\footnotetext{
17925 Indictment, Scheduled Incident E.4.1.

17926 KDZ084, T. 27340 (11 April 2012) (closed session); KDZ084, P4904 (Transcript from Prosecutor v. Popović et al.), T. 14830, 14883 (under seal). See para. 5180.

17927 KDZ084, T. 27341-27342 (11 April 2012) (closed session); KDZ084, P4904 (Transcript from Prosecutor v. Popović et al.), T. 14830-14832, 14883 (under seal). KDZ084 testified that Aleksa was the deputy of a man named Goran, and added that Aleksa was already at the Sandići Meadow when he and his colleagues arrived there. See KDZ084, T. 27357 (11 April 2012) (closed session); KDZ084, P4904 (Transcript from Prosecutor v. Popović et al.), T. 14791, 14797, 14801, 14831, 14886, 14906-14907 (under seal).

17928 KDZ084, P4904 (Transcript from Prosecutor v. Popović et al.), T. 14830-14831, 14884 (under seal); KDZ084, T. 27341-27342 (11 April 2012) (closed session).

17929 KDZ084, T. 27343 (11 April 2012) (closed session); KDZ084, P4904 (Transcript from Prosecutor v. Popović et al.), T. 14833 (under seal). KDZ084 was kept in a solitary cell for one night, without food, as punishment for refusing to kill the detainees. KDZ084, T. 27345 (11 April 2012) (closed session); KDZ084, P4904 (Transcript from Prosecutor v. Popović et al., T. 14833-14834 (under seal).

17930 KDZ084, P4904 (Transcript from Prosecutor v. Popović et al.), T. 14832-14833, 14884-14885 (under seal). One of those involved in the executions was a Jahorina Recruit known as "Crnogorac", who came from Kupreš, Montenegro; Crnogorac stated that he had participated in the killings as revenge for the killing of his family by Bosnian Muslims in Kupreš. [REDACTED]. See also P6378 (List of conviction verdicts of BiH Court against members of RS MUP Special Police Brigade).

17931 KDZ084, P4904 (Transcript from Prosecutor v. Popović et al.), T. 14832 (under seal).

17932 KDZ084, P4904 (Transcript from Prosecutor v. Popović et al.), T. 14832, 14884-14885 (under seal).
} 
KDZ084 talked to one of his colleagues who volunteered to kill the detainees, who told him that some had been killed while going up towards the meadow, with a shot in the head, and that the rest were executed with a burst of fire. ${ }^{17933}$

5290. The BiHCMP exhumed a gravesite near the Sandići Meadow between 14 and 21 June 2004. ${ }^{17934} 17$ individuals who had been reported missing after the fall of Srebrenica were identified, based upon DNA analysis, from the human remains located at the gravesite. ${ }^{17935}$ However, given the lack of evidence as to the location of the gravesite and the manner in which the 17 individuals were killed, the Chamber is unable to find the connection of this mass grave to the killings at the Sandići Meadow, as charged in the Indictment.

5291. Nevertheless, based on the account of KDZ084, the Chamber finds that, on 13 July 1995, approximately 10 to 15 Bosnian Muslim men from Srebrenica were killed at the Sandići Meadow by members of the Bosnian Serb Forces.

\section{v. Bratunac town}

\section{(A) Detention of Bosnian Muslim men}

5292. As stated above, starting on the afternoon of 12 July and throughout 13 July 1995, the Bosnian Muslim men who had been separated from the women, children, and the elderly and detained in the White House at Potočari were transported to Bratunac town. ${ }^{17936}$ On 13 July, Bosnian Muslim men from the column who were held at the various detention sites along the

17933 KDZ084, P4904 (Transcript from Prosecutor v. Popović et al.), T. 14833-14834 (under seal). KDZ084 did not see the bodies of those killed nor did he know what happened to them. KDZ084, T. 27344 (11 April 2012) (closed session); KDZ084, P4904 (Transcript from Prosecutor v. Popović et al.), T. 14834, 14886 (under seal). See also Jean-René Ruez, T. 24031 (1 February 2012) (stating that "we also know from witness testimonies that those at the end of the 13 who had no transportation to go to Bratunac were killed at the location where they were"); Richard Butler, T. 27768 (20 April 2012) (stating that "I am aware of one case at Sandići where apparently after all the buses and trucks stopped there were still some prisoners and they were summarily executed at that site").

${ }^{17934}$ P4772 (Dušan Janc's report entitled "Update to the summary of Forensic Evidence - Exhumation of the Graves and Surface Remains Recoveries related to Srebrenica - January 2012”, 13 January 2012), e-court pp. 4, 33. See also D3896 (Dušan Dunjić's expert report entitled "Forensic Analysis of Exhumation Reports from the Bišina Site and Documents Relating to the Update to the Summary of Forensic Evidence from Graves in the Srebrenica Area", April 2009), pp. 45-65.

17935 P4772 (Dušan Janc's report entitled "Update to the summary of Forensic Evidence - Exhumation of the Graves and Surface Remains Recoveries related to Srebrenica - January 2012”, 13 January 2012), e-court pp. 4, 33; P4771 (Dušan Janc's report entitled "Update to the summary of Forensic Evidence - Exhumation of the Graves and Surface Remains Recoveries related to Srebrenica - January 2012", 13 January 2012), Annex D, e-court p. 410 (under seal); P4642 (ICMP list of identified Srebrenica victims, 15 December 2011) (under seal); P4773 (ICMP unmatched DNA victim profiles related to Srebrenica, 23 December 2011), p. 6; P4774 (ICMP lists of unmatched unique DNA victims profiles related to Srebrenica, 15 February 2010). See also P6705 (Ewa Tabeau's expert report entitled "Srebrenica Missing: Persons Reported Missing and Dead after the Take-Over of the Srebrenica Enclave by the Bosnian Serb Army on 11 July 1995”, 9 April 2009); P5916 (2012 ICMP updated list of Srebrenica missing). 
Bratunac-Konjević Polje-Milići Road after having surrendered to, or having been captured by, members of the Bosnian Serb Forces were also transported to Bratunac town. ${ }^{17937}$

5293. Bosnian Muslim men transported to Bratunac town were detained in the Vuk Karadžić School ${ }^{17938}$ and the hangar located behind it. ${ }^{17939}$ Detainees were also held aboard 80 to 120 buses and trucks parked on the streets of Bratunac town, ${ }^{17940}$ at sites including outside the Vuk Karadžić School complex, ${ }^{17941}$ the MUP Headquarters, ${ }^{17942}$ the municipal building, ${ }^{17943}$ the Bratunac

17936 See para. 5117

17937 See Momir Nikolić, T. 24672-24673 (14 February 2012); D2081 (Momir Nikolić’s statement of facts from Plea Agreement, 7 May 2003), para. 9; Mevludin Orić, P350 (Transcript from Prosecutor v. Popović et al.), T. 887889, 897-898, 907-908; KDZ064, P769 (Transcript from Prosecutor v. Popović et al.), T. 663, 665; KDZ069, P339 (Transcript from Prosecutor v. Blagojević \& Jokić), T. 1397-1398; KDZ333, T. 24147 (2 February 2012); KDZ333, P4342 (Transcript from Prosecutor v. Krstić), T. 3027-3028. See also Adjudicated Fact 1625; para. 5292.

17938 Momir Nikolić, T. 24644, 24659, 24673 (14 February 2012); Ahmo Hasić, P354 (Transcript from Prosecutor v. Popović et al.), T. 1179, 1260; Zlatan Čelanović, P377 (Transcript from Prosecutor v. Popović et al.), T. 6653; P257 (Aerial photograph of Bratunac marked by Zlatan Čelanović); Srbislav Davidović, P4100 (Transcript from Prosecutor v. Popović et al.), T. 9218; Srbislav Davidović, T. 24420 (9 February 2012); Mile Janjić, P372 (Transcript from Prosecutor v. Popović et al.), T. 17934; KW582, D4291 (Transcript from Prosecutor v. Blagojević \& Jokić), T. 3551-3553; D4293 (Aerial photograph of Bratunac town marked by KW582) (under seal); P4374 (Witness statement of Milenko Katanić dated 11 October 2011), para. 79. See also Adjudicated Facts 1668, 1669; Mevludin Orić, P350 (Transcript from Prosecutor v. Popović et al.), T. 918-919; Jean-René Ruez, T. 23781-23784 (27 January 2012); P4308 (Book of photographs and maps prepared by Jean-René Ruez, 22 June 2009), e-court pp. 129-130, 282.

17939 Momir Nikolić, T. 24673 (14 February 2012); KDZ039, P3940 (Transcript from Prosecutor v. Popović et al.), T. 17315-17316, 17318, 17384; KDZ039, T. 21938 (24 November 2011). See Adjudicated Fact 1674. See also Jean-René Ruez, T. 23719-23720 (26 January 2012), T. 23781-23784 (27 January 2012); P4308 (Book of photographs and maps prepared by Jean-René Ruez, 22 June 2009), e-court pp. 21, 23, 129-130, 282. The Chamber notes that KDZ039 provided inconsistent evidence about the location of the hangar in relation to the Vuk Karadžić School complex. See KDZ039, T. 21939 (24 November 2011) (testifying that the hangar he was detained in was not close to the school); KDZ039, P3940 (Transcript from Prosecutor v. Popović et al.), T. 17318, 17330 (testifying that the hangar was behind the school). Having reviewed the evidence in its entirety, however, the Chamber is satisfied that KDZ039 was detained in the hangar behind the Vuk Karadžić School.

17940 Momir Nikolić, T. 24672-24673 (14 February 2012); Zlatan Čelanović, P377 (Transcript from Prosecutor v. Popović et al.), T. 6638, 6640, 6652; Mile Janjić, P1194 (Transcript from Prosecutor v. Blagojević \& Jokić), T. 9807; D3118 (Witness statement of Aleksandar Tešić dated 10 March 2013), para. 41; P4374 (Witness statement of Milenko Katanić dated 11 October 2011), paras. 79-80. See also Adjudicated Facts 1668, 1685; Jean-René Ruez, T. 23781-23784 (27 January 2012); P4308 (Book of photographs and maps prepared by JeanRené Ruez, 22 June 2009), e-court pp. 129, 131, 282.

17941 Mevludin Orić, P350 (Transcript from Prosecutor v. Popović et al.), T. 908, 923-924; P267 (Sketch of Bratunac marked by Mevludin Orić); KDZ333, P4342 (Transcript from Prosecutor v. Krstić), T. 3028-3029; Zlatan Čelanović, P377 (Transcript from Prosecutor v. Popović et al.), T. 6652; Mile Janjić, P1194 (Transcript from Prosecutor v. Blagojević \& Jokić), T. 9808; D3115 (Witness statement of Branimir Tešić dated 9 March 2013), para. 37; P4374 (Witness statement of Milenko Katanić dated 11 October 2011), para. 80. See also Adjudicated Fact 1682; Jean-René Ruez, T. 23719-23720 (26 January 2012), T. 23781-23784 (27 January 2012); P4308 (Book of photographs and maps prepared by Jean-René Ruez, 22 June 2009), e-court pp. 129-131, 282; P4290 (Aerial image of Bratunac marked by Jean-René Ruez) .

17942 Mile Janjić, P1194 (Transcript from Prosecutor v. Blagojević \& Jokić), T. 9809 . See also P4308 (Book of photographs and maps prepared by Jean-René Ruez, 22 June 2009), e-court p. 282.

17943 Srbislav Davidović, P4100 (Transcript from Prosecutor v. Popović et al.), T. 9212-9215; Srbislav Davidović, T. 24437 (9 February 2012); KDZ107, P345 (Transcript from Prosecutor v. Popović et al.), T. 9494, 9513; Aleksandar Tešić, T. 35312-35313 (13 March 2013); Mile Janjić, P1194 (Transcript from Prosecutor v. Blagojević \& Jokić), T. 9809. See also Jean-René Ruez, T. 23781-23784 (27 January 2012); P4308 (Book of photographs and maps prepared by Jean-René Ruez, 22 June 2009), e-court p. 282. 
stadium, ${ }^{17944}$ and the Vihor Company Garages. ${ }^{17945}$ Throughout these locations, the Bosnian Muslim detainees were guarded by members of the Bratunac Brigade MP, ${ }^{17946}$ assisted by members of the MUP. ${ }^{17947}$

5294. The detainees were held in cramped conditions at the various locations. ${ }^{17948}$ For example, approximately 400 people were detained in the hangar, which was so crowded that the detainees could not walk. ${ }^{17949}$ The detainees in the hangar complained to the men guarding them that they would suffocate due to the lack of space and air, but were threatened that they would be killed if they did not keep silent. ${ }^{17950}$ Similarly, between 150 to 200 detainees were held in one of the classrooms at the Vuk Karadžić School, and there was not enough space for everyone to sit down. ${ }^{17951}$ Further, Bosnian Muslim detainees held on the buses parked outside the Vihor Company Garages had to sit on top of one another because of the number of people crammed into

17944 Zlatan Čelanović, P377 (Transcript from Prosecutor v. Popović et al.), T. 6641-6642, 6652; Momir Nikolić, T. 24672-24673 (14 February 2012); P4374 (Witness statement of Milenko Katanić dated 11 October 2011), paras. 79-80. See also Jean-René Ruez, T. 23781-23784 (27 January 2012); P4308 (Book of photographs and maps prepared by Jean-René Ruez, 22 June 2009), e-court pp. 129, 282; P4290 (Aerial image of Bratunac marked by Jean-René Ruez).

17945 KDZ064, P769 (Transcript from Prosecutor v. Popović et al.), T. 663-665; KDZ069, P339 (Transcript from Prosecutor v. Blagojević \& Jokić), T. 1398-1399; KDZ069, P339 (Transcript from Prosecutor v. Popović et al.), T. 3371. The Chamber notes that KDZ069 was not aware of his location during his detention in Bratunac; however, noting the similarities between the circumstances surrounding the transportation of KDZ064 and KDZ069 from the Sandići Meadow, detention in Bratunac, and departure to Zvornik, the Chamber is satisfied that KDZ069 was detained in a truck outside the Vihor Company Garages. See also Jean-René Ruez, T. 2378123782 (27 January 2012); P4308 (Book of photographs and maps prepared by Jean-René Ruez, 22 June 2009), e-court pp. 129, 282; P408 (Witness statement of Desimir Đukanović dated 23 March 2007), para. 8.

17946 Momir Nikolić, T. 24674-24675 (14 February 2012) (testifying that the security at the Vuk Karadžić School was provided, amongst others, by members of the MP Platoon); D2081 (Momir Nikolić's statement of facts from Plea Agreement, 7 May 2003), pp. 6-7 (stating that it was decided at the meeting between himself, Beara, Deronjić, and Vasić that elements of the Bratunac Brigade MP would provide security in Bratunac town); Mile Janjić, P1194 (Transcript from Prosecutor v. Blagojević \& Jokić), T. 9804, 9807-9808 (testifying that, following Momir Nikolić's instructions, he and other members of the MP Platoon guarded the Vuk Karadžić School, as well as the buses parked outside the school and on the streets of Bratunac town); Mile Janjić, P372 (Transcript from Prosecutor v. Popović et al.), T. 17934 (testifying further that members of the MP escorted buses carrying Bosnian Muslim men to the Vuk Karadžić school on 13 July), T. 17935-17936; Zlatan Čelanović, P377 (Transcript from Prosecutor v. Popović et al.), T. 6689-6690; Branimir Tešić T. 35245 (12 March 2013). See also Adjudicated Facts 1670, 1685.

17947 Momir Nikolić, T. 24674 (14 February 2012) (testifying that members of the Bratunac SJB provided security for the Vuk Karadžić School, and that detainees in the other facilities around Bratunac town were guarded mainly by police from various units, including members of the Bratunac SJB, PJPs, and civilian police). See also Adjudicated Fact 1670; Zlatan Čelanović, P377 (Transcript from Prosecutor v. Popović et al.), T. 6645, 6647; Srbislav Davidović, P4100 (Transcript from Prosecutor v. Popović et al.), T. 9213; Srbislav Davidović, T. 24411 (9 February 2012); Ljubisav Simić, T. 37289 (16 April 2013); KDZ107, P345 (Transcript from Prosecutor v. Popović et al.), T. 9494, 9526-9527; P4563 (Statement by KDZ122), p. 4 (under seal).

17948 See e.g. D2081 (Momir Nikolić's statement of facts from Plea Agreement, 7 May 2003), para. 9; Ahmo Hasić, P354 (Transcript from Prosecutor v. Popović et al.), T. 1222; KDZ039, P3940 (Transcript from Prosecutor v. Popović et al.), T. 17316, 17319; D1949 (Interview with KDZ039, 31 March 1996), p. 3; KDZ069, P339 (Transcript from Prosecutor v. Blagojević \& Jokić), T. 1397-1399; KDZ333, P4342 (Transcript from Prosecutor v. Krstić), T. 3027.

17949 KDZ039, T. 21939 (24 November 2011); KDZ039, P3940 (Transcript from Prosecutor v. Popović et al.), T. 17316; D1949 (Interview with KDZ039, 31 March 1996), p. 3.

17950 KDZ039, P3940 (Transcript from Prosecutor v. Popović et al.), T. 17319. See also Adjudicated Fact 1675. 
each vehicle. ${ }^{17952}$ KDZ069, who was detained on a bus at this location, testified that the detainees were pressed so tightly together that his body was numb. ${ }^{17953}$

5295. As detainees were forced to enter both the Vuk Karadžić School and the hangar behind the school, they were ordered to leave their belongings outside, including any food that they had brought with them. ${ }^{17954}$ Inside, they were deprived of food. ${ }^{17955}$ While some of the detainees held on buses parked around town were given food, it was not nearly enough. ${ }^{17956}$ Similarly, water was provided at the various detention facilities but it was not sufficient. ${ }^{17957}$

5296. Bosnian Muslim detainees held at the various locations in Bratunac town were constantly beaten by members of the Bosnian Serb Forces. ${ }^{17958}$ The sound of detainees groaning and screaming, bursts of machine gunfire, and blunt blows could be heard coming from the areas in which detainees were held. ${ }^{17959}$ Men were frequently taken away by members of the Bosnian Serb

\footnotetext{
17951 Ahmo Hasić, P354 (Transcript from Prosecutor v. Popović et al.), T. 1222.

17952 KDZ069, P339 (Transcript from Prosecutor v. Blagojević \& Jokić), T. 1398-1399. See also KDZ064, P769 (Transcript from Prosecutor v. Popović et al.), T. 666.

17953 KDZ069, P339 (Transcript from Prosecutor v. Blagojević \& Jokić), T. 1399.

17954 Ahmo Hasić, P354 (Transcript from Prosecutor v. Popović et al.), T. 1179-1180, 1252, 1259; KDZ039, P3940 (Transcript from Prosecutor v. Popović et al.), T. 17326.

17955 Ahmo Hasić, P354 (Transcript from Prosecutor v. Popović et al.), T. 1189-1190; KDZ039, P3940 (Transcript from Prosecutor v. Popović et al.), T. 17319, 17326; D1947 (Statement of KDZ039 to Tuzla SDB, 25 July 1995), p. 1. See also D2081 (Momir Nikolić's statement of facts from Plea Agreement, 7 May 2003), para. 9.

17956 Mevludin Orić, P350 (Transcript from Prosecutor v. Popović et al.), T. 919; KDZ064, P769 (Transcript from Prosecutor v. Popović et al.), T. 668. See also D2081 (Momir Nikolić's statement of facts from Plea Agreement, 7 May 2003), para. 10; Mile Janjić, P1194 (Transcript from Prosecutor v. Blagojević \& Jokić), T. 9848 .

17957 Ahmo Hasić, P354 (Transcript from Prosecutor v. Popović et al.), T. 1189-1190; KDZ039, P3940 (Transcript from Prosecutor v. Popović et al.), T. 17319, 17326; D1947 (Statement of KDZ039 to Tuzla SDB, 25 July 1995), p. 1; Mevludin Orić, P350 (Transcript from Prosecutor v. Popović et al.), T. 919; KDZ069, P339 (Transcript from Prosecutor v. Blagojević \& Jokić), T. 1399; KDZ333, T. 24150 (2 February 2012); KDZ064, P769 (Transcript from Prosecutor v. Popović et al.), T. 668; Mile Janjić, P1194 (Transcript from Prosecutor v. Blagojević \& Jokić), T. 9848; Srbislav Davidović, P4100 (Transcript from Prosecutor v. Popović et al.), T. 9213; Srbislav Davidović, T. 24411-24412 (9 February 2012). See also Adjudicated Facts 1668, 1671; D2081 (Momir Nikolić's statement of facts from Plea Agreement, 7 May 2003), para. 9. When detainees on the buses outside the Vihor Company Garages asked for water, the members of the Bosnian Serb Forces ordered them to be quiet and hit the sides of the bus with their rifles. KDZ069, P339 (Transcript from Prosecutor v. Blagojević \& Jokić), T. 1399.

17958 See e.g. Ahmo Hasić, P354 (Transcript from Prosecutor v. Popović et al.), T. 1180, 1222, 1252; KDZ039, P3940 (Transcript from Prosecutor v. Popović et al.), T. 17320-17321, 17323, 17387; D1949 (Interview with KDZ039, 31 March 1996), p. 3; KDZ064, P769 (Transcript from Prosecutor v. Popović et al.), T. 666; Mevludin Orić, P350 (Transcript from Prosecutor v. Popović et al.), T. 914, 1070. See also Adjudicated Fact 1673.

17959 Ahmo Hasić, P354 (Transcript from Prosecutor v. Popović et al.), T. 1187, 1222; KDZ064, P769 (Transcript from Prosecutor v. Popović et al.), T. 664, 667, 810-811; Mevludin Orić, P350 (Transcript from Prosecutor v. Popović et al.), T. 911, 913, 918-919; KDZ039, P3940 (Transcript from Prosecutor v. Popović et al.), T. 17320; KDZ039, T. 21944 (24 November 2011); D1949 (Interview with KDZ039, 31 March 1996), p. 2; KDZ333, P4342 (Transcript from Prosecutor v. Krstić), T. 3029; Mile Janjić, P1194 (Transcript from Prosecutor v. Blagojević \& Jokić), T. 9811-9812, 9851. See also Adjudicated Facts 1673, 1676.
} 
Forces and did not return. ${ }^{17960}$ On at least one occasion, members of the Bosnian Serb Forces brought beaten up detainees back into the hangar behind the Vuk Karadžić School and threatened the other detainees that this would be their fate too. ${ }^{17961}$ Some men had to hold detainees who were badly beaten due to the lack of space. ${ }^{17962}$ At the Vuk Karadžić School detainees had to be escorted to the toilet, and were beaten with rifle butts as they made their way there. ${ }^{17963}$ Later, the detainees were too afraid to go to the toilet, so they urinated where they were. ${ }^{17964}$

(B) Killings

\section{(1) Vuk Karadžić School}

5297. The Indictment refers to the killing of 50 or more Bosnian Muslim men inside and outside the Vuk Karadžić School and in the surrounding area, from approximately 10 p.m. on 12 July until the morning of 15 July 1995 . $^{17965}$

5298. Beginning on or about 10 p.m. on the night of 12 July 1995, members of the Bosnian Serb Forces entered the hangar behind the Vuk Karadžić School with flashlights, calling out for detainees from various villages to identify themselves. ${ }^{17966}$ Few detainees responded. ${ }^{17967}$ Members of the Bosnian Serb Forces then selected people at random with their flashlights, and ordered them to get up and leave. ${ }^{17968}$ When these detainees asked if they needed to take a bag with them, they were told that they would not need anything anymore. ${ }^{17969}$ Blunt blows, screaming, moaning, and the sound of throats being slit could be heard coming from outside the hangar. ${ }^{17970}$

\footnotetext{
17960 KDZ333, P4342 (Transcript from Prosecutor v. Krstić), T. 3029; Mevludin Orić, P350 (Transcript from Prosecutor v. Popović et al.), T. 915-919; KDZ064, P769 (Transcript from Prosecutor v. Popović et al.), T. 811; Ahmo Hasić, P354 (Transcript from Prosecutor v. Popović et al.), T. 1187-1188, 1252. See also Adjudicated Facts 1672, 1673.

17961 D1949 (Interview with KDZ039, 31 March 1996), p. 2 (testifying that when the members of the Bosnian Serb Forces brought the badly beaten detainees back into the hangar, they told the other detainees, "you will all be beaten like this"); KDZ039, P3940 (Transcript from Prosecutor v. Popović et al.), T. 17320-17321; D1947 (Statement of KDZ039 to Tuzla SDB, 25 July 1995), p. 2. See also Adjudicated Fact 1677.

17962 KDZ039, P3940 (Transcript from Prosecutor v. Popović et al.), T. 17321-17322; D1949 (Interview with KDZ039, 31 March 1996), pp. 2-3. See also Adjudicated Fact 1678.

17963 Ahmo Hasić, P354 (Transcript from Prosecutor v. Popović et al.), T. 1188-1189.

17964 Ahmo Hasić, P354 (Transcript from Prosecutor v. Popović et al.), T. 1189.

17965 Indictment, Scheduled Incident E.15.1.

17966 KDZ039, T. 21946-21947 (24 November 2011); KDZ039, P3940 (Transcript from Prosecutor v. Popović et al.), T. 17319; D1949 (Interview with KDZ039, 31 March 1996), p. 2. See Adjudicated Fact 1676.

17967 KDZ039, T. 21946-21947 (24 November 2011); KDZ039, P3940 (Transcript from Prosecutor v. Popovic et al.), T. 17319; D1949 (Interview with KDZ039, 31 March 1996), p. 2. See Adjudicated Fact 1676.

17968 KDZ039, P3940 (Transcript from Prosecutor v. Popović et al.), T. 17320; KDZ039, T. 21947 (24 November 2011); D1949 (Interview with KDZ039, 31 March 1996), p. 2. See Adjudicated Fact 1676.

17969 KDZ039, P3940 (Transcript from Prosecutor v. Popović et al.), T. 17320.

17970 KDZ039, P3940 (Transcript from Prosecutor v. Popović et al.), T. 17320; KDZ039, T. 21944 (24 November 2011); D1949 (Interview with KDZ039, 31 March 1996), p. 2. See also Mile Janjić, P1194 (Transcript from Prosecutor v. Blagojević \& Jokić), T. 9811-9812.
} 
According to KDZ039, who was detained inside, approximately 40 men were selected and removed from the hangar in this way during that first night. ${ }^{17971}$ Most of the detainees taken out of the hangar did not return. ${ }^{17972}$ However, on a few occasions, wounded detainees were brought back and some of them died overnight. ${ }^{17973}$

5299. On the morning of 13 July, detainees were made to carry those who had died overnight out of the hangar. ${ }^{17974}$ Ten detainees were then forced to load the bodies onto trucks and these men never returned. ${ }^{17975}$ That morning, detainees returning from the toilet next to the hangar were taken aside and killed. ${ }^{17976}$ On the way to the toilet, KDZ039 observed members of the Bosnian Serb Forces beating a detainee to death with an iron bar and an axe. ${ }^{17977}$ In the afternoon, a second group of trucks arrived to take away the dead bodies. ${ }^{17978}$ Again, ten detainees were ordered to load the bodies, and they were never seen again. ${ }^{17979}$

5300. The situation at the Vuk Karadžić School was no better than that of the hangar. Detainees were also frequently removed from the school by members of the Bosnian Serb Forces and did not return. ${ }^{17980}$ The sound of detainees groaning and screaming outside the school was constant. ${ }^{17981}$ While Ahmo Hasić was detained at the school, he saw six or seven men taken out of his room; they

17971 KDZ039, P3940 (Transcript from Prosecutor v. Popović et al.), T. 17320, 17324. KDZ039 testified that he saw a man he knew, Hamed Efendić, taken out of the hangar, and then he heard a shot and someone saying "he's dead. Drag him off." KDZ039, P3940 (Transcript from Prosecutor v. Popović et al.), T. 17321. The body of Hamed Efendić was exhumed from the Zeleni Jadar 5 secondary gravesite. See P4771 (Dušan Janc's report entitled "Update to the summary of Forensic Evidence - Exhumation of the Graves and Surface Remains Recoveries related to Srebrenica - January 2012", 13 January 2012), Annex D, e-court p. 370 (under seal).

17972 KDZ039, P3940 (Transcript from Prosecutor v. Popović et al.), T. 17320; KDZ039, T. 21944 (24 November 2011); D1949 (Interview with KDZ039, 31 March 1996), p. 2.

17973 KDZ039, P3940 (Transcript from Prosecutor v. Popović et al.), T. 17320-17321; D1949 (Interview with KDZ039, 31 March 1996), pp. 2-3. See Adjudicated Facts 1677, 1678.

17974 KDZ039, P3940 (Transcript from Prosecutor v. Popović et al.), T. 17322. See Adjudicated Fact 1679. KDZ039 was told by those who took the bodies out, that a pile of bodies could be seen behind the hangar. KDZ039, P3940 (Transcript from Prosecutor v. Popović et al.), T. 17322.

17975 KDZ039, P3940 (Transcript from Prosecutor v. Popović et al.), T. 17322; D1949 (Interview with KDZ039, 31 March 1996), p. 3. See Adjudicated Fact 1679.

17976 KDZ039, P3940 (Transcript from Prosecutor v. Popović et al.), T. 17322-17323; D1949 (Interview with KDZ039, 31 March 1996), p. 3. See Adjudicated Fact 1681.

17977 KDZ039, P3940 (Transcript from Prosecutor v. Popović et al.), T. 17323; KDZ039, T. 21943 (24 November 2011); D1949 (Interview with KDZ039, 31 March 1996), p. 3.

17978 KDZ039, P3940 (Transcript from Prosecutor v. Popović et al.), T. 17324; D1949 (Interview with KDZ039, 31 March 1996), p. 3. See Adjudicated Fact 1680. KDZ039 testified to having seen Mladić at the hangar that afternoon. KDZ039, P3940 (Transcript from Prosecutor v. Popović et al.), T. 17324-17325.

17979 KDZ039, P3940 (Transcript from Prosecutor v. Popović et al.), T. 17324. See Adjudicated Fact 1680.

17980 Ahmo Hasić, P354 (Transcript from Prosecutor v. Popović et al.), T. 1186-1188, 1223, 1252. See Adjudicated Fact 1672. The Accused concedes in his final brief that several tens of victims died as a result of killings in Bratunac town, including at the Vuk Karadžić School, but claims that these incidents were personal revenge killings. See Defence Final Brief, para. 2568.

17981 Ahmo Hasić, P354 (Transcript from Prosecutor v. Popović et al.), T. 1180, 1186-1187, 1222-1223. See also Adjudicated Facts 1673, 1684; Mevludin Orić, P350 (Transcript from Prosecutor v. Popović et al.), T. 918-919; Mile Janjić, P1194 (Transcript from Prosecutor v. Blagojević \& Jokić), T. 9811-9812. 
never returned. ${ }^{17982}$ At one point, a detainee was brutally beaten by a policeman on the head and shoulders - first with a hose and then with an automatic rifle- until he was covered in blood. ${ }^{17983}$ The detainee was then called outside by the same policeman; thereafter, screams and moans were heard and the detainee never returned. ${ }^{17984}$

5301. During the night of 13 July, detainees were also removed from the buses parked outside the Vuk Karadžić School by members of the Bosnian Serb Forces and taken to the school building. ${ }^{17985}$ Detainees on the buses heard screaming and gunfire, and many of the men who were taken off the buses did not return. ${ }^{17986}$ A Bosnian Serb man named "Ilija" boarded the buses and called out the names of detainees. ${ }^{17987}$ With the assistance of two unknown individuals, Ilija took detainees from the buses to the school on several occasions that night; those men were not seen again. ${ }^{17988}$

5302. Members of the Bratunac public utility company and the Bratunac Civilian Protection unit were involved in the collection of bodies from the Vuk Karadžić School and surrounding area, starting on 14 July. ${ }^{17989}$ Between 40 and 50 bodies were scattered across multiple classrooms on the ground and first floors. ${ }^{17990}$ Classrooms were riddled with bullet holes, and blood everywhere. ${ }^{17991}$ Đukanović estimated that he and his colleagues collected between 23 and 28 bodies from the Vuk Karadžić School, and between 27 and 33 bodies from the surrounding area. ${ }^{17992}$ The bodies collected from the Vuk Karadžić School and surrounding area were loaded on to trucks and transported to the Glogova gravesites. ${ }^{17993}$ Following the collection and

\footnotetext{
17982 Ahmo Hasić, P354 (Transcript from Prosecutor v. Popović et al.), T. 1187. According to Hasić, detainees were taken out of the room every couple of hours. Ahmo Hasić, P354 (Transcript from Prosecutor v. Popović et al.), T. 1187-1188.

17983 Ahmo Hasić, P354 (Transcript from Prosecutor v. Popović et al.), T. 1180, 1222, 1260. See Adjudicated Fact 1673.

17984 Ahmo Hasić, P354 (Transcript from Prosecutor v. Popović et al.), T. 1180, 1222. See Adjudicated Facts 1673, 1684.

17985 Mevludin Orić, P350 (Transcript from Prosecutor v. Popović et al.), T. 915-919; KDZ333, P4342 (Transcript from Prosecutor v. Krstić), T. 3029. See Adjudicated Fact 1683.

17986 Mevludin Orić, P350 (Transcript from Prosecutor v. Popović et al.), T. 915-919; KDZ333, P4342 (Transcript from Prosecutor v. Krstić), T. 3029. See also Adjudicated Facts 1683, 1684; Mile Janjić, P1194 (Transcript from Prosecutor v. Blagojević \& Jokić), T. 9811-9812.

17987 Mevludin Orić, P350 (Transcript from Prosecutor v. Popović et al.), T. 915, 918.

17988 Mevludin Orić, P350 (Transcript from Prosecutor v. Popović et al.), T. 915-919.

17989 [REDACTED]; P290 (Aerial photograph of Bratunac marked by KDZ107); P408 (Witness statement of Desimir Đukanović dated 23 March 2007), para. 5.

17990 [REDACTED].

17991 [REDACTED].

17992 P407 (Witness statement of Desimir Đukanović dated 20 March 2007), para. 5; P406 (Desimir Đukanović's evidence in BiH state court), pp. 1-4. See also Milenko Katanić, T. 24545 (10 February 2012).

17993 KDZ480, P4355 (Transcript from Prosecutor v. Blagojević \& Jokić), T. 7920 (under seal); KDZ480, T. 24261, 24267-24268 (8 February 2012) (closed session); P407 (Witness statement of Desimir Đukanović dated 20 March 2007), para. 6; P408 (Witness statement of Desimir Đukanović dated 23 March 2007, paras. 5, 7; P406 (Desimir Đukanović's evidence in BiH state court), p. 3; KDZ107, P345 (Transcript from Prosecutor v. Popović et al.), T. 9372, 9390-9391, 9544. See also Adjudicated Fact 1686; Zoran Petrović-Piroćanac, P376 (Transcript
} 
transportation of the bodies, between 20 and 30 women were assigned by the Bratunac municipality to clean the Vuk Karadžić School. ${ }^{17994}$

5303. Based on the above, the Chamber finds that at least 50 Bosnian Muslim men were killed by members of the Bosnian Serb Forces between 12 and 14 July 1995 inside the Vuk Karadžić School and in the surrounding area.

(2) Killing of mentally challenged man

5304. The Indictment refers to the killing on the evening of 13 July 1995 of a mentally challenged Bosnian Muslim man who was taken off a bus parked in front of the entrance of the Vuk Karadžić School in Bratunac and summarily executed. ${ }^{17995}$

5305. During the night of 13 July 1995, a mentally challenged man detained in one of the buses parked outside the Vuk Karadžić School fell asleep despite being told by members of the Bosnian Serb Forces not to do so. ${ }^{17996}$ A military policeman boarded the bus and hit him on the shoulder. ${ }^{17997}$ The man was woken suddenly and accidentally hit the policeman. ${ }^{17998}$ The policeman cursed the man, while two other military policemen dragged him off the bus in the direction of the school. ${ }^{17999}$ After the man was removed from the bus, Mevludin Orić, who was also on the bus, heard a short burst of gunfire, a scream, and someone saying "drag him into the school". 18000 The man was not seen again. ${ }^{18001}$

5306. The Chamber finds that on the evening of 13 July 1995, this mentally challenged man was killed by members of the Bosnian Serb Forces at the Vuk Karadžić School.

from Prosecutor v. Popović et al.), T. 18813, 18816-18818; D3659 (Witness statement of Ljubomir Borovčanin dated 30 May 2013), para. 39. See para. 5257.

17994 KDZ480, P4355 (Transcript from Prosecutor v. Blagojević \& Jokić), T. 7883-7884 (under seal); KDZ480, T. 24270-24271, (8 February 2012) (closed session). See also Adjudicated Fact 1687.

17995 Indictment, Scheduled Incident E.15.3. The Chamber notes that the Prosecution refers to this man as "mentally retarded" in the Indictment and "mentally ill" in its final brief. See Prosecution Final Brief, Appendix D, para. 95.

17996 Mevludin Orić, P350 (Transcript from Prosecutor v. Popović et al.), T. 911. In relation to the man's mental state, Orić testified that the detainees sitting next to him who probably knew him said that he was not entirely normal and that he was "crazy". Mevludin Orić, P350 (Transcript from Prosecutor v. Popović et al.), T. 911, 1072. See Adjudicated Fact 1688.

17997 Mevludin Orić, P350 (Transcript from Prosecutor v. Popović et al.), T. 911.

17998 Mevludin Orić, P350 (Transcript from Prosecutor v. Popović et al.), T. 911-912, 1071-1072. See Adjudicated Fact 1688.

17999 Mevludin Orić, P350 (Transcript from Prosecutor v. Popović et al.), T. 911-913, 1072. See Adjudicated Fact 1688. Orić added that the man struggled with the policemen, holding on to the seat of the bus so he had to be literally taken off; he physically resisted as they took him to the school. Mevludin Orić, P350 (Transcript from Prosecutor v. Popović et al.), T. 912-913.

18000 Mevludin Orić, P350 (Transcript from Prosecutor v. Popović et al.), T. 911-914, 1072-1073.

18001 Mevludin Orić, P350 (Transcript from Prosecutor v. Popović et al.), T. 913, 1072. See Adjudicated Fact 1688. 


\section{f. Zvornik}

\section{i. Introduction}

5307. As the Chamber has previously described, Zvornik is a municipality in eastern $\mathrm{BiH}$, located on the Drina River, which marks the boundary between BiH and Serbia. ${ }^{18002}$

5308. In July 1995, the area of responsibility of the Zvornik Brigade stretched along the west bank of the Drina River, from the mouth of the Drinjaca tributary in the south, to Pilica in the north. ${ }^{18003}$ It covered the most northern part of the Drina Corps' defence, including Kozluk, Zvornik, and Snagovo. ${ }^{18004}$ The Chamber recalls that the Zvornik Brigade headquarters, known as the Standard Barracks, was situated in Karakaj, about two kilometres north of Zvornik, along the Konjević Polje-Zvornik-Bijeljina Road, which followed the Drina River. ${ }^{18005}$ The Zvornik Brigade IKM was located in the village of Kitovnice, approximately 15 kilometres from the Standard Barracks, in the direction of Orahovac. ${ }^{18006}$

\section{ii. Lead-up to the events in Zvornik}

(1) Preparations in Bratunac between 13 and 14 July

5309. On the evening of 13 July at approximately 7 p.m., Drago Nikolić called Dragan Obrenović at the Standard Barracks and told him that Popović had just telephoned to inform him that a large number of Bosnian Muslims who were being detained in Bratunac would be transferred to Zvornik to be shot. ${ }^{18007}$ Drago Nikolić then reported that Popović had said the order came from Mladić, and that "everyone, including Pandurević was aware of [it]." "18008 Popović told Drago Nikolić that he would send someone to brief him in person and give him additional information. ${ }^{18009}$ Drago Nikolić then asked Obrenović to be relieved from his duties at the IKM, and requested the assistance of the Zvornik Brigade MP Company to be able to carry out the task given to him. ${ }^{18010}$ Obrenović agreed to relieve Nikolić and to send five military policemen and Miomir Jasikovac, the

\footnotetext{
18002 See para. 1228.

18003 P4941 (Srebrenica court binder containing maps), e-court p. 6; P4091 (Map of Srebrenica and Zvornik).

18004 P4941 (Srebrenica court binder containing maps), e-court p. 6.

18005 See para. 198; P4308 (Book of photographs and maps prepared by Jean-René Ruez, 22 June 2009), e-court p. 248.

18006 Milorad Birčaković, P360 (Transcript from Prosecutor v. Popović et al.), T. 11013; P4564 (Map of Zvornik Brigade operations region) (the IKM is marked with number 4).

18007 [REDACTED]. But see D3993 (Witness statement of Vujadin Popović dated 2 November 2013), para. 40 (stating that he only heard of the assignment from Beara the following morning).

18008 [REDACTED]. Nikolić also told Obrenović that Beara and Popović were in charge of the assignment. [REDACTED].

18009 [REDACTED].

18010 [REDACTED].
} 
Commander of the Zvornik Brigade MP Company, ${ }^{18011}$ in order to assist him. ${ }^{18012}$ Jasikovac arrived at the Standard Barracks at approximately 8 p.m., and was ordered by Obrenović to gather five or six of his men and await further orders from Drago Nikolić. ${ }^{18013}$

5310. Momir Nikolić testified that he met with Beara in Bratunac town on the evening of 13 July, and was ordered to meet with Drago Nikolić and convey the decision that detainees in Bratunac were to be transferred to the Zvornik Brigade area of responsibility, and that Drago had to prepare facilities and security for the transfer and detention of these men. ${ }^{18014}$ Momir Nikolić understood from this exchange that the detainees would be executed in Zvornik municipality. ${ }^{18015}$ As instructed, Momir Nikolić then drove to Zvornik and conveyed the order to Drago Nikolić. ${ }^{18016}$ Drago Nikolić replied that he would inform his command. ${ }^{18017}$ Momir Nikolić returned to Bratunac town at around midnight and reported to Beara at the Hotel Fontana. ${ }^{18018}$

5311. At 8:10 p.m., Deronjić spoke to the Accused via an intermediary and informed him that there were 2,000 detainees in Bratunac and that more were expected to arrive during the night. ${ }^{18019}$ The conversation unfolded as follows:

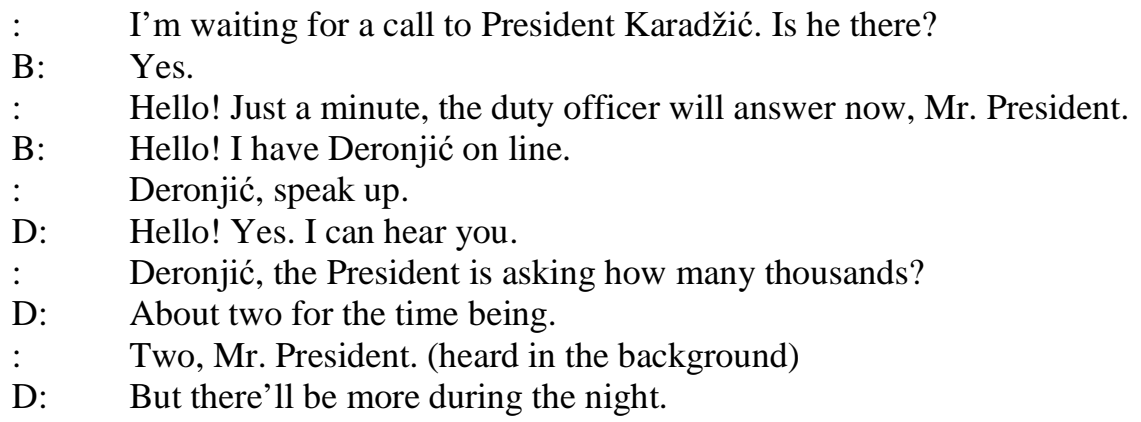

18011 Milorad Birčaković, P360 (Transcript from Prosecutor v. Popović et al.), T. 11012, 11116; D2266 (Nada Stojanović's interview with OTP), pp. 5-6; KDZ407, P378 (Transcript from Prosecutor v. Popović et al.), T. 6440, 6479-6481 (under seal). See also P4914 (Richard Butler's expert report entitled "Srebrenica Military Narrative (Revised): Operation 'Krivaja 95”', 1 November 2002), para. 7.7.

18012 [REDACTED]; P4582 (Zvornik Brigade IKM Operations Duty logbook, July-October 1995), p. 6.

18013 [REDACTED].

18014 Momir Nikolić, T. 24666-24669, 24679 (14 February 2012); D2081 (Momir Nikolić's statement of facts from Plea Agreement, 7 May 2003), para. 10. The Chamber refers to its assessment of Beara's testimony regarding his whereabouts on 13 and 14 July, as discussed in fn. 17583.

18015 Momir Nikolić, T. 24668-24669 (14 February 2012).

18016 Momir Nikolić, T. 24670-24671 (14 February 2012); D2081 (Momir Nikolić's statement of facts from Plea Agreement, 7 May 2003), para. 10.

18017 Momir Nikolić, T. 24671 (14 February 2012); D2081 (Momir Nikolić's statement of facts from Plea Agreement, 7 May 2003), para. 10.

18018 Momir Nikolić, T. 24672, 24676 (14 February 2012); D2081 (Momir Nikolić's statement of facts from Plea Agreement, 7 May 2003), para. 10.

18019 P6692 (Intercept of conversation between Radovan Karadžić, his intermediary, and Miroslav Deronjić, 13 July 1995), p. 1. The Accused acknowledges that this telephone call took place, and that Deronjić informed him of the large number of detainees in Bratunac. See Defence Final Brief, confidential, paras. 2537, 3025-3026. See also KDZ126, T. 26400-26404 (15 March 2012). 
$[\ldots]$

D: $\quad$ Can you hear me, President?

: $\quad$ The President can't hear you, Deronjić, this is the intermediary.

D: $\quad$ I have about two thousand here now by [...]

: Deronjić, the President says: "All the goods must be placed inside the warehouses before twelve tomorrow."

D: Right.

: Deronjić, not in the warehouses over there, but somewhere else.

D: Understood.

: $\quad$ Goodbye. ${ }^{18020}$

5312. Soon after reporting to Beara at Hotel Fontana, Momir Nikolić drove him to the Bratunac SDS Office to meet with Deronjić and Vasić. ${ }^{18021}$ At the meeting, Beara and Deronjić argued about where to kill the detainees; it was already openly agreed that the detainees would be executed. ${ }^{18022}$ Despite Beara's orders earlier that day to prepare facilities and security for the transfer of detainees to Zvornik, Beara insisted that he had instructions from "his boss" that the detainees should remain in Bratunac. ${ }^{18023}$ Deronjić replied that he did not want anyone to be killed in Bratunac and that he had received instructions from the Accused that all of the Bosnian Muslim men being detained in Bratunac should be transferred to Zvornik. ${ }^{18024}$ Eventually, Beara and Deronjić reached an agreement to transfer the detainees to the area of responsibility of the Zvornik Brigade in the

18020 P6692 (Intercept of conversation between Radovan Karadžić, his intermediary, and Miroslav Deronjić, 13 July 1995), p. 1. See KDZ126, T. 26400-26403 (15 March 2012) (noting that he recorded this conversation).

18021 Momir Nikolić, T. 24676 (14 February 2012); D2081 (Momir Nikolić's statement of facts from Plea Agreement, 7 May 2003), para. 10. See also P4374 (Witness statement of Milenko Katanić dated 11 October 2011), paras. 85-87 (stating that Beara was present at the Bratunac SDS Office on 13 July), 95 (referring to the presence of Vasić and Momir Nikolić at the SDS Office that day); KDZ480, P4355 (Transcript from Prosecutor v. Blagojević \& Jokić), T. 7875-7876 (under seal).

18022 Momir Nikolić, T. 24677-24678 (14 February 2012). See also P4374 (Witness statement of Milenko Katanić dated 11 October 2011), paras. 84 (stating that Deronjć told him he had a very unpleasant conversation with Beara regarding the Bosnian Muslim prisoners and the location where they would be imprisoned) and 93 (stating that Deronjić told him that Beara was searching for a location "probably to kill the prisoners" in Bratunac and that the Accused assisted Deronjić by lending his support to the idea of relocating the detainees so that they were not killed in Bratunac). Momir Nikolić testified that after driving Beara to the Bratunac SDS office, he waited in the reception area next to Deronjić's office where he could hear the entire meeting. Momir Nikolić, T. $24676-24677$ (14 February 2012). The Accused challenges Momir Nikolić's evidence on this meeting as unreliable and unacceptable without corroboration. See Defence Final Brief, paras. 3039-3040. Having assessed Momir Nikolić's evidence, the Chamber is satisfied of the truthfulness and reliability of his account of the meeting between Beara, Vasić, and Deronjić.

18023 Momir Nikolić, T. 24677, 24679-24680 (14 February 2012). Momir Nikolić acknowledged that Beara's conduct in this meeting was contrary to his earlier order to inform Drago Nikolić that detainees were to be transferred to Zvornik, but testified that "especially on the 13th, [decisions] changed rapidly. So first you would receive one order and half an hour later the order was amended, you would receive a different order, and that was the situation that prevailed in Bratunac at the time, and in particular on the 13th when there were many problems". Momir Nikolić, T. 24677-24680 (14 February 2012).

18024 Momir Nikolić, T. 24677-24679 (14 February 2012); D2081 (Momir Nikolić's statement of facts from Plea Agreement, 7 May 2003), para. 10. See also Srbislav Davidović, T. 24415-24416, 24452-24453 (9 February 2012); Milenko Katanić, T. 24496 (10 February 2012); P4374 (Witness statement of Milenko Katanić dated 11 October 2011), paras. 91-93. 
following days. ${ }^{18025}$ After the meeting, Momir Nikolić went to the Bratunac Brigade Command and informed Blagojević and other personnel of the plan. ${ }^{18026}$

\section{(2) Transportation of detainees from Bratunac to Zvornik}

5313. The transportation of detainees from the Bratunac area to Zvornik began on the night of 13 July. ${ }^{18027}$ The Bosnian Muslim men detained at the hangar behind the Vuk Karadžić School were forced to board six buses which departed in the direction of Zvornik. ${ }^{18028}$ Momir Nikolić saw buses "full of people" heading in the direction of Zvornik at around midnight. ${ }^{18029}$

5314. Early on the morning of 14 July, Beara and Popović drove to the Standard Barracks to meet with Drago Nikolić. ${ }^{18030}$ After the meeting, Beara ordered Popović to organise a convoy to transport the detainees from Bratunac to the buildings in Zvornik which had been designated for their detention. ${ }^{18031}$ Drago Nikolić ordered his driver, Milorad Birčaković, to drive him to Hotel Vidikovac, located two kilometres from Zvornik. ${ }^{18032}$ Meanwhile, Popović and Beara returned to the Bratunac Brigade Command where Beara ordered Momir Nikolić to help form the convoy. ${ }^{18033}$

5315. Soon after, Popović started forming the convoy with Momir Nikolić's assistance. ${ }^{18034}$ Two members of the Bratunac Brigade MP were ordered to assist with the escort of detainees to Zvornik, by driving an APC that had been seized from DutchBat and parking it at the edge of Bratunac town. ${ }^{18035}$ Throughout the morning, vehicles from various sites in and around Bratunac

18025 Momir Nikolić, T. 24678 (14 February 2012). See also P4374 (Witness statement of Milenko Katanić dated 11 October 2011), paras. 91-93.

18026 Momir Nikolić, T. 24680-24681 (14 February 2012); D2081 (Momir Nikolić's statement of facts from Plea Agreement, 7 May 2003), para. 10.

18027 KDZ039, P3940 (Transcript from Prosecutor v. Popović et al.), T. 17327-17328; Momir Nikolić, T. 2467124672 (14 February 2012); D2081 (Momir Nikolić's statement of facts from Plea Agreement, 7 May 2003), para. 10. See also Jean-René Ruez, T. $23784-23785$ (27 January 2012); P4308 (Book of photographs and maps prepared by Jean-René Ruez, 22 June 2009), e-court p. 132.

18028 KDZ039, P3940 (Transcript from Prosecutor v. Popović et al.), T. 17327-17328.

18029 Momir Nikolić, T. 24671 (14 February 2012); D2081 (Momir Nikolić's statement of facts from Plea Agreement, 7 May 2003), para. 10. Kovač also acknowledged being at the Hotel Vidikovac that evening and seeing buses in Zvornik transporting detainees from Srebrenica. Tomislav Kovač, T. 42776-42778 (1 November 2013); D3960 (Witness Statement of Tomislav Kovač dated 28 October 2013), para. 126.

18030 Milorad Birčaković, P360 (Transcript from Prosecutor v. Popović et al.), T. 11013-11015. See also D3993 (Witness statement of Vujadin Popović dated 2 November 2013), para. 41. The Chamber refers to its assessment of Beara's testimony regarding his whereabouts on 13 and 14 July, as discussed in fn. 17583.

18031 D3993 (Witness statement of Vujadin Popović dated 2 November 2013), para. 42. See also P4374 (Witness statement of Milenko Katanić dated 11 October 2011), para. 91; Adjudicated Fact 1749.

18032 Milorad Birčaković, P360 (Transcript from Prosecutor v. Popović et al.), T. 11011, 11017.

18033 D3993 (Witness statement of Vujadin Popović dated 2 November 2013), para. 44.

18034 D3993 (Witness statement of Vujadin Popović dated 2 November 2013), para. 45.

18035 KW582, D4291 (Transcript from Prosecutor v. Blagojević \& Jokić), T. 3557-3561, 3677-3678; Mile Petrović, T. 45553 (17 January 2014); Momir Nikolić, T. 24681-24682 (14 February 2012); D2081 (Momir Nikolić's statement of facts from Plea Agreement, 7 May 2003), para. 11. 
town were driven towards the edge of town where the APC was waiting. ${ }^{18036}$ Detainees on some vehicles waited for several hours for the entire convoy to assemble. ${ }^{18037}$ By the end of this process, a column was formed which consisted of between 30 and 50 buses and some trucks, and was approximately one to one and a half kilometres in length. ${ }^{18038}$

5316. The convoy left Bratunac for Zvornik around noon, heading in the direction of Konjević Polje, with Popović in the Golf leading the way, followed by the APC. ${ }^{18039}$ The convoy was escorted by the same members of the Bratunac Brigade MP and MUP who had guarded the detention facilities in Bratunac in the preceding days, as well as by other members of the Bosnian Serb Forces. ${ }^{18040}$ It took between an hour and an hour and a half for the first part of the convoy to reach Hotel Vidikovac. ${ }^{18041}$ At this time, Drago Nikolić, Birčaković, and Mane Đurić were at the hotel. ${ }^{18042}$ Shortly after the convoy arrived, Drago Nikolić ordered Birčaković to board the first bus. ${ }^{18043}$ Escorted by Popović, the first part of the convoy went on to the Orahovac School. ${ }^{18044}$

18036 See KW582, D4291 (Transcript from Prosecutor v. Blagojević \& Jokić), T. 3561; Mevludin Orić, P350 (Transcript from Prosecutor v. Popović et al.), T. 934; KDZ069, P339 (Transcript from Prosecutor v. Blagojević \& Jokić), T. 1399; KDZ064, P769 (Transcript from Prosecutor v. Popović et al.), T. 674.

18037 Mevludin Orić, P350 (Transcript from Prosecutor v. Popović et al.), T. 934 (testifying that the detainees were told that they were waiting for UNPROFOR to come); KDZ069, P339 (Transcript from Prosecutor v. Blagojević \& Jokić), T. 1399; KDZ064, P769 (Transcript from Prosecutor v. Popović et al.), T. 674-675 (testifying that he heard "them" shouting: "We're waiting for the UNPROFOR."). See also KW582, D4291 (Transcript from Prosecutor v. Blagojević \& Jokić), T. 3560-3561, 3678.

18038 Momir Nikolić, T. 24681 (14 February 2012); D2081 (Momir Nikolić's statement of facts from Plea Agreement, 7 May 2003), para. 11; D3993 (Witness statement of Vujadin Popović dated 2 November 2013), paras. 45-46; Mane Đurić, T. 35082 (7 March 2013). See also Adjudicated Fact 1747; KDZ064, P769 (Transcript from Prosecutor v. Popović et al.), T. 675-676.

18039 D3993 (Witness statement of Vujadin Popović dated 2 November 2013), para. 47; Vujadin Popović, T. 43059 (6 November 2013); Momir Nikolić, T. 24681 (14 February 2012); KW582, D4291 (Transcript from Prosecutor v. Blagojević \& Jokić), T. 3561; KDZ069, P339 (Transcript from Prosecutor v. Blagojević \& Jokić), T. 14001401; Mevludin Orić, P350 (Transcript from Prosecutor v. Popović et al.), T. 935, 940-941; P268 (Map of BiH marked by Mevludin Orić); KDZ064, P769 (Transcript from Prosecutor v. Popović et al.), T. 675-676. See also KDZ333, P4342 (Transcript from Prosecutor v. Krstić), T. 3029-3031; KDZ045, P5910 (Transcript from Prosecutor v. Krstić), T. 2961-2962; Adjudicated Fact 1748.

18040 Momir Nikolić, T. 24681-24682 (14 February 2012); Milorad Birčaković, P360 (Transcript from Prosecutor v. Popović et al.), T. 11019, 11085, 11122, 11149-11150, 11154; P169 (Bratunac Brigade Military Police log, 30 June-21 July 1995), p. 14. See also KDZ407, P379 (Transcript from Prosecutor v. Popović et al.), T. 6446, 6449, 6475-6476; KDZ333, P4342 (Transcript from Prosecutor v. Krstić), T. 3031; KDZ045, P5910 (Transcript from Prosecutor v. Krstić), T. 2962; Adjudicated Facts 1751, 1752.

18041 KW582, D4291 (Transcript from Prosecutor v. Blagojević \& Jokić), T. 3678-3679; Milorad Birčaković, P360 (Transcript from Prosecutor v. Popović et al.), T. 11017-11018; Mane Đurić, T. 35041, 35081-35082 (7 March 2013). See also Momir Nikolić, T. 24670 (14 February 2012). Birčaković testified that he saw between five and ten buses arrive at the Hotel Vidikovac at around 8:30 or 9 a.m.. Milorad Birčaković, P360 (Transcript from Prosecutor v. Popović et al.), T. 11017-11018. The Chamber notes that the Prosecution relies on Birčaković's evidence and several other witnesses in relation to the time that the convoy left Bratunac and subsequently reached the Hotel Vidikovac. See Prosecution Final Brief, Appendix D, p. 34, fns. 376, 382. Given the significant body of credible evidence suggesting that the convoy reached the Hotel Vidikovac in the early afternoon, the Chamber finds that the events which Birčaković refers to occurred later in the day. This inaccuracy aside, the Chamber is satisfied that Birčaković's evidence was reliable and of probative value, and therefore had no difficulty in relying upon it.

18042 Milorad Birčaković, P360 (Transcript from Prosecutor v. Popović et al.), T. 11017-11018; Mane Đurić, T. 35041 (7 March 2013).

18043 Milorad Birčaković, P360 (Transcript from Prosecutor v. Popović et al.), T. 11019-11020, 11054-11055. 
The movement of the convoy from Hotel Vidikovac continued throughout the day; other vehicles went to the Petkovci School, ${ }^{18045}$ Ročević School, ${ }^{18046}$ and Kula School in Pilica. ${ }^{18047}$

\section{iii. Detentions and Killings}

\section{(1) Orahovac School and field near Orahovac}

\section{(a) Introduction}

5317. The Indictment refers to the killing on or about 14 July 1995 of two Bosnian Muslim detainees who were held at the school in Orahovac; the two detainees were removed from the school and summarily executed by rifle fire. ${ }^{18048}$ The Indictment also refers to the killing on 14 July 1995 of approximately 1,000 Bosnian Muslim men who were detained at the school in Orahovac, blindfolded, transported to a nearby field by truck, and summarily executed. According to the Indictment, the bodies of the victims were buried in mass graves at the execution site on 14 and 15 July $1995 .{ }^{18049}$

18044 D3993 (Witness statement of Vujadin Popović dated 2 November 2013), paras. 49-50; Milorad Birčaković, P360 (Transcript from Prosecutor v. Popović et al.), T. 11019-11020, 11054-11055; KDZ407, P379 (Transcript from Prosecutor v. Popović et al.), T. 6446, 6449, 6468-6469. See also Adjudicated Facts 1755, 1769; KDZ039, T. 21958 (28 November 2011); KDZ039, P3940 (Transcript from Prosecutor v. Popović et al.), T. 17333; Mevludin Orić, P350 (Transcript from Prosecutor v. Popović et al.), T. 937; KDZ064, P769 (Transcript from Prosecutor v. Popović et al.), T. 677, 679, 759-760; KW582, D4291 (Transcript from Prosecutor v. Blagojević \& Jokić), T. 3563-3564, 3679-3680. See para. 5320.

18045 KDZ069, P339 (Transcript from Prosecutor v. Blagojević \& Jokić), T. 1401-1402; KDZ069, P339 (Transcript from Prosecutor v. Popović et al.), T. 3337; KDZ045, P5910 (Transcript from Prosecutor v. Krstić), T. 2962 2964. See also Adjudicated Fact 1790. See para. 5358.

18046 See D3993 (Witness statement of Vujadin Popović dated 2 November 2013), paras. 41, 52; Mile Janjić, P372 (Transcript from Prosecutor v. Popović et al.), T. 17948, 17950-17951, 17998. See para. 5385.

18047 Ahmo Hasić, P354 (Transcript from Prosecutor v. Popović et al.), T. 1192-1193, 1223, 1291-1292; KDZ333, P4342 (Transcript from Prosecutor v. Krstić), T. 3030-3032; KDZ333, T. 24124-24125, 24151 (2 February 2012); P4347 (Photograph of Kula School marked by KDZ333); Rajko Babić, P361 (Transcript from Prosecutor v. Popović et al.), T. 10221-10223. See para. 5417. The Chamber notes that Ahmo Hasić testified that he arrived at Pilica on 15 July. Ahmo Hasić, P354 (Transcript from Prosecutor v. Popović et al.), T. 1193, 1227. However, having compared Hasić's evidence with the totality of evidence received by the Chamber in relation to this killing incident, as discussed in Section C.1.f.iii.4: Kula School and Pilica Cultural Centre, the Chamber considers that Hasić arrived at Kula School on 14 July. The Chamber heard evidence that the vehicles heading to Kula School stopped near Pilica for between an hour and an hour and a half; while they were stopped, a Bosnian Muslim detainee who had been standing in the aisle of one of the buses appeared to lie down; when he did not move again, the other detainees discovered that he had died, and his body was put on the side of the road. Ahmo Hasić, P354 (Transcript from Prosecutor v. Popović et al.), T. 1191-1192, 1291. Another detainee got permission to leave the bus in order to urinate and, when he attempted to flee, the Serb soldiers "cut him down with a burst of gunfire". Ahmo Hasić, P354 (Transcript from Prosecutor v. Popović et al.), T. 1191-1192, 1272-1274. Hasić testified that he did not see the man being killed, but was told by other detainees standing in front of the bus that he was killed. Ahmo Hasić, P354 (Transcript from Prosecutor v. Popović et al.), T. 12731274. This killing is not charged in the Indictment. 
5318. The village of Orahovac is located northwest of Zvornik, ${ }^{18050}$ within the area of responsibility of the $4^{\text {th }}$ Battalion of the Zvornik Brigade. ${ }^{18051}$ The Orahovac School, also known as Grbavci School, ${ }^{18052}$ is located near Orahovac, on the main road towards Križevići, approximately 12 kilometres away from the Standard Barracks in Karakaj. ${ }^{18053}$ The Orahovac School complex is composed of a main building, a gymnasium connected to the main building by a corridor, and a large playground located between the gymnasium and the main road. ${ }^{18054}$

(b) Detention at the Orahovac School and killing of two men

5319. A detachment of the Zvornik Brigade MP Company was sent to the Orahovac School on the night of 13 July; its members were told by Jasikovac that they were to provide security for detainees who were expected to arrive at the school. ${ }^{18055}$ Once at the school, the detachment followed Jasikovac's orders, and started making the necessary preparations. ${ }^{18056}$ At some point on 14 July, other members of the Zvornik Brigade-including members of the $4^{\text {th }}$ Battalion-were also present at the school. ${ }^{18057}$

18050 P4308 (Book of photographs and maps prepared by Jean-René Ruez, 22 June 2009), e-court p. 132; P4091 (Map of Srebrenica and Zvornik); P3187 (Map of Zvornik municipality).

18051 P4914 (Richard Butler's expert report entitled "Srebrenica Military Narrative (Revised): Operation 'Krivaja 95'”, 1 November 2002), para. 7.6. See Adjudicated Fact 1753.

18052 Jean-René Ruez, T. 23788 (27 January 2012). See also P4308 (Book of photographs and maps prepared by Jean-René Ruez, 22 June 2009), e-court p. 133.

18053 KDZ407, P378 (Transcript from Prosecutor v. Popović et al.), T. 6445 (under seal); P3187 (Map of Zvornik municipality). See also P4308 (Book of photographs and maps prepared by Jean-René Ruez, 22 June 2009), ecourt pp. 132, 133; P212 (Photograph of Orahovac school).

18054 Jean-René Ruez, T. 23787-23788 (27 January 2012); P4308 (Book of photographs and maps prepared by JeanRené Ruez, 22 June 2009), p. 133; P4291 (Aerial image of Orahovac school marked by Jean-René Ruez); P4293 (Video footage of Orahovac School).

18055 KDZ407, P379 (Transcript from Prosecutor v. Popović et al.), T. 6446; KDZ407, P378 (Transcript from Prosecutor v. Popović et al.), T. 6444-6445, 6447, 6479-6480 (under seal); P4914 (Richard Butler's expert report entitled "Srebrenica Military Narrative (Revised): Operation 'Krivaja 95'”, 1 November 2002), para. 7.8. See also P6191 (Excerpt from tactical intercepts notebook), p. 2 (referring to a request "to send security for Orahovac"); P4948 (Zvornik Brigade Military Police attendance roster, July 1995); D2266 (Nada Stojanović's interview with OTP), pp. 11-12; P4563 (Statement by KDZ122), p. 1 (under seal); Adjudicated Facts 1754, 1771. The Prosecution claims that the Zvornik Brigade MP attendance roster for 14 July 1995 was altered to conceal the presence and involvement of MPs in the murder operation at Orahovac. See Prosecution Final Brief, Appendix D, confidential, fn. 400; Richard Butler, T. 27562-27564 (18 April 2012). According to the Prosecution, this is consistent with other alterations made with respect to other execution sites. See Prosecution Final Brief, Appendix D, confidential, fn. 499 (referring to the altering of the roster for 15 July to conceal the presence of MP members at Ročević School). See also fn. 18368. The Chamber has reviewed the relevant entries of the duty roster and has found indicia of an apparent alteration. Thus, in light of the evidence demonstrating that members of the Zvornik Brigade's MP Company were present at the Orahovac School on 14 July, and the fact that attempts were also made to conceal the unit's presence at the Ročević School on 15 July, the Chamber finds that the attendance roster was indeed altered in an attempt to conceal the presence of members of the Zvornik Brigade MP Company at the Orahovac School on 14 July 1995.

18056 KDZ407, P379 (Transcript from Prosecutor v. Popović et al.), T. 6446-6447.

18057 Tanacko Tanić, P369 (Transcript from Prosecutor v. Popović et al.), T. 10334-10335, 10382-10383; KDZ407, P379 (Transcript from Prosecutor v. Popović et al.), T. 6448-6449; Milorad Birčaković, P360 (Transcript from Prosecutor v. Popović et al.), T. 11020-11021, 11123-11124; KDZ122, T. 26120 (12 March 2012) (closed session); P4563 (Statement by KDZ122), pp. 2, 5 (under seal). See also Adjudicated Fact 1770; D2266 (Nada 
5320. Around 2 a.m., a convoy of four to six buses carrying approximately 300 men, which had set out earlier from Bratunac, arrived at the Orahovac School. ${ }^{18058}$ Buses continued arriving from Bratunac into the early afternoon of 14 July. ${ }^{18059}$ At least one of these convoys was led by an UNPROFOR APC driven by VRS soldiers. ${ }^{18060}$ Members of the civilian police wearing blue uniforms were on some of the buses together with the detainees. ${ }^{18061}$

5321. As the buses arrived, they pulled over in the playground in front of the school. ${ }^{18062}$ Upon disembarking, the detainees were ordered to run to the gymnasium. ${ }^{18063}$ They were escorted by the policemen who had been on the buses with them. ${ }^{18064}$ The gymnasium was guarded by members of the Zvornik Brigade MP at both of its entrances. ${ }^{18065}$ The detainees had to leave their belongings outside. $^{18066}$

Stojanović's interview with OTP), p. 25. The Chamber received evidence that reinforcements from the Zvornik Brigade's $4^{\text {th }}$ Battalion were sent to the school at the request of Trbić, Drago Nikolić's deputy. P4563 (Statement by KDZ122), p. 5 (under seal). See KDZ122, T. 26120 (12 March 2012) (closed session).

18058 KDZ039, T. 21958 (28 November 2011); KDZ039, P3940 (Transcript from Prosecutor v. Popović et al.), T. 17325, 17327-17328, 17332, 17358. See para. 5313.

18059 Mevludin Orić, P350 (Transcript from Prosecutor v. Popović et al.), T. 944 (testifying that he arrived at the Orahovac School around noon); KDZ064, P769 (Transcript from Prosecutor v. Popović et al.), T. 759-760 (testifying that he arrived at the school either in the afternoon or evening, and explaining that "summer days are very long"). But see KDZ039, T. 21958 (28 November 2011); KDZ039, P3940 (Transcript from Prosecutor v. Popovic et al.), T. 17333, 17363 (testifying that the last detainees arrived the gymnasium around 10 a.m. and that no detainees were brought in the afternoon); Adjudicated Fact 1755 (referring to the arrival to the Orahovac School of 30 vehicles on 14 July). See also KDZ407, P379 (Transcript from Prosecutor v. Popović et al.), T. 6449, 6468-6469 (referring to the arrival of between 10 and 15 buses at the school on 14 July).

18060 Mevludin Orić, P350 (Transcript from Prosecutor v. Popović et al.), T. 934-935, 938; Mile Petrović, T. 45553 (17 January 2014). KDZ064 testified that, upon his arrival at the Orahovac School, he saw an UNPROFOR APC parked in the playground. KDZ064, P769 (Transcript from Prosecutor v. Popović et al.), T. 677, 679, 683.

KDZ407 explained that the policemen were dressed in blue combat overalls, some were armed and some were wearing flak jackets. KDZ407, P379 (Transcript from Prosecutor v. Popović et al.), T. 6446, 6449, 6475. He recognised some civilian policemen from Zvornik who were not part of the Zvornik Brigade. KDZ407, P379 (Transcript from Prosecutor v. Popović et al.), T. 6476; KDZ407, P378 (Transcript from Prosecutor v. Popović et al.), 6481-6482 (under seal). See also D3993 (Witness statement of Vujadin Popović dated 2 November 2013), paras. 42, 44; Mane Đurić, T. 35051-35053 (7 March 2013); P6191 (Excerpt from tactical intercepts notebook), p. 2 (referring to a request "to send security for Orahovac").

18062 KDZ064, P769 (Transcript from Prosecutor v. Popović et al.), T. 677, 684, 686, 848; P770 (Photograph of Orahovac school); P771 (Photograph of Orahovac school).

18063 Mevludin Orić, P350 (Transcript from Prosecutor v. Popović et al.), T. 937; KDZ064, P769 (Transcript from Prosecutor v. Popović et al.), T. 677; KDZ039, P3940 (Transcript from Prosecutor v. Popović et al.), T. 17328 17329; KDZ407, P379 (Transcript from Prosecutor v. Popović et al.), T. 6449; Milorad Birčaković, P360 (Transcript from Prosecutor v. Popović et al.), T. 11020. See also P772 (Photograph of Orahovac school); P773 (Photograph of the interior of Orahovac school); P774 (Photograph of the interior of Orahovac school); P3944 (Photograph of gymnasium at Orahovac school); Jean-René Ruez, T. 23788 (27 January 2012); P4308 (Book of photographs and maps prepared by Jean-René Ruez, 22 June 2009), e-court p. 134.

18064 KDZ407, P379 (Transcript from Prosecutor v. Popović et al.), T. 6446, 6449, 6475-6476; KDZ407, P378 (Transcript from Prosecutor v. Popović et al.), T. 6481 (under seal); Milorad Birčaković, P360 (Transcript from Prosecutor v. Popović et al.), T. 11086, 11122, 11150-11151, 11154. Between 7 and 15 of these policemen were present at the school. KDZ407, P379 (Transcript from Prosecutor v. Popović et al.), T. 6475-6476; Milorad Birčaković, P360 (Transcript from Prosecutor v. Popović et al.), T. 11122-11123.

18065 KDZ407, P379 (Transcript from Prosecutor v. Popović et al.), T. 6454, 6484; KDZ039, P3940 (Transcript from Prosecutor v. Popović et al.), T. 17346. See also Jean-René Ruez, T. 23789 (27 January 2012); P4308 (Book of photographs and maps prepared by Jean-René Ruez, 22 June 2009), e-court p. 135 . KDZ064 described these 
5322. At some point, a crowd of about 100 hostile locals gathered near the school and made comments that all of the detainees ought to be killed. ${ }^{18067}$ Members of the Zvornik Brigade had to control the crowd. ${ }^{18068}$

5323. Once all the detainees had entered, they filled the entire gymnasium. ${ }^{18069}$ The Chamber received evidence that anywhere between 500 and 2,500 Bosnian Muslim men were detained at the Orahovac School. ${ }^{18070}$ The approximate age range of the detainees at the gymnasium was 15 to 70 years old, but there were also four 10 to 14 years old boys. ${ }^{18071}$

5324. The detainees were ordered to sit with their knees touching their chests, and were told that they would be shot if they did not comply. ${ }^{18072}$ There was not enough space for everyone to sit, so some men had to sit on others' laps. ${ }^{18073}$ The detainees were sitting so tightly packed that they could not move. ${ }^{18074}$ With an outside temperature "well in its 30 s", ${ }^{18075}$ it was stuffy in the gymnasium and the detainees started to suffocate and faint. ${ }^{18076}$ The detainees were not given any

men as "young lads [...] holding rifles in their hands", adding that when someone addressed them as soldiers they said that they were not soldiers but "Karadžić's Chetniks, Young Chetniks". KDZ064, P769 (Transcript from Prosecutor v. Popović et al.), T. 698. See KDZ064, P769 (Transcript from Prosecutor v. S. Milošević), T. 28830; KDZ064, T. 1445 (22 April 2010).

18066 Mevludin Orić, P350 (Transcript from Prosecutor v. Popović et al.), T. 938-939; KDZ064, P769 (Transcript from Prosecutor v. Popović et al.), T. 677; Milorad Birčaković, P360 (Transcript from Prosecutor v. Popović et al.), T. 11029. See also Tanacko Tanić, P369 (Transcript from Prosecutor v. Popović et al.), T. 10336; Adjudicated Fact 1758.

18067 KDZ407, P379 (Transcript from Prosecutor v. Popović et al.), T. 6448, 6450-6451, 6467-6468. See also Milorad Birčaković, P360 (Transcript from Prosecutor v. Popović et al.), T. 11022.

18068 KDZ407, P379 (Transcript from Prosecutor v. Popović et al.), T. 6451; Tanacko Tanić, P369 (Transcript from Prosecutor v. Popović et al.), T. 10337.

18069 KDZ407, P379 (Transcript from Prosecutor v. Popović et al.), T. 6450. See also Adjudicated Fact 1756.

18070 KDZ039, P3940 (Transcript from Prosecutor v. Popović et al.), T. 17337-17338, 17352 (stating that while he had not counted the detainees, he thought there were over 2,500 people inside the gymnasium); KDZ064, P769 (Transcript from Prosecutor v. Popović et al.), T. 697-698; KDZ064, P769 (Transcript from Prosecutor v. S. Milošević), T. 28834-28835 (estimating that there were anywhere between 500 and 1,000 people inside the gymnasium despite not having counted the men); Mevludin Orić, P350 (Transcript from Prosecutor v. Popović et al.), T. 943 (stating that there were over 2,000 detainees in the gymnasium); KDZ407, P378 (Transcript from Prosecutor v. Popović et al.), 6478-6479 (under seal) (stating that there may have been approximately 1,000 detainees at the gymnasium); P6220 (Report on the events in and around Srebrenica between 10 and 19 July 1995, June 2004), p. 15 (stating that there were approximately 1,000 detainees at the school); D3993 (Witness statement of Vujadin Popović dated 2 November 2013), para. 50 (referring to between 400 and 500 detainees); Adjudicated Fact 1757 (referring to between 1,000 and 2,500 men being detained at the school).

18071 KDZ064, P769 (Transcript from Prosecutor v. Popović et al.), T. 698. See also Mevludin Orić, P350 (Transcript from Prosecutor v. Popović et al.), T. 944; Tanacko Tanić, P369 (Transcript from Prosecutor v. Popović et al.), T. 10338.

18072 Mevludin Orić, P350 (Transcript from Prosecutor v. Popović et al.), T. 943.

18073 KDZ039, P3940 (Transcript from Prosecutor v. Popović et al.), T. 17333.

18074 KDZ064, P769 (Transcript from Prosecutor v. Popović et al.), T. 696.

18075 KDZ064, P769 (Transcript from Prosecutor v. Popović et al.), T. 700.

18076 Mevludin Orić, P350 (Transcript from Prosecutor v. Popović et al.), T. 944, 1005; KDZ064, P769 (Transcript from Prosecutor v. Popović et al.), T. 700-701; KDZ039, P3940 (Transcript from Prosecutor v. Popović et al.), T. 17333. Adjudicated Facts 1759, 1760. 
food, but the four boys were allowed to fetch water, although it was not sufficient for everyone. ${ }^{18077}$ A bucket served as a toilet. ${ }^{18078}$

5325. At one point, a man stood up and complained to the soldiers guarding the gymnasium, stating that he was suffocating and did not want to stay there any longer. ${ }^{18079}$ The soldiers told the man to come out and cool off a bit, ordering the detainees around him to push him out. ${ }^{18080}$ As the man went through the entrance door, the soldiers shot and killed him, dragging his body away. ${ }^{18081}$ Later, another man commented that the detainees should not be killed; he was then taken out by one of the soldiers guarding the entrance. ${ }^{18082}$ As the man was taken out, a rifle shot was heard, followed by moaning and another shot; then there was silence. ${ }^{18083}$ Two dead bodies were later seen in the playground of the school. ${ }^{18084}$

5326. People dressed in civilian clothes, ${ }^{18085}$ followed later by VRS officers, arrived at the school. ${ }^{18086}$ By the early afternoon, ${ }^{18087}$ a number of soldiers had gathered on the road in front of the school and in the school's playground. ${ }^{18088}$ Drago Nikolić and Sreten Milošević were standing in the schoolyard by the main gate in front of the gymnasium. ${ }^{18089}$ Jasikovac, $^{18090}$ Popović, ${ }^{18091}$

18077 Mevludin Orić, P350 (Transcript from Prosecutor v. Popović et al.), T. 944-945, 1004-1005; KDZ064, P769 (Transcript from Prosecutor v. Popović et al.), T. 700, 704; KDZ407, P379 (Transcript from Prosecutor v. Popović et al.), T. 6452, 6485. See also Adjudicated Fact 1759; KDZ039, P3940 (Transcript from Prosecutor v. Popović et al.), T. 17333; Tanacko Tanić, P369 (Transcript from Prosecutor v. Popović et al.), T. 10338.

18078 KDZ064, P769 (Transcript from Prosecutor v. Popović et al.), T. 701

18079 KDZ039, P3940 (Transcript from Prosecutor v. Popović et al.), T. 17333; Mevludin Orić, P350 (Transcript from Prosecutor v. Popović et al.), T. 945-946.

18080 KDZ039, P3940 (Transcript from Prosecutor v. Popović et al.), T. 17333; Mevludin Orić, P350 (Transcript from Prosecutor v. Popović et al.), T. 945-947.

18081 KDZ039, P3940 (Transcript from Prosecutor v. Popović et al.), T. 17333-17334; Mevludin Orić, P350 (Transcript from Prosecutor v. Popović et al.), T. 946. See Adjudicated Fact 1762. See also KDZ064, P769 (Transcript from Prosecutor v. Popović et al.), T. 703, 765 (referring to a man of about 30 years of age who was taken out and shot).

18082 KDZ064, P769 (Transcript from Prosecutor v. Popović et al.), T. 703, 765.

18083 KDZ064, P769 (Transcript from Prosecutor v. Popović et al.), T. 703, 765.

18084 Tanacko Tanić, P369 (Transcript from Prosecutor v. Popović et al.), T. 10336.

18085 KDZ064, P769 (Transcript from Prosecutor v. Popović et al.), T. 703, 706.

18086 KDZ407, P379 (Transcript from Prosecutor v. Popović et al.), T. 6487-6488; KDZ064, P769 (Transcript from Prosecutor v. Popović et al.), T. 706, 708, 764. See also Mevludin Orić, P350 (Transcript from Prosecutor v. Popović et al.), T. 947.

18087 Tanacko Tanić, P369 (Transcript from Prosecutor v. Popović et al.), T. 10334; KDZ407, P379 (Transcript from Prosecutor v. Popović et al.), T. 6452.

18088 Tanacko Tanić, P369 (Transcript from Prosecutor v. Popović et al.), T. 10334-10335; KDZ407, P379 (Transcript from Prosecutor v. Popović et al.), T. 6452. See also KDZ064, P769 (Transcript from Prosecutor v. Popović et al.), T. 682. One of the policemen belonged to the Doboj police. Tanacko Tanić, P369 (Transcript from Prosecutor v. Popović et al.), T. 10335.

18089 D3993 (Witness statement of Vujadin Popović dated 2 November 2013), para. 53; Tanacko Tanić, P369 (Transcript from Prosecutor v. Popović et al.), T. 10337-10338, 10361-10362; Milorad Birčaković, P360 (Transcript from Prosecutor v. Popović et al.), T. 11022-11023, 11038-11039, 11124-11125; KDZ407, P379 (Transcript from Prosecutor v. Popović et al.), T. 6451-6452, 6484; P4563 (Statement by KDZ122), p. 5 (under seal). 
Trbić, ${ }^{18092}$ Beara, ${ }^{18093}$ as well as Lazar Ristić-the Commander of the Zvornik Brigade's $4^{\text {th }}$ Battalion— ${ }^{18094}$ were also present at the school premises on the afternoon of 14 July $1995 .{ }^{18095}$

5327. By the afternoon, ${ }^{18096}$ one of the officers ordered everyone to "shut up" following which he began instructing the detainees to move out of the gymnasium. ${ }^{18097}$ The detainees were told to prepare to be taken to Batković Camp, ${ }^{18098}$ and were instructed to face the wall. ${ }^{18099}$ After the detainees were lined up, which took 10 to 15 minutes, ${ }^{18100}$ they were taken in groups to a small locker room adjacent to the gymnasium, where five or six armed soldiers in camouflage uniform, including a woman, were standing. ${ }^{18101}$ The detainees were either blindfolded by another detainee or were given strips of cloth about 15 centimetres wide with which they had to cover their eyes

18090 Milorad Birčaković, P360 (Transcript from Prosecutor v. Popović et al.), T. 11021, 11124-11125; KDZ407, P378 (Transcript from Prosecutor v. Popović et al.), T. 6458 (under seal); D3993 (Witness statement of Vujadin Popović dated 2 November 2013), para. 51.

18091 Vujadin Popović, T. 43062-43063 (6 November 2013); D3993 (Witness statement of Vujadin Popović dated 2 November 2013), paras. 50, 53; Milorad Birčaković, P360 (Transcript from Prosecutor v. Popović et al.), T. 11024-11025, 11044, 11057-11058, 11082. See also Tanacko Tanić, P369 (Transcript from Prosecutor v. Popović et al.), T. 10337.

18092 D3993 (Witness statement of Vujadin Popović dated 2 November 2013), para. 53; Milorad Birčaković, P360 (Transcript from Prosecutor v. Popović et al.), T. 11021, 11027. See P4563 (Statement by KDZ122), p. 5 (under seal).

18093 D3993 (Witness statement of Vujadin Popović dated 2 November 2013), para. 53; D2266 (Nada Stojanović's interview with OTP), pp. 27-28, 39, 43-45. See also P4563 (Statement by KDZ122), p. 2 (under seal) (referring to the presence of Beara in Zvornik on 14 July 1995); P4585 (Zvornik Brigade Duty Officers logbook, 29 May27 July 1995), e-court p. 45 (an entry for 14 July 1995 in the Zvornik Brigade Duty Officers Notebook dated 15:00 hours noting that "Colonel Beara is coming in order to Orovoc Petkovci Roćević Pilica"). The Chamber finds that the entry in the Zvornik Brigade Duty Officers Notebook refers to Orahovac. The Chamber refers to its assessment of Beara's testimony regarding his whereabouts on 13 and 14 July, as discussed in fn. 17583.

18094 P4563 (Statement by KDZ122), pp. 2, 5 (under seal).

18095 Both KDZ039 and Mevludin Orić testified to also having seen Mladić at the school. KDZ039, T. 21960-21961 (28 November 2011); KDZ039, P3940 (Transcript from Prosecutor v. Popović et al.), T. 17334, 17381-17382; D1945 (Statement of KDZ039 to Tuzla SJB, 21 July 1995), p. 3; D1947 (Statement of KDZ039 to Tuzla SDB, 25 July 1995), p. 2; D1949 (Interview with KDZ039, 31 March 1996), p. 4; Mevludin Orić, P350 (Transcript from Prosecutor v. Popović et al.), T. 995-996, 1003-1004.

18096 See Mevludin Orić, P350 (Transcript from Prosecutor v. Popović et al.), T. 958 (testifying that he was taken to the execution field by early afternoon, between 1 and 3 p.m.); KDZ407, P379 (Transcript from Prosecutor $v$. Popović et al.), T. 6487 (testifying that the first group of detainees were taken out of the gymnasium "later in the afternoon"); KDZ064, P769 (Transcript from Prosecutor v. Popović et al.), T. 709 (testifying that his turn to leave the gymnasium was sometime in the evening); KDZ039, T. 21972 (28 November 2011); KDZ039, P3940 (Transcript from Prosecutor v. Popović et al.), T. 17347, 17358 (testifying that he was taken out of the gymnasium at around 8 p.m. when the sun was still shining).

18097 KDZ064, P769 (Transcript from Prosecutor v. Popović et al.), T. 703. KDZ064 testified that the man controlling the events was wearing a red beret and was quite young, explaining that, before he arrived, no one was taken out of the gymnasium. KDZ064, P769 (Transcript from Prosecutor v. Popovic et al.), T. 704, 709, 764, 767. See also KDZ064, T. 1443 (22 April 2010). But see KDZ407, P379 (Transcript from Prosecutor $v$. Popović et al.), T. 6485 (testifying that he did not remember anyone being a kind of leader and wearing a red beret).

18098 Mevludin Orić, P350 (Transcript from Prosecutor v. Popović et al.), T. 947-948, 1005.

18099 The first four rows of detainees were to stand up, turn right, and face the wall away from the entrance; the next four rows had to do the same thing, facing the other way. KDZ064, P769 (Transcript from Prosecutor v. Popović et al.), T. 703, 764; Mevludin Orić, P350 (Transcript from Prosecutor v. Popović et al.), T. 943.

18100 KDZ064, P769 (Transcript from Prosecutor v. Popović et al.), T. 764. 
themselves. ${ }^{18102}$ Some detainees also had their hands tied behind their backs. ${ }^{18103}$ The woman then gave each of the detainees water as they left the room. ${ }^{18104}$

5328. As the detainees left the room, they were ordered to board one of the two TAM trucks which were parked close to the entrance of the gymnasium, through a ramp leading to them. ${ }^{18105}$ They were loaded in groups of approximately 20 to $40 .{ }^{18106}$ Two benches ran along the trucks' sides, which served as seats for some of the detainees. ${ }^{18107}$ Some of the detainees took their blindfolds off while on the truck. ${ }^{18108}$ When the detainees asked where they were being taken, they were told they were going to a camp in Bijeljina. ${ }^{18109}$

5329. Once full, the two TAM trucks took off from the Orahovac School, ${ }^{18110}$ turning right in the direction of Tuzla. ${ }^{18111}$ Shortly afterwards, the trucks returned to the school empty. ${ }^{18112}$ This same

18101 Mevludin Orić, P350 (Transcript from Prosecutor v. Popović et al.), T. 948-951; KDZ064, P769 (Transcript from Prosecutor v. Popović et al.), T. 708-709, 765. See also Adjudicated Fact 1764.

18102 Mevludin Orić, P350 (Transcript from Prosecutor v. Popović et al.), T. 948-949, 952-953; KDZ064, T. 1443 (22 April 2010); KDZ064, P769 (Transcript from Prosecutor v. Popović et al.), T. 708-709, 767; KDZ039, T. 21958 (24 November 2011); KDZ039, T. 21958 (28 November 2011); KDZ039, P3940 (Transcript from Prosecutor v. Popović et al.), T. 17335, 17358. During a site visit, members of the Prosecution found a large number of pieces of cloth in a rubbish area at the playground of the Orahovac School. Jean-René Ruez, T. 23792-23793 (27 January 2012); P4308 (Book of photographs and maps prepared by Jean-René Ruez, 22 June 2009), e-court pp. 140-143.

18103 KDZ407, P379 (Transcript from Prosecutor v. Popović et al.), T. 6454; Milorad Birčaković, P360 (Transcript from Prosecutor v. Popović et al.), T. 11026.

18104 KDZ064, P769 (Transcript from Prosecutor v. Popović et al.), T. 709; Mevludin Orić, P350 (Transcript from Prosecutor v. Popović et al.), T. 948-949; KDZ039, P3940 (Transcript from Prosecutor v. Popović et al.), T. 17334-17335; Adjudicated Fact 1764.

18105 Mevludin Orić, P350 (Transcript from Prosecutor v. Popović et al.), T. 952-953; KDZ064, P769 (Transcript from Prosecutor v. Popović et al.), T. 689, 691, 709-710; KDZ039, T. 21923-21924 (24 November 2011); KDZ039, P3940 (Transcript from Prosecutor v. Popović et al.), T. 17335; P3941 (Photograph marked by KDZ039) (where KDZ039 indicated the area in which the TAM trucks parked); Milorad Birčaković, P360 (Transcript from Prosecutor v. Popović et al.), T. 11025-11026, 11037; P3945 (Photograph of Orahovac school). See also Tanacko Tanić, P369 (Transcript from Prosecutor v. Popović et al.), T. 10346, 10395; JeanRené Ruez, T. 23789, 23791 (27 January 2012); P4308 (Book of photographs and maps prepared by Jean-René Ruez, 22 June 2009), e-court pp. 135, 140, 144; P4292 (Photograph of Orahovac school marked by Jean-René Ruez).

18106 KDZ064, P769 (Transcript from Prosecutor v. Popović et al.), T. 709, 712; Milorad Birčaković, P360 (Transcript from Prosecutor v. Popović et al.), T. 11026. See also Mevludin Orić, P350 (Transcript from Prosecutor v. Popović et al.), T. 953.

18107 Mevludin Orić, P350 (Transcript from Prosecutor v. Popović et al.), T. 953-954; KDZ064, P769 (Transcript from Prosecutor v. Popović et al.), T. 709, 711.

18108 KDZ064, T. 1442 (22 April 2010); Mevludin Orić, P350 (Transcript from Prosecutor v. Popović et al.), T. 955; KDZ039, T. 21924, (24 November 2011); T. 21972 (28 November 2011); KDZ039, P3940 (Transcript from Prosecutor v. Popović et al.), T. 17335, 17359.

18109 KDZ064, T. 1442-1443 (22 April 2010); KDZ064, P769 (Transcript from Prosecutor v. Popović et al.), T. 711.

18110 KDZ039, T. 21924 (24 November 2011); KDZ039, P3940 (Transcript from Prosecutor v. Popović et al.), T. 17335; Milorad Birčaković, P360 (Transcript from Prosecutor v. Popović et al.), T. 11037.

18111 KDZ407, P379 (Transcript from Prosecutor v. Popović et al.), T. 6455. See Milorad Birčaković, P360 (Transcript from Prosecutor v. Popović et al.), T. 11026.

18112 KDZ407, P379 (Transcript from Prosecutor v. Popović et al.), T. 6455. 
procedure was repeated until the gymnasium was emptied and it was almost dark. ${ }^{18113}$ After the first few trips, Jasikovac ordered Birčaković to follow the trucks in a red Opel Rekord until reaching a water point further down the main road; thereafter he had to return to the school while the trucks turned left and continued up a macadam road. ${ }^{18114}$

5330. Having left at one point earlier that afternoon, Drago Nikolić returned to the Orahovac School just before night fall. ${ }^{18115}$ When Ristić went to the school that evening and tried to take away the soldiers sent earlier that day as reinforcements, he was stopped by Drago Nikolić, who said that if the men stayed they would be issued with new uniforms. ${ }^{18116}$ Drago Nikolić had also been asking for volunteers to take part in the execution of detainees, and a member of the $4^{\text {th }}$ Battalion volunteered. ${ }^{18117}$

\section{(c) The killings at the field near Orahovac}

5331. From the Orahovac School the detainees were taken to two meadows located approximately 800 metres away. ${ }^{18118}$ The first meadow was reached by going through an underpass under a railroad track ("First Meadow"); the second one was located closer to the main road leading to the Orahovac School, approximately 300 metres away from the First Meadow ("Second Meadow"). ${ }^{18119}$

18113 KDZ407, P379 (Transcript from Prosecutor v. Popović et al.), T. 6455; Milorad Birčaković, P360 (Transcript from Prosecutor v. Popović et al.), T. 11025.

18114 Milorad Birčaković, P360 (Transcript from Prosecutor v. Popović et al.), T. 11026-11031, 11036, 11126; P258 (Photograph of Orahovac School and execution sites LZ-01 and LZ-02 marked by Milorad Birčaković); P259 (Photograph of Orahovac School and execution sites LZ-01 and LZ-02 marked by Milorad Birčaković). See also Milorad Birčaković, P360 (Transcript from Prosecutor v. Popović et al.), T. 11050-11053; P173 (Zvornik Brigade vehicle log, 1-31 July 1995), pp. 1-4; KDZ039, T. 21924 (24 November 2011), T. 21959-21960 (28 November 2011); KDZ039, P3940 (Transcript from Prosecutor v. Popović et al.), T. 17335; Mevludin Orić, P350 (Transcript from Prosecutor v. Popović et al.), T. 955. KDZ039 testified that a man in the red car was at the scene supervising the killings, and would wait until all the men were killed, before going away. KDZ039, T. 21959-21960 (28 November 2011). See also KDZ039, P3940 (Transcript from Prosecutor v. Popović et al.), T. 17336 (describing how a soldier in an olive grey uniform riding in the passenger seat of a red car instructed the detainees not to remove their blindfolds).

18115 Milorad Birčaković, P360 (Transcript from Prosecutor v. Popović et al.), T. 11039.

18116 P4563 (Statement by KDZ122), p. 5 (under seal).

18117 P4563 (Statement by KDZ122), p. 5 (under seal). See KDZ122, T. 26282 (14 March 2012) (closed session). While driving away from the Orahovac School later that night, Drago Nikolić and Birčaković saw between 40 and 50 bodies lying around, about 50 metres from the water point. Milorad Birčaković, P360 (Transcript from Prosecutor v. Popović et al.), T. 11038, 11042, 11132.

18118 Mevludin Orić, P350 (Transcript from Prosecutor v. Popović et al.), T. 955; KDZ064, P769 (Transcript from Prosecutor v. Popović et al.), T. 712; Jean-René Ruez, T. 23795, 23806-23807 (27 January 2012); P4308 (Book of photographs and maps prepared by Jean-René Ruez, 22 June 2009), e-court p. 145; P4299 (Video footage of Orahovac area); P4294 (Aerial image of disturbed earth in Orahovac on 5 and 7 July 1995 marked by Jean-René Ruez). See also Adjudicated Facts 1763, 1765.

18119 Jean-René Ruez, T. 23795-23799, 23804 (27 January 2012); P4308 (Book of photographs and maps prepared by Jean-René Ruez, 22 June 2009), e-court pp. 147-149, 150-152; P4297 (Aerial image of sites LZ-1 and LZ-2 marked by Jean-René Ruez); KDZ064, P768 (Transcript from Prosecutor v. Popović et al.), T. 718 (under seal); KDZ064, P769 (Transcript from Prosecutor v. Popović et al.), T. 720, 724; KDZ039, T. 21925-21926 
5332. Upon arriving at the meadows, the detainees were ordered to jump off the trucks and line up in rows. ${ }^{18120}$ As soon as the trucks departed, bursts of automatic gun fire erupted. ${ }^{18121}$ Soldiers also fired at the bodies once they had fallen to the ground to "finish them off". ${ }^{18122}$ Further, they cursed the wounded and let them suffer in agony for a while before killing them. ${ }^{18123}$ The soldiers also shot at survivors who tried to escape. ${ }^{18124}$ Detainees continued to be brought in trucks, ordered to line up, and shot. ${ }^{18125}$ The process continued for approximately two hours until it was dark. ${ }^{18126}$ Once the First Meadow was full of bodies, the soldiers moved to the Second Meadow, where they continued with the killings. ${ }^{18127}$

5333. Throughout this time, the detainees at the Orahovac School, as well as the soldiers guarding them, could hear bursts of fire coming from the direction in which the trucks had departed;, shortly after, the empty trucks would return to the school. ${ }^{18128}$ Following one of these trips, members of the Zvornik Brigade who were escorting the trucks were overheard saying that the detainees had been executed. ${ }^{18129}$

(24 November 2011), T. 21973 (28 November 2011); KDZ039, P3940 (Transcript from Prosecutor v. Popović et al.), T. 17336; P3942 (Photo of execution site in Orahovac, annotated by KDZ039). See also Adjudicated Fact 1767; P4299 (Video footage of Orahovac area).

18120 KDZ064, P769 (Transcript from Prosecutor v. Popović et al.), T. 712; Mevludin Orić, P350 (Transcript from Prosecutor v. Popović et al.), T. 955; KDZ039, T. 21959, 21973 (28 November 2011); KDZ039, P3940 (Transcript from Prosecutor v. Popović et al.), T. 17336. See Adjudicated Fact 1766.

18121 KDZ039, P3940 (Transcript from Prosecutor v. Popović et al.), T. 17336; KDZ064, P769 (Transcript from Prosecutor v. Popović et al.), T. 712; KDZ064, P769 (Transcript from Prosecutor v. S. Milošević), T. 28835; Mevludin Orić, P350 (Transcript from Prosecutor v. Popović et al.), T. 955-956. See also Adjudicated Fact 1763.

18122 Mevludin Orić, P350 (Transcript from Prosecutor v. Popović et al.), T. 958; KDZ064, P769 (Transcript from Prosecutor v. Popović et al.), T. 712; KDZ064, P769 (Transcript from Prosecutor v. S. Milošević), T. 28835.

18123 Mevludin Orić, P350 (Transcript from Prosecutor v. Popović et al.), T. 957.

18124 Mevludin Orić, P350 (Transcript from Prosecutor v. Popović et al.), T. 958; KDZ064, P769 (Transcript from Prosecutor v. Popović et al.), T. 722; KDZ064, P769 (Transcript from Prosecutor v. S. Milošević), T. 2883528836.

18125 KDZ064, P769 (Transcript from Prosecutor v. Popović et al.), T. 713; Mevludin Orić, P350 (Transcript from Prosecutor v. Popović et al.), T. 956, 959, 962; KDZ039, P3940 (Transcript from Prosecutor v. Popović et al.), T. 17336-17337. See also Adjudicated Fact 1768.

18126 KDZ064, P769 (Transcript from Prosecutor v. Popović et al.), T. 713, 715; Mevludin Orić, P350 (Transcript from Prosecutor v. Popović et al.), T. 959, 962; KDZ039, T. 21972-21973 (28 November 2011); P3940 (Transcript from Prosecutor v. Popović et al.), T. 17337.

18127 KDZ064, P768 (Transcript from Prosecutor v. Popović et al.), T. 718 (under seal); KDZ064, P769 (Transcript from Prosecutor v. Popović et al.), T. 720, 724. See also Adjudicated Fact 1767; Jean-René Ruez, T. 23798, 23801, 23803-23804 (27 January 2012); P4308 (Book of photographs and maps prepared by Jean-René Ruez, 22 June 2009), e-court pp. 160-161; P4295 (Photograph of site LZ-2 marked by Jean-René Ruez); P4296 (Photograph of site LZ-1 marked by Jean-René Ruez); P3946 (Photograph of railway line).

18128 KDZ039, T. 21957 (28 November 2011); KDZ407, P379 (Transcript from Prosecutor v. Popović et al.), T. 6455; Milorad Birčaković, P360 (Transcript from Prosecutor v. Popović et al.), T. 11037. See also Tanacko Tanić, P369 (Transcript from Prosecutor v. Popović et al.), T. 10350.

18129 KDZ407, P379 (Transcript from Prosecutor v. Popović et al.), T. 6455-6456. 
5334. A small boy survived the execution and was taken to a hospital for treatment by a member of the Zvornik Brigade. ${ }^{18130}$ Additionally, Mevludin Orić, KDZ039, and KDZ064 all testified as to how they survived the executions. After falling in and out of consciousness, Orić got out from under the dead bodies. ${ }^{18131}$ KDZ039 also managed to get out from under the dead bodies and reached a bush from where he continued watching the killings. ${ }^{18132}$ Similarly, KDZ064 managed to crawl and climb onto the railway track. ${ }^{18133}$ All escaped the site and reached Bosnian Muslim-held territory days later. ${ }^{18134}$

5335. The Chamber finds that members of the Zvornik Brigade, including at least one member of the $4^{\text {th }}$ Battalion, ${ }^{18135}$ participated in the execution of the detainees previously held at the Orahovac School on 14 July $1995 .{ }^{18136}$ The Chamber also received evidence that Drago Nikolić had personally taken part in the executions at the Orahovac School. ${ }^{18137}$

\footnotetext{
18130 Tanacko Tanić, P368 (Transcript from Prosecutor v. Popović et al.), T. 10351-10352 (under seal); Tanacko Tanić, P369 (Transcript from Prosecutor v. Popović et al.), T. 10353.

18131 Mevludin Orić, P350 (Transcript from Prosecutor v. Popović et al.), T. 959-964.

18132 KDZ039, T. 21963, 21968 (28 November 2011); KDZ039, P3940 (Transcript from Prosecutor v. Popović et al.), T. 17338.

18133 KDZ064, P769 (Transcript from Prosecutor v. Popović et al.), T. 722-723, 775; KDZ064, P769 (Transcript from Prosecutor v. S. Milošević), T. 28835-28836.

18134 KDZ039, P3940 (Transcript from Prosecutor v. Popović et al.), T. 17339-17341, 17369; Mevludin Orić, P350 (Transcript from Prosecutor v. Popović et al.), T. 963-964, 968-970, 996-997; KDZ064, P769 (Transcript from Prosecutor v. Popović et al.), T. 723-725, 776; KDZ064, P769 (Transcript from Prosecutor v. S. Milošević), T. 28836. Soldiers shot at KDZ064 as he ran away from the site. KDZ064, P769 (Transcript from Prosecutor $v$. S. Milošević), T. 28836; KDZ064, P769 (Transcript from Prosecutor v. Popović et al.), T. 723-725, 775-776.

18135 KDZ064, P768 (Transcript from Prosecutor v. Popović), T. 634, 715, 717-719, 731-732, 774 (under seal); KDZ064, P769 (Transcript from Prosecutor v. S. Milošević), T. 28832, 28836; Milorad Birčaković, P360 (Transcript from Prosecutor v. Popović et al.), T. 11038-11039. See Adjudicated Fact 1773. See also P4976 (Death certificate of Gojko Simić, 18 August 1995).

18136 Milorad Birčaković, P360 (Transcript from Prosecutor v. Popović et al.), T. 11038-11039; KDZ407, P379 (Transcript from Prosecutor v. Popović et al.), T. 6456-6457; Adjudicated Facts 1772, 1773, 1774.

18137 P4563 (Statement by KDZ122), p. 5 (under seal). KDZ446 testified that, while at the Standard Barracks in midJuly 1995, he met an officer whose name was "Drago Nikolić", who had come from a site where people were being killed, and who told KDZ446 that he had shot people himself because others were refusing to do so. KDZ446, P29 (Transcript from Prosecutor v. S. Milošević), T. 21041-21043, 21091-21092; KDZ446, P28 (Transcript from Prosecutor v. S. Milošević), T. 21093-21096 (under seal). Nikolić was wearing a camouflage uniform which was covered in black soot that he claimed was from when he had to pick up a weapon himself and shoot. KDZ446, T. 21041-21042 (22 May 2003); KDZ228, P324 (Transcript from Prosecutor v. Popović et al.), T. 14747, 14758. See also KDZ228, P324 (Transcript from Prosecutor v. Popović et al.), T. 14747-14748, 14751, 14758, 14762, 14772; KDZ228, P323 (Transcript from Prosecutor v. Popović et al.), T. 14981 (under seal) (testifying that he was with KDZ446 at the time but did not hear the conversation between KDZ446 and Drago Nikolić; however, after leaving the Standard Barracks, KDZ446 was worried and depressed that something bad was happening on the left bank of the Drina River); Milorad Birčaković, P360 (Transcript from Prosecutor v. Popović et al.), T. 11038, 11041-11044 (testifying that after leaving the Orahovac School on 14 July, he and Drago Nikolić went to the Standard Barracks, arriving at approximately 9 p.m.).
} 


\section{(d) Burials}

5336. Sometime before noon on 14 July, Cvijetin Ristanović-a member of the Zvornik Brigade Engineering Company ${ }^{18138}$ — was ordered by Dragan Jokić - the Chief of Engineering of the Zvornik Brigade ${ }^{18139}$ — to take a backhoe excavator "G-700" to Orahovac. ${ }^{18140}$ Ristanović and a colleague loaded the excavator onto a truck with a trailer, drove to the Orahovac School where they paused briefly, and continued to the water point less than one kilometre away, where they were ordered to stop and wait. ${ }^{18141}$ Approximately an hour later, Ristanović was ordered to unload the excavator. ${ }^{18142}$ Slavko Bogičević—a member of the command of the Zvornik Brigade Engineering

Company ${ }^{18143}$ - then ordered Ristanović to take the excavator to a meadow behind the ŽivniceZvornik railroad underpass, and to dig a pit in an area marked with four wooden poles. ${ }^{18144}$ Soldiers were standing around the meadow. ${ }^{18145}$ At about 2 p.m., a request from the Zvornik Brigade arrived to release machine operators to assist Popović and Drago Nikolić in the work they were carrying out at the Orahovac School. ${ }^{18146}$

18138 Cvijetin Ristanović, P652 (Transcript from Prosecutor v. Blagojević \& Jokić), T. 5360; P660 (Zvornik Brigade Engineering Company roster, July 1995). Dragan Jevtić was the Commander of the Zvornik Brigade Engineering Company at the time. Cvijetin Ristanović, P652 (Transcript from Prosecutor v. Blagojević \& Jokić), T. 5363; Damjan Lazarević, P352 (Transcript from Prosecutor v. Popović et al.), T. 14434.

18139 Cvijetin Ristanović, P652 (Transcript from Prosecutor v. Blagojević \& Jokić), T. 5364; Damjan Lazarević, P352 (Transcript from Prosecutor v. Popović et al.), T. 14433.

18140 Cvijetin Ristanović, P652 (Transcript from Prosecutor v. Blagojević \& Jokić), T. 5363-5366, 5406-5407; Cvijetin Ristanović, P351 (Transcript from Prosecutor v. Popović et al.), T. 13625-13626; P238 (Photograph of an excavator (BGH500)). See P174 (Zvornik Brigade vehicle log, 1-31 July 1995) (where a backhoe excavator is recorded as being used by Cvijetin Ristanović on 14 July 1995 for digging trenches in Orahovac). See also Adjudicated Fact 1777; P175 (Zvornik Brigade vehicle log, 1-31 July 1995) (where a Torpedo excavator is recorded as being used by Cvijetin Ristanović on 14 July 1995 for digging trenches in Orahovac). However, both Ristanović and Lazarević testified that the Torpedo machine was not used in Orahovac on 14 and 15 July. Cvijetin Ristanović, P652 (Transcript from Prosecutor v. Blagojević \& Jokić), T. 5396-5399, 5414; Cvijetin Ristanović, P351 (Transcript from Prosecutor v. Popović et al.), T. 13627-13630; Damjan Lazarević, P352 (Transcript from Prosecutor v. Popović et al.), T. 14478. The Chamber received evidence that the Engineering Company did not have this type of equipment but that whenever it needed special equipment it could requisition it from various private companies. Damjan Lazarević, P352 (Transcript from Prosecutor v. Popović et al.), T. 14438. The backhoe excavator belonged to the Zvornik Putevi company. Cvijetin Ristanović, P652 (Transcript from Prosecutor v. Blagojević \& Jokić), T. 5365, 5406.

18141 Cvijetin Ristanović, P652 (Transcript from Prosecutor v. Blagojević \& Jokić), T. 5367-5370, 5378-5379, 5407; P659 (Sketches made by Cvijetin Ristanović); Cvijetin Ristanović, P351 (Transcript from Prosecutor v. Popović et al.), T. 13619-13621.

18142 Cvijetin Ristanović, P652 (Transcript from Prosecutor v. Blagojević \& Jokić), T. 5370, 5407-5408.

18143 Cvijetin Ristanović, P652 (Transcript from Prosecutor v. Blagojević \& Jokić), T. 5365.

18144 Cvijetin Ristanović, P652 (Transcript from Prosecutor v. Blagojević \& Jokić), T. 5370-5372; Cvijetin Ristanović, P351 (Transcript from Prosecutor v. Popović et al.), T. 13621. Ristanović was told that the pit had to be one and a half to two metres deep. Cvijetin Ristanović, P652 (Transcript from Prosecutor v. Blagojević \& Jokić), T. 5372.

18145 Cvijetin Ristanović, P652 (Transcript from Prosecutor v. Blagojević \& Jokić), T. 5371.

18146 [REDACTED]. The message was sent to Milan Marić, a desk officer in the operations department of the Zvornik Brigade staff, who was acting-following appointment by Obrenović-as commander of the company deployed in Snagovo at the time. [REDACTED]. 
5337. While digging the pit, Ristanović was ordered to stop the machine, go back towards the underpass, and stand facing away from the pit, at which point he heard one truck approaching, followed by shouts and bursts of gunfire. ${ }^{18147}$ When Ristanović was allowed to return to continue digging, he saw corpses of men wearing civilian clothes, as well as blindfolds. ${ }^{18148}$ Ristanović was interrupted on at least one other ocassion by the arrival of trucks and soldiers carrying out the executions. ${ }^{18149}$ Sometime in the afternoon, before Ristanović had finished digging the pit, Milovan Miladinović—another member of the Zvornik Brigade Engineering Company_arrived to relieve him and to continue with the digging. ${ }^{18150}$ Ristanović stayed in the area until that night when he and Miladinović were picked up and returned to Zvornik, leaving the excavator at the site. $^{18151}$

5338. On 15 July, before noon, Ristanović and Damjan Lazarević—Commander of the Roads and Bridges Platoon of the Zvornik Brigade Engineering Company ${ }^{18152}$ - as well as two or three other soldiers, returned to Orahovac to continue with the digging. ${ }^{18153}$ Ristanović continued using the backhoe excavator and began digging where a second pit had been marked, closer to the road, but soon after was ordered to move to a third, unmarked area, after a water hose burst in the second location, forcing him to stop the digging. ${ }^{18154}$ Meanwhile, a ULT 200 was used by members of the Zvornik public utility company/Civilian Protection ${ }^{18155}$ to load bodies and take them to the pits dug by the backhoe excavator. ${ }^{18156}$ After finishing digging the gravesite in the afternoon, Ristanović

18147 Cvijetin Ristanović, P652 (Transcript from Prosecutor v. Blagojević \& Jokić), T. 5373-5374, 5379; P659 (Sketches made by Cvijetin Ristanović); Cvijetin Ristanović, P351 (Transcript from Prosecutor v. Popović et al.), T. 13622.

18148 Cvijetin Ristanović, P652 (Transcript from Prosecutor v. Blagojević \& Jokić), T. 5374-5375.

18149 Cvijetin Ristanović, P652 (Transcript from Prosecutor v. Blagojević \& Jokić), T. 5375.

18150 Cvijetin Ristanović, P652 (Transcript from Prosecutor v. Blagojević \& Jokić), T. 5375-5377, 5409. See also Cvijetin Ristanović, P351 (Transcript from Prosecutor v. Popović et al.), T. 13621-13622; Mevludin Orić, P350 (Transcript from Prosecutor v. Popović et al.), T. 960.

18151 Cvijetin Ristanović, P652 (Transcript from Prosecutor v. Blagojević \& Jokić), T. 5380-5381.

18152 Damjan Lazarević, P352 (Transcript from Prosecutor v. Popović et al.), T. 14436; Cvijetin Ristanović, P652 (Transcript from Prosecutor v. Blagojević \& Jokić), T. 5363.

18153 Cvijetin Ristanović, P652 (Transcript from Prosecutor v. Blagojević \& Jokić), T. 5382-5383; Damjan Lazarević, P352 (Transcript from Prosecutor v. Popović et al.), T. 14439-14443. See also P108 (Extract from Zvornik Brigade Engineering Company logbook, 15 July 1995), p. 1 (recording Damjan Lazarević as the company's duty officer on 15 July 1995); Damjan Lazarević, P352 (Transcript from Prosecutor v. Popović et al.), T. 14470.

18154 Cvijetin Ristanović, P652 (Transcript from Prosecutor v. Blagojević \& Jokić), T. 5385-5386, 5403. See also P108 (Extract from Zvornik Brigade logbook, 15 July 1995), p. 1 (recording “work with BGH-700” at Orahovac on 15 July 1995); Damjan Lazarević, P352 (Transcript from Prosecutor v. Popović et al.), T. 14451.

18155 Damjan Lazarević, P352 (Transcript from Prosecutor v. Popović et al.), T. 14449 (referring to the men loading bodies as workers from the public utility company in Zvornik), T. 14520 (referring to these men as members of the civil protection authorities).

18156 Damjan Lazarević, P352 (Transcript from Prosecutor v. Popović et al.), T. 14446-14451, 14520; Cvijetin Ristanović, P652 (Transcript from Prosecutor v. Blagojević \& Jokić), T. 5387; Cvijetin Ristanović, P351 Transcript from Prosecutor v. Popović et al.), T. 13626; P657 (Brochure for a wheel loader (ULT200)); P239 (Photograph of a wheel loader (ULT200)); P108 (Extract from Zvornik Brigade Engineering Company logbook, 
loaded the excavator onto the truck, and returned to Zvornik. ${ }^{18157}$ The Zvornik Brigade Engineering Company logbook shows that the backhoe excavator and the ULT 200 were used at Orahovac on 16 July $1995 .{ }^{18158}$

5339. Towards the end of September 1995, and as part of the reburial operation to conceal the Srebrenica killings which will be discussed in detail below, ${ }^{18159}$ the bodies initially buried at Orahovac were transported away from the site and reburied in the Hodžići Road secondary gravesites, as demonstrated by the forensic evidence discussed in the paragraphs immediately below.

\section{(e) Forensic evidence}

5340. Aerial images reveal that the Lažete gravesites-which were composed of the smaller Lažete 1 and larger Lažete $2^{18160}$ —were dug between 5 and 27 July 1995, and that they were disturbed again between 7 and 27 September 1995. ${ }^{18161}$ The Lažete gravesites—which are primary but disturbed-are situated close to the village of Orahovac, approximately 800 metres from the Orahovac School. ${ }^{18162}$ They are grass covered fields located west of a paved road that runs between

15 July 1995), p. 1 (recording "work with ULT 220" at Orahovac on 15 July 1995); P176 (Zvornik Brigade vehicle log, 1-31 July 1995) (recording an ULT 220 as being used on 15 July 1995 for digging trenches in Orahovac). See also Cvijetin Ristanović, P652 (Transcript from Prosecutor v. Blagojević \& Jokić), T. $5383-$ 5384, 5412; Damjan Lazarević, P352 (Transcript from Prosecutor v. Popović et al.), T 14469-14471. The ULT truck belonged to the Birać Holding of the aluminium oxide factory. Damjan Lazarević, P352 (Transcript from Prosecutor v. Popović et al.), T. 14446.

18157 Cvijetin Ristanović, P652 (Transcript from Prosecutor v. Blagojević \& Jokić), T. 5388-5389. See also Damjan Lazarević, P352 (Transcript from Prosecutor v. Popović et al.), T. 14452.

18158 P108 (Extract from Zvornik Brigade Engineering Company logbook, 15 July 1995), p. 2. One of the survivors of the executions testified to have seen a ULT loader at the site in the evening of 14 July 1995. Mevludin Orić, P350 (Transcript from Prosecutor v. Popović et al.), T. 965-967; P240 (Sketch drawn and signed by Mevludin Orić).

18159 See Section IV.C.1.g.v: Reburial operation.

18160 The Lažete 2 gravesite was more than twice the size of Lažete 1. Fredy Peccerelli, P4137 (Transcript from Prosecutor v. Tolimir), T. 8468; P4502 (Dean Manning's Report, entitled "Summary of Forensic Evidence, Mass Graves Exhumed in 2000 - Lazete 1, Lazete 2C, Ravnice, Glogova 1”, February 2001), e-court p. 6; JeanRené Ruez, T. 23796-23797 (27 January 2012). See also P4308 (Book of photographs and maps prepared by Jean-René Ruez, 22 June 2009), e-court p. 147; Adjudicated Fact 1779.

18161 P4135 (Fredy Peccerelli report entitled "Lažete 1, Bosnia and Herzegovina, Excavation and Exhumation Report”, 2 February 2001), p. 11; Fredy Peccerelli, T. 22744-22745, 22756 (11 January 2012); Fredy Peccerelli, P4137 (Transcript from Prosecutor v. Tolimir), T. 8457, 8474; P4136 (Final Report of Fredy Peccerelli entitled "Lažete 2 (LZ02C), Bosnia and Herzegovina, Excavation and Exhumation report", 1 May 2007), pp. 11, 16; P4502 (Dean Manning's Report, entitled "Summary of Forensic Evidence, Mass Graves Exhumed in 2000 Lazete 1, Lazete 2C, Ravnice, Glogova 1", February 2001), e-court pp. 6, 9; Jean-René Ruez, T. 23796 (27 January 2012); P4294 (Aerial image of disturbed earth in Orahovac on 5 and 7 July 1995 marked by JeanRené Ruez); P4326 (Photograph of aerial view of Lažete gravesites). See also P4308 (Book of photographs and maps prepared by Jean-René Ruez, 22 June 2009), e-court pp. 146-147, 155; P4139 (Photograph of disturbed earth in Orahovac marked by Fredy Peccerelli); P4512 (Photograph booklet entitled "Srebrenica Mass Graves Primary and Secondary Mass Grave Aerial Imagery"), e-court pp. 17-19; Adjudicated Fact 1778.

18162 Fredy Peccerelli, P4137 (Transcript from Prosecutor v. Tolimir), T. 8456-8457; Jean-René Ruez, T. 23795 , 23806-23807 (27 January 2012); P4502 (Dean Manning's Report, entitled “Summary of Forensic Evidence, 
the villages of Lažete and Križevići. ${ }^{18163}$ A railroad track divides the two Lažete gravesites; Lažete 1 is located at the Second Meadow, adjacent to the main road leading from the Orahovac School alongside a dirt track that passes under the railroad tracks before arriving at the First Meadow, where Lažete 2 is located. ${ }^{18164}$

\section{(i) Lažete 1}

\section{Lažete 1 was partially exhumed by a Tribunal exhumation team from 13 July to 8 August} 2000 under the direction of Fredy Peccerelli. ${ }^{18165}$ The remains found in Lažete 1 were then examined by a team of pathologists under the direction of John Clark. ${ }^{18166}$ The Lažete 1 gravesite showed evidence of robbing or removal of bodies by machinery, thus leaving dismembered parts of bodies behind. ${ }^{18167}$ Despite this, 130 bodies and approximately 15 body parts were found within the grave. ${ }^{18168}$

Mass Graves Exhumed in 2000 - Lazete 1, Lazete 2C, Ravnice, Glogova 1", February 2001), e-court p. 6. See also P4308 (Book of photographs and maps prepared by Jean-René Ruez, 22 June 2009), e-court pp. 145-148.

18163 (Fredy Peccerelli report entitled "Lažete 1, Bosnia and Herzegovina, Excavation and Exhumation Report", 2 February 2001), p. 4; P4136 (Final Report of Fredy Peccerelli entitled "Lažete 2 (LZ02C), Bosnia and Herzegovina, Excavation and Exhumation report", 1 May 2007), p. 4; P4502 (Dean Manning's Report, entitled "Summary of Forensic Evidence, Mass Graves Exhumed in 2000 - Lazete 1, Lazete 2C, Ravnice, Glogova 1", February 2001), e-court p. 6. See also Jean-René Ruez, T. 23795 (27 January 2012); P4308 (Book of photographs and maps prepared by Jean-René Ruez, 22 June 2009), e-court p. 145.

18164 P4502 (Dean Manning's Report, entitled "Summary of Forensic Evidence, Mass Graves Exhumed in 2000 Lazete 1, Lazete 2C, Ravnice, Glogova 1”, February 2001),e-court p. 6; P4136 (Final Report of Fredy Peccerelli entitled "Lažete 2 (LZ02C), Bosnia and Herzegovina, Excavation and Exhumation report", 1 May 2007), p. 4; Fredy Peccerelli, P4137 (Transcript from Prosecutor v. Tolimir), T. 8457; Jean-René Ruez, T. 23795-23796 (27 January 2012); William Haglund, P4310 (Transcript from Prosecutor v. Krstić), T. 3742-3743. See also P4308 (Book of photographs and maps prepared by Jean-René Ruez, 22 June 2009), e-court pp. 145, 161; P4327 (Photograph of grave and execution site at LZ-02, 1 April 1996).

18165 Fredy Peccerelli, T. 22736, 22767 (11 January 2012); Fredy Peccerelli, P4137 (Transcript from Prosecutor v. Tolimir), T.8457, 8491-8492; P4135 (Fredy Peccerelli report entitled "Lažete 1, Bosnia and Herzegovina, Excavation and Exhumation Report", 2 February 2001), p. 4. See also Adjudicated Fact 1780; D3893 (Dušan Dunjić's expert report entitled "Forensic Analysis of Reports on the Locations of Mass Graves in the Area of Eastern Bosnia and Documentation Relating to Exhumations in the Srebrenica Area”, 27 August 2009), pp. $47-$ 48. The Chamber notes the Accused's challenges to Peccerelli's findings in relation to the Lažete gravesite. See Defence Final Brief, paras. 2575-2580, 2583-2588. Having assessed the totality of evidence on this issue, the Chamber accepts Peccerelli's report and the findings therein.

18166 P4104 (John Clark's expert report entitled "Report of the Chief Pathologist, Srebrenica Grave Sites (2000)", 24 February 2001), pp. 1, 28. See also John Clark, John Clark, P4110 (Transcript from Prosecutor v. Krstić), T. 3900-3901; P6461 (Autopsy report for Lažete Grave Site, 22 August 2000). The Chamber notes that Dušan Dunjić challenged Clark's findings in his report for the Lažete gravesite. See Dušan Dunjić, T. 41836-41839 (23 July 2013). Having assessed the totality of evidence on this issue, the Chamber accepts Clark's report and the findings therein.

18167 P4135 (Fredy Peccerelli report entitled "Lažete 1, Bosnia and Herzegovina, Excavation and Exhumation Report", 2 February 2001), pp. 2, 13, 15-18, 21; Fredy Peccerelli, T. 22740-22741 (11 January 2012); Fredy Peccerelli, P4137 (Transcript from Prosecutor v. Tolimir), T. 8460 (testifying that machine tooth marks found on the walls of Lažete 1 supported the conclusion that it was a primary disturbed grave).

18168 P4502 (Dean Manning's Report, entitled "Summary of Forensic Evidence, Mass Graves Exhumed in 2000 Lazete 1, Lazete 2C, Ravnice, Glogova 1", February 2001), e-court p. 6 (noting that the bodies of at least 130 individuals were found in the grave). See Adjudicated Fact 1781. See also P4104 (John Clark's expert report entitled "Report of the Chief Pathologist, Srebrenica Grave Sites (2000)", 24 February 2001), pp. 1, 7 (stating that a total of 129 whole or largely complete bodies were recovered from the grave along with 14 body parts); 
5342. The forensic evidence reviewed by the Chamber shows that all of the victims whose sex could be determined were male. ${ }^{18169}$ The age of the victims ranged from 15 to 85 , with the majority being between 30 and 60 years old. ${ }^{18170}$ Gunshot injury was determined to be the cause of death for at least $97 \%$ of the victims. ${ }^{18171}$ Further, 138 blindfolds were uncovered. ${ }^{18172}$ Bullet holes were present in several of the blindfolds indicating that men were blindfolded when they were shot. ${ }^{18173}$ In addition to these blindfolds, at least two ligatures were recovered during the exhumation and autopsy process. ${ }^{18174}$ None of the victims were found wearing military clothing. ${ }^{18175}$ Additionally,

P4135 (Fredy Peccerelli report entitled "Lažete 1, Bosnia and Herzegovina, Excavation and Exhumation Report”, 2 February 2001), pp. 2, 14, 17; Fredy Peccerelli, P4137 (Transcript from Prosecutor v. Tolimir), T.8460 (noting that 127 bodies were recovered from within the grave and two from within a drainage ditch on the southern border of the gravesite); P4037 (Jose Baraybar's expert report entitled "Calculation of the Minimal Number of Individuals Exhumed by the ICTY between 1996 and 2001", 4 January 2004), p. 7 (noting that at least 131 individuals were found in Lažete 1).

18169 P4104 (John Clark's expert report entitled "Report of the Chief Pathologist, Srebrenica Grave Sites (2000)", 24 February 2001), p. 7 (noting all of the 129 victims were male); P4502 (Dean Manning's Report, entitled "Summary of Forensic Evidence, Mass Graves Exhumed in 2000 - Lazete 1, Lazete 2C, Ravnice, Glogova 1", February 2001), e-court p. 7 (stating that 129 of the bodies were male and the sex of the remaining body could not be determined). See Adjudicated Fact 1781.

18170 P4104 (John Clark's expert report entitled "Report of the Chief Pathologist, Srebrenica Grave Sites (2000)", 24 February 2001), p. 7. See also P4502 (Dean Manning's Report, entitled "Summary of Forensic Evidence, Mass Graves Exhumed in 2000 - Lazete 1, Lazete 2C, Ravnice, Glogova 1”, February 2001), e-court p. 7.

18171 P4104 (John Clark's expert report entitled "Report of the Chief Pathologist, Srebrenica Grave Sites (2000)", 24 February 2001), p. 13; P4502 (Dean Manning's Report, entitled "Summary of Forensic Evidence, Mass Graves Exhumed in 2000 - Lazete 1, Lazete 2C, Ravnice, Glogova 1”, February 2001), e-court p. 7. Many of the individuals exhumed from Lažete 1 suffered multiple gunshot wounds from high velocity rifles. P4104 (John Clark's expert report entitled "Report of the Chief Pathologist, Srebrenica Grave Sites (2000)", 24 February 2001), pp. 9, 12.

18172 P4507 (Chart of photographs of blindfolds, ligatures, and location); P4502 (Dean Manning's Report, entitled "Summary of Forensic Evidence, Mass Graves Exhumed in 2000 - Lazete 1, Lazete 2C, Ravnice, Glogova 1", February 2001), e-court p. 7. See Adjudicated Fact 1782. See also P4135 (Fredy Peccerelli report entitled "Lažete 1, Bosnia and Herzegovina, Excavation and Exhumation Report", 2 February 2001), p. 22; Fredy Peccerelli, T. $22746-22747$ (11 January 2012); P4519 (Photograph of human remains); P4520 (Photograph of human remains); P4521 (Photograph of human remains); P4522 (Autopsy report for Lažete Grave Site, 21 August 2000). The Chamber notes the Accused's claim, supported by Dunjić, that the strips identified as blindfolds found in the Lažete gravesites are more likely "ritual ribbons" wrapped around the head of $\mathrm{ABiH}$ soldiers, or carried for religious reasons by soldiers, and thus that these individuals were killed in combat. See e.g. Defence Final Brief, paras. 2583-2585; Dean Manning T. 25866-25881 (6 March 2012); D3894 (Dušan Dunjić's expert report entitled "Forensic Analysis of Documents Pertaining to Exhumations, Autopsies and Identification of Bodies in the Srebrenica Area", 26 August 2012), p. 19; Dušan Dunjić, T. 41755, 41827-41840 (23 July 2013). See also D2189 (Photograph of human remains marked by Dean Manning); P4502 (Dean Manning's Report, entitled "Summary of Forensic Evidence, Mass Graves Exhumed in 2000 - Lazete 1, Lazete 2C, Ravnice, Glogova 1", February 2001), e-court pp. 21-24. Having considered the totality of the evidence, the Chamber accepts Manning's and Peccerelli's reports and the findings therein.

18173 P4104 (John Clark's expert report entitled "Report of the Chief Pathologist, Srebrenica Grave Sites (2000)", 24 February 2001), p. 8.

18174 P4104 (John Clark's expert report entitled "Report of the Chief Pathologist, Srebrenica Grave Sites (2000)", 24 February 2001), p. 9; P4135 (Fredy Peccerelli report entitled "Lažete 1, Bosnia and Herzegovina, Excavation and Exhumation Report", 2 February 2001), p. 23; P4502 (Dean Manning's Report, entitled "Summary of Forensic Evidence, Mass Graves Exhumed in 2000 - Lazete 1, Lazete 2C, Ravnice, Glogova 1", February 2001), e-court p. 7. See also P4509 (Collage of Srebrenica ligatures, 5 March 2012).

18175 P4104 (John Clark's expert report entitled "Report of the Chief Pathologist, Srebrenica Grave Sites (2000)", 24 February 2001), p. 8. 
at least 454 shell cases and at least nine bullets were found in or around the grave. ${ }^{18176}$ The heavy concentration of shell cases on the roadway and track surrounding the grave indicates that weapons were fired into the area of the grave from the roadway and track, which is consistent with witness accounts of the executions at Lažete $1 .^{18177}$

5343. As of 13 January 2012, DNA analysis led to the identification of 119 individuals in the Lažete 1 grave as persons listed as missing following the take-over of Srebrenica. ${ }^{18178}$

\section{(ii) Lažete 2}

5344. In 1996 and 2000, two exhumations of the Lažete 2 gravesite, uncovering three sub-graves, were carried out. ${ }^{18179}$ Between 19 August and 9 September 1996, a joint team from the Prosecution and Physicians for Human Rights, under the direction of William Haglund, exhumed the sub-graves designated Lažete $2 \mathrm{~A}$ and $2 \mathrm{~B} .{ }^{18180}$ Lažete $2 \mathrm{C}$, an area between sub-graves Lažete $2 \mathrm{~A}$ and Lažete 2B, was exhumed by a Tribunal team led by Fredy Peccerelli from 2 to 17 August $2000 .^{18181}$

18176 P4135 (Fredy Peccerelli report entitled "Lažete 1, Bosnia and Herzegovina, Excavation and Exhumation Report", 2 February 2001), p. 10; Fredy Peccerelli, P4137 (Transcript from Prosecutor v. Tolimir), T. 84618462; P4502 (Dean Manning's Report, entitled "Summary of Forensic Evidence, Mass Graves Exhumed in 2000 - Lazete 1, Lazete 2C, Ravnice, Glogova 1", February 2001), e-court p. 8.

18177 P4502 (Dean Manning's Report, entitled "Summary of Forensic Evidence, Mass Graves Exhumed in 2000 Lazete 1, Lazete 2C, Ravnice, Glogova 1”, February 2001), e-court p. 8. See para. 5332. See also Fredy Peccerelli, P4137 (Transcript from Prosecutor v. Tolimir), T. 8461-8462 (testifying that there was a heavy concentration of shell casings found on the southern edge of the grave, which indicates the shooting occurred there); P4135 (Fredy Peccerelli report entitled "Lažete 1, Bosnia and Herzegovina, Excavation and Exhumation Report", 2 February 2001), p. 10.

18178 P4772 (Dušan Janc's report entitled "Update to the summary of Forensic Evidence - Exhumation of the Graves and Surface Remains Recoveries related to Srebrenica - January 2012”, 13 January 2012), e-court pp. 3, 9, 41; P4771 (Dušan Janc's report entitled "Update to the summary of Forensic Evidence - Exhumation of the Graves and Surface Remains Recoveries related to Srebrenica - January 2012", 13 January 2012) (under seal), e-court pp. 3, 9, 41, 106-112. See also P5917 (ICMP DNA identifications concerning identified victims related to Srebrenica, 6 December 2010); P4773 (ICMP unmatched DNA victim profiles related to Srebrenica, 23 December 2011); P4774 (ICMP lists of unmatched unique DNA victims profiles related to Srebrenica, 15 February 2010).

18179 P4502 (Dean Manning's Report, entitled "Summary of Forensic Evidence, Mass Graves Exhumed in $2000-$ Lazete 1, Lazete 2C, Ravnice, Glogova 1", February 2001), e-court p. 9; P4316 (William Haglund's expert report, entitled "Forensic Investigation of the Lazete 2 Grave Site - Volume I", 15 June 1998), p. 2; P4136 (Final Report of Fredy Peccerelli entitled "Lažete 2 (LZ02C), Bosnia and Herzegovina, Excavation and Exhumation report", 1 May 2007), p. 2.

18180 William Haglund, T. 23873-23874 (30 January 2012); P4316 (William Haglund's expert report, entitled "Forensic Investigation of the Lazete 2 Grave Site - Volume I", 15 June 1998), pp. x, 2; P4502 (Dean Manning's Report, entitled "Summary of Forensic Evidence, Mass Graves Exhumed in 2000 - Lazete 1, Lazete 2C, Ravnice, Glogova 1", February 2001), e-court p. 9; P4504 (Dean Manning's Report entitled "Summary of Forensic Evidence -Execution Points and Mass Graves", 16 May 2000), e-court p. 51. See also Adjudicated Fact 1784; P4328 (Map of LZ-02); P4339 (Map of LZ-02 marked by William Haglund). The remains found within the Lažete 2A and 2B sub-gravesites were examined by a team of pathologists under the direction of Robert H. Kirschnner. P4316 (William Haglund's expert report, entitled "Forensic Investigation of the Lazete 2 Grave Site - Volume I", 15 June 1998), p. xi. The Chamber notes that Dušan Dunjić challenged the methodology used by Haglund in his report for the Lažete 2 gravesite. D3893 (Dušan Dunjić's expert report entitled "Forensic Analysis of Reports on the Locations of Mass Graves in the Area of Eastern Bosnia and 
5345. While Lažete 2A appears to be undisturbed, the Chamber received evidence that subgravesites 2B and 2C of Lažete 2 were disturbed, as they showed evidence of robbing or removal of bodies by machinery, thus leaving dismembered parts of bodies behind. ${ }^{18182}$

5346. The forensic evidence reviewed by the Chamber shows that 165 bodies and approximately 100 partial remains were recovered from sub-gravesites Lažete $2 \mathrm{~A}$ and $2 \mathrm{~B} .{ }^{18183}$ All victims were male, with ages ranging from 13 to 70 , the majority of which were between 16 and $45 .^{18184}$ None of victims were found wearing military clothing. ${ }^{18185}$ Furthermore, at least 104 blindfolds, ${ }^{18186}$ as well as one ligature bound around the legs of a victim, were recovered from the Lažete $2 \mathrm{~A}$ and $2 \mathrm{~B}$ sub-gravesites. ${ }^{18187}$ Evidence suggests that 158 of the 165 individuals died of gunshot wounds from high velocity rifles, while the cause of death for the remaining seven was undetermined. ${ }^{18188}$

Documentation Relating to Exhumations in the Srebrenica Area”, 27 August 2009), pp. 40-42. Having assessed the totality of evidence on this issue, the Chamber accepts Haglund's report and the findings therein.

18181 Fredy Peccerelli, P4137 (Transcript from Prosecutor v. Tolimir), T.8466, 8475; P4136 (Final Report of Fredy Peccerelli entitled "Lažete 2 (LZ02C), Bosnia and Herzegovina, Excavation and Exhumation report", 1 May 2007), p. 4; P4316 (William Haglund's expert report, entitled "Forensic Investigation of the Lazete 2 Grave Site - Volume I", 15 June 1998), p. 2; P4502 (Dean Manning's Report, entitled "Summary of Forensic Evidence, Mass Graves Exhumed in 2000 - Lazete 1, Lazete 2C, Ravnice, Glogova 1", February 2001), e-court p. 9. The remains found within the Lažete $2 \mathrm{C}$ sub-gravesite were examined by a team of pathologists under the direction of John Clark. P4104 (John Clark's expert report entitled "Report of the Chief Pathologist, Srebrenica Grave Sites (2000)", 24 February 2001), pp. 1, 28.

18182 Fredy Peccerelli P4137 (Transcript from Prosecutor v. Tolimir), T.8474; Fredy Peccerelli, T. 22771-22772 (11 January 2012); P4136 (Final Report of Fredy Peccerelli entitled "Lažete 2 (LZ02C), Bosnia and Herzegovina, Excavation and Exhumation report”, 1 May 2007), pp. 16-19; William Haglund, P4310 (Transcript from Prosecutor v. Krstić), T. 3747-3750; William Haglund, T. 23889 (30 January 2012); P4316 (William Haglund's expert report, entitled "Forensic Investigation of the Lazete 2 Grave Site - Volume I", 15 June 1998), pp. 51-52, 61-62; P4104 (John Clark's expert report entitled "Report of the Chief Pathologist, Srebrenica Grave Sites (2000)", 24 February 2001), p. 14.

18183 P4316 (William Haglund's expert report, entitled "Forensic Investigation of the Lazete 2 Grave Site - Volume I”, 15 June 1998), pp. ix, 41; William Haglund, P4310 (Transcript from Prosecutor v. Krstić), T. 3750; William Haglund, T. 23889-23890 (30 January 2012); P4504 (Dean Manning's Report, entitled "Summary of Forensic Evidence - Execution Points and Mass Graves", 16 May 2000), e-court pp. 8, 51. See also P4317 (William Haglund's expert report, entitled "Forensic Investigation of the Lazete 2 Grave Site - Volume II", 15 June 1998); P4318 (William Haglund's expert report, entitled "Forensic Investigation of the Lazete 2 Grave Site Volume III", 15 June 1998); P4319 (William Haglund's expert report, entitled "Forensic Investigation of the Lazete 2 Grave Site - Volume IV", 15 June 1998); P4320 (William Haglund's expert report, entitled "Forensic Investigation of the Lazete 2 Grave Site - Volume V", 15 June 1998).

18184 P4316 (William Haglund's expert report, entitled "Forensic Investigation of the Lazete 2 Grave Site - Volume I", 15 June 1998), pp. x, 41; P4504 (Dean Manning's Report, entitled "Summary of Forensic Evidence Execution Points and Mass Graves", 16 May 2000), e-court pp. 8, 51.

18185 P4316 (William Haglund's expert report, entitled "Forensic Investigation of the Lazete 2 Grave Site - Volume I", 15 June 1998), pp. x, 41.

18186 P4316 (William Haglund's expert report, entitled "Forensic Investigation of the Lazete 2 Grave Site - Volume I", 15 June 1998), pp. x, 48; William Haglund, P4310 (Transcript from Prosecutor v. Krstić), T. 3750 ; P4506 (Photograph booklet entitled "Srebrenica Blindfolds and Ligatures - Volume 2: Lazete 2, Hodzici Road 3, 4 and 5, Petkovci Dam, Liplje 2, Cerska and Zeleni Jadar 5"), e-court p. 3; P4507 (Chart of photographs of blindfolds, ligatures, and location), e-court p. 1 (noting that 107 blindfolds were found within Lažete 2A and 2B); P4506 (Photograph booklet entitled "Srebrenica Blindfolds and Ligatures - Volume 2: Lazete 2, Hodzici Road 3, 4 and 5, Petkovci Dam, Liplje 2, Cerska and Zeleni Jadar 5"), e-court p. 3. See also Adjudicated Fact 1785.

18187 P4316 (William Haglund's expert report, entitled "Forensic Investigation of the Lazete 2 Grave Site - Volume I", 15 June 1998), p. 48; P4504 (Dean Manning's Report, entitled "Summary of Forensic Evidence - Execution 
5347. 17 bodies and approximately 26 body parts were recovered from Lažete $2 \mathrm{C} .{ }^{18189}$ All were males with ages ranging from 17 to $85 .{ }^{18190}$ Furthermore, 40 blindfolds, ${ }^{18191}$ but no ligatures were found. ${ }^{18192}$ None of the victims were found with military clothing. ${ }^{18193}$ The evidence suggests that 15 of the victims were killed by gunshot injuries, while the cause of death for the remaining two was undetermined. ${ }^{18194}$ Furthermore, approximately 671 shell cases and some bullets were found in or around the grave. ${ }^{18195}$ The heavy concentration of shell cases on the east section of the grave indicate that weapons were fired into the area of the grave from the surrounding track. ${ }^{18196}$

Points and Mass Graves", 16 May 2000), e-court pp. 8, 52; P4509 (Collage of Srebrenica ligatures, 5 March 2012). See also Adjudicated Fact 1785.

18188 P4316 (William Haglund's expert report, entitled "Forensic Investigation of the Lazete 2 Grave Site - Volume I", 15 June 1998), pp. 49-50; William Haglund, P4310 (Transcript from Prosecutor v. Krstić), T. 3750; P4504 (Dean Manning's Report, entitled "Summary of Forensic Evidence - Execution Points and Mass Graves", 16 May 2000), e-court pp. 8, 52.

18189 P4104 (John Clark's expert report entitled "Report of the Chief Pathologist, Srebrenica Grave Sites (2000)", 24 February 2001), pp. 1, 14; P4502 (Dean Manning's Report, entitled "Summary of Forensic Evidence, Mass Graves Exhumed in 2000 - Lazete 1, Lazete 2C, Ravnice, Glogova 1", February 2001), e-court p. 9; P4136 (Final Report of Fredy Peccerelli entitled "Lažete 2 (LZ02C), Bosnia and Herzegovina, Excavation and Exhumation report", 1 May 2007), pp. 2, 13, 20, 22; Fredy Peccerelli, P4137 (Transcript from Prosecutor v. Tolimir), T. 8473

18190 P4104 (John Clark's expert report entitled "Report of the Chief Pathologist, Srebrenica Grave Sites (2000)", 24 February 2001), pp. 14, 16.

18191 P4502 (Dean Manning's Report, entitled "Summary of Forensic Evidence, Mass Graves Exhumed in 2000 Lazete 1, Lazete 2C, Ravnice, Glogova 1", February 2001), e-court p. 7; P4507 (Chart of photographs of blindfolds, ligatures, and location), e-court p. 1. Another 102 strips of cloth, similar to those found at the Orahovac School, were found in a "rubbish" site next to the Lažete 2 gravesite. P4502 (Dean Manning's Report, entitled "Summary of Forensic Evidence, Mass Graves Exhumed in 2000 - Lazete 1, Lazete 2C, Ravnice, Glogova 1”, February 2001), e-court p. 7; Jean-René Ruez, T. 23805-23806 (27 January 2012); P4308 (Book of photographs and maps prepared by Jean-René Ruez, 22 June 2009), e-court pp. 163-164; P4298 (Photograph of rubbish site marked by Jean-René Ruez); P4299 (Video footage of Orahovac area). See also P4136 (Final Report of Fredy Peccerelli entitled "Lažete 2 (LZ02C), Bosnia and Herzegovina, Excavation and Exhumation report", 1 May 2007), pp. 22, 25. Fredy Peccerelli, P4137 (Transcript from Prosecutor v. Tolimir), T. 8478 (testifying that there was a systematic placement of blindfolds around the heads of the bodies, and adding that the strips of material found in Lažete 2 were the same as those found in Lažete 1, which links the two gravesites to a single killing incident).

18192 P4502 (Dean Manning's Report, entitled "Summary of Forensic Evidence, Mass Graves Exhumed in 2000 Lazete 1, Lazete 2C, Ravnice, Glogova 1", February 2001), e-court p. 9.

18193 P4104 (John Clark's expert report entitled "Report of the Chief Pathologist, Srebrenica Grave Sites (2000)", 24 February 2001), p. 14.

18194 P4104 (John Clark's expert report entitled "Report of the Chief Pathologist, Srebrenica Grave Sites (2000)", 24 February 2001), p. 15; P4502 (Dean Manning's Report, entitled "Summary of Forensic Evidence, Mass Graves Exhumed in 2000 - Lazete 1, Lazete 2C, Ravnice, Glogova 1", February 2001), pp. 9-10; P4136 (Final Report of Fredy Peccerelli entitled "Lažete 2 (LZ02C), Bosnia and Herzegovina, Excavation and Exhumation report", 1 May 2007), p. 10.

18195 P4136 (Final Report of Fredy Peccerelli entitled "Lažete 2 (LZ02C), Bosnia and Herzegovina, Excavation and Exhumation report", 1 May 2007), p. 10; P4502 (Dean Manning's Report, entitled "Summary of Forensic Evidence, Mass Graves Exhumed in 2000 - Lazete 1, Lazete 2C, Ravnice, Glogova 1”, February 2001), e-court p. 10.

18196 See P4136 (Final Report of Fredy Peccerelli entitled "Lažete 2 (LZ02C), Bosnia and Herzegovina, Excavation and Exhumation report", 1 May 2007), p. 10. 
5348. As of 13 January 2012, DNA analysis led to the identification of 189 victims from the three sub-gravesites in Lažete 2 as persons listed as missing following the take-over of Srebrenica. ${ }^{18197}$ Four of these individuals were those identified by KDZ039 as being in the same TAM truck as him on the way to the execution site. ${ }^{18198}$

\section{(iii) Hodžići Road secondary gravesites}

5349. There are seven known secondary gravesites along the Hodžići road. ${ }^{18199}$ While examination and probing at Hodžići Road 1, 2, 6, and 7 was conducted by a Tribunal team of experts, the exhumation of these gravesites was handed over to the $\mathrm{BiH}$ Government and conducted between October 2004 and October 2006. ${ }^{18200}$ A Tribunal team of experts, led by Richard Wright, conducted the examination and exhumation of Hodžići Road 3 through 5 in June and July 1998. ${ }^{18201}$ The remains from Hodžići Road 3 through 5 were then examined by a team of pathologists under the direction of Christopher Lawrence. ${ }^{18202}$

18197 P4772 (Dušan Janc's report entitled "Update to the summary of Forensic Evidence - Exhumation of the Graves and Surface Remains Recoveries related to Srebrenica - January 2012”, 13 January 2012), e-court pp. 3, 9-10, 41; P4771 (Dušan Janc's report entitled "Update to the summary of Forensic Evidence - Exhumation of the Graves and Surface Remains Recoveries related to Srebrenica - January 2012”, 13 January 2012) (under seal), ecourt pp. 3, 9-10, 41, 113-121. See P5917 (ICMP DNA identifications concerning identified victims related to Srebrenica, 6 December 2010); P4773 (ICMP unmatched DNA victim profiles related to Srebrenica, 23 December 2011); P4774 (ICMP lists of unmatched unique DNA victims profiles related to Srebrenica, 15 February 2010). See also Adjudicated Fact 1786 (refering to the identification of 21 individuals and which is based upon Manning's report as admitted in the Krstić case); P4504 (Dean Manning's Report, entitled "Summary of Forensic Evidence - Execution Points and Mass Graves", 16 May 2000), e-court pp. 53, 97. The Chamber notes that the apparent discrepancy between this fact and the evidence admitted in the present case referring to the identification of 189 individuals can be explained by the fact that in 2001 - the year in which the Krstić Trial Judgement was issued-the identification process of victims was ongoing.

18198 KDZ039, T. 21927 (24 November 2011); D1945 (Statement of KDZ039 to Tuzla SJB, 21 July 1995), p. 2; D1947 (Statement of KDZ039 to Tuzla SDB, 25 July 1995), p. 2; P4996 (Ewa Tabeau's expert report entitled "Srebrenica Missing: Persons Reported Missing and Dead after the Take-Over of the Srebrenica Enclave by the Bosnian Serb Army on 11 July 1995", 9 April 2009) (under seal), pp. 48, 52, 121, 198; P5917 (ICMP DNA identifications concerning identified victims related to Srebrenica, 6 December 2010). See also paras. 53285329, 5332.

18199 P4504 (Dean Manning's Report, entitled "Summary of Forensic Evidence - Execution Points and Mass Graves", 16 May 2000), e-court p. 54; Jean René-Ruez, T. 23865 (30 January 2012); P4308 (Book of photographs and maps prepared by Jean-René Ruez, 22 June 2009), e-court p. 262. See also P4504 (Dean Manning's Report, entitled "Summary of Forensic Evidence - Execution Points and Mass Graves", 16 May 2000), e-court pp. 54, 58, 61; P4000 (Richard Wright's expert report entitled "Exhumations in Eastern Bosnia in 1998”, 12 May 1999), pp. 22-23 (noting Hodžići Road 3 was discovered in 1998 by SFOR troops).

18200 P4772 (Dušan Janc's report entitled "Update to the summary of Forensic Evidence - Exhumation of the Graves and Surface Remains Recoveries related to Srebrenica - January 2012", 13 January 2012), e-court pp. 21-23; P4000 (Richard Wright's expert report entitled "Exhumations in Eastern Bosnia in 1998", 12 May 1999), p. 9.

18201 P4000 (Richard Wright's expert report entitled "Exhumations in Eastern Bosnia in 1998”, 12 May 1999), pp. 3, 9; P4772 (Dušan Janc's report entitled "Update to the summary of Forensic Evidence - Exhumation of the Graves and Surface Remains Recoveries related to Srebrenica - January 2012”, 13 January 2012), e-court pp. 21-23. See also Dean Manning, T. 25836 (6 March 2012).

18202 P4056 (Christopher Lawrence's expert report entitled "Report on Autopsies of Human Remains from Hodžići Road Site 3, October 1998", 17 June 1999); P4057 (Christopher Lawrence's expert report entitled "Report on Autopsies of Human Remains from Hodžići Road Site 4, October 1998", 17 June 1999); P4058 (Christopher Lawrence's expert report entitled "Report on Autopsies of Human Remains from Hodžići Road Site 5, October 
5350. The forensic evidence reviewed by the Chamber shows that the majority of victims at Hodžići Road 3, 4, and 5 whose sex could be determined were male. ${ }^{18203}$ The majority of the victims were older than 25 years old. ${ }^{18204}$ Most of the bodies exhumed presented gunshot injuries. ${ }^{18205}$ Furthermore, approximately 90 blindfolds, ${ }^{18206}$ and at least one ligature, ${ }^{18207}$ were discovered at the three gravesites. No military clothing was found in these gravesites. ${ }^{18208}$

5351. Aerial images show that the Hodžići Road gravesites were created between 7 September and 2 October 1995, which is consistent both with the dates in which the Lažete gravesites were disturbed, ${ }^{18209}$ and the dates the bodies were transferred to the Hodžići Road gravesites. ${ }^{18210}$

1998”, 17 June 1999); Christopher Lawrence, P4051 (Transcript from Prosecutor v. Krstić), T. 3978-3980; P4064 (Chart of primary and secondary graves); Christopher Lawrence, T. 22447 (8 December 2011).

18203 P4056 (Christopher Lawrence's expert report entitled "Report on Autopsies of Human Remains from Hodžići Road Site 3, October 1998”, 17 June 1999), pp. 2, 8; P4057 (Christopher Lawrence's expert report entitled "Report on Autopsies of Human Remains from Hodžići Road Site 4, October 1998”, 17 June 1999), pp. 2, 7; P4058 (Christopher Lawrence's expert report entitled "Report on Autopsies of Human Remains from Hodžići Road Site 5, October 1998”, 17 June 1999), pp. 2, 8. See also P4504 (Dean Manning's Report, entitled "Summary of Forensic Evidence - Execution Points and Mass Graves", 16 May 2000), e-court pp. 9, 54, 59, 62; Adjudicated Fact 1789.

18204 P4056 (Christopher Lawrence's expert report entitled "Report on Autopsies of Human Remains from Hodžići Road Site 3, October 1998”, 17 June 1999), pp. 2, 8; P4057 (Christopher Lawrence's expert report entitled "Report on Autopsies of Human Remains from Hodžići Road Site 4, October 1998”, 17 June 1999), pp. 2, 7; P4058 (Christopher Lawrence's expert report entitled "Report on Autopsies of Human Remains from Hodžići Road Site 5, October 1998”, 17 June 1999), pp. 2, 8; P4504 (Dean Manning's Report, entitled "Summary of Forensic Evidence - Execution Points and Mass Graves", 16 May 2000), e-court p. 55, 59, 62. See also P4030 (Jose Baraybar's expert report entitled "Report on the Anthropology Examination of Human Remains from Eastern Bosnia in 1999”, 8 December 1999), e-court pp. 3-4; P4037 (Jose Baraybar's expert report entitled "Calculation of the Minimal Number of Individuals Exhumed by the ICTY between 1996 and 2001", 4 January 2004), p. 8.

18205 P4056 (Christopher Lawrence's expert report entitled "Report on Autopsies of Human Remains from Hodžići Road Site 3, October 1998”, 17 June 1999), pp. 2-3, 9, 13-15; P4057 (Christopher Lawrence's expert report entitled "Report on Autopsies of Human Remains from Hodžići Road Site 4, October 1998", 17 June 1999), pp. 2-3, 8, 13-15; P4058 (Christopher Lawrence's expert report entitled "Report on Autopsies of Human Remains from Hodžići Road Site 5, October 1998”, 17 June 1999), pp. 2-3, 9-10, 15-16; P4504 (Dean Manning's Report, entitled "Summary of Forensic Evidence - Execution Points and Mass Graves", 16 May 2000), e-court pp. 9, 56, 59-60. See also Adjudicated Fact 1789.

18206 P4056 (Christopher Lawrence's expert report entitled "Report on Autopsies of Human Remains from Hodžići Road Site 3, October 1998”, 17 June 1999), pp. 2, 13; P4057 (Christopher Lawrence's expert report entitled "Report on Autopsies of Human Remains from Hodžići Road Site 4, October 1998", 17 June 1999) pp. 2, 11; P4058 (Christopher Lawrence's expert report entitled "Report on Autopsies of Human Remains from Hodžići Road Site 5, October 1998", 17 June 1999), pp. 2, 13; P4504 (Dean Manning's Report, entitled "Summary of Forensic Evidence - Execution Points and Mass Graves", 16 May 2000), e-court pp. 9, 56, 60, 63. See also Adjudicated Fact 1789.

18207 P4058 (Christopher Lawrence's expert report entitled "Report on Autopsies of Human Remains from Hodžići Road Site 5, October 1998", 17 June 1999), p. 13; P4504 (Dean Manning's Report, entitled "Summary of Forensic Evidence - Execution Points and Mass Graves", 16 May 2000), e-court pp. 9, 60. See also Adjudicated Fact 1789.

18208 P4056 (Christopher Lawrence's expert report entitled "Report on Autopsies of Human Remains from Hodžići Road Site 3, October 1998”, 17 June 1999), pp. 2, 15; P4057 (Christopher Lawrence's expert report entitled "Report on Autopsies of Human Remains from Hodžići Road Site 4, October 1998", 17 June 1999) pp. 2, 15; P4058 (Christopher Lawrence's expert report entitled "Report on Autopsies of Human Remains from Hodžići Road Site 5, October 1998”, 17 June 1999), pp. 2, 16.

18209 See para. 5340.

18210 P4504 (Dean Manning's Report, entitled "Summary of Forensic Evidence - Execution Points and Mass Graves", 16 May 2000), e-court pp. 54, 58, 61; P4502 (Dean Manning's Report, entitled "Summary of Forensic Evidence, 
Further, forensic analysis demonstrated that soil native to the two Lažete gravesites was found in the Hodžići Road secondary graves, ${ }^{18211}$ blindfolds identical to those found in the two Lažete gravesites and in a "rubbish" site on the grounds of the Orahovac School were found in the Hodžići Road secondary gravesites, ${ }^{18212}$ and pieces of a black water hose discovered during the exhumation of the Lažete gravesites were also found in Hodžići Road 5. ${ }^{18213}$ These factors jointly lead to the conclusion that bodies from the Lažete 1 and 2 gravesites were removed and reburied at the Hodžići Road secondary gravesites.

5352. Moreover, DNA-based connections between the Lažete gravesites and the seven Hodžići Road secondary gravesites were found. ${ }^{18214}$ KDZ039 identified two individuals he saw in the truck on the way from the Orahovac School to the execution site, and who were later identified in one of the Hodziči Road secondary gravesites. ${ }^{18215}$

Mass Graves Exhumed in 2000 - Lazete 1, Lazete 2C, Ravnice, Glogova 1", February 2001), e-court p. 6. See also P4512 (Photograph booklet entitled "Srebrenica Mass Graves - Primary and Secondary Mass Grave Aerial Imagery"), e-court pp. 47-50; Adjudicated Fact 1788.

18211 P4000 (Richard Wright's expert report entitled "Exhumations in Eastern Bosnia in 1998", 12 May 1999), pp. 22-23. See also P4504 (Dean Manning's Report, entitled "Summary of Forensic Evidence - Execution Points and Mass Graves", 16 May 2000), e-court p. 55 (noting that lumps of limestone not native to the area were found in the Hodžići Road 3 grave and appeared to be imported with the bodies), 59 (noting that conspicuous lumps of foreign soil were found with the bodies in the Hodžići Road 5 gravesite); Jose Baraybar, P4029 (Transcript from Prosecutor v. Krstić), T. 3878; Adjudicated Fact 1788.

18212 P4504 (Dean Manning's Report, entitled "Summary of Forensic Evidence - Execution Points and Mass Graves", 16 May 2000), e-court p. 52; Jean-René Ruez, T. 23792 (27 January 2012); P4502 (Dean Manning's Report, entitled "Summary of Forensic Evidence, Mass Graves Exhumed in 2000 - Lazete 1, Lazete 2C, Ravnice, Glogova 1", February 2001), e-court p. 7. See also P4308 (Book of photographs and maps prepared by JeanRené Ruez, 22 June 2009), e-court pp. 141-143; Adjudicated Fact 1788.

18213 P4135 (Fredy Peccerelli report entitled "Lažete 1, Bosnia and Herzegovina, Excavation and Exhumation Report”, 2 February 2001), pp. 2, 12; Fredy Peccerelli, T. 22756-22758 (11 January 2012); Fredy Peccerelli, P4137 (Transcript from Prosecutor v. Tolimir), T. 8469-8470; P4136 (Final Report of Fredy Peccerelli entitled "Lažete 2 (LZ02C), Bosnia and Herzegovina, Excavation and Exhumation report", 1 May 2007), pp. 2, 12; P4502 (Dean Manning's Report, entitled "Summary of Forensic Evidence, Mass Graves Exhumed in 2000 Lazete 1, Lazete 2C, Ravnice, Glogova 1", February 2001), e-court p. 6; P4000 (Richard Wright's expert report entitled "Exhumations in Eastern Bosnia in 1998", 12 May 1999), p. 23; P4504 (Dean Manning's Report, entitled "Summary of Forensic Evidence - Execution Points and Mass Graves", 16 May 2000), e-court p. 59. See also para. 5338.

18214 The specific connections are as follows: ten individuals with remains in both Lažete 1 and Hodžići Road 5; nine individuals with remains in both Lažete 2 and Hodžići Road 1; five individuals with remains in both Lažete 2 and Hodžići Road 2; three individuals with remains in both Lažete 2 and Hodžići Road 3; two individuals with remains in both Lažete 2 and Hodžići Road 4; three individuals with remains in both Lažete 2 and Hodžići Road 6; and 19 individuals with remains in both Lažete 2 and Hodžići Road 7. P4772 (Dušan Janc's report entitled "Update to the summary of Forensic Evidence - Exhumation of the Graves and Surface Remains Recoveries related to Srebrenica - January 2012”, 13 January 2012), e-court pp. 48, 82, 84. The Chamber notes Dunjić's claim that not all bodies from secondary gravesites can be linked to the primary Lažete gravesite despite the DNA and other forensics links between the sites. D3894 (Dušan Dunjić's expert report entitled "Forensic Analysis of Documents Pertaining to Exhumations, Autopsies and Identification of Bodies in the Srebrenica Area”, 26 August 2012), pp. 22-24; D3893 (Dušan Dunjić's expert report entitled "Forensic Analysis of Reports on the Locations of Mass Graves in the Area of Eastern Bosnia and Documentation Relating to Exhumations in the Srebrenica Area", 27 August 2009), pp. 13-18. However, considering the totality of evidence the Chamber accepts Janc's report and the findings therein.

18215 KDZ309, T. 21927 (24 November 2011); D1945 (Statement of KDZ039 to Tuzla SJB, 21 July 1995), p. 2; D1947 (Statement of KDZ039 to Tuzla SDB, 25 July 1995), p. 2; P4996 (Ewa Tabeau's expert report entitled 
5353. As of 13 January 2012, DNA analysis led to identification of 533 victims from the Hodžići Road gravesites as persons listed as missing following the take-over of Srebrenica: 90 from Hodžići Road 1; 102 from Hodžići Road 2; 40 from Hodžići Road 3; 69 from Hodžići Road 4; 54 from Hodžići Road 5; 67 from Hodžići Road 6; and 111 from Hodžići Road $7 .{ }^{18216}$

\section{(f) $\underline{\text { Conclusion }}$}

5354. For all the reasons discussed above, the Chamber finds that on 14 July 1995, at least two of the Bosnian Muslim men being detained at the Orahovac School were removed from the gymnasium and summarily executed by members of the Bosnian Serb Forces. The Chamber also finds that the remainder of the at least $839^{18217}$ Bosnian Muslim men being detained at the Orahovac School were killed in a field nearby by members of the Bosnian Serb Forces.

\section{(2) Petkovci School and Dam near Petkovci}

(a) Introduction

5355. The Indictment refers to the killing on or about 14 July 1995 of some of the approximately 1,000 Bosnian Muslim men detained at Petkovci School. ${ }^{18218}$ The Indictment also refers to the killing on or about the evening of 14 July and the morning of 15 July 1995, in an area below the Dam near Petkovci, of the surviving portion of the approximately 1,000 Bosnian Muslim men who were detained at Petkovci School. ${ }^{18219}$

5356. The village of Petkovci is located approximately seven kilometres west from the turn-off on the main Zvornik-Bijeljina road. ${ }^{18220}$ Petkovci fell within the area of responsibility of the $6^{\text {th }}$

"Srebrenica Missing: Persons Reported Missing and Dead after the Take-Over of the Srebrenica Enclave by the Bosnian Serb Army on 11 July 1995”, 9 April 2009) (under seal), pp. 66, 118; P5917 (ICMP DNA identifications concerning identified victims related to Srebrenica, 6 December 2010).

18216 P4772 (Dušan Janc's report entitled "Update to the summary of Forensic Evidence - Exhumation of the Graves and Surface Remains Recoveries related to Srebrenica - January 2012”, 13 January 2012), e-court pp. 4, 21-23, 41; P4771 (Dušan Janc's report entitled "Update to the summary of Forensic Evidence - Exhumation of the Graves and Surface Remains Recoveries related to Srebrenica - January 2012”, 13 January 2012) (under seal), ecourt pp. 4, 21-23, 41, 278-309. See also P5917 (ICMP DNA identifications concerning identified victims related to Srebrenica, 6 December 2010); P4773 (ICMP unmatched DNA victim profiles related to Srebrenica, 23 December 2011); P4774 (ICMP lists of unmatched unique DNA victims profiles related to Srebrenica, 15 February 2010).

18217 The Chamber has reached this number by adding the 119 individuals identified from remains in Lažete 1 , the 189 individuals identified from remains in the three Lažete 2 sub-gravesites, and the 533 individuals identified from remains in the six Hodžići Road gravesites, and subtracted the two individuals who were killed at the Orahovac School and whose remains may have ended in either of these gravesites. See paras. 5343, 5348, 5353.

18218 Indictment, Scheduled Incident E.7.1.

18219 Indictment, Scheduled Incident E.7.2.

18220 The turn-off is located about one kilometre north of the Standard Barracks in Karakaj. P4308 (Book of photographs and maps prepared by Jean-René Ruez, 22 June 2009), e-court p. 166; P3187 (Map of Zvornik municipality). See also Jean-René Ruez, T. 23813 (30 January 2012). 
Battalion of the Zvornik Brigade. ${ }^{1821}$ The Command of the $6^{\text {th }}$ Battalion was stationed in the old school in Petkovci, approximately 600 to 800 metres from the "new" Petkovci School ("Petkovci School"). ${ }^{18222}$ The Petkovci Dam is located less than two kilometres from the Petkovci School. ${ }^{18223}$

\section{(b) Detention and killings at the Petkovci School}

5357. On the morning of 14 July, Marko Milošević-the Deputy Commander of the $6^{\text {th }}$ Battalion-received a phone call from Dragan Jokić - the Duty Officer of the Zvornik Brigadeinforming him that Bosnian Muslim detainees would be brought to the Petkovci School and that "security" would be in place. ${ }^{18224}$ Captain Ostoja Stanišić, the $6^{\text {th }}$ Battalion's Commander, who was not at the Battalion's Command at the time, was notified of the call by Milošević later that day. $^{18225}$

5358. In the afternoon, buses and trucks carrying approximately 1,000 Bosnian Muslim males who had been previously detained in various sites in and around Bratunac arrived at the Petkovci School. ${ }^{18226}$ As the trucks arrived, they pulled over in the playground in front of the school, where many other empty trucks and buses were also parked. ${ }^{18227}$ There, sporadic shooting, as well as cursing and yelling, could be heard. ${ }^{18228}$ Some of the detainees were forced to remain inside the truck in front of the school for about one hour in unbearable conditions. ${ }^{18229}$

5359. As the detainees got off the trucks, they were ordered to put their hands behind their heads, to sing Serb nationalistic songs, and to walk one by one down some steps until they reached the

\footnotetext{
18221 P4914 (Richard Butler's expert report entitled “Srebrenica Military Narrative (Revised): Operation 'Krivaja 95'”, 1 November 2002), para. 7.28.

18222 Ostoja Stanišić, P382 (Transcript from Prosecutor v. Popović et al.), T. 11594-11595, 11606, 11673; P250 (Aerial photograph of Petkovci marked by Ostoja Stanišić) (where the Command of the $6^{\text {th }}$ Battalion is marked with number "1" and Petkovci School is marked with number " 2 ").

18223 Jean-René Ruez, T. 23813 (30 January 2012); P4091 (Map of Srebrenica and Zvornik); P4914 (Richard Butler's expert report entitled "Srebrenica Military Narrative (Revised): Operation 'Krivaja 95”", 1 November 2002), para. 7.28

18224 Ostoja Stanišić, P382 (Transcript from Prosecutor v. Popović et al.), T. 11600-11601, 11621, 11624.

18225 Ostoja Stanišić, P382 (Transcript from Prosecutor v. Popović et al.), T. 11600-11601, 11603, 11702-11703.

18226 KDZ069, P339 (Transcript from Prosecutor v. Blagojević \& Jokić), T. 1399-1402; KDZ069, P339 (Transcript from Prosecutor v. Popović et al.), T. 3337; KDZ045, P5910 (Transcript from Prosecutor v. Krstić), T. 29612964; P4092 (Panoramic photograph of Petkovci school); P4308 (Book of photographs and maps prepared by Jean-René Ruez, 22 June 2009), e-court p. 167. See also Adjudicated Fact 1790; para. 5316.

18227 KDZ069, P339 (Transcript from Prosecutor v. Blagojević \& Jokić), T. 1401-1402. See also KDZ069, P339 (Transcript from Prosecutor v. Popović et al.), T. 3337; KDZ045, T. 22636-22637 (10 January 2012); P4097 (Panoramic photograph of Petkovci school marked by KDZ045).

18228 KDZ045, P5910 (Transcript from Prosecutor v. Krstić), T. 2964.

18229 People were shouting and screaming for water and to be let out. KDZ069, P339 (Transcript from Prosecutor $v$. Blagojević \& Jokić), T. 1402.
} 
front of the building; all the while the soldiers were cursing them. ${ }^{18230}$ The detainees were also hit and kicked as they ran towards the building. ${ }^{18231}$

5360. Once inside the school, the detainees were ordered to climb the stairs to the first floor and, as they did so, they were made to repeat after a Bosnian Serb soldier: "[t]his is Serbian land and will always remain so" and "Srebrenica has always been Serbian and will continue to be that." 18232 The detainees were then ordered to follow a corridor to the left, ${ }^{18233}$ and to enter the various classrooms: ${ }^{18234}$ KDZ045 was put in "classroom number 3", ${ }^{18235}$ while KDZ069 was placed in one of the last two classrooms. ${ }^{18236}$ Other detainees were ordered to enter the classrooms on the ground floor. $^{18237}$

5361. As KDZ045 entered the classroom, he saw two men who were so badly beaten that he initially thought they were dead. ${ }^{18238}$ The classrooms became overcrowded, and the conditions inside were very difficult. ${ }^{18239}$ The detainees were not allowed to go to the toilet, so almost everyone was soaked with urine. ${ }^{18240}$ Despite being very thirsty, the detainees were given very little water. ${ }^{18241}$ The rooms were very stuffy and the detainees could not breathe properly, but they

18230 KDZ069, P339 (Transcript from Prosecutor v. Blagojević \& Jokić), T. 1402-1404; KDZ045, P5910 (Transcript from Prosecutor v. Krstić), T. 2965, 2972; P213 (Photograph of Petkovci school). See also KDZ069, P338 (Transcript from Prosecutor v. Popović et al.), T. 3390-3391 (under seal); Jean-René Ruez, T. 23813-23814 (30 January 2012); P4308 (Book of photographs and maps prepared by Jean-René Ruez, 22 June 2009), e-court p. 170.

18231 KDZ045, T. 22637 (10 January 2012); KDZ045, P5910 (Transcript from Prosecutor v. Krstić), T. 2965; KDZ069, P339 (Transcript from Prosecutor v. Blagojević \& Jokić), T. 1404-1405; P4097 (Panoramic photograph of Petkovci school marked by KDZ045).

18232 KDZ069, P339 (Transcript from Prosecutor v. Blagojević \& Jokić), T. 1403-1405; KDZ069, P339 (Transcript from Prosecutor v. Popović et al.), T. 3338; KDZ045, P5910 (Transcript from Prosecutor v. Krstić), T. 29652966; P214 (Photograph of interior of Petkovci school).

18233 KDZ069, P339 (Transcript from Prosecutor v. Blagojević \& Jokić), T. 1405. See Jean-René Ruez, T. 23814 23815 (30 January 2012); P4308 (Book of photographs and maps prepared by Jean-René Ruez, 22 June 2009), e-court p. 173.

18234 KDZ069, P339 (Transcript from Prosecutor v. Blagojević \& Jokić), T. 1405; KDZ045, T. 22638, 22685-22686 (10 January 2012); KDZ045, P5910 (Transcript from Prosecutor v. Krstić), T. 2965-2966, 2973; P4098 (Photograph of interior of Petkovci school marked by KDZ045).

18235 KDZ045, T. 22638 (10 January 2012); KDZ045, P5910 (Transcript from Prosecutor v. Krstić), T. 2966, 2973, 3000; P4093 (Photograph of interior of Petkovci school); P4098 (Photograph of interior of Petkovci school marked by KDZ045).

18236 KDZ069, P339 (Transcript from Prosecutor v. Blagojević \& Jokić), T. 1405. See also KDZ069, P339 (Transcript from Prosecutor v. Popović et al.), T. 3338, 3359; P215 (Photograph of interior of Petkovci school).

18237 KDZ045, P5910 (Transcript from Prosecutor v. Krstić), T. 2995, 3001.

18238 KDZ045, P5910 (Transcript from Prosecutor v. Krstić), T. 2966.

18239 KDZ069, P339 (Transcript from Prosecutor v. Blagojević \& Jokić), T. 1406; KDZ045, P5910 (Transcript from Prosecutor v. Krstić), T. 2966. See also Adjudicated Fact 1791.

18240 KDZ069, P339 (Transcript from Prosecutor v. Blagojević \& Jokić), T. 1406.

18241 KDZ069, P339 (Transcript from Prosecutor v. Blagojević \& Jokić), T. 1406. See also KDZ045, P5910 (Transcript from Prosecutor v. Krstić), T. 2967; Adjudicated Fact 1791. The detainees clamoured for water but were ordered to be quiet; two detainees were held responsible for the group and threatened to be killed if the group was noisy; despite this warning, nobody kept quiet. KDZ069, P339 (Transcript from Prosecutor v. Blagojević \& Jokić), T. 1407. 
were not allowed to open or look out any windows. ${ }^{18242}$ A detainee's attempt to open a window was followed by a burst of gunfire, which broke the glass panes and wounded five or six men. ${ }^{18243}$ Further, as one detainee tried to look out the window, he was shot and wounded. ${ }^{18244}$

5362. On occasion, soldiers would barge into the classrooms and would demand money from the detainees, threatening to kill them if a certain sum had not been collected in 15 or 20 minutes. ${ }^{18245}$ Some detainees gave the money they had managed to hide before; the soldiers then left. ${ }^{18246}$ Soldiers also walked into the classrooms and asked whether any detainees were from certain villages close to Srebrenica; those who raised their hands in reply were ordered out of the classroom and never returned. ${ }^{18247}$ The detainees who remained inside heard the sounds of beating and moaning in the hallway. ${ }^{18248}$ Further, a relative of KDZ045 who left the classroom in search of water, never returned. ${ }^{18249}$

5363. Between 6 and 7 p.m., Ostoja Stanišić received a call from Dragan Jokić instructing him to notify Beara that he was to report to his command. ${ }^{18250}$ Jokić told Stanišić that Beara would be somewhere around the Petkovci School. ${ }^{18251}$ Stanišić sent Marko Milošević on foot to Petkovci School to convey the order to Beara. ${ }^{18252}$ Milošević found Beara-who was with Drago Nikolić at the time- at an intersection close to the school, relayed the message, and returned to the Battalion's Command about 30 minutes later. ${ }^{18253}$

\footnotetext{
18242 KDZ069, P339 (Transcript from Prosecutor v. Blagojević \& Jokić), T. 1406-1407; KDZ045, P5910 (Transcript from Prosecutor v. Krstić), T. 2966-2967.

18243 KDZ069, P339 (Transcript from Prosecutor v. Blagojević \& Jokić), T. 1407.

18244 KDZ045, P5910 (Transcript from Prosecutor v. Krstić), T. 2967.

18245 KDZ045, P5910 (Transcript from Prosecutor v. Krstić), T. 2966-2967; KDZ069, P339 (Transcript from Prosecutor v. Blagojević \& Jokić), T. 1407.

18246 KDZ069, P339 (Transcript from Prosecutor v. Blagojević \& Jokić), T. 1407.

18247 KDZ069, P339 (Transcript from Prosecutor v. Blagojević \& Jokić), T. 1407-1408. See also Adjudicated Fact 1792.

18248 KDZ069, P339 (Transcript from Prosecutor v. Blagojević \& Jokić), T. 1408. See also Adjudicated Fact 1792.

18249 KDZ045, P5910 (Transcript from Prosecutor v. Krstić), T. 2967.

18250 Ostoja Stanišić, P382 (Transcript from Prosecutor v. Popović et al.), T. 11601, 11604, 11658, $11703-11704$.

18251 Ostoja Stanišić, P382 (Transcript from Prosecutor v. Popović et al.), T. 11604, 11704. See also P4585 (Zvornik Brigade Duty Officers logbook, 29 May-27 July 1995), e-court p. 45 (an entry for 14 July 1995 in the Zvornik Brigade Duty Officers Notebook dated 15:00 hours noting that "Colonel Beara is coming in order to Orovoc Petkovci Roćević Pilica"). The Chamber refers to its assessment of Beara's testimony regarding his whereabouts on 13 and 14 July, as discussed in fn. 17583.

18252 Ostoja Stanišić, P382 (Transcript from Prosecutor v. Popović et al.), T. 11604, 11650.

18253 Ostoja Stanišić, P382 (Transcript from Prosecutor v. Popović et al.), T. 11604-11607, 11650; P271 (Aerial photograph of Petkovci marked by Ostoja Stanišić) (where the intersection is marked with an "X").
} 
5364. Starting at dusk, there was shooting around the Petkovci School. ${ }^{18254}$ Soldiers called detainees out the classrooms in groups, after which bursts of gunfire were heard. ${ }^{18255}$ This lasted until around midnight. ${ }^{18256}$

5365. At some point after midnight, the detainees were taken out of the classrooms in groups of four, and ordered by soldiers to take off their clothes from the waist up, as well as their shoes and socks, and to empty their pockets. ${ }^{18257}$ A pile of clothing, footwear, IDs, and documents lay on the corridor's floor. ${ }^{18258}$ Soldiers then tied the detainees' hands behind their backs and pushed them into a dark classroom, where other partly undressed men were also tied up. ${ }^{18259}$ The detainees were then ordered to exit the school and to get on the back of military trucks. ${ }^{18260}$ As the detainees exited the school they saw dead bodies lying in the hallway of the school and outside of the school. $^{18261}$

\section{(c) Killings at the Dam near Petkovci}

5366. The detainees boarded the trucks until the trucks were full to the point where the detainees could no longer sit, despite being ordered to do so. ${ }^{18262}$ Soldiers shot a burst of fire at the detainees' feet, wounding some of them and forcing others to fall on each other. ${ }^{18263}$ The trucks left the Petkovci School and drove for approximately ten minutes along an asphalt road; they then

\footnotetext{
18254 KDZ069, P339 (Transcript from Prosecutor v. Blagojević \& Jokić), T. 1408. See also Ostoja Stanišić, P382 (Transcript from Prosecutor v. Popović et al.), T. 11607, 11609, 11678 (stating that, in the evening of 14 July, he could hear isolated shots and short bursts of gunfire coming from the direction of Petkovci School).

18255 KDZ069, P339 (Transcript from Prosecutor v. Blagojević \& Jokić), T. 1408; KDZ045, P5910 (Transcript from Prosecutor v. Krstić), T. 2967-2968.

18256 KDZ069, P339 (Transcript from Prosecutor v. Blagojević \& Jokić), T. 1408. See Ostoja Stanišić, P382 (Transcript from Prosecutor v. Popović et al.), T. 11609 (stating that the shots lasted until approximately 1 a.m.).

18257 KDZ069, P339 (Transcript from Prosecutor v. Blagojević \& Jokić), T. 1408-1409; KDZ045, P5910 (Transcript from Prosecutor v. Krstić), T. 2968, 2970.

18258 KDZ045, T. 22638-22639 (10 January 2012); KDZ045, P5910 (Transcript from Prosecutor v. Krstić), T. 2968; P4098 (Photograph of interior of Petkovci school marked by KDZ045).

18259 KDZ069, P339 (Transcript from Prosecutor v. Blagojević \& Jokić), T. 1409-1410; KDZ045, T. 22639 (10 January 2012); KDZ045, P5910 (Transcript from Prosecutor v. Krstić), T. 2969, 3000; P4098 (Photograph of interior of Petkovci school marked by KDZ045).

18260 KDZ069, P339 (Transcript from Prosecutor v. Blagojević \& Jokić), T. 1415-1416; KDZ045, T. 22686-22687 (10 January 2012); KDZ045, P5910 (Transcript from Prosecutor v. Krstić), T. 2969-2970, 2974, 3000.

18261 KDZ069, P339 (Transcript from Prosecutor v. Blagojević \& Jokić), T. 1415; KDZ069, P339 (Transcript from Prosecutor v. Popović et al.), T. 3338; KDZ045, P5910 (Transcript from Prosecutor v. Krstić), T. 2970.

18262 KDZ069, P339 (Transcript from Prosecutor v. Blagojević \& Jokić), T. 1416; KDZ045, P5910 (Transcript from Prosecutor v. Krstić), T. 2970.

18263 KDZ069, P339 (Transcript from Prosecutor v. Blagojević \& Jokić), T. 1416; KDZ045, P5910 (Transcript from Prosecutor v. Krstić), T. 2970-2971.
} 
continued on a bumpy macadam road until they reached a field next to the Petkovci Dam. ${ }^{18264}$ As soon as the trucks stopped, the detainees could hear yelling and bursts of fire close by. ${ }^{18265}$

5367. The Zvornik Brigade vehicle log for two TAM trucks records ten journeys in total on 15 July, between Petkovci and the Petkovci Dam. ${ }^{18266}$ The Chamber therefore finds that drivers and trucks from the $6^{\text {th }}$ Battalion of the Zvornik Brigade were used to transport the detainees from the Petkovci School to the execution site near the Petkovci Dam.

5368. The detainees were ordered to get off the trucks, five to ten at a time, ${ }^{18267}$ while those who remained inside screamed and asked for water. ${ }^{18268}$ As KDZ045 disembarked into a field lit by floodlights, he saw that it was covered with dead bodies, their hands bound, and their faces to the ground. ${ }^{18269}$ KDZ069 jumped off the truck. ${ }^{18270}$ Detainees were ordered to find a spot and to form a row, after which soldiers wearing black balaclavas covering their faces started shooting at the detainees' backs from a distance of seven to ten metres. ${ }^{18271}$ The men fell on top of the bodies of those who had been killed before them. ${ }^{18272}$ Both KDZ045 and KDZ069 were wounded and pretended to be dead. ${ }^{18273}$ As they lay on the ground, they continued to observe other detainees

18264 KDZ069, P339 (Transcript from Prosecutor v. Blagojević \& Jokić), T. 1416-1417; KDZ045, P5910 (Transcript from Prosecutor v. Krstić), T. 2971, 2974; Jean-René Ruez, T. 23815-23816 (30 January 2012); P4308 (Book of photographs and maps prepared by Jean-René Ruez, 22 June 2009), e-court pp. 180, 182. See also Adjudicated Fact 1793. Both KDZ045 and KDZ069 identified the field next to the Dam from a photograph shown to them. KDZ045, T. 22639-22640 (10 January 2012); KDZ069, P339 (Transcript from Prosecutor v. Popović et al.), T. 3338; P216 (Photograph of Petkovci dam); P4099 (Panoramic photograph of Petkovci dam marked by KDZ045).

18265 KDZ069, P339 (Transcript from Prosecutor v. Blagojević \& Jokić), T. 1417; KDZ045, P5910 (Transcript from Prosecutor v. Krstić), T. 2974.

18266 P196 (Zvornik Military Post vehicle work log, 31 July 1995), e-court p. 3; P197 (Zvornik Military Post vehicle work log, 31 July 1995), e-court p. 2. See Adjudicated Fact 1796; Ostoja Stanišić, P382 (Transcript from Prosecutor v. Popovic et al.), T. 11613-11614 (stating that the two names recorded on the log belonged to drivers from the $6^{\text {th }}$ Battalion), T. 11615 (explaining that the term "Brana" refers to the dam that holds back the red lake), T. 11665-11666. In relation to the TAM 80 truck, Stanišić testified that the truck left for Srebrenica on 15 July in the morning and did not return until 16 July so it was thus impossible for it to also have made the trips to the Petkovci Dam. Ostoja Stanišić, P382 (Transcript from Prosecutor v. Popović et al.), T. 1161511616, 11659, 11706-11708. The Chamber gives little weight to Stanišić's testimony in this regard given his interest in distancing himself from the events at Petkovci on 15 July 1995.

18267 KDZ069, P339 (Transcript from Prosecutor v. Blagojević \& Jokić), T. 1417; KDZ045, T. 22686-22687 (10 January 2012); KDZ045, P5910 (Transcript from Prosecutor v. Krstić), T. 2974-2975. See also Adjudicated Fact 1794.

18268 KDZ069, P339 (Transcript from Prosecutor v. Blagojević \& Jokić), T. 1418. See also Adjudicated Fact 1794.

18269 KDZ045, T. 22639-22640, 22686 (10 January 2012); KDZ045, P5910 (Transcript from Prosecutor v. Krstić), T. 2975, 2984, 2987; P4099 (Panoramic photograph of Petkovci dam marked by KDZ045).

18270 KDZ069, P339 (Transcript from Prosecutor v. Blagojević \& Jokić), T. 1418.

18271 KDZ069, P339 (Transcript from Prosecutor v. Blagojević \& Jokić), T. 1418; KDZ045, T. 22686 (10 January 2012); KDZ045, P5910 (Transcript from Prosecutor v. Krstić), T. 2975-2976.

18272 KDZ045, P5910 (Transcript from Prosecutor v. Krstić), T. 2976; KDZ069, P339 (Transcript from Prosecutor v. Blagojević \& Jokić), T. 1418-1419.

18273 KDZ069, P339 (Transcript from Prosecutor v. Blagojević \& Jokić), T. 1419; KDZ045, P5910 (Transcript from Prosecutor v. Krstić), T. 2976-2977. 
being killed around them. ${ }^{18274}$ KDZ045 drifted in and out of consciousness, as a man had fallen on him and he did not have much air to breath. ${ }^{18275}$

5369. After the shooting of the detainees was completed, the soldiers checked the bodies to make sure the men were indeed dead. ${ }^{18276}$ One of the soldiers kicked KDZ045 and presumed him dead. ${ }^{18277}$ A soldier shot an injured man lying next to KDZ069 in the head. ${ }^{18278}$ Soldiers also made derogatory comments about some of the victims. ${ }^{18279}$

5370. After lying still for hours amongst the dead, KDZ045 and KDZ069 managed to escape the execution site together and reach a nearby ditch. ${ }^{18280}$ In the ditch, KDZ045 helped bandage KDZ069's wound with his own T-shirt. ${ }^{18281}$ Heavy fire could still be heard. ${ }^{18282}$ KDZ045 and KDZ069 stayed in the ditch until dawn; they then decided to leave the area through the nearby forest. $^{18283}$ In the evening of 15 July, the two men managed to reach a macadam road which led them to a burned down village; from there KDZ045 saw the ongoing burial operation at the execution site. ${ }^{18284}$ The men then headed in the direction of Karakaj, by following the TV transmitter. ${ }^{18285}$ They wandered through Bosnian Serb villages for four days, passing unnoticed

18274 KDZ069, P339 (Transcript from Prosecutor v. Blagojević \& Jokić), T. 1419; KDZ045, P5910 (Transcript from Prosecutor v. Krstić), T. 2976-2977.

18275 KDZ045, T. 22687 (10 January 2012); KDZ045, P5910 (Transcript from Prosecutor v. Krstić), T. $2976-2977$.

18276 KDZ069, P339 (Transcript from Prosecutor v. Blagojević \& Jokić), T. 1419-1420; KDZ045, P5910 (Transcript from Prosecutor v. Krstić), T. 2976-2977.

18277 KDZ045, P5910 (Transcript from Prosecutor v. Krstić), T. 2976-2977.

18278 KDZ069, P339 (Transcript from Prosecutor v. Blagojević \& Jokić), T. 1420. See also KDZ069, P339 (Transcript from Prosecutor v. Blagojević \& Jokić), T. 1421; KDZ069, P339 (Transcript from Prosecutor v. Popović et al.), T. 3336.

18279 KDZ069, P339 (Transcript from Prosecutor v. Blagojević \& Jokić), T. 1420-1421. See also Adjudicated Fact 1795.

18280 KDZ069, P339 (Transcript from Prosecutor v. Blagojević \& Jokić), T. 1421-1422; KDZ069, P339 (Transcript from Prosecutor v. Popović et al.), T. 3335; KDZ045, P5910 (Transcript from Prosecutor v. Krstić), T. 29772979; Jean-René Ruez, T. 23817-23819 (30 January 2012); P4308 (Book of photographs and maps prepared by Jean-René Ruez, 22 June 2009), e-court p. 183; P4300 (Photograph of Petkovci Dam marked by Jean-René Ruez). Both KDZ045 and KDZ069 recognised the ditch where they hid, from a photograph shown to them. KDZ045, P5910 (Transcript from Prosecutor v. Krstić), T. 2987-2988; KDZ069, P339 (Transcript from Prosecutor v. Popović et al.), T. 3339; P217 (Photograph of ditch); P4095 (Photograph of ditch).

18281 KDZ069, P339 (Transcript from Prosecutor v. Popović et al.), T. 3335; KDZ069, P339 (Transcript from Prosecutor v. Blagojević \& Jokić), T. 1422; KDZ045, P5910 (Transcript from Prosecutor v. Krstić), T. 2979.

18282 KDZ045, P5910 (Transcript from Prosecutor v. Krstić), T. 2979.

18283 KDZ069, P339 (Transcript from Prosecutor v. Blagojević \& Jokić), T. 1422-1423; KDZ045, P5910 (Transcript from Prosecutor v. Krstić), T. 2979.

18284 KDZ045, P5910 (Transcript from Prosecutor v. Krstić), T. 2980-2981, 2983-2984, 2987-2988; KDZ045, T. 22687-22688 (10 January 2012). See also KDZ069, P339 (Transcript from Prosecutor v. Popović et al.), T. 3333; Jean-René Ruez, T. 23818-23820 (30 January 2012); P4308 (Book of photographs and maps prepared by Jean-René Ruez, 22 June 2009), e-court pp. 184-185. KDZ069 testified that he was on the ground because of his wounds, so he could not see that well. KDZ069, P339 (Transcript from Prosecutor v. Blagojević \& Jokić), T. 1423.

18285 KDZ045, P5910 (Transcript from Prosecutor v. Krstić), T. 2982. 
through the lines of the Bosnian Serb troops, until they reached Bosnian Muslim-held territory on 18 July $1995{ }^{18286}$

\section{(d) Burials}

5371. In the early hours of 15 July, a Caterpillar bulldozer and a ULT 160 loader belonging to the Engineering Company of the Zvornik Brigade collected bodies from the execution site-10 to 15 at a time-and deposited them onto a tractor with a trailer. ${ }^{18287}$ When full, the tractor departed in the direction of the Petkovci Dam, returning 15 to 20 minutes later to be refilled. ${ }^{18288}$ Throughout this process, floodlights illuminated the execution site. ${ }^{18289}$ Shots were also heard during that time. ${ }^{18290}$

5372. Also on that day, pursuant to a request from the Petkovci villagers, Stanišić authorised the use of a TAM truck which belonged to the $6^{\text {th }}$ Battalion to assist with the clean up of bodies from Petkovci School. ${ }^{18291}$

5373. Towards the end of September 1995, and as part of the reburial operation to conceal the Srebrenica killings which will be discussed in detail below, ${ }^{18292}$ the bodies initially buried at the gravesite adjacent to the Petkovci Dam were reburied in the Liplje secondary gravesites, as demonstrated by the forensic evidence discussed in the paragraphs immediately below.

18286 KDZ069, P339 (Transcript from Prosecutor v. Blagojević \& Jokić), T. 1423-1424; KDZ069, P339 (Transcript from Prosecutor v. Popović et al.), T. 3336; KDZ045, P5910 (Transcript from Prosecutor v. Krstić), T. 2989. Upon reaching Bosnian Muslim-held territory, KDZ069 was taken to a hospital in Sepna but after a day was transferred to the hospital in Tuzla where he was treated for his injuries, which took approximately two to three months to heal. KDZ069, P339 (Transcript from Prosecutor v. Blagojević \& Jokić), T. 1424-1425; KDZ069, P339 (Transcript from Prosecutor v. Popović et al.), T. 3339-3340; P223 (Photograph of sole of foot of KDZ069); P224 (Photograph of chest injuries of KDZ069).

18287 KDZ045, P5910 (Transcript from Prosecutor v. Krstić), T. 2981, 2983-2984; P108 (Extract from Zvornik Brigade Engineering Company logbook, 15 July 1995), p. 1 (recording "work with ULT" and "work with excavator" at Petkovci on 15 July 1995); Adjudicated Fact 1797. See also KDZ069, P339 (Transcript from Prosecutor v. Blagojević \& Jokić), T. 1423. Despite being listed as the duty officer on that day, Damjan Lazarević denied knowing anything about the two entries relating to Petkovci for 15 July 1995 in the Zvornik Brigade Engineering Company Logbook. Damjan Lazarević, P352 (Transcript from Prosecutor v. Popović et al.), T. 14471-14472; P108 (Extract from Zvornik Brigade Engineering Company logbook, 15 July 1995), p. 1. However, the Chamber gives little weight to this, given Lazarević's interest in distancing himself from the events at Petkovci on 15 July.

18288 KDZ045, P5910 (Transcript from Prosecutor v. Krstić), T. 2981-2982, 3006-3007. See also P4096 (Photograph of Petkovci dam area marked by KDZ045); Jean-René Ruez, T. 23819-23820 (30 January 2012); P4308 (Book of photographs and maps prepared by Jean-René Ruez, 22 June 2009), e-court p. 186; P4301 (Photograph of Petkovci Dam marked by Jean-René Ruez); Adjudicated Fact 1793.

18289 KDZ045, P5910 (Transcript from Prosecutor v. Krstić), T. 2984, 2987.

18290 KDZ045, P5910 (Transcript from Prosecutor v. Krstić), T. 2981-2982.

18291 Ostoja Stanišić, P382 (Transcript from Prosecutor v. Popović et al.), T. 11610-11613, 11681. See P4563 (Statement by KDZ122), pp. 5-6 (under seal).

18292 See Section IV.C.1.g.v: Reburial operation. 


\section{(e) Forensic evidence}

\section{(i) Primary gravesite}

5374. A primary gravesite adjacent to the Petkovci Dam was exhumed between 15 and 25 April 1998, by a Tribunal exhumation team under the direction of Richard Wright. ${ }^{18293}$ The remains found therein were subsequently examined by a team of pathologists under the direction of Christopher Lawrence. ${ }^{18294}$

5375. Aerial images indicate that the gravesite was first excavated between 5 and 27 July 1995, and that the site was later disturbed between 7 and 27 September $1995 .{ }^{18295}$ This gravesite contained grossly disarticulated body parts; the disarticulation was thought to have been caused by the mechanical removal of the bodies during the robbing process. ${ }^{18296}$

5376. Remains of at least 46 individuals were recovered from the gravesite. ${ }^{18297}$ Because of the separation of the body parts within the gravesite, 91 body bags were collected. ${ }^{18298}$ Due to the substantial damage on the remains and their high degree of decomposition, experts were only able

18293 Richard Wright, P3999 (Transcript from Prosecutor v. Krstić), T. 3638; P4000 (Richard Wright's expert report entitled "Exhumations in Eastern Bosnia in 1998", 12 May 1999), e-court pp. 8, 20. See Adjudicated Fact 1798. See also P4772 (Dušan Janc's report entitled "Update to the summary of Forensic Evidence - Exhumation of the Graves and Surface Remains Recoveries related to Srebrenica - January 2012”, 13 January 2012), e-court p. 10; P4504 (Dean Manning's Report, entitled "Summary of Forensic Evidence - Execution Points and Mass Graves", 16 May 2000), e-court p. 66.

18294 Christopher Lawrence, T. $22446-22447$ (8 December 2011); Christopher Lawrence, P4051 (Transcript from Prosecutor v. Krstić), T. 3978-3980; P4064 (Chart of primary and secondary graves). See also P4772 (Dušan Janc's report entitled "Update to the summary of Forensic Evidence - Exhumation of the Graves and Surface Remains Recoveries related to Srebrenica - January 2012”, 13 January 2012), e-court p. 10; P4504 (Dean Manning's Report, entitled "Summary of Forensic Evidence - Execution Points and Mass Graves", 16 May 2000), e-court p. 66; P4053 (Christopher Lawrence's expert report entitled "Report on Autopsies of Human Remains from the Dam Site June 1998”, 17 June 1999), e-court p. 25.

18295 Jean-René Ruez, T. 23861 (30 January 2012), T. 23970-23972 (31 January 2012); P4308 (Book of photographs and maps prepared by Jean-René Ruez, 22 June 2009), e-court p. 252; P4504 (Dean Manning's Report, entitled "Summary of Forensic Evidence - Execution Points and Mass Graves", 16 May 2000), e-court p. 65; P4512 (Photograph booklet entitled "Srebrenica Mass Graves - Primary and Secondary Mass Grave Aerial Imagery"), e-court p. 22. See also D2045 (Aerial image of Petkovci Dam on 7 and 27 September 1995 marked by JeanRené Ruez).

18296 P4000 (Richard Wright's expert report entitled "Exhumations in Eastern Bosnia in 1998", 12 May 1999), ecourt pp. 20-21; Richard Wright, P3999 (Transcript from Prosecutor v. Krstić), T. 3653-3656; P4011 (Photograph of exhumation hole); P4504 (Dean Manning's Report, entitled "Summary of Forensic Evidence Execution Points and Mass Graves", 16 May 2000), e-court p. 66. At the eastern end of the grave, there were traces of a ramp that gave access to the mechanical excavator which was used during the robbing process. P4000 (Richard Wright's expert report entitled "Exhumations in Eastern Bosnia in 1998”, 12 May 1999), ecourt p. 21; P4010 (Photograph of exhumation trench).

18297 P4053 (Christopher Lawrence's expert report entitled "Report on Autopsies of Human Remains from the Dam Site June 1998", 17 June 1999), e-court p. 2.

18298 P4053 (Christopher Lawrence's expert report entitled "Report on Autopsies of Human Remains from the Dam Site June 1998", 17 June 1999), e-court p. 2. 
to determine the sex of 15 of the bodies, all of which were male. ${ }^{18299}$ While the cause of death for the majority of remains could not be determined, gunshot wounds identified in remains of nine body bags were deemed "sufficient" or "probably sufficient to cause death". ${ }^{1800}$ Further, the analysis of 464 skull fragments and 211 shell casings recovered from the surface of the gravesite, was consistent with a number of individuals being shot in the head. ${ }^{18301}$ Finally, one twine ligature was found. ${ }^{18302}$

5377. As of 13 January 2012, DNA analysis led to the identification of 19 bodies from the gravesite adjacent to the Petkovci Dam as persons listed as missing following the take-over of Srebrenica. $^{18303}$

(ii) Liplje secondary gravesites

5378. Four secondary mass gravesites along the Liplje Road-Liplje 1, 2, 3, and 4-were discovered between 1996 and 1998 by a Tribunal team of experts. ${ }^{18304}$ A fifth gravesite-Liplje

18299 P4053 (Christopher Lawrence's expert report entitled "Report on Autopsies of Human Remains from the Dam Site June 1998", 17 June 1999), e-court pp. 2, 8. See Christopher Lawrence, T. 22456, 22512 (8 December 2011). See also P4504 (Dean Manning's Report, entitled "Summary of Forensic Evidence - Execution Points and Mass Graves", 16 May 2000), e-court pp. 10, 66; Adjudicated Fact 1799.

18300 P4053 (Christopher Lawrence's expert report entitled "Report on Autopsies of Human Remains from the Dam Site June 1998”, 17 June 1999), e-court pp. 2, 8, 20, 22. See also P4504 (Dean Manning's Report, entitled "Summary of Forensic Evidence - Execution Points and Mass Graves", 16 May 2000), e-court pp. 66-67. The Chamber notes that Dušan Dunjić challenged Lawrence's findings in his report for this site in relation to the cause of death. D3893 (Dušan Dunjić's expert report entitled "Forensic Analysis of Reports on the Locations of Mass Graves in the Area of Eastern Bosnia and Documentation Relating to Exhumations in the Srebrenica Area", 27 August 2009), pp. 118-119. Having assessed the totality of evidence on this issue, the Chamber accepts Lawrence's report and the findings therein.

18301 P4053 (Christopher Lawrence's expert report entitled "Report on Autopsies of Human Remains from the Dam Site June 1998", 17 June 1999), e-court pp. 2, 22; P4504 (Dean Manning's Report, entitled "Summary of Forensic Evidence - Execution Points and Mass Graves", 16 May 2000), e-court pp. 10, 66-67; Adjudicated Fact 1799. See also Jean-René Ruez, T. 23822-23824 (30 January 2012); P4308 (Book of photographs and maps prepared by Jean-René Ruez, 22 June 2009), e-court pp. 187, 190-193.

18302 P4053 (Christopher Lawrence's expert report entitled "Report on Autopsies of Human Remains from the Dam Site June 1998", 17 June 1999), e-court pp. 2, 20; P4504 (Dean Manning's Report, entitled "Summary of Forensic Evidence - Execution Points and Mass Graves", 16 May 2000), e-court p. 67; P4507 (Chart of photographs of blindfolds, ligatures, and location); P4509 (Collage of Srebrenica ligatures, 5 March 2012).

18303 P4772 (Dušan Janc's report entitled "Update to the summary of Forensic Evidence - Exhumation of the Graves and Surface Remains Recoveries related to Srebrenica - January 2012”, 13 January 2012), e-court pp. 3, 10-11, 41; P4771 (Dušan Janc's report entitled "Update to the summary of Forensic Evidence - Exhumation of the Graves and Surface Remains Recoveries related to Srebrenica - January 2012”, 13 January 2012), Annex D, ecourt pp. 129-130 (under seal). See also P5917 (ICMP DNA identifications concerning identified victims related to Srebrenica, 6 December 2010); P4773 (ICMP unmatched DNA victim profiles related to Srebrenica, 23 December 2011); P4774 (ICMP lists of unmatched unique DNA victims profiles related to Srebrenica, 15 February 2010); Richard Wright, P3999 (Transcript from Prosecutor v. Krstić), T. 3657; P4013 (Photograph of ID recovered from body pocket); P4014 (Excerpt from ICRC Missing Persons list).

18304 P4000 (Richard Wright's expert report entitled "Exhumations in Eastern Bosnia in 1998", 12 May 1999), ecourt p. 11; Jean-René Ruez, T. 23865-23866 (30 January 2012); P4308 (Book of photographs and maps prepared by Jean-René Ruez, 22 June 2009), e-court p. 264. See also P4772 (Dušan Janc's report entitled "Update to the summary of Forensic Evidence - Exhumation of the Graves and Surface Remains Recoveries related to Srebrenica - January 2012”, 13 January 2012), e-court pp. 24-25. 
7-was identified at a later date by the BiHCMP. ${ }^{18305}$ Liplje 2 was completely exhumed in August 1995 by a Tribunal team under the direction of Richard Wright. ${ }^{18306}$ The remains found at Liplje 2 were then examined by a team of pathologists under the direction of Christopher Lawrence. ${ }^{18307}$ While the preliminary examination of Liplje 1,3, and 4 was conducted by a team of Tribunal experts, the responsibility for exhuming the gravesites-as well as Liplje 7-was that of the BiHCMP. ${ }^{18308}$

5379. The Chamber notes that out of all the secondary gravesites associated with the primary gravesite, it only received forensic evidence in relation to Liplje 2. Liplje 2 was situated approximately 14 kilometres south of the Petkovci Dam. ${ }^{18309}$ Aerial images reveal that Liplje 2 was created between 7 September and 2 October $1995 .{ }^{18310}$ The forensic evidence reviewed by the Chamber in relation to Liplje 2 shows that all of the bodies where sex could be determined were male. ${ }^{18311}$ Only four relatively intact bodies were located at Liplje 2; of these, one had died from gunshot wounds, one from possible gunshot wounds, and two had an undetermined cause of

18305 P4772 (Dušan Janc's report entitled "Update to the summary of Forensic Evidence - Exhumation of the Graves and Surface Remains Recoveries related to Srebrenica - January 2012”, 13 January 2012), e-court p. 24.

18306 P4000 (Richard Wright's expert report entitled "Exhumations in Eastern Bosnia in 1998", 12 May 1999), ecourt p. 11; Richard Wright, P3999 (Transcript from Prosecutor v. Krstić), T. 3658; P4013 (Photograph of ID recovered from body pocket); P4015 (Photograph of exhumation trench at Liplje 2 site). See also P4504 (Dean Manning's Report, entitled "Summary of Forensic Evidence - Execution Points and Mass Graves", 16 May 2000), e-court p. 70; P4772 (Dušan Janc's report entitled "Update to the summary of Forensic Evidence Exhumation of the Graves and Surface Remains Recoveries related to Srebrenica - January 2012", 13 January 2012), e-court p. 24; P4020 (Diagram of graves LP 2 and ZJ 5).

18307 Christopher Lawrence, T. 22446-22447 (8 December 2011); P4060 (Christopher Lawrence's expert report entitled "Report on Autopsies of Human Remains from Liplje Site 2, October 1998", 17 June 1999), p. 35; Christopher Lawrence, P4051 (Transcript from Prosecutor v. Krstić), T. 3978-3980; P4064 (Chart of primary and secondary graves). See also P4504 (Dean Manning's Report, entitled "Summary of Forensic Evidence Execution Points and Mass Graves", 16 May 2000), e-court p. 70.

18308 P4000 (Richard Wright's expert report entitled "Exhumations in Eastern Bosnia in 1998", 12 May 1999), ecourt p. 11; P4772 (Dušan Janc's report entitled "Update to the summary of Forensic Evidence - Exhumation of the Graves and Surface Remains Recoveries related to Srebrenica - January 2012", 13 January 2012), e-court pp. 24-25. Cf. D3893 (Dušan Dunjić's expert report entitled "Forensic Analysis of Reports on the Locations of Mass Graves in the Area of Eastern Bosnia and Documentation Relating to Exhumations in the Srebrenica Area", 27 August 2009), pp. 102-116.

18309 P4000 (Richard Wright's expert report entitled "Exhumations in Eastern Bosnia in 1998”, 12 May 1999), ecourt p. 21; P4504 (Dean Manning's Report, entitled "Summary of Forensic Evidence - Execution Points and Mass Graves”, 16 May 2000), e-court pp. 10, 65.

18310 P4504 (Dean Manning's Report, entitled "Summary of Forensic Evidence - Execution Points and Mass Graves", 16 May 2000), e-court p. 69; P4512 (Photograph booklet entitled "Srebrenica Mass Graves - Primary and Secondary Mass Grave Aerial Imagery”), ecourt pp. 57-58 (aerial images showing emergence of disturbed earth at Liplje 1 and 2 between 7 September and 2 October 1995), e-court p. 59 (aerial image showing emergence of disturbed earth at Liplje 3 on or before 2 October 1995), e-court pp. 60-61 (aerial images showing emergence of disturbed earth at Liplje 4 between 7 September and 2 October 1995); Adjudicated Fact 1802.

18311 P4060 (Christopher Lawrence's expert report entitled "Report on Autopsies of Human Remains from Liplje Site 2, October 1998”), e-court pp. 2, 10. See Adjudicated Fact 1804. See also P4504 (Dean Manning's Report, entitled "Summary of Forensic Evidence - Execution Points and Mass Graves", 16 May 2000), e-court pp. 10, 70 . 
death. ${ }^{18312}$ While the extensive post mortem tampering with the bodies and the normal process of decomposition precluded the experts from being able to provide a cause of death for the remaining body parts analysed, ${ }^{18313}$ injuries in some body parts were consistent with gunshot wounds. ${ }^{18314}$ Further, while no definite blindfolds were located, 23 ligatures were found. ${ }^{18315}$

5380. Forensic analysis showed that the bodies removed from the gravesite adjacent to the Petkovci Dam were reburied at Liplje 2. ${ }^{18316}$ Specifically, the gravesite contained unweathered limestone boulders and lumps of green clay, which were characteristic of the robbed gravesite adjacent to the Petkovci Dam. ${ }^{18317}$ Further, a twine ligature found in Liplje 2 was similar to another found at the gravesite adjacent to the Petkovci Dam. ${ }^{18318}$ Moreover, DNA-based connections were found between the gravesite adjacent to the Petkovci Dam and the five Liplje secondary

18312 P4060 (Christopher Lawrence's expert report entitled "Report on Autopsies of Human Remains from Liplje Site 2, October 1998”), e-court pp. 2, 8; P4504 (Dean Manning's Report, entitled “Summary of Forensic Evidence Execution Points and Mass Graves", 16 May 2000), e-court pp. 10, 70.

18313 P4060 (Christopher Lawrence's expert report entitled "Report on Autopsies of Human Remains from Liplje Site 2, October 1998”), e-court pp. 2, 10, 20.

18314 P4060 (Christopher Lawrence's expert report entitled "Report on Autopsies of Human Remains from Liplje Site 2, October 1998”), e-court pp. 2-3, 12, 20-21; P4504 (Dean Manning's Report, entitled "Summary of Forensic Evidence - Execution Points and Mass Graves", 16 May 2000), e-court pp. 70-71. The Chamber notes Dušan Dunjić's extensive challenges to the pathology report for the Liplje 4 gravesite with respect to the findings therein in relation to the cause of death. See D3893 (Dušan Dunjić's expert report entitled "Forensic Analysis of Reports on the Locations of Mass Graves in the Area of Eastern Bosnia and Documentation Relating to Exhumations in the Srebrenica Area”, 27 August 2009), pp. 103-125. The Chamber first notes that the original pathology report for Liplje 4 is not in evidence. In any event, while it may have been impossible to determine with certainty the cause of death for each of the remains retrieved from Liplje 4 due to their high degree of decomposition, the Chamber is satisfied that the remains therein had been moved from the gravesite adjacent to the Petkovci Dam. See P4772 (Dušan Janc's report entitled "Update to the summary of Forensic Evidence Exhumation of the Graves and Surface Remains Recoveries related to Srebrenica - January 2012", 13 January 2012), e-court pp. 49, 82, 84. See para. 5512. Therefore the Chamber is satisfied that the remains retrieved from Liplje 4 are linked to this Scheduled Incident and to the events described in this section.

18315 P4060 (Christopher Lawrence's expert report entitled "Report on Autopsies of Human Remains from Liplje Site 2, October 1998"), e-court pp. 2, 16-17; P4504 (Dean Manning's Report, entitled "Summary of Forensic Evidence - Execution Points and Mass Graves", 16 May 2000), e-court p. 10; P4506 (Photograph booklet entitled "Srebrenica Blindfolds and Ligatures - Volume 2: Lazete 2, Hodzici Road 3, 4 and 5, Petkovci Dam, Liplje 2, Cerska and Zeleni Jadar 5"), e-court pp. 209-232; P4507 (Chart of photographs of blindfolds, ligatures, and location); P4509 (Collage of Srebrenica ligatures, 5 March 2012). See also Adjudicated Fact 1806.

18316 P4000 (Richard Wright's expert report entitled "Exhumations in Eastern Bosnia in 1998", 12 May 1999), ecourt p. 1; P4504 (Dean Manning's Report, entitled "Summary of Forensic Evidence - Execution Points and Mass Graves", 16 May 2000), e-court pp. 10, 65. See also Adjudicated Fact 1800.

18317 P4000 (Richard Wright's expert report entitled "Exhumations in Eastern Bosnia in 1998", 12 May 1999), ecourt pp. 21, 25, 166; Richard Wright, P3999 (Transcript from Prosecutor v. Krstić), T. 3658-3659.

18318 P4053 (Christopher Lawrence's expert report entitled "Report on Autopsies of Human Remains from the Dam Site June 1998”, 17 June 1999), e-court pp. 2, 20-21; P4060 (Christopher Lawrence's expert report entitled "Report on Autopsies of Human Remains from Liplje Site 2, October 1998”), e-court p. 17; Jean-René Ruez, T. 23821 (30 January 2012); P4308 (Book of photographs and maps prepared by Jean-René Ruez, 22 June 2009), e-court pp. 188-189; P4506 (Photograph booklet entitled "Srebrenica Blindfolds and Ligatures - Volume 2: Lazete 2, Hodzici Road 3, 4 and 5, Petkovci Dam, Liplje 2, Cerska and Zeleni Jadar 5”), pp. 205-206. 
gravesites. $^{18319}$ DNA-based connections were also found between the various Liplje secondary gravesites themselves. ${ }^{18320}$

5381. As of 13 January 2012, DNA analysis led to the identification of 796 victims from the Liplje gravesites as persons listed as missing following the take-over of Srebrenica: 159 in Liplje 1; 175 in Liplje 2; 57 in Liplje 3; 289 in Liplje 4, and 116 in Liplje $7{ }^{18321}$

\section{(f) $\underline{\text { Conclusion }}$}

5382. For all these reasons, the Chamber finds that, on 14 and 15 July 1995, at least 815 Bosnian Muslim men detained at the Petkovci School were killed by the Bosnian Serb Forces. Some were summarily executed by members of the Bosnian Serb Forces while being detained at Petkovci School. The rest were killed in a field nearby the Petkovci Dam.

\section{(3) Ročević School and Drina River near Kozluk}

(a) Introduction

5383. The Indictment refers to the killing on or about 14 or 15 July 1995 at Ročević School of some of the approximately 1,000 Bosnian Muslim men detained therein. ${ }^{18322}$ The Indictment also refers to the killing on 15 July 1995 of the surviving portion of the approximately 1,000 Bosnian

18319 The specific connections are as follows: four individuals with remains in both the Petkovci Dam and Liplje 1; five individuals with remains in both the Petkovci Dam and Liplje 2; four individuals with remains in both the Petkovci Dam and Liplje 3; 15 individuals with remains in both the Petkovci Dam and Liplje 4; and 7 individuals with remains in both the Petkovci Dam and Liplje 7. P4772 (Dušan Janc's report entitled "Update to the summary of Forensic Evidence - Exhumation of the Graves and Surface Remains Recoveries related to Srebrenica - January 2012”, 13 January 2012), e-court pp. 49, 82, 84. The Chamber notes Dunjić's claim that there is no evidence that all bodies from the Liplje gravesites are connected to the killings at the Petkovci Dam. D3893 (Dušan Dunjić's expert report entitled "Forensic Analysis of Reports on the Locations of Mass Graves in the Area of Eastern Bosnia and Documentation Relating to Exhumations in the Srebrenica Area", 27 August 2009), p. 117. Having considered the totality of evidence, the Chamber accepts Janc's report and the findings therein, and finds that the bodies from the Liplje gravesites are linked to this Scheduled Incident and to the events described in this section.

18320 The specific connections are as follows: 11 individuals with remains in both Liplje 1 and Liplje 2; 12 individuals with remains in both Liplje 1 and Liplje 3; two individuals with remains in both Liplje 1 and Liplje 4; one individual with remains in both Liplje 2 and Liplje 4; 12 individuals with remains in both Liplje 2 and Liplje 7; 13 individuals with remains in both Liplje 3 and Liplje 4; and one individual with remains in both Liplje 4 and Liplje 7. P4772 (Dušan Janc's report entitled "Update to the summary of Forensic Evidence - Exhumation of the Graves and Surface Remains Recoveries related to Srebrenica - January 2012”, 13 January 2012), e-court pp. $49,82,84$.

18321 P4772 (Dušan Janc's report entitled "Update to the summary of Forensic Evidence - Exhumation of the Graves and Surface Remains Recoveries related to Srebrenica - January 2012”, 13 January 2012), e-court pp. 4, 24-25, 41; P4771 (Dušan Janc's report entitled "Update to the summary of Forensic Evidence - Exhumation of the Graves and Surface Remains Recoveries related to Srebrenica - January 2012", 13 January 2012), Annex D, ecourt pp. 310-353 (under seal). See also P5917 (ICMP DNA identifications concerning identified victims related to Srebrenica, 6 December 2010); P4773 (ICMP unmatched DNA victim profiles related to Srebrenica, 23 December 2011); P4774 (ICMP lists of unmatched unique DNA victims profiles related to Srebrenica, 15 February 2010).

18322 Indictment, Scheduled Incident E.8.1. 
Muslim men who had been detained at Ročević School, at a site on the bank of the Drina River near Kozluk. ${ }^{18323}$

5384. The village of Kozluk is located off the western bank of the Drina River, less than ten kilometres north of Karakaj along the main Zvornik-Bijeljina Road. ${ }^{18324}$ The Ročević School is situated just off the main Zvornik-Bijeljina Road, in the village of Ročević, approximately seven kilometres further north from Kozluk. ${ }^{18325}$ In 1995, the Command of the $2^{\text {nd }}$ Battalion of the Zvornik Brigade was located in Malešić, approximately 15 kilometres from Ročević. ${ }^{18326}$

(b) Detention and killings at the Ročević School

5385. On 14 July 1995, buses carrying Bosnian Muslim males who had been previously detained in various sites in and around Bratunac, arrived at the Ročević School. ${ }^{18327}$ When Popović arrived at the school in the afternoon, he found Bosnian Muslim detainees inside the school's gymnasium. $^{18328}$

5386. On the evening of 14 July, ${ }^{18329}$ five to seven members of the Bratunac Brigade MP set off from Bratunac towards Ročević School. ${ }^{18330}$ Upon arriving, they encountered other members of the

18323 Indictment, Scheduled Incident E.8.2.

18324 P3187 (Map of Zvornik municipality); P4308 (Book of photographs and maps prepared by Jean-René Ruez, (22 June 2009), e-court pp. 195, 198. See also Zlatan Čelanović, P377 (Transcript from Prosecutor v. Popović et al.), T. 6661-6662 (referring to Kozluk as a settlement).

18325 Srećko Aćimović, P343 (Transcript from Prosecutor v. Popović et al.), T. 12997; Mile Janjić, P372 (Transcript from Prosecutor v. Popović et al.), T. 17950; Jean-René Ruez, T. 23826 (30 January 2012); P4308 (Book of photographs and maps prepared by Jean-René Ruez, 22 June 2009), e-court p. 198.

18326 Srećko Aćimović, P343 (Transcript from Prosecutor v. Popović et al.), T. 12930-12931; Veljko Ivanović, P384 (Transcript from Prosecutor v. Popović et al.), T. 18174, 18180; Mitar Lazarević, P363 (Transcript from Prosecutor v. Popović et al.), T. 13362.

18327 See D3993 (Witness statement of Vujadin Popović dated 2 November 2013), paras. 41, 52; Mile Janjić, P372 (Transcript from Prosecutor v. Popović et al.), T. 17948-17951, 17998.

18328 D3993 (Witness statement of Vujadin Popović dated 2 November 2013), para. 52. The Chamber also received evidence that Beara visited the various sites in Zvornik where Bosnian Muslims were being detained on 14 July. See P4563 (Statement by KDZ122), p. 2 (under seal) (referring to the presence of Beara in Zvornik on 14 July 1995); P4585 (Zvornik Brigade Duty Officers logbook, 29 May-27 July 1995), e-court p. 45 (an entry for 14 July 1995 at 15:00 hours noting that "Colonel Beara is coming in order to Orovoc Petkovci Roćević Pilica"). The Chamber refers to its assessment of Beara's testimony regarding his whereabouts on 13 and 14 July discussed in fn. 17583.

18329 Mile Janjić, P372 (Transcript from Prosecutor v. Popović et al.), T. 17948, 17998-17999. Janjić testified that he was not sure whether he left for Zvornik on 14 or 15 July 1995 . Mile Janjić, P372 (Transcript from Prosecutor v. Popović et al.), T. 17948, 17961, 17990-17991. However, in light of the evidence described below showing that the Bosnian Muslim detainees had already been transported to the execution site and subsequently killed by the evening of 15 July, the Chamber considers that he and his colleagues went to Ročević on 14 July 1995. See paras. 5313, 5316.

18330 Mile Janjić, P372 (Transcript from Prosecutor v. Popović et al.), T. 17948-17949, 17997. See Mile Janjić, P1194 (Transcript from Prosecutor v. Blagojević \& Jokić), T. 9756. 
Bratunac Brigade ${ }^{18331}$ who had been tasked with guarding the Bosnian Muslims detained inside the school building and the adjacent gymnasium. ${ }^{18332}$

5387. Between 8 and 9 p.m. on 14 July, ${ }^{18333}$ Srećko Aćimović-the Commander of the Zvornik Brigade's $2^{\text {nd }}$ Battalion ${ }^{18334}$ — was informed by the priest and the president of the Ročević local commune that detainees were being held at the Ročević School and were being killed. ${ }^{18335}$ Aćimović headed to the school immediately and, upon entering the school yard, heard detainees inside the gymnasium screaming for water and asking to go to the bathroom. ${ }^{18336}$ Aćimović also encountered soldiers unknown to him behaving erratically, seemingly under the influence of

18331 Mile Janjić, P372 (Transcript from Prosecutor v. Popović et al.), T. 17951-17952, 17954. Janjić testified that upon arriving at Ročević School he saw a group of between 10 to 15 soldiers who were members of the "Zenica company", which was part of the Bratunac Brigade. Mile Janjić, P372 (Transcript from Prosecutor v. Popović et al.), T. 17951. These men were members of both the $1^{\text {st }}$ and the $2^{\text {nd }}$ Battalions of the Bratunac Brigade, but they were referred to as "the Zenica people" because they had come from Zenica in 1992. Mile Janjić, P372 (Transcript from Prosecutor v. Popović et al.), T. 17952. Janjić testified that Mirko Janković was also present at Ročević School. Mile Janjić, P372 (Transcript from Prosecutor v. Popović et al.), T. 17951, 17968. See Momir Nikolić, T. 24570-24571 (13 February 2012). See also Dragan Jović, P365 (Transcript from Prosecutor v. Popović et al.), T. 18053, 18083 (referring to the presence of members of the MP at Ročević School on 15 July, who did not belong to the Zvornik Brigade, but who might have been part of the Bratunac Brigade).

18332 Mile Janjić, P372 (Transcript from Prosecutor v. Popović et al.), T. 17953-17955. See KDZ407, P379 (Transcript from Prosecutor v. Popović et al.), T. 6461. The members of the Bratunac Brigade MP left in the direction of Bratunac less than half an hour after first arriving at Ročević School, leaving the other soldiers behind. Mile Janjić, P372 (Transcript from Prosecutor v. Popović et al.), T. 17955-17956, 17998-17999. Janković also left around the same time in an unknown direction, driving a UN APC. Mile Janjić, P372 (Transcript from Prosecutor v. Popović et al.), T. 17956, 17989-17990.

18333 Aćimović testified that he was not certain that the events described took place on 14 July but that it was midJuly. Srećko Aćimović, P343 (Transcript from Prosecutor v. Popović et al.), T. 13123-13124. However, in light of the totality of Aćimović's evidence and the timeline of the events described by other witnesses in relation to this killing incident, the Chamber considers that it was indeed 14 July 1995 . The Chamber admitted Aćimović's prior testimony in the Popović et al. case pursuant to Rule 92 bis. The Chamber has analysed Aćimović's testimony in its totality and in the context of other evidence before it. While the Chamber found internal inconsistencies within Aćimović's testimony, as well as between portions of his testimony and other evidence before it, see e.g. fns. 18343, 18367, these inconsistencies, in the Chamber's view, arise from his efforts to downplay his own responsibility and involvement in the events at Ročević on 14 and 15 July 1995. The Chamber also finds that Aćimović was not always forthright in his account of events, but this also arises from his efforts to downplay his own responsibility and involvement in the events described in the following paragraphs. The Chamber has taken all of this into consideration and has decided to rely on the uncontested aspects of Aćimović's evidence, as well as on aspects which are corroborated by other accepted evidence, as it has found such evidence to be reliable and of probative value.

18334 Srećko Aćimović, P343 (Transcript from Prosecutor v. Popović et al.), T. 12930-12931; Veljko Ivanović, P384 (Transcript from Prosecutor v. Popović et al.), T. 18174; Mitar Lazarević, P363 (Transcript from Prosecutor v. Popović et al.), T. 13362.

18335 Srećko Aćimović, P343 (Transcript from Prosecutor v. Popović et al.), T. 12934-12935, 12941. But see Mitar Lazarević, P363 (Transcript from Prosecutor v. Popović et al.), T. 13366, 13389 (stating that Aćimović had told him that he had learned about the detainees being held at Ročević from his parents). KDZ446 testified that one day, while on a trip to Ročević in mid-July 1995, he saw the school's playground full of buses as well as soldiers; KDZ446 heard bursts of fire and was told by the locals that they were killing people from Srebrenica. KDZ446, P29 (Transcript from Prosecutor v. S. Milošević), T. 21040, 21091.

18336 Srećko Aćimović, P343 (Transcript from Prosecutor v. Popović et al.), T. 12935-12937, 13006. 
narcotics or alcohol. ${ }^{18337}$ Aćimović left approximately half an hour later to inform the Zvornik Brigade about the situation at Ročević School. ${ }^{18338}$

5388. Sometime between 1 and 2 a.m. on 15 July, an encrypted telegram from the Zvornik Brigade Command was received over the phone, with the order to dispatch a platoon of soldiers from the $2^{\text {nd }}$ Battalion to the Ročević School "for the execution of the prisoners". 18339 Once the telegram had been decoded, Aćimović discussed it with two close associates in the $2^{\text {nd }}$ Battalion, namely Vujo Lazarević- the Assistant Battalion Commander for Morale and Religious Affairsand Mitar Lazarević - the Officer for General Services—, and together decided that no personnel would be assigned to the task. ${ }^{18340}$ He then sent a response telegram to the Zvornik Brigade, indicating that the $2^{\text {nd }}$ Battalion did not have any personnel available to execute the detainees. ${ }^{18341}$

5389. According to Aćimović, a second telegram was received with the same content approximately 45 minutes to an hour later. ${ }^{18342}$ Aćimović again consulted with his associates, Vujo and Mitar Lazarević, and decided to disobey the order, sending yet another response telegram to the Zvornik Brigade. ${ }^{18343}$ Approximately ten minutes later, at around 2.30 a.m., Aćimović received a phone call from Drago Nikolić telling him that the order "had come from above" and that it had to be carried out. ${ }^{18344}$ Aćimović refused, yet again, to assign the task to anyone. ${ }^{18345}$ Nikolić insisted

\footnotetext{
18337 Aćimović tried to communicate with the soldiers in order to obtain information but they refused to talk and a rifle was pointed at him. Srećko Aćimović, P343 (Transcript from Prosecutor v. Popović et al.), T. 12936. See also Srećko Aćimović, P343 (Transcript from Prosecutor v. Popović et al.), T. 13033 (testifying that he heard that these were guards from Bratunac and Višegrad but acknowledging that he had not heard this from a reliable source); Mitar Lazarević, P363 (Transcript from Prosecutor v. Popović et al.), T. 13366-13367, 13391.

18338 Srećko Aćimović, P343 (Transcript from Prosecutor v. Popović et al.), T. 12937. See also Srećko Aćimović, P343 (Transcript from Prosecutor v. Popović et al.), T. 12937, 12939-12940, 12943, 13007-13009, 1301313017, 13139-13140; Srećko Aćimović, P342 (Transcript from Prosecutor v. Popović et al.), T. 13136 (under seal); Mitar Lazarević, P363 (Transcript from Prosecutor v. Popović et al.), T. 13372-13373, 13388.

18339 Srećko Aćimović, P343 (Transcript from Prosecutor v. Popović et al.), T. 12944-12946; Mitar Lazarević, P363 (Transcript from Prosecutor v. Popović et al.), T. 13374-13375, 13386.

18340 Srećko Aćimović, P343 (Transcript from Prosecutor v. Popović et al.), T. 12943, 12946, 12995, 13011, 1302013021, 13052, 13122; Mitar Lazarević, P363 (Transcript from Prosecutor v. Popović et al.), T. 13358-13359, 13362, 13375-13376; Mitar Lazarević, P362 (Transcript from Prosecutor v. Popović et al.), T. 13420 (under seal). See also Veljko Ivanović, P384 (Transcript from Prosecutor v. Popović et al.), T. 18180.

18341 Srećko Aćimović, P343 (Transcript from Prosecutor v. Popović et al.), T. 12943, 12946-12947, 13011; Mitar Lazarević, P363 (Transcript from Prosecutor v. Popović et al.), T. 13376-13377, 13406-13407.

18342 Srećko Aćimović, P343 (Transcript from Prosecutor v. Popović et al.), T. 12947-12948.

18343 Srećko Aćimović, P343 (Transcript from Prosecutor v. Popović et al.), T. 12948-12949, 13122. Mitar Lazarević testified that only one telegram was received from the Zvornik Brigade and only one response refusing to allocate personnel from the $2^{\text {nd }}$ Battalion was sent back. Mitar Lazarević, P363 (Transcript from Prosecutor v. Popović et al.), T. 13405. The Chamber notes the conflicting evidence between Aćimović and Mitar Lazarević in this regard but finds that these inconsistencies are not sufficient to cast doubt upon the existence of instructions originating from the Zvornik Brigade.

18344 Srećko Aćimović, P343 (Transcript from Prosecutor v. Popović et al.), T. 12949-12950, 13046. See also Srećko Aćimović, P343 (Transcript from Prosecutor v. Popović et al.), T. 13048-13049. Aćimović testified that Vujo and Mitar Lazarević were present when the discussion with Drago Nikolić took place. Srećko Aćimović, P343 (Transcript from Prosecutor v. Popović et al.), T. 13123.
} 
that Aćimović was to dispatch his men by 7 a.m., around which time they would speak again. ${ }^{18346}$ Around 7 or 8 a.m., Drago Nikolić called again and asked Aćimović whether the order had been executed, ${ }^{18347}$ adding that, if Aćimović was unable to put a group of men together, Aćimović and his associates should carry out the executions themselves. ${ }^{18348}$ Aćimović was then ordered by an angry Drago Nikolić to meet him at the Ročević School at 9 or 10 a.m. ${ }^{18349}$

5390. Aćimović drove to the Ročević School between 9 and 10 a.m. but Drago Nikolić was not there. ${ }^{18350}$ Between 15 and 20 VRS MP soldiers were in front of the gymnasium and behind the school. ${ }^{18351}$ Aćimović also saw at least a dozen bodies lying on the ground. ${ }^{18352}$ Aćimović met Popović in front of the school, and together they walked to an office inside the school. ${ }^{18353}$ Popović shouted at Aćimović, asking why he had not brought any soldiers as ordered. ${ }^{18354}$ Popović continued putting pressure on Aćimović to get men, and threatened that he would be held responsible for not following the order. ${ }^{18355}$ Popović then called the Zvornik Brigade Duty Officer and asked that vehicles, as well as either Trbić or Jasikovac, be sent to Ročević urgently. ${ }^{18356}$

18345 Srećko Aćimović, P343 (Transcript from Prosecutor v. Popović et al.), T. 12949-12951. See also Mitar Lazarević, P363 (Transcript from Prosecutor v. Popović et al.), T. 13377-13378, 13387-13388, 13392 (testifying that after the reply telegram was sent, he heard Aćimović cursing and quarrelling with an unknown person over the phone).

18346 Srećko Aćimović, P343 (Transcript from Prosecutor v. Popović et al.), T. 12951.

18347 Srećko Aćimović, P343 (Transcript from Prosecutor v. Popović et al.), T. 12951-12952.

18348 Srećko Aćimović, P343 (Transcript from Prosecutor v. Popović et al.), T. 12952-12956.

18349 Srećko Aćimović, P343 (Transcript from Prosecutor v. Popović et al.), T. 12952-12954.

18350 Srećko Aćimović, P343 (Transcript from Prosecutor v. Popović et al.), T. 12957-12958, 13050; Srećko Aćimović, P342 (Transcript from Prosecutor v. Popović et al.), T. 13022 (under seal); Mitar Lazarević, P363 (Transcript from Prosecutor v. Popović et al.), T. 13379. See also Dragan Jović, P365 (Transcript from Prosecutor v. Popović et al.), T. 18051-18052, 18089 (stating that he drove Aćimović to Ročević School in the morning of 15 July, arriving between 10 a.m. and noon).

18351 Jović testified that these men were not part of the Zvornik Brigade, but heard that they were part of the Bratunac Brigade. Dragan Jović, P365 (Transcript from Prosecutor v. Popović et al.), T. 18053, 18083.

18352 Srećko Aćimović, P343 (Transcript from Prosecutor v. Popović et al.), T. 12958. See also Veljko Ivanović, P383 (Transcript from Prosecutor v. Popović et al.), T. 18183 (under seal); KDZ496, P387 (Transcript from Prosecutor v. Popović et al.), T. 32713-32714; Mitar Lazarević, P363 (Transcript from Prosecutor v. Popović et al.), T. 13390.

18353 Srećko Aćimović, P343 (Transcript from Prosecutor v. Popović et al.), T. 12957-12958. See also Srećko Aćimović, P342 (Transcript from Prosecutor v. Popović et al.), T. 13121 (under seal). The Chamber notes that Popović denied being at Ročević School in the morning of 15 July, and claimed instead that he first went to Dragaševac and later to Šekovići. See D3993 (Witness statement of Vujadin Popović dated 2 November 2013), paras. 58-59; Vujadin Popović, T. $43071-43073$ (6 November 2013). However, in light of the totality of evidence before it, the Chamber does not find Popović's alibi credible, and concludes that Popović was in fact present at Ročević School on 15 July.

18354 Srećko Aćimović, P343 (Transcript from Prosecutor v. Popović et al.), T. 12958-12960, 12964-12965.

18355 Srećko Aćimović, P343 (Transcript from Prosecutor v. Popović et al.), T. 12958-12960, 12964-12966; Srećko Aćimović, P342 (Transcript from Prosecutor v. Popović et al.), T. 13117 (under seal).

18356 Srećko Aćimović, P343 (Transcript from Prosecutor v. Popović et al.), T. 12965-12966, 12986-12988. See also P4563 (Statement by KDZ122), p. 3 (under seal). 
5391. Veljko Ivanović - a driver for the $2^{\text {nd }}$ Battalion $^{18357}$ — was ordered by Mitar Lazarević to be on duty and to work out of the Standard Barracks for as long as necessary after the fall of Srebrenica. ${ }^{18358}$ At around 11:15 a.m. on 15 July, while at the Standard Barracks, an order from Aćimović was conveyed to Ivanović to take three crates of ammunition for automatic rifles to Ročević School. ${ }^{18359}$ Ivanović set out towards Ročević driving a Mercedes T 170 belonging to the $2^{\text {nd }}$ Battalion, and arrived soon after. ${ }^{18360}$ According to Aćimović, Popović became angry when only a single truck arrived. ${ }^{18361}$ Popović then stated that the detainees would have to be killed "somewhere nearby, near the school, and that they should all be killed in Ročević". ${ }^{18362}$ He ordered Aćimović to call the drivers of six or seven civilian trucks and to bring them to the school. ${ }^{18363}$ Fifteen to 20 minutes later, when Djoko Nikolić — another driver for the $2^{\text {nd }}$ Battalion—arrived in a TAM 2001 truck which could only accommodate about 15 people, Popović again became upset. ${ }^{18364}$ According to Aćimović, Dragan Jović—a member of the $2^{\text {nd }}$ Battalion who was present at the school at the time - then offered to secure another vehicle. ${ }^{18365}$ Jović testified, however, that it was Aćimović who ordered him to find volunteers to execute the detainees, and to fetch a civilian truck. ${ }^{18366}$ Aćimović went to the schoolyard to see whether he could find anybody willing to take part in the killings. ${ }^{18367}$

18357 Veljko Ivanović, P384 (Transcript from Prosecutor v. Popović et al.), T. 18174-18175.

18358 Veljko Ivanović, P384 (Transcript from Prosecutor v. Popović et al.), T. 18175-18176.

18359 Veljko Ivanović, P384 (Transcript from Prosecutor v. Popović et al.), T. 18176-18179. Ivanović received this order from a man named Panto Pantić, the head of the transport pool at the Standard Barracks. Veljko Ivanović, P384 (Transcript from Prosecutor v. Popović et al.), T. 18177-18178.

18360 Veljko Ivanović, P384 (Transcript from Prosecutor v. Popović et al.), T. 18175, 18177; P110 (Zvornik Brigade vehicle $\log 1-31$ July 1995), p. 1 (stating that the drivers of the Mercedes truck were Veljko Ivanović and Vukašin Perić). See also Mitar Lazarević, P363 (Transcript from Prosecutor v. Popović et al.), T. 13380; Mitar Lazarević, P362 (Transcript from Prosecutor v. Popović et al.), T. 13380 (under seal); Dragan Jović, P365 (Transcript from Prosecutor v. Popović et al.), T. 18058.

18361 Srećko Aćimović, P342 (Transcript from Prosecutor v. Popović et al.), T. 12967-12968, 12983 (under seal).

18362 Srećko Aćimović, P342 (Transcript from Prosecutor v. Popović et al.), T. 12968-12969 (under seal).

18363 Srećko Aćimović, P342 (Transcript from Prosecutor v. Popović et al.), T. 12969 (under seal). Aćimović testified that he played some tricks in order not to be able to get in touch with those drivers, and lied to Popović, telling him that the drivers were not available at the time. Srećko Aćimović, P342 (Transcript from Prosecutor v. Popović et al.), T. 12969 (under seal); Srećko Aćimović, P343 (Transcript from Prosecutor v. Popović et al.), T. 13104-13105.

18364 Srećko Aćimović, P342 (Transcript from Prosecutor v. Popović et al.), T. 12970, 12972, 12981, 12985 (under seal).

18365 Srećko Aćimović, P342 (Transcript from Prosecutor v. Popović et al.), T. 12972, 13094, 13112, 13115-13117 (under seal). See also Mitar Lazarević, P362 (Transcript from Prosecutor v. Popović et al.), T. 13380-13381 (under seal).

18366 Dragan Jović, P365 (Transcript from Prosecutor v. Popović et al.), T. 18056-18057, 18060-18061, 1808318084. Jović further added that Aćimović had accompanied him to get the civilian truck after Jović was first unsuccessful. Dragan Jović, P365 (Transcript from Prosecutor v. Popović et al.), T. 18061, 18083.

18367 Srećko Aćimović, P343 (Transcript from Prosecutor v. Popović et al.), T. 12960-12961. The Chamber notes that it received conflicting evidence from Aćimović and Jović as to their participation in securing volunteers to carry out the killings, as well as the trucks and additional drivers. See Srećko Aćimović, P342 (Transcript from Prosecutor v. Popović et al.), T. 12969, 13120-13121 (under seal); Srećko Aćimović, P343 (Transcript from Prosecutor v. Popović et al.), T. 13105; Dragan Jović, P365 (Transcript from Prosecutor v. Popović et al.), 
5392. At around 11 a.m. Jasikovac arrived at the Ročević School together with other members of the Zvornik Brigade MP. ${ }^{18368}$ Other members of the Zvornik Brigade were also present at the school. $^{18369}$ Jasikovac ordered his men to secure the facility and the detainees held there. ${ }^{18370}$ Some members of the Zvornik Brigade MP were also ordered to secure the entrance of the school in order to prevent angry Bosnian Serb civilians threatening to harm the detainees from approaching them. ${ }^{18371}$ By this time, approximately 1,000 detainees were being held at the school, and a couple of bodies of Bosnian Muslim detainees could still be seen lying outside. ${ }^{18372}$

5393. Around noon on 15 July 1995, KDZ496-who was 15 years old at the time and was wearing civilian clothes ${ }^{18373}$ — went towards the asphalt road near his home in Zvornik municipality; there, he encountered a member of the $2^{\text {nd }}$ Battalion who told him to go with him by car to Ročević where Bosnian Muslim men were being held prisoners. ${ }^{18374}$ KDZ496 arrived at the Ročević School between 12 and 1 p.m., ${ }^{18375}$ was brought before Popović and Aćimović by one of

T. 18056-18057, 18060-18061, 18083-18084. The Chamber considers that these inconsistencies are largely due to both Jović and Aćimović's interest in distancing themselves from the events at Ročević on 15 July 1995, and in minimising their own contributions to such events. While the specific role played by Aćimović and Jović is secondary to the events surrounding this Scheduled Incident in light of the case against the Accused, the Chamber finds that both Aćimović and Jović were involved, in one way or another, in securing vehicles and/or volunteers. This involvement has warranted the Chamber's more cautious approach to both witnesses' testimony on other points.

18368 KDZ407, P379 (Transcript from Prosecutor v. Popović et al.), T. 6460-6461, 6487-6488; KDZ407, P378 (Transcript from Prosecutor v. Popović et al.), T. 6460, 6489 (under seal); Milorad Birčaković, P360 (Transcript from Prosecutor v. Popović et al.), T. 11047, 11053-11054 (testifying that he drove Jasikovac to Ročević on 15 July). But see Srećko Aćimović, P343 (Transcript from Prosecutor v. Popović et al.), T. 13091 (testifying that he did not see Jasikovac at Ročevic School, but assuming Jasikovac must have arrived after he had left). See Milorad Birčaković, P360 (Transcript from Prosecutor v. Popović et al.), T. 11028 (testifying that he drove an Opel Rekord); P173 (Zvornik Brigade vehicle log, 1-31 July 1995), pp. 3-4 (where an Opel Record is recorded as being used by Milorad Birčaković on 15 July 1995, and used on five journeys from Karakaj to Ročević, carrying four passengers); P4948 (Zvornik Brigade Military Police attendance roster, July 1995). The Prosecution claims that the Zvornik Brigade MP attendance roster for 15 July 1995 was altered to conceal the presence and involvement of MPs in the murder operation at Ročević School. See Prosecution Final Brief, Appendix D, confidential, fn. 499. The Chamber has found that the attendance roster was altered to conceal the presence of members of the Zvornik Brigade's MP Company at Orahovac on 14 July 1995. See fn. 18055. The Chamber is equally satisfied that efforts were made to conceal the presence of the unit at Ročević School on 15 July 1995.

18369 KDZ407, P379 (Transcript from Prosecutor v. Popović et al.), T. 6462, 6487-6488; Milorad Birčaković, P360 (Transcript from Prosecutor v. Popović et al.), T. 11047-11049. See also KDZ496, P386 (Transcript from Prosecutor v. Popović et al.), T. 32704 (under seal); KDZ496, P387 (Transcript from Prosecutor v. Popović et al.), T. 32743-32744.

18370 KDZ407, P379 (Transcript from Prosecutor v. Popović et al.), T. 6461; KDZ407, P378 (Transcript from Prosecutor v. Popović et al.), T. 6462-6463 (under seal). See also Milorad Birčaković, P360 (Transcript from Prosecutor v. Popović et al.), T. 11137.

18371 KDZ407, P379 (Transcript from Prosecutor v. Popović et al.), T. 6461-6463, 6487.

18372 KDZ407, P379 (Transcript from Prosecutor v. Popović et al.), T. 6461-6462; KDZ407, P378 (Transcript from Prosecutor v. Popović et al.), T. 6479 (under seal). See also Veljko Ivanović, P383 (Transcript from Prosecutor v. Popović et al.), T. 18183 (under seal).

18373 KDZ496, P386 (Transcript from Prosecutor v. Popović et al.), T. 32699, 32702, 32723 (under seal).

18374 KDZ496, P387 (Transcript from Prosecutor v. Popović et al.), T. 32701; KDZ496, P386 (Transcript from Prosecutor v. Popović et al.), T. 32747-32750 (under seal).

18375 KDZ496, P387 (Transcript from Prosecutor v. Popović et al.), T. 32701, 32704. 
the soldiers guarding the detainees, and presented himself as a volunteer to participate in the executions. $^{18376}$

5394. Aćimović ordered Ivanović and Jović to transport the detainees to the execution site near Kozluk, ${ }^{18377}$ and left soon after. ${ }^{18378}$ Ivanović, Djoko Nikolić, and Jović were left behind. ${ }^{18379}$

\section{(c) The killings at the Drina River near Kozluk}

5395. The transportation of the detainees from the Ročević School by members of the $2^{\text {nd }}$ Battalion-including Jović, Ivanović, Djoko Nikolić, and at least two other soldiers-began at around 2 or 3 p.m., and continued over the course of the afternoon. ${ }^{18380}$

5396. Aćimović ordered Ivanović to reverse the Mercedes T 170 truck close to the door of the school, and planks were placed to serve as a ramp. ${ }^{18381}$ The three crates of ammunition that Ivanović had brought earlier from the Standard Barracks were placed inside a passenger vehicle. ${ }^{18382}$ The loading of Bosnian Muslim detainees from the school onto the Mercedes truck then began. ${ }^{18383}$ The first group of detainees were blindfolded, with their hands and legs bound, but as they were unable to walk along the narrow planks, the ligatures and blindfolds were ultimately

18376 Srećko Aćimović, P342 (Transcript from Prosecutor v. Popović et al.), T. 12971, 13118 (under seal); Srećko Aćimović, P343 (Transcript from Prosecutor v. Popović et al.), T. 13093.

18377 Dragan Jović, P365 (Transcript from Prosecutor v. Popović et al.), T. 18058-18059; Veljko Ivanović, P384 (Transcript from Prosecutor v. Popović et al.), T. 18177-18178. But see Srećko Aćimović, P342 (Transcript from Prosecutor v. Popović et al.), T. 13109-13110 (under seal); Srećko Aćimović, P343 (Transcript from Prosecutor v. Popović et al.), T. 12988-12989, 13106-13108 (stating that he did not give the order for the transportation of detainees, and adding that when he left the school he did not know whether the boarding and loading of detainees had begun). See fn. 18333.

18378 Srećko Aćimović, P343 (Transcript from Prosecutor v. Popović et al.), T. 12988-12989. See also Veljko Ivanović, P384 (Transcript from Prosecutor v. Popović, Case No. IT-05-88), T. 18178; Veljko Ivanović, P383 (Transcript from Prosecutor v. Popović et al.), T. 18219-18220 (under seal).

18379 Srećko Aćimović, P342 (Transcript from Prosecutor v. Popović et al.), T. 13109-13110 (under seal).

18380 Dragan Jović, P365 (Transcript from Prosecutor v. Popović et al.), T. 18059, 18061-18063; Veljko Ivanović, P383 (Transcript from Prosecutor v. Popović et al.), T. 18181, 18218 (under seal). See also KDZ407, P379 (Transcript from Prosecutor v. Popović et al.), T. 6464; KDZ496, P387 (Transcript from Prosecutor v. Popović et al.), T. 32701, 32704, 32707, 32743. But see Srećko Ačimović, P342 (Transcript from Prosecutor v. Popović et al.), T. 13118-13119 (under seal). Jović testified that he transported detainees from Ročević to Kozluk two or three times with a truck that could carry approximately ten detainees. Dragan Jović, P365 (Transcript from Prosecutor v. Popović et al.), T. 18061-18062. Ivanović also drove between three and four more times from Ročević School to Kozluk and back. Veljko Ivanović, P383 (Transcript from Prosecutor v. Popović et al.), T. 18191 (under seal).

18381 Veljko Ivanović, P384 (Transcript from Prosecutor v. Popović et al.), T. 18177. See also Dragan Jović, P365 (Transcript from Prosecutor v. Popović et al.), T. 18058.

18382 Veljko Ivanović, P383 (Transcript from Prosecutor v. Popović et al.), T. 18182, 18200-18201 (under seal).

18383 Veljko Ivanović, P384 (Transcript from Prosecutor v. Popović et al.), T. 18177; Veljko Ivanović, P383 (Transcript from Prosecutor v. Popović et al.), T. 18182 (under seal). See also KDZ407, P379 (Transcript from Prosecutor v. Popović et al.), T. 6464. 
removed. ${ }^{18384}$ During the whole process, the detainees appeared "half dead" and exhausted; none of them pleaded for their lives. ${ }^{18385}$

5397. Once the loading of the first batch of detainees was completed, Ivanović and Jović set off in the direction of the execution site, ${ }^{18386}$ which was adjacent to the Drina River near the village of Kozluk, less than four kilometres away from Ročević School. ${ }^{18387}$ KDZ496 and three to four members of the MP - all of them armed-were also at the back of the truck. ${ }^{18388}$ The trucks travelled six kilometres from the school to Kozluk and a further three kilometres to the execution site on a very poorly maintained road. ${ }^{18389}$ The trip between Ročević and Kozluk took approximately 20 minutes. ${ }^{18390}$

5398. The trucks progressed as close as possible to the execution site and then reversed into a predug hole. ${ }^{18391}$ The detainees were then ordered to jump off the truck and into the hole. ${ }^{18392}$ Shooters formed two parallel lines on each side of the hole. ${ }^{18393}$ All of the shooters wore multicoloured uniforms and balaclavas, while some also wore white belts. ${ }^{18394}$ The detainees were shot

18384 Veljko Ivanović, P383 (Transcript from Prosecutor v. Popović et al.), T. 18182 (under seal). But see KDZ496, P387 (Transcript from Prosecutor v. Popović et al.), T. 32707, 32741 (stating that the detainees may have been tied up but were not blindfolded).

18385 Veljko Ivanović, P383 (Transcript from Prosecutor v. Popović et al.), T. 18218 (under seal).

18386 Dragan Jović, P365 (Transcript from Prosecutor v. Popović et al.), T. 18058-18060, 18082-18083; Veljko Ivanović, P383 (Transcript from Prosecutor v. Popović et al.), T. 18182 (under seal); Veljko Ivanović, P384 (Transcript from Prosecutor v. Popović et al.), T. 18178. Jović testified that, while Ivanović was driving the truck, he was not familiar with the site at Kozluk, thus Jović was ordered to travel with him to show him the location. Dragan Jović, P365 (Transcript from Prosecutor v. Popović et al.), T. 18058. But see KDZ496, P386 (Transcript from Prosecutor v. Popović et al.), T. 32705-32706 (under seal) (stating that the person driving the truck was Jović).

18387 Jean-René Ruez, T. 23824, 23826 (30 January 2012); P4308 (Book of photographs and maps prepared by JeanRené Ruez, 22 June 2009), e-court pp. 198-199. See also Robert Block, T. 24932-24934 (21 February 2012); P4406 (Map of Kozluk and Branjevo area marked by Robert Block); P4504 (Dean Manning's Report, entitled "Summary of Forensic Evidence - Execution Points and Mass Graves", 16 May 2000), e-court p. 72. The Kozluk execution site was located within the area of responsibility of the Zvornik Brigade. P4914 (Richard Butler's expert report entitled "Srebrenica Military Narrative (Revised): Operation 'Krivaja 95", 1 November 2002), para. 7.53. See also Adjudicated Fact 1810.

18388 Dragan Jović, P365 (Transcript from Prosecutor v. Popović et al.), T. 18059-18060, 18083; KDZ496, P387 (Transcript from Prosecutor v. Popović et al.), T. 32701-32702; KDZ496, P386 (Transcript from Prosecutor v. Popović et al.), T. 32705-32706, 32708 (under seal). Jović testified that these soldiers had assisted in guarding detainees at the school that day but he did not know which unit they belonged to. Dragan Jović, P365 (Transcript from Prosecutor v. Popović et al.), T. 18083.

18389 Dragan Jović, P365 (Transcript from Prosecutor v. Popović et al.), T. 18059, 18061.

18390 KDZ407, P379 (Transcript from Prosecutor v. Popović et al.), T. 6464.

18391 Dragan Jović, P365 (Transcript from Prosecutor v. Popović et al.), T. 18059-18060, 18067; KDZ496, P387 (Transcript from Prosecutor v. Popović et al.), T. 32701-32702, 32707, 32713.

18392 KDZ496, P387 (Transcript from Prosecutor v. Popović et al.), T. 32707, 32713, 32724-32725.

18393 KDZ496, P387 (Transcript from Prosecutor v. Popović et al.), T. 32707. KDZ496 testified that there were between 30 to 50 uniformed men on either side of the hole. KDZ496, P387 (Transcript from Prosecutor v. Popović et al.), T. 32707, 32756. But see Veljko Ivanović, P383 (Transcript from Prosecutor v. Popović et al.), T. 18190 (under seal) (stating that there were up to eight soldiers at Kozluk).

18394 Veljko Ivanović, P383 (Transcript from Prosecutor v. Popović et al.), T. 18191, 18195 (under seal); KDZ496, P386 (Transcript from Prosecutor v. Popović et al.), T. 32761-32762 (under seal); KDZ496, P387 (Transcript 
from both sides as they exited the truck into the pit. ${ }^{18395}$ The shooting was carried out in a disorganised and confused fashion to the point that it appeared as if the shooters might end up shooting each other. ${ }^{18396}$ Wounded detainees tried to flee by going into the Drina River and grabbing the shrubbery, all the while coming under fire. ${ }^{18397}$ A young boy begged for his life to be spared, but was nevertheless killed. ${ }^{18398}$

5399. Once the detainees held inside the school had been taken to the execution site, the loading of the detainees held at the gymnasium began. ${ }^{18399}$ By this point, additional members of the VRS, including the MP, had arrived at the execution site at Kozluk. ${ }^{18400}$ By dusk, all the detainees had been transported from the Ročević School to the killing site. ${ }^{18401}$

(d) Burials

5400. On the morning of 16 July, Damjan Lazarević was ordered by either Bogičević or Vojkan Sekonjić-the Engineering Company's desk officer ${ }^{18402}$ — to go to Kozluk to bury the people who

from Prosecutor v. Popović et al.), T. 32710-32711. According to KDZ496, the soldiers were members of the MP but not from the area. KDZ496, P386 (Transcript from Prosecutor v. Popović et al.), T. 32762 (under seal); KDZ496, P387 (Transcript from Prosecutor v. Popović et al.), T. 32710-32711, 32743-32744. Jović testified that the soldiers unloading the detainees from the trucks were members of the MP who had previously guarded the detainees at Ročević School. Dragan Jović, P365 (Transcript from Prosecutor v. Popović et al.), T. 18060. Ivanović testified that there were up to eight men who he believed belonged to the $6^{\text {th }}$ Battalion. Veljko Ivanović, P383 (Transcript from Prosecutor v. Popović et al.), T. 18190-18191, 18193, 18195 (under seal). KDZ496, P387 (Transcript from Prosecutor v. Popović et al.), T. 32702, 32707. See also Veljko Ivanović, P383 (Transcript from Prosecutor v. Popović et al.), T. 18190 (under seal).

18396 Veljko Ivanović, P383 (Transcript from Prosecutor v. Popović et al.), T. 18222-18224 (under seal). See KDZ496, P386 (Transcript from Prosecutor v. Popović et al.), T. 32702, 32708-32709, 32727, 32764 (under seal).

18397 Veljko Ivanović, P383 (Transcript from Prosecutor v. Popović et al.), T. 18189, 18224 (under seal). See also Robert Block, T. 24927, 24932-24933 (21 February 2012); P4406 (Map of Kozluk and Branjevo area marked by Robert Block) (referring to locals having told him about the presence of bodies floating down the river around 17 July 1995). But see KDZ496, P387 (Transcript from Prosecutor v. Popović et al.), T. 32713 (testifying that the hole was very deep, making it impossible for detainees to climb back out and escape). As stated in fn. 17638, Rešid Sinanović survived the execution at Kozluk by jumping into the Drina River, but his remains were later found at the Čančari Road 4 gravesite, which was linked to the Branjevo Military Farm primary gravesite. See Robert Block, T. 24932-24936 (21 February 2012). See also para. 5461.

18398 Ivanović explained that although the boy was taken off his truck, he had later learned that the boy had also been killed. Veljko Ivanović, P383 (Transcript from Prosecutor v. Popović et al.), T. 18190 (under seal). Veljko Ivanović, P383 (Transcript from Prosecutor v. Popović et al.), T. 18182 (under seal). Dragan Jović, P365 (Transcript from Prosecutor v. Popović et al.), T. 18065, 18084.

KDZ407, P379 (Transcript from Prosecutor v. Popović et al.), T. 6465, 6490; KDZ407, P378 (Transcript from Prosecutor v. Popović et al.), T. 6465 (under seal). See Dragan Jović, P365 (Transcript from Prosecutor v. Popović et al.), T. 18063 (stating that he transported detainees from 2 or 3 p.m. until 6 or 7 p.m.) But see Veljko Ivanović, P384 (Transcript from Prosecutor v. Popović et al.), T. 18176, 18179 (testifying that he arrived at Ročević School at around 11 a.m., and that the transportation to the execution site began some time after this and concluded by $2: 30$ or 3 p.m.).

18402 Damjan Lazarević, P352 (Transcript from Prosecutor v. Popović et al.), T. 14435. 
had been executed at that location. ${ }^{18403}$ Miloš Mitrović-another member of the Engineering Company-was also ordered to take a small skip excavator to the execution site. ${ }^{18404}$

5401. Lazarević arrived at the execution site at approximately 8 a.m. ${ }^{18405} \mathrm{He}$ was driven in a TAM 75 truck until the truck could go no further; thereafter he continued on foot. ${ }^{18406}$ Upon arriving, there was a strong stench emanating from the bodies decomposing in gravel pits, approximately 20 to 30 metres away from the Drina River. ${ }^{18407}$ Pieces of white and green broken glass, which Lazarević believed came from the nearby Vitinka factory, could also be seen in one of the pits. ${ }^{18408}$ Three or four masked men wearing uniforms, whom Lazarević did not recognise, were standing in the field. ${ }^{18409}$

5402. Mitrović started burying the bodies using the small skip, but the machine was not big enough to complete the task. ${ }^{18410}$ Rade Bošković, a civilian, was called in to finish the task with a ULT 220 which belonged to the stone quarry in Josanica. ${ }^{18411}$ Mitrović and Lazarević left, leaving Bošković behind to complete the task. ${ }^{18412}$

5403. Between 7 and 27 September 1995, and as part of the reburial operation to conceal the Srebrenica killings which will be discussed in detail below, ${ }^{18413}$ the bodies initially buried at Kozluk were exhumed, transported, and reburied at some of the Čančari Road secondary gravesites, as demonstrated by the forensic evidence discussed in the paragraphs immediately below.

\footnotetext{
18403 Damjan Lazarević, P352 (Transcript from Prosecutor v. Popović et al.), T. 14454-14455. See P660 (Zvornik Brigade Engineering Company roster, July 1995), p. 6. See also Adjudicated Fact 1812. A bulldozer from the Engineering Company was also used on 18 and 19 July to do work at Kozluk. P4583 (Extract from Zvornik Brigade Engineering Company logbook, 14-19 July 1995), pp. 5-6 (referring to "trench mending" work being carried out at Kozluk).

18404 Damjan Lazarević, P352 (Transcript from Prosecutor v. Popović et al.), T. 14454, 14478, 14515 ; P175 (Zvornik Brigade vehicle log, 1-31 July 1995) (where a Torpedo excavator is recorded as being used by Mitrović on 16 July 1995 for digging trenches in Kozluk).

18405 Damjan Lazarević, P352 (Transcript from Prosecutor v. Popović et al.), T. 14455.

18406 Damjan Lazarević, P352 (Transcript from Prosecutor v. Popović et al.), T. 14455. See also P5118 (Zvornik Brigade vehicle logbook, July 1995), e-court pp. 447-448 (recording that a Zvornik Brigade TAM 75 truck made a trip to Kozluk on 16 July 1995).

18407 Damjan Lazarević, P352 (Transcript from Prosecutor v. Popović et al.), T. 14455-14457.

18408 Damjan Lazarević, P352 (Transcript from Prosecutor v. Popović et al.), T. 14456.

18409 Damjan Lazarević, P352 (Transcript from Prosecutor v. Popović et al.), T. 14457, 14521.

18410 Damjan Lazarević, P352 (Transcript from Prosecutor v. Popović et al.), T. 14457, 14522. See also Adjudicated Facts 1811, 1812.

18411 Damjan Lazarević, P352 (Transcript from Prosecutor v. Popović et al.), T. 14457-14458. See also P657 (Brochure for a wheel loader (ULT200)); P239 (Photograph of a wheel loader (ULT200)).

18412 Damjan Lazarević, P352 (Transcript from Prosecutor v. Popović et al.), T. 14458-14459.

18413 See Section IV.C.1.g.v: Reburial operation.
} 
(e) Forensic evidence

(i) Kozluk primary gravesite

5404. Aerial images reveal that the Kozluk grave was first dug between 5 and 17 July 1995, and that it was disturbed between 7 and 27 September $1995 .^{18414}$ The Kozluk gravesite is located adjacent to the Drina River near the town of Kozluk, less than four kilometres away from the Ročević School. ${ }^{18415}$ The site is approached by a road that passes the Vitinka soft drink bottling factory, and turns into a track as it reaches an area of rubbish dumping and gravel extraction alongside the Drina River. ${ }^{18416}$

5405. The Kozluk gravesite was exhumed by a Tribunal exhumation team from 24 June to 6 August 1999 under the direction of Richard Wright. ${ }^{18417}$ The remains found at the gravesite were then examined by a team of pathologists under the direction of John Clark. ${ }^{18418}$ The Kozluk gravesite contained three areas of disposal of human remains: Kozluk 1, located to the north; Kozluk 2, located to the east; and Kozluk 3, located to the southwest. ${ }^{18419}$ Kozluk 2 and 3 were found to be areas of both execution and burial. ${ }^{18420}$ The Kozluk gravesite showed evidence of robbing or removal of bodies, evidenced by dismembered body parts found at the surface of the

\footnotetext{
18414 Jean-René Ruez, T. 23828, 23861-23862 (30 January 2012); P4504 (Dean Manning's Report, entitled "Summary of Forensic Evidence - Execution Points and Mass Graves", 16 May 2000), e-court p. 72 ; P4308 (Book of photographs and maps prepared by Jean-René Ruez, 22 June 2009), e-court pp. 202, 253. See also Adjudicated Fact 1819.

18415 Jean-René Ruez, T. 23824, 23826 (30 January 2012); P4308 (Book of photographs and maps prepared by JeanRené Ruez, 22 June 2009), e-court pp. 198-199. See also P4504 (Dean Manning's Report, entitled "Summary of Forensic Evidence - Execution Points and Mass Graves", 16 May 2000), e-court p. 72.

18416 P4001 (Richard Wright's expert report entitled "Report on Excavations and Exhumations at Kozluk in 1999: with appendix on visits to Konjević and Potočari", 2 February 2000), e-court p. 5. See also P4504 (Dean Manning's Report, entitled "Summary of Forensic Evidence - Execution Points and Mass Graves", 16 May 2000), e-court p. 72; Jean-René Ruez, T. 23826-23827 (30 January 2012).

18417 P4001 (Richard Wright's expert report entitled "Report on Excavations and Exhumations at Kozluk in 1999: with appendix on visits to Konjević and Potočari”, 2 February 2000), e-court p. 4; Richard Wright, T. 22246 (1 December 2011); Richard Wright, P3999 (Transcript from Prosecutor v. Krstić), T. 3663-3664. See also P4772 (Dušan Janc's report entitled "Update to the summary of Forensic Evidence - Exhumation of the Graves and Surface Remains Recoveries related to Srebrenica - January 2012”, 13 January 2012), e-court p. 11.

18418 John Clark, T. 22693 (10 January 2012); P4103 (John Clark's expert report entitled "Report of Chief Pathologist, Srebrenica Grave Sites (1999)", undated), pp. 1, 26; John Clark, John Clark, P4110 (Transcript from Prosecutor v. Krstić), T. 3900-3901, 3911. See also P4772 (Dušan Janc's report entitled "Update to the summary of Forensic Evidence - Exhumation of the Graves and Surface Remains Recoveries related to Srebrenica - January 2012”, 13 January 2012), e-court p. 11.

18419 P4001 (Richard Wright's expert report entitled "Report on Excavations and Exhumations at Kozluk in 1999: with appendix on visits to Konjević and Potočari”, 2 February 2000), e-court pp. 5-6, 19.

18420 P4001 (Richard Wright's expert report entitled "Report on Excavations and Exhumations at Kozluk in 1999: with appendix on visits to Konjević and Potočari”, 2 February 2000), e-court pp. 5-6. See also P4504 (Dean Manning's Report, entitled "Summary of Forensic Evidence - Execution Points and Mass Graves", 16 May 2000), e-court p. 73; P4023 (Diagram of bodies and shell casings).
} 
grave and machinery tooth marks on the base of the trench. ${ }^{18421}$ Despite this, 292 whole or largely complete bodies and 233 body parts, constituting a minimum of 340 individuals, were recovered from the grave. ${ }^{18422}$

5406. All the individuals for whom sex could be determined were male. ${ }^{18423}$ While it was established that the majority of victims were over 25 years old, the age of the victims ranged from 8 to $85 .{ }^{18424}$ All the victims were found wearing civilian clothing. ${ }^{18425}$ Further, 55 blindfolds and 168 ligatures were recovered at the gravesite. ${ }^{18426} 89 \%$ of the complete bodies, i.e. 260 out of 292 , showed evidence of gunshot injury. ${ }^{18427}$ The final cause of death for 237 bodies was attributed to gunshot injury, with a further 55 cases left as unascertained. ${ }^{18428}$ Additionally, 548 shell cases, 368

18421 Richard Wright, T. 22267 (1 December 2011); P4001 (Richard Wright's expert report entitled "Report on Excavations and Exhumations at Kozluk in 1999: with appendix on visits to Konjević and Potočari”, 2 February 2000), e-court pp. 11, 27; Richard Wright, P3999 (Transcript from Prosecutor v. Krstić), T. 3678, 3683-3684; P4302 (Video footage of Kozluk area).

18422 John Clark, T. 22698 (10 January 2012); John Clark, John Clark, P4110 (Transcript from Prosecutor v. Krstić), T. 3911; P4103 (John Clark's expert report entitled "Report of Chief Pathologist, Srebrenica Grave Sites (1999)", undated), p. 6. See also John Clark, John Clark, P4110 (Transcript from Prosecutor v. Krstić), T. 3952; P4504 (Dean Manning's Report, entitled "Summary of Forensic Evidence - Execution Points and Mass Graves", 16 May 2000), e-court p. 73; Adjudicated Fact 1814.

18423 John Clark, T. 22698 (10 January 2012); John Clark, John Clark, P4110 (Transcript from Prosecutor v. Krstić), T. 3912, 3922; P4103 (John Clark's expert report entitled "Report of Chief Pathologist, Srebrenica Grave Sites (1999)", undated), pp. 6, 12. See also P4504 (Dean Manning's Report, entitled "Summary of Forensic Evidence - Execution Points and Mass Graves", 16 May 2000), e-court p. 73; Adjudicated Fact 1814.

18424 P4103 (John Clark's expert report entitled "Report of Chief Pathologist, Srebrenica Grave Sites (1999)", undated), p. 6; John Clark, John Clark, P4110 (Transcript from Prosecutor v. Krstić), T.3912. The Chamber notes that Dušan Dunjić challenged the methodology used by Clark in his report, in particular, that there was no detailed description of the condition of the bodies, upon which the basis of the victims' age and their time of death could be estimated. D3893 (Dušan Dunjić's expert report entitled "Forensic Analysis of Reports on the Locations of Mass Graves in the Area of Eastern Bosnia and Documentation Relating to Exhumations in the Srebrenica Area", 27 August 2009), p. 50. Having assessed the totality of evidence on this issue, the Chamber accepts Clark's report and the findings therein.

18425 P4001 (Richard Wright's expert report entitled "Report on Excavations and Exhumations at Kozluk in 1999: with appendix on visits to Konjević and Potočari”, 2 February 2000), e-court p. 13; Richard Wright, P3999 (Transcript from Prosecutor v. Krstić), T. 3691, 3716. See also Adjudicated Fact 1825.

18426 P4504 (Dean Manning's Report, entitled "Summary of Forensic Evidence - Execution Points and Mass Graves", 16 May 2000), e-court p. 74; P4505 (Photograph booklet entitled "Srebrenica Blindfolds and Ligatures Volume 1: Kozluk, Cancari Road 3 and 12 and Branjevo Military Farm (Pilica)"), 1-171, 210-266; P4507 (Chart of photographs of blindfolds, ligatures, and location). See also Adjudicated Fact 1817; John Clark, John Clark, P4110 (Transcript from Prosecutor v. Krstić), T. 3914; P4001 (Richard Wright's expert report entitled "Report on Excavations and Exhumations at Kozluk in 1999: with appendix on visits to Konjević and Potočari", 2 February 2000), e-court p.14; Richard Wright, T. 22256, 22258-22260 (1 December 2011); Richard Wright, P3999 (Transcript from Prosecutor v. Krstić), T. 3681; P4002 (Photograph of exhumed body marked by Richard Wright); P4003 (Photograph of exhumed body marked by Richard Wright).

18427 John Clark, T. 22698 (10 January 2012); P4103 (John Clark's expert report entitled "Report of Chief Pathologist, Srebrenica Grave Sites (1999)", undated), pp. 8, 12; John Clark, John Clark, P4110 (Transcript from Prosecutor v. Krstić), T. 3915. See also Adjudicated Fact 1815.

18428 John Clark, T 22698 (10 January 2012); P4103 (John Clark's expert report entitled "Report of Chief Pathologist, Srebrenica Grave Sites (1999)", undated), pp. 8, 11-12; John Clark, John Clark, P4110 (Transcript from Prosecutor v. Krstić), T. 3950-3951. See also Adjudicated Fact 1815; P4112 (John Clark's expert report entitled "Autopsy Report, Kozluk Grave Site", 28 July 1999). The Chamber notes that Dunjić also challenged the methodology used by Clark when determining that gunshot injuries occurred during life or contributed to the cause of death, arguing that such determination was not in accordance with forensic science. D3893 (Dušan Dunjić's expert report entitled "Forensic Analysis of Reports on the Locations of Mass Graves in the Area of 
bullets, and 88 bullet fragments were recovered from the Kozluk gravesite during the exhumation and autopsy processes. ${ }^{18429}$

5407. As of 13 January 2012, DNA analysis has led to the identification of 336 individuals in the Kozluk grave as persons listed as missing following the take-over of Srebrenica. ${ }^{18430}$

\section{(ii) Čančari Road secondary gravesites}

5408. The Čančari Road is an eight kilometre dirt road running through the middle of the Čančari valley, approximately seven kilometres south of Zvornik and about 20 kilometres south of Kozluk. ${ }^{18431}$ There are at least 13 known secondary mass graves along the Čančari Road. ${ }^{18432}$ As will be explained below, ${ }^{18433}$ only Čančari Road 1, 2, 3, 7, and 13 have been linked to the Kozluk primary gravesite. ${ }^{18434}$

5409. A Tribunal team of experts, led by Richard Wright, conducted the exhumation of Čančari Road 3 in May and June 1998. ${ }^{18435}$ The remains found therein were examined by a team of

Eastern Bosnia and Documentation Relating to Exhumations in the Srebrenica Area", 27 August 2009), pp. 5556; D3894 (Dušan Dunjić's expert report entitled "Forensic Analysis of Documents Pertaining to Exhumations, Autopsies and Identification of Bodies in the Srebrenica Area", 26 August 2012), pp. 7-8. Having assessed the totality of evidence on this issue, the Chamber accepts Clark's report and the findings therein.

18429 P4504 (Dean Manning's Report, entitled "Summary of Forensic Evidence - Execution Points and Mass Graves", 16 May 2000), e-court p. 74. See also P4001 (Richard Wright's expert report entitled "Report on Excavations and Exhumations at Kozluk in 1999: with appendix on visits to Konjević and Potočari”, 2 February 2000), ecourt pp. 14, 21-22.

18430 P4772 (Dušan Janc's report entitled "Update to the summary of Forensic Evidence - Exhumation of the Graves and Surface Remains Recoveries related to Srebrenica - January 2012”, 13 January 2012), e-court pp. 3, 11, 41; P4771 (Dušan Janc's report entitled "Update to the summary of Forensic Evidence - Exhumation of the Graves and Surface Remains Recoveries related to Srebrenica - January 2012”, 13 January 2012), Annex D, e-court pp. 131-147 (under seal). See also P5917 (ICMP DNA identifications concerning identified victims related to Srebrenica, 6 December 2010); P4773 (ICMP unmatched DNA victim profiles related to Srebrenica, 23 December 2011); P4774 (ICMP lists of unmatched unique DNA victims profiles related to Srebrenica, 15 February 2010). The remains of Mesa Efendić, who was last seen walking in Potočari on 13 July wearing a red cardigan, were later found at the Kozluk primary gravesite. P667 (Zoran Petrović-Piroćanac's video footage), at 00:01:00-00:01:10; P4066 (Photograph from exhumation KK03 543). See also P4771 (Dušan Janc's report entitled "Update to the summary of Forensic Evidence - Exhumation of the Graves and Surface Remains Recoveries related to Srebrenica - January 2012”, 13 January 2012) (under seal), e-court p. 140.

18431 Jean-René Ruez, T. 23866-23867 (30 January 2012); P4308 (Book of photographs and maps prepared by JeanRené Ruez, 22 June 2009), e-court pp. 265-267, 273.

18432 The gravesite designated as Čančari Road 13 was previously unknown to the Tribunal as it was located by the BiHCMP. P4772 (Dušan Janc's report entitled "Update to the summary of Forensic Evidence - Exhumation of the Graves and Surface Remains Recoveries related to Srebrenica - January 2012", 13 January 2012), e-court p. 15. See also P4308 (Book of photographs and maps prepared by Jean-René Ruez, 22 June 2009), e-court p. 267.

18433 See para. 5411.

18434 The remainder of the secondary mass graves located along Čančari Road are linked to the Branjevo Military Farm primary gravesite. See para. 5461.

18435 P4000 (Richard Wright's expert report entitled "Exhumations in Eastern Bosnia in 1998”, 12 May 1999), p. 7; Richard Wright, T. 22250-22251 (1 December 2011); P4772 (Dušan Janc's report entitled "Update to the summary of Forensic Evidence - Exhumation of the Graves and Surface Remains Recoveries related to Srebrenica - January 2012”, 13 January 2012), e-court p. 16. See also P4504 (Dean Manning's Report, entitled "Summary of Forensic Evidence - Execution Points and Mass Graves", 16 May 2000), e-court p. 76; Adjudicated Fact 1820. 
pathologists under the direction of Christopher Lawrence. ${ }^{18436}$ While examination and probing of Čančari Road 1 was conducted by a Tribunal team of experts, the exhumation was handed over to the BiH Government in 2001. ${ }^{18437}$ Čančari Road 2, 7, and 13 were exhumed by the BiHCMP in 2002. ${ }^{18438}$

5410. Aerial images show that Čančari Road 1, 2, 3, and 7 were each first excavated between 7 and 27 September 1995 and were filled in prior to 2 October $1995 .{ }^{18439}$ The Chamber notes that out of all the secondary gravesites associated with the Kozluk gravesite, it only received forensic evidence in relation to Čančari Road 3. Remains of at least 160 individuals, including 35 relatively intact bodies, were recovered from Čančari Road 3. ${ }^{18440}$ The forensic evidence shows that all of the victims at Čančari Road 3 whose sex could be determined were male. ${ }^{18441}$ It was established that the majority of the victims had a mean age of over $25 .^{18442}$ Furthermore, eight blindfolds and 37 ligatures were found at the gravesite. ${ }^{18443}$ The cause of death for 29 of the 35 complete bodies was

18436 Christopher Lawrence, T. 22447 (8 December 2011); P4055 (Christopher Lawrence's expert report entitled "Report on Autopsies of Human Remains from Čančari Road Site 3, August-September 1998", 17 June 1999), e-court pp. 1, 48; Christopher Lawrence, P4051 (Transcript from Prosecutor v. Krstić), T. 3978, 3980; P4064 (Chart of primary and secondary graves). The Chamber notes that Dušan Dunjić challenged the methodology used by Lawrence in his report for Čančari Road 3, in particular, the fact that he did not provide a professional explanation for the opinions in the report, and that he went beyond the scope of his work as a pathologist. D3894 (Dušan Dunjić's expert report entitled "Forensic Analysis of Documents Pertaining to Exhumations, Autopsies and Identification of Bodies in the Srebrenica Area", 26 August 2012), p. 5. Having assessed the totality of evidence on this issue, the Chamber accepts Lawrence's report and the findings therein.

18437 P4772 (Dušan Janc's report entitled "Update to the summary of Forensic Evidence - Exhumation of the Graves and Surface Remains Recoveries related to Srebrenica - January 2012”, 13 January 2012), e-court p. 15. See also Dušan Janc, T. 26921 (27 March 2012).

18438 P4772 (Dušan Janc's report entitled "Update to the summary of Forensic Evidence - Exhumation of the Graves and Surface Remains Recoveries related to Srebrenica - January 2012”, 13 January 2012), e-court pp. 16, 18, 20.

18439 P4512 (Photograph booklet entitled "Srebrenica Mass Graves - Primary and Secondary Mass Grave Aerial Imagery"), e-court pp. 64-69, 74-75; P4504 (Dean Manning's Report, entitled "Summary of Forensic Evidence - Execution Points and Mass Graves", 16 May 2000), e-court p. 75 (specifying that aerial images reveal that Čančari Road 1 and 3 were first excavated after 27 September). See also Adjudicated Fact 1821.

18440 P4055 (Christopher Lawrence's expert report entitled "Report on Autopsies of Human Remains from Čančari Road Site 3, August-September 1998", 17 June 1999), e-court pp. 2, 9, 33; Christopher Lawrence, P4051 (Transcript from Prosecutor v. Krstić), T. 3998. See also P4504 (Dean Manning's Report, entitled "Summary of Forensic Evidence - Execution Points and Mass Graves", 16 May 2000), e-court p. 76.

18441 P4055 (Christopher Lawrence's expert report entitled "Report on Autopsies of Human Remains from Čančari Road Site 3, August-September 1998", 17 June 1999), e-court pp. 2, 10; Christopher Lawrence, P4051 (Transcript from Prosecutor v. Krstić), T. 3998. See also P4504 (Dean Manning's Report, entitled "Summary of Forensic Evidence - Execution Points and Mass Graves", 16 May 2000), e-court pp. 11, 76; Adjudicated Fact 1823.

18442 P4055 (Christopher Lawrence's expert report entitled "Report on Autopsies of Human Remains from Čančari Road Site 3, August-September 1998”, 17 June 1999), e-court p. 9. See also P4504 (Dean Manning's Report, entitled "Summary of Forensic Evidence - Execution Points and Mass Graves", 16 May 2000), e-court pp. 11, 76.

18443 Christopher Lawrence, P4051 (Transcript from Prosecutor v. Krstić), T. 3999; P4055 (Christopher Lawrence's expert report entitled "Report on Autopsies of Human Remains from Čančari Road Site 3, August-September 1998", 17 June 1999), e-court pp. 2, 20, 28; P4505 (Photograph booklet entitled "Srebrenica Blindfolds and Ligatures - Volume 1: Kozluk, Cancari Road 3 and 12 and Branjevo Military Farm (Pilica)"), pp. 173-209, 267275; P4507 (Chart of photographs of blindfolds, ligatures, and location); P4509 (Collage of Srebrenica ligatures, 5 March 2012). See also P4062 (Christopher Lawrence's expert report entitled "Report on Ligatures found in the Grave in CR03", 17 June 1999); P4504 (Dean Manning's Report, entitled "Summary of Forensic Evidence - 
a result of gunshot wounds; the six remaining had an undetermined cause of death. ${ }^{18444}$ While experts were not able to provide a cause of death for the remaining body parts analysed, injuries in the majority of these remains were consistent with gunshot wounds. ${ }^{18445}$

5411. Forensic analysis showed that the Čančari Road 3 gravesite is secondary to the Kozluk gravesite. ${ }^{18446}$ First, thousands of pieces of broken green bottles along with a pile of unused labels bearing the name of the Vitinka soft drink bottling factory at Kozluk were found at both the Čančari Road 3 and Kozluk gravesites. ${ }^{18447}$ Further, an analysis of soil, materials, and shell cases found at both sites led to the conclusion that bodies from the Kozluk gravesite were removed and reburied at the Čančari Road 3 gravesite. ${ }^{18448}$ Moreover, DNA-based connections were found between the Kozluk gravesite and the secondary gravesites of Čančari Road 1, 2, 3, 7, and $13 .{ }^{18449}$

Execution Points and Mass Graves", 16 May 2000), e-court pp. 11, 22-24, 77; Adjudicated Fact 1824. The Chamber notes that ligatures were also found in the remaining secondary gravesites associated with the Kula gravesite. P4772 (Dušan Janc's report entitled "Update to the summary of Forensic Evidence - Exhumation of the Graves and Surface Remains Recoveries related to Srebrenica - January 2012”, 13 January 2012), e-court p. 15. Similarly, blindfolds were found in Čančari Road 7 and 13. P4772 (Dušan Janc's report entitled "Update to the summary of Forensic Evidence - Exhumation of the Graves and Surface Remains Recoveries related to Srebrenica - January 2012", 13 January 2012), e-court p. 15.

18444 P4055 (Christopher Lawrence's expert report entitled "Report on Autopsies of Human Remains from Čančari Road Site 3, August-September 1998", 17 June 1999), e-court pp. 3, 33; Christopher Lawrence, P4051 (Transcript from Prosecutor v. Krstić), T. 4001-4002. See also P4504 (Dean Manning's Report, entitled "Summary of Forensic Evidence - Execution Points and Mass Graves", 16 May 2000), e-court p. 11, 76. The Chamber notes that Dušan Dunjić challenged the methodology used by Lawrence in his report regarding the undetermined cause of death for six of the victims found at Čančari Road 3. D3893 (Dušan Dunjić's expert report entitled "Forensic Analysis of Reports on the Locations of Mass Graves in the Area of Eastern Bosnia and Documentation Relating to Exhumations in the Srebrenica Area", 27 August 2009), p. 49; D3894 (Dušan Dunjić's expert report entitled "Forensic Analysis of Documents Pertaining to Exhumations, Autopsies and Identification of Bodies in the Srebrenica Area", 26 August 2012), p. 5. Having assessed the totality of evidence on this issue, the Chamber accepts Lawrence's report and the findings therein.

18445 P4055 (Christopher Lawrence's expert report entitled "Report on Autopsies of Human Remains from Čančari Road Site 3, August-September 1998", 17 June 1999), e-court p. 33; Christopher Lawrence, P4051 (Transcript from Prosecutor v. Krstić), T. 3999-4001; P4504 (Dean Manning's Report, entitled "Summary of Forensic Evidence - Execution Points and Mass Graves", 16 May 2000), e-court pp. 4, 18, 76-77.

18446 P4000 (Richard Wright's expert report entitled "Exhumations in Eastern Bosnia in 1998", 12 May 1999), ecourt pp. 22-23; Richard Wright, P3999 (Transcript from Prosecutor v. Krstić), T. 3703. See also P4504 (Dean Manning's Report, entitled "Summary of Forensic Evidence - Execution Points and Mass Graves", 16 May 2000), e-court p. 11; P4052 (Christopher Lawrence's expert report entitled "Report on Bodies Recovered Near Kozluk in 1998”, 17 June 1999); Adjudicated Fact 1820.

18447 Richard Wright, P3999 (Transcript from Prosecutor v. Krstić), T. 3675, 3679; P4001 (Richard Wright's expert report entitled "Report on Excavations and Exhumations at Kozluk in 1999: with appendix on visits to Konjević and Potočari”, 2 February 2000), e-court pp.11, 15; P4000 (Richard Wright's expert report entitled "Exhumations in Eastern Bosnia in 1998", 12 May 1999), e-court pp. 21-23; Richard Wright, T. 22250-22251 (1 December 2011); Jean-René Ruez, T. 23827-23828, 23830-23831, 23867 (30 January 2012); P4308 (Book of photographs and maps prepared by Jean-René Ruez, 22 June 2009), e-court pp. 200, 203-206; P4302 (Video footage of Kozluk area), at 00:03:58-00:04:08.

18448 P4000 (Richard Wright's expert report entitled "Exhumations in Eastern Bosnia in 1998", 12 May 1999), ecourt pp. 22-23; P4504 (Dean Manning's Report, entitled "Summary of Forensic Evidence - Execution Points and Mass Graves", 16 May 2000), e-court p. 75. See also Adjudicated Facts 1822, 1820.

18449 The specific connections are as follows: three individuals with remains in both Kozluk and Čančari Road 1; seven between Kozluk and Čančari Road 2; 51 between Kozluk and Čančari Road 3; ten between Kozluk and Čančari Road 7; and 12 between Kozluk and Čančari Road 13. P4772 (Dušan Janc's report entitled "Update to 
5412. As of 13 January 2012, DNA analysis led to identification of 479 victims from the Čančari Road gravesites as persons listed as missing following the take-over of Srebrenica: 52 from Čančari Road 1; 119 from Čančari Road 2; 138 from Čančari Road 3; 109 from Čančari Road 7; and 61 from Čančari Road 13. ${ }^{18450}$

\section{(f) Conclusion}

5413. For all these reasons, the Chamber finds that, on 14 and 15 July 1995, at least 815 Bosnian Muslim men detained at the Ročević School were killed by members of the Bosnian Serb Forces. Some were killed by members of the Bosnian Serb Forces while being detained at Ročević School. The rest were killed at a site on the bank of the Drina River near Kozluk.

\section{(4) Kula School and Pilica Cultural Centre}

(a) Kula School

5414. The Indictment refers to the killing at Kula School on or about 14 or 15 July 1995 of some of the approximately 1,200 Bosnian Muslim men detained at the school. ${ }^{18451}$ The Indictment also refers to the killing on 16 July 1995 of the surviving portion of the Bosnian Muslim men. ${ }^{8452}$

the summary of Forensic Evidence - Exhumation of the Graves and Surface Remains Recoveries related to Srebrenica - January 2012”, 13 January 2012), e-court p. 48, 82. The Chamber notes that Čančari Road 7 contained the remains of one individual whose DNA was also found in the Čančari Road 11 gravesite. P4772 (Dušan Janc's report entitled "Update to the summary of Forensic Evidence - Exhumation of the Graves and Surface Remains Recoveries related to Srebrenica - January 2012”, 13 January 2012), e-court pp. 49, 82; Dušan Janc, T 26968-26969 (27 March 2012). The Chamber finds that there are many plausible reasons for this, including the way in which the transportation of remains to secondary gravesites was conducted, and is satisfied with Janc's conclusions that Čančari Road 7 is associated with the Kozluk primary gravesite and not with the Branjevo Military Farm gravesite. See P4772 (Dušan Janc's report entitled "Update to the summary of Forensic Evidence - Exhumation of the Graves and Surface Remains Recoveries related to Srebrenica - January 2012", 13January 2012), e-court p. 41. The Chamber further notes Dušan Dunjić's challenge to the DNA-based connections between the primary and secondary gravesites, in particular, that it was "concluded groundlessly" on the basis of 310 DNA links that 4,049 bodies originated from numerous primary mass graves, including Kozluk. D3894 (Dušan Dunjić's expert report entitled "Forensic Analysis of Documents Pertaining to Exhumations, Autopsies and Identification of Bodies in the Srebrenica Area", 26 August 2012), p. 24. See also Defence Final Brief, paras. 2607-2608. The Chamber further notes that Dušan Dunjić argued that there was a possibility that certain Čančari Road gravesites could in fact be primary in relation to each other. D3893 (Dušan Dunjić's expert report entitled "Forensic Analysis of Reports on the Locations of Mass Graves in the Area of Eastern Bosnia and Documentation Relating to Exhumations in the Srebrenica Area", 27 August 2009), pp. 1617. The Chamber will deal with this challenge in detail below. See paras. 5595-5599. However, having assessed the totality of evidence on this issue, the Chamber accepts Janc's report and the findings therein. and Surface Remains Recoveries related to Srebrenica - January 2012”, 13 January 2012), e-court pp. 15-16, 18, 20, 41; P4771 (Dušan Janc's report entitled "Update to the summary of Forensic Evidence - Exhumation of the Graves and Surface Remains Recoveries related to Srebrenica - January 2012”, 13 January 2012), Annex D, ecourt pp. 184-200, 226-231, 274-277.

18451 Indictment, Scheduled Incident E.9.1.

18452 Indictment, Scheduled Incident E.9.2. 
According to the Indictment, the men were transported by bus to the Branjevo Military Farm and summarily executed; the victims were subsequently buried in a nearby mass grave. ${ }^{18453}$

\section{(i) Detention at Kula School}

5415. The Kula School—also known as the Nikola Tesla Primary School or Pilica School—is located in Kula, a hamlet in the village of Pilica. ${ }^{18454}$ The village of Pilica is situated approximately 20 kilometres north of Karakaj along the main Zvornik-Bijeljina Road. ${ }^{18455}$

5416. Early in the morning of 14 July 1995 , the $1^{\text {st }}$ Battalion of the Zvornik Brigade received a telegram from the Brigade's Command with the instruction to prepare the gymnasium at the Kula School for the arrival of between 100 and 200 men from Srebrenica. ${ }^{18456}$ The telegram further stated that, once the detainees had arrived at the school, members of the $1^{\text {st }}$ Battalion were to secure access to the building. ${ }^{18457}$ As a result, a group of 12 members of the $1^{\text {st }}$ Battalion, under the command of Security Officer Slavko Perić, a.k.a. "Captain Muderiz", proceeded to the school. ${ }^{18458}$ Upon arriving, the group split into three smaller groups: one was deployed near the main entrance to control access to the school; another was posted in the schoolyard to secure the auxiliary entrance; and the last was sent inside the school to make arrangements for the arrival of the detainees. $^{18459}$

5417. In the afternoon, several busloads of Bosnian Muslim men who had previously been detained in Bratunac, arrived at the Kula School, guarded by members of the Bosnian Serb Forces who were not from the $1^{\text {st }}$ Battalion. ${ }^{18460}$ The detainees included some elderly men, up to about 80 years old, as well as 15 or 16 year old boys. ${ }^{18461}$

\footnotetext{
18453 Indictment, Scheduled Incident E.9.2.

18454 Rajko Babić, P361 (Transcript from Prosecutor v. Popović et al.), T. 10213; Jevto Bogdanović, P385 (Transcript from Prosecutor v. Popović et al.), T. 11319. See Adjudicated Fact 1829. See also P4308 (Book of photographs and maps prepared by Jean-René Ruez, 22 June 2009), e-court p. 208.

18455 P3187 (Map of Zvornik municipality); P4308 (Book of photographs and maps prepared by Jean-René Ruez, 22 June 2009), e-court pp. 207, 219; Jean-René Ruez, T. 23831 (30 January 2012). See also Adjudicated Fact 1826.

18456 Rajko Babić, P361 (Transcript from Prosecutor v. Popović et al.), T. 10215-10217. The $1^{\text {st }}$ Battalion was also known as the Lokanj-Pilica Battalion. See Jevto Bogdanović, P385 (Transcript from Prosecutor v. Popović et $a l)$, T. 11314. The headquarters of the $1^{\text {st }}$ Battalion were in Manojlovići, in the village of Lokanj. Rajko Babić, P361 (Transcript from Prosecutor v. Popović et al.), T. 10215.

18457 Rajko Babić, P361 (Transcript from Prosecutor v. Popović et al.), T. 10216-10217. The telegram also stated that the detainees would spend the night at the school as they would be exchanged in Tuzla the following day. Rajko Babić, P361 (Transcript from Prosecutor v. Popović et al.), T. 10216, 10249.

18458 Rajko Babić, P361 (Transcript from Prosecutor v. Popović et al.), T. 10218-10220.

18459 Rajko Babić, P361 (Transcript from Prosecutor v. Popović et al.), T. 10220.

18460 Rajko Babić, P361 (Transcript from Prosecutor v. Popović et al.), T. 10221-10223; KDZ333, T. 24151 (2 February 2012); Ahmo Hasić, P354 (Transcript from Prosecutor v. Popović et al.), T. 1190, 1192-1193. See also Ahmo Hasić, P354 (Transcript from Prosecutor v. Popović et al.), T. 1194-1195; KDZ333, P4342
} 
5418. Upon arrival, members of the Bosnian Serb Forces ordered the detainees to disembark, to put their hands behind their heads, and to walk one by one towards the gymnasium. ${ }^{18462}$ Detainees entered the school in waves. ${ }^{18463}$ When the gymnasium could not hold any more men, detainees were left standing in the corridors and stairway while others remained on the buses outside. ${ }^{18464}$ These detainees were subsequently taken to the classrooms on the first floor of the school. ${ }^{18465}$

5419. Conditions at the Kula School were very poor. The gymnasium and the classrooms became overcrowded and were so tightly packed that no one could move. ${ }^{18466}$ With an outside temperature of about $30^{\circ} \mathrm{C}$, the school began to mist up. ${ }^{18467}$ A strong stench emanated from the gymnasium, as there were no windows open and thus no ventilation. ${ }^{18468}$ The members of the Bosnian Serb Forces who were guarding the detainees from the entrance of the gymnasium found the stench so unbearable that they kept asking to change guards frequently. ${ }^{18469}$ Some of the detainees collapsed, ${ }^{18470}$ and two or three detainees died in the crowded gymnasium overnight. ${ }^{18471}$

5420. There was no medical treatment available at the school. ${ }^{18472}$ Detainees were given food, but it was not enough for everyone. ${ }^{18473}$ Several detainees were allowed to fetch water from a nearby

(Transcript from Prosecutor v. Krstić), T. 3030-3031; KDZ333, T. 24124-24125 (2 February 2012); P4347 (Photograph of Kula School marked by KDZ333). The Chamber notes that Ahmo Hasić referred to the location where he was taken both as a school and as a cultural centre or hall. Ahmo Hasić, P354 (Transcript from Prosecutor v. Popović et al.), T. 1192; Ahmo Hasić, P353 (Transcript from Prosecutor v. Popović et al.), T. 1287-1288 (under seal). While Hasić testified that he did not know what these places were called, he was clear that the building where he was detained had a ground floor and one floor upstairs. Ahmo Hasić, P353 (Transcript from Prosecutor v. Popović et al.), T. 1288 (under seal). Having assessed Hasić's evidence as a whole, and in particular in light of other evidence indicating that the section of the Pilica Cultural Centre where the detainees were held had one floor, the Chamber finds that Hasić was detained at Kula School. See para. 5439.

Ahmo Hasić, P354 (Transcript from Prosecutor v. Popović et al.), T. 1194, 1223-1225.

Rajko Babić, P361 (Transcript from Prosecutor v. Popović et al.), T. 10221-10224; KDZ333, T. 24152 (2 February 2012). See also KDZ333, T. 24124-24125 (2 February 2012); P4347 (Photograph of Kula School marked by KDZ333) (where KDZ333 marked with "1" the gymnasium at Kula School); Jean-René Ruez, T. 23832 (30 January 2012); P4308 (Book of photographs and maps prepared by Jean-René Ruez, 22 June 2009), e-court pp. 210-211.

Rajko Babić, P361 (Transcript from Prosecutor v. Popović et al.), T. 10222.

Rajko Babić, P361 (Transcript from Prosecutor v. Popović et al.), T. 10224-10226, 10236. See also KDZ333, P4342 (Transcript from Prosecutor v. Krstić), T. 3031-3032; D2052 (Statement of KDZ333 to State Commission on Gathering Facts on War Crimes, 20 July 1996), p. 3 (under seal).

18465 Rajko Babić, P361 (Transcript from Prosecutor v. Popović et al.), T. 10226-10227.

18466 Ahmo Hasić, P354 (Transcript from Prosecutor v. Popović et al.), T. 1193-1194; Rajko Babić, P361 (Transcript from Prosecutor v. Popović et al.), T. 10224-10225. See also Jevto Bogdanović, P385 (Transcript from Prosecutor v. Popović et al.), T. 11322, 11340-11341. (Transcript from Prosecutor v. Krstić), T. 3036.

Rajko Babić, P361 (Transcript from Prosecutor v. Popović et al.), T. 10224.

Rajko Babić, P361 (Transcript from Prosecutor v. Popović et al.), T. 10224. See also KDZ333, P4342 (Transcript from Prosecutor v. Krstić), T. 3039.

Rajko Babić, P361 (Transcript from Prosecutor v. Popović et al.), T. 10226.

KDZ333, P4342 (Transcript from Prosecutor v. Krstić), T. 3036. See also Adjudicated Facts 1827, 1831.

KDZ333, P4342 (Transcript from Prosecutor v. Krstić), T. 3036. 
water point, while being escorted by members of the Bosnian Serb Forces. ${ }^{18474}$ A detainee was shot as he attempted to escape while fetching water. ${ }^{18475}$ While the detainees were given water, it was not sufficient. ${ }^{18476}$ Some of the detainees inside the gymnasium and classrooms requested to be let out in order to get water and use the toilet. ${ }^{18477}$ The detainees were not always allowed and, when they were, some of them were hit with rifle butts by soldiers. ${ }^{18478}$ Out of fear, many of the detainees urinated where they were. ${ }^{18479}$

5421. On 15 July, additional members of the $1^{\text {st }}$ Battalion were sent by Perić to the school; this brought the total number of soldiers at the school at that time to between 40 and $50 .{ }^{18480}$ A man who was addressed as a "lieutenant-colonel or colonel" and wore a camouflage uniform also visited the school that day, ${ }^{18481}$ as did Jasikovac. ${ }^{18482}$ Rajko Babić, a member of the $1^{\text {st }}$ Battalion, asked the lieutenant-colonel or colonel if any of the detainees would stay at the school but was told: "No, they can't stay, they ha[ve] to be taken away, all of them. I don't want to talk to you anymore." 18483 Babic interpreted the comment made by the lieutenant-colonel or colonel to mean that all of the Bosnian Muslim detainees would be killed. ${ }^{18484}$

18473 Ahmo Hasić, P354 (Transcript from Prosecutor v. Popović et al.), T. 1195; KDZ333, P4342 (Transcript from Prosecutor v. Krstić), T. 3037. See also Jevto Bogdanović, P385 (Transcript from Prosecutor v. Popović et al.), T. 11322.

18474 Rajko Babić, P361 (Transcript from Prosecutor v. Popović et al.), T. 10227-10228; KDZ333, T. 24126, 2415524156 (2 February 2012); KDZ333, P4342 (Transcript from Prosecutor v. Krstić), T. 3032-3033. See also KDZ333, T. $24124-24125$ (2 February 2012); P4347 (Photograph of Kula School marked by KDZ333) (where KDZ333 marked with "2" the water point); Jean-René Ruez, T. 23833 (30 January 2012); P4308 (Book of photographs and maps prepared by Jean-René Ruez, 22 June 2009), e-court pp. 212-213.

18475 Rajko Babić, P361 (Transcript from Prosecutor v. Popović et al.), T. 10229.

18476 Rajko Babić, P361 (Transcript from Prosecutor v. Popović et al.), T. 10227-10228; KDZ333, P4342 (Transcript from Prosecutor v. Krstić), T. 3036-3037; Jevto Bogdanović, P385 (Transcript from Prosecutor v. Popović et al.), T. 11322. See also Adjudicated Fact 1827.

18477 Rajko Babić, P361 (Transcript from Prosecutor v. Popović et al.), T. 10225.

18478 Ahmo Hasić, P354 (Transcript from Prosecutor v. Popović et al.), T. 1193. See Adjudicated Fact 1833.

18479 Ahmo Hasić, P354 (Transcript from Prosecutor v. Popović et al.), T. 1193.

18480 Rajko Babić, P361 (Transcript from Prosecutor v. Popović et al.), T. 10233; P4585 (Zvornik Brigade Duty Officers logbook, 29 May-27 July 1995), e-court p. 75 (an entry in the Zvornik Brigade Duty Officer's logbook for 15 July 1995 recording a request by the $1^{\text {st }}$ Battalion for oil and gasoline for "transport of troops to Kula", and for ten crates of $7.62 \mathrm{~mm}$ ammunition). The soldiers who were already at the school remained at the premises but did not have to stand guard anymore. Rajko Babić, P361 (Transcript from Prosecutor v. Popović et al.), T. 10233. See also Adjudicated Fact 1830; Ahmo Hasić, P354 (Transcript from Prosecutor v. Popović et al.), T. 1194-1195; KDZ333, P4342 (Transcript from Prosecutor v. Krstić), T. 3031, 3039.

18481 Rajko Babić, P361 (Transcript from Prosecutor v. Popović et al.), T. 10237, 10240. While Babić could not recall the officer's name, he described him as rather tall, heavily built, with thin blond hair combed over a receding hairline, no moustache, and wearing a camouflage uniform. Rajko Babić, P361 (Transcript from Prosecutor v. Popović et al.), T. 10240-10241.

18482 Milorad Birčaković, P360 (Transcript from Prosecutor v. Popović et al.), T. 11045-11046. Birčaković testified that he drove Jasikovac to the school but remained outside while Jasikovac went inside to "inspect". Milorad Birčaković, P360 (Transcript from Prosecutor v. Popović et al.), T. 11046.

18483 Rajko Babić, P361 (Transcript from Prosecutor v. Popović et al.), T. 10239-10240.

18484 Rajko Babić, P361 (Transcript from Prosecutor v. Popović et al.), T. 10240. 
5422. Throughout this time, many detainees were taken out of the school by members of the Bosnian Serb Forces. ${ }^{18485}$ Screaming and moaning could then be heard, followed by bursts of gunfire, after which the screaming stopped. ${ }^{18486}$ Only some detainees returned. ${ }^{18487}$ This went on constantly, day and night. ${ }^{18488}$ Detainees did not dare look out of the windows to see what was happening because whenever someone tried to do so, the guards would shoot a burst of gunfire. ${ }^{18489}$ The bodies of detainees killed by members of the Bosnian Serb Forces while trying to escape during the night could be seen lying around the school. ${ }^{18490}$

5423. Members of the Bosnian Serb Forces took jewellery, watches, and money from the detainees. ${ }^{18491}$ Soldiers also requested 10,000 German marks from each detainee and warned them that if they did not manage to collect that sum they would all be killed; the soldiers returned twice for money but the detainees had none left. ${ }^{18492}$

(ii) Transportation of detainees from the Kula School

5424. On the morning of 16 July, Radivoje Lakić-the Commander of the $1^{\text {st }}$ Battalion's Works Platoon ${ }^{18493}$ —ordered some of its members to go to the Kula School. ${ }^{18494}$ When they arrived, they were told by unknown soldiers to stand guard while detainees were put on buses. ${ }^{18495}$

18485 Ahmo Hasić, P354 (Transcript from Prosecutor v. Popović et al.), T. 1192, 1197-1198; KDZ333, P4342 (Transcript from Prosecutor v. Krstić), T. 3038.

18486 Ahmo Hasić, P354 (Transcript from Prosecutor v. Popović et al.), T. 1192, 1196-1198. See also KDZ333, P4342 (Transcript from Prosecutor v. Krstić), T. 3033-3036, 3050; D2052 (Statement of KDZ333 to State Commission on Gathering Facts on War Crimes, 20 July 1996), p. 3 (under seal); KDZ333, T. 24126, 24156 (2 February 2012) (testifying that while fetching water at the water point outside of the school, he heard a bus approaching and, shortly after, heard people crying for help, followed by shots fired from the same direction; the shooting went on for five to ten minutes); P4348 (Photograph of Kula School marked by KDZ333); Jean-René Ruez, T. 23834-23835 (30 January 2012); P4308 (Book of photographs and maps prepared by Jean-René Ruez, 22 June 2009), e-court pp. 214, 216-218; Adjudicated Fact 1832.

18487 KDZ333, P4342 (Transcript from Prosecutor v. Krstić), T. 3038; Ahmo Hasić, P354 (Transcript from Prosecutor v. Popović et al.), T. 1225-1226. See also Adjudicated Fact 1835.

18488 Ahmo Hasić, P354 (Transcript from Prosecutor v. Popović et al.), T. 1197.

18489 Ahmo Hasić, P354 (Transcript from Prosecutor v. Popović et al.), T. 1192, 1197.

18490 D3993 (Witness statement of Vujadin Popović dated 2 November 2013), paras. 69-71; Milorad Birčaković, P360 (Transcript from Prosecutor v. Popović et al.), T. 11046. See also Jevto Bogdanović, P385 (Transcript from Prosecutor v. Popović et al.), T. 11323-11324, 11339, 11344 (testifying to having seen on 16 July nine bodies dressed in civilian clothing about 50 metres away from the school, which were then put on a tractortrailer and taken away).

18491 KDZ333, P4342 (Transcript from Prosecutor v. Krstić), T. 3037; KDZ333, T. 24152 (2 February 2012); Adjudicated Fact 1834.

18492 KDZ333, P4342 (Transcript from Prosecutor v. Krstić), T. 3037-3038.

18493 Jevto Bogdanović, P385 (Transcript from Prosecutor v. Popović et al.), T. 11314, 11343. The Works Platoon was subordinated to the $1^{\text {st }}$ Battalion of the Zvornik Brigade and was stationed at the Branjevo Farm. Jevto Bogdanović, P385 (Transcript from Prosecutor v. Popović et al.), T. 11314-11316. It was in charge, among other things, of preparing food for the troops and distributing it and, whenever necessary, of digging trenches at the frontlines. Jevto Bogdanović, P385 (Transcript from Prosecutor v. Popović et al.), T. 11314-11315.

18494 Jevto Bogdanović, P385 (Transcript from Prosecutor v. Popović et al.), T. 11319-11320, 11341. 
5425. Members of the Bosnian Serb Forces told the detainees that those who had the money to pay for transportation could go to Sarajevo. ${ }^{18496}$ Once those who had money left, the rest of the detainees were told that they would be taken to Tuzla. ${ }^{18497}$ Soon after, detainees began to be taken out of the school in groups of eight. ${ }^{18498}$ As one of the detainees was exiting the school, he saw the body of a dead man lying at the bottom of the stairs in a pool of blood. ${ }^{18499}$ Two long sheets were brought by the soldiers and ripped into strips, so that detainees tied other detainees' hands behind their backs. ${ }^{18500}$ Some detainees were also blindfolded. ${ }^{18501}$ The detainees were then escorted by about ten soldiers to buses lined up outside the school. ${ }^{18502}$ During this process, the soldiers swore at the detainees and hit them with their rifle butts. ${ }^{18503}$ Once the buses were filled they were driven along the same road previously used to get to the school. ${ }^{18504}$ The detainees were told again that they were going to Tuzla. ${ }^{18505}$

5426. Popović testified that, at approximately 10 a.m. that day, while at the Zvornik Brigade Command, Trbić told him that Beara had gone with some people to Pilica and had asked for Popović to join him at the Kula School. ${ }^{18506}$ When Popović arrived at the school, the boarding of the detainees onto the buses was ongoing and he found Beara in front of a house next to the

\footnotetext{
18495 Jevto Bogdanović, P385 (Transcript from Prosecutor v. Popović et al.), T. 11320-11321, 11324. See also Adjudicated Fact 1828 .

18496 Ahmo Hasić, P354 (Transcript from Prosecutor v. Popović et al.), T. 1195. See also KDZ333, T. 24152 (2 February 2012). The Chamber notes that Hasić testified that the executions took place on 17 July, after spending two nights at Kula School. Ahmo Hasić, P354 (Transcript from Prosecutor v. Popović et al.), T. 1193, 1227. See also Adjudicated Fact 1828 (stating that the detainees were held at the Kula School for two nights). However, in light of the Chamber's finding above that Hasić did not arrive at the school on 15 July but on 14 July, the Chamber considers that his evidence pertaining to the transportation of detainees and the subsequent executions at the Branjevo Military Farm refers to events which took place on 16 July 1995. See fn. 18047.

18497 Ahmo Hasić, P354 (Transcript from Prosecutor v. Popović et al.), T. 1195.

18498 Rajko Babić, P361 (Transcript from Prosecutor v. Popović et al.), T. 10234. See also Jevto Bogdanović, P385 (Transcript from Prosecutor v. Popović et al.), T. 11324. Babić testified that on 16 July he was not at the school premises but at the terrace of his nearby apartment from where he could watch the events at the school. Rajko Babić, P361 (Transcript from Prosecutor v. Popović et al.), T. 10234-10236.

18499 Ahmo Hasić, P354 (Transcript from Prosecutor v. Popović et al.), T. 1195-1196, 1198.

18500 Ahmo Hasić, P354 (Transcript from Prosecutor v. Popović et al.), T. 1195; Rajko Babić, P361 (Transcript from Prosecutor v. Popović et al.), T. 10234-10235; KDZ333, P4342 (Transcript from Prosecutor v. Krstić), T. 3040. See also Adjudicated Fact 1838.

18501 Rajko Babić, P361 (Transcript from Prosecutor v. Popović et al.), T. 10234.

18502 See Ahmo Hasić, P354 (Transcript from Prosecutor v. Popović et al.), T. 1198; KDZ333, P4342 (Transcript from Prosecutor v. Krstić), T. 3040; D3927 (Witness statement of Franc Kos dated 26 July 2013), pp. 14-15, 16, 22-23; Franc Kos, T. 42374-42376 (31 July 2013); Jevto Bogdanović, P385 (Transcript from Prosecutor v. Popović et al.), T. 11322; P6451 (Article from Slobodna Bosna entitled "I Killed 'Only' Hundreds of People", 22 March 1996), p. 2. The buses displayed the markings of "Centrotrans Sarajevo" and "Drinatrans Zvornik" transportation companies. Adjudicated Fact 1839.

18503 Ahmo Hasić, P354 (Transcript from Prosecutor v. Popović et al.), T. 1198.

18504 KDZ333, P4342 (Transcript from Prosecutor v. Krstić), T. 3040.

18505 Ahmo Hasić, P354 (Transcript from Prosecutor v. Popović et al.), T. 1198.

18506 D3993 (Witness statement of Vujadin Popović dated 2 November 2013), para. 66.
} 
school. ${ }^{18507}$ An intercepted conversation between Beara and Slobodan Cerović-the Drina Corps Assistant Commander for Morale, Religious, and Legal Affairs, who was serving as duty officer at Drina Corps headquarters in Vlasenica at the time ${ }^{18508}$ —at 11:11 a.m. on 16 July, records Cerović informing Beara that Colonel Trkulja—an operations officer from the Main Staff ${ }^{18509}$ — was looking for Beara because "he got instructions from above [...] to do triage on [the detainees]". ${ }^{18510}$ The Chamber also received evidence that Popović organised and co-ordinated the transportation of detainees from the Kula School. ${ }^{18511}$

(iii) Killings at the Branjevo Military Farm

5427. Members of the $1^{\text {st }}$ or "Bijeljina" Platoon of the $10^{\text {th }}$ Sabotage Detachment were stationed at the $2^{\text {nd }}$ or "Vlasenica" Platoon's headquarters in Dragaševac on 16 July $1995 .{ }^{18512}$ Between 4:30 and 5:30 a.m., Franc Kos received a phone call from Beara requesting that he and seven soldiers

18507 D3993 (Witness statement of Vujadin Popović dated 2 November 2013), paras. 66-69. See also Vujadin Popović, T. 43074-43076 (6 November 2013). The Chamber refers to its assessment of Beara's testimony regarding his whereabouts on 13 and 14 July, as discussed in fn. 17583.

18508 Richard Butler, T. 27586 (18 April 2012).

18509 Richard Butler, T. 27587 (18 April 2012).

18510 Beara interrupted Cerović by stating: "I don't want to talk about it on the phone." P6700 (Intercept of conversation between Col. Beara and Cerović, 16 July 1995); P5075 (Intercept of conversation between Col. Beara and Cerović, 16 July 1995). See P4585 (Zvornik Brigade Duty Officers logbook, 29 May-27 July 1995), e-court p. 81 (noting that it was reported to Beara from Zlatar that a "triage of wounded and prisoners must be carried out"). Zlatar was the code name for the Drina Corps and Palma was the code name of the Zvornik Brigade. Stefanie Frease, T. 26720-26721 (23 March 2012). See also Richard Butler, T. 27586 (18 April 2012).

18511 An intercepted conversation from 16 July at 1:58 p.m. between the duty officer of the Drina Corps Command and Trbić - then Zvornik Brigade duty officer-records the latter transmitting an urgent request from Popović for 500 litres of diesel fuel. P5077 (Intercept of conversation between Zlatar duty officer and Palma duty officer, 16 July 1995), p. 1; Vujadin Popović, T. 43083-43086 (6 November 2013). Trbić was then connected to a certain Bašević, and repeated the same request for fuel from Popović, adding that "or else the work he's doing will stop". P5077 (Intercept of conversation between Zlatar duty officer and Palma duty officer, 16 July 1995), p. 1. See also P4585 (Zvornik Brigade Duty Officers logbook, 29 May-27 July 1995), e-court p. 85; Vujadin Popović, T. 43085, 43087-43088 (6 November 2013). Trbić was subsequently connected to Major Golić, an intelligence officer of the Drina Corps Command, and repeated yet again Popović's request for 500 litres of fuel to be sent immediately. P5077 (Intercept of conversation between Zlatar duty officer and Palma duty officer, 16 July 1995), p. 2. The intercept also records that a fuel tank from the vehicle battalion was to go to Pilica. P5077 (Intercept of conversation between Zlatar duty officer and Palma duty officer, 16 July 1995), p. 2. See also P4585 (Zvornik Brigade Duty Officers logbook, 29 May-27 July 1995), e-court p. 85 (a note in the Zvornik Brigade Duty Officer Logbook at 2 p.m. stating that "Popović requested a bus with a full tank and 500 litres of D2"); P4669 (Intercept authentication binder of Stefanie Frease), pp. 66-68 (where a Zvornik Brigade material dispatch order recorded the disbursement of 500 litres of fuel "for Lt. Col. Popović" on 16 July 1995); P5077 (Intercept of conversation between Zlatar duty officer and Palma duty officer, 16 July 1995), p. 2 (whereby Trbić informed an unidentified individual that a bus loaded with 500 litres of oil was to go to Pilica); P5312 (Intercept of conversation between Major Bašević and an unidentified person, 16 July 1995) (record of an intercepted conversation from 7:12 p.m. on 16 July, in which Bašević reported that the petrol had ran out completely, and was told in response that "Zvornik is solved"). But see Vujadin Popović, T. 43086 (6 November 2013) (testifying that somebody was asking for the oil in his name because he did not need it).

18512 Dražen Erdemović, P332 (Transcript from Prosecutor v. Popović et al.), T. 10960-10962; Dražen Erdemović, T. 25369 (27 February 2012). See also D3927 (Witness statement of Franc Kos dated 26 July 2013), p. 3. The village of Dragaševac was located about four or five kilometres from Vlasenica. Dragan Todorović, P4353 (Transcript from Prosecutor v. Popović et al.), T. 13992. 
come immediately to the Drina Corps Command in Vlasenica. ${ }^{18513}$ Kos refused to comply with the order as he had not been authorised to do so by Pelemiš. ${ }^{18514}$ Beara called a second time at approximately 6 a.m., demanding to know why Kos was not on his way. ${ }^{18515}$

5428. At approximately 7:30 a.m., Dragomir Pećanac-from the Intelligence Administration of the Main Staff ${ }^{18516}$ - as well as Pelemiš, the full $2^{\text {nd }}$ Platoon, and soldiers of the $1^{\text {st }}$ Platoon who had been with the $2^{\text {nd }}$ Platoon, arrived at Dragaševac. ${ }^{18517}$ Soon after, Kos and seven other members of the detachment, including Dražen Erdemović, were ordered to get their equipment ready and leave for an assignment. ${ }^{18518}$ Dragan Todorović—a member of the $2^{\text {nd }}$ Platoon-then proceeded to prepare the ammunition and weapons for the mission. ${ }^{18519}$ Shortly after, the eight soldiers boarded a black minivan and set out in the direction of Zvornik, making a brief stop at the Standard Barracks, where they were to report to the "Command". ${ }^{18520}$ After this stop, the van followed an

18513 D3927 (Witness statement of Franc Kos dated 26 July 2013), pp. 10, 18.

18514 D3927 (Witness statement of Franc Kos dated 26 July 2013), pp. 10-11. See Dragan Todorović, P4353 (Transcript from Prosecutor v. Popović et al.), T. 13993-13994.

18515 D3927 (Witness statement of Franc Kos dated 26 July 2013), pp. 10-11, 18.

18516 D3993 (Witness statement of Vujadin Popović dated 2 November 2013), para. 58; Dražen Erdemović, T. 25424 (28 February 2012). See also D3720 (Witness statement of Petar Salapura dated 17 June 2013), p. 3.

18517 D3927 (Witness statement of Franc Kos dated 26 July 2013), pp. 11, 18; Dragan Todorović, P4353 (Transcript from Prosecutor v. Popović et al.), T. 14012-14013, 14029. See also Tomislav Kovač, T. 42876 (4 November 2013) (closed session). The Chamber notes Todorović's evidence that these events took place on 15 July. Dragan Todorović, P4353 (Transcript from Prosecutor v. Popović et al.), T. 14010-14011, 14044; Dragan Todorović, T. 24204 (7 February 2012). However, having compared Todorović's evidence to that of Kos and Erdemović, the Chamber considers that the events described by him took place on 16 July 1995.

18518 D3927 (Witness statement of Franc Kos dated 26 July 2013), p. 11; Franc Kos, T. 42382 (31 July 2013 ), T. 42407 (1 August 2013); Dragan Todorović, P4353 (Transcript from Prosecutor v. Popović et al.), T. 1401314015, 14029, 14041; Dragan Todorović, T. 24203-24204 (7 February 2012); Dražen Erdemović, T. 25368 (27 February 2012); Dražen Erdemović, P332 (Transcript from Prosecutor v. Popović et al.), T. 10962-10963. These six soldiers, in addition to Kos and Erdemović, were: Brano Gojković, Zoran Goronja, Aleksander Cvetković, Marko Boskić, Stanko Savanović, and Vlastimir Golijanin. Dražen Erdemović, P332 (Transcript from Prosecutor v. Popović et al.), T. 10962-10963, 11005; D3927 (Witness statement of Franc Kos dated 26 July 2013), p. 11. See also Dragan Todorović, P4353 (Transcript from Prosecutor v. Popović et al.), T. 14040; P4351 (Order of $10^{\text {th }}$ Sabotage Detachment, 10 July 1995); P4488 (Dražen Erdemović's VRS contract, 30 April 1995). According to Kos and Todorović, Erdemović had not been originally assigned but volunteered to join the mission and go with Kos because he did not want to stay on base on his own. D3927 (Witness statement of Franc Kos dated 26 July 2013), p. 11; Dragan Todorović, P4353 (Transcript from Prosecutor v. Popović et al.), T. 14042; Dragan Todorović, T. 24204 (7 February 2012).

18519 Dragan Todorović, P4353 (Transcript from Prosecutor v. Popović et al.), T. 13992, 14030-14032, 1403714038; Dragan Todorović, T. 24212 (7 February 2012). These included two hand-held launchers, one M-84 machine gun and a crate of ammunition, made up of 1,200 rounds. Dragan Todorović, P4353 (Transcript from Prosecutor v. Popović et al.), T. 14030-14032, 14063; Dragan Todorović, T. 24206 (7 February 2012); P4352 (Notes related to logistical support issued to the $10^{\text {th }}$ Sabotage Detachment, 14-16 July 1995), p. 2.

18520 D3927 (Witness statement of Franc Kos dated 26 July 2013), pp. 11-12, 18-19; Dražen Erdemović, T. 2537025371 (27 February 2012); Dražen Erdemović, P332 (Transcript from Prosecutor v. Popović et al.), T. 1096410965, 10967-10969; Dragan Todorović, P4353 (Transcript from Prosecutor v. Popović et al.), T. 1403814040; P265 (Photograph of Zvornik Brigade HQ). 
olive-green-grey Opel Cadet car, with a "lieutenant-colonel" and two military policemen onboard. ${ }^{18521}$

5429. At approximately 10 a.m., the two vehicles arrived at the Branjevo Military Farm, ${ }^{18522}$ which was under the direct authority and control of the $1^{\text {st }}$ Battalion of the Zvornik Brigade. ${ }^{18523}$ The Branjevo Military Farm is located near the village of Pilica, and is approached by going 700 to 800 metres through a dirt road leading off the Bijeljina-Zvornik Road from the direction of the Kula School. ${ }^{18524}$

5430. Once the group arrived at the Branjevo Military Farm and, following a conversation between the lieutenant-colonel and an officer "in military uniform" already present at the farm, ${ }^{18525}$ the members of the detachment were told by Brano Gojković — a member of the detachment—and the lieutenant-colonel that buses carrying civilians from Srebrenica would start arriving in a few minutes, and that these people were to be killed that day because they were war criminals. ${ }^{18526}$ The lieutenant-colonel and the two military policemen then left the Branjevo Military Farm. ${ }^{18527}$

18521 Dražen Erdemović, P332 (Transcript from Prosecutor v. Popović et al.), T. 10966-10968, 10993. See also D3927 (Witness statement of Franc Kos dated 26 July 2013), p. 12 (stating that, after stopping at the Standard Barracks, the group started following a red Opel Kadett, with a young officer and a driver in it). The military policemen had the insignia of the MP in their uniforms, and one of them was wearing a white cross belt. Dražen Erdemović, P332 (Transcript from Prosecutor v. Popović et al.), T. 10966; P249 (VRS field dress insignia). Based on his assumption that the Drina Corps headquarters were located in Zvornik, Erdemović believed that these men were members of the Drina Corps MP. Dražen Erdemović, P332 (Transcript from Prosecutor v. Popović et al.), T. 10967. The Chamber recalls, however, that the Drina Corps headquarters was based in Vlasenica at the time. See para. 190.

18522 Dražen Erdemović, P332 (Transcript from Prosecutor v. Popović et al.), T. 10966, 10969, 10978-10979; P264 (Aerial photograph of Branjevo state farm dated 15 July 1995 marked by Dražen Erdemović); D3927 (Witness statement of Franc Kos dated 26 July 2013), pp. 12, 19; Franc Kos, T. 42364 (31 July 2013); P4306 (Video footage of Branjevo Farm), at 00:05:03 to 00:05:30. The Branjevo Military Farm consisted of three or four hectares of land used for military purposes. Jevto Bogdanović, P385 (Transcript from Prosecutor v. Popović et al.), T. 11315-11317, 11336. See also P270 (Photograph of Branjevo state farm marked by Jevto Bogdanović).

18523 Adjudicated Fact 1836.

18524 P4504 (Dean Manning's Report, entitled "Summary of Forensic Evidence - Execution Points and Mass Graves", 16 May 2000), e-court p. 43; D3927 (Witness statement of Franc Kos dated 26 July 2013), p. 12; Jean-René Ruez, T. 23831, 23836, 23841 (30 January 2012); P4308 (Book of photographs and maps prepared by JeanRené Ruez, 22 June 2009), e-court pp. 207, 219, 222; P4304 (Photograph of Pilica Farm marked by Jean-René Ruez); P4306 (Video footage of Branjevo Farm), at 00:00:00-00:02:58; P4332 (Photograph of Branjevo Farm, 21 September 1995); P4321 (William Haglund's expert report, entitled "Forensic Investigation of the Pilica (Branjevo Farm) Grave Site - Volume I", 15 June 1998), e-court p. 18; P4512 (Photograph booklet entitled "Srebrenica Mass Graves - Primary and Secondary Mass Grave Aerial Imagery"), e-court p. 29.

18525 Dražen Erdemović, P332 (Transcript from Prosecutor v. Popović et al.), T. 10969-10970; D3927 (Witness statement of Franc Kos dated 26 July 2013), p. 13. See also Dražen Erdemović, T. 25344 (27 February 2012); P264 (Aerial photograph of Branjevo state farm dated 15 July 1995 marked by Dražen Erdemović); P4489 (Photograph of Branjevo Farm marked by Dražen Erdemović).

18526 Dražen Erdemović, T. 25374, 25377 (27 February 2012); Dražen Erdemović, P332 (Transcript from Prosecutor v. Popović et al.), T. 10970-10971; D3927 (Witness statement of Franc Kos dated 26 July 2013), pp. 13, 21. See also Adjudicated Fact 1849; Dražen Erdemović, P332 (Transcript from Prosecutor v. Popović et al.), T. 10966, 10981, 10986; Dražen Erdemović, T. 25375-25377 (27 February 2012); Franc Kos, T. 42376-42377 (31 July 2013); D3993 (Witness statement of Vujadin Popović dated 2 November 2013), para. 78. 
5431. Shortly thereafter, buses filled with Bosnian Muslim detainees previously held at the Kula School began arriving at the Branjevo Military Farm. ${ }^{18528}$ One or two soldiers escorted the detainees on each of the buses and sat next to the driver. ${ }^{18529}$ After departing from the school, the buses travelled for approximately two and a half kilometres up a hill. ${ }^{18530}$ The buses stopped at a meadow which was littered with a "large number of dead bodies"; gunfire could be heard. ${ }^{18531}$ When the doors opened, Bosnian Serb soldiers gathered around the buses and started cursing the detainees, the detainees' mothers, and Haris Silajdžić's mother. ${ }^{18532}$ The soldiers ordered the detainees to disembark until the buses were half empty. ${ }^{18533}$

5432. A group of soldiers led columns of ten detainees approximately 100 to 200 metres away from the buses towards the meadow. ${ }^{18534}$ On their way, the detainees saw bodies lying on the ground. ${ }^{18535}$ Soldiers asked detainees for money and beat them when they said they did not have any. ${ }^{18536}$ Upon reaching the meadow, the detainees-some of whom were blindfolded and had their hands tied behind their backs—-passed by those who had been killed earlier until they were told to stop and turn around so that they faced away from the eight members of the detachment,

18528 Dražen Erdemović, T. 25375 (27 February 2012); Dražen Erdemović, P332 (Transcript from Prosecutor v. Popović et al.), T. 10971; D3927 (Witness statement of Franc Kos dated 26 July 2013), p. 19. See also Adjudicated Fact 1837.

18529 Ahmo Hasić, P354 (Transcript from Prosecutor v. Popović et al.), T. 1200. See also Dražen Erdemović, P332 (Transcript from Prosecutor v. Popović et al.), T. 10971; Dražen Erdemović, T. 25379 (28 February 2012); D3927 (Witness statement of Franc Kos dated 26 July 2013), p. 14. Ahmo Hasić testified that the soldiers on the buses were the same ones he had seen earlier in the school. Ahmo Hasić, P354 (Transcript from Prosecutor v. Popović et al.), T. 1200. See also Adjudicated Fact 1846.

18530 Ahmo Hasić, P354 (Transcript from Prosecutor v. Popović et al.), T. 1201.

18531 Ahmo Hasić, P354 (Transcript from Prosecutor v. Popović et al.), T. 1201; KDZ333, P4342 (Transcript from Prosecutor v. Krstić), T. 3040. See also KDZ333, T. 24127 (2 February 2012); P4349 (Photograph of Branjevo Military Farm marked by KDZ333); Dražen Erdemović, P332 (Transcript from Prosecutor v. Popović et al.), T. 10978-10979; P264 (Aerial photograph of Branjevo state farm dated 15 July 1995 marked by Dražen Erdemović); Dražen Erdemović, T. 25344 (27 February 2012); P4489 (Photograph of Branjevo Farm marked by Dražen Erdemović); Jean-René Ruez, T. 23836-23837 (30 January 2012); P4303 (Aerial image of Branjevo Farm marked by Jean-René Ruez).

18532 Ahmo Hasić, P354 (Transcript from Prosecutor v. Popović et al.), T. 1201.

18533 Ahmo Hasić, P354 (Transcript from Prosecutor v. Popović et al.), T. 1201-1202.

18534 Dražen Erdemović, P332 (Transcript from Prosecutor v. Popović et al.), T. 10971-10972; Dražen Erdemović, T. 25345 (27 February 2012), T. 25379 (28 February 2012); KDZ333, T. 24157 (2 February 2012); KDZ333, P4342 (Transcript from Prosecutor v. Krstić), T. 3040-3041, 3043; Ahmo Hasić, P354 (Transcript from Prosecutor v. Popović et al.), T. 1201-1202; D3927 (Witness statement of Franc Kos dated 26 July 2013), pp. 15-16. See also Adjudicated Facts 1840, 1841; D3927 (Witness statement of Franc Kos dated 26 July 2013), p. 14; Dražen Erdemović, T. 25381 (28 February 2012); D2134 (Photograph of Branjevo Farm marked by Dražen Erdemović); KDZ333, T. 24127 (2 February 2012); P4349 (Photograph of Branjevo Military Farm marked by KDZ333); D2052 (Statement of KDZ333 to State Commission on Gathering Facts on War Crimes, 20 July 1996), p. 4 (under seal); Jean-René Ruez, T. 23842-23843 (30 January 2012); P4308 (Book of photographs and maps prepared by Jean-René Ruez, 22 June 2009), e-court p. 223.

18535 Ahmo Hasić, P354 (Transcript from Prosecutor v. Popović et al.), T. 1201, 1286.

18536 Ahmo Hasić, P354 (Transcript from Prosecutor v. Popović et al.), T. 1201; D3927 (Witness statement of Franc Kos dated 26 July 2013), p. 17; Franc Kos, T. 42369 (31 July 2013). KDZ333 also heard soldiers asking detainees if they had relatives abroad who could send money so that they could be exchanged; those who spoke up were taken away. KDZ333, P4342 (Transcript from Prosecutor v. Krstić), T. 3041. 
who were standing in a line. ${ }^{18537}$ The soldiers then opened fire with automatic rifles, and the detainees fell to the ground upon being shot. ${ }^{18538}$ Hasić survived the execution by falling down before the shooting began. ${ }^{18539}$ KDZ333 dove to the ground as soon as the shooting started and fell on his stomach, face down, while another man fell on his head. ${ }^{18540}$

5433. After each shooting, soldiers asked for survivors, promising that they would be bandaged, but those who spoke up were then finished off with single bullets to the head. ${ }^{18541}$ KDZ333 was then shot but the bullet passed under his left armpit, through his shirt and jacket, only scratching him in the process. ${ }^{18542}$ KDZ333 heard one man begging to be killed to which the soldiers said: "Let him suffer. We'll kill him later.",18543

5434. For about five hours, detainees would continuously be brought to the meadow to be executed. ${ }^{18544}$ While the executions were ongoing, members of the $10^{\text {th }}$ Sabotage Detachment heard that there was a revolt taking place at the Pilica Culture Centre, and were ordered to shoot the detainees faster. ${ }^{18545}$ One of the soldiers suggested that an M-84 machine gun be used to speed up

18537 Dražen Erdemović, T. 25344 (27 February 2012), T. 25381-25383 (28 February 2012); P4489 (Photograph of Branjevo Farm marked by Dražen Erdemović); D2134 (Photograph of Branjevo Farm marked by Dražen Erdemović); Dražen Erdemović, P332 (Transcript from Prosecutor v. Popović et al.), T. 10971-10972, 10979; P264 (Aerial photograph of Branjevo state farm dated 15 July 1995 marked by Dražen Erdemović); Ahmo Hasić, P354 (Transcript from Prosecutor v. Popović et al.), T. 1202; KDZ333, T. 24127, 24157 (2 February 2012); P4342 (Transcript from Prosecutor v. Krstić), T. 3041, 3043; P4345 (Photograph of Branjevo Military Farm marked by KDZ333); P4349 (Photograph of Branjevo Military Farm marked by KDZ333); D2053 (Photograph of Branjevo Military Farm marked by KDZ333); Franc Kos, T. 42365-42366 (31 July 2013); P4306 (Video footage of Branjevo Farm) at 00:06:15 to 00:08:22. See also Adjudicated Facts 1847, 1848; Dean Manning, T. 25842 (6 March 2012); D2188 (Aerial photograph of Branjevo Military marked by Dean Manning).

18538 Dražen Erdemović, P332 (Transcript from Prosecutor v. Popović et al.), T. 10972; Ahmo Hasić, P354 (Transcript from Prosecutor v. Popović et al.), T. 1202-1203; KDZ333, P4342 (Transcript from Prosecutor v. Krstić), T. 3041. See also D3927 (Witness statement of Franc Kos dated 26 July 2013), p. 14; Franc Kos, T. 42366-42367 (31 July 2013); P4305 (Aerial image of Branjevo Farm); Adjudicated Facts 1837, 1841.

18539 Ahmo Hasić, P354 (Transcript from Prosecutor v. Popović et al.), T. 1203.

18540 KDZ333, P4342 (Transcript from Prosecutor v. Krstić), T. 3041 . KDZ333 could feel the hot blood pouring over him. KDZ333, P4342 (Transcript from Prosecutor v. Krstić), T. 3041.

18541 KDZ333, P4342 (Transcript from Prosecutor v. Krstić), T. 3042; Ahmo Hasić, P354 (Transcript from Prosecutor v. Popović et al.), T. 1203; D3927 (Witness statement of Franc Kos dated 26 July 2013), p. 15; Franc Kos, T. 42369 (31 July 2013). See also Adjudicated Fact 1842.

18542 KDZ333, T. 24158 (2 February 2012); KDZ333, P4342 (Transcript from Prosecutor v. Krstić), T. 3041-3042.

18543 KDZ333, P4342 (Transcript from Prosecutor v. Krstić), T. 3042. See also Ahmo Hasić, P354 (Transcript from Prosecutor v. Popović et al.), T. 1203.

18544 KDZ333, P4342 (Transcript from Prosecutor v. Krstić), T. 3042; Ahmo Hasić, P354 (Transcript from Prosecutor v. Popović et al.), T. 1201; Dražen Erdemović, T. 25375 (27 February 2012); Dražen Erdemović, P332 (Transcript from Prosecutor v. Popović et al.), T. 10972. See also KDZ333, T. 24158 (2 February 2012); D3927 (Witness statement of Franc Kos dated 26 July 2013), pp. 16-17. According to Erdemović, the killings lasted from approximately 10 a.m. until 3 or 4 p.m. Dražen Erdemović, P332 (Transcript from Prosecutor v. Popović et al.), T. 10972, 10975, 10983. See also Jevto Bogdanović, P385 (Transcript from Prosecutor v. Popović et al.), T. 11325. Franc Kos testified that the killings lasted from around 10 a.m. until around 2 p.m. D3927 (Witness statement of Franc Kos dated 26 July 2013), p. 19.

18545 D3927 (Witness statement of Franc Kos dated 26 July 2013), p. 18; Franc Kos, T. 42369-42370 (31 July 2013 ). 
the killings; however, the machine gun had already been used on two groups of detainees and it had only wounded the men, leaving them to beg for someone to kill them. ${ }^{18546}$

5435. In the early afternoon, a group of about ten soldiers from Bratunac, most of whom wore VRS uniforms, arrived at the Branjevo Military Farm to replace members of the $10^{\text {th }}$ Sabotage Detachment and continue with the killings. ${ }^{18547}$ When these soldiers recognised detainees from Srebrenica, they beat and humiliated them before killing them. ${ }^{18548}$ These soldiers also yelled insults at the soldiers of the $10^{\text {th }}$ Sabotage Detachment, accusing them of being cowards and traitors for not finishing the assignment. ${ }^{18549}$

5436. While the soldiers from Bratunac were killing the detainees in the last group brought from the Kula School, the lieutenant-colonel who had earlier ordered the members of the $10^{\text {th }}$ Sabotage Detachment to carry out the executions returned to the Branjevo Military Farm, together with the two military policemen. ${ }^{18550}$ The lieutenant-colonel told the soldiers present at the farm that there were 500 Bosnian Muslim men from Srebrenica detained at the Pilica Cultural Centre who were trying to escape and needed to be executed. ${ }^{18551}$ When the members of the $10^{\text {th }}$ Sabotage Detachment refused to carry out the order, the soldiers from Bratunac volunteered and left for Pilica with the lieutenant-colonel and the two military policemen. ${ }^{18552}$ Upon instructions from the lieutenant-colonel, the members of the $10^{\text {th }}$ Sabotage Detachment packed their things and headed

18546 Dražen Erdemović, P332 (Transcript from Prosecutor v. Popović et al.), T. 10973. See also D3927 (Witness statement of Franc Kos dated 26 July 2013), pp. 13-14; Franc Kos, T. 42361, 42365-42366 (31 July 2013); KDZ333, P4342 (Transcript from Prosecutor v. Krstić), T. 3044.

18547 Dražen Erdemović, P332 (Transcript from Prosecutor v. Popović et al.), T. 10974. See also D3927 (Witness statement of Franc Kos dated 26 July 2013), p. 18; Franc Kos, T. 42362, 42370 (31 July 2013); Dražen Erdemović, P332 (Transcript from Prosecutor v. Popović et al.), T. 10976-10977; P269 (Photograph of men in uniform marked by Dražen Erdemović); P225 (Photograph showing refugees and a man).

18548 Dražen Erdemović, P332 (Transcript from Prosecutor v. Popović et al.), T. 10974-10975; Dražen Erdemović, T. 25400, 25410-25411 (28 February 2012); Franc Kos, T. 42363 (31 July 2013), T. $42420-42421$ (1 August 2013). See Adjudicated Fact 1843.

18549 D3927 (Witness statement of Franc Kos dated 26 July 2013), p. 18; Franc Kos, T. 42363 (31 July 2013).

18550 Dražen Erdemović, P332 (Transcript from Prosecutor v. Popović et al.), T. 10975, 10982. But see D3927 (Witness statement of Franc Kos dated 26 July 2013), p. 18 (testifying that only one military policeman arrived at the Branjevo Military Farm in a military vehicle).

18551 Dražen Erdemović, P332 (Transcript from Prosecutor v. Popović et al.), T. 10982. See also D3927 (Witness statement of Franc Kos dated 26 July 2013), p. 18. The Chamber notes Bogdanović's evidence that detainees were transported from Kula School to the Pilica Cultural Centre. Jevto Bogdanović, P385 (Transcript from Prosecutor v. Popović et al.), T. 11323. However, the Chamber did not receive additional evidence on this point and is thus unable to make a finding as to when such a transfer might have taken place or the circumstances surrounding it.

18552 Dražen Erdemović, P332 (Transcript from Prosecutor v. Popović et al.), T. 10982-10983; D3927 (Witness statement of Franc Kos dated 26 July 2013), p. 18. 
approximately 15 minutes later to a café directly across the road from the Pilica Cultural Centre. $^{18553}$

5437. Hasić lay in the meadow while columns of men were killed, but managed to escape by running over dead bodies and reaching shrubbery approximately 20 metres from where he lay; there, he encountered four other survivors. ${ }^{18554}$ The five men waited until it was dark before escaping through the nearby forest. ${ }^{18555}$ KDZ333 spent the night of 16 July in the meadow and managed to escape the next morning. ${ }^{18556}$ KDZ333 ran into Hasić, with whom he travelled for a few days. ${ }^{18557}$ Tired and hungry, KDZ333 and Hasić decided to surrender approximately a week later to two Bosnian Serb military policemen in a mini bus. ${ }^{18558}$ They were both taken to Karakaj

18553 Dražen Erdemović, P332 (Transcript from Prosecutor v. Popović et al.), T. 10983-10984. See D3927 (Witness statement of Franc Kos dated 26 July 2013), p. 18; Franc Kos, T. 42413-42414 (1 August 2013). See also JeanRené Ruez, T. 23850-23852, 23857 (30 January 2012); P4308 (Book of photographs and maps prepared by Jean-René Ruez, 22 June 2009), e-court pp. 233, 235-236; P4307 (Video footage of Pilica Cultural Centre), at 00:00:34-00:00:58.

18554 Ahmo Hasić, P354 (Transcript from Prosecutor v. Popović et al.), T. 1203-1205. Hasić testified that the men were between 16 and 25 years old, and one of them was from "Jagonje village". Ahmo Hasić, P354 (Transcript from Prosecutor v. Popović et al.), T. 1205-1206. Hasić later learned that they were captured and taken to Zvornik. Ahmo Hasić, P354 (Transcript from Prosecutor v. Popović et al.), T. 1206. The Prosecution claims that these four men were killed after being captured and taken to the Zvornik Brigade headquarters. See Prosecution Final Brief, Appendix D, paras. 139-140. Indeed, the Chamber received evidence that in the days following the fall of Srebrenica, two VRS soldiers from the village of Lokanj, namely Neško Đokić and his son Slobodan, were arrested for having given food and clothing to four Bosnian Muslims, and for trying to help them cross to Bosnian Muslim-held territory. Nebojša Jeremić, P348 (Transcript from Prosecutor v. Popović et al.), T. 10427-10429; KDZ122, T. 26308 (14 March 2012) (closed session); P185 (Zvornik Military Court ruling against Slobodan and Neško Đokić, 25 July 1995); P190 (Record of identification of Slobodan and Neško Đokić, 25 July 1995). After receiving instructions from Đokić and his son as to how to reach Bosnian Muslimheld territory, the four men—namely Fuad Đozić, Almir Halilović, Sakib Kivirić, and Emin Mustafić—got lost and surrendered. P186 (Statement of Sakib Kivirić to Zvornik Military Police, 23 July 1995); P187 (Statement of Emin Mustafić to Zvornik Military Police, 23 July 1995); P188 (Statement of Fuad Đozić to Zvornik Military Police, 26 July 1995); P189 (Statement of Almir Halilović to Zvornik Military Police, 23 July 1995). The men were ultimately taken to the Standard Barracks, where they were forced to identify Đokić and his son, and their statements were taken. Nebojša Jeremić, P348 (Transcript from Prosecutor v. Popović et al.), T. 10430, 10439; P190 (Record of identification of Slobodan and Neško Đokić, 25 July 1995). Đozić, Halilović, Kivirić, and Mustafić were later killed. KDZ122, T. 26308 (14 March 2012) (closed session). These killings, however, are not charged in the Indictment. While their remains have not been found, they are listed as missing after the fall of Srebrenica. See P6705 (Ewa Tabeau's expert report entitled "Srebrenica Missing: Persons Reported Missing and Dead after the Take-Over of the Srebrenica Enclave by the Bosnian Serb Army on 11 July 1995", 9 April 2009), e-court pp. 50, 64, 109, 147. Based amongst other things on the description provided by Hasić and the place where they ran into Đokić and his son, the Chamber finds that these four men were indeed survivors of the executions at the Branjevo Military Farm.

18555 Ahmo Hasić, P354 (Transcript from Prosecutor v. Popović et al.), T. 1205-1206. Upon reaching the forest, and once the other four had left, Hasić was spotted by a group of soldiers, who tried to force him to surrender. Ahmo Hasić, P354 (Transcript from Prosecutor v. Popović et al.), T. 1206-1207.

18556 KDZ333, P4342 (Transcript from Prosecutor v. Krstić), T. 3044.

18557 KDZ333, T. 24128 (2 February 2012) (private session); KDZ333, P4342 (Transcript from Prosecutor v. Krstić), T. 3045; Ahmo Hasić, P353 (Transcript from Prosecutor v. Popović et al.), T. 1209, 1211-1212 (under seal); D2052 (Statement of KDZ333 to State Commission on Gathering Facts on War Crimes, 20 July 1996), p. 5 (under seal). The two men also met another man who eventually got separated from them. Ahmo Hasić, P353 (Transcript from Prosecutor v. Popović et al.), T. 1209 (under seal).

18558 KDZ333, T. 24162 (2 February 2012); KDZ333, P4342 (Transcript from Prosecutor v. Krstić), T. 3045-3046; Ahmo Hasić, P353 (Transcript from Prosecutor v. Popović et al.), T. 1209-1212 (under seal); Ahmo Hasić, P354 (Transcript from Prosecutor v. Popović et al.), T. 1278-1279. 
where a military truck with some 20 to 30 other Bosnian Muslim men captured in the vicinity of Zvornik awaited them. ${ }^{18559}$ KDZ333 and Hasić were handcuffed, placed on the truck with other detainees, and driven to Batković Camp, where they arrived on 26 July $1995 .{ }^{18560}$ KDZ333 and Hasić were exchanged in late December $1995 .{ }^{18561}$

\section{(b) Killings at the Pilica Cultural Centre}

5438. The Indictment refers to the killing on 16 July 1995 of approximately 500 Bosnian Muslim men inside the Pilica Cultural Centre; the victims were subsequently buried in a mass grave at the Branjevo Military Farm. ${ }^{18562}$

5439. The Pilica Cultural Centre ${ }^{18563}$ is a building located next to the Zvornik-Bijeljina Road, which was within the Drina Corps'area of responsibility at the time of the Indictment. ${ }^{18564}$ It has a main hall and a separate cabin on the first floor, accessible through a door located next to the centre's main entrance. ${ }^{18565}$

5440. Popović testified that after visiting the Kula School in the morning of 16 July, he left in the direction of Pilica looking for Beara. ${ }^{18566}$ Popović found Beara at the café across the Pilica Cultural Centre. ${ }^{18567}$ Soon after, Erdemović, Kos, and the other members of the $10^{\text {th }}$ Sabotage Detachment arrived at the café after leaving the Branjevo Military Farm. ${ }^{18568}$ Upon arriving, Erdemović noticed a police check-point between the café and the Pilica Cultural Centre, which was manned by two or

18559 KDZ333, P4342 (Transcript from Prosecutor v. Krstić), T. 3046; Ahmo Hasić, P353 (Transcript from Prosecutor v. Popović et al.), T. 1213 (under seal); Ahmo Hasić, P354 (Transcript from Prosecutor v. Popović et al.), T. 1214, 1283.

18560 KDZ333, T. 24162 (2 February 2012); KDZ333, P4342 (Transcript from Prosecutor v. Krstić), T. 3046; Ahmo Hasić, P354 (Transcript from Prosecutor v. Popović et al.), T. 1214, 1283; D2052 (Statement of KDZ333 to State Commission on Gathering Facts on War Crimes, 20 July 1996), p. 5 (under seal).

18561 KDZ333, P4342 (Transcript from Prosecutor v. Krstić), T. 3046; Ahmo Hasić, P354 (Transcript from Prosecutor v. Popović et al.), T. 1215; Ahmo Hasić, P353 (Transcript from Prosecutor v. Popović et al.), T. 1230 (under seal); D2052 (Statement of KDZ333 to State Commission on Gathering Facts on War Crimes, 20 July 1996), p. 5 (under seal).

18562 Indictment, Scheduled Incident E.10.1.

18563 See fn. 4548.

18564 Jean-René Ruez, T. 23850-23851 (30 January 2012); P4308 (Book of photographs and maps prepared by JeanRené Ruez, 22 June 2009), e-court pp. 233-234, 227; P4307 (Video footage of Pilica Cultural Centre), at 00:00:00-00:01:06; Adjudicated Fact 1859.

18565 Jevto Bogdanović, P385 (Transcript from Prosecutor v. Popović et al.), T. 11327-11328; Jean-René Ruez, T. 23852-23853 (30 January 2012); P4308 (Book of photographs and maps prepared by Jean-René Ruez, 22 June 2009), e-court p. 238; P4307 (Video footage of Pilica Cultural Centre), at 00:01:07-00:01:22.

18566 D3993 (Witness statement of Vujadin Popović dated 2 November 2013), para. 71; Vujadin Popović, T. 4307543076 (6 November 2013).

18567 D3993 (Witness statement of Vujadin Popović dated 2 November 2013), para. 71; Vujadin Popović, T. 43076 (6 November 2013). See also P4308 (Book of photographs and maps prepared by Jean-René Ruez, 22 June 2009), e-court pp. 233, 235-236.

18568 See para. 5436. 
three policemen in blue camouflage uniforms carrying automatic rifles and pistols. ${ }^{18569}$ Kos also saw a heavy presence of MP, civilian police, and other soldiers standing around the centre. ${ }^{18570}$ Both Erdemović and Kos saw several dead bodies in front of the cultural centre; Erdemović also heard firing and explosions coming from that direction. ${ }^{18571}$ Kos further testified to having seen dead bodies when he looked inside the Pilica Cultural Centre. ${ }^{18572}$

5441. A few minutes later, the group of soldiers, who had arrived earlier that day from Bratunac and who had also taken part in the Branjevo Military Farm executions, entered the café, sat down, ordered drinks, and said that "everything was finished". ${ }^{18573}$ Beara, who was by then very drunk, stood up and gave a speech thanking the soldiers for what they had done, stating: "Soldiers, you have done a great job and the state will be grateful to you." ${ }^{18574}$ In an intercepted conversation at 9:16 p.m. that day, Popović indicated that he had "finished the job [...] finished everything" and would return to the Command the following day. ${ }^{18575}$

5442. Forensic examination of the Pilica Cultural Centre conducted in September 1996 and October 1998, revealed the presence of human blood, bones, and tissue adhering to the walls and floor, as well as extensive damage caused by arms and grenades. ${ }^{18576}$ Gunshot markings were found on the wall behind the stage, indicating that detainees were put on the stage before being executed and appear to have been shot at by soldiers positioned on the balcony overlooking the stage. ${ }^{18577}$ Further, shell casings were found scattered on the first floor, stairs, and next to the stage, as well as on the ground outside of the building. ${ }^{18578}$

\footnotetext{
18569 Dražen Erdemović, P332 (Transcript from Prosecutor v. Popović et al.), T. 10984-10985.

18570 D3927 (Witness statement of Franc Kos dated 26 July 2013), p. 18; Franc Kos, T. $42412-42413$ (1 August 2013).

18571 Dražen Erdemović, P332 (Transcript from Prosecutor v. Popović et al.), T. 10983-10985; Franc Kos, T. 42413 (1 August 2013). See also Vujadin Popović, T. 43076-43081 (6 November 2013); D3993 (Witness statement of Vujadin Popović dated 2 November 2013), paras. 71-72. Popović also heard at least one grenade being thrown inside the cultural centre. Vujadin Popović, T. 43080-43081 (6 November 2013).

18572 Franc Kos, T. 42413 (1 August 2013).

18573 Dražen Erdemović, P332 (Transcript from Prosecutor v. Popović et al.), T. 10985-10986, 10992; Vujadin Popović, D3993 (Witness statement of Vujadin Popović dated 2 November 2013), para. 73. See also Vujadin Popović, T. 43082 (6 November 2013).

18574 D3927 (Witness statement of Franc Kos dated 26 July 2013), p. 18; Franc Kos, T. $42413-42414$ (1 August 2013); Vujadin Popović, D3993 (Witness statement of Vujadin Popović dated 2 November 2013), para. 73.

18575 P5079 (Intercept of conversation between Lt. Col. Popović and Rašić, 16 July 1995), e-court p. 1. Popović testified that Trbić arrived at the café soon after Beara's speech, and ordered Popović to report immediately to the Drina Corps Command. Vujadin Popović, D3993 (Witness statement of Vujadin Popović dated 2 November 2013), para. 74.

18576 Jean-René Ruez, T. 23852-23854 (30 January 2012); P4308 (Book of photographs and maps prepared by JeanRené Ruez, 22 June 2009), e-court pp. 239-245. See Adjudicated Facts 1861, 1862, 1863.

18577 Adjudicated Fact 1862.

18578 Jean-René Ruez, T. 23856-23858 (30 January 2012); P4307 (Video footage of Pilica Cultural Centre), at 00:03:15-00:04:09, 00:04:50-00:05:01, 00:09:10-00:09:11.
} 
$\underline{\text { the Pilica Cultural Centre }}$

(c) Burials of detainees killed at the Branjevo Military Farm and

5443. On the morning of 17 July 1995, while at the Engineering Company's headquarters, Damjan Lazarević was ordered by Bogičević and Sekonojić to go to the Branjevo Military Farm, where a pit was to be dug to bury the bodies of those killed. ${ }^{18579}$ Lazarević was informed that people from the Zvornik public utility company would assist in loading the bodies. ${ }^{18580}$ Cvijetin Ristanović was then ordered by Lazarević to load the "BGH-700" excavator onto a Labudica trailer and to prepare to go to the farm. ${ }^{18581}$

5444. Lazarević and a driver drove in a small vehicle and arrived at the Branjevo Military Farm between 8 and 9 a.m. ${ }^{18582}$ Upon arrival they encountered a group of elderly civilians who worked on the farm. ${ }^{18583}$ Ristanović and a driver followed in a Mercedes 2626 truck, which pulled the trailer carrying the BGH-700. ${ }^{18584}$ When he arrived, Ristanović was ordered by Lazarević to dig a hole. ${ }^{18585}$ Ristanović saw bodies lying in a meadow, approximately 100 metres from where he was working. ${ }^{18586}$ Shortly after, Veljko Kovačević—a worker for the Birac Holding company-arrived in a yellow ULT-220 loader and parked in the meadow next to the bodies. ${ }^{18587}$

18579 Damjan Lazarević, P352 (Transcript from Prosecutor v. Popović et al.), T. 14459. See also Adjudicated Fact 1851.

18580 Damjan Lazarević, P352 (Transcript from Prosecutor v. Popović et al.), T. 14459.

18581 Cvijetin Ristanović, P652 (Transcript from Prosecutor v. Blagojević \& Jokić), T. 5389-5390, 5400, 5418; P4583 (Zvornik Brigade Engineering Company logbook, 14-19 July 1995), e-court p. 4 (an entry for 17 July containing an order to "Work with BGH-700 in Branjevo" and "Transport BGH-700 to Branjevo by flat bed"). See also Adjudicated Fact 1850. The Chamber notes that despite testifying to have operated a "G-700" at the Branjevo Farm on 17 July, Ristanović later confirmed that his references were in fact references to the BGH700. Cvijetin Ristanović, P351 (Transcript from Prosecutor v. Popović et al.), T. 13625.

18582 Damjan Lazarević, P352 (Transcript from Prosecutor v. Popović et al.), T. 14460. The vehicle stayed on the road whilst Lazarević continued on foot to the Branjevo Military Farm. Damjan Lazarević, P352 (Transcript from Prosecutor v. Popović et al.), T. 14460.

18583 Damjan Lazarević, P352 (Transcript from Prosecutor v. Popović et al.), T. 14460-14461. See also Cvijetin Ristanović, P652 (Transcript from Prosecutor v. Blagojević \& Jokić), T. 5392; Milenko Tomić, P390 (Transcript from Prosecutor v. Popović et al.), T. 21002; Jevto Bogdanović, P385 (Transcript from Prosecutor v. Popović et al.), T. 11317-11318. The elderly civilian workers occasionally came out of the farm buildings to observe the digging operations taking place. Damjan Lazarević, P352 (Transcript from Prosecutor v. Popović et al.), T. 14461.

18584 Cvijetin Ristanović, P652 (Transcript from Prosecutor v. Blagojević \& Jokić), T. 5390-5391; P1172 (Zvornik Brigade vehicle log, 1-31 July 1995), pp. 1-2 (recording a Mercedes 2626 as being driven to Branjevo on 17 July 1995, to transport a "700 loader"). See also Cvijetin Ristanović, P351 (Transcript from Prosecutor v. Popović et al.), T. 13627.

18585 Cvijetin Ristanović, P652 (Transcript from Prosecutor v. Blagojević \& Jokić), T. 5392; P659 (Sketches made by Cvijetin Ristanović), p. 1 (indicating the location of the workshop and auxiliary buildings at the Branjevo Military Farm).

18586 Cvijetin Ristanović, P652 (Transcript from Prosecutor v. Blagojević \& Jokić), T. 5393; P659 (Sketches made by Cvijetin Ristanović), p. 1 (where Ristanović marked the location of the bodies in the meadow).

18587 Cvijetin Ristanović, P652 (Transcript from Prosecutor v. Blagojević \& Jokić), T. 5394, 5401; Cvijetin Ristanović, P351 (Transcript from Prosecutor v. Popović et al.), T. 13631; Damjan Lazarević, P352 (Transcript from Prosecutor v. Popović et al.), T. 14460, 14472, 14479; P176 (Zvornik Brigade vehicle log, 1-31 July 1995) (recording Kovačević operating the ULT-220 for the purposes of "digging trenches in Branjevo" on 17 July 
5445. A group of elderly civilians from the public utilities company was sent, together with two to three members of the "R" or "Rear" Battalion of the Zvornik Brigade, to the Branjevo Military Farm to assist in the burial operation. ${ }^{18588}$ Once Ristanović finished digging the grave, the group started manually loading the bodies into the bucket of the ULT-220, which was then used to transfer the bodies to the gravesite. ${ }^{18589}$ Lazarević stayed at the farm until the final stages of the burial process, before leaving between 7 and 8 p.m. ${ }^{18590}$

5446. That same day, while the burial operation at the Branjevo Military Farm was ongoing, Milenko Tomić - a driver of the R Battalion—received a travel order from Radislav Pantić to drive a truck to Pilica and then onwards to Kula in order to pick up military personnel. ${ }^{18591}$ Tomić set off in a TAM 130 truck from the Metalno company. ${ }^{18592}$ At Pilica, Tomić was pulled over by a soldier who instructed him to park his vehicle next to the door of the Pilica Cultural Centre. ${ }^{18593}$

5447. Twelve members of the $1^{\text {st }}$ Battalion's Work Platoon-who had earlier that day been ordered by Lakić to go to the Pilica Cultural Centre-loaded the bodies onto two yellow tipper trucks. ${ }^{18594}$ Lakić supervised the entire loading operation, which was concluded at approximately

1995); P4583 (Extract from Zvornik Brigade Engineering Company logbook, 14-19 July 1995), e-court p. 4 (an entry for 17 July 1995 containing an order to "Work with ULT 220 at Branjevo"). See also Adjudicated Fact 1850; P657 (Brochure for a wheel loader (ULT200)); Damjan Lazarević, P352 (Transcript from Prosecutor v. Popović et al.), T. 14480-14481.

18588 Damjan Lazarević, P352 (Transcript from Prosecutor v. Popović et al.), T. 14459, 14461-14462.

18589 Cvijetin Ristanović, P652 (Transcript from Prosecutor v. Blagojević \& Jokić), T. 5395-5396; Damjan Lazarević, P352 (Transcript from Prosecutor v. Popović et al.), T. 14459, 14461-14465; P272 (Aerial photograph of Branjevo state farm marked by Damjan Lazarević); P273 (Aerial photograph of Branjevo state farm marked by Damjan Lazarević). While KDZ333 was hiding under a nearby bridge, he heard the sounds of machines and could hear vehicles continuously moving back and forth. KDZ333, P4342 (Transcript from Prosecutor v. Krstić), T. 3044-3045.

18590 Damjan Lazarević, P352 (Transcript from Prosecutor v. Popović et al.), T. 14462-14463.

18591 Milenko Tomić, P390 (Transcript from Prosecutor v. Popović et al.), T. 20997-20998, 21001, 21003, 21023. See P662 (List of conscripts for R Battalion, 6 December 1994). The Chamber notes that Tomić could not recall the date of this assignment. See Milenko Tomić, P390 (Transcript from Prosecutor v. Popović et al.), T. 21001. However, in light of the totality of evidence before it, the Chamber considers that Tomić's evidence on this point relates to the events that took place on 17 July 1995.

18592 Milenko Tomić, P390 (Transcript from Prosecutor v. Popović et al.), T. 20997, 21022. See also Milenko Tomić, P390 (Transcript from Prosecutor v. Popović et al.), T. 21008-21013; P284 (Zvornik Brigade vehicle $\log$ July 1995 marked by Milenko Tomić) (recording the refuelling of a TAM 130 truck on 17 July 1995, signed by Radislav Pantić); P285 (Zvornik Brigade vehicle log July 1995 marked by Milenko Tomić) (recording the route that Tomić drove on 17 July 1995).

18593 Milenko Tomić, P390 (Transcript from Prosecutor v. Popović et al.), T. 21001, 21005. See also Milenko Tomić, P390 (Transcript from Prosecutor v. Popović et al.), T. 21006-21008; P661 (Sketch drawn by Milenko Tomić); Jean-René Ruez, T. 23855 (30 January 2012); P4308 (Book of photographs and maps prepared by JeanRené Ruez, 22 June 2009), e-court p. 246. The soldier looked to be about 30 years old, and was dressed in an old JNA uniform. Milenko Tomić, P390 (Transcript from Prosecutor v. Popović et al.), T. 21003.

18594 Jevto Bogdanović, P385 (Transcript from Prosecutor v. Popović et al.), T. 11314, 11328-11329. These trucks were the type used for carrying gravel. Jevto Bogdanović, P385 (Transcript from Prosecutor v. Popović et al.), T. 11329. See also Jean-René Ruez, T. 23855-23856 (30 January 2012); P4308 (Book of photographs and maps prepared by Jean-René Ruez, 22 June 2009), e-court p. 246 (an aerial photograph showing a truck parked in front of the Pilica Cultural Centre on 17 July 1995). 
3 p.m. ${ }^{18595}$ While assisting in the process, Bogdanović saw a huge pile of corpses in civilian clothes and other bodies scattered around the room, some curled up and others stretched out. ${ }^{18596}$

5448. Tomić made two separate trips transporting bodies from the Pilica Cultural Centre to the Branjevo Military Farm. ${ }^{18597}$ On the second trip back to Pilica, Tomić was stopped at an intersection and told by another soldier that he was no longer needed. ${ }^{18598}$

5449. As evidenced through a series of intercepts admitted by the Chamber, Popović supervised the burial operation of the Bosnian Muslim detainees killed at the Branjevo Military Farm and at the Pilica Cultural Centre. ${ }^{18599}$

\section{(d) $\underline{\text { Reburials }}$}

5450. On 10 August 1995, Madeleine Albright—-then US Ambassador to the UN-informed the Security Council that classified aerial photographs taken by the US government of disturbed earth indicated mass graves connected with the fall of Srebrenica. ${ }^{18600}$

5451. Towards the end of September 1995, as part of the reburial operation to conceal the Srebrenica killings which will be discussed in detail below, the bodies initially buried at the Branjevo Military Farm were reburied in some of the Čančari Road secondary gravesites, as

18595 Jevto Bogdanović, P385 (Transcript from Prosecutor v. Popović et al.), T. 11328-11329, 11332.

18596 Jevto Bogdanović, P385 (Transcript from Prosecutor v. Popović et al.), T. 11330-11332. Bogdanović also saw two female bodies. Jevto Bogdanović, P385 (Transcript from Prosecutor v. Popović et al.), T. 11330.

18597 Milenko Tomić, P390 (Transcript from Prosecutor v. Popović et al.), T. 21001-21002; Jean-René Ruez, T. 23856 (30 January 2012); P4308 (Book of photographs and maps prepared by Jean-René Ruez, 22 June 2009), e-court p. 247 (showing the road that the trucks would have taken in transporting the bodies from the Pilica Cultural Centre to the Branjevo Farm). During the second trip, and upon arriving at the Branjevo Military Farm, Tomić saw between five and ten corpses lying on the ground near to where he parked his truck. Milenko Tomić, P390 (Transcript from Prosecutor v. Popović et al.), T. 21005.

18598 Milenko Tomić, P390 (Transcript from Prosecutor v. Popović et al.), T. 21002-21003.

18599 An intercepted conversation from 12:42 p.m. on 17 July records Krstić-or someone using the code name "Zlatar 1"- -attempting to reach Popović, but he was informed that Popović was in Zvornik and would be back in the late afternoon. P4961 (Intercept of conversation between Major Golić and Zlatar, 17 July 1995). See also Richard Butler, T. 27604-27605 (18 April 2012). At 12:44 p.m. that same day, someone attempted to reach Popović in the name of "Zlatar 1", and was informed by Trbić that Popović had gone to do "that task". P5080 (Intercept of conversation between Milorad Trbić and an unidentified person, 17 July 1995), e-court p. 1. At 12:49 p.m., an unknown individual told Trbić that Popović should be left to "finish that work that he's doing". Trbić replied that Popović was "working on that, you know. The preparation is mainly finished". P5081 (Intercept of conversation between Milorad Trbić and an unidentified person, 17 July 1995), p. 1. An intercepted conversation from 4:22 p.m. records Popović making a call in which he reported that "everything's alright that job is done and dusted [...] everything's finished up there are no problems." P6702 (Intercept of conversation between Lt. Col. Popović and an unidentified person, 17 July 1995); P4964 (Intercept of conversation between Lt. Col. Popović and an unidentified person, 17 July 1995). An intercepted conversation from 8:26 p.m. that same day records an unidentified individual asking "Pajo"—nickname used by Golićwhere "Pop", i.e. Popović, is, and Pajo replying: "He went home. He is in no mood, I can tell you." P5330 (Intercept of conversation between "Pajo" and an unidentified person, 17 July 1995.

18600 P4504 (Dean Manning's Report, entitled "Summary of Forensic Evidence - Execution Points and Mass Graves", 16 May 2000), e-court p. 43. 
demonstrated by the forensic evidence discussed below. ${ }^{18601}$ On 21 March 1996, the US government released to the public a number of aerial photographs that showed a large number of bodies lying on the field near the Branjevo Military Farm on 17 July $1995 .{ }^{18602}$ Following Albright's visit to the Branjevo Military Farm gravesite on 22 March 1996, the Accused told Mladić that: "[A] big show was put on for Albright, she expected they would find 1200 Muslim bodies at Pilica, but they found some five bodies." 18603 A day later, the Accused issued an order for the creation of a mixed military and civilian commission for the exhumation of bodies in the area of Pilica. $^{18604}$

\section{(e) Forensic evidence}

5452. As discussed above, the victims who had been previously detained at the Kula School and subsequently killed at the Branjevo Military Farm, as well as the victims who were killed at the Pilica Cultural Centre, were all buried at the Branjevo Military Farm primary gravesite and, as will be further discussed, were subsequently reburied at the Čančari Road secondary gravesites. ${ }^{18605}$ Given that the forensic evidence for the bodies found at these gravesites cannot be distinguished, the Chamber has combined its analysis in the following paragraphs.

\section{(i) The Branjevo Military Farm primary gravesite}

5453. Aerial images reveal that the Branjevo Military Farm gravesite_also known as the Pilica gravesite ${ }^{18606}$ — was first created between 5 and 17 July 1995, and was disturbed between 21 and

\footnotetext{
18601 See Section IV.C.1.g.v: Reburial operation.

18602 P4504 (Dean Manning's Report, entitled "Summary of Forensic Evidence - Execution Points and Mass Graves", 16 May 2000), e-court p. 43. See P4512 (Photograph booklet entitled "Srebrenica Mass Graves - Primary and Secondary Mass Grave Aerial Imagery"), e-court p. 28. Images dated 27 September 1995 also showed the disturbance of the gravesite dug in July 1995, as well as a backhoe and a front loader parked at the farm. P4504 (Dean Manning's Report, entitled "Summary of Forensic Evidence - Execution Points and Mass Graves", 16 May 2000), e-court p. 43. See P4512 (Photograph booklet entitled "Srebrenica Mass Graves - Primary and Secondary Mass Grave Aerial Imagery"), e-court p. 30.

18603 P1490 (Ratko Mladić's notebook, 16 January-28 November 1996), e-court p. 47. See Dražen Erdemović, T. 25356 (27 February 2012); P6451 (Article from Slobodna Bosna entitled "I Killed 'Only' Hundreds of People”, 22 March 1996); Jean-René Ruez, T. 23841-23842 (30 January 2012). See also Richard Butler, T. 27632 (18 April 2012). Cf. Radovan Radinović, T. $41582-41585$ (19 July 2013); D3864 (Radovan Radinović's expert report entitled “The Control Authority of Dr. Radovan Karadžić in the Strategic Command System of the VRS”, 2012), para. 428.

18604 P3163 (Report of RS Military Prosecutor's Office, 26 March 1996), e-court pp. 2-3. The Chamber will discuss the implementation of this order below. See para. 5794.

18605 See paras. 5443-5448, 5461.

18606 William Haglund, P4310 (Transcript from Prosecutor v. Krstić), T. 3751; Dušan Janc, T 26968 (27 March 2012); P4772 (Dušan Janc's report entitled "Update to the summary of Forensic Evidence - Exhumation of the Graves and Surface Remains Recoveries related to Srebrenica - January 2012”, 13 January 2012), e-court p. 10. See P4321 (William Haglund's expert report, entitled "Forensic Investigation of the Pilica (Branjevo Farm) Grave Site - Volume I”, 15 June 1998), e-court pp. 10, 17. See Adjudicated Fact 1852.
} 
27 September 1995. ${ }^{18607}$ The gravesite is adjacent to the Branjevo Military Farm complex at the periphery of a large, cultivated field, approximately 150 metres from the gravel driveway leading to the farm. ${ }^{18608}$

5454. The gravesite was exhumed between 10 and 24 September 1996 by a Tribunal exhumation team under the direction of William Haglund. ${ }^{18609}$ The remains found at the gravesite were then examined under the direction of Robert Kirschner. ${ }^{18610}$ William Haglund prepared a report on both the exhumation of the gravesite and the results of the post-mortem examination of the remains found therein. ${ }^{18611}$

5455. The Branjevo Military Farm gravesite is an approximately three metre deep grave, consisting of a trench extending 28 by 10 metres. ${ }^{18612}$ The gravesite showed evidence of robbing and disturbance evidenced, first, by aerial images and the discovery of partial bodies and, further, by soil samples from the surface of the gravesite. ${ }^{18613}$

18607 Jean-René Ruez, T. 23844, 23847 (30 January 2012); P4308 (Book of photographs and maps prepared by JeanRené Ruez, 22 June 2009), e-court pp. 220, 228-230; Dean Manning, T. 25838-25839 (6 March 2012); P4512 (Photograph booklet entitled "Srebrenica Mass Graves - Primary and Secondary Mass Grave Aerial Imagery"), e-court pp. 28-30.

18608 P4321 (William Haglund's expert report, entitled "Forensic Investigation of the Pilica (Branjevo Farm) Grave Site - Volume I", 15 June 1998), e-court pp. 10, 17; Dean Manning, T 25838 (6 March 2012); P4306 (Video footage of Branjevo Farm) at 00:02:02-00:02:30 (showing an aerial view of the Branjevo Military Farm complex), 00:03:17-00:03:22 (showing aerial footage of the gravesite); P4332 (Photograph of Branjevo Farm, 21 September 1995); William Haglund, P4310 (Transcript from Prosecutor v. Krstić), T. 3751; P4504 (Dean Manning's Report, entitled "Summary of Forensic Evidence - Execution Points and Mass Graves", 16 May 2000), e-court p. 43

18609 William Haglund, T. 23874 (30 January 2012); William Haglund, P4310 (Transcript from Prosecutor v. Krstić), T. 3729; P4321 (William Haglund's expert report, entitled "Forensic Investigation of the Pilica (Branjevo Farm) Grave Site - Volume I", 15 June 1998), e-court pp. 12, 14, 30, 82. See also P4772 (Dušan Janc's report entitled "Update to the summary of Forensic Evidence - Exhumation of the Graves and Surface Remains Recoveries related to Srebrenica - January 2012”, 13 January 2012), e-court pp. 3, 10; P4504 (Dean Manning's Report, entitled "Summary of Forensic Evidence - Execution Points and Mass Graves", 16 May 2000), e-court p. 43.

18610 P4321 (William Haglund's expert report, entitled "Forensic Investigation of the Pilica (Branjevo Farm) Grave Site - Volume I", 15 June 1998), e-court pp. 12, 82.

18611 William Haglund, T. 23874 (30 January 2012); P4321 (William Haglund's expert report, entitled "Forensic Investigation of the Pilica (Branjevo Farm) Grave Site - Volume I", 15 June 1998), e-court pp. 1, 12, 82. See also P4504 (Dean Manning's Report, entitled "Summary of Forensic Evidence - Execution Points and Mass Graves", 16 May 2000), e-court p. 43; P4772 (Dušan Janc's report entitled "Update to the summary of Forensic Evidence - Exhumation of the Graves and Surface Remains Recoveries related to Srebrenica - January 2012", 13 January 2012), e-court p. 10.

18612 P4321 (William Haglund's expert report, entitled "Forensic Investigation of the Pilica (Branjevo Farm) Grave Site - Volume I", 15 June 1998), e-court p. 17; William Haglund, P4310 (Transcript from Prosecutor v. Krstić), T. 3751-3752, 3757, 3759; P4333 (Photograph of Branjevo Military Farm gravesite); William Haglund, T. 23893 (31 January 2012).

18613 Dean Manning, T. 25838-25839 (6 March 2012); P4512 (Photograph booklet entitled "Srebrenica Mass Graves - Primary and Secondary Mass Grave Aerial Imagery”), e-court pp. 29-30; P4504 (Dean Manning's Report, entitled "Summary of Forensic Evidence - Execution Points and Mass Graves", 16 May 2000), e-court pp. 9, 18, 42-43. See also P4772 (Dušan Janc's report entitled "Update to the summary of Forensic Evidence Exhumation of the Graves and Surface Remains Recoveries related to Srebrenica - January 2012", 13 January 2012), e-court p. 10; Dean Manning, 25845-25846, 25848 (6 March 2012); William Haglund, T. 23893, 23959 (31 January 2012). 
5456. A minimum of 132 individuals were found at the gravesite. ${ }^{18614}$ All the individuals for whom sex could be determined were male. ${ }^{18615}$ It was established that the victims' ages ranged from 15 to 61, with the majority of the victims being over 25 years old. ${ }^{18616}$ All the victims were found wearing civilian clothing, with the exception of one, who was wearing military-type trousers. ${ }^{18617}$ Further, two blindfolds and 83 ligatures were recovered at the gravesite. ${ }^{18618}$ The cause of death for at least 130 bodies was attributed to gunshot injuries. ${ }^{18619}$

18614 William Haglund, T. 23894 (31 January 2012); William Haglund, P4310 (Transcript from Prosecutor v. Krstić), T. 3752; P4321 (William Haglund's expert report, entitled "Forensic Investigation of the Pilica (Branjevo Farm) Grave Site - Volume I", 15 June 1998), e-court pp. 10, 55, 80; P4037 (Jose Baraybar's expert report entitled "Calculation of the Minimal Number of Individuals Exhumed by the ICTY between 1996 and 2001", 4 January 2004), p. 7; P4504 (Dean Manning's Report, entitled "Summary of Forensic Evidence - Execution Points and Mass Graves", 16 May 2000), e-court p. 43.

18615 P4321 (William Haglund's expert report, entitled "Forensic Investigation of the Pilica (Branjevo Farm) Grave Site - Volume I", 15 June 1998), e-court pp. 11, 55-60, 80. See also P4322 (William Haglund's expert report, entitled "Forensic Investigation of the Pilica (Branjevo Farm) Grave Site - Volume II", 15 June 1998); P4323 (William Haglund's expert report, entitled "Forensic Investigation of the Pilica (Branjevo Farm) Grave Site Volume III", 15 June 1998); P4324 (William Haglund's expert report, entitled "Forensic Investigation of the Pilica (Branjevo Farm) Grave Site - Volume IV”, 15 June 1998); P4504 (Dean Manning's Report, entitled "Summary of Forensic Evidence - Execution Points and Mass Graves", 16 May 2000), e-court p. 44; Adjudicated Fact 1853.

18616 P4321 (William Haglund's expert report, entitled "Forensic Investigation of the Pilica (Branjevo Farm) Grave Site - Volume I", 15 June 1998), e-court pp. 11, 55-60, 80. See also P4322 (William Haglund's expert report, entitled "Forensic Investigation of the Pilica (Branjevo Farm) Grave Site - Volume II", 15 June 1998); P4323 (William Haglund's expert report, entitled "Forensic Investigation of the Pilica (Branjevo Farm) Grave Site Volume III", 15 June 1998); P4324 (William Haglund's expert report, entitled "Forensic Investigation of the Pilica (Branjevo Farm) Grave Site - Volume IV”, 15 June 1998); P4504 (Dean Manning's Report, entitled "Summary of Forensic Evidence - Execution Points and Mass Graves", 16 May 2000), e-court pp. 43-44; P4030 (Jose Baraybar's expert report entitled "Report on the Anthropology Examination of Human Remains from Eastern Bosnia in 1999", 8 December 1999), e-court p. 12.

18617 P4321 (William Haglund's expert report, entitled "Forensic Investigation of the Pilica (Branjevo Farm) Grave Site - Volume I", 15 June 1998), e-court pp. 11, 61, 81. See also P4322 (William Haglund's expert report, entitled "Forensic Investigation of the Pilica (Branjevo Farm) Grave Site - Volume II", 15 June 1998); P4323 (William Haglund's expert report, entitled "Forensic Investigation of the Pilica (Branjevo Farm) Grave Site Volume III", 15 June 1998); P4324 (William Haglund's expert report, entitled "Forensic Investigation of the Pilica (Branjevo Farm) Grave Site - Volume IV", 15 June 1998).

18618 P4504 (Dean Manning's Report, entitled "Summary of Forensic Evidence - Execution Points and Mass Graves", 16 May 2000), e-court pp. 10, 43-44, 120-121, 131; P4505 (Photograph booklet entitled "Srebrenica Blindfolds and Ligatures - Volume 1: Kozluk, Cancari Road 3 and 12 and Branjevo Military Farm (Pilica)"), pp. 276-277, 378; P4507 (Chart of photographs of blindfolds, ligatures, and location); P4508 (Collage of Srebrenica blindfolds, 5 March 2012); P4509 (Collage of Srebrenica ligatures, 5 March 2012). See also P4321 (William Haglund's expert report, entitled "Forensic Investigation of the Pilica (Branjevo Farm) Grave Site - Volume I", 15 June 1998), e-court pp. 11, 61, 80; William Haglund, P4310 (Transcript from Prosecutor v. Krstić), T. 3755; P4336 (Photograph of human remains); Adjudicated Fact 1854.

18619 P4321 (William Haglund's expert report, entitled "Forensic Investigation of the Pilica (Branjevo Farm) Grave Site - Volume I", 15 June 1998), e-court pp. 11-12, 56-60, 62, 80-81. See also P4322 (William Haglund's expert report, entitled "Forensic Investigation of the Pilica (Branjevo Farm) Grave Site - Volume II", 15 June 1998); P4323 (William Haglund's expert report, entitled "Forensic Investigation of the Pilica (Branjevo Farm) Grave Site - Volume III", 15 June 1998); P4324 (William Haglund's expert report, entitled "Forensic Investigation of the Pilica (Branjevo Farm) Grave Site - Volume IV", 15 June 1998); P4504 (Dean Manning's Report, entitled "Summary of Forensic Evidence - Execution Points and Mass Graves", 16 May 2000), e-court pp. 9-10, 44; Adjudicated Fact 1853. 
5457. As of 13 January 2012, DNA analysis has led to the identification of 138 individuals in the Branjevo Military Farm grave as persons listed as missing following the take-over of Srebrenica. ${ }^{18620}$

(ii) Čančari Road secondary gravesites

5458. Of the 13 known secondary mass graves along the Čančari Road, ${ }^{18621}$ only Čančari Road 4 to 6 and 8 to 12 have been linked to the Branjevo Military Farm primary gravesite. ${ }^{18622}$

5459. A Tribunal team of experts, led by Richard Wright, conducted the exhumation of Čančari Road 12 between 10 and 25 May 1998. ${ }^{18623}$ The remains found therein were then examined by a team of pathologists under the direction of Christopher Lawrence. ${ }^{18624}$ While the examination and probing of Čančari Road 4, 6, 8, 9, and 10 were conducted by a Tribunal team of experts under the direction of Richard Wright, the exhumation of these gravesites was handed over to the $\mathrm{BiH}$

18620 P4772 (Dušan Janc's report entitled "Update to the summary of Forensic Evidence - Exhumation of the Graves and Surface Remains Recoveries related to Srebrenica - January 2012”, 13 January 2012), e-court pp. 3, 10, 41; P4771 (Dušan Janc's report entitled "Update to the summary of Forensic Evidence - Exhumation of the Graves and Surface Remains Recoveries related to Srebrenica - January 2012”, 13 January 2012), Annex D, e-court pp. 122-128 (under seal). See also P5917 (ICMP DNA identifications concerning identified victims related to Srebrenica, 6 December 2010); P4773 (ICMP unmatched DNA victim profiles related to Srebrenica, 23 December 2011); P4774 (ICMP lists of unmatched unique DNA victims profiles related to Srebrenica, 15 February 2010).

18621 See para. 5408.

18622 P4772 (Dušan Janc's report entitled "Update to the summary of Forensic Evidence - Exhumation of the Graves and Surface Remains Recoveries related to Srebrenica - January 2012”, 13 January 2012), e-court pp. 41-42. See para. 5461. The Chamber notes that Tribunal experts previously associated Čančari Road 4, 5, and 6 with the Kozluk killing site based on the discovery of green glass at these gravesites; however, DNA analysis later confirmed that these secondary gravesites are associated with the Branjevo Military Farm primary gravesite. P4772 (Dušan Janc's report entitled "Update to the summary of Forensic Evidence - Exhumation of the Graves and Surface Remains Recoveries related to Srebrenica - January 2012", 13 January 2012), e-court p. 40. See also Dušan Janc, T. 26990 (27 March 2012) (referring to Čanćari Road 4 being connected to the Branjevo Military Farm execution site). As stated above, while Čančari Road 7 contains the remains of an individual whose DNA was also found in Čančari Road 11, the Chamber considers that this gravesite is not associated with the Branjevo Military Farm gravesite but with the Kozluk primary gravesite. See para. 5411, fn. 18449.

18623 P4000 (Richard Wright's expert report entitled "Exhumations in Eastern Bosnia in 1998", 12 May 1999), ecourt p. 10; Richard Wright, T. 22276 (1 December 2011); Dean Manning, T. 25841 (6 March 2012). See also P4772 (Dušan Janc's report entitled “Update to the summary of Forensic Evidence - Exhumation of the Graves and Surface Remains Recoveries related to Srebrenica - January 2012”, 13 January 2012), e-court p. 20 ; P4504 (Dean Manning's Report, entitled "Summary of Forensic Evidence - Execution Points and Mass Graves", 16 May 2000), e-court p. 47.

18624 Christopher Lawrence, T. 22447 (8 December 2011); Christopher Lawrence, P4051 (Transcript from Prosecutor v. Krstić), T. 3978-3980; P4064 (Chart of primary and secondary graves); P4054 (Christopher Lawrence's expert report entitled "Report on Autopsies of Human Remains from Čančari Road Site 12, August 1998", 17 June 1999), e-court pp. 3, 52. 
Government in 2001. ${ }^{18625}$ Čančari Road 5 and 11 were exhumed by the BiHCMP in 2002 and 2001 , respectively. ${ }^{18626}$

5460. Aerial images show that Čančari Road 4, 5, 6, 8, 9, 10, 11, and 12 were each first excavated between approximately 7 and 27 September 1995 and were filled in prior to 2 October $1995 .^{18627}$ The Chamber notes that out of all the secondary gravesites associated with the Branjevo Military Farm gravesite, it only received forensic evidence in relation to Čančari Road 12. Remains of at least 177 individuals, including 43 intact bodies, were recovered from Čančari Road 12. ${ }^{18628}$ The forensic evidence reviewed by the Chamber shows that all of the victims at Čančari Road 12 whose sex could be determined were male. ${ }^{18629}$ While the majority of the victims were older than 25 , five individuals were between 8 and 13 years old. ${ }^{18630}$ Furthermore, at least six blindfolds and 16 ligatures were found at the gravesite. ${ }^{18631}$ The cause of death for 39 of the 43 complete bodies was a result of gunshot wounds; the four remaining had an undetermined cause of death. ${ }^{18632}$ While

18625 P4772 (Dušan Janc's report entitled "Update to the summary of Forensic Evidence - Exhumation of the Graves and Surface Remains Recoveries related to Srebrenica - January 2012”, 13 January 2012), e-court pp. 16-19.

18626 P4772 (Dušan Janc's report entitled "Update to the summary of Forensic Evidence - Exhumation of the Graves and Surface Remains Recoveries related to Srebrenica - January 2012”, 13 January 2012), e-court pp. 17, 19.

18627 P4512 (Photograph booklet entitled "Srebrenica Mass Graves - Primary and Secondary Mass Grave Aerial Imagery"), e-court pp. 70-73, 76-88; P4504 (Dean Manning's Report, entitled "Summary of Forensic Evidence - Execution Points and Mass Graves", 16 May 2000), e-court p. 46; Dean Manning, T. 25839-25841 (6 March 2012). See also Adjudicated Fact 1855 (in relation to Čančari Road 12).

18628 P4054 (Christopher Lawrence's expert report entitled "Report on Autopsies of Human Remains from Čančari Road Site 12, August 1998”, 17 June 1999), e-court pp. 2-3, 14, 43; Richard Wright, P3999 (Transcript from Prosecutor v. Krstić), T. 3660. See also P4000 (Richard Wright's expert report entitled "Exhumations in Eastern Bosnia in 1998”, 12 May 1999), e-court p. 33.

18629 P4054 (Christopher Lawrence's expert report entitled "Report on Autopsies of Human Remains from Čančari Road Site 12, August 1998”, 17 June 1999), e-court pp. 2, 14. See also P4504 (Dean Manning's Report, entitled "Summary of Forensic Evidence - Execution Points and Mass Graves", 16 May 2000), e-court p. 47; P4030 (Jose Baraybar's expert report entitled "Report on the Anthropology Examination of Human Remains from Eastern Bosnia in 1999", 8 December 1999), e-court p. 11.

18630 P4054 (Christopher Lawrence's expert report entitled "Report on Autopsies of Human Remains from Čančari Road Site 12, August 1998”, 17 June 1999), e-court pp. 2, 14. See also P4504 (Dean Manning's Report, entitled "Summary of Forensic Evidence - Execution Points and Mass Graves", 16 May 2000), e-court pp. 47-48; P4030 (Jose Baraybar's expert report entitled "Report on the Anthropology Examination of Human Remains from Eastern Bosnia in 1999”, 8 December 1999), e-court pp. 9, 12.

18631 P4504 (Dean Manning's Report, entitled "Summary of Forensic Evidence - Execution Points and Mass Graves", 16 May 2000), e-court p. 48; P4505 (Photograph booklet entitled "Srebrenica Blindfolds and Ligatures Volume 1: Kozluk, Cancari Road 3 and 12 and Branjevo Military Farm (Pilica)"), pp. 361-377, 381-389; P4507 (Chart of photographs of blindfolds, ligatures, and location); P4508 (Collage of Srebrenica blindfolds, 5 March 2012); P4054 (Christopher Lawrence's expert report entitled "Report on Autopsies of Human Remains from Čančari Road Site 12, August 1998”, 17 June 1999), e-court pp. 2, 25, 28-36; Christopher Lawrence, P4051 (Transcript from Prosecutor v. Krstić); P4061 (Christopher Lawrence's expert report entitled "Report on Ligatures found in the Grave in C12", 17 June 1999). See also Adjudicated Fact 1857. The Chamber notes that ligatures were also found in the remaining secondary gravesites associated with the Branjevo Military Farm gravesite, with the exception of Čančari Road 4. P4772 (Dušan Janc's report entitled "Update to the summary of Forensic Evidence - Exhumation of the Graves and Surface Remains Recoveries related to Srebrenica January 2012”, 13 January 2012), e-court p. 15. Similarly, blindfolds were found in Čančari Road 5, 6, 8, 9, and 10. P4772 (Dušan Janc's report entitled "Update to the summary of Forensic Evidence - Exhumation of the Graves and Surface Remains Recoveries related to Srebrenica - January 2012”, 13 January 2012), e-court p. 15.

18632 P4054 (Christopher Lawrence's expert report entitled "Report on Autopsies of Human Remains from Čančari Road Site 12, August 1998”, 17 June 1999), e-court pp. 3, 43-51. See P4054 (Christopher Lawrence's expert 
experts were not able to provide a cause of death for the remainder of the body parts analysed, injuries in the majority of these remains were consistent with gunshot wounds. ${ }^{18633}$

5461. Forensic analysis showed that Čančari Road 12 is a secondary gravesite associated with the Branjevo Military Farm gravesite. ${ }^{18634}$ First, the filling of Čančari Road 12 included lumps of evidently foreign soil and vegetation, including stubble from a cereal field; these were consistent with the evidence that the Branjevo Military Farm had been a primary grave. ${ }^{18635}$ Second, DNAbased connections were found between the Branjevo Military Farm primary gravesite and the secondary gravesites of Čančari Road 4, 5, 6, 8, 9, 10, 11, and 12. ${ }^{18636}$ As of 13 January 2012, DNA analysis has led to the identification of 1,597 victims from the Čančari Road gravesites associated with the Branjevo Military Farm primary gravesite, as persons listed as missing following the take-over of Srebrenica: 180 from Čančari Road 4; 290 from Čančari Road 5; 183

report entitled "Report on Autopsies of Human Remains from Čančari Road Site 12, August 1998", 17 June 1999), e-court p. 20; D1978 (Diagram of a body marked by Christopher Lawrence); Christopher Lawrence, T. 22488-22492 (8 December 2011) (referring to the Lawrence's conclusion that the large number of gunshot wounds found in three bodies raises the possibility that such injuries may have been deliberately inflicted to incapacitate and cause pain). See also P4504 (Dean Manning's Report, entitled "Summary of Forensic Evidence - Execution Points and Mass Graves", 16 May 2000), e-court p. 48; Adjudicated Fact 1856.

18633 P4054 (Christopher Lawrence's expert report entitled "Report on Autopsies of Human Remains from Čančari Road Site 12, August 1998”, 17 June 1999), e-court pp. 3, 32, 40, 43-51; P4504 (Dean Manning's Report, entitled "Summary of Forensic Evidence - Execution Points and Mass Graves", 16 May 2000), e-court pp. 20, 47-48.

18634 Richard Wright, T. 22276, 22282 (1 December 2011); P4000 (Richard Wright's expert report entitled "Exhumations in Eastern Bosnia in 1998", 12 May 1999), e-court pp. 10, 21-22; Christopher Lawrence, P4051 (Transcript from Prosecutor v. Krstić), T. 3999. See also P4504 (Dean Manning's Report, entitled "Summary of Forensic Evidence - Execution Points and Mass Graves", 16 May 2000), e-court p. 10; Adjudicated Fact 1855; P4000 (Richard Wright's expert report entitled "Exhumations in Eastern Bosnia in 1998", 12 May 1999), ecourt pp. 19, 37 (concluding that bodies had been broken up in the process of moving them from the primary gravesite to the secondary gravesite).

18635 P4000 (Richard Wright's expert report entitled "Exhumations in Eastern Bosnia in 1998", 12 May 1999), ecourt pp. 21-22; P4504 (Dean Manning's Report, entitled "Summary of Forensic Evidence - Execution Points and Mass Graves", 16 May 2000), e-court pp. 47.

18636 The specific connections are as follows: one individual with remains in both Branjevo Military Farm and Čančari Road 4; two between Branjevo Military Farm and Čančari Road 8; 28 between Branjevo Military Farm and Čančari Road 9; six between Branjevo Military Farm and Čančari Road 11; and four between Branjevo Military Farm and Čančari Road 12. P4772 (Dušan Janc's report entitled "Update to the summary of Forensic Evidence - Exhumation of the Graves and Surface Remains Recoveries related to Srebrenica - January 2012", 13January 2012), e-court p. 48; Dušan Janc, T. 26968-26970 (27 March 2012). The Chamber notes Dušan Dunjić's challenge to the DNA-based connections between the primary and secondary gravesites and, in particular, that it was "concluded groundlessly" on the basis of 310 DNA links that 4049 bodies originated from numerous primary mass graves including Branjevo Military Farm. D3894 (Dušan Dunjić's expert report entitled "Forensic Analysis of Documents Pertaining to Exhumations, Autopsies and Identification of Bodies in the Srebrenica Area", 26 August 2012), p. 24. See also Defence Final Brief, paras. 2607-2608. The Chamber further notes that Dušan Dunjić argued that there was a possibility that certain Čančari Road gravesites could in fact be primary in relation to each other. D3893 (Dušan Dunjić's expert report entitled "Forensic Analysis of Reports on the Locations of Mass Graves in the Area of Eastern Bosnia and Documentation Relating to Exhumations in the Srebrenica Area”, 27 August 2009), pp. 16-17. However, having assessed the totality of evidence on this issue, the Chamber accepts Janc's report and the findings therein. 
from Čančari Road 6; 49 from Čančari Road 8; 209 from Čančari Road 9; 378 from Čančari Road 10; 140 from Čančari Road 11; and 168 from Čančari Road $12{ }^{18637}$

5462. The Chamber notes Dušan Dunjić's challenge that in the event of the DNA of an individual being found in multiple gravesites, such individual may not be counted in both gravesites, as is the case with respect to Čančari Road 7 and Čančari Road 11. ${ }^{18638}$ The Chamber notes, however, that in calculating the total number of identified individuals for the Branjevo Military Farm primary gravesite and its associated secondary gravesites, Janc did not include any of the individuals identified from the Čančari Road 7 gravesite, as those individuals were instead counted towards the total number of Kozluk victims. ${ }^{18639}$ Thus, having assessed the totality of evidence on this issue, the Chamber accepts Janc's report and the findings therein, particularly the fact that Čančari Road 7 is associated with the primary gravesite in Kozluk.

\section{(f) $\underline{\text { Conclusion }}$}

5463. DNA analysis has led to the identification of 1,735 individuals found at the Branjevo Military Farm gravesite and its associated Čančari Road secondary gravesites as persons missing following the take-over of Srebrenica. ${ }^{18640}$ This number is consistent with other evidence before the Chamber: Ahmo Hasić estimated that there were 1,000 to 1,500 people who had been killed at the Branjevo Military Farm, ${ }^{18641}$ and Erdemović estimated that between 1,000 and 1,200 Bosnian Muslim detainees were killed there. ${ }^{18642}$ In relation to the killings at the Pilica Cultural Centre, Bogdanović estimated that there were approximately 500 there. ${ }^{18643}$

18637 P4772 (Dušan Janc's report entitled "Update to the summary of Forensic Evidence - Exhumation of the Graves and Surface Remains Recoveries related to Srebrenica - January 2012", 13 January 2012), e-court pp. 16-20, 41-43; P4771 (Dušan Janc's report entitled "Update to the summary of Forensic Evidence - Exhumation of the Graves and Surface Remains Recoveries related to Srebrenica - January 2012”, 13 January 2012), Annex D, ecourt pp. 201-225, 232-273. See also P5917 (ICMP DNA identifications concerning identified victims related to Srebrenica, 6 December 2010); P4773 (ICMP unmatched DNA victim profiles related to Srebrenica, 23 December 2011); P4774 (ICMP lists of unmatched unique DNA victims profiles related to Srebrenica, 15 February 2010); Dean Manning, T. 25841 (6 March 2012).

18638 D3893 (Dušan Dunjić's expert report entitled "Forensic Analysis of Reports on the Locations of Mass Graves in the Area of Eastern Bosnia and Documentation Relating to Exhumations in the Srebrenica Area", 27 August 2009), pp. 14-15.

18639 See P4772 (Dušan Janc's report entitled "Update to the summary of Forensic Evidence - Exhumation of the Graves and Surface Remains Recoveries related to Srebrenica - January 2012”, 13 January 2012), e-court pp. 40-41. Janc testified that he did not ever count reassociations, and therefore did not duplicate individuals when their DNA was found in two gravesites. Dušan Janc, T. 26950 (27 March 2012).

18640 P4772 (Dušan Janc's report entitled "Update to the summary of Forensic Evidence - Exhumation of the Graves and Surface Remains Recoveries related to Srebrenica - January 2012”, 13 January 2012), e-court pp. 40-41.

18641 Ahmo Hasić, P354 (Transcript from Prosecutor v. Popović et al.), T. 1205, 1229. See also Adjudicated Fact 1844.

18642 Dražen Erdemović, P332 (Transcript from Prosecutor v. Popović et al.), T. 10983. See also Dražen Erdemović, T. 25384-25386 (28 February 2012). But see Defence Final Brief, para. 2546; D3927 (Witness statement of Franc Kos dated 26 July 2013), p. 23 (testifying that between 350 and 370 people were killed at Branjevo 
5464. On the basis of this evidence, the Chamber finds that on 15 and 16 July 1995, at least 1,735 Bosnian Muslims men were killed at the Kula School, the Branjevo Military Farm, and the Pilica Cultural Centre by members of the Bosnian Serb Forces, including members of the $10^{\text {th }}$ Sabotage Detachment and VRS soldiers from Bratunac. Some of these Bosnian Muslims men were killed at the Kula School, about 1,200 were killed at the Branjevo Military Farm, and about 500 were killed at the Pilica Cultural Centre.

g. The aftermath of the fall of Srebrenica

\section{i. Opening a corridor for the passage of the column}

5465. In the morning of 13 July 1995, groups from the column of Bosnian Muslim men entered the Bratunac area and engaged in combat with members of the Bosnian Serb Forces. ${ }^{18644}$ By that day, the Bosnian Serb Forces believed that parts of the column, led by Zulfo Tursunović and Ibrahim Mandžić, were preparing to break through to Tuzla. ${ }^{18645}$ In the early hours of 14 July, members of the column attacked Bosnian Serb positions in Milići as they moved towards Tuzla. ${ }^{18646}$ The Zvornik Brigade had been expecting and preparing for the arrival of the column to the Zvornik area. ${ }^{18647}$ Obrenović, acting commander of the Zvornik Brigade in the absence of Pandurević, was organising the logistics for the defence. ${ }^{18648}$

Military Farm). According to Kos, eight buses full of detainees, each of which could fit approximately 50 people, arrived at the farm that day; the eighth bus, however, was only half full. D3927 (Witness statement of Franc Kos dated 26 July 2013), pp. 16, 22-23; Franc Kos, T. 42386-42387 (1 August 2013). The Chamber notes, however, that during a prior interview with a Prosecution investigator, Kos estimated that the Detachment members had killed detainees from 11 buses who had come from Kula School, and that the Bratunac soldiers shot detainees from the buses that arrived thereafter; he asserted that therefore, the total number of detainees killed at the Branjevo Military Farm was between 600 and 700. See Franc Kos, T. 42368-42370 (31 July 2013), T. 42389-42392 (1 August 2013). Kos attempted to refute Erdemović's testimony that 1,200 people had been killed at Branjevo Military Farm, arguing that each soldier had only one combat set, made up of five ammunition clips consisting a 30 bullets each, and that none of the soldiers were given an additional charge; according to Kos, he did not fire his complete combat set of 150 bullets and he only fired four ammunition clips. D3927 (Witness statement of Franc Kos dated 26 July 2013), pp. 22-24; Franc Kos, T. 42360-42362 (31 July 2013), T. 42384-42387 (1 August 2013). In light of all the evidence before it, the Chamber does not accept the estimate provided by Kos as to the number of victims killed at the Branjevo Military Farm.

18643 Bogdanović testified that he heard that there were 550 bodies in the Dom; while he did not count, he estimated that number to be a reasonable one. Jevto Bogdanović, P385 (Transcript from Prosecutor v. Popović et al.), T. 11333. See Adjudicated Fact 1860.

18644 See paras. 5162-5163.

18645 P5098 (Report of RS MUP, 13 July 1995); P5099 (Report of Bijeljina RJB , 13 July 1995); P5092 (Report of Sarajevo RDB, 14 July 1995), p. 1; P4579 (Zvornik Brigade combat report, 13 July 1995). See also P5145 (Report of Drina Corps, 13 July 1995), p. 1; P5093 (Report of Sarajevo RDB, 14 July 1995), p. 1; P4389 (Report of Sarajevo RDB, 13 July 1995), p. 1; Dragan Kijac, T. 44337-44338 (3 December 2013).

18646 P5136 (Bulletin of daily events of Zvornik CJB, 13-14 July 1995), p. 2; KDZ122, T. 26259 (14 March 2012) (closed session). See P5093 (Report of Sarajevo RDB, 14 July 1995), p. 1.

18647 See P4579 (Zvornik Brigade combat report, 13 July 1995) (detailing the preparations made in the Zvornik Brigade area of responsibility to block the column).

18648 See Ljubo Bojanović, P116 (Transcript from Prosecutor v. Blagojević \& Jokić), T. 11711-11714 (testifying that Obrenović called him at 2 a.m. on 14 July requesting men and equipment to be sent to the Maričići and Snagovo 
5466. As anticipated, later on 14 July, members of the column attacked positions of the Zvornik Brigade. ${ }^{18649}$ As a result, part of the column passed through the Bosnian Serb lines at Zvornik and continued towards Tuzla. ${ }^{18650}$ During this breakthrough, Bosnian Muslim men captured Zoran Janković, Commander of the Doboj PJP Platoon, as well as six other MUP and VRS members. ${ }^{18651}$ Around 8:20 p.m., a column about two or three kilometres long was observed in the areas of Jošanica and Liplje. ${ }^{18652}$ That night, Obrenović requested the command of the Drina Corps to provide reinforcements. ${ }^{18653}$ At 10:27 p.m., Jokić informed Miletić about problems with the column, and Miletić asked Jokić to check with Vasić, as "everything available should be gathered [...] [e]veryone who can carry a rifle should go up". ${ }^{18654}$ Jokić explained that: "there is a large group going this way [...] we're having some problems [...] they promised me some reinforcements, but they're nowhere to be seen..." and added that "Obrenović is really engaged to the hilt... we are all engaged to the hilt... believe me... this package really did for us... we've been reporting about the number of people since this morning, so... so there."18655

5467. In the early morning of 15 July, the Muslim Forces in Srebrenica at the front of the column attacked positions of the Zvornik Brigade and intense fighting ensued throughout the day. ${ }^{18656}$ At

areas); Ostoja Stanišić, P382 (Transcript from Prosecutor v. Popović et al.), T. 11596, 11598 (testifying that between 8 and 9 a.m. on 14 July, he received a call from Obrenović to send 40 men to the Standard Barracks who would then be deployed to Snagovo).

18649 P4586 (Zvornik Brigade combat report, 15 July 1995), p. 1; P136 (Zvornik Brigade combat report, 14 July 1995); P178 (Zvornik Brigade combat report, 14 July 1995); KDZ122, T. 26260-26261, 26263 (14 March 2012) (closed session). See Radislav Krstić, D4136 (Transcript from Prosecutor v. Krstić), T. 6747-6748.

18650 P4981 (Report of Sarajevo RDB, 15 July 1995). See P178 (Zvornik Brigade combat report, 14 July 1995 ).

18651 P4981 (Report of Sarajevo RDB Report, 15 July 1995). See also P5138 (Report of Zvornik CJB, 16 July 1995 ), p. 2; D3749 (Witness statement of Milenko Karišik dated 23 June 2013), para. 37. Zoran Jovanović had been sent to the Snagovo area with reinforcements earlier that day. Ljubo Bojanović, P116 (Transcript from Prosecutor v. Blagojević \& Jokić), T. 11712; P4563 (Statement by KDZ122), p. 2 (under seal). See also Ljubo Bojanović, P116 (Transcript from Prosecutor v. Blagojević \& Jokić), T. 11716, 11718-11719, 11754, 1175611758.

18652 P137 (Zvornik Brigade interim combat report, 14 July 1995).

18653 [REDACTED]; P137 (Zvornik Brigade interim combat report, 14 July 1995). See Radislav Krstić, D4136 (Transcript from Prosecutor v. Krstić), T. 6745-6748. In an intercepted conversation on 14 July at 8:38 p.m., Živanović ordered Jokić-duty officer at the Zvornik Brigade at the time-to tell Obrenović to "surround the location [...] [p]ress it hard and slowly". P5294 (Intercept of conversation between Major Dragan Jokić and General Milenko Živanović, 14 July 1995), p. 1. Živanović also informed Jokić that reinforcements would arrive the next morning. P5294 (Intercept of conversation between Major Dragan Jokić and General Milenko Živanović, 14 July 1995), p. 1. But see D3932 (Witness statement of Milenko Živanović dated 27 October 2013), para. 40 (where Živanović denied taking part in this conversation and stated that he had never talked to Jokić).

18654 P5071 (Intercept of conversation, 14 July 1995), pp. 1-2.

18655 P5071 (Intercept of conversation, 14 July 1995), pp. 1-2. Miletić insisted that Jokić get in touch with Vasić. P5071 (Intercept of conversation, 14 July 1995), p. 2.

18656 P179 (Zvornik Brigade interim combat report, 15 July 1995); P4586 (Zvornik Brigade combat report, 15 July 1995), p. 1; P138 (Zvornik Brigade interim combat report, 15 July 1995), p. 1; P5191 (Report of Zvornik CJB, 15 July 1995), p. 2; P4582 (Zvornik Brigade IKM Operations Duty logbook, July-October 1995), p. 7; P4585 (Zvornik Brigade Duty Officers logbook, 29 May-27 July 1995), e-court p. 69; P4563 (Statement by KDZ122), p. 5 (under seal); P4587 (Zvornik Brigade combat report, 16 July 1995); P5139 (Bulletin of daily events of Zvornik CJB, 15-16 July 1995), p. 2; P5094 (Report of Sarajevo RDB, 16 July 1995), p. 1; P5138 (Report of 
8:55 a.m., Pandurević was informed about the movement of the column and the situation in the area where the $4^{\text {th }}, 6^{\text {th }}$, and $7^{\text {th }}$ Battalions of the Zvornik Brigade were deployed. ${ }^{18657}$ Between 9 and 10 a.m., Pandurević was informed again about the size of the column and of actions being carried out against it. ${ }^{18658}$ Based on Pandurević's request for reinforcements, the $1^{\text {st }}$ Krajina Corps Company was dispatched to assist the Zvornik Brigade in actions against the column. ${ }^{18659}$

5468. During the course of the day, Obrenović met with Vasić at the Standard Barracks and discussed opening a corridor to allow the column to pass. ${ }^{18660}$ Obrenović tried to contact Pandurević to authorise the plan, but Pandurević could not be reached as he was on his way back to Zvornik. ${ }^{18661}$ Obrenović contacted Miletić at the Main Staff instead and asked for his approval to open a corridor. ${ }^{18662}$ Miletić denied the request and advised Obrenović that the column should be destroyed. ${ }^{18663}$ Vasić then sought approval from an advisor at the MUP but was also denied permission. ${ }^{18664}$ Obrenović subsequently contacted Krstić and was told that he should not worry about the fall of Zvornik because Pandurević and the Drina Wolves were en route. ${ }^{18665}$ Krstić issued an order for the return of part of the Zvornik Brigade forces and the Podrinje Special Forces Detachment to their zones of responsibility in order to prevent the consequences of a possible attack on Zvornik and the link-up of Bosnian Muslim units from Srebrenica and Tuzla. ${ }^{18666}$ Krstić then ordered Zvornik Brigade and MUP forces already present in Zvornik to take all measures to block and, if possible, break up and capture Bosnian Muslim forces until the arrival of the reinforcements. ${ }^{18667}$

5469. Pandurević arrived at the Standard Barracks before noon on 15 July. ${ }^{18668}$ He was initially opposed to the idea of opening a corridor and ordered Obrenović to continue fighting the

Zvornik CJB, 16 July 1995), p. 1; P5095 (Report of Sarajevo RDB, 16 July 1995), p. 2; P180 (Zvornik Brigade interim combat report, 16 July 1995), p. 1; P5140 (Bulletin of daily events of Zvornik CJB, 16-17 July 1995), p. 2; P4960 (Combat report signed by Ljubiša Borovčanin, 10-20 July 1995), p. 3. See also P5117 (Report of Bratunac Brigade to Drina Corps, 15 July 1995), p. 2.

P5304 (Intercept of conversation between Vinko Pandurević, Sreten Milošević, and Miladin Mijatović, 15 July 1995), p. 2.

18658 P5302 (Intercept of conversation between Vinko Pandurević and Miladin Mijatović, 15 July 1995), p. 1.

18659 P5122 (VRS Main Staff Report, 15 July 1995).

18660 [REDACTED].

18661 [REDACTED].

18662 [REDACTED].

18663 [REDACTED].

18664 [REDACTED].

18665 [REDACTED].

18666 D4847 (Drina Corps Order, 15 July 1995).

18667 D4847 (Drina Corps Order, 15 July 1995).

18668 [REDACTED]. Pandurević had been away from the Standard Barracks since 4 July, first, commanding a unit in the takeover of Srebrenica, and then in Žepa. [REDACTED]. 
column. ${ }^{18669}$ Pandurević made an offer to the Bosnian Muslim forces that if the armed members of the column surrendered, civilians in the column would be released; however, they refused, asking that the civilian and armed members of the column be released together. ${ }^{18670}$ Pandurević requested reinforcements, and additional units of the Bosnian Serb Forces were transferred to the Zvornik Brigade's area of responsibility to assist in actions against the column. ${ }^{18671}$ At approximately 11 p.m., Vasić reported to the Accused, among others, that additional forces were urgently needed to comb the terrain and destroy the column due to the danger it posed to the Zvornik area. ${ }^{18672}$

5470. On the morning of 16 July, units of the Zvornik Brigade continued to suffer heavy losses while fighting the column, and thousands of Bosnian Muslims broke through the Bosnian Serb lines in the Baljkovica sector. ${ }^{18673}$ At 7:06 a.m., while at the IKM, Pandurević informed an unidentified person that there had been fighting all morning. ${ }^{18674}$ During this conversation, Pandurević said that most of the enemy forces were surrounded in the Baljkovica sector, and that "when the mass poured forward" deep in the rear of the Zvornik Brigade-held territory, the VRS troops fled, enabling the enemy forces to take two self-propelled guns. ${ }^{18675}$ Pandurević claimed that all of the members of the column were armed, and explained he had some wounded men "down there" and was not able to get them out. ${ }^{18676}$ The unidentified person informed Pandurević that help would be arriving and that he should use it as he saw fit. ${ }^{18677}$ Combat activity ceased from both sides between 10 and 11 a.m. ${ }^{18678}$ Negotiations were held between Pandurević and Šemso Muminović, a member of the column and an officer of the Muslim Forces in Srebrenica, on the passage of the column through Bosnian Serb-held territory in Zvornik municipality. ${ }^{18679}$ At 1 p.m.,

\footnotetext{
18669 [REDACTED].

18670 P138 (Zvornik Brigade interim combat report, 15 July 1995).

18671 P138 (Zvornik Brigade interim combat report, 15 July 1995); P4586 (Zvornik Brigade combat report, 15 July 1995), p. 1; D4131 (Excerpt of the East Bosnia Corps Logbook, 5 March 1995 to 12 June 1996), e-court p. 4; Milenko Todorović, D4124 (Transcript from Prosecutor v. Tolimir), T. 13168-13175, 13179-13181. See P5302 (Intercept of conversation between Vinko Pandurević and Miladin Mijatović, 15 July 1995), p. 2; P5122 (VRS Main Staff Report, 15 July 1995); P5117 (Report of Bratunac Brigade to Drina Corps, 15 July 1995), p. 1.

18672 P5137 (Report of Zvornik CJB, 15 July 1995).

18673 P4587 (Zvornik Brigade combat report, 16 July 1995); P180 (Zvornik Brigade interim combat report, 16 July 1995), p. 1; [REDACTED]; P5322 (Intercept of conversation between Vinko Pandurević and an unidentified person, 16 July 1995), p. 1; P5388 (Intercept of conversation between two unidentified persons, 17 July 1995), p. 1. See also Dragan Kijac, T. 44381-44382 (3 December 2013); D3196 (Witness statement of Dušan Mićić dated 24 March 2013), paras. 36-37; P4960 (Combat report signed by Ljubiša Borovčanin, 10-20 July 1995), p. 4; Adjudicated Fact 1628.

18674 P5322 (Intercept of conversation between Vinko Pandurević and an unidentified person, 16 July 1995 ), p. 1.

18675 P5322 (Intercept of conversation between Vinko Pandurević and an unidentified person, 16 July 1995), p. 1.

18676 P5322 (Intercept of conversation between Vinko Pandurević and an unidentified person, 16 July 1995), p. 1.

18677 P5322 (Intercept of conversation between Vinko Pandurević and an unidentified person, 16 July 1995), p. 1.

18678 Ostoja Stanišić P382 (Transcript from Prosecutor v. Popović et al.), T. 11713.

18679 P4960 (Combat report signed by Ljubiša Borovčanin, 10-20 July 1995), p. 4; P5222 (Report of RS MUP, 16 July 1995); P5138 (Report of Zvornik CJB, 16 July 1995), pp. 1-2; [REDACTED]. See also P180 (Zvornik Brigade interim combat report, 16 July 1995); P5095 (Report of Sarajevo RDB, 16 July 1995), pp. 1-2.
} 
an agreement was reached to open a kilometre-wide corridor to allow the column to pass through. ${ }^{18680}$ In return, the Bosnian Muslims agreed to release Janković and other members of the Bosnian Serb Forces being held. ${ }^{18681}$ The corridor was opened at approximately 2 p.m. and remained open first for approximately 24 hours, followed later by an additional two hours. ${ }^{18682}$ A column about one or two kilometre long, composed of several thousand armed and unarmed Bosnian Muslims, passed through during this time. ${ }^{18683}$

5471. On 16 July, at 1:55 p.m., Pandurević notified the Drina Corps command that a corridor had been opened to allow the civilians through but that Bosnian Serb Forces were still fighting the Muslim Forces in Srebrenica. ${ }^{18684}$ At approximately 3:30 p.m., a conversation between an unknown interlocutor $(\mathrm{X})$ from the Main Staff and the Zvornik Brigade duty officer was intercepted, in which X stated that he was calling from "the main boss [...] the main head of state" and told the duty officer to "have Vinko tell you what happened and send it right away [...] dictate

18680 P4960 (Combat report signed by Ljubiša Borovčanin, 10-20 July 1995), p. 4; KDZ122, T. 26264-26266, 26268-26269 (14 March 2012) (closed session); P4563 (Statement by KDZ122), p. 6 (under seal); P5138 (Report of Zvornik CJB, 16 July 1995), pp. 1-2; P5095 (Report of Sarajevo RDB, 16 July 1995); P5140 (Bulletin of daily events of Zvornik CJB, 16-17 July 1995), p. 2; P180 (Zvornik Brigade interim combat report, 16 July 1995), p. 1. See D4885 (Intercept of conversation between Main Staff duty officer and Ratko Mladić, 16 July 1995); P5222 (Report of RS MUP, 16 July 1995).

18681 P5138 (Report of Zvornik CJB, 16 July 1995), p. 2; KDZ122, T. 26266 (14 March 2012) (closed session). See also Milenko Karišik, T. 40677 (2 July 2013). Sometime between the evening of 14 July and the morning of 16 July, Kovač ordered Milenko Karišik - then Deputy Minister of the Interior and Chief of the RJB-to go to Zvornik to ask Pandurević to try to secure the release of Janković. D3749 (Witness statement of Milenko Karišik dated 23 June 2013), paras. 33, 37. Upon arriving in Zvornik on 16 July, Karišik went immediately to the Zvornik CJB, where he was briefed, and then proceeded to the Zvornik Brigade IKM. D3749 (Witness statement of Milenko Karišik dated 23 June 2013), para. 38. See also D3749 (Witness statement of Milenko Karišik dated 23 June 2013), para. 39; Milenko Karišik, T. 40634 (27 June 2013) (testifying that he could not remember the exact time, but believing that he returned to Bijeljina in the afternoon of 16 July). At the IKM, Karišik asked Pandurević to continue insisting on Janković's release. D3749 (Witness statement of Milenko Karišik dated 23 June 2013), para. 39.

18682 P4563 (Statement by KDZ122), p. 6 (under seal); KDZ122, T. 26264-26265, 26268-26269 (14 March 2012) (closed session); Ostoja Stanišić, P382 (Transcript from Prosecutor v. Popović et al.), T. 11713-11714, 11719. See D3749 (Witness statement of Milenko Karišik dated 23 June 2013), paras. 37-38; P5310 (Intercept of conversation between Zlatar duty officer and Palma duty officer, 16 July 1995). See also P4960 (Combat report signed by Ljubiša Borovčanin, 10-20 July 1995), p. 4 (stating that on 17 July 1995, in co-ordination with the intervention units of the Zvornik Brigade, the $5^{\text {th }}$ Special Police Detachment closed the line in Baljkovica).

18683 Ostoja Stanišić P382 (Transcript from Prosecutor v. Popović et al.), T. 11714; P5138 (Report of Zvornik CJB, 16 July 1995), p. 2 (stating that approximately 4,000 Bosnian Muslims passed through the corridor and that an agreement had been made to allow a further 1,500 civilians coming from Konjević Polje to pass through); P180 (Zvornik Brigade interim combat report, 16 July 1995), p. 1 (wherein Pandurević estimated that approximately 5,000 Bosnian Muslims passed through the corridor); D1998 (Bulletin of ABiH General Staff, 17 July 1995), p. 1 (stating that approximately 10,000 members of the Bosnian Muslim forces arrived in free territory on the evening of 16 July 1995). A member of the Bosnian Serb Forces, who was standing 100 metres away from the corridor from the time that it was opened until dusk, estimated that more than 10,000 people passed through the corridor. [REDACTED]. Captain Salihović, a member of the column, advised the Bosnian Serb Forces on the morning of 16 July, that there were approximately 10,000 people waiting to get through the corridor. [REDACTED]. Cf. Dragan Kijac, T. 44381 (3 December 2013) (testifying that 22,000 men got out during the opening of the corridor).

18684 P5310 (Intercept of conversation between Zlatar duty officer and Palma duty officer, 16 July 1995). 
what has been done and have him send it right away to the Main Staff"' ${ }^{18685}$ Two minutes later, at 3:32 p.m., the Zvornik Brigade duty officer reported that Pandurević was in the field and could not be contacted. ${ }^{18686}$ At 4:02 p.m., Krstić was also urgently looking for Pandurević but was also told that Pandurević could not be reached. ${ }^{18687}$

5472. Some time before 4:15 p.m., the Accused was informed by Karišik that Pandurević had arranged for the opening of the corridor. ${ }^{18688}$ At approximately 4:20 p.m., Krstić ordered Popović to meet Pandurević in the field to report on the situation regarding the corridor. ${ }^{18689}$ Soon after, Popović met Pandurević who provided him with his combat report and Popović reported back to the Drina Corps Command. ${ }^{18690}$ At 6:10 p.m., Pandurević sent an interim combat report to the command of the Drina Corps advising of his decision to open the corridor and that he considered the Krivaja 95 operation incomplete "as long as a single enemy soldier or civilian remains behind the front line". ${ }^{18691}$ Additional reinforcements were sent to the Zvornik area that evening. ${ }^{18692}$

18685 P5076 (Intercept of conversation between a VRS Main Staff member and Palma duty officer, 16 July 1995), p. 1. Obradović confirmed that the phrase "main head of state" referred to the Accused. Ljubomir Obradović, T. 25309-25311 (27 February 2012).

18686

18687 P5316 (Intercept of conversation between a "Palme" duty officer and an unidentified person, 16 July 1995$)$, p. 1. P5320 (Intercept of conversation between Zlatar and Palma, 16 July 1995), p. 1.

18688 D4885 (Intercept of conversation between Main Staff Duty Officer and Ratko Mladić, 16 July 1995) (wherein the Main Staff duty officer told Mladic that the Accused had called "a short while ago" and said that he had been informed by Karišik that Pandurević had arranged passage for "the Muslims over to that territory"). The Main Staff duty officer further told Mladic that he had asked "the duty officer" to urgently connect him with Pandurević, and not to do anything without authorisation until he received the answer of the Main Staff, adding that the column contained both combatants and civilians. D4885 (Intercept of conversation between Main Staff duty officer and Ratko Mladić, 16 July 1995). The Chamber recalls the Accused's case that he was informed by Karišik on 16 July 1995 that Pandurević agreed to the opening of a corridor. See the Accused's line of questioning during cross-examination of Joseph Kingori, T. 22942 (13 January 2012) and during crossexamination of KDZ122, T. 26265 (14 March 2012) (closed session). The Chamber notes that Karišik denied that he informed the Accused about the opening of the corridor on 16 July 1995 because technical capacities at the time would have prevented him from communicating with the Accused, and he was not responsible for reporting to the Accused about Srebrenica at any time. Milenko Karišik, T. 40654, 40656-40658 (2 July 2013). The Chamber notes, however, that Karišik managed to contact the MUP in Pale that same afternoon. P5222 (Report of RS MUP, 16 July 1995). The Chamber therefore rejects Karišik's evidence denying that he informed the Accused of the corridor. The information about opening the corridor was conveyed from the Zvornik CJB to the MUP command staff in Pale, which in turn conveyed it to the Ilidža CJB. P5222 (Report of RS MUP, 16 July 1995).

18689 P4585 (Zvornik Brigade Duty Officers logbook, 29 May-27 July 1995), e-court p. 87; D3993 (Witness statement of Vujadin Popović dated 2 November 2013), para. 74; P5079 (Intercept of conversation between Lt. Col. Popović and Rašić, 16 July 1995), e-court p. 1.

18690 D3993 (Witness statement of Vujadin Popović dated 2 November 2013), paras. 76-77.

18691 P180 (Zvornik Brigade interim combat report, 16 July 1995).

18692 See P5382 (Summaries of three intercepts of conversations, 16 July 1995), p. 1 (recording that at 6:47 p.m. on 16 July, Mladić requested men to be sent to an undisclosed area; this order went through Miletić to Cerović, and finally to Blagojević); P5382 (Summaries of three intercepts of conversations, 16 July 1995), p. 1 (recording that at 8:06 p.m. Blagojević reported having sent 50 men "5 minutes or a half an hour ago", and indicated that he had 60 more in reserve); P5079 (Intercept of conversation between Lt. Col. Popović and Rašić, 16 July 1995), ecourt p. 2 (record of an intercepted conversation at 9:16 p.m. on 16 July, where Popović was asked whether Blagojević men had arrived in Zvornik that day; Popović replied that they had arrived but did not know when exactly, and suggested that maybe the duty officer had that information); P5314 (Summary of conversation between a duty officer and Col. Cerović, 16 July 1995), p. 1 (record of an intercepted conversation at 9:26 p.m., 
5473. At 6:15 a.m. on 17 July, Krstić called the Zvornik Brigade asking for news on the Zvornik area. ${ }^{18693}$ After being told by Trbić that everything was under control and that there were no problems, Krstić asked: "have you killed the Turks up there?",18694 Trbić replied: "Well, I guess you got the report. What more can I tell you? [...] Basically, we did."18695 Krstić then asked to be put through to Pandurević who informed Krstić that there were no changes with respect to the report he had previously sent, adding that "we'll probably finish this today" ${ }^{18696}$ At 8:59 a.m., upon being asked by Cerović for a follow-up to the interim combat report about the column sent the day before by Pandurević, Trbić replied that it was not done yet. ${ }^{18697}$ An intercepted conversation from 9:50 a.m. between two unknown individuals, recorded a discussion on the operations against the column, stating that: "There are many of them. They started a breakthrough yesterday and our men tried to block. They blocked them off and opened fire on them, but it's a living mass [...] [and] you just can't kill them all, there are so many of them."18698

5474. Pandurević was not punished for opening the corridor, although he came under scrutiny by the Main Staff; on 17 July, Mladić sent Colonels Trkulja, Stanković, and Sladojević from the Main Staff to investigate why the corridor had been opened and they questioned whether the Bosnian Serb Forces could have put up a stronger resistance rather than open the corridor. ${ }^{18699}$ Around that same day, the Accused was interviewed by David Frost and adamantly denied that 15,000 men were missing from Srebrenica, assuring him that the Bosnian Serb Forces had opened their lines to allow many of the missing men from Srebrenica through to Bosnian Muslim-held territory. ${ }^{18700}$ However, at the $52^{\text {nd }}$ RS Assembly Session held on 6 August 1995, the Accused expressed regret

where Cerović was informed that 30 men from Blagojević's brigade had arrived at 9 p.m., that 30 men from Doboj had arrived around 5 p.m., and that 100 men had arrived from Banja Luka at 5:25 p.m.).

18693 P5336 (Intercept of conversation between General Krstić, Milorad Trbić, and Vinko Pandurević, 17 July 1995), p. 1.

18694 P5336 (Intercept of conversation between General Krstić, Milorad Trbić, and Vinko Pandurević, 17 July 1995), p. 1.

18695 P5336 (Intercept of conversation between General Krstić, Milorad Trbić, and Vinko Pandurević, 17 July 1995), p. 1.

18696 P5336 (Intercept of conversation between General Krstić, Milorad Trbić, and Vinko Pandurević, 17 July 1995), pp. 1-2.

18697 P5328 (Intercept of conversation between Col. Cerović and Cpt. Milorad Trbić, 17 July 1995).

18698 P5388 (Intercept of conversation between two unidentified persons, 17 July 1995).

18699 KDZ122, T. 26190-26191 (13 March 2012) (closed session), T. 26265 (14 March 2012) (closed session); P4563 (Statement by KDZ122), p. 6 (under seal); P4588 (VRS Main Staff Order, 17 July 1995). See also P5332 (Intercept of conversation between "Mirko" and an unidentified person, 17 July 1995), pp. 1-2 (referring to the presence of Colonel Stanković in Zvornik on 17 July).

18700 P5235 (Video footage of interview of Radovan Karadžić by David Frost, undated, with transcript), pp. 2-3. See P2242 (Radovan Karadžić's agenda, 2 January-25 December 1995), e-court p. 93. 
that "in the end several thousand fighters did manage to get through" and that "[w]e were not able to encircle the enemy and destroy them", adding that he did not say these things in public. ${ }^{18701}$

\section{ii. Continued searches through the terrain}

5475. From 17 July until at least 2 August 1995, Bosnian Serb Forces carried out extensive searches of the Bratunac and Zvornik areas to destroy straggling parts of the column. ${ }^{18702}$ Additional forces were deployed by the VRS and MUP on 17 July for this purpose. ${ }^{18703}$ In an order issued by Mladić that day, subordinate units of the Zvornik Brigade, the Bratunac Brigade, and the Milići Brigade, among others, were assigned to comb the Zvornik and Bratunac areas with the aim to "block, crush and destroy lagging Muslim forces". ${ }^{18704}$ Mladić's order appointed Keserović commander of the units deployed. ${ }^{18705}$ Similarly, an order issued by Goran Šarić-Commander of the SBP - that same day to create two combat groups of MUP units for the purpose of fully

\footnotetext{
18701 P1412 (Transcript of 52 ${ }^{\text {nd }}$ session of RS Assembly, 6 August 1995), p. 17.
}

18702 KDZ122, T. 26198 (13 March 2012) (closed session), T. 26270 (14 March 2012) (closed session); P4563 (Statement by KDZ122), p. 6 (under seal); Radislav Krstić, D4136 (Transcript from Prosecutor v. Krstić), T. 6811-6812; P4588 (VRS Main Staff Order, 17 July 1995); P5097 (Order of the Semizovac IKM and Special Police Brigade, 17 July 1995), p. 1; P4960 (Combat report signed by Ljubiša Borovčanin, 10-20 July 1995), pp. 4-5; P3994 (Drina Corps report, 17 July 1995), p. 1; P181 (Zvornik Brigade interim combat report, 18 July 1995); P5152 (Report of Zvornik CJB, 18 July 1995); P5342 (Intercept of conversation between Col. Cerović and Vinko Pandurević, 19 July 1995), pp. 1-2; P5344 (Intercept of conversation between Major Dragan Obrenović and an unidentified person, 19 July 1995); P4589 (Zvornik Brigade combat report, 19 July 1995); P5188 (Report of Sarajevo RDB, 18 July 1995), p. 1; P5336 (Intercept of conversation between General Krstić, Milorad Trbić, and Vinko Pandurević, 17 July 1995), p. 1; P4965 (Report of Zvornik CJB, 19 July 1995); D4856 (Report of Zvornik Brigade, 22 July 1995); P4590 (Zvornik Brigade combat report, 25 July 1995), p. 1; P6065 (Intercept of conversation, 2 August 1995). See also Adjudicated Facts 1607, 1633, 1639.

18703 See P5097 (Order of the Semizovac IKM and Special Police Brigade, 17 July 1995); P4588 (VRS Main Staff Order, 17 July 1995), p. 1; Dragomir Keserović, T. 42033, 42035-42041, 42043-42044 (25 July 2013); Ljubo Bojanović, P116 (Transcript from Prosecutor v. Blagojević \& Jokić), T. 11735, 11740-11741; P139 (Extract from Zvornik Brigade notebook, 17-18 July 1995), e-court p. 2.

18704 P4588 (VRS Main Staff Order, 17 July 1995), p. 1. See Dragomir Keserović, T. 42034, $42043-42044$ (25 July 2013). When presented with P4588, Krstić explained that this was an example of the way in which the Main Staff took over the command of part of the area of responsibility of the Drina Corps by forming its own command group. Radislav Krstić, D4136 (Transcript from Prosecutor v. Krstić), T. 7365.

18705 P4588 (VRS Main Staff Order, 17 July 1995), p. 1. When Keserović met with Mladić, he was given the same order verbally. Dragomir Keserović, T. 42035-42036 (25 July 2013). Despite the language in the order, Keserović claimed that he told Mladić that the order was a "militarily unacceptable assignment" and that there were several reasons why it should not be executed; Mladić ultimately agreed that Keserović should not take over command of the units, but should still go to the area where the operation was to be carried out to gather information about the operation. Dragomir Keserović, T. 42037-42038, 42040-42041 (25 July 2013). According to Keserović, Blagojević continued with the ordered task. Dragomir Keserović, T. 42038-42039 (25 July 2013). The Chamber notes that an intercepted conversation from 11:15 p.m. on 17 July records two unidentified individuals wherein one asks the other if Keserović has set out already and the second replies "he must have gone first forward over there to Momir Nikolić." P5390 (Intercept of conversation between two unidentified persons, 17 July 1995). In that same conversation, one of the individuals says that he spoke earlier to Miletić who told him that Keserović had come to "solve these issues". P5390 (Intercept of conversation between two unidentified persons, 17 July 1995). The Chamber finds that despite Keserović's efforts to downplay his involvement in the sweeping operation in the Bratunac area, this intercept shows that he was sent to the area by Miletić and the Main Staff. 
mopping up the terrain, put Borovčanin in charge of those forces. ${ }^{18706}$ By the evening of 17 July, about 200 Bosnian Muslims had surrendered, including four children. ${ }^{18707}$

5476. On 18 July, Pandurević noted that increased combat activity may be expected in the Zvornik Brigade area. ${ }^{18708}$ That same day, in response to the shooting of a Bosnian Serb soldier, Pandurević ordered that prisoners should not be taken. ${ }^{18709}$ However, he changed the order three days later, stating that all detainees should be processed according to normal procedures, and Bosnian Serb Forces began to take prisoners again. ${ }^{18710}$ Nevertheless, on or about 23 July, Bosnian Muslim men who were being treated at the Standard Barracks clinic were taken away by members of either the Zvornik Brigade or Drina Corps MP, and executed. ${ }^{18711}$ On 2 August 1995, Krstić ordered Obrenović to kill all individuals captured during the searches of the terrain. ${ }^{18712}$ However, the Chamber received evidence that at least some of the persons being detained by the Zvornik Brigade at that time were being sent to the Drina Corps command and then to Batković Camp. ${ }^{18713}$

\section{iii. Killings}

\section{(A) Snagovo}

5477. The Indictment refers to the killing, on or about 22 July 1995, of six Bosnian Muslim men who were captured upon becoming separated from the column of men retreating from the Srebrenica enclave, and were executed in the woods near the town of Snagovo. ${ }^{18714}$ Snagovo is located along the eastern border of $\mathrm{BiH}$ in Zvornik municipality, approximately 25 kilometres northwest of Srebrenica. ${ }^{18715}$

\footnotetext{
18706 P5097 (Order of the Semizovac IKM and Special Police Brigade, 17 July 1995). See Dragomir Keserović, T. 42035-42036, 42043-42044 (25 July 2013).

18707 Adjudicated Fact 1640. See P5188 (Report of Sarajevo RDB, 18 July 1995), p. 1.

18708 P181 (Zvornik Brigade interim combat report, 18 July 1995), para. 1.

18709 [REDACTED]. See also P4589 (Zvornik Brigade combat report, 19 July 1995) (referring to the capture of two Bosnian Muslim soldiers and the killing of 13); P5344 (Intercept of conversation between Major Dragan Obrenović and an unidentified person, 19 July 1995) (referring to the killing of 11 individuals); P5342 (Intercept of conversation between Col. Cerović and Vinko Pandurević, 19 July 1995) (referring to the killing of 20-odd men).

18710 [REDACTED]. See also D4856 (Report of Zvornik Brigade, 22 July 1995) (referring to the capture of 40 Bosnian Muslim soldiers).

18711 [REDACTED]. These killings are not charged in the Indictment.

18712 P6065 (Intercept of conversation, 2 August 1995). The Chamber notes that Krstić denied the authenticity of this intercepted conversation and stated that he would have never made such an order. Radislav Krstić, D4136 (Transcript from Prosecutor v. Krstić), T. 6809-6811. [REDACTED]. The Chamber is therefore satisfied as to the authenticity of the intercept.

18713 [REDACTED]; D4132 (Eastern Bosnia Corps list of prisoners, 18 July 1995); Milenko Todorović, D4124 (Transcript from Prosecutor v. Tolimir), T. 13201-13203. See para. 5502.

18714 Indictment, Scheduled Incident E. 11.1.

18715 P727 (Map of the Balkans). See also D484 (Map of BiH).
} 
5478. On or about 14 July $1995,{ }^{18716}$ an approximately 14 member unit of the Ugljevik PJP was assembled at the Ugljevik SJB to receive orders. ${ }^{18717}$ The unit was ordered by Dragan KulićCommander of the Ugljevik SJB - to proceed from Ugljevik to the Snagovo area to "clear or cleanse the terrain", adding that "not even a fly could get out". ${ }^{18718}$ KDZ365, [REDACTED], had heard rumours about the fall of the Srebrenica enclave, and interpreted Kulić's orders as ones to kill Bosnian Muslims fleeing through the woods and heading towards Tuzla. ${ }^{18719}$

5479. The Ugljevik PJP unit proceeded to a crossroads near Snagovo where it spent the night, and received further orders from Zlatco Nedić, from the Bijeljina CJB, to "mop up [the] terrain". ${ }^{18720}$ Over the next five days, the Ugljevik PJP unit carried out a series of patrols through the surrounding wooded areas, searching the terrain. ${ }^{18721}$ On the fourth or fifth day, a group of three unarmed Bosnian Muslim males emerged from the woods and immediately surrendered to the Ugljevik PJP unit. ${ }^{18722}$ Two of the Bosnian Muslim males were between 35 and 40 years old; the third presented himself as 16 years old. ${ }^{18723}$

5480. Approximately ten minutes after the surrender of the three Bosnian Muslim males, a group of approximately 20 other police officers from other stations gathered, all wearing uniforms similar

18716 KDZ365, P325 (Transcript from Prosecutor v. Popović et al.), T. 4093, 4104, 4155, 4202-4203 (under seal); P315 (List of policemen from Ugljevik on duty on 13 and 14 July 1995, 28 April 2004).

18717 KDZ365, P325 (Transcript from Prosecutor v. Popović et al.), T. 4093-4094, 4097, 4154-4156, 4185, 4202 (under seal). [REDACTED]. The fact that a unit of the Bijeljina PJP was present in Zvornik municipality after the fall of Srebrenica is documented in the evidence admitted in this case, but no single piece refers to the name of the specific company. See e.g. P316 (Report of Zvornik CJB to MUP of RS, 15 July 1995) (referring to "[t]wo PJP companies from Bijeljina" fighting along the Zlijebac-Zlatne Vode-Kula Grade-Maričići line); P4960 (Combat report signed by Ljubiša Borovčanin, 10-20 July 1995), p. 3 (referring to two companies of the Bijeljina Special Police Unit fighting against enemy columns along the Kula Grad-Marčići axis).

18718 KDZ365, P325 (Transcript from Prosecutor v. Popović et al.), T. 4089, 4094-4095, 4163-4164, 4225-4226 (under seal). The Chamber notes the discussion during the Popovic et al. case as to the various instances where KDZ365 testified about the events in Snagovo in 1995, and the fact that he changed his evidence with respect to the order given by Kulić. See KDZ365, P325 (Transcript from Prosecutor v. Popović et al.), T. 4134-4141, 4144-4145, 4148-4150, 4236 (under seal). However, the Chamber is satisfied with KDZ365's explanation and accepts this portion of his evidence.

18719 KDZ365, P325 (Transcript from Prosecutor v. Popović et al.), T. 4097-4101 (under seal); KDZ365, P326 (Transcript from Prosecutor v. Popović et al.), T. 4250. KDZ365 testified that Kulić's words “meant clearing, cleansing, or mopping up. Actually, killing. What else? He did not use the word "killing," but that's what we understood. What else could it have been? [...] Everybody understood, but nobody dared say it out loud and admit how they understood this, because we had heard what was going on in the Srebrenica sector." KDZ365, P326 (Transcript from Prosecutor v. Popović et al.), T. 4097-4098 (under seal). However, in crossexamination, KDZ365 testified that "it could refer to anything. It could refer to one thing or another thing. [...] [He said] that we were going to be mopping up the terrain, but he didn't say when we would actually be taking up these duties." KDZ365, P326 (Transcript from Prosecutor v. Popović et al.), T. 4226.

18720 KDZ365, P325 (Transcript from Prosecutor v. Popović et al.), T. 4095, 4106-4107, 4109, 4109, 4164, 42114213 (under seal); KDZ365, P326 (Transcript from Prosecutor v. Popović et al.), T. 4107-4109.

18721 KDZ365, P326 (Transcript from Prosecutor v. Popović et al.), T. 4107-4108, 4166.

18722 KDZ365, P326 (Transcript from Prosecutor v. Popović et al.), T. 4107-4108, 4111-4113.

18723 KDZ365, P325 (Transcript from Prosecutor v. Popović et al.), T. 4113, 4117-4118 (under seal); KDZ365, P326 (Transcript from Prosecutor v. Popović et al.), T. 4184. 
to those of the Ugljevik PJP unit. ${ }^{18724}$ One individual from this group stepped up and shot the two older Bosnian Muslims in the head. ${ }^{18725}$ A member of the Ugljevik PJP hid the 16 year old boy behind his back; the boy was spared despite being seen by the group of officers. ${ }^{18726}$ The group of police officers left after approximately ten minutes and "disappeared". ${ }^{18727}$

5481. The Chamber finds that, following the fall of Srebrenica, members of the Bosnian Serb Forces killed two Bosnian Muslim males from Srebrenica near the town of Snagovo.

\section{(B) Bišina}

5482. The Indictment refers to the killing on 23 July 1995 of over 30 Bosnian Muslim men in Bišina, some of whom were previously detained in the Sušica camp. ${ }^{18728}$ Bišina is located in eastern $\mathrm{BiH}$ in Šekovići municipality, approximately 70 kilometres northwest of the town of Srebrenica. ${ }^{18729}$

5483. On the morning of 23 July 1995, a Drina Corps soldier was ordered by Momo AmovićChief of the Drina Corps Administrative Section-to drive a minibus to Dragaševac, collect some men, and deliver them to the Birač Brigade. ${ }^{18730}$ As instructed, he retrieved approximately five

18724 KDZ365, P325 (Transcript from Prosecutor v. Popović et al.), T. 4231 (under seal); KDZ365, P326 (Transcript from Prosecutor v. Popović et al.), T. 4112, 4171-4172. See also P4949 (Zvornik CJB dispatch, 14 July 1995) (referring to the presence of "[o]ne company of the Doboj CJP PJP in coordination with the Janja SOP platoon" blocking enemy forces in the village of Maričići); P316 (Report of Zvornik CJB to MUP of RS, 15 July 1995) (referring to "[t]wo PJP companies from Bijeljina, one company from Doboj, and one platoon of the Zvornik Company" fighting along the Zlijebac-Zlatne Vode-Kula Grade-Maričići line).

18725 KDZ365, P326 (Transcript from Prosecutor v. Popović et al.), T. 4114-4115, 4171. KDZ365 further testified that he was told that this individual may have been from Zvornik, adding that he had a band tied around his head, but had no visible insignia on his military uniform, and otherwise wore the same uniform as the members of the Ugljevik PJP unit. KDZ365, P326 (Transcript from Prosecutor v. Popović et al.), T. 4114, 4171-4173.

18726 [REDACTED].

18727 KDZ365, P326 (Transcript from Prosecutor v. Popović et al.), T. 4179; KDZ365, P325 (Transcript from Prosecutor v. Popović et al.), T. 4231 (under seal).

18728 Indictment, Scheduled Killing Incident E.12.1. In its final brief, the Prosecution submits that "at least 39" Bosnian Muslim men were killed in Bišina. Prosecution Final Brief, Appendix D, para. 155.

18729 P727 (Map of the Balkans). See also D484 (Map of BiH); P33 (Map of Central Bosnia marked by KDZ446).

18730 KDZ285, P370 (Transcript from Prosecutor v. Popović et al.), T. 32782, 32786. 
soldiers from the $10^{\text {th }}$ Sabotage Detachment in Dragaševac. ${ }^{18731}$ On the way back, the soldiers told him to proceed to Bišina instead. ${ }^{18732}$

5484. Meanwhile, three members of the Drina Corps MP Battalion were ordered by their Commander, Ratko Vujović, to drive a truck to pick up Bosnian Muslim detainees from Sušica Camp for a prisoner exchange. ${ }^{18733}$ Upon retrieving these detainees, they were joined by another truck and passenger vehicle and set out for Šekovići in a convoy. ${ }^{18734}$

5485. The convoy stopped near a restaurant between Tišća and Šekovići, where a few more detainees were loaded onto one of the trucks. ${ }^{18735}$ At this point, the minibus transporting the $10^{\text {th }}$ Sabotage Detachment soldiers joined the convoy, which proceeded in a column to Bišina. ${ }^{18736}$

5486. Led by Popović's vehicle, this larger convoy-consisting of two trucks, one additional passenger vehicle, and the minibus—stopped in Bišina near the Command of one of the Birač Brigade's battalions. ${ }^{18737}$ One of the soldiers from the $10^{\text {th }}$ Sabotage Detachment ordered the three members of the Drina Corps MP Battalion to provide security around the trucks. ${ }^{18738}$ Popović had a brief conversation with the five soldiers, ${ }^{18739}$ who proceeded to remove five detainees from the trucks, march them approximately 30 metres away, and shoot them. ${ }^{18740}$ This process was repeated a number of times. ${ }^{18741}$ Popović saw approximately thirty bodies scattered all around. ${ }^{18742}$ One of

18731 KDZ285, P371 (Transcript from Prosecutor v. Popović et al.), T. 32782-32785, 32788, 32790-32793; P663 (Vehicle log, 18 July 1995); KDZ285, P370 (Transcript from Prosecutor v. Popović et al.), T. 32781 (under seal). See also KDZ391, P4761 (Transcript from Prosecutor v. Popović et al.), T. 32580-32581. (under seal). KDZ285 testified that they were masked and in overalls of different colours; some of the men wore camouflage uniforms and they were armed with automatic rifles, and several of these five individuals bore the insignia of the $10^{\text {th }}$ Sabotage Detachment. KDZ285, P371 (Transcript from Prosecutor v. Popović), T. 32784, 32788. See also KDZ391, P4761 (Transcript from Prosecutor v. Popović et al.), T. 32575 (under seal); KDZ391, T. 26907 (26 March 2012) (closed session) (confirming that the five soldiers, who were present at the killing site, had the insignia of the $10^{\text {th }}$ Sabotage Detachment, wearing various sorts of clothes and hats). 
the three MP Battalion members asked Popović, the most senior officer present, what had happened; Popović did not respond and had tears in his eyes. ${ }^{18743}$

5487. An excavator subsequently arrived at the site and dug a hole. ${ }^{18744}$ Upon Popović's request, two of the MP Battalion members assisted in placing the bodies into the hole. ${ }^{18745}$

5488. The Chamber notes that Popović testified in this case that he was only present at Bišina after the killings took place, denying the Prosecution's allegation that he was in charge of the killings there. ${ }^{18746}$ Popović also asserted that had he participated in the killings, he would have relocated the bodies later to hide them, but that he did not. ${ }^{18747}$ However, the Chamber finds Popović's testimony unconvincing in light of other accepted evidence before it. The evidence clearly demonstrates that Popović was present at the time of the killings, when one of the MP Battalion members saw and spoke to him. ${ }^{18748}$ Furthermore, the vehicle log for the minibus used to transport the $10^{\text {th }}$ Sabotage Detachment soldiers on 23 July 1995 contains Popović's name and signature. ${ }^{18749}$ The Chamber further notes that intercepted conversations from 24 July 1995 indicate that Popović knew the whereabouts of Himzo Mujić-one of the victims identified from a

killings lasted approximately three to five hours. KDZ285, P371 (Transcript from Prosecutor v. Popović et al.), T. 32789.

18742 D3993 (Witness statement of Vujadin Popović dated 2 November 2013) para. 88; Vujadin Popović, T. 43109, 43127 (6 November 2013). See also KDZ391, T. 26907 (26 March 2012) (closed session); P4765 (Vehicle log, 19 July to 1 August 1995) (under seal) (indicating that 15 individuals were transported by that truck on 23 July 1995).

18743 KDZ391, P4761 (Transcript from Prosecutor v. Popović et al.), T. 32573-32575, 32585, 32598 (under seal); KDZ391, T. 26909 (26 March 2012) (closed session). See also D3993 (Witness statement of Vujadin Popović dated 2 November 2013), para. 88 (stating that he was shaken by seeing the bodies and that he had hoped that these detainees might be exchanged for his cousin). Vujadin Popović, T. 43112 (6 November 2013) (private session); Vujadin Popović, T. 42135 (6 November 2013).

18744 KDZ391, P4761 (Transcript from Prosecutor v. Popović et al.), T. 32574 (under seal); Vujadin Popović, T. 43128 (6 November 2013).

18745 Vujadin Popović, T. 43112 (6 November 2013) (private session); Vujadin Popović, T. 43125, 43127, 43129 (6 November 2013); KDZ391, P4761 (Transcript from Prosecutor v. Popović et al.), p. 41 (under seal).

18746 Vujadin Popović, T. 43109-43110, 43122 (6 November 2013), T. 43110-43112 (6 November 2013) (private session). See also D3993 (Witness statement of Vujadin Popović dated 2 November 2013), paras. 85-88 (stating that on the morning of 23 July 1995, at the Drina Corps Command, a duty officer told him that two unknown men had arrived at the command and said that they were ordered to take the detainees who were in Sušica camp; the duty officer told him that the men had taken a van from the Command, and that one of them had said that the detainees would be taken to Bišina; Popović headed for Bišina right away and at a new VRS barracks, he was shown the road "those vehicles had taken"); Vujadin Popović, T. 43116 (6 November 2013).

18747 Vujadin Popović, T. 43112 (6 November 2013) (private session); Vujadin Popović, T. 43113-43114, 4312543126, 43128-43129, 43133-43134, 43136 (6 November 2013).

18748 See para. 5486.

18749 P663 (Vehicle log, 18 July 1995). KDZ285 testified that he himself had written "Popović" beside the 23 July 1995 entry as he had been told by his commander that Popović was in charge. KDZ285, P371 (Transcript from Prosecutor v. Popović et al), T. 32792-32797. But see Vujadin Popović, T. 43114-43115, 43122 (6 November 2013) (testifying that he had just signed for all operations of the minibus to justify the use of fuel). 
grave in Bišina ${ }^{18750}$ - and what happened to him. ${ }^{18751}$ The Chamber therefore concludes that

Popović was present at the scene and oversaw the killings at Bišina.

5489. Between 20 May and 7 June 2006, the BiHCMP exhumed a grave in the area of Bišina. ${ }^{18752}$ Based upon DNA analysis, 39 individuals were positively identified as persons listed as missing following the take-over of Srebrenica, ${ }^{18753} 18$ of whom had their wrists ligature-bound, and four of whom were blindfolded. ${ }^{18754}$ One of the bodies in the mass grave was identified by the ICMP as Himzo Mujić. ${ }^{18755}$

$18750 \quad$ See para. 5489, fn. 18755.

18751 P6695 (Intercept of conversation between two unidentified persons from VRS, 24 July 1995) (in which one unidentified speaker says that he could not reach "Kane", told the other unidentified speaker that "Himzo Mujić" was no longer in prison, and that Kane should call Popović as he is "the only one who knows where [Mujić] went from here and what happened to him"); P5391 (Intercept of conversation between two unidentified persons, 24 July 1995); P6499 (Intercept from Notebook 96, 24 July 1995) (in which "Kane" told an unidentified speaker that Himzo Mujić was "here at our place, I don't know if he still is", to which the other speaker responded that: "Check that down there, you know? Maybe Popović, the security guy [...]").

18752 P4772 (Dušan Janc's report entitled "Update to the summary of Forensic Evidence - Exhumation of the Graves and Surface Remains Recoveries related to Srebrenica - January 2012”, 13 January 2012), e-court p. 32

18753 P5917 (ICMP DNA identifications concerning identified victims related to Srebrenica); P4771 (Dušan Janc's report entitled "Update to the summary of Forensic Evidence - Exhumation of the Graves and Surface Remains Recoveries related to Srebrenica - January 2012”, 13 January 2012), e-court pp. 404-406 (under seal). See also D3893 (Dušan Dunjić's expert report entitled "Forensic Analysis of Reports on the Locations of Mass Graves in the Area of Eastern Bosnia and Documentation Relating to Exhumations in the Srebrenica Area", 27 August 2009), pp. 58-100.

18754 P4772 (Dušan Janc's report entitled "Update to the summary of Forensic Evidence - Exhumation of the Graves and Surface Remains Recoveries related to Srebrenica - January 2012”, 13 January 2012), e-court pp. 4, 32.

18755 P4672 (University Clinical Centre of Tuzla record of identification for Himzo Mujić, 22 February 2007); Dušan Janc, T. 26995-26996 (27 March 2012) (private session), T. 26997 (27 March 2012); P4771 (Dušan Janc's report entitled "Update to the summary of Forensic Evidence - Exhumation of the Graves and Surface Remains Recoveries related to Srebrenica - January 2012", 13 January 2012), e-court p. 406 (under seal). See also P4642 (ICMP list of identified Srebrenica victims, 15 December 2011) (under seal), entailing ID numbers BIŠ01ŠEK038 and BIŠ01ŠEK040B ( $\mathrm{z}$ max 2). The Chamber notes that mortal remains with ID numbers BIŠ01ŠEK038 and BIŠ01ŠEK040B ( $\mathrm{z} \max 2$ ) were identified as those of Himzo Mujić and those with ID numbers BIŠ01ŠEK040B (F) and BIŠ01ŠEK040B ( $\mathrm{z} \max 1)$ were identified as those of Ramo Ahmetović. In this respect, defence witness Dušan Dunjić challenges the identifications of these victims based on exhumation and autopsy records. In particular, Dunjić notes that one of the two DNA samples from the Bišina gravesite which were used to confirm the identity of Himzo Mujić-BIŠ01ŠEK040B (z max 2)-was, according to ICMP data, part of the separate, complete body-BIŠ01ŠEK040B-of Ramo Ahmetović. Dunjić suggests that this sample could not possibly belong to Mujić and, accordingly, the matching profiles of Mujić and Ahmetović are inconsistent and flawed. D3896 (Dušan Dunjić's expert report entitled "Forensic Analysis of Exhumation Reports from the Bišina Site and Documents Relating to the Update to the Summary of Forensic Evidence from Graves in the Srebrenica Area", April 2009), pp. 3-6; D3893 (Dušan Dunjić's expert report entitled "Forensic Analysis of Reports on the Locations of Mass Graves in the Area of Eastern Bosnia and Documentation Relating to Exhumations in the Srebrenica Area", 27 August 2009), pp. 101-102. The Chamber is not persuaded by this analysis. Thomas Parsons has explained that individual ICMP samples do not always correspond with complete bodies. In Parsons' opinion, the pathologist recorded the number 040 with respect to both samples as there was some doubt as to whether the entire body came from a single person, and the pathologist thought it possible that the two samples were related to each other; however, the ICMP ultimately concluded that the two samples (040 B and 040 B (Zamax 2)) were not related to the same individual. Thomas Parsons, P4636 (Transcript from Prosecutor v. Popović et al), T. 33470-33472 (under seal). Based on this evidence, the Chamber is satisfied with the identifications of these two victims and the methodologies adopted to reach this finding. 
5490. Based on the above, the Chamber finds that 39 Bosnian Muslims from Srebrenica were killed by members of the Bosnian Serb Forces in Bišina on 23 July $1995 .{ }^{18756}$

\section{(C) Trnovo}

5491. The Indictment refers to the killing in late July or early August 1995 of six Bosnian Muslim "men and boys" from Srebrenica near the town of Trnovo. ${ }^{18757}$ Trnovo is located in the southeast of $\mathrm{BiH}$ in the Sarajevo region, approximately 85 kilometres southwest of Srebrenica. ${ }^{18758}$

5492. In 1995, the so-called Scorpions unit was based in Đeletovci, in the then-RSK, ${ }^{18759}$ and was commanded by Slobodan Medić, a.k.a. "Boca". ${ }^{18760}$ It was composed of approximately 250 members, divided in two companies, ${ }^{18761}$ and operated under the authority of the Serbian MUP. ${ }^{18762}$

5493. In early July 1995, before the takeover of Srebrenica, a company of the Scorpions unitcomposed of approximately 150 men divided in three platoons-commanded by Medić was deployed from Đeletovci to Trnovo for a three week operation. ${ }^{18763}$ On the way to Trnovo, the unit entered Serbia, and was escorted by the SDB to the border crossing with $\mathrm{BiH}$, where it continued

18756 The Chamber recalls that while Schedule E.12.1 of the Indictment alleges that the number killed in Bišina is "over 30", the Prosecution Final Brief indicates "at least 39". See fn. 18720. Based on the evidence before it, the Chamber is satisfied beyond reasonable doubt that 39 Bosnian Muslim men were killed in Bišina and considers that this figure lies within the scope of what is alleged in the Indictment.

18757 Indictment, Scheduled Killing Incident E.13.1.

18758 P727 (Map of the Balkans). See also D484 (Map of BiH).

18759 P409 (Witness Statement of KDZ612 dated 17 February 2005), p. 6 (under seal); Slobodan Stojković, P4751 (Transcript from Prosecutor v. Tolimir), T. 8317.

18760 P409 (Witness Statement of KDZ612 dated 17 February 2005), p. 6 (under seal); Slobodan Stojković, P4751 (Transcript from Prosecutor v. Tolimir), T. 8319. Aleksandar Vukov, a.k.a. "Vuk", was the unit's second in command. Slobodan Stojković, P4751 (Transcript from Prosecutor v. Tolimir), T. 8319; P409 (Witness Statement of KDZ612 dated 17 February 2005), p. 8 (under seal).

18761 P409 (Witness Statement of KDZ612 dated 17 February 2005), p. 8 (under seal); Slobodan Stojković, P4751 (Transcript from Prosecutor v. Tolimir), T. 8317, 8319.

18762 KDZ612 stated that, at the time of its establishment, the Scorpions unit was under the JNA command; however, by 1994, it was already under the command of the Serbian SDB and received orders from the SDB, and KDZ612 added that Medic "used to brag about his association with the DB and all the meetings he had with them to receive orders". P409 (Witness Statement of KDZ612 dated 17 February 2005), p. 6 (under seal). KDZ612 further stated that Medić met with Franko Simatović at the headquarters in Đeletovci some time in 1995, and that Medić would go for meetings with Jovica Stanišić; however, according to KDZ612, Milan Milanović, a.k.a. "Mrgud"—who was "some sort of commander of the police"-also served as the intermediary between Medić and the SDB leadership in Belgrade, and Medić boasted that the orders came from Stanišić and Simatović. P409 (Witness Statement of KDZ612 dated 17 February 2005), p. 7 (under seal). Furthermore, KDZ612 testified that the Scorpions wore a badge with a sword to show that they were a SDB unit, and that it was common knowledge that the sword was the insignia of the SDB; once the Scorpions left for Trnovo the badges were replaced with Serbian MUP badges. P409 (Witness Statement of KDZ612 dated 17 February 2005), p. 7 (under seal). See also P2983 (Report of RS MUP's Special Police Brigade, Trnovo Forward Command Post, 1 July 1995); P5153 (Report of RS MUP, 1 July 1995); P5154 (RS MUP summary of information from and its periphery, 30 June 1995) (referring to the "Škorpija detachments" as part of the MUP of Serbia); Christian Nielsen, T. 16315 (7 July 2011).

18763 P409 (Witness Statement of KDZ612 dated 17 February 2005), pp. 9-11 (under seal); P410 (Witness statement of KDZ612 dated 25 May 2005), para. 6 (under seal); Slobodan Stojković, P4751 (Transcript from Prosecutor v. Tolimir), T. 8321 . 
until stopping at Jahorina. ${ }^{18764}$ After a couple of days, all but a few of the Scorpions' members who had arrived in Jahorina left for Trnovo. ${ }^{18765}$ Upon reaching Trnovo, the Scorpions participated in combat operations as part of the joint VRS and MUP forces operating on the Sarajevo front. ${ }^{18766}$ The Chamber recalls that on 10 July 1995, a part of these joint forces was detached and sent to the Srebrenica sector under Borovčanin's command, ${ }^{18767}$ while another part, including the Scorpions unit, stayed behind. ${ }^{18768}$

5494. During the operation in Trnovo, two members of the Scorpions were ordered by Medić to take a bus and a TAM truck and go to Srebrenica to assist in transporting Bosnian Muslim male detainees. ${ }^{18769}$ The Scorpions transported multiple groups of Bosnian Muslim males who had been

18764 P409 (Witness Statement of KDZ612 dated 17 February 2005), p. 10 (under seal); Slobodan Stojković, P4751 (Transcript from Prosecutor v. Tolimir), T. 8323-8325. KDZ612 stated that while at Jahorina, Nikola Koljević visited the Scorpions' command. P409 (Witness Statement of KDZ612 dated 17 February 2005), p. 10 (under seal); P279 (Photograph of Nikola Koljević and Scorpions). See also Slobodan Stojković, P4751 (Transcript from Prosecutor v. Tolimir), T. 8326-8327 (stating that he heard that Medić attended some meetings while in Jahorina but he did not know whom Medić met or what they discussed).

18765 P409 (Witness Statement of KDZ612 dated 17 February 2005), p. 10 (under seal) (stating that "[a]fter three of four days, we were ordered to go to Trnovo"); Slobodan Stojković, P4751 (Transcript from Prosecutor v. Tolimir), T. 8325, 8327-8328 (stating that approximately 120 men left for Trnovo and that approximately six stayed behind "for a day or two" at Jahorina).

18766 P409 (Witness Statement of KDZ612 dated 17 February 2005), pp. 10-11 (under seal). See also Christian Nielsen, T. 16316-16319 (7 July 2011) (stating that the 'Skorpija' present in Trnovo at the time operated as part of a conglomeration of units referred to as the joint forces of RSK MUP, RS MUP, and MUP of Serbia); D2015 (VRS Main Staff Report, 26 June 1995), p. 5 (a report to the Accused, referring to "the enemy [...] carrying out in force reconnaissance along the Trnovo axis", within the SRK's zone of responsibility); P5150 (RS MUP summary of information from and about the front, 26 June 1995) (reporting on developments from the Trnovo front and referring to information received from the SRK); P5154 (RS MUP summary of information from and its periphery, 30 June 1995) (referring to a problem of agreement with the SRK command); P5175 (Report of Trnovo Forward Command Post, July 1995) (a report from the police forces staff at the Trnovo IKM referring to a joint attack by MUP and VRS units, and reporting on an attack on "our defence lines" which resulted in the killing of a member of the Škorpije and the wounding of many others); P2983 (Report of RS MUP's Special Police Brigade, Trnovo Forward Command Post, 1 July 1995) (a report by Borovčanin, which refers to a combat group operating in Trnovo that included "two platoons from each of the Kajman, Plavi and Škorpija detachments (the MUP of Serbia)"); P5166 (Report of RS MUP, 8 July 1995) (a report by Borovčanin referring to offensive operations by RS MUP, RSK MUP, and VRS units in the area); P2992 (Order of RS MUP, 10 July 1995) and P2993 (Order of RS MUP, 10 July 1995) (an order from Kovač for the deployment from the Trnovo front of a mixed company of joint RSK, Serbian, and RS MUP forces). KDZ612 also stated that Arkan's units were present in the area and that during the Trnovo operation, his unit had communication with such units. P409 (Witness Statement of KDZ612 dated 17 February 2005), pp. 10-11 (under seal).

18767 See para. 5021.

18768 P409 (Witness Statement of KDZ612 dated 17 February 2005), pp. 10-11 (under seal) (stating that Medić communicated with the VRS during the Trnovo operation, and that the Scorpions' mission was to distract the $\mathrm{ABiH}$ by simulating an attack on Sarajevo while the VRS regrouped around Srebrenica); Slobodan Stojković; P4751 (Transcript from Prosecutor v. Tolimir), T. 8322 (stating that the Scorpions were to hold the line at Trnovo and were expected to work in co-ordination with the VRS); D2695 (SRK combat report, 19 July 1995) (an SRK report on an enemy attack along the Trnovo axis and referring to MUP units holding positions); P5176 (Report of Trnovo Forward Command Post, 20 July 1995) (referring to a "combined company" composed of an SBP detachment, a PJP squad, and an RSK MUP unit). See also Christian Nielsen, T. 16315-16317 (7 July 2011) (stating that the combat operations in Trnovo in early July 1995 were co-ordinated with the military forces deployed in the area, and that the deployment of military and police units in the area could not have been done without the involvement of both the RS MUP and the VRS leadership, as well as the Accused).

18769 P409 (Witness Statement of KDZ612 dated 17 February 2005), p. 11 (under seal), as amended in P409 (Correction to Witness Statement dated 25 November 2010), p. 1 (under seal). 
detained in Srebrenica. ${ }^{18770}$ At some point, a "final group" of six Bosnian Muslim men from Srebrenica was brought to the Scorpions command post. ${ }^{18771}$ Medić ordered that these men be killed. $^{18772}$ Slobodan Stojković, a member of the Scorpions, was ordered by Medić to film the execution. ${ }^{18773}$

5495. The six men were driven in a truck to an isolated spot four or five kilometres from the command post. ${ }^{18774}$ While in the truck, a member of the Scorpions kicked one of the men in the head. $^{18775}$ The men, whose hands were tied, were unloaded and made to lie on the side of the road, ${ }^{18776}$ while being insulted by some of the eight members of the Scorpions who were present at the side of the road. ${ }^{18777}$ The Bosnian Muslim men were subsequently led into a forest clearing containing two abandoned cottages. ${ }^{18778}$ Four of the men were forced to walk forward one by one and were shot multiple times with automatic rifles by two members of the Scorpions. ${ }^{18779}$ The remaining two men were untied and ordered to carry the dead into the forest. ${ }^{18780}$ These two men

18770 P409 (Witness Statement of KDZ612 dated 17 February 2005), p. 11 (under seal).

18771 KDZ612 stated that "somebody" in the chain of command above Medić knew the Scorpions had a bus and two trucks; Medić gave the bus to "his superior" to be used to transport Muslims from Srebrenica and take them to an unknown location; on the way back, the "drivers" brought back the six men to the Scorpions command in Trnovo. P409 (Witness Statement of KDZ612 dated 17 February 2005), p. 11 (under seal), as amended in P409 (Correction to Witness Statement dated 25 November 2010), p. 1 (under seal). Stojković stated that he did not know anything about the six men until the morning of the execution when he learned that the men were from Srebrenica. Slobodan Stojković, P4751 (Transcript from Prosecutor v. Tolimir), T. 8343, 8362.

18772 Slobodan Stojković, P4751 (Transcript from Prosecutor v. Tolimir), T. 8381; P409 (Witness Statement of KDZ612 dated 17 February 2005), p. 11 (under seal) (stating that Medić singled out his own bodyguards to kill the detainees, issued the orders, and the men were then taken away and killed); D2247 (Supplemental Statement of KDZ612 dated 14 February 2012), para. 3 (under seal) (stating that "someone" told Medić to kill the six men and that Medić, thereafter, ordered members of the unit to kill them).

18773 Slobodan Stojković, P4751 (Transcript from Prosecutor v. Tolimir), T. 8314, 8341-8343, 8381. When the Scorpions unit returned to Đeletovci, ten copies of the video were made and distributed amongst its members, presumably as souvenirs; one copy was made available for rent at a video rental store in Šid, Serbia. KDZ612, P410 (Witness Statement of KDZ612 dated 25 May 2005), para. 9 (under seal); Slobodan Stojković, P4751 (Transcript from Prosecutor v. Tolimir), T. 8382, 8389-8391.

18774 Slobodan Stojković, P4751 (Transcript from Prosecutor v. Tolimir), T. 8351-8352; P668 (Video footage of executions by Scorpions), at 00:05 to 00:47.

18775 P668 (Video footage of executions by Scorpions), at 00:18-00:20; Slobodan Stojković, P4751 (Transcript from Prosecutor v. Tolimir), T. 8361-8262.

18776 P668 (Video footage of executions by Scorpions), at 01:41 to 02:20; Slobodan Stojković, P4751 (Transcript from Prosecutor v. Tolimir), T. 8363. See also P409 (Witness Statement of KDZ612 dated 17 February 2005), p. 15 (under seal).

18777 See P668 (Video footage of executions by Scorpions), at 02:13-04:02. See also Slobodan Stojković, P4751 (Transcript from Prosecutor v. Tolimir), T. 8374-8378; P409 (Witness Statement of KDZ612 dated 17 February 2005), p. 15 (under seal).

18778 P668 (Video footage of executions by Scorpions), at 09:10 to 10:42. See also P409 (Witness Statement of KDZ612 dated 17 February 2005), p. 15 (under seal); P411 (Witness statement of KDZ612 dated 31 May 2005) (under seal), p. 3.

18779 P668 (Video footage of executions by Scorpions) at 10:55 to 11:37. See also P409 (Witness Statement of KDZ612 dated 17 February 2005), p. 15 (under seal).

18780 P668 (Video footage of executions by Scorpions), at 12:15 to 16:21; Slobodan Stojković, P4751 (Transcript from Prosecutor v. Tolimir), T. 8379. See also P409 (Witness Statement of KDZ612 dated 17 February 2005), p. 15 (under seal). 
were then laid on the floor of one of the abandoned houses and shot multiple times with automatic rifles by one of the same individuals who shot the first four detainees. ${ }^{18781}$

5496. The remains of the six men were exhumed in 1999 from the Gođinjske Bare gravesite near Trnovo, and identified by DNA analysis. ${ }^{18782}$ All six men had been reported as missing or dead after the fall of Srebrenica. ${ }^{18783}$

5497. The Chamber finds that, following the fall of Srebrenica, members of the Scorpions killed six Bosnian Muslim males from Srebrenica near the town of Trnovo.

\section{iv. Transfer to Batković Camp}

5498. The Chamber recalls that Batković Camp was established in June 1992 in a location approximately 12 kilometres from Bijeljina, and that VRS soldiers were assigned to secure it throughout the armed conflict in $\mathrm{BiH} .{ }^{18784}$

5499. On 11 or 12 July 1995, Milenko Todorović, the Chief of Security of the Eastern Bosnia Corps, received a telegram from Tolimir which directed the Eastern Bosnia Corps to prepare accommodation at Batković Camp for approximately 1,000 to 1,200 detained Bosnian Muslim soldiers, who were to arrive in the following days. ${ }^{18785}$ Upon receiving this telegram, Todorović immediately conveyed the order to his commander, Novica Simić, who then began preparations for the arrival of the detainees. ${ }^{18786}$ However, the prisoners did not arrive. ${ }^{18787}$ Approximately one day later, at Simić's request, Todorović consulted Tolimir about the whereabouts of the prisoners and was told to halt further preparations for the detainees as the task had been abandoned. ${ }^{18788}$

\footnotetext{
18781 P668 (Video footage of executions by Scorpions) at 16:54 to 18:24. See also P409 (Witness Statement of KDZ612 dated 17 February 2005), p. 15 (under seal).

18782 P4772 (Dušan Janc's report entitled "Update to the summary of Forensic Evidence - Exhumation of the Graves and Surface Remains Recoveries related to Srebrenica - January 2012”, 13 January 2012), e-court p. 38 ; P4771 (Dušan Janc's report entitled "Update to the summary of Forensic Evidence - Exhumation of the Graves and Surface Remains Recoveries related to Srebrenica - January 2012”, 13 January 2012), Annex D, e-court pp. 438-439 (under seal).

18783 Thomas Parsons, T. 26574-26575 (21 March 2012); Thomas Parsons, P4643 (Transcript from Prosecutor v. Popović), T. 20873-20876; P4642 (ICMP list of identified Srebrenica victims, 15 December 2011) (under seal).

18784 Milenko Todorović, D4124 (Transcript from Prosecutor v. Tolimir), T. 12940, 13041. See Scheduled Detention Facility C.2.1.

18785 Milenko Todorović, D4124 (Transcript from Prosecutor v. Tolimir), T. 12933-12934, 12937-12939; D4134 (Excerpt of OTP interview with Milenko Todorović, 2 February 2010), p. 39. See Milenko Todorović, D4124 (Transcript from Prosecutor v. Tolimir), T. 12954-12956; D4126 (Photograph marked by Milenko Todorović, undated).

18786 Milenko Todorović, D4124 (Transcript from Prosecutor v. Tolimir), T. 12934, 12938-12940, 13134.

18787 Milenko Todorović, D4124 (Transcript from Prosecutor v. Tolimir), T. 12941.

18788 Milenko Todorović, T. 44193-44194 (28 November 2013); D4134 (Excerpt of OTP interview with Milenko Todorović, 2 February 2010), pp. 37-38, 40; Milenko Todorović, D4124 (Transcript from Prosecutor v. Tolimir), T. 12942.
} 
5500. Sometime on or after 15 July, Simić called Pandurević and advised him that if he had any detainees in his AOR, he could send them to Batković. ${ }^{18789}$ Pandurević advised that there were members of the Muslim Forces in Srebrenica who were still trying to break through to Tuzla, and that capturing them and transporting them to Batković Camp would not be a problem. ${ }^{18790}$ Pandurević also advised that they already had a number of detainees that needed to be taken over and transported to the camp. ${ }^{18791}$ Following that conversation, Simić advised Todorović to organise, through the MP Battalion, a number of vehicles and soldiers to transport the detainees from the Zvornik area to Batković Camp, and that these soldiers should report to the Zvornik Brigade Command. ${ }^{18792}$

5501. An MP squad of 10 to 15 men went to the Zvornik area on a daily basis from 18 to 26 July 1995 for the purpose of collecting prisoners of war. ${ }^{18793}$ In total, approximately 160 to 180 detainees were taken to Batković Camp in this period. ${ }^{18794}$ Among these were 22 individuals picked up on 18 July by the Eastern Bosnia Corps MP from the Drina Corps MP in Vlasenica, ${ }^{18795}$ as well as 34 Bosnian Muslims from Srebrenica who surrendered in the course of 26 July. ${ }^{18796}$

18789 Milenko Todorović, T. 44193-44194 (28 November 2013); Milenko Todorović, D4124 (Transcript from Prosecutor v. Tolimir), T. 12942-12943; D4134 (Excerpt of OTP interview with Milenko Todorović, 2 February 2010), p. 38. The Chamber notes that Todorović testified that he was not sure of the date of the phone call between Simić and Pandurević. Milenko Todorović, T. 44194 (28 November 2013). It further notes that in his interview with the Prosecution, Todorović said that he believed the phone call occurred the same morning or the day after he consulted Tolimir about the whereabouts of the detainees. D4134 (Excerpt of OTP interview with Milenko Todorović, 2 February 2010), pp. 37-38. However, the Chamber recalls that Pandurević only returned to the Zvornik Brigade by noon on 15 July. See para. 5469. The Chamber therefore finds that the phone call could not have taken place until at least 15 July.

18790 Milenko Todorović, D4124 (Transcript from Prosecutor v. Tolimir), T. 12943; Milenko Todorović, T. 44195 (28 November 2013).

18791 Milenko Todorović, D4124 (Transcript from Prosecutor v. Tolimir), T. 13193-13194.

18792 Milenko Todorović, T. 44195 (28 November 2013); Milenko Todorović, D4124 (Transcript from Prosecutor v. Tolimir), T. 12943, 13191, 13193-13194.

18793 Milenko Todorović, D4124 (Transcript from Prosecutor v. Tolimir), T. 13144-13145, 13150, 13173-13175, 13179, 13191-13192. See also Milenko Todorović, D4124 (Transcript from Prosecutor v. Tolimir), T. 1316813175, 13179-13181 (testifying that entries in the Duty Operations book of the Eastern Bosnia Corps Command for 15 July 1995 reflect that the corps' deputy commander, General Gavrić, ordered 50 members of the MP unit to be sent to Zvornik on 16 July 1995 to help the Zvornik Brigade carry out combat assignments and were resubordinated to Pandurević, and that a squad of 10 to 15 men who had been sent to Zvornik to escort captured POWs remained under the command of the Eastern Bosnia Corps); D4131 (Excerpt of the Eastern Bosnia Corps logbook, 5 March 1995 to 12 June 1996), e-court p. 3.

18794 Milenko Todorović, D4124 (Transcript from Prosecutor v. Tolimir), T. 13145. See D3236 (Witness statement of Gojko Čekić dated 31 March 2013), paras. 13, 21 (testifying that approximately 120 detainees from Srebrenica arrived at Batković Camp in the second half of July 1995); Gojko Čekić, T. 36504-36505, 3650836509 (3 April 2013). According to a list of persons detained at Batković Camp, over 150 detainees from the Srebrenica area were registered from July to December 1995. P3213 (List of persons detained at Batković Camp), e-court pp. 9, 11, 25, 40, 47, 52, 78, 84, 92, 106, 131, 133, 142, 149, 157, 168, 170, 175, 184, 188, 191, 193.

18795 D4132 (Eastern Bosnia Corps list of prisoners, 18 July 1995); Milenko Todorović, D4124 (Transcript from Prosecutor v. Tolimir), T. 13201-13203. The list of persons detained at Batković Camp confirms that all but one of the men named in the Eastern Bosnia Corps list of prisoners were registered at Batković Camp on 18 July 
5502. As stated previously, detainees at Batković Camp were registered with the ICRC, which visited the camp regularly; this continued in 1995. ${ }^{18797}$ The detainees from the Srebrenica area were exchanged from July 1995 to January $1996 .^{18798}$ Soon after, Batković Camp was shut down. ${ }^{18799}$

\section{v. Reburial operation}

5503. The Chamber recalls its previous findings that the bodies of victims of the Scheduled Incidents at the Kravica Warehouse, Orahovac, Petkovci Dam, Kozluk, Branjevo Military Farm, and Pilica Cultural Centre, which had been buried in primary gravesites in the Bratunac and Zvornik areas, were exhumed, transported, and reburied in remote secondary gravesites in September and October 1995. ${ }^{18800}$ The Chamber will discuss the processes in further detail below.

(A) The reburials from the Bratunac area

5504. In September 1995, Popović visited the Bratunac Brigade to convey an order from the Main Staff, stating that an operation involving the exhumation and reburial of bodies from the Glogova gravesites was to be carried out. ${ }^{18801}$ This operation was known as "asanacija" or the sanitation and hygiene measures operation, and Momir Nikolić was tasked with co-ordinating the logistics. ${ }^{18802}$

1995 and the following days. P3213 (List of persons detained at Batković Camp), e-court pp. 9, 52, 78, 106, 131, 168, 175, 184, 188, 191.

18796 D3244 (Drina Corps combat report, 26 July 1995), p. 2; Milenko Todorović, D4124 (Transcript from Prosecutor v. Tolimir), T. 13144. Two survivors of Scheduled Incident E.9.2 arrived at Batković Camp on 26 July, after surrendering to Bosnian Serb Forces. See para. 5437.

18797 See Scheduled Detention Facility C.2.1. See also Milenko Todorović, D4124 (Transcript from Prosecutor v. Tolimir), T. 12958, 12988, 13088; P5125 (VRS Main Staff instructions, 26 July 1995), p. 1.

18798 Milenko Todorović, D4124 (Transcript from Prosecutor v. Tolimir), T. 13147-13149; D3236 (Witness statement of Gojko Čekić dated 31 March 2013), para. 21; P3213 (List of persons detained at Batković Camp), e-court pp. 9, 11, 25, 40, 47, 52, 78, 84, 92, 106, 131, 133, 149, 157, 168, 170, 175, 184, 188, 191, 193. See also KDZ333, T. 24162 (2 February 2012); KDZ333, P4342 (Transcript from Prosecutor v. Krstić), T. 3046; Ahmo Hasić, P354 (Transcript from Prosecutor v. Popović et al.), T. 1214-1215; Ahmo Hasić, P353 (Transcript from Prosecutor v. Popović et al.), T. 1230 (under seal); D2052 (Statement of KDZ333 to State Commission on Gathering Facts on War Crimes, 20 July 1996), p. 5 (under seal).

18799 See Scheduled Detention Facility C.2.1.

18800 See paras. 5264, 5267, 5352, 5380, 5411, 5461. See also P4512 (Photograph booklet entitled "Srebrenica Mass Graves - Primary and Secondary Mass Grave Aerial Imagery"), e-court p. 7; Adjudicated Facts 1864, 1872.

18801 Momir Nikolić, T. 24688 (14 February 2012); D2081 (Momir Nikolić's statement of facts from Plea Agreement, 7 May 2003), para. 13. See also Petar Salapura, T. 40283 (24 June 2013); Adjudicated Facts 1865, 1872. But see Vujadin Popović, T. 43113-43114 (6 November 2013) (denying having personally participated in the reburial operation, and adding that he merely kept tabs on the use of fuel and was not aware of the location of the secondary gravesites, as the reburial operation was "some sort of secret").

18802 Momir Nikolić, T. 24688, 24693 (14 February 2012); D2081 (Momir Nikolić’s statement of facts from Plea Agreement, 7 May 2003), para. 13. See Adjudicated Fact 1868. 
5505. Drivers, vehicles, and machinery from civilian companies, as well as members of the Bratunac Civilian Protection, were utilised in the reburial operation. ${ }^{18803}$ A number of meetings were held at the Bratunac municipal building, where Deronjić communicated with local companies so that part of the "non-military related tasks" could be carried out. ${ }^{18804}$ Specifically, around midOctober, Deronjić requested workers from the Bratunac Civilian Protection and ordered that they should report to Momir Nikolić that evening. ${ }^{18805}$ The workers were dropped off in front of the Bratunac Brigade Command between 9 and 10 p.m. ${ }^{18806}$

5506. The reburial operation took place over the course of several nights. ${ }^{18807}$ The $5^{\text {th }}$ Engineering Battalion provided some of the machinery and fuel for the operation. ${ }^{18808}$ Members of the Bratunac Brigade MP and the Bratunac SJB secured the Bratunac-Konjević Polje and Bratunac-Ljubovija Roads, and diverted traffic to other routes so that the trucks transporting the bodies from Glogova through Bratunac town, in the direction of Srebrenica, could pass unhindered. ${ }^{18809}$ A stench that could be smelled throughout Bratunac town emanated from the bodies as they were being transported. ${ }^{18810}$ Though intended to be a secret operation, the operation ceased to be covert due to the number of participants involved. ${ }^{18811}$

5507. Aerial images show a front loader at the Glogova gravesites and indicate that earth was disturbed on or before 30 October 1995. ${ }^{18812}$ Additional aerial images indicate that earth was disturbed at six locations along the Zeleni Jadar Road between 24 August and 23 October 1995, and that these secondary graves were backfilled in late October $1995 .{ }^{18813}$ Further, the Chamber has

\footnotetext{
18803 Momir Nikolić, T. 24689 (14 February 2012). These companies included the Rad Utilities Company, the stateowned bricks company in Bratunac, the Radnik construction company, the Sase mine, and the Autoprevoz company from Srebrenica. Momir Nikolić, T. 24689 (14 February 2012).

18804 Momir Nikolić, T. 24690 (14 February 2012).

18805 [REDACTED]. See Momir Nikolić, T. 24691-24693 (14 February 2012); P4391 (Report on meeting of Bratunac Brigade, 16 October 1995).

18806 [REDACTED]. When asked about the nature of the task, Momir Nikolić stated that it would be "the same thing they did recently". [REDACTED].

18807 [REDACTED]. See also Momir Nikolić, T. 24690 (14 February 2012).

18808 Momir Nikolić, T. 24689-24690 (14 February 2012).

18809 Momir Nikolić, T. 24689 (14 February 2012); KW582, D4291 (Transcript from Prosecutor v. Blagojević \& Jokić), T. 3582-3583. See also P407 (Witness statement of Desmir Đukanović dated 20 March 2007), para. 7 (stating that while waiting at a bus station in September, he saw trucks transporting bodies from Glogova in the direction of Srebrenica at night).

18810 P407 (Witness statement of Desmir Đukanović dated 20 March 2007), para. 7; KW582, D4291 (Transcript from Prosecutor v. Blagojević \& Jokić), T. 3582-3583.

18811 Momir Nikolić, T. 24690 (14 February 2012); Damjan Lazarević, P352 (Transcript from Prosecutor v. Popović et al.), T. 14511. Milenko Katanić testified that civilians were aware of bodies being relocated from Glogova and speculated that the trucks driving through the town were carrying bodies. P4374 (Witness statement of Milenko Katanić dated 11 October 2011), para. 98; Milenko Katanić, T. 24547 (10 February 2012) (private session). See also Mile Petrović, T. 45566 (17 January 2014).

18812 See para. 5252.

18813 See para. 5260.
} 
already noted forensic evidence establishing links between the two primary gravesites at Glogova, and the secondary gravesites at Zeleni Jadar, Budak, Blječeva, and Zalažje. ${ }^{18814}$

(B) The reburials from the Zvornik area

5508. On 14 September 1995, the Main Staff sent an urgent order signed by Mladić to the Drina Corps command approving five tonnes of D-2 diesel to be delivered to Trbić at the Standard Barracks. ${ }^{18815}$ Pursuant to Mladić's order, Žarko Ljuboječić of the Main Staff's Sector for Logistics directed the command of the $35^{\text {th }}$ Logistics Base to issue 5,000 litres of D-2 diesel, and requested that a Drina Corps representative collect the fuel and provide transportation for its delivery. ${ }^{18816}$ [REDACTED]. ${ }^{18817}$ [REDACTED ]. ${ }^{18818}$

5509. On 15 September, [REDACTED], Pandurević went the Drina Corps command to look into the issue. ${ }^{18819}$ [REDACTED]. ${ }^{18820}$

5510. One day in September, Damjan Lazarević received a call from Bogičević, who ordered him to report to the Standard Barracks. ${ }^{18821}$ Lazarević was then ordered by Bogičević and Jokić to oversee an operation, which involved exhuming bodies from primary gravesites and transporting them to new graves using Zvornik Brigade equipment. ${ }^{18822}$ Lazarević was given a list of namesincluding three operators from the Engineering Company and members of other units of the Zvornik Brigade-who would assist in the operation. ${ }^{18823}$

\footnotetext{
18814 See paras. 5264-5265, 5267.

18815 P4592 (VRS Main Staff Order, 14 September 1995); KDZ122, T. 26200-26202 (13 March 2012) (closed session); P4563 (Statement by KDZ122), p. 7 (under seal). See also Adjudicated Fact 1870. The Chamber notes that P4592 refers to Captain Milorad "Trpić", but is satisfied that this is a typographical error and that the order in fact refers to Milorad Trbić. See KDZ122, T. 26200 (13 March 2012) (closed session).

18816 P4593 (VRS Main Staff Order, 14 September 1995); [REDACTED]. According to P4992 and P4993, the fuel approved by the VRS Main Staff was to be used for "engineering works" in the Drina Corps area of responsibility. See P4592 (VRS Main Staff Order, 14 September 1995); P4593 (VRS Main Staff Order, 14 September 1995).

18817 [REDACTED].

18818 [REDACTED].

18819 [REDACTED].

18820 [REDACTED]. Popović's involvement in overseeing the reburial operation is further evidenced by an intercepted conversation between Popović and "Mihalić" at 6:44 p.m., where Popović inquired if the fuel had arrived. Popović then asked Mihalić if Trbić was "there somewhere". Mihalić replied that Trbić had left, to which Popović responded "he is working on that, right?" P5360 (Intercept of conversation between Lt. Col. Vujadin Popović and Mihalić, 22 September 1995). [REDACTED]. But see Vujadin Popović, T. 43113-43114 (6 November 2013) (testifying that he did not directly participate in the reburial operation and that he merely "kept tabs on the use of fuel").

18821 Damjan Lazarević, P352 (Transcript from Prosecutor v. Popović et al.), T. 14468, 14525.

18822 Damjan Lazarević, P352 (Transcript from Prosecutor v. Popović et al.), T. 14467-14469, 14522-14523.

18823 Damjan Lazarević, P352 (Transcript from Prosecutor v. Popović et al.), T. 14468, 14484-14485, $14522-14523$.
} 
5511. Machine operators belonging to the Zvornik Brigade Engineering Company and other members of the Zvornik Brigade reopened the primary gravesites. ${ }^{18824}$ Heavy duty tipper trucks driven by civilians and belonging to the Zvornik Brigade and various private companies transported the bodies. ${ }^{18825}$ The reburial operation in Zvornik was conducted over a period of five or six nights. ${ }^{18826}$ Drago Nikolić and the Zvornik Brigade MP provided traffic security. ${ }^{18827}$ Throughout this time, Trbić co-ordinated the operation, and periodically summoned the personnel involved in the reburials, inquiring about the progress of the operation. ${ }^{18828}$

5512. Aerial images reveal the emergence of disturbed earth at the Lažete, Petkovci Dam, Kozluk, and Branjevo Military Farm gravesites between 7 and 27 September $1995 .{ }^{18829}$ Additional aerial images indicate disturbed earth along the Hodžići, Snagovo-Liplje, and Čančari Roads between 7 September and 2 October $1995 .{ }^{18830}$ Further, the Chamber has already noted forensic evidence establishing links between the Lažete primary gravesites and seven secondary gravesites located along the Hodžići Road, the primary gravesites at Petkovci Dam and five secondary gravesites along the Liplje Road, the primary gravesites at Kozluk and five secondary gravesites along the Čančari Road, as well as the primary gravesite at the Branjevo Military Farm and nine gravesites located along the Čančari Road. ${ }^{18831}$

\section{(C) Conclusion}

5513. On the basis of this evidence, the Chamber finds that between September and October 1995, the VRS Main Staff organised the reburial of bodies of individuals killed within the respective AORs of the Bratunac and Zvornik Brigades in July 1995. The bodies were exhumed from their original graves and reburied in remote secondary graves. The reburial operation was carried out by members of the security organs of the Main Staff, Drina Corps, Bratunac Brigade, and Zvornik Brigade, with the assistance of Bosnian Serb civilian authorities and other VRS and MUP units.

\footnotetext{
18824 Damjan Lazarević, P352 (Transcript from Prosecutor v. Popović et al.), T. 14467-14469, 14484-14485. The smell emanating from the bodies was "unbearable" and machine operators took breaks from the task in order to get fresh air. Damjan Lazarević, P352 (Transcript from Prosecutor v. Popović et al.), T. 14485, 14487.

Damjan Lazarević, P352 (Transcript from Prosecutor v. Popović et al.), T. 14484-14485, 14527-14528. Lazarević testified that he was not aware of where the exhumed bodies were reburied, as members of the Engineering Company had not been tasked with the reburials. Damjan Lazarević, P352 (Transcript from Prosecutor v. Popović et al.), T. 14469, 14485-14486, 14509.

18826 Damjan Lazarević, P352 (Transcript from Prosecutor v. Popović et al.), T. 14486, 14510. See also Richard Butler, T. 27632-27633 (18 April 2012).

18827 Adjudicated Fact 1871. See P4563 (Statement by KDZ122), p. 8 (under seal).

18828 Damjan Lazarević, P352 (Transcript from Prosecutor v. Popović et al.), T. 14487-14490. Trbić also contacted Lazarević personally for an update on the reburial operation. Damjan Lazarević, P352 (Transcript from Prosecutor v. Popović et al.), T. 14507-14508.

18829 See paras. 5340, 5375, 5404, 5453.

18830 See paras. 5351, 5379, 5410, 5460.

18831 See paras. 5351-5352, 5380, 5411, 5461.
} 
5514. The Chamber further finds that the reburial operation was triggered by the discovery by the international community of the existence of mass gravesites in Srebrenica following Albright's address to the Security Council in August 1995, and was conducted for the purpose of hiding the evidence of the mass executions that took place in July 1995 in Srebrenica. ${ }^{18832}$

h. Forensic, demographic, and DNA evidence

(A) Introduction

5515. The number of victims killed during the events in Srebrenica in July 1995, as alleged in the Indictment, is a highly contested matter in this case.

5516. The Prosecution asserts that "over 7,000 Bosnian Muslim men and boys" were killed following the fall of Srebrenica in July $1995 .{ }^{18833}$ It supports this assertion by pointing to the 5,850 bodies identified in Srebrenica-related graves as of January 2012, ${ }^{18834}$ and to demographic evidence suggesting that 7,905 people went missing after the fall of Srebrenica. ${ }^{18835}$

5517. The Accused contests the Prosecution's calculation of the number of individuals executed after the fall of Srebrenica, asserting that there is absolutely no reliable evidence to suggest that the Bosnian Serbs captured anywhere close to that many prisoners. ${ }^{18836} \mathrm{He}$ adds that the total number of executed persons cannot exceed the difference between the population of Srebrenica before its fall and the number of people from Srebrenica who arrived in Bosnian Muslim-held territory or elsewhere after the fall of Srebrenica. ${ }^{18837}$ The Accused also claims that the Prosecution's argument in relation to the number of people killed is fallacious, as it fails to account for the commingling of the bodies of persons killed in combat with the bodies of those who were

\footnotetext{
18832 See paras. 5450-5451.

18833 Indictment, para. 47(a). See Prosecution Final Brief, Appendix D, paras. 1, 173; Prosecution Closing Argument, T. 47799, 47802 (30 September 2014). The Prosecution explains that this figure is proven by the totality of the evidence, which can be divided in four broad categories: DNA; testimonial evidence of the number of prisoners killed; evidence of the number of prisoners captured; and the demographic evidence of the number of people missing following the fall of Srebrenica. Prosecution Closing Argument, T. 47799 (30 September 2014).

Prosecution Final Brief, Appendix D, paras. 170-171, 173, referencing P4772 (Dušan Janc's report entitled "Update to the summary of Forensic Evidence - Exhumation of the Graves and Surface Remains Recoveries related to Srebrenica - January 2012", 13 January 2012); Prosecution Closing Argument, T. 47799 (30 September 2014). With regard to any discrepancy with numbers previously used, the Prosecution clarifies that the number of bodies identified is constantly increasing as more Srebrenica-related gravesites are exhumed. Prosecution Final Brief, Appendix D, para. 173; Prosecution Closing Argument, T. 47799 (30 September 2014).

18835 Prosecution Final Brief, Appendix D, paras. 172-173, referencing P4995 (Ewa Tabeau's expert report entitled "The 2009 Integrated Report on Srebrenica Missing Including a Progress Report on DNA-based Identification", 9 April 2009), pp. 28-29; P5005 (2012 ICMP updated list of Srebrenica missing) (under seal); and P5004 (Ewa Tabeau's report describing integration of new 2012 ICMP update to 2009 list of Srebrenica Missing persons).

18837 See Defence Final Brief, paras. 2522-2530.
} 
executed. ${ }^{18838}$ While the Accused concludes that approximately 4,000 persons may be considered as unaccounted for after the fall of Srebrenica, ${ }^{18839}$ he claims that many of those died from mines, suicides, as a result of "legitimate combat activities", or in the aftermath of the mutiny at the Kravica Warehouse. ${ }^{18840}$ He therefore urges the Chamber not to make a determination as to the total number of persons executed after the fall of Srebrenica, as this determination, according to the Accused, cannot be made beyond reasonable doubt. ${ }^{18841}$

5518. The Prosecution responds by stating that the Accused's arguments on the number of Bosnian Muslim men executed in Srebrenica fail to consider the totality of the evidence in this case, which includes evidence of witnesses, intercepts, and other documents corroborated by forensic and demographic evidence. ${ }^{18842}$ The Prosecution adds that the Accused has examined the forensic and demographic evidence in isolation, and that his argument that the number of Srebrenica victims cannot be determined is confused and speculative, and is not supported by the evidence in this case. ${ }^{18843}$

5519. In earlier sections of this Judgement, the Chamber has considered the evidence surrounding the Incidents in Schedule $\mathrm{E}$ of the Indictment and has found that at least 5,115 men were killed by members of the Bosnian Serb Forces in July 1995 in Srebrenica. ${ }^{18844}$ This figure is the result of the Chamber's thorough analysis of the forensic, demographic, and DNA-related evidence admitted in this case.

5520. Specifically, the Chamber received the evidence of several experts who participated in the exhumation of the various gravesites associated with the Srebrenica killings, namely anthropologists José Pablo Baraybar, ${ }^{18845}$ William Haglund, ${ }^{18846}$ Freddy Peccerelli, ${ }^{18847}$ and Richard

\footnotetext{
18838 See Defence Final Brief, para. 2519.

18839 Defence Final Brief, paras. 2530, 2559.

18840 Defence Final Brief, paras. 2548-2572.

18841 Defence Final Brief, paras. 2520, 2702.

18842 Prosecution Closing Argument, T. 47794-47795 (30 September 2014).

18843 Prosecution Closing Argument, T. 47795 (30 September 2014).
}

18844 The Chamber reached this total number of victims of the Schedule E Incidents by adding the following numbers: 15 Bosnian Muslim men killed at the Jadar River; 755 Bosnian Muslim men killed at the Kravica Warehouse; ten Bosnian Muslim men killed at the Sandići Meadow; 21 Bosnian Muslim men killed at the Luke School; 841 Bosnian Muslim men killed at Orahovac; 815 Bosnian Muslim men killed at Petkovci; 815 Bosnian Muslim men killed at Ročević School and Kozluk; 1,735 Bosnian Muslim men killed at the Kula School, the Branjevo Military Farm, and the Pilica Cultural Centre; two Bosnian Muslim men killed at Snagovo; 39 Bosnian Muslim men killed at Bišina; six Bosnian Muslim men killed at Trnovo; ten Bosnian Muslim men killed at Potočari; and 51 Bosnian Muslim men killed at Bratunac Town. See paras. 5141, 5145, 5154, 5205, 5286, 5291, 5303, 5306, 5354, 5382, 5413, 5464, 5481, 5490, 5497.

18845 P4038 (Jose Baraybar's curriculum vitae). Jose Baraybar gave evidence on the exhumations at Kozluk, Čančari Road, Glogova, Zeleni Jadar, Lažete, Hodžići Road, Pilica (Branjevo Military Farm), and Ravnice. P4030 (Jose Baraybar's expert report entitled "Report on the Anthropology Examination of Human Remains from Eastern Bosnia in 1999”, 8 December 1999); P4033 (Jose Baraybar's expert report entitled "Report on Excavations at 
Wright, ${ }^{18848}$ as well as forensic pathologists John Clark ${ }^{18849}$ and Christopher Lawrence. ${ }^{18850}$ Additionally, the Chamber received evidence from other Prosecution witnesses, namely Thomas Parsons, Ewa Tabeau, Dean Manning, Jean-René Ruez, and Dušan Janc, which was used, as appropriate, in determining the number of Bosnian Muslim men killed as a result of the events described for each Scheduled Incident.

5521. Finally, the Chamber received evidence from Dušan Dunjić, a "forensic medical officer", and Stevo Pašalić, a professor in demography and social geography, who testified as Defence witnesses and challenged the evidence of the Prosecution witnesses. ${ }^{1885}$ Dunjić prepared two reports for this case. In the first one-which was admitted into evidence as D3893- he reviewed and analysed, inter alia, exhumation and autopsy records from a number of Srebrenica-related

Glogova 2, BiH 1999-2001"); P4034 (Jose Baraybar's expert report entitled "Report on the Exhumation of Mass Gravesites in Eastern Bosnia, August-October 1999”, 8 December 1999); P4035 (Jose Baraybar's expert report entitled "Report on Excavations at the Site of Zeleni Jadar 6, BiH 2001"); P4036 (Jose Baraybar's expert report entitled "Report on the Anthropology Examination of Human Remains from Eastern Bosnia in 2000", 2 February 2001).

18846 P4309 (Dr. William Haglund's curriculum vitae). William Haglund led the exhumations at Cerska Valley, Lažete, and the Branjevo Military Farm. P4311 (William Haglund's expert report, entitled "Forensic Investigation of the Cerska Grave Site - Volume I", 15 June 1998); P4316 (William Haglund's expert report, entitled "Forensic Investigation of the Lazete 2 Grave Site - Volume I", 15 June1998); P4321 (William Haglund's expert report, entitled "Forensic Investigation of the Pilica (Branjevo Farm) Grave Site - Volume I", 15 June 1998).

18847 P4134 (Fredy Peccerelli's 2007 curriculum vitae). Fredy Peccerelli worked on the exhumations at Lažete. P4135 (Fredy Peccerelli report entitled "Lažete 1, Bosnia and Herzegovina, Excavation and Exhumation Report", 2 February 2001); P4136 (Final Report of Fredy Peccerelli entitled "Lažete 2 (LZ02C), Bosnia and Herzegovina, Excavation and Exhumation report", 1 May 2007).

18848 P3998 (Richard Wright's curriculum vitae). Richard Wright worked on exhumations at Petkovci Dam, Kozluk, Glogova, Liplje, Čančari Road, Hodžići Road, and Zeleni Jadar. P4000 (Richard Wright's expert report entitled "Exhumations in Eastern Bosnia in 1998”, 12 May 1999); P4001 (Richard Wright's expert report entitled "Report on Excavations and Exhumations at Kozluk in 1999: with appendix on visits to Konjević and Potočari", 2 February 2000); P4009 (Richard Wright's expert report entitled "Report on Excavations and Exhumations at the Glogova 1 Mass Grave in 2000", 9 February 2001).

18849 P4102 (Dr. John Clark's curriculum vitae). John Clark worked on remains from Kozluk, Glogova, Lažete, Ravnice, and Zeleni Jadar. P4103 (John Clark's expert report entitled "Report of Chief Pathologist, Srebrenica Grave Sites (1999)", undated); P4104 (John Clark's expert report entitled "Report of the Chief Pathologist, Srebrenica Grave Sites (2000)", 24 February 2001); P4105 (John Clark's expert report entitled "Report of the Chief Pathologist, Srebrenica Grave Sites (2001)", 24 May 2003).

18850 P4063 (Dr. Christopher Lawrence's curriculum vitae). Christopher Lawrence worked on remains from Petkovci Dam, Čančari Road, Hodžići Road, Zeleni Jadar, and Liplje. P4053 (Christopher Lawrence's expert report entitled "Report on Autopsies of Human Remains from the Dam Site June 1998", 17 June 1999); P4054 (Christopher Lawrence's expert report entitled "Report on Autopsies of Human Remains from Čančari Road Site 12, August 1998", 17 June 1999); P4055 (Christopher Lawrence's expert report entitled "Report on Autopsies of Human Remains from Čančari Road Site 3, August-September 1998”, 17 June 1999); P4056 (Christopher Lawrence's expert report entitled "Report on Autopsies of Human Remains from Hodžići Road Site 3, October 1998", 17 June 1999); P4057 (Christopher Lawrence's expert report entitled "Report on Autopsies of Human Remains from Hodžići Road Site 4, October 1998”, 17 June 1999); P4058 (Christopher Lawrence's expert report entitled "Report on Autopsies of Human Remains from Hodžići Road Site 5, October 1998”, 17 June 1999); P4059 (Christopher Lawrence's expert report entitled "Report on Autopsies of Human Remains from Zeleni Jadar Site 5, October 1998”, 17 June 1999); P4060 (Christopher Lawrence's expert report entitled "Report on Autopsies of Human Remains from Liplje Site 2, October 1998", 17 June 1999).

18851 Dušan Dunjić, T. 41728 (22 July 2013); Stevo Pašalić, T. 35344 (13 March 2013); D3124 (Stevo Pašalić’s curriculum vitae), e-court p. 1. 
gravesites, as well as reports prepared by Haglund, Clark, Wright, Lawrence, Peccerelli, and Baraybar in connection with the Srebrenica-related gravesites. ${ }^{1852}$ The second report-which was admitted into evidence as D3894 — was prepared for the purpose of objecting to findings by the Prosecution experts on, inter alia, the cause of death of Srebrenica victims. ${ }^{18853}$ Pašalić prepared a report for this case, which was admitted into evidence as D3125, and gave evidence on the demographic movements in $\mathrm{BiH}$ in the periods before, during, and after the war. ${ }^{18854}$

5522. In reaching its findings on the total number of victims killed during the course of the Scheduled Incidents, as set out in the Potočari, Bratunac, and Zvornik sections of this Srebrenica component of the Judgement, the Chamber has considered and analysed the evidence of all of these witnesses, as well as the corresponding challenges raised by the Accused. The Chamber will deal with general aspects of the witnesses' evidence, Dunjić's challenges thereto, as well as with the Accused's arguments, in the sections below.

\section{(B) Forensic evidence}

5523. In 1996, Prosecution teams of experts began investigating and exhuming gravesites suspected of being connected to the fall of Srebrenica in July 1995. ${ }^{18855}$ Between 1996 and 2001, they identified more than 43 primary and secondary mass graves as being connected to the fall of Srebrenica, and exhumed approximately 22 of those. ${ }^{18856}$ In 2001, the Tribunal handed over the responsibility for the exhumation of all remaining gravesites to the BiHCMP, which was initially monitored by the Tribunal for the remainder of 2001, and later by the ICMP. ${ }^{18857}$ In addition to the graves already exhumed by the Tribunal, the BiHCMP and the ICMP identified additional gravesites connected to Srebrenica. ${ }^{18858}$

18852 Dušan Dunjić, T. 41727 (22 July 2013); D3893 (Dušan Dunjić's expert report entitled "Forensic Analysis of Reports on the Locations of Mass Graves in the Area of Eastern Bosnia and Documentation Relating to Exhumations in the Srebrenica Area”, 27 August 2009), pp. 8-10, 38-39. The Chamber also admitted the reports prepared by Dunjić for the Popović et al. case. See Dušan Dunjić, T. 41806-41807 (23 July 2013); D3896 (Dušan Dunjić's expert report entitled "Forensic Analysis of Exhumation Reports from the Bišina Site and Documents Relating to the Update to the Summary of Forensic Evidence from Graves in the Srebrenica Area", April 2009).

18853 Dušan Dunjić, T. 41775-41776, 41789 (23 July 2013); D3894 (Dušan Dunjić's expert report entitled "Forensic Analysis of Documents Pertaining to Exhumations, Autopsies and Identification of Bodies in the Srebrenica Area", 26 August 2012).

18854 See e.g. Stevo Pašalić, T. 35347-35348 (1 March 2013); D3125 (Stevo Pašalić's expert report entitled "Ethnic Composition, Displaced Persons and Refugees from 27 Municipalities in the Territory of BiH, 1991-1997”, August 2012).

18855 Dean Manning, T. 25803-25804 (6 March 2012).

18856 Dean Manning, T. 25803-25804 (6 March 2012). Manning clarified that this number is a conservative estimate, since many gravesites included multiple smaller sub-graves. Dean Manning, T. 25803-25804 (6 March 2012).

18857 Dean Manning, T. 25804, 25882 (6 March 2012); Dušan Janc, T. 26921 (27 March 2012).

18858 The graves which were identified and/or exhumed by the BiHCMP and the ICMP include Ravnice 2; Čančari Road 1, 2, 4-11, and 13; Hodžići Road 1, 2, 6, and 7; Liplje 1, 3, 4, and 7; Zeleni Jadar 1-4; Blječeva 1-3; 


\section{(1) Date of death}

5524. The Accused claims that, given that the charges against him concern alleged killings which took place between 12 and 23 July 1995, as opposed to legitimate killings or deaths during the course of combat from 1992 to 1995, it is important to establish when the alleged victims of execution died. ${ }^{18859}$

5525. The Accused argues that the Srebrenica-related gravesites were mixed gravesites containing the bodies of those killed in combat over a period of approximately 45 months, including in July 1995. ${ }^{18860}$ The Accused also presents various theories- the most important of which will be discussed in detail in the following paragraphs - to support his claim that many of the Srebrenica missing died in combat and/or prior to the fall of Srebrenica. ${ }^{18861}$

5526. The Chamber notes that the forensic reports tendered by the Prosecution do not include a precise date of death. ${ }^{18862}$ Dunjić testified, however, that in order to make a proper assessment as to whether the bodies of some individuals found in Srebrenica-related gravesites died as a result of events not connected with the fall of Srebrenica, he had to first assess the Prosecution's analysis on the date of death. ${ }^{18863}$ Dunjić concluded, based on his own analysis, that a precise date of death in relation to the bodies exhumed from Srebrenica-related gravesites could not be determined. ${ }^{18864}$

Budak 1 and 2; Zalazje, Bišina, Bišina Cave, Sandići, and Potočari. P4772 (Dušan Janc's report entitled "Update to the summary of Forensic Evidence - Exhumation of the Graves and Surface Remains Recoveries related to Srebrenica - January 2012”, 13 January 2012), e-court pp. 2-5, fn. 5. See also Dean Manning, T. 25805 (6 March 2012); P4504 (Dean Manning's Report, entitled "Summary of Forensic Evidence - Execution Points and Mass Graves", 16 May 2000), e-court p. 4.

18859 Defence Final Brief, paras. 2655-2656, 2658.

18860 See Defence Final Brief, paras. 2548, 2556-2557, 2566, 2641, 2652, 2659. The Accused put his case during cross-examination of: Richard Wright, T. 22290 (1 December 2011); Jose Baraybar, T. 22357-22358 (2 December 2011); Christopher Lawrence, T. 22482, 22493-22494 (8 December 2011); John Clark, T. 2270622708 (10 January 2012); Fredy Peccerelli, T. 22752 (11 January 2012); William Haglund, T. 23915-23916, 23920, 23952 (31 January 2012); Jean-René Ruez, T. 23983 (1 February 2012); Dean Manning, T. 25849, 25854-25855 (6 March 2012); Thomas Parsons, T. 26647-26648 (22 March 2012); and Dušan Janc, T. 27054 (28 March 2012).

18861 See e.g. Defence Final Brief, paras. 2548-2561, 2678.

18862 See e.g. P4103 (John Clark's expert report entitled "Report of Chief Pathologist, Srebrenica Grave Sites (1999)", undated); P4104 (John Clark's expert report entitled "Report of the Chief Pathologist, Srebrenica Grave Sites (2000)", 24 February 2001); P4105 (John Clark's expert report entitled "Report of the Chief Pathologist, Srebrenica Grave Sites (2001)", 24 May 2003); P4052 (Christopher Lawrence's expert report entitled "Report on Bodies Recovered Near Kozluk in 1998", 17 June 1999); P4053 (Christopher Lawrence's expert report entitled "Report on Autopsies of Human Remains from the Dam Site June 1998", 17 June 1999); P4060 (Christopher Lawrence's expert report entitled "Report on Autopsies of Human Remains from Liplje Site 2, October 1998”, 17 June 1999). See also Dušan Janc, T. 27015 (27 March 2012).

18863 D3893 (Dušan Dunjić's expert report entitled "Forensic Analysis of Reports on the Locations of Mass Graves in the Area of Eastern Bosnia and Documentation Relating to Exhumations in the Srebrenica Area", 27 August 2009), p. 39.

18864 See Dušan Dunjić, T. 41746-41747 (22 July 2013), T. 41881-41882 (24 July 2013). See also D3894 (Dušan Dunjić's expert report entitled "Forensic Analysis of Documents Pertaining to Exhumations, Autopsies and Identification of Bodies in the Srebrenica Area”, 26 August 2012), pp. 16-18; D3893 (Dušan Dunjić's expert 
This finding is supported by the evidence of Prosecution experts. For example, Baraybar testified that it is not possible to determine when an individual died through a naked-eye examination of a body, be it preserved or decomposed. ${ }^{18865}$ Similarly, because of all the factors that could alter the decomposition of bodies within a gravesite, Lawrence acknowledged that he could not ascertain when Srebrenica victims died. ${ }^{18866}$ Wright similarly testified that the date of death cannot be determined by merely looking at the remains of an individual. ${ }^{18867}$

(a) Information provided to Prosecution experts

5527. As a general objection to the Prosecution's evidence, the Accused claims that Prosecution experts were not informed about the combat activities in the area before July 1995 or about the possible casualties from such combat activities, and worked under the assumption that all the victims had died during incidents connected to the fall of Srebrenica. ${ }^{18868}$ Experts were thus instructed to find victims of the alleged executions that took place in Srebrenica in July 1995, and did not investigate the date of death and burial, or the cause and manner of death. ${ }^{18869}$ Consequently, the Accused claims that the experts' evidence does not support the conclusions the Prosecution wants the Chamber to reach. ${ }^{18870}$ The Accused urges the Chamber to draw the appropriate conclusions from the 45 month-long military combat activity in the area. ${ }^{18871}$

5528. The Chamber notes that some experts confirmed that they were in fact told that the gravesites being exhumed contained bodies of men who had been executed after the fall of

report entitled "Forensic Analysis of Reports on the Locations of Mass Graves in the Area of Eastern Bosnia and Documentation Relating to Exhumations in the Srebrenica Area”, 27 August 2009), p. 57.

18865 Jose Baraybar, T. 22384 (2 December 2011).

18866 Christopher Lawrence, T. 22485-22486 (8 December 2011).

18867 Richard Wright, T. 22293-22294 (1 December 2011). However, in establishing the victims' date and time of death, Wright testified that watches worn by some of the victims were consistent with the date of the executions. Richard Wright, T. 22293-22294 (1 December 2011). The particular watches in question are Seiko mechanical or automatic watches that stop within 24 to 48 hours of the last movement of the watch. Richard Wright, T. 22293-22294 (1 December 2011); Fredy Peccerelli, P4137 (Transcript from Prosecutor v. Tolimir), T. 84818483; P4135 (Fredy Peccerelli report entitled "Lažete 1, Bosnia and Herzegovina, Excavation and Exhumation Report", 2 February 2001), e-court p. 32; P4136 (Final Report of Fredy Peccerelli entitled "Lažete 2 (LZ02C), Bosnia and Herzegovina, Excavation and Exhumation report", 1 May 2007), e-court p. 27. See P4000 (Richard Wright's expert report entitled "Exhumations in Eastern Bosnia in 1998”, 12 May 1999), e-court pp. 29-30, 181. Wright was told that the executions took place on Friday 14 July 1995, and eight of the ten watches found show the date of Saturday 15 July or Sunday 16 July 1995, consistent with the date of execution. Richard Wright, T. 22293, 22295 (1 December 2011); P4000 (Richard Wright's expert report entitled "Exhumations in Eastern Bosnia in 1998", 12 May 1999), e-court 29-32.

18868 See Defence Final Brief, paras. 2574-2575, 2634-2635, 2640, 2692, 2694. The Accused referred to this point during his cross-examination of Richard Wright, T. 22290-22292 (1 December 2011).

18869 Defence Final Brief, para. 2634. The Chamber will discuss the evidence relating to the cause and manner of death in the next section.

18870 Defence Final Brief, para. 2656.

18871 Defence Final Brief, paras. 2659, 2676. 
Srebrenica. ${ }^{18872}$ While some experts were aware that fighting had been taking place in the area for months prior to the fall of Srebrenica, ${ }^{18873}$ others did not have this information when they first started working in the area. ${ }^{18874}$ Experts focused on gravesites where there was information that people had been executed on 14 to 16 July $1995 ;{ }^{18875}$ as a result, they worked under the assumption that all the bodies exhumed from the Srebrenica-related gravesites were thought to be related to the fall of Srebrenica. ${ }^{18876}$ Clark explained that, based on this understanding, experts were asked whether all of the bodies found within a single gravesite could have been related to one and the same incident. ${ }^{18877}$

5529. Experts also explained that they were provided with limited background information about the bodies in the gravesites, so that they could look at the findings objectively and not be biased. ${ }^{18878}$ They were not told what they would, or should, find within the specific gravesites. ${ }^{18879}$ Thus, as explained by Baraybar, experts were not asked by the Prosecution to make a finding one way or another, but to extract their findings in a scientific manner and to reach opinions based on their findings. ${ }^{18880}$

5530. The Chamber notes that the fact that experts were provided with limited background information about the bodies in the gravesites and, more generally, about the fall of Srebrenica, does not, in and of itself, taint their reports with bias or make them less reliable.

\section{(b) Mixed gravesites}

5531. The Accused claims that throughout the war the remains of soldiers killed in combat and those of the victims of execution were commingled in gravesites, and that single gravesites contained bodies from multiple burials. ${ }^{1881}$ According to the Accused, the Prosecution is in possession of many documents indicating that multiple burials took place. ${ }^{18882}$ Dunjic states that the discovery of a large number of bodies in a single mass grave does not automatically mean that all the victims whose bodies were exhumed died on the same day, in the same place, and in the

\footnotetext{
18872 See e.g. Christopher Lawrence, T. 22493 (8 December 2011); John Clark, T. 22707 (10 January 2012).

18873 See William Haglund, T. 23915 (31 January 2012).

18874 See Fredy Peccerelli, T. 22751-22752, 22784-22785 (11 January 2012); John Clark, T. 22707-22708 (10 January 2012).

18875 Jean-René Ruez, T. 23983-23984, 24000-24001 (1 February 2012).

18876 Richard Wright, T. 22289, 22291 (1 December 2011); John Clark, T. 22707 (10 January 2012).

18877 John Clark, T. 22707 (10 January 2012).

18878 See John Clark, T. 22707 (10 January 2012).

18879 See Jose Baraybar, T. 22383-22384 (2 December 2011).

18880 Jose Baraybar, T. 22358-22359 (2 December 2011).

18881 See Defence Final Brief, paras. 2566, 2699.

18882 Defence Final Brief, paras. 2592-2593.
} 
same way. ${ }^{18883}$ Dunjić claims that, in the present case, the forensic evidence supports the theory of enrichment, as it shows that bodies brought from different areas not directly connected to Srebrenica were buried subsequently in primary and secondary gravesites. ${ }^{18884}$ Referring to evidence received on the fate of many of the men from the column as a result of ambushes by members of the Bosnian Serb Forces, Dunjić also claims that the many casualties were not buried immediately upon their deaths, but were only subsequently brought to the nearest places where they could be buried. ${ }^{18885}$

5532. Contrary to this, the Prosecution claims that there is no archaeological evidence of enrichment in the graves, and argues that all the evidence taken together demonstrates beyond reasonable doubt that all of the Srebrenica-related primary and secondary gravesites exclusively contain the bodies of Srebrenica-related execution victims, ${ }^{18886}$ apart from a few exceptions. ${ }^{18887}$ In support, the Prosecution refers to the following: first, the Prosecution's experts did not see any evidence that those whose bodies were exhumed from the Srebrenica-related graves died in combat; second, the experts saw no evidence that the Srebrenica-related graves had either been created on the sites of existing sites or subsequently re-opened; third, the cause and manner of death of bodies from each of the primary and secondary gravesites support the witness evidence of the executions at each of these sites; fourth, there were blindfolds and ligatures in the graves associated with some of the killing sites; fifth, some graves contained artefacts linking their contents to the specific site

18883 D3893 (Dušan Dunjić's expert report entitled "Forensic Analysis of Reports on the Locations of Mass Graves in the Area of Eastern Bosnia and Documentation Relating to Exhumations in the Srebrenica Area", 27 August 2009), p. 39.

18884 Dušan Dunjić, T. 41751-41752 (22 July 2013), T. 41772 (23 July 2013); T. 41874-41875, 41878-41879, 41905 (24 July 2013). To support this claim, Dunjić refers to the layers of soil between the bodies, which can suggest burials at different time intervals or that the bodies were moved and reburied at different times. D3894 (Dušan Dunjić's expert report entitled "Forensic Analysis of Documents Pertaining to Exhumations, Autopsies and Identification of Bodies in the Srebrenica Area", 26 August 2012), p. 19.

18885 Dušan Dunjić, T. 41757-41758 (23 July 2013). In this regard, the Accused specifically refers to the testimony of KDZ045 to claim that the bodies of seven individuals who died while trying to flee Srebrenica were buried in Srebrenica-related gravesites. Defence Final Brief, paras. 2549-2556. See also Thomas Parsons, T. 26649 (22 March 2012), T. 26650-26651 (22 March 2012) (private session) (where the Accused questioned Parsons on this same issue). The Prosecution submits that among the seven individuals referred to by KDZ045, six were not buried in Srebrenica-related gravesites and thus were not included in Janc's computation; while the remains of the seventh individual were found in a Srebrenica-related gravesite, KDZ045 did not witness this individual being killed in the woods, but only heard that was the case. Prosecution Closing Argument, T. 47797-47798 (30 September 2014). See KDZ045 T. 22677-22679 (10 January 2012) (private session). Having analysed all the evidence in question, the Chamber is satisfied with the Prosecution's explanation, and rejects the Accused's argument in this respect.

18886 Prosecution Final Brief, Appendix D, para. 166; Prosecution Closing Argument, T. 47795-47796 (30 September 2014).

18887 Prosecution Closing Argument, T. 47795-47796 (30 September 2014). The Prosecution states that the exceptions relate to Glogova, Blječeva, and Liplje 8, but adds that the numbers arising from these gravesites have been explained by Dušan Janc, and not included in the total number of Srebrenica victims in Janc's Report. See Prosecution Closing Argument, T. 47795 (30 September 2014). See also Dušan Janc, T. 27016-27017 (27 March 2012), T. 27040-27046, 27060 (28 March 2012). 
where the detainees were killed; and sixth, there is no credible evidence that the secondary graves contain any bodies other than those of victims from the primary graves. ${ }^{18888}$

5533. The Chamber notes that Prosecution experts involved in the exhumation of Srebrenica gravesites stated that they had not seen any signs of enrichment when conducting their work. ${ }^{18889}$ Manning explained that the experts did not see specific evidence pointing to Srebrenica gravesites containing evidence from a previous era, or to bodies buried through the sanitation process. ${ }^{18890}$ Haglund testified that, while it was theoretically possible that bodies of combatants could have been previously buried in mass gravesites due to the sanitisation process during the war, his analysis of the gravesites did not support the theory that the victims had died in combat. ${ }^{18891}$

5534. The Chamber also notes that, when discussing the findings in his report for the Kozluk and Glogova gravesites, Clark acknowledged that, theoretically, he could not completely exclude the possibility that at least some of the bodies in such gravesites could have been from an earlier incident and buried in the same gravesite. ${ }^{18892}$ However, the presence of blindfolds tied tightly around the vast majority of people's eyes, with a substantial number of bullet holes through blindfolds, led to Clark's opinion that the victims were not combatants. ${ }^{18893}$ Similarly, Peccerelli testified that, while he could not entirely rule out the possibility that the victims exhumed from Lažete had died in combat, the evidence analysed left nothing that would lead him to believe that these were deaths resulting from combat. ${ }^{18894}$ Peccerelli further explained, when questioned on how he would rule out the possibility of burials taking place in several stages, that bodies were placed without any layer of foreign soil between them, and that burials taking place in stages would be evidenced by a certain degree of disturbance to the grave, which was not seen at Lažete. ${ }^{18895}$

\footnotetext{
18888 Prosecution Closing Argument, T. 47796 (30 September 2014). On this last point, the Prosecution states that the Accused has ignored all of the linkage between the primary and the secondary graves, apart from the DNA linkage, which includes soil, pollen, other artefacts, as well as the evidence from witnesses and documents about the reburial operation itself. Prosecution Closing Argument, T. 47796 (30 September 2014).

18889 See Richard Wright, T. 22307, 22312-22313 (1 December 2011); Fredy Peccerelli, T. 22741 (11 January 2012); William Haglund, T. 23912-23914 (31 January 2012).

18890 Dean Manning, T. 25855, 25884 (6 March 2012).

18891 William Haglund, T. 23915, 23922-23924, 23943-23944, 23952-23953 (31 January 2012). See Defence Final Brief, paras. 2614-2617 (where the Accused's challenges Haglund's evidence on this point).

18892 John Clark, T. 22707, 22712 (10 January 2012). See also P4103 (John Clark's expert report entitled "Report of Chief Pathologist, Srebrenica Grave Sites (1999)", undated). Clark added that it was entirely possible that some of the victims in the gravesite were killed in combat. John Clark, T. 22709 (10 January 2012).

18893 John Clark, T. 22709-22710 (10 January 2012).

18894 Fredy Peccerelli, T. 22752-22753, 22781 (11 January 2012). Cf. Defence Final Brief, paras. 2575-2580 (challenging Peccerelli's methodology and findings on this point). Peccerelli referred to the presence of ligatures on some of the bodies, probable blindfolds on most of the others, and the organised way the bodies were arranged in the grave, amongst other evidence, to support his claim. See Fredy Peccerelli, T. 22753 (11 January 2012).

18895 See Fredy Peccerelli, T. 22755-22756, 22759-22760, 22762-22763, 22766-22767 (11 January 2012).
} 
5535. To support the theory of the mixed gravesites, Dunjic claims that the strips identified as blindfolds found in various Srebrenica-related gravesites could either be: (i) simple pieces of cloth used to bandage the forehead, or (ii) headbands tied around the forehead by soldiers who belong to a military group or who want to show their affiliation to a religion. ${ }^{18896}$ This argument was also put to experts by the Accused throughout the case. ${ }^{18897}$ According to the Accused, it shows that these individuals were killed in combat. ${ }^{18898}$ The Accused argued, inter alia, that it was customary to wear headbands around the forehead during combat, and that due to decaying tissue these headbands could slide down the head. ${ }^{18899}$ He further argued that in circumstances where combatants cannot be differentiated based on race, language or faith, ribbons or other markings are used to prevent friendly fire. ${ }^{18900}$

5536. The Chamber notes that this theory was consistently discounted by Prosecution witnesses. ${ }^{18901}$ For example, upon being questioned on whether they knew about Bosnian Muslim combatants wearing head pieces, both Peccerelli and Manning testified that, in relation to bodies found at Lažete, there was nothing to indicate that the blindfolds were actually headbands used by combatants. ${ }^{18902}$ When discussing the Branjevo Military Farm gravesite, and upon being questioned on whether he knew about Bosnian Muslim combatants wearing bandanas and the possibility of these being mistaken for blindfolds, Haglund explained that the blindfolds were not bandannas because they had been tied tightly on the eyes and had not moved down. ${ }^{18903}$ Similarly, Lawrence testified that, while he could not discard for certain the possibility that the blindfolds found in the Hodžići Road gravesites could be military headbands, he was of the opinion that,

18896 Dušan Dunjić, T. 41755 (23 July 2013). See D3894 (Dušan Dunjić's expert report entitled "Forensic Analysis of Documents Pertaining to Exhumations, Autopsies and Identification of Bodies in the Srebrenica Area", 26 August 2012), p. 19.

18897 See e.g. the Accused's line of questioning during cross-examination of Christopher Lawrence, T. 22468-22479, 22499 (8 December 2011); John Clark, T. 22710 (10 January 2012); and Dean Manning T. 25866-25881 (6 March 2012). See also Defence Final Brief, paras. 2583-2585, 2685-2690; Dušan Dunjić, T. 41755-41756, 41829, 41833-41834 (23 July 2013); D3894 (Dušan Dunjić's expert report entitled "Forensic Analysis of Documents Pertaining to Exhumations, Autopsies and Identification of Bodies in the Srebrenica Area", 26 August 2012), p. 19.

18898 See Defence Final Brief, paras. 2584-2585, 2639. See also Accused's line of questioning during crossexamination of Dean Manning T. 25866-25881 (6 March 2012); D3894 (Dušan Dunjić's expert report entitled "Forensic Analysis of Documents Pertaining to Exhumations, Autopsies and Identification of Bodies in the Srebrenica Area”, 26 August 2012), p. 19 (where Dunjić reaches the same conclusion).

18899 See the Accused's line of questioning during cross-examination of Fredy Peccerelli, T. 22748-22749 (11 January 2012).

18900 See Fredy Peccerelli, T. 22751 (11 January 2012).

18901 See e.g. William Haglund, T. 23914 (31 January 2012); Christopher Lawrence, T. 22499 (8 December 2011); Dean Manning, T. 25867-25868 (6 March 2012); Fredy Peccerelli, T. 22752-22753 (11 January 2012).

18902 See Fredy Peccerelli, T. 22746-22750 (11 January 2012); Dean Manning, T. 25867-25868 (6 March 2012 ).

18903 William Haglund, T. 23914, 23947-23948 (31 January 2012). Haglund further explained that if the bodies had been on the surface, then the material could have moved from the eyes; however, this was not possible in cases where the bodies were buried compactly in the grave. William Haglund, T. 23914-23915 (31 January 2012). 
based on other evidence, such as the presence of bodies of old people with severe disabilities, the victims were not combatants. ${ }^{18904}$

5537. The Chamber finds that in expounding on his theory on blindfolds, Dunjić ignores the considerable evidence to the contrary and, more generally, the circumstances surrounding the various Scheduled Incidents, as charged in the Indictment. Accordingly, the Chamber considers his analysis to be unacceptable.

5538. To further support the existence of mixed gravesites, the Accused argues that the existence of more than 1,000 surface remains ${ }^{18905}$ confirms that there were many combat casualties and claims that, when examining the gravesites, the Prosecution did not make an effort to differentiate between those who died in combat and those who were allegedly victims of execution. ${ }^{18906}$ Dunjić adds that while experts acknowledged having informed themselves with the events in Srebrenica before conducting their work, they neglected the possibility that there may have been subsequent burials and that bodies from the surface may have been brought to those gravesites later. ${ }^{18907}$

5539. Prosecution experts agreed that, in conducting their work, a holistic approach for the entire investigation needed to be adopted and that they had to examine the mass graves in context. ${ }^{18908}$ The Chamber fully agrees with this. In so far as the various possibilities raised by the Accused are concerned, each piece of forensic evidence has to be considered in light of the totality of the evidence before the Chamber. In the present case, and subject to the Chamber's findings in relation to the Glogova and Blječeva gravesites as referred to below, ${ }^{18909}$ the Chamber is satisfied that there is no evidence to prove the existence of mixed Srebrenica-related gravesites.

\footnotetext{
18904 Christopher Lawrence, T. 22499 (8 December 2011).

18905 Janc explained that surface remains are body parts or bodies which were never buried and were subsequently found on the surface. Dušan Janc, T. 26982 (27 March 2012). However, as will be discussed below, these remains have not been included in Janc's computation of the total number of Srebrenica-related victims. Dušan Janc, T. 26984-26985 (27 March 2012); P4772 (Dušan Janc's report entitled "Update to the summary of Forensic Evidence - Exhumation of the Graves and Surface Remains Recoveries related to Srebrenica - January 2012", 13 January 2012), e-court p. 5.

18906 Defence Final Brief, paras. 2589-2590, 2636, 2638, 2640.

18907 See D3894 (Dušan Dunjić's expert report entitled "Forensic Analysis of Documents Pertaining to Exhumations, Autopsies and Identification of Bodies in the Srebrenica Area", 26 August 2012), p. 16 (referring in particular to evidence presented by Wright and Baraybar).

18908 See Fredy Peccerelli, T. 22781 (11 January 2012); William Haglund, P4310 (Transcript from Prosecutor v. Krstić), T. 3765.

18909 See para. 5594.
} 
(c) Various degrees of decomposition

5540. The Accused also refers to the various degrees of decomposition of bodies found in individual gravesites which, he claims, point to the possibility of multiple burials, and thus support his theory that many of the victims died prior to the fall of Srebrenica. ${ }^{18910}$

5541. In this regard, Dunjic claims that the autopsy reports he reviewed, which describe the state of decomposition of skeletal remains, incontrovertibly point to various dates of death. ${ }^{18911}$ Dunjić also notes that the features of the bodies and the changes to the skeletal remains, as noted in the autopsy reports, indicate varying dates of burial, and hence varying dates of death. ${ }^{18912}$ Specifically, Dunjić challenges the conclusions of Prosecution experts that different degrees of putrefaction of remains in the same gravesite are attributable to the conditions in the gravesite. ${ }^{18913}$ According to Dunjić, different degrees of putrefaction of exhumed bodies in one location could indicate that there are various times of death, subsequent times of burial, that the bodies were brought from other places, or that there were different causes of decomposition. ${ }^{18914}$

5542. The Prosecution claims that it is normal for bodies in a single gravesite to decompose at different rates. ${ }^{18915}$ The Chamber heard evidence that differences in the state of preservation are not necessarily indicative of different periods of burial. ${ }^{18916}$ Prosecution experts testified that there are many factors that could alter the decomposition of bodies, including how long they have been dead, the location of the body within the gravesite, whether they have been buried or exposed to air, the temperature, humidity and acidity of the soil, the degree of disarticulation of the body, and access of insects to the remains. ${ }^{18917}$ Conditions in a mass grave can vary from top to bottom, depending on the amount of moisture present: with adipocere-a process which requires water-

\footnotetext{
18910 Defence Final Brief, paras. 2639, 2675.

18911 These reports are those for Liplje 4, Bišina, Sandići, Potočari, Nova Kasaba, Pilica, and Zeleni Jadar 5. D3893 (Dušan Dunjić's expert report entitled "Forensic Analysis of Reports on the Locations of Mass Graves in the Area of Eastern Bosnia and Documentation Relating to Exhumations in the Srebrenica Area”, 27 August 2009), p. 14.

18912 Dušan Dunjić, T. 41749 (22 July 2013), T. 41761-41763 (23 July 2013); D3893 (Dušan Dunjić's expert report entitled "Forensic Analysis of Reports on the Locations of Mass Graves in the Area of Eastern Bosnia and Documentation Relating to Exhumations in the Srebrenica Area”, 27 August 2009), p. 13.

18913 Dušan Dunjić, T. 41747 (22 July 2013).

18914 Dušan Dunjić, T. 41747 (22 July 2013), T. 41875-41876, 41880-41882, 41914-41916 (24 July 2013); D3893 (Dušan Dunjić's expert report entitled "Forensic Analysis of Reports on the Locations of Mass Graves in the Area of Eastern Bosnia and Documentation Relating to Exhumations in the Srebrenica Area", 27 August 2009), pp. 120-121; D3894 (Dušan Dunjić's expert report entitled "Forensic Analysis of Documents Pertaining to Exhumations, Autopsies and Identification of Bodies in the Srebrenica Area”, 26 August 2012), p. 17.

18915 Prosecution Final Brief, Appendix D, para. 166; Prosecution Closing Argument, T. 47795-47796 (30 September 2014).

18916 Richard Wright, T. 22307-22309 (1 December 2011).
} 
being present at the bottom of a gravesite, and mummification of the body being present at the top of the gravesite. ${ }^{18918}$ Thus, bodies buried at the edge of the mass gravesite will decompose at slightly faster rate than bodies in the middle of the mass grave, where there is almost no oxygen present and remains are protected from the environment. ${ }^{18919}$ It is therefore common to find almost complete loss of tissue in remains close to edge of the gravesite, and entirely preserved remains in the middle of the gravesite. ${ }^{18920}$ Bodies might also decompose differently due to their weight, size, and sex. ${ }^{18921}$

5543. The Chamber finds that various degrees of decomposition within a single gravesite could, in some circumstances, be indicative of bodies having been buried at different times. However, the evidence on the various degrees of decomposition within the Srebrenica-related gravesites ought to be considered in light of the totality of evidence before the Chamber, including that of insiders and eye-witnesses to the killings and burial operations. The Chamber is therefore satisfied with the explanation provided by the Prosecution experts and finds that, in the present case, the existence of various degrees of decomposition within a single gravesite is not indicative of various times of burial and/or of various dates of death.

\section{(d) Victims' clothing}

5544. Dunjić states that some of the bodies found at the various gravesites were wearing winter clothes, which suggests that they were more probably killed in winter, before or after the fall of Srebrenica, and that the time of death of victims within one gravesite differs. ${ }^{18922}$ The Accused claims that bodies found with multiple layers of clothes serve to prove that they died prior to the fall of Srebrenica. ${ }^{18923}$

\footnotetext{
18917 See Christopher Lawrence, T. 22482, 22485 (8 December 2011); Fredy Peccerelli, T. 22742 (11 January 2012); Richard Wright, T. 22306-22307 (1 December 2011); William Haglund, T. 23924-23926 (31 January 2012). See also William Haglund, P4310 (Transcript from Prosecutor v. Krstić), T. 3738.

18918 Christopher Lawrence, T. 22509 (8 December 2011).

18919 Richard Wright, T. $22306-22307$ (1 December 2011); Christopher Lawrence, T. 22509 (8 December 2011); Fredy Peccerelli, T. 22742-22743 (11 January 2012). But see Dušan Dunjić, T. 41878-41881 (24 July 2013) (specifically challenging Wright's findings on different degrees of putrefaction in the Glogova gravesites).

18920 Richard Wright, T. 22306-22307 (1 December 2011); Christopher Lawrence, T. 22509 (8 December 2011).

18921 Fredy Peccerelli, T. 22742 (11 January 2012).

18922 D3894 (Dušan Dunjić's expert report entitled "Forensic Analysis of Documents Pertaining to Exhumations, Autopsies and Identification of Bodies in the Srebrenica Area", 26 August 2012), p. 18. See Dušan Dunjić, T. 41847-41849 (23 July 2013).

18923 Defence Final Brief, para. 2678. See Accused's line of questioning during cross-examination of Christopher Lawrence, T. 22492-22493, 22502-22503 (8 December 2011).
} 
5545. The Chamber has received evidence showing that men fleeing Srebrenica in July 1995 were often wearing multiple layers of clothes. ${ }^{18924}$ The Chamber is thus not persuaded by the Accused's argument and dismisses it in its entirety.

\section{(2) Cause and manner of death}

5546. As discussed in the findings relating to each specific Scheduled Killing Incident, the forensic reports tendered by the Prosecution indicate that the main cause of death was determined to be gunshot injury. However, in a considerable number of cases, the cause of death could not be determined for a number of reasons, including the substantial damage visible on the remains, and their high degree of decomposition. ${ }^{18925}$

5547. The Chamber notes that Clark testified that the primary purpose of autopsies is to examine the bodies for injuries in an attempt to determine the cause of death. ${ }^{18926}$ Due to the length of time that the bodies were buried in the Srebrenica-related gravesites, the majority of bodies had skeletonised and the only option was to examine the bones. ${ }^{18927}$ Clark explained that postmortem injuries include "crushing injuries" caused by the weight of bodies in the grave or vehicles driving over the surface of the graves; perimortem injuries, such as blunt force injuries caused by beatings, can unavoidably be wrongly interpreted as postmortem damage. ${ }^{18928}$ As a result, Clark acknowledged that it is difficult to determine if a particular injury had been caused before or after death, as it is only possible to do so when looking at soft tissue damage such as bruising or

18924 See e.g. P4909 (Photographs of men, 10 April 2012), e-court pp. 2-4; P667 (Zoran Petrović-Piroćanac's video footage), at 00:00:54, 00:00:59, 00:01:14, 00:23:34, 00:23:50; P4202 (Written compilation booklet: Srebrenica Trial video), e-court pp. 160-161. See also Christopher Lawrence, T. 22515 (8 December 2011).

18925 Christopher Lawrence, T. 22456, 22512 (8 December 2011). See e.g. P4053 (Christopher Lawrence's expert report entitled "Report on Autopsies of Human Remains from the Dam Site June 1998", 17 June 1999), e-court pp. 8, 20-22; P4055 (Christopher Lawrence's expert report entitled "Report on Autopsies of Human Remains from Čančari Road Site 3, August-September 1998”, 17 June 1999), e-court pp. 2, 6-9, 32; P4054 (Christopher Lawrence's expert report entitled "Report on Autopsies of Human Remains from Čančari Road Site 12, August 1998”, 17 June 1999), e-court pp. 4, 11, 40; 43; P4056 (Christopher Lawrence's expert report entitled "Report on Autopsies of Human Remains from Hodžići Road Site 3, October 1998”, 17 June 1999), e-court pp. 7-8, 1415; P4057 (Christopher Lawrence's expert report entitled "Report on Autopsies of Human Remains from Hodžići Road Site 4, October 1998”, 17 June 1999), e-court pp. 6, 22; P4058 (Christopher Lawrence's expert report entitled "Report on Autopsies of Human Remains from Hodžići Road Site 5, October 1998", 17 June 1999), e-court pp. 7-8; P4059 (Christopher Lawrence's expert report entitled "Report on Autopsies of Human Remains from Zelani Jadar Site 5, October 1998", 17 June 1999), e-court pp. 9, 31; P4060 (Christopher Lawrence's expert report entitled "Report on Autopsies of Human Remains from Liplje Site 2, October 1998", 17 June 1999), e-court pp. 8, 20. See also P4504 (Dean Manning's Report, entitled "Summary of Forensic Evidence - Execution Points and Mass Graves", 16 May 2000), e-court pp. 20-21.

18926 P4103 (John Clark's expert report entitled "Report of Chief Pathologist, Srebrenica Grave Sites (1999)", undated), p. 3.

18927 P4103 (John Clark's expert report entitled "Report of Chief Pathologist, Srebrenica Grave Sites (1999)", undated), p. 3; John Clark, T. 22706 (10 January 2012); P4105 (John Clark's expert report entitled "Report of the Chief Pathologist, Srebrenica Grave Sites (2001)", 24 May 2003), p. 3; John Clark, John Clark, P4110 (Transcript from Prosecutor v. Krstić), T. 3906. 
haemorrhaging. ${ }^{18929}$ Clark thus assumed that the vast majority of gunshot and other relevant injuries occurred in life and explained that the fact that the vast majority of bodies examined showed evidence of gunshot injury suggests that the gunshot damage occurred when victims were alive; the alternative assumption would be that the victims died in an obscure and undetected way and were shot postmortem. ${ }^{18930}$ When determining the cause of death, based on the assumption that these gunshots were fired perimortem, Clark concluded that evidence of the bullet passing through the skull, chest or abdominal area would be fatal. ${ }^{18931}$ In cases where there was evidence that the bullet passed through the limbs, the cause of death could not be established and, in the absence of any other findings, the cause of death was listed as unascertained. ${ }^{18932}$

5548. The Chamber also notes that Lawrence similarly acknowledged that, while in a number of cases the cause of death was determined, in a considerable number of cases the cause of death could not be determined with certainty due to the high degree of decomposition and disarticulation of the bodies. ${ }^{18933}$ In these cases, Lawrence explained, the injuries would be described as probable or possible cause of death. ${ }^{18934}$ There were other cases, however, where the bodies were so severely disarticulated that a real cause of death could not be determined. ${ }^{18935}$ In these cases, the cause of death was undetermined. ${ }^{18936}$

5549. In relation to the manner of death, the Chamber notes that Haglund testified that one would need to look at the gravesite in context when attempting to determine whether the injuries to the

18928 P4103 (John Clark's expert report entitled "Report of Chief Pathologist, Srebrenica Grave Sites (1999)", undated), p. 3; John Clark, P4110 (Transcript from Prosecutor v. Krstić), T. 3906-3908.

18929 P4103 (John Clark's expert report entitled "Report of Chief Pathologist, Srebrenica Grave Sites (1999)", undated), p. 3; P4105 (John Clark's expert report entitled "Report of the Chief Pathologist, Srebrenica Grave Sites (2001)”, 24 May 2003), p. 3; John Clark, T. 22706 (10 January 2012); John Clark, P4110 (Transcript from Prosecutor v. Krstić), T. 3906-3907.

18930 P4103 (John Clark's expert report entitled "Report of Chief Pathologist, Srebrenica Grave Sites (1999)", undated), pp. 3-4; P4105 (John Clark's expert report entitled "Report of the Chief Pathologist, Srebrenica Grave Sites (2001)”, 24 May 2003), p. 3; John Clark, P4110 (Transcript from Prosecutor v. Krstić), T. 3906-3907. Clark acknowledged the possibility of postmortem injuries to the skeletons. See John Clark, T. 22713-22714 (10 January 2012).

18931 P4103 (John Clark's expert report entitled "Report of Chief Pathologist, Srebrenica Grave Sites (1999)", undated), pp. 3-4; John Clark, P4110 (Transcript from Prosecutor v. Krstić), T. 3906-3907, 3910, 3950.

18932 P4103 (John Clark's expert report entitled "Report of Chief Pathologist, Srebrenica Grave Sites (1999)", undated), p. 4; John Clark, P4110 (Transcript from Prosecutor v. Krstić), T. 3910, 3950.

18933 Christopher Lawrence, T. 22457-22458, 22512 (8 December 2011); P4054 (Christopher Lawrence's expert report entitled "Report on Autopsies of Human Remains from Čančari Road Site 12, August 1998", 17 June 1999), e-court p. 32.

18934 Christopher Lawrence, T. 22458 (8 December 2011). See P4053 (Christopher Lawrence's expert report entitled "Report on Autopsies of Human Remains from the Dam Site June 1998", 17 June 1999), e-court pp. $2,22$.

18935 Christopher Lawrence, T. 22458-22459 (8 December 2011). See P4053 (Christopher Lawrence's expert report entitled "Report on Autopsies of Human Remains from the Dam Site June 1998", 17 June 1999), e-court pp. 2, 22; P4054 (Christopher Lawrence's expert report entitled "Report on Autopsies of Human Remains from Čančari Road Site 12, August 1998”, 17 June 1999), e-court pp. 3, 32, 43.

18936 Christopher Lawrence, T. 22457, 22459, 22513 (8 December 2011). 
bodies were the result of combat operations or of executions. ${ }^{18937}$ Haglund explained that if all the bodies found at a gravesite were shot, and the majority had their hands bound, he would conclude that the gunshot injuries were the result of an execution. ${ }^{18938}$ Similarly, in graves where a significant number of bodies had blindfolds on, there was an assumption that they were not killed in combat, but were rather executed. ${ }^{18939}$

5550. Dunjić criticises the reports prepared by the Prosecution experts and claims they are solely "summary reports" with "cut-and-dried" diagnoses and conclusions, and do not analyse in detail the manner in which injuries were caused. ${ }^{18940}$ In particular, Dunjić states that the reports reviewed failed to give a detailed description of the observed injuries, and drew "prearranged" conclusions that the injuries were gunshot injuries. ${ }^{18941}$ It was thus impossible for him to establish if the injuries present were indeed gunshot injuries. ${ }^{18942}$

5551. Dunjić claims that, "according to forensic doctrine", the cause of death cannot be established with certainty and precision, and must be given very conditionally. ${ }^{18943}$ Similarly, it is very difficult to determine in decomposed and skeletonised bodies whether injuries are antemortem, that is, that they were inflicted when the victims were still alive, or perimortem, that is, that they were inflicted either immediately before or after death. ${ }^{18944}$ Yet, Prosecution experts all categorically speak of injuries occurring in life, immediately before death. ${ }^{18945}$

18937 William Haglund, P4310 (Transcript from Prosecutor v. Krstić), T. 3765

18938 See William Haglund, P4310 (Transcript from Prosecutor v. Krstić), T. 3765, 3769; Dušan Janc, T. 2702027022 (27 March 2012) (supporting this theory).

18939 See William Haglund, T. 23914, 23952 (31 January 2012).

18940 D3893 (Dušan Dunjić's expert report entitled "Forensic Analysis of Reports on the Locations of Mass Graves in the Area of Eastern Bosnia and Documentation Relating to Exhumations in the Srebrenica Area", 27 August 2009), p. 39; D3894 (Dušan Dunjić's expert report entitled "Forensic Analysis of Documents Pertaining to Exhumations, Autopsies and Identification of Bodies in the Srebrenica Area", 26 August 2012), p. 8.

18941 D3894 (Dušan Dunjić's expert report entitled "Forensic Analysis of Documents Pertaining to Exhumations, Autopsies and Identification of Bodies in the Srebrenica Area", 26 August 2012), pp. 7, 9.

18942 D3894 (Dušan Dunjić's expert report entitled "Forensic Analysis of Documents Pertaining to Exhumations, Autopsies and Identification of Bodies in the Srebrenica Area”, 26 August 2012), p. 9; Dušan Dunjić, T. 41780 (23 July 2013).

18943 D3894 (Dušan Dunjić's expert report entitled "Forensic Analysis of Documents Pertaining to Exhumations, Autopsies and Identification of Bodies in the Srebrenica Area", 26 August 2012), p. 4; D3893 (Dušan Dunjić's expert report entitled "Forensic Analysis of Reports on the Locations of Mass Graves in the Area of Eastern Bosnia and Documentation Relating to Exhumations in the Srebrenica Area”, 27 August 2009), p. 118.

18944 D3893 (Dušan Dunjić's expert report entitled "Forensic Analysis of Reports on the Locations of Mass Graves in the Area of Eastern Bosnia and Documentation Relating to Exhumations in the Srebrenica Area", 27 August 2009), p. 51; D3894 (Dušan Dunjić's expert report entitled "Forensic Analysis of Documents Pertaining to Exhumations, Autopsies and Identification of Bodies in the Srebrenica Area", 26 August 2012), p. 12. See Dušan Dunjić, T. 41779-41780 (23 July 2013).

18945 D3893 (Dušan Dunjić's expert report entitled "Forensic Analysis of Reports on the Locations of Mass Graves in the Area of Eastern Bosnia and Documentation Relating to Exhumations in the Srebrenica Area", 27 August 2009), pp. 51-52, 118; D3894 (Dušan Dunjić's expert report entitled "Forensic Analysis of Documents 
5552. Dunjić challenges the findings in the relevant autopsy reports and states that, except for the cases where it had been established beyond reasonable doubt that the bodies were bound by ligatures, wires, or ropes, the findings in such reports could not allow for one to reach the conclusion that individuals had been victims of execution. ${ }^{18946}$ According to Dunjić, there were between 400 and 500 bodies found with ligatures in Srebrenica-related gravesites which could be considered as being victims of executions; this is irrespective of the injuries present on those bodies. ${ }^{18947}$ Further, only a very limited number of bodies presented injuries which would allow for the conclusion that such individuals had been executed; the cause of death for the remainder could be various, including shrapnel and projectiles, which could indicate that the person in question died in combat. ${ }^{18948}$

5553. Specifically referring to the reports prepared by Clark and Lawrence, Dunjić claims that the conclusions on the cause and manner of death contained therein were drafted on the basis of wrong assumptions. ${ }^{18949}$ Dunjić explains that both experts adopted the assumption that the injuries on the victims were caused when they were still alive, and thus the victims had died as a result of those particular injuries. ${ }^{18950}$ These assumptions were, according to Dunjić, also accepted by Baraybar, Haglund, and Wright. ${ }^{18951}$ However, Dunjić claims that in a case of a skull perforation caused by a

Pertaining to Exhumations, Autopsies and Identification of Bodies in the Srebrenica Area”, 26 August 2012), p. 12. See Dušan Dunjić, T. 41779-41780 (23 July 2013).

Dušan Dunjić, T. 41749 (22 July 2013); T. 41887-41888, 41898-41899 (24 July 2013). The Chamber notes that Manning prepared a chart containing a list of blindfolds and ligatures located between 1996 and 2001, as well as the gravesites from which they were exhumed. Dean Manning, T. 25821-25822 (6 March 2012); P4507 (Chart of photographs of blindfolds, ligatures, and location). Manning's methodology in creating the chart included physically examining each item, examining documentation for each item, including photographic logs, evidence logs, autopsy reports, and observations by pathologists, crime scene officers, and other experts. Dean Manning, T. 25821 (6 March 2012). Manning explained that some of the blindfolds and ligatures were located only at the time of autopsy and examination of the body, and on occasion by the time the bodies arrived in the mortuary the blindfolds and ligatures had fallen off or become disassociated with the body. Dean Manning, T. 25821-25822 (6 March 2012). The final numbers in Manning's chart were 423 ligatures and 448 blindfolds; these numbers did not necessarily match with the other experts' numbers because his conservative numbers were based on the examination of all aspects of the exhumation and autopsy process. Dean Manning, T. 2582325824 (6 March 2012).

18947 Dušan Dunjić, T. 41893-41894, 41898-41899 (24 July 2013).

18948 Dušan Dunjić, T. 41749-41750 (22 July 2013).

18949 Dušan Dunjić, T. 41775-41777, 41803 (23 July 2013), T. 41860 (24 July 2013). See Dušan Dunjić, T. $41802-$ 41803 (23 July 2013); D3894 (Dušan Dunjić's expert report entitled "Forensic Analysis of Documents Pertaining to Exhumations, Autopsies and Identification of Bodies in the Srebrenica Area", 26 August 2012), p. 8. See D3896 (Dušan Dunjić's expert report entitled "Forensic Analysis of Exhumation Reports from the Bišina Site and Documents Relating to the Update to the Summary of Forensic Evidence from Graves in the Srebrenica Area", April 2009), p. 212.

18950 Dušan Dunjić, T. 41776-41777 (23 July 2013), T. 41859-41860 (24 July 2013); D3893 (Dušan Dunjić's expert report entitled "Forensic Analysis of Reports on the Locations of Mass Graves in the Area of Eastern Bosnia and Documentation Relating to Exhumations in the Srebrenica Area”, 27 August 2009), pp. 50-51, 54-55; D3894 (Dušan Dunjić's expert report entitled "Forensic Analysis of Documents Pertaining to Exhumations, Autopsies and Identification of Bodies in the Srebrenica Area", 26 August 2012), pp. 7-8.

18951 D3894 (Dušan Dunjić's expert report entitled "Forensic Analysis of Documents Pertaining to Exhumations, Autopsies and Identification of Bodies in the Srebrenica Area”, 26 August 2012), p. 12. See Dušan Dunjić, T. 41777, 41803-41804 (23 July 2013). 
shot from a firearm, this can be the cause of death only if it is proven that the person was alive before the injury was inflicted, which can only be done on fresh bodies. ${ }^{18952}$ Consequently, the experts' characterisation of injuries as perimortem was not properly done. ${ }^{18953}$

5554. Dunjić refers to Clark's evidence acknowledging the limitations faced when conducting his examination of remains found at the Kozluk and Glogova gravesites. ${ }^{18954}$ Similarly, Dunjić refers to Lawrence's evidence acknowledging that in a large number of cases he was not able to determine the cause of death. ${ }^{18955}$ Dunjić goes even further and claims that Lawrence's findings that postmortem injuries tended to obscure perimortem injuries were absolutely arbitrary, if not actually malicious. ${ }^{18956}$

5555. The Chamber notes that the advanced state of skeletonisation and putrefaction of the bodies exhumed from Srebrenica-related gravesites presented problems for the Prosecution experts, particularly when determining the cause of death. While the Chamber acknowledges these difficulties, it is satisfied with the methodology followed by the experts in reaching their conclusions, and with the reliability of such conclusions. Further, the Chamber finds Dunjić's evidence on cause of death to show a complete disregard for the evidence on the various Scheduled Killing Incidents, which comes from many witnesses, including survivors and insider witnesses, such as direct perpetrators, and those involved in the burial and reburial of bodies.

5556. In relation to the manner of death, the Accused argues that at minimum 1,000 individuals, but likely many more, died as a result of mines, suicides, or legitimate combat activities after the fall of Srebrenica. ${ }^{18957}$ Dunjić also claims that, contrary to Clark's findings that for most cases

18952 In putrefied and skeletonised bodies, without soft tissue, such skull perforation is only a possible cause of death given that the person could have died before the injury was inflicted, from many other causes. D3894 (Dušan Dunjić's expert report entitled "Forensic Analysis of Documents Pertaining to Exhumations, Autopsies and Identification of Bodies in the Srebrenica Area", 26 August 2012), p. 8.

18953 Dušan Dunjić, T. 41777-41778 (23 July 2013). See D3894 (Dušan Dunjić's expert report entitled "Forensic Analysis of Documents Pertaining to Exhumations, Autopsies and Identification of Bodies in the Srebrenica Area", 26 August 2012), p. 8.

18954 D3894 (Dušan Dunjić's expert report entitled "Forensic Analysis of Documents Pertaining to Exhumations, Autopsies and Identification of Bodies in the Srebrenica Area", 26 August 2012), pp. 7-8 (referring to P4103 (John Clark's expert report entitled "Report of Chief Pathologist, Srebrenica Grave Sites (1999)", undated), ecourt pp. 3-4). See also Defence Final Brief, para. 2663 (where the Accused discusses the difficulties faced by Clark).

18955 Dušan Dunjić, T. 41781-41782 (23 July 2013). See D3896 (Dušan Dunjić's expert report entitled "Forensic Analysis of Exhumation Reports from the Bišina Site and Documents Relating to the Update to the Summary of Forensic Evidence from Graves in the Srebrenica Area", April 2009), p. 212.

18956 D3896 (Dušan Dunjić's expert report entitled "Forensic Analysis of Exhumation Reports from the Bišina Site and Documents Relating to the Update to the Summary of Forensic Evidence from Graves in the Srebrenica Area", April 2009), p. 212; Dušan Dunjić, T. 41782-41783, 41821-41824 (23 July 2013).

18957 Defence Final Brief, paras. 2557-2561, 2565, 2571, 2636, 2638. 
death cannot be linked to combat, there is a lot of evidence proving the contrary. ${ }^{18958}$ Dunjić refers to evidence supporting his claim, such as the fact that in a large number of cases the relevant autopsy report indicates extensive injuries characteristic of injuries caused by large projectiles or shells, and to the fact that a large presence of individual injuries on different parts of the body is more indicative of combat. ${ }^{18959}$ Dunjić also refers to various witness statements to claim that a large number of the Srebrenica victims were members of the $\mathrm{ABiH}$ who died as a result of the armed conflict and at numerous sites around Srebrenica. ${ }^{18960}$

5557. The Chamber notes that it received evidence of wounds caused by shells and shrapnel in connection with the killings at the Kravica Warehouse. ${ }^{18961}$ While Dunjić argues that these injuries could have been the result of combat activities, the Chamber finds that Dunjic looked at the evidence in question in isolation. The examples referred to by Dunjić relate to gravesites which have been associated with the killings at the Kravica Warehouse. ${ }^{18962}$ The Chamber recalls that it received evidence that a series of hand-grenades were thrown in the warehouse through the windows while the detainees were still inside. ${ }^{18963}$ Accordingly, the Chamber rejects the Accused's argument and Dunjić's evidence in this regard.

\section{(C) ICMP}

5558. Thomas Parsons testified as an expert for the Prosecution in this case. Parsons joined the ICMP as director of forensic sciences, in March 2006. ${ }^{18964}$ The ICMP is an organisation established in 1996 whose mission is to assist governments with locating and identifying

18958 D3894 (Dušan Dunjić's expert report entitled "Forensic Analysis of Documents Pertaining to Exhumations, Autopsies and Identification of Bodies in the Srebrenica Area”, 26 August 2012), p. 11. See Dušan Dunjić, T. 41889-41890, 41892-41894 (24 July 2013).

18959 D3894 (Dušan Dunjić's expert report entitled "Forensic Analysis of Documents Pertaining to Exhumations, Autopsies and Identification of Bodies in the Srebrenica Area”, 26 August 2012), p. 11. See Dušan Dunjić, T. 41781 (23 July 2013); T. 41903-41904 (24 July 2013).

18960 D3894 (Dušan Dunjić's expert report entitled "Forensic Analysis of Documents Pertaining to Exhumations, Autopsies and Identification of Bodies in the Srebrenica Area", 26 August 2012), pp. 13-15; Dušan Dunjić, T. 41904 (24 July 2013).

18961 See paras. 5255, 5263. See also P4105 (John Clark's expert report entitled "Report of the Chief Pathologist, Srebrenica Grave Sites (2001)”, 24 May 2003), pp. 16, 22, 25-26; P4059 (Christopher Lawrence's expert report entitled "Report on Autopsies of Human Remains from Zelani Jadar Site 5, October 1998", 17 June 1999), ecourt pp. 18, 20; P4502 (Dean Manning's Report, entitled "Summary of Forensic Evidence, Mass Graves Exhumed in 2000 - Lazete 1, Lazete 2C, Ravnice, Glogova 1", February 2001), e-court pp. 13-15; Dean Manning, T. 25855-25856 (6 March 2012); Dušan Janc, T. 27046 (28 March 2012).

18962 See D3893 (Dušan Dunjić's expert report entitled "Forensic Analysis of Reports on the Locations of Mass Graves in the Area of Eastern Bosnia and Documentation Relating to Exhumations in the Srebrenica Area", 27 August 2009), p. 48. See also D3893 (Dušan Dunjić's expert report entitled "Forensic Analysis of Reports on the Locations of Mass Graves in the Area of Eastern Bosnia and Documentation Relating to Exhumations in the Srebrenica Area", 27 August 2009), pp. 50-53, 55-56.

18963 See para. 5233.

18964 Thomas Parsons, P4643 (Transcript from Prosecutor v. Popović et al.), T. 20867; Thomas Parsons, T. 26590 (21 March 2012); P4638 (Thomas Parsons' 2011 curriculum vitae). 
individuals who have disappeared during armed conflicts or as a result of human rights violations. ${ }^{18965}$

5559. As director of forensic sciences, Parsons supervises three main forensic science divisions: the archaeology and anthropology division, the DNA laboratories, and the identification coordination division. ${ }^{18966}$ The archaeology and anthropology division provides technical assistance in the exhumation of mass gravesites, the recovery of human remains, and the anthropological and pathological analysis in mortuary facilities. ${ }^{18967}$ The DNA laboratories-which have been active since 2001-perform DNA typing from bone or blood samples received from mortuary facilities and from family members of the missing. ${ }^{18968}$ Finally, the identification co-ordination division oversees the reception of DNA samples and, once the DNA typing is done, matches the samples from family members of the missing and the genetic data from the victims. ${ }^{18969}$

5560. Parsons explained that once the identification co-ordination division receives samples from mortuary facilities and blood samples from an average of three family members of the missing individual, it enters the data into the ICMP system and assigns each sample a random bar code number, ensuring the anonymity of the sample when it reaches the DNA laboratories; this allows for objective testing. ${ }^{18970}$ The ICMP maintains a single DNA database within a forensic data management system, comprising of several subprojects from the areas around the world in which it operates. $^{18971}$

18965 P4644 (ICMP Methodology Report on 2001-2008 DNA Process, 15 January 2008), e-court p. 2; Thomas Parsons, T. 26592-26593 (21 March 2012). See Thomas Parsons, P4643 (Transcript from Prosecutor v. Popović et al.), T. 20867, 20881. The ICMP is currently headquartered in Sarajevo. P4644 (ICMP Methodology Report on 2001-2008 DNA Process, 15 January 2008), e-court p. 2. Parsons explained that the ICMP has an ISO-17025 accreditation since October 2007, and goes annually through technical audits on methods used, results obtained, and processes involved. Thomas Parsons, T. 26556, 26599-26601 (21 March 2012); Thomas Parsons, P4643 (Transcript from Prosecutor v. Popović et al.), T. 20872, 20893, 20913, 33400; P4637 (ICMP report on DNA testing protocol, 14 February 2011), para. 2. Parsons further testified that the ICMP is considered the world's leader in forensic identifications of missing persons. Thomas Parsons, T. 26597, 26601 (21 March 2012).

18966 Thomas Parsons, T. 26554-27556 (21 March 2012); Thomas Parsons, P4643 (Transcript from Prosecutor v. Popović et al.), T. 20868.

18967 Thomas Parsons, T. 26555-26556, 26592-26593, 26601-26602 (21 March 2012); Thomas Parsons, P4643 (Transcript from Prosecutor v. Popović et al.), T. 20868, 20880-20881.

18968 Thomas Parsons, T. 26555, 26601 (21 March 2012); Thomas Parsons, P4643 (Transcript from Prosecutor v. Popović et al.), T. 20868, 20870; P4644 (ICMP Methodology Report on 2001-2008 DNA Process, 15 January 2008), e-court pp. 2-3; P4651 (ICMP statement on Srebrenica killings of July 1995, 30 November 2007).

18969 Thomas Parsons, T. 26555 (21 March 2012); Thomas Parsons, P4643 (Transcript from Prosecutor v. Popović et al.), T. 20868.

18970 Thomas Parsons, T. 26555, 26573 (21 March 2012), T. 26628-26631 (22 March 2012); Thomas Parsons, P4643 (Transcript from Prosecutor v. Popović et al.), T. 20868, 20872, 20876, 20885, 20899. See also P4651 (ICMP statement on Srebrenica killings of July 1995, 30 November 2007).

18971 Thomas Parsons, T. 26604 (21 March 2012), T. 26606-26607 (22 March 2012). 
5561. Parsons testified that the testing at the ICMP DNA laboratories is conducted in accordance with pre-existing standard operating procedures ("SOPs"), which define the actions and procedures of analysts during DNA testing. ${ }^{18972}$ This specific process-a well established technology accepted in the scientific community as a standard for forensic diagnosis-involves extracting DNA from the skeletal remains and performing a polymerase chain reaction amplification of the short tandem repeat locus-a particular place on the DNA that is unique to individuals-resulting in the unique DNA profiles that can be used for genetic comparison. ${ }^{18973}$

5562. As a next step in the process, the laboratories send the testing results to the identification coordination division which then uses software to match the unique DNA profiles from the skeletal remains to the anonymous DNA profiles taken from family members. ${ }^{18974}$ To obtain a positive match, a minimum of $99.95 \%$ certainty is required. ${ }^{18975}$ A DNA match report is then prepared indicating findings, inter alia, with regard to a DNA match between a human remains sample and a set of family reference DNA profiles, and the location of the gravesite where the human remain sample originated from. ${ }^{18976}$ In total, almost 15,000 DNA match reports have been processed in relation to Srebrenica. ${ }^{18977}$

18972 Thomas Parsons, P4643 (Transcript from Prosecutor v. Popović et al.), T. 20869, 20909-20910; Thomas Parsons, T. 26556-26557 (21 March 2012); P4644 (ICMP Methodology Report on 2001-2008 DNA Process, 15 January 2008), paras. 5-6. The SOPs used are not unique to the ICMP but are widely used by other laboratories internationally. Thomas Parsons, T. 26557 (21 March 2012); Thomas Parsons, P4643 (Transcript from Prosecutor v. Popović et al.), T. 20909-20910. The ICMP SOPs have been evolving over the years in order to reflect, inter alia, new models of laboratory equipment, enhanced quality control measures, and validation of new methods. See Thomas Parsons, T. 26556-26557 (21 March 2012); P4637 (ICMP report on DNA testing protocol, 14 February 2011).

18973 Thomas Parsons, T. 26658-26659 (22 March 2012). See Thomas Parsons, P4643 (Transcript from Prosecutor v. Popović et al.), T. 20870-20871; P4644 (ICMP Methodology Report on 2001-2008 DNA Process, 15 January 2008), paras. 5-6. Parsons explained that the ICMP previously used an industry standard extraction method where chemical manipulations were performed on bone samples to retrieve relatively pure DNA. Thomas Parsons, T. 26551-26552, 26559 (21 March 2012); Thomas Parsons, P4643 (Transcript from Prosecutor v. Popović et al.), T. 20870-20871. Since then, a new extraction method that isolates DNA from degraded skeletal remains resulting in a higher DNA extraction success rate, has been introduced. Thomas Parsons, T. 26551-26552, 26559 (21 March 2012); P4637 (ICMP report on DNA testing protocol, 14 February 2011), pp. 1-2.

18974 P4644 (ICMP Methodology Report on 2001-2008 DNA Process, 15 January 2008), paras. 23-24; Thomas Parsons, P4643 (Transcript from Prosecutor v. Popović et al.), T. 20868, 20876. See Thomas Parsons, T. 26628-26629 (22 March 2012); P4651 (ICMP statement on Srebrenica killings of July 1995, 30 November 2007).

18975 Thomas Parsons, T. 26616 (22 March 2012); Thomas Parsons, P4643 (Transcript from Prosecutor v. Popović et al.), T. 20877.

18976 Thomas Parsons, T. 26560, 26572-26573 (21 March 2012), T. 26608-26609 (22 March 2012). See P4640 (DNA reports of persons exhumed from Korićanske Stijene on 3 October 2003). The DNA match reports are reviewed by two experts to verify the matches done by the software. See P4644 (ICMP Methodology Report on 2001-2008 DNA Process, 15 January 2008), para. 27.

18977 Thomas Parsons, T. 26611-26613 (22 March 2012). Parsons explained that this number, which is significantly higher than the total number of Srebrenica missing, is the result of the fragmentation of many of the mortal remains, and multiple samples belonging to the same individual being tested. Thomas Parsons, T. 26612-26613 (22 March 2012). 
5563. The information identifying an individual from the DNA match reports is then incorporated into the ICMP database which, Parsons explained, includes a subproject relating to the entire war period in $\mathrm{BiH} .{ }^{18978}$ The Chamber notes that from this $\mathrm{BiH}$ subproject, a specific list including the name of victims associated with the events surrounding the fall of Srebrenica was created ("Srebrenica List"). ${ }^{18979}$ The Srebrenica List contains information on the names and dates of birth of victims, protocol IDs (an internal number assigned by the ICMP relating to a DNA match report), case IDs (designated to the sample sent to the ICMP), and ICMP IDs (internally assigned by the ICMP and referring to the reported missing person). ${ }^{18980}$ The Srebrenica List also contains information regarding the location and date of disappearance of Srebrenica-related missing persons as provided by their families. ${ }^{18981}$ In this regard, Parsons explained that due to the difficulty in obtaining a consistent place of disappearance, based on the differing accounts from multiple family members, only two categories of place of disappearance were recorded, namely: "Potočari", to refer to men and boys that remained at the DutchBat facility in Potočari and surrounding areas; or "Forest", indicating that the individual attempted to flee Srebrenica by an overland route. ${ }^{18982}$

5564. Parsons further explained that the DNA profiles correspond to individuals who have been identified and named, with the exception of indistinguishable siblings, who are listed twice. ${ }^{18983}$ Inconclusively associated cases, referring to cases where siblings have been reported missing, with one associated with Srebrenica and the other from an unrelated event, are also included on the Srebrenica List, as the DNA information received from the family samples will not allow for the distinction between such siblings. ${ }^{18984}$ Unmatched unique DNA profiles, referring to unidentified individuals but who are uniquely represented by their DNA, are also incorporated into the list. ${ }^{18985}$

\footnotetext{
18978 Thomas Parsons, T. 26604 (21 March 2012), T. 26606-26607 (22 March 2012).

18979 Dušan Janc, T. 26938-26939 (27 March 2012). See e.g. P5915 (ICMP report on identified victims, 3 July 2008).

18980 Thomas Parsons, T. 26573-26575 (21 March 2012), T. 26640-26641 (22 March 2012); Thomas Parsons, P4643 (Transcript from Prosecutor v. Popović et al.), T. 20874-20875. See Dušan Janc, T. 26940-26942 (27 March 2012).

18981 Thomas Parsons, P4643 (Transcript from Prosecutor v. Popović et al.), T. 20873, 20875; Thomas Parsons, T. 26575 (21 March 2012).

18982 Thomas Parsons, T. 26574-26575 (21 March 2012); Thomas Parsons, P4643 (Transcript from Prosecutor v. Popović et al.), T. 20875-20876; P4651 (ICMP statement on Srebrenica killings of July 1995, 30 November 2007). See P5913 (ICMP list of identified Srebrenica victims, 15 December 2011).

18983 Thomas Parsons, T. 26584 (21 March 2012). See P5913 (ICMP list of identified Srebrenica victims, 15 December 2011). See also Dušan Janc, T. 26965-26966 (27 March 2012), T. 27029-27030 (28 March 2012).

18984 Thomas Parsons, T. 26576-26577, 26584 (21 March 2012). See P5913 (ICMP list of identified Srebrenica victims, 15 December 2011).

18985 Thomas Parsons, T. 26584-26585 (21 March 2012). See P5913 (ICMP list of identified Srebrenica victims, 15 December 2011).
} 
5565. The ICMP database is updated periodically due to the identification and exhumation of new graves. ${ }^{18986}$ The ICMP has released updates to the Srebrenica List on multiple occasions, including in July 2008 (“July 2008 ICMP List”), ${ }^{18987}$ December 2010 (“December 2010 ICMP List”), 18988 December 2011 (“December 2011 ICMP List”), ${ }^{18989}$ and January 2012 (“January 2012 ICMP List"). ${ }^{18990}$

5566. The Chamber recalls that on numerous occasions the Accused challenged the ICMP methodology with regard to the identification of Srebrenica victims through DNA analysis. ${ }^{18991}$ Specifically, the Chamber recalls that the Accused requested that he be provided with the ICMP database, which the ICMP refused to do on the basis that it would take a significant amount of time to obtain consent from the affected families. ${ }^{18992}$ The Chamber agreed that the Accused should be able to engage his own DNA expert to run DNA identification tests for the purpose of checking the accuracy of the ICMP's identifications and, if relevant, challenging Parsons' evidence. ${ }^{18993}$ An agreement was then reached between the parties and the ICMP, where 300 cases would be selected from which the ICMP would seek the consent of family members before providing their genetic information to the Accused's expert. ${ }^{18994}$ In 2012, upon the refusal of family members in relation to 14 cases, the Accused requested that the Chamber compel the ICMP to make DNA case files

\footnotetext{
18986 Dušan Janc, T. 26920-26921, 26936 (27 March 2012).

18987 Thomas Parsons, T. 26639 (22 March 2012). See P4662 (ICMP report on identified victims, 3 July 2008) (under seal); P5915 (ICMP report on identified victims, 3 July 2008).

18988 See P4768 (ICMP DNA identifications concerning identified victims related to Srebrenica, 6 December 2010) (under seal); P5917 (ICMP DNA identifications concerning identified victims related to Srebrenica, 6 December 2010); Dušan Janc, T. 26937-26938 (27 March 2012).

18989 Thomas Parsons, T. 26572-26573, 26583-26584 (21 March 2012). See P4642 (ICMP list of identified Srebrenica victims, 15 December 2011) (under seal); P5913 (ICMP list of identified Srebrenica victims, 15 December 2011).

18990 Ewa Tabeau, T. 28249-28250, 28258-28259 (1 May 2012). See P5005 (2012 ICMP updated list of Srebrenica missing) (under seal); P5916 (2012 ICMP updated list of Srebrenica missing).

18991 See para. 6160.

18992 See Order on Selection of Cases for DNA Analysis, 19 March 2010, p. 2.

18993 Order on Selection of Cases for DNA Analysis, 19 March 2010, pp. 2-3; Decision in Relation to Selection of Cases for DNA Analysis, 23 September 2011, p. 2. See also Decision on the Accused's Motion for Binding Order to International Commission for Missing Persons, 4 March 2013, para. 1.

18994 Order on Selection of Cases for DNA Analysis, 19 March 2010, pp. 2-3; Decision in Relation to Selection of Cases for DNA Analysis, 23 September 2011, p. 2. See also Decision on the Accused's Motion for Postponement of Trial, 26 February 2010, para. 35, fn. 57; Submission Pursuant to the Trial Chamber's Order Setting Deadline for Further Submissions, 22 February 2010, Annex C; Prosecution's Further Response to Karadžić's Motion for the Postponement of Trial Pursuant to Trial Chamber's Order of 3 February 2010 with Confidential Appendices A-F, 9 February 2010, Confidential Appendix A, p. 5. The parties agreed that 295 cases would be selected by a random sampling method, whilst five would be hand picked by the Accused. Interim Order on the Accused's Motion for Binding Order to International Commission for Missing Persons, 19 July 2012, p. 2. See also Order on Selection of Cases for DNA Analysis, 19 March 2010; Decision in Relation to Selection of Cases for DNA Analysis, 23 September 2011; Notification on the Accused's NonCompliance with the Trial Chamber's Order on Selection of Cases for DNA Analysis and Request for Further Orders with Public Appendix C and Confidential Appendices A-B and D-F, 21 June 2011, pp. 1-2.
} 
available to him irrespective of the lack of such consent. ${ }^{18995}$ The Chamber denied the request in March 2013 noting, inter alia, that the sample list of 286 cases was sufficiently large for credible testing. ${ }^{18996}$ Despite having a sizeable number of sample names, the Accused refused the ICMP's offer to test selected cases and filed a motion requesting that the Chamber exclude all the DNA analysis conducted by the ICMP; this motion was denied by the Chamber on 16 April 2013, finding that the Accused would still be able to test the ICMP's results and challenge Parsons' evidence based on the available sample test cases. ${ }^{18997}$

5567. Despite this, the Accused chose not to present additional expert evidence to the Chamber challenging the ICMP's methodology and/or results. ${ }^{18998}$ The Chamber notes, however, that during Parsons' and Janc's testimony, the Accused tried to challenge, inter alia, the existence of potential bias by the ICMP due to funding by governmental donors and private foundations, the apparent lack of independent verification and investigation procedures, and portions of the ICMP methodology, including, but not limited to, the integrity of the transfer processes in the samples arriving at the ICMP laboratories. ${ }^{18999}$

5568. The Chamber finds the ICMP to be a reputable, impartial, and reliable institution. Further, having reviewed Parsons' evidence and the ICMP related exhibits admitted through him, the Chamber is satisfied with the propriety and reliability of the ICMP methodology and the reliability of the DNA analysis conducted under Parsons' supervision.

\section{(D) Demographic evidence}

5569. Ewa Tabeau, the Head of the Prosecution's Demographic Unit from 2000 to 2011, testified as an expert for the Prosecution in this case. ${ }^{19000}$ Tabeau gave evidence on demographics related to three components of the case, namely Municipalities, Sarajevo, and Srebrenica. ${ }^{19001}$ In relation to the Srebrenica component of the case, Tabeau was tasked, inter alia, with using the most reliable sources on missing and identified persons to arrive at a reliable estimate of the total number of

\footnotetext{
18995 Motion for Binding Order to International Commission for Missing Persons, 15 May 2012, paras. 1, 7, $28-29$.

18996 Decision on the Accused's Motion for Binding Order to International Commission for Missing Persons, 4 March 2013, paras. 27, 29-30, 34, 36. See also Prosecution's Response to Accused's Motion for Binding Order to International Commission for Missing Persons, 29 May 2012, paras. 1, 16; Reply Brief: Motion for Binding Order to International Commission for Missing Persons, 11 June 2012; Prosecution's Sur-Reply to Accused Reply Brief: Motion for Binding Order to International Commission for Missing Persons, 11 June 2012.

18997 Decision on the Accused's Motion to Exclude DNA Evidence, 16 April 2013, paras. 6-7, 9. See also Motion to Exclude DNA Evidence, 11 March 2013; Prosecution's Response to Motion to Exclude DNA Evidence, 25 March 2013.

18998 See Prosecution's Final Brief, Appendix D, para. 169.

18999 See e.g. Thomas Parsons, T. 26593-26599 (21 March 2012), T. 26609-26611 (22 March 2012); Dušan Janc, T. 27010-27014 (27 March 2012).

19000 Ewa Tabeau, T. 28117 (25 April 2012).
} 
people killed or still missing after the fall of Srebrenica. ${ }^{19002}$ For this purpose, Tabeau, along with Helge Brunborg and Arve Hetland, created a series of lists aimed at cross-referencing and integrating different lists of Srebrenica missing with ICMP lists on DNA identifications; this series of lists was admitted into evidence as P6705 ("2009 Srebrenica Lists of Missing”). ${ }^{19003}$ As part of the same exercise, Tabeau and her colleagues co-authored a report presenting summary statistics, which was admitted into evidence as P4995 (“Tabeau's 2009 Report”). ${ }^{19004}$ The sources and methodology used in producing these documents is explained in detail below.

5570. Tabeau testified that the two main sources used in compiling Tabeau's 2009 Report and the 2009 Srebrenica Lists of Missing include, first, selected ICRC data pertaining to missing persons, as found in a list of missing persons compiled in 2005 by the Prosecution and, second, an update to the Srebrenica List released by the ICMP in November 2008 (“November 2008 ICMP List”). 19005

19001 See e.g. Ewa Tabeau, T. 28119 (25 April 2012), T. $28172-28173$ (26 April 2012), T. 28232 (1 May 2012 ).

19002 See P4995 (Ewa Tabeau's expert report entitled "The 2009 Integrated Report on Srebrenica Missing Including a Progress Report on DNA-based Identification”, 9 April 2009), pp. 2, 35.

19003 P4995 (Ewa Tabeau's expert report entitled "The 2009 Integrated Report on Srebrenica Missing Including a Progress Report on DNA-based Identification”, 9 April 2009), pp. 1, 5, 64. See P6705 (Ewa Tabeau's expert report entitled "Srebrenica Missing: Persons Reported Missing and Dead after the Take-Over of the Srebrenica Enclave by the Bosnian Serb Army on 11 July 1995", 9 April 2009). The under seal version of P6705 is P4996 (Ewa Tabeau's expert report entitled "Srebrenica Missing: Persons Reported Missing and Dead after the TakeOver of the Srebrenica Enclave by the Bosnian Serb Army on 11 July 1995", 9 April 2009) (under seal). See also Dušan Janc, T. 27025-27026 (28 March 2012).

19004 See P4995 (Ewa Tabeau's expert report entitled “The 2009 Integrated Report on Srebrenica Missing Including a Progress Report on DNA-based Identification”, 9 April 2009).

19005 Ewa Tabeau, T. 28232-23233 (1 May 2012). The Chamber notes that the November 2008 ICMP List, which has not been admitted into evidence in this case, is an update to the July 2008 ICMP List referred to above. See P4995 (Ewa Tabeau's expert report entitled “The 2009 Integrated Report on Srebrenica Missing Including a Progress Report on DNA-based Identification”, 9 April 2009) pp. 46, 64-66. See also para. 5565. Tabeau explained that the November 2008 ICMP List was consulted and used as it was the latest update at the time of preparing Tabeau's 2009 Report and the 2009 Srebrenica Lists of Missing. Ewa Tabeau, T. 28233 (1 May 2012). Other sources utilised during the preparation of Tabeau's 2009 Report and the 2009 Srebrenica Lists of Missing include the 1991 Population Census for BiH, the BiH Voters Registers of 1997, 1998, and 2000, and documents pertaining to the official registration of internally displaced persons and refugees in $\mathrm{BiH}$ as of 2000 . P4995 (Ewa Tabeau's expert report entitled "The 2009 Integrated Report on Srebrenica Missing Including a Progress Report on DNA-based Identification”, 9 April 2009), pp. 2, 5; Ewa Tabeau, T. 28233-28234 (1 May 2012). The Chamber notes Pašalić's challenge on the validity and reliability of the data used by the Prosecution experts in their method of data matching and, more specifically, on the methodology used in Tabeau's 2009 Report. D3125 (Stevo Pašalić's expert report entitled "Ethnic Composition, Displaced Persons and Refugees from 27 Municipalities in the Territory of BiH, 1991-1997”, August 2012), pp. 18-20, 105-112; Stevo Pašalić, T. 35359-35363 (13 March 2013), T. 35451-35454, 35466-35467 (14 March 2013). However, the Chamber finds Pašalić's evidence unfounded due to his inability to properly differentiate between the "primary" sources he used and the apparent supplementary nature of the sources consulted by Tabeau and her colleagues, as well as his unsubstantiated argument that Tabeau relied on "imaginary forms and calculations". The Chamber is therefore satisfied with the methodology utilised by Tabeau and her colleagues in arriving at a reliable estimate of the total number of people killed or still missing after the fall of Srebrenica. See generally P4995 (Ewa Tabeau's expert report entitled “The 2009 Integrated Report on Srebrenica Missing Including a Progress Report on DNA-based Identification”, 9 April 2009). 
The Chamber has explained in detail above how the ICMP lists are created. ${ }^{19006}$ This applies as well to the November 2008 ICMP List.

5571. In relation to the list of missing persons compiled by the Prosecution, Tabeau explained that the ICRC started collecting tracing requests for missing persons throughout the war in $\mathrm{BiH}$ and during its aftermath. ${ }^{19007}$ The ICRC thus collected data relating to the surname, first name, father's name, sex, date and place of birth, and date and place of disappearance for each individual reported as missing, as obtained from the missing person's close relatives. ${ }^{19008}$ As a result of this exercise, the ICRC published various volumes of lists of missing persons for the whole war in $\mathrm{BiH} .{ }^{19009}$ Tabeau explained that the Prosecution created its own list of missing persons for Srebrenica based on one of the ICRC volumes, by excluding records of persons reported missing throughout the war in relation to events unconnected to the fall of Srebrenica. ${ }^{19010}$ In relation to the data provided for the date and place of disappearance of missing persons, Tabeau explained that the date of disappearance was not necessarily the date the individual may have been killed, but when he was last seen alive, with records of a reported disappearance between 1 July and 31 August 1995 being deemed the most relevant in the circumstances. ${ }^{19011}$ The place of disappearance referred to the place the individual was last seen alive. ${ }^{19012}$ The Chamber notes that the information in the 2009 Srebrenica Lists of Missing with respect to the place of disappearance of victims does not correspond to the information in the ICMP's Srebrenica List, which only refers to the two

\footnotetext{
19006 See paras. 5559-5565.

19007 P4995 (Ewa Tabeau's expert report entitled "The 2009 Integrated Report on Srebrenica Missing Including a Progress Report on DNA-based Identification”, 9 April 2009), pp. 37-38.

19008 P4995 (Ewa Tabeau's expert report entitled "The 2009 Integrated Report on Srebrenica Missing Including a Progress Report on DNA-based Identification", 9 April 2009), pp. 38-39. See also Dušan Janc, T. 26947 (27 March 2012), T. 27026, 27089-27090 (28 March 2012) (testifying that, for purposes of determining the exact date of disappearance for individuals identified after the fall of Srebrenica, the ICRC is a more reliable source, since the ICMP simply listed individuals as having disappeared on 11 July, while the ICRC collected detailed information from family members and acknowledging also that the ICRC data is not very accurate with respect to some individuals, and cautioning against fully relying on it).

19009 P4995 (Ewa Tabeau's expert report entitled "The 2009 Integrated Report on Srebrenica Missing Including a Progress Report on DNA-based Identification", 9 April 2009), p. 37.

19010 Ewa Tabeau, T. 28239 (1 May 2012). The relevant records pertaining to the victims of the fall of Srebrenica were extracted from the general ICRC list by using, first, the place criterion, which refers to the area of Srebrenica municipality and surrounding municipalities, and, second, the time criterion, which refers to the persons who went missing from July to December 1995. Ewa Tabeau, T. 28239 (1 May 2012). Tabeau and her colleagues used a 2005 version of the ICRC list when compiling the 2009 Srebrenica Lists of Missing. P4995 (Ewa Tabeau's expert report entitled “The 2009 Integrated Report on Srebrenica Missing Including a Progress Report on DNA-based Identification”, 9 April 2009), p. 37.

19011 P4995 (Ewa Tabeau's expert report entitled "The 2009 Integrated Report on Srebrenica Missing Including a Progress Report on DNA-based Identification", 9 April 2009), p. 34. See also P5010 (Courtroom Presentation of Ewa Tabeau 25 April 2012, summarizing main findings discussed in testimony), e-court p. 18 (Figure 1 illustrating the Srebrenica-related missing and dead by month of disappearance).

19012 P4995 (Ewa Tabeau's expert report entitled "The 2009 Integrated Report on Srebrenica Missing Including a Progress Report on DNA-based Identification", 9 April 2009), p. 34. See also P5010 (Courtroom Presentation of Ewa Tabeau 25 April 2012, summarizing main findings discussed in testimony), e-court p. 19 (Figure 3 illustrating the Srebrenica-related missing and dead by place of disappearance).
} 
designated locations of "Potočari" and "Forest". Given that the 2009 Srebrenica Lists of Missing actually aim at providing precise information as to where Srebrenica victims were last seen, this, in the Chamber's view, makes them more probative than the general method used by the ICMP in compiling the corresponding information in the Srebrenica List.

5572. In relation to the methodology followed, Tabeau explained that the list of Srebrenica missing persons compiled by the Prosecution and the November 2008 ICMP List were crossreferenced as two independent sources-a method known as record linkage- - to determine the number of individuals reported missing who were later found in Srebrenica-related gravesites, and thus identified as individuals who died during the fall of Srebrenica. ${ }^{19013}$ This exercise first resulted in the 2009 Srebrenica Lists of Missing, a series of lists containing information from both the Prosecution's list of missing and the ICMP. ${ }^{19014}$ Tabeau and her colleagues then proceeded to draft Tabeau's 2009 Report detailing the methodology and results of the exercise conducted when compiling the 2009 Srebrenica Lists of Missing. ${ }^{19015}$ This document reported, inter alia, on the overlap between ICMP and Prosecution lists confirming the number of Srebrenica-related victims. ${ }^{19016}$ The Chamber notes that, according to Tabeau's 2009 Report, the 2009 total of Srebrenica missing and dead amounted to 7,905 persons. ${ }^{19017}$

5573. In 2012, Tabeau prepared a report incorporating the January 2012 ICMP List with information on Srebrenica victims listed on the 2009 Srebrenica Lists of Missing ("Tabeau's 2012 Report"). ${ }^{19018}$ Tabeau's 2012 Report was created with the aim of identifying the number of additional victims identified by the ICMP since Tabeau's 2009 Report and how these new

19013 Ewa Tabeau, T. 28235, 28237 (1 May 2012); P4995 (Ewa Tabeau's expert report entitled "The 2009 Integrated Report on Srebrenica Missing Including a Progress Report on DNA-based Identification", 9 April 2009), p. 5. Tabeau explained that the 1991 Population Census for $\mathrm{BiH}$ was used as a reference source to validate the information on missing persons, whilst the BIH Voters' registers and lists of refugees were used to eliminate possible survivors. Ewa Tabeau, T. 28233-28235 (1 May 2012).

19014 See P6705 (Ewa Tabeau's expert report entitled “Srebrenica Missing: Persons Reported Missing and Dead after the Take-Over of the Srebrenica Enclave by the Bosnian Serb Army on 11 July 1995", 9 April 2009).

19015 See P4995 (Ewa Tabeau's expert report entitled “The 2009 Integrated Report on Srebrenica Missing Including a Progress Report on DNA-based Identification", 9 April 2009).

19016 P4995 (Ewa Tabeau's expert report entitled "The 2009 Integrated Report on Srebrenica Missing Including a Progress Report on DNA-based Identification", 9 April 2009), pp. 28-29; P6705 (Ewa Tabeau's expert report entitled "Srebrenica Missing: Persons Reported Missing and Dead after the Take-Over of the Srebrenica Enclave by the Bosnian Serb Army on 11 July 1995”, 9 April 2009), e-court pp. 3-4; Ewa Tabeau, T. 28237 28240 (1 May 2012); P5010 (Courtroom Presentation of Ewa Tabeau 25 April 2012, summarising main findings discussed in testimony), e-court pp. 18-19.

19017 P4995 (Ewa Tabeau's expert report entitled "The 2009 Integrated Report on Srebrenica Missing Including a Progress Report on DNA-based Identification”, 9 April 2009), pp. 28, 30; P6705 (Ewa Tabeau's expert report entitled "Srebrenica Missing: Persons Reported Missing and Dead after the Take-Over of the Srebrenica Enclave by the Bosnian Serb Army on 11 July 1995", 9 April 2009), e-court p. 3. See also P5010 (Courtroom Presentation of Ewa Tabeau 25 April 2012, summarising main findings discussed in testimony), e-court p. 20.

19018 P5004 (Ewa Tabeau's report describing integration of new 2012 ICMP update to 2009 list of Srebrenica Missing persons), p. 1. See P5005 (2012 ICMP updated list of Srebrenica missing) (under seal); P5916 (2012 ICMP updated list of Srebrenica missing). 
identifications overlapped with the 2009 Srebrenica Lists of Missing. ${ }^{19019}$ Tabeau's 2012 Report concluded that the total number of missing from the fall of Srebrenica is also totalled at 7,905 persons. $^{19020}$

5574. The Chamber notes Dunjić's challenge that certain victims listed as missing or dead after the fall of Srebrenica on the 2009 Srebrenica Lists of Missing appear to have been ABiH soldiers and military personnel killed between 1992 and July $1995 .^{19021}$ Dunjić specifically refers to a document containing information on the date of death of 142 victims, which is inconsistent with the corresponding information in the 2009 Srebrenica Lists of Missing; according to Dunjić, while these 142 individuals are included in the 2009 Srebrenica Lists of Missing and their remains were identified from various Srebrenica-related gravesites, they were actually killed prior to the fall of Srebrenica, between 1992 and July $1995 .{ }^{19022}$

5575. The Chamber notes that while Dunjić stated in his report that the above document was attached thereto, ${ }^{19023}$ it was neither attached to the report nor tendered as a separate exhibit. However, the Chamber understands the above document to be the one included in pages 7 to 10 of D3815 (hereinafter "so-called ABiH List"). ${ }^{19024}$ The Prosecution, having obtained the so-called

19019 P5004 (Ewa Tabeau's report describing integration of new 2012 ICMP update to 2009 list of Srebrenica Missing persons), p. 3.

19020 Ewa Tabeau, T. 28257-28258 (1 May 2012); P5004 (Ewa Tabeau's report describing integration of new 2012 ICMP update to 2009 list of Srebrenica Missing persons), pp. 1, 6; P5010 (Courtroom Presentation of Ewa Tabeau 25 April 2012, summarizing main findings discussed in testimony), e-court p. 20. The total of 7,905 individuals identified as Srebrenica-related missing was calculated by taking the 7,905 identified individuals from the 2009 Srebrenica Lists of Missing and adding 103 new cases from the January 2012 ICMP List, and then deducting 103 cases which were not associated with Srebrenica but with Žepa. See Ewa Tabeau, T. 2825728258 (1 May 2012); P5004 (Ewa Tabeau's report describing integration of new 2012 ICMP update to 2009 list of Srebrenica Missing persons), p. 4.

19021 See D3893 (Dušan Dunjić's expert report entitled "Forensic Analysis of Reports on the Locations of Mass Graves in the Area of Eastern Bosnia and Documentation Relating to Exhumations in the Srebrenica Area", 27 August 2009), pp. 26-35; D3894 (Dušan Dunjić's expert report entitled "Forensic Analysis of Documents Pertaining to Exhumations, Autopsies and Identification of Bodies in the Srebrenica Area", 26 August 2012), pp. 21-22; Dušan Dunjić, T. 41760-41774 (23 July 2013). The Chamber notes that Dunjić refers to the 2009 Srebrenica Lists of Missing as "Brunborg's list". See Dušan Dunjić, T. 41760 (23 July 2013); D3893 (Dušan Dunjić's expert report entitled "Forensic Analysis of Reports on the Locations of Mass Graves in the Area of Eastern Bosnia and Documentation Relating to Exhumations in the Srebrenica Area", 27 August 2009), p. 26. The Chamber understands this list to be an older version of the 2009 Srebrenica Lists of Missing and, for purposes of this discussion, equivalent to it.

19022 D3893 (Dušan Dunjić's expert report entitled "Forensic Analysis of Reports on the Locations of Mass Graves in the Area of Eastern Bosnia and Documentation Relating to Exhumations in the Srebrenica Area", 27 August 2009), p. 31; Dušan Dunjić, T. 41763-41766, 41790-41791 (23 July 2013). See Defence Final Brief, para. 2630.

19023 D3893 (Dušan Dunjić's expert report entitled "Forensic Analysis of Reports on the Locations of Mass Graves in the Area of Eastern Bosnia and Documentation Relating to Exhumations in the Srebrenica Area", 27 August 2009), p. 31.

19024 D3815 (Collection of documents of BiH Federal Ministry of Defence), pp. 7-10. This exhibit is a compilation of documents related to the Prosecution's request for assistance sent to the BiH Ministry of Defence and the latter's response to the request. D3815 (Collection of documents of BiH Federal Ministry of Defence) pp. 1, 5, 11. See D3893 (Dušan Dunjić's expert report entitled "Forensic Analysis of Reports on the Locations of Mass Graves in the Area of Eastern Bosnia and Documentation Relating to Exhumations in the Srebrenica Area", 
$\mathrm{ABiH}$ List from the $\mathrm{BiH}$ Ministry of Defence in 2001, made a request for assistance to the $\mathrm{BiH}$ Ministry of Defence in June 2004 regarding the circumstances of the death or disappearance of the 142 individuals listed in the so-called $\mathrm{ABiH}$ List-requesting, inter alia, further confirmation of their date of death—and the BiH Ministry of Defence responded to the request in August 2004. ${ }^{19025}$

5576. Dunjić testified that the names of 88 of the above 142 individuals were actually $\mathrm{ABiH}$ soldiers or military personnel killed between 1992 and July 1995. ${ }^{19026}$ Further, the Accused tendered two additional exhibits, D2217 and D3812, which are compilations of parts of the 2009 Srebrenica Lists of Missing, the 2008 ICMP List, and the so-called ABiH List, with apparent discrepancies as to the date of disappearance for a number of individuals included as Srebrenicarelated victims in the report prepared by Janc for this case. ${ }^{19027}$

5577. However, neither Dunjić, even upon the Chamber's specific inquiry, nor any other Defence witness, provided an explanation as to the provenance, authenticity, or accuracy of the so-called ABiH List, D2217, or D3812. ${ }^{19028}$ Dunjić further acknowledged that he had not independently verified the data in those documents. ${ }^{19029}$ The Chamber therefore is not satisfied with the authenticity or veracity of either the so-called ABiH List or D2217 and D3812, and thus cannot rely on those documents. Further and more importantly, according to the BiH Ministry of Defence, contrary to the information on the so-called ABiH List, 135 of the 142 individuals listed therein indeed died or went missing after the fall of Srebrenica. ${ }^{19030}$ This corresponds with the information in the 2009 Srebrenica Lists of Missing. In conclusion, the Chamber is not persuaded by Dunjić's arguments in this respect.

5578. Having reviewed Tabeau's evidence and related exhibits, the Chamber is satisfied with the methodology followed by Tabeau and her colleagues in compiling the 2009 Srebrenica Lists of

27 August 2009), p. 31 (referring to the ERN numbers of the so-called ABiH List). See also Dušan Dunjić, T. 41761-41773, 41790-41794 (23 July 2013).

\section{5}

19026

The so-called ABiH List was attached to these documents.

Dunjić lists these 88 individuals in his report. D3893 (Dušan Dunjić's expert report entitled "Forensic Analysis of Reports on the Locations of Mass Graves in the Area of Eastern Bosnia and Documentation Relating to Exhumations in the Srebrenica Area", 27 August 2009), pp. 31-35. See Dušan Dunjić, T. 41760-41774 (23 July 2013).

19027 See D2217 (Examples of identified persons from Prosecution database and ABiH database); D3812 (List of soldiers killed or missing before July 1995). See also Dušan Janc, T. 27051-27057 (28 March 2012); Dušan Dunjić, T. 41760-41774 (23 July 2013); Defence Final Brief, paras. 2609-2610.

19028 Dušan Dunjić, T. 41766-41767 (23 July 2013). See also D3893 (Dušan Dunjić's expert report entitled "Forensic Analysis of Reports on the Locations of Mass Graves in the Area of Eastern Bosnia and Documentation Relating to Exhumations in the Srebrenica Area", 27 August 2009), p. 31.

19029 See Dušan Dunjić, T. 41767-41768, 41772-41773 (23 July 2013).

19030 See D3815 (Collection of documents of BiH Federal Ministry of Defence), pp. 11-20. The BiH Ministry of Defence stated in the same response that information regarding the remaining seven individuals was not available. D3815 (Collection of documents of BiH Federal Ministry of Defence), p. 11. 
Missing and in creating Tabeau's 2009 Report and Tabeau's 2012 Report. Specifically regarding the 2009 Srebrenica Lists of Missing, the Chamber has taken into consideration the difficulties faced by the ICRC when obtaining data on the missing, ${ }^{19031}$ and accepts the fact that, due to a number of circumstances, including human error on the part of family members when providing information to the ICRC, a few mistakes on the list would be inevitable. Nevertheless, the Chamber finds no reason not to rely on the information contained in the 2009 Srebrenica Lists of Missing, and has used the information therein-taking into consideration the fact that it cannot be considered as completely accurate-when analysing and weighing conflicting forensic evidence before it in relation to each of the various Scheduled Killing Incidents.

\section{(E) Dean Manning}

5579. Dean Manning, a former investigator for the Prosecution, testified before the Chamber. ${ }^{19032}$ The Chamber admitted reports prepared by Manning, as will be discussed below.

5580. While working for the Prosecution from 1996 to 2001, Manning was tasked with coordinating the activities of the investigation, exhumation, and autopsy teams working on the Srebrenica sites, and with providing assistance to the various experts on each team. ${ }^{19033}$ As part of these efforts, Manning visited gravesites, in some cases while the exhumation process was ongoing; examined physical evidence obtained from the exhumation process; assisted experts in preparing their respective reports; summarised the work produced by the respective teams; and presented this evidence in proceedings before the Tribunal. ${ }^{19034}$ Manning wrote one report in 2000, one in 2001, and one in 2003, which were admitted into evidence as P4502, P4503, and P4504, respectively. ${ }^{19035}$ These reports summarise the findings of the experts engaged by the Prosecution during the forensic

19031 P4995 (Ewa Tabeau's expert report entitled "The 2009 Integrated Report on Srebrenica Missing Including a Progress Report on DNA-based Identification”, 9 April 2009), p. 38. See Thomas Parsons, T. 26626 (22 March 2012) (explaining that, generally, lists of missing persons "are very dynamic things to try to resolve" and that often information provided by the families of those missing is contradictory/vague); Amor Mašović, T. 27289 (10 April 2012) (referring to information provided by family members on whether a missing person should be labelled as civilian or combatant). See also Thomas Parsons, P4643 (Transcript from Prosecutor v. Popović et al.), T. 20875-20876.

19032 Dean Manning, T. 25801 (6 March 2012).

19033 Dean Manning, T. 25801-25802 (6 March 2012). The Prosecution's exhumations team included archaeologists, anthropologists, surveying experts, police photographers and police evidence handlers, forensic dentists, and Xray experts. Dean Manning, T. 25803 (6 March 2012). The Prosecution also employed the skills of ballistics and explosives examiners, soil experts, cloth experts, and DNA experts, all of whom provided reports that were summarised by Manning. Dean Manning, T. 25803 (6 March 2012).

19034 Dean Manning, T. 25801-25802 (6 March 2012). See also Dušan Janc, T. 26924 (27 March 2012).

19035 Dean Manning, T. 25805-25806, 25820 (6 March 2012). See P4502 (Dean Manning's Report, entitled "Summary of Forensic Evidence, Mass Graves Exhumed in 2000 - Lazete 1, Lazete 2C, Ravnice, Glogova 1", February 2001); P4503 (Dean Manning's Report, entitled "Srebrenica Investigation, Summary of Forensic Evidence - Execution Points and Mass Graves 2001”, 24 August 2003); P4504 (Dean Manning's Report, entitled "Summary of Forensic Evidence - Execution Points and Mass Graves", 16 May 2000). 
programme in Srebrenica, and include details of Manning's own examination of the sites he visited, as well as of the artefacts recovered from the exhumation process. ${ }^{19036}$

5581. In his reports, Manning also calculated the Minimum Number of Individuals ("MNI") located in the Srebrenica-related gravesites, through the anthropological examination of specific bones conducted by the experts. ${ }^{19037}$ When trying to determine the number of individuals buried in the Srebrenica-related graves, experts realised that it was not possible to calculate the exact figure, due to the degree of disarticulation of the remains. ${ }^{19038}$ When bodies are not complete, a body count will not be adequate to determine the exact number of victims buried in each gravesite, and a conservative number needs to be calculated instead. ${ }^{19039}$ This conservative number is reached by counting the most widely present type of bone throughout the gravesite which can be either a bone, part of a bone, or one of a pair of body parts. ${ }^{19040}$ Thus, when reporting on the forensic evidence from Srebrenica-related gravesites, Manning calculated that the MNI with respect to all exhumations conducted between 1996 and 2001 was $2570 .{ }^{19041}$

19036 Dean Manning, T. 25802, 25805-25806 (6 March 2012).

19037 See P4502 (Dean Manning's Report, entitled "Summary of Forensic Evidence, Mass Graves Exhumed in 2000 Lazete 1, Lazete 2C, Ravnice, Glogova 1", February 2001), e-court p. 3; P4503 (Dean Manning's Report, entitled "Srebrenica Investigation, Summary of Forensic Evidence - Execution Points and Mass Graves 2001", 24 August 2003), e-court p. 2; P4504 (Dean Manning's Report, entitled "Summary of Forensic Evidence Execution Points and Mass Graves", 16 May 2000), e-court p. 5.

19038 P4030 (Jose Baraybar's expert report entitled "Report on the Anthropology Examination of Human Remains from Eastern Bosnia in 1999”, 8 December 1999), e-court p. 5; Jose Baraybar, T. 22347, 22388 (2 December 2011). See P4502 (Dean Manning's Report, entitled "Summary of Forensic Evidence, Mass Graves Exhumed in 2000 - Lazete 1, Lazete 2C, Ravnice, Glogova 1”, February 2001), e-court p. 3; P4503 (Dean Manning's Report, entitled "Srebrenica Investigation, Summary of Forensic Evidence - Execution Points and Mass Graves 2001", 24 August 2003), e-court p. 2; P4504 (Dean Manning's Report, entitled "Summary of Forensic Evidence Execution Points and Mass Graves”, 16 May 2000), e-court p. 5.

19039 P4037 (Jose Baraybar's expert report entitled "Calculation of the Minimal Number of Individuals Exhumed by the ICTY between 1996 and 2001”, 4 January 2004), pp. 3-4; P4030 (Jose Baraybar's expert report entitled "Report on the Anthropology Examination of Human Remains from Eastern Bosnia in 1999", 8 December 1999), pp. 5-6; P4504 (Dean Manning's Report, entitled "Summary of Forensic Evidence - Execution Points and Mass Graves", 16 May 2000), e-court pp. 18-19.

19040 See Jose Baraybar, T. 22350-22551 (2 December 2011); P4037 (Jose Baraybar's expert report entitled "Calculation of the Minimal Number of Individuals Exhumed by the ICTY between 1996 and 2001", 4 January 2004), pp. 3-4; P4030 (Jose Baraybar's expert report entitled "Report on the Anthropology Examination of Human Remains from Eastern Bosnia in 1999", 8 December 1999), pp. 5-6. See also Jose Baraybar, P4029 (Transcript from Prosecutor v. Krstić), T. 3795, 3803-3804. The MNI is calculated per gravesite, so taking into account the separate examination of each gravesite, the overall total MNI would be inflated, as the calculation would not take into account the overlap between remains of individuals found in both primary and secondary gravesites. P4037 (Jose Baraybar's expert report entitled "Calculation of the Minimal Number of Individuals Exhumed by the ICTY between 1996 and 2001”, 4 January 2004), pp. 5-7; Jose Baraybar, T. 22350-22351 (2 December 2011). A Minimum Minimal Number of Individuals ("MMNI") is then calculated taking into account the merging of the MNI of primary and secondary gravesites, and is thus an underestimation of the number of individuals found in each gravesite. P4037 (Jose Baraybar's expert report entitled "Calculation of the Minimal Number of Individuals Exhumed by the ICTY between 1996 and 2001”, 4 January 2004), pp. 5-6; Jose Baraybar, T. 22351 (2 December 2011).

19041 P4503 (Dean Manning's Report, entitled "Srebrenica Investigation, Summary of Forensic Evidence - Execution Points and Mass Graves 2001", 24 August 2003); e-court p. 2. Baraybar subsequently updated this number, concluding that the MNI was 2691. P4037 (Jose Baraybar's expert report entitled "Calculation of the Minimal 
5582. Using the anthropological calculation of the MNI as the initial phase to determine a preliminary number of individuals, experts then moved to DNA testing to corroborate such findings. ${ }^{19042}$ In 2005, Manning was tasked with producing two reports summarising the DNArelated findings of the BiHCMP and ICMP in relation to Srebrenica-related gravesites. ${ }^{19043}$ Manning examined the records of ICMP exhumations and DNA analysis of identified individuals in order to collate them with primary and secondary Srebrenica-related gravesites. ${ }^{19044}$

(F) Dušan Janc

5583. Dušan Janc, a former investigator for the Prosecution, also testified before the Chamber. ${ }^{19045}$ In 2006, Janc took over the DNA-related work initiated by Manning, and started updating the reports prepared by Manning while also preparing his own reports. ${ }^{19046}$ Based on this exercise, Janc prepared a report in 2012 summarising evidence related to the investigation of the Srebrenicarelated gravesites, including DNA and other analysis of the human remains found therein, which was admitted into evidence as P4772 (“Janc's Report”). ${ }^{19047}$

5584. The main source of Janc's Report was the December 2010 ICMP List, as well as other documentary evidence obtained from the $\mathrm{BiH}$ authorities and the ICMP. ${ }^{19048}$ More specifically,

Number of Individuals Exhumed by the ICTY between 1996 and 2001”, 4 January 2004), p. 7; Jose Baraybar, T. 22351-22352 (2 December 2011). In his report, Manning explained that a MMNI was yet to be calculated for all sites. P4503 (Dean Manning's Report, entitled "Srebrenica Investigation, Summary of Forensic Evidence - Execution Points and Mass Graves 2001”, 24 August 2003); e-court p. 2. Baraybar later provided this number, concluding that the MMNI for Srebrenica-related gravesites was 2541. P4037 (Jose Baraybar's expert report entitled "Calculation of the Minimal Number of Individuals Exhumed by the ICTY between 1996 and 2001", 4 January 2004), p. 7; Jose Baraybar, T. 22351-22352 (2 December 2011).

See Jose Baraybar, T. 22353-22354 (2 December 2011).

Dean Manning, T. 25802, 25819 (6 March 2012).

Dean Manning, T. 25819 (6 March 2012).

Dušan Janc, T. 26917-26918 (27 March 2012).

Dušan Janc, T. 26919-26921, 26924, 27005-27007 (27 March 2012); Dean Manning, T. 25819-25820 (6 March 2012); P4772 (Dušan Janc's report entitled "Update to the summary of Forensic Evidence Exhumation of the Graves and Surface Remains Recoveries related to Srebrenica - January 2012", 13 January 2012), e-court p. 2.

19047 Dušan Janc, T. 26918-26920, 26991, 27007 (27 March 2012); P4772 (Dušan Janc's report entitled "Update to the summary of Forensic Evidence - Exhumation of the Graves and Surface Remains Recoveries related to Srebrenica - January 2012”, 13 January 2012) . There is a confidential version of Janc's Report which contains data from the December 2010 ICMP List, including names of identified individuals; this version was admitted as P4771 (Dušan Janc's report entitled "Update to the summary of Forensic Evidence - Exhumation of the Graves and Surface Remains Recoveries related to Srebrenica - January 2012”, 13 January 2012) (under seal).

19048 Dušan Janc, T. 26920, 26930, 26934 (27 March 2012); P4772 (Dušan Janc's report entitled "Update to the summary of Forensic Evidence - Exhumation of the Graves and Surface Remains Recoveries related to Srebrenica - January 2012", 13 January 2012), e-court p. 3. Janc testified that he only received the January January 2012 ICMP List-which contains approximately 80 new cases of persons identified from the Srebrenica gravesites-days before finalising his report and thus was not able to adequately analyse, and incorporate, the new data into his report. Dušan Janc, T. 26934-26937 (27 March 2012). See P4772 (Dušan Janc's report entitled "Update to the summary of Forensic Evidence - Exhumation of the Graves and Surface Remains Recoveries related to Srebrenica - January 2012", 13 January 2012), e-court p. 6. See also P5916 (2012 ICMP updated list of Srebrenica missing). 
Janc compiled records provided by the ICMP, the ICRC, the BiHCMP and later the BiHIMP, ${ }^{19049}$ and other local authorities in $\mathrm{BiH}$, as well as previous reports from Prosecution experts, to create a list of all individuals recovered and identified from gravesites associated with the fall of Srebrenica. ${ }^{19050}$

5585. The primary section of Janc's Report is a table summarising the total number of Srebrenicarelated victims who have been exhumed and identified, and who have been associated with each individual primary or secondary gravesite. ${ }^{19051}$ The report also includes four annexes: Annex A contains a summary of relevant findings for each of the exhumed gravesites determined to be connected to the fall of Srebrenica, including information on the exhumation process, the numbers of identified individuals, and the results of the autopsies conducted on those individuals; ${ }^{19052}$ Annex B details the number of identified surface remains found in and around Srebrenica; ${ }^{19053}$ Annex C details the number of DNA connections between disturbed "primary/primary" and "secondary/secondary" gravesites, and includes diagrams showing some of those connections; ${ }^{19054}$ finally, Annex D contains the names of each of the individuals identified in the December 2010 ICMP List, grouped as per the individual Srebrenica-related gravesite where the specific remains were found. ${ }^{19055}$

5586. Janc cross-checked the December 2010 ICMP List with the 2009 Srebrenica Lists of Missing, in order to ensure that each individual identified by the ICMP matched with a person

19049 Janc testified that the BiHCMP was renamed in 2008 or 2009 and is now called the BiHIMP. Dušan Janc, T. 26921 (27 March 2012).

19050 P4772 (Dušan Janc's report entitled "Update to the summary of Forensic Evidence - Exhumation of the Graves and Surface Remains Recoveries related to Srebrenica - January 2012", 13 January 2012), e-court p. 2; Dušan Janc, T. 26920-26922, 26924-26925 (27 March 2012).

19051 P4772 (Dušan Janc's report entitled "Update to the summary of Forensic Evidence - Exhumation of the Graves and Surface Remains Recoveries related to Srebrenica - January 2012”, 13 January 2012), e-court pp. 2-5. See Dušan Janc, T. 26919 (27 March 2012).

19052 P4772 (Dušan Janc's report entitled "Update to the summary of Forensic Evidence - Exhumation of the Graves and Surface Remains Recoveries related to Srebrenica - January 2012", 13 January 2012), e-court pp. 7-42; Dušan Janc, T. 26922 (27 March 2012). Annex A also contains a summary table showing the primary and secondary mass graves linked to each Scheduled Killing Incident charged in the Indictment, and the total numbers of bodies linked to each incident. P4772 (Dušan Janc's report entitled "Update to the summary of Forensic Evidence - Exhumation of the Graves and Surface Remains Recoveries related to Srebrenica - January 2012", 13 January 2012), e-court pp. 40-42.

19053 P4772 (Dušan Janc's report entitled "Update to the summary of Forensic Evidence - Exhumation of the Graves and Surface Remains Recoveries related to Srebrenica - January 2012", 13 January 2012), e-court pp. 43-46; Dušan Janc, T. 26922 (27 March 2012). See also Dušan Janc, T. 26982-26983 (27 March 2012), T. 2706627069 (28 March 2012); P4770 (Maps of surface remains); D2219 (Map of location of surface remains marked by Dušan Janc) (referring to the location where surface remains were found).

19054 P4772 (Dušan Janc's report entitled "Update to the summary of Forensic Evidence - Exhumation of the Graves and Surface Remains Recoveries related to Srebrenica - January 2012”, 13 January 2012), e-court pp. 47-87; Dušan Janc, T. 26922-26923, 26967-26973 (27 March 2012).

19055 P4771 (Dušan Janc's report entitled "Update to the summary of Forensic Evidence - Exhumation of the Graves and Surface Remains Recoveries related to Srebrenica - January 2012", 13 January 2012) (under seal), e-court pp. 88-625; Dušan Janc, T. 26923 (27 March 2012). 
reported missing following the fall of Srebrenica. ${ }^{19056}$ To compile his report, Janc also referenced information provided to him by the ICMP on DNA profiles extracted from remains found at various gravesites, but which have not yet been matched with a missing person. ${ }^{19057}$ This group includes 260 unidentified individuals, which Janc included in his report because they were found in graves shown to be connected to the fall of Srebrenica. ${ }^{19058}$ In addition, Janc included data of 35 individuals identified as missing following the fall of Srebrenica by Physicians for Human Rights and the ICRC, before the ICMP began its DNA identification process in $2001{ }^{19059}$

5587. Janc compiled his report by separating all entries in the December 2010 ICMP List into separate spreadsheets organised by case ID, ensuring that every spreadsheet referred to only one gravesite or location. ${ }^{19060}$ When calculating the number of individuals per gravesite, Janc counted only the "main cases" representing unique DNA profiles, excluding all "re-association" cases to ensure that each individual was counted only once, even when multiple body parts of one individual were collected from one or more gravesites. ${ }^{19061}$ Janc repeated this process for all 14,303 entries in the December 2010 ICMP List, as well as the unidentified entries provided by the

19056 See Dušan Janc, T. 26947, 27020 (27 March 2012), T. 27027-27035 (28 March 2012); P4772 (Dušan Janc's report entitled "Update to the summary of Forensic Evidence - Exhumation of the Graves and Surface Remains Recoveries related to Srebrenica - January 2012", 13 January 2012), e-court pp. 2-3.

19057 P4772 (Dušan Janc's report entitled "Update to the summary of Forensic Evidence - Exhumation of the Graves and Surface Remains Recoveries related to Srebrenica - January 2012", 13 January 2012), e-court p. 2; Dušan Janc, T. 26925-26926, 26991-26995 (27 March 2012). These unmatched DNA profiles come from lists that Janc especially requested from the ICMP. Dušan Janc, T. 26956-26958, 26991-26992 (27 March 2012). See P4773 (ICMP unmatched DNA victim profiles related to Srebrenica, 23 December 2011); P4774 (ICMP lists of unmatched unique DNA victims profiles related to Srebrenica, 15 February 2010); P5914 (ICMP tables concerning identified Srebrenica victims, 31 January 2009); P4656 (ICMP tables concerning identified Srebrenica victims, 31 January 2009) (under seal).

19058 P4772 (Dušan Janc's report entitled "Update to the summary of Forensic Evidence - Exhumation of the Graves and Surface Remains Recoveries related to Srebrenica - January 2012”, 13 January 2012), e-court p. 2; Dušan Janc, T. 26925-26926, 26952, 26956-26961 (27 March 2012), T. 27039-27040 (28 March 2012). But see Defence Final Brief, para. 2621 (where the Accused argues that the evidence strongly indicates that these remains are not related to the fall of Srebrenica).

19059 P4772 (Dušan Janc's report entitled "Update to the summary of Forensic Evidence - Exhumation of the Graves and Surface Remains Recoveries related to Srebrenica - January 2012", 13 January 2012), e-court p. 2; Dušan Janc, T. 26925, 26953-26954 (27 March 2012). These 35 individuals were identified based on antemortem and postmortem data, primarily through identification of clothing and personal belongings found on the bodies by family members. See P4504 (Dean Manning's Report, entitled "Summary of Forensic Evidence - Execution Points and Mass Graves", 16 May 2000), e-court p. 96.44 individuals were identified in total by the ICRC and Physicians for Human Rights, but nine of them were re-identified by the ICMP and included in the ICMP's December 2010 List. P4772 (Dušan Janc's report entitled "Update to the summary of Forensic Evidence Exhumation of the Graves and Surface Remains Recoveries related to Srebrenica - January 2012", 13 January 2012), e-court p. 2, fn. 4. See generally P4504 (Dean Manning's Report, entitled "Summary of Forensic Evidence - Execution Points and Mass Graves", 16 May 2000), e-court pp. 96-114; P5917 (ICMP DNA identifications concerning identified victims related to Srebrenica, 6 December 2010).

19060 P4772 (Dušan Janc's report entitled "Update to the summary of Forensic Evidence - Exhumation of the Graves and Surface Remains Recoveries related to Srebrenica - January 2012”, 13 January 2012), e-court p. 6; Dušan Janc, T. 26942-26943, 26947-26948 (27 March 2012).

19061 P4772 (Dušan Janc's report entitled "Update to the summary of Forensic Evidence - Exhumation of the Graves and Surface Remains Recoveries related to Srebrenica - January 2012”, 13 January 2012), e-court p. 6; Dušan Janc, T. 26948, 26950-26951 (27 March 2012). 
ICMP. ${ }^{19062}$ The resulting data is summarised by gravesite in Annex A of Janc's Report, which includes the total number of individuals found in each gravesite, as well as in Annex D, which lists each individual found in each gravesite by name, listing every individual only once. ${ }^{19063}$

5588. In addition, Janc analysed the ICMP data to establish DNA connections between gravesites. ${ }^{19064}$ To do so, he sorted the ICMP data by its protocol ID; when one protocol ID appeared at different sites, this meant that body parts from the same individual were found in multiple locations. ${ }^{19065}$ When an individual's DNA profile was found in more than one gravesite, Janc counted a "connection" between the gravesites. ${ }^{19066}$ Janc used these DNA connections between primary gravesites and secondary gravesites to establish a link between each of these gravesites and a Scheduled Killing Incident. ${ }^{19067}$

5589. Through this process, Janc arrived at 5,977 as the total number of individuals identified in Srebrenica-related gravesites as of January $2012 .{ }^{19068}$ Janc also arrived at the total number of individuals identified per execution site, by adding the number of individuals identified in the relevant primary and corresponding secondary gravesites linked to each site. ${ }^{19069}$

5590. The Chamber notes that the Prosecution has relied on Janc's Report in determining the number of Srebrenica victims found in each gravesite and the number of individuals killed at most of the individual Scheduled Killing Incidents charged in the Indictment. The Chamber also notes that there is significant overlap between the 5,977 individuals included in Janc's Report as

19062 Dušan Janc, T. 26947-26948, 26950-26951 (27 March 2012), T. 26949 (27 March 2012) (private session).

19063 P4772 (Dušan Janc's report entitled "Update to the summary of Forensic Evidence - Exhumation of the Graves and Surface Remains Recoveries related to Srebrenica - January 2012", 13 January 2012), e-court pp. 7-42; P4771 (Dušan Janc's report entitled "Update to the summary of Forensic Evidence - Exhumation of the Graves and Surface Remains Recoveries related to Srebrenica - January 2012", 13 January 2012) (under seal), e-court pp. 88-625.

19064 See Dušan Janc, T. 26961-6962 (27 March 2012).

19065 Dušan Janc, T. 26961-6966 (27 March 2012). See para. 5563.

19066 Dušan Janc, T. 26961-26965, 26968 (27 March 2012). Janc clarified that, even if more than one body part from the same person was distributed between two different gravesites, this was still counted as one "connection." Dušan Janc, T. 26964 (27 March 2012). According to Janc, these connections between different sites mean that bodies or body parts were disposed in multiple locations, and provide a clear indication of which gravesites are interconnected. Dušan Janc, T. 26961-26962 (27 March 2012).

19067 See Dušan Janc, T. 26961-26965 (27 March 2012); P4772 (Dušan Janc's report entitled "Update to the summary of Forensic Evidence - Exhumation of the Graves and Surface Remains Recoveries related to Srebrenica - January 2012”, 13 January 2012), e-court pp. 40-42, 48-50, 82, 85, 87.

19068 P4772 (Dušan Janc's report entitled "Update to the summary of Forensic Evidence - Exhumation of the Graves and Surface Remains Recoveries related to Srebrenica - January 2012”, 13 January 2012), e-court pp. 2, 5. See Dušan Janc, T. 26923-26924 (27 March 2012).

19069 P4772 (Dušan Janc's report entitled "Update to the summary of Forensic Evidence - Exhumation of the Graves and Surface Remains Recoveries related to Srebrenica - January 2012”, 13 January 2012), e-court pp. 40-42; Dušan Janc, T. 26973-26975 (27 March 2012). 
identified in Srebrenica-related gravesites, and the 5,115 individuals ${ }^{19070}$ found by the Chamber to have been killed in the specific circumstances alleged in Schedule E of the Indictment. ${ }^{19071}$

5591. The Accused claims that Janc's task was to corroborate what was already known to the Prosecution and that he manipulated the evidence received from the ICMP to adjust his findings. ${ }^{19072}$ By considering that all exhumed bodies were victims of execution, Janc approached his investigation backwards and, when facts got in his way, he simply excluded them. ${ }^{19073}$

5592. Similarly, Dunjić challenges various portions of Janc's Report. The Chamber notes in this regard that Dunjić comments upon, and refers to, an earlier version of Janc's Report, dated 13 March 2009-and not admitted into evidence in the present case-as well as D1975, a corrigendum prepared by Janc to that report. ${ }^{19074}$ For purposes of this section, given that most, if not all, of Dunjić's challenges can be applied to Janc's Report, the Chamber will consider them in its analysis of this latter document.

5593. The Chamber understands the main challenge to Janc's evidence to be the assertion that the Srebrenica-related gravesites are mixed gravesites containing bodies of victims of execution of the various Scheduled Killing Incidents, as well as bodies of individuals who died prior to the fall of Srebrenica and/or as a result of combat activities. In addition to the Chamber's considerations on this issue discussed above, the Chamber will refer below to some of the main arguments raised by the Accused and Dunjić on this point.

5594. Dunjić uses the information in D1975 to conclude that at particular sites connected with Srebrenica, there were also remains of individuals who were killed in various circumstances

19070 See para. 5519.

19071 The Chamber notes that these figures do not fully match for a number of reasons. First, the figures from a number of gravesites relating to incidents which are not charged in the Indictment have not been included by the Chamber in reaching its total number. Further, the Chamber recalls its finding that it was not satisfied beyond reasonable doubt that the incident at the Cerska Valley, as alleged in the Indictment, took place (see para. 522), and therefore has not included the remains found at the Cerska Valley gravesite. Finally, due to the particularity of the executions and the fact that a connection to a specific gravesite has not been established, the Chamber cannot be sure whether the remains of those killed in some of the Scheduled Killing Incidents, such as at the Jadar River, the Sandići Meadow, and Potočari, have been included in Janc's total number of identified individuals.

19072 Defence Final Brief, para. 2622. See Dušan Janc, T. 27007-27010 (27 March 2012). According to the Accused, Janc did not consider burials of casualties from combat activities, different dates of burials, and other discrepancies. See Defence Final Brief, paras. 2623-2624.

19073 Defence Final Brief, para. 2625. See also the Accused's line of questioning during cross-examination of Dušan Janc, T. 27083 (28 March 2012).

19074 D3893 (Dušan Dunjić's expert report entitled "Forensic Analysis of Reports on the Locations of Mass Graves in the Area of Eastern Bosnia and Documentation Relating to Exhumations in the Srebrenica Area", 27 August 2009), p. 11; Dušan Dunjić, T. 41744 (22 July 2013). See Dušan Janc, T. 26918-26919 (27 March 2012); D1975 (Dušan Janc's corrigendum to report entitled "Update to Summary of Forensic Evidence- Exhumation on the Graves Related to Srebrenica -March 2009”, 9 April 2009). 
unconnected to the fall of Srebrenica. ${ }^{19075}$ Similarly, referring to Janc's findings with respect to the Blječeva and Glogova gravesites, the Accused argues that it is undisputed that there were mixed graves in which remains not connected to the Srebrenica events were buried together with the remains of people reported missing after the fall of Srebrenica. ${ }^{19076}$ The Chamber accepts the existence of a number of mixed gravesites connected to the Scheduled Killing Incidents. However, such evidence before the Chamber is limited to the Blječeva 1 and the Glogova gravesites. The Chamber has discussed in detail the implications of D1975 in its section of the Judgement related to the killings at the Kravica Warehouse, and will not repeat its findings here. ${ }^{19077}$

5595. According to the Accused, the DNA connections in Janc's Report only relate to less than $10 \%$ of the remains found in secondary gravesites. ${ }^{19078}$ The remainder of the bodies have not been associated with Srebrenica-related execution sites and thus must result from other events at other times. ${ }^{19079}$ He therefore claims that sites which were labelled as secondary gravesites were indeed gravesites in the vicinity of the confrontation line where casualties had been buried. ${ }^{19080}$ Supporting this theory, Dunjić adds that it is impossible to extrapolate on the basis of DNA analysis that all the bodies from the secondary gravesites originate from the primary gravesites with which a DNA connection has been established. ${ }^{19081}$ According to Dunjić, these connections only related to a significantly smaller number of bodies found in the secondary gravesites which are linked to the executions at the Kravica Warehouse, the field near Orahovac, the dam near Petkovci, Kozluk, or the Branjevo Military Farm, and not the much larger number provided by Janc. ${ }^{19082}$ In other words,

19075 D3893 (Dušan Dunjić's expert report entitled "Forensic Analysis of Reports on the Locations of Mass Graves in the Area of Eastern Bosnia and Documentation Relating to Exhumations in the Srebrenica Area", 27 August 2009), pp. 13-14; D3894 (Dušan Dunjić's expert report entitled "Forensic Analysis of Documents Pertaining to Exhumations, Autopsies and Identification of Bodies in the Srebrenica Area", 26 August 2012), pp. 20, 22. See Dušan Dunjić, T. 41746 (22 July 2013); T. 41876-41878, 41905-41908 (24 July 2013).

19076 Defence Final Brief, paras. 2597-2598, 2601, 2604. See the Accused's line of questioning during crossexamination of Dušan Janc, T 27016-27017 (27 March 2012). The Accused also refers to the Liplje 8 gravesite, which is not associated with a Scheduled Killing Incident, and to surface remains found adjacent to the execution at Kozluk. Defence Final Brief, confidential, para. 2601.

19077 See paras. 5258, 5281-5282, fn. 17879.

19078 See Defence Final Brief, paras. 2605, 2608.

19079 Defence Final Brief, confidential, para. 2605.

19080 Defence Final Brief, para. 2603. See also Accused's line of questioning during cross-examination of Dušan Janc, T. 27071-27081 (28 March 2012).

19081 D3893 (Dušan Dunjić's expert report entitled "Forensic Analysis of Reports on the Locations of Mass Graves in the Area of Eastern Bosnia and Documentation Relating to Exhumations in the Srebrenica Area", 27 August 2009), pp. 13-17; D3894 (Dušan Dunjić's expert report entitled "Forensic Analysis of Documents Pertaining to Exhumations, Autopsies and Identification of Bodies in the Srebrenica Area”, 26 August 2012), pp. 20-24; Dušan Dunjić, T. 41746 (22 July 2013). See Dušan Dunjić, T. 41818 (23 July 2013).

19082 D3893 (Dušan Dunjić's expert report entitled "Forensic Analysis of Reports on the Locations of Mass Graves in the Area of Eastern Bosnia and Documentation Relating to Exhumations in the Srebrenica Area", 27 August 2009), pp. 13-15, 17-18; D3894 (Dušan Dunjić's expert report entitled "Forensic Analysis of Documents Pertaining to Exhumations, Autopsies and Identification of Bodies in the Srebrenica Area", 26 August 2012), pp. 21-24. See Defence Final Brief, para. 2607. See also P4772 (Dušan Janc's report entitled "Update to the summary of Forensic Evidence - Exhumation of the Graves and Surface Remains Recoveries related to 
the Accused and Dunjić claim that the only reasonable conclusion is that, for more than $90 \%$ of the remains for which DNA connections have not been established, the so-called secondary gravesites were indeed primary gravesites where individuals who died in combat were buried for the first time. ${ }^{19083}$

5596. To challenge Janc's Report, Dunjić refers to the same arguments raised when objecting to the forensic and demographic evidence. Referring back to the arguments used in his challenge to the 2009 Srebrenica Lists of Missing, discussed above, Dunjić claims that some of the individuals identified from various Srebrenica-related gravesites are also listed in other documents as having died prior to the fall of Srebrenica. ${ }^{19084}$ However, as discussed above, the Chamber is not satisfied with the authenticity or veracity of the documents which formed the basis for Dunjić's argument, i.e., the so-called ABiH List, D2217, or D3812, and is thus not persuaded by Dunjić's argument in this respect. ${ }^{19085}$

5597. Dunjić also claims that finding parts of a single body in two different locations would indicate that a particular person died and the body putrefied, and then due to external conditions the body parts were separated. ${ }^{19086}$ In this case, Dunjić claims, it is likely that the body was separated before burial and thus the two gravesites where the remains were found ought to be considered primary gravesites with respect to the specific body parts found in each of them. ${ }^{19087}$ However, the Chamber does not accept Dunjić's theories with respect to the existence of body parts of a same individual within two or more gravesites; his theories simply ignore the extensive evidence before

Srebrenica - January 2012", 13 January 2012), e-court pp. 40-42, 48-50. This is irrespective of whether there is other evidence, such as that from ballistic findings, which establishes a connection between the primary and secondary gravesites. Dušan Dunjić, T. 41883-41884 (24 July 2013).

19083 See Defence Final Brief, paras. 2605, 2608; D3893 (Dušan Dunjić's expert report entitled "Forensic Analysis of Reports on the Locations of Mass Graves in the Area of Eastern Bosnia and Documentation Relating to Exhumations in the Srebrenica Area”, 27 August 2009), pp. 15-17; D3894 (Dušan Dunjić's expert report entitled "Forensic Analysis of Documents Pertaining to Exhumations, Autopsies and Identification of Bodies in the Srebrenica Area", 26 August 2012), pp. 18, 22-23. See Dušan Dunjić, T. 41751 (22 July 2013); T. 4188241883 (24 July 2013). But see Dušan Janc, T. 27071-27072 (28 March 2012) (where Janc discarded this possibility).

19084 Dušan Dunjić, T. 41760-41774 (23 July 2013); D3893 (Dušan Dunjić's expert report entitled "Forensic Analysis of Reports on the Locations of Mass Graves in the Area of Eastern Bosnia and Documentation Relating to Exhumations in the Srebrenica Area", 27 August 2009), pp. 26-35; D3894 (Dušan Dunjić's expert report entitled "Forensic Analysis of Documents Pertaining to Exhumations, Autopsies and Identification of Bodies in the Srebrenica Area", 26 August 2012), pp. 21-22. See D3812 (List of soldiers killed or missing before July 1995); D3815 (Collection of documents of BiH Federal Ministry of Defence), BCS, pp. 7-10 (the so-called ABiH List); D2217 (Examples of identified persons from Prosecution database and ABiH database).

19085 See para. 5577.

19086 Dušan Dunjić, T. 41749 (22 July 2013). As an example, Dunjić refers to a person who had an open wound which would attract wild animals and which would then lead to the disarticulation of the body parts which would then be found in different gravesites. Dušan Dunjić, T. 41749 (22 July 2013). See Defence Final Brief, para. 2620 (where the Accused adopts Dunjić's theory). 
the Chamber on the reburial operation which was conducted between September and October 1995. The fact that Dunjić was so quick to craft such theoretical conclusions while wilfully ignoring evidence to the contrary is a serious stain on his credibility as an expert. Further, based on the anthropological, forensic, and witness evidence on burials and reburials of bodies, the Chamber is satisfied, subject to its findings in relation to the Glogova and Blječeva gravesites as referred to above, that there was no enrichment of Srebrenica-related gravesites.

5598. Referring more specifically to the findings in Annex B of Janc's Report on surface remains, the Accused argues that at a minimum, the 1,000 individuals counted by Janc must be subtracted from the total of 4,000 individuals which, in his view, may be considered as unaccounted for after the fall of Srebrenica. ${ }^{19088}$ The Accused adds that, while some of these remains have been subtracted from the total list of victims in Janc's Report, Janc's total is still not entirely correct, given that there is evidence showing that victims who died in artillery attacks, as well as some of those who died in combat but who were buried during the sanitation process, were also included in Janc's total count. ${ }^{19089}$ The Chamber recalls that Annex B of Janc's Report explains that out of a total of 982 surface remains cases, 702 have been identified as Srebrenica-related individuals. ${ }^{19090}$ However, these numbers have not been included in the total number of Srebrenica-related victims provided by Janc. ${ }^{19091}$

5599. Having analysed Janc's evidence in its entirety, the Chamber is satisfied with the methodology he followed in reaching his conclusions, and with the reliability of such conclusions. In this regard, the Chamber recalls that it received other forensic evidence, in addition to the DNA connections between Srebrenica-related primary and secondary gravesites, pointing to additional links between the gravesites. Furthermore, the accepted evidence from many witnesses, including survivors and insiders-such as direct perpetrators, those guarding the detainees, and those involved in the burial and reburial of bodies-as to the circumstances surrounding the Scheduled Killing Incidents, corroborates and supports Janc's Report. For all these reasons, the Chamber is satisfied that there is no evidence that primary or secondary gravesites were enriched and therefore

19087 D3893 (Dušan Dunjić's expert report entitled "Forensic Analysis of Reports on the Locations of Mass Graves in the Area of Eastern Bosnia and Documentation Relating to Exhumations in the Srebrenica Area", 27 August 2009), pp. 15-16.

19088 Defence Final Brief, confidential, para. 2559. See also Defence Final Brief, paras. 2557-2558, 2560-2561, 2565, 2571, 2589, 2636, 2638.

19089 Defence Final Brief, para. 2636. See also Defence Final Brief, para. 2653.

19090 P4772 (Dušan Janc's report entitled "Update to the summary of Forensic Evidence - Exhumation of the Graves and Surface Remains Recoveries related to Srebrenica - January 2012”, 13 January 2012), e-court pp. 44-46. See Dušan Janc, T. 26982-26985 (27 March 2012).

19091 Dušan Janc, T. 26984-26985 (27 March 2012); P4772 (Dušan Janc's report entitled "Update to the summary of Forensic Evidence - Exhumation of the Graves and Surface Remains Recoveries related to Srebrenica - January 2012”, 13 January 2012), e-court p. 5. See also Prosecution Closing Argument, T. 47799 (30 September 2014). 
considers that all the bodies found in Srebrenica-related primary and secondary gravesites can be linked to the corresponding Scheduled Killing Incidents.

\section{Legal findings on crimes}

a. Chapeau requirements for Articles 3 and 5 of the Statute

5600. In the Srebrenica component of the case, in addition to a count of genocide under Article 4 of the Statute, the Accused is charged with a count of violations of the laws or customs of war under Article 3 of the Statute, namely murder, as well as five counts of crimes against humanity under Article 5 of the Statute, namely persecution, murder, extermination, deportation, and forcible transfer as an inhumane act. ${ }^{19092}$ The Prosecution alleges that there was a state of armed conflict at all times relevant to the Indictment. ${ }^{19093}$ It further alleges that all acts and omissions charged as crimes against humanity, except those that formed part of the sniping and shelling campaign in Sarajevo, were part of a widespread or systematic attack directed against the Bosnian Muslim and Bosnian Croat civilian populations of $\mathrm{BiH} .{ }^{19094}$

\section{i. Article 3 of the Statute}

5601. The Chamber found that there was an armed conflict throughout the period relevant to the crimes alleged in the Indictment. At the time of the events charged in the Srebrenica component of the case, namely July 1995, the armed conflict was still ongoing; it officially ended with the signing of the Dayton Agreement on 14 December $1995 .{ }^{19095}$

5602. For murder charged under Article 3 of the Statute, the Chamber has examined whether it was closely related to the armed conflict and made such findings where relevant in this Judgement. ${ }^{19096}$

5603. In relation to the four so called "Tadic Conditions", the Chamber refers to the applicable law sections of this Judgement, which expanded on the legal basis for each of the crimes charged in the Indictment under Article 3 of the Statute. ${ }^{19097}$ In relation to murder, the prohibition stems from Common Article 3 which is deemed to be part of customary international law. ${ }^{19098}$ Further, the

\footnotetext{
19092 See para. 5.

19093 Indictment, para. 89.

19094 Indictment, para. 88.

19095 See paras. 312, 437.

19096 See para. 5611.

19097 See Section III.A.1.a: General requirements for violations of the laws or customs of war.

19098 Čelebići Appeal Judgement, para. 143.
} 
Appeals Chamber has confirmed that violations of the provisions of Common Article 3 entail individual criminal responsibility. ${ }^{1909}$ The Chamber is therefore satisfied that the four Tadic Conditions are met, and consequently that the chapeau requirements for Article 3 of the Statute are fulfilled, in relation to murder.

\section{ii. Article 5 of the Statute}

5604. As found above, there was an armed conflict in $\mathrm{BiH}$ throughout the period of the Indictment. The Chamber also found that there existed a widespread and systematic attack against the Bosnian Muslim and Bosnian Croat civilian populations of $\mathrm{BiH}$ at all times relevant to the crimes charged in the Indictment. As reflected below, the Chamber is also satisfied that the crimes upon which the Chamber has entered findings formed part of that attack and that the perpetrators knew of the attack and that the crimes were part of it. ${ }^{19100}$

5605. As elaborated earlier in this Judgement, Bosnian Serb Forces attacked Srebrenica on 6 July 1995 and succeeded in taking it over by 11 July. ${ }^{19101}$ Following the take-over of the enclave, between 11 and 13 July 1995, up to 30,000 Bosnian Muslim women and children, as well as some elderly men, were forcibly displaced from inside the Srebrenica enclave to Bosnian Muslim-held territory. ${ }^{19102}$ The Chamber further found that at least 5,115 Bosnian Muslim males were killed by Bosnian Serb Forces in the weeks following the fall of Srebrenica on 11 July $1995 .{ }^{19103}$ The Chamber is satisfied that the co-ordinated actions of the Bosnian Serb Forces in a short period of time in various locations in Srebrenica, Bratunac, and Zvornik, as well as the sheer number of Bosnian Muslims killed and forcibly displaced establish both the systematic and widespread aspects of this part of the attack.

5606. The Chamber is therefore satisfied that the chapeau requirements for the crimes charged under Article 5 of the Statute are met.

\footnotetext{
19099 Čelebići Appeal Judgement, paras. 167, 170, 173-174 (holding at para. 173: "It is universally acknowledged that the acts enumerated in common Article 3 are wrongful and shock the conscience of civilised people, and thus are, in the language of Article 15(2) of the ICCPR, 'criminal according to the general principles of law recognised by civilised nations'.").

19100 See paras. 5612, 5620, 5642, 5652.

19101 See paras. 5010-5033.

19102 See para. 5623, 5641.

19103 See para. 5516, fn. 18844.
} 


\section{b. Crimes}

\section{i. Murder: Counts 5 and 6}

\section{(A) Killing incidents}

5607. The Chamber found in Section IV.C.1 above that at least 5,115 Bosnian Muslim males were killed by Bosnian Serb Forces in the weeks following the fall of Srebrenica on 11 July $1995 .{ }^{19104}$ The Chamber also recalls that it did not have sufficient evidence to make a finding beyond reasonable doubt that the incident relating to the killing on 13 July 1995 of 150 Bosnian Muslim men in an area along a dirt road in the Cerska Valley took place, as alleged in the Indictment. ${ }^{19105}$

\section{(B) Intent of perpetrators}

5608. The Chamber also recalls its findings that the death of the victims for each of the incidents identified above was a result of the acts of Bosnian Serb Forces. The Chamber finds that the perpetrators of each of these incidents acted with the intent to kill the victims or at least wilfully caused serious bodily harm, which they should reasonably have known might lead to death.

5609. In reaching that conclusion, the Chamber had regard to the circumstances and the manner in which the victims were killed. In all cases, the Chamber found that the victims were deliberately shot. ${ }^{19106}$ The Chamber also found that many of the victims presented multiple gunshot injuries. ${ }^{19107}$ Further, the Chamber found that, in many instances, the victims were taken to remote locations in a systematic and organised way, and then executed. ${ }^{19108}$

19104 See para. 5519. See fn. 18844, referring to 15 Bosnian Muslim men killed at the Jadar River, 755 Bosnian Muslim men at the Kravica Warehouse, ten Bosnian Muslim men at the Sandići Meadow, 21 Bosnian Muslim men at the Luke School, 841 Bosnian Muslim men at Orahovac, 815 Bosnian Muslim men at Petkovci, 815 Bosnian Muslim men at Ročević School and Kozluk, 1,735 Bosnian Muslim men at Kula School, the Branjevo Military Farm, and the Pilica Cultural Centre, two Bosnian Muslim men at Snagovo, 39 Bosnian Muslim men at Bišina, six Bosnian Muslim men at Trnovo, ten Bosnian Muslim men at Potočari, and 51 Bosnian Muslim men at Bratunac Town. In relation to the killings at Trnovo, the Chamber recalls its finding that they were committed by members of the Scorpions. Trnovo, Scheduled Incident E.13.1.

19105 Cerska Valley, Scheduled Incident E.2.1.

19106 Jadar River, Scheduled Incident E.1.1; Kravica Warehouse, Scheduled Incident E.3.1; Sandići Meadow, Scheduled Incident E.4.1; Luke School, Scheduled Incident E.5.1; Orahovac, Scheduled Incidents E.6.1, E.6.2; Petkovci, Scheduled Incidents E.7.1, E.7.2; Ročević, Scheduled Incidents E.8.1, E.8.2; Kula and Branjevo Military Farm, Scheduled Incidents E.9.1, E.9.2; Pilica Cultural Centre, Scheduled Incident E.10.1; Snagovo, Scheduled Incident E.11.1; Bišina, Scheduled Incident E.12.1; Trnovo, Scheduled Incident E.13.1; Potočari, Scheduled Incidents E.14.1, E.14.2; and Bratunac Town, Scheduled Incidents E.15.1, E.15.3.

19107 Kravica Warehouse, Scheduled Incident E.3.1; Orahovac, Scheduled Incidents E.6.1, E.6.2; Petkovci, Scheduled Incidents E.7.1, E.7.2.

19108 Orahovac, Scheduled Incidents E.6.1, E.6.2; Petkovci, Scheduled Incidents E.7.1, E.7.2; Ročević, Scheduled Incidents E.8.1, E.8.2; Kula and Branjevo Military Farm, Scheduled Incidents E.9.1, E.9.2; Pilica Cultural Centre, Scheduled Incident E.10.1. 


\section{(C) Status of victims}

5610. The Chamber also finds that the victims of each of these incidents were civilians or had been rendered hors de combat at the time of their killing. Some of the victims were as young as eight or as old as $85 .{ }^{19109}$ Some were killed after being captured by members of the Bosnian Serb Forces ${ }^{19110}$ some were killed while trying to escape from members of the Bosnian Serb Forces, ${ }^{19111}$ and some were killed after being detained by members of the Bosnian Serb Forces. ${ }^{19112}$

\section{(D) Conclusion}

5611. The Chamber found that there was an armed conflict in $\mathrm{BiH}$ throughout the period relevant to the Indictment. As demonstrated by the Chamber's factual findings explained above, the Chamber finds that the killings referred to in this section were closely related to that armed conflict and thus constitute murder as a violation of the laws or customs of war.

5612. The Chamber also found that there was a widespread and systematic attack against the Bosnian Muslim and Bosnian Croat populations of $\mathrm{BiH}$. The Chamber finds that the killings referred to above were part of this widespread and systematic attack and the perpetrators of these killings knew of the attack and that their crimes were part of it. In reaching that conclusion, the Chamber considered the locations, time period, and the identity of the victims of these killings, which correspond with the scope of the widespread and systematic attack, as well as the magnitude of the attack on the Bosnian Muslim population of $\mathrm{BiH}$, which had been ongoing for more than three years prior to the events charged in the Srebrenica component of the case. The Chamber therefore finds that these killings thus constitute murder as a crime against humanity.

\footnotetext{
19109 Kravica Warehouse, Scheduled Incident E.3.1; Orahovac, Scheduled Incidents E.6.1, E.6.2; Ročević, Scheduled Incidents E.8.1, E.8.2; Kula and Branjevo Military Farm, Scheduled Incidents E.9.1, E.9.2.

19110 Sandići Meadow, Scheduled Incident E.4.1; Snagovo, Scheduled Incident E.11.1; Bišina, Scheduled Incident E.12.1; Trnovo, Scheduled Incident E.13.1; Potočari, Scheduled Incidents E.14.1, E.14.2; Bratunac Town, Scheduled Incidents E.15.1, E.15.3.

19111 Kravica Warehouse, Scheduled Incident E.3.1; Luke School, Scheduled Incident E.5.1; Orahovac, Scheduled Incidents E.6.1, E.6.2; Ročević, Scheduled Incidents E.8.1, E.8.2; Kula and Branjevo Military Farm, Scheduled Incidents E.9.1, E.9.2.

19112 Jadar River, Scheduled Incident E.1.1; Kravica Warehouse, Scheduled Incident E.3.1; Luke School, Scheduled Incident E.5.1; Orahovac, Scheduled Incidents E.6.1, E.6.2; Petkovci, Scheduled Incidents E.7.1, E.7.2; Ročević, Scheduled Incidents E.8.1, E.8.2; Kula and Branjevo Military Farm, Scheduled Incidents E.9.1, E.9.2; Pilica Cultural Centre, Scheduled Incident E.10.1; Bratunac Town, Scheduled Incidents E.15.1, E.15.3.
} 


\section{ii. Extermination: Count 4}

5613. Earlier in this Judgement, the Chamber recalled that there is no minimum threshold of victims for the purposes of extermination; it still has to be satisfied that the killings occurred on a mass scale and needs to conduct a case-by-case assessment in that regard. ${ }^{19113}$

5614. Further, as previously noted, extermination may be established based on the accumulation of separate incidents. ${ }^{19114}$ However, it has been found that "as a general matter, the element of killing on a large scale cannot be satisfied by a collective consideration of distinct events committed in different prefectures, in different circumstances, by different perpetrators, and over an extended period of time". 19115

5615. Based on its factual findings above, the Chamber notes that each of the killing incidents identified above was committed by Bosnian Serb Forces in the context of the events surrounding the fall of Srebrenica in July 1995. The overwhelming majority of the killings were committed within a few days in Potočari, and in the Bratunac and Zvornik areas. Further, the manner and circumstances in which the killings occurred-including the same violence with which they were committed and the identity of the perpetrators as members of the Bosnian Serb Forcesdemonstrate that they formed part of the same widespread and systematic attack against the Bosnian Muslims in Srebrenica. The Chamber also found that all the victims were Bosnian Muslims from Srebrenica. ${ }^{19116}$

5616. With regard to the killings which took place in other locations in the days following 17 July, the Chamber found that, while the killings at Snagovo and Bišina took place a number of days after the rest of the killing incidents, they were nevertheless connected to the Srebrenica operation, as they were also committed against Bosnian Muslim males from Srebrenica captured following the take-over of the enclave. ${ }^{19117}$ In relation to the killings at Trnovo, the Chamber notes that it was unable to precisely determine the date when they took place. The Chamber also notes the geographic distance between Trnovo and Srebrenica. Nevertheless, the Chamber recalls that the killings were committed by members of the Scorpions unit which had been deployed as part of the

\footnotetext{
19113 See paras. $483,2457$.

19114 See paras. $484,2458$.

19115 See paras. 484, 2458.

19116 Jadar River, Scheduled Incident E.1.1; Kravica Warehouse, Scheduled Incident E.3.1; Sandići Meadow, Scheduled Incident E.4.1; Luke School, Scheduled Incident E.5.1; Orahovac, Scheduled Incidents E.6.1, E.6.2; Petkovci, Scheduled Incidents E.7.1, E.7.2; Ročević, Scheduled Incidents E.8.1, E.8.2; Kula and Branjevo Military Farm, Scheduled Incidents E.9.1, E.9.2; Pilica Cultural Centre, Scheduled Incident E.10.1; Snagovo, Scheduled Incident E.11.1; Bišina, Scheduled Incident E.12.1; Trnovo, Scheduled Incident E.13.1; Potočari, Scheduled Incidents E.14.1, E.14.2; and Bratunac Town, Scheduled Incidents E.15.1, E.15.3.

19117 Snagovo, Scheduled Incident E.11.1; Bišina, Scheduled Incident E.12.1; Trnovo, Scheduled Incident E.13.1.
} 
joint VRS and MUP forces operating on the Sarajevo front, and which was involved in transporting multiple groups of Bosnian Muslim males who had been detained in Srebrenica after the take-over, including the six men who were ultimately killed. ${ }^{19118}$ Consequently, the Chamber finds that the killings at Trnovo were also connected to the Srebrenica operation.

5617. The Chamber finds that at least 5,115 Bosnian Muslims were killed in Srebrenica between 12 July and early August 1995 and that this satisfies the mass scale element of the killings for the purposes of extermination.

5618. The Chamber also notes that a number of the killing incidents referred to above independently reach the level of massiveness required for the purpose of extermination as a crime against humanity. This is the case for instance with respect to the following killing incidents: (i) Kravica Warehouse; (ii) Orahovac School and Field near Orahovac; (iii) Petkovci School and Dam near Petkovci; (iv) Ročević School and Drina River near Kozluk; and (v) Kula School, Branjevo Military Farm, and Pilica Cultural Centre.

5619. The Chamber found above that the perpetrators of each of the killing incidents above acted with the intent to kill the victims or at least wilfully caused serious bodily harm, which they should reasonably have known might lead to death. Having regard to the scale of the killings and the organised manner in which they occurred, the Chamber further finds that with respect to the killing incidents in the previous paragraphs, there was the intention to kill on a mass scale.

5620. The Chamber also found that there was a widespread and systematic attack against the Bosnian Muslim and Bosnian Croat populations of $\mathrm{BiH}$. The Chamber finds that the killings referred to above were part of this widespread and systematic attack and the perpetrators of these killings knew of the attack and that their crimes were part of it. In reaching that conclusion, the Chamber considered the locations, time period, and the identity of the victims of these killings, which correspond with the scope of the widespread and systematic attack, as well as the magnitude of the attack on the Bosnian Muslim population of $\mathrm{BiH}$, which had been ongoing for more than three years prior to the events charged in the Srebrenica component of the case. The Chamber therefore finds that these killings constitute extermination as a crime against humanity.

19118 Trnovo, Scheduled Incident E.13.1. 
5621. The Chamber will deal with the issue of cumulative convictions later in this Judgement and, if relevant, the impermissibility of entering convictions for both extermination and murder under Article 5 of the Statute where the elements of both crimes have been established. ${ }^{19119}$

iii. Inhumane acts (forcible transfer): Count $8^{19120}$

5622. The Prosecution contends that acts of forcible transfer were carried out by Bosnian Serb Forces as part of the objective to eliminate the Bosnian Muslims in Srebrenica. ${ }^{19121}$ The Accused concedes that a large number of Bosnian Muslims from Srebrenica were transported from Potočari to Bosnian Muslim-held territory, but contends that this event did not constitute the crime of forcible transfer. ${ }^{19122}$ The Chamber will address his arguments below where relevant.

\section{(A) Actus reus}

\section{(1) Movement of population}

5623. The Chamber recalls its findings in Section IV.C.1 of this Judgement that between 11 and 13 July, up to 30,000 Bosnian Muslim women and children, as well as some elderly men, from Srebrenica, were displaced from inside the Srebrenica enclave to Bosnian Muslim-held territory. ${ }^{19123}$ The Chamber therefore finds that, having been lawfully present in Srebrenica, these Bosnian Muslim women and children, as well as some elderly men, were displaced within the national boundaries of $\mathrm{BiH}$.

\section{(2) Forcible nature of movement}

5624. The Chamber has found that Directive 7, which was issued on 8 March 1995, ordered the Drina Corps to "create an unbearable situation of total insecurity with no hope of further survival or life for the inhabitants of Srebrenica and Žepa". ${ }^{19124}$ Between that date and the eventual commencement of the attack on the enclave on 6 July 1995, the inhabitants of Srebrenica suffered months of deprivation of basic necessities which resulted from the restrictions placed on

\footnotetext{
19119 See para. 6020.

19120 Although paragraph 74 of the Indictment alleges that this plan extended to deporting the Bosnian Muslim population of Srebrenica, the Prosecution clarified during closing arguments that it does not seek a finding that the Accused is responsible for deportation, under Count 7, in relation to Srebrenica. Prosecution Closing Argument, T. 48034 (7 October 2014).

19121 Indictment, paras. 20, 74-75. Alternatively, it is alleged that these acts of forcible transfer formed part of the objective to permanently remove Bosnian Muslims and Bosnian Croats from Bosnian Serb-claimed territory. Indictment, para. 75.

19122 Defence Final Brief, para. 2401.

19123 See paras. 5029-5030, 5101, 5108.

19124 See paras. 4979-4080.
} 
humanitarian aid convoys by the Bosnian Serb Political Organs and the Bosnian Serb Forces. ${ }^{19125}$ Similar restrictions were placed on DutchBat re-supply convoys, leading to the eventual negation of DutchBat's operational readiness to defend the enclave. ${ }^{19126}$

5625. Beginning in the early morning of 6 July 1995, Bosnian Serb Forces opened fire on the enclave; the town came under heavy shell fire which lasted until it fell to Bosnian Serb Forces on 11 July. ${ }^{19127}$ Shells fell throughout the town and enclave in a scattered manner, and many civilians were wounded or killed. ${ }^{19128}$ As the southern perimeter of the enclave began to collapse and the Bosnian Serb Forces advanced towards Srebrenica town, thousands of refugees streamed towards the centre of the enclave and gathered near the Bravo Company compound and the hospital. ${ }^{19129}$ Bosnian Serb Forces burned Bosnian Muslim houses as they approached Srebrenica town. ${ }^{19130}$ Panic and fear increased as more refugees arrived from the outskirts of town, reporting that the Bosnian Serb Forces were burning their villages, and the representatives of international organisations began to depart for Potočari. ${ }^{19131}$ Upon arriving in Srebrenica town, Bosnian Serb soldiers called on the few people who remained in their houses to leave. ${ }^{19132}$ Desperate to reach safety, the Bosnian Muslims who were gathered outside the Bravo Company compound ultimately broke through the compound's defences. ${ }^{19133}$ When the Bosnian Serb Forces shelled the Bravo Company compound, DutchBat soldiers and panicked Bosnian Muslim civilians began to move towards Potočari, and the Bosnian Serb Forces shot and shelled at the column as it moved towards the UNPROFOR main base. ${ }^{19134}$ By the evening of 11 July, the DutchBat compound in Potočari was overcrowded with thousands of fearful Bosnian Muslims who had fled Srebrenica town. ${ }^{19135}$

5626. There was constant shelling throughout the night of 11 July and into the following morning. ${ }^{19136}$ As Bosnian Serb soldiers approaching in attack formation came into view, the Bosnian Muslim population in Potočari grew even more fearful. ${ }^{19137}$ At the same time, there was

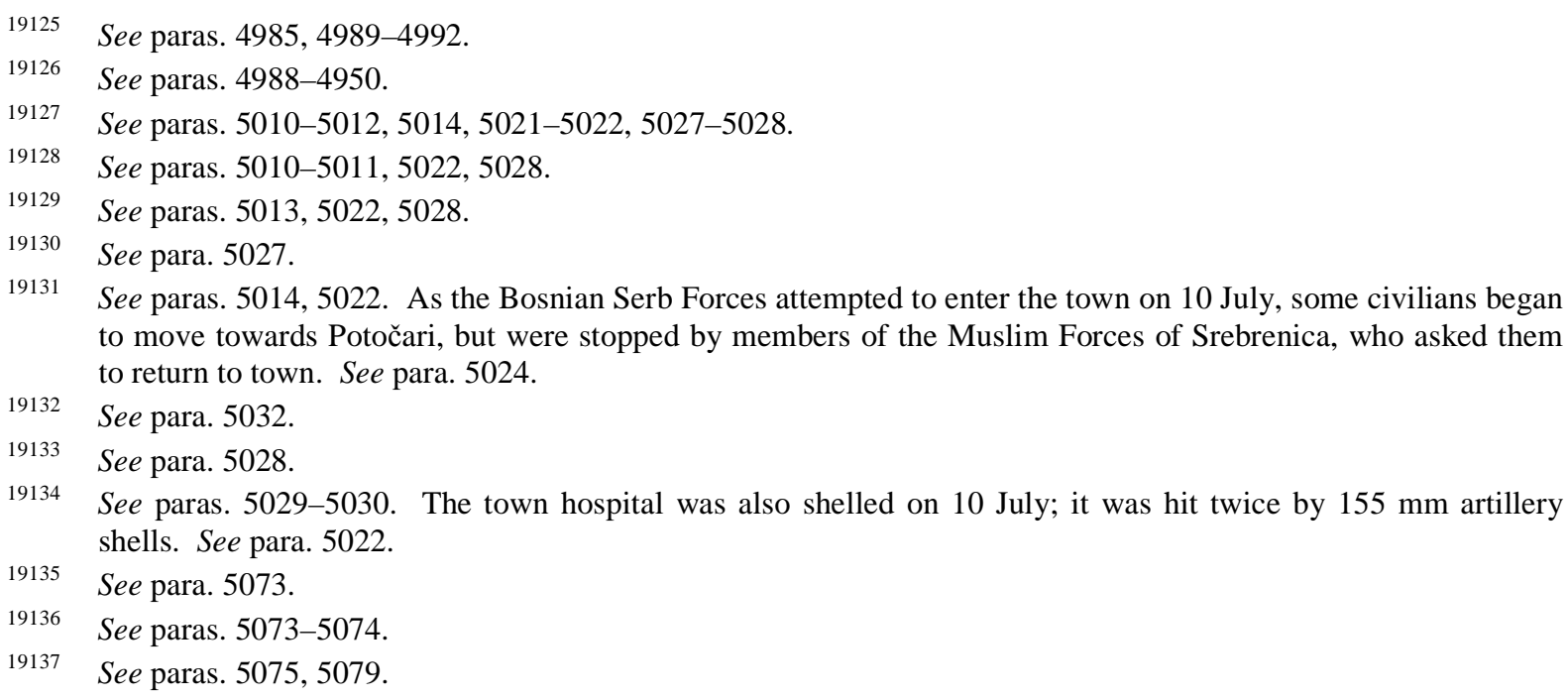
to move towards Potočari, but were stopped by members of the Muslim Forces of Srebrenica, who asked them to return to town. See para. 5024.

19132 See para. 5032.

19133 See para. 5028.

19134 See paras. 5029-5030. The town hospital was also shelled on 10 July; it was hit twice by 155 mm artillery shells. See para. 5022.

19135 See para. 5073.

19136 See paras. 5073-5074.

19137 See paras. 5075, 5079. 
insufficient water, food, and medicine, and for this reason-in addition to the lack of hygienic facilities available in Potočari-the humanitarian situation was catastrophic. ${ }^{19138}$ During the night between 12 and 13 July, the Bosnian Muslims, gathered in Potočari, could hear the sound of gunfire in the vicinity of the UN compound; some observed members of the Bosnian Serb Forces beating and sexually assaulting other Bosnian Muslims, while other Bosnian Muslims were taken away by members of the Bosnian Serb Forces and did not return. ${ }^{19139}$ As the vehicles on which the Bosnian Muslims would be transported arrived on the morning of 12 July, DutchBat soldiers stationed near the bus premises were disarmed by members of the Bosnian Serb Forces at gunpoint. ${ }^{19140}$ Many Bosnian Serb soldiers stood near the buses and trucks aligned along the road outside the UN compound; some were visibly drunk and were accompanied by German Shepherd dogs. ${ }^{19141}$

5627. Bosnian Serb Forces supervised the boarding process. ${ }^{19142}$ Bosnian Muslims were led towards, and began to board, the buses, which were guarded by Bosnian Serb soldiers with guns. ${ }^{19143}$ Bosnian Serb soldiers threatened those who tried to withdraw towards the back of the group and physically forced them to board the vehicles. ${ }^{19144}$ By 8 p.m. on the evening of 13 July, up to 30,000 Bosnian Muslims had been transported from Potočari to ABiH-held territory. ${ }^{19145}$

5628. The Chamber notes that in relation to the issue of whether the movement of the population was voluntary, the Accused contends that the departure of Bosnian Muslims from Potočari reflected a genuine choice on the part of the population, and that this choice was communicated to the Bosnian Serb Forces by UNPROFOR, with whom the suggestion to transport the population from Potočari originated. ${ }^{19146}$.

5629. As mentioned in Section Section IV.C.1 above, the Chamber received evidence indicating that the municipal authorities in Srebrenica attempted to contact the $\mathrm{BiH}$ authorities in Sarajevo multiple times throughout the day on 9 July $1995 .{ }^{19147}$ One of these communications included a request that Izetbegović and Delić arrange a meeting with the Bosnian Serbs to explore the

\footnotetext{
19138 See para. 5076. The Chamber recalls some women gave birth in the open, while conditions were so dire that other people died or committed suicide. See para. 5076.

19139 See para. 5077.

19140 See para. 5080. That morning, members of the Bosnian Serb Forces also conducted "check-ups" for Bosnian Muslims of military age and cursed Bosnian Muslims. See para. 5079.

19141 See para. 5093.

19142 See para. 5099.

19143 See paras. 5094-5095.

19144 See para. 5095. A Bosnian Serb soldier caught a woman by her hair and pushed and kicked her; she had tried to run after her brother, who had been separated and sent towards the White House. See para. 5095.

19145 See paras. 5107-5108.

19146 Defence Final Brief, paras. 2414, 2443. But see Prosecution Closing Argument, T. 47812 (30 September 2014).

19147 See para. 5015, fn. 16945.
} 
possibility of opening a corridor in order to allow the population to the nearest Bosnian Muslimheld territory. ${ }^{19148}$ The Accused contends that this request should be regarded as demonstrative of the wish of the population to leave the enclave. ${ }^{19149}$ However, these communications occurred on the day that the UNMOs departed the PTT building for Potočari, as the southern perimeter of the enclave began to collapse, and as the population began to panic. ${ }^{19150}$ The Chamber therefore does not consider that such a request to the $\mathrm{BiH}$ authorities was the product of genuine choice. ${ }^{19151}$

5630. The Accused also contends that at the first two meetings at the Hotel Fontana, "it was made clear to the Bosnian Serbs that both the UN and the civilian population wanted the people of Srebrenica to be transported from the enclave", and that Mladic made it clear that the population could stay if they wished to do so. ${ }^{19152}$ The Prosecution submits that Mladić's statements should be viewed in the context of "his menace and his threats". ${ }^{19153}$ Indeed, the Chamber has found that Mladić dictated the terms of the first Hotel Fontana meeting, the first ten minutes of which were extremely tense as Mladić berated Karremans for, inter alia, having fired at Bosnian Serb Forces that day. ${ }^{19154}$ Throughout the meeting, Mladić alternated his invitations to Karremans to make suggestions regarding the situation with veiled threats; for example, with regard to the DutchBat members being held at the hotel, he stated that they would not be hosted for long if NATO kept bombing, since "we know how to bomb too". ${ }^{19155}$ A few minutes later, Mladić told Karremans: "You can either all leave, all stay, or all die here."19156 At the second Hotel Fontana meeting,

19148 P4150 (Srebrenica Presidency's message to President of BiH and Commander of ABiH, 9 July 1995).

19149 Defence Final Brief, paras. 2402, 2407.

19150 See paras. 5014-5015. See also D2235 (Report of Presidency of Srebrenica Municipality, 9 July 1995) (reporting intense panic and fear); D2236 (Report of Presidency of Srebrenica Municipality, 9 July 1995) (reporting that the population had no food reserves and that during the last 3 days 4,000 people had left their homes); P4150 (Srebrenica Presidency's message to President of BiH and Commander of ABiH, 9 July 1995) (reporting that "chaos and panic prevail").

19151 See also P4140 (Witness statement of Joseph Kingori dated 8 January 2012), paras. 107-108 (commenting that P4150 was written out of desperation once the UNMOs disclosed their intent to depart to Potočari and that the population "had to look for a safe way out, not necessarily because of their own will to leave the enclave but because they were forced by circumstances [...] they were left with no option but to try to escape").

19152 Defence Final Brief, para. 2422. See also Defence Final Brief, paras. 2409-2414, 2420-2421, 2426-2427 (citing P4202 (Written compilation booklet: Srebrenica Trial video), e-court pp. 210-213, 216-218, 220-221, 230, 235, 237-238, 254). The Accused further contends that at the Third Hotel Fontana Meeting, Mladic communicated that anyone who wished to do so would be allowed to remain in Srebrenica. Defence Final Brief, para. 2426 (quoting P4202 (Written compilation booklet: Srebrenica Trial video), e-court pp. 248-249).

See para. 5042. When Karremans quipped: "Don't shoot the piano player," Mladić responded: "You're one lousy piano player". P4202 (Written compilation booklet: Srebrenica Trial video), e-court p. 217; P4201 (Updated Srebrenica Trial video), 00:55:09-00:55:26.

19156 P4202 (Written compilation booklet: Srebrenica Trial video), e-court p. 221; P4201 (Updated Srebrenica Trial video), 01:01:45-01:01:55. The Chamber further observes that Karremans' statements explicitly reflected the dependent situation in which he found himself, as he couched his first request to be allowed to leave the enclave in the admission that "it's a request because I'm not in a position to demand anything". P4202 (Written compilation booklet: Srebrenica Trial video), e-court p. 210; P4201 (Updated Srebrenica Trial video), 00:43:3900:43:52. See also P4202 (Written compilation booklet: Srebrenica Trial video), e-court p. 216; P4201 
Mladić demanded that Mandžić provide him with "a clear position on the representatives of your people on whether you want to survive [...] stay or vanish". ${ }^{19157}$ He advised Mandžić that "the future of your people is in your hands, not only in this territory". ${ }^{19158}$ When regard is had to such statements, the Chamber finds that Mladić's questioning of Karremans and Mandžić did not solicit answers grounded in genuine choice. ${ }^{19159}$

5631. As described in Section IV.C.1 above, at a meeting held in Potočari on 17 July, Mandžić and Franken were asked to sign a statement declaring, inter alia, that each individual had been allowed to choose whether to stay in the enclave or leave, and that "we decided that the entire population move out of the enclave and be evacuated to the territory of Kladanj municipality". 19160 Franken testified that these portions of the 17 July 1995 Statement were "nonsense", and that he had only signed it in order to ensure that the evacuation of DutchBat and the wounded proceeded smoothly. ${ }^{19161}$ Franken also explained that he had added a proviso to one of the statements in an effort to neutralise the false language in the 17 July 1995 Statement. ${ }^{19162}$ In light of Franken's testimony as well as the prevailing circumstances in Potočari described in more detail above, the Chamber does not consider the 17 July 1995 Statement to be demonstrative of the population's genuine choice to leave the enclave. Moreover, the Chamber recalls that an agreement concluded by military commanders or representatives of the parties to a conflict cannot render displacement lawful per se; commanders and representatives cannot consent on an individual's behalf. ${ }^{19163}$

5632. The Accused also points to evidence on the record which demonstrates that Akashi sent a code cable to Annan at 9:34 p.m. on 11 July, conveying the report of a UNHCR local staff member

(Updated Srebrenica Trial video), 00:53:30-00:53:40 (requesting the "release" of the population). Over the course of the meeting, Karremans explained the desperate situation of his battalion, including its lack of fuel and food, as well as its inability to provide for the population gathered in Potočari. P4202 (Written compilation booklet: Srebrenica Trial video), e-court pp. 211, 213; P4201 (Updated Srebrenica Trial video), 00:46:0800:46:45, 00:49:39-00:49:46.

19157 P4202 (Written compilation booklet: Srebrenica Trial video), e-court p. 241; P4201 (Updated Srebrenica Trial video), 01:35:00-01:35:10. See also Albert Rave, T. 22236 (30 November 2011) (testifying that Mladić's tone implied a threat).

19158 P4202 (Written compilation booklet: Srebrenica Trial video), e-court p. 241; P4201 (Updated Srebrenica Trial video), 01:36:40-01:37:00.

19159 Indeed, the Chamber recalls that Akashi's entire communication to Annan was predicated at the outset on the assessment that "the situation on the ground" at the time "necessitate[d] that [UN] actions in Srebrenica in the coming days be conducted with the consent of the Bosnian Serbs". D1039 (UNPROFOR report, 11 July 1995), p. 1. See also P4175 (Witness statement of Robert Franken dated 15 January 2012), para. 105 (stating that the population did not have a realistic opportunity to stay); P5206 (UNPROFOR report, 12 July 1995), e-court p. 1 (reporting that Mladić had insisted that the movement of people from Potočari begin immediately). P4185 (Declaration by the Civilian Affairs Committee for Srebrenica re: proper implementation of evacuation procedures , 17 July 1995) (emphasis added), cited in para. 5128.

19161 P4175 (Witness statement of Robert Franken dated 15 January 2012), paras. 106-107.

19162 P4175 (Witness statement of Robert Franken dated 15 January 2012), para. 106, cited in fn. 17384.

19163 See para. 490. 
that day that "virtually everyone in the enclave want[ed] to leave". ${ }^{19164}$ However, by the time the cable was sent, tens of thousands of Bosnian Muslims had fled the relentless shelling of Srebrenica town during the Bosnian Serb attack, and had dodged the shooting and shelling of the civilian column as it proceeded north to Potočari. They arrived there only to discover that DutchBat and the other international organisations present, having been under-supplied for months, were woefully unable to accommodate such a number of people. The Chamber finds that these circumstances, which resulted from the actions of Bosnian Serb Forces, were coercive.

5633. The Chamber therefore considers, on the basis of the evidence described above, that the circumstances arising from the imposition of restrictions of humanitarian aid pursuant to Directive 7, the attack on Srebrenica, as well as the atmosphere in Potočari, all of which resulted from the acts of Bosnian Serb Forces, created a coercive environment in which the Bosnian Muslims had no other viable alternative but to leave the enclave in order to stay alive. ${ }^{19165}$ Accordingly, the Chamber finds that the removal of the Bosnian Muslim women, children, and some elderly men from the Srebrenica enclave was forced.

5634. The Chamber further considers that because the catastrophic humanitarian situation in Potočari resulted from the actions of Bosnian Serb Forces, the humanitarian crisis that existed in Potočari does not justify the forcible nature of such displacement. The Chamber also observes that, particularly since military operations had ceased by the time the Bosnian Serb Forces entered Srebrenica town on 11 July, there was no need to remove the population for security reasons. Accordingly, the Chamber finds that the forced nature of the removal of Bosnian Muslims from Potočari was not justified under international law.

(B) Mens rea

5635. As mentioned in Section IV.C.1 above, with the issuance of Directive 7 on 8 March 1995, the Drina Corps was ordered to "create an unbearable situation of total insecurity with no hope of

19164 D1039 (UNPROFOR report, 11 July 1995), p. 2; P5203 (UNPROFOR report, 11 July 1995; Letter from John Ryan to Yasushi Akashi, 11 July 1995), p. 2. The Chamber further notes that Akashi testified that he met with UNHCR on 11 July and that he formed the impression that the Bosnian Serb government wished to permit those who wished to stay to do so, while UNHCR advocated that those who wished to leave should be allowed to do so. Yasushi Akashi, T. 37743 (25 April 2013). The Chamber observes that these impressions were not formed firsthand through personal contact with any member of the Bosnian Serb government and thus does not consider Akashi's testimony to be probative of any intent that could be attributable to the Accused.

19165 The Accused argues that it is improper to consider the coercive effect on the population of earlier events, such as convoy restrictions and the shelling of civilians, as evidence of the intent of the Bosnian Serb Forces because the transportation of the population did not take place until after the population and UNPROFOR had specifically requested it. Defence Final Brief, para. 2437. However, the forcible nature of the movement of a population can be established by reference to coercive circumstances; the Chamber has considered the deliberate imposition of restrictions on humanitarian aid together with all the other evidence in establishing the coercive nature of the environment as described above. 
further survival or life for the inhabitants of Srebrenica and Žepa". ${ }^{19166}$ Bosnian Serb Forces implemented Directive 7 by further restricting humanitarian aid and re-supply convoys over the following months. ${ }^{19167}$

5636. On 10 July, the Bosnian Serb Forces issued an ultimatum to DutchBat, stating, inter alia, that DutchBat would be permitted to leave the enclave with the civilian population if they left their equipment and weapons behind. ${ }^{19168}$ The Bosnian Serb ultimatum further proposed that only representatives of international organisations should be allowed into the UN Compound, and that the Bosnian Muslim population should remain outside. ${ }^{19169}$ Moreover, members of the Bosnian Serb Forces in fact took action to mobilise buses even prior to the commencement of the third meeting at the Hotel Fontana. ${ }^{19170}$ The Chamber therefore does not accept either the Accused's assertion that the VRS only took action to mobilise buses after the conclusion of the Hotel Fontana meetings or his suggestion that such a fact-even if established-would demonstrate that the Bosnian Serb Forces had no intention of forcing the population to leave before that point. ${ }^{19171}$

5637. The Chamber notes that in an intercepted conversation at 12:50 p.m., Mladić was heard telling an unidentified male person: “They've all capitulated and surrendered and we'll evacuate them all-those who want to and those who don't want to."19172 The Accused asserts that as transcribed, this intercept "stands alone as an outlier" and suggests that the word "accommodate" was omitted during transcription such that Mladić's statement should read, "we'll evacuate them all - those who want to and [accommodate] those who don't want to". ${ }^{19173}$ The Chamber observes that no evidence on the record supports the Accused's assertion that a word was omitted. The Chamber also notes that it received the testimony of the intercept operator who transcribed this conversation, who testified that a series of dots were used to denote any passages where the speakers were not well heard. ${ }^{19174}$ The Chamber observes that no dots were inserted between the words "and" and "those" in the original transcription. The Chamber is therefore satisfied that the original transcription of the conversation accurately reflected Mladić's statement.

\footnotetext{
19166 See para. 5624.

19167 See paras. 4989-4992. The Chamber also notes that humanitarian aid had already diminished even prior to the issuance of Directive 7. See paras. 4986-4987.

19168 See paras. 5023, 5026. This ultimatum was conveyed to the Bosnian Muslim military and civilian authorities on the night of 10 July 1995. See para. 5026.

19169 See fn. 16997.

19170 See paras. 5082-5086.

19171 Defence Final Brief, paras. 2422-2423.

19172 P6694 (Intercept of conversation between Ratko Mladić and unknown, 12 July 1995).

19173 Defence Final Brief, paras. 2430-2431.

19174 KDZ357, P4628 (Transcript from Prosecutor v. Tolimir), T. 2077-2078.
} 
5638. Moreover, the Chamber considers that the statement is not an "outlier" when viewed in the overall context of the numerous intimidating statements that Mladić made to Karremans, DutchBat members, and the representative of the Bosnian Muslim population during the first two meetings at the Hotel Fontana, some of which have been highlighted above. ${ }^{19175}$ Additionally, at the third Hotel Fontana meeting, which was held on the morning of 12 July, Mladić opened the meeting by telling the representatives of the Bosnian Muslim population in Potočari,

I want to help you, but I want absolute co-operation from the civilian population because your army has been defeated. There is no need for your people to get killed [...]. All you have to do is say what you want. As I told this gentleman [Mandžić] last night, you can either survive or disappear. ${ }^{19176}$

In support of his challenge to the Prosecution's contention that the Bosnian Serb Forces intended to force the population to leave, the Accused points to a conversation intercepted at 12:40 p.m., approximately 1.5 hours after the end of the third Hotel Fontana meeting and just as the bussing operation in Potočari got underway, ${ }^{19177}$ in which one speaker communicated to Main Staff headquarters that "I talked with them and we'll accept all of the civilians who want to and they can stay". 19178 The Accused claims that the speakers were a superior and a subordinate, that one speaker's reference to having spoken with "them" should be construed as having spoken to the civilian population, and that on the basis of that construction, along with the fact that the speaker on the ground called the Main Staff, the Chamber should infer that the interlocutor on the ground was Mladić. ${ }^{19179}$ Even if the Chamber were to accept these premises, in light of the evidence of Mladić's other contemporaneous statements described above, ${ }^{19180}$ the Chamber would not consider such a statement demonstrative of Mladić's true intent.

5639. Asserting that the Bosnian Muslim population would have been allowed to stay in Srebrenica had they "sheltered in place in their homes", the Accused contends that the fact that requests were conveyed to the Bosnian Serb Forces to transfer the population precludes the Chamber from concluding that the only reasonable inference is that the Bosnian Serb Forces intended to forcibly transfer the population. ${ }^{19181}$ The Chamber notes, firstly, that it has already found that, on the contrary, Bosnian Muslims fled from Srebrenica town to Potočari as a result of

\footnotetext{
19175 See para. 5630.

19176 P4202 (Written compilation booklet: Srebrenica Trial video), e-court p. 248.

19177 See paras. 5070, 5093.

19178 D2258 (Intercept of conversation between unidentified individuals in VRS, 12 July 1995).

19179 Defence Final Brief, paras. 2428-2429. The Prosecution contests this construction but did not elaborate further. See Prosecution Closing Arguments, T. 47813 (30 September 2014).

19180 See paras. 5630, 5638.

19181 Defence Final Brief, paras. 2438-2439, 2442.
} 
the Bosnian Serb attack. ${ }^{19182}$ Second, the Chamber recalls that, as mentioned above, the boarding process, which was coercive, was carried out under the direct supervision of the Bosnian Serb Forces. ${ }^{19183}$ Members of the Bosnian Serb Forces physically forced some of the individuals gathered in Potočari to board the buses. ${ }^{19184}$ Additionally, on 13 July, Radislav Janković ordered a member of the Bratunac Brigade MP to return to Srebrenica to see if any Bosnian Muslims were still there. ${ }^{19185}$ Furthermore, the Chamber recalls that members of the Bosnian Serb Forces threatened to shoot an elderly patient who wished to remain in the Srebrenica hospital if the UNMOs did not remove her and take her with them. ${ }^{19186}$

5640. On the basis of all of this evidence, the Chamber considers that there is no doubt that the Bosnian Serb Forces intended to forcibly remove from the Srebrenica enclave the Bosnian Muslim women, children, and some elderly men who had gathered in Potočari by 11 July.

\section{(C) Conclusion}

5641. With respect to the transfer described in paragraphs 5623 to 5634 above, the Chamber finds that those who were displaced left their places of residence and belongings without any guarantee concerning the possibility to return in the future and that this caused the victims serious mental suffering or injury. Additionally, some of those displaced from Srebrenica had been previously displaced from their homes in other municipalities; ${ }^{19187}$ their displacement from Srebrenica compounded their suffering. These acts were committed with the intent to inflict serious mental suffering, or with knowledge that these acts were likely to cause such suffering. These acts are of similar seriousness to deportation which is listed under Article 5(d) of the Statute. The Chamber therefore finds that these acts are sufficiently serious to amount to "other inhumane acts" pursuant to Article 5(i) of the Statute.

5642. The Chamber found that there was a widespread and systematic attack against the Bosnian Muslim and Bosnian Croat civilian populations of $\mathrm{BiH}$. The Chamber finds that acts referred to in paragraphs 5623 to 5634 of this section were part of this widespread and systematic attack and that the perpetrators of these acts knew of the attack and that their crimes were part of it. In reaching that conclusion, the Chamber considered the locations, time period, and the identity and status of the victims, which correspond with the scope of the widespread and systematic attack, as well as

\footnotetext{
19182 See paras. $5625,5629-5630$.

19183 See paras. 5626-5627.

19184 See para. 5627.

19185 Mile Janjić, P1194 (Transcript from Prosecutor v. Blagojević \& Jokić), T. 9799-9800.

19186 See fn. 17367; P4140 (Witness statement of Joseph Kingori dated 8 January 2002), para. 186.

19187 See para. 2465.
} 
the magnitude of the attack on the Bosnian Muslim civilian population of $\mathrm{BiH}$. The Chamber therefore finds that these incidents constitute other inhumane acts (forcible transfer) as crimes against humanity.

\section{iv. Persecution: Count 3}

\section{(A) Killings}

5643. Earlier in this Judgement, the Chamber found that many Bosnian Muslims were killed by Bosnian Serb Forces in the weeks following the fall of Srebrenica on 11 July $1995 .{ }^{19188}$ The Chamber also found that the perpetrators of each of these incidents acted with the intent to kill the victims or at least wilfully caused serious bodily harm, which they should reasonably have known might lead to death. ${ }^{19189}$ The Chamber therefore found that these killings constituted murder as a crime against humanity and a violation of the laws or customs of war charged under Counts 5 and 6 of the Indictment, respectively. ${ }^{19190}$ The Chamber further found that the victims of each of these incidents were civilians or had been rendered hors de combat at the time of their killing. ${ }^{19191}$

5644. The Chamber found that all the victims of the killings mentioned above were Bosnian Muslims. Therefore, the Chamber finds that the perpetrators of these killings intentionally targeted their victims solely on the basis of their identities as Bosnian Muslims and that these killings were carried out on discriminatory grounds with discriminatory intent.

5645. As found earlier, these killings were part of a widespread and systematic attack against the Bosnian Muslim civilian population of $\mathrm{BiH}$ and the perpetrators knew of the attack and that the crimes were part of it. ${ }^{19192}$ Therefore, the Chamber finds that these killings constitute persecution as a crime against humanity.

\section{(B) Cruel and/or inhumane treatment}

(1) Terrorising and abuse of Bosnian Muslims of Srebrenica in Potočari

5646. Earlier in this Judgement, the Chamber described the appalling conditions inflicted upon the panicked and fearful Bosnian Muslim population gathered at the DutchBat compound in Potočari between 11 and 13 July $1995 .{ }^{19193}$ The Chamber will not repeat its description in full here, but

\footnotetext{
19188 See para. 5519.

19189 See para. 5608.

19190 See paras. 5611-5612.

19191 See para. 5610.

19192 See para. 5612.

19193 See para. 5626.
} 
specifically recalls that at the DutchBat compound, where thousands of Bosnian Muslims sought shelter after having come under shell fire at the Bravo Company compound in Srebrenica town and while en route to Potočari, continuous shell fire could be heard between 11 and 12 July. ${ }^{19194}$ The Chamber also recalls the incidents of physical violence-including physical and sexual assaultsperpetrated by Bosnian Serb Forces which occurred throughout the day and evening of 12 July and into the following day. ${ }^{19195}$

5647. The Chamber further found that in the midst of the fearful atmosphere in Potočari, Bosnian Serb Forces separated between 600 and 700 Bosnian Muslim men and boys from the women and children and took the men to the White House; this intensified the fear of the men as well as those from whom they were separated. ${ }^{19196}$ Before entering the White House, the terrified men were stripped of their ID cards, which the Chamber considers they must have interpreted as a sign of the terrible fate that awaited them, further increasing their fear. ${ }^{19197}$ They were forced to leave behind their other belongings and crowded together in the house without food or water. ${ }^{19198}$ Outside, members of the Bosnian Serb Forces stood guard with German Shepherd dogs. ${ }^{19199}$ During the course of the day on 12 July, the treatment of the Bosnian Muslim men inside the White House deteriorated even further; Bosnian Serb soldiers blocked two DutchBat members who managed to enter the house on the following day from entering an "interrogation room" by threatening them with weapons. ${ }^{19200}$ Throughout their detention at the White House, the Bosnian Muslim men were visibly terrified. ${ }^{19201}$

5648. The Chamber has no doubt that these combined circumstances exacerbated the fear and panic permeating the atmosphere in Potočari and the acts of the Bosnian Serb Forces - namely the shelling of Potočari, the incidents of physical violence inflicted upon the Bosnian Muslims gathered there, and the separation and subsequent detention of Bosnian Muslim men and boys at the White House-deliberately inflicted serious physical and mental suffering on the Bosnian Muslims gathered there. The Chamber considers that this cruel and inhumane treatment is of equal gravity to the crimes listed in Article 5 of the Statute.

\footnotetext{
19194 See paras. 5029-5030, 5074.

19195 See paras. 5077, 5095.

19196 See paras. 5095, 5109.

19197 See para. 5110.

19198 See paras. 5113-5115.

19199 See para. 5113.

19200 See paras. 5115-5116.

19201 See paras. 5113, 5116.
} 
(2) Beating of men and boys of Srebrenica prior to their execution

5649. Earlier in the Judgement, the Chamber described the beatings inflicted upon the Bosnian Muslim men detained by Bosnian Serb Forces at various locations in Bratunac and Zvornik municipalities between 13 and 15 July 1995 prior to their execution. ${ }^{19202}$ The Chamber finds that the circumstances in which these beatings took place clearly establish that they were performed deliberately.

5650. The Chamber also found that while inflicting these beatings, Bosnian Serb soldiers taunted the Bosnian Muslim detainees and cursed their "balija" mothers. ${ }^{19203}$ The beatings were severe; those being beaten screamed and moaned such that they could be heard by the other detainees. ${ }^{19204}$ The Chamber therefore finds that the Bosnian Serb Forces deliberately inflicted beatings causing serious physical and mental suffering on the Bosnian Muslim detainees. In the view of the Chamber, this cruel and inhumane treatment is of equal gravity to the crimes listed in Article 5 of the Statute.

\section{(3) Conclusion on cruel and inhumane treatment}

5651. As found above, the Bosnian Serb Forces deliberately inflicted serious physical and mental suffering upon Muslims gathered in Potočari, as well as upon the Bosnian Muslim men and boys who were subjected to beatings prior to their execution. The circumstances described above demonstrate that the Bosnian Serb Forces intentionally targeted their victims and subjected them to such cruel and inhumane treatment solely on the basis of their identities as Bosnian Muslims. This cruel and inhumane treatment was therefore carried out on discriminatory grounds with discriminatory intent.

5652. The Chamber found that there was a widespread and systematic attack against the Bosnian Muslim civilian population of $\mathrm{BiH}$. The Chamber finds that the acts referred to above were part of this widespread and systematic attack and the perpetrators of these acts knew of the attack and that their crimes were a part of it. Therefore, the Chamber finds that such cruel and inhumane treatment constitutes persecution as a crime against humanity.

\footnotetext{
19202 See paras. 5296, 5299-5300, 5361-5362, 5422.

19203 See para. 5149.

19204 See paras. 5296, 5298, 5300, 5361, 5422.
} 


\section{(C) Forcible transfer}

5653. The Chamber found above that inhumane acts (forcible transfer) was committed and constituted a crime against humanity as charged under Count 8 of the Indictment. The Chamber finds that the Bosnian Serb Forces who carried out that forcible transfer intentionally targeted their victims solely on the basis of their identities as Bosnian Muslims; the forcible transfer was therefore carried out on discriminatory grounds with discriminatory intent.

5654. As the Chamber found above, this forcible transfer formed part of a widespread and systematic attack against the Bosnian Muslim civilian population of $\mathrm{BiH}$, and the perpetrators knew of the attack and that their crimes were a part of it. In addition, the Chamber found that the acts of forcible displacement within national boundaries were sufficiently serious to amount to "other inhumane acts". Therefore, the Chamber finds that this forcible transfer constitutes persecution as a crime against humanity.

\section{v. Genocide: Count 2}

5655. In Count 2 of the Indictment, the Prosecution charges the Accused with genocide pursuant to Article 4 of the Statute. It alleges that between 11 July and 1 November 1995, Bosnian Serb Forces killed over 7,000 Bosnian Muslim men and boys in Srebrenica and the surrounding area through, inter alia, large-scale executions carried out from 12 July until late July $1995 .{ }^{19205}$ The Prosecution further contends that Bosnian Serb Forces caused serious bodily or mental harm to thousands of female and male members of the Bosnian Muslims of Srebrenica by separating the men and boys from their families and by forcibly removing the women, children, and some elderly men. ${ }^{19206}$

5656. The Accused contends that these killings were not committed with genocidal intent and therefore do not constitute genocide. ${ }^{19207}$

\section{(A) The protected group}

5657. As established above in relation to Count 1, the Chamber is satisfied that Bosnian Muslims were a protected group for the purpose of Article 4 of the Statute. ${ }^{19208}$

\footnotetext{
19205 Indictment, paras. 41-42, 46-47, Schedule E (Part 1). See also Prosecution Final Brief, para. 1092. The Prosecution also alleges responsibility for other killings. Indictment, paras. 46, 47(a), Schedule E (Part 2).

19206 Indictment, paras. 46-47. See also Prosecution Final Brief, paras. 1093-1094.

19207 Defence Final Brief, para. 2720. See also Defence Final Brief, para. 2717.

19208 See para. 2574.
} 
5658. In relation to Count 2, the Prosecution charges two types of acts pursuant to Article 4(2) of the Statute: (i) the killing of over 7,000 Bosnian Muslim men and boys of Srebrenica through executions set out in Schedule E of the Indictment; ${ }^{19209}$ and (ii) the causing of serious bodily or mental harm to thousands of female and male members of the Bosnian Muslims of Srebrenica, including but not limited to the separation of men and boys from their families and the forcible removal of women, young children and some elderly men from the enclave. ${ }^{19210}$

5659. The Chamber will examine below each of these charged categories.

(1) Killing members of the group

5660. The Chamber has found that in the aftermath of the fall of Srebrenica, at least 5,115 Bosnian Muslim males were killed by Bosnian Serb Forces. ${ }^{19211}$ The Chamber is therefore satisfied for the purpose of Article 4(2)(a) of the Statute that members of the protected group were killed.

\section{(2) Causing serious bodily or mental harm to members of the group}

5661. Earlier in this Judgement, the Chamber has described in detail the harrowing circumstances under which thousands of Bosnian Muslim males faced the prospect of their imminent deaths.

5662. In this regard, the Chamber recalls the atmosphere of panic in Potočari. The Bosnian Muslims who travelled there with their families on 11 July endured a night permeated with fear as a result of the conditions created by the Bosnian Serb Forces. ${ }^{19212}$ Once the transportation process began on the following day, the Bosnian Muslim males were abruptly separated from their families and stripped of their personal belongings, including identification cards ${ }^{19213}$ as stated above, the Chamber considers that the Bosnian Muslim males must have interpreted this as an ominous sign of the terrible fate that awaited them. ${ }^{19214}$ The Bosnian Muslim males who were separated in Potočari

\footnotetext{
19209 Indictment, para. 47(a) (referring to the crimes listed in Schedule E (Part 1) and Schedule E (Part 2).

19210 Indictment, para. 47(b). The Chamber notes that, in contrast to the open-ended use of the term "including" which the Chamber has mentioned in fn. 13, in para. 47(b) of the Indictment, the Prosecution specifically states that its allegation regarding the causing of serious bodily or mental harm to the Bosnian Muslims of Srebrenica includes the phrase "but [is] not limited to" the separation of the men and boys from their families and the forcible removal of the women, young children, and some elderly men from the enclave. The Chamber will thus consider whether serious bodily or mental harm was caused to thousands of female and male members of the Bosnian Muslims of Srebrenica following the separation of the men and boys from their families as a result of both the killings and the forcible removal of the women, children, and some elderly men. See Prosecution Final Brief, para. 1094.

19211 See para. 5519. See also para. 5607.

19212 See paras. 5073-5077.

19213 See paras. 5095, 5101, 5109-5110.

19214 See para. 5647.
} 
were crammed first into the White House and later moved to various overcrowded locations in Bratunac, where they were held in appalling sanitary conditions and given little if any food or water. ${ }^{19215}$ In Bratunac, the Bosnian Muslim males from Potočari were joined by Bosnian Muslim males who had endured similar deprivation upon being captured or surrendering from the column. ${ }^{19216}$ During their detention, many Bosnian Muslim males were subjected to physical and verbal abuse at the hands of the Bosnian Serb Forces; these conditions persisted upon their transfer from Bratunac to more remote locations in Zvornik. ${ }^{19217}$ Once taken to the execution sites, the Bosnian Muslim males must have realised that they would be killed and thus spent their last terrifying moments in a state of hopelessness. The Chamber finds that the suffering endured by these men in the final days and hours before they were killed by Bosnian Serb Forces constituted serious bodily or mental harm.

5663. The Chamber also finds that the Bosnian Serb Forces caused serious bodily and mental harm to the Bosnian Muslim males who managed to survive the killings and lived to testify. Some witnesses described hiding underneath the bodies of their fellow detainees and escaping the killing sites under perilous circumstances. ${ }^{19218}$ The Chamber is convinced that, in addition to the serious bodily or mental harm suffered by the survivors prior to their attempted execution, their respective close encounters with death have had long-lasting effects on their respective abilities to lead normal and constructive lives.

5664. Likewise, the Chamber finds that the killings of Bosnian Muslim males carried out by the Bosnian Serb Forces following the fall of Srebrenica inflicted serious mental harm upon the surviving family members and loved ones of those killed. Having fled their homes or places of refuge for the UN Compound, these women, children, and some elderly men also endured the sudden separations at Potočari, when their husbands, fathers, brothers and sons were taken away to await an unknown fate. ${ }^{19219}$ The Chamber received evidence that many women suffered serious mental harm as a result of not knowing what happened to their missing male family members. ${ }^{19220}$

19215 See paras. 5113, 5294-5295.
19216 See paras. 5168, 5176-5177, 5183, 5186.
19217 See paras. 5193, 5296, 5298-5299, 5323-5324, 5359-5360, 5418.
19218 See paras. 5152, 5236-5239, 5334, 5368-5370, 5432-5433, 5437. The Chamber recalls that one Bosnian
Muslim man survived by throwing himself in the Jadar River after being hit by a bullet. See para. 5190.
19219 See paras. 5101-5108.
19220 Teufika Ibrahimefendic, P4646 (Transcript from Prosecutor v. Krstić), T. 5817-5818. See e.g. P391 (Witness
statement of Hafiza Salihović dated 17 June 2000), pp. 2-3; P392 (Witness statements of Semija Suljić dated 17
June 2000), p. 2; P393 (Witness statement of Mejra Mešanović dated 19 June 2000), p. 3; P394 (Witness
statement of Mevlida Bektić dated 16 June 2000), p. 3; P395 (Witness statement of Behara Krdžić dated 16 June
2000), p. 3; P396 (Witness statement of Hanifa Hafizović dated 16 June 2000), pp. 3-4; P397 (Witness
statement of Razija Pašagić dated 15 June 2000), p. 3; P398 (Witness statement of Saliha Osmanović dated 18
June 2000), pp. 3-4; P399 (Witness statement of Salih Mehmedović dated 15 June 2000), p. 4; P401 (Witness 
The Chamber heard testimony of the unique nature of this suffering in that in the space of a few days, many women of Srebrenica had lost such large numbers of male family members that they were unable to envision the future. ${ }^{19221}$ Their mental anguish continues in the form of anxiety as well as feelings of helplessness and betrayal, which underpin an unwillingness or inability to return to their former homes. ${ }^{19222}$ Accordingly, the Chamber finds that the mental harm caused to the women, children, and some elderly men as a result of the killing of the men and boys and the forcible removal of the remainder of Bosnian Muslims has had long-lasting effects on the respective abilities of the surviving women, children, and some elderly men to live normal and constructive lives.

5665. The Chamber is therefore satisfied for the purpose of Article 4(2)(b) of the Statute that thousands of female and male members of the Bosnian Muslims of Srebrenica were subjected to serious bodily or mental harm as a result of actions of the Bosnian Serb Forces and that this harm was of such serious nature as to contribute or tend to contribute to the destruction of part of the group.

\section{(C) Mens rea}

5666. The Prosecution contends that the Accused and other members of the Srebrenica JCE intended to destroy the Bosnian Muslims in Srebrenica, which formed a substantial part of the protected Bosnian Muslim group. ${ }^{19223}$ According to the Prosecution, the intent to destroy the

statement of Šehra Ibišević dated 21 June 2000), p. 4; P403 (Witness statement of Rahima Malkić dated 17 June 2000), pp. 2-4; P404 (Witness statement of Samila Salčinović dated 18 June 2000), p. 3.

19221 Teufika Ibrahimefendic, P4646 (Transcript from Prosecutor v. Krstić), T. 5815, 5817-5818, 5832. Considering the patriarchal society, many women endure financial insecurity as their husbands and sons were the main source of income, which renders the process of finding a permanent home difficult. See e.g. P391 (Witness statement of Hafiza Salihović dated 17 June 2000), p. 3; Semija Suljić, P392 (Witness statements of Semija Suljić dated 17 June 2000), p. 2; P393 (Witness statement of Mejra Mešanović dated 19 June 2000), p. 3 ; P394 (Witness statement of Mevlida Bektić dated 16 June 2000), p. 3; P395 (Witness statement of Behara Krdžić dated 16 June 2000), p. 3; P396 (Witness statement of Hanifa Hafizović dated 16 June 2000), p. 3 ; P397 (Witness statement of Razija Pašagić dated 15 June 2000), p. 3; P398 (Witness statement of Saliha Osmanović dated 18 June 2000), p. 4; P399 (Witness statement of Salih Mehmedović dated 15 June 2000), pp. 3-5; P401 (Witness statement of Šehra Ibišević dated 21 June 2000), p. 4; P403 (Witness statement of Rahima Malkić dated 17 June 2000), p. 3; P404 (Witness statement of Samila Salčinović dated 18 June 2000), p. 3.

19222 Teufika Ibrahimefedić, T. 26681-26682 (22 March 2012). This stress manifests physically in the form of insomnia as well as problems with eating. Teufika Ibrahimefedić, T. 26682 (22 March 2012). Many are unable or unwilling to return home because of fear and loss of hope. See e.g. P391 (Witness statement of Hafiza Salihović dated 17 June 2000), p. 3; P392 (Witness statements of Semija Suljić dated 17 June 2000), p. 2; P393 (Witness statement of Mejra Mešanović dated 19 June 2000), p. 3; P394 (Witness statement of Mevlida Bektić dated 16 June 2000), p. 3; P395 (Witness statement of Behara Krdžić dated 16 June 2000), p. 3 ; P396 (Witness statement of Hanifa Hafizović dated 16 June 2000), p. 2; P398 (Witness statement of Saliha Osmanović dated 18 June 2000), p. 4; P401 (Witness statement of Šehra Ibišević dated 21 June 2000), p. 4; Rahima Malkić, P403 (Witness statement of Rahima Malkić dated 17 June 2000), p. 3; P404 (Witness statement of Samila Salčinović dated 18 June 2000), p. 4.

19223 Prosecution Final Brief, paras. 1095-1096. Alternatively, the Prosecution contends that it was foreseeable to the Accused that one or more members of the Overarching JCE might perpetrate genocide against the Bosnian 
Bosnian Muslims in Srebrenica is evident from the scale of the killings and their level of coordination, as well as the systematic method through which they were carried out. ${ }^{19224}$ The Prosecution argues that the killings, as well as the forcible removals and other acts which inflicted serious bodily or mental harm, "were intended to ensure that the Bosnian Muslim community of Srebrenica could not re-constitute itself. ${ }^{19225}$ The Accused denies that he personally had or shared such intent with anyone else. ${ }^{19226}$

5667. The Chamber will address the Accused's mental state in the section concerning his responsibility below, and will limit its immediate consideration to whether the existence of genocidal intent is evident from the pattern of crimes.

\section{(1) Intent to destroy a part of the protected group as such}

5668. As stated above, the Chamber has found that the Bosnian Serb Forces killed at least 5,115 Bosnian Muslim males from Srebrenica following the fall of Srebrenica in July 1995. ${ }^{19227}$ The Chamber notes the commencement of the killings outside the Vuk Karadžić School in Bratunac on the night of 12 July; ${ }^{19228}$ the further killings at Potočari, ${ }^{19229}$ Sandići Meadow, ${ }^{19230}$ Jadar River, ${ }^{19231}$ the Kravica Warehouse, ${ }^{19232}$ Luke School near Tišća, ${ }^{19233}$ and again outside the Vuk Karadžić School on $13 \mathrm{July} ;{ }^{19234}$ and the continued escalation of the killings following the decision on 13 July to transfer the Bosnian Muslim males in Bosnian Serb custody to Zvornik with killings at Orahovac, ${ }^{19235}$ Petkovci, ${ }^{19236}$ Ročević and Kozluk, ${ }^{19237}$ and at Kula School, Branjevo Military Farm, and the Pilica Cultural Centre. ${ }^{19238}$ All of these killings were carried out over a period of several days and in circumstances which demonstrated clear co-ordination between multiple layers and branches of the Bosnian Serb Forces. The Chamber considers that the consistent pattern evident from the movement of the prisoners from their places of detention-sometimes to

Muslims of Srebrenica, that he was aware that such genocide was a possible consequence of implementing the objective of the Overarching JCE, and the Accused willingly took that risk. Indictment, para. 43.

19224 Prosecution Final Brief, para. 1096.

19225 Prosecution Final Brief, para. 1097.

19226 Defence Final Brief, paras. 3167-3169.

19227 See para. 5519. See also para. 5607.

19228 See para. 5298.

19229 See paras. 5141, 5145.

19230 See para. 5291.

19231 See para. 5205.

19232 See para. 5286.

19233 See para. 5154.

19234 See paras. 5299-5303, 5306.

19235 See para. 5354.

19236 See para. 5382.

19237 See para. 5413. 
secondary or even tertiary holding sites-and ultimately to killing sites demonstrates the deliberate nature of the operation pursuant to which the Bosnian Muslim males were executed. The Chamber further observes that the vast scale of the executions as well as the horrendous manner in which they were carried out demonstrated a total disregard for the humanity of the Bosnian Muslim males of Srebrenica.

5669. The Chamber notes that the operation, which was carried out by the Bosnian Serb Forces who vigorously pursued the Bosnian Muslim males in the column, encompassed the killing of all Bosnian Muslim men in Bosnian Serb custody, irrespective of whether they were combatants or civilians and regardless of whether they were captured or had surrendered. The Chamber considers that this, combined with the manner as well as the systematic and highly organised nature of the killings, demonstrates a clear intent to kill every able-bodied Bosnian Muslim male from Srebrenica. Noting that killing every able-bodied male of a group results in severe procreative implications that may lead to the group's extinction, ${ }^{19239}$ the Chamber finds that the only reasonable inference on the basis of such evidence is that members of the Bosnian Serb Forces orchestrating this operation intended to destroy the Bosnian Muslims in Srebrenica as such.

5670. Although a corridor was opened for a period of approximately 24 hours, ${ }^{19240}$ the Chamber finds that this was done by a brigade commander for reasons of military necessity and notes that it was quickly closed, reinforcements were sent to the Zvornik area, and the Main Staff dispatched three colonels to the area to investigate why the corridor had been opened. ${ }^{19241}$ In the following days, members of the Bosnian Serb Forces continued to kill Bosnian Muslim males who came into custody, as exemplified by the killings of Bosnian Muslim males at Snagovo, ${ }^{19242}$ Bišina, ${ }^{19243}$ and Trnovo. ${ }^{19244}$ The Chamber is thus of the view that the opening of the corridor does not raise any doubt that members of the Bosnian Serb Forces intended to destroy the Bosnian Muslims in Srebrenica.

5671. On the basis of the evidence regarding the killing operation, in particular in light of the fact that the Bosnian Serbs tried to kill every able-bodied Bosnian Muslim male from Srebrenica, ${ }^{19245}$

\footnotetext{
19238 See para. 5464.

19239 See Krstić Appeal Judgement, paras. 28-29.

19240 See para. 5470. The Chamber notes that the Main Staff initially denied Obrenović authorisation to open such a corridor. See para. 5468.

19241 See paras. 5468-5474.

19242 See para. 5481.

19243 See para. 5490.

19244 See paras. 5475-5476, 5497.

19245 In this regard, the Chamber considers the example of Rešid Sinanović-the former chief of the SUP in Bratunac - to be illustrative of this intention. The Chamber recalls that Sinanović was captured by Bosnian Serb
} 
the Chamber finds that the only reasonable inference is that members of the Bosnian Serb Forces intended to destroy the Bosnian Muslims in Srebrenica as such. In addition, the Chamber recalls the near-simultaneous execution of the bussing operation which resulted in the removal of the remainder of the Bosnian Muslim population, namely the women, children, and some elderly men, from the Srebrenica enclave. ${ }^{19246}$ The Chamber has found that this process, which also involved the abrupt separation of the Bosnian Muslim males from the women, children, and some elderly men, resulted in serious mental harm. ${ }^{19247}$ Viewing the evidence in its totality, the Chamber considers that the Bosnian Serb Forces must have been aware of the detrimental impact that the eradication of multiple generations of men would have on the Bosnian Muslims in Srebrenica in that the killing of all able-bodied males while forcibly removing the remainder of the population would have severe procreative implications for the Bosnian Muslims in Srebrenica and thus result in their physical extinction. The Chamber therefore finds beyond reasonable doubt that these acts were carried out with the intent to destroy the Bosnian Muslims in Srebrenica as such.

\section{(2) Substantiality of the targeted group}

5672. The Chamber recalls that where part of a protected group is targeted for destruction, such part must be substantial. ${ }^{19248}$ With regard to the targeted group, which was the Bosnian Muslims in Srebrenica, the Chamber recalls that the Appeals Chamber has found that although the Bosnian Muslim population in Srebrenica constituted a numerically small percentage of the Bosnian Muslim population, the enclave's seizure was of particular strategic importance due to its geographic proximity to Serbia, its symbolic stature as a refuge for Bosnian Muslims, and the fact that its elimination despite its status as a safe area would be demonstrative of the potential fate of all Bosnian Muslims. ${ }^{19249}$ The Chamber agrees with this analysis and, accordingly, finds that the Bosnian Muslims in Srebrenica constituted a substantial part of the Bosnian Muslim population.

\section{(3) Conclusion}

5673. On the basis of the analysis set out above, the Chamber finds that-with the intent to destroy the Bosnian Muslims in Srebrenica, which constituted a substantial part of the Bosnian

\footnotetext{
Forces on 13 July and held at the Konjević Polje intersection and later in Bratunac; he was then transferred to Zvornik on 14 July where he survived, and escaped from, a mass execution near Kozluk. See paras. 5171, 5192, 5199 , fn. 17638. On 15 July, after having been found wounded and taken to the Loznica Hospital, the Bratunac SJB became aware of his whereabouts and informed members of the police in Zvornik, who then took Sinanović away. See fn. 17638. Sinanović's remains were ultimately identified from remains found in one of the Srebrenica-related secondary gravesites. See fn. 17638.

19246 See paras. 5093-5095, 5098-5108.

19249 Krstić Appeal Judgement, paras. 15-16.
}

19247 See para. 5665.

19248 See para. 555. 
Muslim protected group-members of the Bosnian Serb Forces killed thousands of Bosnian Muslim males and caused serious bodily or mental harm to thousands of Bosnian Muslims in Srebrenica. The Chamber therefore finds that the acts described above constitute genocide within the meaning of Articles 4(2)(a) and 4(2)(b) of the Statute.

\section{Srebrenica JCE and the Accused's responsibility}

5674. The Prosecution alleges that the Accused committed each of the crimes referred to above in concert with others through his participation in a JCE, the common purpose of which was to "eliminate the Bosnian Muslims in Srebrenica by killing the men and boys of Srebrenica and forcibly removing the women, young children and some elderly men from Srebrenica" ("Srebrenica JCE"). ${ }^{19250}$ The Prosecution alleges that this objective amounted to or included the commission of genocide, persecution, extermination, murder, and forcible transfer as an inhumane act. ${ }^{19251}$ According to the Prosecution, the Srebrenica JCE was "intrinsically related" to the Overarching JCE ${ }^{19252}$ as the Accused had long sought the removal of the Bosnian Muslim population from the enclaves in eastern $\mathrm{BiH}^{19253}$

5675. The Prosecution contends that the Srebrenica JCE-and the Accused's participation therein—commenced in the days immediately preceding 11 July $1995 .{ }^{19254}$ Other alleged members of the Srebrenica JCE include Ratko Mladić as well as republic level members of the Bosnian Serb Political and Governmental Organs; regional, municipal, and local level members of Bosnian Serb Political and Governmental Organs with responsibility in or for the Srebrenica, Vlasenica, Bratunac, and/or Zvornik areas; commanders, assistant commanders, senior officers, and chiefs of the VRS and MUP operating in or with responsibility over territory within the Drina Corps area of responsibility and/or Trnovo municipality; and members of a Serbian MUP unit called the Scorpions. ${ }^{19255}$

5676. The Prosecution alleges that beginning in March 1995, the Accused and Mladić oversaw a "final push to end the Bosnian Muslim presence in Srebrenica and eastern [BiH]" by implementing a plan to take over the Srebrenica enclave and forcibly transfer its Bosnian Muslim population,

\footnotetext{
19250 Indictment, para. 20.

19251 Indictment, paras. 20, 41-42, 48-49, 58, 61-62, 66, 68, 75. See also fn. 19120.

19252 Prosecution Final Brief, para. 799.

19253 Prosecution Final Brief, para. 801; Prosecution Closing Argument, T. 47769 (30 September 2014).

19254 Indictment, para. 20; Prosecution Final Brief, para. 798.

19255 Indictment, paras. 21-23. Alternatively, the Prosecution contends that some or all of these individuals were not members of the Srebrenica JCE but were used as tools by such members in order to carry out crimes committed in furtherance of the common purpose. Indictment, paras. 22-23. The Prosecution further specifies that the Scorpions only operated and committed crimes within Trnovo municipality. Indictment, para. 23.
} 
which formed part of the objective of the Overarching JCE. ${ }^{19256}$ According to the Prosecution, within days of the commencement of the attack on the Srebrenica enclave on 6 July 1995, the Accused and others formed the shared intent to eliminate the Bosnian Muslims in Srebrenica by killing the men and boys and forcibly removing the women, young children, and some elderly men. ${ }^{19257}$ The Prosecution contends that by 11 July, this objective had begun to be implemented through the killing of the Bosnian Muslim men and boys of Srebrenica, as well as the causing of serious bodily or mental harm to thousands of Bosnian Muslims of Srebrenica. ${ }^{19258}$

5677. The Accused denies that there was any plan for forcible transfer and contends that there was no plan to kill any detainees prior to the killings at Kravica Warehouse. ${ }^{19259}$ The Chamber will address the Accused's specific arguments, where relevant, below.

5678. As a preliminary matter, the Chamber is of the view that the alleged common purpose of the Srebrenica JCE to eliminate the Bosnian Muslims in Srebrenica encompasses two distinct but related aspects: the killing of the men and boys along with the forcible removal of the women, children, and the elderly. Accordingly, the Chamber will examine the establishment and subsequent development of these two operations separately below.

a. The existence of a common plan to eliminate the Bosnian Muslims in Srebrenica

\section{from Srebrenica}

i. Overarching JCE and a long term plan to remove the Bosnian Muslim population 5679. Earlier in this Judgement, the Chamber found that as early as May 1992, the Accused and Mladić, amongst others, shared the common purpose of permanently removing Bosnian Muslims and Bosnian Croats from Bosnian Serb-claimed territory through the crimes of, inter alia, inhumane acts (forcible transfer). ${ }^{19260}$

5680. As reflected in Directive 4, issued in November 1992, the VRS devised a military strategy to force the Bosnian Muslim population to leave the wider Srebrenica area. ${ }^{19261}$ After several months of intense combat, the VRS launched a major offensive in the spring of 1993 which resulted in the forcible transfer of Bosnian Muslims from Vlasenica and Bratunac municipalities to Srebrenica and ultimately concluded with the proclamation of Srebrenica as a UN-protected safe

\footnotetext{
19256 Indictment, para. 44; Prosecution Final Brief, para. 801.

19257 Indictment, paras. 45, 58, 75.

19258 Indictment, paras. 45-47. See also Indictment, paras.58, 75; Prosecution Closing Argument, T. 47770-47771 (30 September 2014).

19259 Defence Final Brief, paras. 2402-2407, 2449-2518.

19260 See para. 3447.

19261 See paras. 4947-4948.
} 
area. ${ }^{19262}$ Even prior to the establishment of the safe area, the humanitarian situation in Srebrenica was catastrophic. ${ }^{19263}$ The miserable conditions did not abate once the safe area was proclaimed in April 1993. ${ }^{19264}$

5681. On 8 March 1995, the Accused issued Directive 7, which included an order to the Drina Corps to "create an unbearable situation of total insecurity with no hope of further survival or life for the inhabitants of Srebrenica and Žepa". ${ }^{19265}$ The Chamber finds that such language clearly indicates an intent to force the Bosnian Muslim population to leave the enclave. Directive 7 also included an order to the civilian and military organs responsible for co-operation with UNPROFOR to use

the planned and unobtrusively restrictive issuing of permits, [to] reduce and limit the logistics support of UNPROFOR to the enclaves and the supply of material resources to the Muslim population, [thereby] making them dependent on our good will while at the same time avoiding condemnation by the international community and international public opinion. ${ }^{19266}$

5682. Earlier in this Judgement, the Chamber found that this directive was implemented through the restriction of humanitarian aid to Srebrenica following the issuance of Directive $7 .^{19267}$ The Chamber also found that, although the reference to "creat[ing] an unbearable situation of total insecurity with no hope of further survival or life for the inhabitants" was not repeated in Directive 7/1 which was issued by Mladić on 31 March 1995, Directive 7/1 further elaborated upon Directive 7. ${ }^{19268}$ Additionally, the Chamber recalls that the preparatory order as well as the active combat order issued by the Drina Corps Commander on 2 July 1995 drew reference from both Directives 7 and $7 / 1 .^{19269}$ The Chamber is therefore satisfied that the omission in Directive $7 / 1$ of the language in Directive 7 which ordered the Drina Corps to "create an unbearable situation of total insecurity with no hope of further survival or life for the inhabitants of Srebrenica and Žepa" did not signal its revocation or abandonment, as it was still given effect.

5683. Even prior to the issuance of the Drina Corps orders of 2 July 1995, the Bosnian Serb Forces had begun to intensify military activities towards the Srebrenica enclave. The Chamber recalls that between April and the beginning of July 1995, the Bosnian Serb Forces-including units of the Drina Corps-intensified their firing on DutchBat positions surrounding the enclave

\footnotetext{
19262 See paras. 2465, 2480, 4949, 4952-4956, 4962, 4968.

19263 See paras. 4949-4951, 4957-4961, 4965-4966, 4968

19264 See paras. 4969, 4985, 4987-4988.

19265 P838 (Directive 7, 8 March 1995), p. 10 (emphasis added).

19266 P838 (Directive 7, 8 March 1995), p. 14. See also paras. 4979-4982.

19267 See paras. 4981, 4991.

19268 See para. 4984
} 
and that beginning in May 1995, they began to shell the enclave itself. ${ }^{19270}$ At the beginning of June, the Bosnian Serb Forces took over DutchBat's OP Echo, forcing DutchBat to retreat towards Srebrenica town. ${ }^{19271}$ Several weeks later, members of the $10^{\text {th }}$ Sabotage Detachment, which was a unit directly subordinated to the Main Staff, ${ }^{19272}$ and the Bratunac Brigade entered the enclave through an old mining tunnel and fired infantry weapons into Srebrenica town. ${ }^{19273}$

5684. Based on the foregoing, the Chamber is satisfied that at least by the time Directive 7 was issued in March 1995, the Accused and Mladić had devised a long-term strategy aimed at the eventual forcible removal of the Bosnian Muslims in Srebrenica through the deliberate restriction of humanitarian aid as well as the targeting of the enclave by the Bosnian Serb Forces.

\section{ii. Development of the plan to eliminate the Bosnian Muslim population in Srebrenica}

5685. The Chamber recalls that at the end of June 1995, the Accused and Krajišnik visited the Drina Corps Command in Vlasenica, where they met with Krstić and gave him a combat assignment, which Krstić and other members of the Drina Corps command then began to draft into a combat plan known as Krivaja 95. ${ }^{19274}$ As the Chamber has found above, the Drina Corps order for active combat operations issued on 2 July 1995 did not originally anticipate the take-over of Srebrenica town; instead, it focused on splitting the enclaves of Srebrenica and Žepa and "reduc[ing] them to their urban areas". ${ }^{19275}$

5686. The Chamber recalls that after initially making slow progress following the commencement of active combat operations on 6 July, Mladić arrived in Bratunac on the afternoon of 8 July. ${ }^{19276}$ That same day, the Accused spoke to Živanović regarding the possibility of obtaining reinforcements from the MUP. ${ }^{19277}$ The Accused also told Živanović, "all right General, full speed

\footnotetext{
19269 See para. 5005.

19270 See paras. 4995, 4997-4998.

19271 See para. 4999.

19272 See para. 175.

19273 See para. 5001.

19274 See para. 5004.

19275 See para. 5007.

19276 See paras. 5010-5012, 5017, fn. 16957.

19277 The Accused told Živanović to tell Krstić that although "we could probably reinforce you a little", aside from a group from Zvornik, "the entire MUP [wa]s engaged" and that "there [wa]s no other way"; the Drina Corps would "have to go with [its] own forces". P4484 (Dictaphone conversation between Radovan Karadžić and General Milenko Živanović, 8 July 1995), pp. 1-2 (also mentioning the seising of the Tri Sise feature that day); D2099 (VRS Main Staff Report, 8 July 1995), para. 6(b) (reporting the seising of the Tri Sise feature on 8 July). See also Ljubomir Obradović, T. 25321 (27 February 2012) (confirming that the reference to "Krle" in P4484 pertained to Krstić). In the Drina Corps' daily combat report to the Main Staff, Živanović requested that a company of Zvornik MUP forces be engaged as reserve forces for the Birač Brigade. P4930 (Combat Report of Drina Corps, 8 July 1995), para. 9.
} 
ahead. Tell Krstić, order to go full steam ahead". ${ }^{19278}$ Živanović replied, “we are working pretty much according to plan and it's going well". ${ }^{19279}$ That evening, the Bosnian Serb Forces began to take over DutchBat's OPs. ${ }^{19280}$ The enclave's southern perimeter then began to collapse, sending residents of the Swedish Shelter Project fleeing toward Srebrenica town. ${ }^{19281}$

5687. As the Bosnian Serb Forces pressed further into the enclave on 9 July, Tolimir spoke several times to members of UNPROFOR, denying their progress. ${ }^{19282}$ That day, Mladić, Gvero, and Živanović joined Krstić, who had already been present for several days, at the Drina Corps IKM in Pribićevac. ${ }^{19283}$ By the end of the afternoon, the Bosnian Serb Forces stood only one kilometre from Srebrenica town, and Krstić reported to the Main Staff that the conditions for "extending the attack towards Srebrenica" were created. ${ }^{19284}$

5688. The Chamber recalls that after Krstić reported to the Main Staff the favourable conditions for extending the attack on 9 July, Tolimir contacted the Accused, who approved the expansion of the Krivaja 95 plan and ordered the Bosnian Serb Forces to take over Srebrenica town. ${ }^{19285}$ Tolimir then proceeded to draft a written order to this effect, which Mladić relayed to his subordinates in the field by encrypted radio. ${ }^{19286}$ The order stated that "full protection" was to be given to UNPROFOR members and the Bosnian Muslim civilian population. ${ }^{19287}$ Additionally, pursuant to an order from the Accused, a group of mixed special police units under the command of Borovčanin was redeployed from Sarajevo to the Srebrenica front on 10 July. ${ }^{19288}$ The Main Staff also redeployed units assigned elsewhere towards Srebrenica. ${ }^{19289}$

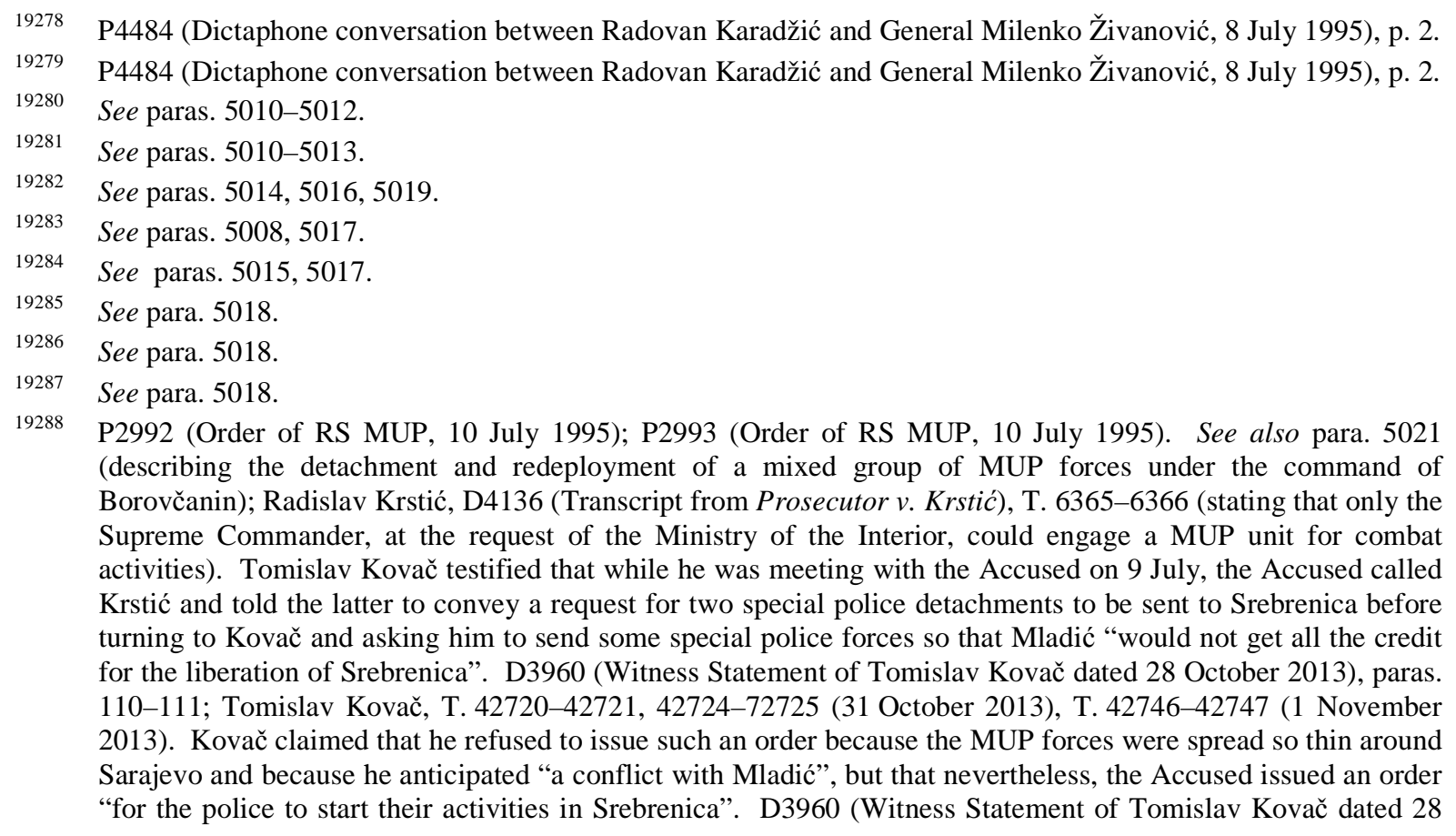


5689. Meanwhile, members of the Main Staff colluded in attempting to deceive UNPROFOR. ${ }^{19290}$ When Tolimir - who had already relayed to the Drina Corps IKM the Accused's order to take the town-spoke to Janvier at 11:10 p.m. on 9 July, he assured Janvier that the VRS "w[ould] do everything [they] c[ould] to calm down the situation". ${ }^{19291}$ Likewise, although Mladić had already relayed the expanded orders received from Tolimir to the subordinate units of Bosnian Serb Forces, when he spoke to Janvier at 10:45 a.m. on 10 July, Mladić claimed: "[W]e are doing everything to keep the situation under control and for it not to escalate". ${ }^{19292}$ That day, the Bosnian Serb Forces advanced further into the enclave and attempted to enter the town, but were repelled by $\mathrm{ABiH}$ and DutchBat fire. ${ }^{19293}$ Nevertheless, the Bosnian Serb Forces continued to draw closer to the town while Tolimir maintained that combat operations had stopped when he spoke to Janvier. ${ }^{19294}$ On the following day, Gvero sent an urgent warning to the Drina Corps Command and IKM, noting that "the monitoring of reactions from UNPROFOR representatives and the world public opinion indicates that the attitude of the VRS personnel towards UNPROFOR personnel and units in the

October 2013), paras. 112-113; Tomislav Kovač, T. 42721 (31 October 2011). The Chamber notes that Kovač further asserted that he went from Pale to Bijeljina in order to be "out of reach" in an attempt to avoid issuing such an order but that nevertheless, the Accused's order of 10 July was conveyed by a MUP duty officer "to the field" using Kovač's name but without his knowledge. D3960 (Witness Statement of Tomislav Kovač dated 28 October 2013), para. 114. See also Tomislav Kovač, T. 42734 (1 November 2013). When Kovač was presented with his own testimony from a previous case in which he had testified that the Accused had called Karišik and Borovčanin to relay his order of 10 July directly, Kovač first asserted that the order had merely been "forwarded to the MUP institution where Karišik and Borovčanin were"; however, when presented with Karišik's testimony denying having seen the Accused's 10 July order at the time, Kovač then stated that the Accused had issued the order "to the MUP institution" and that Borovčanin had "received the order through MUP services", and asserted that "as for Karišik, I don't know whether he saw it the first or the second day, whether he passed it on [...] as my deputy he had insight into it [...]". Tomislav Kovač, T. 42733-42735 (1 November 2013). See also Tomislav Kovač, T. 42717 (31 October 2013) (attesting to the truthfulness of his testimony in the prior case). When asked specifically whether he stood by his prior testimony that the Accused had called Karišik directly, Kovač became evasive and eventually explained that he "didn't know who passed on the order until [he] saw documents in The Hague". Tomislav Kovač, T. 42735-42737 (1 November 2013) (further explaining that when he gave his previous testimony he thought Karišik had forwarded the order but later learned that that was incorrect). The Chamber will explain its assessment of Kovač's credibility in more detail in para. 5766 below, and considers that Kovač had an interest in distancing himself from the implementation of the Accused's 10 July order. See Tomislav Kovač, T. 42737-42738 (1 November 2013) (demonstrating awareness that the commander of the SBP, Goran Sarić, had recently been indicted in connection with the actions of SBP units following their deployment to Srebrenica pursuant to the Accused's order). The Chamber will therefore not rely on Kovač's testimony to the extent that it implicates Karišik in the order's forwarding. However, the Chamber is satisfied that the order was forwarded by the RS MUP and implemented as set out above. See also Christian Nielsen, T. 16335-16336 (7 July 2011).

19289 See para. 5021

19290 Radislav Janković, an officer from the Intelligence Administration who had arrived in Srebrenica on 8 July 1995, informed Momir Nikolić that he would be taking over all contact with international organisations and DutchBat, relieving Nikolić of those duties. Momir Nikolić, T. 24604-24606 (13 February 2012).

19291 See para. 5019.

19292 P5268 (Intercept of conversation between Ratko Mladić and General Bernard Janvier, 10 July 1995), p. 1. Mladić also told Janvier that the DutchBat members who had crossed to Bosnian Serb territory when their OPs fell were not POWs, but "guests". P5268 (Intercept of conversation between Ratko Mladić and General Bernard Janvier, 10 July 1995), p. 2. See also fn. 16989.

19293 See para. 5024

19294 See paras. 5025, 5027. 
area of Srebrenica is in the focus of attention". ${ }^{19295}$ Gvero further ordered the Drina Corps and its subordinate units to "ensure utmost decency in the attitude towards UNPROFOR personnel", as adopting such an attitude was "of multifarious importance for the realisation of the assignment at hand and of our set of objectives". ${ }^{19296}$ The Chamber thus considers that the Main Staff was well aware of the need to maintain cordial relations with UNPROFOR while nevertheless advancing further towards the goal of taking over the enclave. Late in the afternoon of $11 \mathrm{July,} \mathrm{Gvero} \mathrm{spoke}$ to Nicolai and-as Mladić and Tolimir had done the day before when speaking to Janvier-denied that the Bosnian Serb Forces were attacking UN positions or targeting the population. ${ }^{19297}$ Soon thereafter, Gvero reported to the Accused what he had said to Nicolai and then added: "That's right, I told him, Mr. President. [...] Everything is going according to plan and do not worry." 19298 The Chamber finds that these conversations, especially when viewed in light of the clear advance of the Bosnian Serb Forces on the ground, clearly demonstrate that the members of the Main Staff deliberately lied to the UNPROFOR officials with whom they spoke on 10 and 11 July, and that the Accused was aware of this tactic.

5690. The Accused was also promptly informed by Gvero about the fall of Srebrenica in the late afternoon of 11 July. ${ }^{19299}$ The Bosnian Serb Forces had by then entered what was mostly an empty town, although they called upon those who remained to leave their houses. ${ }^{19300}$ Mladic ordered the Bosnian Serb Forces to proceed north towards the UN Compound, which was by then full of Bosnian Muslims who had fled the relentless shelling of the town earlier that day. ${ }^{19301}$ Before leaving the centre of Srebrenica, Mladić turned to the television cameras and said: "Finally [...] the time has come to take revenge on the Turks in this region." 19302

\footnotetext{
19295 P5221 (VRS Main Staff warning re the treatment of UNPROFOR personnel, 11 July 1995).

19296 P5221 (VRS Main Staff warning re the treatment of UNPROFOR personnel, 11 July 1995).

19297 See para. 5034.

19298 P4629 (Intercept of conversation between Milan Gvero and Radovan Karadžić, 11 July 1995).

19299 P4630 (Intercept of conversation between Milan Gvero and Radovan Karadžić, 11 July 1995) (Gvero stating "Mr. President, Serbian silver, Serbian church, and Serbian flag"). See also P4629 (Intercept of conversation between Milan Gvero and Radovan Karadžić, 11 July 1995); P4633 (Intercept of conversation between Radovan Karadžić and an unidentified person, 11 July 1995). Gvero and the Accused then discussed the prospect of further NATO air strikes; Gvero told the Accused that UNPROFOR had no reason to attack the VRS and had probably come under fire from Bosnian Muslim forces, the Accused ordered Gvero to shoot down any planes that went into a dive, and Gvero remarked that planes were once again in the air. P4633 (Intercept of conversation between Radovan Karadžić and an unidentified person, 11 July 1995); P4630 (Intercept of conversation between Milan Gvero and Radovan Karadžić, 11 July 1995).

19300 See paras. 5030-5032. Members of the $10^{\text {th }}$ Sabotage Detachment also summarily killed an able-bodied man who appeared near the centre of town. See para. 5032.

19301 See paras. 5028-5029, 5033. The Chamber recalls that Bosnian Serb shells followed the group of Bosnian Muslims as they moved northward and that Bosnian Serb Forces burned Bosnian Muslim houses as they approached Srebrenica town. See paras. 5029-5030, fn. 17012.

19302 See para. 5033.
} 
(A) Forcible removal of the Bosnian Muslim women, children, and elderly men

5691. The Chamber recalls that on 10 July, the Bosnian Serb Forces conveyed a proposal to DutchBat that in exchange for being given safe passage out, the Bosnian Muslims would leave the enclave within 48 hours. ${ }^{19303}$ After taking the town on 11 July, a series of meetings were held at Hotel Fontana, where the participants discussed what would happen to the Bosnian Muslims gathered in Potočari. As the Chamber has described in more detail earlier in this Judgement, Mladić set an intimidating tone at the outset of the first meeting. ${ }^{19304}$ The atmosphere of intimidation persisted as Mladić alternated between inviting Karremans to make suggestions as to how to resolve the situation and issuing veiled threats to the well-being of the DutchBat soldiers who had surrendered to the Bosnian Serb Forces and were then being held in Bosnian Serb custody. ${ }^{19305}$ The meeting concluded when Mladić dispatched Karremans back to Potočari to retrieve a representative of the Bosnian Muslim population to attend a second meeting that would commence at 11 p.m. ${ }^{19306}$

5692. In between the first and the second meeting on 11 July, Krstić, Pandurević, Andrić, Blagojević, and others met Mladić-who arrived with Živanović-at the Bratunac Brigade Command. ${ }^{19307}$ There, Mladić ordered that the Drina Corps re-deploy towards Žepa under Krstić's command. ${ }^{19308}$ Krstić testified that at the time, those present at the meeting were not aware of the column of Bosnian Muslim men attempting to reach Tuzla and that no information was received

19303

19304

See para. 5041. The Chamber recalls that the first meeting was also attended by Mladić and Živanović as well as Radoslav Janković of the Main Staff and Svetozar Kosorić of the Drina Corps, both of whom were intelligence officers. See para. 5040.

19305 See para. 5041-5042.

19306 See paras. 5042-5043.

19307 Radislav Krstić, D4136 (Transcript from Prosecutor v. Krstić), T. 6198, 6201. See also D3853 (Witness statement of Zvonko Bajagić dated 5 July 2013), paras. 31-33 (stating that he encountered Mladić, Krstić, Pandurević and others outside the Bratunac Brigade Command in the evening of $11 \mathrm{July}$, adding that they had just come out of a meeting); D3886 (Witness statement of Svetozar Andrić dated 16 July 2013), para. 20 (testifying that Mladić and Krstić visited the Birač Brigade on 12 July); D3932 (Witness statement of Milenko Živanović dated 27 October 2013), para. 9 (also referring to Mladić's inspection of the troops on 12 July). Mladić told the participants that he and Živanović had returned from the first Hotel Fontana meeting, but according to Krstić, did not elaborate about that meeting any further. Radislav Krstić, D4136 (Transcript from Prosecutor v. Krstić), T. 6202. The Chamber notes that the parties agreed that, according to Trivić's diary, this meeting took place in the evening of 12 July. See T. 40523 (26 June 2013); D3748 (Excerpt from Mirko Trivić's diary), e-court p. 5. However, given that the majority of evidence received by the Chamber supports the fact that the meeting took place on 11 July, the Chamber considers that Trivić's evidence in fact refers to the same meeting attended by Krstić on 11 July.

19308 Radislav Krstić, D4136 (Transcript from Prosecutor v. Krstić), T. 6202, 6558, 6585. Although Trivić and Pandurević urged Mladić to allow the soldiers to rest, Mladić insisted that they proceed in liberating Žepa the next morning. D3747 (Witness statement of Mirko Trivić dated 22 June 2013), p. 16; D3748 (Excerpt from Mirko Trivić's diary), e-court p. 5. Mladić also gave orders regarding the route to be taken towards Žepa. Radislav Krstić, D4136 (Transcript from Prosecutor v. Krstić), T. 6220-6221, 6223. On 12 July, Mladić and Krstić conducted an inspection of the Birač Brigade subordinate units near Mount Viogor, and informed them of 
during the meeting. ${ }^{19309}$ Trivić testified that during the meeting, Mladić spoke to someone on the phone about logistical issues pertaining to the transport of civilians from the enclave, but did not elaborate further. ${ }^{19310}$ At the end of the meeting, Mladic informed those present that he had received a decree from the Accused appointing Deronjić as civilian commissioner in Srebrenica. ${ }^{19311}$

5693. The Accused had indeed issued an order appointing Deronjić "civilian commissioner for the Serbian Municipality of Srebrenica" with the authority to-in consultation with the Accused and the RS Government- "establish the functions of the appointed municipal authority organs and ensure conditions for their efficient functioning". 19312 Deronjić was also tasked with establishing the functioning of a Bosnian Serb SJB. ${ }^{19313}$ The terms of the order also specified that Deronjic was to "ensure that all civilian and military organs treat[ed] all citizens who participated in combat operations against the [VRS] as prisoners of war, and ensure that the civilian population c[ould] freely choose where they w[ould] live or move to". ${ }^{19314}$ Finally, Deronjić was authorised to appoint his own associates. ${ }^{19315}$ The Accused also issued an order to the RS MUP to form an SJB in "Serb Srebrenica". ${ }^{19316}$ According to the order, "all citizens who participated in combat activities against the [VRS] will be treated as prisoners of war and in accordance with the law and international conventions". ${ }^{19317}$ Others were to be free to choose their place of residence or place of emigration. ${ }^{19318}$ The RS MUP was further instructed to establish close co-operation with Deronjić. ${ }^{19319}$

5694. That same evening, Deronjić held a meeting of about 20 people, including "Serb officials in Srebrenica", as well as managers of public and state-owned companies, at the SDS office in

the forthcoming push towards Žepa. D3886 (Witness statement of Svetozar Andrić dated 16 July 2013), para. 20; D3932 (Witness statement of Milenko Živanović dated 27 October 2013), para. 9.

19309 Radislav Krstić, D4136 (Transcript from Prosecutor v. Krstić), T. 6561-6562. Krstić further stated that brigade commanders of units involved in the take-over of Srebrenica that day were given clear orders not to engage in further assaults towards the town or Potočari, but should instead stop at the lines they had reached. Radislav Krstić, D4136 (Transcript from Prosecutor v. Krstić), T. 6509-6510, 6560.

19310 Mirko Trivić, T. 40549 (27 June 2013).

19311 Radislav Krstić, D4136 (Transcript from Prosecutor v. Krstić), T. 6207-6208.

19312 D2055 (Decision of RS President, 11 July 1995), paras. 1-2.

19313 D2055 (Decision of RS President, 11 July 1995), para. 3.

19314 D2055 (Decision of RS President, 11 July 1995), para. 4.

19315 D2055 (Decision of RS President, 11 July 1995), para. 6.

19316 P2994 (Radovan Karadžić's Order, 11 July 1995). See also para. 226.

19317 P2994 (Radovan Karadžić's Order, 11 July 1995), para. 4.

19318 P2994 (Radovan Karadžić's Order, 11 July 1995), para. 4.

19319 P2994 (Radovan Karadžić's Order, 11 July 1995), para. 5. See also Christian Nielsen, T. 16337-16338 (7 July 2011). 
Bratunac. ${ }^{19320}$ There, Deronjić informed the attendees that he had been appointed civilian commissioner for Srebrenica and established a speaker phone connection with the Accused, who stated that Deronjić was "directly responsible with his life for all civilian affairs in Srebrenica", and that all others were to be directly responsible to Deronjić. ${ }^{19321}$ Deronjić then appointed directors for all public enterprises and institutions in Srebrenica. ${ }^{19322}$ The Chamber considers that the establishment of such Bosnian Serb structures, especially in light of the Bosnian Serb rhetoric advocating the separation of the population along ethnic lines and asserting an inability to coexist, ${ }^{19323}$ is demonstrative that the removal of the Bosnian Muslim population then envisaged by the Bosnian Serb Political and Governmental Organs was intended to be permanent.

5695. The Chamber recalls that Karremans returned to the Hotel Fontana for a second meeting which commenced around 11 p.m. on 11 July, bringing with him other DutchBat officers as well as Nesib Mandžić, a former schoolteacher, who had agreed to act as a spokesperson for the Bosnian Muslim population in Potočari. ${ }^{19324}$ Mladić, Živanović, and intelligence officers Radoslav Janković and Svetozar Kosorić were joined at the second meeting by Krstić and Deronjić. ${ }^{19325}$ As the Chamber has outlined in more detail above, although Mladić's words to Mandžić explicitly portrayed that the population's wishes would be respected, Mladić delivered them in a threatening manner by first stating that he wished to receive "a clear position [...] on whether you want to survive [...] stay or vanish" before reminding Mandžić that "the future of your people is your hands, not only in this territory". ${ }^{19326}$ Mladić then sent Mandžić back to the UN Compound with instructions to return with a delegation of Bosnian Muslim representatives at 10 a.m. the next morning. ${ }^{19327}$

5696. Overnight, shelling continued around the UN Compound and panic was rampant amongst the Bosnian Muslims gathered there. ${ }^{19328}$ Meanwhile, the Bosnian Serb Forces and Bosnian Serb

\footnotetext{
19320 P4374 (Witness statement of Milenko Katanić dated 11 October 2011), para. 59; D3561 (Witness statement of Dane Katanić dated 14 December 2012), para. 6; Dane Katanić, T. 38656 (22 May 2013); Milenko Katanić, T. 24463-24465, 24492 (10 February 2012); KDZ480, P4355 (Transcript from Prosecutor v. Blagojević \& Jokić), T. 7868-7870 (under seal); KDZ480, T. 24227-24228 (7 February 2012) (closed session).

19321 P4374 (Witness statement of Milenko Katanić dated 11 October 2011), para. 59; Milenko Katanić, T. 24465, 24468-24473 (10 February 2012); P4380 (Sketch drawn by Milenko Katanić); P4381 (Sketch drawn by Milenko Katanić). See also D3561 (Witness statement of Dane Katanić dated 14 December 2012), para. 6; KDZ480, P4355 (Transcript from Prosecutor v. Blagojević \& Jokić), T. 7868-7870 (under seal); KDZ480, T. 24227-24229 (7 February 2012) (closed session).

19322 P4374 (Witness statement of Milenko Katanić dated 11 October 2011), para. 60.

19323 See Section IV.A.3.i: Objectives of the Accused and the Bosnian Serb leadership.

19324 See paras. 5043-5044.

19325 See para. 5044.

19326 See para. 5046.

19327 See para. 5046.

19328 See para. 5074.
} 
Political and Governmental Organs began to mobilise the resources for a massive transport operation. Mladić issued an order for the mobilisation of buses, which was then conveyed through the Main Staff to the RS Ministry of Defence. ${ }^{19329}$ Early on 12 July, Živanović ordered the subordinate brigades of the Drina Corps to send all available buses and minibuses to the Bratunac stadium; this was completed by 10 a.m. ${ }^{19330}$ Additionally, Krstić instructed Krsmanović to mobilise 50 buses from municipalities as far away as Pale and send them to the Bratunac stadium by 5 p.m. that day. ${ }^{19331}$ Also that morning, acting pursuant to an order issued by Mladic on the previous evening, the Bosnian Serb Forces_-including members of the Bratunac Brigade as well as Borovčanin's units-took control of OP Papa and, during the course of the morning, proceeded along the road towards the UN Compound in Potočari, where they took control by 1 p.m. ${ }^{19332}$

5697. In the meantime, Mandžić and two other Bosnian Muslim representatives of the population in Potočari-along with Karremans and Boering-returned to the Hotel Fontana for a third meeting with the Bosnian Serbs. ${ }^{19333}$ With the exception of Živanović, all Bosnian Serb participants from the previous evening, as well as Popović and Dragomir Vasić, attended the third meeting. ${ }^{19334}$ Although Mladić gave the impression that the Bosnian Muslim representatives' wishes would be respected, ${ }^{19335}$ he also implied that they had no choice but to leave in order to survive. ${ }^{19336}$ In fact, Mladić had already set in motion the mobilisation of both military and civilian resources to carry out the bussing operation as described above.

5698. When the third Hotel Fontana meeting ended, the Bosnian Muslim representatives were asked to return to the UN Compound to convey the message that transportation would be provided. ${ }^{19337}$ When the vehicles for the transportation of the Bosnian Muslims began to arrive at

\footnotetext{
19329 See para. 5082. Pursuant to this request, the RS Ministry of Defence took immediate action to mobilise buses procured by its secretariats in Sarajevo and Zvornik-as well as departments in Milići, Vlasenica, Šekovići, and Bratunac-which were sent during the course of the day. See para. 5082.

19330 See paras. 5084-5085.

19331 See para. 5083.

19332 See paras. 5078-5079.

19333 See paras. 5067-5072.

19334 See para. 5067.

19335 Mladic told the representatives that he "wanted to help them" and they could "choose to stay in the territory or, if so you wish, go wherever you want". See paras. 5068, 5638.

19336 Mladić stated that "there is no need for your people to get killed [...] as I told this gentleman [Mandžić] last night, you can either survive or disappear". P4201 (Updated Srebrenica Trial video), Part 2, at 00:10:1500:11:10; P4202 (Written compilation booklet: Srebrenica Trial video), e-court p. 248. See also paras. 5068, 5638.

19337 See paras. 5069-5070.
} 
the UN Compound, DutchBat soldiers were disarmed at gunpoint by members of the Bosnian Serb Forces. $^{19338}$

5699. The transportation of Bosnian Muslims from Potočari began at approximately 12:40 p.m. on 12 July. ${ }^{19339}$ Members of the Jahorina Recruits and the Bratunac Brigade MP-assisted by other MUP members-controlled the boarding process. ${ }^{19340}$ During the course of the afternoon, Mladić arrived and addressed the crowd, stating that the population could choose whether to go or stay and that the women and children would be transported first and would not be harmed. ${ }^{19341}$ However, the Chamber notes that Mladic had previously expressed satisfaction at the commencement of the transportation process, adding: “they've all capitulated and surrendered and we'll evacuate them all - those who want to and those who don't want to". ${ }^{19342}$ Overnight and the following day, the Bosnian Serb Forces subjected the Bosnian Muslims who still remained at the UN Compound to numerous incidents of physical and sexual violence. ${ }^{19343}$

5700. As the bussing operation entered its second day, Radoslav Janković reported to Živanović that approximately one third of the Bosnian Muslims in Potočari had been transferred, and estimated that there were approximately 10,000 left. ${ }^{19344}$ Janković assured Živanović that "the job" was "being done [...] at full steam". ${ }^{19345}$ Mladić returned to Potočari on 13 July and oversaw the boarding process again. ${ }^{19346}$ The transportation process continued throughout the day and was completed by 8 p.m. ${ }^{19347}$ As the buses proceeded towards Bosnian Muslim-held territory, they were escorted by members of the SJB or the Bratunac Brigade MP. ${ }^{19348}$ Pursuant to an order issued earlier that day, ${ }^{19349}$ members of the Bratunac Brigade regulated traffic as the buses passed through Bratunac en route to Konjević Polje. ${ }^{19350}$ In total, between 11 and 13 July, up to 30,000 Bosnian

\footnotetext{
19338 See para. 5080.

19339 See para. 5093.

19340 See para. 5099.

19341 See para. 5097.

19342 See para. 5100.

19343 See paras. 5077, 5095.

19344 P5366 (Intercept of conversation between Janković, an unidentified General, and an unidentified person, 13 July 1995), p. 1. [REDACTED].

19345 P5366 (Intercept of conversation between Janković, an unidentified General, and an unidentified person, 13 July 1995), p. 1.

19346 See para. 5100.

19347 See paras. 5098, 5107, 5125

19348 See para. 5104. The Chief of the Drina Corps Intelligence Department, Kosorić, also escorted the vehicles. See para. 5104.

19349 During the course of the day, the Bratunac and Zvornik Brigades were ordered to regulate traffic at the Konjević Polje intersection so that priority could be given to "buses for evacuation". See para. 5088 (referring to P4574).

19350 See paras. 5088, 5104.
} 
Muslim women and children, as well as elderly men, were bussed from Potočari to Bosnian Muslim-held territory. ${ }^{19351}$

(B) Killing of the Bosnian Muslim men and boys

5701. The Chamber recalls that by the time the Bosnian Serb Forces took over the town on the afternoon of 11 July, the vast majority of the able-bodied men of Srebrenica had fled on foot through the woods, fearing that they would be killed if they accompanied their families to Potočari. ${ }^{19352}$ While some able-bodied men were present among the population in Potočari, most of the Bosnian Muslims gathered there consisted of women, children, and the elderly. ${ }^{19353}$ At the time of the meetings at Hotel Fontana on the night of 11 July, the Bosnian Serb Forces were aware that there were at least 1,000 Bosnian Muslim men of military age among the Bosnian Muslims still moving from Srebrenica to Potočari, who were expected to arrive there overnight. ${ }^{19354}$ As the Chamber will analyse further below, that same evening, the Bosnian Serb Forces also began to receive information about the formation and movement of the column of Bosnian Muslim men. ${ }^{19355}$

5702. The Chamber recalls that during a conversation that took place prior to the third meeting at the Hotel Fontana, which began around 10 a.m. the following morning, Popović told Momir Nikolić that the Bosnian Muslim women and children gathered in Potočari would be transferred to Bosnian Muslim-held territory, while the military-aged men would be separated. ${ }^{19356}$ Popović then told Nikolić that "all the balijas should be killed". ${ }^{19357}$ The Accused offers various arguments in an attempt to demonstrate why the Chamber should not consider Momir Nikolić a credible witness or rely on his testimony in relation to the formation of the plan to kill the Bosnian Muslim men and boys in Srebrenica. ${ }^{19358}$ In this regard, the Chamber refers to its earlier discussion and findings on the reliability of Nikolić's testimony regarding his conversation with Popović prior to the commencement of the third Hotel Fontana meeting, and will not repeat them here. ${ }^{19359}$

\footnotetext{
$19351 \quad$ See paras. 5101, 5108.

19352 See paras. 5032-5033, 5036-5037.

19353 See para. 5073.

19354 Momir Nikolić, T. 24613-24615 (13 February 2012). See also P4202 (Written compilation booklet: Srebrenica Trial video), e-court pp. 230-231; P4201 (Updated Srebrenica Trial video), Part 1, at 01:13:55-01:14:27 (discussing the anticipated arrival of further Bosnian Muslims overnight).

19355 See paras. 5157-5158. See also para. 5731.

19356 See paras. 5049, 5066.

19357 See para. 5049. Nikolić and Popović also discussed possible locations where the men could be detained and then killed, including the Ciglana brick factory and the Sase mine. See para. 5050.

19358 See generally Defence Final Brief, paras. 2451-2504.

19359 See paras. 5048-5066.
} 
5703. Once the third meeting got underway, Mladić announced that the Bosnian Muslim men in Potočari between the ages of about 15 and 70 would be subjected to a "screening" procedure. 19360 Immediately after the meeting, Radoslav Janković sent Momir Nikolić to Potočari with instructions to find Duško Jević, who was already there, and to assist with the separation of Bosnian Muslim men. ${ }^{19361}$ After the first convoy departed on 12 July, Bosnian Muslim men and boys approaching the vehicles with their families began to be separated by members of the Bosnian Serb Forcesincluding members of the $10^{\text {th }}$ Sabotage Detachment and the $65^{\text {th }}$ Protection Regiment - who forced them to leave their personal belongings such as ID cards and valuables in piles along the road and took them to the White House. ${ }^{19362}$ The Main Staff Security and Intelligence Administration was made aware of this separation process late that afternoon. ${ }^{19363}$

19360 See para. 5069. See also para. 5111 (describing how, once in Potočari, Mladić informed Franken and Rave that the men would be separated and checked). The Chamber has already found that being a Bosnian Muslim man was the exclusive criterion for separation in Potočari. See paras. 5062, 5109-5113. Although Momir Nikolić attempted to check whether any Bosnian Muslim soldiers were inside the UN Compound on 12 and 13 July, no further effort was made to distinguish soldiers from civilians during the separations. See also para. 5112. The Chamber also recalls that some of those detained in Potočari were as young as 12 or 14 years old. See para. 5109.

19361 See para. 5071. The Accused asserts that the fact that both Blagojević and KW582, [REDACTED] testified that they did not know that those who were separated would be killed should weigh against the credibility of Momir Nikolić's testimony regarding the plan to kill. Defence Final Brief, paras. 2460-2461. Noting both of these witnesses' respective positions and the involvement of their subordinates in various aspects of the operation described below, the Chamber observes that both would have an incentive to disclaim any knowledge of such a plan. See paras. 5079, 5315. Moreover, the Chamber notes that Blagojević exhibited considerable partiality and evasiveness when asked to clarify even matters which were peripheral to his role in the events which took place in Srebrenica in July 1995. See Vidoje Blagojević, T. 45026, 45028-45032, 45035-45036 (12 December 2013). Finally, the Chamber considers that, even if both Blagojević's and KW582's testimonies were true, the fact that they both denied contemporaneous knowledge of the plan to kill would not demonstrate that such a plan did not exist.

19362 See paras. 5095, 5110. The Chamber recalls that the men were not allowed to collect their belongings when they later boarded buses bound for Bratunac, and that after all had left the White House by the evening of 13 July, these piles were set on fire. See paras. 5118-5119. Citing the evidence of two witnesses who testified that they were not required to surrender their personal identification documents, the Accused contends that "there is no evidence of systematic confiscation" of such material. Defence Final Brief, para. 2511. However, the Chamber recalls that numerous witnesses testified to having seen piles of personal belongings, including ID cards, money, wallets, luggage, clothing, and other valuables lying along the road approximately 30 to 40 metres away from the White House. See para. 5110. Moreover, the Chamber notes that both witnesses cited by the Accused testified that they had no personal belongings to surrender. Ahmo Hasić, P353 (Transcript from Prosecutor v. Popović et al.), T. 1252; KDZ039, P3940 (Transcript from Prosecutor v. Popović et al.), T. 17315. The Accused also asserts that the burning of the personal belongings of the Bosnian Muslim men and boys held in the White House should not be considered indicative of a plan to kill them because an equally reasonable inference is that all belongings left behind in Potočari were burned once the Bosnian Muslims had left. Defence Final Brief, para. 2512. However, the Chamber has not received any evidence that the ID cards or personal belongings of the Bosnian Muslims who were transported to Kladanj were confiscated in the same manner as those of the Bosnian Muslim men and boys detained at the White House. The Chamber also observes that the burning of the piles of ID cards and belongings of the men and boys detained in the White House appeared sufficiently anomalous as to motivate the DutchBat deputy commander to personally investigate the incident and another DutchBat officer to take photographs. P4175 (Witness Statement of Robert Franken dated 15 January 2012), para. 100; P3948 (Witness statement of Johannes Rutten dated 8 November 2011), para. 66; P4183 (Photograph of burning personal belongings at Potočari); P3961 (Photograph of burning personal belongings).

19363 P4388 (Drina Corps report to VRS Main Staff, 12 July 1995), p. 2. 
5704. The Chamber has already described above how the Bosnian Muslim males separated from their families and detained in the White House were crammed into the house and not given any food or water. ${ }^{19364}$ Although a total of between 600 and 700 Bosnian Muslim men and boys were separated over the course of 12 and 13 July, the Chamber recalls that beginning on the afternoon of 12 July and continuing throughout the following day, groups of males detained at the White House began to be led out of the house and crowded onto buses bound for Bratunac. ${ }^{19365}$ Once the buses arrived in Bratunac, the Bosnian Muslim males were detained in equally crowded conditions in locations throughout the town, and although some food and water were provided at some detention points, it was woefully insufficient. ${ }^{19366}$

5705. As the Chamber has described earlier in this Judgement, beginning on the night of 11 July, the Bosnian Serb Forces began to receive information about the path of the column of Bosnian Muslim men attempting to reach Tuzla, and the VRS and MUP began taking co-operative actions to block it. ${ }^{19367}$ That night, Kovač dispatched additional MUP units to the area and, on 12 July, members of the MUP forces under Borovčanin's command were deployed along the BratunacKonjević Polje Road, joining the VRS units present in the area. ${ }^{19368}$ The column was tracked by both MUP and VRS units, and intelligence on the column's movement was relayed within the Bosnian Serb Forces throughout 12 and 13 July. ${ }^{19369}$ Early in the morning of 13 July, Mladić,

19364 See para. 5113. In that regard, the Chamber notes the Accused's argument that the cramped conditions in which the Bosnian Muslim men and boys were held at the White House should not be considered indicative of the existence of a plan to kill them, as he claims that the crowding and deprivation were equally attributable to the "chaotic conditions" which prevailed in Potočari. Defence Final Brief, paras. 2505-2506. The Accused also asserts that such treatment resulted from "negative attitude[s] towards the men of Srebrenica". Defence Final Brief, para. 2505. However, the Chamber will examine the existence or implementation of a plan to kill in light of the totality of the evidence.

19365 See paras. 5098, 5109, 5117-5118.

19366 See paras. 5292-5295. The Chamber received evidence of an intercepted conversation between Mladić and Beara at 11:05 p.m. on 13 July wherein Mladić ordered Beara to "take care of all that. Solve it so that there is no lack of food [...] find a way wherever you can find it so that the men are not hungry [...] excellent. Just keep working and feed them all. There are a lot of hungry mouths". D2682 (Intercept of conversation between Ratko Mladić and "Ljubo", 13 July 1995). However, particularly in light of the plethora of other intercepted communications in which Bosnian Serb interlocutors including Mladić used the term "Turk" to refer to Bosnian Muslims generally and euphemisms such as "parcel" to refer to the Bosnian Muslim male detainees, the Chamber considers it unreasonable to infer that when Mladić referred to "the men" being hungry, he was speaking about the detainees as opposed to his troops. See e.g. P5378 (Intercept of conversation between two unidentified persons, 13 July 1995), pp. 1, 3; P5366 (Intercept of conversation between Janković, an unidentified General, and an unidentified person, 13 July 1995); P5070 (Intercept of conversation between Major Jokić and Badem, 14 July 1995). The Chamber also recalls that there is no evidence that any food was provided to the detainees on 14 July or any subsequent day.

19367 See paras. 5158-5159.

19368 See paras. 5158, 5160.

19369 See paras. 5158-5159. See e.g. P6061 (Intercept of conversation, 12 July 1995); KDZ122, T. $26140-26141$ (12 March 2012) (closed session); P5366 (Intercept of conversation between Janković, an unidentified General, and an unidentified person, 13 July 1995), p. 2 (Janković replying, "last night we were supposed to go with the blue one. They have something, they are working, it's going well”); P4946 (Intercept of conversation between Krstić and Borovčanin, 13 July 1995) (showing cooperation between the MUP and VRS). 
Vasić, Krstić, Popović, and Pandurević met at the Bratunac Brigade Command. ${ }^{19370}$ After the meeting, Mladić confronted Popović outside the building, swearing at him and urging him to "be more active". 19371 Additional MUP units under Borovčanin's command were deployed that day to reinforce those present along the Bratunac-Konjević Polje Road. ${ }^{19372}$ Monitoring the movement of the column continued to be a priority for the Bosnian Serb Forces throughout 13 July, as the Main Staff sought information from the Drina Corps. ${ }^{19373}$

5706. The column was subjected to intense shelling by Bosnian Serb Forces since the morning of 12 July. ${ }^{19374}$ Attacks on the column continued throughout the day and into the morning of 13 July, resulting in the encirclement of a large group of men from the column near the Konjević Polje intersection. ${ }^{19375}$ The Chamber recalls that the Bosnian Serb Forces then began using a loudspeaker to call into the woods, urging the members of the column to surrender. ${ }^{19376}$ Large numbers of Bosnian Muslim men began to surrender or to be captured along the Bratunac-Konjević Polje and Konjević Polje-Nova Kasaba Roads, where the various VRS and MUP units were deployed. ${ }^{19377}$ When surrendering, the men were required to leave their belongings, including their ID cards, behind. ${ }^{19378}$ The Chamber considers this as an indication that these men were marked for execution.

5707. On 13 July, between 1,500 and 2,000 Bosnian Muslim men came to be detained in each of three locations: the Konjević Polje intersection, ${ }^{19379}$ the Sandići Meadow, and the Nova Kasaba football field. ${ }^{19380}$ At each location, they were guarded by members of the Bosnian Serb Forces, namely the special MUP units under Borovčanin's command, and the MP of the $65^{\text {th }}$ Protection

\footnotetext{
19370 Momir Nikolić, T. 24651 (14 February 2012).

19371 KW582, D4291 (Transcript from Prosecutor v. Blagojević \& Jokić), T. 3529. Mladić remained in Bratunac that morning. See P4824 (Summary of intercepted conversation, 13 July 1995) (recording that Mladić was in Bratunac as of 10:15 a.m. on 13 July).

19372 See para. 5161.

19373 See P5366 (Intercept of conversation between Janković, an unidentified General, and an unidentified person, 13 July 1995), pp. 1-2; Radislav Krstić, D4136 (Transcript from Prosecutor v. Krstić), T. 6298, 6716-6718; P5276 (Intercept of conversation between Zlatar duty officer and Badem duty officer, 12 July 1995). See also para. 5159.

19374 See para. 5162.

19375 See para. 5162.

19376 See paras. 5163-5165, 5171

19377 See paras. 5106, 5166 (referring to detentions at the Konjević Polje intersection, the Nova Kasaba football field, and the Sandići meadow on 13 July).

19378 See paras. 5168, 5172, 5174-5176.

19379 From Konjević Polje, various groups of Bosnian Muslim men were taken towards Nova Kasaba. See paras. 5168, 5182. At one point that afternoon, a group of 15 Bosnian Muslim men who had been captured or surrendered in the area of the Konjević Polje intersection were executed by members of the Bosnian Serb Forces, including at least one member of the Bratunac SJB. See paras. 5189-5205.

19380 See paras. 5166, 5176.
} 
Regiment. ${ }^{19381}$ Mladić spent the afternoon and evening of 13 July travelling between the various detention sites, speaking to the detainees and assuring them that they would be exchanged. ${ }^{19382}$ However, when Momir Nikolić asked Mladić what was going to happen to the detainees, Mladić made a sweeping gesture across his waist and smiled. ${ }^{19383}$

5708. In the late afternoon and evening of 13 July, in accordance with proposals from Tolimir that detainees were to be moved and placed "somewhere indoors or in the area protected from sighting", ${ }^{19384}$ the detainees were removed from the Sandići Meadow and the Nova Kasaba football field and taken either to the Kravica Warehouse or on trucks and buses to Bratunac town, where they were detained overnight in various locations. ${ }^{19385}$ When some of the detainees at the Nova Kasaba football field tried to retrieve their belongings from the field's entrance, the detainees were told that they would no longer need them. ${ }^{19386}$ Beginning late that afternoon and continuing overnight, Bosnian Serb Forces-including members of the $3^{\text {rd }}$ Skelani Platoon ${ }^{19387}$-killed between 755 and 1,016 Bosnian Muslim males at the Kravica Warehouse. ${ }^{19388}$

5709. The Chamber also notes that that evening, Mladić issued an order adopting the remainder of Tolimir's proposals, which were aimed at limiting access to the area for "all uninvited individuals". 19389 While the killings at the Kravica Warehouse were ongoing, buses filled with Bosnian Muslim men and boys from Potočari as well as with those who had been detained at the Sandići Meadow and the Nova Kasaba football field had begun to arrive in Bratunac town; upon arrival, the Bosnian Muslim males were held in various locations and on buses parked throughout

19381 See paras. 5166, 5175, 5181, 5184. The Chamber notes that the evidence also indicates that the $5^{\text {th }}$ Engineering Battalion and the Zvornik MP were present at the Konjević Polje intersection between 4 and 16 July 1995, but does not establish that those units were involved in guarding the prisoners detained at the three locations on 12 and 13 July. See para. 5167.

19382 See paras. 5170, 5179, 5186. See also D3720 (Witness statement of Petar Salapura dated 17 June 2013), pp. 68; Petar Salapura, T. 40273, 40296-40301 (24 June 2013); P4201 (Updated Srebrenica Trial video), Part 3 at 00:01:40 to 00:02:40; P4163 (UNMO Report, 14 July 1995), para. 6 (stating that Mladić had replied that he would come to Potočari on 14 July).

19383 See para. 5170.

19384 See para. 5184

19385 See paras. 5180, 5292-5293. After the other detainees had left the Sandići Meadow, members of the Jahorina Recruits killed approximately 10 to 15 Bosnian Muslim men who remained behind. See paras. 5288-5291.

19386 See para. 5187.

19387 See para. 5227. Members of the Bratunac Brigade were also present at the Kravica Warehouse prior to the shooting; members of the $10^{\text {th }}$ Sabotage Detachment arrived after the shooting, and one tossed two handgrenades into the warehouse. See paras. 5227, 5233.

19388 See paras. 5227-5234, 5286.

19389 See P4407 (VRS Main Staff Order, 13 July 1995), para. 1. The Chamber notes the Accused's contention that this was "standard procedure" and, accordingly, was "not indicative of any plan or preparations to execute" the detainees. Defence Final Brief, paras. 2515-2516. However, the Chamber will consider Mladić's order and Tolimir's proposals in light of all other evidence. 
the town. ${ }^{19390}$ At these sites, the detainees were guarded by members of the Bratunac Brigade MP as well as members of the MUP. ${ }^{19391}$

5710. The presence of the buses throughout the town caused concern to the Bratunac population; when an officer in the Bratunac Brigade asked Beara why the male detainees were not leaving immediately, Beara replied that there were too few vehicles to transport them until after the transportation of the Bosnian Muslim women and children was complete. ${ }^{19392}$ That evening, Deronjić complained to Beara about the detainees' presence in Bratunac. ${ }^{19393}$ Srbislav Davidović testified that on the evening before the buses left Bratunac, he had encountered Deronjic in Bratunac town and had enquired about the buses' presence. ${ }^{19394}$ According to Davidović, Deronjić replied that Rajko Đukić from Milići was responsible for the buses’ presence; Davidović then urged Deronjić to "use [his] connections" to the Accused in order to have the buses moved. ${ }^{19395}$ Deronjić indeed spoke by phone with the Accused at approximately 8 p.m. ${ }^{19396}$ The Accused asked Deronjić, "how many thousands?", and Deronjić replied that there were "about two for the time being [...] but there'll be more during the night". ${ }^{19397}$ The Accused then told Deronjić that "all the goods must be placed inside the warehouses before twelve tomorrow" before clarifying that he meant "not in the warehouses /?over there/, but somewhere else". ${ }^{9398}$ The Chamber finds that the

\footnotetext{
19390 See paras. 5292-5293.
}

19391 See para. 5293. Between the evening of 12 July and the morning of 14 July, when the majority of Bosnian Muslim males detained in Bratunac town were transported to Zvornik, Bosnian Serb Forces killed at least 51 Bosnian Muslim men who were in and around the Vuk Karadžić School, including one who was taken off a bus parked outside the school. See paras. 5298-5303, 5305-5306.

19392 Zlatan Čelanović, P377 (Transcript from Prosecutor v. Popović et al.), T. 6628-6629, 6638-6641.

19393 D3659 (Witness statement of Ljubomir Borovčanin dated 30 May 2013), paras. 35-36. See also Zlatan Čelanović, P377 (Transcript from Prosecutor v. Popović et al.), T. 6639-6640 (describing how he raised his concerns with Beara).

19394 Srbislav Davidović, P4100 (Transcript from Prosecutor v. Popović et al.), T. 9216; Srbislav Davidović, T. 24415, 24437 (9 February 2012) (stating that, at the time, six buses were parked in front of the municipality building).

19395 Srbislav Davidović, P4100 (Transcript from Prosecutor v. Popović et al.), T. 9217; Srbislav Davidović, T. 24415-24416, 24452-24453 (9 February 2012) (stating that Deronjić had said that they "were being set up" by Rajko Đukić and that Davidović had urged Deronjić to speak with "the president" or "the top of the party itself and of government", which Davidović later admitted was the Accused). The Chamber notes that although Davidović testified that this encounter with Deronjić occurred on 12 July, in view of the fact that the buses left Bratunac on the morning of 14 July, the Chamber considers that Davidović's conversation with Deronjić must have occurred on 13 July. See Srbislav Davidović, P4100 (Transcript from Prosecutor v. Popović et al.), T. 9216; Srbislav Davidović, T. 24415-24416 (9 February 2012).

19396 See para. 5311. The Accused acknowledges that this telephone call took place, and that Deronjić informed him of the large number of detainees in Bratunac. See Defence Final Brief, confidential, paras. 3025-3026.

19397 See para. 5311.

19398 See para. 5311. See also P4374 (Witness statement of Milenko Katanić dated 11 October 2011), para. 93; Milenko Katanić, T. 24495-24496 (10 February 2012) (noting that Deronjić, who wished to move the detainees to Zvornik, could not impose his will on Beara). 
discussion between the Accused and Deronjić pertained to the accommodation of the Bosnian Muslim men who were then being held on buses and in detention facilities in Bratunac. ${ }^{19399}$

5711. Around the same time, Mladić's order for the transfer of a large number of Bosnian Muslims who were being detained in Bratunac to Zvornik, where they were to be detained and, ultimately, shot, was conveyed down the chain of command by members of the VRS security organs. ${ }^{19400}$ The Chamber notes, in particular, that Momir Nikolić conveyed this message to Drago Nikolić in person. ${ }^{19401}$ At approximately 9 p.m., members of a public utility company and the Bratunac Civilian Protection Unit were called separately to the Bratunac SDS Office, where they each met with Beara and Deronjić, respectively, as well as two uniformed VRS officers whom they did not know. ${ }^{19402}$ Both of the individuals from Bratunac were asked to provide equipment for transporting a large number of bodies away from the Kravica Warehouse and burying them elsewhere. ${ }^{19403}$ An agreement was ultimately reached for the removal and burial of the bodies from Kravica, and the process began the next morning. ${ }^{19404}$

5712. In the very early hours of 14 July, just after midnight, Momir Nikolić had driven Beara from the Hotel Fontana to the Bratunac SDS office, where Beara met with Deronjić and Vasić. ${ }^{19405}$ Beara and Deronjić argued about where the Bosnian Muslim men were to be executed, as Beara insisted that he had instructions from his "boss" that the detainees were to remain in Bratunac, and Deronjic countered that the Accused had instructed him that all detainees in Bratunac should be transferred to Zvornik. ${ }^{19406}$ Eventually, Beara and Deronjić agreed that the detainees would indeed

19399 The Prosecution alleges that the Accused used the term "goods" to refer to the detainees in Bratunac in an attempt to conceal the order to move them to detention facilities in Zvornik, and that this demonstrates that his intentions "were malign". Prosecution Final Brief, paras. 961, 964. The Accused does not challenge the inference that the term "goods" was a reference to the detainees in Bratunac, but argues that nothing in the recorded conversation suggests that he was informed of a plan to kill the detainees; it only suggests he was informed of the large number of detainees in Bratunac. Defence Final Brief, confidential, paras. 3025-3027. The Chamber will address the Accused's intent in the section on his individual criminal responsibility below. See para. 5805.

19400 See paras. 5309-5310. The Chamber recalls that Drago Nikolić told Obrenović that Beara and Popović were in charge of the assignment. See fn. 18008.

19401 See para. 5310.

19402 See paras. 5241-5242.

19403 See paras. 5241-5242.

19404 See paras. 5241-5246. One of these individuals was specifically told about the killings at the Kravica Warehouse which had occurred earlier that afternoon and evening. See para. 5242. Members of the Bratunac and the Zvornik Brigades, as well as staff from the Rad Utilities Company and the Bratunac Civilian Protection, participated in the burials of those killed at the Kravica Warehouse. See paras. 5248-5249.

19405 See para. 5312.

19406 See para. 5312. The Chamber received evidence that other locations were also suggested as possible sites for holding the detainees. At 10:30 p.m. that evening, Tolimir sent a communication to the Main Staff and Gvero personally informing him that in case Gvero had been unable to find adequate accommodation, space had been arranged in Sjemeč to accommodate 800 detainees from Srebrenica. P4769 (Message from $1^{\text {st }}$ Podrinje Light Infantry Brigade, 13 July 1995). No detainees were ultimately brought to Sjemeč. Dušan Janc, T. 26976 (27 March 2012). Similarly, on 12 July, Tolimir had instructed the Eastern Bosnian Corps to prepare 
be transferred to Zvornik. ${ }^{19407}$ Deronjić then requested a driver and an escort in order to go to Pale that day. ${ }^{19408}$ After the meeting, some of the detainees being held in Bratunac town began to be transferred to the first of four detention sites in Zvornik, where members of the Zvornik Brigade MP were awaiting their arrival. ${ }^{19409}$

5713. The Chamber finds that members of the security organs at all levels of the VRS command played prominent roles in organising the logistics of the detention, killing, and subsequent burial of the detainees in Zvornik. On the morning of 14 July, Popović, Beara, and Drago Nikolić met at the Standard Barracks in Zvornik. ${ }^{19410}$ After the meeting, pursuant to an order from Beara, Popovićwith the assistance of Momir Nikolić-organised a convoy to transport the remaining Bosnian Muslim males in Bratunac to the buildings in Zvornik which had been designated for their detention. ${ }^{19411}$ As Drago Nikolić and Mane Đurić waited at the Hotel Vidikovac to receive the convoy, members of the Bratunac Brigade MP, the Bratunac MUP, and other members of the Bosnian Serb Forces escorted the buses carrying the Bosnian Muslim males to Zvornik. ${ }^{19412}$

5714. As described in more detail below, Beara, Popović, and Drago Nikolić supervised the ongoing operation at multiple detention and killing sites in the Zvornik area between 14 and 16 July. Over the course of these three days, the Bosnian Muslim males were taken to nearby locations-a field in Orahovac, the Petkovci Dam, the banks of the Drina River near Kozluk, and the Branjevo Military Farm - and killed by members of the Bosnian Serb Forces. At each of these sites, the Bosnian Muslims were either shot by members of the same units who had been detaining them or were transported to the execution site with the resources of those units. ${ }^{19413}$

5715. The Chamber received evidence that during an informal briefing with VRS officers held on 14 July at the Standard Barracks in the presence of municipal authorities, ${ }^{19414}$ a VRS officer who

accommodation at Batković Camp for between 1,000 and 1,200 Bosnian Muslim detainees; when the expected detainees had not arrived by the following day, Todorović again consulted Tolimir, who stated that the task had been abandoned and preparations should be abandoned. See para. 5449.

19407 See para. 5312.

19408 D3659 (Witness statement of Ljubomir Borovčanin dated 30 May 2013), para. 37 (further stating that he offered the services of his own driver to Deronjić).

19409 See paras. 5313, 5319-5320.

19410 See para. 5314. After the meeting, Beara and Popović returned to Bratunac. See para. 5314.

19411 See paras. 5313-5315.

19412 See paras. 5315-5316.

19413 See paras. 5335, 5367-5368, 5395-5397, 5427.

19414 Although KDZ320 could not recall the exact date of the briefing, he testified that he received a telephone call inviting him to the Standard Barracks. See KDZ320, P4990 (Transcript from Prosecutor v. Popović et al.), T. 7941; KDZ320, P4989 (Transcript from Prosecutor v. Popović et al.), T. 8011 (under seal); KDZ320, T. 28083 (25 April 2012). [REDACTED]. 
introduced himself as Beara, ${ }^{19415}$ highlighted that the VRS had a lot of detainees in various locations in the Zvornik municipality, that the VRS had "to get rid of them", and that he expected assistance from the municipality. ${ }^{19416}$ Beara further instructed that his order originated from "two Presidents". 19417

5716. The Chamber found that Popović led a group of buses from Hotel Vidikovac to the Orahovac School on 14 July, where Drago Nikolić was co-ordinating events that day. ${ }^{19418}$ Beara also arrived at Orahovac later that day, ${ }^{19419}$ and both he and Drago Nikolic were present at the Petkovci School shortly before shootings commenced there. ${ }^{19420}$ At the Ročević School, Popović and Jasikovac supervised the detention of Bosnian Muslim males that day. ${ }^{19421}$ Meanwhile, members of the Bosnian Serb Forces-including members of the $1^{\text {st }}, 4^{\text {th }}$, and $6^{\text {th }}$ Battalions of the Zvornik Brigade as well as members of the Bratunac Brigade and its MP Battalion-were deployed to the Orahovac, Petkovci, Ročević, and Kula Schools, where they participated in the detention of the Bosnian Muslim males who had arrived from Bratunac. ${ }^{19422}$ At the schools, the Bosnian Muslim males were held in similarly cramped conditions as they had been subjected to in Potočari and Bratunac, and they were similarly deprived of sufficient food and water. ${ }^{19423}$

5717. That night, the Main Staff sought to contact Beara. ${ }^{19424}$ When Beara and Jokić spoke at 9:02 p.m. on 14 July, Jokić told Beara to call the Main Staff, as "[t]here [we]re big problems. Well, with the people, I mean, with the parcel". ${ }^{19425}$ In view of the circumstances at the time, the

19415 KDZ320, P4990 (Transcript from Prosecutor v. Popović et al.), T. 7941. KDZ320 acknowledged that he had never met Beara before. KDZ320, P4989 (Transcript from Prosecutor v. Popović et al.), T. 8004 (under seal). See also KDZ320, P4990 (Transcript from Prosecutor v. Popović et al.), T. 8015.

19416 KDZ320, P4990 (Transcript from Prosecutor v. Popović et al.), T. 7941-7942, 7944, 8013 (further explaining that the assistance from the municipality meant the burial of the bodies, and that the municipality had to provide assistance in terms of providing equipment and machinery from municipal utility companies). Beara added that he was in command of the barracks. KDZ320, P4990 (Transcript from Prosecutor v. Popović et al.), T. 7942.

19417 KDZ320, P4990 (Transcript from Prosecutor v. Popović et al.), T. 7944. [REDACTED].

19418 See paras. 5315, 5326, 5330. The Chamber also received evidence that Jasikovac directed the transportation of the detainees from the Orahovac School to the execution site on 14 July. See para. 5329.

19419 See para. 5326.

19420 See paras. 5363-5365.

19421 See paras. 5385, 5392.

19422 See paras. 5319, 5357, 5386, 5416. Members of the Zvornik Brigade MP Company had been deployed to the Orahovac School since the previous evening, when the Bosnian Muslim detainees began to arrive. See para. 5319.

19423 See paras. 5324, 5361, 5387, 5419-5420.

19424 The Chamber recalls that between 6 and 7 p.m. on 14 July, upon instructions from Dragan Jokić, the Zvornik Brigade duty officer at the time, Marko Milošević, went to the Petkovci School to relay an order to Beara that he was to report to his command. See para. 5363.

19425 P5070 (Intercept of conversation between Major Jokić and Badem, 14 July 1995). See Richard Butler, T. 27567-27568 (18 April 2012). Jokić said to Beara: "We were together Colonel, Sir. Number 155 called you and asked you to call him urgently"; "Number 155. That's I mean, the higher house, you go ahead and call them, you have, so I don't speak like this"; "What? Call up there number 155 in the higher house and that's it. OK boss". P5070 (Intercept of conversation between Major Jokić and Badem, 14 July 1995). See Richard Butler, T. 
Chamber finds that the term "parcel" referred to the Bosnian Muslim males then being detained in Zvornik by various members of the Bosnian Serb Forces. ${ }^{19426}$

5718. Further, the Chamber recalls that in the early hours of 15 July, Srečko Aćimović received a phone call from Drago Nikolić, who said that the order to deploy soldiers from the Zvornik Brigade's $2^{\text {nd }}$ Battalion "had come from above" and had to be carried out. ${ }^{19427}$ Later that morning, Popović met the Commander of the $2^{\text {nd }}$ Battalion at the Ročević School, yelled at him for not having brought soldiers as he had been ordered, and threatened that the commander would be held responsible for not following orders. ${ }^{19428}$

5719. Meanwhile, from Drago Nikolić's office at the Standard Barracks, Beara contacted the Drina Corps in an attempt to secure additional troops to participate in the killings. ${ }^{19429}$ Beara first contacted Živanović, with whom he discussed the Višegrad Brigade Commander's refusal to comply with an order to send a platoon to a specified location in accordance with the “commander"”s orders. ${ }^{19430}$ Beara asked Živanović to order Furtula to comply, but Živanović directed Beara to contact Krstić, who had taken over as Drina Corps Commander. ${ }^{19431}$ Thereafter, Beara called Krstić, explained that Furtula had not carried out the "boss's" order, and asked Krstić for 30 to 50 men, adding that " $[\mathrm{t}]$ here are still 3,500 'parcels' that I have to distribute and I have no solution". ${ }^{19432}$ Krstić first suggested that members of the Bratunac Brigade or MUP be used but

27568 (18 April 2012) (testifying that extension 155 referred to the phone line at the operations centre of the VRS Main Staff). The Chamber finds, based on the identifying information referred to during the conversation, as well as on the content of the conversation itself, that Beara was a participant in it.

19426 [REDACTED]. Jokić, who was the duty operations officer at the Zvornik Brigade Command on 15 July, stated that Popović had instructed him not to make a record of the activities involving the killing operation or to speak on the radio about it. [REDACTED].

19427 See paras. 5388-5389. Drago Nikolić called again several hours later and told the commander that if he could not put a group of men together, he and his associates should carry out the executions themselves. See para. 5389.

19428 See para. 5390. The Chamber recalls that Popović also called the Zvornik Brigade Duty Officer and requested that vehicles, as well as Trbić or Jasikovac, be dispatched to Ročević immediately. See para. 5390.

19429 At the time, Beara was present at the Standard Barracks. See P5072 (Intercept of conversation between Col. Beara and unidentified person, 15 July 1995); P6698 (Intercept of conversation between Col. Beara and an unidentified person, 15 July 1995), p. 1; Richard Butler, T. 27575 (18 April 2012) (testifying that extension 139 was Drago Nikolić's extension at the security office of the Zvornik Brigade).

19430 P5073 (Intercept of conversation between General Živanović and Col. Beara, 15 July 1995); P6698 (Intercept of conversation between Col. Beara and an unidentified person, 15 July 1995), p. 1; P6699 (Intercept of conversation between General Živanović and Col. Beara, 15 July 1995), p. 1. See Richard Butler, T. 2757627577 (18 April 2012).

19431 P5073 (Intercept of conversation between General Živanović and Col. Beara, 15 July 1995); P6698 (Intercept of conversation between Col. Beara and an unidentified person, 15 July 1995), p. 2; P6699 (Intercept of conversation between General Živanović and Col. Beara, 15 July 1995), pp. 1-2. See Richard Butler, T. 2757627577 (18 April 2012).

19432 P5074 (Intercept of conversation between Col. Beara and General Krstić, 15 July 1995); P5306 (Intercept of conversation between Col. Beara and General Krstić, 15 July 1995), pp. 1-2, 4-5; P5308 (Intercept of conversation between Col. Beara and General Krstić, 15 July 1995). See also Richard Butler, T. 27578-27579 (18 April 2012). The Chamber notes that despite being presented with this intercepted conversation, Krstić denied having had any conversation with Beara between 13 and 17 July 1995. Radislav Krstić, D4136 
ultimately said "Fuck it, I'll see what I can do". ${ }^{19433}$ Beara added that Krstić should have the men go to Drago Nikolić. ${ }^{19434}$

5720. On 16 July, at 11:11 a.m., Beara was intercepted having a conversation with Slobodan Cerović from the Drina Corps, who referred to "instructions from above [...] to do triage on [the detainees]". ${ }^{19435}$ At Beara's request, Popović went to the Kula School that morning; both were present while the detainees were transported to the Branjevo Military Farm for execution. ${ }^{19436}$ The Chamber received evidence about Popović's involvement in the organisation and co-ordination of the transportation of detainees from the Kula School to the Branjevo Military Farm, as he attempted to procure fuel that afternoon. ${ }^{19437}$

5721. Meanwhile, pursuant to an order from Beara, members of the $10^{\text {th }}$ Sabotage Detachment stationed at Dragaševac had reported to the Standard Barracks and were then led towards the Branjevo Military Farm by a "lieutenant-colonel" and two military policemen. ${ }^{19438}$ Upon arriving at the farm, the soldiers were ordered to kill the detainees who would be arriving in a few minutes. ${ }^{19439}$ Shortly thereafter, buses filled with Bosnian Muslim males who had been held at Kula School began arriving; they were subsequently executed. ${ }^{19440}$

5722. Hours later, the lieutenant-colonel ordered the soldiers present at the farm to execute 500 Bosnian Muslim men from Srebrenica detained at the nearby Pilica Cultural Centre. ${ }^{19441}$ Beara and Popović were present at the café across the Pilica Cultural Centre, where Beara congratulated the soldiers who had just carried out the executions at the cultural centre. ${ }^{19442}$ In a phone call from the

(Transcript from Prosecutor v. Krstić), T. 6725-6726. However, in light of the countervailing evidence cited above, as well as the fact that Krstić's testimony was given in his own trial and the fact that this conversation was integral to Krstić's responsbility for the crimes with which he was charged, the Chamber does not believe Krstić's denial of being an interlocutor in this conversation.

19433 P5074 (Intercept of conversation between Col. Beara and General Krstić, 15 July 1995).

19434 P5074 (Intercept of conversation between Col. Beara and General Krstić, 15 July 1995). See Richard Butler, T. 27579 (18 April 2012).

19435 See para. 5426.

19436 See para. 5426. By that time, Drago Nikolić had organised fuel "for the transport of troops to Kula", and ammunition for the $1^{\text {st }}$ Battalion. P4585 (Zvornik Brigade Duty Officers logbook, 29 May-27 July 1995), ecourt p. 72. The Chamber recalls that members of the Zvornik Brigade $1^{\text {st }}$ Battalion guarded the detainees at Kula School that day. See para. 5416.

19437 See para. 5426, fn. 18511. The Chamber also received evidence indicating that the Main Staff was also involved in the procurement of this fuel. P5312 (Intercept of conversation between Major Bašević and an unidentified person, 16 July 1995) (referring to having spoken to Miletić about the fuel earlier that day).

19438 See paras. 5427-5428. The Chamber recalls that Dragomir Pećanac, from the Intelligence Administration of the Main Staff, was present in Dragaševac when the members of the $10^{\text {th }}$ Sabotage Detachment departed. See para. 5428.

19439 See para. 5430.

19440 See paras. 5430-5436.

19441 See para. 5436.

19442 See paras. 5440-5441. 
Standard Barracks at 9:16 p.m. that evening, Popović stated that he had "finished the job [...] finished everything" and would return to Vlasenica the following day. ${ }^{1943}$ Considering this statement in light of the totality of the evidence, the Chamber is of the view that the only reasonable inference is that Popović was referring to the killing operation.

5723. However, the Chamber recalls that Popović in fact remained in the Zvornik area on 17 July to supervise the burial of the Bosnian Muslim males who had been killed at the Branjevo Military Farm and the Pilica Cultural Centre on the previous day. ${ }^{19444}$ After working throughout the day, ${ }^{19445}$ Popović reported at 4:22 p.m. that "everything's alright that job is done and dusted [...] everything's finished up there are no problems." 19446 Over the course of the preceding five days, at least 5,115 Bosnian Muslim males had been killed. ${ }^{19447}$

\section{iii. Conclusions}

(A) The formation of a common plan to eliminate the Bosnian Muslims in Srebrenica by forcible removal

5724. On the basis of the totality of the evidence discussed above, the Chamber finds that, as Srebrenica fell, the long-term strategy aimed at removing the Bosnian Muslim population from Srebrenica, which had been devised in March 1995, began to be transformed into a concrete common plan to eliminate them. In the Chamber's view, this elimination operation first took the form of forcible removal of the Bosnian Muslim population. After receiving the Accused's order to take the town, the Bosnian Serb Forces under the command of Mladić and Krstić used heavy shelling to push the Bosnian Muslims northward, first towards the Bravo Company compound and then north to the UN Compound in Potočari. ${ }^{19448}$ In the meantime, following an initial proposal that in exchange for being given safe passage out of the enclave the Bosnian Muslims would leave within 48 hours, Mladić ordered the Bosnian Serb Forces to proceed to Potočari. ${ }^{19449}$ This was followed by an order to Borovčanin's units to take over OP Papa before proceeding to the UN Compound. ${ }^{19450}$

\footnotetext{
19443 See para. 5441. By 10:33 p.m., Popović had left the Standard Barracks. See P5324 (Intercept of conversation between Štrbić and an unidentified person, 16 July 1995) (indicating: "Yes, he was here and gone.”).

19444 See para. 5449, fn. 18599.

19445 P5081 (Intercept of conversation between Milorad Trbić and an unidentified person, 17 July 1995$)$, p. 1.

19446 P6702 (Intercept of conversation between Lt. Col. Popović and an unidentified person, 17 July 1995), p. 1; P4964 (Intercept of conversation between Lt. Col. Popović and an unidentified person, 17 July 1995).

19447 See para. 5519.

19448 See paras. 5686-5687, 5690, fn. 19301.

19449 See paras. 5689-5690.

19450 See para. 5696.
} 
5725. Overnight, as the Bosnian Serb Forces under their control continued to launch shells near the UN Compound, Mladić, Živanović, and Krstić orchestrated a large-scale mobilisation of buses, which ultimately carried thousands of Bosnian Muslim women, children, and elderly men out of Srebrenica during the following 48 hour period. ${ }^{19451}$ In the meantime, these three were joined first by Radoslav Janković and Kosorić, and later by Popović, at meetings at the Hotel Fontana, where, as the Chamber has already found, representatives of the Bosnian Muslims in Potočari were coerced into agreeing to leave the enclave. ${ }^{19452}$

5726. Noting the mobilisation of such massive resources, which took place simultaneously with military manoeuvres aimed at consolidating the Bosnian Serb Forces' control over the Bosnian Muslims gathered in Potočari, the Chamber is convinced that as the enclave fell on $11 \mathrm{July}$, a concrete plan to forcibly remove the Bosnian Muslim women, children, and elderly men from the UN Compound emerged. This plan then began to be implemented overnight and during the following days. The Chamber has no doubt that Mladić's overtures at the Hotel Fontana meetings were merely a façade intended to mask the fact that a concrete plan was already in place to forcibly remove the Bosnian Muslim women, children, and elderly men from Srebrenica on the vehicles that had already been mobilised by the Bosnian Serb Forces and the Bosnian Serb Political and Governmental Organs. ${ }^{19453}$

5727. The Chamber recalls that, in addition to being present at some or all of the Hotel Fontana meetings, Mladić, Radoslav Janković, Živanović, Krstić, Popović, and Kosorić were also present in Potočari and oversaw and/or assisted the boarding and transportation of women, children, and the elderly, as well as the separation of the men, their detention, and their subsequent transportation to Bratunac. ${ }^{19454}$ Thereafter, Bosnian Serb Forces operating under Mladić's command subjected the Bosnian Muslims waiting to leave Potočari to cruel and inhumane treatment. ${ }^{19455}$

(B) The expansion of the common plan to eliminate the Bosnian Muslims in Srebrenica by killing all the able-bodied men and boys

5728. With regard to the numerous killings described above, the Chamber notes striking similarities between many of the detentions and executions of Bosnian Muslim males from Srebrenica that were carried out in the Zvornik area between 13 and 16 July 1995 . After being

\footnotetext{
19451 See paras. $5696,5699-5700$.

19452 See paras. 5691, 5695, 5697-5698.

19453 As will be described below, by this time, a plan had also been devised to kill the Bosnian Muslim males. See Section IV.C.3.a.iii.B: The expansion of the common plan to eliminate the Bosnian Muslims in Srebrenica by killing all the able-bodied men and boys.

19454 See para. 5120.

19455 See para. 5699.
} 
escorted by members of the Bratunac Brigade MP and Bratunac MUP — as well as other members of the Bosnian Serb Forces-to Zvornik, the Bosnian Muslim males were detained at the Orahovac, Petkovci, Ročević, and Kula Schools, all in the Zvornik area. At these schools, the Bosnian Muslim males were guarded by members of the Zvornik Brigade-usually members of the battalion with responsibility for the area in which each school was located. After being held at the schools for one or two days, beginning on 14 July, the Bosnian Muslim males were taken to various locations nearby where they were shot and killed by members of the Bosnian Serb Forces. At the Pilica Cultural Centre, the Bosnian Muslim males were also killed by members of the Bosnian Serb Forces.

5729. The Chamber also recalls that as early as noon on 14 July, while the killings were being carried out, resources of the Zvornik Brigade Engineering Company were mobilised to dig graves and to bury the bodies of those killed at Orahovac, the Petkovci Dam, Kozluk, and the Branjevo Military Farm. ${ }^{19456}$ Additional Zvornik Brigade resources were used to bury bodies at the Branjevo Military Farm, and to transport the bodies of those killed at the Pilica Cultural Centre to the farm. ${ }^{19457}$ Following the same pattern as in Glogova, municipal resources and manpower were also used in Zvornik during the burial process. ${ }^{19458}$ The Chamber recalls that, at some locations, the burial process began while the killings were still ongoing. ${ }^{19459}$

5730. The Chamber has also found that in September and October 1995, the Main Staff organised a reburial operation which was carried out by members of the security organs from the Main Staff, Drina Corps, Bratunac Brigade, and Zvornik Brigade, with the assistance of Bosnian Serb civilian authorities and other VRS and MUP units. ${ }^{19460}$ The Chamber considers that the re-burial operation itself and the means by which it was carried out are consistent with the Chamber's finding that the killings described above were committed pursuant to a common plan.

5731. On the basis of the totality of the evidence outlined above, the Chamber is satisfied beyond reasonable doubt that these killings were carried out pursuant to a systematic and highly organised plan. In reaching that conclusion, the Chamber is mindful that the Bosnian Serb Forces began to obtain detailed intelligence regarding the presence of Bosnian Muslim males amongst the population in Potočari on the night of 11 July and that, around the same time, as described further below, also began to receive reports about the existence and movement of the column of Bosnian

\footnotetext{
19456 See paras. 5636-5337, 5371, 5400-5402, 5443-5444.

19457 Individuals involved in this process were members of the Zvornik Brigade R Battalion, and the $1^{\text {st }}$ Battalion's Work Platoon. See paras. 5445-5447. A truck belonging to the $6^{\text {th }}$ Battalion was also used. See para. 5372.

19458 See paras. 5338, 5402, 5444

19459 See paras. 5337, 5371.
} 
Muslim men and boys attempting to make their way towards Tuzla. Further, before 10 a.m. on 12 July, Popović told Momir Nikolić that "all the balijas should be killed". ${ }^{19461}$ Accordingly, the Chamber is convinced that a plan to kill all the able-bodied Bosnian Muslim men and boys in Srebrenica had been established by the time that the third Hotel Fontana meeting commenced at 10 a.m. on 12 July. The plan then came to encompass the killing of all Bosnian Muslim males in Bosnian Serb custody.

5732. The Accused contends that the plan to kill the Bosnian Muslim men and boys detained by the Bosnian Serb Forces did not exist until at least the afternoon of 13 July, following the "burned hands" incident at Kravica Warehouse. ${ }^{19462}$ He asserts that "the executions that followed were the result of conduct by persons reacting to events on the ground". ${ }^{19463} \mathrm{He}$ also contends that the fact that although Pandurević was present at the meeting at the Bratunac Brigade Command on the night of 11 July 1995, ${ }^{19464}$ Pandurević did not inform Obrenović of any plan to kill, as well as the fact that Obrenovic was first informed of the plan on the evening of 13 July both demonstrate that no such plan existed before that time. ${ }^{19465}$ However, the Chamber has already found that the final arrangement to transfer the detainees to Zvornik was only agreed upon during a meeting on the night of 13 July. During that meeting, the participants did not debate whether the detainees should be killed, but where such an operation should be carried out. ${ }^{19466}$ Accordingly, the Chamber considers that the fact that Obrenović was not informed before the evening of 13 July bears little relevance to the question of when the plan to kill the Bosnian Muslim males was devised. The Accused also argues that the fact that the Bosnian Muslim males detained at Luke School were not killed until the evening of 13 July also demonstrates that the plan to kill "only emerged after the Kravica incident". ${ }^{19467}$ However, the Chamber recalls that, as described above, Bosnian Muslim men continued to be removed from buses passing through Tišća throughout the day on 13 July, and that during the course of that night, all were removed from Luke School and-with the exception of KDZ070-killed by members of the Bosnian Serb Forces. ${ }^{19468}$ The Chamber therefore does not consider that the passage of time between the detention of the men and their subsequent execution

\footnotetext{
19460 See paras. 5504-5514.

19461 See paras. 5049, 5066, 5702.

19462 Defence Final Brief, paras. 2450, 2518.

19463 Defence Final Brief, para. 2518.

19464 The Chamber notes the Accused's contention that this meeting occurred on the night of 12 July. Defence Final Brief, confidential, para. 2466. However, the Chamber notes that Pandurevic attended the meeting at the Bratunac Brigade Command on the night of 11 July. See para. 5692. The Chamber further considers that the argument outlined in paragraph 2466 of the Defence Final Brief does not hinge on the precise date of the meeting.

19465 Defence Final Brief, confidential, para. 2466.

19466 See para. 5312.

19467 Defence Final Brief, confidential, para. 2490.
} 
indicates that the plan to kill them only arose that evening. Finally, the Chamber recalls that units of the Drina Corps had already begun to look for available bulldozers by the early afternoon of 13 July, although they were unsuccessful in locating any. ${ }^{19469}$ The Chamber therefore rejects the Accused's argument that the plan to kill the Bosnian Muslim males in Srebrenica arose only after the killings at Kravica Warehouse on the evening of 13 July. Rather, the Chamber considers that this incident marks the beginning of the large scale implementation of the plan to kill. ${ }^{19470}$

Srebrenica

(C) Participants in the plan to eliminate the Bosnian Muslim population in

5733. With regard to the aspect of the common plan to eliminate the Bosnian Muslims in Srebrenica by forcibly removing the women, children, and elderly men, the Chamber notes the pervasive involvement of high-ranking VRS officers such as Mladić, Živanović, and Krstić in the encirclement and ultimate take-over of Potočari by the Bosnian Serb Forces; the Chamber also notes the execution of a large scale bussing operation which ferried an estimated 30,000 Bosnian Muslims away from Srebrenica over the course of two days. Further, the Chamber is mindful of their presence and participation-as well as that of Main Staff officer Radoslav Janković and Drina Corps officers Popović and Kosorić-in the Hotel Fontana meetings. The Chamber observes that all of these high-level officers were present during, and either oversaw or assisted in, the boarding process in Potočari. Accordingly, the Chamber is satisfied that Mladić, Živanović, Krstić, Popović, and Kosoric shared the common purpose of eliminating the Bosnian Muslims in Srebrenica by forcibly removing the women, children, and elderly men.

5734. The Chamber considers, however, that the aspect of the common plan to eliminate the Bosnian Muslims in Srebrenica by killing men and boys was formed and executed in conditions designed to ensure its secrecy to the greatest extent possible. In this regard, the Chamber recalls Mladić's order limiting access to the area beginning on the night of 13 July and Tolimir's proposal to remove the detainees from locations where they could be sighted. While such procedures might ordinarily have been standard, in the present circumstances, in light of the instruction not to speak on the radio or create any written record of the killing operation, the Chamber considers that their actions appear more circumspect. The Chamber also notes that when Beara dispatched Momir Nikolić to inform Drago Nikolić that the Bosnian Muslim males would be brought to Zvornik, Momir drove to Zvornik and insisted on delivering the message to Drago in person rather than

\footnotetext{
19468 See paras. 5147-5148, 5150-5152, 5154.

19469 See para. 5241.

19470 Recalling its earlier analysis of the development of the plan to kill, the Chamber thus rejects the Accused's argument that the killings which followed those at the Kravica Warehouse on 13 July were merely an "inappropriate" reaction to the events at Kravica Warehouse. See Defence Final Brief, para. 2451.
} 
through a desk officer. ${ }^{19471}$ The Chamber is therefore satisfied that upon the instruction of members of the Main Staff, a number of measures were taken to limit the extent to which those not directly involved in the killing operation were aware of it.

5735. However, the Chamber recalls that, as described in detail above, the killing operation was eventually overseen and implemented on the ground by numerous VRS officers at all levels of the command hierarchy, from the Main Staff to the members of the battalions of the Zvornik and Bratunac Brigades. In this regard, the Chamber is also mindful of the ubiquitousness of security officers from the Main Staff, Drina Corps, and Zvornik Brigade-namely Beara, Popović, and Drago Nikolić—at the killing sites across Zvornik between 14 and 17 July 1995. The Chamber also recalls, as described above, the various units across the MUP and the VRS-including the $10^{\text {th }}$ Sabotage Detachment which was directly subordinated to the Main Staff-that participated in the implementation of the plan.

5736. The Chamber is of the view that by designing and conducting a simultaneous operation to kill the Bosnian Muslim men and boys of Srebrenica while the forcible removal of the women, children, and elderly men was ongoing, the common purpose of the plan to eliminate the Bosnian Muslims in Srebrenica was expanded so as to include the killing of all the men and boys, ${ }^{19472}$ and multiple members of the plan agreed to it. The Chamber was presented with abundant evidence that establishes that, like the forcible removal operation, the killing operation involved an intricate and co-ordinated effort at all echelons of the VRS and MUP, including high-ranking officers, as well as a variety of units across the MUP and the VRS, with the assistance of municipal authorities. In particular, the Chamber is satisfied that the wide scale of the killings that were carried out over a short period necessitated an elaborate operation organised and directed at all times by multiple levels of the VRS security branch, particularly Beara and Popović. ${ }^{19473}$ The Chamber also finds that the complex operation by which the Bosnian Muslim men and boys of Srebrenica were killed would not have been possible without the authorisation and orders of the VRS Commander, Mladić. Given Mladić's role and function at the time, his presence on the ground after the fall of Srebrenica, and his actions during the days following the take-over and while the execution of the operation to kill was underway, the Chamber is satisfied that Mladić formed an essential part of this operation. $^{19474}$

\footnotetext{
19471 Momir Nikolić, T. 24670 (14 February 2012).

19472 See paras. 5726, 5731.

19473 See paras. 5702, 5705, 5710-5723.

19474 See paras. 5703, 5705, 5707, 5709, 5709, 5711. The Chamber also notes that Drago Nikolić stated that Mladić had ordered the killing operation, and that Beara and Popović were in charge of it. [REDACTED].
} 
5737. Based on all of the above, and recalling the formation of a plan to kill the Bosnian Muslim males in Srebrenica between the night of 11 July and the morning of 12 July, the Chamber finds that Mladić, Beara, and Popović shared the expanded common purpose of eliminating the Bosnian Muslims of Srebrenica by killing the men and boys.

5738. Whether the Accused shared the common purpose to eliminate the Bosnian Muslims in Srebrenica, and if so, the extent to which he contributed to the plan, will be discussed separately below. ${ }^{19475}$

\section{(D) Scope of crimes}

5739. Based on the evidence set out above and the Chamber's findings thereon, the Chamber considers that the original scope of the common purpose involved the commission of inhumane acts (forcible transfer). Further, on the basis of such evidence, and noting in particular the sheer scale of the killings described above, the Chamber finds that the expanded common purpose of eliminating the Bosnian Muslims in Srebrenica involved the commission of murder and extermination, and that Mladić, Beara, and Popović intended those crimes. Considering that these killings concerned Bosnian Muslim males who were marked for execution on the basis of their identities as such, the Chamber is satisfied that the crime of persecution through the underlying act of killing was also within the scope of the expanded common purpose, and that Mladić, Popović, and Beara possessed the requisite persecutory intent.

5740. Indeed, the Chamber recalls that the common plan to eliminate was, by its very nature, a discriminatory plan targeting solely the Bosnian Muslims living in the Srebrenica enclave. In addition, the Chamber considers that, as described above, the circumstances in which the forcible removal of the Bosnian Muslim women, children and elderly men and the execution of the Bosnian Muslim males were carried out were demonstrative of a deliberate intent to inflict serious physical and mental suffering upon them. ${ }^{19476}$ Accordingly, the Chamber finds that the crime of persecution through the underlying act of cruel treatment was within the scope of the common purpose of the Srebrenica JCE.

5741. Further, the Chamber has found that the acts described above amounted to genocide, as the only reasonable inference based on the pattern of the killings and the evident intent to kill every able-bodied Bosnian Muslim male from Srebrenica was that such killings were committed with the

19475 See Section IV.C.3.b: Accused's participation in the Srebrenica JCE.
19476 See paras. 5647-5648, 5650. See also paras. 5691-5700. 
intent to destroy the Bosnian Muslims in Srebrenica. ${ }^{19477}$ The Chamber notes in particular the Bosnian Serb Forces' vigorous pursuit of the members of the column and their dogged commitment to killing all Bosnian Muslim males taken into Bosnian Serb custody, irrespective of whether they were combatants or civilians and regardless of whether they were captured or had surrendered from the column. The Chamber notes the omnipresence and involvement of Popović and Beara at multiple mass killing sites in Zvornik, their numerous actions in furtherance of the killing operation as detailed above, and the fact that, as the Chamber has found, the vast killing operation was conducted with Mladić's essential involvement. On the basis of all of the evidence, the Chamber is therefore satisfied that the members of the Srebrenica JCE who agreed to the expansion of means so as to encompass the killing of the men and boys intended to kill all the able-bodied Bosnian Muslim males, which intent in the circumstances is tantamount to the intent to destroy the Bosnian Muslims in Srebrenica. ${ }^{19478}$

5742. With regard to the scope of the operation, the Chamber has established above that the large scale killings committed in the Bratunac and Zvornik areas were committed pursuant to the common plan to kill the Bosnian Muslim males of Srebrenica. ${ }^{19479}$ Below, the Chamber will consider whether other incidents also fell within the scope of the same killing operation.

5743. The Chamber further recalls that during the forcible removal of the Bosnian Muslim women, children, and elderly men, which was carried out between 12 and 13 July, the Bosnian Serb Forces killed a number of Bosnian Muslim males in Potočari. ${ }^{19480}$ Some of the Bosnian Muslim males who were separated in Potočari and bussed to Bratunac were killed by members of the Bosnian Serb Forces while being held there between 12 and 14 July. ${ }^{19481}$ Bosnian Muslim males who did manage to board the buses heading toward Tuzla were taken off at Luke School and were killed by members of the Bosnian Serb Forces in the very early hours of 14 July. ${ }^{19482}$ Meanwhile, on 13 July, members of the Bosnian Serb Forces, including one member of the Bratunac SJB, killed 15 Bosnian Muslim men from the column in an isolated area on the bank of the Jadar River. ${ }^{19483}$

\footnotetext{
19477 See paras. 5669, 5671. See also paras. 5701-5723, 5728-5732.

19478 See paras. 5735-5737.

19479 See paras. 5728-5732.

19480 During the course of the day on 13 July, members of the Bosnian Serb Forces killed one Bosnian Muslim man behind the White House. See para. 5145. Additionally, on the same day, members of the Bosnian Serb Forces killed nine Bosnian Muslim men in a meadow southwest of the White House. See para. 5141.

19481 See paras. 5303, 5306.

19482 See paras. 5150, 5152, 5154. The Chamber has already rejected the Accused's argument that the fact that the Bosnian Muslim males were held at Luke School until around midnight on 13 July demonstrates that the plan to kill did not arise until after the killings at Kravica Warehouse. See para. 5732.

19483 See para. 5205. The Accused asserts that the killings at Jadar River did not form part of the common plan because they occurred prior to the killings at the Kravica Warehouse. Defence Final Brief, para. 2497.
} 
That same evening, members of the Bosnian Serb Forces killed another 15 Bosnian Muslim men from the column who had been detained at the Sandići Meadow. ${ }^{19484}$ These killings were temporally and geographically proximate, they were each carried out by units of the Bosnian Serb Forces deployed in the area and operating under the overall command of Mladić, ${ }^{19485}$ and the victims of each incident were Bosnian Muslim males from Srebrenica.

5744. The Chamber also received evidence that the Bosnian Serb Forces-including members of the $10^{\text {th }}$ Sabotage Detachment and the MUP_killed other groups of Bosnian Muslim males from Srebrenica at Snagovo and Bišina over the course of the week following the large scale killings in Zvornik, which ended on 16 July. ${ }^{19486}$ The Chamber notes the geographical proximity of these two killing sites to the large scale execution sites in Zvornik, as well as the presence of Popović himself at Bišina. ${ }^{19487}$

5745. The Chamber further recalls that during the attack on Srebrenica, a part of the joint forces operating on the Sarajevo front near Trnovo was detached and sent to the Srebrenica sector under Borovčanin's command, while another part, including the Scorpions, remained behind. ${ }^{19488}$ After the fall of Srebrenica to Bosnian Serb Forces, two members of the Scorpions unit were ordered by their commander to take a bus and a TAM truck to Srebrenica, where they would assist in transporting Bosnian Muslim male detainees. ${ }^{19489}$ The Chamber has already found that the Scorpions transported multiple groups of Bosnian Muslim males who had been detained in Srebrenica, and that at some point, a "final group" of six was brought to the Scorpions command post in Trnovo, where Medić ordered that they be killed. ${ }^{19490}$ The unit complied and the men were executed. ${ }^{19491}$ The Chamber notes that it has not received evidence which would allow it to precisely determine the date on which these executions occurred. The Chamber is also mindful of

However, the Chamber has already found that the common plan was established by the time the third Hotel Fontana meeting commenced at 10 a.m. on 12 July. See para. 5731.

See paras. 5288-5289, 5291. The Accused contends that the killings at Sandići Meadow did not form part of the common plan because they occurred prior to the killings at the Kravica Warehouse. Defence Final Brief, confidential, para. 2499. However, the Chamber has already found that the common plan was established by the time the third Hotel Fontana meeting commenced at 10 a.m. on 12 July. See para. 5731.

As described above, following his arrival in Bratunac on 8 July and at the Drina Corps IKM on 9 July, Mladić assumed overall command of the Bosnian Serb Forces in the area-namely, the VRS and MUP-as demonstrated by his relaying to subordinate units the Accused's order to take the town; his prominent role on the ground in Potočari, as well as at the meetings at the Hotel Fontana and Bratunac Brigade Command; and his orders mobilising Bosnian Serb personnel and materiel. See paras. 5687-5692, 5695-5697, 5699-5700, 5703, $5705,5707,5709,5711$, fn. 19474.

19486 See paras. 5477-5481, 5482-5490.

19487 See paras. 5477, 5482, 5486-5488.

19488 See para. 5493.

19489 See para. 5494.

19490 See para. 5495.

19491 See para. 5494. 
the geographic distance between Trnovo and Srebrenica. However, noting the involvement of members of the Scorpions unit in the process of transporting Bosnian Muslim male detainees in Srebrenica during the killing operation described above, the Chamber is satisfied that the Trnovo killings were carried out as part of the same operation described above.

b. Accused's participation in the Srebrenica JCE

\section{i. Submissions of the parties}

5746. According to the Indictment, the Accused committed the crimes referred to above by virtue of his participation in the Srebrenica JCE. ${ }^{19492}$ The Indictment further claims that the Accused shared the intent for the commission of each of the crimes set forth above with other members of the Srebrenica JCE, including Mladić. ${ }^{19493}$ According to the Prosecution, each of the members of the Srebrenica JCE, including the Accused, contributed to achieving its objective by their acts or omissions. ${ }^{19494}$ Specifically, the Prosecution claims that the ways in which the Accused significantly contributed to achieving the objective of eliminating the Bosnian Muslims in Srebrenica are all reflected in the following three main categories of actions and/or omissions. ${ }^{19495}$

5747. First, the Prosecution submits that the Accused directed and authorised his subordinates within the "three branches of the RS" involved in the forcible removal and killings operations, namely the VRS, the MUP, and the civilian authorities. ${ }^{19496}$ In this regard, the Prosecution claims that, as President of the RS and Supreme Commander of the VRS, the Accused was the only individual in the RS with de jure and de facto authority over the VRS, the MUP, and the civilian authorities, all of whom were involved in the forcible removal of Bosnian Muslim women, children, and elderly men from Srebrenica, as well as in the killing of the men and boys. ${ }^{19497}$ It alleges that the Accused alone could direct, approve, and authorise the participation of all three branches in the forcible removal and murder operations, and that all three branches obeyed his orders, acted in concert, and reported to him while carrying out such operations. ${ }^{19498}$ The Prosecution further claims that there were both official and unofficial functioning chains of reporting to the Accused during the Srebrenica events, and that he was kept informed through various means, such as regular telephone conversations, in-person contacts with his subordinates,

\footnotetext{
19492 Indictment, para. 20-24. See para. 5674.

19493 Indictment, para. 21.

19494 Indictment, para. 21.

19495 See Indictment, para. 24; Prosecution Final Brief, para. 805-813.

19496 Prosecution Final Brief, para. 806. The Prosecution claims that by doing so the Accused contributed to the Srebrenica JCE as alleged in paragraph 14(d) of the Indictment. See Prosecution Final Brief, paras. 806-808.

19497 Prosecution Final Brief, para. 806.

19498 Prosecution Final Brief, para. 806.
} 
and written reports. ${ }^{19499}$ According to the Prosecution, these streams of information put the Accused on notice of the crimes committed in Srebrenica, including the executions of the men, "almost immediately". ${ }^{19500}$ As such, the Accused directed his subordinates to carry out specific acts in furtherance of the objectives of the Srebrenica JCE. ${ }^{19501}$

5748. Second, the Prosecution argues that the Accused participated in the design and formulation of acts carried out by his subordinates in the implementation of the Srebrenica JCE. ${ }^{19502}$ The Prosecution claims that this occurred primarily through the issuance of orders and the maintenance of oversight. ${ }^{19503}$

5749. Third, the Prosecution contends that—by (i) deliberately failing to take measures to prevent, punish, or investigate his subordinates' involvement in crimes which he knew were being and had been committed pursuant to the Srebrenica JCE and (ii) praising and promoting key members of the Srebrenica JCE - the Accused failed to protect the Bosnian Muslims of Srebrenica, and created and sustained an environment of impunity through which he encouraged the ongoing implementation of the Srebrenica JCE. ${ }^{19504}$

5750. In relation to intent, the Prosecution claims that the Accused, together with other members of the Srebrenica JCE, shared the intent to destroy the Bosnian Muslims of Srebrenica, and explains that this intent manifested itself through the Accused's acts, omissions and statements, as well as through the systematic, co-ordinated, and targeted manner in which the genocidal acts were carried out. ${ }^{19505}$ According to the Prosecution, the Accused's endorsement of the genocide plan was both necessary and instrumental to its success. ${ }^{19506}$ The Accused's genocidal intent was also made clear by his statements after the events took place and in his efforts to cover up the forcible removal and killing operations. ${ }^{19507}$

\footnotetext{
19499 Prosecution Final Brief, paras. 848-854.

19500 Prosecution Final Brief, para. 1079 (further claiming that the Accused's active effort to deflect international attention from the Srebrenica events in and of itself constitutes a substantial contribution to the Srebrenica JCE). See also Prosecution Final Brief, paras. 811 (claiming that the Accused took the lead in keeping the international community at bay so that the implementation of the Srebrenica JCE could proceed to its full conclusion unchecked and without internal pressure); 1078-1081.

19501 Prosecution Final Brief, para. 807.

19502 Prosecution Final Brief, para. 809. The Prosecution claims that by doing so the Accused contributed to the Srebrenica JCE as alleged in paragraph 14(e) of the Indictment. See Prosecution Final Brief, para. 809.

19503

Prosecution Final Brief, para. 809.

19504 Prosecution Final Brief, paras. 810-813 (referring to paras. 14(a), 14(c), 14(d), 14(g), 14(h), and 14(i) of the Indictment).

19505 Prosecution Final Brief, paras. 1096, 1100.

19506 Prosecution Final Brief, para. 1098.

19507 Prosecution Final Brief, paras. 1099.
} 
5751. The Accused argues that to be a member of a JCE, a person must form an agreement with others that a crime will be carried out, and that in this instance it must be proven that the agreement was "not only to murder, or exterminate the men of Srebrenica, but that it was to commit genocide". ${ }^{19508}$ The Accused contends that even if some of the VRS members formed an agreement to commit genocide, there is no evidence indicating that he agreed to such a plan. ${ }^{19509}$ Accordingly, the Accused submits, it has not been established beyond reasonable doubt that he was among a plurality of persons who formed a common plan to commit genocide. ${ }^{19510}$

5752. The Accused also claims that he was never informed about the execution of Bosnian Muslim males from Srebrenica, and that the Prosecution failed to adduce sufficient evidence to conclude beyond reasonable doubt that he was informed, either through meetings, by telephone, or through written reports, of any facts from which he could conclude that genocide would be, was being, or had been committed in Srebrenica. ${ }^{19511}$ In this regard, the Accused contends that knowledge of a crime cannot be inferred merely from contact with others who had such knowledge, and adds that the fact that he had various means of communication available to him is not enough to conclude that he had knowledge of the occurrence of a crime. ${ }^{19512}$ Pointing to events after July 1995, including his acts and conduct, international media and reports of killings, the indictment against him, and his efforts to investigate and prosecute the evidence surrounding Srebrenica, the Accused argues that each of these establish that he was not informed of "genocidal" executions. ${ }^{19513}$ Accordingly, the Accused submits, there is reasonable doubt concerning his knowledge, and he cannot be held liable for the execution of Bosnian Muslim males. ${ }^{19514}$

5753. The Accused further submits that he did not contribute to the execution of a "genocidal plan" and that any alleged omission by him to punish persons for genocide in Srebrenica cannot constitute a significant contribution. ${ }^{19515}$ Finally, the Accused submits that he never shared genocidal intent. ${ }^{19516}$

\footnotetext{
19508 Defence Final Brief, para. 3152.

19509 Defence Final Brief, paras. 3153, 3161.

19510 Defence Final Brief, paras. 3015, 3152-3153, 3161.

19511 Defence Final Brief, paras. 3015-3081, 3112.

19512 Defence Final Brief, paras. 3148-3149.

19513 Defence Final Brief, paras. 3119-3147.

19514 Defence Final Brief, paras. 3014-3015.

19515 Defence Final Brief, paras. 3154-3161.

19516 Defence Final Brief, paras. 3167-3169.
} 
5754. The Chamber notes that the Accused's arguments are framed in terms of his lack of assent to a "joint criminal enterprise to commit genocide". ${ }^{19517}$ The Chamber interprets this challenge to relate to the Accused's alleged membership in the Srebrenica JCE as well as to his responsibility for the crime of genocide. The Chamber will therefore first consider whether the Accused was a member of the common plan to eliminate the Bosnian Muslims in Srebrenica before turning to whether he shared the intent to destroy them.

5755. The Chamber has found above that as Srebrenica fell, Mladić, Živanović, Krstić, Popović, and Kosorić formed a common plan to eliminate the Bosnian Muslims in Srebrenica by forcibly removing the women, children, and elderly men. ${ }^{19518}$ This plan expanded to encompass the killing of the men and boys sometime between the night of 11 July and the morning of 12 July, prior to the commencement of the third meeting at the Hotel Fontana. ${ }^{19519}$ The Chamber has also found that at least Mladić, Beara, and Popović shared this expanded common purpose. ${ }^{19520}$ The Chamber will now examine whether the Accused also shared the common purpose; if so, whether he significantly contributed to it; and finally, whether he shared the intent for the commission of each of the crimes set forth above.

\section{ii. Accused's acts and conduct in context}

5756. As the Chamber has described above, the Accused issued Directive 7, which included an order to the Drina Corps to "create an unbearable situation of total insecurity with no hope of further survival or life for the inhabitants of Srebrenica or Žepa", on 8 March $1995 .{ }^{19521}$ The Chamber recalls that Directive 7 instructed the "relevant State and military organs responsible for work with UNPROFOR and humanitarian aid organisations" to "unobtrusively" reduce the resupply of UNPROFOR and limit humanitarian aid to the Bosnian Muslim population, thereby "making them dependent on [the Bosnian Serbs'] good will while at the same time avoiding condemnation by the international community and international public opinion". ${ }^{19522}$ The Chamber has already found that this directive was indeed implemented through the subsequent restriction of access to Srebrenica for humanitarian aid and UNPROFOR re-supply convoys as described above. ${ }^{19523}$

\footnotetext{
19517 See Defence Final Brief, para. 3015. See also Defence Final Brief, paras. 3152 (referring to an "agreement [...] to commit genocide"), 3161 (referring to a "common plan to commit genocide").

19518 See paras. 5724-5727.

19519 See para. 5731.

19520 See paras. 5736-5737.

19521 See para. 5681.

19522 See para. 4980.

19523 See paras. 4989-4992.
} 
5757. Six days after issuing Directive 7, the Accused issued a decision forming a State Committee for Co-operation with the UN and International Humanitarian Organisations ("State Committee"), which-pursuant to the decision of the Accused-was headed by Koljević. ${ }^{19524}$ Following its formation, the State Committee was responsible for approving the passage of humanitarian aid convoys, while the VRS was responsible for approving the passage of UNPROFOR re-supply convoys and retained the right to disagree with the decisions of the State Committee, as well as control over the movement of the convoys. ${ }^{19525}$ However, before negotiating with UNPROFOR, the Main Staff informed the Accused and the RS Presidency about its activities and sought "guidance" in relation to such matters; the Accused thus controlled the policy of restriction which was implemented by Mladić. ${ }^{19526}$

5758. Additionally, in a series of meetings with UNPROFOR which took place in the spring of 1995, the Accused stated that he would not allow humanitarian aid to reach the eastern enclaves, including Srebrenica, as long as the Bosnian Serbs were subject to international sanctions. ${ }^{19527}$ At the beginning of June, the Accused co-ordinated closely with Mladic regarding the passage of convoys in anticipation of Slobodan Milošević conducting negotiations to lift the sanctions. ${ }^{19528}$ The Chamber is thus satisfied that the Accused maintained control over the passage of convoys during the weeks and months following the issuance of Directive 7; during that time, conditions in Srebrenica deteriorated to disastrous levels and by the end of June, some residents had died of starvation. ${ }^{19529}$

\footnotetext{
19524 P4543 (Decision of Radovan Karadžić), pp. 1, 3; D3279 (Radovan Karadžić's Decisions, 14 March 1995), pp. 1, 3.

19525 Manojlo Milovanović, T. 25793-25794 (5 March 2012); Ljubomir Obradović, P4444 (Transcript from Prosecutor v. Tolimir), T. 12022; Slavko Kralj, D3245 (Transcript from Prosecutor v. Popović et al.), T. 29277, 29280 (stating that the co-ordination organ had an influence on the passage of UNPROFOR convoys). See also Radislav Krstić, D4136 (Transcript from Prosecutor v. Krstić), T. 6402-6405; para. 4985.

19526 Slavko Kralj, D3245 (Transcript from Prosecutor v. Popović et al.), T. 29282-29283; Rupert Smith, T. 1141911420 (9 February 2011).

19527 Rupert Smith, T. 11347, 11351, 11355-11359 (8 February 2011); P2260 (UNPROFOR report re meeting with Radovan Karadžić, 5 April 1995), para. 3. See also P2262 (UNPROFOR report re meetings with Bosnian Serb and Bosnian Muslim leadership, 30 April 1995), para. 12; P2264 (UNPROFOR report re meeting with Radovan Karadžić, 9 May 1995), para. 5. The Accused also stated that he had information that the enclaves were well supplied and that aid was being used to supply the ABiH. P2260 (UNPROFOR report re meeting with Radovan Karadžić, 5 April 1995), para. 3; P2262 (UNPROFOR report re meetings with Bosnian Serb and Bosnian Muslim leadership, 30 April 1995), para. 12; P2264 (UNPROFOR report re meeting with Radovan Karadžić, 9 May 1995), para. 5. The Chamber recalls its finding that while isolated incidents of misappropriation or smuggling may have occurred, neither UNPROFOR nor the humanitarian aid organisations supplied the ABiH as a matter of practice; the Chamber further recalls its determination that the regulations on convoy movement were applied arbitrarily and ultimately inhibited the flow of humanitarian aid to Srebrenica completely. See fn. 16804.

19528 P1473 (Ratko Mladić's notebook, 27 January-5 September 1995), pp. 168, 177; P5018 (Aide mémoire to the President for the conversation with Ratko Mladić, 9 June 1995); P2242 (Radovan Karadžić's agenda, 2 January25 December 1995), e-court pp. 73-74.

19529 See paras. 4991-4992.
} 
5759. The Chamber further recalls that on 28 June 1995, the Accused and Krajišnik visited Krstić, who was then Deputy Commander of the Drina Corps, at the Drina Corps Command in Vlasenica and gave him a combat assignment. ${ }^{19530}$ Several days later, Živanović, who was then Commander of the Drina Corps, issued an order for active combat operations aimed at splitting the enclaves of Srebrenica and Žepa and reducing them to their urban areas. ${ }^{19531}$ The Bosnian Serb Forces initially made slow progress towards Srebrenica; when on 8 July Živanović enquired about the possibility of obtaining reinforcements from the RS MUP, the Accused told him that the Drina Corps would have to proceed with its own forces as "the entire MUP" was engaged elsewhere. ${ }^{19532}$ Živanović nevertheless requested that a company of Zvornik MUP forces be engaged as reserve forces for Drina Corps units in his daily combat report that evening. ${ }^{19533}$

5760. The Chamber recalls that in the late afternoon on the following day, Tolimir contacted the Accused and relayed the information that the conditions for taking Srebrenica had been created, and the Accused then approved the expansion of the Krivaja 95 plan and ordered the Bosnian Serb Forces to take over the town. ${ }^{19534}$ On 10 July, pursuant to an order from the Accused, part of the MUP forces which had been deployed in the Trnovo area were redeployed towards Srebrenica. ${ }^{19535}$ Between 5 and 5:20 p.m. on 10 July, the Accused met with Dragan Kijac, the head of the RDB, and Milenko Karišik, the head of the RJB. ${ }^{19536}$

5761. Late in the afternoon on 11 July, after previously telling the Accused that "everything [wa]s going according to plan and do not worry", Gvero informed the Accused that the Bosnian Serb Forces had taken Srebrenica. ${ }^{19537}$ This information was also included in the daily combat report the Accused received from the Main Staff that evening, which stated that the VRS had entered Srebrenica town. ${ }^{19538}$ That evening, the Accused issued three orders which pertained to the situation on the ground in Srebrenica; the first two established Bosnian Serb municipal structures there. First, the Accused appointed Deronjić as civilian commissioner for Srebrenica and

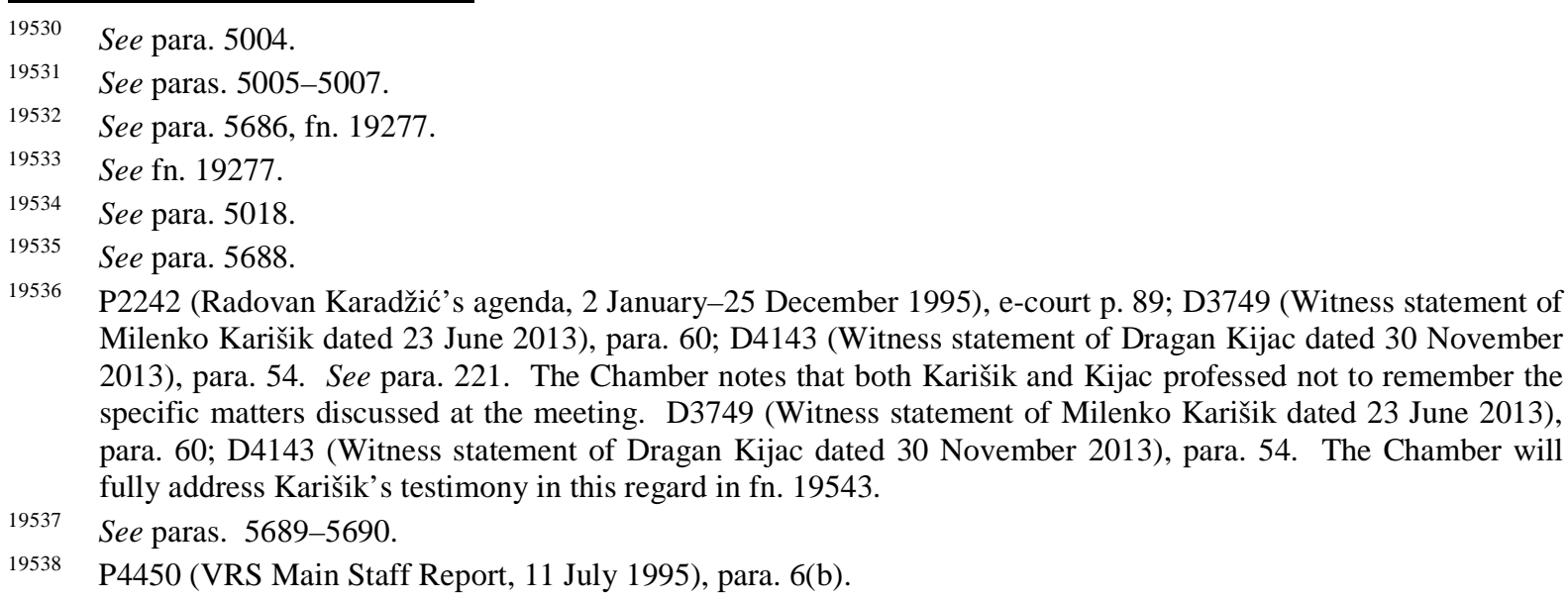

19536 P2242 (Radovan Karadžić's agenda, 2 January-25 December 1995), e-court p. 89; D3749 (Witness statement of Milenko Karišik dated 23 June 2013), para. 60; D4143 (Witness statement of Dragan Kijac dated 30 November 2013), para. 54. See para. 221. The Chamber notes that both Karišik and Kijac professed not to remember the specific matters discussed at the meeting. D3749 (Witness statement of Milenko Karišik dated 23 June 2013), para. 60; D4143 (Witness statement of Dragan Kijac dated 30 November 2013), para. 54. The Chamber will fully address Karišik's testimony in this regard in fn. 19543.

19537 See paras. 5689-5690.

19538 P4450 (VRS Main Staff Report, 11 July 1995), para. 6(b). 
determined the functions he should have while holding that post. ${ }^{19539}$ Second, the Accused issued an order to the RS MUP to form an SJB in "Serb Srebrenica". ${ }^{19540}$ According to the order, the RS MUP was instructed to establish close co-operation with Deronjić. ${ }^{19541}$ Third, the Accused issued an order stating that henceforth, only the State Committee would give approval for humanitarian convoys, following prior consultations with the Accused himself. ${ }^{19542}$

5762. Between 10:30 and 10:45 p.m. on 11 July, the Accused met in his office with Karišik. ${ }^{19543}$ Later that night, at 1 a.m. on 12 July, the Accused had a brief telephone conversation with

19539 See para. 5693. The Chamber further recalls that while meeting with approximately 20 "Serb officials in Srebrenica" that evening, Deronjić established a telephone connection with the Accused, who told the attendees at the meeting that Deronjić was "directly responsible with his life" for all civilian affairs in Srebrenica and that all others were to report directly to Deronjić. See para. 5694.

19540 P2994 (Radovan Karadžić's Order, 11 July 1995). See also para. 226.

19541 P2994 (Radovan Karadžić’s Order, 11 July 1995), para. 5. See also Christian Nielsen, T. 16338 (7 July 2011).

19542 P5183 (RS Presidential Order, 11 July 1995), paras. 1-2. The order was immediately disseminated to the VRS Main Staff and was disseminated by the RS MUP on the following day. See P2803 (RS Communication Centre telegram logbook, 3-18 July 1995), p. 3 (line 326); P2997 (Radovan Karadžić's Order, forwarded by RS MUP, 12 July 1995). Failure to implement the order was to result in swift legal sanctions. P5183 (RS Presidential Order, 11 July 1995), para. 8.

19543 P2242 (Radovan Karadžić's agenda, 2 January-25 December 1995), e-court p. 90; D3749 (Witness statement of Milenko Karišik dated 23 June 2013), para. 60. The Prosecution claims that the purpose of Karišik's visit to the Accused that evening was to report on the deployment of MUP forces to the Srebrenica area. Prosecution Final Brief, para. 905. The Chamber notes that Karišik first testified that he did not recall the meeting specifically, and asserted that, at the time, he had "focused on the fierce fighting that was going on around Sarajevo" and could not recall having any discussions with the Accused regarding Srebrenica. D3749 (Witness statement of Milenko Karišik dated 23 June 2013), para. 60; Milenko Karišik, T. 40608 (27 June 2013), T. 40679-40681 (2 July 2013). See also D3756 (SRNA news report, 7 July 1995); D3757 (SRNA news report, 13 July 1995); D3758 (SRNA news report, 14 July 1995). Furthermore, Karišik affirmatively stated that he had not discussed Srebrenica with the Accused because he had had no information about Srebrenica at the time. Milenko Karišik, T. 40615-40616 (27 June 2013). The Chamber notes, however, that during the days leading up to, and on the day of, his meeting with the Accused and Kijac on 10 July, Karišik had been receiving information from the RDB updating him on the progress of VRS forces towards Srebrenica and other relevant military updates. See e.g. P4927 (Report of Bijeljina RDB, 6 July 1995) (addressed to the RS MUP and the VRS Security Department and reporting intelligence that Naser Orić sought to return from Tuzla to Srebrenica at the time); P4928 (Report of Sarajevo RDB, 6 July 1995) (forwarding P4927 to Karišik personally); P4932 (Report of Bijeljina RDB, 10 July 1995) (addressed to the RS MUP and the VRS Security Department and reporting intelligence about VRS progress towards Srebrenica as well as intelligence regarding the requests of members of the Muslim Forces in Srebrenica then deployed around Sarajevo to return to the enclave); P4933 (Report of Sarajevo RDB, 10 July 1995) (forwarding P4932 to Karišik personally). This reporting continued during the following days. See P5089 (Report of Sarajevo RDB, 11 July 1995); P2986 (Report of Sarajevo RDB, 12 July 1995); P5091 (Report of Sarajevo RDB, 12 July 1995); P4936 (Report of Sarajevo RDB, 12 July 1995); P4939 (Report of Sarajevo RDB, 12 July 1995) (all addressed to Karišik personally). Furthermore, that day, Karišik had in fact travelled to Zvornik, where he "expressed an interest" in the work of the Zvornik SJB. P6190 (Excerpt from Mane Đurić's diary), e-court p. 1; Mane Đurić, T. 35037 (7 March 2013). See also P4581 (Excerpt from tactical intercept notebook, 11 July 1995) (demonstrating that Karišik, a.k.a. "Karlo", was on the ground in Zvornik on 11 July); Milenko Karišik, T. 40612-40615 (27 June 2013) (accepting that "Karlo" was his nickname). That day, Karišik had received a report from the DB that the Muslim Forces in Srebrenica "had enough forces to stop a Serbian offensive". P5089 (Report of Sarajevo RDB, 11 July 1995). At the time, one company of the PJP of the Zvornik CJB was preparing to deploy to Srebrenica in order to reinforce the VRS pursuant to the Accused's order of the previous day. See fn. 16976. When presented with this evidence, Karišik continued to claim that he could not recall whether he had made such a trip, although he eventually accepted that it was a possibility. Milenko Karišik, T. 40611-40615 (27 June 2013). The Chamber considers that Karišik had an interest in distancing himself from the events in Srebrenica and that his evidence in this regard was marked by insincerity and evasiveness. See e.g. D3749 (Witness statement of Milenko Karišik dated 23 June 2013), paras. 40, 60; Milenko Karišik, T. 40590-40594, 40604, 40608-40609, 40617-40624 (27 June 2013). The Chamber finds that 
Živanović. ${ }^{19544}$ Živanović testified that he updated the Accused on the "liberation" of Srebrenica and told him that there had been no casualties on either side. ${ }^{19545}$ According to Živanović, the Accused was satisfied with that fact, and the conversation ended. ${ }^{19546}$

5763. Around the same time, Kovač forwarded the Accused's order to the RS MUP to form an SJB in "Serb Srebrenica" to Vasić, the Chief of the Zvornik CJB at the time, further ordering him to establish the SJB in Srebrenica that day while ensuring close co-operation with Deronjić. ${ }^{19547}$ Regardless of how the order was transmitted to Vasić, it is clear to the Chamber that it was implemented. The Chamber recalls that around 8 a.m. on 12 July, Vasić met with Mladić, Krstić, and Deronjić at the Bratunac Brigade Command. ${ }^{19548}$ Following that meeting, Vasić reported to Kovač that, as ordered, he had contacted Deronjić and had met with Mladić and Krstić during the 8 a.m. meeting at the Bratunac Brigade Command, where "tasks were assigned to all participants". 19549 Vasić also informed Kovač that the third Hotel Fontana meeting was taking place at $10 \mathrm{a} . \mathrm{m}$. in order to reach an agreement on the "evacuation of the civilian population from Potočari to Kladanj", and that 100 trailer trucks had already been provided for that purpose. ${ }^{19550}$ Finally, Vasić reported that joint police forces were advancing on Potočari "with the aim of taking

Karišik's evidence was replete with evasiveness and contradictions, and concludes that despite his denial, Karišik in fact travelled to Zvornik. However, the Chamber will not make a finding as to the content of the conversation between Karišik and the Accused during their meeting on the night of 11 July.

19544 D3932 (Witness statement of Milenko Živanović dated 27 October 2013), para. 8.

19545 D3932 (Witness statement of Milenko Živanović dated 27 October 2013), para. 8.

19546 D3932 (Witness statement of Milenko Živanović dated 27 October 2013), para. 8.

19547 P2995 (Radovan Karadžić's 11 July 1995 Order, forwarded by RS MUP, 12 July 1995); Christian Nielsen, T. 16338-16339 (7 July 2011). Kovač also forwarded the Accused's order requiring the approval for the passage of humanitarian aid convoys through RS territory to be given exclusively by the State Committee following consultation with him personally; Kovač's order incorporated additional instructions for the implementation of the Accused's order. P2997 (Radovan Karadžić's Order, forwarded by the RS MUP on 12 July 1995). The Chamber notes that although in an interview with the Prosecution in 2003, Kovač stated that the RS MUP order forwarding the Accused's order to Vasić had come from his office with his knowledge, when testifying in this case, Kovač denied having signed this order or having been aware of it at the time. Tomislav Kovač, T. 4273842741 (1 November 2013). See also D3960 (Witness Statement of Tomislav Kovač dated 28 October 2013), para. 115 (asserting that the MUP had issued an order for the implementation of the Accused's decision). The Chamber notes that despite the existence of this apparent discrepancy, Kovač refused to acknowledge it. Tomislav Kovač, T. 42740-42741 (1 November 2013). The Chamber also recalls that at the outset of his testimony, Kovač testified to the truthfulness of his prior interviews. Tomislav Kovač, T. 42718 (31 October 2013). The Chamber refers to its credibility assessment of Kovač at para. 5766.

19548 See para. 5086.

19549 P2996 (Report of Zvornik CJB, 12 July 1995), paras. 1-2. The Chamber notes that when presented with Vasić's report, Kovač asserted that the RS MUP was only interested in its content to the extent that it pertained to Vasić's compliance with the order to establish an SJB in Srebrenica. Tomislav Kovač, T. 42742-42745 (1 November 2013). Noting that the sole addressees of Vasić's report were RS MUP entities, the Chamber considers that the only reasonable inference is that Vasić included the totality of the information described above in order to inform his superiors in the RS MUP. The Chamber finds Kovač's assertion that the remainder of that information was of no interest to the RS MUP absurd and does not accept it.

19550 P2996 (Report of Zvornik CJB, 12 July 1995). para. 5. 
UNPROFOR personnel prisoner, surrounding the entire civilian population, and clearing the terrain of enemy groups". ${ }^{19551}$

5764. On the night of 11 July and into the following day, Kovač was personally informed by Kijac that while an estimated 40,000 Bosnian Muslims had begun to gather in and around the UN Compound in Potočari, there were very few able-bodied men amongst this group. ${ }^{19552}$ When, during the course of the night between 11 and 12 July, the Bosnian Serb Forces became aware of the existence and movement of the column of Bosnian Muslim men, Drina Corps and—at Kovač's direction-MUP units were sent to intercept the column and "mo[p] up the terrain". ${ }^{19553}$

5765. Vasić continued to report to his superiors in the RS MUP throughout 12 and 13 July, noting the absence of Bosnian Muslim males in Potočari, their suspected whereabouts, and efforts to intercept the column of Bosnian Muslim males. Following his initial report on 12 July, Vasić reported that of an estimated 25,000 people gathered in Potočari, less than 10\% were able-bodied males, and although they had requested free passage, "depending on Mladić's decision, able-bodied men may be allowed to go in order to have the others from the woods to surrender, since our command urged them to do so". ${ }^{1954}$ Around 5:30 p.m., Vasić relayed to Kovač intelligence from the Zvornik CJB, which had learned that an estimated 8,000 "men of military age" were in the Konjević Polje and Sandići sector. ${ }^{19555}$ On 13 July, Vasić reported to Kovač's and Karišik's respective offices that although the MUP forces were attempting to block the column, because such forces were "working alone" without the assistance of the VRS, "a lot of problems c[ould] be expected until the operation [wa]s completed". ${ }^{19556}$ Later, ${ }^{19557}$ Vasić sent a further report to the same recipients stating that after having met with Mladić that morning, ${ }^{19558}$ the VRS was "continuing operations towards Žepa and leaving all other work to the MUP”, including the transport of an estimated remaining 15,000 Bosnian Muslims to Kladanj, and the "killing of about

\footnotetext{
19551 P2996 (Report of Zvornik CJB, 12 July 1995), para. 6.

19552 P2986 (Report of Sarajevo RDB, 12 July 1995) (reporting on the developments of 11 July); P5091 (Report of Sarajevo RDB, 12 July 1995), p. 1; P4936 (Report of Sarajevo RDB, 12 July 1995); P4939 (Report of Sarajevo RDB, 12 July 1995), pp. 1-2.

19553 See para. 5158.

19554 P4935 (Report of Zvornik CJB, 12 July 1995), paras. 1-4 (emphasis added). Vasić further reported that a company of the Zvornik PJP had been dispatched to Srebrenica town in order to protect facilities against looting and misappropriation of property, and that a platoon of the company would be sent to intercept the column of Bosnian Muslim men fleeing towards Buljim. P4935 (Report of Zvornik CJB, 12 July 1995), para. 5.

19555 P4937 (Report of Zvornik CJB, 12 July 1995).

19556 P6189 (Report of Zvornik CJB, 13 July 1995).

19557 The Chamber notes that although no time stamp appears on P6189, the sequential numbering on P6189 and P4942 reveals that the former preceded the latter. Compare P6189 (Report of Zvornik CJB, 13 July 1995); P4942 (Report of Zvornik CJB, 13 July 1995) (referring to the 8 a.m. meeting at the Bratunac Brigade Command).

19558 The Chamber recalls that that morning, Vasić met with Mladić, Krstić, Popović, and Pandurević at the Bratunac Brigade Command. See para. 5705.
} 
8,000 Bosnian Muslim soldiers whom we blocked in the woods near Konjević Polje". ${ }^{19559}$ Thereafter, Kovač began personally forwarding to Vasić intelligence that the RS MUP had received from the VRS. ${ }^{19560}$ That day, Kovač also dispatched a company of the Doboj PJP to Zvornik. ${ }^{19561}$

5766. Between 3:50 and 4:10 p.m. on 13 July, the Accused met Kovač in Pale. ${ }^{19562}$ Immediately thereafter, Kovač departed towards Vlasenica. ${ }^{19563}$ The Chamber notes that Kovač testified that during this meeting, he and the Accused discussed the situation around Sarajevo, which Kovač claimed he had felt was of far greater concern at the time. ${ }^{19564}$ However, having analysed the entirety of Kovač's testimony in light of the totality of the evidence, the Chamber notes numerous internal inconsistencies within Kovač's testimony, ${ }^{19565}$ as well as inconsistencies with prior statements given under oath. ${ }^{19566}$ In the Chamber's view, these inconsistencies, as well the evasiveness and even intermittent combativeness displayed by Kovač throughout his testimony, ${ }^{19567}$ arise from Kovač's efforts to minimise his own involvement in the events in Srebrenica in July

19559 P4942 (Report of Zvornik CJB, 13 July 1995), paras. 1-2. See also Richard Butler, T. 27542-27543 (18 April 2012) (testifying that the reference to killing referred to an ongoing military operation against the portion of the column which had not managed to cross the Konjević Polje-Nova Kasaba Road).

19560 See P2988 (Report of RS MUP, 13 July 1995) (forwarding to Vasić a dispatch received from the Drina Corps Security Organ describing the movement of the column); P5098 (Report of RS MUP, 13 July 1995) (forwarding to Vasić two dispatches received from the Drina Corps command regarding the movement of the column). The second of these two documents was sent after 12:30 p.m. See P5098 (Report of RS MUP, 13 July 1995), p. 1. At the same time, Vasić was also receiving information about the column from Karišik, who forwarded information received from the RDB through the Police Forces Command Staff in Pale. P4943 (Report of Sarajevo RDB, 13 July 1995) (reporting that an estimated 10,000 "able-bodied Muslims" from Srebrenica had gathered near Šušnjari on the night of 11 July, had begun to depart in an attempt to reach Tuzla the following morning, but had begun to be caught in RS MUP ambush operations along the Bratunac-Konjević Polje Road on the night of 12 July); P5099 (Report of Bijeljina RJB, 13 July 1995) (passing along information contained in P4943).

19561 P5146 (Order of RS MUP, 13 July 1995). See also Tomislav Kovač, T. 42764 (1 November 2013).

19562 P2242 (Radovan Karadžić's agenda, 2 January-25 December 1995), e-court p. 91.

19563 D3960 (Witness Statement of Tomislav Kovač dated 28 October 2013), para. 117 (further asserting that he had departed towards Bijeljina in order to organise the transport of ammunition and fuel towards Sarajevo when he had been stopped at a check-point in Vlasenica and told that Mladić wished to see him.); Tomislav Kovač, T. 42767-42771 (1 November 2013).

19564 D3960 (Witness Statement of Tomislav Kovač dated 28 October 2013), para. 117; Tomislav Kovač, T. 42764 42766 (1 November 2013); T. 42855-42856 (4 November 2013).

19565 For example, after first adopting testimony from a prior case in which he had stated that he had gone to the Srebrenica area pursuant to an order from the Accused, Kovač later denied that he had done so. Compare Tomislav Kovač, T. 42766-42767 (1 November 2013) with Tomislav Kovač, T. 42792-42793 (1 November 2013) (stating that he had gone to the field of his own volition) and Tomislav Kovač, T. 42840-42841 (4 November 2013). Compare also D3960 (Witness statement of Tomislav Kovač dated 28 October 2013), para. 124 with Tomislav Kovač, T. 42785-42789 (1 November 2013).

19566 For example, the Chamber refers to its description of Kovač's testimony regarding the transmission of the Accused's 10 July order to deploy RS MUP forces to Srebrenica set out at fn. 19288. See also Tomislav Kovač, T. 42823-42825 (1 November 2013); D3960 (Witness statement of Tomislav Kovač dated 28 October 2013), para. 133; compare Tomislav Kovač, T. 42827-42830 (1 November 2013).

19567 See e.g. Tomislav Kovač, T. 42782-42783, 42786-42788, 42794-42795, 42808-42813 (1 November 2013). 
1995. ${ }^{19568}$ The Chamber has therefore approached his testimony with extreme caution and has only relied upon it where it is consistent with other evidence.

5767. In this regard, the Chamber is mindful that from the commencement of the Srebrenica operation on 6 July, Kovač had been receiving reports which were forwarded to him personally by Kijac and contained intelligence from the DB and the VRS regarding the progress of the Srebrenica operation. ${ }^{19569}$ This continued throughout the day on 12 and 13 July. ${ }^{19570}$ At the same time, Kovač had begun receiving updates from Vasić—and responded to the developments described by Vasić by forwarding information received by the VRS to him directly—as described above. ${ }^{19571}$ Against this backdrop, mindful of the fact that the RS MUP units had been deployed to the Srebrenica sector pursuant to the Accused's order which was conveyed through Kovač, and considering that Kovač departed immediately towards Vlasenica following their meeting, the Chamber finds it inconceivable that Kovač did not discuss the developments on the ground in Srebrenica-including the reports he had received from the DB, as well as the communications received from Vasić and his own response-with the Accused during their meeting on 13 July.

19568 For example, even when presented with evidence demonstrating that he had ordered the further deployment of "all available guides with police dogs" to Srebrenica on 12 July, Kovač insisted that there had been no need for the MUP to be sent to Srebrenica. Tomislav Kovač, T. 42721 (31 October 2013), T. 42747 (1 November 2013); P4934 (RS MUP Order to the centre for the breeding and training of police dogs, 12 July 1995). He stated that MUP forces were only deployed in order to secure roads and disclaimed any knowledge of DB operatives being involved in the separation and interrogation of men in Potočari. Tomislav Kovač, T. 42721 (31 October 2013) (stating that "only the Sarajevo front was under threat" at the time); Tomislav Kovač, T. 42749-42752, 42755, 42794-42795 (1 November 2013) (distancing himself from the work of the DB before accepting that Kijac had addressed documents to him personally).

19569 See e.g. P4927 (Report of Bijeljina RDB, 6 July 1995); P4932 (Report of Bijeljina RDB, 10 July 1995); P4928 (Report of Sarajevo RDB, 6 July 1995) (forwarding P4927 to Kovač and Karišik personally); P4933 (Report of Sarajevo RDB, 10 July 1995) (forwarding P4932 to Kovač and Karišik personally). See also P5089 (Report of Sarajevo RDB, 11 July 1995).

19570 P2986 (Report of Sarajevo RDB, 12 July 1995) (reporting that by 4 p.m. on 11 July, 20,000 Bosnian Muslims had gathered in Potočari, that by 5 p.m. on the same day, 60,000 "refugees" had "left Srebrenica for the north", and that the latter's overall position was expected to be "hopeless in 48 hours"); P5091 (Report of Sarajevo RDB, 12 July 1995) (reporting that the VRS had advanced towards Potočari, where an estimated 10,000 Bosnian Muslims were reported to be staying on the premises of the UN Compound); P4936 (Report of Sarajevo RDB, 12 July 1995) (providing an update indicating that 30,000 Bosnian Muslims had gathered around the UN Compound, another 8,000 were still attempting to reach it, and stating that "according to reports by military observers, there is not a single armed soldier of the so-called BH Army among th[e] people" present in Potočari and referred to possible means that had been proposed "in the event of evacuation of the population via Zvornik, as reportedly proposed by the Serbian side"); P4939 (Report of Sarajevo RDB, 12 July 1995) (reporting sometime after 4 p.m. on the movement of a column composed of "several thousand people, most of them conscripts from the Srebrenica area" and that approximately 8,500 people-mostly women and children-had been transported that afternoon and reiterating that there were "hardly any" able-bodied men fit for fighting in Potočari); P4389 (Report of Sarajevo RDB, 13 July 1995), p. 1 (reporting that the Bosnian Serb Forces had captured over 300 members of the column during the night between 12 and 13 July); D4152 (Report of Sarajevo RDB, 13 July 1995) (reporting that a UN observer patrol reported to its base in Živnice that a column of refugees from Srebrenica was moving towards Živnice). Kovač continued to receive such reports on 14 July as well. See e.g. P5093 (Report of Sarajevo RDB, 14 July 1995); P5092 (Report of Sarajevo RDB, 14 July 1995); D2058 (Letter from RDB to Bijeljina Public Security Department, 14 July 1995) (noting that the DB's reports had been submitted to the Zvornik SJB and PJP as well as Borovčanin in the field). 
5768. After Kovač's departure, between 5 and 6:40 p.m., the Accused met with three members of the Serbian diaspora, ${ }^{19572}$ Srđa Trifković, Tomislav Premović, and Slavica Ristić. ${ }^{19573}$ Zametica and Krajišnik also attended the meeting intermittently. ${ }^{19574}$ According to Ristić, the outset of the meeting was very relaxed, as the Accused was attempting to establish an external telephone connection with "somebody", 19575 while Ristić chatted with Krajišnik. ${ }^{19576}$ At one point during the meeting, a telephone connection was established, and the Accused had an hour-long conversation, part of which occurred over the speakerphone. ${ }^{19577}$ Ristic recalled that it had been very difficult to hear because the line kept going down. ${ }^{19578}$ However, the end result of the conversation was that

19572 P4556 (Slavica Ristić's interview with OTP, 5 April 2009), pp. 9-10; P4911 (Tomislav Premović's interview with the OTP, 27 April 2009), pp. 8-9; D2905 (Witness statement of Srđa Trifković dated 5 February 2013), paras. 5-9. Trifković, who had met the Accused in 1993, arranged the visit to Pale in July 1995 and invited Ristić and Premović to accompany him. D2905 (Witness statement of Srđa Trifković dated 5 February 2013), para. 9; P4556 (Slavica Ristić's interview with OTP, 5 April 2009), pp. 14-18; P4911 (Tomislav Premović's interview with the OTP, 27 April 2009), p. 40.

19573 P4367 (Excerpt from appointment calendar of Radovan Karadžić, 14 July 1995); Slavica Ristić, T. 26071 (12 March 2012); P4556 (Slavica Ristić's interview with OTP, 5 April 2009), pp. 31-35; Tomislav Premović, T. 27406, 27419 (12 April 2012); P4911 (Tomislav Premović's interview with the OTP, 27 April 2009), pp. 54, 56-65. See also D2905 (Witness statement of Srđa Trifković dated 5 February 2013), para. 28; Srđa Trifković, T. 33353 (6 February 2013). The Chamber notes that Premović insisted that his memory of the meeting was limited because it had just been "a friendly visit" that consisted mostly of "small talk". P4911 (Tomislav Premović's interview with the OTP, 27 April 2009), pp. 61, 72. Premović also exhibited confusion regarding the date when the meeting had occurred, as well as whether it had taken place on the day he arrived or the following. See P4911 (Tomislav Premović's interview with the OTP, 27 April 2009), pp. 42-44, 51-54; Tomislav Premović, T. 27391, 27406, 27419 (12 April 2012). However, based on the totality of evidence before it, the Chamber is satisfied that Premović described the same meeting attended by Ristić and Trifković, and that it took place on 13 July. The Chamber also notes that throughout his evidence, Trifković gave many indications of bias, including making negative comments against the Tribunal, as well as against the Islamic faith. See e.g. Srđa Trifković, T. 33337-33359 (6 February 2013); P6099 (Article from Mission Europa Netzwerk Karl Martell entitled "Can the West be Saved?", 10 May 2008); P6100 (Article from Chronicles Magazine entitled "Dinesh the Dhimmi", 26 January 2007); P6101 (Article from Pogledi entitled "Islamic Terrorism in Italy: Shape of Things to Come", 27 February 2002); P6098 (Video clip of Srđa Trifković's university speech, with transcript) (making reference to a "traitor class"). In the Chamber's view, Trifković's evidence was so vitriolic and partisan that the Chamber approached his evidence with the utmost caution and circumspection. The Chamber has therefore only relied upon his evidence where corroborated by Ristić and Premović.

19574 P4556 (Slavica Ristić's interview with OTP, 5 April 2009), pp. 34-40; Slavica Ristić, T. 26075 (12 March 2012); P4560 (Photographs of Slavica Ristić's meeting with Radovan Karadžić, 13 July 1995), p. 3 . See also P4911 (Tomislav Premović's interview with the OTP, 27 April 2009), pp. 58-59.

19575 According to Ristić, the Accused had only one phone on his desk, but he "would go outside to talk to somebody to get him the line or — he was very frustrated: get me the line, or what's wrong with the line or [...] so whether another phone, I don't know." P4556 (Slavica Ristić's interview with OTP, 5 April 2009), p. 74. See also Slavica Ristić, T. 26088 (12 March 2012).

19576 P4556 (Slavica Ristić's interview with OTP, 5 April 2009), pp. 34-35.

19577 P4556 (Slavica Ristić's interview with OTP, 5 April 2009), p. 37; Slavica Ristić, T. 26074-26075 (12 March 2012); P4557 (Photographs of Slavica Ristić's meeting with Radovan Karadžić), pp. 3-4; P4911 (Tomislav Premović's interview with the OTP, 27 April 2009), pp. 61-62. See also P4560 (Photographs of Slavica Ristić's meeting with Radovan Karadžić, 13 July 1995), pp. 1, 3.

19578 P4556 (Slavica Ristić's interview with OTP, 5 April 2009), pp. 37-38; Slavica Ristić, T. $26072-26073$ (12 March 2012). Ristić further described the Accused as mostly listening and giving responses such as "uh-huh" or "okay", and did not remember him asking any questions. P4556 (Slavica Ristić's interview with OTP, 5 April 2009), pp. 38-39; Slavica Ristić, T. 26088 (12 March 2012); P4911 (Tomislav Premović's interview with the OTP, 27 April 2009), p. 64 (describing the Accused as mainly responding with "okay"). 
the participants in the meeting understood that Srebrenica "[wa]s done". ${ }^{19579}$ At the end of the conversation, the Accused thanked the person to whom he was speaking personally. ${ }^{19580}$ The Accused also "awarded, rewarded and promoted a couple [...] of the generals", including Krstić. ${ }^{19581}$

5769. Ristic testified that the Accused had addressed the person on the other end of the line as "General Mladić". ${ }^{19582}$ Premović also testified that the person who had called the Accused during their meeting was Mladić. ${ }^{19583}$ The Chamber notes that Trifković insisted that the Accused did not speak with Mladić; ${ }^{19584}$ however, the Chamber recalls its assessment of Trifković's credibility outlined above. ${ }^{19585}$ The Accused acknowledges having spoken to someone from the VRS who informed him about the situation in Srebrenica, but denies that he actually spoke with Mladić, referring to "conflicting evidence", and citing the testimony of Milovanović, ${ }^{19586}$ who agreed that the Accused communicated "mainly" with him between 1 July and 4 August 1995. ${ }^{19587}$ The Chamber notes, firstly, that Milovanović explicitly stated that this did not occur "all the time", but only "a few times". ${ }^{19588}$ Moreover, even if Milovanović's testimony in this regard could be read to

19579 P4556 (Slavica Ristić's interview with OTP, 5 April 2009), pp. $37-39$ (further recalling that she had understood that Žepa would be "the next step"); Slavica Ristić, T. 26073-26074, 26077 (12 March 2012); P4911 (Tomislav Premović's interview with the OTP, 27 April 2009), pp. 48, 52-54, 61-63. The Chamber notes that Premović referred to the conversation having yielded the information that "Žepa fell" but, in light of the fact that the meeting occurred on 13 July, it is satisfied that this should be understood as Srebrenica, and that Premović's recollection of Mladić saying that Srebrenica would be "next" should be understood as referring to Žepa. See P4911 (Tomislav Premović's interview with the OTP, 27 April 2009), p. 71; Tomislav Premović, T. 2740627408, 27414-27415 (12 April 2012). See also Slavica Ristić, T. 26087-26088 (describing having gained the impression that Žepa would be next to be "liberated").

19580 P4556 (Slavica Ristić's interview with OTP, 5 April 2009), p. 47. Ristić recalled that the Accused was "very happy". P4556 (Slavica Ristić's interview with OTP, 5 April 2009), pp. 38-39, 73 (further stating that she had understood that the Accused was happy that now the Bosnian Serbs would have diplomatic bargaining power); Slavica Ristić, T. 26077-26078 (12 March 2012). See also D2905 (Witness statement of Srđa Trifković dated 5 February 2013), para. 28. But see P4911 (Tomislav Premović's interview with the OTP, 27 April 2009), pp. 6566 (stating that there was nothing remarkable about the Accused's mood after the phone call).

19581 P4911 (Tomislav Premović's interview with the OTP, 27 April 2009), pp. 62-63; Tomislav Premović, T. 27415 (12 April 2012). See also P4485 (Drina Corps information, 13 July 1995); P3044 (Radovan Karadžić's Decree, 14 July 1995); KDZ122, T. 26107 (12 March 2012) (closed session); Petar Skrbić, T. 25978-25981 (8 March 2012).

19582 P4556 (Slavica Ristić's interview with OTP, 5 April 2009), p. 47.

19583 P4911 (Tomislav Premović's interview with the OTP, 27 April 2009), pp. 54, 61, 63-64 (stating that the Accused had either told the visitors that the other interlocutor was Mladić or the Accused had addressed Mladić directly). When questioned by the Accused, Premović acknowledged that he was not familiar with Mladić's voice, but asserted that he was "under the impression" that the caller was Mladić. Tomislav Premović, T. 27406 (12 April 2012).

19584 D2905 (Witness statement of Srđa Trifković dated 5 February 2013), paras. 29-32; Srđa Trifković, T. 3331733318, 33342, 33354-33357, 33361 (6 February 2013).

19585 See fn. 19573.

19586 Defence Final Brief, paras. 3017-3019. The Accused points to Milovanović's testimony that between 1 July and 3 August 1995, the Accused communicated with the VRS only through Milovanović. Defence Final Brief, para. 3019. By contrast, the Prosecution asserts that the person to whom the Accused spoke was Mladić. See Prosecution Final Brief, paras. 949-954.

19587 Manojlo Milovanović, T. 25648 (1 March 2012).

19588 Manojlo Milovanović, T. 25648 (1 March 2012). 
suggest that the Accused communicated with Milovanović to the exclusion of all other VRS officers during that period, such testimony would have been directly contradicted by, inter alia, the evidence of the conversation between the Accused and Gvero in the afternoon of 11 July, and the evidence of the conversation between the Accused and Živanović on the night of 11 July. ${ }^{19589}$ Accordingly, the Chamber is satisfied that, as testified by Ristić and Premović, the Accused indeed spoke to Mladić during their meeting on 13 July.

5770. Citing the testimony of Ristić, Premović, and Trifković, the Accused further argues that even if he was speaking to Mladić, the evidence does not establish that they exchanged information about a plan to kill during the conversation, but—on the contrary-demonstrates that the Accused insisted that civilians be well-treated. ${ }^{19590}$ Having already found Trifković to be unreliable on the substance of this conversation, ${ }^{19591}$ the Chamber will now assess the reliability of the evidence of Ristić and Premović on this point. Ristić recalled that after the phone call ended, the topic of conversation at the meeting turned to the treatment of civilians, and although she could not remember what was said specifically, she did recall that Trifković had stressed that the mistreatment of civilians would reflect poorly on Bosnian Serbs. ${ }^{19592}$ The Chamber notes, however, that just after mentioning this in her interview, Ristić offered that it was "difficult for [her] after reading Dr. Trifković's testimony" to separate what she recalled from what she had read. ${ }^{19593}$ The Chamber takes this candid admission to be an indication that her memory of this aspect of the conversation was influenced by her familiarity with the evidence given by Trifković in the Popović et al. case, particularly in light of its favourable portrayal of his contribution to the conversation. ${ }^{19594}$ The Chamber therefore does not rely upon it. The Chamber also notes that Premović stated that he did not remember any discussion of the treatment of civilians or prisoners of war. ${ }^{19595}$ Accordingly, the Chamber is not satisfied that there was any discussion of the treatment of civilians or prisoners of war. Furthermore, the evidence does not establish that there was any explicit indication that the Bosnian Muslim men then being held by the Bosnian Serb

\footnotetext{
19589 See paras. $5690,5762$.

19590 Defence Final Brief, paras. 3020-3024.

19591 See para. 5768, fn. 19573.

19592 P4556 (Slavica Ristić's interview with OTP, 5 April 2009), pp. 43-44. See also Slavica Ristić, T. 26078-26079 (12 March 2012).

19593 P4556 (Slavica Ristić's interview with OTP, 5 April 2009), p. 45.

19594 Trifković gave evidence in the Popović et al. case and shared his testimony with Ristić. P4556 (Slavica Ristić's interview with OTP, 5 April 2009), pp. 25-26. See also P6102 (Excerpt from Srđa Trifković's testimony in Prosecutor v. Popović et al.).

19595 P4911 (Tomislav Premović's interview with the OTP, 27 April 2009), p. 69. See also Tomislav Premović, T. 27406-27407 (12 April 2012).
} 
Forces would be killed. However, the Chamber recalls that, as described above, the exchange yielded the information that Srebrenica was "done". 19596

5771. Around 6 p.m., while the Accused was meeting with Ristić, Premović, and Trifković, Mladić, Krstić, and Živanović returned to the Drina Corps Command and held a short ceremony to mark the transfer of command duties from Živanović to Krstić. ${ }^{19597}$ Around the same time, Kovač arrived from Pale and, according to him, found Mladić inebriated and in a good mood. ${ }^{19598}$ Kovač testified that during the approximately 30 minutes that he was present in Vlasenica, Mladić made numerous phone calls to technical or logistics units to bury "those that had been killed". ${ }^{9599}$

5772. At approximately 8:10 p.m., the Accused was recorded in an intercepted conversation with Deronjić, which was conducted through an intermediary and unfolded as follows:

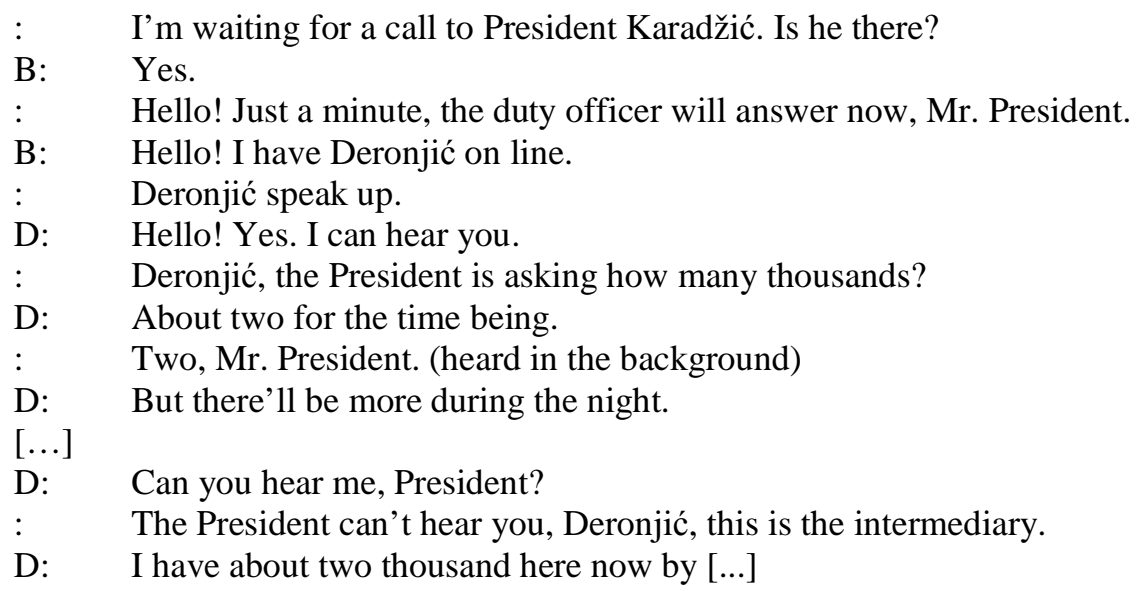

19596 See para. 5768. Both Ristić and Premović understood this to mean that the town had fallen, although Ristić testified that upon later learning that Srebrenica had fallen on 11 July, she did not understand why the Accused would not have already known this by the time they met. P4556 (Slavica Ristić's interview with OTP, 5 April 2009), pp. 37. See also P4911 (Tomislav Premović's interview with the OTP, 27 April 2009), p. 71; Tomislav Premović, T. 27406-27407, 27414-27415 (12 April 2012).

19597 D3932 (Witness statement of Milenko Živanović dated 27 October 2013), paras. 11, 38; P4485 (Drina Corps information, 13 July 1995); P5372 (Intercept of conversation between two unidentified persons, 13 July 1995), p. 2 (indicating that Krstić and Mladić were "outside in front of the building" at 6:22 p.m.). See also Radislav Krstić, D4136 (Transcript from Prosecutor v. Krstić), T. 6233, 6669-6670. Krstić had already been in charge of the attack on Srebrenica since at least 1:45 p.m. on 12 July. See P5278 (Intercept of conversation between Zlatar and a Duty Operations Officer, 12 July 1995) (demonstrating that Krstić was already "in charge" of the attack at 1:45 p.m.).

19598 D3960 (Witness Statement of Tomislav Kovač dated 28 October 2013), para. 117; Tomislav Kovač, T. 42767, 42770-42771 (1 November 2013). See also Zvonko Bajagić, T. 41161-41163 (10 July 2013) (testifying that Mladić was at Bajagić's house on the "afternoon" of 13 July when the chief of police, Milenko Majstorović, arrived and informed Mladić of Kovač's arrival). Kovač testified that when he arrived at the Drina Corps Command, Mladić and the other officers-including Krstić-were bragging about having taken Srebrenica. Tomislav Kovač, T. 42770-42771 (1 November 2013).

19599 D3960 (Witness Statement of Tomislav Kovač dated 28 October 2013), para. 118. Kovač claimed that he understood these calls to relate to the burial of "men who had been killed in combat" rather than to the bodies of those who had been executed. D3960 (Witness Statement of Tomislav Kovač dated 28 October 2013), para. 118. Based on the Chamber's assessment of the credibility of Kovač's evidence as a whole, as discussed above, the Chamber finds Kovač's assertion in this regard to be of extremely low probative value. See para. 5766. 
: Deronjić, the President says: "All the goods must be placed inside the warehouses before twelve tomorrow."

D: Right.

: Deronjić, not in the warehouses over there, but somewhere else.

D: Understood.

: $\quad$ Goodbye. ${ }^{19600}$

5773. The Chamber has already found that the conversation between the Accused and Deronjić pertained to the accommodation of Bosnian Muslim men who were then being held on buses and in detention facilities in Bratunac. ${ }^{19601}$ The Chamber also recalls that Davidović had urged Deronjić to "use [his] connections" with the Accused in order to have the buses moved, that before speaking to the Accused Deronjić had previously complained to Beara about the detainees' presence in Bratunac, and that Beara and Deronjić later argued about whether the detainees would be killed in Bratunac or would be transferred to Zvornik for that purpose. ${ }^{19602}$ During the latter conversation, Deronjić countered Beara's assertion that Beara's "boss" had instructed him that all detainees should remain in Bratunac by saying that the Accused had instructed him that all detainees should be transferred to Zvornik. ${ }^{19603}$ The Chamber therefore finds that during the intercepted conversation described above, the Accused conveyed to Deronjic the direction that the detainees should be transferred to Zvornik.

5774. Between 9:35 and 10:10 p.m., ${ }^{19604}$ the Accused conducted an interview with El País from his office, wherein he stated that "very few Muslims can stay in Srebrenica because they are now beginning to realise that Srebrenica belongs to the Serbian State", but that whoever wanted to stay in Srebrenica could do so. ${ }^{19605}$ The Accused also stated that the enclaves should disappear and that he was willing to put an end to the war "by political or military methods". 19606

5775. Meanwhile, Kovač had left Vlasenica; he arrived at Konjević Polje at approximately 7:30 p.m. and saw Bosnian Muslim male detainees boarding buses. ${ }^{19607}$ The Chamber recalls that, by that time, more than 6,000 Bosnian Muslims had been captured and detained by the Bosnian

\footnotetext{
19600 P6692 (Intercept of conversation between Radovan Karadžić, his intermediary, and Miroslav Deronjić, 13 July 1995), p. 1; KDZ126, T. 26400-26403 (15 March 2012). See paras. 5311, 5710.

19601 See para. 5710.

19602 See paras. 5710, 5712.

19603 See para. 5712.

19604 P2242 (Radovan Karadžić's agenda, 2 January-25 December 1995), e-court p. 91. The Chamber notes that, according to the text of the article, the interview took place on 14 July. P2564 (Radovan Karadžić's interview in El País, 16 July 1995), p. 1. However, according to the Accused's appointment book-the accuracy of which has been established by multiple witnesses-the interview with El País took place on the night of 13 July. P2242 (Radovan Karadžić's agenda, 2 January-25 December 1995), e-court p. 91. The Chamber therefore takes this date as accurate.

19605 P2564 (Radovan Karadžić's interview in El País, 16 July 1995), pp. 3-4.

19606 P2564 (Radovan Karadžić's interview in El País, 16 July 1995), pp. 1-3.

19607 D3960 (Witness Statement of Tomislav Kovač dated 28 October 2013), para. 119.
} 
Serb Forces. ${ }^{19608}$ Kovač spent the night at the Hotel Vidikovac, at the entry of the town of Zvornik. ${ }^{19609}$ That night, Kovač noticed buses transporting detainees from Srebrenica. ${ }^{19610}$ The next morning, around 11 a.m., Kovač travelled to the Bratunac area with Vasić. ${ }^{19611}$ The Chamber notes that while driving to Bratunac, Kovač acknowledged that he passed by the Kravica Warehouse. ${ }^{19612}$ Although Kovač asserted that he did not see anything, the Chamber recalls that the removal of bodies was already well underway by the time Kovač passed by around noon. ${ }^{19613}$ The Chamber is also satisfied that whether he passed the convoy on the road or noticed it waiting at the edge of Bratunac town, Kovač would have seen the convoy of buses carrying the Bosnian Muslim male detainees to Zvornik. ${ }^{19614}$

5776. At 12:15 p.m. on 14 July, the Accused met with Petar Škrbić in the presence of Bogdan Subotić. ${ }^{19615}$ Škrbić brought the Accused documents to sign, including the official decree concerning Živanović's retirement as Commander of the Drina Corps, as well as the decree on Krstić's promotion to Drina Corps Commander and Andrić's promotion as its Chief of Staff. ${ }^{19616}$ During the meeting, the Accused referred to a written report from Gvero which was detrimental to the morale of the VRS, and threatened to "remove" him. ${ }^{19617}$

\footnotetext{
19608 See also para. 5166.

19609 D3960 (Witness Statement of Tomislav Kovač dated 28 October 2013), para. 119; Tomislav Kovač, T. 4279642798 (1 November 2013).

19610 D3960 (Witness Statement of Tomislav Kovač dated 28 October 2013), para. 126; Tomislav Kovač, T. 42776 (1 November 2013).

19611 D3960 (Witness Statement of Tomislav Kovač dated 28 October 2013), para. 120; Tomislav Kovač, T. 4277742778 (1 November 2013); D3659 (Witness statement of Ljubomir Borovčanin dated 30 May 2013), para. 40.

19612 Tomislav Kovač, T. 42778-42780 (1 November 2013).

19613 Tomislav Kovač, T. 42778-42780 (1 November 2013). See also para. 5427.

19614 See paras. 5315-5316.

19615 Petar Škrbić, P4523 (Transcript from Prosecutor v. Popović et al.), T. 15484-15486; P2242 (Radovan Karadžić's agenda, 2 January-25 December 1995), e-court p. 91.

19616 Petar Škrbić, P4523 (Transcript from Prosecutor v. Popović et al.), T. 15484-15486; Petar Škrbić, T. 2597725978, 26035 (8 March 2012). See P3044 (Radovan Karadžić's Decree, 14 July 1995). The appointments were to be effective as of 15 July. P3044 (Radovan Karadžić's Decree, 14 July 1995). Škrbić testified that nobody mentioned Srebrenica during the meeting, and that he only learned about the fall of Srebrenica after the war. Petar Škrbić, P4523 (Transcript from Prosecutor v. Popović et al.), T. 15580-15581, 15601; Petar Škrbić, T. 25987, 25590 (8 March 2012). Given Škrbić's position at the time, as well as the fact that the documents Škrbić brought to the Accused for signature related to the promotion of the officer in charge of the attack on Srebrenica, the Chamber finds this to be inconceivable, and considers that Škrbić's testimony in this regard is yet another example of a witness trying to distance himself from the crimes committed in Srebrenica at the time. The Chamber also notes Subotić's evidence that he had no knowledge of any crimes being committed against the Bosnian Muslims in Srebrenica. D3695 (Witness statement of Bogdan Subotić dated 16 June 2013), para. 237. The Chamber has therefore approached Škrbić and Subotić's evidence with caution.

19617 Petar Škrbić, P4523 (Transcript from Prosecutor v. Popović et al.), T. 15486-15488.
} 
5777. The Accused then met with Deronjić alone between 12:40 p.m. and 1:10 p.m. ${ }^{19618}$ At 2:25 p.m., the Accused met with a larger delegation from Srebrenica-including Dane Katanić, Milenko Čanić, Momčilo Cvjetinović, and Deronjić himself-in the presence of Krajišnik. ${ }^{19619}$ This larger meeting lasted for four hours, ${ }^{19620}$ and during that time, the Accused decided to form the War Presidency of Srebrenica-Skelani Municipality and appointed Deronjić as the president of that body. ${ }^{19621}$ The Accused issued a written decision on the appointment of the War Presidency later that day. ${ }^{19622}$

5778. At around 6 p.m., while meeting with Robert Đurđević, who was seeking to interview the Accused about a rumoured rift between himself and Mladić, ${ }^{19623}$ the Accused received a phone call from a "field commander defending the major road north of Srebrenica", reporting that thousands of "Muslim soldiers" were in the woods trying to "break through towards Tuzla". 19624 The Chamber finds this evidence to be consistent with the development of the events on the ground at

19618 P2242 (Radovan Karadžić's agenda, 2 January-25 December 1995), e-court p. 91 (noting, in parentheses, above Deronjić's name the notation "12:40 p.m.-1:10 p.m."). The Chamber notes that the meeting was originally scheduled to commence at 11 a.m. but did not in fact begin until 12:40 p.m.. See Mira Mihajlović, T. 2430424306 (8 February 2012).

19619 P4382 (Video footage re Miroslav Deronjić's meeting with Radovan Karadžić in Pale, 14 July 1995); Milenko Katanić, T. 24476-24477 (10 February 2012); D3561 (Witness statement of Dane Katanić dated 14 December 2012), para. 7.

19620 P2242 (Radovan Karadžić's agenda, 2 January-25 December 1995), e-court p. 91 (noting that Deronjić and a delegation from Srebrenica met with the Accused from 2:25 to 6:25 p.m. on 14 July).

19621 Milenko Katanić, T. 24476-24477, 24484 (10 February 2012); D3561 (Witness statement of Dane Katanić dated 14 December 2012), para. 7. During the meeting, Katanić, Čanić, and Cvjetinović raised their objections as to the appointment of Deronjić as civilian commissioner, but the Accused insisted that Deronjić should be the Chief of the War Presidency. D3561 (Witness statement of Dane Katanić dated 14 December 2012), para. 7. The Accused also accepted the list of nine officials presented by Deronjić who would form part of the War Presidency. D3561 (Witness statement of Dane Katanić dated 14 December 2012), para. 7.

19622 P5143 (Radovan Karadžić's Decision, 14 July 1995). The decision was to enter into force on the day of its adoption. P5143 (Radovan Karadžić's Decision, 14 July 1995).

19623 Đurđević's aim was to include such material in a "travel vignette" which would be published in his personal newsletter. P4513 (Witness statement of Robert Đurđević dated 18 December 2002), e-court pp. 10, 14-15. See also para. 3134. The Accused told Đurđević that during his meeting with Deronjić, they had discussed the technicalities of the civilian authority in Srebrenica; the Accused added that the attacks in Srebrenica and Žepa were based on "his order number 7" and that the objective of the operations was to "raise the temperature to the boiling point". P4513 (Witness statement of Robert Đurđević dated 18 December 2002), e-court pp. 25; Robert Đurđević, T. 25938-25939, 25950-25953 (7 March 2012); P4515 (Excerpts from Robert Đurđević's diary, 5-31 July 1995), e-court p. 12. Đurđević had also heard the expression "raise the temperature to the boiling point" from Koljević and Krajišnik, and concluded that they were all "speaking in one voice" and were on board with the same strategy as well. P4513 (Witness statement of Robert Đurđević dated 18 December 2002), e-court p. 19; P4515 (Excerpts from Robert Đurđević's diary, 5-31 July 1995), e-court p. 12; Robert Đurđević, T. $25907-$ 25908 (7 March 2012).

19624 Robert Đurđević, T. 25951 (7 March 2012); P4513 (Witness statement of Robert Đurđević dated 18 December 2002), e-court pp. 26-27; P4514 (Article of Robert Đurđević, entitled “All in a Day’s Work”, 14 July 1995), p. 2. See also P2242 (Radovan Karadžić’s agenda, 2 January-25 December 1995), e-court p. 91. 
the time, and with contemporaneous reports issued by the VRS and MUP units engaged in the actions against the column of Bosnian Muslim men. ${ }^{19625}$

5779. The Chamber recalls that on 14 July, the Accused declared a state of war in the area of Srebrenica-Skelani municipality "in order to enable the full engagement of human and material resources in the defence of the RS and final victory over the enemy". ${ }^{19626}$ He ordered the armed forces throughout the area of responsibility of the Drina Corps to "take all necessary measures to accomplish the set goals by the organised and effective use of available resources". ${ }^{19627}$ This declaration allowed the military and police to utilise all human and material resources without submitting requests for mobilisation, and allowed for the military to requisition civilian property, such as equipment for burial, without complicated procedural protocols. ${ }^{19628}$ In the Chamber's view, as discussed in further detail below, the Accused issued this decision to give Deronjić extraordinary powers and to facilitate the use of civilian personnel and equipment for the killing and burial operations. ${ }^{19629}$ Indeed, the Chamber recalls that that day, Beara cited an order originating from "two Presidents" when telling the Zvornik municipal authorities that he expected their co-operation in "get[ting] rid of" the detainees then being held in various locations throughout the municipality. ${ }^{19630}$

5780. Having spent the night of 13 July in Zvornik, and the day of 14 July touring Srebrenica and the Bratunac area together with Vasić, Kovač returned to Pale on 14 July and met with the Accused between 10:45 and 11:10 p.m. ${ }^{19631}$ Earlier that day, while at lunch in Bratunac, Borovčanin, Kovač,

19625 See inter alia P4949 (Report of Zvornik CJB, 14 July 1995) (referring to fighting against Bosnian Muslim forces in the general area of Sandići and Konjević Polje on 13 and 14 July 1995); P5117 (Report of Bratunac Brigade to Drina Corps, 15 July 1995) (referring to combat activities on 14 July 1995 and to the regrouping of "strong enemy forces" in the direction of Konjević Polje); P5136 (Bulletin of daily events of Zvornik CJB, 13-14 July 1995), para. 1 (referring to attacks by Bosnian Muslim forces in the night of 13 to 14 July 1995); KDZ122, T. 26259-26260, 26263 (14 March 2012) (under seal) (describing heavy fighting against the column in the area of Ravni Buljim, Bratunac, Milići, Konjević Polje, and Kasaba on 14 July 1995). See also paras. 5465-5466.

19626 P4553 (Radovan Karadžić's Decision, 14 July 1995), paras. 1-2. See also Petar Škrbić, T. 25984-25987, 26000 (8 March 2012); D3977 (Witness statement of Mile Dmičić dated 29 October 2013), paras. 12-13. This decision was conveyed to the Main Staff and Drina Corps immediately, as well as to the RS MUP. P2803 (RS Communication Centre telegram logbook, 3-18 July 1995), e-court p. 3 (line 340); P2998 (Radovan Karadžić's 14 July Decision, forwarded by the RS MUP, 15 July 1995).

19627 P4553 (Radovan Karadžić's Decision, 14 July 1995), para. 3. The decision also called for the armed forces to observe provisions of international law and international conventions regulating the conduct of a State during the state of war. P4553 (Radovan Karadžić's Decision, 14 July 1995), para. 5. The Chamber recalls, however, that on 14 July, the killings in the Bratunac area had been concluded and that the killing operation in the Zvornik area was ongoing. See paras. 5713-5714.

19628 Petar Škrbić, T. 25986-25987 (8 March 2012).

19629 See para. 5819.

19630 See para. 5715.

19631 D3960 (Witness Statement of Tomislav Kovač dated 28 October 2013), paras. 120, 122; Tomislav Kovač, T. 42777-42778, 42792-42793 (1 November 2013); P2242 (Radovan Karadžić's agenda, 2 January-25 December 1995), e-court p. 91; Christian Nielsen, T. 16344-16345 (7 July 2011). See also Zoran PetrovićPiroćanac, P376 (Transcript from Prosecutor v. Popović et al.), T. 18822 (testifying that Borovčanin and a 
and Vasić had discussed the killings at the Kravica Warehouse which had taken place on the previous day. ${ }^{19632}$

5781. The Prosecution claims that Kovač reported back to the Accused about the murder operation, his meetings with Mladić, Borovčanin, and Vašić, what he had seen and heard in Srebrenica and in the Bratunac and Zvornik areas, and, more importantly, the implementation of the Accused's order to move the detainees from Bratunac to Zvornik. ${ }^{19633}$ The Chamber notes that Kovač denied that he ever reported to the Accused about Srebrenica, and suggested that the Accused had other sources of information, including Kijac, Krstić, and Deronjić. ${ }^{19634}$ The Chamber observes that indeed the Accused may have received additional information through other channels but recalls its earlier findings on Kovač's credibility. ${ }^{19635}$ Moreover, given the reports sent to Kovač on 12 and 13 July, ${ }^{19636}$ Kovač's meeting with the Accused on the afternoon of 13 July, Kovač's presence in both the Bratunac and Zvornik areas, as well as in Srebrenica on 13 and 14 July, and the encounters he had with Mladić, Vasić, and Borovčanin, the Chamber finds that the only reasonable inference is that Kovač indeed shared the knowledge and observations he had gathered during his trip with the Accused during their meeting on 14 July.

5782. The Chamber also notes that on 14 July Kovač was informed that detainees from Srebrenica were being taken to Zvornik and that Beara had requested the assistance of MUP units. ${ }^{19637}$ While Kovač claimed that he had no reason to believe that there was a plan to execute the detainees, the Chamber considers his own suggestion that he issued an order for the police to cease

driver were following Kovač while he was touring the area); D3659 (Witness statement of Ljubomir Borovčanin dated 30 May 2013), para. 40. Kovač testified that he had been travelling to Srebrenica with Vasić and Borovčanin to establish a police station there. Tomislav Kovač, T. 42777, 42786-42787 (1 November 2013). D3659 (Witness statement of Ljubomir Borovčanin dated 30 May 2013), para. 40 (acknowledging that he discussed the events at Kravica with Kovač and Vasić but claiming that Kovač and Vasić stated that they already knew about the incident when they discussed it). See also D3960 (Witness Statement of Tomislav Kovač dated 28 October 2013), para. 122; Tomislav Kovač, T. 42790-42791 (1 November 2013) (testifying that he was informed then, by Borovčanin, about the killings).

19633 Prosecution Final Brief, para. 948.

19634 D3960 (Witness Statement of Tomislav Kovač dated 28 October 2013), para. 129.

19635 See para. 5766.

19636 See fn. 5767, fn. 19570.

19637 The Chamber notes that Kovač claimed that he was told by the MUP that detainees were being taken to the Standard Barracks for screening. D3960 (Witness Statement of Tomislav Kovač dated 28 October 2013), para. 124. Kovač also gave conflicting evidence regarding whether he had learned that Beara had requested the assistance of MUP units on 14 July or two days later. Compare D3960 (Witness statement of Tomislav Kovač dated 28 October 2013), para. 124 (asserting that he learned about Beara's request "perhaps on 14 July") with Tomislav Kovač, T. 42787-42790 (1 November 2013) (first suggesting that this occurred on 16 July then refusing to acknowledge any discrepancy, before finally acknowledging that he might have indeed learned about it on 14 July). Kovač acknowledged that at the time he learned of Beara's request, he was aware that Beara "could abuse these men" and asserted that he had expressly refused and instructed the MUP not to co-operate with Beara. Tomislav Kovač, T. $42787-42788$ (1 November 2013). See also Tomislav Kovač, T. 42801 (1 November 2013). The Chamber refers to its assessment of Kovač's credibility set out above. See para. 5763, 
communication with the VRS security organ so as not to be involved with any of their activities as proof of the contrary. ${ }^{19638}$ Kovač's knowledge of the killing aspect of the plan to eliminate is also supported by his purported warning to Borovčanin that MUP units in the field "should distance themselves from anything other than combat tasks". ${ }^{19639}$ The Chamber finds it incredible that Kovač would not have discussed these matters with the Accused.

5783. Having received a call from the Accused, Zvonko Bajagić came to Pale and met with the Accused between 12:35 and 1:25 a.m. on 15 July. ${ }^{19640}$ The Prosecution contends that the purpose of Bajagić's visit was to brief the Accused on the events in Srebrenica of which he had direct knowledge, including the killings at the Kravica Warehouse and the detention of Bosnian Muslim men at the Nova Kasaba football field. ${ }^{19641}$ The Chamber notes that Bajagić's testimony regarding his meeting with the Accused was full of inconsistencies and contradictions, and has therefore approached it with considerable caution. ${ }^{19642}$ In relation to the date of the meeting, Bajagić claimed that the visit took place in the early morning of 14 July. ${ }^{19643}$ However, based on the evidence before it, the Chamber is satisfied that the meeting took place in the early hours of 15 July. ${ }^{19644}$ Bajagić asserted that before leaving for Pale to meet with the Accused he did not have any knowledge as to the events in Srebrenica so he wanted to ask the Accused what was happening at the time, ${ }^{19645}$ and thus denied discussing any of these topics with the Accused. ${ }^{19646}$ However, the evidence clearly establishes that Bajagić had substantive knowledge of the events in Srebrenica prior to meeting with the Accused. In this regard, the Chamber recalls that Bajagic himself

fn. 19549. Having reviewed the totality of the evidence, the Chamber finds that Kovač learned of Beara's request on 14 July.

19638 D3960 (Witness Statement of Tomislav Kovač dated 28 October 2013), para. 124; Tomislav Kovač, T. 42787, 42801-42802 (1 November 2013).

19639 D3659 (Witness statement of Ljubomir Borovčanin dated 30 May 2013), para. 41.

19640 P2242 (Radovan Karadžić's agenda, 2 January-25 December 1995), e-court p. 91. Bajagić was a member of the Drina Corps' Logistics Department and, according to Milenko Živanović, was on "excellent terms" with the Accused and other members of the leadership in Pale. Milenko Živanović, T. 42655 (31 October 2013).

19641 Prosecution Final Brief, para. 1001.

19642 See e.g. Zvonko Bajagić, T. 41170-41176, 41194-41199, 41176-41181 (10 July 2013).

19643 Bajagić recalled leaving his home on the night of 13 July. Zvonko Bajagić, T. 41188-41192 (10 July 2013).

19644 P2242 (Radovan Karadžić's agenda, 2 January-25 December 1995), e-court p. 91. See P6443 (Excerpt of Vlasenica vehicle work log, June and July 1995), pp. 1, 3 (recording Bajagić as having made two trips to Pale, one on 14 July and one on 15 July); Zvonko Bajagić, T. 41154-41155, 41190-41191 (10 July 2013). But see D3853 (Witness statement of Zvonko Bajagić dated 5 July 2013), para. 36; Zvonko Bajagić, T. 41182-41183 (10 July 2013) (stating that he did not recall whether he had visited the Accused on 13, 14, or 15 July). The Chamber notes that Bajagić first claimed that he only saw the Accused for a couple of minutes, as he ran into him in the hall and testified that the Accused looked angry and told Bajagić to "mind his own business". D3853 (Witness statement of Zvonko Bajagić dated 5 July 2013), para. 36. He later agreed, however, that the meeting had taken place in the Accused's office and had lasted longer, but insisted that part of that time was spent having a drink with a relative who was working at the Accused's office at the time, and not with the Accused. Zvonko Bajagić, T. 41184-41186, 41209 (10 July 2013).

19645 D3853 (Witness statement of Zvonko Bajagić dated 5 July 2013), paras. 36(a)-36(b); Zvonko Bajagić, T. 41166-41167 (10 July 2013).

19646 Zvonko Bajagić, T. 41193, 41207-41212 (10 July 2013). 
acknowledged that, on 13 July, he had seen captured Bosnian Muslim men sitting at the Nova Kasaba football field, had been prevented from taking photos of them, and had met with Mladić and Salapura in Srebrenica town. ${ }^{19647}$ Bajagić also conceded that he heard about the killings at the Kravica Warehouse while present at the Drina Corps Command in Vlasenica on 14 July. ${ }^{19648}$ Noting the extremely late hour of their meeting, as well as the fact that the Accused had invited Bajagić to Pale, the Chamber finds that the only reasonable inference is that Bajagić reported the events in Srebrenica he had witnessed on 13 and 14 July to the Accused during their meeting on 15 July.

5784. In the meantime, around 11 p.m. on 15 July, the Accused received a direct report from Vasić stating that additional forces were needed urgently to assist in intercepting the column of Bosnian Muslim men. ${ }^{19649}$ The Chamber recalls that at 1:55 p.m. on 16 July, Pandurević notified the Drina Corps command that a corridor had been opened to allow civilians to pass through, but that the Bosnian Serb Forces were still fighting the Muslim Forces in Srebrenica. ${ }^{19650}$ Approximately 90 minutes later, an officer from the Main Staff who stated that he was calling from "the boss $[\ldots]$ the main head of state" was intercepted telling the Zvornik Brigade duty officer to "have Vinko tell you about what happened and send it urgently right away [...] dictate what has been done and have him send it right away to the Main Staff". ${ }^{1961}$ That day, Karišik was dispatched to Zvornik. ${ }^{19652}$ Once Karišik arrived in Zvornik, he informed the Accused that Pandurević had arranged for the opening of the corridor. ${ }^{19653}$ The Chamber recalls that additional reinforcements were sent to the Zvornik area that evening as well as the following day, and that the Main Staff sent three colonels to investigate Pandurević's decision to open the corridor. ${ }^{19654}$

19647 Zvonko Bajagić, T. 41149, 41161-41163 (10 July 2013). See also Zvonko Bajagić, T. 41150-41154 (10 July 2013) (testifying to having seen Popović at the football field); para. 5185. Bajagić further testified that in the late afternoon of 13 July Mladić visited him at his house and had a meeting with Kovač. Zvonko Bajagić, T. 41161-41163 (10 July 2013).

19648 Zvonko Bajagić, T. 41169-41170, 41200-41201 (10 July 2013). But see Zvonko Bajagić, T. 41207-41208 (10 July 2013) (stating that he was not sure whether he learned about the killings at Kravica on 14 on or 15 July). See also D3853 (Witness statement of Zvonko Bajagić dated 5 July 2013), para. 36(b) (testifying that at the time of his visit to Pale, he had no information that any people from Srebrenica had been killed); Zvonko Bajagić, T. 41169-41170, 41200-41201 (10 July 2013) (insisting that he only found out about the killings after the meeting with the Accused).

19649 See para. 5469.

19650 See para. 5471.

19651 See para. 5471

19652 D3749 (Witness statement of Milenko Karišik dated 23 June 2013), para. 37; see para. 5472. The Chamber notes that Karišik described having been sent by Kovač to liaise with Pandurević regarding the ongoing negotiations with the members of the column, who had captured a member of the Doboj PJP. D3749 (Witness statement of Milenko Karišik dated 23 June 2013), para. 37. However, the Chamber also recalls that Karišik sought to distance himself from having told the Accused of the corridor's opening. See fn. 18688.

19653 See para. 5472

19654 See paras. 5472, 5474-5475. 
5785. The Chamber received evidence demonstrating that throughout the relevant period, the Accused actively monitored the international media's coverage of the events in Srebrenica. ${ }^{19655}$ On 16 July, a certain "Nikola" informed the Accused that the message being conveyed by American television reports on Srebrenica was "terrible". 19656 "Nikola" then requested the Accused to issue a clear statement on the treatment of the civilian population in Srebrenica and Žepa, which would then assist Robert Đurđević and "Nikola" in giving a speech addressing the "terrible propaganda" about Srebrenica being spread to the American population by the U.S. media. ${ }^{19657}$ The Chamber recalls that at a meeting held at the UN Compound on the following day, the Bosnian Serb representatives produced the 17 July 1995 Statement, a document which outlined the agreement reached at the third Hotel Fontana meeting five days earlier, and requested that both Mandžić and Franken sign it, and that Franken attest that Mandžić had not been forced to do so. ${ }^{19658}$ Miroslav Deronjić also signed the 17 July 1995 Statement. ${ }^{19659}$

5786. Around 6:30 p.m. that evening, the Accused met with Mile Dmičić, who was then Head of Office to the Accused and the Accused's Secretary General. ${ }^{19660}$ During the meeting, Subotic delivered a fax from Bratunac containing the 17 July 1995 Statement to the Accused. ${ }^{19661}$ In an

19655 For example, Robert Đurđević testified that during their meeting on 14 July, the Accused watched CNN and Sky News reports on Srebrenica-which included interviews with women who had by then reached Tuzla-and occasionally commented that the reports were not true. P4513 (Witness statement of Robert Đurđević dated 18 December 2002), e-court pp. 13, 15-18. See P4514 (Article of Robert Đurđević, entitled “All in a Day's Work", 14 July 1995), p. 1; P4515 (Excerpts from Robert Đurđević's diary, 5-31 July 1995), e-court p. 9. Slavica Ristić testified that after Trifković's meeting with Zametica and the Accused late the same evening, she, the Accused, and Trifkovic watched CNN together, as the Accused wanted to see how the take-over of Srebrenica was portrayed, and they discussed the issue of balanced media coverage. P4556 (Slavica Ristić's interview with OTP, 5 April 2009), pp. 49-50, 55-56, 64; Slavica Ristić, T. 26092-26093 (12 March 2012); P4557 (Photographs of Slavica Ristić's meeting with Radovan Karadžić), p. 5; P2242 (Radovan Karadžić's agenda, 2 January-25 December 1995), e-court p. 91. The Chamber also notes that the Accused took steps to control communications between the Bosnian Serb Forces and members of international organisations. On 17 July, the Accused wrote to Gvero, asserting that he was acting contrary to a number of mandatory documents previously issued by the Accused, by inter alia supplying information outside the assigned channels, and establishing unauthorised contact with international organisations. P4536 (Letter from Radovan Karadžić to Lieutenant General Milan Gvero, 17 July 1995), p. 1. The Accused ordered Gvero to immediately send a written statement explaining his non-compliance, which was to be followed by an interview. P4536 (Letter from Radovan Karadžić to Lieutenant General Milan Gvero, 17 July 1995), p. 1. See also Petar Škrbić, P4523 (Transcript from Prosecutor v. Popović et al.), T. 15554-15556. Gvero replied on the following day that he had carried out all the activities mentioned by the Accused as ordered by Mladić, and that all the activities were motivated by the need for the fight of the Bosnian Serb people and for the VRS to be successful. P4537 (Letter from Lieutenant General Milan Gvero to Radovan Karadžić, 18 July 1995).

19656 P5609 (Intercept of conversation between "Nikola” and Radovan Karadžić, 16 July 1995), p. 1.

19657 P5609 (Intercept of conversation between "Nikola" and Radovan Karadžić, 16 July 1995), p. 1 (further providing the Accused with a fax number to which such a statement could be transmitted).

19658 See para. 5128. The Chamber recalls that Franken sought to surreptitiously neutralise his signature by adding a non-sensical addendum. See fn. 17382.

19659 See para. 5129.

19660 D3977 (Witness statement of Mile Dmičić dated 29 October 2013), paras. 4, 9, 16-17.

19661 D3977 (Witness statement of Mile Dmičić dated 29 October 2013), para. 17; P4185 (Declaration by the Civilian Affairs Committee for Srebrenica re: proper implementation of evacuation procedures, 17 July 1995). See para. 5128. Dmičić also stated that he was not aware at the time that it was not a genuine agreement and did not 
interview with David Frost conducted later that evening, the Accused claimed that the civilians had wanted to leave Srebrenica on their own and offered to produce the 17 July 1995 Statement as proof. ${ }^{19662}$ When Frost asked the Accused about the reports in the media about 15,000 men from Srebrenica who were thus far unaccounted for, the Accused replied that the Bosnian Serb Forces had opened the lines and were allowing the men to pass even as he spoke to Frost. ${ }^{19663}$

5787. Around the same period, Mladić met Smith multiple times; Smith repeatedly requested that the ICRC and UNHCR be allowed access to Srebrenica and be allowed to see "all the detained people". ${ }^{19664}$ In an attempt to describe Srebrenica as having been "finished in a correct way", Mladić also referred to the assertions contained in the 17 July 1995 Statement, namely that the Bosnian Muslims in Potočari had been "evacuated" at their own request and according to arrangements made by three civilian representatives of the local population. ${ }^{19665}$ Mladic also referred to a "corridor" which, he claimed, had been opened on the night of 10-11 July to allow "a significant number" of Bosnian Muslim forces to break through Bosnian Serb lines in the direction of Tuzla. ${ }^{19666}$ However, by the following week, many Bosnian Muslim men remained missing and the ICRC remained unable to access the Srebrenica enclave. ${ }^{1967}$ The Chamber recalls that,

doubt its validity because it was certified. Mile Dmičić, T. 42895-42897 (4 November 2013). The Chamber notes that Dmičić insisted that he had no knowledge about the events in Srebrenica and thus never discussed them with the Accused. See Mile Dmičić, T. 42886-42887, 42902-42903 (4 November 2013); D3977 (Witness statement of Mile Dmičić dated 29 October 2013), paras. 21-22 (testifying that he never heard any discussion about executions in Srebrenica and never heard or saw anything which would indicate the Accused's knowledge of such executions). The Chamber notes, however, that while testifying, Dmičić was inconsistent and evasive and displayed clear indications of bias. Compare D3977 (Witness statement of Mile Dmičić dated 29 October 2013), paras. 10-11 (testifying that he met with Subotić on 10 July to discuss the events in Srebrenica and was ordered to immediately forward the Accused's order for the protection of UNPROFOR members and civilians to the Main Staff) with Mile Dmičić, T. 42898-42899, 42904-42906 (4 November 2013) (testifying that he only dealt with mail within the civilian activity of the RS organs and not military mail or reports, and thus trying to distance himself from the VRS and its military operations). See also Mile Dmičić, T. 42902-42903 (4 November 2013) (denying any past or present knowledge about the executions in Srebrenica, stating that he could not accept "the truth" and agreeing with a statement put to him that the cemetery at Potočari was a farce and a set-up). For these reasons, the Chamber has approached Dmičić's evidence with circumspection.

19662 P5235 (Video footage of interview of Radovan Karadžić by David Frost, undated, with transcript), p. 2.

19663 P5235 (Video footage of interview of Radovan Karadžić by David Frost, undated, with transcript), pp. 2-3. During the interview, the Accused also referred to Srebrenica as a "stronghold" with more than 9,000 "well armed and equipped Muslim combatants" and said that the situation could no longer be accepted. P5235 (Video footage of interview of Radovan Karadžić by David Frost, undated, with transcript), p. 1.

19664 Rupert Smith, T. 11431-11432 (9 February 2011); P1488 (Ratko Mladić's notebook, 14 July-18 September 1995), p. 4; P2279 (UNPROFOR report re meeting with Ratko Mladić, 17 July 1995), e-court pp. 1-2 (recording agreement on 15 July that the ICRC and UNHCR would be given immediate access to "prisoners of war"). In the preceding days, UNPROFOR had begun to hear accounts and allegations of crimes committed following the Bosnian Serb take-over of Srebrenica and had noted the absence of men arriving in Tuzla, and thus requested access to the area. Rupert Smith, T. 11428, 11430-11431, 11435-11436 (9 February 2011); P2277 (UNPROFOR report re meeting with Haris Silajdžić, 13 July 1995), para. 6; P2278 (UNPROFOR report re aftermath of fall of Srebrenica, 13 July 1995), para. 3.

19665 P2280 (UNPROFOR report re meeting with Ratko Mladić, 19 July 1995), para. 4.

19666 P2280 (UNPROFOR report re meeting with Ratko Mladić, 19 July 1995), para. 5.

19667 Rupert Smith, T. 11437-11438 (9 February 2011). 
according to the Accused's decision of 11 July, such permission would have required the assent of the State Committee following consultation with him. ${ }^{19668}$

5788. On 24 July, the Special Rapporteur of the Commission on Human Rights, Tadeusz Mazowiecki, wrote to the Accused directly to request access to field staff from the UN Centre for Human Rights in areas under the Accused's control. ${ }^{1969}$ Although this request was received, Mazowiecki did not receive an answer. ${ }^{19670}$ The Chamber recalls that at the time, the Bosnian Serb Forces were carrying out continued searches of the terrain, killing numerous groups of Bosnian Muslim males who were captured or surrendered from the column. ${ }^{19671}$ In late July, representatives of the ICRC were allowed to access Batković Camp but were only able to locate 164 detainees from Srebrenica; they were told that no other detainees were being held. ${ }^{19672}$

5789. In the weeks following the events in Srebrenica, the Accused's press office issued a press release commending both Živanović and Krstić as "the main architect[s] of the Serbian victories in Srebrenica and Žepa". ${ }^{19673}$ The Accused also congratulated the VRS Main Staff, the Drina Corps command, and the "staff of the Police Armed forces" on the "brilliant victory in Srebrenica and Žepa". 19674 On 4 August 1995, the Accused appointed Mladić to the Office of the President of the RS as a Special Adviser to the Supreme Commander for co-ordination of the joint defence of RS and the RSK. ${ }^{19675}$ That same day, during an interview with the Bosnian Serb television, the

19668

19669

P6396 (Letter from UN Centre for Human Rights to Radovan Karadžić, 24 July 1995). Similar concerns were raised by Akashi on 12 August. See P2288 (UNPROFOR report re Srebrenica, 14 August 1995, and Letter from Yasushi Akashi to Radovan Karadžić, 12 August 1995), p. 2; John Zametica, T. 42551-42553 (30 October 2013). See also Defence Final Brief, para. 3131 (suggesting that the Accused may not have seen this letter because he was touring remote regions of the Krajina at the time).

19670

P5177 (Report of UNSG, 30 August 1995), para. 38; D4509 (Intercept of conversation between Radovan Karadžić and Danijela Sremac, 25 July 1995), p. 3. See Defence Final Brief, para. 3130 (claiming that the Accused may not have seen Mazowiecki's request).

19671 See paras. 5475-5476. The Chamber further recalls that members of the Bosnian Serb Forces carried out killings of Bosnian Muslim males at Snagovo and Bišina, and that the Scorpions killed six Bosnian Muslim males at Trnovo in the weeks following the fall of Srebrenica. See paras. 5477-5497.

19672 P2284 (UNSG report entitled "The Fall of Srebrenica", 15 November 1999), para. 409.

19673 P4501 (RS Presidential Press Release, 20 July 1995). See also Petar Škrbić, T. 25982-25983 (8 March 2012) (testifying that the Accused, as the Supreme Commander, had the right to promote, even without proposals, an officer to the rank of a general-major or above, and it was customary when a high-ranking officer, such as a general, would retire, to be conferred another rank because he was going into retirement); D3932 (Witness statement of Milenko Živanović dated 27 October 2013), para. 45 (testifying that, by then, Krstić had already been appointed the new commander of the Drina Corps and all the Accused did was to officially confirm such appointment).

19674 P4501 (RS Presidential Press Release, 20 July 1995). The next day, Mladić--escorted by Tolimir--arrived at the Godjenje IKM by helicopter and met with members of the Main Staff and Drina Corps, as well as a television crew. Radislav Krstić, D4136 (Transcript from Prosecutor v. Krstić), T. 6262-6264. The Chamber notes that Godjenje was a second IKM of the Drina Corps which was located about six or seven kilometres south of Krivaca and was established on 16 or 17 July 1995. See Radislav Krstić, D4136 (Transcript from Prosecutor v. Krstić), T. 6261 (20 October 2000).

19675 D2157 (Radovan Karadžić's Decree, 4 August 1995). This decision was abrogated on 27 August 1995. See para. 3138 . 
Accused explained his reasons for appointing Mladić to the Supreme Command, and praised the VRS corps commanders. ${ }^{19676}$ The Accused also specifically recognised Krstić for having planned the Srebrenica operation, with his approval, and for having conducted the task exceptionally, with the assistance of the Supreme Command and Mladić. ${ }^{19677}$

5790. On 4 August, the Accused took a short trip to Srebrenica together with Nebojša Ristić and his security detail. ${ }^{19678}$ They attended a religious ceremony close to the town, and visited an Orthodox church in the centre of Srebrenica that had been completely destroyed. ${ }^{19679}$ The Accused also met with Deronjić and the other civilian authorities of Srebrenica at the cultural centre which had been prepared for his visit. ${ }^{19680}$

5791. On 6 August 1995, during the $52^{\text {nd }}$ Bosnian Serb Assembly Session, the Accused stated:

As you know, we achieved success in Srebrenica and Žepa, no fault can be found with the success, no objections to it, of course, a lot of stupid things were done afterwards, because many [Bosnian] Muslim soldiers were roaming the woods and that is when we sustained losses; in the action itself we did not sustain losses [...] in the end several thousand fighters did manage to get through [...] we were not able to encircle the enemy and destroy them. ${ }^{19681}$

5792. On 8 November 1995, the Accused issued a statement publicising the fact that that day, he had issued a decision clearing an American journalist, David Rohde, of a charge of espionage. ${ }^{19682}$ Rohde had been arrested by the MUP approximately ten days earlier while photographing the

19676 P4555 (Excerpt from "Srebrenica Trial Video”); P5121 (Excerpt of interview with Radovan Karadžić, 4 August 1995); P2565 (UNPROFOR Telex with summary of Radovan Karadžić's interview to Bosnian Serb television, 4 August 1995), p. 4. The Accused added: "we wanted to turn Mladić into a legend and we did". P4555 (Excerpt from "Srebrenica Trial Video").

19677 P4555 (Excerpt from "Srebrenica Trial Video"). See also P6407 (Radovan Karadžić's interview with Telegraf, 16 August 1995), e-court p. 8.

19678 Nebojša Ristić, T. 15395-15401, 15419 (24 June 2011); P2784 (Report of RS MUP re travel of Radovan Karadžić from Pale to Srebrenica, 3 August 1995). See also P2843 (Map of Zvornik marked by Nebojša Ristić) (marking the route taken on the trip); P2844 (Instructions from VRS Main Staff to Drina Corps, 3 August 1995); P2845 (Report of Bratunac Brigade, 4 August 1995); Neboša Ristić, T. 15399, 15401 (24 June 2011) (testifying that the VRS was tasked with securing the route for the visit).

19679 Nebojša Ristić, T. 15402-15403, 15420, 15427 (24 June 2011). See also P2242 (Radovan Karadžić's agenda, 2 January-25 December 1995), e-court p. 102.

19680 P4374 (Witness statement of Milenko Katanić dated 11 October 2011), paras. 96-97; Milenko Katanić, T. 24545-24546 (10 February 2012). But see Nebojša Ristić, T. 15420 (24 June 2011) (denying that the delegation met with local authorities).

19681 P1412 (Transcript of 52 ${ }^{\text {nd }}$ session of RS Assembly, 6 August 1995), pp. 14, 17 (emphasis added). See also Richard Butler, T. 27877-27878 (23 April 2012).

19682 P6425 (Public statement of RS President's Office, 8 November 1995). Rohde had published an article in the Christian Science Monitor in August 1995 describing an "on-the-spot investigation" which had "uncovered strong evidence that a massacre of Bosnian Muslim prisoners took place last month" near the former enclaves of Srebrenica and Žepa. P6422 (Article from Christian Science Monitor, entitled "Evidence Indicates Bosnia Massacre", 18 August 1995), p. 1. The article featured an unclassified satellite photo showing "possible mass graves" in the Konjević Polje area and described interviews with Bosnian Serb soldiers who mentioned ongoing killings of Bosnian Muslim men from the column who were continuing to be captured. P6422 (Article from Christian Science Monitor, entitled “Evidence Indicates Bosnia Massacre”, 18 August 1995), pp. 1-2. 
Petkovci Dam. ${ }^{19683}$ Upon Rohde's arrest, Kijac sent a report to the VRS Security Administration reporting intelligence gathered during Rohde's interrogation, including evidence found at suspected crime sites. ${ }^{19684}$ According to Kijac's report, Rohde also stated that he had told his editors about his task, and that they had agreed to intervene through the US Embassy if Rohde did not "check in" within two or three days. ${ }^{19685}$ Kijac signed off, stating "this information is provided for your action". 19686 On 3 November, Beara replied with the information that Koljević had told "someone abroad" that Rohde had been arrested and that a request had been sent to the "truce monitoring team" in Banja Luka requesting them to find Rohde. ${ }^{19687}$ That same day, the chief of the RDB centre in Bijeljina issued two orders authorising Rohde's detention retroactively from 29 October to 6 November and initiating criminal proceedings against him. ${ }^{19688}$ On the same day, Kijac spoke to the Accused by telephone; Kijac met with the Accused in person on 4 and 6 November. ${ }^{19689}$ Two days later, the Accused pardoned Rohde. ${ }^{19690}$

5793. During a conversation with Mladić on 22 March 1996, the Accused stated that he, Koljević, and Plavšić had determined that a commission should be formed "on the basis of equal parity to really investigate all the deaths and killings around Srebrenica during the war". ${ }^{1961}$ That day, Slobodna Bosna had published Dražen Erdemović's account of the killings at the Branjevo Military

19683 P5227 (Report of Sarajevo RDB, 31 October 1995), p. 1; P6424 (Request of Bijeljina RDB, 3 November 1995), para. 2; D4143 (Witness statement of Dragan Kijac dated 30 November 2013), para. 62. According to Kijac, Rohde was arrested by the SJB and turned over to the DB, which "recorded and documented the intelligence activities of foreign journalists" as part of its counter-intelligence measures. D4143 (Witness statement of Dragan Kijac dated 30 November 2013), para. 63; Dragan Kijac, T. 44354 (3 December 2013).

19684 P5227 (Report of Sarajevo RDB, 31 October 1995), p. 1. Kijac reported that Rohde had stated that an initiative was being taken to gather such evidence ahead of the Dayton conference, where it could be used as a means of putting pressure on the Bosnian Serbs, and had disclosed that within the next day or two, the New York Times and the Washington Post would be publishing articles estimating the number of victims as 6,000 and 3,000, respectively. P5227 (Report of Sarajevo RDB, 31 October 1995), p. 2.

19685 P5227 (Report of Sarajevo RDB, 31 October 1995), p. 2.

19686 P5227 (Report of Sarajevo RDB, 31 October 1995), p. 2.

19687 P6539 (Information of VRS Main Staff, 3 November 1995), pp. 1-2. Kijac denied that Beara's communication was a reply and asserted that his dispatch had been addressed to the Main Staff Intelligence Administration and that the DB "had no correspondence with the military police and military security". Dragan Kijac, T. 4435744358 (3 December 2013). The Chamber notes, however, that P5227 is clearly addressed to the Main Staff Security Administration and that Beara's notification in fact refers to the reference number, 05-3368/95, which appears on P5227. The Chamber is therefore satisfied that P6539 was in fact a response to P5227 and considers Kijac's testimony to the contrary to be an example of Kijac attempting to distance himself from Rohde's arrest.

19688 P6423 (Order of Bijeljina RDB, 3 November 1995); P6424 (Request of Bijeljina RDB, 3 November 1995). Kijac stated that a criminal complaint was filed because Rohde's interrogation yielded evidence of "a number of misdemeanours". D4143 (Witness statement of Dragan Kijac dated 30 November 2013), para. 62. See also Dragan Kijac, T. 44354 (3 December 2013). The Chamber notes, however, that the criminal complaint was not filed upon the conclusion of Rohde's interview on 31 October, but only upon receipt of the dispatch from Beara on 3 November.

19689 P2242 (Radovan Karadžić’s agenda, 2 January-25 December 1995), e-court pp. 131-133.

19690 P6425 (Public statement of RS President's Office, 8 November 1995).

19691 P1490 (Ratko Mladić's notebook, 16 January-28 November 1996), e-court p. 47. 
Farm and the Pilica Cultural Centre. ${ }^{19692}$ The Chamber recalls that, during the conversation with Mladić on 22 March 1996, the Accused also remarked that "a big show was put on for Albright", who had "expected they would find 1,200 Muslim bodies at Pilica, but they found some five bodies". 19693

5794. On the following day, 23 March, the Accused issued an order to the Main Staff and RS MUP to "immediately form a mixed expert commission of three members each" to investigate the alleged discovery of two decomposed bodies "at the scene of earlier battles with the Muslim side" in the Pilica area ("23 March 1996 Order"). ${ }^{19694}$ The order stated that a request should be made to the "competent IFOR (UN) command" to have an international expert team present at the enquiry, in order "to frustrate the intentions of Ambassador Madeleine Albright and media 'experts' to make and launch arbitrary and biased conclusions about this case". ${ }^{19695}$ Following the issuance of the Accused's 23 March 1996 Order, Vasić held a meeting of a mixed military and civilian commission at the Zvornik CSB; the meeting was attended by RS Military Prosecutor Predrag Drinić as well as Milorad Trbić, who represented the Zvornik Brigade. ${ }^{19696}$ Following the meeting, on 26 March 1996, Drinić wrote to the Main Staff Intelligence and Security Sector describing the meeting and proposing that the Main Staff form a delegation to the commission from the members of the Intelligence and Security Organ, who could then verify the reports giving rise to the commission and, if needed, forward the matter to the relevant military prosecutor. ${ }^{19697}$ Drinić never received an answer. $^{19698}$

5795. One week later, on 1 April 1996, the Accused issued an order to the Main Staff, RS MUP, Ministry of Justice and Administration, the Supreme Court, the Supreme Military Court, the RS Public Prosecutor and the VRS Military Prosecutor to carry out "a detailed investigation" of the locations "where victims of the armed conflict in and around Srebrenica are to be found", and to determine whether any breaches of The Hague or Geneva Conventions had been committed, and if

\footnotetext{
19692 P6451 (Article from Slobodna Bosna, entitled "I Killed 'Only' Hundreds of People”, 22 March 1996), pp. 1-2. The article also recounted the arrest of Erdemović and an associate, and reported a "great possibility" that they would be transferred to the Tribunal. P6451 (Article from Slobodna Bosna, entitled "I Killed 'Only' Hundreds of People", 22 March 1996), pp. 4-5.

19693 P1490 (Ratko Mladić's notebook, 16 January-28 November 1996), e-court p. 47. See para. 5451. In the context of this discussion, Mladić and the Accused referred to the publication of Erdemović's account of the killings. P1490 (Ratko Mladić's notebook, 16 January-28 November 1996), e-court p. 47. See Defence Final Brief, para. 3144.

19694 P3163 (Notice of VRS Military Prosecutor's Office, 26 March 1996), pp. 6, 8. See para. 5451.

19695 P3163 (Notice of VRS Military Prosecutor's Office, 26 March 1996), pp. 6, 8.

19696 Predrag Drinić, P374 (Transcript from Prosecutor v. Blagojević \& Jokić), T. 10879-10881; P3163 (Notice of VRS Military Prosecutor's Office, 26 March 1996), pp. 6, 8.

19697 Predrag Drinić, P374 (Transcript from Prosecutor v. Blagojević \& Jokić), T. 10882-10883; P3163 (Notice of VRS Military Prosecutor's Office, 26 March 1996), pp. 3-4.
} 
so, to identify the perpetrators of such crimes and initiate criminal proceedings against them (“1 April 1996 Order”). ${ }^{19699}$

5796. Despite the existence of both of these orders, no criminal proceedings were initiated. ${ }^{19700}$ Rumours of massive killings were "common knowledge" in Bijeljina "almost immediately", as VRS officers spoke about it openly. ${ }^{19701}$ The Chamber received evidence, however, that the RS Military Prosecutor's Office in Bijeljina never received the Accused's 1 April 1996 Order. ${ }^{19702}$ Drinić stated that the other addressees of the 1 April 1996 Order did not take steps to implement it, and that no prosecutions were undertaken as a result. ${ }^{19703}$

5797. No civilian prosecutions were undertaken either. ${ }^{19704}$ On 23 September 1996, Dragan Kijac, who was by then Minister of the Interior, ${ }^{19705}$ sent a report to the Ministry of Justice and Administration which described purported internal skirmishes between members of the column which resulted in "several individual and mass killings". ${ }^{19706}$ Kijac also described preliminary investigative steps being taken by the Tribunal and closed with the statement, "we are sending you this information believing that it could be used for the defence". 19707

\section{iii. Accused's membership in the Srebrenica JCE}

5798. The Chamber has found that as the Srebrenica enclave fell to the Bosnian Serb Forces, the Accused's and Mladić's long-term strategy, which was devised in March 1995 and aimed at

\footnotetext{
19698 Predrag Drinić, P374 (Transcript from Prosecutor v. Blagojević \& Jokić), T. 10884-10885; P3163 (Notice of VRS Military Prosecutor's Office, 26 March 1996), p. 5.

19699 P164 (Radovan Karadžić's Order to VRS and MUP re Srebrenica, 1 April 1996).

19700 P2929 (Witness statement of KDZ531 dated 25 June 2011) (under seal), p. 13; Predrag Drinić, P374 (Transcript from Prosecutor v. Blagojević \& Jokić), T. 10879.

19701 [REDACTED].

19702 Predrag Drinić, P374 (Transcript from Prosecutor v. Blagojević \& Jokić), T. 10885-10886, 10889. [REDACTED].

19703 Predrag Drinić, P374 (Transcript from Prosecutor v. Blagojević \& Jokić), T. 10886-10888, $10892-10893$. Drinić explained that pursuant to the normal investigative procedure, the military prosecutor's office would have received information from other organs which were also addressees of the 1 April 1996 Order, but no such information was received. Predrag Drinić, P374 (Transcript from Prosecutor v. Blagojević \& Jokić), T. 1088710888, $10903-10904$.

19704 Kovač and Karišik asserted that it had been impossible for the MUP to start an official investigation because of the war and because the MUP had been "re-subordinated" to the VRS, and thus the MUP lacked jurisdiction to prosecute war crimes. Milenko Karišik, T. 40667-40668 (2 July 2013); D3960 (Witness statement of Tomislav Kovač dated 28 October 2013), para. 134; Tomislav Kovač, T. 42819 (1 November 2013). Kovač also asserted that security conditions prevented investigations from being undertaken. D3960 (Witness statement of Tomislav Kovač dated 28 October 2013), para. 134. See also Milenko Karišik, T. 40667 (2 July 2013) (asserting that the MUP had limited information about the crimes in Srebrenica which they received "very late").

19705 D4143 (Witness statement of Dragan Kijac dated 30 November 2013), para. 4. Kijac testified that he did not receive any information about killings in the aftermath of Srebrenica, either as Chief of the DB nor as Minister of Interior. Dragan Kijac, T. 44372 (3 December 2013).

19706 P165 (Report from RS MUP re Srebrenica, 23 September 1996). [REDACTED].

19707 P165 (Report from RS MUP re Srebrenica, 23 September 1996), e-court p. 1.
} 
removing the Bosnian Muslim population from Srebrenica, began to be transformed into a concrete plan to eliminate them, first, through forcible removal of the women, children and elderly men, and then through the killing of the men and boys. ${ }^{19708}$ The Chamber will now analyse whether, taking into account the acts and conduct of the Accused during the period relevant to the Srebrenica JCE established above, ${ }^{19709}$ the Accused shared the objective of eliminating the Bosnian Muslims in Srebrenica, first by forcibly removing the women, children, and elderly men, and then by killing the able-bodied men and boys. In this exercise, the Chamber will also examine particular actions of the Accused which occurred prior to the implementation of the concrete plan to eliminate the Bosnian Muslims in Srebrenica, as well as after the completion of such plan.

5799. Prior to the formation of the concrete plan to eliminate the Bosnian Muslims in Srebrenica, the Accused took a number of actions which, in the Chamber's view, establish that he was a directing force in the events leading up to the take-over of Srebrenica and which also demonstrate his close monitoring of the Bosnian Serb attack on the enclave. In addition to issuing Directive 7 in March 1995 and giving Krstić a combat assignment at the end of June, both of which formed the basis for the attack plan known as Krivaja 95 and which ultimately resulted in the take-over of Srebrenica, the Accused also implemented Directive 7 by restricting access to Srebrenica. ${ }^{19710}$ This restriction, which the Chamber found was implemented by Mladić, allowed the Accused to maintain control over the goods and personnel entering the enclave during the months and weeks leading up to its take-over. ${ }^{19711}$

5800. The Accused acknowledges that he approved the initial plan to "shrink" the Srebrenica enclave and thereafter to "take the undefended town of Srebrenica", but claims that this plan never contemplated the execution of Bosnian Muslim detainees. ${ }^{19712}$ The Accused further adds that the military action to take Srebrenica was not a crime, and that when he authorised the VRS to enter Srebrenica, the VRS had a legitimate right to engage in military operations against the Muslim Forces in Srebrenica. ${ }^{19713}$ However, the Chamber has already found that, at least by the time Directive 7 was issued in March 1995, the Accused and Mladić had devised a long-term plan aimed at the eventual forcible removal of the Bosnian Muslims in Srebrenica. ${ }^{19714}$ This was consistent

\footnotetext{
19708 See paras. 5725, 5730.

19709 See Section IV.C.3.b.ii: Accused's acts and conduct in context.

19710 See paras. 5756-5759.

19711 See paras. 5756-5757.

19712 Defence Final Brief, para. 3011.

19713 Defence Final Brief, paras. 2396-2397. The Accused further contends that indeed, the actions he took in connection with the Srebrenica events were "exemplary" and demonstrate that he did not participate in or have any knowledge of the genocidal execution of detainees. Defence Final Brief, paras. 3127-3128.

19714 See para. 5684.
} 
with their long-term objective of permanently removing Bosnian Muslims and Bosnian Croats from Bosnian Serb-claimed territory. ${ }^{19715}$ The Accused's establishment of Bosnian Serb structures in Srebrenica demonstrates that the removal of the Bosnian Muslim population then envisaged by the Bosnian Serb Political and Governmental Organs was intended to be permanent. ${ }^{19716}$ Thus, while the take-over itself was not a criminal operation per se, the Chamber considers that, like the takeovers of the Municipalities, the take-over of Srebrenica was devised with the intent to permanently remove the Bosnian Muslim population living there.

5801. The Chamber recalls that, as the Bosnian Serb Forces approached Srebrenica, the Accused was constantly kept abreast and informed of the developing situation on the ground. This was achieved particularly through briefings by high-ranking officers, such as Gvero and Tolimir, who were already on the ground near Srebrenica. ${ }^{19717}$ The Accused also received regular written reports from multiple branches of the Bosnian Serb Forces. As Supreme Commander of the VRS, the Accused received daily combat reports compiled by the Main Staff, which provided him detailed information of the developments on the ground. ${ }^{19718}$ The Chamber notes the Accused's contention that none of the written reports that reached him during the Srebrenica events made any reference to the execution of prisoners from Srebrenica. ${ }^{19719}$ Indeed, the Chamber did not receive evidence demonstrating that the written reports which reached the Accused mentioned killings of Bosnian Muslim male detainees. However, the Chamber notes that, beginning on 12 July, the daily combat

19715 See para. 2854.

19716 See para. 5694

19717 See paras. 5689-5690, 5760.

19718 See e.g. P3054 (VRS Main Staff Report, 12 July 1995); P4464 (VRS Main Staff Report 13 July 1995); P4457 (VRS Main Staff Report, 14 July 1995); P4460 (VRS Main Staff Report, 15 July 1995); D2101 (VRS Main Staff Report, 16 July 1995); D2102 (VRS Main Staff Report, 17 July 1995). See also Richard Butler, T. 2747527456 (17 April 2012). Following the Accused's order to take the town on 9 July, these reports described the advance of the Bosnian Serb Forces towards Srebrenica, culminating in its take-over on 11 July. D2100 (VRS Main Staff Report, 9 July 1995), para. 6(b); P4449 (VRS Main Staff Report, 10 July 1995), para. 6(b); P4450 (VRS Main Staff Report, 11 July 1995), paras. 6(a)-6(b). The Chamber observes that Kovač testified that the MUP also compiled reports from all its sources into a single report which was transmitted to the Accused. D3960 (Witness Statement of Tomislav Kovač dated 28 October 2013), para. 128. The Chamber further notes that, between 11 and 17 July, the Accused also received daily communications from the Main Staff Security Organ. P2989 (Record of coded telegrams of the RS Republican Communications Centre, 1995), lines 2251, 2265, 2298, 2320, 2334, 2351, 2355, 2365. For example, on 16 July, the Accused received two such communications, at 5:25 a.m. and at 4:20 p.m., respectively. P2989 (Record of coded telegrams of the RS Republican Communications Centre, 1995), lines 2351, 2355. These documents were never recovered. Christian Nielsen, T. 16328 (7 July 2011); Richard Butler, T. 27612-27613 (18 April 2012).

19719 Defence Final Brief, paras. 3082-3083, 3112. The Accused made a similar claim about media reports from late July onwards on the execution of prisoners which, he submits, did not provide reason for him to believe that men had been executed. See Defence Final Brief, para. 3132. The Accused supported his claim by stating that he had been repeatedly told to consider these reports false propaganda, in particular in light of similar false reports issued in the past. See Defence Final Brief, paras. 3132-3139. The Accused also argued that the letters seised from his computer at the time of his arrest indicate that he had no information about executions of a significant number of people from Srebrenica and believed those allegations to be false. See Defence Final Brief, para. 3147. In light of the Chamber's finding as to when the Accused became aware of the common plan 
reports described the transport of the Bosnian Muslim population as well as the existence and movement of the column of Bosnian Muslim men attempting to reach Tuzla, in addition to the Bosnian Serb Forces' attempts to block the column's progress. ${ }^{19720}$ On 13 and 14 July, the reports described the capture and surrender of large numbers of men from the column. ${ }^{19721}$ Reports from the following days made no mention of prisoners but described continuing efforts by the Bosnian Serb Forces to block the remainder of the column's progress and search the terrain. ${ }^{19722}$ The Chamber further recalls Popović's direction to Dragan Jokić not to make a record of the activities involving the killing aspect of the plan to eliminate or to speak on the radio about it. ${ }^{19723}$

5802. The Chamber notes the Accused's claim that he may not have seen material addressed directly to his office. ${ }^{19724}$ While the Chamber indeed received evidence that documents received by the Accused's office may have been first reviewed by one of his advisors or other staff, ${ }^{19725}$ the Chamber finds it inconceivable-primarily in light of the all the evidence demonstrating the Accused's interest in the unfolding events in Srebrenica, as well as on the proper functioning of the communications capacities between the Accused and the VRS, MUP, and DB ${ }^{19726}$ - that such information would have been withheld from him by members of his staff.

5803. With regard to personal conversations and contacts, the Chamber recalls specifically that, at approximately 1 a.m. on 12 July, Živanović spoke to the Accused. ${ }^{19727}$ The Chamber notes Živanović's claim that, after informing the Accused about the "liberation" of Srebrenica, the conversation ended. ${ }^{19728}$ In that regard, the Chamber recalls, first, that the Accused had already been informed by Gvero that afternoon that the Bosnian Serb Forces had taken Srebrenica. ${ }^{19729}$ Further, according to Živanović's own admission, the Accused told Živanović that he had not yet been able to reach Mladić or Krstić. ${ }^{19730}$ Accordingly, the Chamber considers that at the time of his

to eliminate the Bosnian Muslims in Srebrenica and more specifically of the mass killings, as discussed below, the Chamber will not give these arguments any further consideration. P3054 (VRS Main Staff Report, 12 July 1995), paras. 6(a)-6(b), p. 4; P4464 (VRS Main Staff Report 13 July 1995), paras. 6(a)-6(b); P4457 (VRS Main Staff Report, 14 July 1995), paras. 6(a)-6(b).

19721 P4464 (VRS Main Staff Report 13 July 1995), paras. 6(a)-6(b); P4457 (VRS Main Staff Report, 14 July 1995$)$, paras. 6(a)-6(b). See also P4460 (VRS Main Staff Report, 15 July 1995), paras. 6(a)-6(b) (referring not to previously captured detainees but to the further surrender of "several enemy groups").

19722 P4460 (VRS Main Staff Report, 15 July 1995), paras. 6(a)-6(b); D2101 (VRS Main Staff Report, 16 July 1995$)$, paras. 6(a)-6(b); D2102 (VRS Main Staff Report, 17 July 1995), paras. 6(a)-6(b).

19723 See fn. 19426.

19724 Defence Final Brief, paras. 3130-3131 (specifically referring to P6396 and P2288).

19725 See e.g. P4358 (Witness statement of Mira Mihajlović dated 6 February 2012), paras. 23-24.

19726 See e.g. Christian Nielsen, T. 16330-16334 (7 July 2011); P2990 (Excerpt of logbook of telegrams received, 12-18 July 1995); P2991 (Excerpt of logbook of telegrams sent, 8-16 July 1995).

19727 See para. 5762.

19728 D3932 (Witness statement of Milenko Živanović dated 27 October 2013), para. 8.

19729 See para. 5690.

19730 D3932 (Witness statement of Milenko Živanović dated 27 October 2013), para. 8. 
conversation with Živanović the Accused was seeking additional information beyond the fact that Srebrenica had fallen. The Chamber recalls that Živanović had attended the first and second meetings which had been held at the Hotel Fontana earlier that evening, as well as the meeting at the Bratunac Brigade Command. ${ }^{19731}$ Thus, while the Chamber cannot make a finding as to whether Živanović briefed the Accused on the killing aspect of the plan to eliminate, it finds it inconceivable that Živanović would not have provided the Accused with further updates regarding the events on the ground which had occurred after the Accused's previous conversation with Gvero-including the outcomes of those meetings.

5804. Additionally, Kovač, who had been receiving continuous updates since the commencement of the Srebrenica operation and had received increasingly urgent communications from Vasić on 13 July, also shared such information with the Accused in person that afternoon. ${ }^{19732}$ A few hours later, while meeting with the members of the Serbian diaspora around the time when Kovač reached Vlasenica, the Accused received an hour-long phone call from Mladić, who was then at the Drina Corps Command and reported that Srebrenica was "done". 19733

5805. Finally, the Chamber recalls that, at approximately 8 p.m. on 13 July, Deronjić and the Accused spoke through an intermediary about the fate of the thousands of Bosnian Muslim male detainees then being held on buses and in detention facilities in Bratunac town. ${ }^{19734}$ The Accused claims that no inference can be drawn from the conversation on 13 July with Deronjić that the Accused knew of any plan to kill the detainees from Srebrenica, or that the detainees had been, were being, or would be executed. ${ }^{19735}$ The Chamber notes that, despite the fact that Deronjić and the Accused did not explicitly mention the killing of detainees during the conversation, they spoke in code, referring to the detainees as "goods" which had to be placed "inside the warehouses before twelve tomorrow". ${ }^{19736}$ The Accused further specified, "not in the warehouses /?over there/, but somewhere else", which the Chamber has already interpreted as a direction to move the detainees to Zvornik. ${ }^{19737}$ The Chamber recalls that, earlier that evening, Deronjić had complained to Beara about the detainees' presence in Bratunac, and that upon encountering Deronjić in Bratunac town, Davidović had urged him to use his connections to the Accused to have the buses moved. ${ }^{19738}$ Moreover, the Chamber recalls that immediately after this conversation, Beara and Deronjić

\footnotetext{
19731 See paras. 5040, 5695, fn. 19307.

19732 See paras. 5766-5767.

19733 See paras. 5768-5769.

19734 See para. 5772.

19735 Defence Final Brief, paras. 3024-3026.

19736 See para. 5772.

19737 See para. 5710.

19738 See para. 5710.
} 
discussed where - not whether-the detainees were to be killed. ${ }^{19739}$ It is therefore clear that at the time of Beara and Deronjić's conversation, a decision had already been made to kill the detainees, and Deronjić invoked the Accused's authority to convince Beara to accede to their movement to Zvornik. In the Chamber's view, the use of code to refer to the detainees, as well as the direction to move them toward Zvornik, demonstrates the malign intent behind the conversation. The Chamber finds that this conversation, in addition to the Accused's subsequent acts as described further below, ${ }^{19740}$ demonstrate beyond reasonable doubt the Accused's agreement to the expansion of the objective to encompass the killing of the Bosnian Muslim males.

5806. After this conversation, the Accused continued to seek, and was provided with, information through multiple channels. During the approximately 24 hours that Kovač spent in the area touring Vlasenica, Srebrenica, and the Bratunac and Zvornik areas on 14 July, while the Bosnian Muslim males were being moved to Zvornik and the executions at Orahovac got underway, Kovač met with Mladić, Krstić, Živanović, Borovčanin, and Vasić, thus obtaining additional important information that he ultimately relayed back to the Accused when he returned to Pale on 14 July. ${ }^{19741}$ Furthermore, in the afternoon on 14 July, the Accused received information over the phone from a commander on the ground in Srebrenica, who reported on the movement of the column of Bosnian Muslim men. ${ }^{19742}$

5807. The Chamber recalls that earlier on 14 July, the Accused had met with Deronjić alone between 12:40 p.m. and 1:10 p.m.; both later met together with a larger delegation from Srebrenica for about four hours. ${ }^{19743}$ The Prosecution claims that the only reasonable inference is that Deronjić travelled to Pale in advance in order to meet with the Accused in private, report on significant events relating to the killing aspect of the plan to eliminate, and receive further instructions; thus, during their initial meeting, the Accused and Deronjić must have discussed the murder and burial operations then in progress in the Bratunac and Zvornik areas and, more specifically, Deronjić must have reported on the implementation of the Accused's order to transport the detainees from Bratunac to Zvornik by midday that day. ${ }^{19744}$ The Accused acknowledges that he met alone in his office with Deronjić on 14 July; he also acknowledges the evidence that, by the time of this meeting, Deronjić was aware of the killings at the Kravica Warehouse on 13 and 14 July, and that

\footnotetext{
19739 See para. 5712.

19740 See paras. 5805-5808. Further, the Chamber notes that on the following day, Beara referred to an order emanating from "two Presidents". See para. 5715.

19741 See paras. $5771,5775,5780$.

19742 See para. 5778.

19743 See para. 5777

19744 Prosecution Final Brief, paras. 998-999.
} 
the latter had participated in discussions to bury the bodies of detainees who had been killed. ${ }^{19745}$ However, the Accused argues that it is "reasonably possible" that Deronjić did not inform the Accused of what he knew, suggesting that "there were more pressing issues concerning [the] administrative organisation of Srebrenica" for the two to have discussed, that the Kravica Warehouse killings required no action of the Accused, and that Deronjić would not have wanted to tell the Accused that a negative incident had occurred on his watch. ${ }^{19746}$

5808. In relation to the content of the conversation between Deronjić and the Accused prior to their meeting with the larger group, the Chamber notes that it has no direct evidence thereof. However, it received evidence that, during the second meeting, Deronjić reported on the situation in Srebrenica. ${ }^{19747}$ As stated above, the Chamber is satisfied that Deronjić had been aware of the killings at the Kravica Warehouse since the evening of 13 July. ${ }^{19748}$ More importantly, the Chamber recalls the conversation between the Accused and Deronjić the night before in which the Accused ordered the transfer of the detainees from Bratunac to Zvornik. ${ }^{1974}$ The Chamber also recalls Deronjić's participation in the efforts to bury the bodies of those killed at the Kravica Warehouse, starting in the early hours of 14 July. ${ }^{19750}$ The Chamber also received evidence that the Accused and Deronjić had frequent communications, either by telephone or in person, during the Srebrenica operation. ${ }^{19751}$ According to officials from Bratunac municipality, in his official capacity as civilian commissioner of Srebrenica, Deronjić should have reported about the killings at the Kravica Warehouse to the Accused. ${ }^{19752}$ More specifically, Simić testified that Deronjić told him that he had informed the Accused about the events at the Kravica Warehouse the day after the incident. ${ }^{19753}$ The Chamber received evidence that there was no mention or discussion about the

\footnotetext{
19745 Defence Final Brief, paras. 3030-3031.

19746 Defence Final Brief, paras. 3032-3034.

19747 P4382 (Video footage re Miroslav Deronjić's meeting with Radovan Karadžić in Pale, 14 July 1995). See Milenko Katanić, T. 24475-24778, 24484 (10 February 2012).

19748 See para. 5240. See also P4374 (Witness statement of Milenko Katanić dated 11 October 2011), para. 72; Milenko Katanić, T. 24474, 24506 (10 February 2012). Jovan Nikolić testified that he informed Deronjić and other municipal authorities about additional killings at the Kravica Warehouse in the morning of 14 July. D3126 (Witness statement of Jovan Nikolić dated 10 March 2013), paras. 58-59; Jovan Nikolić, T. 35520 35522 (14 March 2013). See also Ljubisav Simić, T. 37291-37292 (16 April 2013).

19749 See para. 5772.

19750 See paras. 5242, 5244.

19751 P4374 (Witness statement of Milenko Katanić dated 11 October 2011), paras. 70-71; Nebojša Ristić, T. 1539115392 (24 June 2011).

19752 P4374 (Witness statement of Milenko Katanić dated 11 October 2011), para. 72; Ljubisav Simić, T. 37310 (16 April 2013).

19753 Ljubisav Simić, T. 37293, 37306-37307 (16 April 2013). See Ljubisav Simić, T. 37310 (16 April 2013 ) (clarifying that he did not know what Deronjić had told the Accused, or whether he had informed the Accused directly).
} 
executions of detainees in Srebrenica during the meeting with the Srebrenica representatives. ${ }^{19754}$ Nevertheless, the Chamber has no doubt that during the individual meeting between Deronjić and the Accused, they both discussed the killings at the Kravica Warehouse, and the implementation of the Accused's order to transport the detainees from Bratunac to Zvornik by midday that day. ${ }^{19755}$

5809. The Accused continued receiving information from those present in the Srebrenica area during the following days. For example, Bajagić, who had been prevented from taking photos of captured Bosnian Muslim men being detained at Nova Kasaba football field and had heard about the killings at Kravica Warehouse, met with and reported these events to the Accused in the very early hours of 15 July. ${ }^{19756}$ Further, following a direct report from Vasić to the Accused outlining a need for additional forces, as well as Pandurević's report to the Main Staff regarding the opening of the corridor, unsuccessful efforts were made in the Accused's name to contact Pandurević for an explanation of his decision; Karišik was then dispatched to Zvornik, and ultimately reported to the Accused about the opening of the corridor. ${ }^{19757}$

5810. Based on all the evidence discussed above, the Chamber finds that the Accused-who had shared the common purpose of permanently removing the Bosnian Muslims from Bosnian Serbclaimed territory since October $1991^{19758}$ - knew of the concrete plan to eliminate the Bosnian Muslims in Srebrenica by forcibly removing the women, children, and elderly men as the plan began to be transformed as the enclave fell. In reaching this conclusion, the Chamber notes that the Accused immediately issued orders establishing Bosnian Serb institutions in Srebrenica, which the Chamber has already found to be an indication that the removal of the Bosnian Muslim population then envisaged was intended to be permanent. ${ }^{19759}$ In this respect, the Chamber recalls that one of the Accused's orders tasked Deronjić with "ensur[ing] that all civilian and military organs treat[ed] all citizens who participated in combat operations against the [VRS] as prisoners of war, and ensure that the civilian population c[ould] freely choose where they w[ould] live or move to" ${ }^{19760}$ The Chamber considers that, as it has found in relation to similar orders which explicitly promoted respect for international humanitarian law which were issued earlier in the conflict, the Accused's actions were insufficient to prevent criminal acts. Further, in relation to the apparent choice given

\footnotetext{
19754 D3561 (Witness statement of Dane Katanić dated 14 December 2012), para. 8; Dane Katanić, T. 38675 (22 May 2013). While Krajišnik did not recall the meeting with the representatives of Srebrenica specifically, he was categorical in his assertion that nobody spoke in his presence about any crimes committed in Srebrenica. Momčilo Krajišnik, T. 43352 (12 November 2013).

19755 See paras. 5313-5316.

19756 See para. 5783.

19757 See paras. 5784.

19758 See para. 3524.

19759 See para. 5694.

19760 See para. 5693.
} 
to the civilian population as to where to live or move to, the Chamber finds that in light of Deronjić's subsequent actions, including the fact that he held a meeting in Srebrenica that night, where he appointed directors for all public enterprises and institutions, and his subsequent attendance at the second and third Hotel Fontana meetings, where Mladić-despite explicit statements indicating that the population's wishes would be respected-coerced the representatives of the Bosnian Muslims into agreeing to leave the enclave, ${ }^{19761}$ Deronjić clearly did not give effect to this provision of the Accused's order.

5811. The Chamber also finds that the Accused adopted and embraced the expansion of the plan to entail the killing the Bosnian Muslim men and boys in Srebrenica during his conversation with Deronjić on the evening of 13 July. Given the Accused's position as RS President and Supreme Commander, as well as the evidence demonstrating the continuous flow of information he was seeking and receiving from the ground from many different sources the Chamber considers that the Accused must have known about the killing aspect of the plan to eliminate at some point prior to his conversation with Deronjić in the evening of 13 July. However, the Chamber can only make a positive determination as to the Accused's agreement to the expansion of the means so as to encompass the killing of the men and boys as of the moment of the conversation with Deronjić. The Accused's shared intent is reaffirmed by the fact that, from the moment he directed Deronjic to move the detainees to Zvornik the Accused became, and subsequently continued to be, actively involved in overseeing the implementation of the plan to eliminate the Bosnian Muslims in Srebrenica by killing the men and boys.

5812. The Chamber recalls that, throughout the relevant period, the Accused actively monitored the international media's coverage of the events in Srebrenica, as he was concerned about the coverage of such events. ${ }^{19762}$ The Chamber has already found that, during this time, the Accused, together with Mladić, embarked on an effort to disseminate false information about the fate of the Bosnian Muslim males as well as the conditions under which the remainder of the Bosnian Muslim population was transferred to Potočari. ${ }^{19763}$ The Accused also denied international organisations access to Srebrenica and the Bratunac and Zvornik areas. ${ }^{19764}$ In the Chamber's view, given the Accused's nearly-contemporaneous knowledge of the ongoing killing operation, the only reasonable inference is that by disseminating false information, the Accused intended to shield the true actions of the Bosnian Serb Forces from international attention and intervention.

\footnotetext{
19761 See paras. 5691, 5695, 5697, 5703.

19762 See para. 5785.

19763 See paras. 5786-5787.

19764 See para. 5788.
} 
5813. Furthermore, from the point at which the Accused ordered the detainees to be transferred to Zvornik until the spring of 1996, the Accused took no action to initiate investigations or prosecutions of the direct perpetrators of the despicable crimes committed in the Bratunac and Zvornik areas following the fall of the Srebrenica enclave to the Bosnian Serb Forces in July 1995. ${ }^{19765}$ Neither the 23 March 1996 Order nor the 1 April 1996 Order resulted in bona fide investigations or prosecutions. ${ }^{19766}$ By contrast, on 20 July 1995, the Accused's office issued a press release congratulating the units of the Bosnian Serb Forces which had been involved in the killing operation in Zvornik-the Main Staff, Drina Corps and "Staff of the Police Armed Forces"19767_ on the "brilliant victory in Srebrenica and Žepa". ${ }^{19768}$ In the following weeks, the Accused reiterated this praise in an interview with Bosnian Serb television, where he referred to Mladić as a "legend". 19769

5814. Based on all this evidence, and taking into consideration that the Accused knew of the concrete plan of eliminating the Bosnian Muslims in Srebrenica by forcibly removing the women, children, and elderly men as of the evening of $11 \mathrm{July}$, and participated in that plan; and that he agreed to and embraced its expansion to encompass the killing of the able-bodied men and boys as demonstrated by his conversation with Deronjić on the evening of 13 July as well as his subsequent actions, the Chamber is satisfied beyond reasonable doubt that the Accused shared the common purpose of eliminating the Bosnian Muslims in Srebrenica with the other members of the JCE.

\section{iv. Accused's contribution to the Srebrenica JCE}

5815. Having established above that the Accused shared the common purpose of eliminating the Bosnian Muslims in Srebrenica, the Chamber now turns to the means through which the Accused significantly contributed to the Srebrenica JCE. In assessing whether the Accused made a

\footnotetext{
19765 See paras. 5793-5796.
}

19766 See paras. 5793-5795. The Chamber also finds that, while it did not receive evidence as to the Accused's direct participation in the reburial operation conducted in September-October 1995, an inference can be drawn from the conversation between the Accused and Mladić on 22 March 1996, about the Accused's knowledge of the operation. See para. 5793. See also Prosecution Final Brief, para. 812 (alleging that, once it became apparent that the international community had learned of the Srebrenica killings, VRS, MUP, and civilian authorities, with the Accused's approval, engaged in a highly secret and co-ordinated operation for the reburial of bodies to more remote areas).

19767 The Chamber understands the reference to the "Staff of the Police Armed Forces" to be a reference to the MUP units dispatched to the Srebrenica area under Borovčanin's command.

19768 See para. 5789. The Chamber also notes that the Accused indeed promoted Krstić on 13 July and heralded both him and Živanović as "the main architects" of the "brilliant victory in Srebrenica and Žepa". See para. 5789, fn. 19673.

19769 See fn. 19676. The Chamber recalls that before issuing the 23 March 1996 Order, the Accused warned Mladic that, "[i]f they expand the campaign then they would form a joint commission [...] to investigate the killing of every individual”. P1490 (Ratko Mladić's notebook, 16 January-28 November 1996), e-court p. 47. In the Chamber's view, the fact that the Accused forewarned Mladić is yet another indication that the Accused shared the common purpose to eliminate the Bosnian Muslims in Srebrenica. See para. 5793. 
significant contribution to the Srebrenica JCE, the Chamber has limited its examination to the Accused's acts and conduct during the period of this JCE. In this regard, the Chamber recalls its finding that the common plan to eliminate the Bosnian Muslims in Srebrenica was formed as the enclave fell and that although this objective initially encompassed the forcible removal and persecution of the Bosnian Muslims in Srebrenica, some members agreed to an expanded objective which involved the killing of the Bosnian Muslim men and boys. ${ }^{19770}$

5816. The Chamber has already found above that the Accused knew of the concrete plan to eliminate the Bosnian Muslims in Srebrenica by forcibly removing the women, children, and elderly men as the long-term strategy aimed at removing the Bosnian Muslim population from Srebrenica began to be transformed into a concrete plan to eliminate them, as the enclave fell, and that he agreed to the further expansion of that plan so as to involve killings, at the latest during his conversation with Deronjić on the night of 13 July. ${ }^{19771}$

5817. In relation to the removal aspect of the plan to eliminate, the Chamber recalls that the Accused used his de jure powers to issue orders establishing Bosnian Serb municipal structures in "Serb Srebrenica"; this included the appointment of Deronjić as civilian commissioner and the formation of the SJB. ${ }^{19772}$ As the Chamber has already found, the establishment of such structures demonstrates that the removal of the Bosnian Muslim population from Srebrenica was envisaged to be permanent. ${ }^{19773}$ Further, during the take-over, the Accused issued an order which allowed for his continued oversight and control of the restrictions on the access of humanitarian convoys to the enclave, which had the practical effect of limiting international access to the enclave. ${ }^{19774}$ All of these orders were carried out as instructed by the Accused. ${ }^{19775}$

5818. In relation to the killing aspect of the plan to eliminate, the Chamber recalls that when the Accused spoke to Deronjić, who desperately wanted to avoid the Bosnian Muslim males being killed in Bratunac, at approximately 8 p.m., far from intervening to prevent the killings from taking place at all, the Accused himself ordered that the Bosnian Muslim male detainees who were then being held in Bratunac be transferred elsewhere; they were then taken to Zvornik and killed. ${ }^{19776}$ The Chamber also recalls that, as President of the RS and Supreme Commander of the VRS, the

\footnotetext{
19770 See paras. 5731, 5736-5737.

19771 See paras. 5805-5814.

19772 See para. 5693. The Chamber further recalls that in addition to the written orders he issued, the Accused took the time to reiterate and reinforce over the phone, at least once, his written orders. See para. 5694.

19773 See para. 5694.

19774 See para. 5761

19775 See paras. 5693-5694, 5761, 5787-5788.

19776 See paras. 5772, 5805, 5814
} 
Accused had de jure authority over the VRS and the MUP which he exercised in fact: ${ }^{19777}$ Deronjić, as civilian commissioner of Srebrenica, answered directly to the Accused. ${ }^{19778}$ Accordingly, the Accused was the sole person within the RS with the power to intervene to prevent the Bosnian Serb Forces from moving the detainees to Zvornik to be killed. ${ }^{19779}$ Mladić's order, which was consistent with the Accused's decision to move the detainees to Zvornik, was almost immediately communicated down the chain of command and ultimately implemented by members of the VRS security organs, including Beara and Popović, who have been found by the Chamber to have been members of the Srebrenica JCE. ${ }^{19780}$ Furthermore, during a briefing of VRS officers at the Standard Barracks on the following afternoon, Beara stated that he had received an order from "two Presidents" to "get rid" of the detainees who were then being held in various locations in Zvornik. ${ }^{19781}$ The Chamber is thus satisfied that the Accused's order to move the Bosnian Muslim males of Srebrenica enabled their transfer to Zvornik, where they were ultimately killed.

5819. The Chamber also recalls that, with full knowledge of the ongoing killing operation, the Accused declared a state of war in the area of Srebrenica-Skelani Municipality on 14 July, and created the War Presidency of Srebrenica-Skelani Municipality, appointing Deronjić as the president of that body. ${ }^{19782}$ The Chamber recalls that by the time the Accused issued these orders, the Bosnian Serb Forces had already taken Srebrenica and thus, there was no military reason to declare a state of war. The declaration of the state of war had the practical effect of allowing the armed forces deployed in the area of responsibility of the Drina Corps, which also encompassed the Bratunac and Zvornik municipalities, to utilise all human and material resources without having to follow complicated procedural protocols, ${ }^{19783}$ thus facilitating the ongoing killing operation. In this regard, the Chamber recalls specifically that, as early as 14 July, the burial of bodies at Glogova began, with the assistance of civilian resources. ${ }^{19784}$ Civilian resources were also used to assist in the burial of bodies of those killed at the various facilities in Zvornik over the following days. ${ }^{19785}$ The Chamber therefore finds that the Accused's issuance of these orders facilitated the smooth execution of the killing aspect of the plan to eliminate.

\footnotetext{
19777 See para. 3157.

19778 See paras. 5693-5694.

19779 The Chamber recalls the Prosecution's claim that the Accused's failure to take measures to prevent his subordinates' involvement in crimes he knew were being committed pursuant to the Srebrenica JCE constitutes a contribution to such JCE. See para. 5749. However, in light of the Chamber's finding that the Accused came to know of the crimes at the latest by approximately 8 p.m. on $13 \mathrm{July}$, this contribution is irrelevant for the crimes committed prior to this time.

19780 See paras. 5711-5712.

19781 See para. 5715

19782 See paras. 5777, 5779.

19783 See para. 5779.
} 
5820. As the Chamber has described in detail above, the Accused utilised numerous channels in order to obtain information from the ground, which enabled him to maintain constant oversight over the plan to eliminate the Bosnian Muslims in Srebrenica as it unfolded. Such means of monitoring included regular written reports from both the Main Staff and the Main Staff Security Organ, as well as the MUP, all of which described the transport of the Bosnian Muslims from Potočari as well as the existence of and efforts to intercept the column of Bosnian Muslim men and capture its members. ${ }^{19786}$ The information contained in these reports was augmented by conversations with Živanović in the very early hours of 12 July and with Mladić on the afternoon of 13 July. ${ }^{19787}$ By the time the Accused spoke to Mladić, he had already sent Kovač to the field, where the latter met with Mladić and spent more than 24 hours touring the Srebrenica area before returning to Pale and briefing the Accused on the following day. ${ }^{19788}$ The Accused also received information from personal contacts, such as Deronjić—who he appointed as civilian commissioner of Srebrenica-and Bajagić, who came to Pale at the Accused's request in the early morning hours of 15 July in order to share his observations of the events in Srebrenica with the Accused. ${ }^{19789}$ It is thus clear to the Chamber that the Accused maintained a close overview of what happened in the aftermath of the Bosnian Serb Forces' take-over of Srebrenica. This finding is consistent with the fact that, merely 90 minutes after Pandurević reported to the Main Staff that he had opened a corridor to permit members of the column to pass, a Main Staff officer called the Zvornik Brigade on behalf of the "the boss [...] the main head of state" in order to enquire what had happened. 19790 At the same time, Karišik was sent to Bratunac for the same purpose, and by 4:15 p.m., he had informed the Accused that the corridor was open. ${ }^{19791}$ The Chamber recalls that that night, further reinforcements were sent to the Zvornik area, and the following day, the Main Staff sent three colonels to investigate Pandurević's decision. ${ }^{19792}$ While the Chamber cannot draw any conclusions as to whether these latter two actions were taken pursuant to a specific order of the Accused, the Chamber finds that they were consistent with the tenor of his oversight, as had the Accused intended for the corridor to remain open, he would have issued such an order. Particularly given his position as President of the RS and Supreme Commander of the VRS, and the extent of

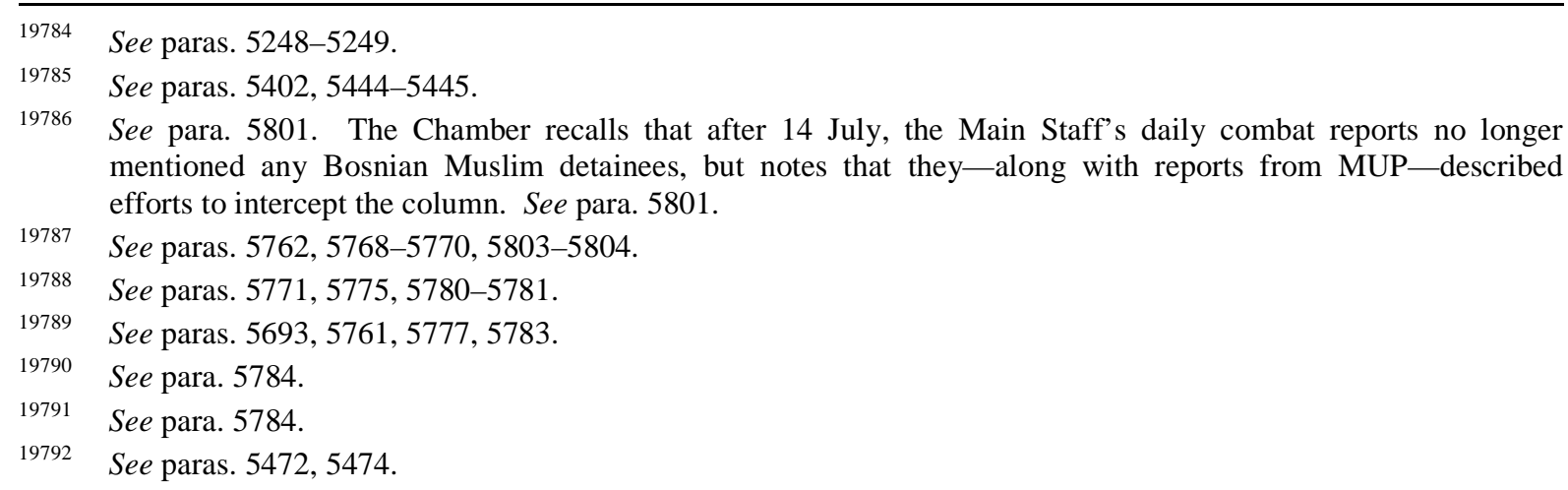

19786 See para. 5801. The Chamber recalls that after 14 July, the Main Staff's daily combat reports no longer mentioned any Bosnian Muslim detainees, but notes that they-along with reports from MUP-described efforts to intercept the column. See para. 5801.

19787 See paras. 5762, 5768-5770, 5803-5804.

19788 See paras. 5771, 5775, 5780-5781.

19789 See paras. 5693, 5761, 5777, 5783.

19790 See para. 5784.

19791 See para. 5784.

19792 See paras. 5472, 5474. 
his contemporaneous knowledge as described in more detail above, the Chamber considers that such oversight, coupled with the fact that the Accused made no other attempt to interfere with or influence what was transpiring on the ground, furthered the objective of eliminating the Bosnian Muslims in Srebrenica.

5821. In the preceding paragraphs, the Chamber has identified the various ways through which the Accused furthered the common plan to eliminate the Bosnian Muslims in Srebrenica. Based on the abundant evidence before it, and considering the totality of the Chamber's findings in this regard, as well as the functions and positions of the Accused at the time-particularly the de jure authority over the VRS and MUP which he exercised in fact-and the impact of his acts and omissions on the implementation of this JCE as set out above, the Chamber finds that the Accused significantly contributed to the Srebrenica JCE.

\section{v. Accused's responsibility for crimes pursuant to the Srebrenica JCE}

5822. The Chamber has found above that the Accused shared the common purpose of eliminating the Bosnian Muslims in Srebrenica by forcibly removing the women, children, and elderly men and by killing the men and boys, ${ }^{19793}$ and that he significantly contributed to the plan to accomplish this objective by these means. ${ }^{19794}$ The Chamber has also found that the crimes of genocide, murder, extermination, persecution, and inhumane acts (forcible transfer) were committed by Bosnian Serb Forces following the fall of the Srebrenica in July 1995. ${ }^{19795}$ The Chamber has further found that these crimes fell within either the original or the expanded scope of that common purpose, which amounted to or involved their commission. ${ }^{19796}$ The Chamber will now examine whether the Accused shared the intent for each of these crimes and is thus criminally responsible for them as alleged in the Indictment.

(A) Murder, extermination, and inhumane acts (forcible transfer)

5823. As set out above, the Chamber has found that the Accused had contemporaneous knowledge of the plan to eliminate as it unfolded and came to encompass both the forcible removal of thousands of Bosnian Muslim women, children, and elderly men of Srebrenica from the UN Compound in Potočari as well as the killing of thousands of able-bodied Bosnian Muslim men and boys, and that he significantly contributed to the plan which accomplished this. The Chamber thus

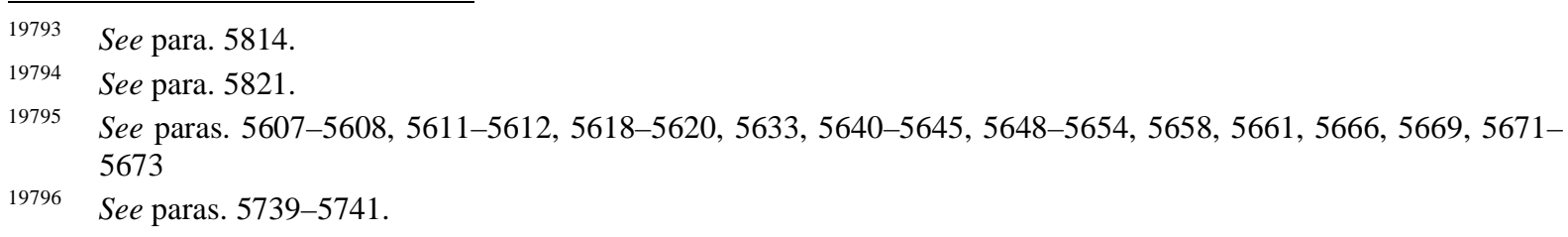


finds that the Accused intended the crimes of murder and inhumane acts (forcible transfer). The Chamber is also satisfied that, given the vast scale of the killing operation and the Accused's knowledge thereof, the Accused possessed the requisite mens rea for extermination.

\section{(B) Persecution}

5824. With regard to persecution, and first the issue of persecutory intent, the Chamber recalls that an accused's intent to discriminate on one of the prohibited grounds may be inferred where the circumstances surrounding the commission of the alleged acts substantiate the existence of discriminatory intent. ${ }^{19797}$ In this regard, the Chamber recalls that the plan to eliminate the Bosnian Muslims in Srebrenica was by nature a discriminatory plan targeting the Bosnian Muslims in Srebrenica. The Chamber is thus satisfied that, as detailed above, the Accused participated in and significantly contributed to this plan with the intent to discriminate against the Bosnian Muslims of Srebrenica, and thus with persecutory intent. Earlier in the Judgement, the Chamber found that the circumstances in which the forcible removal of the Bosnian Muslim population of Srebrenica and the execution of the Bosnian Muslim men and boys were carried out were such that they demonstrated that Bosnian Serb Forces deliberately inflicted serious physical and mental suffering on them, and thus amounted to cruel and inhumane treatment, an act of persecution. ${ }^{19798}$ Having found that the Accused shared the intent for murder, extermination, and forcible transfer, the Chamber finds that the only reasonable inference from the circumstances in which the removal and killing aspects of the plan to eliminate were conducted, and of which he was fully aware, is that he also shared the intent to subject the Bosnian Muslim population in Srebrenica to cruel and inhumane treatment.

\section{(C) Genocide}

5825. With respect to the crime of genocide, the Chamber recalls that, in order for the Accused to be criminally responsible for this crime, it must be satisfied that the Accused intended to destroy the protected group, in whole or in part, as such. ${ }^{19799}$ The Chamber further notes that, as other chambers have held, indications of such intent are "rarely overt", ${ }^{19800}$ and thus intent must often be inferred on the basis of the totality of the evidence, taking into account such factors as the scale of

\footnotetext{
19797 See para. 500.

19798 See paras. 5644-5646.

19799 See para. 549.

19800 Tolimir Trial Judgement, para. 745 (citing Kayishema and Ruzindana Appeal Judgement, para. 159 and Gacumbitsi Appeal Judgement, para. 40).
} 
atrocities as well as the systematic targeting of victims on account of their membership in a particular group. ${ }^{19801}$

5826. The Prosecution argues that the Accused shared with other members of the Srebrenica JCE the intent to destroy the Bosnian Muslims of Srebrenica, which—taking into account the Accused's "supreme position"-manifested itself through his acts, omissions, and statements, as well as the systematic, coordinated, and targeted manner in which the genocidal acts were carried out. ${ }^{19802}$ As stated at the outset of this section, the Chamber has considered the Accused's arguments, which were framed as denials of his membership in a "genocidal plan", in relation to whether the Accused was a member of the Srebrenica JCE above, as they relate primarily to whether the Accused was aware of the killing aspect of the plan to eliminate. ${ }^{19803}$ The Chamber has been mindful of those same arguments when analysing whether the Accused intended to destroy the Bosnian Muslims in Srebrenica, as set out in the analysis below.

5827. The Chamber has already established that the Accused participated in the plan to eliminate the Bosnian Muslims in Srebrenica by forcibly removing the women, children, and elderly men and killing the men and boys with the intent to discriminate against the Bosnian Muslims in Srebrenica. ${ }^{19804}$ However, such discriminatory intent is not necessarily equivalent with the intent to destroy the Bosnian Muslims in Srebrenica as such, which constituted a substantial part of the protected group of Bosnian Muslims. ${ }^{19805}$ The Chamber must therefore further analyse the acts and conduct of the Accused detailed above in order to determine whether, in light of his knowledge of the implementation of the plan to eliminate-particularly his knowledge of its killing aspect-it is satisfied that the only reasonable inference is that the Accused intended to destroy the Bosnian Muslims in Srebrenica as such.

5828. In this regard, the Chamber recalls that, in determining that the killings of thousands of Bosnian Muslim males and the acts causing serious bodily or mental harm to thousands of Bosnian Muslims of Srebrenica were carried out with the intent to destroy that part of the protected group as such, the Chamber had particular regard to the fact that the Bosnian Serbs tried to kill every ablebodied Bosnian Muslim male from Srebrenica. ${ }^{19806}$ Indeed, the plan, which was carried out by Bosnian Serb Forces who vigorously pursued the Bosnian Muslim males in the column,

\footnotetext{
19801 See para. 550.

19802 Prosecution Final Brief, paras. 1096, 1098-1099. The Prosecution points specifically to the Accused's expression of regret that not all of the Bosnian Muslim men were killed, as well as his efforts to cover up the forcible removal and murder operations, in support of its argument. Prosecution Final Brief, para. 1099.

19803 See para. 5754.

19804 See para. 5824.

19805 See para. 5672.
} 
encompassed the killing of all Bosnian Muslim males within Bosnian Serb custody, irrespective of whether they were combatants or civilians and regardless of whether they were captured or had surrendered. ${ }^{19807}$

5829. With respect to the intent of the Accused, the Chamber recalls that the Accused was apprised by Deronjić that as of 8:10 p.m., the Bosnian Serb Forces had "about two thousand" Bosnian Muslim males in custody and expected that number to increase overnight. ${ }^{19808}$ The Chamber also considers that the only reasonable inference is that the Accused must have learned from Kovač_-either during their conversation on 13 July or during their subsequent meeting on 14 July - that most of the able-bodied Bosnian Muslim men had not gone to the UN Compound with their families, but had fled through the woods. ${ }^{19809}$ Moreover, the Chamber recalls that the Accused received daily combat reports from the Main Staff, which, after reporting on the existence of the column of Bosnian Muslim males-as well as on the Bosnian Serb Forces' subsequent organised efforts to intercept it which resulted in the capture and surrender of large numbers of Bosnian Muslim males between 12 and 14 July_made no further mention of detainees. ${ }^{19810}$ Accordingly, in view of his awareness of the number of males in custody, in the Chamber's view, there is no doubt that the Accused knew that the thousands of Bosnian Muslim male detainees being held by the Bosnian Serb Forces in the Srebrenica area constituted a very significant percentage of the Bosnian Muslim males from Srebrenica.

5830. The Chamber therefore takes particular note of the fact that, despite his contemporaneous knowledge of its progress as set out above, the Accused agreed with and therefore did not intervene to halt or hinder the killing aspect of the plan to eliminate between the evening of 13 July and 17 July. Instead, he ordered that the detainees be moved to Zvornik, where they were killed. ${ }^{19811}$ Moreover, once Pandurević reported on 16 July that he had opened a corridor to allow members of the column who had not yet been captured or surrendered to pass through, Karišik was promptly sent to investigate and the corridor was closed within a day. ${ }^{19812}$ Finally, the Chamber recalls that although he touted the opening of the corridor when speaking to the international press, in a closed

\footnotetext{
19806 See para. 5669.

19807 See paras. 5669, 5731.

19808 See para. 5772.

19809 See paras. 5804, 5806.

19810 See para. 5801.

19811 See para. 5818. The Chamber recalls that it received evidence that the Accused agreed to allow the local staff of UNPROFOR, which included Bosnian Muslim males, to leave the UN Compound with UNPROFOR. See para. 5132. The Chamber considers that the reason proffered by the Bosnian Serb Forces for separating and taking custody of the other Bosnian Muslim males in Potočari-namely that they were to be screened for involvement in war crimes-would not have applied to such staff, and the Chamber finds that this action by the Accused does not raise any doubt regarding his intent that all Bosnian Muslim males in Bosnian Serb custody be killed.

19812 See paras. 5470-5472, 5784.
} 
session of the Bosnian Serb Assembly held weeks later, the Accused expressed regret that the Bosnian Muslim males had managed to pass through Bosnian Serb lines. ${ }^{19813}$ Accordingly, the Chamber considers that the only reasonable inference available on such evidence is that the Accused shared with Mladić, Beara, and Popović the intent that every able-bodied Bosnian Muslim male from Srebrenica be killed, which, in the Chamber's view, amounts to the intent to destroy the Bosnian Muslims in Srebrenica.

\section{(D) Conclusion}

5831. Having found above that the Accused shared the intent for the crimes of murder, inhumane acts (forcible transfer), extermination, persecution, and genocide, the Chamber finds that by virtue of his participation in the Srebrenica JCE, the Accused is responsible for these crimes. ${ }^{19814}$ However, the Chamber notes that because it is only able to determine that the Accused agreed to the killing aspect of the plan to eliminate the Bosnian Muslims in Srebrenica by, at the latest, 13 July at 8:10 p.m., it cannot hold the Accused responsible for the killings and the related acts of persecution which occurred prior to that time through his participation in the Srebrenica JCE.

5832. The Chamber takes note of the Prosecution's alternative allegation that the Accused is responsible for the crimes of genocide, murder, extermination, and persecution as foreseeable consequences of the Overarching JCE. ${ }^{19815}$ However, the Chamber considers this allegation to be an alternative charge only if the Chamber had been unable to determine the existence of the common plan to eliminate the Bosnian Muslims in Srebrenica by forcibly removing the women, children, and elderly men and killing the men and boys. Since the Chamber has established the existence of the common purpose of the Srebrenica JCE above, as well as the sharing of this common purpose by a plurality of persons, including the Accused, who significantly contributed to it, the Chamber shall not consider the Prosecution's alternative allegation further.

\section{c. Superior responsibility}

5833. Having found above that the Accused could not be held responsible through his participation in the Srebrenica JCE for the killings which occurred prior to his conversation with Deronjić on 13 July, wherein he agreed to the killing aspect of the common plan to eliminate, the Chamber will now consider the Accused's responsibility as a superior pursuant to Article 7(3) of

\footnotetext{
19813 See paras. 5474, 5791.

19814 In addition, based on all the evidence discussed above, the Chamber finds that the Accused was aware that his conduct was part of a widespread and systematic attack directed against a civilian population.

19815 Indictment, paras. 43, 59, 64.
} 
the Statute. In this regard, the Chamber will consider whether the Accused is responsible for failing to punish these killings. ${ }^{19816}$

\section{i. Submissions of the parties}

5834. The Prosecution generally argues that the Accused is responsible for the crimes in Srebrenica as a superior pursuant to Article 7(3) of the Statute, in his capacity of SDS party leader, President of the SNB, President of the Presidency, Supreme Commander of the VRS, and the acknowledged leader of the Bosnian Serbs. ${ }^{19817}$ It adds that the Accused had command and effective control over a vast network of subordinates in the Bosnian Serb Forces and the Bosnian Serb Political and Governmental Organs. ${ }^{19818}$ According to the Prosecution, during the Indictment period the Accused knew or had reason to know that his subordinates were about to commit or had committed crimes charged in the Indictment and nevertheless failed to take the necessary and reasonable measures to prevent the commission of these crimes and/or punish his subordinates who perpetrated them. ${ }^{19819}$

5835. The Chamber notes that, as he did above in relation to his arguments regarding his participation in the Srebrenica JCE, the Accused focuses his arguments in relation to his responsibility under Article 7(3) of the Statute for the Srebrenica component on his alleged responsibility for failing to prevent or punish genocide. However, the Chamber will interpret these arguments to pertain to the Accused's responsibility for failing to prevent or punish the killings listed above. ${ }^{19820}$

5836. The Accused submits that (i) he lacked knowledge or reason to know that crimes had been committed by his subordinates in Srebrenica, (ii) he lacked effective control over the perpetrators, and (iii) he took necessary and reasonable measures to punish the perpetrators. ${ }^{19821}$ According to the Accused, a review of the information available to him as of August 1995, demonstrates that there was nothing to indicate to him that crimes had occurred. ${ }^{19822}$ Therefore, the Prosecution has failed to prove beyond reasonable doubt that the Accused knew or should have known that crimes

\footnotetext{
19816 In the context of this case-particularly the Chamber's findings regarding the point at which the Accused came to know about to the expansion of the means of carrying out the objective of the Srebrenica JCE-the Chamber considers that the Accused's material ability to prevent the killings which occurred prior to this point is irrelevant. Accordingly, it will only examine the Accused's failure to punish these crimes.

19817 Prosecution Final Brief, para. 1113.

19818 Prosecution Final Brief, para. 1113.

19819 Prosecution Final Brief, para. 1114.

19820 See para. 5754.

19821 Defence Final Brief, paras. 3239-3275.

19822 Defence Final Brief, paras. 3241, 3252, 3273.
} 
had been committed in connection with the fall of Srebrenica. ${ }^{19823}$ Lastly the Accused claims that he took necessary and reasonable measures to punish the perpetrators, even though he no longer was required to request an investigation after the Tribunal indicted him for the Srebrenica events. ${ }^{19824}$ In this regard, the Accused argues that, given that he did not have investigative or prosecutorial organs in his cabinet, the only measure he could take to punish crimes was to ensure that the competent authorities were investigating. ${ }^{19825} \mathrm{He}$ also argues that the Prosecution has failed to establish that he deliberately or wilfully failed to punish the perpetrators, as during and after the killings of the men from Srebrenica, "he was no longer in control of the army". ${ }^{19826}$

\section{ii. Crimes committed by subordinates}

5837. The Chamber has found above that the killings of Bosnian Muslim males which occurred prior to the Accused's agreement to the expansion of the means of eliminating the Bosnian Muslims in Srebrenica, which occurred at the latest by 8:10 p.m. on 13 July, were perpetrated by various members of the Bosnian Serb Forces. Specifically, the Chamber has found that ten Bosnian Muslim men were killed by members of the Bosnian Serb Forces present in Potočari on 13 July 1995, all of whom were either members of the VRS or the MUP. ${ }^{19827}$ The Chamber has also found that, on that same day, 15 Bosnian Muslim men were killed in an isolated area on the bank of the Jadar River by members of the Bosnian Serb Forces, including at least one member of the Bratunac SJB. ${ }^{19828}$ The Chamber also recalls that the killings of 10 to 15 Bosnian Muslim at the Sandići Meadow on 13 July were carried out by members of the Jahorina Recruits, who were part of the Bosnian Serb Forces deployed in the area at the time. ${ }^{19829}$ Similarly, the Chamber found that the killings at the Kravica Warehouse on 13 and 14 July were carried out by members of the Bosnian Serb Forces deployed in the area, including members of the $3^{\text {rd }}$ Skelani Platoon of the $2^{\text {nd }}$ Šekovići Detachment. ${ }^{19830}$ Finally, the Chamber recalls its finding that the killing of at least 50 Bosnian Muslim men in Bratunac town between 12 and 14 July, and the killing of a mentally challenged man outside the Vuk Karadžić School in Bratunac on the evening of 13 July, were carried out by members of the Bosnian Serb Forces. ${ }^{19831}$ In this regard, the Chamber recalls that the Bosnian

\footnotetext{
19823 Defence Final Brief, para. 3275.

19824 Defence Final Brief, paras. 3239, 3287-3300.

19825 Defence Final Brief, para. 3289.

19826 Defence Final Brief, paras. 3298-3299.

19827 See Sections IV.C.1.d.v.A: Near the UN Compound, and IV.C.1.d.v.B: The White House; para. 5120.

19828 See Section IV.C.1.e.iv.A: Jadar River.

19829 See Section IV.C.1.e.iv.D: Sandići Meadow.

19830 See Section IV.C.1.e.iv.C: Kravica Warehouse. The Chamber recalls the evidence that a member of the $10^{\text {th }}$ Sabotage Detachment threw two hand-grenades inside one of the rooms of the warehouse. See para. 5233.

19831 See Section IV.C.2.e.v.B: Vuk Karadžić School and killing of a mentally challenged man.
} 
Muslim men being detained in Bratunac town starting on the afternoon of 12 July were guarded by members of the Bratunac Brigade MP and the MUP. ${ }^{19832}$

5838. The Chamber notes that it has not received evidence which would suggest the presence of armed groups or units not affiliated with the Bosnian Serb Forces operating in the Srebrenica area between the evening of 12 July and the morning of 14 July, i.e. when the killings referred to in the previous paragraph took place. Thus, while the Chamber was unable to precisely identify each individual perpetrator of the killing incidents referred to above, it is satisfied that the units to which such persons belonged were all part of the subordinate Bosnian Serb Forces deployed in the area at the time, and were thus directly subordinated to, and fell under the structure of, the VRS or the MUP.

5839. In relation to the subordinate VRS forces operating in the area at the time, the Chamber recalls that they were part of the units previously deployed in the Drina Corps' area of responsibility pursuant to the deployment orders issued in accordance with the Krivaja 95 plan. ${ }^{1983}$ These forces were operating under the command of Krstić, who was a direct subordinate of the VRS Commander, Mladić. The Chamber recalls that Mladić, as Commander of the Main Staff, was the Accused's direct subordinate. ${ }^{19834}$

5840. In relation to the subordinate MUP units operating in the area at the time, the Chamber recalls that they can be grouped in two main categories, namely the municipal police units belonging to the Zvornik CJB, and those redeployed to the area pursuant to Kovač's order on 10 July. ${ }^{19835}$ While in the Srebrenica area, these units were also operating under the command of the VRS. ${ }^{19836}$ The Chamber recalls that the latter included RS MUP forces previously deployed on the Sarajevo front, including the $2^{\text {nd }}$ Šekovići Detachment and a company of the Jahorina Recruits, which were sent to the Srebrenica sector as a conglomerate of forces under Borovčanin's command. ${ }^{19837}$ According to the order of redeployment, these forces were to make contact with

\footnotetext{
19832 See para. 5293.

19833 See paras. 5005-5006, 5010. The Chamber further recalls that on 10 July, the Main Staff redeployed a part of the $10^{\text {th }}$ Sabotage Detachment to the Srebrenica front. See para. 5021.

19834 See para. 160.

19835 See para. 5021; P4914 (Richard Butler's expert report entitled “Srebrenica Military Narrative (Revised): Operation 'Krivaja 95'," 1 November 2002), paras. 2.14-2.17. The Chamber also recalls its finding that members of the RDB were present in Potočari on 12 and 13 July. See para. 5120. These forces under Kijac were ultimately subordinated to Kovač as the acting head of the RS MUP. See Section II.C.3: Bosnian Serb MUP; para. 5764.

19836 See P4914 (Richard Butler's expert report entitled “Srebrenica Military Narrative (Revised): Operation 'Krivaja 95", 1 November 2002), para. 2.14.

19837 See para. 5021.
} 
Krstić on arrival to its destination on 11 July. ${ }^{19838}$ By reporting to Krstić, they were to receive further instructions. ${ }^{19839}$ In relation to the municipal police units, such as the Bratunac SJB and the PJPs present in the area and assisting in various tasks, including the guarding of detainees in Bratunac town, the Chamber recalls that, as part of the Zvornik CJB, they could be deployed for combat related operations and were to supplement military forces in the area of responsibility of the Drina Corps. ${ }^{19840}$ The Chamber received evidence that these forces were re-subordinated to the VRS upon their deployment on mission. ${ }^{19841}$ Accordingly, these forces were also operating under the command of Krstić, and, ultimately, Mladić.

\section{iii. Superior-subordinate relationship}

5841. With regard to the Accused's authority over the Bosnian Serb Forces during the take-over of Srebrenica, the Chamber recalls its previous finding that since 1992 the Accused had de jure authority over the VRS which he exercised in fact. ${ }^{19842}$ Further, the Chamber reiterates that despite the differences that existed between Mladić, as Commander of the VRS Main Staff, and the Accused, as Supreme Commander, the Accused retained de jure authority over Mladić. ${ }^{19843}$ As such, the Accused and Mladić maintained a superior-subordinate relationship throughout the Indictment period, including the time period relevant to the Srebrenica component of the case. ${ }^{19844}$ The Chamber further notes with particular regard to the attack and eventual take-over of Srebrenica that prior to the attack, the Accused and Krajišnik visited the Drina Corps Command in Vlasenica and gave Krstić a combat assignment; that once the attack was underway, Tolimir sought and received the Accused's prior approval for its expansion so as to include taking over the town; and that Mladić thereafter conveyed the Accused's order to his subordinate commanders. ${ }^{19845}$ Accordingly, the Chamber is satisfied that the Accused continued to have de jure authority over the VRS in July 1995, which he exercised in fact. Furthermore, as outlined in more detail above, once prompted by international attention to the fate of the missing Bosnian Muslim males of Srebrenica-in particular by Madeline Albright's visit to Pilica on 22 March 1996-within one day, the Accused issued an order to the Main Staff and the Bosnian Serb MUP to form a mixed

\footnotetext{
19838 P2992 (Order of RS MUP, 10 July 1995), para. 5.

19839 See Christian Nielsen, T. 16334-16335 (7 July 2011).

19840 See P4914 (Richard Butler's expert report entitled "Srebrenica Military Narrative (Revised): Operation 'Krivaja 95'”, 1 November 2002), para. 2.17.

19841 See paras. 229-230; P4923 (RS Presidential Order, 22 April 1995). See also P4914 (Richard Butler's expert report entitled "Srebrenica Military Narrative (Revised): Operation 'Krivaja 95'”, 1 November 2002), para. 2.17 .

19842 See Section II. C.1.a: Establishment and composition of the VRS.

19843 See paras. $160,3141$.

19844 See paras. $3130,3141$.

19845 See paras. 5008, 5018, 5688
} 
investigative commission. ${ }^{19846}$ In the Chamber's view, this establishes that as late as 1996, the Accused not only had the authority to issue orders as Supreme Commander but also that his orders were followed in fact. ${ }^{19847}$

5842. As noted above, the Law on the Army set out the Accused's exclusive competence in terms of the initial commission of officers, their subsequent appointment, transfer, and termination of service of officers with the rank of General. ${ }^{19848}$ Further, the Chamber found earlier that by the time of the events in the Srebrenica component of the case, military courts were functioning. ${ }^{19849}$ Therefore taking all these circumstances into account, in particular the nature of the orders the Accused had the authority to give, the nature of his position and the powers resulting therefrom, and the fact that military court system was functioning at the relevant time, the Chamber is satisfied that the Accused had the material ability to punish the killings that occurred prior to the point at which he agreed to the killing aspect of the Srebrenica JCE on 13 July 1995.

\section{iv. Knowledge or "reason to know"}

5843. The Chamber has found above that the Accused learned of the expansion of the plan to eliminate such that it involved killing the Bosnian Muslim men and boys of Srebrenica sometime before he spoke to Deronjić at approximately 8 p.m. on 13 July. ${ }^{19850}$ Further, the Chamber recalls its finding that Deronjić specifically informed the Accused about the Kravica Warehouse killings at least by the time they met alone prior to a meeting with a larger group from Srebrenica on 14 July. ${ }^{19851}$ The Chamber is therefore satisfied that the Accused knew of the large scale Kravica Warehouse killings by the day after they were committed. Considering that, at a minimum, this news put the Accused on notice that members of the Bosnian Serb Forces had killed hundreds of Bosnian Muslim detainees who had been in their custody following the fall of the Srebrenica enclave, the Chamber finds that the Accused possessed sufficiently alarming information to justify further inquiry into whether other unlawful acts had been committed.

\footnotetext{
19846 See paras. 5793-5797.

19847 The Chamber recalls that the Accused had de jure authority which he exercised in fact over the military in the RS, including its justice systems, throughout the Indictment period, as demonstrated by his executive action acquitting David Rohde of espionage on 8 November 1995. See paras. 3157, 3412. 5792. The Chamber further notes that, two days after the issuance of the 23 March 1996 Order, Vasić held a meeting in Zvornik pursuant to its terms. See para. 5794.

19848 See para. 167. The Chamber recalls that the Accused himself acknowledged at the Bosnian Serb Assembly that if he did not trust Mladić, he would have dismissed him as he had the authority to do that. See para. 3146.

19849 See para. 3412.

$19850 \quad$ See para. 5811.

19851 See para. 5808.
} 


\section{v. Failure to take necessary and reasonable measures}

5844. The Chamber recalls that the duty of a superior to punish will be fulfilled when necessary and reasonable, or feasible, measures to punish perpetrators have been taken. ${ }^{19852}$ "Necessary" measures are the measures appropriate for the superior to discharge his obligation (showing that he genuinely tried to punish) and "reasonable" measures are those reasonably falling within the material powers of the superior. ${ }^{19853}$

5845. First, the Chamber has found that the Accused had the material ability to remove from service the perpetrators of the killings about which he had received information. Instead of doing so, upon learning of the large scale killings which had just occurred, not only did the Accused take no steps to remove the perpetrators from service, but he joined in the killing aspect of the plan to eliminate. ${ }^{19854}$

5846. With regard to the orders issued by the Accused in March 1996, the Chamber recalls that the 23 March 1996 Order was issued within two days of the U.S. government's release of aerial photographs showing a large number of bodies lying in a field near Branjevo Military Farm on 17 July 1995, and within one day of Madeleine Albright's visit to the Branjevo Military Farm on 22 March 1996. ${ }^{19855}$ In addition, the Chamber notes that the day before the order's issuance the

19852 Popović et al. Appeal Judgement, para. 1927.

19853 Popović et al. Appeal Judgement, para. 1927.

19854 The Chamber recalls that, for a period in August 1995, the Accused removed Mladić as Commander of the VRS and appointed him as Special Advisor to the Supreme Commander. However, on 27 August, he abrogated this decision. See paras. 174, 3138. Around the same time, the Accused also praised and recognised VRS Commanders for their actions in Srebrenica. See para. 5789. The Chamber also recalls that other members of the Srebrenica JCE continued to exercise their functions in the VRS unhindered. See inter alia P1473 (Ratko Mladić's notebook, 27 January-5 September 1995), e-court pp 310-311 (recording a meeting held on 22 August 1995 between VRS officers and Rupert Smith which was attended, among others, by Mladić and Popović); Vujadin Popović, T. 43138-43139 (6 November 2013); P1489 (Ratko Mladić's notebook, 28 August 1995-15 January 1996), e-court p. 117 (recording a meeting of the Main Staff held on 19 November 1995 which was attended, among others, by Mladić and Beara), e-court pp. 123, 126 (recording a meeting of the Main Staff held on 22 November 1995 which was attended, among others, by Mladić and Beara); e-court pp. 189, 201 (recording a meeting of the collegium of Main Staff Commanders held on 24 December 1995 which was attended, among others, by Mladić and Beara); pp. 231 (recording a meeting of the RS core leadership held on 31 December 1995 which was attended, among others, by the Accused, Mladić, and Beara); P1490 (Ratko Mladić's notebook, 16 January-28 November 1996), p. 8 (recording a meeting of the expanded collegium of Main Staff Commanders held on 16 January 1996 which was attended, among others, by Mladić and Beara), ecourt pp. 36, 72-73, 88 (recording three briefings of Main Staff organs held on 4 March, 29 April, and 10 June 1996, which were attended, among others, by Mladić and Beara), e-court p. 82 (recording a meeting held on 30 May 1996 attended by Beara), pp. 124, 128 (recording a meeting held on 16 September 1996 attended by Beara), e-court pp. 132, 138 (recording a meeting of the collegium of Main Staff Commanders held on 12 October 1996 which was attended, among others, by Mladić and Beara), e-court p. 141 (recording a meeting of the Main Staff with the VJ's General Staff held on 15 October 1996 which was attended, among others, by Mladić and Beara), e-court p. 158 (recording a meeting of the expanded collegium of Main Staff Commanders held on 14 November 1996 which was attended, among others, by Mladić and Beara); e-court pp. 163-164 (recording a meeting of Main Staff Generals held on 15 November 1996 which was attended, among others, by Mladić and Beara).

19855 See para. 5451. The Accused argues that the 23 March 1996 Order's reference to the "arbitrary and biased conclusions" drawn by Albright and "media experts" demonstrates that at the time, he did not believe the 
Accused warned Mladić that, "[i]f they expand the campaign then they would form a joint commission [...] to investigate the killing of every individual", ${ }^{19856}$ as well as by the fact that Predrag Drinić's attempt to implement the 23 March 1996 Order was met with silence from the Main Staff. ${ }^{19857}$ In the Chamber's view, the fact, despite the Accused's long-standing awareness of the killings in Pilica, he took no action until that point, the 23 March 1996 Order was a response to international pressure created by the release of the photos and Albright's visit, not a genuine attempt to shed light on what had actually transpired.

5847. In light of all the evidence, the Chamber finds that the Accused failed in his duty to punish the killings which occurred prior to the point at which he joined the Srebrenica JCE on the evening of 13 July 1995. Although he should have taken steps to investigate these crimes and punish the perpetrators either immediately upon learning of them or soon thereafter, the Accused issued the 23 March 1996 Order and the 1 April 1996 Order, more than eight months after the killings in question. In his capacity as Supreme Commander, the Accused had a duty to do more than that.

\section{vi. Conclusion}

5848. Based on the evidence discussed above, the Chamber finds that the Accused knew that crimes had been committed by his subordinates in the aftermath of the fall of the Srebrenica enclave, and had reason to know that others had also been committed. The Accused failed in his duty as Supreme Commander to take necessary and reasonable measures to punish the commission of genocide, murder, extermination, and killing as an underlying act of persecution. He is therefore criminally responsible for such failures pursuant to Article 7(3) of the Statute.

\section{d. Conclusions: Accused's individual criminal responsibility}

5849. The Chamber found above that as Srebrenica fell, a common plan to eliminate the Bosnian Muslims in Srebrenica-first through forcible removal and later through the killing of the men and boys-was established, that the Accused significantly contributed to this common purpose, and that he shared with the other members of the Srebrenica JCE the intent for the crimes within its scope. Accordingly, the Chamber finds that the Accused bears individual criminal responsibility pursuant to Article 7(1) of the Statute for genocide (Count 2); persecution, a crime against humanity (Count 3); extermination, a crime against humanity (Count 4); murder, a crime against humanity (Count 5);

allegations of large-scale executions. Defence Final Brief, para. 3145. The Chamber refers to its analysis of the Accused's membership in the Srebrenica JCE at paras. 5804-5811, 5813. 
murder, a violation of the laws or customs of war (Count 6); and inhumane acts (forcible transfer), a crime against humanity (Count 8), which were found to have been committed in Srebrenica.

5850. In addition, the Chamber found that the Accused failed to punish the crimes of his subordinates which occurred before he agreed to the killing aspect of the Srebrenica JCE. Therefore, the Accused also bears individual criminal responsibility pursuant to Article 7(3) of the Statute in relation to genocide (Count 2); persecution, a crime against humanity (Count 3); extermination, a crime against humanity (Count 4); murder, a crime against humanity (Count 5); and murder, a violation of the laws or customs of war (Count 6). However, since the Chamber has already found the Accused responsible for genocide on the basis of his participation in the Srebrenica JCE as set out above, the Chamber will not enter a conviction pursuant to Article 7(3) of the Statute in relation to Count $2 .{ }^{19858}$

5851. The Chamber will address address the issue of cumulative convictions in Section IV.F. below.

\section{Hostages COMPONENT}

5852. In Count 11, the Accused is charged with taking hostages as a violation of the laws or customs of war punishable under Article 3 of the Statute and Common Article 3. The Indictment alleges that on 25 and 26 May 1995, in response to shelling attacks on Sarajevo and other locations in BiH by the Bosnian Serb Forces, NATO carried out air strikes against Bosnian Serb military targets. ${ }^{19859}$ It is further alleged that between 26 May and 19 June 1995, over 200 UN peacekeepers and military observers in various locations across $\mathrm{BiH}$ were taken hostage by Bosnian Serb Forces. ${ }^{19860}$ According to the Indictment, the purpose of taking the UN personnel hostage was to compel NATO to abstain from conducting further air strikes against Bosnian Serb military targets. ${ }^{19861}$ The Accused is charged both under Article 7(1) of the Statute for having committed in concert with others, through his participation in a JCE, planned, instigated, ordered, and/or aided and abetted the taking of these hostages, and under Article 7(3) as a superior for failing to take the necessary and reasonable measures to prevent such acts or punish the perpetrators thereof. ${ }^{19862}$

\footnotetext{
19858 See para. 591.

19859 Indictment, para. 85.

19860 Indictment, para. 86.

19861 Indictment, para. 84.

19862 Indictment, para. 87.
} 


\section{Facts}

\section{a. NATO air strikes}

5853. As stated earlier, the situation in Sarajevo and BiH deteriorated further in May $1995 .{ }^{19863}$ In Sarajevo in early May 1995, tensions between the VRS and the ABiH increased. ${ }^{19864}$ On 16 May 1995, there was intense shelling in Grbavica. ${ }^{19865}$ Fighting southwest of the Jewish cemetery escalated significantly. ${ }^{19866}$ The VRS used weapons from the Osijek WCP to break through the ABiH defence. ${ }^{19867}$ The shelling continued the following day. ${ }^{19868}$

5854. On 22 May 1995, the activity of NATO jets flying overhead in Goražde increased. ${ }^{19869}$ The VRS had removed heavy weapons from the WCPs near Sarajevo, as did the ABiH, and fighting escalated. $^{19870}$

5855. On 24 May 1995, there was intense shooting in Grbavica and NATO planes flew over the area. ${ }^{19871}$ The VRS removed more heavy weapons from the WCP following an increase in the fighting and refused to return them. ${ }^{19872}$ Smith called Mladić to express his concern that, in and around Sarajevo, weapons were not being returned to the WCPs and that heavy weapons were being fired from there. ${ }^{19873}$ Smith stated that he would issue a warning to both parties and release it to the press. ${ }^{19874}$ The warning was that if the weapons were not returned to the WCPs by 12 p.m. on 25 May 1995, then NATO air strikes would commence. ${ }^{19875}$ Smith told Mladić that they should meet as soon as possible to discuss a way in which the Sarajevo TEZ could be respected. ${ }^{19876}$

\footnotetext{
19863 See paras. 416-418.

19864 P56 (Witness statement of Joseph Gelissen dated 18 January 1996), e-court p. 4. See also para. 3608.

19865 P56 (Witness statement of Joseph Gelissen dated 18 January 1996), e-court p. 4.

19866 P2447 (Witness statement of KDZ182 dated 8 March 2011), p. 74.

19867 P2447 (Witness statement of KDZ182 dated 8 March 2011), p. 74.

19868 P56 (Witness statement of Joseph Gelissen dated 18 January 1996), e-court p. 4.

19869 P50 (Witness statement of Hugh Nightingale dated 5 February 1996), e-court p. 4.

19870 P820 (Witness statement of David Harland dated 4 September 2009), para. 183; P2284 (UNSG report entitled "The Fall of Srebrenica", 15 November 1999), para. 188.

19871 P56 (Witness statement of Joseph Gelissen dated 18 January 1996), e-court p. 5.

19872 Rupert Smith, T. 11366-11367 (8 February 2011). See also Adjudicated Fact 2792.

19873 Rupert Smith, T. 11367-11368 (8 February 2011); P2267 (UNPROFOR report re telephone conversation with Ratko Mladić, 25 May 1995), p. 2.

19874 Rupert Smith, T. 11367-11368 (8 February 2011); P2267 (UNPROFOR report re telephone conversation with Ratko Mladić, 25 May 1995), p. 2.

19875 Rupert Smith, T. 11367-11368 (8 February 2011); P820 (Witness statement of David Harland dated 4 September 2009), para. 183; Patrick Rechner, T. 11083-11084 (2 February 2011). See also P5012 (UNPROFOR report re Sarajevo heavy weapon exclusion zone, 25 May 1995).

19876 P2267 (UNPROFOR report re telephone conversation with Ratko Mladić, 25 May 1995), p. 2.
} 
Mladic agreed to meet but reiterated that the use of force by the UN would lead to a further escalation of the conflict. ${ }^{19877}$

5856. On 25 May 1995, after the failure of the VRS to return heavy weapons to the WCPs, NATO was authorised by the UN to launch air strikes against Bosnian Serb military targets in Pale. ${ }^{19878}$ Smith stated that the purpose behind the air strikes was to re-impose the TEZ and the WCP regime, which were both breaking down. ${ }^{19879}$ Two air strikes were conducted: the first at 4 p.m. striking Jahorinski Potok and the second at 4:25 p.m. striking Ravna Planina. ${ }^{19880}$

\section{b. VRS response to NATO air strikes}

5857. On 25 May 1995, the Accused ordered Milovanović to "activate" a decision made the previous year ordering the VRS to "arrest everything foreign in RS territory and to treat military personnel as prisoners of war and hold them as hostages till the end of the war". ${ }^{19881}$ Consequently, Živanović issued an order to all units of the Drina Corps that following the NATO air strikes, the VRS should respond by conducting operations against selected targets and "if UNPROFOR continues its operations against our military and civilian targets, all units of the Corps must be on stand-by for action against UNPROFOR checkpoints and bases". ${ }^{19882}$ It further ordered the prevention of all movement of UNPROFOR vehicles and of all other international organisations in the area and to fire on UNPROFOR if fired upon. ${ }^{19883}$

19877 P2267 (UNPROFOR report re telephone conversation with Ratko Mladić, 25 May 1995), p, 2.

19878 P5019 (UNPROFOR report re air strike near Pale, 25 May 1995); Rupert Smith, T. 11368 (8 February 2011); P2177 (UNMO report, 25 May 1995), p. 1; Patrick Rechner, T. 11084 (2 February 2011); D3488 (Yasushi Akashi's interview with Joint Information Mission at French National Assembly, 26 April 2001), e-court p. 9. The basis for this authorisation was UN Security Council Resolution 836 (1993). P985 (UNSC Resolution 836, 4 June 1993); David Harland, T. 2121-2123 (7 May 2010). On 25 May 1995, approximately 30 minutes following the NATO air strike, the 7 Lima UNMO Team was informed by the UNMO headquarters that the air strike had been carried out by NATO on behalf of the UN. P2170 (Witness statement of Patrick Rechner dated 31 January 2011), para. 18. See also P820 (Witness statement of David Harland dated 4 September 2009), para. 183; Yasushi Akashi, T. 37706 (24 April 2013); D3489 (Excerpt from Yasushi Akashi's book entitled "In the Valley between War and Peace"), pp. 31-32; P5012 (UNPROFOR report re Sarajevo heavy weapon exclusion zone, 25 May 1995). On 25 and 26 May 1995, the SRK took a number of heavy weapons from the WCPs. Adjudicated Fact 2795.

19879 P2270 (UNPROFOR report, 29 May 1995), p. 1.

19880 P2177 (UNMO report, 25 May 1995), p. 1; P1473 (Ratko Mladić's notebook, 27 January-5 September 1995), p. 147; D2149 (Aide mémoire of Manojlo Milovanović), p. 56. One of the targets was an ammunition depot 300 metres away from the SE-1 UNMO team and approximately five to ten kilometres from the 7 Lima UNMO team, which was chosen because of its military significance and the unlikely chance that there would be civilian casualties. Rupert Smith, T. 11368 (8 February 2011); P2525 (Witness statement of Griffiths Evans dated 6 September 1995), e-court p. 6; Patrick Rechner, T. 11083 (2 February 2011). See also P6575 (Report of VRS Main Staff, 25 May 1995).

19881 D2149 (Aide mémoire of Manojlo Milovanović), pp. 56-57.

19882 P2149 (Order of Drina Corps, 25 May 1995), p. 1.

19883 P2149 (Order of Drina Corps, 25 May 1995), p. 1. 
5858. On the evening of 25 May 1995, the VRS shelled all the safe areas, which also included an attack on Tuzla and Goražde that killed approximately 70 civilians and injured 150 others. ${ }^{19884}$ The following day, NATO air strikes started again around 10 a.m. in Pale and continued until 12 p.m. ${ }^{19885}$ The VRS fired weapons from the Bare, Ilidža, Osijek, and Polinje WCPs in the afternoon, after the expiration of the deadline to return those weapons. ${ }^{1986}$ There were 44 reported incidents involving firing of heavy weapons within the Sarajevo TEZ. ${ }^{1988}$ Negotiations between UNPROFOR and the SRK commander for the return of the weapons continued. ${ }^{19888}$

5859. On 26 May 1995, Dragomir Milošević issued an order to all units of the SRK to immediately establish a full blockade of UN forces at check-points and on all roads in the "entire zone of the Corps" and to "use additional forces if the blockade is detected by the UN forces". ${ }^{19889}$

5860. On 27 May 1995, the VRS Main Staff issued an order, approved by the Accused, to the commands of the $1^{\text {st }}$ Krajina Corps, $2^{\text {nd }}$ Krajina Corps, SRK, Eastern Bosnia Corps, Herzegovina Corps, Drina Corps, as well as other VRS units, stating that based on information that NATO will continue its air strikes on important targets in the RS, captured UNPROFOR personnel were to be disarmed and placed in "the areas of command posts, firing positions and other potential targets that may come under the air strike". ${ }^{1989}$ The order provided for the exact number of UNPROFOR personnel to be detained, ${ }^{19891}$ the location where they should be sent, the manner in which they should be transported, as well as an instruction that "they are to be treated properly with military

19884 Rupert Smith, T. 11369 (8 February 2011). See also P2024 (BBC news report re UN hostage-taking in Sarajevo, with transcript); P2171 (UNPROFOR report, 27 May 1995), p. 2; D1055 (UNPROFOR report to Kofi Annan, 27 May 1995), e-court p. 4; P2447 (Witness statement of KDZ182 dated 8 March 2011), p. 74; P820 (Witness statement of David Harland dated 4 September 2009), para. 183; D1051 (UNPROFOR report on air strikes, 26 May 1995); P5013 (UNPROFOR report re air-strikes in Bosnia, 26 May 1995); see Adjudicated Fact 2794. See also P6573 (Cable of Akashi to Annan re Air Strikes - Sarajevo, 26 May 1995).

19885 D1051 (UNPROFOR report on air strikes, 26 May 1995); Patrick Rechner, T. 11084 (2 February 2011); P2525 (Witness statement of Griffiths Evans dated 6 September 1995), e-court p. 6; see Adjudicated Fact 2796.

19886 P2171 (UNPROFOR report, 27 May 1995), p. 1.

19887 There were 16 reported incidents of weapons fired from the WCPs and eight VRS weapons still remaining in the TEZ. P2171 (UNPROFOR report, 27 May 1995), p. 2.

19888 P2414 (Witness statement of KDZ182 dated 8 March 2011), p. 74 (under seal).

19889 P6097 (SRK Order, 26 May 1995); Dragomir Milošević, T. 33228-33231 (5 February 2013) (testifying that while he did issue this order to detain UN personnel, the portion of the order stating "do not take into account any UN requests regarding the supplies of food, water, etc." did not pertain to the treatment of detained UN personnel, but rather to UN supply convoys and that UN personnel were treated as prisoners of war and provided with food and water). Dragomir Milošević, T. 33228-33231, 33247-33249 (5 February 2013).

19890 P2137 (VRS Main Staff Order, 27 May 1995), p. 1. See also P2151 (Order of Drina Corps, 27 May 1995), pp. 1-2 (implementing the order); Jonathon Riley, T. 10784 (26 January 2011).

19891 Specifically it stated that 18 UNPROFOR members be sent to the $2^{\text {nd }}$ Krajina Corps, 40 UNPROFOR members sent to the $1^{\text {st }}$ Krajina Corps, 27 UNPROFOR members sent to the Eastern Bosnia Corps, and 18 UNPROFOR members sent to the Herzegovina Corps. P2137 (VRS Main Staff Order, 27 May 1995), p. 1. 
respect, treat them as prisoners of war and provide them with food and water like the VRS troops". 19892

5861. On the same day, an urgent message was sent from the Intelligence and Security Sector of the VRS Main Staff, recommending the $1^{\text {st }}$ Krajina Corps, $2^{\text {nd }}$ Krajina Corps, the SRK, the Eastern Bosnian Corps, and the Herzegovina Corps to place the "captured members of UN forces" in areas of possible NATO air strikes. ${ }^{19893}$ The next morning, the VRS again shelled Tuzla. ${ }^{19894}$

5862. As will be explained in further detail below, on 26 May 1995 following the NATO air strikes, a number of UNPROFOR and UNMO personnel throughout $\mathrm{BiH}$ were detained by the VRS. ${ }^{19895}$ Some were taken from their posts or WCPs to various locations in the RS, such as the Bijeljina Barracks, the Lukavica Barracks, Jahorinski Potok, or Banja Luka. ${ }^{1986}$ Others were simply detained at their locations by the VRS. ${ }^{19897}$

5863. By 29 May 1995, UNPROFOR estimated that approximately 347 UN personnel, including 32 UNMOs, were detained as "hostages" at their OPs and WPCs or held in isolated detachments, surrounded by Bosnian Serb Forces. ${ }^{19898}$ Some of the UN personnel were held in locations of military significance for the VRS. ${ }^{19899}$

19892 P2137 (VRS Main Staff Order, 27 May 1995), pp. 1-2.

19893 P2147 (VRS Main Staff Report, 27 May 1995), p. 1.

19894 P2269 (UNPROFOR report re telephone conversation with Ratko Mladić, 29 May 1995), p. 2.

19895 P2171 (UNPROFOR report, 27 May 1995), p. 1; P2284 (UNSG report entitled "The Fall of Srebrenica", 15 November 1999), para. 190. See also P2172 (UNMO report, 26 May 1995), e-court p. 4; P2173 (UNPROFOR report, 28 May 1995), p. 5; P2136 (Map of BiH); P2145 (Map of BiH); P2142 (Map of BiH); P2162 (Map of BiH); P2173 (UNPROFOR report, 28 May 1995), pp. 1-6. In Sector Sarajevo, approximately 260 UNPROFOR personnel were taken by the VRS. P2447 (Witness statement of KDZ182 dated 8 March 2011), p. 75

19896 See P2447 (Witness statement of KDZ182 dated 8 March 2011), p. 75; P2140 (Witness statement of KDZ196 dated 10 March 1998), pp. 6-7 (under seal); P2142 (Map of BiH); P5024 (Annex A to UNPROFOR report re UN hostages, 2 June 1995); P2171 (UNPROFOR report, 27 May 1995); P2172 (UNMO report, 26 May 1995); P2173 (UNPROFOR report, 28 May 1995); P2135 (Record of interview with Aleksandr Vishnevski, 5 February 1996); P2136 (Map of BiH); P2145 (Map of BiH); P2184 (Serbian TV news report re UN personnel, with transcript); P5013 (UNPROFOR report re air-strikes in Bosnia, 26 May 1995); P2179 (Video footage of UN personnel); P2180 (Video footage of UN personnel); P2181 (Video footage of UN personnel); P2432 (UNPROFOR protest letter to SRK, 3 June 1995). UNPROFOR personnel were taken to other locations, including Ilijaš, Rogatica, Sokolac, Knežina, Vlasenica, Vogosča, Višegrad, Blazuy, Milići, Bratunac, and Zvornik. P2150 (UK Report entitled "Final Debriefing Report - Goražde Hostages," 3 July 1995); P5024 (Annex A to UNPROFOR report re UN hostages, 2 June 1995).

19897 See P2171 (UNPROFOR report, 27 May 1995); P2172 (UNMO report, 26 May 1995); P2173 (UNPROFOR report, 28 May 1995); P2145 (Map of BiH); P2270 (UNPROFOR report, 29 May 1995); P5024 (Annex A to UNPROFOR report re UN hostages, 2 June 1995); P5013 (UNPROFOR report re air-strikes in Bosnia, 26 May 1995); P2432 (UNPROFOR protest letter to SRK, 3 June 1995).

19898 P2178 (UNMO report, 30 June 1995); P2270 (UNPROFOR report, 29 May 1995), p. 1; P5023 (UNPROFOR report, 29 May 1995); P2173 (UNPROFOR report, 28 May 1995), p. 1; P2171 (UNPROFOR report, 27 May 1995); P2172 (UNMO report, 26 May 1995), e-court, pp. 3-4.

19899 P2146 (VRS Main Staff Report, 26 May 1995); P2147 (VRS Main Staff Report, 27 May 1995); P2171 (UNPROFOR report, 27 May 1995); P2172 (UNMO report, 26 May 1995), e-court, pp. 3-4; P2173 


\section{c. Detention and treatment of UN personnel}

\section{i. General observations}

5864. UNPROFOR and UNMO personnel were stationed throughout BiH. However, the charges in the Indictment under Count 11 focus on the UNPROFOR and UNMO teams located in Sector Sarajevo, in particular in the areas of Pale, Sarajevo, Banja Luka, and Goražde. ${ }^{19900}$

5865. As mentioned earlier, ${ }^{19901}$ UNPROFOR's responsibilities included monitoring the DMZ and the TEZ, and reporting any incoming or outgoing fire. ${ }^{19902}$ UNPROFOR teams in Sarajevo were also tasked with escorting UNHCR convoys into the city and overseeing the supply of water, gas, and electricity. ${ }^{19903}$ Further responsibilities included observing the parties, reporting any cease-fire violations, controlling traffic, and ensuring free passage for all UN vehicles. ${ }^{19904}$

5866. The role of the UNMO teams included working with the parties to the conflict, monitoring the implementation of cease-fire agreements, monitoring WCPs, reporting on any incoming or outgoing shelling, and drafting investigating reports about shooting incidents. ${ }^{19905}$ All UNMO teams were unarmed. ${ }^{19906}$

5867. In 1995 in the city of Sarajevo, there were approximately 5,000 UNPROFOR personnel comprised of troops mainly from France, Russia, Ukraine, and Egypt. ${ }^{19907}$ Sector Sarajevo UNPROFOR had six battalions and one detachment in charge of the Sarajevo airport. ${ }^{19908}$ In

(UNPROFOR report, 28 May 1995); P2178 (UNMO report, 30 June 1995). For locations where the UN personnel were held, see P2136 (Map of BiH); P2142 (Map of BiH); P2162 (Map of BiH); P2145 (Map of BiH).

19900 Indictment, para. 86.

19901 For more details on UNPROFOR and UNMO, see Section II.E.2: Vance Plan.

19902 P50 (Witness statement of Hugh Nightingale dated 5 February 1996), e-court p. 4; P2447 (Witness statement of KDZ182 dated 8 March 2011), p. 4; P1638 (Witness statement of Michael Rose dated 26 March 2009), para. 44; Michael Rose, T. 7256, 7260 (5 October 2010); P820 (Witness statement of David Harland dated 4 September 2009), paras. 79-80.

19903 P2447 (Witness statement of KDZ182 dated 8 March 2011), p. 4.

19904 P52 (Witness statement of Michael Cornish dated 13 February 1996), e-court p. 4.

19905 Patrick Rechner, T. 11078 (2 February 2011); Marcus Helgers, T. 10747 (26 January 2011); P56 (Witness statement of Joseph Gelissen dated 18 January 1996), e-court p. 4.

19906 Marcus Helgers, T. 10747 (26 January 2011); Patrick Rechner, T. 11078 (2 February 2011); P4140 (Witness statement of Joseph Kingori dated 8 January 2002), para. 5. But see D2762 (Witness statement of KW554 dated 14 September 2012), para. 26 (stating that many of the UNMO teams were armed). On cross-examination, KW554 clarified that he was only familiar with the Canadian UNMO team and that the UNMO teams he thought had weapons were not part of the group that was taken hostage in May 1995. KW554, T. 32034-32035 (16 January 2013). Given the inconsistency of KW554's evidence, his deficiency in candour, and based on the totality of the evidence, the Chamber concludes that the UNMOs were unarmed.

19907 P2447 (Witness statement of KDZ182 dated 8 March 2011), para. 6; D2774 (Witness statement of Milenko Inđić dated 19 January 2013), para. 78.

19908 P2447 (Witness statement of KDZ182 dated 8 March 2011), p. 5. 
Goražde, the UNPROFOR team was comprised of approximately 400 members of BritBat and one Ukrainian company of approximately 100 men. ${ }^{19909}$

5868. It was estimated that approximately 260 UNPROFOR personnel in Sector Sarajevo were taken and detained by the VRS. ${ }^{19910}$ More specifically, a FreBat team stationed in Polinje was taken first to the Bijelina Barracks and then detained in Doboj. ${ }^{19911}$ A FreBat team stationed at the Lukavica Barracks was detained there. ${ }^{19912}$ Another FreBat team stationed at the Sierra Victor post near the Vrbanja Bridge was attacked and detained at the Lukavica Barracks. ${ }^{19913}$ A UkrBat team in Sarajevo was taken to Bijeljina and then detained in Banja Luka. ${ }^{19914}$ Members of the BritBat team based in Goražde were taken to various locations. ${ }^{19915}$

5869. The detained UNMOs in Sector Sarajevo were posted in areas such in Grbavica, ${ }^{19916}$ Kasindo, Vogošća, and Pale. ${ }^{19917}$ The UNMO team posted in the Bosnian Serb controlled area of Grbavica was taken to Jahorinski Potok and detained in the Pale Barracks. ${ }^{19918}$ A UNMO team in Kasindo was taken to Grbavica, then to Pale, and detained at the Jahorina radar station. ${ }^{19919}$ A UNMO team in Vogošća was detained in their accommodations and not allowed access to any communication. ${ }^{19920}$ In Pale, there were two UNMO teams: the 7 Lima UNMO team and the SE-1

\footnotetext{
19909 P50 (Witness statement of Hugh Nightingale dated 5 February 1996), e-court p. 4.

19910 P2447 (Witness statement of KDZ182 dated 8 March 2011), p. 75.

19911 [REDACTED]; P2142 (Map of BiH).

19912 P5024 (Annex A to UNPROFOR report re UN hostages, 2 June 1995), p. 1.

19913 P2171 (UNPROFOR report, 27 May 1995), p. 1; P5024 (Annex A to UNPROFOR report re UN hostages, 2 June 1995), p. 2; [REDACTED]; P2433 (UNPROFOR protest letter to SRK, 3 June 1995); P5924 (UNPROFOR report, 27 May 1995); D1058 (UNPROFOR report to Marrack Goulding, 30 May 1995).

19914 P2135 (Record of interview with Aleksandr Vishnevski, 5 February 1996); P2136 (Map of BiH).

19915 P2150 (UK Report entitled "Final Debriefing Report - Goražde Hostages", 3 July 1995) (indicating that locations included Rogatica, Sokolac, Knežina, Vlasenica, Milići, Bratunac, and Zvornik).

19916 One of the UNMO teams in Grbavica was posted in the Bosnian Serb controlled area in the centre of Sarajevo. The other UNMO team in Grbavica was posted in the Bosnian Muslim area of Sarajevo. P56 (Witness statement of Joseph Gelissen dated 18 January 1996), e-court p. 4; P2171 (UNPROFOR report, 27 May 1995), p. 5. Grbavica was a neighbourhood in the municipality of Novo Sarajevo, located in the southern-central part of the city of Sarajevo. Adjudicated Fact 65.

19917 P2171 (UNPROFOR report, 27 May 1995); P2172 (UNMO report, 26 May 1995); P56 (Witness statement of Joseph Gelissen dated 18 January 1996), e-court p. 4.

19918 P56 (Witness statement of Joseph Gelissen dated 18 January 1996).

19919 P49 (Witness statement of Gunnar Westlund dated 22 November 1995); P2117 (Witness statement of Marcus Helgers dated 3 August 1995).

19920 P2171 (UNPROFOR report, 27 May 1995), p. 4; P2172 (UNMO report, 26 May 1995), e-court p. 3; P2145 (Map of $\mathrm{BiH})$.
} 
UNMO team. ${ }^{19921}$ They were taken to Jahorinski Potok and detained at the Koran Barracks in Pale. ${ }^{19922}$

5870. The Chamber will now examine in more detail the sequence of events in relation to some of these UNMO and UNPROFOR teams.

\section{ii. Evidence from the UkrBat team in Sarajevo}

5871. On 26 May 1995, members of the UkrBat team, including Aleksandr Vishnevski, were at the Zaria check-point when members of the VRS MP arrived. ${ }^{19923}$ The VRS commander ordered that "in order to avoid bloodshed due to the NATO air strike on the Energoinvest plant", the UkrBat team should hand over their weapons and the MP would take them to a safe place. ${ }^{19924}$ While the UkrBat team initially handed over their weapons, the team's lieutenant ordered that they stop doing so after Vishnevski had told him that he had seen on television the FreBat team being taken from their post, handcuffed, and treated harshly by some VRS soldiers. ${ }^{19925}$ A clash ensued with the MP demanding that the UkrBat team hand over their remaining weapons. ${ }^{19926}$ The MP commander put his pistol to the UkrBat Lieutenant's head and threatened to fire if the UkrBat team failed to comply. ${ }^{19927}$ Two UkrBat team members attempted to intervene and hit some of the MP. ${ }^{19928}$ The MP then fired in the UkrBat team's direction, above their heads, and ordered them to lie down. ${ }^{19929}$ The UkrBat team members ultimately surrendered their weapons. ${ }^{19930}$ The UkrBat team was then taken to the police station in Ilidža, moved to a hotel for several hours, and driven back to the Zaria check-point where they spent the night. ${ }^{19931}$

5872. On 27 May 1995, at 4 a.m., they were woken up and told to collect their belongings. ${ }^{19932}$ They boarded a bus going in the direction of Krivoglavci. ${ }^{19933}$ The bus stopped at the Palub check-

\footnotetext{
19921 P2171 (UNPROFOR report, 27 May 1995), p. 4.

19922 Janusz Kalbarczyk, T. 10832-10859 (28 January 2011); P2170 (Witness statement of Patrick Rechner dated 31 January 2011); P2525 (Witness statement of Griffiths Evans dated 6 September 1995); P2173 (UNPROFOR report, 28 May 1995).

19923 Members of this squad were dressed in Bosnian Serb MP uniforms with black armlets around their sleeves. P2135 (Record of interview with Aleksandr Vishnevski, 5 February 1996), pp. 1-2.

19924 P2135 (Record of interview with Aleksandr Vishnevski, 5 February 1996), p. 2; Aleksandr Vishnevski, T. 10707, 10714 (25 January 2011).

19925 P2135 (Record of interview with Aleksandr Vishnevski, 5 February 1996), p. 2; Aleksandr Vishnevski, T. 10707-10708 (25 January 2011).

19926 P2135 (Record of interview with Aleksandr Vishnevski, 5 February 1996), p. 2.

19927 P2135 (Record of interview with Aleksandr Vishnevski, 5 February 1996), p. 2.

19928 P2135 (Record of interview with Aleksandr Vishnevski, 5 February 1996), p. 2.

19929 P2135 (Record of interview with Aleksandr Vishnevski, 5 February 1996), p. 2.

19930 P2135 (Record of interview with Aleksandr Vishnevski, 5 February 1996), p. 2.

19931 P2135 (Record of interview with Aleksandr Vishnevski, 5 February 1996), p. 2.

19932 P2135 (Record of interview with Aleksandr Vishnevski, 5 February 1996), p. 2; P2138 (VRS Main Staff Report, 28 May 1995), p. 6.
} 
point and five other UNPROFOR personnel were brought onboard. ${ }^{19934}$ The bus, escorted by two VRS MP vehicles, arrived in Bijeljina where Vishnevski saw a group of 14 FreBat team members who had also been detained. ${ }^{19935}$ The bus continued to Banja Luka where the UkrBat team members were taken to barracks near an airfield. ${ }^{19936}$ They were ordered to separate into smaller groups. ${ }^{19937}$ They refused to obey the order and as a result their flak jackets, shoulder straps, and shoe laces were taken away. ${ }^{19938}$ They were told that they must carry out the orders of the MP and that they were held captive in order to force NATO to stop the air strikes against Bosnian Serb military positions. ${ }^{19939}$ Leashed German shepherd dogs were set on the UkrBat team so that they were forced to move into the barracks. ${ }^{19940}$ UkrBat members were detained in the Banja Luka Barracks until their release. ${ }^{19941}$ During their detention, they received very little food and only cold water was available to wash but no towels or soap. ${ }^{19942}$ They were released on 6 June 1995, transferred to Novi Sad, and flown to Zagreb. ${ }^{19943}$

\section{iii. Evidence from the UNMO team in Kasindo}

5873. The UNMO team in Kasindo, south of Sarajevo, had six members, including Marcus Helgers, Ahmad Manzoor, and Gunnar Westlund, the acting team leader. ${ }^{19944}$ On 25 May 1995, after the first NATO air strike, a uniformed man claiming to be a VRS security officer entered the accommodations of the UNMO team in Kasindo. ${ }^{19945}$ He informed them that there had been a

19933 P2135 (Record of interview with Aleksandr Vishnevski, 5 February 1996), p. 2; Aleksandr Vishnevski, T. 10710, 10715 (25 January 2011).

19934 P2135 (Record of interview with Aleksandr Vishnevski, 5 February 1996), p. 2.

19935 P2135 (Record of interview with Aleksandr Vishnevski, 5 February 1996), p. 3; Aleksandr Vishnevski, T. 10712 (25 January 2011); P2138 (VRS Main Staff Report, 28 May 1995), p. 6.

19936 P2135 (Record of interview with Aleksandr Vishnevski, 5 February 1996), p. 3; Aleksandr Vishnevski, T. 10709, 10711-10712 (25 January 2011); P2137 (VRS Main Staff Order, 27 May 1995), p. 1.

19937 P2135 (Record of interview with Aleksandr Vishnevski, 5 February 1996), p. 3; Aleksandr Vishnevski, T. 10708 (25 January 2011).

19938 P2135 (Record of interview with Aleksandr Vishnevski, 5 February 1996), p. 3; Aleksandr Vishnevski, T. 10708 (25 January 2011).

19939 P2135 (Record of interview with Aleksandr Vishnevski, 5 February 1996), p. 3 (first stating that they were told that they were "prisoners of war" but later explaining that they were informed that they "had been taken hostage").

19940 Aleksandr Vishnevski, T. 10708 (25 January 2011).

19941 P2135 (Record of interview with Aleksandr Vishnevski, 5 February 1996), p. 3; see also Aleksandr Vishnevski, T. 10708-10709 (25 January 2011); P2137 (VRS Main Staff Order, 27 May 1995), p. 1; P2136 (Map of BiH).

19942 P2135 (Record of interview with Aleksandr Vishnevski, 5 February 1996), p. 3.

19943 P2135 (Record of interview with Aleksandr Vishnevski, 5 February 1996), p. 3; Aleksandr Vishnevski, T. 10712-10713 (25 January 2011); P2139 (VRS Main Staff Order, 6 June 1995); P2136 (Map of BiH).

19944 P49 (Witness statement of Gunnar Westlund dated 22 November 1995), e-court p. 4; Marcus Helgers, T. 10747 (26 January 2011); P2117 (Witness statement of Marcus Helgers dated 3 August 1995), p. 2; P2171 (UNPROFOR report, 27 May 1995), p. 4 (stating that the call signal for the UNMO team in Kasindo was SS-1).

19945 Marcus Helgers, T. 10748 (26 January 2011); P2117 (Witness statement of Marcus Helgers dated 3 August 1995), p. 2; P49 (Witness statement of Gunnar Westlund dated 22 November 1995), e-court p. 4. Although Westlund's witness statement states that the first NATO air strikes occurred on 24 May 1995, the Chamber finds that this is incorrect and the first NATO air strikes occurred on 25 May 1995. 
NATO air strike against the Bosnian Serbs and that the UNMO team was under house arrest. ${ }^{19946}$ They were told that their interpreter would be allowed to go to the VRS barracks with a list of items they may need. ${ }^{19947}$

5874. On 26 May 1995, at noon, Westlund heard the second NATO air strike and saw a large cloud of smoke on the other side of the mountains in the direction of Pale. ${ }^{19948}$ At around 2 p.m., he heard Nicholas Ribić on the radio identifying himself as a VRS soldier and saying: "We have your Pale team. We will kill them if you do not stop the NATO air strikes". ${ }^{19949}$ At 5:15 p.m., two armed soldiers wearing uniform-type trousers and green shirts with no insignia entered the UNMO office. ${ }^{19950}$ They ordered the UNMO team to follow them immediately. ${ }^{19951}$ The UNMO team was told to pack while their radios, flak jackets, and helmets were confiscated. ${ }^{19952}$ Westlund and another UNMO were ordered to drive two UN vehicles with armed VRS soldiers sitting next to them. ${ }^{19953}$ They were not told where they were going, but were ordered to take the back roads. ${ }^{19954}$

5875. The UNMOs eventually arrived in Grbavica, where they were taken to the basement of a civilian high-rise building where ten armed VRS soldiers were sitting. ${ }^{19955}$ A stolen UN vehicle that had been painted black arrived and three armed men came out. ${ }^{19956}$ The two soldiers who arrested the UNMO team appeared wearing stolen UN blue helmets and flak jackets; they were under the command of these three armed men. ${ }^{19957}$ One of the soldiers ordered the UNMO team to take off their UN uniforms and to put on civilian clothing. ${ }^{19958}$ The UNMOs did not have civilian clothing, so the soldiers gave them a combination of civilian clothes and old JNA uniforms to

\footnotetext{
19946 P49 (Witness statement of Gunnar Westlund dated 22 November 1995), e-court p. 4; Marcus Helgers, T. 10748 (26 January 2011); P2117 (Witness statement of Marcus Helgers dated 3 August 1995), p. 2.

19947 P49 (Witness statement of Gunnar Westlund dated 22 November 1995), e-court p. 4.

19948 P49 (Witness statement of Gunnar Westlund dated 22 November 1995), e-court p. 4.

19949 P49 (Witness statement of Gunnar Westlund dated 22 November 1995), e-court p. 4. Patrick Rechner identifies Nicholas Ribić as a "Canadian of Serbian origin" who was a VRS soldier. Patrick Rechner, T. 11087 (2 February 2011).

19950 P49 (Witness statement of Gunnar Westlund dated 22 November 1995), e-court pp. 4-5.

19951 P49 (Witness statement of Gunnar Westlund dated 22 November 1995), e-court p. 4.

19952 P49 (Witness statement of Gunnar Westlund dated 22 November 1995), e-court p. 4.

19953 P49 (Witness statement of Gunnar Westlund dated 22 November 1995), e-court p. 5 (specifying that the armed soldier was pointing the gun at him).

19954 P49 (Witness statement of Gunnar Westlund dated 22 November 1995), e-court p. 5.

19955 P49 (Witness statement of Gunnar Westlund dated 22 November 1995), e-court p. 5.

19956 P49 (Witness statement of Gunnar Westlund dated 22 November 1995), e-court p. 5 (noting that the individual who seemed to be the leader had a long beard, long black hair, was dressed in black, and did not seem to be a "regular VRS soldier").

19957 P49 (Witness statement of Gunnar Westlund dated 22 November 1995), e-court p. 5.

19958 P49 (Witness statement of Gunnar Westlund dated 22 November 1995), e-court p. 5; Marcus Helgers, T. 10749 (26 January 2011).
} 
wear. ${ }^{19959}$ They were allowed to keep their identification cards, wallets, and cigarettes. ${ }^{19960}$ The two soldiers who arrested the UNMO team drove away in the two UN vehicles taken from the UNMO office. ${ }^{19961}$ The UNMO team was placed in the back of the black vehicle and driven towards Pale. ${ }^{19962}$ Around 7 p.m., the vehicle reached the police station in Pale where the leader went inside; he then took them to a cafe in downtown Pale. ${ }^{19963}$ There, the UNMO team was ordered to get out of the vehicle and line up on the pavement. ${ }^{19964}$ Westlund saw many drunken VRS soldiers standing outside the cafe wearing stolen UN equipment. ${ }^{19965}$ They also saw members of the 7 Lima UNMO team from Pale who had been captured earlier that day. ${ }^{19966}$ Ribic told them: "You are now our prisoners and we are going to take you to the radar station where you will be locked-up to protect it". ${ }^{19967}$ Ribić further stated that if there were any more NATO air strikes, one of the UNMOs would be shot, and if there was an air strike on the Mount Jahorina radar station, any of the UNMOs who survived would be executed afterwards. ${ }^{19968}$ The UNMO team was then ordered to get into another stolen UN vehicle that had arrived at the cafe. ${ }^{19969}$

5876. Between 8 and 8:30 p.m., Westlund, Helgers, Manzoor, and other members of the UNMO team were driven to the Mount Jahorina ski resort and stopped en route at a cabin. ${ }^{19970}$ The officer in charge came out of the cabin with three armed VRS soldiers. ${ }^{19971}$ The officer spoke to Ribic and Ribić ordered Westlund to call the UNMO headquarters by radio and instructed him as follows: "Tell them that we will shoot you one by one if NATO does not stop the air strikes. Tell them that you are going to the Jahorina radar station where you will be locked up". ${ }^{19972}$ When UNMO headquarters acknowledged the call, Ribić grabbed the radio, identified himself as a VRS soldier

\footnotetext{
19959 P49 (Witness statement of Gunnar Westlund dated 22 November 1995), e-court p. 5; Marcus Helgers, T. 10749 (26 January 2011).

19960 P49 (Witness statement of Gunnar Westlund dated 22 November 1995), e-court p. 5.

19961 P49 (Witness statement of Gunnar Westlund dated 22 November 1995), e-court p. 5.

19962 P49 (Witness statement of Gunnar Westlund dated 22 November 1995), e-court p. 5.

19963 P49 (Witness statement of Gunnar Westlund dated 22 November 1995), e-court p. 5.

19964 P49 (Witness statement of Gunnar Westlund dated 22 November 1995), e-court p. 5.

19965 P49 (Witness statement of Gunnar Westlund dated 22 November 1995), e-court p. 5.

19966 P2117 (Witness statement of Marcus Helgers dated 3 August 1995), p. 2; Patrick Rechner, T. 11103-11104 (2 February 2011).

19967 Although Westlund does not name Ribić, he states that he recognised his voice as that of the Bosnian Serb soldier from Canada who had previously spoken on the radio, in very good English, stating that he had detained the UNMO team in Pale. P49 (Witness statement of Gunnar Westlund dated 22 November 1995), e-court pp. 56. Rechner and Helgers also testified that it was Ribić who was present and made these statements. Patrick Rechner, T. 11087-11088 (2 February 2011); Marcus Helgers, T. 10750 (26 January 2011); P2117 (Witness statement of Marcus Helgers dated 3 August 1995), p. 2.

19968 Marcus Helgers, T. 10750 (26 January 2011); Patrick Rechner, T. 11087-11088 (2 February 2011).

19969 P49 (Witness statement of Gunnar Westlund dated 22 November 1995), e-court p. 5.

19970 P49 (Witness statement of Gunnar Westlund dated 22 November 1995), e-court p. 6; P2117 (Witness statement of Marcus Helgers dated 3 August 1995), p. 2; Marcus Helgers, T. 10751 (26 January 2011).

19971 P49 (Witness statement of Gunnar Westlund dated 22 November 1995), e-court p. 6.

19972 P49 (Witness statement of Gunnar Westlund dated 22 November 1995), e-court p. 6.
} 
and then repeated the message. ${ }^{19973}$ Westlund, Helgers, and the UNMOs were ordered out of the vehicle and into a camouflaged Volkswagen minibus. ${ }^{19974}$ Ribić and another soldier drove away in the stolen UN vehicle in the direction of Pale. ${ }^{19975}$ The three remaining VRS soldiers were very drunk, aggressive, and hostile, and one of them hit three of the UNMOs on the head with the butt of a Kalashnikov rifle. ${ }^{19976}$ They drove Westlund, Helgers, and the UNMOs up the mountain towards the Mount Jahorina radar station, which was approximately 50 metres from the main radar tower. ${ }^{19977}$ When they arrived at the barracks, a man who introduced himself as the commander of the VRS unit gave the UNMOs paper to write down their names, nationalities, and ID numbers. ${ }^{19978}$ He said he would send the information to the Lukavica Barracks so that the UNMO headquarters would know their whereabouts. ${ }^{19979}$ He informed them that they were prisoners of war. ${ }^{19980}$ Later, the UNMOs were warned that the area around the radar station was mined. ${ }^{19981}$ They were told that they had been taken pursuant to orders from the Bosnian Serb President or the VRS command. ${ }^{19982}$

5877. On 27 May 1995, Westlund, Helgers, Manzoor, and the UNMOs were woken up at 4:45 a.m. and taken by three VRS soldiers towards the radar station 200 metres away. ${ }^{19983}$ Near the radar station, they were taken to a small shelter that contained four beds, blankets, pillows, and a heater. ${ }^{19984}$ Two of the UNMOs were told to go outside with their blankets. ${ }^{19985}$ Two hours later, they returned and told Westlund that they had been forced to sit around the radar station with their blankets and had been guarded by two armed soldiers at all times. ${ }^{19986}$ Next, Westlund and another UNMO were taken outside and forced to sit between the two radar antennas for two hours before returning to the shelter. ${ }^{19987}$ At 3 p.m., three VRS soldiers entered the shelter. ${ }^{19988}$ One of them was the battalion commander and ordered Westlund and Manzoor to get into a car. ${ }^{19989}$ They were

P49 (Witness statement of Gunnar Westlund dated 22 November 1995), e-court p. 6. P49 (Witness statement of Gunnar Westlund dated 22 November 1995), e-court p. 6. P49 (Witness statement of Gunnar Westlund dated 22 November 1995), e-court p. 6. P49 (Witness statement of Gunnar Westlund dated 22 November 1995), e-court p. 6; Marcus Helgers, T. 10751 (26 January 2011); P2117 (Witness statement of Marcus Helgers dated 3 August 1995), p. 3.

P49 (Witness statement of Gunnar Westlund dated 22 November 1995), e-court p. 6 (specifying that after 20 minutes, the minibus stopped and they walked the rest of the way up the mountain).

19978 P49 (Witness statement of Gunnar Westlund dated 22 November 1995), e-court p. 6; P2117 (Witness statement of Marcus Helgers dated 3 August 1995), p. 3.

19979 P49 (Witness statement of Gunnar Westlund dated 22 November 1995), e-court p. 6.

19980 P49 (Witness statement of Gunnar Westlund dated 22 November 1995), e-court p. 6.

19981 Marcus Helgers, T. 10756-10757 (26 January 2011).

19982 Marcus Helgers, T. 10756-10757 (26 January 2011).

19983 P49 (Witness statement of Gunnar Westlund dated 22 November 1995), e-court p. 7.

19984 P49 (Witness statement of Gunnar Westlund dated 22 November 1995), e-court p. 7.

19985 P49 (Witness statement of Gunnar Westlund dated 22 November 1995), e-court p. 7.

19986 P49 (Witness statement of Gunnar Westlund dated 22 November 1995), e-court p. 7.

19987 P49 (Witness statement of Gunnar Westlund dated 22 November 1995), e-court p. 7.

19988 P49 (Witness statement of Gunnar Westlund dated 22 November 1995), e-court p. 7.

19989 P49 (Witness statement of Gunnar Westlund dated 22 November 1995), e-court p. 7.
} 
driven towards the radar station. ${ }^{19990}$ Westlund was ordered to get out and the car was driven off with Manzoor still inside. ${ }^{19991}$ Westlund and a VRS soldier walked 50 metres over a hill to a large army building which housed the radio communication centre. ${ }^{19992}$ A VRS Lieutenant Colonel was present. ${ }^{19993}$ Westlund was locked in a room on the second floor of the radio communications centre building. ${ }^{19994}$ A younger deputy VRS commander told Westlund that he was under orders to shoot him if he attempted to escape. ${ }^{19995}$ Westlund was kept in this building and given meals. ${ }^{19996}$ After several days, Manzoor was brought back and detained with Westlund. ${ }^{19997}$ Several times during the following days, Westlund heard NATO aircraft flying overhead. ${ }^{19998}$ When this occurred Weslund and Manzoor were ordered to go outside until the flights passed. ${ }^{19999}$

5878. On 13 June 1995, Westlund was told that he would be released but that Manzoor would not. $^{20000}$ Westlund was released in Pale where he met a member of his team and eight UNMOs from other teams. ${ }^{20001}$ There were members of the BritBat and FreBat teams who had also been released. ${ }^{20002}$ Helgers, Manzoor, and other members of the UNMO team were released over the next few days. ${ }^{20003}$

\section{iv. Evidence from the UNMO team in Grbavica}

5879. The UNMO team posted in the Bosnian Serb controlled area of Grbavica included Joseph Gelissen, Sergey Golubev, and Harley Alves. ${ }^{20004}$ On 26 May 1995, at 4 p.m., a group of VRS soldiers entered the UNMO team's house in Grbavica. ${ }^{20005}$ The soldiers handcuffed Gelissen and Alves. $^{20006}$ They confiscated the UNMO's equipment and personal items. ${ }^{20007}$ They were then

P49 (Witness statement of Gunnar Westlund dated 22 November 1995), e-court p. 7.

P49 (Witness statement of Gunnar Westlund dated 22 November 1995), e-court p. 7.

P49 (Witness statement of Gunnar Westlund dated 22 November 1995), e-court p. 7.

P49 (Witness statement of Gunnar Westlund dated 22 November 1995), e-court p. 7 (specifying that the Lieutenant Colonel was the commander of the air defence complex).

P49 (Witness statement of Gunnar Westlund dated 22 November 1995), e-court p. 8.

P49 (Witness statement of Gunnar Westlund dated 22 November 1995), e-court p. 8.

P49 (Witness statement of Gunnar Westlund dated 22 November 1995), e-court p. 7.

P49 (Witness statement of Gunnar Westlund dated 22 November 1995), e-court p. 8.

P49 (Witness statement of Gunnar Westlund dated 22 November 1995), e-court p. 8.

P49 (Witness statement of Gunnar Westlund dated 22 November 1995), e-court p. 8.

P49 (Witness statement of Gunnar Westlund dated 22 November 1995), e-court p. 8.

P49 (Witness statement of Gunnar Westlund dated 22 November 1995), e-court p. 8; P2160 (UNPROFOR report re released hostages, 14 June 1995). See also March Helgers, T. 10758 (26 January 2011); P2117 (Witness statement of Marcus Helgers dated 3 August 1995), p. 3; para. 5936.

20002 P49 (Witness statement of Gunnar Westlund dated 22 November 1995), e-court pp. 8-9.

20003 P2117 (Witness statement of Marcus Helgers dated 3 August 1995), e-court p. 4

20004 P56 (Witness statement of Joseph Gelissen dated 18 January 1996), e-court p. 4; P2171 (UNPROFOR report, 27 May 1995), p. 5.

20005 P56 (Witness statement of Joseph Gelissen dated 18 January 1996), e-court p. 5.

20006 P56 (Witness statement of Joseph Gelissen dated 18 January 1996), e-court p. 5.
} 
taken outside by the VRS soldiers and placed in a vehicle, which had been painted black. ${ }^{20008}$ Golubev remained behind at the UNMO team's house. ${ }^{20009}$ The VRS soldiers stated that they had orders to detain the UNMOs and that the person in charge was Ribić. ${ }^{20010}$ Gelissen and Alves were driven towards Pale and their car was joined by two other stolen UN cars, driven by VRS soldiers including Ribić. ${ }^{20011}$ The cars were full of equipment taken from the UNMOs. ${ }^{20012}$

5880. In Pale, they stopped at a hospital, where they were made to wait on the staircase and filmed. $^{20013}$ They were surrounded by about 20 VRS soldiers and civilians who were very aggressive. ${ }^{20014}$ At 5 p.m., they were driven to the front of the Pale Barracks where they were handcuffed to a flagpole. ${ }^{20015}$ Romero Huelin and Griffith Evans, members of the 7 Lima UNMO team in Pale, were already there and also handcuffed to a second flagpole. ${ }^{20016}$ They stayed handcuffed until 7 p.m. ${ }^{20017}$ Gelissen saw NATO aircraft flying overhead and some of the VRS soldiers shouted at the aircraft and one VRS soldier made a gesture pretending to cut the UNMOs' throat. $^{20018}$ A VRS captain named Vojvodić was in charge and he sent a different set of soldiers to guard the UNMOs. ${ }^{20019}$ At 7 p.m., the UNMOs were taken to the canteen to have dinner with the VRS soldiers. ${ }^{20020}$ Thereafter, the UNMOs were taken back outside and handcuffed to the flagpoles again. ${ }^{20021}$ Later in the evening, they were taken to a park where they rested. ${ }^{20022}$ Other members from the 7 Lima UNMO team in Pale, including Patrick Rechner and Janusz Kalbarczyk, were brought in. ${ }^{20023}$ All the UNMOs were then taken to a room in the Pale Barracks to sleep. ${ }^{20024}$ Vojvodic explained to them that they were captured, that he could not give them any more

\footnotetext{
20007 P56 (Witness statement of Joseph Gelissen dated 18 January 1996), e-court p. 5.

20008 P56 (Witness statement of Joseph Gelissen dated 18 January 1996), e-court p. 6.

20009 P56 (Witness statement of Joseph Gelissen dated 18 January 1996), e-court p. 6.

20010 P56 (Witness statement of Joseph Gelissen dated 18 January 1996), e-court p. 6.

20011 P56 (Witness statement of Joseph Gelissen dated 18 January 1996), e-court p. 6.

20012 P56 (Witness statement of Joseph Gelissen dated 18 January 1996), e-court p. 6.

20013 P56 (Witness statement of Joseph Gelissen dated 18 January 1996), e-court p. 6.

20014 P56 (Witness statement of Joseph Gelissen dated 18 January 1996), e-court p. 6.

20015 P56 (Witness statement of Joseph Gelissen dated 18 January 1996), e-court p. 6.

20016 P56 (Witness statement of Joseph Gelissen dated 18 January 1996), e-court p. 6. See paras. $5918,5921$.

20017 P56 (Witness statement of Joseph Gelissen dated 18 January 1996), e-court p. 6.

20018 P56 (Witness statement of Joseph Gelissen dated 18 January 1996), e-court p. 6.

20019 P56 (Witness statement of Joseph Gelissen dated 18 January 1996), e-court p. 6.

20020 P56 (Witness statement of Joseph Gelissen dated 18 January 1996), e-court p. 6.

20021 P56 (Witness statement of Joseph Gelissen dated 18 January 1996), e-court p. 6.

20022 P56 (Witness statement of Joseph Gelissen dated 18 January 1996), e-court p. 6.

20023 P56 (Witness statement of Joseph Gelissen dated 18 January 1996), e-court pp. 6-7.

20024 P56 (Witness statement of Joseph Gelissen dated 18 January 1996), e-court pp. 6-7. The UNMOs included Gelissen, Alves, Rechner, Kalbarczyk, Evans, Huelin, and four others. P56 (Witness statement of Joseph Gelissen dated 18 January 1996), e-court p. 7.
} 
information, but that they should do as they were told because he was responsible for their safety. $^{20025}$

5881. On 27 May 1995, at 10:30 a.m., all the UNMOs held at the Pale Barracks were driven in a truck to Jahorinski Potok and detained in a canteen. ${ }^{20026}$ Alves and Kalbarczyk were taken to the radar station where they were filmed by Pale TV. ${ }^{20027}$ While a NATO aircraft flew overhead, a Serbian reporter interviewed Alves and Kalbarczyk, who were handcuffed to the base of the radar station. ${ }^{20028}$ Ribić came to see the UNMOs and told them they would be released in a few days. ${ }^{20029}$ At 8 p.m., all the UNMOs were taken back to the Pale Barracks. ${ }^{20030}$

5882. On 28 May 1995, Gelissen and the UNMOs were detained in their room at the Pale Barracks the whole day while the two Russian UNMOs were released. ${ }^{20031}$ Vojvodić had promised the UNMOs that they would be released soon but conditions at the Jahorinski Potok Barracks remained tense. $^{20032}$

5883. On 31 May 1995, a VRS Major named Batinić came to see Gelissen and the UNMOs, he introduced himself as Vojvodić's superior. ${ }^{20033}$ Gelissen asked if they could return to their accommodations to pick up their personal items, take a shower, and shave. ${ }^{20034}$ Batinić promised to

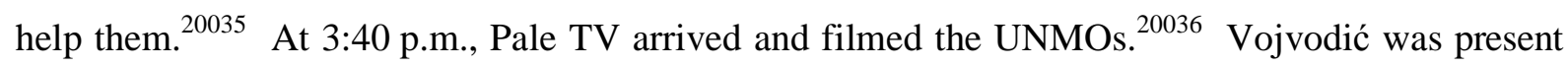
during the filming. ${ }^{20037}$

5884. On 1 June 1995, Gelissen was chosen by his fellow UNMOs to be their representative. ${ }^{20038}$ They drafted a letter to Batinić stating that they knew that the VRS was referring to them as prisoners of war and as such, they made certain demands. ${ }^{20039}$ At 8 p.m., two VRS officers from

\footnotetext{
20025 P56 (Witness statement of Joseph Gelissen dated 18 January 1996), e-court p. 7.

20026 P56 (Witness statement of Joseph Gelissen dated 18 January 1996), e-court p. 7.

20027 P2143 (Serbian TV news report re UN personnel, with transcript); P56 (Witness statement of Joseph Gelissen dated 18 January 1996), e-court p. 7.

20028 P2143 (Serbian TV news report re UN personnel, with transcript). See also Janusz Kalbarczyk, T. 10841-10843 (28 January 2011).

20029 P56 (Witness statement of Joseph Gelissen dated 18 January 1996), e-court p. 7.

20030 P56 (Witness statement of Joseph Gelissen dated 18 January 1996), e-court p. 7.

20031 P56 (Witness statement of Joseph Gelissen dated 18 January 1996), e-court p. 7.

20032 P56 (Witness statement of Joseph Gelissen dated 18 January 1996), e-court p. 7.

20033 P56 (Witness statement of Joseph Gelissen dated 18 January 1996), e-court p. 8.

20034 P56 (Witness statement of Joseph Gelissen dated 18 January 1996), e-court p. 8.

20035 P56 (Witness statement of Joseph Gelissen dated 18 January 1996), e-court p. 8.

20036 P56 (Witness statement of Joseph Gelissen dated 18 January 1996), e-court p. 8.

20037 P56 (Witness statement of Joseph Gelissen dated 18 January 1996), e-court p. 8.

20038 P56 (Witness statement of Joseph Gelissen dated 18 January 1996), e-court p. 8.

20039 P56 (Witness statement of Joseph Gelissen dated 18 January 1996), e-court p. 8 (noting that these demands included having contact with their next of kin, access to the news, visits from a doctor, conversations with the Bosnian Serb authorities, a visit from the ICRC, and access to laundry and to their personal items). D3139
} 
the Lukavica Barracks came to interrogate Evans and another UNMO about guided weapons systems because both men had backgrounds as pilots. ${ }^{20040}$ At 9 p.m., the UNMOs had a meeting with Vojvodić, during which Gelissen gave Vojvodić the letter he had drafted and told him he would not allow Pale TV to film them anymore and even "threatened him with the International Tribunal in The Hague". 20041 Vojvodić got very nervous and promised to deliver the letter to Batinić. $^{20042}$

5885. On 3 June 1995, Batinić visited the UNMOs. ${ }^{20043}$ He informed them that he had received their letter and promised to take some action soon. ${ }^{20044}$ On 5 June 1995, two doctors from the Pale hospital visited the UNMOs. ${ }^{20045}$ The following day, Huelin was released as a result of the doctor's visit. $^{20046}$ The ICRC visited them on 8 and 9 June 1995. ${ }^{20047}$ Professor Mirko Šošić, a doctor at the Koran Hospital, told Gelissen and the other UNMOs that they would soon be released. ${ }^{20048}$ On 10 June 1995, some of the UNMOs were taken to the 7 Lima UNMO team's former accommodations and allowed to call their families. ${ }^{20049}$

5886. On 13 June 1995, Kalbarczyk, Westlund, and other UNMOs were released. ${ }^{20050}$

\section{v. Evidence from the FreBat teams}

\section{(A) FreBat team at Lukavica}

5887. FreBat had three posts in and around Sarajevo. ${ }^{20051}$ On 26 May 1995, at 10:30 a.m., members of the FreBat team who were part of the armed platoon posted at the entrance of the

(Excerpt from manuscript of Mirko Šošić); Patrick Rechner, T. 11114-11115 (2 February 2011); P2525 (Witness statement of Griffiths Evans dated 6 September 1995), e-court pp. 9-10. They were not allowed to meet with the ICRC until 8 June 1995, despite the insistence from the ICRC that they be allowed access to the UNMOs. Patrick Rechner, T. 11115 (2 February 2011).

20040 P56 (Witness statement of Joseph Gelissen dated 18 January 1996), e-court p. 8; see para. 5924.

20041 P56 (Witness statement of Joseph Gelissen dated 18 January 1996), e-court p. 8.

20042 P56 (Witness statement of Joseph Gelissen dated 18 January 1996), e-court p. 8.

20043 P56 (Witness statement of Joseph Gelissen dated 18 January 1996), e-court p. 8.

20044 P56 (Witness statement of Joseph Gelissen dated 18 January 1996), e-court p. 8.

20045 P56 (Witness statement of Joseph Gelissen dated 18 January 1996), e-court p. 9; Mirko Šošić, T. 35756-35758 (21 March 2013); D989 (Medical report for UN personnel, 6 June 1995); D3139 (Excerpt from manuscript of Mirko Šošić).

20046 P56 (Witness statement of Joseph Gelissen dated 18 January 1996), e-court p. 9.

20047 P56 (Witness statement of Joseph Gelissen dated 18 January 1996), e-court p. 9.

20048 P56 (Witness statement of Joseph Gelissen dated 18 January 1996), e-court p. 9; Mirko Šošić, T. 5756-35758 (21 March 2013); D989 (Medical report for UN personnel, 6 June 1995); D3139 (Excerpt from manuscript of Mirko Šošić); D3138 (Witness statement of Mirko Šošić dated 17 March 2013), para. 10.

20049 P56 (Witness statement of Joseph Gelissen dated 18 January 1996), e-court p. 9.

20050 Janus Kalbarczyk, T. 10868-10869 (28 January 2011); P49 (Witness statement of Gunnar Westlund dated 22 November 1995), e-court p. 9; P56 (Witness statement of Joseph Gelissen dated 18 January 1996), e-court p. 9. See also para. 5936.

20051 P2171 (UNPROFOR report, 27 May 1995), p. 1. 
Lukavica Barracks were surrounded by armed VRS soldiers. ${ }^{20052}$ At 12:30 p.m., a group of 30 armed men wearing VRS uniforms surrounded members of the other FreBat team located 800 metres away from the entrance. ${ }^{20053}$ The VRS soldiers ordered this FreBat team to join the FreBat platoon team posted at the entrance of Lukavica Barracks. ${ }^{20054}$ They refused to do so and waited for instructions from their headquarters. ${ }^{20055}$ By this time, the second NATO air strike in Pale had occurred and the Bosnian Serbs wanted to take some FreBat members over to Pale to assess the damage that the civilian population had suffered. ${ }^{20056}$ The FreBat Lieutenant in charge of the platoon at the entrance of the Lukavica Barracks refused. ${ }^{20057}$ Tensions escalated. ${ }^{20058}$ Five of the VRS tank crews were ordered to take up combat positions. ${ }^{20059}$ FreBat also took up combat positions, prepared their rocket-launchers but were ordered not to load their guns. ${ }^{20060}$ This confrontation lasted several hours. ${ }^{20061}$

5888. The FreBat team members at the entrance of the Lukavica Barracks were guarding their post when Milenko Inđić arrived and attempted to negotiate with the FreBat Lieutenant to surrender. ${ }^{20062}$ Inđić stated that an order had come from "higher authorities" to disarm the UNPROFOR members at the Lukavica Barracks. ${ }^{20063}$ The FreBat Lieutenant responded that he did not have the orders to surrender. ${ }^{20064}$ Inđić then ordered the Bosnian Serb soldiers to take up firing positions targeting the building until the FreBat team surrendered. ${ }^{20065}$ Two rocket-propelled grenades hit a truck and an APC. ${ }^{20066}$ Minutes later, the FreBat team came out of the building and surrendered. ${ }^{20067}$

[REDACTED].

[REDACTED].

[REDACTED].

[REDACTED].

[REDACTED].

[REDACTED].

[REDACTED].

[REDACTED].

[REDACTED].

[REDACTED].

Milenko Inđić, T. 32630-32632 (24 January 2013); P6086 (Article from Associated Press entitled "French UN Platoon Surrenders to Bosnian Serbs", 26 May 1995). The UN personnel's main contact with the VRS was Milenko Inđić, the Liaison Officer of the VRS to the UN, see Milenko Inđić, T. 32414-32415, 32428-32429 (22 January 2013); D2774 (Witness statement of Milenko Inđić dated 19 January 2013), paras. 39, 41-42, 44; P2447 (Witness statement of KDZ182 dated 8 March 2011, para. 11; Rupert Smith, T. 11371-11372 (8 February 2011); P56 (Witness statement of Joseph Gelissen dated 18 January 1996), e-court p. 4; P1762 (Witness statement of David Fraser dated 17 October 2010), p. 8.

20063 D2774 (Witness statement of Milenko Inđić dated 19 January 2013), para. 171.

20064 Milenko Inđić, T. 32630-32632 (24 January 2013); P6086 (Article from Associated Press entitled "French UN Platoon Surrenders to Bosnian Serbs", 26 May 1995).

20065 Milenko Inđić, T. 32630-32632 (24 January 2013); P6086 (Article from Associated Press entitled "French UN Platoon Surrenders to Bosnian Serbs", 26 May 1995).

20066 Milenko Inđić, T. 32630-32632 (24 January 2013); P6086 (Article from Associated Press entitled "French UN Platoon Surrenders to Bosnian Serbs", 26 May 1995).
} 
5889. Around 7:30 p.m., the FreBat Lieutenant and his liaison officer, Captain Jouannic, went to the other FreBat post. ${ }^{20068}$ Jouannic explained that, as the liaison officer, he was conveying an order that the FreBat team to lay down their arms and that Inđić would talk to them. ${ }^{20069}$ Then Inđić came and introduced himself to this FreBat team. ${ }^{20070}$ Indić was accompanied by a civilian who was videotaping the entire interaction. ${ }^{20071}$ He informed the FreBat team that they were now prisoners of war of the VRS. ${ }^{20072}$ The two FreBat teams at the Lukavica Barracksspent the night at their respective posts. ${ }^{20073}$

5890. On 27 May 1995, a team of reporters arrived, under VRS escort, to film and photograph the FreBat teams. ${ }^{20074}$ FreBat members were asked to give the contact details of relatives or individuals to be informed but they refused to provide them. ${ }^{20075}$ Around midnight, a number of VRS trucks arrived with more soldiers. ${ }^{20076}$ The FreBat teams were ordered to get into the trucks. $^{20077}$ After being told they were "hostages" and not "prisoners of war" [REDACTED] refused to have any further dealings with the VRS soldiers. ${ }^{20078}$ The FreBat members were held at gunpoint and their equipment and UN IDs were forcibly taken from them. ${ }^{20079}$ They were placed onto the trucks and driven to the Lukavica Barracks command post and detained there. ${ }^{20080}$ Later, one FreBat member was taken to the Lukavica MP building. ${ }^{20081}$ He was locked in a room with two UNMOs already inside. ${ }^{20082}$ During this first week, the conditions were "very poor" and he

\footnotetext{
20067 Milenko Inđić, T. 32630-32632 (24 January 2013); P6086 (Article from Associated Press entitled "French UN Platoon Surrenders to Bosnian Serbs", 26 May 1995). [REDACTED]. Inđić testified that he went into the building unarmed and was told by a FreBat officer that he had not received the order to surrender. Therefore, according to Inđić, there was an agreement that the VRS would fire at the vehicles without jeopardising the lives of the UN personnel and then when the firing stopped, the FreBat officer would come out of the barracks with a white flag and surrender. Milenko Inđić, T. 32632 (24 January 2013). Considering the totality of the evidence and Inđić's lack of credibility on this point, the Chamber does not accept Inđić's evidence that he did not make these statements.

D2774 (Witness statement of Milenko Inđić dated 19 January 2013), para. 171; P6086 (Article from Associated Press entitled "French UN Platoon Surrenders to Bosnian Serbs", 26 May 1995); [REDACTED]. D2774 (Witness statement of Milenko Inđić dated 19 January 2013), para. 171; P6086 (Article from Associated Press entitled "French UN Platoon Surrenders to Bosnian Serbs", 26 May 1995); [REDACTED].

20072 D2774 (Witness statement of Milenko Inđić dated 19 January 2013), para. 171; P6086 (Article from Associated Press entitled "French UN Platoon Surrenders to Bosnian Serbs", 26 May 1995); [REDACTED].

20073 [REDACTED].

20074 [REDACTED].

20075 [REDACTED].

20076 [REDACTED].

20077 [REDACTED].

20078 [REDACTED].

20079 [REDACTED].

20080 [REDACTED].

20081 [REDACTED].

20082 [REDACTED].
} 
was only allowed out of the room to eat. ${ }^{20083}$ There were frequent visits by Inđić and a VRS major, who continued to ask him for personal information about his FreBat team members. ${ }^{20084}$ The following day, [REDACTED] saw ten more UNPROFOR members arrive at the barracks but they were detained on a separate floor of the building. ${ }^{20085}$

5891. On 2 June 1995, at 4 p.m., the commander of the Lukavica MP told [REDACTED] and two UNMOs also detained at the barracks to gather their belongings and follow him. ${ }^{20086}$ Outside the entrance of the Lukavica Barracks there was a bus with other FreBat members onboard. ${ }^{20087}$ Inđić, Jouannic, and a VRS Major were standing next to the bus. ${ }^{20088}$ Jouannic asked [REDACTED] and the two UNMOs to board the bus. ${ }^{20089}$ [REDACTED]. ${ }^{20090}$ [REDACTED]. ${ }^{20091}$

5892. On 6 June 1995, at 8 a.m., [REDACTED] was driven to Pale in a civilian vehicle and taken to a building which served as a prison where he met two other UNMOs. ${ }^{20092}$ The three men were placed in a small VRS van and driven to the Serbian border where they were greeted by an official and were filmed shaking hands with him. ${ }^{20093}$ They were taken to Novi Sad by helicopter and released, where [REDACTED] met the other members of his FreBat team. ${ }^{20094}$

(B) FreBat team at the Vrbanja Bridge

5893. On 27 May 1995, at 4:30 a.m., the UNPROFOR post near the Vrbanja Bridge was taken over by approximately 15 VRS soldiers wearing FreBat uniforms and carrying UNPROFOR equipment. $^{20095}$ The VRS soldiers swiftly encircled the FreBat team stationed there. ${ }^{20096}$ One

\begin{tabular}{|c|c|}
\hline 20083 & [REDACTED]. \\
\hline 20084 & [REDACTED]. \\
\hline 20085 & [REDACTED]. \\
\hline 20086 & [REDACTED]. \\
\hline 20087 & [REDACTED]. \\
\hline 20088 & [REDACTED]. \\
\hline 20089 & [REDACTED]. \\
\hline 20090 & [REDACTED]. \\
\hline 20091 & [REDACTED]. \\
\hline 20092 & [REDACTED]. \\
\hline 20093 & [REDACTED]. \\
\hline 20094 & [REDACTED]. \\
\hline 20095 & $\begin{array}{l}\text { P2171 (UNPROFOR report, } 27 \text { May 1995), p. 1; D1058 (UNPROFOR report to Marrack Goulding, } 30 \text { May } \\
\text { 1995), para. 13; [REDACTED]; P2269 (UNPROFOR report re telephone conversation with Ratko Mladić, } 29 \\
\text { May 1995), p. 2; [REDACTED]; P5924 (UNPROFOR report, } 27 \text { May 1995), pp. 4, 10-11; [REDACTED]; } \\
\text { P2433 (UNPROFOR protest letter to SRK, } 3 \text { June 1995). See also P2028 (BBC news report re UN hostage- } \\
\text { taking in Sarajevo, with transcript); P2433 (UNPROFOR protest letter to SRK, } 3 \text { June 1995). In the attack by } \\
\text { FreBat to retake the bridge, [REDACTED], two FreBat and four VRS soldiers were killed, and both FreBat and } \\
\text { VRS soldiers were injured. FreBat took four VRS soldiers as prisoners and detained them. P2447 (Witness } \\
\text { statement of KDZ182 dated } 8 \text { March 2011), p. 75; [REDACTED]; P5924 (UNPROFOR report, 27 May 1995), } \\
\text { pp. 1, 4-7, 10-11; P2407 (Witness statement of KDZ304), p. 9; [REDACTED]; D1058 (UNPROFOR report to } \\
\text { Marrack Goulding, } 30 \text { May 1995), para. 13; [REDACTED]. Andrey Demurenko stated that the ABiH check- } \\
\text { point had been attacked by the VRS and the ABiH informed FreBat. This resulted in FreBat attacking the VRS }\end{array}$ \\
\hline
\end{tabular}


FreBat member was hit in the chin with the butt of a rifle during the attack. ${ }^{20097}$ Attempts to contact UNPROFOR BiH command failed. ${ }^{20098}$ The FreBat team was taken from the Vrbanja Bridge to the "Prisunic building", which was held by Bosnian Serbs. ${ }^{20099}$ They were then taken to the Lukavica Barracks, in a building previously occupied by UNPROFOR. ${ }^{20100}$ They were detained for approximately three hours, before being taken back to the Prisunic building and led to a room on the second floor. ${ }^{20101}$ They were made to sit on the floor, with their hands behind their necks, for hours at a time and were under constant surveillance. ${ }^{20102}$ They were also forced to change into VRS uniforms. ${ }^{20103}$ One of them was hit and physically mistreated. ${ }^{20104}$

5894. At 6 or 7 p.m., six members of the FreBat team were led outside to the courtyard. ${ }^{20105}$ There was a large crowd gathered outside, including soldiers and civilians. ${ }^{20106}$ [REDACTED] was physically mistreated by the two VRS soldiers who had been in charge of the FreBat team's capture at the outset. ${ }^{20107}$ The FreBat team was taken back inside the Prisunic building. FreBat members were tied, in pairs, with steel wire. ${ }^{20108}$ Once tied together, they were taken back outside and forced to kneel in the middle of the road opposite the UN post which was facing the Bosnian Muslim sector. $^{20109}$ [REDACTED] heard the French interpreter behind him, on the radio, saying that if the UN did not heed the Bosnian Serbs' request, that the UN would be responsible for their subsequent executions. $^{20110}$ This message was repeated twice. ${ }^{2011}$ UNPROFOR was informed that unless

soldiers. D2270 (Witness statement of Andrey Demurenko dated 13 October 2012), para. 38; Andrey Demurenko, T. 28973-28976 (17 October 2012). Considering the totality of the evidence, in particular the accepted relevant UN reports and Demurenko's lack of credibility on this point, the Chamber does not accept his evidence that it was FreBat that initiated the attack against the VRS soldiers at the Vrbanja Bridge at the request of the $\mathrm{ABiH}$.

P2171 (UNPROFOR report, 27 May 1995); [REDACTED]; P2269 (UNPROFOR report re telephone conversation with Ratko Mladić, 29 May 1995), p. 2; [REDACTED].

[REDACTED]. KDZ304 reported that the FreBat members were threatened with death and "when these threats did not have the expected result" the FreBat members were taken back to Lukavica barracks. P2407 (Witness statement of KDZ304), p. 9.

20098 [REDACTED].

20099 [REDACTED]; D2296 (UNPROFOR daily report, 28 May 1995), pp. 10-11; P5924 (UNPROFOR report, 27 May 1995), p. 13.

20100 [REDACTED].

20101 [REDACTED].

20102 [REDACTED].

20103 [REDACTED].

20104 [REDACTED].

20105 [REDACTED].

20106 [REDACTED].

20107 [REDACTED].

20108 [REDACTED].

20109 [REDACTED]; P2434 (UNPROFOR protest letter to SRK, 3 June 1995) (in which Gobilliard protests to Dragomir Milošević against the "disgusting sight of a French officer, Lt. Bonraisin, forced to kneel in the street, his hands tied behind his back, and with a gun at his head, while Serbian soldiers threatened to shoot him if the UNPROFOR troops refused to withdraw from the OP”).

20110

[REDACTED]. 
NATO stopped air strikes, one of the French soldiers would be killed. ${ }^{20112}$ After ten minutes passed, nothing happened and no executions took place. ${ }^{20113}$ The FreBat team was taken back to the first floor of the Prisunic building. ${ }^{20114}$ In the evening, they were moved to different buildings on two different occasions before finally being taken to a warehouse where they were detained overnight. $^{20115}$

5895. On 28 May 1995, in the morning, the FreBat team members were untied. ${ }^{20116}$ They were visited by a young woman, dressed in civilian clothes, who spoke French. ${ }^{20117}$ She informed them that negotiations for their release, which had taken place the previous day between UNPROFOR and the Bosnian Serbs, had not been conclusive and that some of them were scheduled to die. ${ }^{20118}$ She asked [REDACTED] to provide a list of his men along with their ages, which he did. ${ }^{20119}$ She informed [REDACTED] that he and a corporal were to die first and that [REDACTED] was to designate two other individuals. ${ }^{20120}$ After the woman had left, a male wearing a dark suit and a navy blue sailor's cap whom [REDACTED] recognised as "Duke Alexis" came in. ${ }^{20121}$ This man hit [REDACTED] on the side of his head with a dagger and then kicked him in the face. ${ }^{20122}$ After "Duke Alexis" left, two VRS officers entered the room and asked [REDACTED] and others to follow them. ${ }^{20123}$ The FreBat members were told they would be handed over to the "Serbian regular army". ${ }^{20124}$ They were taken and detained in the Lukavica Barrackswhere they met a commander who informed them that they would be well-treated as long as NATO did not conduct any further air strikes. ${ }^{20125}$

5896. On 29 and 30 May 1995, four FreBat members were taken from the Lukavica Barracksand handcuffed to military equipment at a factory near the barracks while being filmed by a Bosnian

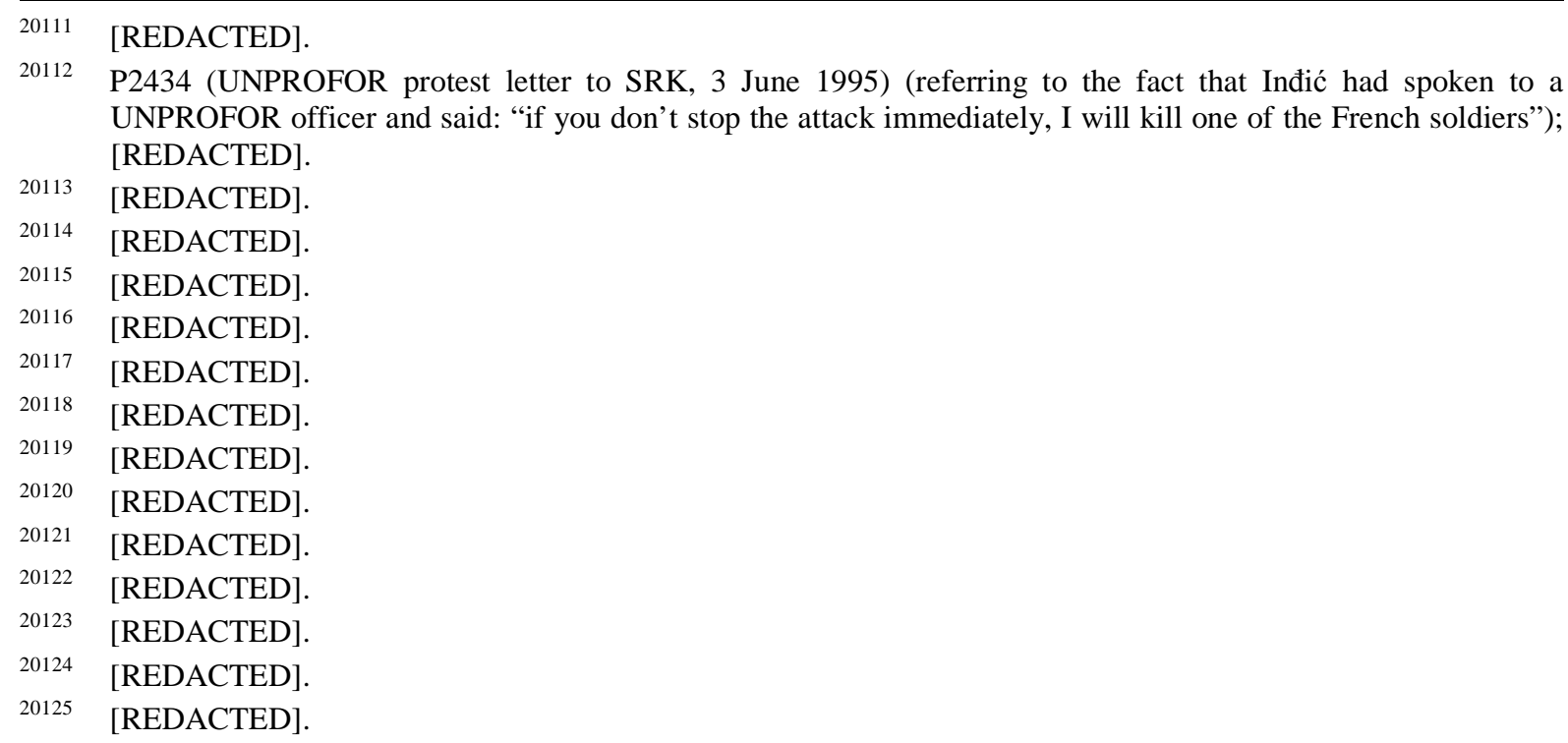
UNPROFOR officer and said: "if you don't stop the attack immediately, I will kill one of the French soldiers"); [REDACTED].

20113 [REDACTED].

20114 [REDACTED].

20115 [REDACTED].

20116 [REDACTED].

20117 [REDACTED].

20118 [REDACTED].

20119 [REDACTED].

20120 [REDACTED].

20121 [REDACTED].

20122 [REDACTED].

20123 [REDACTED].

20124 [REDACTED].

20125 [REDACTED]. 
Serb cameraman. ${ }^{20126}$ When asked how they were feeling, if they were afraid, and if they were being treated well, they responded that they were not afraid and that they were being treated well. $^{20127}$

5897. On 2 June 1995, Gobilliard wrote a letter to Dragomir Milošević protesting that the ICRC had not been allowed to visit the detained FreBat members. ${ }^{20128}$ The following day, Gobilliard wrote again to Milošević noting that although 20 FreBat members had been released, their equipment had been confiscated. ${ }^{20129}$ Gobilliard also noted that UNPROFOR soldiers remained detained at WCPs and other positions and demanded their full release.

5898. On 13 June 1995, [REDACTED] and his FreBat team members were taken to Pale and then released in Belgrade. ${ }^{20130}$

\section{(C) FreBat team at Polinje WCP}

5899. On 26 May 1995 at 2:15 p.m., a VRS soldier came to speak to KDZ196 who was posted at the WCP in Polinje. ${ }^{20131}$ KDZ196 was told that Captain Vlado Medic wanted to see him at the VRS post headquarters which was located approximately 50 metres away. ${ }^{20132}$ KDZ196 and a fellow FreBat member left their WCP to speak to Medić. ${ }^{20133}$ Upon arriving at the VRS post, Medić told them that the FreBat team should surrender, lay down their weapons, and that they were prisoners. $^{20134}$ They were told that they had been detained due to the NATO air strikes and that the Bosnian Serbs hoped to recover the weapons that had been placed under UNPROFOR control. ${ }^{20135}$ A few hours later, KD196 was allowed to return to his UNPROFOR post and establish radio contact with the commander of his battalion who told him that negotiations were underway for their release. $^{20136}$ KDZ196 returned to the VRS post and told Medić about his conversation with the UNPROFOR commander. ${ }^{20137}$ Medić left to make a phone call and upon his return, the situation

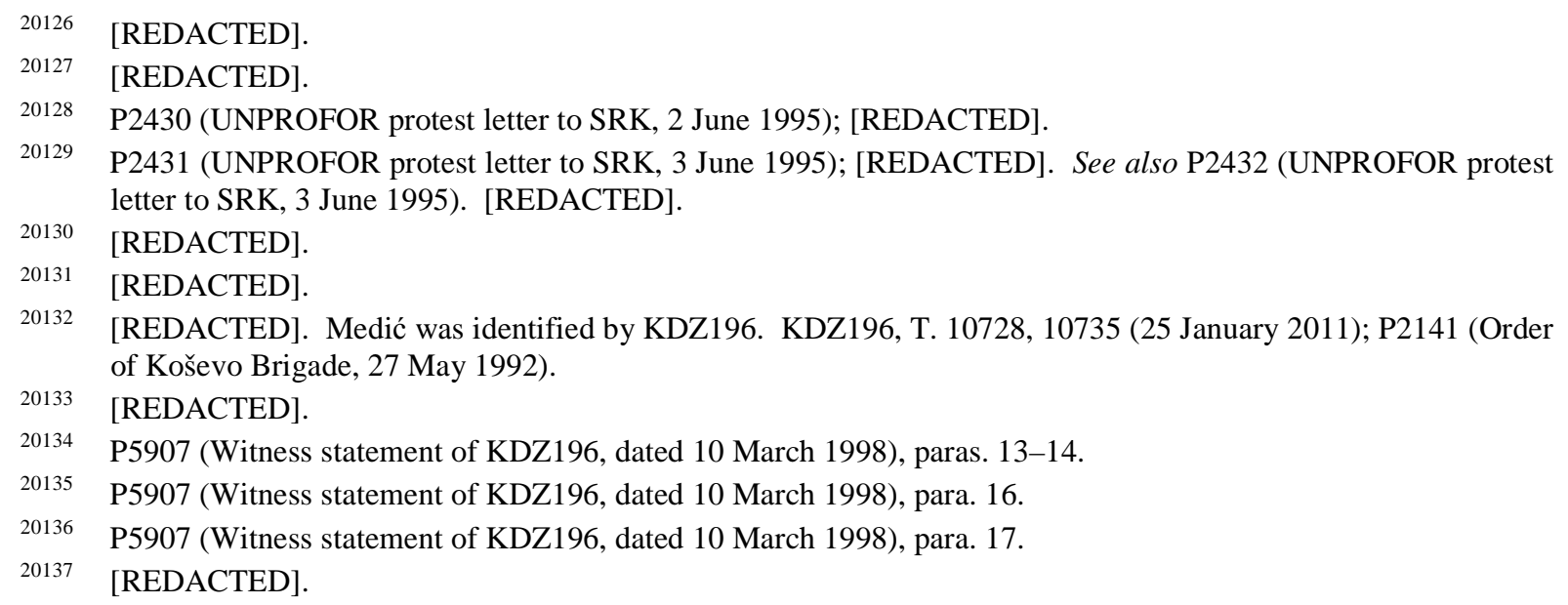


quickly escalated. ${ }^{20138}$ Medić was very upset and accused KDZ196 of lying. ${ }^{20139}$ Medić ordered a VRS soldier to fire a rocket launcher at the UNPROFOR post, which destroyed the watchtower. $^{20140}$ The UNPROFOR personnel took up combat positions and this stand-off lasted for ten minutes. ${ }^{20141}$ They refused to surrender their weapons and Medić stated that next time he would order his soldiers to shoot the UNPROFOR members. ${ }^{20142}$ Later, a Bosnian Serb captain arrived, accompanied by soldiers. ${ }^{20143}$ He threatened to kill KDZ196 and another FreBat member. ${ }^{20144}$ He ordered the VRS soldiers to fire rocket launchers at the UNPROFOR tank. ${ }^{20145}$ KDZ196 realised that they were losing control of the situation and so he laid down his weapons. ${ }^{20146}$ They were immediately surrounded by 50 armed VRS soldiers who confiscated their weapons and equipment. $^{20147}$ Some members of the FreBat team were punched and kicked. ${ }^{20148}$ All members of the FreBat team were placed in a military truck and driven to the military hospital in Jagomir, in the suburbs of Sarajevo where they stayed. ${ }^{20149}$

5900. On the morning of 28 May 1995, KDZ196 and his team were taken to the Bijelina barracks. ${ }^{20150}$ They were first transported in a military truck and later boarded civilian buses where they met with other UNPROFOR and UNMO personnel. ${ }^{20151}$ In discussing amongst themselves, it became clear that the detention of UN personnel had been carried out in the same manner and at the same time across numerous locations. ${ }^{20152}$ The large group of UN personnel were divided into two groups; one of the groups remaining at the Bijelina Barracks and KDZ196 and his group being taken to Doboj. ${ }^{20153}$ In Doboj, KDZ196 and his team were housed in an ammunition depot. ${ }^{20154}$

\footnotetext{
20138 [REDACTED].

20139 [REDACTED].

20140 KDZ196, T. 10728, 10735 (25 January 2011); P5907 (Witness statement of KDZ196, dated 10 March 1998), para. 17.

20141 P5907 (Witness statement of KDZ196, dated 10 March 1998), para. 17.

20142 P5907 (Witness statement of KDZ196, dated 10 March 1998), para. 17.

20143 P5907 (Witness statement of KDZ196, dated 10 March 1998), para. 18.

20144 P5907 (Witness statement of KDZ196, dated 10 March 1998), para. 18.

20145 P5907 (Witness statement of KDZ196, dated 10 March 1998), para. 19.

20146 P5907 (Witness statement of KDZ196, dated 10 March 1998), para. 19.

20147 P5907 (Witness statement of KDZ196, dated 10 March 1998), paras. 20, 22; P2109 (SRK Order, 27 May 1995 ).

20148 P5907 (Witness statement of KDZ196, dated 10 March 1998), para. 22.

20149 KDZ196, T. 10727 (25 January 2011); P5907 (Witness statement of KDZ196, dated 10 March 1998), para. 23.

20150 P5907 (Witness statement of KDZ196, dated 10 March 1998), para. 25. See also P2142 (Map of BiH); KDZ196, T. 10728-10729 (25 January 2011).

20151 P5907 (Witness statement of KDZ196, dated 10 March 1998), para. 26.

20152 P5907 (Witness statement of KDZ196, dated 10 March 1998), para. 26.

20153 P5907 (Witness statement of KDZ196, dated 10 March 1998), paras. 27-31; KDZ196, T. 10722-10723 (25 January 2011). See also P2142 (Map of BiH); KDZ196, T. 10729 (25 January 2011).

20154 KDZ196, T. 10726 (25 January 2011); P5907 (Witness statement of KDZ196, dated 10 March 1998), paras. 2731.
} 
5901. On 6 June 1995, KDZ196 and his fellow FreBat team members were taken back to the Bijelina Barracks by bus. ${ }^{20155}$ Later they were driven to Belgrade, via Novi Sad, together with another bus of UNPROFOR soldiers. ${ }^{20156}$ They were released in Novi Sad. ${ }^{20157}$

\section{vi. Evidence from the BritBat teams in Goražde}

(A) BritBat team, including Nightingale

5902. On 26 May 1995, at 11 a.m., Hugh Nightingale, an OP commander and liaison officer, was asked to meet with the local VRS commander, at the VRS headquarters, 15 metres away from his OP in Goražde. ${ }^{20158}$ The VRS commander informed him that the VRS was taking over the OP, that the BritBat members needed to pack up, and they would be taken to a safe location. ${ }^{20159}$ Nightingale told the VRS commander that he was willing to withdraw from the area but intended to take his troops to UNPROFOR headquarters in Goražde. ${ }^{20160}$ The commander responded: "You do not understand, you are coming with us to Višegrad, we can do it two ways. With shooting or without". ${ }^{20161}$ Nightingale agreed to co-operate. ${ }^{20162}$ He returned to his OP to brief the BritBat team and they packed their kits. ${ }^{20163}$ VRS soldiers entered the OP and the BritBat team got into two UN vehicles. ${ }^{20164}$ They were escorted down the road where they met up with two vehicles from the BritBat team stationed at another OP. ${ }^{20165}$ On the way down, one of the UNPROFOR vehicles slid and rolled over down the hill causing five members of the BritBat team to sustain serious injuries. $^{20166}$ At the bottom of the hill, the vehicles stopped and Nightingale met Lieutenant Colonel Radomir Furtula, the Commander of the $5^{\text {th }}$ Podrinje Light Infantry Brigade. ${ }^{20167}$

\footnotetext{
20155 [REDACTED]; P2139 (VRS Main Staff Order, 6 June 1995); KDZ196, T. 10725-10726 (25 January 2011 ). See also P2142 (Map of BiH); KDZ196, T. 10729 (25 January 2011).

20156 [REDACTED].

20157 [REDACTED].

20158 P50 (Witness statement of Hugh Nightingale dated 5 February 1996), p. 2 (noting that he never learned who this commander was).

20159 P50 (Witness statement of Hugh Nightingale dated 5 February 1996), p. 3. See also P2033 (BBC news report re UN hostage-taking in Goražde, with transcript).

20160 P50 (Witness statement of Hugh Nightingale dated 5 February 1996), p. 3.

20161 P50 (Witness statement of Hugh Nightingale dated 5 February 1996), p. 3.

20162 P50 (Witness statement of Hugh Nightingale dated 5 February 1996), p. 3.

20163 P50 (Witness statement of Hugh Nightingale dated 5 February 1996), p. 3.

20164 P50 (Witness statement of Hugh Nightingale dated 5 February 1996), p. 3.

20165 P50 (Witness statement of Hugh Nightingale dated 5 February 1996), p. 3.

20166 P50 (Witness statement of Hugh Nightingale dated 5 February 1996), p. 3.

20167 P50 (Witness statement of Hugh Nightingale dated 5 February 1996), p. 3. Jonathon Riley identifies "Radomir Fortula" as the VRS commander of the "Goražde/Višegrad Light Mountain Brigade, assigned to the Drina Corps". Riley stated that Fortula told him "by Mladić's orders" if any further air strikes took place, UNPROFOR would be shelled. P2148 (Witness statement of Jonathon Riley dated 30 May 1996), pp. 3-4. The commander of the $5^{\text {th }}$ Podrinje Light Infantry Brigade of the Drina Corps was Lieutenant Colonel Radomir Furtula. P4920 (Diagrams of various VRS Military Command structures), p. 2.
} 
5903. Upon arriving at the military barracks in Višegrad, the BritBat team members were informed by Furtula that they were hostages and if they did as they were told, there would be no problem. ${ }^{20168}$ The VRS soldiers took the BritBat team's protection kits, weapons, ammunition, grenades, and rations. ${ }^{20169}$ Their UN identification numbers and names were written down. ${ }^{20170}$ The injured BritBat team members received medical care. ${ }^{20171}$ Furtula asked Nightingale to guarantee the good behaviour of his soldiers and in return, they would not handcuff them. ${ }^{20172}$ Nightingale did as asked. ${ }^{20173}$ When Nightingale asked Furtula what was going to happen, he responded that it was outside his control. ${ }^{20174}$

5904. Nightingale returned to the room where the BritBat team was being held. ${ }^{20175}$ There were guards outside and seven or eight armed VRS soldiers inside the room. ${ }^{20176}$ A Bosnian Serb television crew who had come to film the detained BritBat team asked Nightingale for an interview, which he gave. ${ }^{20177}$ At 10 p.m., they were placed in a truck. ${ }^{20178}$ The injured members were dropped off at the Sokolac Hospital. ${ }^{20179}$ Some of the remaining BritBat members were paired off and dropped off in various locations where VRS troops were present. ${ }^{20180}$ Nightingale remained on the truck, which drove through Rogatica and continued into the night. ${ }^{20181}$

5905. On the morning of 27 May 1995, Nightingale and another BritBat member were dropped off at an unknown location and taken to a building, which was a jail located next to a warehouse that stored military clothing and equipment. ${ }^{20182}$ They were taken to the guards' accommodations. ${ }^{20183}$ The door to their room was locked. ${ }^{20184}$ There were always two armed guards present with them at

\footnotetext{
20168 P50 (Witness statement of Hugh Nightingale dated 5 February 1996), p. 3.

20169 P50 (Witness statement of Hugh Nightingale dated 5 February 1996), p. 4.

20170 P50 (Witness statement of Hugh Nightingale dated 5 February 1996), p. 4.

20171 P50 (Witness statement of Hugh Nightingale dated 5 February 1996), p. 4.

20172 P50 (Witness statement of Hugh Nightingale dated 5 February 1996), p. 4.

20173 P50 (Witness statement of Hugh Nightingale dated 5 February 1996), p. 4.

20174 P50 (Witness statement of Hugh Nightingale dated 5 February 1996), p. 4.

20175 P50 (Witness statement of Hugh Nightingale dated 5 February 1996), p. 4.

20176 P50 (Witness statement of Hugh Nightingale dated 5 February 1996), p. 4.

20177 P50 (Witness statement of Hugh Nightingale dated 5 February 1996), p. 4.

20178 P50 (Witness statement of Hugh Nightingale dated 5 February 1996), p. 4.

20179 P50 (Witness statement of Hugh Nightingale dated 5 February 1996), p. 4. See also P3805 (VRS Main Staff hospital record, 2 June 1995).

20180 P50 (Witness statement of Hugh Nightingale dated 5 February 1996), p. 4.

20181 P50 (Witness statement of Hugh Nightingale dated 5 February 1996), p. 4.

20182 P50 (Witness statement of Hugh Nightingale dated 5 February 1996), p. 4.

20183 P50 (Witness statement of Hugh Nightingale dated 5 February 1996), p. 4.

20184 P50 (Witness statement of Hugh Nightingale dated 5 February 1996), p. 4.
} 
all times. ${ }^{20185}$ They were occasionally visited by the local VRS soldiers. ${ }^{20186}$ They were fed twice per day the same food as the guards. ${ }^{20187}$ They were detained in this room for six days. ${ }^{20188}$

5906. After the seventh day of detention, they were told to prepare for departure. ${ }^{20189}$ They were blindfolded and placed in the back of a troop carrier. ${ }^{20190}$ Along the way, the vehicle picked other BritBat members from Nightingale's team and the injured BritBat members from the Sokolac Hospital. ${ }^{20191}$ They were taken to the police station, which Nightingale thought was in Višegrad. ${ }^{20192}$ There, they were handed over to the Serbian authorities and driven over the border to Serbia. ${ }^{20193}$ At the border, the vehicle also picked up some French Legionnaires and they met Jovica Stanisić. ${ }^{20194}$ They were all driven to Novi Sad and released in Belgrade where they were flown to Zagreb. ${ }^{20195}$

\section{(B) BritBat team at OP-2 in Goražde}

5907. On 27 May 1995, at 2 p.m., a team of BritBat, including Michael Cornish, ${ }^{20196}$ were stationed at OP-2 in Goražde when they received a radio message from UNPROFOR command directing them to move to check-point $2{ }^{20197}$ Given that check-point 2 did not exist, Cornish understood this as a signal for them to withdraw back to their camp. ${ }^{20198}$ As they made their way past a VRS post called "Scabs 1", VRS soldiers brought out two rocket-propelled grenades and placed them on the road. ${ }^{20199}$ The UNPROFOR vehicle was forced to stop. ${ }^{20200}$ The BritBat Corporal went into the VRS post and spoke to their local commander on the radio. ${ }^{20201}$ He returned to the vehicle and informed the BritBat team that the VRS commander told him that because they were on Bosnian

P50 (Witness statement of Hugh Nightingale dated 5 February 1996), p. 4.

P50 (Witness statement of Hugh Nightingale dated 5 February 1996), p. 5.

P50 (Witness statement of Hugh Nightingale dated 5 February 1996), p. 5.

P50 (Witness statement of Hugh Nightingale dated 5 February 1996), p. 5.

P50 (Witness statement of Hugh Nightingale dated 5 February 1996), p. 5.

P50 (Witness statement of Hugh Nightingale dated 5 February 1996), p. 5.

P50 (Witness statement of Hugh Nightingale dated 5 February 1996), p. 5.

P50 (Witness statement of Hugh Nightingale dated 5 February 1996), p. 5.

P50 (Witness statement of Hugh Nightingale dated 5 February 1996), p. 5.

P50 (Witness statement of Hugh Nightingale dated 5 February 1996), p. 5.

P50 (Witness statement of Hugh Nightingale dated 5 February 1996), p. 5.

Michael Cornish was a Lance Corporal and second in command of the B-company stationed on the east bank of the Drina River. P52 (Witness statement of Michael Cornish dated 13 February 1996), e-court p. 4.

P52 (Witness statement of Michael Cornish dated 13 February 1996), e-court p. 5. Although Cornish's statement does not mention the date, he stated that he heard on the BBC that the FreBat had been detained by the VRS and Goražde was being shelled as a result of the air strikes in Pale, therefore recalling paragraphs 5860, 5893, and 5894, the Chamber concludes that this radio message was received on 27 May 1995.

20198 P52 (Witness statement of Michael Cornish dated 13 February 1996), e-court p. 5.

20199 P52 (Witness statement of Michael Cornish dated 13 February 1996), e-court p. 5.

20200 P52 (Witness statement of Michael Cornish dated 13 February 1996), e-court p. 5.

20201 P52 (Witness statement of Michael Cornish dated 13 February 1996), e-court p. 5.
} 
Serb controlled territory, they were now ordered to follow the VRS soldiers to Scabs $1 .^{20202}$ The BritBat team was escorted by armed VRS soldiers to Scabs 1 where they were disarmed. ${ }^{20203}$ After several hours, they were taken to the cellar. ${ }^{20204}$ They managed to maintain radio contact with the main UNPROFOR camp and reported back every hour, on the hour. ${ }^{20205}$

5908. On 28 May 1995, at 7 a.m., the BritBat team was moved to a house behind the VRS post, and there was a lot of firing coming towards the house from the Bosnian Muslim side. ${ }^{20206}$ The VRS fought back using the weapons and ammunition taken from the UNPROFOR team. ${ }^{20207}$ They took the BritBat team through the valley, on foot. ${ }^{20208}$ Multiple mortars landed near them as they were travelling through the valley towards a house where they were held for a short time. ${ }^{20209}$ From this house, the BritBat team was moved to a house in Karpaci, approximately one kilometre away, where they spent the night. ${ }^{20210}$ The house was on the other side of a bridge leading to Goražde where all the VRS soldiers going to Goražde would stop. ${ }^{20211}$ Five UkrBat soldiers were also detained there. ${ }^{20212}$ Cornish and a BritBat Corporal met a VRS Captain named Kepić who told them that they would be released shortly. ${ }^{20213}$

5909. On 29 May 1995, in the evening, everyone was moved to another house several hundred metres up the road, where they spent one night. ${ }^{20214}$ The following day, a truck arrived, loaded with ammunition and they were all ordered to get inside. ${ }^{20215}$ They were driven for two hours and taken to Cajnice where their kits were taken from them. ${ }^{20216}$ Together with five UkrBat soldiers, they were driven for several hours, having to sit with their heads between their legs. ${ }^{20217}$ After several stops, they stopped at a military camp, where they all got out of the truck and were taken into a

\footnotetext{
20202 P52 (Witness statement of Michael Cornish dated 13 February 1996), e-court p. 5.

20203 P52 (Witness statement of Michael Cornish dated 13 February 1996), e-court p. 6.

20204 P52 (Witness statement of Michael Cornish dated 13 February 1996), e-court p. 6.

20205 P52 (Witness statement of Michael Cornish dated 13 February 1996), e-court p. 6.

20206 P52 (Witness statement of Michael Cornish dated 13 February 1996), e-court p. 6.

20207 P52 (Witness statement of Michael Cornish dated 13 February 1996), e-court p. 6.

20208 P52 (Witness statement of Michael Cornish dated 13 February 1996), e-court p. 6.

20209 P52 (Witness statement of Michael Cornish dated 13 February 1996), e-court pp. 6-7.

20210 P52 (Witness statement of Michael Cornish dated 13 February 1996), e-court p.7.

20211 P52 (Witness statement of Michael Cornish dated 13 February 1996), e-court p. 7.

20212 P52 (Witness statement of Michael Cornish dated 13 February 1996), e-court p. 7.

20213 P52 (Witness statement of Michael Cornish dated 13 February 1996), e-court p. 7.

20214 P52 (Witness statement of Michael Cornish dated 13 February 1996), e-court p. 8.

20215 P52 (Witness statement of Michael Cornish dated 13 February 1996), e-court p. 8.

20216 P52 (Witness statement of Michael Cornish dated 13 February 1996), e-court p. 8.

20217 P52 (Witness statement of Michael Cornish dated 13 February 1996), e-court p. 8.
} 
building, a converted indoor firing range, and placed in a large cell. ${ }^{20218}$ The door to the cell was locked and the VRS soldiers left the building. ${ }^{20219}$

5910. On 30 May 1995, Cornish saw a group of approximately 20 FreBat soldiers who were also being detained in a separate area of the same building. ${ }^{20220}$ They were given meals but were not allowed to leave their cell. ${ }^{20221}$ Cornish requested a visit from the ICRC which was denied. ${ }^{20222}$ They were held for eight or nine days. ${ }^{20223}$ On the day of their release, they were allowed to shower and were given clean clothes to wear. ${ }^{20224}$ They boarded buses and were driven to Novi Sad; they were released and met staff from the British Embassy. ${ }^{20225}$

\section{vii. Evidence from the UNMO teams in Pale}

\section{(A) 7 Lima UNMO team in Pale}

5911. The 7 Lima UNMO team was led by Patrick Rechner and included three other officers. ${ }^{20226}$ Unlike other UNMO teams, the 7 Lima UNMO team was tasked primarily with administrative and political functions. ${ }^{20227}$ It served as the UNMO liaison office to the Bosnian Serb Presidency and the VRS Main Staff. ${ }^{20228}$ The 7 Lima UNMO team's primary contact in the Bosnian Serb leadership was Koljević. ${ }^{20229}$ They also had frequent contact with the Accused's secretary, Mira Mihajlović and Jovan Zametica, his political adviser. ${ }^{20230}$ As the only UN liaison office in Pale, the UNMO office also acted as the liaison office for Akashi. ${ }^{20231}$ It was responsible for facilitating communications between the UN and the Bosnian Serb political and military authorities and

\footnotetext{
20218 P52 (Witness statement of Michael Cornish dated 13 February 1996), e-court p. 8.

20219 P52 (Witness statement of Michael Cornish dated 13 February 1996), e-court p. 8.

20220 P52 (Witness statement of Michael Cornish dated 13 February 1996), e-court p. 9.

20221 P52 (Witness statement of Michael Cornish dated 13 February 1996), e-court p. 9.

20222 P52 (Witness statement of Michael Cornish dated 13 February 1996), e-court p. 9.

20223 P52 (Witness statement of Michael Cornish dated 13 February 1996), e-court p. 9.

20224 P52 (Witness statement of Michael Cornish dated 13 February 1996), e-court p. 9.

20225 P52 (Witness statement of Michael Cornish dated 13 February 1996), e-court p. 9.

20226 Patrick Rechner, T. 11081 (2 February 2011). The other UNMOs included Captains Oldrich Zidlik, Pavel Teterevsky, and Thelmos Reis. However, Reis was on leave during this time period. P2170 (Witness statement of Patrick Rechner dated 31 January 2011), para. 8.

20227 Patrick Rechner, T. 11079 (2 February 2011); P2170 (Witness statement of Patrick Rechner dated 31 January 2011), para. 8 .

20228 Patrick Rechner, T. 11079-11080 (2 February 2011). Their main contact with the VRS was through Inđić, see Milenko Inđić, T. 32414-32415, 32428-32429 (22 January 2013); D2774 (Witness statement of Milenko Inđić dated 19 January 2013), paras. 39, 41-42, 44; P2447 (Witness statement of KDZ182 dated 8 March 2011, para. 11; P56 (Witness statement of Joseph Gelissen dated 18 January 1996), e-court p. 4.

20229 Patrick Rechner, T. 11082-11083 (2 February 2011); P2170 (Witness statement of Patrick Rechner dated 31 January 2011), para. 10-11 (clarifying that he had almost daily communication with Koljević's secretary).

20230 Patrick Rechner, T. 11082-11083 (2 February 2011); P2170 (Witness statement of Patrick Rechner dated 31 January 2011), para. 12.

20231 Patrick Rechner, T. 11145 (2 February 2011).
} 
between the Bosnian Serbs and Bosnian Muslims. ${ }^{20232}$ In addition, this UNMO team worked on behalf of the representative of UN Civil Affairs in Sarajevo and, in an unofficial capacity, assisted in the delivery of humanitarian aid to Pale, such as bringing medicine from Sarajevo to the hospital in Pale. ${ }^{20233}$

5912. On 25 May 1995, Rechner saw two large explosions, due to the NATO air strikes, five to ten kilometres south of his UNMO team's office. ${ }^{20234}$ Rechner made a request to the Accused, through Mihajlović, to make sure that the UNMO team's house and office were being watched by Bosnian Serb security forces in order to protect them from any locals trying to attack them out of revenge for the NATO air strikes. ${ }^{20235}$

5913. On 26 May 1995, at approximately 10:30 a.m. and a few minutes after the NATO air strikes, Rechner, who was on the third floor of the UNMO team's house, heard some shots fired from outside and people yelling. ${ }^{20236}$ Bosnian Serb soldiers had entered the house, one was armed. ${ }^{20237}$ Rechner went downstairs to the kitchen and made two telephone calls. ${ }^{20238}$ First, he phoned Mihajlović and told her that there were some armed people in their office and to send someone to investigate the situation. ${ }^{20239}$ She asked if they were regular VRS soldiers, Rechner replied that he could not tell because they were not dressed in full uniform. ${ }^{20240}$ Mihajlović then informed Rechner that these men were sent officially. ${ }^{20241}$ When Rechner asked for clarification, she did not give any further information. ${ }^{20242}$ The second telephone call was to Zametica. ${ }^{20243}$ Rechner informed him of the situation and Zametica replied that "something had been organised to send some people" and suggested that Rechner be as co-operative as possible. ${ }^{20244}$

\footnotetext{
20232 Patrick Rechner, T. 11079 (2 February 2011).

20233 Patrick Rechner, T. 11080 (2 February 2011).

20234 Patrick Rechner, T. 11083 (2 February 2011); P2170 (Witness statement of Patrick Rechner dated 31 January 2011), para. 16.

20235 Patrick Rechner, T. 11085 (2 February 2011).

20236 Patrick Rechner, T. 11084 (2 February 2011); P2170 (Witness statement of Patrick Rechner dated 31 January 2011), paras. 19-20.

20237 Patrick Rechner, T. 11085 (2 February 2011); P2172 (UNMO report, 26 May 1995), p. 2.

20238 Patrick Rechner, T. 11085 (2 February 2011).

20239 Patrick Rechner, T. 11085 (2 February 2011).

20240 Patrick Rechner, T. 11086 (2 February 2011).

20241 Patrick Rechner, T. 11086 (2 February 2011).

20242 Patrick Rechner, T. 11086 (2 February 2011).

20243 Patrick Rechner, T. 11086 (2 February 2011); P2170 (Witness statement of Patrick Rechner dated 31 January 2011), para. 23.

20244 Patrick Rechner, T. 11086 (2 February 2011); P2170 (Witness statement of Patrick Rechner dated 31 January 2011), para. 23.
} 
5914. Downstairs in the UNMO office, Rechner was met by two VRS soldiers-both heavily armed-one was Ribić, who was very angry and told him to sit down. ${ }^{20245}$ Rechner and the two UNMOs in the office managed to establish radio contact with the UNMO headquarters and notified them that there were armed men in their office. ${ }^{20246}$ Ribic then got on the radio and threatened that if the UNMO headquarters valued the lives of their UNMOs, they should call off the NATO air strikes. ${ }^{20247}$ Ribić continued making threats and said that "for every bomb, one of the UNMOs will be killed". 20248 UNMO headquarters responded that the UNMOs were not involved in the NATO air strikes and had no means of communicating with NATO to stop them. ${ }^{20249}$ Ribić then demanded to speak to Smith and Rechner called Smith's office. ${ }^{20250}$ Ribic made the same threats directly to Smith. ${ }^{20251}$ Another group of VRS soldiers arrived and the UNMO team was ordered to get into the UNMO vehicle outside. ${ }^{20252}$ Ribić told Rechner to radio UNMO headquarters and tell them that the UNMO team would be taken to the target of the NATO air strikes at Jahorinski Potok. ${ }^{20253}$

5915. At 11:45 a.m., Rechner and his UNMO team were handcuffed, placed in the back of their UNMO vehicle, and driven to Jahorinski Potok where they stopped at the logistics and ammunition storage depot. ${ }^{20254}$ They were then taken inside the building where they waited approximately 20 or 30 minutes before they received a call from UNMO headquarters stating that Smith had confirmed the NATO air strikes had been called off. ${ }^{20255}$ Ribić responded to UNMO headquarters that if the air strikes continued, the UNMOs would "die for the sake of NATO". ${ }^{20256}$ The UNMO team was driven to the bunkers, one of which had been destroyed the previous day by the NATO

\footnotetext{
20245 Patrick Rechner, T. 11086-11087 (2 February 2011); P2170 (Witness statement of Patrick Rechner dated 31 January 2011), paras. 25-27.

20246 Patrick Rechner, T. 11087 (2 February 2011).

20247 Patrick Rechner, T. 11088 (2 February 2011); P2170 (Witness statement of Patrick Rechner dated 31 January 2011), para. 27.

20248 Patrick Rechner, T. 11088 (2 February 2011); P2172 (UNMO report, 26 May 1995), p. 2.

20249 Patrick Rechner, T. 11089 (2 February 2011). Gelissen and the SG-1 UNMO team in Grbavica also heard on the radio that the 7 Lima UNMO team had been taken by VRS soldiers and the threats issued by Ribić. P56 (Witness statement of Joseph Gelissen dated 18 January 1996), e-court p. 5.

20250 Patrick Rechner, T. 11089 (2 February 2011); P2170 (Witness statement of Patrick Rechner dated 31 January 2011), para. 28.

20251 Patrick Rechner, T. 11089 (2 February 2011); P2172 (UNMO report, 26 May 1995), p. 2; P2170 (Witness statement of Patrick Rechner dated 31 January 2011), para. 28.

20252 Patrick Rechner, T. 11089-11090 (2 February 2011); P2172 (UNMO report, 26 May 1995), p. 2.

20253 Patrick Rechner, T. 11090 (2 February 2011); P2172 (UNMO report, 26 May 1995), p. 2.

20254 Patrick Rechner, T. 11092-11093 (2 February 2011); P2170 (Witness statement of Patrick Rechner dated 31 January 2011), para. 31.

20255 Patrick Rechner, T. 11093-11094 (2 February 2011); P2170 (Witness statement of Patrick Rechner dated 31 January 2011), para. 38; P2172 (UNMO report, 26 May 1995), p. 2.

20256 P2170 (Witness statement of Patrick Rechner dated 31 January 2011), para. 39; Patrick Rechner, T. 11128 (2 February 2011); P2172 (UNMO report, 26 May 1995), p. 2; P2174 (Video footage of UN personnel, with transcript).
} 
air strike. ${ }^{20257}$ Rechner and another UNMO were handcuffed to the lighting poles in front of the bunker. $^{20258}$ A third UNMO was handcuffed to the door of the bunker. ${ }^{20259}$ The bunker was filled with ammunition. ${ }^{20260}$ Rechner saw an UNMO vehicle drive past him in the back of which were members of the SE-1 UNMO team. ${ }^{20261}$ The vehicle was driven by VRS soldiers. ${ }^{20262}$ Rechner remained handcuffed to the lightning pole for five hours and the other UNMO remained handcuffed for nine hours. ${ }^{20263}$

5916. At 3:30 p.m., a group of Bosnian Serb military officers and government officials, including Zametica, came to inspect the area. ${ }^{20264}$ Zametica spoke to both Rechner and his fellow UNMO. $^{20265}$ Rechner expressed his shock and surprise at the way they were treated and demanded

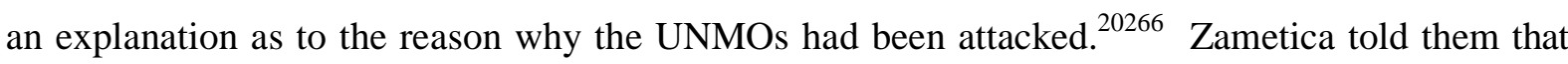
"times have changed". ${ }^{20267}$ At 5 p.m., Rechner was released from the lightning pole, handcuffed and placed in the back of a UN vehicle. ${ }^{20268}$ Kalbarczyk, a member of another UNMO team in Pale, was in the vehicle and also handcuffed. ${ }^{20269}$ They were both blindfolded for the duration of the drive. ${ }^{20270}$ During the drive, they were told that the Bosnian Serbs thought the 7 Lima UNMO

20257 Patrick Rechner, T. 11094-11095 (2 February 2011); P2170 (Witness statement of Patrick Rechner dated 31 January 2011), para. 41.

20258 Patrick Rechner, T. 11094-11095, 11123-11124 (2 February 2011); P2170 (Witness statement of Patrick Rechner dated 31 January 2011), paras. 42-43; P2024 (BBC news report re UN hostage-taking in Sarajevo, with transcript); P2174 (Video footage of UN personnel, with transcript); Janusz Kalbarczyk, T. 10839-10840 (28 January 2011); P2153 (Serbian TV news report re UN personnel, with transcript). See also P2184 (Serbian TV news report re UN personnel, with transcript).

20259 Patrick Rechner, T. 11094-11095, 11123-11124 (2 February 2011); P2170 (Witness statement of Patrick Rechner dated 31 January 2011), paras. 42-43; P2024 (BBC news report re UN hostage-taking in Sarajevo, with transcript); P2174 (Video footage of UN personnel, with transcript); Janusz Kalbarczyk, T. 10839-10840 (28 January 2011); P2153 (Serbian TV news report re UN personnel, with transcript).

20260 Patrick Rechner, T. 11094-11095, 11123-11124 (2 February 2011); P2024 (BBC news report re UN hostagetaking in Sarajevo, with transcript); P2174 (Video footage of UN personnel, with transcript); Janusz Kalbarczyk, T. 10839-10840 (28 January 2011); P2153 (Serbian TV news report re UN personnel, with transcript).

20261 Patrick Rechner, T. 11095 (2 February 2011); P2170 (Witness statement of Patrick Rechner dated 31 January 2011), para. 44.

20262 Patrick Rechner, T. 11098 (2 February 2011).

20263 Patrick Rechner, T. 11098 (2 February 2011).

20264 Patrick Rechner, T. 11098-11099 (2 February 2011); P2170 (Witness statement of Patrick Rechner dated 31 January 2011), paras. 46-47

20265 Patrick Rechner, T. 11098-11099 (2 February 2011); P2170 (Witness statement of Patrick Rechner dated 31 January 2011), para. 47.

20266 Patrick Rechner, T. 11099 (2 February 2011); P2170 (Witness statement of Patrick Rechner dated 31 January 2011), para. 47.

20267 Patrick Rechner, T. 11099 (2 February 2011); P2170 (Witness statement of Patrick Rechner dated 31 January 2011), para. 47.

20268 Patrick Rechner, T. 11099-11100 (2 February 2011); P2170 (Witness statement of Patrick Rechner dated 31 January 2011), para. 51.

20269 Patrick Rechner, T. 11099-11100 (2 February 2011); P2170 (Witness statement of Patrick Rechner dated 31 January 2011), para. 51; see para. 5917.

20270 Janusz Kalbarczyk, T. 10843-10845 (28 January 2011); P2170 (Witness statement of Patrick Rechner dated 31 January 2011), para. 51; P2154 (Video footage of UN personnel, with transcript). 
team was directing the NATO air strikes onto the Bosnian Serb military targets. ${ }^{20271}$ They were taken to Pale, where more VRS soldiers joined them. ${ }^{20272}$ They were then driven to the Mount Jahorina ski resort. ${ }^{20273}$ They stopped in front of a large radar dome. ${ }^{20274}$ Kalbarczyk was taken out of the vehicle and handcuffed to the radar dome. ${ }^{20275}$ Two VRS soldiers guarded Kalbarczyk while he was filmed. ${ }^{20276}$

\section{(B) SE-1 UNMO team in Pale}

5917. The SE-1 UNMO team in Pale had five members, including Kalbarczyk and Evans. ${ }^{20277}$ On 26 May 1995, between 8 and 9 a.m., the sirens went off in Pale and approximately 40 minutes later, Kalbarczyk saw an explosion in the southeast area of Pale. ${ }^{20278}$ He reported this to the UNMO sector headquarters in Sarajevo. ${ }^{20279}$ He was told not to leave the building. ${ }^{20280}$ Around 12:15 p.m., Bosnian Serb policemen came into the UNMO's accommodations; four were dressed in police uniforms and one was dressed as a civilian. ${ }^{20281}$ The UNMOs were informed that they were under arrest and told that if there were any more NATO air strikes, they would be shot. ${ }^{20282}$ Approximately 40 minutes later, two cars arrived and VRS soldiers got out and said that the UNMOs were being taken hostage by the VRS. ${ }^{20283}$ UNMO headquarters attempted to reach them over the radio but they were not allowed to respond. ${ }^{20284}$ Seven additional VRS soldiers came in and confiscated the UNMOs' garage and vehicle keys. ${ }^{20285}$ The UNMOs were handcuffed in pairs, taken outside to the cars, and driven to the Pale police station. ${ }^{20286}$ Ribić came to their vehicle, took

\footnotetext{
20271 P2525 (Witness statement of Griffiths Evans dated 6 September 1995), e-court p. 7.

20272 Patrick Rechner, T. 11099-11100 (2 February 2011).

20273 Patrick Rechner, T. 11099-11100 (2 February 2011).

20274 Patrick Rechner, T. 1110-11101 (2 February 2011).

20275 Patrick Rechner, T. 11101 (2 February 2011).

20276 Patrick Rechner, T. 11101 (2 February 2011); see paras. 5919-5920.

20277 P2525 (Witness statement of Griffiths Evans dated 6 September 1995), e-court p. 6. Other members of the team included Jose Antonio Romero, Dimitri Batiouchenkov, and Zlatko Kozusnik. Evans was the acting team leader at the time of the events alleged in the Indictment. P2525 (Witness statement of Griffiths Evans dated 6 September 1995), e-court p. 6; Janusz Kalbarczyk, T. 10832-10833 (28 January 2011).

20278 Janusz Kalbarczyk, T. 10834 (28 January 2011).

20279 Janusz Kalbarczyk, T. 10834 (28 January 2011).

20280 Janusz Kalbarczyk, T. 10834 (28 January 2011)

20281 Janusz Kalbarczyk, T. 10834-10835 (28 January 2011); P2525 (Witness statement of Griffiths Evans dated 6 September 1995), e-court p. 6.

20282 Janusz Kalbarczyk, T. 10835 (28 January 2011); P2525 (Witness statement of Griffiths Evans dated 6 September 1995), e-court pp. 6-7 (noting that one of the policemen was pointing a gun at them).

20283 Janusz Kalbarczyk, T. 10835-10836 (28 January 2011).

20284 P2525 (Witness statement of Griffiths Evans dated 6 September 1995), e-court p. 6.

20285 P2525 (Witness statement of Griffiths Evans dated 6 September 1995), e-court pp. 6-7.

20286 P2525 (Witness statement of Griffiths Evans dated 6 September 1995), e-court p. 7.
} 
the radio, and spoke to the duty officer at the UNPROFOR Sector Sarajevo headquarters. ${ }^{20287}$ Ribic identified himself as a VRS soldier and stated, "three UN observers are now at the site of the warehouse. Any more bombing, they will be the first to go". ${ }^{20288}$

(C) Detention of the 7 Lima and SE-1 UNMO teams in Pale

5918. The UNMOs were driven to the ammunition depot in the Koran military barracks, which had just been struck by NATO. ${ }^{20289}$ One UNMO was taken from the vehicle and handcuffed to the door of another ammunition bunker. ${ }^{20290}$ The rest of the UNMOs were driven to the headquarters in the Koran barracks. ${ }^{20291}$ Upon arriving in front of the headquarters building, Evans and others were handcuffed to the flagpoles outside. ${ }^{20292}$ Kalbarczyk was taken up to the radar dome and handcuffed to the base where he was filmed and interviewed by a journalist. ${ }^{20293}$ A VRS soldier told Rechner that Mladić wanted them to be filmed. ${ }^{20294}$

5919. Approximately 20 minutes later, Ribić came and spoke to the UNMO headquarters in Sarajevo, telling them that they should inform NATO that two UNMOs had been chained to the bridge leading to Pale and that if NATO decided to bomb that bridge, then the UNMOs would go down with it. ${ }^{20295}$ Evans and a fellow UNMO team member were immediately escorted into a vehicle, taken to the bridge and handcuffed there. ${ }^{20296}$ A reporter from Pale TV came to film them. ${ }^{20297}$ Ribić told them to memorise the following statement: "The NATO aircrafts have bombed civilian targets and killed civilians. This is a crime against humanity and General Smith

20287 P2024 (BBC news report re UN hostage-taking in Sarajevo, with transcript); P2525 (Witness statement of Griffiths Evans dated 6 September 1995), e-court p. 7.

20288 P2024 (BBC news report re UN hostage-taking in Sarajevo, with transcript); P2525 (Witness statement of Griffiths Evans dated 6 September 1995), e-court p. 7.

20289 P2525 (Witness statement of Griffiths Evans dated 6 September 1995), e-court p. 7.

20290 P2525 (Witness statement of Griffiths Evans dated 6 September 1995), e-court p. 7.

20291 P2525 (Witness statement of Griffiths Evans dated 6 September 1995), e-court p. 7.

20292 P2525 (Witness statement of Griffiths Evans dated 6 September 1995), e-court p. 7; Patrick Rechner, T. $11123-$ 11124 (2 February 2011); P2024 (BBC news report re UN hostage-taking in Sarajevo, with transcript); see para. 5880.

20293 Janusz Kalbarczyk, T. 10847-10849 (28 January 2011); P2155 (Serbian TV news report re UN personnel, with transcript); Patrick Rechner, T. 11101, 11121-11122 (2 February 2011); P2024 (BBC news report re UN hostage-taking in Sarajevo, with transcript).

20294 Patrick Rechner, T. 11102, 11122-11123 (2 February 2011). See also P2024 (BBC news report re UN hostagetaking in Sarajevo, with transcript).

20295 P2525 (Witness statement of Griffiths Evans dated 6 September 1995), e-court p. 7.

20296 P2525 (Witness statement of Griffiths Evans dated 6 September 1995), e-court pp. 7-8.

20297 P2525 (Witness statement of Griffiths Evans dated 6 September 1995), e-court p. 8. 
should inform NATO to stop the bombings, otherwise we die". ${ }^{20298}$ They did as instructed and were filmed making this statement on Pale TV. ${ }^{20299}$

5920. After being filmed by Pale TV, the UNMOs were driven back to the Koran Barracks and handcuffed to the flagpoles. ${ }^{20300}$ After a few hours, they were released and allowed to sit together in the shade. ${ }^{20301}$ Kalbarczyk, Rechner, and another UNMO from the 7 Lima UNMO team were also brought to the same place and driven down from the radar station. ${ }^{20302}$ Evans and the other UNMOs were introduced to Vojvodić and Batinić, who were in charge. ${ }^{20303}$ The UNMOs were told that unless there was a clear declaration from NATO to stop the air strikes, they would continue to be held by the VRS in locations of strategic military importance to the VRS, which were the likely targets of the NATO air strikes. ${ }^{20304}$ The UNMOs were then taken back to the Jahorina ski resort hotel where they had dinner with the VRS soldiers. ${ }^{20305}$ After dinner, they were taken back to their accommodations to collect their belongings. ${ }^{20306}$ They were told they would be taken to bunkers or other "strategic targets" to spend the night. ${ }^{20307}$ They were taken back to Pale and en route Rechner saw the UNMO team from Kasindo in another UN vehicle being driven to a different location. ${ }^{20308}$ Rechner, Kalbarczyk and six other UNMOs spent the night at the Koran Barracks in Pale. ${ }^{20309}$

5921. On 27 May 1995, Ribić took Rechner outside the barracks and ordered him to send a message to the UNMO headquarters in Sarajevo. ${ }^{20310}$ He gave Rechner a list of UN personnel and where they were being held. ${ }^{20311}$ Rechner was ordered to relay this to UNMO headquarters, which he did. ${ }^{20312}$ Meanwhile, Evans and the other UNMOs were taken to the ammunition depot near the P2525 (Witness statement of Griffiths Evans dated 6 September 1995), e-court p. 8.

P2024 (BBC news report re UN hostage-taking in Sarajevo, with transcript); P2525 (Witness statement of Griffiths Evans dated 6 September 1995), e-court p. 8; Patrick Rechner, T. 11138 (2 February 2011).

20300 P2525 (Witness statement of Griffiths Evans dated 6 September 1995), e-court p. 8 (specifying that two other UNMOs were also handcuffed to flagpoles).

20301 P2525 (Witness statement of Griffiths Evans dated 6 September 1995), e-court p. 8.

20302 P2525 (Witness statement of Griffiths Evans dated 6 September 1995), e-court p. 8; Janusz Kalbarczyk, T. 10849-10850 (28 January 2011).

20303 P2525 (Witness statement of Griffiths Evans dated 6 September 1995), e-court p. 8; see para. 5880.

20304 Janusz Kalbarczyk, T. 10850 (28 January 2011).

20305 Patrick Rechner, T. 11103-11104 (2 February 2011).

20306 Patrick Rechner, T. 11103 (2 February 2011).

20307 Patrick Rechner, T. 11103 (2 February 2011).

20308 Patrick Rechner, T. 11103 (2 February 2011).

20309 Janusz Kalbarczyk, T. 10849-10850 (28 January 2011); Patrick Rechner, T. 11103-11104 (2 February 2011). The other UNMOs were from the SE-1 UNMO Team and the SG-1 UNMO Team.

20310 Patrick Rechner, T. 11105 (2 February 2011).

20311 Patrick Rechner, T. 11105-11106 (2 February 2011); P2171 (UNPROFOR report, 27 May 1995), p. 2.

20312 Patrick Rechner, T. 11105-11106 (2 February 2011); P2171 (UNPROFOR report, 27 May 1995), p. 2.
} 
Koran barracks. ${ }^{20313}$ They were kept outdoors but not handcuffed. ${ }^{20314}$ Kalbarczyk and another UNMO were taken from the Pale barracks, blindfolded, placed in a car, and driven to the radar station. $^{20315}$ At the radar station, they were handcuffed, interviewed, and filmed again by Pale TV. ${ }^{20316}$ They were taken back to the barracks afterwards and spent the night there with the rest of the UNMOs. ${ }^{20317}$ Later in the afternoon, two Russian UNMOs were brought in and joined the eight UNMOs at the Koran barracks. ${ }^{20318}$ Rechner and a member of the UNMO team from Kasindo were allowed to go back to their accommodations to pick up personal items for themselves and the other UNMOs. $^{20319}$

5922. On 28 May 1995, Evans, Kalbarczyk, and the other UNMOs were moved to another part of the Koran Barracks where they were guarded at all times. ${ }^{20320}$ Food was brought to them but they did not have access to a radio or a television. ${ }^{20321}$ Vojvodić visited them a few times per day and told them they were prisoners of war. ${ }^{20322}$ The UNMOs were detained in this building for one week. ${ }^{20323}$ Once again, Rechner was allowed to go to the 7 Lima UNMO team's accommodations to pick up personal items as they were going to be detained for several more days. ${ }^{20324}$ Rechner saw that confidential UN situation reports had been sent to their office in their absence. ${ }^{20325}$ The landlord of the house told Rechner that Krajišnik had called the house and said telephone calls and faxes were not permitted, and that the UNMOs should just do as they were told and they would be released in a few days. ${ }^{20326}$

\footnotetext{
20313 P2525 (Witness statement of Griffiths Evans dated 6 September 1995), e-court p. 8 (specifying that they included five from SE-1 UNMO team, three from the 7 Lima UNMO team, and two from the SG-1 UNMO team).

20314 P2525 (Witness statement of Griffiths Evans dated 6 September 1995), e-court p. 8.

20315 Janusz Kalbarczyk, T. 10852-10856 (28 January 2011); P2143 (Serbian TV news report re UN personnel, with transcript); Marcus Helgers, T. 10752-10756 (26 January 2011).

20316 Janusz Kalbarczyk, T. 10852-10856 (28 January 2011); P2143 (Serbian TV news report re UN personnel, with transcript); March Helgers, T. 10752-10756 (26 January 2011).

20317 Janusz Kalbarczyk, T. 10857-10858 (28 January 2011).

20318 Patrick Rechner, T. 11106-11107 (2 February 2011).

20319 Patrick Rechner, T. 11107 (2 February 2011).

20320 Janusz Kalbarczyk, T. 10857-10859 (28 January 2011); Patrick Rechner, T. 11104 (2 February 2011); P2170 (Witness statement of Patrick Rechner dated 31 January 2011), para. 57; P2525 (Witness statement of Griffiths Evans dated 6 September 1995), e-court p. 9.

20321 Janusz Kalbarczyk, T. 10858-10859 (28 January 2011); P2525 (Witness statement of Griffiths Evans dated 6 September 1995), e-court p. 9.

20322 P2525 (Witness statement of Griffiths Evans dated 6 September 1995), e-court p. 9.

20323 Janusz Kalbarczyk, T. 10859 (28 January 2011).

20324 Patrick Rechner, T. 11108 (2 February 2011); P2170 (Witness statement of Patrick Rechner dated 31 January 2011), para. 58.

20325 Patrick Rechner, T. 11108 (2 February 2011).

20326 Patrick Rechner, T. 11108-11109 (2 February 2011). Rechner explained that the landlord of the 7 Lima UNMO team's office was a close friend or colleague of Krajišnik and this is why there was this message from Krajišnik to Rechner.
} 
5923. On 29 May 1995, Rechner was again allowed to go back to the 7 Lima UNMO team's accommodations. ${ }^{20327}$ He stopped by the UNMO team in Kasindo's accommodations first and tried to arrange a meeting with Koljević through his secretary. ${ }^{20328}$ When Rechner returned to the Koran barracks, he spoke to Vojvodić and agreed to draft a letter outlining the issues he wanted to discuss with Koljević. $^{20329}$ Topics for discussion included the circumstances surrounding the UNMOs capture and detention, their mistreatment, and possible ways to resolve the situation. ${ }^{20330}$ The proposed meeting with Koljević never took place. ${ }^{20331}$ The next time Rechner met Koljević was on 15 June $1995 .^{20332}$

5924. On 1 June 1995, Mladić visited the barracks to check on the UNMOs and their accommodations. ${ }^{20333}$ He stayed there for 30 minutes and spoke to Evans about whether UNMOs were able to guide NATO aircrafts and direct their air strike targets. ${ }^{20334}$ Evans told them that this was impossible. ${ }^{20335}$ An UNMO from the 7 Lima UNMO team was also interviewed and asked the same questions to which he gave similar answers as Evans. ${ }^{20336}$

5925. On 5 June 1995, two Bosnian Serb doctors came and examined the UNMOs. ${ }^{20337}$ Two days later, one of the UNMOs was released due to the doctor's recommendation. ${ }^{20338}$

5926. On 8 June 1995, the ICRC visited the UNMOs and registered them. ${ }^{20339}$ Dragan Bulajić, the president of the Bosnian Serb Exchange Commission, accompanied the ICRC on this visit. ${ }^{20340}$ Rechner spoke to him about their detention. ${ }^{20341}$ When Bulajić said they were prisoners of war,

\footnotetext{
20327 Patrick Rechner, T. 11109-11110 (2 February 2011); P2170 (Witness statement of Patrick Rechner dated 31 January 2011), para. 59.

20328 Patrick Rechner, T. 11109-11110 (2 February 2011); P2170 (Witness statement of Patrick Rechner dated 31 January 2011), para. 59.

20329 Patrick Rechner, T. 11110-11111 (2 February 2011); P2170 (Witness statement of Patrick Rechner dated 31 January 2011), para. 61.

20330 Patrick Rechner, T. 11111 (2 February 2011).

20331 Patrick Rechner, T. 11111 (2 February 2011).

20332 Patrick Rechner, T. 11111 (2 February 2011); P2170 (Witness statement of Patrick Rechner dated 31 January 2011), para. 62; see para. 5930.

20333 Janusz Kalbarczyk, T. 10859-10860, 10891-10892 (28 January 2011); P653 (Video still of Ratko Mladić with two men). See also Jonathon Riley, T. 10777 (26 January 2011); P2148 (Witness statement of Jonathon Riley dated 30 May 1996), p. 5.

20334 Janusz Kalbarczyk, T. 10860-10861 (28 January 2011); P2525 (Witness statement of Griffiths Evans dated 6 September 1995), e-court p. 9.

20335 P2525 (Witness statement of Griffiths Evans dated 6 September 1995), e-court p. 9.

20336 P2525 (Witness statement of Griffiths Evans dated 6 September 1995), e-court p. 9.

20337 P2525 (Witness statement of Griffiths Evans dated 6 September 1995), e-court p. 10.

20338 P2525 (Witness statement of Griffiths Evans dated 6 September 1995), e-court p. 10.

20339 P2525 (Witness statement of Griffiths Evans dated 6 September 1995), e-court p. 10; Patrick Rechner, T. 11115-11116 (2 February 2011).

20340 Patrick Rechner, T. 11115-11116 (2 February 2011).

20341 Patrick Rechner, T. 11116 (2 February 2011).
} 
Rechner reminded him that they were unarmed UNMOs, and not soldiers, and the UNMOs were working on Bosnian Serb held territory with the permission of the Accused. ${ }^{20342}$

5927. On the morning of 13 June 1995, Kalbarczyk was released and transferred to the police station in Pale where he met other UN personnel who had also been released. ${ }^{20343}$ From Pale, they were driven in buses to Novi Sad. ${ }^{20344}$ Upon arriving in Novi Sad, Kalbarczyk and the UNMOs were taken to a holiday resort called Sloboda and placed under the custody of the VJ. ${ }^{20345}$

5928. On 14 June 1995, 18 UNPROFOR members and eight UNMOs, including Westlund and Kalbarczyk, were transported to Belgrade airport where they were flown to Zagreb and released. ${ }^{20346}$

5929. On 15 June 1995, other UNMOs, including Rechner, Evans, Gelissen, and Helgers, were taken to the police station in Pale where they met with ICRC representatives. ${ }^{20347}$ Afterwards, they were taken back to the Pale Barracksand two more UNMOs from the Banja Luka team were brought in. ${ }^{20348}$

5930. On 15 June 1995, 15 UNMOs remained in detention. ${ }^{20349}$ Rechner, Evans, Gelissen, and six UNMOs were still detained at the Pale barracks. ${ }^{20350}$ Helgers and three UNMOs were detained at the Jaharina radar station. ${ }^{20351}$ There were two UNMOs from Banja Luka whose whereabouts were unknown. ${ }^{20352}$ The following day, the UNMOs detained at the Pale Barrackswere told by Vojvodić that they would be released that day. ${ }^{20353}$ They were taken to their accommodations to pick up personal items and then driven to the Koran Hospital where they met Koljević. ${ }^{20354}$ Rechner related

\footnotetext{
20342 Patrick Rechner, T. 11116 (2 February 2011).

20343 Janusz Kalbarczyk, T. 10861-10863 (28 January 2011); P2525 (Witness statement of Griffiths Evans dated 6 September 1995), e-court p. 10.

20344 Janusz Kalbarczyk, T. 10862, 10865-10866 (28 January 2011); P2157 (Serbian TV news report re UN personnel, with transcript).

20345 Janusz Kalbarczyk, T. 10868 (28 January 2011).

20346 Janusz Kalbarczyk, T. 10869-10870 (28 January 2011); P2159 (UNPROFOR report, 14 June 1995), p. 1; P2160 (UNPROFOR report re released hostages, 14 June 1995), pp. 1-3.

20347 P56 (Witness statement of Joseph Gelissen dated 18 January 1996), e-court p. 9.

20348 P56 (Witness statement of Joseph Gelissen dated 18 January 1996), e-court p. 9.

20349 P2161 (UNPROFOR report re released hostages, 14 June 1995), pp. 1-3; Janusz Kalbarczyk, T. 10870-10872 (28 January 2011).

20350 P2161 (UNPROFOR report re released hostages, 14 June 1995), pp. 1-3; Janusz Kalbarczyk, T. 10870-10872 (28 January 2011).

20351 P2161 (UNPROFOR report re released hostages, 14 June 1995), pp. 1-3; Janusz Kalbarczyk, T. 10870-10872 (28 January 2011).

20352 P2161 (UNPROFOR report re released hostages, 14 June 1995), pp. 1-3; P2525 (Witness statement of Griffiths Evans dated 6 September 1995), e-court p. 10.

20353 P2525 (Witness statement of Griffiths Evans dated 6 September 1995), e-court p. 10.

20354 Patrick Rechner, T. 11111-11112 (2 February 2011); P2525 (Witness statement of Griffiths Evans dated 6 September 1995), e-court p. 10.
} 
all of his concerns about the UNMOs' capture and detention to him, including their limited opportunity to make contact with their families. ${ }^{20355}$ Rechner also discussed the actual details of their capture and detention. ${ }^{20356}$ Koljević knew what had happened but was surprised to hear that the UNMOs had been threatened. ${ }^{20357}$ In relation to the NATO air strikes, Koljević told Rechner that due to the intensity of the air strikes, which was not expected by the Bosnian Serbs, they felt that they needed to react in a way that would send a shock to the UN. ${ }^{20358}$ Koljević also told Rechner that due to these air strikes, the Bosnian Serbs' relationship with the UN would be completely different and the UNMO office in Pale would be closed. ${ }^{20359}$

5931. On 18 June 1995, the UNMOs were taken to the Pale police station by bus and handed over to the Serbian authorities. ${ }^{20360}$ Koljević apologised to the UNMOs for the treatment they had received but emphasised that due to the NATO air strikes, the Bosnian Serbs had needed to react and take extreme measures. ${ }^{20361}$ He informed them that they were being handed over to the Serbian authorities of the FRY. ${ }^{20362}$ Koljević asked them to give a statement and Rechner did so. ${ }^{20363}$ Inđić also spoke to the UNMOs stating that he was happy the situation had ended well. ${ }^{20364}$ Inđic signed a release document and the UNMOs were handed over to the Serbian authorities. ${ }^{20365}$ The UNMOs were escorted by Serbian Special forces, wearing red berets, who accompanied them to Novi Sad. ${ }^{20366}$ The next day, they were taken to Belgrade and then flown to Zagreb where they were met by Akashi. ${ }^{20367}$

\section{d. Negotiations and release}

\footnotetext{
20355 Patrick Rechner, T. 11112-11113 (2 February 2011).

20356 Patrick Rechner, T. 11113 (2 February 2011).

20357 Patrick Rechner, T. 11113 (2 February 2011).

20358 Patrick Rechner, T. 11114 (2 February 2011).

20359 Patrick Rechner, T. 11114 (2 February 2011).

20360 P56 (Witness statement of Joseph Gelissen dated 18 January 1996), e-court p. 10. See also P2156 (Radovan Karadžić's Order to VRS Main Staff, 13 June 1995.)

20361 Marcus Helgers, T. 10758 (26 January 2011); P2117 (Witness statement of Marcus Helgers dated 3 August 1995), p. 4; Patrick Rechner, T. 11117 (2 February 2011).

20362 Marcus Helgers, T. 10758 (26 January 2011); P2117 (Witness statement of Marcus Helgers dated 3 August 1995), p. 4.

20363 P56 (Witness statement of Joseph Gelissen dated 18 January 1996), e-court p. 10.

20364 P2117 (Witness statement of Marcus Helgers dated 3 August 1995), p. 4.

20365 P2117 (Witness statement of Marcus Helgers dated 3 August 1995), p. 4.

20366 P56 (Witness statement of Joseph Gelissen dated 18 January 1996), e-court p. 10.

20367 P56 (Witness statement of Joseph Gelissen dated 18 January 1996), e-court p. 10; P5211 (UNPROFOR daily report, 20 June 1995); D1131 (UNPROFOR Weekly Situation Report, 18 June 1995), p. 2 (specifying that " $[t]$ he Bosnian Serbs had linked the release of these hostages to that of four Bosnian Serb soldiers held by UNPROFOR since the [VRS] attack on the Vrbanja Bridge in Sarajevo on 27 May 1995. These four soldiers were handed over to the Bosnian Serb military authorities at Lukavica Barracksin Sarajevo today.")
} 
5932. Communication between the UN and the Bosnian Serbs on negotiating the release of the UN personnel began shortly after the first group was detained. ${ }^{20368}$ Charles Kirudja, the UN Delegate of the Special Representative of the Secretary General to the FRY, was involved in these negotiations. $^{20369}$ From the FRY, Jovica Stanišić was the special negotiator for Slobodan Milošević. ${ }^{20370}$ Janvier emphasised that the release of the UN personnel was his utmost priority. ${ }^{20371}$ UNPROFOR's strategic aim was to negotiate the release of the detained personnel and re-establish UNPROFOR's mission in $\mathrm{BiH}^{20372}$

5933. By 3 June 1995, 120 UNPROFOR personnel had been released by the VRS and handed over to the Serbian authorities. ${ }^{20373}$ Akashi thanked the Accused for the release of these UNPROFOR members but noted that approximately 264 others were still being detained and demanded their unconditional release. ${ }^{20374}$

5934. By 9 June 1995, due to "increased shelling on Bosnian Serb positions in Trskavica, Majevica, Kalenik and Livansko Polje," the Bosnian Serbs were refusing to release the remaining UN personnel. ${ }^{20375}$ As Jovica Stanišić was planning on meeting with Mladić the following day, he asked Kirudja to provide him with information on the location of the remaining UN personnel, including the precise numbers, the conditions under which they were being held, and whether they were surrounded and blocked by Bosnian Serb forces. ${ }^{20376}$ Kirudja stressed that a condition of their release was that they be released "unconditionally", namely with all of their equipment. ${ }^{20377}$

5935. On 10 June 1995, Kirudja met again with Jovica Stanišić to provide him with the latest information on the numbers and locations of the remaining UN personnel. ${ }^{20378}$ Stanišić was certain

\footnotetext{
20368 P2268 (UNPROFOR report re telephone conversations with Ratko Mladić, 26 May 1995); D1055 (UNPROFOR report to Kofi Annan, 27 May 1995); P5023 (UNPROFOR report, 29 May 1995), p. 5.

20369 P3804 (Witness statement of Charles Kirudja dated 17 November 2010), para. 149.

20370 P3804 (Witness statement of Charles Kirudja dated 17 November 2010), paras. 149-150; P3872 (UNPROFOR report, 10 June 1995), p. 1.

20371 P2284 (UNSG report entitled "The Fall of Srebrenica", 15 November 1999), para. 194.

20372 P5023 (UNPROFOR report, 29 May 1995), p. 3.

20373 P5022 (Letter from Yasushi Akashi to Radovan Karadžić, 3 June 1995); P3873 (Official note of Pale SJB, 2 June 1995); P3874 (Official note of Pale SJB, 2 June 1995); P3875 (Official note of Pale SJB, 2 June 1995); P3876 (RS MUP report re handover of captured UNPROFOR members and military observers, 2 June 1995); P3877 (List of UNPROFOR members released by the VRS, 2 June 1995); P888 (UNPROFOR Weekly Situation Report (Sarajevo), 3 June 1995), p. 2. See also P3804 (Witness statement of Charles Kirudja dated 17 November 2010), paras. 159-160; P889 (Radovan Karadžić's Order to VRS and to RS MUP, 2 June 1995); P2152 (VRS Main Staff Order, 2 June 1995).

20374 P5022 (Letter from Yasushi Akashi to Radovan Karadžić, 3 June 1995).

20375 P3871 (UNPROFOR report, 9 June 1995), p. 1. See also P3804 (Witness statement of Charles Kirudja dated 17 November 2010), paras. 151-152.

20376 P3871 (UNPROFOR report, 9 June 1995), pp. 2-3.

20377 P3871 (UNPROFOR report, 9 June 1995), pp. 2-3.

20378 P3872 (UNPROFOR report, 10 June 1995), p. 1.
} 
that based on the information from the UN, Mladić had been withholding information from him and he would have to revise his approach for negotiations, particularly with respect to the UN personnel held in and around Sarajevo. ${ }^{20379}$ Stanišić told Kirudja that he had spoken with the Accused in the morning and the Accused was very concerned that there may be further NATO air strikes in retaliation for detaining UN personnel whereas Mladić seemed intent on continuing to hold the UN personnel in Sarajevo "fearing that their release would set the conditions for renewed NATO air strikes and/or a renewed assault by government troops". ${ }^{20380}$ Stanišić questioned whether it would be better to put pressure on the Accused and Mladic to release the UN personnel directly to UNPROFOR in Sarajevo or to release them to him for transportation to Belgrade, as had been done with the two previous groups who were released. ${ }^{20381}$ Kirudja stated that it would be best to release them to UNPROFOR in Sarajevo and to propose this to Mladić. ${ }^{20382}$ Stanišić thought that Mladić would rather release them to the FRY and be publicly seen as "handing them over" to Stanišić. ${ }^{20383}$ Stanišić requested that there be a moratorium on any use of external force by the UN and NATO during and immediately after the process of releasing the UN personnel, which Kirudja said he would communicate to the UN and Akashi. ${ }^{20384}$ Smith's response to this was that he would not agree to anything with the Bosnian Serbs, including entering into negotiations with them, and that his demand was they release the hostages immediately and unconditionally. ${ }^{20385}$

5936. By 13 June 1995, additional UNPROFOR personnel were released. ${ }^{20386}$ On 16 June 1995, the Security Council passed resolution 998 demanding the immediate and unconditional release of all remaining UN personnel. ${ }^{20387}$ By 18 June 1995, all remaining UNPROFOR and the remaining 15 UNMOs were released. ${ }^{20388}$ The UNPROFOR and UNMO personnel were released by the VRS and handed over to Jovica Stanišić in Belgrade and flown back to UNPROFOR HQ in Zagreb. ${ }^{20389}$

\footnotetext{
20379 P3872 (UNPROFOR report, 10 June 1995), pp. 1-2.

20380 P3872 (UNPROFOR report, 10 June 1995), p. 2.

20381 P3872 (UNPROFOR report, 10 June 1995), p. 2.

20382 P3872 (UNPROFOR report, 10 June 1995), p. 3.

20383 P3872 (UNPROFOR report, 10 June 1995), p. 3.

20384 P3872 (UNPROFOR report, 10 June 1995), p. 3.

20385 P3804 (Witness statement of Charles Kirudja dated 17 November 2010), para. 157.

20386 P2156 (Radovan Karadžić's Order to VRS Main Staff, 13 June 1995); P2159 (UNPROFOR report, 14 June 1995); P2160 (UNPROFOR report re released hostages, 14 June 1995); P2161 (UNPROFOR report re released hostages, 14 June 1995).

20387 P5014 (UNSC Resolution 998, 16 June 1995), p. 2.

20388 P2156 (Radovan Karadžić's Order to VRS Main Staff, 13 June 1995); P2183 (VRS Main Staff Order, 17 June 1995). See also P2175 (Video footage of UN personnel, with transcript).

20389 P2156 (Radovan Karadžić's Order to VRS Main Staff, 13 June 1995); P2159 (UNPROFOR report, 14 June 1995); P2160 (UNPROFOR report re released hostages, 14 June 1995); P2161 (UNPROFOR report re released hostages, 14 June 1995).
} 


\section{e. Conclusion}

5937. The Chamber finds that on 25 and 26 May 1995, following the NATO air strikes on Bosnian Serb military targets, over 200 UNPROFOR and UNMO personnel in $\mathrm{BiH}$ were detained by Bosnian Serb Forces and taken to various locations throughout $\mathrm{BiH}^{20390}$ Some of the UN personnel were taken from their locations and driven to locations of military significance for the VRS, such as the Mount Jahorina radar station, the Banja Luka barracks, Pale barracks, Lukavica barracks, Bijeljina barracks, Višegrad barracks, Jahorinski Potok, and Koran barracks. Others were simply detained at their locations, including OPs and WCPs. Threats were made by the VRS against the UN personnel, that they would be killed if NATO launched further air strikes and these threats were communicated to the UN.

\section{Legal findings on crimes}

\section{a. Chapeau requirements for Article 3}

5938. In relation to the Hostages component of the case, the Accused is charged with one count of violations of the laws or customs of war under Article 3 of the Statute, namely the taking of hostages. The Chamber recalls that before entering findings on counts under Article 3 of the Statute, the Chamber must first be satisfied that a number of general requirements are met.

5939. The Chamber found that there was an armed conflict in $\mathrm{BiH}$ throughout the period relevant to the crimes alleged in the Indictment. The Chamber further finds that the taking of hostages, as analysed above, is closely related to the armed conflict. In relation to the four so called "Tadic

Conditions", ${ }^{20391}$ the Chamber refers to the applicable law section of this Judgement, which expanded on the legal basis for each of the crimes charged in the Indictment under Article 3 of the Statute. ${ }^{20392}$ In relation to the taking of hostages, the prohibition stems from Common Article 3 which is deemed to be part of customary international law. ${ }^{20393}$ Further, the Appeals Chamber has

\footnotetext{
20390 While paragraph 86 of the Indictment alleges that over 200 UNPROFOR and UNMOs were detained, the evidence reflects that the total number of UNPROFOR personnel detained was more than 300. See P2173 (UNPROFOR report, 28 May 1995); P2270 (UNPROFOR report, 29 May 1995); P5024 (Annex A to UNPROFOR report re UN hostages, 2 June 1995); P5022 (Letter from Yasushi Akashi to Radovan Karadžić, 3 June 1995).

20391 See para. 443.

20392 See Section III.A.1: Article 3 of the Statute of the Tribunal.

20393 Čelebići Appeal Judgement, para. 143.
} 
confirmed that violations of the provisions of Common Article 3 entail individual criminal responsibility. ${ }^{20394}$

5940. The Chamber is therefore satisfied that the four Tadic Conditions are met, and consequently that the chapeau requirements for Article 3 of the Statute are fulfilled, in relation to the crime of taking hostages.

\section{b. Crime of hostage-taking: Count 11}

\section{i. Actus reus of hostage-taking}

5941. The Chamber refers to its findings above that on 25 and 26 May 1995, following the NATO air strikes on Bosnian Serb military targets, over 200 UNPROFOR and UNMO personnel in BiH were detained by Bosnian Serb Forces and taken to various locations in BiH. Some of the UN personnel were taken to locations of military significance for the VRS, such as the Banja Luka barracks, Mount Jahorina radar station, Pale barracks, Lukavica barracks, Bijeljina barracks, Višegrad barracks, Jahorinski Potok, and Koran barracks. Others were simply detained at their locations, including OPs and WCPs.

5942. The Accused has argued throughout the case, that the status of the UN personnel at the time of the alleged hostage taking was determinative for a finding on the existence of the crime. He argued that due to the NATO air strikes, the UN personnel were transformed into persons taking active part in the hostilities and thus not entitled to the protections of Common Article $3 .^{20395}$

5943. The Chamber finds the Accused's argument in this regard to be unconvincing. As a preliminary matter, the Chamber recalls that the UN and its associated peacekeeping forces were not a party to the conflict. UNPROFOR was established and deployed pursuant to Security Council Resolution 743 as "an interim arrangement to create the conditions of peace and security required for the negotiation of an overall settlement of the Yugoslav crisis". ${ }^{20396}$ While the details of its operations were enlarged and strengthened over the course of the conflict in order to preserve the security of its personnel and enable the implementation of its mandate, it remained a peacekeeping

\footnotetext{
20394 Čelebići Appeal Judgement, paras. 167, 170, 173-174 (holding at para. 173: "It is universally acknowledged that the acts enumerated in common Article 3 are wrongful and shock the conscience of civilised people, and thus are, in the language of Article 15(2) of the ICCPR, 'criminal according to the general principles of law recognised by civilised nations'.").

20395 See Prosecutor v. Radovan Karadžić, Case No. IT-95-5/18-AR73.9, Appeal from Denial of Judgement for Acquittal for Hostage Taking, 25 July 2012, paras. 42-52; Hearing, T. 28619-28626 (11 June 2012). See the Accused's line of questioning during the testimony of Michael Rose, T. 7391-7397 (6 October 2010), T. 75687569 (8 October 2010); Rupert Smith, T. 11488-11498 (10 February 2011); John Zametica, T. 42473-42475 (29 October 2013); David Harland, T. 2293-2294 (11 May 2010);

20396 UNSC Resolution 743 (1992), S/RES/743, 21 February 1992.
} 
force. ${ }^{20397}$ Accordingly, at the time the UN personnel were detained on 25 and 26 May 1995, they were persons taking no active part in the hostilities and, as such, were afforded the protection of Common Article 3. The NATO air strikes of 25 and 26 May 1995 did not transform the status of all of the UN personnel in $\mathrm{BiH}$ into that of persons taking active part in the hostilities. However, even if the UN personnel had been combatants prior to their detention, as the Accused argues, they were in any event rendered hors de combat by virtue of their detention and thus were also entitled to the minimum protections guaranteed by Common Article $3 .^{20398}$ As confirmed by the Appeals Chamber in this case, Common Article 3 applies to the detained UN personnel irrespective of their status prior to detention. ${ }^{20399}$ Therefore, the Chamber finds that all UN personnel who were detained by the Bosnian Serb Forces were entitled to the protections under Common Article 3, including the prohibition against hostage-taking.

5944. While the UNPROFOR and UNMO personnel were detained, Bosnian Serb Forces threatened to kill, injure, or continue to detain them unless NATO ceased its air strikes. These threats were communicated by the Bosnian Serb Forces to the detained UN personnel and to UNMO and UNPROFOR headquarters. ${ }^{20400}$

5945. The Chamber therefore finds that between 25 May and 18 June 1995, UNPROFOR and UNMO personnel were detained by Bosnian Serb Forces and threats were used against them in order to obtain a concession, namely that NATO cease its air strikes against Bosnian Serb military targets in $\mathrm{BiH}$.

\section{ii. Mens rea of hostage-taking}

5946. The Chamber finds that the detention of the UNPROFOR and UNMO personnel by Bosnian Serb Forces was intentionally carried out to compel NATO to refrain from conducting further air

20397 See P981 (UNSC Resolution 758, 8 June 1992); P985 (UNSC Resolution 836, 4 June 1993) (authorising UNPROFOR, in carrying out its mandate, acting in self-defence, to take the necessary measures, including the use of force, in reply to bombardments against the safe areas by any of the parties or to armed incursion into them or in the event of any deliberate obstruction in or around those areas to the freedom of movement of UNPROFOR or of protected humanitarian convoys); UNSC Resolution 914 (1994), S/RES/914, 27 April 1994; UNSC Resolution 982 (1995), S/RES/982, 31 March 1995 (extending UNPROFOR's mandate until 30 November 1995 and paying tribute to all UNPROFOR personnel, especially those who have given their lives for the cause of peace); UNSC Resolution 947 (1994), S/RES/947, 30 September 1994 (stressing that UNPROFOR plays an essential role in preventing and containing hostilities and thus creating the conditions for achieving an overall political settlement); P5014 (UNSC Resolution 998, 16 June 1995) (authorising the increase in the number of UNPROFOR personnel in order to carry out its mandate).

20398 See Appeal Decision on Count 11, para. 21 (holding that "Common Article 3's prohibition on hostage-taking applies to all detained individuals, irrespective of whether their detention is explicitly sought in order to use them as hostages and irrespective of their prior status as combatants" and that the Chamber did not err in making this finding). 
strikes on Bosnian Serb military targets. In reaching this conclusion, the Chamber has had regard to orders and reports from the VRS, threats made to the UN personnel and communicated to UNMO and UNPROFOR headquarters, and statements made by the Accused, Mladić, Zametica, and Krajišnik. ${ }^{20401}$

5947. In addition, the Chamber finds that members of the Bosnian Serb Forces knew or should have been aware that when the crime of hostage-taking was committed, the detained UN personnel were taking no active part in the hostilities.

\section{iii. Special defence: reprisals}

5948. The Accused submits that even if the Chamber finds that the elements of hostage-taking are met, the conduct of the Bosnian Serbs was justified by the defence of reprisals. ${ }^{20402}$ The Prosecution submits that detainees may never be subjected to reprisals and therefore, the unlawful act of threatening detainees so as to obtain a concession cannot be justified as a reprisal. ${ }^{20403}$

5949. In the law of armed conflict, a belligerent reprisal is an act that would otherwise be unlawful but, in exceptional circumstances and if strict conditions are met, is considered lawful when it is used as an enforcement measure in reaction to unlawful acts of an adversary. ${ }^{20404}$ However, the prohibition of reprisals against protected persons is absolute and can therefore not be used as a defence for the crime of taking protected persons hostage. ${ }^{20405}$

5950. Therefore, the Chamber finds that the taking of UN personnel hostage cannot be justified as a lawful reprisal and the Accused's argument in this regard is dismissed.

\footnotetext{
20401 See paras. 5857, 5859-5861, 5871-5872, 5874-5876, 5880, 5890, 5894-5895, 5899, 5902, 5914-5915, 5917, 5958-5961.

20402 Defence Final Brief, para. 2743. See also Notice of Special Defence as to Count 11: Reprisals, 14 December 2012, wherein the Accused contends that (i) "the NATO/UN bombing of the Pale ammunition depot on 2526 May 1995, not being in self-defence, was a violation of the law of armed conflict; (ii) he had provided a formal warning that UN personnel would be taken prisoner if air strikes were launched; (iii) the decision to detain UN personnel was made at the highest levels of the [RS]; (iv) the detention of UN personnel was a proportionate response to the air strikes; and (v) there was no impact on the civilian population". Notice of Special Defence as to Count 11: Reprisals, 14 December 2012, para. 7.

20403 Prosecution Final Brief, para. 1109. See also Prosecution's Submission Re. Notice of Special Defence as to Count 11: Reprisals, 5 March 2013.

20404 ICRC Customary IHL, Rule 145; Martić Trial Judgement, paras. 465-467.

20405 ICRC Customary IHL, Rule 146. The Geneva Conventions prohibits belligerent reprisals against "persons in the power of a party of the conflict, including the wounded, sick and shipwrecked, medical and religious personnel, captured combatants, civilians in occupied territory and other categories of civilians in the power of an adverse party to the conflict". ICRC Customary IHL, Rule 146, citing First Geneva Convention, art. 46; Second Geneva Convention, art. 47; Third Geneva Convention, art. 13; and Fourth Geneva Convention, art. 33.
} 
iv. Conclusion

5951. The Chamber therefore finds that the detention of UN personnel by the Bosnian Serb Forces in order to compel NATO to cease its air strikes against Bosnian Serb military targets constitutes the crime of taking hostages, as a violation of the laws or customs of war.

\section{Hostages JCE and the Accused's responsibility}

\section{a. Submissions of the Parties}

5952. The Prosecution charges the Accused with having participated in a JCE during May and June 1995, the objective of which was to take UN personnel hostage in order to compel NATO to abstain from conducting air strikes against Bosnian Serb military targets. ${ }^{20406}$ It alleges that this objective involved the commission of the crime of taking hostages. ${ }^{20407}$

5953. The Prosecution further alleges that the Accused shared the intent for the commission of this crime with other members of the JCE, including Mladić. ${ }^{20408}$ The Prosecution identifies the other members of the JCE as members of the Bosnian Serb Political and Governmental Organs; and commanders, assistant commanders, senior officers, and chiefs of the VRS and MUP. ${ }^{20409}$ It alleges that each member of the JCE implemented its objective by personally committing crimes, and/or through and by using members of the VRS and MUP to carry out the crimes committed in furtherance of the objective. ${ }^{20410}$ Alternatively, the Prosecution alleges that some or all of these individuals were not members of the JCE but were used by members of the JCE to carry out the crimes committed in furtherance of its objective. ${ }^{20411}$

5954. The Prosecution alleges that the Accused significantly contributed to achieving the objective of taking hostages and that he was a central participant at every stage of the implementation of the common purpose. ${ }^{20412}$

5955. The Prosecution submits that following the NATO air strikes on Bosnian Serb military targets on 25 and 26 May 1995, Bosnian Serb Forces took over 200 UN personnel hostage and

\footnotetext{
20406 Indictment, para. 25.

20407 Indictment, para. 25.

20408 Indictment, para. 26.

20409 Indictment, para. 27.

20410 Indictment, para. 28.

20411 Indictment, para. 27.

20412 Indictment, para. 29, referring to paras. 14(a), (b), (d), (e), and (h) of the Indictment. See also Prosecution Final Brief, para. 1108.
} 
informed the UN that the hostages would be killed or injured if the NATO air strikes continued. ${ }^{20413}$ It argues that these acts were part of a JCE to compel NATO to abstain from conducting further air strikes and that the Accused, with others, intended that the UN personnel be taken hostage and that the Accused ordered subordinates in the VRS and the MUP to seize them and use them as human shields. $^{20414}$

5956. In relation to his responsibility under Count 11, the Accused submits that the Prosecution has failed to prove his mens rea for an essential element of the offence. ${ }^{20415}$ The Accused argues that while he did agree that UN personnel should be detained following the NATO air strikes, he never agreed or contemplated that threats should be made against them. ${ }^{20416} \mathrm{He}$ also argues that there is no evidence that the plan to detain the UN personnel included the issuance of threats against them. ${ }^{20417}$ He further argues that the threats that were made to the detained UN personnel were "not part of orders coming down the chain of command" and that while there were VRS orders to place the UN personnel in areas where air strikes may occur, he also ordered that the UN personnel be "treated properly with military respect". ${ }^{20418}$ The Accused submits that the crime of taking hostages requires an essential element, namely that the perpetrator threatened to kill, injure, or continue to detain such person or persons and since he never agreed to this element, he cannot be found guilty of this crime under the basic form of JCE. ${ }^{20419}$

b. Findings on the common purpose and plurality of persons

5957. The Chamber found that following the NATO air strikes on 25 and 26 May 1995, the Bosnian Serb Forces detained UN personnel in various locations throughout $\mathrm{BiH}^{20420}$ The Accused had warned UNPROFOR that he would "treat UN soldiers as enemies" if NATO air strikes were conducted and UNPROFOR had expressed its own concerns about UN personnel being targeted by the VRS. ${ }^{20421}$ Immediately after the air strikes, the Accused ordered Milovanović to "activate" a decision made the previous year to "arrest everything foreign in RS territory and to

\footnotetext{
20413 Prosecution Final Brief, para. 1102.

20414 Prosecution Final Brief, paras. 1102, 1108.

20415 Defence Final Brief, para. 3352. In relation to the third form of JCE, the Accused argues that there is no evidence that he should have foreseen the making of such threats to the detained UN personnel. He argues that since the threats were not foreseeable, he cannot be found guilty of hostage taking under the third form of JCE. Defence Final Brief, paras. 3366-3368. The Chamber notes that for the Hostages component of the case, the Prosecution does not charge the Accused with criminal responsibility through the third form of JCE, therefore the Chamber will not address the Accused's argument with respect to this form of responsibility.

20416 Defence Trial Brief, paras. 3354, 3359-3360.

20417 Defence Trial Brief, para. 3355.

20418 Defence Final Brief, para. 3358.

20419 Defence Final Brief, para. 3360.

$20420 \quad$ See para. 5937.

$20421 \quad$ See para. 5964.
} 
treat military personnel as prisoners of war and hold them as hostages till the end of the war". ${ }^{20422}$ Members of the Bosnian Serb Forces, including Mladić, Milovanović, Dragomir Milošević, and Živanović, carried out an operation with swift efficiency resulting in the detention of over 200 UN personnel throughout $\mathrm{BiH}$ during the few days immediately following the NATO air strikes. ${ }^{20423}$ Some of the UN personnel were taken to locations of military significance to the VRS, while others were detained at their OPs or WCPs. ${ }^{20424}$

5958. Once it was clear that NATO air strikes would cease, the negotiations for the release of the hostages were successful. ${ }^{20425}$ On 2 June 1995, the Accused issued an order to the Main Staff and the MUP that 120 detained UNPROFOR personnel should be released. ${ }^{20426}$ Also on this day, Krajišnik, in a private telephone conversation, stated that the Bosnian Serbs were very pleased with the things they had achieved and that the hostages were the Bosnian Serbs' "trump card" and were used to avert the danger of NATO bombing their positions. ${ }^{20427}$ The following day, Krajišnik stated that "we let some go and we captured some others" but that the Bosnian Serbs were holding on to some of the hostages, as "an excellent method" and they always had "an ace up our sleeve". 20428

5959. On 4 June 1995, Janvier met with Mladić to discuss the remaining detained UN personnel. $^{20429}$ Janvier stated that the situation was unacceptable and demanded that the Bosnian Serbs release all detained UN personnel with all of their material and equipment. ${ }^{20430}$ Mladić stated that the intention of the Bosnian Serbs in detaining UN personnel was that air strikes would never be repeated in the future and that the release of the UN personnel was dependent on this guarantee

\footnotetext{
20422 See paras. $5857,5965$.

20423 See paras. 5857, 5859-5863, 5913, 5916, 5937.

20424 See para. 5937.

20425 See paras. 5932-5936.

20426 P889 (Radovan Karadžić's Order to VRS and to RS MUP, 2 June 1995); P820 (Witness statement of David Harland dated 4 September 2009), para. 189; P3804 (Witness statement of Charles Kirudja dated 17 November 2010), para. 160. See also P3807 (Dispatch from RS MUP to Radovan Karadžić, 2 June 1995).

20427 P6520 (Intercept of conversation between Petar Makara and Momčilo Krajišnik, 02 June 1995); Momčilo Krajišnik, T. 43894-43898 (20 November 2013).

20428 P2271 (Intercept of conversation between Momčilo Vinković and Momčilo Krajišnik, 3 June 1995); Momčilo Krajišnik, T. 43890-43894 (20 November 2013). Krajišnik testified that he did not agree with Vinković, who he qualified as a radical in the Serbian diaspora, but he did not want to offend him during the phone conversation. Momčilo Krajišnik, T. 43890-43894 (20 November 2013).

20429 P2273 (UNPROFOR report re meeting with Ratko Mladić, 4 June 1995); Rupert Smith, T. 11414-11416 (9 February 2011). On 1 June 1995, Mladić visited the Koran barracks to check on the detained UNMOs and their accommodations. Janusz Kalbarczyk, T. 10859-10860, 10891-10892 (28 January 2011); P653 (Video still of Ratko Mladić with two men). See also Jonathon Riley, T. 10777 (26 January 2011); P2148 (Witness statement of Jonathon Riley dated 30 May 1996), p. 5.

20430 P2273 (UNPROFOR report re meeting with Ratko Mladić, 4 June 1995), p. 1; Rupert Smith, T. 11414-11416 (9 February 2011).
} 
by the UN. ${ }^{20431}$ Mladić proposed an agreement that he, as the VRS Commander, and Janvier, as the Commander of UNPROFOR, state the following:

(1) The VRS will no longer threaten the life and the security of members of UNPROFOR by the use of force;

(2) UNPROFOR will not engage any of its forces or air strikes against Bosnian Serb objectives or territory; and

(3) the signing of this agreement immediately engages the liberation of all prisoners of war. ${ }^{20432}$

5960. On 15 June 1995, Krajišnik, in a private conversation, stated that the hostage situation was the "biggest deal and quite a lucrative one, I am not saying we could have gotten more out of it". 20433

5961. In addition to the detention, the Chamber found that threats to kill and harm were used against the detained UN personnel in order to obtain a concession, namely that NATO cease its air strikes, including by the Accused. ${ }^{20434}$ Mladić, Inđić, Zametica, Ribić, and members of the Bosnian Serb Forces communicated these threats directly to the detained UN personnel, Smith, and UNPROFOR. ${ }^{20435}$ These threats were made in order to stop the NATO air strikes. ${ }^{20436}$ Further, both Krajišnik and Zametica issued public statements following the NATO air strikes, that the Bosnian Serbs would treat the UN as their enemy. ${ }^{20437}$ The Accused publicly warned against the

20431 P2273 (UNPROFOR report re meeting with Ratko Mladić, 4 June 1995), p. 4; Rupert Smith, T. 11414-11416 (9 February 2011).

20432 P2273 (UNPROFOR report re meeting with Ratko Mladić, 4 June 1995), p. 4; Rupert Smith, T. 11414-11416 (9 February 2011).

20433 P6521 (Intercept of conversation between Petar Makara and Momčilo Krajišnik, 15 June 1995), p. 1; Momčilo Krajišnik, T. 43899-43900 (20 November 2013). Koljević told Rechner that due to the intensity of the NATO air strikes, which was unexpected on the part of the Bosnian Serbs, the Bosnian Serbs felt that they needed to react in a way that would send a shock to the UN. Patrick Rechner, T. 11113-11114 (2 February 2011).

20434 See paras. 5944-5945.

20435 See paras. 5944-5945, 5871-5872, 5874-5876, 5880, 5890, 5894-5895, 5899, 5902, 5914-5915, 5917. See also P2268 (UNPROFOR report re telephone conversations with Ratko Mladić, 26 May 1995); P5013 (UNPROFOR Report re air strikes in Bosnia, 26 May 1995); Rupert Smith, T. 11371-11373 (8 February 2011); P2269 (UNPROFOR report re telephone conversation with Ratko Mladić, 29 May 1995), p. 2; [REDACTED]; P2434 (UNPROFOR protest letter to SRK, 3 June 1995). [REDACTED]. In discussing the hostage taking with Rechner, Koljević stated that he knew what had happened but was surprised to hear that the UNMOs had been threatened. Patrick Rechner, T. 11113-11114 (2 February 2011). Milenko Inđić stated that he never told Smith that UNPROFOR personnel would be killed or harmed. D2774 (Witness statement of Milenko Inđić dated 19 January 2013), para. 171. The Chamber notes that the evidence shows that repeated threats were made to harm and kill the UN personnel, these threats were communicated to Smith, among others, by Inđić, and the UN personnel were placed in locations of strategic and military importance to the VRS, placing them at great risk of being harmed or killed in the event of a NATO air strike.

20436 See paras. 5871-5872, 5874-5876, 5880, 5890, 5894-5895, 5899, 5902, 5914-5915, 5917.

20437 John Zametica, T. 42498-424501 (29 October 2013); P6474 (Article from Reuters Press entitled "Serb Official Vows Heavy Price for Raids”, 26 May 1995); D1055 (UNPROFOR report to Kofi Annan, 27 May 1995), ecourt p. 6. Krajišnik testified that detaining UN personnel was a "desperate attempt" on the part of the VRS to prevent further NATO air strikes but it was in no way done to harm the actual UN personnel who were shown on television. He further testified that the intent of the Bosnian Serb leadership was to deter the air strikes and that is why the detained UN personnel were shown on television but that "we had no wish to destroy these 
use of military intervention to free the hostages, stating that it would end in "catastrophe" and "a slaughter". ${ }^{20438} \mathrm{He}$ threatened to escalate retaliation by the Bosnian Serbs if the UN ordered more NATO air strikes. ${ }^{20439}$

5962. The Chamber is therefore satisfied beyond reasonable doubt that between 25 May and June 1995, there existed a JCE, the common purpose of which was to take UN personnel hostage in order to compel NATO to abstain from conducting further air strikes against Bosnian Serb targets. This common purpose came to fruition following the NATO air strikes on 25 and 26 May 1995 and involved a plurality of persons. These members of the JCE, including the Accused, ${ }^{20440}$ Mladić, Krajišnik, and Milovanović, shared the intent for the crime of hostage-taking. Members of the JCE implemented the common purpose themselves and/or by using members of the VRS and the MUP to act in furtherance of the common purpose. In doing so, orders were issued to take UN personnel hostage, the orders were implemented, and information was reported about the hostages taken. The common purpose lasted until the last of the UN personnel was released on 18 June 1995.

c. Findings on the Accused's intent: whether the Accused shared the common purpose of the JCE

5963. The Accused argues that, while he did agree that UN personnel should be detained, he never agreed or contemplated that threats should be made against them and that there is no evidence that the plan to detain the UN personnel included the issuance of threats. ${ }^{20441}$ In contrast, the Prosecution submits that the Accused was a central participant at every stage of the hostage taking. ${ }^{20442}$ Given the importance placed by the Accused on whether he shared the intent that threats be issued against the detained UN personnel, the Chamber will examine this element in detail below.

5964. Prior to the hostage-taking events, the Accused warned UNPROFOR that he would treat UN soldiers as enemies if NATO air strikes were conducted. ${ }^{20443}$ UNPROFOR had expressed its

young people”. Momčilo Krajišnik, T. 43339-43340 (12 November 2013). The Chamber notes that whether or not the Bosnian Serb leadership intended to actually harm the hostages is not an element of the crime of hostage taking. The accepted evidence discussed in this section of the Judgement shows that the Bosnian Serb political leadership was involved in the detention of the UN personnel at locations which placed them at a high risk of being harmed and this amounted to threatening to harm the UN personnel.

20438 D1056 (Reuters report re Radovan Karadžić, 1 June 1995), p. 1.

20439 D1056 (Reuters report re Radovan Karadžić, 1 June 1995), p. 2.

20440 The Accused's intent is discussed further below.

20441 Defence Final Brief, paras. 3354-3355, 3359-3360.

20442 Prosecution Final Brief, paras. 1107-1108.

20443 P2264 (UNPROFOR report re meeting with Radovan Karadžić, 9 May 1995); P2265 (UNPROFOR report re meeting with Radovan Karadžić, 9 May 1995), e-court p. 3. See also P2263 (UNPROFOR report re meetings with Bosnian Serb and Bosnian Muslim leadership, 1 May 1995), e-court pp. 2-3 (the Accused stated to Akashi 
own concerns about UN personnel being targeted by the VRS. ${ }^{20444}$ During a meeting with Smith on 9 May 1995, the Accused informed Smith that anyone who attacked the Bosnian Serbs was "their enemy" and made it clear that if NATO were to conduct air strikes against Bosnian Serb targets, then the UN forces would be attacked in retaliation or at least be "detained". 20445 The Accused again warned that the UN and NATO would be treated as enemies of the Bosnian Serbs. ${ }^{20446}$

5965. On 25 May 1995, after a warning issued by Smith prior to the NATO air strikes, the Accused, who was in Banja Luka at the time, again stated in a press interview that if the UN and NATO were to conduct air strikes, that he would "treat UN soldiers as "enemies"". 20447 On the same day, the Accused ordered Milovanović to activate the decision made the previous year ordering the VRS to arrest everything foreign in RS territory and to treat military personnel as prisoners of war and "hold them as hostages" till the end of the war. ${ }^{20448}$

5966. On 27 May 1995, the Accused approved an order issued by Milovanović to the commanders of the VRS corps to "place the captured UNPROFOR staff, as well as staff of the other international humanitarian organisations" at the "warehouses, in the areas of command posts, firing positions and other potential targets that may come under the air strike". ${ }^{20449}$

5967. On 1 June 1995, the Accused gave an interview to the Bosnian Serb television station in Pale stating that any attempt to liberate the detained UN personnel would "end in catastrophe" and it would "be a slaughter". ${ }^{20450} \mathrm{He}$ stated that the detained UN personnel were prisoners of war but he threatened to escalate the Bosnian Serb response if the UN ordered more NATO air strikes. ${ }^{20451}$

that if the international community treated the [Bosnian] Serbs like 'beasts in a cage', then that is how they would behave).

20444 P2260 (UNPROFOR report re meeting with Radovan Karadžić, 5 April 1995); P2263 (UNPROFOR report re meetings with Bosnian Serb and Bosnian Muslim leadership, 1 May 1995), e-court p. 4; P2264 (UNPROFOR report re meeting with Radovan Karadžić, 9 May 1995); P2265 (UNPROFOR report re meeting with Radovan Karadžić, 9 May 1995).

20445 P2265 (UNPROFOR report re meeting with Radovan Karadžić, 9 May 1995), e-court p. 3; John Zametica, T. 42474 (29 October 2013); Rupert Smith, T. 11357-11358 (8 February 2011); P2264 (UNPROFOR report re meeting with Radovan Karadžić, 9 May 1995).

20446 P2265 (UNPROFOR report re meeting with Radovan Karadžić, 9 May 1995), e-court p. 7; John Zametica, T. 42474 (29 October 2013); P2264 (UNPROFOR report re meeting with Radovan Karadžić, 9 May 1995).

20447 D988 (Article from AFP entitled "Serbs Will Treat UN as Enemies if Smith Airstrikes: Karadžić", 25 May 1995); Patrick Rechner, T. 11149 (2 February 2011); P5012 (UNPROFOR report re Sarajevo heavy weapon exclusion zone, 25 May 1995).

20448 D2149 (Aide mémoire of Manojlo Milovanović), pp. 56-57. See para. 5857.

20449 P2137 (Order of VRS Main Staff, 27 May 1995), p. 1. See para. 5860.

20450 D1056 (Reuters report re Radovan Karadžić, 1 June 1995), p. 1; Rupert Smith, T. 11886-11887 (15 February 2011). See also P888 (UNPROFOR Weekly Situation Report (Sarajevo), 3 June 1995), p. 2.

20451 D1056 (Reuters report re Radovan Karadžić, 1 June 1995), p. 2. See also D928 (BBC news report re UN personnel), at 07:30-08:16; Martin Bell, T. 9917-9918 (15 December 2010). 
5968. On 21 June 1995, the Accused gave an interview to the BBC, in which he discussed the detention of the UN personnel. ${ }^{20452}$ He admitted that the detention of the UN personnel was a mistake but that "one drastic move causes another drastic reaction", referring to the NATO air strikes as the first drastic move and the detention as the drastic reaction. ${ }^{20453} \mathrm{He}$ stated that he needed to do something very drastic "in order to prevent further attacks [from NATO]". 20454 The Accused called the detainees "UN war prisoners" and stated that he had ordered their release. ${ }^{20455}$ He stated that he was responsible for the actions of the VRS soldiers on the ground, stating that "we [he and the VRS] function as a State and I am Commander-in-Chief, Supreme Commander and everything that my Army do, I do back". 20456

5969. The Chamber is of the view that the statements, acts, and conduct of the Accused, as described above, are tantamount to having issued threats to injure, kill, or continue to detain the UN personnel and that he deliberately used the detained UN personnel as a bargaining tool to stop NATO air strikes. It is also clear from the Accused's statements and actions that he envisaged using the UN personnel as hostages. The only reasonable inference the Chamber can draw from this evidence is that the Accused intended not only to detain the UN personnel but also to issue threats while they were detained in order to achieve his objective of stopping further NATO air strikes of Bosnian Serb targets.

5970. Further, Mladić, Inđić, Zametica, Ribić, and members of the Bosnian Serb Forces communicated threats directly to UNPROFOR. ${ }^{20457}$ In particular, the evidence shows that Accused's close subordinates who the Chamber finds were the members of the JCE, were involved in issuing threats. When proposing an agreement to Janvier, Mladić stated that the VRS would no longer threaten the life and the security of members of UNPROFOR by the use of force. The only reasonable inference that can be drawn from this is that Mladic was aware of the threats and that he was involved in issuing threats. In addition, public statements were issued by Krajišnik and Zametica and media coverage at that time showed videos of UN personnel being threatened, handcuffed, and detained in locations of potential NATO air strikes. ${ }^{20458}$

\footnotetext{
20452 P5026 (Video footage of interview of Radovan Karadžić by John Simpson).

20453 P5026 (Video footage of interview of Radovan Karadžić by John Simpson).

20454 P5026 (Video footage of interview of Radovan Karadžić by John Simpson).

20455 P5026 (Video footage of interview of Radovan Karadžić by John Simpson).

20456 P5026 (Video footage of interview of Radovan Karadžić by John Simpson).

20457 See para. 5961.

20458 See paras. 5961, 5967-5968; P2184 (Serbian TV news report re UN personnel, with transcript); P2179 (Video footage of UN personnel); P2180 (Video footage of UN personnel); P2181 (Video footage of UN personnel); P2174 (Video footage of UN personnel, with transcript); P2024 (BBC news report re UN hostage-taking in Sarajevo, with transcript); P2153 (Serbian TV news report re UN personnel, with transcript).
} 
5971. On 26 May 1995, at 12 a.m., Zametica gave a statement to Bosnian Serb Radio in response to the NATO air strikes. ${ }^{20459}$ Zametica reiterated that the Bosnian Serbs had always maintained that if there were air strikes against them, the Bosnian Serbs would treat UNPROFOR personnel as their "enemies" and that the UN had "hired an assassin" in the form of NATO to execute its tasks. ${ }^{20460}$ He stated that if the NATO air strikes continued, the Bosnian Serbs would respond in the same manner but that they were also ready to negotiate. ${ }^{20461}$ On the same day, he visited Jahorinski Potok where UN personnel were detained. ${ }^{20462}$ The Chamber notes that as the Accused's personal advisor, Zametica was privy to "everything that was important" in the Presidency and would also communicate with the international community on behalf of the Accused. ${ }^{20463}$

5972. Given his relationship with Mladić, Krajišnik, and Zametica the only reasonable inference that can be drawn is that the Accused knew that threats were issued and that he approved of these threats. Moreover, as will be described below in relation to the Accused's contribution to the JCE, the Accused was closely involved at every stage of these events.

5973. Therefore, in light of the foregoing, the Chamber finds that the Accused intended for the threats to be issued in order to compel NATO to cease its air strikes and that he shared the common purpose and the intent for the crime of hostage taking, along with other members of the JCE.

\section{d. Findings on the Accused's contribution to the JCE}

\section{i. The Accused involvement in the lead up to NATO air strikes}

5974. On 5 April 1995, the Accused met with Smith at a hotel near Pale. ${ }^{20464}$ Smith expressed serious concerns to the Accused about the recent attacks on the safe areas, the breaches of the TEZ, the direct targeting of UNPROFOR personnel, and the disruption of humanitarian aid convoys. ${ }^{20465}$ Smith told the Accused that eventually UNPROFOR would be forced to respond with NATO air

\footnotetext{
20459 D1055 (UNPROFOR report to Kofi Annan, 27 May 1995), e-court p. 5.

20460 D1055 (UNPROFOR report to Kofi Annan, 27 May 1995), e-court p. 5; John Zametica, T. 42498-424501 (29 October 2013); P6474 (Article from Reuters Press entitled "Serb Official Vows Heavy Price for Raids", 26 May 1995).

20461 D1055 (UNPROFOR report to Kofi Annan, 27 May 1995), e-court p. 5; John Zametica, T. 42499-42500, 42504 (29 October 2013).

20462 See para. 5916; P2170 (Witness statement of Patrick Rechner dated 31 January 2011), para. 47; Patrick Rechner, T. 11098-11099 (2 February 2011).

20463 John Zametica, T. 42441, 42443-42444 (29 October 2013) (stating that he would appear in public to present the views of the Bosnian Serb leadership and he could not remember a "single occasion when [the Accused] or anyone else from the leadership, civilian leadership or even military leadership of the [RS] ever denied anything I said in public").

20464 P2260 (UNPROFOR report re meeting with Radovan Karadžić, 5 April 1995), p. 1; Rupert Smith, T. 11344 11347 (8 February 2011).

20465 P2260 (UNPROFOR report re meeting with Radovan Karadžić, 5 April 1995), p. 1. See paras. 4987-4990.
} 
strikes. $^{20466}$ The Accused responded that he thought the UN was assisting the Bosnian Muslims and that the VRS was going to start a counter-offensive. ${ }^{20467}$ The Accused wanted the UN to withdraw from all areas of confrontation. ${ }^{20468}$ Smith responded that as the UN commander, he needed to ensure that the UN's mandate to protect the safe areas was respected and that he could use NATO airpower if the safe areas were attacked. ${ }^{20469}$

5975. On 1 May 1995, the Accused, Krajišnik, Subotica, and Zametica met with Akashi and Smith in Pale to discuss an extension of the COHA. ${ }^{20470}$ The Accused told Akashi that the UN could count on the goodwill of the Bosnian Serbs but if the situation deteriorated (referring to the armed conflict in Croatia), so too would the relationship between the UN and the Bosnian Serbs. ${ }^{20471}$ Following this meeting, the UNPROFOR assessment was that the Bosnian Serbs would strike against their "international enemy" by targeting the UN and taking UN personnel hostage. $^{20472}$ The assessment further stated that

they [the Bosnian Serbs] will seek to bring NATO into play at the earliest opportunity so as to gain Serbian sympathy and to have the excuse to seize hostages and possibly 'punish' the UN by fire; methods that have always neutralized NATO in the past. We [UN] should expect more provocation for NATO and possibly the denial of convoy clearances to or from the enclaves; leave [sic] convoys would be an attractive choice for hostage taking. ${ }^{20473}$

5976. On 9 May 1995, the Accused and Zametica had another meeting with Smith. ${ }^{20474}$ Smith explained to the Accused that he had recommended NATO air strikes against VRS military targets in response to the VRS mortar and artillery attacks in Sarajevo on 7 and 8 May 1995 against the civilian population. ${ }^{20475}$ The Accused informed Smith that anyone who attacked the Bosnian Serbs was "their enemy" and made it clear that if NATO were to conduct air strikes against Bosnian Serb

\footnotetext{
20466 P2260 (UNPROFOR report re meeting with Radovan Karadžić, 5 April 1995), p. 1; Rupert Smith, T. 11346 (8 February 2011).

20467 P2260 (UNPROFOR report re meeting with Radovan Karadžić, 5 April 1995), p. 1.

20468 P2260 (UNPROFOR report re meeting with Radovan Karadžić, 5 April 1995), p. 1.

20469 P2260 (UNPROFOR report re meeting with Radovan Karadžić, 5 April 1995), p. 2.

20470 P2263 (UNPROFOR report re meetings with Bosnian Serb and Bosnian Muslim leadership, 1 May 1995), pp. 2-3; Rupert Smith, T. 11352-11355 (8 February 2011).

20471 P2263 (UNPROFOR report re meetings with Bosnian Serb and Bosnian Muslim leadership, 1 May 1995), pp. 2-3.

20472 P2263 (UNPROFOR report re meetings with Bosnian Serb and Bosnian Muslim leadership, 1 May 1995), p. 3.

20473 P2263 (UNPROFOR report re meetings with Bosnian Serb and Bosnian Muslim leadership, 1 May 1995), pp. 3-4.

20474 P2265 (UNPROFOR report re meeting with Radovan Karadžić, 9 May 1995); Rupert Smith, T. 11355-11360 (8 February 2011).

20475 P2265 (UNPROFOR report re meeting with Radovan Karadžić, 9 May 1995), e-court pp. 3, 6; Rupert Smith, T. 11355-11357 (8 February 2011).
} 
targets, then the UN forces would be attacked in retaliation or at least be "detained". ${ }^{20476}$ Furthermore, the Accused stated that the UN and NATO would be treated as enemies of the Bosnian Serbs. ${ }^{20477}$ The Accused told Smith that he would instruct Mladić to speak to Smith soon because he himself would be away for a few days in Banja Luka. ${ }^{20478}$

5977. On 21 May 1995, the Accused had a meeting with Smith near Pale to discuss, inter alia, the mandate of the UNPROFOR in $\mathrm{BiH}^{20479}$ Smith expressed his concern to the Accused about the "increasing targeting of UN personnel" and the debilitating effect of the denial of supplies and movement to the eastern enclaves. ${ }^{20480}$ The Accused told Smith that he had "no belief in the impartiality, efficiency or credibility of the UN". ${ }^{20481}$

5978. As discussed above, on 24 May 1995, Smith called Mladić to express his concern about the situation in and around Sarajevo and issued a warning that if the heavy weapons taken by the Bosnian Serbs were not returned to the WCPs by 12 p.m. on 25 May 1995, then NATO air strikes would commence. ${ }^{20482}$ The following day, Akashi spoke to the Accused and informed him that the VRS needed to return the four missing heavy weapons taken from the WCP earlier. ${ }^{20483}$ The Accused spoke to Milovanović about the deadline and told him that Akashi "had been after" him all day although the Accused did not want to talk to him and that he told Akashi that the Bosnian Serbs would treat the UN as enemies if they called in the NATO air strikes. ${ }^{20484}$ The Accused stated in a

\footnotetext{
20476 P2265 (UNPROFOR report re meeting with Radovan Karadžić, 9 May 1995), e-court p. 3; John Zametica, T. 42474 (29 October 2013); Rupert Smith, T. 11357-11358 (8 February 2011).

20477 P2265 (UNPROFOR report re meeting with Radovan Karadžić, 9 May 1995), e-court p. 7; John Zametica, T. 42474 (29 October 2013).

20478 P2264 (UNPROFOR report re meeting with Radovan Karadžić, 9 May 1995).

20479 P2266 (UNPROFOR report re meeting with Radovan Karadžić, 21 May 1995); Rupert Smith, T. 11362-11364 (8 February 2011).

20480 P2266 (UNPROFOR report re meeting with Radovan Karadžić, 21 May 1995).

20481 P2266 (UNPROFOR report re meeting with Radovan Karadžić, 21 May 1995).

20482 Rupert Smith, T. 11367-11368 (8 February 2011). See also P820 (Witness statement of David Harland dated 4 September 2009), para. 183.

20483 P5019 (UNPROFOR report re airt strike near Pale, 25 May 1995); D987 (Intercept of conversation between Radovan Karadžić and General Milovanović, 25 May 1995).

20484 D987 (Intercept of conversation between Radovan Karadžić and General Milovanović, 25 May 1995); Patrick Rechner, T. 11150-11151 (2 February 2011). See also Momčilo Krajišnik, T. 43341 (12 November 2013) who testified that there were a number of statements made by the Accused and the Bosnian Serbs in which they warned UNPROFOR and the international community that they should not "meddle" in the conflict and if they did so, they would be considered the "enemies" of the Bosnian Serbs. Later, in June 1995, the Accused stated to the Bosnian Serb Assembly that the Bosnian Serb leadership had decided to heat up the conflict and "take whatever we can, create a fiery atmosphere and dramatize, threaten an escalation, etc." and the Bosnian Serbs did that around Sarajevo by taking the four artillery pieces". P1410 (Transcript of $51^{\text {st }}$ session of RS Assembly, 14-15 June 1995), p. 329.
} 
press interview that if the UN and NATO were to conduct air strikes, that he would "treat UN soldiers as "enemies", 20485

\section{ii. The Accused's involvement in hostage taking}

5979. Following the NATO air strikes, the Accused ordered that the UN personnel be detained and kept in detention until assurances were made that there would be no further NATO air-strikes. On 25 May 1995, the Accused ordered Milovanović to activate the decision made the previous year ordering the VRS to "arrest everything foreign in RS territory and to treat military personnel as prisoners of war and hold them as hostages till the end of the war" ${ }^{20486}$ Consequently, Živanović issued an order to all units of the Drina Corps that "NATO aircrafts, which are a part of UNPROFOR, conducted operations against" the VRS and the VRS should respond by conducting operations against selected targets. ${ }^{20487}$ It stated that "if UNPROFOR continues its operations against our military and civilian targets, all units of the Corps must be on stand-by for action against UNPROFOR checkpoints and bases". ${ }^{20488}$ It further ordered the prevention of all movement of "UNPROFOR vehicles and of all other international organisations" in the area and to

20485 D988 (Article from AFP entitled "Serbs Will Treat UN as Enemies if Smith Airstrikes: Karadžić", 25 May 1995); Patrick Rechner, T. 11149 (2 February 2011).

20486 D2149 (Aide mémoire of Manojlo Milovanović), pp. 56-57. The Chamber notes UN personnel were already detained following the NATO air strikes in Goražde on 10 and 11 April 1994, see P1638 (Witness statement of Michael Rose dated 26 March 2009), paras. 81-82, 84, 90-92, 172; P1661 (Report from Ratko Mladić to VJ General Staff, 11 April 1994) and P1660 (Order of Drina Corps, 10 April 1994) (order from Milutin Skočaljić to the Drina Corps to block UNPROFOR convoys, disarm the UNPROFOR personnel, and take them to a "collection centre at a designated location"); P1662 (VRS Main Staff Report to Radovan Karadžić and VJ General Staff, 11 April 1994), pp. 3-4 (report from Milovanović, on 11 April 1994, to the Accused, Main Staff, and all corps command that following NATO air strikes, the order of the VRS Main Staff to ban all movement of UNPROFOR in the RS is being carried out); P1788 (VRS Main Staff Order, 13 April 1994), p. 1 (wherein Mladić issues an order on 13 April 1994 to place UN personnel in "premises outside of the facilities where they had been stationed to date, that is, in military facilities which are a potential target of the NATO Air Force, as per your choice", to limit their movement, guard them, prevent all communication, and treat them as prisoners of war); P855 (VRS Main Staff Order, 19 April 1994) (wherein Mladić issues an order, on 19 April 1994, to all the commands of the VRS corps to "immediately increase measures for the security and control of UNPROFOR and humanitarian organisations. In the event of massive air-raids against RS units and facilities, disarm and arrest them immediately, confiscate their weapons and combat equipment and use them for PVB/anti-aircraft warfare"); Rupert Smith, T. 7275-7277 (5 October 2010); D3497 (UNPROFOR report, 17 April 1994), p. 1. At other times, threats and orders were issued for the detention of UN personnel, see D3499 (UNPROFOR report, 4 May 1994), pp. 9-10 (at a meeting between the Accused and Akashi on 3 May 1994, the Accused stated that the VRS would retaliate against UNPROFOR if NATO launched air strikes and it would not limit itself to shooting down one plane); D3500 (UNPROFOR report, 7 October 1994) (at a meeting between the Accused, Mladić, Akashi, and others on 5 October 1994, Mladić stated that the next NATO air strikes will be "fatal" for UNPROFOR and he would "launch shelling on your positions immediately"); D2174 (VRS Main Staff Order, 23 November 1994); Manojlo Milovanović, T. 25708-25710 (5 March 2012) (wherein Milovanović testified that he issued an order, on 23 November 1994, to the VRS Main Staff and all VRS corps to arrest, disarm, and "put in prison near the firing positions" all UN personnel and that they "should be held hostage"); D3502 (Letter from Radovan Karadžić to Yasushi Akashi, 22 November 1994), p. 2 (where in the Accused informs Akashi that the Bosnian Serbs would treat UNPROFOR as their enemy if NATO air strikes were conducted in Bihać); Yasushi Akashi, T. 37721 (24 April 2013).

20487 P2149 (Order of Drina Corps, 25 May 1995), p. 1; Marcus Helgers, T. 10778-10779, 10790-10791 (26 January 2011).

20488 P2149 (Order of Drina Corps, 25 May 1995), p. 1. 
fire on UNPROFOR if fired upon. ${ }^{20489}$ The following day, Dragomir Milošević issued an order to all units of the SRK to immediately establish a full blockade of UN forces at check-points and on all roads in the "entire zone of the Corps" and to "use additional forces if the blockade is detected by the UN forces". 20490

5980. On 26 May 1995, Akashi sent a letter to the Accused expressing serious concerns about the situation in $\mathrm{BiH}$ and his wish that the $\mathrm{UN}$ and the Bosnian Serbs could resume a constructive working relationship. ${ }^{20491}$ Akashi warned that the deliberate harming of UNPROFOR personnel would result in pressure from the international community for additional military action, including further air strikes. ${ }^{20492}$

5981. On 27 May 1995, the Accused approved an order issued by Milovanović to the commanders of the VRS corps to "place the captured UNPROFOR staff, as well as staff of the other international humanitarian organisations" at the "warehouses, in the areas of command posts, firing positions and other potential targets that may come under the air strike". ${ }^{20493}$ The purpose of this order was to prevent NATO from carrying out further air strikes. ${ }^{20494}$ The "commanders of the units" were "personally responsible" to Milovanović for the execution of the order and were required to inform him in writing by the following day. ${ }^{20495}$ Following this order, on the same day, Lieutenant Colonel Jovica Karanović of the Main Staff Intelligence and Security Sector, issued an order to the Intelligence and Security Departments of the $1^{\text {st }}$ Krajina Corps, $2^{\text {nd }}$ Krajina Corps, Airforce and Anti-Aircraft Defence, the SRK, the Eastern Bosnia Corps, and the Herzegovina Corps stating that he had information that the NATO air strikes would continue against VRS military positions and that all commanders should familiarise themselves with this information. ${ }^{20496}$ He recommended that the captured UN personnel be placed in areas of possible NATO air

\footnotetext{
20489 P2149 (Order of Drina Corps, 25 May 1995), p. 1.

20490 P6097 (SRK Order, 26 May 1995); Dragomir Milošević, T. 33228-33231 (5 February 2013). Dragomir Milošević testified that while he did issue this order to detain UN personnel, the portion of the order stating "do not take into account any UN requests regarding the supplies of food, water, etc." did not pertain to the treatment of detained UN personnel, but rather to UN supply convoys and that UN personnel were treated as prisoners of war and provided with food and water. Dragomir Milošević, T. 33228-33231, 33247-33249 (5 February 2013).

20491 D1055 (UNPROFOR report to Kofi Annan, 27 May 1995), e-court p. 2; Rupert Smith, T. 11884-11886 (15 February 2011); John Zametica, T. 42498-42501 (29 October 2013).

20492 D1055 (UNPROFOR report to Kofi Annan, 27 May 1995), e-court p. 2.

20493 P2137 (Order of VRS Main Staff, 27 May 1995), p. 1; Rupert Smith, T. 11376 (8 February 2011); Manojlo Milovanović, T. 25721-25722 (5 March 2012). See para. 5860.

20494 P2137 (Order of VRS Main Staff, 27 May 1995), p. 1; Momčilo Krajišnik, T. 43887, 43897-43898 (20 November 2013).

20495 P2137 (Order of VRS Main Staff, 27 May 1995), p. 1; Momčilo Krajišnik, T. 43887, 43897-43898 (20 November 2013). Dragomir Milošević testified that this order was respected. Dragomir Milošević, T. 33247-33249 (5 February 2013).

20496 P2147 (VRS Main Staff Report, 27 May 1995).
} 
strikes. $^{20497}$ Similarly, on this day, Dragomir Milošević ordered all SRK units to include in their regular combat reports for that day the following: (i) the numbers of UN personnel who were "taken prisoner" and what country they were from; (ii) the numbers of UN personnel who were "under blockade" and their locations; and (iii) the number of equipment and ammunition seised from the UN personnel. ${ }^{20498} \mathrm{He}$ also ordered all SRK units to deploy stronger forces at the checkpoints that were "taken from UNPROFOR" and not to allow any recapturing of these check-points from UNPROFOR or "enemy forces". ${ }^{20499}$ Also implementing the order, Živanović issued an order to all commands of the Drina Corps to capture, disarm, and relocate UN personnel to locations such as depots and forward command posts. ${ }^{20500}$

5982. On 28 May 1995, Milovanović sent a report to the Accused and various VRS units stating that the $1^{\text {st }}$ Krajina Corps Command took approximately 57 UNPROFOR soldiers from the Eastern Bosnia Corps, including 43 UkrBat and 14 FreBat members. ${ }^{20501}$ The Herzegovina Corps Command held over 18 UNPROFOR soldiers. ${ }^{20502}$ In addition, the Accused was informed that the Drina Corps had captured 27 members of the BritBat Team. ${ }^{20503}$

5983. On 28 May 1995, at a meeting of the Supreme Command in Pale, attended by, inter alios, the Accused and Mladić, the detention of UN personnel was discussed. ${ }^{20504}$ The Supreme Command decided to further restrict the movement of UN forces in the enclaves, including in Sarajevo, and that the detained UN personnel should be treated as prisoners of war. ${ }^{20505}$

5984. On 29 May 1995, the Accused and Krajišnik spoke with an individual in contact with the British Ministry of Defence about the hostage situation. ${ }^{20506}$ The Accused demanded, as a condition for the release of the UN personnel, that NATO air strikes would cease and "they [UN] need to make a decision at the Security Council about abolishing the use of force. That is very important; that abolishing the use of force and then we'll see. The solution is the more important

\footnotetext{
20497 P2147 (VRS Main Staff Report, 27 May 1995); Marcus Helgers, T. 10760-10761 (26 January 2011).

20498 P2109 (SRK Order, 27 May 1995); [REDACTED]. However, Dragomir Milošević ordered that Russian UNPROFOR members must not be taken and if they were captured, they must be freed. P2109 (SRK Order, 27 May 1995); Rupert Smith, T. 11375 (8 February 2011). With respect to the incident on the Vrbanja Bridge, [REDACTED] could not "believe that General Milošević did not know that the SRK acted in violation of international law”. See para. 5893; P2407 (Witness statement of KDZ304), p. 9.

P5626 (Intercept of conversation between Radovan Karadžić, and unidentified male, and Momčilo Krajišnik, 29 May 1995).
} 
because then negotiations follow". ${ }^{20507}$ On the same day, the Accused sent a letter to Akashi demanding a guarantee that the use of force by the UN and NATO was no longer an option. ${ }^{20508}$ The Bosnian Serbs issued a press release stating that at a session of the VRS Supreme Command chaired by the Accused and attended by Mladić, the VRS declared "all UN Security Council resolutions, all NATO ultimatums, and all agreements with the United Nations that have been abused are hereby declared null and void". 20509

5985. On 30 May 1995, the Accused, the RS representative in Moscow at that time, Todor Dutina, and Krajišnik discussed the hostage situation. ${ }^{20510}$ Dutina told the Accused, "let me tell you, Radovan, we made a move and now we should wait for a move of the other side". 20511 The Accused was informed that an intermediary from France was going to try to negotiate with the Bosnian Serbs. ${ }^{20512}$ The Accused replied, "we are not interested in letting them [the detained UN personnel] go as much as they are interested in us letting them go". ${ }^{20513}$ He further stated that he thought of the UN as opponents and that the UN would not be able to rescue all the UN personnel, "but let them come; how can they come by aircrafts when we keep them [the detained UN personnel] at three hundred places? They can't liberate that, maybe one or none". ${ }^{20514}$ Krajišnik testified that the detention of the UN personnel was a "desperate attempt" by the Bosnian Serbs to prevent further air strikes. ${ }^{20515}$

\section{iii. The Accused's involvement in the release of UN hostages}

5986. Once it became clear that NATO would no longer be conducting air strikes against Bosnian Serb military targets, the Accused ordered the release of the UN hostages. On 2 June 1995, the Accused issued an order to the Main Staff and the MUP that 120 detained UNPROFOR personnel

\footnotetext{
20507 P5626 (Intercept of conversation between Radovan Karadžić, and unidentified male, and Momčilo Krajišnik, 29 May 1995), p. 2.

20508 P5015 (Letter from Radovan Karadžić to Boutros Boutros-Ghali, 29 May 1995).

20509 P887 (SRNA news report, 29 May 1995); P820 (Witness statement of David Harland dated 4 September 2009), para. 185; P2501 (RS Office for Press Contacts statement, 29 May 1995); P2451 (Witness statement of Anthony Banbury dated 19 May 2009), para. 170.

20510 P5607 (Intercept of conversation between Todor Dutina, Momčilo Krajišnik, and Radovan Karadžić, 30 May 1995), e-court pp. 5-6; John Zametica, T. 42492-42493 (29 October 2013); Momčilo Krajišnik, T. 4388443890 (20 November 2013).

20511 P5607 (Intercept of conversation between Todor Dutina, Momčilo Krajišnik, and Radovan Karadžić, 30 May 1995), p. 5.

20512 P5607 (Intercept of conversation between Todor Dutina, Momčilo Krajišnik, and Radovan Karadžić, 30 May 1995), p. 6.

20513 P5607 (Intercept of conversation between Todor Dutina, Momčilo Krajišnik, and Radovan Karadžić, 30 May 1995), p. 6.

20514 P5607 (Intercept of conversation between Todor Dutina, Momčilo Krajišnik, and Radovan Karadžić, 30 May 1995), p. 11.
} 
should be released. ${ }^{20516}$ The Accused also ordered that a detailed report be submitted to him upon completion of this order. ${ }^{20517}$ On the same day, Mladić implemented the order to the $1^{\text {st }}$ Krajina Corps, $2^{\text {nd }}$ Krajina Corps, Airforce and Anti-Aircraft Defence, the SRK, the Eastern Bosnia Corps, the Herzegovina Corps, and the Drina Corps to release 120 UNPROFOR personnel who were "taken prisoner" in the Pale area and turned them over to the MUP who would organise their transport to the FRY. ${ }^{20518}$

5987. On 6 June 1995, the Accused issued an order to release 95 more UNPROFOR soldiers and to hand them over to the MUP in the garrisons of Bijeljina and Višegrad on 7 June 1995. ${ }^{20519}$ Again, Mladić implemented this order but all other UNPROFOR soldiers who were still detained were to remain until further instructions. ${ }^{20520}$ Approximately $150 \mathrm{UN}$ personnel remained detained by the VRS. ${ }^{20521}$

5988. On 13 June 1995, the Accused issued an order to the Commander and Assistant Commander for Intelligence and Security of the Main Staff, directing them to release all captured UN soldiers at 11 a.m. that day and to hand them over to Jovica Stanišić. ${ }^{20522} 15$ UNMOs were to remain in VRS custody near Pale and be released on 18 June $1995 .^{20523}$ The following day, the Accused made a statement to the Belgrade media stating that $15 \mathrm{UN}$ personnel would be released later due to "technical reasons". ${ }^{20524}$ The Accused stated: "[W]e regret what we had to do"; however, the Bosnian Serbs were attacked, they needed to defend themselves by all means. ${ }^{20525}$

\footnotetext{
20516 P889 (Radovan Karadžić's Order to VRS and to RS MUP, 2 June 1995); P820 (Witness statement of David Harland dated 4 September 2009), para. 189; P3804 (Witness statement of Charles Kirudja dated 17 November 2010), para. 160. See also P3807 (Dispatch from RS MUP to Radovan Karadžić, 2 June 1995).

20517 P889 (Radovan Karadžić's Order to VRS and to RS MUP, 2 June 1995); P820 (Witness statement of David Harland dated 4 September 2009), para. 189. See also P3807 (Dispatch from RS MUP to Radovan Karadžić, 2 June 1995).

20518 P2152 (Order of VRS Main Staff, 2 June 1995), p. 1; P3804 (Witness statement of Charles Kirudja dated 17 November 2010), paras. 159-160; see also D4530 (Intercept of conversation between Radovan Karadžić and Fnu Gojević, undated), p. 5 (referring to one third having been released).

P891 (Radovan Karadžić's Order to VRS and RS MUP, 6 June 1995); Aleksandr Vishnevski, T. 10712-10713 (25 January 2011); KDZ196, T. 10725-10726 (25 January 2011); P820 (Witness statement of David Harland dated 4 September 2009), para. 192.

20520 P2139 (Order of VRS Main Staff, 6 June 1995), p. 3.

20521 P890 (UNPROFOR Weekly Situation Report (Sarajevo), 10 June 1995), p. 2; P820 (Witness statement of David Harland dated 4 September 2009), para. 191.

20522 P2156 (Radovan Karadžić's Order to VRS Main Staff, 13 June 1995), p. 1; Janusz Kalbarczyk, T. 10863-10864 (28 January 2011).

20523 P2156 (Radovan Karadžić's Order to VRS Main Staff, 13 June 1995), p. 1.

20524 P2159 (UNPROFOR report, 14 June 1995), p. 1; P2182 (Video footage of Radovan Karadžić's press conference re UN personnel).

20525 P2182 (Video footage of Radovan Karadžić's press conference re UN personnel).
} 
5989. On 15 June 1995, at the $51^{\text {st }}$ Session of the RS Assembly, the Accused recalled the escalation of hostilities, that he "decided to opt for an aggravation of the situation", and that they [Bosnian Serbs] had to "heat up the situation", the Accused stated:

\begin{abstract}
We ordered the arrest, we didn't go into detail as to when they would be tied up, but it had a good effect, it was very shocking for the world, now it's easy, when they ask us if that was a nice gesture, I ask if it's a nice gesture to bomb the Serbian rear and frighten our children and old people. [...] we couldn't let them all go at once, but in proportions, we even left 15 until the end of this week so we could keep the weapons we have in Sarajevo, knowing about the offensive and planning to do something in Sarajevo. Now any return of weapons is out of the question because of this offensive, so that, in a way, we even somewhat benefited from this whole crisis. ${ }^{20526}$
\end{abstract}

5990. The Accused further stated that after assessing the situation and noting that the media was describing the UN personnel as hostages, the Bosnian Serbs realised they may have a "spoil" in their hands which would result in a negative effect and "a justification for a possible military intervention" where they would lose their state. ${ }^{20527}$ They therefore initiated a "cool down process" and "at the same time considered who to give those hostages back to". ${ }^{20528}$

5991. On 16 June 1995, the Security Council passed Resolution 998 condemning the attacks on the UNPROFOR personnel and demanding that the VRS immediately and unconditionally release all detained UNPROFOR personnel. ${ }^{20529}$ On 17 June 1995, the Accused issued an order to the Main Staff that all UN personnel in VRS custody be released by 2 p.m. on 18 June $1995 .{ }^{20530}$ The order was implemented by Mladić, who issued it to the commanders of the $1^{\text {st }}$ Krajina Corps, $2^{\text {nd }}$ Krajina Corps, Eastern Bosnia Corps, Drina Corps, SRK, Herzegovina Corps, Air Force and Air Defence but ordering that 26 UN personnel be handed over to the MUP by 18 June 1995 only after UNPROFOR releases four captured VRS soldiers. ${ }^{20531}$ By 18 June 1995, UNPROFOR reported that all remaining UN personnel had been released and UNPROFOR had also released the four VRS soldiers. ${ }^{20532}$

\title{
iv. Conclusion
}

5992. The Chamber is satisfied beyond reasonable doubt that the Accused significantly contributed to the common purpose to take UN personnel hostage in order to deter NATO from engaging in further air-strikes. The Accused was the driving force behind the hostage taking and an

\footnotetext{
20526 P1410 (Transcript of $51^{\text {st }}$ Session of RS Assembly, 14-15 June 1995), pp. 329-332.

20527 P1410 (Transcript of $51^{\text {st }}$ Session of RS Assembly, 14-15 June 1995), p. 330.

20528 P1410 (Transcript of $51^{\text {st }}$ Session of RS Assembly, 14-15 June 1995), pp. 330-331.

20529 P5014 (UNSC Resolution 998 (1995), 16 June 1995).

20530 P893 (Radovan Karadžić's Order to VRS, 17 June 1995), p. 1; P820 (Witness statement of David Harland dated 4 September 2009), para. 194.

20531 P2183 (Order of VRS Main Staff, 17 June 1995), p. 1; Patrick Rechner, T. 11185 (2 February 2011).

20532 P892 (UNPROFOR Weekly Situation Report Sarajevo), 24 June 1995), pp. 2-3; P820 (Witness statement of David Harland dated 4 September 2009), para. 193.
} 
active participant in every aspect of the events. He directly participated in the operation to take UN personnel hostage as evidenced by his involvement in: (i) formulating and implementing the hostage taking plan, (ii) the statements he made prior to the NATO air strikes to attack and/or detain UN personnel, (iii) directing others to detain the UN personnel and place them in locations of military significance to the VRS after the NATO air strikes, (iv) monitoring the hostage taking operation, (v) receiving reports about the hostages, and vi) placing conditions on the release of the hostages. $^{20533}$ The Accused issued statements that the UN personnel would not be released unless NATO ceased the air strikes. ${ }^{20534}$ Once the UN conceded to his demands that NATO air strikes would cease, the Accused issued orders for the release of the UN personnel. ${ }^{20535}$

\section{e. Count 11: Conclusion}

5993. The Chamber therefore finds that the Accused is criminally responsible, as a member of the Hostages JCE, under Article 7(1) of the Statute for the crime of taking hostages pursuant to Count 11 of the Indictment.

5994. In addition to the Accused's liability through participation in a JCE, the Prosecution also alleges that the Accused is individually criminally responsible for planning, instigating, ordering, and/or aiding and abetting the crime of taking hostages through certain acts and omissions. ${ }^{20536}$ It also charges the Accused with individual criminally responsibility pursuant to Article 7(3) of the Statute. $^{20537}$ However, having considered all of the evidence and in light of the findings made above, the Chamber finds that commission through JCE pursuant to Article 7(1) most accurately and appropriately reflects the Accused's responsibility for the crime of hostage taking as charged in the Indictment. The Chamber will therefore not analyse the Accused's responsibility under the other modes alleged by the Prosecution in the Indictment.

\section{E. SUMMARY OF FINDINGS}

5995. In the previous sections of the Judgement, the Chamber has made findings on the charges related to each of the four components of this case and on the Accused's responsibility in relation thereto. The Chamber will now summarise these findings, first in relation to each of the alleged JCEs and second with regard to each of the Counts of the Indictment.

\footnotetext{
20533 See paras. 5957, 5961, 5964-5966, 5968, 5975-5979, 5989, 5981-5982.

20534 See paras. 5967, 5981-5985.

20535 See paras. 5958, 5986-5988, 5990-5991.

20536 Indictment, paras. 30-31; Prosecution Final Brief, paras. 1115-1118.

20537 Indictment, para. 32; Prosecution Final Brief, paras. 1113-1114.
} 


\section{a. Summary of findings on the four alleged JCEs}

5996. In relation to the Municipalities component, the Chamber found that the Overarching JCE came into existence in October 1991 and continued until 30 November 1995. Its common purpose was to permanently remove Bosnian Muslims and Bosnian Croats from Bosnian Serb claimed territory and was shared by the Accused, Momčilo Krajišnik, Nikola Koljević, Biljana Plavšić, Ratko Mladić, Mićo Stanišić, Momčilo Mandić, Željko Ražnatović (Arkan), and Vojislav Šešelj. The common plan of the Overarching JCE involved the commission of the crimes of deportation, inhumane acts (forcible transfer), and persecution (through forcible transfer, deportation, unlawful detention and imposition of discriminatory measures). The Chamber found that the Accused shared the intent for these crimes and, by virtue of his actions and omissions, significantly contributed to the furtherance of the common purpose of the Overarching JCE. In addition, the Chamber found that the Accused acted in furtherance of the common purpose of the Overarching JCE with the awareness of the possibility that the crimes of murder, extermination, and persecution (through killings, cruel or inhumane treatment, forced labour at the frontline, the use of non-Serbs as human shields, the appropriation or plunder of property, and the wanton destruction of private property, including cultural and sacred sites) might be committed either by members of the Overarching JCE or Serb Forces who were used by him or other members of the Overarching JCE to carry out the common plan, and that he willingly took that risk.

5997. In relation to the Sarajevo component, the Chamber found that the Sarajevo JCE came into existence in late May 1992 and continued until October 1995. The Chamber also found that the common plan of the Sarajevo JCE was to establish a campaign of sniping and shelling, the primary purpose of which was to spread terror among the civilian population of Sarajevo. The common purpose of the Sarajevo JCE was shared by the Accused, Ratko Mladić, Momčilo Krajišnik, Nikola Koljević, Biljana Plavšić, Stanislav Galić, and Dragomir Milošević. The common plan of the Sarajevo JCE involved the commission of murder, unlawful attacks on civilians, and terror. The Chamber found that the Accused shared the intent to commit these crimes and that, by virtue of his actions and omissions, the Accused significantly contributed to the furtherance of the common purpose of the Sarajevo JCE.

5998. In relation to the Srebrenica component, the Chamber found that the Srebrenica JCE came into existence as Srebrenica fell in July 1995. Its common purpose was to eliminate the Bosnian Muslims in Srebrenica-first through the forcible removal of the women, children, and the elderly, and later through the killing of the men and boys-and was shared by the Accused, Ratko Mladić, Ljubiša Beara, and Vujadin Popović. The Chamber found that the original scope of the common plan involved the commission of inhumane acts (forcible transfer) and persecution, and that the 
expanded scope of the common plan also involved the commission of murder and extermination. The Chamber also found that the Accused shared the intent for these crimes and that he agreed with the expanded common purpose, i.e., the killing of the men and boys, on the evening of 13 July 1995. The Chamber further found that the members of the Srebrenica JCE intended to kill every able-bodied Bosnian Muslim male from Srebrenica while forcibly removing women, children and the elderly, and that such intent amounted to the intent to destroy the Bosnian Muslims in Srebrenica. Therefore, the Chamber is satisfied that genocide was within the scope of the expanded common purpose. The Chamber finally found that, by virtue of his actions and omissions, the Accused significantly contributed to the furtherance of the common purpose of the Srebrenica JCE. In addition, the Chamber found that the Accused, as a superior exercising effective control over his subordinates, failed to punish the killings and the related acts of persecution that occurred prior to the evening of 13 July 1995, which he either knew or had reason to know.

5999. The Chamber found that the Hostages JCE existed between 25 May and June 1995 and that its common purpose was to take UN personnel hostage in order to compel NATO to abstain from conducting further air strikes against Bosnian Serb targets. The Chamber found that this common purpose came to fruition following the NATO air strikes on 25 and 26 May 1995 and involved a plurality of persons, including the Accused, Ratko Mladić, Momčilo Krajišnik, and Manojlo Milovanović, who all shared the intent for the crime of hostage-taking. The Chamber further found that Accused significantly contributed to the furtherance of the common purpose the Hostages JCE.

b. Summary of findings on the Counts of the Indictment

\section{i. Count 1 (genocide)}

6000. In relation to Count 1 , genocide in the Count 1 Municipalities, the Chamber found that it was not satisfied beyond reasonable doubt that the acts under Article 4(2) of the Statute in the Count 1 Municipalities were committed with genocidal intent. Further, the Chamber was not satisfied that the only reasonable inference to be drawn from the evidence was that named members of the alleged Overarching JCE, including the Accused, other Bosnian Serbs not named as alleged members of the Overarching JCE, or physical perpetrators possessed such intent to destroy the Bosnian Muslim and/or Bosnian Croat groups in the Count 1 Municipalities as such. Therefore, the Accused bears no individual criminal responsibility in relation to Count 1 .

\section{ii. Count 2 (genocide)}

6001. In relation to Count 2, genocide in Srebrenica, the Chamber found that the Accused bears individual criminal responsibility pursuant to Articles 7(1) and 7(3) of the Statute. However, since 
the Chamber already found the Accused responsible for genocide on the basis of his participation in the Srebrenica JCE, the Chamber will not enter a conviction pursuant to Article 7(3) of the Statute in relation to Count 2 .

iii. Count 3 (persecution, a crime agains humanity)

6002. In relation to the Municipalities component, the Chamber found that the Accused bears individual criminal responsibility pursuant to Article 7(1) on the basis of his participation in the Overarching JCE. For the Srebrenica component, the Chamber found that the Accused bears responsibility pursuant to Article 7(1), on the basis of his participation in the Srebrenica JCE, ${ }^{20538}$ and pursuant to Article 7(3) for having failed to punish the killings committed by his subordinates prior to the evening of 13 July 1995 and the related acts of persecution.

\section{iv. Count 4 (extermination, a crime against humanity)}

6003. In relation to the Municipalities component, the Chamber found that the Accused bears individual criminal responsibility pursuant to Article 7(1) on the basis of his participation in the Overarching JCE. For the Srebrenica component, the Chamber found that the Accused bears responsibility pursuant to Article 7(1), on the basis of his participation in the Srebrenica JCE, ${ }^{20539}$ and pursuant to Article 7(3) for having failed to punish the killings committed by his subordinates prior to the evening of 13 July 1995.

\section{v. Count 5 (murder, a crime against humanity)}

6004. In relation to the Municipalities and Sarajevo components, the Chamber found that the Accused bears individual criminal responsibility pursuant to Article 7(1) with regard to his participation in the Overarching JCE and the Sarajevo JCE. For the Srebrenica component, the Chamber found that the Accused bears responsibility pursuant to Article 7(1), on the basis of his participation in the Srebrenica JCE, ${ }^{20540}$ and pursuant to Article 7(3) for having failed to punish the killings committed by his subordinates prior to the evening of 13 July 1995.

\footnotetext{
20538 The Chamber has held that the Accused cannot be held responsible through his participation in the Srebrenica JCE for the killings and related acts of persecution which occurred prior to the evening of 13 July 1995.

20539 The Chamber has held that the Accused cannot be held responsible through his participation in the Srebrenica JCE for the killings and related acts of persecution which occurred prior to the evening of 13 July 1995.

20540 The Chamber has held that the Accused cannot be held responsible through his participation in the Srebrenica JCE for the killings and related acts of persecution which occurred prior to the evening of 13 July 1995.
} 
vi. Count 6 (murder, a violation of the laws or customs of war)

6005. In relation to the Municipalities and Sarajevo components, the Chamber found that the Accused bears individual criminal responsibility pursuant to Article 7(1) on the basis of his participation in the Overarching JCE and the Sarajevo JCE. For the Srebrenica component, the Chamber found that the Accused bears responsibility pursuant to Article 7(1), on the basis of his participation in the Srebrenica JCE, ${ }^{20541}$ and pursuant to Article 7(3) for having failed to punish the killings committed by his subordinates prior to the evening of 13 July 1995.

vii. Count 7 (deportation, a crime against humanity)

6006. The Chamber found that the Accused bears individual criminal responsibility pursuant to Article 7(1) on the basis of his participation in the Overarching JCE.

viii. Count 8 (inhumane acts-forcible transfer, a crime against humanity)

6007. The Chamber found that the Accused bears individual criminal responsibility pursuant to Article 7(1) on the basis of his participation in the Overarching JCE and the Srebrenica JCE.

ix. Count 9 (terror, a violation of the laws or customs of war)

6008. In relation to Count 9, terror, a violation of the laws or customs of war, the Chamber found that the Accused bears individual criminal responsibility pursuant to Article 7(1) on the basis of his participation in the Sarajevo JCE.

x. Count 10 (unlawful attacks on civilians, a violation of the laws or customs of war)

6009. The Chamber found that the Accused bears individual criminal responsibility pursuant to Article 7(1) on the basis of his participation in the Sarajevo JCE.

xi. Count 11 (hostage taking, a violation of the laws or customs of war)

6010. The Chamber found that the Accused bears individual criminal responsibility pursuant to Article 7(1) on the basis of his participation in the Hostages JCE.

20541 The Chamber has held that the Accused cannot be held responsible through his participation in the Srebrenica JCE for the killings and related acts of persecution which occurred prior to the evening of 13 July 1995. 


\section{F. Cumulative CONVictions}

1. Law on cumulative convictions and specific charges in this case

6011. The Chamber can enter multiple convictions under different provisions of the Statute for the same conduct only if each statutory provision involved has a materially distinct element not contained in the other. An element is materially distinct from another if it requires proof of a fact not required by the other. ${ }^{20542}$ If this test is not met, only a conviction under the more specific provision should be entered because the more specific offence subsumes the less specific one. ${ }^{20543}$ The purpose of the cumulative conviction test is therefore to ensure that an accused "is convicted only for distinct offences, and at the same time, ensuring that convictions entered fully reflect his criminality". 20544

6012. In applying the cumulative convictions test, a Chamber must compare in the abstract all the general requirements of the statutory crimes in question, as well as the elements of the charged offences, to determine whether each crime requires, as a matter of law, proof of an element that the others do not. ${ }^{20545}$ The focus of the test is, however, on the legal elements of each crime that may be subject to cumulative conviction rather than the underlying conduct of an accused. ${ }^{20546}$

a. Cumulative convictions under Articles 3 and 5 of the Statute

6013. In the Indictment, murder is the only offence charged both as a violation of the laws or customs of war punishable under Article 3 of the Statute and as a crime against humanity under Article 5 of the Statute. ${ }^{20547}$

6014. Cumulative convictions for the same conduct under Article 3 and Article 5 of the Statute are permissible given that crimes against humanity constitute crimes distinct from violations of the laws or customs of war because each contains an element not present in the other. ${ }^{20548}$ Specifically, Article 3 requires a close link between the acts of an accused and the armed conflict, which is not

\footnotetext{
20542 Čelebići Appeal Judgement, para. 412 (confirmed in Krajišnik Appeal Judgement, para. 386; Strugar Appeal Judgement, para. 321; Galić Appeal Judgement, para. 163; Naletilić and Martinović Appeal Judgement; para. 584; Stakić Appeal Judgement, para. 355; Kordić and Čerkez Appeal Judgement, para. 1032; Krstić Appeal Judgement, para. 218). See also Kunarac et al. Appeal Judgement, para. 173.

20543 Galić Appeal Judgement, para. 163; Krstić Appeal Judgement, para. 218; Čelebići Appeal Judgement, para. 413.

20544 Kordić and Čerkez Appeal Judgement, para. 1033 (confirmed in Stakić Appeal Judgement, para. 356). See also Naletilić and Martinović Appeal Judgement, para. 585.

20545 Kordić and Čerkez Appeal Judgement, paras. 1033, 1039-1040.

20546 Dragomir Milošević Appeal Judgement, para. 39; Nahimana Appeal Judgement, para. 1020; Stakić Appeal Judgement, para. 356 (confirmed in Strugar Appeal Judgement, para. 322; Krajišnik Appeal Judgement, para. 387).

20547 Indictment, para. 67.

20548 Galić Appeal Judgement, para. 165; Kordić and Čerkez Appeal Judgement, para. 1036; Kunarac Appeal Judgement, para. 176.
} 
required for crimes charged under Article 5; in contrast, Article 5 requires proof that the act occurred as part of a widespread or systematic attack against a civilian population, which is not required for crimes charged under Article $3 .^{20549}$ On this basis, the Appeals Chamber has held that cumulative convictions for murder under Article 3 as a violation of the laws or customs of war and murder as a crime against humanity under Article 5 are permissible given that "each Article has an element requiring proof of a fact not required by the other". ${ }^{20550}$

b. Cumulative convictions for terror and unlawful attacks on civilians under Article 3 of the Statute

6015. Under Count 9 of the Indictment, the Accused is alleged to be criminally responsible for acts of violence the primary purpose of which was to spread terror among the civilian population. ${ }^{20551}$ The Accused is also alleged to be criminally responsible for unlawful attacks on civilians, under Count 10 of the Indictment. ${ }^{20552}$ Both offences are punishable as violations of the laws or customs of war under Article 3 of the Statute.

6016. The Appeals Chamber has clarified, that despite the similarities between the elements of terror and unlawful attacks on civilians, the two are separate and distinct offences as each requires proof of a fact not required by the other. ${ }^{20553}$ Unlawful attacks on civilians require proof of death or serious injury to body or health which is not required for terror. ${ }^{20554}$ Conversely, terror requires proof of a specific intent to spread terror among the civilian population which is not an element of unlawful attacks on civilians. ${ }^{20555}$ Accordingly, the Chamber can enter cumulative convictions for these two offences, even when they are based on the same conduct. ${ }^{20556}$

\section{c. Cumulative convictions for intra Article 5 convictions}

6017. Under Article 5 of the Statute, the Accused is alleged to be criminally responsible for murder, extermination, deportation, other inhumane acts (forcible transfer), and persecution as crimes against humanity. ${ }^{20557}$ With respect to persecution under Article 5(h), the alleged

\footnotetext{
20549 Galić Appeal Judgement, para. 165; Jelisić Appeal Judgement, para. 82 (confirmed in Kordić and Čerkez Appeal Judgement, para. 1036).

20550 Jelisić Appeal Judgement, para. 82. See also Kordić and Čerkez Appeal Judgement, para. 1038.

20551 Indictment, para. 82.

20552 Indictment, para. 82.

20553 Dragomir Milošević Appeal Judgement, para. 39.

20554 See paras. 451-455.

20555 See paras. 463-466.

20556 Dragomir Milošević Appeal Judgement, para. 39.

20557 Indictment, paras. 60, 67, 75.
} 
underlying acts of this crime specifically identified in the Indictment include, inter alia, killings, ${ }^{20558}$ forcible transfer, ${ }^{20559}$ and deportation. ${ }^{20560}$

6018. The Appeals Chamber has held that convictions for persecution as a crime against humanity are permissibly cumulative with other crimes against humanity because each has a materially distinct element not contained in the other. ${ }^{20561}$ Following this reasoning, it is possible for convictions to be entered for persecution as a crime against humanity under Article 5(h) on the one hand and murder under Article 5(a) of the Statute on the other. ${ }^{20562}$

6019. It has also been held that cumulative convictions for persecution and other inhumane acts are permissible given that other inhumane acts require proof that the accused caused serious bodily or mental harm to the victim(s) regardless of whether the act or omission causing the harm discriminates in fact or was specifically intended as discriminatory which is required by persecutions. $^{20563}$ It has been held by the Appeals Chamber that it is thus possible to enter cumulative convictions for persecution, deportation and other inhumane acts (forcible transfer). ${ }^{20564}$ Similarly, it has been held that cumulative convictions for the crime of extermination under Article 5 (b) of the Statute and persecution as a crime against humanity under Article 5(h) of the Statute are permissible. $^{20565}$

6020. In contrast, the crime of murder does not require any material elements to be proven over and above those required for extermination; therefore, where the elements of murder under Article 5(a) of the Statute and extermination under Article 5(b) of the Statute are established on the basis of the same underlying facts, extermination is the more specific crime, and cumulative convictions under Articles 5(a) and 5(b) are impermissible. ${ }^{20566}$

\footnotetext{
20558 Indictment, para. 60(a).

20559 Indictment, para. 60(f).

20560 Indictment, para. 60(f).

20561 Naletilić Appeal Judgement, para. 589; Kordić and Čerkez. Appeal Judgement, paras. 1039-1043.

20562 Kordić and Čerkez. Appeal Judgement, paras. 1041-1043 (confirmed in Bagosora Appeal Judgement, para. 414; Krajišnik Appeal Judgement, paras. 388-391; Naletilić and Martinović Appeal Judgement, para. 589; Stakić Appeal Judgement, paras. 359-362, 367).

20563 Kordić and Čerkez Appeal Judgement, para. 1042.

20564 Krajišnik Appeal Judgement, para. 391; Naletilić Appeal Judgement, para. 589; Stakić Appeal Judgement, paras. 360, 366-367.

20565 Bagosora Appeal Judgement, para. 735; Nahimana Appeal Judgement, para. 1026 (confirming Stakić Appeal Judgement, paras. 364, 367); Naletilić and Martinović Appeal Judgement, para. 589.

20566 Stakić Appeal Judgement, para. 366; Bagosora Appeal Judgement, paras. 416 (confirmed in Ntabakuze Appeal Judgement, paras. 260-261), 736.
} 


\section{d. Cumulative convictions with respect to genocide}

6021. The Appeals Chamber has held that cumulative convictions for genocide and crimes against humanity are permissible on the basis of the same acts, given that each has a materially distinct element from the other. ${ }^{20567}$ For example, cumulative convictions for extermination under Article 5(b) and for genocide under Article 4 are permissible. ${ }^{20568}$ The same principle applies to convictions for genocide, which requires, inter alia, the intent to destroy, in whole or in part, a national, ethnical, racial or religious group as such, and persecution as a crime against humanity, which must have been committed as part of a widespread or systematic attack on a civilian population $^{20569}$ and with the intention to discriminate on political, racial, or religious grounds. ${ }^{20570}$

\section{Findings}

6022. The Chamber found that the Accused's individual criminal responsibility has been established pursuant to Articles 7(1) and/or 7(3) $)^{20571}$ of the Statute for the following Counts:

- Count 2: Genocide (Article 4(3)(a));

- Count 3: Persecution, a crime against humanity (Article 5(h));

- Count 4: Extermination, a crime against humanity (Article 5(b));

- Count 5: Murder, a crime against humanity (Article 5(a));

- Count 6: Murder, a violation of the laws or customs of war (Article 3);

- Count 7: Deportation, a crime against humanity (Article 5(d));

- Count 8: Inhumane Acts (forcible transfer), a crime against humanity (Article 5(i));

- Count 9: Acts of violence the primary purpose of which is to spread terror among the civilian population, a violation of the laws and customs of war (Article 3);

- Count 10: Unlawful attacks on civilians, a violation of the laws or customs of war (Article 3); and

Nahimana Appeal Judgement, paras. 1029-1030. See also Ntagerura Appeal Judgement, para. 426. Simba Appeal Judgement, para. 277; Krstić Appeal Judgement, paras. 219-227.

Nahimana Appeal Judgement, para. 1032; Krstić Appeal Judgement, paras. 228-229. See paras. 497-500.

See paras. 5849-5850 (identifying crimes in Srebrenica for which convictions have been entered pursuant to Article 7(3)). All remaining convictions will be entered pursuant to Article 7(1).
} 
- Count 11: Taking of hostages, a violation of the laws or customs of war (Article 3).

6023. In the present case, the only crimes which are impermissibly cumulative are extermination and murder as crimes against humanity, charged pursuant to Counts 4 and 5 of the Indictment, respectively. Extermination has been found to be the more specific crime because it contains a material element- "that the killings occur on a mass scale and the perpetrator intended by his acts this result"- that murder does not. ${ }^{20572}$ Accordingly, the Chamber will not enter a conviction for murder as a crime against humanity with respect to specific killing incidents which the Chamber found also amounted to extermination. ${ }^{20573}$

6024. For these overlapping incidents, murder as a crime against humanity is considered to be subsumed under extermination and no conviction with regard to these incidents will be entered under Count 5. ${ }^{20574}$ For all remaining established killing incidents, the Chamber will enter a conviction for murder as a crime against humanity. ${ }^{20575}$ This does not impact the conviction for murder as a violation of the laws or customs of war under Article 3 of the Statute, which is not impermissibly cumulative with murder or extermination as crimes against humanity. ${ }^{20576}$

\section{SENTENCING}

\section{A. PURPOSES OF SENTENCING}

6025. According to the Tribunal's case-law, retribution and deterrence are the primary objectives of sentencing. ${ }^{20577}$ The Appeals Chamber has held that "a sentence proportional to the gravity of

20572 Krajišnik Trial Judgement, para. 716 (not challenged on appeal) (relying on Ntakirutimana and Ntakirutimana Appeal Judgement, paras. 522, 542; Stakić Appeal Judgement, para. 260). See also Stakić Appeal Judgement, para. 366.

20573 See paras. 2446-2464, 5607-5621. The Chamber notes that no allegation of extermination was made by the Prosecution with regard to the killing incidents alleged in the Sarajevo JCE. See Indictment, paras. 61-66.

20574 Specifically, the Chamber found that extermination as a crime against humanity was committed with respect to the following incidents of the Overarching JCE: Bijeljina, Scheduled Incident A.1.1; Bratunac, Scheduled Incidents A.3.2, B.4.1; Brčko, Scheduled Incident B.5.1; Foča, Scheduled Incident B.8.1; Ključ, Scheduled Incidents A.7.2, A.7.3. B.10.1; Novi Grad, Scheduled Incident B.12.2 (Judge Morrison dissenting on the issue of the perpetrators of this Scheduled Incident, see Dissenting opinion of Judge Morrison, paras. 6074-6080); Prijedor, Scheduled Incidents A.10.1, A.10.6, A.10.7, A.10.9, B.15.1, B.15.2, B.15.3, B.15.4, B.15.6; Sokolac, Scheduled Incident A.13.1; Višegrad, Scheduled Incident A.14.2; Vlasenica, Scheduled Incidents A.15.2, B.18.2; Zvornik, Scheduled Incidents A.16.3, B.20.1, B.20.2, B.20.3. Additionally, the Chamber found that extermination as a crime against humanity was committed with respect to all Schedule E killing incidents within the Srebrenica JCE, except Scheduled Incident E.2.1, which was found not to have been established. See paras. 5221-5222, 5607; Indictment, Schedule E.

20575 See fn. 20573.

20576 See paras. 6013-6014.

20577 Krajišnik Appeal Judgement, para. 775; Stakić Appeal Judgement, para. 402; Deronjić Sentencing Appeal Judgement, paras. 136-137; Čelebići Appeal Judgement, para. 806. See also Kordić and Čerkez Appeal Judgement, para. 1073. 
the criminal conduct will necessarily provide sufficient retribution and deterrence". ${ }^{20578}$ Other factors, such as rehabilitation, are relevant to be considered in sentencing but should not play a predominant role. ${ }^{20579}$

6026. Retribution is not to be interpreted as desire for revenge or vengeance but as an expression of the outrage of the international community at the crimes committed; retribution, unlike vengeance, requires the imposition of a "just and appropriate punishment, and nothing more" ${ }^{20580}$ In relation to deterrence, the penalty imposed by a Chamber should be adequate to dissuade a convicted person from re-offending (individual deterrence) and should also ensure that other potential perpetrators are dissuaded from committing the same or similar crimes (general deterrence). ${ }^{20581}$

\section{B. SENTENCING PRINCIPLES}

\section{Applicable law}

6027. Sentencing is governed by Articles 23 and 24 of the Statute, as well as Rules 87(C) and 100 to 106 of the Rules. In determining an appropriate sentence, the Chamber is required to take into account "such factors as the gravity of the offence and the individual circumstances of the convicted person". ${ }^{20582}$ The Chamber should also take into account, inter alia, any aggravating and mitigating circumstances, ${ }^{20583}$ the general practice regarding prison sentences in the courts of the former Yugoslavia, ${ }^{20584}$ and the extent to which any penalty imposed by a court of any State on the convicted person for the same act has already been served, as referred to in Article 10(3) of the Statute. $^{20585}$ The Chamber should also give credit to the convicted person for any time spent in detention pending surrender to the Tribunal or pending trial or appeal. ${ }^{20586}$ While the Chamber should consider the factors listed in the Statute and Rules, it retains broad discretion to determine

\footnotetext{
20578 Krajišnik, Appeal Judgement, para. 777.

20579 Stakić Appeal Judgement, para. 402; Deronjić Sentencing Appeal Judgement, para. 136; Kordić and Čerkez Appeal Judgement, para. 1079; Čelebići Appeal Judgement, paras. 805-806.

20580 Kordić and Čerkez. Appeal Judgement, para. 1075 (citing the Supreme Court of Canada judgement $R$. v. M. (C.A.) [1996] 1 S.C.R. 500, para. 80 (emphasis in original)), cited by Krajišnik Appeal Judgement, para. 804. See also Aleksovski Appeal Judgement, para. 185.

20581 Krajišnik, Appeal Judgement, paras. 776, 805; Dragan Nikolić Sentencing Appeal Judgement, paras. 45-46; Kordić and Čerkez. Appeal Judgement, paras. 1076-1078.

20582 Article 24(2) of the Statute.

20583 Rule 101(B)(i) and (ii) of the Rules.

20584 Article 24(1) of the Statute; Rule 101(B)(iii) of the Rules.

20585 Rule 101(B)(iv) of the Rules.

20586 Rule 101(C).
} 
the appropriate sentence to fit the circumstances of the convicted person and the gravity of the crime. $^{20587}$

6028. A convicted person may be sentenced for a term up to and including life imprisonment. ${ }^{20588}$ In addition to imprisonment, the Chamber may order restitution of any property and proceeds acquired by criminal conduct to their rightful owners. ${ }^{20589}$

6029. Previous sentencing decisions in other cases before this Tribunal may provide guidance if they relate to the same offences committed in substantially similar circumstances; ${ }^{20590}$ however, previous sentencing practice is only one factor among a number of others to be considered, and the Chamber will not be bound by it when determining the appropriate sentence in accordance with the gravity of the offence and the individual circumstances of the convicted person. ${ }^{20591}$

\section{Gravity of the offence}

6030. It is clearly established in the jurisprudence of the Tribunal that the primary consideration in determining an appropriate sentence is the gravity of the offence. ${ }^{20592}$

6031. When assessing the gravity of the offence, the Chamber must take into consideration the particular circumstances surrounding the case and the form and degree of the Accused's participation in the crime, ${ }^{20593}$ as well as the scale and brutality of the crimes, ${ }^{20594}$ the vulnerability of the victims, ${ }^{20595}$ the consequences and the effect or impact of the crime upon the victims and

\footnotetext{
20587 Lukić and Lukić Appeal Judgement, para. 640; Boškoski and Tarčulovski Appeal Judgement, para. 204; Strugar Appeal Judgement, para. 336; Hadžihasanović and Kubura Appeal Judgement, para. 302; Limaj et al. Appeal Judgement, para. 127; Brđanin Appeal Judgement, para. 500; Galić Appeal Judgement, para. 393.

20588 Article 24(1) of the Statute; Rule 101(A) of the Rules.

20589 Article 24(3) of the Statute.

20590 Furundžija Appeal Judgement, para. 250. See also Mrkšić and Šljivančanin Appeal Judgement, para. 376; Strugar Appeal Judgement, para. 348; Blagojević and Jokić Appeal Judgement, para. 333; Stakić Appeal Judgement, para. 381; Momir Nikolić Judgement on Sentencing Appeal, para. 38; Čelebići Appeal Judgement, paras. 719-721.

20591 Popović et al. Appeal Judgement, paras. 2093-2094; Strugar Appeal Judgement, paras. 348-349; Blagojević and Jokić Appeal Judgement, para. 333; Stakić Appeal Judgement, para. 381; Momir Nikolić Judgement on Sentencing Appeal, para. 38; Krstić Appeal Judgement, para. 248; Čelebići Appeal Judgement, paras. 720.

20592 Mrkšić and Šljivančanin Appeal Judgement, para. 375; Galić Appeal Judgement, para. 442; Stakić Appeal Judgement, para. 375; Momir Nikolić Judgement on Sentencing Appeal, para. 11; Blaškić Appeal Judgement, para. 683; Kupreškić et al. Appeal Judgement, para. 442; Čelebići Appeal Judgement, para. 731; Aleksovski Appeal Judgement, para. 182.

20593 Mrkšić and Šljivančanin, Appeal Judgement, para. 375; Blaškić Appeal Judgement, para. 683; Aleksovski Appeal Judgement, para. 182.

20594 Lukić and Lukić Appeal Judgement, para. 652; Mrkšić and Šljivančanin, Appeal Judgement, para. 400.

20595 Mrkšić and Šljivančanin, Appeal Judgement, para. 400; Blaškić Appeal Judgement, para. 683; Kunarac et al. Appeal Judgement, para. 352.
} 
their relatives including the "long-term physical, psychological, and emotional suffering of the immediate victims", 20596 and the convicted person's position of authority. ${ }^{20597}$

6032. The gravity of an offence for which an accused is held responsible pursuant to Article 7(3) is assessed by reference to two factors: (i) the gravity of the crimes committed by the accused's subordinate, and (ii) the gravity of the accused's own conduct in failing to prevent or punish the underlying offences committed by the subordinate. ${ }^{20598}$

6033. Further, the Appeals Chamber has established that there is no hierarchy of crimes. Crimes against humanity are therefore not to be sentenced more harshly than violations of the laws or customs of war, in respect of the same acts or vice versa. ${ }^{20599}$

\section{Aggravating and mitigating circumstances}

6034. Given that neither the Statute nor the Rules exhaustively define factors which may constitute aggravating or mitigating circumstances, ${ }^{20600}$ the Chamber has the discretion to determine which factors to take into account and the weight to be attributed to them. ${ }^{20601}$

6035. Aggravating circumstances must be directly related to the commission of the offence charged, ${ }^{20602}$ and the burden of proof falls on the Prosecution to show the existence of such circumstances beyond reasonable doubt. ${ }^{20603}$ The right of an accused to remain silent and not to testify, ${ }^{20604}$ or the absence of a mitigating factor, ${ }^{20605}$ does not constitute aggravating circumstances. Examples of aggravating circumstances identified in the jurisprudence of the Tribunal have included: (i) the accused's abuse of his position of authority; ${ }^{20606}$ (ii) the length of time during

20596 Mrkšić and Šljivančanin, Appeal Judgement, paras. 400, 411; Blaškić Appeal Judgement, para. 683. See also Krnojelac Appeal Judgement, para. 260.

20597 Strugar Appeal Judgement, para. 353; Naletilić and Martinović Appeal Judgement, paras. 608-613, 625-626; Musema Appeal Judgement, paras. 382-383.

20598 Čelebići Appeal Judgement, paras. 732, 741.

20599 Kunarac et al. Appeal Judgement, para. 171; Furundžija Appeal Judgement, para. 247; Tadić Sentencing Appeal Judgement, para. 69.

20600 See Rule 101(B)(i) and (ii) of the Rules. Rule 101(B)(ii) does list "substantial cooperation with the Prosecutor by the convicted person before or after conviction" as an example of mitigating circumstances.

20601 Čelebići Appeal Judgement, paras. 777, 780. See also Dragomir Milošević Appeal Judgement, para. 316; Martić Appeal Judgement, para. 329; Blagojević and Jokić Appeal Judgement, para. 328; Hadžihasanović and Kubura Appeal Judgement, para. 325; Babić Sentencing Appeal Judgement, para. 43; Galić Appeal Judgement, para. 414; Blaškić Appeal Judgement, paras. 685,696.

20602 Deronjić Sentencing Appeal Judgement, para. 124 (citing Kunurac et al. Trial Judgement, para. 850). See also Mrkšić and Šljivančanin Appeal Judgement, paras. 386-387; Simba Appeal Judgement, para. 82.

20603 Blaškić Appeal Judgement, para. 686; Čelebići Appeal Judgement, para. 763.

20604 Blaškić Appeal Judgement, para. 687; Čelebići Appeal Judgement, para. 783.

20605 Blaškić Appeal Judgement, para. 687.

20606 The position of authority of the accused does not per se constitute an aggravating factor to be taken into consideration for sentencing purposes, it is the abuse of such position which may be considered an aggravating 
which the crime continued; ${ }^{20607}$ (iii) premeditation and motive; ${ }^{20608}$ (iv) the sexual, violent, and humiliating nature of the acts and the vulnerability of the victims; ${ }^{20609}$ and (v) the status of the victims, their age and number, and the effect of the crimes upon them. ${ }^{20610}$

6036. Examples of mitigating circumstances identified in the jurisprudence of the Tribunal have included: (i) co-operation with the Prosecution; ${ }^{20611}$ (ii) the admission of guilt or a guilty plea; ${ }^{20612}$ (iii) an expression of remorse, sympathy, compassion, or sorrow for the victims of the crimes; ${ }^{20613}$ (iv) no prior criminal record; ${ }^{20614}$ (v) voluntary surrender; ${ }^{20615}$ (vi) good conduct in detention; ${ }^{20616}$ (vii) family circumstances; ${ }^{20617}$ (viii) the character of the convicted person subsequent to the conflict; ${ }^{20618}$ (ix) duress; ${ }^{20619}$ (x) preventing the commission of crimes; ${ }^{20620}$ (xi) assistance to

factor. Hadžihasanović and Kubura Appeal Judgement, para. 320; Blagojević and Jokić Appeal Judgement, para. 324; Galić Appeal Judgement, para. 412; Stakić Appeal Judgement, para. 411.

Blaškić Appeal Judgement, para. 686 (citing Kunarac et al. Appeal Judgement, para. 356).

Blaškić Appeal Judgement, para. 686 (citing Krstić Trial Judgement, paras. 711-712). See also Krstić Appeal Judgement, para. 258; Čelebići Appeal Judgement, paras. 825, 833.

Blaškić Appeal Judgement, para. 686 (citing Kunarac et al. Trial Judgement, para. 867). See also Kunarac et al. Appeal Judgement, para. 352.

Blaškić Appeal Judgement, para. 686 (citing Kunarac et al. Trial Judgement, paras. 864, 866); Kunarac et al. Appeal Judgement, para. 355.

Babić Sentencing Appeal Judgement para. 43; Blaškić Appeal Judgement, para. 696; Jokić Sentencing Judgement, para. 76. See also Rule 101(B)(ii) of the Rules.

Babić Sentencing Appeal Judgement paras. 43, 67-68; Blaškić Appeal Judgement, para. 696; Jelisić Appeal Judgement, para. 122.

Babić Sentencing Appeal Judgement paras. 43, 72; Blaškić Appeal Judgement, para. 696. See also Strugar Appeal Judgement, para. 366 (noting that although sympathy, compassion, or sorrow for the victims of the crimes "does not amount to remorse as such, it may nonetheless be considered a mitigating factor.").

Krajišnik Appeal Judgement, para. 816; Hadžihasanović and Kubura Appeal Judgement, para. 325; Kordić and Čerkez Appeal Judgement, para. 1090; Blaškić Appeal Judgement, para. 696.

Hadžihasanović and Kubura Appeal Judgement, para. 325; Babić Sentencing Appeal Judgement, paras. 43, 75; Kordić and Čerkez Appeal Judgement, para. 1090; Blaškić Appeal Judgement, para. 696; Jokić Sentencing Judgement, para. 82.

Krajišnik Appeal Judgement, para. 816; Hadžihasanović and Kubura Appeal Judgement, para. 325; Simić Appeal Judgement, para. 266; Babić Sentencing Appeal Judgement, para. 43; Kordić and Čerkez Appeal Judgement, para. 1091; Blaškić Appeal Judgement, paras. 696.

Krajišnik Appeal Judgement, para. 816; Hadžihasanović and Kubura Appeal Judgement, para. 325; Simić Appeal Judgement, para. 266; Kordić and Čerkez Appeal Judgement, para. 1090; Blaškić Appeal Judgement, para. 696; Kunarac et al. Appeal Judgement, paras. 362, 408.

Babić Sentencing Appeal Judgement, para. 43; Blaškić Appeal Judgement, para. 696. See also Jokić Sentencing Judgement, paras. 90-91, 103.

Blaškić Appeal Judgement, para. 696; Erdemović Second Sentencing Judgement, para. 17.

Blagojević and Jokić Appeal Judgement, para. 342. See also Kupreškić et al. Appeal Judgement, para. 430. 
victims; ${ }^{20621}$ and (xii) age. ${ }^{20622}$ Determining whether a fact amounts to a mitigating circumstance will be reached "on a balance of probabilities". 20623

6037. Factors taken into account in assessing the gravity of an offence must not be considered again as separate aggravating circumstances, and vice versa. ${ }^{20624}$ Evaluating both gravity and aggravating circumstances under the same heading is permissible when the Chamber clearly shows that it did not engage in double-counting, and classified each circumstance as either part of the gravity assessment or as an aggravating factor. ${ }^{20625}$ For example for the purposes of convictions under Article 7(3) of the Statute, the Chamber must not, double-count the convicted person's "position of authority as both an element of the offence and an aggravating factor". ${ }^{20626}$

4. General practice regarding prison sentences in the courts of the former Yugoslavia

6038. Under Article 24(1) of the Statute, the Chamber shall have "recourse to the general practice regarding prison sentences in the courts of the former Yugoslavia." ${ }^{20627}$ In conducting this assessment, a Trial Chamber is entitled to consider, in addition to the SFRY law in force at the time of the commission of the relevant crimes, how that law evolved subsequently. ${ }^{20628}$ While the Statute requires the Chamber to take into account the general practice regarding prison sentences in the courts of the former Yugoslavia, "such practices only provide guidance and are not binding". ${ }^{20629}$ However, where a Trial Chamber is to depart from the sentencing practices in the former Yugoslavia, it must give reasons for such departure and must go beyond merely reciting the relevant code provisions. ${ }^{20630}$

20621 Krajišnik Appeal Judgement, para. 816; Blaškić Appeal Judgement, paras. 696. See also Blagojević and Jokić Trial Judgement, para. 854.

20622 Krajišnik Appeal Judgement, para. 816; Simić Appeal Judgement, para. 266; Babić Sentencing Appeal Judgement, para. 43; Blaškić Appeal Judgement, para. 696.

20623 Mrkšić and Šljivančanin Appeal Judgement, para. 352; Hadžihasanović and Kubura, Appeal Judgement, para. 302; Zelenović Sentencing Appeal Judgement, para. 11; Bralo Sentencing Appeal Judgement, para. 8. See also Babić Sentencing Appeal Judgement, para. 43; Blaškić Appeal Judgement, para. 697.

20624 Momir Nikolić Judgement on Sentencing Appeal, para. 58; Deronjić Sentencing Appeal Judgement, para. 106. See also Limaj et al. Appeal Judgement, para. 143.

20625 Krajišnik Appeal Judgement, para. 751. See also Deronjić Sentencing Appeal Judgement, para. 106.

20626 Naletilić and Martinović Appeal Judgement, para. 610.

20627 Article 24(1) of the Statute.

20628 Krstić Appeal Judgement, para. 261.

20629 Krajišnik Appeal Judgement, paras. 749, 811; Hadžihasanović and Kubura Appeal Judgement, para. 335, 346; Galić Appeal Judgement, para. 398; Dragan Nikolić Sentencing Appeal Judgement, para. 69; Blaškić Appeal Judgement, paras. 681-682; Krstić Appeal Judgement, paras. 260-261 (citing Kunarac Trial Judgement, para. 829).

20630 Krstić Appeal Judgement, paras. 260-261 (citing Kunarac Trial Judgement, para. 829). See also Dragan Nikolić Sentencing Appeal Judgement, para. 69; Kordić and Čerkez Appeal Judgement, para. 1085; Blaškić Appeal Judgement, para. 682. 
6039. If a Trial Chamber imposes a sentence in excess of the practice of the courts in the former Yugoslavia, this does not violate the principle of nulla poena sine lege, because the Trial Chamber is bound to apply the law of the Tribunal and not of the former Yugoslavia, ${ }^{20631}$ and the accused must have been aware that the crimes for which he is indicted are the most serious violations of international humanitarian law, punishable by the most severe of penalties. ${ }^{20632}$

6040. The sentencing law in $\mathrm{BiH}$ was regulated during the period of the Indictment by the Criminal Code of the Socialist Federal Republic of Yugoslavia ("SFRY Criminal Code"), adopted by the Federal Assembly on 28 September 1976, and in force since 1 July 1977, and by the Criminal Code of the Socialist Republic of Bosnia and Herzegovina ("SRBH Criminal Code") of 10 June 1977. The SFRY Criminal Code regulated general aspects of criminal law and some specific offences, including genocide and war crimes, while the SRBH Criminal Code regulated specific offences and matters not addressed by the SFRY Criminal Code. ${ }^{20633}$

6041. Under the SFRY Criminal Code, the range of penalties included fines, confiscation of property, imprisonment, and capital punishment. ${ }^{20634}$ In his final brief, the Accused refers to the fact that before the adoption of the Statute of the Tribunal on 25 May 1993, the maximum penalty that could be imposed pursuant to the SFRY Criminal Code was 20 years. $^{20635}$ Indeed, Article 38(1) and (2) of the SFRY Criminal Code provided for a maximum sentence of imprisonment of 15 years, except for offences punishable with the death penalty, in which case the maximum term of imprisonment was extended to 20 years. ${ }^{20636}$ In 1998, BiH abolished the death penalty. ${ }^{20637}$ The maximum sentence that may currently be imposed in $\mathrm{BiH}$ and in the $\mathrm{RS}$ is 45 years for "the gravest forms of serious criminal offences perpetrated with intent". 20638

6042. Chapter 16 of the SFRY Criminal Code outlined criminal offences against humanity and international law. Specifically, Article 141 of the SFRY Criminal Code prohibited genocide, Article 142 prohibited war crimes against the civilian population, Article 143 prohibited war crimes against the wounded and sick, and Article 144 prohibited war crimes against prisoners of war. ${ }^{20639}$

\footnotetext{
20631 Krajišnik Appeal Judgement, para. 750; Stakić Appeal Judgement, para. 398. See also Simić Appeal Judgement, para. 264; Čelebići Appeal Judgement, paras. 816-817; Tadić Sentencing Appeal Judgement, para. 21.

20632 Blaškić Appeal Judgement, para. 681; Čelebići Appeal Judgement, paras. 816-817.

20633 See Deronjić Sentencing Judgement, para. 163; Dragan Nikolić Sentencing Judgement, para. 153.

20634 SFRY Criminal Code, Article 34.

20635 Defence Final Brief, paras. 3376-3378 (referring to this fact as a mitigating circumstance).

20636 SFRY Criminal Code, Article 38(1)-(2).

20637 Tadić Sentencing Judgement, para. 12.

20638 BiH Criminal Code, 2013, Article 42(2); RS Criminal Code, 2013, Article 31a(1).

20639 SFRY Criminal Code, Articles 141-144. See also Articles 145 (organising a group and instigating the commission of genocide and war crimes), 150 (cruel treatment of the wounded, sick, and prisoners of war), 151 (destruction of cultural and historical monuments), and 154 (racial and other discrimination).
} 
The offences under Articles 141, 142, 143 and 144 of the SFRY Criminal Code were punishable by imprisonment for not less than five years or by the death penalty. ${ }^{20640}$ The punishments for specific offences, such as murder, rape, and grievous bodily harm were regulated by the SRBH Criminal Code. $^{20641}$

5. Credit for time spent in prison

6043. Pursuant to Rule 101(C), an accused is entitled to credit for the time spent in detention pending surrender to the Tribunal or pending trial.

\section{Determination of sentence}

6044. Under Rule 87(C), the Chamber may impose either a sentence for each finding of guilt, to be served either consecutively or concurrently, or a single sentence reflecting the totality of the criminal conduct of the accused. ${ }^{20642}$ Due consideration must be given to each particular offence so that the gravity of an accused's conduct may be properly assessed and the single sentence, if imposed, must reflect the totality of the criminal conduct in question. ${ }^{20643}$

\section{Discussion}

\section{Gravity of the offence}

\section{a. Submissions}

6045. In the present case, in relation to the gravity of the offence, the Prosecution identifies the scale and nature of the crimes, their systematic pattern and continuous repetition, the number of victims, and the effect of the crimes upon them. ${ }^{20644}$ It submits:

Under his command and oversight, [the Accused]'s subordinates and those cooperating with them expelled, killed, tortured and otherwise mistreated hundreds of thousands of Muslims and Croats; they bombarded Sarajevo with shells and bullets, killing, maiming, and terrorising its civilian population for over three and a half years. The scale and scope of these criminal campaigns is vast. [The Accused] played a key role throughout each of them. The persistence with which [the Accused] pursued his goal of a 'clean' Drina in the face of immense international pressure, culminating in arguably the biggest single

\footnotetext{
20640 SFRY Criminal Code, Articles 141-144.

20641 SRBH Criminal Code, Articles 36 (punishing murder with imprisonment of not less than five years, and in aggravated cases, not less than 10 years or the death penalty) and 88 (punishing rape with one to 10 years of imprisonment, in aggravated cases the lower limit being three years imprisonment).

20642 Rule 87(C) of the Rules.

20643 Blaškić Appeal Judgement, paras. 718-723; Brđanin Trial Judgement, para. 1149.

20644 Prosecution Final Brief, fn. 4052.
} 
crime in Europe since WWII, is indicative of the 'form and degree' of his
participation.

\section{b. Findings}

6046. The Accused has been found responsible for having committed, through his participation in four different joint criminal enterprises, a wide range of criminal acts throughout the entire period of the conflict in $\mathrm{BiH}$. He has also been found responsible for having failed to punish certain crimes committed by his subordinates in the Srebrenica component. The Chamber finds that the crimes committed in this case, particularly with respect to the Municipalities, Sarajevo, and Srebrenica components, are among the most egregious of crimes in international criminal law and include extermination as a crime against humanity and genocide. The sheer scale of the crimes for which the Accused has been found responsible as well their systematic cruelty and their continued impact on the victims who have survived are evident. As described above, the Accused had a central role and made a significant contribution to the commission of these crimes. In determining the adequate sentence to be imposed on the Accused, the Chamber has given particular regard to these factors.

6047. More specifically, in the Municipalities component of the case, the Accused has been found responsible for having significantly contributed to a joint criminal enterprise the purpose of which was to permanently remove the Bosnian Muslims and Bosnian Croats from Bosnian Serb claimed territory. The Chamber found that the Accused, together with the members of the Overarching JCE, intended that this objective would be achieved through the commission of the crimes of deportation, inhumane acts (forcible transfer), and persecution (through the underlying acts of unlawful detention and the imposition and maintenance of restrictive and discriminatory measures) as crimes against humanity. This common plan resulted in the uprooting of the overwhelming majority of the non-Serb population in the Municipalities and fundamentally changed the ethnic distribution in these territories. The Bosnian Muslim and Bosnian Croat populations of $\mathrm{BiH}$ were also subjected to atrocious crimes which the Chamber found were foreseeable to the Accused in carrying out the common plan of the Overarching JCE. Thousands of civilians were the victims of persecution, murder, and extermination and continue to suffer from the impact of these crimes to this day. These crimes were committed during or following the take-over of the Municipalities by Serb Forces and in the dozens of detentions facilities in which non-Serbs were unlawfully detained. The Chamber further found that as RS President and Supreme Commander of the VRS, the Accused was at the apex of power and played an integral role in this enterprise by promoting an

20645 Prosecution Final Brief, para. 1121. 
ideology of ethnic separation, using a rhetoric that amplified historical ethnic grievances and promoting propaganda to that effect. He also established the institutions used to carry out the objective of the common plan, and created a climate of impunity for criminal acts committed against non-Serbs.

6048. In the Sarajevo component, the Accused has been found responsible for having significantly contributed to a joint criminal enterprise of sniping and shelling, the purpose of which was to spread terror among the civilian population of Sarajevo. For three and a half years, the civilians of Sarajevo lived in the extreme fear of being targeted by sniper and mortar fire and the Chamber found that this in fact subjected them to terror. The Chamber also found that shelling occurred on an almost daily basis throughout the duration of the siege. No place in the city was safe for the civilian population, including their own homes. The civilians of Sarajevo were shot while fetching water, walking in the city, and when using public transport. Children were sniped while playing in front of their houses, walking with their parents or walking home from school, and even when cycling. Hospitals were not spared; civilians were the subject of sniper and mortar fire while receiving treatment and medical staff exposed themselves to the same danger in order to provide medical care to the citizens of Sarajevo. The Chamber found that terror was used intentionally as the SRK wanted to show to the civilian residents of Sarajevo that nobody was safe and that they were helpless. The shelling and sniping campaign ultimately resulted in a large number of civilian casualties. The Chamber found that the Accused's contribution to the Sarajevo JCE was so instrumental that without his support the SRK attacks on civilians could not have in fact occurred.

6049. In the Srebrenica component, the Chamber found the Accused responsible for having significantly contributed to a joint criminal enterprise to eliminate the Bosnian Muslims in Srebrenica by forcibly removing the women, children, and elderly men and killing the men and boys. In this component of the case, the Chamber found the Accused responsible for forcible transfer, persecution, murder, extermination, and genocide. The implementation of the common plan of the Srebrenica JCE resulted in the killing of at least 5,115 Bosnian Muslim men and the forcible transfer of 30,000 Bosnian Muslim women, children, and elderly men, from Srebrenica to Bosnian Muslim-held territory. The Accused was also found responsible as a superior for having failed to punish the killings which occurred prior to the evening of 13 July 1995. In earlier sections of this Judgement, the Chamber described in harrowing detail the systematic brutality with which these men and boys were killed as well as the mental and physical suffering they endured in the period leading up to their execution. As for the women, children, and elderly men who were the subject of the forcible transfer operation, in addition to them being uprooted, the Chamber stressed the serious mental trauma caused by their sudden separation at Potočari from their male relatives 
who were taken away to await an unknown fate. In relation to the gravity of the Accused's conduct in relation to the killings after 13 July, the Chamber found that he was the sole person in the RS with the power to prevent the Bosnian Serb Forces from moving the Bosnian Muslim males to Zvornik to be killed. Instead, he ordered their transfer to Zvornik, where they were ultimately killed. In doing so, the Accused agreed to and enabled the implementation of a systematic, organised, and large scale murder operation.

6050. In the Hostages component, the Chamber found the Accused responsible for having significantly contributed to the common purpose to take UN personnel hostage. The Chamber recalls that the mandate of the UN peace-keepers and monitors who were subjected to the crime of hostage-taking for which the Accused was found responsible was to establish and preserve peace between the parties to the conflict and provide assistance to the civilian population. As such, and in order to fulfil their mandate, the UNPROFOR and UNMOs should have be afforded the highest protection. Instead, they were used as a bargaining tool to obtain the cessation of NATO airstrikes, and the Accused was the driving force behind this entreprise.

\section{Aggravating circumstances}

6051. In addition to the factors identified as relevant to assessing the gravity of the offences for which the Accused is found responsible, the Prosecution submits that abuse of authority may be considered as an aggravating circumstance. ${ }^{20646}$ As an example of such alleged sustained and massive abuse, the Prosecution refers to the fact that while the Accused was more able than any other individual in the RS to stop the course of his subordinates' violent actions, he did not stop them but instead provided strategic supervision and issued specific directives in furtherance of these actions, rewarded perpetrators, lied to internationals, and covered up crimes. ${ }^{20647}$

6052. In its findings on the Accused's responsibility in relation to each of the components of the case, the Chamber gave particular regard to the Accused's unique position at the apex of power in the RS and his de jure authority over the VRS, MUP and other political organs, which he exercised in fact. The essential role the Accused played in the commission of the crimes in each of the components was a reflection of his position and the manner in which he used that position to further his objectives. The Chamber recalls that it also found the Accused responsible as a superior for having failed to punish the killings which took place before the evening of 13 July 1995 in Srebrenica. These factors have been abundantly discussed in the Chamber's findings on the

20646 Prosecution Final Brief, para. 1120, fn. 4051.

20647 Prosecution Final Brief, para. 1120. 
Accused's responsibility and taken into consideration in relation to the gravity of the crimes for which he has been found responsible. The Chamber shall therefore not assess them further as a separate aggravating circumstance.

\section{Mitigating circumstances}

\section{a. Submissions}

6053. The Accused refers to the following mitigating circumstances: (i) the agreement which the Accused submits he entered into with Richard Holbrooke in July 1996 according to which he would not be prosecuted if he resigned from public office, ${ }^{20648}$ (ii) the unprecedented number of disclosure violations by the Prosecution; ${ }^{20649}$ (iii) his conduct during the war, including through the provision of assistance to victims or detainees and his prevention of the commission of crimes; ${ }^{20650}$ (iv) his lack of training and preparation for war and the difficulties he faced in exercising command; ${ }^{20651}$ (v) his personal and family circumstances, including his marital status; character, lack of prior criminal conviction, and age ${ }^{20652}$ (vi) his conduct at the Tribunal, including his good behaviour during the proceedings and at the UNDU, his expression of regret or sympathy to the victims of the crimes charged in the Indictment; ${ }^{20653}$ and (vii) the length of his detention during the proceedings. $^{20654}$

\section{b. Findings}

\section{i. The Holbrooke Agreement}

6054. The Chamber first turns to the evidence presented by the Accused with regard to an agreement he claims to have entered into with Richard Holbrooke in July 1996 whereby he resigned from public and party office and withdrew from public life with the understanding that he would not be prosecuted at the Tribunal ("Holbrooke Agreement").

\footnotetext{
20648 Defence Final Brief, paras. 3379-3406 (contending that this agreement pertains to both his character and acts and conduct subsequent to the conflict as well as to a remedy for a violation of his rights).

20649 Defence Final Brief, paras. 3407-3411 (submitting that such reduction in sentence should be granted as a remedy for the violation of his rights).

20650 Defence Final Brief, paras. 3412-3416.

20651 Defence Final Brief, para. 3417.

20652 Defence Final Brief, paras. 3419-3423.

20653 Defence Final Brief, paras. 3424-3425, 3427-3428.

20654 Defence Final Brief, para. 3426.
} 
6055. Witnesses testified that they were present at a meeting between the Accused and Holbrooke when such an agreement was entered into. ${ }^{20655}$ The Chamber admitted additional evidence tendered by the Accused in support of the existence of this agreement. ${ }^{20656}$

6056. The Chamber admitted a one-page statement signed by the Accused, Krajišnik, Plavšić, and Aleksa Buha, reaffirming their commitment to fulfill the Dayton Agreement; in the statement, reference is made to the fact that "on July 19, 1996, Dr. Radovan Karadžić has relinquished the office of President of the [RS] and has relinquished all powers associated therewith". The statement further provides that the Accused "states that he shall withdraw immediately and permanently from all political activities. He will not appear in public, or on radio or television or other media or means of communication, or participate in any way in the elections." Finally, as of 19 July 1996, the Accused "relinquishes the office of President of the SDS and all the functions, powers and responsibilities of the President of the SDS shall be frozen until the SDS chooses a new President". 20657 Defence witnesses testified that the part of the agreement which contained the undertaking by Holbrooke that the Accused would not be prosecuted by the Tribunal was made orally and not put in writing. ${ }^{20658}$

6057. For the purpose of sentencing, the Chamber is only concerned with the established fact that the Accused indeed resigned from all public and party offices as of 19 July 1996 and that he refrained from making public appearances from then on. The reason, or reasons, behind his decision to step down and withdraw from public life are not relevant. What is relevant is the fact that his decision had a positive influence on the establishment of peace and stability in $\mathrm{BiH}$ and the region in the wake of the Dayton Agreement. The Chamber therefore considers the Accused's decision to resign from public and party offices in July 1996 to be a mitigating factor in determining the sentence to be imposed.

\footnotetext{
20655 Momčilo Krajišnik, T. 43383-43387 (13 November 2013), T. 43933-43934 (20 November 2013); D3051 (Witness statement of Momir Bulatović dated 25 February 2013), paras. 47-48. See also KDZ456, T. 2178521786 (23 November 2011) (closed session).

20656 D3682 (Witness statement of Gordan Milinić dated 8 June 2013), para. 23; D4313 (Witness statement of Gojko Kličković dated 7 February 2014), paras. 14-15; D4423 (Declaration of John Petrie, 16 May 2011); D4436 (Statement of Aleksa Buha, 21 April 2009), pp. 1-2; D4425 (Statement of Radomir Lukić, 16 April 2009), pp. 1-2; D4426 (Excerpt from Charles Ingrao's book); D4431 (Article from Press TV Teheran of interview with Mohammad Sacirbey, 1 August 2008); D4432 (Statement of David Binder, 17 April 2009); D4433 (Statement of Obrad Kesic, 18 April 2009); D4434 (Statement of Victor Ben-Cnaan, 11 June 2009), pp. 1-2; D4435 (Statement of Puniša Lučić, undated); D4427 (Statement of Ljiljana Zelen-Karadžić, 21 April 2009); D4428 (Statement of Sonja Karadžić-Jovičević, 21 April 2009); D4429 (Statement of Branislav Jovičević, 21 April 2009); D4430 (Statement of Dragan Drašković, 21 April 2009).

20657 D4424 (Written agreement between Radovan Karadžić, Momčilo Krajišnik, Biljana Plavšić, and Aleksa Buha, 18 July 1996).

20658 D3051 (Witness statement of Momir Bulatović dated 25 February 2013), para. 48; Momčilo Krajišnik, T. 43383-43384 (13 November 2013).
} 


\section{ii. The Accused's conduct during the proceedings and at the UNDU}

6058. The Chamber notes the Accused's good conduct both during the proceedings before the Chamber and during the course of his detention at the UNDU. ${ }^{20659}$ As such, the Chamber has considered this factor in its determination of the appropriate sentence.

6059. With regard to the Accused's submission that his expression of regret or sympathy to the victims of the crimes charged in the Indictment should have a mitigating effect on the sentence to be imposed, the Chamber notes that in a few instances, the Accused expressed his regret to a witness on the stand for the crimes the witness had suffered. ${ }^{20660}$ In his Final Brief, the Accused stated the following:

President Karadžić expresses his deep regret and sympathy to the victims of the crimes charged in his indictment and to their families. Regardless of the issue of his individual criminal responsibility for those crimes, he understands that as President of Republika Srpska, he bears moral responsibility for any crimes committed by citizens and forces of Republika Srpska. He knows that any expression of regret or sympathy is inadequate to compensate for the suffering that took place during the war. Nevertheless, he offers his heartlfet expression of regret and sympathy to the victims and their families. ${ }^{20661}$

6060. The Chamber recalls that although sympathy for the victims of the crimes does not amount to remorse as such, it may nonetheless be considered a mitigating factor. ${ }^{20662}$ The Chamber has given due consideration to these expressions of regret in determining the appropriate sentence to be imposed.

\section{iii. The Accused's personal circumstances}

6061. The Accused was born on 19 June 1945 and is therefore 70 years old at the time of issuance of this Judgement. The Chamber has given due regard to the Accused's age in determining the appropriate sentence.

6062. The Chamber has also had regard to the Accused's lack of prior criminal conviction.

\section{iv. Other mitigating circumstances identified by the Accused}

6063. The Chamber does not consider the number of disclosure violations by the Prosecution to be a mitigating circumstance. The Prosecution's disclosure practice does not have any bearing on the appropriate sentence to be imposed to the Accused in light of the gravity of the crimes and his

\footnotetext{
20659 D4422 (UNDU behaviour report of Radovan Karadžić, 21 January 2014).

20660 Hearing, T. 8757 (1 November 2010); Hearing, T. 12097 (17 February 2011).

20661 Defence Final Brief, para. 3428.

20662 See Strugar Appeal Judgement, para. 366.
} 
involvement in their commission. Furthermore, the Chamber took all measures to protect the Accused's fair trial rights and suspended proceedings on multiple occasions, to allow him to review and incorporate large batches of newly disclosed material into his preparations. While the Prosecution's disclosure violations continued, to a great extent, the Chamber found that while the violations reflected badly on the Prosecution, the Accused did not suffer any prejudice.

6064. In light of all of the Chamber's findings as to the gravity of the crimes for which the Accused has been found responsible and the Accused's central involvement in these crimes, the Chamber does not consider his conduct during the war to be mitigating in any way. Similarly, in light of the Chamber's findings as to the Accused's authority over the Bosnian Serb Forces and Bosnian Serb Political and Governmental Organs, the Chamber does not consider that the Accused's alleged lack of training and preparation for war is mitigating.

6065. The Chamber recalls that Rule 101(C) of the Rules entitles an accused to credit for the time spent in detention pending surrender to the Tribunal or pending trial. As such, the length of the Accused's detention is not a mitigating factor; rather, time already spent in detention will be duly deducted from the sentence to be imposed by the Chamber.

\section{Sentences in related cases at the Tribunal}

6066. The Accused argues that the Chamber should take into consideration the imposition of sentences in related cases to ensure consistency in its judgements and refers specifically to the sentence of 11 years imposed on Plavšić and the sentence of 20 years imposed on Krajišnik. ${ }^{20663}$

6067. With regard to Plavšić, the Chamber notes that her sentence was imposed following her guilty plea and the dismissal of the remaining counts by the Prosecution. As such, the sentence imposed on Plavšić is of no guidance to the Chamber. The Chamber notes, in relation to Krajišnik, that the case against him was similar to that against the Accused in so far as it pertained to the Municipalities component of this case. It did not involve any of the charges related to the Srebrenica, Sarajevo, and Hostages components of this case. The guidance provided by the sentence imposed on Krajišnik in determining the sentence against the Accused is therefore limited to the Municipalities component of the case.

20663 Defence Final Brief, para. 3429. 
5. General practice regarding prison sentences in the courts of the former Yugoslavia

6068. In determining the appropriate sentence for the Accused, and pursuant to Article 24(1) of the Statute, the Chamber has taken into account the general practice regarding prison sentences in the courts of $\mathrm{BiH}$ at the time of the commission of the crimes in relation to which the Accused was found responsible, and the manner in which it has developed.

\section{Credit for time spent in prison}

6069. The Chamber notes that the Accused was arrested on 21 July 2008 and taken into the custody of the Tribunal on 30 July 2008. Accordingly, he has been in custody for 2,804 days. Pursuant to Rule to Rule 101(C), he is entitled to credit for that period.

\section{CONCLUSION}

6070. Therefore, for all of the foregoing reasons, in particular given the scope and scale of the serious crimes for which the Accused was found responsible and his central involvement in the commission of these crimes, the Chamber decides that the imposition of a single sentence of 40 years is warranted. 


\section{DISPOSITION}

6071. For all of the foregoing reasons, pursuant to Articles 23, 24, and 27 of the Tribunal's Statute and Rules 98 ter, 101, 102, and 103 of the Tribunal's Rules of Procedure and Evidence, the Chamber finds the Accused, Radovan Karadžić:

- NOT GUILTY of COUNT 1: genocide.

- GUILTY of the following counts:

COUNT 2: genocide;

COUNT 3: persecution, a crime against humanity;

COUNT 4: extermination, a crime against humanity;

COUNT 5: murder, a crime against humanity;

COUNT 6: murder, a violation of the laws or customs of war;

COUNT 7: deportation, a crime against humanity;

COUNT 8: inhumane acts-forcible transfer, a crime against humanity;

COUNT 9: terror, a violation of the laws or customs of war;

COUNT 10: unlawful attacks on civilians, a violation of the laws or customs of war; and

COUNT 11: hostage-taking, a violation of the laws or customs of war.

6072. The Chamber hereby sentences the Accused, Radovan Karadžić, to a single sentence of 40 years of imprisonment. The Accused has been in custody since 21 July 2008; and, pursuant to Rule 101(C) of the Rules, he is entitled to credit for time spent in detention thus far.

6073. Pursuant to Rule 103(C) of the Rules, the Accused shall remain in the custody of the Tribunal pending the finalisation of arrangements for his transfer to the state where he shall serve his sentence. 
Judge Howard Morrison and Judge Melville Baird append partially dissenting opinions to this Judgement.

Done in four volumes in English and French, the English text being authoritative.

Judge O-Gon Kwon

Presiding

Judge Howard Morrison

Judge Melville Baird

Dated this twenty-fourth day of March 2016

At The Hague

The Netherlands

[Seal of the Tribunal] 


\section{DISSENTING OPINIONS}

\section{A. DISSENTING OPINION OF JUDGE MORRISON}

6074. In relation to Schedule Incident B.12.2 in Novi Grad municipality, the Majority found that it was satisfied beyond reasonable doubt that on 14 June 1992, Bosnian Serb Forces, including Žuti, other guards, and paramilitaries, attacked a bus filled with Bosnian Muslim male detainees with grenades and automatic weapons, and killed 47 Bosnian Muslim men. ${ }^{20664}$ I agree with the Majority that there was indeed an attack on the bus on 14 June 1992 during which 47 Bosnian Muslim men were killed. However, I have not been able to reach a determinative conclusion as to the identity of the perpetrators. Therefore, I respectfully disagree with the Majority's finding on this Schedule Incident for the following reasons.

6075. First, there is conflicting evidence on the issue of the identity of the alleged perpetrators of the killings. While there is evidence indicating that Serb Forces conducted the attack, the evidence is not consistent in identifying which unit among these forces was responsible. For example, KDZ041 testified that he heard that the main organisers of the attack on the bus were Boro Radić, ${ }^{20665}$ Dragan Ikanović, and Ratko Adžić. ${ }^{20666}$ Further, Eset Muračević, a Bosnian Muslim who was imprisoned in Vogošća municipality in the second half of 1992, stated that he had heard from a fellow detainee that a Serb prison guard by the name Predrag Žarković, alias Božur, was "[a]mong the group of Chetniks" who carried out the attack on the bus. ${ }^{20667}$ For his part, KDZ601, [REDACTED], testified [REDACTED], he heard [REDACTED] that Branislav Gavrilović from Vučija Luka and his unit had attacked the bus with Zoljas. ${ }^{20668}$

6076. There is also evidence suggesting that Muslim forces carried out the attack on the bus by mistake. In a conversation intercepted on 15 June 1992-one day after the attack on the bus-

\footnotetext{
20664 See para. 2231.

20665 According to KDZ020, Boro Radić was a common criminal from Vogošća who had the support of the SDS and was eventually integrated into the VRS and given the rank of colonel. P2344 (Witness statement of KDZ020 dated 17 February 2011), para. 72 (under seal); KDZ020, T. 12524 (28 February 2011).

20666 KDZ041, T. 12075 (17 February 2011); P2310 (Witness statement of KDZ041 dated 14 February 2011), paras. 50,61 (under seal).

20667 P2361 (Witness statement of Eset Muračević dated 24 February 2011), paras. 20, 25, 60.

20668 P3299 (Record of interview with KDZ601, 18 April 2005), pp. 38-42 (under seal); KDZ601, T. 18590-18592 (13 September 2011). There is evidence that Branislav Gavrilović was known and referred to by the municipal authorities of Ilidža as the commander of all SAO Romanija volunteer units. P2302 (Approval of the War Board of Commissioners of Ilidža Municipality, 9 July 1992); Neđeljko Prstojević, T. 12988 (8 March 2011). Witness Velimir Dunjić stated that the unit of Branislav Gavrilović was in the zone of responsibility of the Igman Brigade and that after a while, it put itself under the Igman Brigade command. D2451 (Witness statement of Velimir Dunjić dated 12 November 2012), para. 13.
} 
Mirko Krajišnik informed his brother, Momčilo Krajišnik, that Muslims had intercepted the bus, and mistaking its occupants for Serbs, opened fire on it, killing all the prisoners and heavily wounding two Serb guards. ${ }^{20669}$ The Majority agrees with this. ${ }^{20670}$ I also take note that six days prior to the attack on the bus, Momčilo Krajišnik repeatedly instructed two persons in Rajlovac, a certain Mijatović and Ljubiša Vladušić, the future president of the RS Refugee and Humanitarian Aid Committee, ${ }^{20671}$ not to do anything to the "captured men". ${ }^{20672}$ Again, the Majority agrees with this. $^{20673}$

6077. I have found no direct evidence that Žuti and the other guards attacked the bus as alleged by the Prosecution. KDZ041 for instance testified that he was unable to actually see what was taking place outside of the bus or who was attacking it. ${ }^{20674}$ The Majority found that "notwithstanding his inability to see during and immediately after the attack, KDZ041 heard what was happening around him". 20675 In the circumstances, I cannot agree with this assessment and find it difficult to accept KDZ041's evidence that he heard the escort cars drive off after the attack on the bus had ended. In this regard, I note that the attack on the bus lasted 15 minutes, involved the use of machineguns, hand grenades, and Zoljas, and resulted in KDZ041 himself being wounded in the arm. In these extremely traumatic circumstances, it would have been difficult for KDZ041 to accurately interpret what was happening outside of the bus.

6078. I also find it peculiar that Žuti and the other guards decided to kill the detainees by attacking the bus on or near the confrontation line, thereby risking a number of survivors ${ }^{20676}$ and also injuring themselves. ${ }^{20677}$ In other words, if their intention was to kill the detainees as alleged by the Prosecution, then Žuti and the guards could have easily done so by executing them in a secluded area, where they could also make sure that they themselves were not injured and that there were no

\footnotetext{
20669 D1088 (Intercept of conversation between Momčilo Krajišnik and Mirko Krajišnik, 15 June 1992), pp. 1, 5-6. I note that in an intercepted conversation on 20 June 1992, Mirko Krajišnik informed two Bosnian Muslims, Ćamil and Šemso, that 284 prisoners from the cisterns near the Rajlovac Barracks had been exchanged whereas 50 additional prisoners had been sent home. During the same conversation, Mirko Krajišnik referred to the group of 50 prisoners and told Šemso "[y]ou heard that there were some casualties among them" to which Šemso replied "Yes, I did.” D1089 (Intercept of conversation between Ćamil and Mirko Krajišnik, 20 June 1992), pp. 1-2.

20670 See para. 2220.

20671 Soniboj Škiljević, T. 36957 (10 April 2013);

20672 P2334 (Intercept of conversation between Momčilo Krajišnik, Mijatović and Ljubiša Vladušić, 8 June 1992), pp. $1-4$.

20673 See para. 2221.

20674 See P2310 (Witness statement of KDZ041 dated 14 February 2011), para. 53 (under seal); KDZ041, T. 12074, 12118 (17 February 2011).

20675 See para. 2228.

20676 I note the high number of survivors in this incident; 10 men survived the original attack on the bus, although two of them succumbed to their injuries later.

20677 I note that according to the evidence, two Serb guards were wounded during the attack on the bus.
} 
survivors. In addition, it seems unlikely that Serb Forces would deliberately and unecessarily destroy one of their own vehicles. Many instances of executions have involved the victims being deliberately taken from vehicles and executed nearby. There appears to be no obvious reason why that procedure could not have been followed in this case.

6079. Further, immediately following the incident, the Bosnian Muslim TO appeared to be in control of the territory on which the bus was attacked. ${ }^{20678}$ The Bosnian Muslim TO members not only removed all the bodies from the scene-which would have taken some time- but also filmed the bus. Finally, prior to this incident, Momčilo Krajišnik gave instructions to the Serbs in Rajlovac that nothing should happen to the Bosnian Muslim men detained there. Thus, bearing all those factors in mind, I consider it possible, as recounted by Mirko Krajišnik in the telephone conversation with his brother, ${ }^{20679}$ that the bus strayed into the Bosnian Muslim side of the confrontation line and was mistakenly attacked by the Bosnian Muslim TO. While Mirko Krajišnik may have lied to his brother about the fate of the men on the bus because of his brother's earlier instructions not to harm them, I am unable-in light of the totality of the evidence before the Chamber-to affirmatively conclude that this was the case.

6080. I am therefore unable to conclude, beyond reasonable doubt, that Serb Forces attacked the bus on 14 June 1992 in the incident that resulted in the death of 47 Bosnian Muslim men, and I am therefore of the view that the Accused must be acquitted in this regard.

Done in English and French, the English text being authoritative.

\author{
Howard Morrison
}

Judge

Dated this twenty-fourth day of March 2016

At The Hague

The Netherlands

\title{
[Seal of the Tribunal]
}

$\begin{array}{ll}20678 & \text { See para. } 2229 . \\ 20679 & \text { See } \text { para. } 2220 .\end{array}$ 


\section{B. Dissenting OPINION OF JUdGe B AIRD}

6081. In this matter the majority was satisfied beyond reasonable doubt that the shell that struck the Markale market on 5 February 1994 was fired from SRK held territory by SRK soldiers. I respectfully disagree with this finding.

6082. In his Final brief at paragraph 2056, the Accused submitted that the UN investigators had stated that in extracting the tail fin assembly from the crater, the FreBat 4 team (unavoidably) disturbed the integrity of the crater for any purpose which followed. At paragraph 2069, the Accused stated that the UN Investigative Team collectively and officially concluded that by the time the team had conducted its analyses, six days had elapsed since the explosion: it was reasonable to suspect that the crater had been thoroughly excavated by the local authorities during that period, hence the angles measured on 11 February were not beyond suspicion. They concluded that the results measured on 11 February were not sufficiently accurate to be used as a basis for a finding. At paragraph 2073 the Accused stated that the UN Investigative Team concluded that there was insufficient physical evidence to prove that one party or another had fired the mortar bomb. And at paragraph 2075, the Accused demonstrated that the findings of the UN Investigative Team were endorsed by Colonel Gauthier as he testified as a Defence witness in 2012. As far as I am aware the accuracy of these submissions was never challenged, neither was it made the subject of negative comment by the Chamber. Indeed, in some instances, the pertinent evidence was actually received by the Chamber.

6083. As I see it, this is powerful language employed by the UN Investigative Team. They are in effect saying that there is reasonable doubt that the shell was fired by the Bosnian Serb Forces, and one must not lose sight of the fact that this is a report of Prosecution witnesses. The Prosecution witness Zečević however, was of opinion that the shell could only have been fired from the Bosnian Serb positions.

6084. What I was presented with therefore, was clear and indisputable conflict in the evidence of the Prosecution witnesses. And this conflict went to the root of the Prosecution case.

6085. In this situation I am of the view that the majority should have been driven to resolve this conflict in favour of the Accused.

6086. At paragraph 4247, the majority stated that while the Chamber heard evidence to the effect that measurements and estimates of the angle of descent were unreliable in this incident due to the 
crater having been disturbed, it was also struck by the fact that all but one of the estimated angle ranges were relatively close to each other and in fact overlapped.

6087. Defence witnesses apart, it is the witnesses for the Prosecution whose evidence the majority considered, and which evidence demonstrated that the measurements and estimates of the angle of descent were unreliable due to the disturbance of the crater. There is no clear indication from the majority whether they were accepting the evidence that the measurements and estimates of the angle of descent were unreliable, or whether they were rejecting the evidence on this question. To my mind there was consensus among the UN Investigators who attended the scene, that once the Frebat 4 battalion had removed the tail fin without taking measurements it was not possible to calculate the angle of descent.

6088. In the face of this evidence - evidence which I might add was pointedly favourable to the Accused - I am hard pressed to see why the majority should go on to be 'struck' by the relative closeness of the estimated angle ranges, bar one, and by their overlap.

6089. In a criminal matter where the burden is on the Prosecution to prove the guilt of the Accused beyond the reasonable doubt, this evidence should have been enough to cause reasonable doubt to intrude on the minds of the majority.

6090. Of some significance is the fact that the majority stated at paragraph 4248 , that they could not be sure that the speed of the shell as determined by Zečević was 'absolutely accurate', particularly in light of Allsop's evidence. Irrespective of the language used, the majority is rejecting the evidence of Zečević in this regard, in favour of that of Allsop.

6091. It should be noted that the evidence of Zečević was that any inaccuracy in the measurement of the depth of the crater would have affected the calculations of the impact velocity of the shell and that it was more likely that the depth of the crater was not measured properly in this case, given the disturbance to the crater during the investigations that took place on 5 and 6 February 1994.

6092. I come now to the question of the 'common feature' at paragraph 4248. The majority noticed a 'common feature' in the evidence of Zečević, Higgs, Allsop and Subotić, that is to say, that a mortar bomb fired at one of the higher charges would typically result in the stabiliser penetrating the ground and embedding therein. The majority noted that Higgs referred to 'two highest charges in this respect', Zečević to charges four, five and six, and Subotić to charge three or higher. The majority considered that in the case at hand, the stabiliser was found embedded in the ground with its top at a depth of around nine centimetres from the surface. In the final analysis, 
they concluded that the shell was fired on a charge higher than one or two and therefore from SRK positions.

6093. Without going into the validity or otherwise of their reasoning, my concern is that the Accused was never given an opportunity to address this question as a discrete issue. It was never presented to the Accused for him to comment one way or another thereon. As a result the question was never fully ventilated before the Chamber as a contentious issue. The majority however made a seminal conclusion based on this question, and this in turn, played a crucial role in their decision that the shell had been fired by the Bosnian Serb side. This was unfortunate. It must be borne in mind that we are not within the realm of exact science and it would have been only fair to the Accused for him to be put on notice so that some input from him could have been forthcoming. A decision given under these circumstances therefore, would be flawed as offending against a basic principle of natural justice.

6094. I will add that even if the mortar had been fired on the higher charges, the origin of fire could only have been determined if the proper angle of descent had been calculated and I ingeminate the evidence above quoted that all the Investigators who attended the scene were unanimous that it was not possible to properly calculate the angle of descent once the integrity of the crater had been disturbed.

6095. The majority noted at paragraph 4249, that while Gauthier suggested that the ABiH could have used mobile mortars, they were not convinced that it would have been possible for the $\mathrm{ABiH}$ to fire at the market area from a mobile mortar without being seen, given the densely populated area in the direction of fire and given the proximity of the residential are of Sedrenik to the $\mathrm{ABiH}$ positions in Grdonj. In this particular case, this was flagrant speculation, made in an evidential void, and could form no proper basis for the rejection of evidence that could have introduced reasonable doubt in the minds of the majority. The majority also considered that there was an absence of any evidence as to the sighting of mobile mortars on that date, or shell fire noise coming from within the city. I do not think that this is the proper case in which the absence of the evidence can contribute to the presence of proof beyond reasonable doubt.

\section{KW586}

6096. In paragraph 4252, the majority rejected the evidence of the witness that the Bosnian Muslim side had deliberately targeted Markale so as to achieve international condemnation of the Bosnian Serb and thus further its own political agenda, on the ground that the witness was lacking 
in credibility in relation to this evidence for a number of reasons. I will deal with these reasons seriatim.

6097. As a preface however, I must state that I do not think that the majority would dispute the fact that the witness answered the questions put to him under cross examination - which came from all directions - with a spontaneity and readiness that was quite impressive. Indeed, on occasions he actually corrected the Prosecution.

6098. The first reason identified in paragraph 4252 by the majority is that: "The majority found it unlikely that someone in KW586's position would have been privy to such high level meetings where such sensitive matters were discussed". This is speculation run riot. There is not an atom of evidence to support this conclusion. And this is not a matter of which the majority could properly have taken judicial notice. What is more, the witness gave an explanation that the Prosecution failed to contradict or neutralize. I see no good reason therefore, for the witness to be regarded as lacking in credibility.

6099. The second reason in paragraph 4252 is that: "KW586 exhibited a high degree of animosity towards the current political leadership in $\mathrm{BiH}$, which obviously played a part in his coming forward with his evidence". The witness did in fact, employ intemperate language in referring to the current political leadership in $\mathrm{BiH}$. He explained that he came forward because after the war, he saw what he considered to be injustice - 'if one who is liable is held to account, then another one should be held to account as well'. ${ }^{20680}$ Whether there was merit in his reasoning or not, whether this was misguided reasoning or not, this was the reason he decided to come forward. And I cannot conceive how he could be regarded as lacking in credibility for his reasoning.

6100. The third reason listed in paragraph 4252 is: "There were also inconsistencies between his testimony in court and his witness statement, such as his evidence about the level of involvement of members of the Pakistani UNPROFOR contingent in the Markale incident and the involvement of Halilović, who the witness acknowledged had been removed from his position by Izetbegović at that time".

6101. An examination of the evidence of the witness in this respect might be helpful:.

Q. Well, you said in your statement why they needed that UNPROFOR team. You said that they had some kind of agreements with them that they wouldn't register the firing of missiles from our positions, so UNPROFOR was part of the conspiracy you're alleging in your own words?

20680 KW-586, T. 47206 (17 February 2014). 
A. I never said that, and if it's written somewhere then it needs to be corrected. I never said that the UNPROFOR was part of the conspiracy; UNPROFOR wasn't. It's just that one crew, I don't know whether they were a bit careless or less attentive, but nobody ever said that UNPROFOR was part of the conspiracy. ${ }^{20681}$

6102. I can see no inconsistency in his reply. The Prosecutor began her question by stating that the witness had said in his statement why they needed the UNPROFOR 'team', but in ending the question she dropped the word 'team' and put to the witness: "[...] so UNPROFOR was part of the conspiracy you're alleging in your own words?" The witness then protested that he never said that UNPROFOR was part of the conspiracy; UNPROFOR was not, it was just that one 'crew'. He commented that the way the Prosecutor had put it, it sounded like the whole UNPROFOR conspired against the Bosnian Serbs. 'It was just one crew, two or three men,20682.

6103. I failed to see any inconsistency in this evidence. In paragraph 4252 , the majority also considered the reference of the witness to Halilović as a reason for holding that the witness was inconsistent with his witness statement. The Prosecutor put to the witness that his evidence of conspiracy was fictional because at the time he said the discussions were going on, Halilovic had been ostracised and dismissed from the army. The witness admitted that Halilovic had been ostracised and advanced reasons for his ostracism. He then went on to explain that although Itzetbegović had removed him 'under pressure'; he had not dismissed him from the army. And he would attend meetings whenever he was in Sarajevo. The Prosecutor did not specifically challenge this evidence and introduced no evidence to contradict the witness. ${ }^{20683}$

6104. It cannot be fair to the witness therefore to say that he was inconsistent with his witness statement. I must also emphasize that in the course of cross examination, the Prosecutor sought to contradict the witness by referring to comments he made during an interview with the Prosecution a few days earlier. ${ }^{20684}$ The Prosecutor however, failed to put in evidence any written material that tended to contradict what the witness had said in the interview or to call viva voce evidence to that effect. The Prosecutor therefore, was bound by the answers of the witness and the witness could not be considered to have been contradicted.

6105. The fourth reason identified by the majority in paragraph 4252 is: "Essentially, KW586's evidence implies a conspiracy of a large scale. However, in the majority's view, such conspiracy is not supported by any other evidence on the record". In this particular situation, I harbour the view that the fact that the evidence of conspiracy is not supported by any other evidence could not be a

\footnotetext{
20681 KW586 T.47222 (17 February 2014).

20682 KW586 T.47224 (17 February 2014).

20683 KW586, T. 47225-47226 (17 February 2014).
} 
valid ground for the majority to hold that the witness lacked credibility. The evidence of conspiracy was presented by the Accused as a crucial and integral part of his case and the Defence is under no obligation to call corroborative evidence to support the evidence of any Defence witness. The fact therefore, that there is no other evidence supporting the evidence of conspiracy cannot be reason for the witness to be considered as lacking in credibility.

6106. The fifth reason identified by the majority is: "Finally, if true, it would have meant that the $\mathrm{ABiH}$ was able to make a successful hit on Markale market in only its second attempt. Recalling the evidence the Accused led on the low likelihood of such an intentional hit, the Chamber finds this to be impossible". 'Likelihood' is synonymous with 'probability'. And this is not, by any means, a proper instance in which 'improbability' could have been equated with 'impossibility'. I can see no good reason therefore for deeming the witness to be lacking in credibility in this respect.

6107. In the final analysis I espouse the view that the reasoning the majority advanced for holding the witness to be lacking in credibility was itself deficient in substantiality and was unable to stand up to scrutiny.

6108. The majority also identified 'other evidence' which they considered indicated that the shell was fired from the SRK side. At paragraph 4249 they referred to the evidence that the SRK's $7^{\text {th }}$ battalion of the $1^{\text {st }}$ Romanija Infantry Brigade had $120 \mathrm{~mm}$ mortars in the area of Mrkovići, which was north-northeast of Markale, whereas the evidence before the Chamber was consistent that the ABiH had no mortars in the area of Grdonj. They added that Gengo testified that the ABiH would open fire mostly from the area of Jajce Barracks and Koševo, rather than Grdonj. I experienced profound difficulty in seeing how this evidence could have convinced the majority to hold that beyond reasonable doubt the shell was fired from the Bosnian Serb side.

6109. Also at paragraph 4249, the majority seemed to have accepted the evidence of Gauthier that he could not recall any $\mathrm{ABiH}$ mortar positions in the established directions of fire. This could not possibly have amounted to proof beyond reasonable doubt. It is noteworthy that Gauthier, having given the above evidence, went on to state that the $\mathrm{ABiH}$ could have used mobile mortars. The majority however, rejected this evidence on what I considered to be speculative grounds (ante).

6110. At paragraph 4250, the majority referred to the evidence that the SRK would open fire on the area of Stari Grad from the SRK positions above Sedrenik. They also considered the testimony of Hamill regarding Cvetković's admission that the SRK fired a large number of mortar rounds into

20684 KW586, T. 47212-47213 (17 February 2014). 
Stari Grad prior to the incident in Markale, and the UNMO's report on the morning of 5 February, prior to the Markale incident, that the city centre had been shelled on the night of 4 or 5 February.

6111. I experienced even greater difficulty in comprehending how the majority could have considered that this evidence established beyond reasonable doubt that the shell was fired from the Bosnian Serb side.

\section{KW570}

6112. I refer to an area of the evidence of KW570 which I consider apropos to the issue under consideration. The witness testified that at the meeting on 8 February between General Rose and the leadership of the Bosnian Muslim Military in Sarajevo, Rose stated that evidence was emerging that the market place shelling might have been carried out by their side. The witness testified that there was a complete silence after Rose's statement; thereafter, the Bosnian Military leadership claimed that they had taped a conversation involving the Bosnian Serbs to the effect that they had

confessed to the 'atrocity'. ${ }^{20685}$ The witness further stated that the Bosnian government never produced any such tape or evidence to demonstrate that the Bosnian Serbs had fired the mortar. ${ }^{20686}$ The production of this alleged tape would have put a firm and definitive end to this matter and would have been incontrovertible attestation to the guilt of the Bosnian Serb side. The tape however, was never produced and nothing further was said about it.This left one with the abiding impression that their story was an egregious lie. This conduct on the part of the Bosnian Military Leadership led inexorably to the conclusion that, at the least, there was reasonable doubt that the shell had been fired by the Bosnian Serb side.

6113. To all appearances, the majority made no specific comment on this area of the evidence of this witness. What they did say at paragraph 4252 was that while they accept the 'general evidence' given by KDZ185, KW570 and Milovanović that the Bosnian Moslim side tried to gain sympathy from the international community and would provoke attacks by the SRK with that goal in mind, it was of 'general nature' and did not, as such, cast doubt on the majority's finding that the shell came from SRK positions.

6114. In uno flatu therefore, the majority seemed to be saying that they accepted the evidence of KW570 but dismissed it as being 'of general nature'. And because it was of 'general nature' (as such) it did not cast doubt on their finding that the shell came from the SRK positions.

20685 D2770 (Witness statement of KW570 dated 21 November 2012) (under seal), para. 11.
20686 D2770 (Witness statement of KW570 dated 21 November 2012) (under seal), para. 12. 
6115. The majority failed to clarify what they meant by 'general nature'. And this was vital because it was due to the fact that the evidence was consigned to the category of 'general nature' that it did not succeed in casting doubt on their finding.

6116. Further, it is reasonable to assume that when the majority accepted the evidence of KW570, they accepted his narrative of the taped conversation. In this situation it would have been extremely helpful for the majority to give full reasons why in the face of accepting the evidence of the taped conversation, they were not prepared to address it but were merely disposed to gather it under the amorphous heading of 'general nature'. It is not insignificant that KW570 was a member of UNPROFOR at the time of the incident and he was also a Defence witness. The evidence he gave had the potential for casting doubt that the Bosnian Serb side was responsible for firing the shell. And this evidence formed an integral part of the Defence case.

6117. The Accused was therefore, entitled to some exposure to the minds of the majority for their dismissal of this evidence, other than the cryptic 'of general nature'.

\title{
3. Conclusion
}

6118. I am therefore, of the view that when all the factors I have identified above are collocated, the resulting edifice is of such, that I can hold that there is reasonable doubt that the Bosnian Muslim side fired the mortar bomb on the Markale Market.

6119. In the circumstances I am of opinion that the Accused must be acquitted of this charge.

Done in English and French, the English text being authoritative.

\author{
Melville Baird
}

Judge

Dated this twenty-fourth day of March 2016

At The Hague

The Netherlands

\section{[Seal of the Tribunal]}




\section{ANNEXES}

\section{A. PROCEDURAL HISTORY}

1. Pre-trial proceedings

a. From confirmation of the Indictment to the Accused's plea

6120. On 25 July 1995, an indictment was confirmed against the Accused and Ratko Mladić, charging them for crimes allegedly committed in BiH between April 1992 and July 1995. ${ }^{20687}$ On 16 November 1995, a second indictment against these accused, charging them for crimes alleged to have taken place in Srebrenica in July 1995, was also confirmed. ${ }^{20688}$

6121. Due to the failure to execute their warrants of arrest and to serve the indictments upon them, ${ }^{20689}$ a hearing was subsequently held under Rule 61 of the Rules, and the two indictments were joined on 11 July $1996 .^{20690}$

6122. In 2000, the Prosecution sought to amend the joined indictment insofar as it pertained to the Accused, which was then confirmed. ${ }^{20691}$ In 2002, a similar process was undertaken with regard to Mladić. ${ }^{20692}$ The cases against the two accused were ultimately severed in $2009 .^{20693}$

6123. The Accused was arrested on 21 July 2008 in Belgrade and transferred to The Hague on 30 July 2008. His initial appearance was held the following day. ${ }^{2069}$ Shortly thereafter, the Prosecution requested leave to make certain amendments to the indictment. ${ }^{20695}$ On 16 February 2009, the Chamber issued a decision granting the Prosecution's motion in large part, ${ }^{20696}$ and, on 27 February 2009, the Prosecution filed its Third Amended Indictment, which remains the operative "Indictment". 20697

\footnotetext{
20687 Prosecutor v. Karadžić and Mladić, Case No. IT-95-5-I, Review of the Indictment, 25 July 1995.

20688 Prosecutor v. Karadžić and Mladić, Case No. IT-95-18-I, Review of the Indictment, 16 November 1995.

20689 Prosecutor v. Karadžić and Mladić, Case No. IT-95-18-I, Warrant for Arrest Order for Surrender [Karadžić], 16 November 1995; Prosecutor v. Karadžić and Mladić, Case No. IT-95-18-I, Warrant for Arrest Order for Surrender [Mladić], 16 November 1995.

20690 Prosecutor v. Karadžić and Mladić, Case Nos. IT-95-5-R61 and IT-95-18-R61, Rule 61 Hearing, T. 918-993 (11 July 1996).

20691 Prosecutor v. Karadžić, Case No. IT-95-5/18-I, Order Granting Leave to Amend the Indictment and Confirming the Amended Indictment, 31 May 2000.

20692 Prosecutor v. Mladić, Case No. IT-95-5/18-I, Order Granting Leave to File an Amended Indictment and Confirming the Amended Indictment, 8 November 2002.

20693 Order Severing Ratko Mladić, 15 October 2009.

20694 Initial Appearance, T. 1-28 (31 July 2008).

20695 Motion to Amend the First Amended Indictment, 22 September 2008.

20696 Decision on Prosecution Motion to Amend the First Amended Indictment, 16 February 2009.

20697 Third Amended Indictment, 27 February 2009.
} 
6124. On 3 March 2009, during the Accused's further initial appearance, and upon his failure to enter a plea, the pre-trial Judge entered pleas of not guilty to all eleven counts of the Indictment on behalf of the Accused, pursuant to Rule 62(iv) of the Rules. ${ }^{20698}$

\section{b. Self-representation}

6125. From his transfer to The Hague, the Accused decided to represent himself at all stages of the proceedings. The Registry provided financial support for the assignment of a set number of support staff, ultimately assigning the Accused a team of four legal associates, two case managers, and two investigators. ${ }^{20699}$ Furthermore, as discussed in detail below, after the Accused's refusal to appear before the Chamber for the commencement of trial, an appointed counsel was selected to prepare to represent the Accused's interests, should the Chamber order counsel to do so. ${ }^{20700}$

\section{c. Language}

6126. The Accused initially maintained that his level of English was not sufficient to understand complex legal proceedings and requested that all documents be presented to him in BCS. In a 25 September 2008 decision, the Chamber denied the Accused's requests that all court transcripts be translated into BCS. ${ }^{20701}$ On 26 March 2009, the Chamber granted a Prosecution motion for a determination that the Accused understands English for the purpose of the Rules. ${ }^{20702}$

\section{d. Challenges to jurisdiction and to the form of the Indictment}

6127. From the beginning, the Accused maintained that the Tribunal lacked the authority to prosecute him due to the alleged agreement that he entered into with U.S. Ambassador Richard Holbrooke in July 1996, who promised him immunity in return for his withdrawal from public life in BiH ("Holbrooke Agreement"). ${ }^{20703}$ Throughout the pre-trial phase of the case, the Chamber

\footnotetext{
20698 Further Initial Appearance, T. 133-134 (3 March 2009).

20699 See Registrar's Submission Pursuant to Rule 33(B) regarding Radovan Karadžić's Motion for Adequate Facilities and Equality of Arms, 2 December 2008; Decision on Accused Motion for Adequate Facilities and Equality of Arms: Legal Associates, 28 January 2009; Decision on Accused Request for Judicial Review of the Registry Decision on the Assignment of Mr. Marko Sladojević as Legal Associate, 20 April 2009.

20700 See para. 6133.

20701 Decision on the Accused's Request that All Materials, Including Transcripts, Be Disclosed to Him in Serbian and Cyrillic Script, 25 September 2008.

20702 Decision on Prosecution Motion Seeking Determination that the Accused Understands English for the Purposes of the Statute and the Rules of Procedure and Evidence, 26 March 2009. The Appeals Chamber subsequently upheld the Chamber's decision. Decision on Interlocutory Appeal of the Trial Chamber's Decision on Prosecution Motion Seeking Determination that the Accused Understands English, 4 June 2009.

20703 Official Submission Concerning My First Appearance and My Immunity Agreement with the USA, 6 August 2008.
} 
issued a number of decisions in connection thereto. ${ }^{20704}$ On 8 July 2009, the Chamber denied the Accused's motion seeking dismissal of the Indictment for lack of personal jurisdiction on the basis of the Holbrooke Agreement. ${ }^{20705}$

6128. The Chamber issued a decision disposing of six preliminary motions filed by the Accusedwhich he characterised as challenges to jurisdiction-, granting one of them in part. ${ }^{20706}$ The Accused filed a direct appeal against the Chamber's decision that three of his motions did not raise genuine issues of jurisdiction; the Chamber also granted both the Accused and the Prosecution leave to appeal its decision insofar as it related, respectively, to the crime of hostage-taking, and to the correct mens rea standard for the third form of JCE liability; the Appeals Chamber ultimately confirmed the Chamber's findings appealed by the Accused and found that the Chamber had erred in law in relation to the portion appealed by the Prosecution. ${ }^{20707}$ The Chamber also issued a decision denying two motions filed by the Accused challenging the form of the Indictment. $^{20708}$

20704 See Decision on Accused Motion for Inspection and Disclosure, 9 October 2008; Decision on Accused's Second Motion for Inspection and Disclosure: Immunity Issue, 17 December 2008; Decision on Accused's Application for Certification to Appeal Decision on Inspection and Disclosure, 19 January 2009; Order Pursuant to Rules 54 and 70, 5 March 2009; Decision on Accused Motion for Interview of Defence Witness and Third Motion for Disclosure, 9 April 2009; Decision on Motion for Further Explanation from the Prosecution Concerning General Wesley Clark, 5 June 2009; Order Pursuant to Rules 54 and 70, 18 June 2009; Decision on Motion for Subpoena to Douglas Lute and John Feeley, 8 July 2009. See also Decision on Appellant Radovan Karadžić's Appeal Concerning Holbrooke Agreement Disclosure, 6 April 2009.

20705 Decision on the Accused's Holbrooke Agreement Motion, 8 July 2009. The Chamber granted leave to appeal its decision, and the Appeals Chamber subsequently upheld the Chamber's decision in October 2009. Decision on Accused's Application for Certification to Appeal Decision on Holbrooke Agreement Motion, 17 July 2009; Decision on Karadžić's Appeal of Trial Chamber's Decision on Alleged Holbrooke Agreement, 12 October 2009. On 26 February 2014, the Chamber granted the Accused's request to admit into evidence a number of documents which relate to the issue of the Holbrooke Agreement for the limited purpose of sentencing deliberations. Decision on Admission of Information Relating to Sentencing, 26 February 2014.

20706 Decision on Six Preliminary Motions Challenging Jurisdiction, 28 April 2009. See also Preliminary Motion to Dismiss Paragraph 60 (k) for Lack of Jurisdiction, 10 March 2009; Preliminary Motion to Dismiss Joint Criminal Enterprise III - Foreseeability, 16 March 2009; Preliminary Motion to Dismiss Count 11 for Lack of Jurisdiction, 18 March 2009; Preliminary Motion on Lack of Jurisdiction Concerning Omission Liability, 25 March 2009; Preliminary Motion to Dismiss JCE III - Special Intent Crimes, 27 March 2009; Preliminary Motion on Lack of Jurisdiction: Superior Responsibility, 30 March 2009.

20707 Decision on Radovan Karadžić's Motions Challenging Jurisdiction (Omission Liability, JCE III-Special Intent Crimes, Superior Responsibility), 25 June 2009; Decision on Prosecution's Motion Appealing Trial Chamber's Decision on JCE III Foreseeability, 25 June 2009; Decision on Appeal of Trial Chamber's Decision on Preliminary Motion to Dismiss Count 11 of the Indictment, 9 July 2009.

20708 Decision on Two Motions Alleging Defects in the Form of the Indictment, 12 May 2009. See also Preliminary Motion Alleging Defect in Form of Indictment - Multiple Joint Criminal Enterprises, 19 March 2009; Preliminary Motion Alleging Defect in Form of the Indictment - Joint Criminal Enterprise Members and NonMember Participants, 20 March 2009. After the close of his Defence case, the Chamber denied a motion by the Accused in which he argued that parts of the Indictment were vague and defective and failed to properly inform him of the nature and scope of the charges against him and requested an order precluding considerations of those allegations by the Chamber in its deliberations or, in the alternative, that the Indictment be amended and that he be allowed to re-open his case to defend against the newly specified allegations. Decision on Accused's Motion for Relief from Defects in the Indictment, 30 September 2014. 


\section{e. Motions to disqualify}

6129. In May 2009, the Accused filed a motion requesting that Judge Picard be disqualified from these proceedings because of her former position as President of the Human Rights Chamber of $\mathrm{BiH}$, and other related factors. ${ }^{20709}$ Four months later, following the re-composition of the pre-trial bench, ${ }^{20710}$ the Accused filed a motion seeking the disqualification of Judge Baird, on the basis of the provisions of Article 13 of the Statute. ${ }^{20711}$ Both motions were denied by the panels of three judges ultimately appointed to determine each of them. ${ }^{20712}$

\section{f. Applications under Rule 73 bis of the Rules}

6130. In July 2009, the Chamber issued an order directing the Prosecution to file a written submission on the issue of the application of Rule 73 bis. ${ }^{20713}$ The Prosecution filed its first Rule 73 bis submission on 31 August 2009. ${ }^{20714}$ Having been invited by the Chamber to propose further reductions to its case, ${ }^{20715}$ the Prosecution filed a second submission on 18 September 2009. in which it opposed any further reductions ${ }^{20716}$ During the pre-trial conference held on 6 October 2009, the Chamber rendered an oral decision on the application of Rule 73 bis (C) and (D), reducing the number of crime sites and incidents and allocating the Prosecution 300 hours for the presentation of its case. ${ }^{20717}$

\footnotetext{
20709 Motion to Disqualify Judge Picard, 1 May 2009.

20710 See Order Designating Pre-Trial Judge, 2 September 2009; Order Regarding Composition of a Bench of the Trial Chamber, 4 September 2009.

20711 Motion to Recuse Judge Melville Baird, 22 September 2009.

20712 Decision on Motion to Disqualify Judge Picard and Report to the Vice-President Pursuant to Rule 15(B)(ii), 22 July 2009; Decision on Motion to Recuse Judge Baird and Report to Judge Güney, 20 October 2009. See also Decision on Motion to Disqualify Judge Picard, 18 May 2009; Decision on Appeal from Decision on Motion to Disqualify Judge Picard, 26 June 2009; Report by Presiding Judge to President on Motion to Recuse Judge Baird, 25 September 2009; Order Assigning a Motion to a Judge, 25 September 2009; Decision on Radovan Karadžić's Motion to Recuse Judge Melville Baird, 30 September 2009; Decision on Motion for Leave to File a Reply, 9 October 2009. On 31 July 2014, the Chamber denied the Accused's "Motion to Disqualify Judges Kwon, Morrison, Baird \& Lattanzi" filed on 17 July 2014 in which he argued that the Judges of the Chamber should be disqualified as their four-year terms of office had expired and they had not been re-elected by the General Assembly. The Chamber found that the motion raised an issue of jurisdiction rather than disqualification under Rule 15 of the Rules and held on the contrary that the terms of office of the Judges of the Chamber had been appropriately extended. Decision on Accused's Motion to Disqualify Judges Kwon, Morrison, Baird, and Lattanzi, 31 July 2014.

20713 Order to the Prosecution under Rule 73 bis (D), 22 July 2009; Status Conference, T. 330-336 (1 July 2009). The deadline was extended at the Status Conference of 23 July 2009 to 31 August 2009. Status Conference, T. 386-388, 390 (23 July 2009).

20714 Prosecution Rule 73 bis Submission.

20715 Status Conference, T. 450-454 (8 September 2009).

20716 Prosecution Second Submission Pursuant to Rule 73 bis (D), 18 September 2009. On 30 September 2009, the Accused filed a written response without making any specific proposals or submissions. Response to Prosecution's Second Rule 73 bis Submission, 30 September 2009.

20717 Pre-Trial Conference, T. 465-468 (6 October 2009). See also Decision on the Application of Rule 73 bis, 8 October 2009 (ordering the Prosecution to file a marked-up version of the Indictment in accordance with that decision by 19 October 2009). The Chamber notes its "Decision on Motion for Withdrawal of Charges" issued
} 


\section{Trial proceedings}

\section{a. Delay of commencement of trial proceedings}

6131. The pre-trial Judge declared the case ready for trial during a status conference held on 20 August 2009. During a further status conference held on 9 September 2009, and following a submission by the Accused requesting ten additional months to prepare his defence, the Chamber set the date for commencement of trial at 19 October 2009, and a pre-trial conference was held on 6 October 2009. The Accused appealed the Chamber's decision on the commencement of trial, and the Appeals Chamber subsequently determined that the trial should proceed with a delay of one week. ${ }^{20718}$ The Chamber subsequently issued an order setting the date for the commencement of trial at 26 October $2009 .^{20719}$

6132. On 8 October 2009, the Chamber issued an order adopting a set of detailed guidelines on the manner in which it expected the trial proceedings to be conducted. ${ }^{20720}$ The Chamber also issued a number of orders and decisions in anticipation of the imminent commencement of the case..$^{20721}$

6133. The Chamber held its first hearing on 26 October 2009 in the absence of the Accused who maintained that he was inadequately prepared. ${ }^{20722}$ The Prosecution gave its opening statement on 27 October and 2 November 2009. ${ }^{20723}$ After several warnings to the Accused, the Chamber issued a decision on 5 November 2009, ordering the Registrar to appoint counsel to begin preparing to represent the Accused at trial, should the Chamber order him to do so, and adjourning the trial until 1 March 2010 to allow the appointed counsel sufficient preparation time. ${ }^{20724}$ On 19 November

on 13 October 2014, in which it denied the Accused's motion requesting the Prosecution to withdraw the charges in relation to which it was instructed not to lead evidence as per the 8 October 2009 decision. After the close of the Defence case, the Prosecution notified the Chamber that it would withdraw Scheduled Incident A.5.1 (Foča Municipality) and Scheduled Detention Facility C.25.4 (Vlasenica Municipality) from the Indictment. Notice of Withdrawal of Incident A.5.1., 18 August 2014; Notice of Withdrawal of Incident C.25.4, 22 August 2014.

Decision on Radovan Karadžić's Appeal of the Decision on Commencement of Trial, 13 October 2009.

Scheduling Order for the Commencement of Trial, 14 October 2009.

Order on the Procedure for the Conduct of Trial, 8 October 2009. The Chamber issued a follow-up order following a request from the Prosecution seeking clarification on certain aspects of the guidelines. Order on Prosecution Request for Clarification and Proposal Concerning Guidelines for the Conduct of Trial, 20 October 2009.

See inter alia Order on Prosecution's Notification of Order of Witnesses, 12 October 2009.

During that hearing, the Presiding Judge read a letter sent by the Accused a few days earlier explaining his reasons for his refusal to appear in court. After hearing from the Prosecution on the Accused's absence, the Chamber adjourned the hearing until the following day. Hearing, T. 502-509 (26 October 2009).

Prosecution's opening statement, T. 513-610 (27 October 2009); T. 612-672 (2 November 2009).

Decision on Appointment of Counsel and Order on Further Trial Proceedings, 5 November 2009. 
2009, the Registrar selected Richard Harvey as "counsel to prepare to represent the interests of the Accused at trial". 20725

6134. On 1 February 2010, the Accused filed a motion requesting a further postponement of the trial. ${ }^{20726}$ The Chamber denied the motion and ordered the Accused's opening statement to be heard on 1 and 2 March 2010, following which the trial proceedings would continue on 3 March 2010 with the hearing of evidence. ${ }^{20727}$ The Accused gave his opening statements on 1 and 2 March, as scheduled. However, on 1 March he filed a motion for certification to appeal the Chamber's decision on the postponement of trial, which the Chamber granted. ${ }^{20728}$ On 31 March, the Appeals Chamber issued a decision dismissing the Accused's appeal in its entirety. ${ }^{20729}$

6135. On 13 April 2010, the Chamber designated Harvey as standby counsel. ${ }^{20730}$ On 15 April, through a follow-up written decision, the Chamber set out the specific functions to be carried out by the standby counsel during the proceedings. ${ }^{20731}$

\section{b. Prosecution case}

6136. Following the dismissal of the Accused's appeal on the commencement of the trial, as discussed above, the Chamber ordered that the presentation of evidence in the case should begin on 13 April 2010. ${ }^{20732}$ The Prosecution's first witness began his testimony on that day. ${ }^{20733}$ During the Prosecution case, a total of 195 Prosecution witnesses and one Chamber's witness testified: ${ }^{20734}$

20725 During the adjournment period, the Chamber denied the Accused's motion opposing the Registrar's appointment of Mr. Harvey, and granted his request to appeal the Chamber's decision upholding such appointment (which was eventually upheld by the Appeals Chamber). Decision on the Accused's Motion to Vacate Appointment of Richard Harvey, 23 December 2009; Decision on Accused's Application for Certification to Appeal the Trial Chamber's Decision on Motion to Vacate Appointment of Richard Harvey, 13 January 2010; Prosecutor v. Radovan Karadžić, Case No. IT-05-5/18-AR73.6, Decision on Radovan Karadžić's Appeal from Decision on Motion to Vacate Appointment of Richard Harvey, 12 February 2010.

20726 Motion for Postponement of Trial, 1 February 2010.

20727 Decision on the Accused's Motion for Postponement of Trial, 26 February 2010.

20728 The Chamber granted the Accused leave to appeal the Chamber's decision, and stayed the effect of its decision on postponement until the Appeals Chamber resolved the matter. Oral Ruling, T. 993-995 (2 March 2010).

20729 Decision on Appeal from Decision on Motion for Further Postponement of Trial, 31 March 2010.

20730 Oral Ruling, T. 998-999 (13 April 2010).

20731 Decision on Designation of Standby Counsel, 15 April 2010. On 21 June 2012, after the close of the Prosecution's case, the Chamber issued a decision stating that the role of the standby counsel should remain unchanged during the Defence case. Decision on Continuation of Standby Counsel Assignment, 21 June 2012.

20732 Scheduling Order, 1 April 2010.

20733 Ahmet Zulić, T. 1004 (13 April 2010).

20734 The Chamber issued a subpoena ordering Momčilo Mandić to testify as a Prosecution witness. Mandić appeared before the Chamber on 30 June 2010; however, upon appearing before the Chamber he requested to testify as a Chamber's witness and not as a witness for the Prosecution. The Chamber ultimately granted Mandić's request. Hearing, T. 4403-4412 (30 June 2010). See Decision on Prosecution's Urgent Motion to Subpoena Momčilo Mandić with Appendices A-D, confidential, 16 June 2010. 
19 of these testified as viva voce witnesses and the remainder pursuant to Rule 92 ter of the Rules. The last Prosecution witness testified on 4 May 2012. ${ }^{20735}$

6137. Additionally, the Chamber issued 16 decisions disposing of the Prosecution's motions for the admission of evidence of 232 witnesses pursuant to Rule 92 bis, and 22 witnesses pursuant to Rule 92 quater of the Rules. ${ }^{20736}$ The Chamber ultimately admitted the written evidence of 142 witnesses pursuant to either of these two Rules.

6138. On 26 April 2012, the Chamber issued an order stating that the Prosecution case shall be considered closed on the day that the Chamber issues its decision on the last pending evidencerelated motion filed by the Prosecution. ${ }^{20737}$ The Prosecution case was thus closed on 25 May 2012, following the Chamber's decision on the last pending evidence-related motion filed by the Prosecution. $^{20738}$

20735 KDZ071, T. 28508-28562 (4 May 2012).

20736 Decision on Third Prosecution's Motion for Admission of Evidence of Statements and Transcripts of Evidence In Lieu of Viva Voce Testimony Pursuant to Rule 92 bis (Witnesses for Sarajevo Municipality), 15 October 2009; Decision on Prosecution Motion for Admission of Testimony of Witness KDZ198 and Associated Exhibits Pursuant to Rule 92 quater, 20 August 2009; Decision on Prosecution's Motion for Admission of Evidence of KDZ290 (Mirsad Kučanin) Pursuant to Rule 92 quater, 25 September 2009; Decision on Prosecution Motion for Admission of Testimony of Witness KDZ446 and Associated Exhibits Pursuant to Rule 92 quater, 25 September 2009; Decision on Prosecution's Sixth Motion for Admission of Statements In Lieu of Viva Voce Testimony Pursuant to Rule 92 bis: Hostage Witnesses, 2 November 2009; Decision on Prosecution's Motion for Admission of Evidence of Eight Experts Pursuant to Rules 92 bis and 94 bis, 9 November 2009; Decision on Prosecution's First Motion for Admission of Statements and Transcripts of Evidence In Lieu of Viva Voce Testimony Pursuant to Rule 92 bis (Witnesses for Eleven Municipalities), 10 November 2009; Public Redacted Version of “Decision on Prosecution's Fifth Motion for Admission of Statements In Lieu of Viva Voce Testimony Pursuant to Rule 92 bis (Srebrenica Witnesses)" Issued on 21 December 2009, 6 March 2012; Decision on Prosecution's Seventh Motion for Admission of Transcripts of Evidence in Lieu of Viva Voce Testimony Pursuant to Rule 92 bis: Delayed Disclosure Witnesses, 21 December 2009; Further Decision on Prosecution's First Rule 92 bis Motion (Witnesses for Eleven Municipalities), 9 February 2010; Decision on Prosecution's Fourth Motion for Admission of Statements and Transcripts of Evidence in Lieu of Viva Voce Testimony Pursuant to Rule 92 bis-Sarajevo Siege Witnesses, 5 March 2010; Decision on Prosecution's Second Motion for Admission of Statements and Transcripts of Evidence In Lieu of Viva Voce Testimony Pursuant to Rule 92 bis (Witnesses ARK Municipalities), 18 March 2010; Decision on Prosecution's Motion for Admission of the Evidence of KDZ172 (Milan Babić) Pursuant to Rule 92 quater, 13 April 2010; Decision on Prosecution's Motion for Admission of the Evidence of Milenko Lazić Pursuant to Rule 92 quater and for Leave to Add Exhibits to Rule 65 ter Exhibit List, 9 January 2012; Decision on Prosecution's Second Motion for Admission of Slobodan Stojković's Evidence in Lieu of Viva Voce Testimony Pursuant to Rule 92 bis, 22 March 2012; Decision on Prosecution Motion for Admission of Milan Tupajić's Evidence in Lieu of Viva Voce Testimony Pursuant to Rule 92 bis, 24 May 2012.

20737 Scheduling Order on Close of the Prosecution Case, Rule 98 bis Submissions, and Start of the Defence Case, 26 April 2012.

20738 Further Order on Close of Prosecution Case, 1 June 2012. 


\section{c. Judgement of acquittal pursuant to Rule 98 bis}

6139. Following the parties' Rule 98 bis oral submissions on 12 and 13 June $2012,{ }^{20739}$ on 28 June 2012, the Chamber delivered its oral ruling on the Accused's motion for a judgement of acquittal, pursuant to Rule 98 bis of the Rules. The Chamber dismissed the Accused's motion on ten counts of the Indictment but granted his motion in relation to Count 1.

6140. On 25 July 2012, the Accused filed an appeal in relation to Count 11 before the Appeals Chamber. $^{20740}$ On 11 December 2012, the Appeals Chamber issued its decision in relation to Count 11, dismissing the Accused's appeal. ${ }^{20741}$ On 24 September 2012, the Prosecution filed its appeal in relation to Count 1 before the Appeals Chamber. ${ }^{20742}$ On 11 July 2013, the Appeals Chamber reversed the Chamber's acquittal of the Accused for genocide under Count 1 and reinstated the charges against the Accused. ${ }^{20743}$

20739 Accused's Rule 98 bis Submission, T. 28569-28626 (11 June 2012); Prosecution's Response to Rule 98 bis Submission, T. 28628-28728 (13 June 2012). See also Scheduling Order on Close of the Prosecution Case, Rule 98 bis Submissions, and Start of the Defence Case, 26 April 2012; Further Scheduling Order on Rule 98 bis Submissions, 18 May 2012.

20740 Appeal from Denial of Judgement of Acquittal for Hostage Taking, 25 July 2012. See also Prosecution Response to Appeal from Denial of Judgement of Acquittal for Hostage Taking, 6 August 2012; Reply Brief: Appeal from Denial of Judgement of Acquittal for Hostage Taking, 10 August 2012. By way of background, the Chamber notes that on 5 July 2012, the Accused filed an application for certification to appeal the Judgement of Acquittal in relation to Count 11. Application for Certification to Appeal Denial of Motion for Judgement of Acquittal on Count Eleven, 5 July 2012. The Chamber granted the application on 18 July 2012. Decision on Accused's Application for Certification to Appeal Denial of Motion for Judgement of Acquittal under Rule 98 bis (Count 11), 18 July 2012.

20741 Decision on Appeal from Denial of Judgement of Acquittal for Hostage-Taking, 11 December 2012.

20742 Notice of Filing Public Redacted Version of Prosecution Rule 98 bis Appeal Brief, 25 September 2012; Notice of Filing Public Redacted Version of Respondent's Brief, 5 November 2012. See also Prosecution Notice of Appeal of Judgement of Acquittal under Rule 98 bis, 22 July 2012. On 28 September 2012, the Accused filed a motion to strike the Prosecution's appeal brief which was followed by a response from the Prosecution on 8 October 2012, and a further reply from the Accused on that same date. On 9 November 2012, the Appeals Chamber issued a decision granting the Accused's motion, and ordering the Prosecution to file a corrigendum to its Appeals Brief. The Prosecution filed such corrigendum on 19 November 2012, and a reply to the Accused's response a day later. See Motion to Strike Prosecution's Brief, 27 September 2012; Response to Motion to Strike Prosecution's Rule 98 bis Appeal Brief, 5 October 2012; Reply to Motion to Strike Prosecution's Brief, 5 October 2012; Decision on Motion to Strike Prosecution's Brief, 9 November 2012; Corrigendum to Prosecution Rule 98 bis Appeal Brief, 19 November 2012; Notice of Filing Redacted Public Version of Prosecution Reply Brief for Rule 98 bis Appeal, 20 November 2012. By way of background, the Chamber notes that on 3 July 2012, the Prosecution filed a request for certification to appeal the Chamber's Judgement of Acquittal on Count 1 of the Indictment. Prosecution Request for Certification to Appeal Judgement of Acquittal Under Rule 98 bis, 3 July 2012. The Chamber issued a decision stating that certification was not required before the Judgement of Acquittal could be appealed, but declaring nevertheless that the requirements for certification to appeal under Rule 73(C) were met with respect to the Prosecution's request; Decision on Prosecution Request for Certification to Appeal Judgement of Acquittal under Rule 98 bis, 13 July 2012.

20743 Prosecutor v. Karadžić, Case No. IT-95-5/18-AR98bis.1, Judgement, 11 July 2013 (“Appeal Judgement on Count 1"). The Appeals Chamber subsequently denied the Accused's request to clarify a portion of its judgement, Prosecutor v. Karadžić, Case No. IT-95-5/18-AR98bis.1, Decision on Motion for Clarification, 1 August 2013. See also Prosecutor v. Karadžić, Case. No. IT-95-5/18-AR98bis.1, Motion for Clarification, 22 July 2013. 


\section{d. Defence case}

6141. On 26 April 2012, the Chamber ordered that the Accused shall make his opening statement on 16 October 2012, should he so wish, and call his first witness immediately thereafter. ${ }^{20744}$ On 19 September 2012, the Chamber issued a decision pursuant to Rule 73(B) of the Rules granting the Accused 300 hours for the presentation of his case. ${ }^{20745}$ The Accused made his opening statement on 16 October $2012 .^{20746}$ The first Defence witness began his testimony on that same date. ${ }^{20747}$

6142. On 16 July 2013, following the issuance of the Appeal on Count 1 , as explained above, the Accused filed a motion requesting the Chamber to order that Count 1 be severed from the Indictment pursuant to Rule 54 or, alternatively, direct the Prosecution to proceed on all counts of the Indictment except Count 1 pursuant to Rule 73 bis (E). ${ }^{20748}$ On 24 July 2013, the Accused filed another motion requesting the Chamber to suspend the case for four months to enable him to prepare his defence for Count 1. ${ }^{20749}$ On 2 August 2013, the Chamber disposed of the motions, denying the Accused's request for severance, but suspending the proceedings until 28 October 2013 in order to give the Accused time to adjust his preparations to include a defence on Count $1 .^{20750}$ On 7 August 2013, the Accused simultaneously filed an application before the Chamber for certification to appeal the Chamber's decision, as well as an appeal before the Appeals Chamber. ${ }^{20751}$ The Chamber issued a decision stating that certification was not required in the present case, but declaring nevertheless that the requirements for certification to appeal under Rule

20744 Scheduling Order on Close of the Prosecution Case, Rule 98 bis Submissions, and Start of the Defence Case, 26 April 2012.

20745 Decision on Time Allocated to the Accused for the Presentation of his Case, 19 September 2012. On 5 October 2012, the Chamber issued a decision granting the Accused's request for certification to appeal the Chamber's decision on allocation of time; Decision on Application for Certification to Appeal Decision on Time for Defence Case, 5 October 2012. See also Application for Certification to Appeal Decision on Time for Defence Case, 24 September 2012. On 12 October 2012, the Accused filed his appeal before the Appeals Chamber; Appeal from Decision on Duration of Defence Case, 12 October 2012. See also Prosecution Response to Appeal from Decision on Duration of Defence Case, 22 October 2012; Reply Brief: Appeal from Decision on Duration of Defence Case, 25 October 2012; Prosecution Request for Sur-Reply and Proposed Sur-Reply in Appeal from Decision on Duration of Defence Case, 29 October 2012. On 29 January 2013, the Appeals Chamber issued a decision denying the Accused's request and upholding the Chamber's decision; Decision on Appeal from Decision on Duration of Defence Case, 29 January 2013.

20746 Accused's opening statement, T. 28849-28881 (16 October 2012).

20747 Andrey Demurenko, T. 28881 (16 October 2012).

20748 Motion to Sever Count One, 16 July 2013.

20749 Motion for Suspension of Defence Case, 24 July 2013.

20750 Decision on Accused's Motions for Severance of Count 1 and Suspension of Defence Case, 2 August 2013.

20751 Application for Certification to Appeal Decision on Remand of Count One, 7 August 2013; Prosecutor v. Karadžić, Case No. IT-95-5/18-AR98bis.1, Appeal of Decision on Remand of Count One, 7 August 2013. See also Prosecution Response to Karadžić's Application for Certification to Appeal Decision on Remand of Count One, 9 August 2013. 
73(C) were met. ${ }^{20752}$ On 12 September 2013, the Appeals Chamber issued a decision dismissing the Accused's appeal in its entirety. ${ }^{20753}$

6143. On 28 August 2013, the Chamber issued a decision denying the Accused's request to dismiss the Indictment based on the fact that the Security Council did not have the authority to establish the MICT, that there is therefore no legal entity to which he could appeal in the event he is convicted, and thus his fundamental right to appeal had been abridged. ${ }^{20754}$

6144. On 29 October 2013, in light of the Accused's request to recall witnesses to give testimony relevant to Count 1, and for additional time in which to present his case, the Chamber issued a decision granting the Accused 25 additional hours for the presentation of his case. ${ }^{20755}$

6145. During the Defence case, a total of 238 witnesses testified for the Accused: 24 testified as viva voce witnesses and the remainder testified pursuant to Rule 92 ter of the Rules. The Accused informed the Chamber that he would testify as a witness in his own case in August 2012 and maintained this position for most of the Defence case. ${ }^{20756}$ Subsequently, the Accused requested to testify in a narrative form, which the Chamber denied. ${ }^{20757}$ By the end of the Defence case, the Accused, referring to his "dilemmas and quandaries", informed the Chamber that he had ultimately decided not to testify. ${ }^{20758}$ The last Defence witness testified on 20 February $2014 .{ }^{20759}$

6146. Additionally, the Chamber admitted the evidence of three Defence witnesses pursuant to Rule 92 bis of the Rules, and of seven witnesses pursuant to Rule 92 quater. $^{20760}$

\footnotetext{
20752 Decision on Accused's Application for Certification to Appeal Decision on Remand of Count One, 3 September 2013.

20753 Prosecutor v. Karadžić, Case No. IT-95-5/18-AR98bis.1, Decision on Appeal of Decision on Remand of Count One, 12 September 2013.

20754 Decision on Accused's Motion to Dismiss the Indictment, 28 August 2013.

20755 Decision on Accused's Request for Additional Time to Present his Defence Case and on Motion to Recall Defence Witnesses, 29 October 2013. See also Motion to Recall Defence Witnesses, 16 October 2013.

20756 Defence Submission Pursuant to Rule 65 ter and Related Motions, 27 August 2012; Annex "A" to Rule 65 ter Submission: Defence Witness List, confidential, 27 August 2012, p. 65. See also inter alia Defence Supplemental Submission Pursuant to Rule 65 ter, confidential, 7 November 2013, Annex J, p. 18; Defence Witnesses for February 2014, 20 January 2014, Annex "A".

20757 Oral ruling, T. 45933-45935 (27 January 2014). See Hearing, T. 45187-45188 (16 December 2013); Prosecution Submission on Form of Karadžić's Testimony, 8 January 2014.

20758 Hearing, T. 47541 (20 February 2014). On 15 October 2014, the Chamber dismissed the "Motion to Treat Unsworn Statement as Evidence" filed on 25 September 2014, wherein the Accused requested that the Chamber give the statement which he made on 16 October 2012 pursuant to Rule 84 bis the same consideration in its deliberations as it would give statements admitted pursuant to Rule 92 quater. Decision on Motion to Treat Unsworn Statement as Evidence, 15 October 2014.

20759 Momčilo Gruban, T. 47422-47463 (19 February 2014); T. 47464-47534 (20 February 2014).

20760 Decision on Accused's Motion for Admission of Statement of Srđo Srdić Pursuant to Rule 92 quater, 21 September 2012; Decision on Motion to Admit Statement of Nada Stojanović pursuant to Rule 92 quater, confidential, 27 September 2012; Decision on Accused's Motion for Admission of Statement of Vlado Lizdek
} 
6147. The Defence case was considered closed on 1 May 2014, following the Chamber's decision on the last pending evidence-related motion filed by the Accused. ${ }^{20761}$

e. Re-opening/rebuttal/rejoinder

6148. On 20 March 2014, the Chamber issued a decision denying the Prosecution's motion to reopen its case in order to introduce the evidence of five witnesses in relation to the Tomašica gravesite discovered in September 2013 in Prijedor municipality. ${ }^{20762}$ Further, on 21 March 2014, the Chamber denied the Prosecution's request to allow it to tender the evidence of 14 rebuttal witnesses. $^{20763}$

6149. The Accused also filed motions to re-open his Defence case in order to tender in evidence newly discovered material or to secure the attendance of an additional witness; the Chamber ruled on all of them in writing. ${ }^{20764}$

Pursuant to Rule 92 quater, 10 October 2012; Decision on Accused's Motion to Admit Evidence of Velibor Ostojić Pursuant to Rule 92 quater; 23 October 2012; Decision on Accused's Motion for Admission of Evidence of Milorad Krnojelac Pursuant to Rule 92 quater, 6 December 2012; Decision on Accused's Motion for Admission of Evidence of Radislav Krstić Pursuant to Rule 92 quater, 26 November 2013; Decision on Accused's Motion to Admit Testimony of Witness KW582 Pursuant to Rule 92 quater, 3 February 2014; Decision on Accused's Motion to Admit Testimony of Pero Rendić Pursuant to Rule 92 bis, 6 February 2014; Decision on Accused's Motion to Admit the Testimony of Branko Basara Pursuant to Rule 92 bis, 19 February 2014; Decision on Accused's Motion to Admit Testimony of Borivoje Jakovljević Pursuant to Rule 92 quater, 25 February 2014; Decision on Accused's Motions for Admission of Evidence Pursuant to Rule 92 bis, 18 March 2014; Decision on Motion for Reconsideration of Decision Denying Admission of Dušan Đenadija's Statement Pursuant to Rule 92 bis, 1 May 2014.

20761 Further Order on Closure of Defence Case, 2 May 2014. See Order Regarding the Close of the Defence Case, 20 February 2014.

20762 Decision on Prosecution Motion to Re-open its Case and Prosecution Motion for Protective Measures for Witness KDZ614, 20 March 2014. See Prosecution Motion to Re-open its Case with Public Appendix A and Confidential Appendix B, 4 March 2014; Prosecution's Motion for Protective Measures for Witness KDZ614, 4 March 2014; Response to Prosecution's Motion to Re-open its Case, 18 March 2014.

20763 Decision on Prosecution's Motion to Admit Evidence in Rebuttal, 21 March 2014. See Prosecution Motion to Admit Evidence in Rebuttal, 4 March 2014; Response to Motion for Rebuttal Evidence and 90 ${ }^{\text {th }}$ Disclosure Violation Motion, 17 March 2014; Prosecution Request to Reply to Karadžić's Response to the Prosecution's Motion for Rebuttal Evidence, 21 March 2014. See also Hearing, T. 47078 (14 February 2014); Oral ruling, T. 47544 (3 March 2014); Urgent Prosecution Motion to Exceed Word Limit in Motion to Admit Rebuttal Evidence, 28 February 2014.

20764 Decision on Accused's First Motion to Re-open Defence Case, 12 September 2014; Decision on Accused's Second Motion to Re-open Defence Case, 30 October 2014; Decision on Accused's Third Motion to Re-open Defence Case, 17 December 2014; Decision on Application for Certification to Appeal Denial of Third Motion to Re-open Defence Case, 15 January 2015 (wherein the Chamber denied the Accused's application for leave to appeal the decision on his third motion to re-open his Defence case); Decision on Accused's Fourth Motion to Re-open Defence Case, 24 February 2015; Decision on Accused's Sixth Motion to Re-open Defence Case, confidential, 3 March 2015; Decision on the Accused's Fifth Motion to Re-open Defence Case (Zimmerman Cable), 9 March 2015; Decision on Accused's Seventh Motion to Re-open Defence Case, 20 April 2015; Decision on Accused's Sixth bis Motion to re-open Defence Case, confidential, 7 May 2015; Decision on Accused's Ninth Motion to Re-open Defence Case, 9 July 2015; Decision on Accused's Tenth Motion to Reopen Defence Case, 9 July 2015. 


\section{f. Final briefs and closing arguments}

6150. Having heard from the parties as to the time they would need to file their final trial briefs, ${ }^{20765}$ the Chamber ordered them on 21 March 2014, to file their briefs by no later than 29 August 2014, adding that the briefs shall not exceed 300,000 words, including any appendices. ${ }^{20766}$ On 29 August 2014, the parties filed their final briefs. ${ }^{20767}$

6151. On 7 April 2014, the Chamber issued a decision setting the schedule for the presentation of closing arguments, and ordering that the presentation of closing arguments shall commence on 29 September 2014..$^{20768}$ The Chamber also granted the Prosecution and the Accused up to ten hours each to present their closing arguments, and 1.5 hours each to present their rebuttal and rejoinder arguments, respectively. ${ }^{20769}$ The Chamber heard the parties' closing arguments between 29 September and 7 October 2014.

\section{Various rulings}

6152. Throughout the various phases of the case, the Chamber issued approximately 1,100 written decisions, orders and invitations, as well as more than 350 oral decisions. The summary below gives an illustration of some of the most significant issues the Chamber has dealt with during the course of these proceedings.

\section{a. Disclosure}

6153. Given the unprecedented size of the case, disclosure to the Accused has been voluminous throughout the case. The Chamber did its outmost to protect the Accused's fair trial rights. To ensure that the Accused's preparations for trial were not affected, the Chamber decided to suspend the proceedings on multiple occasions, for a total period of more than four months during the Prosecution case, to allow him time to review and incorporate large batches of newly disclosed

\footnotetext{
20765 The Accused requested the Chamber to set a deadline for the filing of closing briefs 12 months after the testimony of the last Defence witness; Submission on Schedule for Filing of Closing Briefs, 26 February 2014, while the Prosecution requested the Chamber leave to submit a final brief not exceeding 375,000 words on or before 17 September 2014; Prosecution Motion for Variation of the Word Limit for its Final Trial Brief and Submission on Timing of Filing of Final Trial Briefs with Appendix A, 3 March 2014. See also Hearing, T. 47543 (20 February 2014).

20766 Order on Filing of Trial Briefs, 21 March 2014.

20767 Prosecution's Final Trial Brief, confidential, 29 August 2014; Defence Final Trial Brief, confidential, 29 August 2014. Both parties subsequently filed public redacted versions of their final briefs, see Notice of Filing Public Redacted Version of Prosecution Final Trial Brief, 24 September 2014; Notice of Filing Public Redacted Version of Prosecution Final Trial Brief Appendices A to D, 13 October 2014; Defence Final Trial Brief, public redacted version, 29 September 2014.

20768 Order on Closing Arguments, 7 April 2014, p. 3.

20769 Order on Closing Arguments, 7 April 2014, p. 3.
} 
material into his preparations..$^{20770}$ In addition to the suspension of proceedings, the testimony of some Prosecution witnesses had to be postponed or delayed when witness specific material was disclosed in violation of the Prosecution's disclosure obligations. ${ }^{20771}$

6154. During the Prosecution phase of the case, the Accused filed more than 70 motions requesting the Chamber to find the Prosecution in violation of its disclosure obligations under the Rules. The Chamber issued either written or oral decisions disposing of each of them ${ }^{20772}$ and found inter alia that, while the number of disclosure violations reflected badly on the Prosecution, the Accused had not been prejudiced. ${ }^{20773}$ The Accused also filed a motion requesting a new trial

20770 Decision on Accused's Motion for Suspension of Proceedings, 18 August 2010; Hearing, T. 6593-6594 (13 September 2010); Decision on Accused's Seventeenth Motion for Finding of Disclosure Violation and for Remedial Measures, 29 September 2010; Hearing, T. 8907-8908 (3 November 2010); Decision on Accused's Twenty-Second, Twenty-Fourth and Twenty-Sixth Disclosure Violation Motions, 11 November 2010; Hearing, T. 11474-11476 (10 February 2011); Decision on Accused's Motion for Fourth Suspension of Proceedings, 16 February 2011; Decision on Accused's Motion for Fifth Suspension of Proceedings, 17 March 2011; Decision on Accused's Forty-Seventh Motion for Finding of Disclosure Violation and for Further Suspension of Proceedings, 10 May 2011.

20771 See Decision on Accused's Third, Fourth, Fifth and Sixth Motions for Finding of Disclosure Violation and for Remedial Measures, 20 July 2010; Decision on Accused's Eighteenth to Twenty-First Disclosure Violation Motions, 2 November 2010; Decision on Accused's Twenty-Ninth Disclosure Violation Motion, 11 January 2011; Decision on Accused's Forty-Ninth and Fiftieth Disclosure Violation Motions, 30 June 2011.

20772 See Decision on Accused's Second Motion for Finding Disclosure Violation and for Remedial Measures, 17 June 2010; Decision on Accused's Third, Fourth, Fifth, and Sixth Motions for Finding of Disclosure Violations and for Remedial Measures, 20 July 2010; Decision on Accused's Seventh and Eighth Motions for Finding of Disclosure Violations and for Remedial Measures, 18 August 2010; Decision on Accused's Ninth and Tenth Motions for Finding of Disclosure Violations and for Remedial Measures, 26 August 2010; Decision on Accused's Eleventh to Fifteenth Motions for Finding of Disclosure Violation and for Remedial Measures, 24 September 2010; Decision on Accused's Seventeenth Motion for Finding of Disclosure Violation and for Remedial Measures, 29 September 2010; Decision on Accused's Sixteenth Motion for Finding of Disclosure Violation and for Remedial Measures, 5 October 2010; Decision on Accused's Eighteenth to Twenty-First Disclosure Violation Motions, 2 November 2010; Decision on Accused's Twenty-Second, Twenty-Fourth and Twenty-Sixth Disclosure Violation Motions, 11 November 2010; Decision on Accused's Twenty-Seventh Disclosure Violation Motion, 17 November 2010; Decision on Accused's Seventeenth bis and Twenty-Eighth Disclosure Violation Motions, 16 December 2010; Decision on Accused's Twenty-Ninth Disclosure Violation Motion, 11 January 2011; Decision on Accused's Thirtieth and Thirty-First Disclosure Violation Motions, 3 February 2011; Decision on Accused's Thirty-Second, Thirty-Third, Thirty-Fifth and Thirty-Sixth Disclosure Violation Motions, 24 February 2011; Decision on Accused's Thirty-Seventh to Forty-Second Disclosure Violation Motions With Partially Dissenting Opinion of Judge Kwon, 29 March 2011; Decision on Accused's Forty-Third to Forty-Fifth Disclosure Violation Motions, 8 April 2011; Decision on Accused's Forty-Sixth Disclosure Violation Motion, 20 April 2011; Decision on Accused's Forty-Seventh Motion for Finding of Disclosure Violation and for Further Suspension of Proceedings, 10 May 2011; Decision on Accused's FortyEighth Disclosure Violation Motion, 30 May 2011; Decision on Accused's Forty-Ninth and Fiftieth Disclosure Violation Motions, 30 June 2011; Decision on Accused's Fifty-First and Fifty-Second Disclosure Violation Motions, 7 July 2011; Decision on Accused's Fifty-Third and Fifty-Fourth Disclosure Violation Motions, 22 July 2011; Decision on Accused's Fifty-Fifth Disclosure Violation Motion, 19 August 2011; Oral Ruling on $56^{\text {th }}$ Disclosure Violation Motion, T. 17484 (19 August 2011); Oral Ruling on 58 ${ }^{\text {th }}$ Disclosure Violation Motion, T. 18638 (8 September 2011); Decision on Accused's Fifty-Ninth Disclosure Violation Motion, 14 October 2011; Decision on Accused's Sixtieth, Sixty-First, Sixty-Third, and Sixty-Fourth Disclosure Violation Motions, 22 November 2011; Decision on Accused's Sixty-Fifth Disclosure Violation Motion, 12 January 2012; Decision on Accused's Sixty-Sixth Disclosure Violation Motion, 8 February 2012; Public Redacted Version of "Decision on Accused's Sixty-Seventh and Sixty-Eighth Disclosure Violation Motions" Issued on 1 March 2012, 1 March 2012; Oral Ruling on $69^{\text {th }}$ Disclosure Violation Motion, T. 26316-26317 (15 March 2012); Oral Ruling on $70^{\text {th }}$ Disclosure Violation Motion, T. $27902-27903$ (23 April 2012).

20773 See Decision on Accused's Eighteenth to Twenty-First Disclosure Violation Motions, 2 November 2010; Decision on Accused's Twenty-Second, Twenty-Fourth and Twenty-Sixth Disclosure Violation Motions, 
based on the cumulative prejudice he had suffered from such violations. The Chamber issued its decision disposing of the motion in September 2012, and denying the Accused's request. ${ }^{20774}$

6155. The Accused continued filing disclosure violation motions during the Defence case and the Chamber disposed, either orally or in writing, of all of them, finding, for the most part that the Prosecution had violated its disclosure obligations under the Rules with respect to the late disclosure of certain documents, but concluding that the Accused was not prejudiced by such violations having reviewed the underlying documents in light of other material available to the Accused and other evidence received in the case. ${ }^{20775}$

6156. After the completion of the Defence case, the Accused continued to file disclosure violations and the Chamber disposed in writing of all of them, finding that the Prosecution had violated its disclosure obligations under the Rules with respect to the late disclosure of certain documents, but concluding for the most part that the Accused was not prejudiced by such violations, having reviewed the underlying documents in light of other material available to the Accused and other evidence received in the case. ${ }^{20776}$ The Accused also filed a second motion requesting a new trial again based on the cumulative prejudice he had suffered from such

11 November 2010; Decision on Accused's Twenty-Seventh Disclosure Violation Motion, 17 November 2010; Decision on Accused's Twenty-Ninth Disclosure Violation Motion, 11 January 2011; Decision on Accused's Forty-Ninth and Fiftieth Disclosure Violation Motions, 30 June 2011.

20774 Decision on Accused's Motion for New Trial for Disclosure Violations, 3 September 2012.

20775 See Decision on Accused's Seventy-First Disclosure Violation Motion, 1 June 2012; Decision on Accused's Seventy-Second Disclosure Violation Motion, 27 June 2012; Decision on Accused's Seventy-Third Disclosure Violation Motion, 21 August 2012; Decision on Accused's Seventy-Fourth Disclosure Violation Motion, 6 November 2012; Oral Ruling on $75^{\text {th }}$ Disclosure Violation Motion, T. 32151-32152 (17 January 2013); Oral Ruling on $76^{\text {th }}$ Disclosure Violation Motion, T. 32881-32883 (29 January 2013); Decision on Accused's Seventy-Seventh and Seventy-Eighth Disclosure Violation Motions, 11 March 2013; Oral Ruling on $79^{\text {th }}$ Disclosure Violation Motion, T. 38096-38098 (9 May 2013); Decision on Accused's Eightieth and Eighty-First Disclosure Violation Motions, 9 July 2013; Decision on Accused's Eighty-Second Disclosure Violation Motion, 7 November 2013; Decision on Accused's Eighty-Third Motion for Finding of Disclosure Violation, 21 November 2013; Decision on Accused's Eighty-Fourth Disclosure Violation Motion, 16 January 2014; Decision on Accused's Eighty-Fifth Disclosure Violation Motion, 21 January 2014; Decision on Accused's EightySeventh Disclosure Violation Motion, 10 March 2014; Oral Ruling on $86^{\text {th }}$ Disclosure Violation Motion, T. 47545-47546 (3 March 2014); Decision on Accused's Eighty-Eighth Disclosure Violation Motion, 18 March 2014; Decision on Accused's Eighty-Ninth and Ninetieth Disclosure Violation Motions, 16 April 2014; Decision on Accused's Ninety-First Disclosure Violation Motion, 7 May 2014.

20776 Decision on Accused's Ninety-Second Disclosure Violation Motion, 10 June 2014; Public Redacted Version of "Decision on Accused's Ninety-Third Disclosure Violation Motion" Issued on 13 October 2014, 20 March 2015; Decision on Accused's Ninety-Fourth Disclosure Violation Motion, 13 October 2014; Decision on Accused's Ninety-Fifth Disclosure Violation Motion, 5 December 2014; Decision on Accused's Ninety-Sixth Disclosure Violation Motion, 21 January 2015; Decision on Accused's Ninety-Eighth and Ninety-Ninth Disclosure Violation Motions, 8 June 2015; Decision on Accused's One-Hundredth Disclosure Violation Motion, 13 July 2015; Decision on Accused's $101^{\text {st }}$ Disclosure Violation Motion, 20 July 2015; Decision on Accused's 102 ${ }^{\text {nd }}$ and $103^{\text {rd }}$ Disclosure Violation Motion, 4 November 2015; Decision on Accused's $104^{\text {th }}$ and $105^{\text {th }}$ Disclosure Violation Motions, 18 February 2016; Decision on Accused's $106^{\text {th }}$ Disclosure Violation Motion, 4 March 2016; Decision on Accused's $107^{\text {th }}$ Disclosure Violation Motion, 14 March 2016. The Chamber notes that the Accused withdrew his $97^{\text {th }}$ Motion for Disclosure Violation. See Withdrawal of $97^{\text {th }}$ Motion for Finding of Disclosure Violation and for Remedial Measures, 9 March 2015. 
violations. The Chamber issued its decision disposing of the motion in August 2014, and denying the Accused's request. ${ }^{20777}$

6157. The Chamber also issued decisions disposing of Prosecution's motions alleging disclosure violations by the Accused due to his failure to provide adequate 65 ter summaries. ${ }^{20778}$

\section{b. Binding orders}

6158. Throughout the proceedings, the Chamber issued more than 60 invitations in relation to the approximately 40 motions filed by the Accused requesting the Chamber to issue binding orders compelling the governments of various states and several international organisations to produce categories of documents that he intended to use during his trial. ${ }^{20779}$

20777 Decision on Accused's Second Motion for New Trial for Disclosure Violations, 14 August 2014.

20778 Decision on Prosecution's Motion for Relief for Defence Disclosure Violations, 26 March 2013; Decision on Prosecution Motion for Relief for Defence Disclosure Violations - Srebrenica Witnesses, 11 April 2013.

20779 See Invitation to the United States of America, 18 June 2009; Invitation to the Kingdom of Norway, 9 July 2009; Invitation to the Kingdom of Belgium, 21 July 2009; Invitation to the North Atlantic Treaty Organisation, 23 July 2009; Invitation to the Italian Republic, 5 August 2009; Invitation to the Republic of Austria, 5 August 2009; Invitation to the People's Republic of Bangladesh, 6 August 2009; Invitation to the Republic of Malta, 6 August 2009; Invitation to Malaysia, 10 August 2009; Invitation to the Islamic Republic of Pakistan, 11 August 2009; Invitation to the Federal Republic of Germany, 14 August 2009; Invitation to the Republic of Poland, 14 August 2009; Invitation to the Arab Republic of Egypt, 17 August 2009; Invitation to the Hashemite Kingdom of Jordan, 17 August 2009; Invitation to the French Republic, 25 August 2009; Invitation to the Republic of Turkey, 25 August 2009; Invitation to the Islamic Republic of Iran, 31 August 2009; Invitation to Bosnia and Herzegovina, 2 September 2009; Second Invitation to the Republic of Malta, 2 September 2009; Invitation to the Kingdom of Denmark, 4 September 2009; Invitation to the Kingdom of Sweden, 7 September 2009; Invitation to the Republic of Croatia, 15 September 2009; Invitation to the Kingdom of The Netherlands, 15 September 2009; Invitation to the United Kingdom of Great Britain and Northern Ireland, 15 September 2009; Invitation to the United States of America, 15 September 2009; Second Invitation to the Islamic Republic of Pakistan, 23 September 2009; Invitation to the Republic of Greece, 30 September 2009; Second Invitation to the Arab Republic of Egypt, 6 October 2009; Second Invitation to the Kingdom of Norway, 7 October 2009; Second Invitation to the French Republic, 13 October 2009; Second Invitation to the Government of Bosnia and Herzegovina, 13 October 2009; Third Invitation to the Islamic Republic of Pakistan, 13 October 2009; Second Invitation to the Kingdom of the Netherlands, 2 November 2009; Second Invitation to the Republic of Poland, 10 November 2009; Invitation to Bosnia and Herzegovina, 1 March 2010; Invitation to Republic of Croatia, 1 March 2010; Invitation to the Kingdom of The Netherlands, 30 March 2010; Invitation to Canada, 18 August 2010; Invitation to the Kingdom of Belgium, 20 August 2010; Invitation to the Kingdom of Denmark, 3 September 2010; Invitation to France, 8 September 2010; Second Invitation to Canada, 29 September 2010; Invitation to European Union, 27 October 2010; Invitation to United Nations, 2 November 2010; Invitation to the Bolivarian Republic of Venezuela, 2 November 2010; Invitation to the United Nations and the North Atlantic Treaty Organisation, 2 December 2010; Second Invitation to the Bolivarian Republic of Venezuela, 9 December 2010; Third Invitation to Canada, 9 December 2010; Invitation to the Islamic Republic of Iran, 16 December 2010; Invitation to the United States of America, 17 December 2010; Invitation to the Government of Bosnia and Herzegovina, 13 January 2011; Invitation to the Kingdom of Saudi Arabia, 25 January 2011; Invitation to the United Arab Emirates, 25 January 2011; Invitation to the United States of America, 27 January 2011; Second Invitation to European Union, 31 January 2011; Third Invitation to the Bolivarian Republic of Venezuela, 31 January 2011; Second Invitation to Republic of France, 8 February 2011; Invitation to Bosnia and Herzegovina, 10 February 2011; Invitation to the Bolivarian Republic of Venezuela and the United Nations, 17 August 2011; Invitation to the Government of Croatia Regarding Interview of Miroslav Tuđman, 14 September 2011; Invitation to the Kingdom of Spain, 22 September 2011; Invitation to the United Kingdom of Great Britain and Northern Ireland, 17 November 2011; Invitation to France, 27 January 2012; Invitation to Germany Regarding the Accused's Motion to Report Germany to United Nations Security Council, 30 January 2012; Invitation to The United Kingdom of Great Britain and Northern Ireland, 10 February 2012; Invitation to 
6159. As an attempt to give an opportunity to states to be heard, and to resolve some of the pending motions, the Chamber held hearings with states' representatives in 2010, 2011, and 2013. ${ }^{20780}$ The information obtained through these hearings assisted the Chamber in the process of determining some of the motions. The Chamber ultimately issued decisions on 11 of the Accused's motions for binding orders, granting four of them, ${ }^{20781}$ rejecting one without prejudice, ${ }^{20782}$ and denying the Accused's requests on six occasions. ${ }^{20783}$ The remaining motions for binding orders were withdrawn by the Accused as a result of the voluntary co-operation by various states and organisations with the Accused. ${ }^{20784}$

France, 29 March 2012; Invitation to Bosnia and Herzegovina, 17 April 2012; Second Invitation to Germany Regarding the Accused's Motion to Report Germany to United Nations Security Council, 18 April 2012; Invitation to The United States of America, 10 July 2012; Invitation to France, 27 September 2013; Invitation to the Kingdom of The Netherlands, 18 October 2013; Invitation to The United States of America, 30 October 2013.

20780 See Order Scheduling a Hearing Pursuant to Rule 54 bis, 29 January 2010; Order Scheduling a Hearing Pursuant to Rule 54 bis (Bosnia and Herzegovina), 7 September 2010; Order to Bosnia and Herzegovina in Preparation for the Hearing pursuant to Rule 54 bis, 6 October 2010; Scheduling Order Relating to Rule 54 bis Hearing (Bosnia and Herzegovina), 13 October 2010; Invitation to Bosnia and Herzegovina Following Rule 54 bis Hearing, 19 October 2010; Order Scheduling a Hearing Pursuant to Rule 54 bis (Bolivarian Republic of Venezuela), 22 March 2011; Scheduling Order Relating to Rule 54 bis Hearing (Bolivarian Republic of Venezuela), 9 May 2011; Invitation to the Bolivarian Republic of Venezuela Following Rule 54 bis Hearing, 13 May 2011; Scheduling Order for Rule 4 Hearing, confidential, 18 February 2013.

20781 Decision on the Accused's Application for Binding Order Pursuant to Rule 54 bis (Austria), 15 October 2009; Decision on the Accused's Application for Binding Order Pursuant to Rule 54 bis (Federal Republic of Germany), 19 May 2010; Decision on the Accused's Binding Order Motion (The French Republic), 30 June 2010; Decision on the Accused's Third Motion for Binding Order (Bosnia and Herzegovina), 6 May 2011.

20782 Decision on the Accused's Application for Binding Order Pursuant to Rule 54bis (United States of America), 12 October 2009.

20783 Decision on the Accused's Motion for Binding Order (The Islamic Republic of Iran), 9 June 2010; Decision on the Accused's Motion for Binding Order (United Nations and NATO), 11 February 2011; Decision on the Accused's Third Motion for Binding Order (United States of America), 17 February 2011; Decision on the Accused's Second Motion for Binding Order (The Islamic Republic of Iran) and Motion for Subpoena to Interview General Director Sadeghi, 10 May 2011; Decision on the Accused's Motion for Binding Order (The Kingdom of Saudi Arabia), 30 June 2011; Decision on Accused's Fifth Motion for Binding Order (United States of America), 22 August 2012.

20784 See Withdrawal of Motion for Binding Order to NATO, 10 August 2009; Withdrawal of Motion for Binding Order to Bangladesh, 24 August 2009; Withdrawal of Motion for Binding Order to Jordan, 4 September 2009; Withdrawal of Motion for Binding Order: Government of Malaysia, 28 September 2009; Withdrawal of Motion for Binding Order: Government of Sweden, 30 September 2009; Withdrawal of Motion for Binding Order: Government of United Kingdom, 14 October 2009; Withdrawal of Motion for Binding Order: Government of Denmark, 21 October 2009; Withdrawal of Motion for Binding Order: Government of Egypt, 2 November 2009; Withdrawal of Motion for Binding Order: Government of Greece, 2 November 2009; Withdrawal of Motion for Binding Order: Government of Turkey, 2 November 2009; Withdrawal of Motion for Binding Order: Government of Austria, 4 November 2009; Withdrawal of Motion for Binding Order: Government of Belgium, 30 November 2009; Withdrawal of Motion for Binding Order: Government of Norway, 30 November 2009; Withdrawal of Motion for Binding Order: Government of Poland, 1 December 2009; Withdrawal of Motion for Binding Order: Government of Netherlands, 13 April 2010; Withdrawal of Second Motion for Binding Order: Government of Belgium, 10 September 2010; Withdrawal of Motion for Binding Order: Government of Canada, 6 January 2011; Withdrawal of Motion for Binding Order: European Union, 24 February 2011; Withdrawal of Second Motion for Binding Order: Government of Denmark, 5 April 2011; Withdrawal of Second Motion for Binding Order: Government of Bosnia, 11 April 2011; Withdrawal of Fourth Motion for Binding Order: United States of America, 2 May 2011; Withdrawal of Motion for Binding Order: United Arab Emirates, 18 May 2011; Withdrawal of Motion for Binding Order: Government of Bosnia, 27 September 2011; Withdrawal of Motion 
6160. The Accused's wish to challenge the conclusions reached by the ICMP and Prosecution witness Thomas Parsons, as to the identification through DNA analysis of Srebrenica victims, was the subject of considerable discussion throughout the pre-trial phase of the case, and involved ongoing communication between the Prosecution, the Accused's legal adviser, the Accused's expert, and the ICMP. Given the complexity of the topic, the discussion also required the involvement of the Chamber, which issued a number of decisions on the matter. ${ }^{20785}$ In 2012, the Accused filed a binding order motion requesting that the Chamber issue an order compelling the ICMP to make available to him a number of DNA case files for testing by his DNA expert. ${ }^{20786}$ The Chamber denied the binding order motion on 4 March 2013 after receiving additional information from the parties. ${ }^{20787}$ On 16 April 2013, the Chamber denied a motion filed by the Accused requesting the Chamber to exclude all evidence of the results of DNA analysis entered into evidence on behalf of the Prosecution. ${ }^{20788}$

\section{c. Subpoenas}

6161. Throughout the proceedings, the Accused filed a number of motions requesting the Chamber to issue subpoenas compelling various former or current state officials to be interviewed by his Defence team, and the Chamber issued various invitations to a number of the states involved in these matters. ${ }^{20789}$ The Chamber granted the Accused's request on five occasions, issuing

for Binding Order: United Nations, 21 March 2012; Withdrawal of Motion for Binding Order: Government of Venezuela, 21 March 2012.

20785 Order on Selection of Cases for DNA Analysis, 19 March 2010; Decision in Relation to Selection of Cases for DNA Analysis, 23 September 2011; Decision on the Accused's Motion to Unseal ICMP Exhibits, 25 April 2012; Decision on Prosecution's Motion for Partial Reconsideration or Clarification of the Chamber's Decision on the Accused's Motion to Unseal ICMP Exhibits, 5 September 2012. See Interim Decision on Prosecution's Motion for Partial Reconsideration or Clarification on the Chamber's Decision on the Accused's Motion to Unseal ICMP Exhibits, 11 July 2012; Interim Order on the Accused's Motion for Binding Order to International Commission for Missing Persons, 19 July 2012.

20786 Motion for Binding Order to International Commission for Missing Persons, 15 May $2012 . \quad$ See also Prosecution's Response to Accused's Motion for Binding Order to International Commission for Missing Persons, 29 May 2012; Reply Brief: Motion for Binding Order to International Commission for Missing Persons, 11 June 2012; Prosecution's Sur-Reply to Accused Reply Brief: Motion for Binding Order to International Commission for Missing Persons, 11 June 2012.

20787 Decision on the Accused's Motion for Binding Order to International Commission for Missing Persons, 4 March 2013. See also Submission on Motion for Binding Order to International Commission on Missing Persons, 13 December 2012; Prosecution's Submission on Applicability of Rule 54 and Rule 54 bis to ICMP and on Karadžić's Supplemental Submission, 20 December 2012.

20788 Decision on the Accused's Motion to Exclude DNA Evidence, 16 April 2013. See also Motion to Exclude DNA Evidence, 11 March 2013; Prosecution's Response to Motion to Exclude DNA Evidence, 25 March 2013.

20789 See Invitation to Croatia Regarding Motion for Subpoena of Miroslav Tuđman, 8 September 2010; Invitation to France Regarding Motion for Subpoena of Colonel Guy de Haynin de Bry, 17 November 2010; Invitation to Germany Regarding Motion for Subpoena of Christoph Von Bezold, 8 April 2011; Invitation to the Government of Croatia Regarding Interview of Miroslav Tuđman, 14 September 2011; Invitation to Croatia Regarding Interview of Vladimir Zagorec, 25 January 2012; Invitation to Greece Regarding Motion for Subpoena of President Karolos Papoulias, 27 January 2012; Invitation to Norway Regarding Motion for Subpoena of Thorvald Stoltenberg, 1 May 2012; Invitation to The United States of America, 20 July 2012; Invitation to Malaysia, 13 June 2013. 
subpoenas for four individuals ordering each of them to submit to an interview by the Accused's legal adviser, and issuing an order to a State to facilitate an interview with another individual. ${ }^{20790}$ The Accused himself withdrew some of his motions ${ }^{20791}$ and the Chamber denied the remainder. $^{20792}$

6162. The Prosecution filed a number of motions requesting the Chamber to issue subpoenas to various individuals who had refused to testify in this case. The Chamber granted the Prosecution's requests and issued subpoenas to six individuals, namely Momčilo Mandić, Berko Zečević, Milan Tupajić, KDZ310, KDZ379, and KDZ532, to appear before the Chamber. ${ }^{20793}$ Following the Chamber's orders, KDZ310, KDZ379, and KDZ532 appeared before the Chamber and testified as Prosecution witnesses; as discussed above, Momčilo Mandić also testified but as a Chamber's witness. $^{20794}$ Milan Tupajić continued to refuse to testify, and the Chamber held contempt proceedings against him, as described in detail below. ${ }^{20795}$ While Berko Zečević also continued to refuse to testify, following his arrest and subsequent transfer to the Tribunal, he testified voluntarily before the Chamber, as described in detail below. ${ }^{20796}$

6163. Similarly, the Accused also filed various motions requesting the Chamber to issue subpoenas to various individuals to appear for testimony in his Defence case, and the Chamber issued a number of invitations to a number of the states involved in these matters. ${ }^{20797}$ As a result

20790 Decision on Accused's Motion for Subpoena to Interview: General Sead Delić and Brigadier Refik Brđanović, 5 July 2011; Order to the Government of Bosnia and Herzegovina Concerning Subpoena, 5 July 2011; Subpoena, 5 July 2011; Decision on the Accused's Motion for Subpoena to Interview Miroslav Tuđman, 14 July 2011; Order to the Government of Croatia Concerning Subpoena, 14 July 2011; Subpoena, 14 July 2011; Decision on the Accused's Motion for Subpoena to Interview Christoph Von Bezold, 1 December 2011; Order to the Government of the Federal Republic of Germany Concerning Subpoena, 1 December 2011; Subpoena, 1 December 2011; Decision on Accused's Motion for Subpoena to Interview Vladimir Zagorec, 12 March 2012; Order to the Government of Croatia Concerning Subpoena, 12 March 2012; Subpoena, 12 March 2012; Order to France, 4 May 2012. See also Decision on Accused's Motion for Withdrawal of Order to France, 13 June 2012.

20791 See inter alia Withdrawal of Motion for Subpoena to Interview Yasushi Akashi, 27 September 2012.

20792 See inter alia Decision on Motion to Subpoena Prosecution Witness Ronald Eimers for Interview, 29 March 2010; Decision on Accused's Motion to Compel Interview: General Sir Rupert Smith, 25 January 2011; Decision on Accused's Motion to Compel Interviews: Sarajevo 92 bis Witnesses, 21 March 2011; Decision on Accused's Motion to Compel Interview: Griffiths Evans, 20 April 2011; Decision on Motion for Subpoena to Interview Edin Garaplija, 15 November 2012; Decision on Motion for Subpoena to Interview President Karolos Papoulias, 20 March 2012.

20793 Decision on Prosecution's Urgent Motion to Subpoena Momčilo Mandić with Appendices A-D, confidential, 16 June 2010; Decision on Prosecution's Motion to Subpoena KDZ310, confidential, 14 September 2010; Decision on Prosecution's Motion to Subpoena Berko Zečević, confidential, 20 January 2011, made public on 15 February 2011; Decision on Prosecution's Motion to Subpoena Witness, confidential, 24 August 2011; Decision on Prosecution's Motion to Subpoena Milan Tupajić, 23 September 2011; Decision on Prosecution's Motion to Subpoena Witness KDZ532, confidential, 19 October 2011.

20794 See para. 6136, fn. 20734.

20795 See para. 6173.

20796 See para. 6173.

20797 See Invitation to Japan and the United Nations Regarding Motion for Subpoena of Yasushi Akashi, 23 August 2012; Invitation to Greece Regarding Motion to Subpoena President Karolos Papoulias, 23 August 2012; Invitation Regarding Motion to Subpoena Ambassador Jose Cutileiro, 25 September 2012; Invitation to the 
of the Chamber's efforts, at least one individual reconsidered his view and agreed to appear voluntarily before the Chamber. The Chamber ultimately issued 18 decisions denying the Accused's requests. ${ }^{20798}$ The Chamber issued subpoenas to appear before it to 12 individuals who had refused to testify as Defence witnesses, namely Radislav Krstić, Edin Garaplija, Jose Cutileiro, Slavko Puhalić, Milenko Živanović, Zdravko Tolimir, Ljubiša Beara, Radivoje Miletić, Svetozar Andrić, John Zametica, Ratko Mladić, and Mićo Stanišić. ${ }^{20799}$

6164. Following the Chamber's orders, Garaplija, Cutileiro, Puhalić, Živanović, Andrić, Zametica, and Stanišić appeared before the Chamber and testified as Defence witnesses. Radislav Krstić continued to refuse to testify, and the Chamber held contempt proceedings against him, as described in detail below. ${ }^{20800}$ On 4 June 2013, the Chamber granted Tolimir's request to suspend

United States of America, 17 December 2012; Invitation to the Government of Bosnia and Herzegovina, 6 June 2013; Second Invitation to the Government of Bosnia and Herzegovina, 28 June 2013; Invitation to the Government of Bosnia and Herzegovina, 12 December 2013; Invitation to The United States of America, 21 January 2014. See also Invitation to Australia, 25 February 2013.

20798 See Decision on the Accused's Second Motion for Subpoena to Interview President Bill Clinton, 21 August 2012; Decision on Accused's Motion to Subpoena President Karolos Papoulias, 23 October 2012; Decision on Accused's Motion to Subpoena Prime Minister Milan Panić, 13 December 2012; Decision on Accused's Motion to Subpoena Ranko Mijić, 11 January 2013; Decision on Accused's Motion to Subpoena Naser Orić, 11 January 2013; Decision on Accused's Motion to Subpoena Ambassador Hall, 16 January 2013; Decision on Accused's Motion to Subpoena Dragoš Milanković, 18 January 2013; Decision on Accused's Motion to Subpoena Slavko Budimir, 22 January 2013; Decision on Accused's Motion to Subpoena Miloš Tomović, 28 January 2013; Decision on Accused's Motion to Subpoena Fikret Abdić, 26 February 2013; Decision on Accused's Second Motion to Subpoena Naser Orić, 4 April 2013; Decision on Accused's Motion to Subpoena Hasan Čengić, 6 May 2013; Decision on Accused's Motion to Subpoena Thomas Karremans, 29 May 2013; Decision on Accused's Motion to Subpoena Nikola Tomašević, 11 December 2013; Decision on Accused's Motion to Subpoena Dragan Kalinić, 18 December 2013; Decision on Accused's Motion to Subpoena Srđan Forca, 18 December 2013; Public Redacted Version of "Decision on Accused's Motion to Subpoena Witness KW540" Issued on 3 February 2014, 4 March 2015; Decision on Accused's Motion for Subpoena to Norman Schindler, 19 February 2014.

20799 See Public Redacted Version of "Decision on Accused's Motion to Subpoena Radislav Krstić" issued on 23 October 2012; Decision on Second Motion for Subpoena: Edin Garaplija, 18 December 2012; Order to the Government of Bosnia and Herzegovina Concerning Subpoena Ad Testificandum, 18 December 2012; Subpoena Ad Testificandum, 18 December 2012; Decision on Accused's Motion to Subpoena Ambassador José Cutileiro, 19 December 2012; Order to the Government of the Portuguese Republic Concerning Subpoena, 19 December 2012; Subpoena Ad Testificandum, 19 December 2012; Decision on Accused's Motion to Subpoena Slavko Puhalić, 20 March 2013; Subpoena Ad Testificandum, 20 March 2013; Order to the Government of Bosnia and Herzegovina Concerning Subpoena Ad Testificandum, 20 March 2013; Decision on Accused's Motion to Subpoena Milenko Živanović, 23 April 2013; Subpoena Ad Testificandum, 23 April 2013; Order to the Government of the Republic of Serbia Concerning Subpoena Ad Testificandum, 23 April 2013; Decision on Accused's Motion to Subpoena Zdravko Tolimir, 9 May 2013; Subpoena Ad Testificandum, 9 May 2013; Decision on Accused's Motion to Subpoena Ljubiša Beara, 9 May 2013; Subpoena Ad Testificandum, 9 May 2013; Decision on Accused's Motion to Subpoena Radivoje Miletić, 9 May 2013; Subpoena Ad Testificandum, 9 May 2013; Decision on Accused's Motion to Subpoena Svetozar Andrić, 28 May 2013; Subpoena Ad Testificandum, 28 May 2013; Order to the Government of the Republic of Serbia Concerning Subpoena Ad Testificandum, 28 May 2013; Decision on Accused's Motion to Subpoena John Zametica, 27 August 2013; Subpoena Ad Testificandum, 27 August 2013; Order to the Government of the Republic of Austria Concerning Subpoena Ad Testificandum, 27 August 2013; Decision on Accused's Motion to Subpoena Ratko Mladić, 11 December 2013; Subpoena Ad Testificandum, 11 December 2013; Decision on Accused's Motion to Subpoena Mićo Stanišić, 13 December 2013; Subpoena Ad Testificandum, 13 December 2013. See also Decision on Motion for Subpoena: Edin Garaplija, 26 November 2012; Oral Ruling, T. 40841-40842 (5 July 2013); Addendum to Subpoena Ad Testificandum Issued 20 March 2013, 28 August 2013.

20800 See para.6174. 
the subpoena against him and granted him leave to appeal the decision compelling him to testify in the present case. ${ }^{20801}$ On 2 July 2013, the Chamber issued an oral order granting the Accused's request to postpone the testimony of Beara and Miletić until such time as the Appeals Chamber issued its decision on Tolimir's appeal. ${ }^{20802}$ On 13 November 2013, the Appeals Chamber issued a decision denying Tolimir's appeal. ${ }^{20803}$ Tolimir and Beara testified as Defence witnesses in December 2013 and January 2014. ${ }^{20804}$ Mladić appeared before the Chamber on 28 January 2014 after the Chamber denied his request to appeal the decision compelling him to testify, as well as his and the Prosecution's motions for reconsideration of the Chamber's denial to appeal the subpoena. ${ }^{20805}$ Despite appearing before the Chamber, Mladić continued to invoke his right not to testify and the Chamber chose not to compel him to answer the questions put to him by the Accused. ${ }^{20806}$ Finally, following a request from Miletić himself to postpone his testimony, the Chamber proprio motu vacated its decision to subpoena Miletić, as well as the subpoena issued against him. ${ }^{20807}$

\section{d. Judicial notice}

6165. In 2008 and 2009, the Prosecution filed five large motions for judicial notice of adjudicated facts pursuant to Rule 94(B), covering in total more than 3,000 facts. ${ }^{20808}$ The Chamber issued five decisions taking judicial notice of approximately 2,400 of the facts proposed. ${ }^{20809}$

20801 Decision on Tolimir Request for Certification to Appeal Subpoena Decision, 4 June 2013. See also Request to the Trial Chamber to Suspend the Subpoena to Allow Tolimir to File an Appeal Against the Decision on the Accused's Motion to Subpoena Zdravko Tolimir and Against the Subpoena", 15 May 2013.

20802 See T. 40639-40640 (2 July 2013) for parties' submissions. See T. 40717 (2 July 2013) for the Chamber's oral ruling.

20803 Decision on Appeal Against the Decision on the Accused's Motion to Subpoena Zdravko Tolimir, 13 November 2013.

20804 Zdravko Tolimir, T. 45059-45067 (12 December 2013); Ljubiša Beara, T. 45198-45212 (17 December 2013 ); T. 45794-45806 (22 January 2014).

20805 Ratko Mladić, T. 46047-46055 (28 January 2014); Decision on Mladić Request for Certification to Appeal Subpoena Decision, 23 December 2013; Decisions on Urgent Motions for Reconsideration of Decision Denying Mladić Request for Certification to Appeal Subpoena Decision, 22 January 2014. See also Motion of Ratko Mladić for Certification to Appeal Decisions of 11 December 2013 by Karadžić Chamber, 18 December 2013; Mladić Urgent Motion for Reconsideration of Decision on Motion for Certification to Appeal, 14 January 2014; Urgent Prosecution Motion for Reconsideration of Decision on Mladić Request for Certification to Appeal Subpoena Decision, 15 January 2014.

20806 Ratko Mladić, T. 46039-46055 (28 January 2014).

20807 Public Redacted Version of "Decision on Request by Radivoje Miletić to Postpone Date of Testimony" Issued on 13 February 2014, 14 February 2014. See also Request of Radivoje Miletić to Postpone His Court Appearance, confidential, 4 February 2014; Response to General Miletić's Request for Postponement of Subpoena, 6 February 2014.

20808 First Prosecution Motion for Judicial Notice of Adjudicated Facts, 27 October 2008; Second Prosecution Motion for Judicial Notice of Adjudicated Facts and Corrigendum to First Prosecution Motion for Judicial Notice of Adjudicated Facts, 17 March 2009; Third Prosecution Motion for Judicial Notice of Adjudicated Facts, 7 April 2009; Fourth Prosecution Motion for Judicial Notice of Adjudicated Facts, 26 August 2009; Fifth Prosecution Motion for Judicial Notice of Adjudicated Facts, 15 December 2009. See also Submission of Renumbered 
6166. In early 2010, the Prosecution filed a motion pursuant to Rule 94(B), for the judicial notice of the authenticity of hundreds of documents that were admitted into evidence in previous trials, including a large number of intercepts, relating to the Sarajevo component of the case. In March 2010, the Chamber denied the Prosecution's motion with respect to a large number of documents tendered by the Prosecution, and denied without prejudice the admission of various intercepts. ${ }^{20810}$ In February 2011, the Chamber granted in part the motion filed by the Prosecution resubmitting its request to the Chamber to take judicial notice of the authenticity of various intercepts relating to the Sarajevo component of the case. ${ }^{20811}$ The Accused applied for certification to appeal the Chamber's decision, but it was denied. ${ }^{20812}$

Appendix to Fifth Prosecution Motion for Judicial Notice of Adjudicated Facts, 2 February 2010; Corrigendum to Fifth Prosecution Motion for Judicial Notice of Adjudicated Facts with Appendix A", 9 February 2010.

20809 Decision on First Prosecution Motion for Judicial Notice of Adjudicated Facts, 5 June 2009; Decision on Third Prosecution Motion for Judicial Notice of Adjudicated Facts, 9 July 2009; Decision on Second Prosecution Motion for Judicial Notice of Adjudicated Facts, 9 October 2009; Decision on Fourth Prosecution Motion for Judicial Notice of Adjudicated Facts, 14 June 2010; Decision on Fifth Prosecution Motion for Judicial Notice of Adjudicated Facts, 14 June 2010; Corrigendum to the Trial Chamber's Decision on First Prosecution Motion for Judicial Notice of Adjudicated Facts, 24 June 2013. Furthermore, on 14 June 2010, the Chamber rendered a decision denying two motions for reconsideration filed by the Accused, requesting the Chamber to reconsider its findings in the three adjudicated facts decisions issued during the pre-trial phase of the case based upon findings by other Trial Chambers which had allegedly applied a different standard than this Chamber; Decision on Accused's Motions for Reconsideration of Decisions on Judicial Notice of Adjudicated Facts, 14 June 2010; see Motion for Reconsideration of Decisions on Judicial Notice of Adjudicated Facts, 4 March 2010; Second Motion for Reconsideration of Decision on Judicial Notice of Adjudicated Facts, 26 April 2010. Similarly, in 2012, the Chamber rendered a decision denying three motion filed by the Accused requesting the Chamber to reconsider its decisions on adjudicated facts based on the approach taken on a number of adjudicated facts decisions issued by the Mladic Chamber; Decision on Three Accused's Motions for Reconsideration of Decisions of Judicial Notice of Adjudicated Facts, 4 May 2012; see Third Motion for Reconsideration of Decision on Judicial Notice of Adjudicated Facts, 12 March 2012; Fourth Motion for Reconsideration of Decision on Judicial Notice of Adjudicated Facts, 26 March 2012; Fifth Motion for Reconsideration of Decision on Judicial Notice of Adjudicated Facts, 17 April 2012. In its "Notice of Withdrawal of Incident A.5.1" of 18 August 2014, the Prosecution notified that Chamber that it no longer intended to rely on Adjudicated Facts 758 and 759 .

20810 Decision on the Prosecution's First Motion for Judicial Notice of Documentary Evidence Related to the Sarajevo Component, 31 March 2010. See also Decision on Motion for Extension of Time to File Response to Prosecution Motion for Judicial Notice of Documents, 30 October 2009; Decision on the Accused's Response to Prosecution Motion for Judicial Notice of Documents and Motion for Further Extension of Time, 24 December 2009; Order Regarding the Prosecution's Request for Leave to Reply to Karadžić's Response to Prosecution Motion for Judicial Notice of Documents, 30 December 2009; Decision on Prosecution Request for Leave to Reply to "Second Supplemental Response to Motion for Judicial Notice of Documents", 15 March 2010.

20811 Decision on the Prosecution's Motion for Judicial Notice of Intercepts Related to the Sarajevo Component and Request for Leave to Add One Document to the Rule 65 ter Exhibit List, 4 February 2011. Following the amendment to Rule 94(B) of the Rules during the plenary session held on 8 December 2010, the Chamber focused its analysis in the decision on whether to take judicial notice of the authenticity of documentary evidence which had been admitted in prior proceedings, and not in the admission into evidence of the documents.

20812 Decision on Accused's Motion for Certification to Appeal Decision on Judicial Notice of the Authenticity of Intercepts, 17 February 2011. 
6167. On 21 January 2014, the Chamber issued a decision denying the Accused's motion requesting the Chamber to take judicial notice of 26 facts relating to Count 1 , also pursuant to Rule 94(B) of the Rules. ${ }^{20813}$

\section{e. Protective measures}

6168. During 2008 and the first half of 2009, the Chamber issued a number of decisions on protective measures. $^{20814}$ On 24 July 2009, the Chamber issued a confidential decision which included a chart setting out all the protective measures in place for witnesses appearing on the Prosecution's Rule 65 ter witness list at that date (totalling 161 of 541 witnesses). ${ }^{20815}$ Following further submissions from the parties, the chart was finalised and appended to an order issued on 14 August 2009. ${ }^{20816}$

6169. Throughout the case, the Chamber continued to issue a large number of decisions granting, varying, rescinding, augmenting, or noting protective measures for Prosecution witnesses. ${ }^{20817}$ As a result of the various decisions issued by the Chamber, and in order to keep the record of protective measures in place as accurate and up-to-date as possible, the Chamber produced and updated nine charts on protective measures in place for Prosecution witnesses. ${ }^{20818}$

20813 Decision on Accused's Motion for Judicial Notice of Adjudicated Facts Related to Count One, 21 January 2014.

20814 See Preliminary Order on Prosecution Motion for Protective Measures for Witnesses, 26 September 2008 ; Decision on Protective Measures for Witnesses, 30 October 2008; Decision on Motion for and Notifications of Protective Measures, 26 May 2009; Decision on Prosecution's Motion for Delayed Disclosure for KDZ456, KDZ493, KDZ531, and KDZ532 and Variation of Protective Measures for KDZ489, 5 June 2009; Decision on Prosecution's Motion for Protective Measures for Witnesses KDZ182, KDZ185, KDZ304, and KDZ450 Pursuant to Rule 70, 2 July 2009.

20815 Decision on Protective Measures, confidential, 24 July 2009.

20816 Order on Chart of Protective Measures for Witnesses, 14 August 2009.

20817 See Decision on Prosecution's Motion for Rescission of Protective Measures (KDZ546), 29 October 2009; Decision on Prosecution's Motion for Rescission of Protective Measures of KDZ263, 26 February 2010; Decision on Accused's Motion for Modification of Protective Measures: Witnesses KDZ490 and KDZ492, 25 March 2010; Decision on Prosecution's Motion for Rescission of Protective Measures for KDZ323, 22 June 2010; Decision on Video-Conference Link and Request for Protective Measures for KDZ595, 18 August 2010; Reasons for Trial Chamber's Decision on Defence Request for Certification to Appeal: Modification of Protective Measures for KDZ088, 14 September 2010; Decision on Prosecution Motion for Protective Measures for Witness Bogdan Vidović, 21 September 2010; Decision on the Accused's Application for Certification to Appeal Decision on Reconsideration of Protective Measures (KDZ531), 16 August 2011; Decision on Prosecution Motions for Protective Measures for Witnesses KDZ601 and KDZ605, 19 August 2011; Public Redacted Version of "Decision on Accused's Motion to Recall KDZ080 and for Rescission of Protective Measures" Issued on 3 July 2013,12 March 2015; Decision on Accused's Motion to Rescind Protective Measures for Prosecution Witnesses KDZ033 and KDZ523, confidential, 5 February 2014; Decision on Prosecution Motion to Re-open its Case and Prosecution Motion for Protective Measures for Witness KDZ614, 20 March 2013.

20818 Second Order on Chart of Protective Measures for Witnesses, 24 August 2010; Third Order on Chart of Protective Measures for Witnesses, 23 November 2010; Fourth Order on Chart of Protective Measures for Witnesses, 22 August 2011; Fifth Order on Chart of Protective Measures for Witnesses, 6 October 2011; Sixth Order on Chart of Protective Measures for Witnesses, 24 January 2012; Decision on Protective Measures for Witnesses, 2 March 2012; Eight Order on Chart of Protective Measures for Prosecution Witnesses, 18 January 2013; Ninth Order on Chart of Protective Measures for Prosecution Witnesses, 12 December 2013. 
6170. The Chamber was also seised of a large number of motions filed by the Accused for the granting of protective measures to Defence witnesses and issued 19 decisions on the matter. ${ }^{20819}$ The Chamber continued with its practice and created a comprehensive chart, which was attached to an explanatory order. ${ }^{20820}$ The chart was updated as necessary. ${ }^{20821}$

\section{f. Access to confidential material}

6171. The Accused was granted access to confidential material in ongoing cases as well as in more than 30 completed cases. ${ }^{20822}$ The Chamber also issued a number of decisions on motions filed by accused in other proceedings requesting access to confidential materials in the case..$^{20823}$

20819 Order in Relation to Accused's Notice of Request of Protective Measures for Witnesses, 2 October 2012; Addendum to Order in Relation to Accused's Notice of Request of Protective Measures for Witnesses Issued on 8 October 2012, 9 October 2012; Decision on Motion for Protective Measures for Witness KW456, 12 October 2012; Decision on Motion for Consideration of Protective Measures for Witness KW341, 17 October 2012; Decision on Motion for Protective Measures for Witness KW285, 17 October 2012; Decision on Accused's Motions for Protective Measures for Witnesses KW289, KW299, KW378, and KW543, 1 October 2012; Decision on Accused's Motion for Video Link Testimony and Consideration of Protective Measures for Witness KW533, 9 November 2012; Decision on Accused's Motion for Protective Measures for Witness KW194, 12 November 2012; Decision on Accused's Motion for Rescission of Protective Measures for KW60, 14 November 2012; Decision on Accused's Motion for Protective Measures for Miladin Trifunović, 15 November 2012; Decision on Accused's Motion for Video Link Testimony for Witnesses Janko Ivanović and Ilija Miščević, 21 November 2012; Decision on Accused's Motion for Protective Measures for Witness KW492, 23 November 2012; Decision on Accused's Motion for Protective Measures for Witness KW007, 19 December 2012; Decision on Accused's Motion for Protective Measures for Witness KW402, 8 January 2013; Decision on Accused's Motion for Protective Measures for Witness KW466, 25 January 2013; Decision on Accused's Motion for Protective Measures for Witness KW392, 14 February 2013; Decision on Accused's Motion for Protective Measures for Witness KW012, confidential, 24 June 2013; Decision on Accused's Motion for Protective Measures for Witness KW428, 9 July 2013; Decision on Accused's Motion for Protective Measures for Witness KW586, confidential, 19 November 2013; Decision on Accused's Second Motion for Protective Measures for Witness KW586, confidential, 17 January 2014.

20820 Order on Chart of Protective Measures for Defence Witnesses, 18 January 2013.

20821 Second Order on Chart of Protective Measures for Defence Witnesses, 12 December 2013, Third Order on Chart of Protective Measures for Defence Witnesses, 19 May 2014.

20822 Decision on Motion for Access to Confidential Materials in Completed Cases, 5 June 2009; Decision on Motion to Modify Decision Re Access by Karadžić to Confidential Materials in Completed Cases, 3 July 2009; Decision on the Accused's Motion for Access to Ex Parte Filings in the Slobodan Milošević Case (Srebrenica Intercepts), 28 February 2011; Decision on the Accused's Motion for Access to Confidential Material from the Dragomir Milošević Case, 14 July 2011; Decision on Accused's Motion for Access to Exhibits in Orić Case, 18 November 2011; Decision on Prosecution Motion to Modify the Decision Granting the Accused Access to Confidential Materials in the Vasiljević Case, 8 March 2012; Order for Access to Audio Recordings from Brđanin Case, 25 September 2013.

20823 Decision on Momčilo Perišić's Motion for Access to Confidential Materials in the Radovan Karadžić Case, 14 October 2008; Decision on Accused Application for Certification to Appeal Trial Chamber's Decision on Momčilo Perišić's Motion for Access to Confidential Materials in the Radovan Karadžić Case, 13 November 2008; Decision on Supplement to Momčilo Perišić's Motion for Access to Confidential Materials in the Radovan Karadžić Case, 13 November 2008; Decision on Jovica Stanišić's Motion for Access to Confidential Materials in the Karadžić Case, 20 May 2009; Decision on General Miletić's Request for Access to Confidential Information in the Karadžić Case, 31 March 2010; Decision on Mićo Stanišić's and Stojan Župljanin's Requests for Access to Confidential Information in the Karadžić Case, 7 March 2011; Decision on Zdravko Tolimir's Motion for Disclosure of Confidential Materials from the Karadžić Case, 12 January 2012; Decision on Defence Request for Access to Confidential Materials from Karadžić Case, 8 November 2012; Decision on Gvero Defence Request for Access to Confidential Materials from the Karadžić Case, 6 February 2013. 


\section{g. Exhibit-related issues}

6172. Throughout the case, the Chamber was seised of, and issued decisions on, a number of bar table motions filed by the parties covering hundreds of items. ${ }^{20824}$ At the end of the Prosecution's case, the Chamber issued 11 decisions admitting approximately 750 documents. ${ }^{20825}$ Similarly, at the end of the Defence case, the Chamber issued six decisions admitting approximately 415 documents. 20826

\section{Contempt proceeding}

6173. As stated above, at the request of the Prosecution the Chamber issued subpoenas ordering two individuals in the Prosecution's Rule 65 ter witness list, namely Berko Zečević and Milan Tupajić, to appear and testify before the Chamber. ${ }^{20827}$ Following the individuals' continued

20824 Decision on Prosecution Bar Table Motion for the Admission of Bosnian Serb Assembly Records, 22 July 2010 ; Decision on Second Prosecution Bar Table Motion for the Admission of Bosnian Serb Assembly Records, 5 October 2010; Decision on Prosecution's Motion for Admission of an Exhibit from the Bar Table Following Major Thomas's Testimony, 28 October 2010; Decision on Motion for Admission of Evidence from Bar Table: General Michael Rose, 29 October 2010; Decision on Second Motion for Admission of Evidence from Bar Table: General Michael Rose, 17 December 2010; Decision on the Accused's Motion to Admit Document Relevant to Incident G4 from the Bar Table, 3 June 2011; Decision on Prosecution's Motion for the Admission of 68 Sarajevo Romanija Corps Documents from the Bar Table, 16 June 2011; Decision on the Prosecution's Bar Table Motion Relating to Witness Dorothea Hanson, 27 June 2011; Decision on Accused's Motion to Admit Document Relevant to Incident G7 from the Bar Table, 6 July 2011; Decision on Prosecution Bar Table Motion for the Admission of Records of Bosnian Serb Organs, 18 July 2011; Decision on Accused's Motion to Admit Documents Relevant to Witnesses KDZ490 and KDZ492 from the Bar Table, 9 January 2012; Decision on Prosecution's Motion for Admission of Evidence from the Bar Table and for Leave to Add Exhibits to the Rule 65 ter Exhibit List, 21 February 2012; Decision on the Accused's Bar Table Motion (Sarajevo Intercepts), 9 October 2012; Decision on Accused's Motion for Admission of Documents from Bar Table: General Miletić Documents, 27 February 2014.

20825 Decision on Prosecution's Motion for Admission of Evidence from the Bar Table (Hostages), 1 May 2012; Decision on Prosecution's Bar Table Motion for the Admission of Documents Related to the Sarajevo Component, 11 May 2012; Corrigendum to Decision on Prosecution's Bar Table Motion for the Admission of Documents Related to the Sarajevo Component, 14 May 2012; Decision on Prosecution's First Bar Table Motion for the Admission of Intercepts, 14 May 2012; Decision on Prosecution's Motion for the Admission of Evidence from the Bar Table (Srebrenica), 22 May 2012; Decision on Prosecution's Motion for the Admission of Two Intercepts from the Bar Table, 22 May 2012; Corrigendum to Decision on Prosecution's Motion for the Admission of Evidence from the Bar Table (Srebrenica), 24 May 2012; Decision on Prosecution's Third Bar Table Motion for the Admission of Intercepts (Srebrenica), 24 May 2012; Decision on Prosecution's Motion for the Admission of Documents from the Bar Table (Municipalities), 25 May 2012; Decision on Prosecution's Second Bar Table Motion for the Admission of Intercepts, 25 May 2012; Corrigendum to Decision on Prosecution's Third Bar Table Motion for the Admission of Intercepts (Srebrenica), 29 May 2012.

20826 Decision on Accused's Motion for Admission of Documents from Bar Table: General Miletić Documents, 27 February 2014; Decision on Accused's Bar Table Motion: Disclosure Violation Documents, 19 March 2014; Decision on Accused's Bar Table Motion (Karadžić Statements), 2 April 2014; Decision on Accused's Bar Table Motion (Sarajevo Component Documents), 7 April 2014; Decision on Accused's Bar Table Motion for Admission of Intercepts, 7 April 2014; Decision on Accused's Bar Table Motion: Municipality Component Documents, 14 April 2014.

20827 Decision on Prosecution's Motion to Subpoena Berko Zečević, confidential, 20 January 2011 (made public on 15 February 2011); Subpoena Ad Testificandum, confidential, 20 January 2011 (made public on 15 February 2011); Order to the Government of Bosnia and Herzegovina Concerning Subpoena, confidential, 20 January 2011 (made public on 15 February 2011); Subpoena Ad Testificandum, confidential, 23 September 2011; Second Subpoena Ad Testificandum, confidential, 3 November 2011; Order to the Government of Bosnia and 
refusal to comply with the subpoenas and appear before the Chamber, the Chamber ordered that the witnesses be prosecuted for contempt of the Tribunal, therefore issuing a warrant for arrest for each of them. ${ }^{20828}$ Following the arrest and subsequent transfer of Zečević to the Tribunal, he decided to voluntarily testify before the Chamber as a Prosecution witness. ${ }^{20829}$ However, Milan Tupajić continued to refuse to comply with the subpoena so the Chamber conducted contempt proceedings against him, finding him guilty of contempt and sentencing him to two months of imprisonment, which he served at the Tribunal's Detention Unit. ${ }^{20830}$

6174. Following Radislav Krstić's continued refusal to testify as a Defence witness after being ordered by the Chamber to do so, and the preparation of a detailed medical report on the witness's health, the Chamber issued an order in lieu of indictment initiating contempt proceedings against him on 27 March 2013. ${ }^{20831}$ On 18 July 2013, the Chamber issued its Judgement and found by majority, Judge Kwon dissenting, that Krstić was not guilty of contempt. ${ }^{20832}$

\section{Site visits}

6175. During the Prosecution phase of the case, the Chamber conducted two visits aimed at allowing the Chamber to become more familiar with the topography of certain key locations and thus assist its determination of the charges in the Indictment. In May 2011, the Judges visited various locations in and around Sarajevo. ${ }^{20833}$ In June 2012, the Judges visited locations in and around Srebrenica. ${ }^{20834}$ In both cases, a delegation which included, amongst others, a representative of the Prosecution and of the Accused, accompanied the Judges.

Herzegovina Concerning Second Subpoena Ad Testificandum, confidential, 3 November 2011; Decision on Prosecution's Motion to Subpoena Milan Tupajić, 23 September 2011.

Order in Lieu of Indictment, confidential, 4 February 2011 (made public on 15 February 2011); Warrant of Arrest and Order for Surrender, confidential, 4 February 2011 (made public on 15 February 2011); Order in Lieu of Indictment, confidential, 30 November 2011 (made public on 14 December 2011); Warrant of Arrest and Order for Surrender, confidential, 30 November 2011 (made public on 14 December 2011).

20829 Following the filing by the Prosecution of a motion to withdraw the order in lieu of the indictment, the Chamber issued a decision suspending the contempt proceedings; Decision on Motion for Withdrawal of Order In Lieu of Indictment, 18 February 2011.

See Public Redacted Version of "Judgement on Allegations of Contempt" Issued on 24 February 2012.

20831 Order in Lieu of Indictment, 27 March 2013. See Oral ruling, T. 33422-32423 (7 February 2013); Oral ruling, T. 35416-35417 (13 March 2013); Deputy Registrar's Notification Concerning the Appointment of an Independent Medical Expert, confidential, 14 February 2013; Krstić's Request for Reconsideration of the Order dated 13 March 2013, confidential, 19 March 2013; Oral ruling, T. 35748-35749 (21 March 2013).

20832 See Public Redacted Version of Judgement Issued on 18 July 2013.

20833 Order on Submissions for a Site Visit, 15 November 2010; Decision on Site Visit, 28 January 2011; Order Lifting Confidentiality of Decision on Site Visit and Related Pleadings, 24 May 2011.

20834 Decision on Second Site Visit, 10 February 2012; Order Lifting Confidentiality of Decision on Second Site Visit and Related Pleadings, 4 July 2012. 


\section{B. Glossary AND tABLE OF AUTHORITIES}

1. Glossary

\begin{tabular}{|c|c|}
\hline Abbreviation & Full citation \\
\hline ABiH & $\begin{array}{l}\text { Army of the Republic of Bosnia and Herzegovina (Armija Bosne } i \\
\text { Hercegovine) }\end{array}$ \\
\hline Accused & Radovan Karadžić \\
\hline Additional Protocol I & $\begin{array}{l}\text { Protocol Additional to the Geneva Conventions of } 12 \text { August 1949, } \\
\text { and relating to the Protection of Victims of International Armed } \\
\text { Conflicts (Protocol I), } 8 \text { June } 1977\end{array}$ \\
\hline Additional Protocol II & $\begin{array}{l}\text { Protocol Additional to the Geneva Conventions of } 12 \text { August 1949, } \\
\text { and relating to the Protection of Victims of Non-International Armed } \\
\text { Conflicts (Protocol II), } 8 \text { June } 1977\end{array}$ \\
\hline Adjudicated Fact & $\begin{array}{l}\text { Adjudicated fact which judicial notice was taken by decisions of the } \\
\text { Trial Chamber on } 5 \text { June 2009, } 9 \text { July } 2009,9 \text { October } 2009 \text {, and } 14 \\
\text { June } 2010\end{array}$ \\
\hline a.k.a & Also known as \\
\hline APC & Armoured Personnel Carrier \\
\hline ARK & Autonomous Region of Krajina (Autonomna Regija Krajina) \\
\hline art. & Article \\
\hline BiH & Republic of Bosnia and Herzegovina \\
\hline BCS & $\begin{array}{l}\text { Acronym commonly used at the Tribunal to describe the Bosnian- } \\
\text { Croatian-Serbian language }\end{array}$ \\
\hline BiHCMP & $\begin{array}{l}\text { Bosnian Federal Commission on Missing Persons or Bosnian } \\
\text { Commission on Missing Persons }\end{array}$ \\
\hline BiHIMP & Bosnia and Herzegovina Institute for Missing Persons \\
\hline BritBat & British Battalion of UNPROFOR \\
\hline BVP & Armoured Infantry Combat Vehicle \\
\hline CanBat & Canadian Battalion of UNPROFOR \\
\hline CJB & Public Security Centre (regional level) (Centar Javne Bezbjednosti) \\
\hline
\end{tabular}




\begin{tabular}{|c|c|}
\hline COHA & Cessation of Hostilities Agreement of 23 December 1994 \\
\hline Common Article 3 & Common Article 3 of the Geneva Conventions of 1949 \\
\hline Convention Against Torture & $\begin{array}{l}\text { Convention Against Torture and Other Cruel, Inhuman or Degrading } \\
\text { Treatment or Punishment (10 December 1984) }\end{array}$ \\
\hline Croatia & Republic of Croatia \\
\hline CSB & Security Services Centre (Centar Službi Bezbjednosti) \\
\hline CSCE & Conference on Security and Co-operation in Europe \\
\hline D & Defence exhibit admitted into evidence \\
\hline Defence Pre-Trial Brief & $\begin{array}{l}\text { The Prosecutor v. Radovan Karadžić, Case No. IT-95-5/18-PT, } \\
\text { Karadžić Pre-Trial Brief, 29 June } 2009\end{array}$ \\
\hline Defence Final Brief & $\begin{array}{l}\text { The Prosecutor v. Radovan Karadžić, Case No. IT-95-5/18-T, } \\
\text { Defence Final Trial Brief, confidential, } 29 \text { August 2014. A public } \\
\text { redacted version was filed on } 29 \text { September } 2014 .\end{array}$ \\
\hline DMZ & Demilitarised zone \\
\hline DutchBat & Dutch Battalion of UNPROFOR \\
\hline EC & European Community \\
\hline ECHR & $\begin{array}{l}\text { European Convention for the Protection of Human Rights and } \\
\text { Fundamental Freedoms, } 4 \text { November } 1950\end{array}$ \\
\hline ECMM & European Community Monitoring Mission \\
\hline EgyptBat & Egyptian Battalion of UNPROFOR \\
\hline EU & European Union \\
\hline Federal SUP & SUP of the FRY, whose seat was in Belgrade \\
\hline fn. & Footnote \\
\hline FreBat & French Battalion of UNPROFOR \\
\hline FRY & Federal Republic of Yugoslavia \\
\hline Geneva Convention I & $\begin{array}{l}\text { Convention for the Amelioration of the Condition of the Wounded } \\
\text { and Sick in Armed Forces in the Field. Geneva, August 12, 1949, } 75 \\
\text { UNTS } 31\end{array}$ \\
\hline
\end{tabular}




\begin{tabular}{|c|c|}
\hline Geneva Convention II & $\begin{array}{l}\text { Convention for the Amelioration of the Condition of Wounded, Sick } \\
\text { and Shipwrecked Members of Armed Forces at Sea. Geneva, August } \\
12,1949,75 \text { UNTS } 85\end{array}$ \\
\hline Geneva Convention III & $\begin{array}{l}\text { Convention Relative to the Treatment of Prisoners of War. Geneva, } \\
\text { August } 12,1949,75 \text { UNTS } 135\end{array}$ \\
\hline Geneva Convention IV & $\begin{array}{l}\text { Relative to the Protection of Civilian Persons in Time of War. } \\
\text { Geneva, August } 12,1949,75 \text { UNTS } 2\end{array}$ \\
\hline Genocide Convention & $\begin{array}{l}\text { Convention on the Prevention and Punishment of the Crime of } \\
\text { Genocide, } 9 \text { December } 1948\end{array}$ \\
\hline Hague Regulations & $\begin{array}{l}\text { Hague Convention (IV) respecting the Laws and Customs of War on } \\
\text { Land, and its annex: Regulations concerning the Laws and Customs of } \\
\text { War on Land. The Hague, } 18 \text { October } 1907\end{array}$ \\
\hline HDZ & Croatian Democratic Party (Hrvatska Demokratska Zajednica) \\
\hline HQ & Headquarters \\
\hline HV & Croatian Army (Hrvatska Vojska) \\
\hline HVO & Croatian Defence Council (Hrvatsko Vijeće Obrane) \\
\hline ICC & International Criminal Court \\
\hline ICCPR & $\begin{array}{l}\text { International Covenant on Civil and Political Rights, } 16 \text { December } \\
\text { 1966, } 999 \text { UNTS } 171\end{array}$ \\
\hline ICC Statute & $\begin{array}{l}\text { (Rome) Statute of the International Criminal Court, } 17 \text { July 1998, } \\
\text { UN Doc. A/CONF.183/9 }\end{array}$ \\
\hline ICFY & $\begin{array}{l}\text { International Conference on the former Yugoslavia (superseded the } \\
\text { European Community Conference on Yugoslavia (ECCY) in August } \\
\text { 1992) }\end{array}$ \\
\hline ICJ & International Court of Justice \\
\hline ICMP & International Commission on Missing Persons \\
\hline ICRC & International Committee of the Red Cross \\
\hline ICTR & $\begin{array}{l}\text { International Criminal Tribunal for the Prosecution of Persons } \\
\text { Responsible for Genocide and Other Serious Violations of } \\
\text { International Humanitarian Law Committed in the Territory of } \\
\text { Rwanda and Rwandan Citizens Responsible for Genocide and Other } \\
\text { Such Violations Committed in the Territory of Neighbouring States, } \\
\text { between 1 January } 1994 \text { and } 31 \text { December } 1994\end{array}$ \\
\hline
\end{tabular}




\begin{tabular}{|c|c|}
\hline ICTR Rules & $\begin{array}{l}\text { Rules of Procedure and Evidence of the International Criminal } \\
\text { Tribunal for Rwanda, July } 5,1995 \text {, as amended }\end{array}$ \\
\hline ICTR Statute & $\begin{array}{l}\text { Statute of the International Criminal Tribunal for Rwanda, in Security } \\
\text { Council Resolution 955, UN SCOR, } 44^{\text {th }} \text { Year, Res. And Dec., at } 15 \text {, } \\
\text { UN Doc. S/INF/50 (1994) }\end{array}$ \\
\hline IKM & Forward command post (istureno komandno mjesto) \\
\hline ILC & International Law Commission \\
\hline IMT & International Military Tribunal sitting at Nuremberg, Germany \\
\hline Indictment & $\begin{array}{l}\text { The Prosecutor v. Radovan Karadžić, Case No. IT-95-5/18-PT, Third } \\
\text { Amended Indictment, } 27 \text { February } 2009\end{array}$ \\
\hline JCE & Joint Criminal Enterprise \\
\hline JNA & Yugoslav People's Army (Jugoslavenska Narodna Armija) \\
\hline KDZ & $\begin{array}{l}\text { Counter Sabotage Protection Department of Bosnian Muslim Ministry } \\
\text { of Interior (Kontradiverziona Zaštita) }\end{array}$ \\
\hline Lima & UNMO position monitoring SRK forces \\
\hline L UNMO & UNMO team at Lukavica barracks, south of Sarajevo \\
\hline Markale I & $\begin{array}{l}\text { Shelling of Markale Market on } 5 \text { February } 1994 \text { (Scheduled Incident } \\
\text { G8) }\end{array}$ \\
\hline Markale II & $\begin{array}{l}\text { Shelling of Markale Market on } 28 \text { August } 1995 \text { (Scheduled Incident } \\
\text { G19) }\end{array}$ \\
\hline MBO & $\begin{array}{l}\text { Muslim Bosniak Organisation } \quad \text { (Muslimanska Bošnkačka } \\
\text { Organizacija) }\end{array}$ \\
\hline MP & Military Police \\
\hline MSF & Médecins Sans Frontières \\
\hline MUP & Ministry of Internal Affairs (Ministarstvo Unutrašnjih Poslova) \\
\hline NATO & North Atlantic Treaty Organization \\
\hline NGO & Non-governmental organisation \\
\hline
\end{tabular}




\begin{tabular}{|c|c|}
\hline Nuremberg Charter & $\begin{array}{l}\text { Charter of the International Military Tribunal for the Prosecution and } \\
\text { Punishment of the German Major War Criminals, Berlin, } 6 \text { October } \\
1945\end{array}$ \\
\hline Nuremberg Principles & $\begin{array}{l}\text { Principles of International Law Recognized in the Charter of the } \\
\text { Nuremberg Tribunal and in the Judgement of the Tribunal, } \\
\text { unanimously adopted by the International Law Commission, 1950, } \\
\text { UNGAOR, } 5^{\text {th }} \text { Session, Supp. No. } 12 \text {, UN Doc. A/1316 }\end{array}$ \\
\hline $\mathbf{O P}$ & UNPROFOR Observation Post \\
\hline $\mathbf{P}$ & Prosecution Exhibit Admitted into Evidence \\
\hline p. / pp. & Page/pages \\
\hline para. / paras. & Paragraph/paragraphs \\
\hline PJP & Special Police Forces \\
\hline POW & Prisoner of war \\
\hline Prosecution & Office of the Prosecutor \\
\hline Prosecution Pre-Trial Brief & $\begin{array}{l}\text { The Prosecutor v. Radovan Karadžić, Case No. IT-95-5/18-PT, } \\
\text { Prosecutor's Final Pre-trial Brief, } 18 \text { May } 2009\end{array}$ \\
\hline Prosecution Final Brief & $\begin{array}{l}\text { The Prosecutor v. Radovan Karadžić, Case No. IT-95-18-T, } \\
\text { Prosecution's Submission on Final Trial Brief, confidential with } \\
\text { confidential appendices, } 29 \text { August 2014. A public version was filed } \\
\text { on } 13 \text { October 2014. }\end{array}$ \\
\hline RDB & State Security Sector (Resor Državne Bezbjednosti) \\
\hline RJB & Public Security Sector (Resor Javne Bezbjednosti) \\
\hline RS & $\begin{array}{l}\text { Republika Srpska (before } 12 \text { August 1992, named Serbian Republic of } \\
\text { Bosnia and Herzegovina }(\text { SerBiH)) }\end{array}$ \\
\hline RSK & Republic of Serbian Krajina (Republika Srpska Krajina) \\
\hline Rules & $\begin{array}{l}\text { Rules of Procedure and Evidence of the International Criminal } \\
\text { Tribunal for the Former Yugoslavia, } 14 \text { March 1994, as amended }\end{array}$ \\
\hline RusBat & Russian Battalion of UNPROFOR \\
\hline SAO & Serbian Autonomous Region (Srpska Autonomna Oblast) \\
\hline SBP & Special Police Brigade \\
\hline
\end{tabular}




\begin{tabular}{|c|c|}
\hline Scheduled incidents & $\begin{array}{l}\text { Sniping and shelling incidents alleged to have occurred in Sarajevo } \\
\text { during the time-period related to the Indictment contained in the } \\
\text { schedules to the Indictment }\end{array}$ \\
\hline SDA & Party of Democratic Action (Stranka Demokratske Akcije) \\
\hline SDB & State Security Service (Služba Državne Bezbjednosti) \\
\hline SDC & Supreme Defence Council (Vrhovni Savet Odbrane) \\
\hline SDS & Serbian Democratic Party (Srpska Demokratska Stranka) in BiH \\
\hline SDP & Social Democratic Party (Socijaldemokratska Partija) of BiH \\
\hline SerBiH & $\begin{array}{l}\text { Serbian Republic of Bosnia and Herzegovina, renamed Republika } \\
\text { Srpska on } 12 \text { August } 1992\end{array}$ \\
\hline SFOR & Multinational Stabilisation Force \\
\hline SFRY & Socialist Federal Republic of Yugoslavia \\
\hline SJB & Public Security Station (local level) (Stanica Javne Bezbjednosti) \\
\hline SMO & Senior Military Observer \\
\hline SNB & National Security Council (Savjet za Nacionalnu Bezbjednost) \\
\hline SNSC & $\begin{array}{l}\text { Serbian National Security Council (Srpski Savjet za Nacionalnu } \\
\text { Bezbjednost) }\end{array}$ \\
\hline SOS & $\begin{array}{l}\text { Serbian Defence Forces, paramilitary formation (Srpske Odbrambene } \\
\text { Snage) }\end{array}$ \\
\hline SPO & Serbian Movement of Renewal (Sprski Pokret Obnove) \\
\hline SPS & Socialist Party of Serbia (Socijalistička Partija Srbije) \\
\hline SRBiH & Socialist Republic of Bosnia and Herzegovina (1945-1992) \\
\hline SRK & Sarajevo-Romanija Corps of the VRS (Sarajevo-Romanija Korpus) \\
\hline SRNA & Bosnian Serb Press Agency \\
\hline SRS & Serbian Radical Party (Srpska Radikalna Stranka) \\
\hline Statute & $\begin{array}{l}\text { Statute of the International Criminal Tribunal for the Former } \\
\text { Yugoslavia established by Security Council Resolution } 827 \text { (1993) }\end{array}$ \\
\hline
\end{tabular}




\begin{tabular}{|c|c|}
\hline Strategic Goals & $\begin{array}{l}\text { A list of six goals presented by the Accused at the } 16^{\text {th }} \text { Session of } \\
\text { SerBiH Assembly on } 12 \text { May } 1992\end{array}$ \\
\hline SUP & Secretariat for Internal Affairs (Sekretarijat za Unutrašnje Poslove) \\
\hline T. & Trial Transcript \\
\hline TEZ & Total Exclusion Zone \\
\hline TO & Territorial Defence (Teritorijalna Odbrana) \\
\hline Tribunal & International Criminal Tribunal for the former Yugoslavia \\
\hline UK & The United Kingdom of Great Britain and Northern Ireland \\
\hline UkrBat & Ukraine Battalion of UNPROFOR \\
\hline UN & United Nations \\
\hline UNHCR & United Nations High Commissioner for Refugees \\
\hline UNPROFOR & United Nations Protection Forces \\
\hline UNMO & United Nations Military Observers \\
\hline UNTS & United Nations Treaty Series \\
\hline UN Special Representative & United Nations Special Representative to the Former Yugoslavia \\
\hline USA & United States of America \\
\hline Variant A/B Instructions & $\begin{array}{l}\text { Document issued by the Main Board of the SDS on } 19 \text { December } \\
1991 \text { entitled "Instructions for the Organisation and Activity of } \\
\text { Organs of Serbian People in Bosnia and Herzegovina in Extraordinary } \\
\text { Circumstances" }\end{array}$ \\
\hline VJ & $\begin{array}{l}\text { Army of the Federal Republic of Yugoslavia (this came into existence } \\
\text { after the JNA in BiH became the VRS) (Vojska Jugoslavije) }\end{array}$ \\
\hline VRS & Army of Republika Srpska (Vojska Republike Srpske) \\
\hline WCP & Weapons Collection Point \\
\hline ZOBK & $\begin{array}{l}\text { Association of Municipalities of the Bosnian Krajina (Zajednica } \\
\text { opština Bosanske Krajine) }\end{array}$ \\
\hline ZOBK Assembly & Association of the Bosnian Krajina Municipalities Assembly \\
\hline ZOBL & $\begin{array}{l}\text { Banja Luka Community of Municipalities (Zajednica opština Banja } \\
\text { Luke) }\end{array}$ \\
\hline
\end{tabular}




\begin{tabular}{|l|l|}
\hline $\mathbf{1}^{\text {st }}$ Krajina Corps & First Krajina Corps of the VRS \\
\hline $\mathbf{7}$ Lima UNMO & UNMO team stationed in Pale \\
\hline $\mathbf{2 8}^{\text {th }}$ Division & Military unit of the ABiH \\
\hline $\mathbf{2 6}$ April 1992 Instructions & $\begin{array}{l}\text { Document issued by the Bosnian Serb Government under Prime } \\
\text { Minister Đerić on 26 April 1992 entitled "Instructions for the Work of } \\
\text { Crisis Staffs of the Serbian People in Municipalities" }\end{array}$ \\
\hline
\end{tabular}


2. List of authorities

a. ICTY and ICTR jurisprudence

Prosecutor v. Akayesu, Case No. ICTR-96-4-T, Judgement, 2 September 1998 (“Akayesu Trial Judgement")

Prosecutor v. Akayesu, Case No. ICTR-96-4-A, Judgement, 1 June 2001 (“Akayesu Appeal Judgement")

Prosecutorv Aleksovski, Case No. IT-95-14/1-A, Judgement, 24 March 2000 (“Aleksovski Appeal Judgement")

Prosecutor v Aleksovski, Case No. IT-95-14/1-AR73, Decision on Prosecutor's Appeal on Admissibility of Evidence, 16 February 1999 (“Aleksovski Appeal Decision on Admissibility”)

Prosecutor v. Babić, Case No. IT-03-72-A, Judgement on Sentencing Appeal, 18 July 2005 (“Babić Sentencing Appeal Judgement")

Prosecutor v. Bagosora and Nsengiyumva, Case No. ICTR-98-41-A, Judgement, 14 December 2011 ("Bagosora and Nsengiyumva Appeal Judgement")

Prosecutor v. Blagojević and Jokić, Case No. IT-02-60-T, Judgement, 17 January 2005 ("Blagojević and Jokić Trial Judgement")

Prosecutor v. Blagojević and Jokić, Case No. IT-02-60-A, Judgement, 9 May 2007 (“Blagojević and Jokić Appeal Judgement")

Prosecutor v. Blaškić, Case No. IT-95-14-T, Judgement, 3 March 2000 (“Blaškić Trial Judgement”)

Prosecutor v. Blaškić, Case No. IT-95-14-A, Judgement, 29 July 2004 (“Blaškić Appeal Judgement")

Prosecutor v. Bralo, IT-95-17-A, Judgement on Sentencing Appeal, 2 April 2007 ("Bralo Sentencing Appeal Judgement")

Prosecutor v. Boškoski and Tarčulovski, IT-04-82-A, Judgement, 19 May 2010 (“Boškoski and Tarčulovski Appeal Judgement”)

Prosecutor v. Brđanin and Talić, Case No. IT-99-36-AR73.9, Decision on Interlocutory Appeal, 11 December 2002 ("Brđanin 2002 Decision on Interlocutory Appeal")

Prosecutor v. Brđanin, Case No. IT-99-36-A, Decision on Interlocutory Appeal, 19 March 2004 (“Brđanin 2004 Decision on Interlocutory Appeal")

Prosecutor v. Brđanin, Case No. IT-99-36-T, Judgement, 1 September 2004 (“Brđanin Trial Judgement")

Prosecutor v. Brđanin, Case No. IT-99-36-A, Judgement, 3 April 2007 (“Brđanin Appeal Judgement") 
Prosecutor v. Delalić, Mucić, Delić, and Landžo, Case No. IT-96-21-T, Judgement, 16 November 1998 (“Čelebići Trial Judgement”)

Prosecutor v. Delalić, Mucić, Delić, and Landžo, Case No. IT-96-21-A, Judgement, 20 February 2001 (“Čelebići Appeal Judgement”)

Prosecutor v. Delić, Case No. IT-04-83-T, Judgement, 15 September 2008 ("Delić Trial Judgement")

Prosecutor v. Deronjić, Case No. IT-02-61-A, Sentencing Appeal Judgement, 20 July 2005 ("Deronjić Sentencing Appeal Judgement")

Prosecutor v. Đorđević, Case No. IT-05-87/1-T, Judgement, 23 February 2011 ("Đorđević Trial Judgement)

Prosecutor v. Đorđević, Case No. IT-05-87/1-A, Judgement, 27 January 2014 (“Đorđević Appeal Judgement)

Prosecutor v. Furundžija, Case No. IT-95-17/1-A, Judgement, 21 July 2000 (“Furundžija Appeal Judgement")

Prosecutor v. Galić, Case No. IT-98-29-T, Judgement and Opinion, 5 December 2003 (“Galić Trial Judgement")

Prosecutor v. Galić, Case No. IT-98-29-A, Judgement, 30 November 2006 ("Galić Appeal Judgement")

Prosecutor v. Gatete, Case No. ICTR-00-61-A, Judgement, 9 October 2012 ("Gatete Appeal Judgement")

Prosecutor v. Gotovina, Čermak, and Markač, Case No. IT-06-90-T, Judgement, 15 April 2011 (“Gotovina et al. Trial Judgement")

Prosecutor v. Gotovina and Markač, Case No. IT-06-90-A, Judgement, 16 November 2012 ("Gotovina Appeal Judgement")

Prosecutor v. Hadžihasanović et al., Case No. IT-01-47-AR72, Decision on Interlocutory Appeal Challenging Jurisdiction in Relation to Command Responsibility, 16 July 2003 ("Hadžihasanović et al. Interlocutory Decision")

Prosecutor v. Hadžihasanović and Kubura, Case No. IT-01-47-AR73.3, Decision on Joint Defence Interlocutory Appeal of Trial Chamber Decision on Rule 98 bis Motions for Acquittal, 11 March 2005 ("Hadžihasanović and Kubura Rule 98 bis Appeal Decision”)

Prosecutor v. Hadžihasanović and Kubura, Case No. IT-01-47-A, Judgement, 22 April 2008 ("Hadžihasanović and Kubura Appeal Judgement")

Prosecutor v. Halilović, Case No. IT-01-48-T, Judgement, 16 November 2005 ("Halilović Trial Judgement")

Prosecutor v. Halilović, Case No. IT-01-48-A, Judgement, 16 October 2007 ("Halilović Appeal Judgement") 
Prosecutor v. Haradinaj, Balaj, and Brahimaj, Case No. IT-04-84-T, Judgement, 3 April 2008 ("Haradinaj et al. Trial Judgement")

Prosecutor v. Jelisić, Case No. IT-95-10-T, Judgement, 14 December 1999 (“Jelisić Trial Judgement")

Prosecutor v. Jelisić, Case No. IT-95-10-A, Judgement, 5 July 2001 (“Jelisić Appeal Judgement”)

Prosecutor v. Jokić, Case No. IT-01-42/1-S, Sentencing Judgement, 18 March 2004 (“Jokić Sentencing Judgement")

Kamuhanda v. Prosecutor, Case No. ICTR-99-54A-A, Judgement, 19 September 2005 (“Kamuhanda Appeal Judgement”)

Karemera and Ngirumpatse v. Prosecutor, Case No. ICTR-98-44-A, Judgement, 29 September 2014 ("Karemera and Ngirumpatse Appeal Judgement")

Prosecutor v. Karemera et al., Case No. ICTR-98-44-AR73(C), Decision on Prosecutor's Interlocutory Appeal of Decision on Judicial Notice, 16 June 2006 ("Karemera Appeal Decision on Judicial Notice")

Prosecutor v. Kayishema and Ruzidana, Case No. ICTR-95-1-T, Sentence, 21 May 1999 ("Kayishema and Ruzidana Trial Judgement")

Prosecutor v. Kayishema and Ruzidana, Case No. ICTR-95-1-A, Judgement (Reasons), 1 June 2001 ("Kayishema and Ruzidana Appeal Judgement”)

Prosecutor v. Kordić and Čerkez, Case No. IT-95-14/2-T, Judgement, 26 February 2001 (“Kordić and Čerkez Trial Judgement")

Prosecutor v. Kordić and Čerkez, Case No. IT-95-14/2-A, Judgement, 17 December 2004 ("Kordić and Čerkez Appeal Judgement")

Prosecutor v. Krajišnik, Case No. IT-00-39-T, Judgement, 27 September 2006 (“Krajišnik Trial Judgement")

Prosecutor v. Krajišnik, Case No. IT-00-39-A, Judgement, 17 March 2009 (“Krajišnik Appeal Judgement")

Prosecutor v. Krnojelac, Case No. IT-97-25-T, Judgment, 15 March 2002 (“Krnojelac Trial Judgement")

Prosecutor v. Krnojelac, Case No. IT-97-25-A, Judgement, 17 September 2003 (“Krnojelac Appeal Judgement")

Prosecutor v. Krstić, Case No. 98-33-T, Judgement, 2 August 2001 (“Krstić Trial Judgement”)

Prosecutor v. Krstić, Case No. 98-33-A, Judgement, 19 April 2004 (“Krstić Appeal Judgement”)

Prosecutor v. Kunarac, Kovač, and Vuković, Case No. IT-96-23-T and IT-96-23/1-T, Judgement, 22 February 2001 (“Kunarac et al. Trial Judgement”)

Prosecutor v. Kunarac, Kovač, and Vuković, Case No. IT-96-23 and IT-96-23/1-A, Judgement, 12 June 2002 (“Kunarac et al. Appeal Judgement”) 
Prosecutor v. Zoran Kupreškić, Mirjan Kupreškić, Vlatko Kupreškić, Josipović, Papić, and Šantić, Case No. IT-95-16-T, Judgement, 14 January 2000 (“Kupreškić et al. Trial Judgement”)

Prosecutor v. Zoran Kupreškić, Mirjan Kupreškić, Vlatko Kupreškić, Josipović, and Šantić, Case No. IT-95-16-A, Appeal Judgement, 23 October 2001 (“Kupreškić et al. Appeal Judgement”)

Prosecutor v. Kvočka, Kos, Radić, Žigić, Prcać, Case No. IT-98-30/1-T, Judgement, 2 November 2001 (“Kvočka et al. Trial Judgement”)

Prosecutor v. Kvočka, Radić, Žigić, Prcać, Case No. IT-98-30-/1-A, Judgement, 28 February 2005 ("Kvočka et al. Appeal Judgement")

Prosecutor v. Limaj, Bala, and Musliu, Case No. IT-03-66-T, Judgement, 30 November 2005 ("Limaj et al. Trial Judgement")

Prosecutor v. Limaj, Bala, and Musliu, Case No. IT-03-66-A, Judgement, 27 September 2007 ("Limaj et al. Appeal Judgement")

Prosecutor v. Lukić and Lukić, Case No. IT-98-32/1-T, Judgement, 20 July 2009 (“Lukić and Lukić Trial Judgement")

Prosecutor v. Lukić and Lukić, Case No. IT-98-32/1-A, Judgement, 4 December 2012 ("Lukić and Lukić Appeal Judgement")

Prosecutor v. Martić, Case No. IT-95-11-T, Judgement, 12 June 2007 (“Martić Trial Judgement”)

Prosecutor v. Martić, Case No. IT-95-11-A, Judgement, 8 October 2008 ("Martić Appeal Judgement")

Prosecutor v. Dragomir Milošević, Case No. IT-98-29/1-T, Judgement, 12 December 2007 (“Dragomir Milošević Trial Judgement")

Prosecutor v. Dragomir Milošević, Case No. IT-98-29/1-A, Judgement, 12 November 2009 ("Dragomir Milošević Appeal Judgement”)

Prosecutor v. Milutinović, Šainović, and Ojdanić, Case No. IT-99-37-AR72, Decision on Dragoljub Ojdanić's Motion Challenging Jurisdiction - Joint Criminal Enterprise, 21 May 2003 ("Milutinović et al. [May 2003] Appeal Decision")

Prosecutor v. Milutinović, Šainović, Ojdanić, Pavković, Lazarević, and Lukić, Case No. IT-05-87T, Judgement, 26 February 2009 (“Milutinović et al. Trial Judgement”)

Musema v. Prosecutor, Case No. ICTR-96-13-A, Judgement, 16 November 2001 ("Musema Appeal Judgement")

Prosecutor v. Mrkšić, Radić, and Šljivančanin, Case No. IT-95-13/1-T, Judgement, 27 September 2007 (“Mrkšić et al. Trial Judgement”)

Prosecutor v. Mrkšić and Šljivančanin, Case No. IT-95-13/1-A, Judgement, 5 May 2009 ("Mrkšić and Šljivančanin Appeal Judgement")

Prosecutor v. Nahimana, Barayagwiza, and Ngeze, Case No. ICTR-99-52-A, Judgement, 28 November 2007 ("Nahimana et al. Appeal Judgement") 
Prosecutor v. Naletilić and Martinović, Case No. IT-98-34-T, Judgement, 31 March 2003 ("Naletilić and Martinović Trial Judgement")

Prosecutor v. Naletilić and Martinović, Case No. IT-98-34-A, Judgement, 3 May 2006 ("Naletilić and Martinović Appeal Judgement")

Prosecutor v. Dragan Nikolić, Case No. IT-94-2-A, Judgement on Sentencing Appeal, 4 February 2005 (“Dragan Nikolić Sentencing Appeal Judgement")

Prosecutor v. Momir Nikolić, Case No. IT-02-60/1-A, Judgement on Sentencing Appeal, 8 March 2006 ("Momir Nikolić Judgement on Sentencing Appeal")

[Aloys] Ntabakuze v. Prosecutor, Case No. ICTR-98-41A-A, Judgement, 8 May 2012 ("Ntabakuze Appeal Judgement")

Prosecutor v. Ntagerura, Bagambiki, and Imanishimwe, Case No. ICTR-99-46-A, Judgement, 7 July 2006 ("Ntagerura et al. Appeal Judgement”)

Prosecutor v. Ntakirutimana and Ntakirutimana, Cases Nos. ICTR-96-10-A and ICTR-96-17-A, Judgement, 13 December 2004 (“Ntakirutimana and Ntakirutimana Appeal Judgement")

Prosecutor v. Orić, Case No. IT-03-68-T, Judgement, 30 June 2006 (“Orić Trial Judgement”)

Prosecutor v. Orić, Case No. IT-03-68-A, Judgement, 3 July 2008 (“Orić Appeal Judgement”)

Prosecutor v. Plavšić, Case No. IT-00-39 \& 40/1-S, Sentencing Judgement, 27 February 2003 ("Plavšić Sentencing Judgement")

Prosecutor v. Perišić, Case No. IT-04-81-A, Judgement, 28 February 2013 ("Perišić Appeal Judgement")

Prosecutor v. Popović, Beara, Nikolić, Borovčanin, Miletić, Gvero, and Pandurević, Case No. IT05-88-T, Judgement, 10 June 2010 ("Popović et al. Trial Judgement")

Prosecutor v. Popović, Beara, Nikolić, Miletić, and Pandurević, Case No. IT-05-88-A, Judgement, 30 January 2015 (“Popović et al. Appeal Judgement”)

Prosecutor v. Rutaganda, Case No. ICTR-96-3-T, Judgement, 6 December 1999 ("Rutaganda Trial Judgement")

Prosecutor v. Šainović, Pavković, Lazarević, and Lukić, Case No. IT-05-87-A, Judgement, 23 January 2014 (“Šainović et al. Appeal Judgement”)

Semanza v. Prosecutor, Case No. ICTR-97-20-A, Judgement, 20 May 2005 (“Semanza Appeal Judgement")

Prosecutor v. Seromba, Case No. 2001-66-A, Judgement, 12 March 2008 ("Seromba Appeal Judgement")

Prosecutor v. Šešelj, Case No. IT-03-67-AR72.1, Decision on the Interlocutory Appeal Concerning Jurisdiction, 31 August 2004 (“Šě̌elj Appeal Jurisdiction Decision”)

Prosecutor v. Simba, Case No. ICTR-01-76-A, Judgement, 27 November 2007 ("Simba Appeal Judgement") 
Prosecutor v. Simić, Case No. IT-95-9/2-S, Sentencing Judgement, 17 October 2002 ("Simić Sentencing Judgement")

Prosecutor v. Simić, Tadić, and Zarić, Case No. IT-95-9-T, Judgement, 17 October 2003 ("Simić et al. Trial Judgement")

Prosecutor v. Simić, Case No. IT-95-9-A, Judgement, 28 November 2006 ("Simić Appeal Judgement")

Prosecutor v. Stakić, Case No. IT-97-24-T, Judgement, 31 July 2003 (“Stakić Trial Judgement”)

Prosecutor v. Stakić, Case No. IT-97-24-A, Judgement, 22 March 2006 ("Stakić Appeal Judgement")

Prosecutor v. Jovica Stanišić and Simatović, Case No. IT-03-69-T, Judgement, 30 May 2013 ("Stanišić and Simatović Trial Judgement")

Prosecutor v. Mićo Stanišić and Župljanin, Case No. IT-08-91-T, Judgement, 27 March 2013 ("Stanišić and Župljanin Trial Judgement")

Prosecutor v. Strugar, Case No. IT-01-42-T, Judgement, 31 January 2005 ("Strugar Trial Judgement")

Prosecutor v. Strugar, Case No. IT-01-42-A, Judgement, 17 July 2008 ("Strugar Appeal Judgement")

Prosecutor v. Tadić, Case No. IT-94-1-AR72, Decision on the Defence Motion for Interlocutory Appeal on Jurisdiction, 2 October 1995 ("Tadić Jurisdiction Decision on Interlocutory Appeal")

Prosecutor v. Tadić, Case No. IT-94-1-T, Opinion and Judgement, 7 May 1997 ("Tadić Trial Judgement")

Prosecutor v. Tadić, Case No. IT-94-1-A, Judgement, 15 July 1999 (“Tadić Appeal Judgement”)

Prosecutor v. Tadić, Case No. IT-94-1-Tbis-R117, Sentencing Judgement, 11 November 1999 ("Tadić Sentencing Judgement")

Prosecutor v. Tadić, Case No. IT-94-1-A and IT-94-1-Abis, Sentencing Appeal Judgement, 26 January 2000 ("Tadić Sentencing Appeal Judgement")

Prosecutor v. Todorović, Case No. IT-95-9/1-S, Sentencing Judgement, 31 July 2001 ("Todorović Sentencing Judgement")

Prosecutor v. Tolimir, Case No. IT-05-88/2-T, Judgement, 12 December 2012 ("Tolimir Trial Judgement")

Prosecutor v. Tolimir, Case No. IT-05-88/2-A, Judgement, 8 April 2015 ("Tolimir Appeal Judgement")

Prosecutor v. Vasiljević, Case No. IT-98-32-T, Judgement, 29 November 2002 ("Vasiljević Trial Judgement") 
Prosecutor v. Vasiljević, Case No. IT-98-32-A, Judgement, 25 February 2004 ("Vasiljević Appeal Judgement")

Prosecutor v. Zelenović, Case No. IT-96-23/2-S, Sentencing Judgement, 4 April 2007 (“Zelenović Sentencing Judgement")

Prosecutor v. Zelenović, Case No. IT-96-23/2-A, Judgement on Sentencing Appeal, 31 October 2007 (“Zelenović Sentencing Appeal Judgement")

b. Special Court for Sierra Leone jurisprudence

Prosecutor v. Sesay, Kallon and Gbao, Case No. SCSL-04-15-A, Judgment, 26 October 2009 ("Sesay et al. Appeal Judgement")

c. Karadžić decisions and orders

Decision on Six Preliminary Motions Challenging Jurisdiction, 28 April 2009 ("Decision on Motions Challenging Jurisdiction")

Decision on Prosecution's Motion Appealing Trial Chamber's Decision on JCE III Foreseeability, 25 June 2009 (“Appeal Decision on JCE III Foreseeability”)

Decision on Appeal of Trial Chamber's Decision on Preliminary Motion to Dismiss Count 11 of the Indictment, 9 July 2009 (“Appeal Decision on Count 11”)

Decision on the Application of Rule 73 bis, 8 October 2009 ("Rule 73 bis Decision”)

Order on the Procedure for the Conduct of Trial, 8 October 2009 ("First Order on Conduct of Trial")

Order on Prosecution Request for Clarification and Proposal Concerning Guidelines for the Conduct of Trial, 20 October 2009 ("Further Order on Conduct of Trial")

Decision on the Prosecution's First Bar Table Motion, 13 April 2010 ("First Prosecution Bar Table Decision")

Decision on Prosecution's Motion for Admission of the Evidence of KDZ172 (Milan Babić) Pursuant to Rule quater, 13 April 2010 ("Babić Rule 92 quater Decision")

Decision on Guidelines for the Admission of Evidence through Witnesses, 19 May 2010 ("Guidelines for Admission of Evidence")

Decision on Fourth Prosecution Motion for Judicial Notice of Adjudicated Facts, 14 June 2010 ("Decision on Fourth Adjudicated Facts Motion")

Decision on Prosecution's Submission on the Relevancy of Certain Documents Relating to the Testimony of Richard Philipps with Appendix A, 9 July 2010 ("Philipps Decision")

Decision on the Prosecution's Bar Table Motion Relating to Witness Dorothea Hanson, 27 June 2011 ("Hanson Bar Table Decision") 
Decision on Prosecution's Motion for the Admission of Documents from the Bar Table (Municipalities), 25 May 2012 ("Prosecution Municipality Bar Table Decision")

Decision on Accused's Motion for Admission of Evidence of Milorad Krnojelac Pursuant to Rule 92 quater, 6 December 2012 (“Krnojelac Rule 92 quater Decision”)

Decision on Appeal from Denial of Judgement of Acquittal for Hostage-Taking, 11 December 2012 (“Appeal Decision on Hostage-Taking”)

Judgement, 11 July 2013 (“Rule 98 bis Appeal Judgement”)

Case No. IT-95-5/18-AR73.11, Decision on Appeal against the Decision on the Accused's Motion to Subpoena Zdravko Tolimir, 13 November 2013 (“Appeal Decision on Tolimir Subpoena”)

Decision on Accused's Motion for Admission of Evidence of Radislav Krstić Pursuant to Rule 92 quater, 26 November 2013 ("Krstić Rule 92 quater Decision”)

Decision on Urgent Motions for Reconsideration of Decision Denying Mladić Request for Certification to Appeal Subpoena Decision, 22 January 2014 ("Decision on Mladić Motion for Reconsideration")

Decision on Accused's Bar Table Motion: Municipality Component Documents, 14 April 2014 ("Defence Municipality Bar Table Decision")

\section{d. Karadžić filings}

Prosecution Submission Pursuant to Rule 73 bis (D), 31 August 2009 ("Prosecution Rule 73 bis Submission")

\section{e. Treaties and commentaries}

Commentary on the Additional Protocols of 8 June 1977 to the Geneva Convention of 12 August 1949 (Yves Sandoz, Christophe Swinarski and Bruno Zimmermann, eds., 1987) ("ICRC Commentary on Additional Protocols")

Commentary on III Geneva Convention Relative to the Treatment of Prisoners of War (Jean de Preux et al. eds., 1960) (“ICRC Commentary III")

Commentary on IV Geneva Convention Relative to the Protection of Civilian Persons in Time of War (Jean S. Pictet et al. eds., 1958) ("ICRC Commentary IV")

Customary International Humanitarian Law, Volume I: Rules (Jean-Marie Henckaerts and Louise Doswald-Beck, eds., 2005) (“ICRC Customary IHL”)

\section{f. Others}

Case Concerning the Application of the Convention on the Prevention and Punishment of the Crime of Genocide (Bosnia and Herzegovina v. Serbia and Montenegro), Judgement of 26 February 2007 (“ICJ Bosnia Judgement”) 